\title{
Supplementary references for "Colonial history and global economics distort our understanding of deep-time biodiversity"
}

Nussaïbah B. Raja* GeoZentrum Nordbayern, Department of Geography and Geosciences, Friedrich-Alexander University Erlangen-Nürnberg, Erlangen, Germany

Emma Dunne School of Geography, Earth and Environmental Sciences, University of Birmingham, Edgbaston, Birmingham, B15 2TT, UK

Aviwe Matiwane Department of Botany, Rhodes University, 3230 Lucas Ave, Grahamstown, 6139, South Africa Tasnuva Ming Khan GeoZentrum Nordbayern, Department of Geography and Geosciences, Friedrich-Alexander University Erlangen-Nürnberg, Erlangen, Germany

Paulina S. Nätscher GeoZentrum Nordbayern, Department of Geography and Geosciences, Friedrich-Alexander University Erlangen-Nürnberg, Erlangen, Germany

Aline M. Ghilardi Federal University of Rio Grande do Norte (UFRN), Department of Geology, Natal, RN, Brazil Devapriya Chattopadhyay IISER Pune, Department of Earth and Climate Science, Dr. Homi Bhaba Road, Pune 411008, India

This document contains the references for the data sources used in the study:

Raja, N. B., Dunne, E. M., Matiwane, A., Khan, T. M., Nätscher, P. S., Ghilardi, A. M., and Chattopadhyay, D. (2021). Colonial history and global economics distort our understanding of deep-time biodiversity. Nature Ecology \& Evolution. https://doi.org/10.1038/s41559-021-01608-8

Keywords: paleontology, biodiversity, sampling biases, scientific colonialism, research ethics, scientometrics

\section{Overview}

Table 1: Specifications Table

\begin{tabular}{ll}
\hline $\begin{array}{l}\text { Source } \\
\text { Download url for occurrences }\end{array}$ & $\begin{array}{l}\text { The Paleobiology Database } \\
\text { https://paleobiodb.org/data1.2/occs/list.csv?datainf } \\
\text { o\&rowcount\&interval=Ediacaran,Holocene\&show=class,cl } \\
\text { assext,genus,subgenus,coll,coords,loc,paleoloc,strat } \\
\text {,stratext,lith,env,ref,crmod,timebins,timecompar } \\
\text { https://paleobiodb.org/data1.2/occs/refs.csv?interva } \\
\text { l=Ediacaran,Holocene\&select=occs\&show=formatted,entn } \\
\text { am }\end{array}$ \\
Download url for references & $19 / 01 / 2021$ \\
Processed \\
Date downloaded & Available to download from \\
https://dx.doi.org/10.17605/OSF.IO/6WC7A & Global \\
Lata access & $1990-2020$ \\
Location &
\end{tabular}

*Corresponding author, email: nussaibah.raja.schoob@fau.de 


\section{Data Processing}

The affiliate countries of the authors of each of the publications were compiled using (1) webscraping methods and (2) manually when the former was not possible. When the publications could not be found or the metadata could not be found, alternative sources such as personal websites, academic social networks such as ResearchGate or Academia.edu, or published obituaries (in the case when one or more of the authors were deceased). The affiliate dataset was the merged with the occurrences dataset of the Paleobiology Database to link the affiliate countries to where sampling took place. All countries were standardised using the official three-letter country codes (ISO 3166-1 alpha-3) the International Organization for Standardization (ISO, https:/ / www.iso.org/) using the R package countrycode 1.2.0[1].

\section{Data description}

Sample dataset:

\begin{tabular}{|c|c|c|c|c|c|c|}
\hline \#\# & & reference_no & samp_country & aff_country & samp_code & aff_code \\
\hline \#\# & 1 & 71813 & France & France & FRA & FRA \\
\hline \#\# & 2 & 71707 & Mongolia & Russia & MNG & RUS \\
\hline \#\# & 3 & 72371 & Russia & Russia & RUS & \\
\hline \#\# & 4 & 72986 & Russia & Russia & RUS & USS \\
\hline \#\# & 5 & 74895 & United Kingdom & Russia & GBR & RUS \\
\hline \#\# & 6 & 74895 & Japan & Russia & JPN & iUS \\
\hline \#\# & 7 & 74895 & Russia & Russia & RUS & RUS \\
\hline \#\# & 8 & 73353 & Argentina & Argentina & ARG & RG \\
\hline \#\# & 9 & 74204 & Myanmar (Burma) & China & MMR & $\mathrm{CHN}$ \\
\hline \#\# & 10 & 73338 & Argentina & Argentina & ARG & RG \\
\hline \#\# & 11 & 74067 & Myanmar (Burma) & United States & MMR & I \\
\hline
\end{tabular}

The final dataset comprises 5 columns:

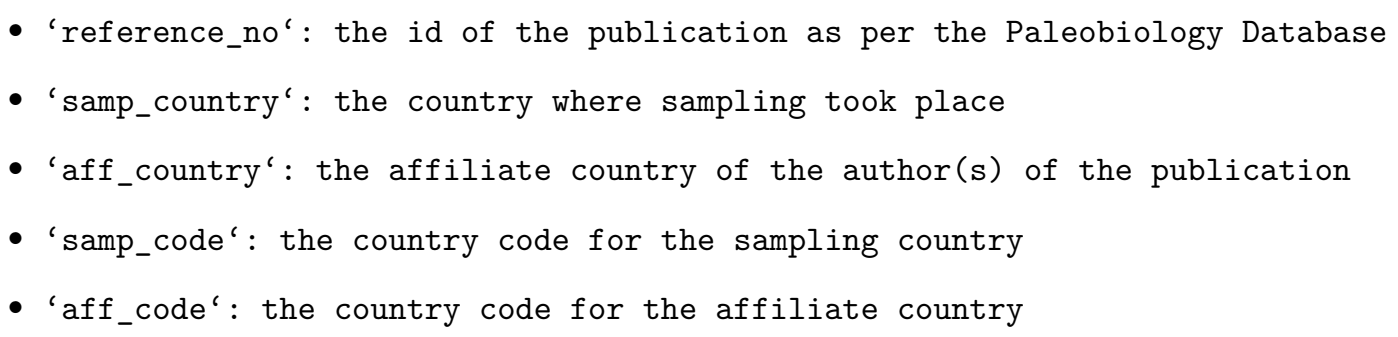

Each row in the reference represents one affiliate country and sampling country. As such, in some cases, one reference can have multiple rows, e.g. 74895 where the authors of the publication were from Russia but the data was obtained from the UK, Japan and Russia. The first occurring row of a reference contains the affiliate country of the first author.

\section{Acknowledgements}

We would like to thank John Alroy and Charles Marshall, in addition to A. Miller, M. Koznik and others for their vision and critical early work in establishing the Paleobiology Database as well as the numerous contributors of data, without all of whom this study would not have been possible. This report was generated using the R package refer 0.0.1 [2]. 


\section{References}

[1] Vincent Arel-Bundock, Nils Enevoldsen, and CJ Yetman. "countrycode: An R package to convert country names and country codes". In: Journal of Open Source Software 3.28 (2018), p. 848.

[2] Nussaibah B. Raja and Ádám T. Kocsis. refer: Reference list from data objects. 2021.

[3] M. Aadjour, H. Slimani, B. Fedan, R. F. Elzaroug, S. Rasul, B. Thusu, and A. Morabet. "Palynostratigraphie des dépots jurassico-crétacés des sondages MAC-1 (bassin de Doukkala) et ADM-1 (bassin d'Essaouira), Ouest du Maroc". English. In: Bulletin de l'Institut Scientifique, Rabat 27 (2005), pp. 1-15.

[4] K. R. Aalto and W. Miller. Sedimentology of the Pliocene Upper Onzole Formation, an inner-trench slope succession in northwestern Ecuador. 1999.

[5] K. Aaris-Sørensen, K. L. Rasmussen, C. Kinze, and K. S. Petersen. "Late Pleistocene and Holocene whale remains (Cetacea) from Denmark and adjacent countries: Species, distribution, chronology, and trace element concentrations". English. In: Marine Mammal Science 26.2 (2010), pp. 253-281.

[6] M. A. Abbasi, A. Ashouri, and K. Khaksar. "Solitary rugose corals from the Givetian of the Khoshyeilagh Formation (Eastern Alborz Mountains, NE Iran)". English. In: Palaeodiversity 7 (2014), pp. 1-21.

[7] N. Abbassi, D. P. Domning, N. N. Izad, and S. Shakeri. "Sirenia fossils from the Qom Formation (Burdigalian) of the Kabudar Ahang Area, Northwest Iran". English. In: Rivista Italiana di Paleontologia e Stratigrafia 1022.1 (2016), pp. 13-24.

[8] N. Abbassi and S. Madanipour. "Dinosaur tracks from the Jurassic Shemshak Group in the central Alborz Mountains (northern Iran)". English. In: Geologica Carpathica 65.2 (2014), pp. 99-115. DOI: 10.2478/geoca-2014-0007.

[9] N. Abbassi, S. D. Porchetti, A. Wagensommer, and M. G. Dehnavi. "Dinosaur and crocodylomorph footprints from the Hojedk Formation (Bajocian, Middle Jurassic) of north Kerman, Central Iran". English. In: International Journal of Geoscience 134.1 (2015), pp. 86-94.

[10] E. Abbate, A. Albianelli, A. Azzaroli, M. Benvenuti, B. Tesfamariam, P. Bruni, N. Cipriani, and et al. et et. A one-million-year-old Homo cranium from the Danakil (Afar) Depression of Eritrea. 1998.

[11] L. Abbazzi, A. Albianelli, P. Ambrosetti, P. Argenti, G. Basilici, A. Bertini, S. Gentili, F. Masini, G. Napoleone, and M. R. Pontini. "Paleontological and sedimentological record in Pliocene distal alluvial fan deposits at Cava Toppetti (Todi, Central Italy)." In: Bollettino della Societa Paleontologica Italiana 36.1-2 (1997), pp. 5-22.

[12] L. Abbazzi, C. Angelone, M. Arca, G. Barisone, C. Bedetti, M. Delfino, T. Kotsakis, F. Marcolini, M. R. Palombo, M. Pavia, P. Piras, L. Rook, D. Torre, C. Tuveri, A. M. F. Valli, and B. Wilkens. "PlioPleistocene fossil vertebrates of Monte Tuttavista (Orosei, Eastern Sardinia, Italy), an overview". In: Rivista Italiana di Paleontologia e Stratigrafia 110.3 (2004), pp. 681-706.

[13] L. Abbazzi, S. Carboni, M. Delfino, G. Gallai, L. Lecca, and L. Rook. "Fossil vertebrates (Mammalia and Reptilia) from Capo Mannu Formation (Late Pliocene, Sardinia, Italy), with description of a new Testudo (Chelonii, Testudinidae) species". English. In: Rivista Italiana di Paleontologia e Stratigrafia 114.1 (2008), pp. 119-132.

[14] L. Abbazzi, M. Delfino, G. Gallai, L. Trebini, and L. Rook. “New Data on the vertebrate assemblage of Fiume Santo (North-West Sardinia, Italy), and overview on the Late Miocene Tusco-Sardinian Palaeobioprovince". English. In: Palaeontology 51.2 (2008), pp. 425-451.

[15] E. Abbey, J. M. Webster, J. C. Braga, K. Sugihara, C. Wallace, Y. Iryu, D. Potts, T. Done, G. Camoin, and C. Seard. "Variation in deglacial coralgal assemblages and their paleoenvironmental significance: IODP Expedition 310, Tahiti Sea Level". English. In: Global and Planetary Change 76 (2011), pp. 1-15.

[16] E. Abbey, J. M. Webster, J. C. Braga, G. E. Jacobsen, G. Thorogood, A. L. Thomas, G. Camoin, P. J. Reimer, and D. C. Potts. "Deglacial mesophotic reef demise on the Great Barrier Reef". English. In: Palaeogeography, Palaeoclimatology, Palaeoecology 392 (2013), pp. 473-494. 
[17] F. Abdala. "Redescription of Platycraniellus elegans (Therapsida, Cynodontia) from the Lower Triassic". English. In: Palaeontology 50 (2007), pp. 591-618.

[18] F. Abdala. "Catalogue of non-mammalian cynodonts in the Vertebrate Paleontology Collection of the Instituto Miguel Lillo, Universidad Nacional de Tucuman, with comments on species". English. In: Ameghiniana 37.4 (2000), pp. 463-475.

[19] F. Abdala, M. C. Barberena, and J. Dornelles. "A new species of the traversodontid cynodont Exaeretodon from the Santa Maria Formation (Middle/Late Triassic) of southern Brazil". English. In: Journal of Vertebrate Paleontology 22.2 (2002), pp. 313-325.

[20] F. Abdala, R. Damiani, A. M. Yates, and J. Neveling. "A non-mammaliaform cynodont from the Upper Triassic of South Africa: a therapsid Lazarus taxon?" English. In: Palaeontologia africana 42 (2007), pp. 17-23.

[21] F. Abdala, S. Dias-da-Silva, and J. C. Cisneros. "First record of non-mammalian cynodonts (Therapsida) in the Sanga do Cabral Formation (Early Triassic) of southern Brazil". English. In: Palaeontologia africana 38 (2002), pp. 93-98.

[22] F. Abdala, L. C. Gaetano, R. M. H. Smith, and B. S. Rubidge. "A new large cynodont from the Late Permian (Lopingian) of the South African Karoo Basin and its phylogenetic significance". English. In: Zoological Journal of the Linnean Society 186 (2019), pp. 983-1005.

[23] F. Abdala, P. J. Hancox, and J. Neveling. "Cynodonts from the uppermost Burgersdorp Formation, South Africa, and their bearing on the biostratigraphy and correlation of the Triassic Cynognathus Assemblage Zone". English. In: Journal of Vertebrate Paleontology 25.1 (2005), pp. 192-199.

[24] F. Abdala, T. Jashashvili, B. S. Rubidge, and J. van den Heever. "New Material of Microgomphodon oligocynus (Eutherapsida, Therocephalia) and the Taxonomy of Southern African Bauriidae". English. In: Early Evolutionary History of the Synapsida. Dordrecht: Springer, 2013, pp. 209231. DOI: $10.1007 / 978-94-007-6841-3 \_13$.

[25] F. Abdala, J. Neveling, and J. Welman. "A new trirachodontid cynodont from the lower levels of the Burgersdorp Formation (Lower Triassic) of the Beaufort Group, South Africa and the cladistic relationships of Gondwanan gomphodonts". English. In: Zoological Journal of the Linnean Society 147 (2006), pp. 383-413.

[26] F. Abdala and A. M. Ribeiro. "A new traversodontid cynodont from the Santa Maria Formation (Ladinian-Carnian) of southern Brazil, with a phylogenetic analysis of Gondwanan traversodontids". English. In: Zoological Journal of the Linnean Society 139 (2003), pp. 529-545.

[27] F. Abdala and A. M. Ribeiro. "Distribution and diversity patterns of Triassic cynodonts (Therapsida, Cynodontia) in Gondwana". English. In: Palaeogeography, Palaeoclimatology, Palaeoecology 286 (2010), pp. 202-217.

[28] F. Abdala and A. M. Ribeiro. "A new therioherpetid cynodont from the Santa Maria Formation (middle Late Triassic), southern Brazil". English. In: Geodiversitas 22.4 (2000), pp. 589-596.

[29] F. Abdala, B. S. Rubidge, and J.v.d. Heever. "The Oldest Therocephalians (Therapsida, Eutheriodonta) and the Early Diversification of Therapsida". English. In: Palaeontology 51.4 (2008), pp. 10111024. DOI: $10.1111 /$ j.1475-4983.2008.00784.x.

[30] F. Abdala and A. M. Sa-Teixeira. "A traversodontid cynodont of African affinity in the South American Triassic". English. In: Palaeontologia africana 40 (2004), pp. 11-22.

[31] H. Abdallah and C. Meister. "The Cenomanian - Turonian boundary in the Gafsa-Chott area (southern part of central Tunisia): biostratigraphy, palaeoenvironments". English. In: Cretaceous Research 18 (1997), pp. 197-236.

[32] G. I. Abdel-Gawad. "Late Cenomanian ammonites from NE Libya and the western desert of Egypt". English. In: Geology of East Libya 3 (2008), pp. 201-218.

[33] M. R. Abdel-Kireem, E. Schrank, A. M. Samir, and M. I. A. Ibrahim. "Cretaceous palaeoecology, palaeogeography and palaeoclimatology of the northern Western Desert, Egypt". English. In: Journal of African Earth Sciences 22.1 (1996), pp. 93-111. 
[34] A. A. Abdelhady and R. S. A. Mohamed. "Paucispecific macroinvertebrate communities in the Upper Cretaceous of El Hassana Dome (Abu Roash, Egypt): Environmental controls vs adaptive strategies". English. In: Cretaceous Research 74 (2017), pp. 120-136.

[35] M. A. Abdelhamid and M. M. Azab. "Aptian-Cenomanian Echinoids from Egypt". English. In: Revue de Paleobiologie, Geneve 22.2 (2003), pp. 851-876.

[36] F. R. Abe, B. S. Lieberman, M. C. Pope, and K. Dilliard. “New information on olenelline trilobites from the Cambrian Sekwi Formation in northwestern Canada". English. In: Canadian Journal of Earth Sciences 47.12 (2010), p. 1445.

[37] J. Abella, D. M. Alba, J. M. Robles, A. Valenciano, C. Rotgers, R. Carmona, P. Montoya, and J. Morales. "Kretzoiarctos gen. nov., the oldest member of the giant panda clade". English. In: PLoS One 17 (2012), e48985. DOI: 10.1371/journal.pone.0048985.

[38] M. A. Abello, M. de los Reyes, A. M. Candela, F. Pujos, D. Voglino, and B. M. Quispe. “Description of a new species of Sparassocynus (Marsupialia: Didelphoidea: Sparassocynidae) from the late Miocene of Jujuy (Argentina) and taxonomic review of Sparassocynus heterotopicus from the Pliocene of Bolivia". English. In: Zootaxa 3937.1 (2015), pp. 147-160.

[39] S. W. Aber, N. Peterson, W. J. May, P. Johnston, and J. S. Aber. "First report of vertebrate fossils in the Snyderville Shale (Oread Formation: Upper Pennsylvanian), Greenwood County, Kansas". English. In: Transactions of the Kansas Academy of Science 117.3/4 (2014), pp. 193-202. DOI: 10.1660/ 062.117.0304.

[40] M. Aberhan. Tendaguru. 2000.

[41] M. Aberhan. "Early Jurassic Bivalvia of western Canada. Part I. Subclasses Palaeotaxodonta, Pteriomorpha, and Isofilibranchia". English. In: Beringeria 21 (1998), pp. 57-150.

[42] M. Aberhan. "Early Jurassic Bivalvia of northern Chile. Part II. Subclass Anomalodesmata". English. In: Beringeria 34 (2004), pp. 117-154.

[43] M. Aberhan. "A new species of Coelastarte (Astartidae; Bivalvia) from the Early Jurassic of Chile and unusual ornamentation in eastern Pacific Jurassic bivalves". English. In: Beringeria 37 (2007), pp. 3-9.

[44] M. Aberhan, R. Bussert, W. -D. Heinrich, E. Schrank, S. Schultka, B. Sames, J. Kriwet, and S. Kapilima. "Palaeoecology and depositional environments of the Tendaguru Beds (Late Jurassic to Early Cretaceous, Tanzania)”. In: Mitt. Mus. Nat.kd. Berl., Geowiss. Reihe 5(2002) (2002), pp. 19-44.

[45] M. Aberhan and F. T. Fursich. "Paleoecology and paleoenvironments of the Pleistocene deposits of Bahia la Choya (Gulf of California, Sonora, Mexico)". In: Zitteliana 18 (1991), pp. 135-163.

[46] M. Aberhan and A. von Hillebrandt. "Taxonomy, ecology, and palaeobiogeography of Gervilleioperna (Gervilleiognoma) aurita n. subgen, n. sp. (Bivalvia) from the Middle Jurassic of northern Chile". English. In: Paläontologische Zeitschrift 70 (1996), pp. 79-96.

[47] M. Aberhan and A. von Hillebrandt. "The bivalve Opisoma in the Lower Jurassic of northern Chile". English. In: Profil 16 (1999), pp. 149-164.

[48] N. M. Aboul Ela, G. L. Abdel-Gawad, and M. F. Aly. "Albian fauna of Gabal Manzour, Maghara area, north Sinai, Egypt". English. In: Journal of African Earth Sciences 13.2 (1991), pp. 201-220.

[49] Z.S. Aboussalam. "Das Taghanic Event im höheren Mittel-Devon von West-Europa und Marokko". German. In: Münstersche Forschungen zur Geologie und Paläontologie 97 (2003), pp. 1-332.

[50] L. M. Abraczinskas. "Pleistocene proboscidean sites in Michigan: New records and an update on published sites". English. In: Michigan Academician 25.4 (1993), pp. 443-490.

[51] M. Abrahams, L. Sciscio, M. Reid, T. Haupt, and E. M. Bordy. "Large tridactyl dinosaur tracks from the Early Jurassic of southern Gondwana - uppermost Elliot Formation, Upper Moyeni, Lesotho". English. In: Annales Societatis Geologorum Poloniae 90 (2020), pp. 1-26.

[52] S. Abramovich and G. Keller. "High stress late Maastrichtian paleoenvironment: inference from planktonic foraminifera in Tunisia". English. In: Palaeogeography, Palaeoclimatology, Palaeoecology 178 (2002), pp. 145-164. 
[53] R.-H. Abu-Zied and R. A. Bantan. "Late Pleistocene gastropods from the raised reefal limestone". English. In: Palaeontologische Zeitschrift 92 (2018), pp. 65-86.

[54] M. B. Abubakar, N. G. Obaje, H. P. Luterbacher, E. F. C. Dike, and A. R. Ashraf. "A report on the occurrence of Albian-Cenomanian elater-bearing pollen in Nasara-1 well, Upper Benue Trough, Nigeria: Biostratigraphic and palaeoclimatological implications". English. In: Journal of African Earth Sciences 45 (2006), pp. 347-354.

[55] H. Accarie, B. Beaudoin, J. Dejax, G. Friés, J. -G. Michard, and P. Taquet. “Découverte d'un Dinosaure théropode nouveau (Genusaurus sisteronis n. g., n. sp.) dans l'Albien marin de Sisteron (Alpes de Haute-Provence, France) et extension au Crétacé inférieur de la lignée cératosaurienne [Discovery of a new theropod dinosaur (Genusaurus sisteronis n. g., n. sp.) in the marine Albian of Sisteron (Alpes de Haute-Provence, France) and extension of the ceratosaur lineage into the Lower Cretaceous]". French. In: Comptes Rendus de l'Académie des Sciences á Paris, série IIa 320 (1995), pp. 327-344.

[56] G. F. Aceñolaza. "Macrocystella? durandi sp. nov. (Echinodermata, Rhombifera) y el registro del géner o Macrocystellaen la cuenca cambro-ordovcica del norte argentino". Spanish. In: Acta Geologica Hispanica 34.1 (1999), pp. 89-101.

[57] G. F. Aceñolaza, R. Albani, E. Bernárdez, D. G. Garca-Bellido, J. C. Gutiérrez-Marco, I. Rábano, and A. A. Sá. "First Furongian (late Cambrian) trilobites from the Cantabrian Zone (north-western Spain)". English. In: Bulletin of Geosciences 89.2 (2014), pp. 239-244.

[58] P. G. Aceñolaza and F. G. Aceñolaza. “Improntas foliares de una Lauraceae en la Formación Paraná (Mioceno Superior), en Villa Urquiza, Entre Ros". Spanish. In: Ameghiniana 33.2 (1996), pp. 155159.

[59] J. Acevedo, A. Aguayo-Lobo, P. Acuna, M. Goto, A. N. Zerbini, and L. A. Pastene. "First Record of the Dwarf Minke Whale Balaenoptera acutorostrata in Chilean Waters". English. In: International Whaling Commission (2005).

[60] A. Achab, E. Asselin, A. Desrochers, J. F. Riva, and C. Farley. "Chitinozoan biostratigraphy of a new Upper Ordovician stratigraphic framework for Anticosti Island, Canada". English. In: Geological Society America Bulletin 123.1/2 (2010), pp. 186-205.

[61] C. Acosta Hospitaleche, J. Canto, and C. P. Tambussi. "Pinguinos (Aves, Spheniscidae) en Coquimbo (Mioceno Medio-Plioceno Tardio), Chile y su vinculacion con las corrientes oceanicas". English. In: Revista Española de Paleontologa 21.1 (2006), pp. 115-122.

[62] C. Acosta Hospitaleche, L. Castro, C. Tambussi, and R. A. Scasso. "Palaeospheniscus patagonicus (Aves, Sphenisciformes): New disoveries from the early Miocene of Argentina". English. In: Journal of Paleontology 82.3 (2008), pp. 565-575.

[63] C. Acosta Hospitaleche, M. Chavez, and O. Fritis. "Pingüinos fósiles (Pygoscelis calderensis sp. nov.) en la Formación Baha Inglesa (Mioceno Medio-Plioceno), Chile". English. In: Revista geológica de Chile 33.2 (2006), pp. 327-338.

[64] C. Acosta Hospitaleche and A. L. Cione. "The most recent record of +Palaeospheniscus bergi Moreno \& Mercerat, 1891 (Aves, Spheniscidae) from the middle Miocene, northeastern Patagonia". English. In: Neues Jahrbuch für Geologie und Paläontologie, Abhandlungen 266.2 (2012), pp. 143148.

[65] C. Acosta Hospitaleche, M. de los Reyes, S. Santillana, and M. Reguero. "First fossilized skin of a giant penguin from the Eocene of Antarctica". English. In: Lethaia 53 (2020), pp. 409-420. DOI: 10.1111/let.12366.

[66] C. Acosta Hospitaleche and J. N. Gelfo. "Procellariiform remains and a new species from the latest Eocene of Antarctica". English. In: Historical Biology 29.6 (2017), pp. 755-769. DOI: 10.1080/ 08912963.2016.1238470.

[67] C. Acosta Hospitaleche, M. Griffin, M. Asensio, A. L. Cione, and C. Tambussi. "Middle Cenozoic penguin remains from the Patagonian Cordillera". English. In: Andean Geology 40.3 (2013), pp. 490503. DOI: $10.5027 /$ andgeoV40n32-a0?5?. 
[68] C. Acosta Hospitaleche, N. Haidr, A. Paulina-Carabajal, and M. Reguero. "The first skull of Anthropornis grandis (Aves, Sphenisciformes) associated with postcranial elements". English. In: Comptes Rendus Palevol 18 (2019), pp. 599-617. DOI: 10.1016/j.crpv.2019.06.003.

[69] C. Acosta Hospitaleche, D. Montalti, and R. del Valle. "Mid-Holocene skua remains from King George Island, Antarctica". English. In: Palaeontologische Zeitschrift 84 (2010), pp. 533-539. DOI: 10.1007/s12542-010-0063-z.

[70] C. Acosta Hospitaleche and E. Olivero. "Re-evaluation of the fossil penguin Palaeeudyptes gunnari from the Eocene Leticia Formation, Argentina: additional material, systematics and palaeobiology". English. In: Alcheringa 40.3 (2016), pp. 373-382. DOI: 10.1080/03115518.2016.1144994.

[71] C. Acosta Hospitaleche and M. Reguero. "First articulated skeleton of Palaeeudyptes gunnari from the Late Eocene of Isla Marimbo (Seymour Island), Antarctica". English. In: Antarctic Science 22.3 (2010), pp. 289-298.

[72] C. Acosta Hospitaleche, M. Reguero, and S. Santillana. “Aprosdokitos mikrotero gen. et sp. nov., the tiniest Sphenisciformes that lived in Antarctica during the Paleogene". English. In: Neues Jahrbuch für Geologie und Paläontologie 283.1 (2017), pp. 25-34. DOI: 10.1127/njgpa/2017/0624.

[73] C. Acosta Hospitaleche and M. Reguero. "Additional Pelagornithidae remains from Seymour Island, Antarctica". English. In: Journal of South American Earth Sciences 99 (2020). DOI: 10.1016/j. jsames.2020.102504.

[74] C. Acosta Hospitaleche and L. Soibelzon. "The southernmost Miocene penguin (Aves, Speniscidae) from South America". English. In: Neues Jahrbuch fuer Geologie und Palaeontologie Abhandlungen 264.1 (2012), pp. 89-93.

[75] C. Acosta Hospitaleche and M. Stucchi. "Nuevos restos terciarios de Spheniscidae (Aves, sphenisciformes) procedentes de la Costa del Peru". Spanish. In: Revista española de paleontologa 20.1 (2005), pp. 1-5.

[76] C. Acosta Hospitaleche, C. Tambussi, M. Donato, and M. Cozzuol. "A new Miocene penguin from Patagonia and its phylogenetic relationships". English. In: Acta Palaeontologica Polonica 52.2 (2007), pp. 299-314.

[77] C. Acosta Hospitaleche and C. Tambussi. "Phorusrhacidae Psilopterinae (Aves) en la Formación Sarmiento de la localidad de Gran Hondonada (Eoceno Superior), Patagonia, Argentina". Spanish. In: Revista Española de Paleontologa 20.2 (2005), pp. 127-132.

[78] R. A. Acuña-Mesen and C. A. Laurito-Mora. "Nueva especie de Rhinoclemmys Fitzinger, 1836 (Chelonii, Cryptodira) del Cenozoico tardo de Costa Rica". Spanish. In: Ameghiniana 33.3 (1996), pp. 271-278.

[79] M. H. Adabi and D. V. Ager. "Late Jurassic brachiopods from north-east Iran". English. In: Palaeontology 40.2 (1997), pp. 355-362.

[80] N. Adachi, Y. Ezaki, and J. W. Pickett. "Interrelations between framework-building and encrusting skeletal organisms and microbes: more-refined growth history of Lower Devonian bindstones". English. In: Sedimentology 54 (2007), pp. 89-105.

[81] N. Adachi, Y. Ezaki, and J. W. Pickett. "Marked accumulation patterns characteristic of Lower Devonian stromatoporoid bindstone: Palaeoecological interactions between skeletal organisms and microbes". English. In: Palaeogeography, Palaeoclimatology, Palaeoecology 231 (2006), pp. 331346.

[82] N. Adachi, Y. Ezaki, J. Liu, and J. Cao. "Early Ordovician reef construction in Anhui Province, South China: A geobiological transition from microbial- to metazoan-dominant reefs". English. In: Sedimentary Geology 220 (2009), pp. 1-11.

[83] N. Adachi and Y. Ezaki. "Microbial impacts on the genesis of Lower Devonian reefal limestones, eastern Australia". English. In: Palaeoworld 16 (2007), pp. 301-310. DOI: 10.1016/j.palwor.2007.05. 018. 
[84] N. Adachi, J. Liu, and Y. Ezaki. “Early Ordovician reefs in South China (Chenjiahe section, Hubei Province): deciphering the early evolution of skeletal-dominated reefs". English. In: Facies 59 (2013), pp. 451-466.

[85] S. Adachi, H. Igo, K. Sashida, and N. Nakornsri. "Triassic coral buildups observed in the Chaiburi Formation, near Phatthalung, Peninsular Thailand". In: Annual Report of the Institute of Geoscience of the University Tsukuba 19 (1993), pp. 27-31.

[86] M. Adaci, R. Tabuce, F. Mebrouk, M. Bensalah, P. -H. Fabre, L. Hautier, J. -J. Jaeger, V. Lazzari, M. Mahboubi, L. Marivaux, O. Otero, S. Peigné, and H. Tong. "Nouveaux sites á vertébrés paléogénes dans la région des Gour Lazib (Sahara nord-occidental, Algérie)". English. In: Comptes Rendus Palevol 6 (2007), pp. 535-544. DOI: 10.1016/j.crpv.2007.09.001.

[87] P. J. Adam and G. G. Garcia. "New information on the natural history, distribution, and skull size of the extinct (?) West Indian monk seal, Monachus tropicalis". English. In: Marine Mammal Science 19.2 (2003), pp. 297-317.

[88] J. W. Adams. "A revised listing of fossil mammals from the Haasgat cave system ex situ deposits (HGD), South". English. In: 15.3.29A (2012), pp. 1-88.

[89] J. W. Adams, D. S. Rovinsky, A. I. R. Herries, and C. G. Menter. "Macromammalian faunas, biochronology and palaeoecology of the early Pleistocene Main Quarry hominin-bearing deposits of the Drimolen Palaeocave System, South Africa". English. In: PeerJ 4.e1941 (2016), pp. 1-45. DOI: 10.7717/peerj.194.

[90] M. P. Adams and R. W. Woods. "Mid-Holocene Falkland Islands bird bones from a peat deposit, including a new species of caracara". English. In: Emu 116 (2016), pp. 370-378.

[91] T. L. Adams. "A new neosuchian crocodyliform from the Lower Cretaceous (late Aptian) Twin Mountains Formation of North-Central Texas". English. In: Journal of Vertebrate Paleontology 33.1 (2013), pp. 85-101. DOI: 10.1080/02724634.2012.713277.

[92] T. L. Adams. "Small crocodyliform from the Lower Cretaceous (late Aptian) of central Texas and its systematic relationship to the evolution of Eusuchia". English. In: Journal of Paleontology 88.5 (2014), pp. 1031-1049. DOI: 10.1666/12-089.

[93] T. L. Adams. "Small terrestrial crocodyliform from the Lower Cretaceous (late Aptian) of central Texas and its implications on the paleoecology of the Proctor Lake dinosaur locality". English. In: Journal of Vertebrate Paleontology (2019), e1623226:1-15. DOI: 10.1080/02724634.2019.1623226.

[94] T. L. Adams and A. R. Fiorillo. “Platypterygius Huene, 1922 (Ichthyosauria, Ophthalmosauridae) from the Late Cretaceous of Texas, USA". English. In: Palaeontologia Electronica 14.3 (2011), 19A.

[95] T. L. Adams, C. R. Noto, and S. K. Drumheller. "A large neosuchian crocodyliform from the Upper Cretaceous (Cenomanian) Woodbine Formation of North Texas". English. In: Journal of Vertebrate Paleontology 37.4 (2017), e1349776:1-17. DOI: 10.1080/02724634.2017.1349776.

[96] T. L. Adams, M. J. Polcyn, O. Mateus, D. A. Winkler, and L. L. Jacobs. "First occurrence of the longsnouted crocodyliform Terminonaris (Pholidosauridae) from the Woodbine Formation (Cenomanian) of Texas". English. In: Journal of Vertebrate Paleontology 31.3 (2011), pp. 712-716. DOI: 10.1080/ 02724634.2011.572938.

[97] A. A. Addi, M. E. Hanbali, and C. Bobier. "Les bioconstructions du Bajocien-Bathonien pp. du Haut-Atlas". English. In: Géologie Méditerranéenne 25.1 (1998), pp. 43-54. DOI: 10.3406 / geolm. 1998.1613.

[98] S. Adnet, P.-O. Antoine, S. R. Hassan Baqri, J. -Y. Crochet, L. Marivaux, J. -L. Welcomme, and G. Métais. "New tropical carcharhinids (chondrichthyes, Carcharhiniformes) from the late Eoceneearly Oligocene of Balochistan, Pakistan: Paleoenvironmental and paleogeographic implications". English. In: Journal of Asian Earth Sciences 30.2 (2007), pp. 303-323. DOI: 10.1016/j.jseaes.2006.10. 002 . 
[99] S. Adnet, A. C. Balbino, M. T. Antunes, and J. M. Marin-Ferrer. “New fossil teeth of the white shark (Carcharodon carcharias) from the Early Pliocene of Spain. Implication for its paleoecology in the Mediterranean". English. In: Neus Jahrbuch fur Geologie und Palaontologie, Abhandlungen 256.1 (2009), pp. 7-16.

[100] S. Adnet, H. Capetta, and R. Mertiniene. "Re-evaluation of squaloid shark records from the Albian and Cenomanian of Lithuania". English. In: Cretaceous Research 29.4 (2008), pp. 711-722. DOI: 10. 1016/j.cretres.2008.01.014.

[101] S. Adnet, H. Cappetta, and J. Reynders. "Nouveaux genres de Squaliformes (Chondrichthyes) du Paléogéne des Landes (Sud-Ouest de la France) [New squaliforms genera (Chondrichthyes: Squalomorphii) from the Paleogene of the Landes Department (southwestern France)". French. In: Paläontologische Zeitschrift 80.1 (2006), pp. 60-67.

[102] S. Adnet, H. Cappetta, and R. Tabuce. "A Middle-Late Eocene vertebrate fauna (marine fish and mammals) from southwestern Morocco; preliminary report: age and palaeobiogeographical implications". English. In: Geological Magazine 147.6 (2010), pp. 860-870.

[103] S. Adnet, H. Cappetta, S. Elnahas, and A. Strougo. "A new Priabonian Chondrichthyans assemblage from the Western desert, Egypt: Correlation with the Fayum oasis". English. In: Journal of African Earth Sciences 61 (2011), pp. 27-37. DOI: 10.1016/j.jafrearsci.2011.04.005.

[104] S. Adnet, R. S. Gismondi, and P. -O. Antoine. "Comparisons of dental morphology in river stingrays (Chondrichthyes: Potamotrygonidae) with new fossils from the middle Eocene of Peruvian Amazonia rekindle debate on their evolution". English. In: Naturwissenschaften 101.1 (2014), pp. 33-45. DOI: $10.1007 / \mathrm{s} 00114-013-1127-1$.

[105] S. Adnet, G. Guinot, H. Cappetta, and J. L. Welcomme. "Oldest evidence of bramble sharks (Elasmobranchii, Echinorhinidae) in the Lower Cretaceous of southeast France and the evolutionary history of orbitostylic sharks". English. In: Cretaceous Research 35 (2012), pp. 81-87. DOI: 10.1016/ j.cretres.2011.11.021.

[106] S. Adnet, R. Hoseinzadeh, M. T. Antunes, A. C. Balbino, V. A. Kozlov, and H. Cappetta. “Review of the enigmatic Eocene shark genus Xiphodolamia (Chondrichthyes, Lamniformes) and description of a new species recovered from Angola, Iran and Jordan". English. In: Journal of African Earth Sciences 66 (2009), pp. 197-204. DOI: 10.1016/j.jafrearsci.2009.04.005.

[107] S. Adnet, L. Marivaux, H. Cappetta, A. -L. Charruault, E. M. Essid, S. Jiquel, H. K. Ammar, B. Marandat, W. Marzougui, G. Merzeraud, R. Temani, M. Vianey-Liaud, and R. Tabuce. "Diversity and renewal of tropical elasmobranchs around the Middle Eocene Climatic Optimum (MECO) in North Africa: New data from the lagoonal deposits of Djebel el Kébar, Central Tunisia". English. In: Palaeontologia Electronica 23.2 (2020), a38.

[108] R. R. Adorno, D. A. do Carmo, G. Germs, D. H. G. Walde, M. Denezine, P. C. Boggiani, S. C. Sousa, J. R. Vasconcelos, T. C. Tobias, E. M. Guimarães, L. C. Vieira, M. F. Figueiredo, R. Moraes, S. A. Caminha, P. A. Z. Suarez, C. V. Rodrigues, G. M. Caixeta, D. Pinho, G. Schneider, and R. Muya. “Cloudina lucianoi (Beurlen \& Sommer, 1957), Tamengo Formation, Ediacaran, Brazil: Taxonomy, analysis of stratigraphic distribution and biostratigraphy". English. In: Precambrian Research 301 (2017), pp. 19-35. DOI: 10.1016/j.precamres.2017.08.023.

[109] J. M. Adrain. "Systematics of the Acanthoparyphinae (Trilobita), with Species from the Silurian of Arctic Canada". English. In: Journal of Paleontology 72.4 (1998), pp. 698-718.

[110] J. M. Adrain. "Validity and composition of the Silurian trilobite genera $<\mathrm{i}>$ Borealarges $</ \mathrm{i}>$ and $<\mathrm{i}>$ Dicranogmus $</ \mathrm{i}>$, with new species from the Canadian Arctic". English. In: Canadian Journal of Earth Sciences 40 (2003), pp. 749-763.

[111] J. M. Adrain. "Proetid trilobites from the Silurian (Wenlock-Ludlow) of the Cape Phillips Formation, Canadian Arctic Archipelago". English. In: Palaeontographic Italica 84 (1997), pp. 21-111.

[112] J. M. Adrain and B. D. E. Chatterton. "The aulacopleurid trilobite Otarion, with new species from the Silurian of northwestern Canada". In: Journal of Paleontology 68.2 (1994), pp. 305-323. 
[113] J. M. Adrain and B. D. E. Chatterton. "The otarionine trilobite Cyphaspis, with new species from the Silurian of northwestern Canada". In: Journal of Paleontology 70.1 (1996), pp. 100-110.

[114] J. M. Adrain and B. D. E. Chatterton. "Aulacopleurine trilobites from the Llandovery of northwestern Canada". In: Journal of Paleontology 69.2 (1995), pp. 326-340.

[115] J. M. Adrain and B. D. E. Chatterton. "The otarionine trilobites Harpidella and Maurotarion, with species from northwestern Canada, the United States, and Australia". In: Journal of Paleontology 69.2 (1995), pp. 307-326.

[116] J. M. Adrain and B. D. E. Chatterton. "A new rorringtoniid trilobite from the Ludlow of Arctic Canada". In: Canadian Journal of Earth Sciences 30 (1993), pp. 1634-1643.

[117] J. M. Adrain, B. D. E. Chatterton, and R. B. Blodgett. "Silurian trilobites from southwestern Alaska". English. In: Journal of Paleontology 69.4 (1995), pp. 723-736.

[118] J. M. Adrain and G. D. Edgecombe. "Silurian (Wenlock) Calymenid trilobites from the Cape Phillips Formation, central Canadian Arctic". In: Journal of Paleontology 71.4 (1997), pp. 657-682.

[119] J. M. Adrain and R. A. Fortey. "Ordovician trilobites from the Tourmakeady Limestone, western Ireland". English. In: Bulletin of the British Museum (Natural History) 53.2 (1997), pp. 79-115.

[120] J. M. Adrain and G. J. Kloc. "Lower Devonian aulacopleuroidean trilobites from Oklahoma". In: Journal of Paleontology 71.4 (1997), pp. 703-712.

[121] J. M. Adrain, D.-C. Lee, S. R. Westrop, B. D. E. Chatterton, and E. Landing. "Classification of the trilobite subfamilies Hystricurinae and Hintzecurinae subfam. nov. with new genera from the Lower Ordovician (Ibexian) of Idaho and Utah". English. In: Memoirs of the Queensland Museum 48.2 (2003), pp. 553-586.

[122] J. M. Adrain and E. W. MacDonald. "Phacopid trilobites from the Silurian of Arctic Canada". In: Journal of Paleontology 70 (1996), pp. 1091-1094.

[123] J. M. Adrain and L. Ramskold. "Silurian Odontopleurinae (Trilobita) from the Cape Phillips Formation, Arctic Canada". English. In: Journal of Paleontology 71.2 (1997), pp. 237-261.

[124] J. M. Adrain and L. Ramskold. "The lichid trilobite Radiolichas in the Silurian of Arctic Canada and Gotland, Sweden". In: Geological Magazine 133 (1996), pp. 147-158.

[125] J. M. Adrain, S. R. Westrop, E. Landing, and R. A. Fortey. "Systematics of the Ordovician trilobites Ischyrotoma and Dimeropygiella, with species from the Type Ibexian area, western U.S.A." English. In: Journal of Paleontology 75.5 (2001), pp. 947-971.

[126] J. M. Adrain and S. R. Westrop. “New earliest Ordovician trilobite genus Millardicurus: the oldest known hystricurid". English. In: Journal of Paleontology 80.4 (2006), pp. 650-671.

[127] J. M. Adrain and S. R. Westrop. "New genus of dimeropygid trilobites from the earliest Ordovician of Laurentia". English. In: Acta Palaeontologica Polonica 51.3 (2006), pp. 541-550.

[128] J. M. Adrain and S. R. Westrop. "The hystricurid trilobite Metabowmania in the Lower Ordovician (Ibexian; Stairsian) of the Great Basin, Utah and Idaho, USA". English. In: Memoirs of the Association of Australasian Palaeontologists 34 (2007), pp. 227-242.

[129] J. M. Adrain and S. R. Westrop. "Bearriverops, a new Lower Ordovician trilobite genus from the Great Basin, western USA, and classification of the family Dimeropygidae". English. In: Canadian Journal of Earth Sciences 44 (2007), pp. 337-366.

[130] J. M. Adrain and S. R. Westrop. "Lower Ordovician trilobites from the Baumann Fiord Formation, Ellesmere Island, Arctic Canada". English. In: Canadian Journal of Earth Sciences 42.9 (2005), pp. 1523-1546.

[131] B. Adrian, P. A. Holroyd, J. H. Hutchison, and K. E. B. Townsend. "Additional records and stratigraphic distribution of the middle Eocene carettochelyid turtle Anosteira pulchra from the Uinta Formation of Utah, North America". English. In: PeerJ 8.e9775 (2020), pp. 1-27. DOI: 10.7717/ peerj. 9775. 
[132] B. Adrian, H. F. Smith, C. R. Noto, and A. Grossman. “A new baenid, Trinitichelys maini sp. nov., and other fossil turtles from the Upper Cretaceous Arlington Archosaur Site (Woodbine Formation, Cenomanian), Texas, USA". English. In: Palaeontologia Electronica 22.3.81 (2019), pp. 1-29.

[133] B. Adrian, L. Werdelin, and A. Grossman. "New Miocene Carnivora (Mammalia) from Moruorot and Kalodirr, Kenya". English. In: Palaeontologia Electronica 21.1.10A (2018), pp. 1-19.

[134] M. S. Afanasieva. "New Taxa and New Middle Famennian Natgorella hirsuta-Spinoalius melekessensis Radiolarian Ecozone of the Volga-Ural Basin". English. In: Paleontological Journal 53.5 (2019), pp. 435-446. DOI: 10.1134/S0031030119050022.

[135] G. A. Afanasjeva. "New Chonetids (Brachiopods) from the Upper Permian Ufimian Stage of the Kanin Peninsula". English. In: Paleontological Journal 38 (2004), pp. 35-38.

[136] G. A. Afanasjeva. "New Permian Chonetids (Brachiopods) from Mongolia". English. In: Paleontological Journal 38.2 (2004), pp. 162-165.

[137] G. A. Afanasjeva. "A new genus Pinegochonetes (Brachiopoda, Chonetida) from the Kazanian of the Russian platform". English. In: Paleontological Journal 34.3 (2000), pp. 287-289.

[138] G. A. Afanasjeva. "New Late Permian chonetids (Brachiopoda) from southeastern Pamirs". English. In: Paleontological Journal 45.1 (2011), pp. 35-39.

[139] G. A. Afanasjeva. "New Middle Carboniferous Genus Neotornquistia (Brachiopoda, Chonetida) from the Moscow Syneclise". English. In: Paleontological Journal 42 (2008), pp. 260-264.

[140] G. A. Afanasjeva, H. Ishiga, and J. I. Tazawa. "New Species of Fanichonetes Xu et Grant (Brachiopoda, Chonetida) from the Lower Permian of South Korea". English. In: Paleontological Journal 45.3 (2011), pp. 266-269.

[141] G. A. Afanasjeva and J. Tazawa. "A new large chonetid (Brachiopoda) from the Middle Permian of the southern Kitakami Mountains, northeast Japan”. English. In: Paleontological Journal 41 (2007), pp. 424-428.

[142] G. A. Afanasjeva and J. Tazawa. "New Genus Kanokurachonetes (Brachiopoda, Chonetida) from the Middle Permian of the Southern Kitakami Mountains, Northeast Japan". English. In: Paleontological Journal 44.1 (2010), pp. 16-20.

[143] G. A. Afanasjeva, J. I. Tazawa, and T. Shintani. "Brachiopods of the order Chonetida from the Lower and Middle Permian of the South Kitakami Mountains, northeast Japan". English. In: Paleontological Journal 49 (2015), pp. 19-25.

[144] G. A. Afanasjeva, J. I. Tazawa, and Y. Miyake. “New brachiopod species Leurosina katasumiensis (Chonetida) from the Kungurian Katasumi Limestone of the Kusu area, central Japan". English. In: Paleontological Journal 52 (2018), pp. 389-9393.

[145] S. Afsari, M. Yadiz, A. Bahrami, and G. Carnevale. "A new deep-sea hatchetfish (Teleostei: Stomiiformes: Sternoptychidae) from the Eocene of Ilam, Zagros Basin, Iran". English. In: Bollettino della Societá Paleontologica Italiana 53.1 (2014), pp. 27-37. DOI: 10.4435/BSPI.2014.03.

[146] R. Agar. “Clockhouse Brickworks 2001-2003”. English. In: Wealden News 6 (2005), pp. 4-5.

[147] S. Agematsu, K. Sashida, S. Salyapongse, and A. Sardsud. “Ordovician Conodonts from the Satun Area, Southern Peninsular Thailand". English. In: Journal of Paleontology 81.1 (2007), pp. 19-37. DOI: 10.1666/0022-3360\%282007\%2981\%5B19\%3AOCFTSA\%5D2.0.CO\%3B2.

[148] S. Agematsu, K. Sashida, and A. B. Ibrahim. "Biostratigraphy and paleobiogeography of Middle and Late Ordovician conodonts from the Langkawi Islands, northwestern peninsular Malaysia". English. In: Journal of Paleontology 82.5 (2008), pp. 957-973.

[149] L. D. Agenbroad, J. I. Mead, C. V. Haynes Jr., and R. H. Hevly. "Fossil fauna and flora from late Pleistocene Cerros Negros Locality, Pinal County, Arizona: With update of Mammuthus and all Mammut localities from Arizona". English. In: 58.1 (2013), pp. 50-53.

[150] L. D. Agenbroad and D. P. Morris. "Giant island/pygmy mammoths: The Late Pleistocene prehistory of Channel Islands National Park". English. In: National Park Service Paleontological Research 4 (1999), pp. 27-316. 
[151] K. Agiadi, A. Antonarakou, G. Kontakiotis, N. Kafousia, P. Moissette, J. J. Cornee, E. Manoutsoglou, and V. Karakitsios. "Connectivity controls on the late Miocene eastern Mediterranean fish fauna". English. In: International Journal of Earth Sciences 106 (2017), pp. 1147-1159.

[152] K. Agiadi, C. Giamali, A. Girone, P. Moissete, E. Koskeridou, and V. Karakitsios. The Zanclean marine fish fauna and palaeoenvironmental reconstruction of a coastal marine setting in the eastern Mediterranean. English. Palaeobiodiversity and Palaeoenvironments. 2020.

[153] K. Agiadi, A. Girone, E. Koskeridou, P. Moissette, J. J. Cornee, and F. Quillevere. "Pleistocene marine fish invasions and paleoenvironmental reconstructions in the eastern Mediterranean". English. In: Quaternary Science Reviews 196 (2018), pp. 80-99. DOI: 10.1016/j.quascirev.2018.07.037.

[154] K. Agiadi, E. Koskeridou, M. Triantaphyllou, A. Girone, and V. Karakitsios. "Paleobathymetry of a Late Pliocene Voutes coast (Heraklion basin, Crete)". English. In: Bulletin of the Geological Society of Greece 47 (2013), pp. 52-61.

[155] K. Agiadi and G. Theodorou. "Tusk paleohistology as a tool in the discrimination of fossil tusks from Greece". English. In: Proceedings of the International Symposium Insular Vertebrate Evolution: the Palaeontological Approach, Palma de Mallorca, 2003. Monografies de la Societat d'História Natural de les Balears (2005), pp. 1-8.

[156] K. Agiadi, M. Triantaphyllou, A. Girone, V. Karakitsios, and M. Dermitzakis. "Paleobathymetric interpretation of the fish otoliths from the lower - middle quaternary deposits of Kephallonia and Zakynthos islands (Ionian Sea, Western Greece)". English. In: Rivista Italiana di Paleontologia $i$ Stratigrafia 116 (2010), pp. 63-78.

[157] H. Agi, A. E. S. Högström, M. Moczydowska, S. Jensen, T. Palacios, G. Meinhold, J. O. R. Ebbestad, W. L. Taylor, and M. Høyberget. "Organically-preserved multicellular eukaryote from the early Ediacaran Nyborg Formation, Arctic Norway". English. In: Scientific Reports 9 (2019), p. 14659. DOI: 10.1038/s41598-019-50650-x.

[158] P. Agnihotri, K. Chandra, A. Shukla, H. Singh, and R. C. Mehrotra. “First fossil record of a nymph (Ephemeroptera, Teloganellidae) from the Indian subcontinent". English. In: Zootaxa 4838 (2020), pp. 137-142.

[159] F. Agnolin. "Comentarios sobre las tortugas Testudinidae (Reptilia, Chelonii) del Pleistoceno de Argentina". Spanish. In: Studia Geologica Salmanticensia 40 (2004), pp. 91-101.

[160] F. Agnolin. "A new Calyptocephalellidae (Anura, Neobatrachia) from the Upper Cretaceous of Patagonia, Argentina, with comments on its systematic position". English. In: Studia Geologica Salmanticensia 48.2 (2012), pp. 129-178.

[161] F. L. Agnolin. "An avian coracoid from the Upper Cretaceous of Patagonia, Argentina”. English. In: Studia Geologica Salmanticensia 46.2 (2010), pp. 99-119.

[162] F. L. Agnolin, S. Bogan, F. Brissón Egli, F. E. Novas, M. P. Isasi, C. Marsicano, A. M. Zavattieri, and A. Mancuso. "A new lungfish (Dipnoi) from the Late Triassic of South America". English. In: Journal of Vertebrate Paleontology 37.1 (2017), e1245665. DOI: 10.1080/02724634.2017.1245665.

[163] F. L. Agnolin and P. Chafrat. "New fossil bird remains from the Chichinales Formation (Early Miocene) of northern Patagonia, Argentina". English. In: Annales de Paléontologie 101 (2015), pp. 8794.

[164] F. L. Agnoln, F. B. Egli, S. Chatterjee, J. A. Garcia Marsá, and F. E. Novas. “Vegaviidae, a new clade of southern diving birds that survived the K/T boundary". English. In: The Science of Nature 104.87 (2017), pp. 1-9. DOI: 10.1007/s00114-017-1508-y.

[165] F. L. Agnolin, M. D. Ezcurra, D. F. Pais, and S. W. Salisbury. "A reappraisal of the Cretaceous non-avian dinosaur faunas from Australia and New Zealand: evidence for their Gondwanan affinities". English. In: Journal of Systematic Palaeontology 8.2 (2010), pp. 257-300. DOI: 10.1080 / 14772011003594870.

[166] F. L. Agnolin and A. G. Martinelli. "Fossil birds from the Late Cretaceous Los Alamitos Formation, Ro Negro Province, Argentina". English. In: Journal of South American Earth Sciences 27 (2009), pp. 42-49. 
[167] F. L. Agnolin, O. Mateus, J. Milán, M. Marzola, O. Wings, J. S. Adolfssen, and L. B. Clemmensen. "Ceratodus tunuensis, sp. nov., a new lungfish (Sarcopterygii, Dipnoi) from the Upper Triassic of central East Greenland". English. In: Journal of Vertebrate Paleontology 38.2 (2018), e1439834. DOI: 10.1080/02724634.2018.1439834.

[168] F. L. Agnolin, F. E. Novas, and G. Lio. "Neornithine bird coracoid from the Upper Cretaceous of Patagonia". English. In: Ameghiniana 43.1 (2006), pp. 245-248.

[169] F. L. Agnolin and F. E. Novas. "A carpometacarpus from the Upper Cretaceous of Patagonia sheds light on the Ornithurine bird radiation". English. In: Palaeontologische Zeitschrift 86.1 (2012), pp. 8589. DOI: $10.1007 / \mathrm{s} 12542-011-0112-2$.

[170] F. L. Agnolin, J. E. Powell, F. E. Novas, and M. Kundrát. “New alvarezsaurid (Dinosauria, Theropoda) from uppermost Cretaceous of north-western Patagonia with associated eggs". English. In: Cretaceous Research 35.1 (2012), pp. 33-56. DOI: 10.1016/j.cretres.2011.11.014.

[171] E. L. Agrasar. "New fossil crocodilians from the Middle/Upper Miocene of Tunisia". In: Annales de Paleontologie 89 (2003), pp. 103-110.

[172] E. L. Agrasar. "Crocodilian remains from the Upper Eocene of Dor-El-Talha, Libya". English. In: Annales de Paléontologie 90 (2004), pp. 209-222.

[173] E. L. Agrasar. "Crocodile remains from the Burdigalian (lower Miocene) of Gebel Zelten (Libya)". English. In: Geodiversitas 26.2 (2004), pp. 309-321.

[174] R. Aguado, M. Company, J. Sandoval, and J. M. Taver. "Biostratigraphic events at the Barremian/Aptian boundary in the Betic Cordillera, southern Spain". English. In: Cretaceous Research 18 (1997), pp. 309329.

[175] R. Aguado, M. Company, and J. M. Tavera. "The Berriasian/Valanginian boundary in the Mediterranean region: new data from the Caravaca and Cehegin sections, SE Spain". English. In: Cretaceous Research 21 (2000), pp. 1-21.

[176] A. P. Aguiar and J. W. Janzen. "An overview of fossil Stephanidae (Hymenoptera), with description of two new taxa from Baltic amber, and key to species of Electrostephanus Brues". English. In: Entomologica Scandinavica 30 (2000), pp. 443-452.

[177] A. Aguilar. "Status of Mediterranean monk seal populations". English. In: RAC-SPA, United Nations Environment Program (UNEP). Tunisua, 1999.

[178] D. H. Aguilar and C. A. Laurito. “El armadillo gigante (Mammalia, Xenarthra, Pampatheriidae) del ro Tomayate, Blancano tardo - Irvingtoniano temprano, El Salvador, América Central". Spanish. In: Revista Geológica de América Central 41 (2009), pp. 25-36.

[179] T. Aguilar. "Organismos de un arrecife fósil (Oligoceno Superior-Mioceno Inferior), del Caribe de Costa Rica". Spanish. In: Revista de Biologa Tropical 47.3 (1999).

[180] T. Aguilar and P. Denyer. “Una especie nueva de Euphyllia (Scleractinia: Caryophylliidae) en las calizas de Barra Honda (Paleogeno), Costa Rica [A new Euphyllia species (Scleractinia, Caryophylliidae) in the Barra Honda Limestone (Paleogene), Costa Rica]". Spanish. In: Revista de Biologia Tropical 49 (2001), pp. 195-201.

[181] O. Aguilera and D. D. de Aguilera. “Goliath grouper (Pisces: Serranidae) from the Upper Miocene Urumaco Formation, Venezuela". English. In: Journal of Paleontology 78.6 (2004), pp. 1202-1206.

[182] O. Aguilera and D. R. de Aguilera. "Giant-toothed White Sharks and Wide-toothed Mako (Lamnidae) from the Venezuela Neogene: Their Role in the Caribbean, Shallow-water Fish Assemblage". English. In: Caribbean Journal of Science 40.3 (2004), pp. 368-382.

[183] O. Aguilera and D. R. de Aguilera. "Bathymetric distribution of Miocene to Pleistocene Caribbean teleostean fishes from the coast of Panama and Costa Rica". English. In: vol. 357. Bulletins of American Paleontology. 1999, pp. 251-269.

[184] O. Aguilera, R. T. Lopes, F. Rodriguez, T. M. dos Santos, C. Rodrigues-Almeida, P. Almeida, A. S. Machado, and T. Moretti. "Fossil sea catfish (Siluriformes; Ariidae) otoliths and in-skull otoliths from the Neogene of the Western Central Atlantic". English. In: Journal of South American Earth Sciences 101 (2020), p. 102619. DOI: 10.1016/j.jsames.2020.102619. 
[185] O. A. Aguilera. Spanish. Tesoros Paleontológicos de Venezuela. Caracas: Universidad Experimental Francisco de Miranda, 2004, pp. 1-148.

[186] O. A. Aguilera, J. Bocquentin, J. G. Lundberg, and A. Maciente. "A new cajaro catfish (Siluriformes : Pimelodidae : Phractocephalus) from the Late Miocene of southwestern Amazonia and its relationship to Phractocephalus nassi of the Urumaco Formation". English. In: Palaeontologische Zeitschrift 82.2 (2008), pp. 231-245.

[187] O. A. Aguilera, L. Garcia, and M. A. Cozzuol. "Giant-toothed white sharks and cetacean trophic interaction from the Pliocene Caribbean Paraguan6 Formation". English. In: Palaontologische Zeitschrift 82.2 (2008), pp. 204-208.

[188] O. A. Aguilera, D. Riff, and J. Bocquentin-Villanueva. "A new giant Purussaurus (Crocodyliformes, Alligatoridae) from the Upper Miocene Urumaco Formation, Venezuela". English. In: Journal of Systematic Palaeontology 4.3 (2006), pp. 221-232.

[189] E. Aguirre and J. Morales. "Villafranchian faunal record of Spain". English. In: Quartärpaläontologie 8 (1990), pp. 7-11.

[190] J. Aguirre, Z. Belaústegui, and R. Doménechb. "Snapshot of a lower Pliocene Dendropoma reef from Sant Onofre (Baix Ebre Basin, Tarragona, NE Spain)". English. In: Palaeogeography, Palaeoclimatology, Palaeoecology 395 (2014), pp. 9-20.

[191] J. Aguirre, J. C. Braga, and D. Bassi. “Taxonomic assessment of coralline algal species (Rhodophyta; Corallinales and Sporolithales) described by Pfender, Lemoine, and Miranda from northern Spain type localities". English. In: Annalen des Naturhistorischen Museums in Wien 113 (2011), pp. 267-289.

[192] J. Aguirre, J. C. Braga, and W. E. Piller. "Reassessment of Palaeothamnium Conti, 1946 (Corallinales, Rhodophyta)". English. In: Review of Palaeobotany and Palynology 94 (1996), pp. 1-9.

[193] J. Aguirre and A. P. Jimenez. "Fossil analogues of present-day Cladocora caespitosa coral banks: sedimentary setting, dwelling community, and taphonomy (Late Pliocene, W Mediterranean)". English. In: Coral Reefs 17 (1998), pp. 203-213.

[194] J. Aguirre and A. P. Jiménez. "Census Assemblages in Hard-Bottom Coastal Communities: a case study from the Plio-Pleistocene Mediterranean". English. In: Palaios 12.6 (1997), pp. 598-608.

[195] M. L. Aguirre, S. Richiano, and Y. Negro Sirch. "Paleoenvrionments and paleoclimates of the Quaternary molluscan faunas from the coastal area of Baha Vera-Camarones (Chubut, Patagonia)". English. In: Palaeogeography, Palaeoclimatology, Palaeoecology 229 (2006), pp. 251-286.

[196] G. Aguirre-Fernández, L. G. Barnes, F. J. Aranda-Manteca, and J. R. Fernández-Rivera. "Protoglobicephala mexicana, a new genus and species of Pliocene fossil dolphin (Cetacea; Odontoceti; Delphinidae) from the Gulf of California, Mexico". English. In: Boletin de la Sociedad Geologica Mexicana 61.2 (2009), pp. 245-265.

[197] G. Aguirre-Fernández, J. D. Carillo-Briceño, R. Sánchez, E. Amsson, and M. R. Sánchez-Villagra. "Fossil Cetaceans (Mammalia, Cetacea) from the Neogene of Colombia and Venezuela". English. In: Journal of Mammalian Evolution 24.1 (2017), pp. 71-90. DOI: 10.1007/s10914-016-9353-x.

[198] G. Aguirre-Fernández and R. E. Fordyce. New Zealand fossils reveal early Miocene global distribution for small Kentriodon dolphins. English. 2011.

[199] G. Aguirre-Fernández and R. E. Fordyce. "Papahu taitapu, gen. et sp. nov., an early Miocene stem odontocete (Cetacea) from New Zealand". English. In: Journal of Vertebrate Paleontology 34.1 (2014), pp. 195-210. DOI: 10.1080/02724634.2013.799069.

[200] M. B. Aguirre-Urreta. "The ammonites Karakaschiceras and Neohoploceras (Valanginian Neocomitidae) from the Neuquen Basin, West-Central Argentina". English. In: Journal of Paleontology 72 (1998), pp. 39-59.

[201] M. B. Aguirre-Urreta. “Tertiary freshwater Decapoda (Crustacea: Parastacidae) from the Nirihuau Basin, Patagonia, Argentina". English. In: Journal of Paleontology 66.5 (1992), pp. 817-825.

[202] M. B. Aguirre-Urreta and P. P. Alvarez. "The Berriasian genus Groebericeras in Argentina and the problem of its age". English. In: Scripta Geologica, Special Issue 3 (1999), pp. 15-29. 
[203] M. B. Aguirre-Urreta and P. F. Rawson. "Lower Cretaceous ammonites from the Neuquen Basin, Argentina: Viluceras, a new Valanginian subgenus of Olcostephanus". English. In: Cretaceous Research 20 (1999), pp. 343-357.

[204] M. B. Aguirre-Urreta and P. F. Rawson. "Lower Cretaceous ammonites from the Neuquen Basin, Argentina: the Hauterivian neocomitid genus Hoplitocrioceras (Giovine, 1950)". English. In: Cretaceous Research 22 (2001), pp. 201-218.

[205] M. B. Aguirre-Urreta and P. F. Rawson. "Lower Cretaceous ammonites from the Neuquén Basin, Argentina: the Hauterivian genus Holcoptychites". English. In: Cretaceous Research 24.5 (2003), pp. 589-613.

[206] M. B. Aguirre-Urreta and P. F. Rawson. "Lower Cretaceous ammonites from the Neuquén Basin, Argentina: a Hauterivian Olcostephanus fauna". English. In: Cretaceous Research 22.6 (2001), pp. $763-$ 778.

[207] J. Agust, H. A. Blain, M. Furió, R. De Marfá, and A. Santos-Cubedo. “The early Pleistocene small vertebrate succession from the Orce region (Guadix-Baza Basin, SE Spain) and its bearing on the first human occupation of Europe". English. In: Quaternary International 223 (2010), pp. 162-169. DOI: 10.1016/j.quaint.2009.12.01.

[208] J. Agusti, I. Casanovas-Vilar, and M. Furió. "Rodents, insectivores and chiropterans (Mammalia) from the late Aragonian of Can Missert (Middle Miocene, Vallés-Penedés Basin, Spain)". English. In: Geobios 38 (2005), pp. 575-583.

[209] J. Agusti, C. Castillo, M. Freudenthal, E. Martin Suarez, and J. A. Pena. "On the presence of Allophaiomys (Rodentia) in the Granada Basin (Spain)". English. In: Scripta Geologica 93 (1993), pp. 35-40.

[210] J. Agusti, O. Oms, and J. M. Pares. "Calibration of the Early-Middle Pleistocene transition in the continental beds of the Guadix-Baza Basin (SE Spain)". In: Quaternary Science Reviews 18 (1999), pp. 1409-1417.

[211] J. Agusti, A. Vekua, O. Oms, D. Lordkipanidze, M. Bukhsianidze, G. Kildaze, and L. Rock. “The Pliocene-Pleistocene succession of Kvabebi (Georgia) and the background to the early human occupation of southern Caucasus". English. In: Quaternary Science Reviews 28.27-28 (2009), pp. 32753280.

[212] P. Ahlberg, H. Szaniawski, E. N. K. Clarkson, and S. Bengston. "Phosphatised olenid trilobites and associated fauna from the Upper Cambrian of Vastergotland, Sweeden". English. In: Acta Palaeontologica Polonica 50.3 (2005), pp. 429-440.

[213] P. E. Ahlberg. "Elginerpeton pancheni and the earliest tetrapod clade". English. In: Nature 373 (1995), pp. 420-425. DOI: 10.1038/373420a0.

[214] P. E. Ahlberg and J. A. Clack. "The smallest known Devonian tetrapod shows unexpectedly derived features". English. In: Royal Society Open Science 7.192117 (2020). DOI: 10.1098/rsos.192117.

[215] P. E. Ahlberg, Z. Johanson, and E. B. Daeschler. "The late Devonian lungfish Soederberghia (Sarcopterygii, Dipnoi) from Australia and North America, and its biogeographical implications". English. In: Journal of Vertebrate Paleontology 21.1 (2001), pp. 1-12. DOI: 10.1671 / 0272-4634(2001) 021[0001:TLDLSS]2.0.CO;2.

[216] P. E. Ahlberg, E. Luksevics, and O. Lebedev. "The First Tetrapod Finds from the Devonian (Upper Famennian) of Latvia". English. In: Philosophical Transactions of the Royal Society: Biological Sciences 343.1305 (1994), pp. 303-328. DOI: 10.1098/rstb.1994.0027.

[217] P. E. Ahlberg, E. Lukevis, and E. Mark-Kurik. "A near-tetrapod from the Baltic Middle Devonian". English. In: Palaeontology 43.3 (2000), pp. 533-548. DOI: 10.1111/j.0031-0239.2000.00138.x.

[218] F. Ahmad. "The heterodont bivalve Aphrodina dutrugei (Coquand, 1862) from the Cenomanian of Jordan". English. In: Rivista Italiana di Paleontologia e Stratigrafia 111.1 (2005), pp. 191-195.

[219] F. Ahmad, A. Abu Hamad, and M. Obeidat. "Palynological study of the Early Cretaceous Kurnub Sandstone Formation, Mahis area, Central Jordan". English. In: Acta Palaeobotanica 52.2 (2012), pp. 303-315. 
[220] F. Ahmad and A. Al-Hammad. "Oysters and echinoids from the Naur Formation (late Aptianearly Cenomanian) of Central Jordan". English. In: Neues Jahrbuch für Geologie und Paläontologie 8 (2002), pp. 449-464.

[221] F. Ahmad, C. Ifrim, and S. Farouk. "The last ammonoids of Jordan - implications from the Outhriate section". English. In: Neues Jahrbuch für Geologie und Paläontologie, Abhandlungen 278 (2015), pp. 245-256.

[222] F. J. Ahmad, R. Barragán, O. Szives, and F. Vega-Vera. “Cenomanian ammonites of the Shuayb Formation, Jordan". English. In: Jordan Journal of Earth and Environmental Sciences 5 (2013), pp. 2330.

[223] W. A. Ahr and R. J. Stanton. "Constituent composition of Early Mississippian carbonate buildups and their level-bottom equivalents, Sacramento Mountains, New Mexico". English. In: in P. Strogen, I. D. Somerville, G. L. Jones, eds., Recent advances in Lower Carboniferous geology. Geological Society Special Publication 107 (1996), pp. 83-95.

[224] H. Ahrens. “Weer een schedel van Protophocaena minima erbij!” English. In: Cranium 22.1 (2005), pp. 41-44.

[225] D. Aiba, H. Yamato, K. Kurihara, and T. Karasawa. "A new species of Eubostrychoceras (Ammonoidea, Nostoceratidae) from the lower Campanian in the northwestern Pacific realm". English. In: Paleontological Research 21 (2017), pp. 255-264.

[226] G. Aiello and J. Szczechura. "Middle Miocene ostracods of the Fore-Carpathian Depression (Central Paratethys, southwestern Poland)". English. In: Bollettino della Societa Paleontologica Italiana 43.1-2 (2004), pp. 11-70.

[227] M. Aiglstorfer, P. Havlik, and Y. Herrera. "The first metriorhynchoid crocodyliform from the Aalenian (Middle Jurassic) of Germany, with implications for the evolution of Metriorhynchoidea". English. In: Zoological Journal of the Linnean Society (2019). DOI: 10.1093/zoolinnean/zlz072.

[228] M. Aiglstorfer and S. Mayda. "Ruminantia from the middle Miocene of the Graanica coalmine (Bugojno Basin, Bosnia-Herzegovina)". English. In: Palaeobiodiversity and Palaeoenvironments (2018), pp. 1-12.

[229] M. Ain Malak, Y. Salamé, and D. Azar. "New phlebotomine flies from Burmese amber (Diptera: Psychodidae: Phlebotominae)". English. In: Terrestrial Arthropod Reviews 6 (2013), pp. 81-101.

[230] A. S. S. Aires, A. W. A. Kellner, R. T. Muller, L. R. Da Silva, C. P. Pacheco, and S. Dias-Da-Silva. "New postcranial elements of the Thalassodrominae (Pterodactyloidea, Tapejaridae) from the Romualdo Formation (Aptian-Albian), Santana Group, Araripe Basin, Brazil". English. In: Palaeontology 57.2 (2013), pp. 343-355.

[231] A. Ait Addi. "The dogger reef horizons of the Moroccan Central High Atlas: New data on their development". English. In: Journal of African Earth Sciences 45 (2006), pp. 162-172.

[232] Y. Aita and J. Grant-MacKie. Late Jurassic radiolaria from the Kowhai point siltstone, Murihiku Terrane, North Island, New Zealand. English. Centenary of Japanese Micropaleontology. 1992, pp. 375-382.

[233] Y. Aita and K. B. Spörli. "Late Triassic Radiolaria from the Torlesse Terrane, Rimutaka Range, North Island, New Zealand". English. In: New Zealand Journal of Geology and Geophysics 37 (1994), pp. 155-162.

[234] J. C. Aitchison, A. M. Davis, J. M. C. Stratford, and F. C. P. Spiller. "Lower and Middle Devonian Radiolarian Biozonation of the Gamilaroi Terrane New England Orogen, Eastern Australia". English. In: Micropaleontology 45.2 (1999), pp. 138-162.

[235] W. A. Akersten and H. G. McDonald. "Nothrotheriops from the Pleistocene of Oklahoma and paleogeography of the genus". English. In: Southwestern Naturalist 36.2 (1991), pp. 178-185.

[236] M. W. Al-Abbasi, S. I. Sakry, and C. A. Karem. "A study of Macro Fossils (Bivalvia) From Fat'ha Formation (Middle Miocene) at Shaqlawa area, Northeast of Iraq". English. In: Tikrit Journal of Pure Science 16.4 (2011). 
[237] N. Y. Al-Banna, M. M. Al-Mutwali, and Z. A. Malak. "Paleocene Stratigraphy in Aqra and Bekhme Areas, Northern Iraq". English. In: Stratigraphic Analysis of Layered Deposits. InTech, 2012, pp. 227252.

[238] E. K. Al-Dulaimi and S. I. Al-Dulaimi. "A study of biostratigraphy of Sinjar Formation in selected sections from northern Iraq". English. In: Iraqi Journal of Science 58.2B (2017), pp. 891-916.

[239] T. Al-Harithi. "Eligmus jordanensis, a new pelecypod species from the Upper Bathonian surface section at the King Talal's Dam area in central Jordan". In: Neues Jahrbuch für Geologie und Paläontologie Monatshefte 1997.10 (1997), pp. 596-604.

[240] T. Al-Harithi and R. Birenheide. "A new record of the scleractinian coral Stylopsammia judaica from the Upper Cretaceous (Campanian) of the Judean Desert". English. In: Senckenbergiana lethaea 73.2 (1993), pp. 269-276.

[241] T. Al-Harithi and K. Ibrahim. "Some Cephalopoda from Maastrichtian outcrops of Wadi Usaykhim, Al Azraw area in east Jordan". English. In: Senckenbergiana Lethaea 71 (1992), pp. 427437.

[242] K. M. Al-Kahtany. "Facies development of the Middle Miocene reefal limestone in northwest Saudi Arabia". English. In: Journal of African Earth Sciences (2017). DOI: 10.1016/j.jafrearsci.2017. 03.012 .

[243] M. Al-Kindi, M. Pickford, Y. Al-Sinani, I. Al-Ismaili, A. Hartman, and A. Heward. "Large Mammals from the Rupelian of Oman - Recent Finds". English. In: Fossil Imprint 73.3-4 (2017), pp. 300321.

[244] A. Al-Sayigh, S. Nasir, A. S. Schulp, and N. J. Stevens. "The first described Arsinoitherium from Eocene Aydim Formation of Oman: Biogeographic implications". English. In: Palaeoworld 17 (2008), pp. $41-46$.

[245] A. S. Al-Sayyab and M. U. Mohmmed. "Middle Cretaceous algal flora from the Mauddud Formation, Ratawi field, south Iraq". English. In: Iraqi Journal of Science 32.3 (1991).

[246] A. Alabushev. "Ammonite faunas and biostratigraphy of the Albian to Middle Cenomanian (Cretaceous) in western Korjak-Kamchatka, NE Russia". English. In: Neues Jahrbuch für Geologie und Paläontologie, Abhandlungen 196 (1995), pp. 109-139.

[247] J. Alarcón-Muñoz, S. Soto-Acuña, L. Codorniú, D. Rubilar-Rogers, M. Sallaberry, and M. Suárez. "New ctenochasmatid pterosaur record for Gondwana: discovery in the Lower". English. In: Cretaceous Research 110 (2020), p. 104378. DOI: 10.1016/j.cretres.2020.104378.

[248] J. Alarcón-Muñoz, S. Soto-Acuña, L. M. E. Manrquez, R. A. Fernández, D. Bajor, J. P. Guevara, F. Suazo Lara, M. A. Leppe, and A. O. Vargas. "Freshwater turtles (Testudines: Pleurodira) in the Upper Cretaceous of Chilean Patagonia". English. In: Journal of South American Earth Sciences 102 (2020), p. 102652. DOI: 10.1016/j.jsames.2020.102652.

[249] D. Alba, I. Casanovas-Vilar, M. Furio, I. Garcia-Paredes, C. Angelone, S. Jovells-Vaque, A. H. Lujan, S. Almecija, and S. Moya-Sola. "Can Pallars i Llobateres: A new hominoid-bearing locality from the late Miocene of the Vallés-Penedés Basin (NE Iberian Peninsula)". English. In: Journal of Human Evolution (2018), pp. 1-11. DOI: 10.1016/j.jhevol.2018.04.008.

[250] D. M. Alba, R. Carmona, A. Bolet, J. M. Robles, I. Casanovas-Vilar, M. Furió, Ó Sanisidro, E. Rifá, J. Balaguer, L. Checa, A. H. Luján, M. Tomás, and S. Moyá-Solá. “Intervención paleontológica en la Autova Oribital de Barcelona B-40, tramo Olesa de Montserrat-Viladecavalls: resultados preliminares [Paleontological intervention at Autovia Orbital de Barcelona B-40, Olesa de MontserratViladecavalls stretch: preliminary results]". Spanish. In: Cidaris 30 (2010), pp. 51-60.

[251] D. M. Alba and S. Moyá-Solá. "A New Pliopithecid Genus (Primates: Pliopithecoidea) From Castell de Barberá (VallésPenedés Basin, Catalonia, Spain)". English. In: American Journal of Physical Anthropology 147.1 (2012), pp. 88-112. 
[252] G. L. Albanesi and G. F. Aceñolaza. “Conodontes de la Formación Rupasca (Ordovcico Inferior) en el Angosto de Chucalezna, Cordillera Oriental de Jujuy: nuevos elementos bioestratigráficos para una localidad clásica del noroeste argentino". English. In: Ameghiniana 42.2 (2005), pp. 295310.

[253] G. L. Albanesi, J. L. Benedetto, and P. Gagnier. Sacabambaspis janvieri (Vertebrata) y conodontes del Llandeiliano temprano en la Formacion La Cantera, Precordillera de San Juan, Argentina. Spanish. 1995.

[254] M. T. Alberdi, J. Arroyo-Cabrales, A. H. Marin-Leyva, and O. J. Polaco. "Study of Cedral Horses and their place in the Mexican Quaternary". English. In: Revista Mexicana de Ciencias Geológicas 31.2 (2014), pp. 221-237.

[255] M. T. Alberdi, J. L. Pardo, and C. Cartelle. "El registro de Stegomastodon (Mammalia, Gomphotheriidae) en el Pleistoceno superior de Brasil". Spanish. In: Revista Española de Paleontologa 17.2 (2002), pp. 217-235.

[256] M. T. Alberdi, J. L. Prado, D. Perea, and M. Ubilla. "Stegomastodon waringi (Mammalia, Proboscidea) from the Late Pleistocene of northeastern Uruguay". English. In: Neues Jahrbuch für Geologie und Paläontologie - Abhandlungen 243.2 (2007), pp. 179-189.

[257] P. C. H. Albers and O. Rieppel. "A new species of the sauropterygian genus Nothosaurus from the Lower Muschelkalk of Winterswijk, The Netherlands". English. In: Journal of Paleontology 77.4 (2003), pp. 738-744.

[258] M. Alberti, D. K. Pandey, and F. T. Fürsich. "Ammonites of the genus Peltoceratoides Spath, 1924 from the Oxfordian of Kachchh, western India". English. In: Neues Jahrbuch für Geologie und Paläontologie, Abhandlungen 262 (2011), pp. 1-18.

[259] M. Alberti, D. K. Pandey, M. Hethke, and F. T. Fürsich. "Ammonites of the subfamily Mayaitinae Spath, 1928 from the Oxfordian of Kachchh, Western India". English. In: Geobios 48 (2015), pp. 85130.

[260] A. Albino, J. D. Carrillo-Briceño, and J. M. Neenan. "An enigmatic aquatic snake from the Cenomanian of northern South America". English. In: PeerJ 4 (2016), e2027:1-26. DOI: 10.7717 / peerj. 2027.

[261] A. Albino and P. J. Gaudioso. "Extant squamates in the Pleistocene of northwestern Argentina". English. In: Revista Brasileira de Paleontologia 21.1 (2018), pp. 63-70. DOI: 10.4072/rbp.2018.1.04.

[262] A. M. Albino. "New record of snakes from the Cretaceous of Patagonia (Argentina)". English. In: Geodiversitas 22.2 (2000), pp. 247-253.

[263] A. M. Albino. "Snakes from the Miocene of Patagonia (Argentina) Part II: The Colubroidea". English. In: Neues Jahrbuch für Geologie und Paläontologie, Abhandlungen 200.3 (1996), pp. 353-360.

[264] A. M. Albino. "Una nueva serpiente (Reptilia) en el Cretácico Superior de Patagonia, Argentina”. Spanish. In: Pesquisas 21 (1994), pp. 58-63.

[265] A. M. Albino. "Snakes from the Miocene of Patagonia (Argentina) Part I: The Booidea". English. In: Neues Jahrbuch für Geologie und Paläontologie, Abhandlungen 199.3 (1996), pp. 417-434.

[266] A. M. Albino. "First snake record from the Sarmiento Formation at La Gran Hondonada (Chubut Province, Argentina)". English. In: Ameghiniana 49.2 (2012), pp. 230-235. DOI: 10.5710 / AMGH. v49i2(428).

[267] A. M. Albino. "Snakes from the Paleocene and Eocene of Patagonia (Argentina): paleoecology and coevolution with mammals". English. In: Historical Biology 7 (1993), pp. 51-69.

[268] A. M. Albino. "New macrostomatan snake from the Paleogene of northwestern Argentina". English. In: Geobios (2018). DOI: 10.1016/j.geobios.2018.04.005.

[269] A. M. Albino and S. Brizuela. "First record of squamate reptiles from the Oligocene of South America". English. In: Alcheringa 38.3 (2014), pp. 412-421. DOI: 10.1080/03115518.2014.886029.

[270] A. M. Albino and A. A. Carlini. "First Record of Boa constrictor (Serpentes, Boidae) in the Quaternary of South America". English. In: Journal of Herpetology 42.1 (2008), pp. 82-88. 
[271] L. B. Albright. "Lower vertebrates from an Arikareean (earliest Miocene) fauna near the Toledo Bend Dam, Newton County, Texas". English. In: Journal of Paleontology 68.5 (1994), pp. 1131-1145.

[272] L. B. Albright. "Insectivores, rodents, and carnivores of the Toledo Bend Local Fauna: an Arikareean (earliest Miocene) assemblage from the Texas Coastal Plain". English. In: Journal of Vertebrate Paleontology 16.3 (1996), pp. 458-473. DOI: 10.1080/02724634.1996.10011334.

[273] L. B. Albright. “New genus of tapir (Mammalia: Tapiridae) from the Arikareean (earliest Miocene) of the Texas Coastal Plain". English. In: Journal of Vertebrate Paleontology 18.1 (1998), pp. 200-217. DOI: $10.1080 / 02724634.1998 .10011044$.

[274] L. B. Albright. "The Arikareean Land Mammal Age in Texas and Florida: Southern extension of Great Plains faunas and Gulf Coastal Plain". English. In: Geological Society of America Special Paper 325 (1998), pp. 167-183.

[275] L. B. Albright. "Ungulates of the Toledo Bend local fauna (late Arikareean, early Miocene), Texas Coastal Plain". English. In: Bulletin of the Florida Museum of Natural History, Biological Sciences 42.1 (1999), pp. 1-80.

[276] L. B. Albright. "Magnetostratigraphy and biochronology of the San Timoteo Badlands, southern California, with implications for local Pliocene-Pleistocene tectonic and depositional patterns". English. In: Geological Society America Bulletin 111.9 (1999), pp. 1265-1293.

[277] L. B. Albright. "Biostratigraphy and Vertebrate Paleontology of the San Timoteo Badlands, Southern California". English. In: University of California Publications in Geological Sciences 144 (1999), pp. 1-121.

[278] L. B. Albright, D. D. Gillette, and A. L. Titus. "Plesiosaurs from the Upper Cretaceous (CenomanianTuronian) Tropic Shale of southern Utah, part 1: new records of the pliosaur Brachauchenius lucasi". English. In: Journal of Vertebrate Paleontology 27.1 (2007), pp. 31-40.

[279] L. B. Albright, D. D. Gillette, and A. L. Titus. "Plesiosaurs from the Upper Cretaceous (CenomanianTuronian) Tropic Shale of southern Utah, part 2: Polycotylidae". English. In: Journal of Vertebrate Paleontology 27.1 (2007), pp. 41-58.

[280] L. B. Albright, A. E. Sanders, and J. H. Geisler. "An unexpectedly derived odontocete from the Ashley Formation (upper Rupelian) of South Carolina, U.S.A." English. In: Journal of Vertebrate Paleontology 38.4 (2018), e1482555. DOI: 10.1080/02724634.2018.1482555.

[281] L. B. Albright, A. E. Sanders, R. E. Weems, D. J. Cicimurri, and J. L. Knight. “Cenozoic vertebrate biostratigraphy of South Carolina, U.S.A. and additions to the fauna". English. In: Bulletin of the Florida Museum of Natural History 57.2 (2019), pp. 77-236.

[282] L. B. Albright, M. O. Woodburne, T. J. Fremd, C. C. Swisher, B. J. MacFadden, and G. R. Scott. "Revised chronostratigraphy and biostratigraphy of the John Day Formation (Turtle Cove and Kimberly Members), Oregon, with implications for updated calibration of the Arikareean North American land mammal age". English. In: 116.3 (2008), pp. 211-237.

[283] L. B. Albright, M. O. Woodburne, J. A. Case, and D. S. Chaney. "A leatherback sea turtle from the Eocene of Antarctica: implications for antiquity of gigantothermy in Dermochelyidae." English. In: Journal of Vertebrate Paleontology 23.4 (2003), pp. 945-949.

[284] N. A. Albury, R. Franz, R. Rimoli, P. Lehman, and A. L. Rosenberg. "Fossil Land Tortoises (Testudines: Testudinidae) from the Dominican Republic, West Indies, with a Description of a New Species". English. In: American Museum Novitates 3904 (2018), pp. 1-28.

[285] L. Alcalá, A. Cobos, E. Espilez, F. Gascó, L. Mampel, C. M. Escorza, and R. Royo-Torres. “Icnitas de dinosaurios en la Formación Villar del Arzobispo de Ababuj (Teruel, España) [Dinosaur footprints from the Villar del Arzobispo Formation in Ababuj (Teruel, Spain)]". Spanish. In: Geogaceta 51 (2012), pp. 35-38. 
[286] L. Alcalá, E. Esplez, L. Mampel, J. I. Kirkland, M. Ortiga, D. Rubio, A. González, D. Ayala, A. Cobos, R. Royo-Torres, F. Gascó, and M. D. Pesquero. "A new Lower Cretaceous vertebrate bonebed near Arino (Tereul, Aragon, Spain); found and managed in a joint collaboration between a mining company and a palaeontological park". English. In: Geoheritage 4 (2012), pp. 275-286. DOI: 10.1007/s12371-012-0068-y.

[287] L. Alcala and J. Morales. "A primitive caprine from the Upper Vallesian of La Roma 2 (Alfambra, Teruel, Aragon, Spain)." French. In: Compter Rendu d'Academie des Sciences Paris 324.ser. IIa (1997), pp. 947-953.

[288] O. Alcober and J. M. Parrish. "A new poposaurid from the Upper Triassic of Argentina". English. In: Journal of Vertebrate Paleontology 17 (1997), pp. 548-556.

[289] O. A. Alcober and R. N. Martnez. "A new herrerasaurid (Dinosauria, Saurischia) from the Upper Triassic Ischigualasto Formation of northwestern Argentina". English. In: Zookeys 63 (2010), pp. 55-81. DOI: $10.3897 /$ zzokeys.66.550.

[290] R. J. Aldridge, S. Turner, G. L. Jones, and D. A. T. Harper. "Late Llandovery thelodonts and conodonts from the Kilbride Formation, Co. Galway, western Ireland". English. In: Geological Journal 31.4 (1996), pp. 359-367.

[291] A. S. Alekseev. "Usonogie raki (Cirripedia, Thoracica) verkhnego Mela Mangyshlaka". Russian. In: Byulletin Moskovskogo Obshchestva Ispytateley Prirody, Otdel Geologicheskiy 84 (2009), pp. 23-38.

[292] A. V. Alekseev. "Jurassic and Lower Cretaceous Buprestidae (Coleoptera) from Eurasia”. English. In: Paleontological Journal 27.1A (1993), pp. 9-34.

[293] V. I. Alekseev. "Sucinoptinus bukejsi sp.nov. (Coleoptera: Ptinidae: Ptinini), the second species of the Tertiary genus from the Baltic amber". English. In: Baltic Journal of Coleopterology 12 (2012), pp. $145-148$.

[294] V. I. Alekseev. “Europs insterburgensis sp. nov., a new root-eating beetle from Baltic amber (Coleoptera: Monotomidae)". English. In: Genus 25 (2014), pp. 415-420.

[295] V. I. Alekseev. "A new species of Triplax Herbst, 1793 (Coleoptera: Erotylidae) from Bitterfeld amber". English. In: Baltic Journal of Coleopterology 14 (2014), pp. 171-177.

[296] V. I. Alekseev. "New taxa of Baltic amber false darkling beetles (Coleoptera: Melandryidae)". English. In: Baltic Journal of Coleopterology 14 (2014), pp. 79-96.

[297] V. I. Alekseev. "The first species of the family Tetratomidae (Coleoptera: Cucujiformia: Tenebrionoidea) from Baltic amber". English. In: Baltic Journal of Coleopterology 13 (2013), pp. 131-135.

[298] V. I. Alekseev. "Description of a second species of the narrow-waisted bark beetles (Coleoptera: Tenebrionoidea: Salpingidae) from Baltic amber (Tertiary, Eocene)". English. In: Baltic Journal of Coleopterology 13 (2013), pp. 137-140.

[299] V. I. Alekseev. "Protolissodema ulrikae, a new genus and species (Coleoptera: Tenebrionoidea: Salpingidae) from Baltic amber". English. In: Baltic Journal of Coleopterology 13 (2013), pp. 67-71.

[300] V. I. Alekseev. "Two new cocoon-forming beetles (Coleoptera: Cucujoidea: Bothrideridae) from Baltic amber". English. In: Baltic Journal of Coleopterology 15 (2015), pp. 9-16.

[301] V. I. Alekseev. "New cylindrical bark and ironclad beetles (Coleoptera: Zopheridae) from Baltic amber". English. In: Baltic Journal of Coleopterology 15 (2015), pp. 17-24.

[302] V. I. Alekseev. "New fossil species of Ptinidae (Insecta: Coleoptera) in Baltic amber (Tertiary, Eocene)". English. In: Zoology and Ecology 24 (2014), pp. 239-255.

[303] V. I. Alekseev. "A description of Quasianisoxya curonensis gen. et sp. nov. (Coleoptera: Melandryidae) from Baltic amber". English. In: Baltic Journal of Coleopterology 15 (2015), pp. 171-174.

[304] V. I. Alekseev. "Clypastraea primainterpares sp. nov. - the first fossil minute hooded beetle". English. In: Baltic Journal of Coleopterology 16 (2016), pp. 21-26.

[305] V. I. Alekseev. "Description of two clown beetles (Coleoptera: Staphyliniformia: Hydrophiloidea: Histeridae) from Baltic amber (Cenozoic, Paleogene, Eocene)". English. In: Baltic Journal of Coleopterology 16 (2016), pp. 27-35. 
[306] V. I. Alekseev. “Third species of Salpinginae (Coleoptera: Tenebrionoidea: Salpingidae) from Baltic amber". English. In: Palaeodiversity 10 (2017), pp. 117-121.

[307] V. I. Alekseev. "A new coleopterous family Wabbelidae fam. nov. (Coleoptera: Cucujoidea) from Baltic amber (Cenozoic, Paleogene, Eocene)". English. In: Baltic Journal of Coleopterology 17 (2017), pp. 29-41.

[308] V. I. Alekseev. "First record of Cathartosilvanus Grouvelle (Coleoptera: Silvanidae) from Baltic amber with description of a new species". English. In: Baltic Journal of Coleopterology 17 (2017), pp. $43-48$.

[309] V. I. Alekseev. "A new species of minute beetle (Coleoptera: Clambidae) from Baltic amber (Paleogene, Eocene)". English. In: Zootaxa 4337 (2017), pp. 141-145.

[310] V. I. Alekseev. “New extinct Eocene Coleoptera in Baltic amber of Friedhelm Eichmann's collection (Germany)". English. In: Baltic Journal of Coleopterology 19 (2019), pp. 11-22.

[311] V. I. Alekseev. "A first putative pelecotomine beetle (Soleoptera: Ripiphoridae) in Tertiary amber of the Kaliningrad Region". English. In: Studies and Reports, Taxonomical Series 15 (2019), pp. 283292.

[312] V. I. Alekseev and P. I. Alekseev. "New fossil cylindrical bark beetle (Zopheridae: Colydiinae: Gempylodini) from Eocene Baltic amber: An abnormal or intermediate form within Tenebrionoidea". English. In: Palaeontologia Electronica 2.2.43A (2019), pp. 1-10.

[313] V. I. Alekseev and A. Bukejs. "A new species of Orchesia Latreille, 1807 from Baltic amber (Coleoptera: Melandryidae)". English. In: Genus 23 (2012), pp. 571-576.

[314] V. I. Alekseev and A. Bukejs. "A new species of the genus Orchesia Latreille (Coleoptera: Melandryidae) from Baltic amber with a key to species described from fossil resins". English. In: Zootaxa 3947 (2015), pp. 590-596.

[315] V. I. Alekseev and A. Bukejs. "New fossil genus of Silvanidae (Insecta: Coleoptera) from Baltic amber (Tertiary, Eocene)". English. In: Zootaxa 4144 (2016), pp. 101-108.

[316] V. I. Alekseev and A. Bukejs. "New Zopheridae (Coleoptera: Tenebrionoidea) from Baltic amber". English. In: Zootaxa 4178 (2016), pp. 409-427.

[317] V. I. Alekseev and A. Bukejs. "New fossil taxa of Ischalia Pascoe (Coleoptera: Ischaliidae) from Eocene Baltic amber". English. In: Zootaxa 4323 (2017), pp. 229-238.

[318] V. I. Alekseev and A. Bukejs. "First fossil representatives of Pharaxonothinae Crowson (Coleoptera: Erotylidae): indirect evidence for cycads existence in Baltic amber forest". English. In: Zootaxa 4337 (2017), pp. 413-422.

[319] V. I. Alekseev and A. Bukejs. "Xyletinus (s. str.) thienemanni sp. nov., a new species of Xyletininae (Coleoptera: Ptinidae) from Eocene Baltic amber". English. In: Acta Biologica Universitatis Daugavpiliensis 19 (2019), pp. 31-35.

[320] V. I. Alekseev and A. Bukejs. "Two new species of Xyletinus Latreille (Ptinidae: Xyletininae) in Eocene Baltic amber". English. In: Zootaxa 4668 (2019), pp. 525-534.

[321] V. I. Alekseev, A. Bukejs, and R. C. McKellar. "The second fossil species of Cathartosilvanus (Coleoptera: Cucujoidea: Silvanidae) from Eocene Baltic amber". English. In: Fossil Record 22 (2019), pp. 111-118. DOI: 10.5194/fr-22-111-2019.

[322] V. I. Alekseev, A. Bukejs, D. M. L. Cooper, G. A. King, and R. C. McKellar. "A new species of Airaphilus Redtenbacher and new record of fossil Silvanidae (Coleoptera) from Eocene Baltic amber of the Sambian Peninsula". English. In: Baltic Journal of Coleopterology 19 (2019), pp. 127-134.

[323] V. I. Alekseev and T. L. Grzymala. "New Aderidae (Coleoptera: Tenebrionoidea) from Baltic and Bitterfeld amber". English. In: Zootaxa 3956 (2015), pp. 239-257.

[324] V. I. Alekseev and M. A. Jäch. "Electrolichas circumbalticus gen. et sp. nov. (Coleoptera: Byrrhoidea:" English. In: Zootaxa 4136 (2016), pp. 593-599. 
[325] V. I. Alekseev and S. V. Kazantsev. “New fossil soldier beetle (Coleoptera: Cantharidae) from Baltic amber". English. In: Baltic Journal of Coleopterology 14 (2014), pp. 167-170.

[326] V. I. Alekseev and N. P. Lord. “A new species of Xylolaemus (Coleoptera: Zopheridae: Colydiinae) from Baltic amber". English. In: Baltic Journal of Coleopterology 14 (2014), pp. 97-102.

[327] V. I. Alekseev and M. Nabozhenko. "A new fossil tenebrionid beetle of the tribe Palorini (Coleoptera: Tenebrionidae) from Eocene Baltic amber". English. In: The Coleopterists Society Monograph 14 (2015), pp. 127-130.

[328] V. I. Alekseev and M. Nabozhenko. "Palorus platycotyloides sp. n., the second fossil representative of the tribe Palorini (Coleoptera: Tenebrionidae) from Baltic amber". English. In: Acta Zoologica Bulgarica 69 (2017), pp. 167-170.

[329] V. I. Alekseev and M. G. Pankowski. "The first new genus of the tribe Hypulini Seidlitz (Coleoptera: Melandryidae) described from late Eocene Baltic amber". English. In: Zootaxa 4869 (2020), pp. 281289.

[330] V. I. Alekseev and M. G. Pankowski. "A new fossil genus of the tribe Synchitini Erichson (Tenebrionoidea: Zopheridae: Colydiinae) from Eocene Baltic amber". English. In: Palaeoentomology 3 (2020), pp. 607-613.

[331] V. I. Alekseev, D. A. Pollock, and A. Bukejs. “Two new fossil representatives of Eurypinae (Coleoptera: Tenebrionoidea: Mycteridae) from Eocene Baltic amber and placement of Neopolypria nigra Abdullah, 1964". English. In: Zootaxa 4551 (2019), pp. 67-78.

[332] V. I. Alekseev and D. Telnov. “First fossil record of Ischaliidae Blair, 1920 (Coleoptera) from Eocene Baltic amber". English. In: Zootaxa 4109 (2016), pp. 595-599.

[333] V. I. Alekseev and W. Tomaszewska. “New handsome fungus beetles (Coleoptera: Coccinelloidea: Anamorphidae, Endomychidae) from European amber of the Upper Eocene". English. In: Palaeontologia Electronica 21.1.6A (2018), pp. 1-23.

[334] V. I. Alekseev and F. Vitali. "Description of the first extinct member of the tribe Anaglyptini (Coleoptera: Cerambycidae) from European Tertiary". English. In: Zootaxa 4816 (2020), pp. 135143.

[335] V. N. Alekseev. "Conostigmus antiquus sp. n., a fossil ceraphronoid species from Baltic amber (Hymenoptera, Ceraphronoidea)". English. In: Amber \& Fossils 1 (1995), pp. 23-25.

[336] G. Alencaster. "New caprinid rudist genera Guzzyella and Muellerriedia (Bivalvia - Hippuritacea) from the Albian (Cretaceous) of Central Mexico". English. In: Revista Mexicana de Ciencias Geológicas 15.1 (1998), pp. 91-105.

[337] G. Alencaster and J. Aguilar-Perez. "Jalpania Queretana, a new Rudist (Bivalvia-Hippuritacea) from the mid-Cretaceous of Central Mexico". English. In: Revista Mexicana de Ciencias Geologicas 12.2 (1995), pp. 117-122.

[338] G. Alencáster and L. Omaña. "Maastrichtian inoceramid bivalves from Central Chiapas, southeaster México". English. In: Journal of Paleontology 80.5 (2006), pp. 946-957.

[339] G. Alencáster, L. Omaña, C. Gonzalez-Arreola, and D. Hernández-Láscares. "First record of the genus Trichites (Mollusca, Bivalvia) from the Upper Jurassic (Kimmeridgian) of Santiago Coatepec, Puebla, Mexico". English. In: Revista Mexicana de Ciencias Geológias 26.3 (2009), pp. 647-657.

[340] G. Alencaster and J. Pantoja-Alor. "New Early Aptian Rudists (Bivalvia-Hippuritacea) from the Huetamo area in southwestern Mexico". English. In: Revista Mexicana de Ciencias Geologicas 12.2 (1995), pp. 123-134.

[341] G. Alencaster and J. Pantoja-Alor. “The rudist Amphitriscoelus (Bivalvia-Hippuritacea) in the lower Cretaceous of southwestern Mexico". English. In: Journal of Paleontology 70.3 (1996), pp. 399407.

[342] G. Alencaster and J. Pantoja-Alor. "Two new Lower Cretaceous rudists (Bivalvia-Hippuritacea) from the Huetamo Region; Southwestern Mexico". English. In: Geobios 22 (1998), pp. 15-28. 
[343] K. Alexander. "Ancient whale bones on display in Santa Cruz". English. In: Silicon Valley Mercury News (2010).

[344] A. V. Alexeev. "On Mesozoic Buprestids (Coleoptera: Buprestidae) from Russia, Kazakhstan, and Mongolia". English. In: Paleontological Journal 34.Suppl 3 (2000), S323-S326.

[345] A. V. Alexeev. "New Jewel Beetles (Coleoptera: Buprestidae) and Similar Beetles from the Cretaceous and Early Paleogene of Asia". English. In: Paleontological Journal 42 (2008), pp. 53-59.

[346] A. V. Alexeev. "New click beetles (Coleoptera: Elateridae) from the Cretaceous of Russia and Kazakhstan". English. In: Paleontological Journal 45.4 (2011), pp. 423-431.

[347] A. V. Alexeev. "New taxa of metallic wood-boring beetles (Coleoptera, Buprestidae) from the Mesozoic of Russia, Kazakhstan, and Mongolia". English. In: Paleontological Journal 30 (1995), pp. 310-317.

[348] A. V. Alexeev. "Buprestid beetles (Coleoptera, Buprestidae) from the Mesozoic and Cenozoic of CIS". English. In: Paleontological Journal 30 (1996), pp. 559-565.

[349] A. V. Alexeev. "New jewel beetles (Coleoptera, Buprestidae) from Cretaceous deposits of Russia". English. In: Paleontological Journal 47 (2013), pp. 303-306.

[350] A. V. Alexeev. "New jewel beetles (Coleoptera: Buprestidae) from the Cretaceous of Russia, Kazakhstan and Mongolia". English. In: Paleontological Journal 43 (2009), pp. 277-281.

[351] K. Alf. "Preliminary study of an eggshell site in the Morrison Formation of Colorado". English. In: Modern Geology 23.1-4 (1998), pp. 241-248.

[352] M. Alfara and A. Cuerda. "Nuevos graptolitos del Ordovicico superior en la Formacion Los azules, Cerro Viejo, Provincia de San Juan, Argentina". Spanish. In: Ameghiniana 27.3-4 (1990), pp. 273-280.

[353] A. Ali, P. J. A. Siddiqui, K. Bromfield, A. A. Khan, and P. Iqbal. "Quaternary fossil coral communities in uplifted strata along the Balochistan coast of Pakistan: understanding modern coral". English. In: Arabian Journal of Geosciences 10.520 (2017). DOI: 10.1007/s12517-017-3306-4.

[354] M. S. M. Ali. Cenomanian Echinoids from Ras al Khaimah, United Arab Emirates. English. 1990.

[355] M. S. M. Ali. "A new genus and species of regular echinoid from the Late Cretaceous of Gebel El Rowdah, Hatta area, Oman-U.A.E”. English. In: Journal of Paleontology 66 (1992), pp. 693-696.

[356] V. Alifanov. "Some peculiarities of the Cretaceous and Palaeogene lizard faunas of the Mongolian people's Republic". English. In: Darmstädter Beiträge zur Naturgeschichte 3 (1993), pp. 9-13.

[357] V. R. Alifanov. "Two new dinosaurs of the infraorder Neoceratopsia (Ornithischia) from the Upper Cretaceous of the Nemegt Depression, Mongolian People's Republic". In: Paleontological Journal 37.5 (2003), pp. 524-534.

[358] V. R. Alifanov. "The tiny horned dinosaur Gobiceratops minutus gen. et sp. nov. (Bagaceratopidae, Neoceratopsia) from the Upper Cretaceous of Mongolia". English. In: Paleontological Journal 42.6 (2008), pp. 621-633. DOI: 10.1134/S0031030108060087.

[359] V. R. Alifanov. "New lizards of the family Macrocephalosauridae (Sauria) from the Upper Cretaceous of Mongolia, critical remarks on the systematics of the Teiidae". English. In: Paleontological Journal 27.1 (1993), pp. 70-90.

[360] V. R. Alifanov. "The fossil record of Cretaceous lizards from Mongolia". English. In: The Age of Dinosaurs in Russia and Mongolia. Cambridge: Cambridge University Press, 2000, pp. 368-389.

[361] V. R. Alifanov. "Lizards of the families Priscagamidae and Hoplocercidae (Sauria, Iguania): phylogenetic position and new representatives from the Late Cretaceous of Mongolia". English. In: Paleontological Journal 30.4 (1996), pp. 466-483.

[362] V. R. Alifanov. "Desertiguana gobiensis gen. et sp. nov., a new lizard (Phrynosomatidae, Iguanomorpha) from the Upper Cretaceous of Mongolia". English. In: Paleontological Journal 47.4 (2013), pp. 417-424. 
[363] V. R. Alifanov. "Macrocephalosaurs and the early evolution of lizards of Central Asia". Russian. In: Transactions of the Palaeontological Institute of the Russian Academy of Sciences 272 (2000).

[364] V. R. Alifanov. "New acrodont lizards (Lacertilia) from the Middle Eocene of southern Mongolia". English. In: Paleontological Journal 43.6 (2009), pp. 675-685. DOI: 10.1134/S0031030109060124.

[365] V. R. Alifanov. "Lizards of the family Arretosauridae Gilmore, 1943 (Iguanomorpha, Iguania) from the Paleogene of Mongolia". English. In: Paleontological Journal 46.4 (2012), pp. 412-420. DOI: 10. 1134/S003103011204002.

[366] V. R. Alifanov. "A New Platynotan Lizard (Parasaniwidae, Anguimorpha) from the Late Paleocene of Southern Mongolia". English. In: Paleontological Journal 52.12 (2018), pp. 1432-1435.

[367] V. R. Alifanov and A. O. Averianov. "Ferganasaurus verzilini, gen. et sp. nov., a new neosauropod (Dinosauria, Saurischia, Sauropoda) from the Middle Jurassic of Fergana Valley, Kirghizia". English. In: Journal of Vertebrate Paleontology 23.2 (2003), pp. 358-372.

[368] V. R. Alifanov and A. O. Averianov. "On the finding of ornithomimid dinosaurs (Saurischia, Ornithomimosauria) in the Upper Cretaceous beds of Tajikistan". English. In: Paleontological Journal 40.1 (2006), pp. 103-108.

[369] V. R. Alifanov and R. Barsbold. "Ceratonykus oculatus gen. et sp. nov., a new dinosaur (? Theropoda, Alvarezsauria) from the Late Cretaceous of Mongolia". English. In: Paleontological Journal 43.1 (2009), pp. 94-106. DOI: 10.1134/S0031030109010109.

[370] V. R. Alifanov and Y. L. Bolotsky. "Arkharavia heterocoelica gen. et sp. nov., a new sauropod dinosaur from the Upper Cretaceous of the Far East of Russia". English. In: Paleontological Journal 44.1 (2010), pp. 84-91. DOI: 10.1134/S0031030110010119.

[371] V. R. Alifanov and E. N. Kurochkin. "Kyrgyzsaurus bukhanchenkoi gen. et sp. nov., a new reptile from the Triassic of southwestern Kyrgyzstan". English. In: Paleontological Journal 45.6 (2011), pp. 42-50. DOI: 10.1134/S0031030111060025.

[372] V. R. Alifanov and S. V. Saveliev. "Two new ornithischian dinosaurs (Hypsilophodontia, Ornithopoda) from the Late Jurassic of Russia". English. In: Paleontological Journal 48.4 (2014), pp. 414425. DOI: $10.1134 /$ S0031030114040029.

[373] V. R. Alifanov and S. V. Saveliev. "The most ancient ornithomimosaur (Theropoda, Dinosauria), with cover imprints from the Upper Jurassic of Russia". English. In: Paleontological Journal 49.6 (2015), pp. 636-650. DOI: 10.1134/s0031030115060039.

[374] V. R. Alifanov and A. G. Sennikov. "Discovery of dinosaur remains in a Moscow suburb”. English. In: Doklady Earth Sciences 376.1 (2001), pp. 1-3.

[375] H. Alimohammadian, A. Sahni, R. Patnaik, R. Singh Rana, and H. Singh. "First record of an exceptionally diverse and well preserved amber-embedded biota from Lower Eocene (52 Ma) lignites, Vastan, Gujarat". English. In: Current Science 89.8 (2005), pp. 1328-1330.

[376] F. Alkaya and C. Meister. "Liassic ammonites from the central and eastern Pontides (Ankara and Kelkit areas, Turkey)". English. In: Revue de Paléobiologie 14 (1995), pp. 125-193.

[377] R. Allain. "Discovery of megalosaur (Dinosauria, Theropoda) in the Middle Bathonian of Normandy (France) and its implications for the phylogeny of basal Tetanurae". In: Journal of Vertebrate Paleontology 22.3 (2002), pp. 548-563.

[378] R. Allain. "Redescription de Streptospondylus altdorfensis, le dinosaure théropode de Cuvier, $\mathrm{du}$ Jurassique de Normandie [Redescription of Streptospondylus altdorfensis, Cuvier's theropod dinosaur from the Jurassic of Normandy]". French. In: Geodiversitas 23.3 (2001), pp. 349-367.

[379] R. Allain, N. Aquesbi, J. Dejax, C. A. Meyer, M. Monbaron, C. Montenat, P. Rechir, M. Rochdy, D. A. Russell, and P. Taquet. "A basal sauropod dinosaur from the Early Jurassic of Morocco". English. In: Comptes Rendus Palevol 3.3 (2004), pp. 199-208.

[380] R. Allain and X. Pereda Suberbiola. "Dinosaurs of France". In: Comptes Rendus Palevol 2 (2003), pp. 27-44. 
[381] R. Allain, P. Taquet, B. Battail, J. Dejax, P. Richir, M. Véran, F. Limon-Duparcmeur, R. Vacant, O. Mateus, P. Sayarath, B. Khenthavong, and S. Phouyavong. "Un nouveau genre de dinosaure sauropode de la formation des Grés supérieurs (Aptien-Albien) du Laos [A new genus of sauropod dinosaur from the Grés supérieurs Formation (Aptian-Albian) of Laos]". French. In: Comptes Rendus de l'Académie des Sciences á Paris, Sciences de la Terre et des Planétes 329 (1999), pp. 609-616.

[382] R. Allain, P. Taquet, B. Battail, J. Dejax, P. Richir, M. Véran, P. Sayarath, B. Khenthavong, P. Thamvirith, and B. Hom. "Pistes des dinosaures dans les niveaux du Crétacé inférieur de Muong Phalane, province de Savannakhet (Laos) [Dinosaur footprints in the Lower Cretaceous beds of Muong Phalane, Savannakhet province (Laos)]". French. In: Comptes Rendus de l'Académie des Sciences á Paris, série IIa 325 (1997), pp. 815-821.

[383] R. Allain and P. Taquet. "A new genus of Dromaeosauridae (Dinosauria, Theropoda) from the Upper Cretaceous of France". English. In: Journal of Vertebrate Paleontology 20.2 (2000), pp. 404407.

[384] R. Allain, R. S. Tykoski, N. Aquesbi, N. -E. Jalil, M. Monbaron, D. A. Russell, and P. Taquet. “An abelisauroid (Dinosauria: Theropoda) from the Early Jurassic of the High Atlas Mountains, Morocco, and the radiation of ceratosaurs". English. In: Journal of Vertebrate Paleontology 27.3 (2007), pp. 610-624.

[385] R. Allain, T. Xaisanavong, P. Richir, and B. Khentavong. "The first definitive Asian spinosaurid (Dinosauria: Theropoda) from the early cretaceous of Laos". English. In: Naturwissenschaften 99 (2012), pp. 369-377. DOI: 10.1007/s00114-012-0911-7.

[386] N. Allaire, B. Lefebvre, E. Martin, E. Nardin, and R. Vaucher. “Taphonomy of new Rhopalocystis assemblages in the Lower Ordovician of the Zagora area (Central Anti-Atlas, Morocco)". English. In: vol. 19. Progress in Echinoderm Paleobiology, Cuadernos del Museo Geominero. Madrid: Instituto Geológico y Minero de España, 2015, pp. 21-26.

[387] N. Allaire, B. Lefebvre, E. Nardin, E. L. O. Martin, R. Vaucher, and G. Escarguel. “Morphological disparity and systematic revision of the eocrinoid genus". English. In: Journal of Paleontology 91.4 (2017), pp. 685-714. DOI: 10.1017/jpa.2017.6.

[388] J. G. Allen and R. M. Feldmann. "Panduralimulus babcocki n. gen. and sp., a new limulacean horseshoe crab from the Permian of Texas". English. In: Journal of Paleontology 79.3 (2005), pp. 594600.

[389] R. Allenbach and J. H. A. van Konijnenburg-van Cittert. "On a small flora with Araucariaceous conifers from the Röschenz Beds of Court, Jura Mountains, Switzerland." In: Eclogae geol. Helv. 90 (1997), pp. 571-579.

[390] N. F. Alley. "Cainozoic stratigraphy, palaeoenvironments and geological evolution of the Lake Eyre Basin”. English. In: Palaeogeography, Palaeoclimatology, Palaeoecology 144.3 - 4 (1998), pp. 239263. DOI: $10.1016 /$ S0031-0182(98)00120-5.

[391] W. Allmon and W. Harris. "A New Species of Turritelline Gastropod from a Turritelline-Dominated Limestone in the Paleocene of North Carolina". English. In: Journal of Paleontology 82.2 (2008), pp. 442-446. DOI: 10.1666/06-005.1.

[392] W. A. Allmon, S. D. Emslie, D. S. Jones, and G. S. Morgan. "Late Neogene Oceanographic Change along Florida's West Coast: Evidence and Mechanisms". English. In: Journal of Geology 104 (1996), pp. 143-162.

[393] W. D. Allmon. "Review of the Bullia Group (Gastropoda: Nassariidae) with comments on its evolution, biogeography, and Phylogeny". In: Bulletins of American Paleontology 99.335 (1990), pp. 1179.

[394] W. D. Allmon and J. L. Knight. “Paleoecological Significance of a Turritelline Gastropod-Dominated Assemblage in the Cretaceous of South Carolina". English. In: 67.3 (1993), pp. 355-360. 
[395] E. Almazan-Vazquez, B. E. Buitron-Sanchez, D. Vachard, C. Mendoza-Madera, and C. GomezEspinosa. "The Late Atokan (Moscovian, Pennsylvanian) chaetetid accumulations of Sierra Agua Verde, Sonora (NW Mexico): composition, facies and palaeoenvironmental signals". English. In: in J. J. Alvaro, M. Aretz, F. Boulvain, A. Munnecke, D. Vachard, E. Vennin, eds., Palaeozoic reefs and bioaccumulations: climatic and evolutionary controls. Geological Society Special Publication 275 (2007), pp. 189-200.

[396] J. Almeida da Silva, L. A. Leal, A. Cherkinsky, and M. A. T. Dantasa. "Late Pleistocene mesomegamammals from Anagé, Bahia, Brazil: Taxonomy and isotopic paleoecology (d13C)". English. In: Journal of South American Earth Sciences 96 (2019), 102362:1-8.

[397] Y. Alméras. “Les brachiopodes toarciens et aaléniens inférieurs du bassin du Rhone, paléontologie et biostratigraphie, révision de la collection Dumortier et compléments". French. In: Documents des Laboratoires de Géologie Lyon 138 (1996), pp. 1-123.

[398] Y. Alméras, M. Bécaud, and M. Cougnon. "Brachiopodes liasiques de la Bordure Sud du Massif Armoricain". French. In: Bulletin de la Société des Sciences Naturelles de l'Ouest de la France (2010), pp. 1-131.

[399] Y. Alméras, E. Cariou, and R. Enay. "Les brachiopodes du Bathonien et du Callovien inférieur de Thakkhola (Népal central): paléontologie et biostratigraphie". French. In: Geobios 29 (1996), pp. 605-618.

[400] Y. Alméras, M. Cougnon, and M. Bécaud. "Les Brachiopodes liasiques de la Bordure Sud du Massif Armoricain: Succession des peuplements et environnements ; chronostratigraphie". French. In: Revue de Paléobiologie 29.2 (2010), pp. 319-339.

[401] Y. Alméras, M. Cougnon, R. Enay, and C. Mangold. "Brachiopodes du Jurasique Inférieur et moyen d'Arabie Saoudite centrale". French. In: Documents des Laboratoires de Géologie de Lyon 168 (2010), pp. 1-247.

[402] Y. Alméras and S. Elmi. "Les brachiopodes jurassiques moyens de la bordure vivaro-cévenole (Bassin du Sud-Est, France)". French. In: Strata 2.29 (1998), pp. 1-145.

[403] Y. Alméras, S. Elmi, and P. Fauré. "Les brachiopods liasiques d'Algérie occidentale". French. In: Documents des Laboratoires de Géologie de la Faculté des Sciences de Lyon 163 (2007), pp. 1-241.

[404] Y. Alméras and P. Fauré. "Lobothyris sinemuriensis (Oppel) et faune de brachiopodes associée (Sinémurien, France). Evolution du genre Lobothyris Buckman (Brachiopodes, Térébratulidés)". French. In: Revue de Paléobiologie, Genéve 26 (2007), pp. 335-358.

[405] Y. Alméras and P. Fauré. “Les brachiopodes liasiques des Pyrénées: paléontologie, biostratigraphie, paléobiogéographie et paléoenvironnements". French. In: Strata, Série 2, Mémoires 36 (2000), pp. 1-394.

[406] Y. Almeras and M. Hanzo. “Les Rhynchonellides du Calcaire a gryphees d'Hettange (SinemurienNE France): etude des peuplements et enregistrement des variations du paleoenvironnement". French. In: Palaeogeography, Palaeoclimatology, Palaeoecology 86 (1991), pp. 313-329.

[407] Y. Alméras, R. Mouterde, M. Benest, S. Elmi, and J. P. Bassoullet. "Les Brachiopodes Toarciens de la Rampe Carbonatée de Tomar (Portugal)". French. In: Documents des Laboratoires de Géologie de Lyon 138 (1996), pp. 125-191.

[408] L. Alonso Santiago and L. Alonso Andrés. “Diferencias anatómicas entre dos formas de Allaeochelys del Eoceno de Corrales (Zamora, España). Nueva especie de tortuga, Allaeochelys jimenezi nov. sp". English. In: Stvdia Geologica Salmanticensia 41 (2005), pp. 103-126.

[409] L. Alonso Santiago and L. Alonso Andrés. "Nuevo género de Crocodylia del Eoceno medio de la Pennsula Ibérica (Zamora, España): Duerosuchus piscator nov. gen., nov. sp." Spanish. In: Studia Geologica Salmanticensia 45.2 (2009), pp. 149-173.

[410] L. Alonso Santiago, L. Alonso Andres, and E. Jimenez-Fuentes. "Primer espaldar en conexion anatomica de Allaeochelys casasecai. Cazurra: nuevo yacimiento del Eoceno de Zamora (Espana)". Spanish. In: Studia Geologica Salmanticensia 44.2 (2008), pp. 177-186. 
[411] J. Alroy. Stop the madness. English. 2010.

[412] P. Alsen. "The Early Cretaceous (Late Ryazanian-Early Hauterivian) ammonite fauna of NorthEast Greenland: taxonomy, biostratigraphy, and biogeography". English. In: Fossils and Strata 53 (2006), pp. 1-229.

[413] P. Alsen and J. Mutterlose. "The Early Cretaceous of north-east Greenland: a crossroads of belemnite migration". English. In: Palaeogeography, Palaeoclimatology, Palaeoecology 280 (2009), pp. 168182.

[414] P. Alsen and P. F. Rawson. "The Early Valanginian (Early Cretaceous) ammonite Delphinites (Pseudogarnieria) from North-East Greenland". English. In: Bulletin of the Geological Society of Denmark 52.2 (2005), pp. 201-212.

[415] D. Altiner and A. Kocyigit. "An Anisian megablock in northern central Anatolia: micropaleontologic, stratigraphic and tectonic implications for the rifting stage of Karakaya Basin, Turkey". English. In: Revue de Paleobiologie 12.1 (1993), pp. 1-17.

[416] A. Altuna, G. Álvarez-Pérez, P. Busquets, and V. Etayo. Five new species of Bartonian (Eocene) corals: Jaca Basin, Pyrenees, Spain. English. Vol. 17. Fossil Corals and Sponges: Proceedings of the 9th International Symposium on Fossil Cnidaria and Porifera, Graz 2003. Österr. Akad. Wiss. Schriftenr. Erdwiss. Komm., 2007, pp. 435-453.

[417] A. Alván, J. Apoln, and C. Chacaltana. “Los dientes de Seláceos (Condrichthyies) y su aplicaión estratigráfica en Las Lomas de Ullujaya (Ica, Perú)". Spanish. In: XIII Congreso Peruano de Geologa. Resúmenes Extendidos (2004), pp. 595-598.

[418] J. Alvarado-Ortega. "Description and Relationships of a New Ichthyodectiform Fish from the Tlayúa Formation (Early Cretaceous: Albian), Puebla, Mexico". English. In: Journal of Vertebrate Paleontology 24.4 (2004), pp. 802-813.

[419] J. Alvarado-Ortega and P. Brito. "A New Ichthyodectiform (Actinopterygii, Teleostei) from the Lower Cretaceous Marizal Formation, North-east Brazil”. English. In: Palaeontology 53.2 (2009), pp. 297-306.

[420] J. Alvarado-Ortega and P. M. Brito. “A New Species of Araripichthys (Teleostei, Elopocephala) from the Tlayúa Formation (Cretaceous, Albian), Mexico". English. In: Journal of Vertebrate Paleontology 31.6 (2011), pp. 1376-1381.

[421] J. Alvarado-Ortega, K. M. Cantalice, J. A. Daz-Cruz, C. Castañeda-Posadas, and V. ZavaletaVillareal. "Vertebrate fossils from the San José de Gracia quarry, a new Late Cretaceous marine fossil site in Puebla, Mexico". English. In: Boletn de la Sociedad Geológica Mexicana 72.1 (2020).

[422] J. Alvarado-Ortega, O. Carranza-Castañeda, and G. Alvarez-Reyes. "A New Fossil Species of Ictiobus (Teleostei: Catostomidae) from Pliocene Lacustrine Sediments near Tula de Allende, Hidalgo, Mexico". English. In: Journal of Paleontology 80.5 (2006), pp. 993-1008.

[423] J. Alvarado-Ortega, M. Cuevas-Garca, M. P. Melgarejo-Damián, K. M. Cantalice, A. Alaniz-Galvan, G. Solano-Templos, and B. A. Than-Marchese. "Paleocene fishes from Palenque, Chiapas, southeastern Mexico". English. In: Palaeontologia Electronica 18.2.39A (2015), pp. 1-22.

[424] J. Alvarado-Ortega and L. Espinosa-Arrubarrena. "A New Genus of Ionoscopiform Fish (Halecomorphi) from the Lower Cretaceous (Albian) Lithographic Limestones of the Tlayúa Quarry, Puebla, Mexico". English. In: Journal of Paleontology 82.1 (2008), pp. 163-175.

[425] J. Alvarado-Ortega, D. Mayrinck, and P. M. Brito. "A basal pachyrhizodontid fish (Actinopterygii, Teleostei) from the Lower Cretaceous of the Tlayua Quarry, central Mexico". English. In: Comptes Rendus Palevol 7 (2008), pp. 269-275. DOI: 10.1016/j.crpv.2008.03.006.

[426] J. Alvarado-Ortega and E. Ovalles-Damián. “Triplomystus applegatei, sp. nov. (Teleostei: Ellimmichthyiformes), a rare triple armored herring from El Espinal Quarry (Early Cretaceous), Chiapas, southeastern Mexico". English. In: Journal of Vertebrate Paleontology 28.1 (2008), pp. 53-60.

[427] J. Alvarado-Ortega, E. Ovalles-Damián, and A. Blanco-Piñón. The fossil fishes from the Sierra Madre Formation, Ocozocoautla, Chiapas, Southern Mexico. English. Vol. 12.2.5A. Palaeontologia Electronica. 2009. 
[428] C. J. S. Alvarenga and R. Trompette. "Glacially influenced sedimentation in the Later Proterozoic of the Paraguay belt (Mato Grosso, Brazil)". English. In: Palaeogeography, Palaeoclimatology, Palaeoecology 92 (1992), pp. 85-105.

[429] H. M. F. Alvarenga and E. Holfing. "Systematic revision of the Phorusrhacidae (Avies: Ralliformes)". English. In: Papeis Avulsos de Zoologia 43.4 (2003), pp. 55-91.

[430] H. M. F. Alvarenga and S. L. Olson. "A new genus of tiny condor from the Pleistocene of Brazil (Aves: Vulturidae)". English. In: Proceedings of the Biological Society of Washington 117 (2004), pp. 19.

[431] A. Alvarez and M. Arnal. "First Approach to the Paleobiology of Extinct Prospaniomys (Rodentia, Hystricognathi, Octodontoidea) Through Head Muscle Reconstruction and the Study of Craniomandibular Shape Variation". English. In: Journal of Mammalian Evolution 22 (2015), pp. 519-533. DOI: 10.1007/s10914-015-9291-z.

[432] A. Alvarez and M. D. Ercoli. "Why pacaranas never say no: analysis of the unique occipitocervical configuration of tTetrastylus intermedius Rovereto, 1914, and other dinomyids (Caviomorpha; Dinomyidae)". English. In: Journal of Vertebrate Paleontology 37.6 (2017), e1385476. DOI: 10.1080 / 02724634.2017.1385476.

[433] G. A. Alvarez, A. A. Herrera, J. Barbadillo, J. C. Garca, R. E. Garca, M. A. G. Valero, J. F. J. Pardo, J. P. Muñoz, B. S. Chillón, A. S. Marco, B. Sanchiz, and C. Sesé. "Prospecciones y excavaciones arquelógicas en el alto valle del Jarama (Valdesotos, Guadalajara, Castilla-La Mancha)". Spanish. In: Toledo: Junta de Comunidades Castilla-La Mancha, 1995, pp. 111-124.

[434] S. Álvarez, E. Aragón, S. Azofra, J. Barrau, M. P. Benzal, J. M. Berger, J. M. Camarón, I. Catalán, A. Coda, L. Colomé, E. Gallego, A. Garrido, M. Gonzalo, A. Hernáez, P. Del Hoyo, S. López, N. Lorente, F. J. Madariaga, M. E. Marn, D. Martnez, J. Menéndez, A. Moneo, and J. Pérez. “El yacimiento de huellas de dinosaurios de Hornillos de Cameros (La Rioja. España) [The dinosaur egg locality of Hornillos de Cameros (La Rioja, Spain)]". Spanish. In: Zuba 18 (2000), pp. 73-95.

[435] M. A. Alvarez Sierra, R. Daams, J. I. Lacomba, N. Lopez Martinez, A. J. Van Der Meulen, C. Sese, and J. De Visser. "Palaeontology and biostratigraphy (micromammals) of the continental Oligocene-Miocene deposits of the North-Central Ebro Basin (Huesca, Spain)". English. In: Scripta Geologica 94 (1991), pp. 1-77.

[436] E. Álvarez-Fernández. "Humans and marine resource interaction reappraised: Archaeofauna remains during the late Pleistocene and Holocene in Cantabrian Spain". English. In: Journal of Anthropological Archaeology 30 (2011), pp. 327-343. DOI: 10.1016/j.jaa.2011.05.005.

[437] S. Álvarez-Parra, E. Peñalver, A. Nel, and X. Delclós. "The oldest representative of the extant barklice genus Psyllipsocus (Psocodea: Trogiomorpha: Psyllipsocidae) from the Cenomanian amber of Myanmar". English. In: Cretaceous Research 113.104480 (2020). DOI: 10.1016/j.cretres.2020.104480.

[438] G. Álvarez-Pérez and P. Busquets. "Formas anomalas en los corales eocenos de la Cuenca de Igualada (Noreste de Espania)". Spanish. In: Revista Española de Paleontologa 27.1 (2012).

[439] C. Álvarez-Ramis, M. Prámparo, and O. H. Papú. “Estudio preliminar de paleofloras cretácicas procedentes de la base de la Formación Loncoche (Mendoza, Argentina)". Spanish. In: Coloquios de Paleontologa 54 (2004), pp. 7-14.

[440] H. Alvargenga, W. Jones, and A. Riderknecht. "The youngest record of phorusrhacid birds (Aves, Phorusrhacidae) from the late Pleistocene of Uruguay". English. In: Neues Jahrbuch für Geologie und Paläontologie - Abhandlungen 256.2 (2010), pp. 229-234.

[441] J. J. Alvaro and I. Cortijo. "Cloudina-microbial reef resilience to substrate instability in a Cadomian retroarc basin of the Iberian Peninsula". English. In: Precambrian Research (2019). DOI: 10.1016/j. precamres.2019.105479.

[442] J. J. Alvaro, P. Courjault-Radé, J. J. Chauvel, M. P. Dabard, F. Debrenne, R. Feist, G. L. Pillola, E. Vennin, and D. Vizcano. "Nouveau découpage stratigraphique: des séries cambriennes des nappes de Pardailhan et du Minervois (versant sud de la Montagne noire)". English. In: Géologie de la France 2 (1998), pp. 3-12. 
[443] J. J. Alvaro and F. Debrenne. "The Great Atlasian Reef Complex: An Early Cambrian subtropical fringing belt that bordered West Gondwana". English. In: Palaeogeography, Palaeoclimatology, Palaeoecology 294 (2010), pp. 120-132.

[444] J. J. Alvaro, O. Elicki, F. Debrenne, and D. Vizcaino. "Small shelly fossils from the Lower Cambrian Lastours Formation, southern Montagne Noir, France". English. In: Geobios 35 (2002), pp. 397-409.

[445] J. J. Alvaro, E. Vennin, E. Moreno-Eiris, A. Perejon, and T. Bechstädt. “Sedimentary patterns across the Lower-Middle Cambrian transition in the Esla nappe (Cantabrian Mountains, northern Spain)". English. In: Sedimentary Geology 137 (2000), pp. 43-61.

[446] J. J. Álvaro, E. Vennin, E. Villas, J. Destombes, and D. Vizcano. “Pre-Hirnantian (latest Ordovician) benthic community assemblages: controls and replacements in a siliciclastic-dominated platform of the eastern Anti-Atlas, Morocco". English. In: Palaeogeography, Palaeoclimatology, Palaeoecology 245 (2007), pp. 20-36. DOI: 10.1016/j.palaeo.2005.09.035.

[447] J. J. Álvaro and D. Vizcano. "Révision biostratigraphique du Cambrien moyen du versant méridional de la Montagne Noire (Languedoc, France)". English. In: Bulletin de la Société géologique de France 169.2 (1998), pp. 233-242.

[448] J. J. Alvaro, S. Zamora, D. Vizcano, and P. Ahlberg. “Guzhangian (mid Cambrian) trilobites from siliceous concretions of the Valtorres Formation, Iberian Chains, NE Spain". English. In: Geology 150.1 (2013), pp. 123-142. DOI: 10.1017/S0016756812000416.

[449] M. F. Aly, A. Smadi, and H. Abu Azzam. "Late Cenomanian-Early Turonian ammonites of Jordan". English. In: Revue de Paléobiologie, Genéve 27 (2008), pp. 43-71.

[450] A. Amaha. "Geographic Variation of the Common Dolphin, Delphinus delphis (Odontoceti Delphinidae)". English. In: Tokyo University of Fisheries (1994).

[451] J. Amalfitano, F. M. Dalla Vecchia, L. Giusberti, E. Fornaciari, V. Luciana, and G. Roghi. “Direct evidence of trophic interaction between a large lamniform shark, Cretodus sp., and a marine turtle from the Cretaceous of northeastern Italy". English. In: Palaeogeography, Palaeoclimatology, Palaeoecology 469 (2017), pp. 104-121. DOI: 10.1016/j.palaeo.2016.12.044.

[452] J. Amalfitano, L. Giusberti, E. Fornaciari, and G. Carnevale. "Upper Cenomanian fishes from the Bonarelli level (OAE2) of northeastern Italy". English. In: Rivista Italiana di Paleontologia e Stratigrafia 126 (2020), pp. 261-314.

[453] F. Amani and D. Geraads. "The Mousterian site of Jebel Irhoud, Morocco: new data on the fauna and biochronology, and description of a new human fossil". French. In: Comptes Rendus de l'Academie des Sciences, Paris Serie II 316 (1993), pp. 847-852.

[454] K. Amano, K. Hryniewicz, and R. G. Jenkins. "A newly discovered Paleocene species of Boreocomitas (Gastropoda: Pseudomelatomidae) from eastern Hokkaido, Japan, with implications for the biogeography of the Paleocene Bering Strait". English. In: The Nautilus 132.3-4 (2018), pp. 117123.

[455] K. Amano and R. G. Jenkins. "Eocene drill holes in cold-seep bivalves of Hokkaido, northern Japan". English. In: Marine Ecology 28 (2007), pp. 108-114.

[456] K. Amano and R. G. Jenkins. "A new species of Provanna (Gastropoda: Provannidae) from an Oligocene seep deposit in eastern Hokkaido, Japan". English. In: Paleontological Research 17 (2013), pp. 325-329. DOI: 10.2517/1342-8144-17.4.325.

[457] K. Amano, R. G. Jenkins, Y. Sako, M. Ohara, and S. Kiel. "A Paleogene deep-sea methane-seep community from Honshu, Japan". English. In: Palaeogeography, Palaeoclimatology, Palaeoecology 387 (2013), pp. 126-133. DOI: 10.1016/j.palaeo.2013.07.015.

[458] K. Amano and V. D. Khudik. "An early Middle Miocene warm-water molluscan fauna in southwestern Sakhalin - Molluscs from the Ausinskaya Formation around Novoselovo". English. In: Transactions and Proceedings of the Paleontological Society of Japan, N.S. 184 (1996), pp. 651-661.

[459] K. Amano and S. Kiel. "Fossil Vesicomyid Bivalves from the North Pacific Region". English. In: The Veliger 49.4 (2007), pp. 270-293. 
[460] K. Amano and S. Kiel. "Fossil Adulomya (Vesicomyidae, Bivalvia) from Japan”. English. In: The Veliger 51.2 (2011), pp. 76-90.

[461] K. Amano and C. T. S. Little. "Miocene abyssochrysoid gastropod Provanna from Japanese seep and whale-fall sites". English. In: Acta Palaeontologica Polonica 59.1 (2014), pp. 163-172. DOI: 10. 4202/app.2012.0002.

[462] K. Amano and C. T. S. Little. "Miocene whale-fall community from Hokkaido, northern Japan". In: Palaeogeography, Palaeoclimatology, Palaeoecology 215 (2005), pp. 345-356.

[463] K. Amano and T. Nobuhara. "A species of Mizuhopecten yessoensis Group from the Kakegawa Group, central Japan". English. In: Bulletin of the Mizunami Fossil Museum 22 (1995), pp. 103-108.

[464] K. Amano and A. Oleinik. "Ancistrolepidine gastropods (Buccinidae) from the upper Eocene hydrocarbon seep deposits in Hokkaido, northern Japan". English. In: The Nautilus 130.4 (2016), pp. 158-163.

[465] K. Amano, M. Suzuki, and T. Sato. "Warm-water influx into Japan Sea in the middle Pliocene Molluscan faunas from the Tentokuji FOrmation around Mt. Taihei in Akita Prefecture". Japanese. In: Journal of the Geological Society of Japan 106.4 (2000), pp. 299-306.

[466] M. Amano, N. Miyazaki, and K. Kureha. "A morphological comparison of skulls of the finless porpoise Neophocaena phocaenoides from the Indian Ocean, Yangtze River and Japanese waters". English. In: Journal of the Mammalogical Society of Japan 17 (1992), pp. 59-69.

[467] B. Amard. "Chuaria pendjariensis n. sp., acritarche du bassin des Volta, Bénin et Burkina-Faso, Afrique de l'ouest: un taxon nouveau du Cambrien inférieur". French. In: Comptes Rendus de l'Académie des Sciences. Série 2. Sciences de la Terre et des Planétes 324 (1997), pp. 477-483.

[468] L. Amati. "Isoteline trilobites of the Viola Group (Ordovician: Oklahoma): systematics and stratigraphic occurrence". English. In: Oklahoma Geological Survey Bulletin 151 (2014), pp. 1-125.

[469] L. Amati and S. R. Westrop. "A systematic revision of Thaleops (Trilobita: Illaenidae) with new species from the middle and late Ordovician of Oklahoma and New York". English. In: Journal of Systematic Palaeontology 2.3 (2004), pp. 207-256.

[470] F. Amédro, F. Robaszynski, B. Matrion, and C. Devalque. "A North American ammonite fauna from the late Middle Turonian of Vaucluse and Gard, southern France: the Romaniceras mexicanum, Prionocyclus hyatti and Coilopoceras cf. springeri association". English. In: Acta Geologica Polonica 66 (2016), pp. 729-736.

[471] H. Ameri, M. Yazdi, and A. Bahrami. "Pseudophillipsia (Carniphillipsia) (Trilobite) from the Permian Jamal Formation, Isfahan, Iran". English. In: Journal of Sciences, Islamic Republic of Iran 28 (2017), pp. 325-336.

[472] M. A. Amin, M. M. Al-Mutwali, and T. A. Thanoon. “Microfacies and paleoenvironment of Sinjar Formation (Paleocene-early Eocene), Sinjar area, Northern Iraq". English. In: Raf. Jour. Science 16.1 (2005), pp. 1-20.

[473] R. Amiot, E. Buffetaut, C. Lécuyer, V. Fernandez, F. Fourel, F. Martineau, and V. Suteethorn. Oxygen isotope composition of continental vertebrate apatites from Mesozoic formations of Thailand; environmental and ecological significance. English. Vol. 315. Late Palaeozoic and Mesozoic Ecosystems in SE Asia. The Geological Society of London, Special Publication. 2009, pp. 271-283.

[474] R. Amiot, N. Kusuhashi, X. Xu, and Y. Wang. "Isolated dinosaur teeth from the Lower Cretaceous Shahai and Fuxin formations of northeastern China". English. In: Journal of Asian Earth Sciences 39 (2010), pp. 347-358. DOI: 10.1016/j.seaes.2010.04.017.

[475] R. Amiot, X. Wang, Z. Zhou, E. Buffetaut, C. Lécuyer, Z. Ding, F. Fluteau, T. Hibino, N. Kusuhashi, J. Mo, V. Suteethorn, Y. Wang, X. Xu, and F. Zhang. “Oxygen isotopes of East Asian dinosaurs reveal exceptionally cold Early Cretaceous climates". English. In: Proceedings of the National Academy of Sciences 108.13 (2011), pp. 5179-5183. DOI: 10.1073/pnas.1011369108. 
[476] R. Amiot, X. Wang, C. Lécuyer, E. Buffetaut, L. Boudad, L. Cavin, Z. Ding, F. Fluteau, A. W. A. Kellner, H. Tong, and F. Zhang. "Oxygen and carbon isotope compositions of middle Cretaceous vertebrates from North Africa and Brazil: Ecological and environmental significance". English. In: Palaeogeography, Palaeoclimatology, Palaeoecology 297.2 (2010), pp. 439-451. DOI: 10.1016/j.palaeo. 2010.08.027.

[477] F. Amirhassankhani, B. Senowbari-Daryan, and K. Rashidi. “Upper Triassic (Norian-Rhaetian) hypercalcified sponges from the Lut Block, east central Iran". English. In: Rivista Italiana di Paleontologia e Stratigrafia 120 (2014), pp. 287-315.

[478] M. R. W. Amler. "Late Devonian (Frasnian) bivalves from the Nocedo Formation - the results of Wilhelm Kegel's 1927 field trip to northern Spain". English. In: Scripta Geologica Special Issue 7 (2010), pp. 13-34.

[479] M. R. W. Amler. "Shallow marine bivalves at the Devonian/Carboniferous boundary from the Velbert Anticline (Rheinisches Schiefergebirge)". English. In: Annales de la Societie géologique de Belgique 115.2 (1992), pp. 405-423.

[480] M. R. W. Amler. "Late Early Devonian Rostroconchia (Mollusca) from Hamar Laghdad (Morocco)". English. In: Neues Jahrbuch für Geologie und Paläontologie - Abhandlungen 290.1-3 (2018), pp. 183-189. DOI: 10.1127/njgpa/2018/0783.

[481] M. R. W. Amler, D. Heidelberger, and H. Schöning. “Gastropoden aus paläozoischen Geschieben des Kies-Sand-Rückens in der Laerheide (Landkreis Osnabrück)". German. In: Osnabrücker Naturwissenschaftliche Mitteilungen 28 (2002), pp. 7-25.

[482] M. R. W. Amler and H. G. Herbi. "Ostrand der Kohlenkalk-Plattform und Übergang in das KulmBecken im westlichsten Deutschland zwischen Aachen und Wuppertal”. English. In: Schriftenreihe der Deutschen Gesellschaft für Geowissenschaften 41 (2006), pp. 441-477.

[483] M. R. W. Amler, E. Thomas, and K. M. Weber. "Bivalven des hoechsten Oberdevons im Bergischen Land (Strunium; noerdliches Rheinisches Schiefergebirge)". German. In: Geologica et Palaeontologica 24 (1990).

[484] M. R. W. Amler and C. F. Winkler Prins. Lower Carboniferous marine bivalves from the Cantabrian Mountains (Spain). English. Vol. 120. Scripta Geologica. 1999, pp. 1-45.

[485] M. R. W. Amler and D. Heidelberger. "Late Famennian Gastropoda from south-west England". In: Palaeontology 46.6 (2003), pp. 1151-1211.

[486] O. Amo Sanjuán, J. I. Canudo, and G. Cuenca-Bescós. "First record of elongatoolithid eggshells from the lower Barremian (Lower Cretaceous) of Europe (Cuesta Corrales 2, Galve Basin, Teruel, Spain)". English. In: First International Symposium on Dinosaur Eggs and Babies, Isona i Conda Dellá, Spain, Extended Abstracts (2000), pp. 7-14.

[487] D. D. S. Amorim and D. E. Greenwalt. "Cretaceous and Eocene fossils of the rare extant genus Synneuron Lundstrom (Diptera: Canthyloscledidae): evidence of a true Pangean clade". English. In: Cladistics 36 (2020), pp. 413-423. DOI: 10.1111/cla.12413.

[488] D. S. Amorim. “Amber fossil Scatopsidae (Diptera: Psychodomorpha). I. Considerations on described taxa, Procolobostema roseni, new species, from Dominican Amber, and the position of Procolobostema in the family". English. In: American Museum Novitates 3227 (1998), pp. 1-17.

[489] D. S. Amorim and D. A. Grimaldi. "Valeseguyidae, a new family of Diptera in the Scatopsoidea, with a new genus in Cretaceous amber from Myanmar". English. In: Systematic Entomology 31 (2006), pp. 508-516.

[490] A. Amorosi, F. Antonioli, A. Bertini, S. Marabini, G. Mastronuzzi, P. Montagna, A. Negri, V. Rossi, D. Scarponi, M. Taviani, L. Angeletti, A. Piva, and G. B. Vai. "The Middle-Upper Pleistocene Fronte Section (Taranto, Italy): An exceptionally preserved marine record of the Last Interglacial". English. In: Global and Planetary Change 119 (2014), pp. 23-38. 
[491] L. Amri, S. B. Lucenti, M. S. Mtimet, N. Karoui-Yaakouba, S. Ros-Montoyad, M. Espigaresd, M. Boughdiria, N. B. H. Alie, and B. Martnez-Navarro. “Canis othmanii sp. nov. (Carnivora, Canidae) from the early Middle Pleistocene site of Wadi Sarrat (Tunisia)". English. In: Academie des sciences (2017).

[492] E. Amson, J. D. Carrillo, and C. Jaramillo. "Neogene sloth assemblages (Mammalia, Pilosa) of the Cocinetas basin (La Guajira, Colombia): implications for the Great American Biotic Interchange". English. In: Palaeontology 59.4 (2016), pp. 563-582. DOI: 10.1111/pala.12244.

[493] E. Amson and C. Muizon. "A new durophagous phocid (Mammalia: Carnivora) from the late Neogene of Peru and considerations on monachine seals phylogeny". English. In: Journal of Systematic Palaeontology 12.5 (2013), pp. 523-548. DOI: 10.1080/14772019.2013.799610.

[494] E. Amson, C. Muizon, D. P. Domning, and C. Argot. "Bone histology as a clue for resolving the puzzle of a dugong rib in the Pisco Formation, Peru". English. In: Journal of Vertebrate Paleontology (2015), e922981. DOI: 10.1080/02724634.2014.922981.

[495] J. E. Amthor, J. P. Grotzinger, S. Schröder, S. A. Bowring, J. Ramezani, M. W. Martin, and A. Matter. "Extinction of Cloudina and Namacalathus at the Precambrian-Cambrian boundary in Oman". English. In: Geology 31.5 (2003), pp. 431-434.

[496] S. Anantharaman, G. P. Wilson, D. C. Das Sarma, and W. A. Clemens. "A possible Late Cretaceous haramiyidan from India". English. In: Journal of Vertebrate Paleontology 26.2 (2006), pp. 488-490.

[497] E. Ancibor. "Determinación xilológica de la madera fósil de una Fagaceae, de la formación Ro Turbio, (Eoceno), Santa Cruz, Argentina". Spanish. In: Ameghiniana 27.1-2 (1990), pp. 179-184.

[498] N. M. Andersen. "Fossil water striders in the Eocene Baltic amber (Hemiptera, Gerromorpha)". English. In: Insect Systematics \& Evolution 31 (2000), pp. 257-284.

[499] N. M. Andersen. "Microvelia polhemi, n. sp. (Heteroptera: Veliidae) from Dominican amber: the first fossil record of a phytotelmic water strider". English. In: Journal of the New York Entomological Society 107 (2000), pp. 135-144.

[500] N. M. Andersen. “Early evolution of a unique structure: a fossil water measurer from Baltic amber (Hemiptera: Gerromorpha; Hydrometridae)". English. In: Insect Systematics \& Evolution 34 (2003), pp. 415-426.

[501] N. M. Andersen. "Fossil water striders in the Oligocene/Miocene Dominican amber (Hemiptera: Gerromorpha)". English. In: Insect Systematics E Evolution 31 (2001), pp. 411-431.

[502] N. M. Andersen, A. Farma, A. Minelli, and G. Piccoli. "A fossil Halobates from the Mediterranea and the origin of sea skaters (Hemiptera, Gerridae)". English. In: Zoological Journal of the Linnean Society 112.4 (1994), pp. 479-489.

[503] N. M. Andersen and D. A. Grimaldi. "A fossil water measurer from the mid-Cretaceous Burmese amber (Hemiptera: Gerromorpha: Hydrometridae)". English. In: Insect Systematics \& Evolution 32 (2001), pp. 381-392.

[504] N. M. Andersen and G. O. Poinar. "A marine water strider (Hemiptera: Veliidae) from Dominican amber". English. In: Entomologica Scandinavica 29 (1998), pp. 1-9.

[505] N. M. Andersen and G. O. Poinar. "Phylogeny and classification of an extinct water strider genus (Hemiptera, Gerridae) from Dominican amber, with evidence of mate guarding in a fossil insect". English. In: Zeitschrift für Zoologische Systematik und Evolutionforschung 30 (1992), pp. 256-267.

[506] S. Andersen. "Silky lacewings (Neuroptera: Psychopsidae) from the Eocene-Paleocene transition of Denmark with a review of the fossil record and comments on phylogeny and zoogeography". English. In: Insect Systematics \& Evolution 32 (2001), pp. 419-438.

[507] A. Anderson, C. Sand, F. Petchey, and T. H. Wright. "Faunal extinction and human habitation in New Caledonia: initial results and implications of new research at the Pindai Caves". English. In: Journal of Pacific Archaeology 1 (2010), pp. 89-109. 
[508] B. G. Anderson, R. E. Barrick, M. L. Droser, and K. L. Stadtman. Hadrosaur skin impressions from the Upper Cretaceous Neslen Formation, Book Cliffs, Utah: morphology and paleoenvironmental context. Vol. 99-1. Vertebrate Paleontology in Utah, Utah Geological Survey Miscellaneous Publication. 1999.

[509] B. G. Anderson, S. G. Lucas, R. E Barrick, A. B. Heckert, and G. T. Basabilvazo. “Dinosaur skin impressions and associated skeletal remains from the Upper Campanian of southwestern New Mexico: new data on the integument morphology of hadrosaurs". English. In: Journal of Vertebrate Paleontology 18.4 (1998), pp. 739-745.

[510] D. K. Anderson. "Three new sciuravids (Rodentia) from the latest-early to middle Eocene of Wyoming: mosaic evolutio and the alpha taxonomy of Sciuravis nitidus". English. In: Contributions from the Museum of Paleontology, University of Michigan 32.12 (2017), pp. 245-258.

[511] J. M. Anderson, H. M. Anderson, and A. R. I. Cruickshank. "Late Triasssic ecosystems of the Molteno/Lower elliot Biome of Southern Africa". English. In: Palaeontology 41 (1998), pp. 387-421.

[512] J. R. Anderson, R. D. Hoare, and M. T. Sturgeon. "The Pennsylvanian gastropod Donaldina Knight of the Appalachian Basin". English. In: Journal of Paleontology 64.3 (1990), pp. 557-562.

[513] J. S. Anderson. "Occipital condyle in the ceratopsian Triceratops, with comments on body size variation". English. In: Contributions from the Museum of Paleontology, University of Michigan 30.8 (1999), pp. 215-231.

[514] J. S. Anderson. "A New Astopod (Tetrapoda: Lepospondyli) from Mazon Creek, Illinois". English. In: Journal of Vertebrate Paleontology 23.1 (2003), pp. 79-88.

[515] J. S. Anderson. "Revision of the Astopod Genus Phlegethontia (Tetrapoda: Lepospondyli)". English. In: Journal of Paleontology 76.6 (2002), pp. 1029-1046. DOI: 10.1666/0022-3360(2002)076<1029: ROTAGP >2.0.CO;2.

[516] J. S. Anderson. "Cranial anatomy of Coloraderpeton brilli, postcranial anatomy of Oestocephalus amphiuminus, and reconsideration of Ophiderpetontidae (Tetrapoda: Lepospondyli: Aistopoda)". English. In: Journal of Vertebrate Paleontology 23.3 (2003), pp. 532-543.

[517] J. S. Anderson and L. G. Barnes. "A Fossil Miocene Whale from the Tipam Sandstone, St. Martin's Island". English. In: Oryctos 3 (2000), pp. 79-84.

[518] J. S. Anderson and J. R. Bolt. “New information on amphibamids (Tetrapoda, Temnospondyli) from Richards Spur (Fort Sill), Oklahoma". English. In: Journal of Vertebrate Paleontology 33 (2013), pp. 553-567. DOI: 10.1080/02724634.2013.726676.

[519] J. S. Anderson, A. C. Henrici, S. S. Sumida, T. Martens, and D. S. Berman. "Georgenthalia clavinasica, a new genus and species of dissorophoid temnospondyl from the Early Permian of Germany, and the relationships of the family Amphibamidae". English. In: Journal of Vertebrate Paleontology 28.1 (2008), pp. 61-75.

[520] J. S. Anderson and R. R. Reisz. "Pyozia mesenensis, a New, Small Vapanopid (Synapsida: Eupelycosauria) from Russia: Pelycosaur Diversity in the Middle Permian". English. In: Journal of Vertebrate Paleontology 24.1 (2004), pp. 173-179.

[521] J. S. Anderson, R. R. Reisz, D. Scott, N. B. Fröbisch, and S. S. Sumida. “A stem batrachian from the Early Permian of Texas and the origin of frogs and salamanders". English. In: Nature 453 (2008), pp. 515-518. DOI: 10.1038/nature06865.

[522] J. S. Anderson and R. R. Reisz. "A new microsaur (Tetrapoda: Lepospondyli) from the Lower Permian of Richards Spur (Fort Sill), Oklahoma". English. In: Canadian Journal of Earth Sciences 40.4 (2003), pp. 499-505. DOI: 10.1139/e02-066.

[523] J. S. Anderson, D. Scott, and R. R. Reisz. “Nannaroter mckinziei, a New Ostodolepid 'Microsaur' (Tetrapoda, Lepospondyli, Recumbirostra) from the Early Permian of Richards Spur (Ft. Sill), Oklahoma". English. In: Journal of Vertebrate Paleontology 29.2 (2009), pp. 379-388. DOI: 10.1671/039. 029.0222 . 
[524] K. D. Anderson and A. D. George. "Evolution of Pennsylvanian inner-platform phylloid algal reef mounds, Pha Nok Khao Platform, northeastern Thailand". English. In: Palaeogeography, Palaeoclimatology, Palaeoecology (2019). DOI: 10.1016/j.palaeo.2019.109380.

[525] L. C. Anderson. "Neogene Paleontology in the Northern Dominican Republic 16. The Family Corbulidae (Mollusca: Bivalvia)". English. In: Bulletins of American Paleontology 110.351 (1996), pp. 534.

[526] L. I. Anderson. "Xiphosurans from the Westphalian D of the Radstock Basin, Somerset Coalfield, the South Wales Coalfield and Mazon Creek, Illinois". English. In: Proceedings of the Geologists' Association 105 (1994), pp. 265-275. DOI: 10.1016/S0016-7878(08)80179-4.

[527] L. I. Anderson, J. A. Dunlop, R. M. C. Eager, C. A. Horrocks, and H. M. Wilson. "Soft-bodied fossils from the roof shales of the Wigan Four Foot coal seem, Westhoughton, Lancashire, UK". English. In: Geological Magazine 135.3 (1999), pp. 321-329. DOI: 10.1017/s0016756899002575.

[528] L. I. Anderson, J. A. Dunlop, C. A. Horrocks, H. M. Winkelmann, and R. M. C. Eager. “Exceptionally preserved fossils from Bickershaw, Lancashire UK (Upper Carboniferous, Westphalian A (Langsettian))". English. In: Geological Journal 32 (1997), pp. 197-210. DOI: 10.1002 / (sici)10991034(199709)32:3\%3C197::aid-gj739\%3E3.0.co;2-6.

[529] L. I. Anderson and C. Horrocks. "Valloisella lievinensis Racheboeuf, 1992 (Chelicerata; Xiphosura) from the Westphalian B of England". English. In: Neues Jahrbuch für Geologie und Paläontologie, Monatschefte 1995 (1995), pp. 647-658.

[530] L. I. Anderson and N. H. Trewin. "An Early Devonian arthropod fauna from the Windyfield Cherts, Aberdeenshire, Scotland". English. In: Palaeontology 46 (2003), pp. 467-509.

[531] C. Anderung, S. Danise, A. G. Glover, N. D. Higgs, L. Jonsson, R. Sabin, and T. G. Dahlgren. “A Swedish subfossil find of a bowhead whale from the late Pleistocene: shore displacement, paleoecology in south-west Sweden and the identity of the Swedenborg whale (Balaena swedenborgii Liljeborg, 1867)". English. In: Historical Biology 26.1 (2014), pp. 58-65. DOI: 10.1080/08912963.2012. 757605.

[532] G. Andjic, C. Baumgartner-Mora, and P. O. Baumgartner. "An upper Paleogene shallowing-upward sequence in the southern Sandino Forearc Basin (NW Costa Rica): response to tectonic uplift". English. In: Facies 62.9 (2016).

[533] T. Ando and K. Fukata. "A well-preserved partial scapula from Japan and the reconstruction of the triosseal canal of plotopterids". English. In: PeerJ 6 (2018), ee5391. DOI: 10.7717/ peerj.5391.

[534] Y. Ando. "Oligocene pteropods (Gastropoda: Thecosomata) from the Kishima Formation, Saga Prefecture, southwest Japan". English. In: Revista Mexicana de Ciencias Geológicas 28.2 (2011), pp. 245253.

[535] B. Andrade. “Los braquiópodos del tránsito Jurásico Inferior-Jurásico Medio de la Cuenca Lusitánica (Portugal)". Spanish. In: Coloquios de Paleontologa 56 (2006), pp. 5-194.

[536] E. J. Andrade. "Turonian inoceramids and biostratigraphy of the Sergipe Basin, northeastern Brazil: an integrated study of the Votorantim and Nassau quarries". English. PhD thesis. Heidelberg, 2005, pp. 1-155.

[537] E. J. Andrade, J. Seeling, P. Bengtson, and W. Souza-Lima. “The bivalve Neithea from the Cretaceous of Brazil". English. In: Journal of South American Earth Sciences 17 (2004), pp. 25-38.

[538] M. B. Andrade, M. T. Young, J. B. Desojo, and S. L. Brusatte. "The evolution of extreme hypercarnivory in Metriorhynchidae (Mesoeucrocodylia: Thalattosuchia) based on evidence from microscopic denticle morphology". English. In: Journal of Vertebrate Paleontology 30.5 (2010), pp. 14511465.

[539] M.B.d. Andrade and R. J. Bertini. "A new Sphagesaurus (Mesoeucrocodylia: Notosuchia) from the Upper Cretaceous of Monte Alto City (Bauru Group, Brazil), and a revision of the Sphagesauridae”. English. In: Historical Biology 20.2 (2008), pp. 101-136. 
[540] M.B.d. Andrade, R. Edmonds, M. J. Benton, and R. Schouten. “A new Berriasian species of Goniopholis (Mesoeucrocodylia, Neosuchia) from England, and a review of the genus". English. In: Zoological Journal of the Linnean Society 163 (2011), S66-S108.

[541] J. D. Andrade Filho, R. P. Brazil, A. L. Falcão, and E. A. B. Galati. "Description of Pintomyia (Pifanomyia) paleotrichia, a Miocene period new species from the Dominican Republic (Diptera: Psychodidae: Phlebotominae)". English. In: Memórias do Instituto Oswaldo Cruz 102 (2007), pp. 901903.

[542] J. D. Andrade Filho, A. L. Falcão, E. A. B. Galati, and R. P. Brazil. “Pintomyia (Pifanomyia) paleotownsendi, a new sand fly from the Miocene amber of Dominican Republic (Diptera: Psychodidae: Phlebotominae)". English. In: Memórias do Instituto Oswaldo Cruz 101.Suppl 2 (2006), pp. 5758.

[543] J. D. Andrade Filho, A. L. Falcão, and R. P. Brazil. “A new phlebotomine fossil species Trichopygomyia killickorum sp. n. (Diptera: Psychodidae) found in the Dominican Republic amber". English. In: Parasite 11 (2004), pp. 71-73.

[544] J. D. Andrade Filho, E. A. B. Galati, and A. L. Falcão. “Description of Pintomyia (Pifanomyia) brazilorum sp. nov. a new fossil species from the Dominican Republic (Diptera: Psychodidae: Phlebotominae)". English. In: Memórias do Instituto Oswaldo Cruz 101 (2006), pp. 141-142.

[545] J. D. Andrade Filho, E. A. B. Galati, A. L. Falcão, and R. P. Brazil. “Description of Micropygomyia brandaoi sp. n. (Diptera: Psychodidae: Phlebotominae), a fossil phlebotomine from the Dominican Republic". English. In: Memórias do Instituto Oswaldo Cruz 103 (2008), pp. 344-346.

[546] J. D. Andrade Filho, E. A. B. Galati, and R. P. Brazil. "Review of American fossil Phlebotominae (Diptera: Psychodidae) with a description of two new species". English. In: Journal of Medical Entomology 46 (2009), pp. 969-979.

[547] J. D. Andrade Filho, P. C. L. Meira, C. C. Sanguinette, and R. P. Brazil. “Description of a new species, Pintomyia dissimilis nov. sp., a phlebotomine fossil from Dominican Republic amber (Diptera: Psychodidae: Phlebotominae)". English. In: Parasites \& Vectors 2.25 (2009), pp. 1-4. DOI: 10.1186/1756-3305-2-25.

[548] J. P. Andre, J. J. Cornee, J. P. Saint Martin, and P. Lapointe. “Organisation sequentielle de la plateforme carbonatee messinienne du seuil pelagien a Lampedusa (Mediterranee centrale) [Sequence stratigraphy of the Messinian carbonate platform of the Pelagian shoal in Lampedusa (central Mediterranean)]". French. In: Geodiversitas 24.3 (2002), pp. 625-639.

[549] C. Andreasen. "The prehistory of the coastal areas of Amdrup Land and Holm Land adjacent to the Northeast Water polynya: an archaeological perspective". English. In: Journal of Marine Systems 10.1-4 (1997), pp. 41-46.

[550] D. A. Andreev. "New Ordovician plectambonitacean brachiopods from Tuva and Leningrad Oblast". English. In: Paleontologicheskii Zhurnal 1993 (1993), pp. 50-55.

[551] P. S. Andreev and G. Cuny. "New Triassic stem Selachimorphs (Chondrichthyes, Elasmobranchii) and their bearing on the evolution of dental enameloid in Neoselachii". English. In: Journal of Vertebrate Paleontology 32 (2012), pp. 255-266.

[552] B. Andres, J. Clark, and X. Xu. "The earliest pterodactyloid and the origin of the group". English. In: Current Biology 24 (2014), pp. 1-6.

[553] B. Andres, J. M. Clark, and X. Xu. "A new rhamphorhynchid pterosaur from the Upper Jurassic of Xinjiang, China, and the phylogenetic relationships of basal pterosaurs". English. In: Journal of Vertebrate Paleontology 30.1 (2010), pp. 163-187.

[554] B. Andres and Q. Ji. "A new pterosaur from the Liaoning Province of China, the phylogeny of the Pterodactyloidea, and convergence in their cervical vertebrae". English. In: Palaeontology 51.2 (2008), pp. 453-469. DOI: 10.1111/j.1475-4983.2008.00761.x.

[555] B. Andres and Q. Ji. "A new species of Istiodactylus (Pterosauria, Pterodactyloidea) from the Lower Cretaceous of Liaoning, China". English. In: Journal of Vertebrate Paleontology 26.1 (2006), pp. 70-78. 
[556] B. Andres and T. S. Myers. "Lone Star Pterosaurs". English. In: Earth and Environmental Science Transactions of the Royal Society of Edinburgh 103 (2013), pp. 383-398.

[557] B. Andres and M. A. Norell. "The first record of a pterosaur from the Early Cretaceous strata of Öösh (Övörkhangai; Mongolia)". English. In: American Museum Novitates 3472 (2005), pp. 1-6.

[558] B. Andreu and G. Tronchetti. “Ostracodes et foraminiféres du Crétace supérieur du synclinal d'El Koubbat, moyen Atlas, Maroc". French. In: Geobios 29.1 (1994), pp. 45-71.

[559] S. M. Andrews and R. L. Carroll. "The Order Adelospondyli: Carboniferous lepospondyl amphibians". English. In: Transactions of the Royal Society of Edinburgh 82.3 (1991), pp. 239-275. DOI: $10.1017 /$ S0263593300005332.

[560] A. Andruchow-Colombo, P. Wilf, and I. H. Escapa. "A South American fossil relative of Phyllocladus:" English. In: Australian Systematic Botany 32 (2019), pp. 290-309. DOI: 10.1071/SB18043.

[561] K. A. Andrzejewski, D. A. Winkler, and L. L. Jacobs. "A new basal ornithopod (Dinosauria: Ornithischia) from the Early Cretaceous of Texas". English. In: PLoS One 14.3 (2019), e0207935:1-44. DOI: 10.1371/journal.pone.0207935.

[562] L. Anelli, A. C. Rocha-Campos, M. G. Simoes, and R. Peck. "Pennsylvanian Heteroconchia (Mollusca, Bivalvia) from the Piau Formation, Parnaba Basin, Brazil". English. In: Revista Brasileira de Paleontologia 12.2 (2009), pp. 93-112. DOI: 10.4072/rbp.2009.2.01.

[563] L. E. Anelli, A. C. Rocha-Campos, and M. G. Simoes. "Pennsylvannian pteriomorphian bivalves from the Piau Formation, Parnaba Basin, Brazil". English. In: Journal of Paleontology 80.6 (2006), pp. 1135-1141.

[564] L. E. Anelli, A. C. Rocha-Campos, P. R. dos Santos, J. A. de J. Perinotto, and F. Quaglio. "Early Miocene bivalves from the Cape Melville Formation, King George Island, West Antarctic". English. In: Alcheringa 30.1 (2006), pp. 111-132.

[565] L. E. Anelli, M. G. Simões, and J. M. David. "A new Permian bivalve (Megadesmidae, Plesiocyprellinae) from the Serrinha Member, Rio do Rasto Formation, Paraná basin, Brazil". English. In: Revista do Instituto de Geociencias - USP 10.2 (2010), pp. 13-21.

[566] L. E. Anelli, M. G. Simões, C. R. González, and P. A. Souza. "A new Pennsylvanian Oriocrassatellinae from Brazil and the distribution of the genus Oriocrassatella in space and time". English. In: Geodiversitas 34 (2012), pp. 489-504.

[567] R. L. Anemone, M. R. Dawson, and K. C. Beard. "The early Eocene rodent Tuscahomys (Cylindrodontidae) from the Great Divide Basin, Wyoming: Phylogeny, biogeography, and paleoecology". English. In: Annals of Carnegie Museum 80.3 (2012), pp. 187-205.

[568] O. A. Anfinson, M. G. Lockley, S. H. Kim, K. S. Kim, and J. Y. Kim. "First report of the small bird track Koreanaornis from the Cretaceous of North America: implications for avian ichnotaxonomy and paleoecology". English. In: Cretaceous Research 30 (2009), pp. 885-894.

[569] P. A. Angelini, D. Azar, and A. Nel. "A new genus and species of snipe fly (Diptera: Rhagionidae) in Lebanese Cretaceous amber". English. In: Cretaceous Research 58 (2016), pp. 10-16.

[570] C. Angelone, S. ermák, B. Moncunill-Solé, J. Quintana, C. Tuveri, M. Arca, and T. Kotsakis. “Systematics and paleobiogeography of Sardolagus obscurus n. gen. n. sp. (Leporidae, Lagomorpha) from the early Pleistocene of Sardinia". English. In: Journal of Paleontology 92.3 (2018), pp. 506-522. DOI: $10.1017 /$ jpa.2017.144.

[571] K. D. Angielczyk. "New specimens of the Tanzanian dicynodont Cryptocynodon parringtoni von Huene, 1942 (Therapsida, Anomodontia), with an expanded analysis of Permian dicynodont phylogeny". English. In: Journal of Vertebrate Paleontology 27.1 (2007), pp. 116-131. DOI: 10.1671/02724634(2007)27[116:NSOTTD]2.0.CO;2.

[572] K. D. Angielczyk, J. Benoit, and B. S. Rubidge. "A new tusked cistecephalid dicynodont (Therapsida, Anomodontia) from the upper Permian upper Madumabisa Mudstone Formation, Luangwa Basin, Zambia". English. In: Papers in Palaeontology (2019). DOI: 10.1002/spp2.1285. 
[573] K. D. Angielczyk and P. D. Gingerich. “New specimen of cf. Asiatosuchus (Crocodyloidea) from the middle Eocene Drazinda formation of the Sulaiman Range, Punjab (Pakistan)". English. In: Contributions from the Museum of Paleontology, University of Michigan 30.5 (1998), pp. 163-189.

[574] K. D. Angielczyk, P. J. Hancox, and A. Nabavizadeh. "A redescription of the Triassic kannemeyeriiform dicynodont Sangusaurus (Therapsida, Anomodontia), with an analysis of its feeding system". English. In: Journal of Vertebrate Paleontology 37.sup1 (2017), pp. 189-227. DOI: 10.1080 / 02724634.2017.1395885.

[575] K. D. Angielczyk, S. Huertas, R. M. H. Smith, N. J. Tabor, C. A. Sidor, J. Steyer, L. A. Tsuji, and N. J. Gostling. "New Dicynodonts (Therapsida, Anomodontia) and Updated Tetrapod Stratigraphy of the Permian Ruhuhu Formation (Songea Group, Ruhuhu Basin) of Southern Tanzania". English. In: Journal of Vertebrate Paleontology 34.6 (2014), pp. 1408-1426. DOI: 10.1080/02724634.2014.880448.

[576] K. D. Angielczyk and C. F. Kammerer. "The cranial morphology, phylogenetic position and biogeography of the upper Permian dicynodont Compsodon helmoedi van Hoepen (Therapsida, Anomodontia)". English. In: Papers in Palaeontology 3.4 (2017), pp. 513-545.

[577] K. D. Angielczyk, B. S. Rubidge, M. O. Day, and F. Lin. “A reevaluation of Brachyprosopus broomi and Chelydontops altidentalis, dicynodonts (Therapsida, Anomodontia) from the middle Permian Tapinocephalus Assemblage Zone of the Karoo Basin, South Africa". English. In: Journal of Vertebrate Paleontology (2016), e1078342. DOI: 10.1080/02724634.2016.1078342.

[578] K. D. Angielczyk and B. S. Rubidge. "Skeletal morphology, phylogenetic relationships and stratigraphic range of Eosimops newtoni Broom, 1921, a pylaecephalid dicynodont (Therapsida, Anomodontia) from the Middle Permian of South Africa". English. In: Journal of Systematic Palaeontology 11.2 (2013), pp. 191-213.

[579] K. D. Angielczyk and B. S. Rubidge. "A new pylaecephalid dicynodont (Therapsida, Anomodontia) from the Tapinocephalus Assemblage Zone, Karoo Basin, Middle Permian of South Africa". English. In: Journal of Vertebrate Paleontology 30.5 (2010).

[580] K. D. Angielczyk, J. S. Steyer, C. A. Sidor, R. H. H. Smith, R. L. Whatley, and S. Tolan. "Permian and Triassic Dicynodont (Therapsida: Anomodontia) Faunas of the Luangwa Basin, Zambia: Taxonomic Update and Implications for Dicynodont Biogeography and Biostratigraphy". English. In: Early Evolutionary History of the Synapsida. Springer Science, 2014, pp. 93-138. DOI: 10.1007/978-94-007-6841-3_7.

[581] L. Angiolini. "Permian brachiopods from Karakorum (Pakistan). Pt. 1 (With Appendix)." In: Revista Italiana di Paleontologia e Stratigrafia 101.2 (1995), pp. 165-214.

[582] L. Angiolini. "Permian brachiopods from Karakorum (Pakistan). Pt. 2." In: Revista Italiana di Paleontologia e Stratigrafia 102.1 (1996), pp. 3-26.

[583] L. Angiolini. "Permian brachiopods from Karakorum (Pakistan), Pt 3". English. In: Rivista Italiana di Paleontologia e Stratigrafia 107.3 (2001), pp. 307-344.

[584] L. Angiolini. “New syringothyridid genus (Spiriferinida, Brachiopoda) from the Early Permian of interior Oman". English. In: Rivista Italiana di Paleontologia e Stratigrafia 107.1 (2001), pp. 125-130.

[585] L. Angiolini. "Quantitative palaeoecology in the Pachycyrtella bed, Early Permian of interior Oman". English. In: Palaeoworld 16 (2007), pp. 233-245.

[586] L. Angiolini, M. Balini, E. Garzanti, A. Nicora, and A. Tintori. “Gondwana deglaciation and opening of Neotethys: the Al Khlata and Saiwan Formations of interior Oman". English. In: Palaeogeography, Palaeoclimatology, Palaeoecology 196 (2003), pp. 99-123.

[587] L. Angiolini, M. Balini, E. Garzanti, A. Nicora, A. Tintori, S. Crasquin, and G. Muttoni. "Permian climatic and paleogeographic changes in northern Gondwana: the Khuff Formation of interior Oman". English. In: Palaeogeography, Palaeoclimatology, Palaeoecology 191 (2003), pp. 269-300.

[588] L. Angiolini, H. Brunton, and A. Zanchi. "Late Carboniferous brachiopods from Karakorum, Pakistan". In: Rivista Italiana di Paleontologia e Stratigrafia 105.1 (1999), pp. 3-22. 
[589] L. Angiolini, H. Brunton, and M. Gaetani. “Early Permian (Asselian) brachiopods from Karakorum (Pakistan) and their paleobiogeographical significance". English. In: Palaeontology 48.1 (2005), pp. 69-86.

[590] L. Angiolini and H. Bucher. "Taxonomy and quantitative biochronology of Guadalupian brachiopods from the Khuff Formation, southeastern Oman". English. In: Géobios 32.5 (1999), pp. 665699.

[591] L. Angiolini, H. Bucher, A. Pillevuit, J. -P. Platel, J. Roger, J. Broutin, A. Baud, J. Marcoux, and H. Al Hashmi. "Early Permian (Sakmarian) brachiopods from southeastern Oman". English. In: Geobios 30.3 (1997), pp. 379-405.

[592] L. Angiolini, M. Campagna, L. Borlenghi, T. Grunt, D. Vachard, G. Vezzoli, I. Vuolo, J. Worthington, A. Nicora, and A. Zanchi. "Brachiopods from the Cisuralian-Guadalupian of Darvaz, Tajikistan and implications for Permian stratigraphic correlations". English. In: Palaeoworld 25 (2016), pp. 539-568.

[593] L. Angiolini, L. Carabelli, and M. Gaetani. "Middle Permian brachiopods from Greece and their palaeobiogeographical significance: new evidence for a Gondwanan affinity of the Chios Island Upper Unit". English. In: Journal of Systematic Palaeontology 3.2 (2005), pp. 169-185.

[594] L. Angiolini, L. Carabelli, A. Nicora, S. Crasquin-Soleau, J. Marcoux, and R. Rettori. “Brachiopods and other fossils from the Permo-Triassic boundary beds of the Antalya Nappes (SW Taurus, Turkey)". English. In: Geobios 40 (2007), pp. 715-729.

[595] L. Angiolini and L. Carabelli. "Upper Permian brachiopods from the Nesen Formation, north Iran". English. In: Special Papers in Palaeontology 84 (2010), pp. 41-90.

[596] L. Angiolini and S. L. Long. "The ENS collection: a systematic study of brachiopods from the Lower Permian Vøringen Member, Kapp Starostin Formation, Spitsbergen". English. In: Proceedings of the Royal Society of Victoria 120.1 (2008), pp. 75-103.

[597] L. Angiolini, D. Vaslet, Y. -M. Le Nindre, and M. Zarbo. "New records and new taxa of Permian brachiopods from the Khuff Formation, Midhnab Member, central Saudi Arabia". English. In: GeoArabia 11.4 (2006), pp. 45-57.

[598] R. P. Angliss and R. B. Outlaw. "Alaska marine mammal stock assessments". English. In: NOAA Technical Memorandum NMFS-AFSC (2005).

[599] D. Angst, E. Buffetaut, J. Tabouelle, and H. Tong. "An ichthyosaur skull from the Late Jurassic of Svalbard". English. In: Bulletin de la Societe Geologique de France 181.5 (2010), pp. 453-458.

[600] D. Angst, E. Buffetaut, C. Lecuyer, and R. Amiot. "Terror Birds (Phorusrhacidae) from the Eocene of Europe Imply Trans-Tethys Dispersal". English. In: PLoS One 8.11 (2013), e80357.

[601] D. Angst, E. Buffetaut, J. C. Corral, and X. Pereda-Suberbiola. "First record of the Late Cretaceous giant bird Gargantuavis philoinos from the Iberian Peninsula". English. In: Annales de Paléontologie 103 (2017), pp. 135-139. DOI: 10.1016/j.annpal.2017.01.003.

[602] L. N. Anisyutkin. "New Cockroaches from the Upper Carboniferous of Siberia (Insecta: Dictyoptera, Mylacridina)". English. In: Paleontological Journal 41.5 (2007), pp. 542-548. DOI: 10.1134/ S0031030107050097.

[603] L. N. Anisyutkin and A. V. Gorochov. "A New Genus and Species of the Cockroach Family Blattulidae from Lebanese Amber (Dictyoptera, Blattina)”. English. In: Paleontological Journal 42.1 (2008), pp. 43-46.

[604] L. N. Anisyutkin and C. Gröhn. "New cockroaches (Dictyoptera: Blattina) from Baltic amber, with the description of a new genus and species: Stegoblatta irmgardgroehni". English. In: Proceedings of the Zoological Institute RAS 316 (2012), pp. 193-202.

[605] F. Ankel-Simons. "Description and evaluation of five primate sacra from the Oligocene of Egypt". English. In: Geological Survey of Egypt,1995, Special Publication; Thirty years of international cooperation on the geology of Egypt and related sciences 69 (1993), pp. 115-134. 
[606] J. M. Anketell and I. Y. Mriheel. "Depositional environment and diagenesis of the Eocene Jdeir Formation, Gabes-Tripoli Basin, western offshore Libya". English. In: Journal of Petroleum Geology 23.4 (2000), pp. 425-447.

[607] J. Anné, B. P. Hedrick, and J. P. Schein. "First diagnosis of septic arthritis in a dinosaur". English. In: Royal Society Open Science 3.8 (2016), 160222:1-7. DOI: 10.1098/rsos.160222.

[608] Anonymous. “Cliff End Iguanodon find". English. In: Wealden News 6 (2005), p. 3.

[609] Anonymous. "Candidatura delle Dolomiti per l'iscrizione nella Lista del Patrimonio Mondiale dell'UNESCO: Dolomiti Friulane - Monte Bivera [Candidacy of the Dolomites for registration in the UNESCO World Heritage List: Dolomiti Friulane - Monte Bivera]". Italian. In: Museo Friulano di Storia Naturale e Privincia di Udine, Udine (2005), pp. 1-35.

[610] Anonymous. "Hastings braincase confirmed as ankylosaur". English. In: Wealden News 7 (2007), p. 1.

[611] J. Anquetin and C. Andre. "The last surviving Thalassochelydia-A new turtle cranium from the Early Cretaceous of the Purbeck Group (Dorset, UK)". English. In: PCI Paleo PaleorXiv 7pa5c.v3 (2020).

[612] J. Anquetin, P. M. Barrett, M. E. H. Jones, S. Moore-Fay, and S. E. Evans. “A new stem turtle from the Middle Jurassic of Scotland: new insights into the evolution and palaeoecology of basal turtles". English. In: Proceedings of the Royal Society B 276 (2009), pp. 879-886. DOI: 10.1098/rspb. 2008.1429 .

[613] J. Anquetin and S. D. Chapman. "First report of Plesiochelys etalloni and Tropidemys langii from the Late Jurassic of the UK and the palaeobiogeography of plesiochelyid turtles". English. In: Royal Society Open Science 3 (2016), p. 150470. DOI: 10.1098/rsos.150470.

[614] J. Anquetin and J. Claude. "Reassessment of the oldest British turtle: Protochelys from the Middle Jurassic Stonesfield Slate of Stonesfield, Oxfordshire, UK". English. In: Geodiversitas 30.2 (2008), pp. 331-344.

[615] J. Anquetin and W. G. Joyce. "A reassessment of the Late Jurassic turtle Eurysternum wagleri (Eucryptodira, Eurysternidae)". English. In: Journal of Vertebrate Paleontology 34.6 (2014), pp. 13171328.

[616] J. Anquetin, C. Puntener, and J. -P. Billon-Bruyat. "A taxonomic review of the Late Jurassic eucryptodiran turtles from the Jura Mountains (Switzerland and France)". English. In: PeerJ 2 (2014), e369.

[617] J. Anquetin, C. Püntener, and J. -P. Billon-Bruyat. "Portlandemys gracilis n. sp., a new coastal marine turtle form the Late Jurassic of Porrentuy (Switzerland) and a reconsideration of plesiochelyid anatomy". English. In: PLoS ONE 10.6 (2015), e0129193. DOI: 10.1371/journal.pone.0129193.

[618] J. Anquetin, C. Puntener, and W. G. Joyce. "A review of the fossil record of turtles of the Clade Thalassochelydia". English. In: Bulletin of the Peabody Museum of Natural History 58.3 (2017), pp. 317369.

[619] J. Anquetin and C. Püntener. "A new species of the large-headed coastal marine turtle Solnhofia (Testudinata, Thalassochelydia) from the Late Jurassic of NW Switzerland". English. In: PeerJ 8.e9931 (2020), pp. 1-52. DOI: 10.7717 / peerj.9931.

[620] P. Ansorena, I. Daz-Martnez, and F. Pérez-Lorente. “Mina Victoria (Navajún) y Valdeperillo (Cornago). Nuevos yacimientos de icnitas de dinosaurio en El Grupo de Urbión (Cuenca de Cameros. La Rioja. España) [Mina Victoria (Navajún) and Valdeperillo (Cornago). New dinosaur footprint localities in the Urbión Group (Cameros Basin. La Rioja. Spain)]". Spanish. In: Zuba 25-26 (2008), pp. 75-96.

[621] J. Ansorge. “Eatonisca tertiaria Meunier, 1905 (Diptera, Psychodidae) aus dem Sächsischen Bernstein". German. In: Studia Dipterologica 3.2 (1996), pp. 195-199.

[622] J. Ansorge. "Locustopsis africanus n. sp. (Saltatoria, Caelifera) from the Lower Cretaceous of SW Egypt". German. In: Neues Jahrbuch für Geologie und Paläontologie, Monatshefte 1991.4 (1991), pp. 205-212. 
[623] J. Ansorge. “Rhoeniella granulata gen. et sp. nov. (Insecta: Hemiptera) aus dem Oberen Buntsandstein der Rhön (Hessen)". German. In: Senckenbergiana Lethaea 74.1/2 (1994), pp. 325-327.

[624] J. Ansorge. "Tanyderidae and Psychodidae (Insecta: Diptera) from the Lower Jurassic of northeastern Germany". English. In: Paläontologische Zeitschrift 68 (1994), pp. 199-210.

[625] J. Ansorge. "Insekten aus dem oberen Lias von Grimmen (Vorpommern, Norddeutschland)". German. In: Neue Paläontologische Abhandlungen 2 (1996), pp. 1-132.

[626] J. Ansorge. "Dobbertiniopteryx capniomimus gen. et sp. nov. - die erste Steinfliege (Insecta: Plecoptera) aus dem europäischen Jura". German. In: Paläontologische Zeitschrift 67 (1993), pp. 287292.

[627] J. Ansorge. "Heterophlebia buckmani (Brodie 1845) (Odonata: Anisozygoptera) - das erste Insekt aus dem untertoarcischen Posidonienschiefer von Holzmaden (Württemberg, SW Deutschland)". English. In: Stuttgarter Beiträge zur Naturkunde Serie B (Geologie und Paläontologie) 275 (1999), pp. 19.

[628] J. Ansorge. “Dobbertinia reticulata Handlirsch 1920 from the Lower Jurassic of Dobbertin (Mecklenburg/Germany) - the oldest representative of Sialidae (Megaloptera)". English. In: Neues Jahrbuch für Geologie und Paläontologie, Monatshefte 2001.9 (2001), pp. 553-564.

[629] J. Ansorge. "Insects from the Lower Toarcian of middle Europe and England". English. In: Acta Zoologica Cracoviensia 46.Suppl (2003), pp. 291-310.

[630] J. Ansorge. "Aenne liasina gen. et sp. n. - the most primitive non biting midge (Diptera: Chironomidae: Aenninae subfam. n.) - from the Lower Jurassic of Germany". English. In: Polskie Pismo Entomologiczne 68 (1999), pp. 431-443.

[631] J. Ansorge. "Lower Jurassic Hennigmatidae (Diptera) from Germany". English. In: Studia Dipterologica 8 (2001), pp. 97-102.

[632] J. Ansorge. "Revision of the Trichoptera described by Geinitz and Handlirsch from the Lower Toarcian of Dobbertin (Germany) based on new material". English. In: Proceedings of the 10th International Symposium on Trichoptera - Nova Supplementa Entomologica 15 (2002), pp. 55-74.

[633] J. Ansorge. “Dixa cimbrica n. sp., ein Vertreter der Dixidae (Diptera, Nematocera) aus der oberpaleozänen/untereozänen Fur-Formation (Moler) Jütlands (Dänemark)". German. In: Neues Jahrbuch für Geologie und Paläontologie, Monatshefte 1992 (1992), pp. 513-518.

[634] J. Ansorge. “Bemerkenswerte Lebensspuren und ? Cretosphex catalunicus n. sp. (Insecta; Hymenoptera) aus den unterkretazischen Plattenkalken der Sierra del Montsec (Provinz Lerida, NE-Spanien)". German. In: Neues Jahrbuch für Geologie und Paläontologie, Abhandlungen 190 (1993), pp. 19-35.

[635] J. Ansorge. "Insekten aus Liasgeoden der Ahrensburger Geschiebesippe - mit einem Ausblick auf lokale Anreicherungen von Liäsgeoden in Mecklenburg-Vorpommern". German. In: Archiv für Geschiebekunde 3 (2004), pp. 779-784.

[636] J. Ansorge. "Insekten aus einem untereozänen Zementsteingeschiebe von Lubmin (Vorpommern)". German. In: Archiv für Geschiebekunde 2 (1997), pp. 161-164.

[637] J. Ansorge. "Insekten in Geschieben - Überblick über den Kenntnisstand und Beschreibung von Neufunden". German. In: Berliner Beiträge zur Geschiebeforschung (1997), pp. 113-126.

[638] J. Ansorge and C. Brauckmann. "Chaulioditidae from Germany with a description of a new specimen from the early Middle Triassic of Gambach/Main, Bavaria (Insecta: Grylloblattida)". English. In: Entomologia Generalis 31.3 (2008), pp. 251-260.

[639] J. Ansorge and W. Krzemiski. “Oligophrynidae, a Lower Jurassic dipteran family (Diptera, Brachycera)”. English. In: Acta Zoologica Cracoviensia 37.2 (1994), pp. 115-119.

[640] J. Ansorge and W. Krzemiski. "Lower Jurassic tanyderids (Diptera: Tanyderidae) from Germany". English. In: Studia Dipterologica 9 (2002), pp. 21-29.

[641] J. Ansorge and T. Schlüter. “The earliest Chrysopid: Liassochrysa stigmatica n. g., n. sp. from the Lower Jurassic of Dobbertin, Germany". English. In: Neuroptera International 6 (1990), pp. 87-93. 
[642] J. Ansorge and F. Schröder. “Bittacomorphinae (Diptera: Ptychopteridae) aus der alttertiären FurFormation (Moler) von Dänemark". German. In: Studia Dipterologica 6 (1999), pp. 305-320.

[643] M. M. Antczak, A. T. Antczaj, and M. Lentino. "Avian remains from late pre-colonial Amerindian sites on islands of the Venezuelan Caribbean". English. In: Environmental Archaeology 24 (2019), pp. 161-181. DOI: 10.1080/14614103.2017.1402980.

[644] G. S. Antell and J. Kathirithamby. "The first twisted-wing parasitoids (Insecta: Strepsiptera) from the early Eocene Green River Formation of Colorado". English. In: Bulletin of the Peabody Museum of Natural History 57 (2016), pp. 165-174.

[645] P. Antoine, M. A. Abello, S. Adnet, A. J. A. Sierra, P. Baby, G. Billet, M. Boivin, Y. Calderón, A. Candela, J. Chabain, and F. Corfu. "A 60-million-year Cenozoic history of western Amazonian ecosystems in Contamana, eastern Peru". English. In: Gondwana Research 31 (2016), pp. 30-59. DOI: $10.1016 /$ j.gr.2015.11.001.

[646] P. O. Antoine, L. Marivaux, D. A. Croft, G. Billet, M. Ganerod, C. Jaramillo, T. Martin, M. Orliac, J. Tejada, A. J. Altamirano, F. Duranthon, G. Fanjat, S. Rousse, and R. Salas-Gismondi. "Middle Eocene rodents from Peruvian Amazonia reveal the pattern and timing of caviomorph origins and biogeography". English. In: Proceedings of The Royal Society B 279 (2011), pp. 1319-1326.

[647] P. O. Antoine, M. Roddaz, S. Brichau, J. Tejada-Lara, R. Salas-Gismondi, A. Altamirano, M. Louterbach, L. Lambs, T. Otto, and S. Brusset. "Middle Miocene vertebrates from the Amazonian Madre de Dios Subandean zone, Peru". English. In: Journal of South American Earth Sciences 42 (2013), pp. 91-102.

[648] P.-O. Antoine, G. Billet, R. Salas-Gismondi, J. T. Lara, P. Baby, S. Brusset, and N. Espurt. “A New Carodnia Simpson, 1935 (Mammalia, Xenungulata) from the Early Eocene of Northwestern Peru and a Phylogeny of Xenungulates at Species Level". English. In: Journal of Mammalian Evolution 22 (2015), pp. 129-140.

[649] P.-O. Antoine, C. Bulot, and L. Ginsburg. “Une faune rare de rhinocérotidés (Mammalia, Perissodactyla) dan le Miocéne inférieur de Pellecahus (Gers, France)". French. In: Geobios 33.2 (2000), pp. 249-255.

[650] P.-O. Antoine, S. Ducrocq, L. Marivaux, Y. Chaimanee, J. -Y. Crochet, J. -J. Jaeger, and J. -L. Welcomme. "Early rhinocerotids (Mammalia: Perissodactyla) from South Asia and a review of the Holarctic Paleogene rhinocerotid record". English. In: Canadian Journal of Earth Sciences 40 (2003), pp. 365-374.

[651] P.-O. Antoine, L. Karadenizli, and G. Saraç. “A giant rhinocerotoid (Mammalia, Perissodactyla) from the Late Oligocene of north-central Anatolia (Turkey)". English. In: Zoological Journal of the Linnean Society 152 (2008), pp. 581-592.

[652] P.-O. Antoine, G. Métais, M. J. Orliac, S. Peigné, S. Rafaß, F. Solé, and M. Vianey-Liaud. “A new late Early Oligocene vertebrate fauna from Moissac, South-West France". English. In: Comptes Rendus Palevol 10 (2011), pp. 239-250.

[653] P.-O. Antoine, R. Salas-Gismondi, P. Baby, M. Benammi, S. Brusset, D. de Franceschi, N. Espurt, C. Goillot, F. Pujos, J. Tejada, and M. Urbina. "The middle Miocene (Laventan) Fitzcarrald Fauna, Amazonian Peru". English. In: Cuadernos del Museo Geominero 8 (2007), pp. 19-24.

[654] P.-O. Antoine and G. Saraç. "Rhinocerotidae from the late Miocene of Akkasdagi, Turkey". English. In: Geodiversitas 27.4 (2005), pp. 601-632.

[655] P.-O. Antoine and J.-L. Welcomme. "A new rhinoceros from the lower Miocene of the Bugti Hills, Baluchistan, Pakistan: the earliest elasmotheriine”. English. In: Palaeontology 43.5 (2000), pp. 795816.

[656] P.-O. Antoine, J.-L. Welcomme, L. Marivaux, I. Baloch, M. Benammi, and P. Tassy. "First record of Paleogene Elephantoidea (Mammalia, Proboscidea) from the Bugti Hills of Pakistan". English. In: Journal of Vertebrate Paleontology 23.4 (2003), pp. 977-980. 
[657] M. Antón, M. J. Salesa, and G. Siliceo. "Machairodont adaptations and affinities of the Holarctic Late Miocene homotherin Machairodus (Mammalia, Carnivora, Felidae): the case of Machairodus catocopis Cope, 1887". English. In: Journal of Vertebrate Paleontology 33.5 (2013), pp. 1202-1213.

[658] L. S. Antonietto, L. E. Park Boush, R. E. Plotnick, and A. L. Stigall. "Paleoecological aspects of western United States nonmarine ostracods during the Eocene-Oligocene transition: the early Oligocene faunas of the Renova Formation, southwestern Montana". English. In: Palaios 35.3 (2020), pp. 165-174. DOI: 10.2110/palo.2019.040.

[659] A. Antoshkina and P. Königshof. "Lower Devonian reef structures in Russia: an example from the Urals". English. In: Facies 54.2 (2008), pp. 233-251. DOI: 10.1007/s10347-008-0135-7.

[660] A. I. Antoshkina. "Origin and evolution of lower Paleozoic reefs in the Pechora Urals, Russia". In: Bulletin of Canadian Petroleum Geology 47.2 (1999), pp. 85-103.

[661] A. I. Antoshkina. "Organic buildups and reefs on the Paleozoic carbonate platform margin, Pechora Urals, Russia". In: Sedimentary Geology 118 (1998), pp. 187-211.

[662] A. I. Antoshkina. "Ordovician reefs of the Ural Mountains, Russia: A review". In: Facies 35 (1996), pp. 1-8.

[663] A. I. Antoshkina. "Palaeoenvironmental implications of Palaeomicridium in Upper Devonian microbial mounds of the Chernyshev Swell, Timan-northern Ural Region". English. In: Facies 52 (2006), pp. 611-625.

[664] A. I. Antoshkina. "Ecology of Early Devonian reefs in the Western Urals, Russia". English. In: Courier Forschungsinstitut Senckenberg 242 (2003), pp. 111-123.

[665] A. I. Antoshkina and E. S. Ponomarenko. "Bioinduced Crustification as a Reaction of Late CarboniferousEarly Permian Reef Ecosystems to Biosphere Changes". English. In: (2013). DOI: 10.1134/S0031030114140044.

[666] A. V. Antropov. "A new species of the genus Trypoxylon Latreille (Hymenoptera; Sphecidae) from Dominican amber". English. In: Paleontological Journal 29.1 (1995), pp. 172-177.

[667] A. V. Antropov. "A new tribe of fossil digger wasps (Insecta: Hymenoptera, Crabronidae) from the Rovno amber, Eocene of Ukraine". English. In: Paleontological Journal 44.3 (2010), pp. 312-321.

[668] A. V. Antropov. A new digger wasp (Hymenoptera, Sphecidae, Pemphredoninae) from New Jersey amber. English. Studies on Fossils in Amber, with Particular Reference to the Cretaceous of New Jersey. Leiden: Backhuys Publishers, 2000, pp. 339-343.

[669] A. V. Antropov. "Digger wasps (Hymenoptera, Sphecidae) in Burmese amber". English. In: Bulletin of the Natural History Museum, Geology Series 56 (2000), pp. 59-77.

[670] A. V. Antropov. "A new tribe of fossil digger wasps (Hymenoptera: Crabronidae) from the Upper Cretaceous New Jersey amber and its place in the subfamily Pemphredoninae". English. In: Russian Entomological Journal 20 (2011), pp. 229-240.

[671] A. V. Antropov. "A new genus of fossil digger wasps (Insecta: Hymenoptera, Crabronidae) from the upper Eocene of Florissant, USA". English. In: Paleontological Journal 51 (2017), pp. 186-190.

[672] A. V. Antropov, S. A. Belokobylskij, S. G. Compton, G. M. Dlussky, A. I. Khalaim, V. A. Kolyada, M. A. Kozlov, K. S. Perfilieva, and A. P. Rasnitsyn. "The wasps, bees and ants (Insecta: Vespida=Hymenoptera) from the Insect Limestone (Late Eocene) of the Isle of Wight, UK". English. In: Earth and Environmental Science Transactions of the Royal Society of Edinburgh 104 (2014), pp. 335-446.

[673] A. V. Antropov and E. E. Perkovsky. "Rovnoecus, a new genus of digger wasps (Hymenoptera, Crabronidae, Pemphredoninae) from the Rovno Amber". English. In: Paleontological Journal 43.9 (2009), pp. 1019-1023.

[674] A. V. Antropov and W. J. Pulawski. "Pison antiquum, a new species from Dominican amber (Hymenoptera: Sphecidae)". English. In: Journal of Hymenoptera Research 5 (1996), pp. 16-21.

[675] E. V. Antropova. "New species of Stromatoporoidea from the Upper Ordovician and Silurian of the Subpolar Urals". English. In: Paleontological Journal 41.6 (2007), pp. 596-599. 
[676] M. T. Antunes. “Lower Paleogene crocodilians from Silveirinha, Portugal”. English. In: Palaeovertebrata 32.1 (2003), pp. 1-26.

[677] M. T. Antunes. "New Late Eocene mammalian remnants from Coja (Portugal) and the presence of Palaeotherium magnum Cuvier". English. In: Ciancias da Terra 11 (1992), pp. 83-89.

[678] M. T. Antunes and A. C. Balbino. "Uppermost Miocene Lamniform Selachians (Pisces) from the Alvalade basin (Portugal)". English. In: Ciencias da Terra 15 (2003), pp. 141-154.

[679] M. T. Antunes, A. C. Balbino, and H. Cappetta. “Sélaciens du Miocéne terminal du bassin d'Alvalade (Portugal) Essai de synthése". French. In: Ciencias da Terra (UNL) 13 (1999), pp. 115-129.

[680] M. T. Antunes and B. Cahuzac. "Crocodilian faunal renewal in the Upper Oligocene of Western Europe". English. In: Comptes Rendus de l'Académie des Sciences - Series IIA - Earth and Planetary Science 328 (1999), pp. 67-73.

[681] M. T. Antunes and J. L. Cardoso. "Quaternary elephants in Portugal: new data". English. In: Ciencias de Terra 11 (1992), pp. 17-37.

[682] M. T. Antunes, M. L. Casanovas, M. A. Cuesta, L. Checa, J. V. Santaf, and J. Agusti. “Eocene mammals from Iberian Peninsula". English. In: Actes du Congres BiochroM'97 - Memoires et Travaux E.P.H.E 21. Montpellier, 1997, pp. 337-352.

[683] M. T. Antunes, P. Legoinha, and A. Balbino. “Megalodon, mako shark and planktonic foraminifera from the continental shelf off Portugal and their age". English. In: Geologica Acta 13.3 (2015), pp. 181-180. DOI: 10.1344/GeologicaActa2015.13.3.1.

[684] M. T. Antunes and O. Mateus. "Dinosaurs of Portugal". English. In: Comptes Rendus Palevol 2 (2003), pp. 77-95.

[685] M. T. Antunes and D. Sigogneau-Russell. "Nouvelles données sur les dinosaures du Crétacé supérieur du Portugal [New data on the dinosaurs from the Upper Cretaceous of Portugal]". French. In: Comptes Rendus de l'Académie des Sciences á Paris, Série II 313 (1991), pp. 113-119.

[686] W. Anyonge. "Fauna from a new Lower Miocene locality west of Lake Turkana, Kenya". English. In: Journal of Vertebrate Paleontology 11.3 (1991), pp. 378-390.

[687] L. M. Anzótegui. “Hojas de Myrtaceae de la Formación San José (Mioceno Medio), provincia de Tucumán, Argentina". Spanish. In: Ameghiniana 39.3 (2002), pp. 321-330.

[688] L. M. Anzótegui. "Megaflora de la Formación Chiquimil, (Mioceno Superior), en los valles de Santa Mara y Villavil, provincias de Catamarca y Tocumán, Argentina". Spanish. In: Ameghiniana 41.3 (2004), pp. 303-314.

[689] L. M. Anzótegui. “Hojas de Angiospermas de la Formación Palo Pintado, Mioceno Superior, Salta, Argentina, Parte I: Anacardiaceae, Lauraceae y Moraceae". Spanish. In: Ameghiniana 35.1 (1998), pp. 25-32.

[690] L. M. Anzótegui and R. Herbst. "Megaflora (hojas y frutos) de la Formación San José (Mioceno Medio) en ro Seco, departamento Santa Mara, provincia de Catamarca, Argentina". Spanish. In: Ameghiniana 41.3 (2004), pp. 423-436.

[691] L. M. Anzótegui, Y. Horn, and R. Herbst. "Paleoflora (Fabaceae y Anacardiaceae) de la Formación Andalhuala (Plioceno Inferior), provincia de Catamarca, Argentina". Spanish. In: Ameghiniana 44.3 (2007), pp. 525-535.

[692] R. Aoki. "Fossil crocodilians from the late Tertiary strata in the Sinda Basin, eastern Zaire". English. In: African Study Monographs 17 (1992), pp. 67-85.

[693] K. Aotsuka and T. Sato. "Hesperornithiformes (Aves: Ornithurae) from the Upper Cretaceous Pierre Shale, Southern Manitoba, Canada". English. In: Cretaceous Research 63 (2016), pp. 154-169.

[694] C. Apaldetti, R. N. Martinez, O. A. Alcober, and D. Pol. "A new basal sauropodomorph (Dinosauria: Saurischia) from Quebrada del Barro Formation (Marayes-El Carrizal Basin), Northwestern Argentina". English. In: PLoS ONE 6.11 (2011), e26964:1-19. DOI: 10.1371/journal.pone. 0026964. 
[695] C. Apaldetti, R. N. Martnez, I. A. Cerda, D. Pol, and O. Alcober. “An early trend towards gigantism in Triassic sauropodomorph dinosaurs". English. In: Nature Ecology E Evolution 2 (2018), pp. 1227-1232.

[696] C. Apaldetti, D. Pol, and A. M. Yates. "The postcranial anatomy of Coloradisaurus brevis (Dinosauria: Sauropodomorpha) from the Late Triassic and its phylogenetic implications". English. In: Palaeontology 56.2 (2013), pp. 277-301.

[697] S. Apestegua. "Bonitasaura salgadoi gen. et sp. nov.: a beaked sauropod from the Late Cretaceous of Patagonia". In: Naturwissenschaften 91.10 (2004), pp. 493-497.

[698] S. Apestegua. "The sauropod diversity of the La Amarga Formation (Barremian), Neuquén (Argentina)". English. In: Gondwana Research 12 (2007), pp. 533-546. DOI: 10.1016/j.gr.2007.04.007.

[699] S. Apestegua. "A Late Campanian sphenodontid (Reptilia, Diapsida) from northern Patagonia". English. In: Comptes Rendus Palevol 4 (2005), pp. 663-669. DOI: 10.1016/j.crpv.2005.06.003.

[700] S. Apestegua, F. L. Agnolin, and G. L. Lio. "An early Late Cretaceous lizard from Patagonia, Argentina". English. In: Comptes Rendus Palevol 4 (2005), pp. 311-315. DOI: 10.1016/j.crpv.2005.03.003.

[701] S. Apestegua, A. Cambiaso, and F. Agnolin. "Vertebrados de la Formacion Paso del Sapo (Campaniano/Maastrichtiano), Provincia de Chubut, Argentina [Vertebrates from the Paso del Sapo Formation (Campanian/Maastrichtian), Chubut province, Argentina]". Spanish. In: Ameghiniana 49.3 (2012), pp. 395-400. DOI: 10.5710/AMGH.v49i3(358).

[702] S. Apesteguia and J. L. Carballido. "A new eilenodontine (Lepidosauria, Sphenodontidae) from the Lower Cretaceous of central Patagonia". English. In: Journal of Vertebrate Paleontology 34.2 (2014), pp. 303-317.

[703] S. Apestegua, Y. Ceballos Izquierdo, and M. Iturralde-Vinent. "New taxonomic assignment for a dinosaur sauropod bone from Cuba". English. In: Historical Biology (2019). DOI: 10.1080/08912963. 2019.1661406.

[704] S. Apestegua, J. D. Daza, T. R. Simões, and J. C. Rage. “The first iguanian lizard from the Mesozoic of Africa". English. In: Royal Society Open Science 3 (2016), 160462:1-13. DOI: 10.1098/rsos.160462.

[705] S. Apestegua, S. de Valais, G. R. Cordero, and O. M. Ramrez. "New ichnological record from the late Campanian Toro Toro Formation at Toro Toro, Potos (Bolivia): first probably dromaeosaurid tracks from South America". English. In: Ameghiniana 48.4 (2011), pp. 662-667.

[706] S. Apestegua and P. A. Gallina. "Tunasniyoj, a dinosaur tracksite from the Jurassic-Cretaceous boundary of Bolivia". English. In: Anais da Academia Brasileira de Ciencias 83.1 (2011), pp. 267-277.

[707] S. Apesteguia, R. O. Gomez, and G. W. Rougier. "A basal sphenodontian (Lepidosauria) from the Jurassic of Patagonia: new insights on the phylogeny and biogeography of Gondwanan rhynchocephalians". English. In: Zoological Journal of the Linnean Society 166 (2012), pp. 342-360. DOI: 10.1111/j.1096-3642.2012.00837.x.

[708] S. Apestegua, R. O. Gómez, and G. W. Rougier. "The youngest South American rhynchocephalian, a survivor of the K/Pg extinction". English. In: Proceedings of the Royal Society B 281 (2014), p. 20140811. DOI: $10.1098 / \mathrm{rspb} .2014 .0811$.

[709] S. Apesteguia and M. E. H. Jones. "A Late Cretaceous tuatara (Lepidosauria; Sphenodontinae) from South America". English. In: Cretaceous Research 34 (2012), pp. 154-160. DOI: 10.1016 / j. cretres.2011.10.014.

[710] S. Apestegua and F. E. Novas. "Large Cretaceous sphenodontian from Patagonia provides insight into lepidosaur evolution in Gondwana". English. In: Nature 425 (2003), pp. 609-612.

[711] S. Apesteguia and G. W. Rougier. "A Late Campanian sphenodontid maxilla from northern Patagonia". English. In: American Museum Novitates 3581 (2007), pp. 1-11.

[712] S. Apesteguia, N. D. Smith, R. J. Valieri, and P. J. Makovicky. "An unusual new theropod with a didactyl manus from the Upper Cretaceous of Patagonia, Argentina". English. In: PLoS One 11.7 (2016), e0157793. DOI: 10.1371/journal.pone.0157793. 
[713] S. Apestegua, J. E. Soto Luzuriaga, P. A. Gallina, J. Tamay Granda, and G. A. Guamán Jaramillo. "The first dinosaur remains from the Cretaceous of Ecuador". English. In: Cretaceous Research 108 (2020), p. 104345. DOI: 10.1016/j.cretres.2019.104345.

[714] S. Apestigua and H. Zaher. "A Cretaceous terrestrial snake with robust hindlimbs and a sacrum." English. In: Nature 440 (2006), pp. 1037-1040.

[715] K. P. Aplin, J. M. Pasveer, and W. E. Boles. “Quaternary vertebrates from the Bird's Head Peninsual, Irian Jaya, Indonesia, including descriptions of two previously unknown marsupial species". English. In: Papers in Vertebrate Paleontology, Records of the Western Australian Museum 57 (1999), pp. 351-387.

[716] J. Apoln, G. González-Barba, and J. N. Martnez. Seláceos del Mioceno superior de Quebrada Pajaritos (Piura, Perú). Spanish. 2007.

[717] S. P. Applegate, B. E. Buitrón-Sánchez, F. A. Sols-Marn, and A. Laguarda-Figueras. "Two Lower Cretaceous (Albian) Fossil Holothurians(Echinodermata) from Tepexi De Rodriguez, Puebla, Mexico". English. In: Proceedings of the Biological Society of Washington 122.1 (2009), pp. 91-102.

[718] S. P. Applegate, L. Espinosa-Arrubarrena, J. Alvarado-Ortega, and M. Benammi. "Revision of recent investigations in the Tlayua Quarry". English. In: vol. 24. Studies on Mexican Paleontology. 2006, pp. 275-304.

[719] A. M. Aranciaga Rolando, F. L. Agnolin, and J. Corsolini. “A new pipoid frog (Anura, Pipimorpha) from the Paleogene of Patagonia. Paleobiogeographical implications". English. In: Comptes Rendus Palevol (2019). DOI: 10.1016/j.crpv.2019.04.003.

[720] M. Aranciaga Rolando, M. A. Cerroni, J. A. Garcia Marsá, F. I. Agnoln, M. J. Motta, S. Rozadilla, F. Brisson Egl, and F. E. Novas. "A new medium-sized abelisaurid (Theropoda, Dinosauria) from the Late Cretaceous (Maastrichtian) Allen Formation of Northern Patagonia, Argentina". English. In: Journal of South American Earth Sciences (2020). DOI: 10.1016/j.jsames.2020.102915.

[721] F. J. Aranda-Manteca, D. P. Domning, and L. G. Barnes. "A new middle Miocene sirenian of the genus Metaxytherium from Baja California and California: Relationships and paleobiogeographic implications". English. In: Proceedings of the San Diego Society of Natural History 29 (1994), pp. 191204.

[722] A. A. Arata. "A Tertiary Proboscidian from Louisiana". English. In: Journal of Vertebrate Paleontology 4.2 (1996), pp. 73-74.

[723] R. Araújo, R. Castanhinha, R. M. S. Martins, O. Mateus, C. Hendrickx, F. Beckmann, N. Schell, and L. C. Alves. "Filling the gaps of dinosaur eggshell phylogeny: Late Jurassic theropod clutch with embryos from Portugal". English. In: Scientific Reports 3 (2013), 1924:1-8. DOI: 10.1038/srep01924.

[724] R. Araújo, M. J. Polcyn, A. S. Schulp, O. Mateus, L. L. Jacobs, A. O. Olmpio Gonçalves, and M. -L. Morais. "A new elasmosaurid from the early Maastrichtian of Angola and the implications of girdle morphology on swimming style in plesiosaurs". English. In: Netherlands Journal of Geosciences — Geologie en Mijnbouw 94.1 (2015), pp. 109-120.

[725] R. Araujo, A. S. Smith, and J. Liston. "Alfred Leeds fossil vertebrate collection of the National Museum of Ireland - Natural History". English. In: Irish Journal of Earth Sciences 26 (2008), pp. 1732.

[726] M. Araujo Carvalho. "Paleoenvironmental reconstruction based on palynological and palynofacies analyses of the Aptian-Albian succession in the Sergipe Basin, northeastern Brazil". English. PhD thesis. 2001.

[727] V. Araujo Tavora, A. A. R. dos Santos, and R. N. Araujo. "Localidades fossiliferas da Formacao Pirabas (Mioceno Inferior)". English. In: Boletim do Museu Paraense Emlio Goeldi Ciencias Naturais, Belém 5.2 (2010), pp. 207-224.

[728] T. Arbez, C. A. Sidor, and J. -S. Steyer. "Laosuchus naga gen. et sp. nov., a new chroniosuchian from South-East Asia (Laos) with internal structures revealed by micro-CT scan and discussion of its palaeobiology". English. In: Journal of Systematic Palaeontology (2019). DOI: 10.1080 /14772019. 2018.1504827. 
[729] B. S. Arbogast. "Mitochondrial DNA Phylogeography of the New World Flying Squirrels (Glaucomys): Implications for Pleistocene Biogeography". English. In: Journal of Mammalogy 80.1 (1999), pp. 142-155.

[730] V. M. Arbour, M. E. Burns, R. M. Sullivan, S. G. Lucas, A. K. Cantrell, J. Fry, and T. L. Suazo. “A new ankylosaurid dinosaur from the Upper Cretaceous (Kirtlandian) of New Mexico with implications for ankylosaurid diversity in the Upper Cretaceous of western North America". English. In: PLoS ONE 9.9 (2014), e108804:1-14. DOI: 10.1371/journal.pone.0108804.

[731] V. M. Arbour and P. J. Currie. "An istiodactylid pterosaur from the Upper Cretaceous Nanaimo Group, Hornby Island, British Columbia, Canada". English. In: Canadian Journal of Earth Sciences 48 (2011), pp. 63-69. DOI: 10.1139/E10-083.

[732] V. M. Arbour and P. J. Currie. "Euoplocephalus tutus and the diversity of ankylosaurid dinosaurs in the Late Cretaceous of Alberta, Canada, and Montana, USA". English. In: PLoS ONE 8.5 (2013), e62421:1.-39. DOI: 10.1371/journal.pone.0062421.

[733] V. M. Arbour and P. J. Currie. "The taxonomic identity of a nearly complete ankylosaurid skeleton from the Gobi Desert of Mongolia". English. In: Cretaceous Research 46 (2013), pp. 24-30.

[734] V. M. Arbour, P. J. Currie, and D. Badamgarav. "The ankylosaurid dinosaurs of the Upper Cretaceous Baruungoyot and Nemegt formations of Mongolia". English. In: Zoological Journal of the Linnean Society 172.3 (2014), pp. 631-652. DOI: 10.1111/zoj.12185.

[735] V. M. Arbour and D. C. Evans. "A new ankylosaurine dinosaur from the Judith River Formation of Montana, USA, based on an exceptional skeleton with soft tissue preservation". English. In: Royal Society Open Science 4.161086 (2017). DOI: 10.1098/rsos.161086.

[736] V. M. Arbour and D. C. Evans. "A new leptoceratopsid dinosaur from Maastrichtian-aged deposits of the Sustut Basin, northern British Columbia, Canada". English. In: PeerJ 7 (2019), e7926. DOI: 10.7717 / peerj.7926.

[737] V. M. Arbour, D. Larson, M. J. Vavrek, L. Buckley, and D. Evans. "An ankylosaurian dinosaur from the Cenomanian DunveganFormation of northeastern British Columbia, Canada". English. In: Fossil Record 23 (2020), pp. 179-189. DOI: 10.5194/fr-23-179-2020.

[738] V. M. Arbour and J. C. Mallon. "Unusual cranial and postcranial anatomy in the archetypal ankylosaur Ankylosaurus magniventris". English. In: Facets 2.2 (2017), pp. 764-794. DOI: 10.1139 / facets-2017-0063.

[739] V. M. Arbour, L. E. Zanno, D. W. Larson, D. C. Evans, and H. -D. Sues. "The furculae of the dromaeosaurid dinosaur Dakotaraptor steini are trionychid turtle entoplastra". English. In: PeerJ 4:e1691 (2016), pp. 1-6. DOI: 10.7717/peerj.1691.

[740] A. Archangelsky, S. Archangelsky, D. G. Poire, and N. D. Canessa. "Aptian Angiosperm Pollen from the Ticó Flora Patagonia, Argentina". English. In: Revista del Museo Argentino de Ciencias Naturales 10.2 (2008), pp. 185-198.

[741] A. Archangelsky and M. Llorens. "Palinologa de la Formación kachaike, Cretácico Inferior de la Cuenca Austral, provincia de Santa Cruz. I-Esporas lisas y cinguladas". Spanish. In: Ameghiniana 40.1 (2003), pp. 71-80.

[742] A. Archangelsky and M. Llorens. "Palinologa de la Formación Kachaike, Cretácico Inferior de la Cuenca Austral, provincia de Santa Cruz. II. Esporas". Spanish. In: Ameghiniana 42.2 (2005), pp. 311-328.

[743] A. Archangelsky and M. Llorens. "Palinologa de la Formación Kachaike, Cretácico Inferior de la Cuenca Austral, provincia de Santa Cruz: Granos de polen de Gimnospermas." Spanish. In: Ameghiniana 46.2 (2009), pp. 225-234.

[744] A. Archangelsky, C. J. Phipps, T. N. Taylor, and E. L. Taylor. "Paleoazolla, a new heterosporous fern from the Upper Cretaceous of Argentina". English. In: American Journal of Botany 86.8 (1999), pp. 1200-1206. 
[745] S. Archangelsky. "Biogeographic implications of Albian Mohria-like spores (Family Anemiaceae) in SW Gondwana (Patagonia)". English. In: Review of Palaeobotany and Palynology 157 (2009), pp. 301308. DOI: 10.1016/j.revpalbo.2009.06.002.

[746] S. Archangelsky and A. Archangelsky. "Aptian angiosperm pollen from the Ticó Flora Patagonia, Argentina". English. In: 174.3 (2013), pp. 559-571. DOI: 10.1086/668693.

[747] S. Archangelsky, A. Archangelsky, and G. Cladera. "Palinologa y paleoambientes en el perfil de Bajo Comisión (Cretácico), provincia de Santa Cruz, Argentina". English. In: Revista del Museo Argentino de Ciencias Naturales 14.1 (2012), pp. 23-39.

[748] S. Archangelsky and L. Villar de Seoane. "Morfologia y estructura de megasporas Cretacicas de Patagonia, Republica Argentina". Spanish. In: Revista Espanola de Micropaleontologia 22.3 (1990), pp. 419-450.

[749] S. Archangelsky and L. Villar de Seoane. "Notas sobre la flora fosil de la zona de Tico, Provincia de Santa Cruz. XI. Morfologia y estructura de tres megasporas". Spanish. In: Ameghiniana 28.3-4 (1991), pp. 353-364.

[750] S. Archangelsky and L. Villar de Seoane. "Estudios palinológicos del Grupo Baqueró (Cretácico inferior), provincia de Santa Cruz, Argentina. IX polen bisacado de Podocarpaceae". Spanish. In: Revista Española de Paleontologa 20.1 (2005), pp. 37-56.

[751] S. Archangelsky and L. Villar de Seoane. “Estudios palinológicos de la Formación Baqueró (Cretácico), Provincia de Santa Cruz, Argentina. VIII". Spanish. In: Ameghiniana 35.1 (1998), pp. 7-19.

[752] S. Archangelsky and L. Villar de Seoane. "Cycadean diversity in the Cretaceous of Patagonia, Argentina. Three new Androstrobus species from the Baqueró Group". English. In: Review of Palaeobotany and Palynology 131 (2004), pp. 1-28. DOI: 10.1016/j.revpalbo.2004.01.008.

[753] N. W. Archbold. "Early Permian Brachiopoda from Irian Jaya". In: BMR Journal of Australian Geology E Geophysics 12 (1991), pp. 287-296.

[754] N. W. Archbold. "Studies on Western Australian Permian brachiopods 14. The fauna of the Artinskian High Cliff Sandstone, Perth Basin". English. In: Proceedings of the Royal Society of Victoria 109.2 (1997), pp. 199-231.

[755] N. W. Archbold. "Studies on Western Australian Permian brachiopods 13. The fauna of the Artinskian Mingenew Formation, Perth Basin". English. In: Proceedings of the Royal Society of Victoria 108.1 (1996), pp. 17-42.

[756] N. W. Archbold. "Studies on Western Australian Permian brachiopods 10. Faunas from the Wooramel Group, Carnarvon Basin”. English. In: Proceedings of the Royal Society of Victoria 103.2 (1991), pp. 5566.

[757] N. W. Archbold. "Additional records of Permian brachiopods from near Rat Buri, Thailand". English. In: Proceedings of the Royal Society of Victoria 111.1 (1999), pp. 71-86.

[758] N. W. Archbold. "Late Paleozoic brachiopod faunas from Irian Jaya, Indonesia". English. In: Brachiopods Through Time: Proceedings of the 2nd International Brachiopod Congress. Rotterdam: A. A. Balkema, 1991, pp. 347-353.

[759] N. W. Archbold. "Ufimian (early Late Permian) brachiopods from the Perth Basin, Western Australia". English. In: Memoirs of the Association of Australasian Palaeontologists 18 (1995), pp. 153-163.

[760] N. W. Archbold. "Studies on Western Australia Permian brachiopods 11. New genera, species and records". English. In: Proceedings of the Royal Society of Victoria 105.1 (1993), pp. 1-29.

[761] N. W. Archbold. "Studies on Western Australian Permian brachiopods 12. Additions to the late Asselian-Tastubian faunas". English. In: Proceedings of the Royal Society of Victoria 107.2 (1995), pp. 95-112.

[762] N. W. Archbold. "Trigonotreta (Spiriferida, Brachiopoda) from the Early Permian of Victoria". English. In: Alcheringa 15 (1991), pp. 321-326.

[763] N. W. Archbold and M. Gaetani. "Early Permian Brachiopoda and Mollusca from the northwest Himalaya, India". English. In: Rivista Italiana di Paleontologia e Stratigrafia 99.1 (1993), pp. 27-56. 
[764] N. W. Archbold and T. Hogeboom. "Subsurface Brachiopoda from borehole cores through the Early Permian sequence of the Carnarvon Basin, Western Australia: correlations with palynological biostratigraphy". English. In: Proceedings of the Royal Society of Victoria 112.1 (2000), pp. 93109.

[765] N. W. Archbold, S. C. Shah, and J. M. Dickins. "Early Permian brachiopod faunas from peninsular India: their Gondwanan relationships". English. In: Historical Biology 11 (1996), pp. 125-135.

[766] N. W. Archbold and G. R. Shi. "Aktastinian (Early Artinskian, Early Permian) brachiopods from the Jimba Jimba Calcarenite, Wooramel Group, Carnarvon Basin, Western Australia". English. In: Proceedings of the Royal Society of Victoria 105.2 (1993), pp. 187-202.

[767] N. W. Archbold and T. Simanauskas. "New Strophalosiidae (Brachiopoda) from the Permian of Argentina". English. In: Proceedings of the Royal Society of Victoria 113.2 (2001), pp. 217-227.

[768] N. W. Archbold and G. A. Thomas. "Imperiospira, a new Western Australian Permian Spiriferidae (Brachiopoda)". English. In: Memoirs of the Association of Australasian Palaeontologists 15 (1993), pp. 313-328.

[769] M. Archer, R. Beck, M. Gott, S. Hand, H. Godthelp, and K. Black. "Australia's first fossil marsupial mole(Notoryctemorphia) resolves controversies about their evolution and palaeoenvironmental origins". English. In: Proceeding of Royal Sosiety. Serie B 3 (2010). DOI: 10.1098/rspb.2010.1943.

[770] M. Archer, K. Black, and K. Nettle. "Giant ringtail possums (Marsupialia, Pseudocheiridae) and gained koalas (Phascolarctidae) from the late Cenozoic of Australia". English. In: Proceedings of the Linnean Society of New South Wales 117 (1997), pp. 3-15.

[771] J. D. Archibald and A. O. Averianov. “The Late Cretaceous placental mammal Kulbeckia”. English. In: Journal of Vertebrate Paleontology 23.2 (2003), pp. 404-419.

[772] J. D. Archibald and A. O. Averianov. "Mammalian faunal succession in the Cretaceous of the Kyzylkum Desert". English. In: Journal of Mammalian Evolution 12.1-2 (2005), pp. 9-22. DOI: 10. 1007/s10914-005-4867-3.

[773] J. D. Archibald, Y. Zhang, T. Harper, and R. L. Cifelli. "Protungulatum, confirmed Cretaceous occurrence of an otherwise Paleocene eutherian (placental?) mammal". English. In: Journal of Mammalian Evolution 18 (2011), pp. 153-161. DOI: 10.1007/s10914-011-9162-1.

[774] S. B. Archibald. "Revision of the scorpionfly family Holcorpidae (Mecoptera), with description of a new species from Early Eocene McAbee, British Columbia, Canada". English. In: Annales de la Société Entomologique de France 46 (2010), pp. 173-182.

[775] S. B. Archibald. "New Cimbrophlebiidae (Insecta: Mecoptera) from the Early Eocene at McAbee, British Columbia, Canada and Republic, Washington, USA". English. In: Zootaxa 2249 (2009), pp. 51-62.

[776] S. B. Archibald. "New Dinopanorpidae (Insecta: Mecoptera) from the Eocene Okanagan Highlands (British Columbia, Canada and Washington State, USA)". English. In: Canadian Journal of Earth Sciences 42 (2005), pp. 119-136.

[777] S. B. Archibald and S. Bradler. "Stem-group stick insects (Phasmatodea) in the early Eocene at McAbee, British Columbia, Canada, and Republic, Washington, United States of America". English. In: The Canadian Entomologist 147 (2015), pp. 744-753.

[778] S. B. Archibald and R. A. Cannings. "Fossil dragonflies (Odonata: Anisoptera)from the early Eocene Okanagan Highlands, western North America". English. In: The Canadian Entomologist 151 (2019), pp. 783-816.

[779] S. B. Archibald, S. P. Cover, and C. S. Moreau. "Bulldog Ants of the Eocene Okanagan Highlands and History of the Subfamily (Hymenoptera: Formicidae: Myrmeciinae)". English. In: Annals of the Entomological Society of America 99.3 (2006), pp. 487-523.

[780] S. B. Archibald, K. R. Johnson, R. W. Mathewes, and D. R. Greenwood. "Intercontinental dispersal of giant thermophilic ants across the Arctic during early Eocene hyperthermals". English. In: Proceedings of the Royal Society B 278 (2011), pp. 3679-3686. DOI: 10.1098/rspb.2011.0729. 
[781] S. B. Archibald, C. Kehlmaier, and R. W. Mathewes. "Early Eocene big headed flies (Diptera: Pipunculidae) from the Okanagan Highlands, western North America". English. In: The Canadian Entomologist 146 (2014), pp. 429-443.

[782] S. B. Archibald and V. N. Makarkin. "Tertiary Giant Lacewings (Neuroptera: Polystoechotidae): revision and description of new taxa from Western North America and Denmark". English. In: Journal of Systematic Palaeontology 4.2 (2006), pp. 119-155.

[783] S. B. Archibald, V. N. Makarkin, and J. Ansorge. “New fossil species of Nymphidae (Neuroptera) from the Eocene of North America and Europe". English. In: Zootaxa 2157 (2009), pp. 59-68.

[784] S. B. Archibald and V. N. Makarkin. "New genus of minute Berothidae (Neuroptera) from Early Eocene amber of British Columbia". English. In: The Canadian Entomologist 136 (2004), pp. 61-76.

[785] S. B. Archibald and V. N. Makarkin. "A new species of Archaeochrysa Adams (Neuroptera: Chrysopidae) from the early Eocene of Driftwood Canyon, British Columbia, Canada". English. In: The Canadian Entomologist 147 (2015), pp. 359-369.

[786] S. B. Archibald and V. N. Makarkin. "The second genus and species of the extinct neuropteroid family Corydasialidae, from early Eocene McAbee, British Columbia, Canada: do they belong to Megaloptera?" English. In: Zootaxa 4040 (2015), pp. 569-575.

[787] S. B. Archibald and V. N. Makarkin. "A new fossil green lacewing (Neuroptera: Chrysopidae) from the early Eocene Driftwood Canyon, Canada". English. In: Zootaxa 4324 (2017), pp. 397-400.

[788] S. B. Archibald and V. N. Makarkin. "A new genus and species of split-footed lacewings (Neuroptera) from the early Eocene of western Canada and revision of the subfamily affinities of Mesozoic Nymphidae". English. In: The Canadian Entomologist 152 (2020), pp. 269-287. DOI: 10.4039/ tce.2020.10.

[789] S. B. Archibald and R. W. Mathewes. "Early Eocene insects from Quilchena, British Columbia, and their paleoclimatic implications". English. In: Canadian Journal of Zoology 78 (2000), pp. 1441-1462.

[790] S. B. Archibald, R. W. Mathewes, and D. R. Greenwood. "The Eocene apex of panorpoid scorpionfly family diversity". English. In: Journal of Paleontology 87 (2013), pp. 677-695.

[791] S. B. Archibald, G. E. Morse, D. R. Greenwood, and R. W. Mathewes. "Fossil palm beetles refine upland winter temperatures in the Early Eocene Climatic Optimum". English. In: Proceedings of the National Academy of Sciences 111 (2014), pp. 8095-8100.

[792] S. B. Archibald, A. P. Rasnitsyn, and M. A. Akhmetiev. "Ecology and distribution of Cenozoic Eomeropidae (Mecoptera), and a new species of Eomerope Cockerell from the Early Eocene McAbee locality, British Columbia, Canada". English. In: Annals of the Entomological Society of America 98.4 (2005), pp. 503-514.

[793] S. B. Archibald and A. P. Rasnitsyn. "New early Eocene Siricomorpha (Hymenoptera: Symphyta: Pamphiliidae, Siricidae, Cephidae) from the Okanagan Highlands, western North America". English. In: The Canadian Entomologist 148 (2016), pp. 209-228.

[794] S. B. Archibald, A. P. Rasnitsyn, D. J. Brothers, and R. W. Mathewes. "Modernisation of the Hymenoptera: ants, bees, wasps, and sawflies of the early Eocene Okanagan Highlands of western North America". English. In: The Canadian Entomologist 150 (2018), pp. 250-257.

[795] S. B. Archibald and A. P. Rasnitsyn. "Two new species of fossil Eomerope (Mecoptera: Eomeropidae) from the Ypresian Okanagan Highlands, far-western North America, and Eocene Holarctic dispersal of the genus". English. In: The Canadian Entomologist 150 (2018), pp. 393-403.

[796] A. Arcucci and C. A. Marsicano. "A distinctive new archosaur from the Middle Triassic (Los Chanares Formation) of Argentina". English. In: Journal of Vertebrate Paleontology 19 (1999), pp. 228232.

[797] A. B. Arcucci and R. A. Coria. "A new Triassic carnivorous dinosaur from Argentina". English. In: Ameghiniana 40.2 (2003), pp. 217-228. 
[798] A. B. Arcucci, L. S. Filippi, and J. O. Calvo. “Un nuevo Mesoeucrocodylia Cretácio del norte de la Cuenca Neuquina, Argentina [A new Cretaceous Mesoeucrocodylia from the north of the Neuquen Basin, Argentina]". Spanish. In: Revista Brasileira de Paleontologia 14.1 (2011), pp. 51-60. DOI: 10.4072/rbp.2011.1.05.

[799] A. B. Arcucci, C. A. Marsicano, and A. T. Caselli. “Tetrapod association and palaeoenvironment of the Los Colorados Formation (Argentina): a significant sample from western Gondwana at the end of the Triassic". English. In: Géobios 37 (2004), pp. 557-568.

[800] Y. Arendt. "New Genera of Five-Armed and Armless Crinoids from the Lower Permian of the Urals". English. In: Paleontological Journal 30.2 (1996), pp. 201-206.

[801] Y. A. Arendt. "New multiarmed crinoids from the Lower Permian of the Urals". English. In: Paleontological Journal 39 (2005), pp. 634-638.

[802] Y. A. Arendt. "New multiarmed crinoids of the Family Catillocrinidae from the Lower Permian of the fore-Urals". English. In: Paleontological Journal 41 (2007), pp. 61-68.

[803] Yu.A. Arendt. "Carboniferous acrocrinid Crinoids (Camerata) from the Moskow Region." In: $P a-$ leontological Journal 29.2 (1995), pp. 75-90.

[804] M. Aretz. "The upper Viséan coral horizons of Royseux - the development of an unusual facies in Berlian Early Carboniferous". In: Bulletin of the Tohoku University Museum 1 (2001), pp. 86-95.

[805] M. Aretz. "Rugose corals and associated carbonate microfossils from the Brigantian (Mississippian) of Catelsec (Montagne Noire, southern France)". In: Géobios 35 (2002), pp. 187-200.

[806] M. Aretz. “Habitatanalyse und Riffbildungspotential kolonialer rugoser Korallen im Unterkarbon (Mississippium) von Westeuropa [Habitat analyses and reef-building potential of colonial rugose corals from the Early Carboniferous (Mississippian) of western Europe]". German. In: Kölner Forum für Geologie und Paläontologie 10 (2002), pp. 1-155.

[807] M. Aretz. "Rugose corals from the Upper Visean (Carboniferous) of the Jerada Massif (NE Morocco): taxonomy, biostratigraphy, facies and palaeobiogeography". English. In: Palaeontologische Zeitschrift 84 (2010), pp. 323-344.

[808] M. Aretz. "Corals from the Carboniferous of the central Sahara (Algeria): the collection Marie Legrand-Blain". English. In: Geodiversitas 33.4 (2011), pp. 581-624.

[809] M. Aretz and H. G. Herbig. "Corals from the Upper Visean of the southern Azrou-Khenifra Basin (Carboniferous, Central Moroccan Meseta)". English. In: Palaeoworld 19 (2010), pp. 294-305.

[810] M. Aretz and H.-G. Herbig. "Coral-rich bioconstructions in the Viséan (Late Mississippian) of southern Wales (Gower Peninsula, UK)". In: Facies 49 (2003), pp. 221-242.

[811] M. Aretz and H.-G. Herbig. Contribution of rugose corals to late Viséan and Serpukhovian bioconstructions in the Montagne Noire (southern France). Vol. 78. Permo-Carboniferous carbonate platforms and reefs. SEPM Special Publication. 2003, pp. 119-132.

[812] M. Aretz and J. Nudds. "The coral fauna of the Holkerian/Asbian boundary stratotype section (Carboniferous) at Little Asby Scar (Cumbria, England) and implications for boundary". English. In: Stratigraphy 2.2 (2005), pp. 167-190.

[813] P. Argenti and P. P. A. Mazza. "Mortality analysis of the Late Pleistocene bears from Grotta Lattaia, central Italy". English. In: Journal of Archaeological Science 33 (2006), pp. 1552-1558. DOI: 10.1016/j. jas.2006.02.007.

[814] T. Argyriou, C. Romano, J. D. Carrillo-Briceno, M. Brosse, and R. Hofmann. "The oldest record of gnathostome fossils from Greece: Chondrichthyes from the Lopingian of Hydra Island". English. In: Palaeontologia Electronica 20.1.8A (2017), pp. 1-9.

[815] C. Aria, V. Perrichot, and A. Nel. "Fossil Ponerinae (Hymenoptera: Formicidae) in Early Eocene amber of France". English. In: Zootaxa 2870 (2011), pp. 53-62.

[816] C. Arias. "Extinction pattern of marine Ostracoda aross the Pliensbachian-Toarcian boundary in the Cordillera Ibérica, NE Spain: Causes and consequences". English. In: Geobios 42 (2009), pp. 115. DOI: $10.1016 /$ j.geobios.2008.09.004. 
[817] C. Arias, J.-P. Masse, and L. Vilas. “Hauterivian shallow marine calcareous biogenic mounds: S.E. Spain". In: Palaeogeography, Palaeoclimatology, Palaeoecology 119 (1995), pp. 3-17.

[818] A. Arillo. "Presencia de la familia Pompilidae (Insecta, Hymenoptera) en el Mioceno Superior de la Cuenca de La Cerdaña (Lleida, NE de España)". Spanish. In: Coloquios de Paleontologa 52 (2001), pp. 79-83.

[819] A. Arillo, V. Blagoderov, and E. Peñalver. "Early Cretaceous parasitism in amber: A new species of Burmazelmira fly (Diptera: Archizelmiridae) parasitized by a Leptus sp. mite (Acari, Erythraeidae)". English. In: Cretaceous Research 86 (2018), pp. 24-32.

[820] A. Arillo and M. S. Engel. "Rock crawlers in Baltic amber (Notoptera: Mantophasmatodea)". English. In: American Museum Novitates 3539 (2006), pp. 1-10.

[821] A. Arillo and M. B. Mostovski. "A new genus of Prioriphorinae (Diptera Phoridae) from the Lower Cretaceous amber of Alava (Spain)". English. In: Studia Dipterologica 6 (1999), pp. 251-255.

[822] A. Arillo and A. Nel. "Two new fossil cecidomyiids flies from the Lower Cretaceous amber of Alava (Spain) (Diptera, Cecidomyiidae)". English. In: Bulletin de la Société Entomologique de France 105 (2000), pp. 285-288.

[823] A. Arillo, A. Nel, and V. M. Ortuño. "Two fossil bees from Oligocene of Izarra (Alava, Spain) (Hymenoptera, Apoidea)". English. In: Bulletin de la Société Entomologique de France 101 (1996), pp. 59-64.

[824] A. Arillo and V. M. Ortuño. "First records of the families Anthicidae and Chrysomelidae from the Oligocene of Izarra (Alava, Spain)". English. In: The Coleopterists Bulletin 51.3 (1997), pp. 293-297.

[825] A. Arillo and V. M. Ortuño. "The fossil Acrididae from the Oligocene of Izarra (Alava, Spain). The antiquity of gregarious behavior (Orthoptera, Caelifera)". English. In: Geobios 30 (1997), pp. 231234.

[826] A. Arillo, E. Peñalver, and V. Garca-Gimeno. "First fossil Litoleptis (Diptera: Spaniidae) from the Lower Cretaceous amber of San Just (Teruel Province, Spain)". English. In: Zootaxa 2026 (2009), pp. 33-39.

[827] A. Arillo, E. Peñalver, and X. Delclós. "Microphorites (Diptera: Dolichopodidae) from the Lower Cretaceous amber of San Just (Spain), and the co-occurrence of two ceratopogonid species in Spanish amber deposits". English. In: Zootaxa 1920 (2008), pp. 29-40.

[828] A. Arillo, E. Peñalver, R. Pérez-de Fuente, X. Delclós, J. Criscione, P. M. Barden, M. L. Riccio, and D. A. Grimaldi. "Long-proboscid brachyceran flies in Cretaceous amber (Diptera: Stratiomyomorpha: Zhangsolvidae)". English. In: Systematic Entomology 40 (2015), pp. 242-267.

[829] A. Arillo, L. S. Subas, and U. Shtanchaeva. "A new fossil species of oribatid mite, Ametroproctus valeriae sp. nov. (Acariformes, Oribatida, Ametroproctidae), from the Lower Cretaceous amber of San Just, Teruel Province, Spain". English. In: Cretaceous Research 30.2 (2009), pp. 322-324. DOI: 10.1016/j.cretres.2008.07.013.

[830] A. Arillo, L. S. Subas, and U. Shtanchaeva. "A new species of fossil oribatid mite (Acariformes, Oribatida, Trhypochthoniidae) from the Lower Cretaceous amber of San Just (Teruel Province, Spain)". English. In: Systematic \& Applied Acarology 17 (2012), pp. 106-112.

[831] A. Arillo, L. S. Subas, and U. Shtanchaeva. "A new genus and species of oribatid mite, Cretaceobodes martinezae gen. et sp. nov., from the Lower Cretaceous amber of San Just (Teruel Province, Spain) (Acariformes, Oribatida, Otocepheidae)". English. In: Paleontological Journal 44 (2010), pp. 287-290.

[832] A. Arillo, L. S. Subas, and U. Shtanchaeva. "A new fossil oribatid mite, Ommatocepheus nortoni sp. nov. (Acariformes, Oribatida, Cepheidae), from a new outcrop of Lower Cretaceous Álava amber (northern Spain)". English. In: Systematic \& Applied Acarology 13 (2008), pp. 252-255.

[833] A. Arillo and L. S. Subas. "A new fossil oribatid mite, Archaeorchestes minguezae n. gen. n. sp. from the Spanish Lower Cretaceous amber. Description of a new family Archaeorchestidae (Acariformes, Oribatida, Zetorchestoidea)". English. In: Mitteilungen aus dem Geologisch-Paläontologischen Institut der Universität Hamburg 84 (2000), pp. 231-236. 
[834] D. S. Aristov. "Review of the stratigraphic distribution of Permian Grylloblattida (Insecta), with descriptions of new taxa". English. In: Paleontological Journal 43.6 (2009), pp. 643-651.

[835] D. S. Aristov. "The fauna of grylloblattid insects (Grylloblattida) from the end of the Late Permian to the first half of the Triassic". English. In: Paleontological Journal 38 (2004), pp. 514-521.

[836] D. S. Aristov. "A new family of early Permian Grylloblattids (Insecta: Grylloblattida) from Ural Mountains". English. In: Far Eastern Entomologist 85 (2000), pp. 1-4.

[837] D. S. Aristov. "New Grylloblattida (Insecta) from the Middle and Upper Permian of Russia". English. In: Far Eastern Entomologist 188 (2008), pp. 1-7.

[838] D. S. Aristov. "New Grylloblattids of the Family Megakhosaridae (Insecta: Grylloblattida) from the Permian of Russia". English. In: Paleontological Journal 42.3 (2008), pp. 269-272.

[839] D. S. Aristov. "Grylloblattids of the Family Liomopteridae (Insecta: Grylloblattida) of the Upper Half of the Upper Permian". English. In: Paleontological Journal 38.Suppl 2 (2004), S150-S157.

[840] D. S. Aristov. "The Fauna of Grylloblattid Insects (Grylloblattida) of the Lower Permian Locality of Tshekarda". English. In: Paleontological Journal 38 (2004), S80-S145.

[841] D. S. Aristov. "Grylloblattids of the Family Chaulioditidae (= Tomiidae syn. nov.) (Insecta: Grylloblattida) from the Upper Permian of the Orenburg Region". English. In: Paleontological Journal 38 (2004), S146-S149.

[842] D. S. Aristov. “New Grylloblattida (Insecta) from Kargala locality (Russia; Middle Permian)". English. In: Far Eastern Entomologist 192 (2009), pp. 1-8.

[843] D. S. Aristov. "New Tatarian Representatives of the Subfamily Chaulioditinae (Insecta: Grylloblattida: Chaulioditidae) from European Russia". English. In: Paleontological Journal 42 (2008), pp. 3235.

[844] D. S. Aristov. "Revision of the Permian genus Parasylviodes Martynov, 1940 (Grylloblattida: Liomopteridae)". English. In: Far Eastern Entomologist 186 (2008), pp. 1-5.

[845] D. S. Aristov. "A New Family of the Order Grylloblattida (Insecta) from the Middle Permian of Russia". English. In: Paleontological Journal 43.2 (2009), pp. 178-182.

[846] D. S. Aristov. "New Grylloblattids of the Family Lemmatophoridae (Insecta: Grylloblattida) from the Permian of Russia". English. In: Paleontological Journal 43.3 (2009), pp. 272-276.

[847] D. S. Aristov. "Revision of the Family Tomiidae (Insecta: Grylloblattida)". English. In: Paleontological Journal 37 (2003), pp. 31-38.

[848] D. S. Aristov. "New Grylloblattids (Insecta: Grylloblattida) from the Triassic of Eastern Europe, Eastern Kazakhstan and Mongolia". English. In: Paleontological Journal 39 (2005), pp. 173-177.

[849] D. S. Aristov. "Review of grylloblattid insects (Insecta: Grylloblattida) from the Solikamsk deposits of the Perm region". English. In: Paleontological Journal 44 (2010), pp. 505-514.

[850] D. S. Aristov. "New and little known Blattogryllidae (Insecta: Grylloblattida) from the Permian and Triassic of Russia, Kazakhstan, and Kyrgyzstan". English. In: Paleontological Journal 45 (2011), pp. 65-72.

[851] D. S. Aristov. "Revision of the Family Epideigmatidae (Insecta: Grylloblattida)". English. In: Paleontological Journal 45.4 (2011), pp. 397-405.

[852] D. S. Aristov. “New Permian grylloblattids (Insecta: Grylloblattida) from Isady locality (Severovdvinian stage of Vologda Region)". Russian. In: Russian Entomological Journal 18.1 (2009), pp. 17-22.

[853] D. S. Aristov. "New and little known Grylloblattida (Insecta) from intertrappean deposits of the Tunguska Basin of Siberia". English. In: Paleontological Journal 45.5 (2011), pp. 537-545.

[854] D. S. Aristov. "A new species of the Permian genus Kungurmica (Grylloblattida: Permembiidae)". English. In: Far Eastern Entomologist 65 (1998), pp. 15-16.

[855] D. S. Aristov. "New insects of the order Grylloblattida (Insecta) from the Lower Permian of the middle Urals". English. In: Paleontological Journal 34 (2000), pp. 519-521. 
[856] D. S. Aristov. "Composition and distribution of the family Cacurgidae (Insecta; Grylloblattida)". English. In: Paleontological Journal 46 (2012), pp. 250-257.

[857] D. S. Aristov. "New Euryptilonids (Insecta: Grylloblattida: Euryptilonidae) from the Lower Permian of the Urals (Russia)". English. In: Neues Jahrbuch für Geologie und Paläontologie, Monatshefte 2002.4 (2002), pp. 252-256.

[858] D. S. Aristov. "New Grylloblattida (Insecta) from the Upper Permian and Lower Triassic of European Russia and Kazakhstan". English. In: Paleontological Journal 47 (2013), pp. 66-76.

[859] D. S. Aristov. "New and little-known Eoblattida (Insecta) from the Paleozoic of Russia". English. In: Paleontological Journal 47 (2013), pp. 272-282.

[860] D. S. Aristov. “Ornaticosta tchekardensis n. sp., the first representative of the Liomopteridae (Insecta: Grylloblattida) from the Lower Permian of Chekarda (Ural)". English. In: Neues Jahrbuch für Geologie und Paläontologie, Monatshefte 1999.12 (1999), pp. 725-727.

[861] D. S. Aristov. "A new representative of the Lemmatophoridae (Insecta, Grylloblattida) from the Lower Permian of the Ural (Russia)". English. In: Neues Jahrbuch für Geologie und Paläontologie, Monatshefte 2001.5 (2001), pp. 257-264.

[862] D. S. Aristov. “Grylloblattids of the family Ideliidae (Insecta: Grylloblattida) from the Lower Permian of the Ural Mountains". English. In: Paleontological Journal 36 (2002), pp. 44-47.

[863] D. S. Aristov. "Morfologiya nekotorykh Permiskikh Grylloblattida (Insecta) iz mestonakhozhdeniya Chekarda (Permskiy Kray)". English. In: Sovremennaya Paleontologiya: Klassicheskie i Noveyshie Metody 2011 (2011), pp. 25-34.

[864] D. S. Aristov. "Predstaviteli roda Narkemina Martynov (Insecta: Eoblattida: Cnemidolestidae) iz Karbona Sibiri". Russian. In: Sovremennaya Paleontologiya: Klassicheskie i Noveyshie Metody 2012 (2012), pp. 37-48.

[865] D. S. Aristov. "New grylloblattids (Insecta: Grylloblattida) from the Upper Permian of the Vologda region". English. In: Paleontological Journal 47 (2013), pp. 751-766.

[866] D. S. Aristov. "Classification of the order Cnemidolestida (Insecta: Perlidea) with descriptions of new taxa". English. In: Far Eastern Entomologist 277 (2014), pp. 1-46.

[867] D. S. Aristov. "New taxa of Mesorthopteridae (Insecta: Grylloblattida) from the Permian of Russia". English. In: Paleontological Journal 48 (2014), pp. 488-499.

[868] D. S. Aristov. "Insects from a new Ufimian locality of Troitsa in the Perm region, Russia". English. In: Paleontological Journal 49 (2015), pp. 496-500.

[869] D. S. Aristov. "New Gryllones (Insecta) from the Permian of Russia". English. In: Paleontological Journal 49 (2015), pp. 1310-1333.

[870] D. S. Aristov. "Classification of the order Eoblattida (Insecta: Blattidea) with description of new taxa". English. In: Far Eastern Entomologist 301 (2015), pp. 1-56.

[871] D. S. Aristov. "New insects (Insecta: Eoblattida, Embiida) from the Permian of Russia and the Triassic of Kyrgyzstan, with observations on the origin of webspinners". English. In: Paleontological Journal 51 (2017), pp. 161-170.

[872] D. S. Aristov. "New and little-known nymphs of Gryllones (Insecta) from the Lower Permian of Russia". English. In: Paleontological Journal 52 (2018), pp. 137-141.

[873] D. S. Aristov. "New and little known Cnemidolestid insects (Insecta: Cnemidolestida) from the Middle Permian-Middle Triassic of Eurasia". English. In: Paleontological Journal 52 (2018), pp. 13811390.

[874] D. S. Aristov. "New insects (Insecta: Eoblattida, Reculida) from the Middle Permian of Russia". English. In: Paleontological Journal 53 (2019), pp. 287-291. DOI: 10.1134/S0031030119030031.

[875] D. S. Aristov. "New Gryllones insects (Insecta: Gryllones) from the Babii Kamen' Locality (Upper Permian of Russia). Part 1. Order Eoblattida". English. In: Paleontological Journal 54 (2020), pp. 4752. DOI: 10.1134/S0031030120010025. 
[876] D. S. Aristov. “New Gryllones insects (Insecta: Gryllones) from the Babii Kamen' Locality (Upper Permian of Russia). 2. Order Reculida and Gryllones ordinis incertis". English. In: Paleontological Journal 54 (2020), pp. 132-142. DOI: 10.1134/S0031030120020021.

[877] D. S. Aristov. "New and little known Gryllones insects (Insecta: Gryllones: Cnemidolestida, Reculida) from the Triassic of Eurasia". English. In: Paleontological Journal 54 (2020), pp. 524-530. DOI: 10.1134/S0031030120050020.

[878] D. S. Aristov and A. S. Bashkuev. "New Insects (Insecta Mecoptera, Grylloblattida) from the Middle Permian Chepanikha Locality, Udmurtia". English. In: Paleontological Journal 42 (2008), pp. 159-165.

[879] D. S. Aristov and A. V. Gorochov. "Orthoptera from the Lower Permian Vorkuta locality (Russia: Komi Republic; Kungurian Stage)". English. In: Far Eastern Entomologist 10 (2020), pp. 17-20.

[880] D. S. Aristov, L. Grauvogel-Stamm, and F. Marchal-Papier. “New grylloblattid insects (Insecta: Grylloblattida) from the Gres a Voltzia of the Vosges (Middle Triassic of France)". English. In: Paleontological Journal 45.2 (2011), pp. 159-166.

[881] D. S. Aristov and M. B. Mostovski. “Grylloblattids (Insecta, Grylloblattida) from the Upper Permian of South Africa". English. In: Paleontological Journal 47 (2013), pp. 495-502.

[882] D. S. Aristov, V. G. Novokshonov, and N. N. Pan'kov. "Taxonomy of the Fossil Grylloblattid Nymphs (Insecta: Grylloblattida)". English. In: Paleontological Journal 40.1 (2006), pp. 79-89.

[883] D. S. Aristov, R. Prevec, and M. B. Mostovski. "New and poorly known grylloblattids (Insecta: Grylloblattida) from the Lopingian of the Lebombo Basin, South Africa". English. In: African Invertebrates 50 (2009), pp. 279-286.

[884] D. S. Aristov and A. P. Rasnitsyn. "A new eoblattids (Insecta: Eoblattida) from the Permian of Russia". English. In: Far Eastern Entomologist 230 (2011), pp. 1-12.

[885] D. S. Aristov and A. P. Rasnitsyn. "Position and taxonomy of the Permian fossil insect family Permembiidae (Insecta: Palaeomanteida = Miomoptera)". English. In: Russian Entomological Journal 17.4 (2008), pp. 327-334.

[886] D. S. Aristov and A. P. Rasnitsyn. "The family Tillyardembiidae Zalessky, 1938 and the system of the plecopteroid insects". English. In: Russian Entomological Journal 18.4 (2010), pp. 257-264.

[887] D. S. Aristov and A. P. Rasnitsyn. "Revision of the family Idelinellidae, with a review of the Permian Eoblattida (Insecta)". English. In: Paleontological Journal 46 (2012), pp. 49-60.

[888] D. S. Aristov and A. P. Rasnitsyn. "A review of the family Protembiidae (Insecta: Eoblattida)". English. In: Russian Entomological Journal 20 (2011), pp. 119-127.

[889] D. S. Aristov and A. P. Rasnitsyn. "New Eoblattida from the Permian of Russia and the United States and the Origin of earwigs (Insecta: Eoblattida, Forficulida)". English. In: Paleontological Journal 48 (2014), pp. 407-413.

[890] D. S. Aristov and A. P. Rasnitsyn. "New insects from the Kungurian of Tshekarda fossil site in Permian territory of Russia". English. In: Russian Entomological Journal 24 (2015), pp. 17-35.

[891] D. S. Aristov, S. Y. Storozhenko, and Y. Y. Cui. "Review of the Permian Camptoneuritidae (Insecta: Grylloblattida)". English. In: Acta Geologica Sinica 84 (2010), pp. 756-761.

[892] D. S. Aristov and S. Y. Storozhenko. "Review of the Permian family Permulidae nomen novum pro Aliculidae Storozhenko, 1997 (Grylloblattida)". English. In: ZooKeys 130 (2011), pp. 111-130.

[893] D. S. Aristov and S. Y. Storozhenko. "A new subfamily of grylloblattids Uralopriscinae subfam. n. (Grylloblattida: Lemmatophoridae) from the Permian of Russia". English. In: Far Eastern Entomologist 219 (2010), pp. 1-8.

[894] D. S. Aristov and S. Y. Storozhenko. "A new genus of the family Mesorthopteridae (Grylloblattida) from the Triassic of Kyrgyzstan". English. In: Far Eastern Entomologist 264 (2013), pp. 7-12.

[895] D. S. Aristov and I. D. Sukatcheva. "New insects (Insecta: Trichoptera, Reculida, Eoblattida) from the Mesozoic of Asia". English. In: Paleontological Journal 52 (2018), pp. 405-413. 
[896] D. S. Aristov, T. Wappler, and A. P. Rasnitsyn. “New and Little-Known Grylloblattids of the Family Geinitziidae (Insecta: Grylloblattida) from the Triassic and Jurassic of Europe, Asia, and South Africa". English. In: Paleontological Journal 43 (2009), pp. 418-424.

[897] D. S. Aristov and W. Zessin. "Mallorcagryllus hispanicus n. gen. et sp. - eine neue Grylloblattide (Insecta: Grylloblattida: Blattogryllidae) aus dem Buntsandstein der Insel Mallorca, Spanien". German. In: Virgo, Mitteilungsblatt des Entomologischen Vereins Mecklenburg 12 (2009), pp. 30-34.

[898] D. S. Aristov, D. ya, and P. Wegierek. "Chauliodites niedzwiedzkii sp. n. (Grylloblattida: Chaulioditidae) from Triassic sediments of Poland". English. In: Zootaxa 3721 (2013), pp. 281-285.

[899] Y. Ariunchimeg. "New Lower Carboniferous Bryozoans from Mongolia". English. In: Paleontological Journal 30.2 (1996), pp. 191-197.

[900] Ya. Ariunchimeg. "New Late Ordovician Bryozoans from the Tsagaan-Del Section of Central Mongolia". English. In: Paleontological Journal 43.4 (2009), pp. 401-407.

[901] V. V. Arkad'ev, A. A. Fedorova, Y. N. Savale'eva, and E. M. Tesakova. “Biostratigraphy of JurassicCretaceous Boundary Sediments in the Eastern Crimea". English. In: Stratigraphy and Geological Correlation 14.3 (2006), pp. 302-330.

[902] V. V. Arkadiev. "New data on ammonoids of the genus Paraulacosphinctes from the Upper Tithonian of the Mountainous Crimea". English. In: Stratigraphy and Geological Correlation 19 (2011), pp. 238-242.

[903] V. V. Arkadiev, A. A. Atabekian, E. Y. Baraboshkin, and T. N. Bogdanova. "Stratigraphy and ammonites of Cretaceous deposits of south-west Crimea". English. In: Palaeontographica Abteilung A 255 (2000), pp. 85-128.

[904] V. V. Arkadiev and T. N. Bogdanova. "Genus Delphinella (Ammonoidea) from the Berriasian of the Crimean Mountains". English. In: Paleontological Journal 39 (2005), pp. 487-497.

[905] V. V. Arkadiev and I.Yu. Bugrova. "Facies of the Cretaceous (Berriasian) deposits from the River Belbek Area (Southwestern Crimea)". In: Facies 40 (1999), pp. 71-80.

[906] M. S. Arkhangelsky. "On the ichthyosaurian fossils from the Volgian Stage of the Saratov Basin". Russian. In: Palaeontological Journal 2 (1998), pp. 87-91.

[907] M. S. Arkhangelsky. "On an ichthyosaur from the Callovian Stage of the Volga Region near Saratov". Russian. In: Palaeontological Journal 1 (1999), pp. 88-91.

[908] M. S. Arkhangelsky and A. O. Averianov. "On the find of a primitive hadrosauroid dinosaur (Ornithischia, Hadrosauroidea) in the Cretaceous of the Belgorod region". In: Paleontological Journal 37.1 (2003), pp. 58-61.

[909] M. S. Arkhangelsky, A. O. Averianov, E. M. Pervushov, V. Yu. Ratnikov, and N. Yu. Zozyrev. “On ichthyosaur remains from the Cretaceous of the Voronezh Region". English. In: Paleontological Journal 42.3 (2008), pp. 287-291.

[910] M. S. Arkhangelsky, A. O. Averianov, and E. M. Pervushov. "Short-necked plesiosaurs of the Family Polycotylidae from the Campanian of the Saratov Region". English. In: Paleontological Journal 41.6 (2007), pp. 656-660. DOI: 10.1134/S0031030107060093.

[911] M. S. Arkhangelsky and N. G. Zverkov. "On a new ichthyosaur of the genus Undurosaurus". English. In: Proceedings of the Zoological Institute RAS 318.5 (2014), pp. 187-196.

[912] M. S. Arkhangelsky, N. G. Zverkov, Y. D. Zakharov, and I. V. Borisov. “On the First Reliable Find of the Genus Tholodus (Reptilia: Ichthyopterygia) in the Asian Peripheral Area of the Panthalassic Ocean". English. In: Paleontological Journal 50.1 (2016), pp. 78-86. DOI: 10.1134/S0031030115060040.

[913] L. Armand, W. D. L. Ride, and G. Taylor. "The stratigraphy and palaeontology of Teapot Creek, MacLaughlin River, NSW". English. In: Proceedings of the Linnean Society of New South Wales 122 (2000), pp. 101-121.

[914] M. A. Armella and R. A. Bonini. "Biostratigraphic significance of the presence of Protypotherium cf. P. antiquum Ameghino 1885 (Interatheriidae, Notoungulata) in the late Miocene of Northwestern Argentina". English. In: Journal of South American Earth Sciences 102 (2020), p. 102676. 
[915] M. A. Armella, D. A. Garca-lópez, and L. Dominguez. “A new species of Xotodon (Notoungulata, Toxodontidae) from northwestern Argentina". English. In: Journal of Vertebrate Paleontology 38.1 (2018), e1425882. DOI: 10.1080/02724634.2017.1425882.

[916] M. A. Armella, D. A. Garca-López, M. J. Babot, V. Deraco, C. M. Herrera, L. Saade, and S. Bertelli. "Postcranial remains of basal typotherian notoungulates from the Eocene of northwestern Argentina". English. In: Acta Palaeontologica Polonica 65 (2020).

[917] M. A. Armella, N. L. Nasif, and E. Cerdeño. "Small-sized mesotheriines (Mesotheriidae, Notoungulata) from Northwestern Argentina: Systematic, chronological, and paleobiogeographic implications". English. In: Journal of South American Earth Sciences 83 (2018), pp. 14-26.

[918] A. Armstrong, T. Nyborg, G. A. Bishop, A. Ossó-Morales, and F. J. Vega. “Decapod crustaceans from the Paleocene of Central Texas, USA". English. In: Revista Mexixana de Ciencias Geologicas 26.3 (2009), pp. 745-763.

[919] H. A. Armstrong. "Conodonts from the Ordovician Shinnel Formation, Southern Uplands, Scotland". English. In: Palaeontology 40.3 (1997), pp. 763-797.

[920] M. Arnal, A. G. Kramarz, M. G. Vucetich, and E. C. Vieytes. “A new early Miocene octodontoid rodent (Hystricognathi, Caviomorpha) from Patagonia (Argentina) and a reassessment of the early evolution of Octodontoidea". English. In: Journal of Vertebrate Paleontology 34.2 (2014), pp. 397-406. DOI: $10.1080 / 02724634.2013 .808203$.

[921] M. Arnal and A. G. Kramarz. "First complete skull of an octodontoid (Rodentia, Caviomorpha) from the Early Miocene of South America and its bearing in the early evolution of Octodontoidea". English. In: Geobios 44 (2011), pp. 435-444. DOI: 10.1016/j.geobios.2010.12.003.

[922] M. Arnal, A. G. Kramarz, M. G. Vucetich, C. D. Frailey, and K. E. Campbell Jr. "New Palaeogene caviomorphs (Rodentia, Hystricognathi) from Santa Rosa, Peru: systematics, biochronology, biogeography and early evolutionary trends". English. In: Papers in Palaeontology (2019). DOI: 10.1002/spp2.1264.

[923] M. Arnal and M. E. Pérez. "A new acaremyid rodent (Hystricognathi: Octodontoidea) from the middle Miocene of Patagonia (South America) and considerations on the early evolution of Octodontoidea". English. In: Zootaxa 3616.2 (2013), pp. 119-134.

[924] M. Arnal, M. E. Perez, and C. M. Deschamps. "Revision of the Miocene caviomorph rodents from the Ro Santa Cruz (Argentinean Patagonia)". English. In: vol. 19. Early-Middle Miocene Paleontology in the Ro Santa Cruz, Southern Patagonia, Argentina. 130 years since Ameghino, 1887 2. Publicación Electrónica de la Asociación Paleontológica Argentina, 2019, pp. 193-229. DOI: 10.5710/PEAPA.25.09.2019.299.

[925] M. Arnal and M. Vucetich. "Revision of the fossil rodent Acaremys Ameghino, 1887 (Hystricognathi, Octodontoidea, Acaremyidae) from the Miocene of Patagonia (Argentina) and the description of a new acaremyid". English. In: Historical Biology 27.1 (2015), pp. 42-59. DOI: 10.1080 / 08912963.2013.863881.

[926] M. Arnal and M. G. Vucetich. "First record of supernumerary teeth in South American fossil rodents". English. In: Journal of Vertebrate Paleontology 31.4 (2011), pp. 925-927. DOI: 10.1080 / 02724634.2011.576732.

[927] M. Arnal, M. G. Vucetich, D. A. Croft, M. S. Bargo, J. C. Ferncola, and S. F. Viscaino. "Systematic revision and evolutionary history of Acarechimys Patterson in Kraglievich 1965 (Rodentia, Caviomorpha, Octodontoidea)". English. In: Ameghiniana 54.3 (2017), pp. 307-330. DOI: 10.5710/ AMGH.17.02.2017.3048.

[928] R. H. Arnett Jr. American Insects: A Handbook of the Insects of America North of Mexico. English. The Sandhill Crane Press, Inc. 1993.

[929] E. N. Arnold, D. Azar, I. Ineich, and A. Nel. "The oldest reptile in amber: a 120 million year old lizard from Lebanon". English. In: Journal of Zoology 258 (2002), pp. 7-10.

[930] P. W. Arnold. "Irrawaddy dolphin Orcaella brevirostris". English. In: Encyclopedia of Marine Mammals. Academic Press, 2002, pp. 652-654. 
[931] C. Aroldi and I. I. Bucur. "Palaeogene microfacies in some calcareous blocks of the Roaia Formation (Wildflysch Nappe-Maramures)". English. In: Studia Universitatis Babes-Bolyai Special Issue 1 (2002), pp. 13-30.

[932] G. Arp and S. Seppelt. "The bipolar bivalve Oxytoma (Palmoxytoma) cygnipes (Young and Bird, 1822) in the Upper Pliensbachian of Germany". English. In: Palaeontologische Zeitschrift 86 (2012), pp. 43-57.

[933] P. Arpita and R. L. Jain. "Quaternary corals of Okha- An evidence of Sea level changes and environment of deposition". English. In: Indian Journal of Marine Sciences 43.7 (2014).

[934] G. Arratia. "Remarkable teleostean fishes from the Late Jurassic of southern Germany and their phylogenetic relationships". English. In: Mitteilungen aus dem Museum für Naturkunde in Berlin, Geowissenschaften Reihe 3 (2000), pp. 137-179.

[935] G. Arratia. "Morphology, taxonomy, and phylogeny of Triassic Pholidophorid fishes (Actinopterygii, Teleostei)". English. In: Journal of Vertebrate Paleontology 33 (2013), pp. 1-138.

[936] G. Arratia. “New Triassic teleosts (Actinopterygii, Teleosteomorpha) from northern Italy and their phylogenetic relationships among the most basal teleosts". English. In: Journal of Vertebrate Paleontology 37 (2017), e1312690.

[937] G. Arratia and J. Chorn. "A New Primitive Acanthomorph Fish from the Greenhorn Formation (Late Cretaceous) of Nebraska". English. In: Journal of Vertebrate Paleontology 18.2 (1998), pp. 301314.

[938] G. Arratia and A. Cione. "The Record of Fossil Fishes of Southern South America". English. In: Munchner Geowiss Abh 30 (1996), pp. 9-72.

[939] G. Arratia and R. Cloutier. "A new cheirolepidid fish from the Middle-Upper Devonian of Red Hill, Nevada, USA". English. In: Recent Advances in the Origin and Early Radiation of Vertebrates. Munchen: Verlag Dr. Friedrich Pfeil, 2004, pp. 583-598.

[940] G. Arratia and A. Herzog. "A New Halecomorph Fish from the Middle Triassic of Switzerland and its Systematic Implications". English. In: Journal of Vertebrate Paleontology 27.4 (2007), pp. 838849.

[941] G. Arratia and D. C. H. Hikuroa. "Jurassic Fishes from the Latady Group, Antarctic Peninsula, and the Oldest Teleosts from Antarctica". English. In: Journal of Vertebrate Paleontology 30 (2010), pp. 1331-1342.

[942] G. Arratia, J. Kriwet, and W. -D. Heinrich. "Selachians and actinopterygians from the Upper Jurassic of Tendaguru, Tanzania". English. In: Mitteilungen aus dem Museum für Naturkunde in Berlin, Geowissenschaften Reihe 5 (2002), pp. 207-230.

[943] G. Arratia, R. Scasso, and W. Kiessling. "Late Jurassic fishes from Longing Gap, Antarctic Peninsula". English. In: Journal of Vertebrate Paleontology 24.1 (2004), pp. 41-55.

[944] G. Arratia and H. P. Schultze. "A new fossil actinistian from the Early Jurassic of Chile and its bearing on the phylogeny of Actinistia". English. In: Journal of Vertebrate Paleontology 35 (2015), e983524.

[945] G. Arratia and H.-P. Schultze. "Semionotiform fish from the Upper Jurassic of Tendaguru (Tanzania)". English. In: Mitteilungen aus dem Museum für Naturkunde in Berlin, Geowissenschaften Reihe 2 (1999), pp. 135-153.

[946] G. Arratia and H.-P. Schultze. "Outstanding features of a new Late Jurassic pachycormiform fish from the Kimmeridgian of Brunn, Germany and comments on current understanding of pachycormiforms". English. In: Mesozoic Fishes 5 - Global Diversity and Evolution. Munich: Verlag Dr. Friedrich Pfeil, 2013, pp. 87-120.

[947] G. Arratia and H.-P. Schultze. "The macrosemiiform fish companion of the Late Jurassic theropod Juravenator from Schamhaupten, Bavaria, Germany". English. In: Fossil Record 15.5 (2012), pp. 525. DOI: $10.1002 / \mathrm{mmng} .201200001$. 
[948] G. Arratia and D. Thies. "A new teleost (Ostichthyes, Actinopterygii) from the Early Jurassic Posidonia shale of Northern Germany". English. In: Mitteilungen aus dem Museum für Naturkunde in Berlin, Geowissenschaftliche Reihe 4 (2001), pp. 167-187.

[949] G. Arratia and H. Tischlinger. "The first record of Late Jurassic crossognathiform fishes from Europe and their phylogenetic importance for teleostean phylogeny". English. In: Fossil Record 13.2 (2010), pp. 317-341. DOI: 10.1002/mmng.201000005.

[950] A. Arribas. "El yacimiento mesopleistoceno de Villacastin (Segovia, Espana): geologia y paleontologia de micromamiferos". Spanish. In: Boletin Geologico y Minero 105 (1994), pp. 146-166.

[951] A. Arribas. "Paleontologa de macromamferos del yacimiento mesopleistoceno de Villacastn (Segovia, España)". Spanish. In: Boletn Geológico y Minero 105.4 (1994), pp. 22-39.

[952] A. Arribas and G. Garrido. "Meles iberica n. sp., a new Eurasian badger (Mammalia, Carnivora, Mustelidae) from Fonelas P-1 (Plio-Pleistocene boundary, Guadix Basin, Granada, Spain)". English. In: Comptes Rendus Palevol 6.8 (2007), pp. 545-555. DOI: 10.1016/j.crpv.2007.06.002.

[953] A. Arribas, G. Garrido, C. Viseras, J. M. Soria, S. Pla, J. G. Solano, M. Garces, E. Beamud, and J. S. Carrion. "A Mammalian Lost World in Southwest Europe during the Late Pliocene". English. In: PLoS one 4.9 (2009), pp. 1-10. DOI: 10.1371/journal.pone.0007127.

[954] A. Arribas and P. Palmqvist. “Taphonomy and palaeoecology of an assemblage of large mammals: hyaenid activity in the Lower Pleistocene site at Venta MIcena (Orce, Guadix-Baza basin, Granada, Spain)". In: Géobios 31.3 (1998), pp. 1-47.

[955] I. Arribas, A. D. Buscalioni, R. Royo Torres, E. Esplez, L. Mampel, and L. Alcalá. “A new goniopholidid crocodyliform, Hulkepholis rori sp. nov. from the Camarillas Formation (early Barremian) in Galve, Spain)". English. In: PeerJ 7 (2019), e7911:1-47. DOI: 10.7717/peerj.7911.

[956] A. Arribas Herrera and J. Bernad Garcia. "Catalogo de mamiferos pliocenos del yacimiento de Villarroya (La Rioja), en la coleccion del Museo Geominero". Spanish. In: Boletin Geologico y Minero 105.3 (1994), pp. 236-248.

[957] J. Arroyo-Cabrales, R. Gregorin, D. A. Schlitter, and A. Walker. "The oldest African molossid bat cranium (Chiroptera: Molossidae)". English. In: Journal of Vertebrate Paleontology 22.2 (2002), pp. 380-387.

[958] A. Artabe and M. Brea. "A new approach to Corystospermales based on Triassic permineralized stems from Argentina". English. In: Alcheringa 27.3 (2003), pp. 209-229. DOI: 10.1080/03115510308619353.

[959] A. E. Artabe, E. M. Morel, and A. B. Zamuner. "Estudio paleobotanico y tafonomico en la Formacion Paso Flores (Triasico Superior), en el Canadon de Pancho, Neuquen, Argentina". Spanish. In: Ameghiniana 31.2 (1994), pp. 153-160.

[960] A. E. Artabe, A. B. Zamuner, and D. W. Stevenson. “Two New Petrified Cycad Stems, Brunoa gen. nov. and Worsdellia gen. nov., from the Cretaceous of Patagonia (Bajo de Santa Rosa, Rio Negro Province), Argentina". English. In: The Botanical Review 70.2 (2004), pp. 121-133.

[961] A. E. Artabe, A. B. Zamuner, and D. W. Stevenson. "A new genus of Late Cretaceous cycad stem from Argentina, with reappraisal of known forms". English. In: Alcheringa 29.1 (2005), pp. 87-100. DOI: $10.1080 / 03115510508619561$.

[962] A. J. Arthur, P. L. Smith, J. W. H. Monger, and H. W. Tipper. “Mesozoic stratigraphy and Jurassic paleontology west of Harrison Lake, southwestern British Columbia". English. In: Geological Survey of Canada Bulletin 441 (1993), pp. 1-62.

[963] H. Arzani, S. L. Lanzelotti, G. E. Acuña Suárez, and N. M. Novo. “Primer Registro de Pelos Fósiles en Glossotherium robustum (Xenarthra, Mylodontidae), Pleistoceno Tardo, Mercedes, Provincia de Buenos Aires, Argentina". English. In: Ameghiniana 51.6 (2014), pp. 585-590.

[964] K. Asato, T. Kase, T. Ono, K. Sashida, and S. Agematsu. "Nipponomaria, a new pleurotomarioidean gastropod genus (Mollusca) from the Permian Akasaka Limestone, central Japan". English. In: Paleontological Research 20 (2016), pp. 385-393. 
[965] K. Asato, T. Kase, T. Ono, K. Sashida, and S. Agematsu. "Morphology, systematics and paleoecology of Shikamaia, aberrant Permian bivalves (Alatoconchidae: Ambonychioidea) from Japan". English. In: Paleontological Research 21 (2017), pp. 358-379.

[966] B. Asfaw, Y. Beyene, G. Suwa, R. Walter, T. White, G. WoldeGabriel, and T. Yemane. The earliest Acheulean from Konso-Gardula. 1992.

[967] S. Ash. "An Upper Triassic upland flora from north-central New Mexico, U.S.A". In: Review of Palaeobotany and Palynology 105 (1999), pp. 183-199.

[968] S. Ash. "A new Jurassic Phlebopteris (Plantae, Filicales) from the Wallowa terrane in the Snake River Canyon, Oregon and Idaho". In: Journal of Paleontology 65.2 (1991), pp. 322-329.

[969] S. Ash. "First occurrence of Czekanowskia (Gymnospermae, Czekanowskiales) in the United States". In: Review of Palaeobotany and Palynology 81 (1994), pp. 129-140.

[970] S. R. Ash. "A New Pinnate Cycad Leaf from the Upper Triassic Chinle Formation of Arizona". English. In: Botanical Gazette 152.1 (1991), pp. 123-131.

[971] S. R. Ash and J. F. Basinger. "A high latitude Upper Triassic flora from the Heiberg Formation, Sverdrup Basin, Arctic Archipelago". In: Contributions to Canadian Paleontology, Geological Survey of Canada, Bulletin 412 (1991), pp. 101-131.

[972] S. R. Ash and G. T. Creber. "The late Triassic Araucarixylon arizonicum trees of the Petrified Forest National Park Arizona, USA". English. In: Palaeontology 43.1 (2000), pp. 15-28. DOI: 10.1111/14754983.00116.

[973] E. Ashe-Jepson, A. Garbout, and D. Ouvrard. "Phylogeny of the Eocene Aphalarinae (Hemiptera: Psylloidea) from Baltic amber, with description of a new species using X-ray micro-computed tomography scanning, and a new genus synonymy". English. In: Journal of Systematic Palaeontology 17 (2019), pp. 1013-1024. DOI: 10.1080/14772019.2018.1518345.

[974] R. J. Asher and D. M. Avery. "New Golden Moles (Afrotheria, Chrysochloridae) from the Early Pliocene of South Africa". English. In: Palaeontologia Electronica 13.1.3A (2010), pp. 1-12.

[975] R. J. Asher, R. J. Emry, and M. C. McKenna. “New material of Centetodon (Mammalia, Lipotyphla) and the importance of (missing) DNA sequences in systematic paleontology". English. In: Journal of Vertebrate Paleontology 25.4 (2005), pp. 911-923.

[976] R. J. Asher and D. W. Krause. "The first pre-Holocene (Cretaceous) record of Anura from Madagascar". English. In: Journal of Vertebrate Paleontology 18.4 (1998), pp. 696-699.

[977] R. J. Asher, M. C. McKenna, R. J. Emry, A. R. Tabrum, and D. G. Kron. "Morphology and relationships of Apternodus and other extinct, zalambdodont, placental mammals". English. In: Bulletin of the American Museum of Natural History 273 (2002), pp. 1-117.

[978] L. G. Ashman, R. G. Oberprieler, and A. lipiski. "Rhopalomma stefaniae gen. et sp. n., the first ommatid beetle from the Upper Jurassic in Australia (Coleoptera: Archostemata: Ommatidae)". English. In: Zootaxa 3980 (2015), pp. 136-142.

[979] A. C. Ashworth and T. L. Erwin. "Antarctotrechus balli sp. n. (Carabidae, Trechini): the first ground beetle from Antarctica". English. In: ZooKeys 635 (2016), pp. 109-122.

[980] A. C. Ashworth and G. Kuschel. "Fossil weevils (Coleoptera: Curculionidae) from latitude 85S Antarctica". English. In: Palaeogeography, Palaeoclimatology, Palaeoecology 191 (2003), pp. 191-202.

[981] A. C. Ashworth and R. E. Nelson. "The paleoenvironment of the Olympia beds based on fossil beetles from Discovery Park, Seattle, Washington, U.S.A." English. In: Quaternary International 341 (2014), pp. 243-254.

[982] A. C. Ashworth and F. C. Thompson. "A fly in the biogeographic ointment". English. In: Nature 423 (2003), pp. 135-136.

[983] I. S. Askevold. "Classification of Tertiary fossil Donaciinae of North America and their implications about evolution of Donaciinae (Coleoptera: Chrysomelidae)". English. In: Canadian Journal of Zoology 68 (1990), pp. 2135-2145. 
[984] R. A. Askin. "Monosulcate angiosperm pollen from the López de Bertodano Formation (Upper Campanian-Maastrichtian-Danian) of Seymour Island, Antarctica". English. In: Review of Palaeobotany and Palynology 81 (1994), pp. 151-164.

[985] R. A. Askin. "Cryptogam spores from the upper Campanian and Maastrichtian of Seymour Island, Antarctica". English. In: Micropaleontology 36 (1990), pp. 141-156.

[986] R. A. Askin. “Campanian to Paleocene spore and pollen assemblages of Seymour Island, Antarctica". English. In: Review of Palaeobotany and Palynology 65 (1990), pp. 105-113.

[987] U. Aspöck and H. Aspöck. "Two significant new snakeflies from Baltic amber, with discussion on autapomorphies of the order and its included taxa (Raphidioptera)". English. In: Systematic Entomology 29.1 (2004), pp. 11-19.

[988] A. Assemat, M. Boivin, L. Marivaux, F. Pujos, A. Benites-Palomino, R. Salas-Gismondi, J. V. TejadaLara, R. M. Varas-Malca, F. R. Negri, A. M. Ribeiro, and P. -O. Antoine. "Restes inédits de rongeurs caviomorphes du Paléogéne de la région de Juanjui (Amazonie péruvienne) : systématique, implications macro-évolutives et biostratigraphiques". English. In: Geodiversitas 41.20 (2019), pp. 699730.

[989] M. M. Astafieva. "New representatives of the Aviculopectinidae (Bivalvia)". English. In: Paleontological Journal 31.1 (1997), pp. 22-27.

[990] M. M. Astafieva. "Permskie inotseramopodobnye dvustvorchatye mollyuski Rossii". Russian. In: Rossiyskaya Akademiya Nauk, Trudy Paleontologicheskogo Instituta 246 (1993), pp. 1-128.

[991] H. Astibia, A. Aranburu, X. Pereda Suberbiola, X. Murelaga, C. Sesé, M. A. Cuesta, S. Moyá-Solá, J. E. Baceta, A. Badiola, and M. Köhler. "Un nouveau site á vertébrés continentaux de l’Éocéne supérieur de Zambrana (Bassin de Maranda-Treviño, Alava, Pays basque)". French. In: Géobios 32.2 (2000), pp. 233-248.

[992] H. Astibia, N. Bardet, X. Pereda-Suberbiola, A. Payros, V. de Buffrenil, J. Elorza, J. Tosquella, A. Berretega, and A. Badiola. "New fossils of Sirenia from the Middle Eocene of Navarre (Western Pyrenees): the oldest West European sea cow record". English. In: Geological Magazine 147.5 (2010), pp. 665-673. DOI: 10.1017/S0016756810000130.

[993] H. Astibia, E. Buffetaut, A. D. Buscalioni, H. Cappetta, C. Corral, R. Estes, F. Garcia-Garmilla, J. J. Jaeger, E. Jiminez-Fuentes, J. Le Loeuff, J. M. Mazin, X. Orue-Etexebarria, J. Pereda-Suberbiola, J. E. Powell, J. C. Rage, J. Rodriguez-Lazaro, J. L. Sanz, and H. Tong. “The fossil vertebrates from the Lano (Basque Country, Spain); new evidence on the composition and affinities of the Late Cretaceous continental faunas of Europe". English. In: Terra Nova 2 (1990), pp. 460-466.

[994] H. Astibia, J. Elorza, A. Pisera, G. Alvarez-Perez, A. Payros, and S. Ortiz. "Sponges and corals from the Middle Eocene (Bartonian) marly formations of the Pamplona Basin (Navarre, western Pyrenees): taphonomy, taxonomy, and paleoenvironments". English. In: Facies (2013).

[995] H. Astibia, X. Murelaga, A. Payros, X. Pereda, and J. Tosquella. "Tortugas y sirenios fosiles en el Eoceno marino de Navarra y Cuenca de Jaca". English. In: Geogaceta 25 (1999), pp. 15-18.

[996] H. Astibia, A. Payros, X. P. Suberbiola, J. Elorza, A. Berreteaga, N. Etxebarria, A. Badiola, and J. Tosquella. "Sedimentology and taphonomy of sirenian remains from the Middle Eocene of the Pamplona Basin (Navarre, western Pyrenees". English. In: Facies 50 (2005), pp. 463-475.

[997] H. Astibia, A. Payros, S. Ortiz, J. Elorza, G. Álvarez-Pérez, A. Badiola, N. Bardet, A. Berreteaga, M. A. Bitner, S. Calzada, J. C. Corral, I. Daz-Martnez, D. Merle, J. -M. Pacaud, X. Pereda-Suberbiola, A. Pisera, F. J. Rodrguez-Tovar, and J. Tosquella. "Fossil associations from the middle and upper Eocene strata of the Pamplona Basin and surrounding areas (Navarre, western Pyrenees)". English. In: Journal of Iberian Geology 42.1 (2016), pp. 7-28. DOI: 10.5209/rev_JIGE.2016.v42.n1.51601.

[998] H. Astibia, X. Pereda Suberbiola, N. Bardet, A. Payros, A. Berreteaga, and A. Badiola. "Nuevos fosiles de sirenios en el Eoceno medio de La Cuenca de Pamplona (Navarra)". Spanish. In: Revista Espanola de Paleontologia 21.1 (2006), pp. 79-91. 
[999] R. A. Astini, W. A. Thomas, and E. L. Yochelson. "Salterella in the Argentine Precordillera: an Early Cambrian palaeobiogeographic indicator of Laurentian affinity". English. In: Palaeogeography, Palaeoclimatology, Palaeoecology 213 (2004), pp. 125-132. DOI: 10.1016/j.palaeo.2004.07.008.

[1000] J. G. Astruc, M. Hugueney, G. Escarguel, S. Legendre, J. Rage, R. Simon-Coincon, J. Sudre, and Bernard Sigé. "Puycelci, nouveau site á vertébrés de la série molassique d'Aquitaine. Densité et continuité biochronologique dans la zone Quercy et bassins périphériques au Paléogéne". French. In: Geobios 36 (2003), pp. 629-648.

[1001] Z. Y. Aswan. "Milankovitch 41 000-year cycles in lithofaciesa and molluscan content in the tropical Middle Miocene Nyalindung Formation, Jawa, Indonesia". English. In: Palaeogeography, Palaeoclimatology, Palaeoecology 235 (2006), pp. 382-405.

[1002] M. M. Ataabadi, A. Bahrami, M. Yazdi, and A. Nel. "A locust witness of a trans-oceanic Oligocene migration between Arabia and Iran (Orthoptera: Acrididae)". English. In: Historical Biology 31 (2019), pp. 574-580. DOI: 10.1080/08912963.2017.1378651.

[1003] A. Atakul-Özdemir, M. A. Purnell, and N. J. Riley. “Cladistic tests of monophyly and relationships of biostratigraphically significant conodonts using multielement skeletal data -Lochriea homopunctatus and the genus Lochriea". English. In: Palaeontology 55.6 (2012), pp. 1279-1291. DOI: 10.1111/j.1475-4983.2012.01190.x.

[1004] A. Athanassiou. "Pleistocene vertebrates from the Kyparssia lignite mine, Megalopolis Basin, S. Greece: Rodentia, Carnivora, Proboscidea, Perissodactyla, Ruminantia". English. In: Quaternary International (2018). DOI: 10.1016/j.quaint.2018.06.042.

[1005] A. Athanassiou. "Craniomandibular remains of Anancus arvernensis (Proboscidea, Mammalia) from Greece: The samples from Kallphytos (E. Macedonia) and Sésklo (Thessaly)". English. In: Quaternary International 406 (2016), pp. 25-34. DOI: 10.1016/j.quaint.2015.03.048.

[1006] A. Athanassiou. A cranial specimen of Anancus arvernensis from Nigrta, Northern Greece. English. 2017.

[1007] A. Athanassiou. "On a Deinotherium (Proboscidea) finding in the Neogene of Crete". English. In: Carnets de Géologie - Notebooks on Geology - Letter 5 (2004), pp. 1-7.

[1008] A. Athanassiou. "New findings of fossil large mammal remains in the Peniós Valley (area of Larissa, Thessaly, Greece)". English. In: Bulletin of the Geological Society of Greece 34 (2001), pp. 6376.

[1009] A. Athanassiou. The Late Pleistocene fauna of Peneiós Valley (Lárissa, Thessaly, Greece): new collected material. English. 2011.

[1010] A. Athanassiou. "A new elephant site in the Haliákmon River valley (W. Macedonia, Greece)". English. In: Proceedings of the 5th International Symposium on Eastern Mediterranean Geology, Thessaloniki (2004), pp. 299-302.

[1011] A. Athanassiou. "Presence of fossil elephants in the area of Peniós valley (NW Peloponnesus, Greece)". English. In: Annales Geologiques des Pays Helleniques 38 (2000), pp. 63-76.

[1012] A. Athanassiou. "A skeleton of Mammuthus trogontherii (Proboscidea, Elephantidae) from NW". English. In: Quaternary International 255 (2012), pp. 9-28. DOI: 10.1016/j.quaint.2011.03.030.

[1013] A. Athanassiou. "Reghnio, a new mammal locality from the Plio-Pleistocene of Central Greece". English. In: Neues Jahrbuch für Geologie und Paläontologie 2006.2 (2006), pp. 116-128.

[1014] A. Athanassiou. "A Villafranchian Hipparion-Bearing Mammal Fauna from Sésklo (E. Thessaly, Greece): Implications for the Question of Hipparion-Equus Sympatry in Europe". English. In: Quaternary MDPI 1.12 (2018), pp. 1-24. DOI: 10.3390/quat1020012.

[1015] A. Athanassiou. "New giraffid (Artiodactyla) material from the Lower Pleistocene locality of Sésklo (SE Thessaly, Greece): evidence for an extension of the genus Palaeotragus into the Pleistocene". English. In: Zitteliana B 32 (2014), pp. 71-89. 
[1016] A. Athanassiou and D. Bouzas. "New hippopotamid finds in Eurotas valley (Laconia, Greece)". English. In: Scientific Annals, School of Geology, Aristotle University of Thessaloniki. Proceedings of the XIX CBGA Congress, Thessaloniki, Greece 99 (2010), pp. 57-62.

[1017] A. Athanassiou and D. S. Kostopoulos. "Proboscidea of the Greek Pliocene-Early Pleistocene faunas; biostratigraphic and palaeoecological implications". English. In: Proceedings of the 1st International Congress The World of Elephants, Rome, 2001 (2001), pp. 85-90.

[1018] A. Athanassiou and D. S. Kostopoulos. "On mammal remains in the area of Epanomi (Macedonia, Greece)". English. In: Proceedings of the XIX Congress of the Carpathian-Balkan Geological Association, Thessaloniki, 2010. Scientific Annals of the School of Geology, Faculty of Sciences, Aristotle University of Thessaloniki 99 (2010), pp. 63-68.

[1019] A. Athanassiou, D. Michailidis, E. Vlachos, V. Tourloukis, N. Thompson, and K. Harvati. "Pleistocene vertebrates from the Kyparssia lignite mine, Megalopolis Basin, S. Greece: Testudines, Aves, Suiformes". English. In: Quaternary International 478 (2018), pp. 178-197. DOI: 10.1016/j. quaint.2018.06.030.

[1020] A. Athanassiou, S. J. Roussiakis, I. X. Giaourtsakis, G. E. Theodorou, and G. Iliopoulos. “A new hornless rhinoceros of the genus Acerorhinus (Perissodactyla: Rhinocerotidae) from the Upper Miocene of Kerassiá (Euboea, Greece), with a revision of related forms". English. In: Palaeontographica Abteilung A 303.1-3 (2014), pp. 23-59.

[1021] A. Athanassiou, A. A. E. van der Geer, and G. A. Lyras. "Pleistocene insular Proboscidea of the Eastern Mediterranean: A review and update". English. In: Quaternary Science Reviews 218 (2019), pp. 306-321. DOI: 10.1016/j.quascirev.2019.06.028.

[1022] A. Athanassiou. "[Biostratigraphical implications of the fossil tusks' structure]". other. In: Bulletin of the Geological Society of Greece 39 (2006), pp. 9-16.

[1023] C. J. Atkins and J. S. Peel. "New species of Yochelcionella (Mollusca; Helcionelloida) from the Lower Cambrian of North Greenland". English. In: Bulletin of the Geological Society of Denmark 51.1 (2004), pp. 1-9.

[1024] C. J. Atkins and J. S. Peel. "Yochelcionella (Mollusca, Helcionelloida) from the lower Cambrian of North America". English. In: Bulletin of Geosciences 83.1 (2008), pp. 23-38. DOI: 10.3140/bull. geosci.2008.01.023.

[1025] N. Atkinson. “A 10400-year-old bowhead whale (Balaena mysticetus) skull from Ellef Ringnes Island, Nunavut: Implications for sea-ice conditions in High arctic Canada at the end of the last glaciation". English. In: Arctic 62.1 (2009), pp. 38-44.

[1026] N. Atkinson. "A 10 400-Year-Old Bowhead Whale (Balaena mysticetus) Skull from Ellef Ringnes Island, Nunavut: Implications for Sea-Ice Conditions in High Arctic Canada at the End of the Last Glaciation". English. In: Arctic 62.1 (2008), pp. 38-44.

[1027] T. P. Atkinson. Arthropod body fossils from the Union Chapel Mine. English. Vol. 1. Alabama Paleontological Society Monograph. 2005, pp. 169-176.

[1028] F. Atrops and Y. Alméras. “Les Brachiopodes du Callovien de l'Ouarsenis (Tell algérien): paléontologie, biostratigraphie et paléoenvironnements". French. In: Revue de Paléobiologie 24.2 (2005), pp. 563-595.

[1029] D. Atta-Peters and M. B. Salami. "Aptian-Maastrichtian palynomorphs from the offshore Tano Basin, western Ghana". English. In: Journal of African Earth Sciences 43 (2006), pp. 379-394.

[1030] J. Atterholt, J. H. Hutchison, and J. K. O'Connor. "The most complete enantiornithine from North America and a phylogenetic analysis of the Avisauridae". English. In: PeerJ 6 (2018), e5910:1-45. DOI: $10.7717 /$ peerj.5910.

[1031] M. Augé. “La faune de Lacertilia (Reptilia, Squamata) de l'Éocéne inférieur de Prémontré (Bassin de Paris, France)". English. In: Geodiversitas 25.3 (2003), pp. 539-574.

[1032] M. Auge. "Past and present distribution of iguanid lizards". English. In: Arquivos do Museu Nacional, Rio de Janeiro 65.4 (2007), pp. 403-416. 
[1033] M. Augé, S. Duffaud, F. de Lapparent de Broin, J. -C. Rage, and D. Vasse. “Les amphibiens et les reptiles de Prémontré (Cuisien, Bassin parisien): une herpétofaune de référence pour l’Eocéne inférieur". French. In: Géologie de la France 1 (1997), pp. 23-33.

[1034] M. Augé, L. Ginsburg, F. L. de Broin, M. Makinsky, C. Mourer, D. Poiut, and S. Sen. "Les vertébrés du Miocéne moyen de Contres (Loir-et-Cher, France)". French. In: Revue de Paléobiologie 21.2 (2002), pp. 819-852.

[1035] M. Augé and D. Pouit. "Presence of iguanid lizards in the European Oligocene Lazarus taxa and fossil abundance". English. In: Bulletin de la Société Géologique de France 183.6 (2012), pp. 653-660. DOI: 10.2113/gssgfbull.183.6.653.

[1036] M. Augé and D. Pouit. “Un lacertidé des faluns du Miocéne moyen d'Anjou”. French. In: Symbioses 23 (2009), pp. 23-27.

[1037] M. Augé and J.-C. Rage. "Herpetofaunas from the Upper Paleocene and Lower Eocene of Morocco". English. In: Annales de Paléontologie 92.3 (2006), pp. 235-253. DOI: 10.1016/j.annpal.2005. 09.001.

[1038] M. Augé and J.-C. Rage. “Le Garouillas et les sites contemporains (Oligocene, MP 25) des Phosphorites du Quercy (Lot, Tarn-et-Garonne, France) et leurs faunas de vertebres. 2. Amphibiens et squamates". French. In: Palaeontographica Abteilung A 236.1-6 (1995), pp. 11-32.

[1039] M. Augé and J.-C. Rage. “Les squamates (Reptilia) du Miocéne moyen de Sansan”. French. In: Mémoires du Muséum National d'Histoire Naturelle 183 (2000), pp. 263-313.

[1040] M. Augé and R. Smith. “Nouveaux Lacertidae (Reptilia, Squamata) de l'Eocéne inférieur européen". French. In: Belgian Journal of Zoology 131.1 (2002), pp. 3-15.

[1041] M. Auge and R. Smith. "An assemblage of early Oligocene lizards (Squamata) from the locality of Boutersem (Belgium), with comments on the Eocene-Oligocene transition". English. In: Zoological Journal of the Linnean Society 155 (2009), pp. 148-170.

[1042] M. Auge and R. M. Sullivan. "A new genus, Paraplacosauriops (Squamata, Anguidae, Glyptosaurinae), from the Eocene of France". English. In: Journal of Vertebrate Paleontology 26.1 (2006), pp. 133-137.

[1043] M. L. Augé. "Evolution des lézards du Paléogéne en Europe". French. In: Mémoires du Muséum national d'histoire naturelle 192 (2005), pp. 1-369.

[1044] M. L. Auge. "Amphisbaenians from the European Eocene: a biogeographical review". English. In: Palaeobiodiversity and Palaeoenvironments 92.4 (2012), pp. 425-443. DOI: 10.1007/s12549-012-0104-6.

[1045] M. L. Augé and S. Brizuela. "Transient presence of a teiid lizard in the European Eocene suggests transatlantic dispersal and rapid extinction". English. In: Palaeobiodiversity and Palaeoenvironments (2020). DOI: 10.1007/s12549-019-00414-2.

[1046] M. L. Augé and B. Guével. “New varanid remains from the Miocene (MN4-MN5) of France: inferring fossil lizard phylogeny from subsets of large morphological data sets". English. In: Journal of Vertebrate Paleontology (2018), e1410483. DOI: 10.1080/02724634.2017.1410483.

[1047] M. L. Auge and S. Hervet. "Fossil lizards from the locality of Gannat (late Oligocene-early Miocene, France) and a revision of the genus Pseudeumeces (Squamata, Lacertidae)". English. In: Palaeobiodiversity and Palaeoenvironments 89 (2009), pp. 191-201. DOI: 10.1007/s12549-009-0009-1.

[1048] K. R. Aulenback and B. A. LePage. Taxodium wallisii sp. nov.: First occurence of Taxodium from the Upper Cretaceous. 1998.

[1049] A. K. Aung. “New Middle Devonian (Eifelian) rugose corals from Myanmar". English. In: Journal of Southeast Asian Earth Sciences 11.1 (1995), pp. 23-32.

[1050] A. K. Aung, T. F. Ng, K. K. Nyien, and M. H. Zin. "New Late Permian rugose corals from Pahang, peninsular Malaysia". English. In: Alcheringa 37 (2013), pp. 422-434.

[1051] T. Aureliano, A. M. Gilhardi, R. R. C. Duque, and A. M. F. Barreto. “On the occurrence of Pterosauria in Exu, Pernambuco (Lower Cretaceous Romualdo Formation, Araripe Basin), Northeastern Brazil". English. In: Estudos Geológicos 24.2 (2014), pp. 15-27. 
[1052] W. I. Ausich. "Lower Mississipian crinoid (Echinodermata) fauna from Utah County, Utah". In: Journal of Paleontology 77.1 (2003), pp. 139-145.

[1053] W. I. Ausich and P. Copper. "The Crinoidea of Anticosti Island, Quebec (Late Ordovician to Early Silurian)". English. In: Palaeontographica Canadiana 29 (2010), pp. 1-157.

[1054] W. I. Ausich and M. E. Cournoyer. "New taxa and revised stratigraphic distribution of the crinoid fauna from Anticosti Island, Québec, Canada (Late Ordovician-early Silurian)". English. In: Journal of Paleontology 93 (2019).

[1055] W. I. Ausich, M. D. Gil Cid, and P. Dominguez Alonso. “Ordovician [Dobrotivian (Llandeillian stage) to Ashgill] crinoids (Phylum Echinodermata) from the Montes de Toledo and Sierra Morena Spain". English. In: Journal of Paleontology 76.6 (2002), pp. 975-992.

[1056] W. I. Ausich, A. Goldstein, and R. Yates. "Crinoids from the Muldraugh Member of the Borden Formation in north-central Kentucky (Echinodermata, Lower Mississippian)". In: Journal of Paleontology 74.6 (2000), pp. 1072-1082.

[1057] W. I. Ausich and T. W. Kammer. "Systematic revisions to Aorocrinus, Dorycrinus, Macrocrinus, Paradichocrinus, Strotocrinus, and Uperocrinus: Mississippian camerate crinoids (Echinodermata) from the stratotype region". In: Journal of Paleontology 65.6 (1991), pp. 936-944.

[1058] W. I. Ausich and T. W. Kammer. "Late Osagean and Meramecian Actinocrinites (Echinodermata: Crinoidea) from the Mississippian stratotype region". In: Journal of Paleontology 65.3 (1991), pp. 485499.

[1059] W. I. Ausich and D. L. Meyer. “Crinoidea Flexibilia (Echinodermata) from the Fort Payne Formation (Lower Mississippian; Kentucky and Tennessee)". In: Journal of Paleontology 66.5 (1992), pp. 825-838.

[1060] W. I. Ausich and D. L. Meyer. "Origin and composition of carbonate buildups and associated facies in the Fort Payne Formation (Lower Mississippian, south-central Kentucky): an integrated sedimentologic and paleoecologic analysis". English. In: Geological Society of America Bulletin 102 (1990), pp. 129-146.

[1061] W. I. Ausich, S. V. Rozhnov, and T. W. Kammer. "Iocrinid Crinoids from the Ordovician of the Baltic Region, Estonia". English. In: Paleontological Journal 49.2 (2015), pp. 145-152.

[1062] W. I. Ausich, A. A. Sa, and J. C. Gutierrez-Marco. "New and revised occurrences of Ordovician crinoids from southwestern Europe". English. In: Journal of Paleontology 81.6 (2007), pp. 1374-1383.

[1063] W. I. Ausich, M. A. Wilson, and U. Toom. "Early Silurian recovery of Baltica crinoids following the end-Ordovician extinctions (Llandovery, Estonia)". English. In: Journal of Paleontology (2019). DOI: $10.1017 /$ jpa.2019.89.

[1064] W. I. Ausich and M. A. Wislon. "New Tethyan Apiocrinitidae (Crinoidea, Articulata) from the Jurassic of Israel”. English. In: Journal of Paleontology (2012), pp. 1051-1055.

[1065] W. I. Ausich, D. F. Wright, S. R. Cole, and J. M. Koniecki. “Disparid and hybocrinid crinoids (Echinodermata) from the Upper Ordovician (lower Katian) Brechin Lagerstätte of Ontario". English. In: Journal of Paleontology 92.5 (2018), pp. 850-871. DOI: 10.1017/jpa.2017.154.

[1066] W. I. Ausich, T. E. Bolton, and L. M. Cumming. “Whiterockian (Ordovician) crinoid fauna from the Table Head Group, western Newfoundland, Canada". English. In: Canadian Journal of Earth Sciences 35 (1998), pp. 121-130.

[1067] P. Austen. "Smokejacks fieldwork 2001-2004". English. In: Wealden News 6 (2005), pp. 6-8.

[1068] P. Austen. “Smokejacks fieldwork 2007-2009". English. In: Wealden News 8 (2010), pp. $28-31$.

[1069] P. Austen, D. Brockhurst, and K. Honeysett. "Vertebrate fauna from Ashdown Brickworks, Bexhill, East Sussex". English. In: Wealden News 8 (2010), pp. 13-23.

[1070] M. Avanzini. "Dinosauromorph tracks from the Middle Triassic (Anisian) of the Southern Alps (Valle di Non - Italy)". English. In: Bolletino della Societá Paleontologica Italiana 41.1 (2002), pp. 3740. 
[1071] M. Avanzini. "Anatomy of a footprint: bioturbation as a key to understanding dinosaur walk dynamics". English. In: Ichnos 6.3 (1998), pp. 129-139. DOI: 10.1080/10420949809386444.

[1072] M. Avanzini. "Synaptichnium tracks with skin impressions from the Anisian (Middle Triassic) of the Southern alps (Val di Non - Italy)". English. In: Ichnos 7.4 (2000), pp. 243-251. DOI: 10.1080 / 10420940009380164.

[1073] M. Avanzini, J. C. Garcia-Ramos, J. Lires, M. Menegon, L. Pinuela, and L. A. Fernandez. “Turtle tracks from the Late Jurassic of Asturias, Spain". English. In: Acta Palaeontologica Polonica 50.4 (2005), pp. 743-755.

[1074] M. Avanzini, J. C. Garciia-Ramos, J. Lires, L. Pinuela, and M. G. Lockley. “Crocodylomorph tracks from the Late Jurassic of Asturias (Spain)". English. In: Ichnos 14 (2007), pp. 143-153. DOI: 10.1080/ 10420940601010943.

[1075] M. Avanzini, G. D. Gierlinski, and G. Leonardi. “First report of sitting Anomoepus tracks in European Lower Jurassic (Lavini di Marco site - northern Italy)". English. In: Rivista Italiana di Paleontologia e Stratigrafia 107.1 (2001), pp. 131-136.

[1076] M. Avanzini and G. Leonardi. "Dinosauri nel Trentino: il giacimento dei Lavini di Marco [Dinosaurs in Trentino: the locality of Lavini di Marco]". Italian. In: UCT (Uomo - Cittá - Territorio) 214 (1993), pp. 35-41.

[1077] M. Avanzini, G. Leonardi, and P. Mietto. "Lavinipes cheminii ichnogen., ichnosp. nov., a possible sauropodomorph track from the Lower Jurassic of the Italian Alps". English. In: Ichnos 10.2-4 (2003), pp. 179-193. DOI: 10.1080/10420940390256195.

[1078] M. Avanzini, G. Leonardi, R. Tomasoni, and M. Campolongo. “Enigmatic dinosaur trackways from the Lower Jurassic (Pliensbachian) of the Sarca Valley, northeast Italy". English. In: Ichnos 8 (2001), pp. 235-242.

[1079] M. Avanzini and F. M. Petti. "Updating the dinosaur tracksites from the Lower Jurassic Calcari Grigi Group (Southern Alps, northern Italy)". English. In: Studi Trentini di Scienze Naturali, Acta Geologica 83 (2008), pp. 289-301.

[1080] M. Avanzini, D. Piubelli, P. Mietto, G. Roghi, R. Romano, and D. Masetti. “Lower Jurassic (HettangianSinemurian) dinosaur track megasites, southern Alps, northern Italy". English. In: vol. 37. The Triassic-Jurassic Terrestrial Transition. New Mexico Museum of Natural History and Science Bulletin. Albuquerque: New Mexico Museum of Natural History and Science, 2006, pp. 207-216.

[1081] M. Avanzini and M. Wachtler. "Sphingopus ladinicus isp. nov. from the Anisian of the Braies Dolomites (Southern Alps, Italy)". English. In: Bollettino della Societá Paleontologica Italiana 51.1 (2012), p. 64.

[1082] A. Averianov. "A new species of multituberculate mammal. Uzbekbaatar from the Late Cretaceous of Uzbekistan". English. In: Acta Palaeontologica Polonica 44.3 (1999), pp. 301-304.

[1083] A. Averianov. "Artiodactyla from the early Eocene of Kyrgyzstan". English. In: Palaeovertebrata 25.2-4 (1996), pp. 359-369.

[1084] A. Averianov and J. D. Archibald. "Mammals from the mid-Cretaceous Khodzhakul Formation, Kyzylkum Desert, Uzbekistan". English. In: Cretaceous Research 26.4 (2005), pp. 593-608.

[1085] A. Averianov, J. D. Archibald, and G. J. Dyke. “A new eutherian mammal from the Late Cretaceous of Kazakhstan". English. In: Acta Palaeontologica Polonica (2012). DOI: 10.4202/app.2011.0143.

[1086] A. Averianov, I. Danilov, J. Jin, and Y. Wang. "A new amynodontid from the Eocene of South China and phylogeny of Amynodontidae (Perissodactyla: Rhinocerotoidea)". English. In: Journal of Systematic Palaeontology 15.11 (2017), pp. 927-945. DOI: 10.1080/14772019.2016.1256914.

[1087] A. Averianov, I. Danilov, W. Chen, and J. Jin. "A new brontothere from the Eocene of South China". English. In: Acta Palaeontologica Polonica 63.1 (2018), pp. 189-196. DOI: 10.4202/app.00431.2017.

[1088] A. Averianov and V. Efimov. "The oldest titanosaurian sauropod of the Northern Hemisphere". English. In: Biological Communications 63.3 (2018), pp. 145-162. 
[1089] A. Averianov, S. Ivantsov, P. Skutschas, A. Faingertz, and S. Leshchinskiy. "A new sauropod dinosaur from the Lower Cretaceous Ilek Formation, Western Siberia, Russia". English. In: Geobios 51 (2018), pp. 1-14.

[1090] A. Averianov and A. Lopatin. "Mammal remains from the Lower Cretaceous Bol'shoi Terekhtyul' locality in West Siberia, Russia". English. In: Cretaceous Research 54 (2015), pp. 145-153. DOI: 10. 1016/j.cretres.2014.12.007.

[1091] A. Averianov, A. Lopatin, P. Skutschas, and S. Leschinsky. "Two new mammal localities within the Lower Cretaceous Ilek Formation of West Siberia, Russia". English. In: Geobios 48 (2015), pp. 131136.

[1092] A. Averianov, T. Martin, P. Skutschas, I. Danilov, J. Schultz, R. Schellhorn, E. Obraztsova, A. Lopatin, E. Sttchevskaya, I. Kuzmin, S. Krasnotutskii, and S. Ivantsov. "Middle Jurassic vertebrate assemblage of Berezovsk coal mine in western Siberia (Russia)". English. In: Global Geology 19.4 (2016), pp. 187-204. DOI: 10.3969/j.issn.1673-9736.2016.04.01.

[1093] A. Averianov, T. Martin, A. Lopatin, P. Skutschas, R. Schellhorn, P. Kolosov, and D. D. Vitenko. "A high-latitude fauna of mid-Mesozoic mammals from Yakutia, Russia". English. In: PLoS ONE 13.7 (2018), e0199983:1-17.

[1094] A. Averianov, E. Obraztsova, I. Danilov, P. Skutschas, and J. Jin. "First nimravid skull from Asia". English. In: Scientific Reports 6 (2016), 25812:1-8.

[1095] A. Averianov, E. Obraztsova, I. Danilov, and J. Jin. "Anthracotheriid artiodactyl Anthracokeryx and an upper Eocene age for the". English. In: Historical Biology 31 (2019), pp. 1115-1122. DOI: 10.1080/08912963.2017.1421639.

[1096] A. Averianov and E. Popov. "A new species of chimaeroid fish from the Upper Cretaceous of the Saratov region, Russia". English. In: Palaeontology 38 (1995), pp. 659-664.

[1097] A. Averianov and P. Skutschas. "A eutherian mammal from the Early Cretaceous of Russia and biostratigraphy of the Asian Early Cretaceous vertebrate assemblages". English. In: Lethaia 33 (2000), pp. 330-340.

[1098] A. Averianov and P. Skutschas. "A new lithostrotian titanosaur (Dinosauria, Sauropoda) from the Early Cretaceous of Transbaikalia, Russia". English. In: Biological Communications 62.1 (2017), pp. 6-18.

[1099] A. O. Averianov. "Paleogene sea snakes from the eastern part of Tethys". In: Russian Journal of Herpetology 4.2 (1997), pp. 128-142.

[1100] A. O. Averianov. "On an ornithomimid dinosaur (Saurischia, Ornithomimosauria) from the Cenomanian of Fergana". English. In: Paleontological Journal 40.3 (2006), pp. 323-327.

[1101] A. O. Averianov. Mammals from the Mesozoic of Kirgizstan, Uzbekistan, Kazakhstan and Tadzhikistan. English. The Age of Dinosaurs in Russia and Mongolia. Cambridge: Cambridge University Press, 2000, pp. 627-652.

[1102] A. O. Averianov. "New records of azhdarchids (Pterosauria, Azhdarchidae) from the Late Cretaceous of Russia, Kazakhstan, and Central Asia". English. In: Paleontological Journal 41.2 (2007), pp. 189-197.

[1103] A. O. Averianov. "Theropod dinosaurs from Late Cretaceous deposits in the northeastern Aral Sea region, Kazakhstan". English. In: Cretaceous Research 28 (2007), pp. 532-544.

[1104] A. O. Averianov. "New Late Cretaceous mammals of southern Kazakhstan". English. In: Acta Palaeontologica Polonica 42.2 (1997), pp. 243-256.

[1105] A. O. Averianov. "Mid-Cretaceous ornithocheirids (Pterosauria, Ornithocheiridae) from Russia and Uzbekistan". English. In: Paleontological Journal 41 (2007), pp. 79-86.

[1106] A. O. Averianov. "New data on Cretaceous flying reptiles (Pterosauria) from Russia, Kazakhstan, and Kyrgyzstan". English. In: Paleontological Journal 38.4 (2004), pp. 426-436. 
[1107] A. O. Averianov. "An ankylosaurid (Ornithischia: Ankylosauria) braincase from the Upper Cretaceous Bissekty Formation of Uzbekistan". English. In: Bulletin de l'Institute Royal des Sciences Naturelles de Belgique, Sciences de la Terre 72 (2002), pp. 97-110.

[1108] A. O. Averianov. "Sunosuchus sp. (Crocodylomorpha, Goniopholididae) from the Middle Jurassic of Kirghisia". English. In: Journal of Vertebrate Paleontology 20.4 (2000), pp. 776-779. DOI: 10.1671/ 0272-4634(2000)020[0776:SSCGFT]2.0.CO;2.

[1109] A. O. Averianov. "The first choristoderes (Diapsida, Choristodera) from the Paleogene of Asia". English. In: Palaeontological Journal 39.1 (2005), pp. 79-84.

[1110] A. O. Averianov. "Review of Mesozoic and Cenozoic sea turtles from the former USSR". English. In: Russian Journal of Herpetology 9.2 (2002), pp. 137-154.

[1111] A. O. Averianov. "A New Sea Turtle (Testudines, Cheloniidae) from the Middle Eocene of Uzbekistan". English. In: Paleontological Journal 39.6 (2005), pp. 646-651.

[1112] A. O. Averianov. "Early Eocene mimotonids of Kyrgyzstan and the problem of Mixodontia". English. In: Acta Palaeontologica Polonica 39.4 (1994), pp. 393-411.

[1113] A. O. Averianov. "A new species of Sarcodon (Mammalia, Palaeoryctoidea) from the Lower Eocene of Kirgizia". English. In: Geobios 27.2 (1994), pp. 255-258.

[1114] A. O. Averianov. "Early Eocene Rodentia of Kyrgyzstan". English. In: Bulletin du Museum national d'Histoire naturelle, Paris, 4e serie 18 (1996), pp. 629-662.

[1115] A. O. Averianov. "Sunosuchus sp. (Crocodylomorpha, Goniopholididae) from the Middle Jurassic of Kirghisia". English. In: Journal of Vertebrate Paleontology 20.4 (2001), pp. 776-779. DOI: 10.1671/ 0272-4634(2000)020[0776:SSCGFT]2.0.CO;2.

[1116] A. O. Averianov. "The first find of a dolichosaur (Squamata, Dolichosauridae) in central Asia". English. In: Paleontological Journal 35.5 (2001), pp. 525-527.

[1117] A. O. Averianov. "A rare find of a vomerine toothplate of an elephant fish (Holocephali, Callorhinchidae) from the Upper Cretaceous of Russia". English. In: Paleontological Journal 31 (1997), pp. 79-80.

[1118] A. O. Averianov. "Systematics of the Cretaceous-Paleogene chimaeroid fish of the genus Elasmodus (Chondrichthyes, Holocephali)". English. In: Paleontological Journal 35 (2001), pp. 289-300.

[1119] A. O. Averianov and V. R. Alifanov. "New data on duck-billed dinosaurs (Ornithischia, Hadrosauridae) from the Upper Cretaceous of Tajikistan". English. In: Paleontological Journal 46.5 (2012), pp. 512-519. DOI: $10.1134 /$ s0031030112050036.

[1120] A. O. Averianov, J. D. Archibald, and E. G. Ekdale. “New material of the Late Cretaceous deltatheroidan mammal Sulestes from Uzbekistan and phylogenetic reassessment of the metatherian-eutherian dichotomy". English. In: Journal of Systematic Palaeontology 8.3 (2010), pp. 301-330. DOI: 10.1080/ 14772011003603499.

[1121] A. O. Averianov and J. D. Archibald. "New specimens of the multituberculate mammal Uzbekbaatar from the Late Cretaceous of Uzbekistan". English. In: Acta Palaeontologica Polonica 51.2 (2006), pp. 377-380.

[1122] A. O. Averianov and J. D. Archibald. "Mammals from the Upper Cretaceous Aitym Formation, Kyzylkum Desert, Uzbekistan". English. In: Cretaceous Research 24 (2003), pp. 171-191.

[1123] A. O. Averianov, J. D. Archibald, and T. Martin. "Placental nature of the alleged marsupial from the Cretaceous of Madagascar". English. In: Acta Palaeontologica Polonica 48.1 (2003), pp. 149-151.

[1124] A. O. Averianov and J. D. Archibald. "New material and reinterpretation of the Late Cretaceous eutherian mammal Paranyctoides from Uzbekistan". English. In: Acta Palaeontologica Polonica 58.1 (2013), pp. 17-23.

[1125] A. O. Averianov, J. D. Archibald, P. P. Skutschas, and G. J. Dyke. "New mammal remains from the Late Cretaceous Bostobe Formation (northeast Aral Sea Region, Kazakhstan)". English. In: Palaeoworld 23 (2014), pp. 314-320. 
[1126] A. O. Averianov, M. S. Arkhangelsky, and E. M. Pervushov. "A new Late Cretaceous azhdarchid (Pterosauria, Azhdarchidae) from the Volga region". English. In: Paleontological Journal 42.6 (2008), pp. 634-642. DOI: 10.1134/S0031030108060099.

[1127] A. O. Averianov, M. S. Arkhangelsky, E. M. Pervushov, and A. V. Ivanov. "A new record of an azhdarchid (Pterosauria: Azhdarchidae) from the Upper Cretaceous of the Volga Region". English. In: Paleontological Journal 39.4 (2005), pp. 433-439.

[1128] A. O. Averianov and M. S. Arkhangelsky. "A large pteranodontid pterosaur from the Late Cretaceous of Eastern Europe". English. In: Geological Magazine (2020). DOI: 10.1017/S0016756820001119.

[1129] A. O. Averianov and A. A. Atabekyan. "The first discovery of a flying reptile (Pterosauria) in Armenia". English. In: Paleontological Journal 39 (2005), pp. 210-212.

[1130] A. O. Averianov and I. G. Danilov. "A varanid lizard (Squamata: Varanidae) from the early Eocene of Kirghizia". English. In: Russian Journal of Herpetology 4.2 (1997), pp. 143-147.

[1131] A. O. Averianov and I. G. Danilov. "Agamid lizards (Reptilia, Sauria, Agamidae) from the early Eocene of Kyrgyzstan". English. In: Neues Jahrbuch für Geologie und Paläontologie - Monatshefte 1996.12 (1996), pp. 739-750.

[1132] A. O. Averianov and M. Godinot. "Ceratomorphs (Mammalia, Perissodactyla) from the early Eocene Andarak 2 locality in Kyrgyzstan". English. In: Geodiversitas 27.2 (2005), pp. 221-237.

[1133] A. O. Averianov, S. V. Ivantsov, and P. P. Skutschas. "Theropod teeth from the Lower Cretaceous Ilek Formation of Western Siberia, Russia". English. In: Proceedings of the Zoological Institute, Russian Academy of Sciences 323.2 (2019), pp. 65-84.

[1134] A. O. Averianov, S. V. Ivantsov, and P. P. Skutschas. "Caudal vertebrae of titanosaurian sauropod dinosaurs from the Lower Cretaceous Ilek Formation in Western Siberia, Russia". English. In: Cretaceous Research 107 (2020), 104309:1-9.

[1135] A. O. Averianov, S. A. Krasnolutskii, and S. V. Ivantsov. "A new basal coelurosaur (Dinosauria: Theropoda) from the Middle Jurassic of Siberia". English. In: Proceedings of the Zoological Institute, Russian Academy of Science 314.1 (2010), pp. 42-57.

[1136] A. O. Averianov, E. N. Kurochkin, E. M. Pervushov, and A. V. Ivanov. "Two bone fragments of ornithocheiroid pterosaurs from the Cenomanian of Volgograd Region, southern Russia". English. In: Acta Palaeontologica Polonica 50.2 (2005), pp. 289-294.

[1137] A. O. Averianov and E. N. Kurochkin. "A new pterosaurian record from the Cenomanian of the Volga Region". English. In: Paleontological Journal 44.6 (2010), pp. 695-697. DOI: 10.1134 / S0031030110060110.

[1138] A. O. Averianov, S. Leshchinskiy, P. Skutschas, A. Fayngertz, and A. Rezvyi. Dinosaurs from the Early Cretaceous Ilek Formation in West Siberia, Russia. English. 2004.

[1139] A. O. Averianov, S. V. Leshchinskiy, and V. I. Kudryavtsev. "Braincase of a Late Jurassic stegosaurian dinosaur from Tuva, Russia (Central Asia)". English. In: Journal of Vertebrate Paleontology 27.3 (2007), pp. 727-733.

[1140] A. O. Averianov, A. V. Lopatin, S. A. Krasnolutskii, and S. V. Ivantsov. “New docodontans from the Middle Jurassic of Siberia and reanalysis of Docodonta interrelationships". English. In: Proceedings of the Zoological Institute RAS 314.2 (2010), pp. 121-148.

[1141] A. O. Averianov, A. V. Lopatin, and S. A. Krasnolutskii. "The first haramiyid (Mammalia, Allotheria) from the Jurassic of Russia". English. In: Doklady Biological Sciences 437 (2011), pp. 103-106. DOI: $10.1134 /$ S0012496611020074.

[1142] A. O. Averianov, A. V. Lopatin, P. P. Skutschas, N. V. Matynovich, S. V. Leschinkskiy, A. S. Rezvyi, S. A. Krasnolutskii, and A. V. Fayngertz. "Discovery of Middle Jurassic mammals from Siberia". English. In: Acta Palaeontologica Polonica 50.4 (2005), pp. 789-797.

[1143] A. O. Averianov, A. V. Lopatin, and S. A. Krasnolutskii. "An amphilestid-grade eutriconodontan from the Middle Jurassic of Russia". English. In: Russian Journal of Theriology 7.1 (2008), pp. 1-4. 
[1144] A. O. Averianov and A. V. Lopatin. “Eocene Lagomorphs (Mammalia) of Asia: 1. Aktashmys (Strenulagidae fam. nov.)" English. In: Paleontological Journal 39.3 (2005), pp. 308-317.

[1145] A. O. Averianov, A. V. Lopatin, P. P. Skutschas, S. Ivantsov, E. Boitsova, and I. Kuzman. “An enigmatic multituberculate mammal from the Early Cretaceous of Siberia, Russia". English. In: Journal of Vertebrate Paleontology 37.2 (2017), e1293070:1-9. DOI: 10.1080/02724634.2017.1293070.

[1146] A. O. Averianov and A. V. Lopatin. "An unusual new sauropod dinosaur from the Late Cretaceous of Mongolia". English. In: Journal of Systematic Palaeontology 18.12 (2020), pp. 1009-1032. DOI: 10. 1080/14772019.2020.1716402.

[1147] A. O. Averianov, T. Martin, and A. A. Bakirov. "Pterosaur and dinosaur remains from the Middle Jurassic Balabansai Svita in the northern Fergana depression, Kyrgyzstan (central Asia)". In: Palaeontology 48.1 (2005), pp. 135-155.

[1148] A. O. Averianov, T. Martin, P. P. Skutschas, A. S. Rezvyi, and A. A. Bakirov. "Amphibians from the Middle Jurassic Balabansai Svita in the Fergana Depression, Kyrgyzstan (Central Asia)". English. In: Palaeontology 51.2 (2008), pp. 471-485. DOI: 10.1111/j.1475-4983.2007.00748.x.

[1149] A. O. Averianov, T. Martin, S. E. Evans, and A. A. Bakirov. "First Jurassic Choristodera from Asia". English. In: Naturwissenschaften 93 (2006), pp. 46-50.

[1150] A. O. Averianov, T. Martin, and A. Lopatin. "The oldest dryolestid mammal from the Middle Jurassic of Siberia". English. In: Journal of Vertebrate Paleontology 34.4 (2014), pp. 924-931. DOI: 10.1080/02724634.2014.837471.

[1151] A. O. Averianov, T. Martin, A. V. Lopatin, J. A. Schultz, P. P. Skutschas, R. Schellhorn, and S. A. Krasnolutskii. "A tritylodontid synapsid from the Middle Jurassic of Siberia and the taxonomy of derived tritylodontids". English. In: Journal of Vertebrate Paleontology 37.5 (2017), e1363767:1-10. DOI: 10.1080/02724634.2017.1363767.

[1152] A. O. Averianov, T. Martin, A. V. Lopatin, P. P. Skutschas, R. Schellhorn, P. N. Kolosov, and D. D. Vitenko. "A new euharamiyidan mammaliaform from the Lower Cretaceous of Yakutia, Russia". English. In: Scientific Reports (2020), e1762089:1-6. DOI: 10.1080/02724634.2019.1762089.

[1153] A. O. Averianov and V. K. Popov. "The first plesiosaur from the Primorye Krai". English. In: Doklady Biological Sciences 401.1-6 (2005), pp. 104-106. DOI: 10.1007/s10630-005-0056-3.

[1154] A. O. Averianov and P. P. Skutschas. "Additions to the Early Cretaceous dinosaur fauna of Transbaikalia, eastern Russia". English. In: Proceedings of the Zoological Institute, Russian Academy of Sciences 313.4 (2009), pp. 363-378.

[1155] A. O. Averianov, P. P. Skutschas, A. V. Lopatin, S. V. Leschinskiy, A. S. Rezvyi, and A. V. Fayngerts. "Early Cretaceous mammals from Bol'Shoi Kemchug 3 locality in West Siberia, Russia". English. In: Russian Journal of Theriology 4.1 (2005), pp. 1-12.

[1156] A. O. Averianov, P. P. Skutschas, R. Schellhorn, A. V. Lopatin, P. N. Kolosov, V. V. Kolchanov, D. D. Vitenko, D. V. Grigoriev, and T. Martin. "The northernmost sauropod record in the Northern Hemisphere". English. In: Lethaia 53 (2019), pp. 362-368. DOI: 10.1111/let.12362.

[1157] A. O. Averianov, A. Starkov, and P. Skutschas. "Dinosaurs from the Early Cretaceous Murtoi Formation in Buryatia, eastern Russia". English. In: Journal of Vertebrate Paleontology 23.3 (2003), pp. 586-594.

[1158] A. O. Averianov and H.-D. Sues. "A new troodontid (Dinosauria: Theropoda) from the Cenomanian of Uzbekistan, with a review of troodontid records from the territories of the former Soviet Union". English. In: Journal of Vertebrate Paleontology 27.1 (2007), pp. 87-98.

[1159] A. O. Averianov, H.-D. Sues, and P. A. Tleuberdina. "The forgotten dinosaurs of Zhetysu (Eastern Kazakhstan; Late Cretaceous)". English. In: Proceedings of the Zoological Institute, Russian Academy of Sciences 316.2 (2012), pp. 139-147.

[1160] A. O. Averianov, H.-D. Sues, G. J. Dyke, and B. Bayshashov. "Hind limb bones of an ornithomimid dinosaur from the Upper Cretaceous Bostobe Formation, northeastern Aral Sea region, Kazakhstan". English. In: Palaeoworld 26 (2017), pp. 194-201. DOI: 10.1016/j.palwor.2016.01.003. 
[1161] A. O. Averianov and H.-D. Sues. “Skeletal remains of Tyrannosauroidea (Dinosauria: Theropoda) from the Bissekty Formation (Upper Cretaceous: Turonian) of Uzbekistan". English. In: Cretaceous Research 34 (2012), pp. 284-297. DOI: 10.1016/j.cretres.2011.11.009.

[1162] A. O. Averianov, A. V. Voronkevich, E. N. Maschenko, S. V. Leshchinskiy, and A. V. Fayngertz. "A sauropod foot from the Early Cretaceous of western Siberia, Russia". In: Acta Palaeontologica Polonica 47.1 (2002), pp. 117-124.

[1163] A. O. Averianov and A. V. Voronkevich. "A new crown-group salamander from the Early Cretaceous of western Siberia". English. In: Russian Journal of Herpetology 9.3 (2002), pp. 209-214.

[1164] A. O. Averianov, A. V. Voronkevich, S. V. Lechchinskiy, and A. Fayngertz. “A ceratopsian dinosaur Psittacosaurus sibiricus from the Early Cretaceous of west Siberia, Russia and its phylogenetic relationships". English. In: Journal of Systematic Palaeontology 4.4 (2006), pp. 359-395.

[1165] A. O. Averianov and A. A. Yarkov. "Carnivorous dinosaurs (Saurischia, Theropoda) from the Maastrichtian of the Volga-Don interfluve, Russia". In: Paleontological Journal 38.1 (2004), pp. 7882.

[1166] A. O. Averianov and A. A. Yarkov. "On the occurrence of a giant flying reptile (Pterosauria) in the terminal Late Cretaceous of the Lower Volga Region". English. In: Paleontological Journal 38.6 (2004), pp. 669-671.

[1167] A. O. Averianov and A. A. Yarkov. "New turtle remains from the Late Cretaceous and Paleogene of Volgograd Region, Russia". English. In: Russian Journal of Herpetology 11.1 (2004), pp. 41-50.

[1168] A. O. Averianov and A. A. Yarkov. "Some turtle remains from the Cretaceous and Paleogene of Volgograd Region, Russia". English. In: Russian Journal of Herpetology 7.2 (2000), pp. 161-166.

[1169] A. O. Averianov and N. G. Zverkov. "New diplodocoid sauropod dinosaur material from the Middle Jurassic of European Russia". English. In: Acta Palaeontologica Polonica 65.3 (2020), pp. 499 509. DOI: 10.4202 /app.00724.2020.

[1170] A. V. Averianov and E. V. Popov. "A pterosaurian vertebra from the Upper Cretaceous of the Saratov Region". English. In: Paleontological Journal 48.3 (2014), pp. 326-329. DOI: 10.1134/S0031030114030034.

[1171] A. O. Averianov. "Nyctitheriid insectivores from the Upper Paleocene of Southern Kazakhstan (Mammalia: Lipotyphla)". English. In: Senckenbergiana lethaea 75 (1995), pp. 215-220.

[1172] A. O. Averianov and J. Erfurt. "Artiodactyla from the Early Eocene of southern Kazakhstan". English. In: Hallesches Jahrb. Geowiss 18 (1996), pp. 171-178.

[1173] A. O. Averianov and A. A. Yarkov. "Enigmatic bilophodont molariform tooth from the Eocene of Central Russia". English. In: Russian Journal of Theriology 2 (2006), pp. 55-57.

[1174] D. M. Avery. "Early and Middle Pleistocene environments and hominid biogeography; micromammalian evidence from Kabwe, Twin Rivers and Mumbwa Caves in central Zambia". English. In: Palaeogeography, Palaeoclimatology, Palaeoecology 189.1-2 (2003), pp. 55-69.

[1175] G. Avery, D. Halkett, J. Orton, T. Steele, M. Tusenius, and R. Klein. “The Ysterfontein 1 Middle Stone Age rock shelter and the evolution of coastal foraging". English. In: South African Archaeological Society Goodwin Series 10 (2008), pp. 66-89.

[1176] G. A. Avery and R. G. Klein. "Review of fossil phocid and otariid seals from the southern and western coasts of South Africa". English. In: Transactions of the Royal Society of South Africa 66.1 (2011), pp. 14-24.

[1177] S. P. Ávila, R. Amen, J. M. N. Azevedo, M. Cachão, and F. Garca-Talavera. "Checklist of the Pleistocene marine molluscs of Prainha and Lagoinhas (Santa Maria Island, Azores)". English. In: Açoreana 9 (2002), pp. 343-370.

[1178] S. P. Avila, R. Cordeiro, A. R. Rodrigues, A. C. Rebelo, C. Melo, P. Madeira, and N. D. Pyenson. "Fossil Mysticeti from the Pleistocene of Santa Maria Island, Azores (Northeast Atlantic Ocean), and the prevalence of fossil cetaceans on oceanic islands". English. In: Palaeontologia Electronica 18.2.27A (2015), pp. 1-12. 
[1179] S. P. Ávila, P. Madeira, C. Zazo, A. Kroh, M. Kirby, C. Marques da Silva, M. Cachao, and A. M. de Frias Martins. "Palaeoecology of the Pleistocene (MIS 5) outcrops of Santa Maria Island (Azores) in a complex oceanic tectonic setting". English. In: Palaeogeography, Palaeoclimatology, Palaeoecology 274 (2009), pp. 18-31.

[1180] S. P. Avila, C. Melo, B. Berning, R. Cordeiro, B. Landau, and C. M. da Silva. "Persististrombus coronatus (Mollusca: Strombidae) in the lower Pliocene of Santa Maria Island (Azores, NE Atlantic): Paleoecology, paleoclimatology and paleobiogeographic implications". English. In: Palaeogeography, Palaeoclimatology, Palaeoecology 441 (2016), pp. 912-923.

[1181] S. P. Ávila, R. S. Ramalho, and R. Vullo. "Systematics, palaeoecology and palaeobiogeography of the Neogene fossil sharks from the Azores (Northeast Atlantic)". English. In: Annales de Paléontologie 98 (2012), pp. 167-189. DOI: 10.1016/j.annpal.2012.04.001.

[1182] S. P. Avila, R. S. Ramalho, J. M. Habermann, R. Quartau, A. Kroh, B. Berning, M. Johnson, M. X. Kirby, V. Zanon, J. Titschack, A. Goss, A. C. Rebelo, C. Melo, P. Madeira, R. Cordeiro, R. Meireles, L. Bagaço, A. Hipólito, A. Uchman, C. M. da Silva, M. Cachãoi, and J. Madeira. "Palaeoecology, taphonomy, and preservation of a lower Pliocene shell bed (coquina) froma volcanic oceanic island (Santa Maria Island, Azores)". English. In: Palaeogeography, Palaeoclimatology, Palaeoecology 430 (2015), pp. 57-73.

[1183] L. S. Avilla, R. Fernandes, and D. F. B. Ramos. "Bite marks on a crocodylomorph from the Upper Cretaceous of Brazil: evidence of social behaviour?" English. In: Journal of Vertebrate Paleontology 24.4 (2004), pp. 971-973.

[1184] L. S. Avilla, L. Müller, G. M. Gasparini, L. Soibelzon, B. Absolon, F. Bonissoni Pego, R. C. Silva, A. Kinoshita, A. M. Graciano Figueiredo, and O. Baffa. "The norhternmost record of Catagonus stenocephalus (Lund in Reinhardt, 1880) (Mammalia, Cetartiodactyla) and its palaeoenvironmental and palaeobiogeographical significance". English. In: Journal of South American Earth Sciences 42 (2013), pp. 39-46. DOI: 10.1016/J.JSAMES.2012.10.001.

[1185] H. M. Avrahami, T. A. Gates, A. B. Heckert, P. J. Makovicky, and L. E. Zanno. “A new microvertebrate assemblage from the Mussentuchit Member, Cedar Mountain Formation: insights into the paleobiodiversity and paleobiogeography of early Late Cretaceous ecosystems in western North America". English. In: PeerJ (2018), pp. 1-52. DOI: 10.7717/peerj.5883.

[1186] E. Avram. "Barremitites, new genus of the family Eodesmoceratidae Wright, 1955 (Ammonitina)". English. In: Acta Palaeontologica Romaniae 1 (1997), pp. 176-179.

[1187] E. Avram and E. Gradinaru. "A peculiar Upper Valanginian cephalopod fauna from the Carpatic Bend (Codlea town area, Romania): biostratigraphic and paleobiogeographic implications". English. In: Jahrbuch der Geologischen Bundesanstalt 136.4 (1993), pp. 665-700.

[1188] D. I. Axelrod. "The Early Miocene Buffalo Canyon Flora of Western Nevada". In: University of California Publications in Geological Sciences 135 (1991), pp. 1-76.

[1189] D. I. Axelrod. "A Miocene (10-12 Ma) Evergreen Laurel-Oak Forest from Carmel Valley, California". In: University of California Publications in Geological Sciences 145 (2000), pp. 1-34.

[1190] D. I. Axelrod. “The Miocene Purple Mountain Flora of Western Nevada". In: 139 (1995), pp. 1-62.

[1191] D. I. Axelrod. "The Middle Miocene Pyramid Flora of Western Nevada". In: University of California Publications in Geological Sciences 137 (1992), pp. 1-50.

[1192] B. J. Axsmith and B. F. Jacobs. "The conifer Frenelopsis ramosissima (Cheirolepidiaceae) in the Lower Cretaceous of Texas: systematic, biogeographical, and paleobotanical implications". English. In: International Journal of Plant Sciences 166.2 (2005), pp. 327-337.

[1193] B. J. Axsmith, M. Krings, and K. Waselkov. "Conifer pollen cones from the Cretaceous of Arkansas: Implications for diversity and reproduction in the Cheirolepidiaceae". English. In: Journal of Paleontology 78.2 (2004), pp. 402-409.

[1194] A. Aye Ko. "New Middle Devonian (Eifelian) rugose corals from Myanmar". English. In: Journal of Southeast Asian Earth Sciences 11.1 (1995), pp. 23-32. 
[1195] J. E. Ayer. “Note sur une vertébre d'Ichthyosaure (Platypterygius Sp.) d'age Aptien trouvée á la Presta (Jura central, canton de Neuchatel, Suisse)". English. In: Bulletin de la Société Neuchateloise des Sciences Naturelles 126.1 (2003), pp. 121-125. DOI: 10.5169/seals-89594.

[1196] W. Ayoub-Hannaa and F. T. Fürsich. "Apricardia noncarinata n. sp. (Bivalvia, Requieniidae) from the Cenomanian (Upper Cretaceous) of central-east Sinai, Egypt". English. In: Neues Jahrbuch für Geologie und Paläontologie, Abhandlungen 263.1 (2012), pp. 75-84. DOI: 10.1127 / 0077-7749 / 2012 / 0212.

[1197] W. Ayoub-Hannaa and F. T. Fürsich. "Palaeoecology and environmental significance of benthic associations from the Cenomanian-Turonian of eastern Sinai, Egypt". English. In: Beringeria 42 (2012), pp. 93-138.

[1198] W. Ayoub-Hannaa and F. T. Fürsich. "Cenomanian-Turonian ammonites from eastern Sinai, Egypt, and their biostratigraphic significance". English. In: Beringeria Heft 42 (2012), pp. 57-92.

[1199] W. S. Ayoub-Hannaa. "Taxonomy and palaeoecology of the Cenomanian-Turonian macroinvertebrates from eastern Sinai, Egypt (part A)". English. PhD thesis. Würzburg, 2011, pp. 1-418.

[1200] M. A. Ayress. "Late Eocene Ostracoda (Crustacea) from the Waihao District, South Canterbury, New Zealand". English. In: Journal of Paleontology 69.5 (1995), pp. 897-921.

[1201] K. Ayyasami. "Raoceras, a new Cretaceous ammonoid genus from southern India and some observations on the distribution of pachydiscids in India". English. In: Journal of the Geological Society of India 41.1 (1993), pp. 1-8.

[1202] K. Ayyasami and I. Das. “Unusual preservation of a Cretaceous turtle fossil”. English. In: Journal of the Geological Society of India 36.5 (1990), pp. 519-522.

[1203] K. Ayyasami, S. Elamparuthi, and B. Gowtham. "An ichthyosaur vertebra from the Cretaceous (Middle Cenomanian) Karai Formation, Southern India". English. In: Journal of the Geological Society of India 87 (2016), pp. 706-708.

[1204] B. Azanza, A. M. Alonso-Zarza, M. A. Álvarez-Sierra, J. P. Calvo, S. Fraile, I. Garca-Paredes, E. Gómez, M. Hernández-Fernández, A. Van der Meulen, D. De Miguel, and P. Montoya. "Los yacimientos de vertebrados continentales del Aragoniense superior (Mioceno medio) de Toril, Cuenca de Calatayud-Daroca". Spanish. In: Geo-Temas 6.2 (2004), pp. 271-274.

[1205] B. Azanza, M. Nieto, and J. Morales. "Samotragus pilgrimi n. sp., a new species of Oiocerini (Bovidae, Mammalia) from the Middle Miocene of Spain". English. In: Comptes Rendus de l'Academie des Sciences, Serie II. Sciences de la Terre et des Planetes 326.5 (1998), pp. 377-382.

[1206] D. Azar. "Tertiary bark lice (Insecta: Psocodea) from the Insect Limestone (Bembridge Marls, Late Eocene) of the Isle of Wight, UK". English. In: Earth and Environmental Science Transactions of the Royal Society of Edinburgh 104 (2014), pp. 307-316.

[1207] D. Azar, C. Adaymeh, and N. Jreich. "Paleopsychoda zherikhini, a new Cretaceous species of moth flies from Taimyr amber (Diptera: Psychodidae: Psychodinae)". English. In: African Invertebrates 48.1 (2007), pp. 163-168.

[1208] D. Azar and M. S. Engel. “A sphaeropsocid bark louse in Late Cretaceous amber from Siberia (Psocoptera: Sphaeropsocidae)". English. In: Transactions of the Kansas Academy of Science 111 (2008), pp. 141-146.

[1209] D. Azar, M. S. Engel, and D. A. Grimaldi. "A new genus of sphaeropsocid bark lice from the Early Cretaceous amber of Lebanon (Psocodea: Sphaeropsocidae)". English. In: Annales de la Société Entomologique de France 46 (2010), pp. 103-107.

[1210] D. Azar, G. Fleck, A. Nel, and M. Solignac. "A new enicocephalid bug, Enicocephalinus acragrimaldii gen. nov., sp. nov., from the Lower Cretaceous amber of Lebanon (Insecta, Heteroptera, Enicocephalidae)". English. In: Estudios del Museo de Ciencias Naturales de Álava 14 (1999), pp. 217230.

[1211] D. Azar, L. Hajar, C. Indary, and A. Nel. "Paramesopsocidae, a new Mesozoic psocid family (Insecta: Psocodea Psocoptera: Psocomorpha)". English. In: Annales de la Société Entomologique de France 44 (2008), pp. 459-470. 
[1212] D. Azar, M. Hakim, and D. Y. Huang. “A new compsocid booklouse from the Cretaceous amber of Myanmar (Psocodea: Troctomorpha: Amphientometae: Compsocidae)". English. In: Cretaceous Research 68 (2016), pp. 28-33.

[1213] D. Azar, M. Hakim, D. Y. Huang, C. Y. Cai, and A. Nel. "New fossil booklice from the Cretaceous amber of Myanmar (Psocodea: Troctomorpha: Amphientometae: Manicapsocidae)". English. In: Cretaceous Research 70 (2016), pp. 8-14.

[1214] D. Azar, D. Y. Huang, C. Y. Cai, and A. Nel. "The first trichomyiine from Burmese Cretaceous amber (Diptera, Psychodidae, Trichomyiinae)". English. In: Cretaceous Research 53 (2015), pp. 4858.

[1215] D. Azar, D. Y. Huang, C. Y. Cai, and A. Nel. “The earliest records of pachytroctid booklice from Lebanese and Burmese Cretaceous ambers (Psocodea, Troctomorpha, Nanopsocetae, Pachytroctidae)". English. In: Cretaceous Research 52 (2015), pp. 336-347.

[1216] D. Azar, D. Y. Huang, L. El-Hajj, C. Y. Cai, A. Nel, and S. Maksoud. “New Prionoglarididae from Burmese amber (Psocodea: Trogiomorpha: Prionoglaridetae)". English. In: Cretaceous Research 75 (2017), pp. 146-156.

[1217] D. Azar, S. Maksoud, C. Nammour, A. Nel, and B. Wang. “A new trogiid genus from lower Eocene Fushun amber (Insecta: Psocodea: Trogiomorpha)". English. In: Geobios 51 (2018), pp. 101-106.

[1218] D. Azar, S. Maksoud, D. Y. Huang, and A. Nel. "First Lebanese dragonflies (Insecta: Odonata, Aeshnoptera, Cavilabiata) from the Arabo-African mid-Cretaceous paleocontinent". English. In: Cretaceous Research 93 (2019), pp. 78-89. DOI: 10.1016/j.cretres.2018.08.025.

[1219] D. Azar, R. Mouawad, and Y. Salamé. “A new genus of Trichomyiinae (Diptera: Psychodidae) from Upper Cretaceous amber of New Jersey". English. In: Cretaceous Research 52 (2015), pp. 531538.

[1220] D. Azar, A. Nel, and D. Néraudeau. "A new Cretaceous psocodean family from the CharenteMaritime amber (France) (Insecta, Psocodea, Psocomorpha)". English. In: Geodiversitas 31 (2009), pp. 117-127.

[1221] D. Azar, A. Nel, M. S. Engel, R. Garrouste, and A. Matocq. "A new family of Coreoidea from the Lower Cretaceous Lebanese amber (Hemiptera: Pentatomomorpha)". English. In: Polish Journal of Entomology 80 (2011), pp. 627-644.

[1222] D. Azar, A. Nel, D. Coty, and R. Garrouste. "The second fossil ceratocombid bug from the Miocene amber of Chiapas (Mexico) (Hemiptera: Ceratocombidae)". English. In: Annales de la Société Entomologique de France 46 (2010), pp. 100-102.

[1223] D. Azar and A. Nel. "The earliest fossil schizopterid bug (Insecta: Heteroptera) in the Lower Cretaceous amber of Lebanon". English. In: Annales de la Société Entomologique de France 46 (2010), pp. 193-197.

[1224] D. Azar and A. Nel. "Two new non-biting midges from the Early Cretaceous Lebanese amber (Diptera: Chironomidae)". English. In: Annales de la Société Entomologique de France 46 (2010), pp. 198-203.

[1225] D. Azar and A. Nel. "First Tridactylidae from the Eocene French amber (Insecta: Orthoptera)". English. In: Alavesia 2 (2008), pp. 169-175.

[1226] D. Azar, A. Nel, M. Solignac, J. Paicheler, and F. Bouchet. "New genera and species of psychodoid flies from the Lower Cretaceous amber of Lebanon". English. In: Palaeontology 42.6 (1999), pp. 1101-1136.

[1227] D. Azar and A. Nel. "First Baltic amber megapodagrionid damselfly (Odonata: Zygoptera)". English. In: Annales de la Société Entomologique de France 44 (2008), pp. 451-457.

[1228] D. Azar and A. Nel. "Four new Psocoptera from Lebanese amber (Insecta: Psocomorpha: Trogiomorpha)". English. In: Annales de la Société Entomologique de France 40 (2004), pp. 185-192.

[1229] D. Azar, A. Nel, and J. F. Petruleviius. "First Psocodean (Psocodea, Empheriidae) from the Cretaceous amber of New Jersey". English. In: Acta Geologica Sinica 84 (2010), pp. 762-767. 
[1230] D. Azar and A. Nel. “The oldest psyllipsocid booklice, in Lower Cretaceous amber from Lebanon (Psocodea, Trogiomorpha, Psocathropetae, Psyllipsocidae)". English. In: ZooKeys 130 (2011), pp. 153165.

[1231] D. Azar, A. Nel, and M. Solignac. "A new Coniopterygidae from Lebanese amber". English. In: Acta Geologica Hispanica 35.1-2 (2000), pp. 31-36.

[1232] D. Azar and A. Nel. "New Cretaceous psychodid flies from Lebanese amber and Santana Formation (Chapada do Araripe, Brazil) (Diptera)". English. In: Annales de la Société Entomologique de France 38 (2002), pp. 253-262.

[1233] D. Azar, A. Nel, and A. Waller. "Two new Ptiloneuridae from Colombian copal (Psocodea: Psocomorpha)". English. In: Denisia 26 (2009), pp. 21-28.

[1234] D. Azar, A. Nel, and E. Perkovsky. "A new Sycorax species from Eocene Ukrainian Rovno amber (Diptera: Psychodidae: Sycoracinae)". English. In: Insect Evolution in an Ambiferous and Stone Alphabet. Leiden: Brill, 2013, pp. 27-46.

[1235] D. Azar and A. Nel. "A new beaded lacewing from a new Lower Cretaceous amber outcrop in Lebanon (Neuroptera: Berothidae)". English. In: Insect Evolution in an Ambiferous and Stone Alphabet. Leiden: Brill, 2013, pp. 111-130.

[1236] D. Azar, A. Nel, and V. Perrichot. "Diverse barklice (Psocodea) from Late Cretaceous Vendean amber". English. In: Paleontological Contributions 10 (2014), pp. 9-15.

[1237] D. Azar, V. Perrichot, D. Néraudeau, and A. Nel. "New Psychodids from the Cretaceous Ambers of Lebanon and France, with a Discussion of Eophlebotomus connectens Cockerell, 1920 (Diptera, Psychodidae)". English. In: Annals of the Entomological Society of America 96 (2003), pp. 117-126.

[1238] D. Azar, J. Prokop, and A. Nel. "The first damselfly from the Early Cretaceous Lebanese amber (Odonata, Zygoptera, Lestomorpha)". English. In: Alavesia 3 (2010), pp. 73-79.

[1239] D. Azar and Y. Salamé. "A new genus of Sycoracinae (Diptera: Psychodidae) from Upper Cretaceous amber of New Jersey". English. In: Cretaceous Research 52 (2015), pp. 539-547.

[1240] D. Azar, A. Tahchy, and V. Perrichot. "The oldest Sycoracinae (Diptera: Psychodidae) from the French Cretaceous Amber". English. In: Alavesia 1 (2007), pp. 5-10.

[1241] D. Azar, I. Veltz, and A. Nel. "Mandibulate chironomids: primitive or derived? (Diptera: Chironomidae)". English. In: Systematic Entomology 33 (2008), pp. 688-699.

[1242] D. Azar and A. Waller. "Redescription of Eatonisca tertiaria Meunier 1905 from Baltic amber (Diptera: Psychodidae: Trichomyiinae)". English. In: Annales de la Société Entomologique de France 46 (2010), pp. 237-241.

[1243] D. Azar, A. Waller, and A. Nel. "A phantom midge from Lower Cretaceous Lebanese amber (Diptera, Chaoboridae)". English. In: Denisia 26 (2009), pp. 29-34.

[1244] D. Azar and K. Ziadé. "Xenopsychoda harbi, a new psychodoid fly from the Lower Cretaceous amber of Lebanon (Diptera; Psychodoidea)". English. In: Comptes Rendus Palevol 4 (2005), pp. 2530.

[1245] C. O. Azevedo and D. Azar. "A new fossil subfamily of Bethylidae (Hymenoptera) from the Early Cretaceous Lebanese amber and its phylogenetic position". English. In: Zoologia 29 (2012), pp. 210218.

[1246] S. A. Azevedo, V. Gallo, and J. Ferigolo. "A possible chelonian egg from the Brazilian Late Cretaceous". English. In: Anais da Academia Brasileira de Ciencias 72.2 (2000), pp. 187-193.

[1247] S. A. Aziz and R. M. Badve. "Occurrence of Hemipneustes Agassiz (Echinoid) from Tiruchirapalli Cretaceous, Tamil Nadu, India". In: Journal of the Geological Society of India 36.3 (1990), pp. 326-330.

[1248] K. Azmy, E. Edinger, J. Lundberg, and W. Diegor. "Sea level and paleotemperature records from a mid-Holocene reef on the north coast of Java, Indonesia". English. In: International Journal of Earth Sciences 99 (2010), pp. 231-244. 
[1249] M. M. Azpelicueta and A. L. Cione. "Redescription of the Eocene Catfish Bachmannia chubutensis (Teleostei : Bachmanniidae) of Southern South America". English. In: Journal of Vertebrate Paleontology 31.2 (2011), pp. 258-269.

[1250] M. M. Azpelicueta and A. Rubilar. "A Miocene Nematogenys (Teleostei: Siluriformes: Nematogenyidae) from South-Central Chile". English. In: Journal of Vertebrate Paleontology 18.3 (1998), pp. 475483.

[1251] Y. Azuma. "Early Cretaceous vertebrate remains from Katsuyama city, Fukui prefecture, Japan". In: Memoir of the Fukui Prefectural Dinosaur Museum 2 (2003), pp. 17-21.

[1252] Y. Azuma. Dinosaur remains from Katsuyama City, Fukui Prefecture. English. 2002.

[1253] Y. Azuma, Y. Arakawa, Y. Tomida, and P. J. Currie. "Early Cretaceous bird tracks from the Tetori Group, Fukui Prefecture, Japan". English. In: Memoir of the Fukui Prefectural Dinosaur Museum 1 (2002), pp. 1-6.

[1254] Y. Azuma and P. J. Currie. "A new carnosaur (Dinosauria: Theropoda) from the Lower Cretaceous of Japan". In: Canadian Journal of Earth Sciences 37 (2000), pp. 1735-1753.

[1255] Y. Azuma, R. Li, P. J. Currie, Z. Dong, M. Shibata, and J. Lü. “Dinosaur footprints from the Lower Cretaceous of Inner Mongolia, China". English. In: Memoir of the Fukui Prefectural Dinosaur Museum 5 (2006), pp. 1-14.

[1256] Y. Azuma and M. Shibata. "Fukuititan nipponensis, a new titanosauriform sauropod from the Early Cretaceous Tetori Group of Fukui Prefecture, Japan". English. In: Acta Geologica Sinica 84.3 (2010), pp. 454-462.

[1257] Y. Azuma, T. Sugimori, K. Yamada, T. Kojima, and K. -i. Takeyama. "Two dinosaur footprints from the Tetori Group of Izumi Village, Fukui Prefecture, central Japan". Japanese. In: Bulletin of the Japan Sea Research Institute, Kanazawa University, Kanazawa 24 (1992), pp. 19-33.

[1258] Y. Azuma and K.-i. Takeyama. “Dinosaur footprints from the Tetori Group, central Japan—research of dinosaurs from the Tetori Group (4)". English. In: Bulletin of the Fukui Prefectural Museum 4 (1991), pp. 33-51.

[1259] Y. Azuma and Y. Tomida. Early Cretaceous dinosaur fauna of the Tetori Group in Japan. English. Sixth Symposium on Mesozoic Terrestrial Ecosystems and Biota, Short Papers. Beijing: China Ocean Press, 1995, pp. 125-131.

[1260] Y. Azuma, X. Xu, M. Shibata, S. Kawabe, K. Miyata, and T. Imai. "A bizarre theropod from the Early Cretaceous of Japan highlighting mosaic evolution among coelurosaurians". English. In: Scientific Reports 6 (2016), p. 20478. DOI: 10.1038/srep20478.

[1261] H. Azurduy. "Una nueva especie fósil de Ctenomys (Rodentia) y breve panorama paleontológico del género en Bolivia". English. In: Kempffiana 1 (2005), pp. 29-39.

[1262] B. G. Baarli. "The early Rhuddanian survival interval in the Lower Silurian of the Oslo Region: A third pulse of the end-Ordovician extinction". English. In: Palaeogeography, Palaeoclimatology, Palaeoecology 395 (2014), pp. 29-41. DOI: 10.1016/j.palaeo.2013.12.018.

[1263] B. G. Baarli, A. Santos, C. M. da Silva, J. Ledesma-Vazquez, E. Mayoral, M. Cachao, and M. E. Johnson. "Diverse Macroids and Rhodoliths from the Upper Pleistocene of Baja California Sur, Mexico". English. In: Journal of Coastal Research 28.1 (2012), pp. 296-305.

[1264] B. G. Baarli, A. G. Santos, E. J. Mayoral, J. Ledesma-Vazquez, M. E. Johnson, C. M. da Silva, and M. Cachao. "What Darwin did not see: Pleistocene fossil assemblages on a high energy coast at Ponta das Bicudas, Santiago, Cape Verde Islands". English. In: Geological Magazine 150.1 (2013), pp. 183-189.

[1265] C. Baars, L. Popov, F. Rhebergen, and I. A. Klishevich. “Early Silurian (Rhuddanian) rugose corals and sponges from the Ak-Kerme Peninsula, Kazakhstan". English. In: Paläontologische Zeitschrift 88 (2014), pp. 279-295.

[1266] C. Baars, M. G. Pour, and R. C. Atwood. "The earliest rugose coral". English. In: Geological Magazine 150.2 (2013), pp. 371-380. 
[1267] C. Babbitt. "Pyctis inamatus, gen. et sp. nov., a new mustelid from the Hsanda Gol Formation, Oligocene, Mongolia". English. In: Journal of Vertebrate Paleontology 19.4 (1999), pp. 791-792.

[1268] L. Babcock, M. Baranoski, and E. Cook. "Cambrian (Guzhangian Stage) trilobites from Ohio, USA, and modification of the Cedaria Zone as used in Laurentia". English. In: GFF - Geological Society of Sweden 136.1 (2014), pp. 6-15.

[1269] L. E. Babcock, J. Gray, A. J. Boucot, G. T. Himes, and P. K. Siegele. “First Silurian conulariids from Paraguay". In: Journal of Paleontology 64.6 (1990), pp. 897-902.

[1270] L. E. Babcock, D. F. Merriam, and R. R. West. "Paleolimulus, an early limuline (Xiphosurida), from Pennsylvanian-Permian Lagerstatten of Kansas and taphonomic comparison with modern Limulus". English. In: Lethaia 33 (2000), pp. 129-141.

[1271] L. E. Babcock and D. F. Merriam. "Horseshoe crabs (Arthropoda: Xiphosura) from the Pennsylvanian of Kansas and elsewhere". English. In: Transactions of the Kansas Academy of Science 103 (2000), pp. 76-94. DOI: $10.2307 / 3627941$.

[1272] L. E. Babcock and J. S. Peel. "Palaeobiology, taphonomy and stratigraphic significance of the trilobite Buenellus from the Sirius Passet Biota, Cambrian of North Greenland". English. In: Memoirs of the Association of Australasian Palaeontologists 34 (2007), pp. 401-418.

[1273] L. E. Babcock, M. N. Rees, R. A. Robison, E. S. Langenburg, and S. Peng. "Potential Global Standard Stratotype-section and Point (GSSP) for a Cambrian stage boundary defined by the first appearance of the trilobite Ptychagnostus atavus, Drum Mountains, Utah, USA". English. In: Geobios 37 (2004), pp. 149-158.

[1274] L. E. Babcock, M. D. Wegweiser, A. E. Wegweiser, T. M. Stanley, and S. C. McKenzie. "Horseshoe crabs and their trace fossils from the Devonian of Pennsylvania". English. In: Pennsylvania Geology 26 (1995), pp. $2-7$.

[1275] C. Babin and J. Destombes. "Les mollusques bivalves et rostroconches Ordoviciens de l'Anti-Atlas marocain: Intéret paléogéographique de leur inventaire". French. In: Géologie Méditerranéenne 17 (1990), pp. 243-261.

[1276] C. Babin and J. C. Gutiérrez-Marco. "Middle Ordovician bivalves from Spain and their phyletic and palaeogeographic significance". In: Palaeontology 34 (1991), pp. 109-147.

[1277] C. Babin, J. Garca-Alcalde, J. C. Guttiérrez-Marco, and M. L. Martnez-Chacón. “Conocardiacea (Mollusca, Rostroconchia) du Dévonien et du Carbonifére d'Espagne". English. In: Revue Paléobiologie 18.1 (1999), pp. 173-186.

[1278] J. F. Babinot and J. P. Colin. "Barremian ostracods from the Serre de Bleyton (Drome, SE France)". English. In: Annalen des Naturhistorischen Museums in Wien, Serie A 113 (2011), pp. 735-775.

[1279] M. J. Babot and D. A. Garca-López. "Redescription of the argyrolagid Microtragulus bolivianus (Metatheria, Polydolopimorphia, Bonapartheriiformes)". English. In: Palaeontologia Electronica 19.2.23A (2016), pp. 1-23.

[1280] M. J. Babot, J. E. Powell, and C. de Muizon. "Callistoe vincei, a new Proborhyaenidae (Borhyaenoidea, Metatheria, Mammalia) from the Early Eocene of Argentina”. English. In: Geobios 35 (2002), pp. 615629.

[1281] M. J. Babot, G. W. Rougier, D. Garca-Lopez, and B. M. Davis. "New Small Bunodont Metatherian from the Late Eocene of the Argentinean Puna". English. In: Journal of Mammalian Evolution 27 (2020), pp. 373-384.

[1282] J. I. Baceta, V. Pujalte, and G. Bernaola. "Paleocene coralgal reefs of the western Pyrenean basin, northern Spain: New evidence supporting an earliest Paleogene recovery of reefal ecosystems". English. In: Palaeogeography, Palaeoclimatology, Palaeoecology 224 (2005), pp. 117-143.

[1283] B. Bachelet, J.-P. Aguilar, M. Calvet, and J. Michaux. "Nouvelles faunes de rongeurs du Pliocene des Pyrenees-Orientales: consequences pour le genre Stephanomys (Schaub, 1938)". French. In: Géobios 23.1 (1990), pp. 117-120. 
[1284] G. H. Bachmann. "A lamellibranch-stromatolite bioherm in the Lower Keuper (Ladinian, Middle Triassic), south Germany". In: Facies 46 (2002), pp. 83-88.

[1285] D. S. Baciu and B. Chanet. “Les Poissons plats fossiles (Teleostei: Pleuronectiformes) de l'Oligocéne de Piatra Neamt (Roumanie)". French. In: Oryctos 4 (2002), pp. 17-38.

[1286] D.-S. Baciu, A. F. Bannikov, and J. C. Tyler. "Revision of the fossil fishes of the family Zeidae (Zeiformes)". English. In: Bollettino del Museo civico di storia naturale di Verona. Geologia, paleontologia, preistoria 29 (2005), pp. 95-128.

[1287] D.-S. Baciu and A. F. Bannikov. "Paucaichthys neamtensis gen. et sp. nova-the First Discovery of Sea Breams (Bramidae) in the Oligocene of Romania". English. In: Joumal ofIchthyology 43.8 (2003), pp. 508-602.

[1288] D. Badano, M. S. Engel, A. Basso, B. Wang, and P. Cerretti. "Diverse Cretaceous larvae reveal the evolutionary and behavioural history of antlions and lacewings". English. In: Nature Communications 9.3257 (2018), pp. 1-14.

[1289] G. Badino, A. De Vivo, P. Forti, and L. Piccini. “The Puerto Princesa Underground River (Palawan, Philippines): some peculiar features of a tropical, high-energy coastal karst system". English. In: Geological Society, London, Special Publications 466 (2018). DOI: 10.1144/SP466.22.

[1290] A. Badiola, H. Astibia, X. Pereda Suberbiola, and X. Murelaga. "First record of the genus Leptolophus Remy, 1965 (Mammalia, Perissodactyla) in the late Eocene (Priabonian) of Europe". In: Geodiversitas 24.4 (2002), pp. 841-848.

[1291] A. Badiola, J. I. Canudo, and G. Cuenca-Bescós. Multituberculate fossils from the Early Cretaceous of La Cantalera (Teruel, Spain). English. 2007.

[1292] A. Badiola, J. I. Canudo, and G. Cuenca-Bescós. Los fósiles de multituberculados del Hauteriviense y Barremiense de la Pennsula Ibérica [The multituberculate fossils from the Hauterivian and Barremian of the Iberian Peninsula]. Spanish. 2007.

[1293] A. Badiola, J. I. Canudo, and G. Cuenca-Bescós. "New multituberculate mammals from the Hauterivian/Barremian transition of Europe (Iberian Peninsula)". English. In: Palaeontology 51.6 (2008), pp. 1455-1469. DOI: 10.1111/j.1475-4983.2008.00822.x.

[1294] A. Badiola, J. I. Canudo, and G. Cuenca-Bescós. "A systematic reassessment of Early Cretaceous multituberculates from Galve (Teruel, Spain)". English. In: Cretaceous Research 32.1 (2011), pp. 4557. DOI: 10.1016/j.cretres.2010.10.003.

[1295] A. Badiola and M. A. Cuesta. "Los marsupiales del yacimiento del Eoceno Superior de Zambrana (Álava, Región Vasco-Cantábrica)". Spanish. In: Estudios Geológicos 62 (2006), pp. 349-358.

[1296] A. Badiola and M.-A. Cuesta. "New endemic Eocene equoids from the Iberian Peninsula (western Europe)". English. In: Journal of Vertebrate Paleontology 28.4 (2008), pp. 1149-1161.

[1297] A. Badiola, X. Pereda-Suberbiola, N. Bardet, H. Astibia, A. Berreteaga, J. I. Canudo, and G. CuencaBescos. Eocene mammalian fossil record and biodiversity from Iberia: New primate and sirenian discoveries and palaeobiogeographic implications. English. 2011.

[1298] A. Badiola, X. Pereda-Suberbiola, and M. A. Cuesta. “Una nueva especie de Pachynolophus (Mammalia, Perissodactyla) de Zambrana (Álava, Región Vasco-Cantábrica). Análisis filogenético de Pachynolophus y primera cita en el Eoceno superior de la Pennsula Ibérica". Spanish. In: Geobios 38.1 (2005), pp. 1-16.

[1299] R. M. Badve and P. Kundal. "Dasycladacean algae from Paleocene to Oligocene rocks of Baratang Island, Andaman, India". English. In: Journal Geological Society of India 51 (1998), pp. 485-492.

[1300] K. A. Badyrka, M. E. Clapham, and S. Lopez. "Paleoecology of brachiopod communities during the late Paleozoic ice age in Bolivia (Copacabana Formation, Pennsylvanian-Early Permian)". English. In: Palaeogeography, Palaeoclimatology, Palaeoecology 387 (2013), pp. 56-65.

[1301] K. S. Baek and S. Y. Yang. "Cockroaches from the early Cretaceous of Korea (Blattaria: Mesoblattinidae)". other. In: Journal of the Paleontological Society of Korea 20 (2004), pp. 71-98. 
[1302] A. M. Baez. “Anurans from the Early Cretaceous Lagerstätte of Las Hoyas, Spain: New evidence on the Mesozoic diversification of crown-clade Anura". English. In: Cretaceous Research 41 (2013), pp. 90-106. DOI: 10.1016/j.cretres.2012.11.002.

[1303] A. M. Báez, R. O. Gómez, L. C. B. Ribeiro, A. G. Martinelli, V. P. A. Teixeira, and M. L. F. Ferraz. "The diverse Cretaceous neobatrachian fauna of South America: Uberabatrachus carvalhoi, a new frog from the Maastrichtian Marlia Formation, Minas Gerais, Brazil". English. In: Gondwana Research 22 (2012), pp. 1141-1150. DOI: 10.1016/j.gr.2012.02.021.

[1304] A. M. Báez and T. Harrison. "A new pipine frog from an Eocene crater lake in north-central Tanzania". English. In: Palaeontology 48.4 (2005), pp. 723-737.

[1305] A. M. Baez, G. J. B. Moura, and R. O. Gómez. "Anurans from the Lower Cretaceous Crato Formation of northeastern Brazil: implications for the early divergence of neobatrachians". English. In: Cretaceous Research 30.4 (2009), pp. 829-846. DOI: 10.1016/j.cretres.2009.01.002.

[1306] A. M. Báez, P. Muzzopappa, and L. Nicoli. "Anurans from the Candeleros Formation (? CenomanianTuronian) of west-central Argentina: new evidence for pipoid evolution". English. In: Cretaceous Research 28 (2007), pp. 1005-1016.

[1307] A. M. Báez and L. Nicoli. "A new species of Notobatrachus (Amphibia, Salientia) from the Middle Jurassic of northwestern Patagonia". English. In: Journal of Paleontology 82.2 (2008), pp. 372-376. DOI: 10.1666/06-117.1.

[1308] A. M. Baez and S. Peri. "Revision de Wawelia gerholdi, un anuro del Mioceno de Patagonia". Spanish. In: Ameghiniana 27.3-4 (1990), pp. 379-386.

[1309] A. M. Baez and L. A. Pugener. "A new Paleogene pipid frog from northwestern Patagonia". English. In: Journal of Vertebrate Paleontology 18.3 (1998), pp. 511-524.

[1310] A. M. Báez and L. A. Pugener. “Ontogeny of a new Palaeogene pipid frog from southern South America and xenopodinomorph evolution". English. In: Zoological Journal of the Linnean Society 139.3 (2003), pp. 439-476.

[1311] A. M. Báez and B. Sanchiz. "A review of Neusibatrachus wilferti, an Early Cretaceous frog from the Montsec Range, northeastern Spain". English. In: Acta Palaeontologica Polonica 52.3 (2007), pp. $477-487$.

[1312] A. M. Baez and L. Trueb. "Redescription of the Paleogene Shelania pascuali from Patagonia and its bearing on the relationships of fossil and Recent pipoid frogs". English. In: Scientific Papers, Natural History Museum, University of Kansas 4 (1997), pp. 1-41.

[1313] A. M. Báez, L. Trueb, and J. O. Calvo. "The earliest known pipoid frog from South America: a new genus from the Middle Cretaceous of Argentina". English. In: Journal of Vertebrate Paleontology 20.3 (2000), pp. 490-500.

[1314] A. M. Baez, M. C. Zamaloa, and E. J. Romero. “Nuevos hallazgos de microfloras y anuros Paleógenos en el Noroeste de Patagonia: implicancias Paleoambientales y Paleobiogeográficas". Spanish. In: Ameghiniana 27.1-2 (1990), pp. 83-94.

[1315] D. A. Baez Gomez. "Estudio paleoambiental de la formacion Pisco: Localidad Ocucaje". Spanish. In: Revista del Instituto de Investigaciones FIGMMG 9.18 (2006), pp. 64-69.

[1316] J. F. Baeza-Carratalá. "New Early Jurassic brachiopods from the Western Tethys (Eastern Subbetic, Spain) and their systematic and paleobiogeographic affinities". English. In: Geobios 44 (2011), pp. 345-360.

[1317] J. F. Baeza-Carratalá, A. Dulai, and J. Sandoval. “First evidence of brachiopod diversification after the end-Triassic extinction from the pre-Pliensbachian Internal Subbetic platform (South-Iberian Paleomargin)". English. In: Geobios 51 (2018), pp. 367-384.

[1318] J. F. Baeza-Carratalá, F. G. Joral, A. Giannetti, and J. E. Tent-Manclús. “Evolution of the last koninckinids (Athyridida, Koninckinidae), a precursor signal of the early Toarcian mass extinction event in the Western Tethys". English. In: Palaeogeography, Palaeoclimatology, Palaeoecology 429 (2015), pp. 41-56. 
[1319] J. F. Baeza-Carratalá, F. Pérez-Valera, and J. A. Pérez-Valera. “The oldest post-Paleozoic (Ladinian, Triassic) brachiopods from the Betic Range, SE Spain". English. In: Acta Palaeontologica Polonica 63 (2018), pp. 71-85.

[1320] J. F. Baeza-Carratalá and B. Sepehriannasab. "Early Jurassic (latest Toarcian) brachiopods from the northeastern margin of the Western Tethys (Central Iran) and their paleobiogeographical significance". English. In: Geobios 47 (2014), pp. 3-17.

[1321] J. F. Baeza-Carratalá, A. Vörös, A. Dulai, and J. E. Tent-Manclús. “Brachiopod assemblages from the Early-Middle Jurassic transition in the Eastern Subbetic (SE Spain): Systematic and palaeobiogeographic implications and palaeoenvironmental significance". English. In: Neues Jahrbuch für Geologie und Paläontologie, Abhandlungen 262 (2011), pp. 171-197.

[1322] O. Baffa, A. Brunetti, I. Karmann, and C. M. Dias Neto. "ESR dating of a toxodon tooth from a Brazilian karstic cave". English. In: Applied Radiation and Isotopes 52.5 (2000), pp. 1345-1349.

[1323] B. Bagherpour and M. R. Vaziri. "Facies, paleoenvironment, carbonate platform and facies changes across Paleocene Eocene of the Taleh Zang Formation in the Zagros Basin, SW-Iran". English. In: Historical Biology 24.2 (2011), pp. 121-142.

[1324] L. Bagli and G. Gentilini. "Nuove libellule fossili del Miocene superiore di Monte Castellaro, Pesaro (Marche, Italia centrale) (Insecta Odonata Libellulidae)". Italian. In: Quaderno di Studi e Notizie di Storia Naturale della Romagna 18 (2003), pp. 37-50.

[1325] G. Bagnoli and S. Stouge. "Upper Furongian (Cambrian) conodonts from the Degerhamn quarry road section, southern Öland, Sweden". English. In: Geologiska Föreningen 13.1 (2014), pp. 436-458. DOI: $10.1080 / 11035897.2013 .858768 .$.

[1326] J. R. Bahamonde, J. A. M. Kenter, G. Della Porta, L. Keim, A. Immenhauser, and J. J. G. Reijmer. "Lithofacies and depositional processes on a high, steep-margined Carboniferous (BashkirianMoscovian) carbonate platform slope, Sierra del Cuera, NW Spain". English. In: Sedimentary Geology 166 (2004), pp. 145-156.

[1327] D. Bahamonde-Vinueza, H. Cadena-Ortiz, C. Cajas-Bermeo, and E. Bonaccorso. "Unusual records of Cochlearius cochlearius (Linnaeus, 1766) (Aves: Ardeidae) in the Andes of Ecuador". English. In: Check List 10.3 (2014), pp. 687-688.

[1328] H. Bahlburg, C. Breitkreuz, J. Maletz, M. C. Moya, and J. A. Salfity. “The Ordovician sedimentary rocks in the northern Puna of Argentina and Chile: New stratigraphical data based on graptolites". English. In: Newsletters in Stratigraphy 23.2 (1990), pp. 69-89.

[1329] B. Bai. "New materials of Eocene Dinocerata (Mammalia) from the Erlian Basin, Nei Mongol (Inner Mongolia)". English. In: Vertebrata PalAsiatica 44.3 (2006), pp. 250-261.

[1330] B. Bai. "Eocene Pachynolophinae (Perissodactyla, Palaeotheriidae) from China, and their palaeobiogeographical implications". English. In: Palaeontology 60.6 (2017), pp. 837-852. DOI: 10.1111 / pala.12319.

[1331] B. Bai, Y. Wang, J. Meng, Q. Li, and X. Jin. “New Early Eocene Basal tapiromorph from Southern China and its Phylogenetic Implications". English. In: PLoS ONE 9.10 (2014), e110806:1-9.

[1332] B. Bai, Y. Wang, and J. Meng. "New Craniodental Materials of Litolophus gobiensis (Perissodactyla, Eomoropidae) from Inner Mongolia, China, and Phylogenetic Analyses of Eocene Chalicotheres". English. In: American Museum Novitates 3688 (2010), pp. 1-27.

[1333] B. Bai and Y.-Q. Wang. "Proeggysodon gen. nov., a primitive Eocene eggysodontine (Mammalia, Perissodactyla) from Erden Obo, Siziwangqi, Nei Mongol, China". English. In: Vertebrata PalAsiatica 50.3 (2012), pp. 204-218.

[1334] B. Bai, Y.-Q. Wang, and Z. -Q. Zhang. "The late Eocene hyracodontid perissodactyl Ardynia from Saint Jacques,Inner Mongolia, China and its implications for the potentialEocene-Oligocene boundary". English. In: Palaeoworld 27 (2018), pp. 247-257.

[1335] B. Bai, Y.-Q. Wang, and J. Meng. "The divergence and dispersal of early perissodactyls as evidenced by early Eocene equids from Asia". English. In: Communications Biology 1.115 (2018), pp. 110. DOI: $10.1038 /$ s42003-018-0116-5. 
[1336] B. Bai, Y.-Q. Wang, and J. Meng. "A new late Paleocene phenacodontid 'condylarth' Lophocion from the Clark's Fork Basin of Wyoming". English. In: Historical Biology (2019). DOI: 10.1080 / 08912963.2019.1652283.

[1337] H. Y. Bai, Y. Chang, C. K. Shih, D. Ren, and Y. J. Wang. "New silky lacewings from mid-Cretaceous Burmese amber (Insecta: Neuroptera: Psychopsidae)". English. In: Zootaxa 4661 (2019), pp. 182188.

[1338] M. Bai, D. Ahrens, X. K. Yang, and D. Ren. "New fossil evidence of the early diversification of scarabs: Alloioscarabaeus cheni (Coleoptera: Scarabaeoidea) from the Middle Jurassic of Inner Mongolia, China". English. In: Insect Science 19 (2012), pp. 159-171.

[1339] M. Bai, R. G. Beutel, C. K. Shih, D. Ren, and X. K. Yang. "Septiventeridae, a new and ancestral fossil family of Scarabaeoidea (Insecta: Coleoptera) from the Late Jurassic to Early Cretaceous Yixian Formation". English. In: Journal of Systematic Palaeontology 11 (2013), pp. 359-374. DOI: 10. 1080/14772019.2012.660995.

[1340] M. Bai, R. G. Beutel, W. G. Liu, S. Li, M. N. Zhang, Y. Y. Lu, K. Q. Song, D. Ren, and X. K. Yang. "Description of a new species of Glaresidae (Coleoptera: Scarabaeoidea) from the Jehol Biota of China with a geometric morphometric evaluation". English. In: Arthropod Systematics \& Phylogeny 72 (2014), pp. 223-236.

[1341] M. Bai, R. G. Beutel, K. D. Klass, W. W. Zhang, X. K. Yang, and B. Wipfler. “†Alienoptera - A new insect order in the roach-mantodean twilight zone". English. In: Gondwana Research 39 (2016), pp. 317-326.

[1342] M. Bai, R. G. Beutel, W. W. Zhang, S. Wang, M. Hörnig, C. Gröhn, E. Yan, X. K. Yang, and B. Wipfler. "A new Cretaceous insect with a unique cephalo-thoracic scissor device". English. In: Current Biology 28 (2018), pp. 438-443.

[1343] M. Bai, F. T. Krell, D. Ren, and X. Yang. "A new, well-preserved species of Glaresidae (Coleoptera: Scarabaeoidea) from the Jehol Biota of China". English. In: Acta Geologica Sinica 84.4 (2010), pp. 676679.

[1344] M. Bai, R. Nie, W. W. Zhang, D. Ren, C. K. Shih, and X. K. Yang. “The first fossil Athyreini beetle (Coleoptera: Geotrupidae)". English. In: Organisms Diversity \& Evolution 17 (2017), pp. 157-162.

[1345] M. Bai, D. Ren, and X. K. Yang. "Prophaenognatha, a new Aclopinae genus from the Yixian Formation, China and its phylogenetic position based on morphological characters (Coleoptera: Scarabaeidae)". English. In: Acta Geologica Sinica 85.5 (2011), pp. 984-993.

[1346] M. Bai, D. Ren, and X. K. Yang. "Prosinodendron krelli from the Yixian Formation, China: A missing link among Lucanidae, Diphyllostomatidae and Passalidae (Coleoptera: Scarabaeoidea)". English. In: Cretaceous Research 34 (2012), pp. 334-339.

[1347] M. Bai, W. W. Zhang, D. Ren, C. K. Shih, and X. K. Yang. "Hybosorus ocampoi: the first hybosorid from the Cretaceous Myanmar amber (Coleoptera: Scarabaeoidea)". English. In: Organisms Diversity and Evolution 16 (2016), pp. 233-240.

[1348] Z. Bai, J. Yang, and G. Wang. "[Yimenosaurus, a new genus of Prosauropoda from Yimen County, Yunnan province]". Chinese. In: Yuxiwenbo (Yuxi Culture and Scholarship) 1 (1990), pp. 14-23.

[1349] M. A. Baiano, R. A. Coria, and A. Cau. "A new abelisauroid (Dinosauria: Theropoda) from the Huincul formation (lower upper Cretaceous, Neuquén Basin) of Patagonia, Argentina". English. In: Cretaceous Research 110 (2020), p. 104408. DOI: 10.1016/j.cretres.2020.104408.

[1350] B. E. Bailey. New Arikareean/Hemingfordian micromammal faunas from western Nebraska and their biostratigraphic significance. English. 1999.

[1351] A. M. Bailleul, B. K. Hall, and J. R. Horner. “Secondary cartilage revealed in a non-avian dinosaur embryo". English. In: PLoS ONE 8.2 (2013), e56937:1-5. DOI: 10.1371/journal.pone.0056937.

[1352] S. Bailon. "Amphibiens et reptiles du Pliocéne terminal d'Ahl al Oughlam (Casablanca, Maroc)". French. In: Geodiversitas 22.4 (2000), pp. 539-558. 
[1353] S. Bailon and M. Auge. “Un nouveau genre, Ragesaurus (Squamata, Anguidae, Anguinae), du Pléistocéne inférieur des les Medas (Catalogne, Espagne)". French. In: Bulletin de la Société Géologique de France 183.6 (2012), pp. 683-688.

[1354] S. Bailon, P. Bover, J. Quintana, and J. A. Alcover. “First fossil record of Vipera Laurenti 1768 Oriental vipers complex (Serpentes: Viperidae) from the Early Pliocene of the western Mediterranean islands". English. In: Comptes Rendus Palevol 9.4 (2010), pp. 147-154. DOI: 10.1016/j.crpv.2010.04.001.

[1355] S. Bailon, J. Garcia-Porta, and J. Quintana-Cardona. “Premiére découverte de Viperidae (Reptilia, Serpentes) dans les les Baléaresă(Espagne): des vipéres du Néogéne de Minorque. Description d'une nouvelle espéce du Pliocéne [The first record of viperid snakes (Reptilia, Serpentes) from the Balearic Islands (Spain): fossils from the Neogene, with description of a new species from the Pliocene]". French. In: Comptes Rendus Palevol 1.4 (2002), pp. 227-234. DOI: 10.1016 / S16310683(02)00034-9.

[1356] R. F. Baird. "Fossil avian assemblage of Pitfall Origin from Holocene sediments in Amphitheatre Cave (G-2), South-western Victoria, Australia". English. In: Records of the Australian Museum 44 (1992), pp. 21-44.

[1357] R. F. Baird. “The fossil avian assemblage from Weekes Cave (N-15), Nullarbor Plain, South Australia: corrections, additions and reinterpretation". English. In: South Australian Ornithologist 31 (1990), pp. 29-35.

[1358] R. F. Baird. "Pleistocene avian fossils from Pyramids Cave (M-89), eastern Victoria, Australia". English. In: Alcheringa 17 (1993), pp. 383-404.

[1359] R. F. Baird. "Holocene avian assemblage from Skull Cave (AU-8), south-western Western Australia". English. In: Records of the Western Australian Museum 15 (1991), pp. 267-286.

[1360] R. F. Baird and P. Vickers-Rich. "Eutreptodactylus itaboraiensis gen. et sp. nov., an early cuckoo (Aves: Cuculidae) from the Late Paleocene of Brazil". English. In: Alcheringa 21.2 (1997), pp. 123127.

[1361] R. W. Baird. "Foraging behaviour and ecology of transient killer whales (Orcinus orca)". English. In: Simon Fraser University (1994).

[1362] S. Bajpai and D. P. Domning. "A new dugongine sirenian from the early Miocene of India". English. In: Journal of Vertebrate Paleontology 17.1 (1997), pp. 219-228.

[1363] S. Bajpai, D. P. Domning, D. P. Das, and V. P. Mishra. "A new middle Eocene sirenian (Mammalia, Protosirenidae) from India". English. In: Neus Jahrbuch fur Mineralogie, Geologie, und Palaeontologie 252/3 (2009), pp. 257-267.

[1364] S. Bajpai, D. P. Domning, D. P. Das, J. Velez-Juarbe, and V. P. Mishra. "A new fossil sirenian (Mammalia, Dugonginae) from the Miocene of India". English. In: Neus Jahrbuch fur Geologie und Palaeontologie, Abhandlungen 258.1 (2010), pp. 39-50. DOI: 10.1127/0077-7749/2010/0082.

[1365] S. Bajpai and P. D. Gingerich. "A new Eocene archaeocete (Mammalia, Cetacea) from India and the time of origin of whales". English. In: Proceedings of the National Academy of Sciences 95 (1998), pp. 15464-15468.

[1366] S. Bajpai, V. V. Kapur, D. P. Das, B. N. Tiwari, N. Saravanan, and R. Sharma. "Early Eocene land mammals from Vastan Lignite Mine, District Surat (Gujarat), Western India". English. In: Journal of the Palaeontological Society of India 50.1 (2005), pp. 101-113.

[1367] S. Bajpai, V. V. Kapur, J. G. M. Thewissen, B. N. Tiwari, and D. P. Das. “First fossil marsupials from India: Early Eocene Indodelphis n. gen. and Jaegeria n. gen. from Vastan Lignite Mine, District Surat, Gujarat". English. In: Journal of the Palaeontological Society of India 50.1 (2005), pp. 147-151.

[1368] S. Bajpai, V. V. Kapur, J. G. M. Thewissen, D. P. Das, and B. N. Tiwari. “New early Eocene cambaytheres (Perissodactyla, Mammalia) from the Vastan Lignite Mine (Gujarat, India) and an evaluation of cambaythere relationships". English. In: Journal of the Palaeontological Society of India 51.1 (2006), pp. 101-110. 
[1369] S. Bajpai, V. V. Kapur, J. G. M. Thewissen, D. P. Das, B. N. Tiwari, R. Sharma, and N. Saravanan. "Early Eocene primates from Vastan Lignite Mine, Gujarat, western India". English. In: Journal of the Palaeontological Society of India 50.2 (2005), pp. 43-54.

[1370] S. Bajpai, V. V. Kapur, and J. G. M. Thewissen. "Creodont and condylarth from the Cambay Shale (Early Eocene, 55-54MA), Vastan Lignite Mine, Gujarat, Western India". English. In: Journal of the Palaeontological Society of India 54.1 (2009), pp. 103-109.

[1371] S. Bajpai, R. F. Kay, B. A. Williams, D. P. Das, V. V. Kapur, and B. N. Tiwari. “Oldest Asian record of Anthropoidea". English. In: Proceedings of the National Academy of Sciences 105 (2008), pp. 1109311098.

[1372] S. Bajpai and G. V. R. Prasad. "Cretaceous age for Ir-rich Deccan intertrappean deposits: palaeontological evidence from Anjar, western India". English. In: Journal of the Geological Society, London 157 (2000), pp. 257-260.

[1373] S. Bajpai and J. G. M. Thewissen. Middle Eocene Cetaceans from the Harudi and Subathu Formations of India. English. The Emergence of Whales. 1998, pp. 213-233.

[1374] S. Bajpai, J. G. M. Thewissen, V. V. Kapur, B. N. Tiwari, and A. Sahni. “Eocene and Oligocene sirenians (Mammalia) from Kachchh, India". English. In: Journal of Vertebrate Paleontology 26.2 (2006), pp. $400-410$.

[1375] S. Bajpai and J. G. M. Thewissen. "Vertebrate fauna from Panandhro lignite field (Lower Eocene), District Kachchh, western India". English. In: Current Science 82.5 (2002), pp. 507-509.

[1376] S. Bajpai and J. G. M. Thewissen. "Protocetid cetaceans (Mammalia) from the Eocene of India". English. In: Palaeontologia Electronica 17.3 (2014), 34A.

[1377] M. Bak. “Uppermost Maastrichtian Radiolaria from the Magura Nappe deposits, Czech Outer Carpathians". English. In: Annales Societatis Geologorum Poloniae 69 (1999), pp. 137-159.

[1378] M. Bak. "Radiolaria from the Upper Cenomanian - Lower Turonian deposits of the Silesian Unit (Polish Flysch Carpathians)". English. In: Geologica Carpathica 51.5 (2000), pp. 309-324.

[1379] M. Bak. "Cretaceous Radiolaria from Niedzica Succession of the Pieniny Klippen Belt in Polish Carpathians". English. In: Acta Palaeontologica Polonica 41.1 (1996), pp. 91-110.

[1380] A. N. Baker and A. L. van Helden. "New records of beaked whales, genus Mesoplodon, from New Zealand (Cetacea: Ziphiidae)". English. In: Journal of the Royal Society of New Zealand 29.3 (1999), pp. 235-244.

[1381] B. W. Baker, M. B. Collins, and C. B. Bousman. "Late-Pleistocene horse (Equus sp.) from the Wilson-Leonard archaeological site, central Texas". English. In: Current Research in the Pleistocene 19 (2002), pp. 97-100.

[1382] C. S. Baker, R. W. Slade, J. L. Bannister, R. B. Abernethy, M. T. Weinrich, J. Lien, J. Urban, P. Corkeron, J. Calmabokidis, O. Vasquez, and S. R. Palumbi. "Hierarchical structure of mitochondrial DNA gene flow among humpback whales Megaptera novaeangliae, world-wide". English. In: Molecular Ecology 4 (1994), pp. 313-327.

[1383] P. G. Baker. "A new lacazellin thecideoid brachiopod from the Middle Jurassic of the Cotswolds, England". English. In: Palaeontology 48.6 (2005), pp. 1311-1319.

[1384] N. N. Bakhurina and D. M. Unwin. "a survey of pterosaurs from the Jurassic and Cretaceous of the former Soviet Union and Mongolia". English. In: Historical Biology 10 (1995), pp. 197-245.

[1385] R. T. Bakker. "A new latest Jurassic vertebrate fauna, from the highest levels of the Morrison Formation at Como Bluff, Wyoming, with comments on Morrison biochronology. Part I. Biochronology". English. In: Hunteria 2.6 (1990), pp. 1-3.

[1386] R. T. Bakker. Dinosaur mid-life crisis: the Jurassic-Cretaceous transition in Wyoming and Colorado. English. Vol. 14. Lower and Middle Cretaceous Terrestrial Ecosystems, New Mexico Museum of Natural History and Science Bulletin. 1998, pp. 67-77. 
[1387] R. T. Bakker and K. Carpenter. "A new latest Jurassic vertebrate fauna, from the highest levels of the Morrison Formation at Como Bluff, Wyoming, with comments on Morrison biochronology. Part III. The mammals: a new multituberculate and a new paurodont". English. In: Hunteria 2.6 (1990), pp. 4-8.

[1388] R. T. Bakker, P. M. Galton, J. Siegwarth, and J. Filla. "A new latest Jurassic vertebrate fauna, from the highest levels of the Morrison Formation at Como Bluff, Wyoming, with comments on Morrison biochronology. Part IV. The dinosaurs: a new Othnielia-like hypsilophodontoid". English. In: Hunteria 2.6 (1990), pp. 8-19.

[1389] R. T. Bakker, J. Siegwarth, D. Kralis, and J. Filla. "Edmarka rex, a new, gigantic theropod dinosaur from the middle Morrison Formation, Late Jurassic of the Como Bluff outcrop region". English. In: Hunteria 2.9 (1992), pp. 1-24.

[1390] R. T. Bakker, R. M. Sullivan, V. Porter, P. Larson, and S. J. Saulsbury. Dracorex hogwartsia, n. gen., $n$. sp., a spiked, flat-headed pachycephalosaurid dinosaur from the Upper Cretaceous Hell Creek Formation of South Dakota. English. Vol. 35. Late Cretaceous Vertebrates from the Western Interior. New Mexico Museum of Natural History and Science Bulletin. 2006, pp. 331-345.

[1391] J. Balaguer and D. M. Alba. "A new dugong species (Sirenia, Dugongidae) from the Eocene of Catalonia (NE Iberian Peninsula)". English. In: Comptes Rendus Palevol (2016). DOI: 10.1016/j.crpv. 2015.10.002.

[1392] L. T. Balance and R. L. Pitman. "Cetaceans of the western tropical Indian Ocean: distribution, relative abundance, and comparisons with cetacean communities of two other tropical ecosystems". English. In: Marine Mammal Science 14 (1998), pp. 429-459.

[1393] A. C. Balbino and M. T. Antunes. "Latest Miocene Dasyatidae (Neoselachii, Batomorphii) from the Alvalade Basin, Portugal". English. In: Geobios 39 (2006), pp. 747-755.

[1394] A. Baldanza, R. Bizzarii, F. Famiani, P. Monaco, R. Pellegrino, and P. Sassi. "Enigmatic, biogenically induced structures in Pleistocene marine deposits: A first record of fossil ambergris". English. In: Geology 41.10 (2013), pp. 1075-1078. DOI: 10.1130/G34731.1.

[1395] A. Baldanza, R. Bizzarri, F. Famiani, A. Garassino, G. Pasini, M. Cherin, and F. Rosatini. “The early Pleistocene whale-fall community of Bargiano (Umbria, Central Italy): Paleoecological insights from benthic foraminifera and brachyuran crabs". English. In: Palaeontologia Electronica 21.1 (2018), $11 \mathrm{~A}$.

[1396] B. A. J. Baldis. Ordovician trilobite zonation in western Argentina. English. Ordovician Odyssey: Short Papers for the 7th International Symposium on the Ordovician System. 1995, pp. 125-128.

[1397] A. M. Baldoni. "Palynology of the Lower Lefipan Formation (Upper Cretaceous) of Barranca de Los Perros,Chubut Province, Argentina. Part I. Cryptogam Spores and Gymnosperm Pollen". English. In: American Association of Stratigraphic Palynologists 16 (1992), pp. 117-136.

[1398] A. M. Baldoni and R. A. Askin. "Palynoogy of the Lower Lefipan Formation (Upper Cretaceous) of Barranca de los Perros, Chubut Province, Argentina. Part II. Angiosperm pollen and discussion". English. In: Palynology 17 (1993), pp. 241-264.

[1399] A. M. Baldoni and D. J. Batten. "Megaspores from the Lower Cretaceous Kachaike Formation, Santa Cruz Province, Argentina". English. In: Neues Jahrbuch für Geologie und Paläontologie, Abhandlungen 182.3 (1991), pp. 377-393.

[1400] A. M. Baldoni and D. J. Batten. "Cretaceous megaspores from two boreholes in the Austral Basin, Santa Cruz Province, Argentina, and their stratigraphic and paleoenvironmental significance". English. In: Neues Jahrbuch für Geologie und Paläontologie, Abhandlungen 205.1 (1997), pp. 97-110.

[1401] A. Baliski. "The brachiopod succession through the Silurian-Devonian boundary beds at Dnistrove, Podolia, Ukraine". English. In: Acta Palaeontologica Polonica 57.4 (2012), pp. 897-924.

[1402] M. Balini. "Taxonomy, stratigraphy and phylogeny of the new genus Lanceoptychites (Ammonoidea, Anisian)". English. In: Rivista Italiana di Paleontologia e Stratigrafia 104 (1998), pp. 143-166. 
[1403] M. Balini. "Discovery of Upper Ladinian ammonoids at the type locality of the lower Carnian Desatoyense zone (South Canyon, New Pass Range, Nevada)". English. In: Journal of Paleontology 82 (2008), pp. 176-182.

[1404] M. Balini. "Middle Triassic ceratitids (Ammonoidea) collected by C. Renz from Hydra (Greece)". English. In: Rivista Italiana di Paleontologia e Stratigrafia 100.3 (1994), pp. 351-364.

[1405] M. Balini. "Lardaroceras gen. n., a new late Anisian ammonoid genus from the Prezzo Limestone (Southern Alps)". English. In: Rivista Italiana di Paleontologia e Stratigrafia 98.1 (1992), pp. 3-28.

[1406] M. Balini, D. Germani, A. Nicora, and E. Rizzi. "Ladinian/Carnian ammonoids and conodonts from the classic Schilpario-Pizzo Camino area (Lombardy): revalutation of the biostratigraphic support to chronostratigraphy and paleogeography". English. In: Rivista Italiana di Paleontologia e Stratigrafia 106 (2000), pp. 19-589.

[1407] M. Balini, J. Jenks, and R. Martin. "Taxonomy and stratigraphic significance of Trachyceras silberlingi n. sp., from the Lower Carnian of South Canyon (New Pass Range, central Nevada, USA)". English. In: Bollettino della Societá Paleontologica Italiana 51 (2012), pp. 127-136.

[1408] M. Balini, J. F. Jenks, R. Martin, C. A. McRoberts, M. J. Orchard, and N. J. Silberling. “The Carnian/Norian boundary succession at Berlin-Ichthyosaur State Park (Upper Triassic, central Nevada, USA)". English. In: Paläontologische Zeitung 89 (2015), pp. 399-433.

[1409] M. Balini and J. F. Jenks. “The Trachyceratidae from South Canyon (central Nevada): record, taxonomic problems and stratigraphic significance for the definition of the Ladinian-Carnian boundary". English. In: The Global Triassic. New Mexico Museum of Natural History and Science Bulletin 41 (2007), pp. 14-22.

[1410] M. Balini, B. Jurkovsek, and T. Kolar-Jurkovsek. "New Ladinian ammonoids from Mt. Svilaja (External Dinarides, Croatia)". English. In: Rivista Italiana di Paleontologia e Stratigrafia 112 (2006), pp. 383-395.

[1411] A. Balinski. "Frasnian-Famennian brachiopod extinction and recovery in southern Poland". In: Acta Palaeontologica Polonica 47.2 (2002), pp. 289-305.

[1412] A. Balinski. "Brachiopods and conodonts from the Early Carboniferous of South China". English. In: Acta Palaeontologica Polonica 44.4 (1999), pp. 437-451.

[1413] A. Balinski. "Brachiopods and conodont biostratigraphy of the Famennian from the Debnik anticline, southern Poland". English. In: Palaeontologia Polonica 54 (1995), pp. 3-88.

[1414] A. Baliski. "First color-patterned strophomenid brachiopod from the earliest Devonian of Podolia, Ukraine". English. In: Acta Palaeontologica Polonica 55.4 (2010), pp. 695-700. DOI: 10.4202/app.2010. 0066.

[1415] A. Balinski and Y. Sun. "A new Early Carboniferous microproductid brachiopod from South China". English. In: Palaeontology 48.3 (2005), pp. 447-454.

[1416] M. Balke, A. Beigel, and L. Hendrich. "Hydroporus carstengroehni sp. n. und zwei unbestimmte Hydroporinae aus dem baltischen Bernstein (Dytiscidae: Hydroporinae)". German. In: Nachrichtenblatt Bayerischen Entomologen 59 (2010), pp. 2-8.

[1417] M. Balke and L. Hendrich. "†Japanolaccophilus beatificus sp. n. from Baltic amber and a key to the Laccophilinae genera of the world (Coleoptera: Laccophilinae)". English. In: Zootaxa 4567 (2019), pp. 176-182.

[1418] M. Balke, M. Toledo, C. Gröhn, I. Rappsilber, and L. Hendrich. "†Electruphilus wendeli gen.n., sp.n. - the first diving beetle recorded from Saxonian (Bitterfeld) amber (Coleoptera: Dytiscidae: Laccophilinae)". English. In: Russian Entomological Journal 28 (2019), pp. 350-357.

[1419] G. A. Ballen and J. W. Moreno-Bernal. "New records of the enigmatic Neotropical fossil fish Acregoliath rancii (Teleostei incertae sedis) from the middle Miocene Honda group of Colombia". English. In: Ameghiniana 56.6 (2019), pp. 431-440. 
[1420] S. Ballent, A. P. Carignano, A. Iglesias, and D. Poiré. “Non-Marine Calcareous microfossils and seeds in the type locality of Piedra Clavada Formation (Albian), Santa Cruz Province, Argentina". English. In: Ameghiniana 48.4 (2011), pp. 541-555.

[1421] S. C. Ballent. "Metacopina (Ostracoda) del Hettangiano superior en el sudoeste de la provincia de Mendoza, Argentina". Spanish. In: Ameghiniana 29.2 (1992), pp. 153-157.

[1422] D. Balseiro, B. G. Waisfeld, and L. A. Buatois. "Unusual trilobite biofacies from the Lower Ordovician of the Argentine Cordillera Oriental: new insights into olenid palaeoecology". English. In: Lethaia 44 (2011), pp. 58-75. DOI: 10.1111/j.1502-3931.2010.00224.x.

[1423] D. Balseiro, B. G. Waisfield, and N. E. Vaccari. "Paleoecological dynamics of Furongian (Late Cambrian) trilobite-dominated communities from northwestern Argentina". English. In: Palaios 26 (2011), pp. 484-499.

[1424] P. S. Balson. "The Neogene of East Anglia - a field excursion report". English. In: Tertiary Research 11.2-4 (1990), pp. 179-189.

[1425] U. Balthasar and N. J. Butterfield. "Early Cambrian soft-shelled brachiopods as possible stemgroup phoronids". English. In: Acta Palaeontologica Polonica 54 (2009), pp. 307-314. DOI: 10.4202/ app.2008.0042.

[1426] U. Balthasar, C. B. Skovsted, L. E. Holmer, and G. A. Brock. "Homologous skeletal secretion in tommotiids and brachiopods". English. In: Geology 37.12 (2009), pp. 1143-1146. DOI: 10.1130 / G30323A.1.

[1427] W. Baluk. "Middle Miocene (Badenian) gastropods from Korytnica, Poland; Part V Addenda et Corrigenda ad Prosobranchia". English. In: Acta Geologica Polonica 56 (2006), pp. 177-220.

[1428] W. Baluk. “Middle Miocene (Badenian) gastropods from Korytnica, Poland; Part II". English. In: Acta Geologica Polonica 45.3-4 (1995), pp. 153-255.

[1429] E. L. Bamforth, G. M. Narbonne, and M. M. Anderson. "Growth and ecology of a multi-branched Ediacaran rangeomorph from the Mistaken Point Assemblage, Newfoundland". English. In: Journal of Paleontology 82.4 (2008), pp. 763-777.

[1430] E. L. Bamforth and G. M. Narbonne. "New Ediacaran Rangeomorphs from Mistaken Point, Newfoundland, Canada". English. In: Journal of Paleontology 83.6 (2009), pp. 897-913. DOI: 10.1666/09047.1.

[1431] M. B. Bande. “The Paleogene vegetation of peninsular India (megafossil evidence)". English. In: Paleobotanist 40 (1992), pp. 275-284.

[1432] K. L. N. Bandeira, F. Medeiros Simbras, E. Batista Machado, D. de Almeida Campos, G. R. Oliveira, and A. W. A. Kellner. "A new giant Titanosauria (Dinosauria: Sauropoda) from the Late Cretaceous Bauru Group, Brazil”. English. In: PLoS ONE 11.10 (2016), e0163373:1-25.

[1433] K. Bandel. "Some heterostrophic gastropods from Triassic St. Cassian Formation with a discussion on the classification of the Allogastropoda". English. In: Paläontologische Zeitschrift 70 (1996), pp. 325-365.

[1434] K. Bandel. “Über triassische Loxonematoidea und ihre Beziehungen zu rezenten und paläozoischen Schnecken". German. In: Palaeontologische Zeitschrift 65 (1991), pp. 239-268.

[1435] K. Bandel. "Schlitzbandschnecken mit perlmutteriger Schale aus den triassischen St. Cassian Schichten der Dolomiten [Gastropods from the Triassic St. Cassian Formation of the Dolomites]". German. In: Annalen des Naturhistorischen Museums in Wien, A 92 (1991), pp. 1-53.

[1436] K. Bandel. "Description and classification of Late Triassic Neritimorpha (Gastropoda, Mollusca) from the St Cassian Formation, Italian Alps". English. In: Bulletin of Geosciences 82.3 (2007), pp. 215274.

[1437] K. Bandel. “Caenogastropoda during Mesozoic times". English. In: Scripta Geologica, Special Issue 2 (1993), pp. 7-56.

[1438] K. Bandel. "Platyceratidae from the Triassic St. Cassian Formation and the evolutionary history of the Neritomorpha (Gastropoda)". English. In: Paläontologische Zeitschrift 66 (1992), pp. 231-240. 
[1439] K. Bandel. "Relationships of the Triassic Eucycloidea Koken, 1897 (Mollusca, Gastropoda) to modern genera such as Pagodatrochus, Calliotropis and Euchelus, based on morphology of the early shell". English. In: Bulletin of Geosciences 85 (2010), pp. 435-486. DOI: 10.3140/bull.geosci.1208.

[1440] K. Bandel and J. Frýda. "Babinipleura, a new slit bearing archaeogastropod (Vetigastopoda) from the Early Devonian of Bohemia and the Early Carboniferous of Belgium". English. In: Neues Jahrbuch für Geologie und Paläontologie Monatshefte 1996.6 (1996), pp. 325-344.

[1441] K. Bandel and D. Heidelberger. "A Devonian member of the subclass Heterostropha (Gastropoda) with valvatoid shell shape". English. In: Neues Jahrbuch für Geologie und Paläontologie Monatshefte 2002 (2002), pp. 533-550.

[1442] A. N. Bandini, P. O. Baumgartner, and M. Caron. "Turonian radiolarians from Karnezeika, Argolis Peninsula, Peloponnesus (Greece)". English. In: Eclogae Geologicae Helvetiae, Supplement 99.S1 (2006), pp. 1-20.

[1443] S. Bandyopadhyay, D. D. Gillette, S. Ray, and D. P. Sengupta. “Osteology of Barapasaurus tagorei (Dinosauria: Sauropoda) from the Early Jurassic of India". English. In: Palaeontology 53.3 (2010), pp. 533-569. DOI: $10.1111 /$ j.1475-4983.2010.00933.x.

[1444] P. K. Banerjee. "Holocene and Late Pleistocene relative sea level fluctuations along the east coast of India". English. In: Marine Geology 167 (2000), pp. 243-260.

[1445] A. F. Banikov and L. Sorbini. "Eocoris bloti, a new genus and species of labrid fish (Perciformes, Labroidei) from the Eocene of Monte Bolca, Italy". English. In: Stud. e Ric. sui giacimenti Terziari di Bolca 6 (1990), pp. 133-148.

[1446] A. F. Bannikov. "The systematic composition of the Eocene actinopterygian fish fauna from Monte Bolca, northern Italy, as known to date". English. In: Studi e ricerche sui giacimenti terziari di Bolca, XV - Miscellanea paleontologica 12 (2014), pp. 23-34.

[1447] A. F. Bannikov. "The First Discovery of an Anglerfish (Teleostei, Lophiidae) in the Eocene of the Northern Caucasus". English. In: Paleontological Journal 38.4 (2004), pp. 420-425.

[1448] A. F. Bannikov. "A new genus and species of putative centrolophid fish (Perciformes, Stromateoidei) from the Eocene of Bolca, northern Italy". English. In: Bollettino del Museo Civico di Storia Naturale di Verona 24 (2000), pp. 37-46.

[1449] A. F. Bannikov. "A New Genus and Species of Stromateoid Fishes (Perciformes, Stromateoidei) from the Lower Oligocene of the Northern Caucasus". English. In: Paleontological Journal 52.6 (2018), pp. 631-638.

[1450] A. F. Bannikov. "A review of fossil Lampridiformes (Teleostei) finds with a description of a new Lophotidae genus and species from the Oligocene of the Northern Caucasus". English. In: Paleontological Journal 33.1 (1999), pp. 68-76.

[1451] A. F. Bannikov. "On the belonging to Family Champsodontidae (Perciformes) of a Caucasian Oligocene species previously classified with Family Chiasmodontidae". English. In: Journal of Ichthyology 38.6 (1998), pp. 478-480.

[1452] A. F. Bannikov. "A new species of Psettopsis (Perciformes, Monodactylidae) from the Eocene of northern Italy (Bolca)". English. In: Miscellanea Paleontologica n. 8. Studi e Ricerche sui Giacimenti Terziari di Bolca 11 (2005), pp. 141-148.

[1453] A. F. Bannikov. "The first record of the genus Isurichthys (Perciformes, Ariommatidae) in the Lower Oligocene of the Northern Caucasus". English. In: Paleontological Journal 46.2 (2012), pp. 171176.

[1454] A. F. Bannikov. "A new species of the percoid fish genus Pavarottia (Perciformes) from the Eocene of Bolca, northern Italy". English. In: Studi e ricerche sui giacimenti terziari di Bolca 17.14 (2016), pp. 5-11.

[1455] A. F. Bannikov and D. R. Bellwood. "A new genus and species of pomacentrid fish (Perciformes) from the Eocene of Bolca in northern Italy". English. In: Studi e ricerche sui giacimenti terziari di Bolca 55 (2014), pp. 7-14. 
[1456] A. F. Bannikov and D. R. Bellwood. "A new genus and species of labrid fish (Perciformes) from the Eocene of Bolca in northern Italy". English. In: Studi e ricerche sui giacimenti terziari di Bolca, XVI - Miscellanea Paleontologica 57 (2015), pp. 5-16.

[1457] A. F. Bannikov and D. R. Bellwood. "Zorzinilabrus furcatus, a new genus and species of labrid fish (Perciformes) from the Eocene of Bolca in northern Italy". English. In: Studi e ricerche sui giacimenti terziari di Bolca 18.15 (2017), pp. 5-14.

[1458] A. F. Bannikov and G. Carnevale. "A new percoid fish from the Eocene of Monte Bolca, Italy: Hendrixella grandei gen. \& sp nov." English. In: Swiss Journal of Geosciences 102.3 (2009), pp. 481488.

[1459] A. F. Bannikov and G. Carnevale. "Bellwoodilabrus landinii n. gen., n. sp., a new genus and species of labrid fish (Teleostei, Perciformes) from the Eocene of Monte Bolca". English. In: Geodiversitas 32.2 (2010), pp. 201-220.

[1460] A. F. Bannikov and G. Carnevale. "†Carlomonnius quasigobius gen. et sp. nov.: The first gobioid fish from the Eocene of Monte Bolca, Italy". English. In: Bulletin of Geosciences 91.1 (2016), pp. 1322. DOI: $10.3140 /$ bull.geosci.1577.

[1461] A. F. Bannikov and T. H. Fraser. "A new genus and species of cardinalfish (Percomorpha, Apogonidae) from the Eocene of Bolca, northern Italy (Monte Postale site)". English. In: Studi e ricerche sui giacimenti terziari di Bolca 17.14 (2016), pp. 13-23.

[1462] A. F. Bannikov and A. N. Kotylar. "A new genus and species of Early Sarmatian Porgies (Perciformes, Sparidae) from the Krasnodar Region". English. In: Paleontological Journal 49.6 (2015), pp. 627-635.

[1463] A. F. Bannikov and N. N. Parrin. "The list of marine fishes from Cenozoic (Upper PaleoceneMiddle Miocene) localities in Southern European Russia and adjacent countries". English. In: Journal of Ichthyology 37.2 (1997), pp. 33-146.

[1464] A. F. Bannikov and J. C. Tyler. "Phylogenetic revision fo the fish families Luvaridae and Kushlukidae (Acanthuroidei), with a new genus and two new species of Eocene luvarids". English. In: 81 (1995), pp. 1-45.

[1465] A. F. Bannikov and J. C. Tyler. "A new genus and species of triggerfish from the Middle Eocene of the Northern Caucasus, the earliest member of the Balistidae (Tetraodontiformes)". English. In: Paleontological Journal 42.6 (2008), pp. 615-620.

[1466] A. F. Bannikov and J. C. Tyler. "A New Species of the Pufferfish Eotetraodon (Tetraodontiformes, Tetraodontidae) from the Eocene of the Northern Caucasus". English. In: Paleontological Journal 42.5 (2008), pp. 526-530.

[1467] A. F. Bannikov and R. Zorzin. "A new genus and species of incertae sedis percomorph fish (Perciformes) from the Eocene of Bolca in northern Italy," English. In: Studi e ricerche sui giacimenti terziari di Bolca 19 (2019), pp. 5-15.

[1468] A. F. Bannikov and R. Zorzin. "A new genus and species of lutjanid fish (Perciformes) from the Eocene of Bolca, Northern Italy". English. In: Studi e ricerche sui giacimenti terziari di Bolca 40.12 (2014), pp. 15-22.

[1469] A. F. Bannikov and R. Zorzin. "Paralabrus rossiae, a new genus and species of putative labroid fish (Perciformes) from the Eocene of Bolca in northern Italy". English. In: Studi e ricerche sui giacimenti terziari di Bolca 19.16 (2019), pp. 39-47.

[1470] A. F. Bannikov. "A new genus of the Family Palaeocentrotidae (Teleosti, Lampridiformes) from the Oligocene of the Northern Caucasus and comments on other fossil Veliferoidei". English. In: Paleontological Journal 48.6 (2014), pp. 624-632.

[1471] J. L. Bannister. "Status of southern right whales (Eubalaena australis) off southern Australia". English. In: . Journal of Cetacean Research and Management 2 (2001), pp. 103-110.

[1472] J. M. Bannister, J. G. Conran, and D. E. Lee. "Lauraceae from rainforest surrounding an early Miocene maar lake, Otago, southern New Zealand". English. In: Review of Palaeobotany and Palynology 178 (2012), pp. 13-34. 
[1473] R. A. M. Bantim, A. A. F. Saraiva, G. R. Oliveira, and J. M. Sayao. "A new toothed pterosaur (Pterodactyloidea: Anhangueridae) from the Early Cretaceous Romualdo Formation, NE Brazil". English. In: Zootaxa 3869.3 (2014), pp. 201-223.

[1474] J.-S. Bao and J. B. Jago. "Late Late Cambrian trilobites from near Birch Inlet, south-western Tasmania". English. In: Palaeontology 43.5 (2000), pp. 881-917.

[1475] T. Bao and C. Antunes-Carvalho. "Two new polyphagan beetles (Tenebrionidae, Leiodidae) from lower Cenomanian amber of Myanmar". English. In: Cretaceous Research 116.104599 (2020). DOI: 10.1016/j.cretres.2020.104599.

[1476] T. Bao, J. Rust, and B. Wang. "Systematics, phylogeny and taphonomy of Cretaceous Psephenidae (Insecta: Coleoptera) from Burmese amber". English. In: Palaeontographica Abteilung A 310 (2018), pp. 131-159.

[1477] T. Bao, K. S. Walczyska, S. Moody, B. Wang, and J. Rust. "New family Apotomouridae fam. nov. (Coleoptera: Tenebrionoidea) from lower Cenomanian amber of Myanmar". English. In: Cretaceous Research 91 (2018), pp. 14-19.

[1478] T. Bao, K. S. Walczyska, S. Moody, B. Wang, and J. Rust. “The first true Mordellidae (Coleoptera: Tenebrionoidea) from lower Cenomanian amber of Myanmar". English. In: Cretaceous Research 93 (2018), pp. 60-65.

[1479] T. Bao, K. S. Walczyska, B. Bojarski, E. Jarzembowski, B. Wang, and J. Rust. "A new species of tumbling fower beetle (Coleoptera: Mordellidae) from Baltic amber". English. In: PalZ 93 (2018), pp. 31-36.

[1480] T. Bao, B. Wang, J. G. Li, and D. Dilcher. "Pollination of Cretaceous flowers". English. In: Proceedings of the National Academy of Sciences 116 (2019), pp. 24707-24711. DOI: 10.1073/pnas.1916186116.

[1481] T. Bao, X. S. Zhang, K. S. Walczyska, B. Wang, and J. Rust. "Earliest mordellid-like beetles from the Jurassic of Kazakhstan and China (Coleoptera: Tenebrionoidea)". English. In: Proceedings of the Geologists' Association 130 (2019), pp. 247-256. DOI: 10.1016/j.pgeola.2019.02.002.

[1482] E. J. Baraboshkin and J. Mutterlose. "Correlation of the Barremian belemnite successions of northwest Europe and the Ulyanovsk Saratov area (Russian Platform)". English. In: Acta Geologica Polonica 54.4 (2004), pp. 499-510.

[1483] E. Y. Baraboshkin and V. A. Musatov. "A unique find of Hercoglossa pavlovi (Arkh.) (Nautiloidea) in Paleocene sediments of the Volga region". English. In: Moscow University Geology Bulletin 66 (2011), pp. 369-372.

[1484] V. Baranov, T. Andersen, and E. Perkovsky. "A new genus of Podonominae (Diptera: Chironomidae) in late Eocene Rovno amber from Ukraine". English. In: Zootaxa 3794 (2014), pp. 581-586.

[1485] V. Baranov, T. Andersen, and E. E. Perkovsky. “Orthoclads from Eocene amber from Sakhalin (Diptera: Chironomidae, Orthocladiinae)". English. In: Insect Systematics \& Evolution 46 (2015), pp. 359-378. DOI: 10.1163/1876312X-45032122.

[1486] V. Baranov, T. Andersen, and L. K. Hagenlund. "A new species of Bryophaenocladius Thienemann, 1934 (Diptera, Chironomidae, Orthocladiinae) from Baltic amber". English. In: Norwegian Journal of Entomology 62 (2015), pp. 53-56.

[1487] V. Baranov, W. Gika, M. Zakrzewska, and E. Jarzembowski. “New non-biting midges (Diptera: Chironomidae) from Lower Cretaceous Wealden amber of the Isle of Wight (UK)". English. In: Cretaceous Research 95 (2018), pp. 138-145.

[1488] V. Baranov, T. Góral, and A. Ross. "A new genus of Buchonomyiinae (Diptera, Chironomidae) from Upper Cretaceous Burmese amber, with the phylogeny of the subfamily revisited". English. In: Cretaceous Research 79 (2017), pp. 146-152.

[1489] V. Baranov, C. Hoffeins, H. W. Hoffeins, and J. T. Haug. "Reaching across the ocean of time: A midge morphotype from the Cretaceous of Gondwana found in the Eocene Baltic amber". English. In: Palaeontologia Electronica 22.2.38A (2019), pp. 1-17. 
[1490] V. Baranov, G. M. Kvifte, P. Müller, and X. E. Bernal. “A new species of fossil Corethrella (Diptera, Corethrellidae) from mid-Cretaceous Burmese amber". English. In: Cretaceous Research 101 (2019), pp. 84-91. DOI: 10.1016/j.cretres.2019.05.002.

[1491] V. Baranov and E. Perkovsky. "First record of gynandromorphy in fossil Chironomidae (Diptera) from Late Eocene Rovno amber". English. In: Chironomus, Newsletter on Chironomidae Research, Short Communications 27 (2014), pp. 55-57.

[1492] V. Baranov and E. E. Perkovsky. "New chironomids from Eocene Sakhalinian amber (Diptera; Chironomidae; Orthocladiinae)". English. In: Terrestrial Arthropod Reviews 6 (2013), pp. 61-69.

[1493] V. A. Baranov, G. M. Kvifte, and E. E. Perkovsky. "Two new species of fossil Corethrella Coquillett from Late Eocene Rovno amber, with a species-level phylogeny for the family based on morphological traits (Diptera: Corethrellidae)". English. In: Systematic Entomology 41 (2016), pp. 531-540.

[1494] V. V. Baranov. "New Devonian Brachiopods from Northeastern Russia". English. In: Paleontological Journal 41.3 (2007), pp. 252-259.

[1495] V. V. Baranov. "The Middle and Upper Devonian in southeastern flank of the Siberian Platform (southern Verkhoyansk region, Sette-Daban Mountain Range)". English. In: Stratigraphy and Geological Correlation 15.5 (2007), pp. 470-484.

[1496] V. V. Baranov. "New Brachiopods from the Ordovician of Northeastern Russia". English. In: Paleontological Journal 51.1 (2017), pp. 47-52. DOI: 10.1134/S0031030117010038.

[1497] V. V. Baranov and R. B. Blodgett. "Revision of the rhynchonellid and atrypid brachiopods from the lower Pragian (Devonian) of Southeast Alaska (Heceta Island)". English. In: Bulletin of Geosciences 90.1 (2015), pp. 21-32. DOI: 10.3140/bull.geosci.1494.

[1498] V. V. Baranov and R. B. Blodgett. "Two New Brachiopod Genera from the Lower Pragian (Lower Devonian, Soda Creek Limestone) of West Central Alaska". English. In: Paleontological Journal 50.1 (2016), pp. 34-40. DOI: 10.1134/S0031030116010020.

[1499] D. Barasoain, V. H. Contreras, R. L. Tomassini, and A. E. Zurita. “A new pygmy armadillo (Cingulata, Euphractinae) from the late Miocene of Andean Argentina reveals an unexpected evolutionary history of the singular Prozaedyus lineage". English. In: Journal of South American Earth Sciences 100 (2020), 102589:1-13.

[1500] D. Barasoain, R. L. Tomassini, A. E. Zurita, C. I. Montalvo, and M. Superina. "A new fairy armadillo (Cingulata, Chlamyphorinae) from the upper Miocene of Argentina: first fossil record of the most enigmatic Xenarthra". English. In: Journal of Vertebrate Paleontology 39.5 (2019), e1716778:117.

[1501] F. Barattolo, D. Bassi, and R. Romano. “Upper Eocene larger foraminiferal-coralline algal facies from the Klokova Mountain (southern continental Greece)". English. In: Facies 53 (2007), pp. 361375.

[1502] A. J. Barber. "The origin of the Woyla Terranes in Sumatra and the Late Mesozoic evolution of the Sundaland margin". English. In: Journal of Asian Earth Sciences 18 (2000), pp. 713-738.

[1503] E. Barbero, C. Palestrini, and A. Roggero. "Systematics and phylogeny of Eodrepanus, a new drepanocerine genus, with comments on biogeographical data (Coleoptera: Scarabaeidae: Oniticellini)". English. In: Journal of Natural History 43 (2009), pp. 1835-1878.

[1504] F. Barbiere, L. E. Cruz, P. E. Ortiz, and U. F. J. Pardiñas. “A new genus of Sigmodontinae (Mammalia, Rodentia, Cricetidae) from the Pliocene of Central Argentina". English. In: Journal of Vertebrate Paleontology 36.5 (2016), e1199557. DOI: 10.1080/02724634.2016.1199557.

[1505] F. Barbiére, P. E. Ortiz, and U. F. J. Pardiñas. “The oldest sigmodontine rodent revisited and the age of the first South American cricetids". English. In: Journal of Paleontology 93.2 (2019), pp. 368-384. DOI: $10.1017 /$ jpa.2018.74.

[1506] D. N. Barbosa, E. E. Perkovsky, and C. O. Azevedo. "Two new species of Laelius Ashmead (Hymenoptera: Bethylidae) from Upper Eocene Rovno amber". English. In: Neues Jahrbuch für Geologie und Paläontologie, Abhandlungen 267 (2013), pp. 67-73. 
[1507] J. A. Barbosa, A. W. A. Kellner, and M. S. S. Viana. “New dyrosaurid crocodylomorph and evidences for faunal turnover at the K-P transition in Brazil". English. In: Proceedings of the Royal Society of London B 275 (2008), pp. 1385-1391. DOI: 10.1098/rspb.2008.0110.

[1508] M. M. Barboza, J. F. Parham, G. -P. Santos, B. N. Kussman, and J. Velez-Juarbe. “The age of the Oso Member, Capistrano Formation, and a review of fossil crocodylians from California". English. In: PaleoBios 34 (2017), pp. 1-16.

[1509] A. Barck. Paleontology of the Glen Rose Formation (lower Cretaceous), Hood County, Texas. 1992.

[1510] J. I. Barco, J. I. Canudo, and J. I. Ruiz-Omeñaca. “Presencia de la icnoasociación MegalosauripusTherangospondus en el Barremiense (Cretácico inferior) de la Pennsula Ibérica (Cuenca de Cameros, Soria): implicaciones paleobiogeograficas [Presence of the Megalosauripus-Therangospondus ichnoassociation in the Barremian (Lower Cretaceous) of the Iberian peninsula (Cameros Basin, Soria): paleobiogeographic implications]". Spanish. In: Geo-Temas 6.5 (2004), pp. 15-18.

[1511] J. L. Barco. “Estudio y comparación del esqueleto axial de un saurópodo (Dinosauria, Sauropodomorpha) procedente de la Formación Villar del Arzobispo (Titónico-Berriasiense) de Galve, Teruel [Study and comparison of the axial skeleton of a sauropod (Dinosauria, Sauropodomorpha) from the Villar del Arzobispo Formation (Tithonian-Berriasian) of Galve, Teruel]". Spanish. In: Treballs del Museu de Geologa de Barcelona 13 (2005), pp. 15-59.

[1512] J. L. Barco, J. I. Canudo, J. I. Ruiz-Omeñaca, and J. L. Rubio. “Evidencia icnológica de un dinosaurio terópodo gigante en el Berriasiense (Cretácico Inferior) de Laurasia (Las Villasecas, Soria, España) [Ichnological evidence of a giant theropod dinosaur in the Berriasian (Lower Cretaceous) of Laurasia (Las Villasecas, Soria, Spain)]". Spanish. In: Revista Española de Paleontologa 10 (2005), pp. 59-71.

[1513] J. L. Barco, J. I. Canudo, G. Cuenca-Bescós, and J. I. Ruiz-Omeñaca. “Un nuevo dinosaurio saurópodo, Galvesaurus herreroi gen. nov., sp. nov., del tránsito Jurásico-Cretácico en Galve (Teruel, NE de España) [A new sauropod dinosaur, Galvesaurus herreroi gen. nov., sp. nov., from the JurassicCretaceous transition in Galve (Teruel, NE Spain)]". Spanish. In: Naturaleza Aragonesa 15 (2005), pp. 4-17.

[1514] J. L. Barco and J. I. Ruiz-Omeñaca. La Ruta de las Icnitas de dinosaurio de Soria. Una excursión a los comienzos del Cretácico [The Footprint Route of the dinosaurs of Soria. An excursion to the beginnings of the Cretaceous]. Spanish. Vol. 4. In G. Meléndez Hevia, S. A. Zamora Iranzo, \& L. M. Sender Palomar (eds.), IX Jornadas Aragonesa de Paleontologa. Asociación Cultural Bajo Jalón, Cuadernos de Paleontologa Aragonesa. 2005, pp. 60-90.

[1515] W. Barczyk. "Succession of the Tithonian to Berriasian brachiopod faunas at Rogoznik, Pieniny Klippen Belt". English. In: Acta Geologica Polonica 41.1-2 (1991), pp. 101-107.

[1516] I. A. Bardashev, N. P. Bardasheva, K. Weddige, and W. Ziegler. "Stratigraphy and facies of the Middle Paleozoic of parts of southern Tien-Shan in Tajikistan and Uzbekistan". English. In: Senckenbergiana lethaea 85.2 (2005), pp. 319-364.

[1517] P. Barden, B. Boudinot, and A. Lucky. "Where fossils dare and males matter: combined morphological and molecular analysis untangles the evolutionary history of the spider ant genus Leptomyrmex Mayr (Hymenoptera : Dolichoderinae)". English. In: Invertebrate Systematics 31 (2017), pp. 765-780.

[1518] P. Barden and D. Grimaldi. "Rediscovery of the bizarre Cretaceous ant Haidomyrmex Dlussky (Hymenoptera: Formicidae), with two new species". English. In: American Museum Novitates 3755 (2012), pp. 1-16.

[1519] P. Barden and D. Grimaldi. "A new genus of highly specialized ants in Cretaceous Burmese amber (Hymenoptera: Formicidae)". English. In: Zootaxa 3681 (2013), pp. 405-412.

[1520] P. Barden and D. Grimaldi. "A diverse ant fauna from the mid-Cretaceous of Myanmar (Hymenoptera: Formicidae)". English. In: PLoS One 9.4 (2014), e93627.

[1521] P. Barden and D. A. Grimaldi. "Adaptive radiation in socially advanced stem-group ants from the Cretaceous". English. In: Current Biology 26 (2016), pp. 515-521. 
[1522] P. Barden, H. W. Herhold, and D. A. Grimaldi. "A new genus of hell ants from the Cretaceous (Hymenoptera: Formicidae: Haidomyrmecini) with a novel head structure". English. In: Systematic Entomology 42 (2017), pp. 837-846.

[1523] P. Barden, V. Perrichot, and B. Wang. "Specialized predation drives aberrant morphological integration and diversity in the earliest ants". English. In: Current Biology 30 (2020), pp. 3818-3824. DOI: $10.1016 /$ j.cub.2020.06.106.

[1524] N. Bardet. "Stratigraphic evidence for the extinction of the ichthyosaurs". English. In: Terra Nova 4 (1992), pp. 649-656.

[1525] N. Bardet. "The mosasaur collections of the Museum National d'Histoire Naturelle of Paris". English. In: Bulletin de la Societe Geologique de France 183.1 (2012), pp. 35-53.

[1526] N. Bardet, J. F. Baeza Carratalá, V. Dez Daz, A. Carbonell, M. Garca Ávila, and V. Giner. "First occurrence of Mosasauridae (Squamata) in the Maastrichtian (latest Cretaceous) of Alicante (Valencia Community, Eastern Spain)". English. In: Estudios Geológicos 69.1 (2013), pp. 97-104. DOI: 10.3989/egeol.40792.169.

[1527] N. Bardet, H. Cappetta, X. Pereda Suberbiola, M. Mouty, A. K. Al Maleh, A. M. Ahmed, O. Khrata, and N. Gannoum. "The marine vertebrate faunas from the Late Cretaceous phosphates of Syria". English. In: Geological Magazine 137.3 (2000), pp. 269-290.

[1528] N. Bardet, J. C. Corral, and X. Pereda Superbiola. "Les mosasaures (Squamata) du Cretace Superieur du Bassin Basco-Cantabrique". French. In: Geobios 20 (1997), pp. 19-26.

[1529] N. Bardet, M. Fernandez, J. C. Garcia-Ramos, X. P. Suberbiola, L. Pinuela, J. I. Ruiz-Omenaca, and P. Vincent. "A juvenile plesiosaur from the Pliensbachian (Lower Jurassic) of Asturias, Spain". English. In: Journal of Vertebrate Paleontology 28.1 (2008), pp. 258-263.

[1530] N. Bardet and M. Fernandez. "A new ichthyosaur from the Upper Jurassic lithographic limestones of Bavaria". English. In: Journal of Paleontology 74.3 (2000), pp. 503-511.

[1531] N. Bardet, V. Fischer, and M. Machalski. "Large predatory marine reptiles from the Albian-Cenomanian of Annopol, Poland". English. In: Geological Magazine 153.1 (2015), pp. 1-16. DOI: 10.1017/S0016756815000254.

[1532] N. Bardet, P. Godefroit, and J. Sciau. "A new elasmosaurid Plesiosaur from the Lower Jurassic of southern France". English. In: Palaeontology 42.5 (1999), pp. 927-952.

[1533] N. Bardet, N.-E. Jalil, F. de Lapparent de Broin, D. Germain, O. Lambert, and M. Amaghzaz. “A giant chelonioid turtle from the Late Cretaceous of Morocco with a suction feeding apparatus unique among tetrapods". English. In: PLoS One 8.7 (2013), e63586. DOI: 10.1371/journal.pone. 0063586.

[1534] N. Bardet, X. Pereda Suberbiola, M. Iarochene, F. Bouyahyaoui, B. Bouya, and M. Amaghzaz. "Mosasaurus beaugei Arambourg, 1952 (Squamata, Mosasauridae) from the Late Cretaceous phosphates of Morocco". English. In: Geobios 37 (2004), pp. 315-324.

[1535] N. Bardet, X. Pereda Suberbiola, and N. -E. Jalil. "A new mosasauroid (Squamata) from the Late Cretaceous (Turonian) of Morocco". English. In: Comptes Rendus Palevol 2 (2003), pp. 607-616.

[1536] N. Bardet, X. Pereda Suberbiola, and N. -E. Jalil. "A new polycotylid plesiosaur from the Late Cretaceous (Turonian) of Morocco". English. In: Comptes Rendus Palevol 2 (2003), pp. 307-315.

[1537] N. Bardet, X. Pereda Suberbiola, M. Iarochéne, M. Amalik, and B. Bouya. “Durophagous Mosasauridae (Squamata) from the Upper Cretaceous phosphates of Morocco, with description of a new species of Globidens". English. In: Netherlands Journal of Geosciences - Geologie en Mijnbouw 84.3 (2005), pp. 167-175.

[1538] N. Bardet, X. Pereda Suberbiola, M. Iarochene, B. Bouya, and M. Amaghaz. "A new species of Halisaurus from the Late Cretaceous phosphates of Morocco, and the phylogenetical relationships of the Halisaurinae (Squamata: Mosasauridae)". English. In: Zoological Journal of the Linnean Society 143 (2005), pp. 447-472.

[1539] N. Bardet and X. Pereda Suberbiola. "Marine reptiles from the Late Cretaceous Phosphates of Jordan: palaeobiogeographical implications". English. In: Geodiversitas 24.4 (2002), pp. 831-839. 
[1540] N. Bardet, X. Pereda Suberbiola, and E. Metais. “Un lézard varanode (Squamata, Mosasauroidea) dans le Crétacé supérieur de Touraine". French. In: Géologie de la France 1 (1998), pp. 69-72.

[1541] N. Bardet, X. Pereda Suberbiola, J. -C. Corral, J. I. Baceta, J. A. Torres, B. Botantz, and G. Martin. “A skull fragment of the mosasaurid Prognathodon cf. sectorius from the Late Cretaceous of Navarre (Basque-Cantabrian Region)". English. In: Bulletin de la Société Géologique de France 183.2 (2012), pp. 117-121.

[1542] N. Bardet, X. Pereda Suberbiola, and J. C. Coral. "A tylosaurine Mosasauridae (Squamata) from the Late Cretaceous of the Basque-Cantabrian region". English. In: Estudios Geológicos 62.1 (2006), pp. 213-218.

[1543] N. Bardet, X. Pereda Suberbiola, and G. Badillet. "A primitive chelonioid turtle from the Late Cretaceous of Touraine, France". English. In: Bulletin de la Societe Geologique de France 167.2 (1996), pp. 257-262.

[1544] N. Bardet, M. Segura, and A. Pérez-Garca. "A plesiosaur (Reptilia, Sauropterygia) from the Cenomanian (Late Cretaceous) of Algora (Guadalajara Province, Central Spain)". English. In: Cretaceous Research 91 (2018), pp. 33-40.

[1545] N. Bardet and C. Tunoglu. "The first mosasaur (Squamata) from the Late Cretaceous of Turkey". English. In: Journal of Vertebrate Paleontology 22.3 (2002), pp. 712-715.

[1546] N. Bardet, P. Wellenhofer, and D. Herm. "Discovery of ichthyosaur remains (Reptilia) in the Cenomanian of Bavaria". Italian. In: Mitteilungen der Bayerischen Staatssammlung für Paläont. Hist. Geol 34 (1994), pp. 213-220.

[1547] S. Bardhan, K. Halder, and S. K. Jana. "Earliest sexual dimorphism in Nautiloidea from the Jurassic of Kutch, India". English. In: Neues Jahrbuch für Geologie und Paläontologie, Abhandlungen 193 (1994), pp. 287-309.

[1548] J. Bardin, I. Rouget, and F. Cecca. "Late Pliensbachian (Early Jurassic) ammonites from Lac de Charmes (Haute-Marne, France): systematic, biostratigraphy and palaeobiogeography". English. In: Geodiversitas 35 (2013), pp. 309-334.

[1549] G. H. Barfod, F. Albarede, A. H. Knoll, S. Xiao, P. Telouk, R. Frei, and J. Baker. “New LutetiumHafnium and Lead-Lead age constraints on the earliest animal fossils". English. In: Earth and Planetary Science Letters 201 (2002), pp. 203-212.

[1550] M. S. Bargo, G. De Iuliis, and N. Toledo. "Early Miocene Sloths (Xenarthra, Folivora) From the Ro Santa Cruz Valley (Southern Patagonia, Argentina), Ameghino, 1887 Revisited". English. In: vol. 19. Early-Middle Miocene Paleontology in the Ro Santa Cruz, Southern Patagonia, Argentina. 130 years since Ameghino, 1887 2. Publicación Electrónica de la Asociación Paleontológica Argentina, 2019, pp. 102-137. DOI: 10.5710/PEAPA.06.08.2019.297.

[1551] M. S. Bargo and C. M. Deschamps. “El registro de Mylodon Owen, 1840 (Mammalia, Tardigrada) en el Pleistoceno del sur de la Provincia de Buenos Aires. Comentarios sobre la distribucion de los sedimentos pampeanos". Spanish. In: Ameghiniana 33.3 (1996), pp. 343-348.

[1552] M. S. Bargo and M. A. Reguero. "Annotated catalogue of the fossil vertebrates from Antarctica housed in the Museo de la Plata, Argentina. I. Birds and Land Mammals from La Meseta Formation (Eocene - Early Oligocene)". English. In: Associacion Paleontologica Argentina, Publicacion Especial 5 (1998), pp. 211-221.

[1553] M. S. Bargo, S. F. Vizcano, F. M. Archuby, and R. E. Blanco. “Limb bone proportions, strength and digging in some Lujanian (Late Pleistocene-Early Holocene) mylodontid ground sloths (Mammalia, Xenarthra)". English. In: Journal of Vertebrate Paleontology 20.3 (2000), pp. 601-610.

[1554] C. T. Barker, D. Naish, C. E. Clarkin, P. Farrell, G. Hullmann, J. Lockyer, P. Schneider, R. K. C. Ward, and N. J. Gostling. "A highly pneumatic middle Cretaceous theropod from the British Lower Greensand". English. In: Papers in Palaeontology (2020). DOI: 10.1002/spp2.1338.

[1555] N. Barling, S. W. Heads, and D. M. Martill. "A new parasitoid wasp (Hymenoptera: Chalcidoidea) from the Lower Cretaceous Crato Formation of Brazil: the first Mesozoic Pteromalidae". English. In: Cretaceous Research 45 (2013), pp. 258-264. 
[1556] N. Barling, D. M. Martill, S. W. Heads, and F. Gallien. “High fidelity preservation of fossil insects from the Crato Formation (Lower Cretaceous) of Brazil". English. In: Cretaceous Research 52 (2015), pp. 605-622.

[1557] J. Barlow. "Preliminary estimates of the abundance of cetaceans along the U.S. west coast: 19912001". English. In: Southwest Fisheries Center Administrative Report (2003).

[1558] J. Barlow. "Cetacean abundance in Hawaiian waters estimated from a summer/fall survey in 2002". English. In: Marine Mammal Science 22.2 (2006), pp. 446-464.

[1559] J. Barlow and G. A. Cameron. "Field experiments show that acoustic pingers reduce marine mammal by-catch in the California drift gill net fishery". English. In: Marine Mammal Science 19.2 (2003), pp. 265-283.

[1560] J. Barlow and K. A. Forney. "Abundance and density of cetaceans in the California Current ecosystem". English. In: Fishery Bulletin (2007).

[1561] G. Barmak, L. Chornogubsky, and L. C. Gaetano. "New insights on Pachybiotherium illuminatum (Mammalia, Marsupialia, Microbiotheriidae) from the early Miocene of the Pinturas Formation (Santa Cruz Province, Argentina)". English. In: Ameghiniana 58.1 (2021). DOI: 10.5710/ AMGH.01. 09.2020.3371.

[1562] P. Barna. "Low diversity cockroach assemblage from Chernovskie Kopi in Russia confirms wing deformities in insects at the Jurassic/Cretaceous boundary". English. In: Biologia 69 (2014), pp. $651-$ 675.

[1563] P. Barna, L. mdová, and M. A. Coutiño José. “Living cockroach genus Anaplecta discovered in Chiapas amber (Blattaria: Ectobiidae: Anaplecta vega sp.n.)" English. In: PeerJ 7.e7922 (2019). DOI: 10.7717 / peerj.7922.

[1564] K. M. Barnes and N. Hiller. "The taphonomic attributes of a Late Cretaceous plesiosaur skeleton from New Zealand". English. In: Alcheringa (2010), pp. 333-344.

[1565] L. G. Barnes. "The fossil marine vertebrate fauna of the latest Miocene Almejas Formation, Isla Cedros, Baja California, Mexico". English. In: Memorias Universidad Autonoma de Baja California Sur: Primera Reunion Internacional Sobre Geologia de la Peninsula de Baja California (1991), pp. 147166.

[1566] L. G. Barnes. "The sequence of fossil marine mammal assemblages in Mexico". English. In: Avances en investigacion 1 (1998).

[1567] L. G. Barnes. "A new genus and species of middle Miocene enaliarctine pinniped (Mammalia, Carnivora, Otariidae) from the Astoria Formation in Coastal Oregon". English. In: Contributions in Science 431 (1992), pp. 1-27.

[1568] L. G. Barnes. "A new Miocene enaliarctine pinniped of the genus Pteronarctos (Mammalia: Otariidae) from the Astoria Formation, Oregon". English. In: Contributions in Science 422 (1990), pp. 120.

[1569] L. G. Barnes. "A phylogenetic analysis of the superfamily Platanistoidea (Mammalia, Cetacea, Odontoceti)". English. In: Beitrage zur Palaontologie 30 (2006), pp. 25-42.

[1570] L. G. Barnes. "Miocene and Pliocene Albireonidae (Ceatcea, Odontoceti), Rare and unusual fossil dolphins from the Eastern North Pacific Ocean". English. In: Natural History of Los Angeles County Science Series 41 (2008), pp. 99-152.

[1571] L. G. Barnes. Otarioidea. English. Vol. 2. Evolution of Tertiary Mammals of North America. 2008, pp. 523-541.

[1572] L. G. Barnes. “A new genus and species of Late Miocene paleoparadoxiid (Mammalia, Desmostylia) from California". English. In: Contributions in Science 521 (2013), pp. 51-114.

[1573] L. G. Barnes. "Evolutionary history of the fossil marine mammals of Mexico". English. In: Advances en los Estudios Paleomastozoologicos en Mexico. Mexico City: Instituto Nacional de Antropologia e Historia, 2002, pp. 125-225. 
[1574] L. G. Barnes and T. A. Deméré. A new beluga-like monodontid (Mammalia: Cetacea) from the late Miocene San Mateo Formation at Oceanside, California. English. 1991.

[1575] L. G. Barnes and J. L. Goedert. "The earliest known echolocating toothed whales (Mammalia; Odontoceti): preliminary observations of fossils from Washington State". In: Mesa Southwest Museum Bulletin 8 (2001), pp. 91-101.

[1576] L. G. Barnes and J. L. Goedert. "Stratigraphy and paleoecology of Oligocene and Miocene desmostylian occurrences in Western Washington State, U.S.A." English. In: Bulletin of the Ashoro Museum of Paleontology 2 (2001), pp. 7-22.

[1577] L. G. Barnes and K. Hirota. "Miocene pinnipeds of the otariid subfamily Allodesminae in the North Pacific Ocean: Systematics and relationships". English. In: The Island Arc 3 (1995), pp. 329360.

[1578] L. G. Barnes, M. Kimura, H. Furusawa, and H. Sawamura. "Classification and distribution of Oligocene Aetiocetidae (Mammalia; Cetacea; Mysticeti) from western North America and Japan". English. In: The Island Arc 3.4 (1995), pp. 392-431.

[1579] L. G. Barnes and R. E. Raschke. “Gomphotaria pugnax, a new genus and species of late Miocene dusignathine otariid pinniped (Mammalia: Carnivora) from California". English. In: Contributions in Science 426 (1991), pp. 1-16.

[1580] L. G. Barnes, C. E. Ray, and I. Koretsky. A new Pliocene sea lion, Proterozetes ulysses (Mammalia: Otariidae) from Oregon, U.S.A. English. Mesozoic and Cenozoic Vertebrates and Paleoenvironments. 2006, pp. 57-77.

[1581] R. W. Barnes and R. S. Hill. "Macrofossils of Callicoma and Codia (Cunoniaceae) from Australian Cainozoic sediments". English. In: Australian Systematic Botany 12.5 (1999), pp. 647-670. DOI: 10. $1071 /$ SB98016.

[1582] R. W. Barnes and G. J. Jordan. "Eucryphia (Cunoniaceae) Reproductive and Leaf Macrofossils from Australian Cainozoic Sediments". English. In: Australian Systematic Botany 13.3 (2000), pp. 373394. DOI: $10.1071 /$ SB99004.

[1583] R. Baron-szabo. pers. comm. 2002.

[1584] R. Baron-Szabo. "Corals of the K/T-boundary: scleractinian corals of the suborders Astrocoeniina, Faviina, Rhipidogyrina and Amphiastraeina". English. In: Journal of Systematic Palaeontology 4.1 (2006), pp. 1-108.

[1585] R. Baron-Szabo. "Corals of the KT-boundary: Scleractinian corals of the suborders Dendrophylliina, Caryophylliina, Fungiina, Microsolenina, and Stylinina". English. In: Zootaxa 1952 (2008), pp. 1-244.

[1586] R. C. Baron-Szabo. "Late Campanian-Maastrichtian corals from the United Arab Emirates-Oman border region". In: Bulletin of the Natural History Museum of London (Geology) 56.2 (2000), pp. 91131.

[1587] R. C. Baron-Szabo. "Miocene (Badenian) corals from Duplek, NE Slovenia”. In: Razprave IV. Razreda Sazu 38.5 (1997), pp. 97-115.

[1588] R. C. Baron-Szabo. "Taxonomy of Upper Cretaceous scleractinian corals of the Gosau Group (Weissenbackalm, Steiermark, Austria)". In: Abhandlungen der Geologischen Bundesanstalt Wien 56.2 (1999), pp. 441-464.

[1589] R. C. Baron-Szabo. “Die Korallenfazies der ostalpinen Kreide (Helvetikum: Allgäuer Schrattenkalk; Nördliche Kalkalpen: Brandenberger Gosau) - Taxonomie, Palökologie". German. In: Zitteliana 21 (1997), pp. 3-97.

[1590] R. C. Baron-Szabo. "Corals of the Theresienstein reef (upper Turonian-Coniacian, Salzburg, Austria)". In: Bulletin of the Biological Society of Washington 10 (2001), pp. 257-268.

[1591] R. C. Baron-Szabo. Scleractinian corals of the Cretaceous. Scleractinian corals of the Cretaceous, Knoxville, Tennessee. 2002, pp. 1-539. 
[1592] R. C. Baron-Szabo. “Taxonomy and palaeoecology of Late Miocene corals of NW-Crete (Gramvoússa, Roka- and Koukounaras-Fms.)" In: Berliner geowissenschaftliche Abhandlungen E16 (1995), pp. 569577.

[1593] R. C. Baron-Szabo. Late Aptian-early Albian corals from the Mural Limestone of the Bisbee Group (Tuape and Cerro de Oro areas), Sonora, Mexico. English. Vol. 1. Cretaceous Stratigraphy and Paleoecology, Texas and Mexico: Perkins Memorial Volume. Gulf Coast Section Society of Economic Paleontologists and Mineralogists Foundation, Special Publications in Geology. 2003, pp. 187-225.

[1594] R. C. Baron-Szabo. "Korallen der höheren Unterkreide (Urgon) von Nordspanien (Playa de Laga, Prov. Guernica)". German. In: Berliner geowissenschaftliche Abhandlungen (E) 9 (1993), pp. 147-181.

[1595] R. C. Baron-Szabo. "A new coral fauna of the Campanian from north Spain (Torallola village, Prov. Lléida)". English. In: Geologisch-Paläontologische Mitteilungen Innsbruck 23 (1998), pp. 127-191.

[1596] R. C. Baron-Szabo. “Taxonomie und Ontogenie von Korallen der ostalpinen Oberkreide (Hochmoosund Grabenbachschichten, Gosau Gruppe, Santon)". German. In: Jahrbuch der Geologischen Bundesanstalt Wien 143.2 (2003), pp. 107-201.

[1597] R. C. Baron-Szabo. "Remarks on the genus Bathangia Keferstein, 1859, with the re-description of the holotype of the type species Bathangia sessilis (Schlotheim, 1820)(Anthozoa, Scleractinia; Middle Eocene [Lutetian])". English. In: Proceedings of the Biological Society of Washington 122.4 (2009), pp. 393-398.

[1598] R. C. Baron-Szabo. "Scleractinian corals from the upper Berriasian of central Europe and comparison with contemporaneous coral assemblages". English. In: Zootaxa 4383.1 (2018), pp. 001-098.

[1599] R. C. Baron-Szabo. "Scleractinian corals from the upper Aptian-Albian of the Garschella Formation of central Europe (western Austria; eastern Switzerland): The Albian". English. In: Jahrbuch der Geologischen Bundesanstalt 157.1-4 (2017), pp. 241-260.

[1600] R. C. Baron-Szabo and P. A. Fernández-Mendiola. "Cretaceous scleractinian corals from the Albian of Cabo de Ajo (Cantabria Province, N-Spain)". English. In: Paläontologische Zeitschrift 71.1/2 (1997), pp. 35-50.

[1601] R. C. Baron-Szabo and C. M. González-León. "Lower Cretaceous corals and stratigraphy of the Bisbee Group (Cerro de Oro and Lampazos areas), Sonora, Mexico". English. In: Cretaceous Research 20 (1999), pp. 465-497.

[1602] R. C. Baron-Szabo, A. Hamedani, and B. Senowbari-Daryan. "Scleractinian corals from Lower Cretaceous deposits north of Esfahan (central Iran)". In: Facies 48 (2003), pp. 199-216.

[1603] R. C. Baron-Szabo, A. Schafhauser, S. Götz, and W. Stinnesbeck. "Scleractinian corals from the Cardenas Formation (Maastrichtian), San Luis Potosi, Mexico". English. In: Journal of Paleontology 80.6 (2006), pp. 1033-1046.

[1604] R. C. Baron-Szabo and T. Steuber. "Korallen und Rudisten aus dem Apt im tertiären Flysch des Parnass-Gebirges bei Delphi-Arachowa (Mittelgriechenland)". German. In: Berliner geowissenschaftliche Abhandlungen Reihe E 18 (1996), pp. 3-75.

[1605] C. Baroni Urbani. "The Identity of the Dominican Paraponera (Amber Collection Stuttgart: Hymenoptera, Formicidae. V: Ponerinae, partim)". English. In: Stuttgarter Beiträge zur Naturkunde Serie B (Geologie und Paläontologie) 197 (1994), pp. 1-9.

[1606] C. Baroni Urbani. "Invasion and extinction in the West Indian ant fauna revised: the example of Pheidole (amber collection Stuttgart: Hymenoptera, Formicidae. VIII: Myrmicinae, partim)". English. In: Stuttgarter Beiträge zur Naturkunde Serie B (Geologie und Paläontologie) 222 (1995), pp. 129.

[1607] C. Baroni Urbani. "Rediscovery of the Baltic amber ant genus Prionomyrmex (Hymenoptera, Formicidae) and its taxonomic consequences". English. In: Eclogae Geologicae Helvetiae 93 (2000), pp. $471-480$. 
[1608] C. Baroni Urbani and M. L. de Andrade. "First description of fossil Dacetini ants with a critical analysis of the current classification of the tribe (amber collection Stuttgart: Hymenoptera, Formicidae. VI: Dacetini)". English. In: Stuttgarter Beiträge zur Naturkunde Serie B (Geologie und Paläontologie) 198 (1994), pp. 1-65.

[1609] C. Baroni Urbani and M. L. de Andrade. "The ant tribe Dacetini: limits and constituent genera, with descriptions of new species (Hymenoptera, Formicidae)". English. In: Annali del Museo Civico di Storia Naturale Giacomo Doria 99 (2007), pp. 1-191.

[1610] R. Barragan. "Sedimentological and paleoecological aspects of the Aptian transgressive event of Sierra del Rosario, Durango, northeast Mexico". English. In: Journal of South American Earth Sciences 14 (2001), pp. 189-202.

[1611] R. Barragan, C. Gonzalez-Arreola, and A. B. Villasenor. "Palaeoecological significance of Barremian ammonite assemblages and facies variations from Southwest Mexico". English. In: Lethaia 37 (2004), pp. 223-234.

[1612] R. Barragán and F. J.-M. Maurrasse. "Lower Aptian (Lower Cretaceous) ammonites from the basal strata of the La Peña Formation of Nuevo León State, northeast Mexico: biochronostratigraphic implications". English. In: Revista Mexicana de Ciencias Geológicas 25.1 (2008), pp. 145-157.

[1613] R. Barragán and O. Szives. "New records of Mathoceras Casey (Deshayesitidae, Ammonoidea) from the Aptian (Lower Cretaceous) of Mexico and Hungary: Biostratigraphic and paleobiogeographic implications". English. In: Geobios 40 (2007), pp. 21-30.

[1614] R. Barragan-Manzo and A. L. Méndez-Franco. "Towards a standard ammonite zonation for the Aptian (Lower Cretaceous) of northern Mexico". English. In: Revista Mexicana de Ciencias Geológicas 22.1 (2005), pp. 39-47.

[1615] V. Barreda. "Palinomorph assemblage of the Chenque Formation, Late Oligocene?- Miocene from Golfo San Jorge Basin, Patagonia, Argentina, Part 1: terrestrial Algae, trilete and monolete spores". English. In: Ameghiniana 34.1 (1997), pp. 69-80.

[1616] V. Barreda. "Palinomorph assemblage of the Chenque Formation, Late Oligocene?- Miocene from Golfo San Jorge Basin, Patagonia, Argentina, Part 2: Gymnosperm and colpate pollen". English. In: Ameghiniana 34.1 (1997), pp. 81-92.

[1617] V. Barreda. "Palynomorph assemblage of the Chenque Formation, Late Oligocene?-Miocene from Golfo San Jorge Basin, Patagonia, Argentina. Part 3. Polycolpate and tricolporate pollen". English. In: Ameghiniana 34.2 (1997), pp. 131-144.

[1618] V. Barreda. "Palinomorph assemblage of the Chenque Formation, Late Oligocene?- Miocene from Golfo San Jorge Basin, Patagonia, Argentina, Part 4: polycolporate and porate pollen". English. In: Ameghiniana 34.2 (1997), pp. 145-154.

[1619] V. Barreda. "Palinoestratigrafa de la Formación San Julián en el área de Playa La Mina (provincia de Santa Cruz), Oligoceno de la Cuenca Austral". Spanish. In: Ameghiniana 34.3 (1997), pp. 283294.

[1620] V. Barreda and S. Archangelsky. "The southernmost record of tropical pollen grains in the midCretaceous of Patagonia, Argentina". English. In: Cretaceous Research 27 (2006), pp. 778-787. DOI: 10.1016/j.cretres.2006.02.002.

[1621] V. Barreda and S. Palamarczuk. "Palinoestratigrafa de depósitos del Oligoceno tardo-Mioceno en el área sur del Golfo San Jorge, provincia de Santa Cruz, Argentina". Spanish. In: Ameghiniana 37.1 (2000), pp. 103-117.

[1622] V. Barreda and S. Palamarczuk. "Palinomorfos continentales y marinos de la Formación Monte León en su área tipo, provincia de Santa Cruz, Argentina". Spanish. In: Ameghiniana 37.1 (2000), pp. 3-12.

[1623] V. D. Barreda. "Late Oligocene?-Miocene pollen of the families Compositae, Malvaceae and Polygonaceae from the Chenque Formation, Golfo San Jorge basin, southeastern Argentina". English. In: Palynology 17 (1993), pp. 169-186. 
[1624] V. D. Barreda. “Bioestratigrafa de polen y esporas de la Formación Chenque, Oligoceno tardo?Mioceno de las provincias de Chubut y Santa Cruz, Patagonia, Argentina". Spanish. In: Ameghiniana 33 (1996), pp. 35-56.

[1625] V. D. Barreda, N. R. Cúneo, P. Wilf, E. D. Currano, R. A. Scasso, and H. Brinkhuis. “Cretaceous/Paleogene Floral Turnover in Patagonia: Drop in Diversity, Low Extinction, and a Classopollis Spike". English. In: PLoS ONE 7.12 (2012), e52455. DOI: 10.1371/journal.pone.0052455.

[1626] V. D. Barreda, P. R. Gutiérrez, and C. O. Limarino. “Edad y paleoambiente de la Serie del Yeso, Valle del Cura, provincia de San Juan: evidencias palinológicas". Spanish. In: Ameghiniana 35.3 (1998), pp. 321-335.

[1627] V. D. Barreda, E. G. Ottone, F. M. Dávila, and R. A. Astini. “Edad y paleoambiente de la Formación del Buey (Mioceno), sierra de Famatina, La Rioja, Argentina: evidencias sedimentológicas y palinológicas". Spanish. In: Ameghiniana 42.1 (2006), pp. 215-226.

[1628] V. D. Barreda, S. Palamarczuk, and F. Medina. "Palinologa de la Formación Hidden Lake (ConiacianoSantoniano), Isla James Ross, Antártida". English. In: Revista Española de Micropaleontologa 31 (1999), pp. 53-72.

[1629] V. D. Barreda, L. Palazzesi, M. C. Tellera, L. Katinas, J. V. Crisci K. Bremer, M. G. Passalia, R. Corsolini, R. Rodrguez Brizuela, and F. Bechis. "Eocene Patagonia Fossils of the Daisy Family". English. In: Science 329.5999 (2010), p. 1621. DOI: 10.1126/science.1193108.

[1630] V. D. Barreda, L. Palazzesi, L. Katinas, J. V. Criscri, M. C. Telleria, K. Bremer, M. G. Passala, F. Bechis, and R. Corsolini. "An extinct Eocene taxon of the daisy family (Asteraceae): evolutionary, ecological and biogeographical implications". English. In: Annals of Botany 109.1 (2012), pp. 127134. DOI: $10.1093 / \mathrm{aob} / \mathrm{mcr} 240$.

[1631] P. M. Barrett. "Sauropodomorph dinosaur diversity in the upper Elliot Formation (Massospondylus range zone: Lower Jurassic) of South Africa". In: South African Journal of Science 100 (2004), pp. 501-503.

[1632] P. M. Barrett. "A sauropod dinosaur tooth from the Middle Jurassic of Skye, Scotland". English. In: Transactions of the Royal Society of Edinburgh: Earth Sciences 97 (2006), pp. 25-29.

[1633] P. M. Barrett. "A new basal sauropodomorph dinosaur from the Upper Elliot Formation (Lower Jurassic) of South Africa". English. In: Journal of Vertebrate Paleontology 29.4 (2009), pp. 1032-1045. DOI: 10.1671/039.029.0401.

[1634] P. M. Barrett. "A sauropod dinosaur from the Lower Lufeng Formation (Lower Jurassic) of Yunnan Province, People's Republic of China". English. In: Journal of Vertebrate Paleontology 19.4 (1999), pp. 785-787.

[1635] P. M. Barrett, R. B. J. Benson, and P. Upchurch. "Dinosaurs of Dorset: Part II, the sauropod dinosaurs (Saurischia, Sauropoda) with additional comments of the theropods". English. In: Proceedings of the Dorset Natural History and Archaeological Society 131 (2010), pp. 113-126.

[1636] P. M. Barrett, R. J. Butler, N. P. Edwards, and A. R. Milner. "Pterosaur distribution in time and space: an atlas". English. In: Zitteliana B 28 (2008), pp. 61-107.

[1637] P. M. Barrett, R. J. Butler, F. E. Novas, S. C. Moore-Fay, J. M. Moody, J. M. Clark, and M. R. SanchezVillagra. "Dinosaur remains from the La Quinta Formation (Lower or Middle Jurassic) of the Venezuelan Andes". English. In: Palaeontologische Zeitschrift 82.2 (2008), pp. 163-177.

[1638] P. M. Barrett, R. J. Butler, R. Mundil, T. M. Scheyer, R. B. Irmis, and M. R. Sánchez-Villagra. “A palaeoequatorial ornithischian and new constraints on early dinosaur diversification". English. In: Proceedings of the Royal Society B 281 (2014), 20141147:1-6. DOI: 10.1098/rspb.2014.1147.

[1639] P. M. Barrett and S. E. Evans. "A reassessment of the Early Cretaceous reptile 'Patricosaurus merocratus' Seeley from the Cambridge Greensand, Cambridgeshire, UK". English. In: Cretaceous Research 23 (2002), pp. 231-240.

[1640] P. M. Barrett, Y. Hasegawa, M. Manabe, S. Isaji, and H. Matsuoka. "Sauropod dinosaurs from the Lower Cretaceous of eastern Asia: taxonomic and biogeographical implications". English. In: Palaeontology 45.6 (2002), pp. 1197-1217. 
[1641] P. M. Barrett, B. B. Kear, and R. B. J. Benson. “Opalized archosaur remains from the Bulldog Shale (Aptian: Lower Cretaceous) of South Australia". English. In: Alcheringa 34.3 (2010), pp. 293-301.

[1642] P. M. Barrett, S. J. Nesbitt, and B. R. Peecook. "A large-bodied silesaurid from the Lifua Member of the Manda beds (Middle Triassic) of Tanzania and its implications for body-size evolution in Dinosauromorpha". English. In: Gondwana Research (2014). DOI: 10.1016/j.gr.2013.12.015.

[1643] P. M. Barrett, T. H. Rich, P. Vickers-Rich, T. A. Tumanova, M. Inglis, D. Pickering, L. Kool, and B. P. Kear. "Ankylosaurian dinosaur remains from the Lower Cretaceous of southeastern Australia". English. In: Alcheringa 34.3 (2010), pp. 205-217. DOI: 10.1080/03115511003655430.

[1644] P. M. Barrett and X.-L. Wang. "Basal titanosauriform (Dinosauria: Sauropoda) teeth from the Lower Cretaceous Yixian Formation of Liaoning Province, China". English. In: Palaeoworld 16 (2007), pp. 265-271. DOI: 10.1016/j.palwor.2007.07.001.

[1645] P. M. Barrett and X. Xu. “A reassessment of Dianchungosaurus lufengensis Yang, 1982a, an enigmatic reptile from the Lower Lufeng Formation (Lower Jurassic) of Yunnan Province, People's Republic of China". English. In: Journal of Paleontology 79.5 (2005), pp. 981-986.

[1646] P. M. Barrett and X. Xu. "The enigmatic reptile Pachysuchus imperfectus Young, 1951 from the Lower Lufeng Formation (Lower Jurassic) of Yunnan, China". English. In: Vertebrata PalAsiatica 50.2 (2012), pp. 151-159.

[1647] P. M. Barrett and A. M. Yates. "New information on the palate and lower jaw of Massospondylus (Dinosauria: Sauropodomorpha)". English. In: Palaeontologia Africana 41 (2005), pp. 123-130.

[1648] P. M. Barrett, H. You, P. Upchurch, and A. C. Burton. "A new ankylosaurian dinosaur (Ornithischia: Ankylosauria) from the Upper Cretaceous of Shanxi Province, People's Republic of China". English. In: Journal of Vertebrate Paleontology 18.2 (1998), pp. 376-384.

[1649] P. Z. Barrett, L. Finkelman, G. Perdue, W. N. F. McLaughlin, D. M. Reuter, and S. S. B. Hopkins. "Small carnivoran fauna of the Mascall Formation, Crooked River Basin, central Oregon". English. In: Journal of Vertebrate Paleontology e1717506 (2020), pp. 1-11. DOI: 10.1080/02724634.2020.1717506.

[1650] A. S. Barretto and F. C. W. Rosas. "Comparative growth analysiss of two populations of Pontoporia blainvillei on the Brazilian Coast". English. In: Marine Mammal Science 22.3 (2006), pp. 644-653.

[1651] J. E. Barrick, G. Klapper, M. A. Kleffner, and H. K. Karlsson. “Conodont biostratigraphy and stable isotope chemostratigraphy of the lower Henryhouse Formation (Gorstian-early Ludfordian, Ludlow, Silurian), southern Oklahoma,USA". English. In: Australasian Palaeontological Memoirs 39 (2010), pp. 51-70.

[1652] J. E. Barrick, M. A. Kleffner, and H. R. Karlsson. “Conodont faunas and stable isotopes across the Mulde Event (late Wenlock; Silurian) in southwestern Laurentia (south-central Oklahoma and subsurface West Texas)". English. In: Palaeontographica Americana 62 (2009), pp. 41-56.

[1653] J. E. Barrick and P. J. Noble. “Early Devonian coodonts from a limestone horizon in the Caballos Novaculite, Marathon Uplift, west Texas". In: Journal of Paleontology 69.6 (1995), pp. 1112-1122.

[1654] D. J. Barrie. "Skull elements and additional remains of the Pleistocene boid snake Wonambi naracoortensis". English. In: Memoirs of the Queensland Museum 28.1 (1990), pp. 139-151.

[1655] J. I. Barrientos-Lara, J. Alvarado-Ortega, and M. S. Fernandez. "The marine crocodile Maledictosuchus (Thalattosuchia, Metriorhynchidae) from the Kimmeridgian deposits of Tlaxiaco, Oaxaca, southern Mexico". English. In: Journal of Vertebrate Paleontology 38.4 (2018), pp. 1-14. DOI: 10.1080/02724634.2018.1478419.

[1656] J. I. Barrientos-Lara and J. Alvarado-Ortega. "Acuetzpalin carranzai gen et sp. nov. A new ophthalmosauridae (Ichthyosauria) from the Upper Jurassic of Durango, North Mexico". English. In: Journal of South American Earth Sciences 98 (2020), pp. 102456-102456. DOI: 10.1016/j.jsames.2019. 102456.

[1657] J. I. Barrientos-Lara, Y. Herrera, M. S. Fernandez, and J. Alvarado-Ortega. "Occurrence of Torvoneustes (Crocodylomorpha, Metriorhynchidae) in marine Jurassic deposits of Oaxaca, Mexico". English. In: Revista Brasileira de Paleontologia 19.3 (2016), pp. 415-424. DOI: 10.4072/rbp.2016.3.07. 
[1658] P. Barrier, H. Zibrowius, P. Lozouet, C. Montenat, P. Ott d'Estévou, F. Serrano, and H. -J. Soudet. "Une faune de fond dur du Bathyal supérieur dans le Miocéne terminal des cordilléres bétiques (Carboneras, SE Espagne)". French. In: Mésogée 51 (1991), pp. 3-13.

[1659] F. Barrios. "Presencia de Caiman latirostris (Daudin, 1802) (Crocodylia, Alligatoridae) en la Formación Piquete (Plioceno-Pleistoceno temprano) de la Provincia de Salta, Argentina implicancias paleoambientales y sistemáticas". Spanish. In: Ameghiniana 50.5 (2013), pp. 522-534.

[1660] F. Barrios, A. Paulina-Carabajal, and P. Bona. "A new peirosaurid (Crocodyliformes, Mesoeucrocodylia) from the Upper Cretaceous of Patagonia, Argentina". English. In: Ameghiniana 53.1 (2016), pp. 14-25.

[1661] M. Barrios-Izás and D. Coty. "A new fossil species of Caulophilus Wollaston, 1854 (Coleoptera: Curculionidae: Cossoninae) from Mexican amber". English. In: The Coleopterists Bulletin 70 (2016), pp. 177-179.

[1662] F. Barroso-Barcenilla. "Acanthoceratidae y zonación de ammonites del Cenomaniense superior y del Turoniense inferior en el área de Puentedey, Cuenca Vasco-Cantábrica, España". Spanish. In: Coloquios de Paleontologa 54 (2004), pp. 83-114.

[1663] F. Barroso-Barcenilla, M. Berrocal-Casero, H. A. Blain, P. M. Callapez, O. Cambra-Moo, F. Escaso, C. Martin-Closas, F. Ortega, A. Perez-Garcia, I. Prieto, J. Rodriguez-Lazaro, A. Ruiz-Galvan, J. L. Sanz, M. Segura, and P. Sevilla. "Geological and palaeontological context of three new Barremian (Lower Cretaceous) vertebrate sites in the Iberian Peninsula (Cuenca province, central Spain)". English. In: Proceedings of the Geologists' Association 128.2 (2017), pp. 256-270.

[1664] F. Barroso-Barcenilla, P. M. Callapez, and M. Segura. "Revision and new data on the Coniacian ammonite genus Hemitissotia in the Iberian Peninsula (Spain and Portugal)". English. In: Paläontologische Zeitschrift 87.2 (2013), pp. 201-217.

[1665] F. Barroso-Barcenilla, O. Cambra-Moo, F. Escaso, F. Ortega, A. Pascual, A. Pérez-Garca, J. RodrguezLázaro, J. L. Sanz, M. Segura, and A. Torices. "New and exceptional discovery in the Upper Cretaceous of the Iberian Peninsula: the palaeontological site of Lo Hueco, Cuenca, Spain". English. In: Cretaceous Research 30 (2009), pp. 1368-1378. DOI: 10.1016/j.cretres.2009.07.010.

[1666] F. Barroso-Barcenilla, M. J. Comas-Rengifo, L. V. Duarte, A. Goy, and G. Martnez. "A new genus of nautiloid in the Toarcian of the Iberian peninsula (Spain and Portugal)". English. In: Bulletin de la Société Géologique de France 182 (2011), pp. 391-404.

[1667] F. Barroso-Barcenilla and A. Goy. "The ammonite genera Fagesia and Neoptychites (family Vascoceratidae) in the Iberian Trough, Spain". English. In: Geobios 42 (2009), pp. 17-42.

[1668] F. Barroso-Barcenilla and A. Goy. "Revision and new data of the ammonite family Pseudotissotiidae in the Iberian Trough, Spain". English. In: Geobios 40 (2007), pp. 455-487.

[1669] E. Barrow, E. R. Seiffert, and E. L. Simons. "A primitive hyracoid (Mammalia, Paenungulata) from the early Priabonian (Late Eocene) of Egypt". English. In: Journal of Systematic Palaeontology 8.2 (2010), pp. 213-244.

[1670] R. Barsbold, H. Osmólska, M. Watabe, P. J. Currie, and K. Tsogtbaatar. "A new oviraptorosaur (Dinosauria, Theropoda) from Mongolia: the first dinosaur with a pygostyle". English. In: Acta Palaeontologica Polonica 45.2 (2000), pp. 97-106.

[1671] A. Barsevskis. "Catalogue of click-beetles (Coleoptera: Elateridae) of Latvia". English. In: Proceedings on Taxonomy and Faunistics of Beetles (Coleoptera) Dedicated to the 100th Birthday of the Latvian Entomologist Mihails Stiprais (1905 - 1990). 2005, pp. 7-28.

[1672] I. S. Barskov, T. B. Leonova, and O. P. Shilovsky. “Middle Permian cephalopods of the Volga-Ural region". English. In: Paleontological Journal 48 (2014), pp. 1331-1414.

[1673] I. S. Barskov and P. E. Morozov. "Chiton (Mollusca, Polyplacophora) from the Upper Carboniferous of the Moscow Region". In: Paleontological Journal 30.5 (1996), pp. 493-496.

[1674] M. Barták. "Yantaromyiidae, a new family of Diptera (Brachycera: Schizophora) from Tertiary Baltic amber and X-ray synchrotron microtomography imaging of its structures". English. In: Journal of Systematic Palaeontology 18 (2019), pp. 187-195. DOI: 10.1080/14772019.2019.1592991. 
[1675] C. Bartel, J. A. Dunlop, and T. L. Bird. "The second camel spider (Arachnida, Solifugae) from Burmese amber". English. In: Arachnology 17 (2016), pp. 161-164.

[1676] C. Bartel and J. A. Dunlop. "Two laniatorid harvestmen (Opiliones: Cladonychiidae) from Eocene Baltic amber". English. In: Arachnologische Mitteilungen 58 (2019), pp. 9-12.

[1677] C. Bartel, J. A. Dunlop, P. P. Sharma, P. A. Selden, D. Ren, and C. K. Shih. "Laniatorean harvestmen (Arachnida: Opiliones) from mid-Cretaceous Burmese amber". English. In: Cretaceous Research 119.104703 (2020). DOI: 10.1016/j.cretres.2020.104703.

[1678] C. Bartel, M. Konikiewicz, J. Makol, A. Wohltmann, and J. A. Dunlop. "Smaridid mites in Baltic and Bitterfeld amber, with notes on the fossil record of terrestrial Parasitengona (Trombidiformes: Prostigmata)". English. In: Annales Zoologici 65 (2015), pp. 641-659.

[1679] G. Barth, J. Ansorge, and C. Brauckmann. "First record of the genus Ipsvicia (Hemiptera: Ipsviciidae) outside Gondwana - an Australian genus from the Upper Triassic of Germany". English. In: Polish Journal of Entomology 80 (2011), pp. 645-657.

[1680] G. Barth, A. Nel, and M. Franz. "Two new odonate-like insect wings from the latest Norian of northern Germany". English. In: Polish Journal of Entomology 82 (2013), pp. 127-142.

[1681] A. Bartholomai. "Lower Cretaceous chimaeroids (Chondrichthyes: Holocephali) from the Great Artesian Basin, Australia". English. In: Memoirs of the Queensland Museum 52 (2008), pp. 49-56.

[1682] J. K. Bartley, M. Pope, A. H. Knoll, M. A. Semikhatov, and P. Y. Petrov. “A Vendian-Cambrian boundary succession from the northwestern margin of the Siberian Platform: stratigraphy, palaeontology, chemostratigraphy and correlation". English. In: Geological Magazine 135.4 (1998), pp. 473494.

[1683] R. E. Barwick, K. S. W. Campbell, and E. Mark-Kurik. "Tarachomylax: a new Early Devonian dipnoan from Severnaya Zemlya, and its place in the evolution of the Dipnoi". English. In: Geobios 30.1 (1997), pp. 45-73.

[1684] G. F. Baryshnikov. "Pleistocene Mustelidae (Carnivora) from Paleolithic site in Kudaro Caves in the Caucasus". English. In: Russian Journal of Theriology 8.2 (2009), pp. 75-95.

[1685] G. F. Baryshnikov and D. S. Zakharov. "Early Pliocene Bear Ursus thibetanus (Mammalia, Carnivora) from Priozernoe Locality in the Dniester Basin (Moldova Republic)". English. In: Proceedings of the Zoological Institute RAS 317.1 (2013), pp. 3-10.

[1686] A. M. Basden and G. C. Young. "A primitive actinopterygian neurocranium from the Early Devonian of southeastern Australia". English. In: Journal of Vertebrate Paleontology 21.4 (2011), pp. 754766. DOI: 10.1671/0272-4634(2001)021[0754:APANFT]2.0.CO;2.

[1687] A. Bashkuev, J. Sell, D. Aristov, A. Ponomarenko, N. Sinitshenkova, and H. Mahler. "Insects from the Buntsandstein of Lower Franconia and Thuringia". English. In: Paläontologische Zeitschrift 86 (2012), pp. 175-185.

[1688] A. S. Bashkuev. "The First Record of Kaltanidae (Insecta: Mecoptera: Kaltanidae) from the Permian of European Russia". English. In: Paleontological Journal 42.4 (2008), pp. 401-405.

[1689] A. S. Bashkuev. "New scorpionflies (Insecta: Mecoptera: Permochoristidae) from the Ufimian of Cisuralia". English. In: Paleontological Journal 44.3 (2010), pp. 291-296.

[1690] A. S. Bashkuev. "The earliest Mesopsychidae and revision of the family Mesopanorpodidae (Mecoptera)". English. In: ZooKeys 130 (2011), pp. 263-279.

[1691] A. S. Bashkuev. "Nedubroviidae, a new family of Mecoptera: the first Paleozoic long-proboscid scorpionflies". English. In: Zootaxa 2895 (2011), pp. 47-57.

[1692] A. S. Bashkuev. "New Mecoptera from the end-Permian intertrappean deposits of the Tunguska Basin". English. In: Russian Entomological Journal 22 (2013), pp. 1-4.

[1693] A. S. Bashkuev. "New Permochoristidae (Insecta: Mecoptera) from the Isady locality". English. In: Paleontological Journal 47 (2013), pp. 735-741. 
[1694] H. H. Basibuyuk, M. G. Fitton, A. P. Rasnitsyn, and D. L. J. Quicke. Two new genera of the Evaniidae (Insecta: Hymenoptera) from Late Cretaceous New Jersey amber. English. Studies on Fossils in Amber, with Particular Reference to the Cretaceous of New Jersey. Leiden: Backhuys Publishers, 2000, pp. 313-325.

[1695] H. H. Basibuyuk, D. L. J. Quicke, and A. P. Rasnitsyn. A new genus of the Orussidae (Insecta: Hymenoptera) from Late Cretaceous New Jersey amber. English. Studies on Fossils in Amber, with Particular Reference to the Cretaceous of New Jersey. Leiden: Backhuys Publishers, 2000, pp. 305311.

[1696] H. H. Basibuyuk, A. P. Rasnitsyn, K. van Achterberg, M. G. Fitton, and D. L. J. Quicke. “A new, putatively primitive Cretaceous fossil braconid subfamily from New Jersey amber (Hymenoptera, Braconidae)". English. In: Zoologica Scripta 28.1-2 (1999), pp. 211-214. DOI: 10.1046/j.1463-6409. 1999.00006.x.

[1697] H. H. Basibuyuk, A. P. Rasnitsyn, M. G. Fitton, and D. L. J. Quicke. “An archaic new genus of Evaniidae (Insecta: Hymenoptera) and implications for the biology of ancestral evanioids". English. In: Bulletin of the Natural History Museum, Geology Series 56 (2000), pp. 53-58.

[1698] H. H. Basibuyuk, A. P. Rasnitsyn, M. G. Fitton, and D. L. J. Quicke. "The limits of the family Evaniidae (Insecta: Hymenoptera) and a new genus from Lebanese amber". English. In: Insect Systematics \& Evolution 33 (2002), pp. 23-34.

[1699] J. F. Basinger, D. R. Greenwood, P. G. Wilson, and D. C. Chistophel. "Fossil Flowers and Fruits of Capsular Myrtaceae from the Eocene of South Australia". English. In: Canadian Journal of Botany 85.2 (2007), pp. 204-215. DOI: 10.1139/B07-001.

[1700] J. A. Baskin. "Evolutionary trends in the late Miocene hyena-like dog Epicyon (Carnivora, Canidae)". English. In: National Science Museum Monographs 14 (1998), pp. 191-214.

[1701] J. A. Baskin. "New procyonines from the Hemingfordian and Barstovian of the Gulf Coast and Nevada, including the first fossil record of the Potosini". English. In: Bulletin of the American Museum of Natural History 279 (2003), pp. 125-146.

[1702] J. A. Baskin. "Carnivora from the late Miocene Love Bone Bed of Florida". English. In: Bulletin of the Florida Museum of Natural History 45.4 (2005), pp. 413-434.

[1703] J. A. Baskin. "A new species of Cernictis (Mammalia, Carnivora, Mustelidae) from the Late Miocene Bidahochi Formation of Arizona, USA". English. In: Palaeontologia Electronica 14.3 (2011), pp. 1-7.

[1704] J. A. Baskin. "Bassariscus and Probassariscus (Mammalia, Carnivora, Procyonidae) from the early Barstovian (Middle Miocene)". English. In: Journal of Vertebrate Paleontology 24.3 (2004), pp. 709720.

[1705] J. A. Baskin. "Additional Carnivorans from the Early Hemingfordian Miller Local Fauna, Florida". English. In: Journal of Vertebrate Paleontology 37.2 (2017), e1293069.

[1706] J. A. Baskin and R. C. Hulbert. "A Late Clarendonian Local Fauna From the Goliad Formation of South Texas". English. In: Paludicola 8.4 (2012), pp. 187-193.

[1707] J. A. Baskin and W. W. Korth. "Copemys mariae (Rodentia, Muridae) a replacement name for Copemys lindsayi Dalquest, Baskin, Schultz, 1996 non Copemys lindsayi Sutton and Korth, 1995". English. In: Paludicola 1.1 (1996), pp. 1-32.

[1708] M. Basse, L. Koch, and U. Lemke. “Dechenella burmeisteri emstae n. ssp. und verwandte Taxa im nördlichen Schelf des Rheia-Ozeans (Mitteldevon: Givetium; Trilobita: Proetida; Rhenoherzynikum)". German. In: Dortmunder Beiträge zur Landeskunde. Naturwissenschaftliche Mitteilungen 47 (2016), pp. 161-199.

[1709] M. Basse and P. Müller. Eifel-Trilobiten III. Corynexochida, Proetida (2), Harpetida, Phacopida (2), Lichida. German. Goldschneck, 2004.

[1710] M. Basse and K. Weddige. "Typen-Katalog der Trilobiten-Sammlung des Naturmuseums und Forschungsinstituts Senckenberg". German. In: Senckenbergiana lethaea 84.1/2 (2004), pp. 141-172. 
[1711] M. G. Bassett and C. Bryant. “A Tournaisian brachiopod fauna from south-east Wales”. English. In: Palaeontology 49.3 (2006), pp. 485-535.

[1712] M. G. Bassett, L. E. Popov, and L. E. Holmer. The oldest-known metazoan parasite. English. 2012. DOI: 10.1666/0022-3360\%282004\%29078\%3C1214\%3ATOMP\%3E2.0.CO\%3B2.

[1713] D. Bassi. "Coralline algal facies and their palaeoenvironments in the Late Eocene of northern Italy (Calcare di Nago, Trento)". English. In: Facies 39 (1998), pp. 179-202.

[1714] D. Bassi. "The Upper Eocene crustose coralline algal pavement in the Colli Berici, north-eastern Italy". English. In: Annali dell'Universitá degli Studi di Ferrara Museologia Scientifica e Naturalistica (2005).

[1715] D. Bassi. "Crustose corallina algal pavements from late Eocene Colliberici of northern Italy". English. In: Rivista Italiana di Paleontologia e Stratigrafia 101.1 (1995), pp. 81-92.

[1716] D. Bassi, J. C. Braga, E. Zakrevskaya, and P. Radionova. "Redescription of the type collections of Maslov's species of Corallinales (Rhodophyta). II. Species included by Maslov in Archaeolithothamnium Rothpletz, 1891". English. In: Revista Española de Paleontologa 22.2 (2007), pp. 115-125.

[1717] D. Bassi and J. H. Nebelsick. "Coralline red algae in the middle-upper Eocene shallow water carbonates of the Colli Berici, north-eastern Italy". English. In: Studi Trent Sci Nat, Acta Geol 80.Suppl. 1 (2003), pp. 7-14.

[1718] D. Bassi, W. J. Woelkerling, and J. H. Nebelsick. "Taxonomic and biostratigraphical re-assessments of Subterraniphyllum Elliott (Corallinales, Rhodophyta)". English. In: Palaeontology 43.3 (2000), pp. 405-425.

[1719] D. Basso, G. Coletti, V. A. Bracchi, and M. Yazdi-Moghadam. "Lower Oligocene coralline algae of the Uromieh section (Qom Formation, NW Iran) and the oldest record of Titanoderma pustulatum (Corallinophycidae, Rhodophyta)". English. In: Rivista Italiana di Paleontologia e Stratigrafia 125.1 (2019), pp. 197-218.

[1720] D. Bastiaans, J. J. F. Kroll, D. Cornelissen, J. W. M. Jagt, and A. S. Schulp. “Cranial palaeopathologies in a Late Cretaceous mosasaur from the Netherlands". English. In: Cretaceous Research 112 (2020). DOI: 10.1016/j.cretres.2020.104425.

[1721] K. Bastl, D. Nagel, M. Morlo, and U. B. Göhlich. “The Carnivora (Mammalia) from the middle Miocene locality of Graanica (Bugojno Basin, Gornji Vakuf, Bosnia and Herzegovina)". English. In: Palaeobiodiversity and Palaeoenvironments 100 (2020), pp. 307-319. DOI: 10.1007 / s12549-0180353-0.

[1722] P. K. Basu. "Siwalik mammals of the Jammu Sub-Himalaya, India: an appraisal of their diversity and habitats." In: Quaternary International 117 (2004), pp. 105-118.

[1723] R. A. Batchelor and R. E. Garton. "An occurrence of Palaeohelcura tridactyla in the ArbuthnottGarvock Group, Lower Devonian at Friarton Quarry, Perth". English. In: Scottish Journal of Geology 49.2 (2013), pp. 149-152. DOI: 10.1144/sjg2013-003.

[1724] J. Batelka. “Olemehlia krali, a new genus and species of Ripidiinae from Baltic amber (Coleoptera: Ripiphoridae)". English. In: Annales de la Société Entomologique de France 47 (2011), pp. 361-364.

[1725] J. Batelka, F. Collomb, and A. Nel. "Macrosiagon deuvei n. sp. (Coleoptera: Ripiphoridae) from the French Eocene amber". English. In: Annales de la Société Entomologique de France 42.1 (2006), pp. 75-78.

[1726] J. Batelka, M. S. Engel, Z. H. Falin, and J. Prokop. "Two new ripidiine species in Dominican amber with evidence of aggregative behaviour of males frozen in the fossil record (Coleoptera: Ripiphoridae)". English. In: European Journal of Entomology 108 (2011), pp. 275-286.

[1727] J. Batelka, M. S. Engel, and J. Prokop. “A remarkable diversity of parasitoid beetles (Ripiphoridae) in Cretaceous amber, with a summary of the Mesozoic record of Tenebrionoidea". English. In: Cretaceous Research 90 (2018), pp. 296-310. 
[1728] J. Batelka, E. E. Perkovsky, and J. Prokop. “Diversity of Eocene Ripiphoridae with descriptions of the first species of Pelecotominae and larva of Ripidiinae (Coleoptera)". English. In: Zoological Journal of the Linnean Society 188 (2019), pp. 412-433.

[1729] J. Batelka, J. Prokop, and M. S. Engel. "New ripiphorid beetles in mid-Cretaceous amber from Myanmar (Coleoptera: Ripiphoridae): first Pelecotominae and possible Mesozoic aggregative behaviour in male Ripidiinae". English. In: Cretaceous Research 68 (2016), pp. 70-78.

[1730] J. Batelka, J. Prokop, H. Pohl, M. Bai, W. W. Zhang, and R. G. Beutel. "Highly specialized Cretaceous beetle parasitoids (Ripiphoridae) identified with optimized visualization of microstructures". English. In: Systematic Entomology 44 (2019), pp. 396-407.

[1731] R. M. Bateman, N. Morton, and B. L. Dower. “Early Middle Jurassic plant communities in Northwest Scotland: Paleoecological and paleoclimatic significance". In: GeoResearch Forum 6 (2000), pp. 501-512.

[1732] R. M. Bateman and G. W. Rothwell. "A reappraisal of the Dinantian floras at Oxroad Bay, East Lothian, Scotland. 1. Floristics and the development of whole-plant concepts". In: Transactions of the Royal Society of Edinburgh 81 (1990), pp. 127-159.

[1733] R. M. Bateman and A. C. Scott. "A reappraisal of the Dinantian floras at Oxroad Bay, East Lothian, Scotland. 2. Volcanicity, palaeoenvironments and palaeoecology". In: Transactions of the Royal Society of Edinburgh 81 (1990), pp. 161-194.

[1734] H. Bates, K. J. Travoullion, B. Cooke, R. M. D. Beck, S. J. Hand, and M. Archer. "Three new Miocene species of musky rat-kangaroos (Hypsiprymnodontidae, Macropodoidea): description, phyloecology, and paleoecology". English. In: Journal of Vertebrate Paleontology 34.2 (2014), pp. 383-396.

[1735] R. J. Batt. "A test of a new technique illustrating faunal dominance trends: Application to the Trilobite Beds interval of the Middle Devonian Wanakah Shale in western New York". English. In: Lethaia 28 (1995), pp. 245-258.

[1736] B. Battail. "Late Permian dicynodont fauna from Laos". English. In: Geological Society, London, Special Publications 315.1 (2009), pp. 33-40.

[1737] B. Battail and M. V. Surkov. Mammal-like reptiles from Russia. English. The Age of Dinosaurs in Russia and Mongolia. Cambridge University Press, Cambridge. 2000, pp. 86-119.

[1738] D. J. Batten and M. E. Collinson. "Revision of species of Minerisporites, Azolla and associated plant microfossils from deposits of the Upper Palaeocene and Palaeocene/Eocene transition in the Netherlands, Belgium and the USA". In: Review of Palaeobotany and Palynology 115 (2001), pp. 1-32.

[1739] R. L. Batten. "Pennsylvanina (Morrowan) gastropods from the Magdalena Formation of the Hueco Mountains, Texas". English. In: American Museum Novitates 3122 (1995), pp. 1-46.

[1740] K. L. Batten Hender and G. R. Dix. "Facies, geometry and geological significance of Late Ordovician (Early Caradocian) coral bioherms: Lourdes Formation, western Newfoundland". English. In: Sedimentology 53 (2006), pp. 1361-1379.

[1741] T. Bauch, J. J. G. Reijmer, D. F. McNeill, and P. Schäfer. “Development of a Pliocene mixed-carbonate siliciclastic reef (Limon, Costa Rica)". English. In: Sedimentary Geology 239 (2011), pp. 37-47.

[1742] A. Baucon and M. Avanzini. "Zoophycos-like structures associated with dinosaur tracks in a tidalflat environment: Lower Jurassic (Southern Alps, Italy)". English. In: Studi Trentini di Scienze Naturali, Acta Geologica 83 (2008), pp. 123-131.

[1743] A. Baud, R. Brandner, and D. A. Donofrio. "The Sefid Kuh Limestone - a late Lower Triassic carbonate ramp (Aghdarband, NE-Iran)". English. In: Abhandlungen der Geologischen Bundesanstalt 38 (1991), pp. 111-123.

[1744] A. Baud, S. Richoz, B. Beauchamp, F. Cordey, S. Grasby, C. M. Henderson, L. Krystyn, and A. Nicora. "The Buday'ah Formation, Sultanate of Oman: a Middle Permian to Early Triassic oceanic record of the Neotethys and the late Induan microsphere bloom". English. In: Journal of Asian Earth Sciences 43 (2012), pp. 130-144. 
[1745] C. Baudouin, P. Boselli, and D. Bert. "The Oppeliidae of the Acanthicum Zone (Upper Kimmeridgian) from Mount Crussol (Ardéche, France): ontogeny, variability and dimorphism of the genera". English. In: Revue de Paléobiologie, Genéve 30 (2011), pp. 619-684.

[1746] C. Baudouin, G. Delanoy, J. A. Moreno-Bedmar, A. Pictet, J. Vermeulen, G. Conte, R. Gonnet, P. Boselli, and M. Boselli. "Revision of the Early Cretaceous genera Heminautilus Spath, 1927, and Josanautilus Martnez \& Grauges, 2006 (Nautilida, Cenoceratidae)". English. In: Carnets de Géologie 16.5 (2016), pp. 61-212.

[1747] M. Baudry. "Les Gisements de mammiféres du Miocéne supérieur de Kemiklitepe, Turquie: 6. Hyracoidea". French. In: Bulletin du Muséum National d'Histoire Naturelle. Section C: Sciences de la Terre: Paléontologie, Géologie, Minéralogie 16.1 (1994), pp. 113-141.

[1748] A. M. Bauer, W. Böhme, and W. Weitschat. "An Early Eocene gecko from Baltic amber and its implications for the evolution of gecko adhesion". English. In: Journal of Zoology 265 (2005), pp. 327332.

[1749] J. E. Bauer and A. L. Stigall. "A combined morphometric and phylogenetic revision of the Late Ordovician brachiopod genera Eochonetes and Thaerodonta". English. In: Journal of Paleontology 90.5 (2016), pp. 888-909. DOI: 10.1017/jpa.2016.56.

[1750] K. Bauer, L. Grauvogel-Stamm, E. Kustatscher, and M. Krings. “Fossil ginkgophyte seedlings from the Triassic of France resemble modern Ginkgo biloba". English. In: BMC Evolutionary Biology 13 (2013), p. 177.

[1751] K. Bauer, E. Kustatscher, and M. Krings. "The ginkgophytes from the German Kupferschiefer (Permian), with considerations on the taxonomic history and use of Baiera and Sphenobaiera". English. In: Bulletin of Geosciences 88.3 (2013), pp. 539-556.

[1752] P. O. Baumgartner, K. Flores, A. N. Bandini, F. Girault, and D. Cruz. "Upper Triassic to Cretaceous radiolaria from Nicaragua and northern Costa Rica - the Mesquito composite oceanic terrane". English. In: Ofioliti 33 (2008), pp. 1-19.

[1753] P. O. Baumgartner, L. O'Dogherty, S. Gorican, R. Dumitrica-Jud, P. Dumitrica, A. Pillevuit, E. Urquhart, A. Matsuoka, T. Danelian, A. Bartolini, E. S. Carter, P. De Wever, N. Kito, M. Marcucci, and T. Steiger. Radiolarian catalogue and systematics of Middle Jurassic to Early Cretaceous Tethyan genera and species. Vol. 23. Mémoires de Géologie (Lausanne). 1995, pp. 37-685.

[1754] C. Baumgartner-Mora and P. O. Baumgartner. "Paleocene-earliest Eocene larger benthic foraminifera and Ranikothalia-bearing carbonate paleo-environments of Costa Rica (South Central America)". English. In: Micropaleontology 62.6 (2016), pp. 453-508.

[1755] T. K. Baumiller, L. R. Leighton, and D. L. Thompson. "Boreholes in Mississippian spiriferide brachiopods and their implications for Paleozoic gastropod drilling". English. In: Palaeogeography, Palaeoclimatology, Palaeoecology 147 (1999), pp. 283-289.

[1756] N. Bauzá, J. N. Gelfo, and G. M. López. "Early steps in the radiation of notoungulate mammals in southern South America: A new henricosborniid from the Eocene of Patagonia". English. In: Acta Palaeontologica Polonica 64.3 (2019), pp. 597-603.

[1757] J. E. Baxter and G. O. Poinar. "A new genus and new species of fungus gnats (Diptera: Mycetophilidae) from Dominican amber". English. In: Annales de la Société Entomologique de France 30.1 (1994), pp. 93-102.

[1758] M. E. Baxter and R. B. Blodgett. “A new species of Droharhynchia (Brachiopoda) from the Lower Middle Devonian (Eifelian) of west-central Alaska". English. In: Journal of Paleontology 68.6 (1994), pp. 1235-1240.

[1759] E. M. Baykina. "A revision of Clupea doljeana Kramberger and Sarmatella vukotinovici (Kramberger) (Pisces, Clupeidae) from the Sarmatian of Croatia". English. In: Paleontological Journal 47.5 (2013), pp. 523-532.

[1760] B. U. Bayshashov and E. M. E. Billia. "Records of Tapiroidea Gray, 1825 (Mammalia, Perissodactyla) from Kazakhstan - An overview". English. In: Acta Palaeontologica Romaniae 74 (2011), pp. 1-7. 
[1761] A. Baz and V. Ortuño. "A new electrotomoid psocid (Psocoptera) from the Cretaceous amber of Alava (northern Spain)". English. In: Deutsche Entomologische Zeitschrift 48 (2001), pp. 27-32.

[1762] A. Baz and V. M. Ortuño. "New genera and species of empheriids (Psocoptera: Empheriidae) from the Cretaceous amber of Alava, northern Spain". English. In: Cretaceous Research 22 (2001), pp. 575-584.

[1763] A. Baz and V. M. Ortuño. "Archaeatropidae, a new family of Psocoptera from the Cretaceous Amber of Alava, northern Spain". English. In: Annals of the Entomological Society of America 93 (2000), pp. 367-373.

[1764] K. C. Beard. "A new species of Carpocristes (Mammalia: Primatomorpha) from the middle Tiffanian of the Bison Basin, Wyoming, with notes on carpolestid phylogeny". English. In: Annals of Carnegie Museum 69.3 (2000), pp. 195-208.

[1765] K. C. Beard. "A new genus of Tarsiidae (Mammalia: Primates) from the middle Eocene of Shanxi Province, China, with notes on the historical biogeography of tarsiers". English. In: Bulletin of the Carnegie Museum of Natural History 34 (1998), pp. 260-277.

[1766] K. C. Beard. "The oldest North American primate and mammalian biogeography during the Paleocene-Eocene Thermal Maximum." English. In: Proceedings of the National Academy of Sciences 105.10 (2008), pp. 3815-3818.

[1767] K. C. Beard, P. M. C. Coster, M. J. Salem, Y. Chaimanee, and J. -J. Jaeger. “A new species of Apidium (Anthropoidea, Parapithecidae) from the Sirt Basin, central Libya: first record of Oligocene primates from Libya". English. In: Journal of Human Evolution 90 (2016), pp. 29-37. DOI: 10.1016/j. jhevol.2015.08.010.

[1768] K. C. Beard, M. R. Dawson, and A. R. Tabrum. First diverse land mammal fauna from the early Cenozoic of the Southeastern United States; the early Wasatchian Red Hot local fauna, Lauderdale County, Mississippi. English. 1995.

[1769] K. C. Beard and M. R. Dawson. "Early Wasatchian mammals of the Red Hot local fauna, uppermost Tuscahoma Formation, Lauderdale County, Mississippi". English. In: Annals of Carnegie Museum 78.3 (2009), pp. 193-243.

[1770] K. C. Beard and M. R. Dawson. "Northernmost Global Record for Multituberculata from the Eocene of Ellesmere Island, Arctic Canada". English. In: Journal of Vertebrate Paleontology 34.6 (2014), pp. 1476-1480. DOI: 10.1080/02724634.2014.875032.

[1771] K. C. Beard, M. F. Jones, N. A. Thurber, and O. Sanisidro. "Systematics and paleobiology of Chiromyoides (Mammalia, Plesiadapidae) from the upper Paleocene of western North America and western Europe". English. In: Journal of Vertebrate Paleontology (2020), e1730389:1-22. DOI: 10.1080/ 02724634.2019.1730389.

[1772] K. C. Beard, L. Kristalka, and R. K. Stucky. "Revision of the Wind River faunas, early Eocene of central Wyoming. Part 12. New species of omomyid primates (Mammalia: Primates: Omomyidae)". English. In: Annals of Carnegie Museum 61.1 (1992), pp. 39-62.

[1773] K. C. Beard, L. Marivaux, S. T. Tun, A. N. Soe, Y. Chaimanee, W. Htoon, B. Marandat, H. H. Aung, and J. -J. Jaeger. "New sivaladapid primates from the Eocene Pondaung Formation of Myanmar and the anthropoid status of Amphipithecidae". English. In: Bulletin of Carnegie Museum of Natural History 39 (2007), pp. 67-76.

[1774] K. C. Beard, L. Marivaux, Y. Chaimanee, J. -J. Jaeger, B. Marandat, P. Tafforeau, A. N. Soe, S. T. Tun, and A. A. Kyaw. "A new primate from the Eocene Pondaung Formation of Myanmar and the monophyly of Burmese amphipithecids". English. In: Proceedings of the Royal Society B (Biological Sciences) 276 (2009), pp. 3285-3294. DOI: 10.1098/rspb.2009.0836.

[1775] K. C. Beard, G. Métais, F. Ocakolu, and A. Licht. "An omomyid primate from the Pontide microcontinent of north-central Anatolia: Implications for sweepstakes dispersal of terrestrial mammals during the Eocene". English. In: Geobios (2020). DOI: 10.1016/j.geobios.2020.06.008.

[1776] K. C. Beard, T. Qi, M. R. Dawson, B. Wang, and C. Li. "A diverse new primate fauna from middle Eocene fissure-fillings in southeastern China". English. In: Nature 368 (1994), pp. 604-609. 
[1777] K. C. Beard, B. Sigé, and L. Krishtalka. "A primitive vespertilionoid bat from the early Eocene of central Wyoming". English. In: Comptes Rendus de l'Academie des Sciences, Paris, Serie II 314 (1992), pp. 735-741.

[1778] K. C. Beard, Y. Tong, M. R. Dawson, J. Wang, and X. Huang. "Earliest complete dentition of an anthropoid primate from the Late Middle Eocene of Shanxi Province, China". English. In: Science 272 (1996), pp. 82-85.

[1779] K. C. Beard and J. Wang. “The first Asian plesiadapoids". English. In: Annals of Carnegie Museum 64.1 (1995), pp. 1-33.

[1780] K. C. Beard and J. Wang. “The eosimiid primates (Anthropoidea) of the Heti Formation, Yuanqu Basin, Shanxi and Henan Provinces, People's Republic of China". English. In: Journal of Human Evolution 46.4 (2004), pp. 401-432.

[1781] K. C. Beard, Y.-Q. Wang, J. Meng, X. -J. Ni, D. L. Gebo, and C. -K. Li. "Paleocene Hapalodectes (Mammalia: Mesonychia) from Subeng, Nei Mongol: Further evidence of East of Eden dispersal at the Paleocene-Eocene boundary". English. In: Vertebrata PalAsiatica 48.4 (2010), pp. 375-389.

[1782] I. Beasley, K. M. Robertson, and P. Arnold. "Description of a new dolphin, the australian snubfin dolphin Orcaella heinsohni sp. n. (Cetacea, Delphinidae)". English. In: Marine Mammal Science 21.3 (2005), pp. 365-400.

[1783] R. G. Beattie and A. Nel. “A new dragonfly, Austroprotolindenia jurassica (Odonata: Anisoptera), from the Upper Jurassic of Australia". English. In: Alcheringa 36 (2012), pp. 189-193.

[1784] B. L. Beatty. "New material of Cornwallius sookensis (Mammalia: Desmostylia) from the Yaquina Formation of Oregon". English. In: Journal of Vertebrate Paleontology 29.3 (2009), pp. 894-909.

[1785] B. L. Beatty. "Specimens of Cornwallius sookensis (Desmostylia, Mammalia) from Unalaska Island, Alaska". English. In: Journal of Vertebrate Paleontology 26.3 (2006), pp. 785-787.

[1786] B. L. Beatty. "Rediscovered specimens of Cornwallius (Mammalia, Desmostylia), from Vancouver Island, British Columbia, Canada". English. In: PalArch's Journal of Vertebrate Palaeontology 2006.1 (2006), pp. 1-6.

[1787] B. L. Beatty. "A new aletomerycine (Artiodactyla, Palaeomerycidae) from the Early Miocene of Florida". English. In: Journal of Vertebrate Paleontology 30.2 (2010), pp. 613-617. DOI: 10.1080 / 02724631003617266.

[1788] B. L. Beatty and T. C. Cockburn. "New insights on the most primitive desmostylian from a partial skeleton of Behemotops (Desmostylia, Mammalia) from Vancouver Island, British Columbia". English. In: Journal of Vertebrate Paleontology (2015), e979939. DOI: 10.1080/02724634.2015.979939.

[1789] B. L. Beatty and A. C. Dooley. "The first terrestrial mammal from the Late Miocene Eastover Formation of Virginia". English. In: Jeffersoniana 29 (2013), pp. 1-6.

[1790] B. L. Beatty and L. D. Martin. "The earliest North American record of the Antilocapridae (Artiodactyla, Mammalia)". English. In: PaleoBios 29.1 (2009), pp. 29-35.

[1791] B. Beauchamp and B. Olchowy. "Early Permian buildups (Tolkien Reefs) associated with subaqueous evaporites, Canadian Arctic: a record of syn-tectonic to post-tectonic reciprocal uplift and subsidence". English. In: SEPM Special Publication 78 (2003), pp. 133-153.

[1792] J. C. Beaucournu. "Palaeopsylla groehni n. sp., quatriéme espéce de Puce connue de l'ambre de la Baltique (Siphonaptera, Ctenophthalmidae)". French. In: Bulletin de la Société Entomologique de France 108 (2003), pp. 217-220.

[1793] B. Beaury, L. Krogmann, and A. Nel. “The first fossil insect from the deep-water marine Early Miocene of Zillerleite, Germany (Diptera: Bibionidae)". English. In: Palaeontologia Electronica 20.3.58A (2017), pp. 1-5.

[1794] L. Beauvais and S. Nouiouat. “Une nouvelle faune de coralliaire jurassiques dans l'Atlas sahariens d'Algerie [A new Jurassic coral fauna from the Saharan Atlas of Algeria]". French. In: Geobios 26.3 (1993), pp. 291-318. 
[1795] N. R. Beavan and A. P. Russell. "An elasmobranch assemblage from the terrestrial-marine transitional Lethbridge Coal Zone (Dinosaur Park Formation: Upper Campanian), Alberta, Canada". English. In: Journal of Paleontology 73.3 (1999), pp. 494-503.

[1796] H. H. Beaver and A. J. Fabian. "Color patterns in Mississippian (Chesterian) blastoids". English. In: Journal of Paleontology 72.2 (1998), pp. 332-338.

[1797] S. J. Beavington-Penny, V. P. Wright, and W. J. Welkerling. “Recognising macrophyte-vegetated environments in the rock record: a new criterion using 'hooked' forms of crustose coralline red algae". English. In: Sedimentary Geology 166 (2004), pp. 1-9.

[1798] R. M. Bebej, M. ul-Haq, I. S. Zalmout, and P. D. Gingerich. "Morphology and function of the vertebral column in Remingtonocetus domandaensis (Mammalia, Cetacea) from the middle Eocene Domanda Formation of Pakistan". English. In: Journal of Mammalian Evolution 19 (2012), pp. 77104.

[1799] R. M. Bebej, I. S. Zalmout, A. A. A. El-Aziz, M. S. M. Antar, and P. D. Gingerich. “First remingtonocetid archaeocete (Mammalia, Cetacea) from the middle Eocene of Egypt with implications for biogeography and locomotion in early cetacean evolution". English. In: Journal of Paleontology 89.5 (2015), pp. 882-893. DOI: 10.1017/jpa.2015.57.

[1800] M. Bécaud. "Les Harpoceratinae, Hildoceratinae et Parinoceratinae du Toarcien de la Vendée et des Deux-Sévres (France)". French. In: Documents des Laboratoires de Géologie Lyon 162 (2006), pp. 1149.

[1801] M. Bécaud. "Nouveau gisement à traces de pas de vertébrés dans le Jurassique inférieur de Vendée littorale (France). Discussion sur l'âge des assises". French. In: Le Naturaliste Vendéen 7 (2007), pp. 27-32.

[1802] P. Beccaro, P. O. Baumgartner, and L. Martire. "Radiolarian biostratigraphy of the Fonzaso Formation, Middle- Upper Jurassic, Southern Alps, Italy". In: Micropaleontology 48.51 (2002), pp. 4360.

[1803] P. Beccaro, M. O. Diserens, S. Gorican, and L. Martire. "Callovian radiolarians from the lowermost Calcare Selcifero di Fonzaso at Ponte Serra (Trento Plateau, southern Alps, Italy)". English. In: Rivista Italiana di Paleontologia e Stratigrafia 114.3 (2008), pp. 489-504.

[1804] P. Beccaro and I. Lazar. "Oxfordian and Callovian radiolarians from the Bucegi Massif and Piatra Craiului Mountains (Southern Carpathians, Romania)". English. In: Geologica Carpathica 58.4 (2007), pp. 305-320.

[1805] M. G. Becerra, K. L. Gomez, and D. Pol. "A sauropodomorph tooth increases the diversity of dental morphotypes in the Canadón Asfalto Formation (Early - Middle Jurassic) of Patagonia". English. In: Comptes Rendus Palevol 16 (2017), pp. 832-840.

[1806] G. Bechly. "Two new fossil dragonfly species (Insecta: Odonata: Pananisoptera: Aeschnidiidae and Atassiidae) from the Solnhofen lithographic limestones (Upper Jurassic, Germany)". In: Stuttgarter Beiträge zur Naturkunde, Serie B (Geologie und Paläontologie) 288 (2000), pp. 1-9.

[1807] G. Bechly. "A new species of Cymatophlebia (Insecta: Odonata: Anisoptera: Cymatophlebiidae) from the Solnhofen Lithographic Limestone (Upper Jurassic, Germany)". English. In: Stuttgarter Beiträge zur Naturkunde B (Geologie und Paläontologie) 301 (2001), pp. 1-5.

[1808] G. Bechly. "Additions to the fossil dragonfly fauna from the Lower Cretaceous Crato Formation of Brazil (Insecta: Odonata)". English. In: Palaeodiversity 3.Supplement (2010), pp. 11-77.

[1809] G. Bechly. "A new fossil dragonfly (Anisoptera: Corduliidae) from the Paleocene Fur Formation (Mo clay) of Denmark". English. In: Stuttgarter Beiträge zur Naturkunde Serie B (Geologie und Paläontologie) 358 (2005), pp. 1-7.

[1810] G. Bechly. “Description of a new species of Nannogomphus (Insecta: Odonata: Nannogomphidae) from the Upper Jurassic Solnhofen Limestone in Germany". English. In: Stuttgarter Beiträge zur Naturkunde Serie B (Geologie und Paläontologie) 339 (2003), pp. 1-6. 
[1811] G. Bechly. "New fossil dragonflies from the Lower Cretaceous Crato Formation of north-east Brazil (Insecta: Odonata)". English. In: Stuttgarter Beiträge zur Naturkunde Serie B (Geologie und Paläontologie) 264 (1998), pp. 1-66.

[1812] G. Bechly. "Juracordulia schiemenzi gen. et. sp. nov., Eine neue Libelle aus den Solnhofener Plattenkalken (Insecta: Odonata: Anisoptera)". German. In: Archaeopteryx 16 (1998), pp. 29-36.

[1813] G. Bechly. “New Fossil Odonates from the Upper Triassic of Italy, with a redescription of Italophlebia gervasuttii Whalley, and a reclassification of Triassic dragonflies (Insecta: Odonata)". English. In: Rivista del Museo Civico di Scienze Naturali Enrico Caffi 19 (1997), pp. 31-70.

[1814] G. Bechly. "A new fossil damselfly species (Insecta: Odonata: Zygoptera: Coenagrionidae: Ischnurinae) from Dominican Amber". English. In: Stuttgarter Beiträge zur Naturkunde Serie B (Geologie und Paläontologie) 299 (2000), pp. 1-9.

[1815] G. Bechly. "A revision of the fossil dragonfly genus Urogomphus, with description of a new species (Insecta: Odonata: Pananisoptera: Aeschnidiidae)". English. In: Stuttgarter Beiträge zur Naturkunde Serie B (Geologie und Paläontologie) 270 (1998), pp. 1-47.

[1816] G. Bechly. "A re-description of Stenophlebia casta (Insecta: Odonata: Parastenophlebiidae n. fam) from the Upper Jurassic Solnhofen Limestone in Germany". English. In: Stuttgarter Beiträge zur Naturkunde Serie B (Geologie und Paläontologie) 359 (2005), pp. 1-12.

[1817] G. Bechly. "Two new fossil dragonfly species (Insecta: Odonata: Anisoptera: Araripegomphidae and Lindeniidae) from the Crato Limestone (Lower Cretaceous, Brazil)". English. In: Stuttgarter Beiträge zur Naturkunde Serie B (Geologie und Paläontologie) 296 (2000), pp. 1-16.

[1818] G. Bechly. "An interesting new fossil relict damselfly (Odonata: Zygoptera: Coenagrionoidea) from Eocene Baltic amber". English. In: Palaeodiversity 5 (2012), pp. 51-55.

[1819] G. Bechly. "New fossil damselflies from Baltic amber, with description of a new species, a redescription of Litheuphaea carpenteri Fraser, and a discussion on the phylogeny of the Epallagidae (Zygoptera: Caloptera)". English. In: International Journal of Odonatology 1 (1998), pp. 33-63.

[1820] G. Bechly. "Chrismooreia michaelbehei gen. et sp. nov. (Insecta: Odonata: Asiopteridae), a new fossil damsel-dragonfly from the Early Jurassic of England". English. In: BIO-Complexity 2018.1 (2018), pp. 1-10.

[1821] G. Bechly. "First record and a new species of the fossil dragonfly genus Proinogomphus (Odonata: Liassogomphidae) from the Early Jurassic of Bascharage in the Grand Duchy of Luxembourg". English. In: Zootaxa 4450 (2018), pp. 108-114.

[1822] G. Bechly, C. Brauckmann, W. Zessin, and E. Groning. "New results concerning the morphology of the most ancient dragonflies (Insecta: Odonatoptera) from the Namurian of Hagen-Vorhalle (Germany)". English. In: Journal of Zoology and Systematic Evolution 39 (2001), pp. 209-226.

[1823] G. Bechly, G. Dietl, and G. Schweigert. "A new species of Stenophlebia (Insecta: Odonata: Stenophlebiidae) from the Nusplingen Lithographic Limestone (Upper Jurassic, SW Germany)". English. In: Stuttgarter Beiträge zur Naturkunde Serie B (Geologie und Paläontologie) 338 (2003), pp. 1-10.

[1824] G. Bechly and A. Kin. "First record of the fossil dragonfly family Eumorbaeschnidae from the Upper Jurassic of Poland". English. In: Acta Palaeontologica Polonica 58 (2013), pp. 121-124.

[1825] G. Bechly and V. N. Makarkin. "A new gigantic lacewing species (Insecta: Neuroptera) from the Lower Cretaceous of Brazil confirms the occurrence of Kalligrammatidae in". English. In: Cretaceous Research 58 (2016), pp. 135-140.

[1826] G. Bechly, A. Nel, X. Martnez-Delclós, and G. Fleck. “Four new dragonflies from the Upper Jurassic of Germany and the Lower Cretaceous of Mongolia (Anisoptera: Hemeroscopidae, Sonidae, and Proterogomphidae fam. nov.)" English. In: Odonatologica 27.2 (1998), pp. 149-187.

[1827] G. Bechly, A. Nel, X. Martnez-Declós, E. A. Jarzembowski, R. Coram, D. Martill, G. Fleck, F. Escuillié, M. M. Wisshak, and M. Maisch. "A revision and phylogenetic study of Mesozoic Aeshnoptera, with description of numerous new taxa (Insecta: Odonata: Anisoptera)". English. In: Neue Paläontologische Abhandlungen 4 (2001), pp. 1-219. 
[1828] G. Bechly and G. Poinar. "Burmaphlebia reifi gen. et sp. nov., the first anisozygopteran damseldragonfly (Odonata: Epiophlebioptera: Burmaphlebiidae fam. nov.) from Early Cretaceous Burmese amber". English. In: Historical Biology 25 (2013), pp. 233-237.

[1829] G. Bechly and J. A. Rasmussen. "A new genus of hawker dragonfly (Odonata: Anisoptera: Aeshnidae) from the Early Eocene Fur Formation of Denmark". English. In: Zootaxa 4550 (2019), pp. 123128.

[1830] G. Bechly and V. J. Sach. “An interesting new fossil dragonfly (Anisoptera: Libellulidae: Brachydiplacini) from the Miocene of Germany, with a discussion on the phylogeny of Tetrathemistinae and a fossil list for the locality Heggbach". English. In: Stuttgarter Beiträge zur Naturkunde Serie B (Geologie und Paläontologie) 325 (2002), pp. 1-11.

[1831] G. Bechly and G. Schweigart. “The first fossil hanging flies (Insecta: Mecoptera: Raptipedia: Cimbrophlebiidae and Bittacidae) from the limestones of Solnhofen and Nusplingen (Upper Jurassic, Germany)". English. In: Stuttgarter Beiträge zur Naturkunde, Serie B (Geologie und Paläontologie) 287 (2000), pp. 1-18.

[1832] G. Bechly and R. Stockar. "The first Mesozoic record of the extinct apterygote insect Dasyleptus (Insecta: Archaeognatha: Monura: Dasyleptidae) from the Triassic of Monte San Giorgio (Switzerland)". English. In: Palaeodiversity 4 (2011), pp. 23-37.

[1833] G. Bechly and K. Ueda. “The first fossil record and first New World record for the dragonfly clade Chlorogomphida (Insecta: Odonata: Anisoptera: Araripechlorogomphidae $n$ fam) from the Crato Limestone (Lower Cretaceous, Brazil)". English. In: Stuttgarter Beiträge zur Naturkunde Serie B (Geologie und Paläontologie) 328 (2002), pp. 1-11.

[1834] G. Bechly and W. Wichard. "Damselfly and dragonfly nymphs in Eocene Baltic amber (Insecta: Odonata), with aspects of their palaeobiology". English. In: Palaeodiversity 1 (2008), pp. 37-73.

[1835] G. Bechly and M. Wittmann. "Two new tropical bugs (Insecta: Heteroptera: Thaumastocoridae - Xylastodorinae and Hypsipterygidae) from Baltic amber". English. In: Stuttgarter Beiträge zur Naturkunde Serie B (Geologie und Paläontologie) 289 (2000), pp. 1-11.

[1836] G. Bechly and K. Wolf-Schwenninger. "A new fossil genus and species of snakefly (Raphidioptera: Mesoraphidiidae) from Lower Cretaceous Lebanese amber, with a discussion of snakefly phylogeny and fossil history". English. In: Insect Systematics \& Evolution 42 (2011), pp. 221-236.

[1837] C. A. Beck and N. B. Barros. "The impact of debris on the Florida manatee". English. In: Marine Pollution Bulletin 22 (1991), pp. 508-510.

[1838] C. B. Beck and W. E. Stein. “Crossia virginiana gen. et sp. nov., A new member of the Stenokoleales from the Middle Devonian of southwestern Virginia". English. In: Palaeontographica Abteilung B 229 (1993), pp. 115-135.

[1839] R. M. D. Beck. "An 'ameridelphian' marsupial from the early Eocene of Australia supports a complex model of Southern Hemisphere marsupial biogeography". English. In: Naturwissenschaften 99 (2012), pp. 715-729.

[1840] R. M. D. Beck. “A peculiar faunivorous metatherian from the early Eocene of Australia”. English. In: Acta Palaeontologica Polonica 60.1 (2013), pp. 123-129.

[1841] R. M. D. Beck, M. Archer, H. Godthelp, B. S. Mackness, S. J. Hand, and J. Muirhead. “A bizarre new family of Marsupialia (Incertae sedis) from the Early Pliocene of northeastern Australia: implications for the phylogeny of bunodont marsupials". English. In: Journal of Paleontology 82.4 (2008), pp. 749-762. DOI: 10.1666/06-124.1.

[1842] R. M. D. Beck, J. Louys, P. Brewer, M. Archer, K. H. Black, and R. H. Tedford. "A new family of diprotodontian marsupials from the latest Oligocene of Australia and the evolution of wombats, koalas, and their relatives (Vombatiformes)". English. In: Scientific Reports 10 (2020), 9741:1-13. DOI: $10.1038 /$ s41598-020-66425-8. 
[1843] R. M. D. Beck and M. L. Taglioretti. “A Nearly Complete Juvenile Skull of the Marsupial Sparassocynus derivatus from the Pliocene of Argentina, the Affinities of Sparassocynids, and the Diversification of Opossums (Marsupialia; Didelphimorphia; Didelphidae)". English. In: Journal of Mammalian Evolution 27 (2020), pp. 385-417. DOI: 10.1007/s10914-019-09471-y.

[1844] R. J. Beckemeyer. "Raaschiidae (Grylloblattida: Protoperlina), a new insect family from the Lower Permian Wellington Formation of Noble County, Oklahoma". English. In: Journal of the Kansas Entomological Society 77.3 (2004), pp. 215-221.

[1845] R. J. Beckemeyer. "A new species of the extinct family tLophioneuridae from the Lower Permian Wellington Formation of Noble County, Oklahoma". English. In: Journal of the Kansas Entomological Society 77.2 (2004), pp. 132-136.

[1846] R. J. Beckemeyer. "A New Species of +Martynovia Tillyard, 1932 (Insecta: †Diaphanopterodea: +Martynoviidae) from the Lower Permian Wellington Formation of Noble County, Oklahoma". English. In: Journal of the Kansas Entomological Society 77 (2004), pp. 127-131.

[1847] R. J. Beckemeyer. “Artinska ovata (Sellards) and Paraprisca fragilis (Sellards) (Insecta: Polyneoptera: Lemmatophoridae) newly reported from the Lower Permian of Noble County, Oklahoma, with notes on Wellington Formation Lemmatophoridae". English. In: Transactions of the Kansas Academy of Science 112 (2009), pp. 45-56.

[1848] R. J. Beckemeyer. “Ligogramma wichita, a new species of Caloneurodea (Polyneoptera: Orthopterida) from the Lower Permian Wellington Formation of Noble County, Oklahoma". English. In: Journal of the Kansas Entomological Society 82 (2009), pp. 300-304.

[1849] R. J. Beckemeyer. "A new species of Liomopterella Sharov, 1961 (Polyneoptera: Liomopteridae) from the Early Permian Wellington Formation of Noble County, Oklahoma". English. In: Transactions of the Kansas Academy of Science 113 (2010), pp. 151-160.

[1850] R. J. Beckemeyer. “Nobloedischia rasnitsyni, a new genus and species of Oedischiidae (Orthoptera) from the Lower Permian Wellington Formation of Oklahoma, USA". English. In: ZooKeys 130 (2011), pp. 103-110.

[1851] R. J. Beckemeyer. “A new genus and species of Orthoptera from the Lower Permian Wellington Formation of Noble County, Oklahoma, USA". English. In: Transactions of the Kansas Academy of Science 114 (2011), pp. 88-94.

[1852] R. J. Beckemeyer. "A new species of Glaphyrophlebia Handlirsch, 1906 (Insecta: Neoptera: Blattinopsidae) from the Lower Permian Wellington Formation of Noble County, Oklahoma, USA". English. In: The Carboniferous-Permian Transition. New Mexico Museum of Natural History and Science Bulletin 60 (2013), pp. 7-11.

[1853] R. J. Beckemeyer. "A new genus and species of Blattogryllidae from Kansas with notes on Stereopterum rotundum Carpenter, 1950 (Euryptilonidae) in Oklahoma (Insecta: Polyneoptera: Eoblattida; Lower Permian)". English. In: Transactions of the Kansas Academy of Science 121 (2018), pp. 8797.

[1854] R. J. Beckemeyer and G. W. Byers. “Forewing morphology of Dunbaria fasciipennis Tillyard (Palaeodictyoptera: Spilapteridae), with notes on a specimen from the University of Kansas Natural History Museum". English. In: Journal of the Kansas Entomological Society 74.4 (2001), pp. 221-230.

[1855] R. J. Beckemeyer and M. S. Engel. "A Second Specimen of Permocoleus (Coleoptera) from the Lower Permian Wellington Formation of Noble County, Oklahoma". English. In: Journal of the Kansas Entomological Society 81 (2008), pp. 4-7.

[1856] R. J. Beckemeyer and M. S. Engel. "An enigmatic new genus of biarmohymenid from the Early Permian Wellington Formation of Noble County, Oklahoma (Palaeodictyopterida: Diaphanopterodea)". English. In: Transactions of the Kansas Academy of Science 112 (2009), pp. 103-108.

[1857] R. J. Beckemeyer and M. S. Engel. "Upper Carboniferous insects from the Pottsville Formation of northern Alabama (Insecta: Ephemeropterida, Palaeodictyopterida, Odonatoptera)". English. In: Scientific Papers, Natural History Museum, The University of Kansas 44 (2011), pp. 1-19. 
[1858] R. J. Beckemeyer and M. S. Engel. "First North American species of the European genus Archaemegaptilus from the Upper Carboniferous Pottsville Formation of northern Alabama (Palaeodictyoptera: Archaemegaptilidae)". English. In: Novitates Paleoentomologicae 21 (2018), pp. 1-7.

[1859] R. J. Beckemeyer and J. D. Hall. “Permopanorpa inaequalis Tillyard, 1926 (Insecta: Holometabola: Panorpida: Permopanorpidae): A fossil mecopteroid newly reported for the Lower Permian Wellington Formation of Noble County, Oklahoma". English. In: Transactions of the Kansas Academy of Science 110.1/2 (2007), pp. 23-29.

[1860] D. Becker. "Earliest record of rhinocerotoids (Mammalia: Perissodactyla) from Switzerland: systematics and biostratigraphy". English. In: Swiss Journal of Geosciences 102 (2009), pp. 489-504. DOI: 10.1007/s00015-009-1330-4.

[1861] D. Becker, P.-O. Antoine, and O. Maridet. "A new genus of Rhinocerotidae (Mammalia, Perissodactyla) from the Oligocene of Europe". English. In: Journal of Systematic Palaeontology 11.8 (2013), pp. 947-972.

[1862] D. Becker, G. Rauber, and L. Scherler. "New small mammal fauna of late Middle Eocene age from a fissure filling at La Verrerie de Roches (Jura, NW Switzerland)". English. In: Revue de Paléobiologie, Genéve 32.2 (2013), pp. 433-446.

[1863] G. Becker and S. Q. Wang. “Kirkbyacea and Bairdiacea (Ostracoda) from the Palaeozoic of China". English. In: Palaeontographica Abteilung A 224 (1992), pp. 1-54.

[1864] M. A. Becker, C. S. Mallery, and J. A. Chamberlain. "Osteichthyans from an Arkadelphia FormationMidway Group lag deposit (Late Maastrichtian-Paleocene), Hot Spring County, Arkansas, U.S.A." English. In: Journal of Vertebrate Paleontology 30.4 (2010), pp. 1019-1036.

[1865] R. T. Becker. "Taxonomy, evolutionary history and distribution of the middle to late Famennian Wocklumeriina (Ammonoidea, Clymeniida)". English. In: Mitteilungen aus dem Museum für Naturkunde in Berlin, Geowissenschaftliche Reihe 3 (2000), pp. 27-75.

[1866] R. T. Becker. "Alpinites and other Posttornoceratidae (Goniatitida, Famennian)". English. In: Mitteilungen aus dem Museum für Naturkunde in Berlin, Geowissenschaftliche Reihe 5 (2002), pp. 51-73.

[1867] R. T. Becker, Z. S. Aboussalam, S. Stichling, A. May, and E. Eichholt. "The Givetian-Frasnian Hönne Valley Reef Complex (northern Sauerland) - an outline of stratigraphy and facies development". English. In: Münstersche Forschungen zur Geologie und Palaeontologie 108 (2016), pp. 126140.

[1868] R. T. Becker, S. Hartenfels, S. Helling, and G. Schreiber. “The Nehden Goniatite Shale (lower Famennian, Brilon Reef Complex, NE Rhenish Massif)". English. In: Münstersche Forschungen zur Geologie und Paläontologie 108 (2016), pp. 179-195.

[1869] R. T. Becker, M. R. House, and W. T. Kirchgasser. Devonian goniatite biostratigraphy and timing of facies movements in the Frasnian of the Canning Basin, Western Australia. in E. A. Hailwood and R. B. Kidd, eds. High Resolution Stratigraphy (Geological Society of London Special Publication no. 70). 1997, pp. 293-321.

[1870] R. T. Becker, M. R. House, W. T. Kirchgasser, and P. E. Playford. “Sedimentary and faunal changes across the Frasnian/Famennian boundary in the Canning Basin of Western Australia". In: Historical Biology 5.2-4 (1991), pp. 183-196.

[1871] R. T. Becker, M. R. House, J. Bockwinkel, V. Ebbighausen, and Z. S. Aboussalam. "Famennian ammonoid zones of the eastern Anti-Atlas (southern Morocco)". English. In: Münstersche Forschungen zur Geologie und Paläontologie 93 (2002), pp. 159-205.

[1872] R. T. Becker, M. R. House, V. V. Menner, and N. S. Ovnatanova. "Revision of ammonoid biostratigraphy in the Frasnian (Upper Devonian) of the Southern Timan (northeast Russian Platform)". English. In: Acta Geologica Polonica 50 (2000), pp. 67-97.

[1873] R. T. Becker and R. H. Mapes. “Uppermost Devonian ammonoids from Oklahoma and their palaeobiogeographic significance". English. In: Acta Geologica Polonica 60 (2010), pp. 139-163. 
[1874] C. Bedetti and M. Pavia. "Reinterpretation of the late Pleistocene Ingarano cave deposit based on the fossil bird associations (Apulia, south-eastern Italy)". English. In: Rivista Italiana di Paleontologia e Stratigrafia 113 (2007), pp. 487-507.

[1875] C. Bedetti and M. Pavia. "Early Pleistocene birds from Pirro Nord (Puglia, southern Italy)". English. In: Palaeontographica Abteilung A 298 (2013), pp. 31-53.

[1876] J. Bednarski. “An Early Holocene Bowhead Whale (Balaena mysticetus) in Nansen Sound, Canadian Arctic Archipelago". English. In: Arctic 43.1 (1990), pp. 50-54.

[1877] J. G. Begg and H. R. Ballard. "An Early Permian fauna from the Mantle Volcanics Formation, Skippers Range, northwest Otago". English. In: New Zealand Journal of Geology and Geophysics 34 (1991), pp. 145-155.

[1878] J. G. Begg and J. A. Grant-Mackie. “New Zealand and New Caledonian Triassic Pleurotomariidae (Gastropoda, Mollusca)". English. In: Journal of the Royal Society of New Zealand 33 (2003), pp. 223268.

[1879] A. K. Behrensmeyer. English. 1994.

[1880] G. Behrmann. “Der Bartenwal aus dem Miozan von Gr.-Pampau (Schleswig-Holstein)”. English. In: Geoschiebekunde aktuell 11.4 (1995), pp. 119-129.

[1881] E. Beilinson, G. M. Gasparini, R. L. Tomassini, M. A. Zarate, C. M. Deschamps, R. W. Barendregt, and J. Rabassa. "The Quequen Salado river basin: Geology and biochronostratigraphy of the MioPliocene boundary in the southern Pampean plain, Argentina". English. In: Journal of South American Earth Sciences 76 (2017), pp. 362-374. DOI: 10.1016/j.jsames.2017.04.002.

[1882] A. Belahmira, J. W. Schneider, F. Scholze, and H. Saber. "Phyloblattidae and Compsoblattidae (Insecta, Blattodea) from the late Carboniferous Souss basin, Morocco". English. In: Journal of Paleontology 93 (2019), pp. 945-965. DOI: 10.1017/jpa.2019.20.

[1883] Z. Belaústegui, J. M. Gilbert, R. Domenech, F. Muniz, and J. Martinell. “Tafonomia y contexto paleoambiental de los restos de un cetaceo del Mioceno medio de Tarragona (NE Espana)". Spanish. In: Geobios 44.1 (2011), pp. 19-31. DOI: 10.1016/j.geobios.2010.07.002.

[1884] Z. Belka, S. Skompski, J. Dopieralska, and R. Feist. "Flow paths of hydrothermal vent fluids in the Devonian Kess-Kess mounds, Anti-Atlas, Morocco". English. In: 290.1-3 (2018), pp. 49-63. DOI: 10.1127/njgpa/2018/0779.

[1885] L. Belkebir, B. Mansour, M. Bessedik, J. P. Saint Martin, M. Belarbi, and C. Chaix. “Presence d'une construction recifale corallienne a Djebel Chott (Dahra occidental, Algerie): temoin du maximum transgressif du Miocene moyen en Mediterranee [The coral reef of Djebel Chott (western Dahra, Algeria): evidence of the maximum Middle Miocene transgression in the Mediterranean]". French. In: Geologie Mediterraneenne 21.1-2 (1994), pp. 1-7.

[1886] A. Bell and L. M. Chiappe. "Identification of a new hesperornithiform from the Cretaceous Niobrara Chalk and implications for ecologic diversity among early diving birds". English. In: PLoS ONE 10.11 (2015), e0141690:1-34. DOI: 10.1371/journal.pone.0141690.

[1887] A. Bell and L. M. Chiappe. "Anatomy of Parahesperornis: Evolutionary Mosaicism in the Cretaceous Hesperornithiformes (Aves)". English. In: Life 10.5 (2020), 62:1-95.

[1888] A. Bell and M. J. Everhart. "Remains of small ornithurine birds from a Late Cretaceous (Cenomanian) microsite in Russell County, north-central Kansas". English. In: Transactions of the Kansas Academy of Science 114.1-2 (2011), pp. 115-123. DOI: 10.1660/062.114.0111.

[1889] A. Bell, K. J. Irwin, and L. C. Davis. "Hesperornithiform birds from the Late Cretaceous (Campanian) of Arkansas, USA". English. In: Transactions of the Kansas Academy of Science 118.3-4 (2015), pp. 219-229.

[1890] A. K. Bell, L. M. Chiappe, G. M. Erickson, S. Suzuki, M. Watabe, R. Barsbold, and K. Tsogtbaatar. "Description and ecologic analysis of Hollanda luceria, a Late Cretaceous bird from the Gobi Desert (Mongolia)". English. In: Cretaceous Research 31.1 (2010), pp. 16-26. DOI: 10.1016/j.cretres. 2009.09.001. 
[1891] C. J. Bell and G. S. Bever. “Description and significance of the Microtus (Rodentia : Arvicolinae) from the type Irvington fauna, Alameda County, California". English. In: Journal of Vertebrate Paleontology 26.2 (2006), pp. 371-380.

[1892] C. J. Bell and J. Glennon. Arvicoline rodents from Screaming Neotoma Cave, southern Colorado Plateau, Apache County, Arizona, with comments on the Pleistocene biogeography of Lemmiscus curtatus. English. Pp. 54-63 in Ice Age Cave Faunas of North America (B. W. Schubert, J. I. Mead, and R. W. Graham, eds.). Indiana University Press, Bloomington, Indiana. 2003.

[1893] C. J. Bell and J. I. Mead. "Late Pleistocene microtine rodents from Snake Creek Burial Cave, White Pine County, Nevada". English. In: Great Basin Naturalist 58.1 (1998), pp. 82-86.

[1894] C. M. Bell and K. Padian. "Pterosaur fossils from the Cretaceous of Chile: evidence for a pterosaur colony on an inland desert plain". English. In: Geological Magazine 132 (1995), pp. 31-38.

[1895] C. M. Bell and M. Suarez. "Late Triassic fluvial and marine shelf succession, Quebrada Dona Ines Chica, Atacama region, northern Chile". In: Journal of South American Earth Sciences 4.4 (1991), pp. 287-293.

[1896] G. L. Bell and M. J. Polcyn. "Dallasaurus turneri, a new primitive mosasauroid from the Middle Turonian of Texas and comments on the phylogeny of Mosasauridae (Squamata)". English. In: Netherlands Journal of Geosciences 84.3 (2005), pp. 177-194.

[1897] P. R. Bell, T. Brougham, M. C. Herne, T. Frauenfelder, and E. T. Smith. "Fostoria dhimbangunmal, gen. et sp. nov., a new iguanodontian (Dinosauria, Ornithopoda) from the mid-Cretaceous of Lightning Ridge, New South Wales, Australia". English. In: Journal of Vertebrate Paleontology 39.1 (2019), e1564757:1-18. DOI: 10.1080/02724634.2019.1564757.

[1898] P. R. Bell, P. J. Currie, and D. A. Russell. “Large caenagnathids (Dinosauria, Oviraptorosauria) from the uppermost Cretaceous of western Canada". English. In: Cretaceous Research 52 (2015), pp. 101-107.

[1899] P. R. Bell and P. J. Currie. "A high-latitude dromaeosaurid, Boreonykus certekorum, gen. et sp. nov. (Theropoda), from the upper Campanian Wapiti Formation, west-central Alberta". English. In: Journal of Vertebrate Paleontology 36.1 (2016), e1034359:1-9. DOI: 10.1080/02724634.2015.1034359.

[1900] P. R. Bell, F. Fanti, J. Acorn, and R. S. Sissons. "Fossil mayfly larvae (Ephemeroptera, cf. Heptageniidae) from the Late Cretaceous Wapiti Formation, Alberta, Canada". English. In: Journal of Paleontology 87 (2013), pp. 147-150.

[1901] P. R. Bell, F. Fanti, M. T. Mitchell, and P. J. Currie. “Marine reptiles (Plesiosauria and Mosasauridae) from the Puskwaskau Formation (Santonian-Campanian), West-Central Alberta". English. In: Journal of Paleontology 88.1 (2014), pp. 187-194.

[1902] P. R. Bell, F. Fanti, P. J. Currie, and V. M. Arbour. "A mummified duck-billed dinosaur with a softtissue cock's comb". English. In: Current Biology 24.1 (2014), pp. 70-75. DOI: 10.1016/j.cub.2013.11. 008.

[1903] P. R. Bell, M. C. Herne, T. Brougham, and E. T. Smith. “Ornithopod diversity in the Griman Creek Formation (Cenomanian), New South Wales, Australia". English. In: PeerJ 6 (2018), e6008:1-40. DOI: 10.7717 / peerj.6008.

[1904] P. R. Bell, B. M. Rothschild, and D. H. Tanke. "First report of gout in an ornithomimid (Dinosauria: Theropoda) from the Horseshoe Canyon Formation, Alberta". English. In: vol. 53. Fossil Record 3. New Mexico Museum of Natural History and Science Bulletin. Albuquerque: New Mexico Museum of Natural History and Science, 2011, pp. 166-168.

[1905] G. L. Bell Jr., K. R. Barnes, and M. J. Polcyn. “Late Cretaceous mosasauroids (Reptilia, Squamata) of the Big bend region in Texas, USA". English. In: Earth and Environmental Science Transactions of the Royal Society of Edinburgh 103 (2013), pp. 1-11.

[1906] C. L. Bellamy. "A New Species of Buprestidae (Coleoptera) from Dominican Amber". English. In: The Coleopterists Bulletin 53.4 (1999), pp. 321-323. 
[1907] X. Bellés. "Systematics of the genus Oviedinus nov. (Coleoptera: Ptinidae), including a fossil new species from Dominican amber, biogeographical remarks and an account of fossil ptinids". English. In: Elytron 24 (2010), pp. 77-88.

[1908] X. Bellés and E. E. Perkovsky. "New data on the genus Sucinoptinus (Coleoptera, Ptinidae) from Rovno amber". English. In: Vestnik Zoologii 50 (2016), pp. 17-22.

[1909] X. Bellés and F. Vitali. "New fossil spider beetles from Baltic amber (Coleoptera Ptinidae)". English. In: Entomapeiron (P.S.) 2.2 (2007), pp. 17-28.

[1910] D. R. Bellwood. "A new fossil fish PHyllopharyngodon longipinnis gen. et sp. nov. (family Labridae) from the Eocenw, Monte Bolca, Italy". English. In: Studi e ricerche sui giacimenti terziari di Bolca 6 (1990), pp. 149-160.

[1911] D. R. Bellwood and O. Schultz. "A review of the fossil record of the parrotfishes (Labroidei: Scaridae) with a description of a new Calotomus species from the Middle Miocene (Badenian) of Austria". English. In: Annalen des Naturhistorischen Museums in Wien, A 92 (1991), pp. 55-71.

[1912] D. R. Bellwood and L. Sorbini. "A review of the fossil record of the Pomacentridae (Teleostei: Labroidei) with a description of a new genus and species from the Eocene of Monte Bolca, Italy". English. In: Zoological Journal of the Linnean Society 117 (1996), pp. 159-174.

[1913] S. A. Belokobylskij. "Cretaceous braconid wasps from the Magadan Province of Russia". English. In: Acta Palaeontologica Polonica 57 (2012), pp. 351-361.

[1914] S. A. Belokobylskij, A. Nel, A. Waller, and G. Plöeg. "New fossil non-cyclostome braconid wasps from the lowermost Eocene amber of Paris Basin". English. In: Acta Palaeontologica Polonica 55.3 (2010), pp. 519-527.

[1915] L. S. Belokrys. "New Eocene Gastrochaenids (Bivalvia) from the Ukraine". In: Paleontological Journal 25.2 (1991), pp. 9-17.

[1916] L. S. Belokrys. "Pseudarcella (Tintinnida, Infusoria) from the Eocene of the Ukraine". In: Paleontological Journal 27.2 (1993), pp. 20-35.

[1917] L. S. Belokrys. "Genus Voorthuyseniella (Problematic Microfossils) from the Eocene of Ukraine". In: Paleontological Journal 27.3 (1993), pp. 15-28.

[1918] A. P. Belperio and D. G. Fotheringham. "Geological setting of two Quaternary footprint sites, western South Australia". English. In: Australian Journal of Earth Sciences 37.1 (1990), pp. 37-42. DOI: $10.1080 / 08120099008727903$.

[1919] M. Belvedere, M. Avanzini, P. Mietto, and M. Rigo. "Norian dinosaur footprints from the Strada delle Gallerie (Monte Pasubio, NE Italy)". English. In: Studi Trentini di Scienze Naturali, Acta Geologica 83 (2008), pp. 267-275.

[1920] M. Belvedere, G. Dyke, M. Hadri, and S. Ishigaki. "The oldest evidence for birds in northern Gondwana? Small tridactyl footprints from the Middle Jurassic of Msemrir (Morocco)". English. In: Gondwana Research 19 (2011), pp. 542-549. DOI: 10.1016/j.gr.2010.08.004.

[1921] G. V. Belyaeva. "New taxa of Sphictozoa from the Permian reefs of southeastern China". In: Paleontological Journal 34.2 (2000), pp. 155-160.

[1922] K. E. Bemis, J. C. Tyler, W. E. Bemis, K. Kumar, R. S. Rana, and T. Smith. “A gymnodont fish jaw with remarkable molariform teeth from the early Eocene of Gujarat, India (Teleostei, Tetraodontiformes)". English. In: Journal of Vertebrate Paleontology 37.6 (2017), e136944. DOI: 10.1080/02724634. 2017.1369422.

[1923] M. Benammi. "Nouveaux rongeurs du Miocéne continental du Jebel Rhassoul (Moyen Moulouya, Maroc)." French. In: Geobios 30.5 (1997), pp. 713-721.

[1924] M. Benammi, E. Centeno-Garca, E. Martnez-Hernández, M. Morales-Gámez, G. Tolson, and J. Urrutia-Fucugauchi. "Presencia de dinosaurios en la Barranca Los Bonetes en el sur de México (Región de Tiquicheo, Estado de Michoacán) y sus implicaciones cronoestratigráficas [Presence of dinosaurs in the Barranca Los Bonetes in southern Mexico (Tiquicheo region, Michoacán state) and their chronostratigraphic implications]". Spanish. In: Revista Mexicana de Ciencias Geológicas 22.3 (2005), pp. 429-435. 
[1925] S. Benatov. "Costirhynchopsis vidlicis (Urosevic, 1981) - a new brachiopod species for the Bulgarian Middle Triassic". English. In: Geologica Balcanica 27.1-2 (1997), pp. 37-43.

[1926] P. A. Bender and P. J. Hancox. "Newly Discovered Fish Faunas from the Early Triassic, Karoo Basin, South Africa, and their Correlative Implications". English. In: Gondwana Research 7.1 (2004), pp. 185-192.

[1927] J. Benedetto. “Chaniella a new lower Tremadocian (Ordovician) brachiopod from northwestern Argentina and its phylogenetic relationships within basal rhynchonelliforms". English. In: Palaeontologische Zeitschrift 83.3 (2009), pp. 393-405. DOI: 10.1007/s12542-009-0023-7.

[1928] J. Benedetto and L. R. M. Cocks. "Early Silurian (Rhuddanian) brachiopods from the Argentine Precordillera and their biogeographic affinities". English. In: Ameghiniana 46.2 (2009), pp. 241-253.

[1929] J. L. Benedetto. "Braquiopodos del Silurica temprano malvinocafrico (Formacion La Chilca), Precordillera Argentina". Spanish. In: Géobios 28.4 (1995), pp. 425-457.

[1930] J. L. Benedetto. “New Upper Cambrian-Tremadoc rhynchonelliformean brachiopods from northwestern Argentina: evolutionary trends and early diversification of plectorthoideans in the Andean Gondwana". English. In: Journal of Paleontology 81.2 (2007), pp. 261-285.

[1931] J. L. Benedetto. "Early Ordovician (Arenig) brachiopods from volcanicalstic rocks of the Famatina Range, northwest Argentina". English. In: Journal of Paleontology 77.2 (2003), pp. 212-242.

[1932] J. L. Benedetto. "Los generos Cliftonia y Paomalomena (Brachiopoda) en el Asgilliano tardio de la Sierra de Villicum, Precordillera de San Juan, Argentina". Portugese. In: Ameghiniana 27.1-2 (1990), pp. 151-159.

[1933] J. L. Benedetto. "Gatosella, a new basal plectambonitoid brachiopod with undercut cardinal process from Middle Ordovician limestones of the Precordillera terrane, Argentina". English. In: Journal of Systematic Palaeontology 10.3 (2012), pp. 435-443. DOI: 10.1080/14772019.2011.590536.

[1934] J. L. Benedetto. "Upper Ordovician Brachiopods from the San Benito Formation, Cordillera del Tunari, Bolivia". English. In: Ameghiniana 50.4 (2013), pp. 418-428. DOI: 10.5710 / AMGH.05.03. 2013.558.

[1935] J. L. Benedetto. “A Middle Ordovician (Darriwilian) dysaerobic brachiopod assemblage from the Precordillera terrane of Argentina: implications for early colonization of deep waters". English. In: Ameghiniana 52.1 (2015), pp. 69-106. DOI: 10.5710/AMGH.05.08.2014.2752.

[1936] J. L. Benedetto and P. A. Carrasco. “Tremadoc (earliest Ordovician) brachiopods from Purmamarca and the Sierra de Mojotoro, Cordillera Oriental of northwestern Argentina". English. In: Géobios 35 (2002), pp. 647-661.

[1937] J. L. Benedetto, N. Cech, and C. Esbry. “New Late Tremadoc-Early Arenig silicified brachiopods from the lower part of the San Juan Formation, Argentine Precordillera". English. In: Ameghiniana 40.4 (2003), pp. 513-530.

[1938] J. L. Benedetto and M. Franciosi. “Braquiopodos Siluricos de las Formaciones Tambolar y Rinconada en la Precordillera de San Juan, Argentina". Spanish. In: Ameghiniana 35.2 (1998), pp. 115132.

[1939] J. L. Benedetto, K. Halpern, and J. C. Galeano Inchausti. "High-latitude Hirnantian (latest Ordovician) brachiopods from the Eusebio Ayala Formation of Paraguay, Paraná Basin". English. In: Palaeontology 56.1 (2013), pp. 61-78. DOI: 10.1111/j.1475-4983.2012.01158.x.

[1940] J. L. Benedetto and Z. A. Herrera. “New early Ordovician Leptellinae (Brachiopoda) from the San Juan Formation, west-central Argentina". English. In: Ameghiniana 30 (1993), pp. 39-58.

[1941] J. L. Benedetto, P. R. Racheboeuf, Z. Herrera, E. D. Brussa, and B. A. Toro. “Brachiopodes et biostratigraphie de la Formation de Los Espejos, Siluro-Devonien de la Precordillere (NW Argentine)". Spanish. In: Géobios 25.5 (1992), pp. 599-637.

[1942] M. Benest, F. Atrops, and B. Clavel. "Les echinides du Kimméridgien inférieur des Monts de Chellala (ouest Algérien); révision, paléoenvironnement, et eustatisme". French. In: Geobios 27 (1994), pp. 61-71. 
[1943] M. Benest, D. Gaspard, and M. Ghali. “Les brachiopodes de l'avant-pays ouest-algerien lors de la phase transgressive maximale du Berriasien superieur; systematique, environnement, paleogeographie [The brachiopods of the Western-Algerian foreland during the maximum transgressive interval of Upper Berriasian age; systematics, environment and palaeogeography]". French. In: Géobios 29.1 (1996), pp. 13-34.

[1944] A. Benetti and N. Pezzoni. "Brachiopods from the Calcari Oolitici di S. Vigilio (Toarcian-Aalenian) and Rosso Ammonitico (Upper Bajocian) in the central Lessinian Alps (Province of Verona, Italy): a preliminary note". English. In: Mesozoic brachiopods of Alpine Europe. Budapest: Hungarian Geological Society, 1993, pp. 23-26.

[1945] E. M. Benfrika, P. Bultynck, and A. El Hassani. “Upper Silurian to Middle Devonian conodont faunas from the Rabat-Tiflet area (northwestern Moroccan Meseta)". English. In: Geological Quarterly 51.4 (2007), pp. 393-406.

[1946] J. L. Bengston and P. Boveng. "Antibodies to canine distemper virus in Antarctic seals". English. In: Marine Mammal Science 7 (1991), pp. 85-87.

[1947] J. A. Bengtson. "Crabeater seal Lobodon carcinophaga". English. In: Encyclopedia of marine mammals. London: Academic Press, 2002, pp. 302-304.

[1948] P. Bengtson and J. Lindgren. "First record of the mosasaur Platecarpus Cope, 1869 from South America and its systematic implications". English. In: Revista Brasileira de Paleontologia 8.1 (2005), pp. 5-12.

[1949] S. Bengtson, S. Conway Morris, B. J. Cooper, P. A. Jell, and B. N. Runnegar. “Early Cambrian fossils from South Australia". English. In: Association of Australasian Palaeontologists 9 (1990), pp. 1-364.

[1950] S. Bengtson and X. Hou. "The integument of Cambrian chancelloriids". English. In: Acta Palaeontologica Polonica 46.1 (2001), pp. 1-22.

[1951] M. Benhamou, S. Elmi, and Y. Almeras. "Age et contexte dynamique des calcaires a brachiopodes tethysiens (Zeilleriides multiplisses) du Grand Pic de l'Ouarsenis (Tell algerien)[Age and dynamic context of the multicostate zeilleriids limestones of the Grand Pic de l'Ouarsenis (Algerian Tell)]". French. In: Comptes rendus de l'Académie des Sciences, Sciences de la Terre et des Planétes 331 (2000), pp. 717-723.

[1952] C. Benigni and C. Ferliga. "Diplospirella Bittner, 1890 (Brachiopoda): morphology and review of the Carnian species from the San Cassiano Formation (Cortina d'Ampezzo, Italy)". English. In: Rivista Italiana di Paleontologia e Stratigrafia 96.1 (1990), pp. 39-76.

[1953] A. Benites-Palomino, G. Aguirre-Fernández, J. W. Moreno- Bernal, A. Vanegas, and C. Jaramillo. "Miocene Freshwater Dolphins from La Venta, Huila, Colombia Suggest Independent Invasions of Riverine Environments in Tropical South America". English. In: Journal of Vertebrate Paleontology (2020), e1812078. DOI: 10.1080/02724634.2020.1812078.

[1954] A. Benites-Palomino, J. Vélez-Juarbe, R. Salas-Gismondi, and M. Urbina. “Scaphokogia totajpe, sp. nov., a new bulky-faced pygmy sperm whale (Kogiidae) from the late Miocene of Peru". English. In: Journal of Vertebrate Paleontology (2020), e1728538. DOI: 10.1080/02724634.2019.1728538.

[1955] D. J. Bennett and M. S. Engel. "A New Moustache Wasp in Dominican Amber, with an Account of Apoid Wasp Evolution Emphasizing Crabroninae (Hymenoptera: Crabronidae)". English. In: American Museum Novitates 3529 (2006), pp. 1-10.

[1956] D. J. Bennett and M. S. Engel. "A primitive sapygid wasp in Burmese amber (Hymenoptera: Sapygidae)". English. In: Acta Zoologica Cracoviensia 48B (2005), pp. 1-9.

[1957] D. J. Bennett, V. Perrichot, and M. S. Engel. "A new genus and species of pemphredonine wasp in Late Cretaceous Vendean amber (Hymenoptera: Crabronidae)". English. In: Paleontological Contributions 10 (2014), pp. 41-45.

[1958] S. C. Bennett. "A review of the pterosaur Ctenochasma: taxonomy and ontogeny". English. In: Neues Jahrbuch für Geologie und Paläontologie, Abhandlungen 245 (2007), pp. 23-31. 
[1959] S. C. Bennett. "Taxonomy and systematics of the Late Cretaceous pterosaur Pteranodon (Pterosauria, Pterodactyloidea)". English. In: Occasional Papers of the Natural History Museum of the University of Kansas 169 (1994), pp. 1-70.

[1960] S. C. Bennett. "New crested specimens of the Late Cretaceous pterosaur Nyctosaurus". English. In: Palaeontologische Zeitschrift 77.1 (2003), pp. 61-75.

[1961] S. C. Bennett. "Morphology of the Late Cretaceous pterosaur Pteranodon and systematics of the Pterodactyloidea. University of Kansas". English. PhD thesis. 1991, pp. 1-680.

[1962] S. C. Bennett. "A new speicmen of the pterosaur Scaphognathus crassirostris, with comments on constraint of cervical vertebrae number in pterosaurs". English. In: Neues Jahrbuch für Geologie und Paläontologie - Abhandlungen 271.3 (2014), pp. 327-348.

[1963] S. C. Bennett. "Juvenile specimens of the pterosaur Germanodactylus cristatus, with a review of the genus". English. In: Journal of Vertebrate Paleontology 26.4 (2006), pp. 872-878.

[1964] S. C. Bennett and J. A. Long. "A large pterodactyloid pterosaur from the Late Cretaceous (Late Maastrichtian) of Western Australia". English. In: Records of the Western Australian Museum 15.2 (1991), pp. 435-443.

[1965] S. P. Bennett, P. M. Barrett, M. E. Collinson, S. Moore-Fay, P. G. Davis, and C. P. Palmer. “A new specimen of Ichthyosaurus communis from Dorset, UK, and its bearing on the stratigraphical range of the species". English. In: Proceedings of the Geologists' Association 123 (2012), pp. 146-154.

[1966] O. Bennike, K. B. Hansen, K. L. Knudsen, D. N. Penney, and K. L. Rasmussen. “Quaternary marine stratigraphy and geochronology in central West Greenland". English. In: Boreas 23 (1994), pp. 194215.

[1967] O. Bennike. “Quaternary vertebrates of Greenland: A review”. English. In: Quaternary Science Reviews 16.8 (1997), pp. 899-909.

[1968] O. Bennike. "An early Holocene Greenland whale from Melville Bugt, Greenland". English. In: Quaternary Research 69 (2008), pp. 72-76.

[1969] O. Bennike. "Late quaternary history of Washington land, North Greenland". English. In: Boreas 31 (2002), pp. 260-272.

[1970] O. Bennike. "Marine mammals in Peary Land, North Greenland". English. In: Polar Record 27.163 (1991), pp. 357-359.

[1971] O. Bennike, M. Goodsite, and J. Heinemeier. "Palaeoecology of Holocene peat deposits from Nordvestø, north-west Greenland". English. In: Journal of Paleolimnology 40 (2008), pp. 557-565. DOI: 10.1007/s10933-007-9181-3.

[1972] J. Benoit, S. Adnet, J. -L. Welcomme, and P. -H. Fabre. “New skull of Schizodelphis sulcatus Gervais, 1861 (Mammalia, Odontoceti, Eurhinodelphinidae) from the Lower Miocene of Pignan (Hérault, France) and its implications for systematics of Eurhinodelphinidae". English. In: Geobios 44.2011 (2011), pp. 323-334.

[1973] J. Benoit, S. Adnet, E. El Mabrouk, H. Khayati, M. Ben Haj Ali, L. Marivaux, G. Merzeraud, S. Merigeaud, M. Vianey-Liaud, and R. Tabuce. "Cranial remain from Tunisia provides new clues for the origin and evolution of Sirenia (Mammalia, Afrotheria) in Africa". English. In: PLoS One 8.1 (2013), e54307.

[1974] J. Benoit, P. R. Manger, V. Fernandez, and B. S. Rubidge. "Cranial Bosses of Choerosaurus dejageri (Therapsida, Therocephalia): Earliest Evidence of Cranial Display Structures in Eutheriodonts". English. In: PLOS 11.8 (2016), e0161457. DOI: 10.1371/journal.pone.0161457.

[1975] R. B. J. Benson. "New information on Stokesosaurus, a tyrannosauroid (Dinosauria: Theropoda) from North America and the United Kingdom". English. In: Journal of Vertebrate Paleontology 28.3 (2008), pp. 732-750. DOI: 10.1671/0272-4634(2008)28[732:NIOSAT]2.0.CO;2.

[1976] R. B. J. Benson and P. M. Barrett. “Dinosaurs of Dorset: part I, the carnivorous dinosaurs (Saurischia, Theropoda)". English. In: Proceedings of the Dorset Natural History and Archaeological Society 130 (2009), pp. 133-147. 
[1977] R. B. J. Benson and P. S. Druckenmiller. "Faunal turnover of marine tetrapods during the JurassicCretaceous transition". English. In: Biological Reviews 89.1 (2014), pp. 1-23. DOI: 10.1111/brv.12038.

[1978] R. B. J. Benson, M. Evans, and P. S. Druckenmiller. "High diversity, low disparity and small body size in plesiosaurs (Reptilia, Sauropterygia) from the Triassic-Jurassic boundary". English. In: PLoS ONE 7.3 (2012), e31838. DOI: 10.1371/journal.pone.0031838.

[1979] R. B. J. Benson, M. Evans, A. S. Smith, J. Sassoon, S. Moore-Faye, H. F. Ketchum, and R. Forrest. "A giant pliosaurid skull from the Late Jurassic of England". English. In: PLoS ONE 8.5 (2013), e65989. DOI: 10.1371/journal.pone.0065989.

[1980] R. B. J. Benson, E. M. G. Fitzgerald, T. H. Rich, and P. Vickers Rich. “Large freshwater plesiosaurian from the Cretaceous (Aptian) of Australia". English. In: Alcheringa (2013). DOI: 10.1080/03115518. 2013.772825.

[1981] R. B. J. Benson, H. F. Ketchum, L. F. Noe, and M. Gomez-Perez. "New information on Hauffiosaurus (Reptilia, Plesiosauria) based on a new species from the Alum Shale Member (Lower Toarcian: Lower Jurassic) of Yorkshire, UK". English. In: Palaeontology 54.3 (2011), pp. 547-571.

[1982] R. B. J. Benson, H. F. Ketchum, D. Naish, and L. E. Turner. “A new leptocleidid (Sauropterygia, Plesiosauria) from the Vectis Formation (Early Barremian-early Aptian; Early Cretaceous) of the Isle of Wight and the evolution of Leptocleididae, a controversial clade". English. In: Journal of Systematic Palaeontology 11.2 (2013), pp. 233-250. DOI: 10.1080/14772019.2011.634444.

[1983] R. B. J. Benson and J. D. Radley. "A new large-bodied theropod dinosaur from the Middle Jurassic of Warwickshire, United Kingdom". English. In: Acta Palaeontologica Polonica 55.1 (2010), pp. 3542. DOI: 10.4202 /app.2009.0083.

[1984] R. B. J. Benson, T. H. Rich, P. Vickers Rich, and M. Hall. “Theropod fauna from southern Australia indicates high polar diversity and climate-driven dinosaur provinciality". English. In: PLoS ONE 7.5 (2012), e37122. DOI: 10.1371/journal.pone.0037122.

[1985] R. B. J. Benson and X. Xing. "The anatomy and systematic position of the theropod dinosaur Chilantaisaurus tashuikouensis Hu, 1964 from the Early Cretaceous of Alanshan, People's Republic of China". English. In: Geological Magazine 145.6 (2008), pp. 778-789. DOI: 10.1017/S0016756808005475.

[1986] M. J. Benton. "The species of Rhynchosaurus, a rhynchosaur (Reptilia, Diapsida) from the Middle Triassic of England". English. In: Philosophical Transactions of the Royal Society of London, Series B 328 (1990), pp. 213-306.

[1987] M. J. Benton. "Late Triassic to Middle Jurassic extinctions among continental tetrapods: testing the pattern". English. In: In the shadow of the dinosaurs: early Mesozoic tetrapods. Cambridge University Press, 1997, pp. 366-397.

[1988] M. J. Benton, E. Cook, D. Grigorescu, E. Popa, and E. Tallódi. “Dinosaurs and other tetrapods in an Early Cretaceous bauxite-filled fissure, northwestern Romania". English. In: Palaeogeography, Palaeoclimatology, Palaeoecology 130 (1997), pp. 275-292.

[1989] M. J. Benton, E. Cook, and J. J. Hooker. Mesozoic and Tertiary Fossil Mammals and Birds of Great Britain. English. Vol. 32. Geological Conservation Review Series. Peterborough: Joint Nature Conservation Commitee, 2005, p. 215.

[1990] M. J. Benton and D. J. Gower. “Richard Owen's giant Triassic frogs: archosaurs from the Middle Triassic of England". English. In: Journal of Vertebrate Paleontology 17.1 (1997), pp. 74-88.

[1991] M. J. Benton, L. Juul, G. W. Storrs, and P. M. Galton. “Anatomy and systematics of the prosauropod dinosaur Thecodontosaurus antiquus from the upper Triassic of southwest England". English. In: Journal of Vertebrate Paleontology 20.1 (2000), pp. 77-108.

[1992] M. J. Benton, D. M. Martill, and M. A. Taylor. “The first Lower Jurassic dinosaur from Scotland: limb bone of a ceratosaur theropod from Skye". In: Scottish Journal of Geology 31.2 (1995), pp. 177182.

[1993] M. J. Benton and P. S. Spencer. English. Fossil Reptiles of Great Britain. Chapman \& Hall, London. 1995, pp. 1-386. 
[1994] M. J. Benton, G. Warrington, A. J. Newell, and P. S. Spencer. A review of the British Middle Triassic tetrapod assemblages. English. In N. C. Fraser \& H.-D. Sues (eds.), In the Shadow of the Dinosaurs: Early Mesozoic Tetrapods. Cambridge University Press, Cambridge. 1994, pp. 131-160.

[1995] M. J. Benton and R. Wild. "Localities in Baden-Württemberg that have yielded Late Triassic terrestrial tetrapod remains". English. In: Paleontologia Lombarda, Nuova Serie 2 (1994), pp. 35-38.

[1996] M. Benzaggagh, M. Oumhamed, B. Ferré, and J. L. Latil. “Turonian cephalopods (ammonoids and a nautiloid) from the Wadi Daya Formation of the Talerzha Basin (South Riffian Ridges Domain, northern Morocco)". English. In: Cretaceous Research 74 (2017), pp. 109-119.

[1997] A. Benzecry and S. D. Brack-Hanes. "A new hydrocharitacean seagrass from the Eocene of Florida". English. In: Botanical Journal of the Linnean Society 157 (2008), pp. 19-30.

[1998] S. Bera, S. Mitra, M. Banerjee, and J. Szwedo. "First discovery of the Coccoidea (Hemiptera: Sternorrhyncha) from the Siwalik sediments (Middle Miocene) of Darjeeling foothills, Eastern Himalaya, India". English. In: Polskie Pismo Entomologiczne 75 (2006), pp. 199-206.

[1999] M. S. Beresi. “Oxfordian sponge association from the Neuquen basin, Mendoza, west central Argentina". English. In: Journal of South American Earth Sciences 16.3 (2003), pp. 105-112.

[2000] M. S. Beresi. "Oxfordian sponge association from the Neuquen basin, Mendoza, west central Argentina". English. In: Journal of South American Earth Sciences 16 (2003), pp. 105-112. DOI: 10.1016/ S0895-9811(03)00047-6.

[2001] M. S. Beresi, O. L. Bordonaro, S. E. Heredia, A. Mestre, and B. A. Toro. “El Darriwiliense inferior (Ordovcico Medio) en el extremo norte de Mendoza, Argentina: implicaciones estratigráficas y bioestratigráficas. Boletn Geológico y Minero. 128 (1): 93-110". English. In: (2016).

[2002] M. S. Beresi, J. P. Botting, and E. N. K. Clarkson. "A new demosponge, Choiaella scotica, from the Caradoc (Ordovician) of Wallace's Cast, Southern Uplands". English. In: Scottish Journal of Geology 46 (2010), pp. 77-84. DOI: 10.1144/0036-9276/01-387.

[2003] M. S. Beresi, J. P. Botting, J. J. Palafox, and B. E. Buitron Sanchez. "New reticulosan sponges from the middle Cambrian of Sonora, Mexico". English. In: Acta Palaeontologica Polonica 62.4 (2017), pp. 691-703. DOI: 10.4202/app.00378.2017.

[2004] M. S. Beresi, N. G. Cabaleri, H. Löser, and C. Armella. "Coral patch reef system and associated facies from southwestern Gondwana: paleoenvironmental evolution of the Oxfordian shallowmarine carbonate platform at Portada Covunco, Neuquén Basin, Argentina". English. In: Facies 63.4 (2017).

[2005] M. S. Beresi and J. K. Rigby. "The Lower Ordovician sponges of San Juan, Argentina". English. In: Brigham Young University Geology Studies 39 (1993), pp. 1-63.

[2006] M. S. Beresi and J. K. Rigby. "Sponges and chancelloriids from the Cambrian of western Argentina". English. In: Journal of Paleontology 68.2 (1994), pp. 208-217.

[2007] A. Y. Berezin. "A new plesiosaur of the family Aristonectidae from the Early Cretaceous of the center of the Russian Platform". English. In: Paleontological Journal 45.6 (2011), pp. 648-660.

[2008] A. A. Berezovskiy. "New Eocene Species of Coralliophaga (Bivalvia) from Ukraine". In: Paleontological Journal 28.1 (1994), pp. 12-18.

[2009] A. Berezovsky. "A new genus of Carditidae (Bivalvia) from the Eocene of Ukraine". English. In: Paleontological Journal 33.4 (1999), pp. 350-353.

[2010] V. Berg-Madsen and J. S. Peel. "A tergomyan mollusc from the Upper Cambrian of Wales". English. In: Palaeontology 37.3 (1994), pp. 505-512.

[2011] L. R. Berger, D. J. de Ruiter, S. E. Churchill, P. Schmid, K. J. Carlson, P. H. G. M. Dirks, and J. M. Kibii. "Australopithecus sediba: a new species of Homo-like australopith from South Africa". English. In: Science 328 (2010), pp. 195-204.

[2012] R. E. Berglund and J. L. Goedert. "A new crab (Brachyura: Cancridae) from lower Miocene rocks of the Northwestern Olympic Peninsula, Washington". English. In: Journal of Paleontology 70.5 (1996), pp. 830-835. 
[2013] L. P. Bergqvist. "Postcranial skeleton of the Upper Paleocene (Itaboraian) Condylarthra (Mammalia) of Itabora Basin, Brazil". English. In: Mammalian Evolutionary Morphology. A Tribute to Frederick S. Szalay. Springer Netherlands, 2008, pp. 107-133. DOI: 10.1007/978-1-4020-6997-0_6.

[2014] L. P. Bergqvist, A. M. Ribeiro, and J. Bocquentin Villanueva. "Primata, Roedores e Litopternas do Mio/Plioceno da Amazonia Sul-Ocidental (Formacao Solimoes, Bacia do Acre), Brasil". English. In: Geologia Colombiana 23 (1998), pp. 19-29.

[2015] L. P. Bergqvist, S. R. Torres, and L.d.S. Avilla. "Short note on dinosaur osteoderms from the Adamantina Formation, Upper Cretaceous of São Paolo state, Brazil". English. In: Boletim do Museu Nacional, Nova Série 62 (2002), pp. 1-6.

[2016] J. Bergström, Z. Zhou, P. Ahlberg, and N. Axheimer. "Upper lower Cambrian (provisional Cambrian Series 2) trilobites from northwestern Gansu Province, China". English. In: Estonian Journal of Earth Sciences 63.3 (2014), pp. 123-143. DOI: 10.3176/earth.2014.12.

[2017] S. M. Bergström and J. Bergström. “The Ordovician-Silurian boundary successions in Östergötland and Västergötland, S. Sweden". English. In: Geologiska Föreningens i Stockholm Förhandlingar 118 (1996), pp. 25-42.

[2018] S. M. Bergström, S. C. Finney, X. Chen, C. Pålsson, Z. H. Wang, and Y. Grahn. “A proposed global boundary stratotype for the base of the Upper Series of the Ordovician System: The Fågelsång section, Scania, southern Sweden". English. In: Episodes 23.2 (2000), pp. 102-109.

[2019] B. Berkowski. "Monospecific rugosan assemblage from the Emsian hydrothermal vents of Morocco". English. In: Acta Palaeontologica Polonica 49.1 (2004), pp. 75-84.

[2020] B. Berkowski. "Vent and mound rugose coral associations from the Middle Devonian of Hamar Laghdad (Anti-Atlas, Morocco)". English. In: Geobios 39 (2006), pp. 155-170.

[2021] B. Berkowski. "Famennian Rugosa and Heterocorallia from southern Poland". English. In: Palaeontologia Polonica 61 (2002), pp. 1-87.

[2022] B. Berkowski. "New genus and species Wendticyathus nudus (Rugosa) and a short review of Emsian rugose corals from Hamar Laghdad, Morocco". English. In: Neues Jahrbuch für Geologie und Paläontologie - Abhandlungen 290.1-3 (2018), pp. 117-125. DOI: 10.1127/njgpa/2018/0770.

[2023] B. Berkowski and D. Weyer. "Hamaraxonia, a new pseudocolumellate genus of Middle Devonian deep-water Rugosa (Anthozoa) from Morocco". English. In: Geologica Belgica 15.4 (2012), pp. 245253.

[2024] B. Berkowski and M. K. Zapalski. "Large dwellers of the Silurian Halysites biostrome: rhizosessile life strategies of cystiphyllid rugose corals from the Llandovery of Gotland". English. In: Lethaia 51 (2018), pp. 581-595. DOI: 10.1111/let.12279.

[2025] D. S. Berman. "Lower Permian vertebrate localities of New Mexico and their assemblages". English. In: Vertebrate Paleontology of New Mexico. New Mexico Museum of Natural History and Science Bulletin 2. 1993, pp. 11-21.

[2026] D. S. Berman, A. C. Henrici, S. S. Sumida, and T. Martens. "Redescription of Seymouria sanjuanensis (Seymouriomorpha) from the Lower Permian of Germany based on complete, mature specimens with a discussion of paleoecology of Bromacker locality assemblage". English. In: Journal of Vertebrate Paleontology 20.2 (2000), pp. 253-268.

[2027] D. S. Berman, A. C. Henrici, R. A. Kissel, S. S. Sumida, and T. Martens. "A New Diadectid (Diadectomorpha), Orobates pabsti, from the Early Permian of Central Germany". English. In: Bulletin of Carnegie Museum of Natural History 35.1 (2004), pp. 1-36.

[2028] D. S. Berman, A. C. Henrici, T. Martens, S. S. Sumida, and J. S. Anderson. "Rotaryus gothae, a New Trematopid (Temnospondyli: Dissorophoidea) from the Lower Permian of Central Germany". English. In: Annals of Carnegie Museum 80.1 (2011), pp. 49-65. DOI: 10.2992/007.080.0106. 
[2029] D. S. Berman, A. C. Henrici, S. S. Sumida, T. Martens, and V. Pelletier. "First European record of a Varanodontine (Synapsida: Varanopidae): member of a unique Early Permian upland paleoecosystem, Tambach Basin, central Germany". English. In: Early Evolutionary History of the Synapsida. Dordrecht: Springer Science and Business Media, 2014, pp. 69-86. DOI: 10.1007/97894-007-6841-3_5.

[2030] D. S. Berman, A. C. Henrici, D. K. Brezinki, and A. D. Kollar. "A new trematopid amphibian (Temnospondyli: Dissorophoidea) from the Upper Pennsylvanian of western Pennsylvania:earliest record of terrestrial vertebrates responding to a warmer, dryer climate". English. In: Annals of Carnegie Museum 78 (2010), pp. 289-318.

[2031] D. S. Berman, H. C. Maddin, A. C. Henrici, S. S. Sumida, D. Scott, and R. R. Reisz. "New primitive caseid (Synapsida, Caseasauria) from the early Permian of Germany". English. In: Annals of Carnegie Museum 86.1 (2020), pp. 43-75.

[2032] D. S. Berman, R. R. Reisz, T. Martens, and A. C. Henrici. “A new species of Dimetrodon (Synapsida: Sphenacodontidae) from the Lower Permian of Germany records first occurrence of genus outside of North America". English. In: Canadian Journal of Earth Sciences 38.5 (2001), pp. 803-812.

[2033] D. S. Berman, R. R. Reisz, D. Scott, A. C. Henrici, S. S. Sumida, and T. Martens. "Early Permian Bipedal Reptile". English. In: Science 290 (2000), pp. 969-972.

[2034] D. S. Berman and R. R. Reisz. "Dolabrosaurus aquatilis, a small lepidosauromorph reptile from the Upper Triassic Chinle Formation of north-central New Mexico". English. In: Journal of Paleontology 66.6 (1992), pp. 1001-1009.

[2035] D. S. Berman, S. S. Sumida, and T. Martens. "Diadectes (Diadectomorpha: Diadectidae) from the Early Permian of Central Germany, with description of a new species". English. In: Annals of Carnegie Museum 67.1 (1998), pp. 53-93.

[2036] D. D. Bermúdez-Rochas. "New hybodont shark assemblage from the Early Cretaceous of the Basque-Cantabrian Basin". English. In: Geobios 42 (2009), pp. 675-686.

[2037] D. Bernal-Casasola. “Whale Hunting in the Strait of Gibraltar during the Roman Period?" English. In: SAA Archaeological Record 18.4 (2018), pp. 15-22.

[2038] D. Bernal-Casasola, A. Gardeisen, P. Morgenstern, L. Kolska Horwitz, G. Piqués, T. Theodoropoulou, and B. Wilkens. "Ancient whale exploitation in the Mediterranean: the archaeological record". English. In: Antiquity 90.352 (2016), pp. 914-927.

[2039] M. Bernardi, M. Avanzini, and F. Bizzarini. "Vertebrate fauna from the San Cassiano Formation (early Carnian) of the Dolomites region". English. In: Geo.Alp 8 (2011), pp. 122-127.

[2040] M. Bernardi, F. M. Petti, and M. Avanzini. "A webbed archosaur footprint from the Upper Triassic (Carnian) of the Italian southern Alps". English. In: vol. 51. Crocodyle Tracks and Traces. New Mexico Museum of Natural History and Science Bulletin. Albuquerque: New Mexico Museum of Natural History and Science, 2010, pp. 65-68.

[2041] M. P. Bernasconi, M. Cefala, and E. Perri. “Mid-latitude coralgal bioconstruction and endolithic microbialites: environmental significance during Quaternary climate variations". English. In: $F a-$ cies 61.4 (2015).

[2042] M. P. Bernasconi and E. Robba. "Notes on some Pliocene gastropods from Rio Torsero, Western Liguria, Italy". English. In: Rivista Italiana di Paleontologia e Stratigrafia 100.1 (1994), pp. 71-102.

[2043] M. P. Bernasconi and E. Robba. "Molluscan palaeoecology and sedimentological features: an integrated appraoch from the Miocene Meduna section, northern Italy". In: Palaeogeography, Palaeoclimatology, Palaeoecology 100 (1993), pp. 267-290.

[2044] M. Berndt and J. Welle. “Ahermatype Korallen aus dem Oberoligozän der Schächte Rheinberg und Sophia Jacoba 8 (Niederrheinische Bucht) [Ahermatypic corals from Upper Oligocene of the Rheinberg and Sophia Jacoba 8 wells (Lower Rhine Embayment)]". German. In: Neues Jahrbuch für Geologie und Paläontologie Abhandlungen 198.1/2 (1995), pp. 47-68. 
[2045] R. Berndt. “Cenomanian echinoids from Southern Jordan”. English. In: N. Jb. Geol. Palaont. Mh 2003.2 (2003), pp. 73-90.

[2046] R. Berndt. "Palaeoecology and taxonomy of the macrobenthic fauna from the Upper Cretaceous Ajlun Group, southern Jordan". English. PhD thesis. 2004.

[2047] M. Bernecker. "Upper Triassic reefs of the Oman Mountains: Data from the south Tethyan margin". In: Facies 34 (1996), pp. 41-76.

[2048] M. Bernecker. "Late Triassic reefs from the Northwest and South Tethys: distribution, setting, and biotic composition". English. In: Facies 51 (2005), pp. 442-453.

[2049] M. Bernecker, O. Weidlich, and E. Flügel. "Response of Triassic reef coral communities to sea-level fluctuations, storms and sedimentation: Evidence from a spectacular outcrop (Adnet, Austria)". In: Facies 40 (1999), pp. 229-280.

[2050] M. Bernecker and O. Weidlich. "The Danian (Paleocene) coral limestone of Fakse, Denmark: a model for ancient aphotic, azooxanthellate coral mounds". In: Facies 22 (1990), pp. 103-138.

[2051] M. Bernecker and O. Weidlich. "Azooxanthellate corals in the Late Maastrichtian - Early Paleocene of the Danish basin: bryozoan and coral mounds in a boreal shelf setting". English. In: Cold-water Corals and Ecosystems (2005), pp. 3-25.

[2052] B. Berning. "The cheilostome bryozoan fauna from the Late Miocene of Niebla (Guadalquivir Basin, SW Spain): environmental and biogeographic implications". English. In: Mitteilungen aus dem Geologisch-Paläontologischen Institut der Universität Hamburg 90 (2006), pp. 7-156.

[2053] B. Berning, P. Noissette, and C. Betzler. "Late Miocene Bryozoa from the Guadalquivir Basin (SW Spain): eastern Atlantic and western Mediterranean environment and biogeography". English. In: Bryozoan Studies 2004. Leiden: A.A. Balkema Publishers, 2005, pp. 15-24.

[2054] R. L. Bernor, L. Kordos, and L. Rook et al. "Recent Advances on Multidisciplinary Research at Rudabánya, Late Miocene (MN9), Hungary: a compendium”. English. In: Palaeontographia Italica 89 (2004), pp. 3-36.

[2055] D. Bernoulli, L. Hottinger, S. Spezzaferri, and P. Stille. "Miocene shallow-water limestones from Sao Nicolau (Cabo Verde): Caribbean-type benthic fauna and time constraints for volcanism". English. In: Swiss Journal of Geosciences 100 (2007), pp. 215-225.

[2056] D. Bernoulli, H. Weissert, and C. D. Blome. "Evolution of the Triassic Hawasina Basin, Central Oman Mountains". English. In: Geological Society Special Publications 49 (1990), pp. 189-202. DOI: 10.1144/GSL.SP.1992.049.01.12.

[2057] F. Berra and F. Jadoul. "Norian serpulid and microbial bioconstructions: implications for the platform evolution in the Lombardy Basin (Southern Alps, Italy)". English. In: Facies 35 (1996), pp. 143-162.

[2058] M. Berrocal-Casero, F. Barroso-Barcenilla, P. Callapez, F. Garca Joral, and M. Segura. “Bioestratigrafa de macrofósiles del Cenomaniense Superior-Turoniense Inferior en el área de Satamera y Riofro del Llano (Guadalajara, España)". Spanish. In: Revista de la Sociedad Geológica de España 26.2 (2013).

[2059] M. Berrocal-Casero, F. Barroso-Barcenilla, and F. Garca Joral. “Coniacian (Upper Cretaceous) rhynchonellides from Northern Spain: taxonomy and palaeobiogeography". English. In: Cretaceous Research 106.104216 (2020). DOI: 10.1016/j.cretres.2019.104216.

[2060] Á J. Berrocoso, B. T. Huber, K. G. MacLeod, M. R. Petrizzo, J. A. Lees, I. Wendler, H. Coxall, A. K. Mweneinda, F. Falzoni, H. Birch, J. M. Singano, S. Haynes, L. Cotton, J. Wendler, P. R. Bown, S. A. Robinson, and J. Gould. "Lithostratigraphy, biostratigraphy and chemostratigraphy of Upper Cretaceous and Paleogene sediments from southern Tanzania: Tanzania Drilling Project Sites 2735". English. In: Journal of African Earth Sciences 70 (2012), pp. 36-57. DOI: 10.1016/j.jafrearsci.2012. 05.006. 
[2061] Á J. Berrocoso, K. G. MacLeod, B. T. Huber, J. A. Lees, I. Wendler, P. R. Bown, A. K. Mweneinda, C. I. Londoño, and J. M. Singano. "Lithostratigraphy, biostratigraphy and chemostratigraphy of Upper Cretaceous sediments from southern Tanzania: Tanzania drilling project sites 21-26". English. In: Journal of African Earth Sciences 57 (2010), pp. 47-69. DOI: 10.1016/j.jafrearsci.2009.07.010.

[2062] C. M. Berry. "First record of the Devonian lycophyte Leclercquia from South America". In: Geology Magazine 131.2 (1994), pp. 269-272.

[2063] C. M. Berry and D. Edwards. "Anapaulia moodyi gen. et sp. nov.: a probable iridopteridalean compression fossil from the Devonian of western Venezuela". In: Review of Palaeobotany and Palynology 93 (1996), pp. 127-145.

[2064] C. M. Berry and D. Edwards. "The herbaceous lycophyte Haskinsia Grierson and Banks from the Devonian of western Venezuela, with observations on leaf morphology and fertile specimens". In: Botanical Journal of the Linnean Society 122 (1996), pp. 103-122.

[2065] C. M. Berry and D. Edwards. "A new species of the lycopsid Gilboaphyton Arnold from the Devonian of Venezuela and New York State, with a revision of the closely related genus Archaeosigillaria Kidston". In: Review of Palaeobotany and Palynology 96 (1997), pp. 47-70.

[2066] C. M. Berry, Y. Wang, and C. Cai. "A Lycopsid with Novel Reproductive Structures from the Upper Devonian of Jiangsu, China". English. In: International Journal of Plant Sciences 164.2 (2003), pp. 263-273.

[2067] C. M. Berry and W. E. Stein. "A New Iridopteridalean from the Devonian of Venezuela". In: International Journal of Plant Sciences 161 (2000), pp. 807-827.

[2068] S. Bersac and D. Bert. “Two ammonite species under the same name: Revision of Deshayesites deshayesi (d'Orbigny, 1841) based on topotype material (Lower Aptian, Lower Cretaceous, northeast of France)". English. In: Annales de Paléontologie 101 (2015), pp. 265-294.

[2069] D. Bert. “Etude de Paraspidoceras colloti Zeiss, 1962 (Aspidoceratidae Zittel, 1895, Ammonitina) au sommet de la sous-zone á Vertebrale (Oxfordien moyen, zone á Plicatilis) du Sud-Est de la France". French. In: Revue de Paléobiologie, Genéve 27 (2008), pp. 335-356.

[2070] D. Bert. "Etude de Protophites vannii sp. nov. (Ammonoidea), sous-zone á Cardioceras vertebrale, Oxfordien moyen, et evolution du genre Protophites Ebray, 1860". French. In: Riviéra Scientifique 87 (2003), pp. 69-84.

[2071] D. Bert. "Discussion, evolution and new interpretation of the Tornquistes Lemoine, 1910 (Pachyceratidae, Ammonitina) with the exemple [sic] of the Vertebrale Subzone sample (Middle Oxfordian) of southeastern France". English. In: Revue de Paléobiologie, Genéve 28 (2009), pp. 471-489.

[2072] D. Bert and A. Bonnot. "Étude paléobiologique d'une population d'Euaspidoceras davouxi sp. nov. (Aspidoceratidae Zittel 1895, Ammonitina) du sommet de la sous-zone á Vertebrale (Oxfordien moyen, zone á Plicatilis) dans le sud-est de la France". French. In: Revue de Paléobiologie, Genéve 23 (2004), pp. 81-98.

[2073] D. Bert and P. Courville. "First record of Late Callovian to Early Oxfordian heteromorph ammonites". English. In: Annales de Paléontologie 102 (2016), pp. 117-121.

[2074] D. Bert and R. Enay. “Les Gregoryceras (Ammonitina, Oxfordien moyen) de la Cluse de Chabriéres (sud-est de la France): étude paléobiologique et nouvelles interprétations". French. In: Revue de Paléobiologie, Genéve 23 (2004), pp. 441-461.

[2075] A. Berta. "Fossil carnivores from the Leisey Shell Pits, Hillsborough County, Florida". English. In: Bulletin of the Florida Museum of Natural History 37.14 (1995), pp. 463-499.

[2076] A. Berta. "New specimens of the pinnipediform Pteronarctos from the Miocene of Oregon". English. In: Smithsonian Contributions to Paleobiology 78 (1994), pp. 1-30.

[2077] A. Berta. "A new species of phocoid pinniped Pinnarctidion from the early Miocene of Oregon". English. In: Journal of Vertebrate Paleontology 14.3 (1994), pp. 405-413. 
[2078] A. Berta and M. Churchill. "Pinniped taxonomy: review of currently recognized species and subspecies, and evidence used for their description". English. In: Mammal Review 42.3 (2012), pp. 207234. DOI: $10.1111 /$ j.1365-2907.2011.00193.x.

[2079] A. Berta, S. Kienle, G. Bianucci, and S. Sorbi. "A reevaluation of Pliophoca etrusca (Pinnipedia, Phocidae) from the Pliocene of Italy: phylogenetic and biogeographic implications". English. In: Journal of Vertebrate Paleontology (2015), e889144. DOI: 10.1080/02724634.2014.889144.

[2080] S. Bertelli, L. M. Chiappe, and C. Tambussi. "A new phorusrhacid (Aves: Cariamae) from the Middle Miocene of Patagonia, Argentina". English. In: Journal of Vertebrate Paleontology 27.2 (2007), pp. 409-419.

[2081] S. Bertelli, L. M. Chiappe, and G. Mayr. "A new Messel rail from the Early Eocene Fur Formation of Denmark (Aves, Messelornithidae)". English. In: Journal of Systematic Palaeontology 9.4 (2011), pp. 551-562.

[2082] S. Bertelli, B. E. K. Lindow, G. J. Dyke, and L. M. Chiappe. "A wellpreserved 'charadriiformlike' fossil bird from the Early Eocene Fur Formation of Denmark". English. In: Palaeontology 53.3 (2010), pp. 507-531. DOI: 10.1111/j.1475-4983.2010.00950.x.

[2083] S. Bertelli, B. E. K. Lindow, G. J. Dyke, and G. Mayr. "Another charadriiform-like bird from the Lower Eocene of Denmark". English. In: Paleontological Journal 47.11 (2013), pp. 1282-1301. DOI: 10.1134/S0031030113110026.

[2084] M. Berthelin, J. Broutin, H. Kerp, S. Crasquin-Soleau, J. P. Platel, and J. Roger. "The Oman Gharif mixed paleoflora: A useful tool for testing Permian Pangea reconstructions". In: Palaeogeography, Palaeoclimatology, Palaeoecology 196 (2003), pp. 85-98.

[2085] A. Bertinelli, C. Nannarone, L. Passeri, and F. Venturi. "Hettangian Ammonites and Radiolarians in the Mt. Camica (Gran Sasso, Central Apennines)". English. In: Rivista Italiana di Paleontologia e Stratigrafia 110.1 (2003), pp. 87-95.

[2086] R. J. Bertini, R. M. Santucci, and A. C. Arruda-Campos. "Titanossauros (Sauropoda: Saurischia) no Cretáceo Superior continental (Formação Marlia, Membro Echaporã) de Monte Alto, Estado de São Paulo, e correlação com formas associadas do Triangulo Mineiro [Titanosaurs (Sauropoda: Saurischia) from the continental Upper Cretaceous (Marlia Formation, Echaporã Member) of Monte Alto, São Paulo state, and correlation with associated forms from Triangulo Mineiro]". English. In: Geosciencias 20.1 (2001), pp. 93-103.

[2087] M. Bertling and E. Insalaco. "Late Jurassic coral/microbial reefs from the northern Paris Basin facies, paleoecology and paleobiogeography". In: Palaeogeography, Palaeoclimatology, Palaeoecology 139 (1998), pp. 139-175.

[2088] R. Bertolani and D. Grimaldi. A new Eutardigrade (Tardigrada: Milnesiidae) in amber from the Upper Cretaceous (Turonian) of New Jersey. English. Studies on Fossils in Amber, with Particular Reference to the Cretaceous of New Jersey. Leiden: Backhuys Publishers, 2000, pp. 103-110.

[2089] L. Bertolaso, E. Borghi, and D. G. Ramos. "Brachiopodi neogenici e pleistocenici dell’Emilia (parte seconda)". Italian. In: Parva Naturalia 8 (2009), pp. 3-42.

[2090] M. Bertrand, E. Sidorchuk, and C. Hoffeins. "Before the summer turns to winter: the third labidostommatid genus from Baltic amber has subtropical kin". English. In: Acarologia 55 (2015), pp. 321336.

[2091] O. C. Bertrand, J. J. Flynn, D. A. Croft, and A. R. Wyss. “Two new taxa (Caviomorpha, Rodentia) from the Early Oligocene Tinguiririca fauna (Chile)". English. In: American Museum Novitates 3750 (2012), pp. 1-36. DOI: 10.1206/3750.2.

[2092] J. Bertrand-Sarfati and A. Moussine-Pouchkine. "First Ediacaran fauna found in Western Africa and evidence for an Early Cambrian glaciation". In: Geology 23.2 (1995), pp. 133-136.

[2093] C. Beschin, A. Bussulini, and G. Tessier. “Nuova segnalizione di crostacei associati a coralli nell’Eocene inferiore de Lessini orientali (Vestenanova - Verona)". Italian. In: Societá Veneziana di Scienze Naturali Lavori 40 (2015), pp. 47-109. 
[2094] C. Beschin, A. Busulini, A. De Angeli, and G. Tessier. "Aggiornamento ai crostacei di cava Main di Arzignano (Vicenza - Italia settentrionale) (Crustacea, Decapoda)". Italian. In: Studi e RicercheAssociazione Amici del Museo-Museo Civico G. Zannato, Montecchio Maggiore (Vicenza) (2002), pp. 728.

[2095] C. Beschin and A. Busulini. "The Eocene decapod crustacean fauna of the main quarry in Arzigano (Vicenz - NE Italy) with the description of a new species of Raninidae". English. In: Lavori-Societá Veneziana di Scienze Naturali 29 (2004), pp. 109-117.

[2096] C. Beschin, A. Busulini, G. Tessier, and R. Zorzin. "I crostacei associati a coralli nell'Eocene inferiore dell'area di Bolca (Verona e Vicenza, Italia nordorientale)". English. In: Memorie del Museo Civico di Storia Naturale di Verona - 2. serie, Sezione Scienze della Terra 9 (2016), pp. 1-189.

[2097] C. Beschin, A. Busulini, E. Fomaciari, C. A. Papazzoni, and G. Tessier. "La fauna di crostacei associati a coralli dell'Eocene Superiore di Campolongo di Val Liona (Monti Berici, Vicenz, Italia nordorientale)". English. In: Bolletino del Museo di Storia Naturale di Venezia 69 (2018), pp. 129-215.

[2098] C. Beschin, A. Busulini, A. de Angeli, and G. Tessier. "Retroplumoidea (Crustacea, Brachyura) nel Terziario del Vicentino (Italia Settentrionale)". English. In: Lavori-Societá Veneziana di Scienze Naturali 21 (1996), pp. 82-102.

[2099] C. Beschin, A. Busulini, A. de Angeli, G. tessier, and S. Ungaro. "Due nuovi generi di Raninidae dell'Eocene del Veneto (Italia)". English. In: Lavori-Societá Veneziana di Scienze Naturali 16 (1991), pp. 187-212.

[2100] C. Beschin, A. Busulini, A. de Angeli, and G. Tessier. "I crostacei Eocenici della Cava Boschetto di Nogarole Vicentino (VIcenza - Italia settentrionale". English. In: Lavori-Societá Veneziana di Scienze Naturali 19 (1994), pp. 159-215.

[2101] C. Beschin, A. Busulini, A. de Angeli, and G. Tessier. "Eopalicus nuovo genre di brachiuro (Decapoda) del Terziario Veneto (Italia settentrionale)". English. In: Lavori-Societá Veneziana di Scienze Naturali 21 (1996), pp. 75-82.

[2102] C. Beschin, A. Busulini, and G. Tessier. "The decapod crustacean from the Upper Eocene of Parona (Veronese Lessini - NE Italy)". English. In: Studi e Ricerche-Associazione Amici del Museo-Museo Civico G. Zannato, Montecchio Maggiore (Vicenza) 16 (2009), pp. 5-22.

[2103] C. Beschin, A. Busulini, and G. Tessier. "Crostacei decapodi dell'Eocene medio (Bartoniano) di Soave (Verona - Italia nordorientale)". English. In: Studi e Ricerche-Associazione Amici del MuseoMuseo Civico G. Zannato, Montecchio Maggiore (Vicenza) 17 (2010), pp. 11-28.

[2104] C. Beschin, A. De Angeli, and A. Checchi. "Crostacei decapodi associate a coralli della Formazione di Castelgomberto (Oligocene) (Vicenza-Italia Settentrionale)". Italian. In: Studie Ricerche-Associazione Amici del Museo-Museo Civico G. Zannato, Montecchio Maggiore (Vicenza) (2001), pp. 13-30.

[2105] C. Beschin, A. De Angeli, and R. Zorzin. "Crostacei fossili del Veneto: una inedita fauna eocenica dei Lessini orientali (Monte Serea di San Giovanni Ilarione, Verona), con descrizione di tre nuove specie". Italian. In: Bollettino del Museo civico di Storia naturale di Verona 33 (2009), pp. 59-83.

[2106] C. Beschin and A. de Angeli. "Nuovi brachiuri Eocenici dei Monti Lessini vicentini (Italia Nordorientale)". English. In: Studi e Ricerche - Associazione Amici del Museo - Museo Civico G. Zannato Montecchio Maggiore (Vicenza) 11 (2004), pp. 13-22.

[2107] C. Beschin, A. De Angeli, A. Checchi, and G. Zarantonello. “Crostacei decapodi del Tufo A Lophoranina (Luteziano inferiore) dalla valle del Chiampo (Vincenza-Italia Nordorientale)". English. In: Collaboratori del Museo Civico G. Zannato 15 (2016), pp. 1-75.

[2108] C. Beschin and A. de Angeli. "Crostacei decapodi del Veneto occidentale (Vicenza, Italia Settentrionale)". English. In: Studi e Ricerche - Associazione Amici del Museo - Museo Civico G. Zannato Montecchio Maggiore (Vicenza) 19 (2012), pp. 5-14.

[2109] C. Beschin, A. De Angeli, and R. Zorzin. "Il genere Lophoranina Fabiani, 1910 (Crustacea, Decapoda, Brachyura, Raninidae) nel Terziario dei Lessini veronesi (Italia settentrionale)". English. In: Bollettino del Museo Civico di Storia Naturale di Verona 35 (2011), pp. 33-56. 
[2110] C. Beschin, A. De Angeli, A. Checchi, and G. Zarantonello. “Crostacei del Giacimento Eocenico di Grola Presso Spangnago di Cornedo Vincentino (Vincenza, Italia Settentrionale) Decapoda, Stomatopoda, Isopoda". English. In: Montecchio Maggiore (Museo di Archeologia e Scienze Naturali G. Zannato (2012), pp. 1-99.

[2111] M. Bessedik, C. Mammeri, L. Belkebir, M. Mahboubi, M. Adaci, H. Hebib, M. Bensalah, B. Mansour, and M. E. H. Mansouri. “Nouvelles données sur les ichnites de dinosaures de la region d'El Bayadh (Crétacé Inferieur, Algérie) [New data on the dinosaur tracks of the El Bayadh region (Lower Cretaceous, Algeria)]". English. In: Palaeovertebrata 30.1-4 (2008), pp. 7-35.

[2112] O. Béthoux. "Reassigned and new basal Archaeorthoptera from the Upper Carboniferous of Mazon Creek (IL, USA)". English. In: Journal of Orthoptera Research 14.2 (2005), pp. 121-126.

[2113] O. Béthoux. “The earliest beetle identified". English. In: Journal of Paleontology 83 (2009), pp. 931937.

[2114] O. Béthoux. "Head and leg morphology of elongata Brongniart, 1893: 433 (Late Carboniferous, Archaeorthoptera): phylogenetic and palaeoecological implications". English. In: Annales Zoologici 59 (2009), pp. 141-147.

[2115] O. Béthoux, R. G. Beattie, and A. Nel. "Wing venation and relationships of the order Glosselytrodea (Insecta)". English. In: Alcheringa 31 (2007), pp. 285-296.

[2116] O. Béthoux and R. G. Beattie. "Iverya averyi gen. nov. and sp. nov., a New Triadotypomorphan Species from the Middle Triassic at Picton, New South Wales, Australia". English. In: Acta Geologica Sinica 84.4 (2010), pp. 688-692. DOI: 10.1111/j.1755-6724.2010.00240.x.

[2117] O. Béthoux, R. J. Beckemeyer, M. S. Engel, and J. D. Hall. “New data on Homocladus grandis, a Permian Stem-Mantodean (Polyneoptera: Dictyoptera)". English. In: Journal of Paleontology 84.4 (2010), pp. 746-753.

[2118] O. Béthoux, Y. Cui, B. Kondratieff, B. Stark, and D. Ren. "At last, a Pennsylvanian stem-stonefly (Plecoptera) discovered". English. In: BMC Evolutionary Biology 11.248 (2011), pp. 1-12. DOI: 10. 1186/1471-2148-11-248.

[2119] O. Béthoux, R. De la Horra, M. I. Benito, J. F. Barrenechea, A. B. Galán, and J. López-Gómez. “A new triadotypomorphan insect from the Anisian (Middle Triassic) Buntsandstein facies, Spain". English. In: Journal of Iberian Geology 35.2 (2009), pp. 179-184.

[2120] O. Béthoux and C. Grossmann. "Sumixam maximus gen. and sp. nov., a new Pennsylvanian species of Archaeorthoptera (Neoptera; Indiana, USA)". English. In: Acta Geologica Sinica 85.3 (2011), pp. 515-520.

[2121] O. Béthoux, J. J. Gu, Y. L. Yue, and D. Ren. "Miamia maimai n. sp., a new Pennsylvanian stemorthopteran insect, and a case study on the application of cladotypic nomenclature". English. In: Fossil Record 15 (2012), pp. 103-113.

[2122] O. Béthoux, J. J. Gu, and D. Ren. "A new Upper Carboniferous stem-orthopteran (Insecta) from Ningxia (China)". English. In: Insect Science 19 (2012), pp. 153-158.

[2123] O. Béthoux and K. J. Herd. "Discovery of an enigmatic and gigantic Pennsylvanian Archaeorthoptera". English. In: Journal of Orthoptera Research 18.1 (2009), pp. 23-28.

[2124] O. Bethoux and J. Kukalová-Peck. Royal Ontario Museum - Species List. English. 2011.

[2125] O. Béthoux, A. Nel, and J. Lapeyrie. "The extinct order Caloneurodea (Insecta: Pterygota: Panorthoptera): Wing venation, systematic and phylogenetic relationships". English. In: Annales Zoologici 54 (2004), pp. 289-318.

[2126] O. Béthoux, A. Nel, J. Lapeyrie, and G. Gand. “New data on Paleozoic grylloblattid insects (Neoptera)". English. In: Journal of Paleontology 79 (2005), pp. 125-138.

[2127] O. Béthoux, A. Nel, G. Gand, and J. Lapeyrie. "Surijoka lutevensis nov. sp.: The first Glosselytrodea (Insecta) from the Upper Permian of France (Lodeve Basin)". English. In: Geobios 34.4 (2001), pp. 405-413. 
[2128] O. Béthoux and A. Nel. “Description of a new grylloblattidan insect from Montceau-les-Mines (Late Carboniferous; France) and definition of Phenopterum Carpenter, 1950". English. In: Systematic Entomology 35 (2010), pp. 546-553.

[2129] O. Béthoux and A. Nel. "New data on Tcholmanvissiidae (Orthoptera; Permian)". English. In: Journal of Orthoptera Research 11.2 (2002), pp. 223-235.

[2130] O. Béthoux, A. Nel, J. Lapeyrie, G. Gand, and J. Galtier. “Raphogla rubra gen. n. sp. n. the oldest representative of the clade of modern Ensifera (Orthoptera: Tettigoniidea, Gryllidea)". English. In: European Journal of Entomology 99 (2002), pp. 111-116.

[2131] O. Béthoux, A. Nel, G. Gand, J. Lapeyrie, and J. Galtier. “Discovery of the genus Iasvia Zalessky, 1934 in the Upper Permian of France (Lodéve basin) (Orthoptera, Ensifera, Oedischiidae)". English. In: Geobios 35 (2002), pp. 293-302.

[2132] O. Béthoux, A. Nel, J. Lapeyrie, and G. Gand. “The Permostridulidae fam. n. (Panorthoptera), a new enigmatic insect family from the Upper Permian of France". English. In: European Journal of Entomology 100 (2003), pp. 581-585.

[2133] O. Béthoux, A. Nel, J. Lapeyrie, G. Gand, and J. Galtier. “New Martynoviidae from the Permian of Southern France (Lodéve basin) (Insecta: Palaeoptera: Diaphanopterodea)". English. In: Geobios 36 (2003), pp. 131-139.

[2134] O. Béthoux, A. Nel, J. Galtier, J. Lapeyrie, and G. Gand. "A new species of Tococladidae Carpenter, 1966 from the Permian of France (Insecta: Archaeorthoptera)". English. In: Geobios 36 (2003), pp. 275-283.

[2135] O. Béthoux, A. Nel, J. W. Schneider, and G. Gand. “Lodetiella magnifica nov. gen. and nov. sp. (Insecta: Palaeodictyoptera; Permian), an extreme situation in wing morphology of palaeopterous insects". English. In: Geobios 40 (2007), pp. 181-189.

[2136] O. Béthoux and A. Nel. "Some Palaeozoic Protorthoptera are ancestral Orthopteroides: major wing braces as clues to a new split among the Protorthoptera (Insecta)". English. In: Journal of Systematic Palaeontology 2 (2005), pp. 285-309.

[2137] O. Béthoux and A. Nel. "Venation pattern and revision of Orthoptera sensu nov. and sister". English. In: Zootaxa 96 (2002), pp. 1-88.

[2138] O. Béthoux and M. Poschmann. "A New Lobeattid from the Permo-Carboniferous of Niedermoschel, Southwestern Germany (Archaeorthoptera)". English. In: Journal of Orthoptera Research 18.2 (2009), pp. 139-143.

[2139] O. Béthoux, S. Voigt, and J. W. Schneider. "A Triassic palaeodictyopteran from Kyrgyzstan". English. In: Palaeodiversity 3 (2010), pp. 9-13.

[2140] M. Betts, T. P. Topper, J. L. Valentine, C. B. Skovsted, J. R. Paterson, and G. A. Brock. “A new early Cambrian bradoriid (Arthropoda) assemblage from the northern Flinders Ranges, South Australia". English. In: Gondwana Research 25.1 (2014), pp. 420-437.

[2141] A. G. Beu. "Marine Mollusca of oxygen isotope stages of the last 2 million years in New Zealand. Part 2. Biostratigraphically useful and new Pliocene to Recent bivalves". English. In: Journal of the Royal Society of New Zealand 36.4 (2006), pp. 151-338.

[2142] A. G. Beu. "Neogene fossil tonnoidean gastropods of Indonesia". English. In: Scripta Geologica 130 (2005), pp. 1-186.

[2143] A. G. Beu. "The Inoceramus limpet Gigantocapulus problematicus (Nagao and Otatume, 1938) in New Zealand (Late Cretaceous Gastropoda or Monoplacophora, Gigantocapulidae n. fam.)" English. In: Palaeontologische Zeitschrift 81.3 (2007), pp. 267-282.

[2144] A. G. Beu. "Neogene Tonnoidean Gastropods of Tropical and South America; contributions to the Dominican Republic and Panama Paleontology Projects and Uplift of the Central American Isthmus". English. In: Bulletins of American Paleontology 377-378 (2010), pp. 1-550. 
[2145] A. G. Beu. "Marine Mollusca of oxygen isotope stages of the last 2 million years in New Zealand. Part 1: Revised generic positions and recognition of warm-water and cool-water migrants". English. In: Journal of the Royal Society of New Zealand 34.2 (2004), pp. 111-265.

[2146] A. G. Beu and T. A. Darragh. "Revision of southern Australian Cenozoic fossil Pectinidae (Mollusca: Bivalvia)". English. In: Proceedings of the Royal Sociey of Victoria 113.1 (2001), pp. 1-205.

[2147] A. G. Beu and B. A. Marshall. "New Cenozoic records of genera and families from New Zealand (Mollusca, Gastropoda): highlights from Phillip Maxwell's collection". English. In: New Zealand Journal of Geology and Geophysics 54.1 (2011), pp. 13-34.

[2148] A. G. Beu, P. A. Maxwell, and R. C. Brazier. "Cenozoic Mollusca of New Zealand". In: New Zealand Geological Survey Paleontological Bulletin 58 (1990).

[2149] L. Beuck, M. Wisshak, A. Munnecke, and A. Freiwald. "A giant boring in a Silurian stromatoporoid analysed by computer tomography". English. In: Acta Palaeontologica Polonica 53.1 (2008), pp. 149-160.

[2150] R. G. Beutel, Z. H. Liu, M. Fikáek, D. Ren, H. Pang, and A. lipiski. “Burmapseudomorphus planus gen. et sp. nov. - a Late Cretaceous stem group member of the specialized Pseudomorphini (Carabidae, Coleoptera) from northern Myanmar". English. In: Cretaceous Research 107.104274 (2020). DOI: $10.1016 /$ j.cretres.2019.104274.

[2151] R. G. Beutel, J. Prokop, P. Müller, and H. Pohl. "+Bittacopsocus - a new bizarre genus of +Permopsocida (Insecta) from Burmese Cretaceous amber". English. In: Zootaxa 4576 (2019), pp. 357366.

[2152] G. S. Bever. “New record of Bassariscus ogallalae (Carnivora: Procyonidae) from the Ogallala Group (Miocene) of Ellis County, Kansas, with comments on variation within Bassariscus". English. In: Southwestern Naturalist 48.2 (2003), pp. 249-256.

[2153] G. S. Bever and M. A. Norell. "The perinate skull of Byronosaurus (Troodontidae) with observations on the cranial ontogeny of paravian theropods". English. In: American Museum Novitates 3657 (2009), pp. 1-51.

[2154] G. S. Bever and M. A. Norell. "A new rhynchocephalian (Reptilia: Lepidosauria) from the Late Jurassic of Solnhofen (Germany) and the origin of the marine Pleurosauridae". English. In: Royal Society Open Science 4 (2017), p. 170570. DOI: 10.1098/rsos.170570.

[2155] G. S. Bever and R. J. Zakrzewski. "A New Species of the Miocene Leptarctine Leptarctus (Carnivora: Mustelidae) From the Early Hemphillian of Kansas". English. In: Papers on Geology, Vertebrate Paleontology, and Biostratigraphy in Honor of Michael O. Woodburne (Museum of Northern Arizona Bulletin 65). Flagstaff, AZ: University of Northern Arizona, 2009, pp. 465-481.

[2156] F. I. Bezerra, M. Mendes, and O. De Souza. "New record of Mastotermitidae from Fonseca Basin, Eocene-Oligocene boundary of southeastern Brazil". English. In: Biologia 75 (2020), pp. 1881-1890. DOI: $10.2478 /$ s11756-020-00441-x.

[2157] P. A. Beznosov, J. A. Clack, E. Lukevis, M. Ruta, and P. E. Ahlberg. "Morphology of the earliest reconstructable tetrapod Parmastega aelidae". English. In: Nature 574 (2019), pp. 527-531. DOI: 10.1038/s41586-019-1636-y.

[2158] T. M. Beznosova. "Silurian brachiopods in the Timan - Northern Ural region: zonation and palaeoecology". English. In: Proceedings of the Estonian Academy of Sciences, Geology 49.2 (2000), pp. 126146.

[2159] K. M. Bezusko. "Biotic Interaction Versus Abiotic Response as Mediators of Biodiversity in the Middle Devonian (Givetian) Upper Hamilton Group of New York State". PhD thesis. 2001, pp. 1122.

[2160] A. Bhandari, R. F. Kay, B. A. Williams, B. N. Tiwari, S. Bajpai, and T. Hieronymus. "First record of the Miocene hominoid Sivapithecus from Kutch, Gujarat state, western India". English. In: PLoS ONE 13.e0206314 (2018), pp. 1-20. DOI: 10.1371/journal.pone.0206314. 
[2161] S. Bi, R. Amiot, C. Peyre de Fabrégues, M. Pittman, M. C. Lamanna, Y. Yu, C. Yu, T. Yang, S. Zhang, Q. Zhao, and X. Xu. "An oviraptorid preserved atop an embryo-bearing egg clutch sheds light on". English. In: Science Bulletin (2020). DOI: 10.1016/j.scib.2020.12.018.

[2162] S. Bi, X. Jin, S. Li, and T. Du. "A new Cretaceous metatherian mammal from Henan, China". English. In: PeerJ 3 (2015), e896. DOI: 10.7717/peerj.896.

[2163] S. Bi, J. Meng, S. McLean, W. Wu, X. Ni, and J. Ye. "A New Genus of Aplodontid Rodent (Mammalia, Rodentia) from the Late Oligocene of Northern Junggar Basin, China". English. In: PLoS ONE 8.1 (2013), e52625:1-8.

[2164] S. Bi, Y. Wang, J. Guan, Z. Sheng, and J. Meng. "Three new Jurassic euharamiyidan species reinforce early divergence of mammals". English. In: Nature 514 (2014), pp. 579-584.

[2165] S. Bi, X. Zheng, J. Meng, X. Wang, N. Robinson, and B. Davis. "A new symmetrodont mammal (Trechnotheria: Zhangheotheriidae) from the Early Cretaceous of China and trechnotherian character evolution". English. In: Scientific Reports 6 (2016), 26668:1-9. DOI: 10.1038/srep26668.

[2166] S. Bi, X. Zheng, X. Wang, N. E. Cignetti, S. Yang, and J. R. Wible. "An Early Cretaceous eutherian and the placental-marsupial dichotomy". English. In: Nature 558 (2018), pp. 390-395. DOI: 10. 1038/s41586-018-0210-3.

[2167] A. S. Biakov. "Permian Inoceramus-like mollusks of the genus Intomodesma Popov". English. In: Paleontological Journal 25.4 (1991), pp. 159-164.

[2168] A. S. Biakov. "New ideas on the system of the Permian Inoceramus-like bivalves of the eastern Boreal Zone". English. In: Paleontological Journal 42.3 (2008), pp. 232-242.

[2169] A. S. Biakov. "Permian ctenodont bivalves from northeastern Russia". English. In: Paleontological Journal 32.2 (1998), pp. 129-132.

[2170] A. S. Biakov. "New species of astartids and pholadomyids (Bivalvia) and beds with fauna from the Lower Permian of the Omolon Massif, northeastern Asia". English. In: Paleontological Journal 39.2 (2005), pp. 133-140.

[2171] A. S. Biakov. "Permian biostratigraphy of the northern Okhotsk region (northeast Asia)". English. In: Stratigraphy and Geological Correlation 15.2 (2007), pp. 161-184.

[2172] A. S. Biakov. "Permian bivalves from the Transbaikal Region". English. In: Paleontological Journal 36.5 (2002), pp. 460-468.

[2173] A. S. Biakov. "Two new zonal species of inoceram-like bivalves from the Upper Permian of northeastern Asia". English. In: Paleontological Journal 33 (1999), pp. 229-231.

[2174] A. S. Biakov. "Complete succession of the Permian in northeast Asia: paleontological evidence form the presence of Changhsingian analogues". English. In: Doklady Earth Sciences 378 (2001), pp. 399-401.

[2175] A. S. Biakov. "New species of Inoceramus-like bivalves of the genus Aphanaia Koninck from the Lower Permian of northeast Asia". English. In: Paleontological Journal 45 (2011), pp. 5-12.

[2176] A. S. Biakov. "New Inoceramus-like bivalves of the genus Kolymia Licharew from the Middle Permian of northeast Asia". English. In: Paleontological Journal 46 (2012), pp. 552-559.

[2177] A. S. Biakov. "New Permian Pteronites (Bivalvia, Pinnidae) from the Lower Permian of the Omolon Massif, northeastern Asia". English. In: Paleontological Journal 47 (2013), pp. 363-365.

[2178] A. S. Biakov. "New species of the Inoceramus-like bivalve genus Maitaia Marwick from the Permian of northeastern Asia". English. In: Paleontological Journal 47 (2013), pp. 463-469.

[2179] A. S. Biakov. "New Inoceramus-like bivalves of the genus Praekolymia Biakov from the Lower Permian of the western Verkhoyansk region, northeastern Asia". English. In: Paleontological Journal 48 (2014), pp. 571-574.

[2180] A. S. Biakov. "New records of bipolar nuculanid bivalves of the genus Glyptoleda in the Permian of northeastern Asia". English. In: Paleontological Journal 50 (2016), pp. 573-577. 
[2181] A. S. Biakov. "New species of Inoceramus-like bivalves of the subfamily Kolymiinae from the Middle Permian of northeastern Asia". English. In: Paleontological Journal 52 (2018), pp. 1-8.

[2182] A. S. Biakov. "Bivalves of northeast Asia at the Carboniferous-Permian transition". English. In: Paleontological Journal 53 (2019), pp. 241-251. DOI: 10.1134/S0031030119030055.

[2183] A. S. Biakov and R. V. Kutygin. "A new most ancient Permian Inoceramus-like bivalve of the genus Aphanaia Koninck from northeastern Asia". English. In: Paleontological Journal 49 (2015), pp. 356-360.

[2184] A. S. Biakov and R. V. Kutygin. "Bivalves from the Delendzhian-Dulgalakhian boundary beds of the Middle Permian of the lower reaches of the Lena River (Northern Verkhoyansk region, Northern Siberia)". English. In: Paleontological Journal 52 (2018), pp. 761-767.

[2185] A. S. Biakov, R. V. Kutygin, N. A. Goryachev, S. S. Burnatny, A. N. Naumov, A. V. Yadrenkin, I. L. Vedernikov, M. F. Tretyakov, and I. V. Brynko. "Discovery of the Late Changhsingian Bivalve Complex and Two Fauna Extinction Episodes in Northeastern Asia at the End of the Permian". English. In: Doklady Biological Sciences 480 (2018), pp. 78-81. DOI: 10.1134/S0012496618030018.

[2186] A. S. Biakov and R. V. Kutygin. "New find of Inoceramus-like bivalves of the genus Atomodesma in the southern Verkhoyansk region, and invasions of extra-boreal mollusks into northeastern Asia during the Permian". English. In: Paleontological Journal 54 (2020), pp. 459-463. DOI: 10.1134/ S0031030120050032.

[2187] A. S. Biakov, I. L. Vedernikov, Y. Y. Ivanov, and E. V. Kolesov. "New data on Permian bivalves and the age of the volcanogenic beds". English. In: Paleontological Journal 52 (2018), pp. 755-760.

[2188] G. Bianucci. “The Odontoceti (Mammalia, Cetacea) from Italian Pliocene. The Ziphiidae.” English. In: Palaeontographica Italica 84 (1997), pp. 163-192.

[2189] G. Bianucci. "The Odontoceti (Mammalia, Cetacea) from Italian Pliocene systematics and phylogenesis of Delphinidae". English. In: Palaeontologrphia Italia 83 (1996), pp. 73-167.

[2190] G. Bianucci. "A new record of baleen whale from the Pliocene of Tuscany (Italy)". In: Atti della Societá toscana di scienze naturali residente in Pisa. Serie A : memorie. 102 (1995), pp. 101-104.

[2191] G. Bianucci. "Hemisyntrachelus cortesii (Cetacea, Delphinidae) from the Pliocene sediments of Campore Quarry (Salsomaggiore Terme, Italy)". English. In: Buollettino della Societa Paleontologica Italiana 36.1-2 (1997), pp. 75-83.

[2192] G. Bianucci. "I cetaci fossili del Museo di Storia Naturale dell'Universita di Pisa". Italian. In: Atta della Societa Toscana di Scienze Naturali Memoire Serie A 103 (1996), pp. 63-68.

[2193] G. Bianucci. "Arimidelphis sorbinii a new small killer whale-like dolphin from the Pliocene of Marecchia River (Central eastern Italy) and a phylogenetic analysis of the Orcininae (Cetacea: Odontoceti)". English. In: Rivista Italiana di Paleontologia e Stratigrafia 111.2 (2005), pp. 329-344.

[2194] G. Bianucci. "Septidelphis morii, n. gen. et sp., from the Pliocene of Italy: new evidence of the explosive radiation of true dolphins (Odontoceti, Delphinidae)". English. In: Journal of Vertebrate Paleontology 33.3 (2013), pp. 722-749. DOI: 10.1080/02724634.2013.744757.

[2195] G. Bianucci, O. Lambert, R. Salas-Gismondi, J. Tejada, F. Pujos, M. Urbina, and P. -O. Antoine. "A Miocene relative of the Ganges River dolphin (Odontoceti, Platanistidae) from the Amazonian Basin". English. In: Journal of Vertebrate Paleontology 33.3 (2013), pp. 741-745.

[2196] G. Bianucci, G. Bosio, E. Malinverno, C. de Muizon, I. M. Villa, M. Urbina, and O. Lambert. "A new large squalodelphinid (Cetacea, Odontoceti) from Peru sheds light on the Early Miocene platanistoid disparity and ecology". English. In: Royal Society Open Science 5.4 (2018), p. 172302. DOI: $10.1098 /$ rsos.172302.

[2197] G. Bianucci, G. Carone, D. P. Domning, W. Landini, L. Rook, and S. Sorbi. "Peri-Messinian Dwarfing in Mediterranean Metaxytherium (Mammalia: Sirenia): Evidence of Habitat Degradation Related to the Messinian Salinity Crisis". English. In: Garyounis Scientific Bulletin 5 (2008), pp. 145157. 
[2198] G. Bianucci, C. de Muizon, M. Urbina, and O. Lambert. "Extensive diversity and disparity of the early Miocene platanistoids (Cetacea, Odontoceti) in the Southeastern Pacific (Chilcatay Formation, Peru)". English. In: Life 10.27 (2020), pp. 1-62. DOI: 10.3390/life10030027.

[2199] G. Bianucci, C. Di Celma, W. Landini, and J. Buckeridge. "Palaeoecology and taphonomy of an extraordinary whale barnacle accumulation from the Plio-Pleistocene of Ecuador". English. In: Palaeogeography, Palaeoclimatology, Palaeoecology 242 (2006), pp. 326-342.

[2200] G. Bianucci, C. Di Celma, M. Urbina, and O. Lambert. “New beaked whales from the late Miocene of Peru and evidence for convergent evolution in stem and crown Ziphiidae (Cetacea, Odontoceti)". English. In: PeerJ 4 (2016), e2479. DOI: 10.7717/peerj.2479.

[2201] G. Bianucci, C. Doi Celma, W. Landini, K. Post, C. Tinelli, C. de Muizon, K. Gariboldi, E. Malinverno, G. Cantalamessa, A. Gioncada, A. Collareta, R. Salas-Gismondi, R. M. Varas-Malca, M. Urbina, and O. Lambert. "Distribution of fossil marine vertebrates in Cerro Colorado, the type locality of the giant raptorial sperm whale Livyatan melvillei (Miocene, Pisco Formation, Peru)". English. In: Journal of Maps 12.3 (2016), pp. 543-557. DOI: 10.1080/17445647.2015.1048315.

[2202] G. Bianucci, M. Gatt, R. Catanzariti, S. Sorbi, C. G. Bonavia, R. Curmi, and A. Varola. "Systematics, biostratigraphy and evolutionary pattern of the Oligo-Miocene marine mammals from the Maltese Islands". English. In: Geobios 44 (2011), pp. 549-585.

[2203] G. Bianucci and P. D. Gingerich. “Aegyptocetus tarfa, n. gen. et sp. (Mammalia, Cetacea), from the middle Eocene of Egypt: clinorhynchy, olfaction, and hearing in a protocetid whale". English. In: Journal of Vertebrate Paleontology 31.6 (2011), pp. 1173-1188.

[2204] G. Bianucci, O. Lambert, and K. Post. "A high diversity in fossil beaked whales (Mammalia, Odontoceti, Ziphiidae) recovered by trawling from the sea floor off South Africa". English. In: Geodiversitas 29.4 (2007), pp. 561-618.

[2205] G. Bianucci, O. Lambert, and K. Post. "High concentration of long-snouted beaked whales (Genus Messapicetus) from the Miocene of Peru". English. In: Palaeontology 53.5 (2010), pp. 1077-1098.

[2206] G. Bianucci, W. Landini, and A. Varola. "Messapicetus longirostris, a new genus and species of Ziphiidae (Cetacea) from the late Miocene of Pietra leccese (Apulia, Italy)". English. In: Bollettino della Societa Paleontologica Italiana 31.2 (1992), pp. 261-264.

[2207] G. Bianucci and W. Landini. "A new short-rostrum odontocete (Mammalia: Cetacea) from the middle Miocene of the eastern Netherlands". English. In: Beaufortia 52.11 (2002), pp. 187-196.

[2208] G. Bianucci, W. Landini, and A. Varola. "New remains of Cetacea Odontoceti from the Pietra leccesse (Apulia, Italy)". English. In: Bollettino della Societa Paleontologica Italiana 33.2 (1994), pp. 215230.

[2209] G. Bianucci, W. Landini, and A. Varola. "First discovery of the Miocene northern Atlantic sperm whale Orycterocetus in the Mediterranean". English. In: Géobios 37 (2004), pp. 569-573.

[2210] G. Bianucci and W. Landini. "Kogia pusilla from the middle Pliocene of Tuscany (Taly) and a phylogenetic analysis of the family Kogiidae (Odontoceti, Cetacea)". English. In: Rivista Italiana di Paleontologia e Stratigrafia 105.3 (1999), pp. 445-453.

[2211] G. Bianucci, W. Landini, G. Valleri, L. Ragaini, and A. Varola. "First cetacean fossil records from Ecuador, collected from the Miocene of Esmeraldas Province". English. In: Rivista Italiana di Paleontologia e Stratigrafia 111.2 (2005), pp. 345-350.

[2212] G. Bianucci and W. Landini. "Killer sperm whale: a new basal physeteroid (Mammalia, Cetacea) from the Late Miocene of Italy". English. In: Zoological Journal of the Linnaean Society 148 (2006), pp. 103-131.

[2213] G. Bianucci and W. Landini. "I paleositi a vertebrati fossili della Provinia di Pisa". English. In: Atti della Societá Toscana di Scienze Naturali - Memorie serie A 110 (2005), pp. 1-21.

[2214] G. Bianucci and W. Landini. "Change in diversity, ecological significance and biogeographical relationships of the Mediterranean Miocene toothed whale fauna". English. In: Geobios Mémoire spécial 24 (2002), pp. 19-28. 
[2215] G. Bianucci, S. Llácer, J. Q. Cardona, A. Collareta, and A. R. Florit. "A new beaked whale record from the upper Miocene". English. In: Acta Palaeontologica Polonica 64.2 (2019), pp. 291-302. DOI: 10.4202/app.00593.2019.

[2216] G. Bianucci, F. G. Marx, A. Collareta, A. Di Stefano, W. Landini, C. Morigi, and A. Varola. "Rise of the titans: baleen whales became giants earlier than thought". English. In: Biology Letters 15.5 (2019), p. 20190175. DOI: 10.1098/rsbl.2019.0175.

[2217] G. Bianucci, P. Mazza, D. Merola, G. sarti, and A. Cascella. "The early Pliocene mammal assemblage of Val di Pugna (Tuscany, Italy) in the light of calcareous plankton biostratigraphical data and paleoecological observations". English. In: Rivista Italiana di Paleontologia e Stratigrafia 107.3 (2001), pp. 425-438.

[2218] G. Bianucci, I. Miján, and O. Lambert. "Bizarre fossil beaked whales (Odontoceti, Ziphiidae) fished from the Atlantic Ocean floor off the Iberian Peninsula". English. In: Geodiversitas 35.1 (2013), pp. 105-153. DOI: 10.5252/g2013n1a6.

[2219] G. Bianucci, F. Pesci, A. Collaretta, and C. Tinelli. "A new Monodontidae (Cetacea, Delphinoidea) from the lower Pliocene of Italy supports a warm- water origin for narwhals and white whales". English. In: Journal of Vertebrate Paleontology (2019), e1645148. DOI: 10.1080/02724634.2019.1645148.

[2220] G. Bianucci and K. Post. "Caviziphius altirostris, a new beaked whale from the Miocene southern North Sea basin". English. In: Deinsea 11 (2005), pp. 1-6.

[2221] G. Bianucci, G. Sarti, R. Catanzariti, and U. Santini. "Middle Pliocene cetaceans from Monte Voltraio (Tuscany, Italy). Biostratigraphical, paleoecological and paleoclimatic observations". English. In: Rivista Italiana di Paleontologia e Stratigrafia 104.1 (1998), pp. 123-130.

[2222] G. Bianucci, S. Sorbi, M. E. Suarez, and W. Landini. "The southernmost sirenian record in the eastern Pacific Ocean, from the Late Miocene of Chile". English. In: Systematic Palaeontology 5 (2006), pp. 945-952.

[2223] G. Bianucci and C. Sorbini. “Le collezioni a cetacei fossili del Museo di Storia Naturale dell'Università di Pisa". Italian. In: Museologia Scientifica Memorie 13 (2014), pp. 93-102.

[2224] G. Bianucci, B. Sorce, T. Storai, and W. Landini. "Killing in the Pliocene: Shark attack on a dolphin from Italy". English. In: Palaeontology 53.2 (2010), pp. 457-470. DOI: 10.1111/j.1475-4983.2010. 00945.x.

[2225] G. Bianucci, M. Urbina, and O. Lambert. "A new record of Notocetus vanbenedeni (Squalodelphinidae, Odontoceti, Cetacea) from the Early Miocene of Peru". English. In: Comptes Rendus Palevol 14 (2015), pp. 5-13. DOI: 10.1016/j.crpv.2014.08.003.

[226] G. Bianucci, S. C. Vaiani, and S. Casati. "A new delphinid record (Odontoceti, Cetacea) from the Early Pliocene of Tuscany (Central Italy): systematics and biostratigraphic considerations". English. In: Neus Jahrbuch fur Geologie und Palaontologie Abhandlungen 254.3 (2009), pp. 275-292. DOI: 10.1127/0077-7749/2009/0018.

[2227] G. Bianucci and A. Varola. "Kentriodontidae (Odontoceti, Cetacea) from Miocene sediments of the Pietra Leccese (Apulia, Italy)". English. In: Atti della Societa Toscana di Scienze Naturali Memorie Serie A 101 (1994), pp. 201-212.

[2228] G. Bianucci and A. Varola. "I cetacei fossili della Pietra leccese nei musei del Salento". English. In: Museologia Scientifica Memoire 13 (2014), pp. 114-119.

[2229] F. Bibi, B. P. Kraatz, N. Craig, M. Beech, M. Schuster, and A. P. Hill. "Early evidence for complex social structure in Proboscidea from a late Miocene trackway site in the United Arab Emirates". English. In: Biology Letters 8 (2012), pp. 670-673. DOI: 10.1098/rsbl.2011.1185.

[2230] K. N. Bice and K. Shimada. "Fossil marine vertebrates from the Codell Sandstone Member (middle Turonian) of the Upper Cretaceous Carlile Shale in Jewell County, Kansas, USA". English. In: Cretaceous Research 65 (2016), pp. 172-198. DOI: 10.1016/j.cretres.2016.04.017.

[2231] K. N. Bice, K. Shimada, and J. I. Kirkland. "Late Cretaceous marine fishes from the upper Greenhorn Limestone in southeastern Nebraska". English. In: Transactions of the Kansas Academy of Science 116 (2013), pp. 22-26. DOI: 10.1660/062.116.0104. 
[2232] D. J. Bickel. "The first species described from Cape York amber, Australia: Chaetogonopteron bethnorrisae n. sp. (Diptera: Dolichopodidae)". English. In: Denisia 26 (2009), pp. 35-39.

[2233] D. J. Bickel. "A fossil Gymnopternus Loew (Diptera: Dolichopodidae) from the Florissant beds, Colorado". English. In: Psyche 102 (1995), pp. 169-172.

[2234] D. J. Bickel and M. M. Solórzano Kraemer. "The Dolichopodidae (Diptera) of Mexican amber". English. In: Boletn de la Sociedad Geológica Mexicana 68 (2016), pp. 11-21.

[2235] C. Bickelmann and P. M. Sander. "A partial skeleton and isolated humeri of Nothosaurus (Reptilia: Eosauropterygia) from Winterswijk, The Netherlands". English. In: Journal of Vertebrate Paleontology 28.2 (2008), pp. 326-338.

[2236] R. D. C. Bicknell. “Xiphosurid from the Upper Permian of Tasmania confirms Palaeozoic origin of Austrolimulidae". English. In: Palaeontologia Electronica 22.3 (2019), pp. 1-15.

[2237] R. D. C. Bicknell, S. V. Naugolnykh, and T. Brougham. "A reappraisal of Paleozoic horseshoe crabs from Russia and Ukraine". English. In: The Science of Nature 107.46 (2020). DOI: 10.1007/ s00114020-01701-1.

[2238] R. D. C. Bicknell and S. Pates. "Xiphosurid from the Tournaisian (Carboniferous) of Scotland confirms deep origin of Limuloidea". English. In: Scientific Reports 9 (2019). DOI: 10.1038/s41598-01953442-5.

[2239] R. D. C. Bicknell, J. alohar, P. Miklavc, B. Celarc, M. Krinar, and T. Hitij. "A new limulid genus from the Strelovec Formation (Middle Triassic, Anisian) of northern Slovenia". English. In: Geological Magazine 156 (2019), pp. 2017-2030. DOI: 10.1017/S0016756819000323.

[2240] F. G. Bidashko, K. P. Proskurin, and A. G. Shatrovskii. "Paleogeography of the lower Volga at the end of Atelian time based on entomological and botanical data". English. In: Paleontological Journal 30 (1995), pp. 332-336.

[2241] L. S. Bielokrys. Lepidopleurida (Polyplacophora) from the Upper Eocene of Ukraine. 2000.

[2242] L. S. Bielokrys. "New Skyloniids (Eurystomate Bryozoans) from the Eocene of Ukraine". In: Paleontological Journal 29.3 (1995), pp. 45-60.

[2243] M. Bienkowska-Wasiluk and N. Bonde. "A new Oligocene relative of the Caproidae (Teleostei: Acanthopterygii) from the Outer Carpathians, Poland". English. In: Bulletin of Geosciences 90.2 (2015), pp. 461-478. DOI: 10.3140/bull.geosci.1520.

[2244] A. O. Bienkowski. "The first record of reed beetles (Coleoptera, Chrysomelidae, Donaciinae) in the early Paleocene of Amur Region". English. In: Paleontological Journal 49 (2015), pp. 51-56.

[2245] G. Biernat. "A New Jurassic discinid brachiopod from Spitsbergen". English. In: Polish Polar Research 16.1-2 (1995), pp. 37-46.

[2246] J. Biewer, J. Sankey, J. H. Hutchison, and D. Garber. "A fossil giant tortoise from the Mehrten Formation of Northern California". English. In: PaleoBios 33 (2016), pp. 1-15.

[2247] J. N. Biewer, J. Velez-Juarbe, and J. F. Parham. "Insights on the dental evolution of walruses based on new fossil specimens from California". English. In: Journal of Vertebrate Paleontology (2020), e1833896. DOI: $10.1080 / 02724634.2020 .1833896$.

[2248] P. K. Bigelow. "Occurrence of a squaloid shark (Chondrichthyes: Squaliformes) with the pinniped Allodesmus from the Upper Miocene of Washington". English. In: Journal of Paleontology 68.3 (1994), pp. 680-684.

[2249] S. A. Bilbey and J. E. Hall. Marsh and Megalosaurus - Utah's first theropod dinosaur. Vol. 99-1. Vertebrate Paleontology in Utah, Utah Geological Survey Miscellaneous Publication. 1999, pp. 6769.

[2250] G. Billet and C. de Muizon. "External and internal anatomy of a petrosal from the late Paleocene of Itabora, Brazil, referred to Notoungulata (Placentalia)". English. In: Journal of Vertebrate Paleontology 33.2 (2013), pp. 455-469. 
[2251] G. Billet, L. Hautier, C. Muizon, and X. Valentin. “Oldest cingulate skulls provide congruence between morphological and molecular scenarios of armadillo evolution". English. In: Proceedings of the Royal Society B 278 (2011), pp. 2791-2797. DOI: 10.1098/rspb.2010.2443.

[2252] G. Billet, C. Muizon, and B. Mamani-Quispe. "Late Oligocene mesotheriids (Mammalia, Notoungulata) from Salla and Lacayani (Bolivia): implications for basal mesotheriid phylogeny and distribution". English. In: Zoological Journal of the Linnean Society 152 (2008), pp. 153-200.

[2253] G. Billet, M. Orliac, P. -O. Antoine, and C. Jaramillo. "New observations and reinterpretation on the enigmatic taxon Colombitherium (Pyrotheria, Mammalia) from Colombia". English. In: Palaeontology 53.2 (2010), pp. 319-325.

[2254] G. Billet, B. Patterson, and C. de Muizon. "Craniodental anatomy of late Oligocene archaeohyracids (Notoungulata, Mammalia) from Bolivia and Argentina and new phylogenetic hypotheses". English. In: Zoological Journal of the Linnean Society 155 (2009), pp. 458-509.

[2255] J.-P. Billon-Bruyat. "First record of a non-pterodactyloid pterosaur (Reptilia: Archosauria) from Switzerland". English. In: Eclogae Geologicae Helvetiae 98.3 (2005), pp. 313-317.

[2256] J.-P. Billon-Bruyat, J.-M. Mazin, and J. Pouech. “A stegosaur tooth (Dinosauria, Ornithischia) from the Early Cretaceous of southwestern France". English. In: Swiss Journal of Geosciences 103 (2010), pp. 143-153. DOI: 10.1007/s00015-010-0028-y.

[2257] M. Bilotte, Y. Laurent, and D. Téodori. "Restes d'hadrosaure dans le Crétacé terminal marin de Larcan (Petites Pyrénées, Haute-Garonne, France) [Hadrosaur remains in the terminal marine Cretaceous of Larcan (Petites Pyrénées, Haute-Garonne, France)]". French. In: Carnets de Géologie/Notebooks on Geology, Note bréve, Letter 2010.02 (2010), pp. 1-10.

[2258] S. Blý and A. G. Kirejtshuk. "Philanthaxoides gallicus gen. nov. sp. nov. from the lowermost Eocene French amber (Coleoptera: Buprestidae)". English. In: Folia Heyrovskyana, Series A 14 (2007), pp. 181-186.

[2259] G. Bindellini and C. Dal Sasso. "Sauropod teeth from the Middle Jurassic of Madagascar, and the oldest record of Titanosauriformes". English. In: Papers in Palaeontology 7.1 (2021), pp. 137-161. DOI: $10.1002 / \mathrm{spp} 2.1282$.

[2260] L. Bingli, J. K. Rigby, J. Yanwen, and Z. Zhongde. "Lower Ordovician lithistid sponges from the eastern Yangtze Gorge area, Hubei, China. Journal Of Paleontology". English. In: Journal of Paleontology 71.2 (1997), pp. 194-207.

[2261] M. Biondi. "Paolaltica eocenica new genus and new species of flea beetle (Coleoptera: Chrysomelidae: Galerucinae: Alticini) from Baltic amber". English. In: Zootaxa 3852 (2014), pp. 496-500.

[2262] R. Birenheide and S. Schröder. "Neue rugose Korallen-Arten der Gattung Catactotoechus Hill 1954 aus dem Devon der algerischen Sahara (Mittel-Devon/Givetium; Ahanet Becken/Süd-Algerien)". German. In: Senckenbergiana lethaea 79.1 (1999), pp. 89-103.

[2263] T. Birkelund. "Ammonites from the Maastrichtian White Chalk of Denmark". English. In: Bulletin of the Geological Society of Denmark 40.1-2 (1993), pp. 33-81.

[2264] E. A. Bischof, B. Hostettler, and U. Menkveld-Gfeller. "The cidaroids from the Middle Oxfordian St-Ursanne Formation of the Swiss Jura Mountains". English. In: Revue de Paléobiologie, Genéve 37 (2018), pp. 1-27.

[2265] E. A. Bischof and J. Lehmann. "Ontogenetic analysis of Anisian (Middle Triassic) ptychitid ammonoids from Nevada, USA". English. In: Journal of Paleontology 94 (2020), pp. 829-851. DOI: 10. 1017 /jpa.2020.25.

[2266] M. Bisconti. "An early Late Pliocene right whale (Genus Eubalaena) from Tuscany (Central Italy)". English. In: Bollettino della Societa Paleontologica Italiana 41.1 (2002), pp. 83-91.

[2267] M. Bisconti. "Skull morphology and phylogenetic relationships of a new diminutive balaenid from the lower Pliocene of Belgium". English. In: Palaeontology 48.4 (2005), pp. 793-816.

[2268] M. Bisconti. "A new basal balaenopterid whale from the Pliocene of northern Italy". English. In: Palaeontology 50.5 (2007), pp. 1103-1122. 
[2269] M. Bisconti. "Morphology and phylogenetic relationships of a new eschrichtiid genus (Cetacea: Mysticeti) from the early Pliocene of northern Italy". English. In: Zoological Journal of the Linnean Society 153 (2008), pp. 161-186.

[2270] M. Bisconti. "A new balaenopterid whale from the late Miocene of the Stirone River, Northern Italy (Mammalia, Cetacea, Mysticeti)". English. In: Journal of Vertebrate Paleontology 30.3 (2010), pp. $943-958$.

[2271] M. Bisconti. "Comparative osteology and phylogenetic relationships of Miocaperea pulchra, the first fossil pygmy right whale genus and species (Cetacea, Mysticeti, Neobalaenidae)". English. In: Zoological Journal of the Linnean Society 166 (2012), pp. 876-911.

[2272] M. Bisconti. "Anatomy of a new cetotheriid genus and species from the Miocene of Herentals, Belgium, and the phylogenetic and palaeobiogeographical relationships of Cetotheriidae s.s. (Mammalia, Cetacea, Mysticeti)". English. In: Journal of Systematic Palaeontology (2014). DOI: 10.1080 / 14772019.2014.890136.

[2273] M. Bisconti and M. Bosselaers. A large balaenopterid skeleton from the Early Pliocene of the North Sea sheds light on the affinities of 'Balaenoptera' sibbaldina (Mammalia, Cetacea, Mysticeti). English. 2014.

[2274] M. Bisconti and M. Bosselaers. "Fragilicetus velponi: a new mysticete genus and species and its implications for the origin of Balaenopteridae (Mammalia, Cetacea, Mysticeti)". English. In: Zoological Journal of the Linnean Society 177 (2016), pp. 450-474. DOI: 10.1111/zoj.12370.

[2275] M. Bisconti and M. E. J. Bosselaers. "A new balaenopterid species from the Southern North Sea Basin informs about phylogeny and taxonomy of Burtinopsis and Protororqualus (Cetacea, Mysticeti, Balaenopteridae)". English. In: PeerJ 8.e9570 (2020), pp. 1-47. DOI: 10.7717/peerj.9570.

[2276] M. Bisconti, P. DaMarco, S. Mao, M. Pavia, and G. Carnevale. "The earliest baleen whale from the Mediterranean: Large-scale implications of an Early Miocene thalassotherian mysticete from Piedmont, Italy". English. In: Papers in Palaeontology (2020). DOI: 10.1002/spp2.1336.

[2277] M. Bisconti and C. Francou. "I cetacei fossili conservati presso il Museo Geologico di Castell'Arquato (Piacenza)". English. In: Museologia Scientifica Memoire 13 (2014), pp. 31-36.

[2278] M. Bisconti, O. Lambert, and M. Bosselaers. "Taxonomic revision of Isocetus depauwi (Mammalia, Cetacea, Mysticeti) and the phylogenetic relationships of archaic 'cetothere' mysticetes". English. In: Palaeontology 56.1 (2013), pp. 95-127. DOI: 10.1111/j.1475-4983.2012.01168.x.

[2279] M. Bisconti, O. Lambert, and M. Bosselaers. "Revision of Balaena belgica reveals a new right whale species, the possible ancestry of the northern right whale, Eubalaena glacialis, and the ages of divergence for the living right whale species". English. In: PeerJ 5 (2017), e3464. DOI: 10.7717 / peerj.3464.

[2280] M. Bisconti, D. K. Munsterman, and K. Post. "A new balaenopterid whale from the late Miocene of the Southern North Sea Basin and the evolution of balaenopterid diversity (Cetacea, Mysticeti)". English. In: PeerJ 7.e6915 (2019), pp. 1-54. DOI: 10.7717/ peerj.6915.

[2281] M. Bisconti, D. K. Munsterman, R. H. B. Fraaije, M. E. J. Bosselaers, and K. Post. “A new species of rorqual whale (Cetacea, Mysticeti, Balaenopteridae) from the Late Miocene of the Southern North". English. In: PeerJ 8 (2020), e8315. DOI: 10.7717/peerj.8315.

[2282] M. Bisconti and A. Varola. "Functional hypothesis on an unusual mysticete dentary with double coronoid process from the Miocene of Apulia and its systematic and behavioural implications". English. In: Paleontolographia Italica 87 (2000), pp. 19-35.

[2283] M. Bisconti and A. Varola. "The oldest eschrictiid mysticete: and a new morphological diagnosis of Eschrichtiidae (gray whales)". English. In: Rivista Italiana di Paleontologia e Stratigafia 112.3 (2006), pp. 447-457.

[2284] G. A. Bishop and B. T. Palmer. "A new genus and species of crab from the bryozoan bioherms of the Eocene Santee Limestone, South Carolina, USA". English. In: Revista Mexicana de Ciencias Geologicas 23.3 (2006), pp. 334-337. 
[2285] M. A. Bitner. "Middle Miocene (Badenian) brachiopods from coral reefs of north-western Bulgaria". English. In: Acta Geologica Polonica 43.1-2 (1993), pp. 147-155.

[2286] M. A. Bitner. "A supposedly new brachiopod from the Paleogene of Seymour Island, West Antarctica". English. In: Polish Polar Research 12.2 (1991), pp. 243-246.

[2287] M. A. Bitner. "Brachiopods from the Eocene La Meseta Formation of Seymour Island, Antarctic Peninsula". English. In: Palaeontologia Polonica 55 (1996), pp. 65-100.

[2288] M. A. Bitner. "Lower Eocene (Middle Ilerdian) Brachiopods from the Campo Region, Central Pyrenees, North-Eastern Spain". English. In: Revista Española de Paleontologa 15.2 (2000), pp. 117-128.

[2289] M. A. Bitner. "Middle Miocene (Badenian) brachiopods from the Roztocze Hills, south-eastern Poland". English. In: Acta Geologica Polonica 40.3-4 (1990), pp. 129-157.

[2290] M. A. Bitner and M. Boukhary. "First Record of Brachiopods from the Eocene of Egypt". English. In: Natura Croatica 18.2 (2009), pp. 393-400.

[2291] M. A. Bitner and M. Boukhary. "First record of Eocene brachiopods from the United Arab Emirates, Arabian Gulf and their paleogeographical significance". English. In: Neues Jahrbuch für Geologie und Paläontologie, Abhandlungen 265 (2012), pp. 275-279.

[2292] M. A. Bitner and B. Cahuzac. "New record of the Discradisca (Brachiopoda: Discinidae) from the Early Miocene of the Aquitaine Basin, south-western France". English. In: Comptes Rendus Palevol 12 (2013), pp. 23-29.

[2293] M. A. Bitner and J. A. Crame. "Brachiopods from the Lower Miocene of King George Island, West Antarctica". English. In: Polish Polar Research 23.1 (2002), pp. 75-84.

[2294] M. A. Bitner and I. Dieni. "Late Eocene brachiopods from the Euganean Hills (NE Italy)". English. In: Eclogae Geologicae Helvetiae 98 (2005), pp. 103-111. DOI: 10.1007/S00015-005-1145-x.

[2295] M. A. Bitner and A. Dulai. "Revision of Miocene brachiopods of the Hungarian Natural History Museum, with special regard to the Meznerics collection". English. In: Fragmenta Palaeontologica Hungarica 22 (2004), pp. 69-82.

[2296] M. A. Bitner, A. Dulai, L. Kocsis, and P. M. Müller. "Lingula dregeri (Brachiopoda) from the middle Miocene of Hungary". English. In: Annales Societatis Geologorum Poloniae 82 (2012), pp. 39-43.

[2297] M. A. Bitner and A. Dulai. "Eocene micromorphic brachiopods from north-western Hungary". English. In: Geologica Carpathica 59.1 (2008), pp. 31-43.

[2298] M. A. Bitner, A. Dulai, and A. Galácz. "Middle Eocene brachiopods from the Szoc Limestone Formation (Bakony Mountains, Hungary), with a description of a new genus". English. In: Neues Jahrbuch für Geologie und Paläontologie, Abhandlungen 259 (2011), pp. 113-128.

[2299] M. A. Bitner and A. Kaim. "The Miocene brachiopods from the silty facies of the intra-Carpathian Nowy Sacz Basin (Poland)". English. In: Geological Quarterly 48.2 (2004), pp. 193-198.

[2300] M. A. Bitner and A. Kroh. "First record of the genus Bronnothyris (Brachiopoda: Megathyrididae) from the Oligocene of the Mainz Basin (Germany)". English. In: Geologica Carpathica 62.3 (2011), pp. 203-209. DOI: $10.2478 /$ v10096-011-0017-8.

[2301] M. A. Bitner, P. Lozouet, and B. Cahuzac. “Upper Oligocene (Chattian) brachiopod fauna from the Aquitaine Basin, southwestern France and its paleoenviornmental implications". English. In: Geodiversitas 35.3 (2013), pp. 579-606.

[2302] M. A. Bitner and J. Martinell. "Pliocene brachiopods from the Estepona area (Málaga, South Spain)". English. In: Revista Española de Paleontologa 16.2 (2001), pp. 177-185.

[2303] M. A. Bitner and P. Moissette. "Pliocene brachiopods from north-western Africa". English. In: Geodiversitas 25.3 (2003), pp. 463-479.

[2304] M. A. Bitner and N. Motchurova-Dekova. "Brachiopods from the Sanadinovo Formation (Lower Cenomanian) in northern Bulgaria". English. In: Cretaceous Research 26 (2005), pp. 525-539. 
[2305] M. A. Bitner and N. Motchurova-Dekova. "Middle Miocene (Badenian) brachiopods from Yasen, northwestern Bulgaria: taxonomic composition and biogeographical significance". English. In: Neues Jahrbuch für Geologie und Paläontologie, Abhandlungen 279 (2016), pp. 7-22.

[2306] M. A. Bitner and A. Müller. "Brachiopods from the Silberberg Formation (Late Eocene to Early Oligocene) of Atzendorf, Central Germany". English. In: Palaeontologische Zeitschrift (2015).

[2307] M. A. Bitner and A. Müller. "Late Eocene (Priabonian) brachiopod fauna from Dnipropetrovsk, eastern Ukraine". English. In: Bulletin of Geosciences 92 (2017), pp. 211-231.

[2308] M. A. Bitner and S. Schneider. "The Upper Burdigalian (Ottnangian) brachiopod fauna from the northern coast of the Upper Marine Molasse Sea in Bavaria, southern Germany". English. In: Neues Jahrbuch für Geologie und Paläontologie, Abhandlungen 254 (2009), pp. 117-133.

[2309] M. A. Bitner, K. Zagorsek, and S. Hladilova. “Deep-water brachiopod assemblage from the Middle Miocene of Kralice nad Oslavou, Moravia, southeastern Czech Republic". English. In: Comptes Rendus Palevol 12.2 (2013), pp. 81-89. DOI: 10.1016/j.crpv.2013.01.004.

[2310] R. Biton, G. Sharon, M. Oron, T. Steiner, and R. Rabinovich. "Freshwater turtle or tortoise? The exploitation of testudines at the Mousterian site of Nahal Mahanayeem Outlet, Hula Valley, Israel". English. In: Journal of Archaeological Science: Reports 14 (2017), pp. 409-419. DOI: 10.1016/j.jasrep. 2017.05.058.

[2311] J.d.S. Bittencourt and A. W. A. Kellner. "On a sequence of sacrocaudal theropod dinosaur vertebrae from the Lower Cretaceous Santana Formation, northeastern Brazil". English. In: Arquivos do Museu Nacional, Rio de Janeiro 62.3 (2004), pp. 309-320.

[2312] J. S. Bittencourt, L. A. Leal, M. C. Langer, and S. A. K. Azevedo. “An additional basal sauropodomorph specimen from the Upper Triassic Caturrita Formation, southern Brazil, with comments on the biogeography of plateosaurids". English. In: Alcheringa 36.2 (2012), pp. 269-278. DOI: 10.1080 / 03115518.2012.634111.

[2313] F. Bizzarini and G. Braga. "Tendenze evolutive ed aspetti paleoecologici dei briozoi Triassici della paleotetide occidentale". Italian. In: Atti della Accademia Roveretana degli Agiatil 243.ser. VII (1993), pp. 37-62.

[2314] F. Bizzarini and G. Braga. Corynotrypoides ladina gen. et sp. nov., a questionable cyclostomatous bryozoan from the Upper Triassic of the Eastern Dolomites (NE Italy). in P. J. Hayward, J. S. Ryland, and P. D. Taylor, Biology and Paleobiology of Bryozoans. Olsen \& Olsen, Fredensborg, Denmark. 1994, pp. 29-32.

[2315] F. Bizzarini, G. Prosser, F. Prosser, and I. Prosser. “Osservazioni preliminari sui resti di vertebrati della formazione di S. Cassiano del Bosco di Stuores (Dolomiti nord-orientali)". Italian. In: Annali del Museo Civico di Rovereto 17 (2003), pp. 137-148.

[2316] M. Bjerager, L. Seidler, L. Stemmerik, and F. Surlyk. "Ammonoid stratigraphy and sedimentary evolution across the Permian-Triassic boundary in East Greenland". English. In: Geological Magazine 143.5 (2006), pp. 635-656.

[2317] M. Bjerager, F. Surlyk, H. Lykke-Andersen, N. Thibault, and L. Stemmerik. "Danian cool-water coral reefs in southern Scandinavia localised over seafloor highs". English. In: Marine and Petroleum Geology 27 (2010), pp. 455-466.

[2318] K. Black. "Maradidae: a new family of vombatomorphian marsupial from the late Oligocene of Riversleigh, northwestern Queensland". English. In: Alcheringa 31.1 (2007), pp. 17-32. DOI: 10. 1080/03115510601123601.

[2319] K. Black and M. Archer. "Silvabestius gen. nov., a primitive zygomaturine (Marsupialia, Diprotodontidae) from Riversleigh, Northwestern Queensland". English. In: Memoirs of the Queensland Museum 41.2 (1996), pp. 193-208.

[2320] K. Black and M. Archer. "Nimiokoala gen. nov. (Marsupialia, Phascolarctidae) from Riversleigh, northwestern Queensland, with a revision of Litokoala". English. In: Memoirs of the Queensland Museum 41.2 (1997), pp. 209-228. 
[2321] K. H. Black. “Ngapakaldia bonythoni (Marsupialia, Diprotodontidae): new material from Riversleigh, northwestern Queensland, and a reassessment of the genus Bematherium". English. In: Alcheringa 34.4 (2010), pp. 471-492. DOI: 10.1080/03115511003793496.

[2322] K. H. Black, M. Archer, and S. J. Hand. “New Tertiary koala (Marsupialia, Phascolarctidae) from Riversleigh, Australia, with a revision of phascolarctid phylogenetics, paleoecology, and paleobiodiversity". English. In: Journal of Vertebrate Paleontology 32.1 (2012), pp. 125-138.

[2323] D. C. Blackburn, R. M. Keeffe, M. C. Vallejo-Pareja, and J. Vélez-Juarbe. “The earliest record of Caribbean frogs: A fossil coqu from Puerto Rico". English. In: Biology Letters 16 (2020), 20190947:16. DOI: $10.1098 / \mathrm{rsbl} .2019 .0947$.

[2324] D. C. Blackburn, D. J. Paluh, I. Krone, E. M. Roberts, E. L. Stanley, and N. J. Stevens. “The Earliest Fossil of the African Clawed Frog (Genus Xenopus) from Sub-Saharan Africa". English. In: Journal of Herpetology 53.2 (2019), pp. 125-130. DOI: 10.1670/18-139.

[2325] D. C. Blackburn, E. M. Roberts, and N. J. Stevens. "The earliest record of the endemic African frog family Ptychadenidae from the Oligocene Nsungwe Formation of Tanzania". English. In: Journal of Vertebrate Paleontology 35.2 (2015), e907174:1-5.

[2326] D. T. Blackburn and I. R. K. Sluiter. "The Oligo-Miocene coal floras of southeastern Australia". English. In: History of the Australian Vegetation: Cretaceous to Recent. Cambridge University Press, 1994, pp. 328-367.

[2327] D. C. Blackburn, L. Roberts, M. C. Vallejo-Pareja, and E. L. Stanley. "First Record of the Anuran Family Rhinophrynidae from the Oligocene of Eastern North America". English. In: Journal of Herpetology 53.4 (2019), pp. 316-323.

[2328] V. Blagoderov, W. Krzemiski, and K. Skibiska. "A new species of Micrepimera Matile (Diptera: Keroplatidae) from Baltic Amber". English. In: Palaeoentomology 2 (2019), pp. 643-649.

[2329] V. A. Blagoderov. "New species of Fungus Gnats (Diptera: Mycetophilidae) from the Palaeocene Sakhalin Amber, Russia". English. In: Alavesia 1 (2007), pp. 27-36.

[2330] V. A. Blagoderov. "New Bibionomorpha from the Triassic of Australia and Jurassic of central Asia with notes on Paraxymyiidae Rohdendorf (Insecta, Diptera)". English. In: Proceedings of the First International Palaeoentomological Conference (1999), pp. 11-15.

[2331] V. A. Blagoderov. "New fungus gnats (Diptera: Mycetophilidae) from the Cretaceous and Paleogene of Asia". English. In: Paleontological Journal 34.suppl 3 (2000), S355-S359.

[2332] V. A. Blagoderov. "Fungus Gnats of the tribes Gnoristini and Leiini (Diptera, Mycetophilidae) from the Early Cretaceous of Transbaikalia". English. In: Paleontological Journal 32.1 (1998), pp. 5459.

[2333] V. A. Blagoderov. "Dipterans (Mesosciophilidae) from the Lower Cretaceous of Transbaykal". English. In: Paleontological Journal 27.1A (1993), pp. 123-130.

[2334] V. A. Blagoderov. "Fungus Gnats of the Tribe Gnoristini (Diptera, Mycetophilidae) from the Lower Cretaceous of Transbaikalia". English. In: Paleontological Journal 31.6 (1997), pp. 609-615.

[2335] V. A. Blagoderov. "Fungus Gnats (Diptera, Mycetophilidae) from the Lower Cretaceous of Mongolia". English. In: Paleontological Journal 32.6 (1998), pp. 598-604.

[2336] V. A. Blagoderov. "Fungus gnats of the tribe Sciophilini (Diptera, Mycetophilidae) from the Early Cretaceous of Transbaikalia". English. In: Paleontological Journal 29.1 (1995), pp. 72-83.

[2337] V. A. Blagoderov and A. Arillo. "New Sciaroidea (Insecta: Diptera) in Lower Cretaceous amber from Spain". English. In: Studia Dipterologica 9 (2002), pp. 31-40.

[2338] V. A. Blagoderov and D. Grimaldi. "Fossil Sciaroidea (Diptera) in Cretaceous ambers, exclusive of Cecidomyiidae, Sciaridae, and Keroplatidae". English. In: American Museum Novitates 3433 (2004), pp. 1-76.

[2339] V. A. Blagoderov, D. A. Grimaldi, and N. C. Fraser. "How time flies for flies: diverse Diptera from the Triassic of Virginia and early radiation of the order". English. In: American Museum Novitates 3572 (2007), pp. 1-39. 
[2340] V. A. Blagoderov, H. Hippa, and A. Nel. “Parisognoriste, a new genus of Lygistorrhinidae (Diptera: Sciaroidea) from the Oise amber with redescription of Palaeognoriste Meunier". English. In: ZooKeys 50 (2010), pp. 79-90.

[2341] V. A. Blagoderov, E. Krzemiska, and W. Krzeminski. “Fossil and recent Anisopodomorpha (Diptera, Oligoneura): family Cramptonomyiidae". English. In: Acta Zoologica Cracoviensia 35.3 (1993), pp. 573579 .

[2342] V. A. Blagoderov and E. D. Lukashevich. "New Axymyiidae (Insecta: Diptera) from the Mesozoic of east Siberia". English. In: Polish Journal of Entomology 82 (2013), pp. 257-271.

[2343] V. A. Blagoderov and X. Martnez-Delclós. "Two new fungus gnats (Insecta, Diptera, Mycetophilidae) from the Lower Cretaceous of Spain". English. In: Geobios 34.1 (2001), pp. 63-67.

[2344] I. V. Blagovetshenskiy and I. A. Shumilkin. “Gastropod Mollusks from the Hauterivian of Ulyanovsk (Volga Region): 1. Family Aporrhaidae". English. In: Paleontological Journal 40.1 (2006), pp. 34-45.

[2345] I. V. Blagovetshenskiy and I. V. Shumilkin. "Gastropods of the Family Aporrhaidae from the Lower Cretaceous of Ulyanovsk, Volga Region". English. In: Paleontological Journal 46.4 (2012), pp. 343-353. DOI: 10.1134/S003103011204003X.

[2346] I. V. Blagovetshenskiy and I. A. Shumilkin. "Gastropod Mollusks from the Hauterivian of Ulyanovsk (Volga Region): 2. Genera Khetella Beisel, 1977 and Cretadmete gen. nov." English. In: Paleontological Journal 40.2 (2006), pp. 29-33.

[2347] H.-A. Blain, S. Bailon, G. Cuenca-Bescós, J. L. Arsuaga, J. M. Bermýdez de Castro, and E. Carbonell. "Long-term climate record inferred from early-middle Pleistocene amphibian and squamate reptile assemblages at the Gran Dolina Cave, Atapuerca, Spain". English. In: Journal of Human Evolution 56 (2009), pp. 55-65. DOI: 10.1016/j.jhevol.2008.08.020.

[2348] H.-A. Blain, J. Agusti, D. Lordkipanidze, L. Rook, and M. Delfino. "Paleoclimatic and paleoenvironmental context of the Early Pleistocene". English. In: Quaternary Science Reviews 105 (2014), pp. 136-150. DOI: 10.1016/j.quascirev.2014.10.004.

[2349] H.-A. Blain, S. Bailon, and J. Agust. "Anurans and squamate reptiles from the latest early Pleistocene of Almenara-Casablanca-3 (Castellón, East of Spain. Systematic, climatic and environmental considerations". English. In: Geodiversitas 29.2 (2007), pp. 269-295.

[2350] H.-A. Blain and S. Bailon. Catalogue of Spanish Plio-Pleistocene amphibians and squamate reptiles from the Museu de Geologia de Barcelona. English. Vol. 14. Treballs del Museu de Geologia de Barcelona. 2006, pp. 61-80.

[2351] H.-A. Blain, S. Bailon, J. Agust, P. Piñero-Garca, I. Lozano-Fernández, P. Sevilla, J. M. López-Garca, G. Romero, and M. A. Mancheño. "Youngest Agamid Lizards from Western Europe (Sierra de Quibas," English. In: Acta Palaeontologica Polonica 59.4 (2014), pp. 873-878.

[2352] H.-A. Blain, J.-I. Canudo, G. Cuenca-Bescós, and N. López-Martnez. “Amphibians and squamate reptiles from the latest Maastrichtian (Upper Cretaceous) of Blasi 2 (Huesca, Spain)". English. In: Cretaceous Research 31.4 (2010), pp. 433-446.

[2353] H.-A. Blain, J. M. Lopez-Garcia, and G. Cuenca-Bescos. "A very diverse amphibian and reptile assemblage from the late Middle". English. In: Geobios 44 (2011), pp. 157-172. DOI: 10.1016/j. geobios.2010.08.003.

[2354] H.-A. Blain, J. M. López-Garca, J. -M. Cordy, s. Pirson, G. Abrams, K. Di Modica, and D. Bonjean. "Middle to Late Pleistocene herpetofauna from Scladina and Sous-Saint-Paul caves (Namur, Belgium)". English. In: Comptes Rendus Palevol 13 (2014), pp. 681-690. DOI: 10.1016/j.crpv.2014.03.006.

[2355] H.-A. Blain, G. Pennetier, and E. Pennetier. "Présence du genre Platypterygius (Ichthyosauria, Reptilia) dans le Cénomanien inférieur de Villers-sur-Mer (Normandie, France)". French. In: L'Echo des Falaises 7 (2003), pp. 35-49.

[2356] H.-A. Blain, S. Rubio-Jara, J. Panera, D. Uribelarrea, C. Laplana, E. Herráez, and A. Pérez-González. "A new middle Pleistocene (Marine Oxygen Isotope Stage 6) cold herpetofaunal assemblage from the central Iberian Peninsula (Manzanares Valley, Madrid)". English. In: Quaternary Research 87 (2017), pp. 499-515. DOI: 10.1017/qua.2017.17. 
[2357] D. B. Blake. "Redescription and interpretation of the asteroid species Tropidaster pectinatus from the Jurassic of England". In: Palaeontology 39.1 (1996), pp. 179-188.

[2358] D. B. Blake. "Hettangian Asteriidae (Asteroidea: Echinodermata) from southern Germany: taxonomy, phylogeny and life habits". English. In: Paläontologische Zeitschrift 64.1/2 (1990), pp. 103123.

[2359] D. B. Blake. "A new asteroid genus from the Jurassic of England and its functional significance". English. In: Palaeontology 36.1 (1993), pp. 147-154.

[2360] D. B. Blake. "An Archegonaster-like somasteroid (Echinodermata) from Pomeroy, co. Tyrone, Northern Ireland". English. In: Irish Journal of Earth Sciences 18 (2000), pp. 89-99.

[2361] D. B. Blake. “Compsaster formosus Worthen \& Miller (Asteroidea; Echinodermata): a Carboniferous homeomorph of post-Paleozoic Asteriidae". English. In: Paläontologische Zeitschrift 76.2 (2002), pp. 357-367.

[2362] D. B. Blake. "A new asteroid genus from the Carboniferous of Ireland and its phylogenetic position and paleoecology". English. In: Irish Journal of Earth Sciences 14 (1995), pp. 65-80.

[2363] D. B. Blake. "Re-evaluation of the Palasteriscidae Gregory 1900 and the early phylogeny of the Asteroidea (Echinodermata)." English. In: Journal of Paleontology 68 (1994), pp. 123-134.

[2364] D. B. Blake. "Two Late Ordovician asteroids (Echinodermata) with characters suggestive of early ophiuroids." English. In: Journal of Paleontology 81.6 (2007), pp. 1476-1485.

[2365] D. B. Blake. "A new Ordovician asteroid (Echinodermata) with somasteroid-like skeletal elements." English. In: Journal of Paleontology 82.4 (2008), pp. 645-656.

[2366] D. B. Blake. "Paleobiological implications of some Upper Ordovician juvenile asteroids (Echinodermata)". English. In: Lethaia 23 (1990), pp. 347-357.

[2367] D. B. Blake. "Comptoniaster adamsi nov. sp. (Echinodermata, Asteroidea) from the middle Cretaceous of Texas and its phylogenetic position". English. In: Geobios 43 (2010), pp. 179-190.

[2368] D. B. Blake. “Two Ordovician asterozoans (Echinodermata) of problematic affinities". English. In: Journal of Paleontology 88.6 (2014), pp. 1163-1173. DOI: 10.1666/13-114.

[2369] D. B. Blake. "Two new Carboniferous Asteroidea (Echinodermata) of the family Urasterellidae". English. In: Journal of Paleontology 284.1 (2017), pp. 65-73.

[2370] D. B. Blake, L. Angiolini, and A. Tintori. "Omanaster imbricatus (Echinodermata, Asteroidea), a new genus and species from the Sakmarian (Lower Permian) Saiwan Formation of Oman, Arabian peninsula". English. In: Rivista Italiana di Paleontologia e Stratigrafia 120 (2014), pp. 263-269.

[2371] D. B. Blake and R. B. Aronson. "Eocene stelleroids (Echinodermata) at Seymour Island, Antarctic Peninsula". English. In: Journal of Paleontology 72.2 (1998), pp. 339-353.

[2372] D. B. Blake, F. Bielert, and U. Bielert. “New early crown-group asteroids (Echinodermata; Triassic of Germany)". English. In: Paläontologische Zeitschrift 80.3 (2006), pp. 284-295.

[2373] D. B. Blake, S. K. Donovan, and D. A. T. Harper. "A new Silurian ophiuroid from the west of Ireland". English. In: Irish Journal of Earth Sciences 25 (2017), pp. 57-66. DOI: 10.3318/ijes.2017.35.57.

[2374] D. B. Blake and D. R. Elliott. "Ossicular homologies, systematics, and phylogenetic implications of certain North American Carboniferous asteroids (Echinodermata)". English. In: Journal of Paleontology 77.3 (2003), pp. 476-489.

[2375] D. B. Blake and F. R. Ettensohn. "The complex morphology of a new Lower Silurian asteroid (Echinodermata)". English. In: Journal of Paleontology 83.1 (2009), pp. 63-69.

[2376] D. B. Blake, F. J. Gahn, and T. E. Guensburg. "An Early Ordovician (Floian) asterozoan (Echinodermata) of problematic class-level affinities". English. In: Journal of Paleontology (2019). DOI: $10.1017 /$ jpa.2019.82.

[2377] D. B. Blake, T. E. Guensberg, and B. Lefebvre. "New Early Paleozoic Asterozoa (Echinodermata) from the Armorican". English. In: Annales de Paléontologie 102 (2016), pp. 161-181. 
[2378] D. B. Blake and T. E. Guensburg. "New Lower Ordovician stelleroids (Echinodermata) and their bearing on the origins and early history of the stelleroid echinoderms". English. In: Journal of Paleontology 67.1 (1993), pp. 103-113.

[2379] D. B. Blake and T. E. Guensburg. "Implications of a new Early Ordovician asteroid (Echinodermata) for the phylogeny of asterozoans." English. In: Journal of Paleontology 79.2 (2005), pp. 395399.

[2380] D. B. Blake, T. E. Guensburg, J. Sprinkle, and C. Sumrall. “A new, phylogenetically significant Early Ordocivian asteroid (Echinodermata)". English. In: Journal of Paleontology 81.6 (2007), pp. 12571265. DOI: 10.1666/06-002.1.

[2381] D. B. Blake and T. E. Guensburg. "An asteroid (Echinodermata) faunule from the Oxfordian Swift Formation (Upper Jurassic) of Montana". English. In: Journal of Paleontology 90.6 (2016), pp. 11601168. DOI: $10.1017 /$ jpa.2016.70.

[2382] D. B. Blake and H. Hagdorn. “The Asteroidea (Echinodermata) of the Muschelkalk (Middle Triassic of Germany)". English. In: Paläontologische Zeitschrift 77.1 (2003), pp. 23-58.

[2383] D. B. Blake and J. W. M. Jagt. "New latest Cretaceous and earliest Paleogene asteroids (Echinodermata) from the Netherlands and Denmark and their palaebiological significance." English. In: Bulletin de l'Institut Royal des Sciences Naturelles de Belgique 75 (2005), pp. 183-200.

[2384] D. B. Blake and J. Koniecki. "Two new Paleozoic Asteroidea (Echinodermata) and their taxonomic and evolutionary significance". English. In: Journal of Paleontology 93.1 (2019), pp. 105-114. DOI: 10.1017/jpa.2018.70.

[2385] D. B. Blake and J. Koniecki. “Taxonomy and functional morphology of the Urasterellidae (Paleozoic Asteroidea, Echinodermata)". English. In: Journal of Paleontology 94 (2020).

[2386] D. B. Blake and B. S. Kues. "Homeomorphy in the Asteroidea (Echinodermata); a new Late Cretaceous genus and species from Colorado". English. In: Journal of Paleontology 76.6 (2002), pp. 10071013.

[2387] D. B. Blake and D. S. Peterson. "An unusual new asteriid (Echinodermata: Asteroidea) from the Cretaceous of California”. English. In: Journal of Paleontology 67.4 (1993), pp. 586-589.

[2388] D. B. Blake and R. W. Portell. "Implications for the study of fossil Asteroidea (Echinodermata) of new genera and species from the Eocene of Florida". English. In: Journal of Paleontology 83.4 (2009), pp. 562-574.

[2389] D. B. Blake and R. W. Portell. "Kionaster petersonae, n. gen. and sp. (Asteroidea), the first fossil occurrence of the Asterodiscididae, from the Miocene of Florida". English. In: Swiss Journal of Palaeontology 130 (2011), pp. 25-42.

[2390] D. B. Blake and R. Reboul. "A new asteroid (Echinodermata) faunule from the Early Cretaceous (Barremian) of Morocco". English. In: Journal of Paleontology 85.6 (2011), pp. 1021-1034.

[2391] D. B. Blake and R. Reid. "Some Albian (Cretaceous) asteroids (Echinodermata) from Texas and their paleobiological implications". English. In: Journal of Paleontology 72.3 (1998), pp. 512-532.

[2392] D. B. Blake and S. Rozhnov. "Aspects of life mode among Ordovician asteroids: Implications of new specimens from Baltica". English. In: Acta Palaeontologica Polonica 52.3 (2007), pp. 519-533.

[2393] D. B. Blake and K. Sturgeon. "Aldebarania arenitea, a new genus and species of Astropectinidae (Asteroidea; Echinodermata) from the Maastrichtian (Upper Cretaceous) Peedee formation of North Carolina". English. In: Journal of Paleontology 69.2 (1995), pp. 376-380.

[2394] D. B. Blake, A. Tintori, and H. Hagdorn. "A new, crown-group asteroid (Echinodermata) from the Norian (Triassic) of Northern Italy". English. In: Rivista Italiana di Paleontologia e Stratigrafia 106.2 (2000), pp. 141-156.

[2395] D. B. Blake, A. Tintori, and T. Kolar-Jurkovsek. "New Triassic Asteroidea (Echinodermata) specimens and their evolutionary significance". English. In: Rivista Italiana di Paleontologia e Stratigrafia 123 (2017), pp. 319-333. 
[2396] M. R. Blaker, C. A. Nelson, and J. S. Peel. "Perissopyge, a new trilobite from the Lower Cambrian of Greenland and North America". In: Journal of the Czech Geological Society 41.3-4 (1996), pp. 209216.

[2397] M. R. Blaker and J. S. Peel. “Lower Cambrian trilobites from North Greenland". English. In: Meddelelser om Grønland, Geoscience 35 (1997), p. 145.

[2398] P. Blanchon and A. Eisenhauer. "Multi-stage reef development on Barbados during the Last Interglaciation". English. In: Quaternary Science Reviews 20 (2001), pp. 1093-1112.

[2399] P. Blanchon, A. Eisenhauer, J. Fietzke, and V. Liebetrau. "Rapid sea-level rise and reef back-stepping at the close of the last interglacial highstand". English. In: Nature 458 (2009), pp. 881-884.

[2400] P. Blanchon, M. Granados-Corea, E. Abbey, J. C. Braga, and C. Braithwaite. "Postglacial FringingReef to Barrier-Reef conversion on Tahiti links Darwin's reef types". English. In: Scientific Reports 4.4997 (2014), pp. 1-9. DOI: 10.1038/srep04997.

[2401] P. Blanchon, B. Jones, and D. C. Ford. "Discovery of a submerged relic reef and shoreline off Grand Cayman: further support for an Early Holocene jump in sea level". English. In: Sedimentary Geology 147 (2002), pp. 253-270.

[2402] A. Blanco and J. Alvarado-Ortega. "Rhynchodercetis regio sp. nov., a dercetid fish (Teleostei: Aulopiformes) from Vallecillo, Nuevo León state, northeastern Mexico". English. In: Journal of Vertebrate Paleontology 26.3 (2006), pp. 552-558.

[2403] A. Blanco and C. A. Brochu. "Intra- and interspecific variability in allodaposuchid crocodylomorphs and the status of western European taxa". English. In: Historical Biology (2016). DOI: 10. 1080/08912963.2016.1201081.

[2404] A. Blanco, J. Fortuny, A. Vicente, Á H. Luján, J. A. Garca-Marçá, and A. G. Sellés. "A new species of Allodaposuchus (Eusuchia, Crocodylia) from the Maastrichtian (Late Cretaceous) of Spain: phylogenetic and paleobiological implications". English. In: PeerJ 3 (2015), e1171:1-35. DOI: 10.7717/ peerj.1171.

[2405] A. Blanco, J. M. Méndez, and J. Marmi. "The fossil record of the uppermost Maastrichtian Reptile Sandstone (Tremp Formation, northeastern Iberian Peninsula)". English. In: Spanish Journal of Palaeontology 30.1 (2015), pp. 147-160.

[2406] A. Blanco, A. Prieto-Márquez, and S. De Esteban-Trivigno. "Diversity of hadrosauroid dinosaurs from the Late Cretaceous Ibero-Armorican Island (European Archipelago) assessed from dentary morphology". English. In: Cretaceous Research 56 (2015), pp. 447-457. DOI: 10.1016/j.cretres.2015. 04.001.

[2407] A. Blanco, E. Puértolas Pascual, J. Marmi, B. Vila, and A. G. Sellés. “Allodaposuchus palustris sp. nov. from the Upper Cretaceous of Fumanya (South-Eastern Pyrenees, Iberian Peninsula): Systematics, Palaeoecology and Palaeobiogeography of the Enigmatic Allodaposuchian Crocodylians". English. In: PLoS One 9.12 (2014), e115837. DOI: 10.1371/journal.pone.0115837.

[2408] M. Blanco, S. Caro, A. López, F. Pérez-Lorente, E. Requeta, and M. Romero. “El yacimiento de icnitas de dinosaurio del Cretácico Inferior de Las Losas (Enciso, La Rioja, España) [The Lower Cretaceous dinosaur footprint locality of Las Losas (Enciso, La Rioja, Spain)]". Spanish. In: Zuba 18 (2000), pp. 97-138.

[2409] R. Blasco, H.-A. Blain, J. Rosell, J. C. Dez, R. Huguet, J. Rodrguez, J. L. Arsuaga, J. M. Bermúdez de Castro, and E. Carbonell. "Earliest evidence for human consumption of tortoises in the European Early Pleistocene from Sima del Elefante, Sierra de Atapuerca, Spain". English. In: Journal of Human Evolution 61.4 (2011), pp. 503-509. DOI: 10.1016/j.jhevol.2011.06.002.

[2410] M. Bläser, L. Krogmann, and R. S. Peters. "Two new fossil genera and species of Cerocephalinae (Hymenoptera, Chalcidoidea, Pteromalidae), including the first record from the Eocene". English. In: ZooKeys 545 (2015), pp. 89-100.

[2411] C. Blaszak, J. C. Cokendolpher, and V. J. Polyak. "Paleozercon cavernicolus, n. gen., n. sp., fossil mite from a cave in the southwestern U.S.A. (Acari, Gamasida: Zerconidae), with a key to nearctic genera of Zerconidae". English. In: International Journal of Acarology 21 (1995), pp. 253-259. 
[2412] J. Blau. "Monographie der Ammoniten des Obersinemuriums (Lotharingium, Lias) der Lienzer Dolomiten (Österreich): Biostratigraphie, Systematik und Paläobiogeographie". German. In: Revue de Paléobiologie, Genéve 17 (1998), pp. 177-285.

[2413] J. Blau, C. Meister, R. Schmidt-Effing, and A. B. Villaseñor. "A new fossiliferous site of Lower Liassic (Upper Sinemurian) marine sediments from the southern Sierra Madre Oriental (Puebla, Mexico): ammonite fauna, biostratigraphy, and description of Ectocentrites hillebrandti new species". English. In: Revista Mexicana de Ciencias Geológicas 25 (2008), pp. 402-407.

[2414] J. Blau and C. Meister. "Liassic (Pliensbachian) ammonites from the Lienz Dolomites (Eastern Tyrol, Austria)". English. In: Jahrbuch der Geologischen Bundesanstalt 134 (1991), pp. 171-204.

[2415] J. Blau, C. Meister, R. Ebel, and R. Schlatter. "Upper Sinemurian and lower Pliensbachian ammonite faunas from Herford-Diebrock area (NW Germany)". English. In: Paläontologische Zeitschrift 74 (2000), pp. 259-280.

[2416] I. Blechschmidt, P. Dumitrica, A. Matter, L. Krystyn, and T. Peters. "Stratigraphic architecture of the northern Oman continental margin - Mesozoic Hamrat Duru Group Hawasina complex, Oman". English. In: GeoArabia 9.2 (2004), pp. 81-132.

[2417] W. Blendinger. "Upper Triassic (Norian) cephalopod limestones of the Hallstatt-type, Oman". English. In: Sedimentology 38 (1991), pp. 223-242.

[2418] W. Blendinger. "Triassic carbonate buildup flanks in the Dolomites, northern Italy: breccias, boulder fabric and the importance of early diagenesis". English. In: Sedimentology 48 (2001), pp. $919-$ 933.

[2419] W. Blendinger and H. W. Flügel. "Permische Stockkorallen aus dem Hawasina-Becken, Oman". German. In: Facies 22 (1990), pp. 139-146.

[2420] W. Blendinger, W. M. Furnish, and B. F. Glenister. "Permian cephalopod limestones, Oman Mountains: evidence for a Permian seaway along the northern margin of Gondwana". English. In: Palaeogeography, Palaeoclimatology, Palaeoecology 93 (1992), pp. 13-20.

[2421] A. R. M. Blieck, V. N. Karatajute-Talimaa, and E. Mark-Kurik. “Upper Silurian and Devonian heterostracan pteraspidomorphs (Vertebrata) from Severnaya Zemlya (Russia): a preliminary report with biogeographical and biostratigraphical implications". English. In: Geodiversitas 24.4 (2002), pp. 805-820.

[2422] W. Blind. “Über die Anlage und Funktion von Kammerablagerungen in Orthoceren-Gehäusen". German. In: Palaeontographica Abteilung A 218 (1991), pp. 35-47.

[2423] A. S. Blix and E. S. Nordoy. "Ross seal (Ommatophoca rossii) annual distribution, diving behaviour, breeding and moulting, off Queen Maud Land, Antarctica". English. In: Polar Biology 30 (2007), pp. 1449-1458.

[2424] R. W. Blob, M. T. Carrano, R. R. Rogers, C. A. Forster, and N. R. Espinoza. "A new fossil frog from the Upper Cretaceous Judith River Formation of Montana". English. In: Journal of Vertebrate Paleontology 21.1 (2001), pp. 190-194.

[2425] J. D. Bloch, C. J. Schröder-Adams, D. A. Leckie, J. Craig, and D. J. McIntyre. "Sedimentology, micropaleontology, geochemistry and hydrocarbon potential of shale from the cretaceous Lower Colorado Group in Western Canada". English. In: Geological Survey of Canada, Bulletin 531 (1999), pp. 1-185.

[2426] J. I. Bloch, D. M. Boyer, P. D. Gingerich, and G. F. Gunnell. “New primitive paromomyid from the Clarkforkian of Wyoming and dental eruption in Plesiadapiformes". English. In: Journal of Vertebrate Paleontology 22.2 (2002), pp. 366-379.

[2427] J. I. Bloch, K. D. Rose, and P. D. Gingerich. "New species of Batodonoides (Lipotyphla, Geolabididae) from the early Eocene of Wyoming: smallest known mammal?" English. In: Journal of Mammalogy 79.3 (1998), pp. 804-827.

[2428] J. I. Bloch, R. Secord, and P. D. Gingerich. "Systematics and phylogeny of late Paleocene and early Eocene Palaeoryctinae (Mammalia, Insectivora) from the Clarks Fork Basin, Wyoming". English. In: Contributions from the Museum of Paleontology, University of Michigan 31.5 (2004), pp. 119-154. 
[2429] J. I. Bloch and M. T. Silcox. "New basicrania of Paleocene-Eocene Ignacius: re-evaluation of the plesiadapiform-dermopteran link". English. In: American Journal of Physical Anthropology 116 (2001), pp. 184-198.

[2430] J. I. Bloch, M. T. Silcox, D. M. Boyer, and E. J. Sargis. “New Paleocene skeletons and the relationship of plesiadapiformes to crown-clade primates". English. In: Proceedings of the National Academy of Sciences, USA 104.4 (2007), pp. 1159-1164.

[2431] J. I. Bloch, E. D. Woodruff, A. R. Wood, A. F. Rincon, A. R. Harrington, G. S. Morgan, D. A. Foster, C. Montes, C. A. Jarmillo, N. A. Jud, D. S. Jones, and B. J. MacFadden. "First North American fossil monkey and early Miocene tropical biotic interchange". English. In: Nature 533 (2016), pp. 243-246. DOI: $10.1038 /$ nature17415.

[2432] R. B. Blodgett. “Taxonomy and paleobiogeographic affinities of an early Middle Devonian (Eifelian) Gastropod faunule from the Livengood Quadrangle, East-Central Alaska". English. In: Palaeontographica Abteilung A 221 (1992), pp. 125-168.

[2433] R. B. Blodgett. "Dutrochus, a new microdomatid (Gastropoda) genus from the Middle Devonian (Eifelian) of West-Central Alaska". English. In: Journal of Paleontology 67.2 (1993), pp. 194-197.

[2434] R. B. Blodgett. "Paleontology and stratigraphy of the Upper Triassic Kamishak Formation in the Puale Bay-Cape Kekurnoi-Alinchak Bay area, Karluk C-4 and C-5 quadrangle, Alaska Peninsula". English. In: Report of Investigation, Alaska Division of Geological and Geophysical Surveys $2008.1 \mathrm{H}$ (2008), pp. 131-160.

[2435] R. B. Blodgett and A. J. Boucot. "Late Early Devonian (late Emsian) eospiriferinid brachiopods from Shellabarger Pass, south-central Alaska, and their biogeographic importance; further evidence for a Siberian origin of the Farewell and allied Alaskan accreted terranes". In: Senckenbergiana Lethaea 79.1 (1999), pp. 209-221.

[2436] R. B. Blodgett and K. H. Clautice. "Fossil locality map for the Healy A-6 quadrangle, south-central Alaska". In: Report of Investigations 2000-5, State of Alaska, Dept. of Natural Resources (2000), pp. 143.

[2437] R. B. Blodgett and A. G. Cook. "Cheeneetnukiidae, a new Middle Devonian murchisonioid gastropod family, including the new genera Cheeneetnukia and Ulungaratoconcha based on representatives from Alaska and Australia". In: Memoirs of the Queensland Museum 48.1 (2002), pp. 1728.

[2438] R. B. Blodgett, J. Fryda, and P. R. Racheboeuf. “Upper Middle Devonian (Givetian) gastropods from the Kersadiou Formation, Brittany, France". English. In: Journal of Paleontology 73.6 (1999), pp. 1081-1100.

[2439] R. B. Blodgett, J. Fryda, and A. C. Lenz. "Semitubina yukonensis new species, first occurrence of this biogeographically distinctive Old World realm gastropod genus in the Lower Devonian of the Western Hemisphere". English. In: Journal of Paleontology 75.2 (2001), pp. 466-470. DOI: 10.1666/ 0022-3360(2001)075\%3C0466\%3ASYNSFO\%3E2.0.CO\%3B2.

[2440] R. B. Blodgett and J. Frýda. "New Devonian gastropod genera important for paleogeographic reconstructions". English. In: Journal of the Czech Geological Society 44.3/4 (1999), pp. 293-308.

[2441] R. B. Blodgett, J. Frýda, and P. R. Racheboeuf. "Murchisonia gourvenneci, new name for Muchisonia oehlerti Blodgett, Frýda and Racheboeuf, 1999". In: Géobios 36.5 (2003), pp. 503-503.

[2442] R. B. Blodgett, J. Frýda, and A. J. Boucot. "New Silurian-Devonian pseudophorid gastropods". English. In: Bulletin of Geosciences 78.4 (2003), pp. 359-367.

[2443] R. B. Blodgett and J. Fryda. "On the occurrence of Spinidelphinulopsis whaleni (Gastropoda) in the Late Triassic (Early Norian) Cornwallis Limestone, Kuiu Island, southwestern Alaska (Alexander Terrane) and its paleobiogeographic significance". English. In: Bulletin of the Czech Geological Survey 76.4 (2001), pp. 235-242.

[2444] R. B. Blodgett, J. Fryda, G. D. Stanley, and Jr. “Delphinulopsidae, a new neritopsoidean gastropod family from the Upper Triassic (upper Carnian or lower Norian) of the Wallowa terrane, northeastern Oregon". English. In: Journal of the Czech Geological Society 46.3-4 (2001), pp. 307-318. 
[2445] R. B. Blodgett and W. G. Gilbert. Upper Devonian shallow-marine siliciclastic strata and associated fauna and flora, Lime Hills D-4 Quadrangle, southwest Alaska. 1992.

[2446] R. B. Blodgett and J. G. Johnson. "Early Middle Devonian (Eifelian) Gastropods of Central Nevada". English. In: Palaeontographica Abteilung A 222 (1992), pp. 85-139.

[2447] R. B. Blodgett and J. G. Johnson. "First recognition of the genus Verneuilia Hall and Clarke (Brachiopoda, Spiriferida) from North America (west-central Alaska)". English. In: Journal of Paleontology 68.6 (1994), pp. 1240-1242.

[2448] R. B. Blodgett, T. E. Moore, and F. Gray. "Stratigraphy and paleontology of Lower Permian rocks north of Cananea, northern Sonora, Mexico". English. In: Journal of South American Earth Sciences 15 (2002), pp. 481-495.

[2449] R. B. Blodgett, D. M. Rohr, S. M. Karl, and J. F. Baichtal. “Early Middle Devonian (Eifelian) Gastropods from the Wadleigh Limestone in the Alexander Terrane of Southeastern Alaska Demonstrate Biogeographic Affinities with Central Alaskan Terranes (Farewell and Livengood) and Eurasia". English. In: United States Geological Survey Professional Paper 1678 (2001), pp. 105-110.

[2450] R. B. Blodgett, D. M. Rohr, J. Frýda, and A. C. Lenz. "Stenoloron (Stenoloron) boucoti, a new gastropod species from the Lower Devonian of the Royal Creek area, Yukon Territory, Canada". English. In: Memoirs of the Association of Australasian Palaeontologists 39 (2010), pp. 131-137.

[2451] R. B. Blodgett, D. M. Rohr, E. A. Measures, N. M. Savage, A. E. H. Pedder, and R. W. Chalmers. The Soda Creek Limestone, a new upper Lower Devonian formation in the Medfra Quadrangle, west-central Alaska. English. Vol. 119. Short notes on Alaska geology: Alaska Division of Geological and Geophysical Surveys Professional Report. 1999, pp. 1-10.

[2452] R. B. Blodgett, D. M. Rohr, and A. J. Boucot. "Paleozoic links among some Alaskan accreted terranes and Siberia based on megafossils". English. In: Geological Society of America Special Paper 360 (2002), pp. 273-290.

[2453] J. C. Blokland, C. M. Reid, T. H. Worthy, A. J. D. Tennyson, J. A. Clarke, and R. P. Scofield. "Chatham Island Paleocene fossils provide insight into the palaeobiology, evolution, and diversity of early penguins (Aves, Sphenisciformes)". English. In: Palaeontologia Electronica 22.3 (2019), 78:1-92.

[2454] H. Blom. "A new anapsid fish from the middle Silurian Cowie Harbour fish bed of Stonehaven, Scotland". English. In: Journal of Vertebrate Paleontology 28.3 (2008), pp. 594-600.

[2455] H. Blom. "Taxonomic revision of the Late Devonian tetrapod Ichthyostega from East Greenland". English. In: Palaeontology 48.1 (2005), pp. 111-134. DOI: 10.1111/j.1475-4983.2004.00435.x.

[2456] H. Blom, J. A. Clack, and P. E. Ahlberg. "Localities, distribution and stratigraphical context of the Late Devonian tetrapods of East Greenland". English. In: Meddelelser om Grønland, Geosci 43 (2005), pp. 4-50.

[2457] C. D. Blome and K. M. Reed. "Permian and Early(?) Triassic radiolarian faunas from the Grindstone Terrane, central Oregon". English. In: Journal of Paleontology 66.3 (1992), pp. 351-383.

[2458] C. Blondel. "New data on the Cainotheriidae (Mammalia, Artiodactyla) from the early Oligocene of south-western France". English. In: Zoological Journal fo the Linnaean Society 144 (2005), pp. 125166.

[2459] C. Blondel. “Les ruminants de Pech Desse et de Pech du Fraysse (Quercy; MP28); évolution des ruminants de l'oligocéne d'Europe". French. In: Geobios 30.4 (1997), pp. 573-591.

[2460] G. Bloos. "Psiloceratids of the earliest Jurassic in the North-West European and Mediterranean Provinces - remarks and new observations". English. In: Stuttgarter Beiträge zur Naturkunde Serie B (Geologie und Paläontologie) 347 (2004), pp. 1-15.

[2461] G. Bloos. "Frühe Arietitidae (Ammonoidea) aus dem Hettangium (Angulata-Zone, Unt. Lias) von Württemberg (SW-Deutschland)". German. In: Stuttgarter Beiträge zur Naturkunde Serie B (Geologie und Paläontologie) 219 (1994), pp. 1-67. 
[2462] W. T. Blows. "A new species of Polacanthus (Ornithischia: Ankylosauria) from the Lower Cretaceous of Sussex, England". English. In: Geological Magazine 133.6 (1996), pp. 671-682.

[2463] W. T. Blows. "The Early Cretaceous brachiosaurid dinosaurs Ornithopsis and Eucamerotus from the Isle of Wight, England". English. In: Palaeontology 38.1 (1995), pp. 187-197.

[2464] W. T. Blows. "Notice of nodosaur (Dinosauria, Ankylosauria) remains from the mid-Cretaceous of Cambridge, England, with comments on cervical half-ring armour". English. In: Proceedings of the Geologists' Association 125 (2014), pp. 56-62. DOI: 10.1016/j.pgeola.2013.07.001.

[2465] W. T. Blows and K. Honeysett. "New nodosaurid teeth (Dinosauria, Ankylosauria) from the Lower Cretaceous of southern England". English. In: Acta Palaeontologica Polonica 59.4 (2014), pp. 835-841.

[2466] G. S. Boardman and B. W. Schubert. "First Mio-Pliocene salamander fossil assemblage from the southern Appalachians". English. In: Palaeontologia Electronica 14.2 (2011), 0-16A.

[2467] G. S. Boardman, J. A. Shiebout, and J. H. Wrenn. "How many species of the fossil rodent Copemys occur at a single prolific screening site in the Miocene, Fleming Formation at Fort Polk, Louisiana?" English. In: Transactions - Gulf Coast Association of Geological Societies 53 (2003), pp. 7885.

[2468] N. T. Boaz. Evolution of environments and Hominidae in the African Western Rift Valley. 1990.

[2469] L. Bocak, Y. Li, and S. Ellenberger. "The discovery of Burmolycus compactus gen. et sp. nov. from the mid-Cretaceous of Myanmar provides the evidence for early diversification of net-winged beetles (Coleoptera, Lycidae)". English. In: Cretaceous Research 99 (2019), pp. 149-155. DOI: 10 . 1016/j.cretres.2019.02.018.

[2470] C. Bochaton and S. Bailon. "A new fossil species of Boa Linnaeus, 1758 (Squamata, Boidae), from the Pleistocene of Marie-Galante Island (French West Indies)". English. In: Journal of Vertebrate Paleontology e1462829 (2018). DOI: 10.1080/02724634.2018.1462829.

[2471] Z. Bocheski. "Pleistocene bird fauna from Bir Tarfawi (Egyptian western desert)". English. In: Ostrich 62 (1991), pp. 29-34.

[2472] Z. M. Bochenski, T. Tomek, K. Wertz, J. Happ, M. Bujoczek, and E. Swidnicka. "Articulated avian remains from the early Oligocene of Poland adds to our". English. In: Palaeontologia Electronica 21.2.32A (2018), pp. 1-12.

[2473] Z. M. Bochenski, K. Wertz, T. Tomek, and L. Gorobets. "A new species of the late Miocene charadriiform bird (Aves: Charadriiformes), with a summary of all Paleogene and Miocene Charadrii remains". English. In: Zootaxa 4624.1 (2019), pp. 41-58.

[2474] P. E. Bock and P. L. Cook. "A review of Australian Siphonicytara Busk (Bryozoa: Cheilostomatida)". English. In: Records of the Western Australian Museum 20 (2001), pp. 307-322.

[2475] J. Bockwinkel, R. T. Becker, and V. Ebbighausen. “Upper Givetian ammonoids from Dar Kaoua (Tafilalt, SE Anti-Atlas, Morocco)". English. In: Berliner Paläobiologische Abhandlungen 10 (2009), pp. 61-128.

[2476] J. Bockwinkel, R. T. Becker, and V. Ebbighausen. "Late Givetian ammonoids from Hassi Nebech (Tafilalt Basin, Anti-Atlas, southern Morocco)". English. In: Fossil Record 16 (2013), pp. 5-65.

[2477] J. Bockwinkel, R. T. Becker, and V. Ebbighausen. "Late Givetian ammonoids from Ait Ou Amar (northern Maider, Anti-Atlas, southeastern Morocco)". English. In: Neues Jahrbuch für Geologie und Paläontologie, Abhandlungen 278 (2015), pp. 123-158.

[2478] J. Bockwinkel and V. Ebbighausen. "A new ammonoid fauna from the Gattendorfia-Eocanites Genozone of the Anti-Atlas (Early Carboniferous; Morocco)". English. In: Fossil Record 9.1 (2006), pp. 87-129.

[2479] J. Bockwinkel and D. Korn. "Late Givetian ammonoids from Oberberge (Middle Devonian; Rhenish Mountains)". English. In: Neues Jahrbuch für Geologie und Paläontologie, Abhandlungen 278 (2015), pp. 351-363. 
[2480] J. Bockwinkel, D. Korn, V. Ebbighausen, and S. Graf. “Late Givetian ammonoids from HagenHerbeck, Donnerkuhle quarry (Devonian, Rhenish Mountains)". English. In: Neues Jahrbuch für Geologie und Paläontologie, Abhandlungen 270 (2013), pp. 257-274.

[2481] J. Bocquentin, J. P. S. Filho, and F. R. Negri. “Neoepiblema acreensis, sp. n. (Mammalia, Rodentia) do Neogeno do Acre, Brasil". Portugese. In: Boletim do Museu Paraense Emilio Goeldi Serie Ciencias da Terra 2 (1990), pp. 65-72.

[2482] J.-C. Bocquentin and J. P. Souza Filho. "O Crogodiliano Sul-Americano Carandaisuchus Como Sinonmia De Mourasuchus (Nettosuchidae)". Portugese. In: Revista Brasileira de Geociencias 20.1-4 (1990), pp. 230-233.

[2483] J. Bocquetin and J. Melo. "Stupendemys souza sp. nov. (Pleurodira, Podocnemididae) from the Miocene - Pliocene of the Solimoes Formation, Brazil". English. In: Revista Brasileira de Paleontologia 9.2 (2006), pp. 187-192.

[2484] A. Boczarowski. "Palaeoenvironmental interpretation of echinoderm assemblages from Bathonian ore-bearing clays at Gnaszyn (Kraków-Silesia Homocline, Poland)". English. In: Acta Palaeontologica Polonica 62.3 (2012), pp. 351-366.

[2485] E. H. Bodenham and P. M. Barrett. "A new specimen of the sauropodomorph dinosaur Ignavusaurus rachelis from the Early Jurassic of Lesotho". English. In: Palaeontologia Africana 54 (2020), pp. 4855.

[2486] A. M. Bodergat, L. Bonnet, J. P. Colin, R. Cubaynes, and J. Rey. “Opportunistic development of Ogmoconcha amalthei (ostracod) in the lower Liassic of Quercy (SW France): an indicator of sedimentary disturbance". English. In: Palaeogeography, Palaeoclimatology, Palaeoecology 143 (1998), pp. 179-190.

[2487] A. Bodzioch, W. Kozlowski, and A. Poplawska. "A Cooksonia-type flora from the Upper Silurian of the Holy Cross Mountains, Poland". English. In: Acta Palaeontologica Polonica 48.4 (2003), pp. 653-656.

[2488] F. Boehm, O. Ebli, L. Krystyn, H. Lobitzer, M. Rakus, and M. Siblik. "Fauna, stratigraphy and depositional environment of the Hettangian-Sinemurian (Early Jurassic) of Adnet (Salzburg, Austria)". In: Abhandlunegn der Geologischen Bundesanstalt 56.2 (1999), pp. 143-271.

[2489] A. Boersma and N. D. Pyenson. “Arktocara yakataga, a new fossil odontocete (Mammalia, Cetacea) from the Oligocene of Alaska and the antiquity of Platanistoidea". English. In: PeerJ 4 (2016), e2321. DOI: $10.7717 /$ peerj.2321.

[2490] A. T. Boersma, M. R. McCurry, and N. D. Pyenson. "A new fossil dolphin Dilophodelphis fordycei provides insight into the evolution of supraorbital crests in Platanistoidea (Mammalia, Cetacea)". English. In: Royal Society Open Science (2017). DOI: 10.1098/rsos.170022.

[2491] G. G. Boeskorov, A. N. Tikhonov, A. V. Protopopov, A. D. Stepanov, V. V. Plotnikov, J. van der Plicht, M. V. Shchelchkova, and G. F. Baryshnikov. "New records of Holocene polar bear and walrus (Carnivora)". English. In: Russian Journal of Theriology 17.2 (2018), pp. 68-77.

[2492] R. W. Boessenecker. "Herpetocetine (Cetacea: Mysticeti) dentaries from the Upper Miocene Santa Margarita Sandstone of Central California". English. In: PaleoBios 30.1 (2011), pp. 1-12.

[2493] R. W. Boessenecker. "New records of the fur seal Callorhinus (Carnivora: Otariidae) from the PlioPleistocene Rio Dell Formation of Northern California and comments on otariid dental evolution". English. In: Journal of Vertebrate Paleontology 31.2 (2011), pp. 454-467.

[2494] R. W. Boessenecker. "A new marine vertebrate assemblage from the Late Neogene Purisima Formation in Central California, Part I: Fossil sharks, bony fish, birds, and implications for the age of the Purisimia Formation west of the San Gregorio Fault". English. In: PalArch's Journal of Vertebrate Palaeontology 8.4 (2011), pp. 1-30.

[2495] R. W. Boessenecker. "Pleistocene survival of an archaic dwarf baleen whale (Mysticeti: Cetotheriidae)". English. In: Naturwissenschaften (2013). DOI: 10.1007/s00114-013-1037-2. 
[2496] R. W. Boessenecker. "Taphonomic implications of barnacle encrusted sea lion bones from the Middle Pleistocene Port Orford Formation, coastal Oregon". English. In: Journal of Paleontology 87.4 (2013), pp. 657-663. DOI: 10.1666/13-005.

[2497] R. W. Boessenecker. "A new marine vertebrate assemblage from the Late Neogene Purisima Formation in Central California, part II: Pinnipeds and Cetaceans". English. In: Geodiversitas 35.4 (2013), pp. 815-939. DOI: 10.5252/g2013n4a5.

[2498] R. W. Boessenecker. “A Middle Pleistocene Sea Otter from Northern California and the Antiquity of Enhydra in the Pacific Basin". English. In: Journal of Mammalian Evolution 25 (2018), pp. 27-35. DOI: $10.1007 /$ s10914-016-9373-6.

[2499] R. W. Boessenecker. "A new early Pliocene record of the toothless walrus Valenictus (Carnivora, Odobenidae) from the Purisima Formation of northern California". English. In: PaleoBios 34 (2017), pp. 1-6.

[2500] R. W. Boessenecker. "Problematic archaic whale Phococetus (Cetacea: Odontoceti) from the Lee Creek Mine, North Carolina, USA, with comments on geochronology of the Pungo River Formation". English. In: Palaeontologische Zeitschrift (2018). DOI: 10.1007/s12542-018-0419-3.

[2501] R. W. Boessenecker, E. Ahmed, and J. H. Geisler. "New records of the dolphin Albertocetus meffordorum (Odontoceti: Xenorophidae) from the lower Oligocene of South Carolina: Encephalization, sensory anatomy, postcranial morphology, and ontogeny of early odontocetes". English. In: PLoS One 12.11 (2017), e0186476. DOI: 10.1371/journal.pone.0186476.

[2502] R. W. Boessenecker and S. J. Boessenecker. "Paleontology of the Ashley Phosphate Beds of Charleston: Insights from Northbridge Park, Charleston, South Carolina". English. In: Geological Society of America Field Guide 53 (2019), pp. 1-8. DOI: 10.1130/2019.0053(01).

[2503] R. W. Boessenecker and M. Churchill. "A reevaluation of the morphology, paleoecology, and phylogenetic relationships of the enigmatic walrus Pelagiarctos". English. In: PLoS One 8.1 (2013), e5411.

[2504] R. W. Boessenecker and M. Churchill. "The oldest known fur seal". English. In: Biology Letters (2015). DOI: 10.1098/rsbl.2014.0835.

[2505] R. W. Boessenecker and M. Churchill. "The origin of elephant seals: implications of a fragmentary late Pliocene seal (Phocidae: Miroungini) from New Zealand". English. In: New Zealand Journal of Geology and Geophysics (2016). DOI: 10.1080/00288306.2016.1199437.

[2506] R. W. Boessenecker and M. Churchill. "The last of the desmatophocid seals: a new species of Allodesmus from the upper Miocene of Washington, USA, and a revision of the taxonomy of Desmatophocidae". English. In: Zoological Journal of the Linnean Society 184.1 (2018), pp. 211-235. DOI: $10.1093 /$ zoolinnean/zlx098/4783131.

[2507] R. W. Boessenecker, M. Churchill, E. A. Buchholtz, B. L. Beatty, and J. H. Geisler. "Convergent Evolution of Swimming Adaptations in Modern Whales Revealed by a Large Macrophagous Dolphin from the Oligocene of South Carolina". English. In: Current Biology 30 (2020), pp. 1-7. DOI: 10.1016/j.cub.2020.06.012.

[2508] R. W. Boessenecker, D. J. Eheret, D. J. Long, M. Churchill, E. Martin, and S. J. Boessenecker. “The Early Pliocene extinction of the mega-toothed shark Otodus megalodon: a view from the eastern North Pacific". English. In: PeerJ 7 (2019), e6088. DOI: 10.7717/ peerj.6088.

[2509] R. W. Boessenecker and R. E. Fordyce. "A new eomysticetid (Mammalia: Cetacea) from the Late Oligocene of New Zealand and re-evaluation of 'Mauicetus' waitakiensis". English. In: Zoological Journal of the Linnean Society 175 (2015), pp. 607-660. DOI: 10.1002/spp2.1005.

[2510] R. W. Boessenecker and R. E. Fordyce. "A new genus and species of eomysticetid (Cetacea: Mysticeti) and a reinterpretation of 'Mauicetus' lophocephalus Marples, 1956: Transitional baleen whales from the upper Oligocene of New Zealand". English. In: Zoological Journal of the Linnean Society (2015). DOI: 10.1111/zoj.12297. 
[2511] R. W. Boessenecker and R. E. Fordyce. “Anatomy, feeding ecology, and ontogeny of a transitional baleen whale: a new genus and species of Eomysticetidae (Mammalia: Cetacea) from the Oligocene of New Zealand". English. In: PeerJ 3 (2015), e1129.

[2512] R. W. Boessenecker and R. E. Fordyce. "A new eomysticetid from the Oligocene Kokoamu Greensand of New Zealand and a review of the Eomysticetidae (Mammalia, Cetacea)". English. In: Journal of Systematic Palaeontology 15.6 (2017), pp. 429-469. DOI: 10.1080/14772019.2016.1191045.

[2513] R. W. Boessenecker and R. E. Fordyce. “Cosmopolitanism and Miocene survival of Eomysticetidae (Cetacea: Mysticeti) revealed by new fossils from New Zealand". English. In: New Zealand Journal of Geology and Geophysics (2017). DOI: 10.1080/00288306.2017.1300176.

[2514] R. W. Boessenecker, D. Fraser, M. Churchill, and J. H. Geisler. "A toothless dwarf dolphin (Odontoceti: Xenorophidae) points to explosive feeding diversification of modern whales (Neoceti)". English. In: Proceedings of the Royal Society B 284 (2017), p. 20170531. DOI: 10.1098/rspb.2017.0531.

[2515] R. W. Boessenecker and J. H. Geisler. "New records of the archaic dolphin Agorophius (Mammalia: Cetacea) from the upper Oligocene Chandler Bridge Formation of South Carolina, USA". English. In: PeerJ 6 (2018), e5290. DOI: 10.7717/peerj.5290.

[2516] R. W. Boessenecker and F. A. Perry. "Mammalian bite marks on juvenile fur seal bones from the Late Neogene Purisima Formation of central California". English. In: Palaios 26.2 (2011), pp. 115120.

[2517] R. W. Boessenecker, F. A. Perry, and J. H. Geisler. "Globicephaline whales from the Mio-Pliocene Purisima Formation of central California, USA". English. In: Acta Palaenotologica Polonica 60.1 (2015), pp. 113-122. DOI: 10.4202/app.2013.0019.

[2518] R. W. Boessenecker and A. W. Poust. "Freshwater occurrence of the extinct dolphin Parapontoporia (Cetacea: Lipotidae) from the Upper Pliocene nonmarine Tulare Formation of California". English. In: (2015). DOI: 10.1111/pala.12153.

[2519] R. W. Boessenecker and N. A. Smith. "Latest Pacific Basin Record of a Bony-Toothed Bird (Aves, Pelagornithidae) from the Pliocene Purisima Formation of California, U.S.A." English. In: Journal of Vertebrate Paleontology 31.3 (2011), pp. 652-657.

[2520] S. J. Boessenecker, R. W. Boessenecker, and J. Geisler. Youngest record of extinct walrus Ontocetus ommonsi (Carnivora: Odobenidae): Plio-Pleistocene Austin Sand Pit, South Carolina, USA. English. 2017.

[2521] S. J. Boessenecker, R. W. Boessenecker, and J. H. Geisler. "Youngest record of the extinct walrus Ontocetus emmonsi from the Early Pleistocene of South Carolina and a review of North Atlantic walrus biochronology". English. In: Acta Palaeontologica Polonica 63.2 (2018), pp. 279-286. DOI: 10.4202/app.00454.2018.

[2522] S. Boessenkool, J. J. Austin, T. H. Worthy, P. Scofield, A. Cooper, P. J. Seddon, and J. M. Waters. "Relict or colonizer? Extinction and range expansion of penguins in southern New Zealand". English. In: Proceedings of the Royal Society B 276 (2009), pp. 815-821.

[2523] O. Boeuf, D. Geraads, and C. Guth. "Cervides Villafranchiens de Blassac-la-Girondie (HauteLoire, France)". French. In: Annales de Paleontologie 78.3 (1992), pp. 159-187.

[2524] Z. Boev. "First finds of giant land tortoises discovered in Bulgaria". English. In: News of the Bulgarian Academy of Sciences 56.4 (2008), pp. 2-4.

[2525] Z. Boev. "First European Neogene record of true pheasants from Gorna Sushitsa (SW Bulgaria)". English. In: Historia naturalis bulgarica 41 (2020), pp. 33-39.

[2526] Z. Boev. "A Lower Miocene gull (Larinae gen. indet.) (Laridae Vigors, 1825 - Charadriiformes Huxley, 1867) from Hrabarsko (W Bulgaria)". English. In: Geologica Balcanica 30.1-2 (2000), pp. 2531.

[2527] Z. Boev and N. Spassov. "First record of ostriches (Aves, Struthioniformes, Struthionidae) from the late Miocene of Bulgaria with taxonomic and zoogeographic discussion". English. In: Geodiversitas 31.3 (2009), pp. 493-507. DOI: 10.5252/g2009n3a1. 
[2528] S. Bogan, F. L. Agnolin, and F. E. Novas. "New selachian records from the Upper Cretaceous of southern Patagonia: paleobiogeographical implications and the description of a new taxon". English. In: Journal of Vertebrate Paleontology 36.3 (2016), e1105235:1-9. DOI: 10.1080 / 02724634. 2016.1105235.

[2529] S. Bogan, F. L. Agnolin, and A. Scanferla. "A new Andinichthyidae catfish (Ostariophysi, Siluriformes) from the Paleogene of northwestern Argentina". English. In: Journal of Vertebrate Paleontology 38.3 (2018), e1449117. DOI: 10.1080/02724634.2018.1449117.

[2530] J. Bogner, G. L. Hoffman, and K. R. Aulenback. “A fossilized aroid infructescence, Albertarum pueri geno. nov. et sp. nov., of Late Cretaceous (late Campanian) age from the Horseshoe Canyon Formation of southern Alberta, Canada". English. In: Canadian Journal of Earth Sciences 83 (2005), pp. 591-598.

[2531] O. K. Bogolepova, A. P. Gubanov, and V. I. Pease. “Bohemian-type Silurian (Telychian) bivalves from Arctic Russia". English. In: Geologiska Föreningen 127.4 (2005), pp. 247-252.

[2532] O. K. Bogolepova and J. K. "Ancestral forms of Bohemian type Bivalvia from the lower Silurian of Siberia (Tungusskaja Syneclise, Russia)". English. In: Géobios 28.6 (1995), pp. 691-699.

[2533] O. K. Bogolepova, B. Kröger, M. Falahatgar, and M. Javidan. “Middle Ordovician cephalopods from the Abarsaj area, northern Iran". English. In: GFF - Geological Society of Sweden 136.1 (2014), pp. 34-37.

[2534] M. F. Bogoslovskaya. "Permian Ammonoids from the Pai-Khoy Range and Vaigach Island". English. In: Paleontological Journal 31.6 (1997), pp. 588-594.

[2535] M. F. Bogoslovskaya and M. S. Boiko. "The evolution and distribution of the Early Permian genus Uraloceras (Ammonoidea)". English. In: Paleontological Journal 36.6 (2002), pp. 598-605.

[2536] M. F. Bogoslovskaya, T. B. Leonova, and A. A. Shkolin. "The Carboniferous-Permian boundary and ammonoids from the Aidaralash section, southern Urals". English. In: Journal of Paleontology 69.2 (1995), pp. 288-301.

[2537] A. Bogri, A. Solodovnikov, and D. ya. "Baltic amber impact on historical biogeography and palaeoclimate research: oriental rove beetle Dysanabatium found in the Eocene of Europe (Coleoptera, Staphylinidae, Paederinae)". English. In: Papers in Palaeontology 4 (2018), pp. 433-452.

[2538] A. Bogri, A. Solodovnikov, J. L. Kypke, and D. ya. "Baltic amber members of the extant MicrillusScymbalium lineage of the Paederinae rove beetles (Coleoptera, Staphylinidae) and their systematic and ecological significance". English. In: Invertebrate Systematics 34 (2020), pp. 451-473. DOI: 10.1071/IS19070.

[2539] L. L. Bohach and E. K. Frampton. "Middle Cenomanian (Late Cretaceous) molluscs of the Shaftesbury Formation, Birch Mountains, northeastern Alberta, Canada". English. In: Canadian Journal of Earth Sciences 52.8 (2015), pp. 542-556. DOI: 10.1139/cjes-2014-016.

[2540] J. Bohaty and H.-G. Herbig. "Middle Givetian echinoderms from the Schlade Valley (Rhenish Massif, Germany): habitats, taxonomy and ecostratigraphy". English. In: Palaeontologische Zeitschrift 84 (2010), pp. 365-385.

[2541] F. Böhm, O. Ebli, L. Krystyn, H. Lobitzer, M. Rakús, and M. Siblk. “Fauna, Stratigraphy and Depositional Environment of the Hettangian-Sinemurian (Early Jurassic) of Adnet (Salzburg, Austria)". In: Abhandlungen der Geologischen Bundesanstalt Wien 56.2 (1999), pp. 143-271.

[2542] M. Böhme. “Die Landsäugerfauna des Unteroligozäns der Leipziger Bucht - Stratigraphie, Genese und Ökologie". German. In: Neues Jahrbuch für Geologie und Paläontologie, Abhandlungen 220.1 (2001), pp. 63-82.

[2543] M. Böhme. 3. Herpetofauna (Anura, Squamata) and palaeoclimatic implications: preliminary results. English. Vol. 108A. Oligocene-Miocene Vertebrates from the Valley of Lakes (Central Mongolia): Morphology, phylogenetic and stratigraphic implications. Annalen des Naturhistorischen Museums in Wien. 2007, pp. 43-52. 
[2544] M. Böhme. “Ectothermic vertebrates (Actinopterygii, Allocaudata, Urodela, Anura, Crocodylia, Squamata) from the Miocene of Sandelzhausen (Germany, Bavaria) and their implications for environment reconstruction and palaeoclimate". English. In: Paläontologische Zeitschrift 84.1 (2010), pp. 3-41. DOI: $10.1007 /$ s12542-010-0050-4.

[2545] M. Böhme. "Ectothermic vertebrates (Teleostei, Allocaudata, Urodela, Anura, Testudines, Choristodera, Crocodylia, Squamata) from the Upper Oligocene of Oberleichtersbach (Northern Bavaria, Germany)". English. In: Courier Forschungsinstitut Senckenberg 260 (2008), pp. 161-183.

[2546] M. Böhme. "Lower Vertebrates (Teleostei, Amphibia, Sauria) from the Karpatian of the Korneuburg Basin - Paleoecological, environmental and paleoclimatical implications". English. In: Beiträge Paläontologie 27 (2002), pp. 339-353.

[2547] M. Böhme. “Doppelschleichen (Sauria, Amphisbaenia) aus dem Untermiozän von Stubersheim 3 (Süddeutschland)". German. In: Mitteilungen der Bayerischen Staatssammlung für Paläontologie und historischen Geologie 39 (1999), pp. 85-90.

[2548] M. Böhme, M. Aiglstorfer, P. -O. Antoine, E. Appel, P. Havlik, G. Métais, Laq The Phuc, S. Schneider, F. Setzer, R. Tappert, Dang Ngoc Tran, and D. Uhl. J. Prieto. “Na Duong (northern Vietnam) an exceptional window into Eocene ecosystems from Southeast Asia". English. In: Zitteliana A 53 (2013), pp. 120-167.

[2549] M. Böhme, N. Spassov, M. Ebner, D. Geraads, L. Hristova, U. Kirscher, S. Kötter, U. Linnemann, J. Prieto, S. Roussiakis, G. Theodorou, G. Uhlig, and M. Winklhofer. "Messinian age and savannah environment of the possible hominin Graecopithecus from Europe". English. In: PLoS One 12.5 (2017). DOI: 10.1371/journal.pone.0177347.

[2550] M. Bohme, N. Spassov, J. Fuss, A. Troscher, A. S. Deane, J. Prieto, T. Lechner, and D. R. Begun. “A new Miocene ape and locomotion in the ancestor of great apes and humans". English. In: Nature (2019), pp. 1-18.

[2551] M. Böhme and D. Vasilyan. "Ectothermic vertebrates from the late Middle Miocene of Gratkorn (Austria, Styria)". English. In: Palaeobiodiversity and Palaeoenvironments 92 (2014), pp. 21-40. DOI: 10.1007/s12549-013-0143-7.

[2552] M. S. Boiko, T. B. Leonova, and L. Mu. "Phylogeny of the Permian Family Metalegoceratidae (Goniatitida, Ammonoidea)". English. In: Paleontological Journal 42.6 (2008), pp. 585-595.

[2553] J.-R. Boisserie. "The phylogeny and taxonomy of Hippopotamidae (Mammalia: Artiodactyla): a review based on morphology and cladistic analysis". English. In: Zoological Journal of the Linnean Society 143 (2005), pp. 1-26.

[2554] J.-R. Boisserie. “A new species of Hippopotamidae (Mammalia, Artiodactyla) from the Sgantole Formation, Middle Awash, Ethiopia". English. In: Bulletin de la Societe Geologique de France 175.5 (2004), pp. 525-533.

[2555] J.-R. Boisserie, M. Brunet, L. Andossa, and P. Vignaud. "Hippopotamids from the Djurab Pliocene faunas, Chad, Central Africa". English. In: Journal of African Earth Sciences 36 (2003), pp. 15-27.

[2556] J.-R. Boisserie, A. Likius, P. Vignaud, and M. Brunet. "A New Late Miocene Hippopotamid from Toros-Menalla, Chad". English. In: Journal of Vertebrate Paleontology 25.3 (2005), pp. 665-673.

[2557] J.-R. Boisserie, G. Suwa, B. Asfaw, F. Lihoreau, R. L. Bernor, S. Katoh, and Y. Beyene. "Basal hippopotamines from the upper Miocene of Chorora, Ethiopia". English. In: Journal of Vertebrate Paleontology 37.3 (2003), e1297718. DOI: 10.1080/02724634.2017.1297718.

[2558] J.-R. Boisserie and T. D. White. "A new species of Pliocene Hippopotamidae from the Middle Awash, Ethiopia". English. In: Journal of Vertebrate Paleontology 24.2 (2004), pp. 464-473.

[2559] M. Boivin, L. Marivaux, M. J. Orliac, F. Pujos, R. Salas-Gismondi, J. V. Tejada-Lara, and P. -O. Antoine. "Late middle Eocene caviomorph rodents from Contamana, Peruvian Amazonia". English. In: Palaeontologia Electronica 20.1 (2017), 19A:1-50.

[2560] M. Boivin, L. Marivaux, A. M. Candela, M. J. Orliac, F. Pujos, R. Salas-Gismondi, J. V. Tejada-Lara, and P. -O. Antoine. "Late Oligocene caviomorph rodents from Contamana, Peruvian Amazonia". English. In: Papers in Palaeontology 3.1 (2017), pp. 69-109. 
[2561] M. Boivin, M. J. Orliac, M. Antunes Telles, M. Godinot, Y. Laurent, B. Marandat, D. Vidalenc, and R. Tabuce. "New material of Diacodexis (Mammalia, Artiodactyla) from the early Eocene of Southern Europe". English. In: Geobios 51.4 (2018), pp. 285-306. DOI: 10.1016/j.geobios.2018.06. 003.

[2562] M. Boivin, A. Pierre-Olivier, A. Benites-Palomino, L. Marivaux, and R. Salas-Gismondi. "A new record of a giant neoepiblemid rodent from Peruvian Amazonia and an overview of lower tooth dental homologies among chinchilloids". English. In: Acta Palaeontologica Polonica 64 (2019).

[2563] S. Boivin, M. Gretz, B. Lathuiliere, N. Olivier, A. Bartolini, and R. Martini. "Coral- and oystermicrobialite patch reefs in the aftermath of the Triassic-Jurassic biotic crisis (Sinemurian, Southeast France)". English. In: Swiss Journal of Geosciences (2018). DOI: 10.1007/s00015-018-0310-y.

[2564] A.-V. Bojar, Z. Ciski, and D. Grigorescu. "Stable isotope distribution in Maastrichtian vertebrates and paleosols from the Hateg Basin, South Carpathians". English. In: Palaeogeography, Palaeoclimatology, Palaeoecology 239 (2010), pp. 329-342. DOI: 10.1016/j.palaeo.2009.08.027.

[2565] W. E. Boles. "A preliminary analysis of the Passeriformes from Riversleigh, Northwestern Queensland, Australia, with the description of a new species of Lyrebird". English. In: Courier Forschungsinstitut Senckenberg 181 (1995), pp. 163-170.

[2566] W. E. Boles. "Early Eocene shorebirds (Aves: Charadriiformes) from the Tingamarra Local Fauna, Murgon, Queensland, Australia". English. In: Records of the Western Australian Museum, Supplement 57 (1999), pp. 229-238.

[2567] W. E. Boles. "A new flightless gallinule (Aves: Rallidae: Gallinula) from the Oligo-Miocene of Riversleigh, Northwestern Queensland, Australia". English. In: Records of the Australian Museum 57 (2005), pp. 179-190.

[2568] W. E. Boles and B. Backness. "Birds from the Bluffs Downs Local Fauna, Allingham Formation, Queensland". English. In: Records of the South Australian Museum 27.2 (1994), pp. 139-149.

[2569] A. Bolet. "First early Eocene lizards from Spain and a study of the compositional changes between late Mesozoic and early Cenozoic Iberian lizard assemblages". English. In: Palaeontologia Electronica 20.2 (2017), pp. 1-22.

[2570] A. Bolet and M. Auge. "A new miniaturized lizard from the late Eocene of France and Spain". English. In: The Anatomical Record 297.3 (2014), pp. 505-515. DOI: 10.1002/ar.22855.

[2571] A. Bolet, J. D. Daza, M. Auge, and A. M. Bauer. "New genus and species names for the Eocene lizard Cadurcogekko rugosus Augé, 2005". English. In: Zootaxa 3985.2 (2015), pp. 265-274.

[2572] A. Bolet, M. Delfino, J. Fortuny, S. Amécija, J. M. Robles, and D. M. Alba. “An Amphisbaenian Skull from the European Miocene". English. In: PLoS ONE 9.6 (2014). DOI: 10.1371/journal.pone. 0098082.

[2573] A. Bolet and S. E. Evans. "A new lizard from the Early Cretaceous of Catalonia (Spain), and the Mesozoic lizards of the Iberian Peninsula". English. In: Cretaceous Research 31 (2010), pp. 447-457. DOI: 10.1016/j.cretres.2010.06.002.

[2574] A. Bolet and S. E. Evans. "A tiny lizard (Lepidosauria, Squamata) from the Lower Cretaceous of Spain”. English. In: Palaeontology 55.3 (2012), pp. 491-500. DOI: 10.1111/j.1475-4983.2012.01145.x.

[2575] A. Bolet and S. E. Evans. "Lizards and amphisbaenians (Reptilia, Squamata) from the late Eocene of Sosss (Catalonia, Spain)". English. In: Palaeontologia Electronica 16.1 (2013), 8A.

[2576] H. R. Bollan. "The Bollan Stegosaurus". English. In: Guidebook for Dinosaur Quarries and Tracksites Tour, Western Colorado and Eastern Utah. Grand Junction, CO: Grand Junction Geological Society, 1991, pp. 53-54.

[2577] T. Bollinger. “Geologie und Paläontologie der Glimmersandgrube Helsighausen (Kt. Thurgau); Geology and paleontology of the mica-rich sand pit of Helsighausen (Canton Thurgau)". German. In: Mitteilungen der thurgauischen naturforschenden Gesellschaft 52 (1994), pp. 63-79. 
[2578] Th. Bollinger. “Die Obere SüSSwassermolasse in Bayern und der Ostschweiz: bio- und lithostratigraphische Korrelationen (Upper Freshwater molasse in Bavaria and Eastern Switzerland: bioand lithostratigraphic correlations)". German. In: Mitteilungen der Bayerischen Staatssammlung für Paläontologie und Historische Geologie 34 (1994), pp. 109-144.

[2579] Y. L. Bolotsky and P. Godefroit. "A new hadrosaurine dinosaur from the Late Cretaceous of Far Eastern Russia". In: Journal of Vertebrate Paleontology 24.2 (2004), pp. 351-365.

[2580] Y. L. Bolotsky and S. M. Kurzanov. "Gadrosavry Priamuriy [The hadrosaurs of the pre-Amur Region]". Russian. In: Geology of the Pacific Ocean Border (1991), pp. 94-103.

[2581] J. R. Bolt and S. Chatterjee. "A new temnospondyl amphibian from the Late Triassic of Texas". English. In: Journal of Paleontology 74.4 (2000), pp. 670-683.

[2582] J. R. Bolt and R. E. Lombard. "The mandible of the primitive tetrapod Greererpeton, and the early evolution of the tetrapod lower jaw". English. In: Journal of Paleontology 75.5 (2001), pp. 1016-1042.

[2583] J. R. Bolt and R. E. Lombard. "Sigournea multidentata, a New Stem Tetrapod from the Upper Mississippian of Iowa, USA". English. In: Journal of Paleontology 80.4 (2006), pp. 717-725.

[2584] J. R. Bolt and R. E. Lombard. "Deltaherpeton hiemstrae, a new colosteid tetrapod from the Mississippian of Iowa". English. In: Journal of Paleontology 84.6 (2010), pp. 1135-1151.

[2585] T. E. Bolton and R. J. Cuffey. "Bryozoa of the Romaine and Mingan Formations (Lower and Middle Ordovician) of the Mingan Islands, Quebec, Canada". English. In: Bryozoan Studies 2004: Proceedings of the 13th International Bryozoology. 2005, pp. 25-42.

[2586] B. Bomfleur and I. Escapa. "A silicifed Todea trunk (Osmundaceae) from the Eocene of Patagonia". English. In: PalZ (2019), pp. 1-6. DOI: 10.1007/s12542-019-00479-6.

[2587] M. Bon, G. Piccoli, and B. Sala. "I giacimenti Quaternari di vertebrati fossili nell'Italia NordOrientale". Italian. In: Memorie degli Instituti di Geologia e Mineralogia dell'Universita di Padova 47 (1991), pp. 185-231.

[2588] P. Bona. "A new species of Eocaiman Simpson (Crocodylia, Alligatoridae) from the Lower Paleocene of Patagonia [Una nueva especie de Eocaiman Simpson (Crododylia, Alligatoridae) del Paleoceno Inferior de Patagonia]". Spanish. In: Ameghiniana 44.2 (2007), pp. 435-445.

[2589] P. Bona and F. Barrios. "The Alligatoroidea of Argentina: an update of its fossil record". English. In: Publicación Electrónica de la Asociación Paleontológica Argentina 15.1 (2015), pp. 143-158.

[2590] P. Bona and A. P. Carabajal. "Caiman gasparinae sp. nov., a huge alligatorid (Caimaninae) from the late Miocene of Paraná, Argentina". English. In: Alcheringa 37 (2013), pp. 462-473.

[2591] P. Bona and M. S. de la Fuente. "Phylogenetic and paleobiogeographic implications of Yaminuechelys maior (Staesche, 1929) new comb, a large long-necked chelid turtle from the early Paleocene of Patagonia, Argentina". English. In: Journal of Vertebrate Paleontology 25.3 (2005), pp. 569582.

[2592] P. Bona, M. S. De la Fuente, and M. A. Reguero. "Short note new fossil turtle remains from the Eocene of the Antarctic Peninsula". English. In: Antarctic Science 22.5 (2010), pp. 531-532. DOI: 10.1017/S0954102010000362.

[2593] P. Bona, M. D. Ezcurra, F. Barrios, and M. V. Fernandez Blanco. “A new Palaeocene crocodylian from southern Argentina sheds light on the early history of caimanines". English. In: Proceedings of the Royal Society B 285 (2018), 20180843:1-6.

[2594] P. Bona, M. V. Fernandez Blanco, T. M. Scheyer, and C. Foth. "Shedding light on the taxonomic diversity of the South American Miocene caimans: the status of Melanosuchus fisheri (Crocodylia, Alligatoroidea)". English. In: Ameghiniana 54.6 (2017), pp. 681-687. DOI: 10.5710/ AMGH.08.06. 2017.3103.

[2595] P. Bona, S. Heredia, and M. de la Fuente. "Tortugas continentales (Pleurodira: Chelidae) en la Formación Roca (Daniano), provincia de Ro Negro, Argentina [Continental turtles (Pleurodira: Chelidae) from the Roca Formation (Danian), Ro Negro Province, Argentina]". Spanish. In: Ameghiniana 46.2 (2009), pp. 255-262. 
[2596] P. Bona, D. Starck, C. Galli, Z. Gasparini, and M. Reguero. “Caiman cf. latirostris (Alligatoridae, Caimaninae) in the Late Miocene Palo Pintado Formation, Salta Province, Argentina: Paleogeographic and Paleoenvironmental considerations". English. In: Ameghiniana 51.1 (2014), pp. 26-36.

[2597] S. Bonanno and G. Sirna. "Revision of some species of Cenomanian caprinid rudists instituted by G. G. Gemmellaro in 1865". English. In: Revista Mexicana de Ciencias Geo1ógicas 12.2 (1995), pp. 135144.

[2598] J. F. Bonaparte. “Los vertebrados fósiles de la Formación Rio Colorado, de la Ciudad de Neuquén y Cercanas, Cretácico Superior, Argentina [The vertebrate fossils of the Rio Colorado Formation, from the city of Neuquén and surrounding areas, Upper Cretaceous, Argentina]". Spanish. In: Revista del Museo Argentino de Ciencias Naturales Bernardino Rivadavia e Instituto Nacional de Investigación de las Ciencias Naturales: Paleontologa 4.3 (1991), pp. 17-123.

[2599] J. F. Bonaparte. An armoured sauropod from the Aptian of northern Patagonia, Argentina. English. Vol. 15. Y. Tomida, T. H. Rich, and P. Vickers-Rich (eds.), Proceedings of the Second Gondwanan Dinosaur Symposium, National Science Museum Monographs. 1999, pp. 1-12.

[2600] J. F. Bonaparte. "Evolución de las vértebras presacras en Sauropodomorpha [Evolution of the presacral vertebrae in Sauropodomorpha]". Spanish. In: Ameghiniana 36.2 (1999), pp. 115-187.

[2601] J. F. Bonaparte. "New Late Cretaceous mammals from the Los Alamitos Formation, Northern Patagonia". English. In: National Geographic Research 6.1 (1990), pp. 63-93.

[2602] J. F. Bonaparte. “New Dryolestida (Theria) from the Late Cretaceous of Los Alamitos, Argentina, and paleogeographical comments". English. In: Neues Jahrbuch für Geologie und Paläontologie Abhandlungen 224.3 (2002), pp. 339-371.

[2603] J. F. Bonaparte and M. C. Barberena. “On two advanced carnivorous cynodonts from the Late Triassic of Southern Brazil". English. In: Bulletin of the Museum of Comparative Zoology 156 (2001), pp. 59-80.

[2604] J. F. Bonaparte, G. Brea, C. L. Schultz, and A. G. Martinelli. "A new specimen of Guaibasaurus candelariensis (basal Saurischia) from the Late Triassic Caturrita Formation of southern Brazil". English. In: Historical Biology 19 (2007), pp. 73-82.

[2605] J. F. Bonaparte and R. A. Coria. “Un neuvo y gigantesco saurópodo titanosaurio de la Formación Rio Limay (Albanio-Cenomaniano) de la Provincia del Neuquén, Argentina [A new and huge titanosaur sauropod from the Rio Limay Formation (Albian-Cenomanian) of Neuquén Province, Argentina]". Spanish. In: Ameghiniana 30.3 (1993), pp. 271-282.

[2606] J. F. Bonaparte, J. Ferigolo, and A. M. Ribeiro. A new early Late Triassic saurischian dinosaur from Rio Grande do Sol state, Brazil. English. Vol. 15. Proceedings of the Second Gondwanan Dinosaur Symposium, National Science Museum Monographs. 1999, pp. 89-109.

[2607] J. F. Bonaparte, J. Ferigolo, and A. M. Ribeiro. “A primitive Late Triassic 'ictidosaur' from Rio Grande do Sul, Brazil". English. In: Palaeontology 44.4 (2001), pp. 623-635.

[2608] J. F. Bonaparte, B. J. González Riga, and S. Apestegua. “Ligabuesaurus leanzai gen. et sp. nov. (Dinosauria, Sauropoda), a new titanosaur from the Lohan Cura Formation (Aptian, Lower Cretaceous) of Neuquén, Patagonia, Argentina". English. In: Cretaceous Research 27 (2006), pp. 364376.

[2609] J. F. Bonaparte, W.-D. Heinrich, and R. Wild. "Review of Janenschia Wild, with the description of a new sauropod from the Tendaguru beds of Tanzania and a discussion on the systematic value of procoelous caudal vertebrae in the Sauropoda". English. In: Palaeontographica Abteilung A 256.1-3 (2000), pp. 25-76.

[2610] J. F. Bonaparte, A. G. Martinelli, C. L. Schultz, and R. Rubert. “The sister group of mammals: small cynodonts from the Late Triassic of southern Brazil". English. In: Revista Brasileira de Paleontologa 5 (2003), pp. 5-27. 
[2611] J. F. Bonaparte and O. Mateus. “A new diplodocid, Dinheirosaurus lourinhanensis gen. et sp. nov., from the Late Jurassic beds of Portugal". English. In: Revista del Museo Argentino de Ciencias Naturales Bernardino Rivadavia e Instituto Nacional de Investigación de las Ciencias Naturales, Paleontologa 5.2 (1999), pp. 13-29.

[2612] J. F. Bonaparte and J. Morales. “Un primitivo Notonychopidae (Litopterna) del Paleoceno inferior de Punta Peligro, Chubut, Argentina". Spanish. In: Estudios Geológicos 53.5-6 (1997), pp. 263-274.

[2613] J. F. Bonaparte and J. A. Pumares. "Notas sobre el primer craneo de Riojasaurus incertus (Dinosauria, Prosauropoda, Melanorosauridae) del Triasico Superior de La Rioja, Argentina [Notes on the first skull and jaws of Riojasaurus incertus (Dinosauria, Prosauropoda, Melanorosauridae), Late Triassic of La Rioja, Argentina]". Spanish. In: Ameghiniana 32.4 (1995), pp. 341-349.

[2614] J. F. Bonaparte, C. L. Schultz, and M. B. Soares. Pterosauria from the Late Triassic of southern Brazil. English. Vol. 132. New Aspects of Mesozoic Biodiversity, Lecture Notes in Earth Sciences. 2010, pp. 63-71.

[2615] J. F. Bonaparte, C. L. Schultz, M. B. Soares, and A. G. Martinelli. "La fauna local de Faxinal do Soturno, Triásico Tardo de Rio Grande do Sul, Brasil". Portugese. In: Revista Brasileira de Paleontologa 13.3 (2010), pp. 233-246.

[2616] J. F. Bonaparte and H.-D. Sues. “A new species of Clevosaurus (Lepidosauria: Rhynchocephalia) from the Upper Triassic of Rio Grande do Sul, Brazil". English. In: Palaeontology 49 (2006), pp. 917923.

[2617] L. Bonato, G. D. Edgecombe, and A. Minelli. "Geophilomorph centipedes from the Cretaceous amber of Burma". English. In: Palaeontology 57 (2014), pp. 97-110.

[2618] I. Boncheva, V. Sachanski, I. Lakova, and M. Yaneva. "Facies transition and biostratigraphic correlation of the Upper Silurian and Lower Devonian in West Bulgaria". English. In: Geological Quarterly 51.4 (2007), pp. 407-418.

[2619] C. Bonci, G. Cirone, B. Merlino, and L. Zaliani. "The Oligocene mollusc fauna of the Piedmont Basin (north-western Italy) 1 . Scaphopoda and Archaeogastropoda". English. In: Rivista Italiana di Paleontologia e Stratigrafia 106.2 (2000), pp. 203-236.

[2620] M. Bond and M. Garca. "Nuevos restos de toxodonte (Mamalia, Notoungulata) en estratos de la Formación Chucal, Mioceno, Altiplano de Arica, norte de Chile". English. In: Revista Geológica de Chile 29.1 (2002), pp. 81-91.

[2621] M. Bond, A. Kramarz, R. D. E. MacPhee, and M. Reguero. “A new astrapothere (Mammalia, Meridiungulata) from La Meseta Formation, Seymour (Marambio) Island, and a reassessment of previous records of antarctic astrapotheres". English. In: American Museum Novitates 3718 (2011), pp. 1-16. DOI: 10.1206/3718.2.

[2622] M. Bond, G. López, M. A. Reguero, G. J. Scillato-Yané, and M. G. Vucetich. “Los mamferos de la Formación Fray Bentos (Edad Mamfero Deseadense, Oligoceno superior?) de las provincias de Corrientes y Entre Ros, Argentina". English. In: Asociación Paleontológica Argentina, Publicación Especial 5 (1998), pp. 41-50.

[2623] M. Bond and G. M. López. “El primer Notohippidae (Mammalia, Notoungulata) de la Formación Lumbrera (Grupo Salta) del noroeste Argentino. Consideraciones sobre la sistematica de la familia Notohippidae". Spanish. In: Ameghiniana 30.1 (1993), pp. 59-68.

[2624] M. Bond and G. M. López. “Los Mamferos de la Formación Casa Grande (Eoceno) de la Provincia de Jujuy, Argentina". Spanish. In: Ameghiniana 32.3 (1995), pp. 301-309.

[2625] M. Bond, D. Perea, M. Ubilla, and M. Tauber. "Neolicaphrium recens Frenguelli, 1921, the only surviving Proterotheriidae (Litopterna, Mammalia) into the South American Pleistocene". English. In: Palaeovertebrata 30.1-2 (2001), pp. 37-50.

[2626] M. Bond, M. A. Reguero, S. F. Vizcaino, and S. A. Marenssi. "A new 'South American ungulate' (Mammalia: Litopterna) from the Eocene of the Antarctic Peninsula". English. In: Geological Society, London, Special Publications 258 (2006), pp. 163-176. 
[2627] M. Bond, M. Tejedor, K. E. Campbell, L. Chornogubsky, N. Novo, and F. Goin. “Eocene primates of South America and the African origins of New World monkeys". English. In: Nature 520 (2015), pp. 538-541. DOI: $10.1038 /$ nature14120.

[2628] J. W. Bonde, R. P. Hilton, F. D. Jackson, and P. A. Druschke. "Fauna of the Newark Canyon Formation (Lower Cretaceous), east-central Nevada". English. In: vol. 2. New Concepts and Discoveries. 2015 Geological Society of Nevada Symposium. Reno: DEStech Publications, Inc., 2015, pp. 721732.

[2629] J. W. Bonde, D. J. Varricchio, F. D. Jackson, D. B. Loope, and A. M. Shirk. “Dinosaurs and dunes! Sedimentology and paleontology of the Mesozoic in the Valley of Fire State Park". English. In: vol. 11. Field Guide to Plutons, Volcanoes, Faults, Reefs, Dinosaurs, and Possible Glaciation in Selected Areas of Arizona, California, and Nevada: Geological Society of America Field Guide. Geological Society of America, 2008, pp. 249-262. DOI: 10.1130/2008.fld011(11).

[2630] N. Bonde. An Early Cretaceous (Ryazanian) fauna of Purbeck-Wealden type at Robbedale, Bornholm, Denmark. English. In G. Arratia \& A. Tintori (eds.), Mesozoic Fishes 3 - Systematics, Paleoenvironments and Biodiversity. Verlag Dr. Friedrich Pfeil, München. 2004, pp. 507-528.

[2631] N. Bonde and P. Christiansen. "New dinosaurs from Denmark". English. In: Comptes Rendus Palevol 2.1 (2003), pp. 13-26. DOI: 10.1016/S1631-0683(03)00009-5.

[2632] D. A. Bone, J. A. Todd, and S. Tracey. "Fossils from the Bracklesham Group exposed in the M27 Motorway excavations, Southampton, Hampshire". English. In: Tertiary Research 12.3-4 (1991), pp. 131-137.

[2633] J. R. Bonelli Jr., C. E. Brett, A. I. Miller, and J. B. Bennington. "Testing for faunal stability across a regional biotic transition: quantifying stasis and variation among recurring coral-rich biofacies in the Middle Devonian Appalachian Basin”. English. In: Paleobiology 32.1 (2006), pp. 20-37.

[2634] D. C. Bonfim Júnior and R. B. Marques. "Um novo lagarto do Cretáceo do Brazil (Lepidosauria, Squamata, Lacertilia - Formação Santana, Aptiano da Bacia do Araripe". Portugese. In: Anuário do Instituto do Geociencias 20 (1997), pp. 233-240.

[2635] M. Boni, A. Iannace, M. Torre, and V. Zamparelli. "The Ladinian-Carnian reef facies of Monte Caramolo (Calbria, Southern Italy)". English. In: Facies 30 (1994), pp. 101-118.

[2636] O. Bonilla, M. A. López-Horgue, and P. A. Fernandez-Mendiola. "Morphological diversity of Lower Cretaceous (Aptian-Albian) Scleractinian corals, Basque-Cantabrian Basin, Spain". English. In: Jornadas de Paleontologa y IV Congreso Ibérico de Paleontologa (2018).

[2637] I. Bonilla-Salomón, R. Minwer-Barakat, M. Vianey-Liaud, and S. Moyá-Solá. "Middle Eocene rodents from Sant Jaume de Frontanyá (eastern Pyrenees, northern Spain) and biochronological implications". English. In: Journal of Vertebrate Paleontology (2016). DOI: 10.1080/02724634.2016.1121.

[2638] R. A. Bonini and D. Brandon. "Pyramiodontherium Rovereto (Xenarthra, Tardigrada, Megatheriinae) from the Early Pliocene of San Fernando, Catamarca Province, Argentina". English. In: Ameghiniana 52.6 (2015), pp. 647-655.

[2639] R. A. Bonini, A. R. Miño-Boilini, D. Brandoni, and S. M. Georgieff. "New data on the diversity and chronology of late Neogene sloths (Xenarthra, Folivora) from the Villavil-Quillay Basin, Catamarca, Argentina Ricardo". English. In: Historical Biology (2020), pp. 1-12. DOI: 10.1080/08912963. 2020.1826470ARTICLE.

[2640] R. A. Bonini, G. I. Schmidt, M. A. Reguero, E. Cerdeño, A. M. Candela, and N. Sols. “First record of Toxodontidae (Mammalia, Notoungulata) from the late Miocene-early Pliocene of the southern central Andes, NW Argentina". English. In: Journal of Paleontology 91.3 (2017), pp. 566-576. DOI: 10.1017/jpa.2016.160.

[2641] M. F. Bonnan and M. J. Wedel. "First occurrence of Brachiosaurus (Dinosauria: Sauropoda) from the Upper Jurassic Morrison Formation of Oklahoma". English. In: PaleoBios 24.2 (2004), pp. 1321.

[2642] S. Bonneville. "Molecular identification of fungi microfossils in a Neoproterozoic shale rock". English. In: Science Advances 6 (2020), eaax7599. DOI: 10.1126/sciadv.aax7599. 
[2643] A. Bonnot and R. A. Gygi. “Les Euaspidoceratinae (Ammonitina, Aspidoceratidae) d'Herznach (Suisse septentrionale) á la fin de la zone á Cordatum (Oxfordien inférieur)". French. In: Eclogae Geologicae Helvetiae 91 (1998), pp. 493-512.

[2644] R. K. Bono, J. Clarke, J. A. Tarduno, and D. Brinkman. "A Large Ornithurine Bird (Tingmiatornis arctica) from the Turonian High Arctic: Climatic and Evolutionary Implications". English. In: Scientific Reports 6 (2016), 38876:1-8.

[2645] N. Bonuso, S. Loyd, and N. J. Lorentz. "Pioneer reef communities within a Middle Triassic (Anisian) to Upper". English. In: Palaeogeography, Palaeoclimatology, Palaeoecology 503 (2018), pp. 1-12. DOI: 10.1016/j.palaeo.2018.03.038.

[2646] I. Boomer. "Lower Jurassic ostracods from Ilminster, Somerset, England". In: Journal of Micropalaeontology 11.1 (1992), pp. 47-57.

[2647] I. Boomer. "Lower Jurassic ostracod biozonation of the Mochras borehole". In: Journal of Micropalaeontology 9.2 (1991), pp. 205-218.

[2648] I. Boomer, N. R. Ainsworth, and J. Exton. "A re-examination of the Pliensbachian and Toarcian Ostracoda of Zambujal, west-central Portugal". In: Journal of Micropalaeontology 17.1 (1998), pp. 114.

[2649] N. Boonchai, P. J. Grote, and P. Jintasakul. Paleontological parks and museums and prominent fossil sites in Thailand and their importance in the conservation of fossils. English. Vol. Chapter 07. PaleoParks The Protection and Conservation of Fossil Sites Worldwide. Carnets de Géologie/Notebooks on Geology, Book 2009/03, Brest. 2009, pp. 75-95.

[2650] A. D. S. Boos, C. F. Kammerer, C. L. Schultz, M. B. Soares, and A. L. R. Ilha. “A New Dicynodont (Therapsida: Anomodontia) from the Permian of Southern Brazil and Its Implications for Bidentalian Origins". English. In: PLoS ONE 11.5 (2016), e0155000.

[2651] A. D. S. Boos, C. F. Kammerer, C. L. Schultz, and V. D. Paes Neto. “A tapinocephalid dinocephalian (Synapsida, Therapsida) from the Rio do Rasto Formation (Paraná Basin, Brazil): Taxonomic, ontogenetic and biostratigraphic considerations". English. In: Journal of South American Earth Sciences 63 (2015), pp. 375-384.

[2652] A. D. S. Boos, C. L. Schultz, C. S. Vega, and J. J. Aumond. “On the presence of the Late Permian dicynodont Endothiodon in Brazil". English. In: Palaeontology 56.4 (2013), pp. 837-848.

[2653] O. Bordonaro. “Nuevos datos sobre Athabaskia anax (Walcott, 1916) (Trilobita, Corynexochida) del Cámbrico medio de la Precordillera de Mendoza, Argentina." Spanish. In: Boletn Geológico y Minero 125.4 (2014), pp. 561-571.

[2654] O. L. Bordonaro and A. L. Banchig. "Biofacies de trilobites cámbricos en la Formación Alojamiento, Precordillera de San Juan y Mendoza, Argentina. Ameghiniana, 44 (1):91-107. Buenos Aires". English. In: (2007).

[2655] O. L. Bordonaro, B. R. Pratt, and V. Robledo. "Systematic morphometric and palaeobiogeographic study of Blania gregaria Walcott, 1916 (Trilobita, Ptychopariida), Middle Cambrian of the Precordillera of western Argentina". English. In: Geological Journal 46.126-141 (2013).

[2656] E. M. Bordy, F. Knoll, and A. J. Bumby. "New data on the palaeontology and sedimentology of the Lower Jurassic Lisbon Formation (Karoo Supergroup), Ellisras Basin, South Africa". English. In: Neues Jahrbuch für Geologie und Paläontologie Abhandlungen 258.2 (2010), pp. 145-155. DOI: 10. $1127 / 0077-7749 / 2010 / 0091$.

[2657] E. Borghi. "Gli ofiuroidi del Pleistocene di San Nicomede (PR)". Italian. In: Societá Reggiana di Scienze Naturali 16.1 (1996), pp. 1-13.

[2658] E. Borghi and P. Stara. “I cidaroidi (Echinoidea) del Miocene inferiore-medio dell'Emilia-Romagna e di San Marino". Italian. In: Parva Naturalia 11 (2016), pp. 13-45.

[2659] S. Borgohain, A. Borgohain, R. Buragohain, V. C. Tewari, and R. K. Ranjan. "Microfossils, microfacies and depositional environment of the PAleocene-Eocene carbonates of the Shillong Plateau, Meghalaya, NE India". English. In: Jour. Ind. Geol. Cong 10.1 (2018), pp. 5-14. 
[2660] H. V. Borisova, R. Y. Dudko, A. A. Gurina, E. V. Zinovyev, K. A. Tsepelev, and A. A. Legalov. “First records of Tychius alexii (Korotyaev, 1991) (Coleoptera, Curculionidae) in recent and Pleistocene faunas of Siberia". Russian. In: Euroasian Entomological Journal 13 (2014), pp. 163-164.

[2661] K. V. Borissenkov. "On some Permian Somoholitids (Ammonoidea) from the Ural Mountains". English. In: Paleontological Journal 38.1 (2004), pp. 20-26.

[2662] K. V. Borissenkov. "A new Permian ammonoid fauna of the Kobylka River (north Urals)". English. In: Paleontological Journal 44.3 (2010), pp. 261-266.

[2663] A. Borkent. "Biting Midges from Upper Cretaceous New Jersey Amber (Diptera: Ceratopogonidae)". English. In: American Museum Novitates 3159 (1996), pp. 1-13.

[2664] A. Borkent. "Upper and Lower Cretaceous Biting Midges (Ceratopogonidae: Diptera) from Hungarian and Austrian Amber and the Koonwarra Fossil Bed of Australia". English. In: Stuttgarter Beiträge zur Naturkunde Serie B (Geologie und Paläontologie) 249 (1997), pp. 1-10.

[2665] A. Borkent. "Leptoconops (Diptera: Ceratopohonidae), the earliest extant lineage of biting midge, discovered in 120-122 million-year-old Lebanese amber". English. In: American Museum Novitates 3328 (2001), pp. 1-11.

[2666] A. Borkent. Biting midges (Ceratopogonidae: Diptera) from Lower Cretaceous Lebanese amber with a discussion of the diversity and patterns found in other ambers. English. Studies on Fossils in Amber, with Particular Reference to the Cretaceous of New Jersey. Leiden: Backhuys Publishers, 2000, pp. 355451.

[2667] A. Borkent. Further biting midges (Diptera: Ceratopogonidae) from Upper Cretaceous New Jersey amber. English. Studies on Fossils in Amber, with Particular Reference to the Cretaceous of New Jersey. Leiden: Backhuys Publishers, 2000, pp. 453-472.

[2668] A. Borkent. "Further biting midges (Diptera: Ceratopogonidae) in Canadian Cretaceous amber". English. In: The Canadian Entomologist 144 (2012), pp. 758-766.

[2669] A. Borkent. “The frog-biting midges of the world (Corethrellidae: Diptera)". English. In: Zootaxa 1804 (2008), pp. 1-456.

[2670] A. Borkent. "The phylogenetic relationships of Cretaceous biting midges, with a key to all known genera (Diptera: Ceratopogonidae)". English. In: American Museum Novitates 3921 (2019), pp. 1-48. DOI: $10.1206 / 3921.1$.

[2671] A. Borkent, R. A. Coram, and E. A. Jarzembowski. "The oldest fossil biting midge (Diptera: Ceratopogonidae) from the Purbeck Limestone Group (Lower Cretaceous) of southern Great Britain". English. In: Polish Journal of Entomology 82 (2013), pp. 273-279.

[2672] A. Borkent and D. A. Grimaldi. "The earliest fossil mosquito (Diptera: Culicidae), in mid-Cretaceous Burmese amber". English. In: Annals of the Entomological Society of America 97.5 (2004), pp. 882-888.

[2673] A. Borkent and D. A. Grimaldi. "The Cretaceous fossil Burmaculex antiquus confirmed as the earliest known lineage of mosquitoes (Diptera: Culicidae)". English. In: Zootaxa 4079 (2016), pp. 457466.

[2674] A. Borkent and R. Szadziewski. "The first records of fossil Corethrellidae (Diptera)". English. In: Entomologica Scandinavica 22 (1992), pp. 457-463.

[2675] A. N. Borkent and B. Bissett. "A revision of the Holarctic species of Serromyia Meigen (Diptera: Ceratopogonidae)". English. In: Systematic Entomology 15 (1990), pp. 153-217.

[2676] E. W. Born. "An assessment of the effects of hunting and climate on walruses in Greenland". English. In: University of Oslo (2005).

[2677] L. A. Borrero and F. M. Martin. "A reinterpretation of the Pleistocene human and faunal association at Las Buitreras Cave, Santa Cruz, Argentina". English. In: Quaternary Science Reviews 27 (2008), pp. 2509-2515.

[2678] P. Borsa. "Marine mammal strandings in the New Caledonia region, Southwest Pacific". English. In: Comptes Rendus Biologies 329.4 (2006), pp. 277-288. 
[2679] M. BorsukBiaynicka and S. E. Evans. "A longnecked archosauromorph from the Early Triassic of Poland". English. In: Palaeontologia Polonica 65 (2009), pp. 203-234.

[2680] M. BorsukBiaynicka and M. Lubka. "Procolophonids from the Early Triassic of Poland". English. In: Palaeontologia Polonica 65 (2009), pp. 107-144.

[2681] M. BorsukBiaynicka and A. G. Sennikov. "Archosauriform postcranial remains from the Early Triassic karst deposits of southern Poland". English. In: Palaeontologia Polonica 65 (2009), pp. 283328.

[2682] M. Borsuk-Bialynicka. “Gobekko cretacicus gen. et sp. n., a new gekkonid lizard from the Cretaceous of the Gobi Desert". English. In: Acta Palaeontologica Polonica 35.1-2 (1990), pp. 67-76.

[2683] M. Borsuk-Bialynicka and V. Alifanov. "First Asiatic 'iguanid' lizards in the Late Cretaceous of Mongolia". English. In: Acta Palaeontologica Polonica 36.3 (1991), pp. 325-342.

[2684] M. Borsuk-Bialynicka, E. Cook, S. E. Evans, and T. Maryanska. "A microvertebrate assemblage from the Early Triassic of Poland". In: Acta Palaeontologica Polonica 44.2 (1999), pp. 167-188.

[2685] M. Borsuk-Bialynicka and S. E. Evans. "A basal archosauriform from the Early Triassic of Poland". In: Acta Palaeontologica Polonica 48.4 (2003), pp. 649-652.

[2686] M. Borsuk-Bialynicka, T. Maryanska, and M. A. Shishkin. "New data on the age of the bone breccia from the locality Czatkowice 1 (Cracow Upland, Poland)". In: Acta Palaeontologica Polonica 48.1 (2003), pp. 153-155.

[2687] T. Borszcz and M. Zaton. "The oldest record of predation on echinoids: evidence from the Middle Jurassic of Poland". English. In: Lethaia 46.2 (2013), pp. 141-145. DOI: 10.1111/let.12007.

[2688] M. R. Borths, P. A. Holroyd, and E. R. Seiffert. “Hyainailourine and teratodontine cranial material from the late Eocene of Egypt and the application of parsimony and Bayesian methods to the phylogeny and biogeography of Hyaenodonta (Placentalia, Mammalia)". English. In: PeerJ 4 (2016), e2639:1-87. DOI: 10.7717 / peerj.2639.

[2689] M. R. Borths and E. R. Seiffert. "Craniodental and humeral morphology of a new species of Masrasector (Teratodontinae, Hyaenodonta, Placentalia) from the late Eocene of Egypt and locomotor diversity in hyaenodonts". English. In: PLoS ONE 12.4 (2017), e0173527:1-60.

[2690] M. R. Borths and N. J. Stevens. "The first hyaenodont from the late Oligocene Nsungwe Formation of Tanzania: Paleoecological insights into the Paleogene-Neogene carnivore transition". English. In: PLoS ONE 12.10 (2017), e0185301:1-30.

[2691] M. R. Borths and N. J. Stevens. “Deciduous dentition and dental eruption of Hyainailouroidea (Hyaenodonta, Creodonta, Placentalia, Mammalia)". English. In: Palaeontologia Electronica 20.3.55A (2017).

[2692] R. E. Bosboom, G. Dupont-Nivet, A. J. P. Houben, H. Brinkhuis, G. Villa, O. Mandic, M. Stoica, W. J. Zachariasse, Z. Guo, C. Li, and W. Krijgsman. "Late Eocene sea retreat from the Tarim Basin (west China) and concomitant Asian paleoenvironmental change". English. In: Palaeogeography, Palaeoclimatology, Palaeoecology 299 (2011), pp. 385-398.

[2693] A. Boscaini, T. J. Gaudin, B. Mamani Quispe, P. Munch, P. -O. Antoine, and F. Pujos. “New wellpreserved craniodental remains of Simomylodon uccasamamensis (Xenarthra: Mylodontidae) from the Pliocene of the Bolivian Altiplano: phylogenetic, chronostratigraphic and palaeobiogeographical implications". English. In: Zoological Journal of the Linnean Society 185.2 (2019), pp. 459-486. DOI: 10.1093/zoolinnean/zly075/5187717.

[2694] A. Boscaini, D. A. Iurino, B. Mamani Quispe, R. Andrade Flores, R. Sardella, F. Pujos, and T. J. Gaudin. "Cranial Anatomy and Paleoneurology of the Extinct Sloth Catonyx tarijensis (Xenarthra, Mylodontidae) From the Late Pleistocene of Oruro, Southwestern Bolivia". English. In: Frontiers in Ecology and Evolution 8 (2020), 69:1-16. DOI: 10.3389/fevo.2020.00069.

[2695] H. C. J. Bosch. “De Needsche Berg: devondst van een kleine walvisschedel". English. In: Cranium 16 (1999), pp. 77-83. 
[2696] M. N. Bose, E. L. Taylor, and T. N. Taylor. Gondwana Floras of India and Antarctica - a Survey and Reappraisal. English. Antarctic Paleobiology, Its Role in the Reconstruction of Gondwana. New York: Springer-Verlag, 1990, pp. 118-148.

[2697] R. Bose, C. Schneider, P. D. Polly, and M. M. Yacobucci. “Ecological interactions between Rhipidomella (Orthides, Brachiopoda) and its endoskeletobionts and predators from the Middle Devonian Dundee Formation of Ohio, United States". English. In: Palaios 25 (2010), pp. 196-208.

[2698] A. Bosellini, A. Russo, and R. Schroeder. "Stratigraphic evidence for an Early Aptian sea-level fluctuation: the Graua Limestone of south-eastern Ethiopia". In: Cretaceous Research 20 (1999), pp. $783-$ 791.

[2699] F. R. Bosellini. "Diversity, composition and structure of Late Eocene shelf-edge coral associations (Nago Limestone, Northern Italy)". In: Facies 39 (1998), pp. 203-226.

[2700] F. R. Bosellini. "The scleractinian genus Hydnophora (revision of Tertiary species)". English. In: Palaeontologische Zeitschrift 73.3-4 (1999), pp. 217-240.

[2701] F. R. Bosellini and C. A. Papazzoni. "Palaeoecological significance of coralencrusting foraminiferan associations: A casestudy from the Upper Eocene of northern Italy". English. In: Acta Palaeontologica Polonica 48.2 (2013), pp. 279-292.

[2702] F. R. Bosellini and C. Perrin. "The coral fauna of Vitigliano: qualitative and quantitative analysis in a back reef environment (Castro Limestone, Late Oligocene, Salento Peninsula, southern Italy)". In: Bolletino della Societá Paleontologica Italiana 33.2 (1994), pp. 171-181.

[2703] F. R. Bosellini and A. Russo. "Stratigraphy and facies of an Oligocene fringing reef (Castro Limestone, Salento Peninsula, southern Italy)". In: Facies 26 (1992), pp. 145-166.

[2704] F. R. Bosellini, A. Russo, and A. Vescogni. "Messinian reef-building assemblages of the Salento Peninsula (southern Italy): palaeobathymetric and palaeoclimatic significance". In: Palaeogeography, Palaeoclimatology, Palaeoecology 175 (2001), pp. 7-26.

[2705] F. R. Bosellini and E. Trevisani. "Coral facies and cyclicity in the Castelgomberto Limestone (Early Oligocene, Eastern Lessini Mountains, Northern Italy)". English. In: Rivista Italiana di Paleontologia e Stratigrafia 98.3 (1992), pp. 339-352.

[2706] E. P. Bosetti, Y. Grahn, R. S. Horodyski, P. Mendlowicz Mauller, P. Breuer, and C. Zabini. "An earliest Givetian Lilliput effect in the Parana Basin, and the collapse of the Malvinokaffric shelly fauna". English. In: Palaeontologische Zeitschrift 85 (2011), pp. 49-65.

[2707] G. Bosio, E. Malinverno, A. Collareta, C. Di Celma, A. Gioncada, M. Parente, F. Berra, F. G. Marxf, A. Vertino, M. Urbina, and G. Bianucci. "Strontium Isotope Stratigraphy and the thermophilic fossil fauna from the middle Miocene of the East Pisco Basin (Peru)". English. In: Journal of South American Earth Sciences 97 (2020). DOI: 10.1016/j.jsames.2019.102399.

[2708] D. P. Bosscha Erdbrink and P. J. H. Van Bree. "Fossil axial skeletal walrus material from the North Sea and the estuary of the Schelde, and a fossil Sirenian rib (Mammalia, Carnivora; Sirenia)". English. In: Beaufortia 49.2 (1999), pp. 11-20.

[2709] D. P. Bosscha Erdbrink and P. J. H. Van Bree. "Fossil appendicular skeletal walrus material from the North Sea and the estuary of the Schelde (Mammalia, Carnivora)". English. In: Beaufortia 49.8 (1999), pp. 63-81.

[2710] D. P. Bosscha Erdbrink and P. J. H. Van Bree. "Further observations on fossil and subfossil odobenid material (Mammalia, Carnivora) from the North Sea". English. In: 40.5 (1990), pp. 85-101.

[2711] J. Bosselaers. "A new Garcorops species from Madagascar copal (Araneae: Selenopidae)". English. In: Zootaxa 445 (2004), pp. 1-7.

[2712] J. Bosselaers, M. Dierick, V. Cnudde, B. Masschaele, L. van Hoorebeke, and P. Jacobs. "Highresolution X-ray computed tomography of an extant new Donuea (Araneae: Liocranidae) species in Madagascan copal". English. In: Zootaxa 2427 (2010), pp. 25-35. 
[2713] M. Bosselaers, J. Herman, K. Hoedemakers, O. Lambert, R. Marquet, and K. Wouters. “Geology and Palaeontology of a temporary exposure of the Late Miocene Deurne Sand Member in Antwerpen (N. Belgium)". English. In: Geologica Belgica 7.1-2 (2004), pp. 27-39.

[2714] M. Bosselaers and K. Post. "A new fossil rorqual (Mammalia, Cetacea, Balaenopteridae) from the Early Pliocene of the North Sea, with a review of the rorqual species described by Owen and Van Beneden". English. In: Geodiversitas 32.2 (2010), pp. 331-363.

[2715] A. Bossio, B. Dall'Antonia, S. Da Prato, L. M. Foresi, and G. Oggiano. "Preliminary stratigraphical investigations of the Miocene successions of the Porto Torres Basin (northern Sardinia, Italy)". English. In: Atti della Societá Toscana di Scienze Naturali, Memorie Seria A 111 (2006), pp. 67-74.

[2716] A. Bossio, M. Esteban, R. Mazzanti, R. Mazzei, and G. Salvatorini. "Rosignano reef complex (Messinian), Livornesi Mountains, Tuscany, central Italy". English. In: SEPM Concepts in Sedimentology and Paleontology 5 (1996), pp. 277-294.

[2717] E. Bostelmann, K. Moreno, and D. A. Croft. "Hegetotherium cerdasensis (Mammalia, Notoungulata. Hegetoteriidae) in the early Late Miocene of Northern Chile". English. In: V Simposio de Paleontologa en Chile (2016).

[2718] J. E. Bostelmann, J. P. Le Roux, A. Vásquez, N. M. Gutiérrez, J. L. Oyarzún, C. Carreño, T. Torres, R. Otero, A. Llanos, C. M. Fanning, and F. Hervé. "Burdigalian deposits of the Santa Cruz Formation in the Sierra Baguales, Austral (Magallanes) Basin: Age, depositional environment and vertebrate fossils". English. In: Andean Geology 40.3 (2013), pp. 458-489. DOI: 10.5027/andgeoV40n3-a04.

[2719] H. Botella, P. Plascencia, A. Marquez-Aliaga, G. Cuny, and M. Dorka. "Pseudodalatias Henarejensis Nov. Sp. A New Pseudodalatiid (Elasmobranchii) from the Middle Triassic of Spain". English. In: Journal of Vertebrate Paleontology 29.4 (2009), pp. 1006-1012.

[2720] J. Botha, F. Abdala, and R. M. H. Smith. “The oldest cynodont: new clues on the origin and early diversification of the Cynodontia". English. In: Zoological Journal of the Linnean Society 149.3 (2007), pp. 477-492.

[2721] J. Botha and T. Gaudin. “An early Pliocene pangolin (Mammalia; Pholidota) from Langebaanweg, South Africa". English. In: Journal of Vertebrate Paleontology 27.2 (2007), pp. 484-491.

[2722] J. Botha, S. P. Modesto, and R. M. H. Smith. "Extended procolophonoid reptile survivorship after the end-Permian extinction". English. In: South African Journal of Science 103 (2007), pp. 54-56.

[2723] J. Botha and R. M. H. Smith. "Lystrosaurus species composition across the Permo-Triassic boundary in the Karoo Basin of South Africa". English. In: Lethaia 40 (2007), pp. 125-137. DOI: 10.1111/j. 1502-3931.2007.00011.x.

[2724] J. Botha-Brink. "Do extraordinarily high growth rates in Permo-Triassic dicynodonts (Therapsida, Anomodontia) explain their success before and after the end-Permian extinction?" English. In: Zoological Journal of the Linnean Society 160.2 (2010), pp. 341-365.

[2725] J. Botha-Brink, A. K. Huttenlocker, and S. P. Modesto. "Vertebrate Paleontology of Nooitgedacht 68: A Lystrosaurus maccaigi-Rich Permo-Triassic Boundary Locality in South Africa". English. In: Early Evolutionary History of the Synapsida. Springer, 2013, pp. 289-304.

[2726] O. Botkova. “Eocenni korali z lokality u obce Jaseno, Borovske souvrstvi (Podtatranska Skupina) [Eocene corals from the locality near Jaseno, Borova Formation (Sub-Tatra Group)]". other. In: Zpravy o geologickych vyzkumech v roce 2002 (2002), pp. 110-113.

[2727] O. Botkova. "Eocenni korali rodu Balanophyllia z lokality Skacany, Borovske souvrstvi (Podtatranska Skupina) [Eocene corals of the genus Balanophyllia from the locality Skacany, Borova Formation (Sub-Tatra Group)]". other. In: Zpravy o geologickych vyzkumech v roce 2002 (2002), pp. 114117.

[2728] L. Botosaneanu. “Caddis flies (Trichoptera) from Turonian (Upper Cretaceous) Amber of New Jersey". English. In: American Museum Novitates 3140 (1995), pp. 1-7.

[2729] A. Botquelen, J. Le Menn, and A. Loi. “Échinodermes de l'Ordovicien supérieur (Ashgill) de Sardaigne et d'Algérie". English. In: Geobios 39.1 (2006), pp. 13-23. DOI: 10.1016/j.geobios.2004.09.004. 
[2730] A. Botquelen and P. R. Racheboeuf. "Benthic paleoecology in the givetian: an example from the Kersadiou Formation (massif armoricain, NW France)". English. In: Palaios 23 (2008), pp. 246-259.

[2731] R. Böttcher and C. J. Duffin. "The neoselachian shark Sphenodus from the Late Kimmeridgian (Late Jurassic) of Nusplingen and Egesheim (Baden-Württemberg, Germany)". English. In: Stuttgarter Beiträge zur Naturkunde B, Geologie und Paläontologie 283 (2000), pp. 1-31.

[2732] R. Böttcher, E. P. J. Heizmann, M. W. Rasser, and R. Ziegler. “Biostratigraphy and palaeoecology of a Middle Miocene (Karpathian, MN 5) fauna from the northern margin of the North Alpine Foreland Basin (Oggenhausen 2, SW' Germany)". English. In: Neues Jahrbuch für Geologie und Paläontologie, Abhandlungen 254.1/2 (2009), pp. 237-260. DOI: 10.1127/0077-7749/2009/0011.

[2733] J. P. Botting. "Exceptionally well-preserved Middle Ordovician sponges from the Llandegley Rocks Lagerstätte, Wales". English. In: Palaeontology 48.3 (2005), pp. 577-617.

[2734] J. P. Botting. "Cambrian demosponges in the Ordovician of Morocco: Insights into the early evolutionary history of sponges". English. In: Geobios 40 (2007), pp. 737-748.

[2735] J. P. Botting. "An exceptional Caradoc sponge fauna from the Llanfawr Quarries, central Wales and phylogenetic implications". English. In: Journal of Systematic Palaeontology 2.1 (2004), pp. 3163.

[2736] J. P. Botting. “Llanvirn (Middle Ordovician) echinoderms from Llandegley Rocks, Central Wales". English. In: Palaeontology 46.4 (2003), pp. 685-708.

[2737] J. P. Botting. "Diversity and ecology of sponges in the Early Ordovician Fezouata". English. In: Palaeogeography, Palaeoclimatology, Palaeoecology 460 (2016), pp. 75-86.

[2738] J. P. Botting, P. Appleton, L. A. Muir, J. Malpas, and K. Riddington. “A new species of Siluraster (Echinodermata: Asteroidea) from the Late Ordovician of North Wales". English. In: Geological Journal 46 (2011), pp. 427-433.

[2739] J. P. Botting, A. Brayard, and T. Paris Biota Team. "A late-surviving Triassic protomonaxonid sponge from the Paris Biota (Bear Lake County, Idaho, USA)". English. In: Geobios 54 (2019), pp. 511. DOI: $10.1016 /$ j.geobios.2019.04.006.

[2740] J. P. Botting and L. A. Muir. "A new Middle Ordovician (Late Dapingian) hexactinellid sponge from Cumbria, UK". English. In: Geological Journal 46 (2011), pp. 501-506.

[2741] J. P. Botting and L. A. Muir. "Fauna and ecology of the holothurian bed, Llandrindod, Wales, UK (Darriwilian, Middle Ordovician), and the oldest articulated holothuria". English. In: Palaeontologia Electronica Vol. 15, Issue 1; ,28p; 15.1 (2012), 9A.

[2742] J. P. Botting, Y. Zhang, and L. A. Muir. “A candidate stem-group rossellid (Porifera, Hexactinellida) from the latest". English. In: Bulletin of Geosciences 93.3 (2018), pp. 275-285.

[2743] M. A. Bouchard, C. R. Harington, and J. -P. Guilbault. "First evidence of walrus (Odobenus rosmarus L) in Late Pleistocene Champlain Sea sediments, Quebec". English. In: Canadian Journal of Earth Sciences 30.8 (1993), pp. 1715-1719.

[2744] L. D. Boucher, S. R. Manchester, and W. S. Judd. "An extinct genus of Salicaceae based on twigs with attached flowers, fruits, and foliage from the Eocene Green River Formation of Utah and Colorado, USA". In: American Journal of Botany 90 (2003), pp. 1389-1399.

[2745] S. Boucher, M. Bai, B. Wang, W. W. Zhang, and X. K. Yang. "†Passalopalpidae, a new family from the Cretaceous Burmese amber, as the possible sister group of Passalidae Leach (Coleoptera: Scarabaeoidea)". English. In: Cretaceous Research 64 (2016), pp. 67-78.

[2746] S. Boucher, M. Bai, B. Wang, and O. Montreuil. "Ceracyclini, tribe nov. of Passalidae Aulacocyclinae for Cylindrocaulus Fairmaire and +Ceracyclus, gen. nov., with two new species from the Cenomanian Burmese amber (Coleoptera, Scarabaeoidea)". English. In: Les Cahiers Magellanes (HS) 37 (2017), pp. 1-13.

[2747] A. J. Boucot, H. Bahlburg, C. Breitkreuz, P. E. Isaacson, H. Niemeyer, and F. Urzua. “Devonian brachiopods from northern Chile". English. In: Journal of Paleontology 69.2 (1995), pp. 257-263. 
[2748] A. J. Boucot, R. B. Blodgett, and J. H. Stewart. European province Late Silurian brachiopods from the Ciudad Victoria area, Tamaulipas, northeastern Mexico. 1997.

[2749] A. J. Boucot, J. H. G. Melo, E. V. Santos Neto, and S. Wolff. "First Clarkeia and Heterorthella (Brachiopoda; Lower Silurian) occurrence from the Parana Basin in eastern Paraguay". In: Journal of Paleontology 65.3 (1991), pp. 512-514.

[2750] B. E. Boudinot and D. R. Dungey. "†Eorhopalosoma lohrmanni, a new species of Rhopalosomatidae from mid-Cretaceous amber of northern Myanmar (Hymenoptera, Aculeata: Vespoidea)". English. In: Cretaceous Research 108.104339 (2020). DOI: 10.1016/j.cretres.2019.104339.

[2751] B. E. Boudinot, V. Perrichot, and J. C. M. Chaul. "+Camelosphecia gen. nov., lost ant-wasp intermediates from the mid-Cretaceous (Hymenoptera, Formicoidea)". English. In: ZooKeys 1005 (2020), pp. 21-55. DOI: $10.3897 /$ zookeys.1005.57629.

[2752] V. Bouetel and C. Muizon. "The anatomy and relationships of Piscobalaena nanna (Cetacea, Mysticeti), a Cetotheriidae s.s. from the early Pliocene of Peru". English. In: Geodiversitas 28.2 (2006), pp. 319-395.

[2753] M. Boughdiri, R. Enay, G. Le Hegarat, and L. Memmi. “Hegaratites nov. gen.(Ammonitina): Himalayitidae nouveau du Tithonien supérieur de la coupe du Jebel Rhéouis (Axe nord-sud, Tunisie centrale). Précisions stratigraphiques, approche phylétique et signification biogéographique". French. In: Revue de Paléobiologie, Genéve 18 (1999), pp. 105-121.

[2754] M. Boulard and A. Nel. "Sur deux Cigales fossiles des terrains tertiaires de la France (Homoptera, Cicadoidea)". French. In: Revue Française d'Entomologie (N.S.) 12 (1990), pp. 37-45.

[2755] A. Boullier and R. Filippi. “Distribution des assemblages de brachiopodes dans l'Oxfordien du centre de la France". French. In: Carnets de Géologie 2012.1 (2012), pp. 1-14.

[2756] F. Boulvain. Frasnian carbonate mounds from Belgium: sedimentology and palaeoceanography. English. Vol. 275. Geological Society, London, Special Publications. J. J. Álvaro, M. Aretz, F. Boulvain, A. Munnecke, D. Vachard, E. Vennin, 2007, pp. 125-142.

[2757] F. Boulvain, B. Demany, and M. Coen-Aubert. "Frasnian Carbonate Buildups of southern Belgium: The Arche and Lion Members interpreted as Atolls". English. In: Geologica Belgica 8/1.2 (2005), pp. 69-89.

[2758] E. Bourdon, M. Amaghzaz, and B. Bouya. "A new seabird (Aves, cf. Phaethontidae) from the Lower Eocene phosphates of Morocco". English. In: GeoBios 41.4 (2008), pp. 455-459.

[2759] E. Bourdon, M. Amaghzaz, and B. Bouya. "Pseudotoothed birds (Aves, Odontopterygiformes) from the early Tertiary of Morocco". English. In: American Museum Novitates 3704 (2010), pp. 1-71.

[2760] E. Bourdon, B. Bouya, and M. Iarochene. "Earliest African neornithine bird: a new species of Prophaethontidae (Aves) from the Paleocene of Morocco". English. In: Journal of Vertebrate Paleontology 25.1 (2005), pp. 157-170.

[2761] E. Bourdon and H. Cappetta. "Pseudo-toothed birds (Aves, Odontopterygiformes) from the Eocene phosphate deposits of Togo, Africa". English. In: Journal of Vertebrate Paleontology 32.4 (2012), pp. 965-970.

[2762] E. Bourdon, C. Mourer-Chauviré, M. Amaghzaz, and B. Bouya. "New specimens of Lithoptila abdounensis (Aves, Prophaethontidae) from the lower Paleogene of Morocco". English. In: Journal of Vertebrate Paleontology 28.3 (2008), pp. 751-761. DOI: 10.1671/0272-4634(2008)28[751:NSOLAA] 2.0.CO;2.

[2763] E. Bourdon, C. Mourer-Chauviré, and Y. Laurent. "Early Eocene birds from La Borie, southern France". English. In: Acta Palaeontologica Polonica 61.1 (2014), pp. 175-190. DOI: 10.4202 / app. 00083.2014.

[2764] J. Bourdon, K. Wright, S. G. Lucas, J. A. Spielmann, and R. Pence. "Selachians from the Upper Cretaceous (Santonian) Hosta Tongue of the Point Lookout Sandstone, central New Mexico". English. In: New Mexico Museum of Natural History and Science Bulletin 52 (2011), pp. 1-54. 
[2765] H. Bourget and J. S. Anderson. "A new amphibamid (Temnospondyli: Dissorophoidea) from the Early Permian of Texas". English. In: Journal of Vertebrate Paleontology 31.1 (2011), pp. 32-49. DOI: 10.1080/02724634.2011.539652.

[2766] T. Bourgoin and F. Lefébvre. "A new fossil Kinnaridae from Dominican amber (Hemiptera: Fulgoromorpha)". English. In: Annales Zoologici 52 (2002), pp. 583-585.

[2767] T. Bourgoin, M. L. Wang, and A. Nel. “The oldest fossil of the family Issidae (Hemiptera, Fulgoromorpha) from the Paleocene of Menat (France)". English. In: European Journal of Taxonomy 596 (2020), pp. 1-8. DOI: 10.5852/ejt.2020.596.

[2768] T. Bourgoin, R. R. Wang, and V. M. Gnezdilov. "First fossil record of Caliscelidae (Hemiptera: Fulgoroidea): a new Early Miocene Dominican amber genus extends the distribution of Augilini to the Neotropics". English. In: Journal of Systematic Palaeontology 14 (2016), pp. 211-218.

[2769] T. Bourgoin, R. R. Wang, J. Szwedo, X. Y. Li, and X. Chen. “A new early Miocene fossil genus from Dominican amber extends the Eastern Asia distribution of Paricanini (Hemiptera: Fulgoromorpha: Tropiduchidae) to the Neotropics". English. In: Palaeontologia Electronica 22.3.77 (2019), pp. 1-15.

[2770] R. Bourillot, P. Neige, A. Pierre, and C. Durlet. "Early-Middle Jurassic lytoceratid ammonites with constrictions from Morocco: palaeobiogeographical and evolutionary implications". English. In: Palaeontology 51 (2008), pp. 597-609.

[2771] W. R. P. Bourne, N. P. Ashmole, and K. E. L. Simmons. "A new subfossil night heron and a new genus for the extinct rail Ascension Island, central tropical Atlantic Ocean". English. In: Ardea 91 (2003), pp. 45-51.

[2772] J. R. Bourque. "Reassessment of a putative fossil stinkpot (Kinosternidae: Sternotherus) from the late Miocene (Clarendonian) of Kansas". English. In: Journal of Herpetology 45.2 (2011), pp. 234-237.

[2773] J. R. Bourque. "Fossil Kinosternidae from the Oligocene and Miocene of Florida, USA". English. In: Morphology and Evolution of Turtles, Vertebrate Paleobiology and Paleoanthropology. Dordrecht: Springer Science, 2013, pp. 459-475. DOI: 10.1007/978-94-007-4309-0_25.

[2774] J. R. Bourque. "Side-Necked Turtles (Testudines, Pleurodira) from the Ancient Gulf Coastal Plain of Florida During Middle Cenozoic Megathermals". English. In: Chelonian Conservation and Biology 15.1 (2016), pp. 23-35.

[2775] J. R. Bourque. “A spotted turtle (Testudines, Emydidae) from the early Pleistocene (late Blancan) of north-central Florida". English. In: Bulletin of the Florida Museum of Natural History 55.2 (2016), pp. 39-50.

[2776] J. R. Bourque. "New mud turtles (Kinosternidae,Kinosternon) from the middle-late Miocene of the United States". English. In: Journal of Paleontology 89.5 (2015), pp. 821-844. DOI: 10.1017/jpa. 2015.63.

[2777] J. R. Bourque. "An extinct mud turtle of the Kinosternon flavescens group (Testudines, Kinosternidae) from the middle Miocene (late Barstovian) of New Mexico". English. In: Journal of Vertebrate Paleontology 32 (2012), pp. 68-81.

[2778] J. R. Bourque. "A fossil mud turtle (Testudines, Kinosternidae) from the early middle Miocene (early Barstovian) of New Mexico". English. In: Journal of Vertebrate Paleontology 32 (2012), pp. 836853.

[2779] J. R. Bourque, J. H. Hutchison, P. A. Holroyd, and J. I. Bloch. "A new dermatemydid (Testudines, Kinosternoidea) from the Paleocene-Eocene Thermal Maximum, Willwood Formation, southeastern Bighorn Basin, Wyoming". English. In: Journal of Vertebrate Paleontology e905481 (2015), pp. 119. DOI: $10.1080 / 02724634.2014 .905481$.

[2780] J. R. Bourque and B. W. Schubert. "Fossil musk turtles (Kinosternidae, Sternotherus) from the late Miocene-early Pliocene (Hemphillian) of Tennessee and Florida". English. In: Journal of Vertebrate Paleontology 35.1 (2015), pp. 1-19. 
[2781] J.-P. Bourseau, H. Hess, P. Bernier, G. Barale, E. Buffetaut, C. Gaillard, J. C. Gall, and S. Wenz. “Découverte d'ophiures dans les calcaires lithographiques de Cerin (Kimméridgien supérieur, Ain, France). Systématique et implications taphonomiques." French. In: Comptes Rendus de l'Académie des Sciences, Paris 312 (1991), pp. 793-799.

[2782] Y. Bousquet. "Catalogue of Geadephaga (Coleoptera, Adephaga) of America, north of Mexico". English. In: ZooKeys 245 (2012), pp. 1-1722.

[2783] M. Boutakiout, M. Hadri, J. Nouri, I. Daz-Martnez, and F. Pérez-Lorente. "Rastrilladas de icnitas terópodas gigantes del Jurásico superior (sinclinal de Iouaridéne, Marruecos) [Trackways of gigantic theropod footprints from the Upper Jurassic (Iouaridéne syncline, Morocco)]". Spanish. In: Revista Española de Paleontologa 24.1 (2009), pp. 31-46.

[2784] M. Boutakiout, M. Masrour, L. Ladel, I. Daz-Martnez, and F. Pérez-Lorente. “Nuevos yacimientos de icnitas domerienses en Ibaqalliwn (At Bou Guemez, Alto Atlas Central. Marruecos) [New Domerian dinosaur footprint sites from Ibaqalliwn (At Bou Guemez, Central High Atlas, Morocco)]". Spanish. In: Geogaceta 48 (2010), pp. 91-94.

[2785] M. Boutakiout, M. Masrour, and F. Pérez-Lorente. “Icnitas tireóforas y terópodas en Ansous (Pliensbachiense, Alto Atlas Central, Marruecos) [Thyreophoran and theropod prints from Ansous (Pliensbachian, Central High Atlas, Morocco)]". Spanish. In: Geogaceta 55 (2014), pp. 75-78.

[2786] M. Boutakiout, J. Nouri, L. Ladel, I. Daz-Martnez, and F. Pérez-Lorente. “Contenido anómalo de icnitas semiplantígradas terópodas en el yacimiento de Oumzawrou (36IGR) del Atlas Marroquí [Anomalous content of semiplantigrade theropod footprints in the Oumzawrou (36IGR) outcrop of the Moroccan Atlas]". English. In: Geogaceta 52 (2012), pp. 173-176.

[2787] M. Boutkiout, J. Nouri, L. Ladel, I. Daz-Martnez, and F. Pérez-Lorente. "El yacimiento de icnitas de dinosaurio 34IGR. Iouaridéne, Alto Atlas Central. Marruecos [The 34IGR dinosaur palaeoichnological site. Iouaridéne, High Central Atlas. Morocco]". Spanish. In: Geogaceta 51 (2012), pp. 4346.

[2788] G. Bouvrain. "Le gisement de vertebres pliocenes de Calta, Ankara, Turquie. 10. Bovidae". French. In: Geodiversitas 20.3 (1998), pp. 467-485.

[2789] G. Bouvrain and L. de Bonis. "Ruminants (Mammalia, Artiodactyla : Tragulidae, Cervidae, Bovidae) des gisements du Miocéne supérieur (Turolien) de Dytiko (Gréce)". French. In: Annales de Paleontologie 93.2 (2007), pp. 121-147.

[2790] P. Bover, A. Valenzuela, C. Guerra, J. Rofes, J. A. Alcover, J. Ginés, J. J. Fornós, G. Cuenca-Bescós, and A. Merino. "The Cova des Pas de Vallgornera (Llucmajor, Mallorca): a singular deposit bearing an exceptional well preserved Early Pleistocene vertebrate fauna". English. In: International Journal of Speleology 43.2 (2014), pp. 175-192. DOI: 10.5038/1827-806X.43.2.6.

[2791] T. Bover-Arnal, H. Löser, J. A. Moreno-Bedmar, R. Salas, and A. Strasser. "Corals on the slope (Aptian, Maestrat Basin, Spain)". English. In: Cretaceous Research 37 (2012), pp. 43-64.

[2792] T. M. Bown and J. G. Fleagle. "Systematics, Biostratigraphy, and Dental Evolution of the Palaeothentidae, Later Oligocene to Early-Middle Miocene (Deseadan-Santacrucian) Caenolestoid Marsupials of South America". English. In: Memoir (The Paleontological Society) 29 (1993), pp. 1-76.

[2793] T. M. Bown and K. D. Rose. "Evolutionary relationships of a new genus and three new species of Omomyid primates (Willwood Formation, Lower Eocene, Bighorn Basin, Wyoming)". English. In: Journal of Human Evolution 20.6 (1991), pp. 465-480.

[2794] T. M. Bown, K. D. Rose, E. L. Simons, and S. L. Wing. "Distribution and stratigraphic correlation of upper Paleocene and lower Eocene fossil mammal and plant localities of the Fort Union, Willwood, and Tatman formations, southern Bighorn Basin, Wyoming". English. In: United States Geological Survey Professional Paper 1540 (1994), pp. 1-103.

[2795] J. A. Boy. "Über die Mircomelerpetonidae (Amphibia: Temnospondyli). 2. Micromelerpeton ulmetense n. sp. und Micromelerpeton(?) boyi Heyler". English. In: Neues Jahrbuch für Geologie und Paläontologie Abhandlungen 223 (2002), pp. 241-274. 
[2796] W. D. Boyce. "An occurrence of the Scottish trilobite Olenellus lapworthi Peach and Horne, 1892 in the early Cambrian Forteau Formation (Labrador Group) Hawkes Bay, Great Northern Peninsula, western Newfoundland, Canada". English. In: Canadian Paleontology Conference 2006-Proceedings No. 44 (2006), pp. 6-7.

[2797] W. D. Boyce, I. Knight, D. M. Rohr, S. H. Williams, and E. A. Measures. “The upper St. George Group, western Port au Port Penensula: lithostratigraphy, biostratigraphy, depositional environments and regional implications". English. In: Current Research (2000) Newfoundland Department of Mines and Energy Geological Survey, Report 2000.1 (2000), pp. 101-105.

[2798] W. D. Boyce and I. Knight. "Macropaleontological investigation of the Upper St. George Group, West Isthmus Bay to East Bay section, Port au Port Peninsula, Western Newfoundland". English. In: Current Research 10.1 (2010), pp. 219-44.

[2799] W. D. Boyce and I. Knight. "Cambrian Macrofossils from the Phillips Brook and North Brook Anticlines, Western Newfoundland". English. In: Current Research 05.1 (2005), pp. 39-62.

[2800] W. D. Boyce and I. Knight. "New fossil localities in the Middle Ordovician Table Point Formation, Bonne Bay Little Pond area, western Newfoundland". English. In: Current Research 09.1 (2009), pp. 123-129.

[2801] W. D. Boyce, L. M. E. McCobb, and I. Knight. "Stratigraphic studies of the Watts Bight Formation (St. George Group), Port au Port Peninsula, Western Newfoundland". English. In: Current Research 11.1 (2011), pp. 215-240.

[2802] W. D. Boyce, L. M. E. McCobb, and I. Knight. "Continuing Stratigraphic and Trilobite Studies of the Watts Bight Formation (St. George Group), Port au Port Peninsula, Western Newfoundland". English. In: Current Research 13.1 (2013), pp. 205-222.

[2803] W. D. Boyce and S. Stouge. "Trilobite and Conodont Biostratigraphy of the St. George Group, Eddies Cove west area, Western Newfoundland". English. In: Current Research 97.1 (1997), pp. 183200.

[2804] A. Boyd. "Revision of the Late Cretaceous Pautut Flora from West Greenland: Gymnospermopsida (Cycadales, Cycadeoidales, Caytoniales, Ginkgoales, Coniferales)". In: Palaeontographica Abteilung B 225 (1992), pp. 105-172.

[2805] A. Boyd. "Paleodepositional setting of the Late Cretaceous Pautut Flora from West Greenland as determined by sedimentological and plant taphonomical data". English. In: Palaeogeography, Palaeoclimatology, Palaeoecology 103 (1993), pp. 251-280.

[2806] C. A. Boyd, C. M. Brown, R. D. Scheetz, and J. A. Clarke. "Taxonomic revision of the basal neornithischian taxa Thescelosaurus and Bugenasaura". English. In: Journal of Vertebrate Paleontology 29.3 (2009), pp. 758-770. DOI: 10.1671/039.029.0328.

[2807] C. A. Boyd, S. K. Drumheller, and T. A. Gates. "Crocodyliform feeding traces on juvenile ornithischian dinosaurs from the Upper Cretaceous (Campanian) Kaiparowits Formation, Utah". English. In: PLoS ONE 8.2 (2013), e57605:1-8. DOI: 10.1371/journal.pone.0057605.

[2808] C. A. Boyd, J. J. Person, and B. Barnes. "Additions to the Lancian mammalian fauna from southwest North Dakota". English. In: Journal of Vertebrate Paleontology (2017), e1325368:1-15. DOI: 10. 1080/02724634.2017.1325368.

[2809] C. A. Boyd and E. Welsh. "Description of an Earliest Orellan Fauna From Badlands National Park, Interior, South Dakota and Implications for the Stratigraphic Position of the Bloom Basin Limestone Bed". English. In: Dakoterra 6 (2014), pp. 124-147.

[2810] D. W. Boyd. "Morphology and Diagenesis of Dimorphosiphon talbotorum n. sp., an Ordovician Skeleton-Building Alga (Chlorophyta: Dimorphosiphonaceae)". English. In: Journal of Paleontology 81.1 (2007).

[2811] D. W. Boyd and N. D. Newell. "A reappraisal of Trigoniacean families (Bivalvia) and a description of two new Early Triassic species". English. In: American Museum Novitates 3216 (1997), pp. 1-14. 
[2812] D. W. Boyd and N. D. Newell. "A unique pterioid bivalve from the Early Triassic of Utah". English. In: American Museum Novitates 3375 (2002), pp. 1-9.

[2813] D. W. Boyd and N. D. Newell. "Silicified Leptodesma (Bivalvia; Pteriomorphia) from the Texas Permian". In: American Museum Novitates 3347 (2001), pp. 1-10.

[2814] D. W. Boyd, D. E. Nice, and N. D. Newell. "Silt injection as a mode of fossilization: a Triassic example". English. In: Palaios 14 (1999), pp. 545-554.

[2815] D. L. Boyer and M. L. Droser. "Devonian monspecific assemblages: new insights into the ecology of reduced-oxygen depositional settings". English. In: Lethaia 40.4 (2007), pp. 321-333.

[2816] D. M. Boyer, L. Costeur, and Y. Lipman. "Earliest record of Platychoerops (Primates, Plesiadapidae), a new species from Mouras Quarry, Mont de Berru, France". English. In: American Journal of Physical Anthropology 149.3 (2012), pp. 329-346.

[2817] D. M. Boyer, C. S. Scott, and R. C. Fox. "New craniodental material of Pronothodectes gaoi Fox (Mammalia, Plesiadapiformes) and relationships among members of Plesiadapidae". English. In: American Journal of Physical Anthropology 147.4 (2012), pp. 511-550.

[2818] V. A. Bracchi, R. Nalin, and D. Basso. "Paleoecology and dynamics of coralline dominated facies during a Pleistocene transgressive-regressive cycle (Capo Colonna marine terrace, Southern Italy)". English. In: Palaeogeography, Palaeoclimatology, Palaeoecology 414 (2014), pp. 296-309.

[2819] T. C. Brachert, W. Buggisch, E. Flügel, H. M. Hüssner, M. M. Joachimski, F. Tourneur, and O. H. Walliser. "Controls of mud mound formation: the Early Devonian Kess-Kess carbonates of the Hamar Laghdad, Antiatlas, Morocco". English. In: Geologische Rundschau 81.1 (1992), pp. 15-44.

[2820] P. Brack and H. Rieber. "Towards a better definition of the Anisian/Ladinian boundary: new biostratigraphic data and correlations of boundary sections from the Southern Alps". In: Eclogae Geologicae Helvetiae 86.2 (1993), pp. 415-527.

[2821] P. Brack, H. Rieber, and A. Nicora. "The Global Stratotype Section and Point (GGSP) of the base of the Ladinian Stage (Middle Triassic): A proposal for the GSSP at the base of the Curionii Zone in the Bagolino section (Southern Alps, Northern Italy)". In: Albertiana 28 (2003), pp. 13-25.

[2822] P. Brack and H. Rieber. "Chieseiceras dolomiticum n. sp. (Ammonoidea) and its significance for the calibration of the Triassic platform interior stratigraphy at Latemar (Southern Alps, Italy)". English. In: Swiss Journal of Palaeontology 138 (2019), pp. 27-35. DOI: 10.1007/s13358-019-00184-6.

[2823] S. J. Braddy, R. J. Aldridge, and J. N. Theron. "A new eurypterid from the Late Ordovician Table Mountain Group, South Africa". English. In: Palaeontology 38.3 (1995), pp. 563-581.

[2824] S. J. Braddy, P. A. Selden, and D. N. Truong. "A new carcinosomatid eurypterid from the upper Silurian of northern Vietnam". English. In: Palaeontology 45 (2002), pp. 897-915.

[2825] J. Bradham, J. J. Flynn, D. A. Croft, and A. R. Wyss. “New Notoungulates (Notostylopidae and Basal Toxodontians) from the Early Oligocene Tinguiririca Fauna of the Andean Main Range, Central Chile". English. In: American Museum Novitates 3841 (2015), pp. 1-24.

[2826] M. A. Bradshaw and L. McCartan. "Palaeoecology and systematics of Early Devonian bivalves from the Horlick Formation, Ohio Range, Antarctica". In: Alcheringa 15.1 (1991), pp. 1-42.

[2827] J. C. Braga and J. Aguirre. "Taxonomy of fossil coralline algal species: Neogene Lithophylloideae (Rhodophyta, Corallinaceae) from southern Spain". English. In: Review of Palaeobotany and Palynology 86 (1995), pp. 265-285.

[2828] J. C. Braga and J. Aguirre. "Coralline algal assemblages in upper Neogene reef and temperate carbonates in Southern Spain". English. In: Palaeogeography, Palaeoclimatology, Palaeoecology 175 (2001), pp. 27-41.

[2829] J. C. Braga and D. Bassi. "Facies and coralline algae from Oligocene limestones in the Malaguide Complex (SE Spain)". English. In: Ann. Naturhist. Mus. Wien, Serie A 113 (2011), pp. 291-308.

[2830] J. C. Braga, J. M. Martin, and B. Alcala. "Coral reefs in coarse-terrigenous sedimentary envrinoments (Upper Tortonian, Granada Basin, southern Spain)". In: Sedimentary Geology 66 (1990), pp. 135-150. 
[2831] J. C. Braga, J. M. Martin, and R. Riding. “Internal structure of segment reefs: Halimeds algal mounds in the Mediterranean Miocene". In: Geology 24.1 (1996), pp. 35-38.

[2832] J. C. Braga, A. Vescogni, F. R. Bosellini, and J. Aguirre. “Coralline algae (Corallinales, Rhodophyta) in western and central Mediterranean Messinian reefs". English. In: Palaeogeography, Palaeoclimatology, Palaeoecology 275 (2009), pp. 113-128.

[2833] N. Y. Bragin. "Radiolaria from the phosphorite basal horizons of the Volgian stage in the Moscow region (Russia)". English. In: Revue de Micropaléontologie 40.4 (1997), pp. 285-296.

[2834] N. Y. Bragin. "Late Triassic radiolarians of southern Cyprus". English. In: Paleontological Journal 41.10 (2007), pp. 951-1029.

[2835] N. Y. Bragin and K. A. Krylov. "Early Norian Radiolaria from Cyprus". English. In: Geodiversitas 21.4 (1999), pp. 539-569.

[2836] L. G. Bragina. "Radiolarians of the family Neosciadiocapsidae from the Turonian-Santonian of the Perapedhi Formation, southern Cyprus". English. In: Paleontological Journal 42.2 (2008), pp. 127138.

[2837] L. G. Bragina and N. Y. Bragin. “New Data on Albian-Coniacian Radiolarians from the Kelevudag Section (Northeastern Azerbaijan)". English. In: Stratigraphy and Geological Correlation 23.1 (2015), pp. $45-56$.

[2838] C. K. Brain. Swartkrans: A Cave's Chronicle of Early Man. 1993.

[2839] C. K. Brain. The Swartkrans Palaeontological Research Project in perspective: results and conclusions. 1994.

[2840] C. J. R. Braithwaite, L. F. Montaggioni, G. F. Camoin, H. Dalmasso, W. C. Dullo, and A. Mangini. "Origins and development of Holocene coral reefs: a revisited model based on reef boreholes in the Seychelles, Indian Ocean". English. In: International Journal of Earth Sciences 89 (2000), pp. 431445.

[2841] I. Brake. "Diverse Milichiella Giglio-Tos (Diptera: Milichiidae) in Miocene Dominican amber". English. In: Insect Systematics \& Evolution 37 (2006), pp. 371-394.

[2842] L. Brambilla and D. A. Ibarra. "Archaeomylodon sampedrinensis, gen. et sp. nov., a new mylodontine from the middle Pleistocene of Pampean Region, Argentina". English. In: Journal of Vertebrate Paleontology 38.6 (2018), e1542308:1-13.

[2843] L. Brambilla, M. J. Toledo, J. A. Haro, and J. L. Aguilar. “New osteoderm morphotype (Xenarthra, Mylodontidae) from the middle Pleistocene of Argentina". English. In: Journal of South American Earth Sciences 95.102298 (2019), pp. 1-8.

[2844] J. Brammall and M. Archer. "A new Oligocene-Miocene species of Burramys (Marsupilia, Burramyidae) from Riversleigh, Northwestern Queensland". English. In: Memoirs of the Queensland Museum 41.2 (1997), pp. 247-268.

[2845] S. Bramuzzo, D. Coty, and A. Nel. "A new species of Ferneiella from the Eocene French amber (Diptera: Scatopsidae)". English. In: Zootaxa 4350 (2017), pp. 177-184.

[2846] S. Bramuzzo and A. Nel. "Youngest representative of the extinct genus Microphorites in the Eocene amber of France (Diptera: Dolichopodidae: Microphorinae)". English. In: Zootaxa 4231 (2017), pp. 590-594.

[2847] L. R. Brand, H. T. Goodwin, P. D. Ambrose, and H. P. Buchheim. "Taphonomy of turtles in the Middle Eocene Bridger Formation, SW Wyoming". English. In: Palaeogeography, Palaeoclimatology, Palaeoecology 162.1-2 (2000), pp. 171-189.

[2848] P. J. Brand. "The Serpukhovian and Bashkirian (Carboniferous, Namurian and basal Westphalian) faunas of northern England". English. In: Proceedings of the Yorkshire Geological Society 58.3 (2011), pp. 143-165. DOI: 10.1144/pygs.58.3.283.

[2849] M. Brandano and M. Loche. "The Coniacian-Campanian Latium-Abruzzi carbonate platform,an example of a facies mosaic". English. In: Facies 60 (2014), pp. 489-500. DOI: 10.1007/ s10347-0130393-x. 
[2850] M. Brandano, L. Tomassetti, and I. Cornacchia. "The lower Rupelian cluster reefs of Majella platform, the shallow water record of Eocene to Oligocene transition". English. In: Sedimentary Geology (2018). DOI: 10.1016/j.sedgeo.2018.11.013.

[2851] C. R. F. Brandão, C. Baroni Urbani, J. Wagensberg, and C. I. Yamamoto. "New Technomyrmex in Dominican amber (Hymenoptera: Formicidae), with a reappraisal of Dolichoderinae phylogeny". English. In: Entomologica Scandinavica 29 (1999), pp. 411-428.

[2852] C. R. F. Brandão, R. G. Martins-Neto, and M. A. Vulcano. "The earliest known fossil ant (first southern hemisphere Mesozoic record) (Hymenoptera: Formicidae: Myrmeciinae)". English. In: Psyche 96 (1990), pp. 195-208.

[2853] R. Brandner, E. Flügel, and B. Senowbari-Daryan. "Microfacies of carbonate slope boulders: indicator of the source area (Middle Triassic: Mahlknecht Cliff, Western Dolomites)". English. In: Facies 25 (1991), pp. 279-296.

[2854] J. Brandon and P. R. Wade. "Assessment of the Bering-Chukchi-Beaufort Seas stock of bowhead whales". English. In: International Whaling Commission Scientific Committee (2004).

[2855] D. Brandoni. “Descripción del fémur de Protomegalonyx chasicoensis Scillato-Yané (Mammalia, Xenarthra, Megalonychidae) de la Formación Arroyo Chasicó (Mioceno tardo), provincia de Buenos Aires, Argentina. Consideraciones sistemáticas sobre los perezosos de Edad Chasiquense". Spanish. In: Ameghiniana 46.3 (2009), pp. 513-521.

[2856] D. Brandoni. "Los Tardigrada (Mammalia, Xenarthra) del Mioceno tardo de Entre Ros Argentina". Spanish. In: El Neógeno de la Mesopotamia argentina 14 (2013), pp. 135-144.

[2857] D. Brandoni. "Los mamferos continentales del Mesopotamiense (Mioceno tardo) de Entre Ros, Argentina. Diversidad, edad y paleobiogeografa". Spanish. In: Asociación Paleontológica Argentina. Publicación Especial. El Neógeno de la Mesopotamia Argentina 14 (2013), pp. 179-191.

[2858] D. Brandoni. “Xyophorus sp. en El Mioceno Medio de Chubut: Implicancias Sistemáticas, Biogeográficas y Biocronológicas Del Registro de un Nothrotheriinae en el Neógeno de la Argentina". English. In: Ameghiniana 51.2 (2014), pp. 94-105.

[2859] D. Brandoni. “Nuevos materiales de Ortotheriinae (Xenarthra, Tardigrada, Megalonychidae) procedentes del Mesopotamiense (Mioceno tardio) de Entre Rios". Spanish. In: Instituto Superior de Correlacion Geologica (INSUGEO) Serie Miscelanea 17 (2008), pp. 11-20.

[2860] D. Brandoni, A. A. Carlini, F. Anaya, P. Gans, and D. A. Croft. "New Remains of Megathericulus patagonicus Ameghino, 1904 (Xenarthra, Tardigrada) from the Serravallian (Middle Miocene) of Bolivia; Chronological and Biogeographical Implications". English. In: Journal of Mammalian Evolution 25 (2018), pp. 327-337. DOI: 10.1007/s10914-017-9384-y.

[2861] D. Brandoni and A. A. Carlini. “On the presence of Pyramiodontherium (Mammalia, Xenarthra, Megatheriidae) in the late Miocene of northeastern Argentina and its biogeographical implications". English. In: Rivista Italiana di Paleontologia e Stratigrafia 115.1 (2009), pp. 111-123.

[2862] D. Brandoni and G. De Iuliis. "A new genus for the Megatheriinae (Xenarthra, Tardigrada, Megatheriidae) from the Arroyo Chasicó Formation (Upper Miocene) of Buenos Aires Province, Argentina". English. In: Neues Jahrbuch für Geologie und Paläontologie - Abhandlungen 244.1 (2007), pp. 53-64. DOI: 10.1127/0077-7749/2007/0244-0053.

[2863] D. Brandoni, B. S. Ferrero, and E. Brunetto. “Mylodon darwini Owen (Xenarthra, Mylodontinae) from the late Pleistocene of Mesopotamia, Argentina, with remarks on individual variability, paleobiology, paleobiogeography, and paleoenvironment". English. In: Journal of Vertebrate Paleontology 30.5 (2010), pp. 1547-1558.

[2864] D. Brandoni, L. González Ruiz, and J. Bucher. “Evolutive Implications of Megathericulus patagonicus (Xenarthra, Megatheriinae) from the Miocene of Patagonia Argentina". English. In: Journal of Mammalian Evolution (2019), pp. 1-16. DOI: 10.1007/s10914-019-09469-6.

[2865] D. Brandoni, L. González Ruiz, A. Reato, and G. Martin. "Chronological implications of the nothrotheriid 'Xyophorus' (Mammalia, Xenarthra) from the Collón Curá Formation (Miocene of Patagonia, Argentina)". English. In: Historical Biology (2017). DOI: 10.1080/08912963.2017.1398748. 
[2866] D. Brandoni, L. Gonzalez-Ruiz, M. F. Tejedon, G. Martin, and J. G. Fleagle. “Megatherioidea (Mammalia, Xenarthra, Tardigrada) from the Pinturas Formation (Early Miocene), Santa Cruz Province (Argentina) and their chronological implications". English. In: Paläontologische Zeitschrift 90 (2016), pp. 619-628. DOI: $10.1007 / \mathrm{s} 12542-016-0306-8$.

[2867] D. Brandoni, N. M. Novo, J. Tarquini, and M. F. Tejedor. "First record of Nematherium (Xenarthra, Mylodontidae) from the Pinturas Formation (Burdigalian, early Miocene), Santa Cruz Province, Argentina". English. In: Journal of South American Earth Sciences 96 (2019), 102234:1-8.

[2868] D. Brandoni, J. E. Powell, and O. E. González. "Anisodontherium from the Late Miocene of northwestern Argentina". English. In: Acta Palaeontologica Polonica 57.2 (2012), pp. 241-249.

[2869] D. Brandoni, G. I. Schmidt, A. M. Candela, J. I. Noriega, E. Brunetto, and L. E. Fiorelli. "Mammals from the Salicas Formation (Late Miocene), la Rioja Province, northwestern Argentina: Paleobiogeography, age and environment". English. In: Ameghiniana 49.3 (2012), pp. 375-387.

[2870] D. Brandoni and R. I. Vezzosi. "Nothrotheriops sp. (Mammalia, Xenarthra) from the Late Pleistocene of Argentina: implications for the dispersion of groundsloths during the Great". English. In: Boreas 48.4 (2019), pp. 879-890. DOI: 10.1111/bor.12401.

[2871] D. S. Brandt, M. Seitz, V. McCoy, J. Csonka, J. Barringer, E. Holmquist, S. Kraig, R. Morgan, J. Myers, and L. Paquette. "A new ichnospecies of $<\mathrm{i}>$ Arthrophycus $</ \mathrm{i}>$ from the Late Carboniferous (Pennsylvanian) of Michigan, USA". English. In: Ichnos 17 (2010), pp. 12-19. DOI: 10.1080/ 10420940903358404.

[2872] W. S. Brandt. "Janassa korni (Weigelt) - Neubeschreibung eines petalodonten Elasmobranchiers aus dem Kupferschiefer und Zechsteinkalk (Perm) von Eisleben (Sachsen-Anhalt)". German. In: Paläontologische Zeitschrift 70 (1996), pp. 505-520.

[2873] P. Branger. "Middle Jurassic Nautiloidea from western France". English. In: Rivista Italiana di Paleontologia e Stratigrafia 110 (2004), pp. 141-149.

[2874] M. Brasier, O. Green, and G. Shields. “Ediacaran sponge spicule clusters from southwestern Mongolia and the origins of the Cambrian fauna". In: Geology 25.4 (1997), pp. 303-306.

[2875] A. Bratishko, W. Schwarzhans, B. Reichenbacher, Y. Vernyhorova, and S. Coric. "Fish otoliths from the Konkian (Miocene, early Serravallian) of Mangyshlak (Kazakhstan): testimony to an early endemic evolution in the Eastern Paratethys". English. In: Paläontologische Zeitschrift 89 (2015), pp. 839-889.

[2876] J. Bratvold, L. L. Delsett, and J. H. Hurum. “Chondrichthyans from the Grippia bonebed (Early Triassic) of Marmierfjellet, Spitsbergen". English. In: Norwegian Journal of Geology 98 (2018), pp. 189217.

[2877] C. Brauckmann. "Neue Insekten-funde (Palaeodictyoptera: Breyeriidae) aus dem Ober-Karbon von Osnabrück (Deutschland)". German. In: Osnabrücker Naturwissenschaftliche Mitteilungen 20/21 (1995), pp. 157-166.

[2878] C. Brauckmann. "Ein neuer Insekten-Rest (Megasecoptera) aus dem Ober-Karbon von Osnabrück". German. In: Osnabrücker Naturwissenschaftliche Mitteilungen 17 (1991), pp. 25-32.

[2879] C. Brauckmann, A. Arillo, and V. M. Ortuño. "A new Geraridae (Insecta, hemipteroid stem assemblage) from the Upper Carboniferous of La Magdalena (León, Northern Spain)". English. In: Boletn Geológico y Minero 112 (2001), pp. 57-62.

[2880] C. Brauckmann, I. Chlupac, and R. Feist. "Trilobites at the Devonian-Carboniferous boundary". English. In: Annales de la Societe geologique de Belgique 115.2 (1993), pp. 507-518.

[2881] C. Brauckmann, O. F. Gallego, N. Hauschke, R. G. Martins-Neto, E. Groening, J. M. Ilger, and M. B. Lara. "First Late Triassic record of a paleoentomofauna from South America (Malargüe Basin, Mendoza Province, Argentina)". English. In: Acta Geologica Sinica 84 (2010), pp. 915-924.

[2882] C. Brauckmann and E. Gröning. “Ein neuer ober-karbonischer Insekten-Flügel aus Süd-Limburg (Palaeodictyoptera: Breyeriidae, Westfalium, Niederlande)". German. In: Neues Jahrbuch für Geologie und Paläontologie, Monatshefte 1996.2 (1996), pp. 72-82. 
[2883] C. Brauckmann and E. Gröning. "A first record of Insecta from the Late Jurassic sequence of the Langenberg near Oker, Lower Saxony (Germany)". English. In: Clausthaler Geowissenschaften 6 (2007), pp. $45-48$.

[2884] C. Brauckmann and K. J. Herd. "Insekten-funde aus dem Westfalium D (Ober-Karbon) des Piesberges bei Osnabrück (Deutschland). Teil 1: Palaeoptera". German. In: Osnabrïcker Naturwissenschaftliche Mitteilungen 28 (2002), pp. 27-69.

[2885] C. Brauckmann and K. J. Herd. "A subcircular insect wing from the Late Carboniferous of Osnabrück, Germany". English. In: Clausthaler Geowissenschaften 6 (2007), pp. 79-85.

[2886] C. Brauckmann and K. J. Herd. "Eine weitere neue Breyeriiden-Art (Insecta: Palaeodictyoptera) aus dem Ober-Karbon von Osnabrück (Deutschland)". German. In: Neues Jahrbuch für Geologie und Paläontologie, Monatshefte 2000.6 (2000), pp. 333-344.

[2887] C. Brauckmann and K. J. Herd. "Insekten-Funde aus dem Westfalium D (Ober-Karbon) des Piesberges bei Osnabrück (Deutschland). Teil 2: Neoptera". German. In: Osnabrücker Naturwissenschaftliche Mitteilungen 30/31 (2005), pp. 19-65.

[2888] C. Brauckmann, K. J. Herd, and A. Leipner. "Insekten-Funde aus dem Westfalium D (Ober-Karbon) des Piesberges bei Osnabrück (Deutschland), Nachtrag 1: Palaeodictyopteroida". German. In: Osnabrücker Naturwissenschaftliche Mitteilungen 35 (2009), pp. 5-30.

[2889] C. Brauckmann and T. Schlüter. “Neue Insekten aus der Trias von Unter-Franken”. German. In: Geologica et Palaeontologica 27 (1993), pp. 181-199.

[2890] C. Brauckmann and J. Schneider. "Ein unter-karbonisches Insekt aus dem Raum Bitterfeld/Delitzsch (Pterygota, Arnsbergium, Deutschland)". German. In: Neues Jahrbuch für Geologie und Paläontologie, Monatshefte 1996.1 (1996), pp. 17-30.

[2891] C. Brauckmann, L. Schöllmann, and W. Sippel. "Die fossilen Insekten, Spinnentiere und Eurypteriden von Hagen-Vorhalle". German. In: Geologie und Paläontologie in Westfalen 59 (2003), pp. 1-89.

[2892] C. Brauckmann and R. Willmann. "Insekten aus dem Permo-Silesium der Bohrung Weiterstadt 1 (Blattodea, Protorthoptera; Oberrheinische Tiefebene, SW-Deutschland)". German. In: Neues Jahrbuch für Geologie und Paläontologie, Montashefte 1990.8 (1990), pp. 470-478.

[2893] A. Braun and R. Schmidt-Effling. "Biozonation, diagenesis and evolution of radiolarians in the Lower Carboniferous of Germany". English. In: Marine Micropaleontology 21 (1993), pp. 369-383.

[2894] W. F. Braunberger and R. L. Hall. "Ammonoid faunas from the Cardium Formation (TuronianConiacian, Upper Cretaceous) and contiguous units, Alberta, Canada: I. Scaphitidae". English. In: Canadian Journal of Earth Sciences 38 (2001), pp. 333-346.

[2895] S. Bravi, M. Coppa, A. Garassino, and R. Patricelli. "Palaemon vesolensis n. sp. (Crustacea, Decapoda) from the Platten kalk of Vesole Mount (Salerno, Southern Italy)". English. In: Atti della Societa Italiana di Scienze Naturali e del Museo Civico di Storia Naturale di Milano 140.2 (1999), pp. 141169.

[2896] S. Bravi and A. Garassino. "Plattenkalk of the Lower Cretaceous (Albian) of Petina, in the Alburni Mounts (Campania, S Italy), and its decapod crustacean assemblage". English. In: Atti della Societá Italiana di Scienze Naturali e del Museo Civico di Storia Naturale in Milano 138.1-2 (1998), pp. 89-118.

[2897] S. Bravi and A. Garassino. "New biostratigraphic and palaeoecologic observations on the Plattenkalk of the Lower Cretaceous (Albian) of Pietraroia (Benevento, S Italy), and its decapod crustaceans assemblage". English. In: Atti della Societá Italiana di Scienze Naturali e del Museo Civico di Storia Naturale in Milano 138.1-2 (1998), pp. 119-171.

[2898] A. M. Bravo, B. Vila, A. Galobart, and O. Oms. "Restos de huevos de dinosaurio en el Cretácico Superior del sinclinal de Vallcebre (Berguedá, provincia de Barcelona) [Remains of dinosaur eggs in the Upper Cretaceous of the Vellcebre syncline (Berguedá, Barcelona province)]". Spanish. In: Revista Española de Paleontologa Num.Ext.10 (2005), pp. 49-57.

[2899] V. M. Bravo-Cuevas and I. Ferrusqua-Villafranca. “Merychippus (Mammalia, Perissodactyla, Equidae) from the Middle Miocene of state of Oaxaca, southeastern Mexico". English. In: Géobios 39 (2006), pp. 771-784. 
[2900] V. M. Bravo-Cuevas and I. Ferrusquia-Villafranca. "Cormohipparion (Mammalia, Perissodactyla, Equidae) from the middle Miocene of Oaxaca, southeastern Mexico". English. In: Journal of Vertebrate Paleontology 28.1 (2008), pp. 243-250. DOI: 10.1671/0272-4634(2008)28[243:CMPEFT]2.0.CO;2.

[2901] V. M. Bravo-Cuevas, E. Jiménez-Hidalgo, G. E. Cuevas-Ruiz, and M. A. Cabral-Perdomo. “A Small Camelid Hemiauchenia from the Late Pleistocene of Hidalgo, Central Mexico". English. In: Acta Palaeontologica Polonica 57.3 (2012), pp. 497-508. DOI: 10.4202/app.2011.0005.

[2902] V. M. Bravo-Cuevas, E. Jimenez-Hidalgo, M. A. Cabral-Perdomo, and J. Priego-Vargas. “Taxonomy and notes on the paleobiology of the late Pleistocene (Rancholabrean) antilocaprids (Mammalia, Artiodactyla, Antilocapridae) from the state of Hidalgo, central Mexico". English. In: Revista Mexicana de Ciencias Geológicas 30.3 (2013), pp. 601-613.

[2903] V. M. Bravo-Cuevas, E. Ortiz-Caballero, and M. A. Cabral-Perdomo. "Gliptodontes (Xenarthra, Glyptodontidae) del Pleistoceno Tardo (Rancholabreano) de Hidalgo, Centro de México". Spanish. In: Boletin de la Sociedad Geologica Mexicana 61.2 (2009), pp. 267-276.

[2904] V. M. Bravo-Cuevas, F. Rivals, and J. Presto-Vargas. "Paleoecology (C13 and O18 stable isotopes analysis) of a mammalian assemblage from the Late Pleistocene of Hidalgo, central Mexico and implications for a better understanding of environmental conditions in temperate North America (18 degrees - 36 degrees N Lat.)" English. In: Palaeogeography, Palaeoclimatology, Palaeoecology 485 (2017), pp. 632-643.

[2905] E. S. Bray. Eggs and eggshell from the Upper Cretaceous North Horn Formation, central Utah. English. Vol. 99-1. Vertebrate Paleontology in Utah, Utah Geological Survey Miscellaneous Publication. 1999, pp. 361-375.

[2906] E. S. Bray and K. F. Hirsch. "Eggshell from the Upper Jurassic Morrison Formation". English. In: Modern Geology 23.1-4 (1998), pp. 219-240.

[2907] A. Brayard, T. Brühwiler, H. Bucher, and J. Jenks. "Guodunites, a low-palaeolatitude and transPanthalassic Smithian (Early Triassic) ammonoid genus". English. In: Palaeontology 52.2 (2009), pp. 471-481.

[2908] A. Brayard and H. Bucher. "Smithian (Early Triassic) ammonoid faunas from northwestern Guangxi (South China): taxonomy and biochronology". English. In: Fossils and Strata 55 (2008), pp. 1-179.

[2909] A. Brayard, K. G. Bylund, J. F. Jenks, D. A. Stephen, N. Olivier, G. Escarguel, E. Fara, and E. Vennin. "Smithian ammonoid faunas from Utah: implications for Early Triassic biostratigraphy, correlation and basinal paleogeography". English. In: Swiss Journal of Palaeontology 132 (2013), pp. 141-219.

[2910] A. Brayard, J. F. Jenks, K. G. Bylund, and The Paris Biota Team. "Ammonoids and nautiloids from the earliest Spathian Paris Biota and other early Spathian localities in southeastern Idaho, USA". English. In: Geobios 54 (2019), pp. 13-36. DOI: 10.1016/j.geobios.2019.04.007.

[2911] A. Brayard, L. J. Krumenacker, J. P. Botting, J. F. Jenks, K. G. Bylund, E. Fara, E. Vennin, N. Olivier, N. Goudemand, T. Saucéde, S. Charbonnier, C. Romano, L. Doguzhaeva, B. Thuy, M. Hautmann, D. A. Stephen, C. Thomazo, and G. Escarguel. "Unexpected Early Triassic marine ecosystem and the rise of the Modern evolutionary fauna". English. In: Science Advances 3 (2017), e1602159.

[2912] A. Brazauskas and P. Musteikis. "Brachiopod and Conodont Distribution at the Wenlock - Ludlow boundary of Lithuania". English. In: Proceedings of the Estonian Academy of Sciences 40.2 (1991), pp. 61-68.

[2913] R. P. Brazil and J. D. Andrade Filho. "Description of Pintomyia (Pifanomyia) falcaorum sp. n. (Diptera: Psychodidae: Phlebotominae), a fossil sand fly from Dominican Amber". English. In: Memórias do Instituto Oswaldo Cruz 97 (2002), pp. 501-503.

[2914] G. Brea, J. F. Bonaparte, C. L. Schultz, and A. G. Martinelli. A new specimen of Guaibasaurus candelariensis (basal Saurischia) from the Late Triassic Caturrita Formation of southern Brazil. English. 2005.

[2915] M. Brea. “Ulminium mucilaginosum n. sp. y Ulminium artabeae n. sp., dos leños fósiles de Lauraceae en la Formación El Palmar, provincia de Entre Ros, Argentina". Spanish. In: Ameghiniana 35.2 (1998), pp. 193-204. 
[2916] M. Brea, S. D. Matheos, M. S. Raigemborn, A. Iglesias, A. F. Zucol, and M. Prámparo. “Paleoecology and paleoenvironments of Podocarp trees in the Ameghino Petrified forest (Golfo San Jorge Basin, Patagonia, Argentina): Constraints for Early Paleogene paleoclimate". English. In: Geologica Acta 9.1 (2011), pp. 13-28. DOI: 10.1344/105.000001647.

[2917] M. Brea, A. B. Zamuner, S. D. Matheos, A. Iglesias, and A. F. Zucol. "Fossil wood of the Mimosoideae from the early Paleocene of Patagonia, Argentina". English. In: Alcheringa 32 (2008), pp. 427-441.

[2918] M. Brea and A. F. Zucol. “Maderas fósiles de Combretaceae de la Formación El Palmar (Pleistoceno), Entre Ros, Argentina". Spanish. In: Ameghiniana 38.4 (2001), pp. 409-417.

[2919] M. Brea and A. F. Zucol. “Leños fósiles de Boraginaceae de la Formación Peñas Coloradas (Paleoceno superior), Puerto Visser, Chubut, Argentina". Spanish. In: Ameghiniana 43.1 (2006), pp. 139146.

[2920] S. Q. Breard. "Paleoecology of a late Eocene (Bartonian) vertebrate fauna, Moodys Branch Formation, Techeva Creek, Mississippi". English. In: Gulf Coast Association of Geological Societies Transactions 41 (1991), pp. 43-55.

[2921] S. Q. Breard and G. L. Stringer. "Integrated Paleoecology and Marine Vertebrate Fauna of the Stone City Formation (Middle Eocene), Brazos River Section, Texas". English. In: Gulf Coast Association of Geological Societies Transactions 49 (1999), pp. 132-142.

[2922] B. T. Breeden and K. Izumi. "A review of the vertebrate fossil assemblage from the Lower Jurassic Nishinakayama Formation in the Ischimachi district of Toyota Town, Yamaguchi Prefecture, Japan". English. In: Bulletin of the Firefly Museum of Toyota Town 11 (2019), pp. 9-23.

[2923] B. T. Breeden and T. B. Rowe. "New specimens of Scutellosaurus lawleri Colbert,1981, from the Lower Jurassic Kayenta Formation in Arizona elucidate the early evolution of thyreophoran dinosaurs". English. In: Journal of Vertebrate Paleontology 40.4 (2020), e1791894:1-32. DOI: 10.1080 / 02724634.2020.1791894.

[2924] B. H. Breithaupt, E. H. Southwell, and N. A. Matthews. Dynamosaurus imperiosus and the earliest discoveries of Tyrannosaurus rex in Wyoming and the West. English. Vol. 35. Late Cretaceous Vertebrates from the Western Interior. New Mexico Museum of Natural History and Science Bulletin. 2006, pp. 257-258.

[2925] O. Bremer, E. Jarochowska, and T. Märss. "Vertebrate dermal remains and conodont distribution in the upper Silurian Hamra and Sundre formations of Gotland, Sweden". English. In: Gff (2019).

[2926] P. J. Brenchley, J. D. Marshall, D. A. T. Harper, C. J. Buttler, and C. J. Underwood. “A late Ordovician (Hirnantian) karstic surface in the submarine channel, recording glacio-eustatic sea-level changes: Meifod, central Wales". English. In: Geological Journal 41 (2006), pp. 1-22. DOI: 10.1002/ gj.1029.

[2927] P. J. Brenchley, J. D. Marshall, L. Hints, and J. Nolvak. "New isotopic data solving an old biostratigraphic problem: the age of the upper Ordovician brachiopod Holorhynchus giganteus". English. In: Journal of the Geological Society 154 (1997), pp. 335-342. DOI: 10.1144/gsjgs.154.2.0335.

[2928] P. L. Brenckle and N. V. Milkina. "Foraminiferal timing of carbonate deposition on the Late Devonian (Famennian)-Middle Pennsylvanian (Bashkirian) Tengiz Platform, Kazakhstan". English. In: Rivista Italiana di Paleontologia e Stratigrafia 109.2 (2003), pp. 131-158.

[2929] G. J. Brenner and I. S. Bickoff. "Palynology and age of the Lower Cretaceous basal Kurnub Group from the coastal plain to the Northern Negev of Israel". English. In: Palynology 16 (1992), pp. 137185.

[2930] G. Breton. “Les Goniasteridae (Asteroidea, Echinodermata) jurassiques et crétacés de France. Taphonomie, systématique, biostratigraphie, paléobiogéographie, évolution." French. In: Bulletin trimestriel de la Société géologique de Normandie et des Amis du Muséum du Havre, numéro hors série 78 (1992), pp. 1590. 
[2931] G. Breton. "Deux étoiles de mer du Bajocien du Nord-Ouest du Bassin de Paris (France) : leurs alliés actuels sont des fossiles vivants". French. In: Bulletin trimestriel de la Société géologique de Normandie et des Amis du Muséum du Havre 84.1 (1997), pp. 23-34.

[2932] G. Breton. "Tethyaster guerangeri sp. nov. (Astropectinidae, Asteroidea, Echinodermata) : deux spécimens d'astérides d'une conservation exceptionnelle du cénomanien du Mans (Sarthe, France)". French. In: Bulletin trimestriel de la Société géologique de Normandie et des Amis du Muséum du Havre 82.4 (1995), pp. 17-29.

[2933] G. Breton. “Une carapace de crabe préservée dans le moule interne d'un gastéropode du Cénomanien de Basse-Normandie (France)". French. In: L'écho des falaises 12 (2008), pp. 51-57.

[2934] G. Breton. "Un cas de paléocoprophagie chez un crabe du Cénomanien du Mans (Collection Boutillier, Université de caen)". French. In: Bulletin de la Société Linnéenne de Normandie 119 (2006), pp. 41-43.

[2935] G. Breton, M. Bilotte, and G. Sigro. “Dipsacaster jadeti sp. nov. Astropectinidae (Asteroidea, Echinodermata) du Maastrichtien des Petites Pyrénées (France)". French. In: Bulletin Trimestriel de la Société géologique de Normandie et des Amis du Muséum du Havre 82.4 (1995), pp. 35-42.

[2936] G. Breton, J. P. Bourseau, G. Barale, E. Buffetaut, C. Gaillard, J. C. Gall, and S. Wenz. “Les astérides (Asteroidea, Echinodermata) des calcaires lithographiques kimméridgiens de Cerin (Ain, France)". French. In: Geobios, mémoire spécial 16 (1994), pp. 49-60.

[2937] G. Breton and V. Decombe. "Comparaison des faunes d'astérides de deux gisements cénomaniens de Basse-Normandie (France) et du Devon (Angleterre)". French. In: Bulletin trimestriel de la Société géologique de Normandie et des Amis du Muséum du Havre 84.1 (1997), pp. 9-11.

[2938] G. Breton and B. Ferré. "Premiére observation d'éléments squelettiques d'Asteriidae (Asteroidea, Echinodermata) dans les craies du Cénomanien au Coniacien du Bassin de Paris (France)". French. In: Revue de Micropaléontologie 38.4 (1995), pp. 299-309.

[2939] G. Breton, G. Fily, R. Cousin, and P. Maurizot. "Asteriacites lumbricalis von Schloteim, 1820. Trace de repos ou d'enfouissement d'ophiure préservée dans le calcaire de Creully, Bathonien moyen du Calvados (Normandie)". French. In: Bulletin trimestriel de la Société Géologique de Normandie et des Amis du Muséum du Havre 87.1 (2001), pp. 97-98.

[2940] G. Breton and D. Vizcano. "Astérides (Echinodermata) de l'Ilerdien moyen (Yprésien) des Corbiéres (Aude, France) : systématique, relations paléobiogéographiques et évolutives". French. In: Bulletin de la Société d'Etudes Scientifiques de l'Aude 97 (1997), pp. 11-28.

[2941] C. E. Brett. Wenlockian fossil communities in New York State and adjacent areas: Paleontology and Paleoecology. English. Paleocommunities: A Case Study from the Silurian and Lower Devonian. 1999, pp. 592-637.

[2942] C. E. Brett, V. B. Dick, and G. C. Baird. Comparative Taphonomy and Paleoecology of Middle Devonian Dark Gray and Black Shale Facies from Western New York. 1991.

[2943] C. E. Brett, T. E. Whiteley, P. A. Allison, and E. L. Yochelson. “The Walcott-Rust Quarry: Middle Ordovician Trilobite Konservat-Lagerstätten". English. In: Journal of Paleontology 73.2 (1999), pp. 288-305.

[2944] K. D. Brett and S. R. Westrop. "Trilobites of the Lower Ordovician (Ibexian) For Cassin Formation, Champlain Valley Region, New York State and Vermont". English. In: Journal of Paleontology 70.3 (1996), pp. 408-427.

[2945] P. Brewer. "New record of Warendja wakefieldi (Vombatidae; Marsupialia) from Wombeyan Caves, New South Wales". English. In: Alcheringa 31.2 (2007), pp. 153-171. DOI: 10.1080/03115510701305132.

[2946] P. Brewer, M. Archer, S. Hand, and H. Godthelp. "A new species of the wombat Warendja from the Late Miocene deposits at Riversleigh, North-West Queensland, Australia". English. In: Palaeontology 50.4 (2007), pp. 811-828. 
[2947] P. Brewer, M. Archer, and S. Hand. "Additional specimens of the oldest wombat Rhizophascolonus crowcrofti (Vombatidae; Marsupialia) from the Wipajiri Formation, South Australia: an intermediate morphology?" English. In: Journal of Vertebrate Paleontology 28.4 (2008), pp. 11441148. DOI: 10.1671/0272-4634-28.4.1144.

[2948] P. Brewer, M. Archer, S. J. Hand, and R. Abel. "New genus of primitive wombat (Vombatidae, Marsupialia) from Miocene deposits in the Riversleigh World Heritage Area (Queensland, Australia)". English. In: Palaeontologia Electronica 18.1.9A (2015), pp. 1-40.

[2949] J. Brezina, A. Lujan, G. Calabkova, and M. Ivanov. "Revision on historical finding of the giant turtle from the Brno Sand (middle Miocene, lower Badenian)". other. In: Acta Mus. Moraviae, Sci. Geol 104.1 (2019), pp. 113-128.

[2950] D. K. Brezinski. "Trilobites from the Lower Mississippian starved basin facies of the southern United States". English. In: Journal of Paleontology 72.4 (1998), pp. 718-725.

[2951] D. K. Brezinski. "Permian trilobites from west Texas". English. In: Journal of Paleontology 66.6 (1992), pp. 924-943.

[2952] D. K. Brezinski. "Lower Mississippian trilobites from southern New Mexico". English. In: Journal of Paleontology 74.6 (2000), pp. 1043-1064.

[2953] D. K. Brezinski. "New Lower Mississippian trilobites from the Chouteau Group of Missouri". English. In: Annals of Carnegie Museum 69.2 (2000), pp. 135-144.

[2954] D. K. Brezinski. "Permian trilobites from the San Andres Formation, New Mexico, and their relationship to species from the Kaibab Formation of Arizona". English. In: Journal of Paleontology 65.3 (1991), pp. 480-484.

[2955] D. Brice. "Brachiopod assemblages in the Devonian of Ferques (Boulonnais, France). Relations to palaeoenvironments and global eustatic curves." English. In: Bulletin of Geosciences 78.4 (2003), pp. 405-417.

[2956] D. Brice. "New data on systematics of some Famennian spiriferid brachiopods from Afghanistan and Iran". English. In: Senckenbergiana lethaea 79.1 (1999), pp. 281-295.

[2957] D. Brice, B. Mistiaen, and J. -C. Rohart. “New data on distribution of brachiopods, rugose corals and stromatoporoids in the Upper Devonian of central and eastern Iran. Paleobiogeographic implications". English. In: Annales de la Societe Geologique du Nord 7.2 (1999), pp. 21-32.

[2958] D. E. Briggs, B. S. Lieberman, S. L. Halgedahl, and R. D. Jarrard. "A new metazoan from the Middle Cambrian of Utah and the nature of the Vetulicolia". English. In: Palaeontology 48.4 (2005), pp. 681-686.

[2959] D. E. Briggs, D. J. Siveter, M. D. Sutton, and I. A. Rahman. "An edrioasteroid from the Silurian Herefordshire Lagerstätte of England reveals the nature of the water vascular system in an extinct echinoderm". English. In: Proceedings of the Royal Society B 284.1862 (2017), p. 20171189.

[2960] D. E. G. Briggs. "Soft-bodied fossils from a Silurian volcaniclastic deposit". English. In: Nature 382 (1996), pp. 248-250.

[2961] D. E. G. Briggs, B. S. Lieberman, J. R. Hendricks, S. L Halgedahl, and R. D. Jarrard. "Middle Cambrian arthropods from Utah". English. In: Journal of Paleontology 82.2 (2008), pp. 238-254.

[2962] D. E. G. Briggs, M. D. Sutton, and D. J. Siveter. "A new phyllocarid (Crustacea: Malacostraca) from the Silurian Fossil-Lagerstätte of Herefordshire, UK". English. In: Proceedings of the Royal Society of London B 271 (2004), pp. 131-138.

[2963] D. J. C. Briggs. "Permian Productidina and Strophalosiidina from the Sydney-Bowen Basin and New England Orogen: systematics and biostratigraphic significance". English. In: Memoirs of the Association of Australasian Palaeontologists 19 (1998), pp. 1-258.

[2964] D. E. Bright and G. O. Poinar. "Scolytidae and Platypodidae (Coleoptera) from Dominican Republic Amber". English. In: Annals of the Entomological Society of America 87.2 (1994), pp. 170-194.

[2965] J. A. Bright, B. H. Tiffney, and A. R. Wyss. "A mid-Oligocene (Whitneyan) rhinocerotid from northeastern California". English. In: Journal of Paleontology 89.1 (2015), pp. 135-139. 
[2966] J. B. Brink and S. P. Modesto. "A new skeleton of the therocephalian synapsid Olivierosuchus parringtoni from the Lower Triassic South African Karoo Basin". English. In: Palaeontology 54.3 (2011), pp. 591-606.

[2967] K. S. Brink, R. A. Stockey, G. Beard, and W. C. Wehr. “Cunninghamia hornbyensis sp. nov.: Permineralized twigs and leaves from the Upper Cretaceous of Hornby Island, British Columbia, Canada". English. In: Review of Palaeobotany and Palynology 155.1-2 (2009), pp. 89-98.

[2968] D. Brinkman, M. C. Aguillon-Martinez, J. H. Hutchison, and C. M. Brown. "Yelmochelys rosarioae gen. et sp. nov., a stem kinosternid (Testudines; Kinosternidae) from the Late Cretaceous of Coahuila, Mexico". English. In: PaleoBios 33 (2016), pp. 1-20.

[2969] D. Brinkman, M. C. Aquillon-Martinez, C. A. De Leon Dávila, H. Jamniczky, D. A. Eberth, and M. Colbert. "Euclastes coahuilaensis sp. nov., a basal cheloniid turtle from the late Campanian Cerro del Pueblo Formation of Coahuila State, Mexico". English. In: PaleoBios 28.3 (2009), pp. 76-88.

[2970] D. Brinkman, M. Hart, H. Jamniczky, and M. Colbert. “Nichollsemys baieri gen. et sp. nov., a primitive chelonioid turtle from the late Campanian of North America". English. In: Paludicola 5.4 (2006), pp. 111-124.

[2971] D. Brinkman, M. Rabi, and L. Zhao. "Lower Cretaceous fossils from China shed light on the ancestral body plan of crown softshell turtles (Trionychidae, Cryptodira)". English. In: Scientific Reports 7 (2017), 6719:1-11. DOI: 10.1038/s41598-017-04101-0.

[2972] D. B. Brinkman. "Paleontology of the Judith River Formation (Campanian) of Dinosaur National Park, Alberta, Canada: evidence from vertebrate microfossil locality". English. In: Palaeogeography, Palaeoclimatology, Palaeoecology 78 (1990), pp. 37-54.

[2973] D. B. Brinkman. "Anatomy and systematics of Plesiobaena antiqua (Testudines: Baenidae) from the mid-Campanian Judith River Group of Alberta, Canada". English. In: Journal of Vertebrate Paleontology 23.1 (2003), pp. 146-155.

[2974] D. B. Brinkman. "New material of Dracochelys (Eucryptodira: Sinemydidae) from the Junggar Basin, Xinjiang, People's Republic of China". English. In: Canadian Journal of Earth Sciences 38 (2001), pp. 1645-1651.

[2975] D. B. Brinkman. "Non-trionychid turtles from the Paleocene of Alberta, Canada". English. In: Canadian Journal of Earth Sciences 50 (2013), pp. 282-293.

[2976] D. B. Brinkman. "A review of nonmarine turtles from the Late Cretaceous of Alberta". English. In: Canadian Journal of Earth Sciences 40.4 (2003), pp. 557-571. DOI: 10.1139/e02-080.

[2977] D. B. Brinkman. "A sea turtle skull (Cheloniidae: Carettini) from the lower Miocene Nye Formation of Oregon, U.S.A". English. In: Paludicola 7.2 (2009), pp. 39-46.

[2978] D. B. Brinkman, D. R. Braman, A. G. Neuman, P. E. Ralrick, and T. Sato. A vertebrate assemblage from the marine shales of the Lethbridge Coal Zone. English. Dinosaur Provincial Park: A Spectacular Ancient Ecosystem Revealed. Indiana University Press, Bloomington. 2005, pp. 486-500.

[2979] D. B. Brinkman, R. L. Cifelli, and N. J. Czaplewski. "First occurrence of Deinonychus antirrhopus (Dinosauria: Theropoda) from the Antlers Formation (Lower Cretaceous: Aptian-Albian) of Oklahoma". In: Oklahoma Geological Survey Bulletin 146 (1998), pp. 1-27.

[2980] D. B. Brinkman, M. Densmore, M. Rabi, M. J. Ryan, and D. C. Evans. "Marine turtles from the Late Cretaceous of Alberta, Canada". English. In: Canadian Journal of Earth Sciences 52 (2015), pp. 581589.

[2981] D. B. Brinkman, M. J. Densmore, and W. G. Joyce. “Macrobaenidae (Testudines: Eucryptodira) from the Late Paleocene (Clarkforkian) of Montana and the taxonomic treatment of Clemmys backmani". English. In: Bulletin of the Peabody Museum of Natural History 51.2 (2010), pp. 147-155.

[2982] D. B. Brinkman and Z.-M. Dong. "New material of Ikechosaurus sunailinae (Reptilia: Choristodera) from the Early Cretaceous Laohongdong Formation, Ordos Basin, Inner Mongolia, and the interrelationships of the genus". English. In: Canadian Journal of Earth Sciences 30.10-11 (1994), pp. 2153-2162. 
[2983] D. B. Brinkman, D. A. Eberth, M. J. Ryan, and P. Chen. “The occurrence of Psittacosaurus xinjiangensis Sereno and Chow, 1988 in the Urho area, Junggar Basin, Xinjiang, People's Republic of China". English. In: Canadian Journal of Earth Sciences 38 (2001), pp. 1781-1786.

[2984] D. B. Brinkman, D. A. Eberth, X. Xu, J. M. Clark, and X. -C. Wu. "Turtles from the Jurassic Shishugou Formation of the Junggar Basin, People's Republic of China, with comments on the basicranial region of basal eucryptodires". English. In: Morphology and Evolution of Turtles. 2013, pp. 147-172. DOI: 10.1007/978-94-007-4309-0_10.

[2985] D. B. Brinkman, L. A. Nessov, and J. -H. Peng. “Khunnuchelys gen. nov., a new trionychid (Testudines: Trionychidae) from the Late Cretaceous of Inner Mongolia and Uzbekistan". English. In: Canadian Journal of Earth Sciences 30.10-11 (1993), pp. 2214-2223.

[2986] D. B. Brinkman and A. G. Neuman. "Teleost centra from uppermost Judith River Group (Dinosaur Park Formation, Campanian) of Alberta, Canada". In: Journal of Paleontology 76.1 (2002), pp. 138155.

[2987] D. B. Brinkman, A. G. Neuman, and J. D. Divay. "Non-marine fishes of the late Santonian Milk River Formation of Alberta, Canada - evidence from vertebrate microfossil localities". English. In: Vertebrate Anatomy Morphology Paleontology 3 (2017), pp. 7-46.

[2988] D. B. Brinkman and E. L. Nicholls. “The skull of Neurankylus eximius (Testudines: Baenidae) and a reinterpretation of the relationships of this taxon". English. In: Journal of Vertebrate Paleontology 13.3 (1993), pp. 273-281.

[2989] D. B. Brinkman and J.-H. Peng. “Ordosemys leios, n. gen., n. sp., a new turtle from the Early Cretaceous of the Ordos Basin, Inner Mongolia". English. In: Canadian Journal of Earth Sciences 30.10-11 (1993), pp. 2128-2138.

[2990] D. B. Brinkman and J.-H. Peng. "New material of Sinemys (Testudines, Sinemydidae) from the Early Cretaceous of China". English. In: Canadian Journal of Earth Sciences 30.10-11 (1993), pp. 2139 2152.

[2991] D. B. Brinkman and R. A. Rodrguez de la Rosa. Nonmarine turtles from the Cerro del Pueblo Formation (Campanian), Coahuila State, Mexico. English. Vol. 35. Late Cretaceous Vertebrates from the Western Interior. New Mexico Museum of Natural History and Science Bulletin. 2006, pp. 229-233.

[2992] D. B. Brinkman, A. P. Russell, D. A. Eberth, and J. Peng. "Vertebrate palaeocommunities of the lower Judith River Group (Campanian) of southeastern Alberta, Canada, as interpreted from vertebrate microfossil assemblages". In: Palaeogeography, Palaeoclimatology, Palaeoecology 213 (2004), pp. 295-313.

[2993] D. B. Brinkman, M. J. Ryan, and D. A. Eberth. "The paleogeographic and stratigraphic distribution of ceratopsids (Ornithischia) in the Upper Judith River Group of western Canada". English. In: Palaios 13 (1998), pp. 160-169.

[2994] D. B. Brinkman, K. Stadtman, and D. Smith. "New material of Dinochelys whitei Gaffney, 1979, from the Dry Mesa Quarry (Morrison Formation, Jurassic) of Colorado". English. In: Journal of Vertebrate Paleontology 20.2 (2000), pp. 269-274. DOI: 10.1671/0272-4634(2000)020[0269:NMODWG]2. $0 . \mathrm{CO} ; 2$.

[2995] D. B. Brinkman and J. A. Tarduno. "A Late Cretaceous (Turonian-Coniacian) high-latitude turtle assemblage from the Canadian Arctic". English. In: Canadian Journal of Earth Sciences 42 (2005), pp. 2073-2080.

[2996] D. B. Brinkman, H. Tong, H. Li, Y. Sun, J. -S. Zhang, P. Godefroit, and Z. -M. Zhang. “New exceptionally well-preserved specimens of Zangerlia neimongolensis from Bayan Mandahu, Inner Mongolia, and their taxonomic significance". English. In: Comptes Rendus Palevol 14 (2015), pp. 577-587.

[2997] D. B. Brinkman, Z. Xijin, and E. L. Nicholls. "A primitive ichthyosaur from the Lower Triassic of British Columbia, Canada". English. In: Palaeontology 35.2 (1992), pp. 465-474. 
[2998] D. B. Brinkman, C.-X. Yuan, Q. Ji, D. -Q. Ji, and H. -L. You. “A new turtle from the Xiagou Formation (Early Cretaceous) of Changma Basin, Gansu Province, P. R. China". English. In: Palaeobiodiversity and Palaeoenvironments (2013). DOI: 10.1007/s12549-013-0113-0.

[2999] W. Brinkmann and M. Rauhe. “Diplocynodon ratelii Pomel, 1847 (Crocodylia, Leidyosuchidae) aus dem Unter-Oligozän von Céreste (Südfrankreich)". German. In: Neues Jahrbuch für Geologie und Paläontologie, Abhandlungen 209.3 (1998), pp. 295-321.

[3000] C. R. Bristow. Geology of the Petersfield district, Hampshire. English. 1991.

[3001] P. Brito and M. Ebert. "A new aspidorhynchid fish (Teleostei: Aspidorhynchiformes) from the Upper Jurassic of Ettling, Solnhofen, Bavaria, Germany". English. In: Comptes Rendus Palevol 8.4 (2009), pp. 395-402.

[3002] P. M. Brito. “A new halecomorph with two dorsal fins, Placidichthys bidorsalis n. g., n. sp. (Actinopterygii: Halecomorphi) from the Lower Cretaceous of the Araripe Basin, northeast Brazil". English. In: Comptes Rendus de l'Academie des Sciences Paris, Sciences de la Terre et des planétes 331 (2000), pp. 749 754.

[3003] P. M. Brito and V. Gallo. “A new pleuropholid, Gondwanapleuropholis longimaxillaris n. g., n. sp. (Actinopterygii: Teleostei) from the Jurassic of north east Brazil”. English. In: Comptes Rendus Palevol 1.8 (2002), pp. 697-703.

[3004] P. M. Brito and V. Gallo. "A new species of Lepidotes (Neopterygii: Semionotiformes: Semionotidae) from the Santana Formation, Lower Cretaceous of Northeastern Brazil". English. In: Journal of Vertebrate Paleontology 23.1 (2003), pp. 47-53.

[3005] P. M. Brito and D. M. Martill. “Discovery of a juvenile coelacanth in the Lower Cretaceous, Crato Formation, Northeastern Brazil”. English. In: Cybium 23.3 (1999), pp. 311-314.

[3006] P. M. Brito and M. E. Suarez. "Late Cretaceous Belonostomus (Pisces, Actinopterygii, Aspidorhynchidae) from Algarrobo, Chile, with comments on aspidorhynchid paleodistribution in South America". English. In: Revista Geológica de Chile 30.1 (2003), pp. 117-127. DOI: 10.4067 /S0716-02082003000100008.

[3007] B. Britt. "Theropods of Dry Mesa Quarry (Morrison Formation, Late Jurassic), Colorado, with emphasis on the osteology of Torvosaurus tanneri". In: BYU Geology Studies 37 (1991), pp. 1-72.

[3008] B. B. Britt, D. J. Chure, G. F. Engelmann, and J. D. Shumway. "Rise of the erg-paleontology and paleoenvironments of the Triassic-Jurassic transition in northeastern Utah". English. In: Geology of the Intermountain West 3 (2016), pp. 1-32.

[3009] B. B. Britt, D. A. Eberth, R. Scheetz, and B. Greenhalgh. Taphonomy of the Dalton Wells Dinosaur Quarry (Cedar Mountain Formation, Lower Cretaceous, Utah). English. 2004.

[3010] B. B. Britt, D. A. Eberth, R. D. Scheetz, B. W. Greenhalgh, and K. L. Stadtman. "Taphonomy of debris-flow hosted dinosaur bonebeds at Dalton Wells, Utah (Lower Cretaceous, Cedar Mountain Formation, USA)". English. In: Palaeogeography, Palaeoclimatology, Palaeoecology 280 (2009), pp. 122. DOI: $10.1016 /$ j.palaeo.2009.06.004.

[3011] B. B. Britt, R. D. Scheetz, D. B. Brinkman, and D. A. Eberth. "A Barremian neochoristodere from the Cedar Mountain Formation, Utah, U.S.A." English. In: Journal of Vertebrate Paleontology 26.4 (2006), pp. 1005-1008.

[3012] B. B. Britt, R. D. Scheetz, M. F. Whiting, and D. R. Wilhite. “Moabosaurus utahensis, n. gen., n. sp., a new sauropod from the Early Cretaceous (Aptian) of North America". English. In: Contributions from the Museum of Paleontology, University of Michigan 32.11 (2017), pp. 189-243.

[3013] C. Brizio. “The Great Transylvanian Dinosaur Expedition 1997: una bellissima rosa con qualche spina di troppo [The Great Transylvanian Dinosaur Expedition 1997: a most beautiful rose with a few too many thorns]". Italian. In: Natura Nascosta 15 (1997), pp. 3-21.

[3014] S. Brizuela and A. Albino. "A Scincomorpha lizard from the Campanian of Patagonia". English. In: Cretaceous Research 32 (2011), pp. 781-785. DOI: 10.1016/j.cretres.2011.05.006. 
[3015] T. W. Broadhead and C. D. Sumrall. "Heterochrony and paedomorphic morphology of Sprinkleocystis ektopios, new genus and species, (Rhombifera, Glyptocystida) from the Middle Ordovician (Caradoc) of Tennessee". English. In: Journal of Paleontology 77.1 (2003), pp. 113-120.

[3016] D. G. Broadley. "A new species of Psammobates (Reptilia: Testudinidae) from the Early Pleistocene of South Africa". English. In: Palaeontologia Africana 34 (1997), pp. 111-114.

[3017] J.-C. Brocard. "Le genre Hadrodelphis (Cetacea, Kentriodontidae) dans les Faluns Miocenes de L'Ouest de la France". French. In: Bulletin de la Societe des Sciences Naturelles de l'Ouest de la France 22.2 (2000), pp. 92-95.

[3018] C. A. Brochu. "Borealosuchus (Crocodylia) from the Paleocene of Big Bend National Park, Texas". English. In: Journal of Paleontology 74.1 (2000), pp. 181-187.

[3019] C. A. Brochu. "Systematics and taxonomy of Eocene tomistomine crocodylians from Britain and northern Europe". English. In: Palaeontology 50.4 (2007), pp. 917-928.

[3020] C. A. Brochu. "A New Late Cretaceous gavialoid crocodylian from Eastern North America and the phylogenetic relationships of thoracosaurs". English. In: Journal of Vertebrate Paleontology 24.3 (2004), pp. 610-633. DOI: 10.1671/0272-4634(2004)024[0610:ANLCGC]2.0.CO.

[3021] C. A. Brochu. “Osteology and phylogenetic significance of Eosuchus minor (Marsh, 1870) new combination, a longirostrine crocodylian from the late Paleocene of North America". English. In: Journal of Paleontology 80.1 (2006), pp. 162-186. DOI: 10.1666/0022-3360(2006)080[0162:OAPSOE]2. $0 . \mathrm{CO} ; 2$.

[3022] C. A. Brochu. "Phylogenetic relationships of Necrosuchus ionensis Simpson, 1937 and the early history of caimanines". English. In: Zoological Journal of the Linnean Society 163 (2011), S228-S256.

[3023] C. A. Brochu. "A new alligatorid from the lower Eocene Green River Formation of Wyoming and the origin of caimans". English. In: Journal of Vertebrate Paleontology 30.4 (2010), pp. 1109-1126.

[3024] C. A. Brochu. "Eosuchus (Crocodylia, Gavialoidea) from the Lower Eocene of the Isle of Sheppey, England". English. In: Journal of Vertebrate Paleontology 26.2 (2006), pp. 466-470.

[3025] C. A. Brochu. "A New Miniature Horned Crocodile from the Quaternary of Aldabra Atoll, Western Indian Ocean". English. In: Copeia 2006.2 (2006), pp. 149-158.

[3026] C. A. Brochu. "Fossil crocodylians from the Eocene Devil's Graveyard and Canoe Formations, Brewster County, Texas". English. In: Texas Journal of Science 52.1 (2000), pp. 3-12.

[3027] C. A. Brochu. "Phylogenetic relationships of Palaeogene ziphodont eusuchians and the status of Pristichampsus Gervais, 1853". English. In: Earth and Environmental Science Transactions of the Royal Society of Edinburgh 103 (2013), pp. 1-30.

[3028] C. A. Brochu. "Phylogenetic Relationships and Divergence Timing of Crocodylus Based on Morphology and the Fossil Record". English. In: Copeia 2000.3 (2000), pp. 657-673.

[3029] C. A. Brochu. "Pliocene crocodiles from Kanapoi, Turkana Basin, Kenya". English. In: Journal of Human Evolution 140 (2020), p. 102410.

[3030] C. A. Brochu, M. L. Bouaré, F. Sissoko, E. M. Roberts, and M. A. O’Leary. “A dryosaurid crocodyliform braincase from Mali". English. In: Journal of Paleontology 76.6 (2002), pp. 1060-1071.

[3031] C. A. Brochu and G. Carbot-Chanona. "Biogeographic and Systematic Implications of a Caimanine from the Late Miocene of Southern Mexico". English. In: Journal of Herpetology 49.1 (2015), pp. 138 142.

[3032] C. A. Brochu and P. D. Gingerich. "New tomistomine crocodylian from the middle Eocene (Bartonian) of Wadi Hitan, Fayum Province, Egypt". English. In: Contributions from the Museum of Paleontology The University of Michgian 30.10 (2000), pp. 251-268.

[3033] C. A. Brochu, A. M. Nieves-Rivera, J. Vélez-Juarbe, J. D. Daza-Vaca, and H. Santos. “Tertiary crocodylians from Puerto Rico: Evidence for Late Tertiary endemic crocodylians in the West Indies?" English. In: Geobios 40 (2007), pp. 51-59. 
[3034] C. A. Brochu, J. Njau, R. J. Blumenschine, and L. D. Densmore. “A New Horned Crocodile from the Plio-Pleistocene Hominid Sites at Olduvai Gorge, Tanzania". English. In: PLoS One 5.2 (2010), e9333. DOI: 10.1371/journal.pone.0009333.

[3035] C. A. Brochu, D. C. Parris, B. S. Grandstaff, R. K. Denton Jr., and W. B. Gallagher. “A new species of Borealosuchus (Crocodyliformes, Eusuchia) from the Late Cretaceous-early Paleogene of New Jersey". English. In: Journal of Vertebrate Paleontology 32.1 (2012), pp. 105-116. DOI: 10.1080 / 02724634.2012.633585.

[3036] C. A. Brochu and A. D. Rincón. "A gavialoid crocodylian from the Lower Miocene of Venezuela". English. In: Special Papers in Palaeontology 71 (2004), pp. 61-79.

[3037] C. A. Brochu and G. W. Storrs. "A giant crocodile from the Plio-Pleistocene of Kenya, the phylogenetic relationships of Neogene African crocodylines, and the antiquity of Crocodylus in Africa". English. In: Journal of Vertebrate Paleontology 32.3 (2012), pp. 587-602.

[3038] G. A. Brock. "Middle Cambrian articulate brachiopods from the southern New England fold Belt, northeastern N.S.W., Australia". In: Journal of Paleontology 72.4 (1998), pp. 604-619.

[3039] G. A. Brock. "Middle Cambrian molluscs from the southern New England fold belt, New South Wales, Australia". In: Géobios 31.5 (1998), pp. 571-586.

[3040] G. A. Brock. "An Unusual Micromorphic Brachiopod from the Middle Cambrian of North-Eastern New South Wales, Australia". English. In: Records of the Australian Museum 51 (1999), pp. 179-186.

[3041] G. A. Brock and B. J. Cooper. "Shelly fossils from the Early Cambrian (Toyonian) Wirrealpa, Arrona Creek, and Ramsay Limestones of South Australia". English. In: Journal of Paleontology 67.5 (1993), pp. 758-787.

[3042] G. A. Brock and L. E. Holmer. "Early Ordovician lingulate brachiopods from the Emanuel Formation, Canning Basin, Western Australia". English. In: Memoirs of the Association of Australasian Palaeontologists 30 (2004), pp. 113-132.

[3043] G. A. Brock and J. R. Patterson. "A new species of Tannuella (Helcionellida, Mollusca) from the Early Cambrian of South Australia". English. In: Memoirs of the Association of Australasian Palaeontologists 30 (2004), pp. 133-143.

[3044] G. A. Brock and J. A. Talent. "Emsian (Early Devonian) brachiopods from the Ukalunda Beds and Douglas Creek, north Queensland". In: Memoirs of the Association of Australasian Palaeontologists 15 (1993), pp. 225-248.

[3045] T. Brockhaus, O. Müller, A. Nel, M. J. Poschmann, and T. Wappler. "Fossil dragonflies (Odonata: Anisoptera) from the late Oligocene Fossil-Lagerstätte Enspel (Rhineland-Palatinate, SW Germany)". English. In: Palaeoentomology 3 (2020), pp. 284-300.

[3046] C. Broglio Loriga, S. Cirilli, V. de Zanche, D. di Bari, P. Gianolla, G. F. Laghi, W. Lowrie, S. Manfrin, A. Mastandrea, P. Mietto, G. Muttoni, C. Neri, R. Posenato, M. Rechichi, R. Rettori, and G. Roghi. “The Prati di Stuores/Stuores Wiesen Section (Dolomites, Italy): a candidate Global Stratotype Section and Point for the base of the Carnian stage." English. In: Rivista Italiana di Paleontologia e Stratigrafia 105.1 (1999), pp. 37-78.

[3047] C. Broglio Loriga, F. Goczan, J. Haas, K. Lenner, C. Neri, A. S. Oravecz, R. Posenato, I. Szabo, and A. M. Toth. "The lower Triassic sequences of the Dolomites (Italy) and transdanubian midmountains (Hungary) and their correlation". English. In: Memorie di Scienze Geologiche 42 (1990), pp. 41-103.

[3048] P. Broly, S. Maillet, and A. J. Ross. "The first terrestrial isopod (Crustacea: Isopoda: Oniscidea) from Cretaceous Burmese amber of Myanmar". English. In: Cretaceous Research 55 (2015), pp. 220228.

[3049] P. Broly, M. L. Serrano-Sánchez, S. Rodrguez-Garca, and F. J. Vega. “Fossil evidence of extended brood care in new Miocene Peracarida (Crustacea) from Mexico". English. In: Journal of Systematic Palaeontology 15 (2017), pp. 1037-1049. 
[3050] K. R. Brom, T. Brachaniec, and M. A. Salamon. "Troglomorphism in the middle Triassic crinoids from Poland". English. In: The Science of Nature 102.60 (2015). DOI: 10.1007/s00114-015-1310-7.

[3051] T. G. Bromage, F. Schrenk, and Y. M. Juwayeyi. “Paleobiogeography of the Malawi Rift: Age and vertebrate paleontology of the Chiwondo Beds, northern Malawi". English. In: Journal of Human Evolution 28 (1995), pp. 37-57.

[3052] K. Bromfield. "Neogene Corals from the Indo-Pacific: Indonesia, Papua New Guinea, and Fiji". English. In: Bulletins of American Paleontology 387 (2013).

[3053] C. Bronnert, E. Gheerbrant, M. Godinot, and G. Métais. "A primitive perissodactyl (Mammalia) from the early Eocene of Le Quesnoy (MP7, France)". English. In: Historical Biology (2017). DOI: 10.1080/08912963.2017.1341502.

[3054] C. Bronnert, E. Gheerbrant, M. Godinot, and G. Métais. "First European 'Isectolophidae' (Mammalia, Perissodactyla): Chowliia europea, sp. nov., from the lower Eocene of Le Quesnoy, France". English. In: Journal of Vertebrate Paleontology 38.4 (2019), e1487448:1-9.

[3055] F. J. Brook. "Stratigraphy and paleontology of Pleistocene submarine volcanic-sedimentary sequences at the northern Kermadec Islands". English. In: Journal of the Royal Society of New Zealand 28.2 (1998), pp. 235-257.

[3056] G. A. Brook, D. A. Burney, and J. Coward. Desert paleoenvironmental data from cave speleothems with examples from the Chihuahuan. 1990.

[3057] I. A. Brookes. "Vertebra of a Bowhead whale (Balaena mysticetus) in Late Wisconsinan deglacial marine sediments, Trout River, Newfoundland, and local late-glacial sea-level change". English. In: Géographie physique et Quaternaire 61.2-3 (2007), pp. 225-228. DOI: 10.7202/038995ar.

[3058] M. E. Brookfield, R. J. Twitchett, and C. Goodings. "Palaeoenvironments of the Permian-Triassic transition sections in Kashmir, India". English. In: Palaeogeography, Palaeoclimatology, Palaeoecology 198 (2003), pp. 353-371.

[3059] S. E. Brooks, J. M. Cumming, and D. A. Grimaldi. "Remarkable new fossil species of Schistostoma Becker (Diptera: Dolichopodidae: Microphorinae) from mid-Cretaceous Burmese amber". English. In: Zootaxa 4624 (2019), pp. 121-131.

[3060] A. Broschinski. "Ein Lacertilier (Scincomorpha, Paramacellodidae) aus dem Oberen Jura von Tendaguru (Tansania)". German. In: Mitteilungen aus dem Museum für Naturkunde in Berlin: Fossil Record 2.1 (1999), pp. 155-158. DOI: 10.1002/mmng.1999.4860020111.

[3061] M. Brosse, H. Bucher, A. Baud, Å M. Frisk, N. Goudemand, H. Hagdorn, A. Nützel, D. Ware, and M. Hautmann. "New data from Oman indicate benthic high biomass productivity coupled with low taxonomic diversity in the aftermath of the Permian-Triassic Boundary mass extinction". English. In: Lethaia 52 (2019), pp. 165-187. DOI: 10.1111/let.12281.

[3062] D. J. Brothers. “The first Mesozoic Vespidae from the Southern Hemisphere, Botswana". English. In: Journal of Hymenoptera Research 1 (1992), pp. 119-124.

[3063] D. J. Brothers. "A new Late Cretaceous family of Hymenoptera, and phylogeny of the Plumariidae and Chrysidoidea (Aculeata)". English. In: ZooKeys 130 (2011), pp. 515-542.

[3064] D. J. Brothers. "The first fossil Ephutini (Hymenoptera: Mutillidae), a new species of Ephuta Say from Dominican amber". English. In: Acta Zoologica Cracoviensia 46.Suppl (2003), pp. 101-107.

[3065] D. J. Brothers and A. P. Rasnitsyn. "Diversity of Hymenoptera and other insects in the Late Cretaceous (Turonian) deposits at Orapa, Botswana: a Preliminary review". English. In: African Entomology 11.2 (2003), pp. 221-226.

[3066] D. J. Brothers and A. P. Rasnitsyn. "A new genus and species of Euparagiinae from the Late Cretaceous of southern Africa (Hymenoptera: Vespidae)". English. In: Alavesia 2 (2008), pp. 73-76.

[3067] T. Brougham, E. T. Smith, and P. R. Bell. "Isolated teeth of Anhangueria (Pterosauria: Pterodactyloidea) from the Lower Cretaceous of Lightning Ridge, New South Wales, Australia". English. In: Peer 5 (2017). DOI: 10.7717 / peerj.3256. 
[3068] T. Brougham, E. T. Smith, and P. R. Bell. “New theropod (Tetanurae: Avetheropoda) material from the 'mid'-Cretaceous Griman Greek Formation at Lightning Ridge, New South Wales, Australia". English. In: Royal Society Open Science 6 (2019), 180826:1-18. DOI: 10.1098/rsos.180826.

[3069] J. M. Broughton. "Prehistoric human impacts on California birds: evidence from the Emeryville shellmoumd avifauna". English. In: Ornithological Monographs 56 (2004), pp. 1-90.

[3070] J. Broutin, J. Roger, J. P. Platel, L. Angiolini, A. Baud, H. Bucher, J. Marcoux, and H. Al Hasmi. "The Permian Pangea. Phytogeographic implications of new paleontological discoveries in Oman (Arabian Peninsula)". In: Comptes rendu de l'Academie des Sciences Serie II 321 (1995), pp. 1069-1086.

[3071] E. M. Brouwers. "Microfossil assemblages from the Eocene Sylhet Limestone and Kopili Formation, Sylhet district, northeast Bangladesh". English. In: United States Geological Survey Open-File Report 92-191 (1992), pp. 1-44.

[3072] J. C. Brower. "Cupulocrinid crinoids from the Middle Ordovician (Galena Group, Dunleith Formation) of northern Iowa and southern Minnesota". English. In: Journal of Paleontology 66 (1992), pp. 99-128.

[3073] J. C. Brower. "Paleoecology of Echinoderm Assemblages from the Upper Ordovician (Katian) Dunleith Formation of Northern Iowa and Southern Minnesota". English. In: Journal of Paleontology 87.1 (2013), pp. 16-43.

[3074] J. C. Brower. "A New Pleurocystitid Rhombiferan Echinoderm from the Middle Ordovician Galena Group of Northern Iowa and Southern Minnesota". English. In: Journal of Paleontology 73.1 (1999), pp. 129-153.

[3075] J. C. Brower. "Systematics and paleoecology of Haptocrinus buttsi, a new species of disparid crinoid from the Upper Ordovician Hatter Limestone of central Pennsylvania". English. In: Journal of Paleontology 82.3 (2008), pp. 576-584.

[3076] J. C. Brower and O. B. Nye Jr. Quantitative Analysis of Paleocommunities in the Lower Part of the Hamilton Group near Cazenovia, New York. 1991.

[3077] B. V. Brown. "A fossil Hypocera species (Diptera: Phoridae) and its phylogenetic implications". English. In: Studia Dipterologica 6 (1999), pp. 273-277.

[3078] B. V. Brown. "Re-evaluation of the fossil Phoridae (Diptera)". English. In: Journal Natural History 33 (1999), pp. 1561-1573.

[3079] B. V. Brown. "A new species of Xenotriphleba Buck (Diptera: Phoridae) from Baltic amber". English. In: Proceedings of the Entomological Society of Washington 111.1 (2009), pp. 33-37.

[3080] B. V. Brown. "An enigmatic new genus and species of phorid fly from Baltic amber". English. In: Studia Dipterologica 16 (2009), pp. 43-46.

[3081] B. V. Brown. "A further new genus of primitive phorid fly (Diptera: Phoridae) from Baltic amber and its phylogenetic implications". English. In: Contributions in Science, Natural History Museum of Los Angeles County 513 (2007), pp. 1-14.

[3082] B. V. Brown. "A new species of Anevrina from Baltic amber (Diptera: Phoridae)". English. In: Annals of the Entomological Society of America 106 (2013), pp. 310-312.

[3083] B. V. Brown. "A new primitive phorid (Diptera: Phoridae) from Baltic amber". English. In: Studia Dipterologica 8 (2002), pp. 423-426.

[3084] B. V. Brown. "A new species of Triphleba (Diptera: Phoridae) with bifurcate antennae from Baltic amber". English. In: Studia Dipterologica 10 (2003), pp. 195-197.

[3085] B. V. Brown. "Fossil evidence of social insect commensalism in the Phoridae (Insecta: Diptera)". English. In: Journal of Systematic Palaeontology 15 (2016), pp. 276-286.

[3086] B. V. Brown. "Novel character states in fossil species of modern phorid genera (Diptera: Phoridae)". English. In: Studia Dipterologica 14 (2007), pp. 107-116.

[3087] B. V. Brown and E. M. Pike. "Three new fossil phorid flies (Diptera: Phoridae) from Canadian Late Cretaceous amber". English. In: Canadian Journal of Earth Sciences 27 (1990), pp. 845-848. 
[3088] C. J. Brown and R. D. Hoare. "Patellilabia laevigata (Girty) (Mollusca, Gastropoda?) from the Mississippian (Chesterian) of Arkansas". English. In: Journal of Paleontology 65.2 (1991), pp. 341341.

[3089] C. M. Brown, C. A. Boyd, and A. P. Russell. "A new basal ornithopod dinosaur (Frenchman Formation, Saskatchewan, Canada), and implications for late Maastrichtian ornithischian diversity in North America". English. In: Zoological Journal of the Linnean Society 163.4 (2011), pp. 1157-1198.

[3090] C. M. Brown and P. S. Druckenmiller. "Basal ornithopod (Dinosauria: Ornithischia) teeth from the Prince Creek Formation (early Maastrichtian) of Alaska". English. In: Canadian Journal of Earth Sciences 48 (2011), pp. 1342-1354. DOI: 10.1139/E11-017.

[3091] C. M. Brown, D. C. Evans, M. J. Ryan, and A. P. Russell. "New data on the diversity and abundance of small-bodied ornithopods (Dinosauria, Ornithischia) from the Belly River Group (Campanian) of Alberta". English. In: Journal of Vertebrate Paleontology 33.3 (2013), pp. 495-520. DOI: 10.1080 / 02724634.2013.746229.

[3092] C. M. Brown, D. R. Greenwood, J. E. Kalyniuk, D. R. Braman, D. M. Henderson, C. L. Greenwood, and J. F. Basinger. "Dietary palaeoecology of an Early Cretaceous armoured dinosaur (Ornithischia; Nodosauridae) based on floral analysis of stomach contents". English. In: Royal Society Open Science 7 (2020), 200305:1-21. DOI: 10.1098/rsos.200305.

[3093] C. M. Brown and D. M. Henderson. "A new horned dinosaur reveals convergent evolution in cranial ornamentation in Ceratopsidae". English. In: Current Biology 25 (2015), pp. 1641-1648. DOI: 10.1016/j.cub.2015.04.041.

[3094] C. M. Brown, D. M. Henderson, J. Vinther, and PARSE ERROR. “An exceptionally preserved threedimensional armored dinosaur reveals insights into coloration and Cretaceous predator-prey dynamics". English. In: Current Biology 27 (2017), pp. 2514-2521. DOI: 10.1016/j.cub.2017.06.071.

[3095] R. L. S. Brownlaw and J. S. Jell. "Middle and Upper Devonian rugose corals from the Canning Basin, Western Australia". English. In: Memoirs of the Association of Australasian Palaeontologists 35 (2008), pp. 1-126.

[3096] C. D. Brownstein. "The distinctive theropod assemblage of the Ellisdale site of New Jersey and". English. In: Journal of Paleontology 92.6 (2018), pp. 1115-1129. DOI: 10.1017/jpa.2018.42.

[3097] C. D. Brownstein. "First Record of a Small Juvenile Giant Crocodyliform and its Ontogenetic and Biogeographic Implications". English. In: Bulletin of the Peabody Museum of Natural History 60.1 (2019), pp. 81-90.

[3098] C. D. Brownstein. "The northernmost occurrence of Chelydra serpentina in the Eastern US during the Pleistocene". English. In: The Mosasaur, The Journal of the Delaware Valley Paleontological Society 10 (2018), pp. 13-19.

[3099] C. D. Brownstein. "Osteology and phylogeny of small-bodied hadrosauromorphs from an endCretaceous marine assemblage". English. In: Zoological Journal of the Linnean Society 191.1 (2021), pp. 180-200. DOI: 10.1093/zoolinnean/zlaa085/5892979.

[3100] C. D. Brownstein. "New records of theropods from the latest Cretaceous of New Jersey and the Maastrichtian Appalachian fauna". English. In: Royal Society Open Science 6 (2019), 191206:1-13.

[3101] R. L. Brownwell Jr., P. J. Clapham, T. Miyashita, and T. Kasuya. "Conservation status of North Pacific right whales". English. In: Journal of Cetacean Research and Management 2 (2001), pp. 269286.

[3102] A. Brückner, D. Janussen, and S. Schneider. "Eine neue Poriferen-Fauna aus dem Septarienton (Oligozän, Rupelium) von Bad Freienwalde (NE-Deutschland) und der erste fossil erhaltene Vertreter der nicht-rigiden Hexactinelliden-Gattung Asconema [A new Poriferan fauna from the Septarienton (Oligocene, Rupelian) of Bad Freienwalde (NE Germany) and the first fossil representative of the non-rigid hexactinellid genus Asconema". German. In: Palaeontologische Zeitschrift 77.2 (2003), pp. 263-280. 
[3103] A. Brückner and D. Janussen. "Rossella bromleyi n. sp.: the first entirely preserved fossil sponge species of the genus Rossella (Hexactinellida) from the Upper Cretaceous of Bornholm, Denmark". English. In: Journal of Paleontology 79.1 (2005), pp. 21-28.

[3104] J.-P. Brugal. “Le bison (Bovidae, Artiodactyla) de Pleistocene moyen ancien de Durfort (Gard, France)". French. In: Bulletin Musee Nationale de Histoire Naturelle, Paris, 4th Series, Section C 16.2-4 (1994), pp. 349-381.

[3105] J. H. Bruggemann, R. T. Buffler, M. M. M. Guillaume, R. C. Walter, R.v. Cosel, B. N. Ghebretensae, and S. M. Berhe. "Stratigraphy, palaeoenvironments and model for the deposition of the Abdur Reef Limestone: context for an important archaeological site from the last interglacial on the Red Sea coast of Eritrea". English. In: Palaeogeography, Palaeoclimatology, Palaeoecology 203.3 (2004), pp. 179-206.

[3106] D. Brühl. "Stratigraphie, Fazies und Tabulaten-Fauna des oberen Eifelium (Mittel-Devon) der Dollendorfer Mulde/Eifel (Rheinisches Schiefergebirge)". German. In: Kölner Forum 4 (1999), pp. 1155.

[3107] T. Brühwiler, A. Brayard, H. Bucher, and G. D. Kuang. “Griesbachian and Dienerian (Early Triassic) ammonoid faunas from northwestern Guangxi and southern Guizhou (south China)". English. In: Palaeontology 51.5 (2008), pp. 1151-1180.

[3108] T. Brühwiler, H. Bucher, and N. Goudemand. "Smithian (Early Triassic) ammonoids from Tulong, south Tibet". English. In: Geobios 43 (2010), pp. 403-431.

[3109] T. Brühwiler, H. Bucher, G. Roohi, A. Yaseen, and K. Rehman. "A new early Smithian ammonoid fauna from the Salt Range (Pakistan)". English. In: Swiss Journal of Palaeontology 130.2 (2011), pp. 187-201.

[3110] T. Brühwiler and H. Bucher. "Systematic palaeontology, in Smithian (Early Triassic) ammonoid faunas from exotic blocks from Oman: taxonomy and biochronology". English. In: Palaeontographica Abteilung A 296 (2012), pp. 3-107.

[3111] T. Brühwiler, H. Bucher, N. Goudemand, and T. Galfetti. "Smithian (Early Triassic) ammonoid faunas from exotic blocks from Oman: taxonomy and biochronology". English. In: Palaeontographica Abteilung A 296 (2012), pp. 3-107.

[3112] T. Brühwiler, H. Bucher, D. Ware, E. Schneebeli-Hermann, P. A. Hochuli, G. Roohi, K. Reahman, and A. Yaseen. "Smithian (Early Triassic) ammonoids from the Salt Range, Pakistan". English. In: Special papers in Palaeontology 88 (2012), pp. 5-114.

[3113] T. Brühwiler, H. Bucher, and L. Krystyn. "Middle and Late Smithian (Early Triassic) ammonoids from Spiti, India". English. In: Special Papers in Palaeontology 88 (2012), pp. 115-174.

[3114] T. Brühwiler, D. Ware, H. Bucher, L. Krystyn, and N. Goudemand. "New Early Triassic ammonoid faunas from the Dienerian/Smithian boundary beds at the Induan/Olenekian GSSP candidate at Mud (Spiti, Northern India)". English. In: Journal of Asian Earth Sciences 39 (2010), pp. 724-739.

[3115] A. Brumm, F. Aziz, G. D. van den Bergh, M. J. Morwood, M. W. Moore, I. Kurniawan, D. R. Hobbs, and R. Fullagar. "Early stone technology on Flores and its implications for Homo floresiensis". English. In: Nature 441 (2006), pp. 624-628.

[3116] J. C. Bruner. "A Catalogue of Type Specimen of Fossil Vertebrates in the Field Museum of Natural History". English. In: Fieldiana: Geology 22 (1991).

[3117] M. Brunet, A. Beauvilain, Y. Coppens, E. Heintz, A. H. E. Moutaye, and D. Pilbeam. The first australopithecine 2500 kilometres west of the Rift Valley (Chad). 1995.

[3118] M. Brunet, A. Beuavilain, D. Billiou, H. Bocherens, J. R. Boisserie, L. De Bonis, P. Branger, A. Brunet, Y. Coppens, R. Daams, J. Dejax, C. Denys, P. Duringer, V. Eisenmann, F. Fanoné, P. Fronty M. Gayet, D. Gerrads, F. Guy, M. Kasser, G. Koufos, A. Likus, N. Lopez-Martinez, and A. Lo. "Chad: discovery of a vertebrate fauna close to the Mio-Pliocene boundary". English. In: Journal of Vertebrate Paleontology 20.1 (2000), pp. 205-209. 
[3119] M. Brunet, F. Guy, D. Pilbeam, H. T. Mackaye, A. Likius, D. Ahounta, A. Beauvilain, C. Blondel, H. Bocherens, J. -R. Boisserie, L. De Bonis, Y. Coppens, J. Dejax, C. Denys, P. Duringer, V. Eisenmann, G. Fanone, P. Fronty, D. Geraads, T. Lehmann, F. Lihoreau, and A. Louchart. "A new hominid from the Upper Miocene of Chad, Central Africa". English. In: Nature 418 (2002), pp. 145-151.

[3120] R. F. J. Brunet. "New Species of Mollusca from the Entrerriense Formation (Upper Miocene) of Chubut Province, Argentina and species not previously reported from this formation. Part 2 Gastropoda". English. In: Tulane Studies in Geology and Paleontology 30.2 (1997), pp. 61-98.

[3121] M. M. Brunetti and G. D. Bella. "La famiglia Buccinidae Rafinesque, 1815 nel Plio-Pleistocene italiano: i generi Aplus De Gregorio, 1884, Engina Gray, 1839 e Gemophos Olsson \& Harbinson, 1953 (Gastropoda)". Italian. In: Bollettino Malacologico 50 (2014), pp. 11-32.

[3122] M. M. Brunetti, M. Forli, and G. Vecchi. "La Famiglia Cancellariidae Gray J.E., 1853 nel PlioPleistocene mediterraneo. I generi Tribia Jousseaume, 1887 e Scalptia Jousseaume, 1887 con descrizione di due nuove specie". English. In: Bollettino Malacologico 42.5/8 (2006), pp. 39-57.

[3123] M. M. Brunetti and M. Forli. "The genus Aporrhais Da Costa, 1778 (Gastropoda Aporrhaidae) in the italian Plio-Pleistocene". English. In: Biodiversity Journal 4.1 (2013), pp. 183-208.

[3124] M. M. Brunetti and G. Vecchi. "La Malacofauna Plio-Pleistocenica del Torrente Stirone Parte IX. Strombidae, Aporrhaiidae, Calyptreidae, Capulidae, Xenophoridae, Vermetidae, Cypraeidae, Eocypraeidae, Triviidae, Eratoidae, Ovulidae, Naticidae". English. In: Parva Naturalia 11 (2015), pp. 61147.

[3125] A. J. Brunke, S. Chatzimanolis, B. D. Metscher, K. Wolf-Schwenninger, and A. Solodovnikov. "Dispersal of thermophilic beetles across the intercontinental Arctic forest belt during the early Eocene". English. In: Scientific Reports 7.12972 (2017), pp. 1-8.

[3126] A. J. Brunke, H. Schillhammer, and S. Chatzimanolis. "The first fossil rove beetle from the middle Eocene Kishenehn Formation (North America) provides evidence for ancient Eocene relicts within the hyperdiverse Staphylinini (Coleoptera: Staphylinidae: Staphylininae)". English. In: Journal of Systematic Palaeontology 15 (2017), pp. 1015-1025.

[3127] A. J. Brunke, D. ya, S. Yamamoto, and A. Solodovnikov. "Baltic amber Staphylinini (Coleoptera: Staphylinidae: Staphylininae): a rove beetle fauna on the eve of our modern climate". English. In: Zoological Journal of the Linnean Society 187 (2019), pp. 166-197.

[3128] C. H. C. Brunton and N. Hiller. "Late Cainozoic Brachiopods from the coast of Namaqualand, South Africa". English. In: Palaeontology 33.2 (1990), pp. 313-342.

[3129] C. H. C. Brunton and D. J. C. Mundy. "A new elythid spiriferide brachiopod from the Lower Carboniferous (Asbian) reef facies of the British Isles". In: Proceedings of the Yorkshire Geological Society 51.3 (1997), pp. 229-234.

[3130] F. R. Brunton and P. Copper. "Paleoecologic, temporal, and spatial analysis of Early Silurian reefs of the Chicotte Formation, Anticosti Island, Quebec, Canada". In: Facies 31 (1994), pp. 57-80.

[3131] S. Brusatte and P. C. Sereno. “A new species of Carcharodontosaurus (Dinosauria: Theropoda) from the Cenomanian of Niger and a revision of the genus". English. In: Journal of Vertebrate Paleontology 27.4 (2007), pp. 902-916.

[3132] S. Brusatte, M. Vremir, A. Watanabe, Z. Csiki-Sava, D. Naish, G. J. Dyke, G. M. Erickson, and M. A. Norell. "An infant ornithopod dinosaur tibia from the Late Cretaceous of Sebes, Romania". English. In: Terra Sebus. Acta Musei Sabesiensis 5 (2013), pp. 627-644.

[3133] S. L. Brusatte, A. Averianov, H. -D. sues, A. Muir, and I. B. Butler. "New tyrannosaur from the midCretaceous of Uzbekistan clarifies evolution of giant body sizes and advanced senses in tyrant dinosaurs". English. In: Proceedings of the National Academy of Sciences 113.13 (2016), pp. 3447-3452.

[3134] S. L. Brusatte, R. J. Butler, T. Sulej, and G. Niedzwiedzki. "The taxonomy and anatomy of rauisuchian archosaurs from the Late Triassic of Germany and Poland". English. In: Acta Palaeontologica Polonica 54 (2009), pp. 221-230. 
[3135] S. L. Brusatte, R. J. Butler, G. Niedzwiedzki, T. Sulej, R. Bronowicz, and J. Satkunas. “First record of Mesozoic terrestrial vertebrates from Lithuania: phytosaurs (Diapsida: Archosauriformes) of probable Late Triassic age, with a review of phytosaur biogeography". English. In: Geological Magazine 150.1 (2013), pp. 110-122. DOI: 10.1017/S0016756812000428.

[3136] S. L. Brusatte, R. J. Butler, O. Mateus, and J. S. Steyer. "A new species of Metoposaurus from the Late Triassic of Portugal and comments on the systematics and biogeography of metoposaurid temnospondyls". English. In: Journal of Vertebrate Paleontology (2015).

[3137] S. L. Brusatte, T. D. Carr, G. M. Erickson, G. S. Bever, and M. A. Norell. "A long-snouted, multihorned tyrannosaurid from the Late Cretaceous of Mongolia". English. In: Proceedings of the National Academy of Sciences 106.41 (2009), pp. 17261-17266. DOI: 10.1073/pnas.0906911106.

[3138] S. L. Brusatte, T. J. Challands, D. A. Ross, and M. Wilkinson. "Sauropod dinosaur trackways in a Middle Jurassic lagoon on the Isle of Skye, Scotland". English. In: Scottish Journal of Geology 52.1 (2016), pp. 1-9. DOI: 10.1144/sjg2015-005.

[3139] S. L. Brusatte, G. Niedzwiedzki, and R. J. Butler. "Footprints pull origin and diversification of dinosaur stem lineage deep into Early Triassic". English. In: Proceedings of the Royal Society of London B: Biological Sciences 278.1708 (2011), pp. 1107-1113. DOI: 10.1098/rspb.2010.1746.

[3140] S. L. Brusatte, M. T. Young, T. J. Challands, N. D. L. Clark, V. Fischer, N. C. Fraser, J. J. Liston, C. C. J. MacFayden, D. A. Ross, S. Walsh, and M. Wilkinson. "Ichthyosaurs from the Jurassic of Skye, Scotland". English. In: Scottish Journal of Geology (2015). DOI: 10.1144/sjg2014-018.

[3141] J. P. Bruthans, M. Filippi, M. Gerl, M. Zare, J. Melkova, A. Pazdur, and P. Bosak. "Holocene marine terraces on two salt diapirs in the Persian Gulf, Iran: age, depositional history and uplift rates". English. In: Journal of Quaternary Science 21.8 (2006), pp. 843-857.

[3142] D. L. Bruton and D. A. T. Harper. "A mid-Cambrian shelly fauna from Ritland, western Norway and its palaeogeographical implications". English. In: Bulletin of the Geological Society of Denmark 47 (2000), pp. 29-51.

[3143] D. L. Bruton, A. J. Wright, and M. A. Hamedi. "Ordovician Trilobites from Iran". English. In: Palaeontographica Abteilung A 271.5-6 (2004), pp. 111-149.

[3144] J. R. Bryan. "A Paleocene coral-algal-sponge reef from southwestern Alabama and the ecology of Early Tertiary reefs". English. In: Lethaia 24 (1991), pp. 423-438.

[3145] J. R. Bryan, B. C. Carter, R. J. Flugeman Jr., D. K. Krumm, and T. A. Stemann. “The Salt Mountain Limestone of Alabama". English. In: Tulane Studies in Geology and Paleontology 30.1 (1997), pp. 2-60.

[3146] J. R. Bryan, D. L. Frederick, D. R. Schwimmer, and W. G. Siesser. "First dinosaur record from Tennessee: a Campanian hadrosaur". In: Journal of Paleontology 65.4 (1991), pp. 696-697.

[3147] H. N. Bryant. "Reidentification of the Chadronian supposed didelphid marsupialăAlloeodectes mcgrewiăas part of the deciduous dentition of the canidăHesperocyon". English. In: Canadian Journal of Earth Sciences 28 (1991).

[3148] H. N. Bryant. "The Carnivora of the Lac Pelletier Lower Fauna (Eocene Duchesnean), Cypress Hills Formation, Saskatchewan". English. In: Journal of Paleontology 66.5 (1992), pp. 847-855.

[3149] H. N. Bryant. "Carnivora and Creodonta of the Calf Creek Local Fauna (Late Eocene, Chadronian), Cypress Hills Formation, Saskatchewan". English. In: Journal of Paleontology 67.6 (1993), pp. 1032 1046.

[3150] J. D. Bryant. “New early Barstovian (middle Miocene) vertebrates from the upper Torreya Formation, eastern Florida panhandle". English. In: Journal of Vertebrate Paleontology 11.4 (1991), pp. 472489.

[3151] J. D. Bryant, B. J. MacFadden, and P. A. Mueller. "Improved chronologic resolution of the Hawthorn and the Alum Bluff Groups in northern Florida: Implications for Miocene chronostratigraphy". English. In: Geological Society America Bulletin 104.2 (1992), pp. 208-218.

[3152] P. J. Bryant. "Dating remains of gray whales from the eastern North Atlantic". English. In: Journal of Mammalogy 76.3 (1995), pp. 857-861. 
[3153] R. Brzobohaty and D. Nolf. "Diaphus otoliths from the European Oligocene (Myctophidae, Teleostei)". English. In: Bulletin de l'Istitute Royal des Sciences Naturelles de Belgique, Sciences de la Terre 65 (1995), pp. 257-268.

[3154] L. A. Buatois, M. G. Mangano, C. G. Maples, and W. P. Lanier. “Ichnology of an Upper Carboniferous fluvio-estuarine paleovalley: The Tonganoxie Sandstone, Buildex Quarry, eastern Kansas, U.S.A". In: Journal of Paleontology 72.1 (1998), pp. 152-180.

[3155] L. A. Buchanan. "Kambara taraina sp. nov. (Crocodylia, Crocodyloidea), a New Eocene Mekosuchine from Queensland, Australia, and a revision of the genus". English. In: Journal of Vertebrate Paleontology 29.2 (2009), pp. 473-486.

[3156] L. A. Buchanan, C. P. Consoli, and J. D. Stilwell. "Early Paleocene marine vertebrates from the Wangaloa Formation, South Island, New Zealand". English. In: New Zealand Journal of Geology and Geophysics 2007.50 (2007), pp. 33-37.

[3157] B. Buchardt and L. A. Simonarson. "Isotope palaeotemperatures from the Tjornes Beds in Iceland; evidence of Pliocene cooling". English. In: Palaeogeography, Palaeoclimatology, Palaeoecology 189.1-2 (2003), pp. 71-95.

[3158] B. Buchbinder. "Middle and Upper Miocene reefs and carbonate platforms in Israel". English. In: SEPM Concepts in Sedimentology and Paleontology 5 (1996), pp. 333-345.

[3159] H. Bucher. "Ammonoids of the Hyatti Zone and the Anisian transgression in the Star Peak Group, Northwestern Nevada, USA". English. In: Palaeontographica Abteilung A 233 (1992), pp. 137-166.

[3160] H. Bucher. "Early Anisian (Middle Triassic) ammonoid biostratigraphy of northeastern British Columbia". English. In: Eclogae Geologicae Helvetiae 95 (2002), pp. 277-287.

[3161] H. Bucher. "New ammonoids from the Taylori Zone (Middle Anisian, Middle Triassic) from northwestern Nevada (USA)". English. In: Mémoires de Géologie (Lausanne) 22 (1994), pp. 1-8.

[3162] H. Bucher. "Ammonoids of the Shoshonensis Zone (Middle Anisian, Middle Triassic) from northwestern Nevada (USA)". English. In: Jahrbuch der Geologischen Bundesanstalt 135 (1992), pp. 425465.

[3163] H. Bucher, W. W. Nassichuk, and C. Spinosa. "A new occurrence of the Upper Permian ammonoid Stacheoceras trimurti Diener from the Himalayas; Himachal Pradesh, India". English. In: Eclogae Geologicae Helvetiae 90 (1997), pp. 599-604.

[3164] J. Bucher, M. E. Pérez, L. R. González Ruiz, L. D’Elia, and A. Bilmes. “New middle Miocene (Langhian - Serravallian) vertebrate localities in northwestern Patagonia, Argentina: A contribution to high latitude south american land mammal ages sequence". English. In: Journal of South American Earth Sciences (2020). DOI: 10.1016/j.jsames.2020.103024.

[3165] F. S. Buchmann and G. R. Filho. "Fosseis de vertebrados marinhos do Pleistoceno Superior na Porcao sul da planicie costeira do Rio Grande Do Sul, Brasil". English. In: Notas Tecnicas 10 (1997), pp. 7-16.

[3166] F. S. Buchmann, F. M. Zurlo, F. S. Vannucchi, and C. Cavalcante de Albuquerque Martins. "First Record of a Fossil Blue Whale in São Paulo State, Brazil". English. In: Aquatic Mammals 43.6 (2017), pp. 649-654. DOI: 10.1578/AM.43.6.2017.649.

[3167] M.-C. Buchy, F. Métayer, and E. Frey. "Osteology of Manemergus anguirostris n. gen. et sp., a new plesiosaur (Reptilia, Sauropterygia) from the Upper Cretaceous of Morocco". English. In: Palaeontographica Abteilung A 272 (2005), pp. 97-120.

[3168] M.-C. Buchy. "First Record of Ophthalmosaurus (Reptilia: Ichthyosauria) from the Tithonian (Upper Jurassic) of Mexico". English. In: Journal of Paleontology 84.1 (2010), pp. 149-155.

[3169] M.-C. Buchy. "An elasmosaur (Reptilia: Sauropterygia) from the Turonian (Upper Cretaceous) of Morocco". English. In: Carolinea 63 (2005), pp. 5-28.

[3170] M.-C. Buchy. "New occurrence of the genus Dakosaurus (Reptilia, Thalattosuchia) in the Upper Jurassic of north-eastern Mexico, with comments upon skull architecture of Dakosaurus and Geosaurus". English. In: Neues Jahrbuch für Geologie und Paläontologie - Abhandlungen 249.1 (2008), pp. 1-8. DOI: 10.1127/0077-7749/2008/0249-0001. 
[3171] M.-C. Buchy, E. Frey, S. W. Salisbury, J. G. López-Olivia, and M. Götte. “An unusual pliosaur (Reptilia, Sauropterygia) from the Kimmeridgian (Upper Jurassic) of northeastern Mexico". English. In: Neues Jahrbuch fuer Geologie und Palaeontologie. Abhandlungen 240.2 (2006), pp. 241-270.

[3172] M.-C. Buchy, E. Frey, W. Stinnesbeck, and J. G. Lopez-Oliva. "First occurrence of a gigantic pliosaurid plesiosaur in the Late Jurassic (Kimmeridgian) of Mexico". English. In: Bulletin de la Societe Geologique de France 174.3 (2003), pp. 271-278.

[3173] M.-C. Buchy, E. Frey, W. Stinnesback, and J. G. Lopez-Oliva. "An annotated catalogue of the Upper Jurassic (Kimmeridgian and Tithonian) marine reptiles in the collections of the Universidad Autonoma de Nuevo Leon, Facultad de Ciencias de la Tierra, Linares, Mexico". English. In: Oryctos 6 (2006), pp. 1-18.

[3174] M.-C. Buchy and J. G. López Oliva. “Occurrence of a second ichthyosaur genus (Reptilia: Ichthyosauria) in the Late Jurassic Gulf of Mexico". English. In: Boletn de la Sociedad Geológica Mexicana 61.2 (2009), pp. 233-238.

[3175] M.-C. Buchy, W. Stinnesbeck, and A. H. Gonzalez Gonzalez. A new Tithonian (Upper Jurassic) marine vertebrate concentration Lagerstätte in north-eastern Mexico. English. Budapest, 2006.

[3176] M.-C. Buchy, W. Stinnesbeck, E. Frey, and A. H. Gonzalez Gonzalez. "Premiére mention du genre Dakosaurus (Crocodyliformes, Thalattosuchia) dans le Jurassique supérieur du Mexique". French. In: Bulletin de la Societe Geologique de France 178.5 (2007), pp. 391-397.

[3177] M.-C. Buchy, P. Vignaud, E. Frey, W. Stinnesbeck, and A. H. G. Gonzalez. "A new thalattosuchian crocodyliform from the Tithonian (Upper Jurassic) of northeastern Mexico". English. In: Comptes Rendus Palevol 5 (2006), pp. 785-794.

[3178] M.-C. Buchy, M. T. Young, and M. B. de Andrade. “A new specimen of Cricosaurus saltillensis (Crocodylomorpha: Metriorhynchidae) from the Upper Jurassic of Mexico: evidence for craniofacial convergence within Metriorhynchidae". English. In: Oryctos 10 (2013), pp. 9-21.

[3179] J. S. Buckeridge. "A new species of Austrobalanus (Cirripedia, Thoracia) from Eocene erratics, Mount Discovery, McMurdo Sound, East Antarctica". In: Antarctic Research Series 76 (2000), pp. 329 333.

[3180] J. S. Buckeridge. “Taphonomy and systematics of a new Late Cretaceous verrucid barnacle (Cirripedia, Thoracica) from Canterbury, New Zealand". English. In: Palaeontology 54 (2011), pp. 365372. DOI: $10.1111 /$ j.1475-4983.2010.00998.x.

[3181] J. S. Buckeridge, B. K. K. Chan, and S. -W. Lee. "Accumulations of Fossils of the Whale Barnacle Coronula bifida Bronn, 1831 (Thoracica: Coronulidae) Provides Evidence of a Late Pliocene Cetacean Migration Route through the Straits of Taiwan". English. In: Zoological Studies 57.54 (2018), pp. 1-12. DOI: 10.6620/ZS.2018.57-54.

[3182] J. S. Buckeridge, B. K. K. Chan, and J. -P. Lin. "Paleontological Studies of Whale Barnacles in Taiwan Reveal New Cetacean Migration Routes in the Western Pacific Since the Miocene". English. In: Zoological Studies 58.39 (2019). DOI: 10.6620/ZS.2019.58-39.

[3183] G. A. Buckley. “The multituberculate Catopsalis from the early Paleocene of the Crazy Mountains Basin in Montana". English. In: Acta Palaeontologica Polonica 40.4 (1995), pp. 389-398.

[3184] G. A. Buckley. "A New Species of Purgatorius (Mammalia; Primatomorpha) from the Lower Paleocene Bear Formation, Crazy Mountains Basin, South-Central Montana". English. In: Journal of Paleontology 71.1 (1997).

[3185] G. A. Buckley, C. A. Brochu, D. W. Krause, and D. Pol. “A pug-nosed crocodyliform from the Late Cretaceous of Madagascar". English. In: Nature 405 (2000), pp. 941-944. DOI: 10.1038/35016061.

[3186] J. O. Buckman. "An unusual new trace fossil from the lower Carboniferous of Ireland: Intexalvichnus magnus". In: Journal of Paleontology 71.2 (1997), pp. 316-324.

[3187] S. Buckman and J. C. Aitchison. "Middle Ordovician (Llandeilan) Radiolarians from West Junggar, Xinjiang, China”. English. In: Micropaleontology 47.4 (2001), pp. 359-367. 
[3188] I. I. Bucur, K. H. Karim, H. Daoud, B. Granier, and P. A. Khanaqa. “A new organ-species dasycladalean green alga from Darbandikhan, Kurdistan, Iraq". English. In: Arabian Journal of Geosciences 11.484 (2018), pp. 1-10.

[3189] I. I. Bucur, W. Kiessling, and R. A. Scasso. "Re-description and neotypification of Archamphiroa jurassica Steinmann 1930, a calcareous red alga from the Jurassic of Argentina". English. In: Journal of Paleontology 83.6 (2009), pp. 962-968.

[3190] I. I. Bucur and E. Nicorici. "Calcareous algae from the Sarmatian deposits in the Simleu Basin (Romania)". English. In: Studia Universitatis Babes-Bolyai, Geologia 37.2 (1992), pp. 3-7.

[3191] I. I. Bucur, E. Nicorici, I. Huica, and B. Ionesi. "Calcareous microfacies in the Sarmatian deposits from Romania". English. In: Studia Universitatis Babes-Bolyai, Geologia 37.2 (1992), pp. 9-16.

[3192] I. I. Bucur, K. Rashidi, and B. Senowbari-Daryan. "Early Cretaceous calcareous algae from central Iran (Taft Formation, south of Aliabad, near Yazd)". English. In: Facies 58 (2012), pp. 605-636. DOI: 10.1007/s10347-012-0303-7.

[3193] I. I. Bucur, B. Senowbari-Daryan, and B. Abate. "Remarks on some foraminifera from the Upper Jurassic (Tithonian) reef limestone of Madonie Mountains (Sicily)". English. In: Bollettino della Societa Paleontologica Italiana 35.1 (1996), pp. 65-80.

[3194] A. Buczek, A. Hendy, M. Hopkins, and J. Sessa. "On the reconciliation of biostratigraphy and strontium isotope stratigraphy of three southern Californian Plio-Pleistocene formations". English. In: Geological Society America Bulletin (2020).

[3195] T. Budai, J. Haas, H. Lobitzer, O. Piros, and A. Vörös. “Cephalopod coquina beds in the Wetterstein Limestone of the eastern Höllengebirge Mts (Salzkammergut, Upper Austria)". English. In: Acta Geologica Hungarica 49.3 (2007), pp. 253-269. DOI: 10.1556/AGeol.49.2006.3.4.

[3196] T. Budai, G. Lelkes, and O. Piros. "Evolution of Middle Triassic shallow marine carbonates in the Balaton Highland (Hungary)". English. In: Acta Geologica Hungarica 36.1 (1993), pp. 145-165.

[3197] A. F. Budd. "Neogene paleontology in the northern Dominican Republic, 11. The family Faviidae (Anthozoa, Scleractinia), part 1. The genera Montastrea and Solenastrea". English. In: Bulletins of American Paleontology 101 (1991), pp. 5-83.

[3198] A. F. Budd, F. R. Bosellini, and T. A. Stemann. "Systematics of the Oligocene to Miocene reef coral Tarbellastraea in the northern Mediterranean". English. In: Palaeontology 39.3 (1996), pp. 515-560.

[3199] A. F. Budd and F. R. Bosellini. "Revision of Oligocene Mediterranean meandroid corals in the scleractinian families Mussidae, Merulinidae and Lobophylliidae". English. In: Journal of Systematic Palaeontology 14 (2016), pp. 771-798. DOI: 10.1080/14772019.2015.1102171.

[3200] A. F. Budd and K. G. Johnson. "Origination preceding extinction during late Cenozoic turnover of Caribbean reefs". In: Paleobiology 25.2 (1999), pp. 188-200.

[3201] A. F. Budd, K. G. Johnson, T. A. Stemann, and B. H. Tompkins. "Pliocene to Pleistocene reef coral assemblages in the Limon Group of Costa Rica". English. In: Bulletins of American Paleontology 357 (1999), pp. 119-158.

[3202] A. F. Budd and K. G. Johnson. "Neogene Paleontology in the northern Dominican Republic 19: The family Faviidae (Anthozoa, Scleractinia) part II: The genera Caulastraea, Favia, Diploria, Thysanus, Hadrophyllia, Manicina and Colpophyllia". English. In: Bulletins of American Paleontology 356 (1999), pp. 1-83.

[3203] A. F. Budd, K. G. Johnson, and J. C. Edwards. "Caribbean reef coral diversity during the Early to Middle Miocene: an Example from the Anguilla Formation". In: Coral Reefs 14.2 (1995), pp. 109117.

[3204] A. F. Budd and C. Manfrino. Coral assemblages and reef environments in the Bahamas Drilling Project cores. English. in R. N. Ginsburg, ed., Subsurface geology of a prograding carbonate platform margin, Great Bahama Bank: results of the Bahamas Drilling Project. SEPM Special Publication 70. 2001, pp. 41-59. 
[3205] A. F. Budd and D. F. McNeill. "Zooxanthellate scleractinian corals of the Bowden shell bed, Southeast Jamaica". English. In: Contributions to Tertiary and Quaternary Geology 35.1-4 (1998), pp. 47-62.

[3206] A. F. Budd and J. M. Pandolfi. "Overlapping species boundaries and hybridization within the Montastrea annularis reef coral complex in the Pleistocene of the Bahama Islands". English. In: Paleobiology 30.3 (2004), pp. 396-425.

[3207] A. F. Budd, T. A. Stemann, and K. G. Johnson. "Stratigraphic distributions of genera and species of Neogene to recent Carribean reef corals". English. In: Journal of Paleontology 68.5 (1994), pp. 951977.

[3208] A. F. Budd, T. S. Stemann, and R. H. Stewart. "Eocene Caribbean Reef Corals: A Unique Fauna from the Gatuncillo Formation of Panama". In: Journal of Paleontology 66.4 (1992), pp. 570-594.

[3209] A. F. Budd and C. C. Wallace. "First record of the Indo-Pacific reef coral genus Isopora in the Caribbean region: two new species from the Neogene of Curacao, Netherlands Antilles". English. In: Palaeontology 51.6 (2008), pp. 1387-1401.

[3210] G. E. Budd. "A Cambrian gilled lobopod from Greenland". English. In: Nature 364 (1993), pp. 709_ 711.

[3211] G. E. Budd. "A nektaspid arthropod from the Early Cambrian Sirius Passet Fauna, with a description of retrodeformation based on functional morphology". English. In: Palaeontology 42 (1999), pp. 99-122.

[3212] G. E. Budd. “The morphology and phylogenetic significance of Kerygmachela kierkegaardi Budd (Buen Formation, Lower Cambrian, N Greenland)". English. In: Transactions of the Royal Society of Edinburgh: Earth Sciences 89 (1999), pp. 249-290.

[3213] G. E. Budd. "Kleptothule rasmusseni gen et sp nov an olenellinid-like trilobite from the Sirius Passet fauna (Buen Formation, Lower Cambrian, North Greenland)". English. In: Transactions of the Royal Society of Edinburgh: Earth Sciences 86 (1995), pp. 1-12.

[3214] G. E. Budd and J. S. Peel. "A new xenusiid lobopod from the Early Cambrian Sirius Passet fauna of North Greenland". In: Palaeontology 41.6 (1998), pp. 1201-1213.

[3215] P. Budil. "Representatives of genera Mucronaspis and Songxites (Trilobita) from the Bohemian Upper Ordovician". English. In: Journal of the Czech Geological Society 41.1-2 (1996), pp. 63-78.

[3216] E. Budrys. "Digger wasps of the subfamily Pemphredoninae (Hymenoptera, Sphecidae) from the Baltic and Taimyr amber". English. In: Acta Entomologica Lithuanica 11 (1993), pp. 34-56.

[3217] E. Buffetaut. "A new crocodilian from the Cretaceous of southern Morocco". English. In: Comptes Rendus de l'Academie des Sciences. Serie II 319.12 (1994), pp. 1563-1568.

[3218] E. Buffetaut. "An azhdarchid pterosaur from the Upper Cretaceous of Cruzy (Herault, France)". In: Comptes Rendus de l'Academie des Sciences, Serie II. Sciences de la Terre et des Planetes 333.6 (2001), pp. 357-361.

[3219] E. Buffetaut. "An ankylosaurid dinosaur from the Upper Cretaceous of Shandong (China)". In: Geological Magazine 132.6 (1995), pp. 683-692.

[3220] E. Buffetaut. "An Iguanodon jaw (Dinosauria, Ornithopoda) from the Lower Cretaceous of Aube (eastern Paris Basin, France)". In: Oryctos 5 (2004), pp. 63-68.

[3221] E. Buffetaut. "First evidence of enantiornithine birds from the Upper Cretaceous of Europe: postcranial bones from Cruzy (Hérault, southern France)". In: Oryctos 1 (1998), pp. 131-136.

[3222] E. Buffetaut. "A new sauropod dinosaur with prosauropod-like teeth from the Middle Jurassic of MadagascarBulletin de la Societé Géologique de France". English. In: Bulletin de la Societé Géologique de France 176.5 (2005), pp. 467-473.

[3223] E. Buffetaut. "The significance of dinosaur remains in marine sediments: an investigation based on the French record". English. In: In R. Kohring \& T. Martin (eds.), Miscellanea Palaeontologica 3: Festschrift Bernard Krebs. Berliner Geowissenschaften Abhandlungen, Reihe E 13 (1994), pp. 125-133. 
[3224] E. Buffetaut. "The spinosaurid dinosaur Baryonyx (Saurischia, Theropoda) in the Early Cretaceous of Portugal". English. In: Geological Magazine (2007). DOI: 10.1017/S0016756807003883.

[3225] E. Buffetaut. Spinosaurid teeth from the Late Jurassic of Tendaguru, Tanzania, with remarks on the evolutionary and biogeographical history of the Spinosauridae. English. 2008.

[3226] E. Buffetaut. "Late Cretaceous vertebrates from the Saint-Chinian area (southern France): a review of previous research and an update on recent finds". English. In: Acta Palaeontologica Romaniae 5 (2005), pp. 39-48.

[3227] E. Buffetaut. “Late Cretaceous pterosaurs from France: a review”. English. In: Zitteliana B 28 (2008), pp. 249-255.

[3228] E. Buffetaut. "Ptérosaures et oisaux du Crétacé supérieur de l'Aude". English. In: Bulletin de la Société d'Etudes Scientifiques de l'Aude 98 (1998), pp. 11-17.

[3229] E. Buffetaut. "The ornithurine from the Lower Cretaceous of Changi, Xinjiang (China): bird or pterosaur?" English. In: Cretaceous Research 17 (1996), pp. 505-508.

[3230] E. Buffetaut. "A giant pterosaur from the Lower Cretaceous of the eastern Paris Basin". English. In: Bulletin de la Société Géologique de France 175 (2004), pp. 573-577.

[3231] E. Buffetaut. "A basal bird from the Campanian (Late Cretaceous) of Dinosaur Provincial Park (Alberta, Canada)". English. In: Geological Magazine 147.3 (2010), pp. 469-472.

[3232] E. Buffetaut. "Phytosaurs in time and space". English. In: Paleontologia Lombardia, Nuova serie 2 (1993), pp. 39-44.

[3233] E. Buffetaut. "A forgotten episode in the history of dinosaur ichnology: Carl Degenhardt's report on the first discovery of fossil footprints in South America (Colombia, 1839)". English. In: Bulletin de la Société Géologique de France 171.1 (2000), pp. 137-140.

[3234] E. Buffetaut. The succession of dinosaur assemblages in Thailand. English. I Encontro Internacional sobre Paleobiologia dos Dinossáurios. Museu Nacional de História Natural, Lisboa. 1998, pp. 8997.

[3235] E. Buffetaut. "An early azhdarchid pterosaur from the Lower Cretaceous of the eastern Paris basin". English. In: Bulletin de la Société Géologique de France 183.6 (2012), pp. 525-528.

[3236] E. Buffetaut. "An early spinosaurid dinosaur from the Late Jurassic of Tendaguru (Tanzania) and the evolution of the spinosaurid dentition". English. In: Oryctos 10 (2013), pp. 1-8.

[3237] E. Buffetaut. "Spinosaurs before Stromer: early finds of spinosaurid dinosaurs and their interpretations". English. In: Dinosaurs and Other Extinct Saurians: A Historical Perspective. Geological Society, London, Special Publications 343 (2010), pp. 175-188. DOI: 10.1144/SP343.10.

[3238] E. Buffetaut. "Tertiary ground birds from Patagonia (Argentina) in the Tournouër collection of the Muséum National d'Histoire Naturelle, Paris". English. In: Bulletin de la Société Géologique de France 185.3 (2014), pp. 207-214.

[3239] E. Buffetaut. "A reassessment of the giant birds Liornis floweri Ameghino, 1895 and Callornis giganteus Ameghino, 1895, from the Santacrucian (late Early Miocene) of Argentina". English. In: Palaeovertebrata 40.2 (2016).

[3240] E. Buffetaut and D. Angst. "New evidence of a giant bird from the Late Cretaceous of France". English. In: Geological Magazine 150.1 (2013), pp. 173-176. DOI: 10.1017/S001675681200043X.

[3241] E. Buffetaut, D. Azar, A. Nel, K. Ziadé, and A. Acra. "First nonavian dinosaur from Lebanon: a brachiosaurid sauropod from the Lower Cretaceous of the Jezzine District". English. In: Naturwissenschaften (2006).

[3242] E. Buffetaut and N. Bardet. "The mosasaurid (Squamata) Prognathodon in the Maastrichtian (Late Cretaceous) of the Cotentin Peninsula (Normandy, northwestern France)". English. In: Bulletin de la Société Géologique de France 183.2 (2012), pp. 111-115.

[3243] E. Buffetaut, P. Bernier, G. Barale, J. -P. Bourseau, C. Gaillard, J. -C. Gall, and S. Wenz. "A new pterosaur bone from the Kimmeridgian lithographic limestones of Cerin (France)". English. In: Neues Jahrbuch für Geologie und Paläontologie, Monatshefte 1990 (1990), pp. 321-328. 
[3244] E. Buffetaut and A. Brignon. “Une dent de Nodosauridé (Dinosauria, Ankylosauria) dans le Cénomanien de Touraine [A nodosaurid tooth (Dinosauria, Ankylosauria) from the Cenomanian of Touraine]". French. In: Géologie de la France 1 (1999), pp. 49-52.

[3245] E. Buffetaut, R. Bussert, and W. Brinkman. "A new nonmarine vertebrate fauna in the Upper Cretaceous of northern Sudan". English. In: Berliner Geowissenschaftlische Abhandlungen A 120.1 (1990), pp. 183-202.

[3246] E. Buffetaut and E. Cacheleux. “The dinosaur $<$ i $>$ Dryosaurus $</ i>$ (Ornithopoda, Dryosauridae) in the Kimmeridgian (Late Jurassic) of Normandy: palaeobiogeographical implications". In: Compte Rendus de l'Academie des Sciences, Paris, série IIa 324 (1997), pp. 499-503.

[3247] E. Buffetaut, J. B. Clarke, and J. Le Loeuff. "A terminal Cretaceous pterosaur from the Corbiéres (southern France) and the problem of pterosaur extinction". English. In: Bulletin de la Société géologique de France 167 (1996), pp. 753-759.

[3248] E. Buffetaut, C. Colletté, B. Dubus, and J. -L. Petit. “The sauropod from the Albian of MesnilSaint-Pére (Aube, France): a pliosaur, not a dinosaur". English. In: Carnets de Géologie/Notebooks on Geology - Letter 2005.1 (2005), pp. 1-5.

[3249] E. Buffetaut, G. Costa, J. Le Loeuff, M. Martin, J. -C. Rage, X. Valentin, and H. Tong. “An early Campanian vertebrate fauna from the Villeveyrac Basin (Hérault, southern France)". English. In: Neues Jahrbuch für Geologie und Paläontologie Monatshefte 1996.1 (1996), pp. 1-16.

[3250] E. Buffetaut, G. Cuny, and J. Le Loeuff. "French dinosaurs: the best record in Europe?" English. In: Modern Geology 16 (1991), pp. 17-42.

[3251] E. Buffetaut, G. Cuny, G. Lachkar, D. Contini, A. Pharisat, and B. Vienet. “Le fémur de dinosaure théropode du Musée d'Histoire naturelle de Gray (Haute-Saone): identification, datation et essai de localisation de l'origine d'un fossile inhabituel [The theropod dinosaur femur from the Natural History Museum of Gray Haute-Saone, France): identification, dating and determination of the geographic origin of an unusual fossil]". French. In: Bulletin de la Société Géologique de France 166.1 (1995), pp. 69-75.

[3252] E. Buffetaut, G. Dyke, V. Suteethorn, and H. Tong. "First record of a fossil bird from the Early Cretaceous of Thailand". English. In: Comptes Rendus Palevol 4.8 (2005), pp. 681-686. DOI: 10.1016/ j.crpv.2005.06.002.

[3253] E. Buffetaut, B. Gibout, and D. Drouin. "A pterosaur from the Toarcian (Early Jurassic) of the Ardennes (northeastern France)". English. In: Carnets de Géologie/Notebooks on Geology 2010/01 (2010), pp. 1-6.

[3254] E. Buffetaut, B. Gibout, I. Launois, and C. Delacroix. "The sauropod dinosaur Cetiosaurus OWEN in the Bathonian (Middle Jurassic) of the Ardennes (NE France): insular, but not dwarf". English. In: Carnets de Géologie/Notebooks on Geology 2011/06 (2011), pp. 149-161.

[3255] E. Buffetaut, G. Grellet-Tinner, V. Suteethorn, G. Cuny, H. Tong, A. Kosir, L. Cavin, S. Chitsing, P. J. Griffiths, J. Tabouelle, and J. Le Loeuff. "Minute theropod eggs and embryo from the Lower Cretaceous of Thailand and the dinosaur-bird transition". English. In: Naturwissenschaften 92.10 (2005), pp. 477-482. DOI: 10.1007/s00114-005-0022-9.

[3256] E. Buffetaut, D. Grigorescu, and Z. Csiki. "A new giant pterosaur with a robust skull from the latest Cretaceous of Romania". English. In: Naturwissenschaften 89 (2002), pp. 180-184.

[3257] E. Buffetaut and J.-P. Guibert. "An early pterodactyloid pterosaur from the Oxfordian of Normandy (northwestern France)". English. In: Comptes Rendus de l'Academie des Sciences: Series IIA, Earth and Planetary Science 333 (2001), pp. 405-409.

[3258] E. Buffetaut, F. Hebert, and T. Rebours. "Un metatarsien de dinosaure theropode dans le Jurassique des Falaises des Vaches Noires (Calvados, Normandie, France)". French. In: Bulletin Sciences et Geologie Normandes 1 (2010), pp. 49-53.

[3259] E. Buffetaut and R. Ingavat. "A new species of the ornithischian dinosaur $<i>$ Psittacosaurus $</ i>$ from the Early Cretaceous of Thailand". In: Palaeontology 35.4 (1992), pp. 801-812. 
[3260] E. Buffetaut and P. Jeffrey. "A ctenochasmatid pterosaur from the Stonesfield Slate (Bathonian, Middle Jurassic) of Oxfordshire, England". English. In: Geological Magazine 149.3 (2012), pp. 552556.

[3261] E. Buffetaut, B. Jurkovek, and T. Kolar-Jurkovek. "A fossil feather from the Upper Cretaceous of Kras (Slovenia)". English. In: Comptes Rendus Palevol 1 (2002), pp. 705-710.

[3262] E. Buffetaut, Y. Laurent, J. Le Loeuff, and M. Bilotte. "A terminal Cretaceous giant pterosaur from the French Pyrenees". In: Geological Magazine 134.4 (1997), pp. 553-556.

[3263] E. Buffetaut and J. Le Loeuff. "Late Cretaceous dinosaurs from the foothills of the Pyrenees". In: Geology Today 1997.3-4 (1997), pp. 60-68.

[3264] E. Buffetaut and J. Le Loeuff. "A new giant ground bird from the Upper Cretaceous of southern France". In: Journal of the Geological Society, London 155 (1998), pp. 1-4.

[3265] E. Buffetaut, J. Le Loeuff, H. Tong, S. Duffaud, L. Cavin, G. Garcia, D. Ward, and l'Association culturelle archéologique et paléontologique de Cruzy. "Un nouveau gisement de vertébrés du Crétacé supérieur á Cruzy (Hérault, Sud de la France) [A new Late Cretaceous vetebrate locality at Cruzy (Hérault, southern France)]". French. In: Comptes Rendus de l'Académie des Sciences á Paris, Sciences de la Terre et des Planétes 328 (1999), pp. 203-208.

[3266] E. Buffetaut and J. Le Loeuff. “Une nouvelle espéce de Rhabdodon (Dinosauria, Ornithischia) du Crétacé supérieur de l'Hérault (Sud de la France) [A new species of Rhabdodon (Dinosauria, Ornithischia) from the Upper Cretaceous of Hérault (southern France)]". French. In: Comptes-Rendus de l'Académie des Sciences de Paris, série II 312 (1991), pp. 943-948.

[3267] E. Buffetaut, J. Le Loeuff, and V. Martin. “Un fémur de dinosaure sauropode dans le Barrémien de Ville-sur-Saulx (Meuse) [A sauropod dinosaur femur in the Barremian of Ville-sur-Saulx (Meuse)]". French. In: Bulletin d'Information das Géologues du Bassin de Paris 29.2 (1992), pp. 9-13.

[3268] E. Buffetaut and J. Le Loeuff. "Gargantuavis philoinos: Giant bird or giant pterosaur?" English. In: Annales de Paléontologie 96 (2011), pp. 135-141.

[3269] E. Buffetaut, J.-J. Lepage, and G. Lepage. "A new pterodactyloid pterosaur from the Kimmeridgian of the Cap de la Héve (Normandy, France)”. English. In: Geological Magazine 135 (1998), pp. 719 722.

[3270] E. Buffetaut, J. Li, H. Tong, and H. Zhang. "A two-headed reptile from the Cretaceous of China". English. In: Biology Letters 3 (2007), pp. 80-81. DOI: 10.1098/rsbl.2006.0580.

[3271] E. Buffetaut and L. G. Marshall. “A new crocodilian, Sebecus querejazus, nov. sp. (Mesosuchia, Sebecidae) from the Santa Lucia Formation (Early Paleocene) at Vila Vila, Southern Bolivia". English. In: Revista Técnica de Yacimientos Petrolferos Fiscales Bolivianos 12.3-4 (1991), pp. 545-557.

[3272] E. Buffetaut, P. Mechin, and A. Mechin-Salessy. "An archaic bird (Enantiornithes) from the Upper Cretaceous of Provence (southern France)". French. In: Comptes Rendus de l'Académie des Sciences, Sciences de la Terre et des Planétes 331 (2000), pp. 557-561.

[3273] E. Buffetaut and N. Morel. "A stegosaur vertebra (Dinosauria: Ornithischia) from the Callovian (Middle Jurassic) of Sarthe, western France". English. In: Comptes Rendus Palevol 8 (2009), pp. 545549. DOI: 10.1016/j.crpv.2009.05.001.

[3274] E. Buffetaut and M. Novak. "A cyamodontid placodont (Reptilia: Sauropterygia) from the Triassic of Slovenia". English. In: Palaeontology 51.6 (2008), pp. 1301-1306.

[3275] E. Buffetaut, A. Osi, and E. Prondvai. "The pterosaurian remains from the Grünbach Formation (Campanian, Gosau Group) of Austria: a reappraisal of 'Ornithocheirus buenzeli". English. In: Geological Magazine 148 (2011), pp. 334-339.

[3276] E. Buffetaut and M. Ouaja. "A new specimen of Spinosaurus (Dinosauria, Theropoda) from the Lower Cretaceous of Tunisia, with remarks on the evolutionary history of the Spinosauridae". In: Bulletin de la Société Géologique de France 173.5 (2002), pp. 412-421. 
[3277] E. Buffetaut, G. Pennetier, and E. Pennetier. “Un fragment de machoire de Megalosaurus dans le Callovien supérier des Vaches Noires (Calvados, France) [A jaw fragment from Megalosaurus in the upper Callovian of Vaches Noires (Calvados, France)]". French. In: Revue de Paléobiologie 10.2 (1991), pp. 379-387.

[3278] E. Buffetaut and D. Pouit. "Restes de dinosaures et de crocodiliens dans le Crétacé supérieur du Centre-Ouest de la France [Dinosaur and crocodilian remains from the Upper Cretaceous of westcentral France]". French. In: Comptes Rendus de l'Académie des Sciences á Paris, Série II 319 (1994), pp. 253-259.

[3279] E. Buffetaut and V. Suteethorn. "The dinosaurs of Thailand". In: Journal of Southeast Asian Earth Sciences 8.1-4 (1993), pp. 77-82.

[3280] E. Buffetaut and V. Suteethorn. "The dinosaur fauna of the Sao Khua Formation of Thailand and the beginning of the Cretaceous radiation of dinosaurs in Asia". In: Palaeogeography, Palaeoclimatology, Palaeoecology 150 (1999), pp. 13-23.

[3281] E. Buffetaut, V. Suteethorn, G. Cuny, H. Tong, J. Le Loeuff, S. Khansubha, and S. Jongautchariyakul. "The earliest known sauropod dinosaur". English. In: Nature 407 (2000), pp. 72-74.

[3282] E. Buffetaut, V. Suteethorn, J. Le Loeuff, G. Cuny, H. Tong, and S. Khansubha. "The first giant dinosaurs: a large sauropod from the Late Triassic of Thailand". In: Comptes Rendus Palevol 1 (2002), pp. 103-109.

[3283] E. Buffetaut, V. Suteethorn, H. Tong, and A. Kosir. "First dinosaur from the Shan-Thai Block of SE Asia: a Jurassic sauropod from the southern peninsula of Thailand". English. In: Journal of the Geological Society, London 162.3 (2005), pp. 481-484.

[3284] E. Buffetaut, V. Suteethorn, and H. Tong. "The earliest known tyrannosaur from the Lower Cretaceous of Thailand". English. In: Nature 381 (1996), pp. 689-691. DOI: 10.1038/381689a0.

[3285] E. Buffetaut and V. Suteethorn. "A sinraptorid theropod (Dinosauria: Saurischia) from the Phu Kradung Formation of northeastern Thailand". English. In: Bulletin de la Société Géologique de France 178.6 (2007), pp. 497-502.

[3286] E. Buffetaut, V. Suteethorn, H. Tong, and R. Amiot. "An Early Cretaceous spinosaurid theropod from southern China". English. In: Geological Magazine 145.2 (2008), pp. 745-748. DOI: 10.1017 / S0016756808005360.

[3287] E. Buffetaut, V. Suteethorn, and H. Tong. An early 'ostrich dinosaur' (Theropoda: Ornithomimosauria) from the Early Cretaceous Sao Khua Formation of NE Thailand. English. Vol. 315. Late Palaeozoic and Mesozoic Ecosystems in SE Asia. The Geological Society of London, Special Publication. 2009, pp. 229-243.

[3288] E. Buffetaut, V. Suteethorn, J. Le Loeuff, S. Khansubha, H. Tong, and K. Wongko. "The dinosaur fauna from the Khok Kruat Formation (Early Cretaceous) of Thailand". English. In: International Conference on Geology, Geotechnology and Mineral Resources of Indochina (GEOINDO 2005), 28-30 November 2005, Khon Kaen, Thailand (2005), pp. 575-581.

[3289] E. Buffetaut, V. Suteethorn, J. Le Loeuff, G. Cuny, H. Tong, and S. Khansubha. "A review of the sauropod dinosaurs of Thailand". English. In: The Symposium on Geology of Thailand, Bangkok, 26-31 August 2002 (2002), pp. 95-101.

[3290] E. Buffetaut, V. Suteethorn, and S. Khansubha. The ceratopsian dinosaur Psittacosaurus in the Early Cretaceous of southeast Asia: a review of old and recent finds. English. Proceedings of the International Conference on Geology of Thailand: Towards Sustainable Development and Sufficiency Economy (GEOTHAI'07). 2007, pp. 338-343.

[3291] E. Buffetaut, V. Suteethorn, T. Saenyamoon, R. Liard, H. Tong, J. Le Loeuff, and G. Cuny. A prosauropod skeleton (Dinosauria: Saurischia) from the Nam Phong Formation of northeastern Thailand. English. Vol. Abstracts. 6th Meeting of the European Association of Vertebrate Palaeontologists, Spiská Nová Ves, Slovak Republic. The Museum of Spi, Spiská Nová Ves. 2008, p. 22. 
[3292] E. Buffetaut, V. Suteethorn, S. Suteethorn, U. Deesrie, and H. Tong. “An azhdarchoid pterosaur humerus from the latest Jurassic (Phu Kradung Formation) of Phu Noi, north-eastern Thailand". English. In: Research and Knowledge 1 (2015), pp. 43-47.

[3293] M. L. Buffington, E. E. Perkovsky, and S. G. Brady. "The description of Rovnoeucoila tympanomorpha Buffington and Perkovsky, a new genus and species of fossil eucoiline, with observations on the asynchronous evolution of Diglyphosematini (Hymenoptera: Figitidae: Eucoilinae)". English. In: Proceedings of the Entomological Society of Washington 116 (2014), pp. 243-254.

[3294] W. Buggisch and S. Krumm. "Palaeozoic cold seep carbonates from Europe and North Africa - an integrated isotopic and geochemical approach". English. In: Facies 51 (2005), pp. 566-583.

[3295] I. J. Bugrova. "The facies zonation and scleractinians of the early Hauterivian reef complex of Bolshoy Balkhan". English. In: Cretaceous Research 11.3 (1990), pp. 229-236.

[3296] P. N. Buhl. “On a Baltic amber collection of Platygastridae and Diapriidae (Hymenoptera)". English. In: Entomologiske Meddelelser 70.1 (2002), pp. 57-61.

[3297] P. N. Buhl. "On a collection of Hymenoptera in Baltic amber, with the description of a new species of Pantolyta Förster, 1856 (Hymenoptera, Diapriidae)". English. In: Enomologica Fennica 10 (1999), pp. 187-189.

[3298] B. E. Buitron-Sanchez, C. Gomez-Espinosa, E. Almazan-Vazquez, and D. Vachard. "A Late Atokan regional encrinite (early Late Moscovian, Middle Pennsylvanian) in the Sierra Agua Verde, Sonora state, NW Mexico". English. In: in J. J. Alvaro, M. Aretz, F. Boulvain, A. Munnecke, D. Vachard, E. Vennin, eds., Palaeozoic reefs and bioaccumulations: climatic and evolutionary controls. Geological Society Special Publication 275 (2007), pp. 201-209.

[3299] B. E. Buitrón-Sánchez and Y. López-Tinajero. "Mollusk gastropods in a Lower Cretaceous rudistbearing formation of Jalisco, west central Mexico". English. In: Revista Mexicana de Ciencias Geológicas 12.2 (1995), pp. 157-169.

[3300] L. Bujtor. "Early Valanginian brachiopods from the Mecsek Mts. (southern Hungary) and their palaeobiogeographical significance". English. In: Neues Jahrbuch für Geologie und Paläontologie, Abhandlungen 241.1 (2006), pp. 111-152.

[3301] L. Bujtor, H. J. Gawlick, A. Miklósy, R. Albrecht, C. Farkas, A. Kovács, B. Makó, D. Maróti, and S. Missoni. "The first recording of the presence of nautiloids (Eutrephoceras ex gr. boissieri) from the Lower Cretaceous of the Mecsek Mountains, southern Hungary". English. In: Földtani Közlöny 149 (2019), pp. 19-24.

[3302] L. Bujtor and A. Vörös. “New kingenoid (Terebratellidina) brachiopods with larger body sizes from". English. In: Journal of Paleontology 94 (2020), pp. 475-488. DOI: 10.1017/jpa.2019.94.

[3303] A. Bukejs. "A new species of the genus Crepidodera Chevrolat (Coleoptera: Chrysomelidae) from Baltic amber". English. In: Zootaxa 3815 (2014), pp. 286-290.

[3304] A. Bukejs. "New genus and species of Lamprosomatinae (Coleoptera: Chrysomelidae) from Eocene Baltic amber". English. In: Palaeontologia Electronica 22.2.33A (2019), pp. 1-10.

[3305] A. Bukejs and V. I. Alekseev. "Description of the second fossil Baltic amber species of Monotomidae (Coleoptera: Cucujoidea)". English. In: Zootaxa 3946 (2015), pp. 445-450.

[3306] A. Bukejs and V. I. Alekseev. "A second Eocene species of death-watch beetle belonging to the genus Microbregma Seidlitz (Coleoptera: Bostrichoidea) with a checklist of fossil Ptinidae". English. In: Zootaxa 3947 (2015), pp. 553-562.

[3307] A. Bukejs, V. I. Alekseev, and M. A. Jäch. "The riffle beetles (Coleoptera: Elmidae) of the Eocene Baltic amber: Heterelmis groehni sp. nov. and Heterlimnius samlandicus (Bollow, 1940) comb. nov". English. In: Zootaxa 3986 (2015), pp. 452-460.

[3308] A. Bukejs and V. I. Alekseev. "First record of Microscapha LeConte from Baltic amber with description of a new species and list of fossil Melandryidae (Coleoptera: Tenebrionoidea)". English. In: Zootaxa 4012 (2015), pp. 351-360. 
[3309] A. Bukejs, V. I. Alekseev, and R. C. McKellar. "Passandra septentrionaria sp. nov.: the first described species of Passandridae (Coleoptera: Cucujoidea) from Eocene Baltic amber". English. In: Zootaxa 4144 (2016), pp. 117-123.

[3310] A. Bukejs, V. I. Alekseev, D. M. L. Cooper, G. A. King, and R. C. McKellar. "Contributions to the palaeofauna of Ptinidae (Coleptera) known from Baltic amber". English. In: Zootaxa 4344 (2017), pp. 181-188.

[3311] A. Bukejs and V. I. Alekseev. "A new extinct species of Ataenius Harold from Baltic amber (Coleoptera: Scarabaeidae: Aphodiinae)". English. In: Zootaxa 4442 (2018), pp. 153-160.

[3312] A. Bukejs, V. I. Alekseev, D. M. L. Cooper, G. A. King, and R. C. McKellar. "A new fossil species of Pycnomerus Erichson (Coleoptera: Zopheridae) from Baltic amber, and a replacement name for a Recent North American congener". English. In: Zootaxa 4550 (2019), pp. 565-572.

[3313] A. Bukejs, V. I. Alekseev, and D. A. Pollock. "Waidelotinae, a new subfamily of Pyrochroidae (Coleoptera: Tenebrionoidea) from Baltic amber of the Sambian peninsula and the interpretation of Sambian amber stratigraphy, age and location". English. In: Zootaxa 4664 (2019), pp. 261-273.

[3314] A. Bukejs, V. I. Alekseev, and A. A. Legalov. "A new Eocene genus of the subtribe Tylodina (Coleoptera: Curculionidae) and notes concerning local differences of Baltic amber in the Kaliningrad Region". English. In: Fossil Record 23 (2020), pp. 75-81. DOI: 10.5194/fr-23-75-2020.

[3315] A. Bukejs and J. Bezdk. “Calomicrus eocenicus sp. nov. (Coleoptera: Chrysomelidae: Galerucinae) from Baltic amber". English. In: Baltic Journal of Coleopterology 14 (2014), pp. 73-78.

[3316] A. Bukejs, J. Bezdk, V. I. Alekseev, K. Kairis, and R. C. McKellar. “Description of the male of fossil Calomicrus eocenicus Bukejs et Bezdk (Coleoptera: Chrysomelidae: Galerucinae) from Eocene Baltic amber using X-ray microtomography". English. In: Fossil Record 23 (2020), pp. 105-115. DOI: 10.5194/fr-23-105-2020.

[3317] A. Bukejs, M. Biondi, and V. I. Alekseev. "Sucinolivolia torpida-a new genus and species of fleabeetles (Coleoptera: Chrysomelidae: Galerucinae) from Baltic amber". English. In: Zootaxa 4058 (2015), pp. 119-126.

[3318] A. Bukejs, M. Biondi, and V. I. Alekseev. "New records and species of Crepidodera Chevrolat (Coleoptera: Chrysomelidae) in Eocene European amber, with a brief review of described fossil beetles from Bitterfeld amber". English. In: Zootaxa 4193 (2016), pp. 390-400.

[3319] A. Bukejs and M. L. Chamorro. "Two new fossil species of Cryptocephalus Geoffroy (Coleoptera: Chrysomelidae) from Baltic and Dominican amber". English. In: Proceedings of the Entomological Society of Washington 117 (2015), pp. 116-125.

[3320] A. Bukejs, F. Fanti, and R. C. McKellar. "A new species of Cacomorphocerus Schaufuss, 1892 (Coleoptera: Cantharidae) from Baltic amber with a key to known species". English. In: Palaeontologia Electronica 22.2.28A (2019), pp. 1-7.

[3321] A. Bukejs, J. Háva, and V. I. Alekseev. “New fossil species of Trichodesma LeConte, 1861 (Coleoptera: Ptinidae) from Eocene Baltic amber collected in the Kaliningrad region, Russia". English. In: Palaeontologia Electronica 21.2.17A (2018), pp. 1-7.

[3322] A. Bukejs and J. Háva. "A new species of Globicornis Latreille (Coleoptera: Dermestidae) from Baltic amber, with a key to fossil species". English. In: Zootaxa 4483 (2018), pp. 395-400.

[3323] A. Bukejs, J. Háva, and V. I. Alekseev. “A new fossil species of Attagenus Latreille (Coleoptera: Dermestidae) in Rovno and Baltic ambers, with a brief review of known fossil beetles from the Rovno amber Lagerstätte". English. In: Fossil Record 23 (2020), pp. 95-104. DOI: 10.5194/fr-23-952020.

[3324] A. Bukejs and A. G. Kirejtshuk. "A new species of the genus Smicrips Le Conte (Coleoptera: Smicripidae) from Baltic amber". English. In: Paleontological Journal 49 (2015), pp. 1417-1419.

[3325] A. Bukejs and A. S. Konstantinov. "New genus of flea beetle (Coleoptera: Chrysomelidae: Galerucinae: Alticini) from the Upper Eocene Baltic amber". English. In: Insecta Mundi 306 (2013), pp. 15. 
[3326] A. Bukejs and A. A. Legalov. "New species of sub-fossil weevils (Coleoptera, Curculionidae) in Madagascar copal". English. In: Paleontological Journal 51 (2017), pp. 196-202.

[3327] A. Bukejs and A. A. Legalov. "First record of the tribe Naupactini (Coleoptera: Curculionidae) in Rovno amber". English. In: Fossil Record 22 (2019), pp. 25-30. DOI: 10.5194/fr-22-25-2019.

[3328] A. Bukejs and A. A. Legalov. “Groehnius, a new genus of Eugnomini (Coleoptera: Curculionidae) from Eocene Baltic amber". English. In: Fossil Record 22 (2019), pp. 45-49. DOI: 10.5194/fr-22-452019.

[3329] A. Bukejs and A. A. Legalov. "A new species of the genus Dorytomus Germar, 1817 (Coleoptera: Curculionidae) from Baltic amber". English. In: Entomologica Fennica 30 (2019), pp. 173-178.

[3330] A. Bukejs and A. A. Legalov. "The first record of Rhynchitidae (Coleoptera) from Rovno amber". English. In: Entomologica Fennica 30 (2019), pp. 168-172.

[3331] A. Bukejs and A. A. Legalov. “The first record of Brentidae (Coleoptera) in Eocene Rovno amber with description of a new fossil species of Toxorhynchus Scudder, 1893". English. In: Fossil Record 23 (2020), pp. 169-177. DOI: 10.5194/fr-23-169-2020.

[3332] A. Bukejs and A. G. Moseyko. “Two new species of the genus Taphioporus Moseyko \& Kirejtshuk (Chrysomelidae: Eumolpinae) from Baltic amber". English. In: Zootaxa 4032 (2015), pp. 395-406.

[3333] A. Bukejs and K. Nadein. "A second species of Psyllototus (Coleoptera: Chrysomelidae: Galerucinae: Alticini) from the Upper Eocene Baltic amber". English. In: Zootaxa 3609 (2013), pp. 465-470.

[3334] A. Bukejs and K. Nadein. "Psyllototus groehni sp. nov. (Coleoptera: Chrysomelidae), a new species of the palaeoendemic genus from Baltic amber". English. In: Baltic Journal of Coleopterology 14 (2014), pp. 163-166.

[3335] A. Bukejs and K. Nadein. "First fossil Lamprosomatinae leaf beetles (Coleoptera: Chrysomelidae) with descriptions of new genera and species from Baltic amber". English. In: Zootaxa 3931 (2015), pp. 127-139.

[3336] A. Bukejs, H. P. Reike, and W. H. Rücker. "Enicmus adrianae sp. nov. - a new scavenger beetle (Coleoptera: Latridiidae) from Baltic amber". English. In: Baltic Journal of Coleopterology 12 (2012), pp. 149-154.

[3337] A. Bukejs, W. H. Rücker, and A. G. Kirejtshuk. "Cartodere (Aridius) succinobaltica sp. nov. (Coleoptera: Latridiidae) from Baltic amber". English. In: Latridiidae 9 (2012), pp. 25-28.

[3338] A. Bukejs and M. Schmitt. "Lilioceris groehni sp. n.: the first authentic species of Criocerinae (Coleoptera, Chrysomelidae) from Baltic amber". English. In: ZooKeys 618 (2016), pp. 67-77.

[3339] V. V. Bulanov. "Novye Dannye po Prokolofonam Permi Vostochnoi Evropy [New Data on Procolophons from the Permian of Eastern Europe]". Russian. In: Paleontologicheskii Zhurnal 2002.5 (2002), pp. 83-88.

[3340] V. V. Bulanov. "Evolution and systematics of seymouriamorph parareptiles". English. In: Paleontological Journal 37.Suppl. 1 (2003), S1-S105.

[3341] V. V. Bulanov and A. G. Sennikov. "The First Gliding Reptiles from the Upper Permian of Russia". English. In: Paleontological Journal 40.Suppl. 5 (2006), S567-S570.

[3342] V. V. Bulanov and A. G. Sennikov. "Glaurung schneideri gen. et sp. nov., a New Weigeltisaurid (Reptilia) from the Kupfershiefer (Upper Permian) of Germany". English. In: Paleontological Journal 49.12 (2015), pp. 1353-1364.

[3343] V. V. Bulanov and O. V. Yashina. "Elginiid Pareiasaurs of Eastern Europe". English. In: Paleontological Journal 39.4 (2005), pp. 428-432.

[3344] K. V. Bulinski. "Analysis of sample-level properties along a paleoenvironmental gradient: the behavior of evenness as a function of sample size". English. In: Palaeogeography, Palaeoclimatology, Palaeoecology 243.3-4 (2007), pp. 490-508.

[3345] T. S. Bullard and M. W. Caldwell. "Redescription and rediagnosis of the tylosaurine mosasaur Hainosaurus pembinensis Nicholls, 1988, as Tylosaurus pembinensis (Nicholls, 1988)". English. In: Journal of Vertebrate Paleontology 30.2 (2010), pp. 416-426. 
[3346] L. G. Bulot, C. Frau, and W. A. P. Wimbledon. “New and poorly known Perisphinctoidea (Ammonitina) from the Upper Tithonian of Le Chouet (Drome, SE France)". English. In: Volumina Jurassica 12 (2014), pp. 113-128.

[3347] L. G. Bulot, W. J. Kennedy, E. Jaillard, and E. Robert. "Late Middle-early Late Albian ammonites from Ecuador". English. In: Cretaceous Research 26 (2005), pp. 450-459.

[3348] L. G. Bulot, J. L. Latil, J. Vermeulen, and M. F. Aly. “Mogharaeceras priscum (Douvillé, 1916) a peculiar Barremian ammonite (Desmoceratoidea, Barremitinae) from Northern Sinai (Egypt)". English. In: Geologica Carpathica 62 (2011), pp. 575-578.

[3349] P. Bultynck and C. Hollevoet. "The Eifelian-Givetian boundary and Struve's Middle Devonian Great Gap in the Couvin area (Ardennes, southern Belgium)". English. In: Senckenbergiana lethaea 79.1 (1999), pp. 3-11.

[3350] H. T. Bunn. Early Pleistocene hominid foraging strategies long the ancestral Omo River at Koobi Fora, Kenya. 1994.

[3351] M. R. Buono and M. A. Cozzuol. Un nuevo Ziphiidae (Cetacea: Odontoceti) del Mioceno tardo temprano de Patagonia, Argentina. Spanish. 2010.

[3352] M. R. Buono and M. A. Cozzuol. "A new beaked whale (Cetacea, Odontoceti) from the Late Miocene of Patagonia, Argentina". English. In: Journal of Vertebrate Paleontology 33.4 (2013), pp. $986-$ 997. DOI: $10.1080 / 02724634.2013 .752377$.

[3353] M. R. Buono, M. S. Fernández, M. A. Reguero, S. A. Marenssi, S. N. Santilana, and T. Mörs. “Eocene basilosaurid whales from the La Meseta Formation, Marambio (Seymour) Island, Antarctica". English. In: Ameghiniana 53.3 (2016), pp. 296-315. DOI: 10.5710/AMGH.02.02.2016.2922.

[3354] Bur. of Geol. and Min. Resources of Hubei. Regional geology of Hubei Provence. English. Vol. 1. People's Republic of China Ministry of Geology and Mineral Resources, Geological Memoirs 20. Beijing: Geological Publishing House, 1990, pp. 1-705.

[3355] Bur. of Geol. and Min. Resources of Yunnan. Regional Geology of Yunnan Province. English. Vol. 1. People's Republic of China Ministry of Geology and Mineral Resources, Geological Memoirs 21. Beijing: Geological Publishing House, 1990, pp. 1-728.

[3356] D. W. Burbank and A. D. Barnosky. "The magnetochronology of Barstovian mammals in southwestern Montana and implications for the initiation of Neogene crustal extension in the northern Rocky Mountains". English. In: Geological Society America Bulletin 102 (1990).

[3357] S. H. Burch and M. T. Carrano. "An articulated pectoral girdle and forelimb of the abelisaurid theropod Majungasaurus crenatissimus from the Late Cretaceous of Madagascar". English. In: Journal of Vertebrate Paleontology 32.1 (2012), pp. 1-16. DOI: 10.1080/02724634.2012.622027.

[3358] N. I. Burchak-Abramovich and D. N. Burchak. "The birds of the late Quaternary of the Altai Mts". English. In: Acta Zoologica Cracoviensis 41 (1998), pp. 51-60.

[3359] D. Burckhardt and G. Poinar. “The first jumping plant-louse from mid-Cretaceous Burmese amber and its impact on the classification of Mesozoic psylloids (Hemiptera: Sternorrhyncha: Psylloidea s. 1.)" English. In: Cretaceous Research 106.104240 (2019). DOI: 10.1016/j.cretres.2019.104240.

[3360] D. Burckhardt and D. L. Queiroz. "The jumping plant-lice of the Neotropical genus Tainarys (Hemiptera: Psylloidea) associated with Anacardiaceae". English. In: Zootaxa 4232 (2017), pp. 535567.

[3361] B. J. Burger. "A New Late Paleocene Vertebrate Fauna from the Ohio Creek Formation of Western Colorado". English. In: Mountain Geologist 44.3 (2007), pp. 141-150.

[3362] B. J. Burger. "A new species of the archaic primate Zanycteris from the late Paleocene of western Colorado and the phylogenetic position of the family Picrodontidae". English. In: PeerJ 1 (2013), e191:1-11. DOI: 10.7717/ peerj.191.

[3363] B. J. Burger and J. G. Honey. "Plesiadapidae (Mammalia, Primates) from the Late Paleocene Fort Union Formation of the Piceance Creek Basin, Colorado". English. In: Journal of Vertebrate Paleontology 28.3 (2008), pp. 816-825. DOI: 10.1671/0272-4634(2008)28[816:PMPFTL]2.0.CO;2. 
[3364] B. J. Burger and L. A. Jolley. "A new large body helohyid (Artiodactyla) from the Bridgerian Middle Eocene Washakie Formation of southern Wyoming". English. In: Paludicola 12.4 (2020), pp. $175-184$.

[3365] T. Bürgin. "Actinopterygian fishes (Osteichthyes; Actinopterygii) from the Kalkschieferzone (uppermost Ladinian) near Meride (Canton Ticino, southern Switzerland)". English. In: Eclogae Geologicae Helvetiae 88.3 (1995), pp. 803-826.

[3366] T. Bürgin. "Basal ray-finned fishes (Osteichthyes; Actinopterygii) from the Middle Triassic of Monte San Giorgio (Canton Tessin, Switzerland)". English. In: Schweizerische Paläontologische Abhandlungen 114 (1992), pp. 1-164.

[3367] T. Bürgin and H. Furrer. "Zähne und Kieferreste der Gattung Birgeria (Osteichthyes, Actinopterygii) aus der ostalpinen Obertrias der Bergüner Stöcke (Kanton Graubünden, Schweiz)". German. In: Eclogae Geologicae Helvetiae 85 (1992), pp. 931-946.

[3368] R. A. Burks, J. M. Heraty, J. D. Pinto, and D. Grimaldi. “Small but not ephemeral: newly discovered species of Aphelinidae and Trichogrammatidae (Insecta: Hymenoptera: Chalcidoidea) from Eocene amber". English. In: Systematic Entomology 40 (2015), pp. 592-605.

[3369] R. A. Burks, L. Krogmann, and J. M. Heraty. "Simultaneous discovery and taxonomic placement of new extant and fossil genera of Herbertiinae (Hymenoptera: Chalcidoidea: Pteromalidae)". English. In: Insect Systematics and Diversity 2.5 (2018), pp. 1-8.

[3370] R. A. Burks, L. Krogmann, and J. M. Heraty. “Chrysolampine wasps (Chalcidoidea: Perilampidae sensu lato) from Baltic amber". English. In: Insect Systematics and Diversity 3.6:10 (2019). DOI: 10. 1093/isd/ixz027.

[3371] K. C. Burmeister, J. J. Flynn, J. M. Parrish, and A. R. Wyss. "Paleogeographic and biostratigraphic implications of new early Mesozoic vertebrates from Poamay central Morondava Basin, Madagascar". English. In: vol. 37. The Triassic-Jurassic Terrestrial Transition. New Mexico Museum of Natural History and Science Bulletin. Albuquerque: New Mexico Museum of Natural History and Science, 2006, pp. 457-475.

[3372] D. A. Burney, H. Andriamialison, R. A. Andrianaivoarivelo, S. Bourne, B. E. Crowley, E. J. de Boer, L. R. Godfrey, S. M. Goodman, C. Griffiths, O. Griffiths, J. P. Hume, W. G. Joyce, W. L. Jungers, S. Marciniak, G. J. Middleton, K. M. Muldoon, E. Noromalala, V. R. Pérez, and G. H. Perry. "Subfossil lemur discoveries from the Beanka Protected Area in western Madagascar". English. In: Quaternary Research (2019), pp. 1-17. DOI: 10.1017/qua.2019.54.

[3373] D. A. Burney, N. Vasey, Ramilisonina Godfrey L.R., W. L. Jungers, M. Ramarolahy, and L. Raharivony. "New findings at Andrahomana Cave, southeastern Madagascar". English. In: Journal of Cave and Karst Studies 70.1 (2008), pp. 13-24.

[3374] D. A. Burnham, K. L. Derstler, P. J. Currie, R. T. Bakker, Z. Zhou, and J. H. Ostrom. "Remarkable new birdlike dinosaur (Theropoda: Maniraptora) from the Upper Cretaceous of Montana". English. In: University of Kansas Paleontological Contributions 13 (2000), pp. 1-14.

[3375] R. J. Burnham. "Paleoecological and Floristic Heterogeneity in the Plant-Fossil Record - An Analysis Based on the Eocene of Washington". In: United States Geological Survey Bulletin 2085-B (1994), pp. 1-36.

[3376] R. J. Burnham. "A new species of winged fruit from the Miocene of Ecuador: Tipuana ecuatoriana (Leguminosae)". In: American Journal of Botany 82.12 (1995), pp. 1599-1607.

[3377] R. J. Burnham and N. L. Carranco. "Miocene winged fruits of Loxopterygium (Anacardiaceae) from the Ecuadorian Andes". English. In: American Journal of Botany 91.11 (2004), pp. 1767-1773. DOI: 10.3732/ajb.91.11.1767.

[3378] C. Burns, K. A. Campbell, and R. Mooi. "Exceptional crinoid occurrences and associated carbonates of the Keasey Formation (Early Oligocene) at Mist, Oregon, USA". English. In: Palaeogeography, Palaeoclimatology, Palaeoecology 227 (2005), pp. 210-231. DOI: 10.1016/j.palaeo.2005.04.023.

[3379] J. A. Burns. "Mid-Wisconsinan vertebrates and their environment from January Cave, Alberta, Canada". English. In: Quaternary Research 35.1 (1991), pp. 130-143. 
[3380] M. E. Burns. “Taxonomic utility of ankylosaur (Dinosauria, Ornithischia) osteoderms: Glyptodontopelta mimus Ford, 2000: a test case". English. In: Journal of Vertebrate Paleontology 28.4 (2008), pp. 1102-1109. DOI: 10.1671/0272-4634-28.4.1102.

[3381] M. E. Burns and J. A. Ebersole. New Appalachian armored dinosaur material (Nodosauridae, Ankylosauria) from the Maastrichtian Ripley Formation of Alabama. English. 2016. DOI: 10.1130 / abs / 2016SE-273236.

[3382] M. E. Burns and R. M. Sullivan. "A new ankylosaurid from the Upper Cretaceous Kirtland Formation, San Juan Basin, with comments on the diversity of ankylosaurids in New Mexico". English. In: vol. 53. Fossil Record 3. New Mexico Museum of Natural History and Science Bulletin. Albuquerque: New Mexico Museum of Natural History and Science, 2011, pp. 169-178.

[3383] M. E. Burns and R. M. Sullivan. "The tail club of Nodocephalosaurus kirtlandensis (Dinosauria: Ankylosauridae), with a review of ankylosaurid tail club morphology and homology". English. In: vol. 53. Fossil Record 3. New Mexico Museum of Natural History and Science Bulletin. Albuquerque: New Mexico Museum of Natural History and Science, 2011, pp. 179-186.

[3384] M. E. Burns and M. J. Vavrek. "Probable ankylosaur ossicles from the Middle Cenomanian Dunvegan Formation of northwestern Alberta, Canada". English. In: PLoS One 9.5 (2014), e96075.

[3385] C. Burrett, M. Udchachon, H. Thassanapak, and A. Chitnarin. "Conodonts, radiolarians and ostracodes in the Permian E-Lert Formation, Loei Fold Belt, Indochina Terrane, Thailand". English. In: Geological Magazine 152 (2015), pp. 106-142.

[3386] C. Burrow. "A partial articulated acanthodian from the Silurian of New Brunswick, Canada". English. In: Canadian Journal of Earth Sciences 48 (2011), pp. 1329-1341. DOI: 10.1139/E11-023.

[3387] C. J. Burrow, K. Trinajstic, and J. Long. "First acanthodian from the Upper Devonian (Frasnian) Gogo Formation, Western Australia". English. In: Historical Biology 24.4 (2012), pp. 349-357. DOI: 10.1080/08912963.2012.660150.

[3388] J. W. Busanus and R. D. Hoare. “Bivalves (Mollusca) from the Mauch Chunk Group (Mississippian, Chesterian) of northern West Virginia and southwestern Pennsylvania". In: Journal of Paleontology 65.3 (1991), pp. 465-480.

[3389] A. D. Buscalioni. "The Gobiosuchidae in the early evolution of Crocodyliformes". English. In: Journal of Vertebrate Paleontology 37.3 (2017), e1324459:1-21. DOI: 10.1080/02724634.2017.1324459.

[3390] A. D. Buscalioni, L. Alcalá, E. Esplez, and L. Mampel. “European Goniopholididae from the Early Albian Escucha Formation in Ariño (Teruel, Aragón, España)". English. In: Spanish Journal of Paleontology 28.1 (2013), pp. 103-121.

[3391] A. D. Buscalioni, M. A. Fregenal, A. Bravo, F. J. Poyato-Ariza, B. Sanchz, A. M. Báez, O. Cambra Moo, C. Martn Closas, S. E. Evans, and J. Marugán Lobón. "The vertebrate assemblage of Buenache de la Sierra (upper Barremian of Serrana de Cuenca, Spain) with insights into its taphonomy and palaeoecology". English. In: Cretaceous Research 29 (2008), pp. 671-710. DOI: 10.1016/j. cretres.2008.02.004.

[3392] A. D. Buscalioni and M. Frenegal-Martinez. "Archosaurian size bias in Jurassic and Cretaceous freshwater ecosystems". English. In: 9th International Symposium on Mesozoic Terrestrial Ecosystems and Biota, Abstracts and Proceedings Volume (2006), pp. 9-12.

[3393] A. D. Buscalioni, F. Ortega, D. B. Weishampel, and C. M. Jianu. “A revision of the crocodyliform Allodaposuchus precedens from the Upper Cretaceous of the Hateg Basin, Romania. Its relevance in the phylogeny of Eusuchia". English. In: Journal of Vertebrate Paleontology 21.1 (2001), pp. 74-86.

[3394] A. D. Buscalioni, F. L. Ortega, and D. Vasse. "New crocodiles (Eusuchia: Alligatoroidea) from the Upper Cretaceous of southern Europe". English. In: Compte rendu hebdomadaire des seances de l'Academie des Sciences Paris, terre et des planetes 325 (1997), pp. 525-530.

[3395] A. D. Buscalioni, P. Piras, R. Vullo, M. Signore, and C. Barbera. "Early eusuchia crocodylomorpha from the vertebrate-rich Plattenkalk of Pietraroia (Lower Albian, southern Apennines, Italy)". English. In: Zoological Journal of the Linnean Society 163 (2011), S199-S227. 
[3396] A. D. Buscalioni and J. L. Sanz. "Montsecosuchus depereti (Crocodylomorpha, Atoposauridae), new denomination for Alligatorium depereti Vidal, 1915 (Early Cretaceous, Spain): Redescription and phylogenetic relationships". English. In: Journal of Vertebrate Paleontology 10.2 (1990), pp. 244254.

[3397] A. D. Buscalioni, A. S. Schulp, J. W. M. Jagt, S. S. Hanna, and A. F. Hartman. "Late Cretaceous neosuchian crocodiles from the Sultanate of Oman". English. In: Cretaceous Research 25 (2004), pp. 267-275.

[3398] S. Buser and I. Debeljak. "Lower Jurassic beds with bivalves in south Slovenia”. In: Geologija 37/38 (1996), pp. 23-62.

[3399] S. Buser and I. Debeljak. "Lower Jurassic beds with bivalves in south Slovenia (Spodnjejurske plasti s koljkami v juni Sloveniji)". English. In: Geologija (Ljubljana) 37 (1994), pp. 23-62. DOI: 10. 5474/geologija.1995.001.

[3400] E. Bushuev, E. Goryaeva, and V. Pereladov. "New discoveries of the oldest trilobites Profallotaspis and Nevadella in the northeastern Siberian Platform, Russia". English. In: Bulletin of Geosciences 89.2 (2014), pp. 347-364. DOI: 10.3140/bull.geosci.1406.

[3401] F. Busker and M. T. Dozo. "First confirmed record of Incamys bolivianus (Caviomorpha, Chinchilloidea) in the Deseadan of Patagonia (Argentina)". English. In: Ameghiniana 54.6 (2017), pp. $706-$ 712. DOI: 10.5710/AMGH.24.05.2017.3098.

[3402] F. Busker, M. T. Dozo, and I. M. Soto. "New remains of Cephalomys arcidens (Rodentia, Caviomorpha) and a redefinition of the enigmatic Cephalomyidae". English. In: Journal of Systematic Palaeontology 18.19 (2020), pp. 1589-1629. DOI: 10.1080/14772019.2020.1796833.

[3403] F. Busker, M. E. Pérez, and M. T. Dozo. "A new chinchilloid (Rodentia, Hystricognathi) from the early Miocene of the localities of Bryn Gwyn and Gran Barranca (Patagonia, Argentina)". English. In: Comptes Rendus Palevol 18.5 (2019), pp. 525-540. DOI: 10.1016/j.crpv.2019.05.003.

[3404] F. Busker, M. E. Pérez, J. M. Krause, and M. G. Vucetich. "First record of Banderomys leanzai Kramarz, 2005 (Rodentia, Caviomorpha) in Chubut Province, Patagonia (Argentina)". English. In: Revista del Museo Argentino de Ciencias Naturales 19.2 (2017), pp. 121-129.

[3405] A. Busulini, G. Tessier, and C. Beschin. "The genus Phlyctenodes Milne Edwards, 1862 (Crustacea: Decapoda: Xanthidae) in the Eocene of Europe". English. In: Revista Mexicana de Ciencias Geologicas 23.3 (2006), pp. 350-360.

[3406] A. Busulini, G. Tessier, C. Beschin, and A. de Angeli. “Boschettia giampietroi, nuovo genre e epecie di Portunidae (Crustacea, Decapoda) dell'Eocene medio della valle del Chiamp (Vicenza, Italia Settentrionale)". Italian. In: Studi e Ricerche - Associazione Amici del Museo - Museo Civico G. Zannato 15 (2003), pp. 13-18.

[3407] B. A. Butcher, A. Zaldivar-Riverón, T. Van De Kamp, T. Dos Santos Rolo, T. Baumbach, and D. L. J. Quicke. "Extension of historical range of Betylobraconinae (Hymenoptera: Braconidae) into Palaearctic Region based on a Baltic amber fossil, and description of a new species of Mesocentrus Szépligeti from Papua New Guinea". English. In: Zootaxa 3860 (2014), pp. 449-463.

[3408] E. Butler, F. Abdala, and J. Botha-Brink. "Postcranial morphology of the Early Triassic epicynodont Galesaurus planiceps (Owen) from the Karoo Basin, South Africa". English. In: Papers in Palaeontology (2018). DOI: 10.1002/spp2.1220.

[3409] K. Butler, K. J. Travouillon, G. J. Price, M. Archer, and S. J. Hand. “Cookeroo, a new genus of fossil kangaroo (Marsupialia, Macropodidae) from the Oligo-Miocene of Riversleigh, Northwestern Queensland, Australia". English. In: Journal of Vertebrate Paleontology 36.3 (2016), e1083029. DOI: 10.1080/02724634.2016.1083029.

[3410] P. M. Butler and W. A. Clemens. "Dental morphology of the Jurassic holotherian mammal Amphitherium, with a discussion oif the evolution of mammalian post-canine dental formulae". English. In: Palaeontology 44.1 (2001), pp. 1-20. 
[3411] P. M. Butler and J. J. Hooker. "New teeth of allotherian mammals from the English Bathonian, including the earliest multituberculates". English. In: Acta Palaeontologica Polonica 50.2 (2005), pp. 185-207.

[3412] P. M. Butler and G. T. Macintyre. "Review of the British Haramiyidae (? Mammalia, Allotheria), their molar occlusion and relationships". English. In: Philosophical Transactions: Biological Sciences 345.1314 (1994), pp. 433-458.

[3413] P. M. Butler and D. Sigogneau-Russel. "Diversity of triconodonts in the Middle Jurassic of Great Britain". English. In: Palaeontologia Polonica 67 (2016), pp. 35-65. DOI: 10.4202/pp.2016.67_035.

[3414] P. M. Butler, D. Sigogneau-Russell, and P. C. Ensom. "Possible persistence of the morganucodontans in the Lower Cretaceous Purbeck Limestone Group (Dorset, England)". English. In: Cretaceous Research 33 (2012), pp. 135-145.

[3415] R. J. Butler. "The 'fabrosaurid' ornithischian dinosaurs of the Upper Elliot Formation (Lower Jurassic) of South Africa and Lesotho". English. In: Zoological Journal of the Linnean Society 145.2 (2005), pp. 175-218.

[3416] R. J. Butler, P. M. Barrett, R. L. Abel, and D. J. Gower. “A possible ctenosauriscid archosaur from the Middle Triassic Manda Beds of Tanzania". English. In: Journal of Vertebrate Paleontology 29.4 (2009), pp. 1022-1031.

[3417] R. J. Butler, S. L. Brusatte, M. Reich, S. J. Nesbitt, R. R. Schoch, and J. J. Hornung. “The sail-backed reptile Ctenosauriscus from the latest Early Triassic of Germany and the timing and biogeography of the early archosaur radiation". English. In: Plos One 6.10 (2011), e25693. DOI: 10.1371/journal. pone.0025693.

[3418] R. J. Butler, M. D. Ezcurra, F. C. Montefeltro, A. Samathi, and G. Sobral. "A new species of basal rhynchosaur (Diapsida: Archosauromorpha) from the early Middle Triassic of South Africa, and the early evolution of Rhynchosauria". English. In: Zoological Journal of the Linnean Society 174.3 (2015), pp. 571-588.

[3419] R. J. Butler, P. M. Galton, L. B. Porro, L. M. Chiappe, D. M. Henderson, and G. M. Erickson. “A new Upper Jurassic heterodontosaurid from North America: lower limits of ornithischian dinosaur body size inferred from North America". English. In: Proceedings of the Royal Society B: Biological Sciences 277 (2010), pp. 375-381. DOI: 10.1098/rspb.2009.1494.

[3420] R. J. Butler, S. J. Nesbitt, A. J. Charig, D. J. Gower, and P. M. Barrett. "Mandasuchus tanyauchen, gen. et sp. nov., a pseudosuchian archosaur from the Manda Beds (?Middle Triassic) of Tanzania". English. In: Journal of Vertebrate Paleontology, Memoir 37 (suppl. (2018), pp. 96-121.

[3421] R. J. Butler, L. B. Porro, and D. B. Norman. "A juvenile skull of the primitive ornithischian dinosaur Heterodontosaurus tucki from the 'Stormberg' of southern Africa". English. In: Journal of Vertebrate Paleontology 28.3 (2008), pp. 700-711. DOI: 10.1671/0272-4634(2008)28[702:AJSOTP]2.0.CO;2.

[3422] R. J. Butler, O. W. M. Rauhut, M. R. Stocker, and R. Bronowicz. "Redescription of the phytosaurs Paleorhinus ('Francosuchus') angustifrons and Ebrachosuchus neukami from Germany, with implications for Late Triassic biochronology". English. In: Zoological Journal of the Linnean Society (2014). DOI: $10.1111 /$ zoj.12094.

[3423] R. J. Butler, R. M. H. Smith, and D. B. Norman. "A primitive ornithischian dinosaur from the Late Triassic of South Africa, and the early evolution and diversification of Ornithischia". English. In: Proceedings of the Royal Society of London B 274 (2007), pp. 2041-2046.

[3424] R. J. Butler, A. M. Yates, O. W. M. Rauhut, and C. Foth. "A pathological tail in a basal sauropodomorph dinosaur from South Africa: evidence of traumatic amputation?" English. In: Journal of Vertebrate Paleontology 33.1 (2013), pp. 224-228.

[3425] N. J. Butterfield. Burgess Shale-type fossils from a Lower Cambrian shallow-shelf sequence in northwestern Canada. 1994.

[3426] N. J. Butterfield and C. J. Nicholas. "Burgess Shale-type preservation of both non-mineralizing and 'shelly' Cambrian organisms from the MacKenzie Mountains, Northwestern Canada". In: Journal of Paleontology 70.6 (1996), pp. 893-899. 
[3427] C. J. Buttler. "A new Upper-Ordovician bryozoan fauna from the Slade \& Red Hill beds, South Wales". In: Palaeontology 34 (1991), pp. 77-108.

[3428] C. J. Buttler, L. Cherns, and D. Massa. "Bryozoan mud-mounds from the Upper Ordovician Jifarah (Djeffara) Formation of Tripolitania, north-west Libya". English. In: Palaeontology 50.2 (2007), pp. 479-494.

[3429] S. H. Butts. "Silicified Carboniferous (Chesterian) Brachiopoda of the Arco Hills Formation, Idaho". English. In: Journal of Paleontology 81.1 (2007), pp. 48-63.

[3430] G. W. Byers. "A Miocene Tipula from Nevada (Diptera: Tipulidae)". English. In: Journal of the Kansas Entomological Society 84.3 (2011), pp. 169-173.

[3431] B. Baejowski. "Shark Teeth from the Lower Triassic of Spitsbergen and their histology". English. In: Polish Polar Research 25.2 (2004), pp. 153-167.

[3432] B. Baejowski, C. J. Duffin, P. Gieszcz, K. Makowski, M. Binkowski, M. Calczak, S. A. McDonald, and P. J. Withers. "Saurichthys (Pisces, Actinopterygii) teeth from the Lower Triassic of Spitsbergen, with comments on their stable isotope composition ( $\mathrm{d} 13 \mathrm{C}$ and $\mathrm{d} 18 \mathrm{O}$ ) and X-ray microtomography". English. In: Polish Polar Research 34 (2013), pp. 23-38.

[3433] B. Baejowski, G. Niedwiedzki, K. Boukhalfa, and M. Soussi. "Limulitella tejraensis, a new species of limulid (Chelicerata, Xiphosura) from the Middle Triassic of southern Tunisia (Saharan Platform)". English. In: Journal of Paleontology 91 (2017), pp. 960-967. DOI: 10.1017/jpa.2017.29.

[3434] G. Cabioch and L. K. Ayliffe. "Raised coral terraces at Malakula, Vanuatu, southwest Pacific, indicate high sea level during marine isotope stage 3". English. In: Quaternary Research 56 (2001), pp. 357-365.

[3435] G. Cabioch, K. A. Banks-Cutler, W. J. Beck, G. S. Burr, T. Correge, R. L. Edwards, and F. W. Taylor. "Continuous reef growth during the last $23 \mathrm{cal} \mathrm{kyr}$ BP in a tectonically active zone (Vanuatu, southwest Pacific)". English. In: Quaternary Science Reviews 22 (2003), pp. 1771-1786.

[3436] G. Cabioch, G. F. Camoin, and L. F. Montaggioni. "Postglacial growth history of a French Polynesian barrier reef tract, Tahiti, central Pacific". English. In: Sedimentology 46 (1999), pp. 985-1000.

[3437] G. Cabioch, L. Montaggioni, N. Thouveny, N. Frank, T. Sato, V. Chazottes, H. Dalamasso, C. Payri, M. Pichon, and A. M. Semah. "The chronology and structure of the western New Caledonian barrier reef tracts". English. In: Palaeogeography, Palaeoclimatology, Palaeoecology 268 (2008), pp. 91105.

[3438] G. Cabioch, L. F. Montaggioni, and G. Faure. "Holocene initiation and development of New Caledonian fringing reefs, SW Pacific". English. In: Coral Reefs 14 (1995), pp. 131-140.

[3439] G. Cabioch, F. W. Taylor, J. Recy, R. L. Edwards, S. C. Gray, G. Faure, G. S. Burr, and T. Correge. Environmental and tectonic influence on growth and internal structure of a fringing reef at Tasmaloum (SW Espiritu Santo, New Hebrides island arc, SW Pacific). English. Vol. 25. Reefs and Carbonate Platforms in the pacific and Indian Oceans, IAS Special Publication. 1998, pp. 261-277.

[3440] M. C. Cabral, A. Lord, I. Boomer, I. Loureiro, and H. Malz. "Tanycythere new genus and its significance for Jurassic ostracod diversity". English. In: Journal of Paleontology 88.3 (2014), pp. 519530.

[3441] E. Cabral-Cano, H. R. Lang, and C. G. A. Harrison. "Stratigraphic Assessment of the ArceliaTeloloapan area, Southern Mexico: Implications for Southern Mexico's Post-Neocomian Tectonic Evolution." In: Journal of South American Earth Science 13 (2000), pp. 443-457.

[3442] S. F. Cabreira, A. W. A. Kellner, S. Dias-da-Silva, L. R. da Silva, M. Bronzati, J. C. A. Marsola, R. T. Müller, J. S. Bittencourt, B. J. Batista, T. Raugust, R. Carrilho, A. Brodt, and M. C. Langer. "A unique Late Triassic dinosauromorph assemblage reveals dinosaur ancestral anatomy and diet". English. In: Current Biology 26.22 (2016), pp. 3090-3095. DOI: 10.1016/j.cub.2016.09.040.

[3443] S. F. Cabreira, C. L. Schultz, J. S. Bittencourt, M. B. Soares, D. C. Fortier, L. R. Silva, and M. C. Langer. "New stem-sauropodomorph (Dinosauria, Saurischia) from the Triassic of Brazil". English. In: Naturwissenschaften 98.12 (2011), pp. 1035-1040. DOI: 10.1007/s00114-011-0858-0. 
[3444] L. Cabrera, W. Jung, M. Kirchner, A. Sáez, and H. H. Schleich. “Crocodilian and palaeobotanical findings from the Tertiary Lignites of the As Pontes Basin (Galicia, NW-Spain) (Crocodylia, Plantae)". English. In: Courier Forschungsinstitut Senckenberg 173 (1994), pp. 153-165.

[3445] M. A. Caccavari and M. V. Guler. "Acaciapollenites acaciae sp. nov., a new mimosoid polyad species from the Neogene of Colorado Basin, Argentina". English. In: Ameghiniana 43.3 (2006), pp. 585-590.

[3446] E. Cadena. "The first South American sandownid turtle from the Lower Cretaceous of Colombia". English. In: PeerJ 3:e1431 (2015), pp. 1-24. DOI: 10.7717/ peerj.1431.

[3447] E. Cadena. "A global phylogeny of Pelomedusoides turtles with new material of Neochelys franzeni Schleich, 1993 (Testudines, Podocnemididae) from the middle Eocene, Messel Pit, of Germany". English. In: PeerJ 3.e1221 (2015). DOI: 10.7717/peerj.1221.

[3448] E. Cadena. "Palaeoamyda messeliana nov. comb. (Testudines, Pan-Trionychidae) from the Eocene Messel Pit and Geiseltal localities, Germany, taxonomic and phylogenetic insights". English. In: PeerJ 4 (2016), e2647:1-26. DOI: 10.7717/ peerj.2647.

[3449] E. Cadena, J. Abella, and M. D. Gregori. “New findings of Pleistocene fossil turtles (Geoemydidae, Kinosternidae and". English. In: PeerJ e3215 (2017), pp. 1-15. DOI: 10.7717/peerj.3215.

[3450] E. Cadena, J. Abella, and M. Gregori. "The first Oligocene sea turtle (Pan-Cheloniidae) record of South America". English. In: PeerJ 6.e4554 (2018), pp. 1-10. DOI: 10.7717/peerj.4554.

[3451] E. Cadena, F. Anaya, and D. Croft. "Giant fossil tortoise and freshwater chelid turtle remains from the middle Miocene, Quebrada Honda, Bolivia: Evidence for lower paleoelevations for the southern Altiplano". English. In: Journal of South American Earth Sciences 64 (2015), pp. 190-198. DOI: $10.1016 /$ j.jsames.2015.10.013.

[3452] E. Cadena, J. R. Bourque, A. F. Rincon, J. I. Bloch, C. A. Jaramillo, and B. J. MacFadden. "New turtles (Chelonia) from the late Eocene through Late Miocene of the Panama Canal Basin". English. In: Journal of Paleontology 86.3 (2012), pp. 539-557.

[3453] E. Cadena, C. Jaramillo, and M. E. Paramo. "New material of Chelus colombiana (Testudines; Pleurodira) from the Lower Miocene of Colombia". English. In: Journal of Vertebrate Paleontology 28.4 (2008), pp. 1206-1212.

[3454] E. Cadena and C. Jaramillo. "Early to Middle Miocene turtles from the northernmost tip of South America: giant testudinids, chelids, and podocnemidids from the Castilletes Formation, Colombia". English. In: Ameghiniana 52.2 (2015), pp. 188-203. DOI: 10.5710/AMGH.10.11.2014.2835.

[3455] E. Cadena, C. M. Jaramillo, and M. Paramo. "The first Late Pleistocene record of Kinosternon (Cryptodira: Kinosternidae) turtles from northern South America, Pubenza locality, Colombia". English. In: South American Journal of Herpetology 2.3 (2008), pp. 201-205.

[3456] E. Cadena and W. G. Joyce. "A Review of the Fossil Record of Turtles of the Clades Platychelyidae and Dortokidae". English. In: Bulletin of the Peabody Museum of Natural History 56.1 (2015), pp. 320.

[3457] E. Cadena, A. Vanegas, C. Jaramillo, J. M. Cottle, and T. A. Johnson. "A new Miocene turtle from Colombia sheds light on the evolutionary history of the extant genus Mesoclemmys Gray, 1873". English. In: Journal of Vertebrate Paleontology e1716777 (2020), pp. 1-12. DOI: 10.1080 / 02724634. 2019.1716777.

[3458] E. A. Cadena. "Potential earliest record of podocnemidoid turtles from the Early Cretaceous (Valanginian) of Colombia". English. In: Journal of Paleontology 85.5 (2011), pp. 877-881. DOI: 10.1666/10-097.1.

[3459] E. A. Cadena. "First record of eucryptodiran turtles from the Early Cretaceous (Valanginian), at the northernmost part of South America". English. In: South American Journal of Herpetology 6.1 (2011), pp. 49-53.

[3460] E. A. Cadena, J. I. Bloch, and C. A. Jaramillo. “New podocnemidid turtle (Testudines: Pleurodira) from the middle-upper Paleocene of South America". English. In: Journal of Vertebrate Paleontology 30.2 (2010), pp. 367-382. 
[3461] E. A. Cadena, J. I. Bloch, and C. A. Jaramillo. “New bothremydid turtle (Testudines, Pleurodira) from the Paleocene of Northeastern Colombia". English. In: Journal of Paleontology 86.4 (2012), pp. 688-698. DOI: 10.1666/11-128R1.1.

[3462] E. A. Cadena and J. D. Carrillo-Briceno. “First Fossil of Rhinoclemmys Fitzinger, 1826 (Cryptodira, Geoemydidae) East of the Andes". English. In: South American Journal of Herpetology 14.1 (2019), pp. 19-23. DOI: 10.2994/SAJH-D-17-00099.1.

[3463] E. A. Cadena, D. T. Ksepka, C. A. Jaramillo, and J. I. Bloch. "New pelomedusoid turtles from the late Palaeocene Cerrejon Formation of Colombia and their implications for phylogeny and body size evolution". English. In: Journal of Systematic Palaeontology 10.2 (2012), pp. 313-331.

[3464] E. A. Cadena, D. T. Ksepka, and M. A. Norell. "New material of Mongolemys elegans Khosatzky and Mlynarski, 1971 (Testudines: Lindholmemydidae), from the Late Cretaceous of Mongolia with comments on bone histology and phylogeny". English. In: American Museum Novitates 3766 (2013), pp. 1-28.

[3465] E. A. Cadena and J. F. Parham. "Oldest known marine turtle? A new protostegid from the Lower Cretaceous of Colombia". English. In: PaleoBios 32.1 (2015), pp. 1-42.

[3466] E. A. Cadena, M. L. Parra-Ruge, J. de Parra-Ruge, and S. Padilla-Bernal. “A gravid fossil turtle from the Early Cretaceous reveals a different egg development strategy to that of extant marine turtles". English. In: Palaeontology (2018), pp. 1-13. DOI: 10.1111/pala.12413.

[3467] E. A. Cadena and M. H. Schweitzer. "A Pelomedusoid Turtle from the Paleocene-Eocene of Colombia Exhibiting Preservation of Blood Vessels and Osteocytes". English. In: Journal of Herpetology 48.4 (2014), pp. 461-465.

[3468] E.-A. Cadena. "The first remains of vertebrates from the Paleocene Lisama formation, Middle". English. In: Journal of South American Earth Sciences 103 (2020), p. 102772. DOI: 10.1016/j.jsames. 2020.102745.

[3469] E.-A. Cadena. "Valanginian occurrence of Pelomedusoides turtles in northern South America: revision of this hypothesis based on a new fossil remain". English. In: PeerJ 8.e9810 (2020), pp. 112. DOI: 10.7717 / peerj. 9810 .

[3470] E.-A. Cadena, D. M. Unwin, and D. M. Martill. "Lower Cretaceous pterosaurs from Colombia". English. In: Cretaceous Research (2020), p. 104526. DOI: 10.1016/j.cretres.2020.104526.

[3471] E. A. Cadena Rueda and E. S. Gaffney. "Notoemys zapatocaensis, a new side-necked turtle (Pleurodira: Platychelyidae) from the Early Cretaceous of Colombia". English. In: American Museum Novitates 3470 (2005), pp. 1-19.

[3472] M. Caffau. "Biometrical analysis of three species of the genus Lapeirouseia from the CampanianMaastrichtian of Stranice (North-East Slovenia)". English. In: Geologija 43.2 (2000), pp. 223-234.

[3473] M. Caffau. "Bournonia excavata (D'Orbigny) from the Campanian - Maastrichtian of Stranice (north-east of Slovenia)". English. In: Geologija 45.1 (2002), pp. 91-96.

[3474] M. Caffau, C. Pirini Radrizzani, M. Plenicar, and N. Pugliese. "Rudist fauna and microfossils of the late Senonian (Monte Grisa area, Karst of Trieste, Italy)”. In: Geologica Romana 28 (1992), pp. 163171.

[3475] M. Caffau and M. Plenicar. "Biradiolites zucchii n. sp. from the Cava Romana di Aurisina". Italian. In: Geologija 33 (1990), pp. 207-213.

[3476] M. Caffau, M. Plenicar, N. Pugliese, and K. Drobne. “Late Maastrichtian Rudists and microfossils in the Karst Region (NE Italy and Slovenia)". English. In: Geobios 22 (1998), pp. 37-46.

[3477] M. Caffau, M. Plenicar, and B. Ogorelec. "Remarks on the morphological variability of Biradiolites angulosus D'Orbigny in a sector of the Trieste Karst (Italy)". English. In: Geobios 22 (1998), pp. 2936.

[3478] M. Caffau and M. Plenicar. "Rudist and foraminifer assemblages in the Santonian-Campanian sequence of Nanos Mountain (Western Slovenia)". English. In: Geologija 47.1 (2004), pp. 41-54. DOI: 10.5474/geologija.2004.004. 
[3479] M. Caffau, N. Pugliese, and M. Plenicar. "The development of the mollusc fauna in the Cenomanian of the stratigraphie sequence of Visogliano (Karst of Trieste, Italy)". English. In: Geologija 37 (1995), pp. 87-121.

[3480] M. Caglar and M. Onal. “Systematic Paleontology, Biostratigraphy, Paleobiogeography of Loftusia (Foraminifera) and Rudist Assemblages in a Regressive Sequence in the Hekimhan-Malatya Area (Eastern Anatolia) Turkey". English. In: Geological Society of India 74 (2009), pp. 329-342.

[3481] B. Cahuzac, S. Adnet, H. Cappetta, and R. Vullo. "Les espéces et genres de poissons Sélaciens fossiles (Crétacé, Tertiaire) créés dans le Bassin d'Aquitaine ; recensement, taxonomie". French. In: Bulletin de la Société Linnéenne de Bordeaux 142.35 (2007), pp. 3-43.

[3482] B. Cahuzac and M. Audouin. "About a vertebra of Halitherium (Sirenia), found in the Oligocene Calcaire a Asteries at Rauzan (Gironde). Paleoecologic survey". French. In: Bulletin de la Societe Linneenne de Bordeaux 140.33(3) (2005), pp. 170-192.

[3483] B. Cahuzac, S. Buisson, M. Pommiés, and P. Rocher. "Discovery of two teeth of Squalodon (Cetacea Odontoceti) in the Burdigalian of SW France (Martillac, Leognan). Comments about the Squalodon from Aquitaine Basin, the paleoecology of the outcrops, and the type species of the genus". English. In: Neus Jahrbuch fur Geologie und Palaeontologie, Abhandlungen 238.3 (2005), pp. 413-451.

[3484] B. Cahuzac and C. Chaix. "Structural and faunal evolution of Chattian-Miocene reefs and corals in western France and the northeastern Atlantic Ocean". English. In: SEPM Concepts in Sedimentology and Paleontology 5 (1996), pp. 105-127.

[3485] B. Cahuzac and A. W. Janssen. "Eocene to Miocene holoplanktonic Mollusca (Gastropoda) of the Aquitaine Basin, southwest France". English. In: Scripta geologica 141 (2010), pp. 1-193.

[3486] C. Y. Cai, R. Beattie, and D. Y. Huang. "Jurassic olisthaerine rove beetles (Coleoptera: Staphylinidae): 165 million years of morphological and probably behavioral stasis". English. In: Gondwana Research 28 (2015), pp. 425-431.

[3487] C. Y. Cai, D. J. Clarke, D. Y. Huang, and A. Nel. "A new genus and species of Steninae from the late Eocene of France (Coleoptera, Staphylinidae)". English. In: Alcheringa 38 (2014), pp. 557-562.

[3488] C. Y. Cai, D. J. Clarke, Z. W. Yin, Y. Z. Fu, and D. Y. Huang. “A specialized prey-capture apparatus in mid-Cretaceous rove beetles". English. In: Current Biology 29 (2019), R116-R117. DOI: 10.1016/ j.cub.2019.01.002.

[3489] C. Y. Cai, Y. W. Dou, and D. Edwards. "New observations on a Pridoli plant assemblage from north Xinjiang, northwest China, with comments on its evolutionary and palaeogeographica significance". In: Geological Magazine 130.2 (1993), pp. 155-170.

[3490] C. Y. Cai, H. E. Escalona, L. Q. Li, Z. W. Yin, D. Y. Huang, and M. S. Engel. "Beetle pollination of cycads in the Mesozoic". English. In: Current Biology 28 (2018), pp. 2806-2812.

[3491] C. Y. Cai, J. Hava, and D. Y. Huang. “The earliest Attagenus species (Coleoptera: Dermestidae: Attageninae) from Upper Cretaceous Burmese amber". English. In: Cretaceous Research 72 (2016), pp. 95-99.

[3492] C. Y. Cai, Y. Hsiao, and D. Y. Huang. "A new genus and species of polypore fungus beetle in Upper Cretaceous Burmese amber (Coleoptera, Tetratomidae, Eustrophinae)". English. In: Cretaceous Research 60 (2016), pp. 275-280.

[3493] C. Y. Cai, D. Y. Huang, and A. Solodovnikov. "A new species of Hesterniasca (Coleoptera: Staphylinidae: Tachyporinae) from the Early Cretaceous of China with discussion of its systematic position". English. In: Insect Systematics \& Evolution 42 (2011), pp. 213-220.

[3494] C. Y. Cai and D. Y. Huang. "Megolisthaerus, interpreted as staphylinine rove beetle (Coleoptera: Staphylinidae) based on new Early Cretaceous material from China". English. In: Cretaceous Research 40 (2013), pp. 207-211.

[3495] C. Y. Cai, D. Y. Huang, M. K. Thayer, and A. F. Newton. "Glypholomatine rove beetles (Coleoptera: Staphylinidae): a southern hemisphere Recent group recorded from the Middle Jurassic of China". English. In: Journal of the Kansas Entomological Society 85 (2012), pp. 239-244. 
[3496] C. Y. Cai and D. Y. Huang. "A new species of small-eyed Quedius (Coleoptera: Staphylinidae: Staphylininae) from the Early Cretaceous of China". English. In: Cretaceous Research 44 (2013), pp. 54-57.

[3497] C. Y. Cai and D. Y. Huang. "Sinanthobium daohugouense, a tiny new omaliine rove beetle (Coleoptera: Staphylinidae) from the Middle Jurassic of China". English. In: The Canadian Entomologist 145 (2013), pp. 496-500.

[3498] C. Y. Cai and D. Y. Huang. "Mesocoprophilus clavatus, a new oxyteline rove beetle (Coleoptera: Staphylinidae) from the Early Cretaceous of China". English. In: Insect Systematics \& Evolution 44 (2013), pp. 213-220.

[3499] C. Y. Cai and D. Y. Huang. "Discussion on the systematic position of the oxyteline rove beetle Anotylus archaicus Yue, Makranczy \& Ren, 2012 (Coleoptera: Staphylinidae)". English. In: Insect Systematics \& Evolution 44 (2013), pp. 203-212.

[3500] C. Y. Cai, D. Y. Huang, A. F. Newton, and M. K. Thayer. "Mesapatetica aenigmatica, a new genus and species of rove beetles (Coleoptera, Staphylinidae) from the Middle Jurassic of China". English. In: Journal of the Kansas Entomological Society 87 (2014), pp. 219-224.

[3501] C. Y. Cai and D. Y. Huang. "Diverse oxyporine rove beetles from the Early Cretaceous of China (Coleoptera: Staphylinidae)". English. In: Systematic Entomology 39 (2014), pp. 500-505.

[3502] C. Y. Cai and D. Y. Huang. "The oldest micropepline beetle from Cretaceous Burmese amber and its phylogenetic implications (Coleoptera: Staphylinidae)". English. In: Naturwissenschaften 101 (2014), pp. 813-817.

[3503] C. Y. Cai and D. Y. Huang. "The oldest osoriine rove beetle from Cretaceous Burmese amber (Coleoptera: Staphylinidae)". English. In: Cretaceous Research 52 (2015), pp. 495-500.

[3504] C. Y. Cai and D. Y. Huang. "The oldest aleocharine rove beetle (Coleoptera, Staphylinidae) in Cretaceous Burmese amber and its implications for the early evolution of the basal group of hyperdiverse Aleocharinae". English. In: Gondwana Research 28 (2015), pp. 1579-1584.

[3505] C. Y. Cai and D. Y. Huang. "Cretoleptochromus archaicus gen. et sp. nov., a new genus of ant-like stone beetles in Upper Cretaceous Burmese amber (Coleoptera, Staphylinidae, Scydmaeninae)". English. In: Cretaceous Research 63 (2016), pp. 7-13.

[3506] C. Y. Cai and D. Y. Huang. "The first Mesozoic palmetto beetle (Coleoptera: Smicripidae) in Upper Cretaceous Burmese amber". English. In: Cretaceous Research 64 (2016), pp. 45-49.

[3507] C. Y. Cai and D. Y. Huang. "A new genus of whip-scorpions in Upper Cretaceous Burmese amber: earliest fossil record of the extant subfamily Thelyphoninae (Arachnida: Thelyphonida: Thelyphonidae)". English. In: Cretaceous Research 69 (2017), pp. 100-105.

[3508] C. Y. Cai and D. Y. Huang. "Omma daxishanense sp. nov., a fossil representative of an extant Australian endemic genus recorded from the Late Jurassic of China (Coleoptera: Ommatidae)". English. In: Alcheringa 41 (2017), pp. 277-283.

[3509] C. Y. Cai, D. Y. Huang, A. F. Newton, K. T. Eldredge, and M. S. Engel. "Early evolution of specialized termitophily in Cretaceous rove beetles". English. In: Current Biology 27 (2017), pp. 12291235.

[3510] C. Y. Cai and D. Y. Huang. "First fossil Coloninae from Upper Cretaceous Burmese amber (Coleoptera: Staphylinoidea: Leiodidae)". English. In: Cretaceous Research 77 (2017), pp. 69-74.

[3511] C. Y. Cai and D. Y. Huang. "First definitive fossil agyrtodine beetles: An extant southern hemisphere group recorded from Upper Cretaceous Burmese amber (Coleoptera: Staphylinoidea: Leiodidae)". English. In: Cretaceous Research 78 (2017), pp. 161-165.

[3512] C. Y. Cai and D. Y. Huang. "First fossil thaneroclerid beetle from mid-Cretaceous Burmese amber (Coleoptera: Cleroidea: Thanerocleridae)". English. In: Alcheringa 42 (2018), pp. 115-119.

[3513] C. Y. Cai and D. Y. Huang. "First amber inclusion of a glaresid beetle from the Upper Cretaceous of Myanmar (Coleoptera: Scarabaeoidea)". English. In: Cretaceous Research 90 (2018), pp. 115-119. 
[3514] C. Y. Cai and D. Y. Huang. "First Mesozoic water-penny beetles from Upper Cretaceous Burmese amber (Coleoptera: Psephenidae)". English. In: Cretaceous Research 91 (2018), pp. 202-207.

[3515] C. Y. Cai and D. Y. Huang. "First boganiine beetle in mid-Cretaceous amber from northern Myanmar (Coleoptera: Boganiidae)". English. In: Proceedings of the Geologists' Association 130 (2018), pp. 81-86.

[3516] C. Y. Cai, D. Y. Huang, F. X. Wu, M. Zhao, and N. Wang. “Tertiary water striders (Hemiptera, Gerromorpha, Gerridae) from the central Tibetan Plateau and their palaeobiogeographic implications". English. In: Journal of Asian Earth Sciences 175 (2019), pp. 121-127. DOI: 10.1016/j.jseaes. 2017.12.014.

[3517] C. Y. Cai, J. F. Lawrence, A. lipiski, and D. Y. Huang. "First fossil tooth-necked fungus beetle (Coleoptera: Derodontidae): Juropeltastica sinica gen. n. sp. n. from the Middle Jurassic of China". English. In: European Journal of Entomology 111 (2014), pp. 299-302.

[3518] C. Y. Cai, J. F. Lawrence, A. lipiski, and D. Y. Huang. "Jurassic artematopodid beetles and their implications for the early evolution of Artematopodidae (Coleoptera)". English. In: Systematic Entomology 40 (2015), pp. 779-788.

[3519] C. Y. Cai, J. F. Lawrence, S. Yamamoto, R. A. B. Leschen, A. F. Newton, A. lipiski, Z. W. Yin, D. Y. Huang, and M. S. Engel. "Basal polyphagan beetles in mid-Cretaceous amber from Myanmar: biogeographic implications and long-term morphological stasis". English. In: Proceedings of the Royal Society B 286.20182175 (2019). DOI: 10.1098/rspb.2018.2175.

[3520] C. Y. Cai, R. A. B. Leschen, Y. Liu, and D. Y. Huang. "First fossil jacobsoniid beetle (Coleoptera): Derolathrus groehni n. sp. from Eocene Baltic amber". English. In: Journal of Paleontology 89 (2016), pp. 762-767.

[3521] C. Y. Cai, R. A. B. Leschen, D. S. Hibbett, F. Y. Xia, and D. Y. Huang. “Mycophagous rove beetles highlight diverse mushrooms in the Cretaceous". English. In: Nature Communications 8.14894 (2017), pp. 1-7.

[3522] C. Y. Cai, Y. Liu, and D. Ren. "A new species of Loricera Latreille from Eocene Baltic amber (Coleoptera: Carabidae: Loricerinae)". English. In: Alcheringa 41 (2017), pp. 315-320.

[3523] C. Y. Cai, L. Lu, E. Caron, S. Bortoluzzi, A. F. Newton, M. K. Thayer, and D. Y. Huang. "First piestine rove beetle in Eocene Baltic amber (Coleoptera, Staphylinidae, Piestinae)". English. In: Journal of the Kansas Entomological Society 89 (2016), pp. 345-357.

[3524] C. Y. Cai, C. A. Maier, and D. Y. Huang. "A new riffle beetle in Upper Cretaceous amber from northern Myanmar (Coleoptera: Elmidae)". English. In: Cretaceous Research 89 (2018), pp. 154-159.

[3525] C. Y. Cai, A. F. Newton, D. Y. Huang, and L. Tang. "A new species of Platydracus Thomson, 1858 (Coleoptera, Staphylinidae, Staphylininae) from the upper Eocene Florissant beds, Colorado, USA". English. In: Palaeoworld 23 (2014), pp. 321-326.

[3526] C. Y. Cai, A. F. Newton, M. K. Thayer, R. A. B. Leschen, and D. Y. Huang. "Specialized proteinine rove beetles shed light on insect-fungal associations in the Cretaceous". English. In: Proceedings of the Royal Society B 283 (2016), p. 20161439.

[3527] C. Y. Cai, S. Ouyang, Y. Wang, Z. J. Fang, J. Y. Rong, L. Y. Geng, and X. X. Li. “An Early Silurian vascular plant". In: Nature 379 (1996), p. 592.

[3528] C. Y. Cai, A. E. Z. Short, and D. Y. Huang. “The first skiff beetle (Coleoptera: Myxophaga: Hydroscaphidae) from Early Cretaceous Jehol biota". English. In: Journal of Paleontology 86.1 (2012), pp. 116-119.

[3529] C. Y. Cai, A. Slipiski, and D. Y. Huang. "First false jewel beetle (Coleoptera: Schizopodidae) from the Lower Cretaceous of China". English. In: Cretaceous Research 52 (2015), pp. 490-494.

[3530] C. Y. Cai, A. lipiski, and D. Y. Huang. "The oldest root-eating beetle from the Middle Jurassic of China (Coleoptera, Monotomidae)". English. In: Alcheringa 39 (2015), pp. 488-493. 
[3531] C. Y. Cai, A. lipiski, R. A. B. Leschen, Z. W. Yin, D. Zhuo, and D. Y. Huang. “The first Mesozoic Jacobson's beetle (Coleoptera: Jacobsoniidae) in Cretaceous Burmese amber and biogeographical stasis". English. In: Journal of Systematic Palaeontology 16 (2017), pp. 543-550.

[3532] C. Y. Cai, M. K. Thayer, D. Y. Huang, X. D. Wang, and A. F. Newton. "A basal oxyteline rove beetle (Coleoptera: Staphylinidae) from the Early Cretaceous of China: Oldest record for the tribe Euphaniini". English. In: Comptes Rendus Palevol 12 (2013), pp. 159-163.

[3533] C. Y. Cai, M. K. Thayer, M. S. Engel, A. F. Newton, J. Ortega-Blanco, B. Wang, X. D. Wang, and D. Y. Huang. "Early origin of parental care in Mesozoic carrion beetles". English. In: Proceedings of the National Academy of Sciences 111 (2014), pp. 14170-14174.

[3534] C. Y. Cai, M. K. Thayer, A. F. Newton, Z. W. Yin, and D. Y. Huang. "A new genus of dasycerine rove beetles from Upper Cretaceous Burmese amber and its phylogenetic implications (Coleoptera, Staphylinidae)". English. In: Cretaceous Research 84 (2017), pp. 431-436.

[3535] C. Y. Cai and B. Wang. "The oldest silken fungus beetle from the Early Cretaceous of southern China (Coleoptera: Cryptophagidae: Atomariinae)". English. In: Alcheringa 37 (2013), pp. 452-455.

[3536] C. Y. Cai, E. V. Yan, and D. V. Vasilenko. "First record of Sinoxytelus (Coleoptera: Staphylinidae) from the Urey locality of Transbaikalia, Russia, with discussion on its systematic position". English. In: Cretaceous Research 41 (2013), pp. 237-241.

[3537] C. Y. Cai, E. V. Yan, R. Beattie, B. Wang, and D. Y. Huang. "First rove beetles from the Jurassic Talbragar Fish Bed of Australia (Coleoptera, Staphylinidae)". English. In: Journal of Paleontology 87 (2013), pp. 650-656.

[3538] C. Y. Cai, Z. W. Yin, Y. Liu, and D. Y. Huang. "Protonicagus tani gen. et sp. nov., the first stag beetles from Upper Cretaceous Burmese amber (Coleoptera: Lucanidae: Aesalinae: Nicagini)". English. In: Cretaceous Research 78 (2017), pp. 109-112.

[3539] C. Y. Cai, Z. W. Yin, and D. Y. Huang. "A new ripiphorid beetle from Upper Cretaceous Burmese amber sheds light on early evolution of the extant subfamily Ripidiinae (Coleoptera: Ripiphoridae)". English. In: Comptes Rendus Palevol 17 (2018), pp. 351-356.

[3540] Y. Cai, H. Hua, S. Xiao, J. D. Schiffbauer, and P. Li. "Biostratinomy of the Late Ediacaran pyritized Gaojiashan Lagerstätte from southern Shaanxi, south China: importance of event deposits". English. In: Palaios 25 (2010), pp. 487-506.

[3541] Y. Cai, S. Xiao, G. Li, and H. Hua. "Diverse biomineralizing animals in the terminal Ediacaran Period herald the Cambrian explosion". English. In: Geology 47.4 (2019). DOI: 10.1130/G45949.1.

[3542] Y. P. Cai, Y. Y. Zhao, C. K. Shih, and D. Ren. "A new genus of Scolebythidae (Hymenoptera: Chrysidoidea) from the Early Cretaceous of China". English. In: Zootaxa 3504 (2012), pp. 56-66.

[3543] Z. Cai and F. Wei. "Zhejiangopterus linhaiensis (Pterosauria) from the Upper Cretaceous of Linhai, Zhejiang, China". Chinese. In: Vertebrata PalAsiatica 32.3 (1994), pp. 181-194.

[3544] Z. Cai and L. Zhao. "[A long-tailed bird from the Late Cretaceous of Zhejiang]". Chinese. In: Science in China (Scientia Sinica), Series D 42.4 (1999), pp. 434-441.

[3545] H. Caine and M. J. Benton. "Ichthyosauria from the Upper Lias of Strawberry Bank, England". English. In: Palaeontology 54.5 (2011), pp. 1069-1093.

[3546] B. Cairncross, N. J. Beukes, L. L. Coetzee, and U. Rehfeld. "The Bivalve Megadesmus from the Permian Volksrust Shale Formation (Karoo Supergroup), northeastern Karoo Basin, South Africa: implications for late Permian Basin development". English. In: South African Journal of Geology 108 (2005), pp. 547-556.

[3547] S. D. Cairns. "A generic revision and phylogenetic analysis of the Dendrophylliidae (Cnidaria: Scleractinia)". English. In: Smithsonian Contributions to Zoology 615 (2001), pp. 1-75.

[3548] S. D. Cairns. "A generic revision and phylogenetic analysis of the Turbinoliidae". English. In: Smithsonian Contributions to Zoology 591 (1997), pp. 1-55.

[3549] S. D. Cairns. "A new species of Sphenotrochus (Scleractinia: Turbinoliidae) from the Late Miocene (Tortonian) of Chile". English. In: Zoologische Verhandelingen 345.31 (2003), pp. 79-84. 
[3550] S. D. Cairns. "New records of azooxanthellate stony corals (Cnidaria: Scleractinia and Stylasteridae) from the Neogene of Panama and Costa Rica". English. In: Proceedings of the Biological Society of Washington 108.3 (1995), pp. 533-550.

[3551] S. D. Cairns. "The azooxanthellate Scleractinia (Coelenterata: Anthozoa) of Australia". English. In: Records of the Australian Museum 56.3 (2004), pp. 259-329.

[3552] S. D. Cairns. "Scleractinia of the Temperate North Pacific". English. In: Smithsonian Contributions to Zoology 557 (1994), pp. 1-150.

[3553] S. D. Cairns. "New azooxanthellate genus of Scleractinia (Flabellidae) from the Australian Cenozoic". English. In: Journal of Paleontology 91.3 (2017), pp. 407-416. DOI: 10.1017/jpa.2016.83.

[3554] S. D. Cairns and J. A. Grant-Mackie. "Review of the fossil Stylasteridae (Cnidaria: Hydrozoa) from the New Zealand region". English. In: New Zealand Journal of Geology and Geophysics 36 (1993), pp. 1-8.

[3555] L. Calabrese and M. Balini. "The discovery of ammonoids in the Cunardo Formation (Varese). A new chronostratigraphic interpretation". English. In: Rivista Italiana di Paleontologia e Stratigrafia 101.3 (1995), pp. 367-370.

[3556] M. W. Caldwell. “On the aquatic squamate Dolichosaurus longicollis (Cenomanian, Upper Cretaceous), and the evolution of elongate necks in squamates". English. In: Journal of Vertebrate Paleontology 20.4 (2000), pp. 720-735.

[3557] M. W. Caldwell. "Description and phylogenetic relationships of a new species of Coniasaurus Owen, 1850 (Squamata)". English. In: Journal of Vertebrate Paleontology 19.3 (1999), pp. 438-455.

[3558] M. W. Caldwell and G. L. Bell Jr. "Halisaurus sp. (Mosasauridae) from the Upper Cretaceous (Santonian) of east-central Peru, and the taxonomic utility of mosasaur cervical vertebrae". English. In: Journal of Vertebrate Paleontology 15.3 (1995), pp. 532-544.

[3559] M. W. Caldwell, R. L. Carroll, and H. Kaiser. "The pectoral girdle and forelimb of Carsosaurus marchesetti (Aigialosauridae), with a preliminary phylogenetic analysis of mosasauroids and varanoids". English. In: Journal of Vertebrate Paleontology 15.3 (1995), pp. 516-531.

[3560] M. W. Caldwell and B. D. E. Chatterton. "Phylogenetic analysis of some Silurian rostroconchs (Mollusca) from northwestern Canada". In: Canadian Journal of Earth Sciences 32 (1995), pp. 806827.

[3561] M. W. Caldwell and J. A. Cooper. "Redescription, palaeobiogeography and palaeoecology of Coniasaurus crassidens Owen, 1850 (Squamata) from the Lower Chalk (Cretaceous; Cenomanian) of SE England". English. In: Zoological Journal of the Linnean Society of London 127 (1999), pp. 423-452.

[3562] M. W. Caldwell, R. Holmes, G. L. Bell Jr., and J. Wiffen. "An unusual tylosaurine mosasaur from New Zealand: a new skull of Taniwhasaurus oweni (Lower Haumurian; Upper Cretaceous)". English. In: Journal of Vertebrate Paleontology 25.2 (2005), pp. 393-401.

[3563] M. W. Caldwell and T. Konishi. "Taxonomic re-assignment of the first-known mosasaur specimen from Japan, and a discussion of circum-Pacific mosasaur paleobiogeography". English. In: Journal of Vertebrate Paleontology 27.2 (2007), pp. 517-520.

[3564] M. W. Caldwell, T. Konishi, I. Obata, and K. Muramoto. "A new species of Taniwhasaurus (Mosasauridae, Tylosaurinae) from the Upper Santonian-Lower Campanian (Upper Cretaceous) of Hokkaido, Japan". English. In: Journal of Vertebrate Paleontology 28.2 (2008), pp. 339-348.

[3565] M. W. Caldwell and M. S. Y. Lee. "A snake with legs from the marine Cretaceous of the Middle East". English. In: Nature 386 (1997), pp. 705-709.

[3566] M. W. Caldwell and M. S. Y. Lee. "Reevaluation of the Cretaceous marine lizard Acteosaurus crassicostatus Calligaris, 1993". English. In: Journal of Paleontology 78.3 (2004), pp. 617-619.

[3567] M. W. Caldwell, R. L. Nydam, A. Palci, and S. Apestegua. "The oldest known snakes from the Middle Jurassic-Lower Cretaceous provide insights on snake evolution". English. In: Nature Communications 6.5996 (2015), pp. 1-11. DOI: 10.1038/ncomms6996. 
[3568] M. W. Caldwell and A. Palci. "A new basal mosasauroid from the Cenomanian (U. Cretaceous) of Slovenia with a review of mosasauroid phylogeny and evolution". English. In: Journal of Vertebrate Paleontology 27.4 (2007), pp. 863-880.

[3569] M. W. Caldwell and A. Palci. "A new species of marine ophidiomorph lizard, Adriosaurus skrbinensis, from the Upper Cretaceous of Slovenia". English. In: Journal of Vertebrate Paleontology 30.3 (2010), pp. 747-755.

[3570] M. W. Caldwell and A. M. Albino. "Palaeoenvironment and palaeoecology of three Cretaceous snakes: Pachyophis, Pachyrhachis, and Dinilysia." In: Acta Palaeontologica Polonica 46.2 (2001), pp. 203-218.

[3571] J. J. Calede, W. A. Kehl, and E. B. Davis. “Craniodental morphology and diet of Leptarctus oregonensis (Mammalia, Carnivora, Mustelidae) from the Mascall Formation (Miocene) of central Oregon". English. In: Journal of Paleontology (2017), pp. 1-16. DOI: 10.1017/jpa.2017.78.

[3572] J. J. M. Calede and S. S. B. Hopkins. “New Material of Alphagaulus pristinus (Mammalia, Rodentia, Mylagaulidae) from the Deep River Formation (Montana, U.S.A.): Implications for Ecology, Ontogeny, and Phylogeny". English. In: Journal of Vertebrate Paleontology 32.1 (2012), pp. 151-165. DOI: $10.1080 / 02724634.2012 .634356$.

[3573] J. J. M. Calede, J. D. Orcutt, W. A. Kehl, and B. D. Richards. “The first tetrapod from the midMiocene Clarkia lagerstatte". English. In: PeerJ 6.e4880 (2018). DOI: 10.7717/peerj.4880.

[3574] J. J. M. Calede and J. X. Samuels. “A new species". English. In: Journal of Systematic Palaeontology (2020), pp. 1-20. DOI: 10.1080/14772019.2020.1765889.

[3575] V. Calisto and G. Piñeiro. "A large cockroach from the mesosaur-bearing Konservat-Lagerstätte (Mangrullo Formation), Late Paleozoic of Uruguay". English. In: PeerJ 7.e6289 (2019). DOI: 10. 7717 / peerj.6289.

[3576] P. Callapez and A. Ferreira Soares. "Late Quaternary warm marine mollusks from Santa Maria (Azores) paleoecologic and paleobiogeographic considerations". English. In: Ciencias da Terra 14 (2000), pp. 313-322.

[3577] M. Calner, M. E. Eriksson, E. N. K. Clarkson, and L. Jeppsson. "An atypical intra-platform environment and biota from the Silurian of Gotland, Sweden". English. In: Gff 130.2 (2008), pp. 7986.

[3578] M. Calner and L. Jeppsson. "Carbonate platform evolution and conodont stratigraphy during the middle Silurian Mulde Event, Gotland, Sweden". English. In: Geological Magazine (2003). DOI: 10.1017/S0016756802007070.

[3579] M. Calner, O. Sandström, and M. A. Motus. "Significance of a halysitid-heliolitid mud-facies autobiostrome from the Middle Silurian of Gotland, Sweden". English. In: Palaios 15 (2000), pp. 511523.

[3580] G. Calvano, D. R. Prothero, J. Ludtke, and E. B. Lander. "Magnetic stratigraphy of the Eocene to Miocene Sespe and Vaqueros formations, Los Angeles and Orange counties, California". English. In: Natural History Museum of Los Angeles County Science Series 41 (2008), pp. 43-61.

[3581] C. R. Calver. "Isotope stratigraphy of the Ediacarian (Neoproterozoic III) of the Adelaide Rift Complex, Australia, and the overprint of water column stratification". English. In: Precambrian Research 100 (2000), pp. 121-150.

[3582] F. Calvet and M. E. Tucker. Mud-mounds with reefal caps in the Upper Muschelkalk (Triassic), eastern Spain. English. Vol. 23. in C. L. V. Monty, D. W. J. Bosence, P. H. Bridges, B. R. Pratt, eds., Carbonate mud-mounds - their origin and evolution. Special Publication International Association of Sedimentologists. 1995, pp. 311-333.

[3583] F. Calvet, I. Zamarreno, and D. Valles. "Late Miocene reefs of the Alicante-Elche Basin, southeast Spain". English. In: SEPM Concepts in Sedimentology and Paleontology 5 (1996), pp. 177-190. 
[3584] J. O. Calvo. Dinosaurs and other vertebrates of the Lake Ezequiel Ramos Mexa area, Neuquén-Patagonia, Argentina. English. Vol. 15. Y. Tomida, T. H. Rich, and P. Vickers-Rich (eds.), Proceedings of the Second Gondwanan Dinosaur Symposium, National Science Museum Monographs. 1999, pp. 1345.

[3585] J. O. Calvo. "Huellas de dinosaurios en la Formación Ro Limay (Albiano-Cenomaniano?), Picun Leufú, Provincia de Neuquén, Republica Argentina. (Ornithischia-Saurischia: SauropodaTheropoda) [Dinosaur footprints in the Ro Limay Formation (Albian-Cenomanian?), Picun Leufú, Neuquén Province, Argentine Republic. (Ornithischia-Saurischia: Sauropoda-Theropoda)]". Spanish. In: Ameghiniana 28.3-4 (1991), pp. 241-258.

[3586] J. O. Calvo. “Ichnology". English. In: Patagonian Mesozoic Reptiles. Bloomington: Indiana University Press, 2007, pp. 314-334.

[3587] J. O. Calvo and J. F. Bonaparte. “Andesaurus delgadoi gen. et sp. nov. (Saurischia-Sauropoda), dinosaurio Titanosauridae de la Formacion Rio Limay (Albiano-Cenomaniano), Neuquén, Argentina [Andesaurus delgadoi gen. et sp. nov. (Saurischia-Sauropoda), a titnosaurid dinosaur from Rio Limay Formation (Albian-Cenomanian), Neuquén, Argentina]". Spanish. In: Ameghiniana 28.3-4 (1991), pp. 303-310.

[3588] J. O. Calvo and B. Gonzalez Riga. "Baalsaurus mansillai gen. et sp. nov. a new titanosaurian sauropod (Late Cretaceous) from Neuquén, Patagonia, Argentina". English. In: Anais da Academia Brasileira de Ciencias 91.2 (2019), e20180661:-11. DOI: 10.1590/0001-3765201820180661.

[3589] J. O. Calvo and B. J. González Riga. "Rinconsaurus caudamirus gen. et sp. nov., a new titanosaurid (Dinosauria, Sauropoda) from the Late Cretaceous of Patagonia, Argentina". English. In: Revista Geológica de Chile 30.2 (2003), pp. 333-353.

[3590] J. O. Calvo, B. J. González Riga, and J. D. Porfiri. “A new titanosaur sauropod from the Late Cretaceous of Neuquén, Patagonia, Argentina". English. In: Arquivos do Museu Nacional, Rio de Janeiro 65.4 (2007), pp. 485-504.

[3591] J. O. Calvo and A. W. A. Kellner. "Description of a sauropod dinosaur braincase (Titanosauridae) from the Late Cretaceous Ro Colorado Subgroup, Patagonia". English. In: Anais da Academia Brasileira de Ciencias 78.1 (2006), pp. 175-182.

[3592] J. O. Calvo and M. G. Lockley. "The first pterosaur tracks from Gondwana". In: Cretaceous Research 22 (2001), pp. 585-590.

[3593] J. O. Calvo and G. V. Mazzetta. "Nuevos hallazgos de huellas de dinosaurios en la Formación Candeleros (Albiano-Cenomaniano), Picún Leufú, Neuquén, Argentina". Spanish. In: Ameghiniana 41.4 (2004), pp. 545-554.

[3594] J. O. Calvo and G. V. Mazzetta. Nuevos hallazgos de huellas de dinosaurios en la Formación Ro Limay (Albiano-Cenomaniano), Picún Leufú, Argentina [New discoveries of dinosaur tracks in the Ro Limay Formation (Albian-Cenomanian), Picún Leufú, Argentina]. Spanish. 2002.

[3595] J. O. Calvo, K. Moreno, and D. Rubilar-Rogers. A new record of a titanosaurid sauropod from Los Barreales lake, Neuquén Province, Argentina. English. 1999.

[3596] J. O. Calvo, J. D. Porfiri, and A. W. A. Kellner. “On a new maniraptoran dinosaur (Theropoda) from the Upper Cretaceous of Neuquén, Patagonia, Argentina". English. In: Arquivos do Museu Nacional, Rio de Janeiro 62.4 (2004), pp. 549-566.

[3597] J. O. Calvo and J. D. Porfiri. More evidence of basal iguanodontians from Barreales Lake (upper Turonianlower Coniacian), Neuquén, Patagonia, Argentina. English. 2003.

[3598] J. O. Calvo, J. D. Porfiri, B. J. González Riga, and A. W. A. Kellner. “A new Cretaceous terrestrial ecosystem from Gondwana with the description of a new sauropod dinosaur". English. In: Anais da Academia Brasileira de Ciencias 79.3 (2007), pp. 529-541.

[3599] J. O. Calvo, J. D. Porfiri, and F. E. Novas. "Discovery of a new ornithopod dinosaur from the Portezuelo Formation (Upper Cretaceous), Neuquén, Patagonia, Argentina". English. In: Arquivos do Museu Nacional, Rio de Janeiro 65.4 (2007), pp. 471-483. 
[3600] J. O. Calvo and J. D. Porfiri. “Panamericansaurus schroederi gen. nov. sp. nov. Un nuevo Sauropoda (Titanosauridae-Aeolosaurini) de la Provincia del Neuquén, Cretácico Superior de Patagonia, Argentina [Panamericansaurus schroederi gen. nov. sp. nov. A new Sauropoda (TitanosauridaeAeolosaurini) from Neuquén Province, Upper Cretaceous of Patagonia, Argentina]". Spanish. In: Brazilian Geographical Journal: Geosciences and Humanities Research Medium 1 (2010), pp. 100-115.

[3601] J. O. Calvo and J. D. Porfiri. "New material of Peirosaurids from Neuquén, Patagonia: its age". English. In: Brazilian Geographical Journal: Geosciences and Humanities research medium 1 (2010), pp. 5064 .

[3602] J. O. Calvo, D. Rubilar-Rogers, and K. Moreno. “A new Abelisauridae (Dinosauria: Theropoda) from northwest Patagonia". English. In: Ameghiniana 41.4 (2004), pp. 555-563.

[3603] J. O. Calvo and L. Salgado. "Rebbachisaurus tessonei sp. nov. a new Sauropoda from the AlbianCenomanian of Argentina; new evidence on the origin of the Diplodocidae". English. In: GAIA 11 (1995), pp. 13-33.

[3604] S. Calzada. "Gasteropodos hauterivienses de Castellfort (Castellon)". Spanish. In: Batalleria (Barcelona) 6 (1996), pp. 67-75.

[3605] S. Calzada and M. Mar Urquiola. Algunos nerineidos del Cretacico de Castellon. Spanish. 1995.

[3606] S. Calzada, B. Peybernes, F. Kamoun, and M. B. Youssef. “Tunethyris, un nouveau genre de brachiopode du Trias de Tunisie centrale [Tunethyris, a new genus of Triassic brachiopod from central Tunisia]". French. In: Revue de Paleobiologie 13.1 (1994), pp. 117-124.

[3607] H. H. Camacho, J. O. Chiesa, S. G. Parma, and C. J. del Rio. "Invertebrado marinos eocenos de los cerros Palique y Castillo, subdoeste de la provincia de Santa Cruz, Argentina". Spanish. In: Ameghiniana 37.1 (2000), pp. 59-72.

[3608] J. M. F. Camargo. “The Extinct Fauna of Stingless Bees (Hymenoptera: Apidae: Meliponini) in Dominican Amber: Two New Species and Redescription of the Male of Proplebeia dominicana (Wille and Chandler)". English. In: American Museum Novitates 3293 (2000), pp. 1-24.

[3609] O. Cambra-Moo, F. Barroso-Barcenilla, A. Berreteaga, B. Carenas, F. Coruña, L. Domingo, M. S. Domingo, A. Elvira, F. Escaso, F. Ortega, A. Pérez-Garca, D. Peyrot, J. L. Sanz, M. Segura, A. Sopelana, and A. Torices. "Preliminary taphonomic approach to Lo Hueco palaeontological site (Upper Cretaceous, Cuenca, Spain)". English. In: Geobios 45 (2012), pp. 157-166. DOI: 10.1016/j. geobios.2011.04.002.

[3610] O. Cambra-Moo, A. D. Buscalioni, J. Cubo, J. Castanet, M. -M. Loth, E. de Margerie, and A. de Ricqlés. "Histological observations of enantiornithine bone (Saurischia, Aves) from the Lower Cretaceous of Las Hoyas (Spain)". English. In: Comptes Rendus Palevol 5 (2006), pp. 685-691. DOI: 10.1016/j.crpv.2005.12.018.

[3611] A. Camens and R. Wells. "Diprotodontid footprints from the Pliocene of Central Australia". English. In: Journal of Vertebrate Paleontology 29.3 (2009), pp. 863-869.

[3612] A. B. Camens and R. T. Wells. "Palaeobiology of Euowenia grata (Marsupialia: Diprotodontinae) and its Presence in Northern South Australia". English. In: Journal of Mammal Evolution 17 (2010), pp. 3-19. DOI: 10.1007/s10914-009-9121-2.

[3613] C. B. Cameron. "Saccoglossus testa from the Mazon Creek fauna (Pennsylvanian of Illinois) and the evolution of acorn worms (Enteropneusta: Hemichordata)". English. In: Palaeontology 59 (2016), pp. 329-336.

[3614] G. Camoin and L. F. Montaggioni. "High energy coralgal-stromatolite frameworks from Holocene reefs". English. In: Sedimentology 41 (1994), pp. 655-676.

[3615] G. F. Camoin, M. Colonna, L. F. Montaggioni, J. Casanova, G. Faure, and B. A. Thomassin. “Holocene sea level changes and reef development in the southwestern Indian Ocean". English. In: Coral Reefs 16 (1997), pp. 247-259.

[3616] G. F. Camoin, P. Ebren, A. Eisenhauer, E. Bard, and G. Faure. “A 300000-yr coral reef record of sea level changes, Mururoa atoll (Tuamotu archipelago, French Polynesia)". English. In: Palaeogeography, Palaeoclimatology, Palaeoecology 175 (2001), pp. 325-341. 
[3617] G. F. Camoin, Y. Iryu, and D. B. McInroy. “Tiarei outer ridge: Sites M0009, M0021, and M0024M0026". English. In: Proceedings of the Integrated Ocean Drilling Program 310 (2007), pp. 1-94.

[3618] G. F. Camoin, Y. Iryu, and D. B. McInroy. "Maraa western transect: Sites M0005-M0007". English. In: Proceedings of the Integrated Ocean Drilling Program 310 (2007), pp. 1-91.

[3619] G. F. Camoin, Y. Iryu, and D. B. McInroy. "Faaa: Sites M0019 and M0020". English. In: Proceedings of the Integrated Ocean Drilling Program 310 (2007), pp. 1-44.

[3620] G. F. Camoin, L. F. Montaggioni, and C. J. R. Braithwaite. "Late glacial to post glacial sea levels in the western Indian Ocean". English. In: Marine Geology 206 (2004), pp. 119-146.

[3621] G. F. Camoin, A. A. Vanneau, D. D. Bergersen, M. Colonna, P. Ebren, P. Enos, and J. G. Ogg. Anatomy and evolution of the inner perimeter ridge (sites 874 and 877) of a Campanian-Maastrichtian atoll-like structure (Wodejebato Guyot, Marshall Islands). English. Vol. 144. in J. A. Haggerty, I. Premoli Silva, F. Rack and M. K. McNutt, eds., Proceedings of the Ocean Drilling Program, Scientific Results. 1995, pp. 271-294.

[3622] D. Campbell. "New molluscan faunas from the Eocene of South Carolina". English. In: Tulane Studies in Geology and Paleontology 27 (1995), pp. 119-152.

[3623] H. J. Campbell. "The Triassic bivalves Daonella and Halobia in New Zealand, New Caledonia, and Svalbard." In: Institute of Geological and Nuclear Sciences Monograph 4 (1994), pp. 1-165.

[3624] H. J. Campbell and J. A. Grant-Mackie. "Jurassic Pholadomyidae (Bivalvia) from New Zealand and New Caledonia". English. In: New Zealand Journal of Geology and Geophysics 38 (1995), pp. 4759.

[3625] J. A. Campbell, C. J. Schroder-Adams, J. W. Haggart, P. S. Druckenmiller, M. J. Ryan, and G. D. Zazula. "First records of a plesiosaurian (Reptilia: Sauropterygia) and an ichthyosaur (Reptilia: Ichthyosauria) from Yukon, Canada". English. In: Canadian Field-Naturalist 127.3 (2013), pp. 234239.

[3626] J. D. Campbell. "A Late Triassic spiriferinacean brachiopod (family Laballidae) from the Taringatura Hills, Southland, New Zealand". English. In: New Zealand Journal of Geology and Geophysics 34 (1991), pp. 359-363.

[3627] J. D. Campbell. “Late Triassic brachiopods from a dredge haul on the slope below Rowley Terrace, northwest Australia". English. In: AGSO Journal of Australian Geology and Geophysics 15.1 (1994), pp. 135-136.

[3628] J. D. Campbell, D. S. Coombs, and A. Grebneff. "Willsher Group and geology of the Triassic Kaka Point coastal section, south-east Otago, New Zealand". English. In: Journal of the Royal Society of New Zealand 33.1 (2003), pp. 7-38.

[3629] K. E. Campbell and Z. M. Bochenski. "A new genus for the extinct late Pleistocene owl Strix brea Howard (Aves: Strigiformes) from Rancho La Brea, California". English. In: Records of the Australian Museum 62 (2010), pp. 123-144.

[3630] K. E. Campbell, C. D. Frailey, and L. Romero-Pittman. The Late Miocene Gomphothere Amahuacatherium peruvium (Proboscidea: Gomphotheriidae) from Amazonian Peru: Implications for the great american faunal interchange. English. INGEMMET, Boletin N. 23. Lima (Peru): INGEMMET, 2000, pp. 1-127.

[3631] K. E. Campbell, C. D. Frailey, and L. Romero-Pittman. "The Pan-Amazonia Ucayali peneplain, late Neogene sefimentation in Amazonia, and the birth of the modern Amazon river system". English. In: Palaeogeography, Palaeoclimatology, Palaeoecology 239 (2006), pp. 166-219. DOI: 10.1016/ J.PALAEO.2006.01.020.

[3632] K. S. W. Campbell, R. E. Barwick, and T. J. Senden. "Evolution of dipnoans (lungfish) in the Early Devonian of southeastern Australia". English. In: Alcheringa 33 (2009), pp. 59-78. DOI: 10.1080 / 03115510802618300.

[3633] K. S. W. Campbell and R. E. Barwick. "A new species of the Devonian lungfish Dipnorhynchus from Wee Jasper, New South Wales". English. In: Records of the Australian Museum 51 (1999), pp. 123-140. 
[3634] K. S. W. Campbell and R. E. Barwick. "A new tooth-plated dipnoan from the Upper Devonian Gogo Formation and its relationships". English. In: Memoirs of the Queensland Museum 42.2 (1998), pp. 403-437.

[3635] K. S. W. Campbell, R. E. Barwick, B. D. E. Chatterton, and T. R. Smithson. "A new Middle Devonian dipnoan from Morocco: structure and histology of the dental plates". English. In: Records of the Western Australian Museum 21 (2002), pp. 39-61.

[3636] L. D. Campbell and E. G. Otvos. "Neogene bivalve Rangia (Miorangia) johnsoni; taxonomy, depositional facies and stratigriphic range". In: Tulane Studies in Geology and Paleontology 25 (1992), pp. 157-169.

[3637] M. J. Campbell and B. D. E. Chatterton. "Late Ordovician and Silurian lichid trilobites from Northwestern Canada: Hemiarges, Borealarges, and Richterarges". English. In: Journal of Paleontology 81.6 (2007), pp. 1348-1364. DOI: 10.1666/06-008.1.

[3638] M. J. Campbell and B. D. E. Chatterton. "Late Ordovician and Silurian lichid trilobites from northwestern Canada: eight new species from subfamilies Lichinae, Platylichinae, and Trochurinae". English. In: Journal of Paleontology 80.3 (2006), pp. 514-528.

[3639] M. R. Campbell and L. D. Campbell. "Preliminary biostratigraphy and molluscan fauna of the Goose Creek Limestone of eastern South Carolina". English. In: Tulane Studies in Geology and Paleontology 27 (1995), pp. 53-100.

[3640] R. A. Campbell, N. J. Gales, G. M. Lento, and C. S. Baker. "Islands in the sea: extreme female natal site fidelity in the Australian sea lion, Neophoca cinerea". English. In: Biology Letters 4 (2009), pp. 139-142.

[3641] M. Campbell Mekarski, D. Japundi, K. Krizmani, and M. W. Caldwell. “Description of a new basal mosasauroid from the Late Cretaceous of Croatia," English. In: Journal of Vertebrate Paleontology (2019), e1577872:1-15. DOI: 10.1080/02724634.2019.1577872.

[3642] K. Camphuysen, C. Smeenk, M. Addink, H. van Grouw, and O. E. Jansen. "Cetaceans stranded in the Netherlands from 1998 to 2007". English. In: Lutra 51.2 (2008), pp. 87-122.

[3643] M. J. Campi, S. Z. Shen, M. S. Leman, and G. R. Shi. "First record of Permianella He \& Zhu, 1979 (Permianellidae; Brachiopoda) from peninsular Malaysia". English. In: Alcheringa 24 (2000), pp. 37-43.

[3644] M. J. Campi and G. R. Shi. "New Lopingian (Late Permian) rugosochonetid species from Sichuan, South China". English. In: Alcheringa 29.2 (2005), pp. 275-285.

[3645] M. J. Campi, G. R. Shi, and M. S. Leman. “Guadalupian (Middle Permian) brachiopods from Sungai Toh, a Leptodus Shale locality in the central belt of peninsular Malaysia". English. In: Palaeontographica Abteilung A 273.3-6 (2005), pp. 97-160.

[3646] M. J. Campi and G. R. Shi. "The Linshuichonetes-Crurithyris community and new productid species from the Cisuralian (Early Permian) of Sichuan, China". English. In: Alcheringa 31 (2007), pp. 185-198.

[3647] C. J. Campisano, E. C. Kirk, K. E. B. Townsend, and A. L. Deino. “Geochronological and Taxonomic Revisions of the Middle Eocene Whistler Squat Quarry (Devil's Graveyard Formation, Texas) and Implications for the Early Uintan in Trans-Pecos Texas". English. In: PLoS ONE 9.7 (2014), e101516. DOI: 10.1371/journal.pone.0101516.

[3648] D. A. Campos and A. W. A. Kellner. "Short note on the first occurrence of Tapejaridae in the Crato Member (Aptian), Santana Formation, Araripe Basin, northeast Brazil". English. In: Anais da Academia Brasileira de Ciencias 69 (1997), pp. 83-87.

[3649] D. A. Campos, G. R. Oliveira, R. G. Figueiredo, D. Riff, S. A. K. Azevedo, L. B. Carvalho, and A. W. A. Kellner. "On a new peirosaurid crocodyliform from the Upper Cretaceous, Bauru Group, southeastern Brazi". English. In: Anais da Academia Brasileira de Ciencias 83.1 (2011), pp. 317-327.

[3650] D.d.A. Campos, A. W. A. Kellner, R. J. Bertini, and R. M. Santucci. "On a titanosaurid (Dinosauria, Sauropoda) vertebral column from the Bauru Group, Late Cretaceous of Brazil". English. In: Arquivos do Museu Nacional, Rio de Janeiro 63.3 (2005), pp. 565-593. 
[3651] D.d.A. Campos, J. M. Suarez, D. Riff, and A. W. A. Kellner. "Short note on a new Baurusuchidae (Crocodyliformes, Metasuchia) from the Upper Cretaceous of Brazil". English. In: Boletim do Museu Nacional, Geologia 57 (2001), pp. 1-7.

[3652] L. Campos, M. S. Fernandez, and Y. Herrera. "A new ichthyosaur from the Late Jurassic of northwest Patagonia (Argentina) and its significance for the evolution of the narial complex of the ophthalmosaurids". English. In: Zoological Journal of the Linnean Society 188 (2020), pp. 180-201.

[3653] J. I. Canale, C. A. Scanferla, F. L. Agnoln, and F. E. Novas. "New carnivorous dinosaur from the Late Cretaceous of NW Patagonia and the evolution of abelisaurid theropods". English. In: Naturwissenschaften 96 (2008), pp. 409-414. DOI: 10.1007/s00114-008-0487-4.

[3654] M. L. Canales, J. J. Gomez, S. Ureta, and A. Goy. "Palaeoclimatic and biotic changes during the Aalenian (Middle Jurassic) at the southern Laurasian Seaway (Basque-Cantabrian Basin, northern Spain)". English. In: Palaeogeography, Palaeoclimatology, Palaeoecology 275 (2009), pp. 14-27.

[3655] F. Canas and M. Carrera. Early Ordovician microbial-sponge-receptaculitid bioherms of the Precordillera, Western Argentina. English. 1993.

[3656] C. R. A. Candeiro. "Record of the genus Aeolosaurus (Sauropoda, Titanosauria) in the Late Cretaceous of South America: paleogeographic implications". English. In: Estudios Geológicos 66.2 (2010), pp. 243-253. DOI: 10.3989/egeol.40338.081.

[3657] C. R. A. Candeiro, C. T. Abranches, E. A. Abrantes, L. S. Avilla, V. C. Martins, A. L. Moreira, S. R. Torres, and L. P. Bergqvist. "Dinosaurs remains from western São Paulo state, Brazil (Bauru Basin, Adamantina Formation, Upper Cretaceous)". English. In: Journal of South American Earth Sciences 18 (2004), pp. 1-10.

[3658] C. R. A. Candeiro, F. Agnolin, A. G. Martinelli, and P. A. Buckup. "First bird remains from the Upper Cretaceous of the Peirópolis site, Minas Gerais state, Brazil". English. In: Geodiversitas 34.3 (2012), pp. 617-624. DOI: 10.5252/g2012n3a8.

[3659] C. R. A. Candeiro, A. Cau, F. Fanti, W. R. Nava, and F. E. Novas. "First evidence of an unenlagiid (Dinosauria, Theropoda, Maniraptora) from the Bauru Group, Brazil". English. In: Cretaceous Research 37 (2012), pp. 223-226. DOI: 10.1016/j.cretres.2012.04.001.

[3660] C. R. A. Candeiro, P. J. Currie, and L. P. Bergqvist. "Theropod teeth from the Marlia Formation (late Maastrichtian) at the paleontological site of Peirópolis in Minas Gerais State, Brazil". English. In: Revista Brasileira de Geosciencias 42.2 (2012), pp. 323-330.

[3661] C. R. A. Candeiro, F. Fanti, F. Therrien, and M. C. Lamanna. “Continental fossil vertebrates from the mid-Cretaceous (Albian-Cenomanian) Alcantara Formation, Brazil, and their relationship with contemporaneous faunas from North Africa". English. In: Journal of African Earth Sciences 60.3 (2011), pp. 79-92. DOI: 10.1016/j.jafrearsci.2011.02.004.

[3662] C. R. A. Candeiro, A. G. Martinelli, L.d.S. Avilla, and T. H. Rich. "Tetrapods from the Upper Cretaceous (Turonian-Maastrichtian) Bauru Group of Brazil: a reappraisal". English. In: Cretaceous Research 27 (2006), pp. 923-946.

[3663] C. R. A. Candeiro and A. G. Martinelli. "Abelisauroidea and Carcharodontosauridae (Theropoda, Dinosauria) in the Cretaceous of South America. Paleogeographical and geochronological implications". English. In: Sociedade \& Natureza, Uberlandia 17.33 (2005), pp. 5-19.

[3664] C. R. A. Candeiro, W. Nava, A. G. Martinelli, A. M. Forasiepi, C. A. Scanferla, and P. Muzzopappa. "New lizard record (Diapsida, Lepidosauria) from the Upper Cretaceous Adamantina Formation, Brazil". English. In: Bulletin of Geosciences 84.3 (2009), pp. 573-576.

[3665] C. R. A. Candeiro, A. R. Santos, T. H. Rich, T. S. Marinho, and E. C. Oliveira. "Vertebrate fossils from the Adamantina Formation (Late Cretaceous), Prata paleontological district, Minas Gerais state, Brazil". English. In: Géobios 39 (2006), pp. 319-327.

[3666] C. R. A. Candeiro, A. R. Santos, L. P. Bergqvist, L. C. B. Ribeiro, and S. Apestegua. "The Late Cretaceous fauna and flora of the Uberaba area (Minas Gerais state, Brazil)". English. In: Journal of South American Earth Sciences 25 (2008), pp. 203-216. DOI: 10.1016/j.jsames.2007.06.005. 
[3667] A. Candela and N. L. Nasif. "Systematics and biogeographic significance of Drytomomys typicus (Scalabrini in Ameghino, 1889) nov. comb., a Miocene Dinomyidae (Rodentia, Hystricognathi) from Northeast of Argentina". English. In: Neues Jahrbuch für Geologie und Paläontologie, Abhandlungen 3 (2006), pp. 165-181.

[3668] A. M. Candela. "The evolution of the molar pattern of the Erethizontidae (Rodentia, Hystricognathi) and the validity of Parasteiromys Ameghino, 1904". English. In: Palaeovertebrata 28.1 (1999), pp. 53-73.

[3669] A. M. Candela. "A new giant porcupine (Rodentia, Erethizontidae) from the late Miocene of Argentina". English. In: Journal of Vertebrate Paleontology 24.3 (2004), pp. 732-741. DOI: 10.1671/02724634(2004)024[0732:ANGPRE]2.0.CO;2.

[3670] A. M. Candela. "Los roedores del Mesopotamiense (Mioceno tardo, Formación Ituzaingó) de la provincia de Entre Ros (Ar- gentina)". Spanish. In: Temas de la Biodiversidad del Litoral fluvial argentino II, INSUGEO, Miscelánea 14 (2005), pp. 37-48.

[3671] A. M. Candela. "A new porcupine (Rodentia, Hystricognathi, Erethizontidae) from the Early and Middle Miocene of Patagonia". English. In: Ameghiniana 40.3 (2003), pp. 483-493.

[3672] A. M. Candela, R. A. Bonini, and J. I. Noriega. "First continental vertebrates from the marine Parana Formation (Late Miocene, Mesopotamia, Argentina): Chronology, biogeography, and paleoenvironments". English. In: Geobios 45 (2012), pp. 515-526. DOI: 10.1016/j.geobios.2012.05.003.

[3673] A. M. Candela and R. A. Bonini. "A new guinea pig (Rodentia, Caviomorpha) from northwestern Argentina: Implications for the origin of the genus Cavia". English. In: Journal of Vertebrate Paleontology (2017), e1352591. DOI: 10.1080/02724634.2017.1352591.

[3674] A. M. Candela, M. Cenizo, D. Tassara, L. L. Rasia, C. Robinet, N. A. Muñoz, C. Cañón Valenzuela, and U. F. J. Pardiñas. "A new echimyid genus (Rodentia, Caviomorpha) in Central Argentina: uncovered diversity of a Brazilian group of mammals in the Pleistocene". English. In: Journal of Paleontology 94.1 (2020), pp. 165-179. DOI: 10.1017/jpa.2019.73.

[3675] A. M. Candela, J. I. Noriega, and M. A. Reguero. “The First Pliocene Mammals from the Northeast (Mesopotamia) of Argentina: Biostratigraphic and Paleoenvironmental Significance". English. In: Journal of Vertebrate Paleontology 27.2 (2007), pp. 476-483.

[3676] M. A. Candela and M. G. Vucetich. "Hypsosteiromys (Rodentia, Hystricognathi) from the Early Miocene of Patagonia (Argentina), the only Erethizontidae with a tendency to hypsodonty". English. In: Geobios 35 (2002), pp. 153-161.

[3677] Y. Candela and D. A. T. Harper. "Synoptic revision of the Ordovician brachiopods of the Barr and Lower Ardmillan groups of the Girvan area, Scotland". English. In: Earth and Environmental Science Transactions of the Royal Society of Edinburgh 105.1 (2014), pp. 61-69. DOI: 10.1017 / S1755691014000140.

[3678] J.-M. Canevet. "The Chondrichthyans of the Middle Miocene (Serravallian) of Salles (Gironde, France)". French. In: Cossmanniana 13 (2011), pp. 59-79.

[3679] G. Cantalamessa, C. Di Celma, and L. Ragaini. "Sequence stratigraphy of the Punta Ballena Member of the Jama Formation (Early Pleistocene, Ecuador): insights from integrated sedimentologic, taphonomic and paleoecologic analysis of molluscan shell concentrations". In: Palaeogeography, Palaeoclimatology, Palaeoecology 216 (2005), pp. 1-25.

[3680] G. Cantalamessa, C. Di Celma, G. Bianucci, G. Carnevale, M. Coltorti, M. Delfino, G. Ficcarelli, M. Moreno Espinosa, D. Naldini, P. Pieruccini, L. Ragaini, L. Rook, M. Rossi, G. Tito, D. Torre, G. Valleri, and W. Landini. "A new vertebrate fossiliferous site from the Late Quaternary at San Jose on the north coast of Ecuador: preliminary note". English. In: Journal of South American Earth Science 14 (2001), pp. 331-334.

[3681] K. M. Cantalice and J. Alvarado-Ortega. "Kelemejtubus castroi, gen. et sp. nov., an ancient percomorph (Teleostei, Actinopterygii) from the Paleocene marine deposits near Palenque, Chiapas". English. In: Journal of Vertebrate Paleontology e1383265 (2017), pp. 1-12. DOI: 10.1080 / 02724634. 2017.1383265. 
[3682] J. Canto, R. Salas-Gismondi, M. Cozzuol, and J. Yanez. “The aquatic sloth Thalassocnus (Mammalia, Xenarthra) from the late Miocene of North-Central Chile: Biogeographic and ecological implications". English. In: Journal of Vertebrate Paleontology 28.3 (2008), pp. 918-922.

[3683] J. Canto, J. Yanez, and J. Rovira. "Estado actual del conocimiento de los mamferos fósiles de Chile". Spanish. In: Estudios Geologicos 66.2 (2010), pp. 255-284. DOI: 10.3989/egeol.39778.05.

[3684] D. J. Cantrill, A. N. Drinnan, and J. A. Webb. "Late Triassic plant fossils from the Prince Charles Mountains, East Antarctica". English. In: Antarctic Science 7.1 (1995), pp. 51-62.

[3685] D. J. Cantrill and N. S. Nagalingum. "Ferns from the Cretaceous of Alexander Island, Antarctica: Implications for Cretaceous phytogeography of the Southern Hemisphere". English. In: Review of Palaeobotany and Palynology (2005). DOI: 10.1016/j.revpalbo.2005.08.004.

[3686] D. J. Cantrill and G. J. Nichols. “Taxonomy and palaeoecology of Early Cretaceous (Late Albian) angiosperm leaves from Alexander Island, Antarctica". English. In: Review of Palaeobotany and Palynology 92.1-2 (1996), pp. 1-28.

[3687] D. J. Cantrill and I. J. Raine. "Wairarapaia mildenhallii gen. et sp. nov., a New Araucarian Cone Related to Wollemia from the Cretaceous (Albian-Cenomanian) of New Zealand". English. In: International Journal of Plant Sciences 167.6 (2006), pp. 1259-1269.

[3688] D. J. Cantrill and J. A. Webb. "Permineralized pleuromeid lycopsid remains from the Early Triassic Arcadia Formation, Queensland, Australia". English. In: Review of Palaeobotany and Palynology 102 (1998), pp. 189-211. DOI: 10.1016/S0034-6667(98)80005-5.

[3689] A. Cantu-Chapa. "New Upper Tithonian (Jurassic) Ammonites from the Chinameca Fomation in South Veracruz, Eastern Mexico". English. In: Journal of Paleontology 80.2 (2006), pp. 294-308. DOI: 10.1666/0022-3360\%282006\%29080\%5B0294\%3ANUTJAF\%5D2.0.CO\%3B2.

[3690] J. I. Canudo, O. Amo, G. Cuenca-Bescós, A. Meléndez, J. I. Ruiz-Omeñaca, and A. R. Soria. “Los vertebrados del Tithónico-Barremiense de Galve (Teruel, España) [The Tithonian-Barremian vertebrates of Galve (Teruel, Spain)]". Spanish. In: Cuadernos de Geologia Ibérica 23 (1997), pp. 209241.

[3691] J. I. Canudo, M. Aurell, J. L. Barco, G. Cuenca-Bescós, and J. I. Ruiz-Omeñaca. “Los dinosaurios de la Formación Villar del Arzobispo (Titónico medio-Berriasiense inferior) en Galve (Teruel) [The dinosaurs of the Villar del Arzobispo Formation (middle Tithonian-lower Berriasian) in Galve (Teruel)]". Spanish. In: Geogaceta 38 (2005), pp. 39-42.

[3692] J. I. Canudo, M. Aurell, J. L. Barco, A. Cobos, G. Cuenca-Bescós, C. Martn-Closas, X. Murelaga, X. Pereda-Suberbiola, R. Royo-Torres, and J. I. Ruiz-Omeñaca. La Cantalera: un resumen de los dinosaurios del tránsito Hauteriviense-Barremiense (Cretácico Inferior) de la Cordillera Ibérica (Josa, Teruel) [La Cantalera: a summary of the dinosaurs from the Hauterivian-Barremian transition (Lower Cretaceous) of the Iberian Cordillera (Josa, Teruel)]. Spanish. 2002.

[3693] J. I. Canudo, J. L. Barco, P. Cruzado-Caballero, G. Cuenca-Bescós, J. I. Ruiz-Omeñaca, and R. RoyoTorres. "Evidencias de predación de dinosaurios terópodos en el Maastrichtiense superior, Cretácico superior de Arén (Huesca) [Evidence of theropod dinosaur predation in the upper Maastrichtian, Upper Cretaceous of Arén (Huesca)]". Spanish. In: Lucas Mallada 12 (2005), pp. 29-58.

[3694] J. I. Canudo, J. L. Barco, D. Castanera, and F. T. Fernández-Baldor. “New record of a sauropod in the Jurassic-Cretaceous transition of the Iberian Peninsular (Spain): palaeobiogeographical implications". English. In: Palaeontologische Zeitschrift 84 (2010), pp. 427-435. DOI: 10.1007/s12542-0100057-x.

[3695] J. I. Canudo, J. L. Barco, R. Royo-Torres, and J. I. Ruiz-Omeñaca. “Los saurópodos (Dinosauria) del Tithónico (Jurásico Superior) y del Cretácico de Aragón [The sauropoda (Dinosauria) from the Tithonian (Upper Jurassic) and Cretaceous of Aragón]". Spanish. In: vol. Actas. I Jornadas Internacionales sobre Paleontologa de Dinosaurios y Su Entorno. Salas de Los Infantes: Colectivo Arqueológico-Paleontológico de Salas, C.A.S., 2001, pp. 309-318. 
[3696] J. I. Canudo, J. L. Carballido, A. Garrido, and L. Salgado. “A new rebbachisaurid sauropod from the Aptian-Albian, Lower Cretaceous Rayoso Formation, Neuquén, Argentina". English. In: Acta Palaeontologica Polonica 63.4 (2018), pp. 679-691. DOI: 10.4202/app.00524.2018.

[3697] J. I. Canudo, A. Cobos, C. Martn-Closas, X. Murelaga, X. Pereda-Suberbiola, R. Royo-Torres, J. I. Ruiz-Omeñaca, and L. M. Sender. "Sobre la presencia de dinosaurios ornitópodos en la Formación Escucha (Cretácico Inferior, Albiense): redescubierto Iguanodon en Utrillas (Teruel) [On the presence of ornithopod dinosaurs in the Escucha Formation (Lower Cretaceous, Albian): redescribing Iguanodon in Utrillas (Teruel)]". Spanish. In: Fundamental 6 (2005), pp. 51-56.

[3698] J. I. Canudo, G. Cuenca-Bescós, and J. I. Ruiz-Omeñaca. “Dinosaurios dromaeosaúridos (Saurischia: Theropoda) en el Barremiense Superior (Cretácico Inferior) de Castellote, Teruel [Dromaeosaurid dinosaurs (Saurischia: Theropoda) in the upper Barremian (Lower Cretaceous) of Castellote, Teruel)]". Spanish. In: Geogaceta 22 (1997), pp. 39-42.

[3699] J. I. Canudo and G. Cuenca-Bescós. “Two new mammalian teeth (Multituberculata and Peramura) from the Lower Cretaceous (Barremian) of Spain". English. In: Cretaceous Research 17 (1996), pp. 215-228.

[3700] J. I. Canudo, L. S. Filippi, L. Salgado, A. C. Garrido, I. Cerda, R. A. Garca, and A. Otero. “Nuevos datos sobre los titanosaurios (Dinosauria, Sauropoda) de la Formación Plottier (Coniaciense-Santoniense) en Rincón de los Sauces (Neuquén, Patagonia, Argentina) [New data on the titanosaurs (Dinosauria, Sauropoda) from the Plottier Formation (Coniacian-Santonian) in Rincón de los Sauces (Neuquén, Patagonia, Argentina)]". Spanish. In: In E. Daz-Martnez E I. Rábano (eds.), 4th European Meeting on the Palaeontology and Stratigraphy of Latin America, Madrid. Instituto Geológico y Minero de España, Cuadernos del Museo Geominero 8 (2007), pp. 81-84.

[3701] J. I. Canudo, J. M. Gasca, M. Aurell, A. Badiola, H. -A. Blain, P. Cruzado-Caballero, D. GómezFernández, M. Moreno-Azanza, J. Parrilla, R. Rabal-Garcés, and J. I. Ruiz-Omeñaca. “La Cantalera: an exceptional window onto the vertebrate biodiversity of the Hauterivian-Barremian transition in the Iberian Peninsula". English. In: Journal of Iberian Geology 36.2 (2010), pp. 205-224. DOI: 10. 5209/rev_JIGE.2010.v36.n2.8.

[3702] J. I. Canudo, J. M. Gasulla, F. Ortega, and J. I. Ruiz-Omeñaca. Presencia de Baryonychinae (Theropoda) en el Aptiense inferior (Cretácico Inferior) de Laurasia: Cantera Mas de la Parreta, Formación Arcillas de Morella (Morella, Castellón) [Presence of Baryonychinae (Theropoda) in the lower Aptian (Lower Cretaceous) of Laurasia: Cantera Mas de la Parreta, Arcillas de Morella Formation (Morella, Castellón)]. Spanish. Salas de los Infantes, Spain, 2004.

[3703] J. I. Canudo, J. M. Gasulla, D. Gömez-Fernández, F. Ortega, J. L. Sanz, and P. Yagüe. “Primer evidencia de dientes aislados atribuidos a Spinosauridae (Theropoda) en al Aptiano inferior (Cretácico Inferior) de Europa: Formación Arcillas se Morella (España) [First evidence of isolated teeth attributed to Spinosauridae (Theropoda) in the lower Aptian (Lower Cretaceous) of Europe: Arcillas Formation of Morella (Spain)]". Spanish. In: Ameghiniana 45.4 (2008), pp. 649-662.

[3704] J. I. Canudo, P. Infante, and X. Murelaga. "Primer registro de vertebrados continentales (Dinosauria y Quelonii) en el Maastrichtiense de Teruel (Cirugeda, Aliaga) [First report of continental vertebrates (Dinosauria and Chelonia) in the Maastrichtian of Teruel (Cirugeda, Aliaga)]". Spanish. In: Fundamental 6 (2005), pp. 57-62.

[3705] J. I. Canudo, R. Royo-Torres, and G. Cuenca-Bescós. "A new sauropod: Tastavinsaurus sanzi gen. et sp. nov. from the Early Cretaceous (Aptian) of Spain". English. In: Journal of Vertebrate Paleontology 28.3 (2008), pp. 712-731. DOI: 10.1671/0272-4634(2008)28[712:ANSTSG]2.0.CO;2.

[3706] J. I. Canudo, J. I. Ruiz-Omeñaca, and L. M. Sender. “Primera evidencia de un dinosaurio saurópodo en la Formación Escucha (Utrillas, Teruel), Albiense medio (Cretácico inferior) [First evidence of a sauropod dinosaur in the Escucha Formation (Utrillas, Teruel), middle Albian (Lower Cretaceous)]". Spanish. In: Geo-Temas 6.5 (2004), pp. 27-30. 
[3707] J. I. Canudo, J. I. Ruiz-Omeñaca, and M. Aurell. “Primera evidencia de dinosaurios (Dinosauria: Ornithopoda) en la Formación Calizas de Oliete (Oliete, Teruel), Aptiense superior (Cretácico inferior) [First evidence of dinosaurs (Dinosauria: Ornithopoda) in the Calizas de Oliete Formation (Oliete, Teruel), upper Aptian (Lower Cretaceous)]". Spanish. In: Geo-Temas 6.5 (2004), pp. 23-26.

[3708] J. I. Canudo and J. I. Ruiz-Omeñaca. "Los restos directos de dinosaurios teropódos (excluyendo Aves) en España [Direct remains of theropod dinosaurs (excluding Aves) in Spain]". Spanish. In: Ciencias de la Tierra 26 (2003), pp. 347-373.

[3709] J. I. Canudo, J. I. Ruiz-Omeñaca, and G. Cuenca-Bescós. “Los primeros dientes de anquilosaurio (Ornithischia: Thyreophora) descritos en el Cretácico Inferior de España [The first ankylosaurian teeth (Ornithischia: Thyreophora) described from the Lower Cretaceous of Spain]". Spanish. In: Revista Española de Paleontologa 19.1 (2004), pp. 33-46.

[3710] J. I. Canudo, L. Salgado, J. L. Barco, R. Bolatti, and J. I. Ruiz-Omeñaca. “Dientes de dinosaurios terópodos y saurópodos de la Formación Cerro Lisandro (Cenomaniense superior-Turoniense inferior, Cretácico superior) en Ro Negro (Argentina) [Theropod and sauropod dinosaur teeth from the Cerro Lisandro Formation (upper Cenomanian-lower Turonian, Upper Cretaceous) in Ro Negro (Argentina)]". Spanish. In: Geo-Temas 6.5 (2004), pp. 31-34.

[3711] J. I. Canudo, L. Salgado, A. Garrido, and J. Carballido. "Primera evidencia de dinosaurios ornitópodos en la base de la Formación Huincul (Cenomaniense Superior-Turoniense, Cuenca Neuquina, Argentina) [First evidence of ornithopod dinosaurs at the base of the Huincul Formation (Cenomanianupper Turonian, Neuquén Basin, Argentina)]". Spanish. In: Geogaceta 53 (2013), pp. 9-12.

[3712] C. Q. Cao, S. Z. Chen, and Z. Yin. "A new genus and a new species of pygmy mole cricket in Cretaceous amber from Burma (Orthoptera: Tridactylidae)". English. In: Zootaxa 4559 (2019), pp. 193195.

[3713] H. J. Cao, B. E. Boudinot, Z. Wang, X. F. Miao, C. K. Shih, D. Ren, and T. P. Gao. "Two new iron maiden ants from Burmese amber (Hymenoptera: Formicidae: †Zigrasimeciini)". English. In: Myrmecological News 30 (2020), pp. 161-173.

[3714] H. J. Cao, B. E. Boudinot, C. K. Shih, D. Ren, and T. P. Gao. “Cretaceous ants shed new light on the origins of worker polymorphism". English. In: Science China Life Sciences 63 (2020), pp. 1085-1088. DOI: $10.1007 / \mathrm{s} 11427-019-1617-4$.

[3715] H. J. Cao, V. Perrichot, C. K. Shih, D. Ren, and T. P. Gao. "A revision of Haidomyrmex cerberus Dlussky (Hymenoptera: Formicidae: Sphecomyrminae) from mid-Cretaceous Burmese amber". English. In: Cretaceous Research 106.104226 (2020). DOI: 10.1016/j.cretres.2019.104226.

[3716] L. Cao and X. Wang. "Heterospores of the Genus Ariadnaesporites (Salviniaceae) from the Late Cretaceous, Heilongjiang". In: Acta Micropalaeontologica Sinica 16.1 (1999), pp. 50-53.

[3717] Y. Z. Cao, C. K. Shih, A. Bashkuev, and D. Ren. "Revision and two new species of Itaphlebia (Nannochoristidae: Mecoptera) from the Middle Jurassic of Inner Mongolia, China". English. In: Alcheringa 40 (2016), pp. 24-33.

[3718] Z. Cao, S. Wu, P. Zhang, and J. Li. "Discovery of fossil monocotyledons from Yixian Formation, western Liaoning". In: Chinese Science Bulletin 43.3 (1998), pp. 230-233.

[3719] L. Capasso Barbato and E. Gliozzi. "Biochronological and palaeogeographical implications of a well-balanced late Middle Pleistocene fauna from Quisiana-Certosa (Capri, Southern Italy)". In: Bollettino della Societa Paleontologica Italiana 34.2 (1995), pp. 235-261.

[3720] A. Capobianco, E. Foreman, and M. Friedman. "A Paleocene (Danian) osteoglossid (Teleostei, Osteoglossomorpha) from the Nuussuaq Basin of Greenland, with a brief review of Palaeogene marine bony tongue fishes". English. In: Papers in Palaeontology 2019 (2019), pp. 1-16. DOI: 10. 1002/spp2.1291.

[3721] H. Cappetta. “Carcharhiniformes nouveaux (Chondrichthyes, Neoselachii) de l’Ypresien du Bassin de Paris”. English. In: Geobios 25.2 (1992), pp. 639-646. DOI: 10.1016/0016-6995(92)80103-K.

[3722] H. Cappetta. "Hexanchiforme nouveau (Neoselachii) du Crétacé inférieur du Sud de la France". French. In: Palaeovertebrata 20 (1990), pp. 33-54. 
[3723] H. Cappetta, S. Adnet, D. Akkrim, and M. Amalik. “New Squalicorax species (Neoselachii: Lamniformes) from the Lower Maastrichtian of Ganntour phosphate deposit, Morocco". English. In: Palaeovertebrata 38.3 (2014), e3.

[3724] H. Cappetta, N. Bardet, X. Pereda Suberbiola, S. Adnet, D. Akkrim, M. Amalik, and A. Benabdallah. "Marine vertebrate faunas from the Maastrichtian phosphates of Benguérir (Ganntour Basin, Morocco): Biostratigraphy, palaeobiogeography and palaeoecology". English. In: Palaeogeography, Palaeoclimatology, Palaeoecology 409 (2014), pp. 217-238. DOI: 10.1016/j.palaeo.2014.04.020.

[3725] H. Cappetta, E. Buffetaut, G. Cuny, and V. Suteethorn. "A new elasmobranch assemblage from the Lower Cretaceous of Thailand". English. In: Palaeontology 49.3 (2006), pp. 547-555.

[3726] H. Cappetta and J. C. Corral. "Upper Maastrichtian selachians from the Condado de Treviño (Basque-Cantabrian Region, Iberian Peninsula)". English. In: Estudios del Museo de Ciencias Naturales de Álava 14.núm.esp. 1 (1999), pp. 339-372.

[3727] H. Cappetta, F. Pfeil, N. Schmidt-Kittler, and E. Martini. New biostratigraphical data on the marine Upper Cretaceous and Palaeogene of Jordan. English. Vol. 38. Newsletters on Stratigraphy 1. 2000, pp. 81-95.

[3728] J. E. Caracuel, F. Oloriz, and J. Sandoval. “Datos preliminares sobre el Bajociense superior en el sector de Coll Baix (Peninsula de Alcudia, Mallorca) [Preliminary data on the Upper Bajocian in the Coll Baix sector, Alcudia Peninsula, Mallorca]". Spanish. In: Geogaceta 16 (1994), pp. 67-69.

[3729] G. Carannante and A. Cherchi. "Chlorozoan versus foramol lithofacies in Upper Cretaceous rudist limestones". English. In: Palaeogeography, Palaeoclimatology, Palaeoecology 119 (1995), pp. 137-154.

[3730] G. Carannante, R. Graziano, G. Pappone, D. Ruberti, C. Simone, and L. Simone. “Depositional System and Response to Sea Level Oscillations of the Senonian Rudist-bearing Carbonate Shelves. Examples from Central Mediterranean Areas". English. In: Facies 40 (1999), pp. 1-24.

[3731] G. Carannante, D. Ruberti, and G. Sirna. "Senonian Rudist limestones in the Sorrento Peninsula sequences (southern Italy)". English. In: Geobios 31.22 (1998), pp. 47-68.

[3732] J. L. Carballido, F. M. Holwerda, D. Pol, and O. W. Rauhut. "An Early Jurassic sauropod tooth from Patagonia (Cañadón Asfalto Formation): implications for sauropod diversity". English. In: Publicación Electrónica de la Asociación Paleontológica Argentina 17.2 (2017), pp. 50-57. DOI: 10.5710/ PEAPA.17.11.2017.249.

[3733] J. L. Carballido, J. S. Marpmann, D. Schwarz-Wings, and B. Pabst. “New information on a juvenile sauropod specimen from the Morrison Formation and the reassessment of its systematic position". English. In: Palaeontology 55.3 (2012), pp. 567-582. DOI: 10.1111/j.1475-4983.2012.01139.x.

[3734] J. L. Carballido, D. Pol, M. L. Parra Ruge, S. Padilla Bernal, M. E. Páramo-Fonseca, and F. EtayoSerna. "A new Early Cretaceous brachiosaurid (Dinosauria, Neosauropoda) from northwestern Gondwana (Villa de Leiva, Colombia)". English. In: Journal of Vertebrate Paleontology 35.5 (2015), e980505:1-12. DOI: 10.1080/02724634.2015.980505.

[3735] J. L. Carballido, D. Pol, A. Otero, I. A. Cerda, L. Salgado, A. C. Garrido, J. Ramezani, N. R. Cúneo, and J. M. Krause. "A new giant titanosaur sheds light on body mass evolution among sauropod dinosaurs". English. In: Proceedings of the Royal Society of London B 284 (2017), 20171219:1-10. DOI: 10.1098/rspb.2017.1219.

[3736] J. L. Carballido, L. Salgado, D. Pol, J. I. Canudo, and A. Garrido. “A new basal rebbachisaurid (Sauropoda, Diplodocoidea) from the Early Cretaceous of the Neuquén Basin; evolution and biogeography of the group". English. In: Historical Biology 24.6 (2012), pp. 631-654.

[3737] F. Carbone and G. Accordi. "The Indian Ocean coast of Somalia". English. In: Marine Pollution Bulletin 41 (2000), pp. 141-159.

[3738] F. Carbone, R. Matteucci, J. S. Pignatti, and A. Russo. "Facies analysis and biostratigraphy of the Auradu Limestone Formation in the Berbera-Sheikh area, northwestern Somalia". In: Geologica Romana 29 (1993), pp. 213-235. 
[3739] E. Carbonell and X. P. Rodriguez. “Early Middle Pleistocene deposits and artefacts in the Gran Dolina site (TD4) of the 'Sierra de Atapuerca' (Burgos, Spain)". English. In: Journal of Human Evolution 26 (1994), pp. 291-311.

[3740] G. Carbot-Chanona. "Restos de cf. Crocodylus sp. en el Mioceno tardo de Chiapas, México: importancia paleobiogeográfica y paleoambiental". Spanish. In: Quehacer Cientfico en Chiapas 12.2 (2017), pp. 24-34.

[3741] G. Carbot-Chanona, J. Juárez-Woo, and J. R. Guzmán-Gutiérrez. “Contribución al conocimiento de los rinocerontes fósiles de la Cuenca de Tecolotlán, en el estado de Jalisco, México". Spanish. In: Boletn de la Sociedad Geológica Mexicana 61.2 (2009), pp. 277-286.

[3742] G. Carbot-Chanona and H. E. Rivera-Sylva. "Presence of a maniraptoriform dinosaur in the Late Cretaceous (Maastrichtian) of Chiapas, southern Mexico". English. In: Boletn de la Sociedad Geológica Mexicana 63.3 (2011), pp. 393-398.

[3743] B. Carbuccia, H. M. Wood, C. Rollad, A. Nel, and R. Garrouste. "A new Myrmecarchaea (Araneae: Archaeidae) species from Oise amber (earliest Eocene, France)". English. In: BSGF - Earth Sciences Bulletin 191.24 (2020), pp. 1-5. DOI: 10.1051/bsgf/2020023.

[3744] J. Q. Cardona and J. Agusti. "First evidence of faunal succession in terrestrial vertebrates of the Plio-Pleistocene of the Balearic Islands, western Mediterranean". English. In: Comptes Rendus Palevol (2019), pp. 1-8. DOI: 10.1016/j.crpv.2019.02.001.

[3745] M. C. Cardonatto and R. N. Melchor. "Large mammal burrows in late Miocene calcic paleosols from central Argentina: paleoenvironment, taphonomy and producers". English. In: PeerJ 6 (2018), e4787. DOI: $10.7717 /$ peerj. 4787.

[3746] C. N. Cardoso, J. Sanz-López, S. Blanco-Ferrera, V. B. Lemos, and A. K. Scomazzon. "Frasnian conodonts at high palaeolatitude (Amazonas Basin, north Brazil)". English. In: Palaeogeography, Palaeoclimatology, Palaeoecology 418 (2015), pp. 57-64.

[3747] I. Carevi, B. Radulovi, D. Ljubovi-Obradovi, D. Rabrenovi, and V. Jovanovi. “First record of a Middle Jurassic macrofauna from the Brnjica (NE Serbia): stratigraphy, palaeoecology and correlation with adjacent regions". English. In: Neues Jahrbuch für Geologie und Paläontologie, Abhandlungen 260.3 (2011), pp. 365-379. DOI: 10.1127/0077-7749/2011/0148.

[3748] S. P. Carey, M. L. Cupper, R. Gruen, J. C. Hellstrom, S. W. McKnight, I. McLennan, D. A. Pickering, P. Trusler, and M. Aubert. "A diverse Pleistocene marsupial trackway assemblage from the Victorian volcanic plains, Australia". English. In: Quaternary Science Reviews 30.5-6 (2011), pp. 591610.

[3749] M. Caridroit, A. Lamerandt, J. -M. Dégardin, A. Flores de Dios, and D. Vachard. “Discovery of radiolaria and conodonts in the Carboniferous-Permian of San Salvador Patlanoaya (Puebla, Mexico); biostratigraphic implications". English. In: C R Palevol 1 (2002), pp. 205-211.

[3750] B. Cariglino, A. M. Zavattieri, P. Gutierrez, and M. L. Balarino. "The paleobotanical record of the Triassic Cerro de Las Cabras Formation at its type locality, Potrerillos, Mendoza (Uspallata Group): An historical account at first record of fossil flora. Ameghiniana 53 (2):184- 204". English. In: (2016).

[3751] J. D. Carillo-Briceño, O. A. Aguilera, and F. Rodriguez. "Fossil Chondrichthyes from the central eastern Pacific Ocean and their paleoceanographic significance". English. In: Journal of South American Earth Sciences 51 (2014), pp. 76-90. DOI: 10.1016/j.jsames.2014.01.001.

[3752] M. D. Carleton and S. L. Olson. "Amerigo Vespucci and the rat of Fernando de Noronha: a new genus and species of Rodentia (Muridae: Sigmodontinae) from a volcanic island off Brazil's continental shelf". English. In: American Museum Novitates 3256 (1999), pp. 1-59.

[3753] A. A. Carlini, D. Brandoni, and R. Sánchez. "First Megatheriines (Xenarthra, Phyllophaga, Megatheriidae) from the Urumaco (late Miocene) and Codore (Pliocene) Formations, Estado Falcón, Venezuela". English. In: Journal of Systematic Paleontology 4.3 (2006), pp. 269-278. DOI: 10.1017/s1477201906001878. 
[3754] A. A. Carlini, D. Brandoni, R. Sanchez, and M. R. Sanchez-Villagra. “A new Megatheriinae skull (Xenarthra, Tardigrada) from the Pliocene of Northern Venezuela - implications for a giant sloth dispersal to Central and North America". English. In: Paleontologia Electronica 21.2.16A (2018), pp. 1-12.

[3755] A. A. Carlini, D. Brandoni, and R. Sanchez. "Additions to the knowledge of Urumaquia robusta (Xenarthra, Phyllophaga, Megatheriidae) from the Urumaco Formation (Late Miocene), Estado Falc6n, Venezuela". English. In: Palaeontologische Zeitschrift 82.2 (2008), pp. 153-162.

[3756] A. A. Carlini, D. Brandoni, and C. N. Dal Molin. "A new genus and species of Planopinae (Xenarthra: Tardigrada) from the Miocene of Santa Cruz Province, Argentina". English. In: Zootaxa 3694.6 (2013), pp. 565-578.

[3757] A. A. Carlini, D. Brandoni, G. J. Scillato-Yané, and F. Pujos. "Una nueva especie de megaterino (Xenarthra, Megatheriidae) del Mioceno Tardo-Plioceno de Catamarca, Argentina". Spanish. In: Ameghiniana 39.3 (2002), pp. 367-377.

[3758] A. A. Carlini, M. Cancio, and G. J. Scillato-Yané. “Los Xenarthra de Gran Barranca: Más de 20 Ma de historia". Spanish. In: Actas del XVI Congreso Geológico Argentino. La Plata 2005 (2005).

[3759] A. A. Carlini, M. C. Castro, R. H. Madden, and G. J. Scillato-Yané. “A new species of Dasypodidae (Xenarthra: Cingulata) from the late Mioceneof northwestern South America: implications in the Dasypodini phylogeny and diversity". English. In: Historical Biology 26.6 (2014), pp. 728-736.

[3760] A. A. Carlini, M. R. Ciancio, J. J. Flynn, G. J. Scillato-Yané, and A. R. Wyss. “The phylogenetic and biostratigraphic significance of new armadillos (Mammalia, Xenarthra, Dasypodidae, Euphractinae) from the Tinguirirican (early Oligocene) of Chile". English. In: Journal of Systematic Palaeontology 7.4 (2009), pp. 489-503.

[3761] A. A. Carlini, J. N. Gelfo, and R. Sánchez. "A new Megadolodinae (Mammalia, Litopterna, Protherotheriidae) from the Urumaco Formation (Late Miocene) of Venezuela". English. In: Journal of Systematic Palaeontology 4.3 (2006), pp. 279-284. DOI: 10.1017/S1477201906001830.

[3762] A. A. Carlini, R. Pascual, and F. J. Goin. "A new argyrolagid marsupial from the Early Miocene of Patagonia (Argentina)". English. In: Neues Jahrbuch für Geologie und Paläontologie, Abhandlungen 245.3 (2007), pp. 323-330. DOI: 10.1127/0077-7749/2007/0245-0323.

[3763] A. A. Carlini, G. J. Scillato-Yané, and R. Sánchez. “New Mylodontoidea (Xenarthra, Phyllophaga) from the Middle Miocene-Pliocene of Venezuela". English. In: Journal of Systematic Palaeontology 4.3 (2006), pp. 255-267.

[3764] A. A. Carlini and G. J. Scillato-Yane. “Chorobates recens (Xenarthra, Dasypodidae) y un analisis de la filogenia de los Euphractini". Spanish. In: Revista del Museo de la Plata (NS) Paleontologia 9.59 (1995).

[3765] A. A. Carlini, A. E. Zurita, G. J. Scillato-Yane, R. Sanchez, and O. A. Aguilera. "New Glyptodont from the Codore Formation (Pliocene), Falcon State, Venezuela, its relationship with the Asterostemma problem, and the paleobiogeography of the Glyptodontinae". English. In: Palaontologische Zeitschrift 82.2 (2008), pp. 139-152.

[3766] A. A. Carlini, A. E. Zurita, and O. A. Aguilera. "North American Glyptodontines (Xenarthra, Mammalia) in the Upper Pleistocene of northern South America". English. In: Palaontologische Zeitschrift 82.2 (2008), pp. 125-138.

[3767] J. Carlorosi, S. B. Esteban, and M. F. Tortello. "Early Ordovician conodonts from the Santa Rosita Formation at Pantipampa, Iruya area, northwestern Argentina". English. In: Andean Geology 46.1 (2019), pp. 168-182. DOI: 10.5027/andgeoV46n1-3141.

[3768] J. Carlorosi, G. Sarmiento, and S. Heredia. "Selected Middle Ordovician key conodont species from the Santa". English. In: Geological Magazine 155.4 (2018), pp. 878-892. DOI: 10.1017/S0016756816001035.

[3769] J. M. T. Carlorosi and S. E. Heredia. "The Ordovician conodont Trapezognathus Lindström, 1955 in the Andean Basin, Argentina". English. In: Neues Jahrbuch für Geologie und Paläontologie-Abhandlungen 2676.3 (2013), pp. 309-321. DOI: 10.1127/0077-7749/2013/0311. 
[3770] P. Carls, L. Slavik, and J. I. Valenzuela-Rios. "Revision of conodont biostraigraphy across the Silurian-Devonian boundary". English. In: Bulletin of Geosciences 82.2 (2007), pp. 145-164.

[3771] J. R. Carlucci, S. R. Westrop, and L. Amati. "Tetralichine Trilobites from the Upper Ordovician of Oklahoma and Virginia and phylogenetic systematics of the Tetralichini". English. In: Journal of Paleontology 84.6 (2010), pp. 1099-1120. DOI: 10.1666/10-012.1.

[3772] J. R. Carlucci and S. R. Westrop. “Trilobite Biofacies along an Ordovician (Sandbian) Carbonate Buildup to Basin Gradient, Southwestern Virginia". English. In: Palaios 27 (2012), pp. 19-34.

[3773] R. Carmona, D. M. Alba, M. Delfino, J. M. Robles, C. Rotgers, J. V. Bertó Mengual, J. Balaguer, J. Galindo, and S. Moyá-Solá. "Snake fossil remains from the middle Miocene stratigraphic series of Abocador de Can Mata (Els Hostalets de Pierola, Catalonia, Spain)". English. In: Cidaris 30 (2010), pp. 77-84.

[3774] L. M. Carneiro. "A new species of Varalphadon (Mammalia, Metatheria, Sparassodonta) from the upper Cenomanian of southern Utah, North America: Phylogenetic and biogeographic insights". English. In: Cretaceous Research 84 (2018), pp. 88-96. DOI: 10.1016/j.cretres.2017.11.004.

[3775] L. M. Carneiro. "A new protodidelphid (Mammalia, Marsupialia, Didelphimorphia) from the Itabora Basin and its implications for the evolution of the Protodidelphidae". English. In: Anais da Academia Brasileira de Ciencias (2018). DOI: 10.1590/0001-3765201820180440.

[3776] G. Carnevale. "The first fossil ribbonfish (Teleostei, Lampridiformes, Trachipteridae)". English. In: Geological Magazine 141.5 (2004), pp. 573-582.

[3777] G. Carnevale. "Miniature deep-sea hatchetfish (Teleostei: Stomiiformes) from the Miocene of Italy". English. In: Geological Magazine 145.1 (2008), pp. 73-84.

[3778] G. Carnevale. "A new barbeled dragonfish (Teleostei: Stomiiformes: Stomiidae) from the Miocene of Torricella Peligna, Italy: Abruzzoichthys erminioi gen. \& sp. nov". English. In: Eclogae Geologicae Helvetiae 95 (2002), pp. 471-479.

[3779] G. Carnevale. "Fossil fishes from the Serravallian (Middle Miocene) of Torricella Peligna, Italy". English. In: Palaeontographia Italica 91 (2007), pp. 1-67.

[3780] G. Carnevale. "Morphology and biology of the Miocene butterflyfish Chaetodon ficheuri (Teleostei: Chaetodontidae)". English. In: Zoological Journal of the Linnean Society 146 (2006), pp. 251-267.

[3781] G. Carnevale. "A new snake mackerel from the Miocene of Algeria". English. In: Palaeontology 49.2 (2006), pp. 391-403.

[3782] G. Carnevale and A. Bannikov. "Pietschellidae fam. nov., a new family of miniature percomorph fishes from the Eocene of Bolca, with the description of a new genus and species". English. In: Studi e ricerche sui giacimenti terziari di Bolca 16.13 (2015), pp. 17-26.

[3783] G. Carnevale, A. F. Bannikov, G. Marramá, J. C. Tyler, and R. Zorzin. “The Pesciara-Monte Postale Fossil-Lagerstätte: 2. Fishes and other vertebrates". English. In: Rendiconti della Societá Paleontologica Italiana 4 (2014), pp. 37-63.

[3784] G. Carnevale, A. F. Bannikov, W. Landini, and C. Sorbini. “Volhynian (early Sarmatian sensu lato) fishes from Tsurevsky, North Caucasus, Russia". English. In: Journal of Paleontology 80.4 (2006), pp. 684-689.

[3785] G. Carnevale, S. J. Godfrey, and T. W. Pietsch. "Stargazer (Teleostei, Uranoscopidae) Cranial Remains from the Miocene Calvert Cliffs, Maryland, U.S.A. (St. Marys Formation, Chesapeake Group)". English. In: Journal of Vertebrate Paleontology 31.6 (2011), pp. 1200-1209.

[3786] G. Carnevale and S. J. Godfrey. “Tilefish (Teleostei, Malacanthidae) remains from the Miocene Calvert Formation, Maryland and Virginia: taxonomical and paleoecological remarks". English. In: Journal of Vertebrate Paleontology 34.5 (2014), pp. 1018-1032. DOI: 10.1080/02724634.2014.845202.

[3787] G. Carnevale, W. Landini, L. Radgaini, C. di Celma, and G. Cantalamessa. “Taphonomic and paleoecological analyses (mollusks and fishes) of the Súa Member condensed shelled, upper Onzole Formation (Early Pliocene, Ecuador)". English. In: Palaios 26.3 (2011), pp. 160-172. 
[3788] G. Carnevale and T. W. Pietsch. “The Deep-Sea Anglerfish Genus Acentrophryne (Teleostei, Ceratioidei, Linophrynidae) in the Miocene of California". English. In: Journal of Vertebrate Paleontology 29.2 (2009), pp. 372-378.

[3789] G. Carnevale, T. W. Pietsch, G. T. Takeuchi, and R. W. Huddleston. "Fossil Ceratioid Anglerfishes (Teleostei: Lophiiformes) from the Miocene of the Los Angeles Basin, California". English. In: Journal of Paleontology 85.2 (2008), pp. 996-1008.

[3790] G. Carnevale and T. W. Pietsch. "Eocene handfishes from Monte Bolca, with description of a new genus and species, and a phylogeny of the family Brachionichthyidae (Teleostei: Lophiiformes)". English. In: Zoological Journal of the Linnean Society 160 (2010), pp. 621-64710.1111. DOI: 10.1111/j. 1096-3642.2009.00623.x.

[3791] G. Carnevale and T. W. Pietsch. "Filling the gap: a fossil frogfish, genus Antennarius (Teleostei, Lophiiformes, Antennariidae), from the Miocene of Algeria". English. In: Journal of Zoology 270 (2006), pp. 448-457. DOI: 10.1111/j.1469-7998.2006.00163.x.

[3792] G. Carnevale, T. W. Pietsch, N. Bonde, M. E. C. Leal, and G. Marramá. “+Neilpeartia ceratoi, gen. et sp. nov., a new frogfish from the Eocene of Bolca, Italy". English. In: Journal of Vertebrate Paleontology (2020), e1778711. DOI: 10.1080/02724634.2020.1778711.

[3793] G. Carnevale and A. Rindone. "The teleost fish Paravinciguerria praecursor Arambourg, 1954 in the Cenomanian of north-eastern Sicily". English. In: Bollettino della Società Paleontologica Italiana 50.1 (2011), pp. 1-10.

[3794] G. Carnevale and F. Santini. "Archaeotetraodon cerrinaferoni, sp. nov. (Teleostei: Tetraodontidae), from the Miocene (Messinian) of Chelif Basin, Algeria". English. In: Journal of Vertebrate Paleontology 26.4 (2006), pp. 815-821.

[3795] G. Carnevale, C. Sorbini, and W. Landini. "†Oreochromis lorenzoi, a New Species of Tilapiine Cichlid from the Late Miocene of Central Italy". English. In: Journal of Vertebrate Paleontology 23.3 (2003), pp. 508-516.

[3796] G. Carnevale and J. C. Tyler. "A new pufferfish (Teleostei, Tetraodontidae) from the Middle Miocene of St. Margarethen, Austria". English. In: Paläontologische Zeitschrift 89 (2015), pp. 435-447.

[3797] J. B. Caron, R. R. Gaines, C. Aria, M. G. Mángano, and M. Steng. "A new phyllopod bed-like assemblage from the Burgess Shale of the Canadian Rockies". English. In: Nature Communications 5.3210 (2014), pp. 1-6. DOI: $10.1038 /$ ncomms4210.

[3798] J.-B. Caron and D. A. Jackson. "Paleoecology of the Greater Phyllopod Bed community, Burgess Shale". English. In: Palaeogeography, Palaeoclimatology, Palaeoecology 258 (2008), pp. 222-256.

[3799] G. Carone and D. P. Domning. "Metaxytherium serresii (Mammalia: Sirenia): new pre-Pliocene record, and implicaitons for Mediterranean paleoecology before and after the Messinian Salinity Crisis". English. In: Bollettino della Societa Paleontologica Italiana 46.1 (2007), pp. 55-92.

[3800] G. Carone, A. C. Marra, and C. Mesiano. "First record of Dugongidae (Mammalia: Sirenia) from the Floresta calcarenites formatino (Late Burdigalian-Early Langian, Reggio Calabria, Southern Italy)". English. In: Rivista Italiana di Paleontologia e Stratigrafia 122.1 (2016), pp. 1-6.

[3801] G. Carone and A. C. Marra. "I cetacei fossili del Civico Museo Paleontologico del Comune di Ricadi (Vibo Valentia)". Italian. In: Museologia Scientifica Memorie 13 (2014), pp. 120-123.

[3802] G. Carone and R. Rizzo. "A new record of fossil sirenians from the Miocene of Sardinia (Italy)". English. In: Bollettino della Societá Paleontologica Italiana (2020). DOI: 10.4435/BSPI.2020.07.

[3803] F. M. Carpenter. Studies of North American Carboniferous Insects: Part 8. New Paleodictyoptera from Kansas, USA. 1992.

[3804] F. M. Carpenter. "Studies on North American Carboniferous Insects. 9. A New species of Eubleptidae from Mazon Creek (Paleodictyoptera)". English. In: Psyche 99 (1992), pp. 147-152.

[3805] J. M. Carpenter. A Vespid wasp from New Jersey Cretaceous amber. English. Studies on Fossils in Amber, with Particular Reference to the Cretaceous of New Jersey. Leiden: Backhuys Publishers, 2000, pp. 333-337. 
[3806] J. M. Carpenter and D. A. Grimaldi. “Social wasps in amber". English. In: American Museum Novitates 3203 (1997), pp. 1-7.

[3807] J. M. Carpenter and A. P. Rasnitsyn. “Mesozoic Vespidae”. English. In: Psyche 97.1-2 (1990), pp. 120.

[3808] K. Carpenter. "A giant coelophysoid (Ceratosauria) theropod from the Upper Triassic of New Mexico, USA". In: Neues Jahrbuch für Geologie und Paläontologie, Abhandlungen 205.2 (1997), pp. 189208.

[3809] K. Carpenter. "Redescription of Ankylosaurus magniventris Brown 1908 (Ankylosauridae) from the Upper Cretaceous of the Western Interior of North America". In: Canadian Journal of Earth Sciences 41 (2004), pp. 961-986.

[3810] K. Carpenter. "Behavior of hadrosaurs as interpreted from footprints in the Mesaverde Group (Campanian) of Colorado, Utah, and Wyoming". In: Contributions to Geology, University of Wyoming 29.2 (1992), pp. 81-96.

[3811] K. Carpenter. "Vertebrate biostratigraphy of the Morrison Formation near Cañon City, Colorado". In: Modern Geology 23 (1998), pp. 407-426.

[3812] K. Carpenter. "Revision of North American elasmosaurs from the Cretaceous of the Western Interior". English. In: Paludicola 2.2 (1999), pp. 148-173.

[3813] K. Carpenter. "A review of short-necked plesiosaurs of the Western Interior, North America". English. In: Neues Jahrbuch fur Geologie und Palaontologie, Abhandlungen 201.2 (1996), pp. 259-287.

[3814] K. Carpenter. “Cañon City”. English. In: Encyclopedia of Dinosaurs. New York: Academic Press, 1997, pp. 91-92.

[3815] K. Carpenter. "History, sedimentology, and taphonomy of the Carnegie Quarry, Dinosaur National Monument, Utah". English. In: Annals of Carnegie Museum 81.3 (2013), pp. 153-232.

[3816] K. Carpenter. "Soft-Bodied Fossil of a Lizard From the Parachute Creek Member, Green River Formation (Eocene), Utah". English. In: Geology of the Intermountain West 5 (2018), pp. 263-269.

[3817] K. Carpenter and K. Alf. Global distribution of dinosaur eggs, nests, and babies. English. Dinosaur Eggs and Babies, Cambridge University Press, Cambridge. 1994, pp. 13-30.

[3818] K. Carpenter, J. Bartlett, J. Bird, and R. Barrick. “Ankylosaurs from the Price River Quarries, Cedar Mountain Formation (Lower Cretaceous), east-central Utah". English. In: Journal of Vertebrate Paleontology 28.4 (2008), pp. 1089-1101. DOI: 10.1671/0272-4634-28.4.1089.

[3819] K. Carpenter, D. W. Dilkes, and D. B. Weishampel. "The dinosaurs of the Niobrara Chalk Formation (Upper Cretaceous, Kansas)". In: Journal of Vertebrate Paleontology 15.2 (1995), pp. 275-297.

[3820] K. Carpenter and M. J. Everhart. "Skull of the ankylosaur Niobrarasaurus coleii (Ankylosauria: Nodosauridae) from the Smoky Hill Chalk (Coniacian) of western Kansas". English. In: Transactions of the Kansas Academy of Science 110.1/2 (2007), pp. 1-9.

[3821] K. Carpenter and Y. Ishida. "Early and middle Cretaceous iguanodonts in time and space". English. In: Journal of Iberian Geology 36.2 (2010), pp. 145-164. DOI: 10.5209/rev_JIGE.2010.v36.n2.3.

[3822] K. Carpenter, J. I. Kirkland, D. Burge, and J. Bird. "Ankylosaurs (Dinosauria: Ornithischia) of the Cedar Mountain Formation, Utah, and their stratigraphic distribution". In: Vertebrate Paleontology in Utah, D. D. Gillette (ed.), Utah Geological Survey Miscellaneous Publication 99-1 (1999), pp. 243-251.

[3823] K. Carpenter and J. McIntosh. Upper Jurassic sauropod babies from the Morrison Formation. English. Dinosaur Eggs and Babies. Cambridge: Cambridge University Press, 1994, pp. 265-278.

[3824] K. Carpenter, C. Miles, and K. Cloward. "Skull of a Jurassic ankylosaur (Dinosauria)". In: Nature 393 (1998), pp. 782-783.

[3825] K. Carpenter, C. A. Miles, J. H. Ostrom, and K. C. Cloward. Redescription of the small maniraptoran theropods Ornitholestes and Coelurus from the Upper Jurassic Morrison Formation of Wyoming. English. The Carnivorous Dinosaurs. Indiana University Press, Bloomington. 2005, pp. 49-71. 
[3826] K. Carpenter, C. A. Miles, and K. C. Cloward. New small theropod from the Upper Jurassic Morrison Formation of Wyoming. English. The Carnivorous Dinosaurs. Indiana University Press, Bloomington. 2005, pp. 23-48.

[3827] K. Carpenter, D. M. Unwin, K. C. Cloward, C. A. Miles, and C. miles. A new scaphognathine pterosaur from the Upper Jurassic Morrison Formation of Wyoming, USA. Vol. 217. E. Buffetaut \& J.-M. Mazin (eds.), Evolution and Palaeobiology of Pterosaurs, Geological Society Special Publication. 2003, pp. 45-54.

[3828] K. Carpenter and Y. Wilson. "A new species of Camptosaurus (Ornithopoda: Dinosauria) from the Morrison Formation (Upper Jurassic) of Dinosaur National Monument, Utah, and a biomechanical analysis of Its forelimb". English. In: Annals of Carnegie Museum 76.4 (2008), pp. 227-263.

[3829] K. Carpenter and D. B. Young. "Late Cretaceous dinosaurs from the Denver Basin, Colorado". In: Rocky Mountain Geology 37.2 (2002), pp. 237-254.

[3830] M. C. Carpenter and J. I. Mead. "Late Pleistocene roadrunner (Geococcyx) from Kartchner Caverns State Park, southeastern Arizona." English. In: The Southwestern Naturalist 48.3 (2003), pp. 402-410.

[3831] R. J. Carpenter. "Palaeovegetation and Environment at Cethana, Tasmania." English. PhD thesis. 1991.

[3832] R. J. Carpenter, J. M. Bannister, G. J. Jordan, and D. E. Lee. "Leaf fossils of Proteaceae tribe Persoonieae from the Late Oligocene-Early Miocene of New Zealand". English. In: Australian Systematic Botany 23.1 (2010), pp. 1-15. DOI: 10.1071/SB09015.

[3833] R. J. Carpenter, J. M. Bannister, D. E. Lee, and G. J. Jordan. “Proteaceae leaf fossils from the OligoMiocene of New Zealand: new species and evidence of biome and trait conservatism". English. In: Australian Systematic Botany 25.6 (2012), pp. 375-389. DOI: 10.1071/SB12018.

[3834] R. J. Carpenter, J. M. Bannister, D. E. Lee, and G. J. Jordan. “Nothofagus subgenus Brassospora (Nothofagaceae) leaf fossils from New Zealand: a link to Australia and New Guinea?" English. In: Botanical Journal of the Linnean Society 174.4 (2014), pp. 503-515. DOI: 10.1111/boj.12143.

[3835] R. J. Carpenter and A. M. Buchanan. “Oligocene Leaves, Fruit and Flowers of the Cunoniaceae from Cethana, Tasmania". English. In: Australian Systematic Botany 6.2 (1993), pp. 91-109. DOI: 10.1071/SB9930091.

[3836] R. J. Carpenter, A. Iglesias, and P. Wilf. "Early Cenozoic Vegetation in Patagonia: New Insights from Organically Preserved Plant Fossils (Ligorio Márquez Formation, Argentina)". English. In: International Journal of Plant Sciences 179.2 (2018). DOI: 10.1086/695488.

[3837] R. J. Carpenter and G. J. Jordan. "Early Tertiary Macrofossils of Proteaceae from Tasmania". English. In: Australian Systematic Botany 10.4 (1997), pp. 533-563. DOI: 10.1071/SB96016.

[3838] R. J. Carpenter, G. J. Jordan, and R. S. Hill. “A Toothed Lauraceae Leaf from the Early Eocene of Tasmania, Australia". English. In: International Journal of Plant Sciences 168.8 (2007), pp. 1191-1198.

[3839] R. J. Carpenter, G. J. Jordan, M. K. Macphail, and R. S. Hill. "Near-tropical Early Eocene terrestrial temperatures at the Australo-Antarctic margin, western Tasmania". English. In: Geology 40.3 (2012), pp. 267-270. DOI: 10.1130/G32584.1.

[3840] R. J. Carpenter, G. J. Jordan, D. E. Lee, and R. S. Hill. “Leaf Fossils of Banksia (Proteaceae) from New Zealand: an Australian Abroad". English. In: American Journal of Botany 97.2 (2010), pp. 288297. DOI: 10.3732 / ajb.0900199.

[3841] R. J. Carpenter, G. J. Jordan, D. C. Mildenhall, and D. E. Lee. "Leaf Fossils of the Ancient Tasmanian Relict Microcachrys (Podocarpaceae) from New Zealand". English. In: American Journal of Botany 98.7 (2011), pp. 1164-1172. DOI: 10.3732/ajb.1000506.

[3842] R. J. Carpenter and M. Pole. "Eocene Plant Fossils from the Lefroy and Cowan Paleodrainages, Western Australia". English. In: Australian Systematic Botany 8.6 (1995), pp. 1107-1154. DOI: 10. 1071/SB9951107. 
[3843] R. K. Carr and W. J. Hlavin. “Two new species of Dunkleosteus Lehman, 1956, from the Ohio Shale Formation (USA, Famennian) and the Kettle Point Formation (Canada, Upper Devonian), and a cladistic analysis of the Eubrachythoraci (Placodermi, Arthrodira)". English. In: Zoological Journal of the Linnean Society 159.1 (2010), pp. 195-222. DOI: 10.1111/j.1096-3642.2009.00578.x.

[3844] T. D. Carr, D. J. Varricchio, J. C. Sedlmayr, E. M. Roberts, and J. R. Moore. "A new tyrannosaur with evidence for anagenesis and crocodile-like facial sensory system". English. In: Scientific Reports 7 (2017), 44942:1-11. DOI: 10.1038/srep44942.

[3845] T. D. Carr, T. E. Williamson, and D. R. Schwimmer. "A new genus and species of tyrannosauroid from the Late Cretaceous (Middle Campanian) Demopolis formation of Alabama". In: Journal of Vertebrate Paleontology 25.1 (2005), pp. 119-143.

[3846] T. D. Carr and T. E. Williamson. A reappraisal of tyrannosauroids from Iren Dabasu, Inner Mongolia, People's Republic of China. English. 2005.

[3847] T. D. Carr and T. E. Williamson. A review of Tyrannosauridae (Dinosauria, Coelurosauria) from New Mexico. English. Vol. 17. Dinosaurs of New Mexico. New Mexico Museum of Natural History and Science Bulletin. 2000, pp. 113-145.

[3848] T. D. Carr and T. E. Williamson. "Bistahieversor sealeyi, gen. et sp. nov., a new tyrannosauroid from New Mexico and the origin of deep snouts in Tyrannosauroidea". English. In: Journal of Vertebrate Paleontology 30.1 (2010), pp. 1-16.

[3849] T. D. Carr, T. E. Williamson, B. B. Britt, and K. L. Stadtman. "Evidence for high taxonomic and morphologic tyrannosauroid diversity in the Late Cretaceous (Late Campanian) of the American Southwest and a new short-skulled tyrannosaurid from the Kaiparowits Formation of Utah". English. In: Naturwissenschaften 98.3 (2011), pp. 241-246. DOI: 10.1007/s00114-011-0762-7.

[3850] M. T. Carrano, R. B. J. Benson, and S. D. Sampson. “The phylogeny of Tetanurae (Dinosauria: Theropoda)". English. In: Journal of Systematic Palaeontology 10.2 (2012), pp. 211-300. DOI: 10.1080/ 14772019.2011.630927.

[3851] M. T. Carrano, S. D. Sampson, and C. A. Forster. "The osteology of $<i>$ Masiakasaurus knopfleri $</ i>$, a small abelisauroid (Dinosauria: Theropoda) from the Late Cretaceous of Madagascar". In: Journal of Vertebrate Paleontology 22.3 (2002), pp. 510-534.

[3852] M. T. Carrano and S. D. Sampson. "A review of coelophysoids (Dinosauria: Theropoda) from the Early Jurassic of Europe, with comments on the late history of the Coelophysoidea". English. In: Neues Jahrbuch für Geologie und Paläontologie Monatshefte 2004.9 (2004), pp. 537-558.

[3853] M. T. Carrano and S. D. Sampson. "The phylogeny of Ceratosauria (Dinosauria: Theropoda)". English. In: Journal of Systematic Palaeontology 6.2 (2008), pp. 183-236. DOI: 10.1017/S1477201907002246.

[3854] M. T. Carrano and J. Velez-Juarbe. "Paleoecology of the Quarry 9 vertebrate assemblage from Como Bluff, Wyoming (Morrison Formation, Late Jurassic)". English. In: Palaeogeography, Palaeoclimatology, Palaeoecology 234.2-4 (2006), pp. 147-159.

[3855] O. Carranza-Castaneda. "Una nueva localidad del henfiliano tardio en la mesa central de Mexico". Spanish. In: Revista Mexicana de Ciencias Geologicas 10.2 (1992), pp. 179-196.

[3856] O. Carranza-Castaneda, J. J. Aranda-Gómez, X. Wang, and A. Iriondo. “The Early-Late Hemphillian (Hh2) Faunal Assemblage From Juchipila Basin, State of Zacatecas, Mexico, and Its Biochronologic Correlation with Other Hemphillian Faunas in Central Mexico". English. In: Contributions to Science, Natural History Museum of Los Angeles County 521 (2013), pp. 13-49.

[3857] O. Carranza-Castaneda and L. Espinosa-Arrubarrena. "Late Tertiary equids from the state of Hidalgo, Mexico". English. In: Revista Mexicana de Ciencias Geológicas 11.2 (1994), pp. 182-192.

[3858] O. Carranza-Castaneda and W. E. Miller. "Hemphillian and Blancan felids from central Mexico". English. In: Journal of Paleontology 70.3 (1996), pp. 509-518.

[3859] O. Carranza-Castaneda and W. E. Miller. Hemphillian and Blancan equids from Hidalgo, Mexico. English. 1993. 
[3860] O. Carranza-Castañeda and A. H. Walton. "Cricetid rodents from the Rancho El Ocote fauna, late Hemphillian (Pliocene), State of Guanajuato". English. In: Universidad Nacional Autónoma de México, Instituto de Geologia, Revista 10.1 (1992), pp. 71-93.

[3861] A. L. Carreño and T. M. Cronin. "Middle Eocene Ostracoda from Baja California Sur, Mexico". English. In: Journal of Micropalaeontology 12.2 (1993), pp. 141-153.

[3862] L. Carrera, M. Pavia, M. Peresani, and M. Romandini. “Late Pleistocene fossil birds from Buso Doppio del Broion Cave (North-Eastern Italy): implications for palaeoecology, palaeoenvironment and palaeoclimate". English. In: Bollettino della Societá Paleontologica Italiana 57 (2018), pp. 145-174.

[3863] L. Carrera, M. Pavia, M. Romandini, and M. Peresani. "Avian fossil assemblages at the onset of the LGM in the eastern Alps: A palaecological contribution from the Rio Secco Cave (Italy)". English. In: Comptes Rendus Palevol 17 (2018), pp. 166-177.

[3864] M. G. Carrera. "An Ordovician sponge fauna from the San Juan Formation, Precordillera Basin, western Argentina". English. In: Neues Jahrbuch für Geologie und Paläontologie, Abhandlungen 191.2 (1994), pp. 201-220.

[3865] M. G. Carrera. "First Ordovician sponge from the Puna Region, Northwestern Argentina". English. In: Ameghiniana 35.2 (1998), pp. 205-210.

[3866] M. G. Carrera. "Epizoan-sponge Interactions in the Early Ordovician of the Argentine Precordillera". English. In: Palaios 15 (2000), pp. 261-272.

[3867] M. G. Carrera. “Ordovician megamorinid demosponges from San Juan Formation, Precordillera, western Argentina". English. In: Geobios 29.6 (1996), pp. 643-650.

[3868] M. G. Carrera. "Nuevos poriferos de la formacion San Juan (Ordovicico), Precordillera Argentina". Spanish. In: Ameghiniana 33.3 (1996), pp. 335-342.

[3869] M. G. Carrera. "The new genus Multispongia (Porifera) from the Lower Ordovician limestones of the Argentine Precordillera". English. In: Ameghiniana 43.2 (2006), pp. 493-498.

[3870] M. G. Carrera. "The oldest hindiid demosponge from the Darriwilian (Middle Ordovician) of the Argentine Precordillera: evolutionary implications for the triclanocladines". English. In: Journal of Paleontology 81.4 (2007), pp. 754-759.

[3871] M. G. Carrera, R. A. Astini, and F. J. Gomez. "A lowermost Ordovician tabulate-like coralomorph from the Precordillera of western Argentina: a main component of a reef-framework consortium". English. In: Journal of Paleontology 91.1 (2017), pp. 73-85.

[3872] M. G. Carrera and S. Casado. "Solenoporacean red algae from lower Danian (Paleogene) coral reefs of northern Patagonia, La Pampa, Argentina". English. In: Ameghiniana 53.5 (2016), pp. 623628.

[3873] M. G. Carrera and A. Ernst. “Darriwilian bryozoans from the San Juan Formation (Ordovician), Argentine Precordillera". English. In: Ameghiniana 47.3 (2010), pp. 343-354.

[3874] M. G. Carrera and G. Ortega. "The hexactinellid sponge Cyathophycus from the Upper Ordovician of the Argentine Precordillera". English. In: Ameghiniana 46.3 (2009), pp. 449-459.

[3875] M. G. Carrera, J. J. Rustan, N. E. Vaccari, and M. Ezpeleta. “A new Mississippian hexactinellid sponge from the western Gondwana: Taxonomic and paleobiogeographic implications". English. In: Acta Palaeontologica Polonica 63.1 (2018), pp. 63-70.

[3876] M. G. Carrera, A. F. Sterren, G. A. Cisterna, and H. R. Niemeyer. “Pinegopora chilensis, a new Permian bryozoan species of the Andean bryozoan province in southwestern Gondwana". English. In: Journal of Paleontology 94 (2020), pp. 180-184. DOI: 10.1017/jpa.2019.32.

[3877] J. D. Carrillo, E. Amson, C. Jaramillo, R. Sánchez, L. Quiroz, C. Cuartas, A. F. Rincón, and M. R. Sánchez-Villagra. "The Neogene record of northern South American native ungulates". English. In: Smithsonian Contributions to Paleobiology 101 (2018).

[3878] J. D. Carrillo and M. S. Sánchez-Villagra. "Giant rodents from the Neotropics: diversity and dental variation of late Miocene neoepiblemid remains from Urumaco, Venezuela". English. In: Palaeontologische Zeitschrift 89.4 (2015), pp. 1057-1071. 
[3879] J. D. Carrillo-Briceño, T. Argyriou, V. Zapata, R. Kindlimann, and C. Jaramillo. “A new Early Miocene (Aquitanian) Elasmobranchii assemblage from the la Guajira Peninsula, Colombia". English. In: Ameghiniana 53.2 (2016), pp. 77-99. DOI: 10.5710/ AMGH.26.10.2015.2931.

[3880] J. D. Carrillo-Briceño, C. De Gracia, C. Pimiento, O. A. Aguilera, R. Kindlimann, P. Santamarina, and C. Jaramillo. "A new Late Miocene chondrichthyan assemblage from the Chagres Formation, Panama". English. In: Journal of South American Earth Sciences 60 (2015), 56e70.

[3881] J. D. Carrillo-Briceno, A. E. Reyes-Cespedes, R. Salas-Gismondi, and R. Sanchez. "A new vertebrate continental assemblage from the Tortonian of Venezuela". English. In: Swiss Journal of Palaeontology (2018), pp. 1-12. DOI: 10.1007/s13358-018-0180-y.

[3882] R.-P. Carriol and J. S. H. Collins. "New records of cirripedes (Crustacea, Thoracica) from the Albian of Yonne (France)". English. In: Bulletin of the Mizunami Fossil Museum 27 (2000), pp. 141-145.

[3883] R.-P. Carriol, H. Leyrit, and A. Giret. “Balanoidea (Crustacea, Cirripedia) du Miocene des Kerguelen". French. In: Géobios 25.3 (1992), pp. 383-388.

[3884] R. L. Carroll. "Batropetes from the Lower Permian of Europe - a Microsaur, not a Reptile". English. In: Journal of Vertebrate Paleontology 11.2 (1991), pp. 229-242.

[3885] R. L. Carroll. "A tiny microsaur from the lower Permian of Texas: size constraints in Palaeozoic tetrapods". English. In: Palaeontology 33 (1990), pp. 893-909.

[3886] R. L. Carroll, P. Bybee, and W. D. Tidwell. “The Oldest Microsaur (Amphibia)”. English. In: Palaeontology 65.2 (1991), pp. 314-322.

[3887] R. L. Carroll and Z.-M. Dong. "Hupehsuchus, an enigmatic reptile from the Triassic of China, and the problem of establishing relationships". English. In: Philosophical Transactions of the Royal Society of London B 331 (1991), pp. 131-153.

[3888] C. Cartelle, G. De Iuliis, and F. Pujos. "A new species of Megalonychidae (Mammalia, Xenarthra) from the Quaternary of Poço Azul (Bahia, Brazil)”. English. In: Comptes Rendus Palevol 7.6 (2008), pp. 335-346.

[3889] C. Cartelle, G. De Iuliis, A. Boscaini, and F. Pujos. "Anatomy, possible sexual dimorphism, and phylogenetic affinities of a new". English. In: Journal of Systematic Palaeontology 17.23 (2019), pp. 19571988.

[3890] C. Cartelle and W. C. Hartwig. A new extinct primate among the Pleistocene megafauna of Bahia, Brazil. English. 1996.

[3891] C. Cartelle and S. Hirooka. "Primeiro registro pleistocenico de Pteronura brasiliensis (Gmelin, 1788) (Carnivora, Mustelidae)". Portugese. In: Arquivos do Museu Nacional, Rio de Janeiro 63.3 (2005), pp. 595-598.

[3892] E. Carter. "Biochronology and paleontology of uppermost Triassic (Rhaetian) radiolarians, Queen Charlotte Islands, British Columbia, Canada". English. In: Memoires de Geologie 11 (1993), pp. 1175.

[3893] E. S. Carter, S. Gorian, J. Guex, L. O'Dogherty, P. De Wever, P. Dumitrica, R. S. Hori, A. Matsuoka, and P. A. Whalen. "Global radiolarian zonation for the Pliensbachian, Toarcian and Aalenian". English. In: Palaeogeography, Palaeoclimatology, Palaeoecology 297 (2010), pp. 401-419. DOI: 10.1016/ j.palaeo.2010.08.024.

[3894] E. S. Carter and R. S. Hori. "Global correlation of the radiolarian faunal change across the TriassicJurassic boundary". English. In: Canadian Journal of Earth Sciences 42.5 (2005), pp. 777-790.

[3895] E. S. Carter and M. J. Orchard. "Intercalibrated conodont-radiolarian biostratigraphy and potential datums for the Carnian-Norian boundary within the Upper Triassic Peril Formation, Queen Charlotte Islands, British Columbia". English. In: Geological Survey of Canada, Current Research A7 (2000), pp. 1-11.

[3896] E. S. Carter, P. A. Whalen, and J. Guex. "Biochronology and paleontology of Lower Jurassic (Hettangian and Sinemurian) radiolarians, Queen Charlotte Islands, British Columbia". English. In: Geological Survey of Canada Bulletin 496 (1998), pp. 1-162. 
[3897] J. G. Carter and G. D. Stanley. "Late Triassic Gastrochaenid and Lithophaginid Borings (Mollusca: Bivalvia) from Nevada (USA) and Austria". English. In: Journal of Paleontology 78.1 (2004), pp. 230 234.

[3898] J. L. Carter. Tournaisian (Early Osagean) brachiopods from a bioherm in the St. Joe Formation near Kenwood, Oklahoma. 1999.

[3899] J. L. Carter and V. I. Poletaev. "Atokan (Late Bashkirian or Early Moscovian) brachiopods from the Hare Fiord Formation of Ellesmere Island, Canadian Arctic Archipelago". English. In: Annals of Carnegie Museum 67.2 (1998), pp. 105-180.

[3900] A. M. Cartwright, T. P. Cleland, S. F. Derby, E. E. Ergas, H. I. Fay, K. M. Loughney, J. A. Riedel, M. K. Rocheford, C. L. Scott, and K. L. Skaggs. Aspects of the paleontology and stratigraphy of the lower Triassic-Lower Cretaceous strata of the eastern Bighorn Basin, WY. English. 2005.

[3901] P. Cartwright, S. Halgedahl, J. Hendricks, R. Jarrard, A. Marques, A. Collins, and B. Lieberman. "Exceptionally Preserved Jellyfishes from the Middle Cambrian". English. In: PLoS One 2.10 (2007), e1121.

[3902] C. Caruso and W. Wichard. "Paleogeographic distribution of Leuctridae and Nemouridae genera preserved in Baltic amber, with the description of Palaeopsole weiterschani n. gen., n. sp. (Plecoptera)". English. In: Entomologie Heute 23 (2011), pp. 69-77.

[3903] C. Caruso and W. Wichard. "Overview and descriptions of fossil Stoneflies (Plecoptera) in Baltic amber". English. In: Entomologie Heute 22 (2010), pp. 85-97.

[3904] F. Caruso Jr., K. Suguio, and T. Nakamura. “The Quaternary geological history of the Santa Catarina southeastern region (Brazil)". In: Anais da Academia Brasileira de Ciencias 72.2 (2000).

[3905] A. H. Caruthers and P. L. Smith. "Pliensbachian ammonoids from the Talkeetna Mountains (Peninsular Terrane) of Southern Alaska". English. In: Revue de Paléobiologie, Genéve, vol. spéc 11 (2012), pp. 365-378.

[3906] A. H. Caruthers and G. D. Stanley Jr. "Systematic analysis of upper triassic silicified scleractinian corals from Wrangellia and the Alexander Terrane, Alaska and British Columbia". English. In: Journal of Paleontology 82.3 (2008), pp. 470-491.

[3907] G. S. Carvalho and L. O. Salles. "Relationships among extant and fossil echimyids (Rodentia: Hystricognathi)". English. In: Zoological Journal of the Linnean Society 142 (2004), pp. 445-477.

[3908] I.d.S. Carvalho. "As pegadas de dinossauros da Bacia de Uiraúna-Brejo das Freiras (Cretáceo Inferior, estado da Paraba) [Dinosaur footprints in the Uiraúna-Brejo das Freiras Basin (Lower Cretaceous, Paraba state)]". Portugese. In: Boletim do 40 Simpósio sobre o Cretáceo do Brasil, Águas de São Pedro/Rio Claro. UNESP (1996), pp. 115-121.

[3909] I.d.S. Carvalho. “Huellas de saurópodos de la Formación Antenor Navarro (Cretácico Temprano de la cuenca de Sousa), Serrote do Letreiro, Paraba, Brasil [Sauropod footprints from the Antenor Navarro Formation (Early Cretaceous of the Sousa Basin), Serrote do Letreiro, Paraba, Brazil]". Spanish. In: Ameghiniana 37.3 (2000), pp. 353-362.

[3910] I.d.S. Carvalho. “Dinosaur footprints from northeastern Brazil: taphonomy and environmental setting". English. In: Ichnos 11.3-4 (2004), pp. 311-321. DOI: 10.1080/10420940490442368.

[3911] I.d.S. Carvalho, L.d.S. Avilla, and L. Salgado. "Amazonsaurus maranhensis gen. et sp. nov. (Sauropoda, Diplodocoidea) from the Lower Cretaceous (Aptian-Albian) of Brazil". English. In: Cretaceous Research 24 (2003), pp. 697-713.

[3912] I.d.S. Carvalho and R. J. Bertini. "Mariliasuchus, um novo Crocodylomorpha (Notosuchia) do Cretáceo da Bacia Bauru, Brasil". Spanish. In: Revista Geologia Colombiana 24 (1999), pp. 83-105.

[3913] I.d.S. Carvalho, I. V. Boas, and L. P. Bergqvist. "Plesiossauros da regiao equatorial brasileira Bacia de Sao Luis (Cretaceous Superior), Brasil". Portugese. In: Acta Geologica Leopoldensia 23.51 (2000), pp. 33-41. 
[3914] I.d.S. Carvalho and S.d.S. Kattah. “As pegadas fósseis do paleodeserto da Bacia Sanfranciscana (Jurássico Superior-Cretáceo Inferior; Minas Gerais) [Footprint fossils from the paleodesert of the Sanfranciscana Basin (Upper Jurassic-Lower Cretaceous; Minas Gerais)]". Portugese. In: Anais da Academia Brasileira de Ciencias 70.1 (1998), pp. 53-67.

[3915] I.d.S. Carvalho and E. Pedrão. "Brazilian theropods from the equatorial Atlantic margin: behavior and environmental setting". English. In: GAIA 15 (2000), pp. 369-378.

[3916] I.d.S. Carvalho, L. C. B. Ribeiro, and L.d.S. Avilla. “Uberabasuchus terrificus sp. nov., a new Crocodylomorpha from the Bauru Basin (Upper Cretaceous), Brazil". English. In: Gondwana Research 7.4 (2004), pp. 975-1002.

[3917] I.d.S. Carvalho, V. P. A. Teixeira, M.L.d.F. Ferraz, L. C. B. Ribeiro, A. G. Martinelli, F. M. Neto, J. J. W. Sertich, G. C. Cunha, I. C. Cunha, and P. F. Ferraz. "Campinasuchus dinizi gen. et sp. nov., a new Late Cretaceous baurusuchid (Crocodyliformes) from the Bauru Basin, Brazil". English. In: Zootaxa 2871 (2011), pp. 19-42.

[3918] I.d.S. Carvalho, F.M.d. Vasconcellos, and S. A. S. Tavares. "Montealtosuchus arrudacamposi, a new peirosaurid crocodile (Mesoeucrocodylia) from the Late Cretaceous Adamantina Formation of Brazil". English. In: Zootaxa 1607 (2007), pp. 35-46.

[3919] I.d.S. Carvalho, M. S. S. Viana, and M.F.d.L. Filho. “Os icnofósseis de dinossauros da Bacia do Araripe (Crétaceo Inferior, Ceará-Brasil) [Dinosaur ichnofossils from the Araripe Basin (Lower Cretaceous, Ceará, Brazil)]". Portugese. In: Anais da Academia Brasileira de Ciencias 67.4 (1995), pp. 433-442.

[3920] I.d.S. Carvalho, M. S. S. Viana, and M.F.d.L. Filho. “Bacia de Cedro: a icnofauna Cretácea de vertebrados [Cedro Basin: a Cretaceous vertebrate ichnofauna]". Portugese. In: Anais da Academia Brasileira de Ciencias 67.1 (1995), pp. 25-31.

[3921] I.d.S. Carvalho and M. S. S. Viana. “A Bacia de Padre Marcos (Cretáceo Inferior, estado do Piau) e sua icnofauna dinossauriana [On the Padre Marcos Basin (Lower Cretaceous, Piau State) and its dinosaurian ichnofauna]". Portugese. In: XXXIX Congresso Brasiliero de Geologia: Geologia e Sociedade, Sergipe. Sociedade Brasiliera de Geologia, Núcleo Bahia. Sessões Temáticas, Anas 2 (1996), pp. 265-267.

[3922] I. S. Carvalho, F. Agnolin, M. A. Aranciaga Rolando, F. E. Novas, J. Xavier-Neto, F. I. Freitas, and J. A. F. G. Andrade. "A new genus of pipimorph frog (Anura) from the Early Cretaceous Crato Formation (Aptian) and the evolution of South American tongueless frogs". English. In: Journal of South American Earth Sciences 92 (2019), pp. 368-373. DOI: 10.1016/j.jsames.2019.03.005.

[3923] I. S. Carvalho, A. C. A. Campos, and P. H. Nobre. "Baurusuchus salgadoensis, a new crocodylomorpha from the Bauru Basin (Cretaceous), Brazil". English. In: Gondwana Research 8.1 (2005), pp. 11-30.

[3924] I. S. Carvalho, F. E. Novas, F. L. Agnoln, M. P. Isasi, F. I. Freitas, and J. A. Andrade. "A new genus and species of enantiornithine bird from the Early Cretaceous of Brazil". English. In: Brazilian Journal of Geology 45.2 (2015), pp. 161-171.

[3925] I. S. Carvalho, L. Salgado, R. M. Lindoso, H. I. de Araújo-Júnior, F. C. Costa Nogueira, and J. A. Soares. "A new basal titanosaur (Dinosauria, Sauropoda) from the Lower Cretaceous of Brazil". English. In: Journal of South American Earth Sciences 75 (2017), pp. 74-84. DOI: 10.1016/j.jsames. 2017.01.010.

[3926] M. D. G. Carvalho and J. Moody. "A Middle Devonian Trilobite Assemblage from Venezuela". English. In: American Museum Novitates 3292 (2000), pp. 1-15.

[3927] M. G. P. Carvalho, G. D. Edgecombe, and B. S. Lieberman. “Devonian calmoniid trilobites from the Parnaba Basin, Piau State, Brazil". English. In: American Museum Novitates 3192 (1997), pp. 111.

[3928] M. R. Carvalho, F. A. Herrera, C. A. Jaramillo, S. L. Wing, and R. Callejas. "Paleocene Malvaceae from northern South America and their biogeographical implications". English. In: American Journal of Botany 98.8 (2011), pp. 1-19. 
[3929] M. R. Carvalho, P. Wilf, E. J Hermsen, M. A. Gandolfo, N. R. Cúneo, and K. R. Johnson. “First record of Todea (Osmundaceae) in South America, from the early Eocene paleorainforests of Laguna del Hunco (Patagonia, Argentina)". English. In: American Journal of Botany 100 (2013), pp. 1831-1848.

[3930] P. Carvalho, J. Bocquentin, and F. de Lapparent de Broin. "Une nouvelle espéce de Podocnemis (Pleurodira, Podocnemididae) provenant du Néogéne de la formation Solimões, Acre, Brésil". English. In: Géobios 35.6 (2002), pp. 677-686.

[3931] A. Casadei-Ferreira, J. C. M. Chaul, and R. M. Feitosa. "A new species of Pheidole (Formicidae, Myrmicinae) from Dominican amber with a review of the fossil records for the genus". English. In: ZooKeys 866 (2019), pp. 117-125.

[3932] S. Casadio, A. De Angeli, R. M. Feldmann, A. Garassino, J. L. Hetler, A. Parras, and C. E. Schweitzer. "New decapod crustaceans (Thalassinidea, Galatheoidea, Brachyura) from the Middle Oligocene of Patagonia, Argentina". English. In: Annals of Carnegie Museum 73.2 (2004), pp. 25-47.

[3933] S. Casadio, R. M. Feldmann, and K. A. Foland. "40Ar/39Ar age and oxygen isotope temperature of the Centinela Formation, southwestern Argentina: An Eocene age for crustacean-rich Patagonian beds". English. In: Journal of South American Earth Sciences 13 (2000), pp. 123-132.

[3934] S. Casadio, R. M. Feldmann, A. Parras, and C. E. Schweitzer. "Miocene fossil Decapoda (Crustacea: Brachyura) from Patagonia, Argentina, and their paleoecological setting". English. In: Annals of Carnegie Museum 74.3 (2005), pp. 151-188.

[3935] S. Casadio, M. Griffin, and A. Parras. "Camptonectes and Plicatula (Bivalvia, Pteriomorphia) from the Upper Maastrichtian of northrern Patagonia: palaeobiogeographic implications". English. In: Cretaceous Research 26 (2005), pp. 507-524.

[3936] S. Casado, T. Manera, A. Parras, and C. I. Montalvo. "Huevos de dinosaurios (Faveoloolithidae) del Cretácico Superior de la cuenca del Colorado, provincia de La Pampa, Argentina". Spanish. In: Ameghiniana 39.3 (2002), pp. 285-293.

[3937] S. Casado, M. F. Rodriguez, V. A. Reichler, and H. H. Camacho. "Tertiary nautiloids from Patagonia, southern Argentina". English. In: Ameghiniana 36 (1999), pp. 189-202.

[3938] G. Casal and L. Ibiricu. "Materiales asignables a Epachthosaurus Powell, 1990 (Sauropoda: Titanosauria), de la Formación Bajo Barreal, Cretácico Superior, Chubut, Argentina [Materials assignable to Epachthosaurus Powell, 1990 (Sauropoda: Titanosauria), from the Bajo Barreal Formation, Upper Cretaceous, Chubut, Argentina]". Spanish. In: Revista Brasileira de Paleontologia 13.3 (2010), pp. 247-256. DOI: 10.4072/rbp.2010.3.08.

[3939] G. Casal, R. D. Martnez, M. Luna, J. C. Sciutto, and M. C. Lamanna. “Aeolosaurus colhuehuapensis sp. nov. (Sauropoda, Titanosauria) de la Formación Bajo Barreal, Cretácico Superior de Argentina [Aeolosaurus colhuehuapensis sp. nov. (Sauropoda, Titanosauria) from the Bajo Barreal Formation, Upper Cretaceous of Argentina]". Spanish. In: Revista Brasileira de Paleontologia 10.1 (2007), pp. 53-62.

[3940] G. A. Casal, L. M. Ibiricu, R. D. Martinez, M. Luna, B. N. Alvarez, and X. Castano. Nuevos hallazgos de vertebrados fosiles en la formacion Lago Colhue Huapi (Cretacico Superior), Grupo Chubut, Patagonia Argentina. Spanish. 2018.

[3941] G. A. Casal, R. D. Martinez, M. Luna, and L. M. Ibiricu. “Ordenamiento y caracterización faunisitica del Cretacico superior del Grupo Chubut, Cuenca del Golfo San Jorge, Argentina". Spanish. In: Revista Brasileira de Paleontologia 19.1 (2016), pp. 53-70. DOI: 10.4072/rbp.2016.1.05.

[3942] M. L. Casanovas, R. Ezquerra, A. Fernández, F. Pérez-Lorente, J. V. Santafé, and F. Torcida. “Dos nuevos yacimentos de icnitas de dinosaurios en La Rioja y en la provincia de Soria (España) [Two new dinosaur tracksites in La Rioja and Soria Province (Spain)]". Spanish. In: Coloquios de Paleontologia 47 (1995), pp. 9-23. 
[3943] M. L. Casanovas, R. Ezquerra, A. Fernández, D. Montero, F. Pérez-Lorente, J. V. Santafé, F. Torcida, and L. I. Viera. "El yacimento de La Canal (Munilla, La Rioja, España). La variación de velocidad en función del tamaño del pie de los ornitópodos [The La Canal locality (Munilla, La Rioja, Spain). The variation of velocity as a function of the size of the foot of ornithopods]". Spanish. In: Zuba 13 (1995), pp. 55-81.

[3944] M. L. Casanovas, R. Ezquerra, A. Fernández, F. Pérez-Lorente, J. V. Santafé, and F. Torcida. “Huellas de dinosaurio en la Era del Peladillo 3 (La Rioja, España). Primera nota [Dinosaur tracks in the Era del Peladillo 3 (La Rioja, Spain). First notice]". Spanish. In: Zuba 13 (1995), pp. 83-101.

[3945] M. L. Casanovas, A. Fernández, F. Pérez-Lorente, and J. V. Santafé. "Sauropod trackways from site El Sobaquillo (Munilla, La Rioja, Spain) indicate amble walking". English. In: Ichnos 5 (1997), pp. 101-107.

[3946] M. L. Casanovas, X. Pereda-Suberbiola, J. V. Santafé, and D. B. Weishampel. “First lambeosaurine hadrosaurid from Europe: palaeobiogeographical implications". In: Geological Magazine 136.2 (1999), pp. 205-211.

[3947] M. L. Casanovas-Cladellas, J. V. Santafé-Llopis, J. L. Sanz, and J. E. Powell. “Nuevos restos de dinosaurios (Titanosauria y Ornithopoda) en el Cretácico Superior de las cuencas de Tremp y Dellá (Lleida, España) [New remains of dinosaurs (Titanosauria and Ornithopoda) in the Upper Cretaceous of the Temp and Dellá basins (Lleida, Spain)]". Spanish. In: Estudios Geológicos 51 (1995), pp. 277-283.

[3948] L. R. Casazza. "Symbiosis in the Fossil Record: Eocene Nummulites and Pleistocene Reefs of Egypt". English. PhD thesis. 2012.

[3949] G. R. Case. "A new selachian fauna from the Coleraine Formation (Upper Cretaceous/Cenomanian) of Minnesota". English. In: Palaeontographica Abteilung A 261.Lfg. 4-6 (2001), pp. 103-112.

[3950] G. R. Case. "Selachians (sharks) from the Tupelo Tongue of the Coffee Sand (Campanian, Upper Cretaceous) in northern Lee County, Mississippi". English. In: Mississippi Geology 11.3 (1991), pp. 1-8.

[3951] G. R. Case. "A new selachian fauna from the Lower Hornerstown Formation (Early Paleocene/Montian) of Monmouth County, New Jersey". English. In: Palaeontographica Abteilung A 242.Lfg. 1-3 (1996), pp. 1-14.

[3952] G. R. Case. "A New Species of Chimaeroid Fish from the Upper Paleocene (Thanetian) of Maryland, USA". English. In: Palaeovertebrata 21.1-2 (1991), pp. 85-94.

[3953] G. R. Case, P. D. Borodin, and J. J. Leggett. "Fossil selachians from the New Egypt Formation (Upper Cretaceous, Late Maastrichtian) of Arneytown, Monmouth County, New Jersey". English. In: Palaeontographica Abteilung A 261.Lfg. 4-6 (2001), pp. 113-124.

[3954] G. R. Case and H. Cappetta. "The Eocene selachian fauna from the Fayum Depression in Egypt". English. In: Palaeontographica Abteilung A 212.Lfg. 1-6 (1990), pp. 1-30.

[3955] G. R. Case and H. Cappetta. "Additions to the elasmobranch fauna from the Late Cretaceous of New Jersey (lower Navesink Formation, early Maastrichtian)". English. In: Palaeovertebrata 33 (2004), pp. 1-16.

[3956] G. R. Case, T. D. Cook, and M. V. H. Wilson. "A new elasmobranch assemblage from the early Eocene (Ypresian) Fishburne Formation of Berkeley County, South Carolina, USA". English. In: Canadian Journal of Earth Sciences 52 (2015), pp. 1121-1136. DOI: 10.1139/cjes-2015-0061.

[3957] G. R. Case, T. D. Cook, M. V. H. Wilson, and P. D. Borodin. "A new species of the sclerorhynchid sawfish Borodinopristis from the Campanian (Upper Cretaceous) of North Carolina, USA". English. In: Historical Biology 24 (2012), pp. 592-597. DOI: 10.1080/08912963.2012.663367.

[3958] G. R. Case, T. D. Cook, and M. V. H. Wilson. English. In: Historical Biology 23.2-3 (2011), pp. 139144.

[3959] G. R. Case, D. R. Schwimmer, P. D. Borodin, and J. J. Leggett. "A new selachian fauna from the Eutaw Formation (Upper Cretaceous/Early to Middle Santonian) of Chattahoochee County, Georgia". English. In: Palaeontographica Abteilung A 261.Lfg. 4-6 (2001), pp. 83-102. 
[3960] G. R. Case, T. T. Tokaryk, and D. Baird. "Selachians from the Niobrara Formation of the Upper Cretaceous (Coniacian) of Carrot River, Saskatchewan, Canada". English. In: Canadian Journal of Earth Sciences 27 (1990), pp. 1084-1094.

[3961] G. R. Case, N. I. Udovichenko, L. A. Nessov, A. O. Averianov, and P. D. Borodin. “A Middle Eocene selachian fauna from the White Mountain Formation of the Kizylum Desert, Uzbekistan, C.I.S". English. In: Palaeontographica Abteilung A 242.Lfg.4-6 (1996), pp. 99-126.

[3962] G. R. Case and R. M. West. "Geology and Paleontology of the Eocene Drazinda Shale Member of the Khirthar Formation, central Western Pakistan, Part II Late Eocene fishes". English. In: Tertiary Research 12.3-4 (1991), pp. 105-120.

[3963] J. A. Case. "The late middle Eocene terrestrial vertebrate fauna from Seymour Island; the tails of the Eocene Patagonian size distribution". English. In: Geological Society Special Publications 258 (2006), pp. 177-186.

[3964] J. A. Case, F. J. Goin, and M. O. Woodburne. "South American marsupials from the Late Cretaceous of North America and the origin of marsupial cohorts". English. In: Journal of Mammalian Evolution 11.3/4 (2004), pp. 223-255.

[3965] J. A. Case, J. E. Martin, and M. A. Reguero. “A dromaeosaur from the Maastrichtian of James Ross Island and the Late Cretaceous Antarctic dinosaur fauna". English. In: In A. K. Cooper, C. R. Raymond, \& the ISAES Editorial Team (eds.), Antarctica: A Keystone in a Changing World. Online Proceedings of the 10th ISAES. United States Geological Survey and the National Academies. USGS OpenFile Report 2007-1047, Short Research Paper 083 (2007), pp. 1-4. DOI: 10.3133/0f2007-1047.srp083.

[3966] J. G. Casier and F. Lethiers. "The recovery of the ostracod fauna after the Late Devonian mass extinction: the devils Gate Pass section exemple (Nevada, USA)". English. In: Palaeontology 327 (1998), pp. 501-507.

[3967] J.-G. Casier, X. Devleeschouwer, F. Lethiers, A. Preat, and G. Racki. “Ostracods and fore-reef sedimentology of the Frasnian-Famennian boundary beds in Kielce (Holy Cross Mountains, Poland)". In: Acta Palaeontologica Polonica 47.2 (2002), pp. 227-246.

[3968] M. Cassiliano. "Stenomylus (Stenomylus) taylori, s.p. nov. (Stenomylinae, Camelidae) from the early Miocene (Hemingfordian) Blick Quarry in New Mexico". English. In: Rocky Mountain Geology 43.2 (2008), pp. 143-154.

[3969] M. L. Cassiliano. "Biostratigraphy of Blancan and Irvingtonian mammals in the Fish Creek-Vallecito Creek section, southern California, and a review of the Blancan-Irvingtonian boundary". In: Journal of Vertebrate Paleontology 19.1 (1999), pp. 169-186.

[3970] M. L. Cassiliano. “A new genus and species of Stenomylinae (Camelidae, Artiodactyla) from the Moonstone Formation (late Barstovian-early Hemphillian) of central Wyoming". English. In: Rocky Mountain Geology 43.1 (2008), pp. 41-110. DOI: 10.2113/gsrocky.43.1.41.

[3971] F. Cassola and K. Werner. "A fossil tiger beetle specimen from the Brazilian Mesozoic: Oxycheilopsis cretacicus n. gen., n. sp." English. In: Mitteilungen der Münchner Entomologischen Gesellschaft 94 (2004), pp. 75-81.

[3972] M. Casson, L. G. Bulot, J. Jeremiah, and J. Redfern. "Deep sea rock record exhumed on oceanic volcanic islands: the Cretaceous sediments of Maio, Cape Verde". English. In: Gondwana Research 81 (2020), pp. 252-264. DOI: 10.1016/j.gr.2019.11.007.

[3973] D. Castanera, J. L. Barco, I. Daz-Martnez, J. H. Gascón, F. Pérez-Lorente, and J. I. Canudo. “New evidence of a herd of titanosauriform sauropods from the lower Berriasian of the Iberian range (Spain)". English. In: Palaeogeography, Palaeoclimatology, Palaeoecology 310 (2011), pp. 227-237.

[3974] D. Castanera, C. Pascual, and J. I. Canudo. "Primera evidencia de morfologa del pie en saurópodos en el grupo Urbión de la Cuenca de Cameros (Cretácico Inferior, Soria, España) [First evidence of sauropod pedal morphology in the Urbión Group of the Cameros Basin (Lower Cretaceous, Soria, Spain)]". Spanish. In: Geogaceta 53 (2013), pp. 13-16. 
[3975] R. Castanhinha, R. Araújo, L. C. Júnior, K. D. Angielczyk, G. G. Martins, R. M. S. Martins, C. Chaouiya, F. Beckmann, and F. Wilde. "Bringing Dicynodonts Back to Life: Paleobiology and Anatomy of a New Emydopoid Genus from the Upper Permian of Mozambique". English. In: PLOS ONE 9.4 (2014), e94720.

[3976] D. F. Castro, R. J. Bertini, R. M. Santucci, and M. A. Medeiros. "Sauropods of the Itapecuru Group (lower/middle Albian), São Luis-Grajaú Basin, Maranhão State, Brazil". English. In: Revista Brasileira de Paleontologia 10.3 (2007), pp. 195-200.

[3977] M. Castro and M. C. Langer. "New postcranial remains of Smilodon populator Lund, 1842 from southeastern Brazil". English. In: Revista Brasileira de Paleontologia 11.3 (2008), pp. 199-206.

[3978] M. C. Castro, A. A. Carlini, R. Sanchez, and M. R. Sanchez-Villagra. "A new Dasypodini armadillo (Xenarthra: Cingulata) from San Gregorio Formation, Pliocene of Venezuela: affinities and biogeographic interpretations". English. In: Naturwissenschafen 101.2 (2014), pp. 77-86. DOI: 10.1007/s00114-013-1131-5.

[3979] M. C. Castro, F. J. Goin, E. Ortiz-Jaureguizar, E. C. Vieytes, K. Tsukui, J. Ramezani, A. Batezelli, J. C. A. Marsola, and M. C. Langer. "A Late Cretaceous mammal from Brazil and the first radioisotopic age for the Bauru Group". English. In: Royal Society Open Science 5 (2018), 180482:1-11. DOI: 10.1098/rsos.180482.

[3980] C. S. Cataldo. "A new Early Cretaceous nerineoid gastropod from Argentina and its palaeobiogeographic and palaeoecological implications". English. In: Cretaceous Research (2012). DOI: 10.1016/ j.cretres.2012.05.007.

[3981] C. S. Cataldo. "The gastropod family Aporrhaidae in the Lower Cretaceous of the Neuquén Basin, west-central Argentina". English. In: Journal of Paleontology 88.6 (2014), pp. 1222-1239. DOI: 10. 1666/13-182.

[3982] M. S. Caterino and D. R. Maddison. "An early and mysterious histerid inquiline from Cretaceous Burmese amber (Coleoptera, Histeridae)". English. In: ZooKeys 733 (2018), pp. 119-129.

[3983] M. S. Caterino, K. Wolf-Schwenninger, and G. Bechly. “Cretonthophilus tuberculatus, a remarkable new genus and species of hister beetle (Coleoptera: Histeridae) from Cretaceous Burmese amber". English. In: Zootaxa 4052 (2015), pp. 241-245.

[3984] A. Cau. "The affinities of 'Steneosaurus barettoni' (Crocodylomorpha, Thalattosuchia), from the Jurassic of Northern Italy, and implications for cranial evolution among geosaurine metriorhynchids". English. In: Historical Biology (2013). DOI: 10.1080/08912963.2013.784906.

[3985] A. Cau and P. Arduini. "Enantiophoenix electrophyla gen. et sp. nov. (Aves, Enantiornithes) from the Upper Cretaceous (Cenomanian) of Lebanon and its phylogenetic relationships". English. In: Atti della Societa Italiana di Scienze Naturali e del Museo Civico di Storia Naturale di Milano 149.2 (2008), pp. 293-324.

[3986] A. Cau, M. A. Baiano, and P. Raia. “A new sphenodontian (Reptilia, Lepidosauria) from the Lower Cretaceous of Southern Italy and the phylogenetic afnities of the Pietraroia Plattenkalk rhynchocephalians". English. In: Cretaceous Research 49 (2014), pp. 172-180.

[3987] A. Cau, V. Beyrand, D. F. A. E. Voeten, V. Fernandez, P. Tafforeau, K. Stein, R. Barsbold, K. Tsogtbaatar, P. J. Currie, and P. Godefroit. "Synchrotron scanning reveals amphibious ecomorphology in a new clade of bird-like dinosaurs". English. In: Nature (2017). DOI: 10.1038/nature24679.

[3988] A. Cau, F. M. Dalla Vecchia, and M. Fabri. "A thick-skulled theropod (Dinosauria, Saurischia) from the Upper Cretaceous of Morocco with implications for carcharodontosaurid cranial evolution". English. In: Cretaceous Research 40 (2013), pp. 251-260. DOI: 10.1016/j.cretres.2012.09.002.

[3989] A. Cau and F. Fanti. "The oldest known metriorhynchid crocodylian from the Middle Jurassic of North-eastern Italy: Neptunidraco ammoniticus gen. et sp. nov." English. In: Gondwana Research 19 (2011), pp. 550-565.

[3990] A. Cau and F. Fanti. "A pliosaurid (Reptilia, Plesiosauria) from the Rosso Ammonitico Veronese Formation of Italy". English. In: Acta Palaeontologica Polonica (2014). DOI: 10.4202/app.2012.0117. 
[3991] A. Cau and F. Fanti. "High evolutionary rates and the origin of the Rosso Ammonitico Veronese Formation (Middle-Upper Jurassic of Italy) reptiles". English. In: Historical Biology 28.7 (2016), pp. 952-962. DOI: 10.1080/08912963.2015.1073726.

[3992] A. Cau and S. Maganuco. "A new theropod dinosaur, represented by a single unusual caudal vertebra, from the Kem Kem Beds (Cretaceous) of Morocco". English. In: Atti della Societá italiana di scienze naturali e del museo civico di storia naturale di Milano 150 (2009), pp. 239-257.

[3993] R. R. Cavalcanti Duque and A. M. Franca Barreto. “New Fossiliferous Sites of the Romualdo Formation, Lower Cretaceous, Araripe Basin, Exu, Pernambuco, Northeast of Brazil". Portugese. In: Anuário do Instituto de Geociencias - UFRJ 41.1 (2018), pp. 5-14.

[3994] I. Cavicchini, M. Zaher, and M. J. Benton. "An enigmatic neodiapsid reptile from the Middle Triassic of England". English. In: Journal of Vertebrate Paleontology 40.3 (2020), e1781143:1-18. DOI: 10.1080/02724634.2020.1781143.

[3995] L. Cavin. “Nouveaux teleostei du gisement du Turonien inférieur de Goulmima (Maroc)[New Teleostei from the Eraly Turonian locality of Goulmima (Morocco)]". French. In: Comptes Rendus de l'Académie des Sciences, Sciences de la Terre et des Planétes 325 (1997), pp. 719-724.

[3996] L. Cavin. "A new Clupavidae (Teleostei, Ostariophysi) from the Cenomanian of Daoura (Morocco)". English. In: Comptes Rendus de l'Académie des Sciences, Série IIA - Sciences de la Terre et des Planétes 329.9 (1999), pp. 689-695.

[3997] L. Cavin, A. Alexopoulos, and A. Piuz. "Cavin, L., Alexopoulos, A., \& Piuz, A. (2012). Late Cretaceous (Maastrichtian) ray-finned fishes from the island of Gavdos, southern Greece, with comments on the evolutionary history of the aulopiform teleost Enchodus". English. In: ulletin de La Societe Geologique de France 183.6 (2012), pp. 561-572. DOI: 10.2113/gssgfbull.183.6.561ă.

[3998] L. Cavin and P. M. Brito. “A new Lepisosteidae (Actinopterygii: Ginglymodi) from the Cretaceous of the Kem Kem beds, southern Morocco". English. In: Bulletin de la Société Géologique de France 172.5 (2001), pp. 661-670.

[3999] L. Cavin, U. Deesri, and V. Suteethorn. The Jurassic and Cretaceous bony fish record (Actinopterygii, Dipnoi) from Thailand. English. Vol. 315. Late Palaeozoic and Mesozoic Ecosystems in SE Asia. The Geological Society of London, Special Publication. 2009, pp. 125-139.

[4000] L. Cavin, P. L. Forey, E. Buffetaut, and H. Tong. "Latest European coelacanth shows Gondwanan affinities". English. In: Biology Letters 1 (2005), pp. 176-177.

[4001] L. Cavin, H. Furrer, and C. Obrist. "New coelacanth material from the Middle Triassic of eastern Switzerland, and comments on the taxic diversity of actinistans". English. In: Swiss Journal of Geosciences 106 (2013), pp. 161-177.

[4002] L. Cavin and E. Grdinaru. "Dobrogeria aegyssensis, a new early Spathian (Early Triassic) coelacanth from North Dobrogea (Romania)". English. In: Acta Geologica Polonica 64 (2014), pp. 161187.

[4003] L. Cavin and D. Grigorescu. "A new Crossognathus (Actinopterygii, Teleostei) from the Lower Cretaceous of Romania with comments on Crossognathidae relationships". English. In: Geodiversitas 27.1 (2005), pp. 5-16.

[4004] L. Cavin, B. Mennecart, C. Obrist, L. Costeur, and H. Furrer. "Heterochronic evolution explains novel body shape in a Triassic coelacanth from Switzerland". English. In: Scientific Reports 7.13695 (2017), pp. 1-7.

[4005] L. Cavin, V. Suteethorn, E. Buffetaut, and H. Tong. "A new Thai Mesozoic lungsh (Sarcopterygii, Dipnoi) with an insight into post-Palaeozoic dipnoan evolution". English. In: Zoological Journal of the Linnean Society 149 (2007), pp. 141-177.

[4006] L. Cavin and V. Suteethorn. "A new Semionotiform (Actinopterygii Neopterygii) from Upper Jurassic-Lower Cretaceous Deposits of North-East Thailand, with Comments on the Relationships of Semionotiforms". English. In: Palaeontology 49 (2006), pp. 339-353. 
[4007] L. Cavin, V. Suteethorn, E. Buffetaut, J. Claude, G. Cuny, J. Le Loeuff, and H. Tong. “The first sinamiid fish (Holostei: Halecomorpha) from Southeast Asia (Early Cretaceous of Thailand)". English. In: Journal of Vertebrate Paleontology 27.4 (2007), pp. 827-837. DOI: 10.1671/0272-4634(2007) 27[827:TFSFHH]2.0.CO;2.

[4008] J. J. Cawley, J. Kriwet, S. Klug, and M. J. Benton. “The stem group teleost Pachycormus (Pachycormiformes: Pachycormidae) from the Upper Lias (Lower Jurassic) of Strawberry Bank, UK". English. In: PalZ 93 (2019), pp. 285-302. DOI: 10.1007/s12542-018-0431-7.

[4009] B. Caze, J. P. Saint Martin, and J. Pacaud. "Les mollusques éocénes se dévoilent sous ultraviolets". French. In: Les coquillages de l'Éocéne du Bassin parisien, un trésor inestimable vieux de 40 (2012), pp. $15-56$.

[4010] B. Caze, D. Merle, J. M. Pacaud, and J. P. Saint Martin. "First systematic study using the variability of the residual colour patterns: the case of the Paleogene Seraphsidae (Mollusca, Gastropoda, Stromboidea)". English. In: Geodiversitas 32.3 (2010), pp. 417-477. DOI: 10.5252/g2010n3a4.

[4011] B. Caze, D. Merle, M. Le Meur, J. -M. Pacaud, D. Ledon, and J. -P. Saint Martin. “Taxonomic Implications of the Residual Colour Patterns of Ampullinid Gastropods and Their Contribution to the Discrimination from Naticids". English. In: Acta Palaeontologica Polonica 56.2 (2009), pp. 329347.

[4012] F. Cecca. "The late Albian genus Semenoviceras (Hoplitidae, Ammonitina): palaeontologic study of a fauna of the Semenoviceras litschkovi zone from Mangyshlak (west Khazakstan)". English. In: Rivista Italiana di Paleontologia e Stratigrafia 103 (1997), pp. 323-342.

[4013] F. Cecca, A. V. Dhondt, and T. N. Bogdanova. "The Aptian stratigraphy of the southern Tuarkyr (NW Turkmenistan, Central Asia)". English. In: Rivista Italiana di Paleontologia e Stratigrafia 105.3 (1999), pp. 377-396.

[4014] F. Cecca, P. Faragni, and A. Marini. “Latest Hauterivian (Early Cretaceous) ammonites from UmbriaMarche Apennines (central Italy)". English. In: Palaeontographia Italica 85 (1998), pp. 61-110.

[4015] F. Cecca, G. Pallini, E. Erba, I. Permoli-Silva, and R. Coccioni. "Hauterivian-Barremian chronostratigraphy based on ammonites, nannofossils, planktonic foraminifera and magnetic chrons from the Mediterranean domain". In: Cretaceous Research 15 (1994), pp. 457-467.

[4016] F. Cecca, B. Savary, A. Bartolini, J. Remane, and F. Cordey. "The Middle Jurassic-Lower Cretaceous Rosso Ammonitico succession of Monte Inici (Trapanese Domain, western Sicily): sedimentology, biostratigraphy and isotope stratigraphy". In: Bulletin de la Societé Géologique de France 172.5 (2001), pp. 647-659.

[4017] F. Cecca, B. Savary, T. Lavoyer, and H. Gaget. “The Middle Jurassic-Lower Cretaceous Rosso Ammonitico succession of Monte Inici (Trapanese Domain, western Sicily); sedimentology, biostratigraphy and isotope stratigraphy". English. In: Bulletin de la Société Géologique de France 172.5 (2001), pp. 647-660.

[4018] F. Cecca, K. Seyed-Emami, J. Schnyder, M. Benzaggagh, M. R. Majidifard, and M. M. Monfared. "Systematic palaeontology, in Early Berriasian ammonites from Shal, Talesh region (NW Alborz Mountains, Iran)". English. In: Cretaceous Research 33 (2012), pp. 106-115.

[4019] F. A. Cecca, S. T. Cresta, G. I. Pallini, and M. A. Santantonio. "Il Giurassico di Monte Nerone (Appennino marchigiano, Italia Centrale): biostratigrafia, litostratigrafia ed evoluzione paleogeografica". English. In: Atti del II Convegno Internazionale Ossili, Evoluzione, Ambiente 1990 (1990), pp. 63-139.

[4020] C. Ceccon and A. De Angeli. "Galathea mainensis n. sp., (Crustacea, Decapoda, Anomura, Galatheidae) Middle Eocene of Cava Main Arzignano (Vicenza, northern Italy)". English. In: Societa Veneziana di Scienze Naturali 37 (2012), pp. 25-31.

[4021] L. Ceccon. "Segnalazione di crostacei brachiuri (Crustacea, Decapoda) nelle marne priaboniane del Buso della Rana (Monte di Malo, Vicenza-Italia settentrionale)". English. In: Societá Veneziana di Scienze Naturali Lavori 36 (2011), pp. 97-101.

[4022] C. B. Cecil. "Paleoclimate controls on stratigraphic repetition of chemical and siliciclastic rocks". In: Geology 18.6 (1990), pp. 533-536. 
[4023] P. Cejchan and J. Hladil. Searching for extinction/recovery gradients: the Frasnian-Fammennian interval, Mokra section, Moravia, central Europe. Vol. 120. in M. B. Hart, ed. Biotic Recovery from Mass Extinction Events (Geological Society of London Special Publication). 1996, pp. 135-162.

[4024] M. Cenizo, C. Acosta Hospitaleche, and M. Reguero. "Diversity of pseudo-toothed birds (Pelagornithidae) from the Eocene of Antarctica". English. In: Journal of Paleontology 89.5 (2015), pp. 870881. DOI: $10.1017 /$ jpa.2015.48.

[4025] M. M. Cenizo. "Review of the putative Phorusrhacidae from the Cretaceous and Paleogene of Antarctica: new records of ratites and pelagornithid birds". English. In: Polish Polar Research 33.3 (2012), pp. 225-244. DOI: 10.2478/v1018301200143.

[4026] M. M. Cenizo, F. L. Agnolin, and L. H. Pomi. "A New Pleistocene bird assemblage from the Southern Pampas (Buenos Aires, Argentina)". English. In: Palaeogeography, Palaeoclimatology, Palaeoecology 420 (2015), pp. 63-81. DOI: 10.1016/j.palaeo.2014.12.009.

[4027] M. M. Cenizo and F. L. Agnolín. "The southernmost records of Anhingidae and a new basal species of Anatidae (Aves) from the lower-middle Miocene of Patagonia, Argentina". English. In: Alcheringa 34.4 (2010), pp. 493-514. DOI: 10.1080/03115511003793504.

[4028] M. M. Cenizo, C. P. Tambussi, and C. I. Montalvo. "Late Miocene continental birds from the Cerro Azul Formation in the Pampean region (central- southern Argentina)". English. In: Alcheringa: An Australasian Journal of Palaeontology 36.1 (2012), pp. 47-68. DOI: 10.1080/03115518.2011.582806.

[4029] I. A. Cerda. "Gastroliths in an ornithopod dinosaur". English. In: Acta Palaeontologica Polonica 53.2 (2008), pp. 351-355.

[4030] I. A. Cerda, A. Paulina Carabajal, L. Salgado, R. A. Coria, M. A. Reguero, C. P. Tambussi, and J. J. Moly. "The first record of a sauropod dinosaur from Antarctica". English. In: Naturwissenschaften 99 (2012), pp. 83-87. DOI: 10.1007/s00114-011-0869-x.

[4031] E. Cerdeño. "Quebrada Fiera (Mendoza), an important paleobiogeographic center in the South American late Oligocene". English. In: Estudios Geológicos 67.2 (2012), pp. 375-384. DOI: 10.3989/ egeol.40519.194.

[4032] E. Cerdeño. "First Record of Mesotheriidae in the Late Oligocene of Mendoza Province, Argentina". English. In: Ameghiniana 51.4 (2014), pp. 366-370.

[4033] E. Cerdeno. "Neobrachytherium ullumense (Proterotheriidae, Litopterna) en el Mioceno Superior de la Provincia de Buenos Aires (Argentina)". Spanish. In: Ameghiniana 40.3 (2003), pp. 505-508.

[4034] E. Cerdeno. "Los mamiferos de la Formacion Arroyo Chasico (Mioceno Superior), provincia de Buenos Aires, del Museo J. C. Moyano de Mendoza". Spanish. In: Ameghiniana 37.4 (2000), pp. 503508.

[4035] E. Cerdeño, J. Chiesa, and G. Ojeda. "Presence of Oxyodontherium (Macraucheniidae, Litopterna) in the Ro Quinto Formation, San Luis (Argentina)". English. In: Journal of South American Earth Sciences 25 (2008), pp. 217-226.

[4036] E. Cerdeño, G. M. López, and M. A. Reguero. "Biostratigraphic considerations of the Divisaderan faunal assemblage". English. In: Journal of Vertebrate Paleontology 28.2 (2008), pp. 574-577. DOI: 10.1671/0272-4634(2008)28[574:BCOTDF]2.0.CO;2.

[4037] E. Cerdeño, C. I. Montalvo, and R. Sostillo. “Deciduous dentition and eruption pattern in late Miocene Pachyrukhinae (Hegetotheriidae, Notoungulata) from La Pampa Province, Argentina". English. In: Historical Biology 29.3 (2017), pp. 359-375.

[4038] E. Cerdeño and C. I. Montalvo. "Los Hegetotheriinae (Hegetotheriidae, Notoungulata) del Mioceno superior de la provincia de La Pampa, Argentina". English. In: Revista del Museo Argentina de Ciencias Naturales 41.1 (2002), pp. 35-43.

[4039] E. Cerdeño, M. E. Pérez, C. M. Deschamps, and V. H. Contreras. "A new capybara from the late Miocene of San Juan Province, Argentina, and its phylogenetic implications". English. In: Acta Palaeontologica Polonica 64.XX (2019). DOI: 10.4202/app.00544.2018. 
[4040] E. Cerdeño, M. Reguero, and B. Vera. “Deseadan Archaeohyracidae (Notoungulata) from Quebrada Fiera (Mendoza, Argentina) in the Paleobiogeographic Context of the South American Late Oligocene". English. In: Journal of Paleontology 84.6 (2010), pp. 1177-1187.

[4041] E. Cerdeño and M. Reguero. "The Hegetotheriidae (Mammalia, Notoungulata) assemblage from the late Oligocene of Mendoza, central-western Argentina". English. In: Journal of Vertebrate Paleontology 35.2 (2015), e907173:1-14.

[4042] E. Cerdeno and G. I. Schmidt. "Milk molars or extra premolars in Mesotheriinae (Mesotheriidae, Notoungulata): New insights into an old controversy". English. In: Geobios 46 (2013), pp. 195-202. DOI: 10.1016/j.geobios.2012.10.014.

[4043] E. Cerdeño, G. I. Schmidt, A. R. Miño-Boilini, and A. E. Zurita. "New data on the diversity of Notoungulata (Mammalia) from the Fray Bentos Formation (Late Oligocene) in Corrientes Province, Argentina". English. In: Ameghiniana (2020). DOI: 10.5710/AMGH.20.04.2020.3329.

[4044] E. Cerdeño and B. Vera. “Mendozahippus fierensis, gen. et sp. nov., new Notohippidae (Notoungulata) from the Late Oligocene of Mendoza (Argentina)". English. In: Journal of Vertebrate Paleontology 30.6 (2010), pp. 1805-1817. DOI: 10.1080/02724634.2010.520781.

[4045] E. Cerdeño and B. Vera. "A new Leontiniidae (Notoungulata) from the Late Oligocene beds of Mendoza". English. In: Journal of Systematic Palaeontology 13.11 (2015), pp. 943-962.

[4046] E. Cerdeño and B. Vera. "New data on diversity of Notohippidae from the Oligocene of Mendoza, Argentina". English. In: Journal of Vertebrate Paleontology 34.4 (2014), pp. 941-950.

[4047] E. Cerdeño and B. Vera. "New anatomical data on Pyrotherium (Pyrotheriidae) from the late Oligocene of Mendoza, Argentina". English. In: Ameghiniana 54.3 (2017), pp. 290-306.

[4048] E. Cerdeño, B. Vera, and A. M. Combina. "A new early Miocene Mesotheriidae (Notoungulata) from the Mariño Formation (Argentina): Taxonomic and biostratigraphic implications". English. In: Journal of South American Earth Sciences 88 (2018), pp. 118-131.

[4049] E. Cerdeño, B. Vera, G. I. Schmidt, F. Pujos, and B. M. Quispe. “An almost complete skeleton of a new Mesotheriidae (Notoungulata) from the Late Miocene of Casira, Bolivia". English. In: Journal of Systematic Palaeontology 10.2 (2012), pp. 341-360.

[4050] E. Cerdeño and M. G. Vucetich. "The first rodent from the Marino Formation (Miocene) at Divisadero Largo (Mendoza, Argentina) and its biochronological implications". English. In: Revista geológica de Chile 34.2 (2007). DOI: 10.4067/S0716-02082007000200002.

[4051] A. Ceregato, E. Rinaldi, and C. Tabanelli. “Conferma della presenza di Personopsis grasi (D'Ancona, 1872 ex Bellardi ms.) nel Pliocene di Castrocaro". English. In: Quad. Studi Nat. Romagna 16 (2002), pp. 1-9.

[4052] A. Cernansky. "New finds of the Neogene lizard and snake fauna (Squamata: Lacertilia; Serpentes) from the Slovak Republic". English. In: Biologia 66.5 (2011), pp. 899-911. DOI: 10.2478/s11756-0110098-y.

[4053] A. eranský. "A revision of chamaeleonids from the Lower Miocene of the Czech Republic with description of a new species of Chamaeleo (Squamata, Chamaeleonidae)". English. In: Geobios 43 (2010), pp. 605-613. DOI: 10.1016/j.geobios.2010.04.001.

[4054] A. eranský. "Earliest world record of green lizards (Lacertilia, Lacertidae) from the Lower Miocene of Central Europe". English. In: Biologia 65.4 (2010), pp. 737-741. DOI: 10.2478/s11756-010-0066-y.

[4055] A. eranský. "A revision of the chameleon species Chamaeleo pfeili Schleich (Squamata; Chamaeleonidae) with description of a new material of chamaeleonids from the Miocene deposits of southern Germany". English. In: Bulletin of Geosciences 86.2 (2011), pp. 275-282. DOI: 10.3140/bull.geosci.1259.

[4056] A. eranský. “The oldest known European Neogene girdled lizard fauna (Squamata, Cordylidae), with comments on Early Miocene immigration of African taxa". English. In: Geodiversitas 34.4 (2012), pp. 837-848. DOI: 10.5252/g2012n4a6. 
[4057] A. eranský. "Another piece of the puzzle: the first report on the Early Miocene lizard fauna from Austria (Ottnangian, MN 4; Oberdorf locality)". English. In: Palaeontologische Zeitschrift 90 (2016), pp. 723-746. DOI: 10.1007/s12542-016-0329-1.

[4058] A. eranský. "The first potential fossil record of a dibamid reptile (Squamata: Dibamidae): a new taxon from the early Oligocene of Central Mongolia". English. In: Zoological Journal of the Linnean Society (2019). DOI: 10.1093/zoolinnean/zlz047.

[4059] A. Cernansky and M. L. Augé. “New species of the genus Plesiolacerta (Squamata: Lacertidae) from the Upper Oligocene (MP28) of southern Germany and a revision of the type species Plesiolacerta lydekkeri". English. In: Palaeontology 56.1 (2013), pp. 79-94. DOI: 10.1111/j.1475-4983.2012. 01167.x.

[4060] A. Cernansky, M. L. Auge, and J. -C. Rage. "A complete mandible of a new amphisbaenian reptile (Squamata, Amphisbaenia) from the Late Middle Eocene (Bartonian, MP 16) of France". English. In: Journal of Vertebrate Paleontology 35.1 (2015), e902379-1-e902379-9. DOI: 10.1080/02724634.2014. 902379.

[4061] A. eranský, M. L. Augé, and A. Phelizon. “Dawn of Lacertids (Squamata, Lacertidae): New Finds from the Upper Paleocene and the Lower Eocene". English. In: Journal of Vertebrate Paleontology (2020), e1768539:1-4. DOI: 10.1080/02724634.2020.1768539.

[4062] A. eranský and A. M. Bauer. “Euleptes gallica Müller (Squamata: Gekkota: Sphaerodactylidae) from the Lower Miocene of North-West Bohemia, Czech Republic". English. In: Folia Zoologica 59.4 (2010), pp. 323-328.

[4063] A. eranský, J. D. Daza, and A. M. Bauer. “Geckos from the middle Miocene of Devnska Nová Ves (Slovakia): new material and a review of the previous record". English. In: Swiss Journal of Geosciences 111 (2018), pp. 183-190. DOI: 10.1007/s00015-017-0292-1.

[4064] A. eranský, N. Klein, J. Soták, M. Olavský, J. urka, and P. Herich. “A Middle Triassic pachypleurosaur (Diapsida: Eosauropterygia) from a restricted carbonate ramp in the Western Carpathians (Gutenstein Formation, Fatric Unit): paleogeographic implications". English. In: Geologica Carpathica 69.1 (2018), pp. 3-16. DOI: 10.1515/geoca-2018-0001.

[4065] A. Cernansky, J. Klembara, and J. Muller. "The new rare record of the late Oligocene lizards and amphisbaenians from Germany and its impact on our knowledge of the European terminal Palaeogene". English. In: Palaeobiodiversity and Palaeoenvironments (2016), pp. 1-29. DOI: 10.1007 / s12549-015-0226-8.

[4066] A. eranský and J. Klembara. "A skeleton of Ophisaurus (Squamata: Anguidae) from the middle Miocene of Germany, with a revision of the partly articulated postcranial material from Slovakia using micro-computed tomography". English. In: Journal of Vertebrate Paleontology (2017), e1333515. DOI: 10.1080/02724634.2017.1333515.

[4067] A. eranský, J. Klembara, and K. T. Smith. "Fossil lizard from central Europe resolves the origin of large body size and herbivory in giant Canary Island lacertids". English. In: Zoological Journal of the Linnean Society 176 (2016), pp. 861-877. DOI: 10.1111/zoj.12340.

[4068] A. Cernansky, J. C. Rage, and J. Klembara. “The Early Miocene squamates of Amöneburg (Germany): the first stages of modern squamates in Europe". English. In: Journal of Systematic Palaeontology 13.2 (2015), pp. 97-128. DOI: 10.1080/14772019.2014.897266.

[4069] A. eranský, E. V. Syromyatnikova, and D. Jablonski. "The first record of amphisbaenian and anguimorph lizards (Reptilia, Squamata) from the upper Miocene Solnechnodolsk locality in Russia". English. In: Historical Biology (2018). DOI: 10.1080/08912963.2018.1539973.

[4070] A. eranský, E. V. Syromyatnikova, E. S. Kovalenko, K. M. Podurets, and A. A. Kaloyan. “The key to understanding the European Miocene Chalcides (Squamata, Scincidae) comes from Asia: the lizards of the East Siberian Tagay locality (Baikal Lake) in Russia". English. In: The Anatomical Record (2019). DOI: 10.1002/ar.24289. 
[4071] A. eranský and E. V. Syromyatnikova. “The first Miocene fossils of Lacerta cf. trilineata (Squamata, Lacertidae) with a comparative study of the main cranial osteological differences in green lizards and their relatives". English. In: PLOS ONE 14.8 (2019), pp. 1-54. DOI: 10.1371 / journal.pone. 0216191.

[4072] A. eranský and E. V. Syromyatnikova. "The first pre-Quaternary fossil record of the clade Mabuyidae with a comment on the enclosure of the meckelian canal in skinks". English. In: Papers in Palaeontology (2019), pp. 1-21. DOI: 10.1002/spp2.1279.

[4073] A. eranský, Z. Szyndlar, and T. Mörs. "Fossil squamate faunas from the Neogene of Hambach (northwestern Germany)". English. In: Palaeobiodiversity and Palaeoenvironments 97 (2017), pp. 329354. DOI: $10.1007 / \mathrm{s} 12549-016-0252-1$.

[4074] A. Cernansky, C. Toth, and J. Surka. "Crocodylian and turtle finds from the Early Miocene of the Baa Dolina Mine in Veký Krt (Slovakia)". other. In: Acta Geologica Slovaca 4.2 (2012), pp. 113-123.

[4075] A. eranský, D. Vasilyan, G. L. Georgalis, P. Jorniak, S. Mayda, and J. Klembara. "First record of fossil anguines (Squamata; Anguidae) from the Oligocene and Miocene of Turkey". English. In: Swiss Journal of Geosciences 110 (2017), pp. 741-751. DOI: 10.1007/s00015-017-0272-5.

[4076] P. Cerretti, J. O. Stireman, T. Pape, J. E. O'Hara, M. A. T. Marinho, K. Rognes, and D. A. Grimaldi. "First fossil of an oestroid fly (Diptera: Calyptratae: Oestroidea) and the dating of oestroid divergences". English. In: PLoS One 12.8 (2017), e0182101.

[4077] S. N. Césari, S. A. Marenssi, and S. N. Santillana. "Conifers from the Upper Cretaceous of Cape Lamb, Vega Island, Antartica". English. In: Cretaceous Research 22 (2001), pp. 309-319.

[4078] R. Cestari and A. Laviano. "Rudist facies distribution in the late Cretaceous of Cilento and western Basilicata (southern Italy)". English. In: Revista Italiana di Paleontologia e Stratigrafia 118.2 (2012), pp. 277-294.

[4079] R. Cestari and J. M. Pons. Radiolitids, sediment accumulation rates and hydrodynamic regimes in Cretaceous carbonate platforms, Italy. English. Vol. 87. Cretaceous rudists and carbonate platforms: environmental feedback, SEPM Special Publication. 2007, pp. 27-36.

[4080] S. R. S. Cevallos-Ferriz, E. Estrada-Ruiz, and B. R. Pérez-Hernández. "Phytolaccaceae infructescence from Cerro del Pueblo Formation, Upper Cretaceous (late Campanian), Coahuila, Mexico". English. In: American Journal of Botany 95.1 (2008), pp. 77-83.

[4081] J. Chablais, R. M. Feldmann, and C. E. Schweitzer. "A new Triassic decapod, Platykotta akaina, from the Arabian shelf of the northern United Arab Emirates: earliest occurrence of the Anomura". English. In: Palaeontologische Zeitschrift 85 (2010), pp. 93-102. DOI: 10.1007/s12542-010-0080-y.

[4082] J. Chablais, T. Onoue, and R. Martini. "Upper Triassic reef-limestone blocks of southwestern Japan: New data from a Panthalassan seamount". English. In: Palaeogeography, Palaeoclimatology, Palaeoecology 293 (2010), pp. 206-222.

[4083] C. S. Chaboo and M. S. Engel. "Eocene tortoise beetles from the Green River Formation in Colorado, U.S.A. (Coleoptera: Chrysomelidae: Cassidinae)". English. In: Systematic Entomology 34 (2009), pp. 202-209.

[4084] M. C. Chabou, M. Y. Laghouag, and A. Bendaoud. Les empreintes de pas de dinosauriens en Algérie: un patrimoine géologique a protéger et valoriser [Dinosaur footprints in Algeria: a geological heritage to protect and enhance]. English. El Jadida, Morocco, 2011.

[4085] M. C. Chabou, M. Y. Laghouag, and A. Bendaoud. "Dinosaur track sites in Algeria: a significant national geological heritage in danger". English. In: From Geoheritage to Geoparks: Case Studies from Africa and Beyond. Cham, Switzerland: Springer International Publishing, 2015, pp. 157166. DOI: $10.1007 / 978-3-319-10708-0$.

[4086] D. Chafiki, J. Canerot, A. Souhel, K. El Hariri, and K. T. Eddine. "The Sinemurian carbonate mudmounds from central High Atlas (Morocco): stratigraphy, geometry, sedimentology and geodynamic patterns". English. In: Journal of African Earth Sciences 39 (2004), pp. 337-346. 
[4087] A. Chahud, T. R. Fairchild, and S. Petri. "Chondrichthyans from the base of the Irati Formation (Early Permian, Paraná Basin), São Paulo, Brazil”. English. In: Gondwana Research 18 (2010), pp. 528-537.

[4088] A. Chahud and M. Okumura. "The youngest Tapir from a Quaternary deposit of the Americas". English. In: Historical Biology (2020). DOI: 10.1080/08912963.2020.1798420.

[4089] Y. Chaid-Saoudi, D. Geraads, and J. -P. Raynal. "The fauna and associated artefacts from the Lower Pleistocene site of Mansourah (Constantine, Algeria)". English. In: Comptes Rendus Palevol 5.8 (2006), pp. 963-971.

[4090] Y. Chaimanee, O. Chavasseau, V. Lazzari, A. Euriat, and J. -J. Jaeger. "A new Late Eocene primate from the Krabi Basin (Thailand) and the diversity of Palaeogene anthropoids in southeast Asia". English. In: Proceedings of the Royal Society B 280 (2013), p. 20132268. DOI: 10.1098/rspb.2013.2268.

[4091] Y. Chaimanee, O. Chavasseau, K. C. Beard, Aung Aung Kyaw, Aung Naing Soe, Chit Sein, V. Lazzari, L. Marivaux, B. Marandat, Myat Swe, M. Rugbumrung, Thit Lwin, X. Valentin, Zin-MaungMaung-Thein, and J. -J. Jaeger. "Late middle Eocene primate from Myanmar and the initial anthropoid colonization of Africa". English. In: Proceedings of the National Academy of Sciences 109.26 (2012), pp. 10293-10297.

[4092] Y. Chaimanee, D. Jolly, M. Benammi, P. Tafforeau, D. Duzer, I. Moussa, and J. -J. Jaeger. “A Middle Miocene hominoid from Thailand and orangutan origins". English. In: Nature 422 (2003), pp. 6165.

[4093] Y. Chaimanee, R. Lebrun, C. Yamee, and J. -J. Jaeger. "A new Middle Miocene tarsier from Thailand and the reconstruction of its orbital morphology using a geometric-morphometric method". English. In: Proceedings of the Royal Society B 278 (2011), pp. 1956-1963. DOI: 10.1098 / rspb.2010. 2062.

[4094] Y. Chaimanee, V. Suteethorn, P. Jintasakul, C. Vidthayanon, B. Marandat, and J. -J. Jaeger. “A new orang-utan relative from the Late Miocene of Thailand". English. In: Nature 427 (2004), pp. 439441.

[4095] Y. Chaimanee, V. Suteethorn, J. -J. Jaeger, and S. Ducrocq. "A new Late Eocene anthropoid primate from Thailand". English. In: Nature 385 (1997), pp. 429-431.

[4096] Y. Chaimanee, C. Yamee, P. Tian, K. Khaowiset, B. Marandat, P. Tafforeau, C. Nemoz, and J. J. Jaeger. "Khoratpithecus piriyai, a Late Miocene hominoid of Thailand". English. In: American Journal of Physical Anthropology 131 (2006), pp. 311-323.

[4097] Y. Chaimanee, C. Yamee, P. Tian, O. Chavasseau, and J. -J. Jaeger. “First middle Miocene sivaladapid primate from Thailand". English. In: Journal of Human Evolution 54.3 (2008), pp. 434-443.

[4098] C. Chaix. "Cahuzacopsammia meandrinoides nov. gen. et sp., Scléractiniaire dendrophylliidé de l'Oligocéne supérieur d'Aquitaine (France)". French. In: Geobios 32.6 (1999), pp. 805-813.

[4099] C. Chaix and B. Cahuzac. "Une faune inédite de coraux scléractiniaires dans le gisement chattien d'Escornebéou (Landes, SW France); stratigraphie, systématique et paléoécologie". French. In: Annales de Paléontologie 87.1 (2001), pp. 3-47.

[4100] C. Chaix, B. Cahuzac, and A. Cluzaud. "Les Scléractiniaires du Serravallien de Pessac (NordAquitaine, France) : approche paléoécologique". French. In: Géobios 32.1 (1999), pp. 33-62.

[4101] C. Chaix and B. Cahuzac. "Les faunes de Scleractiniaires dans les faluns du Miocene moyen d'Atlantique-Est (bassins de la Loire et d'Aquitaine): paleobiogeographie et evolution climatique [The faunas of Scleractinian corals in the faluns of the Eastern Atlantic Middle Miocene (Loire and Aquitaine Basins): paleobiogeography and climatic evolution]". French. In: Annales de Paleontologie 91 (2005), pp. 33-72.

[4102] C. Chaix and B. Cahuzac. "Le genre Culicia (Scleractiniaire): systematique, ecologie et biogeographie au Cenozoique [The genus Culicia (Scleractinia): systematics, ecology and biogeography in the Cenozoic]". French. In: Eclogae Geologica Helvetiae 98 (2005), pp. 169-187. 
[4103] C. Chaix, F. Galloni, M. Ferrandini, and J. -J. Cornée. “Les coraux scléractiniaires du Burdigalien supérieur du Bassin de Bonifacio (Corse-du-Sud)". French. In: Geodiversitas 37.3 (2015).

[4104] C. Chaix and J.-P. Saint Martin. "Les faunes de scléractiniaires hermatypiques dans les platesformes carbonatées méditerranéennes au Miocéne supérieur". English. In: Geodiversitas 30.1 (2008), pp. 181-209.

[4105] A. Chakraborty and H. N. Bhattacharya. "Anal sac of a cladid crinoid from Permo-Carboniferous Talchir Formation, Talchir basin, Odisha". English. In: Journal of the Geological Society of India 85.4 (2015), pp. 434-438. DOI: 10.1007/s12594-015-0234-3.

[4106] T. J. Challands, T. R. Smithson, J. A. Clack, C. E. Bennett, J. E. A. Marshall, S. M. Wallace-Johnson, and H. Hill. "A lungfish survivor of the end-Devonian extinction". English. In: Journal of Systematic Palaeontology (2019). DOI: 10.1080/14772019.2019.1572234.

[4107] F. Chalumeau and B. Brochier. "Une forme fossile nouvelle de Chiasognathinae: Protognathinus spielbergi (Coleoptera, Lucanidae)". French. In: Lambillionea 101 (2001), pp. 593-595.

[4108] P. M. Chamberlain, K. J. Travouillon, M. Archer, and S. J. Hand. "Kutjamarcoot brevirostrum gen. et sp. nov., a new short-snouted, early Miocene bandicoot (Marsupialia: Peramelemorphia) from the Kutjamarpu Local Fauna (Wipajiri Formation) in South Australia". English. In: Alcheringa 40 (2015), pp. 1-10. DOI: 10.1080/03115518.2016.1103525.

[4109] P. Chandler. "Heterotricha Loew and allied genera (Diptera: Sciaroidea): offshoots of the stem group of Mycetophilidae and/or Sciaridae?" English. In: Annales de la Société Entomologique de France 38 (2002), pp. 101-144.

[4110] R. Chandler and J. Callomon. "The Inferior Oolite at Coombe Quarry, near Mapperton, Dorset, and a new Middle Jurassic ammonite faunal horizon, Aa-3b, Leioceras comptocostosum n.biosp. in the Scissum Zone of the Lower Aalenian". English. In: Proceedings of the Dorset Natural History and Archaeological Society 130 (2009), pp. 99-132.

[4111] R. B. Chandler and V. Dietze. "New data on the Lower Bajocian (Middle Jurassic) ammonite genus Mollistephanus Buckman, 1922 from southern England". English. In: Proceedings of the Geologists' Association 115 (2004), pp. 221-234.

[4112] R. M. Chandler. Fossil birds of Florissant, Colorado: with a description of a new genus and species of cuckoo. English. National Park Service Paleontological Research, Volume 4. Geologic Resources Division Technical Report NPS/NRGRD/GRDTR-99/03. 1999, pp. 49-53.

[4113] R. M. Chandler. "Fossil birds of the San Diego Formation, Late Pliocene, Blancan, San Diego County, California". English. In: Ornithological Monographs 44 (1990), pp. 73-161.

[4114] R. M. Chandler. "A new species of Tinamou (Aves: Tinamiformes, Tinamidae) from the EarlyMiddle Miocene of Argentina". English. In: Palarch's Journal of Vertebrate Palaeontology 9.2 (2012), pp. 1-8.

[4115] R. M. Chandler and C. C. Bentley. "Fossil birds of the Ardis Local Fauna, Late Pleistocene, South Carolina". English. In: Current Research in the Pleistocene 24 (2007), pp. 8-9.

[4116] R. M. Chandler and D. Parmley. "The earliest North American record of auk (Aves; Alcidae) from the late Eocene of central Georgia". English. In: The Oriole 68.1-2 (2003), pp. 7-9.

[4117] B. Chanet and O. Schultz. "Pleuronectiform fishes from the Upper Badenian (Middle Miocene) of St. Margarethen (Austria)". English. In: Annalen des Naturhistorischen Museums in Wien. Serie A für Mineralogie und Petrographie, Geologie und Paläontologie, Anthropologie und Prähistorie 96 (1994), pp. 95-115.

[4118] C.-H. Chang. "The first fossil record of a short-finned pilot whale (Globicephala macrorhynchus) from the Penghu Channel". English. In: Bulletin of the National Museum of Science (Taichung) 8 (1996), pp. 73-80.

[4119] C.-H. Chang, Y. Kaifu, M. Takai, R. T. Kono, R. Grun, S. Matsu'ura, L. Kinsley, and L. -K. Lin. "The first archaic Homo from Taiwan". English. In: Nature Communications (2015). DOI: 10.1038 / ncomms7037. 
[4120] C.-H. Chang, M. Takai, and S. Ogino. "First discovery of colobine fossils from the early to middle Pleistocene of southern". English. In: Journal of Human Evolution 63 (2012), pp. 439-451. DOI: 10. 1016/j.jhevol.2012.03.005..

[4121] H. L. Chang, A. Kirejtshuk, and D. Ren. "New fossil elaterids (Coleoptera: Polyphaga: Elateridae) from the Jehol biota in China". English. In: Annals of the Entomological Society of America 103.6 (2010), pp. 866-874.

[4122] H. L. Chang, A. Kirejtshuk, and D. Ren. "New genus and species of Cerophytidae (Insecta: Coleoptera) from the Lower Cretaceous of Baissa". English. In: Cretaceous Research 32 (2011), pp. 700-704.

[4123] H. L. Chang, A. G. Kirejtshuk, and D. Ren. "On taxonomy and distribution of fossil Cerophytidae (Coleoptera: Elateriformia) with description of a new Mesozoic species of Necromera Martynov 1926". English. In: Annales de la Société Entomologique de France 47 (2011), pp. 33-44.

[4124] H. L. Chang, A. G. Kirejtshuk, D. Ren, and C. K. Shih. "First fossil click beetles from the Middle Jurassic of Inner Mongolia, China (Coleoptera: Elateridae)". English. In: Annales Zoologici 59 (2009), pp. 7-14.

[4125] H. L. Chang, J. Muona, H. Y. Pu, L. Xu, C. Wang, M. Teräväinen, D. Ren, Q. Yang, X. L. Zhang, and S. H. Jia. "Chinese Cretaceous larva exposes a southern Californian living fossil (Insecta, Coleoptera, Eucnemidae)". English. In: Cladistics 32 (2016), pp. 211-214.

[4126] H. L. Chang, M. Nabozhenko, H. Y. Pu, L. Xu, S. H. Jia, and T. R. Li. "First record of fossil combclawed beetles of the tribe Cteniopodini (Insecta: Coleoptera: Tenebrionidae) from the Jehol Biota (Yixian formation of China), Lower Cretaceous". English. In: Cretaceous Research 57 (2016), pp. 289293.

[4127] H. L. Chang and D. Ren. "New fossil beetles of the family Elateridae from the Jehol Biota of China (Coleoptera: Polyphaga)". English. In: Acta Geologica Sinica 82 (2008), pp. 236-243.

[4128] H. L. Chang, D. Ren, and C. K. Shih. "New fossil elaterid (Coleoptera: Polyphaga: Elateridae) from Yixian Formation of western Liaoning, China". English. In: Progress in Natural Science 17 (2007), pp. 1244-1249.

[4129] H. L. Chang, F. Zhang, and D. Ren. "A new genus and two new species of fossil Elaterids from the Yixian Formation of western Liaoning, China (Coleoptera: Elateridae)". English. In: Zootaxa 1785 (2008), pp. 54-62.

[4130] H. L. Chang, Y. Y. Zhao, and D. Ren. "New fossil elaterids (Insect: Coleoptera: Polyphaga: Elateridae) from the Middle Jurassic of Inner Mongolia, China". English. In: Progress in Natural Science 19 (2009), pp. 1433-1437.

[4131] J. P. Chang. "Some new species of spider and Sacculinidae fossils in Jehol biota". Chinese. In: Global Geology 23 (2004), pp. 313-319.

[4132] J. P. Chang and Z. S. Sun. "New discovery of fossil dobsons in Jehol biota from western Liaoning, China". Chinese. In: Global Geology 24 (2005), pp. 105-110.

[4133] J. P. Chang and Z. S. Sun. "New taxa of Gomphidae (Insecta: Odonata) in Jehol Biota from western Liaoning, China”. English. In: Global Geology 25 (2006), pp. 105-111.

[4134] M. Chang, J. Zhang, and D. Miao. "A lamprey from the Cretaceous Jehol biota of China”. English. In: Nature 441 (2006), pp. 972-974.

[4135] M.-M. Chang and J.-Q. Wang. "A new Emsian dipnorhynchid (Dipnoi) from Guangnan, southeastern Yunnan, China". English. In: Geobios 19 (1995), pp. 233-239.

[4136] M.-M. Chang and M. Zhu. "A new Middle Devonian osteolepidid from Qujing, Yunnan". English. In: Memoirs of the Association of Australasian Palaeontologists 15 (1993), pp. 183-198.

[4137] Y. Chang, H. Fang, C. K. Shih, D. Ren, and Y. J. Wang. "Reevaluation of the subfamily Cretanallachiinae Makarkin, 2017 (Insecta: Neuroptera) from Upper Cretaceous Myanmar amber". English. In: Cretaceous Research 84 (2017), pp. 533-539. 
[4138] J. E. T. Channell, H. W. Kozur, T. Sievers, R. Mock, R. Aubrecht, and M. Sykora. “Carnian-Norian biomagnetostratigraphy at Silická Brezová (Slovakia): correlation to other Tethyan sections and to the Newark Basin". English. In: Palaeogeography, Palaeoclimatology, Palaeoecology 191 (2003), pp. 65109.

[4139] P. Chanthasit and E. Buffetaut. "New data on the Dromaeosauridae (Dinosauria: Theropoda) from the Late Cretaceous of southern France". English. In: Bulletin de la Société Géologique de France 180.2 (2009), pp. 145-154.

[4140] P. Chanthasit, S. Suteethorn, W. Naksri, H. Tong, K. Wongko, and T. Sonoda. "New vertebrate fossil site from the Early Cretaceous Sao Khua Formation, Sakon Nakhon Province, northeastern Thailand". English. In: Open Journal of Geology 9 (2019), pp. 619-622.

[4141] J. D. Chapelin-Viscardi, J. F. Voisin, P. Ponel, and N. Van der Putten. "Pachnobium dreuxi n. g., n. sp., ses occurrences modernes et fossiles sur l'archipel Crozet (Coléoptére Curculionidae Ectemnorrhininae)". French. In: Annales de la Société Entomologique de France 46 (2010), pp. 125-131.

[4142] K. E. J. Chapelle, P. M. Barrett, J. Botha, and J. N. Choiniere. “Ngwevu intloko: a new early sauropodomorph dinosaur from the Lower Jurassic Elliot Formation of South Africa and comments on cranial ontogeny in Massospondylus carinatus". English. In: PeerJ 7 (2019), e7240:1-59. DOI: 10.7717 / peerj.7240.

[4143] S. Charbonnier, A. Brayard, and T. Paris Biota Team. "New thylacocephalans from the Early Triassic Paris Biota (Bear Lake County, Idaho, USA)". English. In: Geobios 54 (2019), pp. 37-43. DOI: 10.1016/j.geobios.2019.04.005.

[4144] S. Charbonnier, J. M. C. Vannier, C. Gaillard, J. P. Bourseau, and P. Hantzpergue. "The La Voulte Lagerstätte (Callovian): Evidence for a deep water setting from sponge and crinoid communities". English. In: Palaeogeography, Palaeoclimatology, Palaeoecology 250 (2007), pp. 216-236.

[4145] A. J. Charig and C. Gans. "Two new amphisbaenians from the Lower Miocene of Kenya." English. In: Bulletin of the British Museum of Natural History (Geology) 46.1 (1990), pp. 19-36.

[4146] A. J. Charig and A. C. Milner. "Baryonyx walkeri, a fish-eating dinosaur from the Wealden of Surrey". In: Bulletin of the Natural History Museum, Geology Series 53.1 (1997), pp. 11-70.

[4147] A. J. Charig and A. C. Milner. The systematic position of Baryonyx walkeri, in the light of Gauthier's reclassification of the Theropoda. English. Dinosaur Systematics: Perspectives and Approaches. Cambridge: Cambridge University Press, 1990, pp. 127-140.

[4148] K. Charlton-Robb, L. Gershwin, R. Thompson, J. Austin, K. Owen, and S. McKechnie. “A New Dolphin Species, the Burrunan Dolphin Tursiops australis sp. nov., Endemic to Southern Australian Coastal Waters". English. In: PLoS One 6.9 (2011), e2407. DOI: 10.1371 / journal . pone. 0024047.

[4149] R. Charrier and D. A. Croft. "Marco geológico-tectónico, contenido fosilfero y cronologa de lo yacimientos cenozoicos pre-pleistocénicos de mamferos terrestres fósiles de Chile". Spanish. In: Publicación Ocasional del Museo Nacional de Historia Natural, Chile 63 (2015), pp. 293-338.

[4150] A. Chartrousse and J. P. Masse. “Offneria arabica nov. sp. (rudiste, Caprinidae) de l'Aptien inferieur du Jebel Madar (Sultanat d'Oman) [Offneria arabica nov. sp. (rudist, Caprinidae) of the Lower Aptian of Jebel Madar (Sultanate of Oman)]". French. In: Cretaceous Research 19 (1998), pp. 827-841.

[4151] A. Chartrousse and J. P. Masse. “Coalcomaninae (Rudistes, Caprinidae) nouveaux de l'Aptien inferieur des mid-pacific mountains [New Lower Aptian Coalcomaninae from the Mid Pacific Mountains]". French. In: Geobios, Memoire Special 22 (1998), pp. 87-92.

[4152] S. Chatterjee. "Shuvosaurus, a new theropod: an unusual theropod dinosaur from the Triassic of Texas". English. In: National Geographic Research and Exploration 9.3 (1993), pp. 274-285.

[4153] S. Chatterjee. "Cranial anatomy and relationships of a new Triassic bird from Texas". English. In: Philosophical Transactions of the Royal Society of London B 332 (1991), pp. 277-342. 
[4154] S. Chatterjee. The morphology and systematics of Polarornis, a Cretaceous Loon (Aves: Gaviidae) from Antarctica. English. Proceedings of the 5th Symposium of the Society of Avian Paleontology and Evolution. 2002, pp. 125-155.

[4155] S. Chatterjee, R. Tewari, and D. Agnihotri. "A Dicroidium flora from the Triassic of Allan Hills, South Victoria Land, Transantarctic Mountains, Antarctica". English. In: Alcheringa 37.2 (2013), pp. 209-221. DOI: 10.1080/03115518.2013.736799.

[4156] B. D. Chatterton, R. A. Fortey, K. D. Brett, S. L. Gibb, and R. C. McKellar. “Trilobites from the upper Lower to Middle Devonian Timrhanrhart Formation, Jbel Gara el Zguilma, southern Morocco". English. In: Palaeontolographica Canadiana 25 (2006), pp. 1-177.

[4157] B. D. E. Chatterton and S. Gibb. "Latest Early to Early Middle Devonian trilobites from he Erbenochile bed, Jbel Issoumour, southeastern Morocco". English. In: Journal of Paleontology 84.6 (2010), pp. 1188-1205.

[4158] B. D. E. Chatterton and R. Ludvigsen. "Early Silurian trilobites of Anticosti Island, Québec, Canada". English. In: Palaeontographica Canadiana 22 (2004).

[4159] B. D. E. Chatterton. "Ordovician proetide trilobite Dimeropyge, with a new species from northwestern Canada". English. In: Journal of Paleontology 68.3 (1994), pp. 541-556.

[4160] B. D. E. Chatterton, G. D. Edgecombe, N. E. Vaccari, and B. G. Waisfeld. “Ontogeny and Relationships of the Ordovician Odontopleurid Trilobite Ceratocara, with New Species from Argentina and New York". English. In: Journal of Paleontology 71.1 (1997), pp. 108-135.

[4161] B. D. E. Chatterton, G. D. Edgecombe, B. G. Waisfeld, and N. E. Vaccari. “Ontogeny and systematics of Toernquistiidae (Trilobita, Proetida) from the Ordovician of the Argentine Precordillera". English. In: Journal of Paleontology 72.2 (1998), pp. 273-303.

[4162] B. D. E. Chatterton and R. Ludvigsen. "Upper Steptoean (Upper Cambrian) trilobites from the McKay Group of southeastern British Columbia, Canada". English. In: Journal of Paleontology 72.2 (1998), p. 43.

[4163] D. Chattopadhyay. "New record of a coral-mollusca reefal community from the early tertiary of Kutch, Gujarat". English. In: Indian Minerals 58.3 (2004), pp. 169-182.

[4164] S. Chatzimanolis. "A review of the fossil history of Staphylinoidea". English. In: Biology of Rove Beetles (Staphylinidae): Life History, Evolution, Ecology and Distribution. 2018, pp. 27-45.

[4165] S. Chatzimanolis, M. E. Cashion, M. S. Engel, and Z. H. Falin. "A new genus of Ptilodactylidae (Coleoptera: Byrrhoidea) in mid-Cretaceous amber from Myanmar (Burma)". English. In: Geodiversitas 34 (2012), pp. 569-574.

[4166] S. Chatzimanolis, M. S. Caterino, and M. S. Engel. "The First Fossil of the Subfamily Trypanaeinae (Coleoptera: Histeridae): A New Species of Trypanaeus in Dominican Amber". English. In: The Coleopterists Bulletin 60.4 (2006), pp. 330-340.

[4167] S. Chatzimanolis, M. S. Engel, A. F. Newton, and D. A. Grimaldi. "New ant-like stone beetles in mid-Cretaceous amber from Myanmar (Coleoptera: Staphylinidae: Scydmaeninae)". English. In: Cretaceous Research 31 (2010), pp. 77-84.

[4168] S. Chatzimanolis and M. S. Engel. "A new species of Diochus from Baltic amber (Coleoptera, Staphylinidae, Diochini)". English. In: ZooKeys 138 (2011), pp. 65-73.

[4169] S. Chatzimanolis and M. S. Engel. "Laasbium Scudder: a genus of Tertiary earwigs, not rove beetles, and the classification of Florissant fossil Dermaptera (Insecta)". English. In: Annales Zoologici 60 (2010), pp. 101-108.

[4170] S. Chatzimanolis and M. S. Engel. “The fauna of Staphylininae in Dominican amber (Coleoptera: Staphylindae)". English. In: Annals of the Carnegie Museum 81 (2013), pp. 281-294.

[4171] S. Chatzimanolis, D. A. Grimaldi, M. S. Engel, and N. C. Fraser. "Leehermania prorova, the earliest staphyliniform beetle, from the Late Triassic of Virginia (Coleoptera: Staphylinidae)". English. In: American Museum Novitates 3761 (2012), pp. 1-28. 
[4172] S. Chatzimanolis, A. F. Newton, C. Soriano, and M. S. Engel. “Remarkable stasis in a phloeocharine rove beetle from the Late Cretaceous of New Jersey (Coleoptera, Staphylinidae)". English. In: Journal of Paleontology 87 (2013), pp. 177-182.

[4173] K. Chatzopoulou. "The micromammals of the Quaternary deposits from Cave A, Loutra Almopias (Pella, Northern Greece): Stratigraphy-Taphonomy-Paleoenvironment". other. PhD thesis. 2014, pp. 1-390.

[4174] S. N. Chaurpagar, S. K. Humane, P. Kundal, and S. S. Humane. "The geniculate coralline algae from the Sylhet Limestone Formation (early-middle Eocene), Bengal Basin, India: paleonvironmental implications". English. In: Gondwana Geology Magazine 24.2 (2009), pp. 137-145.

[4175] S. N. Chaurpagar, S. K. Humane, P. Kundal, and S. S. Humane. "Paleoenvironmental implications of the non-geniculate Coralline algae from the Middle Eocene Sylhet Limestone, Bengal Basin". English. In: ONGC Bulletin 47.2 (2012), pp. 50-69.

[4176] B. Chauviré, M. Houadria, A. Donini, B. T. Berger, B. Rondeau, G. Kritsky, and P. Lhussier. “Arthropod entombment in weathering-formed opal: new horizons for recording life in rocks". English. In: Scientific Reports 10.10575 (2020). DOI: 10.1038/s41598-020-67412-9.

[4177] M. L. Chavarria-Arellano, T. R. Simões, and M. Montellano-Ballesteros. "New data on the Late Cretaceous lizard Dicothodon bajaensis (Squamata, Borioteiioidea) from Baja California, Mexico reveals an unusual tooth replacement pattern in squamates". English. In: Anais da Academia Brasileira de Ciencias 90.3 (2018), pp. 2781-2795. DOI: 10.1590/0001-3765201820170563.

[4178] M. Chavez. "Sobre la presencia de Paraptenodytes y Palaeospheniscus (Aves: Sphenisciformes) en la Formacion Bahia Inglesa, Chile". English. In: Revista Chilena de Historia Natural 80 (2007), pp. 255-259.

[4179] M. Chavez, M. Stucchi, and M. Urbina. “El registro de Pelagornithidae (Aves: Pelecaniformes) y la avifauna neogena del Pacifico sudeste". English. In: Bulletin de l'Institut Francais d'Etudes Andines 36.2 (2007), pp. 175-197.

[4180] E. O. Chávez-Aponte, I. Alfonso-Hernández, and J. D. Carrillo-Briceño. "Morfologa dentaria de los gonfoterios de la localidad de Muaco, Estado de Falcón, Venezuela". Spanish. In: Interciencia 33.10 (2008), pp. 771-775.

[4181] L. Checa and F. Colombo. "A new Early Eocene palaeothere (Mammalia, Perissodactyla) from northeastern Spain". English. In: Journal of Vertebrate Paleontology 24 (2004), pp. 507-512.

[4182] L. Checa Soler. "Avance descriptivo de un nuevo Paleotérido (Mammalia, Perissodactyla) del yacimiento eoceno de Sant Jaume de Forntanyá 3 (Fm. Bellmunt, Prepirineo catalán)". Spanish. In: Treballs del Museu de Geologia de Barcelona 3 (1993), pp. 91-116.

[4183] A. Checconi, D. Bassi, L. Passeri, and R. Rettori. "Coralline red algal assemblage from the Middle Pliocene shallow-water temperate carbonates of the Monte Cetona (Northern Apennines, Italy)". English. In: Facies 53 (2007), pp. 57-66.

[4184] A. H. Cheetham and J. B. C. Jackson. "Neogene cheilostome Bryozoa of tropical America: Comparison and contrast between the Central American Isthmus (Panama, Costa Rica) and the northcentral Caribbean (Dominican Republic)". English. In: Bulletin of the American Museum of Natural History 357 (1999), pp. 159-192.

[4185] R. Chelaru, E. Ssran, T. Tma, R. Blc, I. I. Bucur, and G. Ple. “Middle Miocene carbonate facies with rhodoliths from the NW". English. In: Facies 65.4 (2019). DOI: 10.1007/s10347-018-0546-z.

[4186] P. Chellouche, F. T. Fürsich, and M. Mäuser. "Taphonomy of neopterygian fishes from the Upper Kimmeridgian Wattendorf Plattenkalk of Southern Germany". English. In: Palaeobio Palaeoenv (2012).

[4187] L. Cheme-Arriaga, M. T. Dozo, and J. N. Gelfo. “A new Cramaucheniinae (Litopterna, Macraucheniidae) from the early Miocene of Patagonia, Argentina". English. In: Journal of Vertebrate Paleontology 36.3 (2016), e1229672. DOI: 10.1080/02724634.2017.1229672. 
[4188] A. Chen, H. Feng, M. Zhu, D. Ma, and M. Li. “A new vetulicolian from the Early Cambrian Chengjiang Fauna in Yunnan of China". English. In: Acta Geologica Sinica 77.3 (2003), pp. 281287.

[4189] B. Chen, X. Xie, I. S. Al-Aasm, F. Wu, and M. Zhou. "Depositional Architecture and Facies of a Complete Reef Complex Succession: A Case Study of the Permian Jiantianba Reefs, Western Hubei, South China". English. In: Minerals 8.533 (2018). DOI: 10.3390/min8110533.

[4190] D. Chen. Devonian-Carboniferous Carbonates around Guilin, South China: Stratigraphy and Sedimentology. English. 2010 IGCP - 580 Meeting November 28-December 4 Guilin, South China: Applications of Magnetic Susceptibility on Paleozoic Rocks. 2010, pp. 1-29.

[4191] D. Chen, Y. Alavi, M. D. Brazeau, H. Blom, D. Millward, and P. E. Ahlberg. "A partial lower jaw of a tetrapod from Romer's Gap". English. In: Earth and Environmental Science Transactions of the Royal Society of Edinburgh 108 (2018), pp. 55-65.

[4192] D. Chen, Y. Z. Yao, and D. Ren. "A new species of fossil Procercopidae (Hemiptera, Cicadomorpha) from the Lower Cretaceous of northeastern China". English. In: Cretaceous Research 52 (2015), pp. 402-406.

[4193] G. Chen, F. Fang, and M. Chang. "A New Cyprinid Closely Related to Cultrins and Xenocyprinins from the Mid-Tertiary of South China". English. In: Journal of Vertebrate Paleontology 25.3 (2005), pp. 492-501.

[4194] G.-F. Chen and Z.-Q. Zhang. "Lantiantragus gen. nov. (Urmiatheriinae, Bovidae, Artiodactyla) from the Bahe Formation, Lantian, China". Chinese. In: Vertebrata PalAsiatica 42.3 (2004), pp. 205215.

[4195] H. Y. Chen, C. van Achterberg, H. Pang, and J. X. Liu. "Three new genera of Braconidae (Hymenoptera) from mid-Cretaceous amber of northern Myanmar". English. In: Cretaceous Research 118.104669 (2020). DOI: 10.1016/j.cretres.2020.104669.

[4196] J. Chen, R. Beattie, B. Wang, H. Jiang, Y. Zheng, and H. C. Zhang. "The first palaeontinid from the Late Jurassic of Australia (Hemiptera, Cicadomorpha, Palaeontinidae)". English. In: Alcheringa 43 (2019), pp. 449-454. DOI: 10.1080/03115518.2019.1587787.

[4197] J. Chen, G. S. Bever, H. -Y. Yi, and M. A. Norell. "A burrowing frog from the late Paleocene of Mongolia uncovers a deep history of spadefoot toads (Pelobatoidea) in East Asia". English. In: Scientific Reports 6 (2016), 19209:1-7. DOI: 10.1038/srep19209.

[4198] J. Chen, R. J. Butler, and L. Jin. "New material of large-bodied ornithischian dinosaurs, including an iguanodontian ornithopod, from the Quantou Formation (middle Cretaceous; AptianCenomanian) of Jilin Province, northeastern China". English. In: Neues Jahrbuch für Geologie und Paläontologie Abhandlungen 248.3 (2008), pp. 309-314. DOI: 10.1127/0077-7749/2008/0248-0309.

[4199] J. Chen, Z. Chen, and J. Tong. "Palaeoecology and taphonomy of two brachiopod shell beds from the Anisian (Middle Triassic) of Guizhou, Southwest China: Recovery of benthic communities from the end-Permian". English. In: Global and Planetary Change 73 (2010), pp. 149-160.

[4200] J. Chen and J. Liu. "The youngest occurrence of embolomeres (Tetrapoda: Anthracosauria) from the Sunjiagou Formation (Lopingian, Permian) of North China". English. In: Fossil Record 23 (2020), pp. 205-213. DOI: 10.5194/fr-23-205-2020.

[4201] J. Chen and F. Stiller. “Two new Late Triassic nuculanoidean bivalve genera from north-west Yunnan, China". English. In: Neues Jahrbuch für Geologie und Paläontologie, Abhandlungen 249 (2008), pp. 357-370. DOI: 10.1127/0077-7749/2008/0249-0357.

[4202] J. Chen, J. Szwedo, B. Wang, Y. Zheng, Y. Wang, X. L. Wang, and H. C. Zhang. "The first Mesozoic froghopper in amber from northern Myanmar (Hemiptera, Cercopoidea, Sinoalidae)". English. In: Cretaceous Research 85 (2018), pp. 243-249.

[4203] J. Chen, J. Szwedo, B. Wang, Y. Zheng, H. Jiang, T. Jiang, X. L. Wang, and H. C. Zhang. “A new bizarre cicadomorph family in mid-Cretaceous Burmese amber (Hemiptera, Clypeata)". English. In: Cretaceous Research 97 (2019), pp. 1-15. DOI: 10.1016/j.cretres.2019.01.010. 
[4204] J. Chen, B. Wang, M. S. Engel, T. Wappler, E. A. Jarzembowski, H. C. Zhang, X. L. Wang, X. T. Zheng, and J. Rust. "Extreme adaptations for aquatic ectoparasitism in a Jurassic fly larva". English. In: eLife 3 (2014), e02844.

[4205] J. Chen, B. Wang, H. C. Zhang, and X. L. Wang. "A remarkable new genus of Tettigarctidae (Insecta, Hemiptera, Cicadoidea) from the Middle Jurassic of northeastern China". English. In: Zootaxa 3764 (2014), pp. 581-586.

[4206] J. Chen, B. Wang, H. C. Zhang, X. L. Wang, and Z. T. Zheng. “New fossil Procercopidae (Hemiptera: Cicadomorpha) from the Middle Jurassic of Daohugou, Inner Mongolia, China". English. In: European Journal of Entomology 112 (2015), pp. 373-380.

[4207] J. Chen and B. Wang. "A giant tettigarctid cicada from the Mesozoic of northeastern China". English. In: Spixiana 39 (2016), pp. 119-124.

[4208] J. Chen, B. Wang, Y. Zheng, H. Jiang, T. Jiang, J. Q. Zhang, and H. C. Zhang. "A new sinoalid froghopper in mid-Cretaceous Burmese amber, with inference of its phylogenetic position (Hemiptera, Cicadomorpha)". English. In: Cretaceous Research 95 (2018), pp. 121-129.

[4209] J. Chen, B. Wang, J. R. Jones, Y. Zheng, H. Jiang, T. Jiang, J. Q. Zhang, and H. C. Zhang. “A representative of the modern leafhopper subfamily Ledrinae in mid-Cretaceous Burmese amber (Hemiptera, Cicadellidae)". English. In: Cretaceous Research 95 (2018), pp. 252-259.

[4210] J. Chen, B. Wang, Y. Zheng, and H. C. Zhang. "A well-preserved minute litter bug in mid-Cretaceous Kachin amber from northern Myanmar (Heteroptera, Dipsocoromorpha)". English. In: Cretaceous Research 96 (2018), pp. 6-13.

[4211] J. Chen, B. Wang, H. C. Zhang, H. Jiang, T. Jiang, B. Z. An, Y. Zheng, and X. L. Wag. “A remarkable new sinoalid froghopper with probable disruptive colouration in mid-Cretaceous Burmese amber (Hemiptera, Cicadomorpha)". English. In: Cretaceous Research 98 (2019), pp. 9-17. DOI: 10.1016/j. cretres.2019.02.004.

[4212] J. Chen, B. Wang, Y. Zheng, H. Jiang, T. Jiang, J. Q. Zhang, B. Z. An, and H. C. Zhang. “New fossil data and phylogenetic inferences shed light on the morphological disparity of Mesozoic Sinoalidae (Hemiptera, Cicadomorpha)". English. In: Organisms Diversity \& Evolution 19 (2019), pp. 287-302. DOI: 10.1007/s13127-019-00399-y.

[4213] J. Chen, B. Wang, H. C. Zhang, H. Jiang, T. Jiang, Y. Zheng, and X. L. Wang. "New discovery of Minlagerrontidae in mid-Cretaceous Burmese amber (Hemiptera, Cicadomorpha, Clypeata)". English. In: Cretaceous Research 106.104204 (2019). DOI: 10.1016/j.cretres.2019.104204.

[4214] J. Chen, B. Wang, Y. Zheng, H. Jiang, T. Jiang, X. L. Wang, and H. C. Zhang. "The youngest record of the leafhopper family Archijassidae in Kachin amber from the lowermost Upper Cretaceous of northern Myanmar (Cicadomorpha, Cicadelloidea)". English. In: Cretaceous Research 106.104252 (2019). DOI: 10.1016/j.cretres.2019.104252.

[4215] J. Chen, B. Wang, Y. Zheng, E. Jarzembowski, T. Jiang, X. L. Wang, X. T. Zheng, and H. C. Zhang. "Female-biased froghoppers (Hemiptera, Cercopoidea) from the Mesozoic of China and phylogenetic reconstruction of early Cercopoidea". English. In: Journal of Systematic Palaeontology 17 (2019), pp. 2091-2103. DOI: 10.1080/14772019.2019.1587526.

[4216] J. Chen, B. Wang, Y. Zheng, H. Jiang, T. Jiang, H. Bozdoan, J. Q. Zhang, B. Z. An, X. L. Wang, and H. C. Zhang. "Taxonomic review and phylogenetic inference elucidate the evolutionary history of Mesozoic Procercopidae, with new data from the Cretaceous Jehol Biota of NE China (Hemiptera, Cicadomorpha)". English. In: Journal of Zoological Systematics and Evolutionary Research 58 (2020), pp. 174-193. DOI: $10.1111 /$ jzs.12349.

[4217] J. Chen, B. Wang, Y. Zheng, H. Jiang, Y. L. Li, T. Jiang, and H. C. Zhang. “Giants trapped in resin: new material of Sinoalidae in mid-Cretaceous Kachin amber from northern Myanmar (Insecta, Cicadomorpha)". English. In: Cretaceous Research 112.104450 (2020).

[4218] J. Chen, H. C. Zhang, B. Wang, X. T. Zheng, and X. L. Wang. "High variability in tegminal venation of primitive cercopoids (Hemiptera: Cicadomorpha), as implied by the new discovery of fossils from the Middle Jurassic of China". English. In: Entomological Science 18 (2015), pp. 147-152. 
[4219] J. Chen, H. C. Zhang, B. Wang, X. T. Zheng, and X. L. Wang. “New Jurassic Sinopalaeocossus and related genera with notes on their evolutionary implications (Hemiptera, Palaeontinidae)". English. In: Insect Systematics \& Evolution 47 (2016), pp. 113-129.

[4220] J. Chen, H. C. Zhang, B. Wang, Y. Zheng, X. L. Wang, and X. T. Zheng. "New Jurassic tettigarctid cicadas from China with a novel example of disruptive coloration". English. In: Acta Palaeontologica Polonica 61 (2016), pp. 853-862.

[4221] J. Chen, H. C. Zhang, B. Wang, X. T. Zheng, and X. L. Wang. “A new genus and species of Palaeontinidae (Insecta, Hemiptera) from the Middle Jurassic of Daohugou, Inner Mongolia". Chinese. In: Acta Palaeontologica Sinica 53 (2014), pp. 345-351.

[4222] J. Chen, H. C. Zhang, B. Wang, and Y. Zheng. "A new whitefly (Hemiptera, Sternorrhyncha, Aleyrodidae) in mid-Cretaceous Kachin amber, northern Myanmar". English. In: Cretaceous Research 106.104256 (2019). DOI: 10.1016/j.cretres.2019.104256.

[4223] J. Chen, H. C. Zhang, B. Wang, H. Jiang, T. Jiang, Y. Zheng, and X. L. Wang. “Female sinoalid froghoppers in mid-Cretaceous Kachin amber with description of a new genus and species (Hemiptera, Cicadomorpha)". English. In: Cretaceous Research 104.104194 (2019). DOI: 10.1016/j.cretres.2019. 104194.

[4224] J. Chen, H. C. Zhang, H. Jiang, Y. L. Li, T. Jiang, Y. Zheng, and X. L. Wang. “Eurypterogerron kachinensis gen. et sp. nov., a remarkable minlagerrontid (Hemiptera, Cicadomorpha) in midCretaceous Burmese amber". English. In: Cretaceous Research 110.104418 (2020). DOI: 10.1016/j. cretres.2020.104418.

[4225] J. Chen, H. C. Zhang, Y. Zheng, and X. L. Wang. "The whitefly subfamily Aleurodicinae (Hemiptera, Sternorrhyncha, Aleyrodidae) in mid-Cretaceous Kachin amber, northern Myanmar". English. In: Cretaceous Research 118.104668 (2020). DOI: 10.1016/j.cretres.2020.104668.

[4226] J. Chen, Y. Zheng, G. J. Wei, and X. L. Wang. “New data on Jurassic Sinoalidae from northeastern China (Insecta, Hemiptera)". English. In: Journal of Paleontology 91 (2017), pp. 994-1000.

[4227] J. H. Chen, H. A. Curren, B. White, and G. J. Wasserburg. "Precise chronology of the last interglacial period: $234 \mathrm{U}-230 \mathrm{Th}$ data from fossil coral reefs in the Bahamas". English. In: Geological Society America Bulletin 103 (1991), pp. 82-97.

[4228] J. H. Chen and T. Komatsu. "So-called Middle Triassic Claraia (Bivalvia) from Guangxi, south China". Chinese. In: Acta Palaeontologica Sinica 41.3 (2002), pp. 434-447.

[4229] J. H. Chen and F. Stiller. "The halobiid bivalve genus Enteropleura and a new species from the Middle Anisian of Guangxi, southern China". English. In: Acta Palaeontologica Polonica 52.1 (2007), pp. 53-61.

[4230] J. H. Chen and F. Stiller. "An early Daonella from the Middle Anisian of Guangxi, southwestern China, and its phylogenetic significance". English. In: Swiss Journal of Geosciences 103 (2010), pp. 523-533.

[4231] J. Y. Chen, X. G. Hou, and G. X. Li. “New Lower Cambrian demosponges - Quadrolaminiella gen. nov. from Chengjiang, Yunnan". Chinese. In: Acta Palaeontologica Sinica 29.4 (1990), pp. 402-414.

[4232] J.-Y. Chen, D.-Y. Huang, Q. -Q. Peng, H. -M. Chi, X. -Q. Wang, and M. Feng. “The first tunicate from the Early Cambrian of South China". English. In: Proceedings of the National Academy of Sciences 100.14 (2003), pp. 8314-8318.

[4233] J.-Y. Chen, D.-Y. Huang, and D. J. Bottjer. "An Early Cambrian problematic fossil: Vetustovermis and Its possible affinities". English. In: 272 (2005), pp. 2003-2007.

[4234] L. Chen and G. Cuny. "Discovery of the Middle-Late Triassic elasmobranch ichthyoliths from the Guanling area, Guizhou, SW China". English. In: Geological Bulletin of China 22.4 (2003), pp. 237247.

[4235] L. Chen, H. Luo, S. Hu, J. Yin, Z. Jiang, Z. Wu, F. Li, and A. Chen. Early Cambrian Chengjiang fauna in eastern Yunnan, CHina. English. Yunnan Science and Technology Press, Kunming. 2002, pp. 1199. 
[4236] L. Chen, D. Ren, and O. Béthoux. "A new, rare and small lobeattid species (Insecta: Archaeorthoptera) found at Xiaheyan (Pennsylvanian; Ningxia, China)". English. In: Fossil Record 23 (2020), pp. 71-74. DOI: 10.5194/fr-23-71-2020.

[4237] L. D. Chen, G. Cuny, and X. F. Wang. "The chondrichthyan fauna from the Middle-Late Triassic of Guanling (Guizhou province, SW China)". English. In: Historical Biology 19.4 (2007), pp. 291-300.

[4238] P. Chen, J. Jin, and A. C. Lenz. "Evolution, palaeoecology, and palaeobiogeography of the Late Ordovician-Early Silurian brachiopod Epitomyonia". English. In: Palaeoworld 17.1 (2008), pp. 85101. DOI: 10.1016/j.palwor.2008.03.002.

[4239] Q. Chen and Q. Gao. "The discovery of Asiocoryphodon conicus in Yangxi Formation on the northwest margin of Jianghan Basin and its stratigraphic significance". Chinese. In: Acta Petrolei Sinica 13.2 (1992), pp. 127-129.

[4240] R. Chen, W. Zheng, Y. Azuma, M. Shibata, T. Lou, Q. Jin, and X. Jin. "A new nodosaurid ankylosaur from the Chaochuan Formation of Dongyang, Zhejiang Province, China". English. In: Acta Geologica Sinica (English Edition) 87.3 (2013), pp. 658-671.

[4241] R.-j. Chen, J.-c. Lü, Y. -x. Zhu, Y. Azuma, W. -j. Zheng, X. -s. Jin, Y. Noda, and M. Shibata. “Pterosaur tracks from the early Late Cretaceous of Dongyang City, Zhejiang Province, China". English. In: Geological Bulletin of China 32.5 (2013), pp. 693-698.

[4242] S. Chen, S. W. Deng, C. K. Shih, W. W. Zhang, P. Zhang, D. Ren, Y. N. Zhu, and T. P. Gao. "The earliest timematids in Burmese amber reveal diverse tarsal pads of stick insects in the midCretaceous". English. In: Insect Science 26 (2019), pp. 945-957. DOI: 10.1111/1744-7917.12601.

[4243] S. Chen, X. C. Yin, X. D. Lin, C. K. Shih, R. Z. Zhang, T. P. Gao, and D. Ren. "Stick insect in Burmese amber reveals an early evolution of lateral lamellae in the Mesozoic". English. In: Proceedings of the Royal Society B 285 (2018), p. 20180425.

[4244] S. Chen, W. W. Zhang, C. K. Shih, and D. Ren. "Two new species of Archipseudophasmatidae (Insecta: Phasmatodea) from Upper Cretaceous Myanmar amber". English. In: Cretaceous Research 73 (2017), pp. 65-70.

[4245] T. Chen, S. H. Liu, X. J. Lei, and L. Chen. "A new cockroach (Insecta: Blattaria: Blattulidae) from the Lower Cretaceous Laiyang Formation of China". English. In: Cretaceous Research 101 (2019), pp. 17-22. DOI: 10.1016/j.cretres.2019.03.003.

[4246] W. Chen. "New Data of Middle-Late Triassic Elasmobranch Ichthyoliths from Falang Formation in Guanling, Guizhou". Chinese. In: Acta Palaeontologica Sinica 19.3 (2002), pp. 276-287.

[4247] W. Q. Chen, Z. Y. Sun, A. Tintori, and D. Y. Jiang. "A new species of Sangiorgioichthys Tintori \& Lombardo, 2007 (Actinopterygii; Semionotiformes) from the Pelsonian (Anisian, Middle Triassic) of Guizhou Province, South China". English. In: Neues Jahrbuch für Geologie und Paläontologie, Abhandlungen 273 (2014), pp. 65-74.

[4248] X. Chen, L. Cheng, and K. Yin. "The first record of Helicoprion Karpinsky (Helicoprionidae) from China". English. In: Chinese Science Bulletin 52.16 (2007), pp. 2246-2251.

[4249] X. Chen, R. Motani, L. Cheng, D. Jiang, and O. Rieppel. "The enigmatic marine reptile Nanchangosaurus from the Lower Triassic of Hubei, China and the phylogenetic affinities of Hupehsuchia". English. In: Plos One 9.7 (2014), e102361. DOI: 10.1371/journal.pone.0102361.

[4250] X. Chen, Y.-N. Nan, C. E. Mitchell, and X. -D. Qiao. "Graptolites from the Qilang and Yingan formations (Caradoc, Ordovician) of Kalpin, western Tarim, Xinjiang, China". English. In: Journal of Paleontology 74.2 (2000), pp. 282-300. DOI: 10.1017/S0022336000031498.

[4251] X. Chen, J. Rong, C. E. Mitchell, D. A. T. Harper, J. Fan, R. Zhan, Y. Zhang, R. Li, and Y. Wang. “Late Ordovician to earliest Silurian graptolite and brachiopod biozonation from the Yangtze region, South China, with global correlation". English. In: Geological Magazine 137.6 (2000), pp. 623-650.

[4252] X. Chen, J.-Y. Rong, C. -Y. Wang, L. -U. Geng, Z. -Q. Zhan, H. -J. Wu, J. -T. Xu, and T. -E. Chen. "Stratigraphical data. 3. Telychian rocks in the Yangtze region". English. In: vol. 21. Telychian rocks of the British Isles and China (Silurian, Llandovery Series): an experiment to test precision in stratigraphy. Cardiff: National Museum of Wales Geological Series, 2002, pp. 13-43. 
[4253] X. Chen, P. M. Sander, L. Cheng, and X. Wang. "A new Triassic primitive ichthyosaur from Yuanan, South China". English. In: Acta Geologica Sinica 87.3 (2013), pp. 672-677.

[4254] X.-H. Chen, R. Motani, L. Cheng, D. -Y. Jiang, and O. Rieppel. "A carapace-like bony 'body tube' in an Early Triassic marine reptile and the onset of marine tetrapod predation". English. In: PLoS ONE 9.4 (2014), e94396. DOI: 10.1371/journal.pone.0094396.

[4255] X. H. Chen and D. W. Boyd. "Marine fossils from Permian redbeds (Satanka Shale) at Laramie, Wyoming". English. In: Contributions to Geology, University of Wyoming 31.2 (1997), pp. 27-32.

[4256] X. T. Chen, Y. Z. Zhao, and D. Ren. "A new genus and species of Rhopalidae (Hemiptera: Heteroptera) from the Early Cretaceous of Liaoning Province, China". English. In: Zootaxa 4058 (2015), pp. 135-140.

[4257] X. Y. Chen. "A new genus and species of Lymexylidae (Insecta: Coleoptera) from Mid-Cretaceous Amber of northern Myanmar". English. In: Paleontological Journal 53 (2019), pp. 1203-1205. DOI: 10.1134/S003103011911008X.

[4258] X. Y. Chen and G. F. Su. "First eggs of fossil bristletails (Meinertellidae: Microcoryphia) from Burmese amber". English. In: Acta Geologica Sinica 91 (2017), pp. 1489-1490.

[4259] X. Y. Chen and G. F. Su. "Zorotypus hukawngi sp. nov., a fossil winged Zoraptera (Insect)". English. In: Zootaxa 4571 (2019), pp. 263-269.

[4260] X. Y. Chen and G. F. Su. "A new species of Zorotypus (Insecta, Zoraptera, Zorotypidae) and the earliest known suspicious mating behavior of zorapterans from the mid-Cretaceous amber of northern Myanmar". English. In: Journal of Zoological Systematics and Evolutionary Research 57 (2019), pp. 555-560. DOI: 10.1111/jzs.12283.

[4261] X.-H. Chen, L. Cheng, and P. M. Sander. “A new species of Callawayia (Reptilia: Ichthyosauria) from the Late Triassic in Guanling, Guizhou". Chinese. In: Geology in China 34.6 (2007), pp. 974982.

[4262] X.-H. Chen and L. Cheng. "A new species of Mixosaurus (Reptilia: Ichthyosauria) from the Middle Triassic of Pu'an, Guizhou, China". English. In: Acta Palaeontologica Sinica 2 (2010), pp. 251-260.

[4263] X.-H. Chen and L. Cheng. "The discovery of Mixosaurus (Reptilia: Ichthyopterygia) from the Middle Triassic of Luoping, Yunnan Province". English. In: Acta Geologica Sinica 83.9 (2009), pp. 12141220.

[4264] X.-H. Chen, R. Motani, L. Cheng, D. -Y. Jiang, and O. Rieppel. “A new specimen of Carroll's mystery hupehsuchian from the Lower Triassic of China". English. In: PLoS ONE 10.5 (2015), e0126024. DOI: 10.1371/journal.pone.0126024.

[4265] X.-H. Chen, R. Motani, L. Cheng, D. -Y. Jiang, and O. Rieppel. “A small short-necked hupehsuchian from the Lower Triassic of Hubei Province, China". English. In: PLoS One 9.12 (2014), e115244. DOI: 10.1371/journal.pone.0115244.

[4266] Y. Chen and X. Li. "Paleocommunity Replacements of Benthic Brachiopod in the Middle - Upper Devonian in the Longmenshan Area, Southwestern China: Responses to Sea Level Fluctuations". English. In: Acta Geologica Sinica (English Edition) 79.3 (2005), pp. 313-324.

[4267] Y. Chen, Y.-X. Li, J. -S. Shi, Y. -X. Zhang, and K. Xie. “Pleistocene fossil snakes (Squamata, Reptilia) from". English. In: Historical Biology (2019), pp. 1-13. DOI: 10.1080/08912963.2019.1658094.

[4268] Y. Chen, Q. Ye, H. Jiang, P. B. Wignall, and J. Yuan. "Conodonts and Carbon Isotopes during the Permian-Triassic Transition on the Napo Platform, South China". English. In: Journal of Earth Science (2018). DOI: 10.1007/s12583-018-0884-3.

[4269] Z. Chen and N. W. Archibold. "Tournaisian-Visean brachiopods from the Gancaohu area of southern Tienshan Mountains, Xinjiang, NW China". In: Géobios 33.2 (2000), pp. 183-199.

[4270] Z. Chen, C. Wang, and R. Fan. "Restudy of the Llandovery conodont biostratigraphy in the Xiushan area, Chongqing City, China". English. In: NRC Research Press (2015).

[4271] Z. Chen, C. Zhou, S. Xiao W. Wang, C. Guan, H. Hua, and X. Yuan. "New Ediacara fossils preserved in marine limestone and their ecological implications". English. In: (2014). 
[4272] Z. Q. Chen. "Lower Permian reef-dwelling brachiopod faunas from the Tarim Basin, Northwest China: biostratigraphy, palaeoecology and biogeography". English. In: Palaeontographica Abteilung A 272.1-4 (2004), pp. 1-96.

[4273] Z. Q. Chen. "Systematic paleontology, in Survival brachiopod faunas of the end-Permian mass extinction from the southern Alps (Italy) and South China". English. In: Geological Magazine 143 (2006), pp. 301-327.

[4274] Z. Q. Chen, A. D. George, and W. R. Yang. "Effects of Middle-Late Permian sea-level changes and mass extinction on the formation of the Tieqiao skeletal mound in the Laibin area, South China". English. In: Australian Journal of Earth Sciences 56 (2009), pp. 745-763.

[4275] Z. Q. Chen, K. Kaiho, A. D. George, and J. N. Tong. "Survival brachiopod faunas of the endPermian mass extinction from the southern Alps (Italy) and South China". English. In: Geological Magazine 143.3 (2006), pp. 301-327.

[4276] Z. Q. Chen and Z. T. Liao. "Last orthotetid brachiopods from the uppermost Permian of south China". English. In: Journal of Paleontology 81.5 (2007), pp. 986-997.

[4277] Z. Q. Chen and Z. T. Liao. "Brachiopod faunas across the Wuchiapingian-Changhsingian (Late Permian) boundary at the stratotype section and subsurface of Changxing area, South China". English. In: Neues Jahrbuch für Geologie und Paläontologie, Abhandlungen 254.3 (2009), pp. 315-335.

[4278] Z. Q. Chen, G. R. Shi, and L. P. Zhan. "Early Carboniferous athyridid brachiopods from the Qaidam Basin, northwest China". In: Journal of Paleontology 77.5 (2003), pp. 844-862.

[4279] Z. Q. Chen and G. R. Shi. "A new tribe of Dictyoclostid brachiopods from the Lower Permian of the Tarim Basin, North-West China". In: Palaeontology 43 (2000), pp. 325-342.

[4280] Z. Q. Chen and G. R. Shi. "Latest Devonian (Famennian) to earliest Carboniferous (Tournaisian) brachiopods from the Bachu Formation of the Tarim Basin, Xinjiang Province, northwest China". English. In: Rivista Italiana di Paleontologia e Stratigrafia 105.2 (1999), pp. 231-250.

[4281] Z. Q. Chen, G. R. Shi, and K. Kaiho. "A new genus of rhynchonellid brachiopod from the Lower Triassic of south China and implications for timing the recovery of Brachiopoda after the endpermian mass extinction". English. In: Palaeontology 45.1 (2002), pp. 149-164.

[4282] Z. Q. Chen, G. R. Shi, and K. Kaiho. "New ophiuroids from the Permian/Triassic boundary beds of South China". English. In: Palaeontology 47.5 (2004), pp. 1301-1312.

[4283] Z. Q. Chen and G. R. Shi. "Artinskian-Kungurian (Early Permian) brachiopod faunas from the Tarim Basin, Northwest China, Part 1: Biostratigraphy and systematics of Productida". English. In: Palaeontographica Abteilung A 274.3-6 (2006), pp. 113-177.

[4284] Z. Q. Chen and G. R. Shi. “Artinskian-Kungurian (Early Permian) brachiopod faunas from the Tarim Basin, Northwest China, Part 2: Paleobiogeography, and systematics of Orthotetida, Orthida, Spiriferida, Spiriferinida, Rhynchonellida, Athyridida and Terebratulida". English. In: Palaeontographica Abteilung A 275.1-3 (2006), pp. 1-53.

[4285] Z. Q. Chen, G. R. Shi, Y. Q. Gao, J. N. Tong, F. Q. Yang, and Y. Q. Peng. “A late Changhsingian (latest Permian) deep-water brachiopod fauna from Guizhou, South China". English. In: Alcheringa 33 (2009), pp. 163-183.

[4286] Z. Q. Chen, G. R. Shi, F. Q. Yang, Y. Q. Gao, J. N. Tong, and Y. Q. Peng. “An ecologically mixed brachiopod fauna from Changhsingian deep-water basin of South China: consequence of endPermian global warming". English. In: Lethaia 39 (2006), pp. 79-90.

[4287] Z. Q. Chen and G. R. Shi. "Chuiella gen. nov. (Brachiopoda) and palaeoecology from the Lower Carboniferous of the Kunlun Mountains, NW China". English. In: Alcheringa 23 (1999), pp. 259275.

[4288] Z. Q. Chen and R. Shi. "Bashkirian to Moscovian (late Carboniferous) brachiopod faunas from the western Kunlun Mountains, northwest China”. English. In: Géobios 33.5 (2000), pp. 543-560. 
[4289] Z. Q. Chen, J. I. Tazawa, G. R. Shi, and N. S. Matsuda. "Pennsylvanian (Carboniferous) brachiopods from the Itaituba Formation of the Amazon Basin, Brazil". English. In: Alcheringa 28.2 (2004), pp. 441-468.

[4290] Z. Q. Chen, J. Tong, K. Zhang, H. Yang, Z. Liao, H. Song, and J. Chen. “Environmental and biotic turnover across the Permian-Triassic boundary on a shallow carbonate platform in western Zhejiang, South China". English. In: Australian Journal of Earth Sciences 56.6 (2009), pp. 775-797.

[4291] Z. Q. Chen, J. Tong, Z. Liao, and J. Chen. "Structural changes of marine communities over the Permian-Triassic transition: Ecologically assessing the end-Permian mass extinctiion and its aftermath". English. In: Global and Planetary Change 73 (2010), pp. 123-140.

[4292] Z. T. Chen. "Pinguisoperla, a new fossil genus of Perlidae (Insecta: Plecoptera) from mid-Cretaceous Burmese amber". English. In: Zootaxa 4425 (2018), pp. 596-600.

[4293] Z. T. Chen. "Baltileuctra gen. nov., a new genus of Leuctridae (Insecta: Plecoptera) in Baltic amber". English. In: Zootaxa 4407 (2018), pp. 281-287.

[4294] Z. T. Chen. "Description of Euroleuctra gen. nov., a new fossil genus of Leuctridae (Insecta: Plecoptera) in Eocene Baltic amber". English. In: Zootaxa 4462 (2018), pp. 291-295.

[4295] Z. T. Chen. "First tergal structures for the fossil stonefly genus Largusoperla (Plecoptera: Perlidae): a new species and a new tribe of Acroneuriinae". English. In: Zootaxa 4462 (2018), pp. 296-300.

[4296] Z. T. Chen. "A new fossil species of Largusoperla (Plecoptera: Perlidae) and its evolutionary implications". English. In: Zootaxa 4442 (2018), pp. 572-578.

[4297] Z. T. Chen. "First record of subfamily Brachypterainae (Plecoptera: Taeniopterygidae) in Baltic amber: a new genus and species". English. In: Zootaxa 4527 (2018), pp. 569-574.

[4298] Z. T. Chen. "A new stonefly of Acroneuriinae (Plecoptera: Perlidae) from mid-Cretaceous amber of northern Myanmar". English. In: Cretaceous Research 99 (2019), pp. 128-132. DOI: 10.1016/j. cretres.2019.02.020.

[4299] Z. T. Chen. "Key to the fossil genus Largusoperla (Plecoptera: Perlidae), with description of two new species from mid-Cretaceous Burmese amber". English. In: Zootaxa 4550 (2018), pp. 495-500.

[4300] Z. T. Chen. "A remarkable new stonefly with bisexual structures in mid-Cretaceous Burmese amber (Insecta: Perlidae)". English. In: Cretaceous Research 104.104189 (2019). DOI: 10.1016/j.cretres. 2019.07.019.

[4301] Z. T. Chen. "A new stonefly (Plecoptera: Perlidae) from the mid-Cretaceous Burmese amber". English. In: Cretaceous Research 113.104489 (2020). DOI: 10.1016/j.cretres.2020.104489.

[4302] Z. T. Chen, B. Wang, and Y. Z. Du. "Discovery of a new stonefly genus with three new species from mid-Cretaceous Burmese amber (Plecoptera: Perlidae)". English. In: Zootaxa 4378 (2018), pp. 573580.

[4303] Z. T. Chen and B. Wang. "Review of the fossil genus Largusoperla (Plecoptera: Perlidae): annotated checklist, taxonomic identification, and description of a new species". English. In: Zootaxa 4565 (2019), pp. 281-291.

[4304] Z. T. Chen and B. Wang. “New females of Perlidae (Insecta: Plecoptera) from Cenomanian Burmese amber". English. In: Cretaceous Research 106.104203 (2020). DOI: 10.1016/j.cretres.2019.104203.

[4305] Z. T. Chen and C. P. Xu. "First Peltoperlidae (Insecta: Plecoptera) from mid-Cretaceous Burmese amber". English. In: Cretaceous Research 114.104506 (2020). DOI: 10.1016/j.cretres.2020.104506.

[4306] Z.-Q. Chen. "Devonian-Carboniferous brachiopod zonation in the Tarim Basin, northwest China: implications for biostratigraphy and biogeography." In: Geological Journal 39 (2004), pp. 431-458.

[4307] Z.-Q. Chen. "A Late Carboniferous algal mound from the Tarim Basin, NW China: internal structure and palaeoecology". English. In: Geological Journal 47 (2012), pp. 477-494. DOI: 10.1002 / gj. 2438.

[4308] Z.-Q. Chen and N. W. Archibold. "New chonostrophiid brachiopods from the Famennian (Late Devonian) of the Santanghu, Xinjiang, northwest China". English. In: Journal of Paleontology 76.2 (2002), pp. 229-238. 
[4309] Z.-Q. Chen, M. J. Campi, G. R. Shi, and K. Kaiho. "Post-extinction brachiopod faunas from the Late Permian Wuchiapingian coal series of South China". English. In: Acta Palaeontologica Polonica 50.2 (2005), pp. 343-363.

[4310] Z.-Q. Chen, G. R. Shi, and W. -R. Yang. "Internal Structure and Paleoecology of the Lower Permian Uzunbulak Reef Complex of the Tarim Basin, Northwest China". In: Facies 49 (2003), pp. 119-134.

[4311] Z.-Q. Chen, J.-I. Tazawa, G. R. Shi, and N. S. Matsuda. “Uppermost Mississippian brachiopods from the basal Itaituba Formation of the Amazon Basin, Brazil". English. In: Journal of Paleontology 79.5 (2005), pp. 907-926.

[4312] Z. Q. Chen and G. R. Shi. “Revision of Prelissorhynchia Xu \& Grant, 1994 (Brachiopoda) from the Upper Permian of South China". In: Proceedings of the Royal Society of Victoria 111.1 (1999), pp. 1526.

[4313] Z. Q. Chen, G. R. Shi, S. Z. Shen, and N. W. Archbold. "Tethyochonetes gen. nov. (Chonetida, Brachiopoda) from the Lopingian (Late Permian) of China". English. In: Proceedings of the Royal Society of Victoria 112.1 (2000), pp. 1-15.

[4314] Z. Q. Chen and G. R. Shi. "Late Carboniferous to Early Permian brachiopod faunas from the Bachu and Kalpin areas, Tarim basin, NW China". English. In: Alcheringa 25 (2002), pp. 293-326.

[4315] G. F. Cheng, S. Y. Mu, G. Z. Yin, and G. B. Liu. "The helicoprionid fossil from Lower Permian Maokou Stage in Weining, Guizhou province". Chinese. In: Acta Geoscientia Sinica 24 (2004), pp. $443-$ 445.

[4316] J. Cheng and A. Ma. "The New Mammalian Materials from the Eocene of Liguanqiao Basin". English. In: Vertebrata PalAsiatica 28.3 (1990), pp. 228-244.

[4317] L. Cheng, X. Chen, B. Zhang, and Y. Cai. "New Study of Anshunsaurus huangnihensis Cheng, 2007 (Reptilia: Thalattosauria): Revealing its Transitional Position in Askeptosauridae". English. In: Acta Geologica Sinica 85.6 (2011), pp. 1231-1237.

[4318] L. Cheng, X.-H. Chen, X. -W. Zeng, and Y. -J. Cai. “A new eosauropterygian (Diapsida: Sauropterygia) from the Middle Triassic of Luoping, Yunnan Province". English. In: Journal of Earth Science 23.1 (2012), pp. 33-40. DOI: 10.1007/s12583-012-0231-z.

[4319] L. Cheng, X.-H. Chen, Q. -H. Shang, and X. -C. Wu. "A new marine reptile from the Triassic of China, with a highly specialized feeding adaptation". English. In: Natuwissenschaften (2014). DOI: 10.1007/s00114-014-1148-4.

[4320] L. Cheng, O. Wings, X. Chen, and P. M. Sander. "Gastroliths in the Triassic ichthyosaur Panjiangsaurus from China". English. In: Journal of Paleontology 80.3 (2006), pp. 583-588.

[4321] L. R. Cheng, Y. J. Zhang, Y. C. Zhang, and S. Z. Wu. “Discovery of Mufushanella from the Middle Permian in Xainza area of Tibet". Chinese. In: Acta Palaeontologica Sinica 44 (2005), pp. 74-78.

[4322] X. Cheng, X. Wang, S. Jiang, and A. W. A. Kellner. "A new scaphognathid pterosaur from western Liaoning, China". English. In: Historical Biology 24.1 (2012), pp. 101-111.

[4323] X. Cheng, X. Wang, S. Jiang, and A. W. A. Kellner. "Short note on a non-pterodactyloid pterosaur from Upper Jurassic deposits of Inner Mongolia, China". English. In: Historical Biology 27.6 (2015), pp. 749-754.

[4324] X. D. Cheng, S. Z. Liu, W. J. Huang, L. Liu, H. M. Li, and Y. X. Li. “A new species of Mongolarachnidae from the Yixian Formation of western Liaoning, China". English. In: Acta Geologica Sinica 93 (2019), pp. 227-228. DOI: 10.1111/1755-6724.13780.

[4325] X. D. Cheng, Q. J. Meng, X. R. Wang, and C. L. Gao. “New discovery of Nephilidae in Jehol biota (Araneae, Nephilidae)". Chinese. In: Acta Zootaxonomica Sinica 33 (2008), pp. 330-334.

[4326] Y.-N. Cheng, X.-C. Wu, T. Sato, and H. - Y. Shan. "A new eosauropterygian (Diapsida, Sauropterygia) from the Triassic of China". English. In: Journal of Vertebrate Paleontology 32.6 (2012), pp. 13351349. DOI: $10.1080 / 02724634.2012 .695983$. 
[4327] Y.-n. Cheng, Q. Ji, X. -c. Wu, and H. -y. Shan. “Oviraptorosaurian eggs (Dinosauria) with embryonic skeletons discovered for the first time in China". English. In: Acta Geologica Sinica 82.6 (2008), pp. 1089-1094.

[4328] Y.-N. Cheng, T. Sato, X. -C. Wu, and C. Li. "First complete pistosauroid from the Triassic of China". English. In: Journal of Vertebrate Paleontology 26.2 (2006), pp. 501-504. DOI: 10.1671/0272-4634(2006) 26[501:FCPFTT]2.0.CO;2.

[4329] Y.-N. Cheng, X.-C. Wu, T. Sato, and H. -Y. Shan. “Dawazisaurus brevis, a new eosauropterygian from the Middle Triassic of Yunnan, China". English. In: Acta Geologica Sinica 90.2 (2016), pp. 401424.

[4330] C. Chény, E. Guillam, A. Nel, and V. Perrichot. "A new species of Ampulicomorpha Ashmead from Eocene French amber, with a list of fossil and extant Embolemidae (Insecta: Hymenoptera) of the world". English. In: BSGF - Earth Sciences Bulletin 191.20 (2020), pp. 1-7. DOI: 10.1051/bsgf/ 2020020.

[4331] C. Chény, B. Wang, and V. Perrichot. "A new genus of myrmicine ant (Hymenoptera: Formicidae) from Eocene Baltic amber". English. In: Comptes Rendus Palevol 18 (2019), pp. 589-597. DOI: 10. 1016/j.crpv.2019.05.005.

[4332] A. Cherchi, M. Murru, and L. Simone. "Miocene Carbonate Factories in the Syn-rift Sardinia Graben Subbasins (Italy)". English. In: Facies 43 (2000), pp. 223-240.

[4333] M. Cherin, D. Berte, and L. Rook. "Re-Defining Canis etruscus (Canidae, Mammalia): A New Look into the Evolutionary History of Early Pleistocene Dogs Resulting from the Outstanding Fossil Record from Pantalla (Italy)". English. In: Journal of Mammal Evolution 21 (2014), pp. 95-110. DOI: 10.1007/s10914-013-9227-4).

[4334] M. Cherin, D. A. Iurino, and R. Sardella. "New well-preserved material of Lynx issiodorensis valdarnensis (Felidae, Mammalia) from the Early Pleistocene of Pantalla (central Italy)". English. In: Bollettino della Societá Paleontologica Italiana 52 (2013), pp. 103-111. DOI: 10.4435/BSPI.2013.16.

[4335] M. Cherin, D. A. Iurino, and R. Sardella. "Earliest occurrence of Puma pardoides (Owen, 1846) (Carnivora, Felidae) at the Plio/Pleistocene transition in western Europe: New evidence from the Middle Villafranchian assemblage of Montopoli, Italy". English. In: C. R. Palevol 12 (2013), pp. 165171. DOI: $10.1016 /$ j.crpv.2013.01.002.

[4336] M. Cherin, D. A. Iurino, G. F. Willemsen, and G. Carnevale. "A new otter from the Early Pleistocene of Pantalla (Italy), with remarks on the evolutionary history of Mediterranean Quaternary Lutrinae (Carnivora, Mustelidae)". English. In: Quaternary Science Reviews 135 (2016), pp. 92-102. DOI: 10.1016/j.quascirev.2016.01.008.

[4337] M. Cherin, D. A. Lurino, R. Sardella, and L. Rook. "Actinomycetes pardinensis (Carnivora, Felidae) from the Early Pleistocene of Pantalla (Italy): predatory behavior and ecological role of the giant Plio-Pleistocene cheetah". English. In: Quaternary Science Review 87 (2014), pp. 82-97.

[4338] M. D. Cherney, J. A. Wilson Mantilla, I. S. Zalmout, M. S. M. Antar, and P. D. Gingerich. "New Specimens of the Late Eocene Turtle Cordichelys (Pleurodira: Podocnemididae) From Wadi Al Hitan and Qasr El-Sagha in the Fayum Province of Egypt". English. In: Contributions from the Museum of Paleontology, University of Michigan 33.2 (2020), pp. 29-64.

[4339] F. Chesi, M. Delfino, L. Abbazzi, S. Carboni, L. Lecca, and L. Rook. "New fossil vertebrate remains from San Giovanni di Sinis (Late Pleistocene, Sardinia): the last Mauremys (Reptilia, Testudines) in the central Mediterranean". English. In: Rivista Italiana di Paleontologia e Stratigrafia 113.2 (2007), pp. 287-297.

[4340] F. Chesi, M. Delfino, A. Varola, and L. Rook. “Fossil sea turtles (Chelonii, Dermochelyidae and Cheloniidae) from the Miocene of Pietra Leccese (late Burdigalian-early Messinian), Southern Italy". English. In: Geodiversitas 29.2 (2007), pp. 321-333.

[4341] F. Chesi and M. Delfino. "The Italian fossil record of the sea turtles". English. In: Atti del 6r Congresso Nazionale della Societas Herpetologica Italica (Roma, 27.IX-1.X.2006) (2006), pp. 95-116. 
[4342] D. R. Chesnut and E. R. Slucher. "Color-banded gastropods from the Kendrick Shale Member (Middle Pennsylvanian, Westphalian B) of Eastern Kentucky". English. In: Journal of Paleontology 64.3 (1990), pp. 475-477. DOI: 10.1017/s0022336000018722.

[4343] D. R. Chesnut Jr. "Paleontological survey of the Pennsylvanian rocks of the eastern Kentucky coal field: Part 1, invertebrates". English. In: Kentucky Geological Survey Information Circular XI.36 (1991), pp. 1-71.

[4344] R. T. Chesser, K. J. Burns, C. Cicero, J. L. Dunn, A. W. Kratter, I. J. Lovette, P. C. Rasmussen, J. V. Remsen Jr., J. D. Rising, D. F. Stotz, and K. Winker. “Fifty-seventh supplement to the American Ornithologists' Union Check-list of North American Birds". English. In: The Auk 133 (2016), pp. 544560.

[4345] R. T. Chesser, K. J. Burns, C. Cicero, J. L. Dunn, A. W. Kratter, I. J. Lovette, P. C. Rasmussen, J. V. Remsen Jr., J. D. Rising, D. F. Stotz, and K. Winker. "Fifty-eighth supplement to the American Ornithological Society's Check-list of North American Birds". English. In: The Auk 134 (2017), pp. 751-773.

[4346] S. G. B. Chester and K. C. Beard. “New micromomyid plesiadapiforms (Mammalia, Euarchonta) from the late Paleocene of Big Multi Quarry, Washakie Basin, Wyoming". English. In: Annals of Carnegie Museum 80.2 (2012), pp. 159-172.

[4347] S. G. B. Chester, J. I. Bloch, R. Secord, and D. M. Boyer. "A new small-bodied species of Palaeonictis (Creodonta, Oxyaenidae) from the Paleocene-Eocene thermal maximum". English. In: Journal of Mammalian Evolution 17.4 (2010), pp. 227-243.

[4348] E. Chevalier and M. Aretz. "A microbe-bryozoan reef from the Middle Visean of the Namur Syncline (Engihoul Quarry)". English. In: Geologica Belgica 8 (2005), pp. 109-119.

[4349] N. L. Chhabra and V. P. Mishra. "Middle Triassic fish teeth from the Kalapani Limestone of Malla Johar, Chamoli District (Uttaranchal)". English. In: 47 (2002), pp. 151-155.

[4350] L. M. Chiappe. “Cretaceous birds of Latin America”. English. In: Cretaceous Research 12.1 (1991), pp. 55-63.

[4351] L. M. Chiappe. "Early avian evolution on the southern hemisphere: the fossil record of birds in the Mesozoic of Gondwana". English. In: Memoirs of the Queensland Museum 39.3 (1996), pp. 533-554.

[4352] L. M. Chiappe. "Enantiornithine (Aves) tarsometatarsi from the Cretaceous Lecho Formation of northwestern Argentina". English. In: American Museum Novitates 3083 (1993), pp. 1-27.

[4353] L. M. Chiappe. “Aves”. English. In: Patagonian Mesozoic Reptiles. Bloomington: Indiana University Press, 2007, pp. 257-270.

[4354] L. M. Chiappe, Z. Bo, J. K. O'Connor, G. Chunling, W. Xuri, M. Habib, J. Marugan-Lobon, M. Qingjin, and C. Xiaodong. "A new specimen of the Early Cretaceous bird Hongshanornis longicresta: insights into the aerodynamics and diet of a basal ornithuromorph". English. In: PeerJ 2.e234 (2014). DOI: 10.7717 / peerj.234.

[4355] L. M. Chiappe and J. O. Calvo. "Neuquenornis volans, a new Late Cretaceous bird (Enantiornithes, Avisauridae) from Patagonia, Argentina". English. In: Journal of Vertebrate Paleontology 14.2 (1994), pp. 230-246.

[4356] L. M. Chiappe, R. A. Coria, F. D. Jackson, and L. Dingus. "The Late Cretaceous nesting site of Auca Mahuevo (Patagonia, Argentina): eggs, nests, and embryos of titanosaurian sauropods". English. In: Palaeovertebrata 22.2-4 (2003), pp. 97-108.

[4357] L. M. Chiappe, S. Ji, and Q. Ji. "Juvenile birds from the Early Cretaceous of China: implications for enantiornithine phylogeny". English. In: American Museum Novitates 3594 (2007), pp. 1-46.

[4358] L. M. Chiappe, J. P. Lamb, and P. G. P. Ericson. "New enantiornithine bird from the marine upper Cretaceous of Alabama". English. In: Journal of Vertebrate Paleontology 22.1 (2002), pp. 170-174.

[4359] L. M. Chiappe, Q.-J. Meng, F. Serrano, T. Sigurdsen, M. Wang, A. Bell, and D. Liu. “New Bohaiornislike bird from the Early Cretaceous of China: enantiornithine interrelationships and flight performance". English. In: PeerJ 7 (2019), e7846. DOI: 10.7717/peerj.7846. 
[4360] L. M. Chiappe, M. Norell, and J. Clark. “A new skull of Gobipteryx minuta (Aves, Enantiornithes) from the Cretaceous of the Gobi Desert". English. In: American Museum Novitates 3346 (2001), pp. 1-15.

[4361] L. M. Chiappe, M. A. Norell, and J. M. Clark. "The skull of a relative of the stem-group bird Mononykus". In: Nature 392 (1998), pp. 275-278.

[4362] L. M. Chiappe, D. Rivarola, E. Romero, S. Davila, and L. Codorniú. Recent advances in the paleontology of the Lower Cretaceous Lagarcito Formation (Parque Nacional Sierra de las Quijadas, San Luis, Argentina). English. Vol. 14. Lower and Middle Cretaceous Terrestrial Ecosystems, New Mexico Museum of Natural History and Science Bulletin. 1998, pp. 187-192.

[4363] L. M. Chiappe, S. Suzuki, G. J. Dyke, M. Watabe, K. Tsogtbaatar, and R. Barsbold. "A new enantiornithine bird from the Late Cretaceous of the Gobi Desert". English. In: Journal of Systematic Palaeontology 5.2 (2007), pp. 193-208. DOI: 10.1017/S1477201906001969.

[4364] A. A. Chiarenza, A. R. Fiorillo, R. S. Tykoski, P. J. McCarthy, P. P. Flaig, and D. L. Contreras. “The first juvenile dromaeosaurid (Dinosauria: Theropoda) from Arctic Alaska". English. In: PLoS ONE 15.7 (2020), e0235078:1-30. DOI: 10.1371/journal.pone.0235078.

[4365] A. A. Chiarenza, D. Foffa, M. T. Young, G. Insacco, A. Cau, G. Carnevale, and R. Catanzariti. "The youngest record of metriorhynchid crocodylomorphs, with implications for the extinction of Thalattosuchia". English. In: Cretaceous Research 56 (2015), pp. 608-616.

[4366] M. Chiari, P. O. Baumgartner, D. Bernoulli, V. Bortolotti, M. Marcucci, A. Photiades, and G. Principi. "Late Triassic, Early and Middle Jurassic Radiolaria from ferromanganese-chert 'nodules' (Angelokastron, Argolis, Greece): evidence for prolonged radiolarite sedimentation in the MaliacVardar Ocean". English. In: Facies 59 (2013), pp. 391-424.

[4367] M. Chiari, M. Marcucci, and M. Prela. "New species of Jurassic radiolarians in the sedimentary cover of ophiolites in the Mirdita area, Albania". In: Micropaleontology 48.S1 (2002), pp. 61-87.

[4368] M. Chiari, M. Marcucci, G. Cortese, A. Ondrejickova, and A. Kodra. "Triassic radiolarian assemblages in the Rubik area, and Cukali zone, Albania". English. In: Ofioliti 21.1 (1996), pp. 77-84.

[4369] K. Chiba, A. R. Fiorillo, L. L. Jacobs, Y. Kimura, Y. Kobayashi, N. Kohno, Y. Nishida, M. J. Polcyn, and K. Tanaka. "A new desmostylian mammal from Unalaska (USA) and the robust Sanjussen jaw from Hokkaido (Japan), with comments on feeding in derived desmostylids". English. In: Historical Biology 28.1-2 (2016), pp. 289-303. DOI: 10.1080/08912963.2015.1046718.

[4370] S. Chicchi and M. Bisconti. "Valentina, una balena fossile nelle collezioni dei Musei Civici di Reggio Emilia". Italian. In: Museologia Scientifica Memorie 13 (2014), pp. 54-55.

[4371] T. C. Chidsey, D. A. Sprinkel, G. C. Willis, and P. B. Anderson. “Geologic lake guide along Lake Powell, Glen Canyon National Recreation Area and Rainbow Bridge National Monument, UtahArizona". English. In: vol. 29. Geologic Road, Trail, and Lake Guides to Utah's Parks and Monuments. Utah Geological Association Publication. Utah Geological Association, 2000, pp. 1-76.

[4372] F. Chikhi-Aouimeur. Late Cretaceous hippuritids of Algeria: a critical review of bibliographic data. English. Vol. 87. Cretaceous rudists and carbonate platforms: environmental feedback, SEPM Special Publication. 2007, pp. 213-220.

[4373] S. Childerhouse and N. Gales. "Historical and modern distribution and abundance of the New Zealand sea lion Phocarctos hookeri". English. In: New Zealand Journal of Zoology 25.1 (1998), pp. 116. DOI: $10.1080 / 03014223.1998 .9518131$.

[4374] J. J. Chiment and W. W. Korth. "A New Genus of Eomyid Rodent (Mammalia) from the Eocene (Uintan-Duchesnean) of Southern California". English. In: Journal of Vertebrate Paleontology 16.1 (1996), pp. 116-124.

[4375] N. R. Chimento and F. L. Agnolin. "Mam'iferos del Pleistoceno superior de Santiago del Estero (Argentina) y sus afinidades paleobiogeográficas". Spanish. In: Papéis Avulsos de Zoologia 51.6 (2011), pp. 83-100. 
[4376] N. R. Chimento and F. L. Agnolin. “The fossil American lion (Panthera atrox) in South America: Palaeobiogeographical implications". English. In: Palevol 16 (2017), pp. 850-864.

[4377] N. R. Chimento and A. Dondas. "First Record of Puma concolor (Mammalia, Felidae) in the Early-Middle Pleistocene of South America". English. In: Journal of Mammalian Evolution 25 (2018), pp. 381-389.

[4378] N. R. Chimento, J. I. Zuccari, J. M. Marchetto, and L. Berbach. “Nuevos Restos de Ciervos (Cervidae, Mammalia) Para el Pleistoceno de la Región Pampeana (Argentina): Consideraciones Paleobiogeográficas y Paleoecológicas". Spanish. In: Revista Brasileira de Paleontologia 22.1 (2019), pp. 6785. DOI: $10.4072 / \mathrm{rbp} .2018 .1 .06$.

[4379] K. Chin. "The paleobiological implications of herbivorous dinosaur coprolites from the Upper Cretaceous Two Medicine Formation: why eat wood?" English. In: Palaios 22 (2007), pp. 554-566. DOI: $10.2110 /$ palo.2006.p06-087r.

[4380] K. Chin and J. I. Kirkland. "Probable herbivore coprolites from the Upper Jurassic Mygatt-Moore Quarry, western Colorado". English. In: Modern Geology 23.1-4 (1998), pp. 249-275.

[4381] B. J. Chinnery. "Description of Prenoceratops pieganensis gen. et sp. nov. (Dinosauria: Neoceratopsia) from the Two Medicine Formation of Montana". English. In: Journal of Vertebrate Paleontology 24.3 (2004), pp. 572-590.

[4382] B. J. Chinnery and J. R. Horner. "A new neoceratopsian dinosaur linking North American and Asian taxa". English. In: Journal of Vertebrate Paleontology 27.3 (2007), pp. 625-641.

[4383] B. J. Chinnery, T. R. Lipka, J. I. Kirkland, J. M. Parrish, and M. K. Brett-Surman. Neoceratopsian teeth from the Lower to Middle Cretaceous of North America. English. Vol. 14. Lower and Middle Cretaceous Terrestrial Ecosystems, New Mexico Museum of Natural History and Science Bulletin. 1998, pp. 297-302.

[4384] B. J. Chinnery and D. B. Weishampel. "Montanoceratops cerorhynchus (Dinosauria: Ceratopsia) and relationships among basal neoceratopsians". English. In: Journal of Vertebrate Paleontology 18.3 (1998), pp. 569-585.

[4385] T. Chinzorig, Y. Kobayashi, K. Tsogtbaatar, P. J. Currie, M. Watabe, and R. Barsbold. “First ornithomimid (Theropoda, Ornithomimosauria) from the Upper Cretaceous Djadokhta Formation of Tögrögiin Shiree, Mongolia". English. In: Scientific Reports 7.1 (2017), 5835:1-14.

[4386] R. Chirat. "The so-called 'cosmopolitan palaeobiogeographic distribution' of Tertiary Nautilida of the genus Aturia Bronn 1838: the result of post-mortem transport by oceanic palaeocurrents". English. In: Palaeogeography, Palaeoclimatology, Palaeoecology 157 (2000), pp. 59-77.

[4387] R. Chirat, R. Enay, P. Hantzpergue, and C. Mangold. "Developmental integration related to buoyancy control in nautiloids: evidence from unusual septal approximation and ontogenetic allometries in a Jurassic species". English. In: Palaeontology 51 (2008), pp. 251-261.

[4388] R. Chirat, D. Vaslet, and Y. -M. Le Nindre. "Nautiloids of the Permian-Triassic Khuff Formation, central Saudi Arabia". English. In: GeoArabia 11.1 (2006), pp. 81-92.

[4389] Chita-kujira Excavation Research Group. "Odontocete fossils from the Miocene Morozaki Group, Chita Peninsula, Aichi Prefecture, Central Japan". English. In: Chikyu Kagaku 47.2 (1993), pp. 153157.

[4390] S. Chitaley. "On the occurrence of Prototaxites in the Cleveland Black Shale of Ohio, USA". In: Review of Palaeobotany and Palynology 72 (1992), pp. 257-271.

[4391] S. Chitaley and K. B. Pigg. "Clevelandodendron ohioensis, gen. et sp. nov., A Slender Upright Lycopsid from the Late Devonian Cleveland Shale of Ohio". In: American Journal of Botany 83.6 (1996), pp. 781-789.

[4392] A. Chitnarin, S. Crasquin, C. Chonglakmani, J. Broutin, P. J. Grote, and N. Thanee. "Middle Permian ostracods from Tak Fa limestone, Phetchabun Province, central Thailand". English. In: Geobios 41 (2008), pp. 341-353. 
[4393] A. Chitnarin, S. Crasquin, T. Charoentitirat, P. Tepnarong, and N. Thanee. “Ostracods (Crustacea) of the Early-Middle Permian from central Thailand (Indochina block). Part I. Order Palaeocopida". English. In: Geodiversitas 34 (2012), pp. 801-835.

[4394] I. Chlupac. Middle Devonian trilobites from Celechovice in Moravia (Czechoslovakia). 1992.

[4395] I. Chlupac. Geology of the Barrandian: A Field Trip Guide. Senckenberg-Buchen, Frankfurt. English. 1993.

[4396] I. Chlupac. "Trilobites from the Givetian and Frasnian of the Holy Cross Mountains". English. In: Acta Palaeontologica Polonica 37 (1992), pp. 395-406.

[4397] I. Chlupac and V. Kordule. "Arthropods of Burgess Shale type from the Middle Cambrian of Bohemia (Czech Republic)". English. In: Bulletin of the Czech Geological Survey 77.3 (2002), pp. 167182.

[4398] I. Chlupác, O. Fatka, R. J. Prokop, and V. Turek. "Research of the classical paleontological locality Luh in the Cambrian of Skryje". English. In: Journal of the Czech Geological Society 43 (1998), pp. 169173.

[4399] H. S. Cho and J. Y. Kim. “A New Graptolite Species Adelograptus brevibrachiatus from the Mungok Formation of Yeongwol Area, Korea". English. In: Journal of the Korean Earth Science Society 28.5 (2007), pp. 563-571.

[4400] S.-J. Choh, J. Hong, N. Sun, S. -W. Kwon, Tae-Yoon Park, J. Woo, Y. K. Kwon, and D. -C. Lee. "Early Ordovician reefs from the Taebaek Group, Korea: constituents, types, and geological implications". English. In: Geosciences Journal 17.2 (2013), pp. 139-149.

[4401] S. J. Choh and B. L. Kirkland. "Sedimentologic role of microproblematica Donezella in a Lower Pennsylvanian Donezella-siliceous sponge-dominated carbonate buildup, frontal Ouachita Thrust Belt, Oklahoma, USA". English. In: Journal of Sedimentary Research 76 (2006), pp. 152-161.

[4402] D. K. Choi and E. Y. Kim. "Occurrence of Changshania (Trilobita, Cambrian) in the Taebaeksan Basin, Korea and its stratigraphic and paleogeographic significance". English. In: Palaeogeography, Palaeoclimatology, Palaeoecology 242.3-4 (2006), pp. 343-354.

[4403] D. K. Choi, E. Y. Kim, and J. G. Lee. "Upper Cambrian polymerid trilobites from the Machari Formation, Yongwol, Korea". English. In: Geobios 41 (2008), pp. 183-204.

[4404] D. K. Choi and J. G. Lee. “Occurrence of Glyptagnostus stolidotus Opik, 1961 (Trilobita, Late Cambrian) in the Machari Formation of Korea". In: Journal of Paleontology 69.3 (1995), pp. 590-594.

[4405] D. K. Choi, J. G. Lee, and B. C. Sheen. "Upper Cambrian agnostoid trilobites from the Machari Formation, Yongwol, Korea". English. In: Geobios 37 (2004), pp. 159-189.

[4406] J. N. Choiniere and P. M. Barrett. "A sauropodomorph dinosaur from the ?Early Jurassic of Lusitu, Zambia". English. In: Palaeontologia Africana 49 (2015), pp. 42-52.

[4407] J. N. Choiniere, J. M. Clark, C. A. Forster, and X. Xu. "A basal coelurosaur (Dinosauria: Theropoda) from the Late Jurassic (Oxfordian) of the Shishugou Formation in Wucaiwan, People's Republic of China". English. In: Journal of Vertebrate Paleontology 30.6 (2010), pp. 1773-1796. DOI: 10.1080 / 02724634.2010.520779.

[4408] J. N. Choiniere, J. M. Clark, C. A. Forster, M. A. Norell, D. A. Eberth. G. M. Erickson, H. Chu, and $\mathrm{X} . \mathrm{Xu}$. "A juvenile specimen of a new coelurosaur (Dinosauria: Theropoda) from the MiddleLate Jurassic Shishugou Formation of Xinjiang, People's Republic of China". English. In: Journal of Systematic Palaeontology (2013). DOI: 10.1080/14772019.2013.781067.

[4409] D. Chokchaloemwong, S. Hattori, E. Cuesta, P. Jintasakul, M. Shibata, and Y. Azuma. "A new carcharodontosaurian theropod (Dinosauria: Saurischia) from the Lower Cretaceous of Thailand". English. In: PLoS ONE 14.10 (2019), e0222489. DOI: 10.1371/journal.pone.0222489.

[4410] B. Choo. "Cretaceous ichthyosaurs from Western Australia". English. In: Records of the Western Australian Museum Supplement 57 (1999), pp. 207-218. 
[4411] B. Choo. "A new species of the Devonian actinopterygian Moythomasia from Bergisch Gladbach, Germany, and fresh observations on M. durgaringa from the Gogo Formation of Western Australia". English. In: Journal of Vertebrate Paleontology 35.4 (2015), e952817. DOI: 10.1080 / 02724634. 2015.952817.

[4412] B. Choo. "Revision of the actinopterygian genus Mimipiscis (=Mimia) from the Upper Devonian Gogo Formation of Western Australia and the interrelationships of the early Actinopterygii". English. In: Earth and Environmental Science Transactions of The Royal Society of Edinburgh 102.2 (2012), pp. 72-104. DOI: 10.1017/S1755691011011029.

[4413] A. Chopey-Jones, M. Williams, and J. A. Zalasiewicz. "Biostratigraphy, palaeobiogeography and morphology of the Llandovery (Silurian) graptolites Campograptus lobiferus (M'Coy) and Campograptus harpago (Törnquist)". English. In: Scottish Journal of Geology 39.1 (2003), pp. 71-85. DOI: $10.1144 /$ sjg39010071.

[4414] L. Chornogubsky. "Interrelationships of Polydolopidae (Mammalia: Marsupialia) from South America and Antarctica". English. In: Zoological Journal of the Linnean Society (2020), pp. 1-42.

[4415] L. Chornogubsky, M. A. Abello, and G. D. Barmak. "The Metatheria from the Ro Santa Cruz (Santa Cruz Formation, Early-Middle Miocene, Argentina): History and new records". English. In: vol. 19. Early-Middle Miocene Paleontology in the Ro Santa Cruz, Southern Patagonia, Argentina. 130 years since Ameghino, 1887 2. Publicación Electrónica de la Asociación Paleontológica Argentina, 2019, pp. 62-68. DOI: 10.5710/PEAPA.04.10.2019.287.

[4416] L. Chornogubsky, F. J. Goin, and M. Reguero. "A reassessment of Antarctic polydolopid marsupials (Middle Eocene, La Meseta Formation)". English. In: Antarctic Science 21.3 (2009), pp. 285-297. DOI: $10.1017 /$ S0954102009001916.

[4417] L. Chornogubsky and A. G. Kramarz. “Nuevos hallazgos de Microbiotheriidae (Mammalia, Marsupialia) en la Formación Pinturas (Mioceno temprano, Argentina)". Spanish. In: Ameghiniana 49.4 (2012), pp. 442-450. DOI: 10.5710/AMGH.22.2.2012.524.

[4418] L. Chornogubsky, N. Zimicz, F. J. Goin, J. C. Fernicola, P. Payrola, and M. Cárdenas. “New Palaeogene metatherians from the Quebrada de Los Colorados Formation at Los Cardones National Park (Salta Province, Argentina)". English. In: Journal of Systematic Palaeontology 17.7 (2019), pp. 539555. DOI: 10.1080/14772019.2017.1417333.

[4419] J. Choufani, D. Azar, V. Perrichot, C. Soriano, P. Tafforeau, and A. Nel. “The genus Leptoconops Skuse (Diptera: Ceratopogonidae) in Early Cretaceous Charentese amber". English. In: Palaeobiodiversity and Palaeoenvironments 91 (2011), pp. 285-291.

[4420] J. Choufani, D. Azar, and A. Nel. "The oldest amphientomete booklouce from Lower Cretaceous amber of Lebanon (Psocodea: Troctomorpha)". English. In: Insect Systematics \& Evolution 42 (2011), pp. 149-159.

[4421] J. Choufani, D. Azar, and A. Nel. "New biting midges from the Cretaceous amber of Lebanon (Diptera: Ceratopogonidae)". English. In: Annales de la Société Entomologique de France 50 (2015), pp. 272-285.

[4422] J. Choufani, W. El-Halabi, D. Azar, and A. Nel. “First fossil insect from Lower Cretaceous Lebanese amber in Syria (Diptera: Ceratopogonidae)". English. In: Cretaceous Research 54 (2015), pp. 106-116.

[4423] J. Choufani, V. Perrichot, V. Girard, R. Garrouste, D. Azar, and A. Nel. “Two new biting midges of the modern type from Santonian amber of France (Diptera: Ceratopogonidae)". English. In: Insect Evolution in an Amberiferous and Stone Alphabet. Leiden: Brill, 2013, pp. 73-95.

[4424] J. Choufani, V. Perrichot, D. Azar, and A. Nel. "New biting midges (Diptera: Ceratopogonidae) in Late Cretaceous Vendean amber". English. In: Paleontological Contributions 10 (2014), pp. 34-40.

[4425] K. Chovanec. "East Tennessee State University". English. PhD thesis. 2014.

[4426] M. Chow, J. Wang, and J. Meng. "A New Species of Chungchienia (Tillodontia, Mammalia) from the Eocene of Lushi, China". English. In: American Museum Novitates 3171 (1996), pp. 1-10. 
[4427] A. M. Christensen. Brachiopod Paleontology and Paleoecology of the Lower Mississippian Lodgepole Limestone in Southeastern Idaho. English. Guidebook to the Geology of Eastern Idaho: Pocatello, Idaho Museum of Natural History. 1999, pp. 57-67.

[4428] W. K. Christensen. "Belemnitella schulzi sp. nov. from the uppermost Campanian and lowest Maastrichtian chalks of Northwest Germany and Denmark". In: Acta Geologica Polonica 50.1 (2000), pp. 55-66.

[4429] K. Christiansen and P. Nascimbene. "Collembola (Arthropoda, Hexapoda) from the mid Cretaceous of Myanmar (Burma)". English. In: Cretaceous Research 27 (2006), pp. 318-363.

[4430] K. Christiansen and E. Pike. "Cretaceous Collembola (Arthropoda, Hexapoda) from the Upper Cretaceous of Canada". English. In: Cretaceous Research 23 (2002), pp. 165-188.

[4431] N. A. Christiansen and E. Tschopp. "Exceptional stegosaur integument impressions from the Upper Jurassic Morrison Formation of Wyoming". English. In: Swiss Journal of Geosciences 103.2 (2010), pp. 163-171. DOI: 10.1007/s00015-010-0026-0.

[4432] P. Christiansen and N. Bonde. "A new species of gigantic mosasaur from the Late Cretaceous of Israel". In: Journal of Vertebrate Paleontology 22.3 (2002), pp. 629-644.

[4433] P. Christiansen and N. Bonde. "The first dinosaur from Denmark". English. In: Neues Jahrbuch für Geologie und Paläontologie, Abhandlungen 227.2 (2003), pp. 287-299.

[4434] M. Christie, S. M. Holland, and A. M. Bush. "Contrasting the ecological and taxonomic consequences of extinction". English. In: Paleobiology 39.4 (2013), pp. 538-559. DOI: 10.1666/12033.

[4435] D. C. Christophel, L. J. Scriven, and D. R. Greenwood. "An Eocene Megafossil Flora from Nelly Creek, South Australia". English. In: Transactions of the Royal Society of South Australia 116.2 (1992), pp. 65-76.

[4436] A. Chrzastek. "Vertebrate remains from the Lower Muschelkalk of Raciborowice Górne (NorthSudetic Basin, SW Poland)". English. In: Geological Quarterly 52 (2008), pp. 225-238.

[4437] D. Chu, J. Tong, M. J. Benton, J. Yu, and Y. Huang. "Mixed continental-marine biotas following the Permian-Triassic mass extinction in South and North China". English. In: Palaeogeography, Palaeoclimatology, Palaeoecology 519 (2017), pp. 95-107. DOI: 10.1016/j.palaeo.2017.10.028.

[4438] L. Chun, O. Rieppel, C. Long, and N. C. Fraser. "The earliest herbivorous marine reptile and its remarkable jaw apparatus". English. In: Science Advances 2.5 (2016), e1501659. DOI: 10.1126/sciadv. 1501659.

[4439] S. B. Church. "A new Lower Ordovician species of Calathium, and skeletal structure of western Utah calathids". English. In: Journal of Paleontology 65.4 (1991), pp. 602-610.

[4440] C. S. Churcher and G. De Iuliis. "A new species of Protopterus and a revision of Ceratodus humei (Dipnoi: Ceratodontiformes) from the Late Cretaceous Mut Formation of eastern Dakhleh Oasis, Western Desert of Egypt". English. In: Palaeontology 44.2 (2001), pp. 305-323.

[4441] C. S. Churcher, A. V. Morgan, and L. D. Carter. "Arctodus simus from the Alaskan Arctic Slope". English. In: Canadian Journal of Earth Sciences 30.5 (1993), pp. 1007-1013.

[4442] C. S. Churcher, J. J. Pilny, and A. V. Morgan. "Late Pleistocene Vertebrate, Plant and Insect Remains from the lnnerkip Site, Southwestern Ontario". English. In: Geographie physique et Quaternaire 44.3 (1990).

[4443] M. Churchill, M. Martinez-Cáceres, C. de Muizon, J. Mnieckowski, and J. H. Geisler. “The Origin of High-Frequency Hearing in Whales". English. In: Current Biology 26 (2016), pp. 1-6. DOI: 10. 1016/j.cub.2016.06.004.

[4444] D. Chure, C. Turner, and F. Peterson. An embryo of Camptosaurus from the Morrison Formation (Jurassic, Middle Tithonian) in Dinosaur National Monument, Utah. English. In K. Carpenter, K.F. Hirsh \& J.R. Horner (eds.), Dinosaur Eggs and Babies (Cambridge: Cambridge University Press). 1994, pp. 298-311.

[4445] D. J. Chure. "The first record of Ichthyosaurs from Utah". English. In: Geology Studies (BYU) 39 (1993), pp. 65-69. 
[4446] D. J. Chure. “Koparion douglassi, a new dinosaur from the Morrison Formation (Upper Jurassic) of Dinosaur National Monument; the oldest troodontid (Theropoda: Maniraptora)". English. In: Brigham Young University Geology Studies 40 (1994), pp. 11-15.

[4447] D. J. Chure. "Utah's first Allosaurus-Marsh's Megalosaurus specimen rediscovered". English. In: Brigham Young University Geology Studies 45 (2000), pp. 1-4.

[4448] D. J. Chure, B. B. Britt, J. A. Whitlock, and J. A. Wilson. "First complete sauropod dinosaur skull from the Cretaceous of the Americas and the evolution of sauropod dentition". English. In: Naturwissenschaften (2010). DOI: 10.1007/s00114-010-0650-6.

[4449] D. J. Chure, A. R. Fiorillo, and A. Jacobsen. "Prey bone utilization by predatory dinosaurs in the Late Jurassic of North America, with comments on prey bone use by dinosaurs throughout the Mesozoic". English. In: Gaia 15 (2000), pp. 227-232.

[4450] D. J. Chure and M. A. Loewen. "Cranial anatomy of Allosaurus jimmadseni, a new species from the lower part of the Morrison Formation (Upper Jurassic) of Western North America". English. In: PeerJ 8.e7803 (2020), pp. 1-65. DOI: 10.7717/peerj.7803.

[4451] D. J. Chure and J. H. Madsen. "An unusual braincase (?Stokesosaurus clevelandi) from the ClevelandLloyd Dinosaur Quarry, Utah (Morrison Formation; Late Jurassic)". English. In: Journal of Vertebrate Paleontology 18.1 (1998), pp. 115-125.

[4452] D. J. Chure, M. Manabe, M. Tanimoto, and Y. Tomida. An unusual theropod tooth from the Mifune Group (Late Cenomanian to Early Turonian), Kumamoto, Japan. English. Vol. 15. Proceedings of the Second Gondwanan Dinosaur Symposium, National Science Museum Monographs. 1999, pp. 291-296.

[4453] E. Chwieduk. "Middle Permian rugose corals from the Kapp Starostin Formation, South Spitsbergen (Treskelen Peninsula)". English. In: Acta Geologica Polonica 57.3 (2007), pp. 281-304.

[4454] E. Chwieduk. "Early Permian solitary rugose corals from Kruseryggen (Treskelodden Fm, Hornsund area, southern Spitsbergen)". English. In: Geologos 15 (2009), pp. 57-75.

[4455] C. N. Ciampaglio, L. E. Babcock, C. L. Wellmann, A. R. York, and H. K. Brunswick. "Phylogenetic affinities and taphonomy of Brooksella from the Cambrian of Georgia and Alabama, USA". English. In: Palaeoworld 15.3-4 (2006), pp. 256-265.

[4456] C. N. Ciampaglio, S. K. Donovan, and P. G. Weaver. "A new bourgueticrinid (Crinoidea) from the Castle Hayne Formation (Eocene) of southeastern North Carolina, USA". English. In: Swiss Journal of Geoscience 100 (2007), pp. 243-249. DOI: 10.1007/s00015-007-1221-5.

[4457] A. Ciampalini, M. Forli, and F. Sammartino. "The marine fossils malacofauna in a Plio-Pleistocene section from Vallin Buio (Livorno, Italy)". English. In: Biodiversity Journal 5.1 (2014), pp. 9-18.

[4458] M. R. Ciancio, A. A. Carlini, K. E. Campbell, and G. J. Scillato-Yané. "New Palaeogene cingulates (Mammalia, Xenarthra) from Santa Rosa, Peru; and their importance in the context of South American faunas". English. In: Journal of Systematic Palaeontology 11.6 (2012), pp. 727-741. DOI: 10.1080/14772019.2012.704949.

[4459] M. R. Ciancio, C. Herrera, A. Aramayo, P. Payrola, and J. Babot. "Diversity of cingulate xenarthrans in the middle-late Eocene of Northwestern Argentina". English. In: Acta Palaeontologica Polonica 61.3 (2016), pp. 575-590.

[4460] S. G. Ciarapica, S. Cirilli, R. Martini, R. Rettori, L. Zaninetti, and G. Salvini-Bonnard. "Carbonate buildups and associated facies in the Monte Facito Formation (southern Apennines)". English. In: Boll. Soc. Geol. Italiana 109 (1990), pp. 151-164.

[4461] M. Cichowolski. "A review of the endocerid cephalopod Protocyptendoceras from the Floian (Lower Ordovician) of the Eastern Cordillera, Argentina". English. In: Acta Palaeontologica Polonica 54.1 (2009), pp. 99-109.

[4462] M. Cichowolski. "The nautiloid genus Cymatoceras from the Cretaceous of the Neuquén and Austral basins, Argentina". English. In: Cretaceous Research 24.4 (2003), pp. 375-390. 
[4463] M. Cichowolski, A. Ambrosio, and A. Concheyro. "Nautilids from the Upper Cretaceous of the James Ross Basin, Antarctic Peninsula". English. In: Antarctic Science 17 (2005), pp. 267-280.

[4464] M. Cichowolski, F. A. Mourgues, and E. Pérez. "El género Cymatoceras (Nautilida) en el Cretácio Inferior de la Cuenca de Atacama, norte de Chile". English. In: Revista Geológica de Chile 31.1 (2004), pp. 119-131.

[4465] D. J. Cicimurri. "A partial rostrum of the sawfish Pristis lathami Galeotti, 1837, from the Eocene of South Carolina". English. In: Journal of Paleontology 81.3 (2007), pp. 597-601.

[4466] D. J. Cicimurri and M. J. Everhart. "An elasmosaur with stomach contents and gastroliths from the Pierre Shale (Late Cretaceous) of Kansas". English. In: Transactions of the Kansas Academy of Science 104.3-4 (2001), pp. 129-143.

[4467] D. J. Cicimurri and M. D. Fahrenbach. "Chondrichthyes from the Upper Part of the Minnelusa Formation (Middle Pennsylvanian: Desmoinesian) Meade County, South Dakota". English. In: Proceedings of the south Dakota Academy of Science 81 (2002), pp. 81-92.

[4468] D. J. Cicimurri and J. L. Knight. "Two shark-bitten whale skeletons from Coastal Plain Deposits of South Carolina". English. In: Southeastern Naturalist 8.1 (2009), pp. 71-82.

[4469] D. J. Cicimurri and J. L. Knight. "Late Oligocene sharks and rays from the Chandler Bridge Formation, Dorchester County, South Carolina, USA". English. In: Acta Palaeontologica Polonica 54.4 (2009), pp. 627-647.

[4470] D. J. Cicimurri, J. L. Knight, J. M. Self-Trail, and S. M. Ebersole. “Late Paleocene glyptosaur (Reptilia: Anguidae) osteoderms from South Carolina, USA". English. In: Journal of Paleontology 90.1 (2016), pp. 147-153. DOI: 10.1017/jpa.2016.16.

[4471] D. J. Cicimurri and J. L. Knight. "Late Eocene (Priabonian) elasmobranchs from the Dry Branch Formation (Barnwell Group) of Aiken County, South Carolina, USA". English. In: PaleoBios 36.43964 (2019), pp. 1-31.

[4472] D. J. Cicimurri and D. A. Ebersole. "Paleocene chimaeroid fishes (Chondrichthyes: Holocephali) from the eastern United States, including two new species of Callorhinchus". English. In: PaleoBios 32 (2015), pp. 1-29.

[4473] G. M. Cidade, D. Riff, J. P. de Souza-Filho, and A. Schmaltz Hsiou. "A reassessment of the osteology of Mourasuchus amazonensis Price, 1964 with comments on the taxonomy of the species". English. In: Palaeontologia Electronica 22.2 (2019), 44A:1-23.

[4474] G. M. Cidade, A. D. Rincón, and A. Solórzano. “New cranial and postcranial elements of Mourasuchus (Alligatoroidea: Caimaninae) from the late Miocene of Venezuela and their palaeobiological implications". English. In: Historical Biology (2020). DOI: 10.1080/08912963.2020.1795844.

[4475] G. M. Cidade, A. Solórzano, A. D. Rincón, D. Riff, and A. S. Hsiou. “A new Mourasuchus (Alligatoroidea, Caimaninae) from the late Miocene of Venezuela, the phylogeny of Caimaninae and considerations on the feeding habits of Mourasuchus". English. In: PeerJ 5 (2017), e3056:1-37. DOI: 10.7717 / peerj.3056.

[4476] G. M. Cidade, J. P. Souza-Filho, A. S. Hsiou, C. A. Brochu, and D. Riff. “New specimens of Mourasuchus (Alligatorioidea, Caimaninae) from the Miocene of Brazil and Bolivia and their taxonomic and morphological implications". English. In: Alcheringa 43.2 (2019), pp. 261-278. DOI: 10.1080 / 03115518.2019.1566495.

[4477] M. Cieszkowski, J. Golonka, M. Krobicki, A. Slaczka, N. Oszczypko, A. Waskowska-Oliwa, and M. Wendorff. "The Northern Carpathians plate tectonic evolutionary stages and origin of olistoliths and olistostromes". English. In: Geodinamica Acta 22.1-3 (2009), pp. 101-126.

[4478] M. Cieszlowski, J. Golonka, T. Lesniak, and A. Waskowska-Oliwa. "Paleocene bryozoan-algal allodapic limestones-Czerwin glauconitic sandstones-their geological position in the flysch of the Subsilesian Unit of Outer Carpathian in Poland". English. In: Mineralia Slovaca 37 (2005), pp. $263-$ 265. 
[4479] R. L. Cifelli. "Cretaceous mammals from southern Utah. I. Marsupials from the Kaiparowits Formation (Judithian)". In: Journal of Vertebrate Paleontology 10.3 (1990), pp. 295-319.

[4480] R. L. Cifelli. "Cretaceous mammals from southern Utah. II. Marsupials and marsupial-like mammals from the Wahweap Formation (early Campanian)". In: Journal of Vertebrate Paleontology 10.3 (1990), pp. 320-331.

[4481] R. L. Cifelli. "Cretaceous mammals from southern Utah. III. Therian mammals from the Turonian (early Late Cretaceous)". In: Journal of Vertebrate Paleontology 10.3 (1990), pp. 332-345.

[4482] R. L. Cifelli. "Cretaceous mammals from southern Utah. IV. Eutherian mammals from the Wahweap (Aquilean) and Kaiparowits (Judithian) Formations". In: Journal of Vertebrate Paleontology 10.3 (1990), pp. 346-360.

[4483] R. L. Cifelli. "A primitive higher mammal from the Late Cretaceous of southern Utah". English. In: Journal of Mammalogy 71.3 (1990), pp. 343-350.

[4484] R. L. Cifelli. "Early Cretaceous mammal from North America and the evolution of marsupial dental characters". English. In: Proceedings of the National Academy of Sciences, USA 90.20 (1993), pp. 9413-9416.

[4485] R. L. Cifelli. "Therian mammals of the Terlingua local fauna (Judithian), Aguja Formation, Big Bend of the Rio Grande, Texas". In: Contributions to Geology, University of Wyoming 30.2 (1994), pp. 117-136.

[4486] R. L. Cifelli. "First notice on Mesozoic mammals from Oklahoma". English. In: Oklahoma Geology Notes 57.1 (1997), pp. 4-17.

[4487] R. L. Cifelli. "Therian Teeth of Unusual Design from the Mid-Cretaceous (Albian-Cenomanian) Cedar Mountain Formation of Utah". English. In: Journal of Mammalian Evolution 6.3 (1999), pp. 247270.

[4488] R. L. Cifelli. “Chapter 5: Marsupial Mammals from the Albian-Cenomanian (Early-Late Cretaceous) Boundary, Utah". English. In: Bulletin of the American Museum of Natural History 285 (2004), pp. 62-79.

[4489] R. L. Cifelli. "A new Adianthid Litoptern (Mammalia) from the Miocene of Chile". English. In: Revista Chilena de Historia Natural 64 (1991), pp. 119-125.

[4490] R. L. Cifelli, J. E. Cohen, and B. M. Davis. "New tribosphenic mammals from the Mussentuchit Local Fauna (Cedar Mountain Formation, Cenomanian), Utah, USA". English. In: Palaeontologia Polonica 67 (2016), pp. 67-81. DOI: 10.4202/pp.2016.67_067.

[4491] R. L. Cifelli, N. J. Czaplewski, and K. D. Rose. “Additions to knowledge of Paleocene mammals from the North Horn formation, Central Utah". English. In: Great Basin Naturalist 55.3 (1995), pp. 304-314.

[4492] R. L. Cifelli, B. M. Davis, and B. Sames. "Earliest Cretaceous mammals from the western United States". English. In: Acta Palaeontologica Polonica 59.1 (2014), pp. 31-52. DOI: 10.4202 / app. 2012. 0089.

[4493] R. L. Cifelli and B. M. Davis. "Tribosphenic mammals from the Lower Cretaceous Cloverly Formation of Montana and Wyoming". English. In: Journal of Vertebrate Paleontology 35.3 (2015), e920848:118. DOI: $10.1080 / 02724634.2014 .920848$.

[4494] R. L. Cifelli and C. de Muizon. "Marsupial mammal from the Upper Cretaceous North Horn Foramtion, central Utah". English. In: Journal of Paleontology 72.3 (1998), pp. 532-537.

[4495] R. L. Cifelli, J. D. Gardner, R. L. Nydam, and D. L. Brinkman. "Additions to the vertebrate fauna of the Antlers Formation (Lower Cretaceous), southeastern Oklahoma". In: Oklahoma Geology Notes 57.4 (1997), pp. 124-131.

[4496] R. L. Cifelli and C. L. Gordon. "Symmetrodonts from the Late Cretaceous of southern Utah and distribution of archaic mammals in the Cretaceous of North America". English. In: Brigham Young University Geology Studies 44 (1999), pp. 1-15. 
[4497] R. L. Cifelli, C. L. Gordon, and T. R. Lipka. "New multituberculate mammal from the Early Cretaceous of eastern North America". English. In: Canadian Journal of Earth Sciences 50.3 (2013), pp. 315323. DOI: $10.1139 / \mathrm{e} 2012-051$.

[4498] R. L. Cifelli and Z. Johanson. "New marsupial from the Upper Cretaceous of Utah". In: Journal of Vertebrate Paleontology 14.2 (1994), pp. 292-295.

[4499] R. L. Cifelli, T. R. Lipka, C. R. Schaff, and T. B. Rowe. "First Early Cretaceous mammal from the eastern seaboard of the United States". In: Journal of Vertebrate Paleontology 19.2 (1999), pp. 199203.

[4500] R. L. Cifelli and S. K. Madsen. "Triconodont mammals from the medial Cretaceous of Utah". In: Journal of Vertebrate Paleontology 18.2 (1998), pp. 403-411.

[4501] R. L. Cifelli and S. K. Madsen. "Spalacotheriid symmetrodonts (Mammalia) from the medial Cretaceous (upper Albian or lower Cenomanian) Mussentuchit local fauna, Cedar Mountain Formation, Utah, USA". English. In: Geodiversitas 21.2 (1999), pp. 167-214.

[4502] R. L. Cifelli, R. L. Nydam, J. G. Eaton, J. D. Gardner, and J. I. Kirkland. "Vertebrate faunas of the North Horn Formation (Upper Cretaceous-Lower Paleocene), Emery and Sanpete Counties." In: Utah Geological Survey Miscellaneous Publication 99-1 (1999), pp. 377-388.

[4503] R. L. Cifelli, J. R. Wible, F. A. Jenkins, and Jr. "Triconodont mammals from the Cloverly Formation (Lower Cretaceous), Montana and Wyoming". English. In: Journal of Vertebrate Paleontology 18.1 (1998), pp. 237-241.

[4504] P. Cifuentes-Ruiz, F. J. Vega, S. R. S. Cevallos-Ferriz, E. González-Soriano, S. Zaragoza-Caballero, and L. Garibayromero. "Oligocene scorpion and insects (Plecoptera and Coleoptera) from the Los Ahuehuetes locality, Puebla, Mexico". English. In: Ameghiniana 44 (2007), pp. 673-679.

[4505] P. Cifuentes-Ruiz, P. Vranský, F. J. Vega, S. R. S. Cevallos-Ferriz, E. González-Soriano, and C. R. Delgado de Jesús. "Campanian terrestrial arthropods from the Cerro del Pueblo Formation, Difunta Group in northeastern Mexico". English. In: Geologica Carpathica 57.5 (2006), pp. 347-354.

[4506] F. Cigala-Fulgosi. "Predation (or possible scavenging) by a great white shark on an extinct species of bottlenosed dolphin in the Italian Pliocene". English. In: Tertiary Research 12.1 (1990), pp. 17-36.

[4507] R. L. Ciochon, P. D. Gingerich, G. F. Gunnell, and E. L. Simons. "Primate postcrania from the late middle Eocene of Myanmar". In: Proceedings of the National Academy of Sciences 98.14 (2001), pp. 7672-7677.

[4508] A. L. Cione, M. M. Azpelicueta, M. Bond, A. A. Carlini, J. R. Casciotta, M. A. Cozzuol, M. Fuente, Z. Gasparini, F. J. Goin, J. Noriega, G. J. Scillato-Yane, L. Soibelzon, E. P. Tonni, D. H. Verzi, and M. G. Vucetich. "Miocene vertebrates from Entre Rios province, eastern Argentina". English. In: Serie Correlacion Geologica 14 (2000), pp. 191-237.

[4509] A. L. Cione, D. A. Cabrera, and M. J. Barla. “Oldest record of the Great White Shark (Lamnidae, Carcharodon; Miocene) in the Southern Atlantic". English. In: Geobios 45 (2012), pp. 167-172. DOI: 10.1016/j.geobios.2011.06.002.

[4510] A. L. Cione and M. A. Cozzuol. "Reidentification of Portheus patagonicus Ameghino, 1901, a supposed fish from the Middle Tertiary of Patagonia as a delphinoid cetacean". English. In: Journal of Paleontology 64.3 (1990), pp. 451-453.

[4511] A. L. Cione, M. de las Mercedes Azpelicueta, and D. R. Bellwood. “An oplegnathid fish from the Eocene of Antarctica". In: Palaeontology 37.4 (1995), pp. 931-940.

[4512] A. L. Cione, S. Gouiric, F. Goin, and D. Poire. "Atlantoceratodus, a new genus of lungfish from the upper Cretaceous of South America and Africa". English. In: Revista del Museo de La Plata 10.62 (2007), pp. 1-12.

[4513] A. L. Cione, S. Gouiric-Cavalli, J. A. Mennucci, D. A. Cabrera, and R. H. Freije. "First vertebrate body remains from the Permian of Argentina (Elasmobranchii and Actinopterygii)". English. In: Proceedings of the Geologists' Association 121 (2010), pp. 301-312. 
[4514] A. L. Cione, S. Gouiric-Cavalli, J. N. Gelfo, and F. J. Goin. “The youngest non-lepidosirenid lungfish of South America (Dipnoi, latest Paleocene-earliest Eocene, Argentina)". English. In: Alcheringa 35 (2011), pp. 193-198. DOI: 10.1080/03115518.2010.489418.

[4515] A. L. Cione and M. A. Reguero. "A middle Eocene basking shark (Lamniformes, Cetorhinidae) from Antarctica". English. In: Antarctic Science 10.1 (1998), pp. 83-88.

[4516] A. L. Cione and M. A. Reguero. "New records of the sharks Isurus and Hexanchus from the Eocene of Seymour Island, Antarctica". English. In: Proceedings of the Geologists' Association 105 (1994), pp. 1-14.

[4517] A. L. Cione and E. P. Tonni. "Reassesment of the Pliocene-Pleistocene continental time scale of Southern South America. Correlation of the type Chapadmalalan with Bolivian sections". English. In: Journal of South American Earth Sciences 9.3/4 (1996), pp. 221-236.

[4518] A. L. Cione, E. P. Tonni, and A. Dondas. "A mastodont (Mammalia, Gomphotheriidae) from the Argentinian continental shelf". English. In: Neues Jahrbuch fur Geologie und Palaontologie - Monatshefte 10 (2005), pp. 614-630.

[4519] L. A. Cione, W. M. Dahdul, J. G. Lundberg, and A. Machado-Allison. “Megapiranha paranensis, a new genus and species of Serrasalmidae (Characiformes, Teleostei) from the upper Miocene of Argentina". English. In: Journal of Vertebrate Paleontology 29.2 (2009), pp. 350-358.

[4520] E. Cioppi. "I cetacei fossili a Firenze, una storia lunga più di 250 anni". Italian. In: Museologia Scientifica Memorie 13 (2014), pp. 81-89.

[4521] O. Cirilli, M. G. Benvenuti, G. Carnevale, I. Casanovas Vilar, M. Delfino, M. Furió, M. Papini, A. Villa, and L. Rook. "Fosso della Fittaia: the oldest Tusco-Sardinian late Miocene endemic vertebrate assemblages (Baccinello-Cinigiano Basin, Tuscany, Italy)". English. In: Rivista Italiana di Paleontologia e Stratigrafia 122.2 (2016), pp. 13-34.

[4522] S. Cirilli. "Upper Triassic biogenic mounds in the Northern and Central Apennines (Italy): palaeoecology and palaeobiogeographical implications". English. In: Palaeopelagos 6 (1996), pp. 63-73.

[4523] S. Cirilli, A. Iannace, F. Jadoul, and V. Zamparelli. "Microbial-serpulid build-ups in the NorianRhaetian of the Western Mediterranean area: ecological response of shelf margin". English. In: Terra Nova 11 (1999), pp. 195-202.

[4524] E. Cirot and L. de Bonis. "Revision du genre Amphicynodon, carnivore de l'Oligocene. [Revision of the genus Amphicynodon, Oligocene carnivores.]" French. In: Palaeontographica Abteilung A 220.4-6 (1992), pp. 103-130.

[4525] E. Cirot and M. Wolsan. "Late Oligocene Amphictids (Mammalia: Carnivora) from la Milloque, Aquitaine Basin, France". English. In: Géobios 28 (1995), pp. 757-767.

[4526] A. E. H. Cisneros. "A new group of late Oligocene mysticetes from México". English. In: Palaeontologia Electronica 21.1.7A (2018), pp. 1-30.

[4527] J. C. Cisneros. "New Pleistocene vertebrate fauna from El Salvador". English. In: Revista Brasileira de Paleontologia 8.3 (2005), pp. 239-255.

[4528] J. C. Cisneros. "New basal procolophonid reptile from the Katberg formation (Lower Triassic) of the South African Karoo". English. In: Paleoworld 17.2 (2008), pp. 126-134. DOI: 10.1016/j.palwor. 2008.06.003.

[4529] J. C. Cisneros. "Taxonomic status of the reptile genus Procolophon from the Gondwanan Triassic". English. In: Palaeontologia Africana 43 (2008), pp. 7-17.

[4530] J. C. Cisneros. "The fossil mammals of El Salvador". English. In: New Mexico Museum of Natural History and Science Bulletin 44 (2008), pp. 375-380.

[4531] J. C. Cisneros, F. Abdala, and M. C. Malabarba. "Pareiasaurids from the Rio do Rasto Formation, Southern Brazil: biostratigraphic implications for Permian faunas of the Paraná basin". English. In: Revista Brasileira de Paleontologia 8.1 (2005), pp. 13-24. 
[4532] J. C. Cisneros, F. Abdala, B. S. Rubidge, P. C. Dentzien-Dias, and A. de Oliveira Bueno. “Dental occlusion in a 260-million-year-old therapsid with saber canines from the Permian of Brazil". English. In: Science 331 (2011), pp. 1603-1605. DOI: 10.1126/science.1200305.

[4533] J. C. Cisneros, F. Abdala, S. Atayman-Güven, B. S. Rubidge, A. M. Celal Sengör, and C. L. Schultz. "Carnivorous dinocephalian from the Middle Permian of Brazil and tetrapod dispersal in Pangaea". English. In: Proceedings of the National Academy of Sciences of the USA 109.5 (2012), pp. 15841588.

[4534] J. C. Cisneros, R. Damiani, C. Schultz, Á Da Rosa, C. Schwanke, L. W. Neto, and P. L. P. Aurélio. “A procolophonoid reptile with temporal fenestration from the Middle Triassic of Brazil". English. In: Proceedings of the Royal Society of London, Series B 271 (2004), pp. 1541-1546.

[4535] J. C. Cisneros, C. Marsicano, K. D. Angielczyk, R. M. H. Smith, M. Richter, J. Frobisch, C. F. Kammerer, and R. W. Sadleir. "New Permian fauna from tropical Gondwana". English. In: Nature Communications 6.8676 (2015). DOI: 10.1038/ncomms9676.

[4536] J. C. Cisneros, B. S. Rubidge, R. Mason, and C. Dube. "Analysis of millerettid parareptile relationships in the light of new material of Broomia perplexa Watson, 1914, from the Permian of South Africa". English. In: Journal of Systematic Paleontology 6.4 (2008), pp. 453-462. DOI: 10.1017/ S147720190800254X.

[4537] J. C. Cisneros and C. L. Schultz. "Procolophon brasiliensis n. sp., a new procolophonid reptile from the Lower Triassic of southern Brazil". English. In: Neues Jahrbuch für Geologie und Paläontologie Monatshefte 2002.11 (2002), pp. 641-648.

[4538] J. C. Cisneros and C. L. Schultz. "Soturnia caliodon n. g. n. sp., a procolophonid reptile from the upper Triassic of Southern Brazil". English. In: Neues Jahrbuch für Geologie und Paläontologie, Abhandlungen 227.3 (2003), pp. 365-380.

[4539] G. A. Cisterna and N. W. Archbold. "Spiriferoidea (Brachiopoda) from the Early Permian Del Salto Formation of Argentina". English. In: Alcheringa 31.1 (2007), pp. 3-16.

[4540] G. A. Cisterna and P. E. Isaacson. "A new Carboniferous brachiopod genus from South America". English. In: Alcheringa 27 (2003), pp. 63-73.

[4541] G. A. Cisterna and G. R. Shi. "Lower Permian brachiopods from Wasp Head Formation, Sydney Basin, southeastern Australia". English. In: Journal of Paleontology 88 (2014), pp. 531-544.

[4542] G. A. Cisterna, T. Simanauskas, and N. W. Archbold. "Permian brachiopods from the Tupe Formation, San Juan Province, Precordillera, Argentina". English. In: Alcheringa 26 (2002), pp. 177200.

[4543] G. A. Cisterna, A. F. Sterren, and H. R. Niemeyer. "Las sucesiones carbonáticas marinas del Pérmico Temprano en Antofagasta, norte de Chile". Spanish. In: Andean Geology 41 (2014), pp. 626638.

[4544] S. J. Ciurca and O. E. Tetlie. "Pterygotids (Chelicerata; Eurypterida) from the Silurian Vernon Formation of New York". English. In: Journal of Paleontology 81.4 (2007), pp. 725-736.

[4545] G. Civitelli, R. Combemorel, and N. Mariotti. "Marine sedimentation in the Valanginian-Hauterivian of northern Mozambique, with a description of Lower Cretaceous belemnites". English. In: Geobios 24.2 (1991), pp. 157-166.

[4546] J. A. Clack. “An early tetrapod from Romer's Gap". English. In: Nature 418 (2002), pp. 72-76.

[4547] J. A. Clack. "A new Early Carboniferous tetrapod with a mélange of crown-group characters". English. In: Nature 394 (1998), pp. 66-69.

[4548] J. A. Clack. "Silvanerpeton miripedes, a new anthracosauroid from the Viséan of East Kirkton, West Lothian, Scotland". English. In: Transactions of the Royal Society of Edinburgh: Earth Sciences 84 (1994), pp. 369-376. DOI: 10.1017/S0263593300006179.

[4549] J. A. Clack. "A new Microsaur from the Early Carboniferous (Visean) of East Kirkton Scotland, showing soft tissue evidence". English. In: Special Papers in Palaeontology 86 (2011), pp. 1-11. DOI: 10.1111/j.1475-4983.2011.01073.x. 
[4550] J. A. Clack. "A new baphetid (stem tetrapod) from the Upper Carboniferous of Tyne and Wear, U.K, and the evolution of the tetrapod occiput". English. In: Canadian Journal of Earth Sciences 40.4 (2003), pp. 483-498. DOI: 10.1139/E02-065.

[4551] J. A. Clack, P. E. Ahlberg, H. Blom, and S. M. Finney. "A new genus of Devonian tetrapod from North-East Greenland, with new information on the lower jaw of Ichthyostega". English. In: Palaeontology 55.1 (2012), pp. 73-86. DOI: 10.1111/j.1475-4983.2011.01117.x.

[4552] J. A. Clack and P. E. Ahlberg. "A new stem tetrapod from the Early Carboniferous of Northern Ireland". English. In: Recent Advances in the Origin and Early Radiation of Vertebrates. München: Verlag Dr. Friedrich Pfeil, 2004, pp. 309-320.

[4553] J. A. Clack, C. E. Bennett, D. K. Carpenter, S. J. Davies, N. C. Fraser, T. I. Kearsey, J. E. A. Marshall, D. Millward, B. K. A. Otoo, E. J. Reeves, A. J. Ross, M. Ruta, K. Z. Smithson, T. R. Smithson, and S. A. Walsh. "Phylogenetic and environmental context of a Tournaisian tetrapod fauna". English. In: Nature Ecology \& Evolution 1.0002 (2016). DOI: 10.1038/s41559-016-0002.

[4554] J. A. Clack, F. Witzmann, J. Muller, and D. Snyder. "A Colosteid-Like Early Tetrapod from the St. Louis Limestone (Early Carboniferous, Meramecian), St. Louis, Missouri, USA". English. In: Fieldiana: Life and Earth Sciences 5 (2012), pp. 17-39. DOI: 10.3158/2158-5520-5.1.17.

[4555] G. Cladera, G. M. del Fueyo, L. V. de Seoane, and S. Archangelsky. “Early Cretaceous riparian vegetation in Patagonia, Argentina". English. In: Revista del Museo Argentino de Ciencias Naturales 9.1 (2007), pp. 49-58.

[4556] K. M. Claeson, M. A. O'Leary, E. M. Roberts, F. Sissoko, M. Bouare, and L. Tapanial. “First Mesozoic record of the stingray Myliobatis wurnoensis from Mali and a phylogenetic analysis of Myliobatidae incorporating dental characters". English. In: Acta Palaeontologica Polonica (2010).

[4557] K. M. Claeson, R. Sarr, R. V. Hill, El Hadji Sow, R. Malou, and M. A. O'Leary. "New fossil scombrid (Pelagia: Scombridae) fishes preserved as predator and prey from the Eocene of Senegal". English. In: Proceedings of the Academy of Natural Sciences of Philadelphia 164.1 (2015), pp. 133-147. DOI: 10. 1635/053.164.0111.

[4558] K. M. Claeson, C. J. Underwood, and D. J. Ward. "†Tingitanius enuimandibulus, a New Platyrhinid Batoid from the Turonian (Cretaceous) of Morocco and the Cretaceous Radiation of the Platyrhinidae". English. In: Journal of Vertebrate Paleontology 33.5 (2013), pp. 1019-1036. DOI: 10.1080 / 02724634. 2013.767266.

[4559] L. P. A. Claessens and M. A. Loewen. "A redescription of Ornithomimus velox Marsh, 1890 (Dinosauria, Theropoda)". English. In: Journal of Vertebrate Paleontology 36.1 (2016), e1034593:1-15. DOI: $10.1080 / 02724634.2015 .1034593$.

[4560] M. E. Clapham. Lower to Middle Jurassic Stratigraphy and Ammonite Fauna of the Northern Whitehorse Trough, Yukon, Canada. English. 2000.

[4561] M. E. Clapham and D. J. Bottjer. "Permian marine paleoecology and its implications for largescale decoupling of brachiopod and bivalve abundance and diversity during the Lopingian (Late Permian)". English. In: Palaeogeography, Palaeoclimatology, Palaeoecology 249 (2007), pp. 283-301.

[4562] M. E. Clapham, G. M. Narbonne, J. G. Gehling, C. Greentree, and M. M. Anderson. “Thectardis avalonensis: a new Ediacaran fossil from the Mistaken Point biota, Newfoundland". English. In: Journal of Paleontology 78.6 (2004), pp. 1031-1036.

[4563] M. E. Clapham, G. M. Narbonne, and J. G. Gehling. "Paleoecology of the oldest known animal communities: Ediacaran assemblages at Mistaken Point, Newfoundland". English. In: Paleobiology 29.4 (2003), pp. 527-544.

[4564] M. E. Clapham, P. L. Smith, and H. W. Tipper. "Lower to Middle Jurassic stratigraphy, ammonoid fauna and sedimentary history of the Laberge Group in the Fish Lake syncline, northern Whitehorse Trough, Yukon, Canada". English. In: Yukon Exploration and Geology 2001. Whitehorse: Exploration, Geological Services Division, Yukon Region, Indian, and Northern Affairs Canada, 2002, pp. 73-85. 
[4565] D. L. Clark, J. K. Sorenson, and A. N. Ladd. “Probable Microvertebrates, Vertebrate-like Fossils, and Weird Things from the Wisconsin Ordovician". English. In: Journal of Paleontology 73.6 (1999), pp. 1201-1209.

[4566] G. N. Clark and M. K. Boudagher-Fadel. "The larger benthic foraminifers and stratigraphy of the Upper Jurassic, Lower Cretaceous of central Lebanon". English. In: Revue de Micropaleontologie 44.3 (2001), pp. 215-232.

[4567] J. D. Clark, Y. Beyene, G. WoldeGabriel, W. K. Hart, P. R. Renne, H. Gilbert, A. Defleur, G. Suwa, S. Katoh, K. R. Ludwig, J. -R. Boisserie, B. Asfaw, and T. D. White. "Stratigraphic, chronological and behavioural contexts of Pleistocene Homo sapiens from Middle Awash, Ethiopia". English. In: Nature 423 (2003), pp. 747-752.

[4568] J. M. Clark. "A new early Miocene species of Paleoparadoxia (Mammalia: Desmostylia) from California". English. In: Journal of Vertebrate Paleontology 11.4 (1991), pp. 490-508.

[4569] J. M. Clark. "A new shartegosuchid crocodyliform from the Upper Jurassic Morrison Formation of western Colorado". English. In: Zoological Journal of the Linnean Society 163 (2011), S152-S172.

[4570] J. M. Clark and R. Hernandez. "A new burrowing diapsid from the Jurassic La Boca Formation of Tamaulipas, Mexico". English. In: Journal of Vertebrate Paleontology 14.2 (1994), pp. 180-195.

[4571] J. M. Clark, J. A. Hopson, R. Hernández R., D. E. Fastovsky, and M. Montellano. "Foot posture in a primitive pterosaur". English. In: Nature 391 (1998), pp. 886-889.

[4572] J. M. Clark, M. A. Norell, and R. Barsbold. “Two new oviraptorids (Theropoda: Oviraptorosauria), Upper Cretaceous Djadokhta Formation, Ukhaa Tolgod, Mongolia". In: Journal of Vertebrate Paleontology 21.2 (2001), pp. 209-213.

[4573] J. M. Clark and M. A. Norell. "The Early Cretaceous crocodylomorph Hylaeochampsa vectiana from the Wealden of the Isle of Wight". English. In: American Museum Novitates 3032 (1992), pp. 119.

[4574] J. M. Clark and H.-D. Sues. "Two new basal crocodylomorph archosaur from the Lower Jurassic and the monophyly of the Sphenosuchia". English. In: Zoological Journal of the Linnean Society 136 (2002), pp. 77-95.

[4575] J. M. Clark, X. Xu, C. A. Forster, and Y. Wang. “A Middle Jurassic 'sphenosuchian' from China and the origin of the crocodylian skull”. English. In: Nature 430 (2004), pp. 1021-1024. DOI: 10.1038 / nature02802.

[4576] N. A. Clark, M. Williams, D. J. Hill, P. G. Quilty, J. L. Smellie, J. A. Zalasiewicz, M. J. Leng, and M. A. Ellis. "Fossil proxies of near-shore sea surface temperatures and seasonality from the late Neogene Antarctic shelf". English. In: Naturwissenschaften 100 (2013), pp. 699-722. DOI: 10.1007/ s00114-013-1075-9.

[4577] N. D. L. Clark and J. L. Barco Rodrguez. "The first dinosaur trackway from the Valtos Sandstone Formation (Bathonian, Jurassic) of the Isle of Skye, Scotland, UK". English. In: Geogaceta 24 (1998), pp. 79-82.

[4578] N. D. L. Clark, P. Booth, C. Booth, and D. A. Ross. "Dinosaur footprints from the Duntulm Formation (Bathonian, Jurassic) of the Isle of Skye". English. In: Scottish Journal of Geology 40.1 (2004), pp. 13-21.

[4579] N. D. L. Clark, J. D. Boyd, R. J. Dixon, and D. A. Ross. “The first Middle Jurassic dinosaur from Scotland: a cetiosaurid? (Sauropoda) from the Bathonian of the Isle of Skye". In: Scottish Journal of Geology 31.2 (1995), pp. 171-176.

[4580] N. D. L. Clark and H. Corrance. "New discoveries of $<\mathrm{i}>$ Isochirotherium herculis $</ \mathrm{i}>$ (Egerton 1838) and a reassessment of chirotheriid footprints from the Triassic of the Isle of Arran, Scotland". English. In: Scottish Journal of Geology 45 (2009), pp. 69-82.

[4581] N. D. L. Clark, R. Gillespie, S. F. Morris, and G. Clayton. "A new early Carboniferous crustacean from the Forest of Dean, England". English. In: Journal of Systematic Palaeontology 14 (2016). DOI: 10.1080/14772019.2015.1096848. 
[4582] N. D. L. Clark and M. Jewkes. “Tetrapod trackways (Matthewichnus sp. and ?Pseudobradypus sp.) from the Coal Measures (Carboniferous) of Central Scotland". English. In: Scottish Journal of Geology 36.1 (2000), pp. 87-90.

[4583] N. D. L. Clark, F. Nimmo, and C. J. Nicholas. "A new occurrence of Scottish plesiosaurian remains from the Island of Skye". English. In: Scottish Journal of Geology 29 (1993), pp. 197-199. DOI: 10. 1144/sjg29020197.

[4584] N. D. L. Clark, D. A. Ross, and P. Booth. "Dinosaur Tracks from the Kilmaluag Formation (Bathonian, Middle Jurassic) of Score Bay, Isle of Skye, Scotland, UK". English. In: Ichnos 12 (2005), pp. 93-104. DOI: 10.1080/10420940590914516.

[4585] D. J. Clarke and S. Chatzimanolis. "Antiquity and long-term morphological stasis in a group of rove beetles (Coleoptera: Staphylinidae): Description of the oldest Octavius species from Cretaceous Burmese amber and a review of the Euaesthetine subgroup fossil record". English. In: Cretaceous Research 30 (2009), pp. 1426-1434.

[4586] D. J. Clarke, A. Limaye, D. D. McKenna, and R. G. Oberprieler. "The weevil fauna preserved in Burmese amber-snapshot of a unique, extinct lineage (Coleoptera: Curculionoidea)". English. In: Diversity 11.1 (2018), pp. 1-219.

[4587] J. Clarke and S. Etches. "Predation amongst Jurassic marine reptiles". English. In: Proceedings of the Dorset Natural History and Archaeological Society 113 (1992), pp. 202-205.

[4588] J. A. Clarke and L. M. Chiappe. "A new carinate bird from the late Cretaceous of Patagonia (Argentina". English. In: American Museum Novitates 3323 (2001), pp. 1-23.

[4589] J. A. Clarke, D. T. Ksepka, M. Stucchi, M. Urbina, N. Giannini, S. Bertelli, Y. Narvaez, and C. A. Boyd. "Paleogene equatorial penguins challenge the proposed relationship between biogeography, diversity and Cenozoic climate change". English. In: Proceedings of the Academy of Natural Sciences 104.28 (2007), pp. 11545-11550.

[4590] J. A. Clarke, D. T. Ksepka, R. Salas-Gismondi, A. J. Altamirano, M. D. Shawkey, L. D’Alba, J. Vinther, T. J. DeVries, and P. Baby. "Fossil evidence for evolution of the shape and color of penguin feathers". English. In: Science 330 (2010). DOI: 10.1126/science.1193604.

[4591] J. A. Clarke, C. P. Tambussi, J. I. Noriega, G. M. Erickson, and R. A. Ketcham. "Definitive fossil evidence for the extant avian radiation in the Cretaceous". English. In: Nature 433.20 (2005), pp. 305308.

[4592] M. J. Clarke. "Hellyerian and Tamarian (Late Carboniferous-Lower Permian) invertebrate faunas from Tasmania". English. In: Tasmania Geological Survey Bulletin 69 (1992), pp. 1-54.

[4593] M. J. Clarke. “Late Palaeozoic (Tamarian; Late Carboniferous-Early Permian) cold-water brachiopods from Tasmania". English. In: Alcheringa 14 (1990), pp. 53-76.

[4594] M. J. Clarke. “A new notospiriferine genus (Spiriferida: Brachiopoda) from the Permian of Tasmania". English. In: Papers and Proceedings of the Royal Society of Tasmania 126 (1992), pp. 73-76.

[4595] E. N. K. Clarkson, D. A. T. Harper, and J. S. Peel. "Taxonomy and palaeoecology of the mollusc Pterotheca from the Ordovician and Silurian of Scotland". English. In: Lethaia 28.1 (1995), pp. 101114.

[4596] E. N. K. Clarkson and X.-g. Zhang. "Ontogeny of the Carboniferous trilobite Paladin eichwaldi shunnerensis (King 1914)". English. In: Transactions of the Royal Society of Edinburgh 82.4 (1991), pp. 277-295.

[4597] J. Claude, P. Auetrakulvit, W. Naksri, and C. Bochaton. "The recent fossil turtle record of the central plain of Thailand reveals local extinctions". English. In: Annales de Paléontologie (2019), pp. 1-11. DOI: 10.1016/j.annpal.2019.04.005.

[4598] J. Claude, W. Naksri, N. Boonchai, E. Buffetaut, J. Duangkrayom, C. Laojumpon, P. Jintasakul, K. Lauprasert, J. Martin, V. Suteethorn, and H. Tong. "Neogene reptiles of northeastern Thailand and their paleogeographical significance". English. In: Annales de Paléontologie 97 (2011), pp. 113-131. 
[4599] J. Claude, V. Suteethorn, and H. Tong. “Turtles from the late Eocene - early Oligocene of the Krabi Basin (Thailand)". English. In: Bulletin de la Société Géologique de France 178.4 (2007), pp. 305-316.

[4600] J. Claude and H. Tong. "Early Eocene testudinoid turtles from Saint-Papoul, France, with comments on the early evolution of modern Testudinoidea". English. In: Oryctos 5 (2004), pp. 3-45.

[4601] J. Claude, J.-Y. Zhang, J. -J. Li, J. -Y. Mo, X. -W. Kuang, and H. Tong. "Geoemydid turtles from the Late Eocene Maoming basin, southern China". English. In: Bulletin de la Societe Geologique de France 183.6 (2012), pp. 641-651.

[4602] S. Clausen. "New Early Cambrian eocrinoids from the Iberian Chains (NE Spain) and their role in nonreefal benthic communities". English. In: Eclogae Geologicae Helvetiae 97.3 (2004), pp. 371-379.

[4603] S. Clausen and J. J. Álvaro. "Skeletonized microfossils from the Lower-Middle Cambrian transition of the". English. In: Acta Palaeontologica Polonica 51.2 (2006), pp. 223-238.

[4604] T. M. Claybourn, S. M. Jacquet, C. B. Skovsted, T. P. Topper, L. E. Holmer, and G. A. Brock. “Mollusks from the upper Shackleton Limestone (Cambrian Series 2), Central Transantarctic Mountains, East Antarctica". English. In: Journal of Paleontology 93.3 (2019), pp. 437-459. DOI: 10.1017 / jpa.2018.84.

[4605] A. A. Clayton. Analysis of an Eocene Bonebed Contained within the Tallahatta Formation, of Covington County, Alabama. English. 2009.

[4606] A. A. Clayton, C. N. Ciampaglio, and D. J. Cicimurri. "An inquiry into the stratigraphic occurrence of a Claibornian (Eocene) vertebrate fauna from Covington County, Alabama". English. In: Bulletin of the Alabama Museum of Natural History 31.2 (2013), pp. 60-73.

[4607] C. J. Cleal and P. M. Rees. "The Middle Jurassic flora from Stonesfield, Oxfordshire, UK”. English. In: Palaeontology 46.4 (2003), pp. 739-801.

[4608] C. J. Cleal and B. A. Thomas. Palaeozoic Palaeobotany of Great Britain. Vol. 9. Geological Conservation Review Series, Chapman \& Hall: London. 1995.

[4609] W. A. Clemens. A latest Cretaceous, high paleolatitude mammalian fauna from the North Slope of Alaska. English. Vol. 364. In Z. Kielan-Jaworowska, N. Heintz, \& H. A. Nakrem (eds.), Fifth Symposium on Mesozoic Terrestrial Ecosystems and Biota, Extended Abstracts. Contributions from the Paleontological Museum, Unviersity of Oslo. 1991, pp. 15-16.

[4610] W. A. Clemens. "New morganucodontans from an Early Jurassic fissure filling in Wales (united Kingdom)". English. In: Palaeontology 54.5 (2011), pp. 1139-1156.

[4611] W. A. Clemens. "Early Jurassic allotherians from South Wales (United Kingdom)". English. In: Fossil Record 10.1 (2007), pp. 50-59.

[4612] W. A. Clemens. "Eoconodon (Triisodontidae, Mammalia) from the Early Paleocene (Puercan) of northeastern Montana, USA". English. In: Palaeontologia Electronica 14.3 (2011).

[4613] W. A. Clemens. "Cf. Wortmania from the early Paleocene of Montana and an evaluation of the fossil record of the initial diversification of the Taeniodonta (Mammalia)". English. In: Canadian Journal of Earth Sciences 50 (2013), pp. 341-354.

[4614] W. A. Clemens. "Prodiacodon crustulum (Leptictidae, Mammalia) from the Tullock Member of the Fort Union Formation, Garfield and McCone Counties, Montana, USA". English. In: PaleoBios 32.1 (2015), pp. 1-17.

[4615] W. A. Clemens. "Procerberus (Cimolestidae, Mammalia) from the Latest Cretaceous and Earliest Paleocene of the Northern Western Interior, US". English. In: PaleoBios 34 (2017), pp. 1-26.

[4616] W. A. Clemens, M. B. Goodwin, J. H. Hutchison, C. R. Shaff, C. B. Wood, and M. W. Colbert. "First record of a Jurassic mammal (?Peramura) from Ethiopia". English. In: Acta Palaeontologica Polonica 52.3 (2009), pp. 433-439.

[4617] W. A. Clemens and T. Martin. "Review of the non-tritylodontid synapsids from bone beds in the Rhaetic Sandstone, southern Germany". English. In: Palaeontologische Zeitschrift 88 (2014), pp. 461479 . 
[4618] W. A. Clemens and T. E. Williamson. “A new species of Eoconodon (Triisodontidae, Mammalia) from the San Juan Basin, New Mexico". English. In: Journal of Vertebrate Paleontology 25.1 (2005), pp. 208-213.

[4619] W. A. Clemens, G. P. Wilson, and R. E. Molnar. "An enigmatic (synapsid?) tooth from the Early Cretaceous of New South Wales, Australia". English. In: Journal of Vertebrate Paleontology 23.1 (2003), pp. 232-237.

[4620] W. A. Clemens. "A pantodont (Mammalia) from the latest Puercan North American Land Mammal Age (earliest Paleocene) of the Western Interior, USA". English. In: Historical Biology (2017), pp. 1-5. DOI: 10.1080/08912963.2016.1276178.

[4621] A. M. Clement. "A New Genus of Lungfish from the Givetian (Middle Devonian) of Central Australia". English. In: Acta Palaeontologica Polonica 54.4 (2009), pp. 615-626.

[4622] A. M. Clement. "A new species of longsnouted lungfish from the Late Devonian of Australia, and its functional and biogeographical implications". English. In: Palaeontology 55.1 (2012), pp. 51-71. DOI: $10.1111 /$ j.1475-4983.2011.01118.x.

[4623] A. M. Clement and J. A. Long. "Xeradipterus hatcheri, a New Dipnoan from the Late Devonian (Frasnian) Gogo Formation, Western Australia, and Other New Holodontid Material". English. In: Journal of Vertebrate Paleontology 30.3 (2010), pp. 681-695.

[4624] G. Clement. "The actinistian (Sarcopterygii) Piveteauia madagascariensis Lehman from the Lower Triassic of northwestern Madagascar: a redescription on the basis of new material". English. In: Journal of Vertebrate Paleontology 19.2 (1999), pp. 234-242.

[4625] G. Clement. "A new coelacanth (Actinistia, Sarcopterygii) from the Jurassic of France, and the question of the closest fossil relative to Latimeria". English. In: Journal of Vertebrate Paleontology 25.3 (2005), pp. 481-491. DOI: 10.1671/0272-4634(2005)025[0481:ANCASF]2.0.CO;2.

[4626] G. Clement and O. Lebedev. "Revision of the Early Tetrapod Obruchevichthys Vorobyeva, 1977 from the Frasnian (Upper Devonian) of the North western East European Platform". English. In: Paleontological Journal 48.10 (2014), pp. 1082-1091.

[4627] G. Clement, D. Snitting, and P. E. Ahlberg. "A new tristichopterid (Sarcopterygii, Tetrapodomorpha) from the upper Famennian Evieux Formation (Upper Devonian) of Belgium". English. In: Palaeontology 52.4 (2009), pp. 823-836.

[4628] M. Clementz, R. E. Fordyce, S. L. Peek, and D. L. Fox. “Ancient marine isoscapes and isotopic evidence of bulk-feeding by Oligocene cetaceans". English. In: Palaeogeography, Palaeoclimatology, Palaeoecology (2014).

[4629] L. B. Clemmensen, J. Milán, G. K. Pedersen, A. B. Johannesen, and C. Larsen. “Dinosaur tracks in Lower Jurassic coastal plain sediments (Sose Bugt Member, Rønne Formation) on Bornholm, Denmark". English. In: Lethaia 47.4 (2014), pp. 485-493. DOI: 10.1111/let.12073.

[4630] A. Climaco. “Upper Triassic (Norian-Rhaetian) coral fauna in the Verbicaro Unit (Northern Calabria, Southern Italy)". English. In: Studi Trentini di Scienze Naturali - Acta Geologica 69 (1994), pp. 51-59.

[4631] E. C. Clites, M. L. Droser, and J. G. Gehling. "The advent of hard-part structural support among the Ediacara biota: Ediacaran harbinger of a Cambrian mode of body construction". English. In: Geology 40.4 (2012), pp. 307-310.

[4632] L. M. Clos. "A new species of Varanus (Reptilia: Sauria) from the Miocene of Kenya". English. In: Journal of Vertebrate Paleontology 15.2 (1995), pp. 254-267.

[4633] R. A. Close, Z. Johanson, J. C. Tyler, R. C. Harrington, and M. Friedman. "Mosaicism in a new Eocen pufferfish highlights rapid morphological innovation near the origin of crown Tetraodontiforms". English. In: Palaeontology 59.4 (2016), pp. 499-514. DOI: 10.1111/pala.12245.

[4634] R. A. Close, P. Vickers-Rich, P. Trusler, L. M. Chiappe, J. O'Connor, T. H. Rich, L. Kool, and P. Komarower. "Earliest Gondwanan bird from the Cretaceous of southeastern Australia". English. In: Journal of Vertebrate Paleontology 29.2 (2009), pp. 616-619. DOI: 10.1671/039.029.0214. 
[4635] W. C. Clyde. "Stratigraphy and mammalian paleontology of the McCullough Peaks, northern Bighorn Basin, Wyoming: Implications for biochronology, basin development, and community reorganization across the Paleocene-Eocene boundary". English. PhD thesis. 1997.

[4636] W. C. Clyde, P. Wilf, A. iglesias, R. L. Slingerland, T. Barnum, P. K. Bijl, T. J. Bralower, H. Brinkhuis, E. E. Comer, B. T. Huber, and M. Ibañez-Mejia. "New age constraints for the Salamanca Formation and lower Ro Chico Group in the western San Jorge Basin, Patagonia, Argentina: Implications for Cretaceous-Paleogene extinction recovery and land mammal age correlations". English. In: Geological Society America Bulletin 126.3-4 (2014), pp. 289-306. DOI: 10.1130/B30915.1.

[4637] W. C. Clyde, J.-P. Zonneveld, J. Stamatakos, G. F. Gunnell, and W. S. Bartels. “Magnetostratigraphy across the Wasatchian-Bridgerian boundary (early to middle Eocene) in the western Green River Basin, Wyoming". In: Journal of Geology 105 (1997), pp. 657-669.

[4638] E. V. Coan and P. Valentich-Scott. "Bivalve Seashells of Tropical West America. Marine Bivalve Mollusks from Baja California to Northern Peru". English. In: Santa Barbara museum of Natural history monographs 6 (2012), pp. 1-1258.

[4639] A. G. Coates, D. F. McNeill, M. P. Aubry, W. A. Berggren, and L. S. Collins. "An introduction to the geology of the Bocas del Toro archipelago, Panama". English. In: Caribbean Journal of Science 41.3 (2005), pp. 374-391.

[4640] M. I. Coates. "New actinopterygian fish from the Namurian Manse Burn Formation of Bearsden, Scotland". English. In: Palaeontology 36.1 (1993), pp. 123-146.

[4641] M. I. Coates. "New Actinopterygian Fish From The Namurian Manse Burn Formation Of Bearsden, Scotland". English. In: Palaeontology 36.1 (1993), pp. 123-146.

[4642] M. I. Coates and S. E. K. Sequeira. "A New Stethacanthid Chondrichthyan from the Lower Carboniferous of Bearsden, Scotland". English. In: Journal of Vertebrate Paleontology 21.3 (2001), pp. 438459.

[4643] E. A. CoBabe and W. D. Allmon. "Effects of sampling on paleoecologic and taphonomic analyses in high-diversity fossil accumulations: an example from the Eocene Gosport Sand, Alabama". English. In: Lethaia 27 (1994), pp. 167-178.

[4644] W. A. Cobban, T. S. Dyman, and K. W. Porter. "Paleontology and stratigraphy of upper Coniacianmiddle Santonian ammonite zones and application to erosion surfaces and marine transgressive strata in Montana and Alberta". English. In: Cretaceous Research 26.3 (2005), pp. 429-449.

[4645] W. A. Cobban and W. J. Kennedy. "Campanian Trachyscaphites spiniger ammonite fauna in northeast Texas". English. In: Palaeontology 35.1 (1992), pp. 63-93.

[4646] W. A. Cobban and W. J. Kennedy. "Evolution and biogeography of the Cenomanian (Upper Cretaceous) ammonite Metoicoceras Hyatt, 1903, with a revision of Metoicoceras praecox Haas, 1949". English. In: United States Geological Survey Bulletin 1934 (1991), B1-B11.

[4647] A. Cobos and F. Gascó. "New vertebral remains of the stegosaurian dinosaur Dacentrurus from Riodeva (Teruel, Spain)”. English. In: Geogaceta 53 (2013), pp. 17-20.

[4648] A. Cobos and F. Gascó. "Presencia del icnogénero Iguanodontipus en el Cretácico Inferior de la provincia de Teruel (España) [Presence of the ichnogenus Iguanotontipus in the Lower Cretaceous of Teruel Province (Spain)]". Spanish. In: Geogaceta 52 (2012), pp. 185-188.

[4649] A. Cobos, M. G. Lockley, F. Gascó, R. Royo-Torres, and L. Alcalá. “Megatheropods as apex predators in the typically Jurassic ecosystems of the Villar del Arzobispo Formation (Iberian Range, Spain)". English. In: Palaeogeography, Palaeoclimatology, Palaeoecology 399 (2014), pp. 31-41. DOI: 10.1016/j.palaeo.2014.02.008.

[4650] A. Cobos, L. Mampel, R. Royo-Torres, E. Esplez, and L. Alcalá. "Nuevos yacimientos de icnitas de dinosaurio en Formiche Alto (Teruel) [New localities with dinosaur footprints from Formiche Alto (Teruel)]". Spanish. In: Geogaceta 38 (2005), pp. 19-22.

[4651] A. Cobos, R. Royo-Torres, L. Alcalá, L. Luque, and A. Aberasturi. Nuevos datos de las icnitas de dinosaurios en la Formación Villar del Arzobispo (Teruel) [New data on the dinosaur ichnites in the Villar del Arzobispo Formation (Teruel)]. Spanish. 2008. 
[4652] A. Cobos, R. Royo-Torres, and L. Alcalá. Presencia del estegosaurio Dacentrurus en Riodeva (Teruel) [Presence of the stegosaur Dacentrurus in Riodeva (Teruel)]. Spanish. 2008.

[4653] A. Cobos, R. Royo-Torres, L. Alcalá, and L. Mampel. "An Iberian stegosaurs paradise: The Villar del Arzobispo Formation (Tithonian-Berriasian) in Teruel (Spain)". English. In: Palaeogeography, Palaeoclimatology, Palaeoecology 293.1-2 (2010), pp. 223-236. DOI: 10.1016/j.palaeo.2010.05.024.

[4654] A. Cobos, R. Royo-Torres, and L. Alcalá. "Restos postcraneales de ornitópodo en el Cretácico Inferior de El Castellar (Subcuenca de Peñagolosa, Teruel) [Ornithopod postcranial remains in the Lower Cretaceous of El Castellar (Peñagolosa Subbasin, Teruel)]". Spanish. In: Geogaceta 52 (2012), pp. 181-184.

[4655] L. R. M. Cocks and R.-b. Zhan. "Caradoc brachiopods from the Shan States, Burma (Myanmar)". English. In: Bulletin of the Natural History Museum (Geology) 54 (1998), pp. 109-130.

[4656] L. R. Cocks. "Caradoc Strophomenoid and Plectambonitoid Brachiopods from Wales and the Welsh Borderland". English. In: Palaeontology 53.5 (2010), pp. 1155-1200.

[4657] L. R. M. Cocks. “The Middle Llandovery brachiopod Fauna of the Newlands Formation, Girvan, Scotland". English. In: Journal of Systematic Palaeontology 6.1 (2008), pp. 61-100. DOI: 10.1017 / s147720190700226x.

[4658] L. R. M. Cocks. “The Late Ordovician brachiopods of southern Pembrokeshire and adjacent southwestern Wales". English. In: Special Papers in Palaeontology 91 (2014), pp. 1-89.

[4659] L. R. M. Cocks and R. A. Fortey. "A new Hirnantia fauna from Thailand and the biogeography of the latest Ordovician of south-east Asia". English. In: Geobios 20 (1997), pp. 117-126.

[4660] L. R. M. Cocks. "Strophomenate Brachiopods from the late Ordovician Boda Limestone of Sweden: their systematics and implications for palaeogeography". English. In: Journal of Systematic Palaeontology 3 (2005), pp. 243-282. DOI: 10.1017/S1477201905001616.

[4661] L. R. M. Cocks and R. A. Cooper. “Late Ordovician (Hirnantian) shelly fossils from New Zealand and their significance". English. In: New Zealand Journal of Geology and Geophysics 47 (2004), pp. 7180.

[4662] L. R. M. Cocks and T. L. Modzalevskaya. "Late Ordovician brachiopods from Taimyr, Arctic Russia, and their palaeogeographical significance". In: Palaeontology 40 (1997), pp. 1061-1093.

[4663] P. Cockx, R. McKellar, R. Tappert, M. J. Vavrek, and K. Muehlenbachs. “Bonebed amber as a new source of paleontological data: The case of the Pipestone Creek deposit (Upper cretaceous), Alberta, Canada". English. In: Gondwana Research 81 (2020), pp. 378-389. DOI: 10.1016/j.gr.2019.12. 005.

[4664] P. F. D. Cockx and R. C. McKellar. "First record of the family Scolebythidae (Hymenoptera) in mid-Cretaceous amber from Myanmar". English. In: Cretaceous Research 67 (2016), pp. 133-139.

[4665] P. F. D. Cockx, R. C. McKellar, and V. Perrichot. "First records of the subfamilies Bethylinae (Hymenoptera: Bethylidae) and Cleptinae (Hymenoptera: Chrysididae) in Upper Cretaceous amber from France". English. In: Cretaceous Research 68 (2016), pp. 1-8.

[4666] P. F. D. Cockx and R. C. McKellar. "A new genus and species of the subfamily Pemphredoninae (Hymenoptera: Crabronidae) in Upper Cretaceous amber from Myanmar". English. In: Comptes Rendus Palevol 17 (2018), pp. 153-157.

[4667] L. Codorniú, A. P. Carabajal, D. Pol, D. Unwin, and O. W. M. Rauhut. “A Jurassic pterosaur from Patagonia and the origin of the pterodactyloid neurocranium". English. In: PeerJ 4 (2016), e2311:122. DOI: $10.7717 /$ peerj.2311.

[4668] L. Codorniú and A. Garrido. "New fossil record of a Jurassic pterosaur from Neuquen Basin, Vaca Muerta Formation, Argentina". English. In: Journal of South American Earth Sciences 48 (2013), pp. 315-321.

[4669] L. Codorniú and Z. Gasparini. "The Late Jurassic pterosaurs from northern Patagonia, Argentina". English. In: Earth and Environmental Science Transactions of the Royal Society of Edinburgh 103 (2013), pp. 399-408. 
[4670] V. Codrea, A. L. Laslo-Faur, C. Dudas, A. Hosu, and O. Barbu. “Volcanic tuffs from the Transylvania Basin, Romania". English. In: Geological Formations of Transylvania, Romania 3 (1991), pp. 103109.

[4671] V. Codrea and V. Seretan. "A middle Miocene dolphin from Domansnea (Caransebes-Mehadia Miocene Basin)". English. In: Studia Universitatis Babes-Bolyai, Geologia 49.2 (2004), pp. 3-10.

[4672] V. Codrea, T. Smith, P. Dica, A. Folie, G. Garcia, P. Godefroit, and J. Van Itterbeeck. “Dinosaur egg nests, mammals and other vertebrates from a new Maastrichtian site of the Hateg Basin (Romania)". English. In: Comptes Rendus Palevol 1.3 (2002), pp. 173-180.

[4673] V. Codrea and L. Ursachi. "The Sarmatian vertebrates from Draxeni (Moldavian Platform)". English. In: Studia Universitatis Babe-Bolyai, Geologia 52.2 (2007), pp. 19-28.

[4674] V. Codrea, M. Venczel, L. Ursachi, and B. Roi. “A large viper from the early Vallesian (MN 9) of Moldova (Eastern Romania) with notes on the palaeobiogeography of late Miocene Oriental vipers". English. In: Geobios 50 (2017), pp. 401-411. DOI: 10.1016/j.geobios.2017.07.001.

[4675] V. Codrea, M. Vremir, C. Jipa, P. Godefroit, Z. Csiki, T. Smith, and C. Farcas. "More than just Nopcsa's Transylvanian dinosaurs: A look outside the Hateg Basin". English. In: Palaeogeography, Palaeoclimatology, Palaeoecology 293 (2010), pp. 391-405. DOI: 10.1016/j.palaeo.2009.10.027.

[4676] V. A. Codrea, G. B. Ratoi, A. Hiru, and L. Urasachi. “A lower Sarmatian small-sized dolphin (Mammalia: Cetacea, Odontoceti) at Basarabi (Suceava District)". English. In: Oltenia. Studii i comunicri. tiinele Naturii 30.2 (2014), pp. 15-20.

[4677] V. A. Codrea, A. A. Solomon, M. Venczel, and T. Smith. "A new kogaionid multituberculate mammal from the Maastrichtian of the Transylvanian Basin, Romania". English. In: Comptes Rendus Palevol 13.6 (2014), pp. 489-499.

[4678] V. A. Codrea, A. A. Solomon, M. Venczel, and T. Smith. "First mammal species identified from the Upper Cretaceous of the Rusca Montan Basin (Transylvania, Romania)". English. In: Comptes Rendus Palevol 16.1 (2017), pp. 27-38. DOI: 10.1016/j.crpv.2016.04.002.

[4679] V. A. Codrea, M. Venczel, and A. Solomon. "A new family of teiioid lizards from the Upper Cretaceous of Romania with notes on the evolutionary history of early teiioids". English. In: Zoological Journal of the Linnean Society 181.2 (2017), pp. 385-399. DOI: 10.1093/zoolinnean/zlx008.

[4680] M. Coen-Aubert. "New species of Frechastraea Scrutton, 1968 at the base of the Late Frasnian in Belgium". English. In: Geologica Belgica 15.4 (2012), pp. 265-272.

[4681] M. Coen-Aubert. "Phillipsastreids and Ptenophyllids (Rugosa) from the Givetian of Mauritania and Northwestern Spain". English. In: Geologica Belgica 16.3 (2013), pp. 164-178.

[4682] K. Coffing, C. Feibel, M. Leakey, and A. Walker. "Four-million-year-old hominids from East Lake Turkana, Kenya". English. In: American Journal of Physical Anthropology 93 (1994), pp. 55-65.

[4683] A. I. Cognato. "Electroborus brighti: the first Hylesinini bark beetle described from Dominican amber (Coleoptera: Curculionidae: Scolytinae)". English. In: The Canadian Entomologist 145 (2013), pp. 501-508.

[4684] A. I. Cognato and D. Grimaldi. "100 million years of morphological conservation in bark beetles (Coleoptera: Curculionidae: Scolytinae)". English. In: Systematic Entomology 34 (2009), pp. 93-100.

[4685] J. E. Cohen. "Earliest Divergence of Stagodontid (Mammalia: Marsupialiformes) Feeding Strategies from the Late Cretaceous (Turonian) of North America". English. In: Journal of Mammalian Evolution 25 (2018), pp. 165-177. DOI: 10.1007/s10914-017-9382-0.

[4686] J. E. Cohen, B. M. Davis, and R. L. Cifelli. “Geologically oldest Pediomyoidea (Mammalia, Marsupialiformes) from the Late Cretaceous of North America, with implications for taxonomy and diet of earliest Late Cretaceous mammals". English. In: Journal of Vertebrate Paleontology (2020), e1835935:1-13. DOI: 10.1080/02724634.2020.1835935.

[4687] P. A. Cohen and A. H. Knoll. "Scale Microfossils from the mid Neoproterozoic Fifteenmile Group, Yukon". English. In: Journal of Paleontology 86.5 (2012), pp. 775-800. DOI: 10.1666/11-138.1. 
[4688] T. Coillot, R. Smith, P. Gigase, and T. Smith. "Tarsal diversity in the earliest Eocene mammal fauna of Dormaal, Belgium". English. In: Geologica Belgica 16.4 (2013), pp. 274-283.

[4689] J. C. Cokendolpher and G. O. Poinar. "A new fossil harvestman from Dominican Republic amber (Opiliones, Samoidae, Hummelinckiolus)". English. In: The Journal of Arachnology 26 (1998), pp. 913.

[4690] J. C. Cokendolpher and G. O. Poinar. "Tertiary harvestmen from Dominican Republic amber". English. In: Bulletin of British Arachnological Society 9 (1992), pp. 53-56.

[4691] R. Colbach, S. Guérin-Franiatte, and R. Maquil. "Un remarquable site fossilifére dans le Sinémurien inférieur de Bertrange (Grand-Duché de Luxembourg)". French. In: Ferrantia 36 (2003), pp. 53-64.

[4692] E. H. Colbert and P. E. Olsen. "A new and unusual aquatic reptile from the Lockatong Formation of New Jersey (Late Triassic, Newark Supergroup)". English. In: American Museum Novitates 3334 (2001), pp. 1-24.

[4693] M. W. Colbert. "The facial skeleton of the early Oligocene Colodon (Perissodactyla, Tapiroidea)". English. In: Palaeontologia Electronica 8.1 (2005), pp. 1-27.

[4694] M. W. Colbert. "Hesperaletes (Mammalia : Perissodactyla), a new tapiroid from the middle Eocene of southern California". English. In: Journal of Vertebrate Paleontology 26.3 (2006), pp. 697-711. DOI: 10.1671/0272-4634(2006)26[697:HMPANT]2.0.CO;2.

[4695] J. M. Cole, O. Babiker Abdelrahim, A. W. Hunter, E. Schrank, and M. S. Bin Ismael. “Late Cretaceous spore-pollen zonation of the Central African Rift System (CARS), Kaikang Trough, Muglad Basin, South Sudan: angiosperm spread and links to the Elaterates Province". English. In: Palynology 41 (2017), pp. 547-578.

[4696] S. R. Cole. "Phylogeny and evolutionary history of diplobathrid crinoids (Echinodermata)". English. In: Palaeontology (2018), pp. 1-17. DOI: 10.1111/pala.12401.

[4697] S. R. Cole, W. I. Ausich, J. Colmenar, and S. Zamora. "Filling the Gondwanan gap: paleobiogeographic implications of new crinoids from the Castillejo and Fombuena formations (Middle and Upper Ordovician, Iberian Chains, Spain)". English. In: Journal of Paleontology 91.4 (2017), pp. 715734. DOI: $10.1017 /$ jpa.2016.135.

[4698] S. R. Cole, W. I. Ausich, D. F. Wright, and J. M. Koniecki. “An echinoderm Lagerstätte from the Upper Ordovician (Katian), Ontario: taxonomic re-evaluation and description of new dicyclic camerate crinoids". English. In: Journal of Paleontology (2018), pp. 1-18. DOI: 10.1017/jpa.2017.151.

[4699] S. R. Cole, W. I. Ausich, and M. A. Wilson. "A Hirnantian holdover from the Late Ordovician mass extinction: phylogeny and biogeography of a new anthracocrinid crinoid from Estonia". English. In: Papers in Palaeontology (2020). DOI: 10.1002/spp2.1345.

[4700] S. R. Cole, J. T. Haynes, P. C. Lucas, and R. A. Lambert. "Faunal and sedimentological analysis of a latest Silurian stromatoporoid biostrome from the central Appalachian Basin". English. In: Facies 61 (2015).

[4701] T. L. Cole, J. M. Waters, L. D. Shepherd, N. J. Rawlence, L. Joseph, and J. R. Wood. “Ancient DNA reveals that the 'extinct' Hunter Island penguin (Tasidyptes hunteri) is not a distinct taxon". English. In: Zoological Journal of the Linnean Society 182 (2018), pp. 459-464.

[4702] J.-P. Colin and L. Jacobs. "L'age des Couches a Dinosaures du Malawi: apport des ostracodes". English. In: C. R. Acad. Sci. Paris 311.2 (1990), pp. 1025-1029.

[4703] A. Collareta, S. Casati, and A. Di Cencio. "A pristid sawfish from the lower Pliocene of Lucciolabella (Radicofani Basin, Tuscany, Central Italy)". English. In: Atti della Societá toscana di scienze naturali. Memorie, Serie A 124 (2017), pp. 49-55. DOI: 10.2424/ASTSN.M.2017.18.

[4704] A. Collareta, S. Casati, M. A. L. Zuffi, and A. di Cencio. "First authentic record of the freshwater turtle Mauremys from the Upper Pliocene of Italy, with a new occurrence of the rarely reported ichnotaxon Thatchtelithichnus holmani". English. In: Carnets de Geologie 20.16 (2020), pp. 301-313. DOI: $10.2110 /$ carnets.2020.2016. 
[4705] A. Collareta, A. Di Cencio, R. Ricci, and G. Bianucci. "The shark-toothed dolphin Squalodon (Cetacea: Odontoceti) from the remarkable Montagna della Majella marine vertebrate assemblage (Bolognano Formation, central Italy)". English. In: Carnets de Géologie 20.2 (2020), pp. 19-28. DOI: $10.4267 / 2042 / 70716$.

[4706] A. Collareta, F. C. Fulgosi, and G. Gianucci. "A new kogiid sperm whale from northern Italy supports psychrospheric conditions in the early Pliocene Mediterranean Sea". English. In: Acta Palaeontologica Polonica 64.3 (2019), pp. 609-626. DOI: 10.4202/app.00578.2018.

[4707] A. Collareta, G. Insacco, A. Reitano, R. Catanzariti, M. Bosselaers, M. Montes, and G. Bianucci. "Fossil whale barnacles from the lower Pleistocene of Sicily shed light on the coeval Mediterranean cetacean fauna". English. In: Carnets de géologie 18.2 (2018), pp. 9-22. DOI: 10.4267 / 2042/ 65747.

[4708] A. Collareta, O. Lambert, W. Landini, C. Di Celma, E. Malinverno, R. M. Varas-Malca, M. Urbina, and G. Bianucci. "Did the giant extinct shark Carcharocles megalodon target small prey? Bite marks on marine mammal remains from the late Miocene of Peru". English. In: Palaeogeography, Palaeoclimatology, Palaeoecology 469 (2017), pp. 84-91. DOI: 10.1016/j.palaeo.2017.01.001.

[4709] A. Collareta, O. Lambert, C. de Muizon, M. Urbina, and G. Bianucci. "Koristocetus pescei gen. et sp. nov., a diminutive sperm whale (Cetacea: Odontoceti: Kogiidae) from the late Miocene of Peru". English. In: Fossil Record 20 (2017), pp. 259-278. DOI: 10.5194/fr-20-259-2017.

[4710] A. Collareta, O. Lambert, C. de Muizon, A. M. Benites Palomino, M. Urbina, and G. Bianucci. “A new physeteroid from the late Miocene of Peru expands the diversity of extinct dwarf and pygmy sperm whales (Cetacea: Odontoceti: Kogiidae)". English. In: Comptes Rendus Palevol 19.5 (2020), pp. 79-100. DOI: 10.5852/cr-palevol2020v19a5.

[4711] A. Collareta, W. Landini, O. Lambert, K. Post, C. Tinelli, C. Di Celma, D. Panetta, M. Tripodi, P. A. Salvadori, D. Caramella, D. Marchi, M. Urbina, and G. Bianucci. "Piscivory in a Miocene Cetotheriidae of Peru: first record of fossilized stomach content for an extinct baleen-bearing whale". English. In: The Science of Nature 102.70 (2015). DOI: 10.1007/s00114-015-1319-y.

[4712] A. Collareta, C. W. Marean, A. Jerardino, and M. Bosselaers. "Cetopirus complanatus (Cirripedia: Coronulidae) from the late Middle Pleistocene human settlement of Pinnacle Point 13B (Mossel Bay, South Africa)". English. In: Zootaxa 4237.2 (2017), pp. 393-400.

[4713] A. Collareta, L. Tejada-Medina, C. Chacaltana-Budiel, W. Landini, A. Altamirano-Sierra, M. Urbinaschmitt, and G. Bianucci. "A rhinopristiform sawfish (genus Pristis) from the middle Eocene (Lutetian) of southern Peru and its regional implications". English. In: Carnets de Géologie 20.5 (2020), pp. 91-105. DOI: $10.4267 / 2042 / 70759$.

[4714] C. J. Collins, N. J. Rawlence, T. H. Worthy, R. P. Scofield, A. J. D. Tennyson, I. Smith, M. Knapp, and J. M. Waters. "Pre-human New Zealand sea lion (Phocarctos hookeri) rookeries on mainland New Zealand". English. In: Journal of the Royal Society of New Zealand 44.1 (2014), pp. 1-16. DOI: 10.1080/03036758.2013.828761.

[4715] D. Collins. "The Evolution of Anomalocaris and its classification in the arthropod class Dinocarida (nov.) and order Radiodonta (nov.)" In: Journal of Paleontology 70.2 (1996), pp. 280-293.

[4716] H. Collins, Y. Kanie, and H. Karasawa. "Late Cretaceous crabs from Japan". English. In: Transactions and Proceedings of the Paleontological Society of Japan, N.S. 172 (1993), pp. 292-310.

[4717] J. S. H. Collins. "Venipagurus mariae gen. et. sp. nov. (Decapoda, Anomura, Venipaguroidea superfam. nov.) from the Lower Lias of Dorset, England". English. In: Bulletin of the Mizunami Fossil Museum 37 (2011), pp. 17-21.

[4718] J. S. H. Collins and A. J. Barber. “A new Middle Eocene crab, Lobocarcinus pentanodosus sp. nov. (Crustacea, Decapoda) from Doi Doi, Barru, South Sulawesi, Indonesia". English. In: Bulletin of the Mizunami Fossil Museum 25 (1998), pp. 97-101.

[4719] J. S. H. Collins and I. Dieni. "New decapod Crustaceans from the Cenomanian Rudist Limestones of NE Italy". English. In: Bulletin of the Mizunami Fossil Museum 22 (1995), pp. 67-72. 
[4720] J. S. H. Collins, S. K. Donovan, W. Lindsay, and G. A. Simpson. “A new species of portunid crab from early Pleistocene Old Pera beds of Jamaica". English. In: Proceedings of the Geologist's Association 112 (2001), pp. 7-12.

[4721] J. S. H. Collins and S. K. Donovan. "A New Species of Necronectes (Decapoda) from the Upper Oligocene of Anitgua". English. In: Caribbean of Journal of Earth Science 31.1-2 (1995), pp. 122-127.

[4722] J. S. H. Collins, S. K. Donovan, and T. A. Stemann. "Fossil Crustacea of the Late Pleistocene Port Morant Formation, west Port Morant Harbour, southeastern Jamaica". English. In: Scripta Geologica 138 (2009), pp. 23-53.

[4723] J. S. H. Collins, R. H. B. Fraaye, and W. M Jagt. "Late Cretaceous anomurans and brachyurans from the Maastrichtian type area". English. In: Acta Palaeontologica Polonica 40.2 (1995), pp. 165-210.

[4724] J. S. H. Collins and R. H. B. Fraaye. "Cancer parvidens, A new crab (Crustacea, Decapoda) from the Miocene of the Netherlands". English. In: Contributions to Tertiary and Quaternary Geology 28.1 (1991), pp. 1-7.

[4725] J. S. H. Collins, R. H. B. Fraaye, and J. W. M. Jagt. "Laeviranina hollandica, a new Late Oligocene(?) raninid crab (Crustacea, Decapoda) from the Netherlands". English. In: Tertiary Research 18.(1+2) (1997), pp. 1-5.

[4726] J. S. H. Collins and S. L. Jakobsen. "A new crab, Rogeus robustus, from the Middle Paleocene of Denmark". English. In: Bulletin of the Mizunami Fossil Museum 22 (1995), pp. 61-65.

[4727] J. S. H. Collins and S. L. Jakobsen. "New crabs (Crustacea, Decapoda) from the Eocene (Ypresian/Lutetian) Lillebaelt Clay Formation of Jutland, Denmark". English. In: Bulletin of the Mizunami Fossil Museum 30 (2003), pp. 63-96.

[4728] J. S. H. Collins, C. Lee, and J. Noad. "Miocene and Pleistocene Crabs (Crustacea, Decapoda) from Sabah and Sarawak". English. In: Journal of Systematic Palaentology 1 (2003), pp. 187-226.

[4729] J. S. H. Collins, R. W. Portell, and S. K. Donovan. "Decapod crustaceans from the Neogene of the Caribbean: diversity, distribution and prospectus". English. In: Scripta Geologica 138 (2009), pp. 55111.

[4730] J. S. H. Collins and R. Smith. "Ypresian (Lower Eocene) crabs (Decapoda, Crustacea) from Belgium". English. In: Bulletin De L'Insitut Royal Des Sciences Naturelles De Belgique 63 (1993), pp. 260271.

[4731] J. S. H. Collins, R. Higgs, and B. Cortitula. "A new crab, Costacopluma bifida (Crustacea, Decapoda) from the Paleocene of Venezuela". In: Bulletin of the Mizunami Fossil Museum 21 (1994), pp. 29-34.

[4732] L. S. Collins. "The Miocene to Recent diversity of Caribbean benthic foraminifera from the Central American Isthmus". English. In: Bulletins of American Paleontology 357 (1999), pp. 91-108.

[4733] L. S. Collins and A. G. Coates. "A paleobiotic survey of Caribbean faunas from the Neogene of the Isthmus of Panama". English. In: Bulletins of American Paleontology 357 (1999).

[4734] P. W. Collins, D. A. Guthrie, E. L. Whistler, R. L. Vellanoweth, and J. M. Erlandson. “Terminal Pleistocene-Holocene Avifauna of San Miguel and Santa Rosa Islands: Identifications of Previously Unidentified Avian Remains Recovered from Fossil Sites and Prehistoric Cave Deposits". English. In: Western North American Naturalist 78.3 (2018), pp. 370-403. DOI: 10.3398/064.078.0311.

[4735] M. Collinson, Z. Kvacek, and E. Zastawniak. "The aquatic plants Salvinia (Salviniales) and Limnobiophyllum (Arales) from the Late Miocene flora of Sosnica (Poland)". In: Acta Palaeobot. 41.2 (2001), pp. 253-282.

[4736] J. Colmenar. “Ordovician rafinesquinine brachiopods from peri-Gondwana". English. In: Acta Palaeontologica Polonica 61.2 (2016), pp. 293-326. DOI: 10.4202/app.00102.2014.

[4737] J. Colmenar, A. A. Sá, and N. Vaz. "A draboviid brachiopod association from the Upper Ordovician of Portugal: palaeoecological and palaeogeographical significance". English. In: GFF - Journal of the Geological Society of Sweden 136.1 (2014), pp. 60-64. DOI: 10.1080/11035897.2013.848233. 
[4738] J. Colmenar, E. Villas, and D. Vizcano. “Upper Ordovician brachiopods from the Montagne Noire (France): endemic Gondwanan predecessors of Prehirnantian low-latitude immigrants". English. In: Bulletin of Geosciences 88.1 (2013), pp. 153-174.

[4739] S. Colombero, D. M. Alba, C. D'Amico, M. Delfino, D. Esu, P. Giuntelli, M. Harzhauser, P. P. A. Masser, M. Mosca, T. A. Neubauer, G. Pavia, M. Pavia, A. Villa, and G. Carnevale. “Late Messinian mollusks and vertebrates from Moncucco Torinese, north-western Italy. Paleoecological and paleoclimatological implications". English. In: Palaeontologia Electronica 20.1.10A (2017), pp. 1-66.

[4740] S. Colombero, C. Angelone, E. Bonelli, G. Carnevale, O. Cavallo, M. Delfino, P. Giuntelli, P. Mazza, G. Pavia, M. Pavia, and G. Repetto. “The upper Messinian assemblages of fossil vertebrate remains of Verduno (NW Italy): Another brick for a latest Miocene bridge acress the Mediterranean". English. In: Neues Jahrbuch für Geologie und Paläontologie 272.3 (2014), pp. 287-234.

[4741] W. Colpaert, M. Bosselaers, and O. Lambert. "Out of the Pacific: A second fossil porpoise from the Pliocene of the North Sea Basin". English. In: Acata Paleontologica Polonica 60.1 (2015), pp. 1-10. DOI: 10.4202/app.00115.2014.

[4742] M. C. Colson, R. O. Colson, and R. Nellermoe. "Stratigraphy and depositional environments of the upper Fox Hills and lower Hell Creek Formations at the Concordia Hadrosaur Site in northwestern South Dakota". In: Rocky Mountain Geology 39.2 (2004), pp. 93-1117.

[4743] M. Coltorti, L. Abbazzi, M. P. Ferretti, P. Iacumin, F. Paredes-Rios, M. Pellegrini, P. Pieruccini, M. Rustioni, G. Tito, and L. Rook. "Last glacial mammals in South America: a new scenario from the Tarija basin (Bolivia)". English. In: Naturwissenschaften 94 (2007), pp. 288-299. DOI: 10.1007 / s00114-006-0196-9.

[4744] M. J. Comas-Rengifo, J. J. Gomez, A. Goy, C. Herrero, N. Perilli, and A. Rodrigo. “El Jurasico Inferior en la seccion de Almonacid de la Cuba (sector central de la Cordillera Iberica, Zaragoza, Espana) [Lower Jurassic at the Almonacid de la Cuba section (central sector of the Iberian Range, Zaragoza, Spain)]". Spanish. In: Cuadernos de Geologia Iberica 25 (1999), pp. 27-57.

[4745] J. Company, P. Cruzado-Caballero, and J. I. Canudo. "Presence of diminutive hadrosaurids (Dinosauria: Ornithopoda) in the Maastrichtian of the south-central Pyrenees (Spain)". English. In: Journal of Iberian Geology 41.1 (2015), pp. 71-81. DOI: 10.5209/rev_JIGE.2015.v41.n1.48656.

[4746] J. Company, X. Pereda Suberbiola, J. I. Ruiz-Omeñaca, and A. D. Buscalioni. “A new species of Doratodon (Crocodyliformes: Ziphosuchia) from the Late Cretaceous of Spain". English. In: Journal of Vertebrate Paleontology 25.2 (2005), pp. 343-353.

[4747] J. Company, X. Pereda Suberbiola, and J. I. Ruiz-Omenaca. "Nuevos restos fosiles del dinosaurio Lirainosaurus (Sauropoda, Titanosauria) en el Cretacico Superior (Campaniano-Maastrichtiano) de la Peninsula Iberica". Spanish. In: Ameghiniana 46.2 (2009), pp. 391-405.

[4748] J. Company and Z. Szentesi. "Amphibians from the Late Cretaceous Sierra Perenchiza Formation of the Chera Basin, Valencia Province, Spain". English. In: Cretaceous Research 37 (2012), pp. 240245. DOI: $10.1016 /$ j.cretres.2012.04.003.

[4749] J. E. Company, A. Galobart, and R. Gaete. "First data on the hadrosaurid dinosaurs (Ornithischia, Dinosauria) from the Upper Cretaceous of Valencia, Spain". In: Oryctos 1 (1998), pp. 121-126.

[4750] M. Company, J. Sandoval, and J. M. Tavera. "Lower Barremian ammonite biostratigraphy in the Subbetic Domain (Betic Cordillera, southern Spain)". English. In: Cretaceous Research 16.2-3 (1995), pp. 243-256.

[4751] M. Company, J. Sandoval, and J. M. Tavera. "Ammonite biostratigraphy of the uppermost Hauterivian in the Betic Cordillera (SE Spain)". English. In: Géobios 36.6 (2003), pp. 685-694.

[4752] M. Company, J. Sandoval, J. M. Tavera, M. Aoutem, and M. Ettachfini. "Barremian ammonite faunas from the western High Atlas, Morocco - biostratigraphy and palaoebiogeography". English. In: Cretaceous Research 29 (2008), pp. 9-26.

[4753] A. Compte-Sart. “Nueva especie del género Lestes Leach, 1815 (Insecta, Odonata) del Mioceno del Bellver de Cerdanya (Lérida)". Spanish. In: Graellsia 70.1 (2014), e001. 
[4754] B. Comte, M. Sabatier, B. Marandat, and M. Vianey-Liaud. "Les rongeurs de Chéry-Chartreuve et Rocourt-Saint-Martin (est du bassin de Paris; Aisne, France). Leur place parmi les faunes de l'Eocéne Moyen d'Europe". French. In: Palaeovertebrata 37.4-5 (2012), pp. 167-271.

[4755] G. A. R. Conesa, E. Favre, P. Münch, H. Dalmasso, and C. Chaix. "Biosedimentary and paleoenvironmental evolution of the Southern Marion Platform from the Middle to Late Miocene (Northeast Australia, ODP Leg 194, Sites 1196 and 1199)". English. In: Proceedings of the Ocean Drilling Program, Scientific Results 194 (2005), pp. 1-38.

[4756] S. Cong, A. C. Ashworth, D. P. Schwert, and S. M. Totten. "Fossil Beetle Evidence for a Short Warm Interval near 40,000 yr B.P. at Titusville, Pennsylvania". English. In: Quaternary Research 45 (1996), pp. 216-225.

[4757] S. G. Cong. "Fossils of an undescribed blind trechine (Coleoptera: Carabidae) from near Kalaloch, Olympic Peninsula, Washington". English. In: The Coleopterists Bulletin 51 (1997), pp. 208-211.

[4758] S. G. Cong and A. C. Ashworth. "Palaeoenvironmental interpretation of Middle and Late Wisconsinan fossil coleopteran assemblages from western Olympic Peninsula, Washington, USA". English. In: Journal of Quaternary Science 11 (1996), pp. 345-356.

[4759] J. D. Congleton. "Vertebrate Paleontology of the Koum Basin, Northern Cameroon, and Archosaurian Paleobiogeography in the Early Cretaceous". English. PhD thesis. 1990, pp. xv-245.

[4760] L. N. Conkle, C. E. Schweitzer, R. M. Feldmann, and R. B. Blodgett. "A new species of Tymolus and a report on Metacarcinus (Crustacea: Decapoda: Brachyura) from the Miocene of Alaska". English. In: Bulletin of the Mizunami Fossil Museum 33 (2006), pp. 47-57.

[4761] M. V. Connely. "Paleoecology of pterosaur tracks from the upper Sundance and lower Morrison formations in central Wyoming". English. In: vol. 36. Paleontology and Geology of the Upper Jurassic Morrison Formation, New Mexico Museum of Natural History and Science Bulletin. Albuquerque: New Mexico Museum of Natural History and Science, 2006, pp. 199-202.

[4762] C. Conrad, H. G. Van Vlack, B. Marwick, C. Thengcharoenchalklt, R. Shoocongdej, and B. Chaisuwan. "Summary of Vertebrate and Molluscan Assemblages Excavated from Late-Pleistocene and Holocene Deposits at Khao Toh Chong Rockshelter, Krabi, Thailand". English. In: The Thailand Natural History Museum Journal 7.1 (2013).

[4763] J. L. Conrad. "An Eocene shinisaurid (Reptilia, Squamata) from Wyoming, U.S.A." English. In: Journal of Vertebrate Paleontology 26.1 (2006), pp. 113-126.

[4764] J. L. Conrad. "A new Eocene casquehead lizard (Reptilia, Corytophanidae) from North America". English. In: PLoS ONE 10.7 (2015), e127900. DOI: 10.1371/journal.pone.0127900.

[4765] J. L. Conrad. "A new lizard (Squamata) was the last meal of Compsognathus (Theropoda: Dinosauria) and is a holotype in a holotype". English. In: Zoological Journal of the Linnean Society zlx055 (2017), pp. 1-51. DOI: 10.1093/zoolinnean/zlx055.

[4766] J. L. Conrad, A. M. Balcarcel, and C. M. Mehling. "Earliest Example of a Giant Monitor Lizard (Varanus, Varanidae, Squamata)". English. In: PLOS ONE 7.8 (2012), e41767. DOI: 10.1371/journal. pone.0041767.

[4767] J. L. Conrad and J. D. Daza. "Naming and rediagnosing the Cretaceous gekkonomorph (Reptilia, Squamata) from Öösh (Övörkhangai, Mongolia)". English. In: Journal of Vertebrate Paleontology 35.5 (2015), e980891:1-5. DOI: 10.1080/02724634.2015.980891.

[4768] J. L. Conrad, J. J. Head, and M. T. Carrano. “Unusual soft-tissue preservation of a crocodile lizard (Squamata, Shinisauria) from the Green River Formation (Eocene) and shinisaur relationships". English. In: The Anatomical Record 297 (2014), pp. 545-559.

[4769] J. L. Conrad, K. Jenkins, T. Lehmann, F. K. Manthi, D. J. Peppe, S. Nightingale, A. Cossette, H. M. Dunsworth, W. E. H. Harcourt-Smith, and K. P. Mcnulty. "New specimens of 'Crocodylus' pigotti (Crocodylidae) from Rusinga Island, Kenya, and generic reallocation of the species". English. In: Journal of Vertebrate Paleontology 33.3 (2013), pp. 629-646. 
[4770] J. L. Conrad and M. A. Norell. “A complete Late Cretaceous iguanian (Squamata, Reptilia) from the Gobi and identification of a new iguanian clade". English. In: American Museum Novitates 3584 (2007), pp. 1-47.

[4771] J. L. Conrad, O. Rieppel, and L. Grande. "A Green River (Eocene) polychrotid (Squamata, Reptilia) and a re-examination of iguanian systematics". English. In: Journal of Paleontology 81.6 (2007), pp. 1365-1373.

[4772] M. A. Conrad, R. Schroeder, B. Clavel, J. Charollais, R. Busnardo, A. Cherchi, and D. Decrouez. "Dating the Lower Cretaceous in the Organyá section (Catalan Pyrenees, NE Spain): a reinterpretation". In: Cretaceous Research 25.1 (2004), pp. 35-41.

[4773] J. G. Conran, J. M. Bannister, and D. E. Lee. "Earliest orchid macrofossils: early Miocene Dendrobium and Earina (Orchidaceae: Epidendroideae) from New Zealand". English. In: American Journal of Botany 96 (2009), pp. 466-474. DOI: 10.3732/ajb.0800269.

[4774] J. G. Conran, J. M. Bannister, and D. E. Lee. “Conran, J. G., Bannister, J. M. and Lee, D. E. 2013. Fruits and leaves with cuticle of Laurelia otagoensis sp. nov. (Atherospermataceae) from the early Miocene of Otago (New Zealand). Alcheringa: DOI:10.1080/03115518.2013.798765". English. In: Alcheringa 37 (2013), pp. 1-14. DOI: 10.1080/03115518.2013.798765.

[4775] J. G. Conran, J. M. Bannister, D. C. Mildenhall, D. E. Lee, J. Chacón, and S. S. Renner. “Leaf fossils of Luzuriaga and a monocot flower with in situ pollen of Liliacidites contortus Mildenh. \& Bannister sp. nov. (Alstroemeriaceae) from the early Miocene". English. In: American Journal of Botany 101 (2014), pp. 141-155. DOI: 10.3732/ajb.1300351.

[4776] J. G. Conran, R. J. Carpenter, and G. J. Jordan. “Early Eocene Ripogonum (Liliales: Ripogonaceae) leaf macrofossils from southern Australia". English. In: Australian Systematic Botany 22.3 (2009), pp. 219-228. DOI: 10.1071/SB08050.

[4777] J. G. Conran, U. Kaulfuss, J. M. Bannister, D. C. Mildenhall, and D. E. Lee. “Davallia (Polypodiales: Davalliaceae) macrofossils from Early Miocene Otago (New Zealand) with in situ spores". English. In: Review of Palaeobotany and Palynology 162 (2010), pp. 84-94.

[4778] C. A. Cónsole Gonella. "Nuevo registro de gasterópodos en la Formación Yacoraite (MaastrichtianoDaniano) Cordillera Oriental de Jujuy, Argentina: sistemática, bioestratigrafa y correlación geológica". Spanish. In: Serie Correlación Geológica 27.1 (2011), pp. 45-64.

[4779] C. P. Consoli. "Edaphodon kawai, sp. nov. (Chondrichthyes: Holocephali): a Late Cretaceous chimaeroid from the Chatham Islands, southwest Pacific". English. In: Journal of Vertebrate Paleontology 26 (2006), pp. 801-805. DOI: 10.1671/0272-4634(2006)26[801:EKSNCH]2.0.CO;2.

[4780] C. P. Consoli, A. Pisera, and J. D. Stilwell. "Siliceous sponges of the Takatika Grit (CretaceousPaleogene), Chatham Islands, south Pacific". English. In: Journal of Paleontology 83.5 (2009), pp. 811819.

[4781] C. P. Consoli and J. D. Stilwell. “Late Cretaceous marine reptiles (Elasmosauridae and Mosasauridae) of the Chatham Islands, New Zealand". English. In: Cretaceous Research 30 (2009), pp. 991999. DOI: 10.1016/j.cretres.2009.02.009.

[4782] C. P. Consoli and J. D. Stilwell. "Late Cretaceous Cephalopoda (Mollusca) from the Takatika Grit, Chatham Islands, southwest Pacific". English. In: New Zealand Journal of Geology and Geophysics 48 (2005), pp. 389-393.

[4783] K. N. Constenius and M. R. Dawson. "Blickomylus (Artiodactyla, Camelidae, Stenomylinae) and the age of the Moroni Formation, central Utah". English. In: Journal of Vertebrate Paleontology 28.4 (2008), pp. 1228-1231. DOI: 10.1671/0272-4634-28.4.1228.

[4784] G. Conte. "Fossiles peu connus découverts en Vaucluse". French. In: Courrier Scientifique du Parc Naturel Régional du Luberon 9 (2010), pp. 114-119.

[4785] M. Contessi. "First report of mammal-like tracks from the Cretaceous of North Africa (Tunisia)". English. In: Cretaceous Research 42.1 (2013), pp. 48-54. DOI: 10.1016/j.cretres.2013.01.003. 
[4786] M. Contessi and F. Fanti. "First record of bird tracks in the Late Cretaceous (Cenomanian) of Tunisia". English. In: Palaios 27.7 (2012), pp. 455-464. DOI: 10.2110/palo.2011.p11-114r.

[4787] M. Conti and M. Marcucci. "Radiolarian assemblage in the Monte Alpe Cherts at Ponte di Lagoscuro, Val Graveglia (Eastern Liguria, Italy)". English. In: Eclogae Geologicae Helvetiae 84.3 (1991), pp. $791-$ 817.

[4788] M. A. Conti and S. Monari. "Middle Jurassic Gastropods from the Central High Atlas, Morocco". English. In: Geobios 34.2 (2001), pp. 183-214.

[4789] M. A. Conti and S. Monari. "Bivalve and gastropod fauna from the Liassic Ammonitico Rosso facies in the Bilecik area (Western Pontides, Turkey)". English. In: Geologica Romana 27 (1991), pp. 245-301.

[4790] M. A. Conti, M. Morsilli, U. Nicosia, E. Sacchi, V. Savino, A. Wagensommer, L. Di Maggio, and P. Gianolla. "Jurassic dinosaur footprints from southern Italy: footprints as indicators of constraints in paleogeographic interpretation". English. In: Palaios 20 (2005), pp. 534-550.

[4791] S. Conti, B. Vila, A. G. Sellés, A. Galobart, M. J. Benton, and A. Prieto-Márquez. "The oldest lambeosaurine dinosaur from Europe: Insights into the arrival of Tsintaosaurini". English. In: Cretaceous Research 107 (2020), p. 104286.

[4792] D. L. Contreras, I. H. Escapa, R. C. Iribarren, and N. R. Cúneo. "Reconstructing the early evolution of the Cupressaceae: A whole-plant description of a new Austrohamia species from the Cañadón Asfalto Formation(Early Jurassic), Argentina". English. In: International Journal of Plant Sciences 180.8 (2019), pp. 834-868. DOI: 10.1086/704831.

[4793] V. H. Contreras. “Un nuevo Hathlyacyninae (Mammalia: Borhyaenidae) del Chasiquense (Mioceno Superior) de la Provincia de San Juan, Argentina". Spanish. In: Actas V Congreso Argentino de Paleontologa y Bioestratigrafa. Serie Correlación Geológica 7 (1990), pp. 163-168.

[4794] V. J. Contreras, R. L. Tomassini, M. A. Perez, and C. Oliva. "Macrochorobates scalabrinii (Moreno \& Mercerat) (Cingulata, Dasypodidae) en el Mioceno tardio de la provincia de San Juan (Argentina). Implicancias biocronoestratigraficas y paleobiogeograficas". Spanish. In: Revista Brasileira de Paleontologia 16.2 (2013), pp. 309-318. DOI: 10.4072/rbp.2013.2.11.

[4795] S. Conway Morris. "Ediacaran-like fossils in Cambrian Burgess Shale-type faunas of North America". English. In: Palaeontology 36.3 (1993), pp. 593-635.

[4796] S. Conway Morris and J.-B. Caron. "Halwaxiids and the early evolution of lophotrochozoans". English. In: Science 315 (2007), pp. 1255-1258.

[4797] S. Conway Morris and A. J. Chapman. "Mobergellans from the Lower Cambrian of Mongolia, Sweden, and the United States: molluscs or opercula of Incertae Sedis?" In: Journal of Paleontology 71.6 (1997), pp. 968-985.

[4798] S. Conway Morris and A. J. Chapman. "Lower Cambrian Halkieriids and other coeloscleritomorphs from Aksu-Wushi, Xinjiang, China". English. In: Journal of Paleontology 71.1 (1997), pp. 622.

[4799] S. Conway Morris, J. S. Crampton, X. Bing, and A. J. Chapman. "Lower Cambrian Cambroclaves (Incertae sedis) from Xinjiang, China, with comments on the morphological variability of sclerites". In: Palaeontology 40.1 (1997), pp. 167-189.

[4800] S. Conway Morris, S. L. Halgedal, P. Selden, and R. D. Jarrard. "Rare primitive deuterostomes from the Cambrian (Series 3) of Utah". English. In: Journal of Paleontology 89.4 (2015), pp. 631-636. DOI: $10.1017 /$ jpa.2015.40.

[4801] S. Conway Morris, B. W. Mattes, and C. Menge. "The early skeletal organism Cloudina: new occurrences from Oman and possibly China". In: American Journal of Science 290-A (1990), pp. 245260.

[4802] S. Conway Morris and C. Menge. "Cambroclaves and paracarinachitids, early skeletal problematica from the Lower Cambrian of South China". English. In: Palaeontology 34.2 (1991), pp. 357397. 
[4803] S. Conway Morris and C. Menge. "Blastulospongia polytreta n. sp., an enigmatic organism from the Lower Cambrian, Hubei China". In: Journal of Paleontology 64.1 (1990), pp. 26-30.

[4804] S. Conway Morris and C. Menge. "Tommotiids from the Lower Cambrian of South China". In: Journal of Paleontology 64.2 (1990), pp. 169-184.

[4805] S. Conway Morris and J. S. Peel. "Articulated halkieriids from the Lower Cambrian of north Greenland". In: Nature 345.28 (1990), pp. 802-805.

[4806] S. Conway Morris and J. S. Peel. "The earliest annelids: Lower Cambrian polychaetes from the Sirius Passet Lagerstätte, Peary Land, North Greenland". English. In: Acta Palaeontologica Polonica 53 (2008), pp. 137-148.

[4807] S. Conway Morris and J. S. Peel. "Articulated halkieriids from the Lower Cambrian of North Greenland and their role in early protostome evolution". English. In: Philosophical Transactions of the Royal Society of London B 347 (1995), pp. 305-358.

[4808] A. Cook, A. Nützel, and J. Frýda. "Two Mississippian caenogastropod limpets from Australian and their meaning for the ancestry of the Caenogastropoda". English. In: Journal of Paleontology 82.1 (2007), pp. 183-183. DOI: 10.1666/06-028.1.

[4809] A. G. Cook. "Frasnian gastropods from the Bonaparte Gulf Basin, Western Australia". In: Memoirs of the Queensland Museum 42.2 (1998), pp. 449-457.

[4810] A. G. Cook. "Gastropods from the Burdekin Formation, Middle Devonian, north Queensland". English. In: Memoirs of the Queensland Museum 42.1 (1997), pp. 37-49.

[4811] A. G. Cook. Gastropods from the Ukalunda Beds and Douglas Creek, Early Devonian, north Queensland. 1995.

[4812] A. G. Cook. "Fletcherviewia septata: a new high-spired, septate gastropod from the Devonian of North Queensland". English. In: Journal of Paleontology 67.5 (1993), pp. 816-821.

[4813] A. G. Cook. "A septate gastropod from the Silurian Bungonia Limestone, New South Wales". English. In: Memoirs of the Queensland Museum 35.1 (1994), pp. 27-30.

[4814] A. G. Cook. "Heideckernema gen. nov. a replacement name for the Devonian turretllid Trinema Cook". English. In: Memoirs of the Queensland Museum 42.2 (1998), pp. 438-438.

[4815] A. G. Cook. "Stromatoporoid palaeoecology and systematics from the Middle Devonian Fanning River Group, North Queensland". English. In: Memoirs of the Queensland Museum 43.2 (1999), pp. $463-551$.

[4816] A. G. Cook, R. B. Blodgett, and R. T. Becker. "Late Devonian gastropods from the Canning Basin, Western Australia". In: Alcheringa 27.3-4 (2003), pp. 181-207.

[4817] A. G. Cook and N. Camilleri. "Middle Devonian gastropods from the Broken River Province, north Queensland". In: Memoirs of the Queensland Museum 42.1 (1997), pp. 55-79.

[4818] A. G. Cook, P. A. Jell, G. E. Webb, M. E. Johnson, and B. G. Baarli. "Septate gastropods from the Upper Devonian of the Canning Basin: implications for palaeoecology". English. In: Alcheringa (2015).

[4819] A. G. Cook and A. Nützel. "New Devonian gastropods from the Broken River and their palaeoecology". English. In: Memoirs of the Queensland Museum 51 (2005), pp. 391-397.

[4820] A. G. Cook and H.-Z. Pan. "Middle Devonian gastropods from Xiangzhou and Wuxuan, Guangxi, South China". In: Alcheringa 28 (2004), pp. 413-429.

[4821] A. G. Cook and M. Wade. "Symbiotic stromatoporoid-nautiloid association, Middle Devonian, North Queensland". English. In: Memoirs of the Queensland Museum 42.1 (1997), pp. 81-89.

[4822] E. Cook. "Taphonomy of two non-marine Lower Cretaceous bone accumulations from southeastern England". English. In: Palaeogeography, Palaeoclimatology, Palaeoecology 116.3-4 (1995), pp. 263270. 
[4823] E. Cook and A. J. Ross. “The stratigraphy, sedimentology and palaeontology of the Lower Weald Clay (Hauterivian) at Keymer Tileworks, West Sussex, southern England". English. In: Proceedings of the Geologists' Association 107 (1996), pp. 231-239.

[4824] T. D. Cook, J. G. Eaton, M. G. Newbrey, and M. V. H. Wilson. "A new genus and species of freshwater stingray (Myliobatiformes, Dasyatoidea) from the latest middle Eocene of Utah, U.S.A." English. In: Journal of Paleontology 88.3 (2014), pp. 497-503.

[4825] T. D. Cook, M. V. H. Wilson, and A. M. Murray. "A middle Cenomanian euselachian assemblage from the Dunvegan Formation of northwestern Alberta". English. In: Canadian Journal of Earth Sciences 45.10 (2008), pp. 1185-1197. DOI: 10.1139/E08-064.

[4826] T. D. Cook, M. V. H. Wilson, A. M. Murray, A. G. Plint, M. G. Newbrey, and M. J. Everhart. "A high latitude euselachian assemblage from the early Turonian of Alberta, Canada". English. In: Journal of Systematic Palaeontology 11 (2013), pp. 555-587. DOI: 10.1080/14772019.2012.707990.

[4827] B. N. Cooke. “New Miocene bulungamayine kangaroos (Marsupialia: Potoroidae) from Riversleigh,northwestern Queensland". English. In: Memoirs of The Queensland Museum 41 (1997), pp. $281-$ 294.

[4828] B. N. Cooke. “Wanburoo hilarus gen. et sp. nov., a lophodont bulungamayine kangaroo (Marsuoialia: Macropodoidea: Bulungamayinae) from the Miocene deposits of Riversleigh, northwestern Queensland". English. In: Records of the Western Australian Museum Supplement 57 (1999), pp. 239-253.

[4829] B. N. Cooke. "Cranial Remains of a New Species of Balbarine Kangaroo (Marsupialia: Macropodoidea) fromthe Oligo-Miocene Freshwater Limestone Deposits of Riversleigh World Heritage Area,Northern Australia". English. In: Journal of Paleontology 74.2 (2000), pp. 317-326.

[4830] B. N. Cooke. "Two new balbarine kangaroos and lower molar evolution within the subfamily". English. In: Memoirs of the Queensland Museum 41 (1997), pp. 269-280.

[4831] B. N. Cooke. "Primitive macropodids from Riversleigh, north-western Queensland". English. In: Ameghiniana 16.3 (1992), pp. 201-217. DOI: 10.1080/03115519208619119.

[4832] H. B. Cooke. Suid remains from the upper Semliki area,Zaire. 1990.

[4833] R. G. Cooke, T. A. Wake, M. F. Martinez-Polanco, M. Jimenez-Acosta, F. Bustamante, I. Holst, A. Lara-Kraudy, J. G. Martin, and S. Redwood. “Exploitation of dolphins (Cetacea: Delphinidae) at a 6000 yr old Preceramic site in the Pearl Island archipelago, Panama". English. In: Journal of Archaeological Science: Reports 6 (2016), pp. 733-756. DOI: 10.1016/j.jasrep.2015.12.001.

[4834] S. B. Cooke, A. L. Rosenberger, and S. Turvey. "An extinct monkey from Haiti and the origins of the Greater Antillean primates". English. In: Proceedings of the National Academy of Sciences 108 (2011), pp. 2699-2704. DOI: 10.1073/pnas.1009161108.

[4835] M. Coombs. "A juvenile mandible with deciduous teeth of Ancylotherium pentelicum (Perissodactyla, Chalicotheriidae, Schizotheriinae), collected by Barnum Brown from the Late Miocene of Samos (Greece)". English. In: Journal of Vertebrate Paleontology 33.1 (2013), pp. 233-238.

[4836] M. C. Coombs. "Moropus merriami in the early Barstovian Lower Snake Creek fauna of Nebraska, with comments on biogeography of North American chalicotheres". English. In: Bulletin of the American Museum of Natural History 285 (2004), pp. 191-208.

[4837] M. C. Coombs and W. P. Coombs. Analysis of the geology, fauna and taphonomy of Morava Ranch Quarry, early Miocene of Northwest Nebraska. 1997.

[4838] M. C. Coombs and W. P. Coombs Jr. "Analysis of the geology, fauna, and taphonomy of Morava Ranch Quarry, Early Miocene of northwest Nebraska". English. In: Palaios 12 (1997), pp. 165-187. DOI: $10.2307 / 3515305$.

[4839] M. C. Coombs, R. M. Hunt Jr., E. Stepleton, L. B. Albright III, and T. J. Fremd. "Stratigraphy, chronology, biogeography, and taxonomy of early Miocene small chalicotheres of North America". English. In: Journal of Vertebrate Paleontology 21.3 (2001), pp. 607-620. 
[4840] M. C. Coombs and R. M. Hunt Jr. English. In: Journal of Vertebrate Paleontology 35.6 (2015), e100992. DOI: $10.1080 / 02724634.2015 .1009992$.

[4841] W. P. Coombs. "A new nodosaurid ankylosaur (Dinosauria: Ornithischia) from the Lower Cretaceous of Texas". English. In: Journal of Vertebrate Paleontology 15.2 (1995), pp. 298-312.

[4842] W. P. Coombs. "Ankylosaurian tail clubs of middle Campanian to early Maastrichtian age from western North America, with description of a tiny club from Alberta and discussion of tail orientation and tail club function". English. In: Canadian Journal of Earth Sciences 32 (1995), pp. $902-$ 912.

[4843] W. P. Coombs Jr. and T. A. Deméré. “A Late Cretaceous nodosaurid ankylosaur (Dinosauria: Ornithischia) from marine sediments of coastal California". English. In: Journal of Paleontology 70.2 (1996), pp. 311-326.

[4844] A. S. Cooper. Earliest record of a New World quail from the East Lake local fauna, Otay Formation (late Oligocene) of San Diego County, California. English. 2002.

[4845] L. N. Cooper, E. R. Seiffert, M. Clementz, S. I. Madar, S. Bajpai, S. T. Hussain, and J. G. M. Thewissen. "Anthracobunids from the Middle Eocene of India and Pakistan are stem perissodactyls". English. In: PLoS ONE 9.10 (2014), e109232:1-15. DOI: 10.1371/journal.pone.0109232.

[4846] L. N. Cooper, J. G. M. Thewissen, and S. T. Hussain. “New middle Eocene archaeocetes (Cetacea: Mammalia) from the Kuldana Formation of northern Pakistan". English. In: Journal of Vertebrate Paleontology 29.4 (2009), pp. 1289-1299.

[4847] M. R. Cooper. “The Cainozoic palaeontology and stratigraphy of KwaZulu-Natal. Part 5. The False Bay Coral Limestone Formation. Stratigraphy and fauna". English. In: Durban Natural Science Museum Novitates 37 (2014), pp. 7-24.

[4848] M. R. Cooper. "Rectithyrid brachiopods (Terebratulacea) from the Cretaceous of Zululand". English. In: Durban Museum Novitates 18 (1993), pp. 1-12.

[4849] M. R. Cooper. "Upper Cretaceous (Turonian-Coniacian) ammonites from São Nicolau, Angola". English. In: Annals of the South African Museum 110 (2003), pp. 89-146.

[4850] M. R. Cooper. "Stratigraphy and palaeontology of the Upper Cretaceous (Santonian) Baba Formation at São Nicolau, Angola". English. In: Annals of the South African Museum 110 (2003), pp. 147170.

[4851] M. R. Cooper and D. G. Broadley. "A new species of fossil Homopus (Cryptodira: Testudinidae) from South Africa". English. In: Studia Palaeocheloniologica 3.4 (1990), pp. 41-55.

[4852] R. A. Cooper, G. S. Nowlan, and S. H. Williams. "Global Stratotype Section and Point for base of the Ordovician System". English. In: Episodes 24.1 (2001), pp. 19-28.

[4853] J. C. W. Cope. "Middle Ordovician bivalves from Mid-Wales and the Welsh Borderland". In: Palaeontology 42.3 (1999), pp. 467-499.

[4854] J. C. W. Cope. "Early Ordovician (Arenig) bivalves from the Llangynog Inlier, South Wales". English. In: Palaeontology 39.4 (1996), p. 979.

[4855] J. C. W. Cope. “Octocorallian and hydroid fossils from the lower Ordovician of Wales". English. In: Palaeontology 48.2 (2005), pp. 433-445.

[4856] J. C. W. Cope. "The early phylogeny of the Class Bivalvia". English. In: Palaeontology 40.3 (1997), pp. 713-746.

[4857] J. C. W. Cope. "The Upper Jurassic ammonite Virgatopavolovia from NE Scotland: implications for palaeogeography and phylogeny". English. In: Scottish Journal of Geology 51 (2015), pp. 57-62. DOI: 10.1144/sjg2014-008.

[4858] P. Copper. "Reefs during the multiple crises towards the Ordovician-Silurian boundary: Anticosti Island, eastern Canada, and worldwide". English. In: Canadian Journal of Earth Sciences 38.2 (2001), pp. 153-171. 
[4859] P. Copper. “Davidsonia and Rugodavidsonia (new genus), cryptic Devonian atrypid brachiopods from Europe and south China". English. In: Journal of Paleontology 70.4 (1996), pp. 588-602.

[4860] P. Copper. "Five new genera of Late Ordovician - Early Silurian brachiopods from Anticosti Island, eastern Canada". English. In: Journal of Paleontology 69.5 (1995), pp. 846-861. DOI: 10.2307/1306350.

[4861] P. Copper and J. Jin. "Early athyride brachiopod evolution through the Ordovician-Silurian mass extinction and recovery, Anticosti Island, eastern Canada". English. In: Journal of Paleontology 91.6 (2017), pp. 1123-1147. DOI: 10.1017/jpa.2017.74.

[4862] P. Copper, J. Jin, and A. Desrochers. "The Ordovician-Silurian boundary (late Katian-Hirnantian) of western Anticosti Island: revised stratigraphy and benthic megafaunal correlations". English. In: Stratigraphy 10.4 (2013), pp. 213-227.

[4863] P. Copper and J. Jin. “The revised Lower Silurian (Rhuddanian) Becscie Formation, Anticosti Island, eastern Canada records the tropical marine faunal recovery from the end-Ordovician Mass Extinction". English. In: Newsletters on Stratigraphy 47.1 (2014), pp. 61-83. DOI: 10.1127 / 0078 0421/2014/0040.

[4864] P. Copper, C. W. Stock, and J. Jin. “Quasiaulacera, a new Hirnantian (Late Ordovician) aulaceratid stromatoporoid genus from Anticosti Island, Canada". English. In: Journal of Paleontology 87.4 (2013), pp. 664-676. DOI: 10.1666/12-150.

[4865] R. Coram, E. A. Jarzembowski, and M. B. Mostovski. "Two rare eremoneuran flies (Diptera: Empididae and Opetiidae) from the Purbeck Limestone Group". English. In: Paleontological Journal 34.Suppl 3 (2000), S370-S373.

[4866] R. A. Coram and E. A. Jarzembowski. “New fossil flies (Insecta: Diptera) from the Purbeck Limestone Group (Lower Cretaceous, Berriasian) of Dorset, UK". English. In: Cretaceous Research 20 (1999), pp. 853-861.

[4867] R. A. Coram and A. Nel. "A new petalurid dragonfly from the Lower Cretaceous of southern England (Odonata: Petalurida: ? Cretapetaluridae)". English. In: Palaeodiversity 2 (2009), pp. 205208.

[4868] J. Corbacho and F. J. López-Soriano. "Two new species of Trochurinae trilobites from the Middle Devonian (Eifelian) of Southern Morocco". English. In: Batalleria 18 (2013), pp. 15-24.

[4869] J. Corbacho and J. A. Vela. "Giant Trilobites from Lower Ordovician of Morocco". English. In: Batalleria 15 (2010), pp. 3-34.

[4870] M. S. Corchón-Rodriguez, A. Mateos, E. A. Fernández, E. Peñalver, X. Delclós, and J. van der Made. "Ressources complémentaires et mobilité dans le Magdalénien cantabrique. Nouvelles données sur les mammiféres marins, les crustacés, les mollusques et les roches organogénes de la Grotte de Las Caldas (Asturies, Espagne)". English. In: L'anthropologie 112 (2008), pp. 284-327.

[4871] A. Cordes-Person, C. Acosta Hospitaleche, J. Case, and J. Martin. "An enigmatic bird from the lower Maastrichtian of Vega Island, Antarctica". English. In: Cretaceous Research 108 (2020), 104314:110.

[4872] R. A. Coria. "South American hadrosaurs: considerations on their diversity". English. In: Hadrosaurs. Bloomington: Indiana University Press, 2014, pp. 332-339.

[4873] R. A. Coria and A. B. Arcucci. “Nuevos dinosaurios terópodos de Auca Mahuevo, provincia del Neuquén (Cretácico Tardio, Argentina) [New theropod dinosaurs from Auca Mahuevo, Neuquén province (Late Cretaceous, Argentina)]". Spanish. In: Actas I Congreso Latinoamericano de Paleontologa de Vertebrados. Ameghiniana 41.4 (2004), pp. 597-603.

[4874] R. A. Coria and J. O. Calvo. "A new iguanodontian ornithopod from Neuquén Basin, Patagonia, Argentina". English. In: Journal of Vertebrate Paleontology 22.3 (2002), pp. 503-509.

[4875] R. A. Coria, A. V. Cambiaso, and L. Salgado. "New records of basal ornithopod dinosaurs in the Cretaceous of north Patagonia". English. In: Ameghiniana 44.2 (2007), pp. 473-477. 
[4876] R. A. Coria, L. M. Chiappe, and L. Dingus. "A new close relative of $<\mathrm{i}>$ Carnotaurus sastrei $</ \mathrm{i}>$ Bonaparte 1985 (Theropoda: Abelisauridae) from the Late Cretaceous of Patagonia". In: Journal of Vertebrate Paleontology 22.2 (2002), pp. 460-465.

[4877] R. A. Coria and P. J. Currie. "A new carcharodontosaurid (Dinosauria, Theropoda) from the Upper Cretaceous of Argentina". English. In: Geodiversitas 28.1 (2006), pp. 71-118.

[4878] R. A. Coria and P. J. Currie. "A new megaraptoran dinosaur (Dinosauria, Theropoda, Megaraptoridae) from the Late Cretaceous of Patagonia". English. In: PLoS ONE 11.7 (2016), e0157973:1-53. DOI: 10.1371/journal.pone.0157973.

[4879] R. A. Coria, L. S. Filippi, L. M. Chiappe, R. Garcia, and A. B. Arcucci. “Overosaurus paradasorum gen. et sp. nov. , a new sauropod dinosaur (Titanosauria: Lithostrotia) from the Late Cretaceous of Neuquén, Patagonia, Argentina". English. In: Zootaxa 3683.4 (2013), pp. 357-376.

[4880] R. A. Coria, B. González Riga, and S. Casadio. “Un nuevo hadrosáurido (Dinosauria, Ornithopoda) de la Formación Allen, provincia de La Pampa, Argentina [A new hadrosaurid (Dinosauria, Ornithopoda) from the Allen Formation, La Pampa province, Argentina]". Spanish. In: Ameghiniana 49.4 (2012), pp. 552-572.

[4881] R. A. Coria, J. J. Moly, M. Reguero, S. Santillana, and S. Marenssi. “A new ornithopod (Dinosauria; Ornithischia) from Antarctica". English. In: Cretaceous Research 41 (2013), pp. 186-193. DOI: 10. 1016/j.cretres.2012.12.004.

[4882] R. A. Coria, F. Ortega, A. B. Arcucci, and P. J. Currie. "A new and complete peirosaurid (Crocodyliformes, Notosuchia) from Sierra Barrosa (Santonian, Upper Cretaceous) of the Neuquén Basin, Argentina". English. In: Cretaceous Research 95 (2019), pp. 89-105. DOI: 10.1016/j.cretres.2018.11.008.

[4883] R. A. Coria and L. Salgado. "A basal Abelisauria Novas, 1992 (Theropoda-Ceratosauria) from the Cretaceous of Patagonia, Argentina". English. In: GAIA 15 (2000), pp. 89-102.

[4884] R. A. Coria and L. Salgado. "A new giant carnivorous dinosaur from the Cretaceous of Patagonia". English. In: Nature 377 (1995), pp. 224-226.

[4885] R. A. Coria and L. Salgado. "A basal iguanodontian (Ornithischia: Ornithopoda) from the Late Cretaceous of South America". In: Journal of Vertebrate Paleontology 16.3 (1996), pp. 445-457.

[4886] R. A. Coria, F. J. Windholz, F. Ortega, and P. J. Currie. "A new dicraeosaurid sauropod from the Lower Cretaceous (Mulichinco Formation, Valanginian, Neuquén Basin) of Argentina". English. In: Cretaceous Research 93 (2019), pp. 33-48. DOI: 10.1016/j.cretres.2018.08.019.

[4887] J. J. Cornee, J. Butterlin, P. Saint-Marc, J. P. Rehault, C. Honthaas, A. Laurenti-Ribaud, C. Chaix, M. Villeneuve, and Y. Anantasena. "An early Miocene reefal platform in the Rama Ridge (Banda Sea, Indonesia)". English. In: Geo-Marine Letters 18 (1998), pp. 34-39.

[4888] J.-J. Cornée, M. Villeneuve, M. Ferrandini, F. Hinschberger, J. Malod, K. Matsumaru, A. RibaudLaurenti, and J. -P. Rehault. "Oligocene reefal deposits in the Pisang Ridge and the origin of the Lucipara Block (Banda Sea, eastern Indonesia)". English. In: Geo-Marine Letters 22.2 (2002), pp. 6674.

[4889] W. C. Cornell, D. V. Lemone, and W. D. Norland. "Albian Ophiuroids from Cerro de Cristo Rey, Dona Ana County, New Mexico". English. In: Journal of Paleontology 65.6 (1991), pp. 1009-1013.

[4890] B. Cornet and P. E. Olsen. Early to Middle Carnian (Triassic) Flora and Fauna of the Richmond and Taylorsville Basins, Virginia and Maryland, U.S.A. Virginia Museum of Natural History Guidebook 1. 1990, pp. 1-87.

[4891] A. Corona, A. C. Badin, D. Perea, M. Ubilla, and G. I. Schmidt. "A new genus and species and additional reports of the native South American ungulates Proterotheriidae (Mammalia, Litopterna) in the Late Miocene of Uruguay". English. In: Journal of South American Earth Sciences (2020). DOI: 10.1016/j.jsames.2020.102646.

[4892] A. Corona, D. Perea, and G. McDonald. "Catonyx cuvieri (Xenarthra, Mylodontidae, Scelidotheriinae) from the late Pleistocene of Uruguay, with comments regarding the systematics of the subfamily". English. In: Journal of Vertebrate Paleontology 33.5 (2013), pp. 1214-1225. 
[4893] A. Corona, M. Ubilla, and D. Perea. "New records and diet reconstruction using dental microwear analysis for". English. In: Andean Geology 46.1 (2019), pp. 153-167.

[4894] E. Corona-M and M. T. Alberdi. “Two new records of Gomphotheriidae (Mammalia: Proboscidea) in southern México and some biogeographic implications". English. In: Journal of Paleontology 80.2 (2006), pp. 357-366.

[4895] C. Corradini. "The conodont genus Pseudooneotodus Drygant from the Silurian and Lower Devonian of Sardinia and the Carnic Alps (Italy)". English. In: Bollettino della Societá Paleontologica Italiana 46.2-3 (2007), pp. 139-148.

[4896] C. Corradini and M. G. Corriga. "Silurian and lowermost Devonian conodonts from the Passo Volaia area (Carnic Alps, Italy)". English. In: Bollettino della Societa Paleontologica Italiana 49.3 (2010), pp. 237-253.

[4897] C. Corradini, M. Pondrelli, L. Simonetto, M. G. Corriga, C. Spalletta, T. J. Suttner, E. Kido, A. Mossoni, and P. Serventi. "Stratigraphy of the La Valute area (Mt. Zermula massif, Carnic Alps, Italy)". English. In: Bollettino della Societá Paleontologica Italiana 55.1 (2016), pp. 55-78.

[4898] J. C. Corral, N. Bardet, X. Pereda-Suberbiola, and H. Capetta. "First occurrence of the sawfish Onchosaurus from the Late Cretaceous of Spain". English. In: Journal of Vertebrate Paleontology 32.1 (2012), pp. 212-218. DOI: 10.1080/02724634.2012.620675.

[4899] J. C. Corral, A. Berreteaga, and H. Cappetta. “Upper Maastrichtian shallow marine environments and neoselachian assemblages in North Iberian palaeomargin (Castilian Ramp, Spain)". English. In: Cretaceous Research 57 (2016), pp. 639-661.

[4900] E. Correa, C. Jaramillo, S. Manchester, and M. Gutierrez. "A fruit and leaves of Rhamnaceous affinities from late Cretaceous (Masstrichtian) of Colombia". English. In: 91.1 (2010), pp. 71-79.

[4901] L. F. A. Correa and M. I. F. Ramos. “Discinoids (Brachiopoda: Lingulata) from the upper Manacapuru Formation (Early Devonian), south border of Amazonas Basin, Brazil". English. In: Journal of South American Earth Sciences (2020). DOI: 10.1016/j.jsames.2020.102960.

[4902] P. Correia, J. B. Murphy, A. A. Sá, R. Domingos, and D. Flores. “First Palaeozoic arachnid from Portugal and implications for Carboniferous palaeobiogeography". English. In: Geological Journal 48 (2013), pp. 101-107.

[4903] P. Correia, A. Nel, A. A. Sá, R. Domingos, A. Carneiro, and D. Flores. "A new Palaeodictyoptera from the late Carboniferous of Portugal". English. In: Annales de la Société Entomologique de France 49 (2014), pp. 398-401.

[4904] M. G. Corriga, C. Corradini, A. Ferretti, M. Pondrelli, L. Simonetto, and P. Serventi. "Lochkovian conodonts in the Rio Malinfier West section". English. In: International Conodont Symposium 423 (2017).

[4905] M. G. Corriga, C. Corradini, H. P. Schönlaub, and M. Pondrelli. “Lower Lochkovian (Lower Devonian) chonodonts from Cellon section (Carnic Alps, Austria)". English. In: Bulletin of Geosciences 91.2 (2016), pp. 261-270.

[4906] D. Corrochano, D. Vachard, and I. Armenteros. "New insights on the red alga Archaeolithophyllum and its preservation from the Pennsylvanian of the Cantabrian Zone (NW Spain)". English. In: Facies 59 (2013), pp. 949-967.

[4907] J. A. Corsini, M. Bohme, and W. J. Joyce. "Reappraisal of Testudo antiqua (Testudines, Testudinidae) from the Miocene of Hohenhöwen, Germany". English. In: Journal of Paleontology 88.5 (2014), pp. 948-966. DOI: 10.1666/13-036.

[4908] J. Cortes, I. G. Macintyre, and P. W. Glynn. "Holocene growth history of an eastern Pacific fringing reef, Punta Islotes, Costa Rica". English. In: Coral Reefs 13 (1994), pp. 65-73.

[4909] I. Cortijo, M. Marti Mus, S. Jensen, and T. Palacios. "A new species of Cloudina from the terminal Ediacaran of Spain”. English. In: Precambrian Research 176 (2010), pp. 1-10. 
[4910] A. P. Cossette. "A new species of Bottosaurus (Alligatoroidea: Caimaninae) from the Black Peaks Formation (Palaeocene) of Texas indicates an early radiation of North American caimanines". English. In: Zoological Journal of the Linnean Society 191.1 (2021), pp. 276-301. DOI: 10.1093/zoolinnean/ zlz178/5815831.

[4911] A. P. Cossette, A. J. Adams, S. K. Drumheller, J. H. Nestler, B. R. Benefit, M. L. McCrossin, F. K. Manthi, R. Nyaboke Juma, and C. A. Brochu. "A new crocodylid from the middle Miocene of Kenya and the timing of". English. In: Journal of Paleontology 94.6 (2020), pp. 1165-1179. DOI: 10. 1017/jpa.2020.60.

[4912] A. P. Cossette and C. A. Brochu. "A systematic review of the giant alligatoroid Deinosuchus from the Campanian of North America and its implications for the relationships at the root of Crocodylia". English. In: Journal of Vertebrate Paleontology 40.1 (2020), e1767638:1-37. DOI: 10.1080/ 02724634.2020 .1767638$.

[4913] C. Costa, S. A. Vanin, J. F. Lawrence, S. Ide, and M. A. Branham. "Review of the family Brachypsectridae (Coleoptera: Elateroidea)". English. In: Annals of the Entomological Society of America 99 (2006), pp. 409-432.

[4914] D. P. Costa and N. J. Gales. "Energetics of a benthic diver: seasonal foraging ecology of the Australian sea lion, Neophoca cinerea". English. In: Ecology Monographs 73.1 (2003), pp. 27-43.

[4915] F. R. Costa and A. W. A. Kellner. "On two pterosaur humeri from the Tendaguru beds (Upper Jurassic, Tanzania)". English. In: Anais da Academia Brasileira de Ciencias 81.4 (2009), pp. 813-818.

[4916] F. R. Costa, J. M. Sayao, and A. W. A. Kellner. "New pterosaur material from the Upper Jurassic of Tendaguru (Tanzania), Africa". English. In: Historical Biology 27 (2015), pp. 646-655.

[4917] R. Costa, I.d.S. Carvalho, and C. Schwanke. Icnofósseis de vertebrados na Formação Caturrita (Neotriássico da Bacia do Paraná) no Estado do Rio Grande do Sul, Brasil [Vertebrate ichnofossils from the Caturrita Formation (Late Triassic of the Paraná Basin) in Rio Grande do Sul State, Brazill. Portugese. 2003.

[4918] R. Costa da Silva, M. Berbert-Born, D. E. F. Bustamante, T. N. Santoro, F. Sedor, and L. dos Santos Avilla. "Diversity and preservation of Pleistocene tetrapods from caves of southwestern Bahia, Brazil". English. In: Journal of South American Earth Sciences 90 (2019), pp. 233-254.

[4919] P. V. L. G. Costa Pereira, I. M. M. G. Veiga, T. B. Ribeiro, R. H. Bezerra Cardozo, C. R. A. Candeiro, and L. P. Bergqvist. "The path of giants: a new occurrence of Rebbachisauridae (Dinosauria, Diplodocoidea) in the Açu Formation, NE Brazil, and its paleobiogeographic implications". English. In: Journal of South American Earth Sciences 100 (2020), p. 102515. DOI: 10.1016/j.jsames.2020. 102515.

[4920] R. Costa Ribeiro and I. Souza Carvalho. "Megafauna do Quaternário tardio de Baixa Grande , Bahia , Brasil Megafauna of the late Quaternary from Baixa Grande , Bahia , Brazil". Portugese. In: Anuário do Instituto de Geociencias - UFRJ 32 (2009), pp. 42-80.

[4921] P. Coster, K. C. Beard, M. J. Mustafa Salem, Y. Chaimanee, M. Brunet, and J. -J. Jaeger. “A new early Oligocene mammal fauna from the Sirt Basin, central Libya: Biostratigraphic and paleobiogeographic implications". English. In: Journal of African Earth Sciences 104 (2015), pp. 43-55.

[4922] P. Coster, K. C. Beard, M. J. Salem, Y. Chaimanee, and J. J. Jaeger. "New fossils from the Paleogene of central Libya illuminate the evolutionary history of endemic African anomaluroid rodents". English. In: Frontiers in Earth Science 3.56 (2015), pp. 1-15.

[4923] P. Coster, M. Benammi, V. Lazzari, G. Billet, T. Martin, M. Salem, A. Abolhassan Bilal, Y. Chaimanee, M. Schuster, X. Valentin, M. Brunet, and J. -J. Jaeger. “Gaudeamus lavocati sp. nov. (Rodentia, Hystricognathi) from the early Oligocene of Zallah, Libya: first African caviomorph?" English. In: Naturwissenschaften 97 (2010), pp. 697-706.

[4924] P. Coster, M. Benammi, M. Salem, A. A. Bilal, Y. Chaimanee, X. Valentin, M. Brunet, and J. J. Jaeger. "New hystricognathous rodents from the early Oligocene of central Libya (Zallah Oasis, Sahara Desert): systematic, phylogenetic, and biochronological implications". English. In: Annals of Carnegie Museum 80.3 (2012), pp. 239-259. 
[4925] L. Costeur and M. Schneider. Catalogue of the Eocene mammal types of the Natural History Museum Basel. English. Carnets de Géologie - Notebooks on Geology. 2011.

[4926] E. P. Coturel, J. Bodnar, E. M. Morel, D. G. Ganuza, A. J. Sagasti, and M. Beltran. “New species of osmundaceous fertile leaves from". English. In: Acta Palaeobotanica 58.2 (2018), pp. 107-119.

[4927] D. Coty, C. Aria, R. Garrouste, P. Wils, F. Legendre, and A. Nel. “The first ant-termite syninclusion in amber with CT-scan analysis of taphonomy". English. In: PLoS One 9.8 (2014), e104410.

[4928] D. Coty, R. Garrouste, and A. Nel. "The first lace bug from Chiapas amber (Totolapa, Mexico) (Hemiptera: Tingidae)". English. In: Annales de la Société Entomologique de France 50 (2015), pp. 286290.

[4929] D. Coty, J. Háva, J. Prokop, P. Roques, and A. Nel. "New archaeorthopteran insects from the Late Carboniferous of the Nord and Pas-de-Calais basins in northern France (Insecta: Cnemidolestodea, Panorthoptera)". English. In: Zootaxa 3878 (2014), pp. 462-470.

[4930] D. Coty, M. Lebon, and A. Nel. "When phylogeny meets geology and chemistry: doubts on the dating of Ethiopian amber". English. In: Annales de la Société Entomologique de France 52 (2016), pp. 161-166.

[4931] D. Coty and A. Nel. "New fossil Pachygastrinae from Mexican amber (Diptera: Stratiomyidae)". English. In: Annales de la Société Entomologique de France 49 (2013), pp. 267-272.

[4932] A. Coulson, R. Barrick, W. Straight, S. Decherd, and J. Bird. Description of the new brachiosaurid (Dinosauria: Sauropoda) from the Ruby Ranch Member (Cretaceous: Albian) of the Cedar Mountain Formation, Utah. English. 2004.

[4933] L. Courel and G. R. Demathieu. “Une nouvelle ichnoespéce Coelurosaurichnus grancieri du Trias supérieur de l'Ardéche, France [A new ichnospecies Coelurosaurichnus grancieri from the Upper Triassic of Ardéche, France]". French. In: Geodiversitas 22.1 (2000), pp. 35-46.

[4934] N. Court. "An enigmatic new mammal from the Eocene of North Africa". English. In: Journal of Vertebrate Paleontology 13.2 (1993), pp. 267-269.

[4935] N. Court. "A new species of Numidotherium (Mammalia, Proboscidea) from the Eocene of Libya and the early phylogeny of the Proboscidea". English. In: Journal of Vertebrate Paleontology 15.3 (1995), pp. 650-671.

[4936] N. Court and J.-L. Hartenberger. "A new species of the hyracoid mammal Titanohyax from the Eocene of Tunisia". English. In: Palaeontology 35.2 (1992), pp. 309-317.

[4937] N. Court and M. Mahboubi. "Reassessment of Lower Eocene Seggeurius amourensis: aspects of primitive dental morphology in the mammalian order Hyracoidea". English. In: Journal of Paleontology 67.5 (1993), pp. 889-893.

[4938] P. Courville and L. Villier. “L'Oxfordien moyen et supérieur de l'Est du Bassin Parisien (France). L'exemple de Latrecey (Haute-Marne): aspects fauniques, paléoenvironnementaux et stratigraphiques". French. In: Revue de Paléobiologie 22.1 (2003), pp. 175-196.

[4939] R. Cousin, G. Breton, R. Fournier, and J.-P. Watte. Dinosaur egglaying and nesting in France. English. K. Carpenter, K.F. Hirsch \& J.R. Horner (eds.) Dinosaur Eggs and Babies. Cambridge University Press, Cambridge. 1994, pp. 56-74.

[4940] F. J. Coutts, J. G. Gehling, and D. C. Garca-Bellido. "How diverse were early animal communities? An example from Ediacara". English. In: Alcheringa 40 (2016), pp. 407-421. DOI: 10.1080/03115518. 2016.1206326.

[4941] H. H. Covert and M. W. Hamrick. "Description of new skeletal remains of the early Eocene anaptomorphine primateăAbsarokiusă(Omomyidae) and a discussion about its adaptive profile". English. In: Journal of Human Evolution 25 (1993).

[4942] H. H. Covert, M. W. Hamrick, T. Dzanh, and K. C. McKinney. "Fossil mammals from the late Miocene of Vietnam". English. In: Journal of Vertebrate Paleontology 21.3 (2001), pp. 633-636.

[4943] G. S. Cowles. "A new genus, three new species and two new records of extinct Holocene birds from Réunion Island, Indian Ocean". English. In: Geobios 27 (1994), pp. 87-93. 
[4944] C. B. Cox. "The Pangaea dicynodont Rechnisaurus and the comparative biostratigraphy of Triassic dicynodont faunas". English. In: Palaeontology 34.4 (1991), pp. 767-784.

[4945] C. B. Cox and K. D. Angielczyk. "A new endothiodont dicynodont (Therapsida, Anomodontia) from the Permian Ruhuhu Formation (Songea Group) of Tanzania and its feeding system". English. In: Journal of Vertebrate Paleontology 35.4 (2015), e935388. DOI: 10.1020/027246.2014.935388.

[4946] C. B. Cox and P. Hutchinson. "Fishes and Amphibians from the Late Permian Pedra de Fogo Formation of Northern Brazil". English. In: Palaeontology 34.3 (1991), pp. 561-573.

[4947] P. Cozar, I. D. Somerville, M. Aretz, and H. G. Herbig. “Biostratigraphical dating of Upper Visean limestones (NW Ireland) using foraminiferans, calcareous algae and rugose corals". English. In: Irish Journal of Earth Sciences 23 (2005), pp. 1-23.

[4948] M. Cozzuol. "A northern seal from the Miocene of Argentina: Implications for phocid phylogeny and biogeography". English. In: Journal of Vertebrate Paleontology 21.3 (2001), pp. 415-421.

[4949] M. A. Cozzuol. "The record of aquatic mammals in southern South America". English. In: Munchner Geowissenshaftliche Abhandlungen. A, Geoligie und Palaontologie 30 (1996), pp. 321-342.

[4950] M. A. Cozzuol. “The Acre vertebrate fauna: Age, diversity, and geography". English. In: Journal of South American Earth Sciences 21 (2006), pp. 185-203.

[4951] M. A. Cozzuol. Fossil record and the evolutionary history of Iniodea. English. Biology, Evolution, and Conservation of River Dolphins within South America and Asia. 2010, pp. 193-217.

[4952] M. A. Cozzuol and O. A. Aguilera. "Cetacean remains from the Neogene of northwestern Venezuela". English. In: Palaeontologische Zeitschrift 82.2 (2008), pp. 196-203.

[4953] D. A. Craig and N. Porch. "Subfossils of extinct and extant species of Simuliidae (Diptera) from Austral and Cook Islands (Polynesia): anthropogenic extirpation of an aquatic insect?" English. In: Zootaxa 3641 (2013), pp. 448-462.

[4954] R. S. Craig. "The Cenozoic Brachiopoda of the Bremer and Eucla Basins, southwest Western Australia". English. In: Records of the Western Australian Museum 20 (2001), pp. 199-236.

[4955] R. S. Craig. "A new Pliocene terebratulid brachiopod from the Roe Calcarenite, Eucla Basin of southern Australia". English. In: Records of the Western Australian Museum 19 (1999), pp. 267-275.

[4956] R. S. Craig. "Late Cretaceous brachiopods of the Perth and Carnarvon Basins, Western Australia". English. In: Records of the Western Australian Museum 19 (1999), pp. 413-442.

[4957] R. S. Craig. "A new Jurassic Rhynchonellide Brachiopod from the Newmarracarra Limestone, Perth Basin, Western Australia". English. In: Records of the Western Australian Museum 20 (2002), pp. 387-392.

[4958] R. S. Craig. "The brachiopod fauna of the Plio-Pleistocene Ascot Formation, Perth Basin, Western Australia". English. In: Records of the Western Australian Museum 19 (1999), pp. 451-464.

[4959] J. Cramb and S. Hocknull. "Two new species of Antechinus Macleay (Dasyuridae : Marsupialia)from mid-Pleistocene cave deposits in eastern central Queensland". English. In: Australian Mammalogy 32 (2010), pp. 127-144.

[4960] J. A. Crame. "A new oxytomid bivalve from the Upper Jurassic-Lower Cretaceous of Antarctica". English. In: Palaeontology 39.3 (1996), pp. 615-628.

[4961] J. A. Crame. "Occurrence of the bivalve genus Manticula in the Early Cretaceous of Antarctica". English. In: Palaeontology 38.2 (1995), pp. 299-312.

[4962] J. A. Crame, D. Pirrie, J. B. Riding, and M. R. A. Thomson. "Campanian-Maastrichtian (Cretaceous) stratigraphy of the James Ross Island area, Antarctica". English. In: Journal of the Geological Society, London 148 (1991), pp. 1125-1140.

[4963] C. D. Crane, S. J. Culver, and C. A. Rigsby. A Late Cretaceous (Campanian) microvertebrate site in southeastern North Carolina. English. 2011.

[4964] P. R. Crane and P. S. Herendeen. "Cretaceous floras containing angiosperm flowers and fruits from eastern North America". In: Review of Palaeobotany and Palynology 90 (1996), pp. 319-337. 
[4965] P. R. Crane, S. R. Manchester, and D. L. Dilcher. "A Preliminary Survey of Fossil Leaves and WellPreserved Reproductive Structures from the Sentinel Butte Formation (Paleocene) near Almont, North Dakota". English. In: Fieldiana, Geology, New Series 20 (1990).

[4966] P. R. Crane and S. R. Manchester. "Reproductive and vegetative structure of Nordenskioldia (Trochodendraceae), a vesselless dicotyledon from the Early Tertiary of the northern hemisphere". In: American Journal of Botany 78.10 (1991), pp. 1311-1334.

[4967] P. R. Crane, K. R. Pedersen, E. M. Friis, and A. N. Drinnan. “Early Cretaceous (Early to Middle Albian) platanoid inflorescences associated with Sapindopsis leaves from the Potomac Group of eastern North America". In: Syst Bot 18 (1993), pp. 328-344.

[4968] S. Crasquin, L. Carcione, and R. Martini. "Permian ostracods from the Lercara Formation (Middle Triassic-Carnian?), Sicily, Italy". English. In: Palaeontology 51 (2008), pp. 537-560.

[4969] S. Crasquin, M. B. Forel, Q. L. Feng, A. H. Yuan, F. Baudin, and P. Y. Collin. “Ostracods (Crustacea) through the Permian-Triassic boundary in South China: the Meishan stratotype (Zhejiang Province)". English. In: Journal of Systematic Palaeontology 8.3 (2010), pp. 331-370.

[4970] S. Crasquin and M. B. Forel. "Systematic Palaeontology, in Ostracods (Crustacea) through the Permian-Triassic boundary in South China: the Meishan stratotype (Zhejiang Province)". English. In: Journal of Systematic Palaeontology 8.3 (2010), pp. 331-370.

[4971] S. Crasquin, M. C. Perri, A. Nicora, and P. De Wever. "Ostracods across the Permian-Triassic boundary in western Tethys: the Bulla parastratotype (southern Alps, Italy)". English. In: Rivista Italiana di Paleontologia e Stratigrafia 114.2 (2008), pp. 233-262.

[4972] S. Crasquin, M. N. Sudar, D. Jovanovi, and T. Kolar-Jurkovek. “Upper Permian ostracode assemblage from the Jadar Block (Vardar Zone, NW Serbia)". English. In: Annales Géologiques de la Péninsule Balkanique 71 (2010), pp. 23-35.

[4973] S. Crasquin-Soleau. "A new ostracod (Crustacea) species (Geffenina wangi) from the Middle Permian of Jebel Gharif (central Oman)". English. In: Journal of Micropalaeontology 22 (2003), pp. 101105.

[4974] S. Crasquin-Soleau and A. Baud. "New Permian ostracods from Greece (Hydra Island)". English. In: Journal of Micropalaeontology 17 (1998), pp. 131-152.

[4975] S. Crasquin-Soleau, F. Berra, and R. Rettori. "A Late Triassic ostracod assemblage from the Quattervals Nappe (Austroalpine, northern Italy)". English. In: Rivista Italiana di Paleontologia e Stratigrafia 106 (2000), pp. 181-190.

[4976] S. Crasquin-Soleau, J. Broutin, J. Roger, J. P. Platel, H. Al Hashmi, L. Angiolini, A. Baud, H. Bucher, and J. Marcoux. "First Permian Ostracode Fauna from the Arabian Plate (Khuff Formation, Sultanate of Oman)". In: Micropaleontology 45.2 (1999), pp. 163-182.

[4977] S. Crasquin-Soleau, T. Galfetti, H. Bucher, and A. Brayard. "Palaeoecological changes after the end-Permian mass extinction: Early Triassic ostracods from northwestern Guangxi Province, south China". English. In: Rivista Italiana di Paleontologia e Stratigrafia 112.1 (2006), pp. 55-75.

[4978] S. Crasquin-Soleau and E. Gradinaru. "Early Anisian Ostracode Fauna from the Tulcea Unit (Cimmerian North Dobrogean Oragen, Romania)". In: Annales de Paléontologie 82.2 (1996), pp. 59-116.

[4979] S. Crasquin-Soleau and S. Kershaw. "Ostracod fauna from the Permian-Triassic boundary interval of South China (Huaying Mountains, eastern Sichuan Province): palaeoenvironmental significance". In: Palaeogeography, Palaeoclimatology, Palaeoecology 217 (2005), pp. 131-141.

[4980] S. Crasquin-Soleau, J. Marcoux, L. Angiolini, S. Richoz, A. Nicora, A. Baud, and Y. Bertho. “A new ostracode fauna from the Permian - Triassic boundary in Turkey (Taurus, Antalya Nappes)". In: Micropaleontology 50.3 (2004), pp. 281-295.

[4981] S. Crasquin-Soleau and M. J. Orchard. “Upper Paleozoic ostracodes of the Harper Ranch beds (south-central British Columbia, Canada)". In: Micropaleontology 40.3 (1994), pp. 242-254. 
[4982] S. Crasquin-Soleau, S. Z. Shen, W. Z. Li, and C. Q. Cao. “Ostracods from the Lopingian and Permian-Triassic boundary beds at the Gyanyima section in southwest Tibet, China". English. In: Palaeoworld 16 (2007), pp. 222-232.

[4983] S. Crasquin-Soleau and K. Teherani. "Premiére découverte d'ostracodes triasiques dans la formation de Khaneh Kat, Montagne Michparvar (Ouest Iran)". French. In: Revue de Micropaléontologie 38 (1995), pp. 27-36.

[4984] S. Crasquin-Soleau, D. Vaslet, and Y. M. Le Nindre. "Ostracods as markers of the Permian/Triassic boundary in the Khuff Formation of Saudi Arabia". English. In: Palaeontology 48.4 (2005), pp. 853868.

[4985] R. S. Crawford, S. Casadio, R. M. Feldmann, M. Griffin, A. Parras, and C. E. Schweitzer. "Mass mortality of fossil decapods within the Monte Leon Formation (early Miocene), southern Argentina: victims of Andean Volcanism?" English. In: Annals of Carnegie Museum 77.2 (2008), pp. 259287.

[4986] E. Cregut-Bonnoure and E. Tsoukala. "The Pliocene Artiodactyla and Proboscidea (Mammalia) from Gephyra (lower Axios valley, Macedonia, Greece). Discovery of a new boselaphine". English. In: Quaternary International (2017). DOI: 10.1016/j.quaint.2016.10.022.

[4987] E. Cregut-Bonnoure and E. Tsoukala. "The Late Pliocene Bovidae and Cervidae (Mammalia) of Milia (Grevena, Macedonia, Greece)". English. In: Quaternary International 445 (2017), pp. 215-249.

[4988] H. Cremer. "Spicule Pseudomorphs in Upper Triassic (Norian) Chaetetid Sponges from the Western Taurids (Antalya-Region, SW Turkey)". In: Géobios 28.2 (1995), pp. 163-174.

[4989] W. L. Crepet and K. C. Nixon. "Two new fossil flowers of magnoliid affinity from the Late Cretaceous of New Jersey". In: American Journal of Botany 85 (1998), pp. 1273-1288.

[4990] L. D. Crerar, A. P. Crerar, D. P. Domning, and E. C. M. Parsons. "Rewriting the history of an extinction - was a population of Steller's sea cows (Hydrodamalis gigas) at St Lawrence Island also driven to extinction?" English. In: Biology Letters (2014). DOI: 10.1098/rsbl.2014.0878.

[4991] V. D. Crespo, F. J. Goin, P. Montoya, and F. J. Ruiz-Sánchez. English. In: Journal of Paleontology 94.6 (2020), pp. 1213-1227. DOI: 10.1017/jpa.2020.58.

[4992] R. E. Crick and E. S. Sobolev. “Perunautilus quadratus n. gen. et sp. (Cephalopoda, Nautilida) from the Triassic (Norian) of Central Peru". English. In: Palaeontographica Abteilung A 233 (1994), pp. 161-167.

[4993] T. P. Crimes, A. Insole, and B. P. J. Williams. "A rigid-bodied Ediacaran biota from Upper Cambrian strata in Co. Wexford Erie". In: Geological Journal 30 (1995), pp. 89-109.

[4994] T. P. Crimes and D. McIlroy. "A biota of Ediacaran aspect from lower Cambrian strata on the Digermul Peninsula, Arctic Norway". English. In: Geological Magazine 136.6 (1999), pp. 633-642.

[4995] G. Crippa and L. Angiolini. "Guadalupian (Permian) brachiopods from the Ruteh limestone, north Iran". English. In: GeoArabia 17 (2012), pp. 125-176.

[4996] G. Crippa, L. Angiolini, I. Van Waveren, M. J. Crow, F. Hasibuan, M. H. Stephenson, and K. Ueno. "Brachiopods, fusulines and palynomorphs of the Mengkarang Formation (Early Permian, Sumatra) and their palaeobiogeographical significance". English. In: Journal of Asian Earth Sciences 79 (2014), pp. 206-223.

[4997] J. Criscione and D. Grimaldi. "The oldest predaceous water bugs (Insecta, Heteroptera, Belostomatidae), with implications for paleolimnology of the Triassic Cow Branch Formation". English. In: Journal of Paleontology 91 (2017), pp. 1166-1177.

[4998] J. Y. Crochet, P. O. Antoine, M. Benammi, N. Iqbal, L. Marivaux, G. Metais, and J. L. Welcomme. "A herpetotheriid marsupial from the Oligocene of Bugti Hills, Balochistan, Pakistan. Acta Palaeontologica Polonica". English. In: Acta Palaeontologica Polonica 52.3 (2007), pp. 633-637.

[4999] J.-Y. Crochet. "Le Garouillas et les sites contemporains (Oligocene, MP 25) des phosphorites du Quercy (Lot, Tarn-et garonne, France) et leurs faunes de vertebres. 4. Marsupiaux et insectivores." French. In: Palaeontographica Abteilung A 236.1-6 (1995), pp. 39-75. 
[5000] J.-Y. Crochet. “Valbro : un nouveau site á vertébrés de l'Oligocéne inférieur (MP 22) de France (Quercy). IV - Marsupialia, Insectivora". French. In: Annales de Paléontologie 102 (2016), pp. 7-10.

[5001] J.-Y. Crochet, L. Hautier, and T. Lehmann. "A pangolin (Manidae, Pholidota, Mammalia) from the French Quercy phosphorites (Pech du Fraysse, Saint-Projet, Tarn-et-Garonne, late Oligocene, MP 28)". English. In: Palaeovertebrata 39.2 (2015), e4:1-8.

[5002] J.-Y. Crochet, H. Thomas, and J. Roger. "Premiére découverte d'un créodonte dans la péninsule Arabique : Masrasector ligabuei nov. sp. (oligocéne inférieur de Taqah, formation d'Ashawq, sultanat d'Oman)". English. In: Comptes rendus de l'Académie des sciences de Paris, Série 2311.12 (1990), pp. $1455-1460$.

[5003] S. J. Crockford and S. G. Frederick. "Sea ice expansion in the Bering Sea during the Neoglacial: evidence from archaeozoology". English. In: The Holocene 17.6 (2007), pp. 699-706.

[5004] D. Croft, J. Radic, E. Zurita, R. Charrier, J. J. Flynn, and A. R. Wyss. “A Miocene toxodontid (Mammalia: Notoungulata) from the sedimentary series of the Cura-Malln Formation, Lonquimay, Chile". English. In: Revista Geológica de Chile 30.2 (2003), pp. 285-298. DOI: 10.4067/S0716-02082003000200008.

[5005] D. A. Croft. "The middle Miocene (Laventan) Quebrada Honda fauna, southern Bolivia and description of its notoungulates". English. In: Palaeontology 50.1 (2007), pp. 277-303.

[5006] D. A. Croft and F. Anaya. "A new middle Miocene hegetotheriid (Notoungulata: Typotheria) and a phylogeny of the Hegetotheriidae". English. In: Journal of Vertebrate Paleontology 26.2 (2006), pp. 387-399.

[5007] D. A. Croft, F. Anaya, D. Auerbach, C. Garzione, and B. J. MacFadden. “New Data on Miocene Neotropical Provinciality from Cerdas, Bolivia". English. In: Journal of Mammal Evolution 16 (2009), pp. 175-198.

[5008] D. A. Croft and F. Anaya. "A new typothere notoungulate (Mammalia: Interatheriidae), from the Miocene Nazareno Formation of Southern Bolivia". English. In: Ameghiniana 57.2 (2020), pp. 189208.

[5009] D. A. Croft, M. Bond, J. J. Flynn, M. Reguero, and A. R. Wyss. "Large archaeohyracids (Typotheria, Notoungulata) from central Chile and Patagonia including a revision of Archaeotypotherium". In: Fieldiana: Geology (New Series) 49 (2003), pp. 1-38.

[5010] D. A. Croft, A. A. Carlini, M. R. Ciancio, D. Brandoni, N. E. Drew, R. K. Engelman, and F. Anaya. "New mammal faunal data from Cerdas, Bolivia, a middle-latitude Neotropical site that chronicles the end of the Middle Miocene Climatic Optimum in South America". English. In: Journal of Vertebrate Paleontology 36.5 (2016), e1163574. DOI: 10.1080/02724634.2016.1163574.

[5011] D. A. Croft, J. M. H. Chick, and F. Anaya. “New middle Miocene Caviomorph rodents from Quebrada Honda, Bolivia". English. In: Journal of Mammalian Evolution 18.4 (2011), pp. 245-268. DOI: 10.1007/s10914-011-9164-z.

[5012] D. A. Croft, J. J. Flynn, and A. R. Wyss. "A New Basal Glyptodontid and other Xenarthra of the Early Miocene Chucal Fauna, Northern Chile". English. In: Journal of Vertebrate Paleontology 27.4 (2007), pp. 781-797. DOI: 10.1671/0272-4634(2007)27[781:ANBGAO]2.0.CO;2.

[5013] D. A. Croft, L. R. Heaney, J. J. Flynn, and A. P. Bautista. "Fossil remains of a new, diminutive Bubalus (Artiodactyla: Bovidae: Bovini) form Cebu Island, Philippines". English. In: Journal of Mammalogy 87.5 (2006), pp. 1037-1051.

[5014] D. A. Croft, J.-N. Martinez, and P. M. Tapia. "The first record of a Miocene terrestrial mammal (Astrapotheria: Uruguaytheriinae) from northern coastal Peru". English. In: Ameghiniana 57.2 (2020), pp. 146-158.

[5015] C. Cronier, A. Abbache, A. Y. Khaldi, M. Oudot, S. Maillet, and A. O. Mehadji. "Middle Devonian trilobites of the Saoura Valley, Algeria: insights into their biodiversity and Moroccan affinities". English. In: Geological Magazine 155.4 (2018), pp. 811-840. DOI: 10.1017/S001675681600100X.

[5016] C. Cronier and P. Boursicot. "A new decapod crustacean faunule from the Middle Jurassic of north-west France". English. In: Palaeontology 52 (2009), pp. 1275-1289. 
[5017] C. Cronier and P. Courville. "A Rich and Highly Endemic Decapod Crustacean Fauna From the Middle Jurassic of North-East France". English. In: Palaeontology 47.4 (2004), pp. 999-1014.

[5018] C. Cronier and P. Courville. "New xiphosuran merostomata from the Upper Carboniferous of the Graissessac Basin (Massif Central, France)". English. In: Comptes Rendus Palevol 4 (2005), pp. 125133. DOI: $10.1016 /$ j.crpv.2004.11.002.

[5019] C. Cronier, M. Oudot, C. Klug, and K. Baets. "Trilobites from the Red Fauna (latest Emsian, Devonian) of Hamar Laghdad, Morocco and their biodiversity". English. In: Neues Jahrbuch für Geologie und Paläontologie-Abhandlungen 290.1-3 (2018), pp. 241-276. DOI: 10.1127/njgpa/2018/0781.

[5020] K. Crosby and M. Archer. "Durudawirines, a new group of Phalangeroid marsupials from the Miocene of Riversleigh, northwestern Queensland". English. In: Journal of Paleontology 74.2 (2000), pp. 327-335.

[5021] R. W. Crosskey. "On the nominal species of blackfly fossils from the Baltic amber (Diptera: Simuliidae)". English. In: Entomologist's Gazette 53 (2002), pp. 37-50.

[5022] A. R. I. Cruickshank. "A juvenile plesiosaur (Plesiosauria: Reptilia) from the Lower Lias (Hettangian: Lower Jurassic) of Lyme Regis, England: a pliosauroid-plesiosauroid intermediate?" English. In: Zoological Journal of the Linnean Society 112 (1994), pp. 151-178.

[5023] A. R. I. Cruickshank. "Cranial anatomy of the Lower Jurassic pliosaur Rhomaleosaurus megacephalus (Stutchbury) (Reptilia: Plesiosauria)". English. In: Philosophical Transactions of the Royal Society of London B 343 (1994), pp. 247-260.

[5024] A. R. I. Cruickshank and R. E. Fordyce. "A new marine reptile (Sauropterygia) from New Zealand: further evidence for a Late Cretaceous Austral radiation of cryptoclidid plesiosaurs". English. In: Palaeontology 45.3 (2002), pp. 557-575.

[5025] A. R. I. Cruickshank and J. A. Long. "A new species of pliosaurid reptile from the Early Cretaceous Birdrong Sandstone of Western Australia". English. In: Records of the Western Australian Museum 18 (1997), pp. 263-276.

[5026] A. R. I. Cruickshank, D. M. Martill, and L. F. Noe. "A pliosaur (Reptilia, Sauropterygia) exhibiting pachyostosis from the Middle Jurassic of England". English. In: Journal of the Geological Society of London 153 (1996), pp. 873-879.

[5027] L. E. Cruz. "Biostratigraphy and geochronology of the late Cenozoic of Córdoba Province (central Argentina)". English. In: Journal of South American Earth Sciences 42 (2013), pp. 250-259.

[5028] L. E. Cruz, J. C. Fernicola, and C. A. Carignano. "New Vertebrates of the Brochero Formation (Córdoba, Argentina): A Review of the Pliocene of Central Argentina". English. In: Journal of Mammalian Evolution 25 (2018), pp. 315-326. DOI: 10.1007/s10914-017-9390-0.

[5029] L. E. Cruz, J. C. Fernicola, C. A. Carignano, and M. S. Bargo. “Asociaciones Faunsticas del Cuaternario de San Francisco, Provincia de Córdoba, Argentina. Implicancias Bioestratigráficas y Taxonómicas". Spanish. In: Ameghiniana 49.4 (2012), pp. 642-656. DOI: 10.5710/AMGH.27.11.2011.516.

[5030] L. E. Cruz, M. Zamorano, and G. J. Scillato-Yané. "Diagnosis and redescription of Panochthus subintermedius Castellanos (Xenarthra, Glyptodontia) from the Ensenadan (early-middle Pleistocene) of Buenos Aires (Argentina)". English. In: Palaontologische Zeitschrift 85 (2011), pp. 115123. DOI: $10.1007 / \mathrm{s} 12542-010-0084-7$.

[5031] P. Cruzado-Caballero, J. I. Canudo, and J. I. Ruiz-Omeñaca. "Nuevas evidencias de la presencia de hadrosaurios lambeosaurinos (Dinosauria) en el Maastrichiense superior de la Pennsula Ibérica (Arén, Huesca) (New evidence of the presence of lambeosaurine hadrosaurs (Dinosauria) in the upper Maastrichtian of the Iberian Peninsula (Arén, Huesca)]". Spanish. In: Geogaceta 38 (2005), pp. 47-50.

[5032] P. Cruzado-Caballero, J. I. Canudo, and J. I. Ruiz-Omeñaca. Los dinosaurios hadrosaurios (Ornithischia: Ornithopoda) del Maastrichtiense superior (Cretácico Superior) de Arén (Huesca, España) [The hadrosaurian dinosaurs (Ornithischia: Ornithopoda) from the upper Maastrichtian (Upper Cretaceous) of Arén (Huesca, Spain)]. Spanish. 2007. 
[5033] P. Cruzado-Caballero and J. I. Canudo. Biodiversidad de los dinosaurios hadriosaurios de Blasi 1 y 3, Maastrichtiense superior (Cretácico Superior, Arén, Huesca) [Biodiversity of hadrosaurian dinosaurs from Blasi 1 and 3, upper Maastrichtian (Upper Cretaceous, Arén, Huesca)]. Spanish. 2007.

[5034] P. Cruzado-Caballero, J. M. Gasca, L. S. Filippi, I. A. Cerda, and A. C. Garrido. “A new ornithopod dinosaur from the Santonian of northern Patagonia (Rincón de los Sauces, Argentina)". English. In: Cretaceous Research 98 (2019), pp. 211-229.

[5035] P. Cruzado-Caballero, X. Pereda-Suberbiola, and J. I. Ruiz-Omeñaca. “Blasisaurus canudoi gen. et sp. nov., a new lambeosaurine dinosaur (Hadrosauridae) from the latest Cretaceous of Arén (Huesca, Spain)". English. In: Canadian Journal of Earth Sciences 47 (2010), pp. 1507-1517. DOI: 10. 1139/E10-081.

[5036] P. Cruzado-Caballero and J. E. Powell. "Bonapartesaurus rionegrensis, a new hadrosaurine dinosaur from South America: implications for phylogenetic and biogeographic relations with North America". English. In: Journal of Vertebrate Paleontology 37.2 (2017), e1289381:1-16. DOI: 10.1080 / 02724634.2017.1289381.

[5037] P. Cruzado-Caballero, E. Puértolas-Pascual, J. I. Canudo, D. Castanera, J. M. Gasca, and M. MorenoAzanza. New hadrosaur remains from the Late Maastrichtian of Huesca (NE Spain). English. Vol. 20. 10th Annual Meeting of the European Association of Vertebrate Palaeontologists. Teruel: afundamental!, 2012, pp. 45-48.

[5038] P. Cruzado-Caballero, J. I. Ruiz-Omenaca, R. Gaete, V. Riera, R. Oms, and J. I. Canudo. “A new hadrosaurid dentary from the latest Maastrichtian of the Pyrenees (north Spain) and the high diversity of the duck-billed dinosaurs of the Ibero-Armorican Realm at the very end of the Cretaceous". English. In: Historical Biology (2013).

[5039] G. Csázár and D. Turnsek. "Vestiges of atoll-like formations in the Lower Cretaceous of the Mecsek Mountains , Hungary". In: Cretaceous Research 17 (1996), pp. 419-442.

[5040] Z. Csiki, V. Codrea, C. Jipa-Murzea, and P. Godefroit. “A partial titanosaur (Sauropoda, Dinosauria) skeleton from the Maastrichtian of Nalat-Vad, Hateg Basin, Romania". English. In: Neues Jahrbuch für Geologie und Paläontologie Abhandlungen 258.3 (2010), pp. 297-324. DOI: 10.1127 / 0077-7749 / 2010/0098.

[5041] Z. Csiki and D. Grigorescu. A new theropod from Tustea: are there oviraptorosaurs in the Upper Cretaceous of Europe? English. 2005.

[5042] Z. Csiki and D. Grigorescu. "Small theropods from the Late Cretaceous of the Hateg Basin (Western Romania) - an unexpected diversity at the top of the food chain". English. In: Oryctos 1 (1998), pp. 87-104.

[5043] Z. Csiki, A. Ionescu, and D. Grigorescu. "The Budurone microvertebrate site from the Maastrichtian of the Hateg Basin - flora, fauna, taphonomy and paleoenvironment". English. In: Acta Palaeontologica Romaniae 6 (2008), pp. 49-66.

[5044] Z. Csiki, M. Vremir, S. L. Brusatte, and M. A. Norell. "An aberrant island-dwelling theropod dinosaur from the Late Cretaceous of Romania". English. In: Proceedings of the National Academy of Sciences 107.35 (2010), pp. 15357-15361. DOI: 10.1073/pnas.1006970107.

[5045] Z. Csiki-Sava, S. L. Brusatte, and S. Vasile. "Megalosaurus cf. superbus from southeastern Romania: the oldest known Cretaceous carcharodontosaurid (Dinosauria: Theropoda) and its implications for earliest Cretaceous Europe-Gondwana connections". English. In: Cretaceous Research 60 (2016), pp. 221-238. DOI: 10.1016/j.cretres.2015.12.004.

[5046] Z. Csiki-Sava, M. Vremir, J. Meng, S. L. Brusatte, and M. A. Norell. “Dome-headed, small-brained island mammal from the Late Cretaceous of Romania". English. In: Proceedings of the National Academy of Sciences 115.19 (2018), pp. 4857-4862.

[5047] G. Csillag, T. Budai, L. Gyalog, and L. Koloszár. "Contribution to the upper Triassic geology of the Keszthely Mountains (Transdanubian Range), western Hungary". English. In: Acta Geologica Hungarica 38.2 (1995), pp. 111-129. 
[5048] F. Cuadrelli, A. E. Zurita, P. Toriño, Á R. Miño-Boilini, D. Perea, C. A. Luna, D. D. Gillette, and O. Medina. "A new species of glyptodontine (Mammalia, Xenarthra, Glyptodontidae) from the Quaternary of the Eastern Cordillera, Bolivia: phylogeny and palaeobiogeography". English. In: Journal of Systematic Palaeontology 18.18 (2020), pp. 1543-1566. DOI: 10.1080/14772019.2020.1784300.

[5049] F. Cuadrelli, A. E. Zurita, P. Toriño, A. R. Miño-Boilini, S. Rodrguez-Bualó, D. Perea, and G. E. Acuña Suárez. "Late Pleistocene Glyptodontinae (Mammalia, Xenarthra, Glyptodontidae) from southern South America: a comprehensive review". English. In: Journal of Vertebrate Paleontology e1525390 (2019), pp. 1-18.

[5050] G. Cuenca and J. I. Canudo. "Les micromammiféres de l'Oligocéne supérieur des calcaires de Hinojosa de Jarque (Montalban-Aliaga, Teruel, Espangne)". French. In: Geobios 27.3 (1994), pp. 353384.

[5051] G. Cuenca-Bescós, O. Amo, J. L. Barco, J. I. Canudo, R. Royo-Torres, and J. I. Ruiz-Omeñaca. “Dinosaurios de Aragón [Dinosaurs of Aragon]". Spanish. In: Zuba 17 (1999), pp. 235-257.

[5052] G. Cuenca-Bescos, A. Badiola, J. I. Canudo, J. M. Gasca, and M. Moreno-Azanza. “New dryolestidan mammal from the Hauterivian-Barremian transition of the Iberian Peninsula". English. In: Acta Palaeontologica Polonica 56.2 (2011), pp. 257-267. DOI: 10.4202/app.2009.0157.

[5053] G. Cuenca-Bescós and J. I. Canudo. "A new gobiconodontid mammal from the Early Cretaceous of Spain and its palaeogeographic implications". English. In: Acta Palaeontologica Polonica 48.4 (2003), pp. 575-582.

[5054] G. Cuenca-Bescos, J. I. Canudo, J. M. Gasca, M. Moreno-Azana, and R. L. Cifelli. "Spalacotheriid 'symmetrodonts' from the Early Cretaceous of Spain". English. In: Journal of Vertebrate Paleontology 34.6 (2014), pp. 1427-1436.

[5055] G. Cuenca-Bescos, C. Laplana, and J. I. Canudo. "Biochronological implications of the Arvicolidae (Rodentia, Mammalia) from the Lower Pleistocene hominid-bearing level of Trinchera Dolina 6 (TD6, Atapuerca, Spain)". English. In: Journal of Human Evolution 37.3-4 (1999), pp. 353-373.

[5056] M. A. Cuesta. "Los Lophiodontidae (Perissodactyla, Mammalia) del Eoceno de la Cuenca del Duero (Castilla y Leon, España)". Spanish. In: Stvdia Geologica Salmanticensia 29 (1994), pp. 2365.

[5057] M. A. Cuesta. "Los Palaeotheriidae (Perissodactyla, Mammalia) del Eoceno de la Cuenca del Duero (Castilla y Leon, Espana)". Spanish. In: Estudios Geológicos 49 (1993), pp. 87-109.

[5058] M. A. Cuesta and A. Badiola. "Duerotherium sudrei gen. et sp. nov., a new anoplotheriine artiodactyl from the Middle Eocene of the Iberian Peninsula". English. In: Journal of Vertebrate Paleontology 29.1 (2009), pp. 303-308.

[5059] M. A. Cuesta Ruiz-Colmenares. "Presencia de Leptotheridium (Dacrytheriidae, Artiodactyla, Mammalia) en el yacimiento Eocenico de Caenes (Cuenca del Duero, Salamanca, España)". Spanish. In: Studia Geologica Salmanticensia 34 (1998), pp. 69-78.

[5060] M. A. Cuesta Ruiz-Colmenares. “Los Plagiolophinae (Remy, 1976) nuevo rango (Perissodactyla, Mammalia) del Eoceno de la Cuenca del Duero (Castilla y Leon, España)". Spanish. In: Estudios Geológicos 50 (1994), pp. 253-279.

[5061] M. A. Cuesta Ruiz-Colmenares. "Primeros hallazgos de Lophiodontidae (Perissodactyla, Mammalia) en el yacimiento eocénico de Mazaterón (Cuenca del Duero)". Spanish. In: Stvdia Geologica Salmanticensia 32 (1996), pp. 39-48.

[5062] M. A. Cuesta Ruz-Colmenares, L. Checa Soler, and L. Casanovas Cladellas. "Artiodáctilos del yacimiento de Sosss (Eoceno superior, Cuenca Prepirenaica, Pennsula Ibérica)". Spanish. In: Revista Española de Paleontologa 21.2 (2006), pp. 123-144.

[5063] D. N. Cuevas, C. E. Sherman, W. Ramirez, and D. K. Hubbard. "Coral growth rates from the Holocene Canada Honda fossil reef, southwestern Dominican Republic: comparisons with modern counterparts in high sedimentation settings". English. In: Caribbean Journal of Science 45.1 (2009), pp. 94-109. 
[5064] R. J. Cuffey, M. J. Di Nardo-Magilton, and B. J. Herzing. Dinosaur footprints in the basal Navajo Sandstone (Lower Jurassic) at Pipe Spring Naitonal Monument, northwestern Arizona. English. Vol. 3. In V. L. Santucci \& L. McClelland (eds.), National Park Service Geologic Resources Division Technical Report NPS/NRGRD/GRDTR-98/01. National Park Service Paleontological Research Volume. 1998, pp. 149-151.

[5065] R. J. Cuffey, J. D. Inners, G. M. Fleeger, R. C. Smith II, J. C. Neubaum, R. C. Keen, L. Butts, H. L. Delano, V. r A. Neubaum, and R. H. Howe. Geology of the Gettysburg battlefield: how Mesozoic events and processes impacted American history. English. Vol. 8. Excursions in Geology and History: Field Trips in the Middle Atlantic States. Geological Society of America Field Guide. 2006, pp. 1-16. DOI: 10.1130/2006.fld008(01).

[5066] Y. Cui, O. Béthoux, K. D. Klass, and D. Ren. “The Jurassic Bajanzhargalanidae (Insecta: Grylloblattida?): New genera and species, and data on postabdominal morphology". English. In: Arthropod Structure \& Development 44 (2015), pp. 688-716.

[5067] Y. Cui, D. Ren, and O. Béthoux. “The Pangean journey of 'south forestflies' (Insecta: Plecoptera) revealed by their first fossils". English. In: Journal of Systematic Palaeontology 17 (2018), pp. 255-268.

[5068] Y. Y. Cui. "New data on the Blattogryllidae-Plesioblattogryllidae-Grylloblattidae complex (Insecta: Grylloblattida: Blattogryllopterida tax. n.)" English. In: Arthropod Systematics \& Phylogeny 70 (2012), pp. 167-180.

[5069] Y. Y. Cui, O. Béthoux, and D. Ren. "Intraindividual variability in Sinonamuropteridae forewing venation (Grylloblattida; Late Carboniferous): taxonomic and nomenclatural implications". English. In: Systematic Entomology 36 (2011), pp. 44-56.

[5070] Y. Y. Cui, O. Béthoux, C. K. Shih, and D. Ren. "A new species of the family Juraperlidae (Insecta: Grylloblattida) from the Middle Jurassic of China". English. In: Acta Geologica Sinica 84.4 (2010), pp. 710-713.

[5071] Y. Y. Cui, O. Béthoux, B. Kondratieff, C. K. Shih, and D. Ren. "The first fossil salmonfly (Insecta: Plecoptera: Pteronarcyidae), back to the Middle Jurassic". English. In: BMC Evolutionary Biology 16.217 (2016), pp. 1-14.

[5072] Y. Y. Cui, Z. T. Chen, and M. S. Engel. “New species of webspinners (Insecta: Embiodea) from mid-Cretaceous amber of northern Myanmar". English. In: Cretaceous Research 113.104457 (2020). DOI: $10.1016 /$ j.cretres.2020.104457.

[5073] Y. Y. Cui, S. Y. Storozhenko, and D. Ren. "New and little-known species of Geinitziidae (Insecta: Grylloblattida) from the Middle Jurassic of China, with notes on taxonomy, habitus and habitat of these insects". English. In: Alcheringa 36 (2012), pp. 251-261.

[5074] J. I. Cuitiño, M. R. Buono, M. Viglino, N. D. Farroni, and S. Bessone. "Factors affecting the preservation and distribution of cetaceans in the lower T Miocene Gaiman Formation of Patagonia, Argentina". English. In: Palaeogeography, Palaeoclimatology, Palaeoecology 526 (2019), pp. 110-125. DOI: 10.1016/j.palaeo.2019.03.013.

[5075] J. I. Cuitiño, S. F. Vizcano, M. S. Bargo, and I. Aramenda. "Sedimentology and fossil vertebrates of the Santa Cruz formation (early Miocene) in Lago Posadas, southwestern Patagonia, Argentina". English. In: Andean Geology 46.2 (2019), pp. 383-420. DOI: 10.5027/andgeoV46n2-3128.

[5076] B. M. Culik. "Review of small cetaceans: Distribution, behaviour, migration and threats". English. In: Marine Mammal Action Plan/Regional Seas Reports and Studies 177 (2004), p. 343.

[5077] T. M. Cullen, F. Fanti, C. Capobianco, M. J. Ryan, and D. C. Evans. "A vertebrate microsite from a marine-terrestrial transition in the Foremost Formation (Campanian) of Alberta, Canada, and the use of faunal assemblage data as a paleoenvironmental indicator". English. In: Palaeogeography, Palaeoclimatology, Palaeoecology 444 (2016), pp. 101-114. DOI: 10.1016/j.palaeo.2015.12.015.

[5078] S. J. Culver, J. E. Repetski, J. Pojeta Jr., and D. Hunt. "Early and Middle (?) Cambrian metazoan and protistan fossils from West Africa". In: Journal of Paleontology 70.1 (1996), pp. 1-6. 
[5079] S. L. Cumbaa, C. Schröder-Adams, R. G. Day, and A. J. Phillips. Cenomanian bonebed faunas from the northeastern margin, Western Interior Seaway. English. Vol. 35. Late Cretaceous Vertebrates from the Western Interior. New Mexico Museum of Natural History and Science Bulletin. 2006, pp. 139155.

[5080] N. R. Cúneo, M. A. Gandolfo, M. C. Zamaloa, and E. Hermsen. "Late Cretaceous Aquatic Plant World in Patagonia, Argentina". English. In: PlosOne 9.8 (2014), e104749. DOI: 10.1371/journal. pone.0104749.

[5081] N. R. Cúneo, E. J. Hermsen, and M. A. Gandolfo. “Regnellidium (Salviniales, Marsileaceae) macrofossils and associated spores from the Late Cretaceous of South America". English. In: PloSOne 174.3 (2013), pp. 340-349.

[5082] R. Cuneo. "La tafoflora de la Formacion Mojon de Hierro (Grupo Tepuel) en la localidad Arroyo Garrido, Paleozoico Superior, Provincia de Chubut". Spanish. In: Ameghiniana 27 (1990), pp. 225238.

[5083] R. Cunéo and M. A. Gandolfo. "Angiosperm leaves from the Kachaike Formation, Lower Cretaceous of Patagonia, Argentina". English. In: Review of Palaeobotany and Palynology 136 (2005), pp. 29-47. DOI: 10.1016/j.revpalbo.2005.04.003.

[5084] G. O. Cunha, R. Santucci, M. B. Andrade, and C. E. Maia Oliveira. “Description and phylogenetic relationships of a large-bodied sphagesaurid notosuchian from the Upper Cretaceous Adamantina Formation, Bauru Group, São Paulo, southeastern Brazil". English. In: Cretaceous Research (2019). DOI: 10.1016/j.cretres.2019.104259.

[5085] P. P. Cunha, O. Mateus, and M. T. Antunes. The sedimentology of the Paimogo dinosaur nest site (Portugal, Upper Jurassic). English. 2004.

[5086] G. Cuny. "Discovery of Mammals in the Upper Triassic of the Jura (France)". English. In: Lucas, S.G. and Morales, M. eds.: The Nonmarine Triassic. New Mexico Museum of Natural History E Science Bulletin 3 (1993), pp. 95-99.

[5087] G. Cuny, A. M. Cobbett, F. J. Meunier, and M. J. Benton. "Vertebrate microremains from the Early Cretaceous of southern Tunisia". English. In: Geobios 43 (2010), pp. 615-628.

[5088] G. Cuny and P. M. Galton. "Revision of the Airel theropod dinosaur from the Triassic-Jurassic boundary (Normany, France)". In: Neues Jahrbuch für Geologie und Paläontologie, Abhandlungen 187.3 (1993), pp. 261-288.

[5089] G. Cuny, F.-X. Gauffre, and A. Hunt. "First discovery of a cynodont from the Moenkopi Formation (Middle Triassic) of northeastern Arizona". English. In: Oryctos 2 (1999), pp. 17-20.

[5090] G. Cuny, A. Hunt, J. Mazin, and R. Rauscher. "Teeth of enigmatic neoselachian sharks and an ornithischian dinosaur from the uppermost Triassic of Lons-le-Saunier (Jura, France)". English. In: Paläontologische Zeitschrift 74.1/2 (2000), pp. 171-185.

[5091] G. Cuny, J.-J. Jaeger, M. Mahboubi, and J. -C. Rage. “Les plus anciens serpents (Reptilia, Squamata) connus. Mise au point sur l'age géologique des serpents de la partie moyenne du Crétacé". French. In: Comptes rendus des séances de l'Académie des Sciences 311 (1990), pp. 1267-1272.

[5092] G. Cuny, J. B. Kristensen, and L. Stemmerik. "First record of Lagarodus (Chondrichthyes: Euchondrocephali) from the Carboniferous of Svalbard, Arctic Norway". English. In: Norwegian Journal of Geology 96 (2016), pp. 1-5.

[5093] G. Cuny, C. Laojumpon, O. Cheychiw, and K. Lauprasert. "Fossil vertebrate remains from Kut Island (Gulf of Thailand, Early Cretaceous)". English. In: Cretaceous Research 31 (2010), pp. 415423. DOI: $10.1016 /$ j.cretres.2010.05.007.

[5094] G. Cuny, M. Martin, R. Rauscher, and J. Mazin. "A new neoselachian shark from the Upper Triassic of Grozon (Jura, France)". English. In: Geological Magazine 135.5 (1998), pp. 657-668.

[5095] G. Cuny, O. Rieppel, and P. M. Sander. "The shark fauna from the Middle Triassic (Anisian) of north-western Nevada". English. In: Zoological Journal of the Linnean Society 133 (2001), pp. 285301. 
[5096] G. Cuny and S. Risnes. "The Enameloid Microstructure of the Teeth of Synechodontiform Sharks (Chondrichthyes: Neoselachii)". English. In: PalArch 3.2 (2005), pp. 9-19.

[5097] G. Cuny and L. Stemmerik. "New fossil fish microremains from the Upper Carboniferous of eastern North Greenland". English. In: Bulletin of the Geological Society of Denmark 66 (2018), pp. 4760.

[5098] G. Cuny, V. Suteethorn, S. Kamha, and E. Buffetaut. "Hybodont sharks from the Lower Cretaceous Khok Kruat Formation of Thailand, and hybodont diversity during the Early Cretaceous". English. In: Geological Society Special Publications 295 (2008), pp. 93-107.

[5099] G. Cuny, V. Suteethorn, S. Kamha, E. Buffeteut, and M. Philippe. "A new hybodont shark assemblage from the Lower Cretaceous of Thailand". English. In: Historical Biology 18.1 (2006), pp. 2131.

[5100] F. P. Cuozzo. "Dental variation and temporal change in early Eocene Hyopsodus (Mammalia, Condylarthra) from the Powder River Basin, Wyoming". English. In: PaleoBios 22.2 (2002), pp. 19.

[5101] C. D. Cupello, D. D. Bermúdez-Rochas, D. M. Martill, and P. M. Brito. "The hybodontiformes (Chondrichthyes: Elasmobranchii from the Missão Velha Formation (? Lower Cretaceous) of the Araripe Basin, north-east Brazil". English. In: Comptes Rendus Palevol 11 (2012), pp. 41-47. DOI: 10.1016/j.crpv.2011.09.005.

[5102] M. L. Cupper and J. Duncan. "Last glacial megafaunal death assemblage and early human occupation at Lake Menindee, southeastern Australia". English. In: Quaternary Research 66.2 (2006), pp. 332-341. DOI: 10.1016/j.yqres.2006.06.004.

[5103] G. R. Curler, W. Krzemiski, and K. Skibiska. “The first record of fossil Horaiellinae (Diptera: Psychodidae) from mid-Cretaceous amber of northern Myanmar". English. In: Cretaceous Research 98 (2019), pp. 305-315. DOI: 10.1016/j.cretres.2019.02.005.

[5104] D. Curnoe, X. Ji, A. I. R. Herries, K. Bai, P. S. C. Taçon, Z. Bao, D. Fink, Y. Zhu, J. Hellstrom, Y. Luo, G. Cassis, B. Su, S. Wroe, S. Hong, W. C. H. Parr, S. Huang, and N. Rogers. "Human remains from the Pleistocene-Holocene transition of southwest China suggest a complex evolutionary history for East Asians". English. In: PLoS ONE 7.3 (2012), e31918. DOI: 10.1371/journal.pone.0031918.

[5105] P. Currie. "ETE reference number 1703". English. In: (1994).

[5106] P. J. Currie. "Possible evidence of gregarious behavior in tyrannosaurids". English. In: Gaia 15 (2000), pp. 271-277.

[5107] P. J. Currie. History of research. English. Dinosaur Provincial Park: A Spectacular Ancient Ecosystem Revealed. Indiana University Press, Bloomington. 2005, pp. 3-33.

[5108] P. J. Currie. "Dinosaurs of the Gobi: Following in the footsteps of the Polish-Mongolian Expeditions". English. In: Palaeontologia Polonica 67 (2016), pp. 83-100. DOI: 10.4202/pp.2016.67_083.

[5109] P. J. Currie and Y. Azuma. "New specimens, including a growth series, of Fukuiraptor (Dinosauria, Theropoda) from the Lower Cretaceous Kitadani Quarry of Japan". English. In: Journal of the Paleontological Society of Korea 22.1 (2006), pp. 173-193.

[5110] P. J. Currie, D. Badamgarav, and E. B. Koppelhus. "The first Late Cretaceous footprints from the Nemegt locality in the Gobi of Mongolia". English. In: Ichnos 10 (2003), pp. 1-12. DOI: 10.1080 / 10420940390235071.

[5111] P. J. Currie and K. Carpenter. "A new specimen of $<\mathrm{i}>$ Acrocanthosaurus atokensis $</ i>$ (Theropoda, Dinosauria) from the Lower Cretaceous Antlers Formation (Lower Cretaceous, Aptian) of Oklahoma, USA". In: Geodiversitas 22.2 (2000), pp. 207-246.

[5112] P. J. Currie and D. A. Eberth. "Palaeontology, sedimentology and palaeoecology of the Iren Dabasu Formation (Upper Cretaceous), Inner Mongolia, People's Republic of China". In: Cretaceous Research 14 (1993), pp. 127-144. 
[5113] P. J. Currie, S. J. Godfrey, and L. Nessov. “New caenagnathid (Dinosauria, Theropoda) specimens from the Upper Cretaceous of North America and Asia". English. In: Canadian Journal of Earth Sciences 30.10-11 (1994), pp. 2255-2272.

[5114] P. J. Currie and A. R. Jacobsen. "An azhdarchid pterosaur eaten by a velociraptorine theropod". English. In: Canadian Journal of Earth Sciences 32 (1995), pp. 922-925.

[5115] P. J. Currie and E. B. Koppelhus. "Implications of finding a ceratopsian horncore in the Danek bonebed". English. In: Canadian Journal of Earth Sciences 51 (2014), pp. 1034-1038. DOI: 10.1139/ cjes-2014-0065.

[5116] P. J. Currie, G. C. Nadon, and M. G. Lockley. "Dinosaur footprints with skin impressions from the Cretaceous of Alberta and Colorado". English. In: Canadian Journal of Earth Sciences 28 (1991), pp. 102-115.

[5117] P. J. Currie and A. Paulina Carabajal. "A new specimen of Austroraptor cabazai, Pol, Canale, Porfiri and Calvo, 2008 (Dinosauria, Theropoda, Unenlagiidae) from the latest Cretaceous (Maastrichtian) of Ro Negro, Argentina". English. In: Ameghiniana 49.4 (2012), pp. 662-667. DOI: 10 . 5710/AMGH.30.8.2012.574.

[5118] P. J. Currie and J.-H. Peng. "A juvenile specimen of Saurornithoides mongoliensis from the Upper Cretaceous of northern China". English. In: Canadian Journal of Earth Sciences 30.10-11 (1994), pp. 2224-2230.

[5119] P. J. Currie, J. K. Rigby Jr., and R. E. Sloan. Theropod teeth from the Judith River Formation of southern Alberta, Canada. English. In K. Carpenter and P. J. Currie (eds.), Dinosaur Systematics: Perspectives and Approaches. Cambridge University Press, Cambridge. 1990, pp. 107-125.

[5120] P. J. Currie and D. A. Russell. The geographic and stratigraphic distribution of articulated and associated dinosaur remains. English. Dinosaur Provincial Park: A Spectacular Ancient Ecosystem Revealed. Indiana University Press, Bloomington. 2005, pp. 537-569.

[5121] P. J. Currie and D. J. Varricchio. A new dromaeosaurid from the Horseshoe Canyon Formation (Upper Cretaceous) of Alberta, Canada. English. Feathered Dragons. Indiana University Press, Bloomington. 2004, pp. 112-132.

[5122] P. J. Currie and X.-J. Zhao. "A new carnosaur (Dinosauria, Theropoda) from the Jurassic of Xinjiang, People's Republic of China". English. In: Canadian Journal of Earth Sciences 30.10-11 (1994), pp. 2037-2081.

[5123] G. B. Curry. "Original shell colouration in late Pleistocene terebratulid brachiopods from New Zealand". English. In: Palaeontologia Electronica 2.2 (1999), pp. 1-31.

[5124] K. Curry Rogers and J. A. Wilson. "Vahiny depereti, gen. et sp. nov., a new titanosaur (Dinosauria, Sauropoda) from the Upper Cretaceous Maevarano Formation, Madagascar". English. In: Journal of Vertebrate Paleontology 34.3 (2014), pp. 606-617.

[5125] K. A. Curry Rogers and C. A. Forster. "The skull of Rapteosaurus krausei (Sauropoda: Titanosauria) from the Late Cretaceous of Madagascar". In: Journal of Vertebrate Paleontology 24.1 (2004), pp. 121144.

[5126] K. A. Curry Rogers and C. A. Forster. "The last of the dinosaur titans: a new sauropod from Madagascar". English. In: Nature 412 (2001), pp. 530-534.

[5127] K. Curtis and K. Padian. "An Early Jurassic microvertebrate fauna from the Kayenta Formation of northeastern Arizona: microfaunal change across the Triassic-Jurassic boundary". English. In: PaleoBios 19.2 (1999), pp. 19-37.

[5128] N. J. Curtis and P. D. Lane. "The Llandovery trilobites of England and Wales. Part 1". English. In: Monograph of the Palaeontographical Society 151 (1997), pp. 1-50.

[5129] M. Cusack, A. Williams, and J. O. Buckman. "Chemico-structural evolution of linguloid brachiopod shells". English. In: Palaeontology 52.5 (1999), pp. 799-840. DOI: 10.1111/1475-4983.00098. 
[5130] R. S. Cuthbertson and R. B. Holmes. "A new species of Plioplatecarpus (Mosasauridae, Plioplatecarpinae) from the Bearpaw Formation (Campanian, Upper Cretaceous) of Montana, USA". English. In: Journal of Vertebrate Paleontology 35.3 (2015), e922980:1-18. DOI: 10.1080 / 02724634.2014. 922980.

[5131] R. S. Cuthbertson, J. C. Mallon, N. E. Campione, and R. B. Holmes. "A new species of mosasaur (Squamata: Mosasauridae) from the Pierre Shale (lower Campanian) of Manitoba". English. In: Canadian Journal of Earth Sciences 44 (2007), pp. 593-606.

[5132] R. S. Cuthbertson, A. P. Russell, and J. S. Anderson. “Cranial morphology and relationships of a new grippidian (Ichthyopterygia) from the Vega-Phroso Siltstone Member (Lower Triassic) of British Columbia, Canada". English. In: Journal of Vertebrate Paleontology 33.4 (2013), pp. 831-847. DOI: $10.1080 / 02724634.2013 .755989$.

[5133] R. S. Cuthbertson, A. P. Russell, and J. S. Anderson. “The first substantive evidence of Utatsusaurus (Ichthyopterygia) from the Sulphur Mountain Formation (Lower-Middle Triassic) of British Columbia, Canada: a skull roof description in comparison with other early taxa". English. In: Canadian Journal of Earth Sciences 51.2 (2014), pp. 180-185. DOI: 10.1139/cjes-2013-0185.

[5134] N. J. Czaplewski. "The Verde Local Fauna: Small vertebrate fossils from the Verde Formation, Arizona". English. In: San Bernardino County Museum Association Quarterly 37.3 (1990), pp. 1-39.

[5135] N. J. Czaplewski. "Miocene bats from the lower Valentine Formation of northeastern Nebraska". English. In: Journal of Mammalogy 72.4 (1991), pp. 715-722.

[5136] N. J. Czaplewski. "Late Tertiary bats (Mammalia, Chiroptera) from the southwestern United States". In: Southwestern Naturalist 38.2 (1993), pp. 111-118.

[5137] N. J. Czaplewski. "Pizonyx wheeleri Dalquest and Patrick (Mammalia: Chiroptera) from the Miocene of Texas referred to the genus Antrozous H. Allen". In: Journal of Vertebrate Paleontology 13.3 (1993), pp. 378-380.

[5138] N. J. Czaplewski. "Opossums (Didelphidae) and bats (Noctilionidae and Molossidae) from the late Miocene of the Amazon Basin". English. In: Journal of Mammalogy (1996).

[5139] N. J. Czaplewski. "A glyptodont (Mammalia, Xenarthra) from northern Oklahoma". English. In: Oklahoma Geology Notes 64.1-4 (2004), pp. 4-10.

[5140] N. J. Czaplewski. "Miocene Vertebrates From Ogallala Formation Sites in Western Oklahoma". English. In: Neogene Mammals (New Mexico Museum of Natural History and Science Bulletin) 44 (2008), pp. 1-14.

[5141] N. J. Czaplewski, B. E. Bailey, and R. G. Corner. "Tertiary bats (Mammalia: Chiroptera) from northern Nebraska". English. In: Transactions of the Nebraska Academy of Sciences 25 (1999), pp. 8393.

[5142] N. J. Czaplewski and K. E. Campbell. "A possible bat (Mammalia: Chiroptera) from the ?Eocene of Amazonian Peru". English. In: Natural History Museum of Los Angeles County, Science Series 40 (2004), pp. 141-144.

[5143] N. J. Czaplewski, J. I. Mead, C. J. Bell, W. D. Peachey, and T. -L. Ku. "Papago Springs Cave revisited, part II: vertebrate paleofauna". English. In: Occasional Papers of the Oklahoma Museum of Natural History 5 (1999), pp. 1-41.

[5144] N. J. Czaplewski and G. S. Morgan. “A new vespertilionid bat (Mammalia: Chiroptera) from the Early Miocene (Hemingfordian) of Florida". English. In: Journal of Vertebrate Paleontology 20.4 (2001), pp. 736-742.

[5145] N. J. Czaplewski and W. D. Peachey. "Late Pleistocene bats from Arkenstone Cave, Arizona". English. In: Southwestern Naturalist 48.4 (2003), pp. 597-609.

[5146] N. J. Czaplewski, J. Person, C. Boyd, and R. J. Emry. "A new species of bat (Chiroptera: Vespertilionidae) from the early Oligocene global cooling period, Brule Formation, North Dakota, USA". English. In: Palaeo Vertebrata 42.2 (2019). 
[5147] N. J. Czaplewski, W. L. Puckette, and C. Russell. “A Pleistocene tapir and associated mammals from the southwestern Ozark Highland". English. In: 64.2 (2002), pp. 97-107.

[5148] N. J. Czaplewski, A. D. Rincón, and G. S. Morgan. "Fossil bat (Mammalia: Chiroptera) remains from Inciarte tar pit, Sierra de Perijá, Venezuela." English. In: Caribbean Journal of Science 41.4 (2005), pp. 768-781.

[5149] N. J. Czaplewski, M. Takai, T. M. Naeher, N. Shigehara, and T. Setoguchi. “Additional bats from the middle Miocene La Venta fauna of Colombia". English. In: Revista de la Academia Colombiana de Ciecias exactas, fsicas y naturales 27.103 (2003), pp. 263-282.

[5150] S. A. Czerkas and Q. Ji. A new rhamphorhynchoid with a headcrest and complex integumentary structures. English. Feathered Dinosaurs and the Origin of Flight, The Dinosaur Museum, Blanding. 2002, pp. 15-41.

[5151] S. A. Czerkas and Q. Ji. A preliminary report on an omnivorous volant bird from northeast China. English. Feathered Dinosaurs and the Origin of Flight. The Dinosaur Museum Journal 1. The Dinosaur Museum, Blanding, UT. 2002, pp. 127-135.

[5152] S. A. Czerkas and X. Xu. A new toothed bird from China. English. Feathered Dinosaurs and the Origin of Flight. The Dinosaur Museum Journal, Volume 1. The Dinosaur Museum, Blanding, UT. 2002, pp. 43-61.

[5153] S. A. Czerkas and C. Yuan. An arboreal maniraptoran from northeastern China. English. Feathered Dinosaurs and the Origin of Flight. The Dinosaur Museum Journal 1. The Dinosaur Museum, Blanding, UT. 2002, pp. 63-95.

[5154] S. A. Czerkas, D. Zhang, J. Li, and Y. Li. Flying dromaeosaurs. English. Feathered Dinosaurs and the Origin of Flight. The Dinosaur Museum Journal 1. The Dinosaur Museum, Blanding, UT. 2002, pp. 96-126.

[5155] A. Czylok. "Two representatives of the genus Mindarus (Homoptera, Aphidoidea, Mindaridae) in Baltic amber". English. In: Annalen des Naturhistorischen Museums in Wien, Serie A 92 (1991), pp. 73-77.

[5156] M. D'Emic, J. A. Wilson, and T. E. Williamson. "A sauropod dinosaur pes from the latest Cretaceous of North America and the validity of Alamosaurus sanjuanensis (Sauropoda, Titanosauria)". English. In: Journal of Vertebrate Paleontology 31.5 (2011), pp. 1072-1079. DOI: 10.1080 / 02724634. 2011.595856.

[5157] M. D. D'Emic. "Revision of the sauropod dinosaurs of the Lower Cretaceous Trinity Group, southern USA, with the description of a new genus". English. In: Journal of Systematic Palaeontology 11.6 (2013), pp. 707-726. DOI: 10.1080/14772019.2012.667446.

[5158] M. D. D'Emic. “The early evolution of titanosauriform sauropod dinosaurs". English. In: Zoological Journal of the Linnean Society 166 (2012), pp. 624-671.

[5159] M. D. D'Emic and B. Z. Foreman. “The beginning of the sauropod dinosaur hiatus in North America: insights from the Lower Cretaceous Cloverly Formation of Wyoming". English. In: Journal of Vertebrate Paleontology 32.4 (2012), pp. 883-902. DOI: 10.1080/02724634.2012.671204.

[5160] M. D. D'Emic, B. Z. Foreman, and N. A. Jud. “Anatomy, systematics, paleoenvironment, growth, and age of the sauropod dinosaur Sonorasaurus thompsoni from the Cretaceous of Arizona, USA". English. In: Journal of Paleontology 90.1 (2016), pp. 102-132. DOI: 10.1017/jpa.2015.67.

[5161] M. D. D'Emic and J. R. Foster. "The oldest Cretaceous North American sauropod dinosaur". English. In: Historical Biology 28.4 (2016), pp. 470-478. DOI: 10.1080/08912963.2014.976817.

[5162] M. D. D’Emic, P. D. Mannion, P. Upchurch, R. B. J. Benson, Q. Pang, and Z. Cheng. “Osteology of Huabeisaurus allocotus (Sauropoda: Titanosauriformes) from the Upper Cretaceous of China". English. In: PLoS One 8.8 (2013), e69375. DOI: 10.1371/journal.pone.0069375.

[5163] M. D. D'Emic, J. A. Wilson, and S. Chatterjee. “The titanosaur (Dinosauria: Sauropoda) osteoderm record: review and first definitive specimen from India". English. In: Journal of Vertebrate Paleontology 29.1 (2009), pp. 165-177. DOI: 10.1671/039.029.0131. 
[5164] M. D. D'Emic, J. A. Wilson, and R. Thompson. “The end of the sauropod dinosaur hiatus in North America". English. In: Palaeogeography, Palaeoclimatology, Palaeoecology 297 (2010), pp. 486-490.

[5165] S. D'Orazi Porchetti, U. Nicosia, P. Mietto, F. M. Petti, and M. Avanzini. “Atreipus-like footprints and their co-occurrence with Evazoum from the upper Carnian (Tuvalian) of Trentino-Alto Adige". English. In: Studi Trentini di Scienze Naturali, Acta Geologica 83 (2008), pp. 277-287.

[5166] S. D'Orazi Porchetti, U. Nicosia, A. Biava, and S. Maganuco. “New abelisaurid material from the Upper Cretaceous (Cenomanian) of Morocco". English. In: Rivista Italiana di Paleontologia e Stratigrafia 117.3 (2011), pp. 463-472.

[5167] A. A. S. da Rosa, C. Schwanke, J. C. Cisneros, L. W. Neto, P. L. P. Aurelio, and M. Poitevin. "Stio Cortado - uma nova assembléia fossilfera para o Triássico Médio do sul do Brasil". Portugese. In: Revista Brasileira de Paleontologia 7 (2004), pp. 289-300.

[5168] A.-C. Da Silva and F. Boulvain. "Sedimentology, Magnetic Susceptibility and Isotopes of a Middle Frasnian Carbonate Platform: Tailfer Section, Belgium". In: Facies 49 (2002), pp. 89-102.

[5169] A.-C. Da Silva, S. Kershaw, and F. Boulvain. "Sedimentology and stromatoporoid palaeoecology of Frasnian (Upper Devonian) carbonate mounds in southern Belgium". English. In: Lethaia 44 (2011), pp. 255-274.

[5170] C. M. da Silva, M. Cachão, A. C. Rebelo, M. E. Johnson, B. G. Baarli, A. Santos, and E. J. Mayoral. "Paleoenvironment and taphonomy of lower Miocene bivalve". English. In: Facies (2019). DOI: 10.1007/s10347-018-0550-3.

[5171] C. M. da Silva, B. Landau, R. Doménech, and J. Martinell. "Pliocene Atlantic molluscan assemblages from the Mondego Basin (Portugal): Age and palaeoceanographic implications". English. In: Palaeogeography, Palaeoclimatology, Palaeoecology 285 (2010), pp. 248-254.

[5172] P. A. Da Silva, V. H. Borba, J. M. F. Dutra, D. Leles, A. A. S. Da-Rosa, L. F. Ferreira, and A. Araujo. "A new ascarid species in cynodont coprolite dated of 240 million years". English. In: Anais da Academia Brasileira de Ciencias 86 (2014), pp. 265-269.

[5173] R. C. da Silva, R. Barboni, T. Dutra, M. M. Godoy, and R. B. Binotto. “Footprints of large theropod dinosaurs and implications on the age of Triassic biotas from Southern Brazil". English. In: Journal of South American Earth Sciences (2012).

[5174] R. C. da Silva, I.d.S. Carvalho, and A. C. S. Fernandes. "Pegadas de dinossauros do Triássico (Formação Santa Maria) do Brasil [Dinosaur footprints from the Triassic (Santa Maria Formation) of Brazil]". Portugese. In: Ameghiniana 45.4 (2008), pp. 783-790.

[5175] R. C. da Silva, F. A. Sedor, and A. C. S. Fernandes. "Fossil footprints from the Late Permian of Brazil: An example of hidden biodiversity". English. In: Journal of South American Earth Sciences 38 (2012), pp. 31-43. DOI: 10.1016/j.jsames.2012.05.001.

[5176] R. da Silva Santos. “Clupeiformes e Gonorhynchiformes do Cretaceo Inferior (Aptiano) da Formacao Cabo, nordeste do Brasil. Lower Cretaceous (Aptian) Clupeiformes and Gonorhynchiformes from Cabo Formation, northeastern Brazil". Portugese. In: Anais da Academia Brasileira de Ciencias 62.3 (1990), pp. 261-268.

[5177] W. Da-Ning and Z. Ying-Niang. "Late Cretaceous to Tertiary palynofloras in Xinjiang and Qinghai, China". English. In: Review of Palaeobotany and Palynology 65 (1990), pp. 9-104. DOI: 10.1016/00346667(90)90060-V.

[5178] A. A. S. da-Rosa, G. Pineiro, S. Dias-da-Silva, J. C. Cisneros, F. F. Feltrin, and L. W. Neto. "Bica São Tomé, um novo stio fossilfero para o Triássico inferior do sul do Brasil". Portugese. In: Revista Brasileira de Paleontologia 12 (2009), pp. 67-76.

[5179] R. Daams. "Hypsodont Myomiminae (Gliridae, Rodentia) from the Miocene and the OligoceneMiocene boundary interval of Spain." English. In: Scripta Geologica 95 (1991), pp. 1-62.

[5180] R. Daber. "Arachnidenrest aus dem Westfal D von Zwickau-Oelsnitz". German. In: Zeitschrift für Geologische Wissenschaften 18 (1990), pp. 679-682. 
[5181] E. B. Daeschler. "Early tetrapod jaws from the Late Devonian of Pennslyvania". English. In: Journal of Paleontology 74 (2000), pp. 301-308. DOI: 10.1666/0022-3360(2000)074<0301:ETJFTL>2.0.CO;2.

[5182] E. B. Daeschler and J. P. Downs. "New description and diagnosis of Hyneria lindae (Sarcopterygii, Tristichopteridae) from the Upper Devonian Catskill Formation in Pennsylvania, U.S.A." English. In: Journal of Vertebrate Paleontology 38.3 (2018), e1448834. DOI: 10.1080/02724634.2018.1448834.

[5183] E. B. Daeschler, N. H. Shubin, and F. A. Jenkins Jr. "A Devonian tetrapod-like fish and the evolution of the tetrapod body plan". English. In: Nature 440 (2006), pp. 757-763.

[5184] E. B. Daeschler, N. H. Shubin, K. S. Thomson, and W. W. Amaral. "A Devonian Tetrapod from North America”. English. In: Science 265.5172 (1994), pp. 639-642. DOI: 10.1126/science.265.5172. 639.

[5185] A. S. Dagis and S. P. Ermakova. "Early Olenekian ammonoids of Siberia". Russian. In: Trudy Akademiya Nauk SSSR 737 (1990), pp. 1-112.

[5186] A. Dagys. "A new late Olenekian (Triassic) ammonoid of low palaeolatitude affinity from Arctic Asia (Eastern Taimyr)". English. In: Paläontologische Zeitschrift 71 (1997), pp. 217-220.

[5187] A. Dagys and S. Ermakov. "Induan (Triassic) ammonoids from north-east Asia". In: Revue de Paleobiologie 15.2 (1996), pp. 401-447.

[5188] A. S. Dagys and A. G. Konstantinov. "A revision of the Nathorstitidae (Ammonoidea) from Northeastern Asia". English. In: Paleontological Journal 31.5 (1997), pp. 478-488.

[5189] A. S. Dagys and W. Weitschat. "Extensive intraspecific variation in a Triassic ammonoid from Siberia". English. In: Lethaia 26 (1993), pp. 113-121. DOI: 10.1111/j.1502-3931.1993.tb01801.x.

[5190] E. L. Dahlberg, J. J. Eberle, J. J. W. Sertich, and I. M. Miller. "A new earliest Paleocene (Puercan) mammalian fauna from Colorado's Denver Basin, U.S.A". English. In: Rocky Mountain Geology 51.1 (2016), pp. 1-22. DOI: 10.2113/gsrocky.51.1.1.

[5191] P. Dahlqvist and S. M. Bergstrom. "The lowermost Silurian of Jamtland, Central Sweden: Conodont biostratigraphy, correlation and biofacies". English. In: Earth and Environmental Science Transactions of The Royal Society of Edinburgh 96.1 (2005), pp. 1-19. DOI: 10.1017/S0263593300001218.

[5192] P. Dahlqvist, D. A. T. Harper, and L. Wickström. "Late Ordovician shelly faunas from Jämtland: palaeocommunity development along the margin of the Swedish Caledonides". English. In: Bulletin of Geosciences 85.3 (2010), pp. 505-512. DOI: 10.3140/bull.geosci.1175.

[5193] A. Dahoumane, A. Nedjari, R. At-Ouali, P. Taquet, R. Vacant, and J. -S. Steyer. "A new Mastodonsauroid Temnospondyl from the Triassic of Algeria: Implications for the biostratigraphy and palaeoenvironments of the Zarzatine Series, northern Sahara". English. In: Comptes Rendus Palevol 15.8 (2016), pp. 918-926. DOI: 10.1016/j.crpv.2015.09.005.

[5194] H. Dai, R. Benson, X. Hu, C. Tan, N. Li, M. Xiao, H. Hu, Y. Zhou, Z. Wei, F. Zhang, S. Jiang, D. Li, G. Peng, Y. Yu, and X. Xu. "A new possible megalosauroid theropod from the Middle Jurassic Xintiangou Formation of Chongqing, People's Republic of China and its implication for early tetanuran evolution". English. In: Scientific Reports 10 (2020), p. 139.

[5195] T. Dai and X. Zhang. "Morphology and ontogeny of the Eodiscoid Trilobite Sinodiscus Changyangensis from the Lower Cambrian of South China". English. In: Palaeontology 56.Part 2 (2013), pp. 411-420.

[5196] T. Dai and X. Zhang. "Ontogeny of the trilobite Estaingia sinensis (Chang) from the lower Cambrian of South China". English. In: Bulletin of Geosciences 87.1 (2012), pp. 151-158.

[5197] T. Dai, X. Zhang, and S. Peng. "Morphology and ontogeny of Hunanocephalus ovalis (trilobite) from the Cambrian of South China". English. In: Gondwana Research 25 (2014), pp. 991-998.

[5198] X. Dai, H. Song, P. B. Wignall, E. Jia, R. Bai, F. Wang, J. Chen, and L. Tian. “Rapid biotic rebound during the late Griesbachian indicates heterogeneous recovery patterns after the Permian-Triassic mass extinction". English. In: GSA Bulletin 130 (2018), pp. 2015-2030. DOI: 10.1130/B31969.1. 
[5199] X. Dai, H. J. Song, A. Brayard, and D. Ware. “A new Griesbachian-Dienerian (Induan, Early Triassic) ammonoid fauna from Gujiao, South China". English. In: Journal of Paleontology 93 (2019), pp. $48-71$.

[5200] C. Dal Sasso. “Dinosaurs of Italy". English. In: Comptes Rendus Palevol 2 (2003), pp. 45-66.

[5201] C. Dal Sasso, G. Insacco, A. A. Chiarenza, D. Di Franco, and A. Reitano. "First record of Ichthyosaurs in Sicily (Upper Triassic of Monte Scalpello, Catania province)". English. In: Rivista Italiana di Paleontologia e Stratigrafia 120.1 (2014), pp. 71-82.

[5202] C. Dal Sasso, S. Maganuco, E. Buffetaut, and M. A. Mendez. "New information on the skull of the enigmatic theropod Spinosaurus, with remarks on its size and affinities". English. In: Journal of Vertebrate Paleontology 25.4 (2005), pp. 888-896.

[5203] C. Dal Sasso and S. Maganuco. "Scipionyx samniticus (Theropoda: Compsognathidae) from the Lower Cretaceous of Italy: osteology, ontogenetic assessment, phylogeny, soft tissue anatomy, taphonomy and palaeobiology". English. In: Memorie della Societá Italiana di Scienze Naturali e del Museo Civio di Storia Naturales di Milano 37.1 (2011), pp. 1-281.

[5204] C. Dal Sasso, S. Maganuco, and A. Cau. "The oldest ceratosaurian (Dinosauria: Theropoda), from the Lower Jurassic of Italy, sheds light on the evolution of the three-fingered hand of birds". English. In: PeerJ 6 (2018), e5976:1-78. DOI: 10.7717/peerj.5976.

[5205] C. Dal Sasso and G. Pasini. "First record of pterosaurs (Diapsida, Archosauromorpha, Pterosauria) in the Middle Jurassic of Madagascar". English. In: Atti della Societa Italiana di Scienze Naturali e del Museo Civico di Storia Naturale in Milano 144 (2003), pp. 281-296.

[5206] C. Dal Sasso, G. Pierangelini, F. Famiani, A. Cau, and U. Nicosia. "First sauropod bones from Italy offer new insights on the radiation of Titanosauria between Africa and Europe". English. In: Cretaceous Research 64 (2016), pp. 88-109.

[5207] C. Dal Sasso and M. Signore. "Exceptional soft-tissue preservation in a theropod dinosaur from Italy". In: Nature 392 (1996), pp. 383-387.

[5208] M. L. Dalebout, J. G. Mead, C. S. Baker, A. N. Baker, and A. L. van Helden. "A new species of beaked whale Mesoplodon perrini sp. n. (Cetacea: Ziphiidae) discovered through phylogenetic analyses of mitochondrial DNA sequences". English. In: Marine Mammal Science 18.3 (2002), pp. 577-608.

[5209] M. L. Dalebout, G. J. B. Ross, C. S. Baker, R. C. Anderson, P. B. Best, V. G. Cockcroft, H. L. Hinsz, V. Peddemores, and R. L. Pitman. "Appearance, distribution, and genetic distinctivenss of Longman's beaked whale, Indopacetus pacificus". English. In: Marine Mammal Science 19.3 (2003), pp. 421-461.

[5210] A. C. Daley and G. E. Budd. "New anomalocaridid appendages from the Burgess Shale, Canada". English. In: Palaeontology 53.4 (2010), pp. 721-738. DOI: 10.1111/j.1475-4983.2010.00955.x.

[5211] A. C. Daley and J. S. Peel. "A Possible Anomalocaridid from the Cambrian Sirius Passet Lagerstätte, North Greenland". English. In: Journal of Paleontology 84.2 (2010), pp. 352-355.

[5212] P. E. J. Daley. "The first solute which is attached as an adult: a Mid-Cambrian fossil from Utah with echinoderm and chordate affinities". English. In: Zoological Journal of the Linnean Society 117.4 (1996), pp. 405-440.

[5213] F. M. Dalla Vecchia. "Remains of Sauropoda (Reptilia, Saurischia) in the Lower Cretaceous (Upper Hauterivian/Lower Barremian) limestones of SW Istria (Croatia)". In: Geologica Croatica 51.2 (1998), pp. 105-134.

[5214] F. M. Dalla Vecchia. "A sauropod footprint in a limestone block from the Lower Cretaceous of northeastern Italy". In: Ichnos 6.4 (1997), pp. 269-275.

[5215] F. M. Dalla Vecchia. "Atlas of the sauropod bones from the Upper Hauterivian-Lower Barremian of Bale/Valle (SW Istria, Croatia)". English. In: Natura Nascosta 18 (1999), pp. 6-41.

[5216] F. M. Dalla Vecchia. "A vertebra of a large sauropod dinosaur from the Lower Cretaceous of Istria (Croatia)". English. In: Natura Nascosta 22 (2001), pp. 14-33. 
[5217] F. M. Dalla Vecchia. “Triassic Park: impronte di dinosauri nelle Prealpi Carniche (Claut, Andreis, Cimolais, provincia di Pordenone [Triassic Park: dinosaur footprints in the Carnic pre-Alps (Claut, Andreis, Pordenone province)]". Italian. In: Natura Nascosta 16 (1998), pp. 40-45.

[5218] F. M. Dalla Vecchia. Jurassic and Cretaceous sauropod evidence in the Mesozoic carbonate platforms of the southern Alps and Dinarids. English. Vol. 10. Aspects of Sauropod Paleobiology. GAIA. 1995, pp. 65-73.

[5219] F. M. Dalla Vecchia. "Telmatosaurus and the other hadrosaurids of the Cretaceous European Archipelago. An overview". English. In: Natura Nascosta 32 (2006), pp. 1-55.

[5220] F. M. Dalla Vecchia. Between Gondwana and Laurasia: Cretaceous sauropods in an intraoceanic carbonate platform. English. Thunder-Lizards: The Sauropodomorph Dinosaurs. Indiana University Press, Bloomington. 2005, pp. 395-429.

[5221] F. M. Dalla Vecchia. "Second record of a site with dinosaur skeletal remains in Libya (northern Africa)". English. In: Natura Nascosta 11 (1995), pp. 16-21.

[5222] F. M. Dalla Vecchia. "I dinosauri in Italia: stato delle conoscenze [Dinosaurs in Italy: state of knowledge]". Italian. In: Natura Nascosta 11 (1995), pp. 29-35.

[5223] F. M. Dalla Vecchia. "An odd dinosaur bone from the Lower Cretaceous of Istria (Croatia)". English. In: Natura Nascosta 22 (2001), pp. 34-35.

[5224] F. M. Dalla Vecchia. "An Eudimorphodon (Diapsida, Pterosauria) specimen from the Norian (Late Triassic) of north-eastern Italy". English. In: Gortania - Atti del Museo Friulano di Storia Naturale 25 (2004), pp. 47-72.

[5225] F. M. Dalla Vecchia. "A caudal segment of a Late Triassic pterosaur (Diapsida, Pterosauria) from north-eastern Italy". English. In: Gortania - Atti del Museo Friulano di Storia Naturale 23 (2002), pp. 31-58.

[5226] F. M. Dalla Vecchia. New morphological observations on Triassic pterosaurs. English. Vol. 217. E. Buffetaut and J.-M. Mazin, eds., Evolution and Palaeobiology of Pterosaurs. Geological Society, London, Special Publications. 2003, pp. 23-44.

[5227] F. M. Dalla Vecchia. "A wing phalanx of a large basal pterosaur (Diapsida, Pterosauria) from the Norian (Late Triassic) of NE Italy". English. In: Bollettino della Societa Paleontologica Italiana 39.2 (2000), pp. 229-234.

[5228] F. M. Dalla Vecchia. "A new pterosaur (Reptilia, Pterosauria) from the Norian (Late Triassic) of Friuli (northeastern Italy). Preliminary note". English. In: Gortania - Atti del Museo Friulano di Storia Naturale 16 (1995), pp. 59-66.

[5229] F. M. Dalla Vecchia. "A review of the Triassic pterosaur record". English. In: Rivista del Museo Civico di Scienze Naturali E. Caffi Bergamo 22 (2003), pp. 13-29.

[5230] F. M. Dalla Vecchia. "The tetrapod fossil record from the Norian-Rhaetian of Friuli (northeastern Italy)". English. In: vol. 37. The Triassic-Jurassic Terrestrial Transition. New Mexico Museum of Natural History \& Science Bulletin. Albuquerque: New Mexico Museum of Natural History and Science, 2006, pp. 432-444.

[5231] F. M. Dalla Vecchia. "Dinosaur track sites in the upper Cenomanian (Late Cretaceous) of Istrian Peninsula (Croatia)". English. In: Bollettino della Societá Geologica Italiana 40.1 (2001), pp. 25-53.

[5232] F. M. Dalla Vecchia. "Cearadactylus? ligabuei nov. sp., a new early Cretaceous (Aptian) pterosaur from Chapada do Araripe (Northeastern Brazil)". English. In: Bollettino della Societá Paleontologica Italiana 32.3 (1993), pp. 401-409.

[5233] F. M. Dalla Vecchia. "Tethyshadros insularis, a new hadrosauroid dinosaur (Ornithischia) from the Upper Cretaceous of Italy". English. In: Journal of Vertebrate Paleontology 29.4 (2009), pp. 11001116.

[5234] F. M. Dalla Vecchia. "The first Italian specimen of Austriadactylus cristatus (Diapsida, Pterosauria) from the Norian (Upper Triassic) of the Carnic Prealps". English. In: Rivista Italiana di Paleontologia e Stratigrafia 115.3 (2009), pp. 291-304. 
[5235] F. M. Dalla Vecchia. "Archosaurian trackways in the upper Carnian of Dogna Valley (Udine, Friuli, NE Italy)". English. In: Natura Nascosta 20 (1996), pp. 5-17.

[5236] F. M. Dalla Vecchia. "Note sulla stratigrafia, sedimentologia e paleontologia della Dolomia di Forni (Triassico Superiore) nella Valle del Rio Seazza (Preone, Friuli-Venezia Giulia) [Note on the stratigraphy, sedimentology, and paleontology of the Dolomia di Forni (Upper Triassic) of the Rio Seazza Valley (Preone, Friuli-Venezia Giulia)]". English. In: Gortania - Atti del Museo Friulano di Storia Naturale 12.90 (1991), pp. 7-30.

[5237] F. M. Dalla Vecchia. “Un viaggio geo-paleontologico in Marocco". English. In: Natura Nascosta 30 (2005), pp. 16-44.

[5238] F. M. Dalla Vecchia. "Telmatosaurus and the other hadrosauroids of the Cretaceous European Archipelago. An update". English. In: Natura Nascosta 39 (2009), pp. 1-18.

[5239] F. M. Dalla Vecchia. "A new sauropterygian reptile with plesiosaurian affinity from the Late Triassic of Italy". English. In: Rivista Italiana di Paleontologia e Stratigrafia 112.2 (2006), pp. 207-225.

[5240] F. M. Dalla Vecchia. "A new petalodont tooth (Chondrichthyes, Petalodontiformes) from the Lower Permian of the Carnic Alps (Friuli, NE Italy)". English. In: Bollettino della Societá Paleontologica Italiana 39.2 (2000), pp. 225-228.

[5241] F. M. Dalla Vecchia. "Triassic pterosaurs". English. In: vol. 379. Anatomy, Phylogeny and Palaeobiology of Early Archosaurs and their Kin. Geological Society, London, Special Publications. 2013. DOI: $10.1144 /$ SP379.14.

[5242] F. M. Dalla Vecchia. "Theropod footprints in the Cretaceous Adriatic-Dinaric carbonate platform". English. In: Gaia 15 (2000), pp. 355-367.

[5243] F. M. Dalla Vecchia. "Terrestrial tetrapod evidence on the Norian (Late Triassic) and Cretaceous carbonate platforms of northern Adriatic region (Italy, Slovenia and Croatia)". English. In: Sargetia, Acta Musei Devensis, Series Scientia Naturae 17 (1997), pp. 177-201.

[5244] F. M. Dalla Vecchia. "An overview of the latest Cretaceous hadrosauroid record in Europe". English. In: Hadrosaurs. Bloomington: Indiana University Press, 2014, pp. 268-297.

[5245] F. M. Dalla Vecchia. "Terrestrial ecosystems on the Mesozoic peri-Adriatic carbonate platforms: the vertebrate evidence". English. In: VII International Symposium on Mesozoic Terrestrial Ecosystems. Asociación Paleontologa Argentina, Publicación Especial 7 (2001), pp. 77-83.

[5246] F. M. Dalla Vecchia. "First record of Simosaurus (Sauropterygia, Nothosauroidea) from the Carnian (Late Triassic) of Italy". English. In: Rivista Italiana di Paleontologia e Stratigrafia 114.2 (2008), pp. 273-285.

[5247] F. M. Dalla Vecchia. "First record of the rare marine reptile Tholodus schmidi from the Middle Triassic of the Southern Alps". English. In: Rivista Italiana di Paleontologia e Stratigrafia 110.2 (2004), pp. 479-492.

[5248] F. M. Dalla Vecchia. "Tremp, la vallata degli ultimi dinosauri [Tremp, the valley of the last dinosaurs]". Italian. In: Natura Nascosta 40 (2010), pp. 7-40.

[5249] F. M. Dalla Vecchia. "Seazzadactylus venieri gen. et sp. nov., a new pterosaur (Diapsida: Pterosauria) from the Upper Triassic (Norian) of northeastern Italy". English. In: PeerJ 7.e7363 (2019). DOI: 10.7717 / peerj.7363.

[5250] F. M. Dalla Vecchia. "The unusual tail of Tethyshadros insularis (Dinosauria, Hadrosauroidea) from the Adriatic Island of the European archipelago". English. In: Rivista Italiana di Paleontologia e Stratigrafia 126.3 (2020), pp. 583-628.

[5251] F. M. Dalla Vecchia, P. Arduini, and A. W. A. Kellner. "The first pterosaur from the Cenomanian (Late Cretaceous) Lagerstätten of Lebanon". English. In: Cretaceous Research 22 (2001), pp. 219-225.

[5252] F. M. Dalla Vecchia and A. Cau. "The first record of a notosuchian crocodyliform from Italy". English. In: Rivista Italiana di Paleontologia e Stratigrafia 117.2 (2011), pp. 309-321.

[5253] F. M. Dalla Vecchia and A. Cau. "Re-examination of the purported pterosaur wing metacarpals from the Upper Triassic of England". English. In: Historical Biology 27.6 (2015), pp. 684-696. 
[5254] F. M. Dalla Vecchia, R. Gaete, V. Riera, O. Oms, A. Prieto-Márquez, B. Vila, A. Garcia Sellés, and A. Galobart. "The hadrosaurid record in the Maastrichtian of the eastern Tremp Syncline (Northern Spain)". English. In: Hadrosaurs. Bloomington: Indiana University Press, 2014, pp. 298-314.

[5255] F. M. Dalla Vecchia and G. Muscio. "Mesozoic Lagerstaetten of the Friuli-Venezia Giulia region (NE Italy)". English. In: Rivista del Museo Civio di Scienzi Naturali E. Caffi 20.suppl. (1999), pp. 7174.

[5256] F. M. Dalla Vecchia, V. Riera, J. O. Oms, J. Dinares-Turell, R. Gaete, and A. Galobart. "The last pterosaurs: first record from the uppermost Maastrichtian of the Tremp Syncline (northern Spain)". English. In: Acta Geologica Sinica 87.5 (2013), pp. 1198-1227.

[5257] F. M. Dalla Vecchia and P. A. Selden. "A Triassic spider from Italy". English. In: Acta Palaeontologica Polonica 58 (2013), pp. 325-330.

[5258] F. M. Dalla Vecchia, A. Tarlo, M. Tentor, G. Tunis, and S. Venturini. First record of Hauterivian dinosaur footprints in southern Istria (Croatia). English. Proceedings of the 2nd Croatian Geological Congress, Cavtat-Dubrovnik, May 17-20, 2000. Zagreb. 2000, pp. 143-149.

[5259] F. M. Dalla Vecchia and S. Venturini. "The Middle Cenomanian Lagerstaette of Al Nammoura (Kesrouane Caza, N. Lebanon)". English. In: Rivista del Museo Civio di Scienzi Naturali E. Caffi 20.suppl. (1999), pp. 75-77.

[5260] F. M. Dalla Vecchia, S. Venturini, and M. Tentor. "The Cenomanian (Late Cretaceous) KonservatLagerstätte of en Nammoura (Kesrouane Province), northern Lebanon". English. In: Bollettino della Societá Geologica Italiana 41.1 (2002), pp. 51-68.

[5261] F. M. Dalla Vecchia, R. Wild, H. Hopf, and J. Reitner. "A crested rhamphorhynchoid pterosaur from the Late Triassic of Austria". English. In: Journal of Vertebrate Paleontology 22.1 (2002), pp. 196199.

[5262] M. Dalla Vecchia and M. Avanzini. "New findings of isolated remains of Triassic reptiles from Northeastern Italy". English. In: Bollettino della Societa Paleontologica Italiana 42.2-3 (2002), pp. 215235.

[5263] S. Dalman and P. Getty. A study of small dinosaur footprints (Anomoepus) from the Early Jurassic Gary Gaulin tracksite, Holyoke, MA. English. 2003.

[5264] S. G. Dalman. "New examples of Tyrannosaurus rex from the Lance Formation of Wyoming, United States". English. In: Bulletin of the Peabody Museum of Natural History 54.2 (2013), pp. 241254. DOI: $10.3374 / 014.054 .0202$.

[5265] S. G. Dalman. "New data on small theropod dinosaurs from the Upper Jurassic Morrison Formation of Como Bluff, Wyoming, USA". English. In: Volumina Jurassica 12.2 (2014), pp. 181-196.

[5266] S. G. Dalman, J.-P. M. Hodnett, A. J. Lichtig, and S. G. Lucas. "A new ceratopsid dinosaur (Centrosaurinae: Nasutoceratopsini) from the Fort Crittenden Formation, Upper Cretaceous (Campanian) of Arizona". English. In: New Mexico Museum of Natural History and Science Bulletin 79 (2018), pp. 141-164.

[5267] W. W. Dalquest and J. A. Baskin. "Mammals of the Elm Creek Local Fauna, Late Pleistocene of Beaver County, Oklahoma". English. In: American Midland Naturalist 127 (1992), pp. 13-20.

[5268] W. W. Dalquest, J. A. Baskin, and G. E. Schultz. "Fossil mammals from a late Miocene (Clarendonian) site in Beaver County, Oklahoma". English. In: Miscellaneous Publications of the Museum of Natural History, University of Kansas 5 (1996), pp. 107-137.

[5269] W. W. Dalquest, J. V. Grimes, and F. B. Stangle Jr. "Characters of the upper premolar of five species of Dipodomys and evidence for diphyly in the genus". English. In: Southwestern Naturalist 37.3 (1992), pp. 231-246.

[5270] E. Daly. "A list, bibliography and index of the fossil vertebrates of Mississippi". English. In: Mississippi Department of Environmental Quality, Office of Geology Bulletin 128 (1992), pp. 1-47.

[5271] P. Damarco. “I cetacei fossili del Museo Paleontologico Territoriale dell'Astigiano e del Monferrato in Asti”. Italian. In: Museologia Scientifica Memorie 13 (2014), pp. 25-28. 
[5272] S. E. Damborenea. "Middle Jurassic inoceramids from Argentina". English. In: Journal of Paleontology 64.5 (1990), pp. 736-759.

[5273] S. E. Damborenea. "Early Jurassic bivalves of Argentina: Part 3, Superfamilies Monotoidea, Pectinoidea, Plicatuloidea and Dimyoidea". English. In: Palaeontographica Abteilung A 265.1-4 (2002), pp. 1-119.

[5274] S. E. Damborenea and C. M. González-León. "Late Triassic and Early Jurassic bivalves from Sonora, Mexico". In: Revista Mexicana de Ciencias Geológicas 14.2 (1997), pp. 178-201.

[5275] S. E. Damborenea and S. Lanés. "Early Jurassic shell beds from marginal marine environments in southern Mendoza, Argentina". English. In: Palaeogeography, Palaeoclimatology, Palaeoecology 250 (2007), pp. 68-88. DOI: 10.1016/j.palaeo.2007.03.002.

[5276] S. E. Damborenea and H. A. Leanza. "Huncalotis, an enigmatic new pectinoid genus (Bivalvia, Late Jurassic) from South America". English. In: Palaeontologische Zeitschrift 90 (2016), pp. 449-468.

[5277] S. E. Damborenea and M. O. Mancenido. "A comparison of Jurassic marine benthonic faunas from South America and New Zealand". In: Journal of the Royal Society of New Zealand 22.2 (1992), pp. 131-152.

[5278] S. E. Damborenea and M. O. Manceñido. "Late Triassic bivalves and brachiopods from southern Mendoza, Argentina". English. In: Revue de Paléobiologie, Genéve, vol. spéc 11 (2012), pp. 317-344.

[5279] R. Damiani. "A giant skull of the temnospondyl Xenotosuchus africanus from the Middle Triassic of South Africa and its ontogenetic implications". English. In: Acta Palaeontologica Polonica 53.1 (2008), pp. 75-84.

[5280] R. Damiani. "Cranial anatomy and relationships of Microposaurus casei, a temnospondyl from the Middle Triassic of South Africa". English. In: Journal of Vertebrate Paleontology 24.3 (2004), pp. 533541.

[5281] R. Damiani, J. Neveling, J. Hancox, and B. Rubidge. "First trematosaurid temnospondyl from the Lystrosaurus Assemblage Zone of South Africa and its biostratigraphic implications". English. In: Geological Magazine 137.6 (2000), pp. 659-665.

[5282] R. Damiani, J. Neveling, S. Modesto, and A. Yates. "Barendskraal, a diverse amniote locality from the Lystrosaurus assemblage zone, early Triassic of South Africa". English. In: Palaeontologia Africana 39 (2003), pp. 53-62.

[5283] R. Damiani, R. R. Schoch, H. Hellrung, R. Werneburg, and S. Gastou. "The plagiosaurid temnospondyl Plagiosuchus pustuliferus (Amphibia: Temnospondyli) from the Middle Triassic of Germany: anatomy and functional morphology of the skull". English. In: Zoological Journal of the Linnean Society 155 (2009), pp. 348-373.

[5284] R. Damiani, C. A. Sidor, J. S. Steyer, R. M. H. Smith, H. C. E. Larsson, A. Maga, and O. Ide. “The Vertebrate Fauna of the Upper Permian of Niger. V. The Primitive Temnospondyl Saharastega moradiensis". English. In: Journal of Vertebrate Paleontology 26.3 (2006), pp. 559-572.

[5285] R. Damiani, C. Vasconcelos, A. Renaut, J. Hancox, and A. M. Yates. "Dolichuranus primaevus (Therapsida: Anomodontia) from the Middle Triassic of Namibia and its phylogenetic relationships". English. In: Palaeontology 50 (2007), pp. 1531-1546.

[5286] R. J. Damiani. "A systematic revision and phylogenetic analysis of Triassic mastodonsauroids (Temnospondyli: Stereospondyli)". English. In: Zoological Journal of the Linnean Society 133.4 (2001), pp. 379-482. DOI: 10.1006/zjls.2001.0304.

[5287] R. J. Damiani. "Giant temnospondyl amphibians from the Early to Middle Triassic Narrabeen Group of the Sydney Basin, New South Wales, Australia". English. In: Alcheringa 23 (1999), pp. 87109.

[5288] R. J. Damiani. "Temnospondyls from the Beaufort Group (Karoo Basin) of South Africa and their biostratigraphy". English. In: Gondwana Research 7 (2004), pp. 165-173. 
[5289] R. J. Damiani and P. J. Hancox. “New mastodonsaurid temnospondyls from the Cynognathus Assemblage Zone (Upper Beaufort Group; Karoo Basin) of South Africa". English. In: Journal of Vertebrate Paleontology 23.1 (2003), pp. 54-66.

[5290] R. J. Damiani and A. M. Jeannot. "A brachyopid temnospondyl from the Lower Cynognathus Assemblage Zone in the northern Karoo Basin, South Africa". English. In: Palaeontologia africana 38 (2002), pp. 57-69.

[5291] R. J. Damiani and J. W. Kitching. "A new brachyopid temnospondyl from the Cynognathus Assemblage Zone, upper Beaufort Group, South Africa". English. In: Journal of Vertebrate Paleontology 23.1 (2003), pp. 67-78.

[5292] R. J. Damiani, J. Neveling, and P. J. Hancox. "First record of a mastodonsaurid (Temnospondyli, Stereospondyli) from the Early Triassic Lystrosaurus Assemblage Zone (Karoo Basin) of South Africa". English. In: Neues Jahrbuch für Geologie und Paläontologie Abhandlungen 221.1 (2001), pp. 133144.

[5293] R. J. Damiani and B. S. Rubidge. "A review of the South African temnospondyl amphibian record". English. In: Palaeontologia africana 39 (2003), pp. 21-36.

[5294] R. J. Damiani and A. Warren. "A new look at members of the Superfamily Brachyopoidea (Amphibia, Temnospondyli) from the Early Triassic of Queensland and a preliminary analysis of brachyopoid relationships". English. In: Alcheringa 20 (1996), pp. 277-300.

[5295] R. J. Damiani and J. Welman. "A long-snouted trematosaurid amphibian from the Early Triassic of South Africa". English. In: South African Journal of Science 97 (2001), pp. 318-319.

[5296] R. J. Damiani and A. M. Yates. "The Triassic Amphibian Thoosuchus yakovlevi and the Relationships of the Trematosauroidea (Temnospondyli: Stereospondyli)". English. In: Records of the Australian Museum 55 (2003), pp. 331-342.

[5297] T. Danelian. "Palaeo-oceanographic significance of Mid-Jurassic radiolarites from the Maliac (SubPelagonian) margin of Othris (Greece)." In: Bulletin of the Geological Society of Greece 30.2 (1994), pp. 167-175.

[5298] T. Danelian, G. Asatryan, M. Sosson, A. Person, L. Sahakyan, and G. Galoyan. “Discovery of Middle Jurassic (Bajocian) Radiolaria from the sedimentary cover of the Vedi ophiolite (Lesser Caucasus, Armenia)". English. In: Comptes Rendus Palevol 7 (2008), pp. 327-334. DOI: 10.1016/j.crpv. 2008.05.001.

[5299] T. Danelian and F. Baudin. "Découverte d'un horizon carbonaté, rich en matiére organique, au sommet des radiolarites d'Epire (zone ionienne, Gréce): le Membre de Paliambela." French. In: Comptes Rendus de l'Académie des Sciences Paris 311 (1990), pp. 421-428.

[5300] T. Danelian, F. Baudin, S. Gardin, E. Masure, C. Ricordel, I. Fili, T. Mecaj, and K. Mustaq. "The record of mid Cretaceous oceanic anoxic events from the Ionian zone of southern Albania". English. In: Revue de Micropaléontologie 50.3 (2007), pp. 225-237.

[5301] T. Danelian and L. Popov. “Ordovician radiolarian biodiversity: insights based on new and revised data from Kazakhstan". In: Bulletin de la Société géologique de France 174.4 (2003), pp. 325335.

[5302] T. Danelian and A. H. F. Robertson. "Radiolarian evidence for the stratigraphy and palaeo-oceanography of the deep-water passive margin of the Indian Plate (Karamba Formation, Indus Suture Zone, Ladakh Himalya)". English. In: Marine Micropaleontology 30 (1997), pp. 171-195.

[5303] T. Danelian and A. H. F. Robertson. "Palaeogeographic implications of the age of radiolarian-rich sediments in Beotia (Greece)". English. In: Bulletin of the Geological Society of Greece 32.2 (1998), pp. 21-29.

[5304] T. Danelian, H. Tsikos, S. Gardin, F. Baudin, J. -P. Bellier, and L. Emmanuel. “Global and regional palaeoceanographic changes as recorded in the mid-Cretaceous (Aptian-Albian) sequence of the Ionian zone (NW Greece)". In: Journal of the Geological Society 161 (2004), pp. 703-709. 
[5305] E. M. Danielsen and D. J. Over. “Lower Silurian conodonts from the Shine Jinst region, southwestern Mongolia". English. In: Journal of Paleontology 90.1 (2016), pp. 78-91. DOI: 10.1017/jpa.2016.18.

[5306] L. Danilo, J. A. Remy, M. Vianey-Liaud, B. Marandat, J. Sudre, and F. Lihoreau. “A new Eocene locality in southern France sheds light on the basal radiation of Palaeotheriidae (Mammalia, Perissodactyla, Equoidea)". English. In: Journal of Vertebrate Paleontology 33.1 (2013), pp. 195-215.

[5307] I. Danilov. “Gravemys Sukhanov and Narmandakh, 1983 (Testudinoidea: Lindholmemydidae) from the Late Cretaceous of Asia: new data". English. In: PaleoBios 23.3 (2003), pp. 9-19.

[5308] I. Danilov, A. Cernansky, E. V. Syromyatnikova, and P. Joniak. "Fossil turtles of Slovakia: New material and a review of the previous record". English. In: Amphibia-Reptilia 33 (2012), pp. 423442. DOI: $10.1163 / 15685381-00002846$.

[5309] I. G. Danilov. "A new linholmemydid genus (Testudines: Lindholmemydidae) from the midCretaceous of Uzbekistan". English. In: Russian Journal of Herpetology 6.1 (1999), pp. 63-71.

[5310] I. G. Danilov and A. O. Averianov. "A new species of Calamagras Cope 1873 (Serpentes, Boidae, Erycinae) from the early Eocene of Kirghizia." In: Geodiversitas 21.1 (1999), pp. 85-91.

[5311] I. G. Danilov, A. O. Averianov, and A. A. Yarkov. "Itilochelys rasstrigin gen. et sp. nov., a new hard-shelled sea turtle (Cheloniidae sensu lato) from the Lower Palaeocene of Volgograd Province, Russia". English. In: Proceedings of the Zoological Institute RSA 314.1 (2010), pp. 24-41.

[5312] I. G. Danilov, A. O. Averianov, P. P. Skutschas, and A. S. Rezvyi. “Kirgizemys (Testudines, 'Macrobaenidae'): new material from the Lower Cretaceous of Buryatia (Russia) and taxonomic revision". English. In: Russian Journal of Herpetology 1 (2006), pp. 46-62.

[5313] I. G. Danilov and A. O. Averianov. "New data on the turtles from the Early Eocene of Kirghizia". English. In: Russian Journal of Herpetology 4.1 (1997), pp. 40-45.

[5314] I. G. Danilov, Yu.L. Bolotsky, A. O. Averianov, and I. V. Donchenko. "A new genus of lindholmemydid turtle (Testudines: Testudinoidea) from the Late Cretaceous of the Amur River Region, Russia". English. In: Russian Journal of Herpetology 9.2 (2002), pp. 155-168.

[5315] I. G. Danilov, R. Hirayama, V. B. Sukhanov, S. Suzuki, M. Watabe, and N. S. Vitek. "Cretaceous soft-shelled turtles (Trionychidae) of Mongolia: new diversity, records, and a revision". English. In: Journal of Systematic Palaeontology 12.7 (2014), pp. 799-832. DOI: 10.1080/14772019.2013.847870.

[5316] I. G. Danilov, E. M. Obraztsova, E. A. Boitsova, and P. P. Skutchas. "Diversity of Middle Jurassic Turtles from the Berezovsk Quarry Locality, Krasnoyarsk Region, Russia: Morphology and Histological Study". English. In: Paleontological Journal 52.1 (2018), pp. 58-70. DOI: 10.1134/S0031030118010070.

[5317] I. G. Danilov, E. M. Obraztsova, W. Chen, and J. Jin. “The cranial morphology of Anosteira maomingensis (Testudines, Pan-Carettochelys) and the evolution of pan-carettochelyid turtles". English. In: Journal of Vertebrate Paleontology 37.e1335735 (2017), pp. 1-13.

[5318] I. G. Danilov and J. F. Parham. "The type series of 'Sinemys' wuerhoensis, a problematic turtle from the Lower Cretaceous of China, includes at least three taxa". English. In: Palaeontology 50.2 (2007), pp. 431-444. DOI: 10.1111/j.1475-4983.2006.00632.x.

[5319] I. G. Danilov and J. F. Parham. "A reassessment of the referral of an isolated skull from the Late Cretaceous of Uzbekistan to the stem-testudinoid turtle genus Lindholmemys". English. In: Journal of Vertebrate Paleontology 25.4 (2005), pp. 784-791. DOI: 10.1671 / 0272 - 4634(2005) 025[0784: AROTRO]2.0.CO;2.

[5320] I. G. Danilov, V. B. Sukhanov, and E. V. Syromyatnikova. "New Asiatic materials on turtles of the family Adocidae with a review of the adocid record in Asia". English. In: Proceedings of the Zoological Institute, Russian Academy of Sciences 315.2 (2011), pp. 101-132.

[5321] I. G. Danilov and V. B. Sukhanov. "A basal eucryptodiran turtle Sinemys efremovi (= Wuguia efremovi) from the Early Cretaceous of China". English. In: Acta Palaeontologica Polonica 51.1 (2006), pp. 105-110. 
[5322] I. G. Danilov and V. B. Sukhanov. "New data on the lindholmemydid turtle Lindholmemys from the Late Cretaceous of Mongolia". English. In: Acta Palaeontologica Polonica 46.1 (2001), pp. 125131.

[5323] I. G. Danilov and V. B. Sukhanov. "A new basal testudinoid turtle (Testudinoidea: Lindholmemydidae) from the Upper Paleocene of Mongolia". English. In: Paleontological Journal 47.1 (2013), pp. 104-113.

[5324] I. G. Danilov, V. B. Sukhanov, E. M. Obraztsova, and N. S. Vitek. “The First Reliable Record of Trionychid Turtles in the Paleocene of Asia". English. In: Paleontological Journal 49.4 (2015), pp. 407412.

[5325] I. G. Danilov and E. V. Syromyatnikova. "New materials on turtles of the family Nanhsiungchelyidae from the Cretaceous of Uzbekistan and Mongolia, with a review of the Nanhsiungchelyid record in Asia". English. In: Proceedings of the Zoological Institute RAS 312.1/2 (2008), pp. 3-25.

[5326] I. G. Danilov, E. V. Syromyatnikova, P. P. Skutschas, T. M. Kodrul, and J. Jin. “The first true Adocus (Testudines, Adocidae) from the Paleogene of Asia". English. In: Journal of Vertebrate Paleontology 33.5 (2013), pp. 1071-1080.

[5327] I. G. Danilov and N. S. Vitek. "Soft-shelled turtles (Trionychidae) from the Bissekty Formation (Late Cretaceous: late Turonian) of Uzbekistan: shell-based taxa". English. In: Cretaceous Research 41 (2013), pp. 55-64.

[5328] I. G. Danilov, N. S. Vitek, A. O. Averianov, and V. N. Glinskiy. "A new soft-shelled trionychid turtle of the genus Khunnuchelys from the Upper Cretaceous Bostobe Formation of Kazakhstan". English. In: Acta Palaeontologica Polonica 60.1 (2015), pp. 155-161. DOI: 10.4202/app.2013.0045.

[5329] I. G. Danilov and N. S. Vitek. "Cretaceous Trionychids of Asia: An Expanded Review of Their Record and Biogeography". English. In: Morphology and Evolution of Turtles. Springer, 2013, pp. 419-438.

[5330] I. G. Danilov, E. A. Zvonok, E. V. Syromyatnikova, and N. I. Udovichenko. "A new species of soft-shelled turtle (Trionychidae) from the Middle Eocene of Ukraine". English. In: Proceedings of the Zoological Institute RAS 315.4 (2011), pp. 399-411.

[5331] S. Danise and S. Dominici. "A record of fossil shallow-water whale falls from Italy". English. In: Lethaia (2014). DOI: 10.1111/let.12054.

[5332] S. Danise, R. J. Twitchett, C. T. S. Little, and M. E. Clemence. "The Impact of Global Warming and Anoxia on Marine Benthic Community Dynamics: an Example from the Toarcian (Early Jurassic)". English. In: Plos One 8.2 (2013). DOI: 10.1371/journal.pone.0056255.

[5333] M. Danowitz, R. Domalski, and N. Solounias. "A New Species of Prolibytherium (Ruminantia, Mammalia) from Pakistan, and the Functional Implications of an Atypical Atlanto-Occipital Morphology". English. In: Journal of Mammalian Evolution 23.2 (2016), pp. 201-207. DOI: 10.1007 / s10914-015-9307-8.

[5334] M. A. T. Dantas. "Primeiro Registro de Fosseis de Mamiferos Pleistocenicos em Caverna de Sergipe, Brasil". Portugese. In: Revista Brasileira de Paleontologia 12.2 (2009), pp. 161-164.

[5335] M. A. T. Dantas and M. A. L. Tasso. "Megafauna do Pleistoceno final de Vitoria da Conquista, Bahia: taxonomia e aspectos tafonomicos". Portugese. In: Scientia Plena 3.3 (2007), pp. 30-36.

[5336] M. A. T. Dantas and M. H. Zucon. “Occurrence of Catonyx cuvieri (Lund, 1839)(Tardigrada, Scelidotheriinae) in Late Pleistocene-Holocene of Brazil". English. In: Revista Brasileira de Paleontologia 10.2 (2007), pp. 129-132.

[5337] M. A. T. Dantas and M. H. Zucon. "Sobre a Ocorrencia de Fósseis da Megafauna do Plesistoceno Final em Coronel João Sá, Bahia, Brasil”. Portugese. In: Revista Geociencias-UnG 6.1 (2007), pp. 191200.

[5338] M. A. T. Dantas, M. H. Zucon, and A. M. Ribeiro. "Megafauna Pleistocenica da fazenda elefante, Gararu, Sergipe, Brasil”. Portugese. In: Geociencias 24.3 (2005), pp. 277-287. 
[5339] H. Daod. "Carbonate microfacies analysis of Sinjar Formation from Qara Dagh mountains, southwest of Sulaimani city, Kurdistan region, Iraq". English. In: International Journal of Geological and Environmental Engineering 3.10 (2009), pp. 332-342.

[5340] H. Daoud, I. I. Bucur, and C. Bruchental. "Microbialitic structures in the Sarmatian carbonate deposits from Simleu Basin, Romania". English. In: Studia Universitatis Babes-Bolyai, Geologia 51.12 (2006), pp. 3-13.

[5341] H. S. Daoud. "Microfaunal assemblages and microfacies of Nummulitic limestone of Naopurdan Group from Chwarta area, Sulaimaniya governorate, northern Iraq". English. In: Journal of Zankoy Sulaimani 21.1(A) (2019), pp. 61-74.

[5342] G. Darbas and M. Gül. "Ostracoda and Foraminifera assemblages of the Lower-Middle Miocene reefal carbonates within the Deirmençay Area, NW Mersin/S Turkey". English. In: Çukurova University Journal of the Faculty of Engineering and Architecture 34.1 (2019), pp. 91-102.

[5343] R. Darga. Geologie, Paläontologie und Palökologie der südostbayerischen unter-priabonen (Ober-Eozän) Riffkalkvorkommen bei Hallthurm (Nördliche Kalkalpen) und der Kirchbergs bei Neubeuern (Helvetikum). German. 1992.

[5344] R. Darga, M. Böhme, U. B. Göhlich, and G. E. Rössner. “Reste höherer Wirbeltiere aus dem Alttertiär des Alpenvolandes bei Siegsdorf/Oberbayern". German. In: Mitteilungen der Bayerischen Staatssammlung für Paläontologie und Historische Geologie 39 (1999), pp. 91-114.

[5345] D. C. Darling. "A New Species of Spalangiopelta (Hymenoptera; Pteromalidae; Ceinae) from Dominican Amber: Phylogenetic and Biogeographic Implications". English. In: Journal of the Kansas Entomological Society 69.4 (1996), pp. 248-259.

[5346] D. C. Darling and M. J. Sharkey. "Insects from the Santana Formation, Lower Cretaceous, of Brazil. Chapter 7: Order Hymenoptera". English. In: Bulletin of the American Museum of Natural History 195 (1990), pp. 123-153.

[5347] M. K. Darnell and J. R. Thomasson. "First equid remains from the late Miocene Prolithospermum johnstonii-Nassella pohlii assemblage zone stratotype locality, Ellis County, Kansas". English. In: Transactions of the Kansas Academy of Science 110.1-2 (2007), pp. 10-15.

[5348] T. A. Darragh. Gastropoda, Scaphopoda, Cephalopoda, and new Bivalvia of the Paleocene Pebble Point Formation, Victoria, Australia. 1997.

[5349] T. A. Darragh. "A revision of the Australian genus Umbilia (Gastropoda: Cypraeidae)". English. In: Memoirs of the Museum of Victoria 59.2 (2002), pp. 355-392.

[5350] T. A. Darragh. “Campanile (Mollusca: Gastropoda): a new record from the early Miocene of Victoria, Australia". English. In: Alcheringa 26.4 (2002), pp. 501-506. DOI: 10.1080/03115510208619539.

[5351] T. A. Darragh. "A revision of the Australian fossil species of Zoila (Gastropoda: Cypraeidae)". English. In: Memoirs of Museum Victoria 68 (2011), pp. 1-28.

[5352] T. A. Darragh. "Orthochetus (Gastropoda: Cerithiidae) in the Eocene of southern Australia”. English. In: New Zealand Journal of Geology and Geophysics 54.1 (2011), pp. 35-42. DOI: 10.1080 / 00288306.2011.536519.

[5353] T. A. Darragh. "Further Mollusca from the late Eocene Pallinup Formation, Eucla Basin, Western Australia". English. In: Records of the Western Australian Museum 32 (2017), pp. 29-100.

[5354] T. A. Darragh and G. W. Kendrick. "Eocene bivalves and gastropods from the Pallinup Siltstone, Western Australia, with new records from the Eocene and Oligocene of southeastern Australia". English. In: Proceedings of the Royal Society of Victoria 112.1 (2000), pp. 17-58.

[5355] T. A. Darragh and G. W. Kendrick. "Silicified Eocene molluscs from the Lower Murchison district, southern Carnarvon Basin, Western Australia". English. In: Records of the Western Australian Museum 24 (2008), pp. 217-246.

[5356] T. A. Darragh and G. W. Kendrick. "Eocene molluscs from the Merlinleigh Sandstone, Carnarvon Basin, Western Australia". English. In: Records of the Western Australian Museum 26 (2010), pp. 2341. 
[5357] T. A. Darragh. "A revision of the Australian genus Tylospira Harris, 1897 (Gastropoda: Struthiolariidae)". English. In: Alcheringa 15 (1991), pp. 151-175.

[5358] L. Darras, C. Derycke, A. Blieck, and D. Vachard. “The oldest holocephalan (Chondrichthyes) from the Middle Devonian of the Boulonnais (Pas-de-Calais, France)". English. In: 7.5 (2008), pp. 297304. DOI: 10.1016/j.crpv.2008.04.002.

[5359] D. P. Das and P. K. Basu. Study of Palaeogene marine mammals of Kachchh, Guarat. English. 1994.

[5360] D. P. Das, P. K. Basu, and T. C. Lahiri. "Study of Palaeogene marine mammals of Kachchh, Gujarat (Progress Report for the Field Seasons 1989-90, 1990-91 and 1991-92)". English. In: Geological Survey of India Progress Report GSI-CHQ-31 (1993), pp. 1-31.

[5361] D. P. Das and A. Gupta. "A new cynodont record from the Lower Triassic Panchet Formation, Damodar Valley". English. In: Journal of the Geological Society of India 79 (2012), pp. 175-180.

[5362] S. S. Das. "Two new pleurotomariid (Gastropoda) species, including the largest Bathrotomaria, from the Berriasian (Early Cretaceous)of Kutch, western India". English. In: Cretaceous Research 23.1 (2002), pp. 99-109.

[5363] S. S. Das, S. Bardhan, and T. Kase. "A new pleurotomariid gastropod assemblage from the Jurassic sequence of Kutch, western India". English. In: Paleontological Research 9.4 (2005), pp. 329-346.

[5364] D. Dashzeveg. "A new hyracodontid (Perissodactyla, Rhinocerotoidea) from the Ergilin Dzo Formation (Oligocene, Quarry 1) in Dzamyn Ude, Eastern Gobi Desert, Mongolia". English. In: American Museum Novitates 3178 (1996), pp. 1-12.

[5365] D. Dashzeveg. “Two previously unknown eupantotheres (Mammalia, Eupantotheria)". English. In: American Museum Novitates 3107 (1994), pp. 1-11.

[5366] D. Dashzeveg. "A new Ardynomys (Rodentia, Cylindrodontidae) from the Eocene of the Eastern Gobi Desert, Mongolia". English. In: Palaeovertebrata 25.2-4 (1996), pp. 339-348.

[5367] D. Dashzeveg. "Some Carnivorous Mammals from the Paleogene of Eastern Gobi Desert, Mongolia, and the application of Oligocene carnivores to stratigraphic correlation". English. In: American Museum Novitates 3179 (1996), pp. 1-14.

[5368] D. Dashzeveg. “The earliest rodents (Rodentia, Ctenodactyloidea) of Central Asia". English. In: Acta Zoologica Cracoviensia 33.2 (1990), pp. 11-35.

[5369] D. Dashzeveg. "New trends in adaptive radiation of Early Tertiary rodents (Rodentia, Mammalia)". English. In: Acta Zoologica Cracoviensia 33.3 (1990), pp. 37-44.

[5370] D. Dashzeveg. "Hyracodontids and rhinocerotids (Mammalia, Perissodactyla, Rhinocerotoidea) from the Paleogene of Mongolia". English. In: Palaeovertebrata 21.1-2 (1991), pp. 1-84.

[5371] D. Dashzeveg, J.-L. Hartenberger, T. Martin, and S. Legendre. "A peculiar minute Glires (Mammalia) from the early Eocene of Mongolia". English. In: Bulletin of Carnegie Museum of Natural History 34 (1998), pp. 194-209.

[5372] D. Dashzeveg and J. J. Hooker. “New ceratomorph perissodactyls (Mammalia) from the middle and late Eocene of Mongolia: Their implications for phylogeny and dating". English. In: Zoological Journal of the Linnean Society 120 (1997), pp. 105-138.

[5373] D. Dashzeveg and J. Meng. "New Eocene ctenodactyloid rodents from the Eastern Gobi Desert of Mongolia and a phylogenetic analysis of ctenodactyloids based on dental features". English. In: American Museum Novitates 3246 (1998), pp. 1-20.

[5374] D. Dashzeveg and J. Meng. "A New Eocene Cylindrodont Rodent (Mammalia, Rodentia) from the Eastern Gobi of Mongolia". English. In: American Museum Novitates 3253 (1998), pp. 1-18.

[5375] D. Dashzeveg, M. J. Novacek, M. A. Norell, J. M. Clark, L. M. Chiappe, A. Davidson, M. C. McKenna, L. Dingus, C. Swisher, and P. Altangerel. Extraordinary preservation in a new vertebrate assemblage from the Late Cretaceous of Mongolia. 1995.

[5376] D. Dashzeveg and D. E. Russell. “Extension of Dyspternine Pantolestidae (Mammalia, Cimolesta) in the Early Oligocene of Mongolia". English. In: Geobios 25.5 (1992), pp. 647-650. 
[5377] M. Dastanpour, D. H. Evans, and M. G. Bassett. "A new orthoceratoid cephalopod from the Ordovician (Caradoc) of east-central Iran". English. In: Geobios 39.3 (2006), pp. 337-345.

[5378] U. C. M. P. Database. UCMP collections database. 2005.

[5379] D. Datta, S. Ray, and S. Bandyopadhyay. “Cranial morphology of a new phytosaur (Diapsida, Archosauria) from the Upper Triassic of India: implications for phytosaur phylogeny and biostratigraphy". English. In: Papers in Palaeontology (2019). DOI: 10.1002/spp2.1292.

[5380] P. M. Datta. "Earliest mammal with transversely expanded upper molar from the Late Triassic (Carnian) Tiki Formation, South Rewa Gondwana Basin, India". English. In: Journal of Vertebrate Paleontology 25.1 (2005), pp. 200-207.

[5381] P. M. Datta, D. P. Das, and Z.-.. X. Luo. “A late Triassic dromatheriid (Synapsida: Cynodontia) from India". English. In: Annals of Carnegie Museum 73.2 (2004), pp. 72-84.

[5382] P. M. Datta and D. P. Das. "Indozostrodon simpsoni, gen. et sp. nov., an Early Jurassic megazostrodontid mammal from India". English. In: Journal of Vertebrate Paleontology 21.3 (2001), pp. 528 234. DOI: 10.1671/0272-4634(2001)021[0528:ISGESN]2.0.CO;2.

[5383] P. M. Datta, P. Manna, S. C. Ghosh, and D. P. Das. "The first Jurassic turtle from India". English. In: Palaeontology 43.1 (2000), pp. 99-109.

[5384] B. F. Dattilo. "The Lower Ordovician Fillmore Formation of Western Utah: Storm-dominated Sedimentation on a Passive Margin". English. In: Geology Studies 39 (1993).

[5385] Y. Dauphin. "Comparaison des microstructures et de la composition chimique de coquilles d'oeufs fossiles du Sud de la France, de quelques specimens d'Asie et d'oiseaux actuels". French. In: Neues Jahrbuch für Geologie und Paläontologie, Abhandlungen 194.1 (1994), pp. 55-71.

[5386] D. Davesne. "A fossil unicorn crestfish (Teleostei, Lampridiformes, Lophotidae) from the Eocene of Iran". English. In: PeerJ 5.e3381 (2017). DOI: 10.7717/peer.3381.

[5387] A. David. "Predation by naticid gastropods on late Oligocene (Egerian) molluscs collected from Wind Brickyard, Eger, Hungary". English. In: Malakologiai Tajekoztato 17 (1999), pp. 11-19.

[5388] M. David and P. Budil. "Complementary description of the Middle Ordovician trilobite associations". English. In: Folia 49.1-2 (2015), pp. 1-7. DOI: 10.1515/fbgp-2015-0001.

[5389] G. R. Davies, T. F. Moslow, and M. D. Sherwin. "Ganoid fish Albertonia sp. from the Lower Triassic Montney Formation, Western Canada Sedimentary Basin". English. In: Bulltein of Canadian Petroleum Geology 45 (1997), pp. 715-718.

[5390] S. L. Dávila, S. R. Stinnesbeck, S. Gonzalez, S. Lindauer, J. Escamilla, and W. Stinnesbeck. “Guatemala's Late Pleistocene (Rancholabrean) fauna: Revision and interpretation". English. In: Quaternary Science Reviews 219 (2019), pp. 277-296.

[5391] A. M. Davis, J. C. Aitchison, P. G. Flodd, B. S. Morton, R. G. V. Baker, and R. J. Haworth. "Late Holocene higher sea-level indicators from the South China coast". English. In: Marine Geology 171 (2000), pp. 1-5.

[5392] B. M. Davis. "Micro-computed tomography reveals a diversity of peramuran mammals from the Purbeck Group (Berriasian) of England". English. In: Palaeontology 55.4 (2012), pp. 789-817. DOI: 10.1111/j.1475-4983.2012.01161.x.

[5393] B. M. Davis and R. L. Cifelli. "Reappraisal of the tribosphenidan mammals from the Trinity Group (Aptian-Albian) of Texas and Oklahoma". English. In: Acta Palaeontologica Polonica 56.3 (2011), pp. 441-462.

[5394] B. M. Davis, R. L. Cifelli, and Z. Kielan-Jaworowska. 1. Earliest Evidence of Deltatheroida (Mammalia: Metatheria) from the Early Cretaceous of North America. English. Mammalian Evolutionary Morphology: A Tribute to Frederick S. Szalay. 2008, pp. 3-24.

[5395] B. M. Davis, R. L. Cifelli, and J. E. Cohen. "First fossil mammals from the Upper Cretaceous Eagle Formation (Santonian, northern Montana, USA), and mammal diversity during the Aquilan North American Land Mammal Age". English. In: Palaeontologia Polonica 67 (2016), pp. 101-126. DOI: 10.4202/pp.2016.67_101. 
[5396] B. M. Davis, R. L. Cifelli, and G. W. Rougier. "A preliminary report of the fossil mammals from a new microvertebrate locality in the Upper Jurassic Morrison Formation, Grand County, Utah". English. In: Geology of the Intermountain West 5 (2018), pp. 1-8.

[5397] M. C. Davis, N. I. Shubin, and E. B. Daeschler. "A new specimen of Sauripterus taylori (Sarcopterygii; Osteichthyes) from the Famennian Catskill Formation of North America". English. In: Journal of Vertebrate Paleontology 24.1 (2004), pp. 26-40.

[5398] S. N. Davis, C. R. Torres, G. M. Musser, J. V. Proffitt, N. M. A. Crouch, E. L. Lundelius, M. C. Lamanna, and J. A. Clarke. "New mammalian and avian records from the late Eocene La Meseta and Submeseta formations of Seymour Island, Antarctica". English. In: PeerJ 8 (2020), e8268:1-27. DOI: $10.7717 /$ peerj. 8268 .

[5399] S. P. Davis and D. M. Martill. "The Gonorynchiform fish Dastilbe from the Lower Cretaceous of Brazil". English. In: Palaeontology 42.4 (1999), pp. 715-740.

[5400] S. R. Davis and M. L. Engel. "An orthognathine weevil of the genus Mesocordylus in Dominican amber (Coleoptera: Curculionoidea: Dryophthoridae)". English. In: Beiträge zur Entomologie 59 (2009), pp. 233-238.

[5401] S. R. Davis and M. S. Engel. "A new ambrosia beetle in Miocene amber of the Dominican Republic (Coleoptera: Curculionidae: Platypodinae)". English. In: Alavesia 1 (2007), pp. 121-124.

[5402] S. R. Davis and M. S. Engel. "A weevil of the genus Caulophilus in Dominican amber (Coleoptera: Curculionidae)". English. In: Polskie Pismo Entomologiczne 75 (2006), pp. 101-104.

[5403] S. R. Davis and M. S. Engel. “Dryophthorine weevils in Dominican amber (Coleoptera: Curculionidae)". English. In: Transactions of the Kansas Academy of Science 109.3 (2006), pp. 191-198.

[5404] S. R. Davis and M. S. Engel. "A zygopine weevil in early Miocene amber from the Dominican Republic (Coleoptera: Curculionidae)". English. In: Caribbean Journal of Science 42 (2006), pp. 255257.

[5405] S. R. Davis and M. S. Engel. "Cossonine weevils in Dominican amber (Coleoptera: Curculionidae)". English. In: Linzer Biologische Beiträge 39 (2007), pp. 803-820.

[5406] S. R. Davis, M. S. Engel, A. Legalov, and D. Ren. "Weevils of the Yixian Formation, China (Coleoptera: Curculionoidea): phylogenetic considerations and comparison with other Mesozoic faunas". English. In: Journal of Systematic Palaeontology 11 (2013), pp. 399-429.

[5407] S. R. Davis and M. S. Engel. "A new genus of nemonychid weevil from Burmese amber (Coleoptera, Curculionoidea)". English. In: ZooKeys 405 (2014), pp. 127-138.

[5408] S. R. Davis and M. S. Engel. "Antiquity and evolution of prosternal horns in Baridine weevils (Coleoptera: Curculionidae)". English. In: Journal of Paleontology 84 (2010), pp. 918-926.

[5409] S. Davydenko, M. J. Laime, and P. Gol'din. "The earliest record of a marine mammal (Cetacea: Basilosauridae) from the Eocene of the Amazonia". English. In: Journal of Vertebrate Paleontology (2019), e1549060. DOI: 10.1080/02724634.2018.1549060.

[5410] S. Davydenko, T. Mörs, and P. Gol'din. "A small whale reveals diversity of the Eocene cetacean fauna of Antarctica". English. In: Antarctic Science (2020). DOI: 10.1017/S0954102020000516.

[5411] V. Davydov and K. Krainer. "Fusulinid assemblages and facies of the Bombaso Fm. and basal Meledis Fm. (Moscovian-Kasimovian) in the central Carnic alps (Austria/Italy)". English. In: Facies 40 (1999), pp. 157-196.

[5412] V. I. Davydov. "Taxonomy, nomenclature, and evolution of the early schubertellid fusulinids". English. In: Acta Palaeontologica Polonica 56 (2011), pp. 181-194.

[5413] V. I. Davydov and S. Arefifard. "Permian fusulinid fauna of peri-Gondwanan affinity from the Kalmard region, east-central Iran and its significance for tectonics and paleogeography". English. In: Palaeontologia Electronica 10.2.10A (2007), pp. 1-40.

[5414] V. I. Davydov and S. Arefifard. "Middle Permian (Guadalupian) fusulinid taxonomy and biostratigraphy of the mid-latitude Dalan Basin, Zagros, Iran and their applications in paleoclimate dynamics and paleogeography". English. In: GeoArabia 18 (2013), pp. 17-62. 
[5415] V. I. Davydov, P. Belasky, and N. I. Karavayeva. "Permian fusulinids from the Koryak terrane, northeastern Russia, and their paleobiogeographic affinity". English. In: Journal of Foraminiferal Research 26 (1996), pp. 213-243.

[5416] V. I. Davydov and A. S. Biakov. "Discovery of shallow-marine biofacies conodonts in a bioherm within the Carboniferous-Permian transition in the Omolon Massif, NE Russia near the North paleo-pole: Correlation with a warming spike in the southern hemisphere". English. In: Gondwana Research 28 (2015), pp. 888-897.

[5417] V. I. Davydov and I. Nilsson. "Fusulinid Succession from the Middle-Upper Carboniferous Boundary Beds on Spitsbergen, Arctic Norway". English. In: Palaeontologia Electronica 2.1 (1999).

[5418] V. I. Davydov, I. Nilsson, and L. Stemmerik. "Fusulinid zonation of the Upper Carboniferous Kap Jungersen and Foldedal Formations, southern Amdrup Land, eastern North Greenland". English. In: Bulletin of the Geological Society of Denmark 48 (2001), pp. 31-77.

[5419] L. R. S. Dawson. "A new fossil genus of forest wallaby (Marsupialia, Macropodinae) and a review of Protemnodon from eastern Australia and New Guinea". English. In: Alcheringa 28.1 (2004), pp. 275-290. DOI: 10.1080/03115510408619285.

[5420] M. R. Dawson. "Early Eocene rodents (Mammalia) from the Eureka Sound Group of Ellesmere Island, Canada". English. In: Canadian Journal of Earth Sciences 38.7 (2001), pp. 1107-1116. DOI: 10.1139/cjes-38-7-1107.

[5421] M. R. Dawson. "Coryphodon, the northernmost Holarctic Paleogene pantodont (Mammalia), and its global wanderings". English. In: Swiss Journal of Palaeontology 131 (2012), pp. 11-22. DOI: 10. 1007/s13358-011-0028-1.

[5422] M. R. Dawson and K. C. Beard. "New late Paleocene rodents (Mammalia) from Big Multi Quarry, Washakie Basin, Wyoming". English. In: Palaeovertebrata, Montpellier 25.2-4 (1996), pp. 301-321.

[5423] M. R. Dawson and K. C. Beard. "Rodents of the family Cylindrodontidae (Mammalia) from the earliest Eocene of the Tuscahoma Formation, Mississippi". English. In: Annals of Carnegie Museum 76.3 (2007), pp. 135-144.

[5424] M. R. Dawson and C. R. Harington. "Boreameryx, an unusual new artiodactyl (Mammalia) from the Pliocene of Arctic Canada and endemism in Arctic fossil mammal". English. In: Canadian Journal of Earth Sciences 44.5 (2007), pp. 585-592.

[5425] M. R. Dawson, X.-S. Huang, C. -K. Li, and B. -Y. Wang. "Zelomyidae, a new family of Rodentia (Mammalia) from the Eocene of Asia". English. In: Vertebrata PalAsiatica 41.4 (2003), pp. 249-270.

[5426] M. R. Dawson, C. K. Li, and T. Qi. "The Diatomyidae (Mammalia, Rodentia) and bilophodonty in middle Eocene Asian rodents". English. In: Vertebrata PalAsiatica 48.4 (2010), pp. 328-335.

[5427] M. R. Dawson, M. C. McKenna, K. C. Beard, and J. H. Hutchison. "An early Eocene plagiomenid mammal from Ellesmere and Axel Heiberg Islands, Arctic Canada". English. In: Kaupia 3 (1993), pp. 179-192.

[5428] M. R. Dawson, T. Tsubamoto, M. Takai, N. Egi, S. T. Tun, and C. Sein. "Rodents of the family Anomaluridae (Mammalia) from Southeast Asia (Middle Eocene, Pondaung Formation, Myanmar)". English. In: Annals of Carnegie Museum 72.3 (2003), pp. 203-213.

[5429] S. D. Dawson. "A description of the skull and postcrania of Hadrodelphis calvertense Kellog 1966, and its position within the Kentriodontidae (Cetacea; Delphinoidea)". English. In: Journal of Vertebrate Paleontology 16.1 (1996), pp. 125-134.

[5430] S. D. Dawson. "A new kentriodontid dolphin (Cetacea; Delphinoidea) from the middle Miocene Choptank Formation, Maryland". English. In: Journal of Vertebrate Paleontology 16.1 (1996), pp. 135140.

[5431] G. Daxner-Höck. “Ulaancricetodon badamae n. gen., n. sp. (Mammalia, Rodentia, Cricetidae) from the Valley of Lakes in Central Mongolia". English. In: Paläontologische Zeitschrift 74.1/2 (2000), pp. 215-225. 
[5432] G. Daxner-Höck. “New zapodids (Rodentia) from Oligocene-Miocene deposits in Mongolia. Part 1". English. In: Senckenbergiana Lethaea 81.2 (2001), pp. 359-389.

[5433] G. Daxner-Höck, D. Badamgarav, and O. Maridet. "Evolution of Tachyoryctoidinae (Rodentia, Mammalia): evidences of the Oligocene and Early Miocene of Mongolia". English. In: Annalen des Naturhistorischen Museums in Wien, Serie A 117 (2015), pp. 161-195.

[5434] G. Daxner-Höck, D. Badamgarav, and O. Maridet. “Dipodidae (Rodentia, Mammalia) from the Oligocene and Early Miocene of Mongolia". English. In: Annalen des Naturhistorischen Museums in Wien, Serie A 116 (2014), pp. 131-214.

[5435] G. Daxner-Höck, D. Badamgarav, R. Barsbold, B. Bayarmaa, M. Erbajeva, U. B. Göhlich, and Y. Khand. "Oligocene stratigraphy across the Eocene and Miocene boundaries in the Valley of Lakes (Mongolia)". English. In: Palaeobiodiversity and palaeoenvironments 97.1 (2017), pp. 111-218.

[5436] G. Daxner-Höck, P. M. Miklas-Tempfer, U. B. Gohlich, K. Huttenen, E. Kazar, D. Nagel, G. E. Roessner, O. Schultz, and R. Ziegler. "Marine and terrestrial vertebrates from the Middle Miocene of Grund (Lower Austria)". English. In: Geologica Carpathica 55.2 (2004), pp. 191-197.

[5437] G. Daxner-Höck and W. Wu. "Plesiosminthus (Zapodidae, Mammalia) from China and Mongolia: migrations to Europe". English. In: Deinsea 10 (2003), pp. 127-151.

[5438] J. Day and D. J. Over. "Post-extinction survivor fauna from the lowermost Famennian of eastern North America". In: Acta Palaeontologica Polonica 47.2 (2002), pp. 189-202.

[5439] J. Day, T. Uyeno, W. Norris, B. J. Witzke, and B. J. Bunker. "Middle-Upper Devonian relative sealevel histories of central and western North America interior basins". English. In: Geological Society of America Special Paper 306 (1996), pp. 259-275.

[5440] J. J. Day, D. B. Norman, A. S. Gale, P. Upchurch, and H. P. Powell. "A Middle Jurassic dinosaur trackway site from Oxfordshire, UK". English. In: Palaeontology 47.2 (2004), pp. 319-348.

[5441] M. O. Day, S. Güven, F. Abdala, S. Jirah, B. Rubidge, and J. Almond. "Youngest dinocephalian fossils extend the Tapinocephalus Zone, Karoo Basin, South Africa". English. In: South African Journal of Science 111 (2015), pp. 2014-0309.

[5442] M. O. Day, B. S. Rubidge, and F. Abdala. "A new mid-Permian burnetiamorph specimen from the Main Karoo Basin of South Africa and a phylogenetic review of Burnetiamorpha". English. In: Acta Palaeontologica Polonica 61.4 (2016), pp. 701-719.

[5443] M. O. Day, R. M. H. Smith, J. Benoit, V. Fernandez, and B. S. Rubidge. “A new species of burnetiid (Therapsida, Burnetiamorpha) from the early Wuchiapingian of South Africa and implications for the evolutionary ecology of the family Burnetiidae". English. In: Papers in Palaeontology (2018). DOI: $10.1002 / \mathrm{spp} 2.1114$.

[5444] S. M. Daymond. “Gondwanodus irwinensis gen. et sp. nov., a new elasmobranch from the Early Permian (late Sakmarian) Fossil Cliff member of the Holmwood Shale, Perth Basin, Western Australia". English. In: Records of the Western Australian Museum 19 (1999), pp. 371-378.

[5445] J. D. Daza, A. M. Bauer, and E. D. Snively. “On the fossil record of the Gekkota”. English. In: The Anatomical Record 297 (2014), pp. 433-462. DOI: 10.1002/ar.22856.

[5446] J. D. Daza and A. M. Bauer. "A new amber-embedded sphaerodactyl gecko from Hispaniola, with comments on morphological synapomorphies of the Sphaerodactylidae". English. In: Breviora 529 (2012), pp. 1-28. DOI: 10.3099/529.1.

[5447] J. D. Daza, A. M. Bauer, E. L. Stanley, A. Bolet, B. Dickson, and J. B. Losos. “An Enigmatic Miniaturized and Attenuate Whole Lizard from the Mid-Cretaceous Amber of Myanmar". English. In: Breviora 563.1 (2018), pp. 1-18.

[5448] J. D. Daza, E. L. Stanley, P. Wagner, A. M. Bauer, and D. A. Grimaldi. "Mid-Cretaceous amber fossils illuminate the past diversity of tropical lizards". English. In: Science Advances 2.3 (2016), e1501080. DOI: 10.1126/sciadv.1501080. 
[5449] J. D. Daza, E. L. Stanley, A. Bolet, A. M. Bauer, J. S. Arias, A. Cernanský, J. L. Bevitt, P. Wagner, and S. E. Evans. "Enigmatic amphibians in mid-Cretaceous amber were chameleon-like ballistic feeders". English. In: Science 370 (2020), pp. 687-691. DOI: 10.1126/science.abb6005.

[5450] M. L. de Andrade. "Fossil Odontomachiti ants from the Dominican Republic (amber collection Stuttgart: Hymenoptera, Formicidae. VII: Odontomachiti)". English. In: Stuttgarter Beiträge zur Naturkunde Serie B (Geologie und Paläontologie) 199 (1994), pp. 1-28.

[5451] M. L. de Andrade. "A remarkable Dominican amber species of Cylindromyrmex with Brazilian affinities and addition to the generic revision". English. In: Beiträge zur Entomologie 51 (2001), pp. 51-63.

[5452] M. L. de Andrade. "First descriptions of two new amber species of Cyphomyrmex from Mexico and the Dominican Republic". English. In: Beiträge zur Entomologie 53 (2003), pp. 131-139.

[5453] M. L. de Andrade. "A new species of Platythyrea from Dominican amber and description of a new extant species from Honduras (Hymenoptera: Formicidae)". English. In: Revue Suisse de Zoologie 111 (2004), pp. 643-655.

[5454] M. L. de Andrade. "First fossil true Macromischa in amber from the Dominican Republic (Hymenoptera, Formicidae)". English. In: Mitteilungen der Schweizerischen Entomologischen Gesellschaft 65 (1992), pp. 341-351.

[5455] M. L. de Andrade and C. Baroni Urbani. "Diversity and adaptation in the ant genus Cephalotes, past and present". English. In: Stuttgarter Beiträge zur Naturkunde Serie B (Geologie und Paläontologie) 271 (1999), pp. 1-889.

[5456] M. L. de Andrade and C. Baroni Urbani. "The Baltic amber genus Bradoponera (Hymenoptera: Formicidae), with description of two new species and a reassessment of the Proceratiini genera". English. In: Revue Suisse de Zoologie 110 (2003), pp. 913-938.

[5457] M. L. de Andrade and C. Baroni Urbani. "First record of ants from Borneo amber (Hymenoptera, Formicidae)". English. In: Mitteilungen der Schweizerischen Entomologischen Gesselschaft 77 (2004), pp. 247-250.

[5458] M. L. de Andrade, C. Baroni Urbani, C. R. F. Brandão, and J. Wagensberg. "Two new species of Leptothorax Nesomyrmex fossils in Dominican amber". English. In: Beiträge zur Entomologie 49 (1999), pp. 133-140.

[5459] A. De Angeli. "Raniliformis bellini n. sp., nuovo crostaceo Raninidae (Decapoda, Brachyura) dell'Eocene della Valle del Chiampo (Vicenza, Italia settentrionale)". Italian. In: Lavori-Societá Veneziana di Scienze Naturali 36 (2011), pp. 103-109.

[5460] A. De Angeli and R. Alberti. "Tethyscarpilius bericus n. gen., n. sp. (Decapoda, Brachyura, Carpiliidae) dell'Eocene superiore dei Monti Berici (Vicenza, Italia settentrionale)". English. In: 41 (2016), pp. 121-127.

[5461] A. De Angeli and C. Beschin. “Crostacei decapodi dell'Oligocene di Soghe e Valmarana (Monti Berici, Vicenza - Italia Settentrionale)". English. In: Studi e Ricerche - Associazione Amici del Museo Museo Civico G. Zannato Montecchio Maggiore (Vicenza) 15 (2008), pp. 15-39.

[5462] A. De Angeli, C. Beschin, and A. Checchi. "Una nuova specie di Albuneidae Stimpson, 1858 dell'Eocene della Valle del Chiampo (Vicenza, NE Italia) e considerazioni sulle altre forme note (Decapoda, Anomura, Hippoidea)". Italian. In: Lavori-Societá Veneziana di Scienze Naturali 30 (2005), pp. 85-91.

[5463] A. de Angeli and C. Beschin. "Ceronnectes, nuovo genre di brachiuro (Crustacea, Decapoda) dell'Eocene di ungheria e Italia". Italian. In: Lavori - Societá Veneziana di Scienze Naturali 23 (1998), pp. 87-91.

[5464] A. De Angeli and C. Beschin. "Lovaracarcinus granulatus gen. nov., sp. nov., nuovo brachiuro Eocenico della valle del Chiampo (Vicenza-Italia Settentrionale)". English. In: Studi e Ricerche - Associazione Amici del Museo - Museo Civico G. Zannato ISSN 1127-3100 Montecchio Maggiore (Vicenza) 17 (2010), pp. 29-34. 
[5465] A. De Angeli and F. Caporiondo. “Un nuovo Parthenopidae (Crustacea, Decapoda, Brachyura) dell'Eocene inferiore dei Monti Lessini orientali (Verona - Italia settentrionale)". English. In: Societá Veneziana di Scienze Naturali 41 (2016), pp. 137-144.

[5466] A. De Angeli and L. Ceccon. "Montemagralia lata n. gen., n. sp., nuovo crostaceo Trapeziidae (Decapoda, Brachyura) dell'Eocene dei Monti Lessini orientali (Vicenza, Italia settentrionale)". English. In: Lavori-Societá Veneziana di Scienze Naturali 41 (2016), pp. 129-136.

[5467] A. De Angeli and L. Ceccon. “Eouroptychus montemagrensis n. gen., n. sp., (Crustacea, Decapoda, Anomura, Chirostylidae) dell'Eocene inferiore (Ypresiano) di Monte Magré (Vicenza, Italia settentrionale)". Italian. In: Societa Veneziana di Scienze Naturali 37 (2012), pp. 19-24.

[5468] A. De Angeli and L. Ceccon. "Tetraliidae and Trapeziidae (Crustacea, Decapoda, Brachyura) from the Early Eocene of Monte Magré (Vicenza, NE Italy)". English. In: Atti della Societá italiana di scienze naturali e del Museo civico di storia naturale di Milano 154.1 (2013), pp. 25-40.

[5469] A. De Angeli and L. Ceccon. "Latheticocarcinus italicus sp. nov. (Decapoda, Brachyura, Homolidae) dell'Eocene inferiore (Ypresiano) di Monte Magré (Vicenza, Italia settentrionale)". Italian. In: La Societá Veneziana di Scienze Naturali Lavori 38 (2013), pp. 103-109.

[5470] A. de Angeli and A. Garassino. "Galatheid, chirostylid and porcellanid decapods (Crustacea, Decapoda, Anomura) from the Eocene and Oligocene of Vicenza (N Italy)". English. In: Memorie della Societá Italiana di Scienze Naturali e del Museo Civico di Storia Naturale di Milano 30.3 (2002), pp. 1-40.

[5471] A. De Angeli, A. Garassino, and G. Pasini. "New reports of anomurans and brachyurans from the Cenozoic of Tuscany (Italy)". English. In: Atti della Societá Italiana di Scienze Naturali e del Museo Civico di Storia Naturale di Milano 150.2 (2009), pp. 163-196.

[5472] A. De Angeli and A. Garassino. "Pseudosquilla lessinea n. sp. (Crustacea, Stomatopoda, Pseudosquillidae) and Scyllarides bolcensis n. sp. (Crustacea, Decapoda, Scyllaridae) from the lower Eocene (Ypresian) of Monte Postale (Altissimo, Vicenza, NE Italy)". English. In: Atti della Societá Italiana di Scienze Naturali e del Museo Civico di Storia Naturale di Milano 149.2 (2008), pp. 167-178.

[5473] A. De Angeli and A. Garassino. "A new genus and species of panopeid crab, Zovocarcinus muelleri (Decapoda, Brachyura), from the Eocene of Zovo di Bolca, Verona (northeast Italy)". English. In: Scripta Geologica 147 (2014), pp. 185-191.

[5474] A. De Angeli, A. Garassino, and L. Ceccon. "New report of the coral-associated decapods from the Formazione di Castelgomberto (early Oligocene) (Vicenza, NE Italy)". English. In: Atti Soc. it. Sci. nat. Museo civ. Stor. nat. Milano 151.II (2010), pp. 145-177.

[5475] A. de Angeli and A. Garassino. "Bittnerilia, new genus for Lambrus eocaenus Bittner, 1883 (Decapoda, Brachyura, Calappidae) from the middle Eocene of Veneto (N Italy)". English. In: Atti della Societá Italiana di Scienze Naturali e del Museo Civico di Storia Naturale in Milano 144.1 (2003), pp. 13-22.

[5476] A. De Angeli, D. Guinot, and A. Garassino. "New hexapodid crabs from the Eocene of Vicenza (NE Italy) (Crustacea, Decapoda, Brachyura, Hexapodidae)". English. In: Atti Soc. it. Sci. nat. Museo civ. Stor. nat. Milano 151.I (2010), pp. 51-75.

[5477] A. De Angeli and A. Lovato. "Dynamenella miettoi n. sp., nuovo isopode (Crustacea, Flabellifera, Sphaeromatidae) dell'Eocene del Veneto (Vicenza, Italia settentrionale)". English. In: Societá Veneziana di Scienze Naturali 36 (2011), pp. 111-118.

[5478] A. De Angeli and L. Marchiori. “Eomatuta granosa n. gen., n. sp. (Decapoda, Brachyura, Matutidae), Nuovo Crostaceo dell'Eocene dei Monti Berici (Vicenza, Italia Settentrionale)". English. In: 34 (2009), pp. 105-110.

[5479] A. R. de Araujo Carvalho, A. M. Ghilardi, and A. M. Franca Barreto. "A new side-neck turtle (Pelomedusoides: Bothremydidae) from the Early Paleocene (Danian) Maria Farinha Formation, Paraba Basin, Brazil". English. In: Zootaxa 4126.4 (2016), pp. 491-513. 
[5480] R. P. F. de Azevedo, F. M. Simbras, M. R. Furtado, C. R. A. Candeiro, and L. P. Bergqvist. “First Brazilian carcharodontosaurid and other new theropod dinosaur fossils from the CampanianMaastrichtian Presidente Prudente Formation, São Paulo State, southeastern Brazil". English. In: Cretaceous Research 40 (2013), pp. 131-142.

[5481] K. De Baets, S. Goolaerts, U. Jansen, T. Rietbergen, and C. Klug. "The first record of Early Devonian ammonoids from Belgium and their stratigraphic significance". English. In: Geologica Belgica 16.3 (2013), pp. 148-156.

[5482] K. De Baets, C. Klug, and Y. Plusquellec. "Zlchovian faunas with early ammonoids from Morocco and their use for the correlation of the eastern Anti-Atlas and the western Dra Valley". English. In: Bulletin of Geosciences 85.2 (2010), pp. 317-352.

[5483] K. De Baets, C. Klug, D. Korn, C. Bartels, and M. Poschmann. "Emsian Ammonoidea and the age of the Hunsrück Slate (Rhenish Mountains, Western Germany)". English. In: Palaeontographica Abteilung A 299 (2013), pp. 1-113.

[5484] E. De Bast, C. Gagnaison, and T. Smith. "Plesiadapid mammals from the latest Paleocene of France offer new insights on the evolution of Plesiadapis during the Paleocene-Eocene transition". English. In: Journal of Vertebrate Paleontology 38 (2018), e1460602:1-22. DOI: 10.1080 / 02724634.2018. 1460602.

[5485] E. De Bast, B. Sigé, and T. Smith. "Diversity of the adapisoriculid mammals from the early Palaeocene of Hainin, Belgium". English. In: Acta Palaeontologica Polonica 57.1 (2012), pp. 35-52.

[5486] E. De Bast and T. Smith. "The oldest Cenozoic mammal fauna of Europe: implication of the Hainin reference fauna for mammalian evolution and dispersals during the Paleocene". English. In: Journal of Systematic Palaeontology 15.9 (2017), pp. 741-785. DOI: 10.1080/14772019.2016.1237582.

[5487] E. De Bast, E. Steurbaut, and T. Smith. "New mammals from the marine Selandian of Maret, Belgium, and their implications for the age of the Paleocene continental deposits of Walbeck, Germany". English. In: Geologica Belgica 16.4 (2013), pp. 236-244.

[5488] L. de Bones, J. Abella, G. Merceron, and D. R. Begun. "A new late Miocene ailuropodine (Giant Panda) from Rudaba nya (North-central Hungary)". English. In: Geobios 50 (2017), pp. 413-421. DOI: 10.1016/j.geobios.2017.09.003.

[5489] L. de Bonis. "A new species of Adelpharctos (Mammalia, Carnivora, Ursidae) from the late Oligocene of the Phosphorites du Quercy (France)". English. In: Estudios Geológicos 67.2 (2011), pp. 179-186.

[5490] L. de Bonis. "Revival of a species of the rare European Oligocene amphicyonid Goupilictis Ginsburg, 1969 (Mammalia, Carnivora, Amphicyonidae)". English. In: Journal of Vertebrate Paleontology 35.5 (2015), e969401:1-5.

[5491] L. de Bonis. "Ursidae (Mammalia, Carnivora) from the Late Oligocene of the Phosphorites du Quercy (France) and a reappraisal of the genus Cephalogale Geoffroy, 1862". English. In: Geodiversitas 35.4 (2013), pp. 787-814.

[5492] L. de Bonis. "Précisions sur l'age géologique et les relations phylétiques de Mustelictis olivieri nov. sp. (Carnivora, Mustelidae)". French. In: Geobios 20 (1997), pp. 55-60.

[5493] L. de Bonis, G. Bouvrain, D. Geraads, G. D. Koufos, and S. Sen. "The first aardvarks from the Miocene of Macedonia (Greece)". English. In: Neues Jahrbuch für Geologie und Paläontologie Monatshefte 194.2/3 (1994), pp. 343-360.

[5494] L. de Bonis, G. Bouvrain, D. Geraads, and G. D. Koufos. "A skull of Hystrix primigenia from the late Miocene of Macedonia (Greece)". English. In: Neues Jahrbuch für Geologie und Paläontologie 2 (1992), pp. 75-87.

[5495] L. de Bonis, A. Gardin, and C. Blondel. "Carnivora from the early Oligocene of the 'Phosphorites du Quercy' in southwestern France". English. In: Geodiversitas 41.15 (2019), pp. 601-621.

[5496] L. de Bonis, G. D. Koufos, and S. Sen. "The Sanithera (Mammalia, Suoidea) from the Middle Miocene of Chios Island, Aegean Sea, Greece". English. In: Revue de Paléobiologie Genéve 16.1 (1997), pp. 259-270. 
[5497] L. de Bonis, G. D. Koufos, and S. Sen. "Ruminants (Bovidae and Tragulidae) from the Middle Miocene (MN 5) of the island of Chios, Aegean sea (Greece)". English. In: N Jb Geol Paläontol Abh 210.3 (1998), pp. 399-420.

[5498] L. de Bonis, S. Peigné, and M. Hugueney. “Carnivores félodes de l'Oligocéne supérieur de CoderetBransat (Allier, France)". French. In: Bulletin de la Société géologique de France 170.6 (1999), pp. 939949.

[5499] L. de Bonis, S. Piegne, H. T. Mackaye, A. Likius, P. Vignaud, and M. Brunet. "New sabre-toothed cats in the Late Miocene of Toros Menalla (Chad)". English. In: Comptes Rendus Palevol 9.5 (2010), pp. 221-227. DOI: 10.1016/j.crpv.2010.07.018.

[5500] L. de Bonis, F. Solé, Y. Chaimanee, A. N. Soe, C. Sein, V. Lazzari, O. Chavasseau, and J. -J. Jaeger. "New hyaenodonta (Mammalia) from the middle Eocene of Myanmar". English. In: Comptes Rendus Palevol 17.6 (2018), pp. 357-365. DOI: 10.1016/j.crpv.2017.12.003.

[5501] F. De Broin. “Données préliminaires sur les chéloniens du Tithonien Inférieur des calcaires lithographiques de Canjeurs (Var, France)". French. In: Geobios 16 (1994), pp. 167-175.

[5502] F. de Broin. "Fossil Turtles from Bolivia". English. In: FOSILES Y FACIES DE BOLIVIA ůVOL. 1 VERTEBRADOS, Revista Técnica de YPFB 12.34 (1991), pp. 509-527.

[5503] F. de Broin, S. Barta-Calmus, L. Beauvais, G. Camoin, J. Dejax, M. Gayet, J. -G. Michard, T. Olivaux, J. Roman, D. Sigogneau-Russell, P. Taquet, and S. Wenz. “Paléobiogéographie de la Téthys: apports de la paléontologie á la localisation des rivages, des aires émergées et des plates-formes au Jurassique et au Crétacé [Paleobiogeography of the Tethys: contribution of paleontology to the location of shores, emerged lands, and marine platforms in the Jurassic and Cretaceous]". French. In: Bulletin de la Société Géologique de France, 8e série 162.1 (1991), pp. 13-26.

[5504] F. de Broin and M. de la Fuente. "Les tortues fossiles d'Argentine: synthese [The fossil turtles of Argentina: synthesis]". French. In: Annales de Paléontologie (Invertebrés-Vertebrés) 79.3 (1993), pp. 169232.

[5505] F.deL. de Broin, J. Bocquetin, and F. R. Negri. “Gigantic turtles (Pleurodira, Podocnemididae) from the Late Miocene - Early Pliocene of South Western Amazon". English. In: Bulletin de Institute francaises de etudes andines 22.3 (1993), pp. 657-670.

[5506] H. de Bruijn. "A new stage in the evolution of the mole rats (Rodentia, Spalacinae) from the Early Miocene of northern Greece". English. In: Historical Biology 29.5 (2017), pp. 571-575.

[5507] H. de Bruijn, C. S. Doukas, L. W. van den Hoek Ostende, and W. J. Zachariasse. "New finds of rodents and insectivores from the Upper Miocene at Plakias (Crete, Greece)". English. In: Swiss Journal of Palaeontology 131 (2012), pp. 61-75. DOI: 10.1007/s13358-011-0030-7.

[5508] H. de Bruijn, V. Fahlbusch, G. Saraç., and E. Uenay. "Early Miocene faunas from the eastern Mediterranean area. Part III. The genera Deperetomys and Cricetodon with a discussion of the evolutionary history of the Cricetodontini". English. In: Proceedings van de Koninklijke Nederlandse Akademie van Wetenschappen 96.2 (1993), pp. 151-216.

[5509] H. de Bruijn, Z. Markovi, and W. Wessels. "Late Oligocene rodents from Banovii (Bosnia and Herzegovina)". English. In: Palaeodiversity 6 (2013), pp. 63-105.

[5510] H. de Bruijn, Z. Markovi, W. Wessels, and A. A. van de Weerd. "Pappocricetodontinae (Rodentia, Muridae) from the Paleogene of south-east Serbia". English. In: Palaeobiodiversity and Palaeoenvironments 99.3 (2019), pp. 511-526. DOI: 10.1007/s12549-018-0343-2.

[5511] H. de Bruijn, Z. Markovi, W. Wessels, M. Milivojevi, and A. A. van de Weer. "Rodent faunas from the Paleogene of south-east Serbia". English. In: Palaeobiodiversity and Palaeoenvironments 98.3 (2018), pp. 441-458. DOI: 10.1007/s12549-017-0305-0.

[5512] H. de Bruijn, S. Mayda, L. van den Hoek Ostende, T. Kaya, and G. Saraç. "Small mammals from the Early Miocene of Sabuncubeli (Manisa, S.W. Anatolia, Turkey)." English. In: Beiträge zur Paläontologie 30 (2006), pp. 57-87. 
[5513] H. de Bruijn and G. Saraç. "early Miocene rodent faunas from the eastern Mediterranean area. Part II. Mirabella (Paracricetodontinae, Muroidea)". English. In: Proceedings van de Koninklijke Nederlandse Akademie van Wetenschappen 95.1 (1992), pp. 25-40.

[5514] H. de Bruijn, G. Sarac, L. W. van den Hoek Ostende, and S. Roussiakis. "The status of the genus name Parapodemus SCHAUB, 1938; new data bearing on an old controversy". English. In: Elephants have a snorkel! Papers in honour of Paul Y. Sondaar - Deinsea 7 (1999), pp. 95-112.

[5515] H. de Bruijn, E. Uenay, L. van den Hoek Ostende, and G. Saraç. "A new association of small mammals from the lowermost Lower Miocene of Central Anatolia." English. In: Geobios 25.5 (1992), pp. 651-670.

[5516] H. de Bruijn, E. Unay, G. Sarac, and A. Ylmaz. "A rodent assemblage from the Eo/Oligocene boundary interval near Süngülü, Lesser Caucasus, Turkey". English. In: Coloquios de Paleontologa, Volumen Extraordinario 1 (2003), pp. 47-76.

[5517] V. de Buffrenil and J. M. Mazin. "Bone histology of the ichthyosaurs: comparative data and functional interpretation". English. In: Paleobiology 16.4 (1990), pp. 435-447.

[5518] M. G. P. de Carvalho and W. R. Lourenço. "A new family of fossil scorpions from the Early Cretaceous of Brazil". English. In: Comptes Rendus de l'Académie des Sciences Paris, Sciences de la Terre et des Planétes 332 (2001), pp. 711-716.

[5519] M. R. de Carvalho. A Late Cretaceous thornback ray from southern Italy, with a phylogenetic reappraisal of the Platyrhinidae (Chondrichthyes: Batoidea). English. Mesozoic Fishes 3: Systematics, Paleoenvironments and Biodiversity. 2004, pp. 75-100.

[5520] C. L. de Castro Manso. “Primeiro registro de Goniasteridae (Echinodermata, Asteroidea) no Cretaceo do Brasil: Turoniano da Bacia Potiguar". Portugese. In: Geociencias 25.2 (2006), pp. 255-260.

[5521] F. J. De Figueiredo. "A New Clupeiform Fish from the Lower Cretaceous (Barremian) of SergipeAlagoas Basin, Northeastern Brazil”. English. In: Journal of Vertebrate Paleontology 29.4 (2009), pp. $993-$ 1005.

[5522] F. J. De Figueiredo. "A new marine clupeoid fish from the Lower Cretaceous of the SergipeAlagoas Basin, northeastern Brazil”. English. In: Zootaxa 2164 (2009), pp. 21-32.

[5523] F. J. de Figueiredo and V. Gallo. "A New Teleost Fish from the Early Cretaceous of Northeastern Brazil”. English. In: Boletim Do Museu Nacional Geologia 73.23 (2004), pp. 1-23.

[5524] F. J. De Figueiredo and R.da. Silva Santos. "Picnodontes da Formacao Riachuelo, Membro Tauqari, Estado de Sergipe, Nordeste do Brasil". Portugese. In: Anais da Academia Brasileira de Ciencias 63.4 (1991), pp. 369-379.

[5525] F. J. De Figueriredo and B. C. M. Carvalho. "A new actinopterygian fish from the Late Permian of the Paraná Basin, Southern Brazil". English. In: Arquivos do Museu National, Rio de Janeiro 62.4 (2004), pp. 531-542.

[5526] M. de Flores and A. Nel. “Un Raphidioptére mésozoque á la conservation exceptionnelle: de nouvelles pistes pour une phylogénie de l'ordre (Raphidioptera, Baissopteridae)". French. In: Bulletin de la Société Entomologique de France 111 (2006), pp. 449-455.

[5527] M. A. G. De Franca and M. C. Langer. "The skull anatomy of Decuriasuchus quartacolonia (Pseudosuchia: Suchia: Loricata) from the middle Triassic of Brazil". English. In: Geological Society Special Publication 379 (2013), pp. 469-501.

[5528] T. A. de Freitas. "Ludlow (Silurian) lithistid and hexactinellid sponges, Cape Phillips Formation, Canadian Arctic". English. In: Canadian Journal of Earth Sciences 28 (1991), pp. 2042-2061.

[5529] T. A. de Freitas, O. A. Dixon, and U. Mayr. "Silurian pinnacle reefs of the Canadian Arctic". English. In: Palaios 8 (1993), pp. 172-182.

[5530] J. de Heinzelin, J. Clark, T. White, W. Hart, P. Renne, G. WoldeGabriel, Y. Beyene, and E. Vrba. "Environment and Behavior of 2.5-Million-Year-Old Bouri Hominids". English. In: Science 284 (1999), pp. 625-629. 
[5531] G. de Iuliis. "On the taxonomic status of Megatherium sundti Philippi, 1893 (Mammalia: Xenarthra: Megatheriidae)". English. In: Ameghiniana 43.1 (2006), pp. 161-169.

[5532] G. De Iuliis, D. Brandoni, and G. J. Scillato-Yané. "New remains of Megathericulus patagonicus Ameghino 1904 (Xenarthra, Megatheriidae): Information on primitives features of Megatheriines". English. In: Journal of Vertebrate Paleontology 28.1 (2008), pp. 181-196.

[5533] G. De Iuliis and C. Cartelle. "A new giant megatheriine ground sloth (Mammalia: Xenarthra: Megatheriidae) from the late Blancan to early Irvingtonian of Florida". English. In: Zoological Journal of the Linnean Society 127 (1999), pp. 495-515.

[5534] G. De Iuliis, C. Cartelle, H. G. McDonald, and F. Pujos. "The mylodontine ground sloth Glossotherium tropicorum from the late Pleistocene of Ecuador and Peru". English. In: Papers in Palaeontology 3.4 (2017), pp. 613-636.

[5535] G. De Iuliis and A. G. Edmund. “Vassallia maxima Castellanos, 1946 (Mammalia: Xenarthra: Pampatheriidae), from Puerta del Corral Quemado (Late Miocene to Early Pliocene), Catamarca Province, Argentina". English. In: vol. 93. Smithsonian contributions to paleobiology. 2002, pp. 4964.

[5536] G. De Iuliis, T. J. Gaudin, and M. J. Vicars. "A new genus and species of Nothrotheriid sloth (Xenarthra, Tardigrada, Nothrotheriidae) from the Late Miocene (Huayquerian) of Peru". English. In: Palaeontology 54.1 (2011), pp. 171-2005.

[5537] G. De Iuliis, H. G. Mcdonald, N. Stanchly, J. Spenard, and T. G. Powis. “Nothrotheriops shastensis (Sinclair) from Actun Lak: first record of Nothrotheriidae (Mammalia, Xenarthra, Pilosa) from Belize". English. In: Ameghiniana 52 (2015), pp. 153-171.

[5538] G. De Iuliis, F. Pujos, and C. Cartelle. "A new ground sloth (Mammalia: Xenarthra) from the Quaternary of Brazil". English. In: Comptes Rendus Palevol 8 (2009), pp. 705-715.

[5539] G. De Iuliis, F. Pujos, and G. Tito. "Systematic and taxonomic revision of the Pleistocene ground sloth Megatherium (Pseudomegatherium) tarijense (Xenarthra: Megatheriidae)". English. In: Journal of Vertebrate Paleontology 29.4 (2009), pp. 1244-1251.

[5540] G. De Iuliis, F. Pujos, N. Toledo, M. S. Bargo, and S. F. Vizcaino. “Eucholoeops Ameghino, 1887 (Xenarthra, Tardigrada, Megalonychidae) from the Santa Cruz Formation, Argentine Patagonia: implications for the systematics of Santacrucian sloths". English. In: Geodiversitas 36.2 (2014), pp. 209255. DOI: $10.5252 / \mathrm{g} 2014 \mathrm{n} 2 \mathrm{a} 2$.

[5541] G. De Iuliis, G. Ré, and S. F. Vizcano. “The Toro Negro Megatheriinae (Mammalia, Xenarthra: A new species of Pyramiodontherium and a review of Plesiomegatherium". English. In: Journal of Vertebrate Paleontology 24.1 (2004), pp. 214-227. DOI: 10.1671/17.1.

[5542] G. De Iuliis and P. A. Saint-Andre. "Eremotherium sefvei nov. sp. (Mammalia, Xenarthra, Megatheriidae) from the Pleistocene of Ulloma, Bolivia". English. In: Geobios 30.3 (1997), pp. 453-461.

[5543] R. De Jong. “Reconstructing a 55-million-year-old butterfly (Lepidoptera: Hesperiidae)". English. In: European Journal of Entomology 113 (2016), pp. 423-428.

[5544] W. J. de Klerk. "A dicynodont trackway from the Cistecephalus Assemblage Zone in the Karoo, East of Graaff-Reinet, South Africa". English. In: Palaeontologia Africana 38 (2002), pp. 73-91.

[5545] W. J. de Klerk, C. A. Forster, S. D. Sampson, A. Chinsamy, and C. F. Ross. "A new coelurosaurian dinosaur from the Early Cretaceous of South Africa". English. In: Journal of Vertebrate Paleontology 20.2 (2000), pp. 324-332.

[5546] M. de la Fuente, F. de Lapparent de Broin, and T. M. de Bianco. "The oldest and first nearly complete skeleton of a chelid, of the Hydromedusa sub-group (Chelidae, Pleurodira), from the Upper Cretaceous of Patagonia". English. In: Bulletin de la Société Géologique de France 172.2 (2001), pp. 237-244.

[5547] M. de la Fuente and F. de Lapparent de Broin. "An Araripemys-like decorated pleurodire turtle in the Paleocene of northwestern Argentine”. English. In: Geobios 30.2 (1997), pp. 235-242. 
[5548] M. de la Fuente, F. E. Novas, M. P. Isasi, J. M. Lirio, and H. J. Nuñez. “First Cretaceous turtle from Antarctica". English. In: Journal of Vertebrate Paleontology 30.4 (2010), pp. 1275-1278. DOI: 10.1080/02724634.2010.483542.

[5549] M. C. de la Fuente, A. M. Umazano, J. Sterli, and J. L. Carballido. "New chelid turtles of the lower section of the Cerro Barcino Formation (Aptian-Albian?), Patagonia, Argentina". English. In: Cretaceous Research 32 (2011), pp. 527-537.

[5550] M. S. de la Fuente. "Two new pleurodiran turtles from the Portezuelo Formation (Upper Cretaceous) of Northern Patagonia, Argentina". English. In: Journal of Paleontology 77.3 (2003), pp. 559575.

[5551] M. S. de la Fuente. "Las tortugas Chelidae del Terciario superior y Cuaternario del territorio argentino". Spanish. In: Ameghiniana 29.3 (1992), pp. 211-229.

[5552] M. S. de la Fuente. “Descripción de nuevos especmenes y relaciones filogenéticas de Chelonoidis gringorum (Simpsom, 1942) (Chelonii: Testudinidae) del Mioceno temprano de Patagonia Central, Argentina". Spanish. In: Studia Geologica Salmanticencia 30 (1994), pp. 107-131.

[5553] M. S. de la Fuente. "Las tortugas pleistocenas del extremo meridional de la Provincia de Santa Fe, Argentina". Spanish. In: Studia Geologica Salmanticensia 33 (1997), pp. 67-90.

[5554] M. S. de la Fuente, R. Barbieri, and P. Chafrat. “Una tortuga Chelidae (Testudines: Pleurodira) de cuello largo en el Grupo Neuquén, Ro Negro, Argentina. Significado cronológico y paleobiogeográfico". Spanish. In: Andean Geology 37.2 (2010), pp. 398-412.

[5555] M. S. de la Fuente and P. Bona. "Una nueva especie del género Hydromedusa Wagler (Pleurodira, Chelidae) del Paleógeno de Patagonia". Spanish. In: Ameghiniana 39.1 (2002), pp. 77-83.

[5556] M. S. de la Fuente, P. Ciccioli, O. Limarino, P. Gutiérrez, and L. Fauque. “Quelonios podocnemídidos en la Formación Puesto La Flecha (Oligoceno), Precordillera de la Rioja, Argentina". Spanish. In: Ameghiniana 40.4 (2003), pp. 617-614.

[5557] M. S. De La Fuente and M. S. Fernandez. "An unusual pattern of limb morphology in the Tithonian marine turtle Neusticemys neuquina from the Vaca Muerta Formation, Neuquen Basin, Argentina". English. In: Lethaia 44 (2011), pp. 15-25.

[5558] M. S. de la Fuente, M. S. Fernández, A. Parras, and Y. Herrera. "Euclastes meridionalis (DE LA FUENTE \& CASADÍO) (Testudines: Pancheloniidae) from Danian levels of the Jagüel Formation at Cerro Azul, Northern Patagonia, Argentina". English. In: Neues Jahrbuch für Geologie und Paläontologie - Abhandlungen 253.2/3 (2009), pp. 327-339.

[5559] M. S. de la Fuente and M. S. Fernandez. “Un nuevo resto de Meiolaniidae (Chelonii: Cryptodira) del Terciario temprano". Spanish. In: Acta Zoológica Lilloana 41 (1992), pp. 365-369.

[5560] M. S. de la Fuente and M. Iturralde-Vinent. "A new pleurodiran turtle from the Jagua Formation (Oxfordian) of western Cuba". English. In: Journal of Paleontology 75.4 (2001), pp. 860-869.

[5561] M. S. de la Fuente, I. Maniel, J. M. Janello, J. Sterli, B. Gonzalez Riga, and F. Novas. “A new large panchelid turtle (Pleurodira) from the Loncoche Formation (upper Campanian-lower Maastrichtian) of the Mendoza Province (Argentina): Morphological, osteohistological studies, and a preliminary phylogenetic analysis". English. In: Cretaceous Research 69 (2017), pp. 147-168. DOI: 10.1016/j.cretres.2016.09.007.

[5562] M. S. De la Fuente, I. Maniel, J. M. Jannello, J. Sterli, A. C. Garrido, R. A. Garcia, L. Salgado, J. I. Canudo, and R. Bolatti. "Unusual shell anatomy and osteohistology in a new Late Cretaceous panchelid turtle from northwestern Patagonia, Argentina". English. In: Acta Palaeontologica Polonica 62 (2017). DOI: 10.4202/app.00340.2017.

[5563] M. S. de la Fuente, I. J. Maniel, J. M. Jannello, L. S. Filippi, and I. Cerda. “Long-necked chelid turtles from the Campanian of northwestern Patagonia with comments on K/P survivorship of the genus Yaminuechelys". English. In: Comptes Rendus Palevol (2015). DOI: 10.1016/j.crpv.2015.04.008.

[5564] M. S. de la Fuente, J. I. Noriega, C. I. Pina, and R. Araujo. Trachemys dorbigni (Duméril y Bibron, 1835) (Cryptodira: Emydidae) en el Pleistoceno tardo de la provincia de Entre Ros, Argentina. Spanish. 2001. 
[5565] M. S. de la Fuente, S. N. Santillana, and S. A. Marensi. “An Eocene leatherback turtle (Cryptodira; Dermochelyidae) from Seymour Island, Antarctica". English. In: Studia Geologica Salmanticensia 31 (1995), pp. 21-34.

[5566] M. S. de la Fuente and M. G. Vucetich. "Nuevos materiales de tortugas cryptodiras miocenas del Valle de Chubut, Argentina". Spanish. In: Ameghiniana 35.2 (1998), pp. 211-215.

[5567] M. S. de la Fuente, G. G. Zacarias, and E. Vlachos. "A review of the fossil record of the South American turtles of the clade Pan-Testudinoidea". English. In: Bulletin of the Peabody Museum of Natural History (2018).

[5568] R. G. De La Garza, J. L. Gonzalez, and Z. Shen. "Luminescence chronology of a Mass Grave of Giant Gopher Tortoises (Gopherus hexagonatus), Willacy County, TX". English. In: Bulletin of the South Texas Geological Society (2018), pp. 20-33.

[5569] F. de Lapparent de Broin. "Elosuchus, a new genus of crocodile from the Lower Cretaceous of the north of Africa". English. In: Comptes Rendus Palevol 1 (2002), pp. 275-285.

[5570] F. de Lapparent de Broin. "A new Shachemydinae (Chelonii, Cryptodira) from the Lower Cretaceous of Laos: preliminary data". English. In: Comptes Rendus Palevol 3 (2004), pp. 387-396. DOI: 10.1016/j.crpv.2004.05.004.

[5571] F. de Lapparent de Broin. "Miocene Chelonians from southern Namibia". English. In: Memoir of the Geological Survey of Namibia 19 (2003), pp. 67-102.

[5572] F. de Lapparent de Broin. "Miocene Chelonians from South-western Namibia". English. In: Memoir of the Geological Survey of Namibia 20 (2008), pp. 107-145.

[5573] F. de Lapparent de Broin. "African Chelonians from the Jurassic to the Present: Phases of development and preliminary catalogue of the fossil record". English. In: Palaeontologia Africana 36 (2000), pp. 43-82.

[5574] F. de Lapparent de Broin, S. Bailon, M. L. Augé, and J. -C. Rage. “Amphibians and reptiles from the Neogene of Afghanistan". English. In: Geodiversitas 42.22 (2020), pp. 409-426. DOI: 10.5252 / geodiversitas2020v42a22.

[5575] F. de Lapparent de Broin, N. Bardet, M. Amaghzaz, and S. Meslouh. "A strange new chelonioid turtle from the latest Cretaceous phosphates of Morocco". English. In: Comptes Rendus Palevol 13.2 (2014), pp. 87-95.

[5576] F. de Lapparent de Broin, L. Chirio, and R. Bour. "The oldest erymnochelyine turtle skull, Ragechelus sahelica n. gen., n. sp., from the Iullemmeden basin, Upper Cretaceous of Africa, and the associated fauna in its geographical and geological context". English. In: Geodiversitas 42.25 (2020), pp. 455-484. DOI: 10.5252/geodiversitas2020v42a25.

[5577] F. de Lapparent de Broin, M. S. de la Fuente, and M. S. Fernández. "Notoemys laticentralis (Chelonii, Pleurodira), Late Jurassic of Argentina: new examination of the anatomical structures and comparisons". English. In: Revue de Paléobiologie 26.1 (2007), pp. 99-136.

[5578] F. de Lapparent de Broin, X. Murelaga, F. Farrés, and J. Altimiras. "An exceptional cheloniid turtle, Osonachelus decorata nov. gen., nov. sp., from the Eocene (Bartonian) of Catalonia (Spain)". English. In: Geobios 47.3 (2014), pp. 111-132. DOI: 10.1016/j.geobios.2014.02.002.

[5579] F. de Lapparent de Broin, X. Murelaga, A. Pérez-Garca, F. Farrés, and J. Altimiras. “The turtles from the upper Eocene, Osona County (Ebro Basin, Catalonia, Spain): new material and its faunistic and environmental context". English. In: Fossil Record 21 (2018), pp. 237-284. DOI: 10.5194/fr-21-2372018.

[5580] F. de Lapparent de Broin and G. V. R. Prasad. “Chelonian Pelomedusoides Remains from the Late Cretaceous of Upparhatti (Southwestern India): Systematics and Paleobiogeographical Implications". English. In: Biological Consequences of Plate Tectonics: New Perspectives on PostGondwana Break-up-A Tribute to Ashok Sahni. Springer Nature, 2020, pp. 123-180. DOI: 10. 1007/978-3-030-49753-8_7. 
[5581] G. D. de Lavigerie, M. Bosselaers, S. Goolaerts, T. Park, O. Lambert, and F. G. Marx. “New Pliocene right whale from Belgium informs balaenid phylogeny and function". English. In: Journal of Systematic Palaeontology (2020). DOI: 10.1080/14772019.2020.1746422.

[5582] A. de Leeuw, O. Mandic, H. de Bruijn, Z. Markovi, J. Reumer, W. Wessels, E. ii, and W. Krijgsman. "Magnetostratigraphy and small mammals of the Late Oligocene Banovii basin in NE Bosnia and Herzegovina". English. In: Palaeogeography, Palaeoclimatology, Palaeoecology 310 (2011), pp. 400-412.

[5583] S. De Los Arcos, D. Partarrieu, J. Carrillo-Briceño, and E. Amson. "The Southernmost Occurrence of the Aquatic Sloth Thalassocnus (Mammalia, Tardigrada) in Two New Pliocene Localities in Chile". English. In: Ameghiniana 54.4 (2017), pp. 351-369.

[5584] M. de los Reyes, D. Poiré, L. Soibelzon, A. E. Zurita, and M. J. Arrouy. "First evidence of scavenging of a Glyptodont (Mammalia, Glyptodontidae) from the Pliocene of the Pampean region (Argentina): taphonomic and paleoecological remarks". English. In: Palaeontologia Electronica 16.2 (2013), pp. 1-13.

[5585] C. de Miguel Chaves, S. Garca-Gil, F. Ortega, J. L. Sanz, and A. Pérez-Garca. "First Triassic tetrapod (Sauropterygia, Nothosauridae) from Castilla y León: evidence of an unknown taxon for the Spanish record". English. In: Journal of Iberian Geology 42.1 (2016), pp. 29-38. DOI: 10.5209 / rev_ JIGE.2016.v42.n1.51210.

[5586] C. de Miguel Chaves, F. Ortega, and A. Pérez-Garca. "New highly pachyostotic nothosauroid interpreted as a filter-feeding Triassic marine reptile". English. In: Biology Letters 14 (2018), p. 20180130. DOI: $10.1098 / \mathrm{rsbl} .2018 .0130$.

[5587] C. de Muizon and R. L. Cifelli. "The condylarths (archaic Ungulata, Mammalia) from the early Palaeocene of Tiupampa (Bolivia): implications on the origin of the South American ungulates". English. In: Geodiversitas 22.1 (2000), pp. 47-150.

[5588] C. de Muizon and R. L. Cifelli. "A new basal didelphoid (Marsupialia, Mammalia) from the early Paleocene of Tiupampa (Bolivia)". English. In: Journal of Vertebrate Paleontology 21.1 (2001), pp. 8797.

[5589] C. de Muizon and L. G. Marshall. "Alcidedorbignya inopinata (Mammalia: Pantodonta) from the Early Paleocene of Bolivia: Phylogenetic and Paleobiogeographic Implications". English. In: Journal of Paleontology 66.3 (1992), pp. 499-520.

[5590] C. J. de Muizon. "A new carnivorous marsupial from the Palaeocene of Bolivia and the problem of marsupial monophyly". English. In: Nature 370 (1994), pp. 208-211.

[5591] R. S. de Oliveira, A. C. R. Nogueira, G. R. Romero, W. Truckenbrodt, and J. C. da Silva Bandeira. "Ediacaran ramp depositional model of the Tamengo Formation, Brazil". English. In: Journal of South American Earth Sciences (2019). DOI: 10.1016/j.jsames.2019.102348.

[5592] T. V. de Oliveira, C. L. Schultz, M. B. Soares, and C. N. Rodriques. "A new carnivorous cynodont (Synapsida, Therapsida) from the Brazilian Middle Triassic (Santa Maria Formation): Candelariodon barberenai gen. et sp. nov." English. In: Zootaxa 3027 (2011), pp. 19-28.

[5593] T. V. de Oliveira, C. L. Schultz, and M. B. Soares. "O esqueleto pós-craniano de Exaeretodon riograndensis Abdala et al. (Cynodontia, Traversodontidae), Triássico do Brasil". English. In: Revista Brasileira de Paleontologia 10 (2007), pp. 79-94.

[5594] V. L. De Pietri, A. B. Camens, and T. H. Worthy. "A Plains-wanderer (Pedionomidae) that did not wander plains: a new species from the Oligocene of South Australia". English. In: Ibis 157 (2015), pp. 68-74.

[5595] V. L. De Pietri, L. Costeur, M. Güntert, and G. Mayr. "A revision of the Lari (Aves, Charadriiformes) from the Early Miocene of Saint-Gérand-le-Puy (Allier, France)". English. In: Journal of Vertebrate Paleontology 31.4 (2011), pp. 812-828.

[5596] V. L. De Pietri, M. Güntert, and G. Mayr. "A Haematopus-like skull and other remains of Charadrii (Aves, Charadriiformes) from the Early Miocene of Saint-Gérand-le-Puy (Allier, France)". English. In: Proceedings of the Society of Avian Paleontology and Evolution 2013 (2013), pp. 93-101. 
[5597] V. L. De Pietri and G. Mayr. "An assessment of the diversity of Early Micoene Scolopaci (Aves, Schardriiformes) from Saint, Gérand-Le Puy (Allier, France)". English. In: Palaeontology 55.6 (2012), pp. 1177-1197. DOI: 10.1111/j.1475-4983.2012.01182.x.

[5598] V. L. De Pietri, R. P. Scofield, G. J. Prideaux, and T. H. Worthy. "A new species of lapwing (Charadriidae: Vanellus) from the late Pliocene of central Australia". English. In: Emu - Austral Ornithology 118.4 (2018), pp. 334-343. DOI: 10.1080/01584197.2018.1464373.

[5599] V. L. De Pietri, R. P. Scofield, A. J. D. Tennyson, S. J. Hand, and T. H. Worthy. “Wading a lost southern connection: Miocene fossils from New Zealand reveal a new lineage of shorebirds (Charadriiformes) linking Gondwanan avifaunas". English. In: Journal of Systematic Palaeontology (2015). DOI: 10.1080/14772019.2015.1087064.

[5600] V. L. De Pietri, R. P. Scofield, S. J. Hand, A. J. D. Tennyson, and T. H. Worthy. "Sheathbill-like birds (Charadriiformes: Chionoidea) from the Oligocene and Miocene of Australasia". English. In: Journal of the Royal Society of New Zealand (2016). DOI: 10.1080/03036758.2016.1194297.

[5601] V. L. De Pietri, R. P. Scofield, N. V. Zelenkov, W. E. Boles, and T. H. Worthy. "The unexpected survival of an ancient lineage of anseriform birds into the". English. In: Royal Society Open Science 3.150635 (2016), pp. 1-16. DOI: 10.1098/rsos.150635.

[5602] G. De Ploëg and A. Nel. "A new bethylid wasp from the Lowermost Eocene amber of France (Hymenoptera: Bethylidae: Bethylinae)". English. In: Geologica Acta 2 (2004), pp. 75-82.

[5603] N. A. De Santi, D. H. Verzi, A. I. Olivaresa, P. Piñeroa, C. C. Morgana, M. E. Medinab, D. E. Riveroc, and E. P. Tonnid. "A new peculiar species of the subterranean rodent Ctenomys (Rodentia, Ctenomyidae) from the Holocene of central Argentina". English. In: Journal of South American Earth Sciences 100 (2020), 102499:1-10.

[5604] P. De Schutter. “The presence of Megachasma (Chondricthyes: Lamniformes) in the Neogene of Belgium, first occurence in Europe". English. In: Geologica Belgica (2009).

[5605] P. M. de Toledo and D. P. Domning. "Fossil Sirenia (Mammalia: Dugongidae) from the Pirabas Formation (Early Miocene), northern Brazil". English. In: Boll. Mus. Para. Emilio Goeldi, ser. Ciencias da Terra 1.2 (1991), pp. 119-146.

[5606] S. de Valais. "Revision of dinosaur ichnotaxa from the La Matilde Formation (Middle Jurassic), Santa Cruz Province, Argentina". English. In: Ameghiniana 48.1 (2011), pp. 28-42.

[5607] S. de Valais, S. Apestegua, and D. Udrizar Sauthier. "Nuevas evidencias de dinosaurios de la Formación Puerto Yeruá (Cretácico), provincia de Entre Ros, Argentina [New evidence of dinosaurs from the Puerto Yeruá Formation (Cretaceous), Entre Ros province, Argentina]". Spanish. In: Ameghiniana 40.4 (2003), pp. 631-635.

[5608] S. de Valais and R. N. Melchor. "Ichnotaxonomy of bird-like footprints: an example from the Late Triassic-Early Jurassic of northwest Argentina". English. In: Journal of Vertebrate Paleontology 28.1 (2008), pp. 145-159.

[5609] P. R. R. de Vivar, A. G. Martinelli, A. S. Hsiou, and M. B. Soares. "A new rhynchocephalian from the Late Triassic of Southern Brazil enhances eusphenodontian diversity". English. In: Journal of Systematic Palaeontology (2020). DOI: 10.1080/14772019.2020.1732488.

[5610] J. de Vos, J. van der Made, A. Athanassiou, G. Lyras, P. Y. Sondaar, and M. D. Dermitzakis. "Preliminary report on the late Pliocene fauna from Vatera (Lesvos, Greece)". English. In: Annales Geologiques des Pays Helleniques 39 (2002), pp. 37-70.

[5611] V. De Zanche, P. Gianolla, and G. Roghi. "Carnian stratigraphy in the Raibl/Cave del Predil area (Julian Alps, Italy)”. English. In: Ecologae Geologicae Helvetiae 93 (2000), pp. 331-347.

[5612] T. M. De-Oliveira, F. L. Pinheiro, A. A. Stock Da-Rosa, S. Dias-Da-Silva, and L. Kerber. "A new archosauromorph from South America provides insights on the early diversification of tanystropheids". English. In: PLoS ONE 15.4 (2020), e0230890. DOI: 10.1371/journal.pone.0230890.

[5613] W. T. Dean. "Cambrian stratigraphy and trilobites of the Samur Dag area, south of Hakkari, southeastern Turkey". English. In: Turkish Journal of Earth Sciences 15 (2006), pp. 225-257. 
[5614] W. T. Dean, F. Martin, O. Monod, Y. Günay, H. Kozlu, and N. Bozdogan. “Precambrian? and Cambrian stratigraphy of the Penbegli-Tut inlier, southeastern Turkey". English. In: Geological Magazine 134.1 (1997), pp. 37-53.

[5615] J. Dean Shackleton. "Skeletal homologies, phylogeny and classification of the earliest asterozoan echinoderms". English. In: Journal of Systematic Palaeontology 3.1 (2005), pp. 29-114.

[5616] A. R. Deans, H. H. Basibuyuk, D. Azar, and A. Nel. “Descriptions of two new Early Cretaceous (Hauterivian) ensign wasp genera (Hymenoptera: Evaniidae) from Lebanese amber". English. In: Cretaceous Research 25 (2004), pp. 509-516.

[5617] I. Debeljak, A. Kosir, E. Buffetaut, and B. Otonicar. “The Late Cretaceous dinosaurs and crocodiles of Kozine (SW Slovenia): a preliminary study". English. In: Memorie della Societá Geologica Italiana 57 (2002), pp. 193-201.

[5618] D. B. DeBlieux, J. I. Kirkland, J. A. Smith, J. McGuire, and V. L. Santucci. "An overview of the paleontology of Upper Triassic and Lower Jurassic rocks in Zion National Park, Utah". English. In: vol. 37. The Triassic-Jurassic Terrestrial Transition. New Mexico Museum of Natural History and Science Bulletin. Albuquerque: New Mexico Museum of Natural History and Science, 2006, pp. $490-501$.

[5619] M. deBraga and R. R. Reisz. "A new diapsid reptile from the uppermost Carboniferous (Stephanian) of Kansas". English. In: Palaeontology 38.1 (1995), pp. 199-212.

[5620] F. Debrenne, A. Gandin, and R. A. Gangloff. "Analyse sedimentologique et paleontologie de calcaires organogenes du Cambrien inferieur de Battle Mountain (Nevada, USA) [Sedimentology and paleontology of the Lower Cambrian organogenic limestones from Battle Mountain (Nevada, USA)]". French. In: Annales de Paleontologie 76.2 (1990), pp. 73-119.

[5621] F. Debrenne, A. Gandin, and A. Zhuravlev. "Palaeoecological and sedimentological remarks on some Lower Cambrian sediments of the Yangtse platform (China)". English. In: Bulletin de la Societe Geologique de France 162.3 (1991), pp. 575-583.

[5622] F. Debrenne and R. Wood. "A new Cambrian sphinctozoan sponge from North America, its relationship to archaeocyaths and the nature of early sphinctozoans". English. In: Geological Magazine 127.4 (1990), pp. 435-443.

[5623] M. Debuysschere. "The Kuehneotheriidae (Mammaliaformes) from Saint-Nicolas-de-Port (Upper Triassic, France): a Systematic Review". English. In: Journal of Mammalian Evolution 24 (2017), pp. 127-146. DOI: 10.1007/s10914-016-9335-z.

[5624] B. Dechnik, J. M. Webster, G. E. Webb, L. Nothdurft, A. Dutton, J. -C. Braga, J. Zhao, S. Duce, and J. Sadler. "The evolution of the Great Barrier Reef during the Last Interglacial Period". English. In: Global and Planetary Change 149 (2017), pp. 53-71.

[5625] T. DeDiego-Forbis, R. Douglas, D. Gorsline, E. Nava-Sanchez, L. Mack, and J. Banner. "Late Pleistocene (Last Interglacial) terrace deposits, Bahia Coyote, Baja California Sur, Mexico". English. In: Quaternary International 120 (2004), pp. 29-40.

[5626] N. Degallier, R. Garrouste, and A. Nel. “New and poorly known Cenozoic clown beetle compressions from France (Insecta: Coleoptera: Histeridae)". English. In: Annales de la Société Entomologique de France 55 (2019), pp. 471-481. DOI: 10.1080/00379271.2019.1688683.

[5627] F. J. Degrange, D. Eddy, P. Puerta, and J. Clarke. “New skull remains of Phorusrhacos longissimus (Aves, Cariamiformes) from the Miocene of Argentina: implications for the morphology of Phorusrhacidae". English. In: Journal of Paleontology 93.6 (2019), pp. 1221-1233. DOI: 10.1017/jpa.2019. 53.

[5628] F. J. Degrange, C. P. Tambussi, M. L. Taglioretti, A. Dondas, and F. Scaglia. "A new Mesembriornithinae (Aves, Phorusrhacidae) provides new insights into the phylogeny and sensory capabilities of terror birds". English. In: Journal of Vertebrate Paleontology 35.2 (2015), e912656. DOI: 10.1080/02724634.2014.912656. 
[5629] F. J. Degrange and C. P. Tambussi. "Re-examination of Psilopterus lemoinei (Aves, Phorusrhacidae), a late early Miocene little terror bird from Patagonia (Argentina)". English. In: Journal of Vertebrate Paleontology 31.5 (2011), pp. 1080-1092. DOI: 10.1080/02724634.2011.595466.

[5630] J. A. Dehantschutter and A. Lees. "Waulsortian buildups of Waulsort, Belgium". English. In: Geological Journal 31 (1996), pp. 123-142.

[5631] M. Dehon, D. Michez, A. Nel, M. S. Engel, and T. De Meulemeester. "Wing shape of four new bee fossils (Hymenoptera: Anthophila) provides insights to bee evolution". English. In: PLoS One 9.10 (2014), e108865.

[5632] M. Dehon, A. Perrard, M. S. Engel, A. Nel, and D. Michez. "Antiquity of cleptoparasitism among bees revealed by morphometric and phylogenetic analysis of a Paleocene fossil nomadine (Hymenoptera: Apidae)". English. In: Systematic Entomology 42 (2017), pp. 543-554.

[5633] J. E. Deibert and B. H. Breithaupt. Ferdinand Hayden's 1868 huge bird tracks in the Upper Cretaceous Almond Formation: field evidence for the first dinosaur fossil discovered in Wyoming. English. Vol. 35. Late Cretaceous Vertebrates from the Western Interior. New Mexico Museum of Natural History and Science Bulletin. 2006, pp. 69-78.

[5634] G. M. Del Fueyo and A. Archangelsky. "Araucaria grandifolia Feruglio from the Lower Cretaceous of Patagonia, Argentina". English. In: Cretaceous Research 23 (2002), pp. 265-277. DOI: 10. 1006/cres.2002.1001.

[5635] G. M. Del Fueyo and S. Archangelsky. "A new araucarian pollen cone with in situ Cyclusphaera Elsik from the Aptian of Patagonia, Argentina". English. In: Cretaceous Research 26 (2005), pp. 757768. DOI: $10.1016 /$ j.cretres.2005.04.005.

[5636] L. M. del Papa and L. J. M. de Sanctis. “No se les escapó la tortuga. Uso antrópico de Chelonoidis chilensis en un sitio de la región chaco-santiagueña (provincia de Santiago del Estero)". Spanish. In: Arqueología 21.1 (2015), pp. 115-135.

[5637] C. del Rio. "Molluscos del Terciario marino". Spanish. In: Geologa y Recursos Naturales de Santa Cruz 2.9 (2002), pp. 1-22.

[5638] C. J. del Rio. “Tertiary Marine Molluscan Assemblages of Eastern Patagonia (Argentina): A Biostratigraphic Analysis". English. In: Journal of Paleontology 78.6 (2004), pp. 1097-1122.

[5639] C. J. del Rio. "Middle Miocene bivalves of the Puerto Madryn Formation, Valdes Peninsule, Chubut Province, Argentina (Nuculidae-Pectinidae): Part 1". English. In: Palaeontographica Abteilung A 225 (1992), pp. 1-58.

[5640] C. J. Del Rio. "The genus Swiftopecten Hertlein, 1936 (Bivalvia: Pectinidae) in the Tertiary of Southern South America". English. In: Journal of Paleontology 69.6 (1995), pp. 1054-1059.

[5641] M. Del Rio, G. L. Pillola, and F. Muntoni. "The Upper Carboniferous of the San Giorgio basin". English. In: Rendiconti della Societá Paleontologica Italiana 1 (2002), pp. 223-229.

[5642] R. A. Del Valle, D. Montalti, and M. Inbar. "Mid-Holocene macrofossil-bearing raised marine beaches at Potter Peninsula, King George Island, South Shetland Islands". English. In: Antarctic Science 14.3 (2002), pp. 263-269. DOI: 10.1017/S0954102002000081.

[5643] F. Dela Pierre, E. Bernardi, S. Cavagna, P. Clari, R. Gennari, A. Irace, F. Lozar, S. Lugli, V. Manzi, M. Natalicchio, M. Roveri, and D. Violanti. "The record of the Messinian salinity crisis in the Tertiary Piedmont Basin (NW Italy): The Alba section revisited". English. In: Palaeogeography, Palaeoclimatology, Palaeoecology 310 (2011), pp. 238-255. DOI: 10.1016/j.palaeo.2011.07.017.

[5644] A. Delagnes, J.-F. Tournepiche, D. Armand, E. Desclaux, M. -F. Diot, C. Ferrier, V. Le Fillatre, and B. Vandermeersch. "Le gisement Pleistocene moyen et superieur d'Artenac (Saint-Mary, Charent): premier bilan interdisciplinaire". French. In: Bulletin de la Societe Prehistorique Francaise 96.4 (1999), pp. 469-496.

[5645] J. B. Delair. "Reptilia from the Portland Stone (Upper Jurassic) of England: a preliminary survey of the material and the literature". English. In: Modern Geology 18 (1993), pp. 331-348. 
[5646] J. B. Delair and W. A. S. Sarjeant. "The earliest discoveries of dinosaurs: the records re-examined". English. In: Proceedings of the Geologists' Association 113 (2002), pp. 185-197.

[5647] M. Delamette, J. Charollais, D. Decrouez, and M. Caron. "Les grés verts helvétiques (Aptien moyen-Albien supérieur) de Haute-Savoie, Valais et Vaud (Alpes occidentales franco-suisses)". French. In: Publications du Département de Géologie et Paléontologie. Section des Sciences de la Terre 23 (1997), pp. 1-400.

[5648] G. Delanoy, C. Baudouin, R. Gonnet, G. Conte, and C. Frau. "Sur la présence des genres Heminautilus Spath, 1927 et Eucymatoceras Spath, 1927 (Nautilida, Nautilaceae) dans le Barrémien inférieur du Gard (sud-est de la France)". French. In: Annales du Muséum d'Histoire Naturelle de Nice 28 (2012), pp. 155-195.

[5649] G. Delanoy, J. A. Moreno-Bedmar, J. J. Ruiz, and D. Tolós Lládser. “Xerticeras gen. nov., a new genus of micromorphic heteromorph ammonite (Ancyloceratina, Ancyloceratidae)from the lower Aptian of Spain". English. In: Carnets de Géologie [Notebooks on Geology] CG2013_A02 (2013), pp. 89103.

[5650] X. Delclós, A. Nel, D. Azar, G. Bechly, J. A. Dunlop, M. S. Engel, and S. W. Heads. "The enigmatic Mesozoic insect taxon Chresmodidae (Polyneoptera): new palaeobiological and phylogenetic data, with the description of a new species from the Lower Cretaceous of Brazil". English. In: Neues Jahrbuch für Geologie und Paläontologie, Abhandlungen 247 (2008), pp. 353-381.

[5651] X. Delclós, E. Peñalver, A. Arillo, M. S. Engel, A. Nel, D. Azar, and A. Ross. "New mantises (Insecta: Mantodea) in Cretaceous ambers from Lebanon, Spain, and Myanmar". English. In: Cretaceous Research 60 (2016), pp. 91-108.

[5652] R. Delcourt and O. N. Grillo. "On maniraptoran material (Dinosauria: Theropoda) from Vale do Rio do Peixe Formation, Bauru Group, Brazil". English. In: Revista Brasileira de Paleontologia 17.3 (2014), pp. 307-316. DOI: 10.4072/rbp.2014.3.03.

[5653] R. Delcourt and F. V. Iori. "A new Abelisauridae (Dinosauria: Theropoda) from São José do Rio Preto Formation, Upper Cretaceous of Brazil and comments on the Bauru Group fauna". English. In: Historical Biology (2018).

[5654] T. Delevoryas and J. E. Mickle. "Upper Cretaceous Magnoliaceous fruit from British Columbia". In: American Journal of Botany 82.6 (1995), pp. 763-768.

[5655] M. Delfino. “New remains of Crocodylus checchiai Maccagno 1947 (Crocodylia, Crocodylidae) from the Late Miocene of As Sahabi, Libya". English. In: Garyounis Scientific Bulletin, Special Issue 5 (2008), pp. 111-118.

[5656] M. Delfino, M. Böhme, and L. Rook. "First European evidence for transcontinental dispersal of Crocodylus (late Neogene of southern Italy)". English. In: Zoological Journal of the Linnean Society 149 (2007), pp. 293-307.

[5657] M. Delfino, F. Candilio, G. Carnevale, A. Coppa, T. Medin, M. Pavia, L. Rook, A. Urciuoli, and A. Villa. "The early Pleistocene vertebrate fauna of Mulhuli-Amo (Buia area, Danakil Depression, Eritrea)". English. In: Bollettino della Societá Paleontologica Italiana 57.1 (2018), pp. 27-44. DOI: 10. 4435/BSPI.2018.02.

[5658] M. Delfino, V. Codrea, A. Folie, P. Dica, P. Godefroit, and T. Smith. "A complete skull of Allodaposuchus precedens Nopcsa, 1928 (Eusuchia) and a reassessment of the morphology of the taxon based on the Romanian remains". English. In: Journal of Vertebrate Paleontology 28.1 (2008), pp. 111122.

[5659] M. Delfino and C. Dal Sasso. "Marine reptiles (Thalattosuchia) from the Early Jurassic of Lombardy (northern Italy)". English. In: Geobios 39 (2006), pp. 346-354.

[5660] M. Delfino and J. de Vos. "A revision of the Dubois crocodylians, Gavialis bengawanicus and Crocodylus ossifragus, from the Pleistocene Homo erectus beds of Java". English. In: Journal of Vertebrate Paleontology 30.2 (2010), pp. 427-441.

[5661] M. Delfino and J. de Vos. "A giant crocodile in the Dubois Collection from the Pleistocene of Kali Gedeh (Java)”. English. In: Integrative Zoology 9 (2014), pp. 141-147. 
[5662] M. Delfino, T. Kotsakis, M. Arca, C. Tuveri, G. Pitruzzella, and L. Rook. "Agamid lizards from the Plio-Pleistocene of Sardinia (Italy) and an overview of the European fossil record of the family". English. In: Geodiversitas 30.3 (2008), pp. 641-656.

[5663] M. Delfino, Á H. Luján, J. Abella, D. M. Alba, M. Böhme, A. Pérez-Ramos, E. Tschopp, J. Morales, and P. Montoya. "Late Miocene remains from Venta del Moro (Iberian Peninsula) provide further insights on the dispersal of crocodiles across the late Miocene Tethys". English. In: Journal of Paleontology 95.1 (2021), pp. 184-192. DOI: 10.1017/jpa.2020.62.

[5664] M. Delfino, J. E. Martin, and E. Buffetaut. "A new species of Acynodon (Crocodylia) from the Upper Cretaceous (Santonian-Campanian) of Villaggio del Pescatore, Italy". English. In: Palaeontology 51.5 (2008), pp. 1091-1106. DOI: 10.1111/j.1475-4983.2008.00800.x.

[5665] M. Delfino, J. E. Martin, F. de Lapparent de Broin, and T. Smith. “Evidence for a pre-PETM dispersal of the earliest European crocodyloids". English. In: Historical Biology 31 (2019), pp. 845-852. DOI: 10.1080/08912963.2017.1396323.

[5666] M. Delfino, P. Piras, and T. Smith. "Anatomy and phylogeny of the gavialoid crocodylian Eosuchus lerichei from the Paleocene of Europe". English. In: Acta Palaeontologica Polonica 50.3 (2005), pp. 565-580.

[5667] M. Delfino and L. Rook. "African Crocodylians in the Late Neogene of Europe: A Revision of Crocodylus bambolii Ristori, 1890". English. In: Journal of Paleontology 82.2 (2008), pp. 336-343.

[5668] M. Delfino and M. A. Rossi. "Fossil crocodylid remains from Scontrone (Tortonian, Southern Italy) and the late Neogene Mediterranean biogeography of crocodylians". English. In: Geobios 46 (2013), pp. 25-31.

[5669] M. Delfino and M. R. Sanchez-Villagra. "A Late Miocene pipine frog from the Urumaco Formation, Venezuela". English. In: Ameghiniana (2018). DOI: 10.5710/AMGH.04.10.2017.3136.

[5670] M. Delfino, T. M. Scheyer, F. Chesi, T. Fletcher, R. Gemel, S. MacDonald, M. Rabi, and S. W. Salisbury. "Gross morphology and microstructure of type locality ossicles of Psephophorus polygonus Meyer, 1847 (Testudines, Dermochelyidae)". English. In: Geological Magazine (2013), pp. 1-16. DOI: 10.1017/S001675681200091X.

[5671] M. Delfino, A. Segid, D. Yosief, J. Shoshani, L. Rook, and Y. Libsekal. "Fossil reptiles from the Pleistocene Homo-Bearing locality of buia (Eritrea, Northern Danakil Depression)". English. In: Rivista Italiana di Paleontologia e Stratigrafia 110 (2004), pp. 51-60.

[5672] M. Delfino and T. Smith. "Reappraisal of the morphology and phylogenetic relationships of the middle Eocene alligatoroid Diplocynodon deponiae (Frey, Laemmert, and Riess, 1987) based on a three-dimensional specimen". English. In: Journal of Vertebrate Paleontology 32.6 (2012), pp. 13581369.

[5673] M. Delfino and T. Smith. "A reassessment of the morphology and taxonomic status of 'Crocodylus' depressifrons Blainville, 1855 (Crocodylia, Crocodyloidea) based on the Early Eocene remains from Belgium". English. In: Zoological Journal of the Linnean Society 156 (2009), pp. 140-167.

[5674] B. Deline, T. Baumiller, P. Kaplan, M. Kowalewski, and A. P. Hoffmeister. "Edge-drilling on the brachiopod Perditocardinia cf. P. dubia from the Mississippian of Missouri (USA)". English. In: Palaeogeography, Palaeoclimatology, Palaeoecology 201 (2003), pp. 211-219.

[5675] B. Dell'Angelo, A. Bonfitto, and M. Taviani. "Chitons (Polyplacophora) from Paleogene Strata in Western Washington State, U.S.A." English. In: Journal of Paleontology 85.5 (2011), pp. 936-954.

[5676] B. Dell'Angelo, M. Sosso, A. Kroh, and A. Dulai. "Polyplacophora from the Eocene of Gánt, Hungary". English. In: Bulletin of Geosciences 90.2 (2014), pp. 359-370.

[5677] G. Della Porta, B. Mamet, and A. Preat. Microbial mediation in the formation of red limestones, Upper Carboniferous, Cantabrian Mountains, Spain. English. in T. E. Wong, ed., Proceedings of the XVth International Congress on Carboniferous and Permian stratigraphy 2003. 2007, pp. 243-250.

[5678] B. Dell'Angelo, V. Garilli, A. Germaná, A. Reitano, M. Sosso, and A. Bonfitto. "Notes on fossil chitons. 4. Polyplacophora from the Pliocene of Altavilla (NW Sicily)". English. In: Bollettino Malacologico 48.1 (2012), pp. 51-68. 
[5679] C. Delmer, M. Mahboubi, R. Tabuce, and P. Tassy. “A new species of Moeritherium (Proboscidea, Mammalia) from the Eocene of Algeria: New perspectives on the ancestral morphotype of the genus". English. In: Palaeontology 49.2 (2006), pp. 421-434.

[5680] D. Delsate. "Reptiles terrestres (Lepidosauromorpha et Traversodontidae) du Trias superieur de Medernach (G.-D. de Luxembourg) [Terrestrial reptiles (Lepidosauromorpha and Traversodontidae) from the Upper Triassic of Medernach (G. D. of Luxembourg)]". French. In: Travaux Scientifiques du Musee d'Histoire Naturelle de Luxembourg 32 (1999), pp. 55-86.

[5681] D. Delsate. New lepidosaur record (Reptilia) from the Upper Triassic of the Belgian province of Luxembourg. English. Vol. 36. Paléontologie au Luxembourg. Travaux scientifiques du Musée national d'histoire naturelle Luxembourg. Ferrantia. 2003, pp. 39-43.

[5682] D. Delsate. “Une nouvelle faune des poissons et requins Toarciens du sud du Luxembourg (Dudelange) et de L'Allemange (Schömberg)". French. In: Bulletin de l'Académie Lorrain des Sciences 42 (2003), pp. 13-49.

[5683] D. Delsate. "Microrestes de poissons du Lias et du Rhétien de Moselle et de Meurthe-et-Moselle (N-E France)". French. In: Bulletin de la Société d'Histoire Naturelle de la Moselle 51 (2009), pp. 19-33.

[5684] D. Delsate. "L'ichthyofaune du Pliensbachian (Jurassique Inférieur) de Lorraine et des Ardennes (France): premiers résultats". French. In: Bulletin de l'Académie Lorraine des Sciences 40 (2001), pp. 4769.

[5685] D. Delsate. "Presence dun multitubercule de petite taille a la transition Paleocene-Eocene de Dormaal MP7, Belgique [Presence of a small Multituberculata at the Paleocene-Eocene transition of Dormaal (Belgium, MP7)]". French. In: Oryctos 3 (2000), pp. 61-69.

[5686] D. Delsate. “Un nouvelle dent d'Haramiyidae (Thomasia woutersi Butler \& Macintyre 1994, Mammalia, Allotheria) du Rhétien d'Habay-la-Vielle (Lorraine Belge) [A new haramiyid tooth (Thomasia woutersi Butler and MacIntyre 1994, Mammalia, Allotheria) from the Rhaetian of Habay la Vieille (Belgian Lorraine)]". French. In: Bulletin de la Société Belge de Géologie 104.1-2 (1996), pp. 2334.

[5687] D. Delsate and L. W. Candoni. "Description de nouveaux morphotypes dentaires de Batomorphii toarciens (Jurassique inférieur) du Bassin de Paris: Archaeobatidae nov fam". English. In: Bull. Soc. Nat. Luxemb 102 (2001), pp. 131-143.

[5688] D. Delsate, C. J. Duffin, and R. Weis. "A new microvertebrate fauna from the Middle Hettangian (Early Jurassic) of Fontenoille (Province of Luxembourg, south Belgium)". In: Memoirs of the Geological Survey of Belgium 48 (2002), pp. 3-83.

[5689] D. Delsate and M. D. Ezcurra. "The first Early Jurassic (late Hettangian) theropod dinosaur remains from the Grand Duchy of Luxembourg". English. In: Geological Belgica 17.2 (2014), pp. 175181.

[5690] D. Delsate and R. Felten. "Chondrichthyens et Actinoptérygiens du Bajocien inférieur du GrandDuché de Luxembourg et des régions frontaliéres". French. In: Ferrantia 71 (2015), pp. 9-38.

[5691] D. Delsate and P. Godefroit. "Chondrichtyens du Toarcien inferieur d'Aubange (Lorraine belge)". French. In: Belgian Geological Survey, Professional Paper, Elasmobranches et Stratigraphie 278.1994 (1995), pp. 23-43.

[5692] D. Delsate and W. M. Jagt. "A note on an early Jurassic ophiuroid from Rachecourt (Lorraine, Belgium)". English. In: Bulletin de l'Institut Royal des Sciences Naturelles de Belgique, Sciences de Terre 66 (1996), pp. 203-207.

[5693] D. Delsate and J. Kriwet. "Late Triassic pycnodont fish remains (Neopterygii, Pycnodontiformes) from the Germanic Basin". English. In: Eclogae Geologicae Helveticae 97 (2004), pp. 183-191.

[5694] D. Delsate and D. Thies. “Teeth of the fossil shark Annea Thies 1983 (Elasmobranchii, Neoselachii) from the Toarcian of Belgium". English. In: Belgian Geological Survey, Professional Paper, Elasmobranches et Stratigraphie 278 (1995), pp. 45-64. 
[5695] D. Delsate and R. Weis. “La Couche á Crassum (Toarcien moyen) au Luxembourg: stratigraphie et faunes de la coupe de Dudelange-Zoufftgen". French. In: Ferrantia 62 (2010), pp. 35-62.

[5696] D. Delsate and R. Wild. "Premiere decouverte d'un reptile volant determinable (Pterosauria, Dorygnathus cf banthensis) du Toarcien inferieur (Jurassique inferieur) de Nancy (Lorraine, France)". French. In: Bulletin de l'Académie et de la Societé Lorraine des Sciences 39.1-4 (2000), pp. 3-14.

[5697] L. L. Delsett, A. J. Roberts, P. S. Druckenmiller, and J. J. Hurum. “A new ophthalmosaurid (Ichthyosauria) from Svalbard, Norway, and evolution of the ichthyopterygian pelvic girdle". English. In: PLoS ONE 12.1 (2017), e0169971. DOI: 10.1371/journal.pone.0169971.

[5698] E. Delson, H. Thomas, and N. Spassov. "Fossil Old World monkeys (Primates, Cercopithecidae) from the Pliocene of Dorkovo, Bulgaria". English. In: Geodiversitas 27.1 (2005), pp. 159-166.

[5699] G. Delvene. "Middle and Upper Jurassic bivalve associations from the Iberian Range (Spain). Las asociaciones de bivalvos del Jurasico Medio y Superior en la Cordillera Iberica (Espana)". Spanish. In: Géobios 36.5 (2003), pp. 519-531.

[5700] D. G. DeMar Jr., J. L. Conrad, J. J. Head, D. J. Varricchio, and G. P. Wilson. “A new Late Cretaceous iguanomorph from North America and the origin of New World Pleurodonta (Squamata, Iguania)". English. In: Proceedings of the Royal Society of London B 284 (2017), 20161902:1-7.

[5701] D. G. DeMar Jr. "A new fossil salamander (Caudata, Proteidae) from the Upper Cretaceous (Maastrichtian) Hell Creek Formation, Montana, U.S.A." English. In: Journal of Vertebrate Paleontology 33.3 (2013), pp. 588-598.

[5702] D. G. DeMar Jr. and B. H. Breithaupt. “The nonmammalian vertebrate microfossil assemblages of the Mesaverde Formation (Upper Cretaceous, Campanian) of the Wind River and Bighorn Basins, Wyoming". English. In: Late Cretaceous Vertebrates from the Western Interior. New Mexico Museum of Natural History and Science Bulletin 35 (2006), pp. 33-54.

[5703] G. R. Demathieu and J. Sciau. "Des pistes de dinosaures et de crocodiliens dans les dolomies de l'Hettangien du Causse du Larzac [Dinosaur and crocodilian trackways in the Hettangian dolomites of the Larzac Causse]". French. In: Comptes Rendus de l'Académie des Sciences á Paris, Série II 315 (1992), pp. 1561-1566.

[5704] G. R. Demathieu and J. Sciau. "De grandes empreintes de pas de dinosaures dans l'Hettangian de Peyre (Aveyron, France) [Large dinosaur footprints in the Hettangian of Peyre (Aveyron, France)]". French. In: Géobios 32.4 (1999), pp. 609-616.

[5705] G. R. Demathieu and P. Wycisk. "Tetrapod trackways from southern Egypt and northern Sudan". English. In: Journal of African Earth Sciences 10.3 (1990), pp. 435-443.

[5706] G. R. S. Demathieu. "Empreintes de pas de dinosaures dans les Causses (France) [Dinosaur footprints in the Causses (France)]". French. In: Zuba 5 (1993), pp. 229-252.

[5707] T. A. Deméré. Two new species of fossil walruses (Pinnipedia: Odobenidae) from the Upper Pliocene San Diego Formation, California. English. Vol. 29. Proceedings of the San Diego Society of Natural History. 1994, pp. 77-98.

[5708] T. A. Deméré, A. Berta, and M. R. McGowen. "The taxonomic and evolutionary history of modern balaenopteroid mysticetes". English. In: Journal of Mammalian Evolution 12.1/2 (2005), pp. 99-143.

[5709] T. A. Deméré and A. Berta. "Skull anatomy of the Oligocene toothed mysticete Aetiocetus weltoni (Mammalia; Cetacea): implications for mysticete evolution and functional anatomy". English. In: Zoological Journal of the Linnean Society 154 (2008), pp. 308-352.

[5710] T. A. Deméré and A. Berta. "New skeletal material of Thalassoleon (Otariidae: Pinnipedia) from the late Miocene-early Pliocene (Hemphillian) of California". English. In: Bulletin of the Florida Museum of Natural History 45.4 (2005), pp. 379-411.

[5711] A. V. Demers-Potvin, J. Szwedo, C. P. Paragnani, and H. C. E. Larsson. "First North American occurrence of hairy cicadas discovered in the Cenomanian (Late Cretaceous) of Labrador, Canada". English. In: Acta Palaeontologica Polonica 65 (2020), pp. 85-98. DOI: 10.4202/app.00669.2019. 
[5712] Yu.E. Demidenko. "New Chancelloriid sclerites from the Lower Cambrian of South Australia". In: Paleontological Journal 34.4 (2000), pp. 377-383.

[5713] Yu.E. Demidenko. “Morphology, Taxonomic Position, and Stratigraphic Distribution of the Early Cambrian Skeletal Problematics Mobergella radiolata Bengtson, 1968". English. In: Paleontological Journal 50.5 (2016), pp. 435-449. DOI: 10.1134/S003103011605004X.

[5714] J. Denayer. "Corals of the Upper Visean microbial-sponge-bryozoan-coral bioherm and related strata of Kongul Yayla (Taurides, South Turkey)". English. In: Geologica Belgica 15.4 (2012), pp. 317328.

[5715] J. Denayer. "Taxonomy, Biostratigraphy and Palaeobiogeography of the Late Tournaisian rugose corals of north-western Turkey". English. In: Paläontologische Zeitschrift 89 (2015), pp. 313-333. DOI: 10.1007/s12542-014-0245-1.

[5716] J. Denayer, E. Poty, J. M. Marion, and B. Mottequin. "Lower and Middle Famennian (Upper Devonian) rugose corals from southern Belgium and northern France". English. In: Geologica Belgica 15.4 (2012), pp. 273-283.

[5717] J. Denayer and G. E. Webb. “Earliest Mississippian rugose corals of eastern Australia: post-disaster fauna across the Devonian-Carboniferous Boundary?" English. In: Palaeobio Palaeoenv 97 (2017), pp. 655-667.

[5718] C. S. Deng, A. lipiski, D. Ren, and H. Pang. “The oldest dermestid beetle from the Middle Jurassic of China (Coleoptera: Dermestidae)". English. In: Annales Zoologici 67 (2017), pp. 109-112.

[5719] C. S. Deng, A. lipiski, D. Ren, and H. Pang. "New Cretaceous carpet beetles (Coleoptera: Dermestidae) from Burmese amber". English. In: Cretaceous Research 76 (2017), pp. 1-6.

[5720] C. S. Deng, A. lipiski, D. Ren, and H. Pang. “The first Mesozoic colydiid beetles (Coleoptera: Zopheridae: Colydiinae) from the Upper Cretaceous amber of Myanmar". English. In: Cretaceous Research 78 (2017), pp. 71-77.

[5721] C. S. Deng, Y. L. Zhou, A. lipiski, D. Ren, and H. Pang. "The first wounded-tree beetle (Coleoptera: Nosodendridae) from Cretaceous Burmese amber". English. In: Cretaceous Research 93 (2019), pp. 211215. DOI: 10.1016/j.cretres.2018.09.019.

[5722] T. Deng. "New material of Hispanotherium matritense (Rhinocerotidae, Perissodactyla) from Laogou of Hezheng County (Gansu, China), with special reference to the Chinese Middle Miocene elasmotheres". English. In: Geobios 36 (2003), pp. 141-150.

[5723] T. Deng. "New cranial material of Shansirhinus (Rhinocerotidae, Perissodactyla) from the Lower Pliocene of the Linxia Basin in Gansu, China". English. In: Geobios 38.3 (2005), pp. 301-313.

[5724] T. Deng, X. Wang, M. Fortelius, Q. Li, Y. Wang, Z. J. Tseng, G. T. Takeuchi, J. E. Saylor, L. K. Säilä, and G. Xie. "Out of Tibet: Pliocene woolly rhino suggests high-plateau origin of Ice Age megaherbivores". English. In: Science 333 (2011), pp. 1285-1288. DOI: 10.1126/science.1206594.

[5725] Z. Deng. “Upper Devonian sphinctozoan sponges from Guilin”. Chinese. In: Acta Palaeontologica Sinica 41.2 (2002), pp. 280-282.

[5726] Z. Q. Deng. "Middle Triassic corals from W. Guangxi and S. Guizhou". Chinese. In: Acta Palaeontologica Sinica 45.1 (2006), pp. 32-51.

[5727] Z. Q. Deng. “New materials of Permian sponges". Chinese. In: Acta Palaeontologica Sinica 29 (1990), pp. 315-320.

[5728] T. Deng', Y. X. Zhang, Z. J. Tseng, and S. K. Hou. "A skull of Machairodus horribilis and new evidence for gigantism as a mode of mosaic evolution in machairodonts (Felidae, Carnivora)". English. In: Vertebrata PalAsiatica 54.4 (2016), pp. 302-318.

[5729] R. W. Dennel, R. Coard, and A. Turner. "Predators and scavengers in Early Pleistocene southern Asia". English. In: Quaternary International (2008). DOI: 10.1016/j.quaint.2007.06.023.

[5730] S. S. Dennison, P. L. Smith, and H. W. Tipper. "An Early Jurassic ichthyosaur from the Sandilands Formation, Queen Charlotte Islands, British Columbia". English. In: Journal of Paleontology 64.5 (1990), pp. 850-853. 
[5731] J. S. Denton. “Lanternfish (Teleostei, Myctophiformes, Myctophidae) body fossils from the Modelo Formation (Upper Miocene) of Los Angeles County, California". English. In: Journal of Vertebrate Paleontology 33.4 (2013), pp. 786-793. DOI: 10.1080/039.033.0415.

[5732] R. K. Denton and R. C. O’Neill. “Prototeius stageri, gen. et sp. nov., a new teiid lizard from the Upper Cretaceous Marshalltown Formation of New Jersey, with a preliminary phylogenetic revision of the Teiidae". English. In: Journal of Vertebrate Paleontology 15.2 (1995), pp. 235-253.

[5733] R. K. Denton Jr. and R. C. O’Neill. “Parrisia neocesariensis, a new batrachosauroidid salamander and other amphibians from the Campanian of eastern North America". English. In: Journal of Vertebrate Paleontology 18.3 (1998), pp. 484-494.

[5734] R. K. Denton Jr. and R. C. O'Neill. Precocious squamates from the Late Cretaceous of New Jersey, including the earliest record of a North American iguanian. English. 1993.

[5735] C. Denys. Phylogenetic affinities of the oldest East African OtFirst occurrence of Xerus cf. inauris (Rodentia, Mammalia) at Olduvai Bed I (Lower Pleistocene, Tanzania). 1990.

[5736] C. Denys. The oldest Acomys from the Lower Pliocene of South Africa and the problem of its murid affinities. 1990.

[5737] R. DePalma, F. Cichocki, M. Dierick, and R. Feeney. "Preliminary notes on the first recorded amber insects from the Hell Creek Formation". English. In: The Journal of Paleontological Sciences C.10.0001 (2010), pp. 1-7.

[5738] R. A. DePalma, D. A. Burnham, L. D. Martin, P. L. Larson, and R. T. Bakker. "The first giant raptor (Theropoda: Dromaeosauridae) from the Hell Creek Formation". English. In: The University of Kansas Paleontological Contributions 14 (2015), pp. 1-16.

[5739] V. Deraco and D. A. Garcĺa-López. "A new Eocene Toxodontia (Mammalia, Notoungulata) from northwestern Argentina". English. In: Journal of Vertebrate Paleontology 36.1 (2016), e1037884:1-11. DOI: $10.1080 / 02724634.2015 .1037884$.

[5740] I. Deregnaucourt, T. Wappler, J. M. Anderson, and O. Béthoux. "A new triadotypid insect from the Late Triassic of South Africa". English. In: Acta Palaeontologica Polonica 62 (2017), pp. 613-618.

[5741] M. D. Dermitzakis and M. V. Triantaphyllou. "Biostratigraphical observations in Plicoene deposits of Heraklion Province". English. In: Geologie Mediterraneenne 24.1-2 (1997), pp. 15-26.

[5742] M. R. Des Lauriers. "Terminal Pleistocene and Early Holocene Occupations of Isla de Cedros, Baja California, Mexico". English. In: Journal of Island \& Coastal Archaeology 1.2 (2006), pp. 255-270. DOI: $10.1080 / 15564890600882955$.

[5743] S. Desbiens, T. E. Bolton, and A. D. McCracken. "Fauna of the lower Beauharnois Formation (Beekmantown Group, Lower Ordovician), Grand le, Quebec". English. In: Canadian Journal of Earth Sciences 33.8 (1996), pp. 1132-1153.

[5744] C. M. Deschamps. "Late Cenozoic mammal bio-chronostratigraphy in southwestern Buenos Aires Province, Argentina". English. In: Ameghiniana 42.4 (2005), pp. 733-750.

[5745] C. M. Deschamps, A. I. Olivares, E. C. Vieytes, and M. G. Vucetich. “Ontogeny and diversity of the oldest capybaras (Rodentia: Hydrochoeridae; late Miocene of Argentina)". English. In: Journal of Vertebrate Paleontology 27.3 (2007), pp. 683-692.

[5746] C. M. Deschamps and R. L. Tomassini. "Late Cenozoic vertebrates from the Southern Pampean region: systematic and bio-chronostratigraphic update". English. In: vol. 16. Palinologa del MesoCenozoico de Argentina - Volumen en homenaje a Mirta Elena Quattrocchio 2. Publicación Electrónica de la Asociación Paleontológica Argentina, 2016, pp. 202-225. DOI: 10.5710/PEAPA.16.05. 2016.113.

[5747] C. M. Deschamps, E. C. Vieytes, A. I. Olivares, and M. G. Vucetich. "Primer registro de Cardiatherium chasicoense (Rodentia, Hydrochoeridae) fuera del área pampeana (Argentina) y su valor bioestratigráfico". Spanish. In: Ameghiniana 46.2 (2009), pp. 295-305. 
[5748] C. M. Deschamps, M. G. Vucetich, D. H. Verzi, and A. I. Olivares. “Biostratigraphy and correlation of the Monte Hermoso Formation (early Pliocene, Argentina): The evidence from caviomorph rodents". English. In: Journal of South American Earth Sciences 35 (2012), pp. 1-9.

[5749] C. M. Deschamps, M. G. Vucetich, and C. I. Montalvo M. A. Zárate. “Capybaras (Rodentia, Hydrochoeridae, Hydrochoerinae) and their bearing in the calibration of the late Miocene-Pliocene sequences of South America". English. In: Journal of South American Earth Sciences 48 (2013), pp. 145158. DOI: 10.1016/j.jsames.2013.09.007.

[5750] P. Deschamps, N. Durand, E. Bard, B. Hamelin, G. Camoin, A. L. Thomas, G. M. Henderson, J. Okuno, and Y. Yokoyama. "Ice-sheet collapse and sea-level rise at the Bølling warming 14,600 years ago". English. In: Nature 483 (2012), pp. 559-564.

[5751] J. B. Desojo. "Dermal scutes from the Potrerillos Formation (Middle-Late Triassic) of Mendoza Province: evidence for aetosaurs?" English. In: Ameghiniana 38.3 (2001), pp. 349-352.

[5752] J. B. Desojo and A. B. Arcucci. “New material of Luperosuchus fractus (Archosauria: Crurotarsi) from the Middle Triassic of Argentina: the earliest known South American rauisuchian". English. In: Journal of Vertebrate Paleontology 29.4 (2009), pp. 1311-1315. DOI: 10.1671/039.029.0422.

[5753] J. B. Desojo, A. B. Arcucci, and C. A. Marsicano. "Reassessment of Cuyosuchus huenei, a MiddleLate Triassic archosauriform from the Cuyo Basin, west-central Argentina". English. In: New Mexico Museum of Natural History and Science, Bulletin 21 (2002), pp. 143-148.

[5754] J. B. Desojo and A. M. Baez. "Cranial morphology of the Late Triassic South American archosaur Neoaetosauroides engaeus: evidence for aetosaurian diversity". English. In: Palaeontology 50 (2007), pp. 267-276.

[5755] J. B. Desojo and A. M. Baez. "El esqueleto postcraneano de Neoaetosauroides (Archosauria: Aetosauria) del Triásico Superior del centro-oeste de Argentina". Spanish. In: Ameghiniana 42 (2005), pp. 115-126.

[5756] J. B. Desojo, M. D. Ezcurra, and C. L. Schultz. "An unusual new archosauriform from the MiddleLate Triassic of southern Brazil and the monophyly of Doswelliidae". English. In: Zoological Journal of the Linnean Society 161 (2011), pp. 839-871.

[5757] J. B. Desojo and M. D. Ezcurra. "A reappraisal of the taxonomic status of Aetosauroides (Archosauria, Aetosauria) specimens from the Late Triassic of South America and their proposed synonymy with Stagonolepis". English. In: Journal of Vertebrate Paleontology 31.3 (2011), pp. 596609.

[5758] J. B. Desojo, M. D. Ezcurra, and E. E. Kischlat. “A new aetosaur genus (Archosauria: Pseudosuchia) from the early Late Triassic of southern Brazil". English. In: Zootaxa 3166 (2012), pp. 1-33.

[5759] P. Destombes and G. Breton. "Platelicrinus campaniensis nov. gen. nov. sp. Roveacrinidae (Echinodermata, Crinoidea) du Campanien des Charentes (France)". French. In: Bulletin trimestriel de la Société géologique de Normandie et des Amis du Muséum du havre 87.1 (2001), pp. 37-40.

[5760] C. Detre. "Carnian brachiopods of Hungary". English. In: Mesozoic Brachiopods of Alpine Europe. Budapest: Hungarian Geological Society, 1993, pp. 27-30.

[5761] T. Deuve. “Trois fossiles remarquablement conservés du Miocéne de France, appartenant aux genres Carabus L. et Ledouxnebria nov. (Coleoptera, Carabidae et Nebriidae)". French. In: Bulletin de la Société Entomologique de France 103 (1998), pp. 229-236.

[5762] L. Devaere, S. Clausen, J. P. Sosa-Leon, J. J. Palafox-Reyes, B. E. Buitrón-Sánchez, and D. Vachard. "Early Cambrian Small Shelly Fossils from northwest Mexico: Biostratigraphic implications for Laurentia". English. In: Palaeontologia Electronica 22.2 (2019), pp. 1-58.

[5763] J. Deville. Palaeontological Study of the Neerrepen Sands in the Francart Quarry (Tongeren, Belgium). 1996.

[5764] J. Devillez, S. Charbonnier, M. Hyzny, and L. Leroy. "Review of the Early Cretaceous erymid lobsters (Crustacea: Decapoda) from the Western Tethys". English. In: Geodiversitas 38.4 (2016), pp. 515-541. DOI: 10.5252/g2016n4a4. 
[5765] T. J. DeVries. "Oligocene deposition and Cenozoic sequence boundaries in the Pisco Basin (Peru)". English. In: Journal of South American Earth Sciences 11.3 (1998), pp. 217-231.

[5766] T. J. DeVries. “Neogene Ficus (Mesogastropoda: Ficidae) from the Pisco Basin (Peru)". English. In: Boletn de la Sociedad Geológica de Perú 86 (1997), pp. 11-18.

[5767] T. J. DeVries. "Late Cenozoic Muricidae from Peru: Seven new species and a biogeographic summary". English. In: The Veliger 47.4 (2005), pp. 277-293.

[5768] T. J. DeVries. "Pterorytis pacanana new species (Gastropoda: Muricidae): circumstantial evidence for late Pliocene El Niño events in southern Peru". English. In: The Nautilus 119.4 (2005), pp. 164168.

[5769] T. J. DeVries. “Cenozoic Turritellidae (Gastropoda) from southern Peru". English. In: Journal of Paleontology 81.2 (2007), pp. 331-351.

[5770] T. J. DeVries. "Acanthina Fischer von Waldheim, 1807 (Gastropoda: Muricidae), an ocenebrine genus edemic to South America". English. In: The Veliger 46.4 (2003), pp. 332-350.

[5771] T. J. DeVries. "The Late Cenozoic history of Xanthochorus Fischer, 1884 (GastropodaL Muricidae) in western South America". English. In: The Veliger 47.4 (2005), pp. 259-276.

[5772] T. J. DeVries. “The Neogene history of Prisogaster Mörch, 1850 (Gastropoda: Turbinidae) in South America". English. In: The Nautilus 120.4 (2006), pp. 139-149.

[5773] T. J. DeVries. "Two new Neogene species and the evolution of labral teeth in Concholepas Lamarck, 1801 (Neogastropoda: Muricoidea)". English. In: The Veliger 43.1 (2000), pp. 43-50.

[5774] T. J. DeVries. "Five new Cenozoic epitoniids from Southern Peru and the Neogene history of Scalina Conrad, 1865 (Gastropoda: Epitoniidae) in the Americas". English. In: The Veliger 49.4 (2007), pp. 231-251.

[5775] T. J. DeVries. “Concholepas Lamarck, 1801 (Neogastropoda: Muricoidea): A Neogene genus native to South America". English. In: The Veliger 38.4 (1995), pp. 284-297.

[5776] T. J. DeVries. "Pliocene and Pleistocene Fissurella Bruguiére, 1789 (Gastropoda: Fissurellidae) from Southern Peru". English. In: The Veliger 50.2 (2008), pp. 129-148.

[5777] T. J. Devries. "Fossil Cenozoic crassatelline bivalves from Peru: New species and generic insights". English. In: Acta Palaeontologica Polonica 61 (2016).

[5778] T. J. Devries. "Early Paleogene brackish-water molluscs from the Caballas Formation of the East Pisco Basin (Southern Peru)". English. In: Journal of Natural History 53.25-26 (2019), pp. 1533-1584. DOI: $10.1080 / 00222933.2018 .1524032$.

[5779] T. J. DeVries and D. Frassinetti. "Range extensions and biogeographic implications of Chilean Neogene mollusks found in Peru". English. In: Boletn del Museo Nacional de Historia Natural, Chile 52 (2003), pp. 119-135.

[5780] T. J. DeVries, L. T. Groves, and M. Urbina. “A new early Miocene Muracypraea Woodring, 1957 (Gastropoda: Cypraeidae) from the Pisco Basin of southern Peru". English. In: The Nautilus 120.3 (2006), pp. 101-105.

[5781] T. J. DeVries and B. Hess. "Piscoacritia, gen. nov.: first account of Tribe Trochini (Gastropoda: Trochidae: Trochinae) from the Cenozoic of western South America". English. In: The Veliger 47.1 (2004), pp. 6-12.

[5782] T. J. DeVries, M. Urbina, and N. A. Jud. "The Eocene-Oligocene Otuma Depositional Sequence (East Pisco Basin, Peru): Paleogeographic and Paleoceanographic Implications of New Data". English. In: Boletn de la Sociedad Geológica del Perú 112 (2017), pp. 14-38.

[5783] T. J. DeVries and G. J. Vermeij. "Herminespina: New Genus of Neogene Muricid Gastropod from Peru and Chile". English. In: Journal of Paleontology 71.4 (1997), pp. 610-615. DOI: 10.1017/S0022336000040099.

[5784] T. J. DeVries and L. E. Wells. "Thermally-anomalous Holocene molluscan assemblages from coastal Peru: evidence for paleogeographic, not climatic change". English. In: Palaeogeography, Palaeoclimatology, Palaeoecology 81 (1990), pp. 11-32. 
[5785] F. X. Devuyst and A. Lees. "The initiation of Waulsortian buildups in western Ireland". English. In: Sedimentology 48 (2001), pp. 1121-1148.

[5786] V. P. Devyatov, V. G. Knyazev, R. V. Kutygin, S. V. Meledina, B. N. Shurygin, and V. B. Khmelevskii. "First Find of Lower Jurassic Ammonites (Dactylioceras) in West Siberia". English. In: Doklady Earth Sciences 406 (2005), pp. 15-18.

[5787] L. Dewaele, E. Amson, O. Lambert, and S. Louwye. "Reappraisal of the extinct seal Phoca vitulinoides from the Neogene of the North Sea Basin, with bearing on its geological age, phylogenetic affinities, and locomotion". English. In: PeerJ 5 (2017), e3316. DOI: 10.7717/peerj.3316.

[5788] L. Dewaele, O. Lambert, and S. Louwye. "On Prophoca and Leptophoca (Pinnipedia, Phocidae) from the Miocene of the North Atlantic realm: redescription, phylogenetic affinities and paleobiogeographic implications". English. In: PeerJ 5 (2017), e3024. DOI: 10.7717/peerj.3024.

[5789] L. Dewaele, O. Lambert, and S. Louwye. "A critical revision of the fossil record, stratigraphy and diversity of the Neogene seal genus Monotherium (Carnivora, Phocidae)". English. In: Royal Society Open Science 5 (2018), p. 171669. DOI: 10.1098/rsos.171669.

[5790] L. Dewaele and O. Lambert. "A late surviving Pliocene seal from high latitudes of the North Atlantic realm: the latest monachine seal on the southern margin of the North Sea". English. In: PeerJ 6 (2018), e5734. DOI: 10.7717 / peerj.5734.

[5791] L. Dewaele, C. M. Peredo, P. Meyvisch, and S. Louwye. "Diversity of late Neogene Monachinae (Carnivora, Phocidae) from the North Atlantic, with the description of two new species". English. In: Royal Society Open Science 5.172437 (2018), pp. 1-27. DOI: 10.1098/rsos.172437.

[5792] A. Deza, E. A. Cadena, and J. N. Martinez. “Pleistocene Fossil Turtles (Testudinoidea, Cryptodira) from the Talara Tar Seeps, Peru". English. In: Revista peruana de biologa 26.2 (2019), pp. 189-200.

[5793] A. V. Dhondt and E. Jaillard. "Cretaceous bivalves from Ecuador and northern Peru". English. In: Journal of South American Earth Sciences 19 (2005), pp. 325-342.

[5794] A. V. Dhondt, N. Malchus, L. Boumaza, and E. Jaillaerd. "Cretaceous oysters from North Africa : origin and distribution". English. In: Bulletin de la Société Géologique de France 170.1 (1999), pp. 6776.

[5795] A. V. Dhondt, D. P. Naidin, A. P. Levina, E, and Simon. "Maastrichtian faunas from the Turgay Strait (northern Kazakhstan)". English. In: Mitteilungen aus dem Geologisch-Paläontologischen Institut der Universität Hamburg 77 (1996), pp. 49-65.

[5796] C. Di Celma, E. Malinverno, A. Collareta, G. Bosio, K. Gariboldi, O. Lambert, W. Landini, P. P. Pierantoni, A. Gioncada, I. M. Villa, G. Coletti, C. de Muizon, M. Urbina, and G. Bianucci. "Facies analysis, stratigraphy and marine vertebrate assemblage of the lower Miocene Chilcatay Formation at Ullujaya (Pisco basin, Peru)". English. In: Journal of Maps 14.2 (2018), pp. 257-268. DOI: 10.1080/17445647.2018.1456490.

[5797] E. Di Martino and P. D. Taylor. "Systematics and life history of Antoniettella exigua, a new genus and species of cribrimorph bryozoan from the Miocene of East Kalimantan (Indonesia)". English. In: Bollettino della Societá Paleontologica Italiana 51.2 (2012), pp. 99-108.

[5798] E. Di Martino and P. D. Taylor. “Miocene Bryozoa from East Kalimantan, Indonesia. Part I: Cyclostomata and 'Anascan' Cheilostomata". English. In: Scripta Geologica 146 (2014), pp. 17-126.

[5799] E. Di Martino and P. D. Taylor. "Miocene Bryozoa from East Kalimantan, Indonesia. Part II: 'Ascophoran' Cheilostomata.” English. In: Scripta Geologica 148 (2015), pp. 1-142.

[5800] E. Di Martino and P. D. Taylor. "Pyrisinellidae, a new family of anascan cheilostome bryozoans". English. In: Zootaxa 3534.1 (2012), pp. 1-20.

[5801] P. Di Stefano, M. Gullo, and B. Senowbari-Daryan. "The Upper Triassic Reef of Monte Genuardo (Southwestern Sicily)". In: Bollettino della Societá Geologica Italiana 109 (1990), pp. 103-114.

[5802] P. Di Stefano and D. Ruberti. "Cenomanian Rudist-dominated shelf-margin limestones from the Panormide Carbonate Platform (Sicily, Italy): facies analysis and sequence stratigraphy". English. In: Facies 42 (2000), pp. 133-160. 
[5803] E. V. Dias. "A new deep-bodied fossil fish (Actinopterygii) from the Rio do Rasto Formation, Parana Basin, Brazil". English. In: Zootaxa 3192 (2012), pp. 1-23.

[5804] E. V. Dias and M. C. Barberena. "A temnospondyl amphibian from the Rio do Rasto Formation, Upper Permian of Southern Brazil". English. In: Anais da Academia Brasileira de Ciencias 73 (2001), pp. 136-143.

[5805] D. Dias-Brito, E. A. Musacchio, J. C. de Castro, M.d.S.A.S. Maranhão, J. M. Suárez, and R. Rodrigues. "Grupo Bauru: uma unidade continental do Cretáceo no Brasil - concepções baseadas em dados micropaleontológicos, isotópicos e estratigráficos [Bauru Group: a continental unit from the Cretaceous of Brazil - concepts based on micropaleontological, isotopic, and stratigraphic data]". Portugese. In: Revue de Paléobiologie 20.1 (2001), pp. 245-304.

[5806] S. Dias-da-Silva, E. V. Dias, and C. L. Schultz. "First record of stereospondyls (Tetrapoda, Temnospondyli) in the Upper Triassic of Southern Brazil". English. In: Gondwana Research 15 (2009), pp. 131-136.

[5807] S. Dias-Da-Silva, C. Marsicano, and C. L. Schultz. "Early Triassic temnospondyl skull fragments from southern South America (Parana Basin, Brazil)". English. In: Revista Brasileira de Paleontologia 8.2 (2005), pp. 165-172.

[5808] S. Dias-da-Silva, C. Marsicano, and C. L. Schultz. "Rhytidosteid temnospondyls in Gondwana: a new taxon from the Lower Triassic of Brazil". English. In: Palaeontology 49 (2006), pp. 381-390.

[5809] S. Dias-da-Silva and A. R. Milner. "The pustulated temnospondyl revisited - a plagiosternine plagiosaurid from the Lower Triassic of Brazil". English. In: Acta Palaeontologica Polonica 55.3 (2009), pp. 561-563.

[5810] S. Dias-da-Silva, S. Modesto, and C. L. Schultz. "New Material of Procolophon (Parareptilia: Procolophonoidea) from the Lower Triassic of Brazil, with remarks on the ages of the Sanga do Cabral and Buena Vista formations of South America". English. In: Canadian Journal of Earth Sciences 43.11 (2006), pp. 1685-1693. DOI: 10.1139/E06-043.

[5811] S. Dias-da-Silva, D. P. Sengupta, S. F. Cabreira, and L. R. da Silva. “The presence of Compsocerops (Brachyopoidea: Chigutisauridae) (Late Triassic) in southern Brazil with comments on chigutisaurid palaeobiogeography". English. In: Palaeontology 55.1 (2012), pp. 163-172.

[5812] J. L. Daz Aráez, M. Delfino, A. H. Luján, J. Fortuny, F. Bernardini, and D. M. Alba. "New remains of Diplocynodon (Crocodylia: Diplocynodontidae) from the Early Miocene of the Iberian Peninsula". English. In: Comptes Rendus Palevol 16.1 (2017), pp. 12-26. DOI: 10.1016/j.crpv.2015.11.003.

[5813] E. Daz-Martnez, B. Mamet, P. E. Isaacson, and G. W. Grader. "Permian marine sedimentation in northern Chile: new paleontological evidence from the Juan de Morales Foramtion, and regional paleogeographic implications". English. In: Journal of South American Earth Sciences 13 (2000), pp. 511-525.

[5814] I. Daz-Martnez. “Generalidades sobre las icnitas ornitópodas de La Rioja (Cuenca de Cameros, España) [General information about ornithopod footprints from La Rioja (Cameros Basin, Spain)]". Spanish. In: Zuba 29 (2011), pp. 61-84.

[5815] I. Diaz-Martnez, E. Garca-Ortiz de Landaluce, R. Ibisate, and F. Pérez-Lorente. "Nuevas aportaciones al registro paleoicnológico en Cabezón de Cameros (La Rioja. España) [New contributions to the paleoichnological registry in Cabezón de Cameros (La Rioja. Spain)]". Spanish. In: Geogaceta 42 (2007), pp. 87-90.

[5816] I. Daz-Martnez, X. Pereda-Suberbiola, F. Pérez-Lorente, and J. I. Canudo. "Ichnotaxonomic review of large ornithopod dinosaur tracks: temporal and geographic implications". English. In: PLoS 10.2 (2015), e0115477:1-50. DOI: 10.1371/journal.pone.0115477.

[5817] I. Daz-Martnez, F. Pérez-Lorente, X. Pereda-Suberbiola, and J. I. Canudo. Iguanodon-like footprints from the Enciso Group (Aptian, Lower Cretaceous) of La Rioja (Cameros Basin, Spain). English. Brussels, 2009. 
[5818] R. Daz-Sibaja, F. J. Jiménez-Moreno, R. Palomino-Merino, J. E. E. Rosales, Z. Lagunas-Rodrguez, J. Arroyo-Cabrales, I. Alarcón-D, and G. Carbot-Chanona. "A fossil Bison antiquus from Puebla, Mexico and a new minimum age for the Valsequillo fossil area". English. In: Journal of South American Earth Sciences 103 (2020), 102766:1-7.

[5819] E. P. Dica. "A review of the Eocene diodontids and labrids from Transylvania". English. In: Studia Universitatis Babes-Bolyai, Geologia 47.2 (2002), pp. 37-46.

[5820] E. P. Dica and V. Codrea. “On the Hybodus (Euselachii) from the Early Jurassic of Anina (Caras Severin district, Romania)". English. In: Studia Universitatis Babes-Bolyai, Geologica 51.1-2 (2006), pp. 51-54.

[5821] J. M. Dickins. "Mid-Permian (Kubergandian-Murgabian) bivalves from the Khuff Formation, Oman: implications for world events and correlation". English. In: Rivista Italiana di Paleontologia e Stratigrafia 105 (1999), pp. 23-36.

[5822] J. A. D. Dickson, R. A. Wood, and B. L. Kirkland. "Exceptional preservation of the sponge Fissispongia tortacloaca from the Pennsylvanian Holder Formation, New Mexico". English. In: Palaios 11 (1996), pp. 559-570.

[5823] J. M. Diederle and J. I. Noriega. "New records of birds from the Santa Cruz Formation (EarlyMiddle Miocene) at the Ro Santa Cruz Valley, Patagonia, Argentina". English. In: vol. 19. EarlyMiddle Miocene Paleontology in the Ro Santa Cruz, Southern Patagonia, Argentina. 130 years since Ameghino, 1887 2. Publicacion Electronica de la Asociacion Paleontologica Argentina, 2019, pp. 55-61. DOI: 10.5710/PEAPA.16.09.2019.284.

[5824] C. Diedrich. "The world's oldest fossil seal record". English. In: Natural Science 3.11 (2011), pp. 914920.

[5825] C. Diedrich. "Upper Jurassic tidal flat megatracksites of Germany-coastal dinosaur migration highways between European islands, and a review of the dinosaur footprints". English. In: Palaeobiodiversity and Palaeoenvironments 91 (2011), pp. 129-155. DOI: 10.1007/s12549-010-0044-y.

[5826] C. Diedrich and R. Hirayama. "Turtle remains (Testudines, Chelonioidea) from the Middle Turonian of northwest Germany". English. In: Netherlands Journal of Geosciences 82.2 (2003), pp. 161167.

[5827] C. Diedrich and E. W. A. Mulder. "A new record of Clidastes (Squamata, Mosasauridae) from the Upper Campanian of the Munster Basin (NW Germany)". English. In: Netherlands Journal of Geosciences - Geologie en Mijnbouw 83.1 (2004), pp. 73-78.

[5828] C. G. Diedrich. "The food of the miosiren Anomotherium langenwieschei (Siegfried) - indirect proof of seaweed or seagrass by xenomorphic oyster fixation structures in the Upper Oligocene (Neogene) of the Doberg, Bunde (NW Germany) and comparisons to modern Dugong dugon (Muller) feeding strategies". English. In: Senckenbergiana Maritima 38.1 (2008), pp. 59-73.

[5829] C. G. Diedrich. "A coelacanthid-rich site at Hasbergen (NW Germany): taphonomy and palaeoenvironment of a first systematic excavation in the Kupferschiefer (Upper Permian, Lopingian)". English. In: Palaeobiodiversity and Palaeoenvironments 89 (2009), pp. 67-94.

[5830] C. G. Diedrich. "Eocene (Lutetian) Shark-Rich Coastal Paleoenvironments of the Southern North Sea Basin in Europe: Biodiversity of the Marine Fu rstenau Formation Including Early White and Megatooth Sharks". English. In: International Journal of Oceanography 2012.565326 (2012), pp. 1-22. DOI: $10.1155 / 2012 / 565326$.

[5831] C. G. Diedrich. “The shallow marine placodont Cyamodus of the central European Germanic Basin: its evolution, paleobiogeography and paleoecology". English. In: Historical Biology 23.4 (2011), pp. 391-409. DOI: 10.1080/08912963.2011.575938.

[5832] C. G. Diedrich. "The marine pachypleurosaur Serpianosaurus germanicus nov. spec. - skeleton and isolated bone remains from the Pelsonian (Middle Triassic) of the European Germanic Basin carbonate intertidals and its paleobiology and taphonomy". English. In: New Mexico Museum of Natural History and Science Bulletin 61 (2013), pp. 159-168. 
[5833] C. J. Diedrich. "The most northerly record of the sirenian Protosiren and the possible polyphyletic evolution of manatees and dugongs". English. In: Natural Science 5.11 (2013), pp. 1154-1164. DOI: $10.4236 /$ ns.2013.511142.

[5834] I. Dieni. "Pompeian mating molluscs: sexual behaviour frozen by Paleogene submarine volcanic activity in northern Italy". English. In: Bollettino della Societá Paleontologica Italiana 51 (2012), pp. 109 116.

[5835] I. Dieni, F. Massari, and V. Radulovic. "The Mt Perda Liana section (Middle Jurassic, centraleastern Sardinia): revised stratigraphy and brachiopod faunas". English. In: Bollettino della Societá Paleontologica Italiana 52.2 (2013), pp. 123-138.

[5836] C. H. Dietrich and L. L. Dietz. "Superfamily Membracoidea (Homoptera: Auchenorrhyncha). II. Cladistic analysis and conclusions". English. In: Systematic Entomology 18 (1993), pp. 297-311.

[5837] C. H. Dietrich and A. C. Gonçalves. "New Baltic amber leafhoppers representing the oldest Aphrodinae and Megophthalminae (Hemiptera, Cicadellidae)". English. In: European Journal of Taxonomy 74 (2014), pp. 1-13.

[5838] C. H. Dietrich and E. E. Perkovsky. "First record of Cicadellidae (Insecta, Hemiptera, Auchenorrhyncha) from Eocene Sakhalinian amber". English. In: ZooKeys 886 (2019), pp. 127-134.

[5839] C. H. Dietrich and M. J. Thomas. "New eurymeline leafhoppers (Hemiptera, Cicadellidae, Eurymelinae) from Eocene Baltic amber with notes on other fossil Cicadellidae". English. In: ZooKeys 726 (2018), pp. 131-143.

[5840] C. H. Dietrich and F. E. Vega. "Leafhoppers (Homoptera: Cicadellidae) from Dominican Amber". English. In: Annals of the Entomological Society of America 88.3 (1995), pp. 263-270.

[5841] V. Dietze, S. Cresta, L. Martire, and G. Pavia. "Ammonites, taphonomical analysis and biostratigraphy of the". English. In: 284.2 (2017), pp. 161-206. DOI: 10.1127/njgpa/2017/0657.

[5842] V. Dietze and B. Hostettler. "Occurrences of the ammonite genus Clydoniceras Blake, 1905 in the Middle Jurassic (Upper Bathonian, Discus Zone) of NW Switzerland". English. In: Proceedings of the Geologists' Association 127 (2016), pp. 218-229.

[5843] V. Dietze, G. Schweigert, G. Dietl, W. Auer, W. Dangelmaier, R. Furze, S. Gräbenstein, M. Kutz, E. Neisser, E. Schneider, and D. Schreiber. "Rare Middle Jurassic ammonites of the families Erycitidae, Otoitidae and Stephanoceratidae from southern Germany". English. In: Zitteliana A50 (2010), pp. 71-88.

[5844] V. Dietze, K. Seyed-Emami, and A. Raoufian. "Morphoceras Douvillé, 1880 and Ebrayiceras Buckman, 1920 from the Dalichai Formation (Lower Bathonian) north and northeast of Damghan (Northeast Alborz), Iran". English. In: Zitteliana A 54 (2014), pp. 15-22.

[5845] P.-E. Dieudonné, P. Cruzado-Caballero, P. Godefroit, and T. Tortosa. "A new phylogeny of cerapodan dinosaurs". English. In: Historical Biology (2020).

[5846] P.-E. Dieudonné, T. Tortosa, F. Torcida Fernández-Baldor, J. I. Canudo, and I. Daz-Martnez. “An unexpected early rhabdodontid from Europe (Lower Cretaceous of Salas de los Infantes, Burgos Province, Spain) and a re-examination of basal iguanodontian relationships". English. In: PLoS ONE 11.6 (2016), e0156251:1-40. DOI: 10.1371/journal.pone.0156251.

[5847] J. C. Diez, Y. Fernandez-Jalvo, J. Rosell, and I. Caceres. "Zooarchaeology and taphonomy of Aurora Stratum (Gran Dolina, Sierra de Atapuerca, Spain)". English. In: Journal of Human Evolution 37 (1999), pp. 623-652.

[5848] V. Dez Daz, G. Garcia, F. Knoll, X. Pereda Suberbiola, and X. Valentin. "New cranial remains of titanosaurian sauropod dinosaurs from the Late Cretaceous of Fox-Amphoux-Métisson (Var, SE France)". English. In: Proceedings of the Geologists' Association 123.4 (2012), pp. 626-637. DOI: 10.1016/j.pgeola.2012.04.002.

[5849] V. Dez Daz, G. Garcia, X. Pereda Suberbiola, B. Jentgen-Ceschino, K. Stein, P. Godefroit, and X. Valentin. "A new titanosaur (Dinosauria: Sauropoda) from the Upper Cretaceous of Velaux-LaBastide Neuve (southern France)". English. In: Historical Biology (2020). DOI: 10.1080 / 08912963. 2020.1841184 . 
[5850] V. Dez Daz, P. Mocho, A. Páramo, F. Escaso, F. Marcos-Fernández, J. L. Sanz, and F. Ortega. “A new titanosaur (Dinosauria, Sauropoda) from the Upper Cretaceous of Lo Hueco (Cuenca, Spain)". English. In: Cretaceous Research 68 (2016), pp. 49-60. DOI: 10.1016/j.cretres.2016.08.001.

[5851] V. Dez Daz, X. Pereda Suberbiola, and J. L. Sanz. "Juvenile and adult teeth of the titanosaurian dinosaur Lirainosaurus (Sauropoda) from the Late Cretaceous of Iberia". English. In: Geobios 45 (2012), pp. 265-274. DOI: 10.1016/j.geobios.2011.10.002.

[5852] R. Difley, B. Britt, and P. Policelli. A troodontid nest in the North Horn Formation, central Utah. English. 2004.

[5853] R. Difley and A. A. Ekdale. "Biostratigraphic aspects of the Cretaceous-Tertiary (KT) boundary interval at North Horn Mountain, Emery County, Utah". English. In: Utah Geological Survey Miscellaneous Publication 99-.1 (1999), pp. 389-398.

[5854] T. Dikow and K. M. Bayless. "Taxonomic revision of the genus Schildia Aldrich, 1923 (Diptera: Asilidae: Leptogastrinae) with the description of new extant and extinct species". English. In: Insect Systematics \& Evolution 40 (2009), pp. 253-289.

[5855] T. Dikow and D. A. Grimaldi. "Robber flies in Cretaceous ambers (Insecta: Diptera: Asilidae)". English. In: American Museum Novitates 3799 (2014), pp. 1-19.

[5856] D. L. Dilcher and P. W. Basson. "Mid-Cretaceous angiosperm leaves from a new fossil locality in Lebanon". In: Botanical Gazette 151.4 (1990), pp. 538-547.

[5857] D. L. Dilcher, T. A. Lott, and B. J. Axsmith. Fossil plants from the Union Chapel Mine, Alabama. English. Vol. 1. Alabama Paleontological Society Monograph. 2005, pp. 153-168.

[5858] D. L. Dilcher and H. Wang. "An Early Cretaceous fruit with affinities to Ceratophyllaceae". English. In: American Journal of Botany 96.12 (2009), pp. 2256-2269. DOI: 10.3732/ajb.0900049.

[5859] D. Dilkes and H.-D. Sues. "Redescription and phylogenetic relationships of Doswellia kaltenbachi (Diapsida: Archosauriformes) from the Upper Triassic of Virginia". English. In: Journal of Vertebrate Paleontology 29.1 (2009), pp. 58-79.

[5860] D. W. Dilkes. "The Early Triassic rhynchosaur Mesosuchus browni and the interrelationships of basal archosauromorph reptiles". English. In: Philosophical Transactions of the Royal Society of London, Series B 353 (1998), pp. 501-541.

[5861] D. W. Dilkes. "The rhynchosaur Howesia browni from the Lower Triassic of South Africa". English. In: Palaeontology 38.3 (1995), pp. 665-685.

[5862] B. J. Dilley, D. Davies, A. L. Bond, and P. G. Ryan. “Effects of mouse predation on burrowing petrel chicks at Gough Island". English. In: Antarctic Science 27.6 (2015), pp. 543-553.

[5863] R. M. Dillhoff, E. B. Leopold, and S. R. Manchester. “The McAbee flora of British Columbia and its relation to the Early-Middle Eocene Okanagan Highlands flora of the Pacific Northwest". English. In: Canadian Journal of Earth Sciences 42.2 (2005), pp. 151-166. DOI: 10.1139/E04-084.

[5864] M. DiLucia, J. Sayago, G. Frijia, A. Cotti, A. Sitta, and M. Mutti. "Facies and seismic analysis of the Late Carboniferous Early Permian Finnmark carbonate platform (southern Norwegian Barents Sea): An assessment of the carbonate factories and depositional geometries". English. In: Marine and Petroleum Geology 79 (2017), pp. 372-393.

[5865] W. A. DiMichele and R. B. Aronson. "The Pennsylvanian-Permian vegetational transition: a terrestrial analogue to the onshore-offshore hypothesis". In: Evolution 46.3 (1992), pp. 807-824.

[5866] W. A. DiMichele, D. S. Chaney, W. H. Dixon, W. J. Nelson, and R. W. Hook. “An Early Permian Coastal Flora from the Central Basin Platform of Gaines County, West Texas". In: PALAIOS 15 (2000), pp. 524-534.

[5867] W. A. DiMichele, C. F. Eble, and D. S. Chaney. "A drowned lycopsid forest above the Mahoning Coal (Conemaugh Group, Upper Pennsylvanian) in eastern Ohio, U.S.A". In: International Journal of Coal Geology 31 (1996), pp. 249-276. 
[5868] W. A. DiMichele, S. H. Mamay, D. S. Chaney, R. W. Hook, and W. J. Nelson. “An Early Permian flora with Late Permian and Mesozoic affinities from north-central Texas". In: Journal of Paleontology 75.2 (2001), pp. 449-460.

[5869] W. A. Dimichele, T. L. Phillips, and G. E. McBrinn. "Quantitative Analysis and Paleoecology of the Secor Coal and Roof-Shale Floras (Middle Pennsylvanian, Oklahoma)". In: Palaios 6 (1991), pp. 390-409.

[5870] E. K. Dimitrova, A. Goranov, and I. V. Boyanov. “New fossil evidence for the Lower Paleogene (Krumovgrad Goup) in the East Rhodope mountains, SE Bulgaria". English. In: Geologica Balcanica 30.3-4 (2001), pp. 59-63.

[5871] H. Ding, C. K. Shih, A. Bashkuev, Y. Y. Zhao, and D. Ren. "The earliest fossil record of Panorpidae (Mecoptera) from the Middle Jurassic of China". English. In: ZooKeys 431 (2014), pp. 79-92.

[5872] M. Ding, Q. Zhang, H. Wang, Q. Q. Zhang, X. J. Lei, and H. C. Zhang. "New material of Ephialtitidae (Insecta: Hymenoptera: Stephanoidea) from the Middle-Upper Jurassic of Inner Mongolia, China". Chinese. In: Acta Palaeontologica Sinica 55 (2016), pp. 87-97.

[5873] M. Ding, D. R. Zheng, Q. Zhang, and H. C. Zhang. “A new species of Ephialtitidae (Insecta: Hymenoptera: Stephanoidea) from the Middle Jurassic of Inner Mongolia, China". Chinese. In: Acta Palaeontologica Sinica 52 (2013), pp. 51-56.

[5874] R. V. Dingle, I. K. McMillan, S. Majoran, and L. Bisset. "Palaeo-oceanographical implications of Early-Middle Miocene subtropical ostracod faunas from the continental shelf of the SE Atlantic Ocean". English. In: Palaeogeography, Palaeoclimatology, Palaeoecology 173.1-2 (2001), pp. 43-60. DOI: 10.1016/S0031-0182(01)00312-1.

[5875] P. H. G. Dirks, J. M. Kibii, B. F. Kuhn, C. Steininger, S. E. Churchill, J. D. Kramers, R. Pickering, D. L. Farber, A. -S. Mériaux, A. I. R. Herries, G. C. P. King, and L. R. Berger. "Geological setting and age of Australopithecus sediba from southern Africa". English. In: Science 328 (2010), pp. 205208.

[5876] R. H. L. Disney and A. J. Ross. "Abaristophora and Puliciphora (Diptera: Phoridae) from Dominican amber and revisionary notes on modern species". English. In: European Journal of Entomology 93 (1996), pp. 127-135.

[5877] I. L. Dittmann, M. K. Hörnig, J. T. Haug, and C. Haug. “Raptoblatta waddingtonae n. gen. et n. sp. - an Early Cretaceous roach-like insect with a mantodean-type raptorial foreleg". English. In: Palaeodiversity 8 (2015), pp. 103-111.

[5878] J. D. Divay and A. M. Murray. "The fishes of the Farson Cutoff Fishbed, Bridger Formation (Eocene), greater Green River Basin, Wyoming, U. S. A". English. In: Journal of Vertebrate Paleontology 36.6 (2016), e1212867. DOI: 10.1080/02724634.2016.1212867.

[5879] J. D. Divay and A. M. Murray. "An early Eocene fish fauna from the Bitter Creek area of the Wasatch Formation of southwestern Wyoming, U.S.A." English. In: Journal of Vertebrate Paleontology 36.5 (2016), e1196211. DOI: 10.1080/02724634.2016.1196211..

[5880] H. L. Dixon, S. K. Donovan, D. P. Domning, and P. D. Taylor. "Report of a field meeting to the area around Browns Town, parish of St. Ann, north-central Jamaica, 21st February, 1998". English. In: The Journal of the Geological Society of Jamaica 33 (1999), pp. 24-30.

[5881] M. Dixon and D. W. Haig. "Foraminifera and their habitats within a cool-water carbonate succession following glaciation, Early Permian (Sakmarian), Western Australia". English. In: Journal of Foraminiferal Research 34 (2004), pp. 308-324.

[5882] O. A. Dixon. "Heliolitine corals of the Upper Douro Formation (Upper Silurian), Canadian Arctic Islands". In: Journal of Paleontology 70.5 (1996), pp. 718-740.

[5883] O. A. Dixon. “Upper Silurian heliolitine corals, Canadian Arctic: Taxonomic method, keys to identification, and biogeographic relationships". In: Journal of Paleontology 73.6 (1999), pp. 1002-1014.

[5884] O. A. Dixon. "Heliolitine corals of the topmost Douro and overlying formations (Upper Silurian), Canadian Arctic Islands". English. In: Journal of Paleontology 72.6 (1998), pp. 937-966. 
[5885] E. Díaz-Berenguer, A. Badiola, M. Moreno-Azanza, and J. Ignacio Canudo. "First adequatelyknown quadrupedal sirenian from Eurasia (Eocene, Bay of Biscay, Huesca, northeastern Spain)". English. In: Nature Scientific Reports 8.5127 (2018), pp. 1-13. DOI: 10.1038/s41598-018-23355-w.

[5886] G. Dlussky, A. Radchenko, and D. Dubovikoff. "A new enigmatic ant genus from late Eocene Danish Amber and its evolutionary and zoogeographic significance". English. In: Acta Palaeontologica Polonica 59 (2014), pp. 931-939.

[5887] G. M. Dlussky. "New ants (Hymenoptera, Formicidae) from Canadian amber". English. In: Paleontological Journal 33.4 (1999), pp. 409-412.

[5888] G. M. Dlussky. "Ants (Hymenoptera: Formicidae) from Burmese amber". English. In: Paleontological Journal 30 (1996), pp. 449-454.

[5889] G. M. Dlussky. "The first find of the Formicoidea (Hymenoptera) in the Lower Cretaceous of the Northern Hemisphere". English. In: Paleontological Journal 33.3 (1999), pp. 274-277.

[5890] G. M. Dlussky. "New fossil ants of the subfamily Myrmeciinae (Hymenoptera, Formicidae) from Germany". English. In: Paleontological Journal 46 (2012), pp. 288-292.

[5891] G. M. Dlussky. "Ants of the Tribe Formicini (Hymenoptera, Formicidae) from Late Eocene Amber of Europe". English. In: Paleontological Journal 42 (2008), pp. 500-513.

[5892] G. M. Dlussky. "Ants of the genus Dolichoderus (Hymenoptera: Formicidae) from the Baltic and Rovno ambers". English. In: Paleontological Journal 36 (2002), pp. 50-63.

[5893] G. M. Dlussky. “Novye Vidy murav'ev roda Dolichoderus (Hymenoptera, Formicidae) Pozdneeotsenovykh yantarey Europy". English. In: Vestnik Zoologii 42 (2008), pp. 497-514.

[5894] G. M. Dlussky. "Syntypes of Baltic amber ants Formica flori Mayr and Ponera atavia Mayr (Hymenoptera: Formicidae)". English. In: Russian Entomological Journal 11 (2002), pp. 291-298.

[5895] G. M. Dlussky. "The Ant Subfamilies Ponerinae, Cerapachyinae, and Pseudomyrmecinae (Hymenoptera, Formicidae) in the Late Eocene Ambers of Europe". English. In: Paleontological Journal 43 (2009), pp. 1043-1086.

[5896] G. M. Dlussky. "Ants of the genus Plagiolepis Mayr (Hymenoptera, Formicidae) from Late Eocene ambers of Europe". English. In: Paleontological Journal 44 (2010), pp. 546-555.

[5897] G. M. Dlussky, D. J. Brothers, and A. P. Rasnitsyn. "The first Late Cretaceous ants (Hymenoptera: Formicidae) from southern Africa, with comments on the origin of the Myrmicinae". English. In: Insect Systematics E Evolution 35 (2004), pp. 1-13.

[5898] G. M. Dlussky and D. A. Dubovikoff. "Yantaromyrmex gen. n. - a new ant genus (Hymenoptera: Formicidae) from Late Eocene ambers of Europe". English. In: Caucasian Entomological Bulletin 9 (2013), pp. 305-314.

[5899] G. M. Dlussky, H. V. Karl, C. Brauckmann, E. Gröning, and M. Reich. "Two ants (Insecta: Hymenoptera: Formicidae: Formicinae) from the late Pliocene of Willershausen, Germany, with a nomenclatural note on the genus Camponotites". English. In: Paläontologische Zeitschrift 85 (2011), pp. 449-455. DOI: 10.1007/s12542-011-0104-2.

[5900] G. M. Dlussky and E. E. Perkovsky. "Murav'i (Hymenoptera, Formicidae) Rovenskogo yantarya". Russian. In: Vestnik Zoologii 36 (2002), pp. 3-20.

[5901] G. M. Dlussky and T. S. Putyatina. “Early Miocene ants (Hymenoptera, Formicidae) from Radoboj, Croatia". English. In: Neues Jahrbuch für Geologie und Paläontologie, Abhandlungen 272 (2014), pp. 237285.

[5902] G. M. Dlussky and A. Radchenko. "A new ant genus from the late Eocene European amber". English. In: Acta Palaeontologica Polonica 51 (2006), pp. 561-567.

[5903] G. M. Dlussky and A. Radchenko. "Fallomyrma gen. nov., a new myrmicine ant genus (Hymenoptera: Formicidae) from the late Eocene European amber". English. In: Annales Zoologici 56 (2006), pp. 153-157. 
[5904] G. M. Dlussky and A. G. Radchenko. “Two new primitive ant genera from the late Eocene European ambers". English. In: Acta Palaeontologica Polonica 54 (2009), pp. 435-441.

[5905] G. M. Dlussky and A. G. Radchenko. "Pristomyrmex rasnitsyni sp. n., the first known fossil species of the ant genus Pristomyrmex Mayr (Hymenoptera: Formicidae) from the Late Eocene Danish amber". English. In: Russian Entomological Journal 20 (2011), pp. 251-254.

[5906] G. M. Dlussky and A. P. Rasnitsyn. “Two new species of aculeate hymenopterans (Vespida=Hymenoptera) from the Middle Eocene of the United States". English. In: Paleontological Journal 33 (1999), pp. 546549.

[5907] G. M. Dlussky and A. P. Rasnitsyn. “Ants (Hymenoptera: Formicidae) of Formation Green River and some other middle Eocene deposits of North America". English. In: Russian Entomological Journal 11 (2002), pp. 411-436.

[5908] G. M. Dlussky, A. P. Rasnitsyn, and K. S. Perfilieva. "The ants (Hymenoptera: Formicidae) of Bol'shaya Svetlovodnaya (late Eocene of Sikhote-Alin, Russian far east)". English. In: Caucasian Entomological Bulletin 11 (2015), pp. 131-152.

[5909] G. M. Dlussky, T. Wappler, and S. Wedmann. "New midle Eocene formicid species from Germany and the evolution of weaver ants". English. In: Acta Palaeontologica Polonica 53.4 (2008), pp. 615626.

[5910] G. M. Dlussky, T. Wappler, and S. Wedmann. "Fossil ants of the genus Gesomyrmex Mayr (Hymenoptera, Formicidae) from the Eocene of Europe and remarks on the evolution of arboreal ant communities". English. In: Zootaxa 2031 (2009), pp. 1-20.

[5911] G. M. Dlussky and S. Wedmann. "The poneromorph ants (Hymenoptera, Formicidae: Amblyoponinae, Ectatomminae, Ponerinae) of Grube Messel, Germany: high biodiversity in the Eocene". English. In: Journal of Systematic Palaeontology 10 (2012), pp. 725-753.

[5912] R. Dobosz and W. Krzemiski. "A new species of the Coniopterygidae (Neuroptera) from Baltic amber". English. In: Polskie Pismo Entomologiczne 69 (2000), pp. 219-224.

[5913] I. A. Dobruskina. Triassic Floras of Eurasia. Vol. 10. Osterreichische Akademie der Wissenschaften Schriftenreihe der Erdwissenschaftlichen Kommissionen. H. Zapfe (Ed.), Springer-Verlag, New York. 1994, pp. 1-422.

[5914] I. A. Dobruskina. "Keuper (Triassic) Flora from Middle Asia (Madygen, Southern Fergana)". English. In: Bulletin of the New Mexico Museum of Natural History \& Science 5 (1995), pp. 1-49.

[5915] D. Dochev, V. Idakieva, M. Ivanov, S. Velev, and K. Bonev. "Ammonite fauna from the Byers Peninsula, Livingston Island, South Shetland Islands, Antarctica". English. In: Comptes Rendus de l'Académie Bulgare des Sciences 70 (2017), pp. 1557-1566.

[5916] D. Dochev and L. Metodiev. "New record of Diplomoceras cylindraceum (Defrance, 1816) from the Maastrichtian of the Western Fore-Balkan (Bulgaria)". English. In: Geologica Balcanica 45 (2016), pp. 33-45.

[5917] D. T. Dockery. The Streptoneuran gastropods, exclusive of the Stenoglossa, of the coffee sand (Campanian) of Northeastern Mississippi. 1993.

[5918] C. K. Dodd Jr. and G. S. Morgan. "Fossil sea turtles from the early Pliocene Bone Valley Formation, central Florida". English. In: Journal of Herpetology 26.1 (1992), pp. 1-8.

[5919] A. E. Dodonov, A. L. Tchepalyga, C. D. Mihailescu, L. P. Zhou, A. K. Markova, V. M. Trubikhin, A. N. Simakova, and E. G. Konikov. "Last-interglacial records from central Asia to the northern Black Sea shoreline: stratigraphy and correlation". English. In: Geologie en Mijnbouw / Netherlands Journal of Geosciences 79.2/3 (2000), pp. 303-311.

[5920] P. Dodson, D. W. Krause, C. A. Forster, S. D. Sampson, and F. Ravoavy. “Titanosaurid (Sauropoda) osteoderms from the Late Cretaceous of Madagascar". English. In: Journal of Vertebrate Paleontology 18.3 (1998), pp. 563-568.

[5921] S. Doering and M. Kazmierczak. "Stratigraphy, Geometry, and Facies of a Middle Devonian Rampto-Basin Transect (Eastern Anti-Atlas, SE Morocco)". English. In: Facies 44 (2001), pp. 137-150. 
[5922] L. Doguzhaeva. "Adolescent bactritoid, orthoceroid, ammonoid and coleoid shells from the Upper Carboniferous and Lower Permian of the south Urals". English. In: Abhandlungen der Geologischen Bundesanstalt 57 (2002), pp. 9-55.

[5923] L. A. Doguzhaeva. "An Early Cretaceous orthocerid cephalopod from north-western Caucasus". English. In: Palaeontology 37.4 (1994), pp. 889-899.

[5924] L. A. Doguzhaeva, R. H. Mapes, and H. Mutvei. "The shell and ink sac morphology and ultrastructure of the late Pennsylvanian cephalopod Donovaniconus an its phylogenetic significance". English. In: Berliner Paläobiol. Abh. 3 (2003), pp. 61-78.

[5925] P. J. D. Dolding. "Palynology of the Marambio Group (Upper Cretaceous) of northern Humps Island". English. In: Antartic Science 4.3 (1992), pp. 311-326.

[5926] O. Dolgov and T. Meidla. "Trilobite Biostratigraphy in the Middle and Upper Ordovician of Western Leningrad Region". English. In: Stratigraphy and Geological Correlation 19.6 (2011), pp. 618-630.

[5927] L. Dolin. "Cypraeoidea and Lamellarioidea (Mollusca: Gastropoda), from the Chipola Formation (late early Miocene) of northwestern Florida". English. In: Tulane Studies in Geology and Paleontology 24.1-2 (1991), pp. 1-60.

[5928] L. Dolin. “Cypraedia (Eucypraedia) multicarinata (Dall, 1890); a late Eocene Ovulidae from Florida, Mississippi, Colombia, and Peru. Studies on Paleogene Cypraeoidea". English. In: Mississippi Geology 12.3,4 (1991), pp. 28-31.

[5929] L. Dolin. "Jenneria (Projenneria) eniwetokensis subgen. nov., sp. nov.: a Western Pacific new occurrence for the genus". English. In: Cossmanniana, Paris 4 (1997), pp. 20-24.

[5930] L. Dolin. "Redéfinition du genre Loxacypraea Petuch, 2004 (Mollusca, Caenogastropoda) et description d'espéces nouvelles du Miocéne inférieur de Floride (USA) et d'Aquitaine (France)". English. In: Cossmanniana 17 (2015), pp. 5-14.

[5931] L. Dolin, J. Biosca-Munts, and D. Parcerisa. “Olianatrivia riberai n. gen., n. sp. (Mollusca, Caenogastropoda), une Ovulidae singuliére du Bartonien (Éocéne moyen) de Catalogne (Espagne)". English. In: Geodiversitas 35.4 (2013), pp. 777-786. DOI: 10.5252/g2013n4a3.

[5932] L. Dolin and D. Ledon. "Nouveaux taxons et discussion de la systématique des genres correspondants d'Ovulidae (Mollusca, Caenogastropoda) de l'Éocéne inférieur de Gan (France)". French. In: Geodiversitas 24.2 (2002), pp. 329-347.

[5933] L. Dolin and P. Lozouet. “Nouvelles espéces de Gastéropodes (Mollusca: Gastropoda) de l'Oligocéne et du Miocéne inférieur de l'Aquitaine (Sud-Ouest de la France). Partie 3. Cypraeidae et Ovulidae". French. In: Cossmanniana hors série 4 (2004), pp. 1-164.

[5934] L. Dolin and J. M. Pacaud. "Les Cypraeoidea et Velutinoidea (Mollusca, Caenogastropoda) du Lutétien inférieur du Vicentin et du Véronais (nord-est de l'Italie)". English. In: Revue de Paléobiologie, Genéve 28.2 (2009), pp. 277-314.

[5935] V. G. Dolin and A. Nel. “Trois nouveaux Elateridae fossiles du Mésozoque supérieur de Chine (Coleoptera)". French. In: Bulletin de la Société Entomologique de France 107 (2002), pp. 341-346.

[5936] K. N. Dollman, J. M. Clark, M. A. Norell, X. Xu, and J. M. Choiniere. "Convergent Evolution of a Eusuchian-Type Secondary Palate within Shartegosuchidae". English. In: American Museum Novitates 3901 (2018), pp. 1-23.

[5937] K. N. Dollman, P. A. Viglietti, and J. N. Choiniere. "A new specimen of Orthosuchus stormbergi (Nash 1968) and a review of the distribution of Southern African Lower Jurassic crocodylomorphs". English. In: Historical Biology 31.5 (2019), pp. 653-664. DOI: 10.1080 / 08912963.2017. 1387110.

[5938] T. C. Domer, R. A. Burks, L. Krogmann, and J. M. Heraty. "Patching up the past one fossil at a time: A new genus and species of Eulophidae from Eocene Baltic Amber (Hymenoptera, Chalcidoidea)". English. In: Journal of Hymenoptera Research 79 (2020), pp. 27-42. DOI: 10.3897 /jhr.79. 55899. 
[5939] P. Domnguez Alonso. “Sistemática, Anatoma, Estructura y Función de Ctenocystoidea (Echinodermata Carpoidea del Paleozoico inferior)". English. PhD thesis. 1999, pp. 1-538.

[5940] P. Dominiak, R. Szadziewski, and A. Nel. "A new species of the haematophagous genus Austroconops Wirth \& Lee (Diptera: Ceratopogonidae: Leptoconopinae) from middle Cretaceous amber of Charente-Maritime, France". English. In: Cretaceous Research 92 (2018), pp. 231-239.

[5941] S. Dominici, E. Cioppi, S. Danise, U. Betocchi, G. Gallai, F. Tangocci, G. Valleri, and S. Monechi. "Mediterranean fossil whale falls and the adaptation of mollusks to extreme habitats". English. In: Geology 37.9 (2009), pp. 815-818. DOI: 10.1130/G30073A.1.

[5942] S. Dominici, S. Danise, and M. Benvenuti. "Pliocene stratigraphic paleobiology in Tuscany and the fossil record of marine megafauna". English. In: Earth-Science Reviews 176 (2018), pp. 277-310. DOI: 10.1016/j.earscirev.2017.09.018.

[5943] S. Dominici, M. Forli, C. Bogi, A. Guerrini, and M. Benvenuti. "Paleobiology from Museum collections: comparing historical and novel data on Upper Miocene molluscs of the Livorno Hills". English. In: Rivista Italiana di Paleontologia e Stratigrafia 126.1 (2020), pp. 65-109.

[5944] S. Dominici and T. Kowalke. "Depositional dynamics and the record of ecosystem stability: early Eocene faunal gradients in the Pyrenean foreland, Spain". English. In: Palaios 22.3 (2007), pp. 268284.

[5945] S. Dominici and T. Kowalke. "Early Eocene Cerithioidean gastropods of mangrove-fringed coasts (South-central Pyrenees, Spain)". English. In: Bollettino della Societá Paleontologica Italiana 53.3 (2014), pp. 137-162. DOI: 10.4435/BSPI.2014.13.

[5946] J. L. Dommergues and S. Goolaerts. “Oxyarietites boletzkyi n. gen., n. sp., nouveau genre et nouvelle espéce d'ammonite dans le Sinémurien inférieur de Bourgogne (France): un rare précurseur des morphologies oxycones pour le Jurassique". French. In: Geodiversitas 34 (2012), pp. 517-529.

[5947] J. L. Dommergues, C. Meister, and R. B. Rocha. "The Pliensbachian ammonites of the Algarve Basin (Portugal) and their palaeobiogeographical significance for the Iberia-Newfoundland conjugate margins". English. In: Swiss Journal of Geosciences 104 (2011), pp. 81-96.

[5948] J.-L. Dommergues, A. Guiffray, T. Dumont, and F. Chevalier. “La lumachelle á Cardinia (Bivalves) et Alsatites (Ammonites) du Revers de Cote Dure dans l'Hettangien de la couverture sédimentaire du Massif du Rochail (Oisans, Isére, France)". French. In: Revue de Paléobiologie, Genéve 30.1 (2011), pp. 193-221.

[5949] J. L. Dommergues, C. Meister, and R. B. Rocha. "The Sinemurian ammonites of the Lusitanian Basin (Portugal): an example of complex endemic evolution". English. In: Palaeodiversity 3 (2010), pp. 59-87.

[5950] N. S. Domnanovich and C. Marsicano. "The Triassic dicynodont Vinceria (Therapsida, Anomodontia) from Argentina and a discussion on basal Kannemeyeriiformes". English. In: Geobios 45 (2012), pp. 173-186.

[5951] N. S. Domnanovich, R. Tomassini, M. Manera de Bianco, and M. Dalpoonte. “Nuevos aportes al conocimiento de la icnofauna de tetrápodos del Triásico Superior de Los Menucos (Complejo Los Menucos), provincia de Ro Negro, Argentina [New contributions to the knowledge of the tetrapod ichnofauna from the Upper Triassic of Los Menucos (Los Menucos Complex), Ro Negro province, Argentina]". Spanish. In: Ameghiniana 45.1 (2008), pp. 211-224.

[5952] D. P. Domning. "Bibliography and Index of the Sirenia and Desmostylia". English. In: Smithsonian Contributions to Paleobiology 80 (1996), pp. 1-611.

[5953] D. P. Domning. “The earliest known fully quadrupedal sirenian”. English. In: Nature 413 (2001), pp. 625-627.

[5954] D. P. Domning. "Fossil Sirenia of the West Atlantic and Caribbean Region, IV. Corystosiren varguezi, gen. et sp. nov." English. In: Journal of Vertebrate Paleontology 10.3 (1990), pp. 361-371.

[5955] D. P. Domning. "Fossil Sirenia of the West Atlantic and Caribbean Region. VI. Crenatosiren olseni (Reinhart, 1976)". English. In: Journal of Vertebrate Paleontology 17.2 (1997), pp. 397-412. 
[5956] D. P. Domning. Sirenia. English. Cenozoic Mammals of Africa. 2010, pp. 147-160.

[5957] D. P. Domning. "Rytiodus heali, sp. nov., A new sirenian (Mammalia, Dugonginae) from the Miocene of Libya". English. In: Journal of Vertebrate Paleontology 31.6 (2011), pp. 1338-1355.

[5958] D. P. Domning. "Sirenia". English. In: Vertebrate Paleontology in the Neotropics. The Miocene fauna of La Venta, Colombia. Smithsonian Institution Press, 1997, pp. 383-391.

[5959] D. P. Domning. "Fossil Sirenia (Mammalia) of the Miocene Chesapeake Group, Eastern United States". English. In: Smithsonian Contributions to Paleobiology 100 (2018), pp. 241-265.

[5960] D. P. Domning and O. A. Aguilera. "Fossil Sirenia of the West Atlantic and Caribbeaan Region. VIII. Nanosiren garciae, gen. et sp. nov. and Nanosiren sanchezi, sp. nov." English. In: Journal of Vertebrate Paleontology 28.2 (2008), pp. 479-500.

[5961] D. P. Domning and L. G. Barnes. "A new name for the 'Stanford Skeleton' of Paleoparadoxia (Mammalia, Desmostylia)". English. In: Journal of Vertebrate Paleontology 27.3 (2007), pp. 748-751.

[5962] D. P. Domning and B. L. Beatty. "Fossil Sirenia of the West Atlantic and Caribbean region. XII. Stegosiren macei, gen. et sp. nov." English. In: Journal of Vertebrate Paleontology (2019), e1650369.

[5963] D. P. Domning, R. J. Emry, R. W. Portell, S. K. Donovan, and K. S. Schindler. “Oldest West Indian land mammal: rhinocerotoid ungulate from the Eocene of Jamaica". English. In: Journal of Vertebrate Paleontology 17.4 (1997), pp. 638-641.

[5964] D. P. Domning and H. Furusawa. "Summary of taxa and distribution of Sirenia in the North Pacific Ocean". English. In: The Island Arc 3 (1995), pp. 506-512.

[5965] D. P. Domning, P. D. Gingerich, E. L Simons, and F. A. Ankel-Simons. "A new early Oligocene Dugongid (Mammalia, Sirenia) from Fayum Province, Egypt". English. In: Contributions from the Museum of Paleontology, University of Michigan 29.4 (1994), pp. 89-108.

[5966] D. P. Domning and P. D. Gingerich. "Protosiren smithae, new species (Mammalia, Sirenia), from the Late Middle Eocene of Wadi Hitan, Egypt". In: Contributions from the Museum of Paleontology, University of Michigan 29.3 (1994), pp. 69-87.

[5967] D. P. Domning, G. J. Heal, and S. Sorbi. “Libysiren sickenbergi, gen. et sp. nov.: a new sirenian (Mammalia, Protosirenidae) from the middle Eocene of Libya". English. In: Journal of Vertebrate Paleontology 37.2 (2017), e1299158. DOI: 10.1080/02724634.2017.1299158.

[5968] D. P. Domning and P. Pervesler. "The sirenian Metaxytherium (Mammalia: Dugongidae) in the Badenian (Middle Miocene) of Central Europe". English. In: Austrian Journal of Earth Sciences 105.3 (2012), pp. 125-160.

[5969] F. Dong, C. K. Shih, and D. Ren. "Two new species of Trichoceridae from the Middle Jurassic Jiulongshan Formation of Inner Mongolia, China". English. In: ZooKeys 411 (2014), pp. 145-160.

[5970] F. Dong, C. K. Shih, and D. Ren. "A new genus of Tanyderidae (Insecta: Diptera) from Myanmar amber, Upper Cretaceous". English. In: Cretaceous Research 54 (2015), pp. 260-265.

[5971] F. Dong, C. K. Shih, K. Skibiska, W. Krzemiski, and D. Ren. “New species of Tanyderidae (Diptera) from the Jiulongshan Formation of China". English. In: Alcheringa 39 (2015), pp. 494-507.

[5972] F. B. Dong and D. Y. Huang. "A new elaterid from the Middle Jurassic Daohugou biota (Coleoptera: Elateridae: Protagrypninae)". English. In: Acta Geologica Sinica 85.6 (2011), pp. 1224-1230.

[5973] F. B. Dong and D. Y. Huang. "A new click beetle (Coleoptera: Elateridae) from Middle Jurassic Haifanggou Formation of western Liaoning, China". Chinese. In: Acta Palaeontologica Sinica 48 (2009), pp. 102-108.

[5974] L. Dong, D. Huang, and Y. Wang. "Two Jurassic salamanders with stomach contents from Inner Mongolia, China". English. In: Chinese Science Bulletin 57.1 (2012), pp. 72-76. DOI: 10.1007/s11434011-4729-z.

[5975] L. Dong, Z. Roek, Y. Wang, and M. E. H. Jones. “Anurans from the Lower Cretaceous Jehol Group of Western Liaoning, China". English. In: PLoS One 8.7 (2013), e69723. DOI: 10.1371/journal.pone. 0069723. 
[5976] L. Dong, Y. Wang, and S. E. Evans. “A new lizard (Reptilia: Squamata) from the Lower Cretaceous Yixian Formation of China, with a taxonomic revision of Yabeinosaurus". English. In: Cretaceous Research (2017). DOI: 10.1016/j.cretres.2016.12.017.

[5977] L. Dong, Y. Wang, L. Mou, G. Zhang, and S. E. Evans. “A new Jurassic lizard from China”. English. In: Geodiversitas 41.16 (2019), pp. 623-641.

[5978] L. Dong, S. Xiao, B. Shen, C. Zhou, G. Li, and J. Yao. “Basal Cambrian microfossils from the Yangtze Gorges area (south China) and the Aksu area (Tarim Block, northwestern China)". English. In: Journal of Paleontology 83.1 (2009), pp. 30-44.

[5979] L. Dong, S. Xiao, B. Shen, and C. Zhou. "Silicified Horodyskia and Palaeopascichnus from Upper Ediacaran cherts in south China: tentative phylogenetic interpretation and implications for evolutionary stasis". English. In: Journal of the Geological Society 165 (2008), pp. 367-378.

[5980] L. Dong, X. Xu, Y. Wang, and S. E. Evans. "The lizard genera Bainguis and Parmeosaurus from the Upper Cretaceous of China and Mongolia". English. In: Cretaceous Research 85 (2018), pp. 95-108. DOI: 10.1016/j.cretres.2018.01.002.

[5981] L.-P. Dong, S. E. Evans, and Y. Wang. “Taxonomic revision of lizards from the Paleocene deposits of the Qianshan Basin, Anhui, China". English. In: Vertebrata PalAsiatica 54.3 (2016), pp. 243-268.

[5982] L.-P. Dong, R. Matsumoto, N. Kusuhashi, Y.-Q. Wang, Y. Wang, and S. E. Evans. "A new choristodere (Reptilia: Choristodera) from an Aptian-Albian coal deposit in China". English. In: Journal of Systematic Palaeontology (2020). DOI: 10.1080/14772019.2020.1749147.

[5983] Q. P. Dong, Y. Z. Yao, and D. Ren. "A new species of Progonocimicidae (Hemiptera, Coleorrhyncha) from the Middle Jurassic of China". English. In: Alcheringa 37 (2013), pp. 31-37.

[5984] Q. P. Dong, Y. Z. Yao, and D. Ren. “New fossil Progonocimicidae (Hemiptera: Coleorrhyncha: Progonocimicoidea) from the Upper Mesozoic of northeastern China, with a phylogeny of Coleorrhyncha". English. In: Systematic Entomology 39 (2014), pp. 773-782.

[5985] Q. P. Dong, Y. Z. Yao, and D. Ren. “A new species of Progonocimicidae (Hemiptera: Coleorrhyncha) from northeastern China". English. In: Zootaxa 3495 (2012), pp. 73-78.

[5986] W. Dong. "Les Cervidae (Artiodactyla) rusciniens (Pliocéne) du Languedoc et du Roussillon (France)". French. In: Bulletin du Muséum national d'histoire naturelle, series 4, section C 18.1 (1996), pp. 133-163.

[5987] W. Dong, J. Liu, and Y. Pan. “A new Euprox from the Late Miocene of Yuanmou, Yunnan Province, China, with interpretation of its paleoenvironment". English. In: Chinese Science Bulletin 48.5 (2003), pp. 485-491.

[5988] X. Dong and A. H. Knoll. "Middle and Late Cambrian sponge spicules from Hunan, China". English. In: Journal of Paleontology 70.2 (1996), pp. 173-184.

[5989] Z. Dong. "Sauropoda from the Kelamaili region of the Junggar Basin, Xinjiang Autonomous Region". In: Vertebrata PalAsiatica 28.1 (1990), pp. 43-58.

[5990] Z. Dong. "An ankylosaur (ornithischian dinosaur) from the Middle Jurassic of the Junggar Basin, China". English. In: Vertebrata PalAsiatica 31.4 (1993), pp. 257-266.

[5991] Z. Dong. On small theropods from Mazongshan area, Gansu Province, China. Sino-Japanese Silk Road Dinosaur Expedition. China Ocean Press, Beijing. 1997, pp. 13-18.

[5992] Z. Dong. On the sauropods from the Mazongshan area, Gansu Province, China. Sino-Japanese Silk Road Dinosaur Expedition. China Ocean Press, Beijing. 1997, pp. 19-23.

[5993] Z. Dong. A small ornithopod from Mazongshan area, Gansu Province, China. Sino-Japanese Silk Road Dinosaur Expedition. China Ocean Press, Beijing. 1997, pp. 24-26.

[5994] Z. Dong. On the crocodiles from the Mazongshan area, Gansu Province, China. Sino-Japanese Silk Road Dinosaur Expedition. China Ocean Press, Beijing. 1997, pp. 11-12.

[5995] Z. Dong. A gigantic sauropod (Hudiesaurus sinojapanorum gen. et sp. nov.) from the Turpan Basin, China. Sino-Japanese Silk Road Dinosaur Expedition. China Ocean Press, Beijing. 1997, pp. 102-110. 
[5996] Z. Dong. On a large claw of sauropod from the Upper Cretaceous in the Turpan Basin, Xinjiang, China. Sino-Japanese Silk Road Dinosaur Expedition. China Ocean Press, Beijing. 1997, pp. 111-112.

[5997] Z. Dong. Dinosaurian Faunas of China. China Ocean Press, Beijing. 1992, pp. 1-188.

[5998] Z. Dong. Stegosaurs of Asia. Dinosaur Systematics: Perspectives and Approaches, Cambridge University Press, Cambridge. 1990, pp. 255-268.

[5999] Z. Dong and J. Lü. "A new ctenochasmatid pterosaur from the Early Cretaceous of Liaoning Province". English. In: Acta Geologica Sinica 79.2 (2005), pp. 164-167.

[6000] Z. Dong and Y. Wang. "A new urodele (Liaoxitriton zhongjiani gen. et sp. nov.) from the Early Cretaceous of western Liaoning Province, China". Chinese. In: Vertebrata PalAsiatica 36.4 (1998), pp. 159-172.

[6001] Z.-M. Dong. “A new species of stegosaur (Dinosauria) from the Ordos Basin, Inner Mongolia, People's Republic of China". English. In: Canadian Journal of Earth Sciences 30.10-11 (1994), pp. 21742176.

[6002] Z.-M. Dong. "A Lower Cretaceous enantiornithine bird from the Ordos Basin, Inner Mongolia, People's Republic of China". English. In: Canadian Journal of Earth Sciences 30.10-11 (1994), pp. 2177-2179.

[6003] Z.-M. Dong. "The field activities of the Sino-Canadian Dinosaur Project in China, 1987-1990". English. In: Canadian Journal of Earth Sciences 30.10-11 (1994), pp. 1997-2001.

[6004] Z.-M. Dong. "Early Cretaceous dinosaur faunas in China: an introduction". English. In: Canadian Journal of Earth Sciences 30.10-11 (1994), pp. 2096-2100.

[6005] Z.-M. Dong. "A new armored dinosaur (Ankylosauria) from Beipiao Basin, Liaoning Province, northeastern China". Chinese. In: Vertebrata PalAsiatica 40.4 (2002), pp. 276-285.

[6006] Z.-M. Dong and P. J. Currie. "Protoceratopsian embryos from Inner Mongolia, People's Republic of China". English. In: Canadian Journal of Earth Sciences 30.10-11 (1994), pp. 2248-2254.

[6007] Z.-M. Dong, Y.-W. Sun, and S. -Y. Wu. "On a new pterosaur from the Lower Cretaceous of Chaoyang Basin, Western Liaoning, China". Chinese. In: Global Geology 22 (2003), pp. 1-7.

[6008] Z.-M. Dong, Z.-L. Zhou, and S. -Y. Wu. “Note on a hadrosaur footprint from Heilongjiang River area of China". In: Vertebrata PalAsiatica 41.4 (2003), pp. 324-326.

[6009] S. L. Donohue, G. P. Wilson, and B. H. Breithaupt. "Latest Cretaceous multituberculates of the Black Butte Station local fauna (Lance Formation, southwestern Wyoming), with implications for compositional differences among mammalian local faunas of the Western Interior". English. In: Journal of Vertebrate Paleontology 33.3 (2013), pp. 677-695. DOI: 10.1080/02724634.2013.745416.

[6010] D. T. Donovan, L. A. Doguzhaeva, and H. Mutvei. "Two paris of fins in the Late Jurassic Coleoid Trachyteuthis from Southern Germany". English. In: Berliner Paläobiol. Abh. 3 (2003), pp. 91-99.

[6011] D. T. Donovan and S. von Boletzky. "Loligosepia (Cephalopoda: Coleoidea) from the Lower Jurassic of the Dorset coast, England". English. In: Neues Jahrbuch für Geologie und Paläontologie, Abhandlungen 273 (2014), pp. 45-63.

[6012] J. K. Donovan. "Depositional Environments and Paleoecology of the Lower Ordovician Pogonip Group, Opd Unit, Arrow Canyon Range, Clark County, Nevada". English. In: Unlv (1992).

[6013] S. K. Donovan. A Rhuddanian (Silurian, Lower Llandovery) pelmatozoan fauna from south-west Wales. 1993.

[6014] S. K. Donovan. Echinoids of the Upper Eocene Somerset Formation of Jamaica. 1994.

[6015] S. K. Donovan. "A new crinoid from the Ashgill Starfish Bed, Threave Glen". English. In: Scottish Journal of Geology 28 (1992), pp. 123-126.

[6016] S. K. Donovan. "Jamaican Cretaceous Echinoidea". English. In: Geological Society of America Memoir 182 (1993), pp. 93-103.

[6017] S. K. Donovan. Jamaican Cenozoic Echinoidea. English. Vol. 182. Geological Society of America Memoir. 1993, pp. 371-412. 
[6018] S. K. Donovan. "The camerate crinoid Eucalyptocrinites sp. from the Silurian(?) of Scotland". English. In: Scottish Journal of Geology 45 (2009), pp. 89-92. DOI: 10.1144/036-9276/01-372.

[6019] S. K. Donovan and N. D. L. Clark. "A collection of pelmatozoans (Echinodermata) from the Lady Burn Starfish Beds (Upper Ordovician, Katian), SW Scotland". English. In: Scottish Journal of Geology 51 (2015), pp. 125-130. DOI: 10.1144/sjg2015-001.

[6020] S. K. Donovan and E. R. Davis-Strickland. "A possible lepadomorph barnacle from the Maastrichtian (Upper Cretaceous) of Jamaica, West Indies". English. In: Journal of Paleontology 67 (1993), pp. 158-159.

[6021] S. K. Donovan, D. P. Domning, F. A. Garcia, and H. L. Dixon. "A bone bed in the Eocene of Jamaica". English. In: Journal of Paleontology 64.4 (1990), pp. 660-662.

[6022] S. K. Donovan and G. Draper. "Further fossil cephalopods from Jamaica". English. In: Paläontologische Zeitschrift 75 (2001), pp. 17-21.

[6023] S. K. Donovan, F. E. Fearnhead, and E. N. K. Clarkson. "The ichnofossils Gordia Emmons and Chondrites von Stenberg fron the Deerhope Formation, North Esk Inlier (Silurian, Llandovery)". English. In: Scottish Journal of Geology 45 (2009), pp. 83-88. DOI: 10.1144/0036-9276/01-385.

[6024] S. K. Donovan and F. E. Fearnhead. "A Lower Devonian hexacrinitid crinoid (Camerata, Monobathrida) from south-west England". English. In: Paläontologische Zeitschrift 91.2 (2017), pp. 217222. DOI: $10.1007 / \mathrm{s} 12542-017-0344-\mathrm{x}$.

[6025] S. K. Donovan and N. Gilmour. "New camerate crinoids from the Ordovician of Scotland and Wales". English. In: Transactions of the Royal Society of Edinburgh: Earth Sciences 93 (2003), pp. 155161. DOI: $10.1017 /$ S0263593300000389.

[6026] S. K. Donovan, C. M. Gordon, C. J. Veltkamp, and A. D. Scott. Crinoid, asteroids, and ophiuroids in the Jamaican fossil record. English. Vol. 182. Geological Society of America Memoir. 1993, pp. 125-130.

[6027] S. K. Donovan and G. C. Gunter. "Fossil sharks from Jamaica". English. In: Bulletin of the Mizunami Fossil Museum 28 (2001), pp. 211-215.

[6028] S. K. Donovan, D. A. T. Harper, R. -B. Zhan, L. Stemmerik, J. -B. Liu, and S. Stouge. "A primitive cladid crinoid from the Jiacun Group, Tibet (Darriwilian, Middle Ordovician)". English. In: Geological Journal 47.6 (2012), pp. 653-660. DOI: 10.1002/gj.2436.

[6029] S. K. Donovan, A. W. Janssen, R. W. Portell, and A. J. De Winter. "A holoplanktic gastropod in a raised reef: Hopegate Formation, Jamaica (upper Pliocene)". English. In: Paläontologische Zeitschrift (2019).

[6030] S. K. Donovan, D. N. Lewis, and D. A. T. Harper. “The Lady Burn starfish beds". English. In: Geology Today 18.4 (2002), pp. 151-157.

[6031] S. K. Donovan and D. T. J. Littlewood. "The benthic mollusk faunas of two contrasting reef paleosubenvironments: Falmouth Formation (late Pleistocene, last interglacial), Jamaica". English. In: The Nautilus 107.1 (1993), pp. 33-42.

[6032] S. K. Donovan, S. F. Mitchell, and D. N. Lewis. "The irregular echinoid Nucleopygus from the Upper Cretaceous of western Jamaica". English. In: Cretaceous Research 27 (2006), pp. 577-583.

[6033] S. K. Donovan, R. W. Portell, and C. J. Veltkamp. “Lower Miocene echinoderms of Jamaica, West Indies". English. In: Scripta Geologica 129 (2005), pp. 91-135.

[6034] S. K. Donovan and D.-A. C. Rowe. "Spatangoid Echinoids from the Eocene of Jamaica". English. In: Journal of Paleontology 74.4 (2000), pp. 654-661.

[6035] A. Dooley, L. G. Barnes, and M. Kearin. A new taxon of squalodontid (Mammalia, Cetacea) from the lower Miocene Vaqueros Formation in southern California. English. 2004.

[6036] A. C. Dooley. "A new species of Squalodon (Mammalia, Cetacea) from the Middle Miocene of Virginia". English. In: Virginia Museum of Natural History Memoir 8 (2005), pp. 1-43.

[6037] A. C. Dooley. "A middle Miocene beaked whale tooth (Cetacea: Ziphiidae) from the Carmel Church Quarry, Virginia, and implications for the evolution of sexual dimorphism in ziphiids". English. In: Jeffersoniana 24 (2010), pp. 1-11. 
[6038] A. C. Dooley, N. C. Fraser, and Z. Luo. "The earliest known member of the rorqual-gray whale clade (Mammalia, Cetacea)". English. In: Journal of Vertebrate Paleontology 24.2 (2004), pp. 453-463.

[6039] A. C. Dooley, E. Scott, J. Green, K. B. Springer, B. S. Booley, and G. J. Smith. "Mammut pacificus sp. nov., a newly recognized species of mastodon from the Pleistocene of western North America". English. In: PeerJ 7 (2019), e6614. DOI: 10.7717/peerj.6614.

[6040] C. Doorenweerd, E. J. Van Nieukerken, J. C. Sohn, and C. C. Labandeira. “A revised checklist of Nepticulidae fossils (Lepidoptera) indicates an Early Cretaceous origin". English. In: Zootaxa 3963 (2015), pp. 295-334.

[6041] J. Dorado Galindo. "Contribucion al Conocimiento de la Estratigrafia de la Formacion Brechas de Buenavista (Limite Jurasico-Cretacico). Region Noroeste de Villavicencio (Meta)". Spanish. In: Geologia Colombiana 17 (1990), pp. 7-39.

[6042] H. Dorfelt and A. R. Schmidt. "A fossil Aspergillus from Baltic amber". English. In: Mycological Research 109.8 (2005), pp. 956-960.

[6043] G. Doria, C. Jaramillo, and F. Herrera. "Menispermaceae from the Cerrejón Formation, middle to late Paleocene, Colombia". English. In: American Journal of Botany 95.8 (2008), pp. 954-973. DOI: 10.3732/ajb.2007216.

[6044] M. Dorka. "Teeth of Polyacrodus Jaekel, 1889 from the Triassic of the Germanic Basin". English. In: Mitteilungen aus dem Museum für Naturkunde in Berlin, Geowissenschaftliche Reihe 6.1 (2003), pp. 147155.

[6045] S. Q. Dornbos and J.-Y. Chen. "Community palaeoecology of the early Cambrian Maotianshan Shale biota: Ecological dominance of priapulid worms". English. In: Palaeogeography, Palaeoclimatology, Palaeoecology 258 (2008), pp. 200-212.

[6046] S. Q. Dornbos and M. A. Wilson. "Paleoecology of a Pliocene coral reef in Cyprus: recovery of a marine community from the Messinian Salinity Crisis". In: Neues Jahrbuch für Geologie und Paläontologie, Abhandlungen 213.1 (1999), pp. 103-118.

[6047] U. Dorner. Palökologie von Benthosgemeinschaften im Pliensbach von Unterstürmig und Buttenheim (Mittelfranken). German. 2002.

[6048] R. W. Dortangs, A. S. Schulp, E. W. A. Mulder, J. W. M. Jagt, H. H. G. Peeters, and D.T.d. Graaf. "A large new mosasaur from the Upper Cretaceous of the Netherlands". English. In: Netherlands Journal of Geosciences/Geologie en Mijnbouw 81.1 (2002), pp. 1-8.

[6049] I. C. dos Santos Pereira, M. A. T. Dantas, and R. Lopes Ferreira. "Record of the giant sloth Valgipes bucklandi (Lund, 1839) (Tardigrada, Scelidotheriinae) in Rio Grande do Norte state, Brazil, with notes on taphonomy and paleoecology". English. In: Journal of South American Earth Sciences 43 (2013), pp. 42-45.

[6050] O. Dostal and J. Prokop. "New fossil insects (Diaphanopterodea: Martynoviidae) from the Lower Permian of the Boskovice Basin, southern Moravia". English. In: Geobios 42 (2009), pp. 495-502.

[6051] E. M. Doughty, S. C. Wallace, B. W. Schubert, and L. M. Lyon. "First occurrence of the enigmatic peccaries Mylohyus elmorei and Prosthennops serus from the Appalachians: latest Hemphillian to Early Blancan of Gray Fossil Site, Tennessee". English. In: PeerJ 6 (2018), e5926. DOI: 10.7717/ peerj.5926.

[6052] C. Doukas and L. W. van den Hoek Ostende. "Insectivores (Erinaceomorpha, Soricomorpha; Mammalia)from Karydia and Komotini (Thrace, Greece; MN 4/5)". English. In: Beiträge zur Paläontologie 30 (2006), pp. 109-131.

[6053] C. Doukas, T. van Kolfschoten, K. Papayianni, E. Panagopoulou, and K. Harvati. “The small mammal fauna from the palaeolithic site Marathousa 1 (Greece)". English. In: Quaternary International 497 (2018), pp. 95-107.

[6054] C. S. Doukas and C. D. Theocharopoulos. "Smaller mammals from the Oligocene of Kyprinos (Thrace, N . Greece)". English. In: Deinsea 7.1 (1999), pp. 133-146. 
[6055] C. S. Doukas, L. W. van den Hoek Ostende, C. D. Theocharopoulos, and J. W. F. Reumer. "The Vertebrate Locality Maramena (Macedonia, Greece) at the Turolian-Ruscinian Boundary (Neogene). 5. Insectivora (Erinaceidae, Talpidae, Soricidae, Mammalia)". English. In: Münchner Geowissenschaftliche Abhandlungen (A) 28 (1995), pp. 43-64.

[6056] K. F. Downing and R. S. White. "The cingulates (Xenarthra) of the Leisey Shell Pit local fauna (Irvingtonian), Hillsborough County, Florida". English. In: Bulletin of the Florida Museum of Natural History 37.12 (1995), pp. 375-396.

[6057] J. P. Downs and E. B. Daeschler. "Variation within a large sample of Ageleodus pectinatus teeth (Chondrichthyes) from the Late Devonian of Pennsylvania, USA". English. In: Journal of Vertebrate Paleontology 21.4 (2001), pp. 811-814.

[6058] T. Downs and G. J. Miller. "Late Cenozoic equids from the Anza-Borrego desert of California". English. In: Contributions in Science, Natural History Museum of Los Angeles County 440 (1994), pp. 190.

[6059] J. T. Doyen and G. O. Poinar. “Tenebrionidae from Dominican amber (Coleoptera)". English. In: Entomologica Scandinavica 25 (1994), pp. 27-51.

[6060] E. N. Doyle, D. A. T. Harper, and M. A. Parkes. "The Tonalee Fauna: A deep-water shelly assemblage from the Llandovery rocks of the west of Ireland". English. In: Irish Journal of Earth Sciences 10 (1990), pp. 127-143.

[6061] K. D. Doyle and H.-D. Sues. "Phytosaurs (Reptilia: Archosauria) from the Upper Triassic New Oxford Formation of York County, Pennsylvania". English. In: Journal of Vertebrate Paleontology 15.3 (1995), pp. 545-553.

[6062] P. Doyle. "New records of dimitobelid belemnites from the Cretaceous of James Ross Island, Antarctica". English. In: Alcheringa 14 (1990), pp. 159-175.

[6063] P. Doyle and E. V. Shakides. "The Jurassic belemnite suborder Belemnotheutina". English. In: Palaeontology 47.4 (2004), pp. 983-998.

[6064] S. Dozet. "Lower Jurassic carbonate succession between Predole and Mlaevo, Central Slovenia". English. In: Materials and Geoenvironment 56.2 (2009), pp. 164-193.

[6065] M. T. Dozo. "Paleoneurologia de Dolicavia minuscula (Rodentia, Caviidae) y Paedotherium insigne (Notoungulata, Hegetotheriidae) del Plioceno de Buenos Aires, Argentina". Spanish. In: Ameghiniana 34.4 (1997), pp. 427-435.

[6066] M. T. Dozo, P. Bouza, A. Monti, L. Palazzesi, V. Barreda, G. Massaferro, R. A. Scasso, and C. P. Tambussi. "Late Miocene continental biota in Northeastern Patagonia (Peninsula Valdes Chubut Argentina)". English. In: Palaeogeography, Palaeoclimatology, Palaeoecology 297.1 (2010), pp. 100-109. DOI: 10.1016/j.palaeo.2010.07.018.

[6067] M. T. Dozo, M. Ciancio, P. Bouza, and G. Martnez. “Nueva asociación de mamferos del Paleógeno en el este de la Patagonia (provincia de Chubut, Argentina): implicancias biocronológicas y paleobiogeográficas". English. In: Andean Geology 41.1 (2014), pp. 224-247.

[6068] M. T. Dozo and B. Vera. "First skull and associated postcranial bones of Macraucheniidae (Mammalia, Litopterna) from the Deseadan SALMA (late Oligocene) of Cabeza Blanca (Chubut, Argentina)". English. In: Journal of Vertebrate Paleontology 30.6 (2010), pp. 1818-1826.

[6069] M. T. Dozo, M. G. Vucetich, and A. M. Candela. "Skull anatomy and neuromorphology of Hypsosteiromys, a Colhuehuapian erethizontid rodent from Argentina". English. In: Journal of Vertebrate Paleontology 24.1 (2004), pp. 228-234. DOI: 10.1671/18.1.

[6070] M. T. Dozo, A. Monti, P. Bouza, M. G. Vucetich, A. L. Cione, E. P. Tonni, and G. J. Scillato-Yané. “Geologa y vertebrados continentales en cercanas de Punta Delgada (Neógeno de Pennsula Valdés, Chubut, Argentina)". Spanish. In: Actas des XV Congreso geologico Argentino (2002).

[6071] O. Dragastan. "Early Cretaceous Foraminifera, Algal Nodules and Calpionellids from the Lapos Valley, Bicaz Gorges (Eastern Carpathians, Romania)". English. In: Analele Stiintifice ale Universitatii Al. I. Cuza - Seria Geologie 57.1 (2011), pp. 91-105. 
[6072] O. Dragastan, B. Kube, and D. K. Richter. "New Late Triassic calcareous algae from Hydra, Greece". English. In: Acta Palaeontologica Romanae 2 (1999), pp. 139-156.

[6073] O. Dragastan and D. K. Richter. "Non-marine calcareous algae of Upper Jurassic to Lower Cretaceous sequences from the Weserbergland (northwest Germany)". In: Geologica Carpathica 52.5 (2001), pp. 301-318.

[6074] O. N. Dragastan, H. G. Herbig, and M. E. Popa. "Paleogene Halimeda algal biostratigraphy from middle Atlas and central High Atlas (Morocco). Paleoecology, paleogeography and some taxonomical considerations". English. In: Acta Palaeontologica Romaniae 8.1-2 (2012), pp. 43-90.

[6075] J. Drent. “De Miocene walvis van Kervenheim”. English. In: Grondboor en Hamer 44.1 (1990), pp. $14-16$.

[6076] J. Dridi. "New fossils of the giant pholidosaurid genus Sarcosuchus from the Early Cretaceous of Tunisia". English. In: Journal of African Earth Sciences 147 (2018), pp. 268-280.

[6077] H. Drinia, M. D. Dermitzakis, K. Kouli, and Th. Tsourou. "Sedimentary facies analysis and paleoenvironmental interpretation of Vatera Formation, Lesvos Island, Greece". English. In: Annales Geologiques des Pays Helleniques 39 (2002), pp. 15-35.

[6078] A. N. Drinnan, P. R. Crane, E. M. Friis, and K. R. Pedersen. "Angiosperm flowers and Tricolpate pollen of Buxaceous affinity from the Potomac Group (Mid-Cretaceous) of Eastern North America". English. In: American Journal of Botany 78.2 (1991), pp. 153-176.

[6079] A. N. Drinnan, P. R. Crane, E. M. Friis, and K. R. Pedersen. Lauraceous flowers from the Potomac Group (Mid-Cretaceous) of eastern North America. 1990.

[6080] J. Drohojowska. "Eogyropsylla sedzimiri sp. nov. from Eocene Baltic amber with a key to the species of the fossil genus Eogyropsylla Klimaszewski, 1993 (Hemiptera: Sternorrhyncha: Psylloidea)". English. In: Zootaxa 2803 (2011), pp. 41-48.

[6081] J. Drohojowska, E. E. Perkovsky, and J. Szwedo. “New genus and species of Aleyrodidae from Eocene Baltic amber (Hemiptera: Sternorrhyncha: Aleyrodomorpha)". English. In: Polish Journal of Entomology 84 (2015), pp. 259-269.

[6082] J. Drohojowska and J. Szwedo. "New Aleyrodidae (Hemiptera: Sternorrhyncha: Aleyrodomorpha) from Eocene Baltic amber". English. In: Polish Journal of Entomology 80 (2011), pp. 659-677.

[6083] J. Drohojowska, J. Szwedo, and D. Azar. “Talaya batraba gen. et sp. nov. - the first nymph of a protopsyllidiid (Hemiptera: Sternorrhyncha: Psyllomorpha) from the Lower Cretaceous amber of Lebanon". English. In: Acta Geologica Sinica 87 (2013), pp. 21-31.

[6084] J. Drohojowska and J. Szwedo. "The first Aleyrodidae from the lowermost Eocene Oise amber (Hemiptera: Sternorrhyncha)". English. In: Zootaxa 3636 (2013), pp. 319-347.

[6085] J. Drohojowska and J. Szwedo. "A new whitefly from Lower Cretaceous Lebanese amber (Hemiptera: Sternorrhyncha: Aleyrodidae)". English. In: Insect Systematics \& Evolution 42 (2011), pp. 179-196.

[6086] J. Drohojowska and J. Szwedo. "Gapenus rhinariatus gen. sp. n., a new whitefly from Lebanese amber (Hemiptera: Sternorrhyncha: Aleyrodidae)". English. In: Insect Evolution in an Ambiferous and Stone Alphabet. Leiden: Brill, 2013, pp. 99-110.

[6087] J. Drohojowska and J. Szwedo. "Early Cretaceous Aleyrodidae (Hemiptera: Sternorrhyncha) from the Lebanese amber". English. In: Cretaceous Research 52 (2015), pp. 368-389.

[6088] J. Drohojowska, J. Szwedo, D. ya, D. Y. Huang, and P. Müller. “Fossils reshape the Sternorrhyncha evolutionary tree (Insecta, Hemiptera)". English. In: Scientific Reports 10.11390 (2020). DOI: 10. 1038/s41598-020-68220-x.

[6089] J. Drohojowska, J. Szwedo, P. Müller, and D. Burckhardt. “New fossil from mid-Cretaceous Burmese amber confirms monophyly of Liadopsyllidae (Hemiptera: Psylloidea)". English. In: Scientific Reports 10.17607 (2020). DOI: 10.1038/s41598-020-74551-6.

[6090] J. Drohojowska, P. Wegierek, and M. M. Solórzano Kraemer. “First Psylloidea (Hemiptera: Sternorrhyncha) in Miocene Mexican amber". English. In: PalZ 90 (2016), pp. 185-188. 
[6091] A. V. Dronov, T. N. Koren, L. E. Popov, T. J. Tolmacheva, and L. E. Holmer. “Uppermost Cambrian and Lower Ordovician in northwestern Russia: sequence stratigraphy, sea level changes and bioevents". English. In: Ordovician Odyssey: Short Papers From the Seventh International Symposium on the Ordovician System (1995), pp. 319-322.

[6092] D. L. Droser and P. M. Sheehan. Paleoecological significance of the Ordovician Radiation and End Ordovician extinction: Evidence from the Great Basin. English. Ordovician of the Great Basin: Fieldtrip Guidebook and Volume for the Seventh International Symposium on the Ordovician System. Fullerton, California: Pacific Section, SEPM, 1995, pp. 64-106.

[6093] M. L. Droser and J. G. Gehling. "Synchronous aggregate growth in an abundant new Ediacaran tubular organism". English. In: Science 319 (2008), pp. 1660-1662. DOI: 10.1126/science.1152595.

[6094] M. L. Droser, J. G. Gehling, and S. R. Jensen. "Assemblage palaeoecology of the Ediacara biota: The unabridged edition?" English. In: Palaeogeography, Palaeoclimatology, Palaeoecology 232 (2006), pp. 131-147. DOI: 10.1016/j.palaeo.2005.12.015.

[6095] P. S. Druckenmiller. "Osteology of a new plesiosaur from the Lower Cretaceous (Albian) Thermopolis Shale of Montana". English. In: Journal of Vertebrate Paleontology 22.1 (2002), pp. 29-42.

[6096] P. S. Druckenmiller, J. H. Hurum, E. M. Knutsen, and H. A. Nakrem. “Two new ophthalmosaurids (Reptilia: Ichthyosauria) from the Agardhfjellet Formation (Upper Jurassic: Volgian/Tithonian), Svalbard, Norway". English. In: Norwegian Journal of Geology 92 (2012), pp. 311-339.

[6097] P. S. Druckenmiller, N. P. Kelley, E. T. Metz, and J. Baichtal. “An articulated Late Triassic (Norian) thalattosauroid from Alaska and ecomorphology and extinction of Thalattosauria". English. In: Scientific Reports 10.1746 (2020). DOI: 10.1038/s41598-020-57939-2.

[6098] P. S. Druckenmiller and E. E. Maxwell. "A new Lower Cretaceous (lower Albian) ichthyosaur genus from the Clearwater Formation, Alberta, Canada". English. In: Canadian Journal of Earth Sciences 47 (2010), pp. 1037-1053. DOI: 10.1139/E10-028.

[6099] P. S. Druckenmiller and E. E. Maxwell. “A Middle Jurassic (Bajocian) ophthalmosaurid (Reptilia, Ichthyosauria) from the Tuxedni Formation, Alaska and the early diversification of the clade". English. In: Geological Magazine (2013). DOI: 10.1017/S0016756813000125.

[6100] P. S. Druckenmiller and A. P. Russell. "Skeletal anatomy of an exceptionally complete specimen of a new genus of plesiosaur from the Early Cretaceous (Early Albian) of northeastern Alberta, Canada". English. In: Palaeontographica. Abteilung A: Palaeozoologie-Stratigraphie 283.1-3 (2008), pp. 133.

[6101] P. S. Druckenmiller and A. P. Russell. “Earliest North American occurrence of Polycotylidae (Sauropterygia: Plesiosauria) from the Lower Cretaceous (Albian) Clearwater Formation, Alberta, Canada". English. In: Journal of Paleontology 83.6 (2009), pp. 981-989.

[6102] E. T. Drysdale, F. Therrien, D. K. Zelenitsky, D. B. Weishampel, and D. C. Evans. "Description of juvenile specimens of Prosaurolophus maximus (Hadrosauridae: Saurolophinae) from the Upper Cretaceous Bearpaw Formation of southern Alberta, Canada, reveals ontogenetic changes in crest morphology". English. In: Journal of Vertebrate Paleontology 38.6 (2019), e1547310:1-20. DOI: 10. 1080/02724634.2018.1547310.

[6103] S. Du, O. Béthoux, J. J. Gu, and D. Ren. "Protomiamia yangi gen. et sp. nov. (Early Pennsylvanian; Xiaheyan, China), a sexually dimorphic Palaeozoic stem-Orthoptera". English. In: Journal of Systematic Palaeontology 15 (2016), pp. 193-204.

[6104] S. L. Du, Z. K. Hu, Y. Z. Yao, and D. Ren. “New genus and species of the Yuripopovinidae (Pentatomomorpha: Coreoidea) from mid-Cretaceous Burmese amber". English. In: Cretaceous Research 94 (2019), pp. 141-146. DOI: 10.1016/j.cretres.2018.10.022.

[6105] S. L. Du, Y. Z. Yao, and D. Ren. "New fossil species of the Venicoridae (Heteroptera: Pentatomomorpha) from the Lower Cretaceous of northeast China". English. In: Cretaceous Research 68 (2016), pp. 21-27. 
[6106] S. L. Du, Y. Z. Yao, D. Ren, and W. T. Zhang. “Dehiscensicoridae fam. nov. (Insecta: Heteroptera: Pentatomomorpha) from the upper Mesozoic of northeast China". English. In: Journal of Systematic Palaeontology 15 (2017), pp. 991-1013.

[6107] S. L. Du and Y. Z. Yao. "A new genus and species of Tingidae (Heteroptera: Cimicomorpha) from Myanmar, with the analysis of the evolution of hood, carinae and paranota". English. In: Zoological Systematics 43 (2018), pp. 283-293.

[6108] X. Y. Du, A. lipiski, Z. H. Liu, and H. Pang. "Description of a new species of Eucinetidae (Coleoptera, Scirtoidea) from Cretaceous Burmese amber". English. In: ZooKeys 982 (2020), pp. 1-9. DOI: 10. 3897 / zookeys.982.39335.

[6109] Y.-s. Du, D.-q. Li, B. -x. Peng, R. -l. Lei, and Z. -c. Bai. "[Large-scale sauropod dinosaur footprints from Yanguoxia, Yongjing County, Gansu Province]". Chinese. In: Earth Science - Journal of China University of Geosciences 27.4 (2002), pp. 367-372.

[6110] J. Y. Duan and S. L. An. "Early Cambrian Siberian fauna from Yichun of Heilongjiang Province". Chinese. In: Acta Palaeontologica Sinica 40.3 (2001), pp. 362-370.

[6111] Y. Duan. "New polymerid trilobites and the first record of Erixanium from Upper Cambrian in western Hunan, China". English. In: Acta Palaeontologica Sinica 43.1 (2004), pp. 63-71.

[6112] Y. Duan and S. L. Cheng. "A new species of Pelecinidae (Insecta, Hymenoptera, Proctotrupoidea) from the Lower Cretaceous Jiufotang Formation of western Liaoning". Chinese. In: Acta Palaeontologica Sinica 45 (2006), pp. 393-398.

[6113] L. Duarte and R. Silva-Santos. "Plant and fish megafossils of the Codo Formation, Parnaiba Basin, NE Brasil". In: Cretaceous Research 14.6 (1993), pp. 735-746.

[6114] V. N. Dubatolov and V. I. Krasnov. "Paleobiogeography of the west Siberian sea in the Devonian". English. In: Russian Geology and Geophysics 34.4 (1993), pp. 22-29.

[6115] M. Dubied, F. Solé, and B. Mennecart. "The cranium of Provierra typica (Mammalia, Hyaenodonta) and its impact on hyaenodont phylogeny and endocranial evolution". English. In: Palaeontology (2019). DOI: 10.1111/pala.12437.

[6116] M. B. DuBois. “The first fossil Dorylinae with notes on fossil Ecitoninae (Hymenoptera: Formicidae)". English. In: Entomological News 109 (1998), pp. 136-142.

[6117] D. A. Dubovikoff. "The first record of the genus Pheidole Westwood, 1839 (Hymenoptera: Formicidae) from the Baltic amber". English. In: Russian Entomological Journal 20 (2011), pp. 255-257.

[6118] D. A. Dubovikoff, G. M. Dlussky, E. E. Perkovsky, and E. V. Abakumov. "A new species of the genus Eldermyrmex Shattuck, 2011 (Hymenoptera, Formicidae) from Bitterfeld amber (Late Eocene) with species key of the genus". English. In: Paleontological Journal 53 (2019), pp. 994-997. DOI: $10.1134 /$ S0031030119100046.

[6119] D. A. Dubovikoff, G. M. Dlussky, E. E. Perkovsky, and E. V. Abakumov. "New species of the genus Protaneuretus Wheeler (Hymenoptera, Formicidae) from Bitterfeld amber (Late Eocene), with a key to the species of the genus". English. In: Paleontological Journal 54 (2020), pp. 389-391. DOI: 10.1134/S003103012004005X.

[6120] I. A. Dubrovo and A. E. Sanders. "A new species of Patriocetus (Mamammalia, Cetacea) from the Late Oligocene of Kazakstan”. English. In: Journal of Vertebrate Paleontology 20.3 (2000), pp. 577590.

[6121] S. Ducrocq. "An Eocene peccary from Thailand and the biogeographical origins of the artiodactyl family Tayassuidae". English. In: Palaeontology 37.4 (1994), pp. 765-779.

[6122] S. Ducrocq. "The Anthracotheriid Genus Bothriogenys (Mammalia, Artiodactyla) in Africa and Asia During the Paleogene: Phylogenetical and Paleobiogeographical Relationships". English. In: Stuttgarter Beiträge zur Naturkunde, Serie B (Geologie und Paläontologie) 250 (1997), pp. 1-44.

[6123] S. Ducrocq, Y. Chaimanee, V. Suteethorn, and J. J. Jaeger. "Mammalian faunas and the ages of the continental Tertiary fossiliferous localities from Thailand". English. In: Journal of Southeast Asian Earth Sciences 12.1 (1995), pp. 65-78. 
[6124] S. Ducrocq, E. Buffetaut, H. Buffetaut-Tong, R. Helmcke-Ingavat, J. J. Jaeger, Y. Jongkanjanasoontorn, and V. Suteethorn. "A lower Tertiary vertebrate fauna from Krabi (South Thailand)". English. In: Neues Jahrbuch für Geologie und Paläontologie Abhandlungen 184.1 (1992), pp. 101-122.

[6125] S. Ducrocq, A. N. Soe, C. Sein, V. Lazzari, Y. Chaimanee, X. Valentin, and J. J. Jaeger. “First record of a diacodexeid artiodactyl in the middle Eocene Pondaung Formation (Myanmar)". English. In: Palaeontologische Zeitschrift 90.3 (2016), pp. 611-618. DOI: 10.1007/s12542-016-0283-y.

[6126] S. Ducrocq, M. Benammi, O. Chavasseau, Y. Chaimanee, K. Suraprasit, P. dong Pha, V. le Phuong, P. van Phach, and J. -J. Jaeger. "New anthracotheres (Cetartiodactyla, Mammalia) from the Paleogene of northeastern Vietnam: biochronological implications". English. In: Journal of Vertebrate Paleontology 35.3 (2015), e929139:1-11.

[6127] S. Ducrocq, J.-R. Boisserie, J. -J. Tiercelin, C. Delmer, G. Garcia, M. F. Kyalo, M. G. Leakey, L. Marivaux, O. Otero, S. Peigné, P. Tassy, and F. Lihoreau. "New Oligocene vertebrate localities from Northern Kenya (Turkana basin)". English. In: Journal of Vertebrate Paleontology 30.1 (2010), pp. 293-299.

[6128] S. Ducrocq, E. Buffetaut, H. Buffetaut-Tong, J. -J. Jaeger, Y. Jongkanjanasoontorn, and V. Suteethorn. "First fossil marsupial from South Asia". English. In: Journal of Vertebrate Paleontology 12.3 (1992), pp. 395-399.

[6129] S. Ducrocq, E. Buffetaut, H. Buffetaut-Tong, J. -J. Jaeger, Y. Jongkanjanasoontorn, and V. Suteethorn. "First fossil flying lemur: A dermoptera from the Late Eocene of Thailand". English. In: 35.2 (1992), pp. 373-380.

[6130] S. Ducrocq, Y. Chaimane, V. Suteethorn, and J. -J. Jaeger. "An unusual anthracotheriid artiodactyl from the late Eocene of Thailand". English. In: Neues Jahrbuch für Geologie und Paläontologie Monatshefte 1996 (1996), pp. 389-398.

[6131] S. Ducrocq, Y. Chaimanee, J. -J. Jaeger, and G. Métais. “A new ceratomorph (Perissodactyla, Mammalia) from the late Eocene of southeast Asia". English. In: Journal of Vertebrate Paleontology 26.4 (2006), pp. 1024-1027.

[6132] S. Ducrocq, Y. Chaimanee, and J. -J. Jaeger. "New primates from the late Eocene of Thailand: a contribution to primate diversity in the Paleogene of Asia". English. In: Journal of Human Evolution 51 (2006), pp. 153-158. DOI: 10.1016/j.jhevol.2006.02.006.

[6133] S. Ducrocq, Y. Chaimanee, V. Suteethorn, and J. -J. Jaeger. "First discovery of Helohyidae (Artiodactyla, Mammalia) in the Late Eocene of Thailand: a possible transitional form for Anthracotheriidae". English. In: Comptes rendus de l'Académie des Sciences Paris, Sciences de la terre et des planétes 325 (1997), pp. 367-372.

[6134] S. Ducrocq, Y. Chaimanee, V. Suteethorn, and J. -J. Jaeger. “The earliest known pig from the Upper Eocene of Thailand". English. In: Palaeontology 41.1 (1998), pp. 147-156.

[6135] S. Ducrocq, J.-J. Jaeger, Y. Chaimanee, and V. Suteethorn. "New primate from the Palaeogene of Thailand, and the biogeographical origin of anthropoids". English. In: Journal of Human Evolution 28 (1995), pp. 477-485.

[6136] S. Ducrocq and F. Lihoreau. "The occurrence of bothriodontines (Artiodactyla, Mammalia) in the Paleogene of Asia with special reference to Elomeryx: Paleobiogeographical implications". English. In: Journal of Asian Earth Sciences 27 (2006), pp. 885-891.

[6137] S. Ducrocq, F. K. Manthi, and F. Lihoreau. “First record of a parapithecid primate from the Oligocene of Kenya". English. In: Journal of Human Evolution 61 (2011), pp. 327-331.

[6138] S. Ducrocq and S. Sen. "A new Haplobunodontidae (Mammalia, Artiodactyla) from the Eocene of Turkey". English. In: Neues Jahrbuch für Geologie und Paläontologie Monatshefte 1 (1991), pp. 12-20.

[6139] S. Ducrocq, A. N. Soe, B. Bo, M. Benammi, Y. chaimanee, T. Tun, T. thein, and J. J. Jaeger. “First record of an Anthracobunidae (Mammalia, ?Tethytheria) from the Eocene of the Pondaung Formation, Myanmar". In: Comptes Rendus de l'Academie des Sciences, Serie II. Sciences de la Terre et des planetes 330 (2000), pp. 725-730. 
[6140] S. Ducrocq, A. N. Soe, A. K. Aung, M. Benammi, B. Bo, Y. chaimanee, T. Tun, T. Thein, and J. J. Jaeger. "A new anthracotheriid artiodactyl from Myanmar, and the relative ages of the Eocene anthropoid primate-bearing localities of Thailand (Krabi) and Myanmar (Pondaung)". In: Journal of Vertebrate Paleontology 20.4 (2000), pp. 755-760.

[6141] S. Ducrocq, A. N. Soe, O. Chavasseau, C. Sein, Y. Chaimanee, V. Lazzari, and J. -J. Jaeger. “New basal ruminants from the Eocene of the Pondaung Formation, Myanmar". English. In: Journal of Vertebrate Paleontology (2020), e1722682:1-11. DOI: 10.1080/02724634.2019.1722682.

[6142] R. Duerr. “Two new species of Mitrella (Gastropoda: Neogastropoda: Columbellidae) from the lower Miocene Chipola Formation of northwestern Florida". English. In: The Nautilus 122.3 (2008), pp. 151-154.

[6143] S. Duffaud and J.-C. Rage. “Les remplissages karstiques polyphasés (Éocéne, Oligocéne, Pliocéne) de Saint-Maximin (Phosphorites du Gard) et leur apport á la connaissance des faunes Européennes, notamment pour l'Éocéne Moyen (MP 13). 2.-Systématique: amphibiens et reptiles". French. In: École Pratique des Hautes Études. Mémoires et Travaux de l'Institut de Montpellier 21 (1997), pp. 729 735.

[6144] C. J. Duffin. "New shark remains from the British Rhaetian (latest Triassic) 1. The earliest basking shark". English. In: Neues Jahrbuch für Geologie und Paläontologie Monatshefte 3 (1998), pp. 157-181.

[6145] C. J. Duffin. "New shark remains from the British Rhaetian (latest Triassic) 2. Hybodonts and palaeospinacids". English. In: Neues Jahrbuch für Geologie und Paläontologie, Monatshefte 1998.4 (1998), pp. 240-256.

[6146] C. J. Duffin. "The hybodont shark, Priohybodus d'Erasmo, 1960, (Early Cretaceous, northern Africa)". English. In: Zoological Journal of the Linnean Society 133 (2001), pp. 303-308.

[6147] C. J. Duffin. "The dentition of Hybodus hauffianus Fraas, 1895 (Toarcian, Early Jurassic)". English. In: Stuttgarter Beiträge zur Naturkunde Serie B (Geologie und Paläontologie) 256 (1997), pp. 1-22.

[6148] C. J. Duffin. "Holocephalans in the Staatliches Museum für Naturkunde in Stuttgart 3. First chimaeroid from the Lias of Baden-Württemberg (Early Toarcian of Ohmden)". English. In: Stuttgarter Beiträge zur Naturkunde Serie B (Geologie und Paläontologie) 231 (1995), pp. 1-12.

[6149] C. J. Duffin. "Ostenoselache stenosoma n. g. n. sp., a new neoselachian shark from the Sinemurian (Early Jurassic) of Osteno (Lombardy, Italy)". English. In: Paleontologia Lombarda 9 (1998), pp. 1-27.

[6150] C. J. Duffin. "Holocephalans in the Staatliches Museum für Naturkunde in Stuttgart 4. The earliest German chimaeroid". English. In: Stuttgarter Beiträge zur Naturkunde Serie B (Geologie und Paläontologie) 240 (1996), pp. 1-10.

[6151] C. J. Duffin. "Myriacanthid holocephalans (Chondrichthyes) from the British Late Triassic". English. In: Neues Jahrbuch für Geologie und Paläontologie, Abhandlungen 192.1 (1994), pp. 1-16.

[6152] C. J. Duffin. "Late Triassic sharks teeth (Chondrichthyes, Elasmobranchii) from Saint-Nicolas-dePort (north-east France)". English. In: Belgian Geological Survey, Professional Paper, Elasmobranches et Stratigraphie 264.1993 (1993), pp. 7-32.

[6153] C. J. Duffin. "Teeth of Hybodus (Selachii) from the Early Jurassic of Lyme Regis, Dorset (southern England): preliminary note". English. In: Belgian Geological Survey, Professional Paper, Elasmobranches et Stratigraphie 264 (1993), pp. 45-52.

[6154] C. J. Duffin. "Mesozoic chondrichthyan faunas 1. Middle Norian (Upper Triassic) of Luxembourg". English. In: Palaeontographica Abteilung A 229 (1993), pp. 15-36.

[6155] C. J. Duffin. "A myriacanthid holocephalan (Chondrichthyes) from the Sinemurian (Lower Jurassic) of Osteno (Lombardo, Italy)". English. In: Atti della Societá Italiana di Scienze Naturali e del Museo Civico di Storia Naturale di Milano 132 (1991), pp. 293-308.

[6156] C. J. Duffin. "The first sphenodontian remains (Lepidosauromorpha, Reptilia) from the Late Triassic of the Gaume (southern Belgium)". English. In: Bulletin de la Société Belge de Géologie 104.1-2 (1995), pp. 35-41. 
[6157] C. J. Duffin and G. Cuny. "Carcharopsis prototypus and the adaptations of single crystallite enameloid in cutting dentitions". English. In: Acta Geologica Polonica 58.2 (2008), pp. 181-184.

[6158] C. J. Duffin and D. Delsate. "A new myriacanthid holocephalan (Chondrichthyes) from the Early Jurassic of Luxembourg". English. In: Neues Jahrbuch für Geologie und Paläontologie, Monatshefte 1993.11 (1993), pp. 669-680.

[6159] C. J. Duffin and D. Delsate. "The age of the Upper Triassic vertebrate fauna from Attert (Province of Luxembourg, Belgium)". English. In: Belgian Geological Survey, Professional Paper, Elasmobranches et Stratigraphie 264.1993 (1993), pp. 33-44.

[6160] C. J. Duffin and J. Milán. "A new myriacanthid holocephalian from the Early Jurassic of Denmark". English. In: Bulletin of the Geological Society of Denmark 65 (2017), pp. 161-170.

[6161] C. J. Duffin and D. J. Ward. "The Early Jurassic Palaeospinacid sharks of Lyme Regis, southern England". English. In: Belgian Geological Survey, Professional Papers, Elasmobranches et Stratigraphie 264 (1993), pp. 53-102.

[6162] A. Dulai. "Early Jurassic brachiopods from the basal layers of the Pisznice Limestone of Labatlan (Gerecse Mts, Hungary)". English. In: Annales Historico-Naturales musei Nationalis Hungarici 90 (1998), pp. 35-55.

[6163] A. Dulai. "Hettangian (Early Jurassic) megafauna and paleogeography of the Bakony Mts. (Hungary)". English. In: Mesozoic Brachiopods of Alpine Europe. Budapest: Hungarian Geological Society, 1993, pp. 31-37.

[6164] A. Dulai. “Badenian (Middle Miocene) micromorphic brachiopods from Bánd and Devecser (Bakony Mountains, Hungary)". English. In: Fragmenta Palaeontologica Hungarica 24-25 (2007).

[6165] A. Dulai. "Hettangian and Early Sinemurian (Early Jura ssic)brachiopods of the Transdanubian Central Range(Hungary) II(A Dunántúliközéphegység hettangi és kora szinemuri (korajura) brachiopoda faunája II)". other. In: A Bakony Termeszettudomanyi Kutatasanak Eredmenyei 27 (2003), pp. 5-124.

[6166] A. Dulai. "Early Messinian (Late Miocene) micromorphic brachiopods from Borelli (Italy, Piemonte)". English. In: Fragmenta Palaeontologica Hungarica 28 (2010), pp. 21-31.

[6167] A. Dulai. "Sporadic Pliocene and Pleistocene brachiopods in Naturalis Biodiversity Center (Leiden, the Netherlands): records from the Mediterranean, and the North Sea Basin". English. In: Fragmenta Palaeontologica Hungarica 33 (2016), pp. 65-98.

[6168] A. Dulai. "New data on the Late Miocene brachiopod fauna of Tetti Borelli (Piedmont, N Italy)". English. In: Rivista Italiana di Paleontologia e Stratigrafia 125 (2019), pp. 125-145.

[6169] A. Dulai, M. A. Bitner, and P. Muller. "A monospecific assemblage of a new rhynchonellide brachiopod from the Paleocene of Austria". English. In: Fossils and Strata 54 (2008), pp. 193-201.

[6170] W.-C. Dullo. "Facies, Fossil Record, and Age of Pleistocene Reefs from the Red Sea (Saudi Arabia)". English. In: Facies 22 (1990), pp. 1-46.

[6171] B. Dumas, C. T. Hoang, and C. Raffy. "Record of MIS 5 sea-level highstands based on U/Th dated coral terraces of Haiti". English. In: Quaternary International 145/146 (2006), pp. 106-118.

[6172] M. Dumbrava and A. Blieck. "Review of the Pteraspidiform heterostracans (Vertebrata, Agnatha) from the Devonian of Podolia, Ukraine, in the Theodor Vascautanu Collection, Bucharest, Romania". English. In: Acta Palaeontologica Romanniae 5 (2005), pp. 163-171.

[6173] P. Dumitrica. "New Mesozoic and early Cenozoic spicular Nassellaria and Nassellaria-like Radiolaria". English. In: Revue de micropaléontologie 47 (2004), pp. 193-224. DOI: 10.1016/j.revmic.2004. 10.002 .

[6174] P. Dumitrica. "The Oertlispongidae (Radiolaria) from the Middle Triassic of Masirah Island (Oman)". English. In: Revue de Micropaléontologie 42.1 (1999), pp. 33-42.

[6175] P. Dumitrica. "Early Tithonian entactinarian Radiolaria from the Solnhofen area (southern Germany). Part I". English. In: Revue de micropaléontologie 56 (2013), pp. 75-95. DOI: 10.1016/j.revmic. 2013.07.001. 
[6176] P. Dumitrica and E. S. Carter. "Family Kungalariidae, $\mathrm{n}$ fam, new Mesozoic entactinarian Radiolaria with a nassellarian-type initial spicule". English. In: Micropaleontology 45.3 (1999), pp. 418428.

[6177] P. Dumitrica, U. K. Tekin, and Y. Bedi. "Eptingiacea and Saturnaliacea (Radiolaria) from the middle Carnian of Turkey and some late Ladinian to early Norian samples from Oman and Alaska". English. In: Palaeontologische Zeitschrift 84 (2010), pp. 259-292.

[6178] P. Dumitrica and P. Zügel. "Lower Tithonian mono- and dicyrtid Nassellaria (Radiolaria) from the Solnhofen area, southern Germany". English. In: Geodiversitas 25.1 (2003), pp. 5-72.

[6179] P. Dumitrica and P. Zügel. "Early Tithonian Saturnalidae (Radiolaria) from the Solnhofen area (Southern Frankonian Alb, southern Germany)". English. In: Palaeontologische Zeitschrift 82.1 (2008), pp. 55-84.

[6180] P. Dumitrica and P. Zügel. "Mendacastrum n. gen. and Domuzdagia n. gen., two Jurassic spherical Spumellaria (Radiolaria) with hagiastrid medullary shell". English. In: Micropaleontology 48.1 (2002), pp. 23-34.

[6181] P. Dumitrica and P. Zügel. "Hexapylocapsa anachoreta n.gen., n.sp., type of a new monocyrtid nassellarian family (Radiolaria)with double-shelled caphalis". English. In: Palaeontologische Zeitschrift 72.3/4 (1998), pp. 249-256.

[6182] J. A. Dumoulin, A. G. Harris, C. D. Blome, and L. E. Young. "Conodont and radiolarian data from the De Long Mountains Quadrangle and adjacent areas, northern Alaska". English. In: United States Geological Survey Open-File Report 2006.106 (2006), pp. 1-174.

[6183] M. Duncan. "Chondrichthyan genus Lissodus from the Lower Carboniferous of Ireland". English. In: Acta Palaeontologica Polonica 49.3 (2004), pp. 417-428.

[6184] M. Duncan. "Early Carboniferous chondrichthyan Thrinacodus from Ireland, and a reconstruction of jaw apparatus". English. In: Acta Palaeontologica Polonica 48.1 (2003), pp. 113-122.

[6185] R. G. Dundas. The Late Pleistocene vertebrate fauna. English. The Merrell Locality \& Centennial Valley, Southwest Montana, Pleistocene Geology, Paleontology \& Prehistoric Archaeology, Bureau of Land Management Cultural Resources Series No. 4, Montana State Office. 2005, pp. 79-90.

[6186] R. G. Dundas. "A Late Pleistocene Occurrence of Equus and Camelops hesternus From the Flint Creek Area, Western Montana". English. In: PaleoBios 13.51 (1991), pp. 7-11.

[6187] R. G. Dundas and J. C. Chatters. "The mid-Irvingtonian Fairmead Landfill fossil site, Madera County Paleontology Collection, and Fossil Discovery Center of Madera County, California". English. In: Geological Society of America Field Guides 32 (2013), pp. 63-78. DOI: 10.1130/2013.0032(04).

[6188] R. G. Dundas and L. M. Cunningham. "Harlan's Ground Sloth (Glossotherium harlani) and a Columbian Mammoth (Mammuthus columbi) from Stevenson Bridge, Yolo County, California". English. In: PaleoBios 15.3 (1993), pp. 47-62.

[6189] J. A. Dunlop. "A replacement name for the trigonotarbid arachnid Eotarbus Dunlop". English. In: Palaeontology 42.1 (1999), p. 191.

[6190] J. A. Dunlop. “A spiny harvestman (Arachnida: Opiliones) from the Upper Carboniferous of Missouri, USA". English. In: Arthropoda Selecta, Special Issue 1 (2004), pp. 67-74.

[6191] J. A. Dunlop. “A fossil whipscorpion from the Lower Cretaceous of Brazil”. English. In: The Journal of Arachnology 26 (1998), pp. 291-295.

[6192] J. A. Dunlop. "A large parasitengonid mite (Acari, Erythraeoidea) from the Early Cretaceous Crato Formation of Brazil". English. In: Fossil Record 10 (2007), pp. 91-98.

[6193] J. A. Dunlop. "A redescription of the Carboniferous arachnid Plesiosiro madeleyi Pocock, 1911 (Arachnida: Haptopoda)". English. In: Transactions of the Royal Society of Edinburgh: Earth Sciences 90 (1999), pp. 29-47. DOI: 10.1017/S0263593300002492.

[6194] J. A. Dunlop and L. I. Anderson. "A fossil harvestman (Arachnida, Opiliones) from the Mississippian of East Kirkton, Scotland". English. In: The Journal of Arachnology 33 (2005), pp. 482-489. 
[6195] J. A. Dunlop, L. I. Anderson, H. Kerp, and H. Hass. “A harvestman (Arachnida: Opiliones) from the Early Devonian Rhynie cherts, Aberdeenshire, Scotland". English. In: Transactions of the Royal Society of Edinburgh: Earth Sciences 94 (2004), pp. 341-354.

[6196] J. A. Dunlop and V. Barov. "A new fossil whip spider (Arachnida: Amblypygi) from the Crato Formation of Brazil". English. In: Revista Ibérica de Aracnologa 12 (2005), pp. 53-62.

[6197] J. A. Dunlop, C. Bartel, and P. G. Mitov. "An enigmatic spiny harvestman from Baltic amber". English. In: Fossil Record 15 (2012), pp. 91-101.

[6198] J. A. Dunlop and M. Bertrand. "Fossil labidostomatid mites (Prostigmata: Labidostommatidae) from Baltic amber". English. In: Acarologia 51 (2011), pp. 191-198.

[6199] J. A. Dunlop, T. L. Bird, J. O. Brookhart, and G. Bechly. "A camel spider from Cretaceous Burmese amber". English. In: Cretaceous Research 56 (2015), pp. 265-273.

[6200] J. A. Dunlop and C. Brauckmann. "A new trigonotarbid arachnid from the Coal Measures of Hagen-Vorhalle, Germany". English. In: Fossil Record 9 (2006), pp. 130-136.

[6201] J. A. Dunlop, C. Brauckmann, and H. Steur. "A Late Carboniferous fossil scorpion from the Piesberg, near Osnabrück, Germany". English. In: Fossil Record 11 (2008), pp. 25-32. DOI: 10.1002 / mmng.200700010.

[6202] J. A. Dunlop, K. Frahnert, and J. Makol. "A giant mite in Cretaceous Burmese amber". English. In: Fossil Record 21 (2018), pp. 285-290.

[6203] J. A. Dunlop and G. Giribet. "The First Fossil Cyphophthalmid (Arachnida, Opiliones) from Bitterfeld Amber, Germany". English. In: The Journal of Arachnology 31.3 (2003), pp. 371-378.

[6204] J. A. Dunlop, D. Harms, and D. Penney. "A fossil tarantula (Araneae: Theraphosidae) from Miocene Chiapas amber, Mexico". English. In: Revista Ibérica de Aracnologa 15 (2008), pp. 9-17.

[6205] J. A. Dunlop and C. A. Horrocks. "A new specimen of the Carboniferous trigonotarbid arachnid Maiocercus celticus (Pocock 1902) from Lancashire, UK". In: Proceedings of the Yorkshire Geological Society 51.1 (1996), pp. 23-31.

[6206] J. A. Dunlop and C. A. Horrocks. "Phalangiotarbid arachnids from the Coal Measures of Lancashire, UK". English. In: Geological Magazine 134 (1997), pp. 369-381.

[6207] J. A. Dunlop and C. A. Horrocks. "A new Upper Carboniferous whip scorpion (Arachnida: Uropygi: Thelyphonida) with a revision of the British Carboniferous Uropygi". English. In: Zoologischer Anzeiger 234 (1996), pp. 293-306.

[6208] J. A. Dunlop, C. Kamenz, and G. Talarico. "A fossil trigonotarbid arachnid with a ricinuleid-like pedipalpal claw”. English. In: Zoomorphology 128 (2009), pp. 305-313.

[6209] J. A. Dunlop and A. E. Klann. "A second camel spider (Arachnida: Solifugae) from Baltic amber". English. In: Acta Geologica Polonica 59 (2009), pp. 39-44.

[6210] J. A. Dunlop, J. Kontschán, D. E. Walter, and V. Perrichot. “An ant-associated mesostigmatid mite in Baltic amber". English. In: Biology Letters 10 (2014), p. 20140531.

[6211] J. A. Dunlop, J. Kontschán, and M. Zwanzig. "Fossil mesostigmatid mites (Mesostigmata: Gamasina, Microgyniina, Uropodina), associated with longhorn beetles (Coleoptera: Cerambycidae) in Baltic amber". English. In: Naturwissenschaften 100 (2013), pp. 337-344.

[6212] J. A. Dunlop, D. A. Legg, P. A. Selden, V. Fet, J. W. Schneider, and R. RöSSler. “Permian scorpions from the Petrified Forest of Chemnitz, Germany". English. In: BMC Evolutionary Biology 16.72 (2016), pp. 1-16.

[6213] J. A. Dunlop and L. Mammitzsch. "A new genus and species of harvestman from Baltic amber". English. In: Paleodiversity 3 (2010), pp. 23-32.

[6214] J. A. Dunlop and D. M. Martill. "Four additional specimens of the fossil camel spider Cratosolpuga wunderlichi Selden 1996 (Arachnida: Solifugae) from the Lower Cretaceous Crato Formation of Brazil". English. In: Revista Ibérica de Aracnologa 9 (2004), pp. 143-156. 
[6215] J. A. Dunlop and D. M. Martill. “The first whipspider (Arachnida: Amblypygi) and three new whipscorpions (Arachnida: Thelyphonida) from the Lower Cretaceous Crato Formation of Brazil". English. In: Transactions of the Royal Society of Edinburgh: Earth Sciences 92 (2002), pp. 325-334.

[6216] J. A. Dunlop, Y. Marusik, and A. P. Vlaskin. "Comparing arachnids in Rovno amber with the Baltic and Bitterfeld deposits". English. In: Paleontological Journal 53 (2019), pp. 1074-1083. DOI: 10.1134/S0031030119100034.

[6217] J. A. Dunlop and P. G. Mitov. "The rst fossil cyphophthalmid harvestman from Baltic amber". English. In: Arachnologische Mitteilungen 40 (2011), pp. 47-54.

[6218] J. A. Dunlop and P. G. Mitov. "Fossil harvestmen (Arachnida, Opiliones) from Bitterfeld amber". English. In: ZooKeys 16 (2009), pp. 347-375.

[6219] J. A. Dunlop, D. Penney, and D. Jekel. A summary list of fossil spiders and their relatives. English. 2013.

[6220] J. A. Dunlop and M. Poschmann. "On the Emsian (Lower Devonian) arthropods of the Rhenish Schiefergebirge: 1. Xenarachne, an enigmatic arachnid from Willwerath, Germany". English. In: Palaeontologische Zeitschrift 71 (1997), pp. 231-236.

[6221] J. A. Dunlop and R. RöSSler. "The trigonotarbid arachnid Anthracomartus voelkelianus (Anthracomartidae)". English. In: The Journal of Arachnology 30 (2002), pp. 211-218.

[6222] J. A. Dunlop and R. RöSSler. “The youngest trigonotarbid Permotarbus schucherti n. gen., n. sp. from the Permian Petrified Forest of Chemnitz in Germany". English. In: Fossil Record 16 (2013), pp. 229-243.

[6223] J. A. Dunlop and R. Rössler. "An enigmatic, solifuge-like fossil arachnid from the Lower Carboniferous of Kamienna Góra (Intra-Sudetic basin), Poland". English. In: Paläontologische Zeitschrift 77 (2003), pp. 389-400.

[6224] J. A. Dunlop and P. A. Selden. "A trigonotarbid arachnid from the Lower Devonian of Tredomen, Wales". English. In: Palaeontology 47 (2004), pp. 1469-1476.

[6225] J. A. Dunlop and P. A. Selden. "Scorpion fragments from the Silurian of Powys, Wales". English. In: Arachnology 16 (2013), pp. 27-32.

[6226] J. A. Dunlop, P. A. Selden, and G. Giribet. "Penis morphology in a Burmese amber harvestman". English. In: The Science of Nature 103.11 (2016), pp. 1-5.

[6227] J. A. Dunlop, C. Sempf, and J. Wunderlich. A new opilioacarid mite in Baltic Amber. English. European Arachnology 2008. 2010, pp. 59-70.

[6228] J. A. Dunlop, Y. Wang, P. A. Selden, and P. Krautz. “A trigonotarbid arachnid from the Pennsylvanian Astrasado Formation of the Kinney Brick Quarry, New Mexico". English. In: Paleontological Contributions 9 (2014), pp. 1-6.

[6229] J. A. Dunlop, J. Wunderlich, and G. O. Poinar. "The first fossil opilioacariform mite (Acari: Opilioacariformes) and the first Baltic amber camel spider (Solifugae)". English. In: Transactions of the Royal Society of Edinburgh: Earth Sciences 94 (2004), pp. 261-273.

[6230] R. H. Dunn and D. T. Rasmussen. "Skeletal morphology of a new genus of Eocene insectivore (Mammalia, Erinaceomorpha) from Utah". English. In: Journal of Mammalogy 90.2 (2009), pp. 321331.

[6231] R. H. Dunn and D. T. Rasmussen. “Skeletal morphology and locomotor behavior of Pseudotomus eugenei (Rodentia, Paramyinae) from the Uinta Formation, Utah". English. In: Journal of Vertebrate Paleontology 27.4 (2007), pp. 987-1006.

[6232] C. Dupraz and A. Strasser. "Microbialites and micro-encrusters in shallow coral bioherms (Middle to Late Oxfordian, Swiss Jura Mountains)". In: Facies 40 (1999), pp. 101-130.

[6233] C. Durán-Ruiz, F. Riquelme, M. Coutiño-José, G. Carbot-Chanona, G. Castaño-Meneses, and M. Ramos-Arias. "Ants from the Miocene Totolapa amber (Chiapas, Mexico), with the first record of the genus Forelius (Hymenoptera, Formicidae)". English. In: Canadian Journal of Earth Sciences 50 (2013), pp. 495-502. 
[6234] J. F. Durand. "A revised description of the skull of Moschorhinus (Therapsida, Therocephalia)". English. In: Annals of the South African Museum 99 (1991), pp. 381-413.

[6235] J. F. Durand. "The oldest juvenile dinosaurs from Africa". English. In: Journal of African Earth Sciences 33 (2001), pp. 597-603.

[6236] D. Duric, K. Bogicevic, D. Petrovic, and D. Nenadic. "Late Pleistocene Squamate Reptiles from the Baranica Cave near Knjaevac (Eastern Serbia)". English. In: Annales Geologiques de la Peninsule Balkanique 78 (2017), pp. 23-25.

[6237] D. Duric, D. Radosavljevic, D. Petrovic, M. Radonjic, and P. Vojnovic. "A new evidence for pachyostotic snake from Turonianof Bosnia-Herzegovina". English. In: Annales Geologiques de la Peninsule Balkanique 78 (2017), pp. 17-21.

[6238] P. N. Durman and N. V. Sennikov. "A new rhabdopleurid hemichordate from the Middle Cambrian of Siberia". In: Palaeontology 36.2 (1993), pp. 283-296.

[6239] C. Dusel-Bacon and A. G. Harris. "New occurrences of Late Paleozoic and Triassic fossils from the Seventymile and Yukon-Tanana terranes, east-central Alaska, with comments on previously published occurrences in the same area". English. In: United States Geological Survey Professional Paper 1678 (2001), pp. 5-25.

[6240] A. R. Dutchak and M. W. Caldwell. "A redescription of Aigialosaurus (= Opetiosaurus) bucchichi (Kornhuber 1901) (Squamata: Aigialosauridae) with comments on mosasauroid systematics". English. In: Journal of Vertebrate Paleontology 29.2 (2009), pp. 437-452.

[6241] A. R. Dutchak and M. W. Caldwell. "Redescription of Aigialosaurus dalmaticus Kramberger, 1892, a Cenomanian mosasauroid lizard from Hvar Island, Croatia". English. In: Canadian Journal of Earth Sciences 43 (2006), pp. 1821-1834.

[6242] H. Dutel, M. Herbin, and G. Clément. "First occurrence of a mawsoniid coelacanth in the Early Jurassic of Europe". English. In: Journal of Vertebrate Paleontology 35.e929581 (2015), pp. 1-13.

[6243] H. Dutel, J. G. Maisey, D. R. Schwimmer, P. Janvier, M. Herbin, and G. Clément. “The giant Cretaceous coelacanth (Actinistia, Sarcopterygii) Megalocoelacanthus dobiei Schwimmer, Stewart \& Williams, 1994, and Its bearing on Latimerioidei interrelationships". English. In: PLoS ONE 7.11 (2012), e49911:1-27. DOI: 10.1371/journal.pone.0049911.

[6244] T. L. Dutra and D. J. Batten. "Upper Cretaceous floras of King George Island, West Antarctica, and their palaeoenvironmental and phytogeographic implications". English. In: Cretaceous Research 21 (2000), pp. 181-209. DOI: 10.1006/cres.2000.0221.

[6245] D. Dutta and K. Ambwani. "Capers: a food for Upper Cretaceous dinosaurs of Pisdura, India". English. In: Current Science 92.7 (2007), pp. 897-899.

[6246] R. Dutta, S. Bardhan, S. Paul, and S. Mondal. "The taxonomic status of the genus Hubertoceras Spath: A new light on sexual dimorphism from the Callovian ammonites of Kutch, India". English. In: Palaeontologia Electronica 20.2.40 (2017), pp. 1-23.

[6247] R. Dutta and S. Bardhan. "Systematics, endemism and phylogeny of Indian proplanulitins (Ammonoidea) from the Bathonian-Callovian of Kutch, western India". English. In: Swiss Journal of Paleontology 135 (2016), pp. 23-56.

[6248] T. Dvoák, M. Pecharová, W. Krzemiski, and J. Prokop. “New archaeorthopteran insects from the Carboniferous of Poland: Insights into tangled taxonomy". English. In: Acta Palaeontologica Polonica 64 (2019), pp. 787-796. DOI: 10.4202/app.00614.2019.

[6249] A. S. Dyke and J. England. “Canada's Most Northerly Postglacial Bowhead Whales (Balaena mysticetus): Holocene Sea-Ice Conditions and Polynya Development". English. In: Arctic 56.1 (2003), pp. $14-20$.

[6250] A. S. Dyke, J. Hooper, C. R. Harrington, and J. M. Savelle. "The Late Wisconsinan and Holocene record of walrus (Odobenus rosmarus) from North America: A review with new data from Arctic and Atlantic Canada". English. In: Arctic 52.2 (1999), pp. 160-181. 
[6251] A. S. Dyke and J. M. Savelle. "Holocene History of the Bering Sea Bowhead Whale (Balaena mysticetus) in Its Beaufort Sea Summer Grounds off Southwestern Victoria Island, Western Canadian Arctic". English. In: Quaternary Research 55.3 (2001), pp. 371-379.

[6252] G. Dyke, M. Vremir, G. Kaiser, and D. Naish. "A drowned Mesozoic bird breeding colony from the Late Cretaceous of Transylvania". English. In: Naturwissenschaften 99 (2012), pp. 435-442. DOI: 10.1007/s00114-012-0917-1.

[6253] G. Dyke, X. Wang, and G. Kaiser. "Large fossil birds from a Late Cretaceous marine turbidite sequence on Hornby Island (British Columbia)". English. In: Canadian Journal of Earth Sciences 48 (2011), pp. 1489-1496. DOI: 10.1139/E11-050.

[6254] G. J. Dyke. "A primitive swift from the London Clay and the relationships of fossil apodiform birds". English. In: Journal of Vertebrate Paleontology 21.1 (2001), pp. 195-200. DOI: 10.1671 / 02724634(2001)021[0195:APSFTL]2.0.CO;2.

[6255] G. J. Dyke, M. J. Benton, E. Posmosanu, and D. Naish. "Early Cretaceous (Berriasian) birds and pterosaurs from the Cornet bauxite mine, Romania". English. In: Palaeontology 54.1 (2011), pp. 79 95. DOI: 10.1111/j.1475-4983.2010.00997.x.

[6256] G. J. Dyke, R. W. Dortangs, J. W. M. Jagt, E. W. A. Mulder, A. S. Schulp, and L. M. Chiappe. "Europe's last Mesozoic bird". English. In: Naturwissenschaften 89 (2002), pp. 408-411.

[6257] G. J. Dyke and G. Mayr. "Did parrots exist in the Cretaceous period?" English. In: Nature 399 (1999), pp. 317-318.

[6258] G. J. Dyke and A. Osi. "A review of Late Cretaceous fossil birds from Hungary". English. In: Geological Journal 45 (2010), pp. 434-444.

[6259] G. J. Dyke, A. S. Schulp, and J. W. M. Jagt. "Bird remains from the Maastrichtian type area (Late Cretaceous)". English. In: Netherlands Journal of Geosciences — Geologie en Mijnbouw 87.4 (2008), pp. 353-358.

[6260] G. J. Dyke and C. A. Walker. "New records of fossil birds from the Pliocene of Kallo, Belgium". English. In: Neues Jahrbuch für Geologie und Paläontologie 2005.4 (2005), pp. 233-247.

[6261] G. J. Dyke, X. Wong, and M. B. Habib. "Fossil Plotopterid Seabirds from the Eo-Oligocene of the Olympic Peninsula (Washington State, USA): Descriptions and Functional Morphology". English. In: PLoS One 6.10 (2011). DOI: 10.1371/journal.pone.0025672.

[6262] M. R. Dzhailov and V. P. Novikov. “Iskopayemyye sledy dinozavrov na territorii Tadzhikistana [Fossil dinosaur footprints in the territory of Tajikistan]". Russian. In: Sledy Zhiznedeyatelbnosti Drevnikh Organizmov [Trace Fossils of Extinct Organisms]. Moscow: Nauka, 1993, pp. 47-64.

[6263] A. V. Dzhenchuraeva and O. F. Getman. "Stratigraphy and foraminifers from the uppermost Carboniferous (Kasimovian-Gzhelian) of the Jamantoo and Baibichetoo ranges (middle Tien-Shan, Kyrgyzstan)". English. In: Journal of Foraminiferal Research 37 (2007), pp. 46-68.

[6264] P. S. Dziadzio, E. Gadzicka, I. Ploch, and J. Smole. "Biostratigraphy and sequence stratigraphy of the Lower Cretaceous in central and SE Poland". English. In: Annales Societatis Geologorum Poloniae 74.2 (2004), pp. 125-196.

[6265] J. Dzik. "The ammonite Acrochordiceras in the Triassic of Silesia". In: Acta Palaeontologica Polonica 35.1-2 (1990), pp. 49-65.

[6266] J. Dzik. "A beaked herbivorous archosaur with dinosaur affinities from the early Late Triassic of Poland". English. In: Journal of Vertebrate Paleontology 23.3 (2003), pp. 556-574.

[6267] J. Dzik. "Brachiopod identity of alleged monoplacophoran ancestors of cephalopods". English. In: Malacologia 52.1 (2010), pp. 97-113.

[6268] J. Dzik and A. Gazdzicki. "The Eocene expansion of nautilids to high latitudes". English. In: Palaeogeography, Palaeoclimatology, Palaeoecology 172 (2001), pp. 297-312.

[6269] J. Dzik and G. N. Kiselev. "The Baltic nautiloids Cyrtoceras ellipticum Lossen 1860, C. priscum Eichwald 1861, and Orthoceras damesi Krause 1877". English. In: Palaeontologische Zeitschrift 69.1/2 (1995), pp. 61-71. 
[6270] J. Dzik and A. Pisera. "Sedimentation and Fossils of the Mojcza Limestone". English. In: Palaeontologia Polonica (1993).

[6271] J. Dzik and T. Sulej. "A review of the early Late Triassic Krasiejów biota from Silesia, Poland". English. In: Palaeontologia Polonica 64 (2007), pp. 3-27.

[6272] J. Dzik, T. Sulej, and G. Niedzwiedzki. “A dicynodont-theropod association in the latest Triassic of Poland". English. In: Acta Palaeontologica Polonica 53.4 (2008), pp. 733-738.

[6273] J. Dzik and T. Sulej. "An early Late Triassic long-necked reptile with a bony pectoral shield and gracile appendages". English. In: Acta Palaeontologica Polonica 61.4 (2016), pp. 805-823. DOI: 10. 4202/app.00276.2016.

[6274] O. S. Dzyuba and B. de Lagausie. "New belemnites (Megateuthididae, Cylindroteuthididae)". English. In: Palaeontologische Zeitschrift 92 (2018), pp. 87-105. DOI: 10.1007/s12542-017-0380-6.

[6275] M. K. Eagle. "Etalian and Kaihikuan (Middle Triassic) Crinoidea (Echinodermata: Articulata) from Caroline Cutting, Oreti valley, Southland, New Zealand". English. In: Journal of the Royal Society of New Zealand 33.1 (2003), pp. 269-299.

[6276] M. K. Eagle. "A new asteroid (Forcipulatida: Zoroasteridae) from the Eocene of Whangarei, Northland, New Zealand". English. In: Reckords of the Auckland Museum 43 (2006), pp. 81-96.

[6277] M. K. Eagle. "New fossil crinoids (Articulata: Comatulida) from the Late Oligocene of the Pentland Hills and Hurstlea, South Canterbury, New Zealand". English. In: Records of the Auckland Museum 44 (2007), pp. 85-110.

[6278] M. K. Eagle. "A new fossil isocrinid crinoid from the Oligocene of Waitete Bay, Northern Coromandel". English. In: Records of the Auckland Institute and Museum 30 (1993), pp. 1-12.

[6279] M. K. Eagle. "A new Upper Cretaceous species of Isselicrinus (Crinoidea: Articulata) from western Hawkes Bay, New Zealand". English. In: Records of the Auckland Institute and Museum 31 (1994), pp. $175-186$.

[6280] M. K. Eagle. "New Comatulid Crinoids From the Meyers Pass Limestone Member (Waitakian (Chattian)) of the Pentland Hills and Hurstlea, South Canterbury, New Zealand". English. In: Records of the Auckland Museum 45 (2009), pp. 101-129.

[6281] M. K. Eagle, B. J. Gill, and J. A. Grant-Mackie. "Pliocene bird bones from Pitt Island, Chatham Islands, New Zealand". English. In: Records of the Aukland Museum 42 (2005), pp. 62-73.

[6282] M. K. Eagle, B. W. Hayward, J. A. Grant-Mackie, and M. R. Gregory. "Fossil communities in an Early Miocene transgressive sequence, Mathesons Bay, Leigh, Auckland". English. In: Tane 37 (1999), pp. 43-67.

[6283] M. K. Eagle and B. W. Hayward. “Oligocene paleontology and palaeoecology of Waitete Bay, Northern Coromandel Peninsula". English. In: Records of the Auckland Institute and Museum 30 (1993), pp. 13-26.

[6284] M. K. Eagle. "A new early Miocene Pseudarchaster (Asteroida: Echinodermata) from New Zealand". English. In: New Zealand Journal of Geology and Geophysics 42 (1999), pp. 551-556.

[6285] L. C. Easton. "Pleistocene Grey Kangaroos from the fossil chamber of Victoria Fossil Cave, Naracoorte, South Australia". English. In: Transactions of the Royal Society of South Australia 130.1 (2006), pp. 17-28.

[6286] J. G. Eaton. "Mammalian paleontology and correlation of uppermost Cretaceous rocks of the Paunsaugunt Plateau, Utah". English. In: Aspects of Mesozoic Geology and Paleontology of the Colorado Plateau. Museum of Northern Arizona Bulletin 59 (1993), pp. 163-180.

[6287] J. G. Eaton. "Therian mammals from the Cenomanian (Upper Cretaceous) Dakota Formation, southwestern Utah". English. In: Journal of Vertebrate Paleontology 13.1 (1993), pp. 105-124.

[6288] J. G. Eaton. "Cenomanian and Turonian (Early Late Cretaceous) multituberculate mammals from southwestern Utah". In: Journal of Vertebrate Paleontology 15.4 (1995), pp. 761-784. 
[6289] J. G. Eaton. “Vertebrate paleontology of the Iron Springs Formation, Upper Cretaceous, southwestern Utah". In: Vertebrate Paleontology in Utah, Utah Geological Survey Miscellaneous Publication 99-1 (1999), pp. 339-343.

[6290] J. G. Eaton. Late Cretaceous mammals from Cedar Canyon, southwestern Utah. English. Vol. 35. Late Cretaceous Vertebrates from the Western Interior. New Mexico Museum of Natural History and Science Bulletin. 2006, pp. 373-402.

[6291] J. G. Eaton. New screen-washing approaches to biostratigraphy and paleoecology of nonmarine rocks, Cretaceous of Utah. English. Vol. 36. In M. R. Dawson \& J. A. Lillegraven, Fanfare for an Uncommon Paleontologist: Papers in Honor of Malcolm C. McKenna. Bulletin of Carnegie Museum of Natural History. 2004, pp. 21-30.

[6292] J. G. Eaton. "Stratigraphic revision of Campanian (Upper Cretaceous) rocks in the Henry Basin, Utah". English. In: The Mountain Geologist 27.1 (1990), pp. 27-38.

[6293] J. G. Eaton, R. L. Cifelli, J. H. Hutchison, J. I. Kirkland, and J. M. Parrish. “Cretaceous vertebrate faunas from the Kaiparowits Plateau, south-central Utah". In: Utah Geological Survey Miscellaneous Publication 99-1 (1999), pp. 345-353.

[6294] J. G. Eaton and R. L. Cifelli. "Multituberculate mammals from near the Early-Late Cretaceous boundary, Cedar Mountain Formation, Utah". English. In: Acta Palaeontologica Polonica 46.4 (2001), pp. 453-518.

[6295] J. G. Eaton, S. Diem, J. D. Archibald, C. Schierup, and H. Munk. "Vertebrate paleontology of the Upper Cretaceous rocks of the Markagunt Plateau, southwestern Utah". In: Vertebrate Paleontology in Utah, Utah Geological Survey Miscellaneous Publication 99-1 (1999), pp. 323-333.

[6296] J. G. Eaton, W. W. Korth, and D. B. Brinkman. "Vertebrate fossils from the Claron Formation, Sweetwater Creek area, Garfield County, Utah, U.S.A." English. In: Rocky Mountain Geology 53.2 (2018), pp. 113-127.

[6297] J. G. Eaton, H. Munk, and M. A. Hardman. A new vertebrate fossil locality within the Wahweap Formation (Upper Cretaceous) of Bryce Canyon National Park and its bearing on the presence of the Kaiparowits Formation on the Paunsaugunt Plateau. English. Vol. 3. In V. L. Santucci \& L. McClelland (eds.), National Park Service Geologic Resources Division Technical Report NPS/NRGRD/GRDTR-98/01. National Park Service Paleontological Research Volume. 1998, pp. 36-40.

[6298] J. G. Eaton and M. E. Nelson. "Multituberculate mammals from the Lower Cretaceous Cedar Mountain Formation, San Rafael Swell, Utah". English. In: Contributions to Geology, University of Wyoming 29.1 (1991), pp. 1-12.

[6299] M. C. Ebach and K. J. McNamara. "A systematic revision of the family Harpetidae (Trilobita)". English. In: Records of the Western Australian Museum 21 (2002), pp. 135-167.

[6300] J. O. R. Ebbestad and L. Tapanila. "Non-predatory borings in Phanerotrema (Gastropoda), Early Silurian, Anticosti Island, Quebec, Canada". English. In: Palaeogeography, Palaeoclimatology, Palaeoecology 221.3-4 (2005), pp. 325-342.

[6301] J. O. R. Ebbestad. “Gastropoda, Tergomya and Paragastropoda (Mollusca) from the Lower Ordovician Fezouata Formation, Morocco". English. In: Palaeogeography, Palaeoclimatology, Palaeoecology (2016). DOI: 10.1016/j.palaeo.2016.01.003.

[6302] J. O. R. Ebbestad, P. Ahlberg, and M. Høyberget. "Redescription of Holmia inusitata (Trilobita) from the Lower Cambrian of Scandinavia". English. In: Palaeontology 46.5 (2003), pp. 1039-1054.

[6303] J. O. R. Ebbestad, M. G. Bassett, M. Dastanpour, and L. E. Popov. “Ordovician (Caradoc) Gastropoda of the Katkoyeh Formation, Kerman Province, Iran". English. In: Geobios 41.5 (2008), pp. 605-624. DOI: 10.1016/j.geobios.2008.01.004.

[6304] J. O. R. Ebbestad, M. Ghobadi Pour, M. G. Bassett, and L. E. Popov. "First occurrence of Lesueurilla prima (Gastropoda) from the Middle Ordovician (Darriwilian) of Iran". English. In: G F F (2016). DOI: 10.1080/11035897.2016.1186110. 
[6305] J. O. R. Ebbestad and J. C. Gutiérrez-Marco. "First occurrence of Pterotheca (Gastropoda) from the Silurian (Aeronian) of Spain". English. In: Geobios 50 (2017). DOI: 10.1016/j.geobios.2017.02.003.

[6306] J. O. R. Ebbestad, A. E. S. Högström, and Å Frisk. "Gastropods and tergomyans from the Upper Ordovician (Viru-Harju) of the Fågelsång area, Scania, southern Sweden". English. In: Journal of Systematic Palaeontology 11.3 (2013), pp. 295-336. DOI: 10.1080/14772019.2012.660994.

[6307] J. O. R. Ebbestad and B. Lefebvre. "An unusual onychochilid mollusc from the Ordovician (Tremadocian) Fezouata Formation, Morocco". English. In: Geobios 48.6 (2015), pp. 427-438. DOI: 10.1016/j. geobios.2015.09.004.

[6308] J. O. R. Ebbestad, F. Rhebergen, and A. P. Gubanov. "Late Ordovician rostroconchs (Mollusca) from fluvial erratics in northwestern Europe". English. In: Bulletin of Geosciences 92.4 (2017), pp. 405438. DOI: $10.3140 /$ bull.geosci.1675.

[6309] J. O. R. Ebbestad. "Multiple attempted predation in the Middle Ordovician gastropod Bucania gracillima". English. In: Geologiska Föreningens i Stockholm Förhandlingar 120.1 (1998), pp. 27-33.

[6310] J. O. R. Ebbestad. "Bucaniid gastropods from the Upper Ordovician of Baltica, with a discussion of the Bucaniinae". English. In: Palaeontology 42.1 (1999), pp. 149-169.

[6311] J. O. R. Ebbestad. "Bucaniidae (Gastropoda) from the Upper Ordovician of Norway". English. In: Norsk Geologisk Tidsskrift 79 (1999), pp. 241-258.

[6312] J. O. R. Ebbestad. "Trilobites of the Tremadoc Bjørkåsholmen Formation in the Oslo Region, Norway". English. In: Fossils and Strata 47 (1999), pp. 1-118.

[6313] J. O. R. Ebbestad. "The tergomyan mollusc Carcassonnella from the Upper Ordovician of Girvan, Scotland". English. In: Palaeontology 51.3 (2008), pp. 663-675. DOI: 10.1111/j.1475-4983.2008.00774. $\mathrm{x}$.

[6314] J. O. R. Ebbestad and J. S. Peel. "Attempted predation and shell repair in Middle and Upper Ordovician gastropods from Sweden". English. In: Journal of Paleontology 71.6 (1997), pp. 10071019.

[6315] J. O. R. Ebbestad and J. S. Peel. "An unusual trochiform gastropod from the Upper Ordovician of Sweden". English. In: Palaeontology 44.2 (2001), pp. 375-387.

[6316] J. O. R. Ebbestad and E. L. Yochelson. "Isostrophic molluscs (Tergomya and Gastropoda) from the Upper Ordovician of Norway". English. In: Norsk Geologisk Tidsskrift 80.2 (2000), pp. 187-202.

[6317] J. J. Eberle. "Bridging the transition between didelphodonts and taeniodonts". English. In: Journal of Paleontology 73.5 (1999), pp. 936-944.

[6318] J. J. Eberle. Early Eocene Leptictida, Pantolesta, Creodonta, Carnivora, and Cete from Ellesmere IslandArctic Links to Europe and Asia. 2001.

[6319] J. J. Eberle. "A new 'tapir' from Ellesmere Island, Arctic Canada - Implications for northern high latitude palaeobiogeography and tapir palaeobiology". English. In: Palaeogeography, Palaeoclimatology, Palaeoecology 227 (2005), pp. 311-322.

[6320] J. J. Eberle, W. A. Clemens, P. J. McCarthy, A. R. Fiorillo, G. M. Erickson, and P. S. Druckenmiller. "Northernmost record of the Metatheria: a new Late Cretaceous pediomyid from the North Slope of Alaska". English. In: Journal of Systematic Palaeontology 17.21 (2019), pp. 1805-1824. DOI: 10 . 1080/14772019.2018.1560369.

[6321] J. J. Eberle, M. D. Gottfried, J. H. Hutchison, and C. A. Brochu. “First Record of Eocene Bony Fishes and Crocodyliforms from Canada's Western Arctic". English. In: PLoS One 9.5 (2014), e96079. DOI: 10.1371/journal.pone.0096079.

[6322] J. J. Eberle and D. R. Greenwood. "An Eocene brontothere and tillodonts (Mammalia) from British Columbia, and their paleoenvironments". English. In: Canadian Journal of Earth Sciences 54 (2017), pp. 981-992. DOI: 10.1139 / cjes-2017-0061.

[6323] J. J. Eberle, J. H. Hutchison, K. Kennedy, W. von Koenigswald, R. D. E. MacPhee, and G. D. Zazula. "The first Tertiary fossils of mammals, turtles, and fish from Canada's Yukon". English. In: American Museum Novitates 3943 (2019), pp. 1-28. 
[6324] J. J. Eberle and J. A. Lillegraven. “A new important record of earliest Cenozoic mammalian history: geologic setting, Multituberculata, and Peradectia". English. In: Rocky Mountain Geology 33.1 (1998), pp. 3-47.

[6325] J. J. Eberle and J. A. Lillegraven. "A new important record of earliest Cenozoic mammalian history". English. In: Rocky Mountain Geology 33.1 (1998), pp. 49-117.

[6326] J. J. Eberle and M. C. McKenna. "Early Eocene Leptictida, Pantolesta, Creodonta, Carnivora, and Mesonychidae (Mammalia) from the Eureka Sound Group, Ellesmere Island, Nunavut". English. In: Canadian Journal of Earth Sciences 39.6 (2002), pp. 899-910.

[6327] J. J. Eberle, N. Rybczynski, and D. R. Greenwood. "Early Eocene mammals from the Driftwood Creek beds, Driftwood Canyon Provincial Park, northern British Columbia". English. In: Journal of Vertebrate Paleontology 34.4 (2014), pp. 739-746. DOI: 10.1080/02724634.2014.838175.

[6328] J. J. Eberle and J. E. Storer. "Northernmost Record of Brontotheres, Axel Heiberg Island, Canada: Implications for Age of the Buchanan Lake Formation and Brontothere Paleobiology". English. In: Journal of Paleontology 73.5 (1999), pp. 979-983.

[6329] J. A. Ebersole, D. J. Cicimurri, and G. L. Stringer. "Taxonomy and biostratigraphy of the elasmobranchs and bony fishes (Chondrichthyes and Osteichthyes) of the lower-to-middle Eocene (Ypresian to Bartonian) Claiborne Group in Alabama, USA, including an analysis of otoliths". English. In: European Journal of Taxonomy 585 (2019), pp. 1-274. DOI: 10.5852/ejt.2019.585.

[6330] J. A. Ebersole, S. M. Ebersole, and D. J. Cicimurri. “The occurrence of early Pleistocene marine fish remains from the Gulf Coast of Mobile County, Alabama, USA". English. In: Palaeodiversity 10.1 (2017), pp. 97-115.

[6331] D. A. Eberth. Stratigraphy and sedimentology of vertebrate microfossil sites in the uppermost Judith River Formation (Campanian), Dinosaur Provincial Park, Alberta, Canada. 1990.

[6332] D. A. Eberth and D. B. Brinkman. "Paleoecology of an estuarine, incised-valley fill in the Dinosaur Park Formation (Judith River Group, Upper Cretaceous) of southern Alberta, Canada". English. In: Palaios 12 (1997), pp. 43-58.

[6333] D. A. Eberth, B. B. Britt, R. D. Scheetz, K. L. Stadtman, and D. B. Brinkman. “Dalton Wells: geology and significance of debris-flow-hosted dinosaur bonebeds in the Cedar Mountain Formation (Lower Cretaceous) of eastern Utah, USA". English. In: Palaeogeography, Palaeoclimatology, Palaeoecology 236 (2006), pp. 217-245.

[6334] D. A. Eberth and M. A. Getty. Ceratopsian bonebeds: occurrence, origins, and significance. English. Dinosaur Provincial Park: A Spectacular Ancient Ecosystem Revealed. Indiana University Press, Bloomington. 2005, pp. 501-536.

[6335] D. A. Eberth, Y. Kobayashi, Y. -N. Lee, O. Mateus, F. Therrien, D. K. Zelenitsky, and M. A. Norell. "Assignment of Yamaceratops dorngobiensis and associated redbeds at Shine Us Khudag (eastern Gobi, Dorngobi Province, Mongolia) to the redescribed Javkhlant Formation (Upper Cretaceous)". English. In: Journal of Vertebrate Paleontology 29.1 (2009), pp. 295-302. DOI: 10.1671/039.029.0105.

[6336] D. A. Eberth, D. A. Russell, D. R. Braman, and A. L. Deino. "The age of the dinosaur-bearing sediments at Tebch, Inner Mongolia, People's Republic of China". English. In: Canadian Journal of Earth Sciences 30.10-11 (1994), pp. 2101-2106.

[6337] D. A. Eberth, X. Xu, and J. M. Clark. "Dinosaur death pits from the Jurassic of China". English. In: Palaios 25 (2010), pp. 112-125. DOI: 10.2110/palo.2009.p09-028r.

[6338] J. Echevarra, M. S. Odges, S. Damborenea, and G. Stanley y M. Maceñido. "Recovery of scleractinian morphologic diversity during the early Jurassic in Mendoza province, Argentina. Ameghiniana 54 (1): 70-82". English. In: (2017).

[6339] J. D. Eckert. "The Early Silurian myelodactylid crinoid Eomyelodactylus Foerste". English. In: Journal of Paleontology 64 (1990), pp. 135-141.

[6340] H. Ecklund and J. Kvacek. "Lauraceous inflorescences and flowers from the Cenomanian of Bohemia (Czech Republic, Central Europe)". In: International Journal of Plant Sciences 159.4 (1998), pp. 668-686. 
[6341] J. D. Eddy and L. B. McCollum. "Early Middle Cambrian Albertella biozone trilobites of the Pioche Shale, southeastern Nevada". In: Journal of Paleontology 72.5 (1998), pp. 864-887.

[6342] Y. Edelman-Furstenberg. "Macrobenthic community structure in a high-productivity region: Upper Campanian Mishash Formation (Israel)". English. In: Palaeogeography, Palaeoclimatology, Palaeoecology 261 (2008), pp. 58-77.

[6343] G. D. Edgecombe. "New Lower Silurian (Llandovery) encrinurine trilobites from the Mackenzie Mountains, Canada". In: Journal of Paleontology 68.4 (1994), pp. 824-837.

[6344] G. D. Edgecombe. "Acaste (Trilobita: Phacopina) from the Early Devonian of Tasmania". English. In: Alcheringa 31 (2007), pp. 59-66.

[6345] G. D. Edgecombe. "Early myriapodous arthropods from Australia: Maldybulakia from the Devonian of New South Wales". English. In: Records of the Australian Museum 50 (1998), pp. 293-313.

[6346] G. D. Edgecombe, M. R. Banks, and D. M. Banks. "Upper Ordovician Phacopida (Trilobita) from Tasmania". English. In: Alcheringa 23.4 (1999), pp. 235-257. DOI: 10.1080/03115519908527808.

[6347] G. D. Edgecombe, M. R. Banks, and D. M. Banks. "Late Ordovician trilobites from Tasmania: Styginidae, Asaphidae and Lichidae". English. In: Memoirs of the Association of Australasian Palaeontologists 30 (2007), pp. 59-77.

[6348] G. D. Edgecombe and B. D. E. Chatterton. "Silurian (Wenlock-Ludlow) encrinurine trilobites from the Mackenzie Mountains, Canada, and related species". In: Palaeontographica Abteilung A 229.4-6 (1993), pp. 75-112.

[6349] G. D. Edgecombe and B. D. E. Chatterton. "Early Silurian (Llandovery) encrinurine trilobites from the Mackenzie Mountains, Canada". In: Journal of Paleontology 66.1 (1992), pp. 52-74.

[6350] G. D. Edgecombe and B. D. E. Chatterton. "Systematics of Encrinuroides and Curriella (Trilobita), with a new Early Silurian encrinurine from the Mackenzie Mountains". In: Canadian Journal of Earth Sciences 27 (1990), pp. 820-833.

[6351] G. D. Edgecombe and B. D. E. Chatterton. "Mackenziurus, a new genus of the Silurian Encrinurus variolaris plexus (Trilobita)". In: American Museum Novitates 2968 (1990), pp. 1-22.

[6352] G. D. Edgecombe, B. D. E. Chatterton, B. G. Waisfield, and N. E. Vaccari. “Ordovician pliomerid and prosopiscid trilobites from Argentina". English. In: Journal of Paleontology 73.6 (1999), pp. 11441154.

[6353] G. D. Edgecombe, B. D. E. Chatterton, N. E. Vaccari, and B. G. Waisfield. “Ordovician cheirurid trilobites from the Argentine Precordillera". English. In: Journal of Paleontology 73.6 (1999), pp. 11551175.

[6354] G. D. Edgecombe, B. D. E. Chatterton, B. G. Waisfeld, and N. E. Vaccari. “Ordovician (Whiterock) calymenid and encrinurid trilobites from the Precordillera of Argentina". English. In: Journal of Paleontology 72.4 (1998), pp. 678-697.

[6355] G. D. Edgecombe, B. D. E. Chatterton, N. E. Vaccari, and B. G. Waisfeld. "Triarthrinid trilobites (Olenidae) from the Middle and Upper Ordovician, Precordillera of Argentina". English. In: Journal of Paleontology 79.1 (2005), pp. 89-109.

[6356] G. D. Edgecombe, B. D. E. Chatterton, N. E. Vaccari, and B. G. Waisfeld. "Ontogeny of the proetid trilobite Stenoblepharum, and relationships of a new species from the Upper Ordovician of Argentina". English. In: Journal of Paleontology 71.3 (1997), pp. 419-433.

[6357] G. D. Edgecombe, A. Minelli, and L. Bonato. "A geophilomorph centipede (Chilopoda) from La Buzinie amber (Late Cretaceous, Cenomanian), SW France". English. In: Geodiversitas 31 (2009), pp. 29-39.

[6358] G. D. Edgecombe and L. Ramskold. "Earliest Devonian phacopide trilobites from central Bolivia". In: Paläontologische Zeitschrift 68.3/4 (1994), pp. 397-410.

[6359] G. D. Edgecombe and L. Ramsköld. "The Encrinurus variolaris plexus (Trilobita, Silurian): relationships of Llandovery species". English. In: Geobios 29.2 (1996), pp. 209-233. DOI: 10.1016/S00166995(96)80045-3. 
[6360] G. D. Edgecombe, V. Vahtera, S. R. Stock, A. Kallonen, X. H. Xiao, A. Rack, and G. Giribet. “A scolopocryptopid centipede (Chilopoda: Scolopendromorpha) from Mexican amber: synchrotron microtomography and phylogenetic placement using a combined morphological and molecular data set". English. In: Zoological Journal of the Linnean Society 166 (2012), pp. 768-786.

[6361] G. D. Edgecombe, B. G. Waisfeld, and N. E. Vaccari. "Andinacaste (Trilobita) from the earliest Devonian of Argentina". English. In: Journal of Paleontology 68.4 (1994), pp. 837-841.

[6362] G. D. Edgecombe and B. D. Webby. “Ordovician trilobites with eastern Gondwanan affinities from central-west New South Wales and Tasmania". English. In: Memoirs of the Association of Australasian Palaeontologists 34 (2007), pp. 255-281.

[6363] G. D. Edgecombe and B. D. Webby. "The Ordovician encrinurid trilobite Sinocybele from New South Wales and its biogeographic significance". English. In: Memoirs of the Association of Australasian Palaeontologists 32 (2006), pp. 413-422.

[6364] E. N. Edinger and M. J. Risk. "Oligocene-Miocene extinction and geographic restriction od Caribbean corals: Roles of turbidity, termperature, and nutrients". In: Palaios 9 (1994), pp. 576-598.

[6365] M. Edmunds, M. Varah, and A. Bentley. "The ammonite biostratigraphy of the Lower Lias Armatum Bed (Upper Sinemurian-Lower Pliensbachian) at St Peter's Field, Radstock, Somerset". In: Proceedings of the Geologists' Association 114.1 (2003), pp. 65-96.

[6366] M. Edmunds, J. Whicher, P. Langham, and R. B. Chandler. "A systematic account of the ammonite faunas of the Obtusum Zone (Sinemurian Stage, Lower Jurassic) from Marston Magna, Somerset, UK". English. In: Proceedings of the Geologists' Association 127 (2016), pp. 146-171.

[6367] D. Edwards. "New insights into early land ecosystems: a glimpse of a Lilliputian world". In: Review of Palaeobotany and Palynology 90 (1996), pp. 159-174.

[6368] D. Edwards, H. P. Banks, S. J. Ciurca, and R. S. Laub. "New Silurian cooksonias from dolostones of north-eastern North America". English. In: Botanical Journal of the Linnean Society 146 (2004), pp. 399-413.

[6369] D. Edwards, K. L. Davies, J. B. Richardson, C. H. Wellman, and L. Axe. “Ultrastructure of Synorisporites downtonensis and Retusotriletes cf. coronadus in spore masses from the Pridoli of the Welsh Borderland". In: Palaeontology 39.3 (1996), pp. 783-800.

[6370] D. Edwards, K. L. Davies, J. B. Richardson, and L. Axe. "The ultrastructure of spores of Cooksonia pertoni". In: Palaeontology 38 (1995), pp. 153-168.

[6371] D. Edwards, U. Fanning, K. L. Davies, L. Axe, and J. B. Richardson. "Exceptional preservation in Lower Devonian coalified fossils from the Welsh Borderland: a new genus based on reniform sporangia lacking thickened borders". In: Botanical Journal of the Linnean Society 117 (1995), pp. 233254.

[6372] D. Edwards, U. Fanning, and J. B. Richardson. "Lower Devonian coalified sporangia from Shropshire; Salopella Edwards \& Richardson and Tortilicaulis Edwards". In: Botanical Journal of the Linnean Society 116 (1994), pp. 89-110.

[6373] D. Edwards, E. Morel, D. G. Poire, and C. A. Cingolani. "Land plants in the Devonian Villavicencio Formation, Mendoza Province, Argentina". English. In: Review of Palaeobotany and Palynology 116 (2001), pp. 1-18.

[6374] D. Edwards, E. M. Morel, F. Paredes, D. B. Ganuza, and A. Zuniga. "Plant assemblages from the Silurian of southern Bolivia and their palaeogeographic significance". English. In: Botanical Journal of the Linnean Society 135 (2001), pp. 229-250.

[6375] D. Edwards, C. H. Wellman, and L. Axe. "Tetrads in sporangia and spore masses from the Upper Silurian and Lower Devonian of the Welsh Borderland". In: Botanical Journal of the Linnean Society 130 (1999), pp. 111-156.

[6376] L. E. Edwards, J. A. Barron, D. Bukry, L. M. Bybell, T. M. Cronin, C. W. Poag, R. E. Weems, and G. L. Wingard. "Paleontology of the Upper Eocene to Quaternary Post Impact Section in the USGSNASA Langley Core, Hampton Virginia”. English. In: United States Geological Survey Professional Paper 1688 (2005), pp. 1-71. 
[6377] D. V. Efimov and V. N. Komarov. "[The first find of fragments of skeleton ichthyosaurus Jasykovia in Valanginian Crimea] translated from Russia: PERVAA NAHODKA FRAGMENTOV SKELETA IHTIOZAVRA RODA JASYKOVIA V VALANINE KRYMA". English. In: Cretaceous System of Russia and CIS states: problems of stratigraphy and palaeogeography - Materials of the 5th AllRussian Meeting, August 23-28, 2010, Ulyanovsk. 2010, pp. 132-135.

[6378] M. B. Efimov, Y. M. Gubin, and S. M. Kurzanov. "New primitive crocodile (Crocodylomorpha: Shartegosuchidae) from the Jurassic of Mongolia". English. In: Paleontological Journal 34 (2000), S238-S241.

[6379] V. M. Efimov. "A new family of Ichthyosaurs, the Undorosauridae fam. nov. from the Volgian stage of the European part of Russia". English. In: Paleontological Journal 33.2 (1999), pp. 174-181.

[6380] E. Egerquist. "New brachiopods from the Lower-Middle Ordovician (Billingen-Volkhov stages) of the East Baltic". English. In: Acta Palaeontologica Polonica 48.1 (2003), pp. 31-38.

[6381] N. Egi, P. A. Holroyd, T. Tsubamoto, A. N. Soe, M. Takai, and R. L. Ciochon. "Proviverrine hyaenodontids(Creodonta: Mammalia) from the Eocene of Myanmar and a phylogenetic analysis of the proviverrines from the Para-Tethys area". English. In: Journal of Systematic Palaeontology 3.4 (2005), pp. 337-358.

[6382] N. Egi, P. A. Holroyd, T. Tsubamoto, N. Shigehara, M. Takai, A. K. Aung, A. N. Soe, and S. T. Tun. "A new genus and species of hyaenodontid creodont from the Pondaung Formation (Eocene, Myanmar)". English. In: Journal of Vertebrate Paleontology 24.2 (2004), pp. 502-506.

[6383] N. Egi, T. Tsubamoto, and M. Takai. "Systematic status of Asian Pterodon and early evolution of hyaenaelurine hyaenodontid creodonts". English. In: Journal of Paleontology 81.4 (2007), pp. 770778.

[6384] N. Egi and T. Tsubamoto. "A preliminary report on carnivorous mammals from Pondaung fauna". English. In: Asian Paleoprimatology 1 (2000), pp. 103-114.

[6385] N. Egi, T. Tsubamoto, M. Saneyoshi, K. Tsogtbaatar, M. Watabe, B. Mainbayar, T. Chinzorig, and P. Khatanbaatar. "Taxonomic revisions on nimravids and small feliforms (Mammalia, Carnivora) from the Upper Eocene of Mongolia". English. In: Historical Biology 28.1-2 (2016), pp. 105-119.

[6386] N. Egi, T. Tsubamoto, and K. Tsogtbaatar. "New amphicyonid (Mammalia: Carnivora) from the Upper Eocene Ergilin Dzo Formation, Mongolia". English. In: Paleontological Research 13.3 (2009), pp. 245-249.

[6387] M. Ehiro. "Latest Permian ammonoid Paratirolites from the Ofunato district, Southern Kitakami Massif, Northeast Japan". English. In: Transactions and Proceedings of the Paleontological Society of Japan, New Series 184 (1996), pp. 592-596.

[6388] M. Ehiro. "Some addition Wuchiapingian (Late Permian) ammonoids from the Southern Kitakami Massif, Northeast Japan". English. In: Paleontological Research 5.2 (2001), pp. 111-114.

[6389] M. Ehiro. "Cephalopod fauna of the Nakadaira Formation (Lower Permian) in the southern Kitakami Massif, northeast Japan". English. In: Transactions and Proceedings of the Paleontological Society of Japan, N.S. 179 (1995), pp. 184-192.

[6390] M. Ehiro. "A new species of Stacheoceras (Permian ammonoid) from the Upper Permian in the south Kitakami belt, northeast Japan". English. In: Paleontological Research 10 (2006), pp. 261-264.

[6391] M. Ehiro. "Spathian ammonoids Metadagnoceras and Keyserlingites from the Osawa Formation in the southern Kitakami Massif, northeast Japan". English. In: Transactions and Proceedings of the Paleontological Society of Japan, N.S. 171 (1993), pp. 229-236.

[6392] M. Ehiro. "Additional early Triassic (late Olenekian) ammonoids from the Osawa Formation at Yamaya, Motoyoshi area, South Kitakami belt, northeast Japan". English. In: Paleontological Research 20 (2016), pp. 1-6.

[6393] M. Ehiro. "Two additional araxoceratid ammonoids from the Wuchiapingian (upper Permian) of the South Kitakami Belt, Northeast Japan". English. In: Earth Science (Chikyu Kagaku) 73 (2019), pp. 139-148. 
[6394] M. Ehiro and H. Araki. "Permian cephalopods of Kurosawa, Kesennuma City in the Southern Kitakami Massif, northeast Japan". English. In: Paleontological Research 1 (1997), pp. 55-66.

[6395] M. Ehiro, H. Hasegawa, and A. Misaki. "Permian ammonoids Prostacheoceras and Perrinites from the southern Kitakami massif, northeast Japan". English. In: Journal of Paleontology 79 (2005), pp. 1222-1228.

[6396] M. Ehiro and A. Misaki. "Middle Permian ammonoids from the Kamiyasse-Imo district in the southern Kitakami Massif, northeast Japan”. English. In: Paleontological Research 9.1 (2005), pp. 114.

[6397] M. Ehiro, O. Nishikawa, and I. Nishikawa. "Early Permian (Asselian) ammonoids from the Taishaku Limestone, Akiyoshi Belt, southwest Japan". English. In: Paleontological Research 18 (2014), pp. 5163.

[6398] M. Ehiro and T. Ozawa. "Early Asselian (earliest Permian) ammonoids from the Taishaku Limestone, Akiyoshi Belt, Southwest Japan: an Asselian ammonoid fauna of the Mid-Panthalassan Realm". English. In: Paleontological Research 24 (2020), pp. 298-315. DOI: 10.2517/2020PR006.

[6399] M. Ehiro, O. Sasaki, H. Kano, J. Nemoto, and H. Kato. "Thylacocephala (Arthropoda) from the Lower Triassic of the South Kitakami Belt, northeast Japan". English. In: Paleontological Research 19 (2015), pp. 269-282.

[6400] M. Ehiro, O. Sasaki, and H. Kano. "Ammonoid fauna of the upper Olenekian Osawa Formation in the Utatsu area, South Kitakami Belt, northeast Japan". English. In: Paleontological Research 20 (2016), pp. 90-104.

[6401] M. Ehiro and S. Z. Shen. "Permian ammonoid Kufengoceras from the uppermost Maokou Formation (earliest Wuchiapingian) at Penglaitan, Laibin Area, Guangxi Autonomous Region, South China". English. In: Paleontological Research 12 (2008), pp. 255-259.

[6402] M. Ehiro and S.-Z. Shen. "Ammonoid succession across the Wuchiapingian/Changhsingian boundary of the northern Penglaitan Section in the Laibin area, Guangxi, South China". English. In: Geological Journal 45 (2010), pp. 162-169. DOI: 10.1002/gj.1228.

[6403] M. Ehiro, Y. D. Zakharov, and C. Minjin. “Early Triassic (Olenekian) ammonoids from Khentey Province, Mongolia, and their paleobiogeographic significance". English. In: Bulletin of the Tohoku University Museum 5 (2006), pp. 83-97.

[6404] D. Ehret, J. R. Bourque, and R. C. Hulbert Jr. “Case 3628 Terrapene putnami Hay, 1906 (Testudines, Emydidae): replacement of the holotype by designation of a neotype". English. In: Bulletin of Zoological Nomenclature 70.3 (2013), pp. 193-198.

[6405] D. J. Ehret. "Skeletochronology: a method for determing the individual age and growth of modern and fossil tortoises (Reptilia: Testudines)". English. In: Bulletin of the Florida Museum of Natural History 47.2 (2007), pp. 49-72.

[6406] D. J. Ehret. "Paleobiology and taxonomy of extinct Lamnid and Otodontid Sharks (Chondrichthyes, Elasmobranchii, Lamniformes)". English. PhD thesis. Gainesville, 2010, pp. -165.

[6407] D. J. Ehret and B. K. Atkinson. "The fossil record of the diamond-backed terrapin, Malaclemys terrapin (Testudines: Emydidae)". English. In: Journal of Herpetology 46.3 (2012), pp. 351-355.

[6408] D. J. Ehret and J. R. Bourque. "An extinct map turtle Graptemys (Testudines, Emydidae) from the Late Pleistocene of Florida". English. In: Journal of Vertebrate Paleontology 31.3 (2011), pp. 575-587.

[6409] D. J. Ehret, B. J. MacFadden, D. S. Jones, T. J. DeVries, D. A. Foster, and R. Salas-Gismondi. “Origin of the white shark Carcharodon (Lamniformes: Lamnidae) based on recalibration of the upper Neogene Pisco Formation of Peru". English. In: Palaeontology 55.6 (2012), pp. 1139-1153. DOI: 10. 1111/j.1475-4983.2012.01201.x.

[6410] H. Eichenseer and H. Luterbacher. "The marine Paleogene of the Tremp region (NE Spain) - depositional sequences, facies history, biostratigraphy and controlling factors". English. In: Facies 27 (1992), pp. 119-152. 
[6411] S. Eichholt and R. T. Becker. "Middle Devonian reef facies and development in the Oued Cherrat Zone and adjacent regions (Moroccan Meseta)". English. In: Facies 62.7 (2016). DOI: 10.1007 / s10347-015-0459-z.

[6412] T. Eidvin and Y. Rundberg. "Post-Eocene strata of the southern Viking Graben, northern North Sea; integrated biostratigraphic, strontium isotopic and lithostratigraphic study". English. In: Norwegian Journal of Geology 87 (2007), pp. 391-450.

[6413] R. Einasto. Locality 6:3 Jaagarahu Quarries. English. Field Meeting Estonia 1990, Excursion Guidebook. Tallinn: Estonian Academy of Sciences, 1990, pp. 166-167.

[6414] R. Einasto. Locality 6:7 Kogula Quarry. English. Field Meeting Estonia 1990, Excursion Guidebook. Tallinn: Estonian Academy of Sciences, 1990, pp. 170-172.

[6415] R. Einasto. Locality 7:1 Kaarma Quarry. English. Field Meeting Estonia 1990, Excursion Guidebook. Tallinn: Estonian Academy of Sciences, 1990, p. 173.

[6416] R. Einasto. Locality 7:3 Kaugatuma Cliff. English. Field Meeting Estonia 1990, Excursion Guidebook. Tallinn: Estonian Academy of Sciences, 1990, pp. 174-175.

[6417] J. Eiriksson, K. L. Knudsen, and L. A. Simonarson. "Lateglacial oceanographic conditions off Southwest Iceland inferred from shallow-marine deposits in Reykjavik and Seltjarnarnes Peninsula". English. In: Boreas 33 (2004), pp. 269-283.

[6418] A. A. M. Eisawi, A. B. Ibrahim, O. B. A. Rahim, and E. Schrank. "Palynozonation of the Cretaceous to Lower Paleogene Strata of the Muglad Basin, Sudan". English. In: Palynology 36.2 (2012), pp. 191-207.

[6419] V. Eisenmann and T. Kuznetsova. "Early Pleistocene equids (Mammalia, Perissodactyla) of Nalaikha, Mongolia, and the emergence of modern Equus Linnaeus, 1758". English. In: Geodiversitas 26.3 (2004), pp. 535-561.

[6420] E. G. Ekdale and A. A. Ekdale. "Hillichnus lobosensis, an unusually complex trace fossil of burrowing bivalves from the Paleogene of southern California, U.S.A." English. In: Palaeogeography, Palaeoclimatology, Palaeoecology 493 (2018), pp. 119-125. DOI: 10.1016/j.palaeo.2018.01.007.

[6421] C. P. Ekeheien, L. L. Delsett, A. J. Roberts, and J. H. Hurum. "Preliminary report on ichthyopterygian elements from the Early Triassic (Spathian) of Spitsbergen". English. In: Norwegian Journal of Geology 98.2 (2018), pp. 219-237.

[6422] J. J. El Adli, T. A. Deméré, and R. W. Boessenecker. "Herpetocetus morrowi (Cetacea: Mysticeti), a new species of diminutive baleen whale from the Upper Pliocene (Piacenzian) of California, USA, with observations on the evolution and relationships of the Cetotheriidae". English. In: Zoological Journal of the Linnean Society 170 (2014), pp. 400-466. DOI: 10.1111/zoj.12108.

[6423] A. El Albani, D. Vachard, F. Fürsich, B. Buitrón, and A. F. de Dios. "Depositional environment and biofacies characterization of the Upper Pennsylvanian-Lower Permian deposits of the San Salvador Patlanoaya section (Puebla, Mexico)." In: Facies 2005.50 (2005), pp. 629-645.

[6424] S. El Beialy, H. S. El Atfy, M. S. Zavada, and E. M. El Khoriby. "Palynological, palynofacies, paleoenvironmental and organic geochemical studies on the Upper Cretaceous succession of the GPTSW-7 well, North Western Desert, Egypt". English. In: Marine and Petroleum Geology 27 (2010), pp. 370-385.

[6425] G. M. El Qot. "Late Cretaceous macrofossils from Sinai, Egypt”. English. In: Beringeria 36 (2006), pp. 3-163.

[6426] G. M. El Qot. “Aptian-early Cenomanian ammonites from north Sinai, Egypt: systematic paleontology and biostratigraphy". English. In: Cretaceous Research 85 (2018), pp. 142-171.

[6427] M. El Wartiti, J. Broutin, P. Freytet, M. Larhrib, and N. Toutin-Morin. "Continental deposits in Permian basins of the Mesetian Morocco, geodynamic history". English. In: Journal of African Earth Sciences Major African continental Phanerozoic complexes and dynamics of sedimentation 10 (1990), pp. 361-368. 
[6428] G. M. A. El-Asa'ad. “Oxfordian hermatypic corals from central Saudi Arabia”. In: Géobios 24.3 (1991), pp. 267-287.

[6429] M. A. G. El-Asa'ad. "Maastrichtian species of the coral genus Cunnolites from Saudi Arabia". English. In: Journal of African Earth Sciences 10.4 (1990), pp. 633-642.

[6430] M. M. El-Hedeny. "Taphonomy and Paleoecology of the Middle Miocene oysters from Wadi Sudr, Gulf of Suez, Egypt". English. In: Revue de Paléobiologie, Genéve 24.2 (2005), pp. 719-733.

[6431] M. M. El-Hedeny. "Pterotrigonia (Scabrotrigonia) scabra (LAMARCK, 1819), a polymorphic bivalve from the Upper Cretaceous (Coniacian-Santonian) of Egypt". English. In: Revue de Paéobiologie 25.2 (2006), pp. 709-722.

[6432] M. M. El-Hedeny. "New taxonomic and biostratigraphic data on the Upper Cenomanian - Turonian Radiolitidae (Bivalvia: Hippuritoidea) of Abu Roash, Western Desert, Egypt". English. In: Neues Jahrbuch für Geologie und Paläontologie, Abhandlungen 244.1 (2007), pp. 79-98. DOI: 10.1127/ 0077-7749/2007/0244-0079.

[6433] M. M. El-Hedeny, A. A. Abdel Aal, M. Maree, and J. Seeling. "Plicatulid bivalves from the ConiacianSantonian Matulla Formation," English. In: Cretaceous Research 22 (2001), pp. 295-308.

[6434] G. A. A. El-kheir, M. I. El Anbaawy, S. A. Helal, and S. Gibbs. “Dentary of Masracetus markgrafi, Archaeocete in the north of Lake Qaroun, Fayoum Egypt". English. In: Journal of American Science 9.12 (2013), pp. 459-469.

[6435] A. El-Sabbagh, A. A. Tantawy, G. Keller, H. Khozyem, J. Spangenberg, T. Adatte, and B. Gertsch. "Stratigraphy of the Cenomanian-Turonian Oceanic Anoxic Event OAE2 in shallow shelf sequences of NE Egypt". English. In: Cretaceous Research 30 (2011), pp. 1-18. DOI: 10.1016/j.cretres.2011.04. 006.

[6436] S. E. El-Sayed, M. A. Kora, H. M. Sallam, K. M. Claeson, E. R. Seiffert, and M. S. Antar. “A new genus and species of marine catfishes (Siluriformes; Ariidae) from the upper Eocene Birket Qarun Formation, Wadi El-Hitan, Egypt". English. In: PLoS ONE 12.e0172409 (2017), pp. 1-42. DOI: 10. 1371/journal.pone.0172409.

[6437] A. El-Shahat, S. N. Ayyad, and M. A. Abdalla. "Pliocene Facies and Fossil Contents of Qaret EIMuluk Formation at Wadi EI-Natrun Depression, Western Desert, Egypt". English. In: Facies 37 (1997), pp. 211-224.

[6438] S. El-Shazly, M. Kostak, G. Abdel-Gawad, B. Klouckova, S. G. Saber, Y. Felieh Salama, M. Mazuch, and K. ak. "Carbon and oxygen stable isotopes of selected Cenomanian and Turonian rudists from Egypt and Czech Republic, and a note on changes in rudist diversity". English. In: Bulletin of Geosciences 86.2 (2011), pp. 209-226.

[6439] S. H. El-Shazly, G. I. Abdel-Gawad, Y. F. Salama, and D. M. Sayed. "Paleontology, paleobiogeography and paleoecology of Carolia-bearing beds from the Late Eocene rocks at Nile-Fayum Divide, Egypt". English. In: Journal of African Earth Sciences 124 (2016), pp. 447-477.

[6440] A. El-Sorogy, M. Youssef, M. Al-Sabrouty, and N. Al-Otaiby. “Facies pattern and molluscan fauna of the Late Pleistocene raised coral reef of Rabigh area, Red Sea coast, Saudi Arabia". English. In: (2013).

[6441] A. S. El-Sorogy. "Paleontology and depositional environments of the Pleistocene coral reefs of the Gulf of Suez, Egypt". English. In: Neues Jahrbuch für Geologie und Paläontologie, Abhandlungen 225.3 (2002), pp. 337-371.

[6442] A. S. El-Sorogy. "Progressive diagenetic sequence from Pleistocene coral reefs in the area between Quseir and Mersa Alam, Red Sea coast, Egypt". English. In: Egyptian journal of geology 41.1 (1997), pp. 519-540.

[6443] A. S. El-Sorogy and K. M. Al-Kahtany. "Contribution to the scleractinian corals of Hanifa Formation, Upper Jurassic, Jabal Al-Abakkayn, central Saudi Arabia". English. In: Historical Biology: An International Journal of Paleobiology (2014). 
[6444] A. S. El-Sorogy, A. Ismail, M. Youssef, and H. Nour. "Facies development and paleoenvironment of the Hajajah Limestone Member, Aruma Formation, central Saudi Arabia". English. In: Journal of African Earth Sciences (2016). DOI: 10.1016/j.jafrearsci.2016.09.037.

[6445] W. P. Elder. "Bivalves and Gastropods from the Middle Campanian Anacacho Limestone, south central Texas". In: Journal of Paleontology 70.2 (1996), pp. 247-271.

[6446] W. P. Elder. "Tibiaporrhais, a new Late Cretaceous genus of Aporrhaidae resembling Tibia Röding". English. In: The Veliger 33.3 (1990), pp. 293-298.

[6447] W. P. Elder and J. W. Miller. "Map and checklists of Jurassic and Cretaceous macrofossil localities within the San Jose 1:100,000 Quadrangle, California, and discussion of paleontological results". English. In: United States Geological Survey Open-File Report 93-503 (1993), pp. 1-49.

[6448] W. P. Elder and L. R. Saul. "Taxonomy and biostratigraphy of Coniacian through Maastrichtian Anchura (Gastropoda; Aporrhaiidae) of the North American Pacific slope". English. In: Journal of Paleontology 70.3 (1996), pp. 381-399.

[6449] W. P. Elder and L. R. Saul. "Paleogeographic implications of molluscan assemblages in the Upper Cretaceous (Campanian) Pigeon Point Formation, California". English. In: vol. 71. Mesozoic Paleogeography of the Western United States - II. Pacific Section SEPM Book. 1993, pp. 171-186.

[6450] R. A. Elgin and E. Frey. "A new ornithocheirid, Barbosania gracilirostris gen. et sp. nov. (Pterosauria, Pterodactyloidea) from the Santana Formation (Cretaceous) of NE Brazil". English. In: Swiss Journal of Palaeontology 130.259 (2011). DOI: 10.1007/s13358-011-0017-4.

[6451] R. A. Elgin and E. Frey. "A new azhdarchoid pterosaur from the Cenomanian (Late Cretaceous) of Lebanon". English. In: Swiss Journal of Geosciences 104.supp. 1 (2011), S21-S33. DOI: 10.1007 / s00015-011-0081-1.

[6452] R. A. Elgin and D. W. E. Hone. "Pneumatization of an immature azhdarchoid pterosaur". English. In: Cretaceous Research 45 (2013), pp. 16-24.

[6453] F. A. Elias, R. J. Bertini, and M. A. A. Medeiros. "Pterosaur teeth from the Laje do Coringa, middle Cretaceous, São Lus-Grajaú basin, Maranhão state, Northern-Northeastern Brazil". English. In: Revista Brasileira de Geociencias 37.4 (2007), pp. 668-676.

[6454] R. J. Elias and D. Lee. "Microborings and growth in Late Ordovician halysitids and other corals". In: Journal of Paleontology 67.6 (1993), pp. 922-934.

[6455] R. J. Elias, A. W. Potter, and R. Watkins. "Late Ordovician Rugose Corals of the Northern Sierra Nevada, California". In: Journal of Paleontology 68.1 (1994), pp. 164-168.

[6456] S. A. Elias. "Environmental interpretation of fossil insect assemblages from MIS 5 at Ziegler Reservoir, Snowmass Village, Colorado". English. In: Quaternary Research 82 (2014), pp. 592-603.

[6457] H. Eliasova. "Caleria gen. Nov. (Scleractinia, Heterocoeniina) Crétacé supérieur République tchéque”. French. In: Bulletin of the Czech Geological Survey 71.3 (1996), pp. 255-258.

[6458] H. Eliasova. “Coraux solitaires (Zoantharia, Microsolenina) du Crétacé de Boheme (Cénomanien supérieur, République tchéque) [Cretaceous solitary corals (Zoantharia, Microsolenina) from Bohemia (Late Cenomanian, Czech Republic)]". French. In: Bulletin of Geosciences 79.3 (2004), pp. 157166.

[6459] H. Eliasova. “Coraux des Calcaires d'Ernstbrunn (Jurassique superieur-Cretace inferieur dans les Carpates externes, zone de Waschberg, Tchecoslovaquie) [Corals of the Ernstbrunn Limestone (Upper Jurassic-Lower Cretaceous, Outer Carpathians, Waschberg Zone, Czechoslowakia)]". French. In: Casopis pro Mineralogii a Geologii 35.2 (1990), pp. 113-133.

[6460] H. Eliasova. “Cunnolitides du Cretace de Boheme (Scleractiniaires, Fungiina) Cenomanien superieurTuronien inferieur; Republique tcheque". French. In: Bulletin of the Czech Geological Survey 71.2 (1996), pp. 127-134.

[6461] H. Eliasova. "Upper Cenomanian-Turonian two species of cyclostomaceous Bryozoa from the northern part of the Bohemian Cretaceous Basin, Czech Republic". English. In: Journal of the Czech Geological Society 50 (2005), pp. 59-62. 
[6462] O. Elicki. "Palaeoecological significance of calcimicrobial communities during ramp evolution: an example from the Lower Cambrian of Germany". In: Facies 41 (1999), pp. 27-40.

[6463] O. Elicki. "Lower Cambrian carbonates from eastern Germany:palaeontology, stratigraphy and palaeogeography". In: Neues Jahrbuch für Geologie und Paläontologie, Abhandlungen 191.1 (1994), pp. 69-93.

[6464] O. Elicki. "First skeletal microfauna from the Cambrian Series 3 of the Jordan Rift Valley (Middle East)". English. In: Memoirs of the Association of Australasian Palaeontologists 42 (2011), pp. 153-173.

[6465] O. Elicki and S. Gürsu. "First record of Pojetaia runnegari Jell, 1980 and Fordilla Barrande, 1881 from the Middle East (Taurus Mountains, Turkey) and critical review of Cambrian bivalves". English. In: Palaeontologische Zeitschrift 83.2 (2009), pp. 267-291. DOI: 10.1007/s12542-009-0021-9.

[6466] O. Elicki and G. L. Pillola. "Cambrian microfauna and palaeoecology of the Campo Pisano Formation at Gutturu Pala (Iglesiente, SW Sardinia, Italy)". English. In: Bollettino della Societa Paleontologica Italiana 43.3 (2004), pp. 383-401.

[6467] O. Elicki and J. Schneider. "Lower Cambrian (Atdabanian/Botomian) shallow-marine carbonates of the Gorlitz synclinorium (Saxony/Germany)". English. In: Facies 26 (1992), pp. 55-66.

[6468] S. Ellenberger and F. Fanti. "New Cretaceous soldier beetle (Cantharidae) from Burmese amber with preserved coloration on the elytra". English. In: Zootaxa 4609 (2019), pp. 594-600.

[6469] D. K. Elliot and H. G. Johnson. "Use of vertebrates to solve biostratigraphic problems: Examples from the Lower and Middle Devonian of western North America". English. In: vol. 321. Paleozoic Sequence Stratigraphy, Biostratigraphy, and Biogeography: Studies in Honor of J. Granville (Jess) Johnson. Geological Society of America Special Papers, 1997, pp. 179-188. DOI: 10.1130 / 0-81372321-3.179.

[6470] D. K. Elliott and J. P. M. Hodnett. "A new species of Bransonella (Chondrichthyes, Xenacanthimorpha, Bransonelliformes) from the Middle Permian Kaibab Formation of northern Arizona". English. In: Journal of Paleontology 87 (2013), pp. 1136-1142.

[6471] D. K. Elliott and R. R. Ilyes. "New Early Devonian pteraspidids (Agnatha, Heterostraci) from Death Valley National Monument, southeastern California". English. In: Journal of Paleontology 70.1 (1996), pp. 152-161. DOI: 10.1017/S0022336000023180.

[6472] D. K. Elliott, G. V. Irby, and J. H. Hutchison. “Desmatochelys lowi, a marine turtle from the Upper Cretaceous". English. In: Ancient Marine Reptiles. San Diego: Academic Press, 1997, pp. 243-257.

[6473] D. K. Elliott, R. Irmis, M. C. Hansen, and T. J. Olson. "Chondrichthyans from the Pennsylvanian (Desmoinesian) Naco Formation of Central Arizona". English. In: Journal of Vertebrate Paleontology 24.2 (2004), pp. 268-280.

[6474] D. K. Elliott and S. Swift. "A new species of Ariaspis (Agnatha, Heterostraci) from the Late Silurian of the Canadian Arctic". English. In: Journal of Vertebrate Paleontology 30.6 (2010), pp. 1874-1878.

[6475] S. Elmi, A. Marok, A. Sebane, and Y. Alméras. "Importance of the Mellala section (Traras Mountains, northwestern Algeria) for the correlation of the Pliensbachian-Toarcian boundary". English. In: Volumina Jurassica 7 (2009), pp. 37-45.

[6476] E. Eltink, M. Castro, F. C. Montefeltro, M. A. T. Dantas, C. S. Scherer, P. V. Oliveira, and M. C. Langer. "Mammalian fossils from Gruta do Ioio cave and past of the Chapada Diamantina, northeastern Brazil, using taphonomy, radiocarbon dating and paleoecology". English. In: Journal of South American Earth Sciences 98 (2020), 102379:1-16.

[6477] E. Eltink, A. A. S. Da-Rosa, and S. Dias-da-Silva. "A capitosauroid from the Lower Triassic of South America (Sanga do Cabral Supersequence: Paraná Basin), its phylogenetic relationships and biostratigraphic implications". English. In: Historical Biology 29 (2017), pp. 863-874. DOI: 10. 1080/08912963.2016.1255736.

[6478] E. Eltink and M. C. Langer. "A new specimen of the temnospondyl Australerpeton cosgriffi from the late Permian of Brazil (Rio do Rasto Formation, Parana Basin): comparative anatomy and phylogenetic relationships". English. In: Journal of Vertebrate Paleontology 34.3 (2014), pp. 524-538. 
[6479] R. C. Ely and J. A. Case. “Phylogeny of a new gigantic paravian (Theropoda; Coelurosauria; Maniraptora) from the Upper Cretaceous of James Ross Island, Antarctica". English. In: Cretaceous Research 101 (2019), pp. 1-16.

[6480] A. Elzanowski. "A new genus and species for the largest specimen of Archaeopteryx". English. In: Acta Palaeontologica Polonica 46.4 (2001), pp. 519-532.

[6481] A. Elzanowski and W. E. Boles. “Australia's oldest anseriform fossil: a quadrate from the early Eocene Tingamarra Fauna”. English. In: Palaeontology 55.4 (2012), pp. 903-911.

[6482] A. Elzanowski and M. K. Brett-Surman. "Avian premaxilla and tarsometatarsus from the uppermost Cretaceous of Montana". English. In: The Auk 112.3 (1995), pp. 762-767.

[6483] A. Elzanowski, G. S. Paul, and T. A. Stidham. "An avian quadrate from the Late Cretaceous Lance Formation of Wyoming". English. In: Journal of Vertebrate Paleontology 20.4 (2001), pp. 712-719.

[6484] A. Elzanowski and T. A. Stidham. "A galloanserine quadrate from the Late Cretaceous Lance Formation of Wyoming". English. In: The Auk 128.1 (2011), pp. 138-145.

[6485] A. Elzanowski and P. Wellnhofer. "A new link between theropods and birds from the Cretaceous of Mongolia". In: Nature 359 (1992), pp. 821-823.

[6486] A. F. Emeljanov. "Two new genera of the family Derbidae from the new world, with description of Recent and an extinct Miocene new species (Homoptera, Fulgoroidea)". English. In: Entomological Review 88 (2008), pp. 910-915.

[6487] A. F. Emeljanov. "A record of Derbidae (Insecta: Homoptera: Fulgoroidea) in the Miocene of the northern Caucasus". English. In: Paleontological Journal 36 (2002), pp. 277-278.

[6488] A. F. Emeljanov. "A new genus and a new tribe of the family Achilidae (Homoptera, Cicadina) from the Baltic amber". Russian. In: Vestnik Zoologii 1990.6 (1990), pp. 6-10.

[6489] A. F. Emeljanov and D. E. Shcherbakov. "New planthoppers of the tribe Achilini (Homoptera, Fulgoroidea, Achilidae) from Baltic amber". English. In: Paleontological Journal 43 (2009), pp. 10081018.

[6490] A. F. Emeljanov and D. E. Shcherbakov. "A new genus and species of Dictyopharidae (Homoptera) from Rovno and Baltic amber based on nymph". English. In: ZooKeys 130 (2011), pp. 175-184.

[6491] A. F. Emeljanov and D. E. Shcherbakov. "Kinnaridae and Derbidae (Homoptera, Fulgoroidea) from the Dominican amber". English. In: Neues Jahrbuch für Geologie und Paläontologie, Monatshefte 2000.7 (2000), pp. 438-448.

[6492] A. F. Emeljanov and D. E. Shcherbakov. “The longest-nosed Mesozoic Fulgoroidea (Homoptera): a new family from mid-Cretaceous Burmese amber". English. In: Far Eastern Entomologist 354 (2018), pp. 1-14.

[6493] A. F. Emeljanov and D. E. Shcherbakov. "A new genus of Dictyopharidae (Homoptera) from Bitterfeld amber based on a nymph". English. In: Far Eastern Entomologist 403 (2020), pp. 1-12.

[6494] A. F. Emeljanov and D. E. Shcherbakov. “The first Mesozoic Derbidae (Homoptera: Fulgoroidea) from Cretaceous Burmese amber". English. In: Russian Entomological Journal 29 (2020), pp. 237246.

[6495] M. M. Emery, E. B. Davis, and S. S. B. Hopkins. "Systematic reassessment of an agriochoerid oreodont from the Hancock Mammal Quarry, Clarno (Eocene, Duchesnean), Oregon". English. In: Journal of Vertebrate Paleontology 36.2 (2016), e1041970. DOI: 10.1080/02724634.2015.1041970.

[6496] M. M. Emery-Wetherell and J. F. Schilter. "A new early occurrence of Cervidae in North America from the Miocene-Pliocene Ellensburg Formation in Washington, USA". English. In: Palaeontologia Electronica 23.a08 (2020).

[6497] C. C. Emig and M. A. Bitner. "The brachiopod Lingula in the Middle Miocene of the Central Paratethys". English. In: Acta Palaeontologica Polonica 50.1 (2005), pp. 181-184.

[6498] C. C. Emig and M. A. Bitner. "Glottidia (Brachiopod: Lingulidae) from the Eocene La Meseta Formation, Seymour Island, Antarctica". English. In: Palaeontology 48.2 (2005), pp. 423-431. 
[6499] C. C. Emig and Z. Herrera. "Dignomia munsterii (Brachiopoda, Lingulata) from the Ordovician of Bolivia, with redescription of the genus". English. In: Geodiversitas 28.2 (2006), pp. 227-237.

[6500] A. Emmerich, V. Zamparelli, T. Bechstädt, and R. Zühlke. “The reefal margin and slope of a Middle Triassic carbonate platform: the Latemar (Dolomites, Italy)". In: Facies 50.3-4 (2005), pp. 573-614.

[6501] R. J. Emry. Mammals of the Bridgerian (middle Eocene) Elderberry Canyon Local Fauna of eastern Nevada. English. Vol. 243. Dawn of the Age of Mammals in the Northern Part of the Rocky Mountain Interior, North America. Geological Society of America Special Paper. 1990, pp. 187-210.

[6502] R. J. Emry. "Mammalian Range Zones in the Chadronian White River Formation at Flagstaff Rim, Wyoming". English. In: Eocene-Oligocene Climatic and Biotic Evolution. Princeton: Princeton University Press, 1992, pp. 106-115.

[6503] R. J. Emry and W. W. Korth. "Evolution in Yoderimyinae (Eomyidae: Rodentia), with New Material from the White River Formation (Chadronian) at Flagstaff Rim, Wyoming". English. In: Journal of Paleontology 67.6 (1993).

[6504] R. J. Emry, W. W. Korth, and M. A. Bell. "A tree squirrel (Rodentia, Sciuridae, Sciurini) from the late Miocene (Clarendonian) of Nevada". English. In: Journal of Vertebrate Paleontology 25.1 (2005), pp. 228-235.

[6505] R. J. Emry and W. W. Korth. "A new genus of squirrel (Rodentia, Sciuridae) from the mid-Cenozoic of North America". English. In: Journal of Vertebrate Paleontology 27.3 (2007), pp. 693-698. DOI: 10.1671/0272-4634(2007)27[693:ANGOSR]2.0.CO;2.

[6506] R. J. Emry and W. W. Korth. "Early Chadronian (late Eocene) rodents from the Flagstaff Rim area, central Wyoming". English. In: Journal of Vertebrate Paleontology 32.2 (2012), pp. 419-432. DOI: 10.1080/02724634.2012.649329.

[6507] R. J. Emry, L. A. Tyutkova, S. G. Lucas, and B. Wang. "Rodents of the middle Eocene Shinzhaly fauna of Eastern Kazakstan". English. In: Journal of Vertebrate Paleontology 18.1 (1998), pp. 218-227.

[6508] R. J. Emry, B. Wang, L. A. Tjutkova, and S. G. Lucas. "A late Eocene eomyid rodent from the Zaysan Basin of Kazakhstan". English. In: Journal of Vertebrate Paleontology 17.1 (1997), pp. 229234.

[6509] S. D. Emslie. "The fossil record of Arctodus pristinus (Ursidae: Tremarctinae) in Florida". English. In: Bulletin of the Florida Museum of Natural History 37.15 (1995), pp. 501-514.

[6510] S. D. Emslie. "The early and middle Pleistocene avifauna from Porcupine Cave". English. In: Biodiversity response to climate change in the middle Pleistocene; the Porcupine Cave fauna from Colorado. 2004, pp. 127-140.

[6511] S. D. Emslie. "Avian community, climate, and sea-level changes in the Plio-Pleistocene of the Florida Peninsula". English. In: Ornithological Monographs 50 (1998), pp. 1-113.

[6512] S. D. Emslie. "An early Irvingtonian avifauna from Leisey Shell Pit, Florida". English. In: Bulletin of the Florida Museum of Natural History 37.10 (1995), pp. 299-344.

[6513] S. D. Emslie. "Two new late Blancan avifaunas from Florida and the extinction of wetland birds in the Plio-Pleistocene". English. In: Natural History Museum of Los Angeles County, Science Series 36 (1992), pp. 249-269.

[6514] S. D. Emslie. "A catastrophic death assemblage of a new species of cormorant and other sea birds from the late Pliocene of Florida". English. In: Journal of Vertebrate Paleontology 15.2 (1995), pp. 313330.

[6515] S. D. Emslie, W. D. Allmon, F. J. Rich, J. H. Wrenn, and S. D. de France. "Integrated taphonomy of an avian death assemblage in marine sediments from the late Pliocene of Florida". English. In: Palaeogeography, Palaeoclimatology, Palaeoecology 124 (1996), pp. 107-136.

[6516] S. D. Emslie and C. G. Correa. "A new species of penguin (Spheniscidae: Spheniscus) and other birds from the late Pliocene of Chile". English. In: Proceedings of the Biological Society of Washington 116.2 (2003), pp. 308-316. 
[6517] S. D. Emslie and N. J. Czaplewski. "Two new fossil eagles from the late Pliocene (late Blancan) of Florida and Arizona and their biogeographic implications". English. In: Smithsonian Contributions to Paleobiology 89 (1999), pp. 185-198.

[6518] S. D. Emslie and G. S. Morgan. "A catastrophic death assemblage and paleoclimatic implications of Pliocene seabirds of Florida". English. In: Science 264 (1994), pp. 684-684.

[6519] S. D. Emslie and G. S. Morgan. "Taphonomy of a late Pleistocene carnivore den, Dade County, Florida". English. In: Late Quaternary Environments and Deep History: A Tribute to Paul Martin. Hot Springs: Mammoth Site of Hot Springs, 1995, pp. 65-83.

[6520] R. Enay, G. Barale, J. Jacay, and E. Jaillard. "Upper Tithonian Ammonites and Floras from the Chicama Basin, Northern Peruvian Andes". English. In: GeoResearch Forum 1-2 (1996), pp. 221234.

[6521] R. Enay, M. Boughdiri, and G. Le Hégarat. “Toucasiella gen. nov., Himalayitidae (Ammonitina) nouveau du Tithonien supérieur: origine de Durangites". French. In: Comptes Rendus de l'Académie des Sciences Paris, Sciences de la Terre et des Planétes 327 (1998), pp. 471-477.

[6522] A. Encinas. Presencia de vertebrados marinos neógenos en la Formación Lo Abarca, Chile central. Spanish. 2002.

[6523] M. S. Engel. "A New Interpretation of the Oldest Fossil Bee (Hymenoptera: Apidae)". English. In: American Museum Novitates 3296 (2000), pp. 1-12.

[6524] M. S. Engel. "A New Fossil Snake-Fly Species from Baltic Amber (Raphidioptera: Inocelliidae)". English. In: Psyche 102 (1995), pp. 187-193. DOI: 10.1155/1995/23626.

[6525] M. S. Engel. "A New Species of the Baltic Amber Bee Genus Electrapis (Hymenoptera: Apidae)". English. In: Journal of Hymenoptera Research 7.1 (1998), pp. 94-101.

[6526] M. S. Engel. "The fossil pelecinid Pelecinopteron tubuliforme Brues in Baltic amber (Hymenoptera: Pelecinidae)". English. In: Journal of Hymenoptera Research 11 (2002), pp. 5-11.

[6527] M. S. Engel. "A Miocene snakefly from Stewart Valley, Nevada (Raphidioptera: Raphidiidae)". English. In: Transactions of the Kansas Academy of Science 112.4 (2009), pp. 211-214.

[6528] M. S. Engel. "A giant honey bee from the middle Miocene of Japan (Hymenoptera: Apidae)". English. In: American Museum Novitates 3504 (2006), pp. 1-12.

[6529] M. S. Engel. "A New Dustywing (Neuroptera: Coniopterygidae) in Turonian Amber from New Jersey, with a Reassessment of Glaesoconis in Neocomian Amber from Lebanon". English. In: Journal of the Kansas Entomological Society 75.1 (2002), pp. 38-42.

[6530] M. S. Engel. "Megatypus parvus spec. nov., a new giant dragonfly from the Lower Permian of Kansas (Protodonata: Meganeuridae)". English. In: Odonatologica 27.3 (1998), pp. 361-364.

[6531] M. S. Engel. "The first large carpenter bee from the Tertiary of North America, with a consideration of the geological history of Xylocopinae (Hymenoptera: Apidae)". English. In: Transactions of the American Entomological Society 127.2 (2001), pp. 245-254.

[6532] M. S. Engel. “A remarkable kalligrammatid lacewing from the Upper Jurassic Kazakhstan (Neuroptera: Kalligrammatidae)". English. In: Transactions of the Kansas Academy of Science 108.1/2 (2005), pp. 59-62.

[6533] M. S. Engel. “The smallest snakefly (Raphidioptera: Mesoraphidiidae): a new species in Cretaceous amber from Myanmar, with a catalog of fossil snakeflies". English. In: American Museum Novitates 3363 (2002), pp. 1-22.

[6534] M. S. Engel. "The dustywings in Cretaceous Burmese amber (Insecta: Neuroptera: Coniopterygidae)". English. In: Journal of Systematic Palaeontology 2 (2004), pp. 133-136.

[6535] M. S. Engel. “The wasp family Rhopalosomatidae in mid-Cretaceous amber from Myanmar (Hymenoptera: Vespoidea)". English. In: Journal of the Kansas Entomological Society 81.3 (2008), pp. 168174. 
[6536] M. S. Engel. “Thorny lacewings (neuroptera: Rhachiberothidae) in Cretaceous Amber from Myanmar". English. In: Journal of Systematic Palaeontology 2 (2004), pp. 137-140.

[6537] M. S. Engel. "A stem-group cimicid in mid-Cretaceous amber from Myanmar (Hemiptera: Cimicoidea)". English. In: Alavesia 2 (2008), pp. 233-237.

[6538] M. S. Engel. "Gregarious behaviour in Cretaceous earwig nymphs (Insecta, Dermaptera) from southwestern France". English. In: Geodiversitas 31 (2009), pp. 129-135.

[6539] M. S. Engel. "Classification of the bee tribe Augochlorini (Hymenoptera: Halictidae)". English. In: Bulletin of the American Museum of Natural History 250 (2000), pp. 1-90.

[6540] M. S. Engel. "A monograph of the Baltic amber bees and evolution of the Apoidea (Hymenoptera)". English. In: Bulletin of the American Museum of Natural History 259 (2001), pp. 1-192.

[6541] M. S. Engel. "The first fossil of a pleasing lacewing (Neuroptera: Dilaridae)". English. In: Proceedings of the Entomological Society of Washington 101 (1999), pp. 822-826.

[6542] M. S. Engel. "Megachile glaesaria, the First Megachilid Bee Fossil from Amber (Hymenoptera: Megachilidae)". English. In: American Museum Novitates 3276 (1999), pp. 1-13.

[6543] M. S. Engel. "Neocorynura electra, a New Fossil Bee Species from Dominican Amber (Hymenoptera: Halictidae)". English. In: Journal of the New York Entomological Society 103.3 (1995), pp. 317-323.

[6544] M. S. Engel. "Two New Termites in Baltic Amber (Isoptera)". English. In: Journal of the Kansas Entomological Society 81.3 (2008), pp. 194-203.

[6545] M. S. Engel. "An Anteonine Wasp in Cenomanian-Albian Amber from Myanmar (Hymenoptera: Dryinidae)". English. In: Journal of the Kansas Entomological Society 76.4 (2003), pp. 616-621.

[6546] M. S. Engel. "Two new halictine bees in Miocene amber from the Dominican Republic (Hymenoptera, Halictidae)". English. In: ZooKeys 29 (2009), pp. 1-12.

[6547] M. S. Engel. "New augochlorine bees (Hymenoptera: Halictidae) in Dominican amber, with a brief review of fossil Halictidae". English. In: Journal of the Kansas Entomological Society 69 (1996), pp. 334-345.

[6548] M. S. Engel. “The first fossil leptofoenine wasp (Hymenoptera, Pteromalidae): A new species of Leptofoenus in Miocene amber from the Dominican Republic". English. In: ZooKeys 13 (2009), pp. 57-66.

[6549] M. S. Engel. "A new termite bug in Miocene amber from the Dominican Republic (Hemiptera, Termitaphididae)". English. In: ZooKeys 45 (2009), pp. 61-68.

[6550] M. S. Engel. "A new apterous Zorotypus in Miocene amber from the Dominican Republic (Zoraptera: Zorotypidae)". English. In: Acta Entomologica Slovenica 16 (2008), pp. 127-136.

[6551] M. S. Engel. "A new Lower Permian bristletail from the Wellington Formation in Kansas (archaeognatha: Dasyleptidae)". English. In: Transactions of the Kansas Academy of Science 112.1/2 (2009), pp. 40-44.

[6552] M. S. Engel. "A new species of Ctenoplectrella in Baltic amber (Hymenoptera: Megachilidae)". English. In: Acta Zoologica Academiae Scientiarum Hungaricae 54.4 (2008), pp. 319-324.

[6553] M. S. Engel. "A new sawfly from the Triassic of Queensland (Hymenoptera: Xyelidae)". English. In: Memoirs of the Queensland Museum 51.2 (2005), p. 558.

[6554] M. S. Engel. "A new snakefly from the Eocene Green River Formation (Raphidioptera: Raphidiidae)". English. In: Transactions of the Kansas Academy of Science 114 (2011), pp. 77-87.

[6555] M. S. Engel. "A new genus of dustywings allied to Archiconiocompsa in Baltic Amber (Neuroptera: Coniopterygidae)". English. In: Transactions of the Kansas Academy of Science 113 (2010), pp. $145-150$.

[6556] M. S. Engel. “A new Eocene-Oligocene snakefly from Florissant, Colorado (Raphidioptera: Raphidiidae)". English. In: Transactions of the Kansas Academy of Science 106 (2003), pp. 124-128.

[6557] M. S. Engel. "Notes on a megachiline bee (Hymenoptera: Megachilidae) from the Miocene of Idaho". English. In: Transactions of the Kansas Academy of Science 107 (2004), pp. 97-100. 
[6558] M. S. Engel. “The first fossil Euglossa and phylogeny of the orchid bees (Hymenoptera: Apidae; Euglossini". English. In: American Museum Novitates 3272 (1999), pp. 1-14.

[6559] M. S. Engel. "A new xeromelissine bee in Tertiary amber of the Dominican Republic (Hymenoptera: Colletidae)". English. In: Entomologica Scandinavica 30 (1999), pp. 453-458.

[6560] M. S. Engel. "An orussid wood wasp in amber from the Dominican Republic (Hymenoptera: Orussidae)". English. In: Transactions of the Kansas Academy of Science 111 (2008), pp. 39-44.

[6561] M. S. Engel. "A new fossil bee from the Oligo-Miocene Dominican amber (Hymenoptera: Halictidae)". English. In: Apidologie 28 (1997), pp. 97-102.

[6562] M. S. Engel. "A new cuckoo wasp of the genus Ceratochrysis in amber from the Dominican Republic (Hymenoptera: Chrysididae)". English. In: Polskie Pismo Entomologiczne 75 (2006), pp. 499504.

[6563] M. S. Engel. "The first leucospid wasp from the fossil record (Hymenoptera: Leucospidae)". English. In: Journal of Natural History 36 (2002), pp. 435-441.

[6564] M. S. Engel. "An Eocene ectoparasite of bees: the oldest definitive record of phoretic meloid triungulins (Coleoptera: Meloidae; Hymenoptera: Megachilidae)". English. In: Acta Zoologica Cracoviensia 48B (2005), pp. 43-48.

[6565] M. S. Engel. “Two ensign wasps in Cretaceous amber from New Jersey and Myanmar (Hymenoptera: Evaniidae)". English. In: Polish Journal of Entomology 75 (2006), pp. 443-454.

[6566] M. S. Engel. "A ceraphronid wasp in Early Miocene amber from the Dominican Republic (Hymenoptera: Ceraphronidae)". English. In: Novitates Paleoentomologicae 2 (2013), pp. 1-6.

[6567] M. S. Engel. "A new genus and species of Baissidae in Late Cretaceous amber from New Jersey (Hymenoptera: Evanioidea)". English. In: Novitates Paleoentomologicae 3 (2013), pp. 1-8.

[6568] M. S. Engel. "New earwigs in mid-Cretaceous amber from Myanmar (Dermaptera, Neodermaptera)". English. In: ZooKeys 130 (2011), pp. 137-152.

[6569] M. S. Engel. "Fossil honey bees and evolution in the genus Apis (Hymenoptera: Apidae)". English. In: Apidologie 29 (1998), pp. 265-281.

[6570] M. S. Engel. “A dryinine wasp in Burmese amber (Hymenopter: Dryinidae)”. English. In: Polskie Pismo Entomologiczne 74 (2005), pp. 485-494.

[6571] M. S. Engel. “The crown wasp genus Electrostephanus (Hymenoptera: Stephanidae): discovery of the female and a new species". English. In: Polskie Pismo Entomologiczne 74 (2005), pp. 317-332.

[6572] M. S. Engel. "Halictine bees from the Eocene-Oligocene boundary of Florissant, Colorado (Hymenoptera: Halictidae)". English. In: Neues Jahrbuch für Geologie und Paläontologie, Abhandlungen 225 (2002), pp. 251-273.

[6573] M. S. Engel. "An orchid bee of the genus Eulaema in early Miocene Mexican amber (Hymenoptera: Apidae)". English. In: Novitates Paleoentomologicae 7 (2014), pp. 1-15.

[6574] M. S. Engel. "A primitive anobiid beetle in mid-Cretaceous amber from Myanmar (Coleoptera: Anobiidae)". English. In: Alavesia 3 (2010), pp. 31-34.

[6575] M. S. Engel. "A termite (Isoptera) in Late Cretaceous amber from Vendée, northwestern France". English. In: Paleontological Contributions 10 (2014), pp. 21-24.

[6576] M. S. Engel. "The wasp genus Clystopsenella in Early Miocene amber from the Dominican Republic (Hymenoptera: Scolebythidae)". English. In: Novitates Paleoentomologicae 12 (2015), pp. 114.

[6577] M. S. Engel. "A new family of primitive serphitoid wasps in Lebanese amber (Hymenoptera: Serphitoidea)". English. In: Novitates Paleoentomologicae 13 (2015), pp. 1-22.

[6578] M. S. Engel. “Notes on Cretaceous amber Braconidae (Hymenoptera), with descriptions of two new genera". English. In: Novitates Paleoentomologicae 15 (2016), pp. 1-7.

[6579] M. S. Engel. "A new species of the booklouse genus Embidopsocus in Baltic amber (Psocoptera: Liposcelididae)". English. In: Novitates Paleoentomologicae 16 (2016), pp. 1-9. 
[6580] M. S. Engel. “Two new genera of Cretaceous dustywings in amber from northern Myanmar (Neuroptera: Coniopterygidae)". English. In: Novitates Paleoentomologicae 17 (2016), pp. 1-16.

[6581] M. S. Engel. "A new genus and species of maimetshid wasps in Lebanese Early Cretaceous amber (Hymenoptera: Maimetshidae)". English. In: Novitates Paleoentomologicae 18 (2016), pp. 1-14.

[6582] M. S. Engel. “New evanioid wasps from the Cenomanian of Myanmar (Hymenoptera: Othniodellithidae, Aulacidae), with a summary of family-group names among Evanioidea". English. In: American Museum Novitates 3871 (2017), pp. 1-28.

[6583] M. S. Engel and S. B. Archibald. "An Early Eocene bee (Hymenoptera: Halictidae) from Quilchena, British columbia". English. In: The Canadian Entomologist 135 (2003), pp. 63-69.

[6584] M. S. Engel, P. Barden, M. L. Riccio, and D. A. Grimaldi. "Morphologically specialized termite castes and advanced sociality in the Early Cretaceous". English. In: Current Biology 26 (2016), pp. 522-530.

[6585] M. S. Engel and D. J. Bennett. “Anoblepsis, a New, Bizarre Braconid Wasp Genus in Dominican Amber (Hymenoptera: Braconidae)". English. In: Journal of the Kansas Entomological Society 81.4 (2008), pp. 368-372.

[6586] M. S. Engel and L. C. V. Breitkreuz. "A male of the bee genus Agapostemon in Dominican amber (Hymenoptera: Halictidae)". English. In: Journal of Melittology 16 (2013), pp. 1-9.

[6587] M. S. Engel, L. C. V. Breitkreuz, and M. Ohl. "The first male of the extinct bee tribe Melikertini (Hymenoptera: Apidae)". English. In: Journal of Melittology 30 (2014), pp. 1-18.

[6588] M. S. Engel, L. C. V. Breitkreuz, C. Y. Cai, M. Alvarado, D. Azar, and D. Y. Huang. "The first Mesozoic microwhip scorpion (Palpigradi): a new genus and species in mid-Cretaceous amber from Myanmar". English. In: The Science of Nature 103.19 (2016), pp. 1-7.

[6589] M. S. Engel and S. Chatzimanolis. "Early Cretaceous earwigs (Dermaptera) from the Santana Formation, Brazil". English. In: Polskie Pismo Entomologiczne 74 (2005), pp. 219-226.

[6590] M. S. Engel and S. Chatzimanolis. "An oxyteline rove beetle in Dominican amber with possible African affinities (Coleoptera: Staphylinidae: Oxytelinae)". English. In: Annals of the Carnegie Museum 77 (2009), pp. 425-429.

[6591] M. S. Engel, E. D. Currano, and B. F. Jacobs. "The first mastotermitid termite from Africa (Isoptera: Mastotermitidae): a new species of Mastotermes from the early Miocene of Ethiopia". English. In: Journal of Paleontology 89 (2016), pp. 1038-1042.

[6592] M. S. Engel and X. Delclós. "Primitive termites in Cretaceous amber from Spain and Canada (Isoptera)". English. In: Journal of the Kansas Entomological Society 83 (2010), pp. 111-128.

[6593] M. S. Engel and D. A. Grimaldi. "A new rock crawler in Baltic Amber, with comments on the order (Mantophasmatodea: Mantophasmatidae)". English. In: American Museum Novitates 3431 (2004), pp. 1-11.

[6594] M. S. Engel and D. A. Grimaldi. "Primitive New Ants in Cretaceous Amber from Myanmar, New Jersey, and Canada (Hymenoptera: Formicidae)". English. In: American Museum Novitates 3485 (2005), pp. 1-24. DOI: 10.1206/0003-0082(2005)485[0001:PNAICA]2.0.CO;2.

[6595] M. S. Engel and D. A. Grimaldi. “The first Cretaceous spider wasp (Hymenoptera: Pompilidae)". English. In: Journal of the Kansas Entomological Society 79.4 (2006), pp. 359-368.

[6596] M. S. Engel and D. A. Grimaldi. "A primitive earwig in Cretaceous amber from Myanmar (Dermaptera: Pygidicranidae)". English. In: Journal of Paleontology 78 (2004), pp. 1018-1023.

[6597] M. S. Engel and D. A. Grimaldi. "The first Mesozoic Zoraptera (Insecta)". English. In: American Museum Novitates 3362 (2002), pp. 1-20.

[6598] M. S. Engel and D. A. Grimaldi. “The earliest webspinners (Insecta: Embiodea)". English. In: American Museum Novitates 3514 (2006), pp. 1-15.

[6599] M. S. Engel, D. A. Grimaldi, and K. Krishna. "Primitive termites from the Early Cretaceous of Asia (Isoptera)". English. In: Stuttgarter Beiträge zur Naturkunde Serie B (Geologie und Paläontologie) 371 (2007), pp. 1-32. 
[6600] M. S. Engel and D. A. Grimaldi. “The first Mesozoic stephanid wasp (Hymenoptera: Stepanidae)”. English. In: Journal of Paleontology 78 (2004), pp. 1192-1197.

[6601] M. S. Engel and D. A. Grimaldi. “Diversity and phylogeny of the Mesozoic wasp family Stigmaphronidae (Hymenoptera: Ceraphronoidea)". English. In: Denisia 26 (2009), pp. 53-68.

[6602] M. S. Engel and D. A. Grimaldi. "New False Fairy Wasps in Cretaceous Amber from New Jersey and Myanmar (Hymenoptera: Mymarommatoidea)". English. In: Transactions of the Kansas Academy of Science 110.3/4 (2007), pp. 159-168.

[6603] M. S. Engel and D. A. Grimaldi. "The first Cretaceous sclerogibbid wasp (Hymenoptera: Sclerogibbidae)". English. In: American Museum Novitates 3515 (2006), pp. 1-7.

[6604] M. S. Engel, D. A. Grimaldi, H. Singh, and P. C. Nascimbene. "Webspinners in early Eocene amber from western India (Insecta: Embiodea)". English. In: ZooKeys 148 (2011), pp. 197-208.

[6605] M. S. Engel, D. A. Grimaldi, P. C. Nascimbene, and H. Singh. "The termites of Early Eocene Cambay amber, with the earliest record of the Termitidae (Isoptera)". English. In: ZooKeys 148 (2011), pp. 105-123.

[6606] M. S. Engel and D. A. Grimaldi. "A winged Zorotypus in Miocene amber from the Dominican Republic (Zoraptera: Zorotypidae), with discussion on relationships of and within the order". English. In: Acta Geologica Hispanica 35 (2000), pp. 149-164.

[6607] M. S. Engel and D. A. Grimaldi. "A Diminutive Pelecinid Wasp in Cretaceous Amber from New Jersey (Hymenoptera: Pelecinidae)". English. In: Northeastern Naturalist 13.2 (2006), pp. 291-297.

[6608] M. S. Engel and D. A. Grimaldi. "Cretaceous Scolebythidae and phylogeny of the family (Hymenoptera: Chrysidoidea)". English. In: American Museum Novitates 3568 (2007), pp. 1-16.

[6609] M. S. Engel, D. A. Grimaldi, V. H. Gonzalez, I. A. Hinojosa-Daz, and C. D. Michener. "An Exomalopsine bee in early Miocene amber from the Dominican Republic (Hymenoptera: Apidae)". English. In: American Museum Novitates 3758 (2012), pp. 1-16.

[6610] M. S. Engel and D. A. Grimaldi. "The neuropterid fauna of Dominican and Mexican amber (Neuropterida: Megaloptera, Neuroptera)". English. In: American Museum Novitates 3587 (2007), pp. 158.

[6611] M. S. Engel, D. A. Grimaldi, and K. Krishna. "A synopsis of Baltic amber termites (Isoptera)". English. In: Stuttgarter Beiträge zur Naturkunde Serie B (Geologie und Paläontologie) 372 (2007), pp. 120.

[6612] M. S. Engel and D. A. Grimaldi. "A jugular-horned beetle in Cretaceous amber from Myanmar (Coleoptera: Prostomidae)". English. In: Alavesia 2 (2008), pp. 215-218.

[6613] M. S. Engel, D. A. Grimaldi, and J. Ortega-Blanco. "Zoropelecinus zigrasi, a pelecinid wasp in mid-Cretaceous amber from Myanmar (Hymenoptera: Pelecinidae)". English. In: Novitates Paleoentomologicae 4 (2013), pp. 1-10.

[6614] M. S. Engel, D. A. Grimaldi, and J. Ortega-Blanco. “A stephanid wasp in mid-Cretaceous Burmese amber (Hymenoptera: Stephanidae), with comments on the antiquity of the hymenopteran radiation". English. In: Journal of the Kansas Entomological Society 86 (2013), pp. 244-252.

[6615] M. S. Engel, D. A. Grimaldi, and J. Ortega-Blanco. "Serphitid wasps in Cretaceous amber from New Jersey (Hymenoptera: Serphitidae)". English. In: Insect Systematics E Evolution 42 (2011), pp. 197-204.

[6616] M. S. Engel and D. A. Grimaldi. "Diverse Neuropterida in Cretaceous amber, with particular reference to the paleofauna of Myanmar (Insecta)". English. In: Nova Supplementa Entomologica 20 (2008), pp. 1-86.

[6617] M. S. Engel and D. A. Grimaldi. "New mid-Cretaceous earwigs in amber from Myanmar (Dermaptera)". English. In: Novitates Paleoentomologicae 6 (2014), pp. 1-16.

[6618] M. S. Engel and D. A. Grimaldi. "Whipspiders (Arachnida: Amblypygi) in amber from the early Eocene and mid-Cretaceous, including maternal care". English. In: Novitates Paleoentomologicae 9 (2014), pp. 1-17. 
[6619] M. S. Engel and M. Gross. "A giant termite from the Late Miocene of Styria, Austria (Isoptera)". English. In: Naturwissenschaften 96 (2009), pp. 289-295. DOI: 10.1007/s00114-008-0480-y.

[6620] M. S. Engel and M. Gross. "A new fossil crane fly from the early Pannonian of the Styrian basin (Diptera: Tipulidae)". English. In: Journal of the Kansas Entomological Society 85 (2012), pp. 160-163.

[6621] M. S. Engel, I. A. Hinojosa-Daz, and A. P. Rasnitsyn. "A honey bee from the Miocene of Nevada and the biogeography of Apis (Hymenoptera: Apidae: Apini)". English. In: Proceedings of the California Academy of Sciences 60.3 (2009), pp. 23-38.

[6622] M. S. Engel, D. Y. Huang, and Q. B. Lin. "A new genus and species of Aetheogrammatidae from the Jurassic of Inner Mongolia, China (Neuroptera)". English. In: Journal of the Kansas Entomological Society 84.4 (2011), pp. 315-319.

[6623] M. S. Engel, D. Y. Huang, D. Azar, A. Nel, S. R. Davis, M. Alvarado, and L. C. V. Breitkreuz. "The wasp family Spathiopterygidae in mid-Cretaceous amber from Myanmar (Hymenoptera: Diaprioidea)". English. In: Comptes Rendus Palevol 14 (2015), pp. 95-100.

[6624] M. S. Engel, D. Y. Huang, L. C. V. Breitkreuz, C. Y. Cai, and M. Alvarado. "Two new species of mid-Cretaceous webspinners in amber from northern Myanmar (Embiodea: Clothodidae, Oligotomidae)". English. In: Cretaceous Research 58 (2016), pp. 118-124.

[6625] M. S. Engel, D. Y. Huang, L. C. V. Breitkreuz, D. Azar, C. Y. Cai, and M. Alvarado. “A new twistedwing parasitoid from mid-Cretaceous amber of Myanmar (Strepsiptera)". English. In: Cretaceous Research 58 (2016), pp. 160-167.

[6626] M. S. Engel, D. Y. Huang, A. S. Alqarni, and C. Y. Cai. “A remarkable evanioid wasp in midCretaceous amber from northern Myanmar (Hymenoptera: Evanioidea)". English. In: Cretaceous Research 60 (2016), pp. 121-127.

[6627] M. S. Engel, D. Y. Huang, A. S. Alqarni, and C. Y. Cai. "An unusual new lineage of sawflies (Hymenoptera) in Upper Cretaceous amber from northern Myanmar". English. In: Cretaceous Research 60 (2016), pp. 281-286.

[6628] M. S. Engel and D. Y. Huang. "A new crown wasp in Cretaceous amber from Myanmar (Hymenoptera: Stephanidae)". English. In: Cretaceous Research 69 (2016), pp. 56-61.

[6629] M. S. Engel, D. Y. Huang, J. C. Thomas, and C. Y. Cai. "A new genus and species of pygidicranid earwigs from the Upper Cretaceous of southern Asia (Dermaptera: Pygidicranidae)". English. In: Cretaceous Research 69 (2016), pp. 178-183.

[6630] M. S. Engel, D. Y. Huang, A. S. Alqarni, C. Y. Cai, M. Alvarado, L. C. V. Breitkreuz, and D. Azar. "An apterous scelionid wasp in mid-Cretaceous Burmese amber (Hymenoptera: Scelionidae)". English. In: Comptes Rendus Palevol 16 (2016), pp. 5-11.

[6631] M. S. Engel, D. Y. Huang, C. Y. Cai, and A. S. Alqarni. "A new lineage of braconid wasps in Burmese Cenomanian amber (Hymenoptera, Braconidae)". English. In: ZooKeys 730 (2018), pp. 7384.

[6632] M. S. Engel and U. Kaulfuss. "Diverse, primitive termites (Isoptera: Kalotermitidae, incertae sedis) from the early Miocene of New Zealand". English. In: Austral Entomology 56 (2016), pp. 94-103.

[6633] M. S. Engel and R. K. Kinzelbach. "A primitive moth from the earliest Eocene Fur Formation (Moclay) of Denmark (Lepidoptera: Micropterigidae)". English. In: Linzer Biologische Beiträge 40 (2008), pp. 1443-1448.

[6634] M. S. Engel and K. Krishna. "New Dolichorhinotermes from Ecuador and in Mexican Amber (Isoptera: Rhinotermitidae)". English. In: American Museum Novitates 3592 (2007), pp. 1-8.

[6635] M. S. Engel and K. Krishna. "Drywood termites in Dominican amber (Isoptera: Kalotermitidae)". English. In: Beiträge zur Entomologie 57 (2007), pp. 263-275.

[6636] M. S. Engel, J. D. Lim, K. S. Baek, and L. D. Martin. "An earwig from the Lower Cretaceous of Korea (Dermaptera: Forficulina)". English. In: Journal of the Kansas Entomological Society 75 (2002), pp. 86-90. 
[6637] M. S. Engel and Z. W. Liu. "A new species of Ibaliid wasp in Baltic amber (Hymenoptera: Ibaliidae)". English. In: Journal of the Kansas Entomological Society 85 (2012), pp. 164-168.

[6638] M. S. Engel, R. C. McKellar, and J. T. Huber. "A fossil species of the primitive mymarid genus Borneomymar (Hymenoptera: Mymaridae) in Eocene Baltic amber". English. In: Novitates Paleoentomologicae 5 (2013), pp. 1-8.

[6639] M. S. Engel and C. D. Michener. "A minute stingless bee in Eocene Fushan amber from northeastern China (Hymenoptera: Apidae)". English. In: Journal of Melittology 14 (2013), pp. 1-10.

[6640] M. S. Engel, A. Nel, D. Azar, C. Soriano, P. Tafforeau, D. Néraudeau, J. P. Colin, and V. Perrichot. "New, primitive termites (Isoptera) from Early Cretaceous ambers of France and Lebanon". English. In: Palaeodiversity 4 (2011), pp. 39-49.

[6641] M. S. Engel and A. Nel. "A new fossil drywood termite species from the late Eocene of France allied to Cryptotermes and Procryptotermes (Isoptera: Kalotermitidae)". English. In: Novitates Paleoentomologicae 11 (2015), pp. 1-7.

[6642] M. S. Engel, J. Ortega-Blanco, and D. J. Bennett. “A remarkable tiphiiform wasp in mid-Cretaceous amber from Myanmar (Hymenoptera: Tiphiidae)". English. In: Transactions of the Kansas Academy of Science 112 (2009), pp. 1-6.

[6643] M. S. Engel and J. Ortega-Blanco. "The fossil crown wasp Electrostephanus petiolatus Brues in Baltic Amber (Hymenoptera, Stephanidae): designation of a neotype, revised classification, and a key to amber Stephanidae". English. In: ZooKeys 4.4 (2008), pp. 55-64.

[6644] M. S. Engel, J. Ortega-Blanco, C. Soriano, D. A. Grimaldi, and X. Delclós. "A new lineage of enigmatic diaprioid wasps in Cretaceous amber (Hymenoptera: Diaprioidea)". English. In: American Museum Novitates 3771 (2013), pp. 1-23.

[6645] M. S. Engel, J. Ortega-Blanco, and R. C. McKellar. "New scolebythid wasps in Cretaceous amber from Spain and Canada, with implications for the phylogeny of the family (Hymenoptera: Scolebythidae)". English. In: Cretaceous Research 46 (2013), pp. 31-42.

[6646] M. S. Engel, J. Ortega-Blanco, and D. Azar. "The earliest earwigs in amber (Dermaptera): A new genus and species from the Early Cretaceous of Lebanon". English. In: Insect Systematics \& Evolution 42 (2011), pp. 139-148.

[6647] M. S. Engel, J. Ortega-Blanco, P. C. Nascimbene, and H. Singh. "The bees of early Eocene Cambay amber (Hymenoptera: Apidae)". English. In: Journal of Melittology 25 (2013), pp. 1-12.

[6648] M. S. Engel, J. Ortega-Blanco, and C. O. Ozevedo. "A new bethylid wasp in Lebanese Early Cretaceous amber (Hymenoptera: Chrysidoidea), with comments on other Mesozoic taxa". English. In: American Museum Novitates 3855 (2016), pp. 1-14.

[6649] M. S. Engel, A. D. Pan, and B. F. Jacobs. "A termite from the late Oligocene of northern Ethiopia". English. In: Acta Palaeontologica Polonica 58 (2013), pp. 331-334.

[6650] M. S. Engel and E. Peñalver. "A Miocene halictine bee from Rubielos de Mora Basin, Spain (Hymenoptera: Halictidae)". English. In: American Museum Novitates 3503 (2006), pp. 1-10.

[6651] M. S. Engel, D. Peris, S. Chatzimanolis, and X. Delclós. “An earwig (Insecta: Dermaptera) in Early Cretaceous amber from Spain". English. In: Insect Systematics \& Evolution 46 (2015), pp. 291-300. DOI: $10.1163 / 1876312 X-45032121$.

[6652] M. S. Engel and E. E. Perkovsky. "Psocoptera (Insecta) in Eocene Rovno amber (Ukraine)". English. In: Vestnik Zoologii 40 (2006), pp. 175-179.

[6653] M. S. Engel and E. E. Perkovsky. "Sphaeropsocus kuenowii Hagen in Rovno amber from the Ukraine (Psocoptera: Sphaeropsocidae)". English. In: Entomological News 117.2 (2006), pp. 243245.

[6654] M. S. Engel and E. E. Perkovsky. “An Eocene Bee in Rovno Amber, Ukraine (Hymenoptera: Megachilidae)”. English. In: American Museum Novitates 3506 (2006), pp. 1-12.

[6655] M. S. Engel and V. Perrichot. "An earwig in Late Cretaceous Vendean amber (Dermaptera)". English. In: Paleontological Contributions 10 (2014), pp. 16-20. 
[6656] M. S. Engel and V. Perrichot. "The extinct wasp family Serphitidae in Late Cretaceous Vendean amber (Hymenoptera)". English. In: Paleontological Contributions 10 (2014), pp. 46-51.

[6657] M. S. Engel and D. Ren. “New snakeflies from the Jiulongshan Formation of Inner Mongolia, China (Raphidioptera)". English. In: Journal of the Kansas Entomological Society 81.3 (2008), pp. 188193.

[6658] M. S. Engel and M. G. Rightmyer. "A new augochlorine bee species in Tertiary amber from the Dominican Republic (Hymenoptera: Halictidae)". English. In: Apidologie 31 (2000), pp. 431-436.

[6659] M. S. Engel and T. Tanaka. "A giant termite of the genus Gyatermes from the Late Miocene of Nagano Prefecture, Japan (Isoptera)". English. In: Novitates Paleoentomologicae 10 (2015), pp. 1-10.

[6660] M. S. Engel, J. C. Thomas, and A. S. Alqarni. "A new genus of protorhyssaline wasps in Raritan amber (Hymenoptera, Braconidae)". English. In: ZooKeys 711 (2017), pp. 103-111.

[6661] M. S. Engel and B. Wang. "The first oriental protorhyssaline wasp (Hymenoptera: Braconidae): a new genus and species in Upper Cretaceous amber from Myanmar". English. In: Cretaceous Research 63 (2016), pp. 28-32.

[6662] M. S. Engel, B. Wang, and A. S. Alqarni. “A thorny, 'anareolate' stick-insect (Phasmatidae s.1.) in Upper Cretaceous amber from Myanmar, with remarks on diversification times among Phasmatodea". English. In: Cretaceous Research 63 (2016), pp. 45-53.

[6663] M. S. Engel and B. Wang. "A plesiomorphic gasteruptiid wasp in Cenomanian amber from Myanmar (Hymenoptera: Gasteruptiidae)". English. In: Cretaceous Research 63 (2016), pp. 177-182.

[6664] M. S. Engel, B. Wang, A. S. Alqarni, L. B. Jia, T. Su, Z. K. Zou, and T. Wappler. “A primitive honey bee from the Middle Miocene deposits of southeastern Yunnan, China (Hymenoptera, Apidae)". English. In: ZooKeys 775 (2018), pp. 117-129.

[6665] A. Engelbrecht, T. Mörs, M. A. Reguero, and J. Kriwet. "A new sawshark, Pristiophorus laevis, from the Eocene of Antarctica with comments on Pristiophorus lanceolatus". English. In: Historical Biology 29.6 (2017), pp. 841-853. DOI: 10.1080/08912963.2016.1252761.

[6666] A. Engelbrecht, T. Mörs, M. A. Reguero, and J. Kriwet. "New carcharhiniform sharks (Chondrichthyes, Elasmobranchii) from the early to middle Eocene of Seymour Island, Antarctic Peninsula". English. In: Journal of Vertebrate Paleontology 37.6 (2017), e1371724. DOI: 10.1080 / 02724634. 2017.1371724.

[6667] M. J. Engelbretsen. "Cambrian paterinid brachiopods from the Dolodrook River limestones, eastern Victoria, Australia". English. In: Memoirs of the Association of Australasian Palaeontologists 30 (2004), pp. 145-152.

[6668] R. K. Engelman, F. Anaya, and D. A. Croft. “Australogale leptognathus, gen. et sp. nov., a second species of small sparassodont (Mammalia: Metatheria) from the middle Miocene locality of Quebrada Honda, Bolivia". English. In: Journal of Mammalian Evolution 27 (2020), pp. 37-54. DOI: 10.1007/s10914-018-9443-z.

[6669] R. K. Engelman and D. A. Croft. "A new species of small-bodied sparassodont (Mammalia, Metatheria) from the middle Miocene locality of Quebrada Honda, Bolivia". English. In: Journal of Vertebrate Paleontology 34.3 (2014), pp. 672-688. DOI: 10.1080/02724634.2013.827118.

[6670] R. K. Engelman, J. J. Flynn, A. R. Wyss, and D. A. Croft. “Eomakhaira molossus, A New SaberToothed Sparassodont (Metatheria: Thylacosmilinae) from the Early Oligocene (?Tinguirirican) Cachapoal Locality, Andean Main Range, Chile". English. In: American Museum Novitates 3957 (2020), pp. 1-75.

[6671] R. K. Engelman, J. J. Flynn, P. B. Gans, A. R. Wyss, and D. A. Croft. “Chlorocyon phantasma, a Late Eocene Borhyaenoid (Mammalia: Metatheria: Sparassodonta) from the Los Helados Locality, Andean Main Range, Central Chile". English. In: American Museum Novitates 3918 (2018), pp. 1-22.

[6672] G. F. Engelmann and G. Callison. Glirodon grandis, a new multituberculate mammal from the Upper Jurassic Morrison Formation. English. Vertebrate Paleontology of Utah. 1999, pp. 161-178. 
[6673] M. S. Engels, C. H. Fletcher, M. E. Field, C. D. Storlazzi, E. E. Grossman, J. J. B. Rooney, C. L. Conger, and C. Glenn. "Holocene reef accretion: southwest Molokai, Hawaii, USA". English. In: Journal of Sedimentary Research 74.2 (2004), pp. 255-269.

[6674] T. Engeser and J. Reitner. "Description of the first Rhaetian nautiloid (Grypoceras rhaeticum n. sp.) from the Kossen Beds of the Fonsjoch near Achensee (Austria)". English. In: Neues Jahrbuch für Geologie und Paläontologie, Monatshefte 1992.4 (1992), pp. 231-241.

[6675] P. Ensom and D. Sigogneau-Russell. "New symmetrodonts (Mammalia, Theria) from the Purbeck Limestone Group, Lower Cretaceous, southern England". English. In: Cretaceous Research 21 (2000), pp. 767-779.

[6676] P. C. Ensom. "Reptile eggshell, tiny vertebrate remains and globular calcified cartilage from the Purbeck Limestone Group of southern England". English. In: Special Papers in Palaeontology 68 (2002), pp. 221-239.

[6677] P. C. Ensom. "Vertebrate trace fossils in the Purback Limestone Group of southern England". English. In: Special Papers in Palaeontology 68 (2002), pp. 203-220.

[6678] P. C. Ensom. "Dinosaur footprint records for the Purbeck Limestone Group, Dorset, since 1981". English. In: Proceedings of the Dorset Natural History and Archaeological Society 116 (1995), pp. 151152.

[6679] P. C. Ensom, R. G. Clements, S. Fesit-Burkhardt, A. R. Milner, J. Chitolie, P. A. Jeffery, and C. Jones. "The age and identity of an ichthyosaur reputedly from the Purbeck Limestone Group, Lower Cretaceous, Dorset, southern England". English. In: Cretaceous Research 30 (2009), pp. 699709.

[6680] P. C. Ensom, S. E. Evans, and A. R. Milner. Amphibians and reptiles from the Purbeck Limestone Formation (Upper Jurassic) of Dorset. English. Vol. 364. In Z. Kielan-Jaworowska, N. Heintz, \& H. A. Nakrem (eds.), Fifth Symposium on Mesozoic Terrestrial Ecosystems and Biota, Extended Abstracts. Contributions from the Paleontological Museum, Unviersity of Oslo. 1991, pp. 19-20.

[6681] M. Erbajeva, B. Baatarjav, G. Daxner-Höck, and L. J. Flynn. “Occurrences of Sinolagomys (Lagomorpha) from the Valley of Lakes (Mongolia)". English. In: Palaeobiodiversity and Palaeoenvironments 97.1 (2017), pp. 11-24.

[6682] M. Erbajeva and G. Daxner-Höck. "The most prominent Lagomorpha from the Oligocene and Early Miocene of Mongolia". English. In: Annalen des Naturhistorischen Museums in Wien, Serie A 116 (2014), pp. 215-245.

[6683] M. A. Erbajeva. "Paleogene hares (Leporidae, Lagomorpha) from the Zaisan Depression, Eastern Kazakhstan". English. In: Paleontological Journal 33.5 (1999), pp. 557-560.

[6684] M. A. Erbayeva, S. Montuire, and J. Chaline. "New ochotonids (Lagomorpha) from the Pleistocene of France". English. In: Geodiversitas 23.3 (2001), pp. 395-409.

[6685] M. D. Ercoli, A. Álvarez, C. Santamans, S. A. González Patagua, J. P. Villalba Ulberich, and O. E. Constantini. "Los Alisos, a new fossiliferous locality for Guanaco Formation (late Miocene) in Jujuy (Argentina), and a first approach of its paleoecological and biochronology implications". English. In: Journal of South American Earth Sciences 93 (2019), pp. 203-213.

[6686] M. D. Ercoli, M. A. Ramirez, M. M. Morales, A. Alvarez, and A. M. Candela. "First Record of Carnivora (Puma Lineage, Felidae) in the Uqua Formation (Late Pliocene - Early Pleistocene, NW Argentina) and Its significance in the Great American Biotic Interchange". English. In: Ameghiniana (2019). DOI: 10.5710/AMGH.31.03.2019.3206.

[6687] O. Erdal, P.-O. Antoine, and S. Sen. "New material of Palaeoamasia kansui (Embrithopoda, Mammalia) from the Eocene of Turkey and a phylogenetic analysis of Embrithopoda at the species level". English. In: Palaeontology 59.5 (2016), pp. 631-655.

[6688] D. P. B. Erdbrink. "Carnivora and a whale; fossils from the Loowaard and the Rhederlaag". English. In: Proceedings, Koninklijke Nederlandse Akademie van Wetenschappen 96.2 (1993), pp. 117-142. 
[6689] S. Erdmann, E. S. Bellosi, and G. A. Morra. “Una nueva especie de coral solitario (Scleractinia, Turbinoliidae) de la formacion San Julian (Oligocene superior, Santa Cruz) en su contexto estratigrafico y paleoambiental [A new species of a solitary coral (Scleractinia, Turbinoliidae) from the San Julian Formation (Upper Oligocene, Santa Cruz) in its stratigraphic and paleoenvironmental context]". Spanish. In: Revista del Museo Argentino de Ciencias Naturales 10.2 (2008), pp. 255-262.

[6690] B.-D. Erdtmann, B. Weber, H. -P. Schultze, and S. Egenhoff. "A possible agnathan plate from the lower Arenig (Lower Ordovician) of South Bolivia". English. In: Journal of Vertebrate Paleontology 20.2 (2000), pp. 394-399.

[6691] J. Erfurt and A. Averianov. "Mammals of the Eocene locality Toru Ajgyr (Kyrgyzstan)". English. In: Palaeovertebrata 34.3-4 (2006), pp. 207-257.

[6692] B. R. Erickson. "Flora and Fauna of the Wannagan Creek Quarry: Late Paleocene of North America". English. In: Scientific Publications of the Science Museum of Minnesota 7.3 (1991), pp. 1-19.

[6693] B. R. Erickson. "Crocodilians of the Black Mingo Group (Paleocene) of the South Carolina Coastal Plain". English. In: Transactions of the American Philosophical Society, New Series 88.4 (1998), pp. 196214.

[6694] B. R. Erickson. "A palaeophid snake from the Late Paleocene of South Carolina". English. In: Transactions of the American Philosophical Society, New Series 88.4 (1998), pp. 215-220.

[6695] B. R. Erickson. "Crocodile and Arthropod Tracks from the Late Paleocene Wannagan Creek Fauna of North Dakota, USA". English. In: Ichnos 12.4 (2005), pp. 303-308. DOI: 10.1080/1042094050031111.

[6696] G. M. Erickson, P. J. Makovicky, P. J. Currie, M. A. Norell, S. A. Yerby, and C. A. Brochu. “Gigantism and comparative life-history parameters of tyrannosaurid dinosaurs". English. In: Nature 430 (2004), pp. 772-775. DOI: 10.1038/nature02699.

[6697] M. E. Erikkson, J. Lindgren, K. Chin, and U. Månsby. "Coprolite morphotypes from the Upper Cretaceous of Sweden: novel views on an ancient ecosystem and implications for coprolite taphonomy". English. In: Lethaia (2011). DOI: 10.1111/j.1502-3931.2010.00257.x.

[6698] M. Eriksson. "Silurian ramphoprionid polychaetes from Gotland, Sweden". English. In: Journal of Paleontology 75.5 (2001), pp. 993-1015. DOI: 10.1666 / 0022-3360\% 282001 \% 29075\% 3C0993\% 3ASRPFGS\%3E2.0.CO\%3B2.

[6699] O. Eriksson, E. M. Friis, K. R. Pedersen, and P. R. Crane. "Seed size and dispersal systems of Early Cretaceous angiosperms from Famalicao, Portugal". In: International Journal of Plant Sciences 161.2 (2000), pp. 319-329.

[6700] S. P. Ermakova. "Sakhaitoides, a new Early Triassic ammonoid genus". English. In: Paleontological Journal 33 (1999), pp. 610-613.

[6701] A. Ernst. "Some calcareous algae from the Zechstein". In: Neues Jahrbuch für Geologie und Paläontologie Monatshefte 2002.11 (2002), pp. 681-692.

[6702] A. Ernst. "Permian Bryozoans of the NW-Tethys". English. In: Facies 43 (2000), pp. 79-102.

[6703] A. Ernst. "Bryozoa of the Upper Permian Zechstein Formation of Germany". English. In: Senckenbergiana Lethaea 81.1 (2001), pp. 135-181.

[6704] A. Ernst. "Carnocladiidae - a new family of fenestrate bryozoans". English. In: Senckenbergiana Lethaea 81 (2001), pp. 295-305.

[6705] A. Ernst. "Upper Palaeozoic bryozoans from the Carnic Alps (Austria)". English. In: Freiberger Forschungshefte C 499 (2003), pp. 55-77.

[6706] A. Ernst. “A cystoporate bryozoan species from the Zechstein (Late Permian)”. English. In: Paläontologische Zeitschrift 81.2 (2007), pp. 113-117.

[6707] A. Ernst. "Two unusual trepostome bryozoans from the Lower Carboniferous of the Karatau (south Kazakhstan)". English. In: Paläontologische Zeitschrift 72.1/2 (1998), pp. 89-97.

[6708] A. Ernst. "Lower Carboniferous Bryozoa from some localities in Sauerland, Germany". English. In: Bryozoan Studies (2004). 
[6709] A. Ernst. "Non-fenestrate bryozoans from the Middle Devonian of the Eifel (western Rhenish Massif, Germany)". English. In: Neues Jahrbuch für Geologie und Paläontologie - Abhandlungen 250.3 (2008), pp. 313-379.

[6710] A. Ernst. "Trepostome and cryptostome bryozoans from the Koneprusy Limestone (Lower Devonian, Pragian) of Zlaty Kun (Czech Republic)". English. In: Revista Italiana di Paleontologia e Stratigrafia 114.3 (2008), pp. 329-438.

[6711] A. Ernst. "New Data on the Middle Devonian Bryozoans of Germany". English. In: (2008).

[6712] A. Ernst. "Petaloporella (Cryptostomata, Bryozoa) from the Lower Devonian of central Bohemia". English. In: Bulletin of Geosciences 84.4 (2009), pp. 767-770.

[6713] A. Ernst. "Trepostome bryozoans from the Lower - Middle Devonian of NW Spain". English. In: Rivista Italiana di Paleontologia e Stratigrafia 116.3 (2010), pp. 283-308.

[6714] A. Ernst. "Cryptostome (ptilodictyine and rhabdomesine) Bryozoa from the Lower Devonian of NW Spain". English. In: 293 (2011), pp. 147-183.

[6715] A. Ernst. "Inconobotopora (Cystoporata, Bryozoa) from the early Katian (Late Ordovician) Kullsberg Limestone of the Siljan district, Dalarna, central Sweden". English. In: Gff 134 (2012), pp. 1925.

[6716] A. Ernst. "Fenestrate bryozoan fauna from the Lower - Middle Devonian of NW Spain". English. In: Neues Jahrbuch für Geologie und Paläontologie - Abhandlungen 264.3 (2012), pp. 205-247.

[6717] A. Ernst. "Clever scientific publishing". English. In: International Bryozoology Association Bulletin 9.2 (2013), p. 14.

[6718] A. Ernst and J. Bohatý. "Schischcatella (Fenestrata, Bryozoa) from the Devonian of the Rhenish Massif, Germany". English. In: Palaeontology 52.Part 6 (2009), pp. 1291-1310.

[6719] A. Ernst, C. E. Brett, and M. A. Wilson. "Bryozoan fauna from the Reynales Formation (lower Silurian, Aeronian) of New York, USA". English. In: Journal of Paleontology 93 (2019), pp. 628-657. DOI: 10.1017/jpa.2018.101.

[6720] A. Ernst and C. Buttler. "Cystoporate bryozoans from the Lower - Middle Devonian of NW Spain". English. In: Neues Jahrbuch für Geologie und Paläontologie - Abhandlungen 263 (2012), pp. 261285.

[6721] A. Ernst and M. Carrera. "Cryptostomid bryozoans from the Sassito Formation, Upper Ordovician cool-water carbonates of the Argentinean Precordillera". English. In: Palaeontology 51.5 (2008), pp. 1117-1127.

[6722] A. Ernst and M. Carrera. “Upper Ordovician (Sandbian) Bryozoan Fauna from Argentine Precordillera". English. In: Journal of Paleontology 86.5 (2012), pp. 721-752.

[6723] A. Ernst, T. Dorsch, and M. Keller. "A bryozoan fauna from the Santa Lucia Formation (LowerMiddle Devonian) of Cantabrian Mountains, NW Spain”. English. In: Facies 57 (2011), pp. 301329.

[6724] A. Ernst, L. P. Fernández, E. Fernández-Martnez, and C. Vera. “Description of a bryozoan fauna from mud mounds of the Lebanza Formation (Lower Devonian) in the Arauz area (PisuergaCarrión Province, Cantabrian Zone, NW Spain)". English. In: Geodiversitas 34.4 (2012), pp. 693738.

[6725] A. Ernst and M. N. Gorgij. "Lower Permian bryozoan faunas from Kalmard area, central Iran". English. In: Neues Jahrbuch für Geologie und Paläontologie, Abhandlungen 268 (2013), pp. 275-324.

[6726] A. Ernst and H. G. Herbig. "Stenolaemate bryozoans from the latest Devonian (uppermost Famennian) of Western Germany". English. In: Geologica Belgica 13.3 (2010), pp. 173-182.

[6727] A. Ernst, A. Jiménez-Sánchez, and L. Baidder. "Bryozoan fauna of the Upper Ordovician (Katian) of Alnif, Morocco". English. In: Senckenberg Gesellschaft für Naturforschung and Springer-Verlag Berlin Heidelberg 2015. Berlin-Heidelberg: Senckenberg Gesellschaft, 2015. 
[6728] A. Ernst and M. Key. "Upper Ordovician bryozoa from the Montagne de Noire, Southern France". English. In: Journal of Systematic Palaeontology 5.4 (2007), pp. 359-428.

[6729] A. Ernst and P. Königshof. "The role of bryozoans in fossil reefs - an example from the Middle Devonian of the Western Sahara". English. In: Facies 54 (2008), pp. 613-620.

[6730] A. Ernst, P. Königshof, and P. Schäfer. "Unusual skeletal morphology and systematic description of a new Devonian cryptostome bryozoan from the Western Sahara". English. In: Paläontologische Zeitschrift 83 (2009), pp. 449-457.

[6731] A. Ernst and P. Königshof. "Bryozoan fauna and microfacies from a Middle Devonian reef complex (Western Sahara, Morocco)". English. In: Abhandlungen der Senckenbergischen Naturforschenden Gesellschaft 568 (2010), pp. 1-91.

[6732] A. Ernst, P. Königshof, P. D. Taylor, and J. Bohatý. “Microhabitat complexity—an example from Middle Devonian bryozoan-rich sediments in the Blankenheim Syncline (northern Eifel, Rheinisches Schiefergebirge)". English. In: Palaeobiodiversity and Palaeoenvironments 91.4 (2011), pp. 257284.

[6733] A. Ernst, P. Königshof, A. Bahrami, M. Yazdi, and I. Boncheva. "A Late Devonian (Frasnian) bryozoan fauna from central Iran". English. In: Palaeobio Palaeoenv 97 (2017), pp. 541-552.

[6734] A. Ernst, P. Kraft, and K. Zágorsek. "Trepostome bryozoans from the Zahorany Formation (Upper Ordovician) of Lodenice, Prague Basin, Czech Republic". English. In: Palaeontologische Zeitschrift 88 (2014), pp. 11-26. DOI: 10.1007/s12542-013-0183-3.

[6735] A. Ernst, S. Manda, and K. Zágorsek. “Cryptostome bryozoan Stictoporella simplex (Pocta, 1894) from the Silurian of Bohemia". English. In: Neues Jahrbuch für Geologie und Paläontologie, Abhandlungen 260.1 (2011), pp. 79-85.

[6736] A. Ernst and A. May. "Bryozoan fauna from the Konprusy Limestone (Pragian, Lower Devonian) of Zlatý K near Konprusy". English. In: Journal of Paleontology 83.5 (2009), pp. 767-782.

[6737] A. Ernst and A. May. "Bryozoan Fauna from the Lower Devonian (Middle Lochkovian) of Sierra De Guadarrama, Spain". English. In: Journal of Paleontology 86.1 (2012), pp. 60-80.

[6738] A. Ernst, A. May, and S. Marks. "Bryozoans, corals, and microfacies of Lower Eifelian (Middle Devonian) limestones at Kierspe, Germany". English. In: Facies 58 (2012), pp. 727-758.

[6739] A. Ernst and E. Minwegen. "Late Carboniferous bryozoans from La Hermida, Spain". English. In: Acta Palaeontologica Polonica 51.3 (2006), pp. 569-588.

[6740] A. Ernst and M. Mohammadi. "Stenolaemate bryozoans from the Geirud Formation (Upper Devonian/Lower Carboniferous) of central Alborz (Iran)". English. In: Palaeontologische Zeitschrift 83 (2009), pp. 439-447.

[6741] A. Ernst and A. Munnecke. "A Hirnantian (latest Ordovician) reefal bryozoan fauna from Anticosti Island, eastern Canada: taxonomy and chemostratigraphy". English. In: NRC Research Press (2009).

[6742] A. Ernst and H. A. Nakrem. "Lower Permian Bryozoa from Ellesmere Island (Canada)". English. In: Paläontologische Zeitschrift 81 (2007), pp. 17-28.

[6743] A. Ernst and H. A. Nakrem. Bryozoans from the Artinskian (Lower Permian) Great Bear Cape Formation, Ellesmere Island (Canadian Arctic). English. Bryozoan Studies 2004. 2005, pp. 63-68.

[6744] A. Ernst and H. A. Nakrem. "Stenolaemate bryozoans from the Mjøsa Formation (Late Ordovician, Katian) of Helgøya (Mjøsa), southern Norway". English. In: Norwegian Journal of Geology 91 (2011), pp. 163-180.

[6745] A. Ernst and H. A. Nakrem. "Late Ordovician (Sandbian) bryozoans and their depositional environment, Furuberget Formation, Mjøsa District, Oslo Region, Norway". English. In: Bulletin of Geosciences 87.1 (2012), pp. 21-44.

[6746] A. Ernst, T. Parvizi, and K. Rashidi. "Some Bryozoa from the Upper Permian Dalan Formation of Dena Mountain in SW Iran". English. In: Freiberger Forschungshefte C 539 (2011), pp. 71-81. 
[6747] A. Ernst and S. Rodrguez. "Bryozoan fauna from the oolitic limestone from Pajarejos, SW Spain". English. In: Revista Española de Paleontologa 25.2 (2010), pp. 83-88.

[6748] A. Ernst, P. Schäfer, and J. J. G. Reijmer. "Stenolaemate Bryozoa from the Upper Carboniferous of the Cantabrian Basin, Northern Spain". English. In: Senckenbergiana lethaea 85.2 (2005), pp. 301317.

[6749] A. Ernst, P. Schäfer, and J. A. Grant-Mackie. "New Caledonian Triassic Bryozoa". English. In: Journal of Paleontology 89 (2016), pp. 730-747.

[6750] A. Ernst and S. Schroeder. "Stenolaemate bryozoans from the Middle Devonian of the Rhenish Slate Massif (Eifel, Germany)". English. In: Neues Jahrbuch für Geologie und Paläontologie - Abhandlungen 246.2 (2007), pp. 205-233.

[6751] A. Ernst, B. Senowbari-Daryan, and K. Rashidi. "Lower Permian Bryozoa of the Jamal Formation from Bagh-e Vang (Shotori Mountains, northeast Iran)". English. In: Facies 52 (2006), pp. 627-635.

[6752] A. Ernst, B. Senowbari-Daryan, and A. Hamedani. "Middle Permian bryozoa from the Lakaftari area, northeast of Esfahan, (central Iran)". English. In: Geodiversitas 28.4 (2006), pp. 543-590.

[6753] A. Ernst, B. Senowbari-Daryan, and K. Rashidi. "Bryozoa from the Surmaq Formation (Permian) of the Hambast Mountains, south of Abadeh, central Iran". English. In: Facies 55 (2009), pp. 595608.

[6754] A. Ernst, B. Senowbari-Daryan, and K. Rashidi. "Rhabdomesid and cystoporid bryozoans from the Permian of Deh-e Mohammad, Shotori Mountains (northeastern Iran)". English. In: Geobios 42 (2009), pp. 133-140.

[6755] A. Ernst, B. Senowbari-Daryan, and K. Rashidi. "Permian Bryozoa from the Jamal Formation of Shotori Mountains (northeast Iran)". English. In: Revue de Paléobiologie, Genéve 27.2 (2008), pp. 395408.

[6756] A. Ernst, P. D. Taylor, and M. A. Wilson. “Ordovician bryozoans from the Kanosh Formation (Whiterockian) of Utah, USA". English. In: Journal of Paleontology 81.5 (2007), pp. 998-1008.

[6757] A. Ernst, P. D. Taylor, J. Bohaty, and P. N. Wyse Jackson. "Homeomorphy in Lunostoma, a new Middle Devonian". English. In: Paläontol Z 86 (2012), pp. 135-145.

[6758] A. Ernst, Z. Tolokonnikova, and H. Yarahmadzahi. “Upper Devonian (Frasnian) Bryozoa from the Shishtu 1 Formation of Niaz area (eastern Tabas, central Iran)". English. In: Revue de Paléobiologie, Genéve 31.1 (2012), pp. 1-14.

[6759] A. Ernst and E. Voigt. "Zooidai anatomy in Ordovician and Carboniferous trepostome bryozoans". English. In: Paläontologische Zeitschrift 76.2 (2002), pp. 339-345.

[6760] A. Ernst, O. Weidlich, and P. Schäfer. "Stenolaemate Bryozoa from the Permian of Oman (Aseelah Unit, Batain Coast)". English. In: Journal of Paleontology 82.4 (2008), pp. 676-716.

[6761] A. Ernst and C. F. Winkler Prins. "Pennsylvanian bryozoans from the Cantabrian Mountains (northwestern Spain)". English. In: Scripta Geologica 137 (2008), pp. 1-123.

[6762] A. Ernst, H. Yarahmadzahi, and M. N. Gorgij. "Sakmarian Bryozoa from the Dalgan area (Sarab section), southeastern Iran". English. In: Freiberger Forschungshefte C 536 (2010), pp. 75-89.

[6763] H. Erten. "A new genus and species of Muridae (Rodentia) from the Quaternary deposits of the Denizli Basin, South-western Turkey". English. In: Palaeontologia Electronica 20.1.12A (2017), pp. 17.

[6764] H. Erten and D. B. Koralay. "A Zygolophodon turicensis (Proboscidea, Mammalia) mandible". English. In: Springer Nature (2020). DOI: 10.1007/s12549-020-00422-7.

[6765] P. Ervin. Megacerops Kuwagatarhinus skull, from Chadronian Land Mammal Age, doubles this late Eocene species' geographic range. English. 2001.

[6766] I. H. Escapa, B. Bomfleur, N. R. Cuneo, and R. Scasso. "A new marattiaceous fern from the Lower Jurassic of Patagonia (Argentina): the renaissance of Marattiopsis". English. In: Journal of Systematic Palaeontology 8 (2015), pp. 677-689. 
[6767] I. H. Escapa and N. R. Cuneo. "Fertile Osmundaceae from the Early Jurassic of Patagonia, Argentina". English. In: International Journal of Plant Sciences 173.1 (2012), pp. 54-66.

[6768] I. H. Escapa, N. R. Cuneo, and B. Axsmith. "A new genus of the Cupressaceae (sensu lato) from the Jurassic of Patagonia:" English. In: Review of Palaeobotany and Palynology 151 (2008), pp. 110122.

[6769] F. Escaso, F. Ortega, P. Dantas, E. Malafaia, N. L. Pimentel, X. Pereda-Suberbiola, J. L. Sanz, J. C. Kullberg, M. C. Kullberg, and F. Barriga. "New evidence of shared dinosaur across Upper Jurassic proto-North Atlantic: Stegosaurus from Portugal". English. In: Naturwissenschaften 94 (2007), pp. 367-374.

[6770] F. Escaso, F. Ortega, P. Dantas, E. Malafaia, B. Silva, and J. L. Sanz. Elementos postcraneales de Dacentrurus (Dinosauria: Stegosauria) del Jurásico Superior de Moçanfaneira (Torres Vedras, Portugal) [Postcranial elements of Dacentrurus (Dinosauria: Stegosauria) from the Upper Jurassic of Moçanfaneira (Torres Vedras, Portugal)]. Spanish. In Cantera Paleontológica, Diputación Provincial de Cuenca, Cuenca, Spain. 2007, pp. 157-172.

[6771] F. Escaso, F. Ortega, P. Dantas, E. Malafaia, B. Silva, J. M. Gasulla, P. Mocho, I. Narvaeza, and J. L. Sanz. "A new dryosaurid ornithopod (Dinosauria, Ornithischia) from the Late Jurassic of Portugal". English. In: Journal of Vertebrate Paleontology 34.5 (2014), pp. 1102-1112. DOI: 10.1080 / 02724634.2014.849715.

[6772] R. E. Eschelman and F. C. Whitmore. "Early Pliocene (Late Hemphillian) land mammals from the Lee Creek Mine, Aurora, North Carolina". English. In: Virginia Museum of Natural History Special Publication 14 (2008), pp. 17-38.

[6773] M. J. Escudero-Mozo, J. Martn-Chivelet, A. Goy, and J. López-Gómez. “Middle-Upper Triassic carbonate platforms in Minorca (Balearic islands): Implications for Western Tethys correlations". English. In: Sedimentary Geology 310 (2014), pp. 41-58. DOI: 10.1016/j.sedgeo.2014.06.002.

[6774] R. E. Eshelman, D. Lowery, F. Grady, D. Wagner, and H. G. McDonald. "Late Pleistocene (Rancholabrean) Mammalian Assemblage from Paw Paw Cove, Tilghman Island, Maryland". English. In: Smithsonian Contributions to Paleobiology 102 (2018), pp. 1-15.

[6775] Y. Eshet. "Paleozoic-Mesozoic Palynology of Israel: I: Palynological Aspects of the Permo-Triassic Succession in the Subsurface of Israel." In: Geological Survey of Israel 81 (1990), pp. 1-57.

[6776] K. Y. Eskov and P. A. Selden. "First record of spiders from the Permian period (Araneae: Mesothelae)". English. In: Bulletin of the British Arachnological Society 13.4 (2005), pp. 111-116.

[6777] K. Y. Eskov and S. L. Zonstein. "The first ctenizoid mygalomorph spiders from Eocene Baltic amber (Araneida: Mygalomorphae: Ctenizidae)". English. In: Paleontological Journal 34.Suppl 3 (2000), S268-S274.

[6778] R. Esperante, L. Brand, K. E. Nick, O. Poma, and M. Urbina. "Exceptional occurrence of fossil baleen in shallow marine sediments of the Neogene Pisco Formation, Southern Peru". English. In: Palaeogeography, Palaeoclimatology, Palaeoecology 257 (2008), pp. 344-360.

[6779] R. Esperante, F. Funiz Guinea, and K. E. Nick. "Taphonomy of a Mysticeti whale in the Lower Pliocene Huelva Sands Formation (Southern Spain)". English. In: Geologica Acta 7.4 (2009), pp. 489 505.

[6780] C. Esquivel-Macias, W. I. Ausich, B. E. Buitron-Sanchez, and A. Flores de Dios. "Pennsylvanian and Mississippian pluricolumnal assemblages (class Crinoidea) from southern Mexico and a new occurrence of a column with a tetralobate lumen". In: Journal of Paleontology 74.6 (2000), pp. 11871190.

[6781] G. Esteban, S. Georgieff, N. Nasif, L. Ibáñez, and R. Bonini. “Marco estratigráfico, paleontologa de vertebrados y paleoambientes del Plioceno de Catamarca, Tucumán y Santiago del Estero, Argentina". English. In: vol. 52. Mioceno al Pleistoceno del centro y norte de Argentina. Tucumán: Opera Lilloana, 2019, pp. 348-366. 
[6782] G. Esteban, N. Nasif, and S. M. Georgieff. “Cronobioestratigrafa del Mioceno tardo - Plioceno temprano, Puerta de Corral Quemado y Villavil, provincia de Catamarca, Argentina". Spanish. In: Acta geológica lilloana 26.2 (2014), pp. 165-192.

[6783] G. Esteban, N. Nasif, C. I. Montalvo, and G. Visconti. "Nuevos registros de Dasypodidae (Xenarthra) en la Formación Cerro Azul (Mioceno tardo) de Caleufú, La Pampa, Argentina". Spanish. In: Ameghiniana 40.3 (2003), pp. 495-499.

[6784] G. I. Esteban. “Nuevo registro de Sphenotherus (Xenarthra, Mylodontidae) en el Terciario superior del valle de El Cajon (provincia de Catamarca, Argentina). Revision sistematica del genero". Spanish. In: Ameghiniana 36.3 (1999), pp. 317-321.

[6785] G. I. Esteban, N. L. Nasif, and C. I. Montalvo. "Nuevos registros de Dasypodidae (Xenarthra) del Mioceno tardo de la provincia de La Pampa, Argentina". Spanish. In: Revista Espanola de Paleontologa 16.1 (2000), pp. 77-87.

[6786] G. I. Esteban and N. L. Nasif. “Nuevos Dasypodidae (Mammalia, Xenarthra) del Mioceno tardio del Valle del Cajon, Catamarca, Argentina". Spanish. In: Ameghiniana 33.3 (1996), pp. 327-334.

[6787] M. Esteban, J. C. Braga, J. Martin, and C. de Santisteban. "Western mediterranean reef complexes". English. In: SEPM Concepts in Sedimentology and Paleontology 5 (1996), pp. 55-72.

[6788] S. B. Esteban. "Los primeros trilobites ciclopigidos en el Ordovicico de Argentina (Formation Volcancito, Sistema de Famatina) [First Ordovician cyclopygid trilobites from Argentina (Volcancito Formation, Famatina System)]". Spanish. In: Ameghiniana 33.1 (1996), pp. 57-64.

[6789] J. W. Estep, S. G. Lucas, and C. M. González-León. “Middle Triassic Ammonites from Sonora, Mexico". In: Revista Mexicana de Ciencias Geológicas 14.2 (1997), pp. 155-159.

[6790] M. Estevens. "Miocene marine mammals from Portugal: Paleogeographical and Paleoecological significance". English. In: Ciencias da Terra (UNL), Lisboa 14 (2000), pp. 323-344.

[6791] M. Estevens and M. T. Antunes. "Fragmentary remains of odontocetes (Ctacea, Mammalia) from the Miocene of the lower Tagus Basin (Portugal)". English. In: Revista Espanola de Paleontologia 19.1 (2004), pp. 93-108.

[6792] M. Estevens and S. P. Avila. "Fossil whales from the Azores". English. In: Acoreana Supl. 5 (2007), pp. 140-161.

[6793] E. Estrada-Ruiz, L. Calvillo-Canadell, and S. R. S. Cevallos-Ferriz. “Upper Cretaceous aquatic plants from Northern Mexico". English. In: American Journal of Botany 90.4 (2009), pp. 282-288.

[6794] E. Estrada-Ruiz, H. I. Martnez-Cabrera, and S. R. S. Cevallos-Ferriz. “Upper Cretaceous woods from the Olmos Formation (late Campanian-early Maastrichtian), Coahuila, Mexico". English. In: American Journal of Botany 97.7 (2010), pp. 1179-1194.

[6795] E. Estrada-Ruiz, G. R. Upchurch Jr., J. A. Wolfe, and S. R. S. Cevallos-Ferriz. “Comparative Morphology of Fossil and Extant Leaves of Nelumbonaceae, Including a New Genus from the Late Cretaceous of Western North America". English. In: Systematic Botany 36.2 (2011), pp. 337-351.

[6796] C. Estravs. "Nuevos mamferos del Eoceno Inferior de Silveirinha (Baixo Mondego, Portugal)". Spanish. In: Coloquios de Paleontologa 51 (2000), pp. 281-311.

[6797] C. Estravs. "Russellmys denisae, un nouvel Apatémyidé (Mammalia) de Silveirinha, eocéne inférieur du Portugal". French. In: Geobios 23.6 (1990), pp. 761-765.

[6798] C. Estravs and D. E. Russell. "The presence of Taeniodonta (Mammalia) in the Early Eocene of Europe". English. In: Ciencias da Terra 11 (1992), pp. 191-201.

[6799] D. Esu and O. Girotti. “The Late Oligocene molluscan fauna from Otranto (Apulia, Southern Italy): an example of alternating freshwater, lagoonal and emerged environments". English. In: Palaeontology 53.1 (2010), pp. 137-174. DOI: 10.1111/j.1475-4983.2009.00923.x.

[6800] R. L. Ethington and R. L. Austin. "Conodonts of the Dounans Limestone, Highland Border Complex, Scotland". English. In: Journal of Micropaleontology 10.1 (1991), pp. 51-56. 
[6801] M. Ettachfini, M. Company, J. Rey, K. Taj-Eddine, and J. M. Tavera. “Le Valanginien du bassin de Safi (Maroc atlantique) et sa faune d'ammonites. Implications paleobiogeographiques". English. In: Comptes Rendus de l'Academie des Sciences de Paris, Serie IIa 327 (1998), pp. 319-325.

[6802] W. Etter. "Paläontologische Untersuchungen im unteren Opalinuston der Nordschweiz". German. PhD thesis. 1990, 151pp.

[6803] W. Etter. "Decapod crustaceans from the Middle Jurassic Opalinus Clay of northern Switzerland, with comments on crustacean taphonomy". English. In: Eclogae Geologicae Helvetiae 97 (2004), pp. 381-392.

[6804] W. Etter. "A well-preserved isopod from the Middle Jurassic of southern Germany and implications for the isopod fossil record". English. In: Palaeontology 57 (2014), pp. 931-949.

[6805] W. Etter and O. Kuhn. "An articulated dragonfly (Insecta, Odonata) from the Upper Liassic Posidonia Shale of Northern Switzerland". English. In: Palaeontology 43 (2000), pp. 967-977.

[6806] R. L. Evander. Astrohippus walked on faerie toes. English. 1993.

[6807] R. L. Evander. "Craniometry of the Equidae part I: two-dimensional shape analysis". English. In: 7.1 (2008), pp. 1-13.

[6808] E. Evanoff and K. Carpenter. "History, sedimentology, and taphonomy of Felch Quarry 1 and associated sandbodies, Morrison Formation, Garden Park, Colorado". In: Modern Geology 23 (1998), pp. 145-169.

[6809] D. C. Evans, P. M. Barrett, and K. L. Seymour. "Revised identification of a reported Iguanodongrade ornithopod tooth from the Scollard Formation, Alberta, Canada". English. In: Cretaceous Research 33.1 (2012), pp. 11-14. DOI: 10.1016/j.cretres.2011.07.002.

[6810] D. C. Evans, P. M. Barrett, K. S. Brink, and M. T. Carrano. “Osteology and bone microstructure of new, small theropod dinosaur material from the early Late Cretaceous of Morocco". English. In: Gondwana Research 27 (2015), pp. 1034-1041.

[6811] D. C. Evans, D. W. Larson, and P. J. Currie. “A new dromaeosaurid (Dinosauria: Theropoda) with Asian affinities from the latest Cretaceous of North America". English. In: Naturwissenshaften 100 (2013), pp. 1041-1049. DOI: 10.1007/s00114-013-1107-5.

[6812] D. C. Evans, H. C. Maddin, and R. R. Reisz. "A Re-Evaluation of Sphenacodontid Synapsid Material from the Lower Permian Fissure Fills near Richards Spur, Oklahoma". English. In: Palaeontology 52.1 (2009), pp. 219-227. DOI: 10.1111/j.1475-4983.2008.00837.x.

[6813] D. C. Evans and R. R. Reisz. "Anatomy and relationships of Lambeosaurus magnicristatus, a crested hadrosaurid dinosaur (Ornithischia) from the Dinosaur Park Formation, Alberta". English. In: Journal of Vertebrate Paleontology 27.2 (2007), pp. 373-393.

[6814] D. C. Evans, R. R. Reisz, and K. Dupuis. "A juvenile Parasaurolophus (Ornithischia: Hadrosauridae) braincase from Dinosaur Provincial Park, Alberta, with comments on crest ontogeny in the genus". English. In: Journal of Vertebrate Paleontology 27.3 (2007), pp. 642-650.

[6815] D. C. Evans and M. J. Ryan. “Cranial anatomy of Wendiceratops pinhornensis gen. et sp. nov., a centrosaurine ceratopsid (Dinosauria: Ornithischia) from the Oldman Formation (Campanian), Alberta, Canada, and the evolution of ceratopsid nasal ornamentation". English. In: PLoS ONE 10.7 (2015), e0130007. DOI: 10.1371/journal.pone.0130007.

[6816] D. C. Evans, R. K. Schott, D. W. Larson, C. M. Brown, and M. J. Ryan. “The oldest North American pachycephalosaurid and the hidden diversity of small-bodied ornithischian dinosaurs". English. In: Nature Communications 4 (2013), p. 1828. DOI: 10.1038/ncomms2749.

[6817] D. C. Evans, M. J. Vavrek, D. R. Braman, N. E. Campione, T. A. Dececchi, and G. D. Zazula. “Vertebrate fossils (Dinosauria) from the Bonnet Plume Formation, Yukon Territory, Canada". English. In: Canadian Journal of Earth Sciences 49 (2012), pp. 396-411. DOI: 10.1139/E11-064.

[6818] D. C. Evans, M. J. Vavrek, and H. C. E. Larsson. "Pachycephalosaurid (Dinosauria: Ornithischia) cranial remains from the latest Cretaceous (Maastrichtian) Scollard Formation of Alberta, Canada". English. In: Paleobiodiversity and Paleoenvironments (2015). DOI: 10.1007 / s12549-0150188-x. 
[6819] D. E. Evans and J. C. W. Cope. "Systematic position of Pollicina corniculum (Eichwald, 1860) (Mollusca, Tergomya) from the Middle Ordovician of the United Kingdom". English. In: Palaeontology 46.1 (2003), pp. 139-149.

[6820] D. H. Evans. "The Lower and Middle Ordovician cephalopod faunas of England and Wales". English. In: Monograph of the Palaeontographical Society 623 (2005), pp. 1-81.

[6821] D. H. Evans. "A Cephalopod Fauna from the Middle Ordovician of Saudi Arabia". English. In: Palaeontology 43.3 (2000), pp. 573-589.

[6822] D. H. Evans. "The Cephalopod Fauna of the Bardahessaigh Formation (Caradoc Series) of Pomeroy, County Tyrone". English. In: Irish Journal of Earth Sciences 13 (1994), pp. 11-29.

[6823] D. H. Evans. "The Cephalopod Fauna of the Killey Bridge Formation (Ordovician, Ashgill), Pomeroy, County Tyrone". English. In: Irish Journal of Earth Sciences 12 (1993), pp. 155-189.

[6824] D. H. Evans. "Siphonal and cameral deposits in Allumettoceras and the position of the Tripteroceratidae (Nautiloidea)". English. In: Palaeontologische Zeitschrift 68.3/4 (1994), pp. 321-337.

[6825] D. H. Evans. “Ugooloceras oblatum gen. and sp. nov., an Annulate Orthocerid (Orthocerida, Nautiloidea) from the Llanvirn Series of County Mayo". English. In: Irish Journal of Earth Sciences 15 (1996), pp. 71-76.

[6826] D. H. Evans. "Irish Silurian Cephalopods". English. In: Irish Journal of Earth Sciences 13 (1994), pp. 113-148.

[6827] D. H. Evans and A. H. King. "The Affinities of Early Oncocerid Nautiloids from the Lower Ordovician of Spitsbergen and Sweden". English. In: Palaeontology 33.3 (1990), pp. 623-630.

[6828] D. H. Evans. The Lower Ordovician cephalopod faunas of the Durness Group, North-West Scotland. English. Vol. 165. Monograph of the Palaeontographical Society, London. London: Palaeontographical Society, 2011, pp. 1-131.

[6829] K. R. Evans. "Marocella: Antarctic specimens of an enigmatic Cambrian animal". In: Journal of Paleontology 66.4 (1992), pp. 558-562.

[6830] K. R. Evans and A. J. Rowell. "SocietySmall Shelly Fossils from Antarctica: An Early Cambrian Faunal Connection with Australia". English. In: Journal of Paleontology 64.5 (1990), pp. 692-700.

[6831] S. D. Evans, I. V. Hughes, J. G. Gehling, and M. L. Droser. “Discovery of the oldest bilaterian from the Ediacaran of South Australia". English. In: Proceedings of the National Academy of Sciences 117 (2020). DOI: 10.1073/pnas.2001045117.

[6832] S. E. Evans. "Small reptiles and amphibians from the Forest Marble (Middle Jurassic) of Dorset". English. In: Proceedings of the Dorset Natural History and Archaeological Society 113 (1992), pp. 201202.

[6833] S. E. Evans. "A new anguimorph lizard from the Jurassic and Lower Cretaceous of England". English. In: Palaeontology 37.1 (1994), pp. 33-49.

[6834] S. E. Evans. "An early kuehneosaurid reptile (Reptilia: Diapsida) from the Early Triassic of Poland". English. In: Palaeontologia Polonica 65 (2009), pp. 145-178.

[6835] S. E. Evans. "A new lizard-like reptile (Diapsida: Lepidosauromorpha) from the Middle Jurassic of England". English. In: Zoological Journal of the Linnean Society 103 (1991), pp. 391-412.

[6836] S. E. Evans. Parviraptor (Squamata: Anguimorpha) and other lizards from the Morrison Formation at Fruita, Colorado. English. Vol. 60. The Continental Jurassic. Museum of Northern Arizona Bulletin. 1996, pp. 243-248.

[6837] S. E. Evans. "A re-evaluation of the Late Jurassic (Kimmeridgian) reptile Euposaurus (Reptilia: Lepidosauria) from Cerin, France". English. In: Geobios 27.5 (1994), pp. 621-631.

[6838] S. E. Evans. "Crown group lizards (Reptilia, Squamata) from the Middle Jurassic of the British Isles". English. In: Palaeontographica Abteilung A 250 (1998), pp. 123-154.

[6839] S. E. Evans and L. J. Barbadillo. "An unusual lizard (Reptilia: Squamata) from the Early Cretaceous of Las Hoyas, Spain”. English. In: Zoological Journal of the Linnean Society 124 (1998), pp. 235-265. 
[6840] S. E. Evans and L. J. Barbadillo. “The lizard Rubiessaurus Gómez Pallerola, 1979 from the Lower Cretaceous of Catalonia (Montsec, Lleida, Spain)". English. In: Treballs del Museu de Geologa de Barcelona 7 (1998), pp. 5-10.

[6841] S. E. Evans and L. J. Barbadillo. "Early Cretaceous lizards from Las Hoyas, Spain". English. In: Zoological Journal of the Linnean Society 119 (1997), pp. 23-49. DOI: 10.1006/zjls.1996.0063.

[6842] S. E. Evans, P. M. Barrett, and D. J. Ward. "The first record of lizards and amphibians from the Wessex Formation (Lower Cretaceous: Barremian) of the Isle of Wight, England". English. In: Proceedings of the Geologists' Association 115 (2004), pp. 239-247.

[6843] S. E. Evans, P. M. Barrett, J. Hilton, R. J. Butler, M. E. H. Jones, M. -M. Liang, J. C. Parish, E. J. Rayfield, D. Sigogneau-Russell, and C. J. Underwood. The Middle Jurassic vertebrate assemblage of Skye, Scotland. English. 9th International Symposium on Mesozoic Terrestrial Ecosystems and Biota, Abstracts and Proceedings Volume, Natural History Museum, London. 2006, pp. 36-39.

[6844] S. E. Evans and M. BorsukBiaynicka. "A small lepidosauromorph reptile from the Early Triassic of Poland". English. In: Palaeontologia Polonica 65 (2009), pp. 179-202.

[6845] S. E. Evans and M. Borsuk-Bialynicka. "A stem-group frog from the Early Triassic of Poland". In: Acta Palaeontologica Polonica 43.4 (1998), pp. 573-580.

[6846] S. E. Evans and D. C. Chure. "Paramacellodid lizard skulls from the Jurassic Morrison Formation at Dinosaur National Monument, Utah". English. In: Journal of Vertebrate Paleontology 18.1 (1998), pp. 99-114.

[6847] S. E. Evans and N. C. Fraser. "A sphenodontid jaw (Reptilia: Lepidosauria) from the Upper Jurassic of Dorset". English. In: Proceedings of the Dorset Natural History Society 1992 (1992), pp. 199200.

[6848] S. E. Evans, J. R. Groenke, M. E. H. Jones, A. H. Turner, and D. W. Krause. "New material of Beelzebufo, a hyperossified frog (Amphibia: Anura) from the Late Cretaceous of Madagascar". English. In: PLoS One 9.1 (2014), e87236.

[6849] S. E. Evans, M. E. H. Jones, and D. W. Krause. "A giant frog with South American affinities from the Late Cretaceous of Madagascar". English. In: Proceedings of the National Academy of Sciences 105.8 (2008), pp. 2951-2956.

[6850] S. E. Evans, M. E. H. Jones, and R. Matsumoto. "A new lizard skull from the Purbeck Limestone Group (Lower Cretaceous) of England". English. In: Bulletin de la Société Géologique de France 183.6 (2012), pp. 517-524.

[6851] S. E. Evans and M. E. H. Jones. "The origin, early history and diversification of lepidosauromorph reptiles". English. In: vol. 132. Lecture Notes in Earth Sciences. Berlin: Springer-Verlag, 2010, pp. 27-44. DOI: 10.1007/978-3-642-10311-7_2.

[6852] S. E. Evans and K. A. Kermack. Assemblages of small tetrapods from the Early Jurassic of Britain. In the Shadow of the Dinosaurs: Early Mesozoic Tetrapods, N. C. Fraser and H.-D. Sues (eds.), Cambridge University Press. 1994, pp. 271-283.

[6853] S. E. Evans and M. S. King. "A new specimen of Protorosaurus (Reptilia: Diapsida) from the Marl Slate (late Permian) of Britain". English. In: Proceedings of the Yorkshire Geological Society 49.3 (1993), pp. 229-234.

[6854] S. E. Evans and J. Klembara. "A choristoderan reptile (Reptilia: Diapsida) from the Lower Miocene of Northwest Bohemia (Czech Republic)". English. In: Journal of Vertebrate Paleontology 25.1 (2005), pp. 171-184. DOI: 10.1671/0272-4634(2005)025[0171:ACRRDF]2.0.CO;2.

[6855] S. E. Evans, C. Lally, D. J. Chure, A. Elder, and J. A. Maisano. "A Late Jurassic salamander (Amphibia: Caudata) from the Morrison Formation of North America". English. In: Zoological Journal of the Linnean Society 143.4 (2005), pp. 599-616.

[6856] S. E. Evans, M. Manabe, E. Cook, R. Hirayama, S. Isaji, C. J. Nicholas, D. Unwin, and Y. Yabumoto. "An Early Cretaceous assemblage from Gifu Prefecture, Japan". English. In: Lower and Middle Cretaceous Terrestrial Ecosystems, New Mexico Museum of Natural History and Science Bulletin 14 (1998), pp. 183-186. 
[6857] S. E. Evans, M. Manabe, M. Noro, S. Isaji, and M. Yamaguchi. "A long-bodied lizard from the Lower Cretaceous of Japan". English. In: Palaeontology 49.6 (2006), pp. 1143-1165.

[6858] S. E. Evans and M. Manabe. "An early herbivorous lizard from the Lower Cretaceous of Japan". English. In: Palaeontology 51.2 (2008), pp. 487-498. DOI: 10.1111/j.1475-4983.2008.00759.x.

[6859] S. E. Evans and M. Manabe. "Early Cretaceous lizards from the Okurodani Formation of Japan". English. In: Geobios 32.6 (1999), pp. 889-899. DOI: 10.1016/S0016-6995(99)80871-7.

[6860] S. E. Evans and M. Manabe. "A choristoderan reptile from the Lower Cretaceous of Japan". English. In: Special Papers in Palaeontology 60 (1999), pp. 101-119.

[6861] S. E. Evans and R. Matusmoto. "An assemblage of lizards from the Early Cretaceous of Japan". English. In: Palaeontologia Electronica 18.2 (2015), pp. 1-36.

[6862] S. E. Evans and G. J. McGowan. "An amphibian assemblage from the Purbeck Limestone Group". English. In: Special Papers in Palaeontology 68 (2002), pp. 103-119.

[6863] S. E. Evans and A. R. Milner. "Frogs and salamanders from the Upper Jurassic Morrison Formation (Quarry Nine, Como Bluff) of North America". English. In: Journal of Vertebrate Paleontology 13.1 (1993), pp. 24-30. DOI: 10.1080/02724634.1993.10011485.

[6864] S. E. Evans and A. R. Milner. Middle Jurassic microvertebrate assemblages from the British Isles. In the Shadow of the Dinosaurs: Early Mesozoic Tetrapods, N. C. Fraser and H.-D. Sues (eds.), Cambridge University Press. 1994, pp. 303-321.

[6865] S. E. Evans, A. R. Milner, and F. Mussett. "A discoglossid frog from the Middle Jurassic of England". In: Palaeontology 33.1 (1990), pp. 299-311.

[6866] S. E. Evans and A. R. Milner. Middle Jurassic microvertebrate faunas from the British Isles. English. Vol. 364. In Z. Kielan-Jaworowska, N. Heintz, \& H. A. Nakrem (eds.), Fifth Symposium on Mesozoic Terrestrial Ecosystems and Biota, Extended Abstracts. Contributions from the Paleontological Museum, Unviersity of Oslo. 1991, pp. 21-22.

[6867] S. E. Evans and A. R. Milner. "A metamorphosed salamander from the Early Cretaceous of Las Hoyas, Spain". English. In: Philosophical Transactions of the Royal Society of London B 351 (1996), pp. 627-646.

[6868] S. E. Evans, A. R. Milner, and C. Werner. "Sirenid salamanders and a gymnophionan amphibian from the Cretaceous of the Sudan". English. In: Palaeontology 39.1 (1996), pp. 77-95.

[6869] S. E. Evans, G. V. R. Prasad, and B. K. Manhas. "Fossil lizards from the Jurassic Kota Formation of India". English. In: Journal of Vertebrate Paleontology 22.2 (2002), pp. 299-312.

[6870] S. E. Evans, G. V. R. Prasad, and B. K. Manhas. "Rhynchocephalians (Diapsida: Lepidosauria) from the Jurassic Kota Formation of India". English. In: Zoological Journal of the Linnean Society 133 (2001), pp. 309-334.

[6871] S. E. Evans, P. Raia, and C. Barbera. "New lizards and rhynchocephalians from the Lower Cretaceous of southern Italy". English. In: Acta Palaeontologica Polonica 49.3 (2004), pp. 393-408.

[6872] S. E. Evans, A. L. Ruiz, and J. E. Rey. "A lizard from the Early Cretaceous (Berriasian-Valanginian) of Montsec, Catalonia, Spain". English. In: Neues Jahrbuch für Geologie und Paläontologie Abhandlungen 215.1 (2000), pp. 1-15.

[6873] S. E. Evans and B. Searle. Lepidosaurian reptiles from the Purbeck Limestone Group of Dorset, southern England. English. Vol. 68. Life and Environments in Purbeck Times. Special Papers in Palaeontology. 2002, pp. 145-149.

[6874] S. E. Evans and D. Sigogneau-Russell. "New sphenodontians (Diapsida: Lepidosauria: Rhynchocephalia) from the Early Cretaceous of North Africa". English. In: Journal of Vertebrate Paleontology 17.1 (1997), pp. 45-51.

[6875] S. E. Evans and D. Sigogneau-Russell. "A stem-group caecillian (Lissamphibia: Gymnophiona) from the Lower Cretaceous of North Africa". English. In: Palaeontology 44.2 (2001), pp. 259-273. 
[6876] S. E. Evans and M. Waldman. Small reptiles and amphibians from the Middle Jurassic of Skye, Scotland. English. Vol. 60. The Continental Jurassic. Museum of Northern Arizona Bulletin. 1996, pp. 219226.

[6877] S. E. Evans and Y. Wang. "A new lizard (Reptilia: Squamata) with exquisite preservation of soft tissue from the Lower Cretaceous of Inner Mongolia, China". English. In: Journal of Systematic Palaeontology 8.1 (2010), pp. 81-95. DOI: 10.1080/14772010903537773.

[6878] S. E. Evans and Y. Wang. "The Early Cretaceous lizard Dalinghosaurus from China". English. In: Acta Palaeontologica Polonica 50.4 (2005), pp. 725-742.

[6879] S. E. Evans, Y. Wang, and M. E. H. Jones. "An aggregation of lizard skeletons from the Lower Cretaceous of China". English. In: Senkenbergiana Lethaea 87.1 (2007), pp. 109-118.

[6880] S. E. Evans, Y. Wang, and C. Li. "The Early Cretaceous lizard genus Yabeinosaurus from China: resolving an enigma". English. In: Journal of Systematic Palaeontology 3.4 (2005), pp. 319-335. DOI: $10.1017 /$ S1477201905001641.

[6881] S. E. Evans and Y. Wang. "A gravid lizard from the Cretaceous of China and the early history of squamate viviparity". English. In: Naturwissenschaften 98 (2011), pp. 739-743. DOI: 10.1007/s00114011-0820-1.

[6882] S. E. Evans and Y. Wang. "A juvenile lizard specimen with well-preserved skin impressions from the Upper Jurassic/Lower Cretaceous of Daohugou, Inner Mongolia, China". English. In: Naturwissenschaften 94 (2007), pp. 431-439. DOI: 10.1007/s00114-006-0214-y.

[6883] S. E. Evans and Y. Wang. "New material of the Early Cretaceous lizard Yabeinosaurus from China". English. In: Cretaceous Research 34 (2012), pp. 48-60.

[6884] S. E. Evans and Y. Yabumoto. "A lizard from the Early Cretaceous Crato Formation, Araripe Basin, Brazil". English. In: Neues Jahrbuch für Paläontologie und Geologie, Monatshefte 1998 (1998), pp. 349364.

[6885] C. A. Evenchick, F. Ferri, P. S. Mustard, M. E. McMechan, D. Ritcey, V. J. McNicoll, K. G. Osadetz, P. B. O'Sullivan, L. D. Stasiuk, N. S. F. Wilson, T. P. Poulton, C. Lowe, R. J. Enkin, J. Waldron, D. B. Snyder, R. J. W. Turner, G. Nowlan, and M. Bodd. "Highlights of recent research in the Bowser and Sustut basins project, British Columbia". English. In: Geological Survey of Canada, Current Research 2205-A1 (2005), pp. 1-11.

[6886] N. L. Evenhuis. "Pieza, a new genus of microbombyliids from the New World (Diptera: Mythicomyiidae)". English. In: Zootaxa 36 (2002), pp. 1-28.

[6887] N. L. Evenhuis. "Review of the Tertiary microbombyliids (Diptera: Mythicomyiidae) in Baltic, Bitterfeld, and Dominican amber". English. In: Zootaxa 100 (2002), pp. 1-15.

[6888] N. L. Evenhuis. "New microbombyliids (Diptera: Mythicomyiidae) from Eocene Baltic and Rovno ambers, with notes on previously described amber species". English. In: Zootaxa 3731 (2013), pp. 371-380.

[6889] N. L. Evenhuis. "A new species of Hemipenthes Loew (Diptera: Bombyliidae: Anthracinae) from Miocene Dominican amber". English. In: Polish Journal of Entomology 82 (2013), pp. 281-286.

[6890] S. Everaert, P. De Schutter, G. Mariën, G. Cleemput, J. Van Boeckel, D. Rondelez, and T. Bor. "Een vroeg-miocene fauna uit het Zand van Kiel (Formatie van Berchem) bij Post $\mathrm{X}$ in Berchem (Antwerpen)". English. In: Afzettingen Wtkg 40.4 (2019), pp. 83-100.

[6891] M. J. Everhart. "First record of the hybodont shark genus, Polyacrodus sp., (Chondrichthyes; Polyacrodontidae) from the Kiowa Formation (Lower Cretaceous) of McPherson County, Kansas". English. In: Transactions of the Kansas Academy of Science 107.1/2 (2004), pp. 83-87.

[6892] M. J. Everhart. "Earliest record of the genus Tylosaurus (Squamata; Mosasauridae) from the Fort Hays Limestone (Lower Coniacian) of western Kansas". English. In: Transactions of the Kansas Academy of Science 108.3 (2005), pp. 149-155. 
[6893] M. J. Everhart. "Revisions to the biostratigraphy of the Moasasauridae (Squamata) in the Smoky Hill Chalk Member of the Niobara Chalk (Late Cretaceous) of Kansas". English. In: Transactions of the Kansas Academy of Science 104.1-2 (2001), pp. 59-78.

[6894] M. J. Everhart. "First records of plesiosaur remains in the lower Smoky Hill Chalk Member (Upper Coniacian) of the Niobrara Formation in western Kansas". English. In: Transactions of the Kansas Academy of Science 106.3-4 (2003), pp. 139-148.

[6895] M. J. Everhart. “Use of archival photographs to rediscover the locality of the Holyrood elasmosaur (Ellsworth County, Kansas)". English. In: Transactions of the Kansas Academy of Science 110.1-2 (2007), pp. 135-143.

[6896] M. J. Everhart. "Gastroliths associated with plesiosaur remains in the Sharon Springs Member of the Pierre Shale (Late Cretaceous), western Kansas". English. In: Transactions of the Kansas Academy of Science 103.1-2 (2000), pp. 64-75.

[6897] M. J. Everhart. “Tylosaurus kansasensis, a new species of tylosaurine (Squamata, Mosasauridae) from the Niobrara Chalk of western Kansas, USA". English. In: Netherlands Journal of Geosciences - Geologie en Mijnbouw 84.3 (2005), pp. 231-240.

[6898] M. J. Everhart. "Rare occurrence of a Globidens sp. (Reptilia; Mosasauridae) dentary in the Sharon Springs Member of the Pierre Shale (Middle Campanian) of Western Kansas". English. In: Fort Hays Studies, Special Issue 2 (2008), pp. 23-29.

[6899] M. J. Everhart. "Probable plesiosaur remains from the Blue Hill Shale (Carlile Formation; Middle Turonian) of north central Kansas". English. In: Transactions of the Kansas Academy of Science 112.3/4 (2009), pp. 215-221.

[6900] M. J. Everhart. "Rediscovery of the Hesperornis regalis Marsh 1871 holotype locality indicates an earlier stratigraphic occurrence". English. In: Transactions of the Kansas Academy of Science 114.1-2 (2011), pp. 59-68.

[6901] M. J. Everhart. "Late Cretaceous interaction between predators and prey. Evidence of feeding by two species of shark on a mosasaur". English. In: PalArch 1.1 (2004), pp. 1-7.

[6902] M. J. Everhart and A. Bell. "A Hesperornithiform Limb Bone from the Basal Greenhorn Formation (Late Cretaceous; Middle Cenomanian) of North Central Kansas". English. In: Journal of Vertebrate Paleontology 29.3 (2009), pp. 952-956.

[6903] M. J. Everhart and M. K. Darnell. “Occurrence of Ptychodus mammillaris (Elasmobranchii) in the Fairport Chalk Member of the Carlile Shale (Upper Cretaceous) of Ellis County, Kansas". English. In: Transactions of the Kansas Academy of Science 107 (2004), pp. 126-130. DOI: 10.1660/00228443(2004)107[0126:OOPMEI]2.0.CO;2.

[6904] M. J. Everhart and K. Ewell. "Shark-bitten dinosaur (Hadrosauridae) caudal vertebrae from the Niobrara Chalk (upper Coniacian) of western Kansas". English. In: Transactions of the Kansas Academy of Science 109.1/2 (2006), pp. 27-35.

[6905] M. J. Everhart and S. A. Hamm. "A new nodosaur specimen (Dinosauria: Nodosauridae) from the Smoky Hill Chalk (Upper Cretaceous) of western Kansas". In: Transactions of the Kansas Academy of Science 108.1/2 (2005), pp. 15-21.

[6906] M. J. Everhart and R. A. Hawkins. "A Giant Bear Mandible (Agriotherium schneideri Sellards 1916) from Sedgwick County, Kansas". English. In: Transactions of the Kansas Academy of Science 123.1-2 (2020), pp. 191-202. DOI: 10.1660/062.123.0116.

[6907] S. W. Evers and O. Wings. "Late Jurassic theropod dinosaur bones from the Langenberg Quarry (Lower Saxony, Germany) provide evidence for several theropod lineages in the central European archipelago". English. In: PeerJ 8 (2020), e8437.

[6908] K. Ewell and M. J. Everhart. A Paleozoic shark fauna from the Council Grove Group (Lower Permian). English. 2005. 
[6909] T. A. M. Ewin, M. Reich, M. R. Graham, and M. E. Cournoyer. “Perforocycloides nathalieae new genus andăspecies, anăunusual Silurian cyclocystoid (Echinodermata) fromăAnticosti Island, Québec, Canada". English. In: Palaeontologische Zeitschrift 93 (2019), pp. 625-635. DOI: 10. 1007/s12542-019-00483-w.

[6910] T. A. M. Ewin and B. Thuy. "Two new British Mesozoic ophiuroid localities, primary observations and determinations". English. In: vol. 19. Progress in Echinoderm Paleobiology, Cuadernos del Museo Geominero. Madrid: Instituto Geológico y Minero de España, 2015, pp. 53-57.

[6911] T. A. M. Ewin and B. Thuy. "Brittle stars from the British Oxford Clay: unexpected ophiuroid diversity on Jurassic sublittoral mud bottoms". English. In: Journal of Paleontology 91.4 (2017), pp. 781-798. DOI: 10.1017/jpa.2016.162.

[6912] Y. Ezaki. "Palaeoecological and phylogenetic implications of a new scleractiniamorph genus from Permian sponge reefs, South China". English. In: Palaeontology 43.2 (2000), pp. 199-217.

[6913] Y. Ezaki. "Permian corals from Abadeh and Julfa, Iran, West Tethys". English. In: Journal of the Faculty of Science, Hokkaido University, Ser. IV 23.1 (1991), pp. 53-146.

[6914] M. Ezcurra, A. G. Martinelli, L. E. Fiorelli, A. A. S. Da-Rosa, and J. B. Desojo. "Archosauromorph remains from the Tarjados Formation (Early-Middle Triassic, NW Argentina)". English. In: Ameghiniana 52 (2015), pp. 475-486.

[6915] M. D. Ezcurra. "Theropod remains from the uppermost Cretaceous of Colombia and their implications for the palaeozoogeography of western Gondwana". English. In: Cretaceous Research 30 (2009), pp. 1339-1344. DOI: 10.1016/j.cretres.2009.08.004.

[6916] M. D. Ezcurra. "A new early dinosaur (Saurischia: Sauropodomorpha) from the Late Triassic of Argentina: a reassessment of dinosaur origin and phylogeny". English. In: Journal of Systematic Palaeontology 8 (2010), pp. 371-425. DOI: 10.1080/14772019.2010.484650.

[6917] M. D. Ezcurra. "Comments on the taxonomic diversity and paleobiogeography of the earliest known dinosaur assemblages (late Carnian-earliest Norian)". English. In: Historia Natural, Tercera Serie 2.1 (2012), pp. 49-71.

[6918] M. D. Ezcurra. "A new early coelophysoid neotheropod from the Late Triassic of northwestern Argentina". English. In: Ameghiniana 54.5 (2017), pp. 506-538. DOI: 10.5710 / AMGH.04.08.2017. 3100.

[6919] M. D. Ezcurra, F. L. Agnolin, and F. E. Novas. "An abelisauroid dinosaur with a non-atrophied manus from the Late Cretaceous Pari Aike Formation of southern Patagonia". English. In: Zootaxa 2450 (2010), pp. 1-25.

[6920] M. D. Ezcurra and C. Apaldetti. "A robust sauropodomorph specimen from the Upper Triassic of Argentina and insights on the diversity of the Los Colorados Formation". English. In: Proceedings of the Geologists' Association 123 (2012), pp. 155-164. DOI: 10.1016/j.pgeola.2011.05.002.

[6921] M. D. Ezcurra and R. J. Butler. "Taxonomy of the proterosuchid archosauriforms (Diapsida: Archosauromorpha) from the earliest Triassic of South Africa, and implications for the early archosauriform radiation". English. In: Palaeontology 58.1 (2015), pp. 141-170.

[6922] M. D. Ezcurra, J. B. Desojo, and O. W. M. Rauhut. "Redescription and phylogenetic relationships of the proterochampsid Rhadinosuchus gracilis (Diapsida: Archosauriformes) from the early Late Triassic of southern Brazil". English. In: Ameghiniana 52 (2015).

[6923] M. D. Ezcurra, A. Lecuona, and A. Martinelli. "A new basal archosauriform diapsid from the Lower Triassic of Argentina". English. In: Journal of Vertebrate Paleontology 30.5 (2010), pp. 14331450.

[6924] M. D. Ezcurra, F. Montefeltro, and R. J. Butler. "The early evolution of rhynchosaurs". English. In: Frontiers in Ecology and Evolution 3 (2016), p. 142.

[6925] M. D. Ezcurra, S. J. Nesbitt, L. E. Fiorelli, and J. B. Desojo. "New specimen sheds light on the anatomy and taxonomy of the early Late Triassic dinosauriforms from the Chañares Formation, NW Argentina". English. In: The Anatomical Record 303.5 (2020), pp. 1393-1438. DOI: 10.1002/ar. 24243. 
[6926] M. D. Ezcurra and F. E. Novas. "Phylogenetic relationships of the Triassic theropod Zupaysaurus rougieri from NW Argentina". English. In: Historical Biology 19.1 (2007), pp. 35-72.

[6927] M. D. Ezcurra, T. M. Scheyer, and R. J. Butler. "The origin and early evolution of Sauria: reassessing the Permian saurian fossil record and the timing of the crocodile-lizard divergence". English. In: PLoS ONE 9.2 (2014), e89165.

[6928] M. D. Ezcurra, P. Velozo, M. Meneghel, and G. Pineiro. "Early archosauromorph remains from the Permo-Triassic Buena Vista Formation of north-eastern Uruguay". English. In: PeerJ 3 (2015), e776.

[6929] R. Ezquerra, S. Doublet, L. Costeur, P. M. Galton, and F. Pérez-Lorente. "Were non-avian theropod dinosaurs able to swim? Supportive evidence from an Early Cretaceous trackway, Cameros Basin (La Rioja, Spain)". English. In: Geology 35.6 (2007), pp. 507-510.

[6930] I. Fzy, N. M. M. Janssen, G. D. Price, J. Knauer, and J. Pálfy. “Integrated isotope and biostratigraphy of a Lower Cretaceous section from the Bakony Mountains (Transdanubian Range, Hungary): A new Tethyan record of the Weissert event". English. In: Cretaceous Research 31.6 (2010), pp. 525545. DOI: $10.1016 /$ j.cretres.2010.07.003.

[6931] T. S. Fachini, S. Onary, A. Palci, M. S. Y. Lee, M. Bronzati, and A. S. Hsiou. “Cretaceous blindsnake from Brazil fills major gap in snake evolution". English. In: iScience 23.12 (2020), 101834:1-13. DOI: 10.1016/j.isci.2020.101834.

[6932] J. A. Fagerstrom. "The history of Devonian-Carboniferous reef communities: extinctions, effects, recovery". In: Facies 30 (1994), pp. 177-191.

[6933] J. A. Fagerstrom and M. A. Bradshaw. "Early Devonian reefs at Reefton, New Zealand: guilds, origin and paleogeographic significance". In: Lethaia 35.1 (2002), pp. 35-50.

[6934] J. A. Fagerstrom and O. Weidlich. "Strengths and weaknesses of the reef guild concept and quantitative data: Application to the Upper Capitan-massive community (Permian), Guadalupe Mountains, New Mexico-Texas". In: Facies 40 (1999), pp. 131-156.

[6935] V. Fahlbusch. "Ein neuer Primate (Mammalia, Omomyidae) aus dem marinen Ober-Eozän des inneralpinen Tertiärs von Oberaudorf nördlich Kufstein." German. In: Neues Jahrbuch für Geologie und Paläontologie, Abhandlungen 198.1/2 (1995), pp. 15-26.

[6936] V. Fahlbusch. "The Neogene mammalian faunas of Ertemte and Harr Obo in Inner Mongolia (Nei Mongol), China. - 10. Eozapus (Rodentia)". English. In: Senckenbergiana lethaea 72 (1992), pp. 199217.

[6937] I. D. E. Faichney, J. M. Webster, D. A. Clague, J. C. Braga, W. Renema, and D. C. Potts. “The impact of the Mid-Pleistocene Transition on the composition of submerged reefs of the Maui Nui Complex, Hawaii". English. In: Palaeogeography, Palaeoclimatology, Palaeoecology 299 (2011), pp. 493-506.

[6938] M. Fairon-Demaret and T. Smith. "Fruits and seeds from the Tienen Formation at Dormaal, PalaeoeceneEocene transition in eastern Belgium". In: Review of Palaeobotany and Palynology 122 (2002), pp. 4762.

[6939] M. Fairon-Demaret. "Dorinnotheca streelii Fairon-Demaret, gen. et sp. nov., a new early seed plant from the upper Famennian of Belgium". In: Review of Palaeobotany and Palynology 93 (1996), pp. 217-233.

[6940] M. Fairon-Demaret, I. Leponce, and M. Streel. “Archaeopteris from the Upper Famennian of Belgium: heterospory, nomenclature, and palaeobiogeography". In: Review of Palaeobotany and Palynology 115 (2001), pp. 79-97.

[6941] M. Fairon-Demaret and C. S. Li. "Lorophyton goense gen. et sp. nov. from the Lower Givetian of Belgium and a discussion of the MIddle Devonian Cladoxylopsida". In: Review of Palaeobotany and Palynology 77 (1993), pp. 1-22.

[6942] M. Falahatgar, A. May, and M. Sarfi. "First report of the rugose coral Hexagonaria davidsoni from the". English. In: Boletn de la Sociedad Geológica Mexicana 70.3 (2018), pp. 787-795. 
[6943] P. Falaschi, J. Grosfeld, A. B. Zamuner, N. Foix, and S. M. Rivera. “Growth architecture and silhouette of Jurassic conifers from La Matilde Formation, Patagonia, Argentina". English. In: Palaeogeography, Palaeoclimatology, Palaeoecology 302.43 (2011), pp. 122-141. DOI: 10.1016/j.palaeo.2010.12.005.

[6944] A. D. Falbo and F. L. Agnolin. "First record of a chelonioid sea turtle (Testudines, Pan-Cheloniidae) from the late Miocene of Argentina". English. In: Alcheringa (2020), pp. 1-6.

[6945] H. J. Falcon-Lang, E. Henderson, and J. Galtier. "Tree trunks of $<\mathrm{i}>$ Pitus primaeva $</ \mathrm{i}>$ in Mississippian (Courceyan) rocks at Montford, near Rothesday, Isle of Bute, Scotland". English. In: Scottish Journal of Geology 46 (2010), pp. 59-65.

[6946] J. Falconnet. "First evidence of a bolosaurid parareptile in France (latest Carboniferous-earliest Permian of the Autun basin) and the spatiotemporal distribution of the Bolosauridae". English. In: Bulletin de la Société géologique de France 183.6 (2012), pp. 495-508.

[6947] J. Falconnet, M. Andriamihaja, É Läng, and J. S. Steyer. “First procolophonid (Reptilia, Parareptilia) from the Lower Triassic of Madagascar". English. In: Comptes Rendus Palevol 11 (2012), pp. 357369.

[6948] E. Faliéres and A. Nel. “The first sclerodermine and pristocerine flat wasps in Lowermost Eocene amber of France (Hymenoptera: Bethylidae)". English. In: Comptes Rendus Palevol 18 (2019), pp. 509 515. DOI: $10.1016 /$ j.crpv.2019.04.007.

[6949] E. Faliéres and A. Nel. "First fossil of the extant flat wasp genus Dissomphalus Ashmead, 1893 (Hymenoptera: Bethylidae: Pristocerinae)". English. In: Zoosystema 42 (2020), pp. 207-213. DOI: 10.5252/zoosystema2020v42a15.

[6950] B. R. Fallon and R. W. Boessenecker. "First record of a leatherback sea turtle (Dermochelyidae) from the Mio-Pliocene Purisima Formation of northern California, USA". English. In: PaleoBios 36 (2019), p. 44240.

[6951] B. R. Fallon and R. W. Boessenecker. "Multispecies leatherback turtle assemblage from the Oligocene Chandler Bridge and Ashley formations of South Carolina, USA". English. In: Acta Palaeontologica Polonica 65 (2020), pp. 1-14. DOI: 10.4202/app.00740.2020.

[6952] J. S. Fan, J. K. Rigby, and W. Zhang. "Hydrozoa from Middle and Upper Permian reefs of south China". English. In: Journal of Paleontology 65.1 (1991), pp. 45-68.

[6953] J.-S. Fan, Y.-M. Wang, and Y. -S. Wu. “Calcisponges and hydrozoans from Permian reefs in western Guangxi (in Chinese)". In: Acta Palaeontologica Sinica 41 (2002), pp. 334-348.

[6954] H. Fang, C. C. Labandeira, Y. M. Ma, B. Y. Zheng, D. Ren, X. L. Wei, J. X. Liu, and Y. J. Wang. "Lichen mimesis in mid-Mesozoic lacewings". English. In: eLife $9 . e 59007$ (2020). DOI: 10.7554 / eLife.59007.

[6955] H. Fang, D. Ren, and Y. J. Wang. "Familial clarification of Saucrosmylidae stat. nov. and new saucrosmylids from Daohugou, China (Insecta, Neuroptera)". English. In: PLoS One 10.10 (2015), e0141048.

[6956] H. Fang, D. Ren, J. X. Liu, and Y. J. Wang. “Revision of the lacewing genus Laccosmylus with two new species from the Middle Jurassic of China (Insecta, Neuroptera, Saucrosmylidae)". English. In: ZooKeys 790 (2018), pp. 115-126.

[6957] X. Fang, L. Lu, Y. Jiang, and L. Yang. "[Cretaceous fossil eggs from the Tiantai basin of Zhejiang, with a discussion on the extinction of dinosaurs]". Chinese. In: Geological Bulletin of China 22.7 (2003), pp. 512-520.

[6958] X. Fang, X. Ma, Y. Zhang, Z. Zhou, T. Chen, Y. Lü, S. Yu, and J. Fan. “Biostratigraphical constraints on the disconformity within the Upper Ordovician in the Baoshan and Mangshi regions, western Yunnan Province, China". English. In: Lethaia 51 (2018), pp. 312-323. DOI: 10.1111/let.12255.

[6959] X. Fang, Pang, J. Lü, Pan Zhang Y., Li Wang X., and Cheng. [Lower, Middle, and Upper Jurassic divisions of the Lufeng region of Yunnan province]. Chinese. Proceedings of the Third National Stratigraphical Conference of China. Geological Publishing House, Beijing. 2000, pp. 208-214. 
[6960] X. Fang, Y. Wang, and Y. Jiang. "[On the Late Cretaceous fossil eggs of Tiantai, Zhejiang]". Chinese. In: Geological Review 46.1 (2000), pp. 105-112.

[6961] Y. Fang, S. W. Heads, H. Wang, H. C. Zhang, and B. Wang. "The first Archelcaninae (Orthoptera, Elcanidae) from the Cretaceous Jehol Biota of Liaoning, China". English. In: Cretaceous Research 86 (2018), pp. 129-134.

[6962] Y. Fang, A. D. Muscente, S. W. Heads, B. Wang, and S. H. Xiao. “The earliest Elcanidae (Insecta, Orthoptera) from the Upper Triassic of North America". English. In: Journal of Paleontology 92 (2018), pp. 1028-1034.

[6963] Y. Fang, B. Wang, H. C. Zhang, H. Wang, E. A. Jarzembowski, D. R. Zheng, Q. Zhang, S. Li, and Q. Liu. "New Cretaceous Elcanidae from China and Myanmar (Insecta, Orthoptera)". English. In: Cretaceous Research 52 (2015), pp. 323-328.

[6964] Y. Fang, H. Zhang, B. Wang, and Y. Zhang. "New taxa of Aboilinae (Insecta, Orthoptera, Prophalangopsidae) from the Middle Jurassic of Daohugou, Inner Mongolia, China". English. In: Zootaxa 1637 (2007), pp. 55-62.

[6965] Y. Fang, H. C. Zhang, B. Wang, and D. R. Zheng. "A new Chifengiinae species (Orthoptera: Prophalangopsidae) from the Lower Cretaceous Yixian Formation (Liaoning, P.R. China)". English. In: Insect Systematics \& Evolution 44 (2013), pp. 141-147.

[6966] Y. Fang, H. C. Zhang, B. Wang, and D. R. Zheng. "A new cockroach (Blattaria: Caloblattinidae) from the Upper Triassic Xujiahe Formation of Sichuan Province, southwestern China". English. In: Insect Systematics \& Evolution 44 (2013), pp. 167-174.

[6967] Z. Fang, A. Boucot, V. Covacevich, and F. Herve. "Discovery of Late Triassic fossils in the Chronos Metamorphic Complex, southern Chile". English. In: Revista Geologica de Chile 25.2 (1998), pp. 165173.

[6968] Z. J. Fang. "Generic demarcation of Permo-Triassic Claraia-like species and their biogeographic significance". English. In: Alcheringa 34 (2010), pp. 161-178.

[6969] Z. J. Fang, J. H. Chen, C. Z. Chen, J. G. Sha, X. Lan, and S. Z. Wen. "Supraspecific taxa of the Bivalvia first named, described, and published in China (1927-2007)". English. In: The University of Kansas Paleontological Contributions, New Series 17 (2009), pp. 1-157.

[6970] Z. J. Fang and D. W. Yin. “Discovery of fossil bivalves from Early Permian of Dongfang, Hainan Island with a review of glaciomarine origin of Nanlong diamictites". Chinese. In: Acta Palaeontologica Sinica 34 (1995), pp. 301-315.

[6971] U. Fanning, D. Edwards, and J. B. Richardson. "Further evidence for diversity in late Silurian land vegetation". In: Journal of the Geological Society, London 147 (1990), pp. 725-728.

[6972] U. Fanning and D. Edwards. "Further evidence for diversity in late Silurian land vegetation". In: Journal of the Geological Society, London 147 (1990), pp. 725-728.

[6973] F. Fanti. "New fossil Cantharidae genus and species from Baltic amber (Insecta Coleoptera)". English. In: Giornale Italiano di Entomologia 14 (2017), pp. 709-714.

[6974] F. Fanti. "Malthodes michalskii: a new species of Cantharidae from Baltic amber (Coleoptera)". English. In: Giornale Italiano di Entomologia 14 (2017), pp. 685-690.

[6975] F. Fanti. "World catalog of fossil Cantharidae". English. In: Fossils \& Minerals Review 2 (S.I.) (2017), pp. 1-52.

[6976] F. Fanti. "Malthodes meriae sp. nov.: a new fossil Malthodes Kiesenwetter, 1852 from the Eocene Baltic forests (Coleoptera: Cantharidae)". English. In: Studies and Reports, Taxonomical Series 14 (2018), pp. 243-248.

[6977] F. Fanti. "First fossil soldier beetles (Coleoptera Cantharidae) from Bitterfeld amber, Germany". English. In: Zitteliana 93 (2019), pp. 89-96.

[6978] F. Fanti. “New fossil Malthodes Kiesenwetter, 1852 of the subgenus Libertimalthodes Kupryjanowicz \& Fanti, 2019 from Baltic amber (Coleoptera: Cantharidae)". English. In: Palaeodiversity 12 (2019), pp. 65-68. 
[6979] F. Fanti. “Two new fossil soldier beetles from the Baltic amber (Coleoptera: Cantharidae)". English. In: Studies and Reports, Taxonomical Series 16 (2020), pp. 13-19.

[6980] F. Fanti and E. Castiglione. "Description of a new genus and species of Cantharidae from Eocene Baltic amber (Insecta, Coleoptera)". English. In: Palaeodiversity 10 (2017), pp. 123-127.

[6981] F. Fanti, A. Cau, M. Hassine, and M. Contessi. "A new sauropod dinosaur from the Early Cretaceous of Tunisia with extreme avian-like pneumatization". English. In: Nature Communications 4.2080 (2013), pp. 1-7. DOI: 10.1038/ncomms3080.

[6982] F. Fanti, A. Cau, and M. Hassine. "Evidence of titanosauriforms and rebbachisaurids (Dinosauria: Sauropoda) from the Early Cretaceous of Tunisia". English. In: Journal of African Earth Sciences 90 (2014), pp. 1-8.

[6983] F. Fanti, A. Cau, and A. Negri. "A giant mosasaur (Reptilia, Squamata) with an unusually twisted dentition from the Argille Scagliose Complex (late Campanian) of Northern Italy". English. In: Cretaceous Research 49 (2014), pp. 91-104.

[6984] F. Fanti, A. Cau, L. Panzarin, and L. Cantelli. "Evidence of iguanodontian dinosaurs from the Lower Cretaceous of Tunisia". English. In: Cretaceous Research 60 (2016), pp. 267-274. DOI: 10 . 1016/j.cretres.2015.12.008.

[6985] F. Fanti, M. Contessi, A. Nigarov, and P. Esenov. "New data on two large dinosaur tracksites from the Upper Jurassic of eastern Turkmenistan (Central Asia)". English. In: Ichnos 20 (2013), pp. 5471. DOI: $10.1080 / 10420940.2013 .778845$.

[6986] F. Fanti, P. J. Currie, and D. Badamgarav. "New specimens of Nemegtomaia from the Baruungoyot and Nemegt formations (Late Cretaceous) of Mongolia". English. In: PLoS ONE 7.2 (2012), e31330:1-16.

[6987] F. Fanti, A. L. Damgaard, and S. Ellenberger. "Two new genera of Cantharidae from Burmese amber of the Hukawng Valley (Insecta, Coleoptera)". English. In: Cretaceous Research 86 (2018), pp. 170-177.

[6988] F. Fanti and A. L. Damgaard. "Fossil soldier beetles from Baltic amber of the Anders Damgaard amber collection (Coleoptera Cantharidae)". English. In: Baltic Journal of Coleopterology 18 (2018), pp. 1-32.

[6989] F. Fanti and A. L. Damgaard. "New soldier beetles (Cantharidae) from Baltic, Burmese and Dominican ambers of the Anders Damgaard amber collection". English. In: Baltic Journal of Coleopterology 19 (2019), pp. 101-125.

[6990] F. Fanti and S. Ellenberger. "Myamalycocerus vitalii: A new genus and species of soldier beetle in Burmese amber (Coleoptera Cantharidae)". English. In: Cretaceous Research 71 (2016), pp. 166-169.

[6991] F. Fanti and S. Ellenberger. "A new fossil genus of soldier beetles (Coleoptera: Cantharidae) from mid-Cretaceous Burmese amber: A probable case of adaptive convergence". English. In: Cretaceous Research 92 (2018), pp. 201-204.

[6992] F. Fanti and J. Kupryjanowicz. "A new soldier beetle from Eocene Baltic amber". English. In: Acta Palaeontologica Polonica 62 (2017), pp. 785-788.

[6993] F. Fanti and J. Kupryjanowicz. "Discovery of a new fossil soldier beetle in Eocene Baltic amber, with the establishment of the new tribe Cacomorphocerini". English. In: Annales de Paléontologie 104 (2018), pp. 149-153.

[6994] F. Fanti and T. Miyashita. "A high latitude vertebrate fossil assemblage from the Late Cretaceous of west-central Alberta, Canada: evidence for dinosaur nesting and vertebrate latitudinal gradient". English. In: Palaeogeography, Palaeoclimatology, Palaeoecology 275.1-4 (2009), pp. 37-53. DOI: 10.1016/ j.palaeo.2009.02.007.

[6995] F. Fanti, T. Miyashita, L. Cantelli, F. Mnasri, J. Dridi, M. Contessi, and A. Cau. "The largest thalattosuchian (Crocodylomorpha) supports teleosaurid survival across the Jurassic-Cretaceous boundary". English. In: Cretaceous Research (2016). DOI: 10.1016/j.cretres.2015.11.011. 
[6996] F. Fanti, T. Miyashita, L. Cantellia, F. Mnasrid, J. Dridid, M. Contessie, and A. Cau. “The largest thalattosuchian (Crocodylomorpha) supports teleosaurid survival across the Jurassic-Cretaceous boundary". English. In: Cretaceous Research 61 (2016), pp. 263-274. DOI: 10.1016/j.cretres.2015.11. 011.

[6997] F. Fanti and M. G. Pankowski. "A new Eocene soldier beetle (Cantharidae) of the genus +Cacomorphocerus Schaufuss, 1892 from Baltic amber". English. In: Zootaxa 4869 (2020), pp. 437-443.

[6998] F. Fanti and M. G. Pankowski. "Two new species of Cantharis Linnaeus, 1758 from Baltic amber". English. In: Zootaxa 4878 (2020), pp. 401-411.

[6999] F. Fanti and M. J. Pankowski. "A new fossil soldier beetle (Coleoptera, Cantharidae, Silinae) from Eocene Baltic amber". English. In: Zootaxa 4370 (2018), pp. 189-193.

[7000] F. Fanti and M. K. Pankowski. "Three new species of soldier beetles from Baltic amber (Coleoptera, Cantharidae)". English. In: Zootaxa 4455 (2018), pp. 513-524.

[7001] F. Fanti and M. K. Pankowski. "A new soldier beetle of the extinct tribe Cacomorphocerini Fanti \& Kupryjanowicz, 2018”. English. In: Zootaxa 4651 (2019), pp. 589-595.

[7002] F. Fanti and E. Sontag. "A new fossil soldier beetle (Coleoptera: Cantharidae: Malthininae) from Baltic amber". English. In: Zootaxa 4629 (2019), pp. 583-588.

[7003] F. Fanti and F. Therrien. "Theropod tooth assemblages from the Late Cretaceous Maevarano Formation and the possible presence of dromaeosaurids in Madagascar". English. In: Acta Palaeontologica Polonica 52.1 (2007), pp. 155-166.

[7004] F. Fanti and F. Vitali. "Key to fossil Malthininae, with description of two new species in Baltic amber (Coleoptera Cantharidae)". English. In: Baltic Journal of Coleopterology 17 (2017), pp. 19-27.

[7005] F. Fanti and F. Vitali. "A new species of the enigmatic genus Kuskaella Fanti \& Kupryjanowicz, 2017 (Coleoptera, Cantharidae) from Baltic amber". English. In: Baltic Journal of Coleopterology 20 (2020), pp. 1-6.

[7006] F. Fanti and L. J. Walker. "Fossil soldier beetles (Coleoptera: Cantharidae) of the Georg Statz Collection from the Oligocene Rott Formation, Germany". English. In: Palaeoentomology 2.5 (2019), pp. 491-504.

[7007] N. Fantini Sestini. "I Coralli Calcare di Zu (Triassico Superiore) della Lombardia (Italia). Nuove Segnalazioni". Italian. In: Rivista Italiana di paleontologia e stratigrafia 96 (1990), pp. 103-110.

[7008] N. Fantini Sestini. "The Ladinian ammonoids from the Calcare di Esino of Val Parina (Bergamasc Alps, Northern Italy). Part. 1". English. In: Rivista Italiana di Paleontologia e Stratigrafia 100.2 (1994), pp. 227-284.

[7009] N. Fantini Sestini. "The Ladinian ammonoids from the Calcare di Esino of Val Parina (Bergamasc Alps, Northern Italy). Part. 2". English. In: Rivista Italiana di Paleontologia e Stratigrafia 102.2 (1996), pp. 211-226.

[7010] E. Fara, M. Ouaja, E. Buffetaut, and D. Srarfi. "First occurrences of thalattosuchian crocodiles in the Middle and Upper Jurassic of Tunisia". English. In: Neues Jahrbuch für Geologie und Paläontologie, Monatshefte 2002.8 (2002), pp. 465-476.

[7011] M. J. Farabee, E. L. Taylor, and T. N. Taylor. "Correlation of Permian and Triassic palynomorph assemblages from the central Transantartic Mountains, Antartica". In: Review of Palaeobotany and Palynology 65 (1990), pp. 257-265.

[7012] E. Farabegoli, M. C. Perri, and R. Posenato. "Environmental and biotic changes across the PermianTriassic boundary in western Tethys: The Bulla parastratotype, Italy". English. In: Global and Planetary Change 55 (2007), pp. 109-135.

[7013] F. H. A. Farache, J. Y. Rasplus, D. Azar, R. A. S. Pereira, and S. G. Compton. "First record of a non-pollinating fig wasp (Hymenoptera: Sycophaginae) from Dominican amber, with estimation of the size of its host figs". English. In: Journal of Natural History 50 (2016), pp. 2237-2247. 
[7014] C. Faranda, P. Cipollari, D. Cosentino, E. Gliozzi, and G. Pipponzi. “Late Miocene ostracod assemblages from eastern Mediterranean coral reef complexes (central Crete, Greece)". English. In: Revue de micropaléontologie 51 (2008), pp. 287-308.

[7015] P. Faraoni, D. Flore, A. Marini, G. Pallini, and N. Pezzoni. "Valanginian and early Hauterivian ammonite successions in the Mt Catria group (Central Apennines) and the Lessini Mts (Southern Alps), Italy". English. In: Palaeopelagos 7 (1997), pp. 59-100.

[7016] A. A. Farke. "Ceratopsid dinosaurs from the Upper Cretaceous Almond Formation of southwestern Wyoming". English. In: Rocky Mountain Geology 39.1 (2004), pp. 1-5.

[7017] A. A. Farke, M. M. Henn, S. J. Woodward, and H. A. Xu. "Leidyosuchus (Crocodylia: Alligatoroidea) from the Upper Cretaceous Kaiporowits Formation (Late Campanian) of Utah, USA". English. In: PaleoBios 30.3 (2014), pp. 72-88.

[7018] A. A. Farke, W. D. Maxwell, R. L. Cifelli, and M. J. Wedel. “A ceratopsian dinosaur from the Lower Cretaceous of western North America, and the biogeography of Neoceratopsia". English. In: PLoS ONE 9.12 (2014), e11205:15-18. DOI: 10.1371/journal.pone.0112055.

[7019] A. A. Farke and P. P. Patel. "An enantiornithine bird from the Campanian Kaiparowits Formation of Utah, USA". English. In: Cretaceous Research 37 (2012), pp. 227-230.

[7020] A. A. Farke and G. E. Phillips. "The first reported ceratopsid dinosaur from eastern North America (Owl Creek Formation, Upper Cretaceous, Mississippi, USA)". English. In: PeerJ 5 (2017), e3342.

[7021] A. A. Farke, M. J. Ryan, P. M. Barrett, D. H. Tanke, D. R. Braman, M. A. Loewen, and M. R. Graham. "A new centrosaurine from the Late Cretaceous of Alberta, Canada, and the evolution of parietal ornamentation in horned dinosaurs". English. In: Acta Palaeontologica Polonica 56.4 (2011), pp. 691702. DOI: $10.4202 /$ app.2010.0121.

[7022] A. A. Farke and J. J. W. Sertich. "An abelisauroid theropod dinosaur from the Turonian of Madagascar". English. In: PLoS ONE 8.4 (2013), e62047:1-18. DOI: 10.1371/journal.pone.0062047.

[7023] A. A. Farke and C. A. Wilridge. "A possible pterosaur wing phalanx from the Kaiparowits Formation (late Campanian) of southern Utah, USA". English. In: PalArch's Journal of Vertebrate Palaeontology 10.2 (2013), pp. 1-6.

[7024] A. A. Farke and E. Yip. “A juvenile cf. Edmontosaurus annectens (Ornithischia, Hadrosauridae) femur documents a previously unreported intermediate growth stage for this taxon". English. In: Vertebrate Anatomy Morphology Palaeontology 7 (2019), pp. 59-67.

[7025] J. O. Farlow, M. O’Brien, G. J. Kuban, B. F. Dattilo, K. T. Bates, P. L. Falkingham, L. Piñuela, A. Rose, A. Freels, C. Kumagai, C. Libben, J. Smith, and J. Whitcraft. “Dinosaur tracksites of the Paluxy River valley (Glen Rose Formation, Lower Cretaceous), Dinosaur Valley State Park, Somervell County, Texas". English. In: Actas del V Jornadas Internacionales sobre Paleontologa de Dinosaurios y su Entorno. Salas de los Infantes: Colectivo Arqueológico-Paleontológico Salense, 2012, pp. 41-69.

[7026] J. O. Farlow, J. A. Sunderman, J. J. Havens, A. L. Swinehart, J. A. Holman, R. L. Richards, N. G. Miller, R. A. Martin, R. M. Hunt Jr., G. W. Storrs, B. B. Curry, R. H. Fluegeman, M. R. Dawson, and M. E. T. Flint. "The Pipe Creek Sinkhole biota, a diverse late Tertiary continental fossil assemblage from Grant County, Indiana". English. In: American Midland Naturalist 145.2 (2001), pp. 367-378.

[7027] J. Farmer, G. Vidal, M. Moczydlowska, H. Strauss, P. Ahlberg, and A. Siedlecka. “Edicaran fossils from the Innerelv Member (late Proterozoic) of the Tanafjorden area, northeastern Finmark". In: Geological Magazine 2 (1992), pp. 181-195.

[7028] J. R. Farrell. "Siluro-Devonian conodonts from the Camelford Limestone, Wellington, New South Wales, Australia". English. In: Palaeontology 937.982 (2004).

[7029] J. R. Farrell. "Pridoli conodont fauna from tectonically emplaced limestone blocks within the Barnby Hills Shale, central western New South Wales". English. In: Alcheringa: An Australasian Journal of Palaeontology (2006). 
[7030] J. R. Farrell. “Late Pridoli, Lochkovian, and early Pragian conodonts from the Gap area between Larras Lee and Eurimbla, central western NSW, Austalia". English. In: vol. 245. Courier Forschungsinstitut Senckenberg. Stuttgart: E. Schweizerbart'sche Verlagsbuchhandlung, 2003, pp. 107-181.

[7031] M. Fastnacht. "The first dsungaripterid pterosaur from the Kimmeridgian of Germany and the biomechanics of pterosaur long bones". English. In: Acta Palaeontologica Polonica 50.2 (2005), pp. 273288.

[7032] M. Fastnacht. "First record of Coloborhynchus (Pterosauria) from the Santana Formation (Lower Cretaceous) of the Chapada do Araripe, Brazil". English. In: Palaeontologische Zeitschrift 75.1 (2001), pp. 23-36.

[7033] D. E. Fastovsky, D. B. Weishampel, M. Watabe, R. Barsbold, K. Tsogtbaatar, and P. Narmandakh. "A nest of Protoceratops andrewsi (Dinosauria, Ornithischia)". English. In: Journal of Paleontology 85.6 (2011), pp. 1035-1041. DOI: 10.1666/11-008.1.

[7034] C. Fate, J. Lapeyrie, and A. Nel. "A new Permagrionidae from the Middle Permian of the south of France (Odonatoptera: Protozygoptera)". English. In: Zootaxa 3702 (2013), pp. 397-400.

[7035] C. Fate, V. Perrichot, and A. Nel. "A Mid Cretaceous representative of the modern scatopsid genus Ectaetia (Diptera: Scatopsidae: Ectaetiinae)". English. In: Zootaxa 3686 (2013), pp. 396-400.

[7036] O. Fatka. "Association of fossils and history of research at the Týovice - Pod hrukou locality (Middle Cambrian, Skrje-Týovice Basin, Barrandian area)". English. In: Journal of the Czech Geological Society 49.3-4 (2004), pp. 107-118.

[7037] O. Fatka and V. Kordule. "Asturicystis havliceki sp. nov. (Echinodermata, Homostelea) from the Middle Cambrian of Bohemia (Barrandian area, Czech Republic)". English. In: Journal of the Czech Geological Society 46.3/4 (2001), pp. 189-194.

[7038] O. Fatka and V. Kordule. "New fossils sites in the Jince Formation (Middle Cambrian, Bohemia)". English. In: Vstnik eského Geologického Ústavu 67 (1992), pp. 47-60.

[7039] O. Fatka and V. Kordule. "Vyscystis ubaghsi gen. et sp.nov., imbricate eocrinoid from Czechoslovakia (Echinodermata, Middle Cambrian)". English. In: Vestnik Ustredniho Ustavu Geologickeho 65 (1990), pp. 315-320.

[7040] O. Fatka and M. Szabad. "Family Dibrachicystidae (Echinodermata: Rhombifera) from the Middle Cambrian of the Barrandian area, Czech Republic". English. In: Palaeontologische Zeitschrift 88 (2014). DOI: 10.1007/s12542-013-0193-1.

[7041] M. Faure and C. Guerin. "Hippopotamus laloumena nov. sp., la troisieme epece d'hippopotame holocene de Madagascar". English. In: Comtes Rendus de la Academie de Science, Paris, Serie II 310 (1990), pp. 1299-1305.

[7042] P. Faure, Y. Almeras, N. Sekatni, and F. Zargouni. “Le Pliensbachien de Jebel Zaghouan (Tunisie). Nouvelles données fauniques. Implications biostratigraphiques et paléobiogéographiques". French. In: Geodiversitas 29.4 (2007), pp. 473-506.

[7043] P. Fauré, Y. Alméras, N. Sekatni, M. S. Arfaoui, and F. Zargouni. “Les brachiopodes du Jurassique inférieur et moyen en Tunisie centrale (Axe Nord-Sud). Un nouveau témoin du domaine paléobiogéographique ouest-téthysien". French. In: Geodiversitas 37 (2015), pp. 31-57.

[7044] G. Fauth, J. Seeling, and A. Luther. "Campanian (Upper Cretaceous) ostracods from southern James Ross Island, Antarctica". English. In: Journal of Paleontology 49.1 (2003), pp. 95-107.

[7045] S. R. Fayers, J. A. Dunlop, and N. H. Trewin. "A new Early Devonian trigonotarbid ararchnid from the Windyfield chert, Rhynie, Scotland". English. In: Journal of Systematic Palaeontology 2 (2005), pp. 269-284.

[7046] F. E. Fearnhead and S. K. Donovan. "New crinoids (Echinodermata) from the Llandovery (Lower Silurian) of the British Isles". English. In: Palaeontology 50.4 (2006), pp. 905-915. DOI: 10.1111/j. 1475-4983.2007.00681.x. 
[7047] F. E. Fearnhead. "Towards a systematic standard approach to describing fossil crinoids, illustrated by the redescription of a Scottish Pisocrinus de Koninck". English. In: Scripta Geologica 136 (2008), pp. 39-61.

[7048] F. E. Fearnhead and D. A. T. Harper. "Petalocrinus (Echinodermata, Crinoidea_ from the Llandovery (Lower Silurian; Rhudannian) of the Girvan district, SW Scotland". English. In: Scottish Journal of Geology 43.1 (2007), pp. 69-74.

[7049] D. N. Fedorenko. "Wings of Coptoclavidae (Coleoptera, Adephaga) from the Keuper (Triassic) of Franconia, Germany". English. In: Paleontological Journal 48 (2014), pp. 605-609.

[7050] D. N. Fedorenko and A. G. Ponomarenko. "First records of hindwings of Permian beetles (Coleoptera)". English. In: Paleontological Journal 46 (2012), pp. 164-170.

[7051] P. V. Fedorov, A. V. Koromyslova, and S. O. Martha. "The oldest bryozoans of Baltoscandia from the lowermost Floian (Ordovician) of north-western Russia: two new rare, small and simple species of Revalotrypidae". English. In: PalZ 91 (2017), pp. 353-373. DOI: 10.1007/s12542-017-0351-y.

[7052] J. Fedorowski. "Early Bashkirian Rugosa (Anthozoa) from the Donets Basin, Ukraine. Part 1. Introductory considerations and the genus Rotiphyllum Hudson, 1942". English. In: Acta Geologica Polonica 59.1 (2009), pp. 1-37.

[7053] J. Fedorowski and E. W. Bamber. “Guadalupian (Middle Permian) solitary rugose corals from the Degerböls and Trold Fiord formations, Ellesmere and Melville islands, Canadian Arctic Archipelago". English. In: Acta Geologica Polonica 51.1 (2001), pp. 31-79.

[7054] J. Fedorowski, E. W. Bamber, and D. V. Baranova. "An unusual occurrence of Bashkirian (Pennsylvanian) rugose corals from the Sverdrup Basin, Arctic Canada". English. In: Journal of Paleontology 86 (2012), pp. 979-995.

[7055] J. Fedorowski and E. W. Bamber. "Paleobiogeographic significance of Bashkirian (Pennsylvanian) rugose corals from northernmost Ellesmere Island, Arctic Canada". English. In: Geologica Belgica 15.4 (2012), pp. 350-354.

[7056] Z. A. Fedotova and E. E. Perkovsky. "New gall midges of the Tribe Leptosynini (Diptera, Cecidomyiidae) from the Late Eocene ambers and the classification of the Supertribe Heteropezidi". English. In: Paleontological Journal 43 (2009), pp. 1101-1179.

[7057] Z. A. Fedotova and E. E. Perkovsky. "New gall midges (Diptera, Cecidomyiidae) from the Rovno amber: Subfamily Lestremiinae, Tribes Strobliellini and Campylomyzini; Subfamily Porricondylinae, Tribes Diadocidiini and Asynaptini". English. In: Paleontological Journal 38 (2004), pp. 538547.

[7058] Z. A. Fedotova and E. E. Perkovsky. "New gall midges of the Subfamily Lestremiinae (Diptera, Cecidomyiidae) from the Rovno Amber". English. In: Paleontological Journal 41 (2007), pp. 437-450.

[7059] Z. A. Fedotova and E. E. Perkovsky. "Gall midges of the Supertribe Stomatosematidi (Diptera, Cecidomyiidae) in the Palaearctic region, with descriptions of new taxa from the Late Eocene Rovno amber: 1. Stomatosema, Vanchidiplosis, Clarumreddera gen. n." English. In: Entomological Review 92.4 (2011), pp. 427-439.

[7060] Z. A. Fedotova and E. E. Perkovsky. "Gall midges of the Supertribe Stomatosematidi (Diptera, Cecidomyiidae) in the Palaearctic region, with descriptions of new taxa from the Late Eocene Rovno amber: 2. The genera Didactylomyia and Rovnodidactylomyia gen. n." English. In: Entomological Review 92 (2011), pp. 565-575.

[7061] Z. A. Fedotova and E. E. Perkovsky. "Gall midges of the Supertribe Stomatosematidi (Diptera, Cecidomyiidae) in the Palaearctic region, with descriptions of new taxa from the Late Eocene Rovno amber: 3. Groveromyia gen. n. Analysis of biometric parameters of the Recent and Late Eocene genera and species". English. In: Entomological Review 92 (2012), pp. 932-948.

[7062] Z. A. Fedotova and E. E. Perkovsky. "New gall midges (Diptera, Cecidomyiidae) from the Rovno amber: subfamily Porricondylinae (tribtes Bryocryptini and Winnertziini) and subfamily Lasiopterinae (tribes Brachineurini and Oligotrophini)". English. In: Paleontological Journal 39 (2005), pp. 4151. 
[7063] Z. A. Fedotova and E. E. Perkovsky. “New gall midges (Diptera, Cecidomyiidae, Brachineurini, Ledomyiini) from the late Eocene Rovno amber". English. In: Vestnik Zoologii 48 (2014), pp. 35-50.

[7064] Z. A. Fedotova and E. E. Perkovsky. "New gall midges (Diptera, Cecidomyiidae, Stomatosematidi, Brachineuridi) from the Late Eocene amber of Gulyanka (Zhitomir region, Ukraine)". English. In: Paleontological Journal 49 (2015), pp. 270-278.

[7065] Z. A. Fedotova and E. E. Perkovsky. "First gall midges (Diptera, Cecidomyioidea) from Late Cretaceous amber of the Taimyr Peninsula". English. In: Paleontological Journal 50 (2016), pp. 10011026.

[7066] Z. A. Fedotova and E. E. Perkovsky. "A new genus and species of gall midges of the supertribe Heteropezidi (Diptera, Cecidomyiidae) found in Eocene amber from Sakhalin". English. In: Paleontological Journal 50 (2016), pp. 1033-1037.

[7067] Z. A. Fedotova and E. E. Perkovsky. "New genus and species of gall midges (Diptera, Cecidomyiidae, Porricondylinae, Holoneurini) from the late Eocene amber of Olevsk (Zhitomir Region, Ukraine)". English. In: Vestnik Zoologii 51 (2017), pp. 23-30.

[7068] Z. A. Fedotova and E. E. Perkovsky. "New tribe, genus, and species of paedogenetic gall midges (Diptera, Lestremiidae: Krassiloviolini trib. nov.) from the Late Cretaceous Taimyr amber". English. In: Paleontological Journal 51 (2017), pp. 520-532.

[7069] Z. A. Fedotova and E. E. Perkovsky. "First findings of gall midges (Diptera, Cecidomyioidea, Cecidomyiidae) of the tribes Karshomyiini (Mexican amber) and Bremiini (Dominican amber)". English. In: Paleontological Journal 53 (2019), pp. 1060-1073. DOI: 10.1134/S0031030119100058.

[7070] D. Fehse. "A new fossil species of Notocypraea (Mollusca: Gastropoda: Cypraeidae) from the Roe Plains of Australia". English. In: Records of the Western Australian Museum 26 (2011), pp. 179-182.

[7071] D. Fehse. "New Species of fossil Cypraeoidea from Europe and Australia (Mollusca: Gastropoda)". English. In: Palaeontographica Abteilung A 292.1-3 (2010), pp. 1-19.

[7072] D. Fehse. “On the identity of Cypraea cocconii Mayer-Eymar 1875 (Mollusca: Gastropoda: Prosobranchia: Cypraeidae)". English. In: Archiv für Molluskenkunde 141.2 (2012), pp. 145-153. DOI: 10. 1127/arch.moll/1869-0963/141/145-153.

[7073] D. Fehse. “On the identity of Cypraea brocchii Deshayes in Deshayes \& Milne Edwards 1844, Cypraea fabagina Lamarck 1810 and Cypraea amygdalum Brocchi 1814 (Mollusca: Gastropoda: Prosobranchia: Cypraeidae)". English. In: Archiv für Molluskenkunde 136.1 (2007), pp. 59-77.

[7074] D. Fehse. "Die mediterrane, marine Molluskenwelt im Pliozin I. Die Familie Cypraeidae (Gastropoda: Cypraeoidea) mit der Beschreibung einer neuen Art". German. In: Acta Conchyliorum 8 (2004), pp. 1-32.

[7075] D. Fehse. "Contributions to the knowledge of the Pediculariidae (Mollusca, Gastropoda, Cypraeoidea) 2. On the occurrence of the genus Eotrivia Schilder, 1924 in the Ukraine Eocene, with the description of a new species". English. In: Cainozoic Research 8.1 (2011), pp. 29-34.

[7076] D. Fehse and J. Grego. "Contribution to the knowledge of Triviidae (Mollusca: Gastropoda) XXIII. New fossil species in the genera Ellatrivia and Trivellona". English. In: Records of the Western Australian Museum 27 (2012), pp. 1-6.

[7077] D. Fehse and J. Grego. "Contributions to triviid systematics (Mollusca: Gastropoda), 12. A new Trivia species from the Italian Pliocene". English. In: Cainozoic Research 5.1-2 (2006), pp. 89-91.

[7078] D. Fehse and J. Grego. “Contributions to eratoid systematics (Mollusca, Gastropoda, Trivioidea), 5. Middle Miocene, Badenian Eratoidae from Borsodbóta (Hungary)". English. In: Cainozoic Research 9.1 (2012), pp. 15-63.

[7079] D. Fehse and G. W. Kendrick. "A new species of Austrocypraea (Gastropoda: Cypraeidae) from the Late Pliocene of the Eucla Basin, southern Australia". English. In: Records of the Western Australian Museum 20 (2000), pp. 95-101. 
[7080] D. Fehse and B. Landau. “Contributions to triviid systematics (Mollusca, Gastropoda), 6. Early Pliocene Triviidae from the western Mediterranean". English. In: Cainozoic Research 2.1-2 (2002), pp. 87-107.

[7081] D. Fehse and B. Landau. "Contributions to eratoid systematics Mollusca, Gastropoda , 2. Late Miocene Eratoidae from Sceaux d' Anjou Loire Basin, France, with descriptions of new taxa". English. In: Cainozoic Research 1.1-2 (2001), pp. 91-110.

[7082] D. Fehse and B. Landau. “Contributions to eratoid systematics Mollusca, Gastropoda, 1. Early Pliocene Eratoidae from the western Mediterranean". English. In: Cainozoic Research 1.1-2 (2001), pp. 13-33.

[7083] D. Fehse and Z. Vicián. "On the identity of Projenneria neumayri (Hilber, 1879) with the description of a new species of the genus Projenneria Dolin, 1997 from the Badenian of the Central Paratethys (Mollusca: Gastropoda: Cypraeoidea)". English. In: Földtani Közlöny 138.4 (2008), pp. 357-362.

[7084] D. Fehse and Z. Vicián. "A new Zonarina (Mollusca: Gastropoda: Cypraeidae) from the middle Miocene (Badenian) of Hungary". English. In: Földtani Közlöny 134.2 (2004), pp. 201-208.

[7085] C. S. Feibel. Freshwater stingrays from the Plio-Pleistocene of the Turkana Basin, Kenya and Ethiopia. 1994.

[7086] C. S. Feibel and F. H. Brown. Age of the primate-bearing deposits on Maboko Island, Kenya. 1991.

[7087] R. Feist. "Trilobites from the latest Frasnian Kellwasser Crisis in North Africa (Mrirt, central Moroccan Meseta)". In: Acta Palaeontologica Polonica 47.2 (2002), pp. 203-210.

[7088] R. Feist. "Trilobiten aus dem Devon/Karbon-Grenzprofil an der Grünen Schneid (Zentrale Karnische Alpen, Österreich)". German. In: Jahrbuch der Geologischen Bundesanstalt 135.1 (1992), pp. 2147.

[7089] R. Feist and T. Becker. Discovery of Famennian trilobites in Australia (Late Devonian, Canning Basin, NW Australia). in P. R. Racheboeuf and M. Gayet, eds., Actualites paleontologiques (Geobios Mem. Spec. 20), Universite Claude-Bernard, Lyon. 1997, pp. 231-242.

[7090] R. Feist and Z. Belka. "Late Emsian (Devonian) trilobite communities from the Kess-Kess mounds, Hamar Laghdad (Anti-Atlas, Morocco)". English. In: Neues Jahrbuch für Geologie und Paläontologie Abhandlungen 290.1-3 (2018), pp. 277-290. DOI: 10.1127/njgpa/2018/0784.

[7091] R. Feist and B. D. E. Chatterton. "Kolihapeltine trilobites, the spiniest scutelluids from the eastern Anti-Atlas (Morocco, early Devonian): evolution, environment, and classification". English. In: Papers in Palaeontology 1.3 (2015), pp. 225-287.

[7092] R. Feist, U. Lemke, and D. Korn. “Trilobiten aus der Wocklumeria-Stufedes h6chsten Oberdevon von Apricke, Sauerland". English. In: Senckenbergia Lethaea 79.2 (2000), pp. 517-539.

[7093] R. Feist and K. J. McNamara. "Patterns Of Evolution And Extinction In Proetid Trilobites During The Late Devonian Mass Extinction Event, Canning Basin, Western Australia". English. In: Palaeontology 56.2 (2013), pp. 229-259. DOI: 10.1111/j.1475-4983.2012.01191.x.

[7094] R. Feist and K. J. McNamara. “Biodiversity, distribution and patterns of extinction of the last odontopleuroid trilobites during the Devonian (Givetian, Frasnian)". English. In: Geological Magazine 144.5 (2007), pp. 777-796. DOI: 10.1017/S0016756807003779.

[7095] R. Feist and B. Orth. "Trilobites de la limite Eifélien/Givétien de la région stratotypique (Tafilalet, Maider, Maroc)". French. In: Proceedings of the Subcommission on Devonian Stratigraphy (SDS)IGCP 421 Morocco Meeting. 2000, pp. 78-91.

[7096] R. Feist and M. S. Petersen. "Origin and spread of Pudoproetus, a survivor of the Late Devonian trilobite crisis". English. In: Journal of Paleontology 69.1 (1995), pp. 99-109.

[7097] R. Feist and J. A. Talent. “A new Early Ordovician trilobite from the Broken River region northeastern Australia: taxonomy and palaeogeographic implilations". English. In: Records of the Western Australian Museum Supplement 58 (2000), pp. 59-63. 
[7098] O. Fejfar and T. M. Kaiser. "Insect bone-modification and paleoecology of Oligocene mammalbearing sites in the Doupov Mountains, northwestern Bohemia". English. In: Paleontologia Electronica 8.1.8A (2005), pp. 1-11.

[7099] O. Fejfar and C. A. Repenning. "The ancestors of the lemmings (Lemmini, Arvicolinae, Cricetidae, Rodentia) in the early Pliocene of Wölfersheim near Frankfurt am Main; Germany." English. In: Senckenbergiana Lethaea 77.1/2 (1998), pp. 161-193.

[7100] O. Fejfar, M. Rummel, and Y. Tomida. "New eomyid genus and species from the Early Miocene (MN-zones 3-4) of Europe and Japan related to Apeomys (Eomyidae, Rodentia, Mammalia)". English. In: National Science Museum Monographs 14 (1998), pp. 123-143.

[7101] H. R. Feldman. "A new species of Coenothyris (Brachiopoda) from the Triassic (Upper AnisianLadinian) of Israel". English. In: Journal of Paleontology 76.1 (2002), pp. 34-42.

[7102] H. R. Feldman. "Menathyris wilsoni (Brachiopoda), new genus and species from the Middle Triassic (Ladinian) of southern Israel". English. In: Annales Societatis Geologorum Poloniae 83 (2013), pp. 81-85.

[7103] H. R. Feldman. "Tunethyris blodgetti sp. nov. (Brachiopoda, Terebratulida) from the Middle Triassic of Makhtesh Ramon, southern Israel". English. In: Annales Societatis Geologorum Poloniae 87 (2017), pp. 89-99.

[7104] H. R. Feldman, E. F. Owen, and F. Hirsch. "Brachiopods from the Jurassic (Callovian) of Hamakhtesh Hagadol (Kurnub Anticline), southern Israel". English. In: Palaeontology 44.4 (2001), pp. 637658.

[7105] H. R. Feldman, E. F. Owen, and F. Hirsch. "Brachiopods from the Jurassic of Gebel El-Maghara, northern Sinai". English. In: American Museum Novitates 3006 (1991), pp. 1-28.

[7106] H. R. Feldman, V. J. Radulovic, A. A. A. Hegab, and B. V. Radulovic. "Taxonomy and paleobiogeography of late Bathonian brachiopods from Gebel Engabashi, northern Sinai". English. In: Journal of Paleontology 86.2 (2012), pp. 238-252.

[7107] H. R. Feldman, M. Schemm-Gregory, F. Ahmad, and M. A. Wilson. "Jurassic rhynchonellide brachiopods from the Jordan Valley". English. In: Acta Palaeontologica Polonica 57.1 (2012), pp. 191204.

[7108] H. R. Feldman, M. Schemm-Gregory, F. Ahmad, and M. A. Wilson. "A Jurassic (Bathonian-Callovian) Daghanirhynchia brachiopod fauna from Jordan". English. In: Geologica Acta 12 (2014), pp. 1-18.

[7109] H. R. Feldman, M. Schemm-Gregory, M. A. Wilson, and F. Ahmad. "Talexirhynchia, a new rhynchonellid genus from the Jurassic Ethiopian Province of Jordan". English. In: Paläontologische Zeitschrift 89 (2015), pp. 25-35.

[7110] R. M. Feldmann. "Additions to the fossil decapod crustacean fauna of New Zealand". English. In: New Zealand Journal of Geology and Geophysics 36.2 (1993), pp. 201-211. DOI: 10.1080/00288306. 1993.9514568.

[7111] R. M. Feldmann. “The Genus Lyreidus de Haan, 1839 (Crustacea, Decapoda, Raninidae): Systematics and Biogeography". English. In: Journal of Paleontology 66.6 (1992), pp. 943-957.

[7112] R. M. Feldmann. "Antarctomithrax thomsoni, a New Genus and Species of Crab (Brachyura; Majidae) from". English. In: Journal of Paleontology 68.1 (1994), pp. 174-176.

[7113] R. M. Feldmann, K. L. Bice, C. Schweitzer Hopkins, E. W. Salva, and K. Pickford. “Decapod crustaceans from the Eocene Castle Hayne Formation, North Carolina: paleoceanographic implications". English. In: Journal of Paleontology 72.Supplement (1998), pp. 1-28.

[7114] R. M. Feldmann, S. Casadio, L. Chirino-Galvez, and M. Aguirre-Urreta. "Fossil decapod crustaceans from the Jaguel and Roca Formations (Maastrichtian-Danian) of the Neuquen Basin, Argentina". English. In: Journal of Paleontology 69.5 II (1995), pp. 1-22.

[7115] R. M. Feldmann, G. Crisp, and D. Pirrie. "A new species of glypheoid lobster, Pseudoglyphea foersteri (Decapoda: Astacidea: Mecochiridae) from the Lower Jurassic (Pliensbachian) of Raasay, Inner Hebrides, UK". English. In: Palaeontology 45.1 (2002), pp. 23-32. 
[7116] R. M. Feldmann and R. E. Fordyce. "A new cancrid crab from New Zealand". English. In: New Zealand Journal of Geology and Geophysics 39 (1996), pp. 509-513.

[7117] R. M. Feldmann, A. Kolahdouz, B. Biranvand, and G. Schweigert. "A new family, genus, and species of lobster (Decapoda: Achelata) from the Gadvan Formation (Early Cretaceous) of Iran". English. In: Journal of Paleontology 81.2 (2007), pp. 405-407.

[7118] R. M. Feldmann, I. Lazar, and C. E. Schweitzer. “New crabs (Decapoda: Brachyura: Prosopidae) from Jurassic (Oxfordian) sponge bioherms of Dobrogea, Romania". English. In: Bulletin of the Mizunami Fossil Museum 33 (2006), pp. 1-20.

[7119] R. M. Feldmann, R.-Y. Li, and C. E. Schweitzer. "A new family, genus, and species of crab (Crustacea, Decapoda, Brachyura) from the upper Cretaceous (Campanian) of Manitoba, Canada". English. In: Canadian Journal of Earth Sciences 44 (2007), pp. 1741-1752.

[7120] R. M. Feldmann and P. A. Maxwell. "Late Eocene decapod Crustacea from north Westland, South Island, New Zealand". English. In: Journal of Paleontology 64.5 (1990), pp. 779-797.

[7121] R. M. Feldmann and P. A. Maxwell. "A new species of glypheid lobster, Glyphea christeyi (Decapoda: Palinura), from the Eocene (Bortonian) Waihao Greensand, South Canterbury New Zealand". English. In: New Zealand Journal of Geology and Geophysics 42 (1999), pp. 75-78.

[7122] R. M. Feldmann and R. W. Portell. "First report of Costacopluma Collins and Morris, 1975 (Decapoda: Brachyura: Retroplumidae) from the Eocene of Alabama, U.S.A." English. In: Journal of Crustacean Biology 21.1 (2007), pp. 90-96.

[7123] R. M. Feldmann, M. F. Rodriguez, G. A. Martinez, and M. Aguirre-Urreta. “Costacopluma salamanca New Species (Decapoda, Retroplumidae) from the Salamanca Formation (Danian) of Patagonia, Argentina". English. In: Journal of Paleontology 71.1 (1997), pp. 125-130.

[7124] R. M. Feldmann and S. Rust. "Palaega kakatahi n. sp.: the first record of a marine fossil isopod from the Pliocene of New Zealand". English. In: New Zealand Journal of Geology and Geophysics 49 (2006), pp. 411-415.

[7125] R. M. Feldmann, C. E. Schweitzer, and S. A. Marenssi. "Decapod crustaceans from the Eocene La Meseta Formation, Seymour Island, Antarctica: a model for preservation of decapods". In: Journal of the Geological Society, London 160 (2003), pp. 151-160.

[7126] R. M. Feldmann, C. E. Schweitzer, and A. Encinas. "New decapods from the Navidad Formation (Miocene) of Chile". English. In: Journal of Crustacean Biology 25.3 (2005), pp. 427-449.

[7127] R. M. Feldmann, C. E. Schweitzer, and D. McLauchlan. "Additions to the records for decapod Crustacea from Motunau and Glenafric Beaches, North Canterbury, New Zealand". English. In: New Zealand Journal of Geology and Geophysics 49 (2006), pp. 417-427.

[7128] R. M. Feldmann, C. E. Schweitzer, C. M. Redman, N. J. Morris, and D. J. Ward. “New Late Cretaceous lobsters from the Kyzylkum Desert of Uzbekistan". English. In: Journal of Paleontology 81.4 (2007), pp. 701-713.

[7129] R. M. Feldmann, C. E. Schweitzer, P. A. Maxwell, and B. M. Kelley. "Fossil isopod and decapod crustaceans from the Kowai Formation (Pliocene) near Makikihi, South Canterbury, New Zealand". English. In: New Zealand Journal of Geology and Geophysics 51 (2008), pp. 43-58.

[7130] R. M. Feldmann, C. E. Schweitzer, and W. R. Wahl. "Ekalakia (Decapoda: Brachyura): The preservation of eyes links Cretaceous crabs to Jurassic ancestors". English. In: Journal of Paleontology 82.5 (2008), pp. 1030-1034.

[7131] R. M. Feldmann and C. E. Schweitzer. "Revision of Jurassic Homoloidea de Haan, 1839, from the Ernstbrunn and Stramberk limestones, Austria and the Czech Republic". English. In: Annalen des Naturhistorischen Museums in Wien, Serie A 111 (2009), pp. 183-206.

[7132] R. M. Feldmann, C. E. Schweitzer, and R. M. Green. “Unusual Albian (Early Cretaceous) Brachyura (Homoloidea: Componocancroidea new superfamily) from Montana and Wyoming, USA". English. In: Journal of Crustacean Biology 28.3 (2008), pp. 502-509. 
[7133] R. M. Feldmann, C. E. Schweitzer, S. X. Hu, Q. Y. Zhang, C. Y. Zhou, T. Xie, J. Y. Huang, and W. Wen. "Macrurous Decapoda from the Luoping biota (Middle Triassic) of China". English. In: Journal of Paleontology 86 (2012), pp. 425-441.

[7134] R. M. Feldmann, C. E. Schweitzer, and J. W. Haggart. "A new genus and species of polychelid lobster (Crustacea, Decapoda, Eryonidae) from the Early Jurassic (Hettangian) of British Columbia". English. In: Canadian Journal of Earth Sciences 50 (2013), pp. 135-141.

[7135] R. M. Feldmann and C. E. Schweitzer. “A new Early Jurassic lobster (Decapoda: Glypheoidea: Glypheidae) from Lyme Regis, England". English. In: Bulletin of the Mizunami Fossil Museum 39 (2013), pp. 1-5.

[7136] R. M. Feldmann, C. E. Schweitzer, L. M. Baltzly, O. A. Bennett, A. R. Jones, F. F. Mathias, K. L. Weaver, and S. L. Yost. "New and previously known decapod crustaceans from the Late Cretaceous of New Jersey and Delaware, USA". English. In: Bulletin of the Mizunami Fossil Museum 39 (2013), pp. 7-37.

[7137] R. M. Feldmann, C. E. Schweitzer, and J. Lehmann. "A New Species of Crab (Brachyura: Etyidae) from the late Albian of Germany". English. In: Neues Jahrbuch für Geologie und Paläontologie, Abhandlungen 267.3 (2013), pp. 323-330.

[7138] R. M. Feldmann, C. E. Schweitzer, and R. W. Portell. “Crabs (Decapoda, Brachyura) from the lower Paleocene of Alabama, USA". English. In: Scripta Geologica 147 (2014), pp. 135-151.

[7139] R. M. Feldmann, C. E. Schweitzer, S. X. Hu, J. Y. Huang, C. Y. Zhou, Q. Y. Zhang, W. Wen, T. Xie, F. R. Schram, and W. T. Jones. "Earliest occurrence of lophogastrid mysidacean arthropods (Crustacea, Eucopiidae) from the Anisian Luoping Biota, Yunnan Province, China". English. In: Journal of Paleontology 91 (2017), pp. 100-115.

[7140] R. M. Feldmann, C. E. Schweitzer, and G. Phillips. "Paleogene Decapoda (Caridea, Anomura, Axiidea, Brachyura) from Alabama and Mississippi, USA". English. In: Journal of Crustacean Biology 39.3 (2019), pp. 279-302. DOI: 10.1093/jcbiol/ruz002.

[7141] R. M. Feldmann, C. E. Schweitzer, and J. L. Goedert. "Complex taphonomic and depositional history of a new species of Carcinidae (Decapoda: Brachyura: Portunoidea) from Washington state, USA". English. In: Journal of Crustacean Biology 38.5 (2018), pp. 579-585. DOI: 10.1093 / jcbiol / ruy066.

[7142] R. M. Feldmann and C. E. Schweitzer. "Scyllarella (Decopoda: Achelata: Scyllaridae) from the Lookingglass Formation (Eocene): first occurrence on western coast of North America". English. In: Bulletin of the Mizunami Fossil Museum 43 (2017), pp. 11-15.

[7143] R. M. Feldmann, C. E. Schweitzer, B. Datillo, and J. O. Farlow. "Remarkable preservation of a new genus and species of limuline horseshoe crab from the Cretaceous of Texas, USA". English. In: Palaeontology 54 (2011), pp. 1337-1346. DOI: 10.1111/j.1475-4983.2011.01103.x.

[7144] R. M. Feldmann and A. L. Titus. "Eryma jungostrix n. sp. (Decapoda; Erymidae) from the Redwater Shale Member of the Stump Formation (Jurassic; Oxfordian) of Utah". English. In: Journal of Crustacean Biology 26.1 (2006), pp. 63-68.

[7145] R. M. Feldmann, D. M. Tshudy, and M. R. A. Thomson. “Late Cretaceous and Paleocene decapod crustaceans from James Ross Basin, Antarctic Peninsula". English. In: The Paleontological Society Memoir 28 (1993), pp. 1-41. DOI: 10.1017/S0022336000062077.

[7146] R. M. Feldmann, F. J. Vega, P. Garca-Barrera, R. Rico-Montiel, and L. Martnez López. “A new species of Meyeria (Decapoda: Mecochiridae) from San Juan Raya Formation (Aptian: Cretaceous), Puebla State, Mexico". English. In: Journal of Paleontology 69.2 (1995), pp. 402-406. DOI: $10.1017 /$ S0022336000034740.

[7147] R. M. Feldmann, F. J. Vega, S. P. Applegate, and G. A. Bishop. “Early Cretaceous Arthropods from the Tlayua Formation at Tepexi de Rodriguez, Puebla, Mexico". English. In: Journal of Paleontology 72.1 (1998), pp. 79-90. 
[7148] R. M. Feldmann, F. J. Vega, L. Martinez-Lopez, K. A. Gonzalez-Rodrigues, O. Gonzalex-Leon, and M. del Rosario Fernandez-Barajas. "Crustacea from the Muhi Quarry (Albian-Cenomanian), and a review of Aptian Mecochiridae (Astacidea) From Mexico". English. In: Annals of Carnegie Museum 76.3 (2007), pp. 145-156.

[7149] A. S. Felker. "New damselflies of the family Kennedyidae (Odonata) from the Permian of European Russia". English. In: Paleontological Journal 54 (2020), pp. 734-742. DOI: 10.1134/S0031030120070047.

[7150] A. S. Felker and D. V. Vasilenko. "A new genus and species of the damselfly family Hemiphlebiidae from the Lower Cretaceous Chernovskie Kopi locality (eastern Transbaikalia)". English. In: Paleontological Journal 52 (2018), pp. 142-145.

[7151] N. A. Feltes, G. L. Albanesi, and S. M. Bergström. "Conodont biostratigraphy and global correlation of the middle Darriwilian-lower Sandbian (Ordovician) Las Aguaditas Formation, Precordillera of San Juan, Argentina". English. In: Andean Geology 43.1 (2016), pp. 60-85. DOI: 10. 5027/andgeoV43n1-a04.

[7152] E. A. Felton, K. A. W. Crook, B. H. Keating, and E. A. Kay. "Sedimentology of rocky shorelines: 4. Coarse gravel lithofacies, molluscan biofacies, and the stratigraphic and eustatic records in the type area of the Pleistocene Hulopoe Gravel, Lanai, Hawaii”. English. In: Sedimentary Geology 184 (2006), pp. 1-76.

[7153] J. Femenias-Gual, R. Minwer-Barakat, J. Marigo, and S. Moya-Sola. “Agerinia smithorum sp. nov., a new early Eocene primate fromthe Iberian Peninsula". English. In: American Journal of Physical Anthropology 161 (2016), pp. 116-124.

[7154] J. Femenias-Gual, R. Minwer-Barakat, J. Marigó, M. Poyatos-Moré, and S. Moyá-Solá. “Agerinia marandati sp. nov., a new early Eocene primate from the Iberian Peninsula, sheds new light on the evolution of the genus Agerinia". English. In: PeerJ 5 (2017), e3239:1-35. DOI: 10.7717/peerj.3239.

[7155] J. Femenias-Gual, R. Minwer-Barakat, J. Marigó, and S. Moyá-Solá. “New lower Eocene fossil sites with primate remains from the Iberian Peninsula". English. In: Journal of Vertebrate Paleontology (2020), e1766478:1-10. DOI: 10.1080/02724634.2020.1766478.

[7156] M. Fenerci-Masse, J. P. Masse, C. Arias, and L. Vilas. "Archaeoradiolites, a new genus fromthe upper Aptian of the Mediterranean region and the origin of the rudist family Radiolitidae". English. In: Palaeontology 49.4 (2006), pp. 769-794.

[7157] H. Feng, C. K. Shih, D. Ren, and C. X. Liu. "New male pelecinid wasps (Hymenoptera: Pelecinidae) from the Yixian Formation of western Liaoning (China)". English. In: Geologica Carpathica 61 (2010), pp. 463-468.

[7158] Q. Feng, Y. M. Gong, and R. Riding. "Mid-Late Devonian calcified marine algae and cyanobacteria, south China". English. In: Journal of Paleontology 84.4 (2010), pp. 569-587.

[7159] Q. Feng and S. Gu. "Uppermost Changxingian (Permian) radiolarian fauna from southern Guizhou, southwestern China". English. In: Journal of Paleontology 76.5 (2002), pp. 797-809.

[7160] Q. Feng, W. He, S. Gu, Y. Meng, Y. Jin, and F. Zhang. "Radiolarian evolution during the latest Permian in south China". English. In: Global and Planetary Change 55 (2007), pp. 177-192.

[7161] Q. Feng, D. Helmcke, C. Chonglakmani, R. Ingavat-Helmcke, and B. Liu. "Early Carboniferous radiolarians from north-west Thailand: paleogeographical implications". English. In: Palaeontology 47.2 (2004), pp. 377-393.

[7162] Q. Feng and B. Liang. "Ladinian radiolarian fauna from West Sichuan, China". English. In: Revue de micropaléontologie 46 (2003), pp. 217-227. DOI: 10.1016/j.revmic.2003.09.002.

[7163] Q. Feng, K. Malila, N. Wonganan, C. Chonglakmani, D. Helmcke, R. Ingavat-Halmcke, and M. Caridroit. "Permian and Triassic Radiolaria from Northwest Thailand: paleogeographical implications". English. In: Revue de micropaléontologie 48 (2005), pp. 237-255. DOI: 10.1016/j.revmic.2005. 09.004 .

[7164] Q. Feng, Z. Yang, X. Li, and S. Crasquin. "Middle and Late Triassic radiolarians from northern Tibet: implications for the Bayan Har Basin evolution". English. In: Geobios 42 (2009), pp. 581-601. 
[7165] Q. Feng, Z. Zhang, and M. Ye. "Middle Triassic radiolarian fauna from southwest Yunnan, China". English. In: Micropaleontology 47.3 (2001), pp. 173-204.

[7166] Q. L. Feng, X. S. Cui, and B. P. Liu. "Discovery of Late Permian bivalve fauna from Laochang of Lancang, west Yunnan and its biogeographic characteristics". Chinese. In: Earth Science - China University of Geosciences 17 (1992), pp. 512-520.

[7167] W. Feng. "Microgastropod trophic structure of the Yongshu reef, South China Sea, since the late Pleistocene in relation to paleoenvironment". English. In: Journal of Asian Earth Sciences 25 (2005), pp. 291-300.

[7168] W. Feng and W. Sun. "Monoplacophoran Igorella-type pore-channel structures from the Lower Cambrian in China". English. In: Materials Science and Engineering C 26 (2006), pp. 699-702.

[7169] W. M. Feng, W. G. Sun, and Y. Qian. "Earliest Cambrian monoplacophora in northeastern Yunnan with some new genera and species". Chinese. In: Acta Micropalaeontologica Sinica 17 (2000), pp. 365-377.

[7170] W. M. Feng, W. G. Sun, and Y. Qian. "Skeletalization characters, classification and evolutionary significance of Early Cambrian Monoplacophoran maikhanellids". Chinese. In: Acta Palaeontologica Sinica 40 (2001), pp. 195-213.

[7171] W. M. Feng and W. G. Sun. "Phosphate replicated and replaced microstructure of molluscan shells from the earliest Cambrian of China". In: Acta Palaeontologica Polonica 48.1 (2003), pp. 21-30.

[7172] R. S. Feranec. "Stable isotopes, hypsodonty, and the paleodiet of Hemiauchenia (Mammalia: Camelidae): a morphological specialization creating ecological generalization". English. In: Paleobiology 29.2 (2003), pp. 230-242.

[7173] R. S. Feranec. "Implications of radiocarbon dates from Potter Creek Cave, Shasta County, California, USA". English. In: Radiocarbon 51.3 (2009), pp. 931-936.

[7174] R. S. Feranec, D. A. Franzi, and A. L. Kozlowski. "A New Record of Ringed Seal (Pusa hispida) from the Late Pleistocene Champlain Sea and Comments on Its Age and Paleoenvironment". English. In: Journal of Vertebrate Paleontology 34.1 (2014), pp. 230-235. DOI: 10.1080 / 02724634.2013. 784706.

[7175] C. Ferenc. "Középs-miocén sziláscet (Cetacea: Mysticeti) humerusok a Pécs, danitzpusztai homokbányából". other. In: Földtani Közlöny 148.3 (2018), pp. 255-272.

[7176] D. K. Ferguson, D. E. Lee, J. M. Bannister, R. Zetter, G. J. Jordan, N. Vavra, and D. C. Mildenhall. "The taphonomy of a remarkable leaf bed assemblage from the Late Oligocene-Early Miocene Gore Lignite Measures, southern New Zealand". English. In: International Journal of Coal Geology 83.2-3 (2010), pp. 173-181. DOI: 10.1016/j.coal.2009.07.009.

[7177] J. Ferigolo and M. C. Langer. "A Late Triassic dinosauriform from south Brazil and the origin of the ornithischian predentary bone". English. In: Historical Biology 19.1 (2007), pp. 23-33. DOI: 10.1080/08912960600845767.

[7178] F. R. Fernandes, J. Prokop, and A. Nel. "Discovery of the genus Crinoedischia in the Middle Permian of France (Insecta: Orthoptera)". English. In: Annales de la Société Entomologique de France 50 (2015), pp. 260-263.

[7179] L. A. Fernandes, R. Costa, F. A. Sedor, L. R. da Silva, A. A. Azevedon, and A. G. Siqueira. Uma nova icnocenose Neocretácea no interior do deserto Caiuá (Formação Rio Paraná, Bacia Bauru) [A new Late Cretaceous ichnocoenosis from the interior of the Caiuá desert (Rio Paraná Formation, Bauru Basin)]. Portugese. 2003.

[7180] M. A. Fernandes and I. S. Carvalho. As pistas do paleodeserto Botucatu: aspectos preservacionais [The tracks of the Botucatu paleodesert: preservational aspects]. Portugese. 2005.

[7181] D. Fernández, D. Pérez, L. Luci, and M. Carrizo. "An Early Cretaceous astropectinid (Echinodermata, Asteroidea) from Patagonia (Argentina): A new species and the oldest record of the family for the Southern Hemisphere". English. In: Andean Geology 41.1 (2014), pp. 210-223. DOI: 10.5027/andgeoV40n2-a08. 
[7182] F. J. Fernández and U. F. J. Pardiñas. “Small mammals taphonomy and environmental evolution during Late Pleistocene-Holocene in Monte Desert: The evidence of Gruta del Indio (central west Argentina)". English. In: Journal of South American Earth Sciences 84 (2018), pp. 266-275.

[7183] J. Fernandez, V. Markgraf, H. O. Panarello, M. Albero, F. E. Angiolini, S. Valencio, and M. Arriaga. "Late Pleistocene/early Holocene environments and climates, fauna, and human occupation in the argentine altiplano". English. In: Geoarchaeology 6.3 (1991), pp. 251-272.

[7184] L. P. Fernández, M. Nose, E. Fernández-Martnez, I. Méndez-Bedia, St. Schroeder, and F. Soto. "Reefal and mud mound facies development in the Lower Devonian La Vid Group at the Colle outcrops (Léon province, Cantabrian Zone, NW Spain)". English. In: Facies 52 (2006), pp. 307-327.

[7185] M. Fernández. "Redescription and phylogenetic position of Caypullisaurus (Ichthyosauria: Ophthalmosauridae)". English. In: Journal of Paleontology 81.2 (2007), pp. 368-375.

[7186] M. Fernandez and M. B. Aguirre-Urreta. "Revision of Platypterygius hauthali von Huene, 1927 (Ichthyosauria: Ophthalmosauridae) from the early Cretaceous of Patagonia, Argentina". English. In: Journal of Vertebrate Paleontology 25.3 (2005), pp. 583-587.

[7187] M. Fernandez and M. Iturralde-Vinent. "An Oxfordian Ichthyosauria (Reptilia) from Vinales, western Cuba: paleobiogeographic significance". English. In: Journal of Vertebrate Paleontology 20.1 (2000), pp. 191-193.

[7188] M. Fernández, J. Martin, and S. Casado. "Mosasaurs (Reptilia) from the late Maastrichtian (Late Cretaceous) of northern Patagonia (Ro Negro, Argentina)". English. In: Journal of South American Earth Sciences 25 (2008), pp. 176-186.

[7189] M. Fernández and N. A. Muñoz. “Notoungulata and Astrapotheria (Mammalia, Meridiungulata) of the Santa Cruz Formation (Early-Middle Miocene) Along the Ro Santa Cruz, Argentine Patagonia". English. In: vol. 19. Early-Middle Miocene Paleontology in the Ro Santa Cruz, Southern Patagonia, Argentina. 130 years since Ameghino, 1887 2. Publicación Electrónica de la Asociación Paleontológica Argentina, 2019, pp. 138-169. DOI: 10.5710/PEAPA.19.09.2019.288.

[7190] M. E. Fernández, A. I. Vassallo, and M. A. Zárate. "Functional morphology and palaeobiology of the pliocene rodent Actenomys (Caviomorpha: Octodontidae): the evolution to a subterranean mode of life". English. In: Biological Journal of the Linnean Society 71.1 (2000), pp. 71-90.

[7191] M. F. Fernandez. "On the paleogeographic distribution of Callovian and Late Jurassic ichthyosaurs". English. In: Journal of Vertebrate Paleontology 17.4 (1997), pp. 752-754.

[7192] M. S. Fernández. “Ophthalmosauria (Ichthyosauria) forefin from the Aalenian-Bajocian boundary of Mendoza Province, Argentina". English. In: Journal of Vertebrate Paleontology 23.3 (2003), pp. 691-694.

[7193] M. S. Fernandez. "A new ichthyosaur from the Los Molles Formation (Early Bajocian), Neuquen Basin, Argentina". English. In: Journal of Paleontology 73.4 (1999), pp. 677-681.

[7194] M. S. Fernandez. "Late Jurassic ichthyosaurs from the Neuquen Basin, Argentina". English. In: Historical Biology 14.1-2 (2000), pp. 133-136.

[7195] M. S. Fernandez, A. P. Carabajal, Z. Gasparini, and G. C. Diaz. "A metriorhynchid crocodyliform braincase from northern Chile". English. In: Journal of Vertebrate Paleontology 31.2 (2011), pp. 369377.

[7196] M. S. Fernandez, Y. Herrera, V. V. Vennari, L. Campos, M. de la Fuente, M. Talevi, and B. AguirreUrreta. "Marine reptiles from the Jurassic/Cretaceous transition at the High Andes," English. In: Journal of South American Earth Sciences (2019), pp. 1-16. DOI: 10.1016/j.jsames.2019.03.013.

[7197] M. S. Fernandez and E. E. Maxwell. “The genus Arthropterygius Maxwell (Ichthyosauria: Ophthalmosauridae) in the Late Jurassic of the Neuquen Basin, Argentina". English. In: Geobios 45 (2012), pp. 535-540.

[7198] M. S. Fernández and M. Talevi. "An halisaurine (Squamata: Mosasauridae) from the Late Cretaceous of Patagonia, with a preserved tympanic disc: Insights into the mosasaur middle ear". English. In: Comptes Rendus Palevol 14 (2015), pp. 483-493. 
[7199] S. R. Fernandez-Lopez and G. Pavia. "Mollistephaninae and Frebolditinae, new subfamilies of Middle Jurassic stephanoceratid Ammonoidea". English. In: Paläontologische Zeitschrift 89 (2015), pp. 707-727.

[7200] E. Fernández-Martnez, L. P. Fernández, I. Méndez-Bedia, F. Soto, and B. Mistiaen. “Earliest Pragian (Early Devonian) corals and stromatoporoids from reefal settings in the Cantabrian Zone (N Spain)". English. In: Geologica Acta 8.3 (2010), pp. 301-323. DOI: 10.1344/105.000001535.

[7201] E. Fernández-Martnez, F. Tourneur, and A. López-Alcántara. “A new Middle Devonian heterocoral from Spain". English. In: Acta Palaeontologica Polonica 48.4 (2003), pp. 531-546.

[7202] P. A. Fernandez-Mendiola, I. Gomez-Perez, and J. Garcia-Mondejar. "Aptian-Albian Carbonate Platforms: Central Basque-Cantabrian Basin," English. In: AAPG Memoir 56.25 (2017), pp. 315324.

[7203] M. Fernández-Monescillo, P.-O. Antoine, B. Mamami Quispe, P. Münch, R. Andradre Flores, L. Marivaux, and F. Pujos. "Multiple skeletal and dental pathologies in a late Miocene mesotheriid (Mammalia, Notoungulata) from the Altiplano of Bolivia: Palaeoecological inferences". English. In: Palaeogeography, Palaeoclimatology, Palaeoecology 534 (2019), p. 109297. DOI: 10.1016/j.palaeo. 2019.109297.

[7204] F. Fernández-Rubio and A. Nel. "Neurosymploca? oligocenica, a new fossil species of Lepidoptera Zygaenoidea of the Oligocene of Céreste (Lubéron, France)". English. In: Boletn Sociedad Entomológica Aragonesa 27 (2000), pp. 7-16.

[7205] F. Fernández-Rubio, E. Peñalver, and X. Martnez-Delclós. “Zygaena? turolensis, una nueva especie de Lepidoptera Zygaenidae del Mioceno de Rubielos de Mora (Teruel). Descripción y filogenia". Spanish. In: Estudios del Museo de Ciencias Naturales de Álava 6 (1991), pp. 77-93.

[7206] M. FernándezColl, T. Arbez, F. Bernardi, and J. Fortuny. "Cranial anatomy of the Early Triassic trematosaurine Angusaurus (Temnospondyli: Stereospondyli): 3D endocranial insights and phylogenetic implications". English. In: Journal of Iberian Geology (2018), pp. 1-18. DOI: 10.1007/s41513018-0064-4.

[7207] J. C. Fernicola, J. I. Cuitiño, S. F. Vizcano, M. S. Bargo, and R. F. Kay. "Fossil localities of the Santa Cruz Formation (Early Miocene, Patagonia, Argentina) prospected by Carlos Ameghino in 1887 revisited and the location of the Notohippidian". English. In: Journal of South American Earth Sciences 52 (2014), pp. 94-107. DOI: 10.1016/j.jsames.2014.02.002.

[7208] J. C. Fernicola, A. Rinderknecht, W. Jones, S. F. Vizcano, and K. Porpino. "A new species of Neoglyptatelus (Mammalia, Xenarthra, Cingulata) from the Late Miocene of Uruguay provides new insights on the evolution of the dorsal armor in cingulates". English. In: Ameghiniana 55.3 (2018), pp. 233-252. DOI: 10.5710/AMGH.02.12.2017.3150.

[7209] J. C. Fernicola, S. F. Vizcaino, and G. De Iuliis. "The fossil mammals collected by Charles Darwin in South America during his travels on board the HMS Beagle". English. In: Revista de la Asociación Geológica Argentina 64.1 (2009), pp. 147-159.

[7210] J. C. Fernicola and S. F. Vizcaino. “Revision del genero Stegotherium Ameghino, 1887 (Mammalia, Xenarthra, Dasypodidae)". Spanish. In: Ameghiniana 45.2 (2008), pp. 321-332.

[7211] J. C. Fernicola and S. F. Vizcaino. "Cingulates (Mammalia, Xenarthra) of the Santa Cruz Formation (Early-Middle Miocene) From the Ro Santa Cruz, Argentine Patagonia". English. In: vol. 19. EarlyMiddle Miocene Paleontology in the Ro Santa Cruz, Southern Patagonia, Argentina. 130 years since Ameghino, 1887 2. Publicación Electrónica de la Asociación Paleontológica Argentina, 2019, pp. 85-101. DOI: 10.5710/PEAPA.14.10.2019.291.

[7212] S. M. Ferrari. “The genera Cryptaulax and Procerithium (Procerithiidae, Caenogastropoda) in the Early Jurassic of Patagonia, Argentina". English. In: Alcheringa 36 (2012), pp. 323-336.

[7213] S. M. Ferrari. "New Early Jurassic gastropods from westcentral Patagonia, Argentina". English. In: Acta Palaeontologica Polonica 58 (2013), pp. 579-593.

[7214] S. M. Ferrari. "Cosmopolitan Early Jurassic marine gastropods from westcentral Patagonia, Argentina". English. In: Acta Palaeontologica Polonica 54 (2009), pp. 449-461. 
[7215] S. M. Ferrari. "Patellogastropoda and Vetigastropoda (Mollusca, Gastropoda) from the marine Jurassic of Patagonia, Argentina". English. In: Historical Biology 26 (2014), pp. 563-581.

[7216] S. M. Ferrari and S. Bessone. "A new Early Jurassic marine locality from southwestern Chubut Basin, Argentina". English. In: Andean Geology 42.3 (2015), pp. 349-363. DOI: 10.5027/andgeoV42n3a04.

[7217] S. M. Ferrari, A. Kaim, and S. E. Damborenea. “The genera Calliotropis Seguenza and Ambercyclus n. gen. (Vetigastropoda, Eucyclidae) from the Early Jurassic of Argentina". English. In: Journal of Paleontology 88 (2014), pp. 1174-1188.

[7218] S. M. Ferrari and N. Sabattini. "Nuevos Gastrópodos (Eotomariidae y Subulitidae) en las localidades de Piedra Shotel y Cerro La Trampa, Formación Ro Genoa, Pérmico Inferior del Chubut". Spanish. In: Ameghiniana 45.1 (2008), pp. 241-246.

[7219] F. A. Ferratges, S. Zamora, and M. Aurell. "A new genus and species of Parthenopidae MacLeay, 1838 (Decapoda: Brachyura) from the lower Eocene of Spain". English. In: Journal of Crustacean Biology 2019 (2019), pp. 1-9. DOI: 10.1093/jcbiol/ruz014.

[7220] B. Ferré and B. Granier. “Roveacrinus berthoui nov.sp., Early Hauterivian representative of Roveacrinidae (Roveacrinida, Crinoidea) of Busot (Alicante, Spain)". English. In: Geologica Carpathica 51.2 (2000), pp. 101-107.

[7221] D. Ferreira, A. K. B. Silva, and C. H. C. Matos. "Assembleia holocenica de vertebrados de pequeno porte do Stio Alcobaça, Estado de Pernambuco, Brasil". Portugese. In: Revista Brasileira de Paleontologia 15.3 (2012), pp. 359-370.

[7222] G. S. Ferreira, F. V. Iori, G. Hermanson, and M. C. Langer. "New turtle remains from the Late Cretaceous of Monte AltoSP, Brazil, including cranial osteology, neuroanatomy and phylogenetic position of a new taxon". English. In: Palaeontologische Zeitschrift (2018), pp. 1-18. DOI: 10.1007 / s12542-017-0397-x.

[7223] G. S. Ferreira and M. C. Langer. "A pelomedusoid (Testudines, Pleurodira) plastron from the Lower Cretaceous of Alagoas, Brazil”. English. In: Cretaceous Research 46 (2013), pp. 267-271.

[7224] G. S. Ferreira, A. D. Rincón, A. Solórzano, and M. C. Langer. "Review of the fossil matamata turtles: earliest well-dated record and hypotheses on the origin of their present geographical distribution". English. In: The Science of Nature 103.28 (2016), pp. 1-12. DOI: 10.1007/s00114-016-13552..

[7225] G. S. Ferreira, A. D. Rincon, A. Solorzano, and M. C. Langer. "The last marine pelomedusoids (Testudines: Pleurodira): a new species of Bairdemys and the paleoecology of Stereogenyina". English. In: PeerJ (2015), pp. 1-29. DOI: 10.7717/peerj.1063.

[7226] V. S. Ferreira and M. A. Ivie. "The first fossil species of the extant genus Cessator Kazantsev (Coleoptera: Lycidae): a new Leptolycini from Dominican amber". English. In: The Coleopterists Bulletin 71 (2017), pp. 57-60.

[7227] S. A. R. Ferreira Costa, M. Richter, P. M de Toledo, and H. M Moraes-Santos. "Shark teeth from Pirabas Formation (Lower Miocene), northeastern Amazonia, Brazil". English. In: Boletim do Museu Paraense Emlio Goeldi 4.3 (2009), pp. 221-230.

[7228] B. S. Ferrero and J. I. Noriega. "A new upper Pleistocene tapir from Argentina: remarks on the phylogenetics and diversification of neotropical Tapiridae". English. In: Journal of Vertebrate Paleontology 27.2 (2007), pp. 504-511. DOI: 10.1671/0272-4634(2007)27[504:ANUPTF]2.0.CO;2.

[7229] B. S. Ferrero, J. I. Noriega, E. Brunetto, and N. N. Otaño. "Vertebrate continental assemblage from the Last Interglacial in southern South America (Entre Ros, Argentina). Biostratigraphy and paleoenvironment". English. In: Palaeogeography, Palaeoclimatology, Palaeoecology 466 (2017), pp. 8999.

[7230] A. Ferretti. "Late Ordovician conodonts from the Prague Basin, Bohemia". English. In: Palaeontologia Polonica 58 (1998), pp. 123-139. 
[7231] A. Ferretti and C. R. Barnes. “Upper Ordovician conodonts from the Kalkbank limestone of Thuringia, Germany". English. In: Palaeontology 40.1 (1997), pp. 15-42.

[7232] A. Ferretti, S. M. Bergström, and G. D. Sevastopulo. "Katian conodonts from the Portrane Limestone: the first Ordovician conodont fauna described from Ireland". English. In: Bollettino della Societá Paleontologica Italiana 53.2 (2014), pp. 105-119.

[7233] M. P. Ferretti. “The dwarf elephant Palaeoloxodon mnaidriensis from Puntali Cave, Carini (Sicily; late Middle Pleistocene): Anatomy, systematics and phylogenetic relationships". English. In: Quaternary International 182 (2008), pp. 90-108.

[7234] M. P. Ferretti. "Miocene Proboscideans from Italy: African Elements and Paleogeographic Implications". English. In: Geology of East Libya 3 (2008), pp. 325-334.

[7235] F. J. Ferriz, M. Freudenthal, and E. Martin Suarez. "The oldest mammals from the Betic Cordillera: the Oligocene of the internal Prebetic (Nerpio, Albacete, SE Spain)". English. In: Geobios 26.5 (1993), pp. 625-631.

[7236] I. Ferrusqua-Villafranca. "The first Paleogene mammal record of Middle America: Simojovelhyus pocitosense (Helohyidae, Artiodactyla)". English. In: Journal of Vertebrate Paleontology 26.4 (2006), pp. 989-1001.

[7237] I. Ferrusqua-Villafranca, S. P. Applegate, and L. Espinosa-Arrubarrena. "First Paleogene selachifauna of the Middle American-Caribbean-Antillean region, La Mesa de Copoya, west-central Chiapas-geologic setting". English. In: Revista Mexicana de Ciencias Geológicas 17.1 (2000), pp. 123.

[7238] I. Ferrusqua-Villafranca, V. M. Bravo-Cuevas, and E. Jiménez-Hidalgo. "The Xochixtlapilco dinosaur ichnofauna, Middle Jurassic of Oaxaca, southeastern Mexico: description and paleontologic significance". English. In: Contributions in Science, Natural History Museum of Los Angeles County 515 (2007), pp. 1-40.

[7239] I. Ferrusquia-Villafranca, L. J. Flynn, J. E. Ruiz-Gonzalez, J. R. Torres-Hernandez, and E. MartinezHernandez. "New Eocene rodents from Northwestern Oaxaca, Southeastern Mexico, and their paleobiological significance". English. In: Journal of Vertebrate Paleontology (2018), e1514615. DOI: 10.1080/02724634.2018.1514615.

[7240] I. Ferrusqua-Villafranca, J. E. Ruiz-González, E. Martnez-Hernández, J. R. Torres-Hernández, and G. Woolrich-Piña. "A new Miocene local fauna from the Sierra Madre Oriental at San Luis Potos, Central-East Mexico, and its paleontologic significance". English. In: Geobios 47.4 (2014), pp. 199220. DOI: 10.1016/j.geobios.2014.06.004.

[7241] I. Ferrusqua-Villafranca and J. E. Ruiz-González. “The first postcranial oreodont (mammalia, Artiodactyla, Merycoidodontidae) skeleton from Mexico: Description and paleobiological significance". English. In: Journal of South American Earth Sciences 97 (2020), 102388:1-11.

[7242] W. Ferwer and A. Nel. "A new damselfly genus and species from Baltic amber (Odonata: Zygoptera: Euphaeidae)". English. In: BSGF - Earth Sciences Bulletin 191.12 (2020), pp. 1-4. DOI: 10. $1051 /$ bsgf/2020015.

[7243] V. Fet, D. E. Shcherbakov, and M. E. Soleglad. "The first record of Upper Permian and Lower Triassic scorpions from Russia (Chelicerata: Scorpiones)". English. In: Euscorpius - Occasional Publications in Scorpiology 121 (2011), pp. 1-16.

[7244] V. Fet, M. E. Soleglad, Y. V. Mosseichik, and D. E. Shcherbakov. “A scorpion from a peatbog: the first arthropod fossil from the Late Viséan of the Moscow Coal Basin". English. In: Euscorpius Occasional Publications in Scorpiology 13 (2004), pp. 1-5.

[7245] N. Feuillet, P. Tapponnier, I. Manighetti, B. Villemant, and G. C. P. King. “Differential uplift and tilt of Pleistocene reef platforms and Quaternary slip rate on the Morne-Piton normal fault (Guadeloupe, French West Indies)". English. In: Journal of Geophysical Research 109.B02404 (2004), pp. 118. 
[7246] G. Ficcarelli, L. Abbazzi, A. Albianelli, A. Bertini, M. Coltorti, M. Magnatti, F. Masini, P. Mazza, C. Mezzabotta, G. Napoleone, L. Rook, M. Rustioni, and D. Torre. "Cesi, an early Middle Pleistocene site in the Colfiorito Basin (Umbro-Marchean Apennine), central Italy". English. In: Journal of Quaternary Science 12.6 (1997), pp. 507-518.

[7247] D. J. Field, J. Benito, A. Chen, J. W. M. Jagt, and D. T. Ksepka. "Late Cretaceous neornithine from Europe illuminates the origins of crown birds". English. In: Nature 579 (2020), pp. 397-401.

[7248] D. J. Field, R. Boessenecker, R. A. Racicot, L. Ásbjörnsdóttir, K. Jónasson, A. Y. Hsiang, A. D. Behlke, and J. Vinther. "The oldest marin vertebrate fossil from the volcanic island of Iceland: A partial right whale skull from the high latitude Pliocene Tjörnes Formation". English. In: Palaeontology (2017). DOI: 10.1111/ pala.12275.

[7249] D. J. Field, R. A. Racicot, and M. D. Uhen. A new marine tetrapod assemblage from the Eocene of Western Sahara. English. 2011.

[7250] G. J. Field and D. M. Martill. “Unusual soft tissue preservation in the Early Cretaceous (Aptian) crocodile cf. Susisuchus from the Crato Formation of north east Brazil". English. In: Cretaceous Research 75 (2017), pp. 179-192.

[7251] M. H. Field. "Variations in Azolla section Azolla megaspore apparatus and their implications for palaeotaxonomy and European Pleistocene biostratigraphy". In: Review of Palaeobotany and Palynology 105 (1999), pp. 85-92.

[7252] S. Fielding, D. M. Martill, and D. Naish. "Solhofen-style soft-tissue preservation in a new species of turtle from the Crato Formation (Early Cretaceous, Aptian) of North-East Brazil". English. In: Palaeontology 48.6 (2005), pp. 1301-1310. DOI: 10.1111/j.1475-4983.2005.00508.x.

[7253] S. E. Fields. "The ground sloth Megalonyx". English. In: Transactions of the American Philosophical Society 100.4 (2010), pp. 59-73.

[7254] C. Fielitz and D. Bardack. "Deltaichthys albuloides, a new and unusually preserved albulid (Teleostei) probably from the Cretaceous of Texas". English. In: Journal of Vertebrate Paleontology 12.12 (1992), pp. 133-141.

[7255] C. Fielitz and K. A. González-Rodrguez. "A New Species of Enchodus (Aulopiformes: Enchodontidae) from the Cretaceous (Albian to Cenomanian) of Zimapán, Hidalgo, México". English. In: Journal of Vertebrate Paleontology 30.5 (2010), pp. 1343-1351.

[7256] C. Fielitz and K. Shimada. "A new species of Apateodus (Teleostei: Aulopiformes) from the upper Cretaceous Niobrara Chalk of western Kansas, USA". English. In: Journal of Vertebrate Paleontology 29.3 (2009), pp. 650-658.

[7257] H. L. Fierstine. "Makaira sp., cf. M. nigricans Lacepede, 1802 (Teleostei: Perciformes: Istiophoridae) from the late Miocene, Panama, and its probable use of the Panama seaway". English. In: Journal of Vertebrate Paleontology 19.3 (1999), pp. 430-437.

[7258] H. L. Fierstine. "Analysis and new records of billfish (Teleostei: Perciformes: Istiophoridae) from the Yorktown Formation, Early Pliocene of eastern North Carolina at Lee Creek Mine". English. In: Smithsonian Contributions to Paleobiology 90 (2001), pp. 21-69.

[7259] H. L. Fierstine. “Makaira sp, cf. M. nigricans Lacepede, 1802 (Teleostei: Perciformes: Istiophoridae) from the Eastover Formation, Late Miocene, Virginia, and A Reexamination of Istiophorus Calvertensis Berry, 1917". English. In: Journal of Vertebrate Paleontology 18.1 (1998), pp. 30-42.

[7260] H. L. Fierstine. "A New Aglyptorhynchus (Perciformes: Scombroidei) from the Lincoln Creek Formation (Late Oligocene, Washington, U.S.A.)" English. In: Journal of Vertebrate Paleontology 25.2 (2005), pp. 288-299.

[7261] H. L. Fierstine. "A New Shortbilled Marlin of the Genus Makaira, from the Yorktown Formation, (Early Pliocene), Eastern North Carolina at Lee Creek Mine, USA". English. In: Tertiary Research 19.3-4 (1999), pp. 71-77. 
[7262] H. L. Fierstine, S. P. Applegate, G. Gonzalez-Barba, T. Schwennicke, and L. Espinosa-Arrubarrena. "A Fossil Blue Marlin (Makaira nigricans Lacepede) from the Middle Facies of the Trinidad Formation (Upper Miocene to Upper Pliocene), SanJose del Cabo Basin, Baja California Sur, Mexico". English. In: Bulletin of the Southern California Academy of Sciences 100.2 (2001), pp. 59-73.

[7263] H. L. Fierstine and J. E. Starnes. "Xiphiorhynchus cf. X. eocaenicus (Woodward, 1901), (Scombroidei: Xiphiidae: Xiphiorhynchinae) from the middle Eocene of Mississippi, the first transatlantic distribution of a species of Xiphiorhynchus". English. In: Journal of Vertebrate Paleontology 25.2 (2005), pp. 280-287.

[7264] H. L. Fierstine and G. L. Stringer. "Specimens of the Billfish Xiphiorhynchus Van Beneden, 1871, From the Yazoo Clay Formation (Late Eocene), Louisiana". English. In: Journal of Vertebrate Paleontology 27.1 (2007), pp. 226-231. DOI: 10.1671/0272-4634.

[7265] R. G. Figueiredo, J. K. R. Moreira, A. A. F. Saraiva, and A. W. A. Kellner. "Description of a new specimen of Susisuchus anatoceps (Crocodylomorpha: Mesoeucrocodylia) from the Crato Formation (Santana Group) with comments on Neosuchia". English. In: Zoological Journal of the Linnean Society 163 (2011), S273-S288.

[7266] S. Figueiredo, I. Bachtsevanidou Strantzali, M. Gomes, R. Pimenta, and M. Santos. "Preliminary data of new dinosaurs and turtles remains from the basal deposits of the Papo-Seco Formation in Areias do Mastro's Quarry (Cabo Espichel - Portugal)". English. In: Arnava 6.1 (2017), pp. 117-130.

[7267] S. D. Figueiredo, P. P. Cunha, F. Sousa, T. Pereira, and A. Rosa. "Pleistocene birds of Gruta da Furninha (Peniche-Portugal): a paleontological and". English. In: Journal of Environmental Science and Engineering A 6 (2017), pp. 502-509.

[7268] A. Fijalkowska. "Palynological aspects of the Permo-Triassic succession in the Holy Cross Mountains, Poland". In: Documenta Naturae 87 (1994), pp. 1-76.

[7269] M. Fikáek and M. S. Engel. "An aquatic water scavenger beetle in early Miocene amber from the Dominican Republic (Coleoptera: Hydrophilidae)". English. In: Annales Zoologici 61.4 (2011), pp. 621-628.

[7270] M. Fikáek, J. Hájek, and J. Prokop. “New records of the water beetles (Coleoptera: Dytiscidae, Hydrophilidae) from the central European Oligocene-Miocene deposits, with a confirmation of the generic attribution of Hydrobiomorpha enspelense Wedmann 2000". English. In: Annales de la Société Entomologique de France 4 (2008), pp. 187-199.

[7271] M. Fikáek, Y. N. Minoshima, A. Komarek, A. E. Z. Short, D. Y. Huang, and C. Y. Cai. "Cretocrenis burmanicus, the first Mesozoic amber inclusion of a water scavenger beetle (Coleoptera: Hydrophilidae)". English. In: Cretaceous Research 44 (2017), pp. 49-55.

[7272] M. Fikáek, A. Prokin, and R. B. Angus. "A long-living species of the hydrophiloid beetles: Helophorus sibiricus from the early Miocene deposits of Kartashevo (Siberia, Russia)". English. In: ZooKeys 130 (2011), pp. 239-254.

[7273] M. Fikáek, A. Prokin, R. B. Angus, A. Ponomarenko, Y. L. Yue, D. Ren, and J. Prokop. "Revision of Mesozoic fossils of the helophorid lineage of the superfamily Hydrophiloidea (Coleoptera: Polyphaga)". English. In: Acta Entomologica Musei Nationalis Pragae 52 (2012), pp. 89-127.

[7274] M. Fikáek, A. Prokin, E. Yan, Y. Yue, B. Wang, D. Ren, and R. Beattie. “Modern hydrophilid clades present and widespread in the Late Jurassic and Early Cretaceous (Coleoptera: Hydrophiloidea: Hydrophilidae)". English. In: Zoological Journal of the Linnean Society 170 (2014), pp. 710-734.

[7275] M. Fikáek, J. Prokop, and A. Nel. "Fossil water scavenger beetles of the subtribe Hydrobiusina (Coleoptera: Hydrophilidae) from the Late Oligocene locality of Aix-en-Provence (France)". English. In: Acta Entomologica Musei Nationalis Pragae 50 (2010), pp. 445-458.

[7276] M. Fikáek, H. Schmied, and J. Prokop. "Fossil Hydrophilid Beetles (Coleoptera: Hydrophilidae) of the Late Oligocene Rott Formation (Germany)". English. In: Acta Geologica Sinica 84.4 (2010), pp. 732-750. 
[7277] M. Fikáek and H. Schmied. "Insect fauna of the late Miocene locality of Öhningen (Germany) less diverse than reported: an example of the Hydrophilid beetles (Coleoptera)". English. In: Journal of Paleontology 87 (2013), pp. 427-443.

[7278] M. Fikáek, S. Wedmann, and H. Schmied. "Diversification of the greater hydrophilines clade of giant water scavenger beetles dated back to the Middle Eocene (Coleoptera: Hydrophilidae: Hydrophilina)". English. In: Invertebrate Systematics 24 (2010), pp. 9-22.

[7279] P. Filipiak and W. Krawczyski. "Westphalian xiphosurans (Chelicerata) from the Upper Silesia Coal Basin of Sosnowiec, Poland". English. In: Acta Palaeontologica Polonica 41 (1996), pp. 413-425.

[7280] L. S. Filippi. "Los dinosaurios Sauropoda del Cretácico Superior del norte de la Cuenca Neuquina, Patagonia Argentina [The sauropod dinosaurs from the Upper Cretaceous of the north of the Neuquén Basin, Argentine Patagonia]". Spanish. In: Boletn del Instituto de Fisiografa y Geologa 85 (2015), pp. 19-28.

[7281] L. S. Filippi, F. Barrios, and A. C. Garrido. "A new peirosaurid from the Bajo de la Carpa Formation (Upper Cretaceous, Santonian) of Cerro Overo, Neuquén, Argentina". English. In: Cretaceous Research 83 (2018), pp. 75-83.

[7282] L. S. Filippi, J. I. Canudo, J. L. Salgado, A. Garrido, R. Garca, I. Cerda, and A. Otero. “A new sauropod titanosaur from the Plottier Formation (Upper Cretaceous) of Patagonia (Argentina)". English. In: Geologica Acta 9.1 (2011), pp. 1-12. DOI: 10.1344/105.000001648.

[7283] L. S. Filippi, R. A. Garca, and A. C. Garrido. "A new titanosaur sauropod dinosaur from the Upper Cretaceous of North Patagonia, Argentina". English. In: Acta Palaeontologica Polonica 56.3 (2011), pp. 505-520.

[7284] L. S. Filippi and A. C. Garrido. "Pitekunsaurus macayai gen. et sp. nov., nuevo titanosaurio (Saurischia, Sauropoda) del Cretácico Superior de la Cuenca Neuquina, Argentina [Pitekunsaurus macayai gen. et sp. nov., new titanosaur (Saurischia, Sauropoda) from the Upper Cretaceous of the Neuquén Basin, Argentina]". Spanish. In: Ameghiniana 45.3 (2008), pp. 575-590.

[7285] L. S. Filippi and A. C. Garrido. "Nuevo registro del género Dinilysia (Squamata, Serpentes) para la Formación Anacleto (Campaniano inferior-medio), Rincón de los Sauces, Neuquén, Argentina [New record of the genus Dinilysia (Squamata, Serpentes) for the Anacleto Formation (lowermiddle Campanian), Rincón de los Sauces, Neuquén, Argentina]". Spanish. In: Ameghiniana 49.1 (2012), pp. 132-136. DOI: 10.5710/AMGH.v49i1(297).

[7286] L. S. Filippi, A. G. Martinelli, and A. C. Garrido. "Registro de un dinosaurio Aeolosaurini (Sauropoda, Titanosauria) en el Cretácico Superior (Formación Plottier) del norte de la provincia de Neuquén, Argentina, y comentarios sobre los Aeolosaurini sudamericanos [Record of an aeolosaurine dinosaur (Sauropoda, Titanosauria) in the Upper Cretaceous (Plottier Formation) of northern Neuquén Province, Argentina, and comments on the South American Aeolosaurini]". Spanish. In: Revista Brasileira de Paleontologia 16.1 (2013), pp. 147-156. DOI: 10.4072/rbp.2013.1.11.

[7287] L. S. Filippi, A. H. Méndez, R. D. Juárez Valieri, and A. C. Garrido. "A new brachyrostran with hypertrophied axial structures reveals anăunexpected radiation of latest Cretaceous abelisaurids". English. In: Cretaceous Research 60 (2016), pp. 209-219. DOI: 10.1016/j.cretres.2015.12.018.

[7288] L. S. Filippi, L. Salgado, and A. C. Garrido. "A new giant basal titanosaur sauropod in the Upper Cretaceous (Coniacian) of the Neuquén Basin, Argentina". English. In: Cretaceous Research 100 (2019), pp. 61-81. DOI: 10.1016/j.cretres.2019.03.008.

[7289] H. F. Filkorn. "Fossil scleractinian corals from James Ross Basin, Antarctica". In: Antarctic Research Series 65 (1994), pp. 1-96.

[7290] H. F. Filkorn. "The Cretaceous corals of Mexico; occurrences and history of research". English. In: Revista Mexicana de Ciencias Geologicas 20.1 (2003), pp. 52-78.

[7291] H. F. Filkorn, J. Avendano-Gil, M. A. Coutino-Jose, and F. J. Vega-Vera. "Corals from the Upper Cretaceous (Maastrichtian) Ocozocoautla Formation, Chiapas, Mexico". English. In: Revista Mexicana de Ciencias Geologicas 22.1 (2005), pp. 115-128. 
[7292] H. F. Filkorn and J. Pantoja-Alor. "A new Early Cretaceous coral (Anthozoa, Scleractinia, Dendrophylliina) and its evolutionary significance". English. In: Journal of Paleontology 78.3 (2004), pp. 501-512.

[7293] H. F. Filkorn and J. Pantoja-Alor. "Cretaceous corals from the Huetamo region, Michoacan and Guerrero, southwestern Mexico". English. In: Universidad Nacional Autonoma de Mexico, Instituto de Geologia, Boletin 116 (2009), pp. 1-169.

[7294] H. F. Filkorn and R. W. Scott. "Microfossils, paleoenvironments and biostratigraphy of the Mal Paso Formation (Cretaceous, upper Albian), State of Guerrero, Mexico". English. In: Revista Mexicana de Ciencias Geológicas 28.1 (2011).

[7295] A. Filleul. "Baugeichthys caeruleus, gen. et sp. nov., a New Albulifrom Fish from the Hauterivian of the Massif Des Bauges (France)". English. In: Journal of Vertebrate Paleontology 20.4 (2000), pp. 637-644.

[7296] A. Filleul and D. B. Dutheil. "Spinocaudichthys Oumtkoutensis, a Freshwater Acanthomorph from the Cenomanian of Morocco". English. In: Journal of Vertebrate Paleontology 21.4 (2001), pp. 774780.

[7297] A. Filleul and D. B. Dutheil. "A Peculiar Diplospondylous Actinopterygian Fish from the Cretaceous of Morocco". English. In: Journal of Vertebrate Paleontology 24.2 (2004), pp. 290-298.

[7298] T. R. Finger. "A comparison of fish community structure along several paleoenvironments of Eocene Fossil Lake, Wyoming: a preliminary report". English. In: National Park Service Paleontological Research Vol. 3 Technical Report NPS/NRGRD/GRDTR-98/1 (1998), pp. 81-83.

[7299] R. M. Finks. "Some new genera of Paleozoic calcareous sponges". English. In: University of Kansas Paleontological Contributions 6 (1995), pp. 1-9.

[7300] R. M. Finks. "The sponge family Guadalupiidae in the Texas Permian". English. In: Journal of Paleontology 84.5 (2010), pp. 821-847.

[7301] R. M. Finks, K. Hollocher, and K. J. Thies. "A major Eocene sponge fauna (Castle Hayne Formation, North Carolina)". English. In: Journal of the Carolina Academy of Science 127.2 (2011), pp. 39175.

[7302] S. Finnegan and M. L. Droser. "Reworking diversity: effects of storm deposition on evenness and sampled richness, Ordovician of the Basin and Range, Utah and Nevada". English. In: Palaios 23.2 (2008), pp. 87-96.

[7303] L. Fiorelli and J. O. Calvo. "New remains of Notosuchus terrestris Woodward, 1896 (Crocodyliformes: Mesoeucrocodylia) from Late Cretaceous of Neuquen, Patagonia, Argentina". English. In: Arquivos do Museu Nacional, Rio de Janeiro 66.1 (2008), pp. 83-124.

[7304] L. E. Fiorelli. "Predation bite-marks on a peirosaurid crocodyliform from the Upper Cretaceous of Neuquén Province, Argentina". English. In: Ameghiniana 47.3 (2010), pp. 387-400.

[7305] L. E. Fiorelli and J. O. Calvo. "The first protosuchian (Archosauria: Crocodyliformes) from the Cretaceous (Santonian) of Gondwana". English. In: Arquivos do Museu Nacional, Rio de Janeiro 65.4 (2007), pp. 417-459.

[7306] L. E. Fiorelli, J. M. Leardi, E. M. Hechenleitner, D. Pol, G. Basilici, and G. Grellet-Tinner. “A new Late Cretaceous crocodyliform from the western margin of Gondwana (La Rioja Province, Argentina)". English. In: Cretaceous Research 60 (2016), pp. 194-209.

[7307] A. R. Fiorillo. "Stratigraphic distribution of fossil vertebrates in the Judith River Formation (Upper Cretaceous) of Wheatland and Golden Valley counties, south-central Montana". In: Northwest Geology 27 (1997), pp. 1-12.

[7308] A. R. Fiorillo. Non-mammalian microvertebrate remains from the Robison Eggshell site, Cedar Mountain Formation (Lower Cretaceous), Emery County, Utah. Vol. 99-1. Vertebrate Paleontology in Utah, Utah Geological Survey Miscellaneous Publication. 1999, pp. 259-268.

[7309] A. R. Fiorillo. "Turtle tracks in the Judith River Formation (Upper Cretaceous) of south-central Montana". In: Palaeontologia Electronica 9.1 (2005), pp. 1-11. 
[7310] A. R. Fiorillo. Preliminary report on a new sauropod locality in the Javelina Formation (Late Cretaceous), Big Bend National Park, Texas. English. Vol. 3. In V. L. Santucci \& L. McClelland (eds.), National Park Service Geologic Resources Division Technical Report NPS/NRGRD/GRDTR-98/01. National Park Service Paleontological Research Volume. 1998, pp. 29-31.

[7311] A. R. Fiorillo. "Review of the dinosaur record of Alaska with comments regarding Korean dinosaurs as comparable high-latitude fossil faunas". English. In: Journal of the Paleontological Society of Korea 22.1 (2006), pp. 15-27.

[7312] A. R. Fiorillo and T. L. Adams. "A therizinosaur track from the Lower Cantwell Formation (Upper Cretaceous) of Denali National Park, Alaska". English. In: Palaios 27 (2012), pp. 394-400. DOI: 10.2110/palo.2011.p11-083r.

[7313] A. R. Fiorillo, T. L. Adams, and Y. Kobayashi. "New sedimentological, palaeobotanical, and dinosaur ichnological data on the palaeoecology of an unnamed Late Cretaceous rock unit in WrangellSt. Elias National Park and Preserve, Alaska, USA". English. In: Cretaceous Research 37 (2012), pp. 291-299. DOI: 10.1016/j.cretres.2012.04.013.

[7314] A. R. Fiorillo and P. J. Currie. "Theropod teeth from the Judith River Formation (Upper Cretaceous) of south-central Montana". English. In: Journal of Vertebrate Paleontology 14.1 (1994), pp. 7480.

[7315] A. R. Fiorillo and R. Gangloff. Preliminary notes on the taphonomic and paleoecologic setting of a Pachyrhinosaurus bonebed in northern Alaska. English. 2003.

[7316] A. R. Fiorillo and R. A. Gangloff. "Theropod teeth from the Prince Creek Formation (Cretaceous) of northern Alaska, with speculations on Arctic dinosaur paleoecology". English. In: Journal of Vertebrate Paleontology 20.4 (2001), pp. 675-682.

[7317] A. R. Fiorillo, S. T. Hasiotis, Y. Kobayashi, and C. S. Tomsich. "A pterosaur manus track from Denali National Park, Alaska Range, Alaska, United States". English. In: Palaios 24 (2009), pp. 466472.

[7318] A. R. Fiorillo, S. T. Hasiotis, Y. Kobayashi, B. H. Breithaupt, and P. J. McCarthy. "Bird tracks from the Upper Cretaceous Cantwell Formation of Denali National Park, Alaska, USA: a new perspective on ancient northern polar vertebrate biodiversity". English. In: Journal of Systematic Palaeontology 9.1 (2011), pp. 33-49. DOI: 10.1080/14772019.2010.509356.

[7319] A. R. Fiorillo, R. S. Tykoski, P. J. Currie, P. J. McCarthy, and P. Flaig. “Description of two partial Troodon braincases from the Prince Creek Formation (Upper Cretaceous), North Slope Alaska". English. In: Journal of Vertebrate Paleontology 29.1 (2009), pp. 178-187. DOI: 10.1671/039.029.0108.

[7320] A. R. Fiorillo and R. S. Tykoski. "A new Maastrichtian species of the centrosaurine ceratopsid Pachyrhinosaurus from the North Slope of Alaska". English. In: Acta Palaeontologica Polonica 57.3 (2012), pp. 561-573.

[7321] A. R. Fiorillo and R. S. Tykoski. "A diminutive new tyrannosaur from the top of the world". English. In: PLoS ONE 9.3 (2014), e91287. DOI: 10.1371/journal.pone.0091287.

[7322] A. R. Fiorillo, Y. Kobayashi, P. J. McCarthy, T. Tanaka, R. S. Tykoski, Y. -N. Lee, R. Takasaki, and J. Yoshida. "Dinosaur ichnology and sedimentology of the Chignik Formation (Upper Cretaceous), Aniakchak National Monument, southwestern Alaska; further insights on habitat preferences of high-latitude hadrosaurs". English. In: PLoS ONE 14.19 (2019), e0223471:1-19. DOI: 10.1371 / journal.pone.0223471.

[7323] J. C. Fischer. "Remarkable Invertebrates from the Lower Callovian of La Voulte-sur-Rhone (Ardéche, France)". French. In: Annales de Paléontologie 89 (2003), pp. 223-252.

[7324] J. H. Fischer, I. Debski, C. M. Miskelly, C. A. Bost, A. Fromant, A. J. D. Tennyson, J. Tessler, R. Cole, J. H. Hiscock, G. A. Taylor, and H. U. Wittmer. "Analyses of phenotypic differentiations among South Georgian Diving Petrel (Pelecanoides georgicus) populations reveal an undescribed and highly endangered species from New Zealand". English. In: PLoS One 13.6 (2018), e0197766. 
[7325] J.-C. Fischer, F. Rosati, and S. Raffi. "Sinemurian gastropods from Monte Cucco (Umbria-Marche Apennines, Central Italy)". French. In: Geobios 32.4 (2002), pp. 441-456. DOI: 10.1016 / S00166995(02)00039-6.

[7326] T. C. Fischer. "Pygmy moths (Lepidoptera, Nepticulidae) from Baltic amber (Eocene)". English. In: Zitteliana A 53 (2013), pp. 85-92.

[7327] T. C. Fischer. "Caterpillars and cases of Tineidae (clothes moths, Lepidoptera) from Baltic amber (Eocene)". English. In: Zitteliana A 54 (2014), pp. 75-81.

[7328] T. C. Fischer. "Bucculatrix rycki - the first fossil adult ribbed cocoon maker moth (Bucculatricidae, Lepidoptera)". English. In: Zitteliana A 55 (2015), pp. 115-119.

[7329] T. C. Fischer and M. K. Hörnig. "Mating moths (Tineidae, Ditrysia, Lepidoptera) preserved as frozen behavior inclusion in Baltic Amber (Eocene)". English. In: Palaeontologia Electronica 22.1.7A (2019), pp. 1-11.

[7330] T. C. Fischer, A. Michalski, and A. Hausmann. "Geometrid caterpillar in Eocene Baltic amber (Lepidoptera, Geometridae)". English. In: Scientific Reports 9.17201 (2019), pp. 1-4.

[7331] V. Fischer. "New data on the ichthyosaur Platypterygius hercynicus and its implications for the validity of the genus". English. In: Acta Palaeontologica Polonica 57.1 (2012), pp. 123-134.

[7332] V. Fischer. "Origin, biodiversity, and extinction of Cretaceous ichthyosaurs". English. PhD thesis. Liége, Belgique, 2013, pp. 1-576.

[7333] V. Fischer. "Taxonomy of Platypterygius campylodon and the diversity of the last ichthyosaurs". English. In: PeerJ 4 (2016), e2604. DOI: 10.7717/peerj.2604.

[7334] V. Fischer, R. M. Appleby, D. Naish, J. Liston, J. B. Riding, S. Brindley, and P. Godefroit. “A basal thunnosaurian from Iraq reveals disparate phylogenetic origins for Cretaceous ichthyosaurs". English. In: Biology Letters 98.4 (2013), p. 20130021. DOI: 10.1098/rsbl.2013.0021.

[7335] V. Fischer, M. S. Arkhangelsky, G. N. Upensky, I. M. Stenshin, and P. Godefroit. "A new Lower Cretaceous ichthyosaur from Russia reveals skull shape conservatism within Ophthalmosaurinae". English. In: Geological Magazine (2013). DOI: 10.1017/S0016756812000994.

[7336] V. Fischer, M. S. Arkhangelsky, I. M. Stenshin, G. N. Uspensky, N. G. Zverkov, and R. B. J. Benson. "Peculiar macrophagous adaptations in a new Cretaceous pliosaurid". English. In: Royal Society Open Science 2.150552 (2015). DOI: 10.1098/rsos.150552.

[7337] V. Fischer, N. Bardet, M. Guiomar, and P. Godefroit. "High diversity in Cretaceous ichthyosaurs from Europe prior to their extinction". English. In: PLoS ONE 9.1 (2014), e84709.

[7338] V. Fischer, N. Bardet, R. B. J. Benson, M. S. Arkhangelsky, and M. Friedman. "Extinction of fishshaped marine reptiles associated with reduced evolutionary rates and global environmental volatility". English. In: Nature Communications 7.10825 (2016), pp. 1-11. DOI: 10.1038/ncomms10825.

[7339] V. Fischer, R. B. J. Benson, N. G. Zverkov, L. C. Soul, M. S. Arkhangelsky, O. Lambert, I. M. Stenshin, G. N. Uspensky, and P. S. Druckenmiller. "Plasticity and convergence in the evolution of short-necked plesiosaurs". English. In: Current Biology 27 (2017), pp. 1-10. DOI: 10.1016/j.cub. 2017.04.052.

[7340] V. Fischer, H. Capetta, P. Vincent, G. Garcia, S. Goolaerts, J. E. Martin, D. Roggero, and X. Valentin. "Ichthyosaurs from the French Rhaetian indicate a severe turnover across the Triassic-Jurassic boundary". English. In: Naturwissenschaften 101 (2014), pp. 1027-1040. DOI: 10.1007/s00114-0141242-7.

[7341] V. Fischer, A. Clement, M. Guiomar, and P. Godefroit. "The first definite record of a Valanginian ichthyosaur and its implications on the evolution of post-Liassic Ichthyosauria". English. In: Cretaceous Research 32 (2011), pp. 155-163.

[7342] V. Fischer, M. Guiomar, and P. Godefroit. "New data on the palaeobiogeography of Early Jurassic marine reptiles: the Toarcian ichthyosaur fauna of the Vocontian Basin (SE France)". English. In: Neues Jahrbuch für Geologie und Palaontologie. Abhandlungen 261.1 (2011), pp. 111-127. DOI: 10.1127/ 0077-7749/2011/0155. 
[7343] V. Fischer, M. W. Maisch, D. Naish, R. Kosma, J. Liston, U. Joger, F. J. Krüger, J. Pardo Pérez, J. Tainsh, and R. M. Appleby. "New ophthalmosaurid ichthyosaurs from the European Lower Cretaceous demonstrate extensive ichthyosaur survival across the Jurassic-Cretaceous boundary". English. In: PLoS One 7.1 (2012), e29234. DOI: 10.1371/journal.pone.0029234.

[7344] V. Fischer, E. Masure, M. S. Arkhangelsky, and P. Godefroit. "A new Barremian (Early Cretaceous) ichthyosaur from western Russia". English. In: Journal of Vertebrate Paleontology 31.5 (2011), pp. 1010-1025.

[7345] V. Fischer, N. G. Zverkov, M. S. Arkhangelsky, I. M. Stenshin, I. V. Blagovetshensky, and G. N. Uspensky. "A new elasmosaurid plesiosaurian from the Early Cretaceous of Russia marks an early attempt at neck elongation". English. In: Zoological Journal of the Linnean Society (2020). DOI: 10.1093/zoolinnean/zlaa103.

[7346] J. R. Fisher, E. M. Tucker, and M. J. Sharkey. “Colemanus keeleyorum (Braconidae, Ichneutinae s. 1.): a new genus and species of Eocene wasp from the Green River Formation of western North America". English. In: Journal of Hymenoptera Research 44 (2015), pp. 57-67.

[7347] E. Fitzgerald and L. Kool. "The first fossil sea turtles (Testudines: Cheloniidae) from the Cenozoic of Australia". English. In: Alcheringa: An Australasian Journal of Palaeontology 39.1 (2015), pp. 142148. DOI: $10.1080 / 03115518.2015 .964047$.

[7348] E. G. M. Fitzgerald. "A fossil sperm whale (Cetacea, Physeteroidea) from the Pleistocene of Nauru, Equatorial Southwest Pacific". English. In: Journal of Vertebrate Paleontology 31.4 (2011), pp. 929931.

[7349] E. M. G. Fitzgerald. "The fossil record of cetaceans (Mammalia) on the Australian continent". In: The Fossil Collector 72 (2004), pp. 5-32.

[7350] E. M. G. Fitzgerald. "A review of the Tertiary fossil Cetacea (Mammalia) localities in Australia". In: Memoirs of the Museum of Victoria 61.2 (2004), pp. 183-208.

[7351] E. M. G. Fitzgerald. "A bizarre new toothed mysticete (Cetacea) from Australia and the early evolution of baleen whales". English. In: Proceedings of the Royal Society B (2006), pp. 1-9. DOI: 10.1098/rspb.2006.3664.

[7352] E. M. G. Fitzgerald. "Pliocene marine mammals from the Whalers Bluff Formation of Portland, Victoria, Australia". English. In: Memoirs of Museum Victoria 62.1 (2005), pp. 67-89.

[7353] E. M. G. Fitzgerald. "Holocene Record of the Dugong (Dugong dugon) from Victoria, Southeast Australia". English. In: Marine Mammal Science 21.2 (2005), pp. 355-361.

[7354] E. M. G. Fitzgerald. "Archaeocete-like jaws in a baleen whale". English. In: Biology Letters (2011). DOI: $10.1098 / \mathrm{rsbl} .2011 .0690$.

[7355] E. M. G. Fitzgerald. "Possible neobalaenid from the Miocene of Australia implies a long evolutionary history for the pygmy right whale Caperea marginata (Cetacea, Mysticeti)". English. In: Journal of Vertebrate Paleontology 32.4 (2012), pp. 976-980.

[7356] E. M. G. Fitzgerald. "A late Oligocene waipatiid dolphin (Odontoceti: Waipatiidae) from Victoria, Australia". English. In: Memoirs of Museum Victoria 74 (2016), pp. 117-136.

[7357] E. M. G. Fitzgerald, T. Park, and T. H. Worthy. "First giant bony-toothed bird (Pelagornithidae) from Australia". English. In: Journal of Vertebrate Paleontology 32.4 (2012), pp. 971-974.

[7358] S. J. Fitzgerald. "A new species of Plecia from the Green River Formation and new combinations of fossil Bibionidae (Diptera)". English. In: Great Basin Naturalist 59 (1999), pp. 182-187.

[7359] T. F. Flannery, M. Archer, T. H. Rich, and R. Jones. "A new family of monotremes from the Cretaceous of Australia". English. In: Nature 377 (1995), pp. 418-420.

[7360] J. Fleagle, T. Bown, and D. Rasmussen. "Fejej, Southern Ethiopia". English. In: Research and Exploration 8.1 (1992), pp. 119-120.

[7361] J. G. Fleagle. "New fossil platyrrhines from the Pinturas Formation, southern Argentina". English. In: Journal of Human Evolution 19.1-2 (1990), pp. 61-85. DOI: 10.1016/0047-2484(90)90012-Z,. 
[7362] G. Fleck, G. Bechly, X. Martinez-Delclos, E. Jarzembowski, R. Coram, and A. Nel. "Phylogeny and classification of the Stenophlebioptera (Odonata: Epiproctophora)". English. In: Annales de la Société Entomologique de France 39.1 (2003), pp. 55-93.

[7363] G. Fleck, G. Bechly, X. Martnez-Delclós, E. A. Jarzembowski, and A. Nel. "A revision of the Upper Jurassic-Lower Cretaceous dragonfly family Tarsophlebiidae, with a discussion on the phylogenetic positions of the Tarsophlebiidae and Sieblosiidae (Insecta, Odonatoptera, Panodonata". English. In: Geodiversitas 26.1 (2004), pp. 33-59.

[7364] G. Fleck and A. Nel. “The first Isophlebioid Dragonfly (Odonata: Isophlebioptera: Campterophlebiidae) from the Mesozoic of China". English. In: Palaeontology 45.6 (2002), pp. 1123-1136.

[7365] G. Fleck, A. Nel, G. Bechly, and X. Martinez-Delclos. "Revision and phylogenetic affinities of the Jurassic Steleopteridae Handlirsch, 1906 (Odonata: Zygoptera)". English. In: Insect Systematics $\mathcal{E}$ Evolution 32 (2001), pp. 285-305.

[7366] G. Fleck, A. Nel, G. Bechly, and F. Escuillié. “The larvae of the Mesozoic family Aeschnidiidae and their phylogenetic implications (Insecta, Odonata, Anisoptera)". English. In: Palaeontology 45.1 (2002), pp. 165-184.

[7367] G. Fleck, A. Nel, and X. Martnez-Delclós. "The oldest record of libellulid dragonflies from the Upper Cretaceous of Kazakhstan (Insecta: Odonata, Anisoptera)". English. In: Cretaceous Research 20 (1999), pp. 655-658.

[7368] G. Fleck, A. Nel, G. Bechly, X. Martnez-Delclós, E. A. Jarzembowski, and R. A. Coram. “New lower cretaceous 'libelluloid' dragonflies (Insecta: Odonata: Cavilabiata) with notes about estimated divergences dates for this group". English. In: Palaeodiversity 1 (2008), pp. 19-36.

[7369] G. Fleck, A. Nel, G. De Plöeg, and G. Masselot. “A fossil dragonfly from the Paris Basin amber of France (Lowermost Eocene) (Insecta, Odonata, Anisoptera)". English. In: Acta Geologica Hispanica 35.1-2 (2000), pp. 131-134.

[7370] C. Flemming and D. A. McFarlane. "New Caribbean Locality for the Extinct Great White Shark Carcharodon megalodon". English. In: Caribbean Journal of Science 34.3-4 (1998), pp. 317-318.

[7371] T. L. Fletcher and S. W. Salisbury. "New pterosaur fossils from the Early Cretaceous (Albian) of Queensland, Australia". English. In: Journal of Vertebrate Paleontology 30.6 (2010), pp. 1747-1759.

[7372] T. P. Fletcher and D. H. Collins. "The Burgess Shale and associated Cambrian formations west of the Fossil Gully Fault Zone on Mount Stephen, British Columbia". English. In: Canadian Journal of Earth Sciences 40.12 (2003), pp. 1823-1838. DOI: 10.1139/e03-057.

[7373] A. L. Flores. "Occurence of a tylosaurine mosasaur (Mosasauridae; Russellosaurina) from the Turonian of Chihuahua State, Mexico". English. In: Boletin de la Sociedad Geologica Mexicana 65.1 (2013), pp. 99-107.

[7374] P. Flórez, P. Zapata-Ramrez, and J. S. Klaus. “Early Miocene shallow-water corals from La Guajira, Colombia: Part II,Mussidae-Siderastreidae and Milleporidae". English. In: Journal of Paleontology (2018). DOI: 10.1017/jpa.2018.90.

[7375] P. Flórez, P. Zapata-Ramrez, and J. S. Klaus. "Early Miocene shallow-water corals from La Guajira, Colombia: part I," English. In: Journal of Paleontology (2018). DOI: 10.1017/jpa.2018.45.

[7376] L. I. Flude and G. M. Narbonne. “Taphonomy and ontogeny of a multibranched Ediacaran fossil: Bradgatia from the Avalon Peninsula of Newfoundland". English. In: Canadian Journal of Earth Sciences 45 (2008), pp. 1095-1109.

[7377] E. Flügel, P. di Stefano, and B. Senowbari-Daryan. "Microfacies and depositional structure of allochthonous carbonate base-of-slope deposits: The Late Permian Pietra di Salomone megablock, Sosio Valley (Western Sicily)". English. In: Facies 25 (1991), pp. 36-48.

[7378] E. Flügel and I. B. Singh. "Stromatoporoid-Grade and other sponge fossils from the Upper Krol Formation of the Lesser Himalaya (India): Implications for the biotic evolution around the PrecambrianCambrian boundary interval". English. In: Facies 49 (2003), pp. 351-372. 
[7379] H. W. Flügel. "Korallen aus dem Perm von S-Tunesien, W-Iran und NW-Thailand [Permian corals from S-Tunisia, W-Iran and NW-Thailand]". German. In: Sitzungsberichte Österreichische Akademie der Wissenschaften, Mathematisch-Naturwissenschaftliche Klasse, Abteilung I 204 (1997), pp. 79-109.

[7380] H. W. Flügel. "Neue Korallen aus dem Paläozoikum Irans". German. In: Sitzungsberichte und Anzeiger, Abteilung I, Biologische Wissenschaften und Erdwissenschaften 200 (1993), pp. 137-149.

[7381] H. W. Flügel. “Arctophyllum Fedorowski 1975 (Rugosa) aus dem Unter-Perm (Sakmara-Stufe) von Nif, SW-Anatolien". German. In: Senckenbergiana Lethaea 73 (1993), pp. 25-30.

[7382] H. W. Flügel. "Korallen aus dem Mittel-Perm Irans (Aufsammlung O. Thiele)". German. In: $A b-$ handlungen der Geologischen Bundesanstalt 133 (1990), pp. 523-536.

[7383] H. W. Flügel. "Biostratigraphie und Korallenfaunen des Jungpaläozoikums ost-irans". German. In: Geologisch-Paläontologische Mitteilungen Innsbruck 20 (1995), pp. 35-49.

[7384] H. W. Flügel and M. Gaetani. "Permian rugosa from northern Karakorum and Aghil Ranges". English. In: Rivista Italiana di Paleontologia e Stratigrafia 97 (1991), pp. 35-48.

[7385] J. Flynn, J. M. Parrish, L. Ranivoharimanana, W. F. Simpson, and A. R. Wyss. New traversodontid eucynodonts from the Middle or Late Triassic of Madagascar. English. 2000.

[7386] J. J. Flynn, R. Charrier, D. A. Croft, P. B. Gans, T. M. Herriott, J. A. Wertheim, and A. R. Wyss. "Chronologic implications of new Miocene mammals from the Cura-Malln and Trapa Trapa formations, Laguna del Laja area, south Central Chile". English. In: Journal of South American Earth Sciences 26 (2008), pp. 412-426. DOI: 10.1016/j.jsames.2008.05.006.

[7387] J. J. Flynn, D. A. Croft, R. Charrier, G. Herail, and A. R. Wyss. “The first Cenozoic Mammal Fauna from the Chilean Altiplano". English. In: Journal of Vertebrate Paleontology 22.1 (2002), pp. 200-206.

[7388] J. J. Flynn, D. A. Croft, R. Charrier, A. R. Wyss, G. Hérail, and M. Garca. “New Mesotheriidae (Mammalia, Notoungulata, Typotheria), geochronology and tectonics of the Caragua area, northernmost Chile". English. In: Journal of South American Earth Sciences 19.1 (2005), pp. 55-74.

[7389] J. J. Flynn, S. R. Fox, J. M. Parrish, L. Ranivoharimanana, and A. R. Wyss. “Assessing diversity and paleoecology of a Middle Jurassic microvertebrate assemblage from Madagascar". English. In: vol. 37. The Triassic-Jurassic Terrestrial Transition. New Mexico Museum of Natural History and Science Bulletin. Albuquerque: New Mexico Museum of Natural History and Science, 2006, pp. 476-489.

[7390] J. J. Flynn, B. J. Kowallis, C. Nuñez, O. Carranza-Castañeda, W. E. Miller, C. C. Swisher III, and E. Lindsay. "Geochronology of Hemphillian-Blancan aged strata, Guanajuato, Mexico, and implications for the timing of the Great American Biotic Interchange". English. In: Journal of Geology 113 (2005), pp. 287-307.

[7391] J. J. Flynn, S. J. Nesbitt, J. M. Parrish, L. Ranivoharimanana, and A. R. Wyss. “A new species of Azendohsaurus (Diapsida: Archosauromorpha) from the Triassic Isalo Group of southwestern Madagascar: cranium and mandible". English. In: Palaeontology 53.3 (2010), pp. 669-688. DOI: 10. 1111/j.1475-4983.2010.00954.x.

[7392] J. J. Flynn, M. J. Novacek, H. E. Dodson, D. Frassinetti, M. C. McKenna, M. A. Norell, K. E. Sears, C. C. Swisher III, and A. R. Wyss. "A new fossil mammal assemblage from the southern Chilean Andes: implications for geology, geochronology, and tectonics". English. In: Journal of South American Earth Sciences 15.3 (2002), pp. 285-302.

[7393] J. J. Flynn, J. M. Parrish, B. Rakotosamimanana, W. F. Simpson, and A. R. Wyss. “A Middle Jurassic mammal from Madagascar". English. In: Nature 401 (1999), pp. 57-60. DOI: 10.1038/43420.

[7394] J. J. Flynn, J. M. Parrish, B. Rakotosamimanana, W. F. Simpson, R. L. Whatley, and A. R. Wyss. "A Triassic fauna from Madagascar, including early dinosaurs". English. In: Science 286 (1999), pp. 763-765.

[7395] J. J. Flynn, J. M. Parrish, B. Rakotosamimanana, L. Ranivoharimanana, W. F. Simpson, and A. R Wyss. "New traversodontids (Synapsida, Eucynodontia) from the Triassic of Madagascar". English. In: Journal of Vertebrate Paleontology 20.3 (2000), pp. 422-427. 
[7396] J. J. Flynn, A. R. Wyss, R. Charrier, and C. C. Swisher. “An Early Miocene anthropoid skull from the Chilean Andes". English. In: Nature 373.6515 (1995), pp. 603-607. DOI: 10.1038/373603a0.

[7397] J. J. Flynn and A. W. Wyss. "New Marsupials from the Eocene-Oligocene transition of the Andean main range, Chile". English. In: Journal of Vertebrate Paleontology 19.3 (1999), pp. 533-549.

[7398] L. J. Flynn. “Origin and Evolution of the Diatomyidae, with Clues to Paleoecology from the Fossil Record". English. In: Bulletin of Carnegie Museum of Natural History 39 (2007), pp. 173-181.

[7399] L. J. Flynn and M. E. Morgan. "An unusual diatomyid rodent from an infrequently sampled late Miocene interval in the Siwaliks of Pakistan". English. In: Palaeontologia Electronica 8.1.17 (2005), pp. 1-10.

[7400] D. Foffa, D. I. Whiteside, P. A. Viegas, and M. J. Benton. "Vertebrates from the Late Triassic Thecodontosaurus-bearing rocks of Durdham Down, Clifton (Bristol, UK)". English. In: Proceedings of the Geologists' Association 125 (2014), pp. 317-328. DOI: 10.1016/j.pgeola.2014.02.002.

[7401] D. Foffa and M. T. Young. "The cranial osteology of Tyrannoneustes lythrodectikos (Crocodylomorpha: Metriorhynchidae) from the Middle Jurassic of Europe". English. In: PeerJ 2 (2014), e608.

[7402] D. Foffa, M. T. Young, S. L. Brusatte, M. R. Graham, and L. Steel. “A new metriorhynchid crocodylomorph from the Oxford Clay Formation (Middle Jurassic) of England, with implications for the origin and diversification of Geosaurini". English. In: Journal of Systematic Palaeontology 16.13 (2017), pp. 1123-1143. DOI: 10.1080/14772019.2017.1367730.

[7403] B. Fohrer. “Ostracoden aus dem Oberkarbon und Unterperm der Karnischen Alpen (Osterreich): systematik, biostratigraphie und palokologie". German. In: Jahrbuch der Geologischen Bundesanstalt 140.2 (1997), pp. 99-191.

[7404] B. Fohrer, T. I. Nemyrovska, E. Samankassou, and K. Ueno. “The Pennsylvanian (Moscovian) Izvarino Section, Donets Basin, Ukraine: a multidisciplinary study on microfacies, biostratigraphy (conodonts, foraminifers, and ostracodes), and paleoecology". English. In: Journal of Paleontology 81.5 (2007), pp. 1-85.

[7405] A. Folie and V. Codrea. "New lissamphibians and squamates from the Maastrichtian of Hateg Basin, Romania". English. In: Acta Palaeontologica Polonica 50.1 (2005), pp. 57-71.

[7406] A. Folie, R. S. Rana, K. D. Rose, A. Sahni, K. Kumar, L. Singh, and T. Smith. “Early Eocene Frogs from Vastan Lignite Mine, Gujarat, India". English. In: Acta Palaeontologica Polonica 58.3 (2013), pp. 511-524. DOI: 10.4202/app.2011.0063.

[7407] A. Folie, B. Sigé, and T. Smith. "A new scincomorph lizard from the Palaeocene of Belgium and the origin of Scincoidea in Europe". English. In: Naturwissenschaften 92 (2005), pp. 542-546.

[7408] A. Folie, R. Smith, and T. Smith. "New amphisbaenian lizards from the Early Paleogene of Europe and their implications for the early evolution of modern amphisbaenians". English. In: Geologica Belgica 16.4 (2013), pp. 227-235.

[7409] E. J. Follows, A. H. F. Robertson, and T. P. Scoffin. "Tectonic controlls on Miocene reefs and related carbonate facies in Cyprus". English. In: SEPM Concepts in Sedimentology and Paleontology 5 (1996), pp. 295-315.

[7410] H. Fontaine, D. Rodziah, and U. Singh. "Discovery of an Upper Triassic limestone basement in the Malay Basin, offshore Peninsular Malaysia: regional implications". In: Journal of Southeast Asian Earth Sciences 4.3 (1990), pp. 219-232.

[7411] L. R. Fontes and M. A. Vulcano. Cupins fósseis do Novo Mundo. Portugese. Cupins: O Desafio do Conhecimento. Piracicaba, Brazil: FEALQ, 1998, pp. 243-295.

[7412] E. Fookes. "Development and eustatic control of an Upper Jurassic reef complex (Saint Germainde-Joux, Eastern France)". English. In: Facies 33 (1995), pp. 129-150.

[7413] A. Forasiepi, F. J. Goin, and A. A. Tauber. "Las especies de <i $>$ Arctodictis $</ i>$ Mercerat, 1891 (Metatheria, Borhyaenidae), grandes carnvoros del Mioceno de América del Sur". Spanish. In: Revista Española de Paleontologa 19.1 (2004), pp. 1-22. 
[7414] A. M. Forasiepi, M. J. Babot, and N. Zimicz. "Australohyaena antiqua (Mammalia, Metatheria, Sparassodonta), a large predator from the Late Oligocene of Patagonia". English. In: Journal of Systematic Palaeontology 13.6 (2015), pp. 503-525. DOI: 10.1080/14772019.2014.926403.

[7415] A. M. Forasiepi and A. A. Carlini. "A new thylacosmilid (Mammalia, Metatheria, Sparassodonta) from the Miocene of Patagonia, Argentina". English. In: Zootaxa 2552 (2010), pp. 55-68.

[7416] A. M. Forasiepi, E. Cerdeno, M. Bond, G. I. Schmidt, M. Naipauer, F. R. Straehl, A. G. Martinelli, A. C. Garrido, M. D. Schmitz, and J. L. Crowley. "New toxodontid (Notoungulata) from the Early Miocene of Mendoza, Argentina". English. In: Palaeontologische Zeitschrift 89 (2015), pp. 611-634. DOI: $10.1007 / \mathrm{s} 12542-014-0233-5$.

[7417] A. M. Forasiepi, R. A. Coria, J. Hurum, and P. J. Currie. "First dryolestoid (Mammalia, Dryolestoidea, Meridiolestida) from the Coniacian of Patagonia and new evidence on their early radiation in South America". English. In: Ameghiniana 49.4 (2012), pp. 497-504. DOI: 10.5710/AMGH. 8.8.2012.581.

[7418] A. M. Forasiepi, F. J. Goin, and V. di Martino. "Una nueva especie de Lycopsis (Metatheria, Prothylacyninae) de la Formación Arroyo Chasicó (Mioceno Tardo) de la provincia de Buenos Aires". Spanish. In: Ameghiniana 40.2 (2003), pp. 249-253.

[7419] A. M. Forasiepi, F. J. Goin, M. A. Abello, and E. Cerdeño. “A unique, Late Oligocene shrew-like marsupial from western Argentina and the evolution of dental morphology". English. In: Journal of Systematic Palaeontology 12.5 (2014), pp. 549-564. DOI: 10.1080/14772019.2013.799611.

[7420] A. M. Forasiepi, R. D. MacPhee, S. Hernández Del Pino, G. Schmidt, E. Amson, and C. Grohé. “Exceptional skull of Huayqueriana (Mamalia, Litopterna, Macraucheniidae) from the late Miocene of Argentina: Anatomy, systematics and paleobiological implications". English. In: Bulletin of the American Museum of Natural History 404 (2016), pp. 1-76.

[7421] A. M. Forasiepi, A. G. Martinelli, A. E. Zurita, and H. Ponce. “Primer Registro de Glyptodon Owen (Mammalia, Xenarthra, Cingulata) para el Pleistoceno de la Provincia de Mendoza (Argentina)". Spanish. In: Mastozoologa Neotropical 16.1 (2009), pp. 217-222.

[7422] A. M. Forasiepi, A. G. Martinelli, and F. J. Goin. “Revisión taxonómica de Parahyaenodon argentinus Ameghino y sus implicancias en el conocimiento de los grandes mamferos carnvoros del Mio-Plioceno de América de Sur". Spanish. In: Ameghiniana 44.1 (2007), pp. 153-159.

[7423] A. M. Forasiepi, A. G. Martinelli, M. S. de la Fuente, S. Dieguez, and M. Bond. "Paleontology and stratigraphy of the Aisol Formation (Neogene), San Rafael, Mendoza". English. In: Cenozoic Geology of the Central Andes of Argentina. Salta: SCS Publisher, 2011, pp. 135-154.

[7424] A. M. Forasiepi and G. W. Rougier. “Additional data on early Paleocene metatherians (Mammalia) from Punta Peligro (Salamanca Formation, Argentina): comments based on petrosal morphology". English. In: Journal of Zoological Systematics and Evolutionary Research 47.4 (2009), pp. 391398.

[7425] A. M. Forasiepi, M. R. Sanchez-Villagra, F. J. Goin, M. Takai, N. Shigehara, and R. F. Kay. “A new species of Hathliacynidae (Metatheria, Sparassodonta) from the middle Miocene of Quebrada Honda, Bolivia". English. In: Journal of Vertebrate Paleontology 26.3 (2006), pp. 670-684.

[7426] A. M. Forasiepi, L. H. Soibelzon, C. Suarez-Gomez, R. Sánchez, L. I. Quiroz, C. Jaramillo, and M. R. Sánchez-Villagra. "Carnivorans at the Great American Biotic Interchange: new discoveries from the northern neotropics". English. In: Naturwissenschaften 101 (2014), pp. 965-974. DOI: 10. 1007/s00114-014-1237-4.

[7427] S. Ford and L. Davis. "New platyrrhine astragalus from the Miocene of Colombia". English. In: American Journal of Physical Anthropology 12 (1991), pp. 73-74.

[7428] T. L. Ford. A review of ankylosaur osteoderms from New Mexico and a preliminary review of ankylosaur armor. English. Vol. 17. Dinosaurs of New Mexico. New Mexico Museum of Natural History and Science Bulletin. 2000, pp. 157-176. 
[7429] R. E. Fordyce. "Waipatia maerewhenua, New Genus and New Species, Waipatiidae, New Family, an archaic late Oligocene dolphin (Cetacea: Odontoceti: Platanistoidea) from New Zealand". English. In: Proceedings of the San Diego Society of Natural History 29 (1994), pp. 147-176.

[7430] R. E. Fordyce. "Simocetus rayi (Odontoceti, Simocetidae, new family); a bizarre new archaic Oligocene dolphin from the eastern North Pacific". English. In: Smithsonian Contributions to Paleobiology 93 (2002), pp. 185-222.

[7431] R. E. Fordyce. A new look at the fossil vertebrate record of New Zealand. English. Vertebrate Palaeontology of Australasia. 1991, pp. 1191-1316.

[7432] R. E. Fordyce and H. J. Campbell. "Fossil dolphin bones from the Chatham Islands, New Zealand". In: New Zealand Natural Sciences 17 (1990), pp. 61-65.

[7433] R. E. Fordyce and C. de Muizon. Evolutionary history of the cetaceans: a review. Secondary Adaptations of Tetrapods to Life in the Water. 2001, pp. 169-233.

[7434] R. E. Fordyce and F. G. Marx. "Mysticetes baring their teeth: a new fossil whale, Mammalodon hakataramea, from the Southwest Paci c". English. In: Memoirs of Museum Victoria 74 (2016), pp. 107116.

[7435] R. E. Fordyce, P. G. Quilty, and J. Daniels. “Australodelphis mirus, a bizarre new toothless ziphiidlike fossil dolphin (Cetacea: Delphinidae) from the Pliocene of Vestfold Hills, East Antarctica". English. In: Antarctic Science 14.1 (2002), pp. 37-54.

[7436] R. E. Fordyce and P. G. Quilty. Pliocene whales and dolphins (Cetacea) from the Vestfold Hills, Antarctica. English. 1994.

[7437] R. E. Fordyce and D. B. Thomas. "Kaiika maxwelli, a new Early Eocene archaic penguin (Sphenisciformes, Aves) from Waihao Valley, South Canterbury, New Zealand". English. In: New Zealand Journal of Geology and Geophysics 54.1 (2011), pp. 43-51.

[7438] M. B. Forel. “Ostracods (Crustacea) associated with microbialites across the Permian-Triassic boundary in Dajiang (Guizhou Province, south China)". English. In: European Journal of Taxonomy 19 (2012), pp. 1-34.

[7439] M. B. Forel. "Heterochronic growth of ostracods (Crustacea) from microbial deposits in the aftermath of the end-Permian extinction". English. In: Journal of Systematic Palaeontology 13 (2015), pp. 315-349.

[7440] M. B. Forel and S. Crasquin. "In the aftermath of the Permian-Triassic boundary mass-extinction: new ostracod (Crustacea) genus and species from south Tibet". English. In: Geodiversitas 33 (2011), pp. 247-263.

[7441] M. B. Forel and S. Crasquin. "Lower Triassic ostracods (Crustacea) from the Meishan section, Permian-Triassic boundary GSSP (Zhejiang Province, south China)". English. In: Journal of Systematic Palaeontology 9.3 (2011), pp. 455-466.

[7442] M. B. Forel, S. Crasquin, K. Hips, S. Kershaw, P. Y. Collin, and J. Haas. "Biodiversity evolution through the Permian-Triassic boundary event: Ostracods from the Bükk Mountains, Hungary". English. In: Acta Palaeontologica Polonica 58 (2013), pp. 195-219.

[7443] M. B. Forel, S. Crasquin, A. Chitnarin, L. Angiolini, and M. Gaetani. "Precocious sexual dimorphism and the Lilliput effect in Neo-Tethyan Ostracoda (Crustacea) through the Permian-Triassic boundary". English. In: Palaeontology 58 (2015), pp. 409-454.

[7444] M. B. Forel and E. Gradinaru. "First report of ostracods (Crustacea) associated with Bithynian (Anisian, Middle Triassic) Tubiphytes-microbial reef in the North Dobrogean Orogen (Romania)". English. In: Papers in Palaeontology 4 (2018), pp. 211-244.

[7445] M. B. Forel, U. K. Tekin, C. Okuyucu, Y. Bedi, A. Tuncer, and S. Crasquin. “Discovery of a longterm refuge for ostracods (Crustacea) after the end-Permian extinction: a unique Carnian (Late Triassic) fauna from the Mersin Mélange, southern Turkey". English. In: Journal of Systematic Palaeontology 17 (2019), pp. 9-58. DOI: 10.1080/14772019.2017.1391342. 
[7446] B. C. Foreman. "A Revision of the Cranial Morphology of the Lower Permian Temnospondyl Amphibian Acroplous vorax Hotton". English. In: Journal of Vertebrate Paleontology 10.3 (1990), pp. 390-397.

[7447] P. L. Forey, P. E. Ahlberg, E. Lukevics, and I. Zupin. "A New Coelacanth from the Middle Devonian of Latvia". English. In: Journal of Vertebrate Paleontology 20.2 (2000), pp. 243-252.

[7448] P. L. Forey, L. Yi, C. Patterson, and C. E. Davis. "Fossil fishes from the Cenomanian (Upper Cretaceous) of Namoura, Lebanon". English. In: Journal of Systematic Palaeontology 1.4 (2003), pp. 227330. DOI: $10.1017 /$ S147720190300107X.

[7449] H. C. Forke. "Biostratigraphic subdivision and correlation of uppermost Carboniferous/Lower Permian sediments in the southern Alps: fusulinoidean and conodont faunas from the Carnic Alps (Austria/Italy), Karavanke Mountains (Slovenia), and southern Urals (Russia)". English. In: Facies 47 (2002), pp. 201-275.

[7450] M. Fornaseiro and G. Vicariotto. "Fossil cuttlebones in the Vicentinian Priabonian (Late Eocene, Veneto Region, NE Italy)". English. In: Mem. Sci. Geol. 47 (1995), pp. 173-178.

[7451] M. Fornasiero and L. Del Vavero. “I Cetacei fossili del Museo di Geologia e Paleontologia dell'Università di Padova". English. In: Museologia Scientifica Memorie 13 (2014), pp. 62-69.

[7452] M. Fornasiero and M. Vicariottio. "A new species of Spirulirostra (Cephalopoda Coleoidea) from Venetian Middle Eocene (Italy)". English. In: Memorie di Scienze Geologiche 49 (1997), pp. 65-72.

[7453] R. Forrest. "A possible early elasmosaurian plesiosaur from the Triassic/Jurassic boundary of Nottinghamshire". English. In: Mercian Geologist 14.3 (1998), pp. 135-143.

[7454] R. Forrest and N. Oliver. "Ichthyosaurs and plesiosaurs from the Lower Spilsby Sandstone Member (Upper Jurassic), north Lincolnshire". English. In: Proceedings of the Yorkshire Geological Society 54.4 (2003), pp. 269-275.

[7455] M. H. Forst, T. C. Brachert, and J. Pais. "High-resolution correlation of coastal cliff sections in the Lagos- Portimao Formation (Lower - Middle Miocene, central Algarve, Portugal)". English. In: Ciencias da Terra 14 (2000), pp. 289-296.

[7456] A. Forsten. "Size trends in Holarctic anchitherines (Mammalia, Equidae)". English. In: Journal of Paleontology 65.1 (1991), pp. 147-159.

[7457] A. Forsten and S. Sharapov. "Fossil equids (Mammalia, Equidae) from the Neogene and Pleistocene of Tadzhikistan". In: Geodiversitas 22.2 (2000), pp. 293-314.

[7458] C. A. Forster, L. M. Chiappe, D. W. Krause, and S. D. Sampson. "The first Cretaceous bird from Madagascar". In: Nature 382 (1996), pp. 532-535.

[7459] C. A. Forster, S. D. Sampson, L. M. Chiappe, and D. W. Krause. "The theropod ancestry of birds: new evidence from the Late Cretaceous of Madagascar". In: Science 279 (1998), pp. 1915-1919.

[7460] C. A. Forster, P. C. Sereno, T. W. Evans, and T. Rowe. "A complete skull of $<i>$ Chasmosaurus mariscalensis $</ \mathrm{i}>$ (Dinosauria, Ceratopsidae) from the Aguja Formation (late Campanian) of west Texas". In: Journal of Vertebrate Paleontology 13.2 (1993), pp. 161-170.

[7461] G. T. Forsythe. A new synthesis of Permo-Carboniferous phylloid algal reef ecology. Vol. 78. PermoCarboniferous carbonate platforms and reefs, SEPM Special Publication. 2003, pp. 171-188.

[7462] R. Fortey and B. Chatterton. "A Devonian trilobite with an eyeshade". English. In: Science 301 (2003), p. 1689.

[7463] R. A. Fortey. "A critical graptolite correlation into the Lower Ordovician of Gondwana". English. In: Proceedings of the Yorkshire Geological Society 58.4 (2011), pp. 223-226. DOI: 10.1144/pygs.58.4. 297.

[7464] R. A. Fortey. "The first known complete lichakephalid trilobite, Lower Ordovician of Morocco". English. In: Memoirs of the Association of Australasian Palaeontologists 42 (2011), pp. 1-7.

[7465] R. A. Fortey. "A new deep-water Upper Ordovician (Caradocian) trilobite fauna from South-West Wales". English. In: Geological Journal 41 (2006), pp. 243-253. DOI: 10.1002/gj.1042. 
[7466] R. A. Fortey and D. L. Bruton. "Lower Ordovician trilobites of the Kirtonryggen Formation, Spitsbergen". English. In: Fossils and Strata 59 (2013), pp. 1-116.

[7467] R. A. Fortey and M. L. Droser. "Trilobites from the Base of the Type Whiterockian (Middle Ordovician) in Nevada". English. In: Journal of Paleontology 73.2 (1999), pp. 182-201.

[7468] R. A. Fortey and M. L. Droser. "Trilobites at the base of the Middle Ordovician, western United States". English. In: Journal of Paleontology 70.1 (1996), pp. 73-99.

[7469] R. A. Fortey and A. P. Heward. "A new, morphologically diverse Permian trilobite fauna from Oman". English. In: Acta Palaeontologica Polonica 60 (2015), pp. 201-216.

[7470] R. A. Fortey, A. P. Heward, and C. G. Miller. "Sedimentary facies and trilobite and conodont faunas of the Ordovician Rann Formation, Ras Al Khaimah, United Arab Emirates". English. In: GeoArabia 16.4 (2011), pp. 127-152.

[7471] R. A. Fortey and R. M. Owens. "A trilobite fauna from the highest Shineton Shales in Shropshire, and the correlation of the latest Tremadoc". English. In: Geological Magazine 128 (1991), pp. 437464.

[7472] R. A. Fortey and R. M. Owens. "The Habberley Formation: youngest Tremadoc in the Welsh Borderlands". English. In: Geological Magazine 129.5 (1992), pp. 553-566.

[7473] R. A. Fortey and J. S. Peel. "Early Ordovician trilobites and molluscs from the Poulsen Cliff Formation, Washington Land, western North Greenland". English. In: Bulletin of the Geological Society of Denmark 38.1 (1990), pp. 11-32.

[7474] R. A. Fortey and J. N. Theron. "A new Ordovician arthropod, Soomaspis, and the agnostid problem". In: Palaeontology 37.4 (1995), pp. 841-861.

[7475] D. Fortier, D. Perea, and C. Schultz. "Redescription and phylogenetic relationships of Meridiosaurus vallisparadisi, a pholidosaurid from the Late Jurassic of Uruguay". English. In: Zoological Journal of the Linnean Society 163 (2011), S257-S272.

[7476] D. C. Fortier, J. P. de Souza-Filho, E. Guilherme, A. A. R. Maciente, and C. L. Schultz. "A new specimen of Caiman brevirostris (Crocodylia, Alligatoridae) from the late Miocene of Brazil". English. In: Journal of Vertebrate Paleontology 34.4 (2014), pp. 820-834.

[7477] D. C. Fortier and A. D. Rincón. "Pleistocene crocodylians from Venezuela, and the description of a new species of Caiman". English. In: Quaternary International 305 (2013), pp. 141-148.

[7478] D. C. Fortier and C. L. Schultz. "A new neosuchian crocodylomorph (Crocodyliformes, Mesoeucrocodylia) from the Early Cretaceous of North-East Brazil". English. In: Palaeontology 52.5 (2009), pp. 991-1007. DOI: 10.1111/j.1475-4983.2009.00894.x.

[7479] J. Fortuny, A. Bolet, A. G. Selles, and A. Galobart. "A potential record of a procolophonid parareptile from the Triassic of the Iberian Peninsula". English. In: Geologica Acta 12.2 (2014), pp. 121126.

[7480] J. Fortuny, A. Galobart, and C. De Santisteban. "A new capitosaur from the Middle Triassic of Spain and the relationships within the Capitosauria". English. In: Acta Palaeontologica Polonica 56 (2011), pp. 553-566. DOI: 10.4202/app.2010.0025.

[7481] J. Fortuny, S. Gastou, F. Escuillié, L. Ranivoharimanana, and J. -S. Steyer. “A new extreme longirostrine temnospondyl from the Triassic of Madagascar: phylogenetic and palaeobiogeographical implications for trematosaurids". English. In: Journal of Systematic Palaeontology 16 (2017), pp. 675-688. DOI: 10.1080/14772019.2017.1335805.

[7482] P. Fosse and M. F. Bonifay. Les vestiges osseux de Soleilhac: approche taphonomique. French. in E. Bonifay and B. Vandermeersch, eds., Les Premiers Europeens. Edition du comite des Travaux Historiques et Scientifiques (CTHS), Paris, France. 1991, pp. 115-133.

[7483] J. Foster. Evidence of size-classes and scavenging in the theropod Allosaurus fragilis at the Mygatt-Moore Quarry (Late Jurassic), Rabbit Valley, Colorado. English. 2005.

[7484] J. Foster. "New sauropod dinosaur specimens found near Moab, Utah, and the sauropod fauna of the Morrison Formation". English. In: Canyon Legacy 55 (2005), pp. 22-27. 
[7485] J. R. Foster. "Salamander tracks (Ambystomichnus?) from the Cathedral Bluffs Tongue of the Wasatch Formation (Eocene), northeastern Green River Basin, Wyoming". English. In: Journal of Paleontology 75.4 (2001), pp. 901-904.

[7486] J. R. Foster. Sedminentology and taphonomy of the Little Houston Quarry, Morrison Formation (Upper Jurassic), northeast Wyoming. English. 1993.

[7487] J. R. Foster. "Sauropod dinosaurs of the Morrison Formation (Upper Jurassic), Black Hills, South Dakota and Wyoming". In: Contributions to Geology, University of Wyoming 31.1 (1996), pp. 1-25.

[7488] J. R. Foster. "Taphonomy and paleoecology of a microvertebrate assemblage from the Morrison Formation (Upper Jurassic) of the Black Hills, Crook County, Wyoming". English. In: Brigham Young University Geology Studies 46 (2001), pp. 13-33.

[7489] J. R. Foster. "Paleoecological analysis of the vertebrate fauna of the Morrison Formation (Upper Jurassic), Rocky Mountain region, U.S.A." English. In: New Mexico Museum of Natural History and Science Bulletin 23 (2003), pp. 1-95.

[7490] J. R. Foster. New juvenile sauropod material from western Colorado, and the record of juvenile sauropods from the Upper Jurassic Morrison Formation. English. Thunder-Lizards: The Sauropodomorph Dinosaurs. Indiana University Press, Bloomington. 2005, pp. 141-153.

[7491] J. R. Foster. Fossil vertebrate localities in the Morrison Formation (Upper Jurassic) of western South Dakota. English. Vol. 60. The Continental Jurassic. Museum of Northern Arizona Bulletin. 1996, pp. 255-263.

[7492] J. R. Foster. “Theropod dinosaur ichnogenus Hispanosauropus identified from the Morrison Formation (Upper Jurassic), western North America". English. In: Ichnos 22.3-4 (2015), pp. 183-191. DOI: $10.1080 / 10420940.2015 .1059335$.

[7493] J. R. Foster. "A new atoposaurid crocodylomorph from the Morrison Formation (Upper Jurassic) of Wyoming, USA". English. In: Geology of the Intermountain West 5 (2018), pp. 287-295.

[7494] J. R. Foster and D. J. Chure. "Hindlimb allometry in the Late Jurassic theropod dinosaur Allosaurus, with comments on its abundance and distribution". English. In: vol. 36. Paleontology and Geology of the Upper Jurassic Morrison Formation. New Mexico Museum of Natural History and Science Bulletin. Albuquerque: New Mexico Museum of Natural History and Science, 2006, pp. 119-122.

[7495] J. R. Foster, A. H. Hamblin, and M. G. Lockley. "The oldest evidence of a sauropod dinosaur in the western United States and other important vertebrate trackways from Grand Staircase-Escalante National Monument, Utah". English. In: Ichnos 7.3 (2000), pp. 169-181.

[7496] J. R. Foster and A. B. Heckert. "Ichthyoliths and other microvertebrate remains from the Morrison Formation (Upper Jurassic) of northeastern Wyoming: A screen-washed sample indicates a significant aquatic component to the fauna". English. In: Palaeogeography, Palaeoclimatology, Palaeoecology 305 (2011), pp. 264-279.

[7497] J. R. Foster and R. K. Hunt-Foster. "New occurrences of dinosaur skin of two types (Sauropoda? and Dinosauria indet) from the Late Jurassic of North America (Mygatt-Moore Quarry, Morrison Formation)". English. In: Journal of Vertebrate Paleontology 31.3 (2011), pp. 717-721. DOI: 10.1080 / 02724634.2011.557419.

[7498] J. R. Foster and R. K. Hunt-Foster. "First report of a giant neosuchian (Crocodyliformes) in the Williams Fork Formation (Upper Cretaceous: Campanian) of Colorado". English. In: Cretaceous Research 55 (2015), pp. 66-73. DOI: 10.1016/j.cretres.2015.02.003.

[7499] J. R. Foster and M. G. Lockley. "The vertebrate ichnological record of the Morrison Formation (Upper Jurassic, North America)". English. In: vol. 36. Paleontology and Geology of the Upper Jurassic Morrison Formation. New Mexico Museum of Natural History and Science Bulletin. Albuquerque: New Mexico Museum of Natural History and Science, 2006, pp. 203-216.

[7500] J. R. Foster and M. G. Lockley. "Probable crocodilian tracks and traces from the Morrison Formation (Upper Jurassic) of eastern Utah". English. In: Ichnos 5 (1997), pp. 121-129. 
[7501] J. R. Foster, M. G. Lockley, and J. Brockett. "Possible turtle tracks from the Morrison Formation of southern Utah". English. In: vol. 99-1. Vertebrate Paleontology in Utah. Utah Geological Survey Miscellaneous Publication. Salt Lake City: Utah Geological Survey, 1999, pp. 185-191.

[7502] J. R. Foster, J. B. McHugh, J. E. Peterson, and M. F. Leschin. "Major bonebeds in mudrocks of the Morrison Formation (Upper Jurassic), northern Colorado Plateau of Utah and Colorado". English. In: Geology of the Intermountain West 3 (2016), pp. 33-66.

[7503] J. R. Foster and J. E. Peterson. "First report of Apatosaurus (Diplodocidae: Apatosaurinae) from the Cleveland-Lloyd Quarry in the Upper Jurassic Morrison Formation of Utah: abundance, distribution, paleoecology, and taphonomy of an endemic North American sauropod clade". English. In: Palaeoworld 25 (2016), pp. 431-443. DOI: 10.1016/j.palwor.2015.11.006.

[7504] J. R. Foster and K. C. Trujillo. "New occurrences of Cteniogenys (Reptilia, Choristodera) in the Late Jurassic of Wyoming and South Dakota". English. In: Brigham Young University Geology Studies 45 (2000), pp. 11-18.

[7505] J. R. Foster, K. C. Trujillo, S. K. Madsen, and J. E. Martin. “The Late Jurassic mammal Docodon, from the Morrison Formation of The Black Hills, Wyoming: implications for abundance and biogeography of the genus". English. In: vol. 36. Paleontology and Geology of the Upper Jurassic Morrison Formation. New Mexico Museum of Natural History and Science Bulletin. Albuquerque: New Mexico Museum of Natural History and Science, 2006, pp. 165-169.

[7506] J. R. Foster and M. J. Wedel. "Haplocanthosaurus (Saurischia: Sauropoda) from the lower Morrison Formation (Upper Jurassic) near Snowmass, Colorado". English. In: Volumina Jurassica 12.2 (2014), pp. 197-210.

[7507] W. J. Foster, S. Danise, A. Sedlacek, G. D. Price, K. Hips, and R. J. Twitchett. "Environmental controls on the post-Permian recovery of benthic, tropical marine ecosystems in western Palaeotethys (Aggtelek Karst, Hungary)". English. In: Palaeogeography, Palaeoclimatology, Palaeoecology 440 (2015), pp. 374-394. DOI: 10.1016/j.palaeo.2015.09.004.

[7508] W. J. Foster, S. Danise, and R. J. Twitchett. "A silicified Early Triassic marine assemblage from Svalbard". English. In: Journal of Systematic Palaeontology 15 (2017), pp. 851-877. DOI: 10.1080 / 14772019.2016.1245680.

[7509] W. J. Foster, C. L. Garvie, A. M. Weiss, A. D. Muscente, M. Aberhan, J. W. Counts, and R. C. Martindale. "Resilience of marine invertebrate communities during the early Cenozoic hyperthermals". English. In: Scientific Reports 10 (2020), p. 2176. DOI: 10.1038/s41598-020-58986-5.

[7510] W. J. Foster, D. J. Lehrmann, J. A. Hirtz, M. White, M. Yu, J. Li, and R. C. Martindale. “Early Triassic benthic invertebrates from the Great Bank of Guizhou, South China: systematic palaeontology and palaeobiology". English. In: Papers in Palaeontology 5 (2019), pp. 613-656. DOI: 10.1002/spp2.1252.

[7511] W. J. Foster. "Palaeoecology of the late Permian mass extinction and subsequent recovery". English. PhD thesis. 2015.

[7512] W. J. Foster, S. Danise, G. D. Price, and R. J. Twitchett. "Subsequent biotic crises delayed marine". English. In: Plos One 12.3 (2017), e0172321. DOI: 10.1371/journal.pone.0172321.

[7513] W. J. Foster, S. Danise, G. D. Price, and R. J. Twitchett. "Paleoecological Analysis of Benthic Recovery after the Late Permian Mass". English. In: Palaios 33 (2018), pp. 266-281.

[7514] W. J. Foster, D. J. Lehrmann, M. Yu, L. Ji, and R. C. Martindale. “Persistent Environmental Stress Delayed the Recovery". English. In: Paleoceanography and Paleoclimatology 33 (2018), pp. 338-353.

[7515] W. J. Foster and K. Sebe. "Recovery and diversification of marine communities following the late". English. In: Global and Planetary Change 155 (2017), pp. 165-177.

[7516] L. Fostowicz-Frelik. "An enigmatic whale tooth from the Upper Eocene of Seymour Island, Antarctica". English. In: Polish Polar Research 24.1 (2003), pp. 13-28.

[7517] L. Fostowicz-Frelik. "First record of Trogontherium cuvieri (Mammalia, Rodentia) from the middle Pleistocene of Poland and review of the species". English. In: (2008). 
[7518] L. Fostowicz-Frelik. "A new zalambdalestid (Eutheria) from the Late Cretaceous of Mongolia and its implications for the origin of Glires". English. In: Palaeontologia Polonica 67 (2016), pp. 127-136.

[7519] L. Fostowicz-Frelik and A. Gazdzicki. "Anatomy and histology of plesiosaur bones from the Late Cretaceous of Seymour Island, Antarctic Paninsula". In: Palaeontological Results of the Polish Antarctic Expeditions. Part III. Palaeontologica Polonica. 60 (2000), pp. 7-32.

[7520] L. Fostowicz-Frelik, C. Li, F. Mao, J. Meng, and Y. Wang. "A large mimotonid from the Middle Eocene of China sheds light on the evolution of lagomorphs and their kin". English. In: Scientific Reports 5 (2015), 9394:1-9. DOI: 10.1038/srep09394.

[7521] L. Fostowicz-Frelik, C. Li, Q. Li, J. Meng, and Y. Wang. "Strenulagus (Mammalia: Lagomorpha) from the Middle Eocene Irdin Manha Formation of the Erlian Basin, Nei Mongol, China". English. In: Acta Geologica Sinica (English Edition) 89.1 (2015), pp. 12-26.

[7522] L. Fostowicz-Frelik, C.-K. Li, J. Meng, and Y. -Q. Wang. “New Gobiolagus (Mammalia: Lagomorpha) material from the Middle Eocene of Erden Obo (Nei Mongol, China)". English. In: Vertebrata PalAsiatica 50.3 (2012), pp. 219-236.

[7523] H. Fourie and B. S. Rubidge. "The postcranial skeletal anatomy of the therocephalian Regisaurus (Therapsida: Regisauridae) and its utilization for biostratigraphic correlation". English. In: Palaeontologia Africana 42 (2007), pp. 1-16.

[7524] D. W. Fowler and E. A. Freedman Fowler. "Transitional evolutionary forms in chasmosaurine ceratopsid dinosaurs: evidence from the Campanian of New Mexico". English. In: PeerJ 8 (2020), e9251:1-49. DOI: 10.7717/ peerj.9251.

[7525] D. W. Fowler and R. M. Sullivan. "A ceratopsid pelvis with toothmarks from the Upper Cretaceous Kirtland Formation, New Mexico: evidence of Late Campanian tyrannosaurid feeding behavior". English. In: In: S. G. Lucas \& R. M. Sullivan, Late Cretaceous Vertebrates from the Western Interior. New Mexico Museum of Natural History and Science Bulletin 35 (2006), pp. 127-130.

[7526] D. W. Fowler and R. M. Sullivan. "The first giant titanosaurian sauropod from the Upper Cretaceous of North America". English. In: Acta Palaeontologica Polonica 56.4 (2011), pp. 685-690.

[7527] D. L. Fox and D. C. Fisher. "Stable isotope ecology of a late Miocene population of Gomphotherium productus (Mammalia, Proboscidea) from Port of Entry Pit, Oklahoma, USA". English. In: Palaios 16 (2001), pp. 279-293.

[7528] R. C. Fox. "The succession of Paleocene mammals in western Canada". English. In: Geological Society of America Special Paper 243 (1990), pp. 51-70.

[7529] R. C. Fox. "Pronothodectes gaoi n. sp. from the Late Paleocene of Alberta, Canada, and the Early Evolution of the Plesiadapidae (Mammalia, Primates)". English. In: Journal of Paleontology 64.4 (1990).

[7530] R. C. Fox. "Systematic Position of Pronothodectes gaoi Fox from the Paleocene of Alberta: Reply". English. In: Journal of Paleontology 65.4 (1991).

[7531] R. C. Fox. "Saxonella (Plesiadapiformes: ?Primates) in North America: S. Naylori, sp. nov., from the Late Paleocene of Alberta, Canada". English. In: Journal of Vertebrate Paleontology 11.3 (1991), pp. 334-349.

[7532] R. C. Fox. “The oldest Cenozoic mammal?" English. In: Journal of Vertebrate Paleontology 22.2 (2002), pp. $456-459$.

[7533] R. C. Fox. "The dentition and relationships of Carpodaptes cygneus (Russell) (Carpolestidae, Plesiadapiformes, Mammalia), from the late Paleocene of Alberta, Canada". English. In: Journal of Paleontology 76.5 (2002), pp. 864-881.

[7534] R. C. Fox. "A new palaeoryctid (Insectivora: Mammalia) from the late Paleocene of Alberta, Canada". English. In: Journal of Paleontology 78.3 (2004), pp. 612-616.

[7535] R. C. Fox. "An unusual early primate from the Paleocene Paskapoo Formation, Alberta, Canada". English. In: Acta Palaeontologica Polonica 56.1 (2011), pp. 1-10. DOI: 10.4202/app.2009.0079. 
[7536] R. C. Fox and B. G. Naylor. "A Late Cretaceous taeniodont (Eutheria, Mammalia) from Alberta, Canada". In: Neues Jahrbuch für Geologie und Paläontologie 229.3 (2003), pp. 393-420.

[7537] R. C. Fox and B. G. Naylor. "Stagodontid marsupials from the Late Cretaceous of Canada and their systematic and functional implications". English. In: Acta Palaeontologica Polonica 51.1 (2006), pp. 13-36.

[7538] R. C. Fox, B. D. Rankin, C. S. Scott, and A. R. Sweet. "Second known occurrence of the early Paleocene plesiadapiform Pandemonium (Mammalia: Primates), with description of a new species". English. In: Canadian Journal of Earth Sciences 51 (2014), pp. 1059-1066.

[7539] R. C. Fox, C. S. Scott, and H. N. Bryant. "A new, unusual therian mammal from the Upper Cretaceous of Saskatchewan, Canada". English. In: Cretaceous Research 28.5 (2007), pp. 821-829.

[7540] R. C. Fox, C. S. Scott, and B. D. Rankin. "Edworthia lerbekmoi, a new primitive paromomyid primate from the Torrejonian (early Paleocene) of Alberta, Canada". English. In: Journal of Paleontology 84.5 (2010), pp. 868-878.

[7541] R. C. Fox, C. S. Scott, and B. D. Rankin. "New early carnivoran specimens from the Puercan (earliest Paleocene) of Saskatchewan, Canada". English. In: Journal of Paleontology 84.6 (2010), pp. 10351039.

[7542] R. C. Fox and C. S. Scott. "A new, early Puercan (earliest Paleocene) species of Purgatorius (Plesiadapiformes, Primates) from Saskatchewan, Canada". English. In: Journal of Paleontology 85.3 (2011), pp. 537-548.

[7543] R. C. Fox, C. S. Scott, and G. A. Buckley. "A 'giant' purgatoriid (Plesiadapiformes) from the Paleocene of Montana, USA: mosaic evolution in the earliest primates". English. In: Palaeontology 58.2 (2015), pp. 277-291. DOI: 10.1111/pala.12141.

[7544] R. C. Fox, G. P. Youzwyshyn, and D. W. Krause. "Post-Jurassic mammal-like reptile from the Palaeocene". English. In: Nature 358 (1992), pp. 233-235. DOI: 10.1038/358233a0.

[7545] R. C. Fox and G. P. Youzwyshyn. "New primitive carnivorans (Mammalia) from the Paleocene of western Canada, and their bearing on relationships of the order". English. In: Journal of Vertebrate Paleontology 14.3 (1994), pp. 382-404. DOI: 10.1080/02724634.1994.10011566.

[7546] I. Fzy. "Campanian (Late Cretaceous) cephalopods from Sümeg (Transdanubian Central Range, Hungary)". English. In: Fragmenta Palaeontologica Hungarica 19 (2001), pp. 25-37.

[7547] I. Fözy and N. M. M. Janssen. "Integrated Lower Cretaceous biostratigraphy of the Bersek Quarry, Gerecse Mountains, Transdanubian Range. Hungary". English. In: Cretaceous Research 30 (2009), pp. 78-92.

[7548] I. Fozy and N. N. M. Janssen. "The stratigraphic position of the ammonite bearing limestone bank of the Marvany-banya quarry (Zirc, Bakony Mts, Hungary) and the age of the Borzavar Limestone Formation". English. In: Neues Jahrbuch für Geologie und Paläontologie Monatshefte 1 (2006), pp. 4164.

[7549] I. Fozy, M. Kazmer, and I. Szente. "A unique Lower Tithonian fauna in the Gerecse Mts, Hungary". In: Palaeopelagos Special Publication 1 (1994), pp. 155-165.

[7550] I. Fozy, G. Meléndez, A. Scherzinger, B. Szinger, and O. Szives. “Upper Jurassic-lowermost Cretaceous fossil localities of the Gerecse and Pilis Mountains (rocks, fossils and stratigraphy)". English. In: Late Jurassic-Early Cretaceous fauna, biostratigraphy, facies and deformation history of the carbonate formations in the Gerecse and Pilis Mountains (Transdanubian Range, Hungary). Szeged: GeoLitera Publishing House, 2013, pp. 21-93.

[7551] R. Fraaije, J. Hansen, and T. Hansen. "Late Miocene decapod faunas from Gram, Denmark". English. In: Palaeontos 7 (2005), pp. 51-61.

[7552] R. H. B. Fraaije. "The oldest in situ hermit crab from the Lower Cretaceous of Speeton, UK". English. In: Palaeontology 46.1 (2003), pp. 53-57. DOI: 10.1111/1475-4983.00286. 
[7553] R. H. B. Fraaije. "New calappid crabs (Crustacea, Decapoda, Brachyura) from the Late Maastrichtian of the Netherlands". English. In: Journal of Paleontology 76.5 (2002), pp. 913-917. DOI: $10.1017 /$ S0022336000037598.

[7554] R. H. B. Fraaije. "The first record of albuneid crabs (Crustacea, Decapoda) from the Cretaceous". English. In: Bulletin of the Mizunami Fossil Museum 29 (2002), pp. 69-72.

[7555] R. H. B. Fraaije, B. W. M. Bakel, J. W. M. Jagt, A. A. Klompmaker, and P. Artal. "A new hermit crab (Crustacea, Anomura, Paguroidea) from the mid-Cretaceous of Navarra, northern Spain". English. In: Boletn de la Sociedad Geológica Mexicana 61 (2009), pp. 211-214.

[7556] R. H. B. Fraaije, A. A. Klompmaker, and P. Artal. "New species, genera and a family of hermit crabs (Crustacea, Anomura, Paguroidea) from a mid-Cretaceous reef of Navarra, northern Spain". English. In: Neues Jahrbuch für Geologie und Paläontologie, Abhandlungen 263.1 (2012), pp. 85-92.

[7557] R. H. B. Fraaije, W. Krzemiski, B. W. M. Van Bakel, E. Krzemiska, and J. W. M. Jagt. “New Late Jurassic symmetrical hermit crabs from the southern Polish Uplands and early paguroid diversification". English. In: Acta Palaeontologica Polonica (2012).

[7558] R. H. B. Fraaije, M. A. López-Horgue, N. L. Bruce, B. W. M. van Bakel, P. Artal, J. W. M. Jagt, and A. A. Klompmaker. "New isopod and achelatan crustaceans from mid-Cretaceous reefal limestones in the Basque-Cantabrian Basin, northern Spain". English. In: Cretaceous Research (2019). DOI: $10.1016 /$ j.cretres.2019.04.012.

[7559] R. H. B. Fraaije, U. E. Menkveld-Gfeller, B. W. M. van Bakel, and J. W. M. Jagt. "Decapod crustaceans from the type area of the Helvetian Stage (lower Miocene) in the Bern area, Switzerland". English. In: Bulletin of the Mizunami Fossil Museum 36 (2010), pp. 1-11.

[7560] R. H. B. Fraaije and H. W. J. Pennings. "Crab carapaces preserved in nautiloid shells from the Upper Paleocene of Huesca (Pyrenees, Spain)". English. In: Revista Mexicana de Ciencias Geológicas 23.3 (2006), pp. 361-363.

[7561] R. H. B. Fraaije, F. R. Schram, and R. Vonk. "Maastrichtiocaris rostratus new genus and species, the first Cretaceous cycloid". English. In: Journal of Paleontology 77.2 (2003), pp. 386-388.

[7562] R. H. B. Fraaije, B. W. Van Bakel, and J. W. M. Jagt. "A new species of Goniocypoda and the first record of Glyphithyreus wetherelli (Bell, 1858) (Decapoda, Brachyura) from the Eocene of Nieuwvliet-Bad, The Netherlands". English. In: Memorie della Societá Italiana di Scienze Naturali e del Museo Civico di Storia Naturale di Milano 35.2 (2007), pp. 37-42.

[7563] R. H. B. Fraaije, B. W. M. van Bakel, J. W. M. Jagt, and F. H. Mollen. “A new axiid (Crustacea: Decapoda: Axiidea) from the Neogene of Belgium and the Netherlands". English. In: Neues Jahrbuch für Geologie und Paläontologie, Abhandlungen 260.2 (2011), pp. 157-163. DOI: 10.1127 / 0077-7749 / 2011/0167.

[7564] R. H. B. Fraaije, B. W. M. van Bakel, and J. W. M. Jagt. "First record of Dromia neogenica Müller, 1979 (Decapoda, Brachyura, Dromiidae) from Neogene strata in the southern North Sea basin". English. In: vol. 14. Studies on Malacostraca: Lipke Bijdeley Holthuis Memorial Volume. Crustaceana Monographs. Leiden: Brill, 2010, pp. 231-240. DOI: 10.1163/9789047427759_015.

[7565] R. H. B. Fraaije, B. W. M. van Bakel, J. W. M. Jagt, and P. Artal. "New decapod crustaceans (Anomura, Brachyura) from mid-Cretaceous reefal deposits at Monte Orobe (Navarra, northern Spain), and comments on related type-Maastrichtian material". English. In: Bulletin de l'Institut Royal des Sciences Naturelles de Belqique, Sciences de la Terre 78 (2008), pp. 193-208.

[7566] R. H. B. Fraaije, B. W. M. van Bakel, J. W. M. Jagt, and Y. Coole. "Two new Paleogene species of mud shrimp (Crustacea, Decapoda, Upogebiidae) from Europe and North America". English. In: Bulletin of Mizunami Fossil Museum 33 (2006), pp. 77-85.

[7567] R. H. B. Fraaije, B. W. M. van Bakel, J. W. M. Jagt, and S. Polkowsky. "A new Oligocene record of Szaboa (Crustacea, Decapoda, Brachyura, Matutidae) from northern Germany". English. In: Bulletin of the Mizunami Fossil Museum 38 (2012), pp. 29-31. 
[7568] R. H. B. Fraaije, F. J. Vega, B. W. M. van Bakel, and L. M. Garibay-Romero. “Late Cretaceous dwarf decapods from Guerrero, southern Mexico and their migration patterns". English. In: Contributions to Zoology 75.3/4 (2006), pp. 121-132.

[7569] R. Fraaye and M. Jäger. "Decapods in ammonite shells: examples of inquilinism from the Jurassic of England and Germany". English. In: Palaeontology 38 (1995), pp. 63-75.

[7570] R. H. B. Fraaye. "Late Cretaceous swimming crabs: radiation, migration, competition, and extinction". English. In: Acta Palaeontologica Polonica 46.3-4 (1996), pp. 269-278.

[7571] R. H. B. Fraaye. “A new raninid crab, Pseudorogueus rangiferus (Decapoda, Crustacea), from the Eocene of Spain". English. In: Estudios Geológicos 51 (1995), pp. 65-67.

[7572] R. H. B. Fraaye and J. S. H. Collins. "Two new decapod crustaceans from the Portlandian of Dorset, England". English. In: Proceedings of the Geologists Association 107 (1996), pp. 323-326.

[7573] R. H. B. Fraaye and B. W. M. van Bakel. "New raninid crabs (Crustacea, Decapoda, Brachyura) from the late Maastrichtian of the Netherlands". English. In: Geologie en Mijnbouw 76 (1998), pp. 293 299.

[7574] R. H. B. Fraaye and H. Summesberger. "New crustacean records from Late Campanian of the Gschliefgraben (Crateceous, Austria)". In: Beiträge zur Paläontologie 24 (1999), pp. 1-6.

[7575] C. D. Frailey and K. E. Campbell. "Two new genera of peccaries (Mammalia, Artiodactyla, Tayassuidae) from Upper Miocene deposits of the Amazon Basin". English. In: Journal of Paleontology 86.5 (2012), pp. 852-877. DOI: 10.1666/12-012.1.

[7576] C. D. Frailey and K. E. Campbell Jr. "Paleogene Rodents from Amazonian Peru: The Santa Rosa Local Fauna". English. In: Natural History Museum of Los Angeles County Science Series 40 (2004), pp. 71-130.

[7577] M. Fraiser. "When Bivalves Took Over the World: Global Paleoecology of Bivalves During the Aftermath of the End-Permian Mass Extinction". PhD thesis. 2005.

[7578] M. A. G. Franca, J. Ferigolo, and M. C. Langer. "Associated skeletons of a new middle Triassic Rauisuchia from Brazil". English. In: Naturwissenschaften 98 (2011), pp. 389-395. DOI: 10.1007 / s00114-011-0782-3.

[7579] M. A. G. França and M. C. Langer. "A new freshwater turtle (Reptilia, Pleurodira, Podocnemidae) from the Upper Cretaceous (Maastrichtian) of Minas Gerais, Brazil". English. In: Geodiversitas 27.3 (2005), pp. 391-411.

[7580] C. A. M. France, P. M. Zelanko, A. J. Kaufman, and T. R. Holtz. “Carbon and nitrogen isotopic analysis of Pleistocene mammals from the Saltville Quarry (Virginia, USA): Implications for trophic relationships". English. In: Palaeogeography, Palaeoclimatology, Palaeoecology 249 (2007), pp. 271-282.

[7581] M. J. Franco and M. Brea. "Leños fósiles de la Formación Paraná (Mioceno Medio), Toma Vieja, Paraná, Entre Ros, Argentina: registro de bosques estacionales mixtos". Spanish. In: Ameghiniana 45.4 (2008), pp. 699-717.

[7582] A. C. Franco-Rosas, L. Salgado, C. F. Rosas, and I.d.S. Carvalho. "Nuevos materiales de titanosaurios (Sauropoda) en el Cretácico Superior de Mato Grosso, Brasil [New materials of titanosaurs (Sauropoda) from the Upper Cretaceous of Mato Grosso, Brazil]". Spanish. In: Revista Brasileira de Paleontologia 7.3 (2004), pp. 329-336.

[7583] E. Francois and B. David. "Variations morphologiques des Toxaster (Echinoida : Spatangoida) en regard des fluctuations spatiales (Arc de Castellane, SE France) et temporelles (ValanginienHauterivien) du milieu sédimentaire : expression d'un potentiel adaptatif restreint". French. In: Géobios 39 (2006), pp. 355-371.

[7584] N. G. Frankfurt and L. M. Chiappe. "A possible oviraptorosaur from the Late Cretaceous of northwestern Argentina". English. In: Journal of Vertebrate Paleontology 19.1 (1999), pp. 101-105.

[7585] A. L. Frantescu, R. M. Feldmann, and C. E. Schweitzer. "A new genus and species of dromiid crab (Decapoda, Brachyura) from the middle Eocene of South Carolina". English. In: Crustaceana Monographs 14 (2010), pp. 255-267. 
[7586] O. D. Franescu. "Fossil mudshrimps (Decapoda: Axiidea) from the Pawpaw Formation (Cretaceous: Albian), northeast Texas, USA". English. In: Bulletin of the Mizunami Fossil Museum 40 (2014), pp. 13-22.

[7587] O. E. Franescu, F. M. Feldmann, and C. E. Schweitzer. “Cretaceous fossil Raninoida De Haan, 1839 (Crustacea, Decapoda, Brachyura) from northeast Texas". English. In: Journal of Paleontology 90.6 (2016), pp. 1118-1132. DOI: 10.1017/jpa.2016.106.

[7588] F. Franz and S. F. Franz. "A New Fossil Land Tortoise in the Genus Chelonoidis (Testudines: Testudinidae) From the Northern Bahamas, With an Osteological Assessment of Other Neotropical Tortoises". English. In: Bulletin of the Florida Museum of Natural History 44.1 (2009), pp. 1-44.

[7589] N. Franz and G. Y. Zhang. "Three new species of entimine weevils in Early Miocene amber from the Dominican Republic (Coleoptera: Curculionidae)". English. In: Biodiversity Data Journal 5.e10469 (2017), pp. 1-32.

[7590] R. Franz, N. A. Albury, and D. W. Steadman. "Extinct tortoises from the Turks and Caicos Islands". English. In: Bulletin of the Florida Museum of Natural History 58.1 (2020), pp. 1-38.

[7591] R. Franz and I. R. Quitmyer. "A fossil and zooarchaeological history of the gopher tortoise (Gopherus polyphemus) in the Southeastern United States". English. In: Bull. Fla. Mus. Nat. History 45.4 (2005), pp. 179-199.

[7592] J. L. Franzen. "First fossil primates from Eckfeld Maar, Middle Eocene (Eifel, Germany)". English. In: Eclogae Geologicae Helvetiae 97.2 (2004), pp. 213-220.

[7593] J. L. Franzen. “The tapirs (Mammalia, Perissodactyla, Tapiridae) from the late Miocene (early Turolian) of Dorn-Dürkheim 1 (Germany, Rheinhessen)". English. In: Palaeobio Palaeoenv 93 (2013), pp. 171-189. DOI: 10.1007/s12549-012-0111-7.

[7594] J. L. Franzen, P. D. Gingerich, J. Habersetzer, J. H. Hurum, W. Koenigswald, and B. H. Smith. "Complete primate skeleton from the Middle Eocene of Messel in Germany: Morphology and Paleobiology". English. In: PloSone 4.5 (2009), pp. 1-27.

[7595] N. Fraser and H. Furrer. "A new species of Macrocnemus from the Middle Triassic of the eastern Swiss Alps". English. In: Swiss Journal of Geoscience 106 (2013), pp. 199-206.

[7596] N. Fraser, O. Rieppel, and C. Li. "A long-snouted protorosaur from the Middle Triassic of southern China". English. In: Journal of Vertebrate Paleontology 33.5 (2013), pp. 1120-1126.

[7597] N. C. Fraser. Assemblages of small tetrapods from British Late Triassic fissure deposits. In the Shadow of the Dinosaurs: Early Mesozoic Tetrapods, N. C. Fraser and H.-D. Sues (eds.), Cambridge University Press. 1994, pp. 214-226.

[7598] N. C. Fraser, D. A. Grimaldi, P. E. Olsen, and B. Axsmith. "A Triassic Lagerstatte from eastern North America". English. In: Nature 380 (1996), pp. 615-619.

[7599] N. C. Fraser, R. B. Irmis, and D. K. Elliot. "A procolophonid (Parareptilia) from the Owl Rock Member, Chinle Formation of Utah, USA". English. In: Palaeontologia Electronica 8.1 (2005), 13A.

[7600] N. C. Fraser, P. E. Olsen, A. C. Dooley, and T. R. Ryan. “A New Gliding Tetrapod (Diapsida: Archosauromorpha) from the Upper Triassic (Carman) of Virginia". English. In: Journal of Vertebrate Paleontology 27.2 (2007), pp. 261-265.

[7601] N. C. Fraser, K. Padian, G. M. Walkden, and A. L. M. Davis. "Basal dinosauriform remains from Britain and the diagnosis of the Dinosauria". In: Palaeontology 45.1 (2002), pp. 79-95.

[7602] N. C. Fraser and O. Rieppel. "A new protorosaur (Diapsida) from the Upper Buntsandstein of the Black Forest, Germany". English. In: Journal of Vertebrate Paleontology 26.4 (2006), pp. 866-871.

[7603] N. M. Fraser. "Large epifaunal bivalves from Mesozoic buildups of Western North America". PhD thesis. 1997.

[7604] N. M. Fraser, D. J. Bottjer, and A. G. Fischer. "Dissecting Lithiotis Bivalves: Implications for the Early Jurassic Reef Eclipse". In: Palaios 19.1 (2004), pp. 51-67. 
[7605] R. A. Fraser and R. T. Wells. "Palaeontological excavation and taphonomic investigation of the late Pleistocene fossil deposit in Grant Hall, Victoria Fossil Cave, Naracoorte, South Australia". English. In: Alcheringa: An Australasian Journal of Palaeontology 30.S1 (2006), pp. 147-161. DOI: 10. $1080 / 03115510609506860$.

[7606] D. Frassinetti. "Molluscos bivalvos y gastrópodos del Mioceno marino de Isla Stokes, sur de Chile". Spanish. In: Boletn del Museo Nacional de Historia Natural, Chile 50 (2001), pp. 73-90.

[7607] D. Frassinetti. "Moluscos del Plioceno Superior marino de Isla Guafo, Sur de Chile. Part 1. Bivalvia." Spanish. In: Boletn del Museo Nacional de Historia Natural, Chile 46 (1997), pp. 55-79.

[7608] D. Frassinetti. "Moluscos del Plioceno Superior Marino de Isla Guafo, Sur de Chile. Part II. Gastropoda". Spanish. In: Boletn del Museo Nacional de Historia Natural, Chile 49 (2000), pp. 131-161.

[7609] D. Frassinetti and V. Covacevich. "Moluscos del Plioceno Superior marino de Isla Guambln Archpelago de los Chonos, sur de Chile". Spanish. In: Revista Geológica de Chile 22.1 (1995), pp. 47-73.

[7610] D. Frassinetti and V. Covacevich. "Invertibrados fósiles marinos de la Formación Guadal (Oligoceno superio-Mioceno inferior) en Pampa, Castillo region, región de Aisén, Chile". Spanish. In: Servico Nacional de Geologia y Mineria Chile Boletin 51 (1999), pp. 1-96.

[7611] D. Frassinetti and V. Covacevich. "Bivalvos del Mioceno marino de Matanzas (Formacon Navidad, Chile central)". Spanish. In: Boletn del Museo Nacional de Historia Natural, Chile 44 (1993), pp. 73-97.

[7612] C. Frau, L. G. Bulot, and W. A. P. Wimbledon. “Upper Tithonian Himalayitidae Spath, 1925 (Perisphinctoidea, Ammonitina) from Le Chouet (Drome, France): implications for the systematics". English. In: Geologica Carpathica 66 (2015), pp. 117-132.

[7613] C. Frau, L. G. Bulot, W. A. P. Wimbledon, and C. Ifrim. "Systematic palaeontology of the Perisphinctoidea in the Jurassic/Cretaceous boundary interval at Le Chouet (Drome, France), and its implications for biostratigraphy". English. In: Acta Geologica Polonica 66 (2016), pp. 175-204.

[7614] C. Frau, L. G. Bulot, W. A. P. Wimbledon, and C. Ifrim. "Upper Tithonian ammonites (Himalayitidae Spath, 1925 and Neocomitidae Salfeld, 1921) from Charens (Drome, France)". English. In: Geologica Carpathica 67 (2016), pp. 543-559.

[7615] C. Frau, L. G. Bulot, and G. Delanoy. "New and poorly known Aptian Acrioceratidae (Acrioceratidae, Ammonoidea) from Cassis - Roquefort-la-Bédoule (Bouches-du-Rhone, France)". English. In: Neues Jahrbuch für Geologie und Paläontologie, Abhandlungen 283 (2017), pp. 335-346.

[7616] C. Frau, G. Delanoy, J. P. Masse, C. Lanteaume, and A. J. B. Tendil. “New Heteroceratidae (Ammonoidea) from the late Barremian deepening succession of Marseille (Bouches-du-Rhone, France)". English. In: Acta Geologica Polonica 66 (2016), pp. 205-225.

[7617] T. G. Frauenfelder, N. E. Campione, E. T. Smith, and P. R. Bell. “Diversity and palaeoecology of Australia's southernmost sauropods, Griman Creek Formation (Cenomanian), New South Wales, Australia". English. In: Lethaia 54 (2021), pp. 354-367. DOI: 10.1111/let.12407.

[7618] P. Fravega, M. Piazza, R. Stockar, and G. Vannucci. “Oligocene coral and algal reef and related facies of Valzemola (Savona, NW Italy)". In: Rivista Italiana di Paleontologia e Stratigrafia 100 (1994), pp. 423-456.

[7619] J. Frazier, V. Azzara, O. Munoz, L. G. Marcucci, E. Badel, F. Genchi, M. Cattani, M. Tosi, and M. Delfino. "Remains of Leatherback turtles, Dermochelys coriacea, at Mid-Late Holocene archaeological sites in coastal Oman: clues of past worlds". English. In: PeerJ (2018), pp. 1-34. DOI: 10.7717 / peerj.6123.

[7620] J. A. Frederickson, J. E. Cohen, T. C. Hunt, and R. L. Cifelli. "A new occurrence of Dakotasuchus kingi from the Late Cretaceous of Utah, USA, and the diagnostic utility of postcranial characters in Crocodyliformes". English. In: Acta Palaeontologica Polonica 62.2 (2017), pp. 279-286. DOI: 10. 4202/app.00338.2016.

[7621] J. A. Frederickson, M. H. Engel, and R. L. Cifelli. "Niche partitioning in theropod dinosaurs: diet and habitat preference in predators from the uppermost Cedar Mountain Formation (Utah, U.S.A.)" English. In: Scientific Reports 8.1 (2018), 17872:1-13. DOI: 10.1038/s41598-018-35689-6. 
[7622] J. A. Frederickson, T. R. Lipka, and R. L. Cifelli. “A new species of the lungfish Ceratodus (Dipnoi) from the Early Cretaceous of the eastern U.S.A." English. In: Journal of Vertebrate Paleontology 36.4 (2016), e1136316:1-5. DOI: 10.1080/02724634.2016.1136316.

[7623] J. A. Frederickson, T. R. Lipka, and R. L. Cifelli. "Faunal composition and paleoenvironment of the Arundel Clay (Potomac Formation; Early Cretaceous), Maryland, USA". English. In: Palaeontologia Electronica 21.2 (2018), 31A:1-24.

[7624] E. A. Freedman Fowler and J. R. Horner. "A new brachylophosaurin hadrosaur (Dinosauria: Ornithischia) with an intermediate nasal crest from the Campanian Judith River Formation of northcentral Montana". English. In: PLoS One 10.11 (2015), e0141304. DOI: 10.1371/journal.pone. 0141304.

[7625] D. Freile, M. L. DeVore, and D. Parmley. "The first report of Carcharocles auriculatus from the oligocene of Georgia in the context of previous Gulf Coast records". English. In: Georgia Journal of Science 59.3 (2001), pp. 128-136.

[7626] L. C. B. Freitas, G. J. B. De Moura, and A. A. F. Saraiva. "First occurrence and paleo-ecological implications of insects (Orthoptera: Ensifera Gryllidae) in the Romualdo Member of the Santana Formation, Eo-Cretaceous of the Araripe Basin". English. In: Anais da Academia Brasileira de Ciencias 88 (2016), pp. 2113-2120.

[7627] L. C. B. Freitas, A. P. Rasnitsyn, G. J. B. Moura, and M. Mendes. "New species of Myrmicium Westwood (Psedosiricidae = Myrmiciidae: Hymenoptera, Insecta) from the Early Cretaceous (Aptian) of the Araripe Basin, Brazil". English. In: Anais da Academia Brasileira de Ciencias 92.e20200479 (2020). DOI: 10.1590/0001-3765202020200479.

[7628] A. Freiwald. “Insekten aus der Fur-Formation von Dänemark (Moler, ob. Paleozän/unt. Eozän ?). 5. Cylindrotomidae (Diptera: Tipulomorpha)”. German. In: Meyniana 43 (1991), pp. 97-123.

[7629] A. Freiwald and W. Krzemiski. "Cylindrotomidae (Diptera, Tipulomorpha) from the Paleogene of Bolshaya Svetlovodnaya (eastern asiatic USSR)". English. In: Paläontologische Zeitschrift 65 (1991), pp. 339-344.

[7630] S. Freneix. "Bivalves du Trias tariquide de Los Pastores (Algesiras), Espagne. Leur signification [Bivalves from the Tariquide Trias of Los Pastores (Algesiras), Spain]". French. In: Geodiversitas 21.2 (1999), pp. 137-146.

[7631] A. Freschi. "New Carcharodon scavenging evidence on Pliocene whale bones remains from Northern Appennines". English. In: Quaderni del Museo Civico di Storia Naturale di Ferrara 5 (2017), pp. 3336.

[7632] A. Freschi and S. Cau. "Distribuzione geografica dei cetacei fossili del Bacino Plio-Pleistocenico di Castell'Arquato (Piacenzia)". Italian. In: Parva Naturalia 11 (2016), pp. 47-59.

[7633] A. Freschi and G. Raineri. "I cetacei fossili mio-pliocenici conservati nel Museo Paleontologico Il Mare Antico di Salsomaggiore Terme (Parma)". Italian. In: Museologia Scientifica Memoirie 13 (2014), pp. 46-53.

[7634] M. Freudenthal. "Cricetidae (Rodentia, Mammalia) from the Upper Oligocene of Mirambueno and Vivel del Rio (prov. Teruel, Spain)". English. In: Scripta Geologica 104 (1994), pp. 1-55.

[7635] M. Freudenthal. "The Early Oligocene rodent fauna of Olalla 4A (Teruel, Spain)." English. In: Scripta Geologica 112 (1996), pp. 1-67.

[7636] M. Freudenthal. "Fuenferrada 3, the first Eocene mammal locality in the depression of Montalbán (Teruel, Spain), with some remarks on the fauna of Olalla 4A". English. In: Scripta Geologica 115 (1997), pp. 1-28.

[7637] M. Freudenthal. "Gliridae (Rodentia, Mammalia) from the Eocene and Oligocene of the Sierra Palomera (Teruel, Spain)". English. In: Treballs del Museu de Geologia de Barcelona 12 (2004), pp. 97173.

[7638] M. Freudenthal, M. Hugueney, and E. Moissenet. "The genus Pseudocricetodon (Cricetidae, Mammalia) in the Upper Oligocene of the province of Teruel (Spain)". In: Scripta Geologica 104 (1994), pp. 57-114. 
[7639] M. Freudenthal, J. I. Lacomba, and E. Martn Suaréz. “The Cricetidae (Mammalia, Rodentia) from the Late Miocene of Crevillente (prov. Alicante, Spain)". English. In: Scripta Geologica 96 (1991), pp. 9-46.

[7640] M. Freudenthal and E. Martin-Suarez. "Gliridae (Rodentia, Mammalia) from the Late Miocene fissure filling Biancone 1 (Gargano, Province of Foggia, Italy)". English. In: Palaeontologia Electronica 9.2 (2006), pp. 1-23.

[7641] M. Freudenthal and E. Martn-Suárez. "A revision of European Plesiosminthus (Rodentia, Dipodidae), and new material from the upper Oligocene of Teruel (Spain)". English. In: Palaeontologia Electronica 20.2 (2017), 41A:1-25.

[7642] M. Freudenthal, P. Mein, and E. Martn-Suárez. "Revision of Late Miocene and Pliocene Cricetinae (Rodentia, Mammalia) from Spain and France". English. In: Treballs del Museu de Geologia de Barcelona 7 (1998), pp. 11-93.

[7643] E. Frey, M.-C. Buchy, W. Stinnesbeck, and J. G. Lopez-Oliva. “Geosaurus vignaudi n. sp. (Crocodyliformes: Thalattosuchia), first evidence of metriorhynchid crocodilians in the Late Jurassic (Tithonian) of central-east Mexico (State of Puebla)". English. In: Canadian Journal of Earth Sciences 39.10 (2002), pp. 1467-1483.

[7644] E. Frey, M.-C. Buchy, W. Stinnesbeck, A. González González, and A. di Stefano. "Muzquizopteryx coahuilensis n. g., n. sp., a nyctosaurid pterosaur with soft tissue preservation from the Coniacian (Late Cretaceous) of northeast Mexico (Coahuila)". English. In: Oryctos 6 (2006), pp. 19-39.

[7645] E. Frey, R. A. Elgin, W. Stinnesbeck, J. M. Padilla-Gutierrez, C. Ifrim, S. Giersch, and A. H. GonzalezGonzalez. "A new specimen of nyctosaurid pterosaur, cf. Muzquizopteryx sp. from the Late Cretaceous of northeast Mexico". English. In: Revista Mexican de Ciencais Geologicas 29 (2012), pp. 131139.

[7646] E. Frey and D. M. Martill. "A reappraisal of Arambourgiania (Pterosauria, Pterodactyloidea): one of the world's largest flying animals". English. In: Neues Jahrbuch für Geologie und Paläontologie, Abhandlungen 199.2 (1996), pp. 221-247.

[7647] E. Frey and D. M. Martill. "A new pterosaur from the Crato Formation (Lower Cretaceous, Aptian) of Brazil". English. In: Neues Jahrbuch für Paläontologie und Geologie, Abhandlungen 194 (1994), pp. 379-412.

[7648] E. Frey, D. M. Martill, and M. -C. Buchy. A new crested ornithocheirid from the Lower Cretaceous of northeastern Brazil and the unusual death of an unusual pterosaur. English. Vol. 217. Evolution and Palaeobiology of Pterosaurs, Geological Society of London, Special Publications. 2003, pp. 55-63.

[7649] E. Frey, D. M. Martill, and M. -C. Buchy. A new species of tapejarid pterosaur with soft-tissue head crest. English. Vol. 217. Evolution and Palaeobiology of Pterosaurs, Geological Society of London, Special Publications. 2003, pp. 65-72.

[7650] E. Frey, C. A. Meyer, and H. Tischlinger. "The oldest azhdarchoid pterosaur from the Late Jurassic Solnhofen Limestone (Early Tithonian) of Southern Germany". English. In: Swiss Journal of Geosciences 104.supp. 1 (2011), S35-S55. DOI: 10.1007/s00015-011-0073-1.

[7651] E. Frey and S. Monninger. "Lost in action-the isolated crocodilian teeth from Enspel and their interpretive value". English. In: Palaeobiodiversity and Palaeoenvironments 90 (2010), pp. 65-81.

[7652] E. Frey, E. W. A. Mulder, W. Stinnesbeck, H. E. Rivera-Sylva, J. M. Padilla-Gutiérrez, and A. H. González-González. "A new polycotylid plesiosaur with extensive soft tissue preservation from the early Late Cretaceous of northeast Mexico". English. In: Boletn de la Sociedad Geológica Mexicana 69.1 (2017), pp. 87-134.

[7653] E. Frey, W. Munk, M. Böhme, M. Morlo, and M. Hensel. "First creodont carnivore from the Rupelian Clays (Oligocene) of the Clay Pit Unterfeld at Rauenberg (Rhein-Neckar-Kreis, BadenWürttemberg): Apterodon rauenbergensis n.sp". English. In: Kaupia 17 (2010), pp. 103-113.

[7654] E. Frey and S. W. Salisbury. Crocodilians of the Crato Formation: evidence for enigmatic species. English. The Crato Fossil Beds of Brazil - Window into an Ancient World. 2007, pp. 463-474. 
[7655] E. Frey, H.-D. Sues, and W. Munk. "Gliding Mechanism in the Late Permian Reptile Coelurosauravus". English. In: Science 275 (1997), pp. 1450-1452.

[7656] L. Frey, C. Naglik, R. Hofmann, M. Schemm-Gregory, J. Frýda, B. Kröger, P. D. Taylor, M. A. Wilson, and C. Klug. "Diversity and palaeoecology of Early Devonian invertebrate associations in the Tafilalt (Anti-Atlas, Morocco)". English. In: Bulletin of Geosciences 89.1 (2014), pp. 75-112. DOI: 10.3140/bull.geosci.1459.

[7657] R. C. Frey. "Middle and Upper Ordovician nautiloid cephalopods of the Cincinnati Arch region of Kentucky, Indiana, and Ohio". English. In: U.S. Geological Survey Professional Paper 1066P (1995), pp. 1-126.

[7658] P. Freytet, J. Broutin, and M. Durand. "Distribution and palaeoecology of freshwater algae and stromatolites: III, some new forms from the Carboniferous, Permian and Triassic of France and Spain". English. In: Annales de Paleontologie 86.4 (2000), pp. 195-241.

[7659] J. G. Friebe. "Serpulid-bryozoan-foraminiferal biostromes controlled by temperate climate and reduced salinity: middle Miocene of the Styrian Basin, Austria". In: Facies 30 (1994), pp. 51-62.

[7660] M. Friedman. "The evolutionary origin of flatfish asymmetry". English. In: Nature 454 (2008), pp. 209-212.

[7661] M. Friedman and H. L. Blom. "A new Actinopterygian from the Famennian of East Greenland and the interrelationships of Devonian ray-finned fishes". English. In: Journal of Paleontology 80.6 (2006), pp. 1186-1204.

[7662] M. Friedman, M. I. Coates, and P. Anderson. "First discovery of a primitive coelacanth fin fills a major gap in the evolution of lobed fins and limbs". English. In: Evolution \& Development 9.4 (2007), pp. 329-337.

[7663] M. Friedman and E. B. Daeschler. "Late Devonian (Famennian) lungfishes from the Catskill Formation of Pennsylvania, USA". English. In: Palaeontology 49.6 (2006), pp. 1167-1183.

[7664] M. Friedman and G. D. Johnson. "A new species of Mene (Perciformes: Menidae) from the Paleocene of South America, with notes on paleoenvironment and a brief review of menid fishes". English. In: Journal of Vertebrate Paleontology 25.4 (2005), pp. 770-783.

[7665] M. Friedman, J. A. Tarduno, and D. B. Brinkman. "Fossil fishes from the high Canadian Arctic: further palaeobiological evidence for extreme climatic warmth during the Late Cretaceous (Turonian-Coniacian)". In: Cretaceous Research 24 (2003), pp. 615-632.

[7666] M. Friedmann. "Parallel evolutionary trajectories underlie the origin of giant suspension-feeding whales and bony fish". English. In: Proceedings of the Royal Society B 279 (2012), pp. 944-951. DOI: 10.1098/rspb.2011.1381.

[7667] W. P. Friedrich. "Systematik und Funktionsmorphologie mittelkambrischer Cincta (Carpoidea, Echinodermata)". English. In: Beringeria 7 (1993), pp. 3-190.

[7668] T. M. Friesen and C. D. Arnold. "Zooarchaeology of a focal resource: dietary importance of beluga whales to the precontact Mackenzie Inuit". English. In: Arctic 48 (1995), pp. 22-30.

[7669] E. Friesenbichler, M. Hautmann, A. Nützel, M. Urlichs, and H. Bucher. "Palaeoecology of Late Ladinian (Middle Triassic) benthic faunas". English. In: 93 (2019), pp. 1-29. DOI: 10.1007/s12542018-0423-7.

[7670] E. Friesenbichler, M. Hautmann, E. Grdinaru, and H. Bucher. “A highly diverse bivalve fauna from a Bithynian (Anisian, Middle Triassic) Tubiphytesmicrobial buildup in North Dobrogea (Romania)". English. In: Papers in Palaeontology 7 (2019), pp. 447-495. DOI: 10.1002/spp2.1286.

[7671] E. M. Friis, H. Eklund, K. R. Pedersen, and P. R. Crane. "Virginianthus calycanthoides gen. et sp. nov. - A Calycanthaceous flower from the Potomac Group (Early Cretaceous) of Eastern North America". In: International Journal of Plant Sciences 155.6 (1994), pp. 772-785.

[7672] E. M. Friis, K. R. Pedersen, and P. R. Crane. "Appomattoxia ancistrophora gen. et sp. nov., a new Early Cretaceous plant with similarities to Circaeaster and extant Magnoliidae". In: American Journal of Botany 82.7 (1995), pp. 933-943. 
[7673] E. M. Friis, K. R. Pedersen, M. von Balthazar, G. W. Grimm, and P. R. Crane. “Monetianthus mirus gen. et sp. nov. a Nymphaealean flower from the Early Cretaceous of Portugal". English. In: International Journal of Plant Sciences 170.8 (2009), pp. 1086-1101.

[7674] A. R. Friscia and D. T. Rasmussen. "Middle Eocene Carnivoramorpha of the Uinta Basin, Utah". English. In: Annals of Carnegie Museum 79.1 (2010), pp. 51-63.

[7675] Å M. Frisk and J. O. R. Ebbestad. "Paragastropoda, Tergomya and Gastropoda (Mollusca) from the Upper Ordovician Dalby Limestone, Sweden". English. In: Geologiskt Forum 129.2 (2007), pp. 8399.

[7676] V. Frisone, A. Pisera, and N. Preto. "A highly diverse siliceous sponge fauna (Porifera: Hexactinellida, Demospongiae) from the Eocene of north-eastern Italy: systematics and". English. In: Journal of Systematic Palaeontology 14.11 (2016), pp. 949-1002. DOI: 10.1080/14772019.2015.1132015.

[7677] I. Fritz and H. R. Hiden. "Funde von Aturia (Nautiloidea) aus dem miozänen Kalksteinbruch Retznei (Südweststeiermark)". German. In: Mitteilungen der Abteilung für Geologie und Paläontologie am Landesmuseum Joanneum 52/53 (1996), pp. 13-18.

[7678] U. Fritz and B. Farkas. "The proper generic allocation of Clemmys mehelyi Kormos, 1911 (Reptilia, Testudines)". English. In: Fragmenta Mineralogica et Palaeontologica 18 (1996), pp. 103-105.

[7679] W. H. Fritz. "Walcott's Lower Cambrian Olenellid trilobite collection 61k, Mount Robson Area, Canadian Rocky Mountains". In: Geological Survey of Canada Bulletin 432432 (1992), pp. 1-66.

[7680] W. H. Fritz. "Esmeraldina rowei and associated Lower Cambrian trilobites (1f fauna) at the base of Walcott's Waucoban Series, southern Great Basin, U.S.A." English. In: Journal of Paleontology 69.4 (1995), pp. 708-723.

[7681] W. H. Fritz. "Lower Cambrian Trilobites from the Illtyd Formation, Wernecke Mountains, Yukon Territory". English. In: Geological Survey of Canada Bulletin 409 (1991).

[7682] J. Fröbisch. "Composition and similarity of global anomodont-bearing tetrapod faunas". English. In: Earth-Science Reviews 95 (2009), pp. 119-157.

[7683] J. Fröbisch. "The cranial anatomy of Kombuisia frerensis Hotton (Synapsida, Dicynodontia) and a new phylogeny of anomodont therapsids". English. In: Zoological Journal of the Linnean Society 150 (2007), pp. 117-144.

[7684] J. Fröbisch, K. D. Angielczyk, and C. A. Sidor. "The Triassic dicynodont Kombuisia (Synapsida, Anomodontia) from Antarctica, a refuge from the terrestrial Permian-Triassic mass extinction". English. In: Naturwissenschaften 97 (2010), pp. 187-196.

[7685] J. Fröbisch and R. R. Reisz. "A new species of Emydops (Synapsida, Anomodontia) and a discussion of dental variability and pathology in dicynodonts". English. In: Journal of Vertebrate Paleontology 28.3 (2008), pp. 770-787.

[7686] J. Fröbisch, R. R. Schoch, J. Müller, T. Schindler, and D. Schweiss. “A new basal sphenacodontid synapsid from the Late Carboniferous of the SaarNahe Basin, Germany". English. In: Acta Palaeontologica Polonica 56.1 (2011), pp. 113-120. DOI: 10.4202/app.2010.0039.

[7687] N. B. Fröbisch and J. Fröbisch. "A new basal pterosaur genus from the Upper Triassic of the Northern Calcareous Alps of Switzerland". English. In: Palaeontology 49.5 (2006), pp. 1081-1090. DOI: 10.1111/j.1475-4983.2006.00581.x.

[7688] N. B. Fröbisch, J. Fröbisch, P. M. Sander, L. Schmitz, and O. Rieppel. "Macropredatory ichthyosaur from the Middle Triassic and the origin of modern trophic networks". English. In: Proceedings of the National Academy of Sciences 110.4 (2013), pp. 1393-1397. DOI: 10.1073/pnas.1216750110.

[7689] N. B. Fröbisch and R. R. Reisz. "A New Lower Permian Amphibamid (Dissorophoidea, Temnospondyli) from the Fissure Fill Deposits near Richards Spur, Oklahoma". English. In: Journal of Vertebrate Paleontology 28.4 (2008), pp. 1015-1030.

[7690] N. B. Fröbisch, P. M. Sander, and O. Rieppel. "A new species of Cymbospondylus (Diapsida, Ichthyosauria) from the Middle Triassic of Nevada and a re-evaluation of the skull osteology of the genus". English. In: Zoological Journal of the Linnean Society 147.4 (2006), pp. 515-538. DOI: 10. 1111/j.1096-3642.2006.00225.x. 
[7691] D. J. Froehlich. "Phylogenetic systematics of basal perissodactyls". In: Journal of Vertebrate Paleontology 19.1 (1999), pp. 140-159.

[7692] D. J. Froehlich. "Quo vadis Eohippus? The systematics and taxonomy of the early Eocene equids (Perissodactyla)". English. In: Zoological Journal of the Linnean Society 134 (2002), pp. 141-256. DOI: 10.1046/j.1096-3642.2002.00005.x.

[7693] R. C. Froeschner. "The flat bug genus Calisiopsis Champion: a review with descriptions of three new species, including one from Dominican Republic amber (Heteroptera: Aradidae)". English. In: Proceedings of the Biological Society of Washington 105 (1992), pp. 32-39.

[7694] M. Fröhler and T. Bechstädt. "Calcimicrobial-archaeocyathan buildups at the instable northwestern platform margin of the Lower Cambrian Gonnesa Formation, SW-Sardinia (Italy)." In: Neues Jahrbuch für Geologie und Paläontologie Monatshefte 1992.5 (1992), pp. 267-278.

[7695] J. A. Fronimos and T. M. Lehman. "New specimens of a titanosaur sauropod from the Maastrichtian of Big Bend National Park, Texas". English. In: Journal of Vertebrate Paleontology 34.4 (2014), pp. 883-899.

[7696] S. I. Frumin and E. M. Friis. "Liriodendroid seeds from the Late Cretaceous of Kazakhstan and North Carolina, USA". English. In: Review of Palaeobotany and Palynology 94 (1996), pp. 39-55.

[7697] J. Frýda. "Further new gastropods from the Early Devonian Boucotonotus - Palaeozygopleura community of the Prague Basin". In: Journal of the Czech Geological Survey 44.3-4 (1999), pp. 317325.

[7698] J. Frýda. "Some new and better recognized Devonian gastropods from the Prague Basin (Bohemia)". English. In: Bulletin of the Czech Geological Survey 73.1 (1998), pp. 41-49.

[7699] J. Frýda. "Some new Givetian (Late Middle Devonian) gastropods from the Paffrath area (Bergisches Land, Germany)". English. In: Memoirs of the Queensland Museum 45.2 (2000), pp. 359-374.

[7700] J. Frýda. "Three new gastropod genera from the Early Devonian of Bohemia". In: Bulletin of the Czech Geological Survey 74.1 (1999), pp. 31-38.

[7701] J. Frýda. "Secondary shell deposits in a new plectonotid gastropod genus (Bellerophontoidea, Mollusca) from the Early Devonian of Bohemia". In: Journal of the Czech Geological Society 44.3/4 (1999), pp. 309-315.

[7702] J. Frýda. "Mode of life of a new onychochilid mollusc from the Lower Devonian of Bohemia". English. In: Journal of Paleontology 66.2 (1992), pp. 200-205.

[7703] J. Frýda. "Oldest representative of the family Palaeozygpleuridae (Gastropoda) with notes on its higher taxonomy". English. In: Journal of Paleontology 67.5 (1993), pp. 822-828.

[7704] J. Frýda. "New Silurian and Devonian gastropod genera of Bohemia". English. In: Earth Science 52.3 (1998), pp. 229-234.

[7705] J. Frýda, R. B. Blodgett, and A. C. Lenz. "New Early Devonian gastropods from the families Scoliostomatidae (new family) and Crassimarginatidae (new family), Royal Creek Area, Yukon Territory, Canada". In: Journal of Paleontology 76.2 (2002), pp. 246-255.

[7706] J. Frýda and R. B. Blodgett. "Two new cirroidean genera (Vetigastropoda, Archaeogastropoda) from the Emsian (late Early Devonian) of Alaska with notes on the Early Phylogeny of Cirroidea". In: Journal of Paleontology 72.2 (1998), pp. 265-273.

[7707] J. Frýda and R. B. Blodgett. “New Emsian (Late Early Devonian) gastropods from Limestone Mountain, Medfra B-4 Quadrangle, west-central Alaska (Farewell Terrane) and their paleobiogeographic affinities and evolutionary significance". English. In: Journal of Paleontology 78.1 (2004), pp. 111-132.

[7708] J. Frýda, R. B. Blodgett, A. C. Lenz, and S. Manda. "New porcellioidean gastropods from Early Devonian of Royal Creek Area, Yukon Territory, Canada, with notes on their early phylogeny". English. In: Journal of Paleontology 82.3 (2008), pp. 595-603. 
[7709] J. Frýda, R. B. Blodgett, A. C. Lenz, and B. Frýdová. “Jardamarekia enigma, a new Early Devonian tryblidioidean from Royal Creek area (Yukon Territory, Canada), and paleobiogeography of the Early Devonian of northwestern Canada". English. In: Zootaxa 2905 (2011), pp. 57-62.

[7710] J. Frýda, L. Ferrová, S. Berkyová, and B. Frýdová. “A new Early Devonian palaeozygopleurid gastropod from the Prague Basin (Bohemia) with notes on the phylogeny of the Loxonematoidea". English. In: Bulletin of Geosciences 81.1 (2008), pp. 93-100. DOI: 10.3140/bull.geosci.2008.01.093.

[7711] J. Frýda and L. Ferrová. "The oldest evidence of non-coaxial shell heterostrophy in the Class Gastropoda". English. In: Bulletin of Geosciences 86.4 (2011).

[7712] J. Fryda, L. Ferrová, and B. Frýdova. "Review of palaeozygopleurid gastropods (Palaeozygopleuridae, Gastropoda) from Devonian strata of the Perunica microplate (Bohemia), with a reevaluation of their stratigraphic distribution, notes on their ontogeny, and descriptions of new taxa". English. In: Zootaxa 3669.4 (2013), pp. 469-489.

[7713] J. Fryda and J. C. Gutierrez-Marco. "An unusual new sinuitid mollusc (Bellerophontoidea, Gastropoda) from the Ordovician of Spain". In: Journal of Paleontology 70.4 (1996), pp. 602-609.

[7714] J. Frýda and D. Heidelberger. "Systematic position of Cyrtoneritimorpha within the class Gastropoda with description of two new genera from Siluro-Devonian strata of Central Europe". English. In: Bulletin of the Czech Geological Survey 78.1 (2003), pp. 35-39.

[7715] J. Frýda, D. M. Rohr, M. Robardet, and J. C. Gutiérrez-Marco. “A new Late Ordovician microdomatid gastropod genus from Seville, south west Spain, with a revision of Ordovician Mircodomatoidea". English. In: Alcheringa 25.1 (2001), pp. 117-127.

[7716] J. Frýda and D. M. Rohr. "Shell heterostrophy in Early Ordovician Macluritella Kirk 1927 and its implications for phylogeny and classification of Macluritoidea (Gastropoda)". English. In: Journal of Paleontology 80.2 (2006), pp. 264-271.

[7717] J.-F. Fu, J.-W. Wang, and Y. -S. Tong. "The new discovery of the Plesiadapiformes from the Early Eocene of Wutu Basin, Shandong Province". English. In: Vertebrata PalAsiatica 40.3 (2002), pp. 219 227.

[7718] Q.-.. M. Fu, S.-Y. Ming, and G. -Z. Peng. "A new species of Sunosuchus from Zigong, Sichuan, China". Chinese. In: Vertebrata PalAsiatica 43.1 (2005), pp. 76-83.

[7719] W. L. Fu, G. D. F. Wilson, D. Y Jiang, Y. L. Sun, W. C. Hao, and Z. Y. Sun. “A new species of Protamphisophus Nicholls (Crustacea, Isopoda, Phreatoicidea) from Middle Triassic Luoping fauna of Yunnan Province, China". English. In: Journal of Paleontology 84.5 (2010), pp. 1003-1013.

[7720] Y. Fu, O. Béthoux, Q. Yang, and D. Ren. "The earliest and most oriental Calvertiellidae unearthed (Palaeodictyoptera; Late Carboniferous; China)". English. In: Insect Systematics \& Evolution 46 (2015), pp. 485-492.

[7721] Y. Fu, Y. Z. Yao, G. X. Qiao, Y. Y. Zhao, and D. Ren. “A new species of Oviparosiphidae (Hemiptera: Aphidomorpha) from the Lower Cretaceous of China". English. In: Cretaceous Research 75 (2017), pp. 157-161.

[7722] Y. Z. Fu, D. Azar, and D. Y. Huang. "A new species of the extinct family Minlagerrontidae (Insecta: Hemiptera: Cicadomorpha) from mid-Cretaceous Burmese amber". English. In: Cretaceous Research 107.104270 (2020). DOI: 10.1016/j.cretres.2019.104270.

[7723] Y. Z. Fu, C. Y. Cai, and D. Y. Huang. "A new fossil sinoalid species from the Middle Jurassic Daohugou beds (Insecta: Hemiptera: Cercopoidea)". English. In: Alcheringa 42 (2018), pp. 94-100.

[7724] Y. Z. Fu, C. Y. Cai, and D. Y. Huang. "First hairy cicadas in mid-Cretaceous amber from northern Myanmar (Hemiptera: Cicadoidea: Tettigarctidae)". English. In: Cretaceous Research 93 (2018), pp. 285-291.

[7725] Y. Z. Fu, C. Y. Cai, and D. Y. Huang. "First Mesozoic procercopids in mid-Cretaceous amber from northern Myanmar (Hemiptera: Cercopoidea)". English. In: Geological Magazine 157 (2019), pp. 506-512. DOI: 10.1017/S0016756819001018. 
[7726] Y. Z. Fu, C. Y. Cai, and D. Y. Huang. “A new palaeontinid (Insecta, Hemiptera, Cicadomorpha) from the Upper Jurassic Tiaojishan Formation of northeastern China and its biogeographic significance". English. In: Journal of Paleontology 94 (2020), pp. 513-520. DOI: 10.1017/jpa.2019.95.

[7727] Y. Z. Fu and D. Y. Huang. "New fossil genus and species of Sinoalidae (Hemiptera: Cercopoidea) from the Middle to Upper Jurassic deposits in northeastern China". English. In: European Journal of Entomology 115 (2018), pp. 127-133.

[7728] Y. Z. Fu, D. Y. Huang, and M. S. Engel. "A new species of the extinct family Procercopidae (Hemiptera: Cercopoidea) from the Jurassic of northeastern China". English. In: Palaeoentomology 1 (2018), pp. 51-57.

[7729] Y. Z. Fu and D. Y. Huang. "New sinoalids (Insecta: Hemiptera: Cercopoidea) from Middle to Upper Jurassic strata at Daohugou, Inner Mongolia, China". English. In: Alcheringa 43 (2018), pp. 246256.

[7730] Y. Z. Fu and D. Y. Huang. “New sinoalids in mid-Cretaceous amber from northern Myanmar (Insecta: Hemiptera: Cercopoidea)". English. In: Cretaceous Research 104.104187 (2019). DOI: 10. 1016/j.cretres.2019.07.017.

[7731] Y. Z. Fu and D. Y. Huang. "Revision of the genus Jiaotouia (Hemiptera, Cercopoidea) with description of a new species from mid-Cretaceous Burmese amber". English. In: Cretaceous Research 115.104558 (2020). DOI: 10.1016/j.cretres.2020.104558.

[7732] Y. Z. Fu and D. Y. Huang. "New mimarachnids in mid-Cretaceous amber from northern Myanmar (Hemiptera, Fulgoromorpha)". English. In: Cretaceous Research 119.104682 (2020). DOI: 10.1016/j. cretres.2020.104682.

[7733] Y. Z. Fu, J. Szwedo, D. Azar, and D. Y. Huang. “A second species of Dachibangus (Hemiptera: Fulgoromorpha: Mimarachnidae) in mid-Cretaceous amber from northern Myanmar". English. In: Cretaceous Research 103.104170 (2019). DOI: 10.1016/j.cretres.2019.06.016.

[7734] D. Fuchs. "Morphology, taxonomy and diversity of vampyropod Coleoids (Cephalopoda) from the Upper Cretaceous of Lebanon". English. In: Memorie della Societá Italiana di Scienze Naturali e del Museo Civico di Storia Naturale di Milano 34.2 (2006), pp. 1-27.

[7735] D. Fuchs. "Eromangateuthis n. gen., a new genus for a late Albian gladius-bearing giant octobrachian (Cephalopoda: Coleoidea)". English. In: Paleontological Contributions 21 (2019), pp. 1-3.

[7736] D. Fuchs. "Protoconch morphology of Conoteuthis (Diplobelida, Coleoidea) and its implications on the presumed origin of the Sepiida". English. In: Cretaceous Research 34 (2012), pp. 200-207.

[7737] D. Fuchs, G. Bracchi, and R. Weis. "New octopods (Cephalopoda: Coleoidea) from the Late Cretaceous (Upper Cenomanian) of Hakel and Hadjoula, Lebanon". English. In: Palaeontology 52 (2009), pp. 65-81.

[7738] D. Fuchs, D. T. Donovan, and H. Keupp. “Taxonomic revision of Onychoteuthis conocauda Quenstedt, 1849 (Cephalopoda: Coleoidea)". English. In: Neues Jahrbuch für Geologie und Paläontologie Abhandlungen 270.3 (2013), pp. 245-255.

[7739] D. Fuchs, Y. Iba, A. Heyng, M. Iijima, C. Klug, N. L. Larson, and G. Schweigert. "The Muensterelloidea: phylogeny and character evolution of Mesozoic stem octopods". English. In: Papers in Palaeontology 6 (2019), pp. 31-92. DOI: 10.1002/spp2.1254.

[7740] D. Fuchs, Y. Iba, C. Ifrim, T. Nishimura, W. J. Kennedy, H. Keupp, W. Stinnesbeck, and K. Tanabe. "Longibelus gen. nov., a new Cretaceous coleoid genus linking Belemnoidea and early Decabranchia". English. In: Palaeontology 56 (2013), pp. 1081-1106.

[7741] D. Fuchs, C. Ifrim, and W. Stinnesbeck. "A new Palaeoctopus (Cephalopoda: Coleoidea) from the Late Cretaceous of Vallecillo, north-eastern Mexico, and implications for the evolution of Octopoda". English. In: Palaeontology 51.5 (2008), pp. 1129-1139.

[7742] D. Fuchs, H. Keupp, and T. Engeser. "New records of soft parts of Muensterella scutellaris Muenster, 1842 (Coeloidea) from the Late Jurassic plattenkalks or Eichstãtt and their significance for octobrachian relationships". English. In: Berliner Paläobio. Abh. 3 (2003), pp. 101-111. 
[7743] D. Fuchs, H. Keupp, P. Trask, and K. Tanabe. “Taxonomy, morphology and phylogeny of Late Cretaceous spirulid coleoids (Cephalopoda) from Greenland and Canada". English. In: 55 (2012), pp. 285-303.

[7744] D. Fuchs and N. Larson. "Diversity, morphology, and phylogeny of cephalopods from the Upper Cretaceous plattenkalks of Lebanon - part I: Prototeuthidina". English. In: Journal of Paleontology 85 (2011), pp. 234-249.

[7745] D. Fuchs and N. Larson. "Diversity, morphology, and phylogeny of cephalopods from the Upper Cretaceous plattenkalks of Lebanon - part II: Teudopseina". English. In: Journal of Paleontology 85 (2011), pp. 815-834.

[7746] D. Fuchs and S. Niko. “The first diplobelid Coleoid from the Late Cretaceous (Turonian) of Hokkaido (Japan)". English. In: Paleontological Journal 14 (2010), pp. 169-178.

[7747] D. Fuchs, A. Reitano, G. Insacco, and Y. Iba. "The first coleoid cephalopods from the Upper Cenomanian of Sicily (Italy) and their implications for the systematic-phylogenetic position of the Palaeololiginidae (Teudopseina)". English. In: Journal of Systematic Palaeontology 15 (2017), pp. 499_ 512.

[7748] D. Fuchs and H.-P. Schultze. "Trachyteuthis covacevichi n. sp., a Late Jurassic Palaeopacific coleoid cephalopod". English. In: Fossil Record 11.1 (2008), pp. 39-49. DOI: 10.1002/mmng.200700012.

[7749] D. Fuchs, W. Stinnesbeck, C. Ifrim, S. Giersch, J. M. P. Gutierrez, and E. Frey. “Glyphiteuthis rhinophora n. sp., a trachyteuthidid (Coleoidea, Cephalopoda) from the Cenomanian (Late Cretaceous) of Mexico". English. In: Palaeontologische Zeitschrift 84 (2010), pp. 523-532.

[7750] D. Fuchs and K. Tanabe. "Re-investigation of the shell morphology and ultrastructure of the Late Cretaceous spirulid coleoid Naefia matsumotoi". English. In: Cephalopods - Past and Present. Tokyo: Tokai University Press, 2010, pp. 195-207.

[7751] C. Fuentes Vidarte. "Primeras huellas de aves in en Weald de Soria (España). Nuevo icnogenero, Archaeornithipus y nueva icnoespecie A. meijidei [First bird tracks in the Wealden of Soria (Spain). New ichnogenus, Archaeornithipus and new ichnospecies A. meijidiei]". Spanish. In: Estudios Geológicos 52 (1996), pp. 63-75.

[7752] C. Fuentes Vidarte and M. Meijide Calvo. "Icnitas de dinosaurios teropodos en el Weald de Soria (España). Nuevo icnogenero Kalohippus [Theropod dinosaur footprints in the Wealden of Soria (Spain). New ichnogenus Kalohippus]". Spanish. In: Estudios Geológicos 54 (1998), pp. 147-152.

[7753] M. Fujikawa and T. Ishibashi. "Carboniferous and Permian ammonoids from northern Thailand". English. In: Memoirs of the Faculty of Science, Kyushu University, Series D, Earth and Planetary Science 30.3 (1999), pp. 91-110.

[7754] M. Fujikawa and C. Suzuki. "Early Permian ammonoids from the Takakurayama area, Abukuma Mountains, northeast Japan". English. In: Science Reports, Niigata University (Geology) 26 (2011), pp. 61-72.

[7755] M. Fujikawa, K. Ueno, A. Sardsud, W. Saengsrichan, Y. Kamata, and K. I. Hisada. “Early Permian ammonoids from the Kaeng Krachan Group of the Phatthalung-Hat Yai area, southern peninsular Thailand". English. In: Journal of Asian Earth Sciences 24 (2005), pp. 739-752.

[7756] K. Fujioka, H. Matsuoka, G. Kimura, A. Takeuchi, H. Matsugi, and H. Okada. "Age constraint on the obduction of ophiolitic rocks in the Yap Island, Philippine Sea, using nannofossils". English. In: Journal of the Geological Society of Japan 104 (1998), pp. 415-418.

[7757] M. Fujita, Z. Wang, Y. Azuma, M. Shibata, and Z. Dong. "First dinosaur track site from the Lower Cretaceous of Yunnan Province, China". English. In: Memoir of the Fukui Prefectural Dinosaur Museum 7 (2008), pp. 33-43.

[7758] M. J. Fujita, Y. Azuma, M. Goto, Y. Tomida, S. Hayashi, and Y. Arakawa. First ankylosaur footpritns in Japan and their significance. English. 2003.

[7759] S.-i. Fujiwara and Y. Takakuwa. "A sub-adult growth stage indicated in the degree of suture coossification in Triceratops". English. In: Bulletin of the Gunma Museum of Natural History 15 (2011), pp. 1-17. 
[7760] I. Fujiyama. "Late Triassic insects from Miné, Yamaguchi, Japan, Part 1. Odonata". English. In: Bulletin of the National Science Museum, Tokyo, Series C 17.2 (1991), pp. 49-56.

[7761] K. Fukata, A. Kameya, Y. Takakuwa, and K. Fujii. "Discovery of the teeth remains Parotodus benedeni from the Oligocene Ashiya Group in the Hikoshima Nishiyama Area, Shimonoseki City, Yamaguchi Prefecture, Southwest Japan". English. In: Bulletin of the Yamaguchi Museum 40 (2014), pp. 9-20.

[7762] A. Fukuchi and S. Suzuki. "Paleoparadoxia from the middle Miocene of Obara, Misaki-cho, Okayama Prefecture, Japan". Japanese. In: Okayama University Earth Science Reports 21.1 (2014), pp. 7-11.

[7763] Fukui Kenritsu Kyoryu Hakubutsukan. [Exhibit Guidebook of the Fukui Prefectural Dinosaur Museum]. Japanese. Katsuyama: Fukui Prefectural Dinosaur Museum, 2010, pp. 1-212.

[7764] A. J. Fuller and S. J. Godfrey. “A Late Miocene Ziphiid (Messapicetus sp.: Odontoceti: Cetacea) from the St. marys Formation of Calvert Cliffs, Maryland". English. In: Journal of Vertebrate Paleontology 27.2 (2007), pp. 535-540.

[7765] M. Fuller and R. Jenkins. "Reef corals from the Lower Cambrian of the Flinders Ranges, South Australia". English. In: Palaeontology 50.4 (2007), pp. 961-980.

[7766] G. F. Funston. "Caenagnathids of the Dinosaur Park Formation (Campanian) of Alberta, Canada: anatomy, osteohistology, taxonomy, and evolution". English. In: Vertebrate Anatomy Morphology Palaeontology 8 (2020), pp. 105-153.

[7767] G. F. Funston, T. Chinzorig, K. Tsogtbaatar, Y. Kobayashi, C. Sullivan, and P. J. Currie. “A new two-fingered dinosaur sheds light on the radiation of Oviraptorosauria". English. In: Royal Society Open Science 7.104643 (2020), 201184:1-15. DOI: 10.1098/rsos.201184.

[7768] G. F. Funston and P. J. Currie. "A new caenagnathid (Dinosauria: Oviraptorosauria) from the Horseshoe Canyon Formation of Alberta, Canada, and a reevaluation of the relationships of Caenagnathidae". English. In: Journal of Vertebrate Paleontology 36.4 (2016), e1160910:1-18. DOI: 10. 1080/02724634.2016.1160910.

[7769] G. F. Funston, W. S. Persons IV, G. J. Bradley, and P. J. Currie. "New material of the large-bodied caenagnathid Caenagnathus collinsi from the Dinosaur Park Formation of Alberta, Canada". English. In: Cretaceous Research 54.1 (2015), pp. 179-187. DOI: 10.1016/j.cretres.2014.12.002.

[7770] G. F. Funston, E. M. Silverstone, and P. J. Currie. "The first pterosaur pelvic material from the Dinosaur Park Formation (Campanian) and implications for azhdarchid locomotion". English. In: Facets (2017). DOI: 10.1139/facets-2016-0067.

[7771] T. Furey-Greig. "Late Ordovician and Early Silurian conodonts from the Uralba Beds, northern New South Wales". English. In: Alcheringa 24 (2000), pp. 83-97.

[7772] H. Furrer. "Stratigraphie und Facies der Trias/Jura-Grenzschichten in den oberostalpinen Decken Graubündens". German. PhD thesis. 1993, pp. 1-99.

[7773] F. Fürsich, Y. Pan, M. Wilmsen, and M. R. Majidifard. “Biofacies, taphonomy, and paleobiogeography of the Kamar-Mehdi Formation of east-central Iran, a Middle to Upper Jurassic shelf lagoon deposit". English. In: Facies 62.2 (2016). DOI: 10.1007/s10347-015-0452-6.

[7774] F. T. Fürsich. Primary collection data of Cassian Formation used for publication of Fürsich and Wendt (1977) (ref. 9188). English. 2005.

[7775] F. T. Fürsich, R. Berndt, T. Scheuer, and M. Gahr. “Comparative ecological analysis of Toarcian (Lower Jurassic) benthic faunas from southern France and east-central Spain". English. In: Lethaia 34 (2001), pp. 169-199.

[7776] F. T. Fürsich and M. Hautmann. "Bivalve reefs from the Upper Triassic of Iran". English. In: Annali dell'Universita di Ferrara, Museologia Scientifica e Naturalistica, Volume Speciale (2005), pp. 13-23.

[7777] F. T. Fürsich, M. Mäuser, S. Schneider, and W. Werner. “The Wattendorf Plattenkalk (Upper Kimmeridgian) - a new conservation lagerstätte from the northern Franconian Alb, southern Germany". English. In: Neues Jahrbuch für Geologie und Paläontologie, Abhandlungen 245 (2007), pp. 4558. 
[7778] F. T. Fürsich, T. J. Palmer, and K. L. Goodyear. “Growth and disintegration of bivalve-dominated patch reefs in the Upper Jurassic of southern England". English. In: Palaeontology 37.1 (1994), pp. 131-171.

[7779] F. T. Fürsich and D. K. Pandey. "Genesis and environmental significance of Upper Cretaceous shell concentrations from the Cauvery Basin, southern India". English. In: Palaeogeography, Palaeoclimatology, Palaeoecology 145.1 (1999), 119-139(21).

[7780] F. T. Fürsich, D. K. Pandey, W. Oschmann, A. K. Jaitly, and I. B. Singh. “Ecology and adaptive strategies of corals in unfavourable environments: Examples from the Middle Jurassic of the Kachchh Basin, western India". In: Neues Jahrbuch für Geologie und Paläontologie, Abhandlungen 194.2-3 (1994), pp. 269-303.

[7781] F. T. Fürsich and W. Werner. "Palaeoecology of coralline sponge-coral meadows from the Upper Jurassic of Portugal". English. In: Palaeontologische Zeitschrift 65 (1991), pp. 35-69.

[7782] F. T. Fürsich, M. Wilemsen, K. Seyed-Emami, F. Cecca, and M. R. Majidifard. “The upper Shemshak Formation (Toarcian-Aalenian) of the Eastern Alborz (Iran): Biota and palaeoenvironments during a transgressive-regressive cycle". English. In: Fazies 51 (2005), pp. 365-384. DOI: 10.1007 / s10347-005-0051-z.

[7783] V. Fursov, Y. Shirota, T. Nomiya, and K. Yamagishi. “New fossil mymarommatid species, Palaeomymar japonicum sp. nov. (Hymenoptera: Mymarommatidae), discovered in Cretaceous amber from Japan". English. In: Entomological Science 5 (2002), pp. 51-54.

[7784] M. R. Furtado, C. R. A. Candeiro, and L. P. Bergqvist. “Teeth of Abelisauridae and Carcharodontosauridae cf. (Theropoda, Dinosauria) from the Campanian- Maastrichtian Presidente Prudente Formation (southwestern São Paulo State, Brazil)". English. In: Estudios Geológicos 69.1 (2013), pp. 105-114. DOI: 10.3989/egeol.40829.170.

[7785] H. Furusawa. "New material of sirenian fossil from the upper Miocene of Numata-cho, Hokkaido, Japan". Japanese. In: Fossils 60 (1996), pp. 1-11.

[7786] H. Furusawa. "Steller's sea-cow (Hydrodamalis gigas) in the Bearing Island, Kamschatka". Japanese. In: Fossils 58 (1995), pp. 1-9.

[7787] H. Furusawa. "Evolution of the North Pacific Sirenia (Hydrodamalinae) and their paleoenvironment". English. In: Fossils 77 (2005), pp. 29-33.

[7788] H. Furusawa and M. Kimura. "Sirenian fossils (Hydrodamalis) from early Pliocene of Hombetsu and early Pleistocene of Kuromatsunai, Hokkaido". Japanese. In: Chikyu Kagaku 49 (1995), pp. 298301.

[7789] H. Furusawa and N. Kohno. "Steller's sea-cow (Sirenia: Hydrodamalis gigas) from the Middle Pleistocene Mandano Formation of the Boso Peninsula, Central Japan". Japanese. In: Fossils 56 (1994), pp. 26-32.

[7790] H. Furusawa and Numata Fossil Research Group. “Discovery and significance of the Takikawa sea cow (Hydrodamalis spissa) from Numata-cho, Uryu-gun, Hokkaido, Japan". Japanese. In: Earth Science 44.4 (1990), pp. 224-228.

[7791] H. Furusawa, H. Yokoyama, and M. Kimura. "A balaenopterid skull (Order Cetacea) from the Early Pleistocene of Kuromatsunai, Hokkaido, Japan". Japanese. In: Fossils 87 (2010), pp. 23-27.

[7792] M. Furze, A. Pienkowski, and R. Coulthard. "New cetacean R values for Arctic North America and their implications for marine-mammal-based paleoenvironmental reconstructions". English. In: Quaternary Science Reviews 91 (2014), pp. 218-241.

[7793] M. Futakami. "Coniacian collignoniceratid ammonites from Hokkaido". English. In: Journal of Kawamura Gakuen Woman's University 2 (1991), pp. 257-275.

[7794] M. Futakami. "Aptian ammonite fauna from the Yezo Group of the Urakawa area in Hokkaido, Japan". English. In: Cretaceous Research 89 (2018), pp. 224-234. 
[7795] M. Futakami. “Turonian collignoniceratid ammonites from Hokkaido - stratigraphy and paleontology of the Cretaceous in the Ishikari province, central Hokkaido, part 3". English. In: Journal of Kawamura Gakuen Woman's University 1 (1990), pp. 235-280.

[7796] M. Futakami and J. W. Haggart. "Early Albian (Early Cretaceous) douvilleiceratid ammonites from Haida Gwaii, British Columbia, Canada". English. In: Journal of Paleontology 90 (2016), pp. 4358.

[7797] M. Futakami, M. Matsukawa, P. J. Chen, Z. Y. Cao, and J. H. Chen. "Barremian ammonites from the Longzhaogou Group in eastern Heilongjiang, northeast China". English. In: Journal of the Geological Society of Japan 101 (1995), pp. 79-85.

[7798] C. Gbicki and J. Szwedo. "Kulickamia jantaris gen. et sp. n. from Baltic amber (Hemiptera: Fulgoroidea: Cixiidae)". English. In: Polskie Pismo Entomologiczne 69.2 (2000), pp. 167-173.

[7799] S. E. Gabbott. "Orthoconic cephalopods and associated fauna from the Late Ordovician Soom Shale Lagerstaette, South Africa". In: Palaeontology 42.1 (1999), pp. 123-148.

[7800] L. Gabounia, M.-A. de Lumley, A. Vekua, D. Lordkipanidze, and H. de Lumley. "Découverte d'un nouvel hominidé á Dmanissi (Transcaucasie, Géorgie)". French. In: Comptes Rendus Palevol 1.4 (2002), pp. 243-253.

[7801] L. Gabunia, A. Vekua, D. Lordkipanidze, C. C. Swisher III, R. Ferring, A. Justus, M. Nioradze, M. Tvalchrelidze, S. C. Antón, G. Bosinski, O. Jöris, M. -A. de Lumley, Givi Majsuradze, and Aleksander Mouskhelishvili. "Earliest Pleistocene hominid cranial remains from Dmanisi, Republic of Georgia: taxonomy, geological setting, and age". English. In: Science 288 (2000), pp. 1019-1025.

[7802] L. Gabunia and A. Vekua. "A Plio-Pleistocene hominid from Dmanisi, East Georgia, Caucasus". English. In: Nature 373 (1995), pp. 509-512.

[7803] L. K. Gabunia, G. Mchedlidze, V. M. Chkhikvadze, and S. G. Lucas. "Jurassic sauropod dinosaur from the Republic of Georgia". English. In: Journal of Vertebrate Paleontology 18.1 (1998), pp. 233236.

[7804] C. M. Gaetán, M. R. Buono, and L. C. Gaetano. "Prosqualodon australis (Cetacea: Odontoceti) from the Early Miocene of Patagonia, Argentina: Redescription and phylogenetic analysis". English. In: Ameghiniana 56.1 (2019), pp. 1-27. DOI: 10.5710/AMGH.21.11.2018.3208.

[7805] M. Gaetani. "Brachiopods from the type-section of the Bithynian substage (Anisian, Middle Triassic, northwestern Turkey)". English. In: Rivista Italiana di Paleontologia e Stratigrafia 122 (2016), pp. 61-76.

[7806] M. Gaetani, M. Balini, A. Nicora, M. Giorgioni, and G. Pavia. "The Himalayan connection of the Middle Triassic brachiopod fauna from Socotra (Yemen)". English. In: Bulletin of Geosciences 93 (2018), pp. 247-268.

[7807] L. C. Gaetano, C. A. Marsicano, and G. W. Roughier. "A revision of the putative Late Cretaceous triconodonts from South America". English. In: Cretaceous Research 46 (2013), pp. 90-100.

[7808] L. C. Gaetano, H. Mocke, F. Abdala, and P. J. Hancox. "Complex multicusped postcanine teeth from the Lower Triassic of South Africa". English. In: Journal of Vertebrate Paleontology 32.6 (2012), pp. 1411-1420.

[7809] L. C. Gaetano and G. W. Rougier. "First amphilestid from South America: a molariform from the Jurassic Cañadón Asfalto Formation, Patagonia, Argentina". English. In: Journal of Mammalian Evolution (2012). DOI: 10.1007/s10914-012-9194-1.

[7810] E. S. Gaffney. The postcranial morphology of Meiolania platyceps and a review of the Meiolanidae. English. Vol. 229. Bulletin of the American Museum of Natural History. 1996, pp. 1-172.

[7811] E. S. Gaffney, M. Archer, and A. White. "Warkalania, a new meiolaniid turtle from the Tertiary Riversleigh Deposits of Queensland, Australia". English. In: The Beagle, Records of The Northern Territory Museum of Arts and Sciences 9.1 (1992), pp. 35-48. 
[7812] E. S. Gaffney, S. Chatterjee, and D. K. Rudra. "Kurmademys, a new side-necked turtle (Pelomedusoides: Bothremydidae) from the Late Cretaceous of India". English. In: American Museum Novitates 3321 (2001), pp. 1-16.

[7813] E. S. Gaffney, D. de Almeida Campos, and R. Hirayama. "Cearachelys, a new side-necked turtle (Pelomedusoides: Bothremydidae) from the Early Cretaceous of Brazil". English. In: American Museum Novitates 3319 (2001), pp. 1-20.

[7814] E. S. Gaffney, D. D. Deblieux, E. L. Simons, M. R. Sánchez-Villagra, and Peter A. Meylan. “Redescription of the skull of Dacquemys Williams, 1954, a podocnemidid side-necked turtle from the Late Eocene of Egypt". English. In: American Museum Novitates 3372 (2002), pp. 1-16.

[7815] E. S. Gaffney and C. A. Forster. "Side-necked turtle lower jaws (Podocnemididae, Bothremydidae) from the Late Cretaceous Maevarano Formation of Madagascar". English. In: American Museum Novitates 3397 (2003), pp. 1-13.

[7816] E. S. Gaffney, G. E. Hooks III, and V. P. Schneider. “New material of North American side-necked turtles (Pleurodira: Bothremydidae)". English. In: American Museum Novitates 3655 (2009), pp. 126.

[7817] E. S. Gaffney and J. W. Kitching. "The morphology and relationships of Australochelys, an Early Jurassic turtle from South Africa". English. In: American Museum Novitates 3130 (1995), pp. 1-29.

[7818] E. S. Gaffney, L. Kool, D. B. Brinkman, T. H. Rich, and P. Vickers-Rich. “Otwayemys, a new cryptodiran turtle from the Early Cretaceous of Australia". English. In: American Museum Novitates 3233 (1998), pp. 1-28.

[7819] E. S. Gaffney, D. W. Krause, and I. S. Zalmout. "Kinkonychelys, a new side-necked turtle (Pelomedusoides: Bothremydidae) from the Late Cretaceous of Madagascar". English. In: American Museum Novitates 3662 (2009), pp. 1-25.

[7820] E. S. Gaffney and D. W. Krause. “Sokatra, a new side-necked turtle (Late Cretaceous, Madagascar) and the diversification of the main groups of Pelomedusoides". English. In: American Museum Novitates 3728 (2011), pp. 1-28.

[7821] E. S. Gaffney, P. A. Meylan, R. C. Wood, E. Simons, and D. De Almeida Campos. “Evolution of the side-necked turtles: the family Podocnemididae". English. In: American Museum Novitates 350 (2011), pp. 1-237.

[7822] E. S. Gaffney, T. H. Rich, P. Vickers-Rich, A. Constantine, R. Vacca, and L. Kool. “Chubutemys, a New Eucryptodiran Turtle from the Early Cretaceous of Argentina, and the Relationships of the Meiolaniidae". English. In: American Museum Novitates 3599 (2007), pp. 1-35.

[7823] E. S. Gaffney, E. Roberts, F. Sissoko, M. L. Bouaré, L. Tapanila, and M. A. O'Leary. "Acleistochelys, a New Side-Necked Turtle (Pelomedusoides: Bothremydidae) from the Paleocene of Mali". English. In: American Museum Novitates 3549 (2007), pp. 1-24.

[7824] E. S. Gaffney, A. Sahni, H. Schleich, S. D. SIngh, and R. Srivastava. "Sankuchemys, a new sidenecked turtle (Pelomedusoides: Bothremydidae) from the Late Cretaceous of India". English. In: American Museum Novitates 3405 (2003), pp. 1-10.

[7825] E. S. Gaffney, T. M. Scheyer, K. G. Johnson, J. Bocquetin, and O. A. Aguilera. "Two new species of the side necked turtle genus, Bairdemys (Pleurodira, Podocnemididae), from the Miocene of Venezuela". English. In: Palaeontologische Zeitschrift 82.2 (2008), pp. 209-229.

[7826] E. S. Gaffney, H. Tong, and P. A. Meylan. "Evolution of the side-necked turtles: The families Bothremydidae, Euraxemydidae, and Araripemydidae". English. In: Bulletin of the American Museum of Natural History 300 (2006), pp. 1-318.

[7827] E. S. Gaffney and H. Tong. "Phosphatochelys, a new side-necked turtle (Pelomedusoides: Bothremydidae) from the Paleocene of Morocco". English. In: Bulletin of the American Museum of Natural History 279 (2003), pp. 644-659.

[7828] E. S. Gaffney, H. Tong, and P. A. Meylan. "Galianemys, a new side-necked turtle (Pelomedusoides: Bothremydidae) from the Late Cretaceous of Morocco". English. In: American Museum Novitates 3379 (2002), pp. 1-20. 
[7829] E. S. Gaffney and R. C. Wood. “Bairdemys, a New Side-Necked Turtle (Pelomedusoides: Podocnemididae) from the Miocene of the Caribbean". English. In: 3359 (2002), pp. 1-28.

[7830] E. S. Gaffney and X. Ye. "Dracochelys, a new cryptodiran turtle from the Early Cretaceous of China". English. In: American Museum Novitates 3048 (1992), pp. 1-13.

[7831] C. Gagnaison. “Le site paléontologique du Grand Morier (Pont-Boutard, Indre-et-Loire, France): contexte géologique et détail biostratigraphique des formations cénozoïques à partir des assemblages de vertébrés fossiles". French. In: Geodiversitas 39.2 (2017), pp. 251-271. DOI: 10.5252 / g2017n2a5.

[7832] C. Gagnaison, J.-C. Gagnaison, and J. -P. Harmann. "Les fossiles de mammiféres miocénes de la colletion de J.-P. Hartmann conservés dans le Musée du Savignéen". English. In: Symbioses 23 (2009), pp. 1-16.

[7833] C. Gagnaison, Y. Vautier, and B. Proudhon. "Un sirénien éocène dans les Pyrénées aragonaises : contexte géologique du site de Janovas (Huesca, Aragon, Espagne)". French. In: Revue de Paléobiologie, Genève 35.2 (2016), pp. 447-457. DOI: 10.5281/zenodo.269615.

[7834] P. Y. Gagnier, A. Blieck, C. C. Emig, T. Sempere, D. Vachard, and M. Vanguestaine. "New paleontological and geological data on the Ordovician and Silurian of Bolivia". English. In: Journal of South American Earth Science 9.5/6 (1996), pp. 329-347.

[7835] M. Gagnon. "Ecological diversity and community ecology in the Fayum sequence (Egypt)". English. In: Journal of Human Evolution 32 (1997), pp. 133-160.

[7836] F. J. Gahn and T. K. Baumiller. "A bootstrap analysis for comparative taphonomy applied to Early Mississippian (Kinderhookian) crinoids from the Wassonville Cycle of Iowa". English. In: Palaios 19.1 (2004), pp. 17-38.

[7837] M. E. Gahr. "Palökologie benthischer Faunen aus dem Unter-Toarc SW-Europas". German. PhD thesis. 2002.

[7838] C. Gaillard, P. Bernier, G. Barale, J. -P. Bourseau, E. Buffetaut, R. Ezquerra, J. -C. Gall, F. de Lapparent de Broin, S. Renous, and S. Wenz. "A giant upper Jurassic turtle revealed by its trackways". English. In: Lethaia 36 (2003), pp. 315-322.

[7839] C. Gaillard, P. Hantzpergue, J. M. C. Vannier, A. -L. Margerard, and J. -M. Mazin. “Isopod trackways from the Crayssac Lagerstätte, Upper Jurassic, France". English. In: Palaeontology 48.5 (2005), pp. 947-962.

[7840] C. Gaillard, D. Néraudeau, and J. Thierry. "Tithonia oxfordiana, a new irregular echinoid associated with Jurassic seep deposits in south-east France". English. In: Palaeontology 54 (2011), pp. 735752.

[7841] C. Gaillard, M. Rio, and Y. Rolin. "Fossil chemosynthetic communities related to vents or seeps in sedimentary basins: The pseudobioherms of southeastern France compared to other world examples". English. In: Palaios 7 (1992), pp. 451-465.

[7842] S. D. Gaimari and M. B. Mostovski. "Burmapsilocephala cockerelli, a new genus and species of Asiloidea (Diptera) from Burmese amber". English. In: Bulletin of the Natural History Museum, Geology Series 56 (2000), pp. 43-45.

[7843] E. Gál. "Bird remains from Curata and Bordu Mare caves (Romania)". English. In: Archaeofauna 12 (2003), pp. 183-192.

[7844] E. Gál, J. Hr, E. Kessler, J. Kókay, L. Mészáros, and M. Vencel. “Középs -miocén smaradványok, a Mátrasz $1 \mathrm{~s}$, Rákóczi-kápolna alatti útbevágásból. I. A Mátrasz $1 \mathrm{~s} 1$. lel hely [Middle miocene fossils from the road cut below the Rákóczi chapel at Mátrasz $1 \mathrm{~s}$. I. The site Mátrasz $1 \mathrm{~s} 1]^{\prime \prime}$. other. In: Folia Historico Naturalia Musei Matraensis 23 (1999), pp. 33-78.

[7845] M. Gala and A. Lenoble. "Evidence of the former existence of an endemic macaw in Guadeloupe, Lesser Antilles". English. In: Journal of Ornithology 156 (2015), pp. 1061-1066.

[7846] A. Galacz. "Early perisphinctid ammonites from the early/late Bajocian boundary interval (Middle Jurassic) from Lokut, Hungary". English. In: Geobios 45.3 (2012), pp. 285-295. 
[7847] A. Galácz. “Nautiloid cephalopods from the Middle Eocene of Iszkaszentgyörgy, Transdanubian Hungary". English. In: Annales Universitatis Scientiarum Budapestinensis, Sectio Geologica 34 (2004), pp. $1-7$.

[7848] A. Galácz. "Bajocian (Middle Jurassic) ammonites of stratigraphical and Palaeobiogeographical importance from Mombasa, Kenya, East Africa". English. In: Geodiversitas 39.4 (2017), pp. 717727. DOI: $10.5252 / \mathrm{g} 2017 \mathrm{n} 4 \mathrm{a} 4$.

[7849] A. Galácz. "Morphoceratid ammonites from the Upper Bathonian (Middle Jurassic) of Monte Kumeta, western Sicily". English. In: Proceedings of the Geologists' Association 127 (2016), pp. 210217.

[7850] A. Galácz. "Rare and new Late Bathonian (Middle Jurassic) ammonites from Monte Kumeta, western Sicily". English. In: Neues Jahrbuch für Geologie und Paläontologie, Abhandlungen 291.3 (2019), pp. 231-252. DOI: 10.1127/njgpa/2019/0798.

[7851] A. Galácz, G. Császár, B. Géczy, and Z. Kovács. "Ammonite stratigraphy of a Toarcian (Lower Jurassic) section on Nagy-Pisznice Hill (Gerecse Mts, Hungary)". English. In: Central European Geology 53 (2010), pp. 311-342.

[7852] A. Gale. "Thoracican cirripedes (Crustacea) from the Hauterivian (Lower Cretaceous) of Hannover, northern Germany". English. In: Proceedings of the Geologists' Association 130 (2019), pp. 659672. DOI: $10.1016 /$ j.pgeola.2019.03.002.

[7853] A. Gale and L. Villier. "Mass mortality of an asteriid starfish (Forcipulatida, Asteroidea, Echinodermata) from the Late Maastrichtian (Late Cretaceous) of Morocco". English. In: Palaeontology 56.3 (2013), pp. 577-588. DOI: 10.1111/pala.12002.

[7854] A. S. Gale. "Chrispaulia, a new genus of mud star (Asteroidea, Goniopectinidae) from the Cretaceous of England". English. In: Geological Journal 40 (2005), pp. 383-397.

[7855] A. S. Gale. "Asteroidea (Echinodermata) from the Oxfordian (Late Jurassic) of Savigna, Départment du Jura, France". English. In: Swiss Journal of Palaeontology 130 (2011), pp. 69-89.

[7856] A. S. Gale. "Origin and phylogeny of the Cretaceous thoracican cirripede family Stramentidae". English. In: Journal of Systematic Palaeontology 14 (2016), pp. 653-702.

[7857] A. S. Gale. "Cirripedes (Thoracica, Crustacea) from the Cretaceous (Albian and Cenomanian) of Texas and Oklahoma, USA". English. In: Cretaceous Research 115.104556 (2020). DOI: 10.1016/j. cretres.2020.104556.

[7858] A. S. Gale. "Phylogeny of the deep-sea cirripede family Scalpellidae (Crustacea, Thoracica) based on shell capitular plate morphology". English. In: Zoological Journal of the Linnean Society 176 (2016), pp. 266-304.

[7859] A. S. Gale, P. Bengtson, and W. J. Kennedy. "Ammonites at the Cenomanian-Turonian boundary in the Sergipe basin, Brazil". English. In: Bulletin of the Geological Society of Denmark 52 (2005), pp. 167-191.

[7860] A. S. Gale, W. J. Kennedy, J. A. Burnett, M. Caron, and B. E. Kidd. "The late Albian to Early Cenomanian succession at Mount Risou near Rosans (Drome, SE France): an integrated study (ammonites, inoceramids, planktonic foraminifera, nannofossils, oxygen and carbon isotopes)". In: Cretaceous Research 17 (1996), pp. 515-606.

[7861] A. S. Gale, W. J. Kennedy, J. A. Lees, M. R. Petrizzo, and I. Walaszczyk. “An integrated study (inoceramid bivalves, ammonites, calcareous nannofossils, planktonic foraminifera, stable carbon isotopes) of the Ten Mile Creek section, Lancaster, Dallas County, north Texas, a candidate Global Boundary Stratotype Section and point for the base of the Santonian Stage". English. In: Acta Geologica Polonica 57.2 (2007), pp. 113-160.

[7862] A. S. Gale, M. J. Simms, and W. J. Kennedy. "Stratigraphy and ammonite faunas of the Cenomanian rocks of Northern Ireland, UK". English. In: Cretaceous Research 87 (2018), pp. 102-119.

[7863] A. S. Gale and A. M. Sørensen. "Origin of the balanomorph barnacles (Crustacea, Cirripedia, Thoracica): new evidence from the Late Cretaceous (Campanian) of Sweden". English. In: Journal of Systematic Palaeontology 13 (2015), pp. 791-824. 
[7864] L. Gale, C. Peybernes, B. Celarc, M. Hoevar, V. S. elih, and R. Martini. “Biotic composition and microfacies distribution of Upper Triassic". English. In: Facies 64.17 (2018). DOI: 10.1007/s10347018-0531-6.

[7865] L. Gale, R. Rettori, R. Martini, A. Kastelic, J. Praprotnik, M. Jamnik, A. Smuc, and B. Rozic. "Miliolipora species (Foraminifera, Miliolina) from the Rhaetian Dachstein Limestone of Karavanke Mts (Slovenia); palaeoecological and palaeobiogeographic implications". English. In: Revue de Micropaleontologie 55 (2012), pp. 99-112.

[7866] W. B. Gallagher. Faunal changes across the Cretaceous-Tertiary (K-T) boundary in the Atlantic coastal plain of New Jersey: restructuring the marine community after the K-T mass-extinction event. English. Vol. 356. Catastrophic Events and Mass Extinctions: Impacts and beyond. GSA Special Paper. 2002, pp. 291-301.

[7867] W. B. Gallagher. "Recent mosasaur discoveries from New Jersey and Delaware, USA: stratigraphy, taphonomy and implications for mosasaur extinction". English. In: Netherlands Journal of Geosciences 84.3 (2005), pp. 241-245.

[7868] W. B. Gallagher. "The Cretaceous/Tertiary mass extinction event in the North Atlantic coastal plain". English. In: The Mosasaur 5 (1993), pp. 75-154.

[7869] W. B. Gallagher, C. E. Campbell, J. W. Jagt, and E. W. A. Mulder. “Mosasaur (Reptilia, Squamata) material from the Cretaceous-Tertiary boundary interval in Missouri". English. In: Journal of Vertebrate Paleontology 25.2 (2005), pp. 473-475.

[7870] W. B. Gallagher and P. A. Hanczaryk. “The West Paterson Quarry: an Early Jurassic dinosaur track site in the Newark Basin of New Jersey". English. In: vol. 37. The Triassic-Jurassic Terrestrial Transition. New Mexico Museum of Natural History and Science Bulletin. Albuquerque: New Mexico Museum of Natural History and Science, 2006, pp. 238-240.

[7871] W. B. Gallagher, J. W. M. Jagt, E. W. A. Mulder, and A. S. Schulp. “A new mosasaur specimen from Maastricht (the Netherlands), with a review of the Late Cretaceous-Early Paleogene marine faunas of New Jersey and Limburg". English. In: The Mosasaur 7 (2004), pp. 47-57.

[7872] C. Gallardo, K. Shimada, and B. A. Schumacher. "A new Late Cretaceous marine vertebrate assemblage from the Lincoln Limestone Member of the Greenhorn Limestone in southeastern Colorado". English. In: Transactions of the Kansas Academy of Science 115 (2012), pp. 107-116. DOI: 10.1660/062.115.0303.

[7873] A. Galle. Rugose corals of the Acanthopyge Limestone of the Koneprusy (Middle Devonian, Barrandian, Czech Republic). 1994.

[7874] A. Galle. “Middle Devonian Rugosa from Horni Benesov (Moravia, Czech Republic)". English. In: Casopis pro mineralogii a geologii (Journal of the Czech Geological Society) 38.1-2 (1993), pp. 59-70.

[7875] A. Galle. "Spinophyllum Wedekind, 1922 (Anthozoa, Rugosa), in the Lower Givetian (Devonian) of the Bohemian Massif". English. In: Bulletin of Geosciences 82.2 (2007), pp. 133-144.

[7876] A. Galle, J. Hladil, and P. E. Isaacso. "Middle Devonian biogeography of closing south Laurussianorth Gondwana variscides: examples from the Bohemian Massif (Czech Republic), with emphasis on Horni Benesov". English. In: Palaios 10 (1995), pp. 221-239.

[7877] A. Galle and R. L. Parsley. "Epibiont relationships on hyolithids demonstrated by Ordovician trepostomes (Bryozoa) and Devonian tabulates (Anthozoa)". English. In: Bulletin of Geosciences 80.2 (2005), pp. 125-138.

[7878] J. Gallego, M. A. Gandolfo, N. R. Cúneo, and M. C. Zamaloa. "Fossil Araceae from the Upper Cretaceous of Patagonia, Argentina, with implications on the origin of free-floating aquatic aroids". English. In: Review of Palaeobotany and Palynology 211 (2014), pp. 78-86. DOI: 10.1016/j.revpalbo. 2014.08.017.

[7879] O. F. Gallego, R. G. Martins-Neto, and S. N. Nielsen. "Conchostracans and insects from the Upper Triassic of the Biobo river (Santa Juana Formation), south-central Chile". English. In: Revista Geológica de Chile 22 (2005), pp. 293-311. 
[7880] O. F. Gallego, L. O. Rébori, A. M. Zavattieri, N. Sinitshenkova, M. B. Lara, and R. G. Martins-Neto. "The most ancient Platyperlidae (Insecta, Perlida=Plecoptera) from early Late Triassic deposits in southern South America". English. In: Ameghiniana 48 (2011), pp. 447-461.

[7881] J. Gallemi, G. Lopez, R. Martinez, J. Munoz, and J. M. Pons. Albian-Cenomanian and CampanianMaastrichtian biostratigraphy of southeast Spain. 1997.

[7882] J. Gallemi, G. Lopez, R. Martinez, and J. M. Pons. “Macrofauna of the Cantera de Margas section, Olazagutia: Coniacian/Santonian boundary, Navarro-Cantabrian Basin, northern Spain". English. In: Cretaceous Research 28 (2007), pp. 5-17.

[7883] Y. Gallet, K. Leopold, J. Marcoux, and J. Besse. "New constrains on the End-Triassic (Upper NorianRhaetian) magnetostratigraphy". English. In: Earth and Planetary Science Letters 255 (2007), pp. 458470.

[7884] P. A. Gallina and S. Apestegua. "Cathartesaura anaerobica gen. et sp. nov., a new rebbachisaurid (Dinosauria, Sauropoda) from the Huincul Formation (Upper Cretaceous), Ro Negro, Argentina". English. In: Revista del Museo Argentino de Ciencias Naturales, nuevo serie 7.2 (2005), pp. 153-166.

[7885] P. A. Gallina and S. Apestegua. "Cranial anatomy and phylogenetic position of the titanosaurian sauropod Bonitasaura salgadoi". English. In: Acta Palaeontologica Polonica 56.1 (2011), pp. 45-60.

[7886] P. A. Gallina, S. Apesteguia, A. Haluza, and J. I. Canale. "A diplodocid sauropod survivor from the Early Cretaceous of South America". English. In: PLoS One 9.5 (2014), e97128. DOI: 10.1371 / journal.pone.0097128.

[7887] P. A. Gallina, S. Apestegua, J. I. Canale, and A. Haluza. “A new long-spined dinosaur from Patagonia sheds light on sauropod defense system". English. In: Scientific Reports 9 (2019), 1392:1-10. DOI: $10.1038 /$ s41598-018-37943-3.

[7888] V. Gallo, J. O. Calvo, and A. W. A. Kellner. "First record of a clupeomorph fish in the Neuquén Group (Portezuelo Formation), Upper Cretaceous of Patagonia, Argentina". English. In: Cretaceous Research 32 (2011), pp. 223-235. DOI: 10.1016/j.cretres.2010.12.006.

[7889] V. Gallo and F. De Figueiredo. "Farinichthys gigas, a new Albulid fish (Teleostei: Elopomorpha) from the Paleocene of the Pernambuco-Paraiba Basin, northeastern Brazil". English. In: Journal of Vertebrate Paleontology 22.4 (2003), pp. 747-758.

[7890] J.-P. Gallo-REynoso and A.-L. Figueroa-Carranza. “Cetacans of Isla de Guadalupe, Baja California, Mexcico". English. In: Bulletin of the Southern California Academy of Sciences 97.1 (1998), pp. 33-38.

[7891] J.-P. Gallo-Reynoso and A.-L. Figueroa-Carranza. "Occurrence of bottlenose whales in the waters of Isla Guadalupe, Mexico". English. In: Marine Mammal Science 11.4 (1995), pp. 573-575.

[7892] J. Galtier. "Coal-ball floras of the Namurian-Westphalian of Europe". In: Review of Palaeobotany and Palynology 95 (1997), pp. 51-72.

[7893] P. M. Galton. "The species of the basal hypsilophodontid dinosaur Thescelosaurus Gilmore (Ornithischia: Ornithopoda) from the Late Cretaceous of North America". In: Neues Jahrbuch für Geologie und Paläontologie, Abhandlungen 198.3 (1995), pp. 297-311.

[7894] P. M. Galton. "The prosauropod dinosaur Plateosaurus (Dimodosaurus) poligniensis (Pidancet \& Chopard, 1862) (Upper Triassic, Poligny, France)". In: Neues Jahrbuch für Geologie und Paläontologie, Abhandlungen 207.2 (1998), pp. 255-288.

[7895] P. M. Galton. “Are Spondylosoma and Staurikosaurus (Santa Maria Formation, Middle-Upper Triassic, Brazil) the oldest saurischian dinosaurs?" In: Paläontologische Zeitschrift 74.3 (2000), pp. 393423.

[7896] P. M. Galton. “The prosauropod dinosaur Plateosaurus Meyer, 1837 (Saurischia: Sauropodomorpha; Upper Triassic). II. Notes on the referred species". English. In: Revue Paléobiologie, Genéve 20.2 (2001), pp. 435-502.

[7897] P. M. Galton. "Bones of large dinosaurs (Prosauropoda and Stegosauria) from the Rhaetic Bone Bed (Upper Triassic) of Aust Cliff, southwest England". English. In: Revue de Paléobiologie, Genéve 24.1 (2005), pp. 51-74. 
[7898] P. M. Galton. Teeth of ornithischian dinosaurs (mostly Ornithopoda) from the Morrison Formation (Upper Jurassic) of the western United States. English. Horns and Beaks: Ceratopsian and Ornithopod Dinosaurs. Bloomington: Indiana University Press, 2007, pp. 17-47.

[7899] P. M. Galton. "Notes on Dinosauria and Pterodactylia from the Cretaceous of Portugal". English. In: Neues Jahrbuch für Geologie und Paläontologie Abhandlungen 194.2/3 (1994), pp. 253-267.

[7900] P. M. Galton. "Prosauropod dinosaur Sellosaurus gracilis (Upper Triassic, Germany): third sacral vertebra as either a dorsosacral or a caudosacral". English. In: Neues Jahrbuch für Geologie und Paläontologie Monatshefte 2001.11 (2001), pp. 688-704.

[7901] P. M. Galton. "Postcranial remains of stegosaurian dinosaur Dacentrurus from Upper Jurassic of France and Portugal". English. In: Geologica et Palaeontologica 25 (1991), pp. 299-327.

[7902] P. M. Galton. "Notes on the remains of archosaurian reptiles, mostly basal sauropodomorph dinosaurs, from the 1834 fissure fill (Rhaetian, Upper Triassic) at Clifton in Bristol, southwest England". English. In: Revue de Paléobiologie 26.2 (2007), pp. 505-591.

[7903] P. M. Galton. "Notes on Neocomian (Lower Cretaceous) ornithopod dinosaurs from England Hypsilophodon, Valdosaurus, Camptosaurus, Iguanodon - and referred specimens from Romania and elsewhere". English. In: Revue de Paléobiologie, Genéve 28.1 (2009), pp. 211-273.

[7904] P. M. Galton. “Earliest record of an ankylosaurian dinosaur (Ornithischia: Thyreophora): Dermal armor from Lower Kota Formation (Lower Jurassic) of India". English. In: Neues Jahrbuch für Geologie und Paläontologie Abhandlungen 291.2 (2019), pp. 205-219. DOI: 10.1127/njgpa/2019/0800.

[7905] P. M. Galton and K. Ayyasami. "Purported latest bone of a plated dinosaur (Ornithischia: Stegosauria), a dermal plate from the Maastrichtian (Upper Cretaceous) of southern India". English. In: Neues Jahrbuch für Geologie und Palöontologie Abhandlungen 285.1 (2017), pp. 91-96. DOI: 10.1127/njgpa/ $2017 / 0671$.

[7906] P. M. Galton and K. Carpenter. "The plated dinosaur Stegosaurus longispinus Gilmore, 1914 (Dinosauria: Ornithischia; Upper Jurassic, western USA), type species of Alcovasaurus n. gen." English. In: Neues Jahrbuch für Geologie und Paläontologie Abhandlungen 279.2 (2016), pp. 185-208. DOI: 10.1127/njgpa/2016/0551.

[7907] P. M. Galton and F. Knoll. “A saurischian dinosaur braincase from the Middle Jurassic (Bathonian) near Oxford, England: from the theropod Megalosaurus or the sauropod Cetiosaurus?" English. In: Geological Magazine 143.6 (2006), pp. 905-921.

[7908] P. M. Galton and A. D. Walker. "Supposed prosauropod dinosaurs from Middle Triassic of England referred to Parasuchia and Dinosauriformes". English. In: Neues Jahrbuch für Geologie und Paläontologie, Monatshefte 1996 (1996), pp. 727-738.

[7909] P. P. Gambaryan, A. O. Averianov, E. N. Maschenko, and S. V. Leshchinskiy. "Mammalian humerus from the Early Cretaceous of West Siberia". English. In: Russian Journal of Theriology 3.2 (2004), pp. 51-58.

[7910] S. Gamboa and V. M. Ortuño. "A new fossil species of the genus Coptodera Dejean, 1825 (Coleoptera: Carabidae: Lebiinae) from Baltic amber". English. In: Zootaxa 3981 (2015), pp. 592-596.

[7911] S. Gamboa and V. M. Ortuño. "A new fossil species of the genus Limodromus Motschulsky, 1850 (Coleoptera: Carabidae: Platynini) from Baltic amber with remarks on its death process". English. In: Insect Systematics \& Evolution 49 (2017), pp. 399-408.

[7912] M. Gameil. "Palaeoecological implications of Upper Cretaceous solitary corals, United Arab Emirates/Oman Borders". English. In: Revue de Paleobiologie 24.2 (2005), pp. 515-532.

[7913] M. Gameil. "Miocene corals from Wadi El Hommor, Sinai (Egypt)". English. In: Neues Jahrbuch für Geologie und Paläontologie, Abhandlungen 229.2 (2003), pp. 159-187.

[7914] J. C. Gamerro and V. D. Barreda. "New fossil record of the Lactoridaceae in southern South America: a paleobiogeographic approach". English. In: Botanical Journal of the Linnean Society 158 (2008), pp. 41-50. DOI: 10.1071/BT00023. 
[7915] G. Gand, R. Bourillot, B. Brigaud, J. S. Steyer, and J. -B. Peyrouse. “Les Reptiles et Synapsides fossiles de Bourgogne [The fossil reptiles and synapsids of Bourgogne]". French. In: vol. 12. Atlas des Reptiles de Bourgogne [Atlas of the Reptiles of Bourgogne]. Review Scientifique BourgogneNature, Hors-série, 2012, pp. 33-97.

[7916] G. Gand, R. De La Horra, B. Galán-Abellán, J. López-Gómez, J. F. Barrenechea, A. Arche, and M. I. Benito. "New ichnites from the Middle Triassic of the Iberian Ranges (Spain): paleoenvironmental and paleogeographical implications". English. In: Historical Biology 22.1-3 (2010), pp. 40-56. DOI: $10.1080 / 08912961003644096$.

[7917] G. Gand and G. Demathieu. "Les pistes dinosaurods du Trias moyen français: interprétation et réévaluation de la nomenclature [The French Middle Triassic dinosauroid trackways: interpretation and nomenclatural reevaluation]". French. In: Geobios 38 (2005), pp. 725-749.

[7918] G. Gand, G. Demathieu, and C. Montenat. "Les traces de pas d'amphibiens, de dinosaures et autres reptiles du Mesozoque français: Inventaire et interpretations [Footprints of amphibians, dinosaurs, and other reptiles from the French Mesozoic: inventory and interpretations]". English. In: Palaeovertebrata 2007.1-4 (2007), pp. 1-149.

[7919] G. Gand, G. Demathieu, M. Grancier, and J. Sciau. “Les traces dinosauroïdes du Trias supérieur français : discrimination, interprétation et comparaison [Dinosauroid footprints of the French Upper Triassic: discrimination, interpretation, and comparison]". French. In: Bulletin de la Société Géologique de France 176.1 (2005), pp. 69-79.

[7920] G. Gand, J. Garric, G. Demathieu, and P. Ellenberger. "La Palichnofaune de vertebres tetrapodes du Permien Superieur du Bassin de Lodeve (Languedoc - France)". English. In: Palaeovertebrata 29.1 (2000), pp. 1-82.

[7921] G. Gand, M. Vianey-Liaud, G. Demathieu, and J. Garric. “Deux nouvelles traces de pas de Dinosaures du Trias supérieur de la bordure cévenole (La Grand-Combe, Sud-Est de la France) [Two new dinosaur footprints from the Upper Triassic of the Cevennes border (La Grande-Combe, southeastern France)]". French. In: Geobios 33.5 (2000), pp. 599-624.

[7922] A. Gandin, F. Debrenne, and M. Debrenne. "Anatomy of the Early Cambrian La Sentinella reef complex, Serra Scoris, SW Sardinia, Italy". English. In: in J. J. Alvaro, M. Aretz, F. Boulvain, A. Munnecke, D. Vachard, E. Vennin, eds., Palaeozoic reefs and bioaccumulations: climatic and evolutionary controls. Geological Society Special Publication 275 (2007), pp. 29-50.

[7923] M. A. Gandolfo and E. Hermsen. "Ceratopetalum (Cunoniaceae) fruits of Australasian affinity from the early". English. In: Annals of Botany 119 (2017), pp. 507-516. DOI: 10.1093/aob/mcw283.

[7924] M. A. Gandolfo, E. J. Hermsen, M. C. Zamaloa, K. C. Nixon, C. C. González, P. Wilf, N. R. Cúneo, and K. R. Johnsosn. "Oldest Known Eucalyptus Macrofossils Are from South America". English. In: Plos One 6.6 (2011), e21084.

[7925] M. A. Gandolfo, K. C. Nixon, and W. L. Crepet. "Triuridaceae fossil flowers from the Upper Cretaceous of New Jersey". In: 89:1940-1957 89 (2002), pp. 1940-1957.

[7926] M. A. Gandolfo, K. C. Nixon, W. L. Crepet, and G. E. Ratcliffe. "A new fossil fern assignable to Gleicheniaceae from Late Cretaceous sediments of New Jersey". In: American Journal of Botany 84.4 (1997), pp. 483-193.

[7927] M. A. Gandolfo, M. Zamaloa, N. R. Cúneo, and A. Archangelsky. “Potamogetonaceae Fossil Fruits from the Tertiary of Patagonia, Argentina". English. In: International Journal of Plant Sciences 170.3 (2009), pp. 419-428. DOI: 10.1086/595290.

[7928] M. Gane, R. Johnson, H. Maisch, and J. P. Schein. “Redescription of the rare Late Cretaceous ammonite Chesapeakiceras nodatum, from the Chesapeake and Delaware Canal, USA". English. In: Proceedings of the Academy of Natural Sciences of Philadelphia 165 (2016), pp. 9-13.

[7929] V. G. Ganelin and S. S. Lazarev. "Revision of the Permian thin-ribbed Linoproductoids. Article 2. The Cancrinella ogonerensis Zavodowsky, 1960 Group". English. In: Paleontological Journal 34.1 (2000), pp. 40-46. 
[7930] R. A. Gangloff. "Arctic dinosaurs with emphasis on the Cretaceous record of Alaska and the Eurasian-North American connection". English. In: Lower and Middle Cretaceous Terrestrial Ecosystems, New Mexico Museum of Natural History and Science Bulletin 14 (1998), pp. 211-220.

[7931] R. A. Gangloff. "Edmontonia sp., the first record of an ankylosaur from Alaska". English. In: Journal of Vertebrate Paleontology 15.1 (1995), pp. 195-200.

[7932] R. A. Gangloff, K. C. May, and J. E. Storer. "An early Late Cretaceous dinosaur tracksite in central Yukon Territory, Canada". English. In: Ichnos 11 (2004), pp. 299-309.

[7933] T. K. Gangopadhyay and K. Halder. "Significance of the first record of nautiloid from the Upper Cretaceous Bagh Group of rocks". English. In: Current Science 70 (1996), pp. 462-465.

[7934] A. Gannier and K. L. West. "Distribution of the Rough-Toothed Dolphin (Steno bredanensis) around the Windward Islands (French Polynesia)". English. In: Pacific Science 59.1 (2005), pp. 1724.

[7935] C. Gans and R. Montero. "Two new fossil amphisbaenids (Reptilia: Squamata) from the Pleistocene of Lagoa Santa (Minas Gerais, Brazil)." English. In: Steenstrupia 24.1 (1998), pp. 9-22.

[7936] C. Gao, L. M. Chiappe, Q. Meng, J. K. O'Connor, X. Wang, X. Cheng, and J. Liu. “A new basal lineage of Early Cretaceous birds from China and its implications on the evolution of the avian tail". English. In: Palaeontology 51.4 (2008), pp. 775-791. DOI: 10.1111/j.1475-4983.2008.00793.x.

[7937] C. Gao, L. M. Chiappe, F. ZHang, D. L. Pomeroy, C. Shen, A. Chinsamy, and M. O. Walsh. "A subadult specimen of the Early Cretaceous bird Sapeornis chaoyangensis and a taxonomic reassessment of sapeornithids". English. In: Journal of Vertebrate Paleontology 32.5 (2012), pp. 11031112. DOI: $10.1080 / 02724634.2012 .693865$.

[7938] C. Gao, J. Lu, J. Liu, and Q. Ji. "New choristodera from the Lower Cretaceous Jiufotang Formation in Chaoyang area, Liaoning China". Chinese. In: Geological Review 51.6 (2005), pp. 694-697.

[7939] C.-L. Gao, E. M. Morschauser, D. J. Varricchio, J. Liu, and B. Zhao. “A second soundly sleeping dragon: new anatomical details of the Chinese troodontid Mei long with implications for phylogeny and taphonomy". English. In: PLOS ONE 7.9 (2012), e45203:1-17. DOI: 10.1371 / journal. pone.0045203.

[7940] C.-L. Gao, G. P. Wilson, Z. -X. Luo, A. M. Maga, Q. Meng, and X. Wang. “A new mammal skull from the Lower Cretaceous of China with implications for the evolution of obtuse-angled molars and 'amphilestid' eutriconodonts". English. In: Proceedings of the Royal Society of London B 277 (2010), pp. 237-246. DOI: 10.1098/rspb.2009.1014.

[7941] C.-L. Gao and J.-Y. Liu. “A new avian taxon from Lower Cretaceous Jiufotang Formation of western Liaoning". Chinese. In: Global Geology 24.4 (2005), pp. 313-316.

[7942] J. Q. Gao, G. F. Shi, C. K. Shih, and D. Ren. "Two new species of Paramesosciophilodes (Diptera, Nematocera, Mesosciophilidae) from the Middle Jurassic of China". English. In: ZooKeys 511 (2015), pp. 117-129.

[7943] J. Q. Gao, C. K. Shih, K. Kope, W. Krzemiski, and D. Ren. “New species and revisions of Pediciidae (Diptera) from the Middle Jurassic of northeastern China and Russia". English. In: Zootaxa 3963 (2015), pp. 240-249.

[7944] J. Q. Gao, C. K. Shih, and D. Ren. "New species of Limoniidae (Diptera) from Myanmar amber, Upper Cretaceous". English. In: Cretaceous Research 58 (2016), pp. 42-48.

[7945] J. Q. Gao, C. K. Shih, Y. Y. Zhao, and D. Ren. "New species of Cretolimonia and Mesotipula (Diptera: Limoniidae) from the Middle Jurassic of northeastern China". English. In: Acta Geologica Sinica 89 (2015), pp. 1789-1796.

[7946] K. Gao and Z. Cheng. "A new lizard from the Lower Cretaceous of Shandong, China". English. In: Journal of Vertebrate Paleontology 19 (1999), pp. 456-465.

[7947] K. Gao and D. Dashzeveg. "New lizards from the middle Eocene Mergen Formation, Mongolian Gobi Desert". English. In: Palaeontologische Zeitschrift 73.1/2 (1999), pp. 327-335. 
[7948] K. Gao and D. Dashzeveg. "Zephyrosauridion: a replacement name for Zephyrosaurus Gao and Dashzeveg 1999". English. In: Palaeontologische Zeitschrift 74.3 (2000), p. 467.

[7949] K. Gao and M. A. Norell. “Taxonomic composition and systematics of Late Cretaceous lizard assemblages from Ukhaa Tolgod and adjacent localities, Mongolian Gobi Desert". English. In: Bulletin of the American Museum of Natural History 249 (2000), pp. 1-118.

[7950] K.-Q. Gao and S. Chen. "A new frog (Amphibia: Anura) from the Lower Cretaceous of western Liaoning, China". English. In: Cretaceous Research 25 (2004), pp. 761-769.

[7951] K.-Q. Gao, S. E. Evans, Q. Ji, M. Norell, and S. -A. Ji. “Exceptional fossil material of a semi-aquatic reptile from China: the resolution of an enigma". English. In: Journal of Vertebrate Paleontology 20.3 (2000), pp. 417-421.

[7952] K.-Q. Gao and R. C. Fox. "A new choristodere (Reptilia: Diapsida) from the Lower Cretaceous of western Liaoning Province, CHina, and phylognetic relationships of Monjurosuchidae". English. In: Zoological Journal of the Linnean Society of London 145 (2005), pp. 427-444.

[7953] K.-Q. Gao and R. C. Fox. "New choristoderes (Reptilia: Diapsida) from the Upper Cretaceous and Palaeocene, Alberta and Saskatchewan, Canada, a phylogenetic relationships of Choristodera". English. In: Zoological Journal of the Linnean Society 124 (1998), pp. 303-353.

[7954] K.-Q. Gao and R. C. Fox. “Taxonomy and evolution of Late Cretaceous lizards (Reptilia: Squamata) from western Canada". English. In: Bulletin of the Carnegie Museum of natural History 33 (1996), pp. 1-107.

[7955] K.-Q. Gao and L.-H. Hou. "Iguanians from the Upper Cretaceous Djadochta Formation, Gobi Desert, China". English. In: Journal of Vertebrate Paleontology 15.1 (1995), pp. 57-78. DOI: 10.1080 / 02724634.1995.10011207.

[7956] K.-Q. Gao and L.-H. Hou. "Systematics and taxonomic diversity of squamates from the Upper Cretaceous Djadochta Formation, Bayan Mandahu, Gobi Desert, People's Republic of China". English. In: Canadian Journal of Earth Sciences 33 (1996), pp. 578-598.

[7957] K.-Q. Gao and D. T. Ksepka. “Osteology and taxonomic revision of Hyphalosaurus (Diapsida: Choristodera) from the Lower Cretaceous of Liaoning, China". English. In: Journal of Anatomy 212 (2008), pp. 747-768. DOI: 10.1111/j.1469-7580.2008.00907.x.

[7958] K.-Q. Gao and L. A. Nessov. "Early Cretaceous squamates from the Kyzylkum Desert, Uzbekistan". English. In: Neues Jahrbuch für Geologie und Paläontologie 207.3 (1998), pp. 289-309.

[7959] K.-Q. Gao and M. A. Norell. “Taxonomic revision of Carusia (Reptilia: Squamata) from the Late Cretaceous of the Gobi Desert and phylogenetic relationships of anguimorphan lizards". English. In: American Museum Novitates 3230 (1998), pp. 1-51.

[7960] K.-Q. Gao and N. H. Shubin. "Late Jurassic salamandroid from western Liaoning, China”. English. In: Proceedings of the National Academy of Sciences 109.15 (2012), pp. 5767-5772. DOI: 10.1073/pnas. 1009828109.

[7961] K.-Q. Gao, Z.-L. Tang, and X. -L. Wang. "A long-necked diapsid reptile from the Upper Jurassic/Lower Cretaceous of Liaoning Province, Northeastern China". English. In: Vertebrata PalAsiatica 37.1 (1999), pp. 1-8.

[7962] K.-Q. Gao and J. Chen. “A New Crown-Group Frog (Amphibia: Anura) from the Early Cretaceous of Northeastern Inner Mongolia, China". English. In: American Museum Novitates 3876 (2017), pp. 1-39.

[7963] K.-Q. Gao, R. C. Fox, C. -F. Zhou, and D. -Q. Li. “A new nonmammalian eucynodont (Synapsida: Therapsida) from the Triassic of northern Gansu Province, China, and its biostratigraphic and biogeographic implications". English. In: American Museum Novitates 3685 (2010), pp. 1-25.

[7964] K.-Q. Gao, D. T. Ksepka, L. Hou, Y. Duan, and D. Hu. "Cranial morphology of an Early Cretaceous monjurosuchid (Reptilia: Diapsida) from Liaoning Province of China and evolution of the choristoderan palate". English. In: Historical Biology 19.3 (2007), pp. 215-224. DOI: 10.1080 / 08912960601106391. 
[7965] K.-Q. Gao and Q. Li. “Osteology of Monjurosuchus splendens (Diapsida: Choristodera) based on a new specimen from the Lower Cretaceous of western Liaoning, China". English. In: Cretaceous Research 28 (2007), pp. 261-271.

[7966] K.-Q. Gao and N. H. Shubin. "Earliest known crown-group salamanders". English. In: Nature 422 (2003), pp. 424-428. DOI: 10.1038/nature01491.

[7967] K.-Q. Gao and N. H. Shubin. "Late Jurassic salamanders from northern China”. English. In: Nature 410 (2001), pp. 574-577. DOI: 10.1038/35069051.

[7968] K.-Q. Gao and Y. Wang. "Mesozoic anurans from Liaoning Province, China, and phylogenetic relationships of archaeobatrachian anuran clades". English. In: Journal of Vertebrate Paleontology 21.3 (2001), pp. 460-476.

[7969] T. P. Gao, M. S. Engel, J. Ortega-Blanco, C. K. Shih, and D. Ren. "A new xyelydid sawfly from the Early Cretaceous of China (Hymenoptera: Xyelydidae)". English. In: Journal of the Kansas Entomological Society 86 (2013), pp. 78-83.

[7970] T. P. Gao, A. P. Rasnitsyn, D. Ren, and C. K. Shih. "The first Praesiricidae (Hymenoptera) from northeast China". English. In: Annales de la Société Entomologique de France 46 (2010), pp. 148-153.

[7971] T. P. Gao and D. Ren. “Description of a new fossil Anthoxyela species (Hymenoptera, Xyelidae) from Yixian Formation of northeast China". English. In: Zootaxa 1842 (2008), pp. 56-62.

[7972] T. P. Gao, D. Ren, and C. K. Shih. “The first Xyelotomidae (Hymenoptera) from the Middle Jurassic in China". English. In: Annals of the Entomological Society of America 102 (2009), pp. 588-596.

[7973] T. P. Gao, D. Ren, and C. K. Shih. "Abrotoxyela gen. nov. (Insecta, Hymenoptera, Xyelidae) from the Middle Jurassic of Inner Mongolia, China". English. In: Zootaxa 2094 (2009), pp. 52-59.

[7974] T. P. Gao, C. K. Shih, X. Xu, S. Wang, and D. Ren. "Mid-Mesozoic flea-like ectoparasites of feathered or haired vertebrates". English. In: Current Biology 22 (2012), pp. 732-735.

[7975] T. P. Gao, C. K. Shih, A. P. Rasnitsyn, and D. Ren. "Hoplitolyda duolunica gen. et sp. nov. (Insecta, Hymenoptera, Praesiricidae), the hitherto largest sawfly from the Mesozoic of China". English. In: PLoS One 8.5 (2013), e62420.

[7976] T. P. Gao, C. K. Shih, A. P. Rasnitsyn, X. Xu, S. Wang, and D. Ren. “New transitional fleas from China highlighting diversity of Early Cretaceous ectoparasitic insects". English. In: Current Biology 23 (2013), pp. 1261-1266.

[7977] T. P. Gao, C. K. Shih, A. P. Rasnitsyn, X. Xu, S. Wang, and D. Ren. "The first flea with fully distended abdomen from the Early Cretaceous of China". English. In: BMC Evolutionary Biology 14.168 (2014), pp. 1-7.

[7978] T. P. Gao, C. K. Shih, M. S. Engel, and D. Ren. "A new xyelotomid (Hymenoptera) from the Middle Jurassic of China displaying enigmatic venational asymmetry". English. In: BMC Evolutionary Biology 16.155 (2016), pp. 1-7.

[7979] T. P. Gao, C. K. Shih, C. C. Labandeira, J. A. Santiago-Blay, Y. Z. Yao, and D. Ren. “Convergent evolution of ramified antennae in insect lineages from the Early Cretaceous of northeastern China". English. In: Proceedings of the Royal Society B 283 (2016), p. 20161448.

[7980] T. P. Gao, C. K. Shih, C. C. Labandeira, X. Liu, Z. Q. Wang, Y. L. Che, X. C. Yin, and D. Ren. "Maternal care by Early Cretaceous cockroaches". English. In: Journal of Systematic Palaeontology 17 (2018), pp. 379-391.

[7981] T. P. Gao, X. C. Yin, C. K. Shih, A. P. Rasnitsyn, X. Xu, S. Chen, C. Wang, and D. Ren. “New insects feeding on dinosaur feathers in mid-Cretaceous amber". English. In: Nature Communications 10.5424 (2019). DOI: 10.1038/s41467-019-13516-4.

[7982] T. P. Gao, Y. Y. Zhao, and D. Ren. "New fossil Xyelidae (Insecta, Hymenoptera) from the Yixian Formation of western Liaoning, China". English. In: Acta Geologica Sinica 85.3 (2011), pp. 528-532.

[7983] Y. Gao. "Yangchuanosaurus hepingensis - a new species of carnosaur from Zigong, Sichuan". Chinese. In: Vertebrata PalAsiatica 30.4 (1992), pp. 313-324. 
[7984] Y. Gao. "[A new species of Szechuanosaurus from the Middle Jurassic of Dashanpu, Zigong, Sichuan]". Chinese. In: Vertebrata PalAsiatica 31.4 (1993), pp. 308-314.

[7985] Y. Gao, Y. Z. Yao, and D. Ren. "A new Middle Jurassic caddisfly (Trichoptera, Hydrobiosidae) from China". English. In: Fossil Record 16 (2013), pp. 111-116.

[7986] Y. Gao, Y. Z. Yao, and D. Ren. "New genus and species of Rhyacophilidae (Insecta: Trichoptera) from the Middle Jurassic of China". English. In: Acta Geologica Sinica 87 (2013), pp. 1495-1500.

[7987] Y.-H. Gao. "A new species of Hsisosuchus (Mesoeucrocodylia) from Dashanpu, Zigong Municipality, Sichuan Province". Chinese. In: Vertebrata PalAsiatica 39.3 (2001), pp. 177-184.

[7988] Y.-H. Gao, Y. Ye, and S. Jiang. "A new species of Bishanopliosaurus from Middle Jurassic of Zigong, Sichuan". English. In: Vertebrata PalAsiatica 42.2 (2004), pp. 162-165.

[7989] Y. Q. Gao, G. R. Shi, and Y. Q. Peng. "A new bivalve fauna from the Permian-Triassic boundary section of southwestern China". English. In: Alcheringa 33 (2009), pp. 33-47.

[7990] Y.-H. Gao. “New dinosaur footprints from Lower Jurassic of Weiyuan, Sichuan". Chinese. In: Vertebrata PalAsiatica 45.4 (2007), pp. 342-345.

[7991] I. W. Gapp, C. R. Congreve, and B. S. Lieberman. "Unraveling the phylogenetic relationships of the Eccoptochilinae, an enigmatic array of Ordovician cheirurid trilobites". English. In: PLoS ONE 7.11 (2012), e49115. DOI: 10.1371/journal.pone.0049115.

[7992] I. W. Gapp and B. S. Lieberman. "New olenelloid trilobites from the Northwest Territories, Canada". English. In: Zootaxa 3866.4 (2014), pp. 479-498.

[7993] A. Garassino. "New decapod crustaceans from the Cenomanian (Upper Cretaceous) of Lebanon". English. In: Atti della Societá Italiana di Scienze Naturali e del Museo Civico di Storia Naturale di Milano 141.2 (2001), pp. 237-250.

[7994] A. Garassino. "The family Erymidae Van Straelen, 1924 and the superfamily Glypheoidea Zittel, 1885 in the Sinemurian of Osteno in Lombardy (Crustacea, Decapoda)". English. In: Atti della Societá Italiana di Scienze Naturali e del Museo Civico di Storia Naturale di Milano 135.2 (1996), pp. 333373.

[7995] A. Garassino. "The macruran decapod crustaceans of the Lower Cretaceous (Lower Barremian) of Las Hoyas (Cuenca, Spain)". English. In: Atti della Societá Italiana di Scienze Naturali e del Museo Civico di Storia Naturale di Milano 137.1-2 (1997), pp. 101-126.

[7996] A. Garassino, P. Artal, and G. Pasini. “Jabaloya aragonensis n. gen., n. sp. (Crustacea, Decapoda, Mecochiidae) and Cedrillosia jurassica n. gen., n. sp. (Crustacea, Decapoda, Glypheidae) from the Upper Jurassic of Teruel Province (Aragón, Spain)". English. In: Atti della Societá Italiana di Scienze Naturali e del Museo Civico di Storia Naturale di Milano 150.2 (2009), pp. 197-206.

[7997] A. Garassino, P. Artal, and G. Pasini. “Upogebia miocenica n. sp. (Crustacea, Thalassinidea, Upogebiidae) from the Miocene of Catalonia (Spain)". English. In: Atti della Societá Italiana di Scienze Naturali e del Museo Civico di Storia Naturale di Milano 150.1 (2009), pp. 61-68.

[7998] A. Garassino, P. Artal, and G. Pasini. "New records of decapod macrurans from the Cretaceous of Catalonia and the Province of Castellon (Spain)". English. In: Bulletin of the Mizunami Fossil Museum 35 (2009), pp. 87-95.

[7999] A. Garassino, P. Artal, and G. Pasini. “Jaxea nocturna Nardo, 1847 (Crustacea, Thalassinidea, Laomediidae) fm the Pliocene of Catalonia (Spain)". English. In: Atti della Societá Italiana di Scienze Naturali e del Museo Civico di Storia Naturale di Milano 150.1 (2009), pp. 69-76.

[8000] A. Garassino and S. Bravi. "Palaemon antonellae new species (Crustacea, Decapoda, Caridea) from the lower Cretaceous Platydolomite of Profeti (Caserta, Italy)". English. In: Journal of Paleontology 77.3 (2003), pp. 589-592.

[8001] A. Garassino and A. De Angeli. "Decapod crustacean fauna from the Pliocene and Pleistocene of Arda, Stirone and Enza Rivers (Piacenza, Parma and Reggio Emilia Provinces, N Italy)". English. In: Atti della Societá Italiana di Scienze Naturali e del Museo Civico di Storia Naturale di Milano 145 (2004), pp. 29-57. 
[8002] A. Garassino, A. De Angeli, and R. De Polli. "Report of Metanephrops Jenkins, 1972 (Crustacea, Decapoda, Nephropidae) from the upper Eocene of Grancona (Vicenza, N Italy)". English. In: Atti della Societá Italiana di Scienze Naturali e del Museo Civico di Storia Naturale di Milano 144.2 (2003), pp. 383-392.

[8003] A. Garassino and A. De Angeli. "Parthenope angulifrons Latreille, 1825, and Atelecyclus rotundatus (Olivi, 1782) from the Sicilian (upper Pleistocene) of Favignana Island (Egadi Islands, Sicily, S Italy)". English. In: Atti della Societá Italiana di Scienze Naturali e del Museo Civico di Storia Naturale di Milano 145.1 (2004), pp. 19-28.

[8004] A. Garassino, A. De Angeli, L. M. Gallo, and G. Pasini. “Brachyuran and anomuran fauna from the Cenozoic of Piedmont (NW Italy)". English. In: Atti della Societá Italiana di Scienze Naturali e del Museo Civico di Storia Naturale di Milano 145.2 (2004), pp. 251-281.

[8005] A. Garassino, A. De Angeli, and G. Pasini. "In situ hermit crab (Crustacea, Anomura, Paguroidea) from the Early Eocene (Ypresian) of NE Italy". English. In: Atti della Societá Italiana di Scienze Naturali e del Museo Civico di Storia Naturale di Milano 150.2 (2009), pp. 229-238.

[8006] A. Garassino, A. De Angeli, and G. Pasini. "A new hermit crab (Crustacea, Anomura, Paguroidea) from the Late Cretaceous (Cenomanian) of Lebanon". English. In: Atti della Societá Italiana di Scienze Naturali e del Museo Civico di Storia Naturale di Milano 150.2 (2009), pp. 215-228.

[8007] A. Garassino, A. De Angeli, and G. Pasini. "A new species of ghost shrimp (Decapoda, Thalassinidea, Callianassidae) from the Late Cretaceous (Cenomanian) of Agadir (W Morocco)". English. In: Atti della Societá Italiana di Scienze Naturali e del Museo Civico di Storia Naturale di Milano 152.1 (2011), pp. 45-55.

[8008] A. Garassino, A. De Angeli, G. Pasini, and F. Tangocci. "Ocypode italica n. sp. (Crustacea, Decapoda, Brachyura, Ocypodidae) from the Piacentian (middle Pliocene) of Tuscany (Central Italy)". English. In: Atti della Societá Italiana di Scienze Naturali e del Museo Civico di Storia Naturale di Milano 151.2 (2010), pp. 135-144.

[8009] A. Garassino and A. De Angeli. "Ranilia constricta (A. Milne Edwards, 1880) (Brachyura, Raninidae) from the Tyrrhenian (Upper Pleistocene) of Bovetto (Calabria, S Italy)". English. In: Atti della Societá Italiana di Scienze Naturali e del Museo Civico di Storia Naturale di Milano 149.1 (2008), pp. 916.

[8010] A. Garassino, A. De Angeli, and G. Pasini. "New decapod assemblage from the Upper Creaceous (Cenomanian-Turonian) of Gara Sbaa, southeastern Morocco". English. In: Atti della Societá Italiana di Scienze Naturali e del Museo Civico di Storia Naturale di Milano 149.1 (2008), pp. 37-67.

[8011] A. Garassino, H. Hagdorn, and M. Schulz. "A decapod crustacean assemblage from the Middle Triassic Upper Muschelkalk of GroSSenlüder (Hessen, Germany)”. English. In: Geologisches Jahrbuch Hessen 127 (1999), pp. 71-81.

[8012] A. Garassino and S. Harper. "Penaeus hamleti n. sp. and Penaeus furensis n. sp. (Crustacea: Decapoda: Penaeidae) from the Stolle Klint Clay (Paleocene) of Fur Island (Denmark)". English. In: Atti della Societá Italiana di Scienze Naturali e del Museo Civico di Storia Naturale di Milano 145.2 (2004), pp. 329-336.

[8013] A. Garassino and M. Krobicki. “Galicia marianae n. gen., n. sp. (Crustacea, Decapoda, Astacidea) from the Oxfordian (Upper Jurassic) of the Southern Polish Uplands". English. In: Bulletin of the Mizunami Fossil Museum 29 (2002), pp. 51-59.

[8014] A. Garassino, A. Osso-Morales, F. Vega, and P. Artal. "Pleuronassa timerchidouensis n. gen., n. sp. (Axiidea, Callianassidae) from the Calcaires a slumps de Taghit Fm., Late Campnan of the Moyenne Moulouya, NE Morocc". English. In: Atti della Societa Italiana di Scienze Naturali e del Museo Civico di Storia Naturale di MIlano 152.2 (2011), pp. 165-175.

[8015] A. Garassino and G. Pasini. "Studies on Permo-Trias of Madagascar 5: Ambilobeia karojoi n. gen., n. sp. (Crustacea, Decapoda) from the Lower Triassic (Olenekian) of Ambilobe region (NW Madagascar)". English. In: Atti della Societá Italiana di Scienze Naturali e del Museo Civico di Storia Naturale di Milano 143 (2002), pp. 95-104. 
[8016] A. Garassino and G. Pasini. "New report of Dardanus substriats (A. Milne-Edwards, 1861) (Anomura, Paguroidea, Diogenidae) from the Early Pliocene of Ficulle, Terni (Umbria, Central Italy)". English. In: Atti della Societa Italiana di Scienze Naturali e del Museo Civico di Storia Naturale di MIlano 151.1 (2010), pp. 113-116.

[8017] A. Garassino and G. Pasini. "In situ hermit crabs (Crustcea, Anomura, Paguroidea) from the Pliocene of Parma and Reggio Emilia (Emilia Romagna- N Italy)". English. In: Atti della Societa Italiana di Scienze Naturali e del Museo Civico di Storia Naturale di MIlano 151.1 (2010), pp. 105-116.

[8018] A. Garassino and R. Rigo. "Pseudoglyphea friulana n. sp. (Decapoda, Astacidea, Mecochiridae) from the Upper Triassic (Carnian) of Dogna (Udine, Friuli-Venezia Giulia, NE Italy)". English. In: Atti della Societá Italiana di Scienze Naturali e del Museo Civico di Storia Naturale in Milano 149.1 (2008), pp. 69-76.

[8019] A. Garassino and G. Schweigert. "Cycleryon wulfi n. sp. (Crustacea, Decapoda, Eryonidae) from the Upper Jurassic of Eichstätt (Bavaria, S Germany)". English. In: Atti della Societá Italiana di Scienze Naturali e del Museo Civico di Storia Naturale in Milano 145.2 (2004), pp. 243-250.

[8020] A. Garassino, G. Schweigert, and G. Muscio. "Acanthochirana triassica n. sp. and Antrimpos colettoi n. sp. (Decapoda: Aegeridae, Penaeidae) from the Upper Triassic (Norian) of northern Carnic Pre-Alps (Udine, northeastern Italy)". English. In: Gortania 35 (2014), pp. 11-18.

[8021] A. Garassino and G. Teruzzi. "A new decapod crustacean assemblage from the Upper Triassic of Lombardy (N. Italy)". English. In: Paleontologia Lombarda, Nuova Serie 1 (1993), pp. 1-32.

[8022] A. Garassino and G. Teruzzi. "Crangon miocenicus (Garassino \& Teruzzi, 1996) from the Lower Miocene of N Caucasus (Russia) (Crustacea, Decapoda)". English. In: Atti della Societá Italiana di Scienze Naturali e del Museo Civico di Storia Naturale in Milano 142.1 (2001), pp. 147-155.

[8023] A. Garassino and G. Teruzzi. "Studies on Permo-Trias of Madagascar. 3. The decapod crustaceans of the Ambilobe region (NW Madagascar)". English. In: Atti della Societá Italiana di Scienze Naturali e del Museo Civico di Storia Naturale in Milano 134.1 (1995), pp. 85-113.

[8024] A. Garassino, G. Teruzzi, and F. M. Dalla Vecchia. “The macuran decapod crustaceans of the Dolomia di Forni (Norian, Upper Triassic) of Carnia (Udine, NE Italy)". English. In: Atti della Societá Italiana di Scienze Naturali e del Museo Civico di Storia Naturale di Milano 136.1 (1996), pp. 15-60.

[8025] A. Garassino and G. Teruzzi. "The genera Longitergite nov. and Bannikovia nov. in the Lower Miocene of N Caucasus (Russia) (Crustacea, Decapoda)". English. In: Atti della Societá Italiana di Scienze Naturali e del Museo Civico di Storia Naturale in Milano 136.1 (1996), pp. 3-14.

[8026] C. Garbelli, L. Angiolini, S. Z. Shen, G. Crippa, D. X. Yuan, M. Bahrammanesh, S. Abbasi, and M. Birjandi. "Additional brachiopod findings from the Lopingian succession of the Ali Bashi Mountains, NW Iran". English. In: Rivista Italiana di Paleontologia e Stratigrafia 120 (2014), pp. 119-126.

[8027] F. F. Garberoglio, S. Apesteguia, T. R. Simoes, A. Palci, R. O. Gomez, R. L. Nydam, H. C. E. Larsson, M. S. Y. Lee, and M. W. Caldwell. "New skulls and skeletons of the Cretaceous legged snake Najash, and the evolution of the modern snake body plan". English. In: Science Advances 5 (2019), eaax5833:1-8. DOI: 10.1126/sciadv.aax5833.

[8028] R. M. Garberoglio and D. G. Lazo. "Post-mortem and symbiotic Sabellid and Serpulid-coral associations from the Lower Cretaceous of Argentina". English. In: Revista Brasileira de paleontologia 14.3 (2011), pp. 215-228.

[8029] R. M. Garberoglio, D. G. Lazo, and R. M. Palma. “An integrate analysis of an Hauterivian coral biostrome from the Agrio Formation, Neuquén Basin, west-central Argentina". English. In: Cretaceous Research 43 (2013), pp. 97-115.

[8030] R. Garbin, S. Bandyopadhyay, and W. G. Joyce. "A taxonomic revision of geoemydid turtles from Siwalik-age of India and Pakistan". English. In: European Journal of Taxonomy 652 (2020), pp. 1-67. DOI: $10.5852 /$ ejt.2020.652.

[8031] R. C. Garbin, M. Böhme, and W. G. Joyce. "A new testudinoid turtle from the middle to late Eocene of Vietnam". English. In: PeerJ 7 (2019), e6280:1-39. DOI: 10.7717/peerj.6280. 
[8032] E. X. M. Garca, M. Telles-Antunes, A. Cáceres-Balbino, F. Ruiz-Muñoz, and J. Civis-Llovera. “Los tiburones Lamniformes (Chondrichthyes, Galeomorphii) del Plioceno inferior de la Formación Arenas de Huelva, suroeste de la cuenca del Guadalquivir, España". Spanish. In: Revista Mexicana de Ciencias Geológicas 26.3 (2009), pp. 674-686.

[8033] G. Garcia. "Diversité des coquilles minces d'oeufs fossiles du Crétacé supérieur du sud de la France [Diversity of fossil eggshell fragments from the Upper Cretaceous of southern France]". French. In: Géobios 33.1 (2000), pp. 113-126.

[8034] G. Garcia, S. Amico, F. Fournier, E. Thouand, and X. Valentin. "A new titanosaur genus (Dinosauria, Sauropoda) from the Late Cretaceous of southern France and its paleobiogeographic implications". English. In: Bulletin de la Société géologique de France 181.3 (2010), pp. 269-277.

[8035] G. Garcia, S. Duffaud, M. Feist, B. Marandat, Y. Tambareau, J. Villatte, and B. Sigé. "La Neuve, gisement á plantes, invertébrés et vertébrés du Bégudien (Sénonien supérieur continental) du bassin d'Aix-en-Provence [La Neuve, Aix-en-Provence Basin, SE France, a new fossil site bearing plants, invertebrates and vertebrates of Begudian age (continental Late Senonian)]". French. In: Geodiversitas 22.3 (2000), pp. 325-348.

[8036] G. Garcia, M. Feist, A. Cabot, X. Valentin, and M. Vianey-Liaud. "Les oeufs de dinosaures du Crétacé supérieur du bassin de Villeveyrac-Méze (Hérault, France): description d'une nouvelle ooespéce de Prismatoolithus [New Prismatoolithus oospecies and other Upper Cretaceous dinosaur eggs from the Villeveyrac-Méze Basin (Hérault, France)]". French. In: Bulletin de la Société géologique de France 171.3 (2000), pp. 283-289.

[8037] G. Garcia, L. Marivaux, T. Pélissié, and M. Vianey-Liaud. “Earliest Laurasian sauropod eggshells". English. In: Acta Palaeontologica Polonica 51.1 (2006), pp. 99-104.

[8038] G. Garcia and X. Pereda-Suberbiola. “A new species of Struthiosaurus (Dinosauria: Ankylosauria) from the Upper Cretaceous of Villeveyrac (southern France)". English. In: Journal of Vertebrate Paleontology 23.1 (2003), pp. 156-165.

[8039] G. Garcia, M. Pincema, M. Vianey-Liaud, B. Marandat, E. Lorenz, G. Cheylan, H. Cappetta, J. Michaux, and J. Sudre. "Découverte du premier squelette presque complet de Rhabdodon priscus (Dinosauria, Ornithopoda) du Maastrichtien inférieur de Provence [Discovery of the first nearly complete skeleton of Rhabdodon priscus (Dinosauria, Ornithopoda) from the Early Maastrichtian of Provence (southern France)]". French. In: Comptes Rendus de l'Académie des Sciences á Paris, Sciences de la Terre et des Planétes 328 (1999), pp. 415-421.

[8040] G. Garcia, A. Pinton, X. Valentin, D. S. Kostopoulos, G. Merceron, L. de Bonis, and G. D. Koufos. "The earliest known crown-Testudo tortoise from the late Miocene (Vallesian, $9 \mathrm{Ma}$ ) of Greece". English. In: PLoS ONE 15.e0224783 (2020), pp. 1-15. DOI: 10.1371/journal.pone.0224783.

[8041] G. Garcia, R. Tabuce, H. Cappetta, B. Marandat, I. Bentaleb, A. Benabdallah, and M. Vianey-Liaud. "First record of dinosaur eggshells and teeth from the north-west African Maastrichtian (Morocco)". English. In: Palaeovertebrata 32.2-4 (2003), pp. 59-69.

[8042] N. Garcia and J. L. Arsuaga. "Carnivores from the Early Pleistocene hominid-bearing Trinchera Dolina 6 (Sierra de Atapuerca, Spain)". English. In: Journal of Human Evolution 37 (1999), pp. 415430.

[8043] R. Garcia, J. A. Moreno-Bedmar, T. Bover-Arnal, M. Company, R. Salas, J.-L. Latil, J. D. MartnMartn, E. Gomez-Rivas, L. G. Bulot, G. Delanoy, R. Martnez, and A. Grauges. "Lower Cretaceous (Hauterivian-Albian) ammonite biostratigraphy in the Maestrat Basin (E Spain)". English. In: Journal of Iberian Geology 40.1 (2014), pp. 99-112. DOI: 10.5209/rev_JIGE.2014.v40.n1.44090.

[8044] R. A. Garca, L. Salgado, and R. A. Coria. Primeros restos de un saurópodo en el Jurásico Superior de la Cuenca Neuquina [First remains of a sauropod in the Upper Jurassic of the Neuquén Basin]. Spanish. 2002.

[8045] R. A. Garcia and L. Salgado. "The titanosaur sauropods from the late Campanian-early Maastrichtian Allen Formation of Salitral Moreno, Rio Negro, Argentina". English. In: Acta Palaeontologica Polonica 58.2 (2013), pp. 269-284. 
[8046] F. Garca Joral, J. J. Gómez, and A. Goy. "Mass extinction and recovery of the Early Toarcian (Early Jurassic) brachiopods linked to climate change in Northern and Central Spain". English. In: Palaeogeography, Palaeoclimatology, Palaeoecology 302 (2011), pp. 367-380. DOI: 10.1016/j.palaeo.2011.01. 023.

[8047] F. Garca Joral and A. Goy. "Toarcian (Lower Jurassic) brachiopods in Asturias (northern Spain): stratigraphic distribution, critical events and palaeobiogeography". English. In: Geobios 42 (2009), pp. 255-264.

[8048] F. Garca Joral and A. Goy. “Caracterización de Choffatirhynchia nov. gen. (Brachiopoda, Rhynchonellida) en el Toarciense (Jurásico) de la Cordillera Ibérica (España)". Spanish. In: Boletn de la Real Sociedad Española de Historia Natural. Sección geológica 99 (2004), pp. 237-250.

[8049] F. Garca Joral and A. Goy. "The associations of Brachiopods from the Toarcian-Aalenian transition in the Fuentelsaz section (Iberian Range, Spain)". English. In: Geobios MS 17 (1994), pp. 223-228.

[8050] D. A. Garca López. "New information on the interatheriid Antofagastia turneri Garca-Lopez and Babot (Mammalia, Notoungulata) from Northwestern Argentina". English. In: Ameghiniana 52 (2015), pp. 286-293.

[8051] D. A. Garca López and M. J. Babot. "Notoungulate faunas of north-western Argentina: new findings of early-diverging forms from the Eocene Geste Formation". English. In: Journal of Systematic Palaeontology 13.7 (2015), pp. 557-579.

[8052] D. A. Garca López, P. E. Ortiz, C. M. Madozzo Jaen, and M. Carolina M. S. Moyano. “First record of Arctotherium (Ursidae, Tremarctinae) in northwestern Argentina and its paleobiogeographic significance". English. In: Journal of Vertebrate Paleontology 28.4 (2008), pp. 1232-1237.

[8053] D. A. Garca López and J. E. Powell. “Un nuevo Oldfieldthomasiidae (Mammalia: Notoungulata) del Paleógeno de la provincia de Salta, Argentina". Spanish. In: Ameghiniana 46.1 (2009), pp. 153164.

[8054] D. A. Garca López and J. E. Powell. "Griphotherion peiranoi, gen. et sp. nov., a new Eocene Notoungulata (Mammalia, Meridiungulata) from northwestern Argentina". English. In: Journal of Vertebrate Paleontology 31.5 (2011), pp. 1117-1130.

[8055] D. A. Garca Ramos. "Braquiópodos Pliocenos de Águilas". Spanish. In: Boletn de la Asociación Cultural Paleontológica Murciana 3 (2004), pp. 18-39.

[8056] P. Garcia-Barrera. "Rudists of Mexico: Historical Aspects and Selected Areas of Research". English. In: in F. J. Vega, T. G. Nyborg et al., eds., Studies on Mexican Paleontology, Vol. 24 of Topics in Geobiology, Springer, Dordrecht, Netherlands (2006), pp. 61-78.

[8057] P. Garca-Barrera. "Toucasia hancockensis (Hippuritacea-Requienidae) in southwestern Mexico". English. In: Revista Mexicana de Ciencias Geológicas 12.2 (1995), pp. 191-194.

[8058] P. Garcia-Barrera, J. Avendano-Gil, L. Omana, and G. Alencaster. “Antillocaprina trilobata nov. sp. and upper Cretaceous associated fauna from Chiapas, Southeast Mexico". English. In: Geobios 31.1 (1998), pp. 125-135. DOI: 10.1016/S0016-6995(98)80071-5.

[8059] D. C. Garcia-Bellido, M. E. Dies Alvarez, J. A. Gamez Vintaned, E. Linan, and R. Gozalo. “First report of Crumillospongia (Demospongea) from the Cambrian of Europe (Murero biota, Spain)". English. In: Bulletin of Geosciences 86.3 (2011), pp. 641-650.

[8060] D. C. Garca-Bellido, M. S. Y. Lee, G. D Edgecombe, J. B. Jago, J. G. Gehling, and J. R. Paterson. "A new vetulicolian from Australia and its bearing on the chordate affinities of an enigmatic Cambrian group". English. In: BMC Evolutionary Biology 14.214 (2014), pp. 1-13. DOI: 10.1186 / s12862-014-0214-z.

[8061] D. C. Garcia-Bellido and J. K. Rigby. "Devonian and Carboniferous sponges from Spain”. English. In: Journal of Paleontology 78.3 (2004), pp. 431-455.

[8062] D. C. Garca-Bellido, B. Senowbari-Daryan, and J. K. Rigby. "Cystothalamia vandegraaffi new species and other sphinctozoan sponges from the upper Carboniferous of Spain". In: Journal of Paleontology 78.6 (2004), pp. 1037-1055. 
[8063] D. Garcia-Bellido Capdevila. “The demosponge Leptomitus cf. L. lineatus, first occurrence from the Middle Cambrian of Spain (Murero Formation, Western Iberian Chain)". English. In: Geologica Acta 1.1 (2003), pp. 113-119.

[8064] D. Garcia-Bellido Capdevila and S. Conway Morris. "New fossil worms from the Lower Cambrian of the Kinzers Formation, Pennsylvania, with some comments on Burgess Shale-type preservation". In: Journal of Paleontology 73.3 (1999), pp. 394-402.

[8065] D. A. Garca-López, J. Babot, R. González, and A. Scanferla. “Cranial anatomy of an Eocene notoungulate mammal from northwestern Argentina with special reference on the ear region". English. In: Historical Biology 30.7 (2018), pp. 957-975. DOI: 10.1080/08912963.2017.1326112.

[8066] D. A. Garca-López and M. J. Babot. "A late Miocene Argyrolagidae (Mammalia, Metatheria, Bonapartheriiformes) from northwestern Argentina". English. In: Ameghiniana 52 (2015), pp. 314-323.

[8067] D. A. Garca-López, V. Deraco, and C. del Papa. "Fossil mammals of the Quebrada de los Colorados Formation (late middle Eocene) at the locality of La Poma, Salta Province, Argentina". English. In: Historical Biology (2017). DOI: 10.1080/08912963.2017.1299150.

[8068] D. A. Garca-López, V. Deraco, G. W. Rougier, C. del Papa, J. Babot, S. Bertelli, C. M. Herrera, and N. P. Giannini. "New record of Pampahippus secundus (Mammalia, Notoungulata) from the Upper Lumbrera Formation, Eocene of northwestern Argentina". English. In: Journal of Vertebrate Paleontology (2019), e1582537:1-5. DOI: 10.1080/02724634.2019.1582537.

[8069] D. A. Garca-López, J. N. Gelfo, A. Scanferla, J. Babot, A. Ferro, and L. S. Saade. “The Pre-Oligocene Diversity of Hypsodont Typotherians (Mammalia, Notoungulata) in Northwestern Argentina". English. In: Ameghiniana 57.2 (2020), pp. 117-131.

[8070] E. Garca-Ortiz and F. Pérez-Lorente. "Palaeoecological inferences about dinosaur gregarious behaviour based on the study of tracksites from La Rioja area in the Cameros Basin (Lower Cretaceous, Spain)". English. In: Journal of Iberian Geology 40.1 (2014), pp. 113-127.

[8071] E. Garca-Ortiz de Landaluce and I. Daz-Martnez. "Aportaciones de algunos yacimientos representativos la La Rioja al estudio del comportamiento de los dinosaurios [Contributions of somerepresentative localities of La Rioja to the study of dinosaur behavior]". Spanish. In: Palaeontologica Nova 8 (2008), pp. 207-219.

[8072] M. A. Garca-Villafuerte. "Selenopidae y Thomisidae (Arachnida: Araneae) en ámbar de Chiapas, México". Spanish. In: Boletn Sociedad Entomológica Aragonesa 38 (2006), pp. 209-212.

[8073] M. A. Garca-Villafuerte. "A new fossil Episinus (Araneae, Theridiidae) from Tertiary Chiapas amber, Mexico". English. In: Revista Ibérica de Aracnologa 13 (2006), pp. 121-124.

[8074] M. A. Garca-Villafuerte. "La araneofauna (Araneae) reciente y fósil de Chiapas, México". Spanish. In: Revista Mexicana de Biodiversidad 80 (2009), pp. 633-646.

[8075] M. A. Garca-Villafuerte. "Primer registro fósil de un lapsino (Araneae, Salticidae) en el ámbar de Chiapas, México". Spanish. In: Boletn de la Sociedad Geológica Mexicana 70 (2018), pp. 689-708.

[8076] M. A. Garca-Villafuerte and D. Penney. "Lyssomanes (Araneae, Salticidae) in Oligocene-Miocene Chiapas amber". English. In: The Journal of Arachnology 31 (2003), pp. 400-404.

[8077] H. J. L. Gard and R. E. Fordyce. "A fossil sea turtle (Testudines: Pan-Cheloniidae) from the upper Oligocene Pomahaka Formation, New Zealand". English. In: Alcheringa 41 (2017), pp. 134-140. DOI: $10.1080 / 03115518.2016 .1206319$.

[8078] L. Gardiner. "Stability of Late Pleistocene Reef Mollusks from San Salvador Island, Bahamas". English. In: Palaios 16 (2001), pp. 372-386.

[8079] J. D. Gardner. "New albanerpetontid amphibians from the Albian to Coniacian of Utah, USAbridging the gap". English. In: Journal of Vertebrate Paleontology 19.4 (1999), pp. 632-638.

[8080] J. D. Gardner. "The amphibian Albanerpeton arthridion and the Aptian-Albian biogeography of albanerpetonids". English. In: Palaeontology 42.3 (1999), pp. 529-544. 
[8081] J. D. Gardner. “The fossil salamander Proamphiuma cretacea Estes (Caudata; Amphiumidae) and relationships within the Amphiumidae". English. In: Journal of Vertebrate Paleontology 23.4 (2003), pp. 769-782.

[8082] J. D. Gardner. "Albanerpetontid amphibians from the Upper Cretaceous (Campanian and Maastrichtian) of North America". English. In: Geodiversitas 22.3 (2000), pp. 349-388.

[8083] J. D. Gardner. "Revision of Habrosaurus Gilmore (Caudata; Sirenidae) and relationships among sirenid salamanders". English. In: Palaeontology 46.6 (2003), pp. 1089-1122.

[8084] J. D. Gardner. "Revision of Piceoerpeton MESZOELY (Caudata: Scapherpetontidae) and description of a new species from the late Maastrichtian and ? early Paleocene of western North America". English. In: Bulletin de la Société Géologique de France 183.6 (2012), pp. 611-620.

[8085] J. D. Gardner. "An edentulous frog (Lissamphibia; Anura) from the Upper Cretaceous (Campanian) Dinosaur Park Formation of southeastern Alberta, Canada". English. In: Canadian Journal of Earth Sciences 52 (2015), pp. 569-580.

[8086] J. D. Gardner. "Comments on amphibians from the Green River Formation, with a description of a fossil tadpole". English. In: Utah Geological Survey Miscellaneous Publication 99-1 (1999), pp. 455463.

[8087] J. D. Gardner and A. O. Averianov. "Albanerpetontid amphibians from the Upper Cretaceous of Middle Asia". English. In: Acta Palaeontologica Polonica 43.3 (1998), pp. 453-467.

[8088] J. D. Gardner and D. B. Brinkman. "A new frog (Lissamphibia, Anura) from the Late Cretaceous of Alberta, Canada". English. In: All animals are interesting: a Festschrift in honour of Anthony P. Russell. Oldenburg: BIS Verlag, 2015, pp. 35-105.

[8089] J. D. Gardner and D. E. DeMar. "Mesozoic and Palaeocene lissamphibian assemblages of North America: a comprehensive review". English. In: Palaeobiodiversity and Palaeoenvironments 93 (2013), pp. 459-515.

[8090] J. D. Gardner, S. E. Evans, and D. Sigogneau-Russell. "New albanerpetontid amphibians from the Early Cretaceous of Morocco and Middle Jurassic of England". English. In: Acta Palaeontologica Polonica 48.2 (2003), pp. 301-319.

[8091] J. D. Gardner, C. M. Redman, and R. L. Cifelli. “The Hopping Dead: Late Cretaceous frogs from the middle-late Campanian (Judithian) of western North America". English. In: Fossil Imprint 72.1-2 (2016), pp. 78-107.

[8092] J. D. Gardner, A. P. Russell, and D. B. Brinkman. "Systematics and taxonomy of soft-shelled turtles (Family Trionychidae) from the Judith River Group (mid-Campanian) of North America". English. In: Canadian Journal of Earth Science 32 (1995), pp. 631-643.

[8093] R. Gardner. "Middle-Late Jurassic bivalves of the superfamily Veneoridea from New Zealand and New Caledonia". English. In: New Zealand Journal of Geology and Geophysics 48 (2005), pp. 325-376.

[8094] R. N. Gardner and H. J. Campbell. "Middle to Late Jurassic bivalves of the subfamily Astartinae from New Zealand and New Caledonia". English. In: New Zealand Journal of Geology E Geophysics 45.1 (2002), pp. 1-51.

[8095] R. N. Gardner and H. J. Campbell. "Middle to Late Jurassic bivalves of the genera Neocrassina and Trigonopis from New Zealand". English. In: New Zealand Journal of Geology E Geophysics 45.3 (2002), pp. 323-347.

[8096] R. N. Gardner and H. J. Campbell. "The bivalve genus Grammatodon from the Middle Jurassic of the Catlins district, South Otago, New Zealand". English. In: New Zealand Journal of Geology and Geophysics 40 (1997), pp. 487-498.

[8097] G. E. Gardner Jr. and R. H. Mapes. "The relationships of color patterns and habitat for Lower Triassic Ammonoids from Crittenden Springs, Elko County, Nevada". English. In: Revue de Paléobiologie 8 (2000), pp. 109-122. 
[8098] V. Garilli. “On some Neogene to Recent species related to Galeodina Monterosato, 1884, Galeodinopsis Sacco, 1895, and Massotia Bucquoy, Dautzenberg, and Dollfus, 1884 (Caenogastropoda: Rissoidae) with the description of two new Alvania species from the Mediterranean Pleistocene". English. In: The Nautilus 122.1 (2008), pp. 19-51.

[8099] V. Garilli and D. Parrinello. "Taxonomy and palaeobiogeography of the Cenozoic Euro-Mediterranean rissoid gastropod Galeodinopsis and its relationship with close genera". English. In: Acta Palaeontologica Polonica 59.2 (2014), pp. 379-406. DOI: 10.4202/app.2012.0044.

[8100] A. C. Garrido, H. Parent, and L. Brambilla. "Tithonian stratigraphy and ammonite fauna of the Vaca Muerta Formation in Malln Quemado (Neuquén Basin, Argentina), with remarks on the Andean chronostratigraphy". English. In: Volumina Jurassica XVI.1 (2018), pp. 1-26. DOI: 10.5604/ 01.3001.0012.0496.

[8101] A. C. Garrido, G. F. Turazzini, M. Bond, G. Aguirrezabala, and A. M. Forasiepi. "Estratigrafa, vertebrados fósiles y evolución tectosedimentaria de los depósitos neógenos del Bloque de San Rafael (Mioceno-Plioceno), Mendoza, Argentina". Spanish. In: Acta geológica lilloana 26.2 (2014), pp. 133-164.

[8102] E. G. Garrison, G. McFall, A. Cherinsky, and S. E. Noakes. "Discovery of a Pleistocene mysticete whale, Georgia Bight (USA)". English. In: Palaeontologia Electronica 15.3 (2012), 31A.

[8103] E. G. Garrison, G. S. Morgan, K. McGrath, C. Speller, and A. Cherkinsky. "Recent dating of extinct Atlantic gray whale fossils, (Eschrichtius robustus), Georgia Bight and Florida, western Atlantic Ocean". English. In: PeerJ 7.e6381 (2019), pp. 1-22. DOI: 10.7717/peerj.6381.

[8104] J. R. Garrison Jr., D. B. Brinkman, D. J. Nichols, P. Layer, D. L. Burge, and D. Thayn. “A multidisciplinary study of the Lower Cretaceous Cedar Mountain Formation, Mussentuchit Wash, Utah: a determination of the paleoenvironment and paleoecology of the Eolambia caroljonesa dinosaur quarry". English. In: Cretaceous Research 28 (2007), pp. 461-494.

[8105] R. Garrouste, D. Azar, and A. Nel. "The oldest accurate record of Scenopinidae in the Lowermost Eocene amber of France (Diptera: Brachycera)". English. In: Zootaxa 4093 (2016), pp. 444-450.

[8106] R. Garrouste, G. Clemente, P. Nel, M. S. Engel, P. Grandcolas, C. D’Haese, L. Lagebro, J. Denayer, P. Gueriau, P. Lafaite, S. Olive, C. Prestianni, and A. Nel. "A complete insect from the Late Devonian period". English. In: Nature 488 (2012), pp. 82-85.

[8107] R. Garrouste, S. Hugel, L. Jacquelin, P. Rostan, J. S. Steyer, L. Desutter-Grandcolas, and A. Nel. "Insect mimicry of plants dates back to the Permian". English. In: Nature Communications 7.13735 (2016), pp. 1-6.

[8108] R. Garrouste, J. Lapeyrie, J. S. Steyer, S. Giner, and A. Nel. "Insects in the Red Middle Permian of southern France: first Protanisoptera (Odonatoptera) and new Caloneurodea (Panorthoptera), with biostratigraphical implications". English. In: Historical Biology 30 (2017), pp. 546-553.

[8109] R. Garrouste, A. Nel, and G. Gand. "New fossil arthropods (Notostraca and Insecta: Syntonopterida) in the Continental Middle Permian of Provence (Bas-Argens Basin, France)". English. In: Comptes Rendus Palevol 8 (2009), pp. 49-57.

[8110] R. Garrouste and A. Nel. "First semi-aquatic bugs Mesoveliidae and Hebridae (Hemiptera: Heteroptera: Gerromorpha) in Miocene Dominican amber". English. In: Insect Systematics $\mathcal{E}$ Evolution 41 (2010), pp. 93-102.

[8111] R. Garrouste and A. Nel. "New Eocene damselflies and first Cenozoic damsel-dragonfly of the isophlebiopteran lineage (Insecta: Odonata)". English. In: Zootaxa 4028 (2015), pp. 354-366.

[8112] R. Garrouste and A. Nel. "Alaskan Palaeogene insects: a challenge for a better knowledge of the Beringian 'route' (Odonata: Aeshnidae, Dysagrionidae)". English. In: Journal of Systematic Palaeontology 17 (2019), pp. 1939-1946. DOI: 10.1080/14772019.2019.1572235.

[8113] R. Garrouste, J. M. Pouillon, and A. Nel. "The first Cenozoic roproniid wasp from the Paleocene of Menat, France (Hymenoptera: Proctotrupoidea)". English. In: European Journal of Taxonomy 239 (2016), pp. 1-9. 
[8114] R. Garrouste, T. Schubnel, D. Y. Huang, D. Azar, C. Y. Cai, and A. Nel. “Sexual conflict during Mesozoic: the first Cretaceous damsel bug in Burmese amber (Hemiptera: Heteroptera: Nabidae)". English. In: Cretaceous Research 108.104344 (2019). DOI: 10.1016/j.cretres.2019.104344.

[8115] R. Garrouste, S. Wedmann, J. M. Pouillon, and A. Nel. “The oldest 'amphipterygid' damselfly of tropical affinities in the Paleocene of Menat (Zygoptera: Eucaloptera)". English. In: Historical Biology 29 (2016), pp. 818-821.

[8116] J. Garvey. “Economic anatomy of the Bennett's wallaby (Macropus rufogriseus): Implications for understanding human hunting strategies in late Pleistocene Tasmania". English. In: Quaternary International 211 (2010), pp. 144-156. DOI: 10.1016/j.quaint.2009.07.006.

[8117] J. M. Garvey and S. T. Hasiotis. "An ichnofossil assemblage from the Lower Carboniferous Snowy Plains Formation, Mansfield Basin, Australia". English. In: Palaeogeography, Palaeoclimatology, Palaeoecology 258.4 (2008), pp. 257-276.

[8118] C. L. Garvie. “The Molluscan Macrofauna of the Seguin Formation (Upper Paleocene) in Central Texas". English. In: Bulletins of American Paleontology 384 (2013), pp. 1-96.

[8119] C. L. Garvie. "New Eocene Mollusca from the Collections of the Texas Natural Science Center". English. In: Bulletins of American Paleontology 386 (2013), pp. 163-177.

[8120] R. Garwood, A. Ross, D. Sotty, D. Chabard, S. Charbonnier, M. Sutton, and P. J. Withers. "Tomographic reconstruction of neopterous Carboniferous insect nymphs". English. In: PLoS One 7.9 (2012), e45779.

[8121] R. J. Garwood, J. A. Dunlop, G. Giribet, and M. D. Sutton. “Anatomically modern Carboniferous harvestmen demonstrate early cladogenesis and stasis in Opiliones". English. In: Nature Communications 2.444 (2011), pp. 1-7.

[8122] R. J. Garwood, J. A. Dunlop, P. A. Selden, A. R. T. Spencer, R. C. Atwood, N. T. Vo, and M. Drakopoulos. "Almost a spider: a 305-million-year-old fossil arachnid and spider origins". English. In: Proceedings of the Royal Society B 283 (2016), p. 2016125.

[8123] R. J. Garwood, P. P. Sharma, J. A. Dunlop, and G. Giribet. "A Paleozoic stem group to mite harvestmen revealed through integration of phylogenetics and development". English. In: Current Biology 24 (2014), pp. 1017-1023.

[8124] E. Garzanti, L. Angiolini, H. Brunton, D. Sciunnach, and M. Balini. “The Bashkirian Fenestella Shales and the Moscovian Chaetetid Shales of the Tethys Himalaya (South Tibet, Nepal and India)". English. In: Journal of Asian Earth Sciences 16 (1998), pp. 119-141.

[8125] E. Garzanti, A. Nicora, and A. Tintori. "Triassic stratigraphy and sedimentary evolution of the Annapurna Tethys Himalaya (Manang area, central Nepal)". English. In: Rivista Italiana di Paleontologia e Stratigrafia 100.2 (1994), pp. 195-226.

[8126] J. M. Gasca, J. I. Canudo, and M. Moreno-Azanza. Restos de dinosaurios de la Formación El Castellar en Miravete de la Sierrra (Cretácico Inferior, Teruel, España) [Dinosaur remains from the El Castellar Formation at Miravete de la Sierra (Lower Cretaceous, Teruel, Spain)]. Spanish. 2007.

[8127] J. M. Gasca, J. I. Canudo, and M. Moreno-Azanza. Revisión de morfotipos dentales de los iguanodontoideos del Cretácico Inferior de Teruel [Revision of dental morphotypes of the iguanodontoids from the Lower Cretaceous of Teruel]. English. 2008.

[8128] J. M. Gasca, J. I. Canudo, and M. Moreno-Azanza. “A large-bodied theropod (Tetanurae: Carcharodontosauria) from the Mirambel Formation (Barremian) of Spain". English. In: Neues Jahrbuch für Geologie und Paläontologie, Abhandlungen 273.1 (2014), pp. 13-23. DOI: 10.1127 / 0077-7749 / 2014/ 0413.

[8129] J. M. Gasca, J. I. Canudo, and M. Moreno-Azanza. "On the diversity of Iberian iguanodont dinosaurs: New fossils from the lower Barremian, Teruel province, Spain". English. In: Cretaceous Research 50 (2014), pp. 264-272. 
[8130] J. M. Gasca, M. Moreno-Azanza, and J. I. Canudo. “Dientes de dinosaurios teropódos espinosáuridos de la Formación El Castellar (Cretácico Inferior, Teruel) [Teeth of spinosaurid theropod dinosaurs from the El Castellar Formation (Lower Cretaceous, Teruel)]". Spanish. In: Palaeontologica Nova 8 (2008), pp. 233-234.

[8131] F. Gascó, A. Cobos, R. Royo-Torres, L. Mampel, and L. Alcalá. “Theropod teeth diversity from the Villar del Arzobispo Formation (Tithonian-Berriasian) at Riodeva (Teruel, Spain)". English. In: Palaeobiodiversity and Palaeoenvironments (2012). DOI: 10.1007/s12549-012-0079-3.

[8132] G. Gascón-Romero, F. J. Aranda-Manteca, and L. G. Barnes. “Nueva evidencia de la evolucion de las ballenas barbadas en Baja California". Spanish. In: Revista de Investigacion Cientifica de la Universidad Autonoma de Baja California Sur 2 (1994), pp. 1-9.

[8133] D. Gaspard. "Brachiopods from the Barremian turbiditic formations of Serre de Bleyton, Drome (SE France)". English. In: Annalen des Naturhistorischen Museums in Wien, Serie A 113 (2011), pp. 655673.

[8134] G. M. Gasparini. "Records and Stratigraphical Ranges of South American Tayassuidae (Mammalia, Artiodactyla)". English. In: Journal of Mammalian Evolution 20.1 (2013), pp. 57-68. DOI: 10. 1007/s10914-011-9172-z.

[8135] G. M. Gasparini and B. S. Ferrero. "The Tayassuidae (Mammalia, Artiodactyla) from the Quaternary of Entre Rios Province. A paleofaunal review in Argentina". English. In: Neues Jahrbuch fur Geologie und Palaontologie - Abhandlungen 256.2 (2010), pp. 151-160. DOI: 10.1127/0077-7749/2010/ 0040.

[8136] G. M. Gasparini, B. S. Ferrero, R. I. Vezzosi, and E. Brunetto. "El registro de Tayassu pecari (Link, 1795) (Artiodactyla, Tayassuidae) en el Pleistoceno Tardo de la provincia de Santa Fe, Argentina. Aspectos biogeográ cos y de distribución de una especie en retracción". Spanish. In: Revista Mexicana de Ciencias Geológicas 28.2 (2011), pp. 203-211.

[8137] G. M. Gasparini, E. Soibelzon, A. E. Zurita, and A. R. Miño-Boilini. “A review of the Quaternary Tayassuidae (Mammalia, Artiodactyla) from the Tarija valley, Bolivia". English. In: Alcheringa 34.1 (2010), pp. 7-20.

[8138] G. M. Gasparini and M. Ubilla. "Platygonus sp. (Mammalia: Tayassuidae) in Uruguay (Raigón? formation; Pliocene - early Pleistocene), comments about its distribution and paleoenvironmental significance in South America". English. In: Journal of Natural History 45.45-46 (2011), pp. 28552870. DOI: $10.1080 / 00222933.2011 .620716$.

[8139] G. M. Gasparini, L. Kerber, and E. V. Oliveira. "Catagonus stenographers (LUND in REINHARDT, 1880) (mammalia, Tayassuidae) in the Touro Passo formation (Late Pleistocene), Rio Grande do Sul, Brazil. Taxonomic and palaeoenvironmental comments". English. In: Neues Jahrbuch fur Geologie und Palaontologie - Abhandlungen 254.3 (2009), pp. 261-273.

[8140] G.nM. Gasparini, M. De los Reyes, A. Francia, C. S. Scherer, and D. G. Poiré. "The oldest record of Hemiauchenia Gervais and Ameghino (Mammalia, Cetartiodactyla) in South America: Comments about its paleobiogeographic and stratigraphic implications". English. In: Geobios 50 (2017), pp. 141-153. DOI: 10.1016/j.geobios.2016.12.003.

[8141] Z. Gasparini. "A new Oxfordian pliosaurid (Plesiosauria, Pliosauridae) in the Caribbean Seaway". English. In: Palaeontology 52.3 (2009), pp. 661-669. DOI: 10.1111/j.1475-4983.2009.00871.x.

[8142] Z. Gasparini. "A new pliosaur from the Bajocian of the Neuquen Basin, Argentina". English. In: Palaeontology 40.1 (1997), pp. 135-147.

[8143] Z. Gasparini, N. Bardet, J. E. Martin, and M. Fernandez. "The elasmosaurid plesiosaur Aristonectes Cabrera from the latest Cretaceous of South America and Antarctica". English. In: Journal of Vertebrate Paleontology 23.1 (2003), pp. 104-115.

[8144] Z. Gasparini, N. Bardet, and M. Iturralde-Vinent. "A new cryptoclidid plesiosaur from the Oxofrdian (Late Jurassic) of Cuba". English. In: Geobios 35 (2002), pp. 201-211.

[8145] Z. Gasparini, S. Casadio, M. Fernandez, and L. Salgado. "Marine reptiles from the Late Cretaceous of northern Patagonia". English. In: Journal of South American Earth Sciences 14 (2001), pp. 51-60. 
[8146] Z. Gasparini, L. M. Chiappe, and M. Fernandez. “A new Senonian peirosaurid (Crocodylomorpha) from Argentina and a synopsis of the South American Cretaceous crocodilians". English. In: Journal of Vertebrate Paleontology 11.3 (1991), pp. 316-333.

[8147] Z. Gasparini, M. Cichowolski, and D. G. Lazo. "First record of Metriorhynchus (Reptilia: Crocodyliformes) in the Bathonian (Middle Jurassic) of the Eastern Pacific". English. In: Journal of Paleontology 79.4 (2005), pp. 801-805.

[8148] Z. Gasparini and M. de la Fuente. "Tortugas y plesiosaurios de la Formacion la Colonia (Cretacico Superior) de Patagonia, Argentina". Spanish. In: Revista Espanola de Paleontologia 15.1 (2000), pp. 23 35.

[8149] Z. Gasparini, M. Fernandez, and M. de la Fuente. "A new pterosaur from the Jurassic of Cuba". English. In: Palaeontology 47 (2004), pp. 919-927.

[8150] Z. Gasparini, M. Fernandez, and J. Powell. "New Tertiary sebecosuchians (Crocodylomorpha) from South America: phylogenetic implications". English. In: Historical Biology 7.1 (1993), pp. 120.

[8151] Z. Gasparini and M. Fernandez. "Jurassic marine reptiles of the Neuquen Basin: records, faunas, and their palaeobiogeographic significance". English. In: vol. 252. The Neuquen Basin, Argentina: A Case Study in Sequence Stratigraphy and Basin Dynamics; Geological Society, London, Special Publications. London: The Geological Society of London, 2005, pp. 279-294.

[8152] Z. Gasparini and N. Fernandez. "Tithonian marine reptiles of the Eastern Pacific". English. In: Ancient Marine Reptiles. Academic Press, 1997, pp. 435-450.

[8153] Z. Gasparini and M. Iturralde-Vinent. "Metriorhynchid crcodiles (Crocodyliformes) from the Oxfordian of Western Cuba". English. In: Neues Jahrbuch für Geologie und Paläontologie Monatshefte 9 (2001), pp. 534-542.

[8154] Z. Gasparini and J. P. O'Gorman. "A new species of Pliosaurus (Sauropterygia, Plesiosauria) from the Upper Jurassic of northwestern Patagonia, Argentina". English. In: Ameghiniana (2014). DOI: 10.5710/AMGH.03.04.2014.2225.

[8155] Z. Gasparini, A. Paulina-Carabajal, and G. Chong. "Un nuevo espécimen de cocodrilo marino del Jurásico Medio del norte de Chile: revalidación de Metriorhynchus westermanni (Crocodyliformes: Metriorhynchidae)". Spanish. In: Revista Geologica de Chile 35.2 (2008), pp. 335-346.

[8156] Z. Gasparini, D. Pol, and L. A. Spalletti. "An unusual marine crocodyliform from the JurassicCretaceous boundary of Patagonia". English. In: Science 311 (2006), pp. 70-73.

[8157] Z. Gasparini, L. Salgado, and S. Casadio. "Maastrichtian plesiosaurs from northern Patagonia". English. In: Cretaceous Research 240 (2003), pp. 157-170.

[8158] Z. Gasparini, L. Salgado, and A. Parras. "Late Cretaceous plesiosaurs from northern Patagonia, Argentina". English. In: Geological Journal 42 (2007), pp. 185-202.

[8159] Z. Gasparini and L. Spaletti. "First Callovian plesiosaurs from the Neuquen Basin, Argentina". English. In: Ameghiniana 30.3 (1993), pp. 245-254.

[8160] Z. Gasparini, J. Sterli, A. Parras, J. P. O’Gorman, L. Salgado, J. Varela, and D. Pol. “Late Cretaceous reptilian biota of the La Colonia Formation, central Patagonia, Argentina: occurrences, preservation and paleoenvironments". English. In: Cretaceous Research 54 (2015), pp. 154-168.

[8161] Z. Gasparini, P. Vignaud, and G. Chong. "The Jurassic Thalattosuchia (Crocodyliformes) of Chile: a paleobiogeographic approach". English. In: Le Bulletin de la Société géologique de France 171.6 (2000), pp. 657-664.

[8162] J. M. Gasulla, F. Escaso, F. Ortega, and J. L. Sanz. "New hadrosauriform cranial remains from the Arcillas de Morella Formation (lower Aptian) of Morella, Spain". English. In: Cretaceous Research 47.1 (2014), pp. 19-24. DOI: 10.1016/j.cretres.2013.10.004.

[8163] J. M. Gasulla, F. Escaso, I. Narváez, F. Ortega, and J. L. Sanz. “A new sail-backed styracosternan (Dinosauria: Ornithopoda) from the Early Cretaceous of Morella, Spain". English. In: PLoS One 10.12 (2015), e0144167. DOI: 10.1371/journal.pone.0144167. 
[8164] J. M. Gasulla, F. Ortega, X. Pereda Suberbiola, F. Escaso, and J. L. Sanz. “Elementos de la armadura dérmica del dinosaurio anquilosaurio Polacanthus Owen, 1865, en el Cretácico Inferior de Morella (Castellón, España) [Dermal armor elements of the ankylosaurian dinosaur Polacanthus Owen, 1865, in the Lower Cretaceous of Morella (Castellón, Spain)]". Spanish. In: Ameghiniana 48.4 (2011), pp. 508-519.

[8165] J. M. Gasulla, F. Ortega, F. Escaso, and A. Pérez-Garca. "Los yacimientos de vertebrados de la Formación Arcillas de Morella (Aptiense inferior) [The vertebrate localities of the Arcillas Formation of Morella (lower Aptian)]". Spanish. In: Viajando a Mundos Pretéritos. Morella: Ayunamiento de Morella, 2011, pp. 157-171.

[8166] T. A. Gates and A. A. Farke. "Biostratigraphic and biogeographic implications of a hadrosaurid (Ornithopoda: Dinosauria) from the Upper Cretaceous Almond Formation of Wyoming, USA". English. In: Cretaceous Research 30 (2009), pp. 1157-1163. DOI: 10.1016/j.cretres.2009.05.001.

[8167] T. A. Gates, J. R. Horner, R. R. Hanna, and C. R. Nelson. “New unadorned hadrosaurine hadrosaurid (Dinosauria, Ornithopoda) from the Campanian of North America". English. In: Journal of Vertebrate Paleontology 31.4 (2011), pp. 798-811. DOI: 10.1080/02724634.2011.577854.

[8168] T. A. Gates and S. D. Sampson. "A new species of Gryposaurus (Dinosauria: Hadrosauridae) from the late Campanian Kaiparowits Formation, southern Utah, USA". English. In: Zoological Journal of the Linnean Society 151 (2007), pp. 351-376.

[8169] T. A. Gates, S. D. Sampson, C. R. Delgado de Jesús, L. E. Zanno, D. A. Eberth, E. HernándezRivera, M. C. Aguillón Martnez, and J. I. Kirkland. "Velafrons coahuilensis, a new lambeosaurine hadrosaurid (Dinosauria: Ornithopoda) from the late Campanian Cerro del Pueblo Formation, Coahuila, Mexico". English. In: Journal of Vertebrate Paleontology 27.4 (2007), pp. 917-930.

[8170] T. A. Gates and R. Scheetz. "A new saurolophine hadrosaurid (Dinosauria: Ornithopoda) from the Campanian of Utah, North America". English. In: Journal of Systematic Palaeontology (2014).

[8171] M. Gatt. "A new late Oligocene to early Miocene species of Apatopygus (Echinoidea: Cassiduloida) from the Maltese Islands". English. In: Alcheringa 29.1 (2005), pp. 101-112.

[8172] M. Gatt and A. de Angeli. "A new coral-associated decapod assemblage from the Upper Miocene (Messinian) Upper Coralline Limestone of Malta (central Mediterranean)". English. In: Palaeontology 53.6 (2010), pp. 1315-1348.

[8173] R. Gatto and S. Monari. "Pliensbachian gastropods from Venetian Southern Alps (Italy) and their palaeobiogeographical significance". English. In: Palaeontology 53.4 (2010), pp. 771-802.

[8174] J. Gaudant. "Paléobiodiversité et paléoenvironnements: l'exemple des gisements de poissons téléostéens du Messinien préévaporitique d'Oran et du bassin du Chélif (Algérie)". French. In: Geodiversitas 30.1 (2008), pp. 141-163.

[8175] J. Gaudant. “Amnissos: un gisement clé pour la connaissance de l'ichthyofaune du Pliocéne supérieur de Créte". French. In: Annalen des Naturhistorischen Museums in Wien. Serie A für Mineralogie und 102 (2001), pp. 131-187.

[8176] J. Gaudant. "Additions á l'ichthyofaune tortonienne du bassin de Ierapetra (Créte orientale, Gréce)". French. In: Annales Naturhistorisches Museum Wien 105 (2004), pp. 257-285.

[8177] J. Gaudant. "Fish mass mortality in the Upper Miocene laminated gypsum of western Crete (Hania Province, Greece)". English. In: Palaeodiversity 7 (2014), pp. 39-45.

[8178] J. Gaudant. "L'ichthyofaune messinienne du bassin de Sorbas (Almera, Espagne) et ses rapports avec l'en- vironnement sédimentaire". Spanish. In: Revista Española de Paleontologa 23.2 (2008), pp. 211-223.

[8179] J. Gaudant, J.-P. Caulet, I. Di Geronimo, A. Di Stefano, E. Fourtanier, M. Romero, and M.-T. VenecPeyre. "Analyse séquentielle d'un nouveau gisement de poissons fossiles". English. In: Géologie Méditerranéenne 23.2 (1996), pp. 117-153. DOI: 10.3406/geolm.1996.1586.

[8180] J. Gaudant, V. Codrea, P. Dica, and E. Gheerbrant. "Presence du genre Cyclurus AGASSIZ (Poisson actinopterygien, Amiidae) dans le Paleocene superieur de Jibou (Transylvanie, Roumanie)". French. In: Neues Jahrbuch für Geologie und Paläontologie - Monatshefte 10 (2005), pp. 631-640. 
[8181] J. Gaudant and M.-D. Courme. “A new Pliocene marine fish fauna from north-western Cyprus, with a micropalaeontological account". English. In: Neues Jahrbuch für Geologie und Paläontologie 272.2 (2014), pp. 205-212. DOI: 10.1127/0077-7749/2014/0406.

[8182] J. Gaudant, M. D. Courme-rault, and S. Saint-Martin. “On the fossil fishes, diatoms, and foraminifera from Zanclean (Lower Pliocene) diatomitic sediments of Aegina Island (Greece): a stratigraphical and palaeoenvironmental study". English. In: Palaeodiversity 3 (2010), pp. 141-149.

[8183] J. Gaudant, B. Delrieau, M. D. Dermitzakis, and N. K. Symeonidis. "Découverte d'une ichthyofaune marine dans les diatomites du Pliocéne supérieur (Plaisancien) des environs d'Héraklion (Créte centrale, Gréce)". French. In: Comptes Rendus Academie de Seances Paris 319 (1994), pp. 589596.

[8184] J. Gaudant, E. Fourtanier, A. Lauriat-rage, S. Tsagaris, M. T. Venec-Peyre, and I. Zorn. “Découverte d'une ichthyofaune marine dans le Messinien préévaporitique de la Messara (Créte centrale, Gréce) : interprétation paléoécologique". French. In: geologie Mediterraneenee 24.3-4 (1997), pp. 175195.

[8185] J. Gaudant, N. Tsaparas, A. Antonarakou, H. Drinia, and M. D. Dermitzakis. "The Tortonian fish fauna of Gavdos Island (Greece)". English. In: Comptes Rendus Palevol 4 (2005), pp. 687-695. DOI: 10.1016/j.crpv.2005.08.003.

[8186] J. Gaudant, N. Tsaparas, A. Antonarakou, H. Drinia, S. Saint-Martin, and M. D. Dermitzakis. “A new marine fish fauna from the pre-evaporitic Messinian of Gavdos Island (Greece)". English. In: Comptes Rendus Palevol 5.6 (2006), pp. 795-802. DOI: 10.1016/j.crpv.2006.02.004.

[8187] T. J. Gaudin, R. J. Emry, and B. Pogue. "A new genus and species of pangolin (Mammalia, Pholidota) from the Late Eocene of Inner Mongolia, China". English. In: Journal of Vertebrate Paleontology 26.1 (2006), pp. 146-159.

[8188] P. J. Gaudioso, G. M. Gasparini, F. Herbst, and R. M. Barquez. "First record of the Neolicaphrium recens Frenguelli, 1921 (Mammalia, Litopterna) in the Pleistocene of Santiago del Estero Province, Argentina". English. In: Papéis Avulsos de Zoologia 57.3 (2017), pp. 23-29.

[8189] P. J. Gaudioso, M. J. Pérez, A. I. Olivares, and M. M. Daz. "Paramyocastor diligens (Rodentia, Hystricomorpha) from Las Cañas Formation (Pliocene), northwestern Argentina". English. In: Historical Biology (2019). DOI: 10.1080/08912963.2019.1657860.

[8190] S. Gaudzinski. "Subsistence patterns of Early Pleistocene hominids in the Levant - taphonomic evidence from the 'Ubeidiya Formation". In: Journal of Archaeological Science 31 (2004), pp. 65-75.

[8191] F.-X. Gauffre. "The prosauropod dinosaur Azendohsaurus laaroussii from the Upper Triassic of Morocco". English. In: Palaeontology 36.4 (1993), pp. 897-908.

[8192] F.-X. Gauffre. “The most recent Melanorosauridae (Saurischia, Prosauropoda), Lower Jurassic of Lesotho, with remarks on the prosauropod phylogeny". English. In: Neues Jahrbuch für Geologie und Paläontologie Monatshefte 1993.11 (1993), pp. 648-654.

[8193] F.-X. Gauffre. “Premiére description d'un dinosaure prosauropode dans le Trias supérieur du Sud de la France, Alzon (Gard) [First description of a prosauropod dinosaur from the Upper Triassic of southern France (Alzon, Gard)]". French. In: Comptes Rendus de l'Académie des Sciences á Paris, série IIa 320 (1995), pp. 1219-1223.

[8194] J. P. Gautam, B. Pandey, A. K. Jaitly, D. B. Pathak, J. Lehmann, and D. N. Tiwari. “Late Albian ammonites from the Cauvery Basin, south India". English. In: Cretaceous Research 102 (2019), pp. 1229. DOI: 10.1016/j.cretres.2019.04.013.

[8195] H. Gauthier, M. Trévisan, and J. L. Joron. "L'espéce Odontolkites longidens (Quenstedt) in Buckman (= longidoides n. sp.) et le genre Odontolkites Buckman (Garantianinae, Stephanoceratidae, Stephanocerataceae, Ammonoidea)". French. In: Géologie de la France 2 (2000), pp. 17-29.

[8196] J. A. Gauthier, S. J. Nesbitt, E. R. Schachner, G. S. Bever, and W. G. Joyce. "The bipedal stem crocodilian Poposaurus gracilis: inferring function in fossils and innovation in archosaur locomotion". English. In: Bulletin of the Peabody Museum of Natural History 52.1 (2011), pp. 107-126. 
[8197] A. Gautier. "Bovenpleistocene zoogdieren van Oudenaarde Donk (België), fossiele vliegepoppen uit de Vlaamse Valleien elders en nog een en ander over de Vlaamse Vallei". other. In: Cranium 12.2 (1995), pp. 73-81.

[8198] T. G. Gautier, P. N. Wyse Jackson, and F. K. McKinney. "Adlatipora, a distinctive new acanthocladiid bryozoan from the Permian of the Glass Mountains, Texas, U.S.A., and its bearing on fenestrate astogeny and growth". English. In: Journal of Paleontology 87 (2013), pp. 444-455.

[8199] R. J. Gay and I. S. Aude. "The first occurrence of the enigmatic archosauriform Crosbysaurus Heckert 2004 from the Chinle Formation of southern Utah". English. In: PeerJ 3 (2015), e905. DOI: 10.7717 / peerj. 905.

[8200] M. Gayet, L. G. Marshall, and T. Sempere. The Mesozoic and Paleocene vertebrates of Bolivia and their stratigraphic context: a review. English. Vol. 12. In R. Suarez-Soruco (ed.), Fosiles y Facies de Bolivia. Volumen 1-Vertebrados. Revista Técnica de YPFB 3-4. 1991, pp. 393-433.

[8201] M. Gayet, L. G. Marshall, T. Sempere, F. J. Meunier, H. Capetta, and J. -C. Rage. "Middle Maastrichtian vertebrates (fishes, amphibians, dinosaurs and other reptiles, mammals) from Pajcha Pata (Bolivia). Biostratigraphic, palaeoecologic and palaeobiogeographic implications". English. In: Palaeogeography, Palaeoclimatology, Palaeoecology 169.1-2 (2001), pp. 39-68. DOI: 10.1016/S00310182(01)00214-0.

[8202] H. Gebhardt. "Inoceramids, Didymotis and ammonites from the Nkalagu Formation type locakity (late Turonian to Coniacian, southern Nigeria):biostratigraphy and palaeoecologic implications)". English. In: Neues Jahrbuch für Geologie und Palaeontologie, Monatshefte 2001.4 (2001), pp. 193-212.

[8203] C. Gebicki and J. Szwedo. "A fossil ugyopine planthopper from Baltic amber (Hemiptera: Fulgoroidea: Delphacidae)". English. In: Polskie Pismo Entomologiczne 69 (2000), pp. 389-395.

[8204] C. Gebicki and J. Szwedo. "The first record of fossil Mileewinae from Eocene Baltic amber (Hemiptera: Membracoidea: Cicadellidae)". English. In: Annales Zoologici 51 (2001), pp. 417-422.

[8205] C. Gebicki and J. Szwedo. "Protodikraneurini trib. nov. from the Eocene Baltic amber (Hemiptera: Cicadellidae: Typhlocybinae)". English. In: Annales Zoologici 56 (2006), pp. 763-783.

[8206] C. Gebicki and P. Wegierek. "Oligocixia electrina gen. et sp. nov. (Homoptera, Auchenorrhyncha, Cixiidae) from Dominican amber". English. In: Annalen des Naturhistorischen Museums in Wien, Serie A 95 (1993), pp. 121-125.

[8207] D. L. Gebo, M. Dagosto, A. L. Rosenberger, and T. Setoguchi. "New platyrrhine tali from La Venta, Colombia". English. In: Journal of Human Evolution 19 (1990), pp. 737-746.

[8208] D. L. Gebo, L. MacLatchy, R. Kityo, A. Deino, J. Kingston, and D. Pilbeam. "A hominoid genus from the early Miocene of Uganda". English. In: Science 276 (1997), pp. 401-404.

[8209] B. Géczy. “Lower Pliensbachian ammmonites of Villány (Hungary)”. English. In: Hantkeniana 2 (1998), pp. 5-47.

[8210] B. Géczy, Z. Kovács, and I. Szente. "Remarks on the Toarcian-Aalenian fossil assemblage of the Kis-Teke Hill, Gerecse Mts (Hungary)". English. In: Hantkeniana 6 (2008), pp. 33-55.

[8211] B. Géczy and C. Meister. "Les ammonites du Domérien de la montagne du Bakony (Hongrie)". French. In: Revue de Paléobiologie 17.1 (1998), pp. 69-161.

[8212] B. Géczy and I. Szente. "Middle Toarcian Ammonitina from the Gerecse Mts, Hungary". English. In: Acta Geologica Hungarica 49.3 (2006), pp. 223-252. DOI: 10.1556/AGeol.49.2006.3.3.

[8213] F. Gedik. "Foraminiferal description and biostratigraphy of the Oligocene shallow marine sediments in Denizli region, SW Turkey". English. In: Revue de Paleobiologie 27.1 (2008), pp. 25-41.

[8214] B. M. Gee and W. G. Parker. "Morphological and histological description of small metoposaurids from Petrified Forest National Park, AZ, USA and the taxonomy of Apachesaurus". English. In: Historical Biology (2018). DOI: 10.1080/08912963.2018.1480616.

[8215] C. T. Gee. "The mangrove palem Nypa in the geologic past of the New World". English. In: Wetlands Ecology and Management 9 (2001), pp. 181-194. 
[8216] J. Gee, A. Nel, J. Menier, and G. De Ploëg. “A new lovebug fly (Insecta, Diptera) from the lowermost Eocene amber of the Paris Basi". English. In: Geodiversitas 23.3 (2001), pp. 341-348.

[8217] H. Geertsema and J. A. van den Heever. "First record of a Late Cretaceous-Palaeocene tenebrinoid from Southern Africa". English. In: South African Journal of Science 96.11-12 (2000), pp. 553-555.

[8218] H. Geertsema and D. E. van Dijk. "The earliest known Palaeozoic ensiferan insect from Africa, Afroedischia oosthuizeni gen. et sp. nov. (Orthoptera: Oedischiidae)". English. In: South African Journal of Science 95 (1999), pp. 229-230.

[8219] J. G. Gehling and M. L. Droser. "How well do fossil assemblages of the Ediacara Biota tell time?" English. In: Geology 41.4 (2013), pp. 447-450. DOI: 10.1130/G33881.1.

[8220] J. G. Gehling and G. M. Narbonne. "Spindle-shaped Ediacara fossils from the Mistaken Point assemblage, Avalon Zone, Newfoundland". English. In: Canadian Journal of Earth Sciences 44 (2007), pp. 367-387.

[8221] J. G. Gehling and J. K. Rigby. “Long expected sponges from the Neoproterozoic Ediacara fauna of South Australia". In: Journal of Paleontology 70.2 (1996), pp. 185-195.

[8222] J. H. Geisler, R. W. Boessenecker, M. Brown, and B. L. Beatty. "The Origin of Filter Feeding in Whales". English. In: Current Biology 27 (2017), pp. 1-7. DOI: 10.1016/j.cub.2017.06.003.

[8223] J. H. Geisler, M. W. Colbert, and J. L. Carew. "A new fossil species supports an early origin for toothed whale echolocation". English. In: Nature (2014). DOI: 10.1038/nature13086.

[8224] J. H. Geisler, S. J. Godfrey, and O. Lambert. "A new genus and species of late Miocene inioid (Cetacea, Odontoceti) from the Meherrin River, North Carolina, U.S.A." English. In: Journal of Vertebrate Paleontology 32.1 (2012), pp. 198-211.

[8225] J. H. Geisler and M. C. McKenna. "A new species of mesonychian mammal from the lower Eocene of Mongolia and its phylogenetic relationships". English. In: Acta Palaeontologica Polonica 52.1 (2007), pp. 189-212.

[8226] J. H. Geisler, A. E. Sanders, and Z. Luo. "A new protocetid whale (Cetacea: Archaeoceti) from the late middle Eocene of South Carolina". English. In: American Museum Novitates 3480 (2005), pp. 165.

[8227] F. Geissert, H. J. Gregor, D. H. Mai, W. Boenigk, and T. Guenther. "Die Saugbaggerflora, eine Frucht- und Samenflora aus dem Grenzbereich Miozaen- Pliozaen von Sessenheim im Elsass (Frankreich)". German. In: Documenta naturae 57 (1990), pp. 1-207.

[8228] J. N. Gelfo. "The 'condylarth' Raulvaccia peligrensis (Mammalia: Didolodontidae) from the Paleocene of Patagonia, Argentina". English. In: Journal of Vertebrate Paleontology 27.3 (2007), pp. 651660.

[8229] J. N. Gelfo. "A new South American mioclaenid (Mammalia: Ungulatomorpha) from the Tertiary of Patagonia, Argentina". English. In: Ameghiniana 41.3 (2004), pp. 475-484.

[8230] J. N. Gelfo. "Considerations about the evolutionary stasis of Notiolofos arquinotiensis (Mammalia: Sparnotheriodontidae), Eocene of Seymour Island, Antarctica". English. In: Ameghiniana 53.3 (2016), pp. 316-332.

[8231] J. N. Gelfo, R. N. Alonso, R. H. Madden, and A. A. Carlini. "An Eocene Bunodont South American Native Ungulate (Didolodontidae) from the Lumbrera Formation, Salta Province, Argentina". English. In: Ameghiniana 57.2 (2020), pp. 132-145.

[8232] J. N. Gelfo, D. A. Garca-López, and L. P. Bergqvist. "Phylogenetic relationships and palaeobiology of a new xenungulate (Mammalia: Eutheria) from the Palaeogene of Argentina". English. In: Journal of Systematic Palaeontology 18.12 (2020), pp. 993-1107. DOI: 10.1080/14772019.2020.1715496.

[8233] J. N. Gelfo, G. M. López, and M. Bond. “A new Xenungulata (Mammalia) from the Paleocene of Patagonia Argentina". English. In: Journal of Paleontology 82.2 (2008), pp. 329-335.

[8234] J. N. Gelfo, G. M. López, and S. N. Santillana. "Eocene ungulate mammals from West Antarctica: implications from their fossil record and a new species". English. In: Antarctic Science (2017). DOI: $10.1017 /$ S0954102017000244. 
[8235] J. N. Gelfo, T. Mors, M. Lorente, G. M. Lopez, and M. Reguero. “The oldest mammals from Antarctica, Early Eocene of the La Meseta Formation, Seymour Island". English. In: Palaeontology 58.1 (2015), pp. 101-110. DOI: 10.1111/pala.12121.

[8236] J. N. Gelfo, E. Ortiz-Jaureguizar, and G. W. Rougier. "New remains and species of the 'condylarth' genus Escribania (Mammalia: Didolodontidae) from the Palaeocene of Patagonia, Argentina". English. In: Earth and Environmental Science Transactions of the Royal Society of Edinburgh 98 (2007), pp. 127-138.

[8237] J. N. Gelfo and R. Pascual. "Peligrotherium tropicalis (Mammalia, Dryolestida) from the early Paleocene of Patagonia, a survival from a Mesozoic Gondwanan radiation". English. In: Geodiversitas 23.3 (2001), pp. 369-379.

[8238] J. N. Gelfo and B. Sigé. "A new didolodontid mammal from the late Paleocene-earliest Eocene of Laguna Umayo, Peru". English. In: Acta Palaeontologica Polonica 56.4 (2011), pp. 665-678.

[8239] J. K. Gelhaus and R. Johnson. "First record of crane flies (Tipulidae: Limoniinae) in Upper Cretaceous amber from New Jersey, U.S.A." English. In: Transactions of the American Entomological Society 122.1 (1996), pp. 55-65.

[8240] F. Geller-Grimm. "Protoloewinella keilbachi Schumann, 1984 aus dem Baltischen Bernstein (Diptera: Asilidae)". German. In: Studia Dipterologica 5.1 (1998), p. 84.

[8241] R. Gemel. “Weichschildkrötenreste aus dem Karpatium des Korneuburger Beckens (Untermiozän; Niederösterreich)". German. In: Beiträge zur Paläontologie 27 (2002), pp. 355-371.

[8242] B. Geng, M. Zhu, and J. Fan. "A Revision and Phylogenetic Analysis of Guizhoucoelacanthus (Sarcopterygii, Actinisia) from the Triassic of China". English. In: Vertebrata PalAsiatica 47.3 (2009), pp. 165-177.

[8243] B.-Y. Geng. "Studies on Early Devonian flora of Sichuan". In: Acta Phytotaxonomica Sinica 30.3 (1992), pp. 197-211.

[8244] B. H. Geng, F. Jin, F. X. Wu, and Q. Wang. "New perleidid fishes from the Middle Triassic strata of Yunnan Province". English. In: Geological Bulletin of China 31 (2012), pp. 915-927.

[8245] J. F. Genise and L. C. Sarzetti. "Fossil cocoons associated with a dinosaur egg from Patagonia, Argentina". English. In: Palaeontology 54.4 (2011), pp. 815-823. DOI: 10.1111/j.1475-4983.2011. 01064.x.

[8246] P. G. Gensel. Inventory of Devonian Plants from New Brunswick. 2002.

[8247] P. A. Gensler. The vertebrate fauna (late-Irvingtonian, mid-Pleistocene) of Ash Wash, Coyote Badlands, Anza-Borrego Desert State Park, California. English. 2002.

[8248] A. R. Gentil, F. L. Agnolin, J. A. Garcia Marsá, M. J. Motta, and F. E. Novas. “Bridging the gap: sphenodont remains from the Turonian (Upper Cretaceous) of". English. In: Cretaceous Research (2019). DOI: 10.1016/j.cretres.2019.01.016.

[8249] G. Gentilini. "Fossil damselflies and dragonflies from the Eocene of Monte Bolca (Insecta: Odonata)". English. In: Studi e Ricerche sui Giacimenti Terziari di Bolca, Museo Civico di Storia Naturale di Verona 9 (2002), pp. 7-22.

[8250] G. Gentilini. "Finding of the genus Nephrotoma Meigen, 1803 from the Upper Miocene of Monte Castellaro (Marche, Central Italy)". English. In: Bollettino della Societá Entomologica Italiana 121.3 (1990), pp. 220-223.

[8251] G. Gentilini. “Bibionidae (Diptera, Nematocera) from Upper Miocene of Monte Castellaro (Marche, central Italy)". English. In: Bollettino del Museo Civico di Storia Naturale di Verona 15 (1991), pp. 425445.

[8252] G. Gentilini. “Occurrence of the genus Penthetria Meigen, 1803 from the lower Messinian of Central Italy (Diptera Bibionidae)". English. In: Bollettino della Societá Entomologica Italiana 123 (1991), pp. 62-66.

[8253] G. Gentilini. "New species of Plecia from the Oligocene of southeastern France (Diptera Bibionidae)". English. In: Bollettino della Societá Entomologica Italiana 125 (1993), pp. 157-165. 
[8254] G. Gentilini and L. Bagli. "Fossil Zygoptera and Anisoptera from the upper Miocene of Monte Castellaro (Pesaro, Marches, central Italy) (Insecta Odonata Coenagrionidae, Lestidae, Sieblosiidae, Calopterygidae, Libellulidae)". English. In: Quaderno di Studi e Notizie di Storia Naturale della Romagna 19 (2004), pp. 17-44.

[8255] G. Gentilini, V. A. Korneyev, and E. P. Kameneva. “Fossil tephritoid flies (Diptera: Pallopteridae, Ulidiidae, Tephritidae) from the Upper Miocene of Monte Castellaro, Italy, and a review of fossil European tephritoids". English. In: Instrumenta Biodiversitatis 7 (2006), pp. 1-20.

[8256] G. Gentilini and G. Peters. "The Upper Miocene Aeshnids of Monte Castellaro, Central Italy, and their relationships to extant species (Anisoptera: Aeshnidae)". English. In: Odonatologica 22.2 (1993), pp. 147-178.

[8257] A. D. Gentry. "New material of the Late Cretaceous marine turtle Ctenochelys acris Zangerl, 1953 and a phylogenetic reassessment of the 'toxochelyid'-grade taxa". English. In: Journal of Systematic Palaeontology 15.8 (2017), pp. 675-696. DOI: 10.1080/14772019.2016.1217087.

[8258] A. D. Gentry. "Prionochelys matutina Zangerl, 1953 (Testudines: Pan-Cheloniidae) from the Late Cretaceous of the United States and the evolution of epithecal ossifications in marine turtles". English. In: PeerJ 6 (2018), e5876:1-34. DOI: 10.7717/peer.5876.

[8259] A. D. Gentry and J. A. Ebersole. "The first report of Toxochelys latiremis Cope 1873 (Testudines: Panchelonioidea) from the early Campanian of Alabama, USA". English. In: PaleoBios 35.37558 (2018), pp. 1-10.

[8260] A. D. Gentry, J. A. Ebersole, and C. R. Kiernan. "Asmodochelys parhami, a new fossil marine turtle from the Campanian Demopolis Chalk and the stratigraphic congruence of competing marine turtle phylogenies". English. In: Royal Society Open Science 6 (2019), 191950:1-12. DOI: 10.1098 / rsos.191950.

[8261] A. D. Gentry, J. F. Parham, D. J. Ehret, and J. A. Ebersole. “A new species of Peritresius Leidy, 1856 (Testudines: Pan-Cheloniidae) from the Late Cretaceous (Campanian) of Alabama, USA, and the occurrence of the genus within the Mississippi Embayment of North America". English. In: PLoS ONE 13 (2018), e0195651:1-24. DOI: 10.1371/journal.pone.0195651.

[8262] A. W. Gentry. The Semliki fossil bovids. 1990.

[8263] G. Georgalis, A. Villa, and M. Delfino. "The last amphisbaenian (Squamata) from continental Eastern Europe". English. In: Annales de Paléontologie (2018), pp. 1-5. DOI: 10.1016/j.annpal.2018.03. 002.

[8264] G. L. Georgalis. "Poor but classic: The squamate fauna from the late Miocene of Pikermi, near Athens, Greece". English. In: Comptes Rendus Palevol 18 (2019), pp. 801-815. DOI: 10.1016/j.crpv. 2019.09.004.

[8265] G. L. Georgalis, M. K. Abdel Gawad, S. M. Hassan, A. N. El-Barkooky, and M. A. Hamdan. “Oldest co-occurrence of Varanus and Python from Africa-first record of squamates from the early Miocene of Moghra Formation, Western Desert, Egypt". English. In: PeerJ $8 . e 9092$ (2020), pp. 1-26. DOI: 10.7717 / peerj.9092.

[8266] G. L. Georgalis, K. Halaçlar, S. Mayda, T. Kaya, and D. Ayaz. "First fossil find of the Blanus strauchi complex (Amphisbaenia, Blanidae) from the Miocene of Anatolia". English. In: Journal of Vertebrate Paleontology (2018), e1437044. DOI: 10.1080/02724634.2018.1437044.

[8267] G. L. Georgalis, G. Insacco, L. Rook, F. Spadola, and M. Delfino. “Turtle remains from the late Miocene of the Cessaniti area, southern Italy-insights for a probable Tortonian chelonian dispersal from Europe to Africa". English. In: Swiss Journal of Palaeontology 139.1 (2020), pp. 1-13. DOI: 10.1186/s13358-020-00202-y.

[8268] G. L. Georgalis and W. G. Joyce. "A Review of the Fossil Record of Old World Turtles of the Clade Pan-Trionychidae". English. In: Bulletin of the Peabody Museum of Natural History 58.1 (2017), pp. 115-208. DOI: $10.3374 / 014.058 .0106$. 
[8269] G. L. Georgalis, J.-C. Rage, L. de Bonis, and G. D. Koufos. "Lizards and snakes from the late Miocene hominoid locality of Ravin de la Pluie (Axios Valley, Greece)". English. In: Swiss Journal of Geosciences (2017), pp. 1-13. DOI: 10.1007/s00015-017-0291-2.

[8270] G. L. Georgalis and T. M. Scheyer. "A new species of Palaeopython (Serpentes) and other extinct squamates from the Eocene of Dielsdorf (Zurich, Switzerland)". English. In: Swiss Journal of Geosciences (2019). DOI: 10.1007/s00015-019-00341-6.

[8271] G. L. Georgalis, E. Velitzelos, D. E. Velitzelos, and B. P. Kear. “Nostimochelone lampra gen. et sp. nov., an Enigmatic New Podocnemidoidean Turtle from the Early Miocene of Northern Greece". English. In: Morphology and Evolution of Turtles. New York: Springer, 2013, pp. 277-287. DOI: 10.1007/978-94-007-4309-0_17.

[8272] G. L. Georgalis, A. Villa, E. Vlachos, and M. Delfino. “Fossil amphibians and reptiles from Plakias, Crete: A glimpse into the earliest late Miocene herpetofaunas of southeastern Europe". English. In: Geobios 49 (2016), pp. 433-444.

[8273] G. L. Georgalis, A. Villa, M. Ivanov, S. Roussiakis, P. Skandalos, and M. Delfino. “Early Miocene herpetofaunas from the Greek localities of Aliveri and Karydia - bridging a gap in the knowledge of amphibians and reptiles from the early Neogene of southeastern Europe". English. In: Historical Biology (2017), pp. 1-20. DOI: 10.1080/08912963.2017.1417404.

[8274] G. L. Georgalis, A. Villa, and M. Delfino. "The last European varanid: demise and extinction of monitor lizards (Squamata, Varanidae) from Europe". English. In: Journal of Vertebrate Paleontology 37.2 (2017), pp. 1-7. DOI: 10.1080/02724634.2017.1301946.

[8275] G. L. Georgalis, A. Villa, and M. Delfino. "Fossil lizards and snakes from Ano Metochi - a diverse squamate fauna from the latest Miocene of northern Greece". English. In: Historical Biology 29.6 (2017), pp. 730-742. DOI: 10.1080/08912963.2016.1234619.

[8276] G. L. Georgalis, A. Villa, M. Ivanov, D. Vasilyan, and M. Delfino. "Fossil amphibians and reptiles from the Neogene locality of Maramena (Greece), the most diverse European herpetofauna at the Miocene/Pliocene transition boundary". English. In: Palaeontologia Electronica 22.3.68 (2019), pp. 1-99.

[8277] G. L. Georgalis, D. Zoboli, A. Pérez-Garca, G. L. Pillola, and M. Delfino. "The occurrence of Eocenochelus (Testudines," English. In: Rivista Italiana di Paleontologia e Stratigrafia 126.3 (2020), pp. 833-846.

[8278] M. Georgieff, R. Herbst, G. I. Esteban, and N. Nasif. "Análisis paleoambiental y registro paleontológico de la Formación Desencuentro (Mioceno Superior), Alto de San Nicolás, La Rioja, Argentina". Spanish. In: Ameghiniana 41.1 (2004), pp. 45-56.

[8279] M. N. Georgieva, C. K. Paull, C. T. S. Little, M. McGann, D. Sahy, D. Condon, L. Lundsten, and J. Pewsey. "Discovery of an Extensive Deep-Sea Fossil Serpulid Reef Associated with a Cold Seep, Santa Monica Basin, California". English. In: Frontiers in Marine Science 6 (2019). DOI: 10.3389 / fmars.2019.00115.

[8280] D. Geraads. "Evolution of bovid diversity in the Plio-Pleistocene of Africa". English. In: Historical Biology 7.3 (1994), pp. 221-237.

[8281] D. Geraads. "Plio-Pleistocene mammalian biostratigraphy of Atlantic Morocco". In: Quaternaire 13.1 (2002), pp. 43-53.

[8282] D. Geraads. “Rongeurs du Mio-Pliocene de Lissasfa (Casablanca, Maroc)”. French. In: Géobios 31.2 (1998), pp. 229-245.

[8283] D. Geraads. "The late Pliocene locality of Ahl al Oughlam, Morocco; vertebrate fauna and interpretation". English. In: Transactions of the Royal Society of South Africa 61.2 (2006), pp. 97-101.

[8284] D. Geraads. "Large Mammals from the Late Miocene of Corakyerler, Cankiri, Turkey". English. In: Acta Zoologica Bulgarica 65 (2013), pp. 381-390.

[8285] D. Geraads. "Camelus grattardi, sp. nov., a New Camel from the Shungura Formation, Omo Valley, Ethiopia, and the Relationships of African Fossil Camelidae (Mammalia)". English. In: Journal of Vertebrate Paleontology 34.6 (2014), pp. 1481-1485. DOI: 10.1080/02724634.2014.880447. 
[8286] D. Geraads. "Late Miocene large mammals from Mahmutgazi, Denizli province, Western Turkey". English. In: Neues Jahrbuch für Geologie und Paläontologie 284.3 (2017), pp. 241-257. DOI: 10.1127 / njgpa/2017/0661.

[8287] D. Geraads, Z. Alemseged, R. Bobe, and D. Reed. "Enhydriodon dikikae, sp. nov. (Carnivora: Mammalia), a gigantic otter from the Pliocene of Dikika, lower Awash, Ethiopia". English. In: Journal of Vertebrate Paleontology 31.2 (2011), pp. 447-453.

[8288] D. Geraads and L. de Bonis. "First record of Theropithecus (Cercopithecidae) from the Republic of Djibouti". English. In: Journal of Human Evolution 138.102686 (2020). DOI: 10.1016/j.jhevol.2019. 102686.

[8289] D. Geraads, M. S. M. Drapeau, R. Bobe, and J. G. Fleagle. "Vulpes mathisoni, sp. nov., a new fox from the Pliocene Mursi Formation of southern Ethiopia and its contribution to the origin of African foxes". English. In: Journal of Vertebrate Paleontology 25 (2015), e943765. DOI: 10.1080 / 02724634.2014.943765.

[8290] D. Geraads, T. Kaya, and S. Mayda. "Late Miocene large mammals from Yulafli, Thrace region, Turkey, and their biogeographic implications". English. In: Acta Palaeontologica Polonica 50.3 (2005), pp. 523-544.

[8291] D. Geraads, E. Tsoukala, and N. Spassov. "A skull of Ancylotherium (Chalicotheriidae, Mammalia) from the late Miocene of Thermopigi (Serres, N. Greece) and the relationships of the genus". English. In: Journal of Vertebrate Paleontology 27.2 (2007), pp. 461-466.

[8292] J. M. Gerholdt and S. J. Godfrey. “Enigmatic osteology in Miocene odontocete rostra suggests periostitis". English. In: Marine Mammal Science 26.2 (2010), pp. 381-394.

[8293] O. Gerke and O. Wings. "Multivariate and cladistic analyses of isolated teeth reveal sympatry of theropod dinosaurs in the Late Jurassic of northern Germany". English. In: PLoS One 11.7 (2016), e0158334:1-52. DOI: 10.1371/journal.pone.0158334.

[8294] D. Germain. "A new phlegethontiid specimen (Lepospondyli, Aistopoda) from the Late Carboniferous of Montceau-les-Mines (Saone-et-Loire, France)". English. In: Geodiversitas 30.4 (2008), pp. 669-680.

[8295] D. Germani. "New data on ammonoids and biostratigraphy of the classical Spathian Kcira sections (Lower Triassic, Albania)". English. In: Rivista Italiana di Paleontologie e Stratigrafia 103.3 (1997), pp. 267-292.

[8296] M. Germonpré, M. Lázniková-Galetová, R. J. Losey, J. Räikkönen, and M. V. Sablin. “Large canids at the Gravettian Pedmost site, the Czech Republic: The mandible". English. In: Quaternary International 359-360 (2015), pp. 261-279. DOI: 10.1016/j.quaint.2014.07.012.

[8297] C. F. C. Geroto and R. J. Bertini. “New material of Pepesuchus (Crocodyliformes; Mesoeucrocodylia) from the Bauru Group: implications about its phylogeny and the age of the Adamantina Formation". English. In: Zoological Journal of the Linnean Society 185.2 (2019), pp. 312-334. DOI: 10.1093/ zoolinnean/zly037/5047416.

[8298] P. Gerrienne. "Inventaire Des Vegetaux Eodevoniens de Belgique". French. In: Annales dela Societe geologique de Belgique 116 (1993), pp. 105-117.

[8299] P. Gerrienne. "The fossil plants from the Lower Devonian of Marchin (northern margin of Dinant Synclinorium, Belgium). V. Psilophyton genseliae sp. nov., with hypotheses on the origin of Trimerophytina". In: Review of Palaeobotany and Palynology 98 (1997), pp. 303-324.

[8300] P. Gerrienne. "Lower Devonian plant remains from Marchin (northern margin of Dinant Synclinorium, Belgium). IV. Odonax borealis gen. et sp. nov". In: Review of Palaeobotany and Palynology 93 (1996), pp. 83-106.

[8301] P. Gerrienne. “Les Fossiles Vegetaux Du Devonien inferieur de Marchin (Bord Nord du synclinorium de Dinant, Belgique). III. Psilophyton Parvulum nov. sp". French. In: Géobios 28.2 (1995), pp. 131-144. 
[8302] P. Gerrienne. “Deuterophyton stockmansii gen. et sp. nov. from the Lower Devonian of Belgium and the recognition of a new group of early vascular plants". In: Paleontology 326 (1998), pp. 369375.

[8303] P. Gerrienne, S. Bergamaschi, E. Pereira, M. C. Rodrigues, and P. Steemans. "An Early Devonian flora, including Cooksonia, from the Parana Basin (Brazil)". In: Review of Palaeobotany and Palynology 116 (2001), pp. 19-38.

[8304] P. Gerrienne, B. Cascales-Minana, C. Prestianni, P. Steemans, and L. Cheng-Sen. "Lilingostrobus chaloneri gen. et sp. nov., a Late Devonian woody lycopsid from Hunan, China". English. In: PLoS ONE 13.7 (2018), e0198287. DOI: 10.1371/journal.pone.0198287.

[8305] B. Gertsch, G. Keller, T. Adatte, z. Berner, A. S. Kassab, A. A. A. Tantawy, A. M. El-Sabbagh, and D. Stueben. "Cenomanian-Turonian transition in a shallow water sequence of the Sinai, Egypt". English. In: International Journal of Earth Sciences (Geologische Rundschau) 99 (2010), pp. 165-182. DOI: $10.1007 / \mathrm{s} 00531-008-0374-4$.

[8306] R. W. Gess. "The earliest record of terrestrial animals in Gondwana: a scorpion from the Famennian (Late Devonian) Witpoort Formation of South Africa". English. In: African Invertebrates 54 (2013), pp. 373-379.

[8307] R. W. Gess, M. I. Coates, and B. S. Rubidge. "A lamprey from the Devonian period of South Africa". English. In: Nature 443 (2006), pp. 981-984.

[8308] R. W. Gess and M. I. Coates. "High-latitude Chondrichthyans from the late Devonian (Famennian) Witpoort formation of South Africa". English. In: Paläontologische Zeitschrift 89.2 (2015), pp. 147169.

[8309] R. W. Gess and M. I. Coates. "Fossil juvenile coelacanths from the Devonian of South Africa shed light on the order of character acquisition in actinistians". English. In: Zoological Journal of the Linnean Society 175.2 (2015), pp. 360-383. DOI: 10.1111/zoj.12276.

[8310] P. Getty. Ornithischian ichnites from Dinosaur Footprint Reservation (Lower Jurassic Portland Formation), Holyoke, MA. English. 2004.

[8311] P. Getty. In situ dinosaur footprints at the Murray Quarry (Lower Jurassic ?East Berlin Formation), Holyoke, MA. English. 2003.

[8312] G. Geyer. "A new obolellid brachiopod from the Lower Cambrian of Morocco". English. In: Journal of Paleontology 68.5 (1994), pp. 995-1002.

[8313] G. Geyer. "Middle Cambrian mollusks from Idaho and early conchiferan evolution". In: New York State Museum Bulletin 481.1 (1994), pp. 69-86.

[8314] G. Geyer. "Exotic trilobites from the Lower-Middle Cambrian boundary interval in Morocco and their bearing on the Cambrian Series 3 lower boundary". English. In: Paläontologische Zeitschrift 89 (2015), pp. 749-781.

[8315] G. Geyer. "Trilobites of the Galgenberg Member (Tannenknock Formation), middle Cambrian Stage 5, Franconian Forest, Germany: a paradigmatic lowermost middle Cambrian West Gondwanan fauna". English. In: Palaeontologische Zeitschrift 91 (2017), pp. 5-70.

[8316] G. Geyer. "Cambrian and lowermost Ordovician of the Franconian Forest". English. In: The 15th Field Conference of the Cambrian Stage Subdivision Working Group. International Subcommission on Cambrian Stratigraphy, 4-11 June 2010. Abstracts and Excursion Guide. Prague: Czech Geological Survey, 2010, pp. 78-92.

[8317] G. Geyer, B. Buschmann, and O. Elicki. "A new lowermost middle Cambrian (Series 3, Stage 5) faunule from Saxony (Germany) and its bearing on the tectonostratigraphic history of the Saxothuringian domain". English. In: Paläontologische Zeitschrift 88.3 (2014), pp. 239-262.

[8318] G. Geyer, M. Hautmann, H. Hagdorn, W. Ockert, and M. Streng. "Well-preserved mollusks from the Lower Keuper (Ladinian) of Hohenlohe (southwest Germany)". English. In: Palaeontologische Zeitschrift 79.4 (2005), pp. 429-460. 
[8319] G. Geyer and K.-P. Kelber. "Spinicaudata (Conchostraca, Crustacea) from the Middle Keuper (Upper Triassic) of the southern Germanic Basin, with a review of Carnian-Norian taxa and suggested biozones". English. In: Paläontologische Zeitschrift 92.1 (2018), pp. 1-34. DOI: 10.1007/s12542-0170363-7.

[8320] G. Geyer and E. Landing. "Middle Cambrian of Avalonian Massachusetts: Stratigraphy and correlation of the Braintree trilobites". In: Journal of Paleontology 75.1 (2001), pp. 116-135.

[8321] G. Geyer, E. Landing, and W. Heldmaier. "Faunas and depositional environments of the Cambrian of the Moroccan Atlas regions". English. In: Beringeria, Special Issue 2 (1995), pp. 47-119.

[8322] G. Geyer and J. M. Malinky. "Middle Cambrian fossils from Tizi n\&grave;Tichka, the High Atlas, Morocco. Part 1. Introduction and trilobites". English. In: Journal of Paleontology 71.4 (1997), pp. 620-637.

[8323] G. Geyer and J. M. Malinky. "Helcionelloid molluscs and hyoliths from the Miaolingian (middle Cambrian) of the subsurface of the Delitzsch-Torgau-Doberlug Syncline, northern Saxony, Germany". English. In: Palaeontologische Zeitschrift 94 (2020), pp. 271-193. DOI: 10.1007 / s12542-01900472-z.

[8324] G. Geyer and M. Mergl. "Protorthacean brachiopods from the Middle Cambrian of Morocco". In: Journal of Paleontology 71.5 (1997), pp. 791-812.

[8325] G. Geyer and A. R. Palmer. "Neltneriidae and Holmiidae (Trilobita) from Morocco and the problem of Early Cambrian intercontinental correlation". English. In: Journal of Paleontology 69.3 (1995), pp. 459-474.

[8326] G. Geyer, J. S. Peel, M. Streng, S. Voigt, J. Fischer, and M. PreuSSe. "A remarkable Amgan (Middle Cambrian, Stage 5) fauna from the Sauk Tanga, Madygen region, Kyrgyzstan". English. In: Bulletin of Geosciences 89.2 (2014), pp. 375-400. DOI: 10.3140/bull.geosci.1434.

[8327] G. Geyer, M. Valent, and S. Meier. "Helcionelloids, stenothecoids and hyoliths from the Tannenknock Formation (traditional lower middle Stage 4/Wuliuan boundary interval) of the Franconian Forest, Germany". English. In: Palaeontologische Zeitschrift (2018). DOI: 10.1007/s12542-018-0433-5.

[8328] G. Geyer and T. Vincent. "The Paradoxides puzzle resolved: the appearance of the oldest paradoxidines and its bearing on the Cambrian Series 3 lower boundary". English. In: Paläontologische Zeitschrift 89 (2015), pp. 335-398.

[8329] O. F. Geyer, J. Kuss, and M. Bachmann. “On some Albian ammonites from northeastern Sinai (Egypt)". English. In: Paläontologische Zeitschrift 71 (1997), pp. 221-229.

[8330] J. F. Geys. "The genus Temnocidaris (Echinoidea, Cidaroida) in the Upper Cretaceous and lower Tertiary of the Maastricht area (Belgium and The Netherlands)". English. In: Bulletin de l'Institut Royal des Sciences Naturelles de Belgique, Sciences de la Terre 60 (1990), pp. 107-114.

[8331] A. Ghaderi, C. Garbelli, L. Angiolini, A. R. Ashouri, D. Korn, R. Rettori, and M. H. Mahmoudi Gharaie. "Faunal change near the end-Permian extinction: the brachiopods of the Ali Bashi Mountains, NW Iran". English. In: Rivista Italiana di Paleontologia e Stratigrafia 120 (2014), pp. 27-59.

[8332] A. Ghaderi, L. Leda, M. Schobben, D. Korn, and A. R. Ashouri. "High-resolution stratigraphy of the Changhsingian (Late Permian) successions of NW Iran and the Transcaucasus based on lithological features, conodonts and ammonoids". English. In: Fossil Record 17 (2014), pp. 41-57.

[8333] A. Ghaderi, A. Sadeghi, A. R. Ashouri, and D. Korn. "Study of Late Permian (Wuchiapingian) brachiopods of sedimentary succession at the Zal section, Northwest Iran". other. In: Paleontology 2 (2015), pp. 212-229.

[8334] A. Ghaderi and L. Villier. "First record of the Late Cretaceous starfish Metopaster parkinsoni (Forbes, 1848) in Iran". English. In: Annales de paléontologie 99 (2013), pp. 91-100.

[8335] E. Gheerbrant. "Paleocene emergence of elephant relatives and the rapid radiation of African ungulates". English. In: Proceedings of the National Academy of Science 106.26 (2009), pp. 10717-10721.

[8336] E. Gheerbrant. "Bustylus (Eutheria, Adapisoriculidae) and the absence of ascertained Marsupials in the Palaeocene of Europe". English. In: Terra Nova 3 (1991), pp. 586-592. 
[8337] E. Gheerbrant. “Les mammiféres paléocénes du Bassin d'Ouarzazate (Maroc). II. Todralestidae (Eutheria, Proteutheria)". French. In: Palaeontographica Abteilung A 231.4-6 (1994), pp. 133-188.

[8338] E. Gheerbrant. “Les mammiféres Paléocénes du Bassin d'Quarzazate (Maroc). III. Adapisoriculidae et autres mammiféres (Carnivora, ? Creodonta, Condylarthra, ? Ungulata et incertae sedis)". French. In: Palaeontographica Abteilung A 237.1-4 (1995), pp. 39-132.

[8339] E. Gheerbrant, C. Abrial, and G. Cuenca. “Nouveau mammifére condylarthre du Paléocéne supérieur de Campo (Pyrénées Aragonaises, Espagne)". French. In: Comptes Rendus de l'Académie des Sciences de Paris, Serie IIa 324 (1997), pp. 599-606.

[8340] E. Gheerbrant, M. Amaghzaz, B. Bouya, F. Goussard, and C. Letenneur. "Ocepeia (Middle Paleocene of Morocco): The Oldest Skull of an Afrotherian Mammal". English. In: PLoS One 9.2 (2014), e89739. DOI: 10.1371/journal.pone.0089739.

[8341] E. Gheerbrant and H. Astibia. "Un nouveau mammifere du Maastrichtien de Lano". French. In: Comptes Rendus de l'Academie des Sciences 318 (1994), pp. 1125-1131.

[8342] E. Gheerbrant and H. Astibia. "Addition to the Late Cretaceous Laño mammal faunule (Spain) and to the knowledge of European Zhelestidae (Lainodontinae nov.)" English. In: Bulletin de la Société Géologique de France 183.6 (2012), pp. 537-546.

[8343] E. Gheerbrant, V. Codrea, A. Hosu, S. Sen, C. Guernet, F. de Lapparent de Broin, and J. Riveline. "Découverte de vertébrés dans les Calcaires de Rona (Thanétien ou Sparnacien), Transylvanie, Roumanie: les plus anciens mammiféres cénozoques d'Europe Orientale". French. In: Eclogae Geologicae Helvetiae 92 (1999), pp. 517-535.

[8344] E. Gheerbrant and J. L. Hartenberger. “Nouveau mammifére insectivore (?Lipotyphla, ?Erinaceomorpha) de l'Eocéne inférieur de Chambi (Tunisie)". French. In: Paläontologische Zeitschrift 73.1 (1999), pp. 143-156.

[8345] E. Gheerbrant, M. Iarochene, M. Amaghzaz, and B. Bouya. "Early African hyaenodontid mammals and their bearing on the origin of the Creodonta". English. In: Geological Magazine 143.4 (2006), pp. 475-489.

[8346] E. Gheerbrant, F. Khaldoune, A. Schmtt, and R. Tabuce. "Earliest Embrithopod Mammals (Afrotheria, Tethytheria) from the Early Eocene of Morocco: Anatomy, Systematics and Phylogenetic Significance". English. In: Journal of Mammalian Evolution (2020). DOI: 10.1007/s10914-020-09509-6.

[8347] E. Gheerbrant, S. Peigné, and H. Thomas. "Premiére description du squelette d'un Mammifére Hyracode du Paléogéne: Saghatherium antiquum de l'Oligocéne inférieur de Jebel al Hasawnah, Libye". French. In: Palaeontographica Abteilung A 279.4-6 (2007), pp. 93-145.

[8348] E. Gheerbrant, K. D. Rose, and M. Godinot. "First palaeanodont (?pholidotan) mammal from the Eocene of Europe." English. In: Acta Palaeontologica Polonica 50.2 (2005), pp. 209-218.

[8349] E. Gheerbrant and D. E. Russell. "Bustylus cernaysi nov. gen., nov. sp., nouvel Adapisoriculidé (Mammalia, Eutheria) Paléocéne d'Europe". French. In: Geobios 24.4 (1991), pp. 467-481.

[8350] E. Gheerbrant, A. Schmitt, and L. Kocsis. "Early African Fossils Elucidate the Origin of Embrithopod Mammals". English. In: Current Biology 28 (2018), pp. 1-7. DOI: 10.1016/j.cub.2018.05.032.

[8351] E. Gheerbrant, J. Sudre, M. Iarochene, and A. Moumni. "First ascertained African condylarth mammals (primitive ungulates: cf. Bulbulodentata and cf. Phenacodonta) from the earliest Ypresian of the Ouled Abdoun Basin, Morocco". English. In: Journal of Vertebrate Paleontology 21.1 (2001), pp. 107-118.

[8352] E. Gheerbrant, J. Sudre, and H. Cappetta. "A Palaeocene proboscidean from Morocco". English. In: Nature 383 (1996), pp. 68-70.

[8353] E. Gheerbrant, J. Sudre, H. Cappetta, M. Iarochéne, M. Amaghzaz, and B. Bouya. "A new large mammal from the Ypresian of Morocco: evidence of surprising diversity of early proboscideans". English. In: Acta Palaeontologica Polonica 47.3 (2002), pp. 493-506. 
[8354] E. Gheerbrant, J. Sudre, S. Sen, C. Abrial, B. Marandat, B. Sigé, and M. Vianey-Liaud. “Nouvelles données sur les mammiféres du Thanétien et de l'Yprésien du bassin d'Ouarzazate (Maroc) et leur contexte stratigraphique". French. In: Palaeovertebrata 27.3-4 (1998), pp. 155-202.

[8355] E. Gheerbrant, J. Sudre, H. Cappetta, M. Iarochene, M. Amaghzaz, and B. Bouya. New mammal from the Early Eocene of Morocco exemplifying unexpected early diversity of Proboscideans. English. The World of Elephants - International Congress, Rome 2001. 2001, pp. 637-638.

[8356] E. Gheerbrant, H. Thomas, S. Sen, and Z. Al-Sulaimani. “Nouveau primate Oligopithecinae (Simiiformes) de l'Oligocéne inférieur de Taqah, Sultanat d'Oman = New Oligopithecinae Primate (Simiiformes) from the early Oligocene of Taqah, Sultanate of Oman". English. In: Comptes rendus de l'Académie des sciences de Paris, Série 2321 (1995), pp. 425-432.

[8357] E. Gheerbrant, H. Thomas, and J. Roger. “Deux nouveaux primates dans l'Oligocéne inférieur de Taqah (Sultanat d'Oman) : premiers adapiformes (Anchomomyini) de la Péninsule Arabique". English. In: Palaeovertebrata 22 (1993), pp. 141-196.

[8358] D. F. M. Gherardi and D. W. J. Bosence. "Late Holocene reef growth and relative sea-level changes in Atol das Rocas, equatorial south Atlantic". English. In: Coral Reefs 24 (2005), pp. 264-272.

[8359] A. M. Ghilardi, M. A. Fernandes, and M. E. Bichuette. "Megafauna from the Late PleistoceneHolocene deposits of the Upper Ribeira karst area, southeast Brazil". English. In: Quaternary International 245.2 (2011), pp. 369-378.

[8360] M. Ghizzoni, A. Corona, M. Ubilla, and D. Perea. “Estimación de masa corporal de proterotéridos del Cuaternario (Mammalia, Litopterna) y descripción de un nuevo ejemplar de Neolicaphrium recens Frenguelli, 1921". English. In: Revista Brasileira de Paleontologia 23.2 (2020), pp. 153-162.

[8361] M. Ghobadi Pour, M. R. Kebriaee-Zadeh, and L. Popov. "Early Ordovician (Tremadocian) brachiopods from the Eastern Alborz Mountains, Iran". English. In: Estonian Journal of Earth Sciences 60 (2011), pp. 65-82. DOI: 10.3176/earth.2011.2.01.

[8362] M. Ghobadi Pour, L. M. E. McCobb, R. M. Owens, and L. E. Popov. "Late Ordovician trilobites from the Karagach Formation of the western Tarbagatai Range, Kazakhstan". English. In: Earth and Environmental Science Transactions of the Royal Society of Edinburgh 101 (2011), pp. 161-187. DOI: 10.1017/S1755691010010078.

[8363] M. Ghobadi Pour, L. E. Popov, M. R. Kebria-Ee Zadeh, and C. Baars. "Middle Ordovician (Darriwilian) brachiopods associated with the Neseuretus biofacies, eastern Alborz Mountains, Iran". English. In: Memoirs of the Association of Australasian Palaeontologists 42 (2011), pp. 263-283.

[8364] M. Ghobadi Pour and L. E. Popov. "First Report on the Occurrence of Neseuretinus and Ovalocephalus Trilobites in the Middle Ordovician of Iran". English. In: Acta Palaeontologica Polonica 54.1 (2009), pp. 125-133. DOI: 10.4202/app.2009.0113.

[8365] M. Ghobadi Pour, M. Vidal, and M. Hosseini-Nezhad. "An Early Ordovician Trilobite assdemblage from the Lashkarak Formation, Damghan area, northern Iran". English. In: Geodiversitas 40 (2007), pp. 489-500.

[8366] A. K. Ghosh and S. Sarkar. "Palaeoecological implications of Corallinacean red algae and Halimedacean green algae from the Prang Formation of south Shillong Plateau, Meghalaya". English. In: Journal Geological Society of India 81 (2013), pp. 531-542.

[8367] P. Ghosh, S. K. Bhattacharya, A. Sahni, R. K. Kar, D. M. Mohabey, and K. Ambwani. “Dinosaur coprolites from the Late Cretaceous (Maastrichtian) Lameta Formation of India: isotopic and other markers suggesting a C3 plant diet". English. In: Cretaceous Research 24 (2003), pp. 743-750.

[8368] S. C. Ghosh, T. K. Pal, and A. Nandi. "First record of an aquatic beetle larva (Insecta: Coleoptera) from the Parsora Formation (Permo-Triassic), India". English. In: Palaeontology 50 (2007), pp. 13351340.

[8369] S. K. Ghosh. "First record of marine bivalves from the Talchir Formation of the Satpura Gondwana basin, India: palaeobiogeographic implications". English. In: Gondwana Research 6 (2003), pp. 312320. 
[8370] F. A. Gianechini, S. Apestteguia, W. Landini, F. Finotti, R. J. Valieri, and F. Zandonai. “New abelisaurid remains from the Anacleto Formation (Upper Cretaceous), Patagonia, Argentina". English. In: Cretaceous Research 54 (2015), pp. 1-16.

[8371] A. Giannetti, J. F. Baeza-Carratalá, J. M. Soria-Mingorance, A. Dulai, J. E. Tent-Manclús, and J. Peral-Lozano. "New paleobiogeographical and paleoenvironmental insight through the Tortonian brachiopod and ichnofauna assemblages from the MediterraneanAtlantic seaway (Guadix Basin, SE Spain)". English. In: Facies 64 (2018), p. 24. DOI: 10.1007/s10347-018-0536-1.

[8372] A. Giannetti, S. Falces-Delgado, and P. Monaco. "Characterization of the Ophiomorpha rudis 3D boxwork in a turbiditic". English. In: Journal of Iberian Geology 43 (2017), pp. 631-642. DOI: 10.1007/ s41513-017-0046-y.

[8373] G. Gianucci, F. G. Marx, A. Collareta, A. Di Stefano, W. Landini, C. Morigi, and A. Varola. "Rise of the titans: baleen whales became giants earlier than thought". English. In: Biology Letters 15.20190175 (2019), pp. 1-5. DOI: 10.1098/rsbl.2019.0175.

[8374] I. X. Giaourtsakis and G. D. Koufos. "The Late Miocene Mammal Faunas of the Mytilinii Basin, Samos Island, Greece: New Collection. 10. Chalicotheriidae". English. In: Beitrage fur Palaeontologie 31 (2009), pp. 189-205.

[8375] S. Gibb and B. D. E. Chatterton. “Timsaloproetus New Genus (Proetida: Trilobita) and Included Species from Lower and Middle Devonian Strata of Southern Morocco". English. In: Journal of Paleontology 81.2 (2007), pp. 352-367.

[8376] J. W. Gibbons and M. E. Dorcas. North American Watersnakes: A Natural History. English. University of Oklahoma Press, 2004, pp. 1-438.

[8377] W. Gibbons and T. P. Young. "Mid-Caradoc magmatism in central Llyn, rhyolite petrogenesis, and the evolution of the Snowdonia volcanic corridor in NW Wales". English. In: Journal of the Geological Society 156.2 (1999), pp. 301-316. DOI: 10.1144/gsigs.156.2.0301.

[8378] J. Gibert, F. Ribot, L. Gibert, M. Leakey, A. Arribas, and B. Martinez. "Presence of the Cercopithecid genus Theropithecus in Cueva Victoria (Murcia, Spain)". In: Journal of Human Evolution 28 (1995), pp. 487-493.

[8379] B. M. Gibson, I. A. Rahman, K. M. Maloney, R. A. Racicot, H. Mocke, M. Laflamme, and S. A. F. Darroch. "Gregarious suspension feeding in a modular Ediacaran organism". English. In: Science Advances 5.6 (2019), eaaw0260. DOI: 10.1126/sciadv.aaw0260.

[8380] G. A. P. Gibson. “Description of Leptoomus janzeni, n. gen. and n. sp. (Hymenoptera: Chalcidoidea) from Baltic amber, and discussion of its relationships and classification relative to Eupelmidae, Tanaostigmatidae and Encyrtidae". English. In: Zootaxa 1730 (2008), pp. 1-26.

[8381] G. A. P. Gibson. "Description of three new genera and four new species of Neanastatinae (Hymenoptera, Eupelmidae) from Baltic amber, with discussion of their relationships to extant taxa". English. In: ZooKeys 20 (2009), pp. 175-214.

[8382] G. A. P. Gibson, J. Read, and J. T. Huber. “Diversity, classification and higher relationships of Mymarommatoidea (Hymenoptera)". English. In: Journal of Hymenoptera Research 16 (2007), pp. 51146.

[8383] M. L. Gibson and J. H. Geisler. “A new Pliocene dolphin (Cetacea: Pontoporiidae), from the Lee Creek Mine, North Carolina". English. In: Journal of Vertebrate Paleontology 29.3 (2009), pp. 966-971.

[8384] M. L. Gibson, J. Mnieckowski, and J. H. Geisler. “Tupelocetus palmeri, a new species of protocetid whale (Mammalia, Cetacea) from the middle Eocene of South Carolina". English. In: Journal of Vertebrate Paleontology (2019), e1555165. DOI: 10.1080/02724634.2018.1555165.

[8385] J. Gibson-Smith and W. Gibson-Smith. Unpublished notes on Caribbean collection of Jack and Winifred Gibson-Smith, Naturhistorisches Museum Basel. English. 2012.

[8386] G. Gierlinski. "Dinosaur ichnotaxa from the Lower Jurassic of Hungary". English. In: Geological Quarterly 40.1 (1996), pp. 119-128. 
[8387] G. Gierlinski. "New dinosaur ichnotaxa from the Early Jurassic of the Holy Cross Mountains, Poland". English. In: Palaeogeography, Palaeoclimatology, Palaeoecology 85 (1991), pp. 137-148.

[8388] G. Gierlinski and A. Ahlberg. "Late Triassic and Early Jurassic dinosaur footprints in the Höganäs Formation of southern Sweden". English. In: Ichnos 3 (1994), pp. 99-105.

[8389] G. Gierlinski, E. Gazdzicka, G. Niedzwiedzki, and G. Pienkowski. “New ornithischian dinosaur footprints in the Jurassic of Poland". English. In: Geological Quarterly 45.2 (2001), pp. 205-210.

[8390] G. Gierlinski and G. Niedzwiedzki. "New saurischian dinosaur footprints from the Lower Jurassic of Poland". English. In: Geological Quarterly 49.1 (2005), pp. 99-104.

[8391] G. Gierlinski and G. Niedzwiedzki. "Enigmatic dinosaur footprints from the Lower Jurassic of Poland". English. In: Geological Quarterly 46.4 (2002), pp. 467-472.

[8392] G. Gierlinski and G. Niedzwiedzki. "Dinosaur footprints from the Upper Jurassic of Blaziny, Poland". English. In: Geological Quarterly 46.4 (2002), pp. 463-465.

[8393] G. Gierlinski, G. Niedzwiedzki, and G. Pienkowski. "Gigantic footprint of a theropod dinosaur in the Early Jurassic of Poland". English. In: Acta Palaeontologica Polonica 46.3 (2001), pp. 441-446.

[8394] G. Gierlinski, G. Pienkowski, and G. Niedzwiedzki. "Tetrapod track assemblage in the Hettangian of Sotyków, Poland, and its paleoenvironmental background". English. In: Ichnos 11.3-4 (2004), pp. 195-213. DOI: 10.1080/10420940490444861.

[8395] G. Gierlinski and G. Sawicki. "New sauropod tracks from the Lower Jurassic of Poland". English. In: Geological Quarterly 42.4 (1998), pp. 477-480.

[8396] G. D. Gierlinski. "New dinosaur footprints from the Upper Cretaceous of Poland in the light of paleogeographic context". English. In: Ichnos 22.3-4 (2015), pp. 220-226. DOI: 10.1080/10420940. 2015.1063489.

[8397] G. D. Gierlinski and K. Z. Kowalski. "Footprint of a large ornithischian from the ancient sacred site of Kontrewers, Poland". English. In: vol. 37. The Triassic-Jurassic Terrestrial Transition. New Mexico Museum of Natural History and Science Bulletin. Albuquerque: New Mexico Museum of Natural History and Science, 2006, pp. 217-220.

[8398] G. D. Gierlinski, G. Niedzwiedzki, and P. Nowacki. "Small theropod and ornithopod footprints in the Late Jurassic of Poland". English. In: Acta Geologica Polonica 59.2 (2009), pp. 221-234.

[8399] G. D. Gierlinski, I. Ploch, E. Gawor-Biedowa, and G. Niedzwiedzki. "The first evidence of dinosaur tracks in the Upper Cretaceous of Poland". English. In: Oryctos 8 (2008), pp. 107-113.

[8400] P. M. Gignac, P. J. Makovicky, G. M. Erickson, and R. P. Walsh. “A description of Deinonychus antirrhopus bite marks and estimates of bite force using tooth indentation simulations". English. In: Journal of Vertebrate Paleontology 30.4 (2010), pp. 1169-1177.

[8401] J. Gil, J. M. Pons, and M. Segura. "Succession of rudistid lithosomes along the western coastal margin of the Iberian Basin (Coniacian, Castrojimeno Section, central Spain)". English. In: Facies 55 (2009), pp. 523-538.

[8402] M. D. Gil Cid, P. D. Alonso, M. C. C. González, and M. E Ródenas. "Nuevo Macrocystellidae (Echinodermata, Cystoidea Rhombifera) para el Ordovicico Español". Spanish. In: Estudios Geologicos 52.3-4 (1996), pp. 175-183.

[8403] M. D. Gil Cid, P. D. Alonso, E. S. Pobes, and M. E. Ródenas. “Bohemiaecystis jefferiesi n. sp.; primer Cornuta para el Ordovicico Español". Spanish. In: Estudios Geologicos 52.5-6 (1996), pp. 313-326.

[8404] M. D. Gil Cid and P. Domnguez. “Ubaghsicystis segurae nov gen y sp nuevo Eocrinoide (Echinodermata) del Cámbrico Medio del Norte de España". Spanish. In: Coloquios de Paleontologa 53 (2002), pp. 21-32.

[8405] M. D. Gil Cid and P. Domnguez Alonso. “Gyrocystis cruzae, una nueva especie de Cincta (Echinodermata Carpoidea) del Cámbrico Medio de El Ferredal de Quintana (Asturias, España)". English. In: Boletn Geológico y Minero 106.6 (1995), pp. 17-31. 
[8406] C. C. Gilbert, E. D. Goble, J. D. Kingston, and A. Hill. "Partial skeleton of Theropithecus brumpti (Primates, Cercopithecidae) from the Chemeron Formation of the Tugen Hills, Kenya". English. In: Journal of Human Evolution 61.4 (2011), pp. 347-362.

[8407] C. C. Gilbert, B. A. Patel, N. P. Singh, C. J. Campisano, J. G. Fleagle, K. L. Rust, and R. Patnaik. "New sivaladapid primate from Lower Siwalik deposits surrounding Ramnagar (Jammu and Kashmir State), India". English. In: Journal of Human Evolution 102 (2017), pp. 21-41.

[8408] S. Giles, L. Darras, G. Clément, A. Blieck, and M. Friedman. “An exceptionally preserved Late Devonian actinopterygian provides a new model for primitive cranial anatomy in ray-finned fishes". English. In: Proceedings of the Royal Society of London B: Biological Sciences 282.1816 (2015), p. 20151485. DOI: $10.1098 / \mathrm{rspb} .2015 .1485$.

[8409] B. J. Gill. "Prehistoric breeding site of New Zealand sea lions (Phocarctos hookeri, Carnivora: Otariidae) at North Cape". English. In: Records of the Aukland Museum 35 (1998), pp. 55-64.

[8410] G. A. Gill and F. Chikhi. "Remarks on new occurences of Aspidiscus, a Cenomanian scleractinian coral, in the Persian Gulf and in Algeria". English. In: Lethaia 24 (1991), pp. 349-350.

[8411] G. A. Gill, M. Santantonio, and B. Lathuiliere. "The depth of pelagic deposits in the Tethyan Jurassic and the use of corals: an example from the Apennines". English. In: Sedimentary Geology 166 (2004), pp. 311-334.

[8412] P. Gill. "A new symmetrodont from the Early Cretaceous of England". English. In: Journal of Vertebrate Paleontology 24.3 (2004), pp. 748-752.

[8413] P. C. Gill, G. J. B. Ross, W. H. Dawbin, and H. Wapstgra. "Confirmed sightings of dusky dolphins (Lagenorhynchus obscurus) in southern Australian waters". English. In: Marine Mammal Science 16.2 (2000), pp. 452-459.

[8414] A. K. Gillespie, M. Archer, S. J. Hand, and K. H. Black. “New material referable to Wakaleo (Marsupialia: Thylacoleonidae) from the Riversleigh World Heritage Area, northwestern Queensland: revising species boundaries and distributions in Oligo/Miocene marsupial lions". English. In: Alcheringa 38 (2014), pp. 513-527.

[8415] R. Gillespie, A. B. Cames, T. H. Worthy, N. J. Rawlene, C. Reid, F. Bertuch, V. Levchenko, and A. Cooper. "Man and megafauna in Tasmania: closing the gap". English. In: Quaternary Science Reviews 37 (2012), pp. 38-47.

[8416] D. D. Gillette. "Seismosaurus halli, gen. et sp. nov., a new sauropod dinosaur from the Morrison Formation (Upper Jurassic/Lower Cretaceous) of New Mexico, USA". English. In: Journal of Vertebrate Paleontology 11.4 (1991), pp. 417-433.

[8417] D. D. Gillette, M. C. Hayden, and A. L. Titus. Occurrence and biostratigraphic framework of a plesiosaur from the Upper Cretaceous Tropic Shale of southwestern Utah. English. 1999.

[8418] D. D. Gillette and D. B. Madsen. "The short-faced bear Arctodus simus from the late Quaternary in the Wasatch Mountains of central Utah". English. In: Journal of Vertebrate Paleontology 12.1 (1992), pp. 107-112.

[8419] P. M. Gilliland. "Holothurians in the Blue Lias of Southern Britain". English. In: Palaeontology 35.1 (1992), pp. 159-210.

[8420] J. P. Gillung and S. L. Winterton. "New genera of philopotine spider flies (Diptera, Acroceridae) with a key to living and fossil genera". English. In: ZooKeys 127 (2011), pp. 15-27.

[8421] J. P. Gillung and S. L. Winterton. "A review of fossil spider flies (Diptera: Acroceridae) with descriptions of new genera and species from Baltic amber". English. In: Journal of Systematic Palaeontology 16 (2017), pp. 325-350.

[8422] E. H. Gilmour. "New Carboniferous Bryozoa of the Bird Spring Formation, Southern Nevada". English. In: Journal of Paleontology 81.3 (2007), pp. 581-587.

[8423] E. H. Gilmour, M. E. McColloch, and B. R. Wardlaw. "Bryozoa of the Mudrock Mountain Formation (Wordian, Permian), Leach Mountains, Northeastern Nevada". English. In: Journal of Paleontology 71.2 (1997), pp. 214-236. 
[8424] E. H. Gilmour and I. P. Morozova. "Biogeography of the Late Permian bryozoans". English. In: Paleontological Journal 33.1 (1999), pp. 36-51.

[8425] E. H. Gilmour and E. M. Snyder. “Bryozoa of the Mission Argillite (Permian), northeastern Washington". English. In: Journal of Paleontology 74.4 (2000), pp. 540-570.

[8426] M. L. Gimmel, K. Szawaryn, C. Y. Cai, and R. A. B. Leschen. "Mesozoic sooty mould beetles as living relicts in New Zealand". English. In: Proceedings of the Royal Society B 286.20192176 (2019). DOI: $10.1098 / \mathrm{rspb} .2019 .2176$.

[8427] P. D. Gingerich. "Systematics and Evolution of Early Eocene Perissodactyla (Mammalia) in the Clarks Fork Basin, Wyoming". English. In: Contributions from the Museum of Paleontology, University of Michigan 28.8 (1991), pp. 181-213.

[8428] P. D. Gingerich. "New species of Apheliscus, Haplomylus, and Hyopsodus (Mammalia, Condylarthra) from the late Paleocene of southern Montana and early Eocene of northwestern Wyoming". English. In: Contributions from the Museum of Paleontology, University of Michigan 29.6 (1994), pp. 119134.

[8429] P. D. Gingerich. "New Species of Titanoides (Mammalia, Pantodonta) from the Middle Clarkforkian (Late Paleocene) of Northwestern Wyoming". English. In: Contributions from the Museum of Paleontology, University of Michigan 29.14 (1996), pp. 403-412.

[8430] P. D. Gingerich. "Marine Mammals (Cetacean and Sirenia) from the Eocene of Gebel Mokattam and Fayum, Egypt: Stratigraphy, Age, and Paleoenvironments". English. In: University of Michigan Papers on Paleontology 30 (1992), pp. 1-84.

[8431] P. D. Gingerich. “Early Eocene Teilhardina brandti: oldest omomyid primate from North America". English. In: Contributions from the Museum of Paleontology, University of Michigan 28.13 (1993), pp. 321-326.

[8432] P. D. Gingerich. "Stromerius nidensis, New Archaeocete (Mammalia, Cetacea) From The Upper Eocene Qasr El-Sagha Formation, Fayum, Egypt". English. In: Contributions from the Museum of Paleontology, The University of Michigan 31.13 (2007), pp. 363-378.

[8433] P. D. Gingerich. “African dawn for primates". English. In: Nature 346 (1990), p. 411.

[8434] P. D. Gingerich. Cetacea. English. Cenozoic Mammals of Africa. 2010, pp. 873-899.

[8435] P. D. Gingerich. "Aegicetus gehennae, a new late Eocene protocetid (Cetacea, Archaeoceti) from Wadi Al Hitan, Egypt, and the transition to tail- powered swimming in whales". English. In: PLoS Once 14.12 (2019), e0225391. DOI: 10.1371/journal.pone.0225391.

[8436] P. D. Gingerich, S. G. Abbas, and M. Arif. "Early Eocene Quettacyon parachai (Condylarthra) from the Ghazij Formation of Baluchistan (Pakistan): oldest Cenozoic land mammal from south Asia". English. In: Journal of Vertebrate Paleontology 17.4 (1997), pp. 629-637.

[8437] P. D. Gingerich, M. al-Haq, W. von Koenigswald, W. J. Sanders, B. H. Smith, and I. S. Zalmout. "New protocetid whale from the Middle Eocene of Pakistan: Birth on land, precocial development, and sexual dimorphism". English. In: PLoS One 4.2 (2009), pp. 1-20.

[8438] P. D. Gingerich, M. S. M. Antar, and I. S. Zalmout. “New middle-to-late Eocene protocetid (Cetacea, Archaeoceti) from Wadi al Hitan, Egypt: Transition to tail-powered swimming". English. In: International Symposium (2019), p. 19.

[8439] P. D. Gingerich, M. Arif, M. A. Bhatti, M. Anwar, and W. J. Sanders. "Basilosaurus drazindai and Basiloterus hussaini, new archaeoceti (Mammalia, Cetacea) from the Middle Eocene Drazinda Formation, with a revised interpretation of ages of whale-bearing strata in the Kirthar Group of the Sulaiman Range, Punjab (Pakistan)". English. In: Contributions from the Museum of Paleontology, University of Michigan 30.2 (1997), pp. 55-81.

[8440] P. D. Gingerich, M. Arif, and W. C. Clyde. "New archaeocetes (Mammalia, Cetacea) from the Middle Eocene Domanda Formation of the Sulaiman Range, Punjab (Pakistan)". In: Contributions from the Museum of Paleontology, University of Michigan 29.11 (1995), pp. 291-330. 
[8441] P. D. Gingerich, M. Arif, M. A. Bhatti, H. A. Raza, and S. M. Raza. "Protosiren and Babiacetus (Mammalia, Sirenia and Cetacea) from the middle Eocene Drazinda Formation, Sulaiman Range, Punjab, Pakistan". In: Contributions from the Museum of Paleontology, University of Michigan 29.12 (1995), pp. 331-357.

[8442] P. D. Gingerich, M. Arif, I. Hussain, and S. G. Abbas. First early Eocene land mammals from the Upper Ghazij Formation of the Sor Range, Balochistan. English. Siwaliks of South Asia. 1998.

[8443] P. D. Gingerich, M. Arif, I. H. Khan, W. C. Clyde, and J. I. Bloch. "Machocyon abbasi, a new early Eocene quettacynoid (Mammalia, Condylarthra)". English. In: Contributions from the Museum of Paleontology, The University of Michigan 30.9 (1999), pp. 233-250.

[8444] P. D. Gingerich and H. Cappetta. "A new archaeocete and other marine mammals (Cetacea and Sirenia) from lower middle Eocene phosphate deposits of Togo". English. In: Journal of Paleontology 88.1 (2014), pp. 109-129. DOI: 10.1666/13-040.

[8445] P. D. Gingerich, M. Haq, I. S. Zalmout, I. H. Khan, and M. S. Malkani. “Origin of whales from early artiodactyls: Hands and feet of Eocene Protocetidae from Pakistan". In: Science 293 (2001), pp. 2239-2242.

[8446] P. D. Gingerich, P. A. Holroyd, and R. L. Ciochon. Rencunius zhoui, New Primate from the Late Middle Eocene of Henan, China, and a Comparison with Some Early Anthropoidea. English. Anthropoid Origins, edited by J. G. Fleagle and R. F. Kay. Plenum Press, New York, 1994. 1994, pp. 163-177.

[8447] P. D. Gingerich, S. M. Raza, M. Arif, M. Anwar, and X. Zhou. "New whale from the Eocene of Pakistan and the origin of cetacean swimming". In: Nature 368 (1994), pp. 844-847.

[8448] P. D. Gingerich, S. M. Raza, M. Arif, M. Anwar, and X. Zhou. “Partial skeletons of Indocetus ramani (Mammalia, Cetacea) from the lower Middle Eocene Domanda Shale in the Sulaiman Range of Punjab (Pakistan)". In: Contributions from the Museum of Paleontology, University of Michigan 28.16 (1993), pp. 393-416.

[8449] P. D. Gingerich and D. E. Russell. "Dentition of early Eocene Pakicetus (Mammalia, Cetacea)". English. In: Contributions from the Museum of Paleontology, University of Michigan 28.1 (1990), pp. 120.

[8450] P. D. Gingerich and D. E. Russell. “Unusual mammalian limb bones (Cetacea?, Archaeoceti?) from the Early-to-middle Eocene Subathu Formation of Kashmir (Pakistan)". English. In: Contributions from the Museum of Paleontology, University of Michigan 29.5 (1994), pp. 109-117.

[8451] P. D. Gingerich, D. E. Russell, and N. A. Wells. "Astragalus of Anthracobune (Mammalia, Proboscidea) from the Early-Middle Eocene of Kashmir". English. In: Contributions from the Museum of Paleontology, The University of Michigan 28.3 (1990), pp. 71-77.

[8452] P. D. Gingerich and T. Smith. "Paleocene-Eocene land mammals from three new latest Clarkforkian and earliest Wasatchian wash sites at Polecat Bench in the northern Bighorn Basin, Wyoming." English. In: Contributions from the Museum of Paleontology, University of Michigan 31.11 (2006), pp. 245303.

[8453] P. D. Gingerich and M. D. Uhen. “Ancalecetus simonsi, a new dorudontine archaeocete (Mammalia, Cetacea) from the early late Eocene of Wadi Hitan, Egypt". English. In: Contributions from the Museum of Paleontology, University of Michigan 29.13 (1996), pp. 359-401.

[8454] P. D. Gingerich, M. Ul-Haq, I. H. Khan, and I. S. Zalmout. "Eocene stratrigraphy and archaeocete whales (Mammalia, Cetacea) of Drug Lahar in the eastern Sulaiman range, Balochistan (Pakistan)". In: Contributions from the Museum of Paleontology, University of Michigan 30.11 (2001), pp. 269 319.

[8455] P. D. Gingerich, I. S. Zalmout, M. Ul-Haq, and M. A. Bhatti. "Makracetus bidens, a new protocetid archaeocete (Mammalia, Cetacea) from the early middle Eocene of Balochistan (Pakistan)". English. In: Contributions from the Museum of Paleontology, University of Michigan 31.9 (2005), pp. 197210. 
[8456] P. D. Gingerich and S. Zouhri. "New fauna of archaeocete whales (Mammalia, Cetacea) from the Bartonian middle Eocene of southern Morocco". English. In: Journal of African Earth Sciences 111 (2015), pp. 273-286. DOI: 10.1016/j.jafrearsci.2015.08.006.

[8457] L. Ginsburg and M. Bonneau. "La succession des faunes de mammiferes miocenes de Pontigne (Maine-et-Loire, France)". English. In: Bulletin de Musee national Histoire naturell 4.2-4 (1995), pp. 313328.

[8458] L. Ginsburg and C. Bulot. “Les Diplocynodon (Reptilia, Crocodylia) de l'Orléanien (Miocéne inférieur á moyen) de France". French. In: Geodiversitas 19.1 (1997), pp. 107-128.

[8459] L. Ginsburg, K. H. Durrani, A. M. Kassi, and J. -L. Welcomme. "Discovery of a New Anthracobunidae (Tethytheria, Mammalia) from the Lower Eocene lignite of the Kach-Harnai Area in Baluchistan (Pakistan)". English. In: Comptes Rendus de l'Academie des Sciences Series IIA Earth and Planetary Science 328.3 (1999), pp. 209-213.

[8460] L. Ginsburg and P. Janvier. "Les phoques (Phocidae, Pinnipedia, Carnivora, Mammalia) des faluns Miocenes de L'Anjou". French. In: Bulletin de la Societe des Sciences naturelles de l'Ouest de la France, Nouvelle serie 21.4 (1999), pp. 169-178.

[8461] L. Ginsburg, J. Morales, and D. Soria. “The ruminants (Artiodactyla, Mammalia) from the Lower Miocene of Cetina de Aragon (Province of Zaragoza, Aragon, Spain)". English. In: Proceedings van de Koninklijke Nederlandse Akademie van Wetenschappen 97.2 (1994), pp. 141-181.

[8462] L. Ginsburg, J. Morales, D. Soria, and E. Herraez. "Découverte d'une forme ancestrale du Petit Panda dans le Miocéne moyen de Madrid (Espagne)". French. In: Comptes Rendus de l'Académie des Sciences - Series IIA - Earth and Planetary Science 325.6 (1997), pp. 447-451.

[8463] L. Ginsburg and J. Morales. "Zaragocyon daamsi n. gen. sp. nov., Ursidae primitif du Miocéne inférieur d'Espagne". English. In: Comptes rendus de l'Académie des sciences. Série 2. Sciences de la terre et des planétes 321.9 (1995), pp. 811-815.

[8464] M. Ginter. "Taxonomic notes on Phoebodus heslerorum and Symmorium reniforme (Chondrichthyes, Elasmobranchii)". English. In: Acta Palaeontologica Polonica 47.3 (2002), pp. 547-555.

[8465] M. Ginter. "Symmoriiform sharks from the Pennsylvanian of Nebraska". English. In: Acta Geologica Polonica 68 (2018), pp. 391-401.

[8466] M. Ginter, A. Ivanov, and O. Lebedev. "The revision of Cladodus occidentalis, a late Palaeozoic ctenacanthiform shark". English. In: Acta Palaeontologica Polonica 50.3 (2005), pp. 623-631.

[8467] M. Ginter, J.-C. Liao, and J. I. Valenzuela-Rios. “New data on chondrichthyan microremains from the Givetian of the Renanue section in the Aragonian Pyrenees (Spain)". English. In: Acta Geologica Polonica 58.2 (2008), pp. 165-172.

[8468] A. Gioncada, A. Collareta, K. Gariboldi, O. Lambert, C. Di Clema, E. Bonaccorsi, M. Urbina, and G. Bianucci. "Inside baleen: Exceptional microstructure preservation in a late Miocene whale skeleton from Peru". English. In: Geology (2016). DOI: 10.1130/G38216.1.

[8469] G. Giribet and J. A. Dunlop. "First identifiable Mesozoic harvestman (Opiliones: Dyspnoi) from Cretaceous Burmese amber". English. In: Proceedings of the Royal Society B 272 (2005), pp. 10071013.

[8470] G. Giribet, A. L. Tourinho, C. K. Shih, and D. Ren. “An exquisitely preserved harvestman (Arthopoda, Arachnida, Opiliones) from the Middle Jurassic of China". English. In: Organisms Diversity \& Evolution 12 (2012), pp. 51-56.

[8471] A. Girone, D. Nolf, and H. Cappetta. "Pleistocene fish otoliths from the Mediterranean Basin: a synthesis". English. In: Geobios 39 (2006), pp. 651-671.

[8472] O. Girotti, L. Capasso Barbato, D. Esu, E. Gliozzi, T. Kotsakis, E. Martinetto, C. Petronio, R. Sardella, and E. Squazzini. "The section of Torre Picchio (Terni, Umbria, Central Italy): A Villafranchian site rich in vertebrates, molluscs, ostracods and plants." English. In: Rivista Italiana di Paleontologia e Stratigrafia 109.1 (2003), pp. 77-98. 
[8473] E. Gischler. "Pleistocene facies of Belize barrier and atoll reefs". English. In: Facies 53.1 (2007), pp. 27-41.

[8474] E. Gischler, A. Balinski, A. Fuchs, and D. Heidelberger. "Famennian brachiopod and gastropod occurrences on top of Devonian seamounts, Elbingerode and Iberg Reefs, Harz Mts, Germany". English. In: Senckenbergiana Lethaea 84.1/2 (2004), pp. 125-139. DOI: 10.1007/BF03043468.

[8475] E. Gischler, J. H. Hudson, and A. Pisera. "Late Quaternary reef growth and sea level in the Maldives (Indian Ocean)". English. In: Marine Geology 250.1-2 (2008), pp. 104-113.

[8476] E. Gischler and J. H. Hudson. "Holocene development of the Belize Barrier Reef". English. In: Sedimentary Geology 164 (2004), pp. 223-236.

[8477] E. Gischler and J. H. Hudson. "Holocene development of three isolated carbonate platforms, Belize, central America". English. In: Marine Geology 144 (1998), pp. 333-347.

[8478] E. Gischler, M. Humblet, J. C. Braga, and A. Eisenhauer. "Last interglacial reef facies and late Quaternary subsidence in the Maldives, Indian Ocean". English. In: Marine Geology 406 (2018), pp. 34-41. DOI: 10.1016/j.margeo.2018.09.001.

[8479] E. Gischler, M. R. Sandy, and J. Peckmann. “Ibergirynchia contraria (F. A. Roemer, 1850), an Early Carboniferous seep-related Rhynchonellide brachiopod from the Harz Mountains, Germany - a possible cucessor to Dzieduszyckia?" English. In: Journal of Paleontology 77.2 (2003), pp. 293-303.

[8480] L. Giusberti, A. Bannikov, F. B. Galazzo, E. Fornaciari, J. Frieling, V. Luciana, C. A. Pappazoni, G. Roghi, S. Schouten, A. Sluijs, F. R. Bosellini, and R. Zorzin. "A new Fossil-Lagerstätte from the Lower Eocene of Lessini Mountains (northern Italy): A multidisciplinary approach". English. In: Palaeogeography, Palaeoclimatology, Palaeoecology 403 (2014), pp. 1-15. DOI: 10.1016/j.palaeo.2014. 03.012 .

[8481] C. R. Givens. “Old World Tethyan Occurrences of Lyrischapa (Gastropoda; Volutidae) and Biogeographic Implications". English. In: Journal of Paleontology 65.4 (1991), pp. 661-670.

[8482] C. R. Givens. "Occurrence of the Rare Genus Anapteris (Bivalvia: Corbulidae) in the Eocene of California". English. In: Journal of Paleontology 68.1 (1994), pp. 168-171.

[8483] W. Gika. "A new species group in the genus Tanytarsus van der Wulp (Diptera: Chironomidae) based on a fossil record from Baltic amber". English. In: Acta Geologica Sinica 84.4 (2010), pp. 714719 .

[8484] W. Gika. "A new fossil Tanytarsus from Eocene Baltic amber, with notes on systematics of the genus (Diptera: Chironomidae)". English. In: Zootaxa 3069 (2011), pp. 63-68.

[8485] W. Gika, E. A. Makarchenko, M. K. Pankowski, and M. Zakrzewska. "Myanmaro primus gen. et sp. nov., the first orthoclad (Diptera: Chironomidae) from Cretaceous Burmese amber". English. In: Zootaxa 4565 (2019), pp. 61-70.

[8486] W. Gika, M. Zakrzewska, P. Dominiak, and A. Urbanek. "Non-biting midges of the tribe Tanytarsini in Eocene amber from the Rovno region (Ukraine): a pioneer systematic study with notes on the phylogeny (Diptera: Chironomidae)". English. In: Zootaxa 3736 (2013), pp. 569-586.

[8487] W. Gika, M. Zakrzewska, V. Baranov, B. Wang, and F. Stebner. "The first fossil record of Nandeva Wiedenbrug, Reiss \& Fittkau (Diptera: Chironomidae) in early Eocene Fushun amber from China". English. In: Alcheringa 40 (2016), pp. 390-397.

[8488] W. Gika and M. Zakrzewska. "A new species of the subfamily Buchonomyiinae (Diptera: Chironomidae) from Cretaceous Burmese amber". English. In: Dipteron 33 (2017), pp. 26-33.

[8489] W. Gika, M. Zakrzewska, and E. A. Makarchenko. "Burmochlus gen. nov., the first Cretaceous member of the Archaeochlus cluster (Diptera: Chironomidae: Podonominae)". English. In: Cretaceous Research 106.104261 (2019). DOI: 10.1016/j.cretres.2019.104261.

[8490] I. Gjertz. "The narwhal, Monodon monoceros, in the Norwegian high arctic". English. In: Marine Mammal Science 7 (1991), pp. 402-408.

[8491] A. Y. Gladenkov. "First Finds of Eocene Diatoms in the Marine Paleogene Reference". English. In: Stratigraphy and Geological Correlation 21.1 (2013), pp. 96-106. 
[8492] Y. B. Gladenkov and V. N. Sinel'nikova. "Stratigraphy and Mollusks of Lower Paleogene of the Kamchatka Peninsula and Climatic Features". English. In: Stratigraphy and Geological Correlation 22.1 (2014), pp. 44-60. DOI: 10.1134/S0869593814010031.

[8493] A. Glass, W. I. Ausich, and P. Copper. "New cyclocystoid (phylum echinodermata) from Anticosti Island, Quebec, and its bearing on cyclocystoid life modes". In: Journal of Paleontology 77.5 (2003), pp. 949-957.

[8494] A. Glass and M. Poschmann. "A new species of brittlestar (Ophiuroidea, Echinodermata) from the Hunsrück slate (Lower Emsian, Lower Devonian) of Germany". English. In: Palaeontology 49.5 (2006), pp. 969-981.

[8495] L. N. Glawe, J. F. Anderson, and D. E. Bell. "Late Paleocene examples of residual coloration and embryonic features in juvenile marine mollusks from Northwest Louisiana". English. In: Palaeontologia Electronica 17.2 (2014).

[8496] B. F. Glenister, C. Baker, W. M. Furnish, and J. M. Dickins. "Late Permian ammonoid cephalopod Cyclolobus from Western Australia". English. In: Journal of Paleontology 64.3 (1990), pp. 399-402.

[8497] B. F. Glenister, C. Baker, W. M. Furnish, and G. A. Thomas. “Additional Early Permian ammonoid cephalopods from Western Australia". English. In: Journal of Paleontology 64 (1990), pp. 392-399.

[8498] B. F. Glenister, W. M. Furnish, and Z. Zhou. "Paedopronorites, a new Upper Permian (Wuchiapingian) ammonoid from Indonesia (Timor)". English. In: Journal of Paleontology 78.5 (2004), pp. 10141015.

[8499] B. F. Glenister, W. M. Furnish, Z. R. Zhou, and M. Polahan. “Ammonoid cephalopods from the Lower Permian of Thailand". English. In: Journal of Paleontology 64 (1990), pp. 479-480.

[8500] S. Glienke. "A new microsaur (Amphibia; Lepospondyli) from the Rotliegend of the Saar-Palatinate region (Carboniferous/Permian transition; West Germany)". English. In: Palaeontologische Zeitschrift 86 (2012), pp. 297-311.

[8501] S. Glienke. "Two new species of the genus Batropetes (Tetrapoda, Lepospondyli) from the Central European Rotliegend (basal Permian) in Germany". English. In: Journal of Vertebrate Paleontology 35.2 (2015), pp. 1-27. DOI: 10.1080/02724634.2014.918041.

[8502] E. A. Glover and J. D. Taylor. “A new shallow water species of Nucinella from the Philippines (Bivalvia: Protobranchia: Nucinellidae), member of a tropical seagrass chemosynthetic community". English. In: The Natutilus 127.3 (2013), pp. 101-106.

[8503] E. Gluchowski. "Crinoid assemblages in the Polish Givetian and Frasnian". English. In: Acta Palaeontologica Polonica 38.1-2 (1993), pp. 35-92.

[8504] E. Gluchowski. “Crinoids from the Famennian of the Holy Cross Mountains, Poland". English. In: Acta Palaeontologica Polonica 47.2 (2002), pp. 319-328.

[8505] S. Gmira. “Une nouvelle espéce de tortue Testudininei (Testudo kenitrensis n. sp.) de l'inter AmirienTensiftien de Kénitra (Maroc)". French. In: Comptes Rendus de l'Académie des Sciences de Paris 316 (1993), pp. 701-707.

[8506] S. Gmira, F. de Lapparent de Broin, D. Geraads, D. Levefre, A. Mohib, and J. -P. Raynal. “Les tortues du Pliocéne d'Ahl al Oughlam (Casablanca, Maroc) et de localités mio-pliocénes avoisinantes". French. In: Geodiversitas 35.3 (2013), pp. 691-733.

[8507] S. Gnaedinger. "Ginkgoalean woods from the Jurassic of Argentina: Taxonomic considerations and palaeogeographical distribution". English. In: Geobios 45 (2012), pp. 187-198.

[8508] S. Gnaedinger, R. A. Coria, E. Koppelhus, S. Casado, M. Tunik, and P. Currie. "First Lower Cretaceous record of Podocarpaceae wood associated with". English. In: Cretaceous Research 78 (2017), pp. 228-239.

[8509] S. Gnaedinger, J. L. Garca Massini, F. Bechis, and A. M. Zavattieri. "Coniferous woods and wooddecaying fungi from the El Freno Formation (Lower Jurassic), Neuquén Basin, Mendoza Province, Argentina." English. In: Ameghiniana 52.4 (2015), pp. 447-467. DOI: 10.5710/ AMGH.12.05.2015. 2868. 
[8510] S. C. Gnaedinger and A. M. Zavattieri. "Coniferous woods for the Upper Triassic of southwestern Gondwana, Tronquimalal Group, Neuquén Basin, Mendoza Province, Argentina". English. In: Journal of Paleontology (2020). DOI: 10.1017/jpa.2020.1.

[8511] M. Gnoli. "New evidence for faunal links between Sardinia and Bohemia in Silurian time on the basis of nautiloids". In: Bolletino della Societa Paleontologica Italiana 29.3 (1990), pp. 289-307.

[8512] M. Gnoli and E. Serpagli. "Nautiloid assemblages from middle-late Silurian of southwestern Sardinia: a proposal". In: Bolletino della Societa Paleontologica Italiana 30.2 (1991), pp. 187-195.

[8513] J. Godefroid and G. Racki. "Frasnian Gypidulid brachiopods from the Holy Cross Mountains (Poland). Comparative stratigraphic analysis with the Dinant Synclinorium (Belgium)." English. In: Sciences de la Terre 60 (1990), pp. 43-74.

[8514] P. Godefroit. "New traversodontid (Therapsida: Cynodontia) teeth from the Upper Triassic of Habay-la-Vieille (southern Belgium)". English. In: Palaeontologische Zeitschrift 73.3/4 (1999), pp. 385394.

[8515] P. Godefroit. "Reptilian, therapsid and mammalian teeth from the Upper Triassic of Varangéville (northeastern France)". English. In: Bulletin de l'Institut Royal des Sciences Naturelles de Belgique, Sciences de la Terre 67 (1997), pp. 83-102.

[8516] P. Godefroit. "Simolestes keileni sp. nov., un Pliosaure (Plesiosauria, Reptilia) du Bajocien supérieur de Lorraine (France)". English. In: Bulletin des Académie et Société Lorraines des sciences 33.2 (1994), pp. 77-95.

[8517] P. Godefroit. "Les grands ichthyosaures sinémuriens d'Arlon". English. In: Bulletin de l'Institut Royal des sciences naturelles de Belgique. Sciences de la Terre 63 (1993), pp. 25-71.

[8518] P. Godefroit. “Un crane d'Ichthyosaurus communis (Reptilia, Ichthyosauria) du Sinémurien supérieur de Lorraine belge". French. In: Bulletin de Société belge de Géologie 104.1-2 (1995), pp. 77-89.

[8519] P. Godefroit. "Présence de Leptopterygius tenuirostris (Reptilia, Ichthyosauria) dans le Lias moyen de Lorraine belge". French. In: Bulletin de l'Institut Royal des Sciences Naturelles de Belgique, Sciences de la Terre 62 (1992), pp. 163-170.

[8520] P. Godefroit and B. Battail. "Late Triassic cynodonts from Saint-Nicolas-de-Port (north-eastern France)". English. In: Geodiversitas 19.3 (1997), pp. 567-631.

[8521] P. Godefroit, Y. Bolotsky, and V. Alifanov. "A remarkable hollow-crested hadrosaur from Russia: an Asian origin for lambeosaurines". English. In: Comptes Rendus Palevol 2 (2003), pp. 143-151.

[8522] P. Godefroit, Y. L. Bolotsky, and J. Van Itterbeeck. "The lambeosaurine dinosaur Amurosaurus riabinini, from the Maastrichtian of Far Eastern Russia". In: Acta Palaeontologica Polonica 49.4 (2004), pp. 575-618.

[8523] P. Godefroit, Y. L. Bolotsky, and P. Lauters. "A new saurolophine dinosaur from the latest Cretaceous of far eastern Russia”. English. In: PLoS ONE 7.5 (2012), e36849:1-22. DOI: 10.1371/journal. pone.0036849.

[8524] P. Godefroit, A. Cau, D. -Y. Hu, F. Escuillie, W. Wu, and G. Dyke. “A Jurassic avialan dinosaur from China resolves the early phylogenetic history of birds". English. In: Nature (2013). DOI: 10. 1038/nature12168.

[8525] P. Godefroit, G. Cuny, D. Delsate, and M. Roche. "Late Triassic vertebrates from Syren (Luxembourg)". English. In: Neues Jahrbuch für Geologie und Paläontologie, Abhandlungen 210.3 (1998), pp. 305-343.

[8526] P. Godefroit and G. Cuny. "Archosauriform teeth from the Upper Triassic of Saint-Nicolas-de-Port (northeastern France)". English. In: Palaeovertebrata 26.1-4 (1997), pp. 1-34.

[8527] P. Godefroit, P. J. Currie, H. Li, C. Y. Shang, and Z. -M. Dong. "A new species of Velociraptor (Dinosauria: Dromaeosauridae) from the Upper Cretaceous of northern China". English. In: Journal of Vertebrate Paleontology 28.2 (2008), pp. 432-438. 
[8528] P. Godefroit, H. Demuynck, G. Dyke, D. Hu, F. Escuillié, and P. Claeys. "Reduced plumage and flight ability of a new Jurassic paravian theropod from China". English. In: Nature Communications 4.1394 (2013), pp. 1-6. DOI: 10.1038/ncomms2389.

[8529] P. Godefroit, L. Golovneva, S. Shchepetov, G. Garcia, and P. Alekseev. "The last polar dinosaurs: high diversity of latest Cretaceous arctic dinosaurs in Russia". English. In: Naturwissenschaften 96.4 (2009), pp. 495-501. DOI: 10.1007/s00114-008-0499-0.

[8530] P. Godefroit and D.-Y. Guo. "A new amphilestid mammal from the Early Cretaceous of Inner Mongolia (P. R. China)". In: Bulletin de l'Institut Royal des Sciences Naturelles de Belgique, Sciences de la Terre 69.supplement (1999), pp. 7-16.

[8531] P. Godefroit, S. Hai, T. Yu, and P. Lauters. "New hadrosaurid dinosaurs from the uppermost Cretaceous of northeastern China". English. In: Acta Palaeontologica Polonica 53.1 (2008), pp. 47-74.

[8532] P. Godefroit and F. Knoll. "Late Triassic dinosaur teeth from southern Belgium". English. In: Comptes Rendus Palevol 2.1 (2003), pp. 3-11.

[8533] P. Godefroit, H. Li, and C. -Y. Shang. "A new primitive hadrosauroid dinosaur from the Early Cretaceous of Inner Mongolia (P. R. China)". English. In: Comptes Rendus Palevol 4.8 (2005), pp. 697705. DOI: 10.1016/j.crpv.2005.07.004.

[8534] P. Godefroit and N. Motchurova-Dekova. “Latest Cretaceous hadrosauroid (Dinosauria: Ornithopoda) remains from Bulgaria". English. In: Comptes Rendus Palevol 9.4 (2010), pp. 163-169. DOI: 10.1016/ j.crpv.2010.05.003.

[8535] P. Godefroit, X. Pereda-Suberbiola, H. Li, and Z. Dong. "A new species of the ankylosaurid dinosaur Pinacosaurus from the Late Cretaceous of Inner Mongolia (P.R. China)". In: Bulletin de l'Institut Royal des Sciences Naturelles de Belgique, Sciences de la Terre 69.supplement (1999), pp. 17366.

[8536] P. Godefroit and D. Sigogneau-Russell. “Cynodontes et mammiféres primitifs du Trias Supérieur, en region Lorraine et Luxembourgeoise [Cynodonts and primitive mammals form the Upper Triassic, in the Lorraine region and Luxembourg]". English. In: Bulletin de la Société Belge de Géologie 104.1-2 (1995), pp. 9-21.

[8537] P. Godefroit, S. M. Sinitsa, D. Dhouailly, Y. L. Bolotsky, A. V. Sizov, M. E. McNamara, M. J. Benton, and O. Spagna. "A Jurassic ornithischian dinosaur from Siberia with both feathers and scales". English. In: Science 345.6 (2014), pp. 451-455. DOI: 10.1126/science.1253351.

[8538] P. Godefroit, S. Zan, and L. Jin. “Charonosaurus jiayinensis n. g., n. sp., a lambeosaurine dinosaur from the Late Maastrichtian of northeastern China". French. In: Compte Rendus de l'Academie des Sciences, Paris, Sciences de la Terre et des planétes 330 (2000), pp. 875-882.

[8539] L. R. Godfrey, W. L. Jungers, D. A. Burney, Ramilisonina Vasey N., W. Wheeler, P. Lemelin, L. J. Shapiro, G. T. Schwartz, S. J. King, M. F. Ramarolahy, and G. F. N. Randria. "New discoveries of skeletal elements of Hadropithecus stenognathus from Andrahomana Cave, southeastern Madagascar". English. In: Journal of Human Evolution 51.4 (2006), pp. 395-410. DOI: 10.1016/j.jhevol. 2006.04.012.

[8540] S. Godfrey, M. D. Uhen, J. E. Osborne, and L. E. Edwards. "A new specimen of Agorophius pygmaeus (Agorophiidae, Odontoceti, Cetacea) from the early Oligocene Ashley Formation of South Carolina, USA". English. In: Journal of Paleontology 90.1 (2016), pp. 154-169. DOI: 10.1017/jpa.2016. 4.

[8541] S. J. Godfrey and L. G. Barnes. "A new genus and species of late Miocene pontoporiid dolphin (Cetacea: Odontoceti) from the St. Marys Formation in Maryland". English. In: Journal of Vertebrate Paleontology 28.2 (2008), pp. 520-528.

[8542] S. J. Godfrey and P. J. Currie. "A xiphisternal from the Dinosaur Park Formation (Campanian, Upper Cretaceous) of Alberta, Canada". In: Canadian Journal of Earth Sciences 31 (1994), pp. 16611663. 
[8543] S. J. Godfrey and P. J. Currie. A theropod (Dromaeosauridae, Dinosauria) sternal plate from the Dinosaur Park Formation (Campanian, Upper Cretaceous) of Alberta, Canada. English. Feathered Dragons. Indiana University Press, Bloomington. 2004, pp. 144-149.

[8544] S. J. Godfrey, J. H. Geisler, and E. G. M. Fitzgerald. "On the Olfactory Anatomy in an Archaic Whale (Protocetidae, Cetacea) and the Minke Whale Balaenoptera acutorostrata (Balaenopteridae, Cetacea)". English. In: The Anatomical Record 296 (2013), pp. 257-272. DOI: 10.1002/ar.22637.

[8545] S. J. Godfrey and R. Holmes. "Cranial morphology and systematics of Chasmosaurus (Dinosauria: Ceratopsidae) from the Upper Cretaceous of western Canada". English. In: Journal of Vertebrate Paleontology 15.4 (1995), pp. 726-742.

[8546] S. J. Godfrey, R. E. Weems, and B. Palmer. "Turtle Shell Impression in a Coprolite from South Carolina, USA". English. In: Ichnos (2017). DOI: 10.1080/10420940.2017.1386662.

[8547] M. Godinot. "A summary of adapiform systematics and phylogeny". English. In: Folia Primatologica 69.Suppl. 1 (1998), pp. 218-249.

[8548] M. Godinot, H.-P. Labarrére, J. Erfurt, J. L. Franzen, B. Lange-Badre, F. Lapparent de Broin, and D. Vidalenc. “Un nouveau gisement á vertébrés éocénes, Rouzilhac (MP 10-11), dans la série molassique d'Issel (Aude, France)". French. In: Revue de Paléobiologie, Genéve 37 (2018), pp. 141-333.

[8549] M. Godinot and M. Mahboubi. "Earliest known simian primate found in Algeria". English. In: Nature 357 (1992), pp. 324-326.

[8550] M. Godinot, B. Senut, and M. Pickford. "Primitive Adapidae from Namibia sheds light on the early primate radiation in Africa". English. In: Communications of the Geological Survey of Namibia, 20, 140-162. 20 (2018), pp. 140-162.

[8551] P. L. Godoy, F. C. Montefeltro, M. A. Norell, and M. C. Langer. "An additional baurusuchid from the Cretaceous of Brazil with evidence of interspecific predation among Crocodyliformes". English. In: PLoS One 9.5 (2014), e97138.

[8552] H. Godthelp. “Zyzomys rackhami sp. nov. (Rodentia, Muridae) a rockrat from Pliocene Rackham's Roost Site, Riversleigh, northwestern Queensland". English. In: Memoirs of the Queensland Museum 41.2 (1997), pp. 329-333.

[8553] H. Godthelp, M. Archer, R. Cifelli, S. J. Hand, and C. F. Gilkeson. “Earliest known Australian Tertiary mammal fauna". English. In: Nature 356 (1992), pp. 514-516.

[8554] H. Godthelp, S. Wroe, and M. Archer. "A new marsupial from the Early Eocene Tingamarra Local Fauna of Murgon, Southeastern Queensland: A prototypical Australian marsupial?" English. In: Journal of Mammalian Evoultion 6.3 (1999), pp. 289-313.

[8555] R. J. Godunko. "A new fossil subgenus and species of the genus Ecdyonurus Eaton, 1868 from Eocene Baltic amber (Ephemeroptera: Heptageniidae)". English. In: Genus 15 (2004), pp. 323-328.

[8556] R. J. Godunko. "Contribution to the knowledge of the fossil subgenus Nestormeus Godunko, 2004 (Ephemeroptera: Heptageniidae: Ecdyonurus) from the Baltic amber (Eocene)". English. In: Zootaxa 1661 (2007), pp. 63-68.

[8557] R. J. Godunko and M. Klonowska-Olejnik. "The first fossil representative of the genus Analetris Edmunds, 1972 (Insecta: Ephemeroptera: Acanthametropodidae) from the Eocene Baltic Amber". English. In: Annales Zoologici 56 (2006), pp. 785-790.

[8558] R. J. Godunko and W. Krzemiski. "New fossil findings of the mayfly genera Balticobaetisca Staniczek \& Bechly, 2002 (Ephemeroptera: Baetiscidae) and Borinquena Traver, 1938 (Leptophlebiidae: Atalophlebiinae)". English. In: Aquatic Insects: International Journal of Freshwater Entomology 31.Suppl 1 (2009), pp. 125-136.

[8559] R. J. Godunko, C. Neumann, and W. Krzemiski. "Fossil mayfly collections of the Museum für Naturkunde, Humboldt University Berlin. II. Redescription of Baltameletus oligocaenicus Demoulin, 1968 with notes on Ameletidae McCafferty, 1991 (Insecta: Ephemeroptera) from the Eocene Baltic amber". English. In: Annales Zoologici 58 (2008), pp. 105-114. 
[8560] R. J. Godunko and C. Neumann. "Fossil mayfly collections of the Museum fur Naturkunde, Humboldt University Berlin. I. Electroletus soldani gen. and sp. nov. (Ephemeroptera: Ameletidae) from the Eocene Baltic amber". English. In: Annales Zoologici 56 (2006), pp. 175-180.

[8561] R. J. Godunko, C. Neumann, and A. H. Staniczek. "Revision of fossil Metretopodidae (Insecta," English. In: ZooKeys 898 (2019), pp. 1-26.

[8562] R. J. Godunko and E. Sontag. "Burshtynogena fereci gen. and sp. nov. (Ephemeroptera: Heptageniidae) from Eocene Baltic amber". English. In: Annales Zoologici 54 (2004), pp. 515-518.

[8563] J. L. Goedert and S. R. Benham. "A new species of Depressigyra? (Gastropoda: Peltospiridae) from cold-seep carbonates in Eocene and Oligocene rocks of western Washington". English. In: The Veliger 42.2 (1999), pp. 112-116.

[8564] J. L. Goedert and R. E. Berglund. "A new genus and species of sand crab (Decapoda: Hippoidea: Albuneidae) from the Early Eocene Crescent Formation, Washington State, U.S.A." English. In: Proceedings of the Biological Society of Washington 125.3 (2012), pp. 252-257. DOI: 10.2988/11-04.1.

[8565] J. L. Goedert and K. A. Campbell. "An Early Oligocene chemosynthetic community from the Makah Formation, Northwestern Olympic Peninsula, Washington". English. In: The Veliger 38.1 (1995), pp. 22-29.

[8566] J. L. Goedert and J. Cornish. "A preliminary report on the diversity and stratigraphic distribution of the Plotopteridae (Pelecaniformes) in Paleogene rocks of Washington State, USA". English. In: Proceedings of the 5th Symposium of the Society of Avian Paleontology and Evolution (2002), pp. 63-76.

[8567] J. L. Goedert and K. L. Kaler. "A New Species of Abyssochrysos (Gastropoda: Loxonematoidea) from a Middle Eocene Cold-Seep Carbonate in the Humptulips Formation, Western Washington". English. In: The Veliger 39.1 (1996), pp. 65-70.

[8568] J. L. Goedert and S. Kiel. "A lower jaw of the nautiloid Aturia angustata (Conrad, 1849) from Oligocene cold seep limestone, Washington State, U.S.A." English. In: PaleoBios 33 (2016), pp. 1-6.

[8569] J. L. Goedert and J. Peckmann. Corals from deep-water methane-seep deposits in Paleogene strata of western Oregon and Washington, USA. English. Cold-water corals and ecosystems. 2005, pp. 27-40.

[8570] J. L. Goedert, J. Peckmann, and J. Reitner. "Worm Tubes in an Allochthonous Cold-Seep Carbonate from Lower Oligocene Rocks of Western Washington". English. In: Journal of Paleontology 74.6 (2000), pp. 992-999.

[8571] J. L. Goedert, J. Peckmann, S. R. Benham, and A. W. Janssen. "First record of the Eocene pteropod Heliconoides nitens (Gastropoda: Thecosomata: Limacinidae) from the Pacific Basin". English. In: Proceedings of the Biological Society of Washington 126.1 (2013), pp. 72-82.

[8572] J. L. Goedert, R. L. Squires, and L. G. Barnes. "Paleoecology of whale-fall habitats from deepwater Oligocene rocks, Olympic Peninsula, Washington state". In: Palaeogeography, Palaeoclimatology, Palaeoecology 118 (1995), pp. 151-158.

[8573] J. L. Goedert and R. L. Squires. "First Oligocene records of Calyptogena (Bivalvia: Vesicomyidae)". English. In: The Veliger 36.1 (1993), pp. 72-77.

[8574] J. L. Goedert and R. L. Squires. “Eocene deep-sea communities in localized limestones formed by subduction-related methane seeps, southwestern Washington". English. In: Geology 18 (1990), pp. 1182-1185.

[8575] J. L. Goedert, V. Thiel, O. Schmale, W. W. Rau, W. Michaelis, and J. Peckmann. "The Late Eocene 'Whiskey Creek' methane-seep deposit (western Washington State)". English. In: Facies 48.1 (2003), pp. 223-239.

[8576] B. Goetheer. "Zeehondenresten uit de Westerschelde en dan de Kaloot". English. In: Afzettingen Wtkg 29.2 (2008), pp. 40-41.

[8577] U. B. Gohlich. "The oldest fossil record of the extant penguin genus Spheniscus-a new species from the Miocene of Peru". English. In: Acta Palaeontologica Polonica 52.2 (2007), pp. 285-298.

[8578] U. B. Göhlich. “The early Vallesian vertebrates of Atzelsdorf (Late Miocene, Austria) 5. Aves". English. In: Annalen Des Naturhistorischen Museums in Wien 111 A (2009), pp. 509-514. 
[8579] U. B. Gohlich. "The avifauna of the Grund Beds (Middle Miocene, Early Badenian, northern Austria)". English. In: Annalen des Naturhistorischen Museums in Wien, Serie A 104 (2003), pp. 237-249.

[8580] U. B. Göhlich and L. M. Chiappe. "A new carnivorous dinosaur from the Late Jurassic Solnhofen archipelago". English. In: Nature 440 (2006), pp. 329-332.

[8581] U. B. Gohlich, L. M. Chiappe, J. M. Clark, and H. -D. Sues. "The systematic position of the Late Jurassic alleged dinosaur Macelognathus (Crocodylomorpha: Sphenosuchia)". English. In: Canadian Journal of Earth Sciences 42 (2005), pp. 307-321. DOI: 10.1139/E05-005.

[8582] U. B. Göhlich and C. Mourer-Cauvire. "A new cormorant-like bird (Aves: Phalacrocoracoidea) from the Early Miocene of Rauscherod (Southern Germany)". English. In: Records of the Australian Museum 62 (2010), pp. 61-70. DOI: 10.3853/j.0067-1975.62.2010.1536.

[8583] U. B. Gohlich and M. Pavia. "A new species of Palaeortyx (Aves: Galliformes: Phasianidae) from the Neogene of Gargano, Italy". English. In: Oryctos 7 (2008), pp. 95-108.

[8584] G. Goillot, P. O. Antoine, J. Tejada, F. Pujos, and R. Salas-Gismondi. "Middle Miocene Uruguaytheriinae (Mammalia, Astrapotheria) from Peruvian Amazonia and a review of the astrapotheriid fossil record in northern South America". English. In: Geodiversitas 33.2 (2011), pp. 331-345.

[8585] F. Goin. "Thylamys zettii, nueva especie de marmosino (Marsupialia, Didelphidae) del Cenozoico tardio de la region pampeana". Spanish. In: Ameghiniana 34.4 (1997), pp. 481-484.

[8586] F. Goin, A. Abello, E. Bellosi, R. Kay, R. Madden, and A. Carlini. "Los Metatheria sudamericanos de comienzos del Neógeno (Mioceno Temprano, Edad-mamfero Colhuehuapense). Parte I: Introducción, Didelphimorphia y Sparassodonta". Spanish. In: Ameghiniana 44.1 (2007), pp. 29-71.

[8587] F. Goin, M. R. Sánchez-Villagra, R. F. Kay, F. Anaya-Daza, and M. Takai. "New palaeothentid marsupial from the middle Miocene of Bolivia". English. In: Palaeontology 46.2 (2003), pp. 307315.

[8588] F. J. Goin. "New clues for understanding Neogene marsupial radiation". English. In: Vertebrate Paleontology in the Neotropics. The Miocene fauna of La Venta, Colombia. 1997, pp. 187-206.

[8589] F. J. Goin and M. A. Abello. “Los Metatheria sudamericanos de comienzos del Neógeno (Mioceno temprano, Edad Mamfero Colhuehuapense): Microbiotheria y Polydolopimorphia". Spanish. In: Ameghiniana 50.1 (2013), pp. 51-78. DOI: 10.5710/AMGH.9.11.2012.570.

[8590] F. J. Goin, A. Candela, and G. Lopez. "Middle Eocene marsupials from Antofagasta de la Sierra, northwestern Argentina". English. In: Geobios 31.1 (1998), pp. 75-85.

[8591] F. J. Goin, A. M. Candela, M. Bond, R. Pascual, and V. Escribano. Una nueva comadreja (Mammalia, Marsupialia, ?Polydolopimorphia) del Paleoceno de Patagonia, Argentina. Spanish. in S. Casada, ed., Paleógeno de América del Sur y de la Pennsula Antártica. 1998, pp. 71-78.

[8592] F. J. Goin, A. M. Candela, M. A. Abello, and E. V. Oliveira. "Earliest South American paucituberculatans and their significance in the understanding of 'pseudodiprotodont' marsupial radiations". English. In: Zoological Journal of the Linnean Society 155 (2009), pp. 867-884.

[8593] F. J. Goin and A. M. Candela. "New Paleogene Marsupials from the Amazon Basin of Eastern Peru". English. In: Natural History Museum of Los Angeles County, Science Series 40 (2004), pp. 1560.

[8594] F. J. Goin and A. M. Candela. "A new Early Eocene polydolopimorphian (Mammalia, Marsupialia) from Patagonia". English. In: Journal of Vertebrate Paleontology 16.2 (1996), pp. 292-296. DOI: 10. $2307 / 4523719$.

[8595] F. J. Goin, J. A. Case, M. O. Woodburne, S. F. Vizcaino, and M. A. Reguero. "New Discoveries of Opposum-like Marsupials from Antarctica (Seymour Island, Medial Eocene)". English. In: Journal of Mammalian Evolution 6.4 (1999), pp. 335-365.

[8596] F. J. Goin and M. De los Reyes. “Contribución al conocimiento de los representantes extintos de Lutreolina Thomas, 1910 (Mammalia, Marsupialia, Didelphidae)". Spanish. In: Historia Natural 1.2 (2011), pp. 15-25. 
[8597] F. J. Goin, A. G. Martinelli, S. Soto-Acuña, E. C. Vieytes, L. M. E. Manrquez, R. A. Fernández, J. P. Pino, C. Trevisan, J. Kaluza, M. A. Reguero, M. Leppe, H. Ortiz, D. Rubilar-Rogers, and A. O. Vargas. "First Mesozoic mammal from Chile: the southernmost record of a late Cretaceous Gondwanatherian". English. In: Boletn del Museo Nacional de Historia Natural, Chile 69.1 (2020), pp. 531.

[8598] F. J. Goin, C. I. Montalvo, and G. Visconti. “Los marsupiales (Mammalia) del Mioceno Superior de la Formacion Cerro Azul(Provincia de La Pampa, Argentina)". Spanish. In: Estudios Geol 56 (2000), pp. 101-126.

[8599] F. J. Goin, J. I. Noriega, and M. de los Reyes. “Los Metatheria (Mammalia) del Mesopotamiense (Mioceno tardo) de la Provinciade Entre Ros, Argentina, y una reconsideración de Philander entrerianus (Ameghino, 1899)". Spanish. In: El Neógeno de la Mesopotamia argentina 14 (2013), pp. 109117.

[8600] F. J. Goin and E. V. Oliveira. "A new species of Gashternia (Marsupialia) from Itabora (Brazil)". English. In: Neues Jahrbuch für Geologie und Paläontologie, Abhandlungen 245.3 (2007), pp. 309-313. DOI: 10.1127/0077-7749/2007/0245-0309.

[8601] F. J. Goin and U. F. J. Pardiñas. "Revisión de las especies del Género Hyperdidelphys Ameghino, 1904 (Mammalia, Marsupialia, Didelphidae). Su significación filogenética, estratigráfica y adaptativa en el Neógeno del Cono Sur Sudamericano." Spanish. In: Estudios Geológicos 52 (1996), pp. 327-359.

[8602] F. J. Goin, U. F. J. Pardiñas, and M. J. Lezcano. “Un nuevo resto del cenolestido Pliolestes Reig, 1955 (Mammalia, Marsupialia) del Plioceno de la provincia de Buenos Aires (Argentina)". Spanish. In: Ameghiniana 31.1 (1994), pp. 15-21.

[8603] F. J. Goin, R. Pascual, M. F. Tejedor, J. N. Gelfo, M. O. Woodburne, J. A. Case, M. A. Reguero, M. Bond, G. M. Lopez, A. L. Cione, D. Udrizar Sauthier, L. Balarino, R. A Scasso, F. A. Medina, and M. C. Ubaldon. "The earliest Tertiary therian mammal from South America". English. In: Journal of Vertebrate Paleontology 26.2 (2006), pp. 505-510.

[8604] F. J. Goin, D. G. Poire, M. S. De la Fuente, A. L. Cione, F. E. Novas, E. S. Bellosi, A. Ambrosio, O. Ferrer, N. D. Canessa, A. Carloni, J. Ferigolo, A. M. Ribeiro, M. S. Sales Viana, M. A. Reguero, M. G. Vucetich, S. Marenssi, M. F. de Lima Filho, and S. Agostinho. "Paleontologia y geologia de los sedimentos del cretacico superior aflorantes al sur del rio shehuen (Mata Amarilla, Provincia de Santa Cruz, Argentina)". Spanish. In: Actas del XV Congreso Geologico Argentino, El Calafate, 2002 (2002), pp. 1-6.

[8605] F. J. Goin, M. A. Reguero, R. Pascual, W. von Koenigswald, M. O. Woodburne, J. A. Case, S. A. Marenssi, E. C. Vieytes, and S. F. VizcaÃno. "First gondwanatherian mammal from Antarctica". English. In: Geological Society, London, Special Publications 258 (2006), pp. 135-144. DOI: 10.1144 / GSL.SP.2006.258.01.10.

[8606] F. J. Goin, M. R. Sanchez-Villagra, A. Abello, and R. F. Kay. "A new generalized paucituberculatan marsupial from the Oligocene of Bolivia and the origin of 'shrew-like' opossums". English. In: Palaeontology 50.5 (2007), pp. 1267-1276.

[8607] F. J. Goin, M. F. Tejedor, L. Chornogubsky, G. M. López, J. N. Gelfo, M. Bond, M. O. Woodburne, Y. Gurovich, and M. Reguero. "Persistence of a Mesozoic, non-therian mammalian lineage (Gondwanatheria) in the mid-Paleogene of Patagonia". English. In: Naturwissenschaften 99.6 (2012), pp. 449-463. DOI: 10.1007/s00114-012-0919-z.

[8608] F. J. Goin, M. F. Tejedor, M. A. Abello, and G. M. Martin. "Un nuevo microbiotérido (Mammalia, Marsupialia, Microbiotheria) de la Formación Pinturas (Mioceno temprano) de la provincia de Santa Cruz". Spanish. In: Ameghiniana 47.1 (2010), pp. 117-122.

[8609] F. J. Goin, E. C. Vieytes, M. G. Vucetich, A. A. Carlini, and M. Bond. "Enigmatic mammal from the Paleogene of Peru". English. In: Natural History Museum of Los Angeles County, Science Series 40 (2004), pp. 145-153. 
[8610] F. J. Goin, E. C. Vieytes, J. N. Gelfo, L. Chornogubsky, A. N. Zimicz, and M. A. Reguero. “New Metatherian Mammal from the Early Eocene of Antarctica". English. In: Journal of Mammalian Evolution 27 (2020), pp. 17-36. DOI: 10.1007/s10914-018-9449-6.

[8611] F. J. Goin, N. Zimicz, M. A. Reguero, S. N. Santillana, S. A. Marenssi, and J. J. Moly. "New marsupial (Mammalia) from the Eocene of Antarctica, and the origins and affinities of the Microbiotheria". English. In: Revista de la Asociación Geológica Argentina 62.4 (2007), pp. 597-603.

[8612] F. J. Goin, N. L. Zimicz, M. de los Reyes, and L. Soibelzon. “A new large didelphid of the genus Thylophorops (Mammalia: Didelphimorphia: Didelphidae), from the late Tertiary of the Pampean Region (Argentina)”. English. In: Zootaxa 2005 (2009), pp. 35-46.

[8613] B. M. Going, R. Hilton, and B. H. Tiffney. "An Aptian Cycadeoid from the Budden Canyon Formation, Ono Quadrangle, California". English. In: Madrono 54.2 (2007), pp. 167-171.

[8614] F. Góis, L. R. González Ruiz, G. J. Scillato-Yané, and E. Soibelzon. “A Peculiar New Pampatheriidae (Mammalia: Xenarthra: Cingulata) from the Pleistocene of Argentina and Comments on Pampatheriidae Diversity". English. In: PLoS ONE 10.6 (2015), e0128296:1-25.

[8615] F. Gois, G. J. Scillato-Yane, A. A. Carlini, and E. Guilherme. "A new species of Scirrutherium Edmund \& Theodor, 1997 (Xenarthra, Cingulata, Pampatheriidae) from the late Miocene of South America". English. In: Alcheringa 37.2 (2013), pp. 177-188. DOI: 10.1080/03115518.2013.733510.

[8616] F. Góis, G. J. Scillato-Yané, A. A. Carlini, and M. Ubilla. “Una nueva especie de Holmesina simpson (xenarthra, cingulata, pampatheriidae) del pleistoceno de rondonia, sudoeste de la Amazonia, Brasil". Spanish. In: Revista Brasileira de Paleontologia 15.2 (2012), pp. 211-227. DOI: 10.4072 / rbp. 2012.2.09.

[8617] C. A. Góiz-Marques, J. Jesus, M. Menezes de Sequeira, and J. Madeira. “The first Ichneumonid fossil from the Early Pleistocene of Madeira Island (Portugal)". English. In: Zootaxa 4612 (2019), pp. 447-450.

[8618] P. Gol'din. "New Paratethyan dwarf baleen whales mark the origin of cetotheres". English. In: PeerJ 6 (2018), e5800. DOI: 10.7717 / peerj.5800.

[8619] P. Gol'din, B. S. Haiduc, O. Kovalchuk, M. Górka, P. Otryazhyi, M. Branzil, E. L. Pun, Z. Barkaszi, P. ibuleac, and B. G. Roi. "The Volhynian (late Middle Miocene)". English. In: Palaeontologia Electronica 23.3 (2020), a43.

[8620] P. Gol'din, O. M. Kovalchuk, and T. Krakhmalnaya. "The first record of Sirenia (Mammalia) from the early Oligocene of the Paratethys". English. In: Historical Biology (2018). DOI: 10.1080/08912963. 2018.1454444.

[8621] P. Gol'din and P. Radoviç. "A middle Miocene baleen whale from the Bele Vode in Belgrade, Serbia". English. In: Rivista Italiana di Paleontologia e Stratigra a 124.1 (2018), pp. 127-138.

[8622] P. Goldin and D. Startsev. "Brandtocetus, a new genus of baleen whales (Cetacea, Cetotheriidae) from the late Miocene of Crimea, Ukraine". English. In: Journal of Vertebrate Paleontology 34.2 (2014), pp. 419-433. DOI: 10.1080/02724634.2013.799482.

[8623] P. Goldin and D. Startsev. "A systematic review of cetothere baleen whales (Cetacea, Cetotheriidae ) from the Late Miocene of Crimea and Caucasus, with a new genus". English. In: Papers in Paleontology 3.1 (2017), pp. 49-68. DOI: 10.1002/spp2.1066.

[8624] P. Goldin and E. A. Zvonok. "Basilotritus uheni, a New Cetacean (Cetacea, Basilosauridae) from the Late Middle Eocene of Eastern Europe". English. In: Journal of Paleontology 87.2 (2013), pp. 254268. DOI: $10.1666 / 12-080 R .1$.

[8625] P. Goldin, E. A. Zvonok, L. Rkovets, A. Kovalchuk, and T. Krakhmalnaya. “Basilotritus (Cetacea: Pelagiceti) from the Eocene of Nagornoye (Ukraine): New data on anatomy,ontogeny and feeding of early basilosaurids". English. In: Comptes Rendus Palevol (2014). DOI: 10.1016/j.crpv.2013.11.002.

[8626] P. E. Goldin and V. A. Marareskul. "Miocene toothed whales (Cetacea, Odontoceti) from the Dniester Valley: The first record of sperm whales (Physeteroidea) from the Eastern Europe". English. In: Vestnik Zoologii 47.5 (2013), pp. 409-414. DOI: 10.2478/vzoo-2013-0043. 
[8627] P. E. Goldin and K. A. Vishnyakova. "Africanacetus from the subAntarctic region: The southernmost record of fossil beaked whales". English. In: Acta Palaeontologica Polonica 58.3 (2013), pp. 445452. DOI: 10.4202/app.2011.0097.

[8628] P. E. Goldin, E. A. Zvonok, and T. V. Krakhmalnaya. "New material of Eocetus sp. (Mammalia: Cetacea) from the Eocene of Ukraine". Russian. In: Geolog Ukrainy 39.3 (2012), pp. 104-113.

[8629] M. L. Golding and M. J. Orchard. "Magnigondolella, a new conodont genus from the Triassic of North America". English. In: Journal of Paleontology 92.2 (2018), pp. 207-220. DOI: 10.1017/jpa. 2017.123.

[8630] D. Goldman. "Taxonomy, evolution, and biostratigraphy of the Orthograptus quadrimucronatus species group (Ordovician, Graptolithina)". In: Journal of Paleontology 69.3 (1995), pp. 516-540.

[8631] D. Goldman and C. E. Mitchell. "Morphology, Systematics, and Evolution of Middle Devonian Ambocoeliidae (Brachiopoda), Western New York". English. In: Journal of Paleontology 64.1 (1990), pp. 79-99.

[8632] D. Goldman, J. Nõlvak, and J. Maletz. "Middle to Late Ordovician graptolite and chitinozoan biostratigraphy of the Kandava-25 drill core in western Latvia". English. In: G F F 137.3 (2015), pp. 197-211. DOI: 10.1080/11035897.2015.1021375.

[8633] D. M. Goldman, S. M. Bergström, and C. E. Mitchell. "Revision of the Zone 13 graptolite biostratigraphy in the Marathon, Texas, standard succession and its bearing on Upper Ordovician graptolite biogeography". English. In: Lethaia 28 (1995), pp. 115-128.

[8634] M. A. Golovinova and A. V. Guzhov. "Early Cretaceous gastropods of the Middle-Lower Volga river region from PA Gerasimov's collection". English. In: Paleontological Journal 43.5 (2009), pp. 506513. DOI: $10.1134 /$ S0031030109050050.

[8635] V. B. Golub. “Archepopovia yurii n. gen. n. sp. a new remarkable lace bug from Baltic amber, with some notes on phylogeny and classification of Tingidae (Heteroptera, Tingidae)". English. In: Mitteilungen aus dem Geologisch-Paläontologischen Institut der Universität Hamburg 85 (2001), pp. 263276.

[8636] V. B. Golub. “Two unknown nymphs of Cantacaderinae (Heteroptera: Tingidae) from Baltic and Ukrainian amber". English. In: Prace Muzeum Ziemi 47 (2004), pp. 93-96.

[8637] V. B. Golub and E. Heiss. "Two new species of lace bugs from Dominican amber and a new species from Colombian copal (Hemiptera: Heteroptera: Tingidae)". English. In: Zootaxa 4444 (2018), pp. 333-341.

[8638] V. B. Golub and Y. A. Popov. "Cantacaderid lace bugs from the Baltic amber (Heteroptera: Tingidae, Cantacaderinae)". English. In: Mitteilungen aus dem Geologisch-Paläontologischen Institut der Universität Hamburg 81 (1998), pp. 223-250.

[8639] V. B. Golub and Y. A. Popov. "A New Species of Tingidae (Insecta: Hemiptera: Heteroptera) from the Lower Cretaceous of Transbaikalia". English. In: Paleontological Journal 42.1 (2008), pp. 86-89.

[8640] V. B. Golub, Y. A. Popov, and E. Guilbert. "Phymacysta stysi, a new species of lace bug from Dominican amber (Hemiptera: Heteroptera: Tingidae: Tinginae)". English. In: Acta Entomologica Musei Nationalis Pragae 48.2 (2008), pp. 485-490.

[8641] V. B. Golub and Y. A. Popov. “The new fossil genus of Vianaididae (Heteroptera: Tingoidea) from the Cretaceous amber of New Jersey; evolution of the family in the Late Cretaceous". English. In: Acta Zoologica Cracoviensia 46.Suppl (2003), pp. 109-116.

[8642] V. B. Golub and Y. A. Popov. "New cantacaderid lace bugs from Dominican amber (Heteroptera: Tingidae, Cantacaderinae)". English. In: Acta Geologica Hispanica 35.1-2 (2000), pp. 165-169.

[8643] V. B. Golub and Y. A. Popov. A remarkable fossil lace bug from Upper Cretaceous New Jersey amber (Heteroptera: Tingoidea, Vianaididae) with some phylogenetic commentary. English. Studies on Fossils in Amber, with Particular Reference to the Cretaceous of New Jersey. Leiden: Backhuys Publishers, 2000, pp. 231-239. 
[8644] V. B. Golub and Y. A. Popov. “New Cenozoic lace bugs (Heteroptera: Tingidae)". English. In: Paleontological Journal 34.Suppl 3 (2000), S290-S297.

[8645] V. B. Golub and Y. A. Popov. "A new lace bug species of the genus Sinaldocader (Hemiptera: Heteroptera, Tingidae) from the Turonian of southwestern Kazakhstan". English. In: Paleontological Journal 46 (2012), pp. 258-261.

[8646] V. B. Golub, Y. A. Popov, and A. Arillo. “Hispanocaderidae n. fam. (Hemiptera: Heteroptera: Tingoidea), one of the oldest lace bugs from the Lower Cretaceous Álava amber (Spain)". English. In: Zootaxa 3270 (2012), pp. 41-50.

[8647] V. B. Golub and Y. A. Popov. "The third representative of the fossil genus Intercader from Baltic amber (Insecta: Heteroptera: Tingidae, Cantacaderinae)". English. In: Mitteilungen aus dem GeologischPaläontologischen Institut der Universität Hamburg 89 (2005), pp. 167-172.

[8648] V. B. Golub and Y. A. Popov. "A new cantacaderid lace bug from Baltic amber, and a key to fossil Cenozoic species of the family Tingidae (Insecta: Heteroptera)". English. In: Mitteilungen aus dem Geologisch-Paläontologischen Institut der Universität Hamburg 86 (2002), pp. 245-252.

[8649] V. B. Golub and Y. A. Popov. "Two new species of lace bugs from Dominican amber (Heteroptera: Tingidae, Tinginae)". English. In: Annals of the Upper Silesian Museum, Entomology 12 (2003), pp. 101110.

[8650] V. B. Golub and Y. A. Popov. "Intercader saxonicus sp. n., a new lace bug from Saxonian amber, and a discussion of the evolutional changes of the Tingidae fauna (Heteroptera) of Eurasia from the Eocene to Miocene". Russian. In: Euroasian Entomological Journal 6 (2007), pp. 223-228.

[8651] V. B. Golub and Y. A. Popov. "Sinalda applanata sp. n., a new lace bug from Baltic amber, is described, together with notes on the evolution of some morphological structures in the Eocene". Russian. In: Euroasian Entomological Journal 4 (2005), pp. 279-282.

[8652] V. K. Golubev. "New species of Melosaurus (Amphibia, Labyrinthodontia) from the Kazanian of the Kama River drainage area". English. In: Paleontological Journal 29.3 (1995), pp. 107-119.

[8653] V. K. Golubev. "Revision of the Late Permian Chroniosuchians (Amphibia, Anthracosauromorpha) from Eastern Europe". English. In: Paleontological Journal 32.4 (1998), pp. 390-401.

[8654] V. K. Golubev. "A new narrow-armored chroniosuchian (Amphibia, Anthracosauromorpha) from the Upper Permian of Eastern Europe". English. In: Paleontological Journal 33.2 (1999), pp. 166-173.

[8655] V. K. Golubev. "The Faunal Assemblages of Permian Terrestrial Vertebrates from Eastern Europe". English. In: Paleontological Journal 34 (2000), S211-S224.

[8656] V. Golubi. "Sutinaites, a new genus of ammonite and new ammonite species from the Upper Scythian of Mu, Croatia". English. In: Natura Croatica: Periodicum Musei Historiae Naturalis Croatici 8.4 (1999), pp. 439-451.

[8657] E. M. Gomani. “Sauropod dinosaurs from the Early Cretaceous of Malawi”. In: Palaeontologia Electronica 8.1 (2005), pp. 1-37.

[8658] E. M. Gomani. "A crocodyliform from the Early Cretaceous Dinosaur Beds, northern Malawi". English. In: Journal of Vertebrate Paleontology 17.2 (1997), pp. 280-294.

[8659] A. C. Gomes, G. Lessa, C. Cartelle, and L. Kerber. "New fossil remains of Quaternary capybaras (Rodentia: Caviomorpha: Caviidae) from the intertropical region of Brazil: morphology and taxonomy". English. In: Journal of South American Earth Sciences 91 (2019), pp. 36-46.

[8660] H. Gomes Rodrigues, L. Marivaux, and M. Vianey-Liaud. "The Cricetidae (Rodentia, Mammalia) from the Ulantatal area (Inner Mongolia, China): New data concerning the evolution of Asian cricetids during the Oligocene". English. In: Journal of Asian Earth Sciences 56 (2012), pp. 160-179.

[8661] H. Gomes Rodrigues, L. Marivaux, and M. Vianey-Liaud. "Rodent paleocommunities from the Oligocene of Ulantatal (Inner Mongolia, China)". English. In: Palaeovertebrata 38.1 (2014), e3:1-11.

[8662] A. Gomez, C. Jaramillo, M. Parra, and A. Mora. "Huesser Horizon: A lake and marine incursion in Northwestern South America during the Early Miocene". English. In: Palaios 24 (2009), pp. 199_ 210. DOI: $10.2110 /$ palo.2007.p07-074r. 
[8663] J. J. Gómez and C. Arias. "Rapid warming and ostracods mass extinction at the Lower Toarcian (Jurassic) of central Spain". English. In: Marine Micropaleontology 74 (2010), pp. 119-135. DOI: 10. 1016/j.marmicro.2010.02.001.

[8664] J. J. Gomez and A. Goy. "Warming-driven mass extinction in the Early Toarcian (Early Jurassic) of northern and central Spain. Correlation with other time-equivalent European sections". English. In: Palaeogeography, Palaeoclimatology, Palaeoecology 306 (2011), pp. 176-195.

[8665] J. J. Gómez, A. Goy, and A. Márquez-Aliaga. “Bioestatigrafa del tránsito Triásico-jurásico en Asturias: ammonoideos y bivalvos entre Aviles y Caravia (España)". Spanish. In: Geo-Temas 8 (2005), pp. 183-187.

[8666] R. A. Gómez and A. L. Damgaard. "A rare diving beetle from Baltic amber: Hydrotrupes prometheus new species reveals former widespread distribution of the genus (Coleoptera, Dytiscidae)". English. In: Journal of Paleontology 88 (2014), pp. 814-822.

[8667] R. O. Gómez. "A new pipid frog from the Upper Cretaceous of Patagonia and early evolution of crown-group Pipidae". English. In: Cretaceous Research 62 (2016), pp. 52-64.

[8668] R. O. Gómez, A. M. Báez, and G. W. Rougier. "An anilioid snake from the Upper Cretaceous of northern Patagonia". English. In: Cretaceous Research 29 (2008), pp. 481-488. DOI: 10.1016/j.cretres. 2008.01.002.

[8669] R. O. Gómez, F. F. Garberoglio, and G. W. Rougier. "A new Late Cretaceous snake from Patagonia: Phylogeny and trends in body size evolution of madtsoiid snakes". English. In: Comptes Rendus Palevol (2019). DOI: 10.1016/j.crpv.2019.09.003.

[8670] R. O. Gomez, C. M. Perez Ben, and M. I. Stefanini. “Oldest record of Leptodactylus Fitzinger, 1826 (Anura, Leptodactylidae) from the early Pliocene of the south american pampas". English. In: Journal of Vertebrate Paleontology 33.6 (2013), pp. 1321-1327.

[8671] B. Gomez de Soler, G. Campeny Vall-Llosera, J. van der Made, O. Oms, J. Agusti, R. Sala, H. A. Blain, F. Burjachs, J. Claude, S. Garcia Catalan, D. Riba, and R. Rosillo. "A new key locality for the Pliocene vertebrate record of Europe: the Camp dels Ninots maar (NE Spain)". English. In: Geologica Acta 10.1 (2012), pp. 1-17. DOI: 10.1344/105.000001702.

[8672] D. Gómez-Fernández, J. I. Canudo, and V. Cano-Llop. Cintura pelviana de un nuevo dinosaurio terópodo de la Formación Morella (Aptiense inferior) en Vallibona (Castellón) [Pelvic girdle of a new theropod dinosaur from the Morella Formation (lower Aptian) in Vallibona (Castellón)]. Spanish. 2007.

[8673] M. Gómez-Luna, E. Cedillo-Pardo, B. Contreras y Montero, I. Gallo-Padilla, and A. MartnezCortés. “Un nuevo perfil del Ladiniano-Cárnico Inferior con fauna de amonoideos en La Ballena, Zacatecas, México". Spanish. In: Revista Mexicana de Ciencias Geológicas 15.1 (1998), pp. 38-45.

[8674] I. Gomez-Perez. "An Early Jurassic deep-water stromatolitic bioherm related to possible methane seepage (Los Molles Formation, Neuquen, Argentina)". English. In: Palaeogeography, Palaeoclimatology, Palaeoecology 201 (2003), pp. 21-49.

[8675] G. S. Gonçalves and C. A. Sidor. "A new drepanosauromorph, Ancistronychus paradoxus n. gen. et sp.,from the Chinle Formation of Petrified Forest National Park, Arizona, USA". English. In: PaleoBios 36 (2019), pp. 1-10.

[8676] I. A. Goncharova and Y. V. Rostovtseva. "Evolution of Organogenic Carbonate Buildups in the Middle through Late Miocene of the Euxine-Caspian Basin (Eastern Paratethys)". English. In: Paleontological Journal 43.8 (2009), pp. 866-876.

[8677] J. Gonet, L. Rozada, R. Bourgeais, and R. Allain. “Taphonomic study of a pleurosternid turtle shell from the Early Cretaceous of Angeac-Charente, southwest France". English. In: Lethaia 55.2 (2019), pp. 232-243.

[8678] E. Gong, L. Hou, and L. Wang. "Enantiornithine bird with diapsidan skull and its dental development in the Early Cretaceous in Liaoning, China". English. In: Acta Geologica Sinica 78.1 (2004), pp. 1-7. 
[8679] E. Gong, E. Samankassou, C. Guan, Y. Zhang, and B. Sun. "Paleoecology of Pennsylvanian phylloid algal buildups in south Guizhou, China". English. In: Facies 53 (2007), pp. 615-623.

[8680] E.-P. Gong, L. D. Martin, D. A. Burnham, A. R. Falk, and L. -H. Hou. “A new species of Microraptor from the Jehol Biota of northeastern China". English. In: Palaeoworld 21 (2012), pp. 81-91. DOI: 10.1016/j.palwor.2012.05.003.

[8681] S. Y. Gong, S. W. Wang, and T. Y. Lee. "Pleistocene coral reefs associated with claystones, Southwestern Taiwan”. English. In: Coral Reefs 17 (1998), pp. 215-222.

[8682] S.-Y. Gong, T.-R. Wu, F. P. Sirringan, K. Lin, and C.-C. Shen. "An abrupt backreef infilling in a Holocene reef, Paraoir," English. In: Coral Reefs 32 (2012), pp. 293-303.

[8683] R. Goñi and F. Goin. "Morfologa dentaria y biomecánica masticatoria de los cinodontes (Reptilia, Therapsida) del Triásico argentino: II. Exaeretodon frenguellii Cabrera (Traversodontidae)". English. In: Ameghiniana 27 (1991), pp. 327-336.

[8684] P. D. Gonzales, M. F. Tortello, and S. E. Damborenea. "Early Cambrian archaeocyathan limestone blocks in low-grade meta-conglomerate from El Jagüelito Formation (Sierra Grande, Ro Negro, Argentina)". English. In: Geologica Acta 9.2 (2011), pp. 159-173.

[8685] C. C. Gonzalez, M. A. Gandolfo, M. C. Zamaloa, N. R. Cúneo, P. Wilf, and K. R. Johnson. “Revision of the Proteaceae macrofossil record from Patagonia, Argentina". English. In: The Botanical Review 73.3 (2007), pp. 235-266.

[8686] C. R. Gonzalez. "Lower Permian bivalves from central Patagonia, Argentina". English. In: Paläontologische Zeitschrift 80.2 (2006), pp. 130-155.

[8687] E. Gonzalez, R. Labarca, M. Chavez-Hoffmeister, and M. Pino. "First fossil record of the smallest deer cf. Pudu Molina, 1782 (Artiodactyla, Cervidae), in the late Pleistocene of South America". English. In: Journal of Vertebrate Paleontology 34.2 (2014), pp. 483-488. DOI: 10.1080/02724634.2013. 809357.

[8688] L. R. Gonzalez and G. J. Scilalto-Yané. “Una nueva especie de Stegotherium Ameghino (Xenarthra, Dasypodidae, Stegotheriini) del Mioceno de la provincia de Santa Cruz (Argentina)". Spanish. In: Ameghiniana 45.4 (2008), pp. 641-648.

[8689] L. R. Gonzalez and G. J. Scillato-Yané. “A new Stegotheriini (Mammalia, Xenarthra, Dasypodidae) from the Notohippian (early Miocene) of Patagonia, Argentina". English. In: Neues Jahrbuch fur Geologie und Palaontologie - Abhandlungen 252.1 (2009), pp. 81-90. DOI: 10.1127 / 0077-7749/2009/ 0252-0081.

[8690] V. H. Gonzalez and M. S. Engel. "A new species of the bee genus Ctenoplectrella in middle Eocene Baltic amber (Hymenoptera, Megachilidae)". English. In: ZooKeys 111 (2011), pp. 41-49.

[8691] M. S. Gonzalez Estebenet, A. Cereceda, and M. V. Guler. "Late Cretaceous organic-walled dinoflagellate cysts from the Alta Vista Formation, Austral Basin, Argentina". English. In: Ameghiniana 54.6 (2017), pp. 688-699. DOI: 10.5710/AMGH.24.04.2017.3090.

[8692] B. J. González Riga. “Hallazgo de vertebrados fósiles en la Formación Loncoche, Cretácico Superior de la provincia de Mendoza, Argentina". Spanish. In: Ameghiniana 36 (1999), pp. 401-410.

[8693] B. J. González Riga and R. A. Astini. "Preservation of large titanosaur sauropods in overbank fluvial facies: a case study in the Cretaceous of Argentina". English. In: Journal of South American Earth Sciences 23 (2007), pp. 290-303.

[8694] B. J. González Riga and J. O. Calvo. "A new wide-gauge sauropod track site from the Late Cretaceous of Mendoza, Neuquén Basin, Argentina". English. In: Palaeontology 52.3 (2009), pp. 631-640. DOI: $10.1111 /$ j.1475-4983.2009.00869.x.

[8695] B. J. González Riga, M. C. Lamanna, L. D. Ortiz David, J. O. Calvo, and J. P. Coria. “A gigantic new dinosaur from Argentina and the evolution of the sauropod hind foot". English. In: Scientific Reports 6 (2016), 19165:1-15. DOI: 10.1038/srep19165. 
[8696] B. J. González Riga and L. Ortiz David. "A new titanosaur (Dinosauria, Sauropoda) from the Upper Cretaceous (Cerro Lisandro Formation) of Mendoza Province, Argentina". English. In: Ameghiniana 51.1 (2014), pp. 3-25. DOI: 10.5710/AMGH.26.12.2013.1889.

[8697] B. J. González Riga, E. Previtera, and C. A. Pirrone. "Malarguesaurus florenciae gen. et sp. nov., a new titanosauriform (Dinosauria, Sauropoda) from the Upper Cretaceous of Mendoza, Argentina". English. In: Cretaceous Research 30.1 (2009), pp. 135-148. DOI: 10.1016/j.cretres.2008. 06.006 .

[8698] L. R. González Ruiz, D. Brandoni, A. E. Zurita, J. L. Green, N. M. Novo, A. A. Tauber, and M. F. Tejedor. “Juvenile Glyptodont (Mammalia, Cingulata) from the Miocene of Patagonia, Argentina: Insights into Mandibular and Dental Characters". English. In: Journal of Vertebrate Paleontology (2020), e1768398:1-14. DOI: 10.1080/02724634.2020.1768398.

[8699] L. R. Gonzalez Ruiz, A. E. Zurita, J. Fleagle, G. J. Scillato-Yane, M. T. Dozo, and M. Zamorano. “The southernmost record of a Neuryurini Hoffstetter, 1958 (Mammalia, Xenarthra, Glyptodontidae)". English. In: Palaontologische Zeitschrift 85.2 (2011), pp. 155-161.

[8700] P. Gonzalez Ruiz, M. de la Fuente, and M. S. Fernandez. "New cranial fossils of the Jurassic turtle Neusticemys neuquina and phylogenetic relationships of the only thalassochelydian known from the eastern Pacific". English. In: Journal of Paleontology (2019), pp. 1-20. DOI: 10.1017/jpa.2019.74.

[8701] C. Gonzalez-Arreola and R. Barragan. “Oosterella (Ammonoidea) from the Taraises Formation (Upper Valanginian), Durango, northeast Mexico". English. In: Cretaceous Research 28 (2007), pp. 419 427.

[8702] C. González-Arreola, R. Barragán, M. Company, J. A. Moreno-Bedmar, and R. Cruz-Vázquez. “Upper Berriasian ammonites from the Taraises Formation of Cuencamé de Ceniceros section, Durango State, northern Mexico". English. In: Boletn de la Sociedad Geológica Mexicana 69 (2017), pp. 465-477.

[8703] C. Gonzalez-Arreola, J. Pantoja-Alor, F. Oloriz, A. B. Villasenor, and P. Garcia-Barrera. “Lower Aptian Ammonitina Pseudohaploceras liptoviense (Zeuschner) in the Cumburindio Formation (Southwestern Mexico)". English. In: Géobios 29.1 (1996), pp. 35-43.

[8704] G. González-Barba. Cetacean teeth from the Late Oligocene San Gregorio and El Cien Formations, Baja California Sur, Mexico. English. 2001.

[8705] G. González-Barba. "A new primitive dolphin (Odontoceti, Squalodelphidae?) from the Baja California Sur Late Oligocene (El Cien Formation, San Juan Member), Mexico". English. In: Journal of Vertebrate Paleontology 22.3 (2002), 59A.

[8706] G. González-Barba, T. Schwennicke, J. L. Goedert, and L. G. Barnes. “Earliest Pacific Basin record of the Pelagornithidae (Aves: Pelecaniformes)". English. In: Journal of Vertebrate Paleontology 22.3 (2002), pp. 722-725.

[8707] C. Gonzalez-Gomez. "Linguliformean brachiopods of the middle-upper Cambrian transition from the Val d'Homs Formation, Southern Montagne Noire, France". English. In: Journal of Paleontology 79.1 (2005), pp. 29-47.

[8708] C. M. González-Léon, R. W. Scott, H. Löser, T. F. Lawton, E. Robert, and V. A. Valencia. “Upper Aptian-Lower Albian Mural Formation: stratigraphy, biostratigraphy and depositional cycles on the Sonoran shelf, northern Mexico". English. In: Cretaceous Research 29 (2008), pp. 249-266.

[8709] C. M. Gonzalez-Leon, G. D. Stanley Jr., and D. G. Taylor. "Ammonoid discoveries in the Antimonio Formation, Sonora, Mexico: new constraints on the Triassic-Jurassic boundary". English. In: Journal of South American Earth Sciences 13 (2000), pp. 491-497.

[8710] S. González-Mora, P. N. Wyse Jackson, M. A. Torres-Martnez, B. E. Buitrón-Sánchez, R. Barragán, and F. Sour-Tovar. "Hederella carbonaria Condra \& Elias, 1944 from the Roadian (middle Permian) of Mexico". English. In: Bulletin of Geosciences 93 (2018), pp. 457-461.

[8711] B. J. González-Riga. "A new titanosaur (Dinosauria, Sauropoda) from the Upper Cretaceous of Mendoza Province, Argentina". English. In: Ameghiniana 40.2 (2003), pp. 155-172. 
[8712] B. J. González-Riga and S. Casado. “Primer registro de Dinosauria (Ornithischia, Hadrosauridae) en la provincia de La Pampa (Argentina) y sus implicancias paleobiogeográficas". Spanish. In: Ameghiniana 37.3 (2000), pp. 341-351.

[8713] K. González-Rodrguez, S. P. Applegate, and L. Espinosa-Arrubarrena. “A New World macrosemiid (Pisces: Neopterygii-Halecostomi) from the Albian of México". English. In: Journal of Vertebrate Paleontology 24.2 (2004), pp. 281-289.

[8714] L. Gonzalez-Ruiz, M. Ciancio, G. Martin, and A. E. Zurita. "First record of supernumerary teeth in Glyptodontidae (Mammalia, Xenarthra, Cingulata)". English. In: Journal of Vertebrate Paleontology 35.1 (2015), pp. 1-6.

[8715] L. R. González-Ruiz, F. Gois, M. R. Ciancio, and G. J. Scillato-Yane. "Los Peltephilidae (Mammalia, Xenarthra) de la Formación Collón Curá (Colloncurense, Mioceno médio), Argentina". Spanish. In: Revista Brasileira de Paleontologia 16.2 (2013), pp. 319-330. DOI: 10.4072/rbp.2013.2.12.

[8716] L. R. González-Ruiz, A. Reato, M. Cano, and O. Martinez. “Old and new specimens of a poorly known glyptodont from the Miocene of Patagonia and their biochronological implications". English. In: Acta Palaeontologica Polonica 62.1 (2016), pp. 181-194. DOI: 10.4202/app.00280.2016.

[8717] L. R. Gonzalez-Ruiz, G. J. Scillato-Yané, C. M. Krmpotic, and A. A. Carlini. "A new species of Peltephilidae (Mammalia: Xenarthra: Cingulata) from the late Miocene (Chasicoan SALMA) of Argentina". English. In: Zootaxa 3359 (2012), pp. 55-64.

[8718] L. R. González-Ruiz, A. E. Zurita, G. J. Scillato-Yane, M. Zamorano, and M. F. Tejedor. “Un nuevo Glyptodontidae (Mammalia, Xenarthra, Cingulata) del Mioceno de Patagonia (Argentina) y comentarios acerca de la sistematica de los gliptodontes friasenses". Spanish. In: Revista Mexicana de Ciencas Geologicas 28.3 (2011), pp. 566-579.

[8719] R. N. P. Goodall. “Peale's dolphin Lagenorhynchus australis". English. In: Encyclopedia of Marine Mammals. San Diego: Academic Press, 2002, pp. 890-894.

[8720] S. M. Goodman. "Description of a new species of subfossil eagle from Madagascar: Stephanoaetus (Aves: Falconiformes) from the deposits of Ampasambazimba". English. In: Proceedings of the Biological Society of Washington 107 (1994), pp. 421-428.

[8721] S. M. Goodman. "A description of a new species of Brachypteracias (Family Brachypteraciidae) from the Holocene of Madagascar". English. In: Ostrich 71 (2000), pp. 318-322.

[8722] S. M. Goodman. "Holocene bird subfossils from the sites of Ampasambazimba, Antsirabe and Ampoza, Madagascar: changes in the avifauna of south central Madagascar over the past few millennia". English. In: Proceedings of the 22nd International Ornithological Congress, Durban (1999), pp. 3071-3083.

[8723] S. M. Goodman and K. M. Muldoon. "A new subfossil locality for the extinct large Malagasy eagle Stephanoaetus mahery (Aves: Falconiformes): Implications for time of extinction and ecological specificity". English. In: The Holocene 26 (2016), pp. 985-989.

[8724] S. M. Goodman, M. J. Raherilalao, and K. Muldoon. “Bird fossils from Ankilitelo Cave: inference about Holocene environmental". English. In: Zootaxa 3750 (2013), pp. 534-548.

[8725] S. M. Goodman and F. Ravoavy. "Identification of bird subfossils from cave surface deposits at Anjohibe, Madagascar, with a description of a new giant Coua (Cuculidae: Couinae)". English. In: Proceedings of the Biological Society of Washington 106 (1993), pp. 24-33.

[8726] D. H. Goodwin. "Paleontology, Paleoecology, and Depositional Environments Within the Upper Triassic (Norian) Carbonate Strata of the Antimonio Formation, Northwest Sonora, Mexico". PhD thesis. 1999.

[8727] H. T. Goodwin. "Pliocene-Pleistocene Biogeographic History of Prairie Dogs, Genus Cynomys (Sciuridae)". English. In: Journal of Mammalogy 76.1 (1995).

[8728] H. T. Goodwin. "Systematic revision of fossil prairie dogs with descriptions of two new species". English. In: University of Kansas Natural History Museum Miscellaneous Publications 86 (1995), pp. 138. 
[8729] H. T. Goodwin. "Spermophilus elegans (Rodentia, Sciuridae) from the middle Pleistocene of Colorado and the origin of the Spermophilus richardsonii group". English. In: Journal of Vertebrate Paleontology 22.1 (2002), pp. 182-185.

[8730] H. T. Goodwin and F. E. Hayes. "Morphologically derived ground squirrels from the Borchers local fauna, Meade County, Kansas, with a redescription of ?Spermorphilus cragini". English. In: Journal of Vertebrate Paleontology 14.2 (1994), pp. 278-291.

[8731] I. D. Goodwin and E. E. Grossman. "Middle to Late Holocene coastal evolution along the south coast of Upolu Island, Samoa". English. In: Marine Geology 202 (2003), pp. 1-16.

[8732] M. B. Goodwin. Morphometric landmarks of pachycephalosaurid cranial material from the Judith River Formation of northcentral Montana. Dinosaur Systematics: Perspectives and Approaches, Cambridge University Press, Cambridge. 1990, pp. 189-201.

[8733] M. B. Goodwin, E. A. Buccholtz, and R. E. Johnson. “Cranial anatomy and diagnosis of Stygimoloch spinifer (Ornithischia: Pachycephalosauria) with comments on cranial display structures in agonistic behavior". In: Journal of Vertebrate Paleontology 18.2 (1998), pp. 363-375.

[8734] M. B. Goodwin, W. A. Clemens, J. H. Hutchison, C. B. Wood, M. S. Zavada, A. Kemp, C. J. Duffin, and C. R. Schaff. "Mesozoic continental vertebrates with associated palynostratigraphic dates from the northwestern Ethiopian plateau". In: Journal of Vertebrate Paleontology 19.4 (1999), pp. 728 741.

[8735] M. B. Goodwin, W. A. Clemens, J. R. Horner, and K. Padian. "The smallest known Triceratops skull: new observations on ceratopsid cranial anatomy and ontogeny". English. In: Journal of Vertebrate Paleontology 26.1 (2006), pp. 103-112.

[8736] M. B. Goodwin and D. C. Evans. "The early expression of squamosal horns and parietal ornamentation confirmed by new end-stage juvenile Pachycephalosaurus fossils from the Upper Cretaceous Hell Creek Formation, Montana". English. In: Journal of Vertebrate Paleontology 36.2 (2016), e1078343:1-8. DOI: 10.1080/02724634.2016.1078343.

[8737] M. B. Goodwin and J. R. Horner. Historical collecting bias and the fossil record of Triceratops in Montana. English. New Perspectives on Horned Dinosaurs: The Royal Tyrrell Museum Ceratopsian Symposium. Indiana University Press, Bloomington. 2010, pp. 551-563.

[8738] M. B. Goodwin, R. B. Irmis, G. P. Wilson, D. G. DeMar Jr., K. Melstrom, C. Rasmussen, B. Atnafu, T. Alemu, M. Alemayehu, and S. G. Chernet. "The first confirmed sauropod dinosaur from Ethiopia discovered in the Upper Jurassic Mugher Mudstone". English. In: Journal of African Earth Sciences (2019). DOI: 10.1016/j.jafrearsci.2019.103571.

[8739] M. B. Goodwin and R. E. Johnson. A new skull of the pachycephalosaur Stygimoloch casts doubt on head butting behavior. English. 1995.

[8740] S. Gordillo and A. E. Aitken. "Palaeoenvironmental interpretation of Late Quaternary marine molluscan assemblages, Canadian Arctic achipelago". In: Geographie physique et Quaternaire 54.3 (2000), pp. 301-315.

[8741] S. Gordillo, A. M. J. Coronato, and J. O. Rabassa. "Quaternary molluscan faunas from the island of Tierra de Fuega after the Last Glacial Maximum". English. In: Scientia Marina 69.2 (2005), pp. 337348.

[8742] C. L. Gordon and N. J. Czaplewski. "A fossil marmot from the late Miocene of western Oklahoma". In: Oklahoma Geology Notes 60.2 (2000), pp. 28-32.

[8743] C. L. Gordon and N. J. Czaplewski. "Second record of the Pleistocene saber-toothed cat, Smilodon fatalis, in Oklahoma". English. In: Proceedings of the Oklahoma Academy of Science 78 (1998), pp. 133135.

[8744] D. P. Gordon, I. G. Stuart, and J. D. Collen. "Bryozoan fauna of the Kaipuke Siltstone, northwest Nelson: a Miocene homologue of the modern Tasman Bay coralline bryozoan grounds". English. In: New Zealand Journal of Geology and Geophysics 37.3 (1994), pp. 239-247. DOI: 10.1080/00288306. 1994.9514619. 
[8745] D. P. Gordon and P. D. Taylor. "Bryozoa of the Early Eocene Tumaio Limestone, Chatham Island, New Zealand". English. In: Journal of Systematic Palaeontology (2015), pp. 1-88. DOI: 10.1080/ 14772019.2014.991905.

[8746] M. Gordon and K. Young. "Bathonian and Valanginian fossils from Honduras". English. In: Geobios 26.Suppl 1 (1993), pp. 175-179.

[8747] M. Gordon Jr. and T. W. Henry. "Marginovatia, a Mid-Carboniferous Genus of Linoproductid Brachiopods". English. In: Journal of Paleontology 64.4 (1990), pp. 532-551.

[8748] M. Gordon Jr., T. W. Henry, and J. D. Treworgy. "Late Mississippian Productoid Brachiopods Inflatia, Keokukia, and Adairia, Ozark Region of Oklahoma and Arkansas". English. In: Paleontological Society Memoir 30 (1993), pp. 1-29.

[8749] S. Gorican and S. Buser. "Middle Triassic radiolarians from Slovenia (Yugoslavia)". English. In: Geologija 31/32 (1990), pp. 133-197.

[8750] S. Gorican, A. Smuc, and P. O. Baumgartner. "Toarcian Radiolaria from Mt. Mangart (SlovenianItalian border) and their paleoecological implications". English. In: Marine Micropaleontology 49 (2003), pp. 275-301.

[8751] R. V. Gorjunova. “On the Paleozoic bryozoans of the genus Ascopora". English. In: Paleontological Journal 44.1 (2010), pp. 21-35.

[8752] R. V. Gorjunova and K. M. Sedaeva. "New bryozoan species from the stratotype section of the upper Kazanian substage". English. In: Paleontological Journal 42 (2008), pp. 350-362.

[8753] M. Gorka. "The Lower Badenian (Middle Miocene) coral patch reef at Grobie (southern slopes of the Holy Cross Mountains, Central Poland), its origin, development and demise". In: Acta Geologica Polonica 52.4 (2002), pp. 521-534.

[8754] M. Górka. "Late Badenian zooxanthellate corals of the Medobory Hills (western Ukraine) and their environmental significance". English. In: Annales Societatis Geologorum Poloniae 88 (2018).

[8755] K. L. Gorman, K. Shimada, and B. J. Witzke. "Late Cretaceous marine fishes from the basal Greenhorn Limestone in western Iowa". English. In: Transactions of the Kansas Academy of Science 117 (2014), pp. 91-99. DOI: 10.1660/062.117.0114.

[8756] M. Gormus, H. Demircan, Y. K. Kadioglu, F. Yagmurlu, and M. S. Us. “Microborings as indication of cryptic life modes in the foraminifer Orbitoides: Maastrichtian sediments of the Haymana and Nallhan districts (Ankara, Turkey)". English. In: Turkish Journal of Earth Sciences 2019.28 (2019). DOI: 10.3906/yer-1804-17.

[8757] G. M. Gornals, F. E. Daz, and J. Q. Cardona. "Primera cita de un Delphinidae en el Neógeno de las Islas Baleares". English. In: Batalleria 18 (2013), pp. 45-51.

[8758] L. V. Gorobets and V. O. Yanenko. "Late Pleistocene birds from Binagada (Azerbaijan) in collection of the National Museum of Natural History (Kyiv, Ukraine)". English. In: Vestnik Zoologii 52 (2018), pp. 31-36.

[8759] A. V. Gorochov. "New and little known orthopteroid insects (Polyneoptera) from fossil resins: communication 3". English. In: Paleontological Journal 44 (2010), pp. 434-450.

[8760] A. V. Gorochov. "Phasmomimidae: are they Orthoptera or Phasmatoptera?" English. In: Paleontological Journal 34 (2000), pp. 295-300.

[8761] A. V. Gorochov. Iskopayemiye Palochniki (Phasmoptera) iz Yury i Miela [Fossil stick insects (Phasmoptera) from the Jurassic and Cretaceous]. Russian. Mezozoyskie Nasekomye i Ostrakody Azii [Mesozoic Insects and Ostracods from Asia]. 1993, pp. 112-117.

[8762] A. V. Gorochov. "The first representative of the Suborder Mesotitanina from the Paleozoic and notes on the system and evolution of the Order Titanoptera (Insecta: Polyneoptera)". English. In: Paleontological Journal 41.6 (2007), pp. 621-625.

[8763] A. V. Gorochov. "A new, enigmatic family for new genus and species of Polyneoptera from the Upper Permian of Russia". English. In: ZooKeys 130 (2011), pp. 131-136. 
[8764] A. V. Gorochov. "Review of Triassic Orthoptera with Descriptions of New and Little Known Taxa: Part 1". English. In: Paleontological Journal 39.2 (2005), pp. 178-186.

[8765] A. V. Gorochov. "Review of Triassic Orthoptera with Descriptions of New and Little Known Taxa: Part 2". English. In: Paleontological Journal 39.3 (2005), pp. 272-279.

[8766] A. V. Gorochov. "New data on Triassic Orthoptera from Middle Asia". English. In: Zoosystematica Rossica 3.1 (1994), pp. 53-54.

[8767] A. V. Gorochov. "New and little-known orthopteroid insects (Polyneoptera) from fossil resins: communication 4". English. In: Paleontological Journal 44 (2010), pp. 657-671.

[8768] A. V. Gorochov. "Permian and Triassic Walking Sticks (Phasmoptera) from Eurasia". English. In: Paleontological Journal 28.4 (1994), pp. 83-98.

[8769] A. V. Gorochov. "New and Little Known Mesotitanidae and Paratitanidae (Titanoptera) from the Triassic of Kyrgyzstan". English. In: Paleontological Journal 37.4 (2003), pp. 400-406.

[8770] A. V. Gorochov. "New and little known orthopteroid insects (Polyneoptera) from fossil resins: communication 1". English. In: Paleontological Journal 40 (2006), pp. 646-654.

[8771] A. V. Gorochov. "Novye rody i vidy Mezozoyskikh priyamokrylykh nadsemeystva Hagloidea (Orthoptera) s neyasnym sistematicheskim polozheniem". Russian. In: News on Faunistics and Systematics 5 (1990), pp. 32-35.

[8772] A. V. Gorochov. "Primitive Titanoptera and early evolution of Polyneoptera". Russian. In: Meetings in Memory of N.A. Cholodkovsky 57 (2004), pp. 1-54.

[8773] A. V. Gorochov. "New and little known orthopteroid insects (Polyneoptera) from fossil resins: communication 2". English. In: Paleontological Journal 41 (2007), pp. 156-166.

[8774] A. V. Gorochov. "Orthopterans, Gryllida, in Pozdne-Mezozoyskie Nasekomye Vostochnogo Zabaykal'ya”. Russian. In: vol. 239. Akademiya Nauk SSSR, Trudy Paleontologicheskogo Instituta. 1990, pp. $210-$ 214.

[8775] A. V. Gorochov. "New and little-known fossil crickets (Orthoptera, Grylloidea) from Eurasia". English. In: Paleontological Journal 26.2 (1992), pp. 119-127.

[8776] A. V. Gorochov. "Crickets and grasshoppers (Orthoptera) from the latest Eocene of the Isle of Wight, southern England, UK". English. In: Earth and Environmental Science Transactions of the Royal Society of Edinburgh 110 (2019), pp. 317-329. DOI: 10.1017/S1755691018000889.

[8777] A. V. Gorochov, E. A. Jarzembowski, and R. A. Coram. “Grasshoppers and crickets (Insecta: Orthoptera) from the Lower Cretaceous of southern England". English. In: Cretaceous Research 27 (2006), pp. 641-662.

[8778] A. V. Gorochov and C. C. Labandeira. "Eocene Orthoptera from Green River Formation of Wyoming (USA)". English. In: Russian Entomological Journal 21 (2012), pp. 357-370.

[8779] E. N. Gorozhanina, V. M. Gorozhanina, and T. N. Isakova. "The Carbonate Massif of Voskresenka Mount". English. In: Stratigraphy and Geological Correlation 26.2 (2018), pp. 139-156. DOI: 10.1134/ S0869593818010045.

[8780] E. Gorscak, P. M. O'Connor, N. J. Stevens, and E. M. Roberts. “The basal titanosaurian Rukwatitan bisepultus (Dinosauria, Sauropoda) from the middle Cretaceous Galula Formation, Rukwa Rift Basin, southwestern Tanzania". English. In: Journal of Vertebrate Paleontology 34.5 (2014), pp. 11331154. DOI: $10.1080 / 02724634.2014 .845568$.

[8781] E. Gorscak, P. M. O'Connor, E. M. Roberts, and N. J. Stevens. “The second titanosaurian (Dinosauria: Sauropoda) from the middle Cretaceous Galula Formation, southwestern Tanzania, with remarks on African titanosaurian diversity". English. In: Journal of Vertebrate Paleontology 37.4 (2017), e1343250:1-22.

[8782] E. Gorscak and P. M. O'Connor. "A new African titanosaurian sauropod dinosaur from the middle Cretaceous Galula Formation (Mtuka Member), Rukwa Rift Basin, southwestern Tanzania". English. In: PLoS ONE 14.2 (2019), e0211412:1-54. 
[8783] P. Gorzelak, B. Baejowski, A. Uchman, and N. M. Hanken. “First record of catacrinid crinoid from the Lower Permian of Spitsbergen". English. In: Polish Polar Research 34 (2013), pp. 139-150.

[8784] A. Goswami, G. V. R. Prasad, O. Verma, J. J. Flynn, and R. B. J. Benson. “A troodontid dinosaur from the latest Cretaceous of India". English. In: Nature Communications 4 (2013), pp. 1-5. DOI: $10.1038 /$ ncomms2716.

[8785] M. Goto. "Palaeozoic and early Mesozoic fish faunas of the Japanese Islands". English. In: The Island Arc 3.1994 (1994), pp. 247-254.

[8786] M. Goto, N. Kuga, and K. Hachiya. "On the hybodont elasmobranch teeth of three genera from the Mesozoic of Japan". Japanese. In: Journal of the Geological Society of Japan 97.9 (1991), pp. 743-750.

[8787] M. Goto and M. Okura. "The chondrichthyan tooth remains from the Carboniferous and Permian of Fukuji, Gifu Prefecture, central Japan". Japanese. In: Earth Science (Chikyu Kagaku) 58 (2004), pp. 215-228.

[8788] M. Goto, T. Tanaka, and S. Utsunomiya. "On a tooth remain of Lissodus (Elasmobranchii) from the Taho Formation (Lower Triassic) in Seiyo City, Ehime Prefecture, southwest Japan". Japanese. In: Earth Science (Chikyu Kagaku) 64 (2010), pp. 111-116.

[8789] M. Goto, T. Uyeno, and Y. Yabumoto. Summary of Mesozoic elasmobranch remains from Japan. English. Vol. 1. Mesozoic Fishes - Systematics and Paleoecology. München, Germany: Verlag Dr. Friedrich Pfeil, 1996, pp. 73-82.

[8790] M. D. Gottfried. "Miocene basking sharks (Lamniformes: Cetorhinidae) from the Chesapeake Group of Maryland and Virginia". English. In: Journal of Vertebrate Paleontology 15.2 (1995), pp. 443447.

[8791] M. D. Gottfried and R. E. Fordyce. "An associated specimen of Carcharodon angustidens (Chondrichthyes, Lamnidae) from the late Oligocene of New Zealand, with comments on Carcharodon interrelationships". English. In: Journal of Vertebrate Paleontology 21.4 (2000), pp. 730-739.

[8792] M. D. Gottfried, R. E. Fordyce, and S. Rust. "Megalampris keyesi, a Giant Moonfish (Teleostei, Lampridiformes) from the Late Oligocene of New Zealand". English. In: 26.3 (2006), pp. 544-551.

[8793] M. D. Gottfried and R. E. Fordyce. "An Associated Specimen of Carcharodon angustidens (Chondrichthyes, Lamnidae) from the Late Oligocene of New Zealand, with Comments on Carcharodon Interrelationships". English. In: Journal of Vertebrate Paleontology 21.4 (2001), pp. 730-739.

[8794] M. D. Gottfried, R. E. Fordyce, and S. Rust. "A New Billfish (Perciformes, Xiphioidei) from the Late Oligocene of New Zealand". English. In: Journal of Vertebrate Paleontology 32.1 (2012), pp. 2734.

[8795] M. D. Gottfried and D. W. Krause. "First record of gars (Lepisosteidae, Actinopterygii) on Madagascar: Late Cretaceous remains from the Mahajunga Basin". In: Journal of Vertebrate Paleontology 18.2 (1998), pp. 275-279.

[8796] M. D. Gottfried, P. M. O'Connor, F. D. Jackson, E. M. Roberts, and R. Chami. "Dinosaur eggshell from the Red Sandstone Group of Tanzania". In: Journal of Vertebrate Paleontology 24.2 (2004), pp. 494-497.

[8797] M. D. Gottfried, J. A. Rabarison, and L. L. Randriamiarimanana. “Late Cretaceous elasmobranchs from the Mahajanga Basin of Madagascar". English. In: Cretaceous Research 22 (2001), pp. 491-496.

[8798] M. D. Gottfried, N. J. Stevens, E. M. Roberts, P. M. O'Connor, and R. Chami. "A new Cretaceous lungfish (Dipnoi: Ceratodontidae) from the Rukwa Rift Basin, Tanzania". English. In: African Natural History 5 (2009), pp. 31-36.

[8799] S. Götz. "Biotic interaction and synecology in a Late Cretaceous coral-rudist biostrome of southeastern Spain". In: Palaeogeography, Palaeoclimatology, Palaeoecology 193.1 (2003), pp. 125-138.

[8800] S. Götz. Inside rudist ecosystems: growth, reproduction, and population dynamics. English. Vol. 87. Cretaceous rudists and carbonate platforms: environmental feedback, SEPM Special Publication. 2007, pp. 97-113. 
[8801] S. Götz, H. Löser, and D. U. Schmid. "Reef development on a deepening platform: two Early Cretaceous coralgal patch reefs (Cati, Llacova Formation, eastern Spain) compared". English. In: Cretaceous Research 26 (2005), pp. 864-881.

[8802] S. Götz and S. Mitchell. "The Laluzia armini (gen et spec nov) ecosystem: understanding a deeperwater rudist lithosome from the Early Maastrichtian of Mexico". English. In: Facies 55 (2009), pp. 539-551.

[8803] Z. H. Gou and M. B. Lin. “The bivalve fauna of Feixianguan Formation in Majiaoba area, Jiangyou, Sichuan". Chinese. In: Journal of Chengdu Institute of Technology 23 (1996), pp. 80-84.

[8804] S. Gouiric-Cavalli, A. M. Zavattieri, P. Gutierrez, B. Cariglino, and L. Balarino. "Increasing the fish diversity of the Triassic faunas of Gondwana: a new Redfieldiiforme (Actinopterygii) from the Middle Triassic of Argentina and its palaeobiogeographical implications". English. In: Papers in Palaeontology (2017), pp. 1-23. DOI: 10.1002/spp2.1089.

[8805] G. C. Gould and I. R. Quitmyer. “Titanis walleri: Bones of contention”. English. In: Bulletin of the Florida Museum of Natural History 45.4 (2005), pp. 201-229.

[8806] C. Gourrat, J. P. Masse, and P. W. Skelton. “Hypelasma salevensis (Favre, 1913) from the Upper Kimmeridgian of the French Jura, and the origin of the rudist family Requieniidae". English. In: Geologica Croatica 56.2 (2003), pp. 139-148.

[8807] S. Gouwy, M. Benfrika, S. Helsen, and P. Bultynck. "Late Emsian to early Givetian Conodont succession in the Tiflet area (north-western Meseta, Central Morocco)". English. In: Travaux de l'Institut Scientifique de Rabat Série Géologie \& Géographie physique 20 (2000), pp. 1-10.

[8808] S. Gouwy and P. Bultynck. "Conodont data across the Eifelian-Givetian boundary at Aisemont, southern Namur Synclinorium, Belgium: correlation and implications". English. In: Courier ForschungsInstitut Senckenberg 242 (2003), pp. 239-255.

[8809] S. Gouwy, J. C. Liao, and J. I. Valenzuela-Rios. "Eifelian (Middle Devonian) to lower Frasnian (Upper Devonian) conodont biostratigraphy in the Villech section, Spanish Central Pyrenees". English. In: Bulletin of Geosciences 88.2 (2013), pp. 315-338. DOI: 10.3140/bull.geosci.1341.

[8810] S. A. Gouwy, T. T. Uyeno, and A. D. McCracken. "Tortodus dodoensis, a new conodont species, and a Givetian (Middle". English. In: Palaeontologische Zeitschrift 94 (2020), pp. 327-342.

[8811] R. Govender. "Fossil cetaceans from Duinefontein (Koeberg) an early Pliocene site on the southwestern Cape, South Africa". English. In: Palaeontologia Electronica 22.1.6A (2019), pp. 1-21.

[8812] R. Govender. "Extension of the geographic range of Homiphoca into Northern Cape Province, South Africa, with comments on the possible feeding strategies used by Homiphoca". English. In: Journal of Vertebrate Paleontology 38.3 (2018), e1463536. DOI: 10.1080/02724634.2018.1463536.

[8813] R. Govender, M. Bisconti, and A. Chinsamy. "A late Miocene-early Pliocene baleen whale assemblage from Langebaanweg, west coast of South Africa (Mammalia, Cetacea, Mysticeti)". English. In: Alcheringa (2016). DOI: 10.1080/03115518.2016.1159413.

[8814] C. Gow. "An enigmatic new reptile from the Lower Triassic Fremouw Formation of Antarctica". English. In: Palaeontologia africana 29 (1992), pp. 21-23.

[8815] C. Gow. "The skull of Protosuchus haughtoni, an Early Jurassic crocodyliform from southern Africa". English. In: Journal of Vertebrate Paleontology 20 (2000), pp. 49-56.

[8816] C. Gow. "New find of Diarthrognathus (Therapsida: Cynodontia) after seventy years". English. In: Palaeontologia africana 31 (1994), pp. 51-54.

[8817] C. E. Gow. "A Captorhinid with Multiple Tooth Rows from the Upper Permian of Zambia”. English. In: Palaeontologia Africana 36 (2000), pp. 11-14.

[8818] C. E. Gow. "The Triassic reptile Palacrodon browni Broom, synonymy and a new specimen". English. In: Palaeontologia Africana 35 (1999), pp. 21-23.

[8819] C. E. Gow and B. de Klerk. "First Record of Eunotosaurus (Amniota: Parareptilia) from the Eastern Cape". English. In: Palaeontologia Africana 34 (1997), pp. 27-31. 
[8820] D. J. Gower. "The cranial and mandibular osteology of a new rauisuchian archosaur from the Middle Triassic of southern Germany". English. In: Stuttgarter Beiträge zur Naturkunde Serie B (Geologie und Paläontologie) 280 (1999), pp. 1-49.

[8821] D. J. Gower, P. J. Hancox, J. Botha-Brink, A. G. Sennikov, and R. J. Butler. "A New Species of Garjainia Ochev, 1958 (Diapsida: Archosauriformes: Erythrosuchidae) from the Early Triassic of South Africa". English. In: PLoS ONE 9.11 (2014), e111154. DOI: 10.1371/journal.pone.0111154.

[8822] D. J. Gower and R. R. Schoch. "Postcranial anatomy of the rauisuchian archosaur Batrachotomus kupferzellensis". English. In: Journal of Vertebrate Paleontology 29 (2009), pp. 103-122.

[8823] D. J. Gower and A. G. Sennikov. Early Archosaurs from Russia. English. The Age of Dinosaurs in Russia and Mongolia. Cambridge University Press, Cambridge. 2000, pp. 140-159.

[8824] A. Goy, A. Pérez-López, and F. Pérez-Valera. "Ammonoideos del Ladiniense en la Unidad de Cabo Cope (Zonas Internas, Cordillera Bética)”. Spanish. In: Geo-Temas 8 (2005), pp. 179-182.

[8825] R. Gozalo, E. Mayoral, J. A. Gamez Vintaned, M. E. Dies, and F. Muniz. "A new occurrence of the genus Tonkinella in northern Spain and the Middle Cambrian intercontinental correlation". English. In: Geologica Acta 1.1 (2003), pp. 121-126.

[8826] I. Gradianu, T. Prikryl, R. Gregorova, and A. S. Harold. “????Gonostoma dracula sp. nov. (Teleostei, Gonostomatidae) from the Oligocene deposits of the Central Paratethys (Romania): earliest occurrence of the modern bristlemouths". English. In: Bulletin of Geosciences 92.3 (2017), pp. 323-336. DOI: $10.3140 /$ bull.geosci.1683.

[8827] E. Gradinaru, A. Barbulescu, and E. F. Owen. “Latest Albian (Vraconian) brachiopod fauna from North Dobrogea (Romania): taxonomy, palaeoecology and palaeobiogeography". English. In: Acta Geologica Polonica 56.1 (2006), pp. 67-88.

[8828] E. Grdinaru and M. Gaetani. “Upper Spathian to Bithynian (Lower to Middle Triassic) brachiopods from North Dobrogea (Romania)". English. In: Rivista Italiana di Paleontologia e Stratigrafia 125 (2019), pp. 91-123.

[8829] E. Grdinaru, M. J. Orchard, A. Nicora, Y. Gallet, J. Besse, L. Krystyn, E. S. Sobolev, N. -V. Atudorei, and D. Ivanova. "The Global Boundary Stratotype Section and Point (GSSP) for the base of". English. In: Albertiana 36 (2007), pp. 54-71.

[8830] F. M. Gradstein and M. A. Kaminski. “New species of Paleogene deep-water agglutinated foraminifera from the North Sea and Norwegian Sea". English. In: Annales Societatis Geologorum Poloniae 67 (1997), pp. 217-229.

[8831] F. Grady. Fossil Chiroptera From Two West Virginia Caves. English. 1991.

[8832] F. Grady. The sabertooth cat Smilodon from West Virginia caves. English. 2000.

[8833] F. Grady, J. Arroyo-Cabrales, and E. R. Garton. “The northernmost occurrence of the Pleistocene vampire bat Desmodus stocki Jones (Chiroptera, Phyllostomatidae, Desmodontinae) in eastern North America". English. In: Smithsonian Contributions to Paleobiology 93 (2002), pp. 73-75.

[8834] F. Grady, C. Baker, D. A. Hubbard, and P. Lucas. A Pleistocene tapir from a Virginia cave. English. 2006.

[8835] F. Grady, C. Baker, and E. R. Garton. Mississippian and Pleistocene Vertebrates from Haynes Cave, West Virginia. English. 2006.

[8836] F. Grady and E. R. Garton. Paleontology and historic field trip of the John Guilday Cave Preserve (Trout Rock). English. Vol. 14. Bulletin - West Virginia Speleological Survey. 2000, pp. 241-244.

[8837] F. Grady, R. Garton, and M. G. Homes. The Pleistocene peccary Platygonus vetus from Poorfarm Cave, Pocahontas County, WV. English. 2000.

[8838] F. Grady and D. A. Hubbard. The Pleistocene Fauna from Earlys Cave and Earlys Pit, Wythe County, Virginia. English. 2000.

[8839] F. V. Grady and S. L. Olson. "Fossil bats from Quaternary deposits on Bermuda (Chiroptera: Vespertilionidae)". English. In: Journal of Mammalogy 87 (2006), pp. 148-152. 
[8840] J. Graf. "A new Early Cretaceous coelacanth from Texas". English. In: Historical Biology 24.4 (2012), pp. 441-452. DOI: 10.1080/08912963.2012.696636.

[8841] J. Graf, L. Jacobs, M. Polcyn, O. Mateus, and A. Schulp. “New fossil whales from Angola”. English. In: Journal of Vertebrate Paleontology Abstracts (2011), p. 119.

[8842] K.-U. Gräfe. "Benthic foraminifers and palaeoenvironment in the Lower and Middle Jurassic of the Western Basque-Cantabrian Basin (Northern Spain)". English. In: Journal of Iberian Geology 31.2 (2005), pp. 217-233.

[8843] A. Graham. "Studies in Neotropical Paleobotany. X. The Pliocene communities of Panama - Composistion, numerical representations, and paleocommunity paleoenvironmental reconstructions." In: Annals of the Missouri Botanical Garden 78 (1991), pp. 465-475.

[8844] A. Graham, D. Cozadd, A. Areces-Mallea, and N. O. Frederiksen. "Studies in neotropical paleobotany. XIV. A palynoflora from the Middle Eocene Saramaguacan Formation of Cuba". In: American Journal of Botany 87.10 (2000), pp. 1526-1539.

[8845] A. Graham, K. M. Gregory-Wodzicki, and K. L. Wright. "Studies in neotropical paleobotany. XV. A Mio-Pliocene palynoflora from the eastern cordillera, Bolivia: Implications for the uplift history of the Central Andes." In: American Journal of Botany 88.9 (2001), pp. 1545-1557.

[8846] S. A. Graham, M. S. Hendrix, R. Barsbold, D. Badamgarav, D. Sjostrom, W. Kirschner, and J. S. McIntosh. "Stratigraphic occurrence, paleoenvironment, and description of the oldest known dinosaur (Late Jurassic) from Mongolia". English. In: Palaios 12 (1997), pp. 292-297.

[8847] Y. Grahn. "Revision of Silurian and Devonian strata of Brazil". In: Palynology 16 (1992), pp. 35-61.

[8848] J. P. Grandadeiro. "The breeding biology of Cory's Shearwater Calonectris diomedea borealis on Berlenga Island, Portugal". English. In: Seabird 13 (1991), pp. 30-39.

[8849] L. Grande. "The First Esox (Esocidae: Teleostei) from the Eocene Green River Formation, and a Brief Review of Esocid Fishes". English. In: Journal of Vertebrate Paleontology 19.2 (1999), pp. 271292.

[8850] L. Grande and H. P. Buchheim. "Paleontological and sedimentological variation in Earl Eocene Fossil Lake". English. In: University of Wyoming Contributions to Geology 30.1 (1994), pp. 33-56.

[8851] L. Grande and M. De Pinna. "Description of a Second Species of the Catfish Hypsidoris and a Reevaluation of the Genus and the Family Hypsidoridae". English. In: Journal of Vertebrate Paleontology 18.3 (1998), pp. 451-474.

[8852] L. Grande and T. Grande. "A new species of Notogoneus (Teleostei; Gonorynchidae) from the Upper Cretaceous Two Medicine Formation of Montana, and the poor Cretaceous record of freshwater fishes from North America". English. In: Journal of Vertebrate Paleontology 19.4 (1999), pp. 612622.

[8853] L. Grande and E. J. Hilton. "An exquisitely preserved skeleton representing a primitive sturgeon from the Upper Cretaceous Judith River Formation of Montana (Acipenseriformes: Acipenseridae: n. gen. and sp.)" English. In: The Paleontological Society Memoir 65, Journal of Paleontology 80.4, suppl. (2006), pp. 1-39.

[8854] L. Grande, F. Jin, Y. Yabumoto, and W. E. Bemis. "Protopsephurus liui, a Well-Preserved Primitive Paddlefish (Acipenseriformes: Polyodontidae) from the Lower Cretaceous of China". English. In: Journal of Vertebrate Paleontology 22.2 (2002), pp. 209-237.

[8855] L. Grande, G.-Q. Li, and M. V. H. Wilson. "Amia cf. pattersoni from the Paleocene Paskapoo Formation of Alberta". English. In: Canadian Journal of Earth Sciences 37.1 (2000), pp. 31-37. DOI: 10.1139/e99-102.

[8856] F. Grandi and F. Bona. "Prominatherium dalmatinum from the late Eocene of Grancona (Vicenza, NE Italy). The oldest terrestrial mammal of the Italian peninsula". English. In: Comptes Rendus Palevol 16.7 (2017), pp. 738-745. DOI: 10.1016/j.crpv.2017.04.002. 
[8857] M. F. Grandi, S. L. Dans, and E. A. Crespo. “Social composition and spatial distribution of colonies in an expanding population of South American sea lions". English. In: Journal of Mammalogy 89.5 (2008), pp. 1218-1228.

[8858] B. S. Grandstaff, W. B. Gallagher, K. Shannon, and D. C. Parris. New discoveries of Late Cretaceous mammals in eastern North America. English. 2000.

[8859] B. S. Grandstaff, D. C. Parris, R. K. Denton Jr., and W. B. Gallagher. "Alphadon (Marsupialia) and Multituberculata (Allotheria) in the Cretaceous of eastern North America". English. In: Journal of Vertebrate Paleontology 12.2 (1992), pp. 217-222.

[8860] B. S. Grandstaff, J. B. Smith, M. C. Lamanna, K. J. Lacovara, and M. S. Abdel-Ghani. “Bawitius, gen. nov., a giant polypterid (Osteichthyes, Actinopterygii) from the Upper Cretaceous Bahariya Formation of Egypt". English. In: Journal of Vertebrate Paleontology 32.1 (2012), pp. 17-26. DOI: 10. 1080/02724634.2012.626823.

[8861] B. R. C. Granier and T. Grgasovi. “Les algues dasycladales du Permien et du Trias: nouvelle tentative d' inventaire bibliographique, géographique et stratigraphique". French. In: Geologica Croatica 53.1 (2000), pp. 1-197.

[8862] R. E. Grant. "Upper Permian brachiopods of the Superfamily Orthotetoidea from Hydra Island, Greece". In: Journal of Paleontology 69.4 (1995), pp. 655-670.

[8863] R. E. Grant. "Permian brachiopods from Khios Island, Greece". English. In: Journal of Paleontology Memoir 67.4 (1993), pp. 1-21.

[8864] R. E. Grant. "The brachiopod family Gemmellaroiidae". English. In: Journal of Paleontology 67.1 (1993), pp. 53-60.

[8865] J. A. Grant-Mackie. "Mesozoic Bivalvia from Clerke and Mermaid Canyons, northwest Australian continental slope". English. In: AGSO Journal of Australian Geology and Geophysics 15.1 (1994), pp. 119-125.

[8866] J. A. Grant-Mackie. “Makoiamya cotterallae, a new genus and species of bivalve (Ceratomyidae) from the latest Triassic of New Zealand and New Caledonia". English. In: Zootaxa 3741 (2013), pp. 327-348.

[8867] J. A. Grant-Mackie, J. S. Buckeridge, and P. M. Johns. “Two new Upper Jurassic arthropods from New Zealand". English. In: Alcheringa 20.1 (1996), pp. 31-39.

[8868] J. A. Grant-Mackie, J. Hill, and B. J. Gill. "Two Eocene chelonioid turtles from Northland, New Zealand". English. In: New Zealand Journal of Geology and Geophysics 54 (2011), pp. 181-194.

[8869] J. A. Grant-Mackie and N. J. Silberling. “New Data on the Upper Triassic Bivalve Monotis in North America, and the New Subgenus Pacimonotis". English. In: Journal of Paleontology 64.2 (1990), pp. 240-254.

[8870] V. G. Gratshev. "Ulyanidae, and extinct family of weevils (Coleoptera, Curculionoidea)". English. In: Proceedings of the First International Palaeoentomological Conference (1999), pp. 41-47.

[8871] V. G. Gratshev and A. A. Legalov. "New Mesozoic Ithyceridae beetles (Coleoptera)". English. In: Paleontological Journal 45 (2011), pp. 77-82.

[8872] V. G. Gratshev and A. A. Legalov. "New taxa of the family Nemonychidae (Coleoptera) from Jurassic and Early Cretaceous". English. In: Euroasian Entomological Journal 8 (2009), pp. 411-416.

[8873] V. G. Gratshev and A. A. Legalov. “The Mesozoic stage of evolution of the family Nemonychidae (Coleoptera, Curculionoidea)". English. In: Paleontological Journal 48 (2014), pp. 851-944.

[8874] V. G. Gratshev and E. E. Perkovsky. "New species of the genus Glaesotropis (Insecta: Coleoptera: Anthribidae) from Rovno amber". English. In: Paleontological Journal 42.1 (2008), pp. 60-62.

[8875] V. G. Gratshev and V. V. Zherikhin. "A revision of the nemonychid weevil subfamily Brethorrhininae (Insecta, Coleoptera: Nemonychidae)". English. In: Paleontological Journal 29.4 (1995), pp. 112 127. 
[8876] V. G. Gratshev and V. V. Zherikhin. "A revision of the Late Jurassic nemonychid weevil genera Distenorrhinus and Procurculio (Insecta, Coleoptera, Nemonychidae)". English. In: Paleontological Journal 29.2 (1995), pp. 100-114.

[8877] V. G. Gratshev, V. V. Zherikhin, and E. A. Jarzembowski. "A new genus and species of weevil from the Lower Cretaceous of southern England (Insecta: Coleoptera: Curculionoidea)". English. In: Cretaceous Research 19 (1998), pp. 323-327.

[8878] V. G. Gratshev and V. V. Zherikhin. "New Early Cretaceous weevil taxa from Spain (Coleoptera, Curculionoidea)". English. In: Acta Geologica Hispanica 35 (2000), pp. 37-46.

[8879] V. G. Gratshev and V. V. Zherikhin. The weevils from the Late Cretaceous New Jersey amber (Coleoptera, Curculionoidea). English. Studies on Fossils in Amber, with Particular Reference to the Cretaceous of New Jersey. Leiden: Backhuys Publishers, 2000, pp. 241-254.

[8880] V. G. Gratshev and V. V. Zherikhin. “Gobicar (Insecta, Coleoptera: Eccoptarthridae), a New Late Jurassic Genus of Eccoptarthrid Weevils from Mongolia". English. In: Paleontological Journal 33.2 (1999), pp. 163-165.

[8881] V. G. Gratshev and V. V. Zherikhin. "A new anthribid genus from the Baltic amber (Insecta: Coleoptera, Anthribidae)". English. In: Mitteilungen aus dem Geologisch-Paläontologischen Institut der Universität Hamburg 78 (1995), pp. 149-157.

[8882] P. Gravesen. "Early Danian species of the echinoid genus Tylocidaris (Cidaridae, Psychocidarinae) from eastern Denmark". English. In: Contributions of Tertiary and Quaternary Geology 30.1-2 (1993), pp. 41-73.

[8883] J. Grawe-Baumeister, G. Schweigert, and G. Dietl. “Echiniden aus dem Nusplinger Plattenkalk (Ober-Kimmeridgium, Südwestdeutschland)". German. In: Stuttgarter Beiträge zur Naturkunde. Serie B (Geologie und Paläontologie) 286 (2000), pp. 1-39.

[8884] S. C. Gray, J. R. Hein, R. Hausmann, and U. Radtke. “Geochronology and subsurface stratigraphy of Pukapuka and Rakahanga Atolls, Cook Islands: Late Quaternary reef growth and sea level history". English. In: Palaeogeography, Palaeoclimatology, Palaeoecology 91 (1992), pp. 377-394.

[8885] D. Grazhdankin. "Patterns of distribution in the Ediacaran biotas: facies versus biogeography and evolution". English. In: Paleobiology 30.2 (2004), pp. 203-221.

[8886] D. Grazhdankin. "Patterns of evolution of the Ediacaran soft-bodied biota". English. In: Journal of Paleontology 88.2 (2014), pp. 269-283. DOI: 10.1666/13-072.

[8887] A. Grealy, A. Macken, M. E. Allentoft, N. J. Rawlence, E. Reed, and M. Bunce. "An assessment of ancient DNA preservation in Holocene-Pleistocene fossil bone excavated from the world heritage Naracoorte Caves, South Australia". English. In: Journal of Quaternary Science 31.1 (2016), pp. 3345. DOI: $10.1002 /$ jqs.283.

[8888] V. V. Grebennikov. "First Alaocybites weevil (Insecta: Coleoptera: Curculionoidea) from the Eastern Palaearctic: a new microphthalmic species and generic relationships". English. In: Arthropod Systematics \& Phylogeny 68 (2010), pp. 331-365.

[8889] M. K. Greco, P. M. Welz, M. Siegrist, S. J. Ferguson, P. Gallmann, D. W. Roubik, and M. S. Engel. "Description of an ancient social bee trapped in amber using diagnostic radioentomology". English. In: Insectes Sociaux 58 (2011), pp. 487-494.

[8890] C. P. Green, N. P. Branch, G. R. Coope, M. H. Field, D. H. Keen, J. M. Wells, J. L. Schwenninger, R. C. Preece, D. C. Schreve, M. G. Canti, and C. P. Gleed-Owen. "Marine Isotope Stage 9 environments of fluvial deposits at Hackney, north London, UK". English. In: Quaternary Science Reviews 25 (2006), pp. 89-113.

[8891] J. P. Green and D. R. Lomax. "An ichthyosaur (Reptilia: Ichthyosauria) specimen from the Lower Cretaceous (Berriasian) Spilsby Sandstone Formation of Nettelton, Lincolnshire, UK". English. In: Proceedings of the Geologists' Association (2014).

[8892] T. J. Green, B. Cochran, T. W. Fenton, J. C. Woods, G. L. Titmus, L. Tieszen, M. A. Davis, and S. J. Miller. "The Buhl burial: A Paleoindian woman from southern Idaho". English. In: American Antiquity 63.3 (1998), pp. 437-456. 
[8893] B. J. Greenstein, H. A. Curran, and J. M. Pandolfi. “Shifting ecological baselines and the demise of Acropora cervicornis in the western North Atlantic and Caribbean Province: a Pleistocene perspective". English. In: Coral Reefs 17 (1998), pp. 249-261.

[8894] B. J. Greenstein, L. A. Harris, and H. A. Curran. "Comparison of recent coral life and death assemblages to Pleistocene reef communities: implications for rapid faunal replacement on recent reefs". English. In: Carbonates and Evaporites 13.1 (1998), pp. 23-31.

[8895] B. J. Greenstein, J. M. Pandolfi, and D. R. Blakeway. “A fossil reef from the last interglacial, Western Australia". English. In: Coral Reefs 24.4 (2005), p. 593.

[8896] B. J. Greenstein and J. M. Pandolfi. "Escaping the heat: range shifts of reef coral taxa in coastal Western Australia". English. In: Global Change Biology 14 (2008), pp. 513-528.

[8897] D. Greenwalt, T. R. Rose, and S. Chatzimanolis. "Preservation of mandibular zinc in a beetle from the Eocene Kishenehn Formation of Montana, USA". English. In: Canadian Journal of Earth Sciences 53 (2016), pp. 614-621.

[8898] D. E. Greenwalt and G. Bechly. "A re-description of the fossil damselfly Eolestes syntheticus Cockerell, 1940 (Odonata: Zygoptera: Eolestidae n. fam.) with description of new taxa from the Eocene of North America". English. In: Zootaxa 3887 (2014), pp. 138-156.

[8899] D. E. Greenwalt, D. J. Bickel, P. H. Kerr, G. R. Curler, B. V. Brown, H. de Jong, S. J. Fitzgerald, T. Dikow, M. Tko, C. Kehlmaier, and D. D. S. Amorim. "Diptera of the middle Eocene Kishenehn Formation. I. Documentation of diversity at the family level". English. In: Palaeontologia Electronica 22.2.50A (2019), pp. 1-56.

[8900] D. E. Greenwalt and V. A. Blagoderov. "Review of the fossil record of Bolitophilidae, with description of new taxa and discussion of position of Mangas Kovalev (Diptera: Sciaroidea)". English. In: Zootaxa 4567 (2019), pp. 546-560.

[8901] D. E. Greenwalt and M. S. Engel. "A diminutive pelecinid wasp from the Eocene Kishenehn Formation of northwestern Montana (Hymenoptera: Pelecinidae)". English. In: Novitates Paleoentomologicae 8 (2014), pp. 1-9.

[8902] D. E. Greenwalt, Y. S. Goreva, S. M. Siljeström, T. Rose, and R. E. Harbach. “Hemoglobin-derived porphyrins preserved in a Middle Eocene blood-engorged mosquito". English. In: Proceedings of the National Academy of Sciences (2013).

[8903] D. E. Greenwalt and J. K. Moulton. "The first fossil New World Dixidae with a critical discussion of generic definitions". English. In: Palaeontologia Electronica 19.3.55A (2016), pp. 1-32.

[8904] D. E. Greenwalt and J. Rust. "A new species of Pseudotettigonia Zeuner (Orthoptera: Tettigoniidae) with an intact stridulatory field and reexamination of the subfamily Pseudotettigoniinae". English. In: Systematic Entomology 39 (2014), pp. 256-263.

[8905] D. E. Greenwalt and L. Vidlika. “Latiblattella avita sp. nov. (Blattaria: Ectobiidae) from the Eocene Kishenehn Formation, Montana, USA". English. In: Palaeontologia Electronica 18.1.16A (2015), pp. 19.

[8906] D. E. Greenwalt, J. G. Wingerath, and N. L. Evenhuis. "Two new and disparate fossil bee flies (Bombyliidae: Anthracinae) from the Americas and reassessment of Anthrax dentoni Lewis, 1969". English. In: Palaeontologia Electronica 18(3.51A) (2015), pp. 1-10.

[8907] P. H. Greenwood. "A Paleocene Percoid Fish, Tentatively Referred to the Family Serranidae, from Jabal Umm Himar, Kingdom of Saudi Arabia". English. In: vol. 2093. U.S. Geological Survey Bulletin B. 1995, pp. 1-3.

[8908] L. Greer, A. Curran, B. Patterson, and N. Tibert. "The rise and demise of a Holocene coral reef complex, Dominican Republic: The coral-climate connection". English. In: Nineteenth Annual Keck Research Symposium in Geology Proceedings (2006), pp. 27-32.

[8909] H.-J. Gregor. "Erstnachweis von Seegras-Resten (Posidonia) im Oberen Eozan der Nordlichen Kalkalpen bei Hallthurm". German. In: Documenta naturae 148 (2003), pp. 1-19. 
[8910] R. Gregorova. “A new Oligocene genus of lanternfish (family Myctophidae) from the Carpathian Mountains". English. In: Revue de Paléobiologie, Genéve 9 (2004), pp. 81-97.

[8911] R. Gregorova. “Fossil fish fauna (Teleostei, Selachii) from the Dynów marlstone (Rupelian, NP 23) of the Menilitic Formation at the locality of Litenice (Czech Republic)". English. In: Acta Musei Moraviae - Scientiae Geologicae 96.2 (2011), pp. 3-33.

[8912] R. Gregorova, O. Schultz, M. Harzhauser, A. Kroh, and S. Coric. "A giant early Miocene sunfish from the North Alpine foreland basin (Austria) and its implication for molid phylogeny". English. In: Journal of Vertebrate Paleontology 29.2 (2009), pp. 359-371.

[8913] R. Gregorova and K. Zagorsek. "Preliminary report of the discovery of a sirenian rib (order Sirenia) from the Neogene sediments at Bulhary locality (Breclav Distric, Czech Republic)". other. In: Acata Musei Moraviae 93.1-2 (2008), pp. 225-228.

[8914] W. A. Gregory and G. F. Hart. "Distribution of pollen and spores in a subsurface marine Wilcox (Paleocene-Eocene) section in southwest Louisiana". In: Palynology 19 (1995), pp. 1-43.

[8915] K. M. Gregory-Wodzicki, W. C. McIntosh, and K. Velasquez. "Climatic and tectonic implications of the late Miocene Jakokkota flora, Bolivian Altiplano". In: Journal of South American Earth Sciences 11.6 (1998), pp. 533-560.

[8916] G. Grellet-Tinner, V. Codrea, A. Folie, A. Higa, and T. Smith. "First evidence of reproductive adaptation to island effect of a dwarf Cretaceous Romanian titanosaur, with embryonic integument in ovo". English. In: PLoS ONE 7.3 (2012), e32051:1-10.

[8917] G. Grellet-Tinner and V. A. Codrea. "Thalassodromeus sebesensis, an out of place and out of time Gondwanan tapejarid pterosaur". English. In: Gondwana Research 27.4 (2015), pp. 1673-1679.

[8918] G. Grellet-Tinner and L. E. Fiorelli. "A new Argentinean nesting site showing neosauropod dinosaur reproduction in a Cretaceous hydrothermal environment". English. In: Nature Communications 1.32 (2010), pp. 1-8. DOI: 10.1038/ncomms1031.

[8919] G. Grellet-Tinner, L. E. Fiorelli, and R. B. Salvador. "Water vapor conductance of the Lower Cretaceous dinosaurian eggs from Sanagasta, La Rioja, Argentina: paleobiological and paleoecological implications for South American faveoloolithid and megaloolithid eggs". English. In: Palaios 27 (2012), pp. 35-47. DOI: 10.2110/palo.2011.p11-061r.

[8920] G. Grellet-Tinner and H. Zaher. "Taxonomic identification of the megaloolithid egg and eggshells from the Cretaceous Bauru Basin (Minas Gerais, Brazil): comparison with the Auca Mahuevo (Argentina) titanosaurid eggs". English. In: Papéis Avulsos de Zoologia 47.7 (2007), pp. 105-112.

[8921] M. Gretz, B. Lathuiliére, R. Martini, and A. Bartolini. "The Hettangian corals of the Isle of Skye (Scotland): An opportunity to better understand the palaeoenvironmental conditions during the aftermath of the Triassic-Jurassic boundary crisis". English. In: Palaeogeography, Palaeoclimatology, Palaeoecology 376 (2013), pp. 132-148. DOI: 10.1016/j.palaeo.2013.02.029.

[8922] M. Gretz, B. Lathuliére, and R. Martini. "A new coral with simplified morphology from the oldest known Hettangian (Early Jurassic) reef in southern France". English. In: Acta Palaeontologica Polonica 60 (2015), pp. 277-286.

[8923] T. Grgasovic, B. Sokac, and J. Halamic. "Scinderella scopuliformis nov. gen., nov. sp. (Dasycladales, green algae) from the middle Triassic of Croatia". English. In: Géobios 35.3 (2002), pp. 303-312.

[8924] I. Y. Grichanov. "Systematic notes on Sciapodinae from Baltic amber and on Dolichopodidae from Tanzanian copal (Diptera)". English. In: Caucasian Entomological Bulletin 4 (2008), pp. 137-139.

[8925] I. Y. Grichanov. "Notes on Dolichopodidae (Diptera) from Ukrainian and Baltic amber". English. In: International Journal of Dipterological Research 11 (2000), pp. 129-131.

[8926] I. Y. Grichanov. "A new genus of Medeterinae (Diptera: Dolichopodidae) from Baltic amber". English. In: Caucasian Entomological Bulletin 6 (2010), pp. 209-212.

[8927] I. Y. Grichanov, O. P. Negrobov, and O. V. Selivanova. “Two new genera of Medeterinae (Diptera: Dolichopodidae) from Baltic amber and some new combinations". English. In: Russian Entomological Journal 23 (2014), pp. 61-70. 
[8928] I. Y. Grichanov and O. P. Negrobov. "Peloropeodinae (Diptera: Dolichopodidae) from Baltic amber". English. In: Caucasian Entomological Bulletin 14 (2018), pp. 95-104.

[8929] J. C. Grier, J. W. Grier, and J. G. Peterson. “Occurrence of the Upper Cretaceous ammonite Rhaeboceras in the Baculites eliasi Zone of the Pierre Shale". English. In: Journal of Paleontology 66 (1992), pp. 521-523.

[8930] J. C. Grier and J. W. Grier. "New findings of the ammonite Rhaeboceras, including a new species, from the Pierre Shale of eastern Montana". English. In: Journal of Paleontology 72 (1998), pp. 473476.

[8931] C. T. Griffin and S. J. Nesbitt. "The femoral ontogeny and long bone histology of the Middle Triassic (?late Anisian) dinosauriform Asilisaurus kongwe and implications for the growth of early dinosaurs". English. In: Journal of Vertebrate Paleontology 36.3 (2016), e1111224:1-22. DOI: 10.1080/ 02724634.2016.1111224.

[8932] M. Griffin. "Eocene bivalves from the Rio Turbio Formation, southwestern Patagonia (Argentina)". English. In: Journal of Paleontology 65.1 (1991), pp. 119-146.

[8933] M. Griffin, S. Casadio, and A. Parras. "Maastrichtian and Danian species of Turkostreini (Ostreidae, Crassostreinae) from the Neuquén Basin, Argentina". English. In: Ameghiniana 42.2 (2005), pp. 257-276.

[8934] M. Griffin, A. Parras, and S. Casado. "Late Maastrichtian-Danian Mytilids and Pinnids (Mollusca: Bivalvia) from Northern Patagonia, Argentina". English. In: Ameghiniana 45.1 (2008), pp. 139-152.

[8935] D. H. Griffing, J. S. Bridge, and C. L. Hotton. Coastal-fluvial palaeoenvironments and plant palaeoecology of the Lower Devonian (Emsian), Gaspe Bay, Quebec, Canada. Vol. 180. P. F. Friend, B. P. J. Williams, (Editors), New Perspectives on the Old Red Sandstone, Geological Society, London, Special Publications. 2001, pp. 61-84.

[8936] D. Grigore. "Oppelid and haploceratid ammonites from the Upper Jurassic deposits of Hghima Mts. (the Eastern Carpathians - Romania)". English. In: Oltenia - Studii i Comunicri tiinele Naturii 34 (2018), pp. 15-22.

[8937] D. Grigore. "Kimmeridgian-Lower Tithonian ammonite assemblages from Ghilco-Hghima Massif (eastern Carpathians, Romania)". English. In: Acta Palaeontologica Romaniae 7 (2011), pp. 177-189.

[8938] D. Grigore. "Idoceratinae (Presimoceras, Trenerites and Lessiniceras genera) from Acanthicum beds of the Hghima Mts. (the Eastern Carpathians - Romania)". English. In: Oltenia - Studii i Comunicri tiinele Naturii 26 (2010), pp. 287-295.

[8939] D. Grigore. "Phylloceratids from the Upper Jurassic deposits of Hghima Mts. (the Eastern Carpathians - Romania)". English. In: Oltenia - Studii i Comunicri tiinele Naturii 27 (2011), pp. 191-202.

[8940] D. Grigore. “Aulacostefanids species (Sutneria genus) from Acanthicum Beds of Ghilco Massif (the Eastern Carpathians - Romania)". English. In: Oltenia - Studii i Comunicri tiinele Naturii 25 (2009), pp. 366-374.

[8941] D. Grigore. "Idoceratinae (Idoceras and Nebrodites genera) from Acanthicum Beds of the Hghima Mts. (the Eastern Carpathians - Romania)". English. In: Oltenia - Studii i Comunicri tiinele Naturii 26 (2010), pp. 303-314.

[8942] D. Grigore and I. Marcu. "Aulacostephanids species (Aulacostephanus, Ringstedia, Simocosmoceras and Gravesia genera) from Acanthicum Beds of Ghilco (the Eastern Carpathians - Romania)". English. In: Oltenia - Studii i Comunicri tiinele Naturii 25 (2009), pp. 351-354.

[8943] D. Grigorescu. “Dinosaurs of Romania”. English. In: Comptes Rendus Palevol 2.1 (2003), pp. 97-101. DOI: 10.1016/S1631-0683(03)00008-3.

[8944] D. Grigorescu, G. Garcia, Z. Csiki, V. Codrea, and A. -V. Bojar. "Uppermost Cretaceous megaloolithid eggs from the Haeg Basin, Romania, associated with hadrosaur hatchlings: search for explanation". English. In: Palaeogeography, Palaeoclimatology, Palaeoecology 293 (2010), pp. 360-374. DOI: $10.1016 /$ j.palaeo.2010.03.031. 
[8945] D. Grigorescu and E. Kazár. “A new Middle Miocene odontocete (Mammalia: Cetacea) locality and the Sarmatian Marine Mammal Event in the Central Paratethys". English. In: Oryctos 6 (2006), pp. 53-67.

[8946] D. Grigorescu, M. Venczel, Z. Csiki, and R. Limberea. "New latest Cretaceous microvertebrate fossil assemblages from the Haeg Basin (Romania)". English. In: Geologie en Mijnbouw 78 (1999), pp. 301-314.

[8947] D. V. Grigoriev. "Redescription of Prognathodon lutugini (Squamata, Mosasauridae)". English. In: Proceedings of the Zoological Institute RAS 317.3 (2013), pp. 246-261.

[8948] D. V. Grigoriev and A. A. Grabovskiy. "Arctic mosasaurs (Squamata, Mosasauridae) from the Upper Cretaceous of Russia". English. In: Cretaceous Research 114.104499 (2020). DOI: 10.1016/j. cretres.2020.104499.

[8949] S. E. Grigoriev, D. C. Fisher, T. Obad, E. A. Shirley, A. N. Rountrey, G. N. Savvinov, D. K. Garmaeva, G. P. Novgorodov, M. Y. Cheprasov, S. E. Vasilev, and A. E. Goncharov. “A woolly mammoth (Mammuthus primigenius) carcass from Maly Lyakhovsky Island (New Siberian Islands, Russian Federation)". English. In: Quaternary International 445 (2013), pp. 89-103. DOI: 10.1016/j. quaint.2017.01.007.

[8950] D. V. Grigor'ev, A. O. Averianov, M. S. Arkhangelsky, E. M. Pervushov, and N. Y. Zozyrev. “A mosasaur from the Cenomanian of Russia". English. In: Paleontological Journal 43.3 (2009), pp. 311317.

[8951] D. Grimaldi. "Insects from the Santana formation, Lower Cretaceous, of Brazil - Chapter 9. Diptera". English. In: Bulletin of the American Museum of Natural History 195 (1990), pp. 164-183.

[8952] D. Grimaldi. "A revision of Cretaceous mantises and their relationships, including new taxa (Insecta: Dictyoptera: Mantodea)". English. In: American Museum Novitates 3412 (2003), pp. 1-47.

[8953] D. Grimaldi. "Amber Fossil Drosophilidae (Diptera), Part II: Review of the Genus Hyalistata, New Status (Steganinae)". English. In: American Museum Novitates 3084 (1993), pp. 1-15.

[8954] D. Grimaldi. "The bird flies, genus Carnus: species revision, generic relationships, and a fossil Meoneura in amber (Diptera: Carnidae)". English. In: American Museum Novitates 3190 (1997), pp. 1-30.

[8955] D. Grimaldi. A diverse fauna of Neuropterodea in amber from the Cretaceous of New Jersey. English. Studies on Fossils in Amber, with Particular Reference to the Cretaceous of New Jersey. Leiden: Backhuys Publishers, 2000, pp. 259-303.

[8956] D. Grimaldi and D. Agosti. "A formicine in New Jersey Cretaceous amber (Hymenoptera: Formicidae) and early evolution of the ants". English. In: Proceedings of the National Academy of Sciences 97.25 (2000), pp. 13678-13683. DOI: 10.1073/pnas.240452097.

[8957] D. Grimaldi and G. R. Case. "A Feather in Amber from the Upper Cretaceous of New Jersey". English. In: American Museum Novitates 3126 (1995), pp. 1-6.

[8958] D. Grimaldi and M. S. Engel. "Extralimital fossils of the Gondwanan family Sphaeropsocidae (Insecta: Psocodea)". English. In: American Museum Novitates 3523 (2006), pp. 1-18.

[8959] D. Grimaldi and M. S. Engel. "Fossil Liposcelididae and the lice ages (Insecta: Psocodea)". English. In: Proceedings of the Royal Society B 273 (2006), pp. 625-633.

[8960] D. Grimaldi, M. S. Engel, P. C. Nascimbene, and H. Singh. "Coniopterygidae (Neuroptera: Aleuropteryginae) in amber from the Eocene of India and the Miocene of Hispaniola". English. In: American Museum Novitates 3770 (2013), pp. 1-20.

[8961] D. Grimaldi and M. A. Johnston. “The long-tongued Cretaceous scorpionfly Parapolycentropus Grimaldi and Rasnitsyn (Mecoptera: Pseudopolycentropodidae): New data and interpretations". English. In: American Museum Novitates 3793 (2014), pp. 1-23.

[8962] D. Grimaldi, A. Shmakov, and N. Fraser. "Mesozoic thrips and early evolution of the order Thysanoptera (Insecta)". English. In: Journal of Paleontology 78 (2004), pp. 941-952. 
[8963] D. Grimaldi and H. Singh. "The extinct genus Pareuthychaeta in Eocene ambers (Diptera: Schizophora: Ephydroidea)". English. In: The Canadian Entomologist 144 (2012), pp. 17-28.

[8964] D. Grimaldi, J. F. Zhang, N. C. Fraser, and A. Rasnitsyn. "Revision of the bizarre Mesozoic scorpionflies in the Pseudopolycentropodidae (Mecopteroidea)". English. In: Insect Systematics \& Evolution 36 (2005), pp. 443-458.

[8965] D. A. Grimaldi. “A remarkable new species of Ogcodes (Diptera: Acroceridae) in Dominican amber". English. In: American Museum Novitates 3127 (1995), pp. 1-8.

[8966] D. A. Grimaldi. "A Fossil Mantis (Insecta: Mantodea) in Cretaceous Amber of New Jersey, with Comments on the Early History of the Dictyoptera". English. In: American Museum Novitates 3204 (1997), pp. 1-11.

[8967] D. A. Grimaldi. "Mycetobiine woodgnats (Diptera: Anisopodidae) from the Oligo-Miocene amber of the Dominican Republic, and old world affinities". English. In: American Museum Novitates 3014 (1991), pp. 1-24.

[8968] D. A. Grimaldi. “Mosquitoes in Dominican amber". English. In: Tropical Fish Hobbyist 42 (1993), pp. 163-165.

[8969] D. A. Grimaldi. "A stalk-eyed ephydroid fly from the Eocene (Diptera: Ephydroidea: Camillidae)". English. In: Proceedings of the Entomological Society of Washington 110 (2008), pp. 543-550.

[8970] D. A. Grimaldi. "First amber fossils of the extinct family Protopsyllidiidae and their phylogenetic significance among Hemiptera". English. In: Insect Systematics \& Evolution 34 (2003), pp. 329-344.

[8971] D. A. Grimaldi. "Diverse orthorrhaphan flies (Insecta: Diptera: Brachycera) in amber from the Cretaceous of Myanmar: Brachycera in Cretaceous amber, part VII". English. In: Bulletin of the American Museum of Natural History 408 (2016), pp. 1-131.

[8972] D. A. Grimaldi. "Basal Cyclorrhapha in amber from the Cretaceous and Tertiary (Insecta: Diptera), and their relationships: Brachycera in Cretaceous amber part IX". English. In: Bulletin of the American Museum of Natural History 423 (2018), pp. 1-97.

[8973] D. A. Grimaldi, D. Agosti, and J. M. Carpenter. “New and rediscovered primitive ants (Hymenoptera: Formicidae) in Cretaceous amber from New Jersey, and their phylogenetic relationships". English. In: American Museum Novitates 3208 (1997).

[8974] D. A. Grimaldi and D. S. Amorim. "A basal new species of Olbiogaster (Diptera: Anisopididae) in Dominican amber, and its systematic placement". English. In: Proceedings of the Entomological Society of Washington 97.3 (1995), pp. 561-568.

[8975] D. A. Grimaldi, D. S. Amorim, and V. Blagoderov. "The Mesozoic family Archizelmiridae (Diptera: Insecta)". English. In: Journal of Paleontology 77.2 (2003), pp. 368-381.

[8976] D. A. Grimaldi, A. Arillo, J. M. Cumming, and M. Hauser. “Brachyceran Diptera (Insecta) in Cretaceous ambers, Part IV, significant new Orthorrhaphous Taxa". English. In: ZooKeys 148 (2011), pp. 293-332.

[8977] D. A. Grimaldi and A. Arillo. "The Tethepomyiidae, a new family of enigmatic Cretaceous Diptera". English. In: Alavesia 2 (2008), pp. 259-265.

[8978] D. A. Grimaldi and P. Barden. "The Mesozoic family Eremochaetidae (Diptera: Brachycera) in Burmese amber and relationships of Archisargoidea: Brachycera in Cretaceous Amber, Part VIII". English. In: American Museum Novitates 3865 (2016), pp. 1-29.

[8979] D. A. Grimaldi and J. M. Cumming. "Brachyceran Diptera in Cretaceous ambers and Mesozoic diversification of the Eremoneura". English. In: Bulletin of the American Museum of Natural History 239 (1999), pp. 1-121.

[8980] D. A. Grimaldi, J. M. Cumming, and A. Arillo. "Chimeromyiidae, a new family of Eremoneuran Diptera from the Cretaceous". English. In: Zootaxa 2078 (2009), pp. 34-54.

[8981] D. A. Grimaldi, M. S. Engel, and P. C. Nascimbene. "Fossiliferous Cretaceous amber from Myanmar (Burma): Its rediscovery, biotic diversity, and paleontological significance". English. In: American Museum Novitates 3361 (2002), pp. 1-71. 
[8982] D. A. Grimaldi and M. S. Engel. “A Termite Bug in Early Miocene Amber of the Dominican Republic (Hemiptera: Termitaphididae)". English. In: American Museum Novitates 3619 (2008), pp. 110.

[8983] D. A. Grimaldi and M. S. Engel. “An unusual, primitive Piesmatidae (Insecta: Heteroptera) in Cretaceous amber from Myanmar (Burma)". English. In: American Museum Novitates 3611 (2008), pp. 1-17.

[8984] D. A. Grimaldi, M. S. Engel, and K. Krishna. “The species of Isoptera (Insecta) from the Early Cretaceous Crato Formation: a revision". English. In: American Museum Novitates 3626 (2008), pp. 130.

[8985] D. A. Grimaldi, M. S. Engel, and H. Singh. "Bugs in the biogeography: Leptosaldinae (Heteroptera: Leptopodidae) in amber from the Miocene of Hispaniola and Eocene of India". English. In: Journal of the Kansas Entomological Society 86 (2013), pp. 226-243.

[8986] D. A. Grimaldi and M. S. Engel. “The relict scorpionfly family Meropeidae (Mecoptera) in Cretaceous amber". English. In: Journal of the Kansas Entomological Society 86 (2013), pp. 253-263.

[8987] D. A. Grimaldi, J. Kathirithamby, and V. Schawaroch. "Strepsiptera and triungula in Cretaceous amber". English. In: Insect Systematics \& Evolution 36 (2005), pp. 1-20.

[8988] D. A. Grimaldi and A. H. Kirk-Spriggs. "Fossil Curtonotidae (Diptera: Schizophora: Ephydroidea)". English. In: American Museum Novitates 3760 (2012), pp. 1-16.

[8989] D. A. Grimaldi and W. N. Mathis. "Fossil Periscelididae (Diptera)". English. In: Proceedings of the Entomological Society Washington 95.3 (1993), pp. 383-403.

[8990] D. A. Grimaldi, C. Michalski, and K. Schmidt. "Amber fossil Enicocephalidae (Heteroptera) from the Lower Cretaceous of Lebanon and Oligo-Miocene of the Dominican Republic, with biogeographic analysis of Enicocephalus". English. In: American Museum Novitates 3071 (1993), pp. 130.

[8991] D. A. Grimaldi, E. Peñalver, E. Barrón, H. W. Herold, and M. S. Engel. “Direct evidence for eudicot pollen-feeding in a Cretaceous stinging wasp (Angiospermae; Hymenoptera, Aculeata) preserved in Burmese amber". English. In: Communications Biology 2.408 (2019). DOI: 10.1038 / s42003-0190652-7.

[8992] D. A. Grimaldi and A. J. Ross. "Raphidiomimula, an enigmatic new cockroach in Cretaceous amber from Myanmar (Burma) (Insecta: Blattodea: Raphidiomimidae)". English. In: Journal of Systematic Palaeontology 2 (2004), pp. 101-104.

[8993] D. A. Grimaldi, D. Sunderlin, G. A. Aaroe, M. R. Dempsky, N. E. Parker, G. Q. Tillery, J. G. White, P. Barden, P. C. Nascimbene, and C. J. Williams. "Biological inclusions in amber from the Paleogene Chickaloon Formation of Alaska". English. In: American Museum Novitates 3908 (2018), pp. 137.

[8994] D. A. Grimaldi and D. M. Triplehorn. "Insects from the upper Miocene Grubstake Formation of Alaska". English. In: American Museum Novitates 3612 (2008), pp. 1-19.

[8995] F. E. Grine, R. M. Bailey, K. Harvati, R. P. Nathan, A. G. Morris, G. M. Henderson, I. Ribot, and A. W. G. Pike. "Late Pleistocene human skull from Hofmeyr, South Africa, and modern human origins". English. In: Science 315 (2007), pp. 226-229.

[8996] F. E. Grine, R. G. Klein, and T. P. Volman. “Dating, Archaeology and Human Fossils from the Middle Stone Age Levels of Die Kelders, South Africa". English. In: Journal of Human Evolution 21 (1991), pp. 363-395.

[8997] F. E. Grine and R. G. Klein. Late Pleisticene Humans Remains from the Sea Harvest Site, Saldanha Bay, South Africa. 1993.

[8998] G. H. Groenewald, J. Welman, and J. A. MacEachern. "Vertebrate Burrow Complexes from the Early Triassic Cynognathus Zone (Driekoppen Formation, Beaufort Group) of the Karoo Basin, South Africa". English. In: Palaios 16.2 (2001), pp. 148-160. 
[8999] E. D. Grogan and R. Lund. “Debeerius ellefseni (Fam Nov, Gen Nov, Spec Nov), an autodiastylic chondrichthyan from the Mississippian Bear Gulch Limestone of Montana (USA), the relationships of the Chondrichthyes, and comments on gnathostome evolution". English. In: Journal of Morphology 243 (2000), pp. 219-245.

[9000] E. D. Grogan and R. Lund. "Two new iniopterygians (Chondrichthyes) from the Mississippian (Serpukhovian) Bear Gulch Limestone of Montana with evidence of a new form of chondrichthyan neurocranium". English. In: Acta Zoologica 90.Suppl. 1 (2009), pp. 134-151.

[9001] C. Grohé, M. Morlo, Y. Chaimanee, C. Blondel, P. Coster, X. Valentin, M. Salem, A. A. Bilal, J. J. Jaegar, and M. Brunet. "New Apterodontinae (Hyaenodontida) from the Eocene Locality of Dur At-Talah (Libya): Systematic, Paleoecological and Phylogenetical Implications". English. In: PLoS ONE 7.11 (2012), e49054:1-19. DOI: 10.1371/journal.pone.0049054.

[9002] B. Gronnow. "Qeqertasussuk—the archaeology of a frozen Saqqaq site in Disko Bugt, West Greenland". English. In: Threads of arctic prehistory: papers in honour of William E. Taylor, Jr. Mercury Series Paper 149 (1994).

[9003] A. Grossman and P. A. Holroyd. "Miosengi butleri, gen. et sp. nov., (Macroscelidea) from the Kalodirr Member, Lothidok Formation, early Miocene of Kenya". English. In: Journal of Paleontology 29.3 (2009), pp. 957-960.

[9004] E. E. Grossman and C. H. Fletcher. "Holocene reef development where wave energy reduces accomodation space, Kailua Bay, windward Oahu, Hawaii, USA". English. In: Journal of Sedimentary Research 74.1 (2004), pp. 49-63.

[9005] F. Grossmann. "The taxonomic and phylogenetic position of the Plesiosauroidea from the Lower Jurassic Posidonia Shale of south-west Germany". English. In: Palaeontology 50.3 (2007), pp. 545564.

[9006] J. R. Groves, R. Rettori, J. L. Payne, M. D. Boyce, and D. Altiner. “End-permian mass extinction of lagenide foraminifers in the southern alps (Northern Italy)". English. In: Journal of Paleontology 81.3 (2007), pp. 415-434.

[9007] J. R. Groves and G. P. Wahlman. “Biostratigraphy and evolution of Late Carboniferous and Early Permian smaller foraminifers from the Barents Sea (Offshore Arctic Norway)". In: Journal of Paleontology 71.5 (1997), pp. 758-779.

[9008] L. T. Groves. "New Species of Cypraeidae (Mollusca: Gastropoda) from the Miocene of California and the Eocene of Washington". English. In: Veliger 37.3 (1994), pp. 244-252.

[9009] L. T. Groves. "New Species of Late Cretaceous Cypraeacea (Mollusca: Gastropoda) from California and Mississippi, and a Review of Cretaceous Cypraeaceans of North America". English. In: The Veliger 33.3 (1990), pp. 272-285.

[9010] L. T. Groves. "A review of cypraeiform gastropods from Neogene strata of northwestern Ecuador, with the description of two new species". English. In: Tulane Studies in Geology and Paleontology 30.3 (1997), pp. 147-157.

[9011] L. T. Groves. "New species of Late Cretaceous Cypraeidae (Gastropoda) from California and British Columbia and new records from the Pacific slope". English. In: The Nautilus 118.1 (2004), pp. 43-51.

[9012] L. T. Groves. "Jurassic and Cretaceous cypraeacean biogeography and paleontology, with an annotated list of the species". English. In: The Cowry 1.2 (1994), pp. 25-41.

[9013] L. T. Groves and J. M. Alderson. "Earliest record of the genus Haliotis (Mollusca: Gastropoda) from the Late Cretaceous (Campanian) of Los Angeles County, California". English. In: The Veliger 50.1 (2008), pp. 24-26.

[9014] L. T. Groves, H. F. Filkorn, and J. M. Alderson. “A New Species Of Late Cretaceous (Campanian) Cypraeid Gastropod, Santa Ana Mountains, Southern California and New Records of California Cretaceous Cypraeids". English. In: Bulletin of the Southern California Academy of Sciences 110.3 (2011), pp. 177-183. 
[9015] L. T. Groves and S. N. Nielsen. “A New Late Miocene Zonaria (Gastropoda: Cypraeidae) from Central Chile". English. In: The Veliger 46.4 (2003), pp. 351-354.

[9016] L. T. Groves and R. L. Squires. "First Report of the Genus Proadusta Sacco, 1894 (Gastropoda: Cypraeidae) from the Western Hemisphere, with a Description of a New Species from the Eocene of Washington". English. In: The Nautilus 109.4 (1995), pp. 113-116.

[9017] M. Grund. “Chironomids (Diptera: Chironomidae) of Dominican amber. Ablabesmyia electrohispaniolana, sp. n. and paleoecological indications due to subfamily proportions". English. In: Insect Systematics \& Evolution 36 (2005), pp. 29-34.

[9018] M. Grund. "A long-beaked fungus gnat in Dominican amber (Diptera: Lygistorrhinidae)". English. In: Annales Zoologici 62 (2012), pp. 639-642.

[9019] M. Grund and M. Hauser. "Pachygaster hymenaea sp. nov. and P. antiqua James, 1971 (Diptera: Stratiomyidae) in Neotropical ambers". English. In: Zootaxa 1061 (2005), pp. 29-34.

[9020] J. Gründel. "Gastropoden aus dem Jura der südamerikanischen Anden - Gastropods from the Jurassic of the Andes of South America". German. In: Paläontologie, Stratigraphie, Fazies - Heft 9; Freiberger Forschungshefte C 492 (2001), pp. 43-84.

[9021] J. Gründel. “Heterostropha (Gastropoda) aus dem Dogger Norddeutschlands und Nordpolens. I. Mathildoidea (Mathildidae)". German. In: Berliner geowissenschaftliche Abhandlungen, Reihe E 25 (1997), pp. 131-175.

[9022] J. Gründel. “Heterostropha (Gastropoda) aus dem Dogger Norddeutschlands und Nordpolens. II. Weitere Allogastropoda". German. In: Freiberger Forschungsheft C 474, Paläontologie, Stratigraphie, Fazies 6 (1998), pp. 1-37.

[9023] J. Gründel. "Heterostropha (Gastropoda) aus dem Dogger Norddeutschlands und Nordpolens. III. Opisthobranchia". German. In: Berliner geowissenschaftliche Abhandlungen, Reihe E 25 (1997), pp. 177-223.

[9024] J. Gründel. "Die Gastropoden der Dogger-Geschiebe Deutschlands und des nordwestlichen Polens". German. In: Archiv für Geschiebekunde 4.3/4 (2003), pp. 129-240.

[9025] J. Gründel. "Procerithiidae (Gastropoda) aus dem Lias und Dogger Deutschlands und Polens". German. In: Freiberger Forschungsheft C 481, Paläontologie, Stratigraphie, Fazies 7 (1999), pp. 1-37.

[9026] J. Gründel. “Truncatelloidea (Littorinimorpha, Gastropoda) aus dem Lias und Dogger Deutschlands und Nordpolens". German. In: Berliner geowissenschaftliche Abhandlungen, Reihe E 30 (1999), pp. 89-119.

[9027] J. Gründel. “Zygopleuroidea (Gastropoda) aus dem Lias und Dogger Deutschlands und Nordwestpolens". German. In: Paläontologische Zeitschrift 73.3/4 (1999), pp. 247-259.

[9028] J. Gründel. "Gordenellidae n. fam., eine neue Gastropoden-Familie aus dem Dogger und Malm Europas". German. In: Berliner geowissenschaftliche Abhandlungen, Reihe E 34 (2000), pp. 255-267.

[9029] J. Gründel. "Neue Arten der Heterostropha (Gastropoda) aus dem Dogger Deutschlands und Nordpolens". German. In: Greifswalder geowissenschaftliche Beiträge 6 (1999), pp. 291-299.

[9030] J. Gründel. "Archaeogastropoda aus dem Dogger Norddeutschlands und des nordwestlichen Polens". German. In: Berliner geowissenschaftliche Abhandlungen, Reihe E 34 (2000), pp. 205-253.

[9031] J. Gründel. “Archaeo- und Caenogastropoda aus dem Dogger Deutschlands und Nordpolens". German. In: Stuttgarter Beiträge zur Naturkunde, Serie B (Geologie und Paläontologie) 260 (1998), 39pp.

[9032] J. Gründel. “Gastropoden aus dem oberen Toarcium/unteren Aalenium (Jura) von Norddeutschland [Gastropods from the Upper Toarcian/Lower Aalenian (Jurassic) from northern Germany]". German. In: Palaeontologische Zeitschrift 81.3 (2007), pp. 238-253.

[9033] J. Gründel. “Gastropoden aus dem Unteren Lias (Ober-Hettangium bis Unter-Sinemurium) Südwestdeutschlands [Gastropods from the Lower Liassic (Upper Hettangian to Lower Sinemurian) from southwestern Germany]". German. In: Stuttgarter Beiträge zur Naturkunde B, Geologie und Paläontologie 340 (2003), pp. 1-55. 
[9034] J. Grundel. "Gastropoden aus dem höheren Lias von Grimmen, Vorpommern (Deutschland)". German. In: Archiv für Geschiebekunde 2.9 (1999), pp. 629-672.

[9035] J. Gründel and A. Kaim. "Shallow-water gastropods from Late Oxfordian sands in Kleby (Pomerania, Poland)". English. In: Acta Geologica Polonica 56.2 (2006), pp. 121-157.

[9036] J. Gründel, A. Kaim, A. Nützel, and C. T. S. Little. "Early Jurassic Gastropods form England". English. In: Palaeontology 54.3 (2011), pp. 481-510. DOI: 10.1111/j.1475-4983.2011.01043.x.

[9037] J. Gründel and H. A. Kollmann. "The gastropods from the Barremian of Serre de Bleyton (Drome, SE France)". English. In: Annalen des Naturhistorischen Museums in Wien, Serie A 115 (2012), pp. 89165.

[9038] J. Gründel and A. Nützel. "Gastropoden aus dem oberen Pliensbachium (Lias delta , Zone des Pleuroceras spinatum) von Kalchreuth östlich Erlangen". German. In: Mitteilungen der Bayerischen Staatssammlung 38 (1998), pp. 63-96.

[9039] J. Gründel, A. Nützel, and C. Schulbert. “Toarctocera (Gastropoda, Aporrhaidae): a new genus from the Jurassic (Toarcian/ Aalenian) of south Germany and the early evolutionary history of the family Aporrhaidae". English. In: Palaeontologische Zeitschrift 83 (2009), pp. 533-543. DOI: 10.1007/ s12542-009-0037-1.

[9040] J. Gründel and H. Parent. "Lower and Middle Tithonian marine gastropods from the NeuquenMendoza Basin, Argentina". English. In: Boletin del Instituto de Fisiografia y Geologia 71.1-2 (2001), pp. 13-18.

[9041] J. Gründel, T. Pelissie, and M. Guerin. "Brackwasser-Gastropoden des mittleren Doggers von La Balme (Causses du Quercy, Südfrankreich)". German. In: Berliner geowissenschaftliche Abhandlungen, Reihe E 34 (2000), pp. 185-203.

[9042] J. G. Gründel. “Jurassische Gastropoden aus der Betakalkbank (oberes Sinemurium, obere ObtusumZone) Südwestdeutschlands". German. In: Stuttgarter Beiträge zur Naturkunde Serie B (Geologie und Paläontologie) 370 (2007), pp. 1-29.

[9043] M. Grünemaier. "Phoretic springtail (Collembola: Sminthuridae) on a false blister beetle (Coleoptera: Oedemeridae) in Eocene Baltic amber". English. In: Palaeodiversity 9 (2016), pp. 9-13.

[9044] P. Grunert, M. Harzhauser, F. Rogl, R. Sachsenhofer, R. Gratzer, A. Soliman, and W. E. Piller. "Oceanographic conditions as a trigger for the formation of an Early Miocene (Aquitanian) KonservatLagerstätte in the Central Paratethys Sea". English. In: Palaeogeography, Palaeoclimatology, Palaeoecology 292.3-4 (2010), pp. 425-442.

[9045] T. A. Grunt, D. Lisitsyn, I. Morozova, O. Malysheva, G. Kanev, A. Minikh, and O. Shilovsky. "Transitional Ufimian-Kazanian marine deposits in the southeastern seaboard of the Kanin Peninsula, Russia". English. In: Permophiles 41 (2002), pp. 26-30.

[9046] T. A. Grunt and M. V. Novikova. "Late Permian brachiopods from the Crimean Mountains". English. In: Paleontological Journal 36 (2002), pp. 148-156.

[9047] T. A. Grunt and G. Racki. "Late Frasnian Athyridida (Brachiopoda) from Poland and the Late Devonian biotic turnover". English. In: Acta Palaeontologica Polonica 43.2 (1998), pp. 361-378.

[9048] V. Grytsenko. Distribution of corals on the Silurian Podolian Shelf. English. Vol. 17. Fossil Corals and Sponges: Proceedings of the 9th International Symposium on Fossil Cnidaria and Porifera, Graz 2003. Vienna: Austrian Academy of Sciences Press, 2007, pp. 185-198.

[9049] J. J. Gu, O. Béthoux, and D. Ren. "Longzhua loculata n. gen. n. sp., one of the most completely documented Pennsylvanian Archaeorthoptera (Insecta; Ningxia, China)". English. In: Journal of Paleontology 85.2 (2011), pp. 303-314.

[9050] J. J. Gu, O. Béthoux, and D. Ren. "A new cnemidolestodean stem-orthopteran insect from the Late Carboniferous of China". English. In: Acta Palaeontologica Polonica 59 (2014), pp. 689-696.

[9051] J. J. Gu, O. Béthoux, and D. Ren. "A new, rare and distinctive species of Panorthoptera (Insecta, Archaeorthoptera) from the Upper Carboniferous of Xiaheyan (Ningxia, China)". English. In: Fossil Record 20 (2017), pp. 253-257. 
[9052] J. J. Gu, F. Montelaegre-Z, D. Robert, M. S. Engel, G. X. Qiao, and D. Ren. “Wing stridulation in a Jurassic katydid (Insecta, Orthoptera) produced low-pitched musical calls to attract females". English. In: Proceedings of the National Academy of Sciences (2012).

[9053] J. J. Gu, G. X. Qiao, and D. Ren. "The first discovery of Cyrtophyllitinae (Orthoptera, Haglidae) from the Middle Jurassic and its morphological implications". English. In: Alcheringa 36 (2012), pp. 27-34.

[9054] J. J. Gu, G. X. Qiao, and D. Ren. “Revision and new taxa of fossil Prophalangopsidae (Orthoptera: Ensifera)". English. In: Journal of Orthoptera Research 19.1 (2010), pp. 41-56.

[9055] J. J. Gu, G. X. Qiao, and D. Ren. “A exceptionally-preserved new species of Barchaboilus (Orthoptera: Prophalangopsidae) from the Middle Jurassic of Daohugou, China". English. In: Zootaxa 2909 (2011), pp. 64-68.

[9056] J. J. Gu, H. Tian, X. C. Yin, F. M. Shi, and D. Ren. "A new species of Cyrtophyllitinae (Insecta: Ensifera) from the Cretaceous China". English. In: Cretaceous Research 74 (2017), pp. 151-154.

[9057] J. J. Gu, H. Tian, J. Y. Wang, W. Z. Zhang, D. Ren, and Y. L. Yue. "A world key to the genera of Elcanidae (Insecta, Orthoptera), with a Jurassic new genus and species of Archelcaninae from China". English. In: ZooKeys 954 (2020), pp. 65-74. DOI: 10.3897/zookeys.954.52088.

[9058] J. J. Gu, Y. L. Yue, F. M. Shi, H. Tian, and D. Ren. "First Jurassic grasshopper (Insecta, Caelifera) from China". English. In: Zootaxa 4169 (2016), pp. 377-380.

[9059] J. J. Gu, Y. Y. Zhao, and D. Ren. "New fossil Prophalangopsidae (Orthoptera, Hagloidea) from the Middle Jurassic of Inner Mongolia, China". English. In: Zootaxa 2004 (2009), pp. 16-24.

[9060] Y. Gu, W. Huang, D. Chen, X. Guo, and N. G. Jablonski. "Pleistocene fossil Primates from Luoding, Guangdong". Chinese. In: Vertebrata PalAsiatica (Gujizhui dongwu xuebao) 34.3 (1996), pp. 235-250.

[9061] L. Gualitieri, S. Vartanyan, J. Brigham-Grette, and P. M. Anderson. "Pleistocene raised marine deposits on Wrangel Island, northeast Siberia and implications for the presence of an East Siberian ice sheet". English. In: Quaternary Research 59 (2003), pp. 399-410.

[9062] Z. Y. Guan, J. Prokop, P. Roques, J. Lapeyrie, and A. Nel. "Revision of the enigmatic insect family Anthracoptilidae enlightens the evolution of Palaeozoic stem-dictyopterans". English. In: Acta Palaeontologica Polonica 61 (2016), pp. 71-87.

[9063] W. GuangBiao, H. SongMei, Y. KeFu, H. YaMei, L. Xin, J. ChangZhu, W. Yuan, Z. JianXin, and W. WenHua. "New materials of the steppe mammoth, Mammuthus trogontherii, with discussion on the origin and evolutionary patterns of mammoths". English. In: Science China Earth Sciences 53.7 (2010), pp. 956-963.

[9064] A. P. Gubanov, R. B. Blodgett, and V. N. Lytochkin. “Early Devonian (Pragian) gastropods from Kyrgyzstan (central Asia)". In: Journal of Paleontology 69.3 (1995), pp. 431-440.

[9065] A. P. Gubanov and O. K. Bogolepova. "Early Ordovician molluscs with preserved colour pattern from the Timan-Pechora Basin of Russia". English. In: GFF - Geological Society of Sweden 136.1 (2014), pp. 85-89.

[9066] A. P. Gubanov, J.-O. R. Ebbestad, and P. Männik. “The problematic mollusc Jinonicella from the Silurian of North America". English. In: Gff 139 (2017). DOI: 10.1080/11035897.2017.1291539.

[9067] A. P. Gubanov, D. C. Fernández-Remolar, and J. S. Peel. "Early Cambrian molluscs from Sierra de Córdoba (Spain)". English. In: Géobios 37.2 (2004), pp. 199-215.

[9068] A. P. Gubanov, A. V. Kouchinsky, J. S. Peel, and S. Bengston. “Middle Cambrian molluscs of 'Australian' aspect from northern Siberia". English. In: Alcheringa 28.1 (2004), pp. 1-20.

[9069] A. P. Gubanov and J. S. Peel. "Oelandiella, the earliest Cambrian helcionelloid mollusc from Siberia". English. In: Palaeontology 42.2 (1999), pp. 211-222.

[9070] A. P. Gubanov, J. S. Peel, and I. A. Pianovskaya. "Soft-sediment adaptations in a Silurian gastropod from Central Asia". English. In: Palaeontology 38.4 (1995), pp. 831-842. 
[9071] A. P. Gubanov and J. S. Peel. “Latest helcionelloid molluscs from the Lower Ordovician of Kazakhstan". English. In: Palaeontology 44.4 (2001), pp. 682-692.

[9072] A. P. Gubanov, C. B. Skovsted, and J. S. Peel. "Anabarella australis (Mollusca, Helcionelloida) from the Lower Cambrian of Greenland". English. In: Géobios 37.6 (2004), pp. 719-724.

[9073] A. P. Gubanov and E. L. Yochelson. "A Wenlockian (Silurian) gastropod shell and operculum from Siberia”. English. In: Journal of Paleontology 68.3 (1994), pp. 486-491.

[9074] V. S. Gubareva and V. P. Boltaeva. "The species Blasispirifer multiplicicostatus (Netschajew) from the stratotype of the Kazanian Stage, Tatarstan". English. In: Paleontological Journal 32 (1998), pp. 586-588.

[9075] Y. M. Gubin. "Gobiatidy (Anura) iz verkhnemelovogo mestonakhozhdeniya Khermin-Tsav; Gobi, Mongoliya (= Gobiatids (Anura) from the Upper Cretaceous locality Khermeen-Tsav (Gobi Desert, Mongolia))". Russian. In: Paleontologicheskii Zhurnal 1 (1999), pp. 76-87.

[9076] Y. M. Gubin. "Paleocene salamanders from southern Mongolia". English. In: Paleontological Journal 25 (1991), pp. 91-102.

[9077] Y. M. Gubin. "A New Diplocaulid (Nectridea, Amphibia) from the Early Permian of Kansas (USA)". English. In: Paleontological Journal 33.6 (1999), pp. 630-637.

[9078] Y. M. Gubin. "[A new dvinosaur (Amphibia, Temnospondyli) from the Upper Tatarian of the middle Volga Region.]" English. In: Paleontologischeskii Zhurnal 2 (2004), pp. 72-80.

[9079] Y. M. Gubin, V. K. Golubev, V. V. Bulanov, and S. V. Petuchov. "Pareiasaurian Tracks from the Upper Permian of Eastern Europe". English. In: Paleontological Journal 37.5 (2003), pp. 514-523.

[9080] J. L. Gudiño Maussán, F. J. Aguilar, and R. Hernández-Rivera. "Aplicación de fotogrametra digital para el registro de las huellas de dinosaurio de la Formación Cerro del Pueblo (Campaniano tardo), Coahuila, México [Application of digital photogrammetry for recording dinosaur footprints of the Cerro del Pueblo Formation (late Campanian), Coahuila, Mexico]". Spanish. In: Boletn de la Sociedad Geológica Mexicana 70.2 (2018), pp. 307-324.

[9081] T. E. Guensburg. "Alphacrinus New Genus and Origin of the Disparid Clade". English. In: Journal of Paleontology 84.6 (2010), pp. 1209-1216. DOI: 10.1666/10-030.1.

[9082] T. E. Guensburg and J. Sprinkle. "Solving the mystery of crinoid ancestry: new fossil evidence of arm origin and development". English. In: Journal of Paleontology 83.3 (2009), pp. 350-364.

[9083] T. E. Guensburg and J. Sprinkle. "The oldest known crinoids (Early Ordovician, Utah) and a new crinoid plate homology system". English. In: Bulletins of American Paleontology 364 (2003), pp. 143.

[9084] T. E. Guensburg, J. Sprinkle, R. Mooi, B. Lefebvre, B. David, M. Roux, and K. Derstler. "Athenacrinus $n$. gen. and other early echinoderm taxa inform crinoid origin and arm evolution". English. In: Journal of Paleontology 94.2 (2020), pp. 311-333. DOI: 10.1017/jpa.2019.87.

[9085] T. E. Guensburg and B. G. Waisfeld. "South America's earliest (Ordovician, Floian) crinoids". English. In: Journal of Paleontology 89.4 (2015), pp. 622-630.

[9086] P. Gueriau, S. Charbonnier, and G. Clément. "First decapod crustaceans in a Late Devonian continental ecosystem". English. In: Palaeontology 57.6 (2014), pp. 1203-1213.

[9087] C. Guerin, M. A. Curvello, M. Faure, M. Hugueney, and C. Mourer-Chauvire. "La Faune Pleistocene du Piaui (Nordeste du Bresil): Implications Paleoecologiques et Biochronologiques". Portugese. In: Quaternaria Nova 111 (1993), pp. 303-341.

[9088] C. Guerin, Y. Dewolf, and J. P. Lautridou. "Revision d'un site paleontologique celebre: Saint-Prest (Chartres, France)". French. In: Géobios 36 (2003), pp. 55-82.

[9089] C. Guerin and V. Eisenmann. Les tapirs du Miocene superieur Europe occidentale. French. 1994.

[9090] C. Guerin, V. Eisenmann, and M. Faure. Les grands mammiferes du gisement Pleistocene Moyen de Latamne (Vallee de l'Oronte, Syrie). French. Vol. 587. Le Paleolithique de la vallee de moyenne de l'Oronte (Syrie). Edited by P. Sanlaville, J. Besancon, L. Copeland, S. Muhesen. British Archaeological Reports International Series. 1993, pp. 169-178. 
[9091] C. Guerin, M. Faure, and S. Sen. "Le gisement de vertebres pliocenes de Calta, Ankara, Turquie. 8. Suidae". French. In: Geodiversitas 20.3 (1998), pp. 441-453.

[9092] C. Guérin and M. Pickford. “Ougandatherium napakense nov. gen. nov. sp., le plus ancien Rhinocerotidae Iranotheriinae d'Afrique". French. In: Annales de Paléontologie 89.1 (2003), pp. 1-35.

[9093] C. Guerin and S. Sen. "Le gisement de vertebres pliocene de Calta, Ankara, Turquie. 6. Rhinocerotidae". French. In: Geodiversitas 20.3 (1998), pp. 397-407.

[9094] G. Guerin and R. S. Hill. "Gymnostoma tasmanianum sp. nov., a fossil Casuarinaceae from the Early Oligocene of Little Rapid River, Tasmania, Australia". English. In: International Journal of Plant Sciences 164.4 (2003), pp. 629-634.

[9095] S. Guérin-Franiatte and R. Weis. “Le passage Aalénien-Bajocien prés de Rumelange: la série biostratigraphique dans le Bassin d'Eschsur- Alzette (Grand-Duché de Luxembourg)". French. In: Ferrantia 62 (2010), pp. 73-92.

[9096] A. Guerra-Merchán, D. Ramallo, and A. Ruiz Bustos. "New data on the Upper Miocene micromammals of the Betic Cordillera and their interest for marine-continental correlations". English. In: Géobios 34.1 (2001), pp. 85-90.

[9097] M. Guerra-Sommer, M. Cazzulo-Klepzig, and M. M. Toigo. “Gondwanostachyaceae (Equisetopsida) no Gondwana Sul-Brasileiro (Formacao Rio Bonito) com mega e microflora associadas". Portugese. In: Pesquisas, Porto Alegre 22 (1995), pp. 64-73.

[9098] A. Guerrero and A. Pérez-Garca. “On the validity of the British Upper Jurassic turtle Pleurosternon portlandicum (Paracryptodira, Pleurosternidae)". English. In: Journal of Iberian Geology (2020), pp. 1-11. DOI: 10.1007/s41513-020-00136-x.

[9099] V. B. Guerrini, S. A. Matos, R. Rohn, F. G. Varejão, L. V. Warren, and M. G. Simões. "The last chapter of 30 million years of molluscan evolution: Permian non-marine bivalves of the Rio do Rasto Formation, Paraná Basin, Brazil". English. In: PalZ 94 (2020), pp. 487-512. DOI: 10.1007/s12542019-00455-0.

[9100] J. Guex. “Ammonites hettangiennes de la Gabbs Valley Range (Nevada, USA)”. French. In: Mémoires de Géologie (Lausanne) 27 (1995), pp. 1-131.

[9101] J. Guex, A. Hungerbühler, J. F. Jenks, L. O’Dogherty, V. Atudorei, D. G. Taylor, H. Bucher, and A. Bartolini. "Spathian (Lower Triassic) ammonoids from western USA (Idaho, California, Utah and Nevada)". English. In: Mémoires de Géologie (Lausanne) 49 (2010), pp. 1-82.

[9102] J. Guex, M. Rakus, A. Morard, and M. Quartier-la-Tente. “Ammonites sinémuriennes du HautAtlas marocain". French. In: 47 (2008).

[9103] A. Guglielmino and M. Olmi. "Revision of fossil species of Deinodryinus, with description of a new species (Hymenoptera, Dryinidae)". English. In: ZooKeys 130 (2011), pp. 495-504.

[9104] A. Guglielmino, M. Olmi, A. Marletta, and S. Speranza. "Discovery of the first species of Dryinus Latreille (Hymenoptera: Dryinidae) from Burmese amber". English. In: Zootaxa 4394 (2018), pp. 443-448.

[9105] A. K. Guha. “Tertiary bryozoa from Western Kachchh, Gujarat - A Review”. English. In: Journal of the Palaeontological Society of India 58.1 (2013), pp. 3-15.

[9106] A. K. Guha and K. Gipikrishna. "New fossil steginoporellid and schizoporellid species (Bryozoa, Cheilostomata) from the Tertiary sequences of western Kachchh, Gujarat and their significance". English. In: Journal of the Geological Society of India 69 (2007), pp. 803-812.

[9107] A. K. Guha and K. Gopikrishna. "Cyclostoma Bryozoa from the (Eocene) Lutetian of western Kachchh, Gujarat". English. In: Journal of the Geological Society of India 69 (2007), pp. 1271-1278.

[9108] A. K. Guha and K. Gopikrishna. "New calloporid (Bryozoa, Cheilostomata) species from Tertiary sequences of western Kachchh, Gujarat". English. In: Journal of the Geological Society of India 70 (2007), pp. 121-130. 
[9109] A. K. Guha and K. Gopikrishna. “Diversity, evolution and paleoecology of the Tertiary bryozoan assemblages of western Kachchh, Gujarat, India". English. In: Bryozoan Studies 2004. Leiden: A.A. Balkema Publishers, 2005, pp. 107-118.

[9110] A. Guido, S. Kershaw, F. Russo, D. Miriello, and A. Mastandrea. "Application of Raman spectroscopy in comparison between cryptic micorbilaites of recent marine caves and triassic patch reefs". English. In: Palaios 34 (2019), pp. 393-403. DOI: 10.2110/palo.2019.055.

[9111] E. Guilbert and E. Heiss. “First fossil records of Tingidae from Madagascan Copal with description of two new species (Hemiptera, Heteroptera)". English. In: Linzer Biologische Beiträge 48 (2016), pp. 1081-1090.

[9112] E. Guilbert and E. Heiss. "New lacebugs (Hemiptera: Heteroptera: Tingidae) from Upper Cretaceous Burmese amber". English. In: Cretaceous Research 94 (2018), pp. 72-79.

[9113] E. Guilherme, J. Bocquentin, and A. S. Porto. "A New Specimen of the Genus Octodontobradys (Orophodontidae, Octodontobradyinae) From the Late Miocene-Pliocene of the Southwestern Amazon Basin, Brazil". English. In: Anuário do Instituto de Geociencias 34.2 (2011), pp. 38-45.

[9114] A. R. D. Guillaume. English. PhD thesis. Lisbon, 2018, pp. xi-167.

[9115] F. Guillén-Mondéjar, A. del Ramo, J. I. Canudo, F. Pérez-Lorente, and J. I. Ruiz-Omeñaca. Los primeros yacimientos de huesos e icnitas de dinosaurio de Murcia. Un nuevo patrimonio geológico y cultural [The first localities of dinosaur bones and footprints in Murcia. A new geological and cultural patrimony]. Spanish. 2007.

[9116] F. M. Guinea, J. de Haro Ordoñez, E. Castilla Reyes, M. Á López Domnguez, M. C. Quintero Cristóbal, M. M. Oria, P. J. Navarro, C. M. Montoya, and A. T. Grande. "Intervenciones paleontológicas sobre restos de cetáceos misticetos del Plioceno de la Provincia de Huelva, so de España". English. In: Anuario Arqueológico de Andaluca 2006 (2006), pp. 2043-2066.

[9117] D. Guinot, G. Carbot-Chanona, and F. J. Vega. "Archaeochiapasidae n. fam., a new early Cenomanian brachyuran family from Chiapas, Mexico, new hypothesis on Lecythocaridae Schweitzer \& Feldmann, 2009, and phylogenetic implications (Crustacea, Decapoda, Brachyura, Eubrachyura)". English. In: Geodiversitas 41.1 (2019), pp. 285-322. DOI: 10.5252/geodiversitas2019v41a7.

[9118] G. Guinot, S. Adnet, L. Cavin, and H. Cappetta. "Cretaceous stem chondrichthyans survived the end-Permian mass extinction". English. In: Nature Communications 4 (2013), p. 2669. DOI: 10.1038/ ncomms3669.

[9119] G. Guinot, H. Cappetta, C. J. Underwood, and D. J. Ward. “Batoids (Elasmobranchii: Batomorphii) from the British and French Late Cretaceous". English. In: Journal of Systematic Palaeontology 10 (2012), pp. 445-474. DOI: 10.1080/14772019.2011.588255.

[9120] G. Guinot, H. Cappetta, and S. Adnet. "A rare elasmobranch assemblage from the Valanginian (Lower Cretaceous) of southern France". English. In: Cretaceous Research 48 (2014), pp. 54-84. DOI: 10.1016/j.cretres.2013.11.014.

[9121] G. Guinot and J. D. Carrillo-Briceño. "Lamniform sharks from the Cenomanian (Upper Cretaceous) of Venezuela". English. In: Cretaceous Research 82 (2018), pp. 1-20. DOI: 10.1016/j.cretres. 2017.09.021.

[9122] G. Guinot, C. J. Underwood, H. Cappetta, and D. J. Ward. "Sharks (Elasmobranchii: Euselachii) from the Late Cretaceous of France and the UK". English. In: Journal of Systematic Palaeontology 11 (2013), pp. 589-671. DOI: 10.1080/14772019.2013.767286.

[9123] G. Guinot, C. J. Underwood, H. Cappetta, and D. J. Ward. "Squatiniformes (Chondrichthyes, Neoselachii) from the Late Cretaceous of southern England and northern France with redescription of the holotype of Squatina cranei Woodward, 1888". English. In: Palaeontology 55 (2012), pp. 529-551. DOI: 10.1111/j.1475-4983.2012.01140.x.

[9124] B. E. Gulas-Wroblewski and A. F.-J. Wroblewski. "A crown-group galliform bird from the Middle Eocene Bridger Formation of Wyoming". English. In: Palaeontology 46.6 (2003), pp. 1269-1280. 
[9125] E. S. Gulec, A. Sevim, C. Pehlevan, and F. Kaya. "A new great ape from the late Miocene of Turkey". English. In: Anthropological Science 115 (2007), pp. 153-158. DOI: 10.1537/ase.070501.

[9126] M. V. Guler, D. G. Lazo, P. J. Pazos, C. M. Borel, E. G. Ottone, R. V. Tyson, N. Cesaretti, and M. B. Aguirre-Urreta. "Palynofacies analysis and palynology of the Agua de la Mula Member (Agrio Formation) in a sequence stratigraphy framework, Lower Cretaceous, Neuquén Basin, Argentina". English. In: Cretaceous Research 41 (2012), pp. 65-81.

[9127] A. Gumovsky, E. Perkovsky, and A. Rasnitsyn. "Laurasian ancestors and Gondwanan descendants of Rotoitidae (Hymenoptera: Chalcidoidea): What a review of Late Cretaceous Baeomorpha revealed. Cretaceous Research". English. In: Cretaceous Research 84 (2017), pp. 286-322.

[9128] A. V. Gumovsky. "The status of some genera allied to Chrysonotomyia and Closterocerus (Hymenoptera: Eulophidae, Entedoninae), with description of a new species from Dominican Amber". English. In: Phegea 29 (2001), pp. 125-141.

[9129] A. V. Gumovsky and E. E. Perkovsky. "Taxonomic notes on Tetracampidae (Hymenoptera: Chalcidoidea) with description of a new fossil species of Dipricocampe from Rovno amber". English. In: Entomological Problems 35 (2005), pp. 123-130.

[9130] G. O. Gunderson. "New genus of Late Cambrian gastropod”. In: Journal of Paleontology 67.6 (1993), pp. 1083-1084.

[9131] G. F. Gunnel, P. M. Butler, M. Greenwood, and N. B. Simmons. "Bats (Chiroptera) from Olduvai Gorge, early Pleistocene, Bed I (Tanzania)". English. In: American Museum Novitates 3846 (2015), pp. 1-35.

[9132] G. F. Gunnell. "Paleocene mammals and faunal analysis of the Chappo Type Locality (Tiffanian), Green River Basin, Wyoming". In: Journal of Vertebrate Paleontology 14.1 (1994), pp. 81-104.

[9133] G. F. Gunnell. “Omomyid primates (Tarsiiformes) from the Bridger Formation, middle Eocene, southern Green River Basin, Wyoming". English. In: Journal of Human Evolution 28 (1995).

[9134] G. F. Gunnell. "New notharctine (primates, adapiformes) skull from the Uintan (middle Eocene) of San Diego County, California". English. In: American Journal of Physical Anthropology 98 (1995), pp. 447-470.

[9135] G. F. Gunnell. "Notharctine primates (Adapiformes) from the early to middle Eocene (WasatchianBridgerian) of Wyoming: transitional species and the origins of Notharctus and Smilodectes". English. In: Journal of Human Evolution 43.3 (2002), pp. 353-380.

[9136] G. F. Gunnell, W. S. Bartels, P. D. Ginberich, and V. Torres. "Wapiti Valley Faunas: Early and Middle Eocene Fossil Vertebrates from the North Fork of the Shoshone River, Park County, Wyoming". English. In: Contributions from the Museum of Paleontology, University of Michigan 28.11 (1992), pp. 247287.

[9137] G. F. Gunnell and W. S. Bartels. Basin margins, biodiversity, evolutionary innovation, and the origin of new taxa. English. Eocene biodiversity: unusual occurrences and rarely sampled habitats (G. F. Gunnell, ed.) 2001, pp. 403-432.

[9138] G. F. Gunnell, P. D. Gingerich, M. Haq, J. I. Bloch, I. H. Khan, and W. C. Clyde. “New primates (Mammalia) from the early and middle Eocene of Pakistan and their paleobiogeographical implications". English. In: Contributions from the Museum of Paleontology, University of Michigan 32.1 (2008), pp. 1-14.

[9139] G. F. Gunnell, B. F. Jacobs, P. S. Herendeen, J. J. Head, E. Kowalski, C. P. Msuya, and F. A. Mizambwa. “Oldest placental mammal from sub-Saharan Africa: Eocene microbat from Tanzania - evidence for early evolution of sophisticated echolocation". English. In: Palaeontologia Electronica 5.2 (2003), pp. 1-10.

[9140] G. F. Gunnell and F. K. Manthi. "Pliocene bats (Chiroptera) from Kanapoi, Turkana Basin, Kenya". English. In: Journal of Human Evolution (2018), pp. 1-10. DOI: 10.1016/j.jhevol.2018.01.001.

[9141] G. F. Gunnell and E. R. Miller. “Origin of anthropoidea: Dental evidence and recognition of early anthropoids in the fossil record, with comments on the Asian anthropoid radiation". English. In: American Journal of Physical Anthropology 114.3 (2001), pp. 177-191. 
[9142] G. F. Gunnell, E. L. Simons, and E. R. Seiffert. “New bats (Mammalia: Chiroptera) from the late Eocene and early Oligocene, Fayum Depression, Egypt". English. In: Journal of Vertebrate Paleontology 28.1 (2008), pp. 1-11.

[9143] G. F. Gunnell, R. Smith, and T. Smith. "33 million year old Myotis (Chiroptera, Vespertilionidae) and the rapid global radiation of modern bats". English. In: PLoS ONE 13.e0172621 (2017). DOI: 10.1371/journal.pone.0172621.

[9144] G. F. Gunnell and V. L. Yarborough. "Brontotheriidae (Perissodactyla) from the late early and middle Eocene (Brigerian), Wasatch and Bridger formations, southern Green River Basin, southwestern Wyoming". English. In: Journal of Vertebrate Paleontology 20.2 (2000), pp. 349-368.

[9145] G. F. Gunnell, J.-P. Zonneveld, and W. S. Bartels. "Stratigraphy, mammalian paleontology, paleoecology, and age correlation of the Wasatch Formation, Fossil Butte National Monument, Wyoming". English. In: Journal of Paleontology 90.5 (2016), pp. 981-1011. DOI: 10.1017/jpa.2016.100.

[9146] G. C. Gunter. "Two very fossiliferous rudist sites from the Marchmont Inlier, northwestern Jamaica". English. In: Caribbean Journal of Earth Science 36 (2002), pp. 21-26.

[9147] J. Guo, M. R. Dawson, and K. C. Beard. "Zhailimeryx, a new lophiomerycid artiodactyl (Mammalia) from the late middle Eocene of central China and the early evolution of ruminants". English. In: Journal of Mammalian Evolution 7.4 (2000), pp. 239-258.

[9148] J. Guo, Y. Li, J. Han, X. Zhang, Z. Zhang, Q. Ou, J. Liu, D. Shu, S. Maruyama, and T. Komiya. "Fossil association from the Lower Cambrian Yanjiahe Formation in the Yangtze Gorges area, Hubei, south China". English. In: Acta Geologica Sinica 82.6 (2008), pp. 1124-1132.

[9149] J. Guo, Y. Li, and G. Li. "Small shelly fossils from the early Cambrian Yanjiahe Formation, Yichang, Hubei, China". English. In: Gondwana Research 25 (2014), pp. 999-1007.

[9150] J.-W. Guo, T. Qi, and H. -J. Sheng. "A restudy of the Eocene ruminants from Baise and Yongle basins, Guangxi, China". English. In: Vertebrata PalAsiatica 37.1 (1999), pp. 18-39.

[9151] J.-W. Guo, Y. Wang, and X. -A. Yang. "A new Early Eocene ctenodactyloid rodent (Rodentia, Mammalia) and the associated mammalian fossils from Danjiangkou, Hubei". English. In: Vertebrata PalAsiatica 38.4 (2000), pp. 303-313.

[9152] L. Guo, S. J. Vincent, and V. Lavrishchev. “Upper Jurassic Reefs from the Russian Western Caucasus: Implications for the Eastern Black Sea". English. In: Turkish Journal of Earth Sciences 20 (2011), pp. 629-653. DOI: 10.3906/yer-1012-5.

[9153] L. C. Guo, C. K. Shih, L. F. Li, and D. Ren. “New pelecinid wasps (Hymenoptera: Pelecinidae) from the Yixian Formation of western Liaoning, China". English. In: Cretaceous Research 61 (2016), pp. 151-160.

[9154] L. C. Guo, C. K. Shih, L. F. Li, and D. Ren. “New pelecinid wasps (Hymenoptera: Pelecinidae) from Upper Cretaceous Myanmar amber". English. In: Cretaceous Research 67 (2016), pp. 84-90.

[9155] X. B. Guo, P. A. Selden, C. K. Shih, and D. Ren. “Two new lagonomegopid spiders (Arachnida: Araneae) from the mid-Cretaceous of Northern Myanmar, with comments on the superfamilial placement of Lagonomegopidae". English. In: Cretaceous Research 106.104257 (2019). DOI: 10.1016/ j.cretres.2019.104257.

[9156] X. R. Guo and Y.C. Hong. "New genus and species of Permochoristidae Tillyard (Insecta, Mecoptera) from the Middle Triassic Tongchuan Formation, Shaanxi Province, China". English. In: Acta Zootaxonomica Sinica 28 (2003), pp. 712-715.

[9157] Y. X. Guo, O. Béthoux, J. J. Gu, and D. Ren. “Wing venation homologies in Pennsylvanian 'cockroachoids' (Insecta) clarified thanks to a remarkable specimen from the Pennsylvanian of Ningxia (China)". English. In: Journal of Systematic Palaeontology 11 (2013), pp. 41-46.

[9158] Y. X. Guo and D. Ren. "A new cockroach genus of the family Fuziidae from northeastern China (Insecta: Blattida)". English. In: Acta Geologica Sinica 85 (2011), pp. 501-506. 
[9159] Z. Guo, Z.-Q. Chen, and D. A. T. Harper. “The Anisian (Middle Triassic) brachiopod fauna from Qingyan, Guizhou, south-western China". English. In: Journal of Systematic Palaeontology (2019), pp. 1-55. DOI: 10.1080/14772019.2019.1682695.

[9160] L. Guo-Qing and L. Grande. "The Species of tPhareodus (Teleostei: Osteoglossidae) from the Eocene of North America and Their Phylogenetic Relationships". English. In: Journal of Vertebrate Paleontology 17.3 (1997), pp. 487-505.

[9161] L. Guo-Qing and M. V. H. Wilson. “An Eocene Species of Hiodon from Montana, Its Phylogenetic Relationships, and the Evolution of the Postcranial Skeleton in the Hiodontidae (Teleostei)". English. In: Journal of Paleontology 14.2 (1994), pp. 153-162.

[9162] S. Gupta and K. Kumar. "Early Eocene rodents (Mammalia) from the Subathu Formation of type area (Himachal Pradesh), NW sub-Himalaya, India: Palaeobiogeographic implications". English. In: Journal of Earth System Science 124.6 (2015), pp. 1201-1221.

[9163] S. Gupta and K. Kumar. "Ziphodont Crocodilian and other biotic remains from the Paleocenebasal Eocene Kakara Formation, NW Sub-Himalaya: palaeogeographic and palaeoecologic implications". English. In: Himalayan Geology 34.2 (2013), pp. 172-182.

[9164] O. F. Gürer and Y. Yilmaz. "Geology of the Ören and Surrounding Areas, SW Anatolia". English. In: Turkish Journal of Earth Sciences 11 (2002), pp. 1-13.

[9165] V. I. Gusarov. Mesotachyporus puer, a new genus and species of Cretaceous Tachyporinae (Coleoptera, Staphylinidae) from New Jersey amber. English. Studies on Fossils in Amber, with Particular Reference to the Cretaceous of New Jersey. Leiden: Backhuys Publishers, 2000, pp. 255-258.

[9166] S. V. Gusev, A. V. Zagoroulko, and A. V. Porotov. "Sea mammal hunters of Chukotka, Bering Strait: recent archaeological results and problems". English. In: Arctic Archaeology 30.3 (1999), pp. 354369.

[9167] C. A. C. Gushulak. "First Major Appearance of Brachiopod-Dominated Benthic Shelly Communities in the Reef Ecosystem during the Early Silurian". English. PhD thesis. 2016.

[9168] E. P. Gustafson. "New records of rhinoceroses from the Ringold Formation of central Washington and the Hemphillian-Blancan boundary". English. In: Journal of Vertebrate Paleontology 32.3 (2012), pp. 727-731. DOI: 10.1080/02724634.2012.658481.

[9169] E. P. Gustafson, T. Nyborg, and B. W. M. van Bakel. “Neues Jahrbuch für Geologie und Paläontologie - Abhandlungen". English. In: 292.2 (2019), pp. 121-128. DOI: 10.1127/njgpa/2019/0811.

[9170] G. T. Gustafson, M. C. Michat, and M. Balke. "Burmese amber reveals a new stem lineage of whirligig beetle (Coleoptera: Gyrinidae) based on the larval stage". English. In: Zoological Journal of the Linnean Society 189 (2020), pp. 1232-1248. DOI: 10.1093/zoolinnean/zlz161.

[9171] D. A. Guthrie. "Fossil vertebrates from Pleistocene terrestrial deposits on the norhtern Channel Islands, Southern California". English. In: American Association of Petroleum Geologists, Pacific Section MP 45 (1998), pp. 187-192.

[9172] D. A. Guthrie. "Distribution and provenance of fossil avifauna on San Miguel Island". English. In: Sixth California Islands Symposium. Institute of Wildife Studies and National Park Service (2005), pp. 35-42.

[9173] D. A. Guthrie. "Avian material from Rancho del Oro, a Pleistocene locality in San Diego County, California". English. In: Bulletin of the Southern California Academy of Sciences 109.1 (2010), pp. 1-7.

[9174] D. A. Guthrie, H. W. Thomas, and G. L. Kennedy. "An extinct Late Pleistocene Puffin from the Southern California Channel Islands. (Aves: Alcidae)". English. In: Proceedings of a Fifth California Islands Symposium (2000), pp. 525-530.

[9175] E. Gutiérrez and D. E. Pérez-Gelabert. "Annotated checklist of Hispaniolan cockroaches". English. In: Transactions of the American Entomological Society 126 (2000), pp. 423-445.

[9176] M. Gutierrez, C. Guerin, M. Lena, and M. P. da Jesus. "Exploitation d'un grand cetace au Paleolithique ancien: le site de Dungo V a Baia Farta (Benguela, Angola)". French. In: C. R. Acad. Sci. Paris, Sciences de la Terre et des planetes 332 (2001), pp. 357-362. 
[9177] J. C. Gutiérrez-Marco. “Tolmachovia babini nov. sp., nuevo ribeirioide (Mollusca, Rostroconchai) del Ordovco medio de la Zona Centroibérica española". Spanish. In: Geobios Mémoire Spécial 20 (1997), pp. 291-298.

[9178] J. C. Gutiérrez-Marco. “Cistoideos rombferos (Echinodermata) de la Caliza Urbana (Ordovcico Superior) de la Zona Centroibérica, España". Spanish. In: Coloquios de Paleontologa 52 (2001), pp. 107116.

[9179] J. C. Gutiérrez-Marco, G. L. Albanesi, G. N. Sarmiento, and V. Carlotto. “An Early Ordovician (Floian) Conodont Fauna from the Eastern Cordillera of Peru (Central Andean Basin)". English. In: Geologica Acta 6.2 (2008), pp. 147-160. DOI: 10.1344/105.000000248.

[9180] J. C. Gutiérrez-Marco and C. Babin. "Lyrodesma el autres mollusques bivalves des Quartzites Botella (Ordovicien Mayen) de la Zone Centre-ibérique (Espagne)". French. In: Revista Españlla de Paleontologa nř extr. H (1999), pp. 229-238.

[9181] J. C. Gutiérrez-Marco, J. Destombes, I. Rábano, G. F. Aceñolaza, G. N. Sarmiento, and M. Á San José. "El Ordovcico Medio del Anti-Atlas marroqu: paleobiodiversidad, actualización bioestratigráfica y correlación". English. In: Geobios 36.2 (2003), pp. 151-177. DOI: 10.1016/S0016-6995(03) 00004-4.

[9182] J. C. GutiérrezMarco and E. Villas. "Brachiopods from the uppermost Lower Ordovician of Peru and their palaeogeographical significance". English. In: Acta Palaeontologica Polonica 52.3 (2007), pp. 547-562.

[9183] R. C. Gutschick and J. Rodriguez. "By-the-wind-sailors from a Late Devonian foreshore environment in western Montana". English. In: Journal of Paleontology 64.1 (1990), pp. 31-39.

[9184] C. S. Gutstein, M. A. Cozzuol, A. O. Vargas, M. E. Suarez, C. L. Schultz, and D. Rubilar-Rogers. "Patterns of skull variation of Brachydelphis (Cetacea, Odontoceti) from the Neogene of the Southeastern Pacific". English. In: Journal of Mammalogy 90.2 (2009), pp. 504-519.

[9185] C. S. Gutstein, M. A. Cozzuol, and N. D. Pyenson. "The Antiquity of Riverine Adaptations in Iniidae (Cetacea, Odontoceti) Documented by a Humerus from the Late Miocene of the Ituzaingo Formation, Argentina". English. In: Anatomical Record (2014). DOI: 10.1002/ar.22901.

[9186] P. Gutteridge. "The origin and significance of the distribution of shelly macrofauna in Late Dinantian carbonate mud mounds of Derbyshire". English. In: Proceedings of the Yorkshire Geological Society 48.1 (1990), pp. 23-32.

[9187] G. S. Guyer, C. E. Schweitzer, and R. M. Feldmann. "First record of decapod crustaceans (Astacidea, Stenochiridae) from the Gypsum Springs Formation (Jurassic) of Wyoming, USA". English. In: Bulletin of the Mizunami Fossil Museum 40 (2014), pp. 1-11.

[9188] F. Guzzo and K. Shimada. "A new fossil vertebrate locality of the Jetmore Chalk Member of the Upper Cretaceous Greenhorn Limestone in north-central Kansas, U.S.A." English. In: Transactions of the Kansas Academy of Science 121 (2018), pp. 59-68. DOI: 10.1660/062.121.0206.

[9189] M. Haas, R. A. Burks, and L. Krogmann. “A new lineage of Cretaceous jewel wasps (Chalcidoidea: Diversinitidae)". English. In: PeerJ 6 (2018), e4633.

[9190] D. M. Haasl and T. A. Hansen. Timing of latest Eocene molluscan extinction patterns in Mississippi. 1996.

[9191] A. Haber and M. J. Polcyn. "A new marine varanoid from the Cenomanian of the Middle East". English. In: Netherlands Journal of Geosciences 84.3 (2005), pp. 247-255.

[9192] H. Haddoumi, R. Allain, S. Meslouh, G. Metais, M. Monbaron, D. Pons, J. -C. Rage, R. Vullo, S. Zouhri, and E. Gheerbrant. "Guelb el Ahmar (Bathonian, Anoual Syncline, eastern Morocco): first continental flora and fauna including mammals from the Middle Jurassic of Africa". English. In: Gondwana Research 29 (2016), pp. 290-319. DOI: 10.1016/j.gr.2014.12.004.

[9193] C. W. Hädicke, C. Haug, and J. T. Haug. "Adding to the few: a tomocerid collembolan from Baltic amber". English. In: Palaeodiversity 6 (2013), pp. 149-156. 
[9194] C. W. Hädicke, M. K. Hörnig, J. T. Haug, and C. Haug. “New data on fossil Archaeognatha from Baltic amber and the origin of the insect ovipositor". English. In: Palaeodiversity 7 (2014), pp. 167183.

[9195] P. Hadler, J. J. Cherem, R. Turbay, A. Alberti, and U. F. J. Pardiñas. “Diversidade de pequenos mamferos (Didelphimorphia e Rodentia) do Holoceno do nordeste do estado do Rio Grande do Sul, Brasil: implicações taxonomicas e paleo ambientais". Portugese. In: Revista Brasileira de Paleontologia 19.1 (2016), pp. 127-144.

[9196] P. Hadler, D. H. Verzi, M. G. Vucetich, J. Ferigolo, and A. M. Ribeiro. “Caviomorphs (Mammalia, Rodentia) from the Holocene of Ro Grande do Sul state Brazil: Systematics and paleoenvironmental context". English. In: Revista Brasileira de Paleontologia 11.2 (2008), pp. 97-116.

[9197] M. Hadri, M. Boutakiout, and F. Pérez-Lorente. "Nuevos yacimientos de icnitas de dinosaurios carixiensis. Sur del Alto Atlas Central (Goulmima. Marruecos) [New Carixian dinosaur footprint localities. South of the Central High Atlas (Goulmima. Morocco)]". Spanish. In: Geogaceta 41 (2007), pp. 107-110.

[9198] M. Hadri, X. Pereda Suberbiola, M. Boutakiout, and F. Pérez-Lorente. "Icnitas de posibles dinosaurios tireóforos del Jurásico Inferior (Alto Atlas, Goulmima, Marruecos) [Possible thyreophoran dinosaur tracks from the Lower Jurassic (High Atlas, Goulmima. Morocco)]". Spanish. In: Revista Española de Paleontologa 22.2 (2007), pp. 147-156.

[9199] T. Haga. "First Strebloceras (Mollusca: Gastropoda: Caecidae) from the middle Pleistocene of Japan". English. In: Toyohashi Museum of Natural History 30 (2020), pp. 1-19.

[9200] J. W. Hagadorn, C. M. Fedo, and B. M. Waggoner. "Early Cambrian Ediacaran-type fossils from California". English. In: Journal of Paleontology 74.4 (2000), pp. 731-740. DOI: 10.1017/S0022336000032832.

[9201] J. W. Hagadorn, S. A. Schellenberg, and S. A. Bottjer. "Paleoecology of a large Early Cambrian bioturbator". English. In: Lethaia 33 (2000), pp. 142-156.

[9202] J. W. Hagadorn and B. M. Waggoner. “Ediacaran Fossils from the Southwestern Great Basin, United States". English. In: Journal of Paleontology 74.2 (2000), pp. 349-359.

[9203] H. Hagdorn. "Die Seeigel des Germanischen Oberen Muschelkalks". German. In: Geologische und Paläontologische Mitteilungen, Innsbruck 20 (1995), pp. 245-281.

[9204] H. Hagdorn. "Slipped throughătheăbottleneck: Lazarechinus mirabeti gen. et sp. nov., aăPaleozoiclike echinoid fromătheăTriassic Muschelkalk (late Anisian) ofăEast France". English. In: PalZ 92 (2018), pp. 267-282.

[9205] H. Hagdorn and H. J. Campbell. “Paracomatula triadica sp. nov. - an early comatulid crinoid from the Otapirian (Late Triassic) of New Caledonia". English. In: Alcheringa 17.1-2 (1993), pp. 1-17.

[9206] H. Hagdorn, G. Konrád, and A. Török. "Crinoids from the Muschelkalk of the Mecsek Mountains and their stratigraphical significance". English. In: Acta Geologica Hungarica 40.4 (1997), pp. 391410.

[9207] J. W. Haggart and R. Graham. “The crinoid Marsupites in the Upper Cretaceous Nanaimo Group, British Columbia: resolution of the Santonian-Campanian boundary in the North Pacific Province". English. In: Cretaceous Research 87 (2018), pp. 277-295.

[9208] J. W. Haggart, E. L. Nicholls, and R. Bartlett. “The first record of a pliosaurid (Plesiosauria, Pliosauridae) from the Lower Cretaceous of North America". English. In: Cretaceous Research 24.2 (2003), pp. 129-133.

[9209] J. W. Haggart, P. D. Ward, and W. Orr. “Turonian (Upper Cretaceous) lithostratigraphy and biochronology, southern Gulf Islands, British Columbia, and northern San Juan Islands, Washington State". English. In: Canadian Journal of Earth Sciences 42 (2005), pp. 2001-2020. DOI: 10.1139/E05-066.

[9210] H. Hagn and E. Martini. “A lower Eocene shell bed and some Quaternary mollusks from ODP Leg 112 off Peru". In: Proceedings of the Ocean Drilling Program, Scientific Results 112 (1990), pp. 329-333.

[9211] G. Hahn, R. Hahn, and P. Müller. “Trilobiten aus den Erdbacher Kalken (Unter-Karbon) von Steeden in Hessen". German. In: Geologica et Palaeontologica 32 (1998), pp. 161-219. 
[9212] G. Hahn, R. Hahn, and P. Müller. “100 Jahre Trilobiten-Forschung in den Erdbacher Kalken (UnterKarbon) - Zusammenstellung bisheriger Ergebnisse und Beschreibung neuer Taxa". German. In: Geologica et Palaeontologica 30 (1996), pp. 147-193.

[9213] G. Hahn, R. Hahn, and P. Müller. “Trilobiten aus den Erdbacher Kalken (Unter-Karbon) vom Liebstein und Kramberg (Hessen) - Teil 2". German. In: Geologica et Palaeontologica 35 (2001), pp. 81103.

[9214] G. Hahn, R. Hahn, and P. Müller. “Trilobiten aus dem Karbon von Cima di Plotta (Karnische Alpen, N-Italien)." German. In: Jahrbuch der Geologischen Bundesanstalt. 142.2 (2000), pp. 157-179.

[9215] G. Hahn, R. Hahn, and C. Wolf. "Belgibole abruptirhachis, Leit-Trilobit an der Devon/KarbonGrenze". German. In: Senckenbergiana lethaea 70.1/3 (1990), pp. 89-103.

[9216] G. Hahn and R. Hahn. "Kulm trilobites (Lower Carboniferous) from S-China”. English. In: Paläontologische Zeitschrift 79.3 (2005), pp. 371-375.

[9217] G. Hahn, R. Hahn, and A. Ramovs. "Trilobiten aus dem Unter-Perm (Trogkofel-Kalk, Sakmarium) der Karawanken in Slowenien". German. In: Geologica et Palaeontologica 24 (1990), pp. 139-171.

[9218] G. Hahn and R. Hahn. "New multituberculate teeth from the Early Cretaceous of Morocco". English. In: Acta Palaeontologica Polonica 48.3 (2003), pp. 349-356.

[9219] G. Hahn and R. Hahn. “Multituberculaten-Zähne aus der Unter-Kreide (Barremium) von Pié Pajarón (Prov. Cuenca, Spanien)". English. In: Palaeontologische Zeitschrift 74.4 (2001), pp. 587-589.

[9220] G. Hahn and R. Hahn. “Neue Beobachtungen an Plagiaulacoidea (Multituberculata) des OberJuras. 2. Zum Bau des Unterkiefers und des Gebisses bei Meketibolodon und bei Guimarotodon". French. In: Berliner Geowissenschaftliche Abhandlungen, Reihe E 28 (1998), pp. 9-37.

[9221] G. Hahn and R. Hahn. “Neue Beobachtungen an Plagiaulacoidea (Multituberculata) des OberJuras. 3. Der Bau der Molaren bei den Paulchoffatiidae". German. In: Berliner Geowissenschaftliche Abhandlungen, Reihe E 28 (1998), pp. 39-84.

[9222] G. Hahn and R. Hahn. "Neue Beobachtungen an Plagiaulacoidea (Multituberculata) des OberJuras. 4. Ein Vertreter der Albionbaataridae im Lusitanien Portugals". German. In: Berliner Geowissenschaftliche Abhandlungen, Reihe E 28 (1998), pp. 85-89.

[9223] G. Hahn and R. Hahn. "Multituberculaten-Zfihne aus dem Ober-Jura von Porto das Barcas (Portugal)". English. In: Palaeontologische Zeitschrift 74.4 (2001), pp. 583-586.

[9224] G. Hahn, P. Müller, and B. Aghabablou. "Tournaisian trilobites from the Mobarak Formation, North Iran". English. In: Clausthaler Geowissenschaften 9 (2013), pp. 65-72.

[9225] G. Hahn, D. Signogneau-Russell, and P. Godefroit. "New data on Brachyzostrodon (Mammalia; Upper Triassic)". English. In: Geologica et Palaeontologica 25 (1991), pp. 237-249.

[9226] D. Haig. "Palaeobathymetric gradients across Timor during 5.7-3.3 Ma and implications for collision uplift". English. In: Palaeogeography, Palaeoclimatology, Palaeoecology 331-332 (2012), pp. 5059.

[9227] D. W. Haig, E. McCartain, A. J. Mory, G. Borges, V. I. Davydov, M. Dixon, A. Ernst, S. Groflin, E. Håkansson, M. Keep, Z. Dos Santos, G. R. Shi, and J. Soares. "Postglacial Early Permian (late Sakmarian-early Artinskian) shallow-marine carbonate deposition along a $2000 \mathrm{~km}$ transect from Timor to west Australia". English. In: Palaeogeography, Palaeoclimatology, Palaeoecology 409 (2014), pp. 180-204.

[9228] D. W. Haig and A. J. Mory. “New record of siliceous, marine, later Eocene from Kalbarri, Western Australia". English. In: Journal of the Royal Society of Western Australia 86 (2003), pp. 107-113.

[9229] Y. Haile-Selassie. "Late Miocene hominids from the Middle Awash, Ethiopia". English. In: Nature 412 (2001), pp. 178-181.

[9230] Y. Haile-Selassie, L. Gilbert, S. M. Melillo, T. M. Ryan, M. Alene, A. Deino, N. E. Levin, and G. Scott B.Z. Saylor. "New species from Ethiopia further expands Middle Pliocene hominin diversity". English. In: Nature 521 (2015), pp. 483-488. 
[9231] Y. HaileSelassie, G. Woldegabriel, T. D. White, R. L. Bernor, D. Degusta, P. R. Renne, W. K. Hart, E. Vrba, A. Stanley, and F. C. Howell. "Mio-Pliocene Mammals from the Middle Awash, Ethiopia". English. In: Geobios 37 (2004), pp. 536-552.

[9232] V. Hairapetian, M. Ginter, and M. Yazdi. "Early Frasnian sharks from central Iran". English. In: Acta Geologica Polonica 58.2 (2008), pp. 173-179.

[9233] B. Hajlasz. "Tentaculites from the Givetian and Frasnian of the Holy Cross Mountains". English. In: Acta Palaeontologica Polonica 37.2-4 (1993), pp. 385-394.

[9234] E. Håkansson and E. Voigt. "New free-living bryozoans from the northwest European Chalk". English. In: Bulletin of the Geological Society of Denmark 42 (1996), pp. 187-207.

[9235] M. Hakim, D. Azar, J. Szwedo, A. M. Brysz, and D. Y. Huang. “New paraneopterans (Protopsyllidioidea, Hemiptera) from the mid-Cretaceous amber of northern Myanmar". English. In: Cretaceous Research 98 (2019), pp. 136-152. DOI: 10.1016/j.cretres.2018.12.012.

[9236] M. Hakim, D. Azar, and D. Y. Huang. "A unique manicapsocid (Psocodea: Amphientometae) from the mid-Cretaceous Burmese amber". English. In: Cretaceous Research 107.104278 (2019). DOI: 10.1016/j.cretres.2019.104278.

[9237] M. Hakim, D. Azar, J. Szwedo, J. Drohojowska, and D. Y. Huang. "Paraprotopsyllidiidae fam. nov., a new thrips-like protopsyllidioid family from mid-Cretaceous Burmese amber (Hemiptera; Sternorrhyncha)". English. In: Cretaceous Research 120.104726 (2020). DOI: 10.1016/j.cretres.2020. 104726.

[9238] M. Hakim, S. Azar, S. Maksoud, D. Y. Huang, and D. Azar. “New polymorphic psyllipsocids from Burmese amber (Psocodea: Psyllipsocidae)". English. In: Cretaceous Research 84 (2017), pp. 389-400.

[9239] J. Halamic and S. Gorican. "Triassic radiolarites from Mts. Kalnik and Medvednica (northwestern Croatia)". English. In: Geologia Croatica 48.2 (1995), pp. 129-146.

[9240] A. Halamski and A. Balinski. “Early Dalejan (Emsian) brachiopods from Hamar Laghdad (eastern Anti-Atlas, Morocco)". English. In: Neues Jahrbuch für Geologie und Paläontologie - Abhandlungen 290.1-3 (2018), pp. 127-152. DOI: 10.1127/njgpa/2018/0774.

[9241] A. T. Halamski, M. A. Bitner, A. Kaim, T. Kolar-Jurkovsek, and B. Jurkovsek. “Unusual brachiopod fauna from the Middle Triassic algal meadows of Mt. Svilaja (Outer Dinarides, Croatia)". English. In: Journal of Paleontology 89 (2016), pp. 553-575.

[9242] A. T. Halamski and A. Cherif. "Oxfordian brachiopods from the Sada and Frenda Mountains (Tlemcenian Domain, north-western Algeria)". English. In: Annales Societatis Geologorum Poloniae 87 (2017), pp. 141-145.

[9243] K. Halder. "Cenozoic fossil nautiloids (Cephalopoda) from Kutch, western India". English. In: Palaeoworld 22.2 (2012), pp. 116-130.

[9244] K. Halder and S. Bano. “Cenozoic Corbulidae (Bivalvia, Mollusca) from the Indiansubcontinentpalaeobiogeography and revision of threespecies from Kutch, India". English. In: Saudi Society for Geosciences 8 (2015), pp. 2019-2034.

[9245] K. Halder and S. Bardhan. "The fleeting genus Cymatonautilus (Nautiloidea): new record from the Jurassic Chari Formation, Kutch, India". English. In: Canadian Journal of Earth Sciences 33 (1996), pp. 1007-1010.

[9246] K. Halder and S. Bardhan. "The Oxfordian (Upper Jurassic) nautiloid fauna of Kutch, western India". English. In: Neues Jahrbuch für Geologie und Paläontologie, Abhandlungen 201 (1996), pp. 1732.

[9247] K. Halder and S. Bardhan. "On some new late Bathonian paracenoceratids (Nautiloidea) from Kutch, India and their evolutionary and biostratigraphic implications". English. In: Neues Jahrbuch für Geologie und Paläontologie, Monatshefte 1997.9 (1997), pp. 543-561.

[9248] K. Halder and P. Sinha. "Some Eocene Cerithioids (Gastropoda, Mollusca) from Kutch, Western India, and Their Bearing on Palaeobiogeography of the Indian Subcontinent". English. In: Paleontology Journal (2014). 
[9249] J. P. Hall. "A juvenile hadrosaurid from New Mexico". In: Journal of Vertebrate Paleontology 13.3 (1993), pp. 367-369.

[9250] J. P. W. Hall, R. K. Robbins, and D. J. Harvey. "Extinction and biogeography in the Caribbean: new evidence from a fossil riodinid butterfly in Dominican amber". English. In: The Royal Society 271 (2004), pp. 797-801.

[9251] R. Hall and S. Pitaru. “New Hettangian ammonite faunas and a Triassic Jurassic boundary succession, Fernie Formation, Williston Lake, British Columbia". English. In: Rivista Italiana di Paleontologia e Stratigrafia 110.1 (2004), pp. 53-60.

[9252] R. L. Hall. "Seirocrinus subangularis (Miller, 1821), a Pliensbachian (Lower Jurassic) crinoid from the Fernie Formation, Alberta, Canada". English. In: Journal of Paleontology 65.2 (1991), pp. 300307.

[9253] R. L. Hall and S. Moore. "? Tethyaster albertensis, a Late Cretaceous (Turonian) Sea Star from the Cardium Formation,Alberta, Canada". English. In: Journal of Paleontology 64.6 (1990), pp. 10451049.

[9254] R. L. Hall, D. R. Kendall, D. G. Taylor, and J. Craig. “A new ammonite and coccolith fauna from the lowermost Fernie Formation (Hettangian) in northwestern Alberta, Canada". English. In: Canadian Journal of Earth Sciences 37 (2000), pp. 1373-1376. DOI: 10.1139/cjes-37-10-1373.

[9255] S. A. Hall-Aspland and T. L. Rogers. "Summer diet of leopard seals (Hydrurga leptonyx) in Prydz Bay, Eastern Antarctica". English. In: Polar Biology 27 (2004), pp. 729-734.

[9256] A. Haluza, J. I. Canale, A. Otero, L. M. Peréz, and C. A. Scanferla. “Changes in vertebral laminae across the cervicodorsal transition of a well-preserved rebbachisaurid (Dinosauria, Sauropoda) from the Cenomanian of Patagonia, Argentina". English. In: Journal of Vertebrate Paleontology 32.1 (2012), pp. 219-224.

[9257] E. K. Halverson and J. J. Eberle. "A new middle Paleocene (early Tiffanian) mammalian fauna from the Overland Member of the Fort Union Formation, Great Divide Basin, Wyoming, U.S.A." English. In: Rocky Mountain Geology 53.2 (2018), pp. 75-111.

[9258] A. H. Hamblin. Spectrum Tracksite—also known as the Grapevine Pass Wash Tracksite. English. Making Tracks Across the Southwest: The 2006 Desert Symposium. Zzyzx: California State University, Desert Studies Consortium and LSA Associates, Inc., 2006, pp. 29-34.

[9259] A. H. Hamblin and S. A. Bilbey. A dinosaur track site in the Navajo-Nugget Sandstone, Red Fleet Reservoir, Uintah County, Utah. Vol. 99-1. Vertebrate Paleontology in Utah, Utah Geological Survey Miscellaneous Publication. 1999, pp. 51-57.

[9260] A. H. Hamblin, S. A. Bilbey, and J. E. Hall. Prehistoric animal tracks at Red Fleet State Park, northeastern Utah. English. Vol. 28. D. A. Sprinkel, T. C. Chidsey, Jr., \& P. B. Anderson (eds.), Geology of Utah's Parks and Monuments: 2000 Utah Geological Association Publication. 2000, pp. 1-10.

[9261] A. H. Hamblin and J. R. Foster. "Ancient animal footprints and traces in the Grand StaircaseEscalante National Monument, south-central Utah". English. In: D. A. Sprinkel, T. C. Chidsey, Jr., $\mathcal{E}$ P. B. Anderson (eds.), Geology of Utah's Parks and Monuments: 2000 Utah Geological Association Publication 28 (2001), pp. 1-12.

[9262] A. H. Hamblin, M. G. Lockley, and A. R. C. Milner. "More reports of theropod dinosaur tracksites from the Kayenta Formation (Lower Jurassic), Washington County, Utah: implications for describing the Springdale megatracksite". English. In: vol. 37. The Triassic-Jurassic Terrestrial Transition. New Mexico Museum of Natural History and Science Bulletin. Albuquerque: New Mexico Museum of Natural History and Science, 2006, pp. 276-281.

[9263] B. Hamdi, A. Y. Rozanov, and A. Y. Zhuravlev. "Latest Middle Cambrian metazoan reef from northern Iran". English. In: Geological Magazine 132.4 (1995), pp. 367-373.

[9264] H. B. O. Hamed. "Pleistocene Reefs of the Red Sea Coast, Sudan: Depositional Environments, Fossil Coral, Age Dating and Diagenesis". English. PhD thesis. 2015. 
[9265] M. Hamel. “A New Lower Actinopterygian from the Early Permian of the Paraná Basin, Brazil”. English. In: Journal of Vertebrate Paleontology 25.1 (2005), pp. 19-26.

[9266] K. G. A. Hamilton. "Insects from the Santana Formation, Lower Cretaceous, of Brazil. Chapter 6: Homoptera". English. In: Bulletin of the American Museum of Natural History 195 (1990), pp. 82-122.

[9267] K. G. A. Hamilton. "Lower Cretaceous Homoptera from the Koonwarra Fossil Bed in Australia, with a New Superfamily and Synopsis of Mesozoic Homoptera". English. In: Annals of the Entomological Society of America 85.4 (1992), pp. 423-430.

[9268] T. Hamley, J. C. Cisneros, and R. Damiani. "A procolophonid reptile from the Lower Triassic of Australia". English. In: Zoological Journal of the Linnean Society (2020), pp. 1-56.

[9269] S. A. Hamm and D. J. Cicimurri. "Middle Pennsylvanian (Desmoinesian) chondrichthyans from the Lake Neosho Shale Member of the Altamont Limestone in Montgomery County, Kansas". English. In: Paludicola 5.2 (2005), pp. 65-76.

[9270] S. A. Hamm and K. Shimada. "A Late Cretaceous durophagous shark, Ptychodus martini Williston, from Texas". English. In: Texas Journal of Science 56 (2004), pp. 215-222.

[9271] S. A. Hamm and K. Shimada. “The Late Cretaceous anacoracid shark, Pseudocorax laevis (Leriche), from the Niobrara Chalk of western Kansas". English. In: Transactions of the Kansas Academy of Science 110 (2007), pp. 44-52.

[9272] W. Hammann. "The Ordovician trilobites from the Iberian Chains in the province of Aragon, NE Spain, 1: The trilobites of the Cystoid Limestone (Ashgill Series)". English. In: Beringeria 6 (1992), pp. 3-219.

[9273] W. Hammann, R. Laske, and G. L. Pillola. “Tariccoia arrusensis n. gen. n. sp., an unusual trilobitelike arthropod. Rediscovery of the 'phylocarid' beds of Taricco (1922) in the Ordovician 'Puddinga' sequence of Sardinia". English. In: Bolletino della Societa Paleontologica Italiana 29 (1990), pp. $163-178$.

[9274] W. R. Hammer. "New therapsids from the Upper Fremouw Formation of Antarctica". English. In: Journal of Vertebrate Paleontology 15 (1995), pp. 105-112.

[9275] W. R. Hammer, J. W. Collinson, R. A. Askin, and W. J. Hickerson. "The first Upper Triassic vertebrate locality in Antarctica". English. In: Gondwana Research 7.1 (2004), pp. 199-204.

[9276] W. R. Hammer and W. J. Hickerson. "A crested theropod dinosaur from Antarctica". In: Science 264 (1994), pp. 828-830.

[9277] U. Hammes. Initiation and development of small-scale sponge mud-mounds, Late Jurassic, southern Franconian Alb, Germany. English. Vol. 23. in C. L. V. Monty, D. W. J. Bosence, P. H. Bridges and B. R. Pratt, eds., Carbonate Mud-Mounds - Their origin and evolution. Special Publication of the International Association of Sedimentologists, Oxford. 1995, pp. 335-357.

[9278] O. Hampe. "Considerations on a Brachauchenius skeleton (Pliosauroidea)from the lower Paja Formation (late Barremian) of Villa de Leyva area (Colombia)". English. In: Mitteilungen des Museums für Naturkunde Berlin, Geowissenschaftliche Reihe 8 (2005), pp. 37-51.

[9279] O. Hampe. "Middle/late Miocene hoplocetine sperm whale remains (Odontoceti: Physeteridae) of North Germany with an emended clasification of Hoplocetinae". English. In: Fossil Record 9.1 (2006), pp. 61-86.

[9280] O. Hampe. "Ein groSSwüchsiger Pliosauride (Reptilia: Plesiosauria) aus der Unterkreide (oberes Aptium) von Kolumbien". German. In: Courier Forschungsinstitut Senckenberg 145 (1992), pp. 1-25.

[9281] O. Hampe. "The forgotten remains of a leptocleidid plesiosaur (Sauropterygia: Plesiosauroidea) from the Early Cretaceous of Gronau (Münsterland, Westphalia, Germany)". English. In: Palaeontologische Zeitschrift 87 (2013), pp. 473-491. DOI: 10.1007/s12542-013-0175-3.

[9282] O. Hampe, V. Hairapetian, M. Dorka, F. Witzmann, A. M. Akbari, and D. Korn. "A first Late Permian fish fauna from Baghuk Mountain (Neo-Tethyan shelf, central Iran)". English. In: Bulletin of Geosciences 88 (2013), pp. 1-20. 
[9283] O. Hampe, V. Hairapetian, M. M. Ataabadi, and Z. Orak. "Preliminary report on a late Tortonian/Messinian balaenopterid cetacean (Mammalia, Mysticeti) from Sistan and Baluchestan Province (Iran)". English. In: Geopersia 9.1 (2019), pp. 65-79.

[9284] O. Hampe and A. Ivanov. "Bransonelliformes - a new order of the Xenacanthimorpha (Chondrichthyes, Elasmobranchii)". English. In: Fossil Record 10 (2007), pp. 190-194.

[9285] O. Hampe and I. Ritsche. "Bie Bartenwalfauna (Cetacea: Mysticeti: Balaenomorpha) aus dem Luneburgium (Serravallium, Mittelmiozan) von Freetz bei Sittensen (Niedersachsen, Deutschland)". German. In: Zeistschrift fur Geologische Wissenschaften 39.2 (2011), pp. 83-110.

[9286] O. Hampe, D. Schwarz-Wings, C. Bickelmann, and N. Klein. "Fore limb bones of late Pleistocene dwarf hippopotamuses (Mammalia, Cetartiodactyla) from Madagascar previously determined as belonging to the crocodylid Voay Brochu, 2007". English. In: Fossil Record 13.2 (2010), pp. 303-307.

[9287] O. Hampe, F. Witzmann, and P. Asbach. "A benign bone-forming tumour (osteoma) on the skull of a fossil balaenopterid whale from the Pliocene of Chile". English. In: Alcheringa 38 (2014). DOI: 10.1080/03115518.2014.867117.

[9288] M. W. Hamrick. "First carpals of Eocene primate family Omomyidae". English. In: Contributions from the Museum of Paleontology, University of Michigan 30.6 (1999), pp. 191-198.

[9289] O. E. Hamzaoui. “Le pointement récifal d'An El Bergoug (Agoura, sud de Méknés, bordure sud du sillon sud rifain, Maroc): un témoin des échanges atlanto-mediterranéens au Miocéne". French. In: Revista de la Sociedad Geológica de España 18.3-4 (2005), pp. 213-216.

[9290] F. Han, J. M. Clark, X. Xu, C. Sullivan, J. Choiniere, and D. W. E. Hone. “Theropod teeth from the Middle-Upper Jurassic Shishugou Formation of northwest Xinjiang, China". English. In: Journal of Vertebrate Paleontology 31.1 (2011), pp. 111-126. DOI: 10.1080/02724634.2011.546291.

[9291] F. Han, C. A. Forster, J. M. Clark, and X. Xu. "A new taxon of basal ceratopsian from China and the early evolution of Ceratopsia". English. In: PLoS ONE 10.12 (2015), e0143369:1-23.

[9292] F. Han, X. Xu, C. Sullivan, L. Huang, Y. Guo, and R. Wu. “New titanosauriform (Dinosauria: Sauropoda) specimens from the Upper Cretaceous Daijiaping Formation of southern China". English. In: PeerJ 7 (2019), e8237:1-28. DOI: 10.7717/ peerj.8237.

[9293] F. Han, W. Zheng, D. Hu, X. Xu, and P. M. Barrett. "A new basal ankylosaurid (Dinosauria: Ornithischia) from the Lower Cretaceous Jiufotang Formation of Liaoning Province, China". English. In: PLoS ONE 9.8 (2014), e104551:1-17. DOI: 10.1371/journal.pone.0104551.

[9294] G. Han, L. M. Chiappe, S. -A. Ji, M. Habib, A. H. Turner, A. Chinsamy, and L. Han. “A new raptorial dinosaur with exceptionally long feathering provides insights into dromaeosaurid flight performance". English. In: Nature Communications 5.4382 (2014), pp. 1-9. DOI: 10.1038/ncomms5382.

[9295] G. Han, F. Mao, S. Bi, Y. Wang, and J. Meng. "A Jurassic gliding euharamiyidan mammal with an ear of five auditory bones". English. In: Nature 551 (2017), pp. 451-456. DOI: 10.1038/nature24483.

[9296] G. Han and J. Meng. "A new spalacolestine mammal from the Early Cretaceous Jehol Biota and implications for the morphology, phylogeny, and palaeobiology of Laurasian 'symmetrodontans'". English. In: Zoological Journal of the Linnean Society 178 (2016), pp. 343-380.

[9297] J. Han, S. Conway Morris, Q. Ou, D. Shu, and H. Huang. "Meiofaunal deuterostomes from the basal Cambrian of Shaanxi (China)". English. In: Nature 542 (2017), pp. 228-232. DOI: 10.1038 / nature21072.

[9298] J. Han, S. Kubota, H. Uchida, G. D. Stanley Jr., X. Yao, D. Shu, Y. Li, and K. Yasui. "Tiny sea anemone from the Lower Cambrian of China". English. In: PLoS One 5.10 (2010), pp. 1-10.

[9299] Y. Han, Y. J. Cai, D. Ren, and Y. J. Wang. "A new fossil snipe fly with long proboscis from the Middle Jurassic of Inner Mongolia, China (Diptera: Rhagionidae)". English. In: Zootaxa 4691 (2019), pp. 153-160.

[9300] P. J. Hancox. "The continental Triassic of South Africa". English. In: Zentralblatt für Geologie und Paläontologie Teil I 1998.11-12 (2000), pp. 1285-1324. 
[9301] P. J. Hancox, K. D. Angielczyk, and B. S. Rubidge. “Angonisaurus and Shansiodon, dicynodonts (Therapsida, Anomodontia) from Subzone C of the Cynognathus Assemblage Zone (Middle Triassic) of South Africa". English. In: Journal of Vertebrate Paleontology 33.3 (2013), pp. 655-676.

[9302] S. Hand. "Xenorhinos, a new genus of Old World leaf-nosed bats (Microchiroptera: Hipposideridae) from the Australian Miocene". English. In: Journal of Vertebrate Paleontology 18.2 (1998), pp. 430 439.

[9303] S. Hand. "First record of the genus Megaderma Geoffroy (Microchiroptera; Megadermatidae) from Australia". English. In: Paleovertebrata 24.1-2 (1995), pp. 47-66.

[9304] S. Hand. "Hipposideros bernardsigei, a new hipposiderid (Mammalia, Microchiroptera) from the Australian Miocene, and a reconsideration of the monophyly of related species groups". English. In: Muenchner Geowissenschaftliche Abhandlungen, Reihe A: Geologie und Palaeontologie 34 (1997), pp. 73-92.

[9305] S. Hand. "Miophyllorhina riversleighensis gen. et sp. nov., a Miocene leaf-nosed bat (Microchiroptera, Hipposideridae) from Riversleigh, Queensland". English. In: Memoirs of the Queensland Museum 41.2 (1997), pp. 351-354.

[9306] S. Hand. "Riversleigha williamsi gen. et sp. nov., a large Miocene hipposiderid (Microchiroptera) from Riversleigh, Queensland". English. In: Alcheringa 22.3-4 (1998), pp. 259-276.

[9307] S. Hand, M. Novacek, H. Godthelp, and M. Archer. "First Eocene bat from Australia". English. In: Journal of Vertebrate Paleontology 14.3 (1994), pp. 375-381.

[9308] S. J. Hand. "First skull of a species of Hipposideros (Brachipposideros) (Microchiroptera: Hipposideridae), from Australian Miocene sediments". English. In: Memoirs of the Queensland Museum 33 (1993), pp. 179-192.

[9309] S. J. Hand and M. Archer. "A new hipposiderid genus (Microchiroptera) from an early Miocene bat community in Australia". English. In: Palaeontology 48.2 (2005), pp. 371-383.

[9310] S. J. Hand, M. Archer, H. Godthelp, T. H. Rich, and N. S. Pledge. "Nimbadon, a new genus and three new species of Tertiary zygomaturines (Marsupialia: Diprotodontidae) from northern Australia, with a reassessment of Neohelos". English. In: Memoirs of the Queensland Museum 33.1 (1993), pp. 193-210.

[9311] S. J. Hand and J. A. W. Kirsch. "Archerops, a new annectent hipposiderid genus (Mammalia: Microchiroptera) from the Australian Miocene". English. In: Journal of Paleontology 77.6 (2003), pp. 1139-1151.

[9312] S. J. Hand, D. E. Lee, T. H. Worthy, M. Archer, J. P. Worthy, A. J. D. Tennyson, S. W. Salisbury, R. P. Scofield, D. C. Mildenhall, E. M. Kennedy, and J. K. Lindqvist. "Miocene Fossils Reveal Ancient Roots for New Zealand's Endemic Mystacina (Chiroptera) and Its Rainforest Habitat". English. In: PLoS One 10.6 (2015), e0128871. DOI: 10.1371/journal.pone.0128871.

[9313] S. J. Hand, T. H. Worthy, M. Archer, J. P. Worthy, A. J. D. Tennyson, and R. P. Scofield. “Miocene Mystacinids (Chiroptera, Noctilionoidea) Indicate a Long History For Endemic Bats in New Zealand". English. In: Journal of Vertebrate Paleontology 33.6 (2013), pp. 1442-1448. DOI: 10.1080 / 02724634. 2013.775950.

[9314] N. Handa, M. Watabe, and K. Tsogtbaatar. "New specimens of Protoceratops (Dinosauria: Neoceratopsia) from the Upper Cretaceous in Udyn Sayr, southern Gobi area, Mongolia". English. In: Paleontological Research 16.3 (2012), pp. 179-198. DOI: 10.2517/1342-8144-16.3.179.

[9315] R. A. Hanger. "Fauna of the Lower Ordovician Al Rose Formation, Mazourka Canyon, Inyo County, California". English. In: The History of Water: Eastern Sierra Nevada, Owens Valley, White-Inyo Mountains. 1992, pp. 14-16.

[9316] R. A. Hanger and M. Gabadirwe. “Comparative taphonomy and paleoecology of a glaciomarine fauna, Carboniferous (Westphalian - Namurian) La Capilla Fm., Argentina". English. In: Virginia Journal of Science 50.3 (1999), pp. 259-268. 
[9317] R. A. Hanger, R. D. Hoare, and E. E. Strong. “Permian Polyplacophora, Rostroconchia, and problematica from Oregon". English. In: Journal of Paleontology 74.2 (2000), pp. 192-198.

[9318] R. A. Hanger and E. E. Strong. "Helicoprion nevadensis (Wheeler, 1939) from the PennsylvanianPermian Antler Peak Limestone, Lander County, Nevada (Pisces: Selachii: Helicoprionidae)". English. In: Proceedings of the Biological Society of Washington 111 (1998), pp. 531-534.

[9319] R. A. Hanger and E. E. Strong. "Acteonina permiana, a new species from the Permian Coyote Butte Formation, central Oregon (Mollusca: Gastropoda, Actaeonidae)". English. In: Proceedings of the Biological Society of Washington 111 (1998), pp. 795-798.

[9320] Y. Hangjae, Y. Yungnam, and Y. Hyesu. "[A new protosuchian (Archosauria: Crocodyliformes) skull from the Hasandong Formation (Lower Cretaceous) of Hadong, Korea]". other. In: Korean Journal of Paleontology 21.1 (2005), pp. 146-150.

[9321] O. Hankel. "Early Triassic plant microfossils from Sakamena sediments of the Majunga Basin, Madagascar". In: Review of Palaeobotany and Palynology 77 (1993), pp. 213-233.

[9322] R. K. Hanna. Some macrofossils fromteh Aqra Limestone Formation (Maastrichtian), Aqra, northern Iraq. 1995.

[9323] J. K. Hannibal and R. M. Feldmann. Caryocaris (Crustacea: Phyllocarida) from the Ordovician of the Cordillera Oriental of Southern Bolivia. 1996.

[9324] J. T. Hannibal. “Hexecontasoma, a new helminthomorph millipede (Hexecontasomatidae n. fam.) from the Mazon Creek, Illinois, fauna (Carboniferous, North America)". English. In: Fragmenta Faunistica 43 Suppl (2000), pp. 19-35.

[9325] J. T. Hannibal and W. Krzemiski. "A palaeosomatid millipede (Archipolypoda: Palaeosomatida) from the Carboniferous (Namurian A) of Silesia, Poland". English. In: Polskie Pismo Entomologiczne 74 (2005), pp. 205-217.

[9326] J. T. Hannibal, A. J. Lerner, K. E. Zeigler, and S. G. Lucas. “A juliform milliped from the upper Pennsylvanian (Virgilian) Bursum Formation, Carrizo Arroyo, of central New Mexico". English. In: vol. 25. Carboniferous-Permian transition, New Mexico Museum of Natural History and Science Bulletin. 2004, pp. 211-213.

[9327] H. Hansen, D. L. Bruton, and S. L. Jakobsen. "Starfish from the Ordovician of the Oslo Region, Norway". English. In: Norwegian Journal of Geology 85.3 (2005), pp. 209-216.

[9328] H. J. Hansen, D. M. Mohabey, and P. Toft. “No K/T boundary at Anjar, Gujarat, India: evidence from magnetic susceptibility and carbon isotopes". English. In: Proceedings of the Indian Acadamy of Sciences (Earth and Planetary Sciences) 110.2 (2001), pp. 133-142.

[9329] J. Hansen and D. A. T. Harper. "The late Sandbian - earliest Katian (Ordovician) brachiopod immigration and its influence on the brachiopod fauna in the Oslo Region, Norway". English. In: Lethaia 41.1 (2008), pp. 25-35. DOI: 10.1111/j.1502-3931.2007.00038.x.

[9330] J. Hansen and D. A. T. Harper. "Brachiopod macrofaunal distribution through the upper Volkhov - lower Kunda (Low Ordovician) rocks, Lynna River, St. Petersburg region". English. In: Bulletin of the Geological Society of Denmark 50 (2003), pp. 45-53.

[9331] J. Hansen and L. E. Holmer. "Taxonomy and biostratigraphy of Ordovician brachiopods from northeastern Ny Friesland, Spitsbergen". English. In: Zootaxa 3076 (2011), pp. 1-122.

[9332] T. Hansen. "A new trilobite species of Hemisphaerocoryphe from the Arenig of the St. Petersburg area, Russia". English. In: Norwegian Journal of Geology 85 (2005), pp. 203-208.

[9333] T. Hansen. "Cyrtometopinid trilobites from the upper Volkhov and lower Lynna Formation (Lower Darriwilian) of NW Russia". English. In: Bulletin of the Geological Society of Denmark 58 (2010), pp. 1-13.

[9334] T. Hansen and A. T. Nielsen. "Upper Arenig trilobite biostratigraphy and sea-level changes at Lynna River near Volkhov, Russia". English. In: Bulletin of the Geological Society of Denmark 50 (2003), pp. 105-114. 
[9335] T. A. Hansen, B. R. Farrell, B. Upshaw, and III. The first 2 million years after the Cretaceous-Tertiary boundary in east Texas: rate and paleoecology of the molluscan recovery. 1993.

[9336] T. A. Hansen, P. H. Kelley, and D. M. Haasl. “Paleoecological patterns in molluscan extinctions and recoveries: comparison of the Cretaceous-Paleogene and Eocene-Oligocene extinctions in North America". English. In: Palaeogeography, Palaeoclimatology, Palaeoecology 214 (2004), pp. 233-242.

[9337] M. Hanson and P. J. Makovicky. “A new specimen of Torvoaurus tanneri originally collected by Elmer Riggs". English. In: Historical Biology 26.6 (2013), pp. 775-784. DOI: 10.1080/08912963.2013. 853056.

[9338] W. S. Hantoro, P. A. Pirazzoli, C. Jouannic, C. T. Hoang, U. Radtke, C. Causse, M. Borel Best, R. Lafont, S. Bieda, and K. Lambeck. "Quaternary uplifted coral reef terraces on Alor Island, East Indonesia". English. In: Coral Reefs 13 (1994), pp. 215-223.

[9339] P. Hantzpergue, F. Baudin, V. Mitta, A. Olferiev, and V. A. Zakharov. "The Upper Jurassic of the Volga basin: ammonites biostratigraphy and correlations with standard European zonations". English. In: C. R. Acad. Sci. Paris, Sciences de la terre et des planetes 326 (1998), pp. 633-640.

[9340] M. Hanzo, B. Lathuiliere, Y. Almeras, G. Dagallier, S. Guerin-Franiatte, F. Guillocheau, V. Huault, L. Nori, and R. Rauscher. "Paleoenvironnements dans le Calcaire a gryphees du Lias de Lorraine, de la carriere de Xeuilley au Bassin parisien". French. In: Eclogae geologica helvetica 93 (2000), pp. 183-206.

[9341] J. Y. Hao and D. Ren. "Two new fossil species of Limoniidae (Diptera: Nematocera) from the Middle Jurassic of Northeastern, China". English. In: Entomological News 120.2 (2009), pp. 171178.

[9342] J. Y. Hao, D. Ren, and C. K. Shih. "New fossils of Eoptychopteridae (Diptera) from the Middle Jurassic of northeastern China". English. In: Acta Geologica Sinica 83 (2009), pp. 222-228.

[9343] S. Hao, J. Xue, Q. Wang, and Z. Liu. "Yuguangia ordinata gen. et sp. nov., a New Lycopsid from the Middle Devonian (Late Givetian) of Yunnan, China, and Its Phylogenetic Implications". English. In: International Journal of Plant Sciences 168.8 (2007), pp. 1161-1175. DOI: 10.1086/520727.

[9344] S.-G. Hao and C. B. Beck. "Catenalis digitata, gen. et sp. nov., a plant from the Lower Devonian (Siegenian) of Yunnan, China". In: Canadian Journal of Botany 12 (1991), pp. 233-242.

[9345] S.-G. Hao and P. G. Gensel. “Some new plant finds from the Posongchong Formation of Yunnan, and consideration of a possible phytogeographic similarity between South China and Australia during the Early Devonian". In: Science in China, Series D 41 (1998), pp. 1-13.

[9346] S.-G. Hao and D.-M. Wang. “Two species of Zosterophyllum Penhallow (Z. australianum Lang and Cookson, Z. ramosum sp. nov.) from the Lower Devonian (Pragian) of southeastern Yunnan, China". In: Acta Palaeontologica Sinica 39 (2000), pp. 26-41.

[9347] S. G. Hao. "Some observations on Zosterophyllum australianum Lang \& Cookson from the Lower Devonian of Yunnan, China". In: Botanical Journal of the Linnean Society 109 (1992), pp. 189-202.

[9348] U. Hara, A. Ernst, and Z. Mikolajewski. "Permian trepostome bryozoans from the Zechstein Main Dolomite (Ca2) of Western Poland and NE Germany". English. In: Geological Quarterly 53.2 (2009), pp. 249-254.

[9349] U. Hara, M. Slowakiewicz, and P. Raczyñski. "Bryozoans (trepostomes and fenestellids) in the Zechstein Limestone (Wuchiapingian) of the North Sudetic Basin (SW Poland): palaeoecological implications". English. In: Geological Quarterly 57 (2013), pp. 417-432. DOI: 10.7306/gq.1103.

[9350] U. Hara and P. D. Taylor. “Cyclostome bryozoans from the Kimmeridgian (Upper Jurassic) of Poland". English. In: Geodiversitas 31.3 (2009), pp. 555-575.

[9351] M. G. Harasewych and S. Kiel. “Upper Jurassic Pleurotomariidae (Gastropoda) from southwestern Madagascar". English. In: The Nautilus 121.2 (2007), pp. 76-89.

[9352] R. E. Harbach and D. Greenwalt. "Two Eocene species of Culiseta (Diptera: Culicidae) from the Kishenehn Formation in Montana". English. In: Zootaxa 3530 (2012), pp. 25-34. 
[9353] J. Hardenbol, M. Caron, F. Amedro, C. Dupuis, and F. Robaszynski. The Cenomanian-Turonian boundary in central Tunisia in the context of a sequence-stratigraphic interpretation. 1993.

[9354] C. R. Harington. "Vertebrates of the Last Interglaciation in Canada: A Review, with New Data". English. In: Geographie physique et Quaternaire 44.3 (1990).

[9355] C. R. Harington. Life at an early Pliocene beaver pond in the Canadian High Arctic. English. 2003.

[9356] C. R. Harington. Ice Age Vertebrates in the Canadian Arctic Islands. English. Vol. I. Canada's Missing Dimension. 1990, pp. 140-160.

[9357] C. R. Harington. "The evolution of Arctic marine mammals". English. In: Ecological Applications 18.2 Suppl. (2008), S23-S40.

[9358] C. R. Harington. "Pleistocene Walrus (Odobenus rosmarus) from Forteau, Labrador". English. In: Géographie physique et Quaternaire 47.1 (1993), pp. 111-118. DOI: 10.7202/032935ar.

[9359] C. R. Harington. "Giant Beaver, Castoroides ohioensis, Remains in Canada and an Overlooked Report from Ontario". English. In: The Canadian field-naturalist 121 (2007), pp. 330-333.

[9360] C. R. Harington and G. Beard. "The Qualicum walrus: a Late Pleistocene walrus (Odobenus rosmarus) skeleton from Vancouver Island, British Columbia, Canada". English. In: Annales Zoologici Fennici 28 (1992), pp. 311-319.

[9361] C. R. Harington and J. Cinq-Mars. "Radiocarbon dates on Saiga antelope (Saiga Tatarica) fossils from Yukon and the Northwest Territories". English. In: Arctic 48.1 (1995), pp. 1-7.

[9362] C. R. Harington, M. Cournoyer, M. Chartier, T. L. Fulton, and B. Shapiro. "Brown bear (Ursus arctos) (9880 \pm 35 BP) from late-glacial Champlain Sea deposits at Saint-Nicolas, Quebec, Canada, and the dispersal history of brown bears". English. In: Canadian Journal of Earth Science 51 (2014), pp. 527-535. DOI: $10.1139 /$ cjes-2013-0220.

[9363] C. R. Harington, D. R. Grant, and R. J. Mott. “The Hillsborough, New Brunswick, mastodon and comments on other Pleistocene mastodon fossils from Nova Scotia". English. In: Canadian Journal of Earth Sciences 30.6 (1993), pp. 1242-1253. DOI: 10.1139/e93-106.

[9364] C. R. Harington, S. Lebel, M. Paiement, and A. Vernal. "Felix: A Late Pleistocene white whale (Delphinapterus leucas) skeleton from Champlain Sea deposits at Saint-Felix-de-Valois, Quebec". English. In: Geographic physique et Quaternair 60.2 (2006), pp. 183-198.

[9365] C. R. Harington, D. Mol, and J. van der Plicht. "The Muirkirk Mammoth: A Late Pleistocene woolly mammoth (Mammuthus primigenius) skeleton from southern Ontario, Canada". English. In: Quaternary International 255 (2012), pp. 106-113. DOI: 10.1016/j.quaint.2011.05.038.

[9366] C. R. Harington, R. L. M. Ross, R. W. Matthewes, K. M. Stewart, and O. Beattie. “A late Pleistocene Stellar sea lion (Eumetopias jubatus) from Courtenay, British Columbia: its death, associated biota, and paleoenvironment". English. In: Canadian Journal of Earth Sciences 41.11 (2004), pp. 1285-1297.

[9367] T. Harkonen, M. Jüssi, M. Baimukanov, A. Bignert, L. Dmitrieva, Y. Kasimbekov, M. Verevkin, S. Wilson, and S. J. Goodman. "Pup Production and Breeding Distribution of the Caspian Seal (Phoca caspica) in Relation to Human Impacts". English. In: AMBIO: A Journal of the Human Environment 37.5 (2008), pp. 356-361. DOI: 10.1579/07-R-345.1.

[9368] J. N. Harney, E. E. Grossman, B. M. Richmond, and C. H. Fletche. "Ageand composition of carbonate shoreface sediments, Kailua Bay, Oahu, Hawaii". English. In: Coral Reefs 19 (2000), pp. 141154.

[9369] P. G. Harnik. "Direct and indirect effects of biological factors on extinction risk in fossil bivalves". English. In: Proceedings of the National Academy of Sciences 108.33 (2011), pp. 13594-13599. DOI: 10.1073/pnas.1100572108.

[9370] D. A. T. Harper, P. Alsen, E. F. Owen, and M. R. Sandy. "Early Cretaceous brachiopods from North-East Greenland: Biofacies and biogeography". English. In: Bulletin of the Geological Society of Denmark 52.2 (2005), pp. 213-225.

[9371] D. A. T. Harper and S. K. Donovan. "Fossil brachiopods from the Pleistocene of the Antilles". English. In: Scripta Geologica 135 (2007), pp. 213-239. 
[9372] D. A. T. Harper, E. Villas, and G. Ortega. "Lipanorthis Benedetto from the Tremadocian of NW Argentina reidentified as a dalmanellidine: Significance for the origin and early radiation of the punctate orthide brachiopods". English. In: Lethaia 37 (2004), pp. 271-279. DOI: 10.1080/00241160410006537.

[9373] D. A. T. Harper and S. H. Williams. "A relict Ordovician brachiopod fauna from the Parakidograptus acuminatus Biozone (Lower Silurian) of the English Lake District". In: Lethaia 35.1 (2002), pp. 71-78.

[9374] E. M. Harper, T. J. Palmer, and J. D. Hudson. “The Middle Jurassic bivalve 'Cuspidaria' ibbetsoni: A corbulid not a septibranch". English. In: Palaeontology 45.4 (2002), pp. 759-769. DOI: 10.1111/ 1475-4983.00259.

[9375] T. Harper, A. Parras, and G. W. Rougier. "Reigitherium (Meridiolestida, Mesungulatoidea) an Enigmatic Late Cretaceous Mammal from Patagonia, Argentina: Morphology, Affinities, and Dental Evolution". English. In: Journal of Mammalian Evolution (2018). DOI: 10.1007/s10914-018-9437-x.

[9376] S. A. Harrell and D. R. Schwimmer. "Coprolites of Deinosuchus and other Crocodylians from the upper Cretaceous of Western Georgia, USA". English. In: New Mexico of Natural History and Science (2010).

[9377] T. L. Harrell Jr. and J. E. Martin. "A mosasaur from the Maastrichtian Fox Hills Formation of the northern Western Interior Seaway of the United States and the synonymy of Mosasaurus maximus with Mosasaurus hoffmanni (Reptilia: Mosasauridae)". English. In: Netherlands Journal of Geosciences - Geologie en Mijnbouw 94.1 (2015), pp. 23-37.

[9378] P. J. Harries and C. T. S. Little. "The early Toarcian (Early Jurassic) and the Cenomanian-Turonian (Late Cretaceous) mass extinctions: similarities and contrasts". English. In: Palaeogeography, Palaeoclimatology, Palaeoecology 154.1999 (1999), pp. 39-66.

[9379] A. C. Harris, J. M. Bannister, and D. E. Lee. "Fossil scale insects (Hemiptera, Coccoidea, Diaspididae) in life position on an angiosperm leaf from an early Miocene lake deposit, Otago, New Zealand". English. In: Journal of the Royal Society of New Zealand 37.1 (2007), pp. 1-13.

[9380] A. C. Harris and J. I. Raine. "A sclerite from a late Cretaceous moth (Insecta: Lepidoptera) from Rakaia Gorge, Canterbury, New Zealand". English. In: Journal of the Royal Society of New Zealand 32.3 (2002), pp. 457-462.

[9381] A. H. Harris. "Quaternary vertebrates of New Mexico". English. In: New Mexico Museum of Natural History Bulletin 2 (1993), pp. 179-197.

[9382] A. H. Harris. "Taxonomic status of the Pleistocene ringtail Bassariscus sonoitensis (Carnivora)". English. In: Southwestern Naturalist 35.3 (1990), pp. 343-346.

[9383] J. D. Harris. "A reanalysis of Acrocanthosaurus atokensis, its phylogenetic status, and paleobiogeographic implications, based on a new specimen from Texas". English. In: New Mexico Museum of Natural History and Science Bulletin 13 (1998), pp. 1-75.

[9384] J. D. Harris. “Dinosaur footprints from Garden Park, Colorado". English. In: Modern Geology 23 (1998), pp. 291-307.

[9385] J. D. Harris and K. Carpenter. "A large pterodactyloid from the Morrison Formation (Late Jurassic) of Garden Park, Colorado". English. In: Neues Jahrbuch für Geologie und Paläontologie Monatshefte 1996.8 (1996), pp. 473-484.

[9386] J. D. Harris and P. Dodson. “A new diplodocoid sauropod dinosaur from the Upper Jurassic Morrison Formation of Montana, USA". In: Acta Palaeontologica Polonica 49.2 (2004), pp. 197-210.

[9387] J. D. Harris, K. R. Johnson, J. Hicks, and L. Tauxe. "Four-toed theropod footprints and a paleomagnetic age from the Whetstone Falls Member of the Harebell Formation (Upper Cretaceous: Maastrichtian), northwestern Wyoming". In: Cretaceous Research 17 (1996), pp. 381-401.

[9388] J. D. Harris, S. G. Lucas, J. W. Estep, and J. Li. "A new and unusual sphenosuchian (Archosauria: Crocodylomorpha) from the Lower Jurassic Lufeng Formation, People's Republic of China". English. In: Neues Jahrbuch für Geologie und Paläontologie Abhandlungen 215 (2000), pp. 47-68. 
[9389] J. M. Harris. Koobi Fora Research Project, Vol III, The Fossil Ungulates: Geology, Fossil Artiodactyls and Paleoenvironments. 1991.

[9390] J. M. Harris. Family Hippopotamidae. Vol. 3. Koobi Fora Research Project: The Fossil Ungulates: Geology, Fossil Artiodactyls, and Palaeoenvironments. 1991, pp. 31-85.

[9391] J. M. Harris. Family Camelidae. Vol. 3. Koobi Fora Research Project: The Fossil Ungulates: Geology, Fossil Artiodactyls, and Palaeoenvironments. 1991, pp. 86-92.

[9392] J. M. Harris. Family Giraffidae. Vol. 3. Koobi Fora Research Project: The Fossil Ungulates: Geology, Fossil Artiodactyls, and Palaeoenvironments. 1991, pp. 93-138.

[9393] J. M. Harris. Family Bovidae. Vol. 3. Koobi Fora Research Project: The Fossil Ungulates: Geology, Fossil Artiodactyls, and Palaeoenvironments. 1991, pp. 139-320.

[9394] J. M. Harris. "Fossil occurrences of Cercartetus nanus (Marsupialia, Burramyidae) in South Australia". English. In: Transactions of the Royal Society of South Australia 130.2 (2006), pp. 239-244. DOI: 10.1080/3721426.2006.10887063.

[9395] D. L. Harrison. “A new genus of paroxyclaenid (Mammalia: Condylarthra: Paroxyclaenidae: Paravulpavoides) from the Upper Middle Eocene of Creechbarrow, Dorset, S. England". English. In: Cainozoic Research 6.1-2 (2009), pp. 25-35.

[9396] D. L. Harrison. "A new genus and species of 'paramyid' rodent (Rodentia: Ischyromyidae) from the Creechbarrow Limestone Formation (late Middle Eocene) of Dorset, England". English. In: Cainozoic Research 4.1-2 (2006), pp. 51-60.

[9397] D. L. Harrison, P. J. J. Bates, M. Pearch, C. Michaels, and D. J. Ward. "New additions to the late middle Eocene mammal fauna of Creechbarrow, Dorset, southern England". English. In: Cainozoic Research 9.1 (2012), pp. 65-85.

[9398] T. Harrison. Neogene Paleontology of the Manonga Valley, Tanzania A Window into the Evolutionary History of east Africa. 1997.

[9399] T. Harrison and P. Andrews. "The anatomy and systematic position of the early Miocene proconsulid from Meswa Bridge, Kenya". English. In: Journal of Human Evolution 56.5 (2009), pp. 479-496. DOI: 10.1016/j.jhevol.2009.02.005.

[9400] T. Harrison, E. Delson, and J. Guan. "A new species of Pliopithecus from the middle Miocene of China and its implications for early catarrhine zoogeography". English. In: Journal of Human Evolution 21.5 (1991), pp. 329-361.

[9401] T. Harrison and M. L. Mbago. Intoduction: Paleontological and Geological Research in the Manonga Valley, Tanzania. Neogene Paleontology of the Manonga Valley, Tanzania. Plenum Press, New York and London. 1997, pp. 1-32.

[9402] L. J. Hart, P. R. Bell, E. T. Smith, and S. W. Salisbury. “Isisfordia molnari sp. nov., a new basal eusuchian from the mid-Cretaceous of Lightning Ridge, Australia". English. In: PeerJ 7 (2019), e7166:1-22. DOI: 10.7717/ peerj.7166.

[9403] L. J. Hart, P. R. Bell, E. T. Smith, D. R. Mitchell, T. Brougham, and S. W. Salisbury. “A probable skeleton of Isisfordia (Crocodyliformes) and additional crocodyliform remains from the Griman Creek Formation (Cenomanian, New South Wales, Australia)". English. In: Journal of Paleontology (2020). DOI: $10.1017 /$ jpa.2020.98.

[9404] J.-L. Hartenberger, J.-Y. Crochet, C. Martinez, B. Marandat, and B. Sige. The Eocene mammalian fauna of Chambi (Tunisia) in its geological context. English. Eocene Biodiversity: Unusual Occurrences and Rarely Sampled Habitats. 2001, pp. 237-250.

[9405] S. Hartenfels. “Die globalen Annulata-Events und die Dasberg-Krise (Famennium, Oberdevon) in Europa und Nord-Afrika - hochauflösende Conodonten-Stratigraphie, Karbonat-Mikrofazies, Paläoökologie und Paläodiversität". German. In: Münstersche Forschungen zur Geologie und Paläontologie 105 (2011), pp. 17-527. 
[9406] S. Hartman, M. Mortimer, W. R. Wahl, D. R. Lomax, J. Lippincott, and D. M. Lovelace. “A new paravian dinosaur from the Late Jurassic of North America supports a late acquisition of avian flight". English. In: PeerJ 7 (2019), e7247. DOI: 10.7717/peerj.7247.

[9407] A. Hartstone-Rose, D. J. De Ruiter, L. R. Berger, and S. E. Churchill. "A sabre-tooth felid from Coopers Cave (Gauteng, South Africa) and its implications for Megantereon (Felidae: Machairodontinae) taxonomy". English. In: (2007).

[9408] V. Hartung, R. Garrouste, J. M. Pouillon, and A. Nel. "First fossil of Cylindrostethinae (Heteroptera: Gerromorpha: Gerridae) in the Paleocene of Menat, France". English. In: Palaeontologia Electronica 19.3.33A (2016), pp. 1-10.

[9409] V. Hartung, R. Garrouste, and A. Nel. "The first fossil Dipsocoridae found in the early Eocene amber of France (Hemiptera: Heteroptera)". English. In: Comptes Rendus Palevol 16 (2017), pp. 715720 .

[9410] W. C. Hartwig and C. Cartelle. "A complete skeleton of the giant South American primate Protopithecus". English. In: Nature 381 (1996), pp. 307-311. DOI: 10.1038/381307a0.

[9411] K. Harvati, A. Darlas, S. E. Bailey, T. R. Rein, S. El Zaatari, L. Fiorenza, O. Kullmer, and E. Psathi. "New Neanderthal remains from Mani peninsula, Southern Greece: The Kalamakia Middle Paleolithic cave site". English. In: Journal of Human Evolution 64.6 (2013), pp. 486-499. DOI: 10.1016/j. jhevol.2013.02.002.

[9412] K. Harvati, E. Panagopoulou, P. Karkanas, A. Athanassiou, and S. R. Frost. "Preliminary results of the Aliakmon Paleolithic/Paleoanthropological Survey, Greece, 2004-2005". English. In: The Palaeolithic of the Balkans 1819 (2008), pp. 15-20.

[9413] K. Harvati, E. Panagopoulou, and P. Karkanas. "First Neanderthal remains from Greece: the evidence from Lakonis". English. In: Journal of Human Evolution 45 (2003), pp. 465-473.

[9414] K. Harvati, C. Roding, A. M. Bosman, F. A. Karakostis, R. Grün, C. Stringer, P. Karkanas, N. C. Thompson, V. Koutoulidis, L. A. Moulopoulos, V. G. Gorgoulis, and M. Kouloukoussa. "Apidima Cave fossils provide earliestevidence of Homo sapiens in Eurasia”. English. In: Nature 571 (2019), pp. 500-504. DOI: 10.1038/s41586-019-1376-z.

[9415] M. S. Harvey, J. G. Cosgrove, D. Harms, P. A. Selden, C. K. Shih, and C. C. Wang. "The oldest chthonioid pseudoscorpion Arachnida: Pseudoscorpiones: Chthonioidea: Chthoniidae: A new genus and species from mid-Cretaceous Burmese ambe". English. In: Zoologischer Anzeiger 273 (2018), pp. 102-111.

[9416] T. H. P. Harvey and N. J. Butterfield. “Exceptionally preserved Cambrian loriciferans and the early animal invasion of the meiobenthos". English. In: Nature Ecology \& Evolution 1.22 (2017), pp. 1-5. DOI: $10.1038 /$ s41559-016-0022.

[9417] M. Harzhauser. "Oligocene gastropod faunas for the Eastern Mediterranean (Mesohellenic Trough/Greece and Esfahan-Sirjan Basin/Central Iran)". English. In: Courier Forschungsinstitut Senckenberg 248 (2004), pp. 93-181.

[9418] M. Harzhauser. "Oligocene and Aquitanian gastropod faunas from the Sultanate of Oman and their biogeographic implications for the western Indo-Pacific." English. In: Palaeontographica Abteilung A 280 (2007), pp. 75-121.

[9419] M. Harzhauser. "Marine und brachyhaline Gastropoden aus dem Karpatium des Korneubuger Beckens und der Kreuzstettener Bucht (Österreich, Untermiozän)". German. In: Beiträge zur Paläontologie 27 (2002), pp. 61-159.

[9420] M. Harzhauser. "Strombus (Dilatilabrum) roegli sp. nov. - a giant Oligocene strombid (Gastropoda) and its bearing on palaeoclimatic reconstructions of the Western Tethys". English. In: Annalen des Naturhistorischen Museums in Wien 102A (2001), pp. 51-67.

[9421] M. Harzhauser, M. Euter, W. E. Piller, B. Berning, A. Kroh, and O. Mandic. “Oligocene and Early Miocene gastropods from Kutch (NW India) document an early biogeographic switch from Western Tethys to Indo-Pacific". English. In: Palaeontologische Zeitschrift 83 (2009), pp. 333-372. 
[9422] M. Harzhauser, M. Gross, and H. Binder. “Biostratigraphy of Middle Miocene (Sarmatian) wetland systems in an Eastern Alpine intramontane basin (Gratkorn Basin, Austria): the terrestrial gastropod approach". English. In: Geologica Carpathica 59.1 (2008), pp. 45-58.

[9423] M. Harzhauser, I. Hosgor, and J. -M. Pacaud. “Thanetian gastropods from the Mesopotamian high folded zone in northern Iraq". English. In: Palaeontologische Zeitung 87.2 (2013), pp. 179-199.

[9424] M. Harzhauser and T. Kowalke. "Sarmatian (Late Middle Miocene) Gastropod Assemblages of the Central Paratethys". English. In: Facies 46 (2002), pp. 57-82.

[9425] M. Harzhauser and T. Kowalke. “Early Miocene brackish-water Mollusca from the Eastern Mediterranean and from the Central Paratethys - a faunistic and ecological comparison by selected faunas". English. In: Journal of the Czech Geological Society 46.3/4 (2001), pp. 353-374.

[9426] M. Harzhauser and G. Kronenberg. "The Neogene strombid gastropod Persististrombus in the Paratethys Sea". English. In: 58.4 (2013), pp. 785-802. DOI: 10.4202/app.2011.0130.

[9427] M. Harzhauser, O. Mandic, W. E. Piller, M. Reuther, and A. Kroh. "Tracing back the origin of the Indo-Pacific mollusc fauna: Basal Tridacninae from the Oligocene and Miocene of the Sultanate of Oman". English. In: Palaeontology 51.1 (2008), pp. 199-213.

[9428] M. Harzhauser, O. Mandic, and J. Schlögl. "A late Burdigalian bathyal mollusc fauna from the Vienna Basin (Slovakia)". English. In: Geologica Carpathica 62.3 (2011), pp. 211-231.

[9429] M. Harzhauser, T. A. Neubauer, O. Mandic, M. Zuschin, and S. Coric. "A Middle Miocene endemic freshwater mollusc assemblage from an intramontane Alpine lake (Aflenz Basin, Eastern Alps, Austria)". English. In: Palaeontologische Zeitschrift 86 (2012), pp. 23-41.

[9430] M. Harzhauser, T. A. Neubauer, E. Georgopoulou, D. Esu, C. D’Amico, G. Pavia, P. Giuntelli, G. Carnevale, and H. Nordsieck. "Late Messinian continental and Lago-Mare gastropods from the Tertiary Piedmont Basin, NW Italy". English. In: Bollettino della Societá Paleontologica Italiana 54.1 (2015), pp. 1-53.

[9431] M. Harzhauser, J. Peckmann, D. Birgel, E. Draganits, O. Mandic, D. Theobalt, and J. Huemer. "Stromatolites in the Paratethys Sea during the Middle Miocene climate transition as witness of the Badenian salinity crisis". English. In: Facies 60 (2014), pp. 429-444. DOI: 10.1007/s10347-0130391-z.

[9432] M. Harzhauser and W. E. Piller. Molluscs as a major part of subtropical shallow-water carbonate production - an example from a Middle Miocene oolite shoal (Upper Serravallian, Austria). English. Vol. 42. Carbonate Systems during the Oligocene-Miocene climatic transition. International Association of Sedimentologists Special Publication. 2010, pp. 183-200.

[9433] M. Harzhauser, M. Reuter, T. Mohtat, and W. E. Piller. "Early Miocene reef- and mudflat-associated gastropods from Makran (SE-Iran)". English. In: Palaeontologische Zeitschrift 91 (2017), pp. 519-539. DOI: $10.1007 / \mathrm{s} 12542-017-0354-8$.

[9434] M. Harzhauser and J. Schloegl. "Lepadiform and scalpelliform barnacles from the Oligocene and Miocene of the Paratethys Sea". English. In: Palaeontology 55.5 (2012), pp. 923-936. DOI: 10.1111/j. 1475-4983.2012.01155.x.

[9435] Y. Hasegawa, K. Asami, T. Kimura, K. Matsui, and N. Kohno. “On the Early Miocene Paleoparadoxia from the Upper Sankebetsu Formation at Chikubetsu River, Tomamae-gun, north-western Hokaido, Japan". English. In: Bulletin of the Gunma Museum of Natural History 18 (2014), pp. 69-76.

[9436] Y. Hasegawa, E. Buffetaut, M. Manabe, and Y. Takakuwa. "A possible spinosaurid tooth from the Sebayashi Formation (Lower Cretaceous), Gunma, Japan". English. In: Bulletin of the Gunma Museum of Natural History 7 (2003), pp. 1-5.

[9437] Y. Hasegawa, T. Kimura, and R. Matsumoto. "A smaller manus of the Paleoparadoxia (Mammalia: Desmostylia) from the Haratajino Formation, Tomioka Group, Gunma, Japan". English. In: Bulletin of the Gunma Museum of Natural History 10 (2006), pp. 37-48.

[9438] Y. Hasegawa and T. Kimura. "A new specimen of ziphiid (Cetacea) from the Middle Miocene of Shiga-mura, Central Japan". English. In: Bulletin of the Gunma Museum of Natural History 7 (2003), pp. $41-45$. 
[9439] Y. Hasegawa and T. Kimura. "On the two large specimens of Paleoparadoxia (Middle Miocene) from Western Gunma Prefecture, Japan". Japanese. In: Bulletin of the Gunma Museum of Natural History 12 (2008), pp. 15-33.

[9440] Y. Hasegawa, M. Manabe, T. Kase, S. Nakajima, and Y. Takakuwa. "An ornithomimid vertebra from the Early Cretaceous Sebayashi Formation, Sanchu Terrane, Gunma Prefecture, Japan". In: Bulletin of the Gunma Museum of Natural History 3 (1999), pp. 1-6.

[9441] Y. Hasegawa, M. Manabe, S. Isaji, M. Ohkura, I. Shibata, and I. Yamaguchi. “Terminally resorbed iguanodontid teeth from the Neocomian Tetori Group, Ishikawa and Gifu Prefecture, Japan". In: Bulletin of the National Science Museum, Tokyo, Series C 21.1, 2 (1995), pp. 35-49.

[9442] Y. Hasegawa, T. Muramatsu, and Y. Miyazawa. "A desmostylian tooth from the Tomikusa Group, Nagano Prefecture". Japanese. In: Scientific Reports of the Yokohoma National University, Section II 41/42 (1995), pp. 1-11.

[9443] Y. Hasegawa, M. Okura, and M. Manabe. Smaller dinosaur, Hypsilophodon tooth from Gifu Prefecture. Japanese. Mizunami, 1990.

[9444] Y. Hasegawa, Y. Takakuwa, and H. Nakajima. "A balaenopterid whale from the Haraichi Formation (Middle Miocene), Toioka Group, Annaka City, Gunma Prefecture, Japan”. Japanese. In: Bulletin of the Gunma Museum of Natural History 6 (2002), pp. 39-44.

[9445] Y. Hasegawa, Y. Takakuwa, M. Nomura, T. Kurosawa, Y. Sudo, and Y. Takayama. “On occurrence of Desmostylian fossils from the Upper part of the Niwaya Formation, Tomioka Group (Middle Miocene), Yoshii town, Gunma Prefecture, Japan". English. In: Bulletin of the Gunma Museum of Natural History 4 (2000), pp. 57-66.

[9446] Y. Hasegawa, Y. Takakuwa, H. Nakajima, and H. Matsuoka. “Miocene Otariid (Allodesminae) scapula from Haraichi Formation, Tomioka Group, Gunma, Japan". Japanese. In: Bulletin of the Gunma Museum of Natural History 4 (2000), pp. 47-56.

[9447] Y. Hasegawa and Y. Taketani. "Paleoparadoxia tabatai from Yanagawa-machi, Fukushima Prefecture, Northeastern Japan". English. In: Research Report of the Fukushima Museum 30 (1994), pp. 169.

[9448] Y. Hasegawa, Y. Taketani, H. Taru, O. Sakamoto, and M. Manabe. "On sexual dimorphism in Paleoparadoxia tabatai". English. In: The Island Arc 3 (1995), pp. 513-521.

[9449] A. Hassler, J. E. Martin, R. Amiot, T. Tacail, F. Arnaud Godet, R. Allain, and V. Balter. "Calcium isotopes offer clues on resource partitioning among Cretaceous predatory dinosaurs". English. In: Proceedings of the Royal Society B: Biological Sciences 285.876 (2018), 20180197:1-8. DOI: 10.1098 / rspb.2018.0197.

[9450] A. Hastings, J. Bloch, E. Cadena, and C. Jaramillo. "A New Small Short-Snouted Dyrosaurid (Crocodylomorpha, Mesoeucrocodylia) from the Paleocene of Northeastern Colombia". English. In: Journal of Vertebrate Paleontology 30.1 (2010), pp. 139-162. DOI: 10.1080/02724630903409204.

[9451] A. Hastings and J. Bloch. New Long-Snouted Dyrosaurid (Crocodylomorpha, Mesoeucrocodylia) From the Paleocene of Northeastern Colombia. English. 2008.

[9452] A. K. Hastings, J. I. Bloch, and C. A. Jaramillo. "A new longirostrine dyrosaurid (Crocodylomorpha, Mesoeucrocodylia) from the Paleocene of north-eastern Colombia: biogeographic and behavioural implications for New-World Dyrosauridae". English. In: Palaeontology 54.5 (2011), pp. 1095-1116. DOI: 10.1111/j.1475-4983.2011.01092.x.

[9453] A. K. Hastings, J. I. Bloch, C. A. Jaramillo, A. F. Rincon, and B. J. Macfadden. "Systematics and biogeography of crocodylians from the Miocene of Panama". English. In: Journal of Vertebrate Paleontology 33.2 (2013), pp. 239-263.

[9454] A. K. Hastings, J. I. Bloch, and C. A. Jaramillo. "A new blunt-snouted dyrosaurid, Anthracosuchus balrogus gen. et sp. nov. (Crocodylomorpha, Mesoeucrocodylia), from the Palaeocene of Colombia". English. In: Historical Biology 27.8 (2015), pp. 998-1020. DOI: 10.1080/08912963.2014.918968. 
[9455] A. K. Hastings and A. C. Dooley. "Fossil-collecting from the middle Miocene Carmel Church Quarry marine ecosystem in Caroline County, Virginia". English. In: The Geological Society of America Field Guide 47 (2017), pp. 77-88. DOI: 10.1130/2017.0047(03).

[9456] A. K. Hastings and M. Hellmund. "Rare in situ preservation of adult crocodylian with eggs from the Middle Eocene of Geiseltal, Germany". English. In: Palaios 30 (2015), pp. 446-461.

[9457] A. K. Hastings, M. Reisser, and T. M. Scheyer. "Character evolution and the origin of Caimaninae (Crocodylia) in the New World Tropics: new evidence from the Miocene of Panama and Venezuela". English. In: Journal of Paleontology (2016). DOI: 10.1017/jpa.2016.37.

[9458] K. Hattori, C. Kerans, and R. C. Martindale. "Sequence stratigraphic and paleoecologic analysis of an Albian coral-rudist patch reef, Arizona, USA". English. In: Palaios 34 (2019), pp. 600-615. DOI: 10.2110/palo.2019.052.

[9459] H. Haubold, A. Allen, T. P. Atkinson, R. J. Buta, J. A. Lacefield, S. C. Minkin, and B. A. Relihan. Interpretation of the tetrapod footprints from the early Pennsylvanian of Alabama. English. Vol. 1. Alabama Paleontological Society Monograph. 2005, pp. 75-111.

[9460] H. Haubold and S. G. Lucas. "Tetrapod footprints of the Lower Permian Choza Formation at Castle Peak, Texas". English. In: Paläontologische Zeitschrift 77.2 (2003), pp. 247-261.

[9461] R. Haude. "Echinodermen aus dem Unter-Devon der argentinischen Praekordillere". German. In: Neues Jahrbuch für Geologie und Paläontologie, Abhandlungen 197.1 (1995), pp. 37-86.

[9462] R. Haude. 'Worm holothurians' from the Lower Jurassic of Göttingen, Germany. English. In Echinoderm: München, Heinzeller \& Nebelsick (eds), Taylor \& Francis Group, London. 2004, pp. 421423.

[9463] R. Haude. Morphology and paleobiology of echinoderms in the Lower Devonian of the Argentine Precordillera. English. In Echinoderm: München, Heinzeller \& Nebelsick (eds), Taylor \& Francis Group, London. 2004, pp. 417-419.

[9464] C. Haug, D. E. G. Briggs, D. G. Mikulic, J. Kluessendorf, and J. T. Haug. “The implications of a Silurian and other thylacocephalan crustaceans for the functional morphology and systematic affinities of the group". English. In: BMC Evolutionary Biology 14.159 (2014), pp. 1-15.

[9465] C. Haug, T. Nyborg, G. Kovalchuk, B. Nyborg, and J. T. Haug. "Pushing the limits to the north - a fossil mantis shrimp from Oregon, USA". English. In: Neues Jahrbuch für Geologie und Paläontologie - Abhandlungen 278.3 (2015), pp. 281-290. DOI: 10.1127/njgpa/2015/0528.

[9466] C. Haug and M. A. I. Rötzer. "The ontogeny of the 300 million year old xiphosuran Euproops danae (Euchelicerata) and implications for resolving the Euproops species complex". English. In: Development Genes and Evolution 228 (2018), pp. 63-74. DOI: 10.1007/s00427-018-0604-0.

[9467] C. Haug, P. Van Roy, A. Leipner, P. Funch, D. M. Rudkin, L. Schöllmann, and J. T. Haug. “A holomorph approach to xiphosuran evolution - a case study on the ontogeny of Euproops". English. In: Development Genes and Evolution 222 (2012), pp. 253-268. DOI: 10.1007/s00427-012-0407-7.

[9468] J. T. Haug, C. W. Hädicke, C. Haug, and M. K. Hörnig. “A possible hatchling of a jumping bristletail in 50 million years old amber". English. In: Neues Jahrbuch für Geologie und Paläontologie, Abhandlungen 278 (2015), pp. 191-199.

[9469] J. T. Haug, C. C. Labandeira, J. A. Santiago-Blay, C. Haug, and S. Brown. "Life habits, hox genes, and affinities of a 311 million-year-old holometabolan larva". English. In: BMC Evolutionary Biology 15.208 (2015), pp. 1-10.

[9470] J. T. Haug, A. Leipner, T. Wappler, and C. Haug. "Palaeozoic insect nymphs: new finds from the Piesberg quarry (Upper Carboniferous, Germany)". English. In: Bulletin of Geosciences 88 (2013), pp. 779-791.

[9471] J. T. Haug, G. Mayer, C. Haug, and D. E. G. Briggs. “A Carboniferous Non-Onychophoran Lobopodian Reveals Long-Term Survival of a Cambrian Morphotype". English. In: Current Biology 22.18 (2012), pp. 1673-1675. DOI: 10.1016/j.cub.2012.06.066. 
[9472] J. T. Haug, P. Müller, and C. Haug. “The ride of the parasite: a 100-million-year old mantis lacewing larva captured while mounting its spider host". English. In: Zoological Letters 4.31 (2018), pp. 1-8.

[9473] J. T. Haug, C. Nagler, C. Haug, and M. K. Hörnig. "A group of assassin fly pupae preserved in a single piece of Eocene amber". English. In: Bulletin of Geosciences 92 (2017), pp. 283-295.

[9474] N. Hauschke. "Lepadomorphe Cirripedier (Crustacea, Thoracica) aus dem höchsten Cenoman des nördlichen Westfalen (Nordwestdeutschland), mit Bemerkungen zur Verbreitung, Palökologie und Taphonomie der Stramentiden". English. In: Geol. Palaont. Westf 32 (1994), pp. 5-39.

[9475] M. Hauser and M. E. Irwin. "A new remarkable Xestomyzinae (Insecta, Diptera, Therevidae) genus from Mexican amber". English. In: Zootaxa 1008 (2005), pp. 39-45.

[9476] M. Hauser and S. L. Winterton. "A new fossil genus of small-headed flies (Diptera: Acroceridae: Philopotinae) from Baltic amber". English. In: Annals of the Entomological Society of America 100.2 (2007), pp. 152-156.

[9477] I. M. Hausmann and A. Nützel. "Diversity and palaeoecology of a highly diverse Late Triassic marine biota from the Cassian Formation of north Italy". English. In: Lethaia 48 (2015), pp. 235255. DOI: $10.1111 /$ let.12102.

[9478] L. Hautier, R. Sarr, R. Tabuce, F. Lihoreau, S. Adnet, D. P. Domning, M. Samb, and P. M. Hameh. "First prorastomid sirenian from Senegal (Western Africa) and the Old World origin of sea cows". English. In: Journal of Vertebrate Paleontology 32.5 (2012), pp. 1218-1222.

[9479] M. Hautmann. "Taxonomy and phylogeny of cementing Triassic bivalves (Families Prospondylidae, Plicatulidae, Dimyidae and Ostreidae)". English. In: Palaeontology 44.2 (2001), pp. 339-373. DOI: $10.1111 / 1475-4983.00183$.

[9480] M. Hautmann. “Die Muschelfauna der Nayband-Formation (Obertrias, Nor - Rhät) des östlichen Zentraliran". German. In: Beringeria 29 (2001), pp. 3-181.

[9481] M. Hautmann. “The first scallop”. English. In: 84 (2010), pp. 317-322.

[9482] M. Hautmann. "Notes on Gruenewaldia Wöhrmann, 1889 (Bivalvia, Trigonioida, Triassic)". English. In: Neues Jahrbuch für Geologie und Paläontologie Monatshefte 3 (2003), pp. 145-152.

[9483] M. Hautmann, B. Aghababalou, and L. Krystyn. "An unusual Late Triassic nuculid bivalve with divaricate shell ornamentation, and the evolutionary history of oblique ribs in Triassic bivalves". English. In: Journal of Paleontology 85.1 (2011), pp. 22-28.

[9484] M. Hautmann, B. Bagherpour, M. Brosse, A. Frisk, R. Hofmann, A. Baud, A. Nützel, N. Goudemand, and H. Bucher. "Competition in slow motion: the unusual case of benthic marine communities in the wake of the end-Permian mass extinction". English. In: Palaeontology 58 (2015), pp. 871-901.

[9485] M. Hautmann, H. Bucher, T. Brühwiler, N. Goudemand, A. Kaim, and A. Nützel. “An unusually diverse mollusc fauna from the earliest Triassic of South China and its implications for benthic recovery after the end-Permian biotic crisis". English. In: Geobios 44 (2011), pp. 71-85.

[9486] M. Hautmann and M. Golej. "Terquemia (Dentiterquemia) eudesdeslongchampsi new subgenus and species, an interesting cementing bivalve from the Lower Jurassic of the western Carpathians (Slovakia)". English. In: Journal of Paleontology 78.6 (2004), pp. 1090-1094.

[9487] M. Hautmann and H. Hagdorn. "Oysters and oyster-like bivalves from the Middle Triassic Muschelkalk of the Germanic Basin". English. In: Paläontologische Zeitschrift 87 (2012), pp. 19-32.

[9488] M. Hautmann and A. Nützel. "First record of a heterodont bivalve (Mollusca) from the Early Triassic: palaeoecological significance and implications for the 'Lazarus Problem'". English. In: Palaeontology 48.6 (2005), pp. 1131-1138.

[9489] M. Hautmann, A. B. Smith, A. J. McGowan, and H. Bucher. "Bivalves from the Olenekian (Early Triassic) of south-western Utah: systematics and evolutionary significance". English. In: Journal of Systematic Palaeontology 11 (2013), pp. 263-293.

[9490] J. Háva. “Globicornis rakovici n. sp., a new fossil species (Coleoptera: Dermestidae: Megatomini) from Baltic amber". English. In: Alavesia 2 (2008), pp. 3-5. 
[9491] J. Háva. “New data on fossil species from Baltic amber with description of a new species (Coleoptera: Dermestidae)". English. In: Arquivos Entomolóxicos 10 (2014), pp. 211-216.

[9492] J. Háva. "A new Electribius Crowson, 1973 species from Baltic amber (Coleoptera: Artematopodidae)". English. In: Arquivos Entomolóxicos 14 (2015), pp. 67-69.

[9493] J. Háva. “A new species of Paleoendeitoma Deng, lipiski, Ren \& Pang, 2017 (Coleoptera: Zopheridae: Colydiinae) from Upper Cretaceous Burmese amber". English. In: Folia Heyrovskyana, Series A 27.2 (2019), pp. 9-12.

[9494] J. Háva. "A new species of Neolitochropus Lyubarsky \& Perkovsky, 2016 from Eocene Baltic amber (Coleoptera: Cucujoidea: Cyclaxyridae)". English. In: Studies and Reports, Taxonomical Series 16 (2020), pp. 343-346.

[9495] J. Háva. “To the knowledge of the subfamily Attageninae (Coleoptera: Dermestidae) from Cretaceous Burmese amber". English. In: Far Eastern Entomologist 420 (2020), pp. 14-19.

[9496] J. Háva and V. I. Alekseev. "Contribution to the palaeofauna of Dermestidae (Coleoptera) from Baltic and Bitterfeld amber". English. In: Zoology and Ecology 25 (2015), pp. 154-156.

[9497] J. Háva and A. Bukejs. "Attagenus yantarnyi sp. nov., a new species from Baltic amber (Coleoptera: Dermestidae)". English. In: Baltic Journal of Coleopterology 12 (2013), pp. 155-158.

[9498] J. Háva and A. Bukejs. "A short contribution to the Dermestidae (Insecta: Coleoptera) from Baltic amber". English. In: Acta Biologica Universitatis Daugaopiliensis 18 (2018), pp. 207-209.

[9499] J. Háva and A. L. Damgaard. "A new species of Globicornis (Hadrotoma) (Coleoptera, Dermestidae, Megatominae) from Baltic amber". English. In: Vestnik Zoologii 49 (2015), pp. 373-376.

[9500] J. Háva and A. L. Damgaard. "Attagenus lundi sp. nov. from Cretaceous Burmese amber (Coleoptera: Dermestidae: Attageninae)". English. In: Studies and Reports, Taxonomical Series 13 (2017), pp. 303306.

[9501] J. Háva, J. Prokop, and A. Herrmann. "New fossil dermestid beetles (Coleoptera: Dermestidae) from the Baltic amber - III". English. In: Acta Societatis Zoologicae Bohemicae 71 (2008), pp. 151-157.

[9502] J. Háva, J. Prokop, and A. Herrmann. “New fossil dermestid beetles (Coleoptera: Dermestidae) from the Baltic amber". English. In: Acta Societatis Zoologicae Bohemicae 69 (2006), pp. 281-287.

[9503] J. Háva and J. Prokop. “Trinodes puetzi sp. nov., a new fossil species described from the Baltic Amber (Coleoptera: Dermestidae)". English. In: Acta Societatis Zoologicae Bohemicae 69 (2006), pp. 277279.

[9504] J. Háva and J. Prokop. “New fossil dermestid-beetles (Coleoptera: Dermestidae) from the Dominican amber of the Greater Antilles, with an appendix listing known fossil species of this family". English. In: Acta Societatis Zoologicae Bohemicae 68 (2004), pp. 173-182.

[9505] J. Háva, J. Prokop, and M. Kadej. "New fossil dermestid beetles (Coleoptera: Dermestidae) from the Baltic amber - II". English. In: Studies and Reports of District Museum Prague-East, Taxonomical Series 2 (2006), pp. 65-68.

[9506] J. Háva and T. Wappler. “A new genus and species of Dermestidae (Coleoptera) from the Eckfeld Maar crater (Middle Eocene, Germany)". English. In: Bulletin of Geosciences 89 (2014), pp. 67-74.

[9507] J. Háva and P. Zahradnk. "A new Falsogastrallus Pic, 1914 species (Coleoptera: Ptinidae) from Eocene Baltic amber". English. In: Studies and Reports, Taxonomical Series 15 (2019), pp. 59-62.

[9508] J. Háva and P. Zahradnk. "Two new species of the genus Xyletinus Latreille, 1809 from Eocene Baltic amber (Coleoptera: Bostrichoidea: Ptinidae)". English. In: Folia Heyrovskyana, Series A 27.2 (2019), pp. 13-16.

[9509] J. Háva and P. Zahradnk. “Two new species of Ptinidae (Coleoptera) from Eocene Baltic amber". English. In: Natura Somogyiensis 35 (2020), pp. 5-10.

[9510] J. Háva and P. Zahradnk. "A new species of the genus Stagetus Wollaston, 1861 (Coleoptera: Ptinidae: Dorcatominae) from Eocene Baltic amber". English. In: Natura Somogyiensis 35 (2020), pp. $45-50$. 
[9511] J. Háva and P. Zahradnk. “Three new species of Ptininae (Coleoptera: Bostrichoidea: Ptinidae) from Eocene Baltic amber". English. In: Studies and Reports, Taxonomical Series 16 (2020), pp. 85-91.

[9512] V. Havlicek. "New Lower Devonian (Pragian) rhynchonellid brachiopods in the Koneprusy area (Czechoslovakia)". English. In: Vestnik Ustredniho ustavu geologickeho 65.4 (1990), pp. 211-220.

[9513] V. Havlicek and Z. Kukal. Sedimentology, benthic communities, and brachiopods in the Suchomasty (Dalejan) and Acanthopyge (Eifelian) Limestones of the Koneprusy area (Czechoslovakia). 1990.

[9514] V. Havlicek and J. Vanek. "Ordovician Invertebrate communities in black-shale lithofacies (Prague Basin, Czechoslovakia)". English. In: Vestnik Ustredniho Ustavu Geologickeho 65 (1990), pp. 223-236.

[9515] P. E. Havlik, W. G. Joyce, and M. Bohme. "Allaeochelys libyca, a New Carettochelyine Turtle from the Middle Miocene (Langhian) of Libya". English. In: Bulletin of the Peabody Museum of Natural History 55.2 (2014), pp. 201-214.

[9516] T. J. Hawkeswood, D. Makhan, and J. R. Turner. "Latridius jacquelinae sp. nov., a new scavenger beetle from Baltic amber (Coleoptera: Latridiidae)". English. In: Entomologische Zeitschrift 119 (2009), pp. 108-110.

[9517] T. J. Hawkeswood, D. Makhan, and J. R. Turner. "Anobium jacquelinae sp. nov., a new woodboring beetle (Coleoptera: Anobiidae) from Baltic amber". English. In: Giornale Italiano di Entomologia 12 (2009), pp. 181-187.

[9518] J. M. Hawthorne, R. M. Bonem, J. O. Farlow, and J. O. Jones. “Ichnology, stratigraphy and paleoenvironment of the Boerne Lake spillway dinosaur tracksite, south-central Texas". English. In: Texas Journal of Science 54.4 (2002), pp. 309-324.

[9519] M. J. Hay, S. L. Cumbaa, A. M. Murray, and A. G. Plint. "A new paraclupeid fish (Clupeomorpha, Ellimmichthyiformes) from a muddy marine pro-delta environment: middle Cenomanian Dunvegan Formation, Alberta, Canada". English. In: Canadian Journal of Earth Sciences 44 (2007), pp. 775-790. DOI: 10.1139/e07-002.

[9520] H. Hayakawa and T. Takahashi. “Turonian coleoid Naefia matsumotoi from Tappu area, Hokkaido and its taphonomical significance". Japanese. In: Fossils 54 (1993), pp. 61-65.

[9521] M. Hayashi. "An extinct fossil species of the genus Plateumaris from the Lower Pleistocene in Saitama Prefecture, Japan (Coleoptera: Chrysomelidae: Donaciinae)". English. In: Earth Science (Chikyu Kagaku) 51 (1997), pp. 361-370.

[9522] M. Hayashi. "Insect fossil assemblage and paleoenvironments from the Early Pleistocene Bushi Formation in Saitama Prefecture, Japan". Japanese. In: Earth Science (Chikyu Kagaku) 50 (1996), pp. 223-237.

[9523] M. Hayashi. “Neogene donaciine fossils from Tamaniwa district, Yamagata Prefecture, Japan, with description of a new species (Coleoptera: Chrysomelidae: Donaciinae)". English. In: Bulletin of the Osaka Museum of Natural History 55 (2001), pp. 7-14.

[9524] M. Hayashi. "Early Pleistocene ground beetles (Coleoptera: Carabidae) from the Ookui Formation in Nagano Prefecture, central Japan, and their biogeographical and paleoenvironmental significance". English. In: The Quaternary Research 37 (1998), pp. 117-129.

[9525] M. Hayashi. "Late Pliocene to Early Pleistocene donaciine fossils from the Uonuma Formation in Higashikubiki hills, Niigata Prefecture, Japan, with description of a new species (Coleoptera: Chrysomelidae: Donaciinae)". English. In: Bulletin of the Osaka Museum of Natural History 53 (1999), pp. 1-22.

[9526] M. Hayashi. "Late Pliocene to Early Pleistocene donaciine fossils from the Uonuma Formation (part II): a new Donacia from the Uonuma hills in Niigata Prefecture, Japan (Coleoptera: Chrysomelidae: Donaciinae)". English. In: Bulletin of the Osaka Museum of Natural History 54 (2000), pp. 3148.

[9527] M. Hayashi and H. Aiba. "A fossil record of Malacopsephenoides japonicus (Coleoptera, Psephenidae) from the Middle Pleistocene Shiobara Group in Shiobara, Tochigi Prefecture, Japan". English. In: Elytra, New Series 6 (2016), pp. 301-302. 
[9528] M. Hayashi, H. Aiba, E. Nakano, Y. Takahashi, and T. Sato. “Fossilized water pennies (Coleoptera: Psephenidae) in the Middle Pleistocene lake deposits in Shiobara site, Tochigi Prefecture, Japan". English. In: Japanese Journal of Systematic Entomology 26 (2020), pp. 84-86.

[9529] M. Hayashi and Y. Kawakami. "Fossil of the genus Eubrianax (Coleoptera: Psephenidae) from the upper Miocene Ningyotoge Formation in Tottori Prefecture, Japan". English. In: Elytra 37 (2009), pp. 99-103.

[9530] M. Hayashi, S. Shiyake, Y. Miyatake, and D. Iwai. "Pleistocene fossil insects from the underground of Nagai Park, Osaka City, western Japan, with description of three donaciine leaf beetles (Coleoptera: Chrysomelidae)". English. In: Bulletin of the Osaka Museum of Natural History 57 (2003), pp. 39-45.

[9531] M. Hayashi and S. Shiyake. "Pleistocene fossil insects from Tokachi, Hokkaido, north Japan". Japanese. In: Bulletin of the Mizunami Fossil Museum 35 (2009), pp. 101-104.

[9532] M. Hayashi, K. Yahiro, and E. Kitabayashi. "Middle Pleistocene insects from the Tsumori Formation in Mashiki-machi, Kumamoto Prefecture, Japan". Japanese. In: Bulletin of the Mizunami Fossil Museum 28 (2001), pp. 239-243.

[9533] M. Hayashi, K. Yahiro, and E. Kitabayashi. "Middle Pleistocene fossil insects from the Hirabaru Formation of Kitsuki City, Oita Prefecture, Kyushu, Japan". Japanese. In: Bulletin of the Mizunami Fossil Museum 32 (2005), pp. 227-234.

[9534] M. Hayashi, K. Yahiro, and E. Kitabayashi. "Middle Pleistocene fossil insects from the Yoshino Formation of Kawachimachi, Kumamoto City, Kyushu, Japan". Japanese. In: Bulletin of the Mizunami Fossil Museum 34 (2008), pp. 95-98.

[9535] M. Hayashi, K. Yahiro, and E. Kitabayashi. "Middle Pleistocene fossil insects from the Saijo Formation of Higashi-hiroshima City, Hiroshima Prefecture, Japan". Japanese. In: Bulletin of the Mizunami Fossil Museum 34 (2008), pp. 89-93.

[9536] M. Hayashi, K. Yahiro, and E. Kitabayashi. "Early Pleistocene fossil insects from the Oyama Formation at Oyama-machi, Oita Prefecture, Kyushu, Japan". Japanese. In: Bulletin of the Mizunami Fossil Museum 31 (2004), pp. 69-72.

[9537] M. Hayashi, K. Yahiro, N. Kitamura, and E. Kitabayashi. “Middle Pleistocene fossil insects from the Tsumori Formation of Mashiki-machiKumamoto PrefectureJapan (Part 2)". Japanese. In: Bulletin of the Mizunami Fossil Museum 31 (2004), pp. 63-67.

[9538] M. Hayashi, K. Yahiro, and E. Kitabayashi. "Fossil insects and their paleoenvironments of the Pliocene Tsubusagawa Formation in Ajimu Basin, Oita Prefecture, Kyushu, Japan". Japanese. In: Bulletin of the Mizunami Fossil Museum 30 (2003), pp. 167-173.

[9539] M. Hayashi, K. Yahiro, and E. Kitabayashi. "Late Pleistocene insects from the Mizozono Formation in Yoshimatsu-cho, Kagoshima Prefecture, Japan". Japanese. In: Bulletin of the Mizunami Fossil Museum 29 (2002), pp. 161-168.

[9540] M. Hayden. "Discovery of a new pterosaur tracksite at Flaming Gorge Reservoir". English. In: Utah Geological Survey Notes 34.3 (2002), p. 13.

[9541] T. Haye. "Zahnwalreste aus dem Oberoligozän (Neochattium) von Johannistal, Kreis Ostholstein". German. In: Geschiebekunde Aktuell 7 (2009), pp. 45-50.

[9542] F. G. Hayes. "The Brooksville 2 local fauna (Arikareean, latest Oligocene) Hernando County, Florida". English. In: Bulletin of the Florida Museum of Natural History 43.1 (2000), pp. 1-47.

[9543] G. Haynes. Mammoths, mastodons and elephants: biology, behavior and the fossil record. 1991.

[9544] A. B. Hayward, A. H. F. Robertson, and T. C. Scoffin. "Miocene patch reefs from a mediterranean marginal terrigenous setting in southwest Turkey". English. In: SEPM Concepts in Sedimentology and Paleontology 5 (1996), pp. 317-332.

[9545] J. L. Hayward, D. K. Zelenitsky, D. L. Smith, D. M. Zaft, and J. K. Clayburn. “Eggshell taphonomy at modern gull colonies and a dinosaur clutch site". English. In: Palaios 15 (2000), pp. 343-355. 
[9546] M. Hazra, T. Hazra, S. K. Sarkar, S. Bera, and M. A. Khan. "First fossil dragonfly from India". English. In: Current Science 119 (2020), pp. 1204-1207.

[9547] G. He and Y.-M. Wang. "Ladinian ammonoid fauna from northwestern Guangxi, southern China". English. In: Acta Palaeontologica Sinica 35.3 (1997), pp. 334-349.

[9548] L. He, Y. B. Wang, A. Woods, G. S. Li, H. Yang, and W. Liao. "Calcareous tubeworms as disaster forms after the end-Permian mass extinction in south China". English. In: Palaios 27 (2012), pp. 878-886.

[9549] T. He, X.-L. Wang, and Z. -H. Zhou. "A new genus and species of caudipterid dinosaur from the Lower Cretaceous Jiufotang Formation of western Liaoning, China". English. In: Vertebrata PalAsiatica 46.3 (2008), pp. 178-189.

[9550] W. He, Q. Feng, S. Gu, and Y. Jin. “Changxingian (Upper Permian) radiolarian fauna from Meishan D Section, Changxing, Zhejiang, China, and its possible paleoecological significance". English. In: Journal of Paleontology 79.2 (2005), pp. 209-218.

[9551] W. He, S.-Z. Shen, Q. Feng, and S. Gu. "A late Changhsingian (Late Permian) deepwater brachiopod fauna from the Talung Formation at the Dongpan Section, Southern Guangxi, South China". English. In: Journal of Paleontology 79.5 (2005), pp. 927-938.

[9552] W. He, E. A. Weldon, T. Yang, H. Wang, Y. Xiao, H. Wu, K. Zhang, Y. Wang, and S. Wu. “The palaeoenvironmental and palaeobiogeographical significance of the Late". English. In: Journal of Systematic Palaeontology 18 (2019), pp. 885-909. DOI: 10.1080/14772019.2019.1685606.

[9553] W. H. He, J. J. Bu, Z. J. Niu, and Y. Zhang. “A new Late Permian brachiopod fauna from Tanggula, Qinghai-Tibet Plateau and its palaeogeographic implications". English. In: Alcheringa 33 (2009), pp. 113-132.

[9554] W. H. He, Q. L. Feng, E. A. Weldon, S. Z. Gu, Y. Y. Meng, F. Zhang, and S. B. Wu. “A Late Permian to Early Triassic bivalve fauna from the Dongpan section, southern Guangxi, south China". English. In: Journal of Paleontology 81.5 (2007), pp. 1009-1019.

[9555] W. H. He, G. R. Shi, J. J. Bu, and Z. J. Niu. "A new brachiopod fauna from the Early to Middle Permian of southern Qinghai Province, northwest China". English. In: Journal of Paleontology 82.4 (2008), pp. 811-822.

[9556] W. H. He, G. R. Shi, Q. L. Feng, and Y. Q. Peng. “Discovery of late Changhsingian (latest Permian) brachiopod Attenuatella species from South China". English. In: Alcheringa 31 (2007), pp. 271-284.

[9557] W. H. He, G. R. Shi, Y. Zhang, T.L. yang, F. Teng, and S. B. Wu. “Systematics and palaeoecology of Changhsingian (Late Permian) Ambocoeliidae brachiopods from South China and implications for the end-Permian mass extinction". English. In: Alcheringa 36 (2012), pp. 515-530.

[9558] W. H. He, G. R. Shi, Y. Zhang, T. L. Yang, K. X. Zhang, S. B. Wu, Z. J. Niu, and Z. Y. Zhang. "Changhsingian (latest Permian) deep-water brachiopod fauna from South China". English. In: Journal of Systematic Palaeontology 12 (2014), pp. 907-960.

[9559] W. H. He, G. R. Shi, S. Z. Shen, T. L. Yang, Y. Zhang, H. T. Wu, H. Wang, and J. J. Bu. "Systematic palaeontology". English. In: Brachiopods around the Permian-Triassic Boundary of South China. 2019, pp. 61-224. DOI: 10.1007/978-981-13-1041-6_9.

[9560] W. H. He, K. X. Zhang, Z. Q. Chen, J. X. Yan, T. L. Yang, Y. Zhang, S. Z. Gu, and S. B. Wu. “A new genus Liaous of early Anisian Stage (Middle Triassic) brachiopods from southwestern China: systematics, reassessment of classification of the Spiriferinioidea, community paleoecology, and paleoenvironmental implications". English. In: Journal of Paleontology 89 (2016), pp. 966-979.

[9561] X. He, C. Wang, S. Liu, F. Zhou, T. Liu, K. Cai, and B. Dai. "[A new species of sauropod from the Early Jurassic of Gongxian Co., Sichuan]". Chinese. In: A new species of sauropod from the Early Jurassic of Gongxian Co., Sichuan 18.1 (1998), pp. 1-6.

[9562] X. He, S. Yang, K. Cai, K. Li, and Z. Liu. "[A new species of sauropod, Mamenchisaurus anyuensis sp. nov.]" Chinese. In: Papers on Geosciences Contributed to the 30th International Geological Congress (1996), pp. 83-86. 
[9563] Y. He, P. J. Makovicky, K. Wang, S. Chen, C. Sullivan, F. Han, and X. Xu. "A new leptoceratopsid (Ornithischia, Ceratopsia) with a unique ischium from the Upper Cretaceous of Shandong Province, China". English. In: PLoS ONE 10.12 (2015), e0144148.

[9564] Y.-M. He, J. M. Clark, and X. Xing. "A large theropod metatarsal from the upper part of Jurassic Shishugou Formation in Junggar Basin, Xinjiang, China". English. In: Vertebrata PalAsiatica 51.1 (2013), pp. 29-42.

[9565] J. J. Head. "A new species of basal hadrosaurid (Dinosauria, Ornithischia) from the Cenomanian of Texas". In: Journal of Vertebrate Paleontology 18.4 (1998), pp. 718-738.

[9566] J. J. Head. "A South American snake lineage from the Eocene Greenhouse of North America and a reappraisal of the fossil record of anilioid snakes". English. In: Geobios (2020). DOI: 10.1016/j. geobios.2020.09.005.

[9567] J. J. Head, O. A. Aguilera, and M. R. Sanchez-Villagra. "Past Colonization of South America by Trionychid Turtles: Fossil Evidence from the Neogene of Margarita Island, Venezuela". English. In: Journal of Herpetology 40.3 (2006), pp. 378-381. DOI: 10.1670/0022-1511(2006)40[378:PCOSAB] 2.0.CO;2.

[9568] J. J. Head, J. I. Bloch, A. K. Hastings, J. R. Bourque, E. A. Cadena, F. A. Herrera, P. D. Polly, and C. A. Jaramillo. "Giant boid snake from the Paleocene neotropics reveals hotter past equatorial temperatures". English. In: Nature 457 (2009), pp. 715-717.

[9569] J. J. Head, G. F. Gunnell, P. A. Holroyd, J. H. Hutchison, and R. L. Ciochon. “Giant lizards occupied herbivorous mammalian ecospace during the Paleogene greenhouse in Southeast Asia". English. In: Proceedings of the Royal Society B 280.1763 (2013), pp. 1-7. DOI: 10.1098/rspb.2013.0665.

[9570] J. J. Head, P. A. Holroyd, J. H. Hutchison, and R. L. Ciochon. “First report of snakes (Serpentes) from the late Middle Eocene Pondaung Formation, Myanmar". In: Journal of Vertebrate Paleontology 25.1 (2005), pp. 246-250.

[9571] J. J. Head, S. M. Raza, and P. D. Gingerich. "Drazinderetes tethyensis, a new large trionychid (Reptilia: Testudines) from the marine Eocene Drazinda Formation of the Sulaiman Range, Punjab (Pakistan)". English. In: Contributions from the Museum of Paleontology, The University of Michigan 30.7 (1999), pp. 199-214.

[9572] J. J. Head, M. R. Sanchez-Villagra, and O. A. Aguilera. "Fossil snakes from the Neogene of Venezuela (Falcón State)." English. In: Journal of Systematic Paleontology 41.3 (2006), pp. 233-240.

[9573] J. A. Headden and H. B. N. Campos. "An unusual edentulous pterosaur from the Early Cretaceous Romualdo Formation of Brazil". English. In: Historical Biology (2014).

[9574] S. W. Heads. "The first fossil Proscopiidae (Insecta, Orthoptera, Eumastacoidea) with comments on the historical biogeography and evolution of the family". English. In: Palaeontology 51.2 (2008), pp. 499-507.

[9575] S. W. Heads. "A new species of Yuripopovia (Coleorrhyncha: Progonocimicidae) from the Early Cretaceous of the Isle of Wight". English. In: British Journal of Entomology and Natural History 21 (2008), pp. 247-253.

[9576] S. W. Heads. "A new pygmy mole cricket in Cretaceous amber from Burma (Orthoptera: Tridactylidae)". English. In: Denisia 26 (2009), pp. 75-82.

[9577] S. W. Heads. "New Tridactyloidea in Miocene amber from the Dominican Republic (Orthoptera: Caelifera)". English. In: Annales de la Société Entomologique de France 46 (2010), pp. 204-210.

[9578] S. W. Heads. "New pygmy grasshoppers in Miocene amber from the Dominican Republic (Orthoptera: Tetrigidae)". English. In: Denisia 26 (2009), pp. 69-74.

[9579] S. W. Heads. "The first fossil spider cricket (Orthoptera: Gryllidae: Phalangopsinae): 20 million years of troglobiomorphosis or exaptation in the dark?" English. In: Zoological Journal of the Linnean Society 158 (2010), pp. 56-65. 
[9580] S. W. Heads. "A new caddisfly larval case (Insecta, Trichoptera) from the Lower Cretaceous Vectis Formation (Wealden Group) of the Isle of Wight, southern England". English. In: Proceedings of the Geologists' Association 117 (2006), pp. 307-310.

[9581] S. W. Heads and L. Leuzinger. “On the placement of the Cretaceous orthopteran Brauckmannia groeningae from Brazil, with notes on the relationships of Schizodactylidae (Orthoptera, Ensifera)". English. In: ZooKeys 77 (2011), pp. 17-30.

[9582] S. W. Heads, D. M. Martill, and R. F. Loveridge. "An exceptionally preserved antlion (Insecta, Neuroptera) with colour pattern preservation from the Cretaceous of Brazil". English. In: Palaeontology 48.6 (2005), pp. 1409-1417.

[9583] S. W. Heads, A. N. Miller, J. L. Crane, M. J. Thomas, D. M. Ruffatto, A. S. Methven, D. B. Raudabaugh, and Y. N. Wang. “The oldest fossil mushroom". English. In: PLoS One 12.6 (2017), e0178327.

[9584] S. W. Heads, D. Penney, and D. I. Green. "A new fossil cricket of the genus Proanaxipha in Miocene amber from the Dominican Republic (Orthoptera, Gryllidae, Pentacentrinae)". English. In: ZooKeys 229 (2012), pp. 111-118.

[9585] S. W. Heads, M. J. Thomas, and Y. Wang. "A remarkable new pygmy grasshopper (Orthoptera, Tetrigidae) in Miocene amber from the Dominican Republic". English. In: ZooKeys 429 (2014), pp. 87-100.

[9586] S. W. Heads and Y. Wang. "First fossil record of Melanoplus differentialis (Orthoptera: Acrididae: Melanoplinae)". English. In: Entomological News 123 (2013), pp. 33-37.

[9587] P. W. Hearn and B. Deline. "A new species of Paradiabolocrinus from the Upper Ordovician of central Kentucky, USA". English. In: Southeastern Geology 49.1 (2012), pp. 25-30.

[9588] T. H. Heaton. "The Oligocene Rodent Ischyromys of the Great Plains: Replacement Mistaken for Anagenesis". English. In: Journal of Paleontology 67.2 (1993).

[9589] T. H. Heaton. "Whale remains from Puffin Grotto, a raised sea cave on Noyes Island, southeastern Alaska". English. In: Proceedings of the South Dakota Academy of Science 80 (2001), pp. 415-416.

[9590] R. J. Hebda, J. A. Burns, M. Geertsema, and A. J. T. Jull. “AMS-dated late Pleistocene taiga vole (Rodentia: Microtus xanthognathus) from northeast British Columbia, Canada: a cautionary lesson in chronology". English. In: Canadian Journal of Earth Sciences 45.5 (2008), pp. 611-618.

[9591] E. M. Hechenleitner, L. Leuzinger, A. G. Martinelli, S. Rocher, L. E. Fiorelli, J. R. A. Taborda, and L. Salgado. "Two Late Cretaceous sauropods reveal titanosaurian dispersal across South America". English. In: Communications Biology 3 (2020), 622:1-13. DOI: 10.1038/s42003-020-01338-w.

[9592] M. K. Hecht. "A new choristodere (Reptilia, Diapsida) from the Oligocene of France: an example of the Lazarus effect". English. In: Geobios 25.1 (1992), pp. 115-131.

[9593] A. B. Heckert. "Late Triassic microvertebrates from the lower Chinle Group (Otischalkian-Adamanian: Carnian), southwestern U.S.A." English. In: New Mexico Museum of Natural History and Science Bulletin 27 (2004), pp. 1-170.

[9594] A. B. Heckert. The tetrapod fauna of the Upper Triassic lower Chinle Group (Adamanian: latest Carnian) of the Zuni Mountains, west-central New Mexico. English. Vol. 11. In S. G. Lucas, J. W. Estep, T. E. Williamson, \& G. S. Morgan (eds.), New Mexico's Fossil Record 1. New Mexico Museum of Natural History and Science Bulletin. 1997, pp. 29-39.

[9595] A. B. Heckert. A revision of the Upper Triassic ornithischian dinosaur Revueltosaurus, with a description of a new species. English. Vol. 21. Upper Triassic Stratigraphy and Palaeontology, New Mexico Museum of Natural History and Science Bulletin. 2002, pp. 253-266.

[9596] A. B. Heckert. Upper Triassic tetrapods from the Lucero Uplift, central New Mexico. English. Vol. 50. New Mexico Geological Society Guidebook, 50th Field Conference, Albuquerque. 1999, pp. 311315.

[9597] A. B. Heckert. "Geographic and stratigraphic distribution of the enigmatic Upper Triassic (Adamanian: Carnian) vertebrate fossil Colognathus obscurus Case". English. In: Museum of Northern Arizona Bulletin 62 (2006), pp. 155-156. 
[9598] A. B. Heckert, N. C. Fraser, and V. P. Schneider. "A new species of Coahomasuchus (Archosauria, Aetosauria) from the Upper Triassic Pekin Formation, Deep River Basin, North Carolina". English. In: Journal of Paleontology 91.1 (2017), pp. 162-178. DOI: 10.1017/jpa.2016.130.

[9599] A. B. Heckert and H. S. Jenkins. The microvertebrate fauna of the Upper Triassic (Revueltian) Snyder Quarry, north-central New Mexico. English. New Mexico Geological Society, 56th Field Conference Guidebook, Geology of the Chama Basin. 2005, pp. 319-334.

[9600] A. B. Heckert and S. G. Lucas. A new dinosaur track locality from the Dakota Sandstone (Upper Cretaceous: Cenomanian) in west-central New Mexico. English. Vol. 14. Lower and Middle Cretaceous Terrestrial Ecosystems, New Mexico Museum of Natural History and Science Bulletin. 1998, pp. 169171.

[9601] A. B. Heckert, S. G. Lucas, and A. P. Hunt. A late Carnian theropod from New Mexico: implications for the early evolution of Theropoda. English. 1994.

[9602] A. B. Heckert, S. G. Lucas, and S. E. Krzyzanowski. "Vertebrate fauna of the late Campanian (Judithian) Fort Crittenden Formation, and the age of Cretaceous vertebrate faunas of southeastern Arizona (U.S.A.)" English. In: Neues Jahrbuch für Geologie und Paläontologie, Abhandlungen 227.3 (2003), pp. 343-364.

[9603] A. B. Heckert, S. G. Lucas, L. F. Rinehart, and A. P. Hunt. “A new genus and species of sphenodontian from the Ghost Ranch Coelophysis Quarry (Upper Triassic: Apachean), Rock Point Formation, New Mexico, USA". English. In: Palaeontology 51.4 (2008), pp. 827-845. DOI: 10.1111/j.14754983.2008.00786.x.

[9604] A. B. Heckert and S. G. Lucas. "First occurrence of Aetosaurus (Reptilia: Archosauria) in the Upper Triassic Chinle Group (USA) and its biochronological significance". English. In: Neues Jahrbuch für Geologie und Paläontologie, Monatshefte 1998.10 (1998), pp. 604-612.

[9605] A. B. Heckert and S. G. Lucas. "A new aetosaur (Reptilia: Archosauria) from the Upper Triassic of Texas and the phylogeny of aetosaurs". English. In: Journal of Vertebrate Paleontology 19 (1999), pp. 50-68.

[9606] A. B. Heckert and S. G. Lucas. "South American occurrences of the Adamanian (Late Triassic: latest Carnian) index taxon Stagonolepis (Archosauria: Aetosauria) and their biochronological significance". English. In: Journal of Paleontology 76.5 (2002), pp. 852-863.

[9607] A. B. Heckert, S. G. Lucas, and J. D. Harris. "An aetosaur (Reptilia: Archosauria) from the Upper Triassic Chinle Group, Canyonlands National Park, Utah". English. In: National Park Service Paleontological Research 4 (1999), pp. 23-26.

[9608] A. B. Heckert, S. G. Lucas, D. D. DeBlieux, and J. I. Kirkland. "A revueltosaur-like tooth from the Petrified Forest Formation (Upper Triassic: Revueltian), Zion National Park". English. In: vol. 37. The Triassic-Jurassic terrestrial transition, New Mexico Museum of Natural History and Science Bulletin. Albuquerque: New Mexico Museum of Natural History and Science, 2006, pp. 588-591.

[9609] A. B. Heckert, S. G. Lucas, and J. W. Estep. Lower Chinle Group (Upper Triassic: Upper Carnian) tetrapods from the vicinity of Cameron, Arizona. English. Vol. 21. Upper Triassic Stratigraphy and Paleontology, New Mexico Museum of Natural History and Science Bulletin. 2002, pp. 73-76.

[9610] A. B. Heckert, S. G. Lucas, A. P. Hunt, and J. D. Harris. A giant phytosaur (Reptilia: Archosauria) skull from the Redondo Formation (Upper Triassic: Apachean) of east-central New Mexico. English. Vol. 52. New Mexico Geological Society, 52nd Field Conference, Geology of the Llano Estacado. 2001, pp. 169-176.

[9611] A. B. Heckert, S. G. Lucas, L. F. Rinehart, J. A. Spielmann, A. P. Hunt, and R. Kahle. "Revision of the archosauromorph reptile Trilophosaurus, with a description of the first skull of Trilophosaurus jacobsi, from the Upper Triassic Chinle Group, West Texas, USA". English. In: Palaeontology 49.3 (2006), pp. 621-640. 
[9612] A. B. Heckert, S. G. Lucas, R. Kahle, and K. E. Zeigler. New occurrence of Trilophosaurus (Reptilia: Archosauromorpha) from the Upper Triassic of West Texas and its biochronological significance. English. New Mexico Geological Society Guidebook, 52nd Field Conference, Geology of the Llano Estacado. 2001, pp. 115-122.

[9613] A. B. Heckert, S. G. Lucas, and J. A. Spielmann. "A new species of the enigmatic archosauromorph Doswellia from the Upper Triassic Bluewater Creek Formation, New Mexico, USA". English. In: Palaeontology 55.6 (2012), pp. 1333-1348. DOI: 10.1111/j.1475-4983.2012.01200.x.

[9614] A. B. Heckert, S. G. Lucas, and A. P. Hunt. "Triassic vertebrate fossils in Arizona". English. In: Vertebrate Paleontology in Arizona. New Mexico Museum of Natural History and Science Bulletin 29 (2005), pp. 16-44.

[9615] A. B. Heckert, J. S. Mitchell, V. P. Schneider, and P. E. Olsen. “Diverse new microvertebrate assemblage from the Upper Triassic Cumnock Formation, Sanford subbasin, North Carolina, USA". English. In: Journal of Paleontology 86.2 (2012), pp. 368-390.

[9616] A. B. Heckert, V. P. Schneider, N. C. Fraser, and R. A. Webb. "A new aetosaur (Archosauria, Suchia) from the Upper Triassic Pekin Formation, Deep River Basin, North Carolina, U.S.A., and its implications for early aetosaur evolution". English. In: Journal of Vertebrate Paleontology 35 (2015), e881831.

[9617] A. B. Heckert, J. A. Spielmann, S. G. Lucas, R. Altenberg, and D. A. Russell. An Upper Jurassic theropod dinosaur from the Section 19 Mine, Morrison Formation, Grants Uranium District. English. Vol. 54. In: S. G. Lucas, S. C. Semken, W. Berglof, \& D. Ulmer-Scholle (eds.), Geology of the Zuni Plateau. New Mexico Geological Society, Fall Field Conference Guidebook. 2003, pp. 309-314.

[9618] A. B. Heckert, J. A. Spielmann, S.G. lucas, and A. P. Hunt. "Biostratigraphic utility of the Upper Triassic aetosaur Tecovasuchus (Archosauria: Stagonolepididae), an index taxon of St. Johnsian (Adamanian: late Carnian) time". English. In: New Mexico Museum of Natural History and Science Bulletin 41 (2007), pp. 51-57.

[9619] A. B. Heckert, K. E. Zeigler, S. G. Lucas, L. F. Rinehart, and J. D. Harris. Preliminary description of coelophysoids (Dinosauria: Theropoda) from the Upper Triassic (Revueltian: early-mid Norian) Snyder Quarry, north-central New Mexico. English. Vol. 17. Dinosaurs of New Mexico. New Mexico Museum of Natural History and Science Bulletin. 2000, pp. 27-32.

[9620] J.v. Heerden and P. M. Galton. "The affinities of $<\mathrm{i}>$ Melanorosaurus $</ \mathrm{i}>-$ a Late Triassic prosauropod dinosaur from South Africa". In: Neues Jahrbuch für Geologie und Paläontologie Monatshefte 1997.1 (1997), pp. 39-55.

[9621] M. Heethoff, L. Helfen, and R. A. Norton. "Description of Neoliodes dominicus n. sp. (Acari, Oribatida) from Dominican amber, aided by synchrotron x-ray microtomography". English. In: Journal of Paleontology 83 (2009), pp. 153-159.

[9622] H. Heggemann, R. Kohring, and T. Schlüter. "Fossil plants and arthropods from the Phra Wihan Formation, presumably Middle Jurassic, of northern Thailand". English. In: Alcheringa 14 (1990), pp. 311-316.

[9623] T. A. Hegna, F. J. Vega, and K. A. González-Rodrguez. "First Mesozoic thylacocephalans (Arthropoda, Crustacea; Cretaceous) in the western hemisphere: new discoveries from the Muhi Quarry Lagerstätte". English. In: Journal of Paleontology 88.3 (2014), pp. 606-616.

[9624] D. Heidelberger. “Gastropoden aus dem Mittel-Eifelium der Sötenicher Mulde (Eifel)". German. In: Geologica et Palaeontologica 37 (2003), pp. 1-8.

[9625] D. Heidelberger. “Neue Erkenntnisse zu mikromorphen Gastropoden aus Sötenich (Givetium, Mittle-Devon)". English. In: Palaeontologische Zeitschrift 81.3 (2007), pp. 229-237.

[9626] D. Heidelberger and M. R. W. Amler. "Devonian Gastropods from the Dornap Massenkalk complex (Bergisches Land, Germany)". In: Paläontologische Zeitschrift 76.2 (2002), pp. 317-329.

[9627] D. Heidelberger and L. Koch. "Gastropoda from the Givetian Massenkalk of Schwelm and Hohenlimburg (Saureland, Rheinsiches Schiefergebirge, Germany)". English. In: Geologica et Palaeontologica Sonderband 4 (2005), pp. 1-107. 
[9628] D. Heidelberger, D. Korn, and V. Ebbighausen. "Late Visean (Carboniferous) gastropods from the Gara El Itima (eastern Anti-Atlas, Morocco)". English. In: Fossil Record 12.2 (2009), pp. 183-196.

[9629] O. E. Heie. "Fossil aphids (Hemiptera: Sternorrhyncha) from Canadian Cretaceous amber and from the Miocene of Nevada". English. In: Insect Systematics \& Evolution 37 (2006), pp. 91-104.

[9630] O. E. Heie. "Palaeoaphididae and Tajmyraphididae in Cretaceous amber from Alberta, Canada (Hemiptera: Aphidinea)". English. In: Annals of the Upper Silesian Museum, Entomology 6-7 (1996), pp. 97-103.

[9631] O. E. Heie and D. Azar. "Two new species of aphids found in Lebanese amber and a revision of the family Tajmyraphididae Kononova, 1975 (Hemiptera: Sternorrhyncha)". English. In: Annals of the Entomological Society of America 93 (2000), pp. 1222-1225.

[9632] O. E. Heie and E. Peñalver. "Palaeophylloxera nov. gen., the first fossil specimen of the family Phylloxeridae (Hemiptera, Phylloxeroidea); lower Miocene of Spain". English. In: Geobios 32 (1999), pp. 593-597.

[9633] O. E. Heie and E. M. Pike. "Reassessment of the taxonomic position of the fossil aphid family Canadaphididae based on two additional specimens of Canadaphis carpenteri (Hemiptera: Aphidinea)". English. In: European Journal of Entomology 93 (1996), pp. 617-622.

[9634] O. E. Heie and E. M. Pike. "New aphids in Cretaceous amber from Alberta (Insecta, Homoptera)". English. In: The Canadian Entomologist 124 (1992), pp. 1027-1053.

[9635] O. E. Heie and G. O. Poinar. "A Fossil Aphid (Hemiptera: Sternorrhyncha) in Dominican Amber". English. In: Proceedings of the Entomological Society of Washington 101.4 (1999), pp. 816-821.

[9636] M. Heikkilä, J. W. Brown, J. Baixeras, W. Mey, and M. V. Kozlov. "Re-examining the rare and the lost: a review of fossil Tortricidae (Lepidoptera)". English. In: Zootaxa 4394 (2018), pp. 41-60.

[9637] M. Heikkilä, T. J. Simonsen, and M. A. Solis. "Reassessment of known fossil Pyraloidea (Lepidoptera) with descriptions of the oldest fossil pyraloid and a crambid larva in Baltic amber". English. In: Zootaxa 4483 (2018), pp. 101-127.

[9638] N. A. Heim. "Stability of regional brachiopod diversity structure across the Mississippian/Pennsylvanian boundary". English. In: Paleobiology 35.3 (2009), p. 393. DOI: 10.1666/0094-8373-35.3.393.

[9639] U. Heimhofer and P.-A. Hochuli. "Early Cretaceous angiosperm pollen from a low latitude succession (Araripe Basin, NE Brazil)". English. In: Review of Palaeobotany and Palynology 161 (2010), pp. 105-126. DOI: 10.1016/j.revpalbo.2010.03.010.

[9640] C. Heinberg. "Lower Danian bivalves, Stevns Klint, Denmark; continuity across the K/T boundary". In: Palaeogeography, Palaeoclimatology, Palaeoecology 154 (1999), pp. 87-106.

[9641] R. E. Heinrich, J. P. Hunter, and D. B. Weishampel. Mammals from the St. Mary River formation (Upper Cretaceous), Montana: New insights on an 'Edmontonian' land mammal age. English. 1998.

[9642] R. E. Heinrich and K. D. Rose. "Partial skeleton of the primitive carnivoran Miacis petilus from the early Eocene of Wyoming". English. In: Journal of Mammalogy 76.1 (1995), pp. 148-162.

[9643] R. E. Heinrich, S. G. Strait, and P. Houde. “Earliest Eocene Miacidae (Mammalia: Carnivora) from Northwestern Wyoming". English. In: Journal of Paleontology 82.1 (2008), pp. 154-162.

[9644] W.-D. Heinrich. “Late Jurassic mammals from Tendaguru, Tanzania”. English. In: Journal of Mammalian Evolution 5.4 (1998), pp. 269-290.

[9645] W.-D. Heinrich. "New records of Staffia aenigmatica (Mammalia, Allotheria, Haramiyida) from the Upper Jurassic of Tendaguru in southeastern Tanzania, East Africa". English. In: Mitteilungen aus dem Museum für Naturkunde in Berlin: Fossil Record 4.1 (2001), pp. 239-255. DOI: 10.1002/mmng. 20010040114.

[9646] W.-D. Heinrich. "First haramiyid (Mammalia, Allotheria) from the Mesozoic of Gondwana". English. In: Mitteilungen aus dem Museum für Naturkunde in Berlin: Fossil Record 2.1 (1999), pp. 159170. DOI: 10.1002/mmng.1999.4860020112. 
[9647] W.-D. Heinrich. “The taphonomy of dinosaurs from the Upper Jurassic of Tendaguru (Tanzania) based on field sketches of the German Tendaguru Expedition (1909-1913)". In: Mitteilungen aus dem Museum für Naturkunde in Berlin, Geowissenschaften Reihe 28 (1999), pp. 25-61.

[9648] H. Heinsalu, D. Kaljo, T. Kurvits, and V. Viira. "The stratotype of the Orasoja Member (Tremadocian, Northeast Estonia): lithology, mineralogy, and biostratigraphy". English. In: Proceedings of the Estonian Academy of Sciences Geology 52.3 (2003), pp. 135-154.

[9649] E. Heiss. "Revision of the family Aradidae in Baltic Amber IV. Two new Aradus from the collection of the Institut für Paläontologie, Museum für Naturkunde, Berlin (Heteroptera, Aradidae)". English. In: Deutsche Entomologische Zeitschrift 49 (2002), pp. 221-225.

[9650] E. Heiss. "First Record of a Mezirinae Flat Bug from Dominican Amber: Mezira scheveni n. sp. (Heteroptera, Aradidae)". English. In: Entomologisches Nachrichtenblatt 7 (2000), pp. 6-10.

[9651] E. Heiss. “Über Holoptiliinae in Bernstein (Heteroptera, Reduviidae)". German. In: Denisia 26 (2009), pp. 83-92.

[9652] E. Heiss. "Revision der Familie Aradidae des Baltischen Bernsteins III. Zwei neue Aneurus-Arten (Insecta, Heteroptera)". German. In: Entomologisches Nachrichtenblatt 8 (2001), pp. 12-18.

[9653] E. Heiss. "Revision der Familie Aradidae des baltischen Bernsteins V. Eine neue Gattung und zwei neue Arten der Unterfamilie Calisiinae (Heteroptera, Aradidae)". German. In: Linzer Biologische Beiträge 34 (2002), pp. 1127-1136.

[9654] E. Heiss. “Revision der Familie Aradidae des baltischen Bernsteins VI. Neue Arten der Gattung Aradus Fabricius 1803 (Heteroptera, Aradidae)". German. In: Linzer Biologische Beiträge 34 (2002), pp. 1137-1150.

[9655] E. Heiss. "Weitschatiella elenae gen. n., sp. n., in Baltischem Bernstein (Heteroptera, Cantacaderidae)". German. In: Mitteilungen aus dem Geologisch-Paläontologischen Institut der Universität Hamburg 86 (2002), pp. 221-228.

[9656] E. Heiss. “Erstnachweis einer Aneurinae aus dem Baltischen Bernstein: Aneurus ancestralis n. sp. (Heteroptera, Aradidae)". German. In: Carolinea 55 (1997), pp. 111-113.

[9657] E. Heiss. "Revision der Familie Aradidae des Baltischen Bernsteins I. Bisher beschriebene Taxa der Gattung Aradus und zwei neue Arten (Insecta, Heteroptera)". German. In: Mitteilungen aus dem Geologisch-Paläontologischen Institut der Universität Hamburg 81 (1998), pp. 251-268.

[9658] E. Heiss. "Revision der Familie Aradidae des Baltischen Bernsteins II. Drei neue Calisius-Arten (Insecta, Heteroptera)". German. In: Carolinea 58 (2000), pp. 195-201.

[9659] E. Heiss. "Amberobyrsa brandti, gen. n., sp. n. from Dominican amber (Hemiptera, Heteroptera, Tingidae)". English. In: Zeitschrift der Arbeitsgemeinschaft Österreichischer Entomologen 61 (2009), pp. 9-14.

[9660] E. Heiss. "Erstnachweis von Rindenwanzen (Aradidae) in Bitterfelder Bernstein (Insecta, Heteroptera)". German. In: Linzer Biologische Beiträge 45 (2013), pp. 741-753.

[9661] E. Heiss. "Revision of the flat bug family Aradidae from Baltic Amber IX. Aradus macrosomus sp. n. (Hemiptera: Heteroptera)". English. In: Deutsche Entomologische Zeitschrift 61 (2014), pp. 27-29.

[9662] E. Heiss. "Paleocader gusenleitnerorum nov.sp., eine neue Cantacaderinae aus Baltischem Bernstein (Hemiptera, Heteroptera, Tingidae)". German. In: Linzer Biologische Beiträge 45 (2013), pp. 689 695.

[9663] E. Heiss. "Revision der Aradidae des Baltischen Bernsteins VII. Eine neue Aneurus-Art (Heteroptera: Aradidae)". German. In: Entomologische Zeitschrift 122 (2012), pp. 109-110.

[9664] E. Heiss. "Calisiopsis azteca n. sp., the first Aradidae from mid Miocene Mexican amber (Hemiptera: Heteroptera)". English. In: Boletn de la Sociedad Geológica Mexicana 68 (2016), pp. 7-10.

[9665] E. Heiss. "New genera and species of Aradidae in Cretaceous Burmese amber (Hemiptera: Heteroptera)". English. In: Linzer Biologische Beiträge 48 (2016), pp. 419-429. 
[9666] E. Heiss. “Revision der Familie Aradidae (Hemiptera: Heteroptera) des Baltischen Bernsteins: XIII Quilnus rectinotus nov. sp., erster Fossilfund dieser Gattung". German. In: Linzer Biologische Beiträge 48 (2016), pp. 413-418.

[9667] E. Heiss. "Revision der Familie Aradidae des Baltischen Bernsteins X. Zwei neue Aradus-Arten (Hemiptera: Heteroptera)". German. In: Linzer Biologische Beiträge 46 (2014), pp. 623-628.

[9668] E. Heiss. "Revision der Familie Aradidae (Hemiptera: Heteroptera) des Baltischen Bernsteins: XI. Aradus penteneuros sp. n. mit ungewöhnlicher Flügeladerung". German. In: Zeitschrift der Arbeitsgemeinschaft Österreichischer Entomologen 66 (2014), pp. 25-29.

[9669] E. Heiss. "Kachinocoris brevipennis n.gen., n.sp. in Cretaceous Burmese amber (Hemiptera: Heteroptera: Aradidae)". English. In: Zootaxa 3227 (2012), pp. 64-68.

[9670] E. Heiss. "New genus and species of Calisiinae from Cretaceous Burmese amber (Hemiptera, Heteroptera, Aradidae)". English. In: Linzer Biologische Beiträge 51 (2019), pp. 83-87.

[9671] E. Heiss and V. Golub. "Reconsideration of Baltic Amber Sinalda with description of a new genus and species (Hemiptera, Heteroptera, Tingidae)". English. In: Linzer Biologische Beiträge 45 (2013), pp. 1865-1871.

[9672] E. Heiss and V. B. Golub. "Thaumastotingis areolatus nov.gen., nov.sp. a conspicuous new Thaumastocoridae from Baltic Amber (Hemiptera: Heteroptera)". English. In: Linzer Biologische Beiträge 47 (2015), pp. 529-537.

[9673] E. Heiss, V. B. Golub, and Y. A. Popov. “A new subfamily, genus and species of Tingidae (Hemiptera: Heteroptera) from Burmese amber". English. In: Zeitschrift der Arbeitsgemeinschaft Österreichischer Entomologen 67 (2015), pp. 1-9.

[9674] E. Heiss and D. Grimaldi. "The first known female of Archearadus burmensis Heiss \& Grimaldi, 2001, in Cretaceous Burmese amber (Heteroptera: Aradidae)". English. In: Zeitschrift der Arbeitsgemeinschaft Österreichischer Entomologen 54 (2002), pp. 55-59.

[9675] E. Heiss and E. Guilbert. “Two new genera and species of Tingidae from Cretaceous amber from Myanmar (Burma) (Hemiptera: Heteroptera)". English. In: Zootaxa 3736 (2013), pp. 379-386.

[9676] E. Heiss and E. Guilbert. "A new species of Tingidae from Cretaceous amber from Myanmar (Hemiptera, Heteroptera)". English. In: Zootaxa 4457 (2018), pp. 339-345.

[9677] E. Heiss and G. O. Poinar. "The first Carventinae species in Miocene Dominican Amber (Hemiptera: Heteroptera: Aradidae)". English. In: Zootaxa 3268 (2012), pp. 47-54.

[9678] E. Heiss and G. O. Poinar. "New Aradidae in Mesozoic Burmese amber (Hemiptera, Heteroptera)". English. In: Annalen des Naturhistorischen Museums in Wien, Serie A 114 (2012), pp. 307-316.

[9679] E. Heiss and Y. A. Popov. "Reconsideration of the systematic position of Thaicorinae with notes on fossil and extant Thaumastocoridae (Hemiptera: Heteroptera)". English. In: Polskie Pismo Entomologiczne 71 (2002), pp. 247-259.

[9680] K. Heissig. "8. Rhinocerotidae (Perissodactyla, Mammalia)". German. In: Annalen des Naturhistorischen Museums in Wien 108A (2007), pp. 233-269.

[9681] E. Hekkala, M. H. Shirley, G. Amato, J. D. Austin, S. Charter, J. Thorbjarnarson, K. A. Vliet, M. L. Houck, R. DeSalle, and M. J. Blum. "An ancient icon reveals new mysteries: mummy DNA resurrects a cryptic species within the Nile crocodile". English. In: Molecular Ecology 20.20 (2011), pp. 4199-4215. DOI: 10.1111/j.1365-294X.2011.05245.x.

[9682] J. Helenes and M. A. Tellez-Duarte. "Paleontological evidence of the Campanian to Early Paleocene paleogeography of Baja California". In: Palaeogeography, Palaeoclimatology, Palaeoecology 186 (2002), pp. 61-80.

[9683] H. Hellrung. "Gerrothorax pustuloglomeratus, ein Temnospondyle (Amphibia) mit knöcherner Branchialkammer aus dem Unteren Keuper von Kupferzell (Süddeutschland)". German. In: Stuttgarter Beiträge zur Naturkunde Serie B (Geologie und Paläontologie) 330 (2003), pp. 1-130. 
[9684] C. Helm, M. Reuter, and I. Schülke. “Die Korallenfauna des Korallenooliths (Oxfordium, Oberjura, NW-Deutschland): Zusammensetzung, Stratigraphie und regionale Verbreitung". German. In: Paläontologische Zeitschrift 77.1 (2003), pp. 77-94.

[9685] C. Helm, M. Reuter, and I. Schülke. "Comatulid crinoid from Late Jurassic reefal deposits of NW Germany (Lower Saxony Basin)". In: Neues Jahrbuch für Geologie und Paläontologie Monatshefte 2003.9 (2003), pp. 513-528.

[9686] C. Helm, I. Schülke, and F. Schlagintweit. “Calcareous algae (Porostromata, Rhodophyta, Dasycladales) and microproblematica with algal affinity from the NW German Korallenoolith Formation (Oxfordian, Süntel Mountains)". In: Facies 49 (2003), pp. 61-86.

[9687] C. Helm and I. Schülke. "Patch reef development in the florigemma-bank member (Oxfordian) from the Deister Mts (NW Germany): a type example for Late Jurassic coral thrombolite thickets". English. In: Facies 52 (2006), pp. 441-467.

[9688] H. Hemmer, R.-D. Kahlke, and A. K. Vekua. “The jaguar - Panthera onca gombaszoegensis (Kretzoi, 1938) (Carnivora: Felidae) in the late Lower Pleistocene Akhalkalaki (South Georgia: Transcaucasia) and its evolutionary and ecological significance." English. In: Géobios 34.4 (2001), pp. 475486.

[9689] H. Hemmer, R.-D. Kahlke, and A. K. Vekua. “The cheetah Acinonyx pardinensis (Croizet et Jobert, 1828) at the hominin site of Dmanisi (Georgia)-A potential prime meat supplier in Early Pleistocene ecosystems". English. In: Quaternary Science Review 30 (2011), pp. 2703-2714. DOI: 10.1016/ j.quascirev.2011.05.024.

[9690] D. Hempfling. Palökologie von Benthos-Gemeinschaften im oberen Pliensbach (Amaltheenton) von Kalchreuth (Mittelfranken). German. 2002.

[9691] H. Henderickx. "A new Geogarypus from Baltic amber Pseudoscorpiones: Geogarypidae". English. In: Phegea 33 (2005), pp. 87-92.

[9692] H. Henderickx, J. Bosselaers, E. Pauwels, L. Van Hoorebeke, and M. Boone. "X-ray micro-CT reconstruction reveals eight antennomeres in a new fossil taxon that constitutes a sister clade to Dundoxenos and Triozocera (Strepsiptera: Corioxenidae)". English. In: Palaeontologia Electronica 16.3.29A (2013), pp. 1-16.

[9693] H. Henderickx, V. Cnudde, B. Masschaele, M. Dierick, J. Vlassenbroeck, and L. van Hoorebeke. "Description of a new fossil Pseudogarypus (Pseudoscorpiones: Pseudogarypidae) with the use of X-ray micro-CT to penetrate opaque amber". English. In: Zootaxa 1305 (2006), pp. 41-50.

[9694] H. Henderickx and E. E. Perkovsky. "The first geogarypid (Pseudoscorpiones, Geogarypidae) in Rovno amber". English. In: Vestnik Zoologii 46 (2012), e33-e36.

[9695] H. Henderickx, P. Tafforeau, and C. Soriano. "Phase-contrast synchrotron microtomography reveals the morphology of a partially visible new Pseudogarypus in Baltic amber (Pseudoscorpiones: Pseudogarypidae)". English. In: Palaeontologia Electronica 15.2.17A (2012), pp. 1-11.

[9696] A. S. Henderson, A. D. Talwar, and M. B. Hart. "Some Holothurian sclerites from the Corallian Group of north Dorset". English. In: Proceedings of the Ussher Society 8 (1992), pp. 11-14.

[9697] M. D. Henderson and J. E. Peterson. "An azhdarchid pterosaur cervical vertebra from the Hell Creek Formation (Maastrichtian) of southeastern Montana". English. In: Journal of Vertebrate Paleontology 26.1 (2006), pp. 192-195.

[9698] N. Henderson and B. J. Gill. "A mid-Pliocene shearwater skull (Aves: Procellariidae: Puffinus) from the Taihape Mudstone, central North Island, New Zealand". English. In: New Zealand Journal of Geology and Geophysics 53.4 (2010), pp. 327-332.

[9699] R. A. Henderson. "A mid-Cretaceous association of shell beds and organic-rich shale: bivalve exploitation of a nutrient-rich, anoxic seafloor environment". English. In: Palaios 19 (2004), pp. 156169.

[9700] R. A. Henderson. "Late Albian ammonites from the Northern Territory, Australia". English. In: Alcheringa 14 (1990), pp. 109-148. 
[9701] R. A. Henderson and W. J. Kennedy. "Occurence of the ammonite Goodhallites goodhalites (J. Sowerby) in the Eromanga Basin, Queensland: an index species for the late Albian (Cretaceous)". English. In: Alcheringa 26 (2002), pp. 233-247.

[9702] R. A. Henderson, W. J. Kennedy, and K. J. McNamara. "Maastrichtian heteromorph ammonites from the Carnarvon Basin, Western Australia". English. In: Alcheringa 16 (1992), pp. 133-170.

[9703] R. A. Henderson and E. D. McKenzie. "Idanoceras, a new heteromorph ammonite genus from the Late Albian of Eastern Australia". English. In: Journal of Paleontology 76 (2002), pp. 906-909.

[9704] J. R. Hendricks. “The genus Conus (Mollusca: Neogastropoda) in the Plio-Pleistocene of the Southeastern United States". English. In: Bulletins of American Paleontology 375 (2008), pp. 1-178.

[9705] J. R. Hendricks. “Glowing Seashells: Diversity of Fossilized Coloration Patterns on Coral ReefAssociated Cone Snail (Gastropoda: Conidae) Shells from the Neogene of the Dominican Republic". English. In: Plosone (2015). DOI: 10.1371/journal.pone.0120924.

[9706] J. R. Hendricks and R. W. Portell. "Late Eocene Conus (Neogastropoda: Conidae) from Florida, USA". English. In: The Nautilus 122.2 (2008), pp. 79-93.

[9707] C. Hendrickx, L. C. Gaetano, J. N. Choiniere, H. Mocke, and F. Abdala. "A new traversodontid cynodont with a peculiar postcanine dentition from the Middle/Late Triassic of Namibia and dental evolution in basal gomphodonts". English. In: Journal of Systematic Palaeontology 18.29 (2020), pp. 1669-1706. DOI: 10.1080/14772019.2020.1804470.

[9708] C. Hendrickx and O. Mateus. "Abelisauridae (Dinosauria: Theropoda) from the Late Jurassic of Portugal and dentition-based phylogeny as a contribution for the indentification of isolated theropod teeth". English. In: Zootaxa 3759.1 (2014), pp. 1-74.

[9709] C. Hendrickx and O. Mateus. "Torvosaurus gurneyi n. sp., the largest terrestrial predator from Europe, and a proposed terminology of the maxilla anatomy in nonavian theropods". English. In: PLoS ONE 9.3 (2014), e88905:1-25. DOI: 10.1371/journal.pone.0088905.

[9710] A. J. W. Hendy. "Spatial and stratigraphic variation in marine paleoenvironments in the Late Miocene Gatun Formation, Isthmus of Panama". English. In: Palaios (2013).

[9711] A. J. W. Hendy, D. S. Jones, F. Moreno, V. Zapata, and C. Jaramillo. “Neogene molluscs, shallow marine paleoenvironments, and chronostratigraphy of the Guajira Peninsula, Colombia". English. In: Swiss Journal of Palaeontology 134.1 (2015), pp. 45-75.

[9712] D. K. Hennhoefer, S. Goetz, and S. F. Mitchell. "Palaeobiology of a Biradiolites mooretownensis rudist lithosome: seasonality, reproductive cyclicity and population dynamics". English. In: Lethaia 45 (2012), pp. 450-461. DOI: 10.1111/j.1502-3931.2012.00307.

[9713] D. K. Hennhoefer, E. Pascual-Cebrian, T. Korbar, W. Stinnesbeck, and S. Goetz. "Radiolitid rudist colonisation strategies and biostrome development in moderate-energy inner-platform environments (Campanian, Brac Island, Croatia)". English. In: Palaeogeography, Palaeoclimatology, Palaeoecology 403 (2014), pp. 80-87.

[9714] A. C. Henrici. "A new pipoid anuran from the Late Jurassic Morrison Formation at Dinosaur National Monument, Utah". English. In: Journal of Vertebrate Paleontology 18.2 (1998), pp. 321-332.

[9715] A. C. Henrici. "Reassessment of Scaphiopus neuter Kluge, 1966 (Anura: Pelobatoidea: Pelobatidae), based on new material from Anceney, Montana (early Barstovian)". English. In: Annals of Carnegie Museum 78.3 (2009), pp. 273-287.

[9716] A. C. Henrici and A. M. Báez. "First occurrence of Xenopus (Anura: Pipidae) on the Arabian Peninsula: a new species from the Upper Oligocene of Yemen". English. In: Journal of Paleontology 75.4 (2001), pp. 870-882.

[9717] A. C. Henrici, A. M. Báez, and L. Grande. "Aerugoamnis paulus, New Genus and New Species (Anura: Anomocoela): First Reported Anuran from the Early Eocene (Wasatchian) Fossil Butte Member of the Green River Formation, Wyoming". English. In: Annals of Carnegie Museum 81.4 (2013), pp. 295-309. DOI: 10.2992/007.081.0402. 
[9718] A. C. Henrici and A. R. Fiorillo. "Catastrophic death assemblage of Chelomorphrynus bayi (Anura, Rhinophrynidae) from the Middle Eocene Wagon Bed Formation of central Wyoming". English. In: Journal of Paleontology 67.6 (1993), pp. 1016-1026.

[9719] A. C. Henrici and S. R. Haynes. "Elkobatrachus brocki, a new pelobatid (Amphibia: Anura) from the Eocene Elko Formation of Nevada". English. In: Annals of Carnegie Museum 75.1 (2006), pp. 1135.

[9720] A. C. Henrici, T. Martens, D. S. Berman, and S. S. Sumida. “An Ostodolepid 'Microsaur' (Lepospondyli) from the Lower Permian Tambach Formation of Central Germany". English. In: Journal of Vertebrate Paleontology 31.5 (2011), pp. 997-1004. DOI: 10.1080/02724634.2011.596601.

[9721] A. C. Henrici. "Tephrodytes brassicarvalis, new genus and species (Anura: Pelodytidae), from the Arikareean Cabbage Patch beds of Montana, USA, and pelodytid-pelobatid relationships". English. In: Annals of Carnegie Museum 63.2 (1994), pp. 155-183.

[9722] M. Henrotay, A. Nel, and E. A. Jarzembowski. "New Protomyrmeleontid Damselflies from the Triassic of Australia and the Liassic of Luxembourg, with the description of Tillyardomyrmeleon petermilleri gen. nov. \& spec. nov. (Archizygoptera: Protomyrmeleontidae)". English. In: Odonatologica 26.4 (1997), pp. 395-404.

[9723] J. L. Henry, M. Vidal, and L. LaCombe. “Apparition soudaine de Protolloydolithus (Trilobita, Trinucleidae) dans l'Ordovicien (Llandeilo) du Massif Armoricain; un essai d'interpretation". French. In: Géobios 26.2 (1992), pp. 201-206.

[9724] T. W. Henry. "The Brachiopod Antiquatonia coloradoensis (Girty) from the Upper Morrowan and Atokan (Lower Middle Pennsylvanian) of the United States". In: United States Geological Survey Professional Paper 1588 (1998), pp. 1-51.

[9725] C. S. Henshilwood, J. C. Sealy, R. Yates, K. Cruz-Uribe, P. Goldberg, F. E. Grine, R. G. Klein, C. Poggenpoel, K. van Niekerk, and I. Watts. "Blombos Cave, Southern Cape, South Africa: Preliminary Report on the 1992-1999 Excavations of the Middle Stone Age Levels". English. In: Journal of Archaeological Science 28 (2001), pp. 421-448.

[9726] J. M. Heraty and D. C. Darling. "Fossil Eucharitidae and Perilampidae (Hymenoptera: Chalcidoidea) from Baltic Amber". English. In: Zootaxa 2306 (2009), pp. 1-16.

[9727] G. S. Herbert. "Systematic revision of the Genus Eupleura H. and A. Adams, 1853 (Gastropoda: Muricidae) in the Neogene to Recent of Tropical America". English. In: The Veliger 47.4 (2005), pp. 294-331.

[9728] H. G. Herbig and H. J. Grego. "The mangrove-forming palm Nypa from the early Paleogene of southern Morocco. Paleoenvironment and paleoclimate". English. In: Géologie Méditerranéenne 17.2 (1990), pp. 123-137. DOI: 10.3406/geolm.1990.1437.

[9729] A. Herczek. "First Phylinae (Heteroptera: Miridae) from Baltic amber". English. In: Polskie Pismo Entomologiczne 69 (2000), pp. 143-153.

[9730] A. Herczek. "First record of the plant bug subfamily Psallopinae (Hemiptera: Heteroptera, Miridae) from Dominican amber, with a description of a new species of the genus Psallops USINGER, 1946". English. In: Polish Journal of Entomology 80 (2011), pp. 689-697.

[9731] A. Herczek. "Amberofulvius dentatus, a new genus and species of the subfamily Cylapinae (Heterpotera, Miridae) in Baltic amber". English. In: Annalen des Naturhistorischen Museums in Wien, Serie A 92 (1991), pp. 79-84.

[9732] A. Herczek. "Mixocapsus eocenicus gen. n., sp. n. (Miridae, Heteroptera) from Baltic amber". English. In: Annalen des Naturhistorischen Museums in Wien, Serie A 92 (1991), pp. 85-88.

[9733] A. Herczek and J. Gorczyca. "A represenative of the genus Deraeocoris in Baltic amber (Heteroptera, Miridae)". English. In: Annalen des Naturhistorischen Museums in Wien, Serie A 92 (1991), pp. 89-92.

[9734] A. Herczek and Y. A. Popov. "Ambocylapus kulickae gen. et sp. n., a new plant bug from Baltic amber (Heteroptera: Miridae: Cylapinae)". English. In: Polskie Pismo Entomologiczne 69 (2000), pp. 155-160. 
[9735] A. Herczek, Y. A. Popov, and E. Peñalver. "The first record of cylapinous plant bugs from the Lower Miocene of Spain: Aragocylapus miocaenicus n. gen., n. sp. (Heteroptera: Miridae: Cylapinae)". English. In: Acta Geologica Hispanica 35.1-2 (2000), pp. 183-188.

[9736] A. Herczek and Y. A. Popov. "New plant bugs (Insecta, Hemiptera, Heteroptera, Miridae) from the Eocene Baltic amber". English. In: Denisia 26 (2009), pp. 93-98.

[9737] A. Herczek and Y. A. Popov. "New cylapine bugs (Heteroptera: Miridae: Cylapinae) from Baltic amber". English. In: Polskie Pismo Entomologiczne 74 (2005), pp. 299-307.

[9738] A. Herczek, Y. A. Popov, and E. E. Perkovsky. "Another new representative of the isometopine genus Archemyiomma (Hemiptera: Heteroptera: Miridae) from late Eocene Rovno (Ukraine) amber". English. In: Insect Evolution in an Ambiferous and Stone Alphabet. Leiden: Brill, 2013, pp. $47-54$.

[9739] A. Herczek and Y. A. Popov. "Epigonomiris skalskii, a new mirine plant bug from Baltic amber (Heteroptera: Miridae: Cylapinae)". English. In: Polskie Pismo Entomologiczne 67 (1998), pp. 175178.

[9740] A. Herczek, Y. A. Popov, and J. Brozek. "New plant bugs of the tribe Hallodapini (Heteroptera: Miridae: Phylinae) from the Eocene Baltic amber". English. In: Annales Zoologici 50 (2010), pp. 583588.

[9741] A. Herczek, Y. A. Popov, and I. Kania. "A new find of a peculiar cylapine bug (Hemiptera: Heteroptera: Miridae) from the Eocene Baltic amber". English. In: Annals of the Upper Silesian Museum, Entomology 13 (2005), pp. 81-86.

[9742] A. Herczek and Y. A. Popov. "Revision of the genus Metoisops (Hemiptera: Heteroptera, Miridae, Isometopinae) from late Eocene European amber". English. In: Zootaxa 3887 (2014), pp. 401-421.

[9743] A. Herczek and Y. A. Popov. "An unusual new species of Hallodapomimus Herczek, 2000 from the Eocene Baltic amber (Hemiptera, Heteroptera, Miridae, Phylinae)". English. In: ZooKeys 489 (2015), pp. 25-32.

[9744] A. Herczek and Y. A. Popov. "A new peculiar isometopine genus (Hemiptera: Heteroptera: Miridae) from the Eocene Baltic amber". English. In: Zootaxa 3196 (2012), pp. 64-68.

[9745] A. Herczek, Y. A. Popov, and J. Gorczyca. "First new fossil plant bugs of the genus Psallops Usinger, 1946 (Hemiptera: Heteroptera, Miridae, Psallopinae) from the Eocene Baltic amber". English. In: Zootaxa 4052 (2015), pp. 495-500.

[9746] A. Herczek, Y. A. Popov, and J. Drohojowska. “Isomyiomma hirta gen. et sp. n., a new peculiar plant bug (Hemiptera: Heteroptera: Miridae: Isometopinae) from late Eocene Baltic amber". English. In: Acta Zoologica Cracoviensia 63 (2020), pp. 15-19. DOI: 10.3409/azc.63.03.

[9747] P. S. Herendeen, P. R. Crane, and A. N. Drinnan. "Fagaceous flowers, fruits, and cupules from the Campanian (Late Cretaceous) of central Georgia, USA". English. In: International Journal of Plant Sciences 156.1 (1995), pp. 93-116.

[9748] P. S. Herendeen, W. L. Crepet, and K. C. Nixon. "Fossil flowers and pollen of Lauraceae from the Upper Cretaceous of New Jersey". In: Plant Systematics and Evolution 189 (1994), pp. 29-40.

[9749] P. S. Herendeen, W. L. Crepet, and K. C. Nixon. “Chloranthus-like stamens from the Upper Cretaceous of New Jersey". In: American Journal of Botany 80.8 (1993), pp. 865-871.

[9750] P. S. Herendeen and D. L. Dilcher. "Reproductive and vegetative evidence for the occurrence of Crudia (Leguminosae, Caesalpinioideae) in the Eocene of southeastern North America." In: Botanical Gazette 151 (1990), pp. 402-413.

[9751] P. S. Herendeen and B. F. Jacobs. "Fossil Legumes from the Middle Eocene (46.0 Ma) Mahenge Flora of Singida, Tanzania". In: American Journal of Botany 87.9 (2000), pp. 1358-1366.

[9752] P. S. Herendeen, S. Magallon-Puebla, R. Lupia, P. R. Crane, and J. Kobylinska. "A prelimimary conspectus of the Allon flora from the Late Cretaceous (Late Santonian) of central Georgia, U.S.A." In: Annals of the Missouri Botanical Garden 89.2 (1999), pp. 407-471. 
[9753] P. S. Herendeen and D. L. Dilcher. “Diplotropis (Leguminosae, Papilionoideae) from the Middle Eocene of Southeastern North America". In: Systematic Botany 15.4 (1990), pp. 526-533.

[9754] G. Hermanson, G. S. Ferreira, and M. C. Langer. "The largest Cretaceous podocnemidoid turtle (Pleurodira) revealed by an isolated plate from the Bauru Basin, south-central Brazil". English. In: Historical Biology 29.6 (2017), pp. 833-840. DOI: 10.1080/08912963.2016.1248434.

[9755] G. Hermanson, F. V. Iori, S. W. Evers, M. C. Langer, and G. S. Ferreira. “A small podocnemidoid (Pleurodira, Pelomedusoides) from the Late Cretaceous of Brazil, and the innervation and carotid circulation of sidenecked turtles". English. In: Papers in Palaeontology (2020), pp. 1-19. DOI: 10. 1002/spp2.1300.

[9756] E. Hermsen, N. Jud, F. D. De Benedetti, and M. A. Gandolfo. "Azolla Sporophytes and Spores from the Late Cretaceous and Paleocene of Patagonia, Argentina". English. In: International Journal of Plant Sciences 180.7 (2019).

[9757] E. J. Hermsen, M. A. Gandolfo, and M. C. Zamaloa. “The fossil record of Eucalyptus in Patagonia". English. In: American Journal of Botany 99 (2012), pp. 1356-1374. DOI: 10.3732/ajb.1200025.

[9758] E. J. Hermsen and M. A. Gandolfo. "Fruits of Juglandaceae from the Eocene of South America". English. In: Systematic Botany 41.2 (2016), pp. 316-328. DOI: 10.1600/036364416X691830.

[9759] E. J. Hermsen, M. A. Gandolfo, and N. R. Cúneo. “New marsileaceous fossils from the Late Cretaceous of South America and a reevaluation of Marsileaceaephyllum". English. In: Plant Systematics and Evolution 300.2 (2014), pp. 369-386. DOI: 10.1007/s00606-013-0886-7.

[9760] E. C. Hernández, J. L. Sanz, F. Ortega, and F. Escaso. “Restos de dinosaurios del Crátacico Superior de Armuña (Segovia) [Remains of dinosaurs from the Upper Cretaceous of Armuña (Segovia)]". Spanish. In: Cantera Paleontológica. Diputación Provincial de Cuenca, Cuenca (2007), pp. 133-142.

[9761] A. E. Hernández Cisneros, G. González Barba, and R. E. Fordyce. “Oligocene cetaceans from Baja California Sur, Mexico". English. In: Boletn de la Sociedad Geológica Mexicana 69.1 (2017), pp. 149173.

[9762] S. Hernández Del Pino, M. G. Fernández, E. Cerdeño, and J. C. Fernicola. “Anatomy and systematics of Notohippus toxodontoides Ameghino, 1891 (Mammalia, Notoungulata), from the Miocene of Santa Cruz Province, Argentina". English. In: Journal of Vertebrate Paleontology e1577870 (2019). DOI: 10.1080/02724634.2019.1577870.

[9763] S. Hernández Del Pino, F. D. Seoane, and E. Cerdeño. "New postcranial remains of large toxodontian notoungulates from the late Oligocene of Mendoza, Argentina and their systematic implications". English. In: Acta Palaeontologica Polonica 62.1 (2017), pp. 195-210.

[9764] R. E. Hernández Jasso and A. Blanco Piñon. "Late Pleistocene toxodont remains of Tamaulipas, Mexico. Confirmation of the occurrence of Mixotoxodon larensis (Van Frank, 1957) and an analysis of sexual dimorphism". English. In: Journal of South American Earth Sciences (2020), p. 102849. DOI: 10.1016/j.jsames.2020.102849.

[9765] G. R. Hernandez-Castillo, R. A. Stockey, and G. W. Rothwell. "Anemia quatsinoensis sp. nov. (Schizaeaceae), a permineralized fern from the Lower Cretaceous of Vancouver Island". English. In: International Journal of Plant Sciences 167.3 (2006), pp. 665-674.

[9766] O. Hernández-Monzón, F. J. Vega, and M. A. Coutiño. “A review of Lophoranina cristaspina from the Middle Eocene of Chiapas, Mexico and evolutionary implications". English. In: Memorie della Societá Italiana di Scienze Naturali e del Museo Cvico di Storia Naturale di Milano 35.2 (2007), pp. 56-58.

[9767] C. Hernando, K. Szawaryn, and I. Ribera. "A new species of Platypelochares from Baltic amber (Coleoptera: Limnichidae)". English. In: Acta Entomologica Musei Nationalis Pragae 58 (2018), pp. 17-20.

[9768] M. C. Herne, J. P. Nair, and S. W. Salisbury. "Comment on A southern tyrant reptile”. English. In: Science 329 (2010), pp. 1013-c. DOI: 10.1126/science.1190100. 
[9769] M. C. Herne, A. M. Tait, V. Weisbecker, M. Hall, J. P. Nair, M. Cleeland, and S. W. Salisbury. “A new small-bodied ornithopod (Dinosauria, Ornithischia) from a deep, high-energy Early Cretaceous river of the Australian-Antarctic rift system". English. In: PeerJ 5 (2018), e4113:1-77. DOI: 10.7717/ peerj.4113.

[9770] E. Herraez, I. Garcia Paredes, P. Pelaez-Campomanes, and J. Morales. "Los Nogales, nueva fauna de vertebrados del Mioceno medio de Madrid". Spanish. In: Estudios Geologicos 62.1 (2006), pp. 257262.

[9771] P. Herranz Araújo, J. C. Gutiérrez-Marco, A. P. Pieren Pidal, M. Robardet, M. A. San José Lancha, I. Rábano, and G. N. Sarmiento. The Ordovician succession from the western Iberian Ranges (NE Spain): a review with new data. English. Vol. 17. Ordovician from the Andes. San Miguel de Tucumán: INSUGEO, Serie Correlación Geológica, 2003, pp. 417-424.

[9772] C. M. Herrera and G. I. Esteban. "El registro más antiguo de Chasicotatus ameghinoi Scillato-Yané, 1977 (Xenarthra, Dasypodidae) en el Tortoniano medio de la Quebrada de Amaicha (Tucumán, Argentina): consideraciones biostratigráficas". English. In: Revista Brasileira de Paleontologica 20.1 (2017), pp. 115-120.

[9773] C. M. Herrera, J. E. Powell, and C. del Papa. “Un Nuevo Dasypodidae (Mammalia, Xenarthra) de la Formación Casa Grande (Eoceno) de la Provincia de Jujuy, Argentina". Spanish. In: Ameghiniana 49.2 (2012), pp. 267-271.

[9774] C. M. R. Herrera, G. I. Esteban, M. R. Ciancio, and C. Del Papa. "New specimen of Pucatherium parvum (Xenarthra, Dasypodidae), a singular dasypodid of the Paleogene (Eocene) of northwest Argentina:importance in the early evolution of armadillos". English. In: Journal of Vertebrate Paleontology (2019), e1670669:1-11.

[9775] C. M. R. Herrera, J. E. Powell, G. I. Esteban, and C. del Papa. “A New Eocene Dasypodid with Caniniforms (Mammalia, Xenarthra, Cingulata) from Northwest Argentina". English. In: Journal of Mammalian Evolution 24 (2017), pp. 275-288. DOI: 10.1007/s10914-016-9345-x.

[9776] F. Herrera, S. R. Manchester, S. B. Hoot, K. M. Wefferling, M. R. Carvalho, and C. Jaramillo. "Phytogeographic implications of fossil endocarps of Menispermaceae from the Paleocene of Colombia". English. In: American Journal of Botany 98.12 (2011), pp. 2004-2017. DOI: 10.3732/ajb.1000461.

[9777] Y. Herrera, M. S. Fernandez, and Z. Gasparini. "Postcranial skeleton of Cricosaurus araucanensis (Crocodyliformes: Thalattosuchia): morphology and palaeobiological insights". English. In: Alcheringa 37 (2013), pp. 1-14.

[9778] Y. Herrera, Z. Gasparini, and M. S. Fernández. “A new Patagonian species of Cricosaurus (Crocodyliformes, Thalattosuchia): first evidence of Cricosaurus in Middle-Upper Tithonian lithographic limestone from Gondwana". English. In: Palaeontology 56.3 (2013), pp. 663-678.

[9779] Y. Herrera and V. V. Vennari. "Cranial anatomy and neuroanatomical features of a new specimen of Geosaurini (Crocodylomorpha: Metriorhynchidae) from west-Central Argentina". English. In: Historical Biology (2014).

[9780] J. A. Herrera-Flores. "Restos fosiles de tortugas en San Buenaventura Nealtican, Puebla". Spanish. In: Acta Zoológica Mexicana 25.3 (2009), pp. 455-464.

[9781] J. Herrero Gascón and F. Pérez-Lorente. “El Rompido (Aguilar del Alfambra). Icnitas de dinosaurios en la Formación Villar del Arzobispo. Teruel [El Rompido (Aguilar del Alfambra). Dinosaur footprints from the Villar del Arzobispo Formation. Teruel]". Spanish. In: Geogaceta 51 (2012), pp. 3942.

[9782] J. Herrero-Gascón and F. Pérez-Lorente. “Nuevas aportaciones icnológicas de Galve (Teruel, España). Grandes huellas ornitópodas en el yacimiento de Santa Bárbara [New ichnological contributions from Galve (Teruel, Spain). Large ornithopod footprints at the Santa Bárbara locality]". Spanish. In: Geogaceta 53 (2013), pp. 21-24.

[9783] E. Herrig, P. Frenzel, and M. Reich. "Zur Mikrofauna einer Ober-Campan-Scholle von der Halbinsel Wittow (NW Rügen/Ostsee)". German. In: Paläontologie, Stratigraphie, Fazies 5 (1997), pp. 129 169. 
[9784] L. G. Herringshaw and R. J. Raine. “The earliest turrilepadid: a machaeridian from the Lower Ordovician of the Northwest Highlands". English. In: Scottish Journal of Geology 43 (2007), pp. 97100.

[9785] L. G. Herringshaw, A. T. Thomas, and M. P. Smith. "Starfish diversity in the Wenlock of England." English. In: Palaeontology 50.5 (2007), pp. 1211-1229. DOI: 10.1111/j.1475-4983.2007.00699.x.

[9786] R. Herrmann and B. Hubmann. "Devonian udoteacean green algae from the Cantabrian Mountains (Santa Lucia Formation), NW Spain". English. In: Revista espanola de paleontologia 9.2 (1994), pp. 195-202.

[9787] S. Hervet. "A new genus of 'Ptychogasteridae' (Chelonii, Testudinoidea) from the Geiseltal (Lutetian of Germany)". English. In: Comptes Rendu Palevol 3 (2004), pp. 125-132.

[9788] S. Hervet. “Deux nouvelles tortues de l'Éocéne inférieur de Saint-Papoul (Aude, France)”. English. In: C. R. Palevol 2 (2003), pp. 617-624.

[9789] S. Hervet. "Systématique du groupe Palaeochelys sensu lato - Mauremys (Chelonii, Testudinoidea) du Tertiaire d'Europe occidentale: principaux résultats [Systematic of the Palaeochelys sensu lato - Mauremys group (Chelonii, Testudinoidea) from the Tertiary of Western Europe: principal results". French. In: Annales de Paléontologie 90.1 (2004), pp. 13-78. DOI: 10.1016/j.annpal. 2003.12.002.

[9790] S. Hervet. “The oldest European ptychogasterid turtle (Testudinoidea) from the lowermost Eocene amber locality of Le Quesnoy (France, Ypresian, MP7)". English. In: Journal of Vertebrate Paleontology 26.4 (2006), pp. 839-848.

[9791] S. Hervet and F. de Broin. “Palaeochelys mlynarskii n. sp., de l’Oligocéne supérieur de Rott (Allemagne), et redescription de l'espéce type P. bussenensis Meyer, 1847". English. In: Comptes Rendus de l'Académie des Sciences - Series IIA - Earth and Planetary Science 331.8 (2000), pp. 563-569.

[9792] S. Hervet and M. Salotti. "Les tortues pleistocenes de Castiglione (Oletta, Haute-Corse) et la preuve de leur indigenat en Corse." French. In: Comptes Rendus de l'Academie de Sciences, Paris (Serie II) 330.9 (2000), pp. 645-651.

[9793] A. Herzog. “Eine Neubeschreibung der Gattung Eoeugnathus Brough, 1939 (Actinopterygii; Halecomorphi) aus der alpinen Mitteltrais Graubündes (Schweiz)". German. In: Paläontologische Zeitschrift 77.1 (2003), pp. 223-240.

[9794] A. Herzog. “Peltoperleidus obristi sp. nov., ein neuer, kleiner Strahlenflosser (Actinopterygii, Perleidiformes) aus der Prosanto-Formation (Mitteltrias) von Graubünden (Schweiz)". German. In: Eclogae Geologicae Helvetiae 94 (2001), pp. 495-507.

[9795] A. Herzog and T. Bürgin. "A new species of the genus Besania Brough 1939 from the Middle Triassic of Canton Grisons (Switzerland) with a discussion of the phylogenetic status of the taxon". English. In: Eclogae Geologicae Helvetiae 98 (2005), pp. 113-122.

[9796] H. Hess. "Remains of saccocomids (Crinoidea: Echinodermata) from the Upper Jurassic of southern Germany". English. In: Stuttgarter Beiträge zur Naturkunde, Serie B (Geologie und Paläontologie) 329 (2002).

[9797] H. Hess and D. B. Blake. “Coulonia platispina n. sp., a new astropectinid sea star from the Lower Cretaceous of Morocco". English. In: Eclogae geologicae Helvetiae 88.3 (1995), pp. 777-788.

[9798] H. Hess, W. Etter, and H. Hagdorn. "Roveacrinida (Crinoidea) from Late Triassic (early Carnian) black shales of Southwest China". English. In: Swiss Journal of Paleontology 135.2 (2016), pp. 249274. DOI: $10.1007 / \mathrm{s} 13358-016-0116-3$.

[9799] H. Hess and A. S. Gale. "Crinoids from the Shenley Limestone (Albian) of Leighton Buzzard, Bedfordshire, UK". English. In: Journal of Systematic Palaeontology 8.3 (2010), pp. 427-447.

[9800] H. Hess and C. A. Meyer. "A new ophiuroid (Geocoma schoentalensis sp. nov.) from the Middle Jurassic of northeastern Switzerland and remarks on the family Aplocomidae Hess 1965." English. In: Swiss Journal of Geosciences 101 (2008), pp. 29-40. 
[9801] H. Hess and B. Thuy. "Emergence and early radiation of cyrtocrinids, with new species from a Lower to Middle Jurassic rock reef of Feuguerolles (Normandy," English. In: Swiss Journal of Palaeontology (2017). DOI: 10.1007/s13358-018-0160-2.

[9802] M. H. Hessel. “Gervillia (Gervillia) solenoidea Defrance, 1820 (Bivalvia Bakevelliidae) do NeoAptiano de Sergipe, Brasil". other. In: Revista Brasileira de Paleontologia 7.1 (2004), pp. 67-76.

[9803] M. H. Hessel. “Anditrigonia britoi n.sp. (Bivalvia) do Eo-Albiano de Sergipe, Brasil”. Portugese. In: Arquivos do Museu Nacional, Rio de Janeiro 63.3 (2005), pp. 437-450.

[9804] K. Heuss. “Zur Taxonomie und Ökologie der Schlammkäfer des Baltischen Bernsteins mit einem Gattungsschlüssel und der Beschreibung einer neuen Art (Coleoptera: Scirtidae)". English. In: Entomologische Zeitschrift 118 (2008), pp. 131-134.

[9805] C. J. Heusser. Ice age vegetation and climate of subtropical Chile. English. 1990.

[9806] A. G. A. Hewaidy, G. M. El Qot, and E. S. M. Moneer. “Campanian-early Eocene cephalopods from Kharga Oasis, Western Desert, Egypt". English. In: Annales de Paléontologie 105 (2019), pp. 45-61. DOI: 10.1016/j.annpal.2018.10.003.

[9807] D. Heyler. Les branchiosaures stephaniens et permiens de Montceau-les-Mines et des bassins du Massif central. French. Quand le Massiff central etait sous l'equateur un ecosysteme carbonifere a Montceau-les-Mines. Paris: Comite des Travaux Historiques et Scientifiques, 1994, pp. 227-247.

[9808] J. P. Hibbard, J. C. Pollock, M. Brennan, S. D. Samson, and D. Secor. "Significance of New Ediacaran Fossils and U-Pb Zircon Ages from the Albemarle Group, Carolina Terrane of North Carolina". English. In: Journal of Geology 117 (2009), pp. 487-498. DOI: 10.1086/600863.

[9809] D. S. Hibbett, M. Binder, Z. Wang, and Y. Goldman. "Another fossil agaric from Dominican amber". English. In: Mycologia 95 (2003), pp. 685-687.

[9810] D. S. Hibbett, D. Grimaldi, and M. J. Donoghue. "Fossil mushrooms from Miocene and Cretaceous ambers and the evolution of Homobasidiomycetes". English. In: American Journal of Botany 84 (1997), pp. 981-991.

[9811] C. S. Hickman. "Paleogene marine bivalves of the deep-water Keasey Formation in Oregon, part IV: The anomalodesmatans". English. In: PaleoBios 31.3 (2014), pp. 1-21.

[9812] C. S. Hickman. "Paleogene marine bivalves of the deep-water Keasey Formation in Oregon, Part III: The heteroconchs". English. In: PaleoBios 32 (2015), pp. 1-44.

[9813] C. S. Hickman. "A new Calliovarica species (Seguenzioidea: Chilodontidae) from the Eocene of Oregon, USA: Persistence of a relict Mesozoic gastropod group in a unique forearc tectonic setting". English. In: PaleoBios 35.38726 (2018), pp. 1-10.

[9814] J. F. Hicks, D. L. Brinkman, D. J. Nichols, and M. Watabe. "Paleomagnetic and palynologic analyses of Albian to Santonian strata at Bayn Shireh, Burkhant, and Khuren Dukh, eastern Gobi Desert, Mongolia". English. In: Cretaceous Research 20 (1999), pp. 829-850.

[9815] M. Hicks. "A new genus of Early Cambrian coral in Esmeralda County, southwestern Nevada". English. In: Journal of Paleontology 80 (2006), pp. 609-615.

[9816] M. Hicks and S. M. Rowland. "Early Cambrian microbial reefs, archaeocyathan inter-reef communities, and associated facies of the Yangtze Platform". English. In: Palaeogeography, Palaeoclimatology, Palaeoecology 281 (2009), pp. 137-153.

[9817] N. D. Higgs, C. T. S. Little, A. G. Glover, T. G. Bahlgren, C. R. Smith, and S. Dominici. “Evidence of Osedax worm borings in Pliocene ( $3 \mathrm{Ma}$ ) whale bone from the Mediterranean". English. In: Historical Biology 24.3 (2012), pp. 269-277.

[9818] T. F. G. Higham and F. J. Petchey. "On the reliability of archaeological rat bone for hydrocarbon dating in New Zealand". English. In: Journal of the Royal Society of New Zealand 30.4 (2000), pp. 399409. DOI: $10.1080 / 03014223.2000 .9517631$.

[9819] I. R. Higuera, F. G. Garmilla, and P. W. Skelton. Sclerochronology and diagenesis of Late Cretaceous radiolitids (Bivalvia, Hippuritoidea), Spain. English. Vol. 87. Cretaceous rudists and carbonate platforms: environmental feedback, SEPM Special Publication. 2007, pp. 115-139. 
[9820] Y. Hikida, S. Suzuki, Y. Togo, and A. Ijiri. “An exceptionally well-preserved fossil seep community from the Cretaceous Yezo Group in the Nakagawa area, Hokkaido, northern Japan". English. In: Paleontological Research 7.4 (2003), pp. 329-342.

[9821] D. Hikuroa and J. Grant-Mackie. "New species of Late Jurassic Australobuchia (Bivalvia) from the Murihiku Terrane, Port Waikato-Kawhia region, New Zealand". English. In: Alcheringa 32 (2008), pp. 73-98.

[9822] D. C. H. Hikuroa. "Second Jurassic marine reptile from the Antarctic Peninsula". English. In: Antarctic Science 21.2 (2009), pp. 169-170.

[9823] C. L. Hill. "Late Pliocene and Pleistocene geology and paleontology in the Three Rivers Basin, Montana". English. In: Museum of the Rockies Occasional Paper 3 (2001), pp. 113-125.

[9824] C. L. Hill. "Pleistocene mammals of Montana and their geologic context". English. In: Museum of the Rockies Occasional Paper 3 (2001), pp. 127-144.

[9825] R. S. Hill. "Leaves of Eucryphia (Eucryphiaceae) from tertiary sediments in south-eastern Australia". English. In: Australian Systematic Botany 4.3 (1991), pp. 481-497. DOI: 10.1071/SB9910481.

[9826] R. S. Hill. "Araucaria (Araucariaceae) species from Australian Tertiary sediments - a micromorphological study". English. In: Australian Systematic Botany 3 (1990), pp. 203-220.

[9827] R. S. Hill. "Tertiary Nothofagus (Fagaceae) macrofossils from Tasmania and Antarctica and their bearing on the evolution of the genus". English. In: Botanical Journal of the Linnean Society 105 (1991), pp. 73-112.

[9828] R. S. Hill and R. J. Carpenter. “Evolution of Acmopyle and Dacrycarpus (Podocarpaceae) Foliage as Inferred from Macrofossils in South-eastern Australia". English. In: Australian Systematic Botany 4.3 (1991), pp. 449-479. DOI: 10.1071/SB9910449.

[9829] R. S. Hill and D. C. Christophel. "Two New Species of Dacrydium (Podocarpaceae) Based on Vegetative Fossils from Middle Eocene Sediments at Nelly Creek, South Australia". English. In: Australian Systematic Botany 14.2 (2001), pp. 193-205. DOI: 10.1071/SB00025.

[9830] R. S. Hill, D. M. Harwood, and P. -N. Webb. “Nothofagus beardmorensis (Nothofagaceae), a new species based on leaves from the Pliocene Sirius Group, Transantarctic Mountains, Antarctica". In: Review of Palaeobotany and Palynology 94 (1996), pp. 11-24.

[9831] R. S. Hill, G. J. Jordan, and R. J. Carpenter. "Taxodiaceous Macrofossils from Tertiary and Quaternary Sediments in Tasmania." English. In: Australian Systematic Botany 6.3 (1993), pp. 237-249. DOI: $10.1071 /$ SB9930237.

[9832] R. S. Hill, T. Lewis, R. J. Carpenter, and S. S. Whang. “Agathis (Araucariaceae) macrofossils from Cainozoic sediments in south eastern Australia". English. In: Australian Systematic Botany 21 (2008), pp. 162-177.

[9833] R. S. Hill and H. E. Merrifield. "An Early Tertiary macroflora from West Dale, southwestern Australia". English. In: Alcheringa 17.4 (1993), pp. 285-326. DOI: 10.1080/03115519308619596.

[9834] R. S. Hill and R. Paull. “Fitzroya (Cupressaceae) macrofossils from Cenozoic sediments in Tasmania, Australia". English. In: Review of Palaeobotany and Palynology 126 (2003), pp. 145-152.

[9835] R. S. Hill and M. S. Pole. "Leaf and Shoot Morphology of Extant Afrocarpus, Nageia and Retrophyllum (Podocarpaceae) Species, and Species with Similar Leaf Arrangement, from Tertiary Sediments in Australasia". English. In: Australian Systematic Botany 5.3 (1992), pp. 337-358. DOI: 10. 1071/SB9920337.

[9836] R. S. Hill and M. S. Pole. "Two new species of Pterostoma R.S. Hill from Cenozoic sediments in Australasia". English. In: Review of Palaeobotany and Palynology 80.1-2 (1994), pp. 123-130. DOI: 10.1016/0034-6667(94)90097-3.

[9837] R. S. Hill and L. J. Scriven. "Falcatifolium (Podocarpaceae) Macrofossils from Paleogene Sediments in South-eastern Australia: a Reassessment". English. In: Australian Systematic Botany 11.6 (1999), pp. 711-720. DOI: 10.1071/SB97014. 
[9838] R. S. Hill and S. S. Whang. “A New Species of Fitzroya (Cupressaceae) from Oligocene Sediments in North-western Tasmania". English. In: Australian Systematic Botany 9.6 (1996), pp. 867-875. DOI: 10.1071/SB9960867.

[9839] R. V. Hill, J. G. Honey, and M. A. O'Leary. New fossils from the early Eocene Four Mile Area and improved relative dating of vertebrate localities. English. 2000.

[9840] R. V. Hill, E. M. Roberts, L. Tapanila, M. L. Bouaré, F. Sissoko, and M. O’Leary. “Multispecies shark feeding in the trans-saharan seaway: evidence from Late Cretaceous dyrosaurid (Crocodyliformes) fossils from northeastern Mali". English. In: Palaios 30.7 (2015), pp. 589-596.

[9841] R. V. Hill, L. M. Witmer, and M. A. Norell. “A new specimen of Pinacosaurus grangeri (Dinosauria: Ornithischia) from the Late Cretaceous of Mongolia: ontogeny and phylogeny of ankylosaurs". English. In: American Museum Novitates 3395 (2003), pp. 1-29.

[9842] S. A. Hill, S. E. Scheckler, and J. F. Basinger. "Ellesmeris sphenopteroides, gen. et sp. nov., A new zygopterid fern from the Upper Devonian (Frasnian) of Ellesmere, N.W.T., Arctic Canada". In: American Journal of Botany 84.1 (1997), pp. 85-103.

[9843] A. Hillebrandt. "Ammoniten aus dem Pliensbachium (Carixium und Domerium) von Südamerika". German. In: Revue de Paléobiologie, Genéve 25 (2006), pp. 1-403.

[9844] A. Hillebrandt. “Die Ammoniten-Fauna des südamerikanischen Hettangium (basaler Jura), Teil 1". German. In: Paleontographica Abteilung 257.4-6 (2000), pp. 85-189.

[9845] A. Hillebrandt. "The Triassic/Jurassic Boundary and Hettangian biostratigraphy in the area of the Utcubamba Valley (Northern Peru)”. English. In: Géobios Mémoire Spécial 17 (1994), pp. 297-307.

[9846] A. Hillebrandt and K. Kment. "Psiloceratid ammonites from the Lower Hettangian of the Karwendel Mountains (Northern Calcareous Alps, Austria) and their biostratigraphic significance". English. In: Neues Jahrbuch für Geologie und Paläontologie, Abhandlungen 277 (2015), pp. 275-306.

[9847] A. Hillebrandt and L. Krystyn. “On the oldest Jurassic ammonites of Europe (Northern Calcareous Alps, Austria) and their global significance". English. In: Neues Jahrbuch für Geologie und Paläontologie Abhandlungen 253.2-3 (2009), pp. 163-195.

[9848] N. Hiller. "Benthic communities and sedimentary facies in the Lower Witteberg Group, (Devonian, South Africa)". English. In: Annals of the South African Museum 99.7 (1990), pp. 215-230.

[9849] N. Hiller. "Micromorphic brachiopods from the Early Miocene (Otaian) of Northland, New Zealand". English. In: New Zealand Journal of Geology and Geophysics 54.1 (2011), pp. 75-87.

[9850] N. Hiller and R. W. Gess. "Marine algal remains from the Upper Devonian of South Africa". In: Review of Palaeobotany and Palynology 91 (1996), pp. 143-149.

[9851] N. Hiller and D. A. MacKinnon. "A reappraisal of the systematics of the Stethothyris group of brachiopods from the Cenozoic of New Zealand and Australia". English. In: New Zealand Journal of Geology and Geophysics 43 (2000), pp. 59-81.

[9852] N. Hiller, A. A. Mannering, C. M. Jones, and A. R. I. Cruickshank. "The nature of Mauisaurus haasti Hector, 1874 (Reptilia: Plesiosauria)". English. In: Journal of Vertebrate Paleontology 25.3 (2005), pp. 588-601.

[9853] D. J. Hills and B. Jones. "Peyssonnelid Rhodoliths from the Late Pleistocene Ironshore Formation, Grand Cayman, British West Indies". English. In: Palaios 15 (2000), pp. 212-224.

[9854] L. V. Hills, E. L. Nicholls, L. M. Nunez-Betelu, and D. J. McIntyre. "Hesperornis (Aves) from Ellesmere Island and palynological correlation of known Canadian localities". In: Canadian Journal of Earth Sciences 36 (1999), pp. 1583-1588.

[9855] L. V. Hills and M. C. Wilson. "Helmeted muskox (Bootherium bombifrons) from near Fort Saskatchewan, Alberta: dating evidence for redeposition in Late Pleistocene alluvium". English. In: Géographie physique et Quaternaire 57.2-3 (2003), pp. 237-240.

[9856] J. Hilton and D. Edwards. "A new Late Devonian acupulate preovule from the Taff Gorge, South Wales". In: Review of Palaeobotany and Palynology 93 (1996), pp. 235-252. 
[9857] J. Hilton, S.-J. Wang, J. Galtier, and C. -S. Li. “An Early Permian plant assemblage from the Taiyuan Formation of northern China with compression/impression and permineralized preservation". In: Review of Palaeobotany and Palynology 114 (2001), pp. 175-189.

[9858] R. P. Hilton, F. L. Decourten, M. A. Murphy, P. U. Rodda, and P. G. Embree. “An Early Cretaceous ornithopod dinosaur from California". English. In: Journal of Vertebrate Paleontology 17.3 (1997), pp. 557-560.

[9859] J. Hinkelman. "Spinaeblattina myanmarensis gen. et sp. nov. and Blattoothecichnus argenteus ichnogen. et ichnosp. nov. (both Mesoblattinidae) from mid-Cretaceous Myanmar amber". English. In: Cretaceous Research 99 (2019), pp. 229-239. DOI: 10.1016/j.cretres.2019.02.026.

[9860] J. Hinkelman. "Earliest behavioral mimicry and possible food begging in a Mesozoic alienopterid pollinator". English. In: Biologia 75 (2019), pp. 83-92. DOI: 10.2478/s11756-019-00278-z.

[9861] J. Hinkelman and L. Vranská. “A Myanmar amber cockroach with protruding feces contains pollen and a rich microcenosis". English. In: The Science of Nature 107.13 (2020). DOI: 10.1007 / s00114-020-1669-y.

[9862] I. A. Hinojosa-Daz and M. S. Engel. "A new fossil orchid bee in Colombian copal (Hymenoptera: Apidae)". English. In: American Museum Novitates 3589 (2007), pp. 1-7.

[9863] L. Hints. "Oandu stage (Caradoc) in central North Estonia". In: Proceedings of the Estonian Academy of Science 47.3 (1998), pp. 158-172.

[9864] L. Hints. "New Hirnantian orthide brachiopods from the type section of the Porkuni Stage (Porkuni quarry, northeastern Estonia)". English. In: Estonian Journal of Earth Sciences 61.4 (2012), pp. 227241. DOI: 10.3176 /earth.2012.4.04.

[9865] L. Hints. "A new glyptorthid species (Brachiopoda: Orthida) from the Upper Ordovician of Estonia". English. In: Estonian Journal of Earth Sciences 59.3 (2010), pp. 189-194.

[9866] L. Hints. "Revision of the concept of the orthide brachiopod Cyrtonotella in the Middle Ordovician of the East Baltic". English. In: Estonian Journal of Earth Sciences 63.2 (2014), 63Ü-70. DOI: 10.3176/earth.2014.05.

[9867] L. Hints and D. A. T. Harper. "Review of the Ordovician rhynchonelliformean Brachiopoda of the East Baltic: Their distribution and biofacies". English. In: Bulletin of the Geological Society of Denmark 50 (2003), pp. 29-43.

[9868] L. Hints and D. A. T. Harper. "The Hirnantian (Late Ordovician) brachiopod fauna of the East Baltic: Taxonomy of the key species". English. In: Acta Palaeontologica Polonica 60.2 (2015), pp. 395420. DOI: 10.4202/app.2013.0010.

[9869] L. Hints, O. Hints, D. Kaljo, T. Kiipli, P. Männik, J. Nõlvak, and H. Pärnaste. "Hirnantian (latest Ordovician) bio- and chemostratigraphy of the Stirnas-18 core, western Latvia". English. In: Estonian Journal of Earth Sciences 59.1 (2010), pp. 1-24.

[9870] L. Hints, O. Hints, R. Nemliher, and J. Nolvak. "Hulterstad brachiopods and associated faunas in the Vormsi Stage (Upper Ordovician, Katian) of the Lelle core, Central Estonia". English. In: Estonian Journal of Earth Sciences 56.3 (2007), pp. 131-142.

[9871] L. Hints, A. Oraspold, and D. Kaljo. "Stratotype of the Porkuni Stage with comments on the Röa Member (uppermost Ordovician, Estonia)". English. In: Proceedings of the Estonian Academy of Sciences, Geology 49.3 (2000), pp. 177-199.

[9872] L. Hints, H. Pärnaste, and L. -I. Gailite. "Hirnantia sagittifera (Brachiopoda) and Mucronaspis mucronata s.l. (Trilobita) in the Upper Ordovician of the East Baltic: taxonomy and distribution". English. In: Estonian Journal of Earth Science 61.2 (2012), pp. 65-81. DOI: 10.3176/earth.2012.2.01.

[9873] L. Hints, J. Pakeviius, T. Martma, P. Männik, and J. Nõlvak. “Upper Sandbian-lower Katian bioand chemostratigraphy in the Pajevonys-13 core section, Lithuania". English. In: Estonian Journal of Earth Sciences 65.2 (2016), pp. 85-97. 
[9874] L. Hints, L. Popov, and L. E. Holmer. “Morphology, Ontogeny and Affinities of the Hirnantian Triplisiid Brachiopod Streptis undifera from Baltoscandia". English. In: Palaeontology, 20132013 (2013), pp. 1-10.

[9875] O. Hints, V. Viira, and J. Nõlvak. “Darriwilian (Middle Ordovician) conodont biostratigraphy in NW Estonia". English. In: Estonian Journal of Earth Sciences 61.4 (2012), pp. 210-226. DOI: 10.3176/ earth.2012.4.03.

[9876] J. K. Hinz, A. T. Matzke, and H. -U. Pfretzschner. “A new nothosaur (Sauropterygia) from the Ladinian of Vellberg-Eschenau, southern Germany". English. In: Journal of Vertebrate Paleontology (2019). DOI: 10.1080/02724634.2019.1585364.

[9877] H. Hippa. "Review of the genus Paramanota Tuomikoski (Diptera, Mycetophilidae), with the description of new fossil and recent species". English. In: Zootaxa 2618 (2010), pp. 47-60.

[9878] K. Hips and P. Pelikan. "Lower Triassic shallow marine succession in the Bükk Mountains, NE Hungary". English. In: Geologica Carpathica 53.6 (2002), pp. 351-367.

[9879] J. Hr and M. Venczel. "New middle Miocene vertebrate localities from Subpiatr (Bihor District, Romania)". English. In: Acta Palaeontologica Romaniae 5 (2005), pp. 211-221.

[9880] R. Hirayama. “Oldest known sea turtle”. English. In: Nature 392 (1998), pp. 705-708.

[9881] R. Hirayama. "Fossil turtles from the Neogene strata in the Sinda basin, eastern Zaire". English. In: African Study Monographs 17 (1992), pp. 49-65.

[9882] R. Hirayama and T. Chitoku. "Family Dermochelyidae (superfamily Chelonioidea) from the Upper Cretaceous of north Japan". English. In: Transactions and Proceedings of the Palaeontological Society of Japan. New series 184 (1996), pp. 597-622.

[9883] R. Hirayama and Y. Hikida. "Mesodermochelys (Testudines; Chelonioidea; Dermochelyidae) from the Late Cretaceous of Nakagawa-cho, Hokkaido, North Japan". English. In: Bulletin of the Nakagawa Museum of Natural History 1 (1998), pp. 69-76.

[9884] R. Hirayama, S. Isaji, and T. Hibino. Kappachelys okurai gen. et sp. nov., a new stem soft-shelled turtle from the Early Cretaceous of Japan. English. Morphology and Evolution of Turtles. 2013, pp. 179-185. DOI: 10.1007/978-94-007-4309-0_12.

[9885] R. Hirayama, N. Kaneko, and H. Okazaki. “Ocadia nipponica, a new species of aquatic turtle (Testudines: Testudinoidea: Geoemydidae) from the Middle Pleistocene of Chiba Prefecture, central Japan". English. In: Paleontological Research 11.1 (2007), pp. 1-19.

[9886] R. Hirayama, Y. Kobayashi, T. Sonoda, and K. Sasaki. "Preliminary report of terrestrial vertebrates from the Late Cretaceous Tamagawa Formation of the Kuji Group of Kuji City, Iwate Prefecture, northeastern Japan". English. In: Journal of Fossil Research 42.2 (2010), pp. 74-82.

[9887] R. Hirayama, K. Sakurai, T. Chitoku, G. Kawakami, and N. Kito. “Anomalochelys angulata, an unusual land turtle of family Nanhsiungchelyidae (superfamily Trionychoidea; order Testudines) from the Upper Cretaceous of Hokkaido, North Japan". English. In: Russian Journal of Herpetology 8.2 (2001), pp. 127-138.

[9888] R. Hirayama and E. Taguchi. "A huge fossil soft-shelled turtle from the Miocene Bihoku Group of western Japan and its paleoenvironmental significance". Japanese. In: Journal of the Geological Society of Japan 100.4 (1994), pp. 316-318.

[9889] R. Hirayama and S. Teppei. "Fossil turtles from the Lower Cretaceous Tetori Group in the Kuzuryu area, Ono City, Fukui Prefecture, central Japan". Japanese. In: Waseda Global Forum 16 (2019), pp. 31-49.

[9890] R. Hirayama and H. Tong. "Osteopygis (Testudines: Cheloniidae) from the Lower Tertiary of the Ouled Abdoun phosphate basin, Morocco". English. In: Palaeontology 46.5 (2003), pp. 845-856.

[9891] K. Hirota and L. G. Barnes. "A new species of Middle Miocene sperm whale of the genus Scaldicetus (Cetacea; Physeteridae) from Shiga-mura, Japan". English. In: The Island Arc 3 (1995), pp. 453472. 
[9892] K. F. Hirsch. Upper Jurassic eggshells from the Western Interior of North America. English. Dinosaur Eggs and Babies, Cambridge University Press, Cambridge. 1994, pp. 137-150.

[9893] K. F. Hirsch, A. J. Kihm, and D. K. Zelenitsky. "New eggshell of ratite morphotype with predation marks from the Eocene of Colorado". English. In: Journal of Vertebrate Paleontology 17.2 (1997), pp. 360-369.

[9894] K. F. Hirsch and B. Quinn. “Eggs and eggshell fragments from the Upper Cretaceous Two Medicine Formation of Montana". English. In: Journal of Vertebrate Paleontology 10.4 (1990), pp. 491-511.

[9895] M. HiSS and A. Lommerzheim. "Stratigraphische interpretation der makrofauna im Santon /CampanProfil der Bohrung Metelen 1001 im nordwestlichen Muensterland (NW-Deutschland)". German. In: Facies 24 (1991), pp. 125-128.

[9896] T. Hitij, J. Zalohar, B. Celarc, M. Kriznar, S. Renesto, and A. Tintori. “The kingdom of Tethys. The fossilized world of Triassic vertebrates from the Kamnisko-Savinjske Alps". other. In: Scopolia Suppl 5 (2010), pp. 1-197.

[9897] R. Hitz, M. Reguero, A. R. Wyss, and J. J. Flynn. “New interatheriines (Interatheriidae, Notoungulata) from the Paleogene of Central Chile and Southern Argentina". English. In: Fieldiana: Geology (New Series) 42 (2000), pp. 1-26.

[9898] R. B. Hitz, G. Billet, and D. Derryberry. "New interatheres (Mammalia, Notoungulata) from the late Oligocene Salla Beds of Bolivia". English. In: Journal of Paleontology 82.3 (2008), pp. 447-469.

[9899] R. B. Hitz, J. J. Flynn, and A. R. Wyss. “New Basal Interatheriidae (Typotheria, Notoungulata, Mammalia) from the Paleogene of Central Chile". English. In: American Museum Novitates 3520 (2006), pp. 1-32.

[9900] D. Hmich, J. W. Schneider, J. Saber, and M. El Wartiti. “First Permocarboniferous insects (blattids) from North Africa (Morocco) - implications on palaeobiogeography and palaeoclimatology". English. In: Freiberger Forschungshefte C 499 (2003), pp. 117-134.

[9901] D. Hmich, J. W. Schneider, H. Saber, and M. El Wartiti. "Spiloblattinidae (Insecta, Blattida) from the Carboniferous of Morocco, North Africa - implications for biostratigraphy". English. In: The Nonmarine Permian, New Mexico Museum of Natural History and Science Bulletin 30 (2005), pp. 111114.

[9902] D. Hmich, J. W. Schneider, H. Saber, S. Voigt, and M. El Wartiti. "New continental Carboniferous and Permian faunas of Morocco: implications for biostratigraphy, palaeobiogeography and palaeoclimate". English. In: Non-Marine Permian Biostratigraphy and Biochronology. Geological Society of London Special Publication 265 (2006), pp. 297-324.

[9903] A. Hminna, S. Voigt, H. Saber, J. Schneider, and D. Hmich. "On a moderately diverse continental ichnofauna from the Permian Ikakern Formation (Argana Basin, Western High Atlas, Morocco)". English. In: Journal of African Earth Sciences 68 (2012), pp. 15-23. DOI: 10.1016/j.jafrearsci.2012.03. 011.

[9904] I. Hogör and S. tamberg. "A first record of late Middle Permian actinopterygian fish from Anatolia, Turkey". English. In: Acta Geologica Polonica 64 (2014), pp. 147-159.

[9905] R. Hoare and H. Karasawa. "Permian Polyplacophora (Mollusa) from the Akasaka Limestone, Gifu, Japan". English. In: Paleontological Research 12 (2008), pp. 321-327.

[9906] R. D. Hoare. New Permian Polyplacophora (Mollusca) from Malaysia. 2000.

[9907] R. D. Hoare. "Mississippian rostroconch molluscs from Ohio". In: Journal of Paleontology 64.5 (1990), pp. 725-732.

[9908] R. D. Hoare. "Silurian Polyplacophora and Rostroconchia (Mollusca) from Northern California". In: Proceedings of the California Academy of Sciences 52.3 (2000), pp. 23-31.

[9909] R. D. Hoare. "Considerations on Paleozoic Polyplacophora including the description of Palsiochiton curiosus n. gen. and sp." In: American Malacological Bulletin 15.2 (2000), pp. 131-137.

[9910] R. D. Hoare. "Mississippian (Chesterian) bivalves from the Pennsylvanian stratotype area in West Virginia and Virginia". English. In: Journal of Paleontology 67.3 (1993), pp. 374-396. 
[9911] R. D. Hoare. “New genera of Paleozoic Polyplacophora (Mollusca)". English. In: Journal of Paleontology 76.3 (2002), pp. 570-573.

[9912] R. D. Hoare. "Gastropods and Rostroconchs (Mollusca) from the Maxville Limestone (Upper Mississippian) in Ohio". English. In: The Ohio Journal of Science 104.4 (2004), pp. 86-92.

[9913] R. D. Hoare. "Bivalve mollusks from the Maxville Limestone (Mississippian) in Ohio". English. In: The Ohio Journal of Science 107.4 (2007), pp. 63-75.

[9914] R. D. Hoare. “A new species of Conocardium Bronn, 1834 (Mollusca: Rostroconchia) from the Mississippian of Missouri, U.S.A". English. In: American Malacological Bulletin 17.1/2 (2002), pp. 123124.

[9915] R. D. Hoare and B. Aghababula. "Large Devonian and Mississippian rostroconchs (Mollusca) from Iran". English. In: Journal of Paleontology 75.5 (2001), pp. 1047-1051.

[9916] R. D. Hoare, R. H. Mapes, and T. E. Yancey. "Structure, taxonomy, and epifauna of Pennsylvanian rostroconchs (Mollusca)". English. In: Journal of Paleontology Memoir 58 (2002), pp. 1-30.

[9917] R. D. Hoare and R. H. Mapes. "Arceodomus prolata n. sp. (Mollusca, Rostroconcha) from the Pennsylvanian of Texas". English. In: Journal of Paleontology 64.3 (1990), pp. 491-492.

[9918] R. D. Hoare and R. L. Peck. “A new rostroconch (Mollusca) from the Mississippian of West Virginia". English. In: Journal of Paleontology 79.5 (2005), pp. 1019-1020.

[9919] R. D. Hoare and L. P. Plas. "Permian rostroconchs (Mollusca) from Nevada". In: Journal of Paleontology 77.5 (2003), pp. 873-875.

[9920] R. D. Hoare, L. P. Plas, and T. E. Yancey. “Permian Polyplacophra (Mollusca) from Nevada, Utah, and Arizona". English. In: Journal of Paleontology 76.2 (2002), pp. 256-264. DOI: 10.1666 / 0022 3360(2002)076<0256:PPMFNU>2.0.CO;2.

[9921] R. D. Hoare and J. Pojeta Jr. "Ordovician Polyplacophora (Mollusca) from North America". English. In: $80 . s p 64$ (2006), pp. 1-27.

[9922] R. D. Hoare and N. Sabattini. "Lower Permian polyplacophora (Mollusca) from Argentina". English. In: Journal of Paleontology 74.2 (2000), pp. 189-191.

[9923] R. D. Hoare and M. T. Sturgeon. "Pennsylvanian endothyroid foraminifera from the Appalachian Basin". In: Journal of Paleontology 72.3 (1998), pp. 405-418.

[9924] R. D. Hoare, M. T. Sturgeon, J. R. Anderson, and Jr. "Pennsylvannian marine gastropods from the Appalachian basin". English. In: Journal of Paleontology 71.6 (1997), pp. 1019-1039.

[9925] E. Hoch. "Cuvierian analysis, and determination of a delphinoid cetacean from the Late Miocene North Sea". English. In: Revue de Paleobiology 9.special (2004), pp. 1-15.

[9926] E. Hoch. "Olfaction in whales: Evidence from a young odontocete of the Late Oligocene North Sea". English. In: Historical Biology 14 (2000), pp. 67-89.

[9927] S. A. Hocknull. "Remains of an Eocene skink from Queensland". English. In: Alcheringa 24.1 (2000), pp. 63-64.

[9928] S. A. Hocknull. "Late Pleistocene-Holocene occurrence of Chaeropus (Peramelidae) and Macrotis (Thylacomyidae) from Queensland". English. In: Memoirs of the Queensland Museum 51.1 (2005), pp. 37-38.

[9929] S. A. Hocknull. "Additional specimens of Bohra (Marsupialia, Macropodidae) from the Pliocene of Queensland". English. In: Memoirs of the Queensland Museum 51 (2005), p. 26.

[9930] S. A. Hocknull and A. G. Cook. "Hypsilophodontid (Dinosauria: Ornithischia) from latest Albian, Winton Formation, central Queensland". English. In: Memoirs of the Queensland Museum 52.2 (2008), p. 212.

[9931] S. A. Hocknull, R. Lewis, L. J. Arnold, T. Pietsch, R. Joannes-Boyau, G. J. Price, P. Moss, R. Wood, A. Dosseto, J. Louys, J. Olley, and R. A. Lawrence. "Extinction of eastern Sahul megafauna coincides with sustained environmental deterioration". English. In: Nature Communications 11 (2020), p. 2250. 
[9932] S. A. Hocknull, M. A. White, T. R. Tischler, A. G. Cook, N. D. Calleja, T. Sloan, and D. A. Elliot. "New mid-Cretaceous (latest Albian) dinosaurs from Winton, Queensland, Australia". English. In: PLoS ONE 4.7 (2009), e6190: 1-51. DOI: 10.1371/journal.pone.0006190.

[9933] M. S. Hodges and G. D. Stanley. "North American coral recovery after the end-Triassic mass extinction, New York Canyon, Nevada, USA". English. In: GSA Today (2015). DOI: 10.1130 / GSATG249A.

[9934] J. M. Hodnett. “A machairodont felid (Mammalia; Carnivora; Felidae) from the latest Hemphillian (Late Miocene / Early Pliocene) Bidahochi Formation, northeastern Arizona". English. In: PaleoBios 29.3 (2010), pp. 76-91.

[9935] J. P. M. Hodnett, D. K. Elliott, T. J. Olson, and J. H. Wittke. “Ctenacanthiform sharks from the Permian Kaibab Formation, northern Arizona". English. In: Historical Biology 24 (2012), pp. 381395.

[9936] J.-P. M. Hodnett, D. K. Elliott, and T. J. Olson. “A new basal hybodont (Chondrichthyes, Hybodontiformes) from the Middle Permian (Roadian) Kaibab Formation of northern Arizona". English. In: The Carboniferous-Permian Transition, New Mexico Museum of Natural History and Science Bulletin 60 (2013), pp. 103-108.

[9937] L. W. Hoek Ostende, P. Joniak, B. Rojay, C. Aten, M. Bilgin, and P. Paláez-Campomanes. “Early Miocene insectivores of Gökler (Kazan Basin, Central Anatolia, Turkey)". English. In: Palaeobiodiversity and Palaeoenvironments 99 (2019), pp. 701-722. DOI: 10.1007/s12549-019-00396-1.

[9938] O. A. Hoel. "Strophomenidae, Leptostrophiidae, Strophodontidae and Shaleriidae (Brachiopoda, Strophomenida) from the Silurian of Gotland, Sweden". English. In: Palaeontologische Zeitschrift 85 (2011), pp. 201-229. DOI: 10.1007/s12542-010-0088-3.

[9939] O. A. Hoel. "Silurian Leptaeninae (Brachiopoda) from Gotland, Sweden”. English. In: Paläontologische Zeitschrift 79.2 (2005), pp. 263-284.

[9940] O. A. Hoel. "Palaeobiology of Silurian Leptaeninae (Brachiopoda) from Gotland, Sweden". English. In: Paleontology Journal 2014 (2014), pp. 1-14. DOI: 10.1155/2014/716053.

[9941] O. A. Hoel. "Trilobites of the Hagastrand Member (Tøyen Formation, lowermost Arenig) from the Oslo Region, Norway, Part 1: Asaphidae". English. In: Norsk Geologisk Tidsskrift 79 (1999), pp. 179204.

[9942] O. A. Hoel. “Trilobites of the Hagastrand Member (Tøyen Formation, lowermost Arenig) from tbe Oslo Region, Norway, Part Il : Remaining non-asaphid groups". English. In: Norsk Geologisk Tidsskrift 79 (1999), pp. 259-280.

[9943] O. A. Hoel and M. Høyberget. "The Lower Ordovician trilobite Megistaspis (Rhinoferus) hyorrhina (Leuchtenberg, 1843) in Norway, with notes on its autecology". English. In: Norsk Geologisk Tidsskrift 82 (2002), pp. 45-51.

[9944] C. H. J. Hof and F. R. Schram. "Stomatopods (Crustacea: Malacostraca) from the Miocene of California". English. In: Journal of Paleontology 72.2 (1998), pp. 317-331.

[9945] C. Hoffeins, H. W. Hoffeins, and M. Jaschhof. "First record of Antlemon Loew (Dipera: Keroplatidae) in Baltic amber". English. In: Studia Dipterologica 17 (2010), pp. 143-149.

[9946] C. Hoffeins and A. Rung. "Procyamops succini, a new genus and species of Periscelididae (Diptera, Brachycera) from Baltic amber (Tertiary, Eocene)". English. In: Studia Dipterologica 12 (2005), pp. $23-$ 27.

[9947] C. Hoffeins, B. J. Sinclair, and A. Stark. “Description of a further species of Ragas Walker (Diptera: Empididae) from Baltic amber (Tertiary, Eocene)". English. In: Studia Dipterologica 21 (2015), pp. 177180.

[9948] C. Hoffeins and A. J. Wonica. "Description of a new species Eopseudopomyza szadziewskii sp. n. and redescription of E. kuehnei Hennig, 1971 from Eocene Baltic amber (Diptera: Pseudopomyzidae)". English. In: Polish Journal of Entomology 82 (2013), pp. 317-325. 
[9949] G. L. Hoffman and R. A. Stockey. "Sporophytes, megaspores, and massulae of Azolla stanleyi from the Paleocene Joffre Bridge locality, Alberta". In: Canadian Journal of Botany 72 (1994), pp. 301308.

[9950] R. Hoffmann, Y. Iba, F. Kawabe, and J. Mutterlose. "First occurrence of Pictetia (Ammonoidea) from the Albian of Japan and its systematical implications". English. In: Bulletin of Geosciences 88.3 (2013), pp. 517-524.

[9951] R. Hoffmann and H. Keupp. "The myth of the Triassic lytoceratid ammonite Trachyphyllites Arthaber, 1927, in reality an Early Jurassic Analytoceras hermanni Gümbel, 1861". English. In: Acta Geologica Polonica 60 (2010), pp. 219-229.

[9952] H. J. Hofman, G. M. Narbonne, and J. D. Aitken. "Ediacaran remains from intertillite beds in northwestern Canada". English. In: Geology 18.12 (1990), pp. 1199-1202.

[9953] H. J. Hofmann and E. W. Mountjoy. "Namacalathus-Cloudina assemblage in Neoproterozoic Miette Group (Byng Formation), British Columbia: Canada's oldest shelly fossils". English. In: Geology 29.12 (2001), pp. 1091-1094.

[9954] H. J. Hofmann, S. J. O’Brien, and A. F. King. “Ediacaran biota on Bonavista Peninsula, Newfoundland, Canada". English. In: Journal of Paleontology 82.1 (2008), pp. 1-36.

[9955] H. J. Hofmann and R. H. Rainbird. "Carbonaceous megafossils from the Neoproterozoic Shaler Supergroup of Arctic Canada". In: Palaeontology 37.4 (1994), pp. 721-731.

[9956] R. Hofmann, H. Hautmann, A. Brayard, A. Nützel, K. G. Bylund, J. F. Jenks, E. Vennin, N. Olivier, and H. Bucher. "Recovery of benthic marine communities from the end-Permian mass extinction at the low latitudes of eastern Panthalassa". English. In: Palaeontology 57 (2014), pp. 547-589.

[9957] R. Hofmann, M. Hautmann, M. Wasmer, and H. Bucher. "Palaeoecology of the Spathian Virgin Formation (Utah, USA) and its implications for the Early Triassic recovery". English. In: Acta Palaeontologica Polonica 58 (2013), pp. 149-173. DOI: 10.4202/app.2011.0060.

[9958] R. Hofmann, M. Hautmann, and H. Bucher. "A new paleoecological look at the Dinwoody Formation (Lower Triassic, Western USA): intrinsic versus extrinsic controls on ecosystem recovery after the end-Permian mass extinction". English. In: Journal of Paleontology 87 (2013), pp. 854-880.

[9959] R. Hofmann and M. Hautmann. "Systematic palaeontology: bivalves, in Recovery of benthic marine communities from the end-Permian mass extinction at the low latitudes of eastern Panthalassa". English. In: Palaeontology 57 (2013).

[9960] R. Hofmann, M. Hautmann, and H. Bucher. "Recovery dynamics of benthic marine communities from the Lower Triassic Werfen Formation, northern Italy". English. In: Lethaia 48 (2015), pp. 474496.

[9961] J. W. Hoganson. “Dakota: a mummified dinosaur". English. In: North Dakota Department of Mineral Resources Newsletter 35.2 (2008), pp. 1-3.

[9962] J. W. Hoganson, J. M. Campbell, and E. C. Murphy. "Stratigraphy and paleontology of the Cretaceous Hell Creek Formation, Stumpf site, Morton County, North Dakota". English. In: Proceedings of the North Dakota Academy of Sciences 48 (1994), p. 95.

[9963] J. W. Hoganson and J. M. Erickson. “A new species of Ischyodus (Chondrichthyes: Holocephali: Callorhynchidae) from upper Maastrichtian shallow marine facies of the Fox Hills and Hell Creek formations, Williston Basin, North Dakota, USA". English. In: Palaeontology 48.4 (2005), pp. $709-$ 721.

[9964] J. W. Hoganson, J. M. Erickson, and F. D. Holland. “Chondrichthyan and osteichthyan paleofaunas from the Cretaceous (Late Maastrichtian) Fox Hills Formation of North Dakota, USA: paleoecology, paleogeography, and extinction". English. In: Bulletins of American Paleontology 398 (2019), pp. 1-94.

[9965] J. W. Hoganson and H. G. McDonald. "First report of Jefferson's ground sloth (Megalonyx jeffersonii) in North Dakota: Paleobiogeographical and paleoecological significance". English. In: Journal of Mammalogy 88.1 (2007), pp. 73-80. DOI: 10.1644/06-MAMM-A-132R1.1. 
[9966] J. W. Hoganson and B. Woodward. "Skeleton of the rare giant sea turtle, Archelon, recovered from the Cretaceous DeGrey Member of the Pierre Shale near Cooperstown, Griggs County, North Dakota". English. In: North Dakota Geological Society Newsletter 32.1 (2004), pp. 1-4.

[9967] J. A. Hogler. "Taphonomy and paleoecology of Shoniasaurus popularis (Reptilia: Ichthyosauria)". In: Palaios 7 (1992), pp. 108-117.

[9968] J. A. Hogler. “Community structure, paleoecology, and depositional environments within the Upper Triassic Luning Formation of Nevada". PhD thesis. 1992.

[9969] J. Hohenegger and F. Tatzreiter. "Morphometric methods in determination of ammonite species, exemplified through Balatonites shells (Middle Triassic)". English. In: Journal of Paleontology 66 (1992), pp. 801-816.

[9970] E. C. Holanda, J. Ferigolo, and A. M. Ribeiro. “New Tapirus species (Mammalia: Perissodactyla: Tapiridae) from the upper Pleistocene of Amazonia, Brazil". English. In: Journal of Mammalogy 92.1 (2011), pp. 111-120. DOI: 10.1644/10-MAMM-A-144.1.

[9971] E. C. Holanda, A. M. Ribeiro, and J. Ferigolo. “New material of Tapirus (Perissodactyla: Tapiridae) from the Pleistocene of southern Brazil". English. In: Revista Mexicana de Ciencias Geológicas 29.2 (2012), pp. 308-318.

[9972] E. C. Holanda and A. D. Rincon. "Tapirs from the Pleistocene of Venezuela". English. In: Acta Palaeontologica Polonica 53.3 (2012), pp. 463-473.

[9973] E. C. Holanda and M. A. Cozzuol. "New records of Tapirus from the late Pleistocene of southwestern Amazonia, Brazil". English. In: Revista Brasileira de Paleontologia 9.2 (2006), pp. 193-200.

[9974] L. T. Holbrook and S. G. Lucas. "A New Genus of Rhinocerotoid from the Eocene of Utah and the Status of North American Forstercooperia". English. In: Journal of Vertebrate Paleontology 17.2 (1997), pp. 384-396.

[9975] L. T. Holbrook, S. G. Lucas, and R. J. Emry. "Skulls of the Eocene perissodactyls (Mammalia) Homogalax and Isectolophus". English. In: Journal of Vertebrate Paleontology 24.4 (2004), pp. 951956.

[9976] R. N. Holdaway and A. Anderson. “Avifauna from the Emily Bay settlement site, Norfolk Island: a preliminary account". English. In: Records of the Australian Museum, Supplement 27 (2001), pp. 85100.

[9977] R. N. Holdaway and T. H. Worthy. "A new fossil species of shearwater Puffinus from the Late Quaternary of the South Island, New Zealand, and notes on the biogeography and evolution of the Puffinus gavia superspecies". English. In: Emu 94 (1994), pp. 201-214.

[9978] A. R. Holden, M. V. L. Barclay, and R. B. Angus. "Rancho La Brea fossil indicates native Nearctic status for Necrobia violacea (Linnaeus) (Coleoptera: Cleridae), a species previously considered a synanthropic introduction to North America". English. In: The Coleopterists Bulletin 72 (2018), pp. 558-561.

[9979] A. R. Holden, J. B. Koch, T. Griswold, D. M. Erwin, and J. Hall. "Leafcutter bee nests and pupae from the Rancho La Brea tar pits of southern California: implications for understanding the paleoenvironment of the late Pleistocene". English. In: PLoS One 9.4 (2014), e94724.

[9980] B. Holgado, R. V. Pegas, J. I. Canudo, J. Fortuny, T. Rodrigues, J. Company, and A. W. A. Kellner. "On a new crested pterodactyloid from the Early Cretaceous of the Iberian Peninsula and the radiation of the clade Anhangueria". English. In: Scientific Reports 9.4940 (2019). DOI: 10.1038 / s41598-019-41280-4.

[9981] C. H. Holland. "Nautiloid cephalopods of the Kildare Limestone (Ashgill), Ireland". English. In: Geological Journal 28.1 (1993), pp. 37-44.

[9982] C. H. Holland. "Silurian cephalopods from the Pentland Hills". English. In: Scottish Journal of Geology 36.2 (2000), pp. 177-186. DOI: 10.1144/sjg36020177.

[9983] C. H. Holland. "The nautiloid cephalopod order Actinocerida in the British Silurian". English. In: Palaeontology 41.1 (1998), pp. 183-192. 
[9984] C. H. Holland and P. Copper. “Ordovician and Silurian nautiloid cephalopods from Anticosti Island: traject across the Ordovician-Silurian (O-S) boundary". English. In: Canadian Journal of Earth Sciences 45.9 (2008), pp. 1015-1038. DOI: 10.1139/E08-048.

[9985] S. M. Holland and M. E. Patzkowsky. "Ecosystem structure and stability: middle Upper Ordovician of central Kentucky, USA". English. In: Palaios 19.4 (2004), pp. 316-331. DOI: 10.1669 / 08831351(2004)019<0316:ESASMU>2.0.CO;2.

[9986] S. M. Holland and M. E. Patzkowsky. "Gradient ecology of a biotic invasion: biofacies of the type Cincinnatian Series (Upper Ordovician), Cincinnati, Ohio region, USA". English. In: Palaios 22 (2007), pp. 408-423.

[9987] T. Holland, A. Warren, Z. Johanson, J. Long, K. Parker, and J. Garvey. “A new species of Barameda (Rhizodontida) and heterochrony in the rhizodontid pectoral fin". English. In: Journal of Vertebrate Paleontology 27.2 (2007), pp. 295-315.

[9988] F. D. Holland Jr. “A North Dakota Triceratops skull”. English. In: Contributions to Geology, University of Wyoming 32.1 (1997), pp. 37-50.

[9989] M. G. Hollenshead and J. I. Mead. "Early Pliocene Crotaphytus and Gambelia (Squamata: Crotaphytidae) from the Panaca Formation of southeastern Nevada". English. In: Journal of Herpetology 40.4 (2006), pp. 566-569.

[9990] C. M. Holliday and N. M. Gardner. "A new eusuchian crocodyliform with novel cranial integument and its significance for the origin and evolution of Crocodylia". English. In: PLoS One 7.1 (2012), e30471:1-13. DOI: 10.1371/journal.pone.0030471.

[9991] J. S. Hollingsworth. "Fallotaspidoid trilobite assemblage (Lower Cambrian) from the Esmeralda Basin (western Nevada, USA): The oldest trilobites from Laurentia". English. In: Memoirs of the Association of Australasian Palaeontologists 33 (2007), pp. 123-140.

[9992] J. S. Hollingsworth. "Holmiidae (Trilobita: Olenellina) of the Montezuman Stage (Early Cambrian) in Western Nevada". English. In: Journal of Paleontology 80.2 (2006), pp. 309-332.

[9993] J. S. Hollingsworth. "A trilobite fauna in a storm bed in the Poleta Formation (Dyeran, Lower Cambrian), western Nevada, U.S.A." English. In: Geosciences Journal 9.2 (2005), pp. 129-143. DOI: 10.1007/BF02910575.

[9994] J. S. Hollingsworth. "The earliest occurrence of trilobites and brachiopods in the Cambrian of Laurentia". English. In: Palaeogeography, Palaeoclimatology, Palaeoecology 220.1-2 (2005), pp. 153165. DOI: $10.1016 /$ j.palaeo.2004.08.008.

[9995] N. T. J. Hollingworth, D. J. Ward, M. J. Simms, and P. Clothier. “A temporary exposure of Lower Lias (Late Sinemurian) at Dimmer Camp, Castle Cary, Somerset, south-west England". English. In: Mesozoic Research 2 (1990), pp. 163-180.

[9996] N. T. J. Hollingworth and M. J. Barker. “Gastropods from the Upper Permian Zechstein (Cycle 1) reef of north-east England". English. In: Proceedings of the Yorkshire Geological Society 48.4 (1991), pp. 347-365.

[9997] K. T. Hollocher, O. A. Alcober, C. E. Colombi, and T. C. Hollocher. "Carnivore coprolites from the Upper Triassic Ischigualasto Formation, Argentina: chemistry, mineralogy, and evidence for rapid initial mineralization". English. In: Palaios 20.1 (2005), pp. 51-63.

[9998] D. J. Holloway. "Early Silurian trilobites from the Broken River area, north Queensland". In: Memoirs of the Museum of Victoria 54.2 (1994), pp. 243-269.

[9999] D. J. Holloway. "The trilobite subfamily Monorakinae (Pterygometopidae)". English. In: Palaeontology 47.4 (2004), pp. 1015-1036.

[10000] D. J. Holloway and A. Sandford. "An Early Silurian trilobite fauna from Tasmania". In: Memoir of the Association of Australasian Palaeontologists 15 (1993), pp. 85-102.

[10001] W. L. Holloway, K. M. Claeson, H. M. Sallam, S. El-Sayed, M. Kora, J. J. W. Sertich, and P. M .O'Connor. "A new species of the neopterygian fish Enchodus from the Duwi Formation, Campanian, Late Cretaceous, Western Desert, central Egypt". English. In: Acta Palaeontologica Polonica 62.3 (2017), pp. 603-611. DOI: 10.4202/app.00331.2016. 
[10002] J. A. Holman. "Glad Tidings, a late middle Miocene herpetofauna from northeastern Nebraska". English. In: Journal of Herpetology 30.3 (1996), pp. 430-432.

[10003] J. A. Holman. "New records of Michigan Pleistocene vertebrates with comments on the MasonQuimby Line". English. In: Michigan Academician 23.3 (1991), pp. 273-283.

[10004] J. A. Holman. "The status of Emydoidea hutchisoni Holman, 1995 (Testudines: Emydidae). (Note)". English. In: Michigan Academician 35 (2003).

[10005] J. A. Holman. "A new species of Emydoidea (Reptilia: Testudines) from the Late Barstovian (Medial Miocene) of Cherry County, Nebraska". English. In: Journal of Herpetology 29.4 (1995), pp. 548553.

[10006] J. A. Holman. "Paleocene turtles and crocodilians directly above the Cretaceous/Tertiary (K/T) boundary in Pulaski County, Illinois". English. In: Michigan Academician 34.2 (2002), pp. 163-174.

[10007] J. A. Holman. "Early Hemingfordian (Early Miocene) Squamate Reptiles from the Quarry A Local Fauna, Logan County, Colorado". English. In: Michigan Academician 34.4 (2003), pp. 477-480.

[10008] J. A. Holman. "First report of an Eocene reptile fauna from Florida, USA". English. In: Palaeovertebrata 30.1-2 (2001), pp. 1-10.

[10009] J. A. Holman. "Herpetofauna of the Trinity River Local Fauna (Miocene: Early Barstovian), San Jacinto County, Texas, USA". English. In: Tertiary Research 17.1+2 (1996), pp. 5-10.

[10010] J. A. Holman. "Fossil herpetofauna of the Lisco C Quarries (Pliocene: early Blancan) of Nebraska". English. In: Transactions of the Nebraska Academy of Sciences XVIII (1991), pp. 19-29.

[10011] J. A. Holman. "A new genus of diminutive boid snake from the Upper Eocene of Hordle Cliff, Hampshire, England". English. In: Tertiary Research 17.1+2 (1996), pp. 11-13.

[10012] J. A. Holman, G. L. Bell, and J. P. Lamb. “A late Pleistocene herpetofauna from Bell Cave, Alabama". English. In: The Herpetological Journal 1.11 (1990), pp. 521-529.

[10013] J. A. Holman and G. R. Case. "A puzzling new snake (Reptilia: Serpentes) from the Late Paleocene of Mississippi". English. In: Annals of Carnegie Museum 61.3 (1992), pp. 197-205.

[10014] J. A. Holman, D. T. Dockery, and G. R. Case. "Paleogene snakes of Mississippi". English. In: Mississippi Geology 11.1 (1991), pp. 1-12.

[10015] J. A. Holman and U. Fritz. "The box turtle genus Terrapene (Testudines: Emydidae) in the Miocene of the USA". English. In: Herpetological Journal 15 (2005), pp. 81-90.

[10016] J. A. Holman and U. Fritz. "A new emydine species from the Medial Miocene (Barstovian) of Nebraska, USA with a new generic arrangement for the species of Clemmys sensu McDowell (1964) (Reptilia: Testudines: Emydidae)". English. In: Zoologische Abhandlungen: Staatliches Museum für Tierkunde Dresden 51.19 (2001), pp. 321-343.

[10017] J. A. Holman and D. L. Harrison. "A new genus of snake (Serpentes: Boidae) from the upper Eocene of Hordle Cliff, Hampshire, England". In: Acta Zoologica Cracoviensia 41 (1998), pp. 23-27.

[10018] J. A. Holman and D. L. Harrison. "A new helmeted frog of the genus Thaumastosaurus from the Eocene of England". In: Acta Palaeontologica Polonica 48.1 (2003), pp. 157-160.

[10019] J. A. Holman and D. L. Harrison. "A new genus of small boid snake from the Upper Eocene of Hordle Cliff, Hampshire, England". In: Acta Palaeontologica Polonica 41.1 (1998), pp. 29-33.

[10020] J. A. Holman and D. L. Harrison. "Early Oligocene (Whitneyan) snakes from Florida (USA), a unique booid". English. In: Acta Zoologica Cracoviensia 43.1-2 (2000), pp. 127-134.

[10021] J. A. Holman and D. L. Harrison. “Early Oligocene (Whitneyan) snakes from Florida (USA): remaining boids, indeterminate colubroids, summary and discussion of the I-75 Local Fauna snakes". English. In: Acta Zoologica Cracoviensia 44.1 (2001), pp. 25-36.

[10022] J. A. Holman and D. L. Harrison. "A New Thaumastosaurus (Anura: Familia Incertae Sedis) from the Late Eocene of England, with Remarks on the Taxonomic and Zoogeographic Relationships of the Genus". English. In: Journal of Herpetology 36.4 (2002), pp. 621-626. 
[10023] J. A. Holman, D. L. Harrison, and D. J. Ward. "Late Eocene snakes from the Headon Hill Formation, southern England". English. In: Cainozoic Research 5.1-2 (2006), pp. 51-62.

[10024] J. A. Holman and D. Parmley. "Noteworthy turtle remains from the Late Miocene (Late Hemphillian) of northeastern Nebraska". English. In: Texas Journal of Science 57.4 (2005), pp. 307-316.

[10025] J. A. Holman and M. Tanimoto. "cf. Trimeresurus Lacépéde (Reptilia: Squamata: Viperidae: Crotalinae) from the late Early Miocene of Japan". In: Acta Zoologica Cracoviensia 47.1 (2004), pp. 17.

[10026] L. E. Holmer. "Redescription of the Ordovician acrotretoid brachiopod Conotreta Walcott, 1889". English. In: G.F.F 122.3 (2000), pp. 313-318.

[10027] L. E. Holmer. "The Lower Ordovician brachiopod genus Lamanskya and the Family Elkaniidae". English. In: Transactions of the Royal Society of Edinburgh: Earth Sciences 84 (1993), pp. 151-160.

[10028] L. E. Holmer and P. Bengtson. "The first occurrence of a lingulid brachiopod from the Cretaceous of Sergipe, Brazil, with a restudy of 'Lingula' bagualensis Wilckens, 1905 from southern Patagonia". English. In: Palaeontologische Zeitschrift 83 (2009), pp. 255-266.

[10029] L. E. Holmer and G. Biernat. "Lingulate brachiopods from Lower Ordovician (Tremadoc) chalcedonites, Holy Cross Mountains, Poland". English. In: Acta Palaeontologica Polonica 47.1 (2002), pp. 141-156.

[10030] L. E. Holmer and J.-B. Caron. "A spinose stem group brachiopod with pedicle from the Middle Cambrian Burgess Shale". English. In: Acta Zoologica 87 (2006), pp. 273-290.

[10031] L. E. Holmer, L. Popov, and O. Lehnert. "Cambrian phosphatic brachiopods from the Precordillera of western Argentina". English. In: GFF 121 (1999), pp. 227-242.

[10032] L. E. Holmer, L. Popov, and M. G. Bassett. “Ordovician-Silurian Chileida-first post-Cambrian records of an enigmatic group of Brachiopoda". English. In: Journal of Paleontology 88.3 (2014), pp. 488-496.

[10033] L. E. Holmer, L. E. Popov, S. P. Koneva, and J. -Y. Rong. “Early Cambrian Lingulellotreta (Lingulata, Brachiopoda) from south Kazakhstan (Malyi Karatau Range) and south China (eastern Yunnan)". English. In: Journal of Paleontology 71.4 (1997), pp. 577-584.

[10034] L. E. Holmer, L. E. Popov, M. Streng, and J. F. Miller. "Lower Ordovician (Tremadocian) lingulate brachiopods from the House and Fillmore Formations, Ibex area, Western Utah, USA". English. In: Journal of Paleontology 79.5 (2005), pp. 884-906.

[10035] L. E. Holmer, L. E. Popov, S. P. Koneva, and M. G. Bassett. "Cambrian - early Ordovician brachiopods from Malyi Karatau, the western Balkhash region, and Tien Shan, Central Asia". English. In: Special Papers in Palaeontology 65 (2001), pp. 1-180.

[10036] L. E. Holmer and L. E. Popov. “The acrotretacean brachiopod Ceratreta tanneri (Metzger) from the Upper Cambrian of Baltoscandia". English. In: Geologiska Föreningen i Stockholm Förhandlingar 112.3 (1990), pp. 249-263. DOI: 10.1080/11035899009454772.

[10037] L. E. Holmer and L. E. Popov. “Lingulida”. English. In: Brachiopoda (revised), Linguliformea, Craniiformea, and Rhynchonelliformea (part), v. 2-3. In R. L. Kaesler, ed. Treatise on Invertebrate Paleontology. New York and Lawrence, KS: Geological Society of America and University of Kansas, 2000, pp. 32-146.

[10038] L. E. Holmer, L. E. Popov, M. G. Pour, and Z. Zhang. "Unusual pitted Ordovician Brachiopods from the east Baltic: The significance of coarsely pitted ornamentations in Linguliforms". English. In: Palaeontology (2017), pp. 1-13.

[10039] F. C. Holmes. "A new Late Eocene cassiduloid (Echinoidea) from Yorke Peninsula, South Australia". English. In: Memoirs of Museum Victoria 61.2 (2004), pp. 209-216.

[10040] F. C. Holmes, C. Ah Tee, and J. Krause. “Two new Middle Miocene spatangoids (Echinoidea) from the Murray Basin, South Australia". English. In: Memoirs of Museum Victoria 62.1 (2005), pp. 91-99. 
[10041] R. Holmes. "Pliopletecarpus primaevus (Mosasauridae) from the Bearpaw Formation (Campanian, Upper Cretaceous) of the North American Western Interior Seaway". In: Journal of Vertebrate Paleontology 16.4 (1996), pp. 673-687.

[10042] R. B. Holmes, D. S. Berman, and J. S. Anderson. "A new dissorophid (Temnospondyli, Dissorophoidea) from the Early Permian of New Mexico (United States)". English. In: Comptes Rendus Palevol 12 (2013), pp. 419-435.

[10043] R. B. Holmes, C. A. Forster, M. J. Ryan, and K. M. Shepherd. “A new species of Chasmosaurus (Dinosauria: Ceratopsia) from the Dinosaur Park Formation of southern Alberta". English. In: Canadian Journal of Earth Sciences 38 (2001), pp. 1423-1438.

[10044] R. B. Holmes, A. M. Murray, P. Chatarath, Y. S. Attia, and E. L. Simons. "Agamid lizards (Agamidae, Uromastycinae) from the lower Oligocene of Egypt". English. In: Historical Biology 22 (2010), pp. 215-233.

[10045] R. B. Holmes and M. J. Ryan. "The postcranial skeleton of Styracosaurus albertensis". English. In: Kirtlandia 58 (2013), pp. 5-37.

[10046] R. B. Holmes and H.-D. Sues. "A partial skeleton of the basal mosasaur Halisaurus platyspondylus from the Severn Formation (Upper Cretaceous: Maastrichtian) of Maryland". English. In: Journal of Paleontology 74.2 (2000), pp. 309-316.

[10047] P. A. Holroyd. "New record of Anthracotheriidae (Artiodactyla: Mammalia) from the middle Eocene Yegua Formation (Claiborne Group), Houston County, Texas". English. In: Texas Journal of Science 54.4 (2002), pp. 301-308.

[10048] P. A. Holroyd and R. L. Ciochon. "A new artiodactyl (Mammalia) from the Eocene Pondaung Sandstones, Burma". In: Annals of Carnegie Museum 64.3 (1995), pp. 177-183.

[10049] P. A. Holroyd and R. L. Ciochon. "Bunobrontops savagei a new genus and species of brontotheriid perissodactyl from the Eocene Pondaung fauna of Myanmar". English. In: Journal of Vertebrate Paleontology 20.2 (2000), pp. 408-410.

[10050] P. A. Holroyd and J. H. Hutchison. "Patterns of geographic variation in latest Cretaceous vertebrates: evidence from the turtle component". English. In: Geological Society of America Special Paper 361 (2002), pp. 177-190.

[10051] P. A. Holroyd and J. H. Hutchison. "Fauna and setting of the Adelolophus hutchisoni type locality in the Upper Cretaceous (Campanian) Wahweap Formation of Utah". English. In: PaleoBios 33.31196 (2016), pp. 1-9.

[10052] P. A. Holroyd, J. F. Parham, and J. H. Hutchison. "A reappraisal of some Paleogene turtles from the southeastern United States". English. In: Journal of Vertebrate Paleontology 25.4 (2005), pp. 979-982.

[10053] P. A. Holroyd and J. F. Parham. “The antiquity of African tortoises". English. In: Journal of Vertebrate Paleontology 23.3 (2003), pp. 688-690.

[10054] P. A. Holroyd and B. D. Rankin. "Additions to the latest Paleocene Buckman Hollow local fauna, Chappo Member of the Wasatch Formation, Lincoln County, southwestern Wyoming". English. In: Palaeontologia Electronica 17.1 (2014), 16A:1-26.

[10055] P. A. Holroyd, E. L. Simons, T. M. Bown, P. D. Polly, and M. J. Kraus. “New records of terrestrial mammals from the upper Eocene Qasr el Sagha Formation, Fayum Depression, Egypt". English. In: Palaeovertebrata 25.2-4 (1996), pp. 175-192.

[10056] P. A. Holroyd and N. J. Stevens. "Differentiation of Phiomys andrewsi from Lavocatomys aequatorialis (n. gen., n. sp.) (Rodentia: Thryonomyoidea) in the Oligo-Miocene interval on continental Africa". English. In: Journal of Vertebrate Paleontology 29.4 (2009), pp. 1331-1334.

[10057] P. A. Holroyd and S. G. Strait. New data on Loveina (Primates: Omomyidae) from the early Eocene Wasatch Formation and implications for washakiin relationships. English. Elwyn Simons: A Search for Origins. 2008, pp. 243-257. 
[10058] P. A. Holroyd, T. Tsubamoto, N. Egi, R. L. Ciochon, M. Takai, Soe Thura Tun, Chit Sein, and G. F. Gunnell. "A rhinocerotid perissodactyl from the late middle Eocene Pondaung Formation, Myanmar". English. In: Journal of Vertebrate Paleontology 26.2 (2006), pp. 491-494.

[10059] W. T. Holser, H. P. Schonlaub, K. Boeckelmann, and M. Magaritz. "The Permian-Triassic of the Gartnerkofel-1 core (Carnic Alps, Austria): synthesis and conclusions". English. In: Abhandlungen der Geologischen Bundesanstalt 45 (2001), pp. 213-232.

[10060] T. R. Holt, S. W. Salisbury, and P. M. A. Willis. "A new species of mekosuchine crocodilian from the middle Palaeogene Rundle Formation, central Queensland". English. In: Memoirs of the Queensland Museum 50.2 (2005), pp. 207-218.

[10061] P. F. Holterhoff. “Filtration models, guilds, and biofacies: crinoid paleoecology of the Stanton Formation (Upper Pennsylvanian), Midcontinent, North America". In: Palaeogeography, Palaeoclimatology, Palaeoecology 130.1-4 (1997), pp. 177-208.

[10062] F. M. Holwerda, M. Evans, and J. J. Liston. "Additional sauropod dinosaur material from the Callovian Oxford Clay Formation, Peterborough, UK: evidence for higher sauropod diversity". English. In: PeerJ 7 (2019), e6404:1-25.

[10063] F. Hölzforster, H. Stollhofen, and I. G. Stanistreet. "Lithostratigraphy and depositional environments in the Waterberg-Erongo area, central Namibia, and correlation with the main Karoo Basin, South Africa". English. In: Journal of African Earth Sciences 29.1 (1999), pp. 105-123.

[10064] A. Homan and P. Wegierek. "A new family of aphids (Hemiptera, Sternorrhyncha) from the Lower Cretaceous of Baissa, Transbaikalia". English. In: ZooKeys 130 (2011), pp. 167-174.

[10065] A. Homan, D. ya, and P. Wegierek. "Bajsaphididae fam. nov., from the Lower Cretaceous of Baissa, Russia: a new family of aphids and its evolutionary significance". English. In: Cretaceous Research 52 (2015), pp. 357-367.

[10066] D. W. E. Hone, J. N. Choiniere, Q. Tan, and X. Xu. "An articulated pes from a small parvicursorine alvarezsauroid dinosaur from Inner Mongolia, China". English. In: Acta Palaeontologica Polonica 58.3 (2013), pp. 453-458.

[10067] D. W. E. Hone, M. B. Habib, and F. Therrien. “Cryodrakon boreas, gen. et sp. nov., a Late Cretaceous Canadian azhdarchid pterosaur". English. In: Journal of Vertebrate Paleontology 39.3 (2019), e1649681.

[10068] D. W. E. Hone, H. Tischlinger, E. Frey, and M. Röper. “A new non-pterodactyloid pterosaur from the Late Jurassic of southern Germany". English. In: PLoS ONE 7.7 (2012), e38900. DOI: 10.1371/ journal.pone.0038900.

[10069] D. W. E. Hone, K. Wang, C. Sullivan, X. Zhao, S. Chen, D. Li, S. Ji, Q. Ji, and X. Xu. "A new, large tyrannosaurine theropod from the Upper Cretaceous of China". English. In: Cretaceous Research 32 (2011), pp. 495-503. DOI: 10.1016/j.cretres.2011.03.005.

[10070] D. W. E. Hone, X. Xu, and D. -Y. Wang. “A Probable Baryonychine (Theropoda: Spinosauridae) Tooth from the Upper Cretaceous of Henan Province, China". English. In: Vertebrata PalAsiatica 48.1 (2010), pp. 19-26.

[10071] J. G. Honey. "New Washakiin Primates (Omomyidae) from the Eocene of Wyoming and Colorado, and Comments on the Evolution of the Washakiini". English. In: Journal of Vertebrate Paleontology 10.2 (1990).

[10072] J. Hong, S.-H. Cho, S. -J. Choh, J. Woo, and D. -J. Lee. “Middle Cambrian siliceous sponge-calcimicrobe buildups (Daegi Formation, Korea): Metazoan buildup constituents in the aftermath of the Early Cambrian extinction event". English. In: Sedimentary Geology 253-254 (2012), pp. 47-57.

[10073] J. Hong, S.-J. Choh, and J. Park. D. -J. Lee. “Construction of the earliest stromatoporoid framework: Labechiid reefs from the Middle Ordovician of Korea". English. In: Palaeogeography, Palaeoclimatology, Palaeoecology 470 (2017), pp. 54-62.

[10074] P. S. Hong, J. G. Lee, and D. K. Choi. "Trilobites from the Lejopyge armata zone (Upper Middle Cambrian) of the Machari Formation, Yongwol Group, Korea". In: Journal of Paleontology 77.5 (2003), pp. 895-907. 
[10075] Y. C. Hong. "Midtriassic new genera and species of Mesopanorpodidae (Insecta, Mecoptera) from Shaanxi, China". English. In: Acta Zootaxonomica Sinica 32.2 (2007), pp. 261-267.

[10076] Y. C. Hong. "First discovery of fossil Parachoristidae (Insecta: Mecoptera) in China". English. In: Geological Bulletin of China 28 (2009), pp. 1382-1389.

[10077] Y. C. Hong. Chinese. Amber Insects of China. 2002, pp. 1-653.

[10078] Y. C. Hong. "Fossil insects of the northern Ordos Basin". Chinese. In: Acta Geologica Gansu 4.2 (1995), pp. 1-9.

[10079] Y. C. Hong. "Fossil insects of the southern Ordos Basin". Chinese. In: Acta Geologica Gansu 4.1 (1995), pp. 1-13.

[10080] Y. C. Hong. "Discovery of the fossil glosselytrods (Insecta: Glosselytrodea) from Shaanxi, China". Chinese. In: Acta Entomologica Sinica 50 (2007), pp. 271-280.

[10081] Y. C. Hong. "Midtriassic new genera and species of Orthophlebiidae and Neorthophlebiidae (Insecta, Mecoptera) from Shaanxi, China". English. In: Acta Zootaxonomica Sinica 34 (2009), pp. 423427.

[10082] Y. C. Hong. "Two new Middle Triassic genera and species of Permochoristidae (Insecta, Mecoptera) from Tongchuan region, Shaanxi Province, China". Chinese. In: Acta Zootaxonomica Sinica 30 (2005), pp. 697-701.

[10083] Y. C. Hong. “Discovery of fossil insects from Houcheng Formation of Hebei Province and establish of Houcheng entomofauna". Chinese. In: Beijing Geology 1997.1 (1997), pp. 1-10.

[10084] Y. C. Hong. "A new genus Huaxiarhyphus gen. nov. (Diptera, Rhyphoidea) from the Houcheng Formation, Hebei Province". Chinese. In: Memoirs of Beijing Natural History Museum 55 (1996), pp. $47-53$.

[10085] Y. C. Hong. "A fossil new genus Sinosmylites (Insecta: Neuroptera) from Laiyang basin, Shandong Province". Chinese. In: Memoirs of Beijing Natural History Museum 55 (1996), pp. 55-62.

[10086] Y. C. Hong. “A new Early Cretaceous beetle family - Magnocoleidae fam. nov. (Insecta: Coleoptera) in Hebei Province". Chinese. In: Geoscience - Journal of Graduate School, China University of Geoscience 12 (1998), pp. 40-48.

[10087] Y. C. Hong. Chinese. Atlas of Amber Insects of China. Zhengzhou: Henan Scientific and Technological Publishing House, 2002, pp. 1-394.

[10088] Y. C. Hong, S. Chen, and S. T. Liu. "Middle Triassic new fossils of Protorthophlebia Tillyard (Insecta: Mecoptera) from Tongchuan region, Shaanxi province, China". English. In: Entomologia Sinica 9.2 (2002), pp. 51-57.

[10089] Y. C. Hong and X. R. Guo. "Two new Middle Triassic genera and species of Mesopanorpodidae from Shaanxi (Insecta, Mecoptera)". English. In: Acta Zootaxonomica Sinica 28.4 (2003), pp. 716-720.

[10090] Y. C. Hong, X. R. Guo, and W. L. Wang. "Middle Triassic new fossils of Mesopanorpodidae (Insecta: Mecoptera) from Tongchuan, Shaanxi Province, China". English. In: Acta Zootaxonomica Sinica 27.2 (2002), pp. 278-283.

[10091] Y. C. Hong, X. R. Guo, and Z. Li. "A new Middle Triassic genus and species of Neorthophlebiidae (Insecta, Mecoptera) from Tongchuan region, Shaanxi Province, China". Chinese. In: Acta Zootaxonomica Sinica 30 (2005), pp. 467-469.

[10092] Y. C. Hong and X. R. Guo. "Emendation for 3 homonym and 1 species of Orthophlebiidae (Insecta, Mecoptera)". English. In: Geological Bulletin of China 29 (2010), pp. 188-194.

[10093] Y. C. Hong and Z. Li. "Discovery of the oldest fossil Meropeidae (Insecta, Mecoptera) from Shaanxi, China". Chinese. In: Acta Zootaxonomica Sinica 32 (2007), pp. 875-880.

[10094] Y. C. Hong and Z. Y. Li. "A new early Cretaceous family from Liupanshan, Ningxia, China (Insecta: Trichoptera)". Chinese. In: Acta Zootaxonomica Sinica 29 (2004), pp. 224-233. 
[10095] Y. C. Hong, S. J. Liang, and T. Hu. "Study on geology and paleontological assemblage from Tuha Basin of Xinjiang, China". Chinese. In: Geoscience - Journal of Graduate School, China University of Geosciences 9 (1995), pp. 426-440.

[10096] Y. C. Hong and Z. Z. Xiao. "New fossil Blattodea, Coleoptera and Mecoptera (Insecta) from Houcheng Formation of Yanqing County, Beijing". Chinese. In: Beijing Geology 1997.3 (1997), pp. 1-10.

[10097] Y. C. Hong and Z. Z. Xiao. "New fossil cockroaches from Houcheng Formation of Yanqing County, Beijing". Chinese. In: Beijing Geology 1997.2 (1997), pp. 1-9.

[10098] Y. C. Hong, Z. J. Zhang, X. R. Guo, and O. E. Heie. "A new species representing the oldest aphid (Hemiptera, Aphidomorpha) from the Middle Triassic of China". English. In: Journal of Paleontology 83 (2009), pp. 826-831.

[10099] C. Hongo. "Holocene key coral species in the Northwest Pacic: indicators of reef formation and reef ecosystem responses to global climate change and anthropogenic stresses in the near future". English. In: Quaternary Science Reviews 35 (2012), pp. 82-99.

[10100] C. Hongo and H. Kayanne. "Holocene coral reef development under windward and leeward locations at Ishigaki Island, Ryukyu Islands, Japan". English. In: Sedimentary Geology 214 (2009), pp. 62-73.

[10101] A. Honigstein and S. Crasquin. "Late Scythian-Anisian ostracods (Crustacea) from the Meged-2 borehole, central Israel". English. In: Journal of Micropalaeontology 30 (2011), pp. 17-31.

[10102] A. Honigstein, A. R. Lord, and B. Thuy. "Early Jurassic ostracods from the Glasenbach Gorge, Northern Calcareous Alps, Austria, and evidence for upper slope deposition". English. In: Neues Jahrbuch für Geologie und Paläontologie, Abhandlungen 273 (2014), pp. 1-11.

[10103] A. Honigstein, A. Rosenfeld, and B. Derin. "Late Permian ostracodes: new subsurface material from Israel". English. In: Micropaleontology 51.5 (2005), pp. 405-422.

[10104] A. Honigstein and A. Rosenfeld. "Systematic description of ostracodes, in Late Permian ostracodes: new subsurface material from Israel". English. In: Micropaleontology 51.5 (2005), pp. 405422.

[10105] S. C. Hood, C. R. Torres, M. A. Norell, and J. A. Clarke. "New Fossil Birds from the Earliest Eocene of Mongolia". English. In: American Museum Novitates 3934 (2019), pp. 1-22. DOI: 10.1206/3934.1.

[10106] R. W. Hook. "Chenoprosopus lewisi, a new cochleosaurid amphibian (Amphibia: Temnospondyli) from the Permo-Carboniferous of north-central Texas". English. In: Annals of Carnegie Museum 62 (1993), pp. 273-291.

[10107] R. W. Hook and D. Baird. "A new fish and tetrapod assemblage from the Allegheny Group (late Westphalian, Upper Carboniferous) of eastern Ohio, USA". English. In: New Research on PermoCarboniferous Faunas. Bad Durkheim: Pollichia, 1994, pp. 143-154.

[10108] R. W. Hook and N. Hotton. "A New Sphenacodontid Pelycosaur (Synapsida) from the Wichita Group, Lower Permian of North-Central Texas". English. In: Journal of Vertebrate Paleontology 11.1 (1991), pp. 37-44.

[10109] S. C. Hook and W. A. Cobban. "A condensed middle Cenomanian succession in the Dakota Sandstone (Upper Cretaceous), Sevilleta National Wildlife Refuge, Socorro County, New Mexico". English. In: New Mexico Geology 29.3 (2007), pp. 75-96.

[10110] S. C. Hook and W. A. Cobban. "Mecaster batnensis (Coquand, 1862), a late Cenomanian echinoid from New Mexico, with a compilation of Late Cretaceous echinoid records in the Western Interior of the United States and Canada". English. In: Acta Geologica Polonica 67 (2017), pp. 1-30.

[10111] J. J. Hooker. "An additional record of a placental mammal (Order Astrapotheria) from the Eocene of West Antarctica". English. In: Antarctic Science 4.1 (1992), pp. 107-108.

[10112] J. J. Hooker. "Mammalian taphonomy and palaeoecology of the Bembridge Limestone Formation (Late Eocene, S. England)". In: Historical Biology 8 (1994), pp. 49-69.

[10113] J. J. Hooker. "A new microchoerine omomyid (Primates, Mammalia) from the English Early Eocene and its palaeobiogeographical implications". English. In: Palaeontology 50.3 (2007), pp. 739-756. 
[10114] J. J. Hooker. "Bipedal browsing adaptations of the unusual Late Eocene-earliest Oligocene tylopod Anoplotherium (Artiodactyla, Mammalia)". English. In: Zoological Journal of the Linnean Society 151.3 (2007), pp. 609-659.

[10115] J. J. Hooker. “A new species of Platychoerops (Plesiadapiformes, Mammalia) from the latest Palaeocene of the Paris, London and Belgian Basins". English. In: Geobios 27.3 (1994), pp. 343-352.

[10116] J. J. Hooker. "Origin and evolution of the Pseudorhyncocyonidae, a European Paleogene family of insectivorous placental mammals". English. In: Palaeontology 56.4 (2013), pp. 807-835.

[10117] J. J. Hooker. "Skeletal adaptations and phylogeny of the oldest mole Eotalpa (Talpidae, Lipotyphla, Mammalia) from the UK Eocene: the beginning of fossoriality in moles". English. In: Palaeontology 59.2 (2015), pp. 195-216.

[10118] J. J. Hooker. "New postcranial bones of the extinct mammalian family Nyctitheriidae (Paleogene, UK): Primitive euarchontans with scansorial locomotion". English. In: Palaeontologia Electronica 17.3.47A (2014), pp. 1-91.

[10119] J. J. Hooker. "A mammal fauna from the Paleocene-Eocene Thermal Maximum of". English. In: Proceedings of the Geologists' Association (2018), pp. 1-16. DOI: 10.1016/j.pgeola.2018.01.001.

[10120] J. J. Hooker. "Eocene antiquity of the European nyctitheriid euarchontan mammal Darbonetus". English. In: Acta Palaeontologica Polonica 63.2 (2018), pp. 235-239.

[10121] J. J. Hooker and D. L. Harrison. "A new clade of omomyid primates from the European Paleogene". English. In: Journal of Vertebrate Paleontology 28.3 (2008), pp. 826-840.

[10122] J. J. Hooker, A. C. Milner, and S. E. K. Sequeira. "An ornithopod dinosaur from the Late Cretaceous of West Antarctica". English. In: Antarctica Science 3.3 (1991), pp. 331-332.

[10123] J. J. Hooker, D. E. Russell, and A. Phelzion. "A new family of Plesiadapiformes (Mammalia) from the Old World Lower Paleogene". English. In: Palaeontology 42.3 (1999), pp. 377-407.

[10124] J. J. Hooker and D. E. Russell. "Early Palaeogene Louisinidae (Macroscelidea, Mammalia), their relationships and north European diversity". English. In: Zoological Journal of the Linnean Society 164 (2012), pp. 856-936.

[10125] J. J. Hooker, M. R. Sánchez-Villagra, F. J. Goin, E. L. Simons, Y. Attia, and E. R. Seiffert. “The origin of Afro-Arabian 'didelphimorph' marsupials". English. In: Palaeontology 51.3 (2008), pp. 635-648.

[10126] J. J. Hooker and K. M. Thomas. "A new species of Amphirhagatherium (Choeropotamidae, Artiodactyla, Mammalia) from the Late Eocene Headon Hill Formation of southern England and phylogeny of endemic European 'Anthracotherioids'". In: Palaeontology 44.5 (2001), pp. 827-853.

[10127] J. J. Hooker and M. Weidmann. "A diverse rodent fauna from the middle Bartonian (Eocene) of Les Alleveys, Switzerland: snapshot of the early theridomyid radiation". English. In: Swiss journal of Geosciences 100 (2007), pp. 469-493.

[10128] J. J. Hooker. "Skeletal adaptations and phylogeny of the oldest mole Eotalpa (Talpidae, Lipotyphla, Mammalia) from the UK Eocene: the beginning of fossoriality in moles". English. In: Palaeontology 59.2 (2016). DOI: 10.1111/pala.12221.

[10129] G. E. Hooks, D. R. Schwimmer, and G. D. Williams. "Syonymy of the pycnodont Phacodus punctatus Disxon, 1850, and its occurrence in the late Cretaceous of the southeastern United States". English. In: Journal of Vertebrate Paleontology 19.3 (1999), pp. 588-590.

[10130] R. W. Hooley. "VII-Note on a tortoise from the Wealden of the Isle of Wight". English. In: Geological Magazine 7 (1990), pp. 263-265. DOI: 10.1017/S0016756800176915.

[10131] C. Hoorn. "Marine incursions and the influence of Adean tectonics on the Miocene depositional history of northwestern Amazonia: results of a palynostratigraphic study". English. In: Palaeogeography, Palaeoclimatology, Palaeoecology 105 (1993), pp. 267-309.

[10132] P. R. Hoover. "Late Triassic cyrtinoid spiriferinacean brachiopods from western North America and their biostratigraphic and biogeographic implications". English. In: Bulletins of American Paleontology 100.337 (1991), pp. 63-109. 
[10133] E. K. Hopkin and C. A. McRoberts. "A new Middle Triassic flat clam (Pterioida: Halobiidae) from the Middle Anisian of north-central Nevada, USA". English. In: Journal of Paleontology 79.4 (2005), pp. 796-800.

[10134] M. J. Hopkins. "Phylogenetic analysis and revision of the trilobite subfamily Balnibarbiinae (Olenidae)". English. In: American Museum Novitates 3928 (2019), pp. 1-20.

[10135] S. B. Hopkins. “Phylogeny and biogeography of the genus Ansomys Qiu, 1987 (Mammalia: Rodentia: Aplodontidae) and description of a new species from the Barstovian (mid-Miocene) of Montana". English. In: Journal of Paleontology 78.4 (2004), pp. 731-740.

[10136] P. J. Hopley. "Plesiosaur spinal pathology: the first fossil occurrence of Schmorl's nodes". English. In: Journal of Vertebrate Paleontology 21.2 (2001), pp. 253-260.

[10137] P. J. Hopley. "A new plesiosauroid specimen from the Sinemurian, Lower Jurassic, of southern England". English. In: Proceedings of the Dorset Archaeological and Natural History Society 122 (2000), pp. $129-138$.

[10138] K. J. Hopp and M. A. Ivie. "A revision of the West Indian genus Nesocyrtosoma Marcuzzi (Coleoptera: Tenebrionidae)". English. In: The Coleopterists Society Monograph 8 (2009), pp. 1-138.

[10139] J. A. Hopson and J. W. Kitching. "A probainognathian cynodont from South Africa and the phylogeny of nonmammalian cynodonts". English. In: Bulletin of the Museum of Comparative Zoology 156.1 (2001), pp. 5-35.

[10140] J. A. Hopson and H.-D. Sues. "A traversodont cynodont from the Middle Triassic (Ladinian) of Baden-Württemberg (Germany)". English. In: Palaeontologische Zeitschrift 80.2 (2006), pp. 124-129.

[10141] A. D. Horbury. "A Late Dinantian peloid cementstone-palaeoberesellid buildup from North Lancashire, England". English. In: Sedimentary Geology 79 (1992), pp. 117-137.

[10142] K. Hordijk and H. de Bruijn. "The succession of rodent faunas from the Mio/Pliocene lacustrine deposits of the Florina-Ptolemais-Servia Basin (Greece)". English. In: Hellenic Journal of Geosciences 44 (2009), pp. 21-103.

[10143] N. Hori. "Latest Jurassic radiolarians from the northeastern part of the Torinoko Block, Yamizo Mountains, central Japan". English. In: Science Reports of the Institute of Geoscience University of Tsukuba, Section B: Geological Sciences 20 (1999), pp. 47-114.

[10144] N. Hori and K. Wakita. “Early Middle Jurrasic (late Aalenian) radiolarian assemblage in a manganese nodule from the Northern Chichibu Belt in the Ino area, Kochi Prefecture, Southwest Japan". English. In: Journal of Asian Earth Sciences 27 (2006), pp. 45-60.

[10145] R. Hori. "Radiolarian Biostratigraphy at the Triassic/Jurassic Period Boundary in Bedded Cherts from the Inuyama Area, Central Japan". English. In: Journal of Geosciences, Osaka City University 35.4 (1992), pp. 53-65.

[10146] R. S. Hori, Y. Aita, and J. A. Grant-MacKie. "Preliminary report on Lower Jurassic radiolaria of Gondwana origin from the Kawhia coast, New Zealand". English. In: The Island Arc 5 (1996), pp. 104-113.

[10147] R. S. Hori and H. J. Campbell. “Lingularia sp. (Brachiopoda) from Middle Triassic bedded chert in Shikoku, Japan". English. In: Journal of the Geological Society of Japan 110.12 (2004), pp. 758-764. DOI: $10.5575 /$ geosoc. 110.758 .

[10148] R. S. Hori, J. D. Campbell, and J. A. Grant-Mackie. “Triassic Radiolaria from Kaka Point Structural Belt, Otago, New Zealand". English. In: Journal of the Royal Society of New Zealand 33.1 (2003), pp. 39-55.

[10149] R. S. Hori, S. Yamakita, M. Ikehara, K. Kodama, Y. Aita, T. Sakai, A. Takemura, Y. Kamata, N. Suzuki, S. Takahashi, K. B. Spörli, and J. A. Grant-Mackie. “Early Triassic (Induan) Radiolaria and carbon-isotope ratios of a deep-sea sequence from Waiheke Island, North Island, New Zealand". English. In: Palaeoworld 20 (2011), pp. 166-178. DOI: 10.1016/j.palwor.2011.02.001. 
[10150] A. Horiguchi, H. Aiba, Y. Takahashi, H. Inoue, and T. Sato. "First fossil record of a jumping plantlouse (Insecta, Hemiptera, Psylloidea) from Japan". English. In: PalZ 94 (2020), pp. 455-461. DOI: $10.1007 /$ s12542-019-00508-4.

[10151] H. Horikawa. "A primitive odobenine walrus of Early Pliocene age from Japan". English. In: The Island Arc 3 (1995), pp. 309-328.

[10152] H. Horikawa, S. Yoneyama, and K. Watanabe. "A new material of Odobenidae found from late Miocene-early Pliocene deposits in Oosima mura, Nigata, Central Japan". Japanese. In: Chikyo Kagaku 48.6 (1994), pp. 565-570.

[10153] G. S. Horne. "A mid-Cretaceous ornithopod from central Honduras". English. In: Journal of Vertebrate Paleontology 14.1 (1994), pp. 147-150.

[10154] J. R. Horner. “Cranial morphology of Prosaurolophus (Ornithischia: Hadrosauridae) with descriptions of two new hadrosaurid species and an evaluation of hadrosaurid phylogenetic relationships". In: Museum of the Rockies Occasional Paper 2 (1992), pp. 1-119.

[10155] J. R. Horner and P. J. Currie. Embryonic and neonatal morphology and ontogeny of a new species of Hypacrosaurus (Ornithischia, Lambeosauridae) from Montana and Alberta. Dinosaur Eggs and Babies, Cambridge University Press, Cambridge. 1994, pp. 312-336.

[10156] J. R. Horner, A. de Ricqlés, K. Padian, and R. D. Scheetz. “Comparative long bone histology and growth of the hypsilophodontid dinosaurs Orodromeus makelai, Dryosaurus altus, and Tenontosaurus tillettii (Ornithlschla: Euornithopoda)". English. In: Journal of Vertebrate Paleontology 29.3 (2009), pp. 734-747. DOI: 10.1671/039.029.0312.

[10157] J. R. Horner and M. B. Goodwin. "Ontogeny of canial epi-ossifications in Triceratops". English. In: Journal of Vertebrate Paleontology 28.1 (2008), pp. 134-144.

[10158] J. R. Horner and D. B. Weishampel. "A comparative embryological study of two ornithischian dinosaurs (correction)". In: Nature 383 (1996), p. 103.

[10159] M. K. Hörnig, C. Haug, K. J. Herd, and J. T. Haug. “New insights into dictyopteran early development: smallest Palaeozoic roachoid nymph found so far". English. In: Palaeodiversity 7 (2014), pp. 159-165.

[10160] M. K. Hörnig, C. Haug, J. W. Schneider, and J. T. Haug. "Evolution of reproductive strategies in dictyopteran insects - clues from ovipositor morphology of extinct roachoids". English. In: Acta Palaeontologica Polonica 63 (2018), pp. 1-24.

[10161] M. K. Hörnig, J. T. Haug, and C. Haug. “New details of Santanmantis axelrodi and the evolution of the mantodean morphotype". English. In: Palaeodiversity 6 (2013), pp. 157-168.

[10162] M. K. Hörnig, J. T. Haug, and C. Haug. "An exceptionally preserved 110 million years old praying mantis provides new insights into the predatory behaviour of early mantodeans". English. In: PeerJ 5.e3605 (2017), pp. 1-19.

[10163] T. Hörnschemeyer. "New species of Electribius Crowson 1973 (Coleoptera: Artematopodidae) from Baltic amber". English. In: Paläontologische Zeitschrift 72 (1998), pp. 299-306.

[10164] T. Hörnschemeyer and H. Stapf. “Review of Blattinopsidae (Protorthoptera) with description of new species from the Lower Permian of Niedermoschel (Germany)". English. In: Neues Jahrbuch für Geologie und Paläontologie - Abhandlungen 221.1 (2001), pp. 81-109.

[10165] T. Hörnschemeyer, S. Wedmann, and G. Poinar. "How long can insect species exist? Evidence from extant and fossil Micromalthus beetles (Insecta: Coleoptera)". English. In: Zoological Journal of the Linnean Society 158 (2010), pp. 300-311.

[10166] J. J. Hornung, A. Böhme, T. van der Lubbe, M. Reich, and A. Richter. "Vertebrate tracksites in the Obernkirchen Sandstone (late Berriasian, Early Cretaceous) of northwest Germany-their stratigraphical, palaeogeographical, palaeoecological, and historical context". English. In: Paläontologische Zeitschrift 86.3 (2012), pp. 231-267. DOI: 10.1007/s12542-012-0131-7. 
[10167] J. J. Hornung, M. Reich, and U. Frerichs. “A mosasaur fauna (Squamata: Mosasauridae) from the Campanian (Upper Cretaceous) of Hannover, northern Germany". English. In: Alcheringa 42.4 (2018), pp. 543-559. DOI: 10.1080/03115518.2018.1434899.

[10168] J. J. Hornung and M. Reich. "Metatetrapous valdensis Nopcsa, 1923 and the Presence of Ankylosaur Tracks (Dinosauria: Thyreophora) in the Berriasian (Early Cretaceous) of Northwestern Germany". English. In: Ichnos 21.1 (2014), pp. 1-18. DOI: 10.1080/10420940.2013.873720.

[10169] J. J. Hornung and S. Sachs. "First record of Gyrosteus mirabilis (Actinopterygii, Chondrosteidae) from the Toarcian (Lower Jurassic) of the Baltic region". English. In: PeerJ 8.e8400 (2020). DOI: 10.7717 / peerj.8400.

[10170] T. Hornung. "Multistratigraphy of the Draxllehen Quarry near Berchtes-Gaden (Tuvalian-Lacian 2). Implications for Hallstatt Limestone sedimentation and palaeoclimate in the aftermath of the Carnian crisis". English. In: Austrian Journal of Earth Sciences 100 (2007), pp. 82-99.

[10171] T. Hornung. "Kondensierte Ammonitenbänke im Beckenbereich des basalen Kimmeridge der Nördlichen Frankenalb (Alter Steinbruch Ludwag, Ofr.)" English. In: Geologische Blätter von NordostBayern 52 (2002), pp. 195-242.

[10172] T. Hornung, I. Kogan, G. Moosleitner, G. Wolf, and J. van der Wielen. “The Norian fish deposits of Wiestal (Seefeld Member, Northern Calcareous Alps, Salzburg, Austria) - taxonomy and palaeoenvironmental implications". English. In: Austrian Journal of Earth Sciences 112 (2019), pp. 125-165.

[10173] R. J. Horný. “Ordovician Tergomya and Gastropoda (Mollusca) of the Anti-Atlas (Morocco)". English. In: Acta Musei Nationalis Pragae, Series B - Historia Naturalis 53.3-4 (1997), pp. 37-78.

[10174] R. J. Horný. "New Lower Devonian Gastropoda and Tergomya (Mollusca) of Bohemia". English. In: asopis Národniho Muzea, ada podovdná 159.1-4 (1992), pp. 99-119.

[10175] R. J. Horný. "Shell morphology, presumed mode of life, and shell repair of the Lower Devonian paragastropod Antigyra from Bohemia (Czech Republic)". English. In: asopis Národniho Muzea, ada podovdná 173.1-4 (2004), pp. 65-76.

[10176] R. J. Horný. "New Lower Devonian gastropod genera of Bohemia (Mollusca)". English. In: asopis Národniho Muzea, ada podovdná 158.1-4 (1992), pp. 105-107.

[10177] R. J. Horný. "Kosovina, a new Silurian tryblidiid genus (Mollusca, Tergomya) from Bohemia (Czech Republic)". English. In: Acta Musei Nationalis Pragae, Series B, Natural History 60.3-4 (2004), pp. 143-148.

[10178] R. J. Horný. "New, rare, and better recognized Ordovician Tergomya and Gastropoda". English. In: Bulletin of the Czech Geological Survey 72.3 (1997), pp. 223-237.

[10179] R. J. Horný. “Two new bellerophontiform tergomyans (Mollusca) from the Early Devonian (Lochkovian) of the Barrandian Area, Bohemia (Czech Republic)". English. In: asopis Národniho Muzea, ada podovdná 174.1-4 (2005), pp. 7-12.

[10180] R. J. Horný. "Branzovya, a new Lower Devonian murchisoniacean gastropod from Bohemia". English. In: asopis Národniho Muzea, ada podovdná 162.1-4 (1994), pp. 100-100.

[10181] R. J. Horný. "Solandangella, a problematic Lower Ordovician mollusc from the Montagne Noire, southern France". English. In: Acta Musei Nationalis Pragae, Series B - Historia Naturalis 50.1-4 (1995), pp. 1-11.

[10182] R. J. Horný. "Shell breakage and repair in explanate bellerophontoidean gastropods from the Middle Ordovician of Bohemia". English. In: Bulletin of the Czech Geological Survey 72.2 (1997), pp. 159170.

[10183] R. J. Horný. “Circumbilical retractor muscle attachment area in the Ordovician trilobed bellerophontoidean gastropod Tritonophon peeli sp. n. (Mollusca)". English. In: Bulletin of the Czech Geological Survey 72.4 (1997), pp. 333-338.

[10184] R. J. Horný. "Quasisininuites rapax gen. et sp. n., a new Ordovician sinuate cyrtonellid mollusc (Class Tergomya) with involute shell from Morocco". English. In: Bulletin of the Czech Geological Survey 73.4 (1997), pp. 345-350. 
[10185] R. J. Horný. “Tachloconcha gen. n. and Spirina Kayser, 1889, two additional Lower Palaeozoic gastropods with preserved retractor muscle attachment scars". English. In: Bulletin of the Czech Geological Survey 75.4 (2000), pp. 415-426.

[10186] R. J. Horný. "Anomalous development of apertural margin and failed predation in the Lower Devonian gastropod Anarconcha pulchra from the Barrandian (Czech Republic)". English. In: asopis Národniho Muzea, ada podovdná 171.1-4 (2002), pp. 1-6.

[10187] R. J. Horný. "Krolmusium, a new genus of the subfamily Agnesiinae (Gastropoda) from the Lower Devonian of Bohemia (Czech Republic)". English. In: asopis Národniho Muzea, ada podovdná 171.1-4 (2002), pp. 7-11.

[10188] R. J. Horný. "Muscle scars, systematics and mode of life of the Silurian family Drahomiridae (Mollusca, Tergomya)". English. In: Acta Musei Nationalis Pragae, Series B - Historia Naturalis 61.1-2 (2005), pp. 53-76.

[10189] R. J. Horný. “Patelliconus Horný, 1961 and Mytoconula gen. n. (Mollusca, Tergomya) from the Ordovician of Perunica". English. In: Sbornk Národniho Muzea v Praze 65.1-2 (2009), pp. 25-34.

[10190] R. J. Horný and J. I. Henry. "A letter by Joachim Barrande to Daniel Oehlert concerning Praenatica (Gastropoda) written on May 12 1882". English. In: Journal of the Czech Geological Society 44 (1999), pp. 117-125.

[10191] R. J. Horný and J. S. Peel. “Carcassonnella, a new Lower Ordovician bellerophontiform mollusc with dorsally located retractor muscle attachments (Class Tergomya)". English. In: Bulletin of the Czech Geological Survey 71.4 (1996), pp. 305-311.

[10192] R. J. Horný and J. S. Peel. "A new Silurian gastropod from Bohemia with the operculum in situ". English. In: Journal of the Czech Geological Society 40.4 (1995), pp. 50-60.

[10193] R. J. Horný and D. Vizcano. "Thoralispira, a new Lower Ordovician cyrtonellid genus (Mollusca, Tergomya) from the Montagne Noire, southern France". English. In: Bulletin of the Czech Geological Survey 70.4 (1995), pp. 25-41.

[10194] I. Horovitz, T. Martin, J. Bloch, S. Ladevéze, C. Kurz, and M. R. Sánchez-Villagra. “Cranial anatomy of the earliest marsupials and the origin of opossums". English. In: PLoS One 4.12 (2009), e8278. DOI: 10.1371/journal.pone.0008278.

[10195] I. Horovitz, M. R. Sánchez-Villagra, T. Martin, and O. A. Aguilera. “The fossil record of Phoberomys pattersoni Mones 1980 (Mammalia, Rodentia) from Urumaco (Late Miocene, Venezuela), with an analysis of its phylogenetic relationships". English. In: Journal of Systematic Palaeontology 4.3 (2006), pp. 293-306.

[10196] I. Hosgor and Y. Okan. "A New Species of Angariid Gastropod from the Early Thanetian of the Haymana-Polatli Basin, Turkey". English. In: Turkish Journal of Earth Sciences 20 (2011), pp. 243253. DOI: $10.3906 /$ yer-0909-3.

[10197] S. Hossini. "A new species of Latonia (Anura, Discoglossidae) from the lower Miocene of France". English. In: Amphibia-Reptilia 14 (1993), pp. 237-245.

[10198] S. Hossini and J.-C. Rage. "Palaeobatrachid Frogs from the Earliest Miocene (Agenian) of France, with Description of a New Species". English. In: Geobios 33.2 (2000), pp. 223-231. DOI: 10.1016/ S0016-6995(00)80019-4.

[10199] B. Hostettler and U. Menkveld-Gfeller. "Die Cidariden (Echinoidea, Echinodermata) der WildeggFormation (mittleres Oxfordien, Schweizer Jura)". German. In: Revue de Paléobiologie, Genéve 34 (2015), pp. 195-233.

[10200] F. H. C. Hotchkiss. “A new Devonian Ophiuroid (Echinodermata: Oegophiurida) from New York State and its bearing on the origin of ophiuroid upper arm plates". English. In: Proceedings of the Biological Society of Washington 106.1 (1993), pp. 63-84.

[10201] L. Hou. "A carinate bird from the Upper Jurassic of western Liaoning, China". English. In: Chinese Science Bulletin 42.5 (1997), pp. 413-417. 
[10202] L. Hou. "[A late Mesozoic bird from Inner Mongolia]". Chinese. In: Vertebrata PalAsiatica 32.4 (1994), pp. 258-266.

[10203] L. Hou. "A new Paleocene bird from Anhui, China". English. In: Vertebrata PalAsiatica 32 (1994), pp. 60-65.

[10204] L. Hou, L. M. Chiappe, F. Zhang, and C. -M. Chuong. “New Early Cretaceous fossil from China documents a novel trophic specialization for Mesozoic birds". English. In: Naturwissenschaften 91 (2004), pp. 22-25. DOI: 10.1007/s00114-003-0489-1.

[10205] L. Hou, L. D. Martin, Z. Zhou, A. Feduccia, and F. Zhang. "A diapsid skull in a new species of the primitive bird <i>Confuciusornis</i>". In: Nature 399 (1999), pp. 679-682.

[10206] L. Hou and J. Zhang. "[A new fossil bird from Lower Cretaceous of Liaoning]". Chinese. In: Vertebrata PalAsiatica 31.3 (1993), pp. 217-224.

[10207] L. Hou, Z. Zhou, F. Zhang, and Z. Wang. "A Miocene ostrich fossil from Gansu Province, northwest China". English. In: Chinese Science Bulletin 50.16 (2005), pp. 1808-1810.

[10208] L. H. Hou. English. Mesozoic Birds of China. 1997.

[10209] L.-H. Hou and P. G. P. Ericson. "A Middle Eocene shorebird from China". English. In: The Condor 104.4 (2002), pp. 896-899.

[10210] L.-H. Hou, L. D. Martin, Z. -H. Zhou, and A. Feduccia. “Archaeopteryx to opposite birds - missing link from the Mesozoic of China". English. In: Vertebrata PalAsiatica 37.2 (1999), pp. 88-95.

[10211] L.-h. Hou, Z. Zhou, L. D. Martin, and A. Feduccia. "A beaked bird from the Jurassic of China". English. In: Nature 377 (1995), pp. 616-618.

[10212] S. Hou and J. Meng. "A new eutriconodont mammal from the early Cretaceous Jehol Biota of Liaoning, China". English. In: Chinese Science Bulletin 59.5-6 (2014), pp. 546-553. DOI: 10.1007 / s11434-013-0088-2.

[10213] W. J. Hou, Y. Z. Yao, W. T. Zhang, and D. Ren. "The earliest fossil flower bugs (Heteroptera: Cimicomorpha: Cimicoidea: Vetanthocoridae) from the Middle Jurassic of Inner Mongolia, China". English. In: European Journal of Entomology 109 (2012), pp. 281-288.

[10214] X. Hou and J. Bergström. "Arthropods of the Lower Cambrian Chengiiang fauna, southwest China". English. In: Fossils \& Strata 45 (1997), pp. 1-116.

[10215] K. J. Houck. "Sedimentology and stratigraphy of the Morrison Formation in the Dinosaur Ridge area near Morrison, Colorado". English. In: The Mountain Geologist 38.3 (2001), pp. 97-110.

[10216] M. W. Hounslow, M. Hu, A. Mørk, W. Weitschat, J. Os Vigran, V. Karloukovski, and M. J. Orchard. "Intercalibration of Boreal and Tethyan time scales: the magnetobiostratigraphy of the Middle Triassic and the latest Early Triassic from Spitsbergen, Arctic Norway". English. In: Polar Research 27.3 (2008), pp. 469-490. DOI: 10.1111/j.1751-8369.2008.00074.x.

[10217] M. R. House. “Devonian (Frasnian) goniatites from Waterside Cove and Staverton Wood, south Devon". English. In: Geoscience in South-West England 10 (2002), pp. 267-280.

[10218] M. R. House, R. T. Becker, R. Feist, G. Flajs, C. Girard, and G. Klapper. "The Frasnian/Famennian boundary GSSP at Coumiac, southern France". In: Courier Forschungs-Institut Senckenberg 225 (2000), pp. 59-75.

[10219] A. Houssaye. "A new aquatic pythonomorph (Reptilia, Squamata) from the Turonian (Late Cretaceous) of France". English. In: Comptes Rendus Palevol 9 (2010), pp. 39-45.

[10220] A. Houssaye, N. Bardet, J. -C. Rage, X. Pereda-Suberbiola, B. Bouya, M. Amaghzaz, and M. Amalik. "A review of Pachyvaranus crassispondylus Arambourg, 1952, a pachyostotic marine squamate from the latest Cretaceous phosphates of Morocco and Syria". English. In: Geological Magazine 148.2 (2011), pp. 237-249.

[10221] A. Houssaye, N. Bardet, I. Narváez, and F. Ortega. “Squamate finding in Lo Hueco (Late CampanianEarly Maastrichtian, Cuenca Province, Spain): the second non-marine pythonomorph lizard". English. In: Palaeontologische Zeitschrift 87.3 (2013), pp. 415-422. DOI: 10.1007/s12542-013-0164-6. 
[10222] A. Houssaye, J.-C. Rage, F. Torcida Fernández-Baldor, P. Huerta, N. Bardet, and X. Pereda Suberbiola. "A new varanoid squamate from the Early Cretaceous (Barremian-Aptian) of Burgos, Spain". English. In: Cretaceous Research 41 (2013), pp. 127-135. DOI: 10.1016/j.cretres.2012.11.005.

[10223] A. Houssaye, J.-C. Rage, N. Bardet, P. Vincent, M. Amaghzaz, and S. Meeslouh. “New highlights about the enigmatic marine snake Palaeophis maghrebianus (Palaeophiidae; Palaeophiinae) from the Ypresian (Lower Eocene) Phosphates of Morocco". English. In: Palaeontology (2013). DOI: 10. 1111 /pala.12008.

[10224] M. K. Howarth. "The ammonite family Hildoceratidae in the Lower Jurassic of Britain". English. In: Monograph of the Palaeontographical Society (1992), pp. 1-200.

[10225] M. K. Howarth. "Tithonian and Berriasian ammonites from the Chia Gara Formation in northern Iran". English. In: Palaeontology 35.3 (1992), pp. 597-655.

[10226] S. Howe. "Extracting dinosaur trackways: a Welsh experience". English. In: The Geological Curator 6.2 (1994), pp. 83-88.

[10227] F. C. Howell and N. Garcia. "Carnivora (Mammalia) from Lemudong'o (Late Miocene: Narok District, Kenya". English. In: Kirtlandia 56 (2007), pp. 121-139.

[10228] S. C. B. Howse, A. R. Milner, and D. M. Martill. Pterosaurs. English. Dinosaurs from the Isle of Wight, The Palaeontological Association, London. 2001, pp. 324-335.

[10229] L. Hradecka, H. Lobitzer, F. Ottner, F. Schlagintweit, M. Svobodova, I. Szente, L. Svabenicka, and I. Zorn. "Biostratigraphy and paleoenvironment of the lower Gosau subgroup of Eisenbach brook in Salzkammergut (Upper Austria)". English. In: Beiträge zur Geologie des Gmundner Bezirks/Gmundner Geo-Studien 3 (2005), pp. 25-42.

[10230] I. Hradská and J. A. Dunlop. "New records of Pennsylvanian trigonotarbid arachnids from West Bohemia, Czech Republic". English. In: The Journal of Arachnology 41 (2013), pp. 335-341.

[10231] T. Hrbek, V. M. F. da Silva, N. Dutra, W. Gravena, and A. R. Martin. “A New Species of River Dolphin from Brazil or: How Little Do We Know Our Biodiversity". English. In: PLoS One 9.1 (2014), e8623. DOI: 10.1371/journal.pone.0083623.

[10232] K. Hryniewicz, K. Amano, R. G. Jenkins, and S. Kiel. "Thyasirid bivalves from Cretaceous and Paleogene cold seeps". English. In: Acta Palaeontologica Polonica 62.4 (2017), pp. 705-728.

[10233] K. Hryniewicz, M. Jakubowicz, and C. Klug. "Early Devonian bivalves from Hamar Laghdad, Morocco". English. In: 290.1-3 (2018), pp. 191-202. DOI: 10.1127/njgpa/2018/0782.

[10234] K. Hryniewicz, C. T. Little, and H. A. Nakrem. "Bivalves from the latest Jurassic-earliest Cretaceous hydrocarbon seep carbonates from central Spitsbergen, Svalbard". English. In: Zootaxa 3859.1 (2014), pp. 1-66.

[10235] Y. Hsiao. "Taxonomic notes on Eustrophinae from the mid-Cretaceous Burmese amber, with description of a new species (Coleoptera, Tetratomidae)". English. In: PalZ 94 (2020), pp. 263-269. DOI: $10.1007 /$ s12542-019-00480-z.

[10236] Y. Hsiao and C. L. Huang. "Spinotoma ruicheni: A new Late Cretaceous genus and species of wedge-shaped beetle from Burmese amber (Coleoptera, Ripiphoridae, Pelecotominae)". English. In: Cretaceous Research 82 (2017), pp. 29-35.

[10237] Y. Hsiao and C. L. Huang. "Taxonomic revision on the genus Ornatomalthinus Poinar and Fanti (Coleoptera: Cantharidae), with description of a new species from the Cretaceous Burmese amber". English. In: Cretaceous Research 92 (2018), pp. 257-263.

[10238] Y. Hsiao, A. lipiski, C. S. Deng, and H. Pang. "A new genus and species of soldier beetle from Upper Cretaceous Burmese amber (Coleoptera, Cantharidae, Malthininae)". English. In: Cretaceous Research 69 (2016), pp. 119-123.

[10239] Y. Hsiao, A. lipiski, Y. L. Yu, C. S. Deng, and H. Pang. "Allostrophus cretaceus gen. et sp. nov.: A new polypore fungus beetle (Coleoptera, Tetratomidae) from the Cretaceous Myanmar amber". English. In: Cretaceous Research 92 (2018), pp. 195-200. 
[10240] Y. Hsiao, Y. L. Yu, C. S. Deng, and H. Pang. "The first fossil wedge-shaped beetle (Coleoptera, Ripiphoridae) from the middle Jurassic of China". English. In: European Journal of Taxonomy 277 (2017), pp. 1-13.

[10241] A. S. Hsiou and A. M. Albino. "Presence of the Genus Eunectes (Serpentes, Boidae) in the Neogene of Southwestern Amazonia, Brazil". English. In: Journal of Herpetology 43.4 (2009), pp. 612-619.

[10242] A. S. Hsiou, A. M. Albino, and J. Ferigolo. "Reappraisal of the South American Miocene snakes of the genus Colombophis, with description of a new species". English. In: Acta Palaeontologica Polonica 55.3 (2010), pp. 365-379.

[10243] A. S. Hsiou, A. M. Albino, and J. Ferigolo. "First lizard remains (Teiidae) from the Miocene of Brazil (Solimões Formation)". English. In: Revista Brasileira de Paleontologia 12.3 (2010), pp. 225230.

[10244] A. S. Hsiou and A. M. Albino. "New snake remains from the Miocene of northern South America". English. In: Herpetological Journal 20 (2010), pp. 249-259.

[10245] A. S. Hsiou, A. M. Albino, M. A. Medeiros, and R. A. B. Santos. “The oldest Brazilian snakes from the early Late Cretaceous (Cenomanian)". English. In: Acta Palaeontologica Polonica (2013). DOI: 10.4202/app.2012.0091.

[10246] A. S. Hsiou and D. C. Fortier. "Primeiro registro de Caiman (Crocodilya, Alligatoridae) para o Pleistoceno do Estado do Rio Grande do Sul, Brasil". Portugese. In: Gaea 3.1 (2007), pp. 37-44.

[10247] A. S. Hsiou, R. L. Nydam, T. R. Simões, F. A. Pretto, S. Onary, A. G. Martinelli, A. Liparini, P.R.R.d.V. Martnez, M. B. Soares, C. L. Schultz, and M. W. Caldwell. "A new clevosaurid from the Triassic (Carnian) of Brazil and the rise of sphenodontians in Gondwana". English. In: Scientific Reports 9.11821 (2019), pp. 1-12. DOI: 10.1038/s41598-019-48297-9.

[10248] T. Htike, T. Tsubamoto, M. Takai, N. Egi, Z. M. M. Thein, C. Sein, and M. Maung. “Discovery of Propotamochoerus (Artiodactyla, Suidae) from the Neogene of Myanmar". English. In: Asian Paleoprimatology 4 (2006), pp. 173-185.

[10249] T. Htike, T. Tsubamoto, M. Takai, M. Natori, N. Egi, M. Maung, and C. Sein. "A revision of Tetraconodon (Mammalia, Artiodactyla, Suidae) from the Miocene of Myanmar and description of a new species". English. In: Paleontological Research 9.3 (2005), pp. 243-253.

[10250] D. Hu, L. Hou, L. Zhang, and X. Xu. "A pre-Archaeopteryx troodontid theropod from China with long feathers on the metatarsus". English. In: Nature 461 (2009), pp. 640-643. DOI: 10.1038/ nature08322.

[10251] D. Hu, L. Li, L. Hou, and X. Xing. "A new sapeornithid bird from China and its implication for early avian evolution". English. In: Acta Geologica Sinica 84.3 (2010), pp. 472-482.

[10252] D. Hu, L. Li, L. Hou, and X. Xu. "A new enantiornithine bird from the Lower Cretaceous of western Liaoning, China”. English. In: Journal of Vertebrate Paleontology 31.1 (2011), pp. 154-161.

[10253] D. Hu, Y. Liu, J. Li, X. Xu, and L. Hou. "Yuanjiawaornis viriosus, gen. et sp. nov., a large enantiornithine bird from the Lower Cretaceous of western Liaoning, China". English. In: Cretaceous Research 55 (2015), pp. 210-219.

[10254] D.-Y. Hu, X. Xu, L. -H. Hou, and C. Sullivan. "A new enantiornithine bird from the Lower Cretaceous of Western Liaoning, China, and its implications for early avian evolution". English. In: Journal of Vertebrate Paleontology 32.3 (2012), pp. 639-645. DOI: 10.1080/02724634.2012.652321.

[10255] D.-Y. Hu, J. A. Clarke, C. M. Eliason, R. Qiu, Q. -G. Li, M. D. Shawkey, C. -L. Zhao, L. D'Alba, J. K. Jiang, and X. Xu. "A bony-crested Jurassic dinosaur with evidence of iridescent plumage highlights complexity in early paravian evolution". English. In: Nature Communications 9.217 (2018). DOI: 10.1038/s41467-017-02515-y.

[10256] H. Hu, J. K. O'Connor, and Z. Zhou. "A new species of Pengornithidae (Aves: Enantiornithes) from the Lower Cretaceous of China suggests a specialized scansorial habitat previously unknown in early birds". English. In: Plos One 10.6 (2015), e0126791. DOI: 10.1371/journal.pone.0126791. 
[10257] H. Hu and J. K. O'Connor. "First species of Enantiornithes from Sihedang elucidates skeletal development in Early Cretaceous enantiornithines". English. In: Journal of Systematic Palaeontology 15.11 (2017), pp. 909-926. DOI: 10.1080/14772019.2016.1246111.

[10258] H. J. Hu, Y. Z. Yao, and D. Ren. "New fossil Procercopidae (Hemiptera, Cicadomorpha) from the Cretaceous of northeastern China". English. In: Acta Geologica Sinica 88 (2014), pp. 725-729.

[10259] J. H. Hu, X. M. Lu, B. Wang, and X. Y. Liu. “Taxonomic notes on Babinskaiidae from the Cretaceous Burmese amber, with the description of a new species (Insecta, Neuroptera)". English. In: ZooKeys 748 (2018), pp. 31-46.

[10260] S. Hu. "[A new Theropoda (Dilophosaurus sinensis sp. nov.) from Yunnan, China]". Chinese. In: Vertebrata PalAsiatica 31.1 (1993), pp. 65-69.

[10261] S. Hu, D. L. Dilcher, H. Schneider, and D. M. Jarzen. “Eusporangiate ferns from the Dakota Formation, Minnnesota, USA". English. In: International Journal of Plant Sciences 167.3 (2006), pp. 579589.

[10262] S. Hu, M. Steiner, M. Zhu, B.-D. Erdtmann, H. Luo, L. Chen, and B. Weber. “Diverse pelagic predators from the Chengjiang Lagerstätte and the establishment of modern-style pelagic ecosystems in the early Cambrian". English. In: Palaeogeography, Palaeoclimatology, Palaeoecology 254 (2007), pp. 307-316.

[10263] S. X. Hu, M. Steiner, M. Y. Zhu, H. L. Luo, A. Forchielli, H. Keupp, F. C. Zhao, and Q. Liu. “A new priapulid assemblage from the early Cambrian Guanshan fossil Lagerstätte of SW China". English. In: Bulletin of Geosciences 87.1 (2012), pp. 93-106.

[10264] S.-X. Hu. Taphonomy and Palaeoecology of the Early Cambrian Chengjiang Biota from Eastern Yunnan, China. English. Vol. 7. Berliner Paläobiologische Abhandlungen. 2005, pp. 1-197.

[10265] X. Hu, L. Li, H. Dai, P. Wang, E. Buffetaut, G. Wei, C. Xiong, and H. Tong. "Turtle remains from the Middle Jurassic Xintiangou Formation of Yunyang, Sichuan Basin, China". English. In: Annales de Paléontologie 102440 (2020), pp. 1-8. DOI: 10.1016/j.annpal.2020.102440.

[10266] X. Y. Hu, X. J. Lei, C. H. Luo, E. A. Jarzembowski, B. Wang, and C. T. Xiao. "A new whip spider (Arachnida: Amblypygi) in mid-Cretaceous Kachin amber". English. In: Cretaceous Research 116.104596 (2020). DOI: $10.1016 /$ j.cretres.2020.104596.

[10267] Y. Hu. "New late Early Eocene ctenodactyloid rodents (Rodentia, Mammalia) from Danjiangkou, Hubei". English. In: Vertebrata PalAsiatica 33.1 (1995), pp. 24-38.

[10268] Y. Hu, J. Meng, Y. Wang, and C. Li. “Large Mesozoic mammals fed on young dinosaurs". In: Nature 433 (2005), pp. 149-152.

[10269] Y. Hu, J. Meng, C. Li, and Y. Wang. "New basal eutherian mammal from the Early Cretaceous Jehol biota, Liaoning, China". English. In: Proceedings of the Royal Society of London B 277 (2010), pp. 229-236. DOI: 10.1098/rspb.2009.0203.

[10270] Y. Hu, J. Meng, and J. M. Clark. "A new tritylodontid from the Upper Jurassic of Xinjiang, China". English. In: Acta Palaeontologica Polonica 54.3 (2009), pp. 385-391. DOI: 10.4202/app.2008.0053.

[10271] Y. Hu, Y. Wang, Z. Luo, and C. Li. "A new symmetrodont mammal from China and its implications for mammalian evolution". In: Nature 390 (1997), pp. 137-142.

[10272] Y. Hu and Y. Wang. "Sinobaatar gen. nov.: first multituberculate mammal from the Jehol Biota of Liaoning, northeast China". English. In: Chinese Science Bulletin 47.11 (2002), pp. 933-938.

[10273] Y.-M. Hu, R. C. Fox, Y. -Q. Wang, and C. -K. Li. “A new spalacotheriid symmetrodont from the Early Cretaceous of Northeastern China". English. In: American Museum Novitates 3475 (2005), pp. 1-20.

[10274] Y.-M. Hu, J. Meng, and J. M. Clark. "A new Late Jurassic docodont (Mammalia) from northeastern Xinjiang, China". English. In: Vertebrata PalAsiatica 45.3 (2007), pp. 173-194. 
[10275] N. L. Hu Dai, C. Tan, X. Hu, Z. Wei, Y. Lin, G. Wei, D. Li, L. Meng, B. Hao, H. You, and G. Peng. “A neornithischian dinosaur from the Middle Jurassic Xintiangou Formation of Yunyang, Chongqing, China: the earliest record in Asia". English. In: Historical Biology (2019). DOI: 10.1080 / 08912963. 2019.1679129.

[10276] H. Hua, B. R. Pratt, and L. -Y. Zhang. "Borings in Cloudina shells: complex predator-prey dynamics in the terminal Neoproterozoic". English. In: Palaios 18 (2003), pp. 454-459.

[10277] S. Hua, E. Buffetaut, C. Legall, and P. Rogron. “Oceanosuchus boecensis n. gen, n. sp., a marine pholidosaurid (Crocodylia, Mesosuchia) from the Lower Cenomanian of Normandy (western France)". English. In: Bulletin de la Societe Geologique de France 178.6 (2007), pp. 503-513. DOI: 10.2113/gssgfbull.178.6.503.

[10278] S. Hua and S. Jouve. "A primitive marine gavialoid from the Paleocene of Morocco". English. In: Journal of Vertebrate Paleontology 24.2 (2004), pp. 341-350.

[10279] S. Hua, P. Vignaud, F. Atrops, and A. Clément. "Enaliosuchus macrospondylus Koken, 1883 (Crocodylia, Metriorhynchidae) du Valanginien de Barret-le-Bas (Hautes Alpes, France): un cas unique de remontée des narines externes parmi les crocodiliens". French. In: Geobos 33.4 (2000), pp. 467-474.

[10280] B. Huang, B. G. Baarli, R. B. Zhan, and J. Y. Rong. “A new early Silurian brachiopod genus, Thulatrypa, from Norway and South". English. In: Alcheringa 40.1 (2016), pp. 83-97. DOI: 10.1080 / 03115518.2016.1092066.

[10281] B. Huang, D. A. Harper, H. H. Zhou, R. B. Zhan, Y. Wang, P. Tang, J. Y. Ma, G. X. Wang, D. Chen, Y. C. Zhang, and X. C. Luan. "A new Cathaysiorthis (Brachiopoda) fauna from the lower Llandovery of eastern Qinling, China”. English. In: Papers in Palaeontology (2019). DOI: 10.1002/ spp2.1253.

[10282] B. Huang, D. A. T. Harper, H. Zhou, and J. Rong. "From shallow to deep water: an ecological study of the Hirnantia brachiopod Fauna (Late Ordovician) and its global implications". English. In: Lethaia 53 (2019), pp. 332-344. DOI: 10.1111/let.12360.

[10283] B. Huang and J. Rong. "Statistically differentiating Katastrophomena from Strophomena (OrdovicianSilurian strophomenid brachiopods)". English. In: Memoirs of the Association of Australasian Palaeontologists 39 (2010), pp. 245-259.

[10284] B. Huang, J.-Y. Rong, and D. A. T. Harper. “A New Survivor Species of Dicoelosia (Brachiopoda) from Rhuddanian (Silurian) Shallower-Water Biofacies in South China". English. In: Journal of Paleontology 87.2 (2013), pp. 232-242. DOI: 10.1666/12-072r.1.

[10285] B. Huang, H.-H. Zhou, D. A. T. Harper, R. -B. Zhan, X. -L. Zhang, D. Chen, and J. -Y. Rong. “A latest Ordovician Hirnantia brachiopod fauna from western Yunnan, Southwest China and its paleobiogeographic significance". English. In: Palaeoworld (2019). DOI: 10.1016/j.palwor.2019.03. 002.

[10286] C.-Y. Huang, L. Shao, M. -H. Wang, W. -G. Xue, P. -J. Qiao, Y. -C. Cui, and Y. -L. Hou. “Benthic foraminiferal fauna and sedimen provenance of Eocene syn-rift sequences in Taiwan: implication for onset of Asian epi-continental marginal seas off China coast". English. In: Marine Geophysical Research 40.2 (2019), pp. 111-127. DOI: 10.1007/s11001-018-9366-3.

[10287] C.-Y. Huang, Y. Yen, P. -M. Liew, D. -J. He, W. -R. Chi, M. -S. Wu, and M. Zhao. “Significance of indigenous Eocene larger foraminifera Discocyclina dispansa in Western Foothills, Central Taiwan: A Paleogene marine rift basin in Chinese continental margin". English. In: Journal of Asian Earth Sciences 62.30 (2013), pp. 425-437. DOI: 10.1016/j.jseaes.2012.10.026.

[10288] D. Huang, F. Benzoni, H. Fukami, N. Knowlton, N. D. Smith, and Ann F. Budd. "Taxonomic classification of the reef coral families Merulinidae, Montastraeidae, and Diploastraeidae (Cnidaria: Anthozoa: Scleractinia)". English. In: Zoological Journal of the Linnean Society 171.2 (2014), pp. 277355.

[10289] D. Huang, P. A. Selden, and J. A. Dunlop. "Harvestmen (Arachnida: Opiliones) from the Middle Jurassic of China". English. In: Naturwissenschaften 96.8 (2009), pp. 955-962. DOI: 10.1007/s00114009-0556-3. 
[10290] D. Y. Huang, D. Azar, C. Y. Cai, and A. Nel. "New damselfly genera in the Cretaceous Burmese amber attributable to the Platystictidae and Platycnemididae Disparoneurinae (Odonata: Zygoptera)". English. In: Cretaceous Research 56 (2015), pp. 237-243.

[10291] D. Y. Huang, D. Azar, C. Y. Cai, R. Garrouste, and A. Nel. “The first Mesozoic pleasing lacewing (Neuroptera: Dilaridae)". English. In: Cretaceous Research 56 (2015), pp. 274-277.

[10292] D. Y. Huang, D. Azar, M. S. Engel, R. Garrouste, C. Y. Cai, and A. Nel. “The first araripeneurine antlion in Burmese amber (Neuroptera: Myrmeleontidae)". English. In: Cretaceous Research 63 (2016), pp. 1-6.

[10293] D. Y. Huang, D. Azar, M. S. Engel, C. Y. Cai, R. Garrouste, and A. Nel. "A new genus of alderflies (Megaloptera: Sialidae) in Upper Cretaceous Burmese amber". English. In: Cretaceous Research 64 (2016), pp. 7-11.

[10294] D. Y. Huang, D. Azar, C. Y. Cai, S. Maksoud, A. Nel, and G. Bechly. "Mesomegaloprepidae, a remarkable new damselfly family (Odonata: Zygoptera) from mid-Cretaceous Burmese amber". English. In: Cretaceous Research 73 (2017), pp. 1-13.

[10295] D. Y. Huang, D. Azar, and A. Nel. “The oldest 'Megapodagrionidae' (Odonata, Zygoptera) discovered in the Lower Cretaceous Yixian Formation, China". English. In: Cretaceous Research 84 (2017), pp. $426-430$.

[10296] D. Y. Huang, A. Baudoin, and A. Nel. "A new aeschnidiid genus from the Early Cretaceous of China (Odonata: Anisoptera)". English. In: Cretaceous Research 30 (2009), pp. 805-809.

[10297] D. Y. Huang, G. Bechly, P. Nel, M. S. Engel, J. Prokop, D. Azar, C. Y. Cai, T. van de Kamp, A. H. Staniczek, R. Garrouste, L. Krogmann, T. dos Santos Rolo, T. Baumbach, R. Ohlhoff, A. S. Shmakov, T. Bourgoin, and A. Nel. "New fossil insect order Permopsocida elucidates major radiation and evolution of suction feeding in hemimetabolous insects (Hexapoda: Acercaria)". English. In: Scientific Reports 6.23004 (2016), pp. 1-9.

[10298] D. Y. Huang, C. Cai, and A. Chen. "The homonymy of Xishania with reference to Xishania fusiformis Hong, 1981 and X. longiusula Hu, 2002". English. In: Acta Palaeontologica Sinica 51.1 (2012), pp. 102106.

[10299] D. Y. Huang, C. Y. Cai, A. Nel, and G. Bechly. "A new dragonfly family from the mid Cretaceous Burmese amber (Odonata: Aeshnoptera: Burmaeshnidae)". English. In: Cretaceous Research 78 (2017), pp. 8-12.

[10300] D. Y. Huang, C. Y. Cai, and A. Nel. “A new Burmese amber hawker dragonfly helps to redefine the position of the aeshnopteran family Burmaeshnidae (Odonata: Anisoptera: Aeshnoidea)". English. In: Cretaceous Research 79 (2017), pp. 153-158.

[10301] D. Y. Huang, C. Y. Cai, and A. Nel. "New damsel-dragonflies with calopterygid-like wing shape from the Middle Jurassic of China (Odonata: Isophlebioidea: Campterophlebiidae)". English. In: Geobios 51 (2018), pp. 181-186.

[10302] D. Y. Huang, C. Y. Cai, and A. Nel. "A new damsel-dragonfly of the small family Selenothemistidae from the Late Jurassic of China (Odonata, Isophlebioptera)". English. In: Journal of Paleontology 92 (2018), pp. 1049-1053.

[10303] D. Y. Huang, M. S. Engel, C. Y. Cai, and A. Nel. "Mesozoic giant fleas from northeastern China (Siphonaptera): taxonomy and implications for palaeodiversity". English. In: Chinese Science Bulletin 58 (2013), pp. 1682-1690.

[10304] D. Y. Huang, Y. Z. Fu, and A. Nel. “The first amber stenophlebiid damsel-dragonfly (Odonata, Epiproctophora, Stenophlebiidae) from mid-Cretaceous amber of northern Myanmar". English. In: Cretaceous Research 94 (2018), pp. 40-44.

[10305] D. Y. Huang, Y. Z. Fu, J. Gao, and A. Nel. "A new damsel-dragonfly of the small family Selenothemistidae from the earliest Late Jurassic of China (Odonata: Isophlebioptera)". English. In: Palaeoentomology 1 (2018), pp. 37-41. 
[10306] D. Y. Huang, Y. Z. Fu, and A. Nel. "The first Chinese representative of the Jurassic damseldragonfly genus Hypsothemis (Odonata: Isophlebioidea: Campterophlebiidae)". English. In: Alcheringa 44 (2020), pp. 99-103. DOI: 10.1080/03115518.2019.1665709.

[10307] D. Y. Huang, Y. Z. Fu, X. N. Lian, and A. Nel. "Sinaspidoneura magnifica nov. gen., nov. sp., first Chinese Caloneurodea (Insecta: Archaeorthoptera)". English. In: Geobios 63 (2020), pp. 33-37. DOI: 10.1016/j.geobios.2020.10.003.

[10308] D. Y. Huang, J. Gao, C. Dong, Y. T. Su, Y. Z. Fu, X. R. Li, Y. M. Liu, and C. Y. Cai. “Late Triassic fossil insects from the Laohugou Formation of northern China (Qinhuangdao, Hebei Province)". English. In: Palaeoentomology 2 (2019), pp. 183-191.

[10309] D. Y. Huang, R. Garrouste, D. Azar, M. S. Engel, and A. Nel. "The fourth Mesozoic water measurer discovered in mid-Cretaceous Burmese amber (Heteroptera: Hydrometridae: Hydrometrinae)". English. In: Cretaceous Research 52 (2015), pp. 118-126.

[10310] D. Y. Huang and Q. B. Lin. "A new soldier fly (Diptera, Stratiomyidae) from the Lower Cretaceous of Liaoning Province, northeast China". English. In: Cretaceous Research 28 (2007), pp. 317-321.

[10311] D. Y. Huang, A. Nel, Q. B. Lin, and F. B. Dong. "The first Glosselytrodea (Insecta) from the latest Middle Permian of Anhui Province, China". English. In: Annales de la Société Entomologique de France 112 (2007), pp. 179-182.

[10312] D. Y. Huang and A. Nel. "Sinahemeroscopus magnificus, new genus and species of 'libelluloid" dragonfly from the Chinese Mesozoic (Odonata, Anisoptera: Nannogomphidae?)" English. In: Zootaxa 2388 (2010), pp. 44-48.

[10313] D. Y. Huang, A. Nel, O. Zompro, and A. Waller. "Mantophasmatodea now in the Jurassic". English. In: Naturwissenschaften 95.10 (2008), pp. 947-952. DOI: 10.1007/s00114-008-0412-x.

[10314] D. Y. Huang, A. Nel, and Q. B. Lin. "A new genus and species of aeshnopteran dragonfly from the Lower Cretaceous of China". English. In: Cretaceous Research 24 (2003), pp. 141-147.

[10315] D. Y. Huang and A. Nel. "The first Chinese Tarsophlebiidae from the Lower Cretaceous Yixian Formation, with morphological and phylogenetic implications (Odonatoptera: Panodonata)". English. In: Cretaceous Research 30 (2009), pp. 429-433.

[10316] D. Y. Huang and A. Nel. "A new Middle Jurassic grylloblattodean family from China (Insecta: Juraperlidae fam. n. )" English. In: European Journal of Entomology 104 (2007), pp. 837-840.

[10317] D. Y. Huang and A. Nel. "A new Middle Jurassic aphid family (Insecta: Hemiptera: Sternorrhyncha: Sinojuraphididae fam. nov.) from Inner Mongolia, China”. English. In: Palaeontology 51 (2008), pp. 715-719.

[10318] D. Y. Huang, A. Nel, and J. F. Petruleviius. "New evolutionary evidence of Grylloblattida from the Middle Jurassic of Inner Mongolia, north-east China (Insecta, Polyneoptera)". English. In: Zoological Journal of the Linnean Society 152 (2008), pp. 17-24. DOI: 10.1111/j.1096-3642.2007.00351.x.

[10319] D. Y. Huang and A. Nel. "Oldest libelluloid dragonfly from the Middle Jurassic of China (Odonata: Anisoptera: Cavilabiata)". English. In: Neues Jahrbuch für Geologie und Paläontologie, Abhandlungen 246 (2007), pp. 63-68.

[10320] D. Y. Huang and A. Nel. “New Grylloblattida related to the genus Prosepididontus Handlirsch, 1920 in the Middle Jurassic of China (Insecta: Geinitziidae)". English. In: Alcheringa 32 (2008), pp. 395-403.

[10321] D. Y. Huang, A. Nel, and J. Minet. "A new family of moths from the Middle Jurassic (Insecta: Lepidoptera)". English. In: Acta Geologica Sinica 84 (2010), pp. 874-885.

[10322] D. Y. Huang, A. Nel, C. Y. Cai, Q. B. Lin, and M. S. Engel. “Amphibious flies and paedomorphism in the Jurassic period". English. In: Nature 495 (2013), pp. 94-97. DOI: 10.1038/nature11898.

[10323] D. Y. Huang and A. Nel. "Protoliupanshania wangi, a new genus and species from the Chinese Early Cretaceous (Odonata: Aeshnoptera: Liupanshaniidae)". English. In: Zootaxa 2387 (2010), pp. 57-62. 
[10324] D. Y. Huang and A. Nel. "Oldest webspinners from the Middle Jurassic of Inner Mongolia, China (Insecta: Embiodea)". English. In: Zoological Journal of the Linnean Society 156 (2009), pp. 889-895.

[10325] D. Y. Huang, A. Nel, D. Azar, and P. Nel. "Phylogenetic relationships of the Mesozoic paraneopteran family Archipsyllidae (Insecta: Psocodea)". English. In: Geobios 41 (2008), pp. 461-464.

[10326] D. Y. Huang, A. Nel, and C. Y. Cai. "An enigmatic hawker dragonfly from the Middle Jurassic of China (Odonata, Aeshnoptera)". English. In: PalZ 91 (2017), pp. 459-462.

[10327] D. Y. Huang and A. Nel. "New fossil damsel-dragonfly clarifies the phylogenetic position of the small Jurassic family Juraheterophlebiidae (Odonata: Epiproctophora)". English. In: Alcheringa 41 (2017), pp. 536-542.

[10328] D. Y. Huang, A. Nel, and D. Azar. "An additional new taxon belonging to the small Cretaceous lacewing family Babinskaiidae (Insecta: Neuroptera: Myrmeleontoidea) from the Burmese amber". English. In: Cretaceous Research 101 (2019), pp. 43-46. DOI: 10.1016/j.cretres.2019.04.010.

[10329] D. Y. Huang, T. Schubnel, and A. Nel. "A new middle Permian orthopteran family questions the position of the Order Titanoptera (Archaeorthoptera: Orthoptera)". English. In: Journal of Systematic Palaeontology 18 (2020), pp. 1217-1222. DOI: 10.1080/14772019.2020.1733112.

[10330] D. Y. Huang, Y. T. Su, Y. Z. Fu, J. Gao, Y. M. Liu, and C. Y. Cai. “A new Early Jurassic insect outcrop in Xinjiang, northwestern China and its stratigraphic significance". English. In: Palaeoentomology 2 (2019), pp. 430-435.

[10331] D. Y. Huang, P. Wegierek, D. ya, and A. Nel. "The oldest aphid of the family Oviparosiphidae (Hemiptera: Aphidoidea) from the Middle Jurassic of China". English. In: European Journal of Entomology 112 (2015), pp. 187-192.

[10332] D. Y. Huang and J. Yang. "Early Cretaceous fossil Mordellidae (Insecta, Coleoptera) from western Beijing". Chinese. In: Acta Palaeontologica Sinica 38 (1999), pp. 125-132.

[10333] D. Y. Huang and H. C. Zhang. "Fossil Byrrhidae (Insecta, Coleoptera) from the Early Cretaceous of western Beijing". Chinese. In: Journal of Nanjing University (Natural Sciences) 33 (1997), pp. 562569.

[10334] H. Huang, X. C. Jin, Y. K. Shi, and X. N. Yang. "Middle Permian western Tethyan fusulinids from southern Baoshan block, western Yunnan, China". English. In: Journal of Paleontology 83 (2009), pp. 880-896.

[10335] J. Huang, K. Liang, Y. Wang, W. Liao, W. Guo, S. Kershaw, J. Jeon, L. Qiao, J. Song, J. Ma, Y. Li, B. Tu, Y. Tian, M. Luo, and W. Qie. "The Jiwozhai patch reef: A palaeobiodiversity hotspot in middle Givetian". English. In: Palaeogeography, Palaeoclimatology, Palaeoecology (2020). DOI: 10. 1016/j.palaeo.2020.109895.

[10336] J. Huang, R. Motani, D. Jiang, A. Tintori, O. Rieppel, M. Zhou, X. Ren, and R. Zhang. “The new ichthyosauriform Chaohusaurus brevifemoralis (Reptilia, Ichthyosauromorpha) from Majiashan, Chaohu, Anhui Province, China". English. In: PeerJ 7.e7561 (2019). DOI: 10.7717/peerj.7561.

[10337] J. Huang, D. Ren, N. D. Sinitshenkova, and C. Shih. “New genus and species of Hexagenitidae (Insecta: Ephemeroptera) from Yixian Formation, China". English. In: Zootaxa 1629 (2007), pp. 3950.

[10338] J. D. Huang, Y. S. Liu, N. D. Sinitshenkova, and D. Ren. “A new fossil genus of Siphlonuridae (Insecta: Ephemeroptera) from the Daohugou, Inner Mongolia, China". English. In: Annales Zoologici 57 (2007), pp. 221-225.

[10339] J. D. Huang, D. Ren, N. D. Sinitshenkova, and C. K. Shih. “New fossil mayflies (Insecta: Ephemeroptera) from the Middle Jurassic of Daohugou, Inner Mongolia, China". English. In: Insect Science 15 (2008), pp. 193-198.

[10340] J. D. Huang, N. D. Sinitshenkova, and D. Ren. "New mayfly nymphs (Insecta: Ephemeroptera) from Yixian Formation, China”. English. In: Paleontological Journal 45.2 (2011), pp. 167-173. 
[10341] J. Y. Huang, R. M. Feldmann, C. E. Schweitzer, S. X. Hu, C. Y. Zhou, M. J. Benton, Q. Y. Zhang, W. Wen, and T. Xie. "A new shrimp (Decapoda, Dendrobranchiata, Penaeoidea) from the Middle Triassic of Yunnan, southwest China". English. In: Journal of Paleontology 87 (2013), pp. 603-611.

[10342] J.-D. Huang, X. Wang, Y. -C. Hu, J. Liu, J. A. Peteya, and J. A. Clarke. “A new ornithurine from the Early Cretaceous of China sheds light on the evolution of early ecological and cranial diversity in birds". English. In: PeerJ 4 (2018), e1765. DOI: 10.7717/peerj.1765.

[10343] J.-D. Huang, H.-L. You, J. -T. Yang, and X. -X. Ren. “A new sauropod dinosaur from the Middle Jurassic of Huangshan, Anhui Province". Chinese. In: Vertebrata PalAsiatica 52.4 (2014), pp. 390400.

[10344] Q. C. Huang and D. L. Dilcher. "Evolutionary and Paleoecological Implications of Fossil Plants from the Lower Cretaceous Cheyenne Sandstone of the Western Interior". English. In: Geological Society of America Special Paper 287 (1994), pp. 129-144.

[10345] S. Huang, D. Ren, and Y. J. Wang. "A new basal beaded lacewing (Neuroptera: Berothidae) from mid-Cretaceous Myanmar amber". English. In: Cretaceous Research 95 (2019), pp. 1-7. DOI: 10. 1016/j.cretres.2018.10.025.

[10346] T. Huang. "Aturia chaohsini sp. nov. from the Suichangliu Formation (Oligocene) of Taiwan". In: Western Pacific Earth Sciences 2.4 (2002), pp. 439-444.

[10347] T. Huang. "Kummelonautilus taiwanum sp. nov. (Nautilida) from the early Miocene Shihmen Formation, Chungliao, Nantou, west-central Taiwan". In: Western Pacific Earth Sciences 2.4 (2002), pp. 445-454.

[10348] W. Huang, X. Si, Y. Hou, S. Miller-Antonio, and L. A. Schepartz. “Excavations at Panxian Dadong, Guizhou Province, Southern China". In: Current Anthropology 36.5 (1995), pp. 844-846.

[10349] W. T. Huang, Y. L. Zhang, C. Q. Guan, Z. W. Miao, X. H. Chen, Z. -Y. Yang, X. Li, and E. -P. Gong. "Role of calcimicrobes and microbial carbonates in the Late Carboniferous (Moscovian) mounds in southern Guizhou, South China". English. In: Journal of Palaeogeography 8.26 (2019). DOI: 10. 1186/s42501-019-0041-7.

[10350] X. Huang. "A new Hyopsodus from the Early Eocene of Fangxian, Hubei". English. In: Vertebrata PalAsiatica 33.1 (1995), pp. 39-46.

[10351] X. Huang, M. Aretz, X. Zhang, Y. Du, and T. Luand. “Upper Viséan coral biostrome in a volcanicsedimentary setting from the Eastern Tianshan, Northwest China". English. In: Palaeogeography, Palaeoclimatology, Palaeoecology 531.B (2018), pp. 108739-108739. DOI: 10.1016/j.palaeo.2018.04.014.

[10352] X. Huang and L. Chen. "Mammalian remains from the Late Paleocene of Guichi, Anhui". Chinese. In: Vertebrata PalAsiatica 35.1 (1997), pp. 49-67.

[10353] X. Huang, C. Li, M. R. Dawson, and L. Liu. "Hanomys malcolmi, a new simplicidentate mammal from the Paleocene of central China: its relationships and stratigraphic implications". English. In: Bulletin of Carnegie Museum of Natural History 36 (2004), pp. 81-89.

[10354] X. Huang, Y. Tong, J. Wang, and J. Shi. "Discovery of Juxia sharamurenense in Yuanqu Basin". Chinese. In: Vertebrata PalAsiatica 36.1 (1998), pp. 54-57.

[10355] X. Huang and J. Zheng. "Early Tertiary mammals of Xuancheng Basin, Anhui Province and its implication for the age of Shuangtasi Formation". Chinese. In: Vertebrata PalAsiatica 35.4 (1997), pp. 290-306.

[10356] X.-S. Huang. "Mammalian remains from the late Paleocene of Jiashan, Anhui". Chinese. In: Vertebrata PalAsiatica 41.1 (2003), pp. 42-54.

[10357] X.-S. Huang. "A new anagalid (Anagalida, Mammalia) from the Paleocene of Nanxiong basin, Guangdong province". Chinese. In: Vertebrata PalAsiatica 44.3 (2006), pp. 274-277.

[10358] X.-S. Huang. "Cricetid (Rodentia ,Mammalia) remains from the Middle Eocene of Yuanqu,Shanxi". English. In: Vertebrata PalAsiatica 42.1 (2004), pp. 39-44.

[10359] X.-S. Huang. "Primitive rhinocerotid fossil from the Middle Eocene of Yuanqu basin, Shanxi". English. In: Vertebrata PalAsiatica 48.1 (2010), pp. 76-78. 
[10360] X.-S. Huang. "New eomoropid (Mammalia, Perissodactyla) remains from the Middle Eocene of Yuanqu Basin". English. In: Vertebrata PalAsiatica 40.4 (2002), pp. 286-290.

[10361] X.-S. Huang, Y.-S. Tong, and J. -W. Wang. "A new Miacis (Mammalia Carnivora, Miacidae) from the Middle Eocene of Yuanqu Basin, Shanxi Province". English. In: Vertebrata PalAsiatica 37.4 (1999), pp. 291-299.

[10362] X.-S. Huang and J.-W. Wang. “Notes on Hyrachyus (Mammalia, Perissodactyla, Tapiroidea) from the Middle Eocene of Yuanqu Basin, Shanxi Province". English. In: Vertebrata PalAsiatica 40.3 (2002), pp. 211-218.

[10363] X.-S. Huang and J.-J. Zheng. "A new genus of Soricomorpha (Mammalia) from the Late Paleocene of Qianshan Basin, Anhui Province". English. In: Vertebrata PalAsiatica 40 (2002), pp. 127-132.

[10364] X.-S. Huang and J.-J. Zheng. "Note on two new mammalian species from the Late Paleocene of Nanxiong, Guangdong". Chinese. In: Vertebrata PalAsiatica 41.4 (2003), pp. 271-277.

[10365] X.-S. Huang and J.-J. Zheng. "A new tillodont from the Paleocene of Nanxiong Basin, Guangdong". Chinese. In: Vertebrata PalAsiatica 37.2 (1999), pp. 96-104.

[10366] X.-S. Huang and J.-J. Zheng. "A tillodont-like mammal from the Middle Paleocene of Qianshan Basin, Anhui, China". Chinese. In: Vertebrata PalAsiatica 41.2 (2003), pp. 131-136.

[10367] X.-S. Huang and J.-J. Zheng. "A new viverravid (Mammalia, Carnivora) from the Late Eocene of Tianyang, Guangxi". English. In: Vertebrata PalAsiatica 43.3 (2005), pp. 231-236.

[10368] X.-S. Huang and J.-J. Zheng. "Brontotheres (Perissodactyla, Mammalia) from the Middle Eocene of Lunan, Yunnan". English. In: Vertebrata PalAsiatica 42.4 (2004), pp. 334-339.

[10369] X.-S. Huang, J.-J. Zheng, and S. -Y. Ding. “Arctostylopid fossil (Mammalia) of Changtao Basin, Hunan and comments on related stratigraphy". English. In: Vertebrata PalAsiatica 39.1 (2001), pp. 1423.

[10370] X.-S. Huang and B.-C. Zhu. "Creodont (Mammalia) remains from the Early Oligocene of Ulantatal, Nei Mongol". English. In: Vertebrata PalAsiatica 40.1 (2002), pp. 17-22.

[10371] Y. Huang, Z.-Q. Chen, L. Zhaob, G. D. Stanley, J. Yana, Y. Pei, W. Yang, and J. Huang. “Restoration of reef ecosystems following the Guadalupian-Lopingian". English. In: Palaeogeography, Palaeoclimatology, Palaeoecology (2017).

[10372] Y. Huang, J. Tong, and M. L. Fraiser. "A Griesbachian (Early Triassic) Mollusc Fauna from the Sidazhai Section, Southwest China, with Paleoecological Insights on the Proliferation of Genus Claraia (Bivalvia)". English. In: Journal of Earth Science 29.4 (2018), pp. 794-805. DOI: 10.1007 / s12583-017-0966-7.

[10373] Z. Q. Huang, F. Y. Li, and Q. B. Lin. "Some Early Jurassic insects from Meixi of Yiyang County, Jiangxi". Chinese. In: Acta Palaeontologica Sinica 30 (1991), pp. 647-653.

[10374] D. Hubbard and F. Grady. "Mammoth Tooth Found in Endless Caverns, Virginia". English. In: Virginia Minerals 45.1 (1999), pp. 1-3.

[10375] D. A. Hubbard and F. Grady. Let Those Bones Be: Lessons in Paleontological Context at Unthanks Cave, Virginia. English. 2006.

[10376] D. A. Hubbard and F. Grady. "Melrose Caverns: A Late Pleistocene Vertebrate Locality in Virginia, U.S.A." English. In: 13th International Congress of Speleology (2001), pp. 301-304.

[10377] D. K. Hubbard, I. P. Gill, and R. B. Burke. "Holocene reef building on eastern St. Croix, US Virgin Islands: Lang Bank revisited". English. In: Coral Reefs 32 (2013), pp. 653-669.

[10378] D. K. Hubbard, H. Zankl, I. van Heerden, and I. P. Gill. "Holocene reef development along the northeastern St. Croix shelf, Buck Island, US Virgin Islands". English. In: Journal of Sedimentary Research 75.1 (2005), pp. 97-113.

[10379] B. A. Huber and J. Wunderlich. "Fossil and extant species of the genus Leptopholcus in the Dominican Republic, with the first cases of egg-parasitism in pholcid spiders (Araneae: Pholcidae)". English. In: Journal of Natural History 40 (2006), pp. 2341-2360. 
[10380] J. T. Huber. “The genus Dicopomorpha (Hymenoptera, Mymaridae) in Africa and a key to Alaptusgroup genera". English. In: ZooKeys 20 (2009), pp. 233-244.

[10381] J. T. Huber. "World reclassification of the Gonatocerus group of genera (Hymenoptera: Mymaridae)". English. In: Zootaxa 3967 (2015), pp. 1-184.

[10382] J. T. Huber and D. Greenwalt. "Compression fossil Mymaridae (Hymenoptera) from Kishenehn oil shales, with description of two new genera and review of Tertiary amber genera". English. In: ZooKeys 130 (2011), pp. 473-494.

[10383] J. T. Huber, C. K. Shih, and D. Ren. "A new species of Baeomorpha (Hymenoptera, Rotoitidae) from mid-Cretaceous Burmese amber". English. In: Journal of Hymenoptera Research 72 (2019), pp. 1-10. DOI: $10.3897 /$ jhr.72.35502.

[10384] P. Huber and P. M. LeTourneau. "Revised lithostratigraphy of the Norian-Hettangian Pomperaug rift basin, western Connecticut: resolving a century-old conflict in geological interpretation". English. In: vol. 37. The Triassic-Jurassic Terrestrial Transition. New Mexico Museum of Natural History and Science Bulletin. Albuquerque: New Mexico Museum of Natural History and Science, 2006, pp. 43-61.

[10385] J. F. Hubert and P. T. Panish. "Sedimentology and diagenesis of the dinosaur bones exposed at Dinosaur Ridge along Alameda Parkway in the Morrison Formation (Upper Jurassic), Morrison, Colorado". English. In: The Mountain Geologist 37.2 (2000), pp. 73-90.

[10386] J.-J. Hublin, A. Ben-Ncer, S. E. Bailey, S. E. Freidline, S. Neubauer, M. M. Skinner, I. Bergmann, A. Le Cabec, S. Benazzi, K. Harvati, and P. Gunz. "New fossils from Jebel Irhoud, Morocco and the pan-African origin of Homo sapiens". English. In: Nature 546 (2017), pp. 289-292. DOI: 10.1038 / nature22336.

[10387] B. Hubman and T. Suttner. Siluro-Devonian Alpine reefs and pavements. English. Vol. 275. Palaeozoic Reefs and Bioaccumulations: Climatic and Evolutionary Controls. London: Geological Society, Special Publication, 2007, pp. 95-107.

[10388] T. Hübner and A. Müller. "Selachian teeth from Campanian sediments (Upper Cretaceous) of the Münsterland Cretaceous Basin (NW Germany)". English. In: Palaeontologische Zeitschrift 84 (2010), pp. 437-455.

[10389] B. B. Huckell and C. V. Haynes Jr. "The Ventana Complex: new dates and new ideas on its place in early Holocene western prehistory". English. In: American Antiquity 68.2 (2003), pp. 353-371.

[10390] J. D. Hudson, J. B. Riding, M. I. Wakefield, and W. Walton. “Jurassic Paleosalinities and Brackishwater Communities-A Case Study". In: Palaios 10.5 (1995), pp. 392-405.

[10391] A. K. Hufthammer, L. Arntsen, A. C. Kitchener, and M. Buckley. "Grey whale (Eschrichtius robustus) in Norwegian waters 2000 years ago". English. In: Palaeogeography, Palaeoclimatology, Palaeoecology 495 (2018), pp. 42-47. DOI: 10.1016/j.palaeo.2017.12.009.

[10392] N. C. Hughes and D. L. Cooper. "Paleobiologic and taphonomic aspects of the granulosa trilobite cluster, Kope Formation(Upper Ordovician, Cincinnati Region)". English. In: Journal of Paleontology 73.2 (1999), pp. 306-319. DOI: 10.1017/S0022336000027785.

[10393] N. C. Hughes, P. Shanchi, and L. Huilin. "Kunmingaspis (Trilobita) putatively from the Yunling Collage, and the Cambrian history of the Himalayan syntaxial region". English. In: Journal of Paleontology 76.4 (2002), pp. 709-717. DOI: 10.1666/0022-3360(2002)076<0709:KTPFTY>2.0.CO;2.

[10394] J. P. Hugot, S. L. Gardner, V. Borba, P. Araujo, D. Leles, A. A. S. Da-Rosa, J. Dutra, L. F. Ferreira, and A. Araújo. "Discovery of a 240 million year old nematode parasite egg in a cynodont coprolite sheds light on the early origin of pinworms in vertebrates". English. In: Parasites and Vectors 7.486 (2014), pp. 1-8.

[10395] M. Hugueney. “Biochronologie mammalienne dans le Paléogéne et le Miocéne inférieur du Centre de la France: synthése réactualisée". English. In: Mémoires et Travaux de l'Institut de Montpellier 21 (1997), pp. 417-430. 
[10396] M. Hugueney and O. Maridet. “Evolution of Oligo-Miocene talpids (Mammalia, Talpidae) in Europe: focus on the genera Myxomygale and Percymygale n. gen". English. In: Historical Biology (2017). DOI: 10.1080/08912963.2017.1282477.

[10397] M. Hugueney, H. Tachet, and F. Escuillié. “Caddisfly pupae from the Miocene Indusial Limestone of Saint-Gérand-le-Puy, France". English. In: Palaeontology 33.2 (1990), pp. 495-502.

[10398] B. Hugues-Alexandre, J. Agusti, J. M. Lopez-Garcia, H. Haddoumi, H. Aouraghe, K. El Hammouti, A. Perez-Gonzalez, M. Gema Chacon, and R. Sala. "Amphibians and Squamate Reptiles from the Late Miocene (Vallesian) of Eastern Morocco (GuefaIT-1, Jerada Province)". English. In: Journal of Vertebrate Paleontology 33.4 (2013), pp. 804-816. DOI: 10.1080/039.033.0404.

[10399] A. Huguet, A. Nel, X. Martinez-Delclos, G. Bechly, and R. Martins-Neto. "Preliminary phylogenetic analysis of the Protanisoptera (Insecta: Odonatoptera)". English. In: Geobios 35 (2002), pp. 537-560.

[10400] M. Huh, K. G. Hwang, I. S. Paik, C. H. Chung, and B. S. Kim. “Dinosaur tracks from the Cretaceous of South Korea: Distribution, occurrences and paleobiological significance". English. In: The Island Arc 12 (2003), pp. 132-144.

[10401] M. Huh and K. G. Hwang. "[Dinosaur footprints from the Cretaceous of South Korea: with reference to Cheollanam-do dinosaur sites]". other. In: Journal of the Paleontological society of Korea, Special Publication 7 (2004), pp. 319-335.

[10402] M. Huh, D.-G. Lee, J. -K. Kim, J.-.. D. Lim, and P. Godefroit. "A new basal ornithopod dinosaur from the Upper Cretaceous of South Korea". English. In: Neues Jahrbuch für Geologie und Paläontologie Abhandlungen 259.1 (2011), pp. 1-24. DOI: 10.1127/0077-7749/2010/0102.

[10403] M. Huh, I. S. Paik, M. G. Lockley, K. G. Hwang, B. S. Kim, and S. K. Kwak. “Well-preserved theropod tracks from the Upper Cretaceous of Hwasun County, southwestern South Korea, and their paleobiological implications". English. In: Cretaceous Research 27.1 (2006), pp. 123-138.

[10404] M. Huh, I. S. Paik, C. W. Chung, K. G. Hwang, and B. S. Kim. "[Theropod tracks from Seoyuri in Hwasun, Jeollanamdo, Korea: occurrence and paleontological significance]". other. In: Journal of the Geological Society of Korea 39.4 (2003), pp. 461-478.

[10405] M. Huh, I. S. Paik, J. Park, K. G. Hwang, Y. I. Lee, S. Y. Yang, J. D. Lim, Y. U. Lee, D. K. Cheong, S. J. Seo, K. H. Park, and K. H. Moon. "[Occurrence of dinosaur eggs in South Korea]". other. In: Journal of the Geological Society of Korea 42.4 (2006), pp. 523-547.

[10406] M. Huh and D. K. Zelenitsky. "Rich dinosaur nesting site from the Cretaceous of Bosung County, Chullanam-do Province, South Korea". English. In: Journal of Vertebrate Paleontology 22.3 (2002), pp. 716-718.

[10407] R. C. Hulbert. "A new early Pleistocene tapir (Mammalia: Perissodactyla) from Florida, with a review of Blancan tapirs from around the state". English. In: Bulletin of the Florida Museum of Natural History 49.3 (2010), pp. 67-126.

[10408] R. C. Hulbert. "Late Miocene Tapirus (Mammalia, Perissodactyla) from Florida, with description of a new species, Tapirus webbi". English. In: Bulletin of the Florida Museum of Natural History 45.4 (2005), pp. 465-494.

[10409] R. C. Hulbert, A. Kerner, and G. S. Morgan. "Taxonomy of the Pleistocene giant beaver Castoroides (Rodentia: Castoridae) from the southeastern United States". English. In: 53.2 (2014), pp. 26-43.

[10410] R. C. Hulbert, R. M. Petkewich, G. A. Bishop, D. Bukry, and D. P. Aleshire. "A new middle Eocene protocetid whale (Mammalia: Cetacea: Archaeoceti) and associated biota from Georgia". English. In: Journal of Paleontology 72.5 (1998), pp. 907-927.

[10411] R. C. Hulbert, S. C. Wallace, W. W. Klippel, and P. W. Parmalee. "Cranial morphology and systematics of an extraordinary sample of the late Neogene dwarf tapir, Tapirus polkensis (Olsen)". English. In: Journal of Paleontology 83.2 (2009), pp. 238-262. 
[10412] R. C. Hulbert and F. C. Whitmore. "Late Miocene mammals from the Mauvilla Local Fauna, Alabama". English. In: Bulletin of the Florida Museum of Natural History 46.1 (2006), pp. 1-28.

[10413] R. C. Hulbert. "A new late Pliocene porcupine (Rodentia: Erethizontidae) from Florida". English. In: Journal of Vertebrate Paleontology 17.3 (1997), pp. 623-626.

[10414] R. C. Hulbert Jr. "Late Miocene Nannippus (Mammalia: Perissodactyla) from Florida, with a description of the smallest Hipparionine horse". English. In: Journal of Vertebrate Paleontology 13.3 (1993), pp. 350-366.

[10415] R. C. Hulbert Jr. "The giant tapir, Tapirus haysii, from Leisey Shell Pit 1A and other Florida Irvingtonian Localities". English. In: Bulletin of the Florida Museum of Natural History 37.16 (1995), pp. 515-551.

[10416] R. C. Hulbert Jr. "Equus from Leisey Shell Pit 1A and other Irvingtonian localities from Florida". English. In: Bulletin of the Florida Museum of Natural History 37.17 (1995), pp. 553-602.

[10417] R. C. Hulbert Jr. "A new late Pliocene porcupine (Rodentia, Erethizontidae) from Florida". English. In: Journal of Vertebrate Paleontology 17.3 (1997), pp. 623-626.

[10418] R. C. Hulbert Jr. and B. J. MacFadden. "Morphological transformation and cladogenesis at the base of the adaptive radiation of Miocene hypsodont horses". English. In: American Museum Novitates 3000 (1991), pp. 1-61.

[10419] R. C. Hulbert Jr., G. S. Morgan, and A. Kerner. “Collared peccary (Mammalia, Artiodactyla, Tayassuidae, Pecari) from the late Pleistocene of Florida". English. In: Papers on Geology, Vertebrate Paleontology, and Biostratigraphy in Honor of Michael O. Woodburne. Flagstaff: Museum of Northern Arizona, 2009, pp. 543-555.

[10420] R. C. Hulbert Jr. and A. E. Pratt. "Pleistocene (Rancholabrean) vertebrate faunas from coastal Georgia". English. In: Journal of Vertebrate Paleontology 18.2 (1998), pp. 412-429.

[10421] R. C. Hulbert Jr., S. D. Webb, and N. J. Czaplewski. “New records of Pseudhipparion simpsoni (Mammalia, Equidae) from the late Hemphillian of Oklahoma and Florida". English. In: Journal of Vertebrate Paleontology 25.3 (2005), pp. 737-740.

[10422] R. C. Hulbert Jr. and F. C. Whitmore Jr. Early Hemphillian mammals from the Mauvilla local fauna, Alabama. English. 1997.

[10423] D. M. Hull. “Upper Jurassic Tethyan and Southern Boreal radiolarians from western North America". English. In: Micropaleontology 43.S2 (1997), pp. 1-202.

[10424] D. M. Hull. "Morphologic diversity and paleogeographic signficance of the family Parvicingulidae (Radiolaria)". In: Micropaleontology 41 (1995), pp. 1-48.

[10425] S. Humane and P. Kundal. "Morelletpora (a dasycladacean alga) from the Fulra Limestone Formation of the south western Kachch"". English. In: The Paleobotanist 55 (2006), pp. 45-50.

[10426] S. K. Humane, S. N. Chaurpagar, S. S. Humane, and P. Kundal. "Dasycladalean algae and their depositional environments in the Sylhet Limestone Formation (lower-middle Eocene), Bengal Basin". English. In: Journal Geological Society of India 76 (2010), pp. 75-85.

[10427] S. K. Humane and P. Kundal. "Halimedacean and Udoteacean algae from the mid-Tertiary western carbonate plarform of the Kachchh, India: Possible paleoenvironments and evolution". English. In: Microbiology and Meiobenthology 2 (2005), pp. 4-27.

[10428] S. K. Humane and P. Kundal. “Nongeniculate coralline algae from the middle Eocene to late lower Miocene of southwestern part of Kachchh, India". English. In: ONGC Bulletin 45.1 (2010), pp. 3042.

[10429] M. Humblet, Y. Iryu, and T. Nakamori. "Variations in Pleistocene coral assemblages in space and time in southern and northern central Ryukyu Islands, Japan". English. In: Marine Geology 259 (2009), pp. 1-20.

[10430] J. P. Hume. "Systematics, morphology, and ecology of pigeons and doves (Aves: Columbidae) of the Mascarene Islands, with three new species". English. In: Zootaxa 3124 (2011), pp. 1-62. 
[10431] J. P. Hume. "Reappraisal of the parrots (Aves: Psittacidae) from the Mascarene Islands, with comments on their ecology, morphology, and affinities". English. In: Zootaxa 1513 (2007), pp. 1-76.

[10432] J. P. Hume. "A synopsis of the pre-human avifauna of the Mascarene Islands". English. In: Proceedings of the 8th International Meeting of the Society of Avian Paleontology and Evolution (2013), pp. 195237.

[10433] J. P. Hume. “A new subfossil bulbul (Aves: Passerines: Pycnonotidae) from Rodrigues Island, Mascarenes, south-western Indian Ocean". English. In: Ostrich 86 (2015), pp. 247-260.

[10434] J. P. Hume. "Systematics, morphology, and ecological history of the Mascarene starlings (Aves: Sturnidae) with the description of a new genus and species from Mauritius". English. In: Zootaxa 3849 (2014), pp. 1-75.

[10435] J. P. Hume, D. Martill, and R. HIng. “A terrestrial vertebrate palaeontological review of Aldabra Atoll, Aldabra Group, Seychelles". English. In: PLoS ONE 13.3 (2018), pp. 1-20. DOI: 10.1371 / journal.pone.0192675.

[10436] B. R. Hunda and N. C. Hughes. "Evaluating paedomorphic heterochrony in trilobites: the case of the diminutive trilobite Flexicalymene retrorsa minuens from the Cincinnatian Series (Upper Ordovician), Cincinnati region". English. In: Evolution \& Development 9.5 (2007), pp. 483-498. DOI: 10.1111/j.1525-142X.2007.00186.x.

[10437] A. Hungerbühler. "The Late Triassic phytosaur Mystriosuchus westphali, with a revision of the genus". English. In: Palaeontology 45.2 (2002), pp. 377-418.

[10438] A. Hungerbühler. "Cranial anatomy and diversity of the Norian phytosaurs from southwest Germany". English. PhD thesis. 1998, pp. 1-464.

[10439] A. Hungerbühler and A. P. Hunt. "Two new phytosaur species (Archosauria, Crurotarsi) from the Upper Triassic of southwest Germany". English. In: Neues Jahrbuch für Geologie und Paläontologie, Monatshefte 2000.8 (2000), pp. 467-484.

[10440] A. Hungerbühler, B. Mueller, S. Chatterjee, and D. P. Cunningham. "Cranial anatomy of the Late Triassic phytosaur Machaeroprosopus, with the description of a new species from West Texas". English. In: Earth and Environmental Science Transactions of the Royal Society of Edinburgh 103 (2013), pp. 269-312.

[10441] A. P. Hunt. "Preliminary results of the Dawn of the Dinosaurs Project at Petrified Forest National Park, Arizona". English. In: . In V. L. Santucci \& L. McClelland (eds.), National Park Service Geologic Resources Division Technical Report NPS/NRGRD/GRDTR-98/01. National Park Service Paleontological Research Volume 3 (1998), pp. 135-137.

[10442] A. P. Hunt. The vertebrate fauna, biostratigraphy and biochronology of the type Revueltian land-vertebrate faunachron, Bull Canyon Formation (Upper Triassic), east-central New Mexico. English. Vol. 52. New Mexico Geological Society Guidebook, 52nd Field Conference, Geology of the Llano Estacado. 2001, pp. 123-151.

[10443] A. P. Hunt, A. B. Heckert, S. G. Lucas, and A. Downs. The distribution of the enigmatic reptile Vancleavea in the Upper Triassic Chinle Group of the western United States. English. Vol. 21. Upper Triassic Stratigraphy and Paleontology, New Mexico Museum of Natural History and Science Bulletin. 2002, pp. 269-273.

[10444] A. P. Hunt, M. G. Lockley, and S. G. Lucas. "Vertebrate and invertebrate tracks and trackways from Upper Triassic strata of the Tucumcari Basin, east-central New Mexico, USA". English. In: The Nonmarine Triassic. New Mexico Museum of Natural History and Science Bulletin 3 (1993), pp. 199201.

[10445] A. P. Hunt and M. G. Lockley. "A nonmarine tetrapod from the Middle Jurassic of the United States: a primitive crocodyliform from the Entrada Sandstone of eastern Utah". English. In: Journal of Vertebrate Paleontology 15.3 (1995), pp. 554-560.

[10446] A. P. Hunt, M. G. Lockley, K. Hups, and R. J. Schultze. Jurassic vertebrate paleontology of Cactus Park, west-central Colorado. English. 1995. 
[10447] A. P. Hunt and S. G. Lucas. "Cretaceous vertebrates of New Mexico". English. In: New Mexico Museum of Natural History and Science Bulletin 2 (1993), pp. 77-91.

[10448] A. P. Hunt and S. G. Lucas. "The Paleorhinus biochron and the correlation of the non-marine Upper Triassic of Pangaea". English. In: Palaeontology 34.2 (1991), pp. 487-501.

[10449] A. P. Hunt and S. G. Lucas. "Jurassic vertebrates of New Mexico". English. In: New Mexico Museum of Natural History and Science Bulletin 2 (1993), pp. 71-75.

[10450] A. P. Hunt and S. G. Lucas. "Stratigraphy and vertebrate paleontology of the Chinle Group (Upper Triassic), Chama Basin, north-central New Mexico". English. In: New Mexico Museum of Natural History and Science Bulletin 2 (1993), pp. 61-69.

[10451] A. P. Hunt, S. G. Lucas, A. B. Heckert, R. M. Sullivan, and M. G. Lockley. “Late Triassic dinosaurs from the western United States". English. In: Géobios 31.4 (1998), pp. 511-531.

[10452] A. P. Hunt and S. G. Lucas. Tetrapod ichnofaunas from the Lower Cretaceous of northeastern New Mexico, USA. English. Vol. 14. Lower and Middle Cretaceous Terrestrial Ecosystems, New Mexico Museum of Natural History and Science Bulletin. 1998, pp. 163-167.

[10453] A. P. Hunt and S. G. Lucas. Ornithischian dinosaurs from the Upper Triassic of the United States. English. In N. C. Fraser \& H.-D. Sues (eds.), In the Shadow of the Dinosaurs: Early Mesozoic Tetrapods. Cambridge University Press, Cambridge. 1994, pp. 227-241.

[10454] A. P. Hunt, S. G. Lucas, M. G. Lockley, and A. B. Heckert. Occurrence of the dinosaurian ichnogenus Grallator in the Redonda Formation (Upper Triassic: Norian) of eastern New Mexico. English. Vol. 17. Dinosaurs of New Mexico. New Mexico Museum of Natural History and Science Bulletin. 2000, pp. 39-41.

[10455] A. P. Hunt and S. G. Lucas. "Late Triassic tetrapod tracks of western North America". English. In: In S. G. Lucas \& J. A. Spielmann (eds.), Triassic of the American West. New Mexico Museum of Natural History and Science Bulletin 40 (2007), pp. 215-230.

[10456] A. P. Hunt and S. G. Lucas. Late Triassic microvertebrate localities in New Mexico (USA): implications for paleoecology. English. Vol. 3. The Nonmarine Triassic. New Mexico Museum of Natural History and Science Bulletin. 1993, pp. 187-191.

[10457] A. P. Hunt and S. G. Lucas. "A new phytosaur (Reptilia: Archosauria) genus from the uppermost Triassic of the western United States and its biochonological significance". English. In: The Nonmarine Triassic. New Mexico Museum of Natural History and Science Bulletin 3 (1993), pp. 193-196.

[10458] A. P. Hunt and S. G. Lucas. "Re-evaluation of Typothorax meadei, a Late Triassic aetosaur from the United States". English. In: Palaeontologische Zeitschrift 64 (1990), pp. 317-328.

[10459] A. P. Hunt and S. G. Lucas. Vertebrate paleontology and biochronology of the lower Chinle Group (Upper Triassic), Santa Fe County, north-central New Mexico. English. New Mexico Geological Society Guidebook, 46th Field Conference, Geology of the Santa Fe Region. 1995, pp. 243-246.

[10460] A. P. Hunt, S. G. Lucas, and P. Bircheff. Biochronological significance of the co-occurrence of the phytosaurs (Reptilia: Archosauria) Angistorhinus and Rutiodon in the Los Esteros Member of the Santa Rosa Formation, Santa Fe County, New Mexico, USA. English. Vol. 3. The Nonmarine Triassic, New Mexico Museum of Natural History and Science Bulletin. 1993, pp. 203-204.

[10461] A. P. Hunt and S. G. Lucas. "A new aetosaur from the Redonda Formation (Late Triassic: middle Norian) of east central New Mexico, USA". English. In: Neues Jahrbuch für Paläontologie und Geologie 1991 (1991), pp. 728-736.

[10462] A. P. Hunt and S. G. Lucas. Triassic vertebrate paleontology and biochronology of New Mexico. English. Vol. 2. Vertebrate Paleontology in New Mexico. New Mexico Museum of Natural History and Science Bulletin. Albuquerque: New Mexico Museum of Natural History and Science, 1993, pp. 4960.

[10463] A. P. Hunt and S. G. Lucas. "The first occurrence of the aetosaur Paratypothorax andressi (Reptilia, Aetosauria) in the western United States and its biochronological significance". English. In: Palaeontologische Zeitschrift 66 (1992), pp. 147-157. 
[10464] A. P. Hunt and S. G. Lucas. "A new rhynchosaur from the Upper Triassic of West Texas, and the biochronology of Late Triassic rhynchosaurs". English. In: Palaeontology 34.4 (1991), pp. 927-938.

[10465] A. P. Hunt and S. G. Lucas. "Paleontology and biochronology of the Petrified Forest Member of the Upper Triassic Chinle Formation near San Ysidro, Sandoval County, New Mexico". English. In: New Mexico Journal of Science 30.1 (1990), pp. 17-26.

[10466] A. P. Hunt, S. G. Lucas, and D. S. Berman. “A new amphibian (Amphibia: Temnospondyli) from the Late Pennsylvanian (Middle Stephanian) of central New Mexico, USA". English. In: Palaeontologische Zeitschrift 70 (1996), pp. 555-565.

[10467] A. P. Hunt, S. G. Lucas, and D. S. Berman. "The Late Pennsylvanian amphibian fauna of the Kinney Quarry, central New Mexico". English. In: New Mexico Bureau of Mines and Mineral Resources Bulletin 138 (1992), pp. 211-220.

[10468] A. P. Hunt and S. G. Lucas. "A small theropod dinosaur from the Upper Jurassic of eastern New Mexico with a checklist of small theropods from the Morrison Formation of western North America". English. In: vol. 36. Paleontology and Geology of the Upper Jurassic Morrison Formation. New Mexico Museum of Natural History and Science Bulletin. Albuquerque: New Mexico Museum of Natural History and Science, 2006, pp. 115-118.

[10469] A. P. Hunt and S. G. Lucas. "Late Triassic tetrapod tracks from Petrified Forest National Park, Arizona". English. In: vol. 37. The Triassic-Jurassic Terrestrial Transition. New Mexico Museum of Natural History and Science Bulletin. Albuquerque: New Mexico Museum of Natural History and Science, 2006, pp. 221-225.

[10470] A. P. Hunt and S. G. Lucas. "The significance of the St. George Dinosaur Discovery Site at Johnson Farm: a Jurassic Konzentrat-Ichnolagerstätte, Utah, U.S.A." English. In: vol. 37. The TriassicJurassic Terrestrial Transition. New Mexico Museum of Natural History and Science Bulletin. Albuquerque: New Mexico Museum of Natural History and Science, 2006, pp. 282-288.

[10471] A. P. Hunt, S. G. Lucas, and J. A. Spielmann. "Sexual dimorphism in a large brachyrostral phytosaur (Archosauria: Crurotarsi) from the Late Triassic of western North America". English. In: New Mexico Museum of Natural History and Science Bulletin 37 (2006), pp. 563-567.

[10472] A. P. Hunt, V. L. Santucci, M. G. Lockley, and T. J. Olson. Dicynodont trackways from the Holbrook Member of the Moenkopi Formation (Middle Triassic: Anisian), Arizona, USA. English. Vol. 3. The Nonmarine Triassic, New Mexico Museum of Natural History and Science Bulletin. 1993, pp. 213-218.

[10473] A. P. Hunt, J. A. Spielmann, and S. G. Lucas. "A sphenosuchian (Archosauria, Crocodylomorpha) with a partial pelvis from the Upper Triassic Bull Canyon Formation (Norian: Revueltian), eastcentral, New Mexico". English. In: vol. 37. New Mexico Museum of Natural History and Science Bulletin. Albuquerque: New Mexico Museum of Natural History and Science, 2006, pp. 571-574.

[10474] A. P. Hunt and J. Wright. "New discoveries of Late Triassic dinosaurs from Petrified Forest National Park, Arizona". English. In: In V. L. Santucci \& L. McClelland (eds.), National Park Service Geologic Resources Division Technical Report NPS/NRGRD/GRDTR-99/03. National Park Service Paleontological Research Volume 4 (1999), pp. 96-100.

[10475] R. K. Hunt and T. M. Lehman. "Attributes of the ceratopsian dinosaur Torosaurus, and new material from the Javelina Formation (Maastrichtian) of Texas". English. In: Journal of Paleontology 82.6 (2008), pp. 1127-1138.

[10476] R. K. Hunt and J. H. Quinn. "A new ornithomimosaur from the Lower Cretaceous Trinity Group of Arkansas". English. In: Journal of Vertebrate Paleontology 38.1 (2018), e1421209:1-12. DOI: 10.1080/ 02724634.2017.1421209.

[10477] R. M. J. Hunt and L. G. Barnes. "Basicranial evidence for ursid affinity of the oldest pinnipeds". English. In: Proceedings of the San Diego Society of Natural History 29 (1994), pp. 57-67.

[10478] R. M. Hunt Jr. Amphicyonidae. English. The Terrestrial Eocene-Oligocene Transition in North America. Cambridge University Press, 1996, pp. 476-485. DOI: 10.1017/CBO9780511665431.024.

[10479] R. M. Hunt Jr. Amphicyonidae. English. 1998, pp. 196-227. 
[10480] R. M. Hunt Jr. "Evolution of the aeluroid Carnivora: diversity of the earliest aeluroids from Eurasia (Quercy, Hsanda-Gol) and the origin of felids". English. In: American Museum Novitates 3252 (1998), pp. 1-65.

[10481] R. M. Hunt Jr. "Small Oligocene amphicyonids from North America (Paradaphoenus, Mammalia, Carnivora)". English. In: American Museum Novitates 3331 (2001), pp. 1-20.

[10482] R. M. Hunt Jr. "Intercontinental migration of Neogene amphicyonids (Mammalia, Carnivora): appearance of the Eurasian beardog Ysengrinia in North America". English. In: American Museum Novitates 3384 (2002), pp. 1-53.

[10483] R. M. Hunt Jr. "New amphicyonid carnivorans (Mammalia, Daphoeninae) from the early Miocene of southeastern Wyoming". English. In: American Museum Novitates 3385 (2002), pp. 1-41.

[10484] R. M. Hunt Jr. "Intercontinental migration of large mammalian carnivores: earliest occurrence of the Old World beardog Amphicyon (Carnivora, Amphicyonidae) in North America". English. In: Bulletin of the American Museum of Natural History 279 (2003), pp. 77-115.

[10485] R. M. Hunt Jr. “Evolution of Large Carnivores During the Mid-Cenozoic of North America: The Temnocyonine Radiation (Mammalia, Amphicyonidae)". English. In: Bulletin of the American Museum of Natural History 358 (2011), pp. 1-153. DOI: 10.1206/358.1.

[10486] R. M. Hunt Jr. “An Early Miocene Dome-Skulled Chalicothere from the Arikaree Conglomerates of Darton: Calibrating the Ages of High Plains Paleovalleys Against Rocky Mountain Tectonism". English. In: American Museum Novitates 7212 (2005), pp. 1-45. DOI: 10.1206 / 0003 - 0082(2005) 486[0001:AEMDCF]2.0.CO;2.

[10487] R. M. Hunt Jr. “Long-Legged Pursuit Carnivorans (Amphicyonidae, Daphoeninae) From the Early Miocene of North America". English. In: Bulletin of the American Museum of Natural History 318 (2009), pp. 1-95. DOI: 10.1206/593.1.

[10488] R. M. Hunt Jr. and R. Skolnick. “The giant mustelid Megalictis from the Early Miocene carnivore dens at Agate Fossil Beds National Monument, Nebraska: earliest evidence of dimorphism in New World Mustelidae (Carnivora, Mammalia)". English. In: Contributions to Geology, University of Wyoming 31.1 (1996), pp. 35-48.

[10489] R. M. Hunt Jr. and E. Stepleton. "Geology and paleontology of the upper John Day beds, John Day river valley, Oregon: lithostratigraphic and biochronologic revision in the Haystack Valley and Kimberly areas (Kimberly and Mt. Misery quadrangles)". English. In: Bulletin of the American Museum of Natural History 282 (2004), pp. 1-90.

[10490] R. M. Hunt Jr. and E. Stepleton. "A Skull of the Immigrant Eurasian Beardog Cynelos (Carnivora, Amphicyonidae) from the Early Miocene of Southern California". English. In: Journal of Vertebrate Paleontology 35.1 (2015). DOI: 10.1080/02724634.2014.891229.

[10491] A. W. Hunter and K. J. McNamara. "Prolonged co-existence of 'archaic' and 'modern' Palaeozoic ophiuroids - evidence". English. In: Journal of Systematic Palaeontology 16 (2017), pp. 891-907.

[10492] A. W. Hunter, T. Oji, T. M. Ewin, and K. Kitazawa. "Chariocrinus japonicus, a new species of isocrinid crinoid (Articulata) from the Lower Cretaceous of Takayama City, central Japan". English. In: Bulletin of the Mizunami Fossil Museum 37 (2011), pp. 115-121.

[10493] I. G. Hunter and B. Jones. "Coral associations of the Pleistocene Ironshore Formation, Grand Cayman". English. In: Coral Reefs 15.4 (1996), pp. 249-267.

[10494] J. P. Hunter. "Mammals and mollusks across the Cretaceous-Tertiary boundary from Makoshika State Park and vicinity (Williston Basin), Montana". English. In: Contributions to Geology, University of Wyoming 32.1 (1997), pp. 61-114.

[10495] J. P. Hunter and J. D. Archibald. "Mammals from the end of the age of dinosaurs in North Dakota and southeastern Montana, with a reappraisal of geographic differentiation among Lancian mammals". English. In: Geological Society of America Special Paper 361 (2002), pp. 191-216.

[10496] J. P. Hunter, R. E. Heinrich, and D. B. Weishampel. "Mammals from the St. Mary River Formation (Upper Cretaceous), Montana". English. In: Journal of Vertebrate Paleontology 30.3 (2010), pp. 885898. 
[10497] J. P. Hunter and D. A. Pearson. “First record of Lancian (Late Cretaceous) mammals from the Hell Creek Formation of southwestern North Dakota, USA". English. In: Cretaceous Research 17 (1996).

[10498] K. Hunter and B. Breithaupt. Rising from the dust: an Allosaurus' journey to the 21st century. English. 2005.

[10499] J. H. Hurum, M. Bergan, R. Müller, J. P. Nystuen, and N. Klein. “A Late Triassic dinosaur bone, offshore Norway". English. In: Norwegian Journal of Geology 86 (2006), pp. 117-123.

[10500] J. H. Hurum and Z. KielanJaworowska. "Postcranial skeleton of a Cretaceous multituberculate mammal Catopsbaatar". English. In: Acta Palaeontologica Polonica 53.4 (2008), pp. 545-566.

[10501] J. H. Hurum, J. Milán, Ø Hammer, I. /. Midtkandal, H. Amundsen, and B. Sæther. “Tracking polar dinosaurs-new finds from the Lower Cretaceous of Svalbard". English. In: Norwegian Journal of Geology 86 (2006), pp. 397-402.

[10502] J. H. Hurum and K. L. Sabath. "Giant theropod dinosaurs from Asia and North America: skulls of Tarbosaurus bataar and Tyrannosaurus rex compared". English. In: Acta Palaeontologica Polonica 48.2 (2003), pp. 161-190.

[10503] J. R. Hutchinson and L. M. Chiappe. "The first known alvarezsaurid (Theropoda: Aves) from North America". English. In: Journal of Vertebrate Paleontology 18.3 (1998), pp. 447-450.

[10504] M. N. Hutchinson and J. D. Scanlon. "New and unusual plio-pleistocene lizard (Reptilia: Scincidae) from Wellington Caves, New South Wales, Australia". English. In: Journal of Herpetology 43.1 (2009), pp. 139-147.

[10505] J. H. Hutchison. "Early Kinosterninae (Reptilia: Testudines) and their phylogenetic significance". English. In: Journal of Vertebrate Paleontology 11.2 (1991), pp. 145-167.

[10506] J. H. Hutchison. "A new eubaenine, Goleremys mckennai, gen. et. sp. n., (Baenidae: Testudines) from the Paleocene of California". English. In: Bulletin of Carnegie Museum of Natural History 36 (2004), pp. 91-96.

[10507] J. H. Hutchison. "New turtles from the Paleogene of North America". English. In: Morphology and Evolution of Turtles. Dordrecht: Springer Science+Business Media, 2013, pp. 477-497. DOI: 10.1007/978-94-007-4309-0_26.

[10508] J. H. Hutchison. "New soft-shelled turtles (Plastomeninae, Trionychidae, Testudines) from the Cretaceous and Paleocene of North America". English. In: PaleoBios 29.2 (2009), pp. 36-47.

[10509] J. H. Hutchison. "Bridgeremys (Geoemydidae,Testudines), a new genus from the middle Eocene of North America". English. In: Fossil Turtle Research 1 (2006), pp. 63-83.

[10510] J. H. Hutchison and C. R. Harington. "A peculiar new fossil shrew (Lipotyphla, Soricidae) from the High Arctic of Canada". English. In: Canadian Journal of Earth Sciences 39.4 (2002), pp. 439-443.

[10511] J. H. Hutchison, P. A. Holroyd, and R. L. Ciochon. “A preliminary report on southeast Asia's oldest Cenozoic turtle fauna from the late middle Eocene Pondaung Formation, Myanmar". In: Asiatic Herpetological Research 10 (2004), pp. 38-52.

[10512] J. H. Hutchison and P. A. Holroyd. "Late Cretaceous and early Paleocene turtles of the Denver Basin, Colorado". English. In: Rocky Mountain Geology 38.1 (2003), pp. 121-142.

[10513] J. H. Hutchison and A. D. Pasch. "First record of a turtle (Protochelydra, Chelydridae, Testudines) from the Cenozoic of Alaska (Chickaloon Formation, Paleocene-Eocene)". English. In: PaleoBios 24.1 (2004), pp. 1-5.

[10514] J. H. Hutchison and R. E. Weems. "Paleocene turtle remains from South Carolina". English. In: Transactions of the American Philosophical Society 88.4 (1998), pp. 165-195.

[10515] S. Hutt, D. M. Martill, and M. J. Barker. "The first European allosauroid dinosaur (Lower Cretaceous, Wealden Group, England)". English. In: Neues Jahrbuch für Geologie und Paläontologie Monatshefte 1996.10 (1996), pp. 635-644.

[10516] S. Hutt, D. Naish, D. M. Martill, M. J. Barker, and P. Newbery. "A preliminary account of a new tyrannosauroid theropod from the Wessex Formation (Early Cretaceous) of southern England". English. In: Cretaceous Research 22 (2001), pp. 227-242. 
[10517] A. Huttenlocker, C. Sidor, and R. Smith. "A New Specimen of Promoschorhynchus (Therapsida: Therocephalia: Akidnognathidae) from the Lower Triassic of South Africa and its Implications for Theriodont Survivorship Across the Permo-Triassic Boundary". English. In: Journal of Vertebrate Paleontology 31.2 (2011), pp. 405-421.

[10518] A. K. Huttenlocker and F. Abdala. "Revision of the first therocephalian, Theriognathus Owen (Therapsida:" English. In: Journal of Paleontology 89.4 (2015), pp. 645-664. DOI: 10.1017/jpa.2015.32.

[10519] A. K. Huttenlocker and J. Botha-Brink. "Body size and growth patterns in the therocephalian Moschorhinus kitchingi". English. In: Paleobiology 39.2 (2013), pp. 253-277. DOI: 10.1666/12020.

[10520] A. K. Huttenlocker, D. M. Grossnickle, J. I. Kirkland, J. A. Schultz, and Z. -X. Luo. “Late-surviving stem mammal links the lowermost Cretaceous of North America and Gondwana". English. In: Nature (2018). DOI: 10.1038/s41586-018-0126-y.

[10521] A. K. Huttenlocker, J. D. Pardo, and B. J. Small. “An earliest Permian nonmarine vertebrate assemblage from the Eskridge Formation, Nebraska". English. In: New Mexico Museum of Natural History and Science, Bulletin 30 (2005), pp. 133-143.

[10522] A. K. Huttenlocker, J. D. Pardo, and B. K. Small. "Plemmyradytes shintoni, gen. et sp. nov., an Early Permian amphibian (Temnospondyli: Dissorophoidea) from the Eskridge Formation, Nebraska". English. In: Journal of Vertebrate Paleontology 27 (2007), pp. 316-328.

[10523] A. K. Huttenlocker, J. D. Pardo, B. J. Small, and J. S. Anderson. “Cranial morphology of recumbirostrans (Lepospondyli) from the Permian of Kansas and Nebraska, and early morphological evolution inferred by micro-computed tomography". English. In: Journal of Vertebrate Paleontology 33 (2013), pp. 540-552.

[10524] A. K. Huttenlocker and C. A. Sidor. "Taxonomic revision of therocephalians (Therapsida: Theriodontia) from the Lower Triassic of Antarctica". English. In: American Museum Novitates 3738 (2012), pp. 1-19.

[10525] A. K. Huttenlocker, C. A. Sidor, and K. D. Angielczyk. "A new eutherocephalian (Therapsida, Therocephalia) from the upper Permian Madumabisa Mudstone Formation (Luangwa Basin) of Zambia". English. In: Journal of Vertebrate Paleontology (2015).

[10526] A. K. Huttenlocker and C. A. Sidor. "The first karenitid (Therapsida, Therocephalia) from the upper Permian of Gondwana and the biogeography of Permo-Triassic therocephalians". English. In: Journal of Vertebrate Paleontology (2016). DOI: 10.1080/02724634.2016.1111897.

[10527] A. K. Huttenlocker and C. A. Sidor. "A Basal Nonmammaliaform Cynodont from the Permian of Zambia and the Origins of Mammalian Endocranial and Postcranial Anatomy". English. In: Journal of Vertebrate Paleontology (2020), e1827413. DOI: 10.1080/02724634.2020.1827413.

[10528] A. K. Huttenlocker and R. M. H. Smith. "New whaitsioids (Therapsida: Therocephalia) from the Teekloof Formation of South Africa and therocephalian diversity during the end Guadalupian extinction". English. In: PeerJ 5 (2017), e3868.

[10529] K. Huttunen and U. B. Göhlich. "Un squelette partiel de Prodeinotherium bavaricum (Proboscidea, Mammalia) du Miocéne moyen de Unterzolling (Molasse d'eau douce supérieure, Allemagne)". French. In: Geobios 35.4 (2002), pp. 489-514.

[10530] K. G. Hwang, M. Huh, and I. S. Paik. "[Sauropod trackways from the Cretaceous Jindong Formation at Docheon-ri, Changnyeon-gun, Gyeongsangnam-do, Korea]". other. In: Journal of the Geological Society of Korea 40.2 (2004), pp. 145-159.

[10531] K.-G. Hwang, M. Huh, M. G. Lockley, D. M. Unwin, and J. L. Wright. "New pterosaur tracks (Pteraichnidae) from the Late Cretaceous Uhangri Formation, southwestern Korea". English. In: Geological Magazine 139 (2002), pp. 421-435.

[10532] S. Hwang, M. A. Norell, Q. Ji, and K. Gao. "A large compsognathid from the Early Cretaceous Yixian Formation of China". English. In: Journal of Systematic Palaeontology 2.1 (2004), pp. 13-30.

[10533] S. H. Hwang, G. Mayr, and M. Bolortsetseg. "The earliest record of a galliform bird in Asia, from the late Paleocene-early Eocene of the Gobi Desert, Mongolia". English. In: Journal of Vertebrate Paleontology 30.5 (2010), pp. 1642-1644. 
[10534] S. H. Hwang, M. A. Norell, Q. Ji, and K. Gao. “New specimens of Microraptor zhaoianus (Theropoda: Dromaeosauridae) from northeastern China". English. In: American Museum Novitates 3381 (2002), pp. $1-44$.

[10535] S. H. Hwang, M. A. Norell, Q. Ji, and K. -Q. Gao. A new troodontid from the lower Yixian Formation of China and its affinities to Mongolian troodontids. English. 2004.

[10536] F. Hybertsen and S. Kiel. "A middle Eocene seep deposit with silicified fauna from the Humptulips Formation in western Washington State, USA". English. In: Acta Palaeontologica Polonica 63.4 (2018), pp. 751-768. DOI: 10.4202/app.00525.2018.

[10537] M. Hyzny and A. Dávid. “A remarkably well-preserved terrestrial isopod (Peracarida: Isopoda: Armadillidiidae) from the upper Oligocene of Hungary, with remarks on the oniscidean taphonomy". English. In: Palaeontologia Electronica 20.1.5A (2017), pp. 1-11.

[10538] M. Hyzny and A. Dulai. "Deep- water fossorial shrimps from the Oligocene Kiscell Clay of Hungary: Taxonomy and Paleoecology". English. In: Acta Palaeontologica Polonica (2013), pp. 1-58.

[10539] M. Hyzny, N. Hudackova, R. Biskupic, S. Rybar, T. Fuksi, E. Halasova, K. Zagorsek, M. Jamrich, and Peter Ledvak. "Devnska Kobyla- a window into the Middle Miocene shallow-water marine environments of the Central Paratethys (Vienna Basin, Slovakia)". English. In: Acta Geologica Slovaca 4.2 (2012), pp. 95-111.

[10540] M. Hyzny, S. L. Jakobsen, and R. H. B. Fraaije. “Reappraisal of the burrowing lobster Axius (Malacostraca: Decapoda: Axiidea) in the fossil record with notes on palaeobiogeography and description of a new species". English. In: Bulletin of the Geological Society of France 188.12 (2017), pp. 1-11. DOI: $10.1051 /$ bsgf/2017175.

[10541] M. Hyzny, S. Jozsa, J. A. Dunlop, and P. A. Selden. "A fossil arachnid from Slovakia: the Carboniferous trigonotarbid Anthracomartus voelkelianus Karsch, 1882". English. In: Arachnology 16 (2013), pp. 21-26.

[10542] M. Hyzny and P. M. Muller. "The first fossil record of the genus Callichirus (Decapoda, Axiidea, Callianassidae) from the middle Miocene of Hungary, with description of a new species". English. In: Bulletin of the Mizunami Fossil Museum 36 (2010), pp. 37-43.

[10543] M. Hyzny and P. M. Muller. “Loerenthopluma Beschin, Busulini, De Angeli \& Tessier, 1996 (Decapoda, Brachyura, Retroplumidae) from the Oligocene of Hungary". English. In: Atti della Societá italiana di scienze naturali e del Museo civico di storia naturale di Milano 151.2 (2010), pp. 123-134.

[10544] M. Hyný and F. Muñiz. "Podocallichirus laepaensis, a new ghost shrimp (Crustacea, Decapoda, Callianassidae) from the late Miocene of southwest Spain". English. In: Journal of Paleontology 86.4 (2012), pp. 616-625.

[10545] M. Hyzny, J. Schlögl, S. Charbonnier, G. Schweigert, L. Rulleau, and M. Gouttenoire. "Intraspecific variation and taphonomy of a new erymid lobster (Crustacea: Decapoda) from the Middle Jurassic of Belmont (Beaujolais, France)". English. In: Geobios 48 (2015), pp. 371-384. DOI: 10.1016/ j.geobios.2015.07.006.

[10546] M. Hyný and J. Schlögl. “An Early Miocene deep-water decapod crustacean faunule from the Vienna Basin (western Carpathians, Slovakia)". English. In: Palaeontology 54.2 (2011), pp. 323-349. DOI: $10.1111 /$ j.1475-4983.2011.01033.x.

[10547] M. Hyný, J. Schlögl, and M. Krobicki. “Tanidromites insignis (von Meyer, 1857) (Crustacea: Decapoda: Brachyura) from Late Jurassic non-biohermal facies of the Western Tethys (Pieniny Klippen Belt, Western Carpathians, Slovakia)". English. In: Neues Jahrbuch für Geologie und Paläontologie, Abhandlungen 262 (2011), pp. 213-226. DOI: 10.1127/0077-7749/2011/0193.

[10548] M. Høyberget and D. L. Bruton. "Revision of the trilobite genus Sphaerophthalmus and relatives from the Furongian (Cambrian) Alum Shale Formation, Oslo Region, Norway". English. In: Norwegian Journal of Geology 92 (2012), pp. 433-450.

[10549] M. Høyberget, J. O. R. Ebbestad, B. Funke, and H. A. Nakrem. "The shelly fauna and biostratigraphy of the lower Cambrian (provisional series 2, stage 4) Evjevik Member, Ringstrand Formation in the Mjøsa area, Norway". English. In: Norwegian Journal of Geology 95 (2015), pp. 23-56. 
[10550] A. Iannace and V. Zamparelli. “Upper Triassic platform margin biofacies and the paleogeography of Southern Apennines". English. In: Palaeogeography, Palaeoclimatology, Palaeoecology 179 (2002), pp. 1-18.

[10551] A. Iannone, M. Petruzzelli, and R. La Perna. "La cava ad orme di dinosauro di Molfetta: opportunitá di tutela, valorizzazione e divulgazione di una singolaritá geologico-paleontologica del territorio [The dinosaur footprint quarry of Molfetta: opportunity for protection, enhancement, and dissemination of a geological-paleontological singularity of the territory]". Italian. In: Geologi e Territorio 9.2 (2012), pp. 17-21.

[10552] R. Iannuzzi and H. W. Pfefferkorn. "A Pre-Glacial, Warm-Temperate Floral Belt in Gondwana (Late Visean, Early Carboniferous)". In: Palaios 17 (2002), pp. 571-590.

[10553] Y. Iba. "An Early Albian Arctic-type ammonite Arcthoplites from Hokkaido, northern Japan, and its paleobiogeographic and paleoclimatological implications". English. In: Journal of Asian Earth Sciences 34 (2009), pp. 46-50.

[10554] Y. Iba, S. Sano, and K. Tanabe. "A Tethyan bivalve, Neithea (Cretaceous pectinid) from northern California, and its biogeographic implications". English. In: Paleontological Research 15.2 (2011), pp. 79-84.

[10555] Y. Iba, S. I. Sano, and J. Mutterlose. "The early evolutionary history of belemnites: new data from Japan". English. In: PLoS One 9.5 (2014), e95632. DOI: 10.1371/journal.pone.0095632.

[10556] S. Ibáñez-Bernal, M. Solórzano Kraemer, F. Stebner, and R. Wagner. "A new fossil species of Phlebotominae sand fly from Miocene amber of Chiapas, Mexico (Diptera: Psychodidae)". English. In: Paläontologische Zeitschrift 88 (2014), pp. 227-233.

[10557] L. M. Ibiricu, G. A. Casal, M. C. Lamanna, R. D. Martnez, J. D. Harris, and K. J. Lacovara. “The southernmost records of Rebbachisauridae (Sauropoda: Diplodocoidea), from early Late Cretaceous deposits in central Patagonia". English. In: Cretaceous Research 34 (2012), pp. 220-232.

[10558] L. M. Ibiricu, G. A. Casal, R. D. Martinez, M. C. Lamanna, M. Luna, and L. Salgado. "Katepensaurus goicoecheai, gen. et sp. nov., a Late Cretaceous rebbachisaurid (Sauropoda, Diplodocoidea) from central Patagonia, Argentina". English. In: Journal of Vertebrate Paleontology 33.6 (2013), pp. 13511366. DOI: $10.1080 / 02724634.2013 .776562$.

[10559] L. M. Ibiricu, G. A. Casal, R. D. Martnez, M. Luna, J. I. Canale, B. N. Alvarez, and B. González Riga. "A new ornithopod dinosaur (Dinosauria: Ornithischia) from the Late Cretaceous of central Patagonia". English. In: Cretaceous Research 98 (2019), pp. 276-291. DOI: 10.1016/j.cretres.2019.02. 001.

[10560] L. M. Ibiricu, R. D. Martinez, and G. A. Casal. “The first record of Pterosauria in the Bajo Barreal Formation (Upper Cretaceous, Central Patagonia, Argentina". English. In: Ameghiniana 49.4 (2012), pp. 657-661.

[10561] M. I. A. Ibrahim. "Aptian-Turonian palynology of the Ghazalat-1 well (GTX-1), Qattara Depression, Egypt". English. In: Review of Palaeobotany and Palynology 94 (1996), pp. 137-168.

[10562] N. Ibrahim, S. Maganuco, C. Dal Sasso, M. Fabbri, M. Auditore, G. Bindellini, D. M. Martill, S. Zouhri, D. A. Mattarelli, D. M. Unwin, J. Wiemann, D. Bonadonna, A. Amane, J. Jakubczak, U. Joger, G. V. Lauder, and S. E. Pierce. "Tail-propelled aquatic locomotion in a theropod dinosaur". English. In: Nature (2020). DOI: 10.1038/s41586-020-2190-3.

[10563] N. Ibrahim, P. C. Sereno, C. Dal Sasso, S. Maganuco, M. Fabbri, D. M. Martill, S. Zouhri, N. Myhrvold, and D. A. Iurino. "Semiaquatic adaptations in a giant predatory dinosaur". English. In: Science 345.6204 (2014), pp. 1613-1616. DOI: 10.1126/science.1258750.

[10564] N. Ibrahim, D. M. Unwin, D. M. Martill, L. Baidder, and S. Zouhri. "A new pterosaur (Pterodactyloidea: Azharchidae) from the Upper Cretaceous of Morocco". English. In: PLoS One 5.5 (2010), e10875. DOI: 10.1371/journal.pone.0010875.

[10565] N. Ibrahim, D. J. Varricchio, P. C. Sereno, J. A. Wilson, D. B. Dutheil, D. M. Martill, L. Baidder, and S. Zouhri. "Dinosaur footprints and other ichnofauna from the Cretaceous Kem Kem beds of Morocco". English. In: PLoS ONE 9.3 (2014), e90751:1-15. DOI: 10.1371/journal.pone.0090751. 
[10566] H. Ichishima. "Fossil dolphin from the Middle Miocene Takinoue Formation at Hobetsu-cho Hokkaido, Japan". Japanese. In: Bulletin of the Hobetsu Museum 9 (1993), pp. 37-44.

[10567] H. Ichishima. "A new fossil kentriodontid dolphin (Cetacea; Kentriodontidae) from the Middle Miocene Takinoue Formation, Hokkaido, Japan". English. In: The Island Arc 3 (1995), pp. 473-485.

[10568] H. Ichishima, A. H. Agustin, T. Toyofuku, and H. Kitazato. “A new species of Africanacetus (Odontoceti: Ziphiidae) found on the deep ocean floor off the coast of Brazil". English. In: DeepSea Research II (2017). DOI: 10.1016/j.dsr2.2016.12.002.

[10569] H. Ichishima, H. Furusawa, M. Tachibana, and M. Kimura. "First monodontid cetacean (Odontoceti, Delphinoidea) from the early Pliocene of the north-western Pacific Ocean". English. In: Papers in Palaeontology (2019). DOI: 10.1002/spp2.1244.

[10570] H. Ichishima and M. Kimura. "A new fossil porpoise (Cetacea; Delphinoidea; Phocoenidae) from the early Pliocene Horokaoshirarika Formation, Hokkaido, Japan". In: Journal of Vertebrate Paleontology 20.3 (2000), pp. 561-576.

[10571] H. Ichishima and M. Kimura. "Harborophocoena toyoshimai, a anew early Pliocene porpoise (Cetacea, Phocoenidae) from Hokkaido, Japan". English. In: Journal of Vertebrate Paleontology 25.3 (2005), pp. 655-664.

[10572] H. Ichishima and M. Kimura. "A new species of Haborophocoena, an Early Pliocene phocoenid cetacean from Hokkaido, Japan". English. In: Marine Mammal Science 25.4 (2009), pp. 855-874. DOI: 10.1111/j.1748-7692.2009.00293.x.

[10573] H. Ichishima and M. Kimura. “New material of Haborophocoena toyoshimai (Odontoceti: Phocoenidae) from the Lower Pliocene Embetsu Formation of Hokkaido, Japan". English. In: Paleontological Research 17.2 (2013), pp. 127-137.

[10574] H. Ichishima, E. Sato, T. Sagayama, and M. Kimura. "the oldest record of Eschrichtiidae (Cetacea: Mysticeti) from the Late Pliocene, Hokkaido, Japan". English. In: Journal of Paleontology 80.2 (2006), pp. 367-379.

[10575] V. Idakieva and V. Tchechmedjieva. "Wellsimeandra gen. n. du Barremien de la region de Veliko Tirnovo (Prebalkan central) [Wellsimeandra nov. gen. from the Barremian of the Veliko Tirnovo region (central Forebalkan)]". French. In: Dokladi na B'lgarskata Akademia na Naukite 56.1 (2003), pp. 61-66.

[10576] M. B. Idris and K. H. Kok. "Stratigraphy of the Mantanani Islands, Sabah". English. In: Geological Society of Malaysia (1990), pp. 35-46.

[10577] C. Ifrim and W. Stinnesbeck. "Early Turonian ammonites from Vallecillo, north-eastern Mexico: ttaxonomy, biostratigraphy and palaeobiogeographical significance". English. In: Cretaceous Research 28 (2007), pp. 642-663.

[10578] C. Ifrim, W. Stinnesbeck, and J. F. Ventura. "An endemic cephalopod assemblage from the Lower Campanian (Late Cretaceous) Parras Shale, western Coahuila, Mexico". English. In: Journal of Paleontology 87 (2013), pp. 881-901.

[10579] C. Ifrim, W. Stinnesbeck, B. Espinosa, and J. F. Ventura. “Upper Campanian (Upper Cretaceous) cephalopods from the Parras Shale near Saucedas, Coahuila, Mexico". English. In: Journal of South American Earth Sciences 64 (2015), pp. 229-257.

[10580] C. Ifrim, F. J. Vega, and W. Stinnesbeck. "Epizoic stramentid cirripedes on ammonites from Late Cretaceous platy limestones in Mexico". English. In: Journal of Paleontology 85 (2011), pp. 524-536.

[10581] A. Iglesias, P. Wilf, K. R. Johnson, A. B. Zamuner, N. R. Cúneo, and S. D. Matheos. "A Paleocene lowland macroflora from Patagonia reveals signifcantly greater richness than North American analogs". English. In: Geology 35.10 (2007), pp. 947-950. DOI: 10.1130/G23889A.1.

[10582] A. Iglesias, A. B. Zamuner, D. G. Poiré, and F. Larriestra. "Diversity, taphonomy, and palaeoecology of an angiosperm flora from the Cretaceous (Cenomanian-Coniacian) in southern Patagonia, Argentina". English. In: Palaeontology 50.2 (2007), pp. 445-466. DOI: 10.1111/j.1475-4983.2007. 00639.x. 
[10583] H. Igo and S. Adachi. "Description of some Carboniferous corals from the Ichinotani Formation, Fukuji, Hida Massif, central Japan (Upper Paleozoic corals from Fukuji, southeastern part of the Hida Massif, Part 7)." In: Science Reports of the Institute of Geoscience, University of Tsukuba, Section B 21 (2000), pp. 41-69.

[10584] H. Igo and S. Adachi. "Permian rugose corals from Kamisenba, Kuzu Town, Tochigi Prefecture in Japan". English. In: Bulletin of the National Science Museum, Tokyo, Series C 27 (2001), pp. 33-43.

[10585] H. Igo and Y. Kamikawa. "Carboniferous rugose corals from the Nanmoku area, northwestern part of the Kanto Mountains, Gunma Prefecture, Japan". English. In: Science Reports of the Institute of Geoscience, University of Tsukuba, Section B 19 (1998), pp. 29-42.

[10586] H. Igo and Y. Kamikawa. "A new Permian rugose coral, Wentzellophyllum pacificum, from the Sakamotozawa Formation, southern Kitakami Mountains, northeast Japan". English. In: Bulletin of the National Science Museum, Tokyo, Series C 30 (2004), pp. 13-20.

[10587] H. Igo, H. Koizumi, and T. Kaniwa. "A Permian rugose coral, Yatsengia kuzuensis, from north of Kiryu in the Ashio Mountains, Gunma Prefecture, Japan". English. In: Bulletin of the National Science Museum, Tokyo, Series C 26 (2000), pp. 79-86.

[10588] M. Iijima, A. Momohara, Y. Kobayashi, S. Hayashi, T. Ikeda, H. Taruno, K. Watanabe, M. Tanimoto, and S. Furui. "Toyotamaphimeia cf. machikanensis (Crocodylia, Tomistominae) from the". English. In: Palaeogeography, Palaeoclimatology, Palaeoecology 496 (2018), pp. 346-360.

[10589] M. Iijima, K. Takahashi, and Y. Kobayashi. "The oldest record of Alligator sinensis from the Late Pliocene of Western Japan, and its biogeographic implication". English. In: Journal of Asian Earth Sciences 124 (2016), pp. 94-101.

[10590] M. Iijima, T. Tsubamoto, K. Tsogtbaatar, T. Chinzorig, and S. Baasankhuu. "Discovery of a crocodyliform tooth from the upper Eocene Ergilin Dzo Formation, Mongolia". English. In: Acta Palaeontologica Polonica (2019). DOI: 10.4202/app.00633.2019.

[10591] K. Iizumi, Y. Koda, W. Koike, T. Nishimoto, H. Ando, and M. Date. “Latest Pleistocene Japanese Sea lion(Otariidae)fossil from the riverbed of the Hanamurogawa River west of Kasumigaura Lake, Ibaraki Prefecture". Japanese. In: Journal of the Geological Society of Japan 116.5 (2010), pp. $243-$ 251.

[10592] T. Ikeda, H. Ota, and H. Saegusa. "A new fossil lizard from the Lower Cretaceous Sasayama Group of Hyogo Prefecture, western Honshu, Japan". English. In: Journal of Vertebrate Paleontology 35.1 (2015), e885032. DOI: 10.1080/02724634.2014.885032.

[10593] T. Ikeda, H. Otsuka, and H. Ota. "Early Pleistocene Fossil Snakes (Reptilia: Squamata) from Okinawajima Island in the Ryukyu Archipelago, Southwestern Japan". English. In: Herpetological Monographs 30 (2016), pp. 143-156.

[10594] N. Ikegami, A. W. A. Kellner, and Y. Tomida. "The presence of an azhdarchid pterosaur in the Cretaceous of Japan". English. In: Paleontological Research 4.3 (2000), pp. 165-170.

[10595] T. Ikejiri. "Distribution and biochronology of Camarasaurus (Dinosauria, Sauropoda) from the Jurassic Morrison Formation of the Rocky Mountain region". English. In: vol. 56. New Mexico Geological Society, 56th Field Conference, Geology of the Chama Basin. New Mexico Geological Society Guidebook. New Mexico Geological Society, 2005, pp. 367-379.

[10596] T. Ikejiri, D. Schwarz, and B. Breithaupt. A nearly complete skeleton of a baby sauropod from the lower Morrison Formation of the Howe Stephens Quarry, Wyoming: little steps into diplodocid ontogeny and taxonomy. English. 2005.

[10597] T. Ikejiri, V. Tidwell, and D. L. Trexler. New adult specimens of Camarasaurus lentus highlight ontogenetic variation within the species. English. Thunder-Lizards: The Sauropodomorph Dinosaurs. Indiana University Press, Bloomington. 2005, pp. 154-179. 
[10598] T. Ikejiri, P. S. Watkins, and D. J. Gray. "Stratigraphy, sedimentology, and taphonomy of a sauropod quarry from the upper Morrison Formation of Thermopolis, central Wyoming". English. In: vol. 36. Paleontology and Geology of the Upper Jurassic Morrison Formation. New Mexico Museum of Natural History and Science Bulletin. Albuquerque: New Mexico Museum of Natural History and Science, 2006, pp. 39-46.

[10599] L. B. Il'ina. "New Marine Gastropods from the Tarkhan-Konka of Eastern Paratethys". In: Paleontological Journal 28.1A (1994), pp. 27-42.

[10600] A. Ilcheva and N. Motchurova-Dekova. "Catalogue of type collections of Early Cretaceous corals (Scleractinia, Anthozoa) at the National Museum of Natural History, Sofia". English. In: Review of the bulgarian geological society 72 (2011), pp. 129-140.

[10601] J. M. Ilger and C. Brauckmann. "The smallest Neoptera (Baryshnyalidae fam. n) from HagenVorhalle (early Late Carboniferous: Namurian B; Germany)". English. In: ZooKeys 130 (2011), pp. 91-102.

[10602] J. M. Ilger and C. Brauckmann. "First report of Namurian insects (Palaeodictyoptera; Megasecoptera; basal Neoptera) from the Küchenberg near Fröndenberg/Ruhr (Germany)". English. In: Paläontologische Zeitschrift 86 (2012), pp. 161-174.

[10603] G. Iliopoulos, H. Eikamp, and C. Fassoulas. "A new late Pleistocene mammal locality from Western Crete". English. In: Bulletin of the Geological Society of Greece 43 (2010), pp. 918-926.

[10604] G. Iliopoulos, C. Fassoulas, and M. Tzortzi. An almost complete skeleton of a large Deinotherium (Proboscidea, Mammalia). English. Thessaloniki, 2014.

[10605] T. G. Ilyina. "Distribution, taxonomy and morphology of Permian Rugosa of southeastern Pamir (Tadzhikistan)". English. In: Boletin de la Real Sociedad Espanola de Historia Natural, Seccion Geologica 91 (1997), pp. 127-141.

[10606] T. Imai, Y. Azuma, S. Kawabe, M. Shibata, K. Miyata, M. Wang, and Z. Zhou. "An unusual bird (Theropoda, Avialae) from the Early Cretaceous of Japan suggests complex evolutionary history of basal birds". English. In: Communications Biology 2.1 (2019), 399:1-11. DOI: 10.1038/s42003-019$0639-4$.

[10607] N. Inan and S. Inan. "Selandian (Upper Paleocene) benthic foraminiferal assemblages and their stratigraphic ranges in the northeastern part of Turkey". English. In: Yerbilimleri 29.3 (2008), pp. 147158.

[10608] M. Inesta, J. Szabó, and I. Szente. “A Pliensbachian gastropod and bivalve faunula from the Mola Hill (Betic Cordilleras, Spain)". English. In: Annales Historico-Naturales Musei Nationales Hungarici 82 (1990), pp. 19-23.

[10609] P. Infante, J. I. Canudo, and J. I. Ruiz-Omeñaca. "Primera evidencia de dinosaurios terópodos en la Formación Mirambel (Barremiense inferior, Cretácico Inferior) en Castellote, Teruel [First evidence of theropod dinosaurs in the Mirambel Formation (lower Barremian, Lower Cretaceous) in Castellote, Teruel]". Spanish. In: Geogaceta 38 (2005), pp. 31-34.

[10610] P. Infante, J. I. Canudo, M. Aurell, J. I. Ruiz-Omeñaca, L. M. Sender, and S. A. Zamora. Primeros datos sobre los dinosaurios de Zaragoza (Theropoda, Valanginiense-Hauteriviense, Cretácico Inferior) [First data on the dinosaurs of Zaragoza (Theropoda, Valanginian-Hauterivian, Lower Cretaceous)]. Spanish. 2005.

[10611] J. K. Ingham and R. P. Tripp. “The trilobite fauna of the Middle Ordovician Doularg Formation of the Girvan district, Scotland, and its palaeoenvironmental significance". English. In: Transactions of the Royal Society of Edinburgh 82 (1991), pp. 27-54.

[10612] O. Ingolfsson and O. Wiig. "Late Pleistocene fossil find in Svalbard: the oldest remains of a polar bear (Ursus maritimus Phipps, 1744) ever discovered". English. In: Polar Research 28 (2008), pp. 455-462.

[10613] G. Insacco. “I Cetacei fossili del Museo Civico di Storia Naturale di Comiso (Ragusa)". Italian. In: Museologia Scientifica Memoire 13 (2014), pp. 130-134. 
[10614] E. Insalaco. “Upper Jurassic microsolenid biostromes of northern and central Europe: facies and depositional environment". In: Palaeogeography, Palaeoclimatology, Palaeoecology 121 (1996), pp. 169 194.

[10615] E. Insalaco. “Facies and palaeoecology of Upper Jurassic (Middle Oxfordian) coral reefs in England". In: Facies 40 (1999), pp. 81-100.

[10616] N. Inuzuka. "Primitive late Oligocene desmostylians from Japan and Phylogeny of the Desmostylia". English. In: Bulletin of the Ashoro Museum of Paleontology 1 (2000), pp. 91-123.

[10617] N. Inuzuka, H. Sawamura, and H. Watabe. "Paleoparadoxia and the Nishikurosawa specimen from Oga, Akita, northern Japan". Japanese. In: Annual Report of the Akita Prefectural Museum 31 (2006), pp. 1-28.

[10618] M. Iordan. “Triassic brachiopods of Romania". English. In: Mesozoic Brachiopods of Alpine Europe. 1993, pp. 49-58.

[10619] F. V. Iori and I.d.S. Carvalho. "Morrinhosuchus luziae, um novo Crocodylomorpha Notosuchia da Bacia Bauru, Brasil [Morrinhosuchus luziae, a new Crocodylomorpha Notosuchia from the Bauru Basin, Brazil]". Portugese. In: Revista Brasileira de Geociencias 39.4 (2009), pp. 717-725.

[10620] F. V. Iori and I. S. Carvalho. “Caipirasuchus paulistanus, a new sphagesaurid (Crocodylomorpha, Mesoeucrocodylia) from the Adamantina Formation (Upper Cretaceous, Turonian-Santonian), Bauru Basin, Brazil". English. In: Journal of Vertebrate Paleontology 31.6 (2011), pp. 1255-1264.

[10621] F. V. Iori, I. S. Carvalho, and T. S. Marinho. "Postcranial skeletons of Caipirasuchus (Crocodyliformes, Notosuchia, Sphagesauridae) from the Upper Cretaceous (Turonian-Santonian) of the Bauru Basin, Brazil”. English. In: Cretaceous Research 60 (2016), pp. 109-120.

[10622] F. V. Iori and K. L. Garcia. "Barreirosuchus franciscoi, um novo Crocodylomorpha Trematochampsidae da Bacia Bauru, Brasil". Portugese. In: Revista Brasileira de Geociencias 42.2 (2012), pp. 397410.

[10623] F. V. Iori, T. S. Marinho, I. S. Carvalho, and A. C. Arruda Campos. "Taxonomic reappraisal of the sphagesaurid crocodyliform Sphagesaurus montealtensis from the Late Cretaceous Adamantina Formation of São Paulo State, Brazil". English. In: Zootaxa 3686.2 (2013), pp. 183-200.

[10624] F. V. Iori, T. S. Marinho, I. S. Carvalho, and L. A. S. Frare. "Cranial morphology of Morrinhosuchus luziae (Crocodyliformes, Notosuchia) from the Upper Cretaceous of the Bauru Basin, Brazil". English. In: Cretaceous Research 86 (2018), pp. 41-52.

[10625] A. P. Ippolitov, A. Y. Berezin, M. A. Rogov, and B. G. Desai. "The first record of Late Jurassic megateuthidid belemnites- Chuvashiteuthis aenigmatica gen. et sp. nov. from the upper Kimmeridgian of Central Russia". English. In: Bulletin of Geosciences 92.3 (2017).

[10626] G. V. Irby. Early Jurassic dinosaur tracksites, northeastern Arizona. English. Proceedings of the 1st Annual Symposium, Fossils of Arizona. Mesa Southwest Museum and Southwest Paleontological Society, Mesa, AZ. 1993, pp. 15-25.

[10627] G. V. Irby and L. B. Albright III. "Tail-drag marks and dinosaur footprints from the Upper Cretaceous Toreva Formation, northeastern Arizona". In: Palaios 17 (2002), pp. 516-521.

[10628] R. B. Irmis. The vertebrate fauna of the Upper Triassic Chinle Formation in northern Arizona. English. Vol. 9. In S. J. Nesbitt, W. G. Parker, \& R. B. Irmis (eds.), Guidebook to the Triassic Formations of the Colorado Plateau in Northern Arizona: Geology, Paleontology, and History. Mesa Southwest Museum Bulletin. 2005, pp. 63-88.

[10629] R. B. Irmis. "First report of Megapnosaurus (Theropoda: Coelophysoidea) from China". English. In: PaleoBios 24.3 (2004), pp. 11-18.

[10630] R. B. Irmis. A review of the vertebrate fauna of the Lower Jurassic Navajo Sandstone in Arizona. English. Vol. 11. In R. D. McCord (ed.), Vertebrate Paleontolgy of Arizona. Mesa Southwest Museum Bulletin. 2005, pp. 55-71. 
[10631] R. B. Irmis, S. J. Nesbitt, K. Padian, N. D. Smith, A. H. Turner, D. T. Woody, and A. Downs. “A Late Triassic dinosauromorph assemblage from New Mexico and the rise of dinosaurs". English. In: Science 317 (2007), pp. 358-361.

[10632] R. B. Irmis and W. G. Parker. "Unusual tetrapod teeth from the Upper Triassic Chinle Formation, USA". English. In: Canadian Journal of Earth Sciences 42 (2005), pp. 1339-1345.

[10633] R. B. Irmis, W. G. Parker, S. J. Nesbitt, and J. Liu. “Early ornithischian dinosaurs: the Triassic record". English. In: Historical Biology 19.1 (2007), pp. 3-22. DOI: 10.1080/08912960600719988.

[10634] U. Irmler. "Osoriinae (Coleoptera: Staphylinidae) from Dominican Amber". English. In: Stuttgarter Beiträge zur Naturkunde Serie B (Geologie und Paläontologie) 342 (2003), pp. 1-16.

[10635] Y. Iryu, Y. Takahashi, K. Fujita, G. Camoin, G. Cabioch, H. Matsuda, T. Sato, K. Sugihara, J. M. Webster, and H. Westphal. "Sealevel history recorded in the Pleistocene carbonate sequence in IODP Hole 310-M0005D, off Tahiti". English. In: Island Arc 19 (2010), pp. 690-706.

[10636] P. E. Isaacson and J. T. Dutro. "Lower Carboniferous brachiopods from Sierra de Almeida, northern Chile". English. In: Journal of Paleontology 73.4 (1999), pp. 625-633.

[10637] S. Isaji and Y. T. D. Hasegawa. [Discovery of Nippononaia ryosekiana and stegosaurid spine from the Kitadani Formation of the Tetori Group]. Japanese. 1990.

[10638] S. Isaji, A. Matsushita, and R. Hirayama. "Chelonian eggshells from the Lower Cretaceous Kuwajima Formation of the Tetori Group, central Japan". English. In: Paleontological Research 10.1 (2006), pp. 29-36.

[10639] S. Isaji, H. Okazaki, R. Hirayama, H. Matsuoka, P. M. Barrett, T. Tsubamoto, M. Yamaguchi, I. Yamaguchi, and T. Sakumoto. "Depositional environments and taphonomy of the bone-bearing beds of the Lower Cretaceous Kuwajima Formation, Tetori Group, Japan". In: Bulletin of the Kitakyushu Museum of Natural History and Human History, Series A 3 (2005), pp. 123-133.

[10640] M. Isakar. "Harjuan (Late Ordovician) new bivalves and a new gastropod from north Estonia". In: Tartu Riikliku Ulikooli Toimetised 12 (1991), pp. 43-60.

[10641] M. Isakar and J. O. R. Ebbestad. "Bucania (Gastropoda) from the Ordovician of Estonia”. English. In: Paläontologische Zeitschrift 74.1-2 (2000), pp. 51-68.

[10642] M. Isakar, J. O. R. Ebbestad, and J. S. Peel. "Homeomorphic gastropods from the Silurian of Norway, Estonia and Bohemia". English. In: Norsk Geologisk Tidsskrift 79 (1999), pp. 281-288.

[10643] M. Isakar and J. S. Peel. "A new species of Mimospira (Onychochiloidea, Mollusca) from the Middle Ordovician of Estonia”. English. In: Geologiska Föreningens i Stockholm Förhandlingar 119 (1997), pp. 275-277.

[10644] T. Ishibashi. "Dorashamian biostratigraphy of the Doi Pha Phlung area, North Thailand". English. In: Proceedings of the Royal Society of Victoria 110 (1998), pp. 221-226.

[10645] T. Ishibashi and C. Chonglakmani. "Uppermost Permian ammonoids from northern Thailand". English. In: Journal of Southeast Asian Earth Sciences 4.3 (1990), pp. 163-170.

[10646] T. Ishibashi, M. Fujikawa, and N. Nakornsri. "Permian ammonoids from the Loei area, northeast Thailand". English. In: Memoirs of the Faculty of Science, Kyushu University, Series D, Earth and Planetary Science 29.2 (1996), pp. 175-196.

[10647] H. Ishida and M. Pickford. "A new late Miocene hominoid from Kenya: Samburupithecus kiptalami gen. et sp. nov." English. In: Comptes Rendus de l'Academie des Sciences, Serie II 325.10 (1997), pp. 823-829.

[10648] K. Ishida and F. Hirsch. "The Triassic conodonts of the NW Malayan Kodiang Limestone revisited: Taxonomy and paleogeographic significance". English. In: Gondwana Research 19 (2011), pp. 22-36. DOI: 10.1016/j.gr.2010.05.008.

[10649] Y. Ishida. "Fossil ophiuroids from the Oligocene Asagai Formation of Iwaki, Fukushima, Japan". In: Bulletin of the National Science Museum C18.2 (1992), pp. 65-78. 
[10650] Y. Ishida, S. Yoshii, and B. Thuy. “Aplocoma sp. (Echinodermata, Ophiuroidea) from the Middle Triassic Yakuno Group of Kyoto, central Japan”. English. In: Paleontological Research 15 (2011), pp. 31-36.

[10651] S. Ishigaki. "Theropod trampled bedding plane with laboring trackways from the Upper Cretaceous Abdrant Nuru fossil site, Mongolia". English. In: Hayashibura Museum of Natural Sciences Research Bulletin 3 (2010), pp. 133-141.

[10652] S. Ishigaki and Y. Matsumoto. "Re-examination of manus-only and manus-dominated sauropod trackways from Morocco". English. In: Geological Quarterly 53.4 (2009), pp. 441-448.

[10653] S. Ishigaki and Y. Matsumoto. "Off-tracking-like phenomenon observed in the turning sauropod trackway from the Upper Jurassic of Morocco". English. In: Memoir of the Fukui Prefectural Dinosaur Museum 8 (2009), pp. 1-10.

[10654] S. Ishigaki, M. Watabe, K. Tsogtbaatar, and M. Saneyoshi. “Dinosaur footprints from the Upper Cretaceous of Mongolia". English. In: Geological Quarterly 53.4 (2009), pp. 449-460.

[10655] H. Ishiguri and M. Kimura. "Odobenus rosmarus from Lower Pleistocene in the Nopporo Hills, Hokkaido, Japan". Japanese. In: Chikyu Kagaku 47.2 (1993), pp. 147-152.

[10656] Y. Islamoglu. "Kasaba Miyosen havzasinin Gastropoda faunasi (Bati Toroslar, GB Türkiye)". other. In: MTA Dergisi 128 (2004), pp. 137-170.

[10657] Y. Islamoglu. "Molluscan biostratigraphy and paleoenvironmental reconstruction of Oligocene deposits in the Denizli and Kale-Tavas subbasins (SW Turkey)". English. In: Geodiversitas 30.2 (2008), pp. 261-285.

[10658] Y. Islamoglu. "Middle Pleistocene bivalves of the Iznik lake basin (Eastern Marmara, NW Turkey) and a new paleobiogeographical approach". English. In: International Journal of Earth Sciences 98 (2009), pp. 1981-1990.

[10659] Y. Islamoglu, S. Dominici, and T. Kowalke. “Early Eocene Caenogastropods (Mollusca, Gastropoda) from Haymana-Polatli Basin, Central Anatolia (Turkey): taxonomy and palaeoecology". English. In: Geodiversitas 33.2 (2011), pp. 303-330. DOI: 10.5252/g2011n2a7.

[10660] Y. Islamoglu and G. Taner. "Antalya Miyosen havzasnn Gastropoda faunas (Bat-Orta Toroslar, GB Türkiye)". other. In: Maden Tetkik ve Arama Dergisi 127 (2002), pp. 29-65.

[10661] Y. Islamoglus and A. Hakyemez. “Oligocene History of the Çardak-Dazkr Sub-basin (Denizli, SW Turkey): Integrated Molluscan and Planktonic Foraminiferal Biostratigraphy". English. In: Turkish Journal of Earth Sciences 19 (2010), pp. 473-496.

[10662] J. Isogawa, Y. Aita, and T. Sakai. "Early Triassic radiolarians from the bedded chert in the Minowa quarry, Kuzuu Town, Tochigi Prefecture". Japanese. In: News of Osaka Micropaleontologists, Special Volume 11 (1998), pp. 81-93.

[10663] Y. Isozaki and T. Kase. "The occurrence of the large gastropod Pleurotomaria yokoyamai Hayasaka from the Capitanian (Permian) Iwaizaki Limestone in northeast Japan". English. In: Paleontological Research 18 (2014), pp. 250-257.

[10664] Y. Isozaki, J. Yao, T. Matsuda, H. Sakai, Z. Ji, N. Shimizu, N. Kobayashi, H. Kawahata, H. Nishi, M. Takano, and T. Kubo. "Stratigraphy of the Middle-Upper Permian and Lowermost Triassic at Chaotian, Sichuan, China". English. In: Proceedings of the Japan Academy, Series B 80.1 (2004), pp. 10-16.

[10665] W. M. Itano, K. J. Houck, and M. G. Lockley. "Systematics and occurrences of Edestus (Chondrichthyes) worldwide and new occurrences from Colorado and Texas". English. In: Historical Biology 24 (2012), pp. 397-410.

[10666] W. M. Itano, K. J. Houck, and M. G. Lockley. "Ctenacanthus and other chondrichthyan spines and denticles from the Minturn Formation (Pennsylvanian) of Colorado". English. In: Journal of Paleontology 77 (2003), pp. 524-535. 
[10667] W. M. Itano and S. G. Lucas. “A revision of Campyloprion Eastman, 1902 (Chondrichthyes, Helicoprionidae), including new occurrences from the Upper Pennsylvanian of New Mexico and Texas, USA". English. In: Acta Geologica Polonica 68 (2018), pp. 403-419.

[10668] W. M. Itano, G. D. Webster, K. J. Houck, and W. D. Bateman. “The first Pennsylvanian batocrinid and other new echinoderms from the Minturn Formation of central Colorado". English. In: Mountain Geologist 40.3 (2003), pp. 83-100.

[10669] M. Iturralde-Vinent, G. Hubbell, and R. Rojas. “Catalogue of Cuban fossil Elasmobranchii (Paleocene to Pliocene) and paleogeographic implications of their Lower to Middle Miocene occurrence". English. In: Boletn de la Sociedad Jamaicana de Geologa 31 (1996), pp. 7-21.

[10670] M. Iturralde-Vinent and M. A. Norell. "Synopsis of Late Jurassic marine reptiles from Cuba". English. In: American Museum Novitates 3164 (1996), pp. 1-17.

[10671] M. F. Ivakhnenko. “New Late Permian nycteroleterids from Eastern Europe”. English. In: Paleontological Journal 31.5 (1997), pp. 552-558.

[10672] M. F. Ivakhnenko. "Rannepermskie elementy faunicheskikh kompleksov tetrapod vostochnoy evropy". Russian. In: Paleontologicheskii Zhurnal 1990.2 (1990), pp. 102-111.

[10673] M. F. Ivakhnenko. "The First Whaitsiid (Therocephalia, Theromorpha) from the Terminal Permian of Eastern Europe". English. In: Paleontological Journal 42.4 (2008), pp. 409-413.

[10674] M. F. Ivakhnenko. "A new Late Permian dromasaurian (Anomodontia) from Eastern Europe". English. In: Paleontological Journal 28.1 (1994), pp. 96-103.

[10675] M. F. Ivakhnenko. “Permian and Triassic therocephals (Eutherapsida) of Eastern Europe”. English. In: Paleontological Journal 45.9 (2011), pp. 981-1144.

[10676] M. F. Ivakhnenko. “Permian Cynodontia (Theromorpha) of Eastern Europe”. English. In: Paleontological Journal 46.2 (2012), pp. 199-207.

[10677] M. F. Ivakhnenko. "Eotherapsids from the East European Placket (Late Permian)". English. In: Paleontological Journal 37.Suppl. 4 (2003), S339-S465.

[10678] M. F. Ivakhnenko. “Cranial morphology and evolution of Permian Dinomorpha (Eotherapsida) of Eastern Europe". English. In: Paleontological Journal 42.9 (2008), pp. 859-995.

[10679] A. Ivanov. "Early Permian chondrichthyans of the middle and south Urals". English. In: Revista Brasileira de Paleontologia 8.2 (2005), pp. 127-138.

[10680] A. Ivanov. "Late Devonian - Early Permian chondrichthyans of the Russian Arctic". English. In: Acta Palaeontologica Polonica 49.3 (1999), pp. 267-285.

[10681] A. Ivanov and T. Klets. "Triassic marine fishes from Siberia, Russia”. English. In: The Global Triassic. New Mexico Museum of Natural History and Science Bulletin 41 (2007), pp. 108-109.

[10682] A. Ivanov, S. G. Lucas, and K. Krainer. "Pennsylvanian fishes from the Sandia Formation, Socorro County, New Mexico". English. In: New Mexico Geological Society Guidebook, 60th Field Conference, Geology of the Chupadera Mesa Region (2009), pp. 243-248.

[10683] A. Ivanov, M. Nestell, and G. Nestell. "New jalodontid chondrichthyans from the Middle Permian of west Texas, USA". English. In: Historical Biology 24 (2012), pp. 359-368.

[10684] A. O. Ivanov. "Chondrichthyans from the Lower Permian of Mechetlino, south Urals, Russia". English. In: Bulletin of Geosciences 91 (2017), pp. 717-729.

[10685] A. O. Ivanov, C. J. Duffin, and S. V. Naugolnykh. "A new euselachian shark from the early Permian of the Middle Urals, Russia". English. In: Acta Palaeontologica Polonica 62 (2017), pp. 289-298.

[10686] A. O. Ivanov and O. A. Lebedev. "Permian chondrichthyans of the Kanin Peninsula, Russia". English. In: Paleontological Journal 48 (2014), pp. 1030-1043.

[10687] A. O. Ivanov, G. P. Nestell, and M. K. Nestell. "Fish assemblage from the Capitanian (Middle Permian) of the Apache Mountains, west Texas, USA". English. In: The Carboniferous-Permian Transition. New Mexico Museum of Natural History and Science Bulletin 60 (2013), pp. 152-160. 
[10688] A. O. Ivanov, M. K. Nestell, and G. P. Nestell. "Middle Permian fish microremains from the Early Capitanian of the Guadalupe Mountains, West Texas, USA". English. In: Micropaleontology 61 (2015), pp. 301-312.

[10689] A. O. Ivanov, M. K. Nestell, G. P. Nestell, and G. L. Bell. “New fish assemblages from the Middle Permian from the Guadalupe Mountains, West Texas, USA". English. In: Palaeoworld 29 (2020), pp. 239-256. DOI: 10.1016/j.palwor.2018.10.003.

[10690] M. Ivanov. “The oldest known Miocene snake fauna from Central Europe: Merkur-North locality, Czech Republic". In: Acta Palaeontologica Polonica 47.3 (2002), pp. 513-534.

[10691] M. Ivanov. "Snakes of the lower/middle Miocene transition at Vieux Collonges (Rhone, France), with comments on the colonisation of western Europe by colubroids." In: Geodiversitas 22.4 (2000), pp. 559-588.

[10692] M. Ivanov. "The first European pit viper from the Miocene of Ukraine". English. In: Acta Palaeontologica Polonica 44.3 (1999), pp. 327-334.

[10693] M. Ivanov. Fossil snake assemblages from the French Middle Miocene localities at La Grive (France). English. 2002.

[10694] M. Ivanov. "Herpetological assemblages from the Pliocene to middle Pleistocene in Central Europe: palaeoecological significance". English. In: Geodiversitas 29.2 (2007), pp. 297-320.

[10695] M. Ivanov and M. Böhme. “Snakes from Griesbeckerzell (Langhian, Early Badenian), North Alpine Foreland Basin (Germany), with comments on the evolution of snake faunas in Central Europe during the Miocene Climatic Optimum". English. In: Geodiversitas 33.3 (2011), pp. 411-449. DOI: $10.5252 / \mathrm{g} 2011 \mathrm{n} 3 \mathrm{a} 2$.

[10696] M. Ivanov, R. Musil, and R. Brzobohatý. "Terrestrial and marine faunas from the Miocene deposits of the Mokra Plateau (Drahany Upland, Czech Republic) - impact on palaeogeography". English. In: Beiträge zur Paläontologie 30 (2006), pp. 223-239.

[10697] M. Ivanov, M. Ruta, J. Klembara, and M. Böhme. “A new species of Varanus (Anguimorpha: Varanidae) from the early Miocene of the Czech Republic, and its relationships and palaeoecology". English. In: Journal of Systematic Paleontology 16.9 (2018), pp. 767-797. DOI: 10.1080/14772019. 2017.1355338.

[10698] V. D. Ivanov. "Larvae of caddisflies (Insecta: Trichoptera) from the Mesozoic of Siberia". English. In: Paleontological Journal 40 (2006), pp. 178-189.

[10699] V. D. Ivanov and S. I. Melnitsky. “Ten new species of caddisflies (Insecta: Trichoptera) from the Baltic amber". English. In: Paleontological Journal 47 (2013), pp. 166-176.

[10700] V. D. Ivanov and S. I. Melnitsky. "New caddisfly species of the genus Wormaldia (Trichoptera: Philopotamidae) from Baltic amber". English. In: Paleontological Journal 39 (2005), pp. 284-288.

[10701] V. D. Ivanov and S. I. Melnitsky. "Yantarocentridae, a new family of caddisflies (Insecta: Trichoptera) from Eocene Baltic amber". English. In: Journal of Systematic Palaeontology 14 (2016), pp. 253-259.

[10702] V. D. Ivanov and S. I. Melnitsky. “New caddisflies species (Insecta: Trichoptera) from the Cretaceous Taymyr amber". English. In: Cretaceous Research 77 (2017), pp. 124-132.

[10703] V. V. Ivanov. "A new species of Dictyoneurida from the Kungurian deposits of the middle Urals (Dictyoneurida)". English. In: Paleontological Journal 34.Suppl 3 (2000), S288-S289.

[10704] D. Ivanova, B. Kolodziej, E. Koleva- Rekalova, and E. Roniewicz. “Oxfordian to Valanginian palaeoenvironmental evolution on the western Moesian Carbonate Platform: a case study from SW Bulgaria". English. In: Annales Societatis Geologiorum Poloniae 78 (2008), pp. 65-90.

[10705] D. Ivanova and B. Kolodziej. "Late Jurassic-Early Cretaceous foraminifera from tramberk-type limestones, Polish Outer Carpathians". English. In: Geologia 55.2 (2010), pp. 3-31. 
[10706] D. K. Ivanova, J. Schloegl, A. Tomasovych, B. Lathuiliere, and M. Golej. "Revisiting the age of Jurassic coral bioherms in the Pieniny Klippen Belt (Western Carpathians) on the basis of benthic foraminifers". English. In: Geologica Carpathica 70.2 (2019), pp. 113-134. DOI: 10.2478/geoca-20190007.

[10707] O. Ivanova, R. M. Owens, I. Kim, and L. E. Popov. "Late Silurian trilobites from the Nuratau and Turkestan ranges, Uzbekistan and Tajikistan". English. In: Geobios 42 (2009), pp. 715-737. DOI: 10.1016/j.geobios.2009.09.001.

[10708] R. M. Ivanova. "New taxa of foraminifera from the Bashkirian of the Urals". English. In: Paleontological Journal 34 (2000), pp. 147-154.

[10709] A. Y. Ivantsov. "The first Lower Cambrian Phyllocarids from Yakutia". In: Paleontological Journal 24.2 (1990), pp. 124-128.

[10710] A. Y. Ivantsov. "A new Dickinsonid from the Upper Vendian of the White Sea Winter Coast (Russia, Arkhangelsk Region)". In: 33.3 (1999), pp. 211-221.

[10711] A. Y. Ivantsov. "Vendia and Other Precambrian Arthropods". English. In: Palaeontologische Zeitschrift 4 (2001), pp. 3-10.

[10712] A. Y. Ivantsov. "Reconstruction of Charniodiscus yorgensis (Macrobiota from the Vendian of the White Sea)". English. In: Paleontological Journal 50.1 (2016), pp. 1-12. DOI: 10.1134/S0031030116010032.

[10713] A. Y. Ivantsov and D. V. Grazhdankin. "A new representative of the Petalonamae from the Upper Vendian of the Arkhangelsk Region". In: Paleontological Journal 31.1 (1997), pp. 1-16.

[10714] A. Y. Ivantsov and R. Wrona. "Articulated palaeoscolecid sclerite arrays from the Lower Cambrian of eastern Siberia". English. In: Acta Geologica Polonica 54 (2004), pp. 1-22.

[10715] A. Y. Ivantsov, A. Y. Zhuravlev, A. V. Leguta, V. A. Krassilov, L. M. Melnikova, and G. T. Ushatinskaya. "Palaeoecology of the Early Cambrian Sinsk biota from the Siberian Platform". English. In: Palaeogeography, Palaeoclimatology, Palaeoecology 220 (2005), pp. 69-88. DOI: 10.1016/j.palaeo.2004. 01.022 .

[10716] L. C. Ivany. "Faunal stability and environmental change in the middle Eocene Gulf Coastal Plain (PhD Thesis, Harvard University)". English. PhD thesis. 1997, pp. 1-221.

[10717] L. C. Ivany, C. E. Brett, H. L. B. Wall, P. D. Wall, and J. C. Handley. "Relative taxonomic and ecological stability in Devonian marine faunas of New York State: a test of coordinated stasis". English. In: Paleobiology 35.4 (2009), pp. 499-524.

[10718] L. C. Ivany, C. Pietsch, J. C. Handley, R. Lockwood, W. D. Allmon, and J. A. Sessa. "Little lasting impact of the Paleocene-Eocene Thermal Maximum on shallow marine mollusk faunas". English. In: Science Advances (2018).

[10719] L. C. Ivany, R. W. Portell, and D. S. Jones. “Animal-Plant Relationships and Paleobiogeography of an Eocene Seagrass Community from Florida". English. In: Palaios 5.3 (1990), pp. 244-258.

[10720] K. Iwata, Y. Watanabe, and J. Tajika. "Radiolarian biostratigraphic study of the Hakobuchi Group in the Nakatonbetsu area, north Hokkaido". English. In: Report of the Geological Survey of Hokkaido 63 (1992), pp. 1-21.

[10721] A. Izart, O. Kossovaya, D. Vachard, and D. Vaslet. "Stratigraphy, sedimentology and sequence stratigraphy of the early Permian along the Kosva River (Gubakha area, central Urals, Russia)". In: Bulletin de la Societe Geologique de France 170.6 (1999), pp. 799-820.

[10722] V. Jaanusson and M. G. Bassett. "Orthambonites and related Ordovician brachiopod genera". English. In: Palaeontology 36.1 (1993), pp. 21-63.

[10723] V. Jaanusson and L. Ramsköld. "Pterygometopine Trilobites from the Ordovician of Baltoscandia". English. In: Palaeontology 36.4 (1993), pp. 743-769.

[10724] S. Jaccard, M. Munster, P. O. Baumgartner, C. Baumgartner-Mora, and P. Denyer. "Barra Honda (upper Paleocene-lower Eocene) and El Viejo (Campanian-Maastrichtian) Carbonate platforms in the Tempisque area (Guanacaste, Costa Rica)". English. In: Revista Geologica de America Central 24 (2001), pp. 9-28. 
[10725] J. J. Jacisin and S. S. B. Hopkins. "A redescription and phylogenetic analysis based on new material of the fossil newts Taricha oligocenica Van Frank, 1955 and Taricha lindoei Naylor, 1979 (Amphibia, Salamandridae) from the Oligocene of Oregon". English. In: Journal of Paleontology (2018).

[10726] D. E. Jackson and A. C. Lenz. "Taxonomic and biostratigraphical significance of the Tremadoc graptolite fauna from northern Yukon Territory, Canada". English. In: Geological Magazine 140.2 (2003), pp. 131-156. DOI: 10.1017/S0016756802007227.

[10727] D. E. Jackson and A. C. Lenz. “The sequence and correlation of Early Ordovician (Arenig) graptolite faunas in the Richardson Trough and Misty Creek Embayment, Yukon Territory and District of Mackenzie, Canada". English. In: Canadian Journal of Earth Sciences 43 (2006), pp. 1791-1820. DOI: 10.1139/E06-065.

[10728] F. D. Jackson, J. R. Horner, and D. J. Varricchio. “A study of a Troodon egg containing embryonic remains using epiuorescence microscopy and other techniques". English. In: Cretaceous Research 31 (2010), pp. 255-262. DOI: 10.1016/j.cretres.2009.11.006.

[10729] F. D. Jackson, Z. Jin, D. J. Varricchio, Y. Azuma, and Y. Jiang. "The first in situ turtle clutch from the Cretaceous Tiantai Basin, Zhejiang Province, China". English. In: Journal of Vertebrate Paleontology 28.2 (2008), pp. 319-325.

[10730] F. D. Jackson and D. J. Varricchio. "Fossil eggs and eggshell from the lowermost Two Medicine Formation of western Montana, Sevenmile Hill locality". English. In: Journal of Vertebrate Paleontology 30.4 (2010), pp. 1142-1156. DOI: 10.1080/02724634.2010.483537.

[10731] L. L. Jacobs, A. R. Fiorillo, Y. Nishida, and E. M. G. Fitzgerald. "Mid-Cenozoic marine mammals from Alaska". English. In: Museum of Northern Arizona Bulletin 65 (2009), pp. 171-184.

[10732] L. L. Jacobs, D. A. Winkler, Z. M. Kaufulu, and W. R. Downs. The Dinosaur Beds of northern Malawi, Africa. 1990.

[10733] L. L. Jacobs, D. A. Winkler, and E. M. Gomani. “Cretaceous dinosaurs of Africa: examples from Cameroon and Malawi". English. In: Memoirs of the Queensland Museum 39.3 (1996), pp. 595-610.

[10734] L. L. Jacobs, D. A. Winkler, K. D. Newman, E. M. Gomani, and A. Deino. “Therapsids from the Permian Chiweta Beds and the Age of the Karoo Supergroup in Malawi". English. In: Palaeontologia Electronica 8.1 (2005), pp. 1-23.

[10735] M. L. Jacobs, D. M. Martill, N. Ibrahim, and N. Longrich. "A new species of Coloborhynchus (Pterosauria, Ornithocheiridae) from the mid-Cretaceous of North Africa". English. In: Cretaceous Research 95 (2019), pp. 77-88. DOI: 10.1016/j.cretres.2018.10.018.

[10736] M. L. Jacobs, D. M. Martill, D. M. Unwin, N. Ibrahim, S. Zouhri, and N. R. Longrich. “New toothed pterosaurs (Pterosauria: Ornithocheiridae) from the middle Cretaceous Kem Kem beds of Morocco and implications for pterosaur palaeobiogeography and diversity". English. In: Cretaceous Research 110 (2020), p. 104413. DOI: 10.1016/j.cretres.2020.104413.

[10737] S. M. Jacquet and G. A. Brock. "Lower Cambrian helcionelloid macromolluscs from South Australia". English. In: Gondwana Research 36 (2016), pp. 333-358. DOI: 10.1016/j.gr.2015.06.012.

[10738] S. M. Jacquet, G. A. Brock, and J. R. Paterson. "New data on Oikozetetes (Mollusca, Halkieriidae) from the Lower Cambrian of South Australia". English. In: Journal of Paleontology 88.5 (2014), pp. 1072-1084. DOI: 10.1666/13-137.

[10739] S. M. Jacquet, J. B. Jago, and G. A. Brock. "An enigmatic univalve macromollusc from the lower Cambrian (Series 2, Stage 3) Heatherdale Shale, South Australia". English. In: Australasian Palaeontological Memoirs 49 (2016), pp. 21-30.

[10740] P. Jadwiszczak. "An intriguing penguin bone from the Late Eocene of Seymour Island, Antarctic Peninsula". English. In: Antarctic Science 20.6 (2008), pp. 589-590.

[10741] P. Jadwiszczak. "Eocene penguins of Seymour Island, Antarctica: The earliest record, taxonomic problems and some evolutionary considerations". English. In: Polish Polar Research 27.4 (2006), pp. 287-302. 
[10742] P. Jadwiszczak. "The earliest fossil record of a mediumsized penguin". English. In: Polish Polar Research 32.3 (2011), pp. 269-277.

[10743] P. Jadwiszczak. "New data on morphology of late Eocene penguins and implications for their geographic distribution". English. In: Antarctic Science 23.6 (2011), pp. 305-606.

[10744] P. Jadwiszczak, K. P. Krajewski, Z. Pushina, A. Tatur, and G. Zielinski. “The first record of fossil penguins from East Antarctica". English. In: Antarctic Science 25.3 (2013), pp. 397-408. DOI: 10. 1017/S0954102012000909.

[10745] H. Jaeger. "Ein dendroider Graptolith (Ophigraptus hercyniae n. g. n. sp.) von der Unter-MitteldevonGrenze im Harz (Deutschland)". English. In: Palaeontologische Zeitschrift 66.1/2 (1992), pp. 123128.

[10746] J. J. Jaeger, U. A. N. Soe, U. A. K. Aung, M. Benammi, Y. Chaimanee, R. M. Ducrocq, T. Tun, U. T. Thein, and S. Ducrocq. "New Myanmar middle Eocene anthropoids. An Asian origin for catarrhines?" In: Comptes Rendus de l'Academie des Sciences, Serie III. Sciences de la vie 321 (1998), pp. 953-959.

[10747] J. J. Jaeger, T. Thein, M. Benammi, Y. Chaimanee, A. N. Soe, T. Lwin, T. Tun, S. Wai, and S. Ducrocq. "A new primate from the middle Eocene of Myanmar and the Asian early origins of Anthropoids". In: Science 286 (1999), pp. 528-530.

[10748] J.-J. Jaeger, K. C. Beard, Y. Chaimanee, M. Salem, M. Benammi, O. Hlal, P. Coster, A. A. Bilal, P. Duringer, M. Schuster, X. Valentin, B. Marandat, L. Marivaux, E. Metais, O. Hammuda, and M. Brunet. "Late middle Eocene epoch of Libya yields earliest known radiation of African anthropoids". English. In: Nature 467 (2010), pp. 1095-1098. DOI: 10.1038/nature09425.

[10749] J.-J. Jaeger, O. Chavasseau, V. Lazzari, Aung Naing Soe, Chit Sein, A. Le Matre, Hla Shwe, and Y. Chaimanee. "New Eocene primate from Myanmar shares dental characters with African Eocene crown anthropoids". English. In: Nature Communications 10 (2019), 3531:1-10. DOI: 10.1038/s41467019-11295-6.

[10750] J.-J. Jaeger, L. Marivaux, M. Salem, A. A. Bilal, M. Benammi, Y. Chaimanee, P. Duringer, B. Marandat, E. Metais, M. Schuster, X. Valentin, and M. Brunet. "New rodent assemblages from the Eocene Dur At-Talah escarpment (Sahara of central Libya): systematic, biochronological, and palaeobiogeographical implications". English. In: Zoological Journal of the Linnean Society 160 (2010), pp. 195213.

[10751] J.-J. Jaeger, A. N. Soe, O. Chavasseau, P. Coster, E. -G. Emonet, F. Guy, R. Lebrun, A. A. Maung, H. Shwe, S. T. Tun, K. L. Oo, M. Rugbumrung, H. Bocherens, M. Benammi, K. Chaivanich, P. Tafforeau, and Y. Chaimanee. "First Hominoid from the Late Miocene of the Irrawaddy Formation (Myanmar)". English. In: PLoS One 6.4 (2011), pp. 1-14. DOI: 10.1371/journal.pone.0017065.

[10752] M. Jäger. "Crinoids from the Barremian (Lower Cretaceous) of the Serre de Bleyton (Drome, SE France)". English. In: Annalen des Naturhistorischen Museums in Wien, Serie A 112 (2010), pp. 733774.

[10753] M. Jäger. “Echinodermata aus dem Ober-Toarcium und Aalenium Deutschlands I. Crinoidea: Cyrtocrinina und Millericrinina". German. In: Stuttgarter Beiträge zur Naturkunde Serie B (Geologie und Paläontologie) 226 (1995), pp. 1-51.

[10754] J. B. Jago and P. W. Baillie. "An Idamean aglaspidid from northwestern Tasmania". In: Alcheringa 16.1 (1992), pp. 14-14.

[10755] J. B. Jago, J.-S. Bao, and P. W. Baillie. “Late Middle Cambrian trilobites from St Valentines Peak and Native Track Tier, northwestern Tasmania". English. In: Alcheringa 28.1 (2004), pp. 21-52.

[10756] J. B. Jago and K. D. Corbett. "Latest Cambrian trilobites from Misery Hill, western Tasmania". English. In: Alcheringa 14 (1990), pp. 233-246.

[10757] J. Jagt, B. van Bakel, R. Fraaije, and C. Neumann. "in situ fossil hermit crabs (Paguroidea) from northwest Europe and Russia. Preliminary data on new records". English. In: Revista Mexicana de Ciencias Geologicas 23.3 (2006), pp. 364-369. 
[10758] J. M. W. Jagt, B. W. M. van Bakel, and R. H. B. Fraaije. “Coeloma rupeliense (Crustacea, Decapoda, Brachyura) from the Bilzen Formation (Rupel Group, Lower Oligocene) in northeast Belgium". English. In: Bulletin De L'INstitut Royal Des Sciences Naturelles De Belgique 80 (2010), pp. 245-252.

[10759] J. V. M. Jagt and C. Neumann. "Late Campanian polyptychoceratine ammonites from the Lehrte West Syncline, Hannover area, northwest Germany". English. In: Cretaceous Research 27 (2006), pp. 565-576.

[10760] J. W. M. Jagt. Late Maastrichtian and Early Palaeocene index macrofossils in the Maastrichtian type area (SE Netherlands, NE Belgium). 1996.

[10761] J. W. M. Jagt. "Late Cretaceous-Early Paleocene echinoderms and the K/T boundary in the southeast Netherlands and the northeast Belgium. - part 3: Ophiuroids". English. In: Scripta Geologica 21 (2000), pp. 1-179.

[10762] J. W. M. Jagt. "Deckersamphiura vitea, a new Late Campanian ophiuroid from southern Limburg (The Netherlands)". In: Bulletin de l'Institut Royal des Sciences Naturelles de Belgique 71 (2001), pp. 191-193.

[10763] J. W. M. Jagt. "Early Miocene luidiid asteroids (Echinodermata, Asteroidea) from WinterswijkMiste (The Netherlands)". In: Contributions to Tertiary and Quaternary Geology 28.1 (1991), pp. 3543.

[10764] J. W. M. Jagt. "Late Cretaceous-Early Paleocene echinoderms and the K/T boundary in the southeast Netherlands and the northeast Belgium. - part 4: Echinoids". In: Scripta Geologica 21 (2000), pp. 181-375.

[10765] J. W. M. Jagt. "Late Cretaceous-Early Paleocene echinoderms and the K/T boundary in the southeast Netherlands and the northeast Belgium. - part 5: Asteroids". In: Scripta Geologica 21 (2000), pp. 377-503.

[10766] J. W. M. Jagt. "Late Cretaceous-Early Paleocene echinoderms and the K/T boundary in the southeast Netherlands and the northeast Belgium. - part 2: Crinoids". In: Scripta Geologica 116 (1999), pp. 59-255.

[10767] J. W. M. Jagt. "Late Campanian echinoids and crinoids from the Gschliefgraben (Ultrahelvetic, Austria)". In: Beiträge zur Paläontologie 24 (1999), pp. 7-22.

[10768] J. W. M. Jagt. "Stratigraphic ranges of mosasaurs in Belgium and the Netherlands (Late Cretaceous) and cephalopod-based correlations with North America". English. In: Netherlands Journal of Geosciences — Geologie en Mijnbouw 84.3 (2005), pp. 283-301.

[10769] J. W. M. Jagt and V. Codrea. "Agoniasterid starfish (Echinodermata,Asteroidea) preserved in a mid-Miocene rhyolitic ignimbrite, northwest Romania". English. In: Acta Geologica Polonica 60.2 (2010), pp. 275-282.

[10770] J. W. M. Jagt, J. S. H. Collins, and R. H. B. Fraaye. "A new late Maastrichtian xanthid crab from southern Limburg (The Netherlands)". English. In: Cretaceous Research 12 (1991), pp. 553-560.

[10771] J. W. M. Jagt, J. S. H. Collins, and R. H. B. Fraaye. “A new Early Paleocene genus of raninid crab (Crustacea, Decapoda) from Denmark, Southern Sweden and the Netherlands". English. In: Contributions to Tertiary and Quaternary Geology 30.3-4 (1993), pp. 177-182.

[10772] J. W. M. Jagt, M. J. M. Deckers, J. Laffineur, and E. A. Jagt-Yazykova. “Are Rachiosoma krimica and Rachiosoma gigasei (Echinoidea, Phymosomatoida) conspecific? New finds of the latter from the Upper Campanian of Belgium suggest they are: Cosmocyphus krimicus". English. In: New Mexico Museum of Natural History and Science Bulletin 79 (2018), pp. 299-304.

[10773] J. W. M. Jagt, R. H. B. Fraaije, B. W. M van Bakel, and P. Artal. “Necrocarcinus ornatissimus Fourir, 1887, and Prehepatus werneri Fraaye \& Collins, 1987 (Upper Maastrichtian, the Netherlands) Revisited, with notes on ohter Cretaceous Dynomenid Crabs (Decapoda, Brachyura)". English. In: Studies on Brachyura (2010), pp. 173-195.

[10774] J. W. M. Jagt, E. A. Jagt-Yazykova, H. F. Kaddumi, and J. Lindgren. "Ammonite dating of latest Cretaceous mosasaurid reptiles (Squamata, Mosasauroidea) from Jordan-preliminary observations". English. In: Alcheringa 42 (2019), pp. 587-596. DOI: 10.1080/03115518.2017.1308011. 
[10775] J. W. M. Jagt, I. Jaskula, A. Witek, and E. A. Jagt-Yazykova. "A new record of the Late Cretaceous cirripede Eoverruca hewitti (Verrucomorpha, Proverrucidae) from southern Poland". English. In: Zootaxa 1671 (2008), pp. 59-68.

[10776] J. W. M. Jagt, J. Lindgren, M. Machalski, and A. Radwankski. "New records of the tylosaurine mosasaur Hainosaurus from the Campanian-Maastrichtian (Late Cretaceous) of central Poland". English. In: Netherlands Journal of Geosciences — Geologie en Mijnbouw 84.3 (2005), pp. 303-306.

[10777] J. W. M. Jagt, N. Motchurova-Dekova, P. Ivanov, H. Capetta, and A. S. Schulp. “Latest Cretaceous mosasaurs and lamniform sharks from Labirinta cave, Vratsa district (northwest Bulgaria): a preliminary note". English. In: Annales Geologiques de la Peninsule Balkanique 67 (2006), pp. 51-63.

[10778] J. W. M. Jagt, E. W. A. Mulder, A. S. Schulp, R. W. Dortangs, and R. H. B. Fraaije. “Dinosaurs from the Maastrichtian-type area (southeastern Netherlands, northeastern Belgium)". English. In: Comptes Rendus Palevol 2 (2003), pp. 67-76. DOI: 10.1016/S1631-0683(03)00004-6.

[10779] J. W. M. Jagt and W. Riegraf. Late Cretaceous ophiuroids from the Münsterland Basin (Germany): preliminary observations. J.P. Feral, B. David (Eds), Echinoderm Research 2001, Swets \& Zeitlinger, Lisse. 2003, pp. 61-63.

[10780] J. W. M. Jagt, B. Thuy, S. K. Donovan, S. Stöhr, R. W. Portell, R. K. Pickerill, D. A. T. Harper, W. Lindsay, and T. A. Jackson. "A starfish bed in the Middle Miocene Grand Bay Formation of Carriacou, The Grenadines (West Indies)". English. In: Geological Magazine 151 (2014), pp. 381393.

[10781] J. W. M. Jagt, W. M. van Bakel, and R. H. B. Fraaije. "Palaeodromites crypticus, a new early-middle Cenomanian dynomenid crab (Crustacea, Decapoda) from southern Belgium". English. In: Bulletin de L'Institut Royal des Sciences Naturelles de Belgique 77 (2007), pp. 77-82.

[10782] J. W. M. Jagt, R. W. J. Van Der Ham, R. Meuris, and L. Indeherberge. “A Note on Salenia gr. nutrix Peron and Gauthier, 1881 (Echinoidea) from the Maastrichtian Type Area (Southeastern Netherlands, Northeastern Belgium)". English. In: Journal of Paleontology 73.4 (1999), pp. 663-666.

[10783] J. W. M. Jagt and E. Wille. Pliocene echinoid faunules from Kallo (Antwerp area, NW Belgium). English. Vol. 2001. Echinoderm Research. Lisse: Swets \& Zeitlinger, 2003, pp. 65-67.

[10784] J. W. M. Jagt, T. D. Zonova, and E. A. Jagt-Yazykova. "A review of the brachylepadomorph cirripede genus Pycnolepas, including the first record of an Early Cretaceous species from the Russian Far East". English. In: Zootaxa 1545 (2007), pp. 33-47.

[10785] E. Jagt-Yazykova, M. Krawczyski, and M. Rakociski. “Molluscs from the Early Frasnian Goniatite Level at Kostomoty in the Holy Cross Mountains, Poland". English. In: Acta Palaeontologica Polonica 51.4 (2006), pp. 707-718.

[10786] H. Jahangir, M. Ghobadi Pour, A. Ashuri, and A. Amini. "Terminal Cambrian and Early Ordovician (Tremadocian) conodonts from Eastern Alborz, north-central Iran". English. In: Alcheringa 40.2 (2016), pp. 219-243. DOI: 10.1080/03115518.2016.1118298.

[10787] H. Jähnichen and E. Kahlert. "First record of Ephemeropsis, Coptoclava, Coleoptera inc. sed. and Turfanograpta from Lower Cretaceous paper-shales of the western-most site of Mongolia". English. In: Mitteilungen aus dem Museum für Naturkunde in Berlin, Geowissenschaftliche Reihe 3 (2000), pp. 77-86.

[10788] E. Jaillard, H. Cappetta, P. Ellenberger, M. Feist, N. Grambast-Fessard, J. P. Lefranc, and B. Sigé. "Sedimentology, palaeontology, biostratigraphy and correlation of the Late Cretaceous Vilquechico Group of southern Peru". English. In: Cretaceous Research 14 (1993), pp. 623-661.

[10789] S. Jain. "Occurrences, age and paleobiogeography of rare genera Phlycticeras and Pachyerymnoceras from South Tethys". English. In: Neues Jahrbuch für Geologie und Paläontologie, Abhandlungen 283 (2017), pp. 119-149.

[10790] S. Jain. "First Bathonian (Middle Jurassic) nautiloid Paracenoceras Spath from Ethiopia". English. In: Journal of African Earth Sciences 149 (2019), pp. 84-96. DOI: 10.1016/j.jafrearsci.2018.07.027. 
[10791] S. L. Jain and S. Bandyopadhyay. "New titanosaurid (Dinosauria: Sauropoda) from the Late Cretaceous of central India". English. In: Journal of Vertebrate Paleontology 17.1 (1997), pp. 114-136.

[10792] G. K. Jakobs. "Toarcian (Early Jurassic) ammonoids from western North America". English. In: Geological Survey of Canada, Bulletin 428 (1997), 137pp.

[10793] K. G. Jakobsen, G. A. Brock, A. T. Nielsen, T. P. Topper, and D. A. T. Harper. "Middle Ordovician brachiopods from the Stairway Sandstone, Amadeus Basin, central Australia". English. In: Alcheringa 38.2 (2014), pp. 190-208. DOI: 10.1080/03115518.2013.858204.

[10794] K. G. Jakobsen, G. A. Brock, A. T. Nielsen, D. K. Mathieson, and D. A. Harper. “Brachiopods associated with stromatoporoid mounds from the Middle to Upper Ordovician Cashions Creek Limestone, Tasmania". English. In: Memoirs of the Association of Australasian Palaeontologists 4545 (2014), pp. 249-265.

[10795] K. G. Jakobsen, A. T. Nielsen, D. A. T. Harper, and G. A. Brock. “Trilobites from the Middle Ordovician Stairway Sandstone, Amadeus Basin, central Australia". English. In: Alcheringa 38.1 (2014), pp. 70-96. DOI: 10.1080/03115518.2013.828253.

[10796] S. L. Jakobsen and J. S. H. Collins. "New Middle Danian species of anomuran and brachyuran crabs from Fakse, Denmark". English. In: Giological Museum of The University of Copenhagen: Contributions to Palaeontology 44 (1997), pp. 89-100.

[10797] M. Jakubowicz, B. Berkowski, M. L. Correa, E. Jarochowska, M. Joachimski, and Z. Belka. “Stable Isotope Signatures of Middle Palaeozoic Ahermatypic Rugose Corals - Deciphering Secondary Alteration, Vital Fractionation Effects, and Palaeoecological Implications". English. In: Plos one (2015).

[10798] M. Jakubowicz, J. Król, M. K. Zapalski, T. Wrzoek, P. J. Wolniewicz, and B. Berkowski. “At the southern limits of the Devonian reef zone: Palaeoecology of the Aferdou el Mrakib reef (Givetian, eastern AntiAtlas, Morocco)". English. In: Geological Journal (2018), pp. 1-29. DOI: 10.1002/gj.3152.

[10799] N.-E. Jalil. "Continental Permian and Triassic vertebrate localities from Algeria and Morocco and their stratigraphical correlations". English. In: Journal of African Earth Sciences 29.1 (1999), pp. 219226.

[10800] N.-E. Jalil. "A new prolacertiform diapsid from the Triassic of North Africa and the interrelationships of the Prolacertiformes". English. In: Journal of Vertebrate Paleontology 17.3 (1997), pp. 506525.

[10801] N.-E. Jalil and J.-M. Dutuit. "Permian captorhinid reptiles from the Argana formation, Morocco". English. In: Palaeontology 39.4 (1996), pp. 907-918.

[10802] N.-E. Jalil and P. Janvier. "Les pareiasaures (Amniota, Parareptilia) du Permien supérieur du Bassin d'Argana, Maroc". French. In: Geodiversitas 27.1 (2005), pp. 35-132.

[10803] N.-E. Jalil, F.d. Lapparent de Broin, N. Bardet, R. Vacant, B. Bouya, M. Amaghzaz, and S. Meslouh. "Euclastes acutirostris, a new species of littoral turtle (Cryptodira, Cheloniidae) from the Palaeocene phosphates of Morocco (Oulad Abdoun Basin, Danian-Thanetian)". English. In: Comptes Rendus Palevol 8 (2009), pp. 447-459.

[10804] N.-E. Jalil and K. Peyer. "A new rauisuchian (Archosauria: Suchia) from the Upper Triassic of the Argana Basin, Morocco". English. In: Palaeontology 50.2 (2007), pp. 417-430.

[10805] A. Jamalabad. "Records of a White-eyed Gull Ichthyaetus leucophthalmus, and a Black Tern Chlidonias niger from the Karwar coast, Karnataka, India". English. In: Indian Birds 12.1 (2016), pp. 1214.

[10806] N. P. James and D. I. Gravestock. "Lower Cambrian shelf and shelf margin buildups, Flinders Ranges, South Australia". English. In: Sedimentology 37 (1990), pp. 455-480.

[10807] S. A. James. "Coral Biodiversity and Zonation on a Pleistocene Reef, Southeastern Jamaica". English. In: Jamaica Clearing House Mechanism (2006). 
[10808] S. A. James-Williamson and S. F. Mitchell. "Revised lithostratigraphy of the Coastal Group of south-eastern St. Thomas, Jamaica". English. In: Caribbean Journal of Earth Science 44 (2012), pp. 917.

[10809] A. Jamnik and A. Ramovs. "Holothurian sclerites and conodonts in the Upper Carnian (Tuvalian) and Norian Limestones in the Central Kamnik Alps". other. In: Geologija 1992 (1993), pp. 7-63.

[10810] B. N. Jana and A. K. Ghosh. "A megaspore assemblage from the Athgarh Formation and its bearing on the age of the formation". In: The Palaeobotanist 46.1-2 (1997), pp. 149-155.

[10811] S. K. Jana and S. S. Das. "A report of a 157.8 m.y.-old dinosaur bone from the Jurassic marine Chari Formation, Kutch, Gujarat and its taphonomic significance". English. In: Current Science 82.1 (2002), pp. 85-88.

[10812] A. Janoo. "Discovery of isolated dodo bones [Raphus cucullatus (L.), Aves, Columbiformes] from Mauritius cave shelters highlights human predation, with a comment on the status of the family Raphidae Wetmore, 1930". English. In: Annales de Paléontologie 91.2 (2005), pp. 167-180.

[10813] K. R. Jansen, K. Shimada, and J. I. Kirkland. "Fossil fish fauna from the uppermost Graneros Shale (Upper Cretaceous: middle Cenomanian) in southeastern Nebraska". English. In: Transactions of the Kansas Academy of Science 115 (2012), pp. 145-152.

[10814] M. Jansen and N. Klein. “A juvenile turtle (Testudines, Eucryptodira) from the Upper Jurassic of Langenberg Quarry, Oker, northern Germany". English. In: Palaeontology (2013), pp. 1-14.

[10815] A. W. Janssen. "Holoplanktonic molluscan assemblages (Gastropoda, Heteropoda, Thecosomata) from the Pliocene of Estepona (Spain, Málaga)". English. In: Paleontos 5 (2004), pp. 103-131.

[10816] A. W. Janssen. "Holoplanktonic Mollusca (Gastropoda: Heteropoda and Thecosomata) from the Pliocene Bowden Beds, Jamaica. In: Donovan, S.K. (ed.). The Pliocene Bowden shell bed, southeast Jamaica". English. In: Contributions to Tertiary and Quaternary Geology 35.1-4 (1998), pp. 95-111.

[10817] A. W. Janssen. "Neogene Paleontology in the Northern Dominican Republic 20. Holoplanktonic Mollusks (Gastropoda: Heteropoda and Thecosomata)". English. In: Bulletins of American Paleontology 358 (1999), pp. 1-40.

[10818] A. W. Janssen. "Systematic revision of holoplanktonic Mollusca in the collections of the Dipartimento di scienze della terra at Torino, Italy". English. In: Museo regionale di scienze naturali 17 (1995), pp. 1-225.

[10819] A. W. Janssen. "Euthecosomatous gastropods (Mollusca: Heterobranchia) from Buton (SE". English. In: Geologie en Mijnbouw 78 (1999), pp. 179-189.

[10820] A. W. Janssen, A. Kroh, and S. P. Avila. "Early Pliocene heteropods and pteropods (Mollusca, Gastropoda) from SantaMaria Island (Azores, Portugal): systematics and biostratigraphic implications". English. In: Acta Geologica Polonica 58.3 (2008), pp. 355-369.

[10821] N. M. M. Janssen. "Barremian invertebrates from Serre de Bleyton (Drome, SE France): Belemnites". English. In: Annalen des Naturhistorischen Museums in Wien, Serie A 112 (2010), pp. 659-672.

[10822] V. P. Jaquier, N. C. Fraser, H. Furrer, and T. M. Scheyer. “Osteology of a New Specimen of Macrocnemus aff. M. fuyuanensis (Archosauromorpha, Protorosauria) from the Middle Triassic of Europe: Potential Implications for Species Recognition and Paleogeography of Tanystropheid Protorosaurs". English. In: Frontiers in Earth Science 5 (2017), p. 91. DOI: 10.3389/feart.2017.00091.

[10823] C. A. Jaramillo and D. L. Dilcher. "Middle Paleogene palynology of Central Colombia, South America: A study of pollen and spores from tropical latitudes". English. In: Palaeontographica Abteilung B 258.4-6 (2001), pp. 87-213.

[10824] E. Jarochowska. (Embargoed dataset for a paper in preparation). English. 2020.

[10825] E. Jarochowska, O. Bremer, D. Heidlas, S. Pröpster, T. R. A. Vandenbroucke, and A. Munnecke. "End-Wenlock terminal Mulde carbon isotope excursion in Gotland, Sweden: Integration of stratigraphy and taphonomy for correlations across restricted facies and specialized faunas". English. In: Palaeogeography, Palaeoclimatology, Palaeoecology 457 (2016), pp. 304-322. 
[10826] E. Jarochowska and A. Munnecke. "The Paleozoic problematica Wetheredella and Allonema are two aspects of the same organism". English. In: Facies 60.2 (2014), pp. 651-662.

[10827] E. Jarochowska and A. Munnecke. "Late Wenlock carbon isotope excursions and associated conodont fauna in the Podlasie Depression, eastern Poland: a not-so-big crisis?" English. In: Geological Journal 51.5 (2016), pp. 683-703. DOI: 10.1002/gj.2674.

[10828] E. Jarochowska, A. Munnecke, K. Frisch, D. C. Ray, and A. Castagner. "Faunal and facies changes through the mid Homerian (late Wenlock, Silurian) positive carbon isotope excursion in Podolia, western Ukraine". English. In: Lethaia 49.2 (2016), pp. 170-798. DOI: 10.1111/let.12137.

[10829] E. Jarochowska, D. C. Ray, P. Röstel, G. Worton, and A. Munnecke. "Harnessing stratigraphic bias at the section scale: conodont diversity in the Homerian (Silurian) of the midland platform, England". English. In: Palaeontology 61.1 (2017), pp. 57-76. DOI: 10.1111/pala.12326.

[10830] D. E. Jarvis. Paleoenvironment of the plant bearing horizons of the Devonian-Carboniferous Kiltorcan Formation, Kiltorcan Hill, Co. Kilkenny, Ireland. Vol. 180. New Perspectives on the Old Red Sandstone. Geological Society Special Publication. Friend, P.F. \& Williams, B.P.J. (eds). 2000, pp. 333-341.

[10831] E. Jarzembowski and A. Soszyska-Maj. “The first orthophlebiid scorpionfly (Insecta: Mecoptera) from the Wealden (Lower Cretaceous) of southern England". English. In: Earth and Environmental Science Transactions of the Royal Society of Edinburgh 107 (2018), pp. 191-194.

[10832] E. A. Jarzembowski. "Early Cretaceous zygopteroids of southern England, with the description of Cretacoenagrion alleni gen. nov., spec. nov. (Zygoptera: Coenagrionidae; Anisozygoptera: Tarsophlebiidae, Euthemistidae)". English. In: Odontologica 19.1 (1990), pp. 27-37.

[10833] E. A. Jarzembowski. "Fossil caddisflies (Insecta: Trichoptera) from the Early Cretaceous of southern England". English. In: Cretaceous Research 16 (1995), pp. 695-703.

[10834] E. A. Jarzembowski. "Fossil dragonflies in Horsham Museum". English. In: Proceedings of the Geologists' Association 105 (1994), pp. 71-75.

[10835] E. A. Jarzembowski. "The oldest insect from Romania: a new Carboniferous blattodean". English. In: Studia Geologica Polonica 129 (2008), pp. 43-50.

[10836] E. A. Jarzembowski. "Burnt beetles (Insecta: Coleoptera) from the Wealden of southern England". English. In: Acta Zoologica Cracoviensia 46.Suppl (2003), pp. 139-145.

[10837] E. A. Jarzembowski. "New insects from the Weald Clay of the Weald". English. In: Proceedings of the Geological Association 102.2 (1991), pp. 93-108.

[10838] E. A. Jarzembowski, D. Azar, and A. Nel. "A new chironomid (Insecta: Diptera) from Wealden amber (Lower Cretaceous) of the Isle of Wight (UK)". English. In: Geologica Acta 6 (2008), pp. 285291.

[10839] E. A. Jarzembowski, C. Chény, Y. Fang, and B. Wang. "First Mesozoic amphipod crustacean from the Lower Cretaceous of SE England". English. In: Cretaceous Research 112.104429 (2020). DOI: 10. 1016/j.cretres.2020.104429.

[10840] E. A. Jarzembowski, X. Martnez-Delclós, G. Bechly, A. Nel, R. Coram, and F. Escuillié. “The Mesozoic non-calopterygoid Zygoptera: description of new genera and species from the Lower Cretaceous of England and Brazil and their phylogenetic significance (Odonata, Zygoptera, Coenagrionoidea, Hemiphlebioidea, Lestoidea)". English. In: Cretaceous Research 19 (1998), pp. 403-444.

[10841] E. A. Jarzembowski and M. B. Mostovski. "A new species of Sinonemestrius (Diptera: Brachycera) from the Weald Clay (Lower Cretaceous, southern England), with a discussion of its affnities and stratigraphical implications". English. In: Cretaceous Research 21 (2000), pp. 761-765. DOI: 10.1006/ cres.2000.0226.

[10842] E. A. Jarzembowski and A. Nel. "New fossil dragonflies from the Lower Cretaceous of SE England and the phylogeny of the superfamily Libelluloidea (Insecta: Odonata)". English. In: Cretaceous Research 17 (1996), pp. 67-85.

[10843] E. A. Jarzembowski and A. Nel. "A new genus and species of hawker dragonfly (Aeshnidae) from the Lower Cretaceous of southern England". English. In: Cretaceous Research 17 (1996), pp. 97-101. 
[10844] E. A. Jarzembowski and A. Nel. "The earliest damselfly like insect and the origin of modern dragonflies (Insecta: Odonatoptera: Protozygoptera)". English. In: Proceedings of the Geologists' Association 113 (2002), pp. 165-169.

[10845] E. A. Jarzembowski, B. Wang, H. C. Zhang, and Y. Fang. "Boring beetles are not necessarily dull: New notocupedins (Insecta: Coleoptera) from the Mesozoic of Eurasia and East Gondwana". English. In: Cretaceous Research 52 (2015), pp. 431-439.

[10846] E. A. Jarzembowski and B. Wang. "An unusual basal beetle from Myanmar (Coleoptera: Archostemata)". English. In: Alcheringa 40 (2016), pp. 297-302.

[10847] E. A. Jarzembowski, B. Wang, and D. R. Zheng. "A new ommatin beetle (Insecta: Coleoptera) with unusual genitalia from mid-Cretaceous Burmese amber". English. In: Cretaceous Research 71 (2016), pp. 113-117.

[10848] E. A. Jarzembowski, B. Wang, and D. R. Zheng. “An amber double first: a new brochocolein beetle (Coleoptera: Archostemata) from northern Myanmar". English. In: Proceedings of the Geologists' Association 127 (2016), pp. 676-680.

[10849] E. A. Jarzembowski, B. Wang, and D. R. Zheng. "The first cupedine beetle from Burmese amber (Coleoptera: Cupedidae)". English. In: Comptes Rendus Palevol 16 (2017), pp. 241-247.

[10850] E. A. Jarzembowski, B. Wang, and D. R. Zheng. "Another amber first: A tiny tetraphalerin beetle (Coleoptera: Archostemata) in Myanmar birmite". English. In: Cretaceous Research 78 (2017), pp. 84-88.

[10851] E. A. Jarzembowski, B. Wang, and D. R. Zheng. "A new reticulated beetle (Coleoptera: Cupedidae) with aedeagus preserved from mid-Cretaceous amber of Myanmar". English. In: Cretaceous Research 80 (2017), pp. 86-90.

[10852] E. A. Jarzembowski, B. Wang, and D. R. Zheng. "A new spiny reticulated beetle (Coleoptera: Cupedidae) from Cretaceous Burmese amber". English. In: Proceedings of the Geologists' Association 128 (2017), pp. 798-802.

[10853] E. A. Jarzembowski, B. Wang, and D. R. Zheng. "A slender new archaic beetle in Burmese amber (Coleoptera: Archostemata)". English. In: Alcheringa 42 (2017), pp. 110-114.

[10854] E. A. Jarzembowski, B. Wang, and D. R. Zheng. "A new serrated archaic beetle (Coleoptera: Archostemata) from mid-Cretaceous Burmese amber". English. In: Cretaceous Research 92 (2018), pp. 26-30.

[10855] E. A. Jarzembowski, B. Wang, and D. R. Zheng. "A new scaly archaic beetle (Coleoptera: Archostemata) from mid-Cretaceous Burmese amber". English. In: Cretaceous Research 99 (2019), pp. 315-320. DOI: 10.1016/j.cretres.2019.02.027.

[10856] E. A. Jarzembowski and B. Wang. "The first fossil mayfly nymph (Insecta: Ephemeroptera) from the British Isles". English. In: Proceedings of the Geologists' Association 130 (2019), pp. 673-676. DOI: 10.1016/j.pgeola.2019.01.007.

[10857] E. A. Jarzembowski, B. Wang, and D. R. Zheng. “The first notocupedin beetle in mid-Cretaceous amber of northern Myanmar (Insecta: Coleoptera: Archostemata)". English. In: Cretaceous Research 106.104225 (2019). DOI: 10.1016/j.cretres.2019.104225.

[10858] E. A. Jarzembowski, B. Wang, and D. R. Zheng. “An archaic-beetle 'Jaws' from mid-Cretaceous Burmese amber". English. In: Proceedings of the Geologists' Association 131 (2020), pp. 155-159. DOI: 10.1016/j.pgeola.2020.02.003.

[10859] E. A. Jarzembowski, E. V. Yan, B. Wang, and H. C. Zhang. "A new flying water beetle (Coleoptera: Schizophoridae) from the Jurassic Daohugou lagerstätte". English. In: Palaeoworld 21 (2012), pp. 160166.

[10860] E. A. Jarzembowski, E. V. Yan, B. Wang, and H. C. Zhang. “Brochocolein beetles (Insecta: Coleoptera) from the Lower Cretaceous of northeast China and southern England". English. In: Cretaceous Research 44 (2013), pp. 1-11. 
[10861] E. A. Jarzembowski, E. V. Yan, B. Wang, and H. Zhang. “Ommatin beetles (Insecta: Coleoptera) from the Lower Cretaceous of northeast China and southern England". English. In: Terrestrial Arthropod Reviews 6 (2013), pp. 135-161.

[10862] D. M. Jarzen and D. L. Dilcher. "Middle Eocene terrestrial palynomorphs from the Dolime minerals and Gulf Hammock Quarries, Florida, U.S.A." English. In: Palynology 30.1 (2006), pp. 89-110. DOI: 10.2113 /gspalynol.30.1.89.

[10863] B. Jasin. "Late Jurassic to Early Cretaceous Radiolaria from chert blocks in th Lubok Antu melange, Sarawak, Malaysia". English. In: Journal of Southeast Asian Earth Sciences 13.1 (1996), pp. 1-11.

[10864] B. Jasin. "Permo-Triassic radiolaria from the Semanggol Formation, northwest Peninsular Malaysia". English. In: Journal of Asien Earth Science 15.1 (1997), pp. 43-53.

[10865] B. Jasin, C. A. Ali, and K. R. Mohamed. "Late Triassic Radiolaria from the Kodiang Limestone, northwest Peninsular Malaysia". English. In: Journal of Southeast Asian Earth Sciences 12.1 (1995), pp. 31-39.

[10866] B. Jasin, U. Said, and R. A. Rahman. "Late Middle Permian Radiolaria from the Jengka area, central Pahang, Malaysia". English. In: Journal of Southeast Asian Earth Sciences 12 (1995), pp. 79-83.

[10867] S. C. Jasinoski and F. Abdala. "Aggregations and parental care in the Early Triassic basal cynodonts Galesaurus planiceps and Thrinaxodon liorhinus". English. In: PeerJ 5 (2017), e2875. DOI: 10.7717 / peerj. 2875 .

[10868] S. E. Jasinski. "A new dromaeosaurid (Theropoda: Dromaeosauridae) from the Late Cretaceous of New Mexico". English. In: vol. 67. Fossil Record 4. New Mexico Museum of Natural History and Science Bulletin. Albuquerque: New Mexico Museum of Natural History and Science, 2015, pp. 79-88.

[10869] S. E. Jasinski. "Review of the fossil Trionychidae (Testudines) from Alabama, including the oldest record of trionychid turtles from eastern North America". English. In: Bulletin of the Alabama Museum of Natural History 31.2 (2013), pp. 46-59.

[10870] S. E. Jasinski. “A new slider turtle (Testudines: Emydidae: Deirochelyinae: Trachemys) from the late Hemphillian (late Miocene/early Pliocene) of eastern Tennessee and the evolution of the deirochelyines". English. In: PeerJ (2018), pp. 1-92. DOI: 10.7717/peerj.4338.

[10871] S. E. Jasinski and R. M. Sullivan. "Re-evaluation of pachycephalosaurids from the FruitlandKirtland transition (Kirtlandian, late Campanian), San Juan Basin, New Mexico, with a description of a new species of Stegoceras and a reassessment of Texacephale langstoni". English. In: vol. 53. Fossil Record 3. New Mexico Museum of Natural History and Science Bulletin. Albuquerque: New Mexico Museum of Natural History and Science, 2011, pp. 202-215.

[10872] S. E. Jasinski, R. M. Sullivan, and S. G. Lucas. "Taxonomic composition of the Alamo Wash local fauna from the Upper Cretaceous Ojo Alamo Formation (Naashoibito Member), San Juan Basin, New Mexico". English. In: vol. 53. Fossil Record 3. New Mexico Museum of Natural History and Science Bulletin. Albuquerque: New Mexico Museum of Natural History and Science, 2011, pp. 216-271.

[10873] S. E. Jasinski, R. M. Sullivan, A. J. Lichtig, S. G. Lucas, and P. Dodson. "Baenid (Baenidae: Testudines) lower jaws from the Late Cretaceous and Paleocene of the San Juan Basin, New Mexico". English. In: Fossil Record 6. New Mexico Museum of Natural History and Science Bulletin 79 (2018), pp. 311-318.

[10874] S. E. Jasinski, R. M. Sullivan, and P. Dodson. “Dromaeosaurid dinosaur (Theropoda, Dromaeosauridae) from New Mexico and biodiversity of dromaeosaurids at the end of the Cretaceous". English. In: Scientific Reports 10.5105 (2020), pp. 1-10. DOI: 10.1038/s41598-020-61480-7.

[10875] S. E. Jasinski and S. C. Wallace. "A Borophagine canid (Carnivora: Canidae: Borophaginae) from the middle Miocene Chesapeake Group of eastern North America". English. In: Journal of Paleontology 89.6 (2015), pp. 1082-1088. DOI: 10.1017/jpa.2016.17. 
[10876] M. Jasionowski. “Facje i geochemia dolnosarmackich raf z polnocnych obrzezy Paratetydy na Roztoczu (Polska) i Miodoborach (Ukraina): implikacje paleosrodowiskowe [Facies and geochemistry of Lower Sarmatian reefs along the northern margins of the Parathetys in Roztocze (Poland) and Medobory (Ukraine) regions: paleoenvironmental implications". other. In: Przeglad Geologiczny 54.5 (2006), pp. 445-455.

[10877] C. N. Jass. "Preliminary taphonomic analyses of the mammalian microfauna." English. In: Pp. 179190 in Bighorn Cave: Test Excavations of a Stratified Dry Shelter Mohave County, Arizona (P. R. Geib, and D. R. Keller, eds.). Bilby Research Center Occasional Papers 1 (Northern Arizona University, Flagstaff, Arizona). (2002).

[10878] C. N. Jass. "Mid to late Holocene mammals from Bighorn Cave, Arizona". English. In: The Southwestern Naturalist 49.1 (2004), pp. 75-82.

[10879] C. N. Jass. "Pleistocene lagomorphs from Cathedral Cave, Nevada". English. In: PaleoBios 29.1 (2009), pp. 1-12.

[10880] R. Jattiot, G. Bechly, R. Garrouste, and A. Nel. “An enigmatic Nepoidea from the Lower Cretaceous of Brazil (Hemiptera: Heteroptera)". English. In: Cretaceous Research 34 (2012), pp. 344-347.

[10881] R. Jattiot, A. Brayard, E. Fara, and S. Charbonnier. "Gladius-bearing coleoids from the Upper Cretaceous Lebanese Lagerstätten: diversity, morphology, and phylogenetic implications". English. In: Journal of Paleontology 89 (2015), pp. 148-167.

[10882] R. Jattiot, H. Bucher, A. Brayard, C. Monnet, J. F. Jenks, and M. Hautmann. "Revision of the genus Anasibirites Mojsisovics (Ammonoidea): an iconic and cosmopolitan taxon of the late Smithian (Early Triassic) extinction". English. In: Papers in Palaeontology 2.1 (2016), pp. 155-188. DOI: 10. 1002/spp2.1036.

[10883] R. Jattiot, L. Krogmann, and A. Nel. "Revision of Prosyntexis from the Lower Cretaceous Crato Formation of Brazil (Hymenoptera: Sepulcidae: Trematothoracinae)". English. In: Zootaxa 3058 (2011), pp. 55-62.

[10884] A. K. Jauhri. “Carbonate buildup in the Lakadong Formation of the South Shillong Plateau, NE India: A micropaleontological perspective". English. In: vol. 2. Studies on ecology and paleoecology of benthic communities. Modena: Boll. Soc. Paleont. Ital., 1994, pp. 157-169.

[10885] A. K. Jauhri. "Ranikothalia nutalli (Davies), a distinctive early Ilerdian marker, in the Shillong Plateau". English. In: Contrs. XV Indian Colloq. micropal. Strat. Dehra Dun, 1996.

[10886] A. K. Jauhri, B. D. Mandaokar, R. C. Mehrotra, R. P. Tiwari, and A. P. Singh. "Corals and foraminifera from the Miocene (Upper Bhuban Formation) of Mizoram, India". English. In: Jouranl of the Palaeontological Society of India 48 (2003), pp. 135-138.

[10887] A. K. Jauhri, P. K. Mirsa, S. Kishore, and S. K. Singh. "Larger foraminiferal and calcareous algal facies in the Lakadong Formation of the south Shillong Plateau, NE India". English. In: Journal of the Paleontological Society of India 51.2 (2006), pp. 51-61.

[10888] D. Jaume, M. McMinn, and J. A. Alcover. "Fossil birds from the Bujero del Silo, La Gomera (Canary Islands), with a description of a new species of quail (Galliformes: Phasianidae)". English. In: Boletim do Museu Municipal do Funchal 2 (1993), pp. 147-165.

[10889] P. Jaoszyski. "Description of Euroleptochromus gen. n. (Coleoptera, Staphylinidae, Scydmaeninae) from Baltic amber, with discussion of biogeography and mouthpart evolution within Clidicini". English. In: Systematic Entomology 37 (2012), pp. 346-359.

[10890] P. Jaoszyski. "A new Eocene genus of ant-like stone beetles sheds new light on the evolution of Mastigini”. English. In: Journal of Paleontology 89 (2016), pp. 1056-1067.

[10891] P. Jaoszyski. "+Praphennium gen. nov.: Extant mite killers meet their Cenomanian relatives (Coleoptera: Staphylinidae: Scydmaeninae: Cephenniini)". English. In: Cretaceous Research 90 (2018), pp. 142153.

[10892] P. Jaoszyski. "+Cretohlezkus gen. nov. from Upper Cretaceous Burmese amber demonstrates ancient origins of suctorial mouthparts in Eucinetidae (Coleoptera: Scirtoidea)". English. In: Cretaceous Research 100 (2019), pp. 126-133. DOI: 10.1016/j.cretres.2019.03.016. 
[10893] P. Jaoszyski. "Notes on mid-Cretaceous +Pangusyndicus and its relatives, with description of tLoeblitoides gen. nov. and a +Nuegua-like new species (Coleoptera: Staphylinidae: Scydmaeninae)". English. In: Cretaceous Research 107.104273 (2019). DOI: 10.1016/j.cretres.2019.104273.

[10894] P. Jaoszyski, A. J. Brunke, B. Metscher, W. W. Zhang, and M. Bai. “Clidicostigus gen. nov., the first Mesozoic genus of Mastigini (Coleoptera: Staphylinidae: Scydmaeninae) from Cenomanian Burmese amber". English. In: Cretaceous Research 72 (2017), pp. 110-116.

[10895] P. Jaoszyski, A. J. Brunke, S. Yamamoto, and Y. Takahashi. “Evolution of Mastigitae: Mesozoic and Cenozoic fossils crucial for reclassification of extant tribes (Coleoptera: Staphylinidae: Scydmaeninae)". English. In: Zoological Journal of the Linnean Society 184 (2018), pp. 623-652.

[10896] P. Jaoszyski and D. Kubisz. "First records of Chevrolatiini and Cephenniini in Eocene Baltic amber (Coleoptera, Staphylinidae, Scydmaeninae)". English. In: Zootaxa 4114 (2016), pp. 572-580.

[10897] P. Jaoszyski, X. Z. Luo, J. U. Hammel, S. Yamamoto, and R. G. Beutel. “The mid-Cretaceous tLepiceratus gen. nov. and the evolution of the relict beetle family Lepiceridae (Insecta: Coleoptera: Myxophaga)". English. In: Journal of Systematic Palaeontology 18 (2020), pp. 1127-1140. DOI: 10. 1080/14772019.2020.1747561.

[10898] P. Jaoszyski and D. Peris. “Cretaceous amber inclusions of Spain and Myanmar demonstrate early diversification and wide dispersal of Cephenniitae (Coleoptera: Staphylinidae: Scydmaeninae)". English. In: Cretaceous Research 57 (2016), pp. 190-198.

[10899] P. Jaoszyski and E. Perkovsky. "Diversity of Scydmaeninae (Coleoptera: Staphylinidae) in Upper Eocene Rovno amber". English. In: Zootaxa 4157 (2016), pp. 1-85.

[10900] P. Jaoszyski and E. Perkovsky. “The Mastigitae genus +Baltostigus in Upper Eocene Rovno amber (Coleoptera: Staphylinidae: Scydmaeninae)". English. In: Zootaxa 4661 (2019), pp. 594-600.

[10901] P. Jaoszyski and E. E. Perkovsky. "The extant genus Eutheia (Coleoptera: Staphylinidae: Scydmaeninae) discovered in Upper Cretaceous Taimyr amber". English. In: Cretaceous Research 66 (2016), pp. 6-10.

[10902] P. Jaoszyski and E. E. Perkovsky. “Taimyraphes gen. nov., the first glandulariine ant-like stone beetle from Santonian Taimyr amber (Coleoptera: Staphylinidae: Scydmaeninae)". English. In: Cretaceous Research 100 (2019), pp. 164-171. DOI: 10.1016/j.cretres.2019.03.002.

[10903] P. Jaoszyski, V. Perrichot, and D. Peris. "Ninety million years of chasing mites by ant-like stone beetles". English. In: Gondwana Research 48 (2017), pp. 1-6.

[10904] P. Jaoszyski, S. Yamamoto, and Y. Takahashi. "Scydmobisetia gen. nov., the first definite Glandulariini from Upper Cretaceous Burmese amber (Coleoptera: Staphylinidae: Scydmaeninae)". English. In: Cretaceous Research 65 (2016), pp. 59-67.

[10905] P. Jaoszyski, S. Yamamoto, and Y. Takahashi. "A new extinct genus of Glandulariini with two species from Upper Cretaceous Burmese amber (Coleoptera: Staphylinidae: Scydmaeninae)". English. In: Cretaceous Research 72 (2017), pp. 142-150.

[10906] P. Jaoszyski, S. Yamamoto, and Y. Takahashi. "Discovery of a new Mesozoic species of the ancient genus Lepicerus (Coleoptera: Myxophaga: Lepiceridae), with implications for the systematic placement of all previously described extinct 'lepiceroids'". English. In: Cretaceous Research 78 (2017), pp. 95-102.

[10907] P. Jaoszyski and S. Yamamoto. “+Rovnoleptochromus balticus sp. nov., a new upper Eocene antlike stone beetle". English. In: Annales Zoologici 69 (2019), pp. 535-540. DOI: 10.3161 / 00034541 ANZ2019. 69.3.004.

[10908] G. T. Jefferson, H. L. Fierstine, J. R. Wesling, and T. -L. Ku. "Pleistocene terrestrial vertebrates from near Point San Luis, and other localities in San Luis Obispo County, California". English. In: Bulletin of the Southern California Academy of Sciences 91.1 (1992), pp. 26-38.

[10909] T. A. Jefferson, S. Leatherwood, and M. A. Webber. "Marine Mammals of the World: FAO Species Identification Guide". English. In: United Nation Environment Programme and Food and Agricultural Organization of the UN (1993). 
[10910] T. A. Jefferson and H. C. Rosenbaum. "Taxonomic revision of the humpback dolphins (Sousa spp.), and description of a new species from Australia". English. In: Marine Mammal Science 30.4 (2014), pp. 1494-1541. DOI: 10.1111/mms.12152.

[10911] C. H. Jeffery. "All Change at the Cretaceous-Tertiary Boundary? Echinoids from the Maastrichtian and Danian of the Mangyshlak Peninsula, Kazakhstan". In: Palaeontology 40.3 (1997), pp. 659-712.

[10912] D. L. Jeffery, R. D. Hoare, R. H. Mapes, and C. J. Brown. "Gastropods (Mollusca) from the Imo Formation (Mississippian, Chesterian) of north-central Arkansas". In: Journal of Paleontology 68.1 (1994), pp. 58-79.

[10913] P. Jeffery and S. Tracey. The Early Eocene London Clay Formation mollusc fauna of the former Bursledon Brickworks, Lower Swanwick, Hampshire. 1997.

[10914] M. Jehle, M. Godinot, D. Delsate, A. Phélizon, and J. -L. Pellouin. “Evolution of plesiadapid mammals (Eutheria, Euarchonta, Plesiadapiformes) in Europe across the Paleocene/Eocene boundary: implications for phylogeny, biochronology and scenarios of dispersal". English. In: Palaeobiodiversity and Palaeoenvironments (2018), pp. 1-59. DOI: 10.1007/s12549-018-0331-6.

[10915] M. Jehle, M. Godinot, D. Delsate, A. Phélizon, and J. -L. Pellouin. "A new late Paleocene micromammal fauna from Montchenot (Paris Basin). Preliminary results". English. In: Palaeobiodiversity and Palaeoenvironments 92 (2012), pp. 487-496.

[10916] J. S. Jell, A. G. Cook, and P. A. Jell. “Australian Cretaceous Cnidaria and Porifera”. English. In: Alcheringa 35.2 (2011), pp. 241-284.

[10917] J. S. Jell, A. Simpson, R. Mawson, and J. A. Talent. Biostratigraphic summary. in I. W. Withnall and S. C. Lang, eds. Geology of the Broken River Province, north Queensland [Queensland Geology vol. 4; Department of Minerals and Energy]. 1993, pp. 239-245.

[10918] P. Jell. "Early Carboniferous ophiuroids from Crawfordsville, Indiana". In: Journal of Paleontology 71.2 (1997), pp. 306-316.

[10919] P. A. Jell. "Silurian and Devonian crinoids from central Victoria". In: Memoirs of the Queensland Museum 43.1 (1999), pp. 1-114.

[10920] P. A. Jell. "Late Triassic homopterous nymph from Dinmore, Ipswich Basin". English. In: Memoirs of the Queensland Museum 33 (1993), p. 360.

[10921] P. A. Jell. "A Tremadocian asterozoan from Tasmania and a late Llandovery edrioasteroid from Victoria". English. In: Alcheringa 38.4 (2014), pp. 528-540. DOI: 10.1080/03115518.2014.911642.

[10922] P. A. Jell. "Late Silurian echinoderms from the Yass Basin, New South Wales - the earliest holothurian body fossil and two diploporitan cystoids (Sphaeronitidae and Holocystitidae)". English. In: Memoirs of the Association of Australasian Palaeontologists 39 (2010), pp. 27-41.

[10923] P. A. Jell and J. M. Adrain. Available generic names for trilobites. English. Vol. 48. Memoirs of the Queensland Museum 2. 2003, pp. 331-553.

[10924] P. A. Jell and J. S. Jell. "Crinoids, a blastoid, and a cyclocystoid from the Upper Devonian reef complex of the Canning Basin, Western Australia". In: Memoirs of the Queensland Museum 43.1 (1999), pp. 201-236.

[10925] P. A. Jell and K. J. Lambkin. "Middle Triassic orthopteroid (Titanoptera) insect from the Esk Formation at Lake Wivenhoe". English. In: Memoirs of the Queensland Museum 33 (1993), p. 258.

[10926] P. A. Jell and J. N. Theron. "Early Devonian echinoderms from South Africa". In: Memoirs of the Queensland Museum 43.1 (1999), pp. 115-199.

[10927] P. A. Jell and R. J. Willink. "Early Permian cladid crinoids from the Gharif Formation of Oman". English. In: Memoirs of the Association of Australasian Palaeontologists 15 (1993), pp. 305-312.

[10928] F. A. Jenkins, S. M. Gatesy, N. H. Shubin, and W. W. Amaral. "Haramiyids and Triassic mammalian evolution". English. In: Nature 385 (1997), pp. 715-718.

[10929] F. A. Jenkins, N. H. Shubin, S. M. Gatesy, and K. Padian. "A diminutive pterosaur (Pterosauria: Eudimorphodontidae) from the Greenlandic Triassic". English. In: Bulletin Museum of Comparative Zoology 156.1 (2001), pp. 151-170. 
[10930] F. A. Jenkins, N. H. Shubin, S. M. Gatesy, and A. Warren. "Gerrothorax pulcherrimus from the Upper Triassic Fleming Fjord Formation of East Greenland and a reassessment of head lifting in temnospondyl feeding". English. In: Journal of Vertebrate Paleontology 28.4 (2008), pp. 935-950.

[10931] F. A. Jenkins and D. M. Walsh. "An Early Jurassic caecilian with limbs". English. In: Nature 365 (1993), pp. 246-250. DOI: 10.1038/365246a0.

[10932] H. Jenkins and A. B. Heckert. Revueltian (early-mid Norian) microvertebrates from the Upper Triassic Snyder Quarry, Painted Desert Member, Petrified Forest Formation, north-central New Mexico. English. 2004.

[10933] R. G. Jenkins, A. Kaim, K. Amano, K. Sakurai, and K. Matsubara. “A new Miocene whale-fall community dominated by the bathymodiolin mussel Adipicola from the Hobetsu area, Hokkaido, Japan". English. In: Paleontological Research 22.2 (2018), pp. 105-111. DOI: 10.2517/2017PR0006.

[10934] R. G. Jenkins, A. Kaim, K. Sato, K. Moriya, Y. Hikida, and R. Hirayama. “Discovery of chemosynthesisbased association on the Cretaceous basal leatherback sea turtle from Japan". English. In: Acta Palaeontologica Polonica 62 (2017). DOI: 10.4202/app.00405.2017.

[10935] J. Jenkins Shaw, A. Solodovnikov, M. Bai, and U. Kaulfuss. “An amblyopinine rove beetle (Coleoptera, Staphylinidae, Staphylininae, Amblyopinini) from the earliest Miocene Foulden Maar fossil-Lagerstätte, New Zealand". English. In: Journal of Paleontology 94 (2020), pp. 1082-1088. DOI: 10.1017/jpa.2020. 35 .

[10936] J. Jenkins Shaw, B. Wang, M. Bai, and D. ya. "The oldest representative of the rove beetle tribe Pinophilini (Coleoptera: Staphylinidae: Paederinae), from Upper Cretaceous Burmese amber". English. In: Insects 11.174 (2020). DOI: 10.3390/insects11030174.

[10937] J. Jenks, J. Guex, A. Hungerbühler, D. G. Taylor, and H. Bucher. “Ammonoid biostratigraphy of the early Spathian Columbites parisianus zone (Early Triassic) at Bear Lake Hot Springs, Idaho". English. In: The Triassic System. New Mexico Museum of Natural History and Science Bulletin 61 (2013), pp. 268-283.

[10938] J. F. Jenks. "Smithian (Early Triassic) ammonoid biostratigraphy at Crittenden Springs, Elko County, Nevada and a new ammonoid from the Meekoceras gracilitatis zone". English. In: New Mexico Museum of Natural History and Science Bulletin 40 (2007), pp. 81-90.

[10939] J. F. Jenks, A. Brayard, T. Brühwiler, and H. Bucher. "New Smithian (Early Triassic) ammonoids from Crittenden Springs, Elko County, Nevada: implications for taxonomy, biostratigraphy and biogeography". English. In: New Mexico Museum of Natural History and Science Bulletin 48 (2010), pp. 1-41.

[10940] R. A. Jenner, C. H. J. Hof, and F. R. Schram. "Palaeo- and archaeostomatopods (Hoplocarida, Crustacea) from the Bear Gulch Limestone, Mississippian (Namurian), of Central Montana". English. In: Contributions to Zoology 67.3 (1998), pp. 155-185.

[10941] D. S. Jennings and S. T. Hasiotis. "Taphonomic analysis of a dinosaur feeding site using Geographic Information Systems (GIS), Morrison Formation, southern Bighorn Basin, Wyoming, USA". English. In: Palaios 21 (2006), pp. 480-492.

[10942] D. S. Jennings, B. F. Platt, and S. T. Hasiotis. "Distribution of vertebrate trace fossils, Upper Jurassic Morrison Formation, Bighorn Basin, Wyoming, USA: implications for differentiating paleoecological and preservational bias". English. In: vol. 36. Paleontology and Geology of the Upper Jurassic Morrison Formation. New Mexico Museum of Natural History and Science Bulletin. Albuquerque: New Mexico Museum of Natural History and Science, 2006, pp. 183-192.

[10943] J. T. Jennings and L. Krogmann. “A new species of Pristaulacus Kieffer (Hymenoptera: Aulacidae) from Baltic amber". English. In: Insect Systematics \& Evolution 40 (2009), pp. 201-207.

[10944] J. T. Jennings, L. Krogmann, and S. L. Mew. "Hyptia deansi sp. nov., the first record of Evaniidae (Hymenoptera) from Mexican amber". English. In: Zootaxa 3349 (2012), pp. 63-68.

[10945] J. T. Jennings, L. Krogmann, and S. L. Mew. “Cretevania bechlyi sp. nov., from Cretaceous Burmese amber (Hymenoptera: Evaniidae)". English. In: Zootaxa 3609 (2013), pp. 91-95. 
[10946] J. T. Jennings, L. Krogmann, and P. Priya. "Happy birthday Willi Hennig! — Hyptia hennigi sp. nov. (Hymenoptera: Evaniidae), a fossil ensign wasp from Eocene Baltic amber". English. In: Zootaxa 3731 (2013), pp. 395-398.

[10947] J. T. Jennings, D. D. O'Carroll, P. Priya, L. Krogmann, and A. D. Austin. "A new fossil evaniid wasp from Eocene Baltic amber, with highly modified compound eyes unique within the Hymenoptera". English. In: Journal of Paleontology 92 (2018), pp. 189-195.

[10948] S. Jensen. "Predation by early Cambrian trilobites on infaunal worms - evidence from the Swedish Mickwitzia Sandstone". In: Lethaia 23.1 (1990), pp. 29-42.

[10949] S. Jensen, J. G. Gehling, and M. L. Droser. "Ediacara-type fossils in Cambrian sediments". English. In: Nature 393 (1998), pp. 567-569.

[10950] S. Jensen, A. E. S. Högström, M. Høyberget, G. Meinhold, D. McIlroy, J. O. R. Ebbestad, W. L. Taylor, H. Agi, and T. Palacios. "New occurrences of Palaeopascichnus from the Stáhpogieddi Formation, Arctic Norway, and their bearing on the age of the Varanger Ice Age". English. In: Canadian Journal of Earth Sciences 55 (2018), pp. 1253-1261. DOI: 10.1139/cjes-2018-0035.

[10951] S. Jensen and K. Mens. "Trace fossils Didymaulichnus cf. tirasensis and Monomorphichnus isp. from the Estonian Lower Cambrian with a discussion on the early Cambrian ichnocoenoses of Baltica". English. In: Proceedings of the Estonian Academy of Sciences. Geology 50.2 (2001), pp. 75-85.

[10952] S. Jensen and B. N. Runnegar. "A complex trace fossil from the Spitskop Member (terminal Ediacaran? Lower Cambrian) of southern Namibia”. English. In: Geological Magazine 142.5 (2005), pp. 561569.

[10953] J. Jeon, Q. Li, J. -R. Oh, S. -J. Choh, and D. -J. Lee. “A new species of the primitive stromatoporoid Cystostroma". English. In: Geosciences Journal (2018). DOI: 10.1007/s12303-018-0063-7.

[10954] J. Jeon, K. Liang, J. Park, S. -J. Choh5, and D. -J. Lee. "Late Ordovician stromatoporoids from the Xiazhen Formation of South China: Paleoecological and paleogeographical implications". English. In: Geological Journal (2018). DOI: 10.1002/gj.3401.

[10955] L. Jeppsson. "A new latest Telychian, Sheinwoodian and Early Homerian (Early Silurian) Standard Conodont Zonation". English. In: Transactions of the Royal Society of Edinburgh: Earth Sciences 88.2 (1997), pp. 91-114.

[10956] L. Jeppsson. "Conodont-based revisions of the Late Ludfordian on Gotland, Sweden". English. In: Gff 127.4 (2005), pp. 273-282.

[10957] L. Jeppsson. "The lower Wenlock Hangvar Formation - a sequence previously split between the Högklint and Slite beds (Silurian, Gotland, Sweden)". English. In: Gff 130 (2008), pp. 31-40.

[10958] L. Jeppsson and P. Männik. "High-resolution correlations between Gotland and Estonia near the base of the Wenlock". English. In: Terra Nova 5 (2003), pp. 348-358.

[10959] J. Jepson, J. Ansorge, and E. A. Jarzembowski. “New snakeflies (Insecta: Raphidioptera) from the Lower Cretaceous of the UK, Spain and Brazil". English. In: Palaeontology 54.2 (2011), pp. 385-395.

[10960] J. E. Jepson, R. A. Coram, and E. A. Jarzembowski. “Raphidioptera (Insecta: Neuropterida) from the Lower Cretaceous Purbeck Limestone Group, Dorset, UK". English. In: Cretaceous Research 30 (2009), pp. 527-532.

[10961] J. E. Jepson, S. W. Heads, V. N. Makarkin, and D. Ren. "New fossil mantidflies (Insecta: Neuroptera: Mantispidae) from the Mesozoic of north-eastern China". English. In: Palaeontology 56 (2013), pp. 603-613.

[10962] J. E. Jepson and S. W. Heads. “Fossil Megaloptera (Insecta: Neuropterida) from the Lower Cretaceous Crato Formation of Brazil". English. In: Zootaxa 4098 (2016), pp. 134-144.

[10963] J. E. Jepson and E. A. Jarzembowski. "Two new species of snakefly (Insecta: Raphidioptera) from the Lower Cretaceous of England and Spain with a review of other fossil raphidiopterans from the Jurassic/Cretaceous transition". English. In: Alavesia 2 (2008), pp. 193-201.

[10964] J. E. Jepson, A. V. Khramov, and M. Ohl. “New Mesomantispinae (Insecta: Neuroptera: Mantispidae) from the Jurassic of Karatau, Kazakhstan". English. In: Zootaxa 4402 (2018), pp. 563-574. 
[10965] J. E. Jepson, V. N. Makarkin, and R. A. Coram. “Lacewings (Insecta: Neuroptera) from the Lower Cretaceous Purbeck Limestone Group of southern England". English. In: Cretaceous Research 34 (2012), pp. 31-47.

[10966] J. E. Jepson, V. N. Makarkin, and E. A. Jarzembowski. “New lacewings (Insecta: Neuroptera) from the Lower Cretaceous Wealden supergroup of Southern England". English. In: Cretaceous Research 30 (2009), pp. 1325-1338.

[10967] J. E. Jepson, D. Penney, and D. I. Green. “A new species of brown lacewing (Neuroptera: Hemerobiidae) from Eocene Baltic amber". English. In: Zootaxa 2692 (2010), pp. 61-68.

[10968] J. E. Jepson, D. Penney, and D. I. Green. "First fossil Phatnoma (Hemiptera: Heteroptera: Tingidae: Cantacaderinae), in Miocene amber from the Dominican Republic". English. In: Zootaxa 2975 (2011), pp. 59-63.

[10969] A. J. Jeram. "Scorpions from the Viséan of East Kirkton, West Lothian, Scotland, with a revision of the infraorder Mesoscorpionina". English. In: Transactions of the Royal Society of Edinburgh: Earth Sciences 84 (1994), pp. 283-299. DOI: 10.1017/S0263593300006106.

[10970] A. J. Jeram. "Carboniferous Orthosterni and their relationships to living scorpions". English. In: Palaeontology 37 (1994), pp. 513-550.

[10971] A. J. Jeram, P. A. Selden, and D. Edwards. "Land animals in the Silurian: arachnids and myriapods from Shropshire, England". English. In: Science 250 (1990), pp. 658-661.

[10972] K. Jessen. "New fossil ants of the subfamily Myrmicinae (Hymenoptera, Formicidae) from the Upper Oligocene of Enspel (Westerwald Mountains, Rhineland Palatinate, Germany)". English. In: Palaeobiodiversity and Palaeoenvironments 100 (2020), pp. 1007-1045. DOI: 10.1007/s12549-01900406-2.

[10973] C. Ji and H. Bucher. "Anisian (Middle Triassic) ammonoids from British Columbia (Canada): biochronological and palaeobiogeographical implications". English. In: Papers in Palaeontology 4 (2018), pp. 623-642.

[10974] C. Ji, D.-Y. Jiang, R. Motani, W. -C. Hao, Z. -Y. Sun, and T. Cai. “A new juvenile specimen of Guanlingasaurus (Ichthyosauria, Shastasauridae) from the Upper Triassic of southwestern China". English. In: Journal of Vertebrate Paleontology 33.2 (2013), pp. 340-348.

[10975] C. Ji, A. Tintori, D. Y. Jinang, and R. Motani. "New species of Thylacocephala (Arthropoda) from the Spathian (Lower Triassic) of Chaohu, Anhui Province of China". English. In: PalZ 91 (2017), pp. 171-184.

[10976] C. Ji, C. Zhang, D. -Y. Jiang, H. Bucher, R. Motani, and A. Tintori. "Ammonoid age control of the Early Triassic marine reptiles from Chaohu (South China)". English. In: Palaeoworld 24.3 (2015), pp. 277-282. DOI: 10.1016/j.palwor.2014.11.009.

[10977] Q. Ji, L. M. Chiappe, and S. -H. Ji. "A new late Mesozoic confuciusornithid bird from China". English. In: Journal of Vertebrate Paleontology 19.1 (1999), pp. 1-7.

[10978] Q. Ji, P. J. Currie, M. A. Norell, and S. -A. Ji. "Two feathered dinosaurs from northeastern China". English. In: Nature 393 (1998), pp. 753-762.

[10979] Q. Ji, S. Ji, H. You, J. Zhang, C. Yuan, X. Ji, J. Li, and Y. Li. "[Discovery of an Avialae bird from China, Shenzhouraptor sinensis gen. et sp. nov]". Chinese. In: Geological Bulletin of China 21.7 (2002), pp. 363-369.

[10980] Q. Ji, S.-A. Ji, J. -C. Lü, H. -L. You, W. Chen, Y. -Q. Liu, and Y. -X. Liu. "First avialan bird from China". English. In: Geological Bulletin of China 24.3 (2005), pp. 197-210.

[10981] Q. Ji and S.-A. Ji. "[Protarchaeopteryx gen. nov.-a new genus of Archaeopterygidae in China]". Chinese. In: Chinese Geology 238.3 (1997), pp. 38-41.

[10982] Q. Ji, S.-a. Ji, and L. -j. Zhang. "First large tyrannosauroid theropod from the Early Cretaceous Jehol Biota in northeastern China". English. In: Geological Bulletin of China 28.10 (2009), pp. 13691374. 
[10983] Q. Ji, J.-c. Lü, X. -f. Wei, and X. -r. Wang. "A new oviraptorosaur from the Yixian Formation of Jianching, western Liaoning Province, China". English. In: Geological Bulletin of China 31.12 (2012), pp. 2102-2107.

[10984] Q. Ji, Z. Luo, and S. -A. Ji. "A Chinese triconodont mammal and mosaic evolution of the mammalian skeleton". English. In: Nature 398 (1999), pp. 326-330.

[10985] Q. Ji, Z.-X. Luo, C. -X. Yuan, J. R. Wible, J. -P. Zhang, and J. A. Georgi. “The earliest known eutherian mammal". English. In: Nature 416 (2002), pp. 816-822.

[10986] Q. Ji, Z.-X. Luo, C. -X. Yuan, and A. R. Tabrum. "A swimming mammaliaform from the middle Jurassic and ecomorphological diversification of early mammals". English. In: Science 311 (2006), pp. 1123-1127.

[10987] Q. Ji, Z.-X. Luo, X. Zhang, C. -X. Yuan, and L. Xu. “Evolutionary Development of the Middle Ear in Mesozoic Therian Mammals". English. In: Science 326 (2009), pp. 278-281. DOI: 10.1126/science. 1178501.

[10988] Q. Ji, M. A. Norell, P. J. Makovicky, K. -Q. Gao, S. Ji, and C. Yuan. "An early ostrich dinosaur and implications for ornithomimosaur phylogeny". English. In: American Museum Novitates 3420 (2003), pp. 1-19.

[10989] Q. Ji and C. Yuan. "Discovery of two kinds of protofeathered pterosaurs in the Mesozoic Daohugou Biota in the Ningcheng Region and its stratigraphic and biologic significances". English. In: Geological Review 48 (2002), pp. 221-224.

[10990] S. Ji and X. Chen. "[A New Early Cretaceous Turtle from Otog Qi, Inner Mongolia, China]". Chinese. In: Acta Geologica Sinica 92.4 (2018), pp. 629-637.

[10991] S. Ji, Q. Ji, J. Lü, and C. Yuan. “A new giant compsognathid dinosaur with long filamentous integuments from Lower Cretaceous of northeastern China". English. In: Acta Geologica Sinica 81.1 (2007), pp. 8-15.

[10992] S. Ji and Q. Ji. “The first Mesozoic frog from China (Amphibia: Anura), Liaobatrachus grabaui gen. et sp. nov." Chinese. In: Chinese Geology 250 (1998), pp. 39-42.

[10993] S. Ji, L. Zhang, L. Lu, and J. Hao. "The first discovery of the Late Cretaceous protoceratopsid fauna from Alxa, Inner Mongolia, China". English. In: Acta Geologica Sinica (English Edition) 91.5 (2017), pp. 1908-1909.

[10994] S.-A. Ji. "A new Early Cretaceous lizard with well-preserved scale impressions from western Liaoning, China". English. In: Progress in Natural Science 15.2 (2005), pp. 162-168.

[10995] S.-A. Ji, Q. Ji, and K. Padian. "Biostratigraphy of two new pterosaurs from China". English. In: Nature 398 (1999), pp. 573-574.

[10996] S.-A. Ji and Q. Ji. "Postcranial anatomy of the Mesozoic Dalinghosaurus (Squamata): evidence from a new specimen of Western Liaoning". English. In: Acta Geologica Sinica 78.4 (2004), pp. 897906.

[10997] S.-A. Ji, J. Atterholt, J. K. O'Connor, M. C. Lamanna, J. D. Harris, D. -Q. Li, H. -L. You, and P. Dodson. "A new, three-dimensionally preserved enantiornithine bird (Aves: Ornithothoraces) from Gansu Province, north-western China". English. In: Zoological Journal of the Linnean Society 162 (2011), pp. 201-219. DOI: 10.1111/j.1096-3642.2010.00671.x.

[10998] S.-A. Ji and Q. Ji. "The first discovery of a pterosaur from western Liaoning Province (Eosipterus yangi gen. et sp. nov.)" Chinese. In: Acta Geologica Sinica 71.1 (1997), pp. 1-6.

[10999] Z. Ji and C. R. Barnes. "Uppermost Cambrian and Lower Ordovician conodont biostratigraphy of the Survey Peak Formation (Ibexian/Tremadoc), Wilcox Pass, Alberta, Canada". English. In: Journal of Paleontology 70.5 (1996), pp. 871-890.

[11000] C. Jia, C. A. Forster, X. Xu, and J. M. Clark. "The first stegosaur (Dinosauria, Ornithischia) from the Upper Jurassic Shishugou Formation of Xinjiang, China". English. In: Acta Geologica Sinica 81.3 (2007), pp. 351-356. 
[11001] J. Jia and K.-Q. Gao. “A new hynobiid-like salamander (Amphibia, Urodela) from Inner Mongolia, China, provides a rare case study of developmental features in an Early Cretaceous fossil urodele". English. In: PeerJ 4 (2016), e2499:1-44.

[11002] J. Jia and K.-Q. Gao. "A new basal salamandroid (Amphibia, Urodela) from the Late Jurassic of Qinglong, Hebei Province, China". English. In: PLoS ONE 11 (2016), e0153834.

[11003] J. Jia and K.-Q. Gao. "A new stem hynobiid salamander (Urodela, Cryptobranchoidea) from the Upper Jurassic (Oxfordian) of Liaoning Province, China". English. In: Journal of Vertebrate Paleontology 39.2 (2019), e1588285. DOI: 10.1080/02724634.2019.1588285.

[11004] T. Jia, H. B. Liang, H. L. Chang, and D. Ren. "A new genus and species of fossil Eodromeinae from the Yixian Formation of Western Liaoning, China (Coleoptera: Adephaga: Trachypachidae)". English. In: Zootaxa 2736 (2011), pp. 63-68.

[11005] B. Y. Jiang, C. Huawei, and S. Jingeng. "Early Cretaceous Aucellina (bivalvia) from the Dajiashan area, northeastern China". In: Journal of Asian Earth Sciences 23 (2004), pp. 365-371.

[11006] D. Jiang, R. Motani, W. Hao, L. Schmitz, O. Rieppel, Y. Sun, and Z. Sun. “New primitive ichthyosaurian (Reptilia, Diapsida) from the Middle Triassic of Panxian, Guizhou, southwestern China and its position in the Triassic biotic recovery". English. In: Progress in Natural Science 18 (2008), pp. 13151319.

[11007] D.-Y. Jiang, R. Motani, W. -C. Hao, O. Rieppel, Y. -L. Sun, L. Schmitz, and Z. -Y. Sun. “First record of Placodontoidea (Reptilia, Sauropterygia, Placodonta) from the Eastern Tethys". English. In: Journal of Vertebrate Paleontology 28.3 (2008), pp. 904-908. DOI: 10.1671 / 0272-4634(2008) 28[904: FROPRS]2.0.CO;2.

[11008] D.-Y. Jiang, W.-C. Hao, M. W. Maisch, A. T. Matzke, and Y. -L. Sun. “A basal mixosaurid ichthyosaur from the Middle Triassic of China". English. In: Palaeontology 48.4 (2005), pp. 869-882.

[11009] D.-Y. Jiang, W.-B. Lin, R. Motani, and Z. -Y. Sun. "A new Anisian (Middle Triassic) eosauropterygian (Reptilia, Sauropterygia) from Panzhou, Guizhou Province, China". English. In: Journal of Vertebrate Paleontology 38.4 (2018), pp. 1-9. DOI: 10.1080/02724634.2018.1480113.

[11010] D.-Y. Jiang, M. W. Maisch, W. -C. Hao, Y. O. Sun, and Z. -Y. Sun. “Nothosaurus yangyuanensis n. sp. (Reptlia, Sauropterygia, Nothosauridae) from the middle Anisian (Middle Triassic) of Guizhou, southwestern China". English. In: Neues Jahrbuch für Geologie und Paläontologie Monatschefte 2006.5 (2006), pp. 257-276.

[11011] D.-Y. Jiang, M. W. Maisch, Y. -L. Sun, A. T. Matzke, and W. -C. Hao. “A new species of Xinpusaurus (Thalattosauria) from the Upper Triassic of China". English. In: Journal of Vertebrate Paleontology 24 (2004), pp. 80-88.

[11012] D.-Y. Jiang, M. W. Maisch, Z. -Y. Sun, Y. -L. Sun, and W. -C. Hao. “A new species of Lariosaurus (Reptilia, Sauropterygia) from the Middle Anisian (Middle Triassic) of southwestern China". English. In: Neues Jahrbuch für Geologie und Paläontologie-Abhandlungen 242.1 (2006), pp. 19-42. DOI: $10.1127 /$ njgpa/242/2006/19.

[11013] D.-Y. Jiang, R. Motani, J. -D. Huang, A. Tintori, Y. -C. Hu, O. Rieppel, N. C. Fraser, C. Ji, N. P. Kelley, W. -L. Fu, and R. Zhang. "A large aberrant stem ichthyosauriform indicating early rise and demise of ichthyosauromorphs in the wake of the end-Permian extinction". English. In: Scientific Reports 6 (2016), 26232:1-9. DOI: 10.1038/srep26232.

[11014] D.-Y. Jiang, R. Motani, A. Tintori, O. Rieppel, G. -B. Chen, J. -D. Huang, R. Zhang, Z. -Y. Sun, and C. Ji. "The Early Triassic eosauropterygian Majiashanosaurus discocoracoidis, gen. et sp. nov. (Reptilia, Sauropterygia), from Chaohu, Anhui Province, People's Republic of China". English. In: Journal of Vertebrate Paleontology 34.5 (2014), pp. 1044-1052. DOI: 10.1080/02724634.2014.846264.

[11015] D.-Y. Jiang, R. Motani, A. Tintori, O. Rieppel, C. Ji, M. Zhou, X. Wang, H. Lu, and Z. -G. Li. “Evidence supporting predation of 4-m marine reptile by Triassic megapredator". English. In: iScience (2020), p. 101347. 
[11016] D.-Y. Jiang, L. Schmitz, R. Motani, W. -C. Hao, and Y. -L. Sun. “The mixosaurid ichthyosaur Phalarodon cf. P. Fraasi from the Middle Triassic of Guizhou Province, China". English. In: Journal of Paleontology 81.3 (2007), pp. 602-605.

[11017] G. Jiang, N. Christie-Blick, A. J. Kaufman, D. M. Banerjee, and V. Rai. "Sequence stratigraphy of the Neoproterozoic Infra Krol Formation and Krol Group, Lesser Himalaya, India". English. In: Journal of Sedimentary Research 72.4 (2002), pp. 524-542.

[11018] H. Jiang, J. Chen, E. A. Jarzembowski, and B. Wang. "An enigmatic fossil hairy cicada (Hemiptera, Tettigarctidae) from mid-Cretaceous Burmese amber". English. In: Cretaceous Research 96 (2019), pp. 14-18. DOI: 10.1016/j.cretres.2018.11.010.

[11019] J. Q. Jiang, C. Y. Cai, and D. Y. Huang. "Progonocimicids (Hemiptera, Coleorrhyncha) from the Middle Jurassic Haifanggou Formation, western Liaoning, northeast China support stratigraphic correlation with the Daohugou beds". English. In: Alcheringa 40 (2016), pp. 53-61.

[11020] J. Q. Jiang and D. Y. Huang. “New species of Cicadocoris (Hemiptera: Coleorrhyncha: Progonocimicidae) from mid-Jurassic deposits in northeastern China". English. In: European Journal of Entomology 114 (2017), pp. 355-364.

[11021] R. X. Jiang, Z. H. Liu, and S. Wang. "Fossil evidence for sexual dimorphism in Monotomidae beetles from mid-Cretaceous Burmese amber". English. In: Cretaceous Research 102 (2019), pp. 711. DOI: $10.1016 /$ j.cretres.2019.05.008.

[11022] R. X. Jiang, Z. Peng, and S. Wang. “The oldest Micropeplus (Coleoptera, Staphylinidae, Micropeplinae) species from mid-Cretaceous Burmese amber". English. In: Cretaceous Research 106.104218 (2020). DOI: $10.1016 /$ j.cretres.2019.104218.

[11023] R. X. Jiang, W. C. Song, H. Y. Yang, C. Shi, and S. Wang. “Discovery of the first Onthophilus species from mid-Cretaceous Burmese amber (Coleoptera: Histeridae)". English. In: Cretaceous Research 111.104443 (2020). DOI: 10.1016/j.cretres.2020.104443.

[11024] S. Jiang, X. Cheng, Y. Ma, and X. Wang. "A new archaeopterodactyloid pterosaur from the Jiufotang Formation of western Liaoning, China, with a comparison of sterna in Pterodactylomorpha". English. In: Journal of Vertebrate Paleontology 36.6 (2016), e1212058:1-12. DOI: 10.1080 / 02724634.2016.1212058.

[11025] S. Jiang, S.-A. Ji, and J. Mo. "First record of bystrowianid chroniosuchians (Amphibia: Anthracomorpha) from the Middle Permian of China". English. In: Acta Palaeontologica Sinica 91.5 (2017), pp. 1523-1529.

[11026] S. Jiang, F. Li, G. -Z. Peng, and Y. Ye. "[A new species of Omeisaurus from the Middle Jurassic of Zigong, Sichuan]". Chinese. In: Vertebrata PalAsiatica 49.2 (2011), pp. 185-194.

[11027] S. Jiang and X. Wang. "A new ctenochasmatid pterosaur from the Lower Cretaceous, western Liaoning, China". English. In: Anais da Academia Brasileira de Ciencias 83.4 (2011), pp. 1243-1249.

[11028] S. Jiang, X. Wang, X. Cheng, F. R. Costa, J. Huang, and A. W. A. Kellner. "Short note on an anurognathid pterosaur with a long tail from the Upper Jurassic of China". English. In: Historical Biology 27.6 (2015), pp. 718-722.

[11029] S.-X. Jiang, X.-L. Wang, X. Meng, and X. Cheng. "A new boreopterid pterosaur from the Lower Cretaceous of western Liaoning, China, with a reassessment of the phylogenetic relationships of the Boreopteridae". English. In: Journal of Paleontology 88.4 (2014), pp. 823-828. DOI: 10.1666/13068.

[11030] T. Jiang, J. Szwedo, and B. Wang. "A giant fossil Mimarachnidae planthopper from the midCretaceous Burmese amber (Hemiptera, Fulgoromorpha)". English. In: Cretaceous Research 89 (2018), pp. 183-190.

[11031] T. Jiang, J. Szwedo, and B. Wang. "A unique camouflaged mimarachnid planthopper from midCretaceous Burmese amber". English. In: Scientific Reports 9.13112 (2019), pp. 1-11.

[11032] T. Jiang, J. Szwedo, Z. S. Song, J. Chen, Y. L. Li, and H. Jiang. “Ayaimatum trilobatum gen. et sp. nov. of Mimarachnidae (Hemiptera: Fulgoromorpha) from mid-Cretaceous amber of Kachin (northern Myanmar)". English. In: Acta Palaeontologica Sinica 59 (2020), pp. 70-85. 
[11033] T. Jiang, B. Wang, and J. Szwedo. “The first representative of Progonocimicidae (Hemiptera: Coleorrhyncha) from mid-Cretaceous Burmese amber". English. In: Cretaceous Research 93 (2018), pp. 346359.

[11034] X. Jiang, Y. Liu, S. Ji, X. Zhang, L. Xu, S. Jia, J. Lü, C. Yuan, and M. Li. “Dinosaur-bearing strata and K/T boundary in the Luanchuan-Tantou Basin of western Henan Province, China". English. In: Science China: Earth Sciences 54.8 (2011), pp. 1149-1155. DOI: 10.1007/s11430-011-4186-1.

[11035] X. K. Jiang, W. A. Shear, D. A. Hennen, H. M. Chen, and Z. C. Xie. “One hundred million years of stasis: Siphonophora hui sp. nov., the first Mesozoic sucking millipede (Diplopoda: Siphonophorida) from mid-Cretaceous Burmese amber". English. In: Cretaceous Research 97 (2019), pp. 34-39. DOI: 10.1016/j.cretres.2019.01.011.

[11036] Z. Y. Jiang, Y. G. Li, C. J. Song, H. L. Shi, Y. Liu, R. Chen, and F. L. Kong. "A new species of the genus Notocupes from mid-Cretaceous Burmese amber (Coleoptera: Archostemata: Ommatidae)". English. In: Cretaceous Research 108.104335 (2020). DOI: 10.1016/j.cretres.2019.104335.

[11037] Q. Jiangzuo, J. P. Liu, J. Wagner, W. Dong, and J. Chen. "Taxonomical revision of fossil Canis in Middle Pleistocene sites of Zhoukoudian, Beijing, China and a review of fossil records of Canis mosbachensis variabilis in China". English. In: Quaternary International 482 (2018), pp. 93-108. DOI: 10.1016/j.quaint.2018.04.003.

[11038] A. P. Jimenez and J. C. Braga. “Occurence and taphonomy of bivalves from the Nijar reef (Messinian, Late Miocene, SE Spain)”. English. In: Palaeogeography, Palaeoclimatology, Palaeoecology 102 (1993), pp. 239-251.

[11039] E. Jimenez and P. Montoya. "Quelonios del Miocene superior de Crevillente 2 (Alicante, Espana)". Spanish. In: Studia Geologica Salmanticensia 38 (2002), pp. 87-103.

[11040] E. Jimenez Fuentes. "Los Pelomedusidae (Chelonia) del Eoceno de Corrales del Vino (Zamora, Espana)". Spanish. In: Studia Geologica Salmanticensia 43.2 (2007), pp. 227-245.

[11041] E. Jimenez Fuentes. “Tortugas gigantes fosiles de la Provincia de Segovia (Castilla y Leon, España). Nueva localidad: Chañe". Spanish. In: Studia Geologica Salmantisensia 36 (2000), pp. 109-115.

[11042] E. Jimenez Fuentes, S. Gil, and S. Pollos. "Quelonios del Pleistoceno medio de Las Grajas (Archidona: Málaga)”. Spanish. In: Studia Geologica Salmantisensia 31 (1995), pp. 55-62.

[11043] N. Jiménez Hernández, E. Martnez Lafuente, I. Daz-Martnez, and F. Pérez-Lorente. “Icnitas terópodas (Dinosauria) muy grandes en el Grupo de Enciso, yacimiento de Los Piojos (Igea, La Rioja, España) [Very large theropod (Dinosauria) tracks in the Enciso Group, Los Piojos locality (Igea, La Rioja, Spain)]". Spanish. In: Zuba 30 (2012), pp. 29-43.

[11044] A. Jiménez Vela and F. Pérez-Lorente. "El Corral del Totico. Dos nuevos yacimientos con pistas singulares. (Enciso, La Rioja, España) [El Corral del Totico. Two new localities with unique tracks. (Enciso, La Rioja, Spain)]". Spanish. In: Zuba Monográfico 18-19 (2007), pp. 115-144.

[11045] E. Jiménez-Hidalgo and V. M. Bravo-Cuevas. "A Roe Deer from the Pliocene of Hidalgo, Central Mexico". English. In: Acta Palaeontologica Polonica 60.4 (2015), pp. 807-813.

[11046] E. Jimenez-Hidalgo, O. Carranza-Castaneda, and M. Montellano-Ballesteros. "A Pliocene record of Capromeryx (Mammalia: Antilocapridae) in Mexico". English. In: Journal of Paleontology 78.6 (2004), pp. 1179-1186.

[11047] E. Jimenez-Hidalgo and O. Carranza-Castaneda. “Blancan Camelids From San Miguel De Allende, Guanajuato, Central Mexico". English. In: Journal of Paleontology 84.1 (2010), pp. 51-65. DOI: 10.1666/08-154.1.

[11048] E. Jimenez-Hidalgo, R. Guerrero-Arenas, and K. T. Smith. "Gregorymys veloxikua, the oldest pocket gopher (Rodentia: Geomyidae), and the early diversification of Geomyoidea". English. In: Journal of Mammalian Evolution 25 (2018), pp. 427-439.

[11049] E. Jiménez-Hidalgo, R. Hernández-Rivera, and L. Ortega-Palacios. New Late Cretaceous vertebrate tracks from the Sabinas basin, northeastern Coahuila, northeastern Mexico. English. 2004. 
[11050] E. Jiménez-Hidalgo, K. T. Smith, R. Guerrero-Arenas, and J. Alvarado-Ortega. "The first Late Eocene continental faunal assemblage from tropical North America". English. In: Journal of South American Earth Sciences 57 (2015), pp. 39-48.

[11051] P. Jiménez-Huidobro, M. W. Caldwell, I. Paparella, and T. S. Bullard. "A new species of tylosaurine mosasaur from the upper Campanian Bearpaw". English. In: Journal of Systematic Palaeontology (2018). DOI: 10.1080/14772019.2018.1471744.

[11052] P. Jiménez-Huidobro and M. W. Caldwell. "Reassessment and reassignment of the early Maastrichtian mosasaur Hainosaurus bernardi Dollo, 1885, to Tylosaurus Marsh, 1872". English. In: Journal of Vertebrate Paleontology 36.3 (2016), e1096275:1-13.

[11053] P. Jiménez-Huidobro, R. A. Otero, S. Soto-Acuña, and M. W. Caldwell. "Reassessment of cf. Plotosaurus from the upper Maastrichtian of Chile, with comments on the South American distribution of halisaurine mosasaurs". English. In: Cretaceous Research 103 (2019), 104162:1-9. DOI: 10.1016/j. cretres.2019.06.008.

[11054] K. Jiménez-Lara. "Systematic revision and redefinition of the genus Scirrotherium Edmund and Theodor, 1997 (Cingulata, Pampatheriidae): Implications for the origin of pampatheriids and the evolution of the South American lineage including Holmesina". English. In: Geobios (2020). DOI: 10.1016/j.geobios.2020.07.002.

[11055] A. Jiménez-Sánchez. “The upper Katian (Ordovician) bryozoans from the Eastern Iberian Chains (NE Spain)". English. In: Bulletin of Geosciences 84.4 (2009), pp. 687-738. DOI: 10.3140/bull.geosci. 1156.

[11056] A. Jiménez-Sánchez, R. L. Anstey, and B. Azanza. “Description and phylogenetic analysis of Iberostomata fombuenensis new genus and species (Bryozoa, Ptilodictyina)". English. In: Journal of Paleontology 84.4 (2010), pp. 695-708. DOI: 10.1666/09-068.1.

[11057] A. Jiménez-Sánchez, E. Vennin, and E. Villas. "Trepostomate bryozoans from the upper Katian (Upper Ordovician) of Morocco: gigantism in high latitude Gondwana platforms". English. In: Journal of Paleontology 89.2 (2015), pp. 195-221.

[11058] A. Jiménez-Sánchez, E. Villas, and E. Vennin. “New trepostomate bryozoans from the Upper Ordovician of Morocco and the temperature influence on zooid size". English. In: Journal of Paleontology (2015), pp. 1-20. DOI: 10.1017/jpa.2015.20,Publishedonline:21September2015.

[11059] C. Jin, R. L. Ciochon, W. Dong, R. M. Hunt Jr., J. Liu, M. Jaeger, and Q. Zhu. "The first skull of the earliest giant panda". English. In: Proceedings of the National Academy of Sciences 104 (2007), pp. 10932-10937.

[11060] C. Jin, W. Dong, J. -y. Liu, G. -b. Wei, Q. -q. Xu, J. -j. Zheng, L. -t. Zheng, L. -g. Han, and F. z. Wang. "A preliminary study of the early Pleistocene deposits and the mammalian fauna from the Renzi Cave, Fancheng, Anhui, China". English. In: Acta Anthropologica Sinica 19.supplement (2000), pp. 235-245.

[11061] F. Jin. "[A new genus and species of Hiodontidae from Xintai, Shandong]". Chinese. In: Vertebrata PalAsiatica 29.1 (1991), pp. 46-54.

[11062] F. Jin. "Notes on the Discovery of Birgeria in China". English. In: Vertebrata PalAsiatica 39.3 (2001), pp. 168-176.

[11063] F. Jin, N. Z. Wang, and Z. Q. Cai. "A revision of the perleidid fishes from the lower Yangtze region of South China - second report on the fish sequence study near the Permian-Triassic boundary in South China". Chinese. In: Vertebrata PalAsiatica 41 (2003), pp. 169-184.

[11064] H.-Y. Jin. "Middle Eocene mammals of Jeminay, Xinjiang”. English. In: Vertebrata PalAsiatica 38.2 (2000), pp. 135-146.

[11065] J. Jin. "The Early Silurian brachiopod Eocoelia from the Hudson Bay Basin, Canada". English. In: Palaeontology 46.5 (2003), pp. 885-902.

[11066] J. Jin. "Reef-dwelling gypiduloid brachiopods in the Lower Silurian Attawapiskat Formation, Hudson Bay region". English. In: Journal of Paleontology 79.1 (2005), pp. 48-62. 
[11067] J. Jin. "Cincinnetina, a new Late Ordovician dalmanellid brachiopod from the Cincinnati type area, USA: implications for the evolution and palaeogeography of the epicontinental fauna of Laurentia". English. In: Palaeontology 55.1 (2012), pp. 205-228. DOI: 10.1111/j.1475-4983.2011. 01113.x.

[11068] J. Jin, W. G. E. Caldwell, and B. S. Norford. "Early Silurian brachiopods and biostratigraphy of the Hudson Bay Lowlands, Manitoba, Ontario and Quebec". English. In: Bulletin Geological Survey of Canada 457 (1993), pp. 1-221.

[11069] J. Jin, W. G. E. Caldwell, and B. S. Norford. "Late Ordovician brachiopods and biostratigraphy of the Hudson Bay Lowlands, northern Manitoba and Ontario". English. In: Bulletin of the Geological Survey of Canada 513 (1997), pp. 1-115.

[11070] J. Jin and B. D. E. Chatterton. "Latest Ordovician-Silurian articulate brachiopods and biostratigraphy of the Avalanche Lake area, southwestern District of Mackenzie, Canada". In: Palaeontographica Canadiana 13 (1997), pp. 1-62.

[11071] J. Jin and P. Copper. "The deep-water brachiopod Dicoelosia King, 1850, from the early Silurian tropical carbonate shelf of Anticosti Island, eastern Canada". In: Journal of Paleontology 73.6 (1999), pp. 1042-1055.

[11072] J. Jin and P. Copper. "Late Ordovician and Early Silurian pentamerid brachiopods from Anticosti Island, Québec, Canada". English. In: Palaeontographica Canadiana 18 (2000), pp. 1-140.

[11073] J. Jin and P. Copper. "Evolution of the Early Silurian rhynchonellide brachiopod Stegerhynchus, Anticosti Island, eastern Canada". English. In: Journal of Paleontology 78.5 (2004), pp. 866-883. DOI: 10.1666/0022-3360(2004)078<0866:EOTESR>2.0.CO;2.

[11074] J. Jin and P. Copper. “Origin and evolution of the early Silurian (Rhuddanian) virgianid". English. In: Bollettino della Societá Paleontologica Italiana 49.1 (2010), pp. 1-11.

[11075] J. Jin and L. E. Popov. "A new genus of Late Ordovician-Early Silurian pentameride brachiopods and its phylogenetic relationships". English. In: Acta Palaeontologica Polonica 53.2 (2008), pp. 221236. DOI: $10.4202 /$ app.2008.0205.

[11076] J. Jin and R. Zhan. "Evolution of the Late Ordovician orthid brachiopod Gnamptorhynchos Jin, 1989 from Platystrophia King, 1850, in North America". In: Journal of Paleontology 74.6 (2000), pp. 983-991.

[11077] J. Jin, R.-B. Zhan, and J. -Y. Rong. "Taxonomic reassessment of two virgianid brachiopod genera from the Upper Ordovician and Lower Silurian of South China". English. In: Journal of Paleontology 80.1 (2006), pp. 72-82. DOI: 10.1666/0022-3360(2006)080[0072:TROTVB]2.0.CO;2.

[11078] J. Jin and R.-b. Zhan. Late Ordovician Articulate Brachiopods from the Red River and Stony Mountain Formations, Southern Manitoba. English. Toronto: NRC Research Press, 2001, pp. 1-117. DOI: 10. $1139 / 9780660182834$.

[11079] L. Jin, J. Chen, S. Zan, and P. Godefroit. "A new basal neoceratopsian dinosaur from the middle Cretaceous of Jilin Province, China". English. In: Acta Geologica Sinica 83.2 (2009), pp. 200-206.

[11080] L. Jin, J. Chen, S. Zan, R. J. Butler, and P. Godefroit. "Cranial anatomy of the small ornithischian dinosaur Changchunsaurus parvus from the Quantou Formation (Cretaceous: Aptian-Cenomanian) of Jilin Province, northeastern China". English. In: Journal of Vertebrate Paleontology 30.1 (2010), pp. 196-214.

[11081] M. J. Jin, A. lipiski, Y. L. Zhou, and H. Pang. "Mesopassandrinae subfam. nov., a basal group of parasitic flat beetle (Coleoptera: Passandridae) from Cretaceous Burmese amber". English. In: Journal of Systematic Palaeontology 17 (2019), pp. 1947-1956. DOI: 10.1080/14772019.2019.1584923.

[11082] X. Jin. "Mesonychids from Lushi Basin, Henan Province, China". English. In: Vertebrata PalAsiatica 43.2 (2005), pp. 151-164.

[11083] X. Jin. "New Mesonychid (Mammalia) material from the lower Paleogene of the Erlian Basin, Nei Mongol, China". English. In: Vertebrata PalAsiatica 50.3 (2012), pp. 245-257. 
[11084] X. Jin, Y. Azuma, F. D. Jackson, and D. J. Varricchio. “Giant dinosaur eggs from the Tiantai basin, Zhejiang province, China". English. In: Canadian Journal of Earth Sciences 44 (2007), pp. 81-88. DOI: 10.1039/E06-077.

[11085] X. Jin, F. D. Jackson, D. J. Varricchio, Y. Azuma, and T. He. “The first Dictyoolithus egg clutches from the Lishui Basin, Zhejiang Province, China". English. In: Journal of Paleontology 30.1 (2010), pp. 188-195.

[11086] X. C. Jin and L. P. Zhan. "Spatial and temporal distribution of the Cryptospirifer fauna (Middle Permian brachiopods) in the Tethyan realm and its paleogeographic implications". English. In: Acta Geologica Sinica 82 (2008), pp. 1-16.

[11087] Y. Jin, Q. Feng, Y. Meng, W. He, and S. Gu. "Albaillellidae (Radiolaria) from the Latest Permian in Southern Guangxi, China". English. In: Journal of Paleontology 81.1 (2007), pp. 9-18.

[11088] Y. G. Jin, X. G. Hou, and H. Y. Wang. "Lower Cambrian pediculate lingulids from Yunnan, China". English. In: Journal of Paleontology 67.5 (1993), pp. 788-798.

[11089] Z. Y. Jin, A. lipiski, H. Pang, and D. Ren. "A new Mesozoic species of soft-bodied plant beetle (Coleoptera: Dascillidae) from the Early Cretaceous of Inner Mongolia, China with a review of fossil Dascillidae". English. In: Annales Zoologici 63 (2013), pp. 501-509.

[11090] X. Jing, S. Stouge, L. Ding, X. Wang, and H. Zhou. “Upper Ordovician conodont biostratigraphy and biofacies from the Sigang section, Neixiang, Henan, central China". English. In: Palaeogeography, Palaeoclimatology, Palaeoecology 480 (2017), pp. 18-32.

[11091] X. Jing, H. Zhou, and X. Wang. “Ordovician (middle Darriwilian - earliest Sandbian) conodonts from the Wuhai area of Inner Mongolia, North China". English. In: 89.5 (2015), pp. 768-790. DOI: 10.1017/jpa.2015.54.

[11092] Z. A. Jinnah and B. Rubidge. "A double-tusked dicynodont and its biostratigraphic significance". English. In: South African Journal of Science 103 (2007), pp. 51-53.

[11093] R. M. Joeckel, J. M. Cunningham, R. G. Corner, G. W. Brown, P. L. Phillips, and G. A. Ludvigson. "Late Albian dinosaur tracks from the cratonic (eastern) margin of the Western Interior Seaway, Nebraska, USA". English. In: Ichnos 11 (2004), pp. 275-284. DOI: 10.1080/10420940490442377.

[11094] G. G. Johannson. "Provenance Constraints on Early Jurassic Evolution of the Northern Stikinian Arc: Laberge Group, Whitehorse Trough, Northwestern British Columbia". English. PhD thesis. Vancouver, 1994.

[11095] G. G. Johannson, P. L. Smith, and S. P. Gordey. "Early Jurassic evolution of the northern Stikinian arc: evidence from the Laberge Group, northwestern British Columbia". English. In: Canadian Journal of Earth Sciences 34 (1997), pp. 1030-1057.

[11096] M. B. Johansen and F. Surlyk. "Brachiopods and the stratigraphy of the Upper Campanian and Lower Maastrichtian Chalk of Norfolk, England". English. In: Palaeontology 33.4 (1990), pp. 823872.

[11097] T. B. Johansen. "Foraging efficiency and small game: The importance of dovekie (Alle alle) in Inughuit subsistence". English. In: Anthropozoologica 48.1 (2013), pp. 75-88. DOI: 10.5252/az2013n1a4.

[11098] K. A. Johanson and W. Wichard. "Caddisflies of Baltic amber 4. New descriptions of Palaeohelicopsyche (Trichoptera, Helicopsychidae)". English. In: Mitteilungen der Münchner Entomologischen Gesellschaft 87 (1997), pp. 101-108.

[11099] K. A. Johanson and W. Wichard. "Caddis flies of Dominican amber X. Fossil species of Helicopsychidae (Trichoptera)". English. In: Mitteilungen aus dem Geologisch-Paläontologischen Institut der Universität Hamburg 79 (1996), pp. 195-209.

[11100] Z. Johanson. "New Information Concerning the Late Cretaceous Marsupial Albertatherium Fox, 1971". English. In: Journal of Vertebrate Paleontology 14.4 (1995), pp. 595-602.

[11101] Z. Johanson. "New marsupial from the Fort Union Formation, Swain Quarry, Wyoming". English. In: Journal of Paleontology 70.6 (1996), pp. 1023-1031. 
[11102] Z. Johanson and P. E. Ahlberg. "A complete primitive rhizodont from Australia". English. In: Nature 394 (1998), pp. 569-573.

[11103] Z. Johanson and P. E. Ahlberg. "Devonian rhizodontids and tristichopterids (Sarcopterygii; Tetrapodomorpha) from East Gondwana". English. In: Transactions of the Royal Society of Edinburgh 92 (2001), pp. 43-74.

[11104] Z. Johanson, J. A. Long, J. A. Talent, P. Janvier, and J. W. Warren. “New onychodontiform (Osteichthyes; Sarcopterygii) from the Lower Devonian of Victoria, Australia". English. In: Journal of Paleontology 81.5 (2007), pp. 1031-1053.

[11105] Z. Johanson and A. Ritchie. "A new Late Famennian lungfish from New South Wales, Australia, and its bearing on Australian-Asian terrane relations". English. In: Alcheringa 24.2 (2000), pp. 99 118.

[11106] M. J. Johns, C. R. Barnes, and M. J. Orchard. “Taxonomy and biostratigraphy of middle and late Triassic Elasmobranch Ichthyoliths from Northeastern British Columbia". English. In: Geological Survey of Canada Bulletin 502 (1997), pp. 1-238.

[11107] R. A. Johns. "Ordovician lithistid sponges of the Great Basin". English. In: Nevada Bureau of Mines and Geology Open-File Report 94.1 (1994), pp. 1-156.

[11108] R. A. Johns, B. F. Dattilo, and B. Spincer. "Neotype and redescription of the Upper Cambrian anthaspidellid sponge, Wilbernicyathus donegani Wilson, 1950". English. In: Journal of Paleontology 81.3 (2007), pp. 435-444.

[11109] A. K. Johnson, P. Rat, and J. Lang. "Le bassin sedimentaire a phosphates du Togo (MaastrichtienEocene): stratigraphie, environments et evolution". French. In: Journal of African Earth Sciences 30.1 (2000), pp. 183-200.

[11110] C. Johnson, D. Agosti, J. H. Delabie, K. Dumpert, D. J. Williams, M. von Tschirnhaus, and U. Maschwitz. "Acropyga and Azteca ants (Hymenoptera: Formicidae) with scale insects (Sternorrhyncha: Coccoidea): 20 million years of intimate symbiosis". English. In: American Museum Novitates 3335 (2001), pp. 1-18.

[11111] C. C. Johnson, J. K. Njau, D. Van Damme, K. Schick, and N. Toth. "Paleoecologic significance of malacofauna, Olduvai Gorge, Tanzania". English. In: Palaios 31 (2016), pp. 319-326.

[11112] E. Johnson. "The taphonomy of mammoth localities in southeastern Wisconsin (USA)". English. In: Quaternary International 143-143 (2006), pp. 58-78. DOI: 10.1016/j.quaint.2005.03.005.

[11113] G. D. Johnson. "Ctenacanthiform cladodont teeth from the Lower Permian Wichita Group, Texas, U.S.A." English. In: Acta Geologica Polonica 58 (2008), pp. 205-209.

[11114] G. D. Johnson. "Dentitions of Barbclabornia (new genus, Chondrichthyes: Xenacanthiformes) from the Upper Palaeozoic of North America". English. In: Mitteilungen aus dem Museum für Naturkunde in Berlin, Geowissenschaftliche Reihe 6 (2003), pp. 125-160.

[11115] G. D. Johnson and D. W. Thayer. "Early Pennsylvanian Xenacanth Chondrichthyans from the Swisshelm Mountains, Arizona, USA". English. In: Acta Palaeontologica Polonica 54.4 (2009), pp. 649 688.

[11116] J. G. Johnson and R. B. Blodgett. "Russian Devonian Brachiopod Genera Cyrtinoides and Komiella in North America". English. In: Journal of Paleontology 67.6 (1993), pp. 952-958.

[11117] J. G. Johnson and G. Klapper. "Lower and Middle Devonian Brachiopod-Dominated Communities of Nevada, and Their Position in a Biofacies-Province-Realm Model". English. In: Journal of Paleontology 64.6 (1990), pp. 902-941.

[11118] J. G. Johnson, G. Klapper, and M. Elrick. “Devonian Transgressive-Regressive Cycles and Biostratigraphy, Northern Antelope Range, Nevada: Establishment of Reference Horizons for Global Cycles". English. In: Palaios 11.1 (1996), pp. 3-14. DOI: 10.2307/3515112.

[11119] K. G. Johnson. "Middle Miocene recovery of Caribbean reef corals: new data from the Tamana Formation, Trinidad". In: Journal of Paleontology 75.3 (2001), pp. 513-526. 
[11120] K. G. Johnson. "Reef-coral diversity in the Late Oligocene Antigua Formation and temporal variation of local diversity on Caribbean Cenozoic Reefs". English. In: Fossil Corals and Sponges Proceedings of the 9th Internatinal Symposium on Fossil Cnidaria and Porifera. Vienna : Austian Academny of Sciences Press (2003), pp. 471-492.

[11121] K. G. Johnson and M. X. Kirby. "The Emperador Limestone rediscovered: early miocene corals from the Culebra Formation, Panama". English. In: Journal of Paleontology 80.2 (2006), pp. 283-293.

[11122] K. G. Johnson, M. R. Sanchez-Villagra, and O. A. Aguilera. “The Oligocene-Miocene Transition on Coral Reefs in the Falcon Basin (NM Venezuela)". English. In: Palaios 24 (2009), pp. 59-69.

[11123] K. R. Johnson. Megaflora of the Hell Creek and lower Fort Union Formations in the western Dakotas: Vegetational response to climate change, the Cretaceous-Tertiary boundary event, and rapid marine transgression. Vol. 361. The Hell Creek Formation and the Cretaceous-Tertiary boundary in the northern Great Plains: An integrated continental record of the end of the Cretaceous. 2002, pp. 329-391.

[11124] K. R. Johnson. Denver Museum of Nature E Science archival records of Kirk Johnson fieldwork in Cretaceous rocks of the Rocky Mountain region. 2003.

[11125] M. E. Johnson, B. G. Baarli, J. H. Scott, and Jr. "Colonization and reef growth on a Late Pleistocene rocky shore and shore abrasion platform in Western Australia". English. In: Lethaia 28.1 (1995), pp. 85-98.

[11126] M. E. Johnson and B. G. Baarli. "Erosion and burial of granite rocky shores in the recent and Late Pleistocene of the Seychelles Islands: physical and biological perspectives". English. In: Journal of Coastal Research 21.5 (2005), pp. 867-879.

[11127] M. E. Johnson, J. Ledesma-Vázquez, and B. G. Baarli. “Vertebrate remains on ancient rocky shores: a review with report on hadrosaur bones from the Upper Cretaceous of Baja California (México)". English. In: Journal of Coastal Research 22.3 (2006), pp. 574-580. DOI: 10.2112/04-0168.

[11128] M. E. Johnson, R. A. Lopez-Perez, C. R. Ransom, and J. Ledesma-Vazquez. “Late Pleistocene coralreef development on Isla Coronados, Gulf of California". English. In: Ciencias Marinas 33.2 (2007), pp. 105-120.

[11129] M. E. Johnson and W. S. McKerrow. "The Sutton Stone: an early Jurassic rocky shore deposit in South Wales". In: Palaeontology 38.3 (1995), pp. 529-541.

[11130] M. M. Johnson, M. T. Young, L. Steel, and Y. Lepage. “Steneosaurus edwardsi (Thalattosuchia: Teleosauridae), the largest known crocodylomorph of the Middle Jurassic". English. In: Biological Journal of the Linnean Society 115 (2015), pp. 911-918.

[11131] N. F. Johnson, L. Masner, and L. Musetti. "Review of genera of the Tribe Sparasionini (Hymenoptera: Platygastroidea, Scelionidae), and description of two gew genera from the New World". English. In: American Museum Novitates 3629 (2008), pp. 1-24.

[11132] N. F. Johnson, L. Musetti, and L. Masner. "The Cretaceous scelionid Genus Proteroscelio Brues (Hymenoptera: Platygastroidea)". English. In: American Museum Novitates 3603 (2008), pp. 1-7.

[11133] N. F. Johnson, L. Musetti, and J. W. Janzen. "A new fossil species of the Australian endemic genus Peradenia Naumann \& Masner (Hymenoptera: Proctotrupoidea, Peradeniidae) from Baltic amber". English. In: Insect Systematics \& Evolution 32 (2001), pp. 191-194.

[11134] N. G. Johnson and P. G. Gensel. "A reinterpretation of the Early Devonian land plant, Bitelaria Istchenko and Istchenko, 1979, based on new material from New Brunswick, Canada". In: Review of Palaeobotany and Palynology 74 (1992), pp. 109-138.

[11135] R. G. Johnson and R. A. Fortey. "Proetid Trilobites from the Lower Devonian (Pragian) Ihandar Formation, Anti-Atlas, Morocco". English. In: Journal of Paleontology 86.6 (2012), pp. 1032-1050.

[11136] E. Johnson-Ransom and K. Shimada. "Fossil fishes from the Pfeifer Shale Member of the Upper Cretaceous Greenhorn Limestone in north-central Kansas, U.S.A." English. In: Transactions of the Kansas Academy of Science 119 (2016), pp. 201-207. DOI: 10.1660/062.119.0211. 
[11137] E. Johnson-Ransom, K. Shimada, and J. I. Kirkland. “The Late Cretaceous lamniform shark, Cretoxyrhina mantelli, from the Fairport Chalky Shale Member of the Carlile Shale in northeastern Nebraska". English. In: Transactions of the Kansas Academy of Science 119 (2016), pp. 208-210. DOI: 10.1660/062.119.0212.

[11138] E. D. Johnson-Ransom, E. V. Popov, T. A. Deméré, and K. Shimada. “The Late Cretaceous chimaeroid fish, Ischyodus bifurcatus Case (Chondrichthyes: Holocephali), from California, USA, and its paleobiogeographical significance". English. In: Paleontological Research 22 (2018), pp. 364372. DOI: $10.2517 / 2018$ PR004.

[11139] C. T. Johnston. Bioherm Development in the Edgecliff Member of the Onondaga Formation, Port Colburne, Ontario. 1990.

[11140] J. E. Johnston. "Insects, spiders, and plants from the Tallahatta Formation (middle Eocene) in Benton County, Mississippi". English. In: Mississippi Geology 14 (1993), pp. 71-82.

[11141] J. E. Johnston and A. Borkent. "Chaoborus Lichtenstein (Diptera: Chaoboridae) pupae from the Middle Eocene of Mississippi". English. In: Journal of Paleontology 72 (1998), pp. 491-493.

[11142] K. J. Johnston, P. A. Johnston, and W. G. Powell. "A new, Middle Cambrian, Burgess Shale-type biota, Bolaspidella zone, Chancellor Basin, southeastern British Columbia". English. In: Palaeogeography, Palaeoclimatology, Palaeoecology 277 (2009), pp. 106-126.

[11143] P. A. Johnston. "Lower Devonian pelecypods from southeastern Australia". In: Memoir of the Association of Australasian Palaeontologists 14 (1993), pp. 1-134.

[11144] P. A. Johnston, K. J. Johnston, C. J. Collom, W. G. Powell, and R. J. Pollock. “Palaeontology and depositional environments of ancient brine seeps in the Middle Cambrian Burgess Shale at The Monarch, British Columbia, Canada". English. In: Palaeogeography, Palaeoclimatology, Palaeoecology 277 (2009), pp. 86-105.

[11145] A. Jolly and A. Sahni. "Raoellid astragali from the Kalakot zone (Subathu Group): evidence for assignment to the Artiodactyla". English. In: Current Science 59.2 (1990), pp. 102-105.

[11146] S. H. Jon, K. S. So, C. G. Won, and L. J. Hyon. “A new species of Procercopidae (Insecta: Hemiptera) from the Lower Cretaceous of Democratic People's Republic of Korea". English. In: Cretaceous Research 108.104353 (2019). DOI: 10.1016/j.cretres.2019.104353.

[11147] S. H. Jon, C. G. Won, K. S. So, and T. Y. Nam. "New Mesozoic insect fossils from the Democratic People's Republic of Korea". English. In: Cretaceous Research 99 (2019), pp. 240-245. DOI: 10.1016/ j.cretres.2019.02.019.

[11148] C. M. Jones. "The first record of a fossil bird from East Antarctica". English. In: Paleobiology and Paleoenvironments of Eocene Rocks, McMurdo Sound, East Antarctica. Antarctic Research Series. 76 (2000), pp. 359-364.

[11149] D. B. Jones and L. R. G. Desantis. "Dietary ecology of ungulates from the La Brea tar pits in southern California: A multi-proxy approach". English. In: 465.15 (2017), pp. 110-127.

[11150] D. S. Jones, B. J. MacFadden, S. D. Webb, P. A. Mueller, D. A. Hodell, and T. S. Cronin. "Integrated geochronology of a classic Pliocene fossil site in Florida: Linking marine and terrestrial biochronologies". English. In: Journal of Geology 99.5 (1991), pp. 637-648.

[11151] M. E. H. Jones. “The Early Jurassic clevosaurs from China (Diapsida: Lepidosauria)”. English. In: vol. 37. The Triassic-Jurassic Terrestrial Transition. New Mexico Museum of Natural History and Science Bulletin. Albuquerque: New Mexico Museum of Natural History and Science, 2006, pp. 548-562.

[11152] M. E. H. Jones, C. L. Anderson, C. A. Hipsley, J. Müller, S. E. Evans, and R. R. Schoch. “Integration of molecules and new fossils supports a Triassic origin for Lepidosauria (lizards, snakes, and tuatara)". English. In: BMC Evolutionary Biology 13.208 (2013). DOI: 10.1186/1471-2148-13-208.

[11153] M. E. H. Jones, S. E. Evans, and D. Sigogneau-Russell. "Early Cretaceous frogs from Morocco". English. In: Annals of Carnegie Museum 72.2 (2003), pp. 65-97. 
[11154] M. E. H. Jones, A. J. D. Tennyson, J. P. Worthy, S. E. Evans, and T. H. Worthy. “A sphenodontine (Rhynchocephalia) from the Miocene of New Zealand and palaeobiogeography of the tuatara (Sphenodon)". English. In: Proceedings of the Royal Society B 276 (2009), pp. 1385-1390. DOI: 10. 1098/rspb.2008.1785.

[11155] M. F. Jones, P. M. C. Coster, A. Licht, G. Métais, F. Ocakolu, M. H. Taylor, and K. C. Beard. “A stem bat (Chiroptera: Palaeochiropterygidae) from the late middle Eocene of northern Anatolia: implications for the dispersal and palaeobiology of early bats". English. In: Palaeobiodiversity and Palaeoenvironments (2018). DOI: 10.1007/s12549-018-0338-z.

[11156] R. W. Jones. "Aspects of the Cenozoic stratigraphy of the Northern Sulaiman Ranges, Pakistan". English. In: Micropaleontology 16 (1997), pp. 51-58.

[11157] T. L. Jones, J. F. Porcasi, J. M. Erlandson, H. Dallas, T. A. Wake, and R. Schwaderer. "The protracted Holocene extinction of California's flightless sea duck (Chendytes lawi) and its implications for the Pleistocene overkill hypothesis". English. In: Proceedings of the National Academy of Sciences 105.11 (2008), pp. 4105-4108.

[11158] W. Jones, A. Rinderknecht, H. Alvarenga, F. Montenegro, and M. Ubilla. "The last terror birds (Aves, Phorusrhacidae): new evidence from the late Pleistocene of Uruguay". English. In: PalZ 92 (2018), pp. 365-372.

[11159] W. T. Jones, R. M. Feldmann, and A. Garassino. “Three new isopod species and a new occurrence of the tanaidacean Niveotanais brunnensis Polz, 2005 from the Jurassic Plattenkalk Beds of Monte Fallano, Italy". English. In: Journal of Crustacean Biology 34.6 (2014), pp. 739-753.

[11160] W. T. Jones, R. M. Feldmann, C. E. Schweitzer, A. Reitano, and G. Insacco. “New pygocephalomorph (Peracarida) from the Permian of the Sosio Valley (Sicily, Italy)". English. In: Journal of Crustacean Biology 35 (2015), pp. 627-632.

[11161] S. Jones O'Day. "Late Prehistoric Lucayan occupation and subsistence on Middle". English. In: Caribbean Journal of Science 38 (2002), pp. 1-10.

[11162] P. Joniak and H. De Bruijn. "Rodents from the Upper Miocene Tulu Formation (Çankr Basin, Central Anatolia, Turkey)". English. In: Paläontologische Zeitschrift 89.4 (2015), pp. 1039-1056. DOI: 10.1007/s12542-015-0257-5.

[11163] P. Joniak, P. Paláez-Campomanes, S. Mayda, M. Bilgin, K. Halaçar, and L. W. van den Hoek Ostende. "New faunas of small mammals from old Harami Mine (early Miocene, Anatolia, Turkey)". English. In: Palaeobiodiversity and Palaeoenvironments 99 (2019), pp. 673-700.

[11164] P. Joniak, P. Peláez-Campomanes, L. W. van den Hoek Ostende, and B. Rojay. “Early Miocene rodents of Gökler (Kazan Basin, Central Anatolia, Turkey)". English. In: Historical Biology 31.8 (2017), pp. 982-1007. DOI: 10.1080/08912963.2017.1414211.

[11165] G. J. Jordan. "Early Middle Pleistocene leaves of extinct and extant Proteaceae from western Tasmania, Australia". English. In: Botanical Journal of the Linnean Society 118 (1995), pp. 19-35.

[11166] G. J. Jordan. "Extinct conifers and conifer diversity in the Early Pleistocene of western Tasmania". English. In: Review of Palaeobotany and Palynology 84 (1995), pp. 375-387.

[11167] G. J. Jordan. "Evidence of Pleistocene plant extinction and diversity from Regatta Point, western Tasmania, Australia". English. In: Botanical Journal of the Linnean Society 123 (1997), pp. 45-71.

[11168] G. J. Jordan, J. M. Bannister, D. C. Mildenhall, R. Zetter, and D. E. Lee. "Fossil Ericaceae from New Zealand: Deconstructing the Use of Fossil Evidence in Historical Biogeography". English. In: American Journal of Botany 97.1 (2010), pp. 59-70. DOI: 10.3732/ajb.0900109.

[11169] G. J. Jordan, K. E. Bromfield, J. M. K. Sniderman, and D. Crayn. “Diverse fossil Epacrids (Styphelioideae; Ericaceae) from early pleistocene sediments at Stony Creek basin, Victoria, Australia". English. In: International Journal of Plant Sciences 168.9 (2007), pp. 1359-1376. DOI: 10.1086/521686.

[11170] G. J. Jordan, R. J. Carpenter, and R. S. Hill. "The Macrofossil Record of Proteaceae in Tasmania: a Review with New Species". English. In: Australian Systematic Botany 11.4 (1998), pp. 465-501. DOI: 10.1071/SB97020. 
[11171] G. J. Jordan, R. J. Carpenter, J. M. Bannister, D. E. Lee, D. C. Mildenhall, and R. S. Hill. “High conifer diversity in Oligo Miocene New Zealand". English. In: Australian Systematic Botany 24 (2011), pp. 121-136.

[11172] G. J. Jordan and M. K. Macphail. "A Middle-Late Eocene inflorescence of Caryophyllaceae from Tasmania, Australia". In: American Journal of Botany 90 (2003), pp. 761-768.

[11173] G. J. Jordan, M. K. Macphail, R. Barnes, and R. S. Hill. “An Early to Middle Pleistocene Flora of Subalpine Affinities in Lowland Western Tasmania". English. In: Australian Journal of Botany 43.2 (1995), pp. 231-242. DOI: 10.1071/BT9950231.

[11174] C. F. Jordan Jr. and M. Abdullah. Arun Field Indonesia, North Sumatra Basin, Sumatra. English. Atlas of Oil and Gas Fields, Stratigraphic Traps III, AAPG, Treatise of Petroleum Geology. 1992, pp. 139.

[11175] A. V. Joshi. "New occurrence of dinosaur eggs from Lameta rocks (Maestrichtian) near Bagh, Madhya Pradesh". English. In: Journal of the Geological Society of India 46 (1995), pp. 439-443.

[11176] J. Jost, D. Kälin, S. Börner, D. Vasilyan, D. Lawver, and B. Reichenbacher. “Vertebrate microfossils from the Upper Freshwater Molasse in the Swiss Molasse Basin: Implications for the evolution of the North Alpine Foreland Basin during the Miocene Climate Optimum". English. In: Palaeogeography, Palaeoclimatology, Palaeoecology 426 (2015), pp. 22-33. DOI: 10.1016/j.palaeo.2015.02.028.

[11177] C. Jouault, A. Nel, and V. Perrichot. “New evanioid wasps (Hymenoptera: Praeaulacidae, Aulacidae) from Cenomanian Burmese amber". English. In: Cretaceous Research 110.104407 (2020). DOI: 10. 1016/j.cretres.2020.104407.

[11178] C. Jouault, V. Ngo-Muller, J. M. Pouillon, and A. Nel. "Taxonomic additions to the pelecinid wasps (Hymenoptera, Pelecinidae) of the 'mid-Cretaceous' Burmese amber". English. In: Cretaceous Research 114.104505 (2020). DOI: 10.1016/j.cretres.2020.104505.

[11179] C. Jouault, V. Perrichot, and A. Nel. "A new genus and species of parasitic wasps (Hymenoptera: Diapriidae) from Hkamti mid-Cretaceous Burmese amber". English. In: Cretaceous Research 115.104533 (2020). DOI: 10.1016/j.cretres.2020.104533.

[11180] C. Jouault, A. P. Rasnitsyn, and V. Perrichot. "A new myanmarinid wasp (Hymenoptera: Stephanoidea) from mid-Cretaceous Burmese amber". English. In: Cretaceous Research 116.104621 (2020). DOI: 10.1016/j.cretres.2020.104621.

[11181] C. Jouault, A. P. Rasnitsyn, and V. Perrichot. “Ohlhoffiidae, a new Cretaceous family of basal parasitic wasps (Hymenoptera: Stephanoidea)". English. In: Cretaceous Research 117.104635 (2020). DOI: $10.1016 /$ j.cretres.2020.104635.

[11182] C. Jouault, M. M. Solórzano-Kraemer, and V. Perrichot. “New eremoneuran flies (Diptera: Eremoneura) from Cretaceous Charentese amber". English. In: Palaeoentomology 3 (2020), pp. 492499.

[11183] S. Jouve. "Taxonomic revision of the Dyrosaurid Assemblage (Crocodyliformes: Mesoeucrocodylia) from the Paleocene of the Iullemmeden Basin, West Africa". English. In: Journal of Paleontology 81.1 (2007), pp. 163-175.

[11184] S. Jouve. "A new description of the skull of Dyrosaurus phosphaticus (Thomas, 1893) (Mesoeucrocodylia: Dyrosauridae) from the Lower Eocene of North Africa". English. In: Canadian Journal of Earth Sciences 42 (2005), pp. 323-337.

[11185] S. Jouve. "The skull of Teleosaurus cadomensis (Crocodylomorpha; Thalattosuchia), and phylogenetic analysis of Thalattosuchia". English. In: Journal of Vertebrate Paleontology 29.1 (2009), pp. 88102.

[11186] S. Jouve. "A new basal tomistomine (Crocodylia, Crocodyloidea) from Issel (Middle Eocene; France): palaeobiogeography of basal tomistomines and palaeogeographic consequences". English. In: Zoological Journal of the Linnean Society 177 (2016), pp. 165-182.

[11187] S. Jouve. "Leiokarinosuchus brookensis, Pholidosaurus meyeri, or Anteophthalmosuchus hooleyi? What is this croc?" English. In: Journal of Vertebrate Paleontology 37.2 (2017), e1297947:1-15. DOI: $10.1080 / 02724634.2017 .1297947$. 
[11188] S. Jouve, N. Bardet, N. -E. Jalil, X. P. Suberbiola, B. Bouya, and M. Amaghzaz. “The oldest African crocodylomorph: phylogeny, paleobiogeography, and differential survivorship of marine reptiles through the Cretaceous-Tertiary boundary". English. In: Journal of Vertebrate Paleontology 28.2 (2008), pp. 409-421.

[11189] S. Jouve, B. Bouya, and M. Amaghzaz. "A short-snouted dyrosaurid (Crocodyliformes, Mesoeucrocodylia) from the Palaeocene of Morocco". English. In: Palaeontology 48.2 (2005), pp. 359-369.

[11190] S. Jouve, B. Bouya, and M. Amaghzaz. "A long-snouted dyrosaurid (Crocodyliformes, Mesoeucrocodylia) from the Paleocene of Morocco: phylogenetic and palaeobiogeographic implications". English. In: Palaeontology 51.2 (2008), pp. 281-294. DOI: 10.1111/j.1475-4983.2007.00747.x.

[11191] S. Jouve, B. Bouya, M. Amaghzaz, and S. Meslouh. "Maroccosuchus zennaroi (Crocodylia: Tomistominae) from the Eocene of Morocco: phylogenetic and palaeobiogeographical implications of the basalmost tomistomine". English. In: Journal of Systematic Palaeontology 13.5 (2015), pp. 421445. DOI: $10.1080 / 14772019.2014 .913078$.

[11192] S. Jouve, C. de Muizon, R. Cespedes-Paz, V. Sossa-Soruco, and S. Knoll. “The longirostrine crocodyliforms from Bolivia and their evolution through the Cretaceous-Palaeogene boundary". English. In: Zoological Journal of the Linnean Society 192.2 (2021), pp. 475-509. DOI: 10.1093 / zoolinnean / zlaa081/5930140.

[11193] S. Jouve, M. Iarochéne, B. Bouya, and M. Amaghzaz. "A new dyrosaurid crocodyliform from the Palaeocene of Morocco and a phylogenetic analysis of Dyrosauridae". English. In: Acta Palaeontologica Polonica 50.3 (2005), pp. 581-594.

[11194] S. Jouve, M. Iarochene, B. Bouya, and M. Amaghzaz. "New material of Argochampsa krebsi (Crocodylia: Gavialoidea) from the Lower Paleocene of the Oulad Abdoun Basin (Morocco): phylogenetic implications". English. In: Geobios 39 (2006), pp. 817-832. DOI: 10.1016/j.geobios.2005. 07.003.

[11195] S. Jouve, M. Iarochene, B. Bouya, and M. Amaghzaz. "A new species of Dyrosaurus (Crocodylomorpha, Dyrosauridae) from the early Eocene of Morocco: phylogenetic implications". English. In: Zoological Journal of the Linnean Society 148 (2006), pp. 603-656.

[11196] S. Jouve and N.-E. Jalil. "Paleocene resurrection of a crocodylomorph taxon: Biotic crises, climatic and sea level fluctuations". English. In: Gondwana Research 85 (2020), pp. 1-18. DOI: 10.1016/j.gr. 2020.03.010.

[11197] S. Jouve, B. Khalloufi, and S. Zouhri. "Longirostrine crocodylians from the Bartonian of Morocco and Paleogene climatic and sea level oscillations in the Peri-Tethys area". English. In: Journal of Vertebrate Paleontology 39.3 (2019), e1617723:1-10. DOI: 10.1080/02724634.2019.1617723.

[11198] S. Jouve, B. Mennecart, J. Douteau, and N. -E. Jalil. “The oldest durophagous teleosauroid (Crocodylomorpha, Thalattosuchia) from the lower Bathonian of central High Atlas, Morocco". English. In: Palaeontology (2016). DOI: 10.1111/pala.12262.

[11199] S. Jouve, V. Sargül, J. -S. Steyer, and S. Sen. “The first crocodylomorph from the Mesozoic of Turkey (Barremian of Zonguldak) and the dispersal of the eusuchians during the Cretaceous". English. In: Journal of Systematic Palaeontology 17.2 (2019), pp. 111-128. DOI: 10.1080/14772019.2017.1393469.

[11200] S. Jouve and D. Schwarz. "Congosaurus bequaerti, a Paleocene Dyrosaurid (Crocodyliformes; Mesoeucrocodylia) from Landana (Angola)". English. In: Bulletin de l'Institut Royal des Sciences Naturelles de Belgique 74 (2004), pp. 129-146.

[11201] W. Joyce and D. K. Zelenitsky. "Turtle egg pseudomorphs from the Late Jurassic of Schamhaupten, Germany". English. In: Archaeopteryx 20 (2002), pp. 57-62.

[11202] W. G. Joyce. "The first complete skeleton of Solnhofia parsoni (Cryptodira, Eurysternidae) from the Upper Jurassic of Germany and its taxonomic implications". English. In: Journal of Paleontology 74.4 (2000), pp. 684-700. DOI: 10.1666/0022-3360(2000)074<0684:TFCSOS>2.0.CO;2.

[11203] W. G. Joyce. "A new Late Jurassic turtle specimen and the taxonomy of Palaeomedusa testa and Eurysternum wagleri”. English. In: PaleoBios 23.3 (2003), pp. 1-8. 
[11204] W. G. Joyce. "A Review of the Fossil Record of Basal Mesozoic Turtles". English. In: Bulletin of the Peabody Museum of Natural History 58.1 (2017), pp. 65-113. DOI: 10.3374/014.058.0105.

[11205] W. G. Joyce. "A Review of the Fossil Record of Turtles of the Clade Pan-Chelydridae". English. In: Bulletin of the Peabody Museum of Natural History 57.1 (2016), pp. 21-56. DOI: 10.3374/014.057.0103.

[11206] W. G. Joyce. "A Review of the Fossil Record of Turtles of the Clade Pan-Carettochelys". English. In: Bulletin of the Peabody Museum of Natural History 55.1 (2014), pp. 3-33.

[11207] W. G. Joyce and J. Anquetin. "A review of the fossil record of non-baenid turtles of the clade Paracryptodira". English. In: Bulletin of the Peabody Museum of Natural History 60.2 (2019), pp. 129155.

[11208] W. G. Joyce and S. Bandyopadhyay. "A reevaluation of the basal turtle Indochelys spatulata from the Early-Middle Jurassic (Toarcian-Aalenian) of India, with descriptions of new material". English. In: PeerJ 8.e8542 (2020), pp. 1-21. DOI: 10.7717/peerj.8542.

[11209] W. G. Joyce and S. Bandyopadhyay. "A revision of the pelomedusoid turtle Jainemys pisdurensis from the Late Cretaceous (Maastrichtian) Lameta Formation of India". English. In: PeerJ 8 (2020), e9330:1-28. DOI: 10.7717 / peerj.9330.

[11210] W. G. Joyce and J. R. Bourque. "A Review of the Fossil Record of Turtles of the Clade PanKinosternoidea". English. In: Bulletin of the Peabody Museum of Natural History 57.1 (2016), pp. 5795.

[11211] W. G. Joyce, S. D. Chapman, R. T. J. Moody, and C. A. Walker. "The skull of the solemydid turtle Helochelydra nopcsai from the Early Cretaceous of the Isle of Wight (UK) and a review of Solemydidae". English. In: Special Papers in Palaeontology 86 (2011), pp. 75-97.

[11212] W. G. Joyce and C. Faux. "Chelys patagonica from the Pliocene of Argentina: Not lost, not valid, not a chelid turtle". English. In: Ameghiniana 45.4 (2008), pp. 801-803.

[11213] W. G. Joyce, S. G. Lucas, T. M. Scheyer, A. B. Heckert, and A. P. Hunt. "A thin-shelled reptile from the Late Triassic of North America and the origin of the turtle shell". English. In: Proceedings of the Royal Society of London B 276 (2009), pp. 507-513. DOI: 10.1098/rspb.2008.1196.

[11214] W. G. Joyce and T. R. Lyson. “New material of Gilmoremys lancensis nov. comb. (Testudines: Trionychidae) from the Hell Creek Formation and the diagnosis of plastomenid turtles". English. In: Journal of Paleontology 5.3 (2011), pp. 422-459.

[11215] W. G. Joyce, T. R. Lyson, and J. I. Kirkland. "An early bothremydid (Testudines, Pleurodira) from the Late Cretaceous (Cenomanian) of Utah, North America". English. In: PeerJ 4.e2502 (2016), pp. 1-22. DOI: $10.7717 /$ peerj.2502.

[11216] W. G. Joyce and T. R. Lyson. "A Review of the Fossil Record of Turtles of the Clade Baenidae". English. In: Bulletin of the Peabody Museum of Natural History 56.2 (2015), pp. 147-183. DOI: 10. 3374/014.056.0203.

[11217] W. G. Joyce, T. R. Lyson, and S. Williams. "New cranial material of Gilmoremys lancensis (Testudines, Trionychidae) from the Hell Creek Formation of southeastern Montana, U.S.A". English. In: Journal of Vertebrate Paleontology 36.6 (2016), e1225748:1-10.

[11218] W. G. Joyce and T. R. Lyson. "The shell morphology of the latest Cretaceous (Maastrichtian) trionychid". English. In: PeerJ 5.e4169 (2017), pp. 1-20. DOI: 10.7717/peerj.4169.

[11219] W. G. Joyce, T. R. Lyson, and J. J. W. Sertich. "A new species of trionychid turtle from the Upper Cretaceous (Campanian)". English. In: Journal of Paleontology 92.6 (2018), pp. 1107-1114. DOI: 10. 1017/jpa.2018.30.

[11220] W. G. Joyce and T. R. Lyson. "Pangshura tatrotia, a new species of pond turtle (Testudinoidea) from the Pliocene Siwaliks of Pakistan". English. In: Journal of Vertebrate Paleontology 8.3 (2010), pp. 449-458.

[11221] W. G. Joyce and M. Mäuser. "New material of named fossil turtles from the Late Jurassic (late Kimmeridgian) of Wattendorf, Germany". English. In: PLoS ONE 15.6 (2020), e0233483:1-20. DOI: 10.1371/journal.pone.0233483. 
[11222] W. G. Joyce and M. A. Norell. "Zangerlia ukhaachelys, new species, a nanhsiungchelyid turtle from the Late Cretaceous of Ukhaa Tolgod, Mongolia". English. In: American Museum Novitates 3481 (2005), pp. 1-19.

[11223] W. G. Joyce, A. Petrievi, T. R. Lyson, and N. J. Czaplewski. "A new box turtle from the Miocene/Pliocene boundary (latest Hemphillian) of Oklahoma and a refined chronology of box turtle diversification". English. In: Journal of Paleontology 86.1 (2012), pp. 177-190. DOI: 10.1666/11-073.1.

[11224] W. G. Joyce, M. Rabi, J. M. Clark, and X. Xu. "A toothed turtle from the Late Jurassic of China and the global biogeographic history of turtles". English. In: BMC Evolutionary Biology 16.236 (2016), pp. 1-29. DOI: 10.1186/s12862-016-0762-5.

[11225] W. G. Joyce, A. Revan, T. R. Lyson, and I. G. Danilov. “Two new plastomenine softshell turtles from the Paleocene of Montana and Wyoming". English. In: Bulletin of the Peabody Museum of Natural History 50.2 (2009), pp. 307-325.

[11226] W. G. Joyce, V. S. Volpato, and Y. Rollot. "The skull of the carettochelyid turtle Anosteira pulchra from the Eocene (Uintan) of Wyoming and the carotid canal system of carettochelyid turtles". English. In: Fossil Record 21 (2018), pp. 301-310. DOI: 10.5194/fr-21-301-2018.

[11227] W. J. Joyce, D. B. Brinkman, and T. R. Lyson. "A new species of trionychid turtle, Axestemys infernalis sp. nov., from the Late Cretaceous (Maastrichtian) Hell Creek and Lance formations of the Northern Great Plains, USA". English. In: Palaeontologia Electronica 22.3 (2019), 72:1-28.

[11228] W. J. Joyce, Y. Rollot, and R. L. Cifelli. "A new species of baenid turtle from the Early Cretaceous Lakota Formation of South Dakota". English. In: Fossil Record 23 (2020), pp. 1-23. DOI: 10.5194/fr23-1-2020.

[11229] G. H. Juarez. Asphellus elizabethae n. sp. (Trilobita) de la formación Iscayachi. English. Memorias del XX Congresso Geologico Boliviano. 2018, pp. 153-156.

[11230] R. D. Juárez Valieri and J. O. Calvo. Revision of MUCPv 204, a Senonian basal titanosaur from northern Patagonia. English. Dinosaurios y Paleontologa desde América Latina. Anales del III Congreso Latinoamericano de Paleontologa. Editorial de la Universidad Nacional de Cuyo, Neuquén. 2011, pp. 143-152.

[11231] R. D. Juárez Valieri, J. O. Calvo, and S. D. Rios Daz. Sauropods crossing formations: biostratigraphical implications for Patagonian faunal assemblages. English. Dinosaurios y Paleontologa desde América Latina. Anales del III Congreso Latinoamericano de Paleontologa. Editorial de la Universidad Nacional de Cuyo, Neuquén. 2011, pp. 153-160.

[11232] R. D. Juárez Valieri, J. A. Haro, L. E. Fiorelli, and J. O. Calvo. “A new hadrosauroid (Dinosauria: Ornithopoda) from the Allen Formation (Late Cretaceous) of Patagonia, Argentina". English. In: Revista del Museo Argentino de Ciencias Naturales, neuvo serie 12.2 (2010), pp. 217-231.

[11233] R. D. Juárez Valieri, J. D. Porfiri, and J. O. Calvo. New Information on Ekrixinatosaurus novasi Calvo et al 2004, a giant and massively-constructed abelisauroid from the middle Cretaceous of Patagonia. English. Dinosaurios y Paleontologa desde América Latina. Anales del III Congreso Latinoamericano de Paleontologa. Editorial de la Universidad Nacional de Cuyo, Neuquén. 2011, pp. 161-169.

[11234] R. D. Juárez Valieri and S. D. Ros Daz. "Assignation of the vertebra CPP 494 to Trigonosaurus pricei Campos et al., 2005 (Sauropoda: Titanosauriformes) from the Late Cretaceous of Brazil, with comments on the laminar variation among lithostrotian titanosaurs". English. In: Boletn del Museo Nacional de Historia Natural del Paraguay 17.1 (2013), pp. 20-28.

[11235] N. A. Jud, M. D. D’Emic, S. A. Williams, J. C. Matthews, K. M. Tremaine, and J. Bhattacharya. “A new fossil assemblage shows that large angiosperm trees grew in North America by the Turonian (Late Cretaceous)". English. In: Science Advances 4.9 (2018), pp. 1-6. DOI: 10.1126/sciadv.aar8568.

[11236] N. A. Jud, M. A. Gandolfo, A. Iglesias, and P. Wilf. "Fossil flowers from the early Palaeocene of Patagonia, Argentina, with affinity to Schizomerieae (Cunoniaceae)". English. In: Annals of Botany 121 (2017), pp. 431-442. DOI: 10.1093/aob/mcx173. 
[11237] N. A. Jud, M. A. Gandolfo, A. Iglesias, and P. Wilf. “Flowering after disaster: Early Danian buckthorn (Rhamnaceae) flowers and leaves from Patagonia". English. In: PLoS ONE 12.5 (2017). DOI: 10.1371/journal.pone.0176164.

[11238] N. A. Jud, A. Iglesias, P. Wilf, and M. A. Gandolfo. "Fossil moonseeds from the Paleogene of West Gondwana (Patagonia, Argentina)". English. In: American Journal of Botany 105.5 (2018), pp. 927942. DOI: $10.1002 / a j b 2.1092$.

[11239] N. A. Jud, G. W. Rothwell, and R. A. Stockey. "Todea from the Lower Cretaceous of Western North America: implications for the phylogeny, systematics, and evolution of modern Osmundaceae". English. In: American Journal of Botany 95.3 (2008), pp. 330-339.

[11240] M. Judson and J. Wunderlich. "Rhagidiidae (Acari, Eupodoidea) from Baltic amber". English. In: Acta Zoologica Cracoviensia 46.Suppl (2003), pp. 147-152.

[11241] M. L. I. Judson. “Baltic amber pseudoscorpions (Arachnida, Chelonethi): a new species of Neobisium (Neobisiidae) and the status of Obisium rathkii Koch \& Berendt". English. In: Geodiversitas 25.3 (2003), pp. 445-450.

[11242] M. L. I. Judson. “Redescription of Chelifer eucarpus Dalman (Arachnida, Chelonethi, Withiidae) and fi rst records of pseudoscorpions in copal from Madagascar and Colombia". English. In: Palaeodiversity 3 (2010), pp. 33-42.

[11243] M. L. I. Judson. "Cheliferoid pseudoscorpions (Arachnida, Chelonethi) from the Lower Cretaceous of France". English. In: Geodiversitas 31 (2009), pp. 61-71.

[11244] M. L. I. Judson. "Baltic amber fossil Garypinus electri Beier provides first evidence of phoresy in the pseudoscorpion family Garypinidae (Arachnida: Chelonethi)". English. In: Arthropoda Selecta, Special Issue 1 (2003), pp. 127-131.

[11245] M. L. I. Judson. "A sternophorid pseudoscorpion (Chelonethi) in Dominican amber, with remarks on the family". English. In: The Journal of Arachnology 26 (1998), pp. 419-428.

[11246] M. L. I. Judson. "First fossil record of the pseudoscorpion family Pseudochiridiidae (Arachnida, Chelonethi, Cheiridioidea) from Dominican amber". English. In: Zootaxa 1393 (2007), pp. 45-51.

[11247] M. L. I. Judson. "Pseudoscorpions (Arachnida, Chelonethi) in Mexican amber, with a list of extant species associated with mangrove and Hymenaea trees in Chiapas". English. In: Boletn de la Sociedad Geológica Mexicana 68 (2016), pp. 57-79.

[11248] M. L. I. Judson and J. Makol. "A mite of the family Tanaupodidae (Arachnida, Acari, Parasitengona) from the Lower Cretaceous of France". English. In: Geodiversitas 31.1 (2009), pp. 41-47.

[11249] P. Jung. "Neogene Paleontology in the Northern Dominican Republic 15. The Genera Columbella, Eurypyrene, Parametaria, Conella, Nitidella, and Metulella (Gastropoda: Columbellidae)". English. In: Bulletins of American Paleontology 106.344 (1994), pp. 1-45.

[11250] P. Jung. "Neogene paleontology in the northern Dominican Republic: 17. The familes Cuspidariidae and Verticordiidae (Mollusca: Bivalvia)". English. In: Bulletins of American Paleontology 110.351 (1996), pp. 35-54.

[11251] P. Jung and R. E. Petit. “Neogene paleontology in the northern Dominican Republic, 10. The family Cancellariidae (Mollusca: Gastropoda)". English. In: Bulletins of American Paleontology 98.334 (1990), pp. 87-144.

[11252] B. Jurkovsek. "Karnijske plasti s skoljkami juno od Rovt [Carnian beds with pelecypods south of Rovte]". other. In: Geologija 36 (1993), pp. 195-205. DOI: 10.5474/geologija.1994.009.

[11253] B. Jurkovsek, T. Kolar-Jurkovsek, and G. S. Jaecks. “Makrofavna karnijskih plasti meziskega prostora [Macrofauna of the Carnian beds in the Mezica area]". other. In: Geologija 45.2 (2002), pp. 413418.

[11254] A. Jurkowska, E. wierczewska-Gadysz, E. Dubicka, and D. Olszewska-Nejbert. “Porosphaera globularis (Phillips, 1829) (Porifera, Calcarea) in the Campanian (Upper Cretaceous) of extra-Carpathian Poland". English. In: Acta Geologica Polonica 65.1 (2015), pp. 121-139. DOI: 10.1515/agp-2015-0005. 
[11255] J. Juwan, K. Liang, M. Lee, and S. Kershaw. “Earliest known spatial competition between stromatoporoids: evidence". English. In: Journal of Paleontology 94.1 (2020), pp. 1-10. DOI: 10.1017/jpa. 2019.63.

[11256] K. P. Juyal and N. S. Mathur. "Nautilus deluci d'Archiac from the Upper part of the Subathu Formation (Ilerdian-early Lutetian), Himachal Pradesh, India". English. In: Journal of the Paleontological Society of India 39 (1994), pp. 81-86.

[11257] J. K. Silurian field excursions: Prague Basin (Barrandian), Bohemia. English. Vol. 13. National Museum of Wales, Geological Series. 1992, pp. 1-111.

[11258] J. K. “Telychian (Llandovery, Silurian) Bivalves from Spain”. English. In: Palaeontology 48.3 (2005), pp. $455-477$.

[11259] J. K. "A new bivalve community from the lower Ludlow of the Prague Basin (Perunica, Bohemia)". English. In: Bulletin of Geosciences 83.3 (2008), pp. 237-280. DOI: 10.3140/bull.geosci.2008.03.237.

[11260] J. K. “Algerina gen. nov. (Bivalvia, Nepiomorphia) from the Silurian of the North Gondwana margin (Algeria), peri-Gondwanan Europe (France, Italy), Perunica (Prague Basin, Bohemia) and the Siberian Plate (Tajmyr Basin, Russia)". English. In: Bulletin of Geosciences 83.1 (2008), pp. 79-84. DOI: 10.3140/bull.geosci.2008.01.079.

[11261] J. K, P. Dufka, H. Jaeger, and H. P. Schönlaub. "The Wenlock/ludlow Boundary in the Prague Basin (Bohemia)". English. In: Jahrbuch der Geologischen Bundesanstalt 136.4 (1993), pp. 809-839.

[11262] J. K and E. Serpagli. "Upper Silurian and lowermost Devonian Bivalvia of Bohemian type from south-western Sardinia". English. In: Bolletino della Societa Paleontologica Italiana 32.3 (1993), pp. 289 347.

[11263] J. K and M. Steinová. "Uppermost Ordovician bivalves from the Prague Basin (Hirnantian, Perunica, Bohemia)". English. In: Bulletin of Geosciences 84.3 (2009), pp. 409-436.

[11264] P. Kabanov. "The Upper Moscovian and basal Kasimovian (Pennsylvanian) of central European Russia: Facies, subaerial exposures and depositional model". English. In: Facies 49 (2003), pp. 243270.

[11265] R. P. Kachhara, K. Bigyapati Devi, and R. L. Joghawat. "Molluscan Assemblage from the Marine Palaeocene Sequence in Southwestern Kachchh, Gujarat". English. In: Journal Gological Society of India 78 (2011), pp. 81-91.

[11266] H. F. Kaddumi. "A new genus and species of gigantic marine turtles (Chelonioidea: Cheloniidae) from the Maastrichtian of the Harrana Fauna-Jordan". English. In: PalArch Vertebrate Paleontology 2.1 (2006), pp. 1-14.

[11267] M. Kadej and J. Háva. "First record of a fossil Trinodes larva from Baltic amber (Coleoptera: Dermestidae: Trinodinae)". English. In: Genus 22 (2011), pp. 17-22.

[11268] D. Kadolsky. "Lutetiella, a new genus of hydrobioids from the Middle Eocene (Lutetian) of the Upper Rhine Graben and Paris Basin (Mollusca: Gastropoda: Rissooidea s. lat.)" English. In: Geologica Saxonica 61.1 (2015), pp. 35-51.

[11269] A. I. Kafanov and K. Ogasawara. "Neogene and Paleogene Molluscan (Bivalvia) Cenozones of the Russian Northeast." In: Science Reports of the Institute of Geoscience, University of Tsukuba, Section B 25 (2004), pp. 9-45.

[11270] A. I. Kafanov, K. Ogasawara, and Y. Noda. "Cenozoic molluscan (Bivavia) cenozone of Hokkaido, Northern Japan". English. In: Science Report, Institute of Geosciences, Univeristry of Tsukuba 26 (2005), pp. 1-12.

[11271] A. I. Kafanov and K. Ogasawara. "Neogene and Paleogene Molluscan (Bivalvia) Cenozones of Sakhalin and Kurile Islands". English. In: Science Reports, Institute of Geoscience, University of Tsukuba 24 (2003), pp. 45-79.

[11272] A. I. Kafanov, K. Ogasawara, L. Marincovich, and Jr. "Checklist and bibliography of the Cenozoic Bivalvia (Mollusca) of Northeastern Asia (Russian Far East), 1968-1999". English. In: Bulletin of the Mizunami Fossil Museum 28 (2001), pp. 1-138. 
[11273] A. Y. Kahal, A. S. ElSorogy, H. J. Alfaifi, S. Almadani, and O. M. Kassem. “Biofacies and diagenetic alterations of the Pleistocene coral reefs, northwest Red Sea coast, Saudi Arabia". English. In: Geological Journal (2019). DOI: 10.1002/gj.3503.

[11274] C. F. Kahle. "Facies and evolution of a Silurian coral-microbialite reef complex, Maumee, Ohio, USA". English. In: Journal of Sedimentary Research 64.4 (1994), pp. 711-725.

[11275] E. Kahlert. “Ein Arachniden-Opisthosoma aus dem Obervisé von NW-Sachsen”. German. In: Mitteilungen aus dem Museum für Naturkunde in Berlin, Geowissenschaften Reihe 1 (1998), pp. 135-138.

[11276] R.-D. Kahlke, U. Fritz, and U. Kierdorf. "Badger (Meles meles) predation on European pond turtle (Emys orbicularis) during the Eemian interglacial (MIS 5e)". English. In: Palaeobiology and Palaeoenvironments (2014), pp. 1-13. DOI: 10.1007/s12549-014-0170-z.

[11277] A. Kaim. "Brachiopod-bivalve assemblages of the middle Triassic Terebratula Beds, Upper Siesia, Poland". English. In: Acta Palaeontologica Polonica 42.2 (1997), pp. 333-359.

[11278] A. Kaim. "The evolution of conch ontogeny in Mesozoic open sea gastropods". English. In: Palaeontologia Polonica 62 (2004), pp. 1-183.

[11279] A. Kaim. "Faunal dynamics of juvenile gastropods and associated organisms across the Valanginian transgression-regression cycle in central Poland". English. In: Cretaceous Research 22 (2001), pp. 333351.

[11280] A. Kaim. "Faunal dynamics of Gastropods in the Bathoninan (Middle Jurrasic) ore-bearing clays at Gnaszyn, Krakow-Silesia Homocline, Poland". English. In: Acta Palaeontologica Polonica 62.3 (2012), pp. 367-380. DOI: 10.2478/v10263-012-0020-0.

[11281] A. Kaim, A. L. Beisel, and N. I. Kurushin. "Mesozoic gastropods from Siberia and Timan (Russia). Part 1: Vetigastropoda and Caenogastropoda (exclusive of Neogastropoda)". English. In: Polish Polar Research 25.3-4 (2004), pp. 241-266.

[11282] A. Kaim and A. L. Beisel. “Mesozoic gastropods from Siberia and Timan (Russia). Part 2: Neogastropoda and Heterobranchia". English. In: Polish Polar Research 26.1 (2005), pp. 41-64.

[11283] A. Kaim, A. Bitner, and R. G. Jenkins. Y. Hikida. "A monospecific assemblage of terebratulide brachiopods in the Upper Cretaceous seep deposits of Omagari, Hokkaido, Japan". English. In: Acta Palaeontologica Polonica 55.1 (2010), pp. 73-84.

[11284] A. Kaim and M. A. Conti. "A problematic zygopleuroid gastropod Acanthostrophia revisited". English. In: Zitteliana A50 (2010), pp. 21-24.

[11285] A. Kaim, R. G. Jenkins, K. Tanabe, and S. Kiel. “Mollusks from late Mesozoic seep deposits, chiefly in California". English. In: Zootaxa 3861.5 (2014), pp. 401-440.

[11286] A. Kaim, B. Jurkovsek, and T. Kolar-Jurkovsek. “New associations of Carnian gastropods from Mezica region in the Karavanke Mountains of Slovenia". English. In: Facies 52 (2006), pp. 469-482.

[11287] A. Kaim and A. Nützel. "Dead bellerophontids walking - The short Mesozoic history of the Bellerophontoidea (Gastropoda)". English. In: Palaeogeography, Palaeoclimatology, Palaeoecology 308.12 (2011), pp. 190-199. DOI: 10.1016/j.palaeo.2010.04.008.

[11288] A. Kaim, A. Nützel, H. Bucher, T. Brühwiler, and N. Goudemand. "Early Triassic (Late Griesbachian) gastropods from South China (Shanggan, Guangxi)". English. In: Swiss Journal of Geosciences 103 (2010), pp. 121-128.

[11289] A. Kaim and A. Nützel. "Systematic Palaeontology, in Early Triassic (Late Griesbachian) gastropods from South China (Shanggan, Guangxi)". English. In: Swiss Journal of Geosciences 103 (2010), pp. 123-127.

[11290] A. Kaim, A. Nützel, M. Hautmann, and H. Bucher. "Early Triassic gastropods from Salt Range, Pakistan". English. In: Bulletin of Geosciences 88 (2013), pp. 505-516. DOI: 10.3140/bull.geosci.1395.

[11291] A. Kaim and S. Schneider. "A conch with a collar: early ontogeny of the enigmantic fossil bivalve Myoconcha". English. In: Journal of Paleontology 86.4 (2012), pp. 652-658. 
[11292] A. Kaim and P. Sztajner. "Faunal dynamics of bivalves and scaphopods in the Bathonian (Middle Jurassic) ore-bearing clays at Gnaszyn, Kraków-Silesia Homocline, Poland". English. In: Acta Palaeontologica Polonica 62.3 (2012), pp. 381-395.

[11293] G. Kaiser, J. Watanabe, and M. Johns. "A new member of the family Plotopteridae (Aves) from the late Oligocene of British Columbia, Canada". English. In: Palaeontologia Electronica 18.3.5A (2015), pp. 1-18.

[11294] T. M. Kaiser, J. Ansorge, G. Arratia, V. Bullwinkel, G. F. Gunnell, P. S. Herendeen, B. Jacobs, J. Mingram, C. Msuya, A. Musolff, R. Naumann, E. Schulz, and V. Wilde. "The maar lake of Mahenge (Tanzania) - unique evidence of Eocene terrestrial environments in sub-Sahara Africa". English. In: Zeitschrift der Deutschen Gesellschaft für Geowissenschaften 157 (2006), pp. 411-431.

[11295] M. V. Kakabadze and P. J. Hoedemaeker. "New and less known Barremian-Albian Ammonites from Colombia". English. In: Scripta Geologica 114 (1997), pp. 57-117.

[11296] N. N. Kalandadze and A. A. Kurkin. "A new Permian dicynodont and the question of the origin of the Kannemeyeroidae". English. In: Paleontological Journal 34.6 (2000), pp. 642-649.

[11297] J. E. Kalb. Refined stratigraphy of the hominid-bearing Awash Group, Middle Awash Valley, Afar Depression, Ethiopia. 1993.

[11298] J. E. Kalb. Fossil elephantoids, Awash paleolake basins, and the Afar triple junction, Ethiopia. 1995.

[11299] J. E. Kalb and A. Mebrate. Fossil elephantoids from the hominid-bearing Awash Group, Middle Awash Valley, Afar Depression, Ethiopia. 1993.

[11300] D. Kälin. “A new Oligocene (MP 24) mammal fauna (Dürrenberg, Canton Jura, NW Switzerland) from the eastern slope of the Rauracian depression". English. In: Swiss Journal of Geosciences 106 (2013), pp. 207-218.

[11301] K. Kalita and B. Gogoi. "First report of coralline red algae in the late Paleocene Lakadong Limestones of Mawsynram area, Meghalaya". English. In: Journal Geological Society of India 68 (2006), pp. 779-783.

[11302] K. D. Kalita, S. K. Kulshreshtha, and N. Sahni. "Fossil holothurian sclerite assemblage from the Callovian-Oxfordian rocks of Jaisalmer, Western Rajasthan, India". English. In: Journal Palaeontological Society, India 47 (2002), pp. 137-144.

[11303] D. Kaljo, P. Männik, T. Martma, and J. Nõlvak. "More about the OrdovicianÜSilurian transition beds at Mirny Creek, Omulev Mountains, NE Russia: carbon isotopes and conodonts". English. In: Estonian Journal of Earth Sciences 61.4 (2012), pp. 277-294. DOI: 10.3176/earth.2012.4.07.

[11304] J. W. Kallmeyer and W. I. Ausich. “Deepwater occurrence of a new Glyptocrinus (Crinoidea, Camerata) from the Late Ordovician of southwestern Ohio and northern Kentucky: revision of crinoid paleocommunity composition". English. In: Journal of Paleontology 89.6 (2015), pp. 1068-1075. DOI: 10.1017/jpa.2015.72.

[11305] Y. Kamata, K. Sashida, K. Ueno, K. Hisada, N. Nakornsri, and P. Charusiri. "Triassic radiolarian faunas from the Mae Sariang area, northern Thailand and their paleogeographic significance". English. In: Journal of Asian Earth Sciences 20 (2002), pp. 491-506.

[11306] M. Kametaka, H. Nagai, S. Zhu, and M. Takebe. "Middle Permian radiolarians from Anmenkou, Chaohu, northeastern Yangtze platform, China". English. In: Island Arc 18 (2009), pp. 108-125.

[11307] T. W. Kammer and W. I. Ausich. "Stratigraphical and geographical distribution of Mississippian (Lower Carboniferous) Crinoidea from Scotland". English. In: Earth and Environmental Science Transactions of the Royal Society of Edinburgh 98 (2007), pp. 139-150.

[11308] T. W. Kammer, T. K. Baumiller, and W. I. Ausich. "Species longevity as a function of niche breadth: evidence from fossil crinoids". English. In: Geology 25 (1997), pp. 219-222.

[11309] C. F. Kammerer. "Systematics of the Anteosauria (Therapsida: Dinocephalia)". English. In: Journal of Systematic Palaeontology 9.2 (2011), pp. 261-304.

[11310] C. F. Kammerer. "Systematics of the Rubidgeinae (Therapsida: Gorgonopsia)". English. In: PeerJ 4 (2016), e1608. DOI: 10.7717/peerj.1608. 
[11311] C. F. Kammerer. "Two unrecognized burnetiamorph specimens from historical Karoo collections". English. In: Palaeontologia africana 50 (2016), pp. 64-75.

[11312] C. F. Kammerer. "A new taxon of cynodont from the Tropidostoma Assemblage Zone (Upper Permian) of South Africa, and the early evolution of Cynodontia". English. In: Papers in Palaeontology 2.3 (2016), pp. 387-397. DOI: 10.1002/spp2.1046.

[11313] C. F. Kammerer. "Two unrecognised burnetiamorph specimens from historic Karoo collections". English. In: Palaeontologia africana 50 (2016), pp. 64-75.

[11314] C. F. Kammerer. "The first skeletal evidence of a dicynodont from the lower Elliot Formation of South Africa". English. In: Palaeontologia africana 52 (2018), pp. 102-128.

[11315] C. F. Kammerer. "A new dicynodont (Anomodontia: Emydopoidea) from the terminal Permian of KwaZulu-Natal, South Africa". English. In: Palaeontologia africana 53 (2019), pp. 179-191.

[11316] C. F. Kammerer, K. D. Angielczyk, and J. Frobisch. "A comprehensive taxonomic revision of Dicynodon (Therapsida, Anomodontia) and its implications for dicynodont phylogeny, biogeography, and biostratigraphy". English. In: Journal of Vertebrate Paleontology 31.Sup. to 6 (2011), pp. 1158. DOI: $10.1080 / 02724634.2011 .627074$.

[11317] C. F. Kammerer, K. D. Angielczyk, and J. Fröbisch. "Redescription of Digalodon rubidgei, an emydopoid dicynodont (Therapsida, Anomodontia) from the Late Permian of South Africa". English. In: Fossil Record 18 (2015), pp. 43-55. DOI: 10.5194/fr-18-43-2015.

[11318] C. F. Kammerer, K. D. Angielczyk, and J. Fröbisch. "Redescription of the geikiid Pelanomodon (Therapsida, Dicynodontia), with a reconsideration of 'Propelanomodon'". English. In: Journal of Vertebrate Paleontology 36.1 (2016), e1030408. DOI: 10.1080/02724634.2015.1030408.

[11319] C. F. Kammerer, S. Bandyopadhyay, and S. Ray. "A new Taxon of Cistecephalid Dicynodont from the Upper Permian Kundaram Formation of India". English. In: Papers in Palaeontology (2016), pp. 1-16.

[11320] C. F. Kammerer, J. J. Flynn, L. Ranivoharimanana, and A. R. Wyss. “New material of Menadon besairiei (Cynodontia: Traversodontidae) from the Triassic of Madagascar". English. In: Journal of Vertebrate Paleontology 28.2 (2008), pp. 445-462.

[11321] C. F. Kammerer, J. J. Flynn, L. Ranivoharimanana, and A. R. Wyss. "The first record of a probainognathian (Cynodontia: Chiniquodontidae) from the Triassic of Madagascar". English. In: Journal of Vertebrate Paleontology 30.6 (2010), pp. 1889-1894.

[11322] C. F. Kammerer, J. Fröbisch, and K. D. Angielczyk. “On the validity and phylogenetic position of Eubrachiosaurus browni, a kannemeyeriiform dicynodont (Anomodontia) from Triassic North America". English. In: PLoS ONE 8.5 (2013), e64203. DOI: 10.1371/journal.pone.0064203.

[11323] C. F. Kammerer and V. Masyutin. "Gorgonopsian therapsids (Nochnitsa gen. nov. and Viatkogorgon) from the Permian Kotelnich locality of Russia". English. In: PeerJ 6 (2018), e4954.

[11324] C. F. Kammerer and V. Masyutin. "A new therocephalian (Gorynychus masyutinae gen. et sp. nov.) from the Permian Kotelnich locality, Kirov Region, Russia". English. In: PeerJ 6 (2018), e4933.

[11325] C. F. Kammerer, S. J. Nesbitt, and N. H. Shubin. "The first basal dinosauriform (Silesauridae) from the Late Triassic of Morocco". English. In: Acta Palaeontologica Polonica 57.2 (2012), pp. 277284. DOI: 10.4202/app.2011.0015.

[11326] C. F. Kammerer, S. J. Nesbitt, J. J. Flynn, L. Ranivoharimanana, and A. R. Wyss. "A tiny ornithodiran archosaur from the Triassic of Madagascar and the role of miniaturization in dinosaur and pterosaur ancestry". English. In: Proceedings of the National Academy of Sciences (2020), pp. 1-5. DOI: 10.1073/pnas.1916631117.

[11327] C. F. Kammerer, R. M. H. Smith, M. O. Day, and B. S. Rubidge. "New information on the morphology and stratigraphic range of the midPermian gorgonopsian Eriphostoma microdon Broom, 1911". English. In: Papers in Palaeontology (2015). DOI: 10.1002/spp2.1012. 
[11328] C. F. Kammerer and R. M. H. Smith. "An early geikiid dicynodont from the Tropidostoma Assemblage Zone (late Permian) of South Africa". English. In: PeerJ 5.e2913 (2017). DOI: 10.7717/ peerj. 2913.

[11329] F. Kamoun, B. Peyernes, R. Ciszak, and S. Calzada. "Triassic palaeogeography of Tunisia". In: Palaeogeography, Palaeoclimatology, Palaeoecology 172 (2001), pp. 223-242.

[11330] P. Kampouridis, N. Kargopoulos, G. Svorligkou, I. Giaourtsakis, S. Roussiakis, and G. Theodorou. Rhinocerotidae (Mammalia, Perissodactyla) remains from the new Pleistocene locality of Richea (Laconia, Greece). English. 2018.

[11331] P. Kampouridis, D. Michailidis, N. Kargopoulos, S. Roussiakis, and G. Theodorou. "First description of an ostrich from the late Miocene of Kerassia (Euboea, Greece): remarks on its cervical anatomy". English. In: Historical Biology (2020), pp. 1-9. DOI: 10.1080/08912963.2020.1779252.

[11332] H. Kan, N. Hori, T. Kawana, T. Kaigara, and K. Ichikawa. "The evolution of a Holocene fringing reef and island: reefal environmental sequence and sea level change in Tonaki Island, the central Ryukyus". English. In: Atoll Research Bulletin 443 (1997), pp. 1-20.

[11333] H. Kan and T. Kawana. Catch-up of a high-latitude barrier reef by back-reef growth during post-glacial sea level rise, southern Ryukyus, Japan. English. Proceedings of 10th International Coral Reef Symposium. 2006, pp. 494-503.

[11334] K. Kaneko and N. Inuzuka. "Desmostylian fossils from the Yatsuo Group in Toyama Prefecture, Central Japan and their paleoenvironments". English. In: Chikyu Kagaku = Earth Science 46.2 (1992), pp. 153-164.

[11335] I. Kania. "Subfamily Limoniinae Speiser, 1909 (Diptera, Limoniidae) from Baltic amber (Eocene): the genus Dicranomyia Stephens, 1829". English. In: Zoological Journal of the Linnean Society 170 (2014), pp. 748-778.

[11336] I. Kania. "Subfamily Limoniinae Speiser, 1909 (Diptera, Limoniidae) from Baltic amber (Eocene): the genus Helius Lepeletier \& Serville, 1828". English. In: Zootaxa 3814 (2014), pp. 333-352.

[11337] I. Kania. "The taxonomy of selected genera of the subfamily Limoniinae (Diptera: Limoniidae) from Baltic amber (Eocene), with notes on their phylogeny". English. In: Annales Zoologici 65 (2015), pp. 71-100.

[11338] I. Kania. “Subfamily Limoniinae Speiser, 1909 (Diptera, Limoniidae) from Baltic amber (Eocene): the genus Elephantomyia Osten Sacken, 1860". English. In: PLoS One 10.2 (2015), e0117434.

[11339] I. Kania. "Subfamily Limoniinae Speiser, 1909 (Diptera, Limoniidae) from Baltic amber (Eocene): the genus Trichoneura Loew, 1850". English. In: Acta Zoologica Cracoviensia 58 (2015), pp. 1-19.

[11340] I. Kania and W. Krzemiski. "A new species of Palaeopoecilostola Meunier, 1899 (Diptera: Limoniidae) from the Eocene Baltic amber". English. In: Zootaxa 3495 (2012), pp. 42-56.

[11341] I. Kania, W. Krzemiski, and D. Azar. "The oldest representative of Helius Lepeletier \& Serville 1828 (Diptera: Limoniidae) from Lebanese amber (Early Cretaceous)". English. In: Insect Systematics \& Evolution 44 (2013), pp. 231-238.

[11342] I. Kania and W. Krzemiski. "A new species of Dactylolabis (Idiolabis) Alexander, 1931 from the Eocene Baltic amber and its relationships among Dactylolabinae (Diptera: Limoniidae)". English. In: Palaeontologia Electronica 18.1.4A (2015), pp. 1-15.

[11343] I. Kania, W. Krzeminska, and E. Krzeminska. "The oldest representative of the genus Gonomyia (Diptera, Limoniidae) from Lebanese amber (Lower Cretaceous): New subgenus and species". English. In: Cretaceous Research 52 (2015), pp. 516-521.

[11344] I. Kania, W. Krzeminski, and A. Gil. "Revision of the genus Palaeopoecilostola Meunier, 1899 (Diptera: Limoniidae) from Baltic amber (Upper Eocene)". English. In: Polish Journal of Entomology 80 (2011), pp. 747-764.

[11345] I. Kania, W. Krzemiski, and A. Arillo. "First representative of the genus Helius Lepeletier and Serville, 1828 (Diptera, Limoniidae) from the Lower Cretaceous Álava amber (Spain)". English. In: Cretaceous Research 63 (2016), pp. 33-38. 
[11346] I. Kania, W. Krzemiski, and A. Arillo. "A new peculiar species of the genus Helius Lepeletier \& Serville, 1828 (Diptera, Limoniidae) from Cretaceous Alava amber (Spain)". English. In: Earth and Environmental Science Transactions of the Royal Society of Edinburgh 107 (2018), pp. 231-237.

[11347] I. Kania, W. Krzemiski, F. Stebner, and H. Singh. “The first representative of Tipulomorpha (Diptera) from Early Eocene Cambay amber (India)". English. In: Earth and Environmental Science Transactions of the Royal Society of Edinburgh 107 (2018), pp. 263-269.

[11348] I. Kania and A. Nel. “New fossil Tipulidae from the volcano-sedimentary latest Oligocene of BesKonak (Turkey)". English. In: Polish Journal of Entomology 82 (2013), pp. 327-338.

[11349] I. Kania, A. Nel, W. Jordan-Stasio, and K. Skibiska. "A new species of Tipula Linnaeus, 1758 (Diptera: Tipulidae) from Green River Formation, USA". English. In: Acta Zoologica Cracoviensia 61 (2018), pp. 31-38.

[11350] I. Kania, A. Penar, and W. Krzemiski. "A new species of Dicranomyia Stephens, 1829 from Baltic amber (Diptera, Limoniidae)". English. In: Annales Zoologici 63 (2013), pp. 143-148.

[11351] I. Kania, B. Wang, and J. Szwedo. “Dicranoptycha Osten Sacken, 1860 (Diptera, Limoniidae) from the earliest Cenomanian Burmese amber". English. In: Cretaceous Research 52 (2015), pp. 522-530.

[11352] I. Kania and P. Wegierek. "Evolution aspects of Ellinaphididae and phylogeny relationship of new early Cretaceous aphids from Bon-Tsagaan locality (Mongolia)". English. In: Cretaceous Research 44 (2013), pp. 166-182.

[11353] I. Kania and P. Wegierek. "Two new species of alate aphids (Hemiptera: Aphidoidea) from Upper Cretaceous Canadian amber". English. In: Polskie Pismo Entomologiczne 74 (2005), pp. 277-286.

[11354] I. Kania, M. Wojto, K. Kope, O. Owsiak, and W. Jordan. “Helius anetae sp. nov. (Diptera: Limoniidae), a new representative of the genus from the Eocene Baltic amber". English. In: Neues Jahrbuch für Geologie und Paläontologie, Abhandlungen 281 (2016), pp. 101-109.

[11355] I. Kania, M. Wojto, E. Lukashevich, J. Stanek-Tarkowska, B. Wang, and W. Krzemiski. “Anisopodidae (Insecta: Diptera) from Upper Cretaceous amber of northern Myanmar". English. In: Cretaceous Research 94 (2018), pp. 190-206.

[11356] I. Kania, M. Wojto, and W. Krzemiski. “The oldest Mycetobia Meigen, 1818 (Diptera, Anisopodoidea) from Upper Cretaceous amber of northern Myanmar". English. In: Cretaceous Research 95 (2018), pp. 302-309.

[11357] J. Kania and A. A. Legalov. "A new genus of tooth-nosed snout weevils (Coleoptera: Rhynchitidae) in Baltic amber". English. In: Paleontological Journal 53 (2019), pp. 1040-1044. DOI: 10.1134 / S0031030119100083.

[11358] S. Kanjilal and M. S. Srinivasan. "New Bivalves from the Mlocene of Little Andaman Island, Bay of Bengal". In: Journal of the Geological Society of India 60.5 (2002), pp. 527-536.

[11359] A. Kano. "Deposition and diagenesis of a reef-like limestone of the Wenlockian Slite Beds on Gotland, Sweden". English. In: GFF 113 (1991), pp. 207-217.

[11360] A. Kano, T. G. Ferdelman, T. Williams, J. -P. Henriet, T. Ishikawa, N. Kawagoe, C. Takashima, Y. Kakizaki, K. Abe, S. Sakai, E. L. Browning, and X. Li. "Age constraints on the origin and growth history of a deep-water coral mound in the northeast Atlantic drilled during Integrated Ocean Drilling Program Expedition 307". English. In: Geology 35.11 (2007), pp. 1051-1054.

[11361] A. Kano and N. Fujishiro. "Facies and paleoecology of the Late Ordovician (Caradoc-Ashgill) stromatoporoid bioherms of Tasmania, Australia". In: Facies 37 (1997), pp. 65-84.

[11362] A. Kano and K. Jiju. “The Upper Jurassic-Lower Cretaceous carbonate-terrigenous succession and the development of a carbonate mound in western Shikoku, Japan". English. In: Sedimentary Geology 99 (1995), pp. 165-178.

[11363] A. Kano, Y. Kakizaki, C. Takashima, W. Wang, and R. Matsumoto. "Facies and depositional environment of the uppermost Jurassic stromatoporoid biostromes in the Zagros Mountains of Iran". English. In: Gff 129 (2007), pp. 107-112. 
[11364] A. V. Kanygin, A. V. Dronov, T. V. Gonta, A. V. Timokhin, and O. A. Maslova. Ordovician of the Tungus Basin (Siberian Platform). Field excursion guidebook. English. 13th International Symposium on the Ordovician System. Novosibirsk: Trofimuk Institute of Petroleum Geology and Geophysics, Russian Academy of Sciences Siberian Branch, Novosibirsk National Research State University, Novosibirsk Publishing House, 2019, pp. 1-61.

[11365] V. G. Kaplin and E. E. Perkovsky. "On the fauna of bristletails (Zygentoma, Microcoryphia) of the Rovno amber". English. In: Paleontological Journal 52 (2018), pp. 541-545.

[11366] H. M. Kapoor, U. Bajpai, and H. K. Maheshwari. “On a fossil cockroach from the Mamal Formation, Kashmir Himalaya". English. In: Journal of the Palaeontological Society of India 38 (1993), pp. 31-36.

[11367] J. Kappelman, M. C. Maas, S. Sen, B. Alpagut, M. Fortelius, and J. P. Lunkka. “A new early Tertiary mammalian fauna from Turkey and its paleobiogeographic significance". In: Journal of Vertebrate Paleontology 16.3 (1996), pp. 592-595.

[11368] J. Kappelman, D. T. Rasmussen, W. J. Sanders, M. Feseha, T. Bown, P. Copeland, J. Crabaugh, J. Fleagle, M. Glantz, A. Gordon, B. Jacobs, M. Maga, K. Muldoon, A. Pan, L. Pyne, B. Richmond, T. Ryan, E. R. Seiffert, S. Sen, L. Todd, M. C. Wiemann, and A. Winkler. "Oligocene mammals from Ethiopia and faunal exchange between Afro-Arabia and Eurasia". English. In: Nature 426 (2003), pp. 549-552.

[11369] E. J. Kappus, S. G. Lucas, A. P. Hunt, A. B. Heckert, and M. G. Lockley. “Dinosaur footprints from the Lower Cretaceous Sarten Member of the Mojado Formation at Cerro de Cristo Rey, Dona Aña County, New Mexico". English. In: Ichnos 10 (2003), pp. 263-267. DOI: 10.1080/10420940390257905.

[11370] E. J. Kappus, S. G. Lucas, and R. Langford. “The Cerro de Cristo Rey Cretaceous dinosaur tracksites, Sunland Park, New Mexico, USA, and Chihuahua, Mexico". English. In: vol. 53. Fossil Record 3. New Mexico Museum of Natural History and Science Bulletin. Albuquerque: New Mexico Museum of Natural History and Science, 2011, pp. 272-288.

[11371] V. V. Kapur, D. P. Das, S. Bajpai, and G. Prasad. "First mammal of Gondwanan lineage in the early Eocene of India". English. In: Comptes Rendus Palevol 16 (2017), pp. 721-737. DOI: 10.1016/j.crpv. 2017.01.002.

[11372] V. V. Kapur, M. Pickford, G. Chauhan, and M. G. Thakkar. "A Middle Miocene ( 14 Ma) vertebrate assemblage from Palasava, Rapar Taluka, Kutch (Kachchh) District, Gujarat State, western India". English. In: Historical Biology (2019). DOI: 10.1080/08912963.2019.1648451.

[11373] A. Kapuscinska and M. Machalski. “Upper Albian chelonioid turtles from Poland”. English. In: Geobios 28 (2015), pp. 385-395.

[11374] M. Karabiyikoglu, S. Tuzcu, A. Ciner, M. Deynoux, S. Orcen, and A. Hakyemez. “Facies and environmental setting of the Miocene coral reefs in the late-orogenic fill of the Antalya Basin, western Taurides, Turkey: implications for tectonic control and sea-level changes". English. In: Sedimentary Geology 173 (2005), pp. 345-371.

[11375] V. Karakitsios, M. Roveri, S. Lugli, V. Manzi, R. Gennari, A. Antonarakou, M. Triantaphyllou, K. Agiadi, G. Kontakiotis, N. Kafousia, and M. de Rafelis. "A record of the Messinian salinity crisis in the eastern Ionian tectonically active domain". English. In: Basin Research 29 (2017), pp. 203-233.

[11376] H. Karasawa. "Discovery of Early Cretaceous (Barremian) decapod Crustacea from the Arida Formation of Wakayama Prefecture, Japan". English. In: Paleontological Research 4.4 (2000), pp. 235238.

[11377] H. Karasawa. "Shako, a new Miocene stomatopod Crustacea from Japan". English. In: Transactions and Proceedings of the Paleontological Society of Japan, N.S. 182 (1996), pp. 413-418.

[11378] H. Karasawa. "Cenozoic Decapod Crustacea from Southwest Japan". English. In: Bulletin of the Mizunami Fossil Museum 20 (1993), pp. 1-92.

[11379] H. Karasawa. "Fossil decapod crustaceans from the Manda Group (Middle Eocene), Kyushu, Japan". English. In: Transactions and Proceedings of the Paleontological Society of Japan, N.S. 167 (1992), pp. 1247-1258. 
[11380] H. Karasawa. "Decapod crustaceans from the Miocene Mizunami Group, central Japan. Part 2. Section Oxyrhyncha, Cancridea and Brachyrhyncha". English. In: Bulletin of the Mizunami Fossil Museum 17 (1990), pp. 1-33.

[11381] H. Karasawa and Y. Fudouji. "Palaeogene decapod Crustacea from the Kishima and Okinoshima Groups, Jyushu, Japan". English. In: Paleontological Research 4.4 (2000), pp. 239-253.

[11382] H. Karasawa and T. Goda. "Two species of decapod crustaceans from the Middle Pleistocene Atsumi Group, Japan". English. In: Sci Rep Toyohashi Mus Nat Hist 6 (1996), pp. 1-4.

[11383] H. Karasawa and H. Hayakawa. "Additions to Cretaceous decapod crustaceans from Hokkaido, Japan-Part 1. Nephropidae, Micheleidae and Galatheidae". English. In: Paleontological Research 4.2 (2000), pp. 139-145.

[11384] H. Karasawa and H. Kato. "Daldorfia Rathbun, 1904 (Crustacea: De3capoda) from the Neogene of Japan". English. In: Proceedings of the Biological Society of Washington 109.1 (1996), pp. 44-52.

[11385] H. Karasawa and H. Kato. "A new record of Tymolus ingens Takeda \& Tomida, 1984 (Crustacea: Decapoda: Brachyura) from the Miocene Chikubetsu Formation, Northern Hokkaido, Japan". English. In: Bulletin of the Mizunami Fossil Museum 21 (1994), pp. 77-81.

[11386] H. Karasawa and S. Kishimoto. "Two new species of decapod crustaceans from the middle Miocene Katsuta Group, Japan". English. In: Bulletin of the Mizunami Fossil Museum 23 (1996), pp. 35-37.

[11387] H. Karasawa and S. Kishimoto. “Decapod crustaceans from the Katsuta Group (middle Miocene) of Okayama Prefecture, Japan”. English. In: Bulletin Mizunami Fossil Museum 23 (1996), pp. 39-50.

[11388] H. Karasawa and T. Nakagawa. "A new species of ghost shrimp (Decapoda: Thalassinidea) from the Miocene Kunimi Formation, Fukui Prefecture, Japan". English. In: Bulletin of the Mizunami Fossil Museum 36 (2010), pp. 31-36.

[11389] H. Karasawa, T. Nohara, and K. Shimoji. "Decapod Crustacea from the Ryukyu Group (Pleistocene) of Okinawa-jima, Japan". English. In: Bulletin of the Mizunami Fossil Museum 22 (1995), pp. 127-135.

[11390] H. Karasawa, T. Nohara, and K. Shimoji. "Decapod Crustacea from the Tyukyu Group (Pleistocene) of Okinawa-jima, Japan". English. In: Bulletin of the Mizunami Fossil Museum 22 (1995), pp. 127-132.

[11391] H. Karasawa, M. Ohara, and H. Kato. "New Records for Crustacea from the Arida Formation (Lower Cretaceous, Barremian) of Japan". English. In: Boletin De La Socidad Geologica Mexicana 60.1 (2008), pp. 101-110.

[11392] H. Karasawa, F. Takahashi, E. Doi, and H. Ishida. "First notice of the family Coleiidae Van Straelen (Crustacea: Decapoda: Eryonoidea) from the upper Triassic of Japan". English. In: Paleontological Research 7 (2003), pp. 357-362.

[11393] V. Karatajute-Talimaa. “Taxonomy of loganiid thelodonts". English. In: Modern Geology 21 (1997), pp. 1-15.

[11394] A. A. Karhu. "A new genus and species of the family Jungornithidae (Apodiformes) from the Late Eocene of the Northern Caucasus, with comments on the ancestry of hummingbirds". English. In: Smithsonian Contributions to Paleobiology 89 (1999), pp. 207-216.

[11395] A. A. Karhu and A. S. Rautian. "A new family of Maniraptora (Dinosauria: Saurischia) from the Late Cretaceous of Mongolia". In: Paleontological Journal 30.5 (1996), pp. 583-592.

[11396] K. H. Karim, H. S. Daoud, and A. R. H. Kuradawy. "Record of Khurmala Formation (late Paleoceneearly Eocene) in the Sulaimaniah governorate, Kurdistan region, northwest Iraq". English. In: Iraqi geological Journal 51.1 (2018), pp. 34-55.

[11397] H.-V. Karl, E. Groning, C. Brauckmann, and M. Reich. "Ballerstedtia bueckebergensis, a new turtle from the Early Cretaceous Wealden facies of Germany (Testudines: Pleurosternidae)". English. In: Studia Palaeocheloniologica 4 (2012), pp. 47-60.

[11398] H.-V. Karl. "The homology of supramarginals in turtles (Reptilia: Chelonii)". English. In: Studia Geologica Salmanticensia 41 (2005), pp. 63-75. 
[11399] H.-V. Karl. "Paleogeography and systematics of the genus Dogania Gray, 1844 (Testudines: Trionychidae)". English. In: Studia Geological Salmanticensia 35 (1999), pp. 3-8.

[11400] H.-V. Karl. “Einige Bemerkungen über die fossilen Schildkröten (Reptilia, Testudines) des Bundeslandes Salzburg, Österreich [Some remarks on the fossil turtles (Reptilia, Testudines) from the federal country of Salzburg, Austria]". German. In: Mitteilungen der Gesellschaft für Salzburger Landeskunde 136 (1996), pp. 389-426.

[11401] H.-V. Karl. “Über Reptilienreste aus dem Alttertiär des nördlichen Alpenvorlandes bei Siegsdorf/Oberbayern". German. In: Joannea Geologie und Paläontologie 4 (2002), pp. 69-81.

[11402] H.-V. Karl. "The fossil reptiles (Reptilia: Chelonii, Crocodylia) from the marine early Oligocene of the Weisselster Basin (Central Germany: Saxonia)". English. In: Studia Geologica Salamanticensia 43.1 (2007), pp. 25-66.

[11403] H.-V. Karl. “Die fossilen Schildkröten aus der Molasse von Oberschwaben mit taxonomischen Notizen zu Promalacoclemmys Reinach, 1900 und Testudo antiqua Bronn, 1831 (Testudines: Cryptodira)". German. In: Mainzer naturwiss. Archiv 50 (2013), pp. 121-146.

[11404] H.-V. Karl. "Human consumption of turtles of the Homo rudolfensis site Uraha (Malawi, East Africa)". English. In: Archaeofauna 21 (2012), pp. 267-279.

[11405] H.-V. Karl, S. Biermann, and G. Tichy. "The oldest true sea turtle of the world, Oertelia gigantea (oertel, 1914) n. gen. from the Aptian of Kastendamm near Hanover, Germany". English. In: Studia Palaeocheloniologica 4 (2012), pp. 107-128.

[11406] H.-V. Karl and U. Frerichs. "Meeresschildkröten (Cheloniidae) aus dem Campan von Hannover". Italian. In: Arbeitskreis Paläontologie Hannover 48 (2018), pp. 73-78.

[11407] H.-V. Karl, E. Gröning, and C. Brauckmann. "The Mesosauria in the collections of Göttingen and Clausthal: implications for a modified classification". English. In: Clausthaler Geowissenschaften 6 (2007), pp. 63-78.

[11408] H.-V. Karl, E. Groning, C. Brauckmann, D. Schwarz, and N. Knotschke. “The Late Jurassic crocodiles of the Langenberg near Oker, Lower Saxony (Germany), and description of related materials (with remarks on the history of quarrying the Langenberg Limestone and Obernkirchen Sandstone)". English. In: Clausthaler Geowissenschaften 5 (2006), pp. 59-77.

[11409] H.-V. Karl, E. Groning, and C. Brauckmann. “New materials of the giant sea turtle Allopleuron (Testudines: Chelonioidea) from the marine Late Cretaceous of Central Europe and the Palaeogene of Kazakhstan". English. In: Studia Palaeocheloniologica 4 (2012), pp. 153-173.

[11410] H.-V. Karl, E. Groning, C. Brauckmann, and N. Knotschke. "First remains of the head of Steneosaurus (Crocodylomorpha: Teleosauridae) from the Late Jurassic of Oker (Lower Saxony, Germany)". English. In: Studia Geologica Salmanticensia 44.2 (2008), pp. 187-201.

[11411] H.-V. Karl and B. E. K. Lindow. "First evidence of a Late Cretaceous marine turtle (Testudines: Chelonioidea) from Denmark". English. In: Studia Geologica Salmanticensia 45.2 (2009), pp. 175180.

[11412] H.-V. Karl and B. E. K. Lindow. "Eocene leatherback turtle material of the genus Egyptemys (Testudines: Dermochelyidae) from Denmark". English. In: Studia Geologica Salmanticensia 46.1 (2010), pp. 55-63.

[11413] H.-V. Karl and B. E. K. Lindow. "Revision of the Paleocene turtles (Reptilia: Testudines) of Denmark". English. In: Studia Palaeocheloniologica 4 (2012), pp. 175-192.

[11414] H.-V. Karl and H. Madsen. “Tasbacka danica n. sp., a new Eocene marine turtle of Denmark (Testudines: Chelonioidea)". English. In: Studia Palaeocheloniologica 4 (2012), pp. 193-204.

[11415] H.-V. Karl, J. Milan, and G. Tichy. "New shell remains of Peltochelys duchastelli (Dollo, 1884) from Western Europe and the rise of trionychids (Testudines: Trionychoidea)". English. In: Studia Palaeocheloniologica 4 (2012), pp. 87-106. 
[11416] H.-V. Karl and A. Müller. "New Fossil reptil material (Reptilia: Chelonii, Crocodylia) from the lower Oligocene of Borken (Central Germany: Hesse)". English. In: Studia Geologica Salmanticensia 44 (2008), pp. 41-58.

[11417] H.-V. Karl and C. J. Nyhuis. "Ctenochelys stenoporus (Hay, 1905) (Testudines: Toxochelyidae) and Clidastes sp. (Squamata: Mosasauridae) from the Upper Cretaceous of NW-Germany". English. In: Studia Palaeocheloniologica 4 (2012), pp. 129-142.

[11418] H.-V. Karl, C. J. Nyhuis, and L. Schollmann. “The first shell remains of Rhinochelys pulchriceps (Owen, 1851) from the Upper Cretaceous of NW-Germany (Testudines: Protostegidae)". English. In: Studia Palaeocheloniologica 4 (2012), pp. 143-151.

[11419] H.-V. Karl, A. Safi, and H. -D. Philippen. "Evidences of cheloniophagy by early hominid (Homo erectus) during middle of pleistocene from beds of trinil's layers in central Java (Indonesia), with an updated list of trinil's testudines, and a redescription of Duboisemys isoclina (Dubois, 1908)". English. In: International Journal of Zoology Studies 4.6 (2019), pp. 73-84.

[11420] H.-V. Karl and G. Tichy. "Murrhardtia staeschei n. gen. n. sp. - eine neue Schildkröte aus der Oberen Trias von Süddeutschland". German. In: Joannea - Geologie und Paläontologie 2 (2000), pp. 5772.

[11421] H.-V. Karl, G. Tichy, and D. Valdisberri. "Sontiochelys cretacea Stache, 1905 and new description of the families Eurysternidae Dollo, 1886 and Thalassemydidae Rutimeyer, 1873 (Testudines: Cryptodira)". English. In: Studia Geologica Salmanticensia 48.1 (2012), pp. 45-76.

[11422] H.-V. Karl and G. Tichy. "Maorichelys wiffeni n. gen. n. sp., a new sea turtle from the Eocene of New Zealand (Chelonii:Dermochelyidae)". English. In: Studia Geologica Salmanticensia 43.1 (2007), pp. 11-24.

[11423] H.-V. Karl and G. Tichy. “Zur Taxonomie eines neuen Tribus von Seeschildkröten aus dem Oligozän von Deutschland (Testudines: Chelonioidea)". German. In: Joannea Geologie und Paläontologie 1 (1999), pp. 61-77.

[11424] P. F. Karrow, A. Ceska, R. J. Hebda, B. B. Miller, K. L. Seymour, and A. J. Smith. “Diverse nonmarine Biota from the Whidbey Formation (Sangamonian) at Point Wilson, Washington". English. In: Quaternary Research 44.3 (1995), pp. 434-437. DOI: 10.1006/qres.1995.1088.

[11425] P. F. Karrow, T. F. Morris, J. H. McAndrews, A. V. Morgan, A. J. Smith, and I. R. Walker. “A diverse late-glacial (Mackinaw Phase) biota from Leamington, Ontario". English. In: Canadian Journal of Earth Sciences 44 (2007), pp. 287-296.

[11426] P. F. Karrow, K. L. Seymour, B. B. Miller, and J. E. Mirecki. “Pre-Late Wisconsinan Pleistocene biota from southeastern Michigan, U.S.A." English. In: Palaeogeography, Palaeoclimatology, Palaeoecology 133.1-2 (1997), pp. 81-101.

[11427] T. Kase. "Late Cretaceous gastropods from the Izumi Group of southwest Japan". English. In: Journal of Paleontology 64.4 (1990), pp. 563-578.

[11428] T. Kase and Y. M. Aguilar. "Bulacanites obtusiplicatus gen. et sp. nov., a large lucinid bivalve (Mollusca) from the Pliocene of central Luzon, Philippines". English. In: Memoirs of the National Science Museum Tokyo 44 (2006), pp. 175-183.

[11429] T. Kase, Y. Kurihara, H. Hayashi, H. Pandita, and Y. M. Aguilar. "Age refinement of the Sonde molluscan fauna, East Java, Indonesia". English. In: Memoirs of the National Museum of Nature and Science Tokyo 45 (2008), pp. 127-138.

[11430] T. Kase, Y. Kurihara, Y. M. Aguilar, H. Pandita, A. Gil S. Fernando, and H. Hayashi. "A New Cerithioidean Genus Megistocerithium (Gastropoda; Mollusca) from the Miocene of Southeast Asia: A Possible Relict of Mesozoic Eustomatidae". English. In: Paleontological Research 19.4 (2015), pp. 299-311. DOI: 10.2517/2015PR013.

[11431] T. Kase and Y. Shigeta. "New species of Patellogastropoda (Mollusca) from the Cretaceous of Hokkaido, Japan and Sakhalin, Russia". English. In: Journal of Paleontology 70.5 (1996), pp. $762-$ 771. 
[11432] K. Kashiwagi and C. Kurimoto. "Reexamination of radiolarian biochronology of the Shimizu Formation (Northern Chichibu Belt) in the Shimizu-Misato area, western Kii Peninsula, Southwest Japan". English. In: Bulletin of the Geological Survey of Japan 54.7/8 (2003), pp. 279-293.

[11433] K. Kashiwagi, N. Yamagiwa, A. Yao, Y. Ezaki, Y. Sakaori, and Y. Shoji. “Late Jurassic cnidarian and poriferan fossils from the Torinosu-type limestones in the Kurosegawa Terrane, western Kii Peninsula, southwest Japan and their geological significance". Japanese. In: Fossils (Kaseki) 72 (2002), pp. 5-16.

[11434] Y. Kashiyama and T. Oji. "Low-diversity shallow marine benthic fauna from the Smithian of northeast Japan: paleocologic and paleobiogeographic imlications." In: Paleontological Research 8.3 (2004), pp. 199-218.

[11435] D. R. Kasparyan. "A new genus and species of the subfamily Ghilarovitinae from Baltic amber (Hymenoptera: Paxylommatidae)". English. In: Zoosystematica Rossica 10 (2001), pp. 97-99.

[11436] M. S. Kass. Prognathodon stadtmani: (Mosasauridae) a new species from the Mancos Shale (Lower Campanian) of western Colorado. English. 1999.

[11437] A. S. Kassab and N. A. Obaidalla. "Integrated biostratigraphy and inter-regional correlation of the Cenomanian-Turonian deposits of Wadi Feiran, Sinai, Egypt". English. In: Creatceous Research 22 (2001), pp. 105-114. DOI: 10.1006/cres.2000.0240.

[11438] A. S. Kassab and M. M. Ismael. "Upper Cretaceous invertebrate fossils from the area northeast of Abu Zuneima, Sinai, Egypt". English. In: Neues Jahrbuch für Geologie und Paläontologie, Abhandlungen 191.2 (1994), pp. 221-249.

[11439] A. S. Kassab and A. S. Mohamed. Upper Cretaceous macrofossils from the Duwi Formation of the Nile Valley, southern Egypt. 1996.

[11440] J. Kathirithamby and D. A. Grimaldi. "Remarkable stasis in some Lower Tertiary parasitoids: descriptions, new records and review of Strepsiptera in the Oligo-Miocene amber of the Dominican Republic". English. In: Entomologica Scandinavica 24 (1993), pp. 31-41.

[11441] J. Kathirithamby and H. Henderickx. "First record of the Strepsiptera genus Caenocholax in Baltic amber with the description of a new species". English. In: Phegea 36.4 (2008), pp. 149-156.

[11442] J. Kathirithamby, E. E. Perkovsky, Z. H. Falin, and M. S. Engel. "A putative twisted-wing parasitoid planidium (Insecta: Strepsiptera) in Taimyr Upper Cretaceous amber". English. In: Cretaceous Research 69 (2017), pp. 106-112.

[11443] H. Kato and H. Karasawa. "Minohellenus macrocheilus sp. nov. (Decapoda: Crustacea) from the Oligocene Ashiya Group, Kyushu, Japan". English. In: Bulletin of the Kitakyushu Museum of Natural History 13 (1994), pp. 51-58.

[11444] M. Kato, I. Kabayashi, S. Kabayashi, I. Sasagawa, T. Shinmura, K. Tamura, H. Horikawa, and M. Miyawaki. "Discovery of the Hydrodamalinae (Sirenia, Mammalia) from the Late Pliocene Shiroiwa Formation in Nagaoka City, Niigata Prefecture". Japanese. In: Bulletin of the Nagaoka Municipal Science Museum 43 (2008), pp. 1-20.

[11445] T. Kato, K. Hasegawa, and T. Ishibashi. "Discovery of Early Triassic hybodontoid shark tooth from the southern Kitakami Massif". Japanese. In: Journal of the Geological Society of Japan 101 (1995), pp. 466-469.

[11446] T. Kato, T. Sonoda, S. Miyata, S. Kawano, and H. Ando. "Large Soft-shelled Turtle Fossils from the Upper Cretaceous Nakaminato Group in Ibaraki Prefecture and their Significance". Japanese. In: Bulletin of Ibaraki Natural Museum 22 (2019), pp. 31-36.

[11447] E. G. Kauffman, P. J. Harries, C. Meyer, T. Villamil, C. Arango, and G. Jaecks. "Paleoecology of giant Inoceramidae (Platyceramus) on a Santonian (Cretaceous) seafloor in Colorado". English. In: Journal of Paleontology 81.1 (2007), pp. 64-81.

[11448] E. G. Kauffman, D. Herm, C. C. Johnson, P. Harries, and R. Höfling. "The ecology of Cenomanian lithistid sponge frameworks, Regensburg area, Germany". English. In: Lethaia 33 (2000), pp. 214235. 
[11449] E. G. Kauffman and H. A. Leanza. "A Remarkable New Genus of Mytilidae (Bivalvia) from the Lower Cretaceous of Southwestern Gondwanaland". In: Journal of Paleontology 78.6 (2004), pp. 1187-1191.

[11450] U. Kaulfuss, S. D. J. Brown, I. M. Henderson, J. Szwedo, and D. E. Lee. "First insects from the Manuherikia Group, early Miocene, New Zealand". English. In: Journal of the Royal Society of New Zealand 49 (2018), pp. 494-507.

[11451] U. Kaulfuss and G. M. Dlussky. "Early Miocene Formicidae (Amblyoponinae, Ectatomminae, ?Dolichoderinae, Formicinae, and Ponerinae) from the Foulden Maar fossil Lagerstätte, New Zealand, and their biogeographic relevance". English. In: Journal of Paleontology 89 (2016), pp. 1043-1055.

[11452] U. Kaulfuss, A. C. Harris, and D. E. Lee. "A new fossil termite (Isoptera, Stolotermitidae, Stolotermes) from the early Miocene of Otago, New Zealand". English. In: Acta Geologica Sinica 84 (2010), pp. 705-709.

[11453] U. Kaulfuss, A. C. Harris, J. G. Conran, and D. E. Lee. "An early Miocene ant (subfam. Amblyoponinae) from Foulden Maar: the first fossil Hymenoptera from New Zealand". English. In: Alcheringa 38 (2014), pp. 568-574.

[11454] U. Kaulfuss, D. E. Lee, B. L. P. Barratt, R. A. B. Leschen, M. C. Lariviére, G. M. Dlussky, I. M. Henderson, and A. C. Harris. "A diverse fossil terrestrial arthropod fauna from New Zealand: evidence from the early Miocene Foulden Maar fossil lagerstätte". English. In: Lethaia 48 (2015), pp. 299-308.

[11455] U. Kaulfuss and M. Moulds. "A new genus and species of tettigarctid cicada from the early Miocene of New Zealand: Paratettigarcta zealandica (Hemiptera, Auchenorrhyncha, Tettigarctidae)". English. In: ZooKeys 484 (2015), pp. 83-94.

[11456] U. Kaulfuss, T. Wappler, E. Heiss, and M. C. Lariviére. "Aneurus sp. from the early Miocene Foulden Maar, New Zealand: the first southern hemisphere record of fossil Aradidae (Insecta: Hemiptera: Heteroptera)". English. In: Journal of the Royal Society of New Zealand 41 (2011), pp. 279285.

[11457] F. Kawabe. "Cretaceous Stratigraphy in the Oyubari Area, Central Hokkaido, Japan". English. In: Bulletin of the National Science Museum. Series C: Geology and Paleontology 26.1-2 (2000), pp. 9-56.

[11458] F. Kawabe and Y. Shigeta. "The genus Hourcquia (Ammonoidea, Pseudotissotiidae) from the Upper Cretaceous of Hokkaido, Japan: biostratigraphic and biogeographic implications". English. In: Paleontological Research 5.2 (2001), pp. 101-109. DOI: 10.2517/prpsj.5.101.

[11459] A. Kawamur, C.-H. Chang, and Y. Kawamura. "The earliest fossil record of the bandicoot rat (Bandicota indica) from the". English. In: Quaternary International 523 (2019), pp. 37-45. DOI: 10. 1016/j.quaint.2019.06.012.

[11460] T. Kawamura and H. Machiyama. "A Late Permian coral reef complex, South Kitakami Terrane, Japan”. In: Sedimentary Geology 99 (1995), pp. 135-150.

[11461] R. F. Kay. "Giant tamarin from the Miocene of Colombia". English. In: American Journal of Physical Anthropology 95.3 (1994), pp. 333-353.

[11462] R. F. Kay and M. A. Cozzuol. "New platyrrhine monkeys from the Solimoes Formation (late Miocene, Acre State, Brazil)". English. In: Journal of Human Evolution 50.6 (2006), pp. 673-686.

[11463] R. F. Kay, J. G. Fleagle, T. R. T. Mitchell, M. Colbert, T. Bown, and D. W. Powers. “The anatomy of Dolichocebus gaimanensis, a stem platyrrhine monkey from Argentina". English. In: Journal of Human Evolution 54.3 (2008), pp. 323-382. DOI: 10.1016/j.jhevol.2007.09.002.

[11464] R. F. Kay and C. D. Frailey. "Large fossil platyrrhines from the Rio Acre local fauna, late Miocene, western Amazonia". English. In: Journal of Human Evolution 25 (1993), pp. 319-327.

[11465] R. F. Kay, L. A. Gonzales, W. Salenbien, J. -N. Martinez, S. B. Cooke, L. A. Valdivia, C. Rigsby, and P. A. Baker. "Parvimico materdei gen. et sp. nov.: A new platyrrhine from the Early Miocene of the Amazon Basin, Peru". English. In: Journal of Human Evolution 134 (2019), 102628:1-16. DOI: 10.1016/j.jhevol.2019.05.016. 
[11466] R. F. Kay, D. Johnson, and J. Meldrum. "A new Pitheciin Primate from the Middle Miocene of Argentina". English. In: American Journal of Primatology 45 (1998), pp. 317-336.

[11467] R. F. Kay and D. J. Meldrum. "A new small platyrrhine and the phyletic position of Callitrichinae". English. In: A new small platyrrhine and the phyletic position of Callitrichinae. Smithsonian Institution Press, 1997, pp. 435-458.

[11468] R. F. Kay and J. M. G. Perry. “New Primates From the Ro Santa Cruz and Ro Bote (Early-Middle Miocene), Santa Cruz Province, Argentina". English. In: Publicación Electrónica de la Asociación Paleontológica Argentina 19.2 (2019), pp. 230-238. DOI: 10.5710/PEAPA.24.08.2019.289.

[11469] R. F. Kay, S. F. Vizcaino, M. S. Bargo, J. M. G. Perry, F. J. Prevosti, and J. C. Fernicola. “Two new fossil vertebrate localities in the Santa Cruz Formation (late early - early middle Miocene, Argentina), 51ř South latitude". English. In: Journal of South American Earth Sciences 25 (2008), pp. 187-195.

[11470] F. Kaya, N. Kaymakci, F. Bibi, J. Eronen, C. Pehlevan, A. C. Erkman, C. Langereis, and M. Fortelius. "Magnetostratigraphy and paleoecology of the hominid-bearing locality Corakyerler, Tuglu Formation (Cankiri Basin, Central Anatolia)". English. In: Journal of Vertebrate Paleontology 36.2 (2016). DOI: 10.1080/02724634.2015.1071710.

[11471] M. Y. Kaya and D. Altner. "Microencrusters from the Upper Jurassic-Lower Cretaceous nalt Formation (Central Pontides, Turkey): remarks on the development of reefal/peri-reefal facies". English. In: Facies 61.18 (2015). DOI: 10.1007/s10347-015-0445-5.

[11472] T. Kaya and K. Heissig. "Late Miocene rhinocerotids (Mammalia) from Yulafli (Corlu-Thrace/Turkey)". English. In: Geobios 34.4 (2001), pp. 457-467.

[11473] T. T. Kaya, S. Mayda, D. S. Kostopoulos, M. C. Alcicek, G. Merceron, A. Tan, S. Karakutuk, A. K. Giesler, and R. S. Scott. Serefkoy-2, a new Late Miocene mammal locality from the Yatagan Formation, Mugla, SW Turkey. English. Vol. 11. Comptes Rendus Palevol. 2012, pp. 5-12. DOI: 10.1016/j.crpv. 2011.09.001.

[11474] H. Kayanne, T. Ishii, E. Matsumoto, and N. Yonekura. "Late Holocene sea-level change on Rota and Guam, Mariana Islands, and its constraint on geophysical predictions". English. In: Quaternary Research 40 (1993), pp. 189-200.

[11475] H. Kayanne, H. Yamano, and R. H. Randall. "Holocene sea-level changes and barrier reef formation on an oceanic island, Palau Islands, western Pacific". English. In: Sedimentary Geology 150 (2002), pp. 47-60.

[11476] F. T. Kaye and K. Padian. Microvertebrates from the Placerias Quarry: a window on Late Triassic vertebrate diversity in the American Southwest. In the Shadow of the Dinosaurs: Early Mesozoic Tetrapods, N. C. Fraser and H.-D. Sues (eds.), Cambridge University Press. 1994, pp. 172-196.

[11477] N. Kazanci, S. Sen, G. Seyitoglu, L. de Bonis, G. Bouvrain, H. Araz, B. Varol, and L. Karadenizli. "Geology of a new Late Miocene mammal locality in central Anatolia, Turkey". English. In: Comptes Rendus de l'Academie des Sciences, Serie II. Sciences de la Terre et des Planetes 329.7 (1999), pp. 503-510.

[11478] S. Kazantsev. "Retromalisus damzeni, gen. et sp. nov., a second Baltic amber taxon of the extinct family Berendtimiridae (Insecta: Coleoptera)". English. In: Journal of Natural History 54 (2020), pp. 1073-1080. DOI: 10.1080/00222933.2020.1781949.

[11479] S. V. Kazantsev. "A new Lycid Genus from the Dominican Amber (Insecta, Coleoptera, Lycidae, Leptolycinae, Leptolycini)”. English. In: Psyche 2012.982141 (2012), pp. 1-3. DOI: 10.1155 / 2012 / 982141.

[11480] S. V. Kazantsev. "New omethid and lampyrid taxa from the Baltic Amber (Insecta: Coleoptera)". English. In: Zootaxa 3186 (2012), pp. 59-63.

[11481] S. V. Kazantsev. “New Malthodes (Insecta: Cantharidae: Coleoptera) from the Rovno amber (Upper Eocene of Ukraine)". English. In: Russian Entomological Journal 19 (2010), pp. 105-107.

[11482] S. V. Kazantsev. "New taxa of Baltic amber soldier beetles (Insecta: Coleoptera: Cantharidae) with synonymic and taxonomic notes". English. In: Russian Entomological Journal 22 (2013), pp. 283-291. 
[11483] S. V. Kazantsev. "A new fossil genus of net-winged beetles, with a brief review of amber Lycidae (Insecta: Coleoptera)". English. In: Zootaxa 3608 (2013), pp. 94-100.

[11484] S. V. Kazantsev. "A new Luciolinae firefly (Coleoptera: Lampyridae) from the Baltic amber". English. In: Russian Entomological Journal 21 (2012), pp. 319-320.

[11485] S. V. Kazantsev. "Protoluciola albertalleni gen.n., sp.n., a new Luciolinae firefly (Insecta: Coleoptera: Lampyridae) from Burmite amber". English. In: Russian Entomological Journal 24 (2015), pp. 281283.

[11486] S. V. Kazantsev. "New Baltic amber soldier beetles (Coleoptera, Cantharidae, Cantharinae)". English. In: Euroasian Entomological Journal 17 (2018), pp. 146-152.

[11487] S. V. Kazantsev. “New Baltic amber soldier beetles (Insecta: Coleoptera: Cantharidae) with some taxonomic notes". English. In: Palaeoentomology 3 (2020), pp. 260-268.

[11488] S. V. Kazantsev. "First fossil representative of the net-winged beetles genus Plateros Bourgeois, 1879 (Insecta: Coleoptera: Lycidae) from Mexican amber, with redescription of Electropteron avus gen.n., sp.n. from Dominican amber and a note on the time of origin of the family". English. In: Russian Entomological Journal 29 (2020), pp. 377-387.

[11489] S. V. Kazantsev. "Protolycus gedaniensis gen. et sp. nov., the first Baltic amber representative of Lycini (Coleoptera: Lycidae: Lycinae)". English. In: Palaeoentomology 2 (2019), pp. 327-332.

[11490] S. V. Kazantsev and E. E. Perkovsky. "A new Malthodes and some other interesting soldier beetles (Coleoptera: Cantharidae) from Late Eocene Rovno amber". English. In: Russian Entomological Journal 23.2 (2014), pp. 113-116.

[11491] S. V. Kazantsev and E. E. Perkovsky. "The first Cretaceous beetle from Azerbaijan: Katyacantharis zherikhini gen. et sp. n. (Coleoptera, Cantharidae) from Cenomanian Agdzhakend amber". English. In: Palaeoentomology 2 (2019), pp. 7-12.

[11492] S. V. Kazantsev and E. E. Perkovsky. “A new genus of soldier beetles (Insecta: Coleoptera: Cantharidae: Cantharinae) from Sakhalinian amber". English. In: Paleontological Journal 53 (2019), pp. 300-304. DOI: 10.1134/S0031030119030067.

[11493] S. V. Kazantsev and E. E. Perkovsky. "The first Cacomorphocerus species(Coleoptera, Cantharidae) from Rovno amber: a second species of the genus with 11-segmented antennae". English. In: Zootaxa 4751 (2020), pp. 395-400.

[11494] E. Kazár. "Revised phylogeny of the Physeteridae (Mammalia: Cetacea) in light of Placoziphius Van Beneden, 1869 and Aulophyseter Kellogg, 1927". English. In: Bulletin de l'Institute Royal des Sciences Naturelles de Belgique, Sciences de la Terre 72 (2002), pp. 151-170.

[11495] E. Kazár. "A new kentriodontid (Cetacea: Delphinoidea) from the Middle Miocene of Hungary". English. In: Mitteilungen aus dem Museum fur Naturkende in Berlin - Geowissenschaftliche Reihe 8 (2005), pp. 53-73.

[11496] E. Kazár. "Odontocete periotics (Mammalia: Cetacea) from the Carpathian Basin, Middle Miocene (Badenian and Sarmatian Stages), including the Vienna Basin, Austria". English. In: Beitrage zur Palaontologie 30 (2006), pp. 269-292.

[11497] E. Kazár. "Revision of the genus Pachyacanthus Brandt, 1871 (Mammalia: Cetacea: Odontoceti)". English. In: Annalen des Naturhistorischen Museums in Wien, Serie A 112 (2010), pp. 537-568.

[11498] E. Kazár and O. Hampe. "A new species of Kentriodon (Mammalia, Odontoceti, Delphinoidea) from the middle/late Miocene of GroSS Pampau (Schleswig-Holstein, North Germany)". English. In: Journal of Vertebrate Paleontology 34.5 (2014), pp. 1216-1230. DOI: 10.1080/02724634.2014.857347.

[11499] E. Kazár and Z. Lantos. “Taphonomy and palaeoecology of the holotype of Heterodelphis leiodontus Papp, 1905 (Cetacea, Mammalia) from Szentmargita (St. Margerethen, Austria)". English. In: Fragmenta Palaeontologica Hungarica 19 (2001), pp. 51-60.

[11500] E. Kazár and M. Venczel. "Kentriodontid remains (Cetacea: Odontoceti) from the middle Miocene of Bihor County, Romania". English. In: Nyphaea Folia naturae Bihariae 30 (2003), pp. 39-66. 
[11501] E. Kazár, M. Vremir, and V. Codrea. "Dolphin remains (Cetacea: Odontoceti) from the middle Miocene of Cluj-napoca, Romania". English. In: Acta Paleontologica Romanie 4 (2004), pp. 179-189.

[11502] B. P. Kear. "Plesiosaur remains from Cretaceous high-latitude non-marine deposits in southeastern Australia". English. In: Journal of Vertebrate Paleontology 26.1 (2006), pp. 196-199.

[11503] B. P. Kear. "A new elasmosaurid plesiosaur from the Lower Cretaceous of Queensland, Australia". English. In: Journal of Vertebrate Paleontology 25.4 (2005), pp. 792-805.

[11504] B. P. Kear. "A juvenile pliosauroid plesiosaur (Reptilia: Sauropterygia) from the Lower Cretaceous of South Australia". English. In: Journal of Paleontology 81.1 (2007), pp. 154-162.

[11505] B. P. Kear. "Marine reptiles from the Lower Cretaceous of South Australia: elements of a highlatitude cold-water assemblage". English. In: Palaeontology 49.4 (2006), pp. 837-856.

[11506] B. P. Kear. "Dental caries in an Early Cretaceous ichthyosaur". English. In: Alcheringa 25.4 (2001), pp. 387-390.

[11507] B. P. Kear. “Marine reptiles from the Lower Cretaceous (Aptian) deposits of White Cliffs, southeastern Australia: implications of a high latitude, cold water assemblage". English. In: Cretaceous Research 26.5 (2005), pp. 769-782.

[11508] B. P. Kear. "Cretaceous marine reptiles of Australia: a review of taxonomy and distribution". English. In: Cretaceous Research 24.3 (2003), pp. 277-303.

[11509] B. P. Kear. "Proterosuchid archosaur remains from the Early Triassic Bulgo Sandstone of Long Reef, New South Wales". English. In: Alcheringa 33 (2009), pp. 331-337.

[11510] B. P. Kear. “Cranial morphology of Platypterygius longmani Wade, 1990 (Reptilia: Ichthyosauria) from the Lower Cretaceous of Australia". English. In: Zoological Journal of the Linnean Society 145 (2005), pp. 583-622.

[11511] B. P. Kear. "Reassessment of Cratochelone berneyi Longman 1915, a giant sea turtle from the Early Cretaceous of Australia". English. In: Journal of Vertebrate Paleontology 26.3 (2006), pp. 779-783.

[11512] B. P. Kear. “A revision of Australia's Jurassic plesiosaurs". English. In: Palaeontology 55.5 (2012), pp. 1125-1138.

[11513] B. P. Kear, M. Archer, and T. F. Flannery. "Bulungamayine (Marsupialia, Macropodidae) postcranial elements from the late Miocene of Riversleigh, northwestern Queensland". English. In: Memoir of the Association of Australasian Palaeontologists 25 (2001), pp. 103-122.

[11514] B. P. Kear, M. Archer, and T. F. Flannery. “Postcranial morphology of Ganguroo bilamina Cooke, 1997 (Marsupialia, Macropodidae) from the middle Miocene of Riversleigh, northwestern Queensland". English. In: Memoir of the Association of Australasian Paleontologists 25 (2001), pp. 123-138.

[11515] B. P. Kear, W. E. Boles, and E. T. Smith. "Unusual gut contents in a Cretaceous ichthyosaur". English. In: Proceedings of the Royal Society of London B 270 (2003), pp. 206-208.

[11516] B. P. Kear, B. N. Cooke, M. Archer, and T. F. Flannery. “Implications of a new species of the OligoMiocene kangaroo (Marsupialia, Macropodoidea) Nambaroo, from the Riversleigh World Heritage Area, Queensland, Australia". English. In: Journal of Paleontology 81.6 (2007), pp. 1147-1167.

[11517] B. P. Kear, G. L. Deacon, and M. Siverson. "Remains of a Late Cretaceous pterosaur from the Molecap Greensand of Western Australia". English. In: Alcheringa 34.3 (2010), pp. 273-279. DOI: 10.1080/03115511003661651.

[11518] B. P. Kear, B. Ekrt, J. Prokop, and G. L. Georgalis. "Turonian marine amniotes from the Bohemian Cretaceous Basin, Czech Republic". English. In: Geological Magazine 151.1 (2014), pp. 183-198. DOI: 10.1017/S0016756813000502.

[11519] B. P. Kear and M. S. Lee. "A primitive protostegid from Australia and early sea turtle evolution". English. In: Biology Letters 2 (2006), pp. 116-119. DOI: 10.1098/rsbl.2005.0406.

[11520] B. P. Kear, J. A. Long, and J. E. Martin. "A review of Australian mosasaur occurences". English. In: Netherlands Journal of Geosciences — Geologie en Mijnbouw 84.3 (2005), pp. 307-313. 
[11521] B. P. Kear and E. E. Maxwell. “Wiman's forgotten plesiosaurs: the earliest recorded sauropterygian fossils from the High Arctic". English. In: GFF (Geologiska Foreningen) (2013).

[11522] B. P. Kear, A. R. Milner, and P. M. Barrett. "Plesiosaur remains from the Jurassic-Cretaceous Purbeck Limestone Group of southern England". English. In: Proceedings of the Geologists' Association 120 (2009), pp. 121-125. DOI: 10.1016/j.pgeola.2009.06.001.

[11523] B. P. Kear, T. H. Rich, M. A. Ali, Y. A. Al-Mufarrih, A. H. Matiri, A. M. Masary, and Y. Attia. "Late Cretaceous (Campanian-Maastrichtian) marine reptiles from the Adaffa Formation, NW Saudi Arabia". English. In: Geological Magazine 145.5 (2008), pp. 648-654. DOI: 10.1017 / S0016756808005062.

[11524] B. P. Kear, T. H. Rich, P. Vickers-Rich, M. A. Ali, Y. A. Al-Mufarrih, A. D. Matari, A. M. Al-Masary, and M. A. Halawani. "A review of aquatic vertebrate remains from the Middle-Upper Triassic Jilh Formation of Saudi Arabia". English. In: Proceedings of the Royal Society of Victoria 122 (2010), pp. 1-8.

[11525] B. P. Kear, T. H. Rich, P. Vickers-Rich, M. A. Ali, Y. A. Al-Mufarreh, A. H. Matari, A. M. Al-Massari, A. H. Nasser, Y. Attia, and M. A. Halawani. "First dinosaurs from Saudi Arabia". English. In: PLoS One 8.12 (2013), e84041:1-10. DOI: 10.1371/journal.pone.0084041.

[11526] B. P. Kear, N. I. Schroeder, and M. S. Y. Lee. “An archaic crested plesiosaur in opal from the Lower Cretaceous high-latitude deposits of Australia". English. In: Biology Letters 2 (2006), pp. 615-619.

[11527] B. P. Kear and M. Siverson. "First evidence of a Late Cretaceous sea turtle from Australia". English. In: Alcheringa 34 (2010), pp. 265-272. DOI: 10.1080/03115511003659622.

[11528] J. M. Keating. "Palynology of the Lachman Crags Member, Santa Marta Formation (Upper Cretaceous) of north-west James Ross Island". English. In: Antartic Science 4.3 (1992), pp. 293-304.

[11529] E. Keeble, D. I. Whiteside, and M. J. Benton. "The terrestrial fauna of the Late Triassic Pant-yffynnon Quarry fissures, South Wales, UK and a new species of Clevosaurus (Lepidosauria: Rhynchocephalia)". English. In: Proceedings of the Geologists' Association (2018). DOI: 10.1016/j.pgeola. 2017.11.001.

[11530] D. H. Keen, G. R. Coope, R. L. Jones, M. H. Field, H. I. Griffiths, S. G. Lewis, and D. Q. Bowen. "Middle Pleistocene deposits at Frog Hall Pit, Stretton-on-Dunsmore, Warwickshire, English Midlands, and their implications for the age of the type Wolstonian". English. In: Journal of Quaternary Science 12 (1997), pp. 183-208.

[11531] C. Kehlmaier, M. Dierick, and J. H. Skevington. “Micro-CT studies of amber inclusions reveal internal genitalic features of big-headed flies, enabling a systematic placement of Metanephrocerus Aczél, 1948 (Insecta: Diptera: Pipunculidae)". English. In: Arthropod Systematics \& Phylogeny 72 (2014), pp. 23-36.

[11532] K.-P. Kelber and J. H. A. van Konijnenburg-van Cittert. "A new Rhaetian flora from the neighbourhood of Coburg (Germany) - preliminary results." In: Proceedings 4th EPPC 58 (1997), pp. 105-114.

[11533] G. Keller. "Guembelitria-dominated late Maastrichtian planktic foraminiferal assemblages mimic early Danian in central Egypt". English. In: Marine Micropaleontology 47 (2002), pp. 71-99.

[11534] G. Keller, T. Adatte, W. Stinnesbeck, V. Luciani, N. Karoui-Yaakoub, and D. Zaghbib-Turki. "Paleoecology of the Cretaceous-Tertiary mass extinction in planktonic foraminifera". English. In: Palaeogeography, Palaeoclimatology, Palaeoecology 178 (2002), pp. 257-297.

[11535] G. Keller, L. Li, and N. MacLeod. "The Cretaceous/Tertiary boundary stratotype section at El Kef, Tunisia: how catastrophic was the mass extinction?" English. In: Palaeogeography, Palaeoclimatology, Palaeoecology 119 (1995), pp. 221-254.

[11536] G. Keller, H. Qi, T. Adatte, and S. Burns. "Palaeoenvironment of the Cenomanian-Turonian transition at Eastbourne, England". English. In: Cretaceous Research 22 (2001), pp. 391-422.

[11537] J. A. Keller, P. S. Herendeen, and P. R. Crane. "Fossil flowers and fruits of the Actinidiaceae from the Campanian (Late Cretaceous) of Georgia". In: American Journal of Botany 83.4 (1996), pp. 528541. 
[11538] M. Keller, F. Canas, O. Lehnert, and N. E. Vaccari. "The Upper Cambrian and Lower Ordovician of the Precordillera (Western Argentina): Some stratigraphic reconsiderations". English. In: Newsletters on Stratigraphy 31.2 (1994), pp. 115-132.

[11539] M. Keller and E. Flügel. “Early Ordovician reefs from Argentina: stromatoporid vs stromatolite origin". English. In: Facies 34 (1996), pp. 177-192.

[11540] O. Keller and P. E. Skelley. "A new species of Notaepytus Skelley, 2009 (Coleoptera: Erotylidae: Tritomini) from Dominican amber". English. In: Zootaxa 4609 (2019), pp. 191-195.

[11541] N. P. Kelley, R. Motani, P. Embree, and M. J. Orchard. "A new Lower Triassic ichthyopterygian assemblage from Fossil Hill, Nevada". English. In: PeerJ 4.e1626 (2016). DOI: 10.7717/peerj.1626.

[11542] A. W. A. Kellner. "Short note on a new dinosaur (Theropoda, Coelurosauria) from the Santana Formation (Romualdo Member, Albian), northeastern Brazil". English. In: Boletim do Museu Nacional, Nova Série 49 (1999), pp. 1-8.

[11543] A. W. A. Kellner. Preliminary report on the microvertebrate fauna from the Late Cretaceous Bauru strata near Peirópolis, Minas Gerais, Brazil. 1994.

[11544] A. W. A. Kellner. "Comments on the Pteranodontidae (Pterosauria, Pterodactyloidea) with a description of two new species". English. In: Anais da Academia Brasileira de Ciencias 82.4 (2010), pp. 1063-1084.

[11545] A. W. A. Kellner. "A new unusual tapejarid (Pterosauria, Pterodactyloidea) from the Early Cretaceous Romualdo Formation, Araripe Basin, Brazil". English. In: Earth and Environmental Science Transactions of the Royal Society of Edinburgh 103 (2013), pp. 1-13.

[11546] A. W. A. Kellner. "Comments on Triassic pterosaurs with discussion about ontogeny and description of new taxa". English. In: Anais da Academia Brasileira de Ciencias 87.2 (2015), pp. 669-689.

[11547] A. W. A. Kellner, M. B. Aguirre-Urreta, and V. A. Ramos. “On the pterosaur remains from the Ro Belgrano Formation (Barremian), Patagonian Andes of Argentina". English. In: Anais da Academia Brasileira de Ciencias 75.4 (2003), pp. 487-495.

[11548] A. W. A. Kellner, S. A. K. Azevedo, E. B. Machado, L. B. de Carvalho, and D. D. R. Henriques. "A new dinosaur (Theropoda, Spinosauridae) from the Cretaceous (Cenomanian) Alcantara Formation, Cajual Island, Brazil”. English. In: Anais da Academia Brasileira de Ciencias 83.1 (2011), pp. 99 108.

[11549] A. W. A. Kellner and S.A.K.d Azevedo. A new sauropod dinosaur (Titanosauria) from the Late Cretaceous of Brazil. English. Vol. 15. Proceedings of the Second Gondwanan Dinosaur Symposium, National Science Museum Monographs. 1999, pp. 111-142.

[11550] A. W. A. Kellner, M. W. Caldwell, B. Holgado, F. M. Dalla Vecchia, R. Nohra, J. M. Sayão, and P. J. Currie. "First complete pterosaur from the Afro-Arabian continent: insight into pterodactyloid diversity". English. In: Scientific Reports 9 (2019), 17875:1-9. DOI: 10.1038/s41598-019-54042-z.

[11551] A. W. A. Kellner, J. O. Calvo, J. M. Sayão, and J. D. Porfiri. “Pterosaur bones from the Portezuelo Formation (Cretaceous), Neuquén Group, Patagonia, Argentina". English. In: Arquivos do Museu Nacional, Rio de Janeiro 64.4 (2006), pp. 369-375.

[11552] A. W. A. Kellner and D. A. Campos. "The function of the cranial crest and jaws of a unique pterosaur from the Early Cretaceous of Brazil". English. In: Science 297 (2002), pp. 389-392.

[11553] A. W. A. Kellner, D. A. Campos, D. Riff, and M.B.d. Andrade. "A new crocodylomorph (Sphagesauridae, Notosuchia) with horn-like tubercles from Brazil". English. In: Zoological Journal of the Linnean Society 163 (2011), S57-S65. DOI: 10.1111/j.1096-3642.2011.00712.x.

[11554] A. W. A. Kellner and D.d.A. Campos. "On a theropod dinosaur (Abelisauria) from the continental Cretaceous of Brazil". In: Arquivos do Museu Nacional, Rio de Janeiro 60.3 (2002), pp. 163-170.

[11555] A. W. A. Kellner and D.d.A. Campos. "First Early Cretaceous theropod dinosaur from Brazil with comments on Spinosauridae". English. In: Neues Jahrbuch für Geologie und Paläontologie, Abhandlungen 199.2 (1996), pp. 151-166. 
[11556] A. W. A. Kellner and D.d.A. Campos. "Brief review of dinosaur studies and perspectives in Brazil". English. In: Anais da Academia Brasileira de Ciencias 72.4 (2000), pp. 509-538.

[11557] A. W. A. Kellner, D.d.A. Campos, and M. N. F. Trotta. "Description of a titanosaurid caudal series from the Bauru Group, Late Cretaceous of Brazil". English. In: Arquivos do Museu Nacional, Rio de Janeiro 63.3 (2005), pp. 529-564.

[11558] A. W. A. Kellner, D.d.A. Campos, S.A.K.d. Azevedo, M. N. F. Trotta, D. D. R. Henriques, M. M. T. Craik, and H.d.P. Silva. "On a new titanosaur sauropod from the Bauru Group, Late Cretaceous of Brazil”. English. In: Boletim do Museu Nacional, Nova Série, Geologia 74 (2006), pp. 1-31.

[11559] A. W. A. Kellner and D.de.A. Campos. "A new species of Tupuxuara (Pterosauria, Tapejaridae) from the Early Cretaceous of Brazil". English. In: Anais da Academia Brasileira de Ciencias 66 (1994), pp. 467-473.

[11560] A. W. A. Kellner, F. R. Costa, X. Wang, and X. Cheng. "Redescription of the first pterosaur remains from Japan: the largest flying reptile from Asia". English. In: Historical Biology 28 (2016), pp. 304309.

[11561] A. W. A. Kellner, R. G. Figueiredo, S. A. K. Azevedo, and D. A. Campos. "A new cretaceous notosuchian (Mesoeucrocodylia) with bizarre dentition from Brazil". English. In: Zoological Journal of the Linnean Society 163 (2011), S109-S115. DOI: 10.1111/j.1096-3642.2011.00711.x.

[11562] A. W. A. Kellner and W. Langston. "Cranial remains of Quetzalcoatlus (Pterosauria, Azhdarchidae) from Late Cretaceous sediments of Big Bend National Park, Texas". English. In: Journal of Vertebrate Paleontology 16.2 (1996), pp. 222-231.

[11563] A. W. A. Kellner and B. J. Mader. "Archosaur teeth from the Cretaceous of Morocco". English. In: Journal of Paleontology 71 (1997), pp. 525-527.

[11564] A. W. A. Kellner, A. E. P. Pinheiro, S. A. K. Azevedo, D. D. R. Henriques, L. B. de Carvalho, and G. R. Oliveira. "A new crocodyliform from the Alcantara Formation (Cenomanian), Cajual Island, Brazil”. English. In: Zootaxa 2030 (2009), pp. 49-58.

[11565] A. W. A. Kellner, A. E. P. Pinheiro, and D. A. Campos. "A new sebecid from the Paleogene of Brazil and the crocodyliform radiation after the K-Pg boundary". English. In: PLoS ONE 9.1 (2014), e81386. DOI: 10.1371/journal.pone.0081386.

[11566] A. W. A. Kellner, T. H. Rich, F. R. Costa, P. Vickers-Rich, B. P. Kear, M. Walters, and L. Kool. "New isolated pterodactyloid bones from the Albian Toolebuc Formation (western Queensland, Australia) with comments on the Australian pterosaur fauna". English. In: Alcheringa 34.3 (2010), pp. 219-230. DOI: 10.1080/03115511003656552.

[11567] A. W. A. Kellner, T. Rodrigues, and F. R. Costa. "Short note on a pteranodontoid pterosaur (Pterodactyloidea) from western Queensland, Australia". English. In: Anais da Academia Brasileira de Ciencias 83.1 (2011), pp. 301-308.

[11568] A. W. A. Kellner, T. Rodrigues, F. R. Costa, L. C. Weinschütz, R. G. Figueiredo, G. A. Souza, A. S. Brum, L. H. S. Eleutério, C. W. Mueller, and J. M. Sayão. "Pterodactyloid pterosaur bones from Cretaceous deposits of the Antarctic Peninsula". English. In: Anais da Academia Brasileira de Ciencias 91.2 (2019), e20191300.

[11569] A. W. A. Kellner, D. Rubilar-Rogers, A. O. Vargas, and M. Suarez. "A new titanosaur sauropod from the Atacama Desert, Chile". English. In: Anais da Academia Brasileira de Ciencias 83.1 (2011), pp. 211-219.

[11570] A. W. A. Kellner, T. R. Simões, D. Riff, O. Grillo, P. Romano, H.d. Paula, R. Ramos, M. Carvalho, J. Sayão, G. Oliveira, and T. Rodrigues. "The oldest plesiosaur (Reptilia, Sauropterygia) from Antarctica". English. In: Polar Research 30.7265 (2011), pp. 1-6. DOI: 10.3402/polar.v30i0.7265.

[11571] A. W. A. Kellner and Y. Tomida. “Description of a new species of Anhangueridae (Pterodactyloidea) with comments on the pterosaur fauna from the Santana Formation (Aptian-Albian), northeastern Brazil". English. In: National Science Museum Monograph 17 (2000), pp. 1-135. 
[11572] A. W. A. Kellner, L. C. Weinschutz, B. Holgado, R. A. M. Bantim, and J. M. Sayão. “A new toothless pterosaur (Pterodactyloidea) from Southern Brazil with insights into the paleoecology of a Cretaceous desert". English. In: Anais da Academia Brasileira de Ciencias 91.2 (2019), e20190768. DOI: 10.1590/0001-3765201920190768.

[11573] M. Kelly and J. S. Buckeridge. "An Early Paleogene sponge fauna, Chatham Island, New Zealand". English. In: New Zealand Journal of Marine and Freshwater Research 39 (2005), pp. 899-914.

[11574] M. Kelly, D. Lee, S. Kelly, and J. S. Buckeridge. "A recent sponge, Pleroma aotea Kelly (order Lithistida: family Pleromidae), in the Late Eocene Ototara Limestone of Otago, New Zealand". English. In: New Zealand Journal of Marine and Freshwater Research 37 (2003), pp. 129-148.

[11575] R. S. Kelly and A. Nel. "Revision of some damsel-dragonflies (Odonata, Liassophlebiidae and Anglophlebiidae new family) from the Triassic/Jurassic of England and Antarctica". English. In: Journal of Paleontology 92 (2018), pp. 1035-1048.

[11576] R. S. Kelly, A. J. Ross, and P. Davidson. "Mesozoic Holcoptera (Coleoptera: Coptoclavidae) from England and the United States". English. In: Proceedings of the Geologists' Association 128 (2017), pp. 659-674.

[11577] R. S. Kelly, A. J. Ross, and E. A. Jarzembowski. "Earwigs (Dermaptera) from the Mesozoic of England and Australia, described from isolated tegmina, including the first species to be named from the Triassic". English. In: Earth and Environmental Science Transactions of the Royal Society of Edinburgh 107 (2018), pp. 129-143.

[11578] R. S. Kelly, A. J. Ross, and R. A. Coram. "A review of necrotauliids from the Triassic/Jurassic of England (Trichoptera: Necrotauliidae)". English. In: Psyche 2018 (2018), p. 6706120.

[11579] S. R. A. Kelly. "New trigonoid bivalves from the early Jurassic to earliest Cretaceous of the Antarctic Peninsula region: systematics and austral paleobiogeography". In: Journal of Paleontology 69.1 (1995), pp. 66-84.

[11580] S. R. A. Kelly. "Bivalvia of the Spilsby Sandstone and Sandringham Sands (Late Jurassic-Early Cretaceous) of Eastern England; Part 2". English. In: The Palaeontographical Society, London (1992), pp. 95-123.

[11581] S. R. A. Kelly, E. Blanc, S. P. Price, and A. G. Whitham. Early Cretaceous giant bivalves from seeprelated limestone mounds, Wollaston Forland, Northeast Greenland. English. Vol. 177. E.M. Harper, J.D. Taylor, J.A. Crame, The evolutionary biology of the Bivalvia. Geological Society, London, Special Publications. 2000, pp. 227-246.

[11582] S. R. A. Kelly, P. A. Doubleday, C. H. C. Brunton, J. M. Dickins, G. D. Sevastopulo, and P. D. Taylor. "First Carboniferous and ?Permian marine macrofaunas from Antarctica and their tectonic implications". In: Journal of the Geological Society of London 158.2 (2001), pp. 219-232.

[11583] S. R. A. Kelly and P. Doyle. "The bivalve Aulacomyella from the Early Tithonian (Late Jurassic) of Antarctica". English. In: Antarctic Science 3.1 (1991), pp. 97-107.

[11584] S. R. A. Kelly and A. C. M. Moncrieff. "Marine molluscan constraints on the age of Cretaceous fossil forests of Alexander Island, Antarctica". English. In: Geological Magazine 129.6 (1992), pp. 771778.

[11585] S. R. A. Kelly and A. G. Whitham. "Deshayesitid ammonites from the lower Aptian (Lower Cretaceous) of north-east Greenland". English. In: Scripta Geologica, Special Issue 3 (1999), pp. 83-95.

[11586] T. S. Kelly. "Biostratigraphy of Uintan and Duchesnean land mammal assemblages from the Middle Member of the Sespe Formation, Simi Valley, California". English. In: Contributions in Science, Natural History Museum of Los Angeles County 419 (1990), pp. 1-42.

[11587] T. S. Kelly. "New Middle Miocene Camels from the Caliente Formation, Cuyama Valley Badlands, California". English. In: PaleoBios 13.52 (1992), pp. 1-22.

[11588] T. S. Kelly. "New Uintan and Duchesnean (Middle and Late Eocene) Rodents from the Sespe Formation, Simi Valley, California". English. In: Bulletin of the Southern California Academy of Sciences 91.3 (1992), pp. 97-120. 
[11589] T. S. Kelly. “Two Pliocene (Blancan) vertebrate faunas from Douglas County, Nevada”. English. In: PaleoBios 16.1 (1994), pp. 1-23.

[11590] T. S. Kelly. “New Miocene Mammalian Faunas from West Central Nevada”. English. In: Journal of Paleontology 72.1 (1998), pp. 137-149.

[11591] T. S. Kelly. "A new Hemphillian (Late Miocene) mammalian fauna from Hoye Canyon, west central Nevada". English. In: Contributions in Science, Natural History Museum of Los Angeles County 481 (2000), pp. 1-21.

[11592] T. S. Kelly. "Small mammals from the Sespe Formation (Arikareean) of Cañada Chiquita, Orange County, California". English. In: Paludicola 8.3 (2011), pp. 128-141.

[11593] T. S. Kelly. "New Records of Marsupialia, Lipotyphla, and Primates From the Duchesnean (Middle Eocene) Simi Valley Landfill Local Fauna, Sespe Formation, California". English. In: Paludicola 7.4 (2010), pp. 158-169.

[11594] T. S. Kelly. "A New Species of Heliscomys (Rodentia, Heliscomyidae) From the Duchesnean (Middle Eocene) Simi Valley Landfill Local Fauna, Sespe Formation, California". English. In: Paludicola 7.3 (2009), pp. 67-77.

[11595] T. S. Kelly. “Preliminary report on the mammals form Lane's Little Jaw Site Quarry: a latest Cretaceous (earliest Puercan?) local fauna, Hell Creek Formation, southeastern Montana". English. In: Paludicola 10.1 (2014), pp. 50-91.

[11596] T. S. Kelly and W. W. Korth. "A new species of Ansomys (Rodentia; Aplodontidae) from the late Hemingfordian (early Miocene) of northwestern Nevada". English. In: Paludicola 5.4 (2005), pp. 85-91.

[11597] T. S. Kelly, E. B. Lander, D. P. Whistler, M. A. Roder, and R. E. Reynolds. “Preliminary Report on a Paleontologic Investigation of the Lower and Middle Members, Sespe Formation, Simi Valley Landfill, Ventura County, California". English. In: PaleoBios 13.50 (1991), pp. 1-13.

[11598] T. S. Kelly and R. Secord. "A Reevaluation of the Mammalian Fauna From the Hallelujah Formation, Long Valley, Lassen County, California". English. In: Paludicola 8.3 (2011), pp. 142-154.

[11599] T. S. Kelly and J. D. Stewart. "New Records of Middle and Late Miocene Perissodactyla and Artiodactyla From the Western Border of the San Joaquin Valley, Diablo Range, Fresno County, California". English. In: Contributions to Science, Natural History Museum of Los Angeles County 516 (2008), pp. 1-29.

[11600] T. S. Kelly and D. P. Whistler. "Additional Uintan and Duchesnean (Middle and Late Eocene) mammals from the Sespe Formation, Simi Valley, California". English. In: Contributions in Science, Natural History Museum of Los Angeles County 439 (1994), pp. 1-29.

[11601] T. S. Kelly and D. P. Whistler. "A New Eomyid Rodent from the Sespe Formation of Southern California". English. In: Journal of Vertebrate Paleontology 18.2 (1998), pp. 440-443.

[11602] I. V. Kemkin, M. Kametaka, and S. Kojima. "Radiolarian biostratigraphy for transitional facies of chert-clastic sequence of the Taukha Terrane in the Koreyskaya River area, southern Sikhote-Alin, Russia". English. In: The Journal of Earth and Planetary Sciences 46 (1999), pp. $29-47$.

[11603] I. V. Kemkin and R. A. Kemkina. "Radiolarian biostratigraphy of the Jurassic-Early Cretaceous chert-clastic sequence in the Taukha Terrane (south Sikhote-Alin, Russia)". English. In: Geodiversitas 21.4 (1999), pp. 675-685.

[11604] I. V. Kemkin and Y. Taketani. "New radiolarian species from Late Jurassic chert-terrigenous deposits of the Taukha Terrane, southern Sikhote-Alin". English. In: Paleontological Research 8.4 (2004), pp. 325-336.

[11605] A. Kemp. "Chirodipterus potteri, a new Devonian lungfish from New South Wales, Australia: And the ontogeny of chirodipterid tooth plates". English. In: Journal of Vertebrate Paleontology 20.4 (2000), pp. 665-674.

[11606] R. A. Kemp. "Solnhofen tetrapod taphonomy". English. PhD thesis. 1999, pp. 1-459. 
[11607] C. M. Kemper. "Distribution of the pygmy right whale, Caperea marginata, in the Australasian region". English. In: Marine Mammal Science 18.1 (2002), pp. 99-111.

[11608] P. S. Kench, S. G. Smithers, R. F. McLean, and S. L. Nichol. "Holocene reef growth in the Maldives: Evidence of a mid-Holocene sea-level highstand in the central Indian Ocean". English. In: Geology 37 (2009), pp. 455-458.

[11609] G. W. Kendrick. “A Pleistocene molluscan fauna with Anadara trapezia (Deshayes) (Bivalvia: Arcoida) from the Dampier Limestone of Shark Bay, Western Australia". English. In: Report of the France-Australe Bicentenary Expedition Committee: Research in Shark Bay (1990), pp. 33-48.

[11610] G. W. Kendrick, K.-H. Wyrwoll, and B. J. Szabo. “Pliocene-Pleistocene coastal events and history along the western margin of Australia". English. In: Quaternary Science Reviews 10 (1991), pp. 419439.

[11611] J. M. Kennard. “Lower Cambrian archaeocyathan buildups, Todd River Dolomite, northeast Amadeus Basin, central Australia: sedimentology and diagenesis". English. In: Geological and Geophysical Studies in the Amadeus Basin, Central Australia, Bulletin 236 (1991), pp. 195-225.

[11612] D. M. Kennedy and C. D. Woodroffe. "Holocene lagoonal sedimentation at the latitudinal limits of reef growth, Lord Howe Island, Tasman Sea". English. In: Marine Geology 169 (2000), pp. 287-304.

[11613] G. L. Kennedy. "New Cretaceous and Tertiary Pholadidae (Mollusca: Bivalvia) from California". English. In: Journal of Paleontology 67.3 (1993), pp. 397-404.

[11614] W. J. Kennedy, M. Billote, and M. Hansotte. Cenomanian ammonites from Pech de Foix (Ariege, France). English. 1996.

[11615] W. J. Kennedy. "Cenomanian ammonites from Cassis, Bouches-du-Rhone, France". English. In: Palaeopelagos Special Publication 1 (1994), pp. 209-254.

[11616] W. J. Kennedy. “Lower Turonian ammonites from Gard (France)”. English. In: Palaeopelagos Special Publication 1 (1994), pp. 255-275.

[11617] W. J. Kennedy. "Campanian and Maastrichtian ammonites from the Mons Basin and adajcent areas (Belgium)". English. In: Bulletin de L'Institute Royal des Sciences Naturelles de Belgique 63 (1993), pp. 99-131.

[11618] W. J. Kennedy. "Sharpeiceras australe sp. nov., replacement name for Sharpeiceras falloti Kennedy, 2013, non Collignon, 1931". English. In: Acta Geologica Polonica 64 (2014), pp. 109-111.

[11619] W. J. Kennedy. "Maastrichtian ammonites from the United Arab Emirates-Oman border region". English. In: Bulletin of the Natural History Museum, Geology Series 51 (1995), pp. 241-250.

[11620] W. J. Kennedy. "A new species of Lyelliceras (Ammonoidea, Lyelliceratidae) from the Albian (Lower Cretaceous) of France". English. In: Netherlands Journal of Geosciences 90 (2011), pp. 9598.

[11621] W. J. Kennedy and M. Bilotte. “A new ammonite fauna from the sub-Pyrenean Campanian (Upper Cretaceous)". English. In: Geobios 28.3 (1995), pp. 359-370.

[11622] W. J. Kennedy, M. Bilotte, and P. Melchior. "Ammonite faunas, biostratigraphy, and sequence stratigraphy of the Coniacian-Santonian of the Corbiéres (NE Pyrénées)". English. In: Bulletin des Centres de Recherches Elf Exploration-Production Elf-Aquitaine 19 (1995), pp. 377-499.

[11623] W. J. Kennedy and W. K. Christennsen. "Santonian ammonites from the Köpingsberg-1 borehole, Sweden". English. In: Bulletin of the Geological Survey of Denmark 40 (1993), pp. 149-156.

[11624] W. J. Kennedy and W. K. Christensen. "Coniacian and Santonian ammonites from Bornholm, Denmark". English. In: Bulletin of the Geological Society of Denmark 38 (1991), pp. 203-226.

[11625] W. J. Kennedy and W. A. Cobban. Upper Cretaceous (upper Santonian) Boehmoceras fauna from the Gulf Coast region of the United States. 1991.

[11626] W. J. Kennedy and W. A. Cobban. "Rhamphidoceras saxatilis n. gen. and sp., a micromorph ammonite from the lower Turonian of Trans-Pecos Texas". English. In: Journal of Paleontology 64.4 (1990), pp. 666-668. 
[11627] W. J. Kennedy and W. A. Cobban. “The Madagascan ammonite Neogauthiericeras Collignon, 1969 from the Upper Cretaceous (Campanian) of Texas". English. In: Palaeontologische Zeitschrift 64.1/2 (1990), pp. 57-61.

[11628] W. J. Kennedy, W. A. Cobban, and N. H. Landman. "New records of acanthoceratid ammonoids from the Upper Cenomanian of South Dakota". English. In: American Museum Novitates 3161 (1996), pp. 1-18.

[11629] W. J. Kennedy, W. A. Cobban, A. S. Gake, J. M. Hancock, and N. H. Landman. "Ammonites from the Weno Limestone (Albian) in Northeast Texas". English. In: American Museum Novitates 3236 (1998), pp. 1-46.

[11630] W. J. Kennedy, W. A. Cobban, N. H. Landman, and R. O. Johnson. “New ammonoid records from the Merchantville Formation (Upper Cretaceous) of Maryland and New Jersey". English. In: American Museum Novitates 3193 (1997), pp. 1-17.

[11631] W. J. Kennedy, W. A. Cobban, and N. H. Landman. "Maastrichtian ammonites from the Severn Formation of Maryland". English. In: American Museum Novitates 3210 (1997), pp. 1-30.

[11632] W. J. Kennedy and W. A. Cobban. "Ammonites from the Saratoga Chalk (Upper Cretaceous), Arkansas". English. In: Journal of Paleontology 67.3 (1993), pp. 404-434.

[11633] W. J. Kennedy and W. A. Cobban. "Upper Campanian ammonites from the Ozan-Annona Formation boundary in Southwestern Arkansas". English. In: Bulletin of the Geological Society of Denmark 40 (1993), pp. 115-148.

[11634] W. J. Kennedy and W. A. Cobban. "Campanian ammontes from the Annona Chalk near Yancy, Arkansas". English. In: Journal of Paleontology 67.1 (1993), pp. 83-97.

[11635] W. J. Kennedy and W. A. Cobban. "Upper Campanian ammonites from the Mount Laurel Sand at Biggs Farm, Delaware". English. In: Journal of Paleontology 68.6 (1994), pp. 1285-1305.

[11636] W. J. Kennedy, W. A. Cobban, and N. H. Landman. "A revision of the Turonian members of the ammonite subfamily Collignoniceratinae from the United States Western Interior and Gulf Coast". English. In: Bulletin of the American Museum of Natural History 267 (2001), pp. 1-148.

[11637] W. J. Kennedy and W. A. Cobban. "Lower Cenomanian Forbesiceras brundrettei zone ammonite fauna in Texas, USA". English. In: N. Jb. Geol. Palaont. Abh 188.3 (1993), pp. 327-344.

[11638] W. J. Kennedy and W. A. Cobban. "Lower Campanian (Upper Cretaceous) ammonites from the Merchantville Formation of New Jersey, Maryland, and Delaware". English. In: Journal of Paleontology 67.5 (1993), pp. 828-849.

[11639] W. J. Kennedy, W. A. Cobban, J. M. Hancock, and W. S. Gale. “Upper Albian and Lower Cenomanian ammonites from the Main Street Limestone, Grayson Marl and Del Rio Clay in northeast Texas". English. In: Cretaceous Research 26 (2005), pp. 349-428.

[11640] W. J. Kennedy and W. A. Cobban. “Cenomanian micromorphic ammonites from the western interior of the USA". English. In: Palaeontology 33 (1990), pp. 379-422.

[11641] W. J. Kennedy, W. A. Cobban, and G. R. Scott. "Heteromorph ammonites from the Upper Campanian (Upper Cretaceous) Baculites cuneatus and Baculites reesidei zones of the Pierre Shale in Colorado, USA". English. In: Acta Geologica Polonica 50 (2000), pp. 1-20.

[11642] W. J. Kennedy and W. A. Cobban. "Upper Campanian (Upper Cretaceous) ammonites from the Marshalltown Formation-Mount Laurel boundary beds in Delaware". English. In: Journal of Paleontology 71.1 (1997), pp. 62-73.

[11643] W. J. Kennedy and W. A. Cobban. "Maastrichtian ammonites from the Hornerstown Formation in New Jersey". English. In: Journal of Paleontology 70.5 (1996), pp. 798-805.

[11644] W. J. Kennedy, J. A. Crame, P. Bengsten, and M. R. A. Thomson. "Coniacian ammonites from James Ross Island, Antarctica". English. In: Cretaceous Research 28.509 (2007), p. 531.

[11645] W. J. Kennedy and M. Delamette. "Lyelliceratidae and Flickiidae (Ammonoidea) from the Upper Albian and Cenomanian of the Helvetic Shelf (Western Alps, France and Switzerland)". English. In: Journal of Paleontology 68.6 (1994), pp. 1263-1284. 
[11646] W. J. Kennedy and M. Delamette. “Neophlycticeras Spath, 1922 (Ammonoidea) from the Upper Albian of Ain, France". English. In: Neues Jahrbuch für Geologie und Paläontologie, Abhandlungen 191 (1994), pp. 1-24.

[11647] W. J. Kennedy and A. S. Gale. "Turonian ammonites from northwestern Aquitaine, France”. English. In: Cretaceous Research 58 (2016), pp. 265-296.

[11648] W. J. Kennedy, A. S. Gale, D. J. Ward, and C. J. Underwood. “Early Turonian ammonites from Goulmima, southern Morocco". English. In: Bulletin de l'Institut Royal des Sciences Naturelles de Belgique, Sciences de la Terre 78 (2008), pp. 149-177.

[11649] W. J. Kennedy and A. S. Gale. "Late Turonian ammonites from Haute-Normandie, France". English. In: Acta Geologica Polonica 65 (2015), pp. 507-524.

[11650] W. J. Kennedy and J. M. Hancock. “Upper Maastrichtian ammonites from the Marnes de Nay between Gan and Rébénacq (Pyrénées-Atlantiques), France". English. In: Geobios 26 (1993), pp. 575594.

[11651] W. J. Kennedy, M. Hansotte, M. Bilotte, and J. Burnett. "Ammonites and nannofossils from the Campanian of Nalzen (Ariége, France)". English. In: Geobios 25.2 (1992), pp. 263-278.

[11652] W. J. Kennedy and R. A. Henderson. "Non-Heteromorph Ammonites From the Upper Maastrichtian of Pondicherry, South India". English. In: Palaeontology 35.2 (1992), pp. 381-442.

[11653] W. J. Kennedy, J. W. M. Jagt, F. Amédro, and F. Robaszynski. “The late Late Albian (Mortoniceras fallax Zone) cephalopod fauna from the Bracquegnies formation at Strépy-Thieu (Hainaut, southern Belgium)". English. In: Geologica Belgica 11 (2008), pp. 35-69.

[11654] W. J. Kennedy and N. Jolkicev. "Middle Cenomanian ammonites from the type section of the Sanandinovo Formation of northern Bulgaria". English. In: Acta Geologica Polonica 54 (2004), pp. 369 380.

[11655] W. J. Kennedy and U. Kaplan. "Parapuzosia (Parapuzosia) seppenradensis (Landois) und die Ammonitenfauna der Dülmener Schichten, unteres Unter-Campan, Westfalen". German. In: Geologie und Paläontologie in Westfalen 33 (1995), pp. 1-127.

[11656] W. J. Kennedy, C. King, and D. J. Ward. “The upper Albian and lower Cenomanian succession at Kolbay, eastern Mangyshlak (southwest Kazakhstan)". English. In: Bulletin de l'Institut Royal des Sciences Naturelles de Belgique, Sciences de la Terre 78 (2008), pp. 117-147.

[11657] W. J. Kennedy and H. C. Klinger. "Cretaceous faunas from Zululand and Natal, South Africa. Hatchericeras Stanton, 1901 (Cephalopoda, Ammonoidea) from the Barremian of Zululand". English. In: Annals of the South African Museum 99.8 (1990), pp. 231-243.

[11658] W. J. Kennedy and H. C. Klinger. "Cretaceous faunas from Zululand and Natal, South Africa. The ammonite subfamily Lyelliceratinae Spath, 1921". English. In: African Natural History 4 (2008), pp. 57-111.

[11659] W. J. Kennedy and H. C. Klinger. "Hypermorphosis in Salaziceras, a Cretaceous ammonite, from Madagascar". English. In: African Natural History 4 (2008), pp. 113-116.

[11660] W. J. Kennedy and H. C. Klinger. "Cretaceous faunas from Zululand and Natal, South Africa. The ammonite family Forbesiceratidae Wright, 1952". English. In: African Natural History 4 (2008), pp. 117-130.

[11661] W. J. Kennedy, H. C. Klinger, and M. V. Kakabadze. “Macroscaphites Meek, 1876, a heteromorph ammonite from the Lower Aptian of southern Mozambique and northern KwaZulu-Natal". English. In: African Natural History 5 (2009), pp. 37-41.

[11662] W. J. Kennedy and H. C. Klinger. "The heteromorph ammonite Ndumuiceras variabile gen. et sp. nov. from the Albian Mzinene Formation, KwaZulu-Natal, South Africa". English. In: African Natural History 5 (2009), pp. 43-47.

[11663] W. J. Kennedy and H. C. Klinger. "The Upper Cretaceous ammonite Grandidiericeras Collignon, 1961 (Puzosiinae), from the St Lucia Formation of KwaZulu-Natal, South Africa". English. In: African Natural History 7 (2011), pp. 63-67. 
[11664] W. J. Kennedy and H. C. Klinger. “Cretaceous faunas from Zululand and Natal, South Africa. The ammonite genera Mojsisovicsia Steinmann, 1881, Dipoloceroides Breistroffer, 1947, and Falloticeras Parona \& Bonarelli, 1897”. English. In: African Natural History 8 (2012), pp. 1-15.

[11665] W. J. Kennedy and H. C. Klinger. "Cretaceous faunas from Zululand and Natal, South Africa. The Santonian-Campanian ammonite genus Eulophoceras Hyatt, 1903". English. In: African Natural History 8 (2012), pp. 30-54.

[11666] W. J. Kennedy and H. C. Klinger. “Cretaceous faunas from Zululand and Natal, South Africa. The desmoceratoid ammonite genera Moretella Collignon, 1963, Beudanticeras Hitzel, 1902, and Aioloceras Whitehouse, 1926". English. In: African Natural History 8 (2012), pp. 55-75.

[11667] W. J. Kennedy and H. C. Klinger. "Cretaceous faunas from Zululand and Natal, South Africa. The ammonite genus Oxytropidoceras Stieler, 1920". English. In: African Natural History 7 (2011), pp. 69-102.

[11668] W. J. Kennedy and H. C. Klinger. “Cretaceous faunas from Zululand and Natal, South Africa. New records of Maastrichtian ammonites of the Family Kossmaticeratidae". English. In: African Natural History 9 (2013), pp. 55-60.

[11669] W. J. Kennedy and H. C. Klinger. “Cretaceous faunas from Zululand and Natal, South Africa. The ammonite subfamily Desmoceratinae Zittel, 1895". English. In: African Natural History 9 (2013), pp. 39-54.

[11670] W. J. Kennedy, N. H. Landman, and W. A. Cobban. "Engonoceratid ammonites from the Glen Rose Limestone, Walnut Clay, Goodland Limestone, and Comanche Peak Limestone (Albian) in Texas". English. In: American Museum Novitates 3221 (1998), pp. 1-40.

[11671] W. J. Kennedy, N. H. Landman, W. A. Cobban, and R. O. Johnson. "Additions to the ammonite fauna of the Upper Cretaceous Navesink Formation of New Jersey". English. In: American Museum Novitates 3306 (2000), pp. 1-30.

[11672] W. J. Kennedy, N. H. Landman, and W. A. Cobban. "Santonian Ammonites from the Blossom Sand in Northeast Texas". English. In: American Museum Novitates 3332 (2001), pp. 1-9.

[11673] W. J. Kennedy, N. H. Landman, W. A. Cobban, and G. R. Scott. "Late Campanian (Cretaceous) heteromorph ammonites". English. In: Bulletin of the American Museum of Natural History 251 (2000), pp. 1-88.

[11674] W. J. Kennedy, N. H. Landman, and W. A. Cobban. "The Maastrichtian ammonites Coahuilites sheltoni Böse, 1928, and Sphenodiscus pleurisepta (Conrad, 1857), from the uppermost Pierre Shale and basal Fox Hills Formation of Colorado and Wyoming". English. In: American Museum Novitates 3186 (1996), pp. 1-14.

[11675] W. J. Kennedy and J. L. Latil. "The Upper Albian ammonite succession in the Montlaux section, Hautes-Alpes, France". English. In: Acta Geologica Polonica 57.4 (2007), pp. 453-478.

[11676] W. J. Kennedy and G. Lunn. "Upper Campanian (Cretaceous) ammonites from the Shinarish Formation, Djebel Sinjar, northwest Iraq". English. In: Journal of Paleontology 74.3 (2000), pp. 464-473.

[11677] W. J. Kennedy and N. J. Morris. "An early Cenomanian ammonite fauna from near Lindi, Tanzania". English. In: Cretaceous Research 87 (2018), pp. 84-101.

[11678] W. J. Kennedy, H. Nøhr-Hansen, and G. Dam. “The youngest Maastrichtian ammonite faunas from Nuussuaq, West Greenland". English. In: Geology of Greenland Survey Bulletin 184 (1999), pp. 13-17.

[11679] W. J. Kennedy and M. D. Simmons. “Mid-Cretaceous ammonites and associated microfossils from the Central Oman Mountains". English. In: Newsletters on Stratigraphy 25.3 (1991), pp. 127-154.

[11680] W. J. Kennedy and H. Summesberger. "Additional ammonites from the Upper Campanian (Upper Cretaceous) of the Gschliefgraben (Ultrahelvetic; Austria)". English. In: Annalen des Naturhistorischen Museums in Wien, Serie A 102 (2001), pp. 85-107. 
[11681] W. J. Kennedy, C. Tunoglu, I. Walaszczyk, and I. E. Ertekin. “Ammonite and inoceramid faunas from the Davutlar Formation of the Devrekani-Kastamonu area, nothern Turkey, and their biostratigraphical significance". English. In: Cretaceous Research 28 (2007), pp. 861-894. DOI: 10.1016/j. cretres.2006.12.007.

[11682] W. J. Kennedy, I. Walaszczyk, A. S. Gale, K. Dembicz, and T. Praszkier. “Lower and Middle Cenomanian ammonites from the Morondava Basin, Madagascar". English. In: Acta Geologica Polonica 63 (2013), pp. 625-655.

[11683] W. J. Kennedy and W. A. Cobban. "Cenomanian ammonite faunas from the Woodbine Formation and lower part of the Eagle Ford Group, Texas". English. In: Palaeontology (1990).

[11684] B. Kensley and A. B. Williams. "Axiopsis eximia, a new thalassinidean shrimp (Crustacea, Decapoda, Axiidae) from the Middle Eocene of South Carolina". English. In: Journal of Paleontology 64.5 (1990), pp. 798-802.

[11685] B. W. Kent. “The Cartilaginous Fishes (Chimaeras, Sharks, and Rays) of Calvert Cliffs, Maryland, USA". English. In: Smithsonian Contributions to Paleobiology 100 (2018), pp. 45-160.

[11686] J. A. M. Kenter, P. M. Harris, and G. Della Porta. “Steep microbial boundstone-dominated platform margins - examples and implications". English. In: Sedimentary Geology 178 (2005), pp. 5-30.

[11687] L. Kerber. "Imigrantes em um continente perdido: O registro fossilfero de roedores Caviomorpha (Mammalia: Rodentia: Ctenohystrica) do Cenozoico do Brasil". Portugese. In: Terræ Didatica 13.2 (2017), pp. 185-211.

[11688] L. Kerber, M.C.Jr. Bissaro, F. R. Negri, J. P. de Souza-Filho, E. Guilherme, and A. S. Hsiou. “A new rodent (Caviomorpha: Dinomyidae) from the upper Miocene of southwestern Brazilian Amazonia". English. In: Historical Biology 30.7 (2018), pp. 985-993. DOI: 10.1080/08912963.2017.1327529.

[11689] L. Kerber, E. L. Mayer, A. M. Ribeiro, and M. G. Vucetich. "Late Quaternary caviomorph rodents (Rodentia: Hystricognathi) from the Serra da Capivara, northeastern Brazil, with description of a new taxon". English. In: Historical Biology 28.4 (2016), pp. 439-458.

[11690] L. Kerber, F. R. Negri, A. M. Ribeiro, N. Nasif, J. P. Souza-Filho, and J. Ferigolo. “Tropical fossil caviomorph rodents from the Southwestern Brazilian amazonia in the context of the South American faunas: systematics, biochronology and paleobiogeography". English. In: Journal of Mammalian Evolution 24.1 (2017), pp. 57-70. DOI: 10.1007/s10914-016-9340-2.

[11691] L. Kerber, F. R. Negri, A. M. Ribeiro, M. G. Vucetich, and J. P. Souza-Filho. "Late Miocene potamarchine rodents from southwestern Amazonia, Brazil - with description of new taxa". English. In: Acta Palaeontologica Polonica 61.1 (2016), pp. 191-203. DOI: 10.4202/app.00091.2014.

[11692] L. Kerber, F. R. Negri, and D. Sanfelice. "Morphology of cheek teeth and dental replacement in the extinct rodent Neoepiblema Ameghino, 1889 (Caviomorpha, Chinchilloidea, Neoepiblemidae)". English. In: Journal of Vertebrate Paleontology (2019), e1549061. DOI: 10.1080/02724634.2018.1549061.

[11693] L. Kerber and E. V. Oliveria. “Sobre a presença de Tapirus (Tapiridae, Perissodactyla) na Formação Touro Passo (Pleistoceno superior), oeste do Rio Grande do Sul". Portugese. In: Biodiversidade Pampeana 6.1 (2008), pp. 9-14.

[11694] L. Kerber and A. M. Ribeiro. "Capybaras (Rodentia: Hystricognathi: Hydrochoeridae) from the late Pleistocene of southern Brazil". English. In: Neues Jahrbuch für Geologie und Paläontologie - Abhandlungen 261.1 (2011), pp. 1-18.

[11695] K. A. Kermack, D. M. Kermack, P. M. Lees, and J. R. E. Mills. “New multituberculate-like teeth from the Middle Jurassic of England". English. In: Acta Palaeontologica Polonica 43.4 (1998), pp. 581606.

[11696] H. Kerp, F. Penati, G. Brambilla, J. A. Clement-Westerhof, and P. F. van Bergen. “Aspects of Permian palaeobotany and palynology. XVI: Three-dimensionally preserved stromatolite-incrusted conifers from the Permian of the western Orobic Alps (Northern Italy)". In: Review of Palaeobotany and Palynology 91.1-4 (1996), pp. 63-84. 
[11697] J. H. F. Kerp, R. J. Poort, H. A. J. M. Swinkels, and R. Verwer. “Aspects of Permian palaeobotany and palynology. IX. Conifer-dominated Rotliegend floras from the Saar-Nahe Basin (?Late Carboniferous-Early Permian; SW-Germany) with special reference to the reproductive biology of early conifers". In: Review of Palaeobotany and Palynology 62 (1990), pp. 205-248.

[11698] A. P. Kershaw, S. C. Bretherton, and S. van der Kaars. "A complete pollen record of the last 230 ka from Lynch's Crater, north-eastern Australia". English. In: Palaeogeography, Palaeoclimatology, Palaeoecology 251.1 (2007), pp. 23-45. DOI: 10.1016/j.palaeo.2007.02.015.

[11699] S. Kershaw, L. Guo, and J. C. Braga. "A Holocene coral-algal reef at Mavra Litharia, Gulf of Corinth, Greece: structure, history, and applications in relative sea-level change". English. In: Marine Geology 215 (2005), pp. 171-192.

[11700] S. Kershaw and M. A. Motus. "Palaeoecology of corals and stromatoporoids in an Upper Silurian Biostrome in Estonia". English. In: Acta Palaeontologica Polonica (2014).

[11701] E. Kessler, D. Grigorescu, and Z. Csiki. "Elopteryx revisited-A new bird-like specimen from the Maastrichtian of the Hateg Basin (Romania)". English. In: Acta Palaeontologica Romaniae 5 (2005), pp. 249-258.

[11702] K. Ketcher and W. Allmon. “Environment and Mode of Deposition of a Pliocene Coral Bed: Coral Thickets and Storms in the Fossil Record". English. In: Palaios 8 (1993), pp. 3-17.

[11703] H. F. Ketchum. "Marine reptiles". English. In: Palaeontological Association Field Guide to Fossils 14 (2011), pp. 285-294.

[11704] H. F. Ketchum and P. M. Barrett. "New reptile material from the Lower Triassic of Madagascar: implications for the Permian-Triassic extinction event". English. In: Canadian Journal of Earth Sciences 41.1 (2004), pp. 1-8.

[11705] H. F. Ketchum and R. B. J. Benson. "The cranial anatomy and taxonomy of Peloneustes philarchus (Sauropterygia, Pliosauridae) from the Peterborough Member (Callovian, Middle Jurassic) of the United Kingdom". English. In: Palaeontology 54.3 (2011), pp. 639-665.

[11706] H. F. Ketchum and R. B. J. Benson. "A new pliosaurid (Sauropterygia, Plesiosauria) from the Oxford CLay Formation (Middle Jurassic, Callovian) of England: evidence for a gracile, longirostrine grade of Early-Middle Jurassic pliosaurids". English. In: Special Papers in Palaeontology 86 (2011), pp. 109-129.

[11707] H. F. Ketchum and R. B. J. Benson. “Global interrelationships of Plesiosauria (Reptilia, Sauropterygia) and the pivotal role of taxon sampling in determining the outcome of phylogenetic analyses". English. In: Biological Reviews 85 (2010), pp. 361-392. DOI: 10.1111/j.1469-185X.2009.00107.x.

[11708] H. F. Ketchum and A. S. Smith. "The anatomy and taxonomy of Macroplata tenuiceps (Sauropterygia, Plesiosauria) from the Hettangian (Lower Jurassic) of Warwickshire, United Kingdom". English. In: Journal of Vertebrate Paleontology 30.4 (2010), pp. 1069-1081. DOI: 10.1080/02724634.2010. 483604 .

[11709] C. Ketwetsuriya, A. G. Cook, and A. Nützel. "Permian gastropods from the Ratburi Limestone, Khao Phrik, central Thailand". English. In: PalZ 94 (2020), pp. 53-77. DOI: 10.1007 / s12542-01900463-0.

[11710] C. Ketwetsuriya, B. Karapunar, T. Charoentitirat, and A. Nützel. "Middle Permian (Roadian) gastropods from the Khao Khad Formation, central Thailand: Implications for palaeogeography of the Indochina Terrane". English. In: Zootaxa 4766 (2020), pp. 1-47.

[11711] C. Ketwetsuriya, A. Nützel, and P. Kanjanapayont. "A new Permian gastropod fauna from the Tak Fa Limestone, Nakhonsawan, northern Thailand - a report of preliminary results". English. In: Zitteliana A 54 (2014), pp. 137-146.

[11712] C. Ketwetsuriya, A. Nützel, and P. Kanjanapayont. "Permian gastropods from the Tak Fa Limestone, Nakhon Sawan, northern Thailand". English. In: Bulletin of Geosciences 91 (2016), pp. 481513. DOI: 10.3140/bull.geosci.1617. 
[11713] H. Keupp. “Desmoceras (Pseudouhligella) intrapunctatum n. sp. (Ammonoidea) aus dem UnterAlbium von NW-Madagaskar mit Ritzstreifen". English. In: Paläontologische Zeitschrift 82.4 (2008), pp. 437-447.

[11714] H. Keupp and R. Kohring. “Ein Magensteinfund aus dem Lias Epsilon von Altdorf (Mittelfranken); (A gastrolith from the Lias Epsilon of Altdorf (Middle Franken)". German. In: Geologische Blätter für Nordost-Bayern und angrenzende Gebiete 43.1-3 (1993), pp. 95-104.

[11715] Ch. Kevrekidis and D. Mol. "A new partial skeleton of Elephas (Palaeoloxodon) antiquus Falconer and Cautley, 1847 (Proboscidea, Elephantidae) from Amyntaio, Macedonia, Greece". English. In: Quaternary International 406 (2015), pp. 35-56. DOI: 10.1016/j.quaint.2015.11.110.

[11716] M. M. Key, G. A. Schumacher, L. E. Babcock, R. C. Frey, W. P. Heimbrock, S. H. Felton, D. L. Cooper, W. B. Gibson, D. G. Scheid, and S. A. Schumacher. "Paleoecology of commensal epizoans fouling Flexicalymene (Trilobita) from the Upper Ordovician, Cincinnati Arch region, USA". English. In: Journal of Paleontology 84.6 (2010), pp. 1121-1134. DOI: 10.1666/10-018.1.

[11717] C. K. Khajuria and G. V. R. Prasad. "Taphonomy of a Late Cretaceous mammal-bearing microvertebrate assemblage from the Deccan inter-trappean beds of Naskal, peninsular India". In: Palaeogeography, Palaeoclimatology, Palaeoecology 137 (1998), pp. 153-172.

[11718] A. I. Khalaim. “Fossil ichneumon wasps (Hymenoptera: Ichneumonidae) from Biamo (Russia), Oligocene". English. In: Alavesia 2 (2008), pp. 101-112.

[11719] A. I. Khalaim. "First record of the subfamilies Banchinae and Stilbopinae (Hymenoptera: Ichneumonidae) from the Late Eocene Rovno amber (Ukraine)". English. In: Russian Entomological Journal 20 (2011), pp. 295-298.

[11720] B. Khalloufi, R. Zaragüeta-Bagils, and H. Leliévre. “Rhombichthys intoccabilis, gen. et sp. nov. (Ellimmichthyiformes, Clupeomorpha, Teleostei), from the Cenomanian (Upper Cretaceous) of Ein Yabrud, Middle East: anatomical description and phylogenetic implications". English. In: Journal of Vertebrate Paleontology 30.1 (2010), pp. 57-67.

[11721] A. A. Khan and M. Sarwar. "A new Indratherium fossil giraffe Indratherium compressus sp. nov. from Siwalik Formations of Pakistan". English. In: Journal of Research (Science) 13.2 (2002), pp. 139_ 144.

[11722] M. A. Khan, S. S. Butt, A. M. Khan, and M. Akhtar. "A new collection of Giraffokeryx punjabiensis (Giraffidae, Ruminantia, Artiodactyla) from the Lehri outcrops, Jhelum, northern Pakistan". English. In: Pakistan Journal of Science 62.2 (2010), pp. 120-123.

[11723] P. Khanna, H. H. Hopson, A. W. Droxler, D. A. Droxler, D. Lehrmann, B. Kubik, J. Proctor, P. Singh, and P. M. Harris. "Late Cambrian microbial build-ups, Llano Area, Central Texas: A three-phase morphological evolution". English. In: Sedimentology (2019). DOI: 10.1111/sed.12679.

[11724] A. A. Khaustov and E. E. Perkovsky. "The first fossil record of mites of the family Pyemotidae (Acari: Heterostigmata), with description of a new species of the genus Pyemotes from Rovno amber". English. In: Paleontological Journal 44 (2010), pp. 418-421.

[11725] A. A. Khaustov and G. Poinar. "Protoresinacarus brevipedis gen. n., sp. n. from Early Cretaceous Burmese amber: the first fossil record of mites of the Family Resinacaridae (Acari: Heterostigmata: Pyemotoidea)". English. In: Historical Biology 23 (2011), pp. 219-222.

[11726] A. R. Khazaei, P. W. Skelton, and M. Yazdi. "Maastrichtian Rudist Fauna from Tarbur Formation(Zagros Region, SW Iran): Preliminary Observations". English. In: Turkish Journal of Earth Sciences 19 (2010), pp. 703-719.

[11727] V. V. Khomentovsky and A. S. Gibsher. "The Neoproterozoic-lower Cambrian in northern GoviAltay, western Mongolia: regional setting, lithostratigraphy and biostratigraphy". English. In: Geological Magazine 133.4 (1996), pp. 371-390.

[11728] V. V. Khomentovsky and G. A. Karlova. "Biostratigraphy of the Vendian-Cambrian beds and the lower Cambrian boundary in Siberia". English. In: Geological Magazine 130.1 (1993), pp. 29-45. 
[11729] L. I. Khosatzky. "Big turtle of the Late Cretaceous of Mongolia". English. In: Russian Journal of Herpetology 4.2 (1997), pp. 148-154.

[11730] A. Khosla, G. V. R. Prasad, O. Verma, A. K. Jain, and A. Sahni. "Discovery of a micromammalyielding Deccan intertrappean site near Kisalpuri, Dindori District, Madhya Pradesh". English. In: Current Science 87.3 (2004), pp. 380-383.

[11731] A. Khosla and A. Sahni. "Parataxonomic classification of Late Cretaceous dinosaur eggshells from India". English. In: Journal of the Palaeontological Society of India 40 (1995), pp. 87-102.

[11732] A. Khosla, J. J. W. Sertich, G. V. R. Prasad, and O. Verma. "Dyrosaurid remains from the Intertrappean Beds of India and the Late Cretaceous distribution of Dyrosauridae". English. In: Journal of Vertebrate Paleontology 29.4 (2009), pp. 1321-1326. DOI: 10.1671/039.029.0416.

[11733] A. Khosla and O. Verma. "Paleobiota from the Deccan volcano-sedimentary sequences of India: paleoenvironments, age and paleobiogeographic implications". English. In: Historical Biology: An International Journal of Paleobiology 27.7 (2015), pp. 898-914. DOI: 10.1080/08912963.2014.912646.

[11734] A. S. Khosla, V. V. Kapur, P. C. Sereno, J. A. Wilson, G. P. Wilson, D. Dutheil, A. Sahni, M. P. Singh, S. Kumar, and R. S. Rana. "First dinosaur remains from the Cenomanian-Turonian Nimar sandstone (Bagh Beds), district Dhar, Madhya Pradesh, India". In: Journal of the Palaeontological Society of India 48 (2003), pp. 115-127.

[11735] A. V. Khramov. "Two new lacewings (Neuroptera) from the Upper Jurassic locality Shar-Teg (Mongolia)". English. In: Paleontological Journal 45.2 (2011), pp. 174-178.

[11736] A. V. Khramov. “A new lacewing (Insecta: Neuroptera: Grammolingiidae) from the Upper Jurassic of Mongolia". English. In: Paleontological Journal 44.2 (2010), pp. 188-181.

[11737] A. V. Khramov. "Early osmylids (Neuroptera: Osmylidae) from the Lower-Middle Jurassic of Kyrgyzstan". English. In: Russian Entomological Journal 23 (2014), pp. 53-60.

[11738] A. V. Khramov. "New mantidflies (Neuroptera: Mantispidae) from the Upper Jurassic of Kazakhstan". English. In: Insect Systematics \& Evolution 44 (2013), pp. 221-230.

[11739] A. V. Khramov. "Lacewings of the family Osmylidae (Insecta: Neuroptera) from the Upper Jurassic of Asia". English. In: Paleontological Journal 48 (2014), pp. 300-309.

[11740] A. V. Khramov. "Jurassic beaded lacewings (Insecta: Neuroptera: Berothidae) from Kazakhstan and Mongolia". English. In: Paleontological Journal 49 (2015), pp. 26-35.

[11741] A. V. Khramov. "The new fossil lacewings of Grammolingiidae (Neuroptera) from the Jurassic of Central Asia and Mongolia, with notes on biogeography of the family". English. In: Zootaxa 3478 (2012), pp. 297-308.

[11742] A. V. Khramov. "Jurassic lacewings (Insecta: Neuroptera) of western Siberia". English. In: Paleontological Journal 51 (2017), pp. 59-68.

[11743] A. V. Khramov. "A new assemblage of Early Cretaceous green lacewings (Chrysopidae: Neuroptera) from Transbaikalia". English. In: Earth and Environmental Science Transactions of the Royal Society of Edinburgh 107 (2018), pp. 195-202.

[11744] A. V. Khramov and J. Chen. "A new species of Aetheogrammatidae (Insecta: Neuroptera) with a preserved proboscis from the Lower Cretaceous of NE China". English. In: Acta Geologica Sinica 94 (2020), pp. 1714-1715. DOI: 10.1111/1755-6724.14593.

[11745] A. V. Khramov, Q. Liu, H. C. Zhang, and E. A. Jarzembowski. “Early green lacewings (Insecta: Neuroptera: Chrysopidae) from the Jurassic of China and Kazakhstan". English. In: Papers in Palaeontology 2 (2016), pp. 25-39.

[11746] A. V. Khramov, Q. Liu, and H. C. Zhang. "Mesozoic diversity of relict subfamily Kempyninae (Neuroptera: Osmylidae)". English. In: Historical Biology 31 (2017), pp. 938-946.

[11747] A. V. Khramov and V. N. Makarkin. "New fossil Osmylopsychopidae (Neuroptera) from the Early/Middle Jurassic of Kyrgyzstan, central Asia". English. In: Zootaxa 4059 (2015), pp. 115-132. 
[11748] A. V. Khramov, G. S. Nam, and D. V. Vasilenko. “First long-proboscid flies (Diptera: Zhangsolvidae) from the Lower Cretaceous of South Korea". English. In: Alcheringa 44 (2019), pp. 160-168. DOI: 10.1080/03115518.2019.1664634.

[11749] A. V. Khramov and G. S. Nam. “The first record of lacewings (Insecta: Neuroptera: Mesochrysopidae) from the Lower Cretaceous of South Korea". English. In: Paleontological Journal 54 (2020), pp. 613-616. DOI: 10.1134/S003103012005007X.

[11750] A. V. Khramov, W. A. Shear, R. Mercurio, and D. Kopylov. “The first Permian centipedes from Russia". English. In: Acta Palaeontologica Polonica 63 (2018), pp. 549-555.

[11751] A. V. Khramov and D. V. Vasilenko. "New records of Grammolingiidae, Saucrosmylidae, and Panfiloviidae (Insecta: Neuroptera) from the Jurassic of Mongolia and Kyrgyzstan". English. In: Paleontological Journal 52 (2018), pp. 1391-1400.

[11752] A. V. Khramov, E. Yan, and D. S. Kopylov. "Nature's failed experiment: long-proboscid Neuroptera (Sisyridae: Paradoxosisyrinae) from Upper Cretaceous amber of northern Myanmar". English. In: Cretaceous Research 104.104180 (2019). DOI: 10.1016/j.cretres.2019.07.010.

[11753] V. G. Khromykh. "Discovery of Lower Famennian Stromatoporoidea in the Kuznetsk Basin”. English. In: Paleontological Journal 42.3 (2008), pp. 227-231.

[11754] V. Khuc. The Triassic of Indochina Peninsula and its interregional correlation. Permian-Triassic Evolution of Tethys and Western Circum-Pacific. 2000, pp. 221-233.

[11755] M. Kibunjia. Pliocene archaeological occurences in the Lake Turkana basin. 1994.

[11756] E. Kido. "Nanshanophyllum and Shensiphyllum (Silurian Rugosa) from the Kurosegawa Terrane, Southwest Japan, and Their Paleobiogeographic Implications". English. In: Journal of Paleontology 83.2 (2009), pp. 280-292.

[11757] E. Kido. "Silurian Holmophyllidae (Rugosa) from the Gionyama Formation of the Kurosegawa Terrane, Southwest Japan". English. In: Paleontological Research 13.3 (2009), pp. 293-306.

[11758] E. Kido. "Silurian Rugose corals from the Kurosegawa Terrane, Southwest Japan, and the first occurrence of Neobrachyelasma". English. In: Journal of Paleontology 84.3 (2010), pp. 466-476.

[11759] E. Kido and T. Sugiyama. "Silurian rugose corals from the Kurosegawa Terrane, Southwest Japan, and their paleobiogeographic implications". English. In: Bulletin of Geosciences 86.1 (2011), pp. 4961.

[11760] S. Kiel. "New and little-known gastropods from the Albian of the Mahajanga Basin, northwestern Madagascar". English. In: Journal of Paleontology 80.3 (2006), pp. 455-476.

[11761] S. Kiel. "Fossil evidence for micro- and macrofaunal utilization of large nekton-falls: Examples from early Cenozoic deep-water sediments in Washington State, USA". English. In: Palaeogeography, Palaeoclimatology, Palaeoecology 267 (2008), pp. 161-174.

[11762] S. Kiel. "New records and species of molluscs from Tertiary cold-seep carbonates in Washington State, USA". English. In: Journal of Paleontology 80.1 (2006), pp. 121-137. DOI: 10.1666/0022-3360\% 282006\%29080\%5B0121\%3ANRASOM\%5D2.0.CO\%3B2.

[11763] S. Kiel. "Lucinid bivalves from ancient methane seeps”. English. In: Journal of Molluscan Studies 79 (2013), pp. 346-363. DOI: 10.1093/mollus/eyt035.

[11764] S. Kiel. "Three new bivalve genera from Triassic hydrocarbon seep deposits in southern Turkey". English. In: Acta Palaeontologica Polonica 63.2 (2018), pp. 221-234. DOI: 10.4202/app.00466.2018.

[11765] S. Kiel, K. Amano, and R. G. Jenkins. "Bivalves from Cretaceous cold-seep deposits on Hokkaido, Japan". English. In: Acta Palaeontologica Polonica 53.3 (2008), pp. 525-537.

[11766] S. Kiel and K. Amano. "Oligocene and Miocene Vesicomyid Bivalves from the Katalla District, Southern Alaska". English. In: The Veliger 51.1 (2010), pp. 76-84.

[11767] S. Kiel and K. Amano. "The earliest bathymodiolin mussels: An Evaluatio of Eocene and Oligocene taxa from deep-sea methane seep deposits in Western Washington State". English. In: Journal of Paleontology 87.4 (2013), pp. 589-602. DOI: 10.1666/12-135. 
[11768] S. Kiel and K. Bandel. "New taxonomic data for the gastropod fauna of the Umzamba Formation (Santonian-Campanian, South Africa) based on newly collected material". English. In: Cretaceous Research 24 (2003), pp. 449-475.

[11769] S. Kiel and K. Bandel. “The Cenomanian Gastropoda of the Kassenberg quarry in Mülheim (Germany, Late Cretaceous)". English. In: Palaeontologische Zeitschrift 78.1 (2004), pp. 103-126.

[11770] S. Kiel, K. A. Campbell, and C. Gaillard. "New and little known mollusks from ancient chemosynthetic environments". English. In: Zoootaxa 2390 (2010), pp. 26-48.

[11771] S. Kiel and J. L. Goedert. "Deep-sea food bonanzas: early Cenozoic whale-fall communities resemble wood-fall rather than seep communities". English. In: Proceedings of the Royal Society B 273 (2006), pp. 2625-2631.

[11772] S. Kiel and J. L. Goedert. "New mollusks associated with biogenic substrates in Cenozoic deepwater sediments of Washington State". English. In: Acta Palaeontologica Polonica 52.1 (2007), pp. 4152.

[11773] S. Kiel and J. L. Goedert. "A wood-fall association from the Late Eocene deep-water sediments of Washington State, USA". English. In: Palaios 21 (2006), pp. 548-556. DOI: 10.2110/ palo.2005.p05086r.

[11774] S. Kiel, J. L. Goedert, W. -A. Kahl, and G. W. Rouse. "Fossil traces of the bone-eating worm Osedax in early Oligocene whale bones". English. In: Proceedings of the National Academy of Sciences 107.19 (2010), pp. 8656-8659. DOI: 10.1073/pnas.1002014107.

[11775] S. Kiel and B. T. Hansen. "Cenozoic Methane-Seep Faunas of the Caribbean Region”. English. In: PLoS One 10.10 (2015), e0140788. DOI: 10.1371/journal.pone.0140788.

[11776] S. Kiel, W.-A. Kahl, and J. L. Goedert. "Traces of the bone-eating annelid Osedax in Oligocene whale teeth and fish bones". English. In: Paläontologische Zeitschrift 87 (2013), pp. 161-167. DOI: 10.1007/s12542-012-0158-9.

[11777] S. Kiel and F. J. Krüger. "Gastropoda aus dem Mittelsanton (Oberkreide) von Lengede (Niedersachsen)". German. In: Braunschweiger Naturkundliche Schriften 7.3 (2006), pp. 677-696.

[11778] S. Kiel, J. Peckmann, and K. Simon. "Catshark Egg Capsules from a Late Eocene Deep-Water Methane-Seep Deposit in Western Washington State, USA". English. In: Acta Palaeontologica Polonica 58.1 (2013), pp. 77-84. DOI: 10.4202/app.2011.0077.

[11779] S. Kiel and M.d.C. Perrilliat. "New gastropods from the Maastrichtian of the Mexcala Formation in Guerrero, southern Mexico, part 1: Stromboidea". English. In: Neues Jahrbuch für Geologie und Paläontologie, Abhandlungen 222.3 (2001), pp. 407-426.

[11780] S. Kiel, M. Sami, and M. Taviani. "A serpulid-Anodontia-dominated methane-seep deposit from the upper Miocene of northern Italy". English. In: Acta Palaeontologica Polonica 63.3 (2018), pp. 569577. DOI: 10.4202 /app.00472.2018.

[11781] S. Kiel and M. Taviana. "Chemosymbiotic bivalves from the late Pliocene Stirone River hydrocarbon seep complex in northern Italy". English. In: Acta Palaeontologica Polonica 63 (2018). DOI: 10.4202/app.00473.2018.

[11782] S. K. Kiel, K. A. C. Campbell, W. P. Elder, and C. T. S. Little. "Jurassic and Cretaceous Gastropods from Hydrocarbon Seeps in Forearc Basin and Accretionary Prism Settings, California". English. In: Acta Palaeontologica Polonica 53.4 (2008), pp. 679-703. DOI: 10.4202/app.2008.0412.

[11783] Z. Kielan-Jaworowska, J. Bergström, and P. Ahlberg. “Cheirurina (Trilobita) from the upper Ordovician of Västergötland and other regions of Sweden". English. In: Geologiska Föreningens i Stockholm Förhandlingar 113 (1991), pp. 219-244.

[11784] Z. Kielan-Jaworowska and R. L. Cifelli. "Primitive boreosphenidan mammal (?Deltatheroida) from the Early Cretaceous of Oklahoma". In: Acta Palaeontologica Polonica 46.3 (2001), pp. 377391.

[11785] Z. Kielan-Jaworowska, R. L. Cifelli, and Z. -X. Luo. Mammals from the age of dinosaurs: Origins, evolution, and structure. English. Columbia University Press, New York. 2004, pp. 1-630. 
[11786] Z. Kielan-Jaworowska and P. C. Ensom. "Multituberculate mammals from the Upper Jurassic Purbeck Limestone Formation of southern England". English. In: Palaeontology 35.1 (1992), pp. 95126.

[11787] Z. Kielan-Jaworowska and P. C. Ensom. "Tiny plagiaulacoid mammals from the Purbeck Limestone Formation of Dorset, England". English. In: Palaeontology 37.1 (1994), pp. 17-31.

[11788] Z. Kielan-Jaworowska and J. H. Hurum. “Djadochtatheria - a new suborder of multituberculate mammals". English. In: Acta Palaeontologica Polonica 42.2 (1997), pp. 201-242.

[11789] Z. Kielan-Jaworowska, J. H. Hurum, and D. Badamgarav. "An extended range of the multituberculate Kryptobaatar and the distribution of mammals in the Upper Cretaceous of the Gobi Desert". English. In: Acta Palaeontologica Polonica 48.2 (2003), pp. 273-278.

[11790] Z. Kielan-Jaworowska and L. A. Nessov. "Multituberculate mammals from the Cretaceous of Uzbekistan". English. In: Acta Palaeontologica Polonica 37.1 (1992), pp. 1-17.

[11791] Z. Kielan-Jaworowska, E. Ortiz-Jaureguizar, E. C. Vieytes, R. Pascual, and F. J. Goin. "First cimolodontan multituberculate mammal from South America". English. In: Acta Palaeontologica Polonica 52.2 (2007), pp. 257-262.

[11792] P. M. Kier. “Oligocene echinoids of North Carolina”. English. In: Smithsonian Contributions to Paleobiology 83 (1997), pp. 1-37.

[11793] K. Kiernan and D. R. Schwimmer. "First record of a velociraptorine theropod (Tetanurae, Dromaeosauridae) from the eastern Gulf Coastal United States". English. In: The Mosasaur 7 (2004), pp. 89-93.

[11794] W. Kiessling. Late Jurassic radiolarians from the Antarctic Peninsula. 1999.

[11795] W. Kiessling. "Palökologische Verwertbarkeit oberjurassisch-unterkretazischer Radiolarienfaunen mit Beispielen aus Antarktis, Oman und Südalpen". German. PhD thesis. 1995, pp. 1-465.

[11796] W. Kiessling. "Radiolarien im nordbayerischen Oberjura". German. In: Geologische Blätter von NOBayern 47 (1997), pp. 25-52.

[11797] W. Kiessling, E. Aragon, R. Scasso, M. Aberhan, J. Kriwet, F. Medina, and D. Fracchia. “Massive corals in Paleocene siliciclastic sediments of Chubut (Patagonia, Argentina)". English. In: Facies 51 (2005), pp. 233-241.

[11798] W. Kiessling and R. C. Baron-Szabo. "Extinction and recovery patterns of scleractinian corals at the K/T-boundary". English. In: Palaeogeography, Palaeoclimatology, Palaeoecology 214 (2004), pp. 195223.

[11799] W. Kiessling and E. Flügel. "Late Paleozoic and Late Triassic limestones from North Palawan Block (Philippines): Microfacies and paleogeographical implications". In: Facies 43 (2000), pp. 39-78.

[11800] W. Kiessling, D. K. Pandey, M. Schemm-Gregory, H. Mewis, and M. Aberhan. "Marine benthic invertebrates from the Upper Jurassic of northern Ethiopia and their biogeographic affinities". English. In: Journal of African Earth Sciences 59 (2011), pp. 195-214. DOI: 10.1016/j.jafrearsci.2010. 10.006 .

[11801] W. Kiessling, E. Roniewicz, L. Villier, P. Leonide, and U. Struck. "An early Hettangian coral reef in southern France: Implications for the end-Triassic reef crisis". English. In: Palaios 24 (2009).

[11802] W. Kiessling, R. Scasso, A. Zeiss, A. Riccardi, and F. Medina. "Combined radiolarian-ammonite stratigraphy for the Late Jurassic of the Antarctic Peninsula: Implications for radiolarian stratigraphy". English. In: Geodiversitas 21.4 (1999), pp. 687-713.

[11803] A. J. Kihm. "Rodents from the Chadronian (Latest Eocene) Medicine Pole Hills Local Fauna, North Dakota. Part 1. Eutypomyidae, Cylindrodontidae, and Pipestoneomys". English. In: Paludicola 8.2 (2011), pp. 75-90.

[11804] A. J. Kihm. "Rodents from the Chadronian (latest Eocene) Medicine Pole Hills local fauna, North Dakota. Part 2. Ischyromidae, Sciuravidae, Aplodontidae, Sciuridae and Heliscomyidae". English. In: 9.2 (2013), pp. 41-55. 
[11805] A. J. Kihm and J. H. Hartman. A reevaluation of the biochronology of the Brisbane and Judson local faunas (Late Paleocene), North Dakota. English. 1997.

[11806] A. J. Kihm and K. K. Schumaker. "Domnina (Mammalia, Soricomorpha) from the latest Eocene (Chadronian) Medicine Pole Hills Local Fauna of North Dakota". English. In: Paludicola 7.1 (2008), pp. 26-36.

[11807] A. J. Kihm and K. K. Schumaker. The Chadronian Medicine Pole Hills Local Fauna, North Dakota. English. Guide to the vertebrate paleontology of the High Plains - The late Mesozoic-Cenozoic record of North Dakota: University of North Dakota Department of Geology and Geological Engineering Contribution 54. 2004, pp. 77-84.

[11808] A. J. Kihm and M. A. Tornow. "First occurrence of plesiadapiform primates from the Chadronian (latest Eocene)". English. In: Paludicola 9.4 (2014), pp. 176-182.

[11809] R. K. P. Kikuchi and Z. M. A. Leao. "Rocas (southwestern equatorial Atlantic, Brazil): an atoll built primarily by coralline algae". English. In: Proceedings of the 8th International Coral Reef Symposium 1 (1997), pp. 731-736.

[11810] J. A. Kilmer and D. W. Steadman. "A middle Pleistocene bird community from Saint Lucie County, Florida". English. In: Bulletin of the Florida Museum of Natural History 55 (2016), pp. 1-38.

[11811] B. Kim, H. Yun, and Y. -N. Lee. "[The postcranial skeleton of Bagaceratops (Ornithischia: Neoceratopsia) from the Baruungoyot Formation (Upper Cretaceous) in Hermiin Tsav of southwestern Gobi, Mongolia]". other. In: Journal of the Geological Society of Korea 55.2 (2019), pp. 179-190.

[11812] D. H. Kim, S. R. Westrop, and E. Landing. “Middle Cambrian (Acadian series) conocoryphid and paradoxidid trilobites from the upper Chamberlain's Brook Formation, Newfoundland and New Brunswick". English. In: Journal of Paleontology 76.5 (2002), pp. 822-842.

[11813] H. J. Kim, I. S. Paik, J. E. Lee, and M. Huh. Bird footprint from the Upper Cretaceous Jindong Formation at Hogyeri, Masan city, Gyeongsangnamdo, Korea: occurrences and paleoenvironmental implications. English. 2008.

[11814] H. M. Kim, A. D. Gishlick, and T. Takanobu. “The first non-avian maniraptoran skeletal remains from the Lower Cretaceous of Korea". In: Cretaceous Research 26.2 (2005), pp. 299-306.

[11815] J. Kim, H. Lee, and C. Cheong. "Occurence of Carboniferous corals from the Geumcheon Formation of Danyang area, Korea." In: Paleontological Research 3.1 (1999), pp. 49-56.

[11816] J. Y. Kim, S. H. Kim, K. S. Kim, and M. G. Lockley. "The oldest record of webbed bird and pterosaur tracks from South Korea (Cretaceous Haman Formation, Changseon and Sinsu Islands): more evidence of high avian diversity in East Asia". English. In: Cretaceous Research 27 (2006), pp. 56-69.

[11817] J. Y. Kim, M. G. Lockley, H. M. Kim, J. -D. Lim, and K. S. Kim. “New dinosaur tracks from Korea, Ornithopodichnus masanensis ichnogen. et ichnosp. nov. (Jindong Formation, Lower Cretaceous): implications for polarities in ornithopod foot morphology". English. In: Cretaceous Research 30 (2009), pp. 1387-1397. DOI: 10.1016/j.cretres.2009.08.003.

[11818] J. Y. Kim, M. G. Lockley, J. O. Woo, and S. H. Kim. “Unusual didactyl traces from the Jinju Formation (Early Cretaceous, South Korea) indicate a new ichnospecies of Dromaeosauripus". English. In: Ichnos 19 (2012), pp. 75-83.

[11819] J. Y. Kim, M. G. Lockley, S. J. Seo, K. S. Kim, S. H. Kim, and K. S. Baek. “A paradise of Mesozoic birds: the world's richest and most diverse Cretaceous bird track assemblage from the Early Cretaceous Haman Formation of the Gajin Tracksite, Jinju, Korea". English. In: Ichnos 19 (2012), pp. 28-42. DOI: 10.1080/10420940.2012.660414.

[11820] W. H. Kimbel, D. C. Johanson, and Y. Rak. "The First Skull and other new discoveries of Australopithecus afarensis at Hadar, Ethiopia". English. In: Nature 368 (1994), pp. 449-451.

[11821] W. H. Kimbel, R. C. Walter, D. C. Johanson, K. E. Reed, J. L. Aronson, Z. Assefa, C. W. Marean, G. G. Eck, R. Bobe, E. Hovers, Y. Rak, C. Vondra, T. Yemane, D. York, Y. Chen, N. M. Eversen, and P. E. Smith. "Late Pleistocene Homo and oldowan tools from the Hadar Formation (Kada Hadar Member), Ethiopia". English. In: Journal of Human Evolution 31 (1996), pp. 549-561. 
[11822] J. Kimmig and G. Arp. "Phytosaur remains from the Norian Arnstadt Formation (Leine Valley, Germany), with reference to European phytosaur habits". English. In: Palaeodiversity 3 (2010), pp. 215-224.

[11823] J. Kimmig, L. C. Strotz, and B. S. Lieberman. “The stalked filter feeder Siphusauctum lloydguntheri n. sp. from the middle Cambrian (Series 3, Stage 5) Spence Shale of Utah: its biological affinities and taphonomy". English. In: Journal of Paleontology (2017), pp. 1-9. DOI: 10.1017/jpa.2017.57.

[11824] M. Kimura. "Fossil pinniped mandible from the Middle Miocene of Haboro-cho, Hokkaid". Japanese. In: Bulletin of the Hobetsu Museum 13 (1997), pp. 1-7.

[11825] M. Kimura, H. Furusawa, T. Sagayama, Y. Igarashi, A. Suzuki, and H. Fukusawa. "Geologic age and paleoenvirontment of fossil sirenian-bearing deposits (Kinomanai Formation in the Shosambetsu region of northern Hokkaido, Japan". Japanese. In: Journal of the Geological Society of Japan 101.5 (1995), pp. 345-352.

[11826] M. Kimura, K. Sakurai, and T. Katoh. "An extinct fossil bird (Plotopteridae) from the Tokoro Formation (Late Oligocene) in Abashiri City, northeastern Hokkaido, Japan". English. In: Journal of Hokkaido University of Education (Section II B) 48.2 (1998), pp. 11-16.

[11827] M. Kimura, M. Yahata, H. Sawamura, I. Segawa, A. Suzuki, and Y. Muraishi. "The vertebrate fossils and their horizon from Akan-cho, eastern Hokkaido, Japan". Japanese. In: Earth Science (Chikyu Kagaku) 52 (1998), pp. 44-50.

[11828] T. Kimura. "Feeding strategy of an Early Miocene cetothere from the Toyama and Akeyo Formations, central Japan". In: Paleontological Research 6.2 (2002), pp. 179-189.

[11829] T. Kimura. "First squalodelphinid from the early Miocene of the Pacific realm in the Northern Hemisphere". English. In: Journal of Vertebrate Paleontology 38.4 (2018), e1493595. DOI: 10.1080 / 02724634.2018.1493595.

[11830] T. Kimura. "Review of the fossil balaenids from Japan with a re-description of Eubalaena shinshuensis (Mammalia, Cetacea, Mysticeti)". English. In: Quaderni del Museo di Storia Naturale di Livorno 22 (2009), pp. 3-21.

[11831] T. Kimura, A. Adaniya, M. Oishi, F. G. Marx, Y. Hasegawa, and N. Kohno. “A Late Miocene balaenopterid (Shimajiri-kujira) from the Okamishima Formation, Shimajiri Group, Miyako Island, Okinawa, Japan". Japanese. In: Bulletin of the Gunma Museum of Natural History 19 (2015), pp. 3948.

[11832] T. Kimura and L. G. Barnes. "New Miocene fossil Allodelphinidae (Cetacea, Odontoceti, Platanistoidea) from the North Pacific Ocean". English. In: Bulletin of the Gunma Museum of Natural History 20 (2016), pp. 1-58.

[11833] T. Kimura and Y. Hasegawa. "An outline of the Miocene cetotheres of Japan". English. In: Bulletin of the Gunma Museum of Natural History 8 (2004), pp. 79-88.

[11834] T. Kimura, Y. Hasegawa, and L. G. Barnes. "Fossil sperm whales (Cetacea, Physeteridae) from Gunma and Ibaraki prefectures, Japan; with observations on the Miocene fossil sperm whale Scaldicetus shigensis Hirota and Barnes, 1995". English. In: Bulletin of the Gunma Museum of Natural History 10 (2006), pp. 1-23.

[11835] T. Kimura and Y. Hasegawa. "Fossil finless propoise, Neophocaena phocaenoides, from the Seto Island Sea, Japan". Japanese. In: Bulletin of the Gunma Museum of Natural History 9 (2005), pp. 6572.

[11836] T. Kimura and Y. Hasegawa. "A new species of Kentriodon (Cetacea, Odontoceti, Kentriodontidae) from the Miocene of Japan". English. In: Journal of Vertebrate Paleontology (2019), pp. 1-93. DOI: $10.1080 / 02724634.2019 .1566739$.

[11837] T. Kimura, Y. Hasegawa, and Y. Okumura. "Early Miocene platanistoid form the Mizunami Group, Central Japan". English. In: Paleontological Research 13.2 (2009), pp. 167-171.

[11838] T. Kimura and Y. Hasegawa. "A fossil mysticeti from the Plio-Pleistocene Sarumaru Formation, Nagano Prefecture, Japan". English. In: Bulletin of the Gunma Museum of Natural History 13 (2009), pp. 53-57. 
[11839] T. Kimura and Y. Hasegawa. "A new baleen whale (Mysticeti: Cetotheriidae) from the earliest late Miocene of Japan and a reconsideration of the phylogeny of cetotheres". English. In: Journal of Vertebrate Paleontology 30.2 (2010), pp. 577-591.

[11840] T. Kimura, Y. Hasegawa, H. Ohzawa, T. Ueda, and T. Yamaoka. "A fossil mysticete from the middle Miocene Bihoku Group, Hiroshima, Japan". English. In: Bulletin of the Gunma Museum of Natural History 14 (2010), pp. 29-36.

[11841] T. Kimura, Y. Hasegawa, H. Ohzawa, T. Yamaoka, T. Ueda, T. Kiyoshi, Y. Furukawa, and M. Sugihara. "An additional fossil mysticete form the Middle Bihoku Group, Hiroshima, Japan". Japanese. In: Bulletin of the Gunma Museum of Natural History 15 (2011), pp. 81-92.

[11842] T. Kimura, Y. Hasegawa, and N. Kohno. "A New Species of the Genus Eschrichtius (Cetacea: Mysticeti) from the Early Pleistocene of Japan". English. In: Paleontological Research 22.1 (2018), pp. 1-19. DOI: 10.2517/2017PR007.

[11843] T. Kimura and Y. Hasegawa. "Norisdelphis annakaensis, a new Miocene delphinid from Japan". English. In: Journal of Vertebrate Paleontology (2020), e1762628. DOI: 10.1080/02724634.2020.1762628.

[11844] T. Kimura, S. Isaji, and H. Okazaki. "A mysticete fossil from the middle Pleistocene Ichijiku Formation, Chiba Prefecture, Japan". Japanese. In: Fossils 76 (2004), pp. 1-2.

[11845] T. Kimura, S. Kawano, Y. Hasegawa, and H. Furakawa. "A mysticete fossil from the Middle Miocene Omori Formation, Shimane Prefecture, Japan". Japanese. In: Bulletin of the Gunma Museum of Natural History 19 (2015), pp. 49-53.

[11846] T. Kimura, K. Narita, T. Fujita, and Y. Hasegawa. "A new species of Eubalaena (Cetacea: Mysticeti: Balaenidae) from the Gonda Formation (latest Miocene-early Pliocene) of Japan". Japanese. In: Bulletin of the Gunma Museum of Natural History 11 (2007), pp. 15-27.

[11847] T. Kimura and Y. Okumura. "An early Miocene cetothere from the Iwamura Group, Gifu Prefecture, Japan, and its feeding mechanism". Japanese. In: Bulletin of the Mizunami Fossil Museum 27 (2000), pp. 1-12.

[11848] T. Kimura and T. Ozawa. "A new cetothere (Cetacea: Mysticeti) from the early Miocene of Japan". In: Journal of Vertebrate Paleontology 22.3 (2002), pp. 684-702.

[11849] T. Kimura, O. Sakamoto, and Y. Hasegawa. "A middle Miocene cetothere from the Chichibumachi Group, Central Japan". Japanese. In: Bulletin of the Saitama Museum of Natural History 18 (2000), pp. 31-39.

[11850] T. Kimura, O. Sakamoto, and Y. Hasegawa. "A cetothere from the Miocene Chichibumachi Group, Saitama Prefecture, Japan". Japanese. In: Bulletin of the Saitama Museum of Natural History 16 (1998), pp. 1-13.

[11851] T. Kimura, I. Shinji, and T. Yangisawa. "A Pleistocene delphinid from the Ichijiku Formation, Chiba Prefecture, Japan". Japanese. In: Bulletin of the Gunma Museum of Natural History 12 (2008), pp. 35-40.

[11852] T. Kimura, Y. Takakuwa, and Y. Hasegawa. "Cetacean fossils in the Nakajima collection". Japanese. In: Bulletin of the Gunma Museum of Natural History 7 (2003), pp. 19-23.

[11853] T. Kimura, Y. Takakuwa, and K. Yoshida. "A fossil delphinid (Cetacea, Odontoceti) form the Pleistocene Ichijiku Formation, Kazusa Group, Chiba, Japan". English. In: Bulletin of the Gunma Museum of Natural History 16 (2012), pp. 71-76.

[11854] T. Kimura, K. Tanabe, S. Tomida, and Y. Hasegawa. "A fossil cetothere from the Lower Miocene Yoshino Formation, Katsuta Group, Okayama, Japan". Japanese. In: Bulletin of the Gunma Museum of Natural History 12 (2008), pp. 41-44.

[11855] A. Kin and B. Baejowski. "The horseshoe crab of the genus Limulus: living fossil or stabilomorph?" English. In: PLoS One 9.e108036 (2014). DOI: 10.1371/journal.pone.0108036.

[11856] A. Kin and R. Niedwiedzki. "First record of the puzosiine ammonite genus Pachydesmoceras from the middle and upper Turonian of Poland". English. In: Cretaceous Research 33 (2012), pp. 1520. 
[11857] P. Kindler and A. Meyer. "New U/Th and amino-acid racemization dating and interpretation of Pleistocene sequences from West Caicos Island (Caicos platform): Implication for cyclostratigraphy". English. In: Proceedings of the 15th Symposium on the Geology of the Bahamas and other carbonate regions (2012), pp. 82-95.

[11858] P. Kindler, J. L. Reyss, C. Cazala, and V. Plagnes. "Discovery of a composite reefal terrace of Middle and Late Pleistocene age in Great Inagua Island, Bahamas - implications for regional tectonics and sea-level history". English. In: Sedimentary Geology 194 (2007), pp. 141-147.

[11859] B. Kineer, K. Carpenter, and A. Shaw. "Redescription of Gastonia burgei (Dinosauria: Ankylosauria, Polacanthidae), and description of a new species". English. In: Neues Jahrbuch für Geologie und Paläontologie Abhandlungen 282.1 (2016), pp. 37-80. DOI: 10.1127/njgpa/2016/0605.

[11860] A. King. "Fossil Natuiloids from the Upper Lias (Toarcian) 'Junction Bed' of the Ilminster Area, Somerset". English. In: Proceedings of the Somerset Archaeology and Natural History Society 154 (2011), pp. 249-258.

[11861] L. King, J. Foster, and R. Scheetz. Mesadactylus and other new pterosaur specimens from the Morrison Formation (Upper Jurassic) of western Colorado. English. 2005.

[11862] L. R. King, J. R. Foster, and R. D. Scheetz. "New pterosaur specimens from the Morrison Formation and a summary of the Late Jurassic pterosaur record of the Rocky Mountain region". English. In: vol. 36. Paleontology and Geology of the Upper Jurassic Morrison Formation. New Mexico Museum of Natural History and Science Bulletin. Albuquerque: New Mexico Museum of Natural History and Science, 2006, pp. 109-113.

[11863] M. J. King, W. A. S. Sarjeant, D. B. Thompson, and G. Tresise. "A Revised Systematic Ichnotaxonomy and Review of the Vertebrate Footprint Ichnofamily Chirotheriidae from the British Triassic". English. In: Ichnos 12.4 (2005), pp. 241-299. DOI: 10.1080/10420940591009312.

[11864] M. J. King and D. B. Thompson. "Triassic vertebrate footprints from the Sherwood Sandstone Group, Hilbre, Wirral, northwest England". English. In: Proceedings of the Geologists' Association 111 (2000), pp. 111-132.

[11865] R. K. Kinzelbach and H. Pohl. “The Fossil Strepsiptera (Insecta: Strepsiptera)”. English. In: Annals of the Entomological Society of America 87.1 (1994), pp. 59-70.

[11866] J. J. Kirchman and D. W. Steadman. "New species of rails (Aves: Rallidae) from an archaeological site on Huahine, Society Islands". English. In: Pacific Science 60 (2006), pp. 281-297.

[11867] J. J. Kirchman and D. W. Steadman. "New species of extinct rails (Aves: Rallidae) from archaeological sites in the Marquesas Islands, French Polynesia". English. In: Pacific Science 61 (2007), pp. $145-163$.

[11868] J. J. Kirchman and D. W. Steadman. "Rails (Aves: Rallidae: Gallirallus) from prehistoric sites in the Kingdom of Tonga, including a description of a new species". English. In: Proceedings of the Biological Society of Washington 118 (2005), pp. 465-477.

[11869] A. G. Kirejtshuk. "Parandrexidae Fam. Nov. Jurassic Beetles of the Infraorder Cucujiformia (Coleoptera, Polyphaga)". English. In: Paleontological Journal 28.1 (1994), pp. 69-78.

[11870] A. G. Kirejtshuk. “The oldest representatives of the subfamilies Meligethinae (Coleoptera: Nitidulidae) and Brontinae (Coleoptera: Silvanidae) from Baltic amber and some evolutionary notes". English. In: Polish Journal of Entomology 80 (2011), pp. 729-745.

[11871] A. G. Kirejtshuk. "A new genus and species of timber beetle (Coleoptera: Lymexylidae) from the Baltic amber". English. In: Paleontological Journal 42 (2008), pp. 63-65.

[11872] A. G. Kirejtshuk. "The first record of the family Cleridae (Coleoptera): Shartegopsis miranda gen. et sp. nov. in the Mesozoic (Shar-Teg, Upper Jurassic, southwestern Mongolia)". English. In: Paleontological Journal 46 (2012), pp. 601-606.

[11873] A. G. Kirejtshuk. "A revision of the genus Cupes Fabricius, 1801 from Baltic amber and some notes on taxonomy and composition of the family Cupedidae (Coleoptera, Archostemata)". English. In: Mitteilungen aus dem Geologisch-Paläontologischen Institut der Universität Hamburg 89 (2005), pp. 5584 . 
[11874] A. G. Kirejtshuk. "A new genus and species of Sphaeriusidae (Coleoptera, Myxophaga) from Lower Cretaceous Burmese amber". English. In: Denisia 26 (2009), pp. 99-102.

[11875] A. G. Kirejtshuk. "Taxonomic review of fossil coleopterous families (Insecta, Coleoptera). Suborder Archostemata: Superfamilies Coleopseoidea and Cupedoidea". English. In: Geosciences 10.73 (2020). DOI: 10.3390/geosciences10020073.

[11876] A. G. Kirejtshuk and D. Azar. "New taxa of beetles (Insecta, Coleoptera) from Lebanese amber with evolutionary and systematic comments". English. In: Alavesia 2 (2008), pp. 15-46.

[11877] A. G. Kirejtshuk, D. Azar, R. A. Beaver, M. Y. Mandelshtam, and A. Nel. “The most ancient bark beetle known: a new tribe, genus and species from Lebanese amber (Coleoptera, Curculionidae, Scolytinae)". English. In: Systematic Entomology 34 (2009), pp. 101-112.

[11878] A. G. Kirejtshuk, D. Azar, and O. Montreuil. "First Mesozoic representative of the subfamily Liparochrinae (Coleoptera: Hybosoridae) from the Lower Cretaceous Lebanese amber". English. In: Zoosystematica Rossica 20 (2011), pp. 62-70.

[11879] A. G. Kirejtshuk, D. Azar, P. Tafforeau, R. Boistel, and V. Fernandez. "New beetles of Polyphaga (Coleoptera, Polyphaga) from Lower Cretaceous Lebanese amber". English. In: Denisia 26 (2009), pp. 119-130.

[11880] A. G. Kirejtshuk and D. Azar. "Current knowledge of Coleoptera (Insecta) from the Lower Cretaceous Lebanese amber and taxonomical notes for some Mesozoic groups". English. In: Terrestrial Arthropod Reviews 6 (2013), pp. 103-134.

[11881] A. G. Kirejtshuk, H. L. Chang, D. Ren, and C. K. Shih. “Family Lasiosynidae $n$ fam, new palaeoendemic Mesozoic family from the infraorder Elateriformia (Coleoptera: Polyphaga)". English. In: Annales de la Société Entomologique de France 46 (2010), pp. 67-87.

[11882] A. G. Kirejtshuk, P. E. Chetverikov, and D. Azar. "Libanopsinae, new subfamily of the family Sphindidae (Coleoptera, Cucujoidea) from Lower Cretaceous Lebanese amber, with remarks on using confocal microscopy for the study of amber inclusions". English. In: Cretaceous Research 52 (2015), pp. 461-479.

[11883] A. G. Kirejtshuk, P. E. Chetverikov, D. Azar, and P. A. Kirejtshuk. "Ptismidae fam. nov. (Coleoptera, Staphyliniformia) from the Lower Cretaceous Lebanese amber". English. In: Cretaceous Research 59 (2016), pp. 201-213.

[11884] A. G. Kirejtshuk and P. E. Chetverikov. "Discovery of a Nitidulidae in Cretaceous Burmese amber (Coleoptera, Cucujoidea) with description of a new genus and taxonomic notes". English. In: Cretaceous Research 89 (2018), pp. 174-182.

[11885] A. G. Kirejtshuk, J. Háva, and A. Nel. “New genus and species of subfamily Trinodinae (Coleoptera, Polyphaga, Dermestidae) from Lowermost Eocene French amber". English. In: Zoosystematica Rossica 19.1 (2010), pp. 54-69.

[11886] A. G. Kirejtshuk and A. V. Kovalev. "First fossil representative of the family Omalisidae (Coleoptera, Elateroidea sensu lato) from the Baltic amber". English. In: Paleontological Journal 49 (2015), pp. 14131416.

[11887] A. G. Kirejtshuk, A. V. Kovalev, and A. Nel. “The oldest Cenozoic passandrid (Coleoptera: Cucujoidea: Passandridae) from the Paleocene of Menat (France)". English. In: Comptes Rendus Palevol 18 (2019), pp. 977-983. DOI: 10.1016/j.crpv.2019.10.005.

[11888] A. G. Kirejtshuk, S. A. Kurbatov, and A. Nel. "A new species of the genus Clidicus from the Lower Cretaceous of France (Coleoptera: Staphylinidae: Scydmaeninae)". English. In: Proceedings of the Zoological Institute RAS 319 (2015), pp. 508-514.

[11889] A. G. Kirejtshuk and A. S. Kurochkin. "New species of sap beetles (Coleoptera: Nitidulidae: Nitidulini) from the Baltic and Bitterfeld ambers". English. In: Paleontological Journal 44 (2010), pp. 53-67.

[11890] A. G. Kirejtshuk, A. A. Legalov, and A. Nel. “A new genus of the subfamily Apioninae (Coleoptera: Brentidae) from the Lower Eocene Oise amber". English. In: Paleontological Journal 49 (2015), pp. 1436-1441. 
[11891] A. G. Kirejtshuk, O. Merkl, and F. Kernegger. "A new species of the genus Pentaphyllus Dejean, 1821 (Coleoptera, Tenebrionidae, Diaperinae) from the Baltic amber and checklist of the fossil Tenebrionidae". English. In: Zoosystematica Rossica 17 (2008), pp. 131-137.

[11892] A. G. Kirejtshuk, A. G. Moseyko, and D. Ren. "Mesozoic leaf beetles of the tribe Mesolpinini trib. nov. (Coleoptera, Chrysomelidae) from the Lower Cretaceous". English. In: Paleontological Journal 49 (2015), pp. 1424-1435.

[11893] A. G. Kirejtshuk, M. V. Nabozhenko, and A. Nel. "New genus and species of the tribe Opatrini (Coleoptera, Tenebrionidae, Tenebrioninae) from the lowermost Eocene amber of Paris Basin". English. In: Proceedings of the Zoological Institute RAS 314.2 (2010), pp. 191-196.

[11894] A. G. Kirejtshuk, M. V. Nabozhenko, and A. Nel. "First Mesozoic representative of the subfamily Tenebrioninae (Coleoptera, Tenebrionidae) from the Lower Cretaceous of Yixian (China, Liaoning)". English. In: Entomological Review 92 (2011), pp. 97-100.

[11895] A. G. Kirejtshuk, A. Nel, and F. Collomb. "New Archostemata (Insecta: Coleoptera) from the French Paleocene and Early Eocene, with a note on the composition of the suborder". English. In: Annales de la Société Entomologique de France 46.1-2 (2010), pp. 216-227.

[11896] A. G. Kirejtshuk and A. Nel. "New beetles of the suborder Polyphaga from the lowermost Eocene French amber (Insecta: Coleoptera)". English. In: Annales de la Société Entomologique de France 44 (2008), pp. 419-442.

[11897] A. G. Kirejtshuk and A. Nel. "New genera and species of Cucujiformia (Coleoptera, Polyphaga) from lowermost Eocene French amber". English. In: Denisia 26 (2009), pp. 103-118.

[11898] A. G. Kirejtshuk and A. Nel. "The oldest representatives of the family Coccinellidae (Coleoptera: Polyphaga) from the lowermost Eocene Oise amber (France)". English. In: Zoosystematica Rossica 21 (2012), pp. 131-144.

[11899] A. G. Kirejtshuk and A. Nel. "Current knowledge of Coleoptera (Insecta) from the lowermost Eocene Oise amber". English. In: Insect Systematics \& Evolution 44 (2013), pp. 175-201.

[11900] A. G. Kirejtshuk and A. Nel. "Lidryopinae, new byrrhid subfamily from the Lower Cretaceous of France (Coleoptera, Byrrhidae)". English. In: Cretaceous Research 67 (2016), pp. 140-147.

[11901] A. G. Kirejtshuk, A. Nel, and P. A. Kirejtshuk. "Taxonomy of the reticulate beetles of the subfamily Cupedinae (Coleoptera: Archostemata), with a review of the historical development". English. In: Invertebrate Zoology 13.2 (2016), pp. 61-190.

[11902] A. G. Kirejtshuk and A. Nel. "Nitidulidae (Coleoptera) from the Paleocene of Menat (France)". English. In: Zootaxa 4402 (2018), pp. 1-41.

[11903] A. G. Kirejtshuk and G. Poinar. "Haplochelidae, a new family of Cretaceous beetles (Coleoptera: Myxophaga) from Burmese amber". English. In: Proceedings of the Entomological Society of Washington 108 (2006), pp. 155-164.

[11904] A. G. Kirejtshuk and G. Poinar. "Species of two paleoendemic sap beetle genera of the tribe Nitidulini (Nitidulidae: Coleoptera) from the Baltic and Dominican amber". English. In: Paleontological Journal 41 (2007), pp. 629-641.

[11905] A. G. Kirejtshuk and G. Poinar. "On the systematic position of the genera Lepiceroides gen. $\mathrm{n}$. and Haplochelus, with notes on the taxonomy and phylogeny of the Myxophaga (Coleoptera)". English. In: Insect Evolution in an Ambiferous and Stone Alphabet. Leiden: Brill, 2013, pp. 55-69.

[11906] A. G. Kirejtshuk and A. G. Ponomarenko. "Fossil Beetles of the Peltidae and Nitidulidae Families (Coleoptera)". English. In: Paleontological Journal 24.2 (1990), pp. 79-90.

[11907] A. G. Kirejtshuk and A. G. Ponomarenko. "A new coleopterous family Mesocinetidae fam. nov. (Coleoptera: Scirtoidea) from Late Mesozoic and notes on fossil remains from Shar-Teg (Upper Jurassic, South-Western Mongolia)". English. In: Zoosystematica Rossica 19 (2010), pp. 301-325.

[11908] A. G. Kirejtshuk, A. G. Ponomarenko, A. S. Kurochkin, A. V. Alexeev, V. G. Gratshev, A. Y. Solodovnikov, F. T. Krell, and C. Soriano. "The beetle (Coleoptera) fauna of the Insect Limestone (late Eocene), Isle of Wight, southern England". English. In: Earth and Environmental Science Transactions of the Royal Society of Edinburgh 110 (2019), pp. 405-492. DOI: 10.1017/S1755691018000865. 
[11909] A. G. Kirejtshuk, M. Poschmann, J. Prokop, R. Garrouste, and A. Nel. “Evolution of the elytral venation and structural adaptations in the oldest Palaeozoic beetles (Insecta: Coleoptera: Tshekardocoleidae)". English. In: Journal of Systematic Palaeontology 12 (2014), pp. 575-600.

[11910] A. G. Kirejtshuk and A. A. Prokin. "The position of the Palaeozoic genus Tunguskagyrus Yan, Beutel et Lawrence in the family Triaplidae sensu n. (Coleoptera, Archostemata: Schizophoroidea)". English. In: Entomological Review 98 (2018), pp. 872-882.

[11911] E. C. Kirk and B. A. Williams. "New adapiform primate of Old World affinities from the Devil's Graveyard Formation of Texas". English. In: Journal of Human Evolution 61.2 (2011), pp. 156-168. DOI: 10.1016/j.jhevol.2011.02.014.

[11912] J. I. Kirkland. A polacanthine ankylosaur (Ornithischia: Dinosauria) from the Early Cretaceous (Barremian) of eastern Utah. Vol. 14. Lower and Middle Cretaceous Terrestrial Ecosystems (S. G. Lucas, J. I. Kirkland, \& J. W. Estep, eds.), New Mexico Museum of Natural History and Science Bulletin. 1998, pp. 271-281.

[11913] J. I. Kirkland. A new hadrosaurid from the upper Cedar Mountain Formation (Albian-Cenomanian: Cretaceous) of eastern Utah - the oldest known hadrosaurid (lambeosaurine?) English. Vol. 14. Lower and Middle Cretaceous Terrestrial Ecosystems, S. G. Lucas, J. I. Kirkland \& J. W. Estep (eds.). New Mexico Museum of Natural History and Science Bulletin. 1998, pp. 283-295.

[11914] J. I. Kirkland. Predation of dinosaur nests by terrestrial crocodilians. English. K. Carpenter, K.F. Hirsch \& J.R. Horner (eds.) Dinosaur Eggs and Babies. Cambridge University Press, Cambridge. 1994, pp. 124-133.

[11915] J. I. Kirkland. "Paleontology of the Greenhorn cylcothem (Cretaceous: late Cenomanian to middle Turonian) at Black Mesa, northeastern Arizona". English. In: New Mexico Museum of Natural History and Science Bulletin 9 (1996), pp. 1-131.

[11916] J. I. Kirkland. "Fruita Paleontological Area". English. In: Encyclopedia of Dinosaurs. New York: Academic Press, 1997, pp. 254-256.

[11917] J. I. Kirkland. "Fruita Paleontological Area (Upper Jurassic, Morrison Formation), western Colorado: an example of terrestrial taphofacies analysis". English. In: vol. 36. Paleontology and Geology of the Upper Jurassic Morrison Formation. New Mexico Museum of Natural History and Science Bulletin. Albuquerque: New Mexico Museum of Natural History and Science, 2006, pp. 6795.

[11918] J. I. Kirkland and M. C. Aguillón-Martnez. "Schizorhiza: a unique sawfish paradigm from the Difunta Group, Coahuila, Mexico". English. In: Revista Mexicana de Ciencias Geológicas 19.1 (2002), pp. 16-24.

[11919] J. I. Kirkland, L. Alcalá, Esplez Loewen M.A., L. Mampei, and J. P. Wiersma. “The basal nodosaurid Europelta carbonensis n. gen., n. sp. from the Lower Cretaceous (Lower Albian) Escucha Formation of northeastern Spain". English. In: PLoS One 8.12 (2013), e80405:1-40. DOI: 10.1371/journal. pone. 0080405 .

[11920] J. I. Kirkland, B. Britt, D. L. Burge, K. Carpenter, R. Cifelli, F. DeCourten, J. Eaton, S. Hasiotis, and T. Lawton. "Lower to Middle Cretaceous dinosaur faunas of the central Colorado Plateau: a key to understanding 35 million years of tectonics, sedimentology, evolution and biogeography". In: Brigham Young University Geology Studies 42.2 (1997), pp. 69-103.

[11921] J. I. Kirkland, B. B. Britt, C. H. Whittle, S. K. Madsen, and D. L. Burge. “A small coelurosaurian theropod from the Yellow Cat Member of the Cedar Mountain Formation (Lower Cretaceous, Barremian) of eastern Utah". English. In: Lower and Middle Cretaceous Terrestrial Ecosystems, New Mexico Museum of Natural History and Science Bulletin 14 (1998), pp. 239-248.

[11922] J. I. Kirkland, D. Burge, and R. Gaston. "A large dromaeosaur (Theropoda) from the Lower Cretaceous of eastern Utah". In: Hunteria 2.10 (1993), pp. 1-16.

[11923] J. I. Kirkland and K. Carpenter. "North America's first pre-Cretaceous ankylosaur (Dinosauria) from the Upper Jurassic Morrison Formation of western Colorado". In: Brigham Young University Geology Studies 40 (1994), pp. 25-42. 
[11924] J. I. Kirkland, K. Carpenter, A. P. Hunt, and R. D. Scheetz. “Ankylosaur (Dinosauria) specimens from the Upper Jurassic Morrison Formation". In: Modern Geology 23 (1998), pp. 145-177.

[11925] J. I. Kirkland, R. L. Cifelli, B. B. Britt, D. L. Burge, F. L. DeCourten, J. G. Eaton, and J. M. Parrish. Distribution of vertebrate faunas in the Cedar Mountain Formation, east-central Utah. English. Vol. 99. Vertebrate Paleontology in Utah 1. Salt Lake City: Utah Geological Survey, 1999, pp. 201-218.

[11926] J. I. Kirkland and D. D. Deblieux. New basal centrosaurine ceratopsian skulls from the Wahweap Formation (middle Campanian), Grand Staircase-Escalante National Monument, southern Utah. English. New Perspectives on Horned Dinosaurs: The Royal Tyrrell Museum Ceratopsian Symposium. Indiana University Press, Bloomington. 2010, pp. 117-140.

[11927] J. I. Kirkland, R. Hernández-Rivera, T. A. Gates, G. S. Paul, S. J. Nesbitt, C. I. Serrano-Brañas, and J. P. Garcia-de la Garza. Large hadrosaurine dinosaurs from the latest Campanian of Coahuila, Mexico. English. Vol. 35. Late Cretaceous Vertebrates from the Western Interior. New Mexico Museum of Natural History and Science Bulletin. 2006, pp. 299-315.

[11928] J. I. Kirkland, M. G. Lockley, and A. R. Milner. “The St. George dinosaur tracksite". English. In: Utah Geological Survey Notes 34.3 (2002), pp. 4-5, 12.

[11929] J. I. Kirkland and S. K. Madsen. “The Lower Cretaceous Cedar Mountain Formation, Eastern Utah: The view up an always interesting learning curve". English. In: Utah Geological Association Publication 35 (2007), pp. 1-108.

[11930] J. I. Kirkland and A. R. C. Milner. "The Moenave Formation at the St. George Dinosaur Discovery Site at Johnson Farm, St. George, southwestern Utah". English. In: vol. 37. The TriassicJurassic Terrestrial Transition. New Mexico Museum of Natural History and Science Bulletin. Albuquerque: New Mexico Museum of Natural History and Science, 2006, pp. 289-309.

[11931] J. I. Kirkland and D. G. Wolfe. "First definitive therizinosaurid (Dinosauria: Theropoda) from North America". English. In: Journal of Vertebrate Paleontology 21.3 (2001), pp. 410-414.

[11932] J. I. Kirkland, L. E. Zanno, S. D. Sampson, J. M. Clark, and D. D. DeBlieux. "A primitive therizinosauroid dinsoaur from the Early Cretaceous of Utah". In: Nature 435.3468 (2005), pp. 84-87.

[11933] H. Kirkland Jr. "A complete Tertiary camel skull from Roger Mills County: description and CT scan". English. In: Proceedings of the Oklahoma Academy of Science 73 (1993), pp. 63-65.

[11934] H. Kirkland Jr., M. Davis, J. Wood, D. Devine, and K. Giblet. “Some Late Pleistocene Fossils from Washita Local Fauna". English. In: Proceedings of the Oklahoma Academy of Sciences 77 (1997), pp. 113-115.

[11935] E.-E. Kischlat and S. G. Lucas. "A phytosaur from the Upper Triassic of Brazil”. English. In: Journal of Vertebrate Paleontology 23.2 (2003), pp. 464-467.

[11936] D. N. Kiselev. "A new species of the genus Cadoceras (Ammonoidea) from the Callovian of the Unzha River". In: Paleontological Journal 31.6 (1997), pp. 583-587.

[11937] S. V. Kiselev and V. I. Nazarov. "Late Cenozoic insects of northern Eurasia". English. In: Paleontological Journal 43.7 (2009), pp. 732-850.

[11938] S. Kishore, P. K. Misra, D. K. Pandey, A. K. Jauhri, T. Bahadur, S. K. Singh, R. S. Chauchan, and S. K. Tripathi. "Coralline Algae from the Aramda Reef Member of the Chaya Formation, Mithapur, Gujarat". English. In: Journal Geological Society of India 80 (2012), pp. 215-230.

[11939] S. Kishore, A. P. Singh, A. K. Jauhri, P. K. Misra, S. K. Singh, and B. C. Lyngdoh. "Coralline algae from the Prang Formation (Eocene) of the South Khasi Hills, Meghalaya, India". English. In: 26.2 (2007), pp. 615-623.

[11940] S. Kishore and S. K. Singh. "Coralline Algae from the Ninniyur Formation (Thanetian) of the Cauvery Basin, South India". English. In: Our Nature 2 (2004), pp. 1-6.

[11941] R. Kissel. “Morphology, Phylogeny, and Evolution of Diadectidae (Cotylosauria: Diadectomorpha)". English. PhD thesis. 2010. 
[11942] R. A. Kissel, D. W. Dilkes, and R. R. Reisz. “Captorhinus magnus, a new captorhinid (Amniota: Eureptilia) from the Lower Permian of Oklahoma, with new evidence on the homology of the astragalus". English. In: Canadian Journal of Earth Sciences 39.9 (2002), pp. 1363-1372.

[11943] R. A. Kissel and T. M. Lehman. "Upper Pennsylvanian tetrapods from the Ada Formation of Seminole County, Oklahoma". English. In: Journal of Paleontology 76.3 (2002), pp. 529-545.

[11944] R. A. Kissel and R. R. Reisz. Synapsid fauna of the Upper Pennsylvanian Rock Lake Shale near Garnett, Kansas and the diversity pattern of early amniotes. English. Recent Advances in the Origin and Early Radiation of Vertebrates. Verlag Dr. Friedrich Pfeil, Munich. 2004, pp. 409-428.

[11945] R. A. Kissel and R. R. Reisz. "Ambedus pusillus, new genus, new species, a small diadectid (Tetrapoda: Diadectomorpha) from the Lower Permian of Ohio, with a consideration of diadectomorph phylogeny". English. In: Annals of Carnegie Museum 73 (2004), pp. 197-212.

[11946] I. J. Kitching and S. Sadler. "Lepidoptera, Insecta". English. In: Paleontology and Geology of Laetoli: Human Evolution in Context. Volume 2: Fossil Hominins and the Associated Fauna. Dordrecht: Springer, 2011, pp. 549-554.

[11947] R. N. Kittel. "First record of the genus Phanerotomella (Hymenoptera: Braconidae) from Baltic amber with the description of a new species". English. In: Zootaxa 4482 (2018), pp. 197-200.

[11948] B. A. Kittle and R. W. Portell. Mollusca: Fort Thompson Formation (Late Pleistocene). English. Vol. 12. Florida Fossil Invertebrates. 2010, pp. 1-32.

[11949] M. Kiyota. "Site fidelity, territory acquisition and mating success in male northern fur seals (Callorhinus ursinus)". English. In: 30 (2005), pp. 19-27.

[11950] G. Klapper, R. Feist, R. T. Becker, and M. R. House. “Definition of the Frasnian/Famennian Stage boundary". In: Episodes 16.4 (1993), pp. 433-441.

[11951] J. S. Klaus and A. F. Budd. “Comparison of Caribbean coral reef communities before and after Plio-Pleistocene faunal turnover: Analyses of two Dominican Republic reef sequences". In: Palaios 18.1 (2003), pp. 3-21.

[11952] J. S. Klaus, D. F. McNeill, A. F. Budd, and A. G. Coates. "Neogene reef coral assemblages of the Bocas del Toro region, Panama: the rise of Acropora palmata". English. In: Coral Reefs 31.1 (2012), pp. 191-203.

[11953] J. S. Klaus, J. F. Meeder, D. F. McNeill, J. F. Woodhead, and P. K. Swart. “Expanded Florida reef development during the mid-Pliocene". English. In: Global and Planetary Change 152 (2017), pp. 2737.

[11954] J. S. Klaus, S. T. Murray, P. K. Swart, and D. F. McNeill. “Resource partitioning and paleoecology of Neogene free-living corals as determined from skeletal stable isotope composition". English. In: Buletin of marine science 84.4 (2013), pp. 937-954.

[11955] B. Klausnitzer. "Käferlarven (Insecta: Coleoptera) in Baltischem Bernstein - Möglichkeiten und Grenzen der Bestimmung". German. In: Entomologische Abhandlungen 61 (2003), pp. 103-108.

[11956] B. Klausnitzer. "Neue Arten der Familie Scirtidae (Coleoptera) aus Baltischem Bernstein (Teil 1)". German. In: Entomologische Nachrichten und Berichte 48 (2004), pp. 99-103.

[11957] B. Klausnitzer. "Neue Arten der Scirtidae (Coleoptera) aus Baltischem Bernstein (Teil 2)". German. In: Entomologische Zeitschrift 121 (2011), pp. 11-14.

[11958] B. Klausnitzer. “Neue Arten der Familie Scirtidae (Coleoptera) aus Baltischem Bernstein (Teil 3)”. German. In: Linzer Biologische Beiträge 44 (2012), pp. 313-318.

[11959] S. D. Klavins, E. L. Taylor, M. Krings, and T. N. Taylor. “An unusual, structurally preserved ovule from the Permian of Antarctica". In: Review of Palaeobotany and Palynology 115 (2001), pp. 107-117.

[11960] M. A. Kleffner. "Conodont biostratigraphy of the upper part of the Clinton Group and the Lockport Group (Silurian) in the Niagara Gorge region, New York and Ontario". In: Journal of Paleontology 65.3 (1991), pp. 500-511. 
[11961] M. A. Kleffner. "Wenlockian (Silurian) conodont biostratigraphy, depositional environments, and depositional history along the eastern flank of the Cincinnati Arch in southern Ohio". In: Journal of Paleontology 64.2 (1990), pp. 319-328.

[11962] C. Klein and D. Korn. "A morphometric approach to conch ontogeny of Cymaclymenia and related genera (Ammonoidea, Late Devonian)". English. In: Fossil Record 17 (2014), pp. 1-32.

[11963] C. G. Klein, N. R. Longrich, N. Ibrahim, S. Zouhri, and D. M. Martill. "A new basal snake from the mid-Cretaceous of Morocco". English. In: Cretaceous Research 72 (2017), pp. 134-141. DOI: 10.1016/ j.cretres.2016.12.001.

[11964] C. G. Klein, D. I. Whiteside, V. S. de Lucas, P. A. Viegas, and M. J. Benton. “A distinctive Late Triassic microvertebrate fissure fauna and a new species of Clevosaurus (Lepidosauria: Rhynchocephalia) from Woodleaze Quarry, Gloucestershire, UK". English. In: Proceedings of the Geologists' Association 126 (2015), pp. 402-416. DOI: 10.1016/j.pgeola.2015.05.003.

[11965] H. Klein, G. Gierlinski, J. N. Lallensack, A. Abu Hamad, H. Al-Mashakbeh, I. Alhejoj, M. Konopka, and M. Blónski. "First Upper Cretaceous dinosaur track assemblage from Jordan (Middle East) preliminary results". English. In: Annales Societatis Geologorum Poloniae 90 (2020).

[11966] H. Klein and H. Haubold. "Archosaur footprints - potential for biochronology of Triassic continental sequences". English. In: vol. 41. New Mexico Museum of Natural History and Science Bulletin. Albuquerque: New Mexico Museum of Natural History and Science, 2007, pp. 120-130.

[11967] H. Klein and S. G. Lucas. "Review of the tetrapod ichnofauna of the Moenkopi Formation/Group (Early-Middle Triassic) of the American Southwest". English. In: New Mexico Museum of Natural History and Science, Bulletin 50 (2010), pp. 1-67.

[11968] H. Klein and S. G. Lucas. "The Late Triassic tetrapod ichnotaxon Apatopus lineatus (Bock 1952) and its distribution". English. In: The Triassic System: New Mexico Museum of Natural History and Science 61. New Mexico Museum of Natural History and Science, 2013.

[11969] H. Klein, S. Voigt, H. Saber, J. W. Schneider, A. Hminna, J. Fischer, A. Lagnaoui, and A. Brosig. "First occurrence of a Middle Triassic tetrapod ichnofauna from the Argana Basin (Western High Atlas, Morocco)". English. In: Palaeogeography, Palaeoclimatology, Palaeoecology 307.1-4 (2011), pp. 218231. DOI: $10.1016 /$ j.palaeo.2011.05.021.

[11970] H. Klein, S. Voigt, A. Hminna, H. Saber, J. Scnheider, and D. Hmich. "Early Triassic archosaurdominated footprint assemblage from the Argana Basin (western High Atlas, Morocco)". English. In: Ichnos 17 (2010), pp. 1-13. DOI: 10.1080/10420940.2010.510030.

[11971] J. Klein. "Lower Cretaceous Ammonites I. Perisphinctaceae". English. In: Fossilum Catalogus I: Animalia 139 (2005), pp. 1-484.

[11972] N. Klein and P. C. H. Albers. "A new species of the sauropsid reptile Nothosaurus from the Lower Muschelkalk of the western Germanic Basin, Winterswijk, The Netherlands". English. In: Acta Palaeontologica Polonica 54.4 (2009), pp. 589-598. DOI: 10.4202/app.2008.0083.

[11973] N. Klein, R. Bussert, D. Evans, K. A. O. Salih, A. A. Eisawa, M. Nafi, and J. Müller. “Turtle remains from the Wadi Milk Formation (Upper Cretaceous) of Northern Sudan". English. In: Palaeobiodiversity and Palaeoenvironments 96 (2016), pp. 281-303. DOI: 10.1007/s12549-015-0225-9.

[11974] N. Klein and H. Hagdorn. "Humerus morphology and histology of a new marine reptile (Diapsida) from the Muschelkalk-Keuper-Grenzbonebed (Middle Triassic, Ladinian) of Southwest Germany". English. In: Palaeodiversity 7 (2014), pp. 23-38.

[11975] N. Klein and U. Lieven. “Eine Sumpfschildkrote (Bataguridae) aus dem Ober-Miozan der Niederrheinischen Bucht (NW-Deutschland)". German. In: Palaeontologische Zeitschrift 81.2 (2007), pp. 105112.

[11976] N. Klein and T. Mors. “Die Schildkroten (Reptilia: Testudines) aus dem Mittel-Miozan von Hambach (Niederrheinische Bucht, NW-Deutschland)". German. In: Palaeontographica Abteilung A 268.13 (2003), pp. 1-48. 
[11977] N. Klein and T. Scheyer. "A new placodont sauropterygian from the Middle Triassic of the Netherlands". English. In: Acta Palaeontologica Polonica (2014). DOI: 10.4202/app.2012.0147.

[11978] N. Klein and T. M. Scheyer. "Microanatomy and life history in Palaeopleurosaurus (Rhynchocephalia: Pleurosauridae) from the Early Jurassic of Germany". English. In: Science of Nature 104.4 (2017), pp. 1-8. DOI: 10.1007/s00114-016-1427-3.

[11979] N. Klein, L. Schmitz, T. Wintrich, and P. M. Sander. “A new cymbospondylid ichthyosaur (Ichthyosauria) from the Middle Triassic (Anisian) of the Augusta Mountains, Nevada, USA". English. In: Journal of Systematic Palaeontology (2020). DOI: 10.1080/14772019.2020.1748132.

[11980] N. Klein, R. Schoch, and G. Schweigert. “A juvenile eurysternid turtle (Testudines: Eurysternidae) from the upper Kimmeridgian (Upper Jurassic) of Nusplingen (SW Germany)". English. In: Geobios 49.5 (2016), pp. 355-364. DOI: 10.1016/j.geobios.2016.06.008.

[11981] N. Klein, D. F. A. Voeten, A. Haarhuis, and R. Bleeker. "The earliest record of the genus Lariosaurus from the early middle Anisian (Middle Triassic) of the Germanic Basin". English. In: Journal of Vertebrate Paleontology 36.4 (2016), e1163712. DOI: 10.1080/02724634.2016.1163712.

[11982] N. Klein, D. F. A. Voeten, J. Lankamp, R. Bleeker, O. J. Sichelschmidt, M. Liebrand, D. C. Nieweg, and P. M. Sander. "Postcranial material of Nothosaurus marchicus from the Lower Muschelkalk (Anisian) of Winterswijk, The Netherlands, with remarks on swimming styles and taphonomy". English. In: Paläontologische Zeitschrift 89.4 (2015), pp. 961-981. DOI: 10.1007/s12542-015-0273-5.

[11983] R. G. Klein, K. Cruz-Uribe, and P. B. Beaumont. "Environmental, Ecological and Paleoanthropological Implications of the Late Pleistocene Mammalian Fauna from Equus Cave, Northern Cape Province, South Africa". English. In: Quaternary Research 36 (1991), pp. 94-119.

[11984] R. G. Klein and K. Cruz-Uribe. "Middle and later Stone Age large mammal and tortoise remains from Die Kelders Cave 1, Western Cape Province, South Africa". English. In: Journal of Human Evolution 38 (2000), pp. 169-195.

[11985] R. G. Klein, K. Cruz-Uribe, D. Halkett, T. Hart, and J. E. Parkington. "Paleoenvironmental and Human Behavioral Implications of the Boegoeberg 1 Late Pleistocene Hyena Den, Northern Cape Province, South Africa". English. In: Quaternary Research 52 (1999), pp. 393-403.

[11986] J. Klembara. "The skeletal anatomy and relationships of a new discosauriscid seymouriamorph from the Lower Permian of Moravia (Czech Republic)". English. In: Annals of Carnegie Museum 77.4 (2009), pp. 451-483.

[11987] J. Klembara. "A New Anguimorph Lizard from the Lower Miocene of North-West Bohemia (Czech Republic)". English. In: Palaeontology 51.1 (2008), pp. 81-94. DOI: 10.1111/j.1475-4983.2007.00732.x.

[11988] J. Klembara. "A new species of Pseudopus (Squamata, Anguidae) from the early Miocene of Northwest Bohemia (Czech Republic)". English. In: Journal of Vertebrate Paleontology 32.4 (2012), pp. 854-866. DOI: 10.1080/02724634.2012.670177.

[11989] J. Klembara. "A new discosauriscid seymouriamorph tetrapod from the Lower Permian of Moravia, Czech Republic". English. In: Acta Palaeontologica Polonica 50.1 (2005), pp. 25-48.

[11990] J. Klembara. "The cranial anatomy of Discosauriscus Kuhn, a seymouriamorph tetrapod from the Lower Permian of the Boskovice Furrow (Czech Republic)". English. In: Philosophical Transactions of the Royal Society of London B: Biological Sciences 352 (1997), pp. 257-302. DOI: 10.1098/rstb.1997. 0021.

[11991] J. Klembara. “New finds of anguines (Squamata, Anguidae) from the Early Miocene of Northwest Bohemia (Czech Republic)". English. In: Palaeontologische Zeitschrift 89 (2015), pp. 171-195. DOI: 10.1007/s12542-014-0226-4.

[11992] J. Klembara, M. Böhme, and M. Rummel. "Revision of the anguine lizard Pseudopus laurillardi (Squamata, Anguidae) from the Miocene of Europe, with comments on paleoecology". English. In: Journal of Paleontology 84.2 (2010), pp. 159-196.

[11993] J. Klembara and B. Green. "Anguimorph lizards (Squamata, Anguimorpha) from the middle and late Eocene of the Hampshire Basin of southern England". English. In: Journal of Systematic Palaeontology 8.1 (2010), pp. 97-129. DOI: 10.1080/14772011003603531. 
[11994] J. Klembara, M. Hain, and A. eranský. "The first record of anguine lizards (Anguimorpha, Anguidae) from the early Miocene locality Ulm - Westtangente in Germany". English. In: Historical Biology (2017). DOI: 10.1080/08912963.2017.1416469.

[11995] J. Klembara and M. Janiga. "Variation in Discosauriscus austriacus (Makowsky, 1876) from the Lower Permian of the Boskovice Furrow (Czech Republic)". English. In: Zoological Journal of the Linnean Society 108.3 (1993), pp. 247-270. DOI: 10.1111/j.1096-3642.1993.tb00298.x.

[11996] J. Klembara and M. Rummel. “New material of Ophisaurus, Anguis and Pseudopus (Squamata, Anguidae, Anguinae) from the Miocene of the Czech Republic and Germany and systematic revision and palaeobiogeography of the Cenozoic Anguinae". English. In: Geological Magazine 155.1 (2018), pp. 20-44. DOI: 10.1017/S0016756816000753.

[11997] J. Klembara and M. Ruta. “The seymouriamorph tetrapod Ariekanerpeton sigalovi from the Lower Permian of Tadzhikistan. Part I: Cranial anatomy and ontogeny". English. In: Transactions of the Royal Society of Edinburgh: Earth Sciences 96.1 (2005), pp. 43-70. DOI: 10.1017/S0263593300001231.

[11998] J. Klembara and J. S. Steyer. "A new species of Sclerocephalus (Temnospondyli: Stereospondylomorpha) from the early Permian of the Boskovice Basin (Czech Republic)". English. In: Journal of Paleontology 86 (2012), pp. 302-310. DOI: 10.1666/11-051.1.

[11999] K. S. Kleppe, H. A. Nakrem, and S. Stouge. "Cambrian (Series 3 - Furongian) conodonts from the Alum Shale Formation at Slemmestad, Oslo Region, Norway". English. In: Norwegian Journal of Geology 98.1 (2018), pp. 41-53.

[12000] J. Klietmann, D. Nagel, M. Rummel, and L. W. van den Hoek Ostende. "A gap in digging: the Talpidae of Petersbuch 28 (Germany, Early Miocene)". English. In: Paläontologische Zeitschrift 89.3 (2015), pp. 563-592. DOI: 10.1007/s12542-014-0228-2.

[12001] B. T. Kligman, A. D. Marsh, and W. G. Parker. "First records of diapsid Palacrodon from the Norian, Late Triassic Chinle Formation of Arizona, and their biogeographic implications". English. In: Acta Palaeontologica Polonica 63.1 (2018), pp. 117-127. DOI: 10.4202/app.00426.2017.

[12002] B. T. Kligman, A. D. Marsh, H.-D. Sues, and C. A. Sidor. "A new non-mammalian eucynodont from the Chinle Formation (Triassic: Norian), and implications for the early Mesozoic equatorial cynodont record". English. In: Biology Letters 16 (2020), p. 20200631. DOI: 10.1098/rsbl.2020.0631.

[12003] S. M. Klimaszewski. "New psyllids (Homoptera, Psylloidea) from Dominican amber". English. In: Acta Biologica Silesiana 29.46 (1996), pp. 24-44.

[12004] S. M. Klimaszewski. "Protoscena baltica gen. et sp. $\mathrm{n}$ from the Eocene Baltic amber (Hemiptera, Homoptera)". English. In: Annalen des Naturhistorischen Museums in Wien, Serie A 98 (1997), pp. 69 72.

[12005] S. M. Klimaszewski. "New Species of Miocene Psyllids (Homoptera, Psylloidea)". English. In: Acta Biologica Silesiana 22.39 (1993), pp. 19-29.

[12006] S. M. Klimaszewski. "New species of Eocene psyllids representing the tribe Paleopsylloidini BeckerMigdisova (Homoptera, Aphalaridae)". English. In: Acta Biologica Silesiana 22 (1993), pp. 9-18.

[12007] S. M. Klimaszewski. "New psyllids from the Baltic amber (Insecta: Homoptera, Aphalaridae)". English. In: Mitteilungen aus dem Geologisch-Paläontologischen Institut der Universität Hamburg 80 (1997), pp. 157-171.

[12008] S. M. Klimaszewski and Y. A. Popov. "New fossil hemipteran insects from southern England (Hemiptera: Psyllina + Coleorrhyncha)". English. In: Annals of the Upper Silesian Museum, Entomology, Supplement 1 (1993), pp. 13-36.

[12009] D. B. Kline. "Systematics and biostratigraphy of Miocene Cirripedia of the Chesapeake Group; Maryland, North Carolina, and Virginia". English. PhD thesis. 1997.

[12010] B. C. Klingensmith. “GIS-based biogeography of Cincinnatian (Upper Ordovician) brachiopods with special reference to Hebertella". English. PhD thesis. 2007. 
[12011] H. C. Klinger and W. J. Kennedy. "Cretaceous faunas from Zululand and Natal, South Africa. A Koloceras (Cephalopoda, Ammonoidea) from the Mzinene Formation (Albian)". English. In: Annals of the South African Museum 99.2 (1990), pp. 15-21.

[12012] H. C. Klinger and W. J. Kennedy. "Cretaceous faunas from Zululand and Natal, South Africa. Barremian representatives of the ammonite family Ancyloceratidae Gill, 1871". English. In: Annals of the South African Museum 101.5 (1992), pp. 71-138.

[12013] H. C. Klinger and W. J. Kennedy. "Cretaceous faunas from Zululand and Natal, South Africa. The heteromorph ammonite genus Eubaculites Spath, 1926". English. In: Annals of the South African Museum 102.6 (1993), pp. 185-264.

[12014] H. C. Klinger and W. J. Kennedy. "Cretaceous faunas from Zululand and Natal, South Africa. Salaziceras salazacense (Hébert \& Munier-Chalmas, 1875) from the Mzinene Formation of northern Zululand". English. In: South African Journal of Geology 97.2 (1994), pp. 146-148.

[12015] H. C. Klinger and W. J. Kennedy. “Hoplitoplacenticeras (H.) howarthi Collignon, 1970 (Cephalopoda: Ammonoidea) from KwaZulu-Natal, South Africa and Madagascar; intraspecific variation, dimorphism and affinities". English. In: African Natural History 7 (2011), pp. 41-61.

[12016] H. C. Klinger, W. J. Kennedy, J. A. Lees, and S. Kitto. “Upper Maastrichtian ammonites and nannofossils and a Palaeocene nautiloid from Richards Bay, Kwa Zulu, South Africa". English. In: Acta Geologica Polonica 51 (2001), pp. 273-291.

[12017] H. C. Klinger, W. J. Kennedy, and K. P. Minor. "Tarrantites, a new heteromorph ammonite genus from the Albian of Texas and Pakistan". English. In: African Natural History 6 (2010), pp. 91-99.

[12018] H. C. Klinger and N. Malchus. "The first record of Agerostrea ungulata (von Schlotheim, 1813) (Bivalvia: Ostreoidea) from the Upper Maastrichtian of KwaZulu, South Africa, with a discussion of its distribution in southeast Africa and Madagascar". English. In: (2008).

[12019] P. A. Kloess and J. F. Parham. "A specimen-based approach to reconstructing the late Neogene seabird communities of California". English. In: Palaeogeography, Palaeoclimatology, Palaeoecology 468 (2017), pp. 473-484. DOI: 10.1016/j.palaeo.2016.12.042.

[12020] P. A. Kloess, A. W. Poust, and T. A. Stidham. "Earliest fossils of giantsized bonytoothed birds (Aves: Pelagornithidae) from the Eocene of Seymour Island, Antarctica". English. In: Scientific Reports 10.18286 (2020), pp. 1-11. DOI: 10.1038/s41598-020-75248-6.

[12021] H. Klompen and D. Grimaldi. "First Mesozoic Record of a Parasitiform Mite: a Larval Argasid Tick in Cretaceous Amber (Acari: Ixodida: Argasidae)". English. In: Annals of the Entomological Society of America 94.1 (2001), pp. 10-15. DOI: 10.1603/0013-8746(2001)094[0010:FMROAP]2.0.CO;2.

[12022] A. A. Klompmaker, P. Artal, R. H. B. Fraaije, and J. W. M. Jagt. "Revision of the family Gastrodoridae (Crustacea, Decapoda), with description of the first species from the Cretaceous". English. In: Journal of Paleontology 85.2 (2011), pp. 226-233.

[12023] A. A. Klompmaker, R. M. Feldmann, C. M. Robins, and C. E. Schweitzer. "Peak diversity of Cretaceous galatheoids (Crustacea, Decapoda) from northern Spain". English. In: Cretaceous Research 36 (2012), pp. 125-145. DOI: 10.1016/j.cretres.2012.03.003.

[12024] A. A. Klompmaker, R. M. Feldmann, and C. E. Schweitzer. "A Hotspot for Cretaceous Goniodromitids (Decapoda: Brachyura) From Reef Associated Strata In Spain". English. In: Journal of Crustacean Biology 32.5 (2012), pp. 708-801.

[12025] A. A. Klompmaker and R. H. B. Fraaije. "The oldest (Middle Triassic, Anisian) lobsters from the Netherlands: taxonomy, taphonomy, paleoenvironment, and paleoecology". English. In: Palaeontologia Electronica 14.1 (2011), 1A.

[12026] A. A. Klompmaker, G. F. W. Herngreen, and H. W. Oosterink. “Biostratigraphic correlation, paleoenvironment stress, and subrosion pipe collapse: Dutch Rhaetian shales uncover their secrets". English. In: Facies 56 (2010), pp. 597-613. DOI: 10.1007/s10347-010-0227-z.

[12027] J. Kluessendorf and P. Doyle. "Pohlsepia mazonensis, an early octopus from the Carboniferous of Illinois, USA". English. In: Palaeontology 43 (2003), pp. 919-926. 
[12028] C. Klug. "Quantitative stratigraphy and taxonomy of late Emsian and Eifelian ammonoids of the eastern Anti-Atlas (Morocco)". In: Courier Forschungsinstitut Senckenberg 238 (2002), pp. 1-109.

[12029] C. Klug, K. de Baets, and D. Korn. "Exploring the limits of morphospace: Ontogeny and ecology of late Viséan ammonoids from the Tafilalt, Morocco". English. In: Acta Palaeontologica Polonica 61 (2016), pp. 1-14.

[12030] C. Klug, S. Döring, D. Korn, and V. Ebbinghausen. “The Visean sedimentary succession at the Gara el Itima (Anti-Atlas, Morocco) and its ammonoid faunas". English. In: Fossil Record 9.1 (2006), pp. 3-60.

[12031] C. Klug, H. Hagedorn, and M. Montenari. "Phosphatized soft-tissue in Triassic Bivalves". English. In: Palaeontology 48.4 (2005), pp. 833-852.

[12032] C. Klug and R. Hoffmann. "Early Devonian actiniarian trace fossils (Conichnus conicus) from the Anti-Atlas of Morocco". English. In: 290.1-3 (2018), pp. 65-74. DOI: 10.1127/njgpa/2018/0767.

[12033] C. Klug, B. Kröger, D. Korn, M. Rücklin, M. Schemm-Gregory, K. De Baets, and R. H. Mapes. "Ecological Change during the early Emsian (Devonian) in the Tafilalt (Morocco), the Origin of the Ammonoidea, and the First African Pyrgocystid Edrioasteroids,Machaerids and Phyllocarids". English. In: Palaeontographica Abteilung A Band 283 (2008), pp. 83-176.

[12034] C. Klug and A. Lehmkuhl. "Softtissue attachment structures and taphonomy of the Middle Triassic nautiloid Germanonautilus". In: Acta Palaeontologica Polonica 49.2 (2004), pp. 243-258.

[12035] C. Klug, E. SamankassouA., A. Pohle, K. Baets, F. Franchi, and D. Korn. “Oases of biodiversity: Early Devonian palaeoecology at Hamar Laghdad, Morocco". English. In: 290.1-3 (2018), pp. 9-48. DOI: $10.1127 /$ njgpa/2018/0772.

[12036] S. Klug. “The Late Jurassic neoselachian Macrourogaleus FOWLER, 1947 is a palaeospinacid shark (Elasmobranchii; Synechodontiformes)". English. In: Acta Geologica Polonica 58.2 (2008), pp. 229234.

[12037] S. Klug and J. Kriwet. "An offshore fish assemblage (Elasmobranchii, Actinopterygii) from the Late Jurassic of NE Spain". English. In: Palaeontologische Zeitschrift 87.2 (2013), pp. 235-257.

[12038] S. Klug, T. Tütken, O. Wings, H. -U. Pfretzschner, and T. Martin. "A Late Jurassic freshwater shark assemblage (Chondrichthyes, Hybodontiformes) from the southern Junggar Basin, Xinjiang, northwest China". English. In: Palaeobiology and Palaeoenvironments 90.3 (2010), pp. 241-257. DOI: 10.1007/s12549-010-0032-2.

[12039] N. J. Kluge. "A new suborder of Thysanura for the Carboniferous insect originally described as larva of Bojophlebia, with comments on characters of the orders Thysanura and Ephemeroptera". English. In: Zoosystematica Rossica 4 (1996), pp. 71-75.

[12040] N. J. Kluge. "Classification and phylogeny of the Baetidae (Ephemeroptera) with description of the new species from the Upper Cretaceous resins of Taimyr". English. In: Ephemeroptera \& Plecoptera: Biology-Ecology-Systematics. Fribourg: MTL, 1997, pp. 527-535.

[12041] N. J. Kluge, R. J. Godunko, and W. Krzemiski. “A new mayfly family (Insecta: Ephemeroptera) from Eocene Baltic amber". English. In: Annales Zoologici 56 (2006), pp. 181-185.

[12042] N. Y. Kluge. "New data on mayflies (Ephemeroptera) from Mesozoic and Cenozoic resins". English. In: Paleontological Journal 27.1A (1993), pp. 35-49.

[12043] M. J. Knaus, G. R. Upchurch Jr., and W. H. Gillespie. “Charbeckia macrophylla gen. et sp. nov. from the Lower Mississippian Price (Pocono) Formation fo southeastern West Virginia". In: Review of Palaeobotany and Palynology 111.2000 (2000), pp. 71-92.

[12044] G. E. Knauss, W. G. Joyce, T. R. Lyson, and D. Pearson. "A new kinosternoid from the Late Cretaceous Hell Creek Formation of North Dakota and Montana and the origin of the Dermatemys mawii lineage". English. In: Palaeontologische Zeitschrift 85 (2011), pp. 125-142. DOI: 10.1007 / s12542-010-0081-x. 
[12045] M. J. Knell, F. D. Jackson, A. L. Titus, and L. B. Albright. “A gravid fossil turtle from the Upper Cretaceous (Campanian) Kaiparowits Formation, southern Utah". English. In: Historical Biology 23.1 (2011), pp. 57-62. DOI: 10.1080/08912963.2010.499167.

[12046] S. Kneevi, A. van de Weerd, and Z. Markovi. "Overview of the geology of the Leva basin and the fossil mammal and the fossil plants localities in the Sibnica area (Central Serbia)". English. In: Special Issue of the Natural History Museum in Belgrade: Life on the Shore - geological and palaeontological research in the Neogene of Sibnica and vicinity (Leva Basin, Central Serbia) Part 1 (2016), pp. 11-20.

[12047] V. G. Kniazev, S. V. Meledina, A. S. Alifirov, and B. L. Nikitenko. “The Early Callovian Genus Sadochamoussetia (Ammonoidea, Cardioceratidae) in the Lower Reaches of the Anabar River, Northern Central Siberia". English. In: Stratigraphy and Geological Correlation 25.4 (2017), pp. 2641. DOI: $10.1134 /$ S0869593817040049.

[12048] C. Knight and P. Wilf. "Rare leaf fossils of Monimiaceae and Atherospermataceae (Laurales) from Eocene Patagonian rainforests and their biogeographic significance". English. In: Palaeontologia Electronica 16.3 (2013), 26A-39 p.

[12049] I. Knight, K. Azmy, W. D. Boyce, and D. Lavoie. “Tremadocian carbonate rocks of the Lower St. George Group, Port au Port Peninsula, western Newfoundland: lithostratigraphic setting of diagenetic, isotopic and geochemistry studies". English. In: Current Research. Newfoundland and Labrador Department of Natural Resources, Geological Survey Report 08.1 (2008), pp. 115-149.

[12050] I. Knight, W. D. Boyce, C. B. Skovsted, and U. Balthasar. “The Lower Cambrian Forteau Formation, southern Labrador and Great Northern Peninsula, western Newfoundland: Lithostratigraphy, trilobites, and depositional setting". English. In: Geological Survey 1 (2017), pp. 1-72.

[12051] J. Knight. “Dining in the Pleistocene; who's on the menu?” English. In: Geology 33.8 (2005), pp. 649652.

[12052] J. L. Knight, D. J. Cicimurri, and R. W. Purdy. "New Western Hemisphere occurrences of Schizorhiza Weiler, 1930 and Eotorpedo White, 1934 (Chondrichthyes, Batomorphii)". English. In: Paludicola 6.3 (2007), pp. 87-93.

[12053] T. K. Knight, P. S. Bingham, R. D. Lewis, and C. E. Savrda. "Feathers of the Ingersoll shale, Eutaw Formation (Upper Cretaceous), eastern Alabama: the largest collection of feathers from North American Mesozoic rocks". English. In: Palaios 26.6 (2011), pp. 364-376. DOI: 10.2110/ palo.2010. p10-091r.

[12054] A. L. Knipper, M. A. Satian, and N. Yu. Bragin. “Upper Triassic-Lower Jurassic volcanogenis and sedimentary deposits fo the Old Zod Pass (Transcaucasia)". English. In: Stratigraphy and Geological Correlation 5.3 (1997), pp. 257-264.

[12055] A. H. Knoll, J. P. Grotzinger, A. J. Kaufman, and P. Kolosov. "Integrated approaches to terminal Proterozoic stratigraphy: an example from the Olenek Uplift, northeastern Siberia". English. In: Precambrian Research 73 (1995), pp. 251-270.

[12056] F. Knoll. “New skull of Lesothosaurus (Dinosauria: Ornithischia) from the Upper Elliot Formation (Lower Jurassic) of southern Africa". English. In: Géobios 35.5 (2002), pp. 595-603.

[12057] F. Knoll. "Nearly complete skull of Lesothosaurus (Dinosauria: Ornithischia) from the Upper Elliot Formation (Lower Jurassic: Hettangian) of Lesotho". English. In: Journal of Vertebrate Paleontology 22.2 (2002), pp. 238-243.

[12058] F. Knoll. "A primitive sauropodomorph from the upper Elliot Formation of Lesotho". English. In: Geological Magazine 147.6 (2010), pp. 814-829. DOI: 10.1017/S001675681000018X.

[12059] F. Knoll and B. Battail. "New ornithischian remains from the Upper Elliot Formation (Lower Jurassic) of Lesotho and stratigraphical dsitribution of southern African fabrosaurids". English. In: Géobios 34.4 (2001), pp. 415-421.

[12060] F. Knoll and A. Bouveur. "A large pterodactyloid in northern France and a review of the French pterosaur record". English. In: Bulletin de la Société Géologique de France 172 (2001), pp. 447-454. 
[12061] F. Knoll, E. Buffetaut, and B. Dubus. “Un ostéoderme d'ankylosaure (Ornithischia) dans l'Albien de l'Aube (France) [An ankylosaur osteoderm (Ornithischia) in the Albian of Aube (France)]". French. In: Bulletin Annuel de l'Association Géologique Auboise 19 (1998), pp. 61-65.

[12062] F. Knoll, C. Colleté, B. Dubus, and J. -L. Petit. “On the presence of a sauropod dinosaur (Saurischia) in the Albian of Aube (France)". English. In: Geodiversitas 22.3 (2000), pp. 389-394.

[12063] F. Knoll, R. C. Ridgely, F. Ortega, J. L. Sanz, and L. M. Witmer. “Neurocranial osteology and neuroanatomy of a Late Cretaceous titanosaurian sauropod from Spain (Ampelosaurus sp.)" English. In: PLoS ONE 8.1 (2013), e54991:1-11. DOI: 10.1371/journal.pone.0054991.

[12064] F. Knoll and J. I. Ruiz-Omeñaca. “Theropod teeth from the basalmost Cretaceous of Anoual (Morocco) and their palaeobiogeographical significance". English. In: Geological Magazine 146.4 (2009), pp. 602-616. DOI: $10.1017 /$ S0016756809005950.

[12065] N. T. Knudsen, P. Nornberg, J. C. Yde, B. Hasholt, and J. Heinemeier. “Recent marginal changes of the Mittivakkat Glacier, Southeast Greenland and the discovery of remains of reindeer (Rangifer tarandus), polar bear (Ursus maritimus) and peaty material". English. In: Geografisk TidsskriftDanish Journal of Geography 108.1 (2008), pp. 137-142.

[12066] E. M. Knutsen, P. S. Druckenmiller, and J. Hurum. "Redescription and taxonomic clarification of 'Tricleidus' svalbardensis based on new material from the Agardhfjellet Formation (Middle Volgian)". English. In: Norwegian Journal of Geology 92 (2012), pp. 175-186.

[12067] E. M. Knutsen, P. S. Druckenmiller, and J. H. Hurum. "A new species of Pliosaurus (Sauropterygia: Plesiosauria) from the Middle Volgian of central Spitsbergen, Norway". English. In: Norwegian Journal of Geology 92 (2012), pp. 235-258.

[12068] E. M. Knutsen, P. S. Druckenmiller, and J. H. Hurum. "Two new species of long-necked plesiosaurians (Reptilia: Sauropterygia) from the Upper Jurassic (Middle Volgian) Agardhfjellet Formation of central Spitsbergen". English. In: Norwegian Journal of Geology 92 (2012), pp. 187-212.

[12069] E. M. Knutsen, P. S. Druckenmiller, and J. H. Hurum. "A new plesiosauroid (Reptilia: Sauropterygia) from the Agardhfjellet Formation (Middle Volgian) of central Spitsbergen, Norway". English. In: Norwegian Journal of Geology 92 (2012), pp. 213-234.

[12070] B. Koodziej, M. Ivanov, and V. Idakieva. "Prolific development of pachythecaliines in Late Barremian, Bulgaria: coral taxonomy and sedimentary environment". English. In: Annales Societatis Geologorum Poloniae 82 (2012), pp. 291-330.

[12071] F. Kobayashi. “Middle Permian foraminifers of the Izuru and Nabeyama Formations in the Kuzu area, Tochigi Prefecture, Japan Part 1. Schwagerinid, neoschwagerinid, and verbeekinid fusulinoideans". English. In: Paleontological Research 10 (2006), pp. 37-59.

[12072] F. Kobayashi. "Middle Permian foraminifers of the Izuru and Nabeyama Formations in the Kuzu area, Tochigi Prefecture, Japan Part 2. Schubertellid and ozawainellid fusulinoideans, and nonfusulinoidean foraminifers". English. In: Paleontological Research 10 (2006), pp. 61-77.

[12073] F. Kobayashi. "Middle Permian (Wordian) foraminifers of the Furen Limestone, Oita Prefecture, Japan". English. In: Humans and Nature 22 (2011), pp. 21-25.

[12074] F. Kobayashi. "Early Late Permian (Wuchiapingian) foraminifers in the Tatsuno area, Hyogo Late Paleozoic and Early mesozoic foraminifers of Hyogo, Japan, part 4". English. In: Nature and Human Activities 10 (2006), pp. 25-33.

[12075] F. Kobayashi. "Permian fusuline faunas and biostratigraphy of the Akasaka Limestone (Japan)". English. In: Revue de Paléobiologie, Genéve 30 (2011), pp. 431-574.

[12076] F. Kobayashi. "Latest Permian (Changhsingian) foraminifers in the Mikata area, Hyogo - Late Paleozoic and early Mesozoic foraminifers of Hyogo, Japan, Part 3". English. In: Nature and Human Activities 10 (2006), pp. 15-24.

[12077] F. Kobayashi. "Late Middle Permian (Capitanian) foraminifers in the Miharaiyama area, Hyogo Late Paleozoic and early Mesozoic foraminifers of Hyogo, Japan, Part 2". English. In: Nature and Human Activities 10 (2006), pp. 1-13. 
[12078] F. Kobayashi. "Permian foraminifers from the Itsukaichi-Ome area, west Tokyo, Japan". English. In: Journal of Paleontology 79 (2005), pp. 413-432.

[12079] F. Kobayashi. "Middle Permian foraminifer of Kaize, southern part of Saku Basin, Nagano prefecture, central Japan". English. In: Paleontological Research 10.3 (2006), pp. 179-194.

[12080] F. Kobayashi. "Middle and Late Permian foraminifers from the Chichibu belt, Takachiho area, Kyushu, Japan: implications for faunal events". English. In: Journal of Paleontology 86.4 (2012), pp. 669-687.

[12081] F. Kobayashi. "Late Middle Permian (Capitanian) foraminifers in the Mikata area, Hyogo, with special reference to plasticity deformation of their test and their paleobiogeographic affinity with South China - Late Paleozoic and Early Mesozoic foraminifers of Hyogo, Japan, Part 5". English. In: Nature and Human Activities 11 (2007), pp. 17-28.

[12082] F. Kobayashi and D. Altiner. "Fusulinoidean Faunas from the Upper Carboniferous and Lower Permian Platform Limestone in the Hadim Area, Central Taurides, Turkey". English. In: Rivista Italiana di Paleontologia e Stratigrafia 114 (2008), pp. 191-232.

[12083] F. Kobayashi, C. A. Ross, and J. R. P. Ross. "Age and generic assignment of Yabeina columbiana (Guadalupian fusulinacea) in southern British Columbia". English. In: Journal of Paleontology 81 (2007), pp. 238-253.

[12084] S. Kobayashi, H. Horikawa, and S. Miyazaki. "A new species of Sirenia (Mammalia: Hydrodamalinae) from the Shiotsubo Formation in Takasato, Aizu, Fukushima Prefecture, Japan". English. In: Journal of Vertebrate Paleontology 15.4 (1995), pp. 815-829.

[12085] Y. Kobayashi and Y. Azuma. "A new iguanodontian (Dinosauria: Ornithopoda) from the Lower Cretaceous Kitadani Formation of Fukui Prefecture, Japan". In: Journal of Vertebrate Paleontology 23.1 (2003), pp. 166-175.

[12086] Y. Kobayashi and J. Lü. "A new ornithomimid dinosaur with gregarious habits from the Late Cretaceous of China". English. In: Acta Palaeontologica Polonica 48.2 (2003), pp. 235-259.

[12087] Y. Kobayashi, T. Nishimura, R. Takasaki, K. Chiba, A. R. Fiorillo, K. Tanaka, T. Chinzorig, T. Sato, and K. Sakurai. "A new hadrosaurine (Dinosauria: Hadrosauridae) from the marine deposits of the Late Cretaceous Hakobuchi Formation, Yezo Group, Japan". English. In: Scientific Reports 9 (2019), p. 12389. DOI: 10.1038/s41598-019-48607-1.

[12088] D. R. Kobluk and I. Noor. "Coral microatolls and a probable Middle Ordovician example". English. In: Journal of Paleontology 64.1 (1990), pp. 39-43.

[12089] P. Koárek. "The cephalothoracic apparatus of Caputoraptor elegans may have been used to squeeze prey". English. In: Current Biology 28 (2018), R824-R825.

[12090] P. Koárek. "Alienopterella stigmatica gen. et sp. nov.: the second known species and specimen of Alienoptera extends knowledge about this Cretaceous order (Insecta: Polyneoptera)". English. In: Journal of Systematic Palaeontology 17 (2018), pp. 491-500.

[12091] P. Koárek. “A diminutive elcanid from mid-Cretaceous Burmese amber, Ellca nevelka gen. et sp. nov., and the function of metatibial spurs in Elcanidae (Orthoptera)". English. In: Cretaceous Research 116.104574 (2020). DOI: 10.1016/j.cretres.2020.104574.

[12092] A. L. Koch, F. Frost, and K. Trujillo. "Palaeontological discoveries at Curecanti National Recreation Area and Black Canyon of the Gunnison National Park, Upper Jurassic Morrison Formation, Colorado". English. In: Paleontology and Geology of the Upper Jurassic Morrison Formation. New Mexico Museum of Natural History and Science Bulletin 36 (2006), pp. 35-38.

[12093] K. G. D. Kochhann, S. Baecker-Fauth, I. Pujana, A. S. de Silveira, and G. Fauth. "Toarcian-Aalenian (Early-Middle Jurassic) radiolarian fauna from the Los Molles Formation, Neuquén Basin, Argentina: Taxonomy and paleobiogeographic affinities". English. In: Journal of South American Earth Sciences 31 (2011), pp. 253-261. DOI: 10.1016/j.jsames.2011.01.001.

[12094] B. B. Kochnev and G. A. Karlova. "New data on biostratigraphy of the Vendian Nemakit-Daldynian stage in the southern Siberian Platform". English. In: Stratigraphy and Geological Correlation 18.5 (2010), pp. 492-504. 
[12095] M. Koová Veselská, T. Ko, and J. S. Buckeridge. “Cirripedes from hemipelagic deposits of the Bohemian Cretaceous Basin (Czech Republic), with remarks on an exceptionally well-preserved capitulum of Diotascalpellum angustatum (Geinitz, 1843)". English. In: Neues Jahrbuch für Geologie und Paläontologie, Abhandlungen 296 (2020), pp. 129-145. DOI: 10.1127/njgpa/2020/0891.

[12096] L. Kocsis. “Central Paratethyan shark fauna (Ipolytarnóc, Hungary)”. English. In: Geological Carpathica 58.1 (2007), pp. 27-40.

[12097] M. J. Kocurko. “Eunicella sp., Octocorallia from the Red Bluff Formation, Lower Oligocene, Mississippi". English. In: Tulane Studies in Geology and Paleontology 26.1 (1993), pp. 35-39.

[12098] Y. Koda and S. Yamamoto. "Fossil whales from the Pliocene Kume Formation in Kanasago-machi, Kuji-gun, Ibaraki Prefecture, Northern Kanto, Japan". English. In: Monographs of Ibaraki Nature Musuem 1 (2004), pp. 149-162.

[12099] S. Koga, T. Ishibashi, and M. Fujikawa. “Oldhamina and Palaeoldhamina (Permian Brachiopoda) from Thailand". English. In: Memoirs of the Faculty of Science, Kyushu University, Series D, Earth and Planetary Science 30.2 (1998), pp. 59-69.

[12100] I. Kogan. "Remains of Saurichthys (Pisces, Actinopterygii) from the Early Triassic Wordie Creek Formation of east Greenland". English. In: Bulletin of the Geological Society of Denmark 59 (2011), pp. 93-100.

[12101] I. Kogan and C. Romano. "A new postcranium of Saurichthys from the Early Triassic of Spitsbergen". English. In: Freiberger Forschungshefte, C 550 (2016), pp. 205-221.

[12102] M. Kogan, G. Poinar, and J. L. Cook. "A case of mistaken identification of an amber fossil male strepsipteran (Insecta: Strepsiptera)". English. In: Historical Biology 27 (2015), pp. 1062-1069.

[12103] M. Kogan and G. O. Poinar. "Fossil Strepsiptera (Insecta) of the Poinar Amber Collection with description of one new genus and 12 new neotropical species in the families Protelencholacidae, Elenchidae, and Myrmecolacidae". English. In: Historical Biology 32 (2019), pp. 1215-1276. DOI: 10.1080/08912963.2019.1575375.

[12104] E. Köhler, J. Salaj, and S. Bucek. "Paleogeographical development of the Myjava sedimentary area (Western Slovakia) during the existence of the Paleocene reef complex". English. In: Geologica Carpathica 44.6 (1993), pp. 373-380.

[12105] M. Köhler and S. Moyá-Solá. "A finding of Oligocene primates on the European continent". English. In: Proceedings of the National Academy of Sciences 96 (1999), pp. 14664-14667.

[12106] R. Köhler. "A new species of the fossil turtle Psephophorus (Order Testudines) from the Eocene of the South Island, New Zealand". English. In: Journal of The Royal Society of New Zealand 25.3 (1995), pp. 371-384.

[12107] R. Kohler and R. E. Fordyce. "An archaeocete whale (Cetacea: Archaeoceti) from the Eocene Waiho Greensand, New Zealand". In: Journal of Vertebrate Paleontology 17.3 (1997), pp. 574-583.

[12108] M. K. Kohli, J. L. Ware, and G. Bechly. "How to date a dragonfly: fossil calibrations for odonates". English. In: Palaeontologia Electronica 19.1.1FC (2016), pp. 1-14.

[12109] A. J. Kohn and I. Arua. “An Early Pleistocene molluscan assemblage from Fiji: gastropod faunal composition, paleoecology and biogeography". English. In: Palaeogeography, Palaeoclimatology, Palaeoecology 146 (1999), pp. 99-145.

[12110] M. J. Kohn, M. P. McKay, and J. L. Knight. "Dining in the Pleistocene - who's on the menu?" English. In: Geology 33.8 (2005), pp. 649-652. DOI: 10.1130/G21476AR.1.

[12111] E. V. Kohnen and B. L. Murchey. "Age and origin of red chert pebbles in the lower part of the Santa Clara Formation, northern California". English. In: vol. 76. Recent Geologic Studies in the San Francisco Bay Area. Pacific Section SEPM, 1995, pp. 77-86.

[12112] N. Kohno. "A large mesorostral beaked whale (Cetacea: Ziphiidae) from the Pliocene Na-arai Formation on the Boso Peninsula, Central Japan". In: Memoirs of the National Science Museum, Tokyo 38 (2002), pp. 27-32. 
[12113] N. Kohno. “A new Miocene odobenid (Mammalia: Carnivora) from Hokkaido, Japan, and its implications for odobenid phylogeny". English. In: Journal of Vertebrate Paleontology 26.2 (2006), pp. 411-421.

[12114] N. Kohno. "A new Pliocene fur seal (Carnivora: Otariidae) from the Senhata Formation on the Boso Peninsula, Japan". English. In: Natural History Research 2.1 (1992), pp. 15-28.

[12115] N. Kohno. "A new miocene pinniped in the genus Prototaria (Carnivora: Odobenidae) from the Moniwa Formation, Miyagi, Japan". English. In: Journal of Vertebrate Paleontology 14.3 (1994), pp. 414426.

[12116] N. Kohno. "An Early Miocene enaliarctine pinniped (Carnivora: Otariidae) fro the western North Pacific". English. In: Bulletin of the Mizunami Fossil Museum 19 (1992), pp. 273-292.

[12117] N. Kohno. "Miocene pinniped Allodesmus (Mammalia: Carnivora); with special reference to the Mito seal from Ibaraki Prefecture, Central Japan". English. In: Transactions and Proceedings of the Palaeontological Society of Japan, New Series 181 (1996), pp. 388-404.

[12118] N. Kohno, L. G. Barnes, and K. Hirota. "Miocene fossil pinnipeds of the genera Prototaria and Neotherium (Carnivora; Otariidae; Imagotariinae) in the North Pacific Ocean: Evolution, relationships and distribution". English. In: The Island Arc 3 (1995), pp. 285-308.

[12119] N. Kohno and Y. Hasegawa. "A new occurrence of imagotariine pinniped from the middle Miocene Goudo Formation in Higashimatsuyama City, Saitama, Japan". English. In: Transactions and Proceedings of the Palaeontological Society of Japan, New Series 162 (1991), pp. 801-805.

[12120] N. Kohno, K. Narita, and H. Koike. "An early Pliocene odobenid (Mammalia: Carnivora) from the Joshita Formation, Nagano Prefecture, central Japan". Japanese. In: Shinshshinmachi kaseki hakubutsukan kenky hkoku 1 (1998), pp. 1-7.

[12121] N. Kohno and Y. Takaizumi. "The first record of the halitheriine dugongid (Sirenia: Dugongiade) in the western North Pacific Ocean". Japanese. In: Fossils 53 (1992), pp. 1-6.

[12122] N. Kohno and Y. Tomida. "Marine mammal teeth (Otariidae and Delphinidae) from the early Pleistocene Setana Formation, Hokkaido, Japan". English. In: Bulletin of the National Science Museum, Tokyo, Series C 18.4 (1993), pp. 139-146.

[12123] N. Kohno, Y. Tomida, Y. Hasegawa, and H. Furusawa. "Pliocene tusked odobenids (Mammalia: Carnivora) in the Western North Pacific, and their paleobiogeography". English. In: Bulletin of the National Science Museum, Tokyo Series C (Geology \& Paleontology) 21.3, 4 (1995), pp. 111-131.

[12124] N. Kohno and Y. Yanagisawa. "The first record of the Pliocene Gilmore fur seal in the western North Pacific Ocean". English. In: Bulletin of the National Science Museum Tokyo, Series C 23.3, 4 (1997), pp. 119-130.

[12125] T. Koike. "Triassic coniform conodont genera Aduncodina and Neostrachanognathus". English. In: Paleontological Research 2.2 (1998), pp. 120-129.

[12126] T. Koike. "The first occurrence of Griesbachian conodonts in Japan". English. In: Transactions and Proceedings of the Paleontological Society of Japan. New Series 181 (1996), pp. 337-346.

[12127] M. Kokotini, N. Kargopoulos, G. Iliopoulos, S. Roussiakis, P. Skandalos, D. Michailidis, G. Svorligkou, P. Kampouridis, and G. Theodorou. Karnezeika (Argolis, Peloponnese): preliminary data concerning a new Villafranchian locality of Southern Greece. English. 2019.

[12128] T. Kolar-Jurkovek. "Latest Triassic conodonts of the Slovenian Basin and some remarks on their evolution". English. In: Geologija 54.1 (2011), pp. 81-90. DOI: 10.5474/geologija.2011.006.

[12129] T. Kolar-Jurkovsek and B. Jurkovsek. "Valvasoria carniolica n.gen. n.sp., a Triassic worm from Slovenia". English. In: Geologica Croatica 50.1 (1997), pp. 1-5.

[12130] T. Kolar-Jurkovek, V. J. Vuks, D. Aljinovic, M. Hautmann, A. Kaim, and B. Jurkovek. “Olenekian (Early Triassic) fossil assemblage from eastern Julian Alps (Slovenia)". English. In: Annales Societatis Geologorum Poloniae 83 (2013), pp. 213-227. 
[12131] D. R. Kolata, T. J. Frest, and R. H. Mapes. “The youngest carpoid: occurrence, affinities, and life mode of a Pennsylvanian (Morrowan) mitrate from Oklahoma". English. In: Journal of Paleontology 65.5 (1991), pp. 844-855.

[12132] C. Kolb and P. M. Sander. "Redescription of the ichthyosaur Platypterygius hercynicus (Kuhn 1946) from the Lower Cretaceous of Salzgitter (Lower Saxony, Germany)". English. In: Palaeontographica Abteilung A 288 (2009), pp. 151-192.

[12133] M. Kolendrianou, S. Ligkovanlis, I. Maniakas, M. Tzortzi, and G. Iliopoulos. "The Palaeolithic cave of Kalamakia (Mani Peninsula), Greece: new insights". English. In: Heliyon 6.e03958 (2020), pp. 1-17. DOI: 10.1016/j.heliyon.2020.e03958.

[12134] K. Koliadimou. "[Palaeontological and biostratigraphical study of the Neogene/Quaternary micromammals of Mygdonia basin (Macedonia, Greece)]". other. PhD thesis. 1996, pp. 1-465.

[12135] J. Kolibá. "Promanodes alleni sp. nov., the second species of the Tertiary genus Promanodes Kolibá, Schmied, Wappler et Kubisz, 2010, with improved diagnosis of the genus and remarks on its phylogeny (Coleoptera: Trogossitidae)". English. In: Zootaxa 2928 (2011), pp. 57-63.

[12136] J. Kolibá. "Classification of the subfamilies of Cleridae (Coleoptera: Cleroidea)". English. In: Acta Musei Moraviae, Scientiae Naturales 81 (1997), pp. 307-361.

[12137] J. Kolibá, B. Adroit, E. Gröning, C. Brauckmann, and T. Wappler. “First record of the family Trogossitidae (Insecta, Coleoptera) in the Late Pliocene deposits of Willershausen (Germany)". English. In: PalZ 90 (2016), pp. 681-689.

[12138] J. Kolibá and V. Alekseev. "Seidlitzella hoffeinsorum sp. nov., the first representative of the beetle tribe Gymnochilini (Coleoptera: Trogossitidae) from Baltic amber". English. In: Earth and Environmental Science Transactions of the Royal Society of Edinburgh 107 (2018), pp. 289-296.

[12139] J. Kolibá and R. Gerstmeier. "Description of Eurymetopum wachteli sp. n. from the Baltic amber (Coleoptera, Cleridae, Hydnocerinae)". English. In: Mitteilungen der Münchner Entomologischen Gesellschaft 87 (1997), pp. 97-100.

[12140] J. Kolibá and D. Y. Huang. "Mathesius liaoningensis gen. et sp. nov. of Jehol Biota, a presumptive relative of the clerid or thaneroclerid branches of Cleroidea (Coleoptera)". English. In: Zootaxa 2872 (2011), pp. 1-17.

[12141] J. Kolibá and D. Y. Huang. "The oldest known clerid fossils from the Middle Jurassic of China, with a review of Cleridae systematics (Coleoptera)". English. In: Systematic Entomology 41 (2016), pp. 808-823.

[12142] J. Kolibá and D. Y. Huang. "New cleroid beetles from the Middle-Late Jurassic of China". English. In: Acta Palaeontologica Polonica 64 (2019), pp. 143-155. DOI: 10.4202/app.00550.2018.

[12143] J. Kolibá and D. Peris. “A new saproxylic species of Lophocateridae (Coleoptera: Cleroidea) from Upper Cretaceous Kachin amber (Myanmar)”. English. In: Cretaceous Research 117.104647 (2020). DOI: $10.1016 /$ j.cretres.2020.104647.

[12144] J. Kolibá, H. Schmied, T. Wappler, and D. Kubisz. "A description of Promanodes serafini gen. et sp. nov. from Baltic amber, with a review of related New Zealand Promanus Sharp, 1877 (Coleoptera: Trogossitidae)". English. In: Zootaxa 2620 (2010), pp. 29-44.

[12145] H. A. Kollmann. "Gastropods from the Lower Cretaceous of Vorarlberg, Austria. A systematic review". English. In: Annals of the Naturhistorisches Museum Wien 103.A (2002), pp. 23-73.

[12146] H. A. Kollmann. "A Late Cretaceous Aporrhaidae-dominated gastropod assemblage from the Gosau Group of the Pletzach Alm near Kramsach (Tyrol, Austria). With an appendix on the taxonomy of Mesozoic Aporrhaidae and their position in the superfamily Stromboidea". English. In: Annalen des Naturhistorischen Museums in Wien. Serie A für Mineralogie und Petrographie, Geologie und Paläontologie, Anthropologie und Prähistorie 111.A (2009), pp. 33-71.

[12147] H. A. Kollmann and L. H. Peza. “Diptyxis Oppenheim (Nerineacea, Gastropoda) from the Lower Cretaceous of Albania. On the distribution of the genus Diptyxis". English. In: Annalen des Naturhistorischen Museums Wien, A 98 (1997), pp. 17-33. 
[12148] H. A. Kollmann and L. H. Peza. "Adaptyxis n.gen. (Umboniidae, Nerineacea, Gastropoda) from the Mirdita Zone of Albania; remarks on the early phylogeny of the Nerineacea". English. In: Annalen des Naturhistorischen Museums Wien, A 98 (1997), pp. 1-15.

[12149] B. Kolodziej. "Scleractinian corals of suborders Pachythecalina and Rhipidogyrina: discussion on similarities and description of species from Stramberk-Type Limestone, Polish Outer Carpathians". English. In: Annales Societatis Geologorum Poloniae 73 (2003), pp. 193-217.

[12150] B. Kolodziej and E. Gedl. “Nowakocoenia cieszynica gen. et sp. nov. (Scleractinia) and its BarremianAptian age based on dinocysts (Polish Outer Carpathians)". English. In: Annales Societatis Geologorum Poloniae 70 (2000), pp. 181-192.

[12151] B. Kolodziej and A. Marcopoulou-Diacantoni. "Late Eocene-Oligocene corals from Evros (Thrace basin, NE Greece)". English. In: Ber Instituts Geologie Palaontologie Graz 7 (2003).

[12152] P. N. Kolosov, G. V. Ivensen, T. E. Mikhailova, S. M. Kurzanov, M. B. Efimov, and Y. M. Gubin. "Taphonomy of the Upper Mesozoic Tetrapod Teete Locality (Yakutia)". English. In: Paleontological Journal 43.2 (2009), pp. 201-207.

[12153] V. Kolyada and E. Perkovsky. "A new species of the genus Disogmus Förster (Hymenoptera, Proctotrupoidea, Proctotrupidae) from the Eocene Rovno amber". English. In: ZooKeys 130 (2011), pp. $455-459$.

[12154] V. A. Kolyada. "Revision of some parasitic wasps (Hymenoptera: Proctotrupoidea sensu lato) from the Florissant locality, United States". English. In: Paleontological Journal 43 (2009), pp. 191196.

[12155] V. A. Kolyada and M. B. Mostovski. "Revision of Proctotrupidae (Insecta: Hymenoptera) described by Ch. T. Brues from Baltic amber". English. In: Zootaxa 1661 (2007), pp. 29-38.

[12156] T. Komatsu, J. Chen, M. Cao, F. Stiller, and H. Naruse. "Middle Triassic (Anisian) diversified bivavles: depositional environments and bivalve assemblages in the Leidapo Member of the Qingyan Formation, southern China". In: Palaeogeography, Palaeoclimatology, Palaeoecology 208 (2004), pp. 207223.

[12157] T. Komatsu, M. Akasaki, J. -H. Chen, M. -Z. Cao, and F. Stiller. "Benthic fossil assemblages and depositional facies of the Middle Triassic (Anisian) Yuqing Member of the Qingyan Formation, southern China". English. In: Paleontological Research 8.1 (2004), pp. 43-52.

[12158] T. Komatsu, H. Dang Tran, and J. -H. Chen. "Depositional Environments and Fossil Bivalves in the Lowermost Parts of the Triassic Systems in North Vietnam and South China". Japanese. In: Journal of Geography 115.4 (2006), pp. 470-483.

[12159] T. Komatsu and F. T. Fürsich. "Mode of occurence and composition of bivalves of the Middle Jurassic Mitarai Formation, Tetori Group, Japan". English. In: Paleontological Research 5.2 (2001), pp. 121-129.

[12160] T. Komatsu and D. T. Huyen. "Lower Triassic bivalve fossils from the Song Da and An Chau basins, north Vietnam". English. In: Paleontological Research 11.2 (2006), pp. 135-144.

[12161] T. Komatsu, D. T. Huyen, and N. D. Huu. "Radiation of Middle Triassic bivalve: bivalve assemblages characterized by infaunal and semi-infaunal burrowers in a storm- and wave-dominated shelf, An Chau Basin, north Vietnam". English. In: Palaeogeography, Palaeoclimatology, Palaeoecology 291 (2010), pp. 190-204.

[12162] T. Komatsu and H. Maeda. "Stratigraphy and fossil bivalve assemblages of the mid-Cretaceous Goshoura Group, southwest Japan". English. In: Paleontological Research 9.2 (2005), pp. 119-142.

[12163] T. Komatsu, M. Ono, H. Naruse, and T. Kumagae. “Upper Cretaceous depositional environments and bivalve assemblages of far-east Asia: the Himenoura Group, Kyushu, Japan". English. In: Cretaceous Research 29 (2008), pp. 489-508.

[12164] T. Komatsu, Y. Shigeta, T. H. Dang, C. T. Dinh, T. Maekawa, and G. Tanaka. “Crittendenia (Bivalvia) from the Lower Triassic (Olenekian) Bac Thuy Formation, An Chau Basin, northern Vietnam". English. In: Paleontological Research 17 (2013), pp. 1-11. 
[12165] T. Komatsu, Y. Shigeta, H. D. Doan, H. T. Trinh, H. B. Nguyen, M. T. Nguyen, N. Kusuhashi, T. Tsuihiji, T. Maekawa, J. Legrand, and M. Manabe. "Upper Triassic (Carnian) mollusks from the Suoi Bang Formation in Me area, Ninh Binh Province, northern Vietnam". English. In: Bulletin of the National Museum of Nature and Science, Series C 43 (2017), pp. 1-10.

[12166] T. Komatsu, M. Watanabe, and N. Ishida. “Lower Creatceous bivalves form Gumizaki area, Kagoshima prefecture, Japan". English. In: Memoir of the Fukui Prefectural Dinosaur Museum 8 (2009), pp. 11-29.

[12167] T. Komatsu, K. Yoshihara, M. H. Dick, R. Takashima, A. Ostrovsky, and H. Nishi. "Habitats of Bivalves in the Lower-Cretaceous Aptian Tanohata and Aptian to Albian Hiraiga Formations, Iwate Prefecture, Northeastern Japan". English. In: Origin and Evolution of Natural Diversity, Proceedings of International Symposium The Origin and Evolution of Natural Diversity, 1-5 October 2007, Sapporo. Sapporo: Hokkaido University Collection of Scholarly and Academic Papers, 2008, pp. 163-170.

[12168] T. Komishi and M. W. Caldwell. “New material of the mosasaur Plioplatecarpus nichollsae Cuthbertson et al, 2007, clarifies problematic features of the holotype specimen". English. In: Journal of Vertebrate Paleontology 29.2 (2009), pp. 417-436.

[12169] E. J. O. Kompanje and K. Post. "Remarkable mandibular fracture healing in an early Holocene bottlenose dolphin (Tursiops truncatus)". English. In: Lutra 60 (2017), pp. 61-66.

[12170] D. Kondopoulou, S. Sen, G. D. Koufos, and L. de Bonis. "Magneto-and biostratigraphy of the late Miocene mammalian locality of Prochoma (Macedonia, Greece)". English. In: Paleontologia i Evolució 24-25 (1992), pp. 135-139.

[12171] P. Kondrashov and A. K. Agadjanian. "A nearly complete skeleton of Ernanodon (Mammalia, Palaeanodonta) from Mongolia: morphofunctional analysis". English. In: Journal of Vertebrate Paleontology 32.5 (2012), pp. 983-1001.

[12172] P. E. Kondrashov. "A new hyopsodontid (Mammalia, Condylarthra) from the early Eocene of Mongolia". English. In: in Paleogene Mammals, S. G. Lucas, K. E. Zeigler, and P.E. Kondrashov (eds.), New Mexico Museum of Natural History and Science Bulletin 26 (2004), pp. 165-167.

[12173] P. E. Kondrashov, A. V. Lopatin, and S. G. Lucas. “The oldest known Asian artiodactyl (Mammalia)". English. In: New Mexico Museum of Natural History and Science Bulletin 26 (2004), pp. 205208.

[12174] G. E. Konidaris. "Palaeontological and biostratigraphical study of the Neogene Proboscidea from Greece". English. PhD thesis. 2013, pp. 1-326.

[12175] G. E. Konidaris, A. Athanassiou, V. Tourloukis, N. Thompson, D. Giusti, E. Panagopoulou, and K. Harvati. "The skeleton of a straight-tusked elephant (Palaeoloxodon antiquus)and other large mammals from the Middle Pleistocene butcheringlocality Marathousa 1 (Megalopolis Basin, Greece): preliminary results". English. In: Quaternary International 497 (2018), pp. 65-84. DOI: 10.1016/j. quaint.2017.12.001.

[12176] G. E. Konidaris, G. D. Koufos, D. S. Kostopoulos, and G. Merceron. “Taxonomy, biostratigraphy and palaeoecology of Choerolophodon (Proboscidea, Mammalia) in the Miocene of SE Europe-SW Asia: implications for phylogeny and biogeography". English. In: Journal of Systematic Paleontology 14 (2016), pp. 1-27. DOI: 10.1080/14772019.2014.985339.

[12177] G. E. Konidaris and G. D. Koufos. "The Late Miocene Mammal Faunas of the Mytilinii Basin, Samos Island, Greece: New Collection. 8. Proboscidea". English. In: Beitrage fur Palaeontologie Wien 31 (2009), pp. 139-155.

[12178] G. E. Konidaris and G. D. Koufos. “Late Miocene Proboscidea (Mammalia) from Macedonia and Samos Island, Greece: preliminary results". English. In: Palaeontologische Zeitschrift 87 (2013), pp. 121140.

[12179] G. E. Konidaris and G. D. Koufos. "Late Miocene proboscideans from Samos Island (Greece) revisited: new specimens from old collections". English. In: Palaeontologische Zeitschrift 93.1 (2019), pp. 115-134. 
[12180] G. E. Konidaris and G. D. Koufos. "Palaeontology of the upper Miocene vertebrate localities of Nikiti (Chalkidiki Peninsula, Macedonia, Greece): Proboscidea". English. In: Geobios 49 (2016), pp. 37-44.

[12181] G. E. Konidaris and S. J. Roussiakis. "The first record of Anancus (Mammalia, Proboscidea) in the late Miocene of Greece and reappraisal of the primitive anancines from Europe". English. In: Journal of Vertebrate Paleontology e1534118 (2019), pp. 1-19. DOI: 10.1080/02724634.2018.1534118.

[12182] G. E. Konidaris, S. J. Roussiakis, A. Athanassiou, and G. E. Theodorou. "The huge-sized deinothere Deinotherium proavum (Proboscidea, Mammalia) from the Late Miocene localities Pikermi and Halmyropotamos (Greece)". English. In: Quaternary International 430.A (2017), pp. 5-21. DOI: 10. 1016/j.quaint.2016.05.008.

[12183] G. E. Konidaris, S. J. Roussiakis, G. E. Theodorou, and G. D. Koufos. “The Eurasian occurrence of the shovel-tusker Konobelodon (Mammalia, Proboscidea) as illuminated by its presence in the late Miocene of Pikermi (Greece)". English. In: Journal of Vertebrate Paleontology 34 (2014), pp. 14371453.

[12184] G. E. Konidaris and E. Tsoukala. "Proboscideans from the upper Miocene localities of Thermopigi, Neokaisareia and Platania (Northern Greece)". English. In: Annales de Paléontologie (2019), pp. 115. DOI: $10.1016 /$ j.annpal.2019.102380.

[12185] G. E. Konidaris, V. Tourloukis, D. S. Kostopoulos, N. Thompson, D. Giusti, D. Michailidis, G. D. Koufos, and K. Harvatia. "Two new vertebrate localities from the Early Pleistocene". English. In: Comptes Rendus Palevol 14 (2015), pp. 353-362.

[12186] P. Königshof and S. Kershaw. "Growth forms and palaeoenvironmental interpretation of stromatoporoids in a Middle Devonian reef, southern Morocco (west Sahara)". English. In: Facies 52 (2006), pp. 299-306. DOI: 10.1007/s10347-005-0041-1.

[12187] T. Konishi. "The northernmost occurrence of Prognathodon (Squamata: Mosasauridae) from the Western Interior Seaway of North America". English. In: Canadian Journal of Earth Sciences 49.9 (2012), pp. 1111-1115. DOI: 10.1139/E2012-038.

[12188] T. Konishi. "Redescription of UALVP 40, an unusual specimen of Chasmosaurus Lambe, 1914 (Ceratopsidae: Chasmosaurinae) bearing long postorbital horns, and its implications for ontogeny and alpha taxonomy of the genus". English. In: Canadian Journal of Earth Sciences 52.8 (2015), pp. 608-619. DOI: 10.1139/cjes-2014-0167.

[12189] T. Konishi, D. Brinkman, J. A. Massare, and M. W. Caldwell. "New exceptional specimens of Prognathodon overtoni (Squamata, Mosasauridae) from the upper Campanian of Alberta, Canada, and the systematics and ecology of the genus". English. In: Journal of Vertebrate Paleontology 31.5 (2011), pp. 1026-1046. DOI: $10.1080 / 02724634.2011 .601714$.

[12190] T. Konishi and M. W. Caldwell. “New specimens of Platecarpus planifrons (Cope, 1874) (Squamata: Mosasauridae) and a revised taxonomy of the genus". English. In: Journal of Vertebrate Paleontology 27.1 (2007), pp. 59-72.

[12191] T. Konishi, M. W. Caldwell, G. L. Bell, and Jr. "Redescription of the holotype of Platecarpus tympaniticus Cope, 1869 (Mosasauridae: Plioplatecarpinae), and its implications for the alpha taxonomy of the genus". English. In: Journal of Vertebrate Paleontology 30.5 (2010), pp. 1410-1421.

[12192] T. Konishi and M. W. Caldwell. "Two new plioplatecarpine (Squamata, Mosasauridae) genera from the Upper Cretaceous of North America, and a global phylogenetic analysis of plioplatecarpines". English. In: Journal of Vertebrate Paleontology 31.4 (2011), pp. 754-783.

[12193] T. Konishi, M. W. Caldwell, T. Nishimura, K. Sakurai, and K. Tanoue. "A new halisaurine mosasaur (Squamata: Halisaurinae) from Japan: the first record in the western Pacific realm and the first documented insights into binocular vision in mosasaurs". English. In: Journal of Systematic Palaeontology 14.10 (2016), pp. 809-839. 
[12194] T. Konishi, P. Jiménez-Huidobro, and M. W. Caldwell. “The smallest-known neonate individual of Tylosaurus (Mosasauridae, Tylosaurinae) sheds new light on the tylosaurine rostrum and heterochrony". English. In: Journal of Vertebrate Paleontology 38.5 (2018), e1510835. DOI: 10.1080 / 02724634.2018.1510835.

[12195] T. Konishi, M. G. Newbrey, and M. W. Caldwell. "A small, exquisitely preserved specimen of Mosasaurus missouriensis (Squamata, Mosasauridae) from the upper Campanian of the Bearpaw Formation, western Canada, and the first stomach contents for the genus". English. In: Journal of Vertebrate Paleontology 34.4 (2014), pp. 802-819.

[12196] T. Konishi, M. Tanimoto, S. Utsunomiya, M. Sato, and K. Watanabe. "A large mosasaurine (Squamata: Mosasauridae) from the latest Cretaceous of Osaka Prefecture (SW Japan)". English. In: Paleontological Research 16.2 (2012), pp. 79-87. DOI: 10.2517/1342-8144-16.2.079.

[12197] S. V. Kononova. "New species of the egg-parasitizing wasps of the genus Idris (Scelionidae, Proctotrupoidea) of the Rovno amber". English. In: Paleontological Journal 37 (2003), pp. 275-279.

[12198] S. V. Kononova and S. A. Simutnik. "New genera and species of Scelionidae (Insecta: Proctotrupoidea) from Rovno amber". English. In: Paleontological Journal 44.5 (2010), pp. 556-560.

[12199] S. V. Kononova and S. A. Simutnik. "Two new records of Telenominae (Hymenoptera, Scelionidae) from the Rovno amber (Eocene of Ukraine)". English. In: Paleontological Journal 47 (2013), pp. 307310.

[12200] S. V. Kononova and S. A. Simutnik. "A Parasitic Wasp of the Platygastrid Family (Platygastroidea, Platygastridae, Sceliotrachelinae) First Recorded in the Rovno Amber (Eocene of Ukraine)". English. In: Paleontological Journal 47 (2013), pp. 414-416.

[12201] S. V. Kononova, S. A. Simutnik, and S. N. Lazarenko. "New genus and species of egg parasitic wasps (Platygastroidea, Scelionidae) from the Rovno amber". English. In: Paleontological Journal 49 (2015), pp. 394-398.

[12202] A. S. Konopka, P. S. Herendeen, G. L. Smith Merrill, and P. R. Crane. "Sporophytes and gametophytes of Polytrichaceae from the Campanian (Late Cretaceous) of Georgia". English. In: International Journal of Plant Sciences 158 (1997), pp. 489-499.

[12203] A. S. Konopka, P. S. Herendeen, and P. R. Crane. "Sporophytes and gametophytes of Dicranaceae from the Santonian (Late Cretaceous) of Georgia". In: American Journal of Botany 85 (1998), pp. $714-$ 723.

[12204] V. A. Konovalova. "Early Carboniferous ammonoids from the Chatkal River basin (Middle Tien Shan, Uzbekistan)". English. In: Paleontological Journal 49 (2015), pp. 369-382.

[12205] A. G. Konstantinov. "Arctophyllites, a new ammonoid genus from the Carnian of Northeast Asia". In: Paleontological Journal 29.3 (1995), pp. 19-29.

[12206] A. G. Konstantinov. "A revision of the early Carnian Trachyceratidae (Ammonoidea) of northeastern Asia". English. In: Paleontological Journal 46 (2012), pp. 453-460.

[12207] A. G. Konstantinov. "A new ammonoid genus from the Carnian of the northern Okhotsk region". English. In: Paleontological Journal 33 (1999), pp. 132-135.

[12208] A. G. Konstantinov. "Biostratigrafiya i ammonoidei verkhnego Aniziya severa Sibiri". Russian. In: Akademiya Nauk SSSR, Sibirskoe Otdelenie Trudy Instituta Geologii I Geofiziki 787 (1991), pp. 1-136.

[12209] A. G. Konstantinov. “Orientosirenites, a new ammonoid genus (Sirenitidae; Ammonoidea) from the upper Carnian of the Boreal Realm". English. In: Paleontological Journal 52 (2018), pp. 18-26.

[12210] A. G. Konstantinov, E. S. Sobolev, and A. V. Yadrenkin. "Detailed biostratigraphy of Triassic deposits in the Lena lower reaches(northern Yakutia)". English. In: Russian Geology and Geophysics 48 (2007), pp. 721-736. DOI: 10.1016/j.rgg.2006.11.002.

[12211] A. E. Kontorovich, A. I. Varlamov, D. V. Grazhdankin, G. A. Karlova, A. G. Klets, V. A. Kontorovich, S. V. Saraev, A. A. Terleev, S. Y. Belyaev, I. V. Varaksina, A. S. Efimov, B. B. Kochnev, K. E. Nagovitsin, A. A. Postnikov, and Y. F. Filippov. "A section of Vendian in the east of West Siberian Plate (based on data from the borehole Vostok 3)". English. In: Russian Geology and Geophysics 49 (2008), pp. 932-939. 
[12212] M. Konwert. “Orthogonikleithrus francogalliensis, sp. nov. (Teleostei, Orthogonikleithridae) from the Late Jurassic Plattenkalks of Cerin (France)". English. In: Journal of Vertebrate Paleontology 36.3 (2016), e1101377:1-10. DOI: 10.1080/02724634.2016.1101377.

[12213] M. Konwert and M. Hörnig. “Grimmenichthys ansorgei, gen. et sp. nov. (Teleostei, 'Pholidophoriformes'), and other 'pholidophoriform' fishes from the early Toarcian of Grimmen (MecklenburgWestern Pomerania, Germany)". English. In: Journal of Vertebrate Paleontology 38 (2018), e1451871.

[12214] L. Kool, N. A. Van Klaveren, and A. Constantine. "Flat Rocks site excavation report, 1996". English. In: Dinosaur Dreaming: Inverloch Site Report, 1996 (1996), pp. 1-7.

[12215] L. Kool and N. A. Van Klaveren. “Dinosaur Dreaming 1997 field report". English. In: Dinosaur Dreaming: Flat Rocks Site Report, 1997 (1996), pp. 1-9.

[12216] L. Kool, N. A. Van Klaveren, T. H. Rich, D. Seegets-Villiers, K. Bacheller, A. Fraser, and L. Fletcher. “Dinosaur Dreaming 2000 annual report". English. In: Dinosaur Dreaming: Flat Rocks Site Report, 2000 (2000), pp. 1-29.

[12217] M. B. Koot, G. Cuny, A. Tintori, and R. J. Twitchett. "A new diverse shark fauna from the Wordian (Middle Permian) Khuff Formation in the interior Haushi-Huqf area, Sultanate of Oman". English. In: Palaeontology 56 (2013), pp. 303-343.

[12218] M. B. Koot, G. Cuny, M. J. Orchard, S. Richoz, M. B. Hart, and R. J. Twitchett. “New hybodontiform and neoselachian sharks from the Lower Triassic of Oman". English. In: Journal of Systematic Palaeontology 13 (2015), pp. 891-917.

[12219] L. F. Kopaevich, A. S. Alekseev, A. M. Nikishin, V. N. Ben'yamoviskii, E. V. Yakovishina, E. A. Sokolova, and A. I. Voznesenskii. “On Late Maastrichtian-Early Danian Water Masses and Lithologic and Foraminifer Assemblages in Different Tectonic Zones of the Mountainous Crimea". English. In: Moscow University Geology Bulletin 62.3 (2009), pp. 164-172.

[12220] D. C. Kopaska-Merkel and D. W. Haywick. "A lone biodetrital mound in the Chesterian (Carboniferous) of Alabama". English. In: Sedimentary Geology 145 (2001), pp. 253-268.

[12221] K. Kope and I. Kania. "A new species of Cheilotrichia Rossi, 1848 (Diptera, Limoniidae) from Bitterfeld amber". English. In: Annales Zoologici 63 (2013), pp. 537-540.

[12222] K. Kope. "A new species of Mesotipula (Limoniidae, Diptera) from the Lower Jurassic of England". English. In: Annales Zoologici 68 (2018), pp. 93-96.

[12223] K. Kope, I. Kania, and W. Krzemiski. "New and little known crane-fly species of the genera Helius, Elephantomyia and Toxorhina (Diptera, Limoniidae) from Dominican and Mexican amber". English. In: Palaeontologia Electronica 19.2.25A (2016), pp. 1-14.

[12224] K. Kope, W. Krzemiski, K. Skowron, and R. Coram. “The genera Architipula Handlirsch, 1906 and Grimmenia Krzemiski and Zessin, 1990 (Diptera: Limoniidae) from the Lower Jurassic of England". English. In: Palaeontologia Electronica 20.1.15A (2017), pp. 1-7.

[12225] K. Kope, W. Krzemiski, A. Soszyska-Maj, Y. Z. Cao, and D. Ren. “A new species of Orthobittacus (Mecoptera, Bittacidae) from the Middle Jurassic of Daohugou, Inner Mongolia (China)". English. In: Earth and Environmental Science Transactions of the Royal Society of Edinburgh 107 (2018), pp. 157162.

[12226] K. Kope, W. Krzemiski, and M. Albrycht. "The oldest representatives of the Pilaria (Diptera, Limoniidae) genus from mid-Cretaceous Burmese amber, northern Myanmar". English. In: Cretaceous Research 118.104671 (2020). DOI: 10.1016/j.cretres.2020.104671.

[12227] K. Kope, E. Perkovsky, and K. Skibiska. "A new species of a genus Cheilotrichia (Diptera: Limoniidae) from Baltic and Ukrainian amber". English. In: Annales Zoologici 69 (2019), pp. 423-426. DOI: 10.3161/00034541ANZ2019.69.2.009.

[12228] K. Kope, A. Soszyska-Maj, W. Krzemiski, and R. A. Coram. "A new hangingfly (Insecta, Mecoptera, Bittacidae) from the Purbeck Limestone Group (Lower Cretaceous) of southern England and a review of Cretaceous Bittacidae". English. In: Cretaceous Research 57 (2016), pp. 122-130. 
[12229] K. Kope, A. Soszyska-Maj, A. Gehler, J. Ansorge, and W. Krzemiski. “Mecoptera and Diptera from the early Toarcian (Early Jurassic) deposits of Wolfsburg - GroSSe Kley (Lower Saxony, Germany)". English. In: Earth and Environmental Science Transactions of the Royal Society of Edinburgh 107 (2018), pp. 163-171.

[12230] K. Kope, A. Soszyska-Maj, E. Lukashevich, and W. Krzemiski. "Revision of the Mesozoic genus Mesotipula Handlirsch (Limoniidae, Diptera) from Asia extending its evolutionary history up to the Cretaceous". English. In: Cretaceous Research 114.104504 (2020). DOI: 10.1016/j.cretres.2020. 104504.

[12231] E. B. Koppelhus. Palynology of the Wapiti Formation in the northwestern part of Alberta with special emphasis on a new Pachyrhinosaur bonebed. English. 2008.

[12232] E. B. Koppelhus and D. J. Batten. "Megaspore assemblages from the Jurassic and lowermost Cretaceous of Bornholm, Denmark". In: DGU, Danmarks Geologiske Undersogelse, Serie A 32 (1992), pp. $1-81$.

[12233] J. Koppka. "Revision of the Bivalvia from the Upper Jurassic Reuchenette Formation," English. In: Zootaxa 3927.1 (2015), pp. 1-117.

[12234] D. S. Kopylov. "Ichneumon wasps of the Khasurty locality in Transbaikalia (Insecta, Hymenoptera, Ichneumonidae)". English. In: Paleontological Journal 45.4 (2011), pp. 406-413.

[12235] D. S. Kopylov. "Ichneumonids of the Subfamily Tanychorinae (Insecta: Hymenoptera: Ichneumonidae) from the Lower Cretaceous of Transbaikalia and Mongolia". English. In: Paleontological Journal 44.2 (2010), pp. 180-187.

[12236] D. S. Kopylov. "A new subfamily of Ichneumonids from the Lower Cretaceous of Transbaikalia and Mongolia (Insecta: Hymenoptera: Ichneumonidae)". English. In: Paleontological Journal 43.1 (2009), pp. 83-93.

[12237] D. S. Kopylov. "A new subfamily of ichneumon wasps (Insecta: Hymenoptera: Ichneumonidae) from the Upper Cretaceous of the Russian far east". English. In: Paleontological Journal 44.4 (2010), pp. $423-433$.

[12238] D. S. Kopylov. "New species of Praeichneumonidae (Hymenoptera, Ichneumonoidea) from the Lower Cretaceous of Transbaikalia". English. In: Paleontological Journal 46 (2012), pp. 66-72.

[12239] D. S. Kopylov. "New Ichneumonidae (Hymenoptera) from the Upper Cretaceous ambers of the Taimyr Peninsula". English. In: Paleontological Journal 46 (2012), pp. 383-391.

[12240] D. S. Kopylov. "New archaeocynipids (Hymenoptera, Cynipoidea, Archaeocynipidae) from the Lower Cretaceous of Transbaikalia". English. In: Paleontological Journal 48 (2014), pp. 58-64.

[12241] D. S. Kopylov. "New sawflies of the subfamily Madygellinae (Hymenoptera, Xyelidae) from the Middle-Upper Triassic of Kyrgyzstan". English. In: Paleontological Journal 48 (2014), pp. 610-620.

[12242] D. S. Kopylov. "New ichneumonids (Hymenoptera: Ichneumonidae) from the Lower Cretaceous Khasurty locality". English. In: Paleontological Journal 52 (2018), pp. 284-289.

[12243] D. S. Kopylov. "Forgotten giants: new Anaxyelidae (Hymenoptera) from the Jurassic of Karatau". English. In: Zootaxa 4514 (2018), pp. 332-340.

[12244] D. S. Kopylov. "New anaxyelids (Hymenoptera: Anaxyelidae) from the Cretaceous of Asia". English. In: Zootaxa 4603 (2019), pp. 341-353.

[12245] D. S. Kopylov, D. J. Brothers, and A. P. Rasnitsyn. “Two new labenopimpline ichneumonids (Hymenoptera: Ichneumonidae) from the Upper Cretaceous of southern Africa". English. In: African Invertebrates 51.2 (2010), pp. 423-430.

[12246] D. S. Kopylov and A. P. Rasnitsyn. "New Trematothoracinae (Hymenoptera: Sepulcidae) from the Lower Cretaceous of Transbaikalia". English. In: Proceedings of the Russian Entomological Society. St Petersburg 85 (2014), pp. 199-206.

[12247] D. S. Kopylov and A. P. Rasnitsyn. "Cephidae (Hymenoptera) of the Mesozoic". English. In: Euroasian Entomological Journal 15.S1 (2016), pp. 78-83. 
[12248] D. S. Kopylov and A. P. Rasnitsyn. "New sepulcids (Hymenoptera: Sepulcidae) from the Lower Cretaceous of Asia. I. Parapamphiliinae and Xyelulinae". English. In: Paleontological Journal 51 (2017), pp. 69-76.

[12249] D. S. Kopylov and A. P. Rasnitsyn. "New sepulcids (Hymenoptera: Sepulcidae) from the Lower Cretaceous of Asia: II. Ghilarellinae and Trematothoracinae". English. In: Paleontological Journal 51 (2017), pp. 291-303.

[12250] D. S. Kopylov, A. P. Rasnitsyn, H. C. Zhang, and Q. Zhang. “Anaxyelidae of Daohugou: oldest occurrences of the relict family in the fossil record. Part 1: Daosyntexis and Brachysyntexis". English. In: Alcheringa 44 (2020), pp. 104-114. DOI: 10.1080/03115518.2019.1697753.

[12251] D. S. Kopylov, T. Spasojevic, and S. Klopfstein. “New ichneumonids (Hymenoptera, Ichneumonidae) from the Eocene Tadushi Formation, Russian Far East". English. In: Zootaxa 4442 (2018), pp. 319330.

[12252] D. S. Kopylov and H. C. Zhang. “New ichneumonids (Insecta: Hymenoptera: Ichneumonidae) from the Lower Cretaceous of north China". English. In: Cretaceous Research 52 (2015), pp. 591604.

[12253] M. Kora. "Carboniferous macrofauna from Sinai, Egypt: biostratigraphy and paleogeography". In: Journal of African Earth Sciences 20.1 (1995), pp. 37-51.

[12254] M. Kora and Z. Abdel-Fattah. "Pliocene and Plio-Pleistocene macrofauna from the Red Sea coastal plain (Egypt): biostratigraphy and biogeography". English. In: Geologica et Palaeontologica 34 (2000), pp. 219-235.

[12255] M. Kora and Y. Mansour. "Late Carboniferous solitary rugose corals from the western side of the Gulf of Suez, Egypt". In: Neues Jahrbuch für Geologie und Paläontologie Monatshefte 1991.10 (1991), pp. 597-616.

[12256] T. Korbar. Intra-association development and paleobiology of Upper Cretaceous rudist Biradiolites angulosus. English. Vol. 87. Cretaceous rudists and carbonate platforms: environmental feedback, SEPM Special Publication. 2007, pp. 141-150.

[12257] T. Korbar, L. Fucek, A. Husinec, I. Vlahovic, N. Ostric, D. Maticec, and V. Jelaska. “Cenomanian Carbonate Facies and Rudists along Shallow Intraplatform Basin Margin - the Island of Cres (Adriatic Sea, Croatia)". English. In: Facies 45 (2001), pp. 39-58.

[12258] T. Korbar, B. C. Tesovic, I. Radovanovic, K. Krizmanic, T. Steuber, and P. W. Skelton. “Campanian Pseudosabinia from the Pucisca Formation on the island of Hvar (Adriatic Sea, Croatia)". English. In: Turkish Journal of Earth Sciences 19 (2010), pp. 721-731.

[12259] E. G. Kordikova, S. M. Kurzanov, and G. F. Gunnell. Unusual dinosaur claw phalanxes from the Upper Cretaceous of the northeastern Aral Sea region, Kazakhstan. English. 1997.

[12260] E. G. Kordikova, P. D. Polly, V. A. Alifanov, Z. Rocek, G. F. Gunnell, and A. O. Averianov. “Small vertebrates from the Late Cretaceous and Early Tertiary of the northeastern Aral Sea region, Kazakhstan". English. In: Journal of Paleontology 75.2 (2001), pp. 390-400.

[12261] E. G. Kordikova and H. de Bruijn. "Early Miocene rodents from the Aktau Mountains (SouthEastern Kazakhstan)". English. In: Seckenbergiana lethaea 81.2 (2001), pp. 391-405.

[12262] L. Kordos. "Eocene sea cows (Sirenia, Mammalia) from Hungary". In: Fragmenta Palaeontologica Hungarica 20 (2002), pp. 43-48.

[12263] T. N. Koren and R. F. Sobolevskaya. "The regional stratotype section and point for the base of the Hirnantian Stage (the uppermost Ordovician) at Mirny Creek, Omulev Mountains, Northeast Russia". English. In: Estonian Journal of Earth Sciences 57.1 (2008), pp. 1-10. DOI: 10.3176 / earth. 2008.1.01.

[12264] I. Koretsky. "Morphology and systematics of Miocene Phocinae (Mammalia: Carnivora) from Paratethys and the North Atlantic region". English. In: Geologica Hungarica Series Palaeontologica 54 (2001), pp. 1-109. 
[12265] I. Koretsky, S. Rahmat, and N. Peters. "Rare late Miocene seal taxa (Carnivora, Phocidae) from the North Sea Basin". English. In: Vestnik zoologii 48.5 (2014), pp. 419-432. DOI: 10.2478/vzoo-20140050.

[12266] I. A. Koretsky. New finds of Sarmatian seals (Mammalia, Carnivora, Phocinae) from southern Hungary. English. Advances in Vertebrate Paleontology Hen to Panta. 2003, pp. 63-70.

[12267] I. A. Koretsky and D. P. Domning. "One of the oldest seals (Carnivora, Phocidae) from the Old World". English. In: Journal of Vertebrate Paleontology 34.1 (2014), pp. 224-229. DOI: 10.1080 / 02724634.2013.787428.

[12268] I. A. Koretsky and P. Holec. "A primitive seal (Mammalia: Phocidae) from the early middle Miocene of central Paratethys". English. In: Smithsonian Contributions to Paleobiology 93 (2002), pp. 163-178.

[12269] I. A. Koretsky and A. M. M. Peters. "Batavipusa (Carnivora, Phocidae, Phocinae): a new genus from the eastern shore of the North Atlantic Ocean (Miocene seals of the Netherlands, part II)". English. In: Deinsea 12 (2008), pp. 53-62.

[12270] I. A. Koretsky, N. Peters, and S. Rahmat. "New species of Praepusa (Carnivora, Phocidae, Phocinae) from the Netherlands supports east to west Neogene dispersal of true seals". English. In: Vestnik zoologii 49.1 (2015), pp. 57-66. DOI: 10.1515/vzoo-2015-0006.

[12271] I. A. Koretsky and S. J. Rahmat. “First record of fossil Cystophorinae (Carnivora, Phocidae): Middle Miocene seals from the northern Paratethys". English. In: Rivista Italiana di Paleontologia e Stratigrafia 119.3 (2013), pp. 325-350.

[12272] I. A. Koretsky and S. J. Rahmat. "A new species of the Subfamily Devinophocinae (Carnivora, Phocidae) from the Central Paratethys". English. In: Rivista Italiana di Paleontologia e Stratigrafia 121.1 (2015), pp. 31-47.

[12273] I. A. Koretsky and C. E. Ray. "Cryptophoca, a new genus for Phoca maeotica (Mammalia: Pinnipedia: Phocinae), from upper Miocene deposits in the northern Black Sea region". English. In: Proceedings of the Biological Society of Washington 107.1 (1994), pp. 17-26.

[12274] I. A. Koretsky and C. E. Ray. "Phocidae of the Pliocene of eastern USA". English. In: Virginia Museum of Natural History Special Publication 14 (2008), pp. 81-140.

[12275] I. A. Koretsky and A. E. Sanders. "Paleontology of the late Oligocene Ashley and Chandler Bridge Formations of South Carolina, 1: Paleogene Pinniped Remains; The Oldest known seal (Carnivora: Phocidae)". English. In: Smithsonian Contributions to Paleobiology 93 (2002), pp. 179-183.

[12276] D. Korn. "The ammonoid faunal change near the Devonian-Carboniferous boundary". In: Annales de la Societe geologique de Belgique 115.2 (1993), pp. 581-593.

[12277] D. Korn. "Famennian ammonoid stratigraphy of the Ma'der and Tafilalt (eastern Anti-Atlas, Morocco)". English. In: Abhandlungen der Geologischen Bundesanstalt 54 (1999), pp. 147-179.

[12278] D. Korn, J. Bockwinkel, V. Ebbighausen, and C. Klug. "Palaeobiogeographic and evolutionary meaning of an early Late Tournaisian ammonoid fauna from the Tafilalt of Morocco". English. In: Acta Palaeontologica Polonica 48.1 (2003), pp. 71-92.

[12279] D. Korn, J. Bockwinkel, and V. Ebbighausen. "The ammonoids from the Argiles de Teguentour of Oued Temertasset (early Late Tournaisian; Mouydir, Algeria)". English. In: Fossil Record 13.1 (2010), pp. 35-152.

[12280] D. Korn, J. Bockwinkel, V. Ebbighausen, and S. A. Walton. "Beloceras, the most multilobate Late Devonian ammonoid". English. In: Bulletin of Geosciences 86.1 (2011), pp. 1-28.

[12281] D. Korn, J. Bockwinkel, and V. Ebbighausen. "Middle Famennian (Late Devonian) ammonoids from the Anti-Atlas of Morocco. 2. Sporadoceratidae". English. In: Neues Jahrbuch für Geologie und Paläontologie, Abhandlungen 278 (2015), pp. 47-77.

[12282] D. Korn, A. Ghaderi, L. Leda, M. Schobben, and A. R. Ashouri. "The ammonoids from the Late Permian Paratirolites Limestone of Julfa (East Azerbaijan, Iran)". English. In: Journal of Systematic Palaeontology 14 (2016), pp. 841-890. 
[12283] D. Korn, D. Jovanovic, M. Novak, and M. N. Sudar. “Early late Visean ammonoid faunas from the Jadar Block (NW Serbia)". English. In: Geologica Carpathica 61 (2010), pp. 355-364.

[12284] D. Korn, C. Klug, V. Ebbighausen, and J. Bockwinkel. "Palaeogeographical meaning of a Middle Tournaisian ammonoid fauna from Morocco". English. In: Geologica et Palaeontologica 36 (2002), pp. 79-86.

[12285] D. Korn, C. Klug, and A. Reisdorf. "Middle Famennian ammonoid stratigraphy in the Amessoui Syncline (Late Devonian; eastern Anti-Atlas, Morocco)". English. In: Travaux de l'Institut Scientifique Rabat, Serie Geologie et Geographie Physique 20 (2000), pp. 69-77.

[12286] D. Korn, C. Klug, and R. Mapes. "Viséan and Early Namurian Ammonoids from the Tafilalt (Eastern Anti-Atlas, Morocco)". English. In: Abhandlungen der Geologischen Bundesanstalt 54 (1999), pp. 345-375.

[12287] D. Korn and M. N. Sudar. "The Late Devonian and Early Carboniferous ammonoids (Cephalopoda) from Milivojevia Kamenjar, Drueti (NW Serbia) and their stratigraphy". English. In: Bulletin of Geosciences 91 (2016), pp. 187-220.

[12288] D. Korn and A. Titus. "The ammonoids from the Three Forks Shale (Late Devonian) of Montana." English. In: Fossil Record 9.2 (2006), pp. 198-212.

[12289] D. Korn and A. L. Titus. "Goniatites Zone (middle Mississippian) ammonoids of the Antler Foreland Basin (Nevada, Utah)". English. In: Bulletin of Geosciences 86.1 (2011), pp. 107-196.

[12290] D. Korn and A. L. Titus. "Taxonomic descriptions, in Late Viséan (late Mississippian) ammonoids from the Barnett Shale, Sierra Diablo Escarpment, Culberson County, Texas, USA". English. In: Fossil Record 18 (2015), pp. 81-104.

[12291] D. Korngreen and C. Benjamini. “Upper Triassic reef facies in the Asher-Atlit-1 Borehole, Northern Israel: microfacies, cement stratigraphy and paleogeographic implications". English. In: Facies 45 (2001), pp. 1-24.

[12292] L. S. Kornicker and I. G. Sohn. "Myodocopid Ostracoda from the Late Permian of Greece and a basic classification for Paleozoic and Mesozoic Myodocopida". English. In: Smithsonian Contributions to Paleobiology 91 (2000), pp. 1-33.

[12293] A. V. Koromyslova and V. B. Seltser. "Early Maastrichtian cheilostome bryozoans from the middle Volga River region". English. In: PalZ 94 (2020), pp. 697-714. DOI: 10.1007/s12542-019-00509-3.

[12294] A. V. Koromyslova, P. D. Taylor, S. O. Martha, and M. Riley. "Rhagasostoma (Bryozoa) from the Late Cretaceous of Eurasia: taxonomic revision, stratigraphy and palaeobiogeography". English. In: European Journal of Taxonomy 490 (2018), pp. 1-66. DOI: 10.5852/ejt.2018.490.

[12295] A. V. Koromyslova. "Bryozoans of the Latorp and Volkhov Horizons (Lower-Middle Ordovician) of the Leningrad Region". English. In: Paleontological Journal 45.8 (2011), pp. 887-980. DOI: 10. 1134/S0031030111080028.

[12296] I. V. Korovnikov. "Trilobites of the Suborder Eodiscina from the Lower Cambrian of the Northeastern Siberian Platform (Khorbosuonka River Section)". English. In: Paleontological Journal 41.6 (2007), pp. 614-620.

[12297] I. V. Korovnikov and G. T. Ushatinskaya. “A new lingulate genus (Brachiopods) from the Lower Cambrian of Tuva”. In: Paleontological Journal 28.3 (1994), pp. 160-164.

[12298] W. W. Korth. "Fossil small mammals from the Harrison Formation (late Arikareean: earliest Miocene), Cherry County, Nebraska". English. In: Annals of Carnegie Museum 61.2 (1992), pp. 69-132.

[12299] W. W. Korth. "Miosicista angulus, a New Sicistine Rodent (Zapodidae, Rodentia) from the Barstovian (Miocene) of Nebraska". English. In: Transactions of the Nebraska Academy of Sciences 20 (1993), pp. $97-101$.

[12300] W. W. Korth. "Middle Tertiary marsupials (Mammalia) from North America". English. In: Journal of Paleontology 68.2 (1994), pp. 376-397.

[12301] W. W. Korth. "A New Species of the Rodent Prosciurus (Aplodontidae, Prosciurinae) from the Orellan (Oligocene) of North Dakota and Nebraska". English. In: Journal of Mammalogy 75.2 (1994). 
[12302] W. W. Korth. In: The Tertiary Record of Rodents in North America (1994).

[12303] W. W. Korth. "A new heteromyid rodent (Mammalia) from the Barstovian (Miocene) of Saskatchewan". English. In: Canadian Journal of Earth Sciences 32 (1995).

[12304] W. W. Korth. "Rodents from the Late Hemphillian (Latest Miocene), Sioux County, Nebraska". English. In: Transactions of the Nebraska Academy of Sciences 22 (1995), pp. 87-92.

[12305] W. W. Korth. "Additional specimens of Agnotocastor readingi (Rodentia, Castoridae) from the Orellan (Oligocene) of Nebraska and a possible origin for the beavers". English. In: Paludicola 1.1 (1996), pp. 16-20.

[12306] W. W. Korth. "Geomyoid rodents (Mammalia) from the Bijou Hills Local Fauna (Barstovian), South Dakota". English. In: Contributions to Geology, University of Wyoming 31.1 (1996), pp. 4955.

[12307] W. W. Korth. "A New Species of Pleurolocus (Rodentia, Geomyidae) from the Early Miocene (Arikareean) of Nebraska". English. In: Journal of Vertebrate Paleontology 16.4 (1996), pp. 781-784. DOI: 10.1080/02724634.1996.10011367.

[12308] W. W. Korth. "A New Genus of Prairie Dog (Sciuridae, Rodentia) From the Miocene (Barstovian of Montana and Clarendonian of Nebraska) and the Classification of Nearctic Ground Squirrels (Marmotini)". English. In: Transactions of the Nebraska Academy of Sciences 23 (1996), pp. 109-113.

[12309] W. W. Korth. "A new beaver (Rodentia, Castoridae) from the Orellan (Oligocene) of North Dakota". English. In: Paludicola 1.4 (1998), pp. 127-131.

[12310] W. W. Korth. "Cranial morphology of two Tertiary pocket mice, Perognathus and Cupidinimus (Rodentia, Heteromyidae)". English. In: Paludicola 1.4 (1998), pp. 132-142.

[12311] W. W. Korth. "Rodents and lagomorphs (Mammalia) from the Late Clarendonian (Miocene) Ash Hollow Formation, Brown County, Nebraska". English. In: Annals of Carnegie Museum 67.4 (1998), pp. 299-348.

[12312] W. W. Korth. "Hesperogaulus, a new genus of mylagaulid rodent (Mammalia) from the Miocene (Barstovian to Hemphillian) of the Great Basin". English. In: Journal of Paleontology 73.5 (1999), pp. 945-951.

[12313] W. W. Korth. "A new species of beaver (Rodentia, Castoridae) from the earliest Barstovian (Miocene) of Nebraska and the phylogeny of Monosaulax Stirton". English. In: Paludicola 2.3 (1999), pp. 258264.

[12314] W. W. Korth. "A new species of Eutypomys Matthew (Rodentia, Eutypomyidae) from the Orellan (Oligocene) and reevaluation of Eutypomys magnus Wood". English. In: Paludicola 2.4 (2000), pp. 273-278.

[12315] W. W. Korth. "Review of Miocene (Hemingfordian to Clarendonian) mylagaulid rodents (Mammalia) from Nebraska". English. In: Annals of Carnegie Museum 69.4 (2000), pp. 227-280.

[12316] W. W. Korth. "Comments on the systematics and classification of the beavers (Rodentia, Castoridae)". English. In: Journal of Mammalian Evolution 8.4 (2002), pp. 279-296.

[12317] W. W. Korth. "The skull of Nothodipoides (Castoridae, Rodentia) and the occurrence of fossorial adaptations in beavers". English. In: Journal of Paleontology 81.6 (2007), pp. 1533-1537.

[12318] W. W. Korth. "Cranial morphology, systematics and succession of beavers from the middle Miocene Valentine Formation of Nebraska, USA". English. In: Acta Palaeontologica Polonica 53.2 (2008), pp. 169-182.

[12319] W. W. Korth. "Rodents (Mammalia) from the Whitneyan (Middle Oligocene) Cedar Pass Fauna of South Dakota". English. In: Annals of Carnegie Museum 82.4 (2014), pp. 373-398. DOI: 10.2992/007. 082.0404 .

[12320] W. W. Korth. "Mylagaulid Rodents (Mammalia: Rodentia: Mylagaulidae) from the Middle Miocene (Barstovian) of New Mexico". English. In: Annals of Carnegie Museum 81.4 (2013), pp. 233-245. DOI: 10.2992/007.081.0403. 
[12321] W. W. Korth. "A new species of Ansomys (Rodentia, Aplodontidae) from the late Oligocene (latest Whitney-earliest Arikareean) of South Dakota". English. In: Journal of Vertebrate Paleontology 27.3 (2007), pp. 740-743. DOI: 10.1671/0272-4634(2007)27[740:ANSOAR]2.0.CO;2.

[12322] W. W. Korth. "A new genus of beaver (Rodentia, Castoridae) from the miocene (Clarendonian) of North America and systematics of the Castoroidinae based on comparative cranial anatomy". English. In: Annals of Carnegie Museum 76.2 (2007). DOI: 10.2992/0097-4463(2007)76[117:ANGOBR] 2.0.CO;2.

[12323] W. W. Korth. “New Species of Cricetid Rodents (Mammalia) from the Late Miocene (Hemphillian) Previously Referred to Peromyscus pliocenicus Wilson". English. In: Annals of Carnegie Museum 79.2 (2011), pp. 137-147. DOI: 10.2992/007.079.0205.

[12324] W. W. Korth. "A new tribe of castoroidine beavers from the late Arikareean to Hemphillian (OligoceneMiocene) of western North America". English. In: Acta Palaeontologica Polonica 62.2 (2017), pp. 249 258. DOI: 10.4202 /app.00339.2017.

[12325] W. W. Korth. "Mammals from the Blue Ash local fauna (late Oligocene), South Dakota. Rodentia, Part 2: Families Florentiamyidae and Geomyidae". English. In: Paludicola 7.1 (2008), pp. 14-25.

[12326] W. W. Korth. "Two new eomyid rodents (Mammalia) from the Chadronian (latest Eocene) of Montana and Wyoming". English. In: Paludicola 9.1 (2012), pp. 7-12.

[12327] W. W. Korth. "Rodents (Mammalia) from the early Oligocene (Orellan) Cook Ranch local fauna of southwestern Montana". English. In: Annals of Carnegie Museum 85.3 (2019), pp. 223-248.

[12328] W. W. Korth. "Review of the marsupials (Mammalia: Metatheria) from the late Paleogene (ChadronianArikareean: late Eocene-late Oligocene) of North America". English. In: PalZ (2018).

[12329] W. W. Korth and B. E. Bailey. "Additional Specimens of Leptodontomys douglassi (Eomyidae, Rodentia) from the Arikareean (Late Oligocene) of Nebraska". English. In: Journal of Mammalogy 73.3 (1992), pp. 651-662.

[12330] W. W. Korth, B. E. Bailey, R. M. Hunt, and Jr. "Geomyoid rodents from the early Hemingfordian (Miocene) of Nebraska". English. In: Annals of Carnegie Museum 59.1 (1990), pp. 25-47.

[12331] W. W. Korth and B. E. Bailey. "Earliest castoridine beaver (Rodentia, Castoridae) from the Late Arikareean (Early Miocene) of Nebraska". English. In: Annals of Carnegie Museum 75.4 (2006), pp. 237-245. DOI: 10.2992/0097-4463(2006)75[237:ECBRCF]2.0.CO;2.

[12332] W. W. Korth and J. A. Baskin. "A new species of Leptarctus (Carnivora, Mustelidae) from the late Clarendonian (late Miocene) of Kansas". English. In: Annals of Carnegie Museum 78.1 (2009), pp. 29-44.

[12333] W. W. Korth and C. Branciforte. "Geomyoid rodents (Mammalia) from the Ridgeview local fauna, early-Early Arikareean (Late Oligocene) of western Nebraska". English. In: Annals of Carnegie Museum 76.3 (2007), pp. 177-201. DOI: 10.2992/0097-4463(2007)76[177:GRMFTR]2.0.CO;2.

[12334] W. W. Korth and J. L. Cavin. "New material of the marsupial (Mammalia, Metatheria) Herpetotherium". English. In: Journal of Paleontology 90.6 (2016), pp. 1225-1232. DOI: 10.1017/jpa.2016.117.

[12335] W. W. Korth and D. S. Chaney. "A New Subfamily of Geomyoid Rodents (Mammalia) and a Possible Origin of Geomyidae". English. In: Journal of Paleontology 73.6 (1999), pp. 1191-1200.

[12336] W. W. Korth and D. D. De Blieux. "Rodents and lagomorphs (Mammalia) from the Hemphillian (Late Miocene) of Utah". English. In: Journal of Vertebrate Paleontology 30.1 (2010), pp. 226-235.

[12337] W. W. Korth and M. E. Diamond. "Review of Leptomeryx (Artiodactyla, Leptomerycidae) from the Orellan (Oligocene) of Nebraska". English. In: Annals of Carnegie Museum 71.2 (2002), pp. 107129.

[12338] W. W. Korth and J. G. Eaton. "Rodents and a Marsupial (Mammalia) From the Duchesnean (Eocene) Turtle Basin Local Fauna, Sevier Plateau, Utah". English. In: Bulletin of Carnegie Museum of Natural History 36 (2004), pp. 109-119. DOI: 10.2992/0145-9058(2004)36[109:RAAMMF]2.0.CO;2.

[12339] W. W. Korth and R. J. Emry. "The Skull of Cedromus and a Review of the Cedromurinae (Rodentia, Sciuridae)". English. In: Journal of Paleontology 65.6 (1991), pp. 948-994. 
[12340] W. W. Korth and R. J. Emry. "Pipestoneomyidae, a new family of fossil rodents (Mammalia) from the Duchesnean (Late Middle Eocene, Bartonian) to Orellan (Early Oligocene, Priabonian) of North America". English. In: Journal of Paleontology 87.2 (2013), pp. 289-296. DOI: 10.1666/12054R.1.

[12341] W. W. Korth and R. J. Emry. "Additional Cranial Material of the Miocene Beaver Anchitheriomys (Rodentia, Castoridae) from Nebraska". English. In: Bulletin of Carnegie Museum of Natural History 39 (2007), pp. 165-171. DOI: 10.2992/0145-9058(2007)39[165:ACMOTM]2.0.CO;2.

[12342] W. W. Korth and R. L. Evander. "Lipotyphla, Chiroptera, Lagomorpha, and Rodentia (Mammalia) from Observation Quarry, Earliest Barstovian (Miocene), Dawes County, Nebraska". English. In: Annals of Carnegie Museum 83.3 (2016), pp. 219-254. DOI: 10.2992/007.083.0301.

[12343] W. W. Korth and R. E. Reynolds. "A hypsodont gopher (Rodentia, Geomyidae) from the Clarendonian (Miocene) of California". English. In: San Bernardino County Museum Association Special Publication 94-1 (1994), pp. 91-95.

[12344] W. W. Korth and N. Rybczynski. "A new, unusual castorid (Rodentia) from the earliest Miocene of Nebraska". English. In: Journal of Vertebrate Paleontology 23.3 (2003), pp. 667-675.

[12345] W. W. Korth and A. R. Tabrum. "A new aplodontoid rodent (Mammalia) from the early Oligocene (Orellan) of Montana and a suggested origin for the family Mylagaulidae". English. In: Annals of Carnegie Museum 80.1 (2011), pp. 67-81.

[12346] W. W. Korth, J. H. Wahlert, and R. J. Emry. "A New Species of Heliscomys and Recognition of the Family Heliscomyidae (Geomyoidea: Rodentia)". English. In: Journal of Vertebrate Paleontology 11.2 (1991), pp. 247-256.

[12347] M. Koák, J. W. Jagt, R. P. Speijer, P. Stassen, and E. Steurbaut. "New Paleocene Sepiid Coleoids (Cephalopoda) from Egypt: Evolutionary Significance and Origin of the Sepiid Rostrum". English. In: Plos one 8.11 (2013).

[12348] I. N. Kosenko and V. B. Seltser. "Argutostrea gen. nov.: Questions of Taxonomy and Ethology of Middle-Late Jurassic Epibiont Oysters (Bivalvia, Ostreoidea)". English. In: Paleontological Journal 50.6 (2016), pp. 578-584.

[12349] I. N. Kosenkoa. “On Late Jurassic-Early Cretaceous Oysters of the Genus Deltoideum Rollier (Bivalvia, Ostreoidea) from Siberia". English. In: Paleontological Journal 50.4 (2016), pp. 336-346. DOI: 10.1134/S0031030116040055.

[12350] A. Kosir. "Eocenski talozni slijed prijelaza karbonatne platforme u bazeen na podrucju JZ Slvoenije". other. PhD thesis. 1997, pp. 1-130.

[12351] E. Koskeridou. "Pliocene Brachiopods from Rhodes Island (Cape Vagia section)". English. In: Bulletin of the Geological Society of Greece 40 (2007), pp. 121-133.

[12352] M. A. Kosnik. "Changes in Late Cretaceous - early Tertiary benthic marine assemblages: analyses from the North American coastal plain shallow-shelf". English. In: Paleobiology 31.3 (2005), pp. 459-479.

[12353] M. A. Kosnik. "Byzantia: a new genus (Gastropoda: Neritopsidae) from the Permian of west Texas". In: Journal of Paleontology 71.1 (1997), pp. 53-56.

[12354] O. L. Kossovaja. "Correlation of uppermost Carboniferous and Lower Permian rugose coral zones from the Urals to western North America". English. In: Palaios 11 (1996), pp. 71-82.

[12355] O. L. Kossovaya. Ecological aspects of upper Carboniferous - lower Permian 'Cyathaxonia Fauna' taxonomical diversity (the Urals). English. Vol. 17. Fossil Corals and Sponges: Proceedings of the 9th International Symposium on Fossil Cnidaria and Porifera, Graz 2003. Vienna: Austrian Academy of Sciences Press, 2007, pp. 383-405.

[12356] O. L. Kossovaya, E. A. Guseva, A. E. Lukin, and A. V. Zhuravlev. "Middle Artinskian (Early Permian) ecological event: a case study of the Urals and northern Timan". English. In: Proceedings of the Estonian Academy of Science, Geology 50 (2001), pp. 95-113. 
[12357] O. L. Kossovaya, M. Novak, and D. Weyer. "Sloveniaxon, a new genus of ahermatypic Rugosa (Anthozoa) from the basal Permian (Asselian) of Slovenia". English. In: Geologica Belgica 15 (2012), pp. 361-369.

[12358] O. L. Kossovaya, M. Novak, and D. Weyer. "Large-sized Early Permian caninioid corals from the Karavanke Mountains, Slovenia". English. In: Journal of Paleontology 90 (2016), pp. 1049-1067.

[12359] O. L. Kossovaya and D. Weyer. "Lopingian corals from the Omolon Massif (Eastern Siberia), the". English. In: Neues Jahrbuch für Geologie und Paläontologie - Abhandlung 287.2 (2018), pp. 167-194. DOI: $10.1127 /$ njgpa/2018/0711.

[12360] M. Koák. "Teuthoidea from the Bohemian Cretaceous basin (Czech Republic) - a critical review". English. In: Abhandlungen der Geologischen Bundesanstalt 57 (2002), pp. 359-369.

[12361] M. Koak, R. Vodráka, J. Frank, M. Mazuch, and J. Marek. "Late Cretaceous nautilid beaks from near-shore/shallow water deposits of the Bohemian Cretaceous Basin (Czech Republic)". English. In: Acta Geologica Polonica 60.3 (2010), pp. 417-428.

[12362] M. Koták and F. Wiese. “Lower Turonian record of belemnite Praeactinocamax from NW Siberia and its palaeogeographic significance". English. In: Acta Palaeontologica Polonica 53.4 (2008), pp. 669678.

[12363] D. S. Kostopoulos. "Artiodactyla - Palaeontology of the upper Miocene vertebrate localities of Nikiti (Chalkidiki Peninsula, Macedonia, Greece)". English. In: Geobios 49 (2016), pp. 119-234. DOI: 10.1016/j.geobios.2016.01.011.

[12364] D. S. Kostopoulos. "The Late Miocene Mammal Faunas of the Mytilinii Basin, Samos Island, Greece: New Collection 14. Bovidae". English. In: vol. 31. Beitrage fur Paläontologie. 2009, pp. 345389.

[12365] D. S. Kostopoulos. “The Late Miocene vertebrate locality of Perivolaki, Thessaly, Greece. 9. Cervidae and Bovidae". English. In: Palaeontographica Abteilung A 276 (2006), pp. 151-183.

[12366] D. S. Kostopoulos. "The Late Miocene mammal faunas of the Mytilinii Basin, Samos Island, Greece: new collection: 13. Giraffidae". English. In: Beitrage fur Palaeontologie 31 (2009), pp. 299-343.

[12367] D. S. Kostopoulos, F. Guy, Z. Kynigopoulou, G. D. Koufos, X. Valentin, and G. Merceron. “A 2Ma old baboon-like monkey from Northern Greece and new evidence to support the Paradolichopithecus e Procynocephalus synonymy (Primates: Cercopithecidae)". English. In: Journal of Human Evolution (2018), pp. 1-15. DOI: 10.1016/j.jhevol.2018.02.012.

[12368] D. S. Kostopoulos and G. D. Koufos. “Pheraios chryssomallos, gen. et sp. nov.(Mammalia, Bovidae, Tragelaphini), from the Late Miocene of Thessaly (Greece): Implications for tragelaphin biogeography". English. In: Journal of Vertebrate Paleontology 26.2 (2006), pp. 436-445.

[12369] D. S. Kostopoulos, G. D. Koufos, and K. Christanis. "On some anthracotheriid (Artiodactyla, Mammalia) remains from northern Greece: comments on the palaeozoogeography and phylogeny of Elomeryx". English. In: Swiss Journal of Palaeontology 131 (2012), pp. 303-315.

[12370] D. S. Kostopoulos and I. Koulidou. "An early mammoth maxilla from north-western Greece". English. In: Quaternary International 379 (2015), pp. 155-163. DOI: 10.1016/j.quaint.2014.12.033.

[12371] Z. Kotaski, G. Gierliski, and T. Ptaszyski. “Reptile tracks (Rotodactylus) from the Middle Triassic of the Djurdjura Mountains in Algeria". English. In: Geological Quarterly 48.1 (2004), pp. 89-96.

[12372] J. Koteja. "Eomatsucoccus andrewi sp. nov. (Hemiptera: Sternorrhyncha: Coccinea) from the Lower Cretaceous of southern England". English. In: Cretaceous Research 20 (1999), pp. 863-866.

[12373] J. Koteja. "Scale insects (Hemiptera: Coccinea) from Cretaceous Myanmar (Burmese) amber". English. In: Journal of Systematic Palaeontology 2 (2004), pp. 109-114.

[12374] J. Koteja. Scale insects (Hemiptera, Coccinea) from Upper Cretaceous New Jersey amber. English. Studies on Fossils in Amber, with Particular Reference to the Cretaceous of New Jersey. Leiden: Backhuys Publishers, 2000, pp. 147-229.

[12375] J. Koteja. "Xylococcidae and related groups (Hemiptera: Coccinea) from Baltic amber". English. In: Prace Muzeum Ziemi 49 (2008), pp. 19-56. 
[12376] J. Koteja and D. Azar. "Scale insects from Lower Cretaceous amber of Lebanon (Hemiptera: Sternorrhyncha: Coccinea)". English. In: Alavesia 2 (2008), pp. 133-167.

[12377] J. Koteja and G. O. Poinar. "A new family, genus, and species of scale insect (Hemiptera: Coccinea: Kukaspididae, New Family) from Cretaceous Alaskan amber". English. In: Proceedings of the Entomological Society of Washington 103 (2001), pp. 356-363.

[12378] G. V. Kotlyar, G. C. Belyansky, V. I. Burago, A. P. Nikitina, Y. D. Zakharov, and A. V. Zhuravlev. "South Primorye, Far East Russia: A key region for global Permian correlation". English. In: Journal of Asian Earth Sciences 26.3-4 (2006), pp. 280-293. DOI: 10.1016/j.jseaes.2005.10.010.

[12379] G. V. Kotlyar, Y. D. Zakharov, and I. V. Polubotko. "Late Changhsingian fauna of the northwestern Caucasus Mountains, Russia". English. In: Journal of Paleontology 78.3 (2004), pp. 513-527.

[12380] G. V. Kotlyar, A. Baud, G. P. Pronina, Y. D. Zakharov, V. Yu. Vuks, M. K. Nestell, G. V. Belyaeva, and J. Marcoux. "Permian and Triassic exotic blocks of the Crimea". English. In: Geodiversitas 1.3 (1999), pp. 299-323.

[12381] M. Kotrba. "Prosphyracephala kerneggeri spec. nov. - a new stalk-eyed fly from Baltic amber". English. In: Spixiana 32 (2009), pp. 187-192.

[12382] T. Kotsakis, L. Abbazzi, C. Angelone, P. Argenti, G. Barisone, F. Fanfari, F. Marcolini, and F. Masini. "Plio-Pleistocene biogeography of Italian mainland micromammals". English. In: Deinsea 10 (2003), pp. 313-342.

[12383] T. Kotsakis, M. Delfino, and P. Piras. "Italian Cenozoic crocodilians: taxa, timing and palaeobiogeographic implications". English. In: Palaeogeography, Palaeoclimatology, Palaeoecology 210 (2004), pp. 67-87.

[12384] U. Kotthoff and U. Schmid. "A new fossil hoverfly (Insecta: Diptera: Syrphidae) from the Randeck Maar (Early Miocene, south-west Germany)". English. In: Palaeontology 48.5 (2005), pp. 1091-1096.

[12385] U. Kotthoff, T. Wappler, and M. S. Engel. "Miocene honey bees from the Randeck Maar of southwestern Germany (Hymenoptera, Apidae)". English. In: ZooKeys 96 (2011), pp. 11-37.

[12386] M. E. A. Kotyk. "Late Silurian and Early Devonian fossil plants of Bathurst Island, Arctic Canada". PhD thesis. 1998.

[12387] I. Koubová and T. Mlynský. “Two new mid-Cretaceous dictyopterans (Umenocoleidae: Vitisminae) from northern Myanmar exemplify taphonomic bias". English. In: AMBA Projekty 10 (2020), pp. 1-16.

[12388] A. Kouchinsky, S. Bengtson, W. Feng, R. Kutygin, and A. Val'kov. "The Lower Cambrian fossil Anabaritids: affinities, occurrences and systematics". English. In: Journal of Systematic Palaeontology 7.3 (2009), pp. 241-298. DOI: 10.1017/S1477201909002715.

[12389] A. Kouchinsky, S. Bengtson, S. Clausen, A. Gubanov, J. M. Malinky, and J. S. Peel. "A middle Cambrian fauna of skeletal fossils from the Kuonamka Formation, northern Siberia". English. In: Alcheringa 35.1 (2011), pp. 123-189.

[12390] A. Kouchinsky, S. Bengtson, S. Clausen, and M. J. Vendrasco. “An early Cambrian fauna of skeletal fossils from the Emyaksin Formation, northern Siberia". English. In: Acta Palaeontologica Polonica 60.2 (2013), pp. 421-512. DOI: 10.4202/app.2012.0004.

[12391] A. Kouchinsky, L. E. Holmer, M. Steiner, and G. T. Ushatinskaya. "The new stem-group brachiopod Oymurania from the lower Cambrian of Siberia". English. In: Acta Palaeontologica Polonica 60 (2015). DOI: 10.4202/app.00037.2013.

[12392] A. V. Kouchinsky. "Shell microstructures of the early Cambrian Anabarella and Watsonella as new evidence of the origin of the Rostroconchia". English. In: Lethaia 32.2 (1999), pp. 173-180.

[12393] A. V. Kouchinsky. "Shell microstructures in Early Cambrian molluscs". English. In: Acta Palaeontologica Polonica 45.2 (2000), pp. 119-150.

[12394] G. Koufos. "The Neogene mammal localities of Greece: Faunas, chronology and biostratigraphy". English. In: Hellenic Journal of Geosciences 41 (2006), pp. 183-214. 
[12395] G. Koufos. "A new protictithere from the late Miocene hominoid locality Ravin de la Pluie of Axios Valley (Macedonia, Greece)". English. In: Palaeontologische Zeitschrift 86 (2012), pp. 219-229.

[12396] G. D. Koufos. "The Villafranchian mammalian faunas and biochronology of Greece”. In: Bollettino della Societa Paleontologica Italiana 40.2 (2001), pp. 217-223.

[12397] G. D. Koufos. "New material of Carnivora (Mammalia) from the Late Miocene of Axios Valley, Macedonia, Greece". English. In: Comptes Rendus Palevol 11 (2012), pp. 49-64. DOI: 10.1016/j.crpv. 2011.09.004.

[12398] G. D. Koufos. “The Late Miocene vertebrate locality of Perivolaki, Thessaly, Greece. 4. Carnivora”. English. In: Palaeontographica Abteilung A 276 (2006), pp. 39-74.

[12399] G. D. Koufos. "The Late Miocene percrocutas (Carnivora, Mammalia) of Macedonia, Greece". English. In: Palaeovertebrata 24.1-2 (1995), pp. 67-84.

[12400] G. D. Koufos. "New material of Chalicotheriidae (Perissodactyla, Mammalia) from the Late Miocene of Axios Valley, Macedonia (Greece) with the description of a new species". English. In: Annales de Paléontologie 98.3 (2012), pp. 203-224. DOI: 10.1016/j.annpal.2012.06.002.

[12401] G. D. Koufos. "Palaeontology of the upper Miocene vertebrate localities of Nikiti (Chalkidiki Peninsula, Macedonia, Greece): History, stratigraphy and fossiliferous sites". English. In: Geobios 49 (2016), pp. 3-10.

[12402] G. D. Koufos. "New tragulid remains from the early/middle Miocene and a revision of their occurrence in Greece". English. In: Historical Biology (2020), pp. 1-16. DOI: 10.1080 / 08912963. 2020.1795650.

[12403] G. D. Koufos, L. de Bonis, and S. Sen. "Lophocyon paraskevaidisi, a new viverrid (Carnivora, Mammalia) from the Middle Miocene of Chios island, Greece". English. In: Geobios 28.4 (1995), pp. 511-523.

[12404] G. D. Koufos and K. Koliadimou. "Two lagomorphs from the Pliocene of Macedonia (Greece)". English. In: Bulletin of the Geological Society of Greece 28 (1993), pp. 117-129.

[12405] G. D. Koufos, G. E. Konidaris, and K. Harvati. “Revisiting Ursus etruscus (Carnivora, Mammalia) from the Early Pleistocene of Greece with description of new material". English. In: Quaternary International (2018). DOI: 10.1016/j.quaint.2017.09.043.

[12406] G. D. Koufos, D. S. Kostopoulos, and G. E. Konidaris. "Palaeontology of the upper Miocene vertebrate localities of Nikiti (Chalkidiki Peninsula, Macedonia, Greece)". English. In: Geobios 49 (2016), pp. 29-36.

[12407] G. D. Koufos and D. S. Kostopoulos. "New carnivore material from the Plio-Pleistocene of Macedonia (Greece) with the description of a new canid". In: Munchner Geowissenschaft Abteilung A 34 (1997), pp. 33-63.

[12408] G. D. Koufos and G. E. Syrides. "A new Early/Mididle Miocene mammal locality from Macedonia, Greece". English. In: Comptes Rendus de l'Académie des Sciences de Paris - Serie IIa: Sciences de la Terre et des Planétes 325.7 (1997), pp. 511-516.

[12409] G. D. Koufos, G. E. Syrides, D. S. Kostopoulos, K. K. Koliadimou, I. A. Sylvestrou, G. Ch. Seitanidis, and T. D. Vlachos. "New excavations in the Neogene mammalian localities of Mytilinii, Samos Island, Greece". English. In: Geodiversitas 19.4 (1997), pp. 877-885.

[12410] G. D. Koufos and K. Vasileiadou. "Miocene/Pliocene mammal faunas of southern Balkans: implications for biostratigraphy and palaeoecology". English. In: Palaeobiodiversity and Palaeoenvironments 95.3 (2015), pp. 285-303. DOI: 10.1007/s12549-015-0201-4.

[12411] G. D. Koufos, N. Zouros, and O. Mourouzidou. "Prodeinotherium bavaricum (Proboscidea, Mammalia) from Lesvos island, Greece; the appearance of deinotheres in the Eastern Mediterranean". English. In: Geobios 36 (2003), pp. 305-315. DOI: 10.1016/S0016-6995(03)00031-7.

[12412] G. D. Koufos. "New Material and Revision of the Carnivora, Mammalia from the Lower Pleistocene Locality Apollonia 1, Greece". English. In: Quaternary 1.1 (2018), pp. 1-38. DOI: 10.3390 / quat1010006. 
[12413] I. K. Koulidou. "[Study of Plio-Pleistocene Proboscidea from Northern Greece]". other. PhD thesis. 2013, pp. 1-161.

[12414] S. Kovacs and A. Arnaud-Vanneau. "Upper Eocene paleobathymetry approach based on paleoecological assemblages (preliminary report from the Plesca Valley 2. outcrop, Transylvania)". English. In: Acta Palaeontologica Romaniae 4 (2002), pp. 191-202.

[12415] S. Kovács, J. Bóna, and E. Rálisch-Felgenhauer. “Middle Anisian (Pelsonian) platform conodonts from the Triassic of the Villány Hills, South Hungary". English. In: Acta Geologica Hungarica 48.1 (2005), pp. 107-115.

[12416] Z. Kovács. "Toarcian-Aalenian Hammatoceratinae (Ammonitina) from the Gerecse Mts (NE Transdanubian Range, Hungary)". English. In: Fragmenta Palaeontologica Hungarica 27 (2009), pp. 1-72.

[12417] Z. Kovács. "Paroniceratidae (Ammonitina) of the Toarcian from the Gerecse Mts (NE Transdanubian Range, Hungary)". English. In: Földtani Közlöny 140 (2010), pp. 119-134.

[12418] Z. Kovács. "Lower Toarcian Ammonitida fauna and biostratigraphy of the Gerecse Mountains (Hungary)". English. In: Fragmenta Palaeontologica Hungarica 29 (2011), pp. 1-48.

[12419] Z. Kovács and B. Géczy. "Upper Toarcian - Middle Aalenian (Jurassic) Erycitinae Spath (Ammonitina) from the Gerecse Mts, Hungary". English. In: Hantkeniana 6 (2008), pp. 57-108.

[12420] O. M. Kovalchuk, V. A. Marareskul, and T. F. Obad. "Late Miocene bony fishes from Pocsesti (Republic of Moldova)". English. In: Studia Biologica 8.2 (2014), pp. 149-156.

[12421] O. M. Kovalchuk, L. V. Gorobets, E. V. Syromyatnikova, I. G. Danilov, V. V. Titov, T. V. Krakhmalnaya, L. I. Rekovets, and N. V. Zelenkov. "Vertebrates from the Pontian of the Shkodova Gora Locality (Northwestern Black Sea Region, Upper Miocene)". English. In: Paleontological Journal 51.4 (2017), pp. 414-429.

[12422] A. V. Kovalev, A. G. Kirejtshuk, and A. Nel. "New species of the genus Trixagus Kugelann, 1794 (Coleoptera: Throscidae) from the lowermost Eocene amber of Oise (France)". English. In: Proceedings of the Zoological Institute RAS 316 (2012), pp. 83-88.

[12423] A. V. Kovalev, A. G. Kirejtshuk, and D. Azar. "The oldest representatives of the family Throscidae (Coleoptera: Elateriformia) from the Lower Cretaceous Lebanese amber". English. In: Cretaceous Research 44 (2013), pp. 157-165.

[12424] O. V. Kovalev. "New taxa of fossil cynipoids (Hymenoptera, Cynipoidea) from the Cretaceous and Palaeogene". English. In: Amber \& Fossils 1 (1995), pp. 9-16.

[12425] V. G. Kovalev and M. B. Mostovski. "A New Genus of Snipe Flies (Diptera, Rhagionidae) from the Mesozoic of Eastern Transbaikalia”. English. In: Paleontological Journal 31.5 (1997), pp. 523-527.

[12426] T. Kowalke and M. Harzhauser. "Early ontogeny and palaeoecology of the MidMiocene rissoid gastropods of the Central Paratethys". English. In: Acta Palaeontologica Polonica 49.1 (2004), pp. 111134.

[12427] E. A. Kowalski. "Middle to late Miocene environments of southern Ecuador: temperature, elevation and fossil plants of the Nabon Basin." PhD thesis. 2001, pp. 1-437.

[12428] K. Kowalski. "Gliridae (Mammalia: Rodentia) from the Miocene of Belchatow in Poland". English. In: Acta Zoologica Cracoviensia 40.2 (1997), pp. 173-198.

[12429] K. Kowalski. "Neocometes Schaub and Zapfe, 1953 (Rodentia, Mammalia) from the Miocene of Belchatow (Poland)." In: Acta zoologica Cracoviensia 36.2 (1993), pp. 259-265.

[12430] K. Kowalski. “Microtocricetus molassicus Fahlbusch and Mayr, 1975 (Rodentia, Mammalia) from the Miocene of Belchatow (Poland)." In: Acta Zoologica Cracoviensia 36.2 (1993), pp. 251-258.

[12431] K. Kowalski. Stratigraphy of Neogene mammals in Poland. In E.H. Lindsay, V. Fahlbusch and P. Mein, eds., European Neogene Mammal Chronology, Plenum Press, New York. 1990, pp. 193-209.

[12432] J. KowalKasprzyk, M. Krajewski, and P. Gedl. "The oldest stage of the Outer Carpathian evolution in the light of Oxfordian-Kimmeridgian exotic clast studies (southern Poland)". English. In: Facies $66.11(2020)$. 
[12433] T. Kozai, F. Hirsch, K. Ishida, and A. Meesook. “Faunal affinity of Toarcian-Aalenian (Early Jurassic) bivalves from Mae Sot and Umphang (Tak Province), Northwestern Thailand". English. In: Geosciences Journal 10.3 (2006), pp. 205-215.

[12434] T. Kozai, K. Ishida, and Y. Kondo. "Radiolarians, bivalves and the J/K boundary in the Birafu Formation, southern Kurosegawa Belt, Central Shikoku, SW Japan". English. In: Geosciences Journal 10.3 (2006), pp. 217-235.

[12435] T. Kozai, L. Perelis-Grossowicz, A. Bartolini, C. Yamee, J. Sandoval, F. Hirsch, K. Ishida, T. Charoentitirat, A. Meesook, and J. Guex. "New palaeontological investigations in the Jurassic of western Thailand". English. In: Gondwana Research 19 (2011), pp. 37-46. DOI: 10.1016/j.gr.2010.04.003.

[12436] H. Kozur. "Permian deep-water ostracods from Sicily (Italy) part 1: taxonomy". English. In: GeologischPaläontologische Mitteilungen Innsbruck S3 (1991), pp. 1-24.

[12437] H. Kozur. "Upper Permian Radiolarians from the Sosio Valley Area, Western Sicily (Italy) and from the Uppermost Lamar Limestone of West Texas". English. In: Jahrbuch der Geologischen Bundesanstalt (Wien) 136.1 (1993), pp. 99-123.

[12438] H. Kozur and H. Mostler. "Saturnaliacea Deflandre and some other stratigraphically important Radiolaria from the Hettangian of Lenggries/Isar (Bavaria, Northern Calcareous Alps)". English. In: Geologisch-Paläontologische Mitteilungen Innsbruck 17 (1990), pp. 179-248.

[12439] H. Kozur and W. Sadeddin. "Holothurian Sclerites from the Middle Jurassic of Wadi Huni, Northwest Jordan". English. In: Micropaleontology 36.4 (1990), pp. 353-366.

[12440] H. W. Kozur, M. Aydin, O. Demir, H. Yakar, M. C. Göncüoglu, and F. Kuru. “New Stratigraphic and Palaeogeographic Results from the Palaeozoic and Early Mesozoic of the Middle Pontides (Northern Turkey) in the Azdavay, Devrekani, Küre and Inebolu Areas: Implications for the Carboniferous - Early Cretaceous Geodynamic Evolution and Some Related Remarks to the Karakaya Oceanic Rift Basin". English. In: Geologica Croatica 53/2 (2000), pp. 209-268.

[12441] H. W. Kozur, O. Kaya, and H. Mostler. "First evidence of lower to middle Scythian (Dienerian - lower Olenekian) radiolarians from the Karakaya Zone of northwestern Turkey". English. In: Geologisch-Paläontologische Mitteilungen Innsbruck S4 (1996), pp. 271-285.

[12442] H. W. Kozur and W. Mette. "Iranokirkbya brandneri n gen n sp, a new kirkbyid ostracod from the Late Permian (Dorashamian) of Zal, NW Iran". English. In: GeoAlp 3 (2006), pp. 85-91.

[12443] H. W. Kozur, P. Moix, and P. Ozsvart. "New Spumellaria (Radiolaria) from the Early Tuvalian Spongotortilispinus moixi zone of southeastern Turkey, with some remarks on the age of this fauna". English. In: Jahrbuch der Geologischen Bundesanstalt 149.1 (2009), pp. 25-59.

[12444] H. W. Kozur, H. Mostler, and J. E. Repetski. "Well-preserved Tremadocian primitive Radiolaria from the Windfall Formation of the Antelope Range, Eureka County, Nevada, USA". English. In: Geol Paläont Mitt Innsbruck 21 (1996), pp. 245-271.

[12445] H. W. Kozur and H. Mostler. "Neue Holothurien-Sklerite aus dem unteren Wordian vom nordwestrand des Delaware Beckens am sudosthang der Guadalupe Mountains (West-Texas, USA)". German. In: GeoAlp 5 (2008), pp. 107-119.

[12446] H. W. Kozur, H. Mostler, and J. E. Repetski. “Modern siliceous sponges from the lowermost Ordovician (Early Ibexian-Early Tremadocian) Windfall Formation of the Antelope Range, Eureka County, Nevada, USA". English. In: Geologisch-Paläontologische Mitteilungen Innsbruck 21 (1996), pp. 201-221.

[12447] H. W. Kozur, H. Mostler, and J. E. Repetski. "A new heteractinellid calcareous sponge from the lowermost Ordovician of Nevada and a discussion of the suborder Heteractinellidae". English. In: GeoAlp 5 (2008), pp. 53-64.

[12448] W. Kozur, P. Moix, and P. Ozsvart. "Characteristic Nassellaria of the lower Tuvalian (Upper Triassic) Spongotortilispinus moixi Zone of the Huglu Unit in the Mersin Mélange," English. In: Bulletin de la Société Vaudoise des Sciences Naturelles / SVSN 90.3 (2007), pp. 151-173. 
[12449] W. Kozur, P. Moix, and P. Ozsvart. "Stratigraphically important Spumellaria and Entactinaria from the lower Tuvalian (Upper Triassic) of the Hulu Unit in the Mersin Mélange, southeastern Turkey". English. In: Bulletin de la Société Vaudoise des Sciences Naturelles / SVSN 90.3 (2007), pp. 175-195.

[12450] W. Kozur, P. Moix, and P. Ozsvart. "Further new Nassellaria of the lower Tuvalian (Upper Triassic) Spongotortilispinus moixi Zone of the Hulu Unit in the Mersin Mélange". English. In: Bulletin de la Société Vaudoise des Sciences Naturelles / SVSN 90.4 (2007), pp. 197-215.

[12451] B. Koodziej, K. Salamon, E. Morycowaa, J. Szulca, and M. A. abajb. "Platy corals from the Middle Triassic of Upper Silesia, Poland: Implications". English. In: Palaeogeography, Palaeoclimatology, Palaeoecology 490 (2018), pp. 533-545.

[12452] B. P. Kraatz, D. Badamgarav, and F. Bibi. "Gomphos ellae, a new mimotonid from the middle Eocene of Mongolia and its implications for the origin of Lagomorpha". English. In: Journal of Vertebrate Paleontology 29.2 (2009), pp. 576-583.

[12453] B. P. Kraatz, F. Bibi, A. Hill, and M. Beech. "A new fossil thryonomyid from the Late Miocene of the United Arab Emirates and the origin of African cane rats". English. In: Naturwissenschaften 100 (2013), pp. 437-449. DOI: 10.1007/s00114-013-1043-4.

[12454] J. Kraft, M. Mergl, T. Hroch, and P. Kraft. "Index of Fossiliferous Localities of the Trenice Formation (Lower Ordovician of the Prague Basin, Czech Republic)". English. In: Folia Musei rerum naturalium Bohemiae occidentalis. Geologica et Paleobiologica 47.1 (2013), pp. 33-64.

[12455] P. Kraft, P. Storch, and C. E. Mitchell. "Graptolites of the Králv Dvr Formation (mid Katian to earliest Hirnantian, Czech Republic)”. English. In: Bulletin of Geosciences 90.1 (2015), pp. 195-225.

[12456] K. Krainer. "Anthracoporella mounds in the Late Carboniferous Auernig Group, Carnic Alps (Austria)". In: Facies 32 (1995), pp. 195-214.

[12457] K. Krainer, S. G. Lucas, and M. Strasser. "Vertebrate fossils from the Northalpine Raibl Beds, western Northern Calcareous Alps, Tyrol". English. In: Austrian Journal of Earth Sciences 104 (2011), pp. 97-106.

[12458] M. Krajewski. "Lithology of the Upper Jurassic-Lower Cretaceous (Tithonian-Lower Berriasian) Aj-Petri reef complex (southern Ukraine, the Crimea Mountains)". English. In: Neues Jahrbuch für Geologie und Paläontologie Abhandlungen 249.2 (2008), pp. 239-255.

[12459] M. Krajewski and B. Olszewska. "New data about microfacies and stratigraphy of the Late Jurassic Aj-Petri carbonate buildup (SW Crimea Mountains, S Ukraine)". English. In: Neues Jahrbuch für Geologie und Paläontologie Monatshefte 2006.5 (2006), pp. 298-312.

[12460] A. Kramarz. "Neoreomys and Scleromys (Rodentia, Hystricognathi) from the Pinturas Formation, late Early Miocene of Patagonia, Argentina". English. In: Revista del Museo Argentina de Ciencias Naturales n.s 8.1 (2006), pp. 53-62.

[12461] A. Kramarz and M. Bond. "A new early Miocene astrapotheriid (Mammalia, Astrapotheria) from Northern Patagonia, Argentina". English. In: Neues Jahrbuch für Geologie und Paläontologie 260 (2011), pp. 277-287.

[12462] A. Kramarz, A. Garrido, A. Forasiepi, M. Bond, and C. Tambussi. "Estratigrafa y vertebrados (Aves y Mammalia) de la Formación Cerro Bandera, Mioceno Temprano de la Provincia del Neuquén, Argentina". Spanish. In: Revista Geológica de Chile 32.2 (2005), pp. 273-291.

[12463] A. Kramarz, A. Garrido, and M. Bond. "Astrapotherium from the Middle Miocene Collón Cura Formation and the Decline of Astrapotheres in Southern South America". English. In: Ameghiniana 56.4 (2019), pp. 290-306.

[12464] A. Kramarz, M. F. Tejedor, A. M. Forasiepi, and A. C. Garrido. "New early Miocene primate fossils from northern Patagonia, Argentina". English. In: Journal of Human Evolution 62.1 (2012), pp. 186189.

[12465] A. G. Kramarz. "Octodontoids and erethizontoids (Rodentia, Hystricognathi) from the Pinturas Formation, Early-Middle Miocene of Patagonia, Argentina". English. In: Ameghiniana 41.2 (2004), pp. 199-216. 
[12466] A. G. Kramarz. “Roedores chinchilloideos (Hystricognathi) de la Formación Pinturas, Mioceno temprano-medio de la provincia de Santa Cruz, Argentina". Spanish. In: Revista del Museo Argentino de Ciencias Naturales, n.s. 4.2 (2002), pp. 167-180.

[12467] A. G. Kramarz. “Un nuevo Dasyproctidae (Rodentia, Caviomorpha) del Mioceno inferior de Patagonia". Spanish. In: Ameghiniana 35.2 (1998), pp. 181-192.

[12468] A. G. Kramarz. "A primitive cephalomyid hystricognath rodent from the early Miocene of northern Patagonia, Argentina". English. In: Acta Palaeontologica Polonica 50.2 (2005), pp. 249-258.

[12469] A. G. Kramarz. "Eocardiids (Rodentia, Hystricognathi) from the Pinturas Formation, Late early Miocene of Patagonia, Argentina". English. In: Journal of Vertebrate Paleontology 26.3 (2006), pp. 770 778. DOI: 10.1671/0272-4634(2006)26[770:ERHFTP]2.0.CO;2.

[12470] A. G. Kramarz. "Registro de Eoviscaccia (Rodentia, Chinchillidae) en estratos colhuehuapenses de Patagonia, Argentina". Spanish. In: Ameghiniana 38.3 (2002), pp. 237-242.

[12471] A. G. Kramarz. "Revision of the family Cephalomyidae (Rodentia, Caviomorpha) and new cephalomyids from the Early Miocene of Patagonia". English. In: Palaeovertebrata 30.1-2 (2001), pp. 51-88.

[12472] A. G. Kramarz. "Adiciones al conocimiento de Astrapothericulus (Mammalia, Astrapotheria): anatomia craneo-dentaria, diversidad y distribucion". Spanish. In: Revista Brasileira de Paleontologia 12.1 (2009), pp. 55-66. DOI: 10.4072/rbp.2009.1.05.

[12473] A. G. Kramarz and M. Bond. "Los Litopterna (Mammalia) de la Formación Pinturas, Mioceno temprano-medio de Patagonia". Spanish. In: Ameghiniana 42.3 (2005), pp. 611-626.

[12474] A. G. Kramarz and M. Bond. "A new Oligocene astrapothere (Mammalia, Meridiungulata) from Patagonia and a new appraisal of astrapothere phylogeny". English. In: Journal of Systematic Palaeontology 7.1 (2009), pp. 117-128. DOI: 10.1017/S147720190800268X.

[12475] A. G. Kramarz and M. Bond. "Revision of Parastrapotherium (Mammalia, Astrapotheria) and other Deseadan astrapotheres of Patagonia". English. In: Ameghiniana 45.3 (2008), pp. 537-551.

[12476] A. G. Kramarz and M. Bond. "Reconstruction of the dentition of Propyrotherium saxeum Ameghino, 1901 (Mammalia, Pyrotheria): taxonomic and phylogenetic implications". English. In: Journal of Vertebrate Paleontology 34.2 (2014), pp. 434-443.

[12477] A. G. Kramarz and M. Bond. "Systematics and stratigraphical range of the hegetotheriids Hegetotheriopsis". English. In: Journal of Systematic Palaeontology 15.12 (2017), pp. 1027-1036. DOI: 10. 1080/14772019.2016.1266047.

[12478] A. G. Kramarz, M. Bond, and M. Arnal. "Systematic description of three new mammals (Notoungulata and Rodentia) from the Early Miocene Cerro Bandera Formation, Northern Patagonia, Argentina". English. In: Ameghiniana 52.6 (2015), pp. 585-597. DOI: 10.5710/AMGH.27.06.2015.2906.

[12479] A. G. Kramarz, M. Bond, and A. A. Carlini. "Astrapotheres from Cañadón Vaca, middle Eocene of central Patagonia. New insights on diversity, anatomy and early evolution of Astrapotheria". English. In: Palaeontologia Electronica 22.2 (2019), 52:1-22.

[12480] A. G. Kramarz and E. R. Paz. “Un Hegetotheriidae (Mammalia, Notoungulata) basal del Mioceno temprano de Patagonia". Spanish. In: Revista Mexicana de Ciencias Geológicas 30.1 (2013), pp. 186195.

[12481] A. G. Kramarz, M. G. Vucetich, and M. Arnal. "A new Early Miocene chinchilloid hystricognath rodent; an approach to the understanding of the early chinchillid dental evolution". English. In: Journal of Mammalian Evolution 20 (2013), pp. 249-261. DOI: 10.1007/s10914-012-9215-0.

[12482] P. M. Kranz. "New fossil turtles from the Potomac Group (Arundel Formation) (Aptian age), Maryland, USA". English. In: Bulletin - New Mexico Museum of Natural History and Science 14 (1998), pp. 193-194.

[12483] V. Krapovickas and N. L. Nasif. "Large caviomorph rodent footprints of the Late Oligocene Vinchina Formation, Argentina". English. In: Palaeontologia Electronica 14.2 (2011), 12A.

[12484] E. V. Krasnov. "Early Mesozoic reef-like coral communities development in the Russian Far East". In: Boletn de la Real Sociedad Espanola de Historia Natural, Sección Geológica 92 (1997), pp. 61-64. 
[12485] V. Krassilov, D. Vassilenko, A. Sokolova, and S. Barinova. "New fossil plant and insect records bearing on Cretaceous climate of western Gobi, Mongolia". English. In: American Journal of Plant Biology 2 (2017), pp. 43-48.

[12486] V. A. Krassilov and L. B. Golovneva. "A new order of heterosporous plants from the Late Cretaceous of the Kem' River, Western Siberia". In: Paleontological Journal 34.1 (2000), pp. 89-97.

[12487] V. A. Krassilov and P. V. Shilin. "New platanoid staminate heads from the mid-Cretaceous of Kazakhstan". In: Review of Palaeobotany and Palynology 85 (1995), pp. 207-211.

[12488] V. A. Krassilov and T. V. Zakharova. "Moresnetia-like Plants from the Upper Devonian of Minusinsk Basin, Siberia". In: Paleontological Journal 29.1A (1995), pp. 35-43.

[12489] D. W. Krause. “Clemensodon megaloba, A new genus and species of Multituberculata (Mammalia) from the Upper Cretaceous Type Lance Formation, Powder River Basin, Wyoming". English. In: PaleoBios 14.2 (1992), pp. 1-8.

[12490] D. W. Krause. "Gondwanatheria and ? Multituberculata (Mammalia) from the Late Cretaceous of Madagascar". English. In: Canadian Journal of Earth Sciences 50.3 (2013), pp. 324-340. DOI: 10.1139/ e2012-074.

[12491] D. W. Krause, S. E. Evans, and K. -Q. Gao. “First definitive record of Mesozoic lizards from Madagascar". In: Journal of Vertebrate Paleontology 23.4 (2003), pp. 842-856.

[12492] D. W. Krause, M. D. Gottfried, P. M. O'Connor, and E. M. Roberts. “A Cretaceous mammal from Tanzania". In: Acta Palaeontologica Polonica 48.3 (2003), pp. 321-330.

[12493] D. W. Krause, S. Hoffman, and S. Wernining. "First postcranial remains of Multituberculata (Allotheria, Mammalia) from Gondwana". English. In: Cretaceous Research 80 (2017), pp. 91-100. DOI: 10.1016/j.cretres.2017.08.009.

[12494] D. W. Krause, S. Hoffmann, J. R. Wible, E. C. Kirk, J. A. Schultz, W. von Koenigswald, J. R. Groenke, J. B. Rossie, P. M. O'Connor, E. R. Seiffert, E. R. Dumont, W. L. Holloway, R. R. Rogers, L. J. Rahantarisoa, A. D. Kemp, and H. Andriamialison. "First cranial remains of a gondwanatherian mammal reveal remarkable mosaicism". English. In: Nature 515 (2014), pp. 512-517.

[12495] D. W. Krause, S. Hoffmann, Y. Hu, J. R. Wible, G. W. Rougier, E. C. Kirk, J. R. Groenke, and R. R. Rogers. "Skeleton of a Cretaceous mammal from Madagascar reflects long-term insularity". English. In: Nature 3380 (2020), p. 1495.

[12496] D. W. Krause and M. C. Maas. "The biogeographic origins of late Paleocene - early Eocene mammalian immigrants to the Western Interior of North America". English. In: Geological Society of America Special Paper 243 (1990), pp. 71-105.

[12497] D. W. Krause, G. V. R. Prasad, W. von Koenigswald, A. Sahni, and F. E. Grine. “Cosmopolitanism among Gondwanan Late Cretaceous mammals". English. In: Nature 390 (1997), pp. 504-507.

[12498] D. W. Krause, S. D. Sampson, M. T. Carrano, and P. M. O'Connor. Overview of the history of discovery, taxonomy, phylogeny, and biogeography of Majungasaurus crenatissimus (Theropoda: Abelisauridae) from the Late Cretaceous of Madagascar. English. 2007.

[12499] D. W. Krause, J. J. W. Sertich, R. R. Rogers, S. C. Kast, A. H. Rasoamiaramanana, and G. A. Buckley. "Overview of the discovery, distribution, and geological context of Simosuchus clarki (Crocodyliformes: Notosuchia) from the Late Cretaceous of Madagascar". English. In: Society of Vertebrate Paleontology Memoir 10 (2010), pp. 4-12.

[12500] M. Krautter. "Kieselschwämme aus dem unterjurassischen Misonekalk der Trento-Plattform (Südalpen): Taxonomie und phylogenetische Relevanz". German. In: Paläontologische Zeitschrift 70.3/4 (1996), pp. 301-313.

[12501] M. Krawczyski. "Frasnian gastropod synecology and bio-events in the Dyminy reef complex of the Holy Cross Mountains, Poland". English. In: Acta Palaeontologica Polonica 47.2 (2002), pp. 267288. 
[12502] M. Krawczyski. "Gastropod succession across the Early-Middle Frasnian transition in the Holy Cross Mountains, southern Poland". English. In: Acta Palaeontologica Polonica 51.4 (2006), pp. 679693.

[12503] W. Krawczyski. "Color pattern of Naticopsis planispira (Neritimorpha, Gastropoda) shell from upper Carboniferous of Silesian Coal Basin, southern Poland". English. In: Annales Societatis Geologorum Poloniae 83 (2013), pp. 87-97.

[12504] F. T. Krell. “Scarabaeidae, in Beetles (Insecta: Coleoptera)". English. In: Paleontology and Geology of Laetoli: Human Evolution in Context. Volume 2: Fossil Hominins and the Associated Fauna. Dordrecht: Springer, 2011, pp. 535-548.

[12505] F. T. Krell and W. Schawaller. "Beetles (Insecta: Coleoptera)". English. In: Paleontology and Geology of Laetoli: Human Evolution in Context. Volume 2: Fossil Hominins and the Associated Fauna. Dordrecht: Springer, 2011, pp. 535-548.

[12506] O. Krische, H. J. Gawlick, and F. Schlagintweit. "Resedimented upper Paleocene shallow-water clasts (Kambuhel Formation) in the Zwieselalm Formation of the Wietenau area and their tectonic implications (Northern Calcareous Alps, Austria)". English. In: Austrian Journal of Earth Sciences 105.3 (2012), pp. 38-47.

[12507] J. Krishna, D. B. Pathak, and B. Pandey. "Development of Oxfordian (Early Upper Jurassic) in the Most Proximally Exposed Part of the Kachchh Basin at Wagad Outside the Kachchh Mainland". In: Journal of the Geological Society of India 52.5 (1998), pp. 513-522.

[12508] K. Krishna. "New fossil species of termites of the Subfamily Nasutitermitinae from Dominican and Mexican amber (Isoptera, Termitidae)". English. In: American Museum Novitates 3176 (1996), pp. 1-13.

[12509] K. Krishna. "Insects from the Santana Formation, Lower Cretaceous, of Brazil. Chapter 5: Isoptera". English. In: Bulletin of the American Museum of Natural History 195 (1990), pp. 76-81.

[12510] K. Krishna and D. Grimaldi. "A New Fossil Species from Dominican Amber of the Living Australian Termite Genus Mastotermes (Isoptera: Mastotermitidae)". English. In: American Museum Novitates 3021 (1991), pp. 1-10.

[12511] K. Krishna and D. Grimaldi. "Diverse Rhinotermitidae and Termitidae (Isoptera) in Dominican Amber". English. In: American Museum Novitates 3640 (2009), pp. 1-48.

[12512] K. Krishna and D. Grimaldi. A new subfamily, genus, and species of termite (Isoptera) from New Jersey Cretaceous amber. English. Studies on Fossils in Amber, with Particular Reference to the Cretaceous of New Jersey. Leiden: Backhuys Publishers, 2000, pp. 133-140.

[12513] K. Krishna and D. A. Grimaldi. “The first Cretaceous Rhinotermitidae (Isoptera): a new species, genus, and subfamily in Burmese amber". English. In: American Museum Novitates 3390 (2003), pp. 1-10.

[12514] K. Krishna, D. A. Grimaldi, V. Krishna, and M. S. Engel. "Treatise on the Isoptera of the world". English. In: Bulletin of the American Museum of Natural History 377 (2013), pp. 1-2704.

[12515] E. Kristan-Tollmann. "Rhät-Foraminiferen aus dem Kuta-Kalk des Gurumugl-Riffes in ZentralPapua/Neuguinea [Rhaetian foraminifers from the Kuta Limestone of the Gurumugl Reef in central Papua New Guinea]". German. In: Mitteilungen der Österreichischen Geologischen Gesellschaft 82 (1990), pp. 211-289.

[12516] E. Kristan-Tollmann. "Echinoderms from the Middle Triassic Sina Formation (Aghdarband Group) in NE Iran". English. In: Abhandlungen Geologischen Bundesanstalt 38 (1991), pp. 175-194.

[12517] E. Kristan-Tollmann. “Ostracods from the Middle Triassic Sina Formation (Aghdarband Group) in NE-Iran". English. In: Abhandlungen der Geologischen Bundesanstalt 38 (1991), pp. 195-200.

[12518] E. Kristan-Tollmann. "Mikrocrinoiden aus der Obertrias der Tethys". German. In: Geologisch-Paläontologische Mitteilungen Innsbruck 17 (1990), pp. 51-100. 
[12519] E. Kristan-Tollmann and F. Gramann. "Paleontological evidence for the Triassic age of rocks dredged from the northern Exmouth Plateau (Tethyan foraminifers, echinoderms, and ostracodes)". English. In: Proceedings Ocean Drilling Program Scientific Results 122 (1992), pp. 463-474.

[12520] H. V. Kristensen, G. Cuny, A. R. Rasmussen, and H. Madsen. "Earliest record of the fossil snake Palaeophis from the Paleocene/Eocene boundary in Denmark". English. In: Bulletin de la Société Géologique de France 183.6 (2012), pp. 621-625.

[12521] A. V. Kristoffersen. "An early Paleogene trogon (Aves: Trogoniformes) from the Fur Formation, Denmark". English. In: Journal of Vertebrate Paleontology 22.3 (2002), pp. 661-666.

[12522] E. B. Krivicich, W. I. Ausich, and D. L. Meyer. "Crinoid assemblages from the Fort Payne Formation (late Osagean, early Viséan, Mississippian) from Kentucky, Tennessee, and Alabama". English. In: Journal of Paleontology 88.6 (2014), pp. 1154-1162. DOI: 10.1666/13-180.

[12523] J. Kriwet. "An amioid fish (Neopterygii, Amiiformes) from the Late Jurassic of the Iberian peninsula". In: Géobios 38 (2005), pp. 99-106.

[12524] J. Kriwet. "Anew species of extinct bullhead sharks, Paracestracion viohli sp. nov. (Neoselachii, Heterodontiformes), from the Upper Jurassic of South Germany". English. In: Acta Geologica Polonica 58.2 (2008), pp. 235-241.

[12525] J. Kriwet. "Neoselachian remains (Chondrichthyes, Elasmobranchii) from the Middle Jurassic of SW Germany and NW Poland". English. In: Acta Palaeontologica Polonica 48.4 (2003), pp. 583-594.

[12526] J. Kriwet. "Additions to the Eocene Selachian Fauna of Antarctica with Comments on Antarctic Selachian Diversity". English. In: Journal of Vertebrate Paleontology 25.1 (2005), pp. 1-7.

[12527] J. Kriwet. “Revision of Mesturus cordillera Martill et al., 1998 (Actinopterygii, Pycnodontiformes) from the Oxfordian (Upper Jurassic) of Northern Chile." English. In: Journal of Vertebrate Paleontology 20.3 (2000), pp. 450-455.

[12528] J. Kriwet. "Lancetefish teeth (Neoteleostei, Alepisauroidei) from the Early Cretaceous of Alcaine, NE Spain". English. In: Lethaia 36 (2003), pp. 323-332.

[12529] J. Kriwet. "Pycnodont fishes (Neopterygii, +Pycnodontiformes) from the Lower Cretaceous of Uña (E-Spain) with comments on branchial teeth in pycnodontid fishes". English. In: Mesozoic Fishes 2-Systematics and Fossil Record. Munich: Verlag Dr. Friedrich Pfeil, 1999, pp. 215-238.

[12530] J. Kriwet. "Neoselachier (Pisces, Elasmobranchii) aus der Unterkreide (unteres Barremium) von Galve und Alcaine (Spanien, Provinz Teruel)". German. In: Palaeo Ichthyologica 9 (1999), pp. 113142.

[12531] J. Kriwet and A. Gazdizicki. "New Eocene Antarctic chimeroid fish (Holocephali, Chimaeriformes)". English. In: Acta Palaeontologica Polonica 24.1 (2003), pp. 29-51.

[12532] J. Kriwet, S. Klug, J. I. Canudo, and G. Cuenca-Bescós. “A new Early Cretaceous lamniform shark (Chondrichthyes, Neoselachii)". English. In: Zoological Journal of the Linnean Society 154 (2008), pp. 278-290. DOI: 10.1111/j.1096-3642.2008.00410.x.

[12533] J. Kriwet and S. Klug. "An embryonic mandibular tooth plate and associated remains of a Late Jurassic chimaeroid (Holocephali, Chimaeriformes) from the Iberian Peninsula". English. In: Journal of Vertebrate Paleontology 31.5 (2011), pp. 954-961.

[12534] J. Kriwet, O. W. M. Rauhut, and U. Gloy. "Microvertebrate remains (Pisces, Archosauria) from the Middle Jurassic (Bathonian) of southern France". English. In: Neues Jahrbuch für Geologie und Paläontologie, Abhandlungen 206.1 (1997), pp. 1-28.

[12535] J. Kriwet, R. Soler-Gijón, and N. López-Martnez. "Neoselachians from the upper Campanian and lower Maatrichtian (Upper Cretaceous) of the southern Pyrenees, northern Spain". English. In: Palaeontology 50.5 (2007), pp. 1051-1071. DOI: 10.1111/j.1475-4983.2007.00695.x.

[12536] J. Kriz, R. B. Blodgett, and D. M. Rohr. "Silurian Bivalvia from Chichagof Island, Southeast Alaska (Alexander terrane)". English. In: Bulletin of Geosciences 86.2 (2011), pp. 241-258.

[12537] M. Kriznar, J. Zalohar, and T. Hitij. "Terciarne elve v Sloveniji - nove najdbe in spoznanja”. other. In: Drustvene Novice 34 (2006), pp. 33-34. 
[12538] B. Kröger. "A new genus of middle Tremadocian orthoceratoids and the Early Ordovician origin of orthoceratoid cephalopods". English. In: Acta Palaeontologica Polonica 53.4 (2008), pp. 745-749.

[12539] B. Kröger. "Nautiloids before and during the ammonoid origin in a Siluro-Devonian section of the Tafilalt (Morocco)". English. In: Special Papers in Palaeontology 79 (2008), pp. 1-110.

[12540] B. Kröger. "Concentrations of juvenile and small adult cephalopods in the Hirnantian cherts (Late Ordovician) of Porkuni, Estonia". English. In: Acta Palaeontologica Polonica 52.3 (2007), pp. 591-608.

[12541] B. Kröger. "The cephalopods of Boda Limestone, Late Ordovocian, of Dalarna, Sweden". English. In: European Journal of Taxonomy 41 (2013), pp. 1-110.

[12542] B. Kröger. "The 'Vaginaten': the dominant cephalopods of the Baltoscandian Mid Ordovician endocerid limestone". English. In: Geologiska Föreningen i Stockholm Förhandlingar 134.2 (2012), pp. 115-132.

[12543] B. Kröger. "Middle Ordovician cephalopod biofacies and palaeoenvironments of Baltoscandia". English. In: Lethaia (2014). DOI: 10.1111/let.12057.

[12544] B. Kröger and M. Aubrechtova. "Cephalopods from reef limestone of the Vasalemma Formation, northern Estonia (latest Sandbian, Upper Ordovician) and the establishment of a local warmwater fauna". English. In: Journal of Systematic Palaeontology 14.7 (2017), pp. 1-42.

[12545] B. Kröger and M. Aubrechtová. “The cephalopods of the Kullsberg Limestone Formation, Upper Ordovician, central Sweden and the effects of reef diversification on". English. In: Journal of Systematic Palaeontology (2019), pp. 1-35. DOI: 10.1080/14772019.2018.1491899.

[12546] B. Kröger, M. S. Beresi, and E. Landing. "Early orthoceratoid cephalopods from the Argentine Precordillera (Lower-Middle Ordovician)". English. In: Journal of Paleontology 81.6 (2007), pp. 12661283. DOI: $10.1666 / 06-013.1$.

[12547] B. Kröger, A. Desrochers, and A. Ernst. "The reengineering of reef habitats during the great Ordovician biodiversification event". English. In: Palaios 32 (2017), pp. 584-599.

[12548] B. Kröger, J. O. R. Ebbestad, A. E. S. Högström, and Å Frisk. “Mass concentration of Hirnantian cephalopods from the Siljan District, Sweden; taxonomy, palaeoecology and palaeobiogeographic relationships". English. In: Fossil Record 14.1 (2011), pp. 35-53. DOI: 10.1002/mmng.201000014.

[12549] B. Kröger and D. H. Evans. "Review and paleoecological analysis of the late Tremadocian - early Floian (Early Ordovician) cephalopod fauna of the Montagne Noire, France". English. In: Fossil Record 14.1 (2011), pp. 5-34. DOI: 10.1002/mmng.201000013.

[12550] B. Kröger, L. Hints, and O. Lehnert. "Age, facies, and geometry of the Sandbian/Katian (Upper Ordovician) pelmatozoan-bryozoan-receptaculitid reefs of the Vasalemma Formation, northern Estonia". English. In: Facies (2014). DOI: 10.1007/s10347-014-0410-8.

[12551] B. Kröger and M. Isakar. "Revision of annulated orthoceridan cephalopods of the Baltoscandic Ordovician". English. In: Fossil Record 9.1 (2006), pp. 137-163. DOI: 10.1002/mmng.200600005.

[12552] B. Kröger, C. Klug, and R. Mapes. "Soft-tissue attachments in orthocerid and bactritid cephalopods from the Early and Middle Devonian of Germany and Morocco". English. In: Acta Palaeontologica Polonica 50.2 (2005), pp. 329-342.

[12553] B. Kröger and E. Landing. "Onset of the Ordovician cephalopod radiation - evidence from the Rochdale Formation (middle Early Ordovician, Stairsian)in eastern New York". English. In: Geological Magazine 145.4 (2008), pp. 490-520. DOI: 10.1017/S0016756808004585.

[12554] B. Kröger and E. Landing. "The Earliest Ordovician Cephalopods of Eastern Laurentia - Ellesmerocerids of the Tribes Hill Formation, Eastern New York". English. In: Journal of Paleontology 81.5 (2007), pp. 841-857.

[12555] B. Kröger and E. Landing. "Cephalopods and Paleoenvironments of the Fort Cassin Formation (Upper Lower Ordovician), eastern New York and adjacent Vermont". English. In: Journal of Paleontology 83.5 (2009), pp. 664-693. 
[12556] B. Kröger and B. Lefebvre. "Palaeogeography and palaeoecology of early Floian (Early Ordovician) cephalopods from the Upper Fezouata Formation, Anti-Atlas, Morocco". English. In: Fossil Record 15.2 (2012), pp. 61-75.

[12557] B. Kröger and R. H. Mapes. "Revision of some common Carboniferous genera of North American orthocerid nautiloids". English. In: Journal of Paleontology 79.5 (2005), pp. 1002-1011.

[12558] B. Kröger and H. Mutvei. "Nautiloids with multiple paired muscle scars from Lower-Middle Ordovician of Baltoscandia". English. In: Palaeontology 48.4 (2005), pp. 781-791.

[12559] B. Kröger, Y. Zhang, and M. Isakar. "Discosorids and Oncocerids (Cephalopoda) of the Middle Ordovician Kunda and Aseri Regional Stages of Baltoscandia and the early evolution of these groups". English. In: Geobios 42 (2009), pp. 273-293. DOI: 10.1016/j.geobios.2008.09.006.

[12560] L. Krogmann. "First fossil record of cerocephaline wasps with a description of a new genus and species from Dominican amber (Hymenoptera: Chalcidoidea: Pteromalidae: Cerocephalinae)". English. In: Historical Biology 25 (2013), pp. 43-49.

[12561] L. Krogmann, D. Azar, H. Rajaei, and A. Nel. “Mymaropsis baabdaensis sp. n. from Lower Cretaceous Lebanese amber - the earliest spathiopterygid wasp and the first female known for the family". English. In: Comptes Rendus Palevol 15 (2016), pp. 483-487.

[12562] L. Krogmann, M. S. Engel, G. Bechly, and A. Nel. "Lower Cretaceous origin of long-distance mate finding behaviour in Hymenoptera (Insecta)". English. In: Journal of Systematic Palaeontology 11 (2013), pp. 83-89.

[12563] L. Krogmann and A. Nel. “On the edge of parasitoidism: a new Lower Cretaceous woodwasp forming the putative sister group of Xiphydriidae and Euhymenoptera". English. In: Systematic Entomology 37 (2012), pp. 215-222.

[12564] A. Kroh. Palaeobiology and biogeography of a Danian echinoid fauna of Lower Austria. English. Echinoderm Research 2001. Lisse: Swets \& Zeitlinger, 2003, pp. 69-75.

[12565] A. Kroh. "Cottreaucorys kollmanni n. sp. (Echinodermata: Echinoidea) and other new records from the Early Paleocene Bruderndorf Formation in Austria". English. In: Annalen den Naturhistorischen Museum Wien 106A (2004), pp. 309-325.

[12566] A. Kroh. "First record of gorgonocephalid ophiuroids (Echinodermata) from the middle Miocene of the Central Paratethys". English. In: Cenozoic Research 2.1-2 (2003), pp. 143-155.

[12567] A. Kroh. First fossil record of the family Euryalidae (Echinodermata: Ophiuroidea) from the Middle Miocene of the Central Mediterranean. English. Echinoderms: München. London: Taylor \& Francis Group, 2004, pp. 447-452.

[12568] A. Kroh. "Additional records of Late Cretaceous and Early Paleogene echinoids from the Gschliefgraben (Ultrahelvetic, Upper Austria)". English. In: Acta Geologica Polonica 54.4 (2004), pp. 551571.

[12569] A. Kroh. "The Brachiopoda of the Langhian (Lower Badenian) of the Molasse Zone and northern Vienna Basin (Austria". English. In: Annalen des Naturhistorischen Museums in Wien, Serie A 104 (2003), pp. 145-153.

[12570] A. Kroh, M. A. Bitner, and S. P. Avila. "Novocrania turbinata (Brachiopoda) from the Early Pliocene of the Azores (Portugal)". English. In: Acta Palaeontologica Polonica 58.4 (2008), pp. 473-478.

[12571] A. Kroh and A. Lukeneder. "Crinoids from the Late Jurassic of the Nutzhof section (Lower Austria, Gresten Klippenbelt)". English. In: Annalen des Naturhistorischen Museums in Wien 110.A (2009), pp. 383-399.

[12572] A. Kroh and U. Menkveld-Gfeller. "Echinoids from the Belpberg Beds (Obere Meeresmolasse, Middle Burdigalian) in the area of Bern (Switzerland)." English. In: Eclogae geologicae Helvetiae 99 (2006), pp. 193-203.

[12573] A. Kroh and J. H. Nebelsick. "Echinoid assemblages as a tool for palaeoenvironmental reconstruction - an example from the Early Miocene of Egypt". English. In: Palaeogeography, Palaeoclimatology, Palaeoecology 201 (2003), pp. 157-177. 
[12574] J. Krol, M. K. Zapalski, and B. Berkowski. “Emsian tabulate corals of Hamar Laghdad (Morocco): taxonomy and ecological interpretation". English. In: 290.1-3 (2018), pp. 75-102. DOI: 10.1127 / njgpa/2018/0773.

[12575] G. C. Kronenberg and H. G. Lee. "Genera of american strombid gastropods (Gastropoda: Strombidae) and remarks on their phylogeny". English. In: The Veliger 49.4 (2007), pp. 256-264.

[12576] B. Krstic, L. Maslarevic, and M. Sudar. "On the Graptolite Schists Formation (Silurian-Lower Devonian) in the Carpatho-Balkanides of eastern Serbia". English. In: Annales Geologiques de la Peninsule Balkanique 66 (2005), pp. 1-8.

[12577] A. Kruger and S. Badenhorst. "Remains of a barn owl (Tyto alba) from the Dinaledi Chamber, Rising Star Cave, South Africa". English. In: South African Journal of Science 114 (2018), p. 5152.

[12578] A. G. Kruger, B. S. Rubidge, F. Abdala, E. Gomani Chindebvu, and L. L. Jacobs. "Lende chiweta, a new therapsid from Malawi, and its influence on burnetiamorph phylogeny and biogeography". English. In: Journal of Vertebrate Paleontology 35.6 (2015), e1008698.

[12579] L. J. Krumenacker. "Chronostratigraphy and Paleoecology of the mid-Cretaceous Wayan Formation of Eastern Idaho, with a description of the first Oryctodromeus specimens from Idaho". English. PhD thesis. 2010.

[12580] L. J. Krumenacker, D. J. Simon, G. Scofield, and D. J. Varricchio. "Theropod dinosaurs from the Albian-Cenomanian Wayan Formation of eastern Idaho". English. In: Historical Biology 29 (2017), pp. 170-186. DOI: 10.1080/08912963.2015.1137913.

[12581] W. D. Krummeck and E. M. Bordy. “Reniformichnus katikatii (New Ichnogenus and Ichnospecies): Continental Vertebrate Burrows from the Lower Triassic, Main Karoo Basin, South Africa". English. In: Ichnos 25 (2017), pp. 138-149. DOI: 10.1080/10420940.2017.1292909.

[12582] N. I. Krupina. "New species of Rhinodipteurs (Dipnoi) from the Upper Devonian of north-western Russia". English. In: Geobios 19 (1995), pp. 269-274.

[12583] N. I. Krupina and A. A. Prisyazhnaya. "A new dipnoan from the Middle Devonian (Givetian) of central Russia". English. In: Paleontological Journal 48.10 (2014), pp. 1077-1081.

[12584] P. D. Kruse. "Hyolith guts in the Cambrian of northern Australia - turning hyolithomorphs upside down". In: Lethaia 29 (1997), pp. 213-217.

[12585] P. D. Kruse. "Cambrian fauna of the Top Springs Limestone, Georgina Basin". English. In: Beagle 8.1 (1991), pp. 169-188.

[12586] P. D. Kruse. “Cambrian palaeontology of the Daly Basin”. English. In: Northern Territory Geological Survey 7 (1990), pp. 1-58.

[12587] P. D. Kruse. "Biostratigraphic potential of Middle Cambrian hyoliths from the eastern Georgina Basin". English. In: Alcheringa 26.3 (2002), pp. 353-398.

[12588] P. D. Kruse. "Cyanobacterial-archaeocyathan-radiocyathan bioherms in the Wirrealpa Limestone of South Australia". English. In: Canadian Journal of Earth Sciences 28 (1991), pp. 601-615.

[12589] P. D. Kruse. “Update on the northern Australian Cambrian sponges Rankenella, Jawonya and Wagima". English. In: Alcheringa 20 (1996), pp. 161-178.

[12590] P. D. Kruse, A. Gandin, F. Debrenne, and R. Wood. "Early Cambrian bioconstructions in the Zavkhan Basin of western Mongolia". In: Geological Magazine 133.4 (1996), pp. 429-444.

[12591] P. D. Kruse, A. Y. Zhuravlev, and N. P. James. "Primordial metazoan-calcimicrobial reefs: Tommotian (Early Cambrian) of the Siberian Platform". English. In: Palaios 10 (1995), pp. 291-321.

[12592] P. D. Kruse and A. Y. Zhuravlev. "Middle-Late Cambrian Rankenella-Girvanella reefs of the Mila Formation, northern Iran". English. In: Canadian Journal of Earth Sciences 45 (2008), pp. 619-639.

[12593] V. E. Krynicki. "Primitive ants (Hymenoptera: Sphecomyrminae) in the Campanian (Late Cretaceous) of North Carolina (USA)". English. In: Life: The Excitement of Biology 1 (2013), pp. 156-165. 
[12594] L. Krystyn, M. Balini, B. S. Aghababalou, and V. Hairapetian. “Norian ammonoids from the Nayband Formation (Iran) and their bearing on Late Triassic sedimentary and geodynamic history of the Iran Plate". English. In: Rivista Italiana di Paleontologia e Stratigrafia 125.1 (2019), pp. 231-248.

[12595] L. Krystyn, G. W. Mandl, and M. Schauer. "Growth and termination of the Upper Triassic platform margin of the Dachstein area (Northern Calcareous Alps, Austria)". English. In: Austrian Journal of Earth Sciences 102.1 (2009), pp. 23-33.

[12596] L. Krystyn, S. Richoz, A. Baud, and R. Twitchett. "A unique Permian-Triassic boundary section from the Neotethyan Hawasina Basin, Central Oman Mountains". In: Palaeogeography, Palaeoclimatology, Palaeoecology 191 (2003), pp. 329-344.

[12597] L. Krystyn, S. Richoz, Y. Gallet, H. Bouquerel, W. M. Kürschner, and C. Spötl. “Updated bio- and magnetostratigraphy from Steinbergkogel (Austria), candidate GSSP for the base of the Rhaetian stage". English. In: Albertiana 36 (2007), pp. 164-172.

[12598] L. Krystyn and F. Tatzreiter. "Middle Triassic ammonoids from Aghdarband (NE-Iran) and their paleobiogeographical significance". English. In: Abhandlungen der Geologischen Bundesanstalt 38 (1991), pp. 139-163.

[12599] A. Kryukov, M. A. Iwasa, R. Kakizawa, H. Suzuki, W. Pinsker, and E. Haring. "Synchronic eastwest divergence in azurewinged magpies (Cyanopica cyanus) and magpies (Pica pica)". English. In: Journal of Zoological Systematics and Evolutionary Research 42 (2004), pp. 342-351.

[12600] W. Krzemiski. "Fossil Tipulomorpha from Baltic amber (Upper Eocene): a new species of Dactylolabis (Idiolabis) (Diptera: Limoniidae)". English. In: Polskie Pismo Entomologiczne 69 (2000), pp. 247250.

[12601] W. Krzemiski. “Triassic and Lower Jurassic stage of Diptera evolution". English. In: Bulletin de la Société Entomologique Suisse 65 (1992), pp. 39-59.

[12602] W. Krzemiski. “Fossil Limoniidae (Diptera, Tipulomorpha) from Lower Cretaceous Burmese amber of Myanmar". English. In: Journal of Systematic Palaeontology 2 (2004), pp. 123-125.

[12603] W. Krzemiski. “Tipula (s. lato) eva n. sp. from Cretaceous (East Asia) - the oldest representative of the family Tipulidae (Diptera, Polyneura)". English. In: Acta Zoologica Cracoviensia 35.1 (1992), pp. 43-44.

[12604] W. Krzemiski. "Limoniidae (Diptera, Nematocera) from Domincan amber: I Genus Molophilus Curtis, 1833". English. In: Acta Zoologica Cracoviensia 35.1 (1992), pp. 107-111.

[12605] W. Krzemiski. "Fossil Tipulomorpha (Diptera, Nematocera) from Baltic amber (Upper Eocene). Revision of the genus Helius Lepeletier et Serville (Limoniidae)". English. In: Acta Zoologica Cracoviensia 35.3 (1993), pp. 597-601.

[12606] W. Krzemiski. “A revision of fossil Megistocera and Brachypremna (Diptera: Tipulidae)". English. In: Polskie Pismo Entomologiczne 65 (1996), pp. 275-278.

[12607] W. Krzemiski. "Three new species of the genus Helius Lepeletier \& Serville (Diptera, Limoniidae) from the Middle Miocene of Stavropol (northern Caucasus, Russia)". English. In: Acta Zoologica Cracoviensia 45 (2002), pp. 317-320.

[12608] W. Krzemiski. "A revision of Eocene Bittacidae (Mecoptera) from Baltic amber, with the description of a new species". English. In: African Invertebrates 48 (2007), pp. 153-162.

[12609] W. Krzemiski. "The Oligocene Tipulomorpha (Diptera) from Bolshaya Svetlovodnaya (eastern Asia, Russia)". English. In: Polskie Pismo Entomologiczne 69 (2000), pp. 239-245.

[12610] W. Krzemiski. "A new species and other representatives of the genus Dicranomyia (Diptera: Limoniidae) in the collection of the Museum of Amber Inclusions, University of Gdansk". English. In: Polskie Pismo Entomologiczne 69 (2000), pp. 347-353.

[12611] W. Krzemiski. "First record of the genus Lipsothrix Loew (Diptera: Limoniidae) in Baltic amber (Upper Eocene)". English. In: Polskie Pismo Entomologiczne 70 (2001), pp. 329-331. 
[12612] W. Krzemiski. "New fossil Tipuloidea (Diptera) from the Fur Formation of Denmark in the collection of the Natural History Museum in London". English. In: Polskie Pismo Entomologiczne 70 (2001), pp. 333-339.

[12613] W. Krzemiski. “A first fossil Helius (Diptera, Limoniidae) from North America”. English. In: Acta Zoologica Cracoviensia 34 (1991), pp. 311-313.

[12614] W. Krzemiski. "Hexatoma (Eriocera) serafini sp. n. from Baltic amber (Diptera: Limoniidae)”. English. In: Polskie Pismo Entomologiczne 67 (1998), pp. 309-310.

[12615] W. Krzemiski. "Cyttaromyia frelloi sp. n., the first representative of the family Cylindrotomidae in Baltic Amber (Diptera: Tipulomorpha)". English. In: Polskie Pismo Entomologiczne 67 (1998), pp. 303-308.

[12616] W. Krzemiski. “Fossil Tipulomorpha (Diptera, Nematocera) from Baltic amber (Upper Eocene). Systematic position of Pseudolimnophila (Baltilimnophila) subgen. n. (Limoniidae, Hexatominae)". English. In: Polskie Pismo Entomologiczne 60 (1990), pp. 51-58.

[12617] W. Krzemiski and J. Ansorge. "New Upper Jurassic Diptera (Limoniidae, Eoptychopteridae) from the Solnhofen Lithographie Limestone (Bavaria, Germany)". English. In: Stuttgarter Beiträge zur Naturkunde Serie B (Geologie und Paläontologie) 221 (1995), pp. 1-7.

[12618] W. Krzemiski and J. Ansorge. "A new rhagionid fly from the Lower Jurassic of Germany (Diptera: Brachycera: Rhagionidae)". English. In: Polskie Pismo Entomologiczne 74 (2005), pp. 369-372.

[12619] W. Krzemiski and J. Ansorge. “On Protobrachyceron Handlirsch, 1920 (Diptera: Brachycera) from the Lower Jurassic of Germany". English. In: Polskie Pismo Entomologiczne 69 (2000), pp. 231-237.

[12620] W. Krzemiski and A. Arillo. "Alavia neli n.gen. and n. sp. the first Limoniidae (Diptera) from the lower Cretaceous amber of Álava (Spain)". English. In: Alavesia 1 (2007), pp. 11-13.

[12621] W. Krzemiski and A. Arillo. "A new species, Symplecta (Psiloconopa) penalveri n. sp. (Diptera, Limoniidae) from the Miocene of Spain”. English. In: Alavesia 2 (2008), pp. 211-213.

[12622] W. Krzemiski and A. Freiwald. "Toxorhina (Ceratocheilus) caucasiensis, a new species from the Middle Miocene of Stavropol (northern Caucasus, USSR) (Diptera, Limoniidae)". English. In: Paläontologische Zeitschrift 65 (1991), pp. 153-155.

[12623] W. Krzemiski and G. Gentilini. "New information on Limoniidae from Monte Castellaro, Italy (Upper Miocene)". English. In: Acta Zoologica Cracoviensia 35 (1992), pp. 87-95.

[12624] W. Krzemiski, I. Kania, and A. Nel. "Probittacomorpha brisaci n. sp. (Ptychopteridae, Bittacomorphinae) from the Late Miocene of Montagne d'Andance, Saint Bauzile, Ardéche (France)". English. In: Zootaxa 3521 (2012), pp. 80-88.

[12625] W. Krzemiski, I. Kania, and D. Azar. "The Early Cretaceous evidence of rapid evolution of the genus Helius Lepeletier and Serville, 1828 (Limoniidae, Diptera)". English. In: Cretaceous Research 48 (2014), pp. 96-101.

[12626] W. Krzemiski, I. Kania, and E. Lukashevich. "The first South American record of fossil Eoptychopterinae (Ptychopteridae, Diptera) from Lower Cretaceous Santana Formation". English. In: Cretaceous Research 52 (2015), pp. 548-555.

[12627] W. Krzemiski and E. Krzemiska. "Triassic Diptera: descriptions, revisions and phylogenetic relations". English. In: Acta Zoologica Cracoviensia 46.Suppl (2003), pp. 153-184.

[12628] W. Krzemiski and E. Krzemiska. "Aenne triassica sp. n., the oldest representative of the family Chironomidae (Insecta: Diptera)". English. In: Polskie Pismo Entomologiczne 68 (1999), pp. 445-449.

[12629] W. Krzemiski, E. Krzemiska, and F. Papier. "Grauvogelia arzvilleriana sp. n. - the oldest diptera species (Lower/Middle Triassic of France)". English. In: Acta Zoologica Cracoviensia 37.2 (1994), pp. 95-99.

[12630] W. Krzemiski and E. Krzemiska. "Revision of Laurentiptera gallica from the Lower/Middle Triassic of France (Mecoptera: Liassophilidae)". English. In: Polskie Pismo Entomologiczne 65 (1996), pp. 267-274. 
[12631] W. Krzemiski, E. Krzemiska, I. Kania, and A. J. Ross. “New taxa of Tanyderidae (Diptera) from Eocene Baltic amber". English. In: Zootaxa 3599 (2013), pp. 59-66.

[12632] W. Krzemiski and E. Krzemiska. "Procramptonomyia marianna, a new species from the Upper Jurassic of Great Britain (Diptera, Anisopodomorpha, Procramptonomyiidae)". English. In: Acta Zoologica Cracoviensia 37 (1994), pp. 101-105.

[12633] W. Krzemiski and E. Krzemiska. “Tipulomorpha (Diptera) of the Middle Eocene deposits from Pesciara di Bolca near Verona (Italy)". English. In: Acta Zoologica Cracoviensia 33 (1990), pp. 495499.

[12634] W. Krzemiski and E. Krzemiska. "A new species of Cheilotrichia (Empeda) from the Sakhalin amber (Diptera, Limoniidae)". English. In: Acta Zoologica Cracoviensia 37 (1994), pp. 91-93.

[12635] W. Krzemiski and C. Lombardo. "New fossil Ephemeroptera and Coleoptera from the Ladinian (Middle Triassic) of Canton Ticino (Switzerland)". English. In: Rivista Italiana di Paleontologia e Stratigrafia 107 (2001), pp. 69-78.

[12636] W. Krzemiski and E. D. Lukashevich. "Ansorgiidae, a new family from the Upper Cretaceous of Kazakhstan (Diptera, Ptychopteromorpha)". English. In: Acta Zoologica Cracoviensia 35.3 (1993), pp. 593-596.

[12637] W. Krzemiski and D. Ren. "Praemacrochile chinensis sp. n. from the Middle Jurassic of China (Diptera: Tanyderidae)". English. In: Polskie Pismo Entomologiczne 70 (2001), pp. 127-129.

[12638] W. Krzemiski and W. Zessin. "The Lower Jurassic Limoniidae from Grimmen (GDR) (Dipt. Nematocera)". English. In: Deutsche Entomologische Zeitschrift 37 (1990), pp. 39-43.

[12639] E. Krzemiska, V. A. Blagoderov, and W. Krzeminski. "Elliidae, a new fossil family of infraorder Axymyiomorpha (Diptera)". English. In: Acta Zoologica Cracoviensia 35.3 (1993), pp. 581-591.

[12640] E. Krzemiska, R. A. Coram, and W. Krzeminski. “A new species of Megarhyphus, an interesting discovery from the Lower Jurassic of England (Diptera, Anisopodidae)". English. In: Acta Geologica Sinica 84.4 (2010), pp. 693-695.

[12641] E. Krzemiska and E. Lukashevich. "The Late Jurassic fossil from Asian ancestory to a recent genus, Nothotrichocera Alexander 1926 (Diptera: Trichoceridae)". English. In: Zoosymposia 3 (2009), pp. 103110.

[12642] E. Krzemiska and E. Lukashevich. “The oldest Trichoceridae (Diptera) from the Lower Jurassic of Kyrgyzstan: implications of the biomechanical properties of their wings". English. In: Earth and Environmental Science Transactions of the Royal Society of Edinburgh 107 (2018), pp. 173-176.

[12643] W. Krzeminska, I. Kania, and E. Krzeminska. "A new species of Dactylolabis (Eobothrophorus) from Baltic amber (Diptera: Limoniidae)". English. In: Acta Geologica Sinica 84 (2010), pp. 768-771.

[12644] W. Krzemiski. "Fossil Tipulomorpha (Diptera, Nematocera) from Baltic amber (Upper Eocene). Introductory part. Subfamily Lechriinae (Limoniidae)". English. In: Polskie Pismo Entomologiczne 60 (1990), pp. 177-194.

[12645] W. Krzemiski, D. Azar, and K. Skibiska. "Nannotanyderus ansorgei sp. n., the first member of the family Tanyderidae from Lebanese amber (Lower Cretaceous)". English. In: Insect Evolution in an Ambiferous and Stone Alphabet. Leiden: Brill, 2013, pp. 131-143.

[12646] W. Krzemiski, V. Blagoderov, D. Azar, E. Lukashevich, R. Szadziewski, S. Wedmann, A. Nel, F. M. Collomb, A. Waller, and D. B. Nicholson. "True flies (Insecta: Diptera) from the late Eocene insect limestone (Bembridge Marls) of the Isle of Wight, England, UK". English. In: Earth and Environmental Science Transactions of the Royal Society of Edinburgh 110 (2019), pp. 495-554. DOI: 10.1017/ S1755691018000464.

[12647] W. Krzemiski, I. Kania, and R. Durak. "A new species of Dicranomyia Stephens, 1829 (Diptera: Limoniidae) from Baltic amber (Eocene)". English. In: Neues Jahrbuch für Geologie und Paläontologie, Abhandlungen 277 (2015), pp. 167-174. 
[12648] W. Krzemiski, I. Kania, and M. Wojto. “A new Eocene Dicranomyia Stephens, 1829 (Diptera: Limoniidae) from Baltic amber". English. In: Earth and Environmental Science Transactions of the Royal Society of Edinburgh 107 (2018), pp. 271-277.

[12649] W. Krzemiski, K. Kope, and I. Kania. "New and little known species from the genus Leptotarsus Guerin-Meneville, 1831 (Diptera: Tipulidae) from the Lower Cretaceous of northern Brazil". English. In: Cretaceous Research 78 (2017), pp. 103-108.

[12650] W. Krzemiski and A. Soszyska-Maj. "A new genus and species of scorpionfly (Mecoptera) from Baltic amber, with an unusually developed postnotal organ". English. In: Systematic Entomology 37 (2012), pp. 223-228.

[12651] W. Krzemiskia, A. Soszyska-Maj, A. S. Bashkuev, and K. Koped. "Revision of the unique Early Cretaceous Mecoptera from Koonwarra (Australia) with description of a new genus and family". English. In: Cretaceous Research 52 (2015), pp. 501-506.

[12652] D. Ksepka. A sauropod from Bur Gove, Mongolia. English. 2004.

[12653] D. T. Ksepka. "Flight performance of the largest volant bird". English. In: Proceedings of the National Academy of Sciences (2014). DOI: 10.1073/pnas.1320297111.

[12654] D. T. Ksepka, J. A. Clarke, S. J. Nesbitt, F. B. Kulp, and L. Grande. “Fossil evidence of wing shape in a stem relative of swifts and hummingbirds (Aves, Pan-Apodiformes)". English. In: Proceedings of the Royal Society B 280 (2013), p. 20130580. DOI: 10.1098/rspb.2013.0580.

[12655] D. T. Ksepka and J. Cracraft. "An avian tarsometatarsus from near the K-T boundary of New Zealand". English. In: Journal of Vertebrate Paleontology 28.4 (2008), pp. 1224-1227.

[12656] D. T. Ksepka, R. E. Fordyce, T. Ando, and C. M. Jones. "New fossil penguins (AVes, Sphenisciformes) from the Oligocene of New Zealand reveal the skeletal plan of stem penguins". English. In: Journal of Vertebrate Paleontology 32.2 (2012), pp. 235-254.

[12657] D. T. Ksepka, K.-.. Q. Gao, and M. A. Norell. “A new choristodere from the Cretaceous of Mongolia". English. In: American Museum Novitates 3468 (2005), pp. 1-22.

[12658] D. T. Ksepka, L. Grande, and G. Mayr. "Oldest Finch-Beaked Birds Reveal Parallel Ecological Radiations in the Earliest Evolution of Passerines". English. In: Current Biology 29 (2019), pp. 657663. DOI: $10.1016 /$ j.cub.2018.12.040.

[12659] D. T. Ksepka and M. A. Norell. “Ornithomimosaur cranial material from Ukhaa Tolgog (Omnogov, Mongolia)". In: American Museum Novitates 3448 (2004), pp. 1-4.

[12660] D. T. Ksepka and M. A. Norell. "Erketu ellisoni, a long-necked sauropod from Bor Guvé (Dornogov Aimag, Mongolia)". English. In: American Museum Novitates 3508 (2006), pp. 1-16.

[12661] D. T. Ksepka and M. A. Norell. “The Illusory Evidence for Asian Brachiosauridae: New Material of Erketu ellisoni and a Phylogenetic Reappraisal of Basal Titanosauriformes". English. In: American Museum Novitates 3700 (2010), pp. 1-27.

[12662] D. T. Ksepka, T. A. Stidham, and T. E. Williamson. "Early Paleocene landbird supports rapid phylogenetic and morphological diversification of crown birds after the K-Pg mass extinction". English. In: Proceedings of the National Academy of Sciences 114.30 (2017), pp. 8047-8052. DOI: 10.1073/ pnas.1700188114.

[12663] A. Kuka and I. Kania. "New soldier beetles (Coleoptera, Cantharidae) from the Eocene Baltic amber". English. In: Zootaxa 2400 (2010), pp. 49-56.

[12664] D. Kubisz. "Fossil beetles (Coleoptera) from Baltic amber in the collection of the Museum of Natural History of ISEA in Kraków". English. In: Polskie Pismo Entomologiczne 69 (2000), pp. 225-230.

[12665] D. Kubisz. "A new fossil species from the genus Falsomordellistena Ermisch, 1941 (Coleoptera, Mordellidae) with description of a new subgenus". English. In: Acta Zoologica Cracoviensia 46.Suppl (2003), pp. 185-188.

[12666] D. Kubisz. "Succimorda rubromaculata, a new genus and species from Baltic amber (Coleoptera, Mordellidae)". English. In: Deutsche Entomologische Zeitschrift 48 (2001), pp. 273-275. 
[12667] D. Kubisz. "Beetles in the collection of the Museum of Amber Inclusions, University of Gdánsk, with description of Colotes sambicus sp. n. (Coleoptera: Melyridae)". English. In: Polskie Pismo Entomologiczne 70 (2001), pp. 259-265.

[12668] T. Kubo, M. T. Mitchell, and D. M. Henderson. "Albertonectes vanderveldei, a new elasmosaur (Reptilia, Sauropterygia) from the Upper Cretaceous of Alberta". English. In: Journal of Vertebrate Paleontology 32.3 (2012), pp. 557-572. DOI: 10.1080/02724634.2012.658124.

[12669] T. Kubo, M. Shibata, W. Naksri, P. Jintasakul, and Y. Azuma. "The earliest record of Asian Eusuchia from the Lower Cretaceous Khok Kruat Formation of northeastern Thailand". English. In: Cretaceous Research 82 (2018), pp. 21-28.

[12670] U. Kuch, J. Müller, C. Mödden, and D. Mebs. "Snake fangs from the Lower Miocene of Germany: evolutionary stability of perfect weapons". English. In: Naturwissenschaften 93.2 (2006), pp. 84-87. DOI: 10.1007/s00114-005-0065-y.

[12671] B. S. Kues. "New bivalve taxa from the Tucumcari Formation (Cretaceous, Albian), New Mexico, and the biostratigraphic significance of the basal Tucumcari fauna". English. In: Journal of Paleontology 71.5 (1997), pp. 820-839.

[12672] B. S. Kues. "New genera and species of Middle Pennsylvanian gastropods from west Texas". English. In: Journal of Paleontology 76.1 (2002), pp. 52-62.

[12673] B. S. Kues. Some gastropods from the Lower Wolfcampian (basal Permian) Laborcita Formation. English. Vol. 42. New Mexico Geological Society Guidebook. 1991, pp. 221-230.

[12674] B. S. Kues. A marine invertebrate fauna from the upper part of the Panther Seep Formation (earliest Wolfcampian) near Hembrillo Pass, San Andres Mountains, south-central New Mexico. English. New Mexico Geological Society Guidebook, 53rd Field Conference, Geology of White Sands. 2002, pp. 241-256.

[12675] B. S. Kues. "Marine invertebrate assemblages from the Late Pennsylvanian (Virgilian) Holder Formation, Dry Canyon, Sacramento Mountains, south-central New Mexico". English. In: New Mexico Geology 26.2 (2004), pp. 43-53.

[12676] B. S. Kues. "Stratigraphy and brachiopod and molluscan paleontology of the Red Tanks Formation (Madera Group) near the Pennsylvanian-Permian boundary, Lucero uplift, west-central New Mexico". English. In: vol. 25. Carboniferous-Permian transition at Carrizo Arroyo, central New Mexico. Albuqurque: Bulletin of the New Mexico Museum of Natural History and Science, 2004, pp. 143-210.

[12677] B. S. Kues. Some pelecypods and scaphopods from the Lower Wolfcampian (basal Permian) Laborcita Formation. English. Vol. 42. New Mexico Geological Society Guidebook. 1991, pp. 231-242.

[12678] B. S. Kues and R. L. Batten. "Middle Pennsylvanian gastropods from the Flechado Formation, north-central New Mexico". English. In: Journal of Paleontology 75.1, supp (2001), pp. 1-95.

[12679] B. S. Kues and H. R. Duchene. "The largest late Paleozoic bellerophontid gastropod". English. In: Journal of Paleontology 64 (1990), pp. 478-479.

[12680] B. S. Kues, K. A. Giles, G. H. Mack, and T. F. Lawton. “A Late Pennsylvanian outer shelf marine fauna from a highstand systems tract, Derry Hills, south-central New Mexico". In: New Mexico Geology 24.4 (2002), pp. 121-130.

[12681] B. S. Kues and S. G. Lucas. "Nearshore fauna of the Tucumcari Formation (Lower Cretaceous, Albian), Quay County, New Mexico". English. In: New Mexico Geological Society Guidebook (2001).

[12682] B. S. Kues. Late Pennsylvanian invertebrate paleontology of Bruton Canyon, northern Sierra Oscura, Socorro County, New Mexico. English. Geology of the Chupadera Mesa. New Mexico Geological Society 60th Annual Fall Field Conference Guiodebook, 2009, pp. 249-266.

[12683] G. Kühl, D. E. G. Briggs, and J. Rust. "A great-appendage arthropod with a radial mouth from the Lower Devonian Hunsrück Slate, Germany”. English. In: Science 323 (2009), p. 771. DOI: 10.1126/ science.1166586.

[12684] G. Kühl and W. R. Lourenço. "A new genus and species of fossil scorpion (?Euscorpiidae) from the Early-Middle Eocene of Pesciara (Bolca, Italy)”. English. In: PalZ 91 (2017), pp. 283-290. 
[12685] B. F. Kuhn, A. Hartstone-Rose, R. Lacruz, A. I. R. Herries, L. Werdelin, M. K. Bamford, and L. R. Berger. "The carnivore guild circa 1.98 million years: biodiversity and implications for the palaeoenvironment at Malapa, South Africa". English. In: Palaeobiodiversity and Palaeoenrivonment 96 (2016), pp. 611-616. DOI: 10.1007/s12549-016-0245-0.

[12686] J. Kukalova-Peck. "Carboniferous protodonatoid dragonfly nymphs and the synapomorphies of Odonatoptera and Ephemeroptera (Insecta: Palaeoptera)". English. In: Palaeodiversity 2009.2 (2009), pp. 169-198.

[12687] J. Kukalová-Peck and R. G. Beutel. "Is the Carboniferous tAdiphlebia lacoana really the oldest beetle? Critical reassessment and description of a new Permian beetle family". English. In: European Journal of Entomology 109 (2012), pp. 633-645.

[12688] J. Kukalová-Peck and C. Brauckmann. "Most Paleozoic Protorthoptera are ancestral hemipteroids: major wing braces as clues to a new phylogeny of Neoptera (Insecta)". English. In: Canadian Journal of Zoology 70 (1992), pp. 2452-2473.

[12689] J. Kukalová-Peck and C. Brauckmann. "Wing folding in pterygote insects, and the oldest Diaphanopterodea from the early Late Carboniferous of West Germany". English. In: Canadian Journal of Zoology 68 (1990), pp. 1104-1111.

[12690] J. Kukalová-Peck and N. D. Sinichenkova. "The wing venation and systematics of Lower Permian Diaphanopterodea from the Ural Mountains, Russia (Insecta: Paleoptera)". English. In: Canadian Journal of Zoology 70 (1992), pp. 229-235.

[12691] J. Kukalová-Peck and R. Willmann. "Lower Permian mecopteroid-like insects from central Europe (Insecta, Endopterygota)". English. In: Canadian Journal of Earth Sciences 27 (1990), pp. 459-468.

[12692] R. Kukihara and M. G. Lockley. "Fossil footprints from the Dakota Group (Cretaceous) John Martin Reservoir, Bent County, Colorado: New insights into the paleoecology of the Dinosaur Freeway". English. In: Cretaceous Research 33 (2012), pp. 165-182. DOI: 10.1016/j.cretres.2011.09.013.

[12693] H. A. Kulas and R. L. Batten. "Silicified gastropods from the Permian Phosphoria rock complex of Wyoming". English. In: Contributions to Geology, University of Wyoming 31.2 (1997), pp. 33-58.

[12694] K. G. Kulkarni, S. Bhattacharjee, and V. D. Borkar. "Entobian bioerosion of Miocene oysters, Kachchh, Gujarat". English. In: Journal of the Geological Society of India 69 (2007), pp. 827-833.

[12695] O. Kullmar, O. Sandrock, R. Abel, F. Schrenk, T. Bromage, and Y. Juwayeyi. The first Paranthropus from the Malawi Rift. 1999.

[12696] T. Kumagae, H. Maeda, and T. Komatsu. "Paleoecology of Inoceramus amakusensis Nagao et Matsumoto, 1940 (Bivalvia) in a Late Cretaceous shallow clastic sea: The Himenoura Group, Kyushu, Japan". English. In: Cretaceous Research 32 (2011), pp. 738-749.

[12697] A. Kumar. "Record of Well Preserved Trilobites from the Cambrian of Zanskar". In: Journal of the Geological Society of India 51.5 (1998), pp. 671-678.

[12698] D. K. Kumar. "Paratritemnodon indicus (Creodonta, Mammalia) from the early Middle Eocene Subathu Formation, NW Himalaya, India". English. In: Palaeontologische Zeitschrift 66.3/4 (1992), pp. 387-403.

[12699] J. Kumar and K. M. Sharma. "Micro and mega-vertebrate fossils from the Late Triassic Tiki Formation, South Rewa Gondwana Basin, India: palaeoenvironmental and palaeobiogeographic implications". English. In: Journal of the Palaeontological Society of India 64.2 (2019), pp. 151-168.

[12700] K. Kumar. "Anthracobune aijiensis nov. sp. (Mammalia: Proboscidea) from the Subathu Formation, Eocene from NW Himalaya, India". English. In: Geobios 24.2 (1991), pp. 221-239.

[12701] K. Kumar, M. W. Hamrick, and J. G. M. Thewissen. "Middle Eocene prosimian primate from the Subathu Group of Kalakot, northwestern Himalaya, India". English. In: Current Science 83.10 (2002), pp. 1255-1259.

[12702] K. Kumar, A. C. Nanda, and B. N. Tiwari. "Rodents from the Oligo-Miocene Kargil Formation, Ladakh, India: Biochronologic and palaeobiogeographic implications". English. In: Neues Jahrbuch für Geologie und Paläontologie - Abhandlungen 202.3 (1996), pp. 383-407. 
[12703] K. Kumar, P. Pandey, S. Bajpai, D. Bhattacharya, and B. Pandey. “Middle Eocene (Bartonian) vertebrate fauna from Bandah Formation, Jaisalmer Basin, Rajasthan, Western India". English. In: Historical Biology (2020).

[12704] K. Kumar, R. S. Rana, and B. S. Paliwal. “Osteoglossid and lepisosteid fish remains from the Paleocene Palana Formation, Rajasthan, India”. English. In: Palaeontology 48.6 (2005), pp. 1187-1209.

[12705] K. Kumar, K. D. Rose, R. S. Rana, L. Singh, T. Smith, and A. Sahni. "Early Eocene artiodactyls (Mammalia) from western India". English. In: Journal of Vertebrate Paleontology 30.4 (2010), pp. 12451274.

[12706] K. Kumar, R. Srivastava, and A. Sahni. "Middle Eocene rodents from the Subathu group, Northwest Himalya". English. In: Palaeovertebrata 26.1-4 (1997), pp. 83-128.

[12707] S. Kumar and S. K. Pandey. "Arumberia and associated fossils from the Neoproterozoic Maihar Sandstone, Vindhyan Supergroup, Central India". English. In: Journal of the Palaeontological Society of India 53.1 (2008), pp. 83-97.

[12708] M. P. Kundal and S. K. Humane. "Geniculate coralline algae from the Early Miocene Godhra Formation of the Kachchh offshore basin, western India". English. In: Journal of the Palaeontological Society of India 57.2 (2012), pp. 143-151.

[12709] P. Kundal. "First Record of Bryozoa from Late Miocene Limestone of Baratang Island, Andaman, India". In: Journal of the Geological Society of India 56.4 (2000), pp. 441-444.

[12710] P. Kundal, M. B. Bhagat, and M. P. Kundal. "Coralline algae from the Bassein Formation (middle to late Eocene) of Mumbai offshore basin and its paleo environmental significance". English. In: ONGC Bulletin 48.5 (2013), pp. 15-34.

[12711] P. Kundal and A. P. Dharashivkar. "Record of rhodoliths from Aramda Reef Member (Late Pleistocene to Holocene) of Chaya Formation, Dwarka-Okha area, Gujarat and their paleoenvironmental significance". English. In: Current Science 88.10 (2005), pp. 1684-1689.

[12712] P. Kundal and A. P. Dharashivkar. "Nongeniculate Coralline Algae from Lower Pliocene to Late Pleistocene of Dwarka - Okha Area, Jamnagar, Gujarat". English. In: Bulletin of the Oil and Natural Gas Corporation Limited (2003).

[12713] P. Kundal and S. K. Humane. Stratigraphic, paleobiogeographic and paleoenvironmental significance of Mesophyllum, a nongeniculate coralline alga from western Kachchh (middle Eocene to Oligocene), India. English. Micropaleontology: Application in stratigraphy and paleoceanography. New Delhi: Narosa Publishing House Pvt. Ltd., 2007, pp. 145-154.

[12714] P. Kundal and S. K. Humane. "On the first record of fossil calcareous alga Subterraniphyllum from late Lutetian of Western Kutch and its biostratigraphical and paleobiogeographical assessment". English. In: Gondwana Geology Magazine 20.2 (2005), pp. 119-124.

[12715] P. Kundal and S. K. Humane. "Jania, a geniculate coralline alga from middle Eocene to lower Miocene of Kachchh, Gujarat”. English. In: Journal Geological Society of India 68 (2006), pp. 630-638.

[12716] P. Kundal and S. K. Humane. "Geniculate coralline algae from middle Eocene to lower Miocene of Kachchh, Gujarat, India". English. In: Gondwana Geology Magazine 17.2 (2002), pp. 89-101.

[12717] P. Kundal and S. N. Mude. "Geniculate Coralline Algae from the Neogene-Quaternary sediments in and around Porbandar, Southwest Coast of India". English. In: Journal geological society of India 74 (2009), pp. 267-274.

[12718] P. Kundal and K. M. Wanjarwadkar. "On stratigraphy, age and depositional environment of algal limestone of middle Andaman Island, Andaman, India". English. In: Gondwana Geological Magazine 17.2 (2002), pp. 103-108.

[12719] P. Kundal and K. M. Wanjerwadkar. "Dasycladacean algae from the late Paleocene limestone member of middle Andaman Island, Andaman, India: implication to paleoenvironments, paleobathymetry and stratigraphy". English. In: Gondwana Geology Magazine 6 (2003), pp. 277-28. 
[12720] P. P. Kundal, S. S. Humane, S. K. Humane, and S. P. Petkar. “Discovery of marine benthic Chlorophycean algae in early Danian Deccan Intertrappean at Jhilmili, central India: new insights into existence of marine seaway close to Cretaceous-Paleogene boundary". English. In: Journal of the Paleontological Society of India 63.2 (2018), pp. 203-211.

[12721] M. Kundrát, A. R. I. Cruickshank, T. W. Manning, and J. R. Nudds. "Embryos of therizinosauroid theropods from the Upper Cretaceous of China: diagnosis and analysis of ossification patterns". English. In: Acta Zoologica 89.3 (2008), pp. 231-251.

[12722] M. Kundrát and J. Janácek. "Cranial pneumatization and auditory perceptions of the oviraptorid dinosaur Conchoraptor gracilis (Theropoda, Maniraptora) from the Late Cretaceous of Mongolia". English. In: Naturwissenschaften 94 (2007), pp. 769-778. DOI: 10.1007/s00114-007-0258-7.

[12723] M. Kundrát, J. Nudds, B. P. Kear, J. Lü, and P. Ahlberg. "The first specimen of Archaeopteryx from the Upper Jurassic Mörnsheim Formation of Germany". English. In: Historical Biology 31.1 (2019), pp. 3-63. DOI: 10.1080/08912963.2018.1518443.

[12724] R. Kundrata, A. Bukejs, A. S. Prosvirov, and J. Homannova. "X-ray micro-computed tomography reveals a unique morphology in a new clickbeetle (Coleoptera, Elateridae) from the Eocene Baltic amber". English. In: Scientific Reports 10.20158 (2020). DOI: 10.1038/s41598-020-76908-3.

[12725] Y. Kunimatsu. "New Species of Nyanzapithecus from Nachola, Northern Kenya". English. In: Anthropological Science 105 (1997), pp. 117-141.

[12726] Y. Kunimatsu, H. Tsujikawa, M. Nakatsukasa, D. Shimizu, N. Ogihara, Y. Kikuchi, Y. Nakono, T. Takano, N. Morimoto, and H. Ishida. "A new species of Mioeuoticus (Lorisiformes, Primates) from the early Middle Miocene of Kenya". English. In: Anthropological Science 125.2 (2017), pp. 5965.

[12727] L. Kunzmann, C. Müller, K. Moraweck, D. Bräutigam, T. Wappler, and A. Nel. "First record of insects in lignite-bearing formations (upper Eocene) of the central German Leipzig Embayment". English. In: PalZ 91 (2017), pp. 315-326.

[12728] J. Kuo. “A revision of the genus Heterozostera (Zosteraceae)". English. In: Aquatic Botany 81 (2005), pp. 97-140.

[12729] J. Kupryjanowicz and F. Fanti. "New subgenus and three new species of soldier beetles from the Eocene of Baltic amber". English. In: Palaeontologia Electronica 22.2.22A (2019), pp. 1-13.

[12730] J. Kupryjanowicz, G. Y. Lyubarsky, and E. E. Perkovsky. "A new species of the family Smicripidae (Coleoptera: Cucujoidea) from Rovno amber". English. In: Paleontological Journal 53 (2019), pp. 165-171. DOI: 10.1134/S0031030119020059.

[12731] J. Kupryjanowicz, G. Y. Lyubarsky, and E. E. Perkovsky. "Not so wide face: The first root-eating beetle of the genus Europs (Coleoptera: Monotomidae) in Mexican amber". English. In: Invertebrate Zoology 17 (2020), pp. 145-153.

[12732] J. Kupryjanowicz and V. N. Makarkin. "Archiconiocompsa prisca Enderlein (Neuroptera: Coniopterygidae): The first neuropteran fossil in Rovno amber (Ukraine)". English. In: Entomologica Fennica 19 (2008), pp. 25-31.

[12733] K. Kurihara, M. Kano, H. Sawamura, and Y. Sato. "The last surviving ammonoid at the end of the Cretaceous in the north Pacific region". English. In: Paleontological Research 20 (2016), pp. 116-120.

[12734] T. Kurihara and M. Kametaka. "Radiolaria-dated Lower Permian clastic-rock sequence in the Fukuji area of the Hida-gaien terrane, central Japan, and its inter-terrane correlation across Southwest Japan". English. In: Island Arc 17 (2008), pp. 531-545.

[12735] Y. Kurihara and T. Kase. "First record of the Northeastern Pacific patellogastropod genus Acmaea from the Miocene of Japan and its paleobiogeographic implications". English. In: The Veliger 50.1 (2008), pp. 39-47.

[12736] A. A. Kurkin. "A New Dicynodont (Anomodontia, Eotherapsida) from the Upper Permian of Tatarstan". English. In: Paleontological Journal 40.4 (2006), pp. 434-437. 
[12737] A. A. Kurkin. "New Late Permian dicynodonts from the Vyazniki Assemblage of terrestrial tetrapods of Eastern Europe". English. In: Paleontological Journal 35.1 (2001), pp. 53-59.

[12738] A. A. Kurkin. "New dicynodonts from the Upper Permian of the Vyatka Basin". English. In: Paleontological Journal 34.2 (2000), S203-S210.

[12739] A. A. Kurkin. “A New Galeopid (Anomodontia, Galeopidae) from the Permian of Eastern Europe". English. In: Paleontological Journal 51.3 (2017), pp. 308-312.

[12740] A. S. Kurochkin and A. G. Kirejtshuk. “New species of sap beetles (Coleoptera: Nitidulidae: Epuraeinae, Cybocephalinae) from the Baltic amber". English. In: Paleontological Journal 44 (2010), pp. 534-545.

[12741] E. N. Kurochkin. "Mesozoic birds of Mongolia and the former USSR". English. In: The Age of Dinosaurs in Russia and Mongolia. Cambridge: Cambridge University Press, 2000, pp. 533-559.

[12742] E. N. Kurochkin. "A new large enantiornithid from the Upper Cretaceous of Mongolia". Russian. In: Trudy Zoologicheskogo Instituta 277 (1999), pp. 130-141.

[12743] E. N. Kurochkin, S. Chatterjee, and K. E. Mikhailov. "An emryonic enantiornithine bird and associated eggs from the Cretaceous of Mongolia". English. In: Paleontological Journal 47.11 (2013), pp. 1252-1269.

[12744] E. N. Kurochkin, G. J. Dyke, and A. A. Karhu. "A new presbyornithid bird (Aves, Anseriformes) from the Late Cretaceous of southern Mongolia". English. In: American Museum Novitates 3386 (2002), pp. 1-11.

[12745] E. N. Kurochkin and G. J. Dyke. “The First Fossil Owls (Aves: Strigiformes) from the Paleogene of Asia and a Review of the Fossil Record of Strigiformes". English. In: Paleontological Journal 45.4 (2011), pp. 445-458.

[12746] E. N. Kurochkin and G. J. Dyke. "A large collection of Presbyornis (Aves, Anseriformes, Presbyornithidae) from the late Paleocene and early Eocene of Mongolia". English. In: Geological Journal 45 (2010), pp. 375-387. DOI: 10.1002/gj.1177.

[12747] E. N. Kurochkin and R. E. Molnar. "New material of enantiornithine birds from the Early Cretaceous of Australia". English. In: Alcheringa 21.4 (1997), pp. 291-297.

[12748] E. N. Kurochkin, S. V. Saveliev, A. A. Postnov, E. M. Pervushov, and E. V. Popov. “On the brain of a primitive bird from the Upper Cretaceous of European Russia". English. In: Paleontological Journal 40.6 (2006), pp. 655-667. DOI: 10.1134/S0031030106060086.

[12749] E. N. Kurochkin, N. V. Zelenkov, A. O. Averianov, and S. V. Leshchinskiy. “A new taxon of birds (Aves) from the Early Cretaceous of Western Siberia, Russia". English. In: Journal of Systematic Palaeontology 9.1 (2011), pp. 109-117.

[12750] B. Kurtén and L. Werdelin. "Relationships between North and South American Smilodon". English. In: Journal of Vertebrate Paleontology 10.2 (1990), pp. 158-169.

[12751] W. J. Kurtz, M. G. Lockley, and D. J. Engard. “Dinosaur tracks in the Plainview Formation, Dakota Group (Cretaceous, Albian) near Cañon City, Colorado: a preliminary report on another Dinosaur Ridge". English. In: The Mountain Geologist 38.3 (2001), pp. 155-164.

[12752] N. I. Kurushin and A. M. Truschelev. "Magnolobia: a new bivalve genus from the boreal Ladinian". In: Paleontological Journal 35.3 (2001), pp. 243-248.

[12753] M. Kurz. "On the systematic position of Electrocrania Kusnezov, 1941 with the description of a new species from Baltic amber (Lepidoptera: Micropterigidae)". English. In: Zootaxa 4044 (2015), pp. 446-450.

[12754] M. A. Kurz and M. E. Kurz. “Micropterix gertraudae sp n”. English. In: TaxOn (Taxonomy Online) (2010), pp. 1-3.

[12755] S. M. Kurzanov. "A gigantic protoceratopsid from the Upper Cretaceous of Mongolia". English. In: Paleontological Journal 26.3 (1992), pp. 103-116. 
[12756] S. M. Kurzanov, M. B. Efimov, and Y. M. Gubin. "New archosaurs from the Jurassic of Siberia and Mongolia". In: Paleontological Journal 37.1 (2003), pp. 53-57.

[12757] S. M. Kurzanov and H. Osmólska. "Tochisaurus nemegtensis gen. et sp. n., a new troodontid dinosaur (Dinosauria, Theropoda) from Mongolia". English. In: Acta Palaeontologica Polonica 36.1 (1991), pp. 69-76.

[12758] G. Kuschel, R. G. Oberprieler, and R. J. Rayner. “Cretaceous weevils from southern Africa, with description of a new genus and species and phylogenetic and zoogeographical comments (Coleoptera: Curculionoidea)". English. In: Entomologica Scandinavica 25 (1994), pp. 137-149.

[12759] G. Kuschel and G. O. Poinar. "Libanorhinus succinus gen. \& sp. n. (Coleoptera: Nemonychidae) from Lebanese amber". English. In: Entomologica Scandinavica 24 (1993), pp. 143-146.

[12760] A. Kuska and J. Kupryjanowicz. "Soldier beetles (Coleoptera: Cantharidae) from Baltic amber". English. In: Polskie Pismo Entomologiczne 74 (2005), pp. 309-316.

[12761] J. Kuss and M. A. Conrad. "Calcareous Algae from Cretaceous Carbonates of Egypt, Sinai, and Southern Jordan". English. In: Journal of Paleontology 65.5 (1991).

[12762] E. Kustatscher, K. Bauer, and M. Reich. "A new Middle Triassic (Pelsonian) plant locality in the Non Valley (Trentino, Northern Italy)". English. In: Geo.Alp 9 (2012), pp. 60-73.

[12763] E. Kustatscher, F. Bizzarini, and G. Roghi. "Plant fossils in the Cassian Beds and Other Carnian Formations of the Southern Alps (Italy)". English. In: Geo.Alp 8 (2011), pp. 146-155.

[12764] E. Kustatscher, H. Falcon-Lang, and A. Lukeneder. "Early Cretaceous araucarian driftwood from hemipelagic sediments of the Puez area, South Tyrol, Italy". English. In: Cretaceous Research 41 (2013), pp. 270-276.

[12765] E. Kustatscher, D. Giordano, and A. Riva. "La flora anisica della Valle di San Lucano". Italian. In: L'armonia fra uomo e natura nelle valli dolomitiche - Atti delle giornate di studio di Agordo, 12-13 novembre 2010. Roma: Aracne Ed., 2011.

[12766] E. Kustatscher, A. Hemsley, and J. H. A. van Konijnenburg-van Cittert. “Lugardonia paradoxa gen. et sp. nov., a new strobilus from the Anisian flora of Kühwiesenkopf, the Dolomites, Italy and its affinities with emphasis on spore ultrastructure". English. In: Review of Palaeobotany and Palynology 156 (2009), pp. 90-97.

[12767] E. Kustatscher, K.-P. Kelber, and J. H. A. Van Konijnenburg-van Cittert. “Danaeopsis Heer ex Schimper 1869 and its European Triassic species". English. In: Review of Palaeobotany and Palynology 183 (2012), pp. 32-49.

[12768] E. Kustatscher, B. Meller, and J. H. A. van Konijnenburg-van Cittert. “Old treasures newly discovered: Scytophyllum bergeri from the Ladinian of the Dolomites in the historical collections of the Geologische Bundesanstalt". English. In: Geo.Alp 3 (2006), pp. 47-53.

[12769] E. Kustatscher, C. Pott, and J. H. A. Van Konijnenburg-van Cittert. "A contribution to the knowledge of the Triassic fern genus Symopteris". English. In: Review of Palaeobotany and Palynology 165 (2011), pp. 41-60.

[12770] E. Kustatscher, C. Pott, and J. H. A. Van Konijnenburg-van Cittert. "Scytophyllum waehneri (Stur) nov. comb., the correct name for Scytophyllum persicum (Schenk) Kilpper, 1975". English. In: Zitteliana 51 (2011), pp. 9-18.

[12771] E. Kustatscher and J. H. A. van Konijnenburg-van Cittert. "Considerations on Phylladelphia strigata Bronn from the historical Raibl flora (Carnian, lower Upper Triassic, Italy)". English. In: Geo.Alp 5 (2008), pp. 69-81.

[12772] E. Kustatscher and J. H. A. van Konijnenburg-van Cittert. "Lycophytes and horsetails from the Triassic flora of Thale (Germany)". English. In: Neues Jahrbuch für Geologie und Paläontologie, Abhandlungen 250.1 (2008), pp. 65-77.

[12773] E. Kustatscher and J. H. A. Van Konijnenburg-van Cittert. "Seed ferns and Cycadophytes from the Triassic Flora of Thale (Germany)". English. In: Neues Jahrbuch für Geologie und Paläontologie, Abhandlungen 258.2 (2010), pp. 195-217. 
[12774] E. Kustatscher and J. H. A. Van Konijnenburg-van Cittert. "The ferns of the Middle Triassic flora from Thale (Germany)". English. In: Neues Jahrbuch für Geologie und Paläontologie, Abhandlungen 261.2 (2011), pp. 209-248.

[12775] E. Kustatscher and J. H. A. Van Konijnenburg-van Cittert. “Taxonomical and palaeogeographic considerations on the seedfern genus Ptilozamites with some comments on Anomozamites, Dicroidium, Pseudoctenis and Ctenozamites". English. In: Neues Jahrbuch für Geologie und Paläontologie, Abhandlungen 243.1 (2007), pp. 71-100.

[12776] E. Kustatscher, M. Wachtler, and J. H. A. van Konijnenburg-van Cittert. "A number of additional and revised taxa from the Ladinian flora of the Dolomites, Northern Italy". English. In: Geo.Alp 1 (2004), pp. 57-69.

[12777] E. Kustatscher, M. Wachtler, and J. H. A. van Konijnenburg-van Cittert. "Horsetails and seed ferns from the Middle Triassic (Anisian) locality Kühwiesenkopf (Monte Prá Della Vacca), Dolomites, Northern Italy". English. In: Palaeontology 50.5 (2007), pp. 1277-1298.

[12778] E. Kustatscher, M. Wachtler, and J. H. A. van Konijnenburg-van Cittert. "Lycophytes from the Middle Triassic (Anisian) Locality Kühwiesenkopf (Monte Prá Della Vacca) in the Dolomites". English. In: Palaeontology 53.3 (2010), pp. 595-626.

[12779] N. Kusuhashi. "Early Cretaceous multituberculate mammals from the Kuwajima Formation (Tetori Group), central Japan". English. In: Acta Palaeontologica Polonica 53.3 (2008), pp. 379-390.

[12780] N. Kusuhashi, Y. Hu, Y. Wang, S. Hirasawa, and H. Matsuoka. “New triconodontids (Mammalia) from the Lower Cretaceous Shahai and Fuxin formations, northeastern China". English. In: Geobios 42 (2009), pp. 765-781.

[12781] N. Kusuhashi, Y. Hu, T. Setoguchi, and H. Matsuoka. "New multituberculate mammals from the Lower Cretaceous (Shahai and Fuxin formations), northeastern China". English. In: Journal of Vertebrate Paleontology 30.5 (2010), pp. 1501-1514.

[12782] N. Kusuhashi, Y. Hu, Y. Wang, T. Setoguchi, and H. Matsuoka. "Two eobaatarid (Multituberculata; Mammalia) genera from the Lower Cretaceous Shahai and Fuxin formation, northeastern China". English. In: Journal of Vertebrate Paleontology 29.4 (2009), pp. 1264-1288.

[12783] N. Kusuhashi, Y. Tsutsumi, H. Saegusa, K. Horie, T. Ikeda, K. Yokoyama, and K. Shiraishi. "A new Early Cretaceous eutherian mammal from the Sasayama Group, Hyogo, Japan". English. In: Proceedings of the Royal Society B 280 (2013).

[12784] N. Kusuhashi, Y.-Q. Wang, C. -K. Li, and X. Jin. “Two new species of Gobiconodon (Mammalia, Eutriconodonta, Gobiconodontidae) from the Lower Cretaceous Shahai and Fuxin formations, northeastern China". English. In: Historical Biology 28.1-2 (2016), pp. 14-26. DOI: 10.1080/08912963. 2014.977881.

[12785] A. Kusworo, S. Reich, F. P. Wesselingh, N. Santodomingo, K. G. Johnson, J. A. Todd, and W. Renema. "Diversity and Paleoecology of Miocene Coral-Associated Mollusks from East Kalimantan (Indonesia)". English. In: Palaios 30 (2015), pp. 116-127. DOI: 10.2110/palo.2013.124.

[12786] M. Kutscher. “Echinodermata aus dem Ober-Toarcium und Aalenium Deutschlands II: Ophiuroidea". German. In: Stuttgarter Beiträge zur Naturkunde, serie B, Geologie und Paläontologie 242 (1996), pp. 1-33.

[12787] M. Kutscher. "Schlangensterne (Ophiuroidea) aus dem Oberen Muschelkalk von Atzendorf bei Magdeburg". German. In: Aufschluss 51 (2000), pp. 301-304.

[12788] M. Kutscher. “Ophiomusium geisingense n.sp. eine neue Ophiurenart aus dem Lias Epsilon (Unteres Toarcium) von Bachhausen/Bayern". German. In: Archaeopteryx 10 (1992), pp. 25-30.

[12789] M. Kutscher and M. Röper. "Die Ophiuren des Papierschiefers von Hienheim (Malm zeta 3, Untertithon)". German. In: Archaeopteryx 13 (1995), pp. 85-89.

[12790] M. Kutscher and M. Röper. “Die Asteroidea (seesterne) aus den Papierschifern von Hienheim und Ried (Malm Zeta 3, Untertithonium)". German. In: Archaeopteryx 17 (1999), pp. 1-13. 
[12791] M. Kutscher and L. Villier. “Ophiuroid remains from the Toarcian of Sainte-Verge (Deux-Sevres, France): paleobiological perspectives". In: Géobios 36.2 (2003), pp. 179-194.

[12792] M. Kutscher, C. Neumann, S. Nielsen, M. Reich, and L. Villier. Echinoderms from the Miocene of Chile. English. In Echinoderm: München, Heinzeller \& Nebelsick (eds), Taylor \& Francis Group, London. 2004, pp. 453-456.

[12793] T. S. Kutty, S. Chatterjee, P. M. Galton, and P. Upchurch. "Basal sauropodomorphs (Dinosauria, Saurischia) from the Lower Jurassic of India: their anatomy and relationships". English. In: Journal of Paleontology 81.6 (2007), pp. 1552-1574.

[12794] R. V. Kutygin. "Spirolegoceratids (Ammonoidea) from northeastern Russia". English. In: Paleontological Journal 30.5 (1996), pp. 506-514.

[12795] R. V. Kutygin. "Paratumaroceras, a new paragastrioceratid genus (Ammonoidea) from the Lower Permian of the western Verkhoyansk region". English. In: Paleontological Journal 37.3 (2003), pp. 252256.

[12796] R. V. Kutygin. "On the Early Permian Somoholites (Ammonoidea) from the Verkhoyansk region". English. In: Paleontological Journal 33 (1999), pp. 516-521.

[12797] R. V. Kutygin. “Uraloceras subsimense, a new goniatite species from the Lower Permian of the Verkhoyansk region". Russian. In: News on Paleontology and Stratigraphy 6-7 (2004), pp. 125-131.

[12798] R. V. Kutygin. "Permian ammonoid associations of the Verkhoyansk Region, northeast Russia". English. In: Journal of Asian Earth Sciences 26 (2006), pp. 243-257.

[12799] R. V. Kutygin. "Clausiuraloceras mechetlense, a new ammonoid species from the Kungurian of the southern Cisuralian region". English. In: Paleontological Journal 52 (2018), pp. 365-378.

[12800] R. V. Kutygin. "The Permian ammonoid family Medlicottiidae in the Verkhoyansk region". English. In: Paleontological Journal 54 (2020), pp. 571-583. DOI: 10.1134/S0031030120060039.

[12801] R. V. Kutygin and A. S. Biakov. "Permian ammonoids of the Okhotsk region, northeast Asia". English. In: Paleontological Journal 49 (2015), pp. 1275-1281.

[12802] R. V. Kutygin and V. G. Ganelin. "Permian ammonoids of the Kolyma-Omolon region: Kyrian association". English. In: Paleontological Journal 45.3 (2011), pp. 249-259.

[12803] R. V. Kutygin and V. G. Ganelin. "Permian ammonoids of the Kolyma-Omolon Region: Ogonerian Association". English. In: Paleontological Journal 47 (2013), pp. 1-10.

[12804] R. V. Kutygin, V. G. Ganelin, and A. S. Biakov. "New records of the late Carboniferous ammonoid genus Eoshumardites in the Kolyma-Omolon Region, and notes on the evolution of Eoshumarditidae". English. In: Paleontological Journal 50 (2016), pp. 347-357.

[12805] K. Kuwahara. "Evolutionary patterns of Late Permian Albaillella (Radiolaria) as seen in bedded chert sections in the Mino Belt, Japan". English. In: Marine Micropaleontology 30 (1997), pp. 65-78.

[12806] K. Kuwahara, A. Yao, and T. An. "Paleozoic and Mesozoic complexes in the Yunnan area, China (Part 1): Preliminary report of Middle-Late Permian radiolarian assemblages". English. In: Journal of Geosciences, Osaka City University 40 (1997), pp. 37-49.

[12807] K. Kuwahara, A. Yao, J. Yao, and J. Li. "Late Permian radiolarians and sponge spicules from the Tongtianyan section, Liuzhou, Gungxi, China”. English. In: Journal of Geosciences, Osaka City University 47 (2004), pp. 85-99.

[12808] I. T. Kuzmin, P. P. Skutschas, O. I. Grigorieva, and S. A. Krasnolutskii. "Goniopholidid crocodylomorph from the Middle Jurassic Berezovsk Quarry Locality (Western Siberia, Russia)". English. In: Proceedings of the Zoological Institute of the Russian Academy of Sciences 317.4 (2013), pp. 452-458.

[12809] N. N. Kuznetsov, A. A. Khaustov, and E. E. Perkovsky. "First record of mites of the family Stigmaeidae (Acari, Raphignathoidea) from Rovno amber with description of a new spceies of the genus Mediolata". English. In: Vestnik Zoologii 44 (2010), e49-e51. 
[12810] Z. Kvacek and H. Walther. "The Oligocene Volcanic Flora of Kundratice near Litomerice, Ceske Stredohori Volcanic Complex (Czech Republic) - A review". In: Sbornik Narodniho Muzea v Praze, Rada B - Prirodni Vedy (Acta Musei Nationalis Pragae, Series B, Historia Naturalis) 54.1-2 (1998), pp. 143.

[12811] Z. Kvacek. "A new Tertiary Ceratozamia (Zamiaceae, Cycadopsida) from the European Oligocene". English. In: Flora 197 (2002), pp. 303-316.

[12812] E. P. Kvale, S. T. Hasiotis, D. L. Mickelson, and G. D. Johnson. Middle and Late Jurassic dinosaur fossil-bearing horizons: implications for dinosaur paleoecology, northeastern Bighorn Basin, Wyoming. English. Vol. 3. In C. L. Hill (ed), Society of Vertebrate Paleontology, 61st Annual Meeting, Bozeman. Guidebook for the Field Trips: Mesozoic and Cenozoic Paleontology in the Western Plains and Rocky Mountains, Museum of the Rockies Occasional Paper. 2001, pp. 17-45.

[12813] E. P. Kvale, D. L. Mickelson, S. T. Hasiotis, and G. D. Johnson. "The history of dinosaur footprint discoveries in Wyoming with emphasis on the Bighorn Basin". English. In: Ichnos 11.1 (2004), pp. 3-9. DOI: $10.1080 / 10420940490428823$.

[12814] S.-W. Kwon, J. Park, and S. J. Choh. "Tetradiid-siliceous sponge patch reefs from the Xiazhen Formation (late Katian), southeast China: A new Late Ordovician reef association". English. In: Sedimentary Geology (2012), pp. 15-24.

[12815] Y. K. Kwon and S. K. Chough. "Sequence stratigraphy of the cyclic successions in the Dumugol Formation (Lower Ordovician), mideast Korea". English. In: Geosciences Journal 9.4 (2005), pp. 305324.

[12816] Y. K. Kwon, D. J. Lee, D. K. Choi, and S. K. Chough. "Lower Ordovician sponge bioherms in the Makkol Formation, Taebaeksan Basin, mideast Korea". In: Facies 48 (2003), pp. 79-90.

[12817] J. L. Kypke, A. Solodovnikov, A. Brunke, S. Yamamoto, and D. ya. "The past and the present through phylogenetic analysis: the rove beetle tribe Othiini now and 99 Ma". English. In: Systematic Entomology 44 (2018), pp. 1-18.

[12818] R. La Perna. "A revision of the genus Europicardium Popov, 1977 (Bivalvia: Cardiidae) from the European Neogene: tracking palaeogeography and climate changes". English. In: Journal of Systematic Palaeontology (2016). DOI: 10.1080/14772019.2016.1170733.

[12819] R. La Perna and M. D'Abramo. “The genus Nemocardium Meek 1876 in the Plio-Pleistocene of Italy (Bivalvia, Cardiidae)". English. In: Journal of Conchology 40.5 (2011), pp. 559-568.

[12820] C. C. Labandeira, B. A. LePage, and A. H. Johnson. "A Dendroctonus bark engraving (Coleoptera: Scolytidae) from a middle Eocene Larix (Coniferales: Pinaceae): early or delayed colonization?" English. In: American Journal of Botany 88.11 (2001), pp. 2026-2039.

[12821] R. Labarca, E. González-Guarda, Á Lizama-Catalán, N. A. Villavicencio, J. Alarcón-Muñoz, F. Suazo-Lara, P. Oyanadel-Urbina, P. Soto-Huenchuman, C. Salazar, S. Soto-Acuña, and K. E. Buldrini. "Taguatagua 1: New insights into the late Pleistocene fauna, paleoenvironment, and human subsistence in a unique lacustrine context in central Chile". English. In: Quaternary Science Reviews 238.106282 (2020), pp. 1-24.

[12822] H.-P. Labarrére and C. Montenat. “Le Lophiodon (Mammifére périssodactyle) du Lutétien d’Eygalayes (Drome, France)". French. In: Annales de Paléontologie 97 (2011), pp. 139-156.

[12823] C. Labita and D. M. Martill. "An articulated pterosaur wing from the Upper Cretaceous (Maastrichtian) phosphates of Morocco". English. In: Cretaceous Research (2020), p. 104679. DOI: 10.1016/ j.cretres.2020.104679.

[12824] J. Labs Hochstein. "A new species of Zodiolestes (Mammalia, Mustelidae) from the early Miocene of Florida". English. In: Journal of Vertebrate Paleontology 27.2 (2007), pp. 532-534.

[12825] S. Lacau, A. Nel, C. Villemant, J. J. Menier, M. J. Orliac, and G. De Plöeg. “A fossil Scolebythidae from the lowermost Eocene amber of France (Insecta: Hymenoptera)". English. In: Annals of the Entomological Society of America 93 (2000), pp. 701-706. 
[12826] M. B. Lacerda, M. A. G. de França, and C. L. Schultz. "A new erpetosuchid (Pseudosuchia, Archosauria) from the Middle-Late Triassic of Southern Brazil". English. In: Zoological Journal of the Linnean Society (2018), pp. 1-21. DOI: 10.1093/zoolinnean/zly008.

[12827] M. B. Lacerda, C. L. Schultz, and C. Bertoni-Machado. "First 'Rauisuchian' archosaur (Pseudosuchia, Loricata) for the Middle Triassic Santacruzodon Assemblage Zone (Santa Maria Supersequence), Rio Grande do Sul State, Brazil". English. In: PLoS One 10.2 (2015), e0118563.

[12828] R. Lach and M. A. Salamon. "Late Cretaceous crinoids (Echinodermata) from the southwestern margin of the Holy Cross Mts. (southern Poland) and phylogenetic relationships among bourgueticrinids". English. In: Palaeontologische Zeitschrift 90 (2016), pp. 503-520. DOI: 10.1007/s12542016-0313-9.

[12829] F. Lacombat. “Les rhinocéros fossiles des sites préhistoriques de l’Europe méditerranéenne et du Massif Central: paléontologie et implications biochronologiques". French. In: BAR International Series 1419 (2005), pp. 1-175.

[12830] F. Lacombat, L. Abbazzi, M. P. Ferretti, B. Martinez-Navarro, P. -E. Moulle, M. -R. Palombo, L. Rook, A. Turner, and A. M. -F. Valli. "New data on the Early Villafranchian fauna from Vialette (Haute-Loire, France) based on the collection of the Crozatier Museum (Le Puy-en-Velay, HauteLoire, France)". English. In: Quaternary International 179 (2008), pp. 64-71. DOI: 10.1016/j.quaint. 2007.09.005.

[12831] K. J. Lacovara, M. C. Lamanna, L. M. Ibiricu, J. C. Poole, E. R. Schroeter, P. V. Ullmann, K. K. Voegele, Z. M. Boles, A. M. Carter, E. K. Fowler, V. M. Egerton, A. E. Moyer, C. L. Coughenour, J. P. Schein, J. D. Harris, R. D. Martnez, and F. E. Novas. "A gigantic, exceptionally complete titanosaurian sauropod dinosaur from southern Patagonia, Argentina". English. In: Scientific Reports 4 (2014), 6196:1-9. DOI: 10.1038/srep06196.

[12832] S. Ladaveze and C. Muizon. "Evidence of early evolution of Australidelphia (Metatheria, Mammalia) in South America: phylogenetic relationships of the metatherians from the Late Palaeocene of Itabora (Brazil) based on teeth and petrosal bones". English. In: Zoological Journal of the Linnean Society 159.3 (2010), pp. 746-784.

[12833] S. Ladevéze, P. Missiaen, and T. Smith. "First skull of Orthaspidotherium edwardsi (Mammalia, Condylarthra) from the late Paleocene of Berru (France) and phylogenetic affinities of the enigmatic European family Pleuraspidotheriidae". English. In: Journal of Vertebrate Paleontology 30.5 (2010), pp. 1559-1578.

[12834] T. C. LaDuke, D. W. Krause, J. D. Scanlon, and N. J. Kley. “A Late Cretaceous (Maastrichtian) snake assemblage from the Maevarano Formation, Mahajanga Basin, Madagascar". English. In: Journal of Vertebrate Paleontology 30.1 (2010), pp. 109-138.

[12835] M. Laflamme, S. A. F. Darroch, S. M. Tweedt, K. J. Peterson, and D. H. Erwin. "The end of the Ediacara biota: Extinction, biotic replacement, or Cheshire Cat?" English. In: Gondwana Research 23.2 (2013), pp. 558-573. DOI: 10.1016/j.gr.2012.11.004.

[12836] M. Laflamme, L. I. Flude, and G. M. Narbonne. "Ecological tiering and the evolution of a stem: The oldest stemmed frond from the Ediacaran of Newfoundland Canada". English. In: Journal of Paleontology 86.2 (2012), pp. 193-200.

[12837] M. Laflamme, G. M. Narbonne, and M. M. Anderson. "Morphometric analysis of the Ediacaran frond Charniodiscus from the Mistaken Point Formation, Newfoundland". English. In: Journal of Paleontology 78.5 (2004), pp. 827-837.

[12838] M. Laflamme, G. M. Narbonne, C. Greentree, and M. M. Anderson. Morphology and taphonomy of an Ediacaran frond: Charnia from the Avalon Peninsula of Newfoundland. English. Vol. 286. The Rise and Fall of the Ediacaran Biota, Geological Society, London, Special Publications. 2007, pp. 237257. DOI: $10.1144 /$ SP286.17.

[12839] J. Lafuste, F. Debrenne, A. Gandin, and D. Gravestock. "The oldest tabulate coral and the associated Archaeocyatha, Lower Cambrian, Flinders Ranges, South Australia". English. In: Geobios 24.6 (1991), pp. 697-718. 
[12840] A. Lagnaoui, H. Klein, H. Saber, A. Fekkak, A. Belahmira, and J. W. Schneider. “New discoveries of archosaur and other tetrapod footprints from the Timezgadiouine Formation (Irohalene Member, Upper Triassic) of the Argana Basin, western High Atlas, Morocco - Ichnotaxonomic implications". English. In: Palaeogeography, Palaeoclimatology, Palaeoecology 453 (2016), pp. 1-9. DOI: 10.1016/j.palaeo.2016.03.022.

[12841] A. Lagnaoui, H. Klein, S. Voigt, A. Hminna, H. Saber, J. W. Schneider, and R. Werneburg. "Late Triassic tetrapod-dominated ichnoassemblages from the Argana Basin (Western High Atlas, Morocco)". English. In: Ichnos 19 (2012), pp. 238-253. DOI: 10.1080/10420940.2012.718014.

[12842] M. Lak, D. Azar, A. Nel, D. Neraudeau, and P. Tafforeau. "The oldest representative of the Trichomyiinae (Diptera: Psychodidae) from the Lower Cenomanian French amber studied with phase contrast synchrotron X-ray imaging". English. In: Invertebrate Systematics 22.4 (2008), pp. 471-478.

[12843] M. Lak, G. Fleck, D. Azar, M. S. Engel, H. F. Kaddumi, D. Neraudeau, P. Tafforeau, and A. Nel. "Phase contrast X-ray synchrotron microtomography and the oldest damselflies in amber (Odonata: Zygoptera: Hemiphlebiidae)". English. In: Zoological Journal of the Linnean Society 156 (2009), pp. $913-$ 923.

[12844] M. Lak and A. Nel. “An enigmatic diapriid wasp (Insecta, Hymenoptera) from French Cretaceous amber". English. In: Geodiversitas 31 (2009), pp. 137-144.

[12845] T. Lakew. "Microfacies and cyclic sedimentation of the Upper Triassic (Rhaetian) Calcare di Zu (Southern Alps)". English. In: Facies 22 (1990), pp. 187-232.

[12846] J. N. Lallensack, P. M. Sander, N. Knötschke, and O. Wings. “Dinosaur tracks from the Langenberg Quarry (Late Jurassic, Germany) reconstructed with historical photogrammetry: evidence for large theropods soon after insular dwarfism". English. In: Palaeontologia Electronica 18.2 (2015), 31A:1-34.

[12847] A. M. C. Lalor and V. A. Tavora. "Novos elementos da coralinofauna da formacao pirabas (miocene inferior), estado do para [Coralinofaune of the Pirabas Formation (Lower Miocene), State of Para: new Taxa]". Portugese. In: Geociencias 25.2 (2006), pp. 187-195.

[12848] F. Laloy, J.-C. Rage, S. E. Evans, R. Boistel, N. Lenoir, and M. Laurin. "A Re-Interpretation of the Eocene Anuran Thaumastosaurus Based on MicroCT Examination of a 'Mummified' Specimen". English. In: PLoS ONE 8.12 (2013), e74874:1. DOI: 10.1371/journal.pone.0074874.

[12849] M. C. Lamanna, G. A. Casal, L. M. Ibiricu, and R. D. F. Martnez. “A new peirosaurid crocodyliform from the Upper Cretaceous Lago Colhué Huapi Formation of central Patagonia, Argentina". English. In: Annals of Carnegie Museum 85.3 (2019), pp. 193-211.

[12850] M. C. Lamanna and Y. Hasegawa. “New titanosauriform sauropod dinosaur material from the Cenomanian of Morocco: implications for paleoecology and sauropod diversity in the Late Cretaceous of North Africa". English. In: Bulletin of Gunma Museum of Natural History 18 (2014), pp. 119.

[12851] M. C. Lamanna, R. D. Martnez, and J. B. Smith. "A definitive abelisaurid theropod dinosaur from the Early Cretaceous of Patagonia". English. In: Journal of Vertebrate Paleontology 22.1 (2002), pp. 5969.

[12852] M. C. Lamanna, R. D. Martnez, and J. B. Smith. A new abelisaurid (Theropoda: Ceratosauria) skeleton from the Upper Cretaceous Bajo Barreal Formation of Chubut Province, Argentina. English. 2012.

[12853] M. C. Lamanna, H.-D. Sues, E. R. Schachner, and T. R. Lyson. “A New large-bodied oviraptorosaurian theropod dinosaur from the latest Cretaceous of western North America". English. In: PLoS ONE 9.3 (2014), e92022:1-16. DOI: 10.1371/journal.pone.0092022.

[12854] L. L. Lambert, P. H. Heckel, and J. E. Barrick. "Swadelina New Genus (Pennsylvanian Conodonta), a Taxon with potential chronostratigraphic significance". English. In: Micropaleontology 49.2 (2003), pp. 151-158. DOI: 10.2113/49.2.151.

[12855] O. Lambert. "Systematic revision of the Miocene long-snouted dolphin Eurhinodelphis longirostris Du Bus, 1872." In: Bulletin de l'Institut royal des Sciences naturelles de Belgique, Sciences de la Terre 74 (2004), pp. 147-174. 
[12856] O. Lambert. "Phylogenetic affinities of the long-snouted dolphin Eurhinodelphis (Cetacea, Odontoceti) from the Miocene of Antwerp, Belgium". English. In: Palaeontology 48.3 (2005), pp. 653679.

[12857] O. Lambert. "Review of the Miocene long-snouted dolphin Priscodelphinus cristatus Du Bus, 1872 (Cetacea, Odontoceti) and phylogeny among eurhinodelphinids". English. In: Bulletin de L'Institute Royal des Sciences Naturelles de Belgique Sciences de la Terre 75 (2005), pp. 211-235.

[12858] O. Lambert. "Systematics and phylogeny of the fossil beaked whales Ziphirostrum du Bus, 1868 and Choneziphius Duvernoy, 1851 (Mammalia, Cetacea, Odontoceti), from the Neogene of Antwerp (North of Belgium)". English. In: Geodiversitas 27.3 (2005), pp. 443-497.

[12859] O. Lambert. "First record of a platanistid (Cetacea, Odontoceti) in the North Sea Basin: a review of Cyrtodelphis Abel, 1899 from the Miocene fo Belgium". English. In: Oryctos 6 (2006), pp. 69-79.

[12860] O. Lambert. "A new porpoise (Cetacea, Odontoceti, Phocoenidae) from the Pliocene of the North Sea". English. In: Journal of Vertebrate Paleontology 28.3 (2008), pp. 863-872.

[12861] O. Lambert, G. Bianucci, and K. Post. "A new beaked whale (Odontoceti, Ziphiidae) from the middle Miocene of Peru". English. In: Journal of Vertebrate Paleontology 29.3 (2009), pp. 910-922.

[12862] O. Lambert. "Sperm whales from the Miocene of the North Sea: a re-appraisal". English. In: Bulletin del'Institut Royal des Sciences Naturelles de Belgique, Sciences de la Terre 78 (2008), pp. 277-316.

[12863] O. Lambert. "Bony outgrowths on the jaws of an extinct sperm whale support macroraptorial feeding in several stem physeteroids". English. In: Naturwissenschaften (2014). DOI: 10.1007 / s00114-014-1182-2.

[12864] O. Lambert. "A new longirostrine sperm whale (Cetacea, Physeteroidea) from the lower Miocene of the Pisco Basin (southern coast of Peru)". English. In: Journal of Systematic Palaeontology 18.20 (2020), pp. 1707-1742. DOI: 10.1080/14772019.2020.1805520.

[12865] O. Lambert, C. Auclair, C. Cauxeiro, M. Lopez, and S. Adnet. “A close relative of the Amazon river dolphin in marine deposits: a new Iniidae from the late Miocene of Angola". English. In: PeerJ 6.e5556 (2018), pp. 1-33. DOI: 10.7717/ peerj.5556.

[12866] O. Lambert, G. Bianucci, R. Salas-Gismondi, C. Di Celma, E. Steurbaut, M. Urbina, and C. de Muizon. "An Amphibious Whale from the Middle Eocene of Peru Reveals Early South Pacific Dispersal of Quadrupedal Cetaceans". English. In: Current Biology 29 (2019), pp. 1-8. DOI: 10. 1016/j.cub.2019.02.050.

[12867] O. Lambert, G. Bianucci, and M. Urbina. "Huaridelphis raimondii, a new early Miocene Squalodelphinidae (Cetacea, Odontoceti) from the Chilcatay Formation, Peru". English. In: Journal of Vertebrate Paleontology 34.5 (2014), pp. 987-1004. DOI: 10.1080/02724634.2014.858050.

[12868] O. Lambert, G. Bianucci, and C. de Muizon. "Macroraptorial sperm whales (Cetacea, Odontoceti, Physeteroidea) from the Miocene of Peru". English. In: Zoological Journal of the Linnean Society 179 (2017), pp. 404-474. DOI: 10.1111/zoj.12456.

[12869] O. Lambert, G. Bianucci, M. Urbina, and J. H. Geisler. "A new inioid (Cetacea, Odontoceti, Delphinida) from the Miocene of Peru and the origin of modern dolphin and porpoise families". English. In: Zoological Journal of the Linnean Society 179 (2017), pp. 919-946. DOI: 10.1111/zoj.12479.

[12870] O. Lambert and G. Bianucci. "How to break a sperm whale's teeth: dental damage in a large Miocene physeteroid from the North Sea basin". English. In: Journal of Vertebrate Paleontology (2019). DOI: 10.1080/02724634.2019.1660987.

[12871] O. Lambert, A. Collareta, W. Landini, K. Post, B. Ramanssamy, C. Di Celma, M. Urbina, and G. Bianucci. "No deep diving: evidence of predation on epipelagic fish for a stem beaked whale from the Late Miocene of Peru". English. In: Proceedings of the Royal Society B 282 (2015), p. 20151530. DOI: $10.1098 / \mathrm{rspb} .2015 .1530$.

[12872] O. Lambert, A. Collareta, A. Benites-Palomino, C. Di Celma, C. de Muizon, M. Urbina, and G. Bianucci. "A new small, mesorostrine inioid (Cetacea, Odontoceti, Delphinida) from four upper Miocene localities in the Pisco Basin, Peru". English. In: Papers in Palaeontology 7.2 (2021), pp. 10431064. DOI: $10.1002 /$ spp2.1332. 
[12873] O. Lambert, C. de Muizon, and G. Bianucci. "A new archaic homodont toothed cetacean (Mammalia, Cetacea, Odontoceti) from the early Miocene of Peru". English. In: Geodiversitas 37.1 (2015), pp. 79-108. DOI: 10.5252/g2015n1a4.

[12874] O. Lambert, C. de Muizon, E. Malinverno, C. Di Celma, M. Urbina, and G. Bianucci. “A new odontocete (toothed cetacean) from the Early Miocene of Peru expands the morphological disparity of extinct heterodont dolphins". English. In: Journal of Systematic Palaeontology (2017). DOI: 10.1080/14772019.2017.1359689.

[12875] O. Lambert, C. de Muizon, G. Duhamel, and J. Van der Plight. “Neogene and Quaternary fossil remains of beaked whales (Cetacea, Odontoceti, Ziphiidae) from deep-sea deposits off Crozet and Kerguelen islands, Southern Ocean". English. In: Geodiversitas 40.6 (2018), pp. 135-160. DOI: 10.5252/geodiversitas2018v40a6.

[12876] O. Lambert, M. Estevens, and R. Smith. "A new kentriodontine from the middle Miocene of Portugal". English. In: Acta Palaeontologica Polonica 50.2 (2005), pp. 239-248.

[12877] O. Lambert and P. Gigase. A relative of the beluga and narwhal (Odontoceti, Monodontidae) from the early Pliocene of the North Sea. English. 2006.

[12878] O. Lambert and P. Gigase. "A monodontid cetacean from the Early Pliocene of the North Sea". English. In: Bulletin de l'Institut Royal des Sciences Naturelles de Belgique Sciences de la Terre 77 (2007), pp. 197-210.

[12879] O. Lambert, P. Godefroit, H. Li, C. -Y. Shang, and Z. -M. Dong. “A new species of Protoceratops (Dinosauria, Neoceratopsia) from the Late Cretaceous of Inner Mongolia (P. R. China)". English. In: Bulletin de l'Institut Royal des Sciences Naturelles de Belgique, Science de la Terre 71.supplement (2001), pp. 5-28.

[12880] O. Lambert, S. J. Godfrey, and E. M. G. Fitzgerald. English. In: Journal of Vertebrate Paleontology (2019), e1559174. DOI: 10.1080/02724634.2018.1559174.

[12881] O. Lambert, S. J. Godfrey, and A. J. Fuller. "A Miocene ziphiid (Cetacea: Odontoceti) from Calvert Cliffs, Maryland, U.S.A." English. In: Journal of Vertebrate Paleontology 30.5 (2010), pp. 1645-1651.

[12882] O. Lambert and S. Louwye. "Archaeoziphius microglenoideus, a new primitive beaked whale (Mammalia, Cetacea, Odontoceti) from the middle Miocene of Belgium". English. In: Journal of Vertebrate Paleontology 26.1 (2006), pp. 182-191.

[12883] O. Lambert and S. Louwye. "A new early Pliocene species of Mesoplodon: a calibration mark for the radiation of this species- rich beaked whale genus". English. In: Journal of Vertebrate Paleontology (2016), e1055754. DOI: 10.1080/02724634.2015.1055754.

[12884] O. Lambert, M. Martnez-Cáeres, G. Bianucci, E. Steurbaut, M. Urbina, and C. de Muizon. “Earliest Mysticete from the Late Eocene of Peru Sheds New Light on the Origin of Baleen Whales". English. In: Current Biology 27 (2017), pp. 0-17. DOI: 10.1016/j.cub.2017.04.026.

[12885] O. Lambert and C. Muizon. "A new long-snouted species of the Miocene pontoporiid dolphin Brachydelphis and a review of the Mio-Pliocene marine mammal levels in the Sacaco Basin, Peru". English. In: Journal of Vertebrate Paleontology 33.3 (2013), pp. 709-721. DOI: 10.1080/02724634.2013. 743405.

[12886] O. Lambert, J. Schlogl, and M. Kovac. "Middle Miocene toothed whale with Platanista-like teeth from the Vienna Basin (Western Carpathians, Slovakia)". English. In: Neues Jahrbuch für Geologie und Palæontologie, Abhandlungen 250.2 (2008), pp. 157-166.

[12887] W. D. Lambert. "Rediagnosis of the Genus Amebelodon (Mammalia, Proboscidea, Gomphotheriidae), with a New Subgenus and Species, Amebelodon (Konobelodon) britti". English. In: Journal of Paleontology 64.6 (1990), pp. 1032-1040.

[12888] W. D. Lambert. "The osteology and paleoecology of the giant otter Enhydritherium terraenovae". In: Journal of Vertebrate Paleontology 17.4 (1997), pp. 738-749.

[12889] W. D. Lambert. "New tetralophodont gomphothere material from Nebraska and its implications for the status of North American Tetralophodon". English. In: Journal of Vertebrate Paleontology 27.3 (2007), pp. 676-682. 
[12890] W. D. Lambert. “Eurybelodon shoshanii, an unusual new shovel- tusked gomphothere (Mammalia, Proboscidea) from the late Miocene of Oregon". English. In: Journal of Vertebrate Paleontology 36.3 (2016), e1091352. DOI: 10.1080/02724634.2016.1091352.

[12891] K. J. Lambkin. "Palparites deichmuelleri Handlirsch from the Tithonian Solnhofen Plattenkalk belongs to the Kalligrammatidae (Insecta: Neuroptera)". English. In: Palaeontologische Zeitschrift 68 (1994), pp. 163-168.

[12892] K. J. Lambkin. "Psychopsoid Neuroptera (Psychopsidae, Osmylopsycopidae) from the Queensland Triassic". English. In: Australian Entomologist 41 (2014), pp. 57-76.

[12893] K. J. Lambkin. "Revision of the Dysmorphoptilidae with emarginate tegmina (Hemiptera: Auchenorryncha: Cicadomorpha: Prosboloidea) of the Queensland Triassic". English. In: Zootaxa 3936 (2015), pp. 357-374.

[12894] K. J. Lambkin. “The Mesopsychidae (Mecoptera) of the Queensland Triassic”. English. In: Australian Entomologist 41 (2014), pp. 135-146.

[12895] K. J. Lambkin. "Revision of the Scytinopteridae (Hemiptera: Cicadomorpha: Scytinopteroidea) of the Queensland Triassic". English. In: Zootaxa 4117 (2016), pp. 580-590.

[12896] K. J. Lambkin. "Revision of the Dysmorphoptilidae (Hemiptera: Cicadomorpha: Prosboloidea) of the Queensland Triassic - Part 2". English. In: Zootaxa 4092 (2016), pp. 207-218.

[12897] K. J. Lambkin. "Archebittacus exilis Riek—the oldest hangingfly (Insecta: Mecoptera: Bittacidae)". English. In: Zootaxa 4290 (2017), pp. 385-389.

[12898] K. J. Lambkin. "A new genus and species of the family Archipsyllidae (Insecta: Paraneoptera: Permopsocida) from the Late Triassic of Queensland". English. In: Zootaxa 4382 (2018), pp. 192194.

[12899] K. J. Lambkin. "Mesodiphthera Tillyard, 1919, from the Late Triassic of Queensland, the oldest cicada (Hemiptera: Cicadomorpha: Cicadoidea: Tettigarctidae)". English. In: Zootaxa 4567 (2019), pp. 358-366.

[12900] K. J. Lambkin. "Revision of Mesothymbris Evans, 1956, from the Late Triassic of Mount Crosby, Queensland (Hemiptera: Cicadomorpha: Hylicelloidea: Hylicellidae)". English. In: Zootaxa 4629 (2019), pp. 389-396.

[12901] K. J. Lambkin. “The Mecoptera of the Paleogene Redbank Plains Formation, southeastern Queensland". English. In: The Australian Entomologist 45 (2018), pp. 149-158.

[12902] K. J. Lambkin. "Planthoppers (Insecta: Hemiptera: Fulgoromorpha: Fulgoroidea: Surijokocixiidae) of the Queensland Triassic". English. In: Memoirs of the Queensland Museum-Nature 60 (2020), pp. 123-131.

[12903] J. Lamsdell, S. Braddy, E. Loeffler, and D. Dineley. “Early Devonian stylonurine eurypterids from Arctic Canada". English. In: Canadian Journal of Earth Sciences 47.11 (2010), pp. 1405-1415.

[12904] J. C. Lamsdell, I. Hosgor, and P. A. Selden. "A new Ordovician eurypterid (Arthropoda: Chelicerata) from southeast Turkey: evidence for a cryptic Ordovician record of Eurypterida". English. In: Gondwana Research 23 (2013), pp. 354-366.

[12905] J. C. Lamsdell and S. C. McKenzie. "Tachypleus syriacus (Woodward) - a sexually dimorphic Cretaceous crown limulid reveals underestimated horseshoe crab divergence times". English. In: Organisms Diversity \& Evolution 15 (2015), pp. 681-693. DOI: 10.1007/s13127-015-0229-3.

[12906] J. C. Lamsdell and P. A. Selden. "Phylogenetic support for the monophyly of proetide trilobites". English. In: Lethaia 48 (2015), pp. 375-386. DOI: 10.1111/let.12113.

[12907] J. C. Lamsdell, L. Simonetto, and P. A. Selden. "First eurypterid from Italy: a new species of Adelophthalmus (Chelocerata: Eurypterida) from the upper Carboniferous of the Carnic Alps (Friuli, NE Italy)". English. In: Rivista Italiana di Paleontologia e Stratigrafia 119 (2013), pp. 147-151.

[12908] J. C. Lamsdell, J. N. Tashman, G. Pasini, and A. Garassino. "A new limulid (Chelicerata, Xiphosurida) from the Late Cretaceous (Cenomanian-Turonian) of Gara Sbaa, southeast Morocco". English. In: Cretaceous Research 106.104230 (2020). DOI: 10.1016/j.cretres.2019.104230. 
[12909] J. C. Lamsdell, J. Z. Xue, and P. A. Selden. “A horseshoe crab (Arthropoda: Chelicerata: Xiphosura) from the Lower Devonian (Lochkovian) of Yunnan, China". English. In: Geological Magazine 150 (2013), pp. 367-370. DOI: 10.1017/S0016756812000891.

[12910] C. C. Lana and I. S. Carvalho. "Cretaceous conchostracans from Potiguar Basin (northeas Brazin): relationships with West African conchostracan faunas and palaeoecological inferences". In: Cretaceous Research 23 (2002), pp. 351-362.

[12911] F. A. Lanc, P. D. McDermott, and C. R. C. Paul. “The identity of the British Ordovician cystoid 'Hemicosmites rugatus Forbes'”. English. In: Geological Journal 50.1 (2015), pp. 1-16. DOI: 10.1002/ gj.2522.

[12912] B. Landau, A. Beu, and R. Marquet. "The Early Pliocene Gastropoda (Mollusca) of Estepona, Southern Spain. Part 5: Tonnoidea, Ficoidea". English. In: Paleontos 5 (2004), pp. 35-102.

[12913] B. Landau and D. Fehse. “The Early Pliocene Gastropoda (Mollusca) of Estepona, Southern Spain. Part 3: Trivioidea, Cypraeoidea". English. In: Paleontos 5 (2004), pp. 1-34.

[12914] B. Landau, M. Harzhauser, and A. G. Beu. "A revision of the Tonnoidea (Caenogastropoda, Gastropoda) from the Miocene Paratethys and their palaeobiogeographic implications". English. In: Jahrbuch der Geologischen Bundesanstalt 149.1 (2009), pp. 61-109.

[12915] B. Landau and C. Marques da Silva. “Early Pliocene gastropods of Cubagua, Venezuela: Taxonomy, palaeobiogeography and ecostratigraphy". English. In: Palaeontos 19 (2010), pp. 1-221.

[12916] B. Landau, R. Petit, and C. M. de Silva. “The Pliocene Cancellariidae (Mollusca: Gastropoda) of the Cubagua Formation (Cerro Negro Member) from Cubagua Island, with a new species from the Miocene Cantaure Formation, Venezuela". English. In: The Veliger 49.1 (2007).

[12917] B. Landau, R. E. Petit, and C. M. da Silva. "New Cancellariidae (Mollusca, Gastropoda) from the Miocene Gatun Formation of Panama, with eleven new species". English. In: Journal of Paleontology 86.6 (2012), pp. 907-930.

[12918] B. Landau, G. Vermeij, and C. M. da Silva. "Southern Caribbean Neogene palaebiogeography revisisted. New data from the Pliocene of Cubagua, Venezuela". English. In: Palaeogeography, Palaeoclimatology, Palaeoecology 257 (2008), pp. 445-461.

[12919] B. Landau and G. J. Vermeij. “The genera Engina and Ameranna nov. gen. (Mollusca: Gastropoda, Buccinoidea, Buccinidae, Pisaniinae) from the Western Atlantic Neogene". English. In: Cainozoic Research 9.1 (2012), pp. 121-133.

[12920] B. D. Landau, R. E. Petit, and C. M. da Silva. “The family Cancellariidae (Mollusca: Gastropoda) in the Neogene of the Bocas del Toro region, Panama, with the description of seven new species". English. In: Journal of Paleontology 86.2 (2012), pp. 311-339.

[12921] B. M. Landau and L. T. Groves. “Cypraeidae (Mollusca: Gastropoda) from the early Miocene Cantaure Formation of northern Venezuela". English. In: Novaplex 12.1-2 (2011), pp. 1-38.

[12922] B. M. Landau, G. C. Kronenberg, and G. S. Herbert. "A large species of Lobatus (Gastropoda: Strombidae) from the Neogene of the Dominican Republic, with notes on the genus". English. In: The Veliger 50.1 (2008), pp. 31-38.

[12923] B. M. Landau and R. E. Petit. “New species of Cancellaroidea (Mollusca: Gastropoda) from the lower Miocene Cantaure Formation of Venezuela". In: Tulane Studies in Geology and Paleontology 29 (1996), pp. 145-150.

[12924] B. M. Landau. "A new species of Morum (Gastropoda: Harpidae) from the lower Miocene Cantaure Formation of Venezuela". In: Tulane Studies in Geology and Paleontology 29 (1996), pp. 53-58.

[12925] E. B. Lander and E. H. Lindsay. "Merychyus calaminthus (Mammalia, Artiodactyla, Oreodontidae) of probable early late Arikareean (late Oligocene to late early Miocene) age from the lower part of the Chalk Canyon Formation, Maricopa and Yavapai counties, central Arizona". English. In: Journal of Vertebrate Paleontology 31.1 (2011), pp. 215-226. DOI: 10.1080/02724634.2011.539645. 
[12926] E. Landing. “Upper Placentian-Branchian series of mainland Nova Scotia (middle-upper Lower Cambrian) faunas, paleoenvironments, and stratigraphic revision". In: Journal of Paleontology 69.3 (1995), pp. 475-495.

[12927] E. Landing. "In situ Earliest Cambrian tube worms and the oldest metazoan-constructed biostrome (Placentian Series, southeastern Newfoundland)". English. In: Journal of Paleontology 67.3 (1993), pp. 333-342.

[12928] E. Landing and K. E. Bartowski. “Oldest shelly fossils from the Taconic Allochthon and late Early Cambrian sea-levels in eastern Laurentia". In: Journal of Paleontology 70.5 (1996), pp. 741-761.

[12929] E. Landing and K. E. Bartowski. "Correction to Oldest shelly fossils from the Taconic Allochthon and late Early Cambrian sea-levels in eastern Laurentia". English. In: Journal of Paleontology 71.2 (1997), pp. 353-353.

[12930] E. Landing, A. English, and J. D. Keppie. “Cambrian origin of all skeletalized metazoan phylaDiscovery of Earth's oldest bryozoans (Upper Cambrian, southern Mexico)". English. In: Geology 38.6 (2010), pp. 547-550.

[12931] E. Landing, G. Geyer, and K. E. Bartowski. “Latest Early Cambrian small shelly fossils, trilobites and Hatch Hill dysaerobic interval on the Québec contental slope". English. In: Journal of Paleontology 76.2 (2002), pp. 287-305.

[12932] E. Landing, G. Geyer, R. Buchwaldt, and S. A. Bowring. "Geochronology of the Cambrian: a precise Middle Cambrian U-Pb zircon date from the German margin of West Gondwana". English. In: Geology Magazine (2014), pp. 1-13.

[12933] E. Landing, S. C. Johnson, and G. Geyer. "Faunas and Cambrian volcanism on the Avalonian marginal platform, southern New Brunswick". English. In: Journal of Paleontology 82.5 (2008), pp. 884-905.

[12934] E. Landing and B. Kröger. "The Oldest Cephalopods from East Laurentia". English. In: Journal of Paleontology 83.1 (2009), pp. 123-127.

[12935] E. Landing and J. B. Murphy. “Uppermost Precambrian(?)-Lower Cambrian of mainland Nova Scotia: faunas, depositional environments, and stratigraphic revision". English. In: Journal of Paleontology 65.3 (1991), pp. 382-396.

[12936] E. Landing and S. R. Westrop. “Lower Ordovician faunas, stratigraphy, and sea-level history of the Middle Beekmantown Group, Northeastern New York". English. In: Journal of Paleontology 80.5 (2006), pp. 958-980.

[12937] E. Landing, S. R. Westrop, and L. van Aller Hernick. “Uppermost Cambrian-Lower Ordovician Faunas and Laurentian Platform Sequence Stratigraphy, Eastern New York and Vermont". English. In: Journal of Paleontology 77.1 (2003), pp. 78-98.

[12938] E. Landing, S. R. Westrop, and L. A. Knox. “Conodonts, Stratigraphy, and Relative Sea-Level Changes of the Tribes Hill Formation (Lower Ordovician, East-Central New York)". English. In: Journal of Paleontology 70.4 (1996), pp. 656-680.

[12939] E. D. Landing. “Upper Precambrian through Lower Cambrian of Cape Breton Island: faunas, paleoenvironments, and stratigraphic revision". In: Journal of Paleontology 65.4 (1991), pp. 570-595.

[12940] W. Landini, A. Collareta, C. Di Celma, E. Malinverno, M. Urbina, and G. Bianucci. "The early Miocene elasmobranch assemblage from Zamaca (Chilcatay T Formation, Peru)". English. In: Journal of South American Earth Sciences 91 (2019), pp. 352-371. DOI: 10.1016/j.jsames.2018.08.004.

[12941] W. Landini and L. Sorbini. "Biogeographic and palaeoclimatic relationships of the Middle Pliocene ichthyofauna of the Samoggia Torrent (Bologna, Italy)". English. In: Ciencias da Terra, Lisboa 12 (1993), pp. 83-89.

[12942] W. Landini and L. Sorbini. "Données récentes sur Les téléostéens du Miocéne et du Pliocéne d'Italie". English. In: Geobios 14 (1992), pp. 151-157.

[12943] N. H. Landman and W. A. Cobban. "Ammonites from the upper part of the Pierre Shale and Fox Hills Formation of Colorado”. English. In: American Museum Novitates 3388 (2003), pp. 1-45. 
[12944] N. H. Landman and K. M. Waage. "Scaphitid ammonites of the Upper Cretaceous (Maastrichtian) Fox Hills Formation in South Dakota and Wyoming". English. In: Bulletin of the American Museum of Natural History 215 (1993), pp. 1-257.

[12945] G. Landra, F. Cecca, and Z. Vasicek. "Early Aptian ammonites from the top of the Maiolica and the anoxic Selli level (Lombardy, Southern Alps)". English. In: Bollettino della Societa Paleontologica Italiana 39.1 (2000), pp. 29-45.

[12946] N. G. Lane, J. A. Waters, and C. G. Maples. Echinoderm faunas of the Hongguleleng Formation, Late Devonian (Famennian), Xinjiang-Uyger Autonomous Region, People"s Republic of China. 1997.

[12947] N. G. Lane, J. A. Waters, C. G. Maples, S. A. Marcus, and Z. -T. Liao. “A camerate-rich Late Carboniferous (Moscovian) crinoid fauna from volcanic conglomerate, Xinjiang, People's Republic of China". English. In: Journal of Paleontology 70 (1996), pp. 117-128.

[12948] E. Läng, L. Boudad, L. Maio, E. Samankassou, J. Tabouelle, H. Tong, and L. Cavin. “Unbalanced food web in a Late Cretaceous dinosaur assemblage". English. In: Palaeogeography, Palaeoclimatology, Palaeoecology 381-382 (2013), pp. 26-32. DOI: 10.1016/j.palaeo.2013.04.011.

[12949] E. Läng and F. Goussard. "Redescription of the wrist and manus of ?Bothriospondylus madagascariensis: new data on carpus morphology in Sauropoda". English. In: Geodiversitas 29.4 (2007), pp. 549-560.

[12950] F. Lang, J. Gründel, M. Jäger, H. Löser, V. Schlampp, S. Schneider, and W. Werner. “Fossilien aus dem Riffschuttkalk des Kimmeridgium (Oberjura) von Saal a. d. Donau bei Kelheim (Bayern)". German. In: Der Steinkern 30 (2017), pp. 4-113.

[12951] B. Lange-Badré. “Découverte d'empreintes de pas de dinosaures dans le Jurassique supérieur des Causses du Quercy (Lot, France) [Discovery of dinosaur footprints from the Upper Jurassic of the Causses du Quercy (Lot, France)]". French. In: Comptes Rendus de l'Académie des Sciences á Paris, Série IIa 323 (1996), pp. 89-96.

[12952] B. Lange-Badré and M. Böhme. "Apterodon intermedius, sp. nov., a new European Creodont Mammal from MP22 of Espenhain (Germany)". English. In: Annales de Paléontologie 91 (2005), pp. 311-328.

[12953] B. Lange-Badré and J.-P. Laffon. “Découverte de pistes de dinosaures théropodes dans le Lias inférieur des environs de Figeac (Lot)". French. In: Comptes Rendus de l'Academie des Sciences, Paris. Sciences de la Terre et des Planétes 330 (2000), pp. 379-384.

[12954] M. Langer, M. Boniface, G. Cuny, and L. Barbieri. “The phylogenetic position of Isalorhynchus genovefae, a Late Triassic rhynchosaur from Madagascar". English. In: Annales de Paléontologie 86.2 (2000), pp. 101-127.

[12955] M. C. Langer. "Studies on continental Late Triassic tetrapod biochronology. I. The type locality of Saturnalia tupiniquim and the faunal succession in south Brazil". English. In: Journal of South American Earth Sciences 19 (2005), pp. 205-218.

[12956] M. C. Langer. “The first record of dinocephalians in South America: Late Permian (Rio do Rasto Formation) of the Parana Basin, Brazil”. English. In: Neues Jahrbuch für Geologie und Paläontologie, Abhandlungen 215.1 (2000), pp. 69-95.

[12957] M. C. Langer, F. Abdala, M. Richter, and M. J. Benton. "A sauropodomorph dinosaur from the Upper Triassic (Carnian) of southern Brazil". In: Comptes Rendus de l'Academie des Sciences, Paris: Sciences de la terre et des planétes 329 (1999), pp. 511-517.

[12958] M. C. Langer, N. Martins, P. C. Manzig, G. S. Ferreira, J. C. Marsola, E. Fortes, R. Lima, L. C. F. Sant'ana, L. S. Vidal, R. H. Lorençato, and M. D. Ezcurra. "A new desert-dwelling dinosaur (Theropoda, Noasaurinae) from the Cretaceous of south Brazil". English. In: Scientific Reports 9.9379 (2019).

[12959] M. C. Langer, F. C. Montefeltro, D. W. E. Hone, R. L. Whatley, and C. L. Schultz. “On Fodonyx spenceri and a new rhynchosaur from the Middle Triassic of Devon". English. In: Journal of Vertebrate Paleontology 30.6 (2010), pp. 1884-1888. 
[12960] M. C. Langer, A. M. Ribeiro, C. L. Schultz, and J. Ferigolo. The continental tetrapod-bearing Triassic of south Brazil. English. Vol. 41. The Global Triassic, New Mexico Museum of History and Science Bulletin. 2007, pp. 201-218.

[12961] M. C. Langer, A. D. Rincón, J. Ramezani, A. Solórzano, and O. W. M. Rauhut. "New dinosaur (Theropoda, stem-Averostra) from the earliest Jurassic of the La Quinta Formation, Venezuelan Andes". English. In: Royal Society Open Science 1.2 (2014), pp. 1-15. DOI: 10.1098/rsos.140184.

[12962] M. C. Langer and C. L. Schultz. "A new species of the Late Triassic rhynchosaur Hyperodapedon from the Santa Maria Formation of south Brazil". English. In: Palaeontology 43.4 (2000), pp. 633652.

[12963] K.-P. Lanser and U. Heinhofer. "Evidence of theropod dinosaurs from a Lower Cretaceous karst filling in the northern Sauerland (Rhenish Massif, Germany)". English. In: Palaeontologische Zeitschrift 89 (2015), pp. 79-94. DOI: 10.1007/s12542-013-0215-z.

[12964] J. S. LaPolla. “Ancient Trophophoresy: A Fossil Acropyga (Hymenoptera: Formicidae) from Dominican Amber". English. In: Transactions of the American Entomological Society 131.1/2 (2005), pp. 21-28.

[12965] J. S. LaPolla and P. Barden. "A new aneuretine ant from the Paleocene Paskapoo Formation of Canada". English. In: Acta Palaeontologica Polonica 63 (2018), pp. 435-440.

[12966] J. S. LaPolla and G. M. Dlussky. "Review of fossil Prenolepis genus-group species (Hymenoptera: Formicidae)". English. In: Proceedings of the Entomological Society of Washington 112 (2010), pp. 258273.

[12967] J. S. LaPolla and D. E. Greenwalt. "Fossil ants (Hymenoptera: Formicidae) of the Middle Eocene Kishenehn Formation". English. In: Sociobiology 62 (2015), pp. 163-174.

[12968] J. S. LaPolla, R. J. Kallal, and S. G. Brady. "A new ant genus from the Greater Antilles and Central America, Zatania (Hymenoptera: Formicidae), exemplifies the utility of male and molecular character systems". English. In: Systematic Entomology 37 (2012), pp. 200-214.

[12969] F. Lapparent de Broin. "The European turtle fauna from the Triassic to the Present". English. In: Dumerilia 4.3 (2001), pp. 155-217.

[12970] F. Lapparent de Broin. “Neochelys sp. (Chelonii, Erymnochelyinae), from Silveirinha, early Eocene, Portugal". English. In: Ciencias da Terra (UNL) 15 (2003), pp. 117-132.

[12971] F. Lapparent de Broin and R. E. Molnar. "Eocene chelid turtles from Redbank Plains, Southeast Queensland". English. In: Geodiversitas 23.1 (2001), pp. 41-79.

[12972] F. Lapparent de Broin and X. Murelaga. "Turtles from the Upper Cretaceous of Lano (Iberian Peninsula)". English. In: Estudios del Museo de Ciencias Naturales de Alava 14.1 (1999), pp. 135-211.

[12973] F. Lapparent de Broin and C. Werner. "New Late Cretaceous turtles from the Western Desert, Egypt". English. In: Annales de Paléontologie 84.2 (1998), pp. 131-214. DOI: 10.1016/S0753-3969(98) 80005-0.

[12974] F.d. Lapparent de Broin. "The oldest pre-Podocnemidid turtle (Chelonii, Pleurodira), from the early Cretaceous, Ceará state, Brasil, and its environment". English. In: Treballs del Museu de Geologia de Barcelona 9 (2000), pp. 43-95.

[12975] F.d. Lapparent de Broin, B. Lange-Badré, and M. Dutrieux. "Nouvelles decouvertes de tortues dans le Jurassique Supérieur du Lot (France) et examen du taxon Plesiochelyidae". English. In: Revue de Paléobiologie 15.2 (1996), pp. 533-570.

[12976] F.d. Lapparent de Broin, X. Murelaga Bereikua, and V. Codrea. "Presence of Dortokidae (Chelonii, Pleurodira) in the earliest Tertiary of the Jibou Formation, Romania: paleobiogeographical implications". English. In: Acta Palaeontologica Romaniae 4 (2004), pp. 203-215.

[12977] F.de Lapparent de Broin and M. S. de la Fuente. “Oldest world Chelidae (Chelonii, Pleurodira), from the Cretaceous of Patagonia, Argentina". English. In: C. R. Acad. Sci. Paris, Sciences de la Terre et des planétes 333 (2001), pp. 463-470. 
[12978] C. Laprida, G. Bozzano, R. Garberoglio, and R. A. Violante. “Late Cenozoic fossil cold-water coral concentrations and mounds on the". English. In: Conference: 2nd Deep-Water Circulation Congress, At Ghent, Belgium (2014).

[12979] M. B. Lara and D. Aristov. "First records of Geinitziidae (Insecta: Grylloblattida) from the Upper Triassic of Argentina (Mendoza)". English. In: Alcheringa 41 (2017), pp. 207-214.

[12980] M. B. Lara, A. Bashkuev, and B. Wang. “Argentinopanorpa miguezi gen. et sp. nov.: first record of Triassic Mecoptera (Permochoristidae) from the Cuyo Basin (Mendoza, Argentina)". English. In: Alcheringa 39 (2015), pp. 175-180.

[12981] M. B. Lara, B. Cariglino, and A. M. Zavattieri. "Palaeoenvironmental interpretation of an Upper Triassic deposit in Southwestern Gondwana (Argentina) based on an insect fauna, plant assemblage and their interactions. Palaeogeographic, Palaeoclimatology and Palaeoecology 476: 163180". English. In: (2017).

[12982] M. B. Lara and E. D. Lukashevich. "The first Triassic dipteran (Insecta) from South America, with review of Hennigmatidae". English. In: Zootaxa 3710 (2013), pp. 81-92.

[12983] M. B. Lara, A. P. Rasnitsyn, and A. M. Zavattieri. “Potrerilloxyela menendezi gen. et sp. nov. from the Late Triassic of Argentina: the oldest representative of Xyelidae (Hymenoptera: Symphyta) for Americas". English. In: Paleontological Journal 48 (2014), pp. 182-190.

[12984] M. B. Lara and B. Wang. "New hemipteran insects (Eoscarterellidae, Scytinopteridae, and Protopsyllidiidae) from the Upper Triassic Potrerillos Formation of Mendoza, Argentina". English. In: PalZ 90 (2016), pp. 49-61.

[12985] M. B. Lara and A. Bashkuev. “New Triassic Hemiptera and Mecoptera from south-western Gondwana (Potrerillos Formation, Mendoza Province,Argentina)". English. In: Palaeontographica Abteilung A 317.1-6 (2020), pp. 139-163. DOI: 10.1127/pala/2020/0099.

[12986] C. Larghi. "Brachyuran decapod Crustacea from the Upper Cretaceous of Lebanon". English. In: Journal of Paleontology 78.3 (2004), pp. 528-541.

[12987] C. Larghi. "Dickinsartella fauna from the Saiwan Formation (Oman): a bivalve fauna testifying to the late Sakmarian (Early Permian) climatic amelioration along the north-eastern Gondwanan fringe". English. In: Rivista Italiana di Paleontologia e Stratigrafia 111.3 (2005), pp. 353-375.

[12988] C. Larghi. "Marmaronia angiolinii, new genus and new species of Bakevelliidae (Pterioida, Bivalvia) from the Middle Permian of Chios (Greece)". English. In: Rivista Italiana di Paleontologia e Stratigrafia 108 (2002), pp. 359-368.

[12989] C. Larghi, M. Balini, and V. Torti. "A new Daonella from the Ladinian platform of the Esino Limestone (Southern Alps, Italy)”. English. In: Rivista Italiana di Paleontologia e Stratigrafia 12.1 (2006), pp. 167-174.

[12990] E. Larina, M. Garb, N. Landman, N. Dastas, N. Thibault, L. Edwards, G. Phillips, R. Rovelli, C. Myers, and J. Naujokaityte. "Upper Maastrichtian ammonite biostratigraphy of the Gulf Coastal Plain (Mississippi Embayment, southern USA)". English. In: Cretaceous Research 60 (2016), pp. 128151. DOI: $10.1016 /$ j.cretres.2015.11.010.

[12991] D. W. Larson, D. B. Brinkman, and P. R. Bell. "Faunal assemblages from the upper Horseshoe Canyon Formation, an early Maastrichtian cool-climate assemblage from Alberta, with special reference to the Albertosaurus sarcophagus bonebed". English. In: Canadian Journal of Earth Sciences 47 (2010), pp. 1159-1181. DOI: 10.1139/E10-005.

[12992] D. W. Larson and P. J. Currie. "Multivariate analyses of small theropod dinosaur teeth and implications for paleoecological turnover through time". English. In: PLoS ONE 8.1 (2013), e54329:1-14. DOI: 10.1371/journal.pone.0054329.

[12993] D. W. Larson, N. R. Longrich, D. C. Evans, and M. J. Ryan. “A new species of Neurankylus from the Milk River Formation (Cretaceous: Santonian) of Alberta, Canada, and a revision of the type species N. eximius". English. In: Morphology and Evolution of Turtles. 2013, pp. 389-405. 
[12994] N. L. Larson. "Fossil coleoids from the Late Cretaceous (Campanian \& Maastrichtian) of the Western Interior". English. In: Ferrantia 59 (2010), pp. 78-113.

[12995] C. M. Larsson, C. B. Skovsted, G. A. Brock, U. Balthasar, T. P. Topper, and L. E. Holmer. "<i>Paterimitra pyramidalis $</ i>$ from South Australia: scleritome, shell structure and evolution of a lower Cambrian stem group brachiopod". English. In: Palaeontology 57.2 (2014), pp. 417-446. DOI: 10.1111/ pala.12072.

[12996] H. C. E. Larsson and B. Gado. "A new Early Cretaceous crocodyliform from Niger". English. In: Neues Jahrbuch für Geologie und Paläontologie - Abhandlungen 217.1 (2000), pp. 131-141.

[12997] H. C. E. Larsson and C. A. Sidor. "Unusual crocodyliform teeth from the Late Cretaceous (Cenomanian) of southeastern Morocco". English. In: Journal of Vertebrate Paleontology 19.2 (1999), pp. 398401.

[12998] H. C. E. Larsson and H.-D. Sues. "Cranial osteology and phylogenetic relationships of Hamadasuchus rebouli (Crocodyliformes: Mesoeucrocodylia) from the Cretaceous of Morocco". English. In: Zoological Journal of the Linnean Society 149 (2007), pp. 533-567.

[12999] Z. Lasemi and R. D. Norby. "Mississippian carbonate buildups and development of cool-waterlike carbonate platforms in the Illinois Basin, Midcontinent U.S.A." English. In: in W. M. Ahr, P. M. Harris, W. A. Morgan, I. D. Somerville, eds., Permo-Carboniferous carbonate platforms and reefs. SEPM Special Publication 78 (2003), pp. 69-95.

[13000] R. A. Lashari, P. Usmani, M. A. Baryar, and H. Naz. "Distribution and affinities of the ostracod fauna of the Tiyon Formation (Middle Eocene) of Laki Range, Sindh". English. In: Sindh University Research Journal (Science Series) 41.1 (2009), pp. 41-46.

[13001] J. Laskovas, V. Marcinkevicius, and J. Paskevicius. “The Stratigraphy and Structure of Ordovician Rocks of the South - East Part of the Baltic Basin (Druksiu Area)". Russian. In: Geologija, Detailed Stratigraphy 14 (1993), pp. 81-98.

[13002] M. Lasseron, R. Allain, E. Gheerbrant, H. Haddoumi, N. -E. Jalil, G. Métais, J. -C. Rage, R. Vullo, and S. Zouhri. "New data on the microvertebrate fauna from the Upper Jurassic or lowest Cretaceous of Ksar Metlili (Anoual Syncline, eastern Morocco)". English. In: Geological Magazine (2019), pp. 1-26. DOI: 10.1017/S0016756819000761.

[13003] B. Lathuiliére. "Coraux constructeurs du Bajocien inférieur de France. 1ére Partie". French. In: Géobios 33 (2000), pp. 51-72.

[13004] B. Lathuiliére. "Coraux constructeurs du Bajocien inférieure de France. 2éme Partie". French. In: Géobios 33 (2000), pp. 153-181.

[13005] B. Lathuiliere, C. Gaillard, N. Habrant, Y. Bodeur, A. Boullier, R. Enay, M. Hanzo, D. Marchand, J. Thierry, and W. Werner. "Coral zonation of an Oxfordian reef tract in the northern French Jura". English. In: Facies 50 (2005), pp. 545-559.

[13006] K. Latif, E. Xiao, M. Riaz, and A. A. Hussein. "Calcified cyanobacteria fossils from the leiolitic bioherm in the Furongian Changshan Formation, Datong (North China Platform)". English. In: Carbonates and Evaporites (2018). DOI: 10.1007/s13146-018-0472-8.

[13007] A. E. Latimer and S. Giles. "A giant dapediid from the Late Triassic of Switzerland and insights into neopterygian phylogeny". English. In: Royal Society Open Science 5 (2018), p. 180497.

[13008] E. M. Latimer, P. J. Hancox, B. S. Rubidge, M. A. Shishkin, and J. W. Kitching. "The temnospondyl amphibian Uranocentrodon, another victim of the end-Permian extinction event". English. In: South African Journal of Science 98.3-4 (2002), pp. 191-193.

[13009] P. Latorre Macarrón, C. Pascual Arribas, E. Sanz Pérez, and N. Hernández Medrano. “El yacimiento con huellas de saurópodos de Miraftores 1, Fuentes de Magaña (Soria, España) [The sauropod ichnite site of Miraflores 1, Fuentes de Magaña (Soria, Spain)]". Spanish. In: III Jornadas Internacionales sobre Paleontologa de Dinosaurios y su Entorno Actas (2006), pp. 273-296.

[13010] E. M. Latrubesse, M. Cozzuol, S. A. F. da Silva-Caminha, C. A. Rigsby, M. L. Absy, and C. Jaramillo. "The Late Miocene paleogeography of the Amazon Basin and the evolution of the Amazon River system". English. In: Earth-Science Reviews 99 (2010), pp. 99-124. 
[13011] P. Lattig and S. D. Cairns. "A new species of Tethocyathus (Cnidaria: Anthozoa: Scleractinia: Caryophylliidae), a trans-isthmian azooxanthellate species". English. In: Proceedings of the Biological Society of Washington 113.3 (2000), pp. 590-595.

[13012] J. E. Lattke. “The genus Platythyrea Roger, 1863 in Dominican Amber (Hymenoptera: Formicidae: Ponerinae)". English. In: Entomotropica 18.2 (2003), pp. 107-111.

[13013] J. E. Lattke. “Nuevas especies de Gnamptogenys Roger, 1863 de América (Hymenoptera: Formicidae: Ponerinae)". Spanish. In: Entomotropica 17 (2002), pp. 135-144.

[13014] J. E. Lattke. "The genus Proceratium in Dominican amber (Hymenoptera: Formicidae)". English. In: Caribbean Journal of Science 26 (1991), pp. 101-103.

[13015] J. E. Lattke and G. A. R. Melo. “New haidomyrmecine ants (Hymenoptera: Formicidae) from midCretaceous amber of northern Myanmar". English. In: Cretaceous Research 114.104502 (2020). DOI: 10.1016/j.cretres.2020.104502.

[13016] K. Lauprasert, G. Cuny, E. Buffetaut, V. Suteethorn, and K. Thirakhupt. "Siamosuchus phuphokensis, a new goniopholidid from the Early Cretaceous (ante-Aptian) of northeastern Thailand". English. In: Bulletin de la Société Géologique de France 178.3 (2007), pp. 201-216.

[13017] K. Lauprasert, G. Cuny, K. Thirakhupt, and V. Suteethorn. Khoratosuchus jintasakuli gen. et sp. nov., an advanced neosuchian crocodyliform from the Early Cretaceous (Aptian-Albian) of NE Thailand. English. Vol. 315. Late Palaeozoic and Mesozoic Ecosystems in SE Asia. The Geological Society of London, Special Publication. 2009, pp. 175-187.

[13018] K. Lauprasert, C. Laojumpon, W. Saenphala, G. Cuny, K. Thirakhupt, and V. Suteethorn. “Atoposaurid crocodyliforms from the Khorat Group of Thailand: first record of Theriosuchus from Southeast Asia". English. In: Paläontologische Zeitschrift 85 (2011), pp. 37-47. DOI: 10.1007/s12542010-0071-z.

[13019] K. Lauprasert, P. Watchajittaphan, S. Juanngam, and S. Bhuttarach. "Freshwater crocodile, Crocodylus siamensis Schneider, 1801, from the Middle Pleistocene deposits in Chaloem Phrakiat District, Nakhon Ratchasima, Thailand". English. In: Annales de Paléontologie 105 (2019), pp. 269-274.

[13020] Y. Laurent. "Les faunes de vertébrés continentaux du Maastrichtien supérieur d'Europe: systématique et biodiversité [The continental vertebrate faunas of the upper Maastrichtian of Europe: systematics and biodiversity]". French. In: Strata, Série 241 (2003), pp. 1-81.

[13021] Y. Laurent, S. Adnet, E. Bourdon, D. Corbalan, L. Danilo, S. Duffaud, G. Fleury, G. Garcia, M. Godinot, G. Le Roux, C. Maisonnave, G. Métais, C. Mourer-Chauviré, B. Presseq, B. Sigé, and F. Solé. “La Borie (Saint-Papoul, Aude) : un gisement exceptionnel dans l’Éocéne basal du Sud de la France". French. In: Bulletin de la Société d'Histoire Naturelle de Toulouse 146 (2010), pp. 89-103.

[13022] Y. Laurent, M. Bilotte, and J. Le Loeuff. "Late Maastrichtian continental vertebrates from southwestern France: correlation with marine fauna". English. In: Palaeogeography, Palaeoclimatology, Palaeoecology 187 (2002), pp. 121-135.

[13023] Y. Laurent, L. Cavin, and M. Bilotte. “Découverte d'un gisement á vertébrés dans le Maastrichtien supérieur des Petites-Pyrénées [Discovery of a vertebrate locality in the upper Maastrichtian of the Petites-Pyrenees]". French. In: Comptes Rendus de l'Académie des Sciences á Paris, Sciences de la Terre et des Planétes 628 (1999), pp. 781-787.

[13024] Y. Laurent, H. Tong, and J. Claude. "New side-necked turtle (Pleurodira: Bothremydidae) from the Upper Maastrichtian of the Petites-Pyrenees (Haute-Garonne, France)". English. In: Cretaceous Research 23 (2002), pp. 465-471.

[13025] A. Lauriat-Rage, R.-P. Carriol, P. Lozouet, A. Giret, and H. Leyrit. "Mlocene molluscs and barnacles from Mont Rond, Kerguelen Islands". English. In: Alcheringa 26 (2002), pp. 275-287.

[13026] B. W. Lauridsen and K. I. Schnetler. "A catalogue of Danian gastropods from the Baunekule facies, Faxe Formation, Denmark". English. In: Geological Survey of Denmark \& Greenland Bulletin 32 (2014), pp. 1-117. 
[13027] J. R. Laurie. "Silicified Late Cambrian brachiopods from the Georgina Basin, western Queensland". English. In: Alcheringa 21 (1997), pp. 179-189.

[13028] J. R. Laurie. "Articulate brachiopods from the Ordovician and Lower Silurian of Tasmania". English. In: Association of Australasian Palaeontologists Memoir 11 (1991), pp. 1-106.

[13029] J. R. Laurie. "Early Ordovician fauna of the Gap Creek Formation, Canning Basin, Western Australia". English. In: Journal of Australian Geology E Geophysics 16.5 (1997), pp. 701-716.

[13030] J. R. Laurie. "Ordovician trilobites from the Horn Valley Siltstone and basal Stairway Sandstone, Amadeus Basin, Northern Territory". English. In: Memoirs of the Association of Australasian Palaeontologists 32 (2006), pp. 287-345.

[13031] J. R. Laurie and C. Burrett. "Biogeographic significance of Ordovician brachiopods from Thailand and Malaysia". English. In: Journal of Paleontology 66.1 (1992), pp. 16-23. DOI: 10.1017 / S0022336000033448.

[13032] J. R. Laurie and J. H. Shergold. "Early Ordovician trilobite taxonomy and biostratigraphy of the Emanuel Formation, Canning Basin, western Australia. Part 1". English. In: Palaeontographica Abteilung A 240.1-3 (1996), pp. 65-103.

[13033] M. Laurin. "The osteology of a Lower Permian eosuchian from Texas and a review of diapsid phylogeny". English. In: Zoological Journal of the Linnean Society 101.1 (1991), pp. 59-95.

[13034] M. Laurin, F.-J. Meunier, D. Germain, and M. Lemoine. "A microanatomical and histological study of the paired fin skeleton of the Devonian sarcopterygian Eusthenopteron foordi". English. In: Journal of Paleontology 81.1 (2007), pp. 143-154. DOI: 10.1666/0022-3360(2007)81[143:AMAHSO]2. $0 . \mathrm{CO} ; 2$.

[13035] M. Laurin and R. Soler-Gijón. "The oldest stegocephalian from the Iberian Peninsula: evidence that temnospondyls were euryhaline". English. In: Comptes Rendus de l'Académie des Sciences - Series III - Sciences de la Vie 324 (2001), pp. 495-501. DOI: 10.1016/S0764-4469(01)01318-X.

[13036] C. A. Laurito. "Análisis topológico y sistemático del toxodonte de Bajo de los Barrantes, Provincia de Alajuela, Costa Rica". Spanish. In: Revista Geológica de América Central 16 (1993), pp. 61-68.

[13037] C. A. Laurito and D. H. Aguilar. "El registro de Mammuthus (Proboscidea, Elephantidae) en la República de El Salvador, América Central". Spanish. In: Revista Geológica de América Central 34 (2007), pp. 73-81.

[13038] C. A. Laurito, C. Calvo, A. L. Valerio, A. Calvo, and R. .Chacón. "Ictiofauna del Mioceno inferior de localidad de Pacuare des Tres Equis, Formación Ro Banao, Provincia de Cartago, Costa Rica, y descripción de un nuevo género y una Nueva Especie de Scaridae". Spanish. In: Revista Geológica de América Central 50 (2014), pp. 153-192.

[13039] C. A. Laurito and M. J. Mora. "Nuevo registro fósil de Aturia cubaensis (Lea, 1841) [Cephalopoda, Nautilidae] para el Mioceno inferior - medio de Costa Rica". Spanish. In: Revista Geológica de América Central 58 (2018), pp. 171-178.

[13040] C. A. Laurito, A. L. Valerio, A. C. Hernandez, and E. Ovares. "Primer registro de un cetaceo fosil (Mammalia, Cetacea, Odontoceti, Squalodontidae) en la Formacion Rio Banano, Mioceno medio de Costa Rica, America Central". Spanish. In: Revista Geologica de America Central 44 (2011), pp. 153-156.

[13041] C. A. Laurito and A. L. Valerio. "The first record of Gavialosuchus americanus Sellards (1915)† (Eusuchia: Crocodylidae, Tomistominae) for the Late Tertiary of Costa Rica and Central America". English. In: Revista Geológica de América Central 39 (2008), pp. 107-115.

[13042] C. A. Laurito and A. L. Valerio. "Paleobiogeografa del arribo de mamferos suramericanos al sur de América Central de previo al Gran Intercambio Biótico Americano: un vistazo al GABI en América Central". English. In: Revista Geológica de América Central 46 (2012), pp. 123-144.

[13043] C. A. Laurito and A. L. Valerio. "Scirrotherium antelucanus, una nueva especie de Pampatheriidae (Mammalia, Xenarthra, Cingulata) del Mioceno superior de Costa Rica, América Central". Spanish. In: Revista Geológica de América Central 49 (2013), pp. 45-62. 
[13044] C. A. Laurito, A. L. Valerio, and E. A. Pérez Gamboa. “Los Xenarthras fósiles de la localidad de Buenos Aires de Palmares (Blancano tardo- Irvingtoniano temprano), provincia de Alajuela, Costa Rica". Spanish. In: Revista Geológica de América Central 33 (2005), pp. 83-90.

[13045] C. A. Laurito and A. L. Valerio. "Camellos Laminos del Mioceno tardo (Henfiliano temprano) de la Formación Curré, San Gerardo de Limoncito, Cantón de Coto Brus, Provincia de Puntarenas, Costa Rica". Spanish. In: Revista Geológica de América Central 54 (2016), pp. 7-55.

[13046] C. A. Laurito and A. L. Valerio. Los caballos fósiles de la Formación Curré, Cantón de Coto Brus, Costa Rica. Spanish. San José: Museo Nacional de Costa Rica, 2010, pp. 1-131.

[13047] C. M. Laurito, A. L. Valerio, L. D. Gomez, J. I. Mead, E. A. Perez, and L. G. Perez. "A Trionychidae (Reptilia: Testudines, Cryptodira) from the Pliocene of Costa Rica, Southern Central America". English. In: Revista Geologica de America Central 32 (2005), pp. 7-11.

[13048] A. Laviano and P. W. Skelton. "Favus antei, a new genus and species of a bizarre big cell radiolitid from the Upper Cretaceous of eastern Tethys". English. In: Geologica Romana 28 (1992), pp. 61-77.

[13049] F. J. Lavié and J. L. Benedetto. "First lingulate brachiopods from the Ordovician volcano-sedimentary". English. In: Palaeontologische Zeitschrift 94 (2020), pp. 295-309.

[13050] A. V. Lavrov. "New Species of Paroxyaena (Hyaenodontidae, Creodonta) from Phosphorites of Quercy, Late Eocene, France". English. In: Paleontological Journal 41.3 (2007), pp. 298-311.

[13051] A. V. Lavrov and A. O. Averianov. "The Oldest Asiatic Hyaenodontidae (Mammalia, Creodonta) from the Early Eocene of the Southern Fergana Basin (Andarak-2 Locality)". English. In: Paleontological Journal 32.2 (1998), pp. 200-205.

[13052] A. V. Lavrov and R. J. Emry. "Hyaenodon venturae (Hyaenodontidae, Creodonta, Mammalia) from the early Chadronian (latest Eocene) of Wyoming". English. In: Journal of Paleontology 72.4 (1998), pp. 752-757.

[13053] A. V. Lavrov and A. V. Lopatin. "A New Species of Arfia (Hyaenodontidae, Creodonta) from the Basal Eocene of Mongolia". English. In: Paleontological Journal 38.4 (2004), pp. 448-457.

[13054] O. Lawal. "Palynological age and correlation of a black shale section in the Eze-Aku Formation, Lower benue Trough, Nigeria". English. In: Journal African Earth Sciences 12.3 (1991), pp. 473-482.

[13055] J. F. Lawrence, S. B. Archibald, and A. lipiski. "A new species of Prionoceridae (Coleoptera: Cleroidea) from the Eocene of British Columbia, Canada". English. In: Annales Zoologici 58 (2008), pp. 689-693.

[13056] J. F. Lawrence, R. A. B. Leschen, and A. lipiski. "Antillipeltis, a new genus of Antillean Trogossitidae (Coleoptera: Cleroidea) with a key to the Cleroidea". English. In: Zootaxa 3794 (2014), pp. 435454.

[13057] D. R. Lawver, A. J. M. Debee, J. A. Clarke, and G. W. Rougier. "A new enantiornithine bird from the Upper Cretaceous La Colonia Formation of Patagonia, Argentina". English. In: Annals of Carnegie Museum 80.1 (2011), pp. 35-42.

[13058] D. R. Lawver, X. Jin, F. D. Jackson, and Q. Wang. “An avian egg from the Lower Cretaceous (Albian) Liangtoutang Formation of Zhejiang Province, China". English. In: Journal of Vertebrate Paleontology 36.3 (2016), e1100631:1-7. DOI: 10.1080/02724634.2016.1100631.

[13059] K. M. Layou. "Ecological restructuring after extinction: the Late Ordovician (Mohawkian) of the eastern United States". English. In: Palaios 24 (2009), pp. 118-128. DOI: 10.2110/palo.2009.p08-12r.

[13060] D. F. Lazar, I. I. Bucur, I. Cociuba, and E. Sasaran. "Sedimentary succession of the Lower Cretaceous deposits from the north-western part of Pdurea Craiului (Apuseni Mountains, Romania)". English. In: Studia UBB Geologia 57.1 (2012), pp. 33-51.

[13061] I. Lazar. "The Jurassic bivalve fauna from the western side of the Bucegi Mountains, part 1 subclasses Palaeotaxodonta and Pteriomorphia (Orders Arcoida, Pterioida, Limoida)". English. In: Acta Palaeontologica Romaniae 4 (2004), pp. 217-231. 
[13062] I. Lazar. "The Jurassic bivalve fauna from the western side of the Bucegi Mountains, part II subclass Pteriomorphia (Order Pectinoida)". English. In: Acta Palaeontologica Romaniae 5 (2005), pp. 277-294.

[13063] I. Lazar, V. Barbu, and M. E. Popa. "Contributions to the Middle Jurassic of the Anina area - The bivalve fauna (part 1)". English. In: Acta Palaeontologica Romaniae 4 (2004), pp. 233-246.

[13064] N. P. Lazarenko, I. Y. Gogin, T. V. Pegel, and G. P. Abaimova. “The Khos-Nelege section of the Ogon'or Formation: a potential candidate for the GSSP of stage 10, Cambrian System". English. In: Bulletin of Geosciences 86.3 (2011), pp. 555-568.

[13065] S. S. Lazarev. "Revision of the brachiopod family Schrenkiellidae Lazarev, 1990". English. In: Paleontological Journal 38.2 (2004), pp. 154-161.

[13066] S. S. Lazarev. "Brachiopods of the Tribe Horridoniini (Order Productida): 2. Evolution and Systematics". English. In: Paleontological Journal 39.2 (2005), pp. 148-157.

[13067] S. S. Lazarev. "Evolution and systematics of late Paleozoic brachiopod family Linoproductidae with descriptions of species from the Lower Permian of the northern Timan". English. In: Paleontological Journal 44.2 (2010), pp. 140-150.

[13068] S. S. Lazarev. "Brachiopods of the subfamily Chaoiellinae subfam. nov.: phylogeny and position in the Productidin systematics". English. In: Paleontological Journal 45.1 (2011), pp. 23-34.

[13069] S. S. Lazarev and J. L. Carter. "New Atokan productoid brachiopods from the Upper Carboniferous Ladrones Limestone of southeastern Alaska, with a preliminary note on the phylogeny and classification of the tribe Retariini". English. In: Annals of Carnegie Museum 69.1 (2000), pp. 11-21.

[13070] G. Lazaridis, D. S. Kostopoulos, G. Lyras, and S. Roussiakis. “A new Late Miocene ovibovine-like bovid (Bovidae, Mammalia) from the Kassandra Peninsula (Chalkidiki, Northern Greece) and implications to the phylogeography of the group". English. In: Palaeontologische Zeitschrift 91 (2017), pp. 427-437. DOI: 10.1007/s12542-017-0360-x.

[13071] G. Lazaridis and E. Tsoukala. "Hipparion phlegrae, sp. nov. (Mammalia, Perissodactyla): a new species from the Turolian locality of Kryopigi (Kassandra, Chalkidiki, Greece)". English. In: Journal of Vertebrate Paleontology 34.1 (2014), pp. 164-178.

[13072] G. Lazaridis, E. Tsoukala, T. C. Rae, A. Gomez-Olivencia, D. Nagel, and A. Bartsiokas. "Mesopithecus pentelicus from the Turolian locality of Kryopigi (Kassandra, Chalkidiki, Greece)". English. In: Journal of Human Evolution (2018), pp. 1-19. DOI: 10.1016/j.jhevol.2018.04.003.

[13073] G. Lazaridis and E. Tsoukala. Tetralophodon longirostris (Kaup, 1832) from Late Miocene of the Kassandra peninsula (Chalkidiki, Greece). English. 2014.

[13074] G. Lazaridis, E. Tsoukala, and L. C. Maul. “The earliest Hystrix refossa: a new Early Villafranchian record from Milia (Grevena, Macedonia, Greece)". English. In: Hystrix, the Italian Journal of Mammalogy (2019), pp. 1-7. DOI: 10.4404/hystrix00140-2018.

[13075] J. Lazell. "Tortoise, cf. Geochelone carbonaria, from the Pleistocene of Anguilla, Northern Lesser Antilles". English. In: Journal of Herpetology 27.4 (1993), pp. 485-486.

[13076] D. G. Lazo. "Taxonomy, facies relationships and palaeobiology of bakevelliid bivalves from the Lower Cretaceous of west-central Argentina". English. In: Cretaceous Research 24.6 (2003), pp. 765788.

[13077] D. G. Lazo. "The genus Steinmanella (Bivalvia, Trigonioida) in the lower member of the Agrio Formation (Lower Cretaceous), Neuquen Basin, Argentina." English. In: Journal of Paleontology 77.6 (2003), pp. 1069-1085.

[13078] D. G. Lazo and M. Cichowolski. "First plesiosaur remains from the Lower Cretaceous of the Neuquen Basin, Argentina". English. In: Journal of Paleontology 77.4 (2003), pp. 784-789.

[13079] D. G. Lazo and S. E. Damborenea. "Barremian Bivalves From the Huitrn Formation, West-Central Argentina: Taxonomy and Paleoecology Of A Restricted Marine Association". English. In: Journal of Paleontology 85.4 (2011), pp. 721-749. 
[13080] J. Le Loeuff. “Ampelosaurus atacis (nov, gen., nov. sp.), un nouveau Titanosauridae (Dinosauria, Sauropoda) du Crétacé supérieur de la Haute Vallée de l'Aude (France) [Ampelosaurus atacis (nov, gen., nov. sp.), a new titanosaurid (Dinosauria, Sauropoda) from the Upper Cretaceous of the Upper Aude Valley (France)]". French. In: Comptes Rendus de l'Académie des Sciences á Paris, Série IIa 321 (1995), pp. 693-699.

[13081] J. Le Loeuff. “European titanosaurids”. English. In: Revue de Paléobiologie, Volume Spéciale 7 (1993), pp. 105-117.

[13082] J. Le Loeuff. Osteology of Ampelosaurus atacis (Titanosauria) from southern France. English. ThunderLizards: The Sauropodomorph Dinosaurs. Indiana University Press, Bloomington. 2005, pp. 115137.

[13083] J. Le Loeuff and E. Buffetaut. "A new dromaeosaurid theropod from the Upper Cretaceous of southern France". English. In: Oryctos 1 (1998), pp. 105-112.

[13084] J. Le Loeuff, E. Buffetaut, P. Méchin, and A. Méchin-Salessy. “The first record of dromaeosaurid dinosaurs (Saurischia, Theropoda) in the Maastrichtian of southern Europe: palaeobiogeographical implications". English. In: Bulletin de la Société géologique de la France 163.3 (1992), pp. 337-343.

[13085] J. Le Loeuff and E. Buffetaut. “Tarascosaurus salluvicus nov. gen., nov. sp., dinosaure théropode du Crétacé supérieur du sud de la France [Tarascosaurus salluvicus nov. gen., nov. sp., a theropod dinosaur from the Upper Cretaceous of southern France]". French. In: Géobios 25.5 (1991), pp. 585594.

[13086] J. Le Loeuff, E. Buffetaut, M. Martin, V. Martin, and H. Tong. “Découverte d'Hadrosauridae (Dinosauria, Ornithischia) dans le Maastrichtian des Corbiéres (Aude, France) [Discovery of Hadrosauridae (Dinosauria, Ornithischia) in the Maastrichtian of Corbiéres (Aude, France)]". French. In: Comptes Rendus de l'Academie des Sciences, Paris, Série II 316 (1993), pp. 1023-1029.

[13087] J. Le Loeuff, E. Buffetaut, and C. Merser. "Découverte d'un dinosaure sauropode tithonien dans la région de Cognac (Charente) [Discovery of a Tithonian sauropod dinosaur in the Cognac region (Charente)]". French. In: Géologie de la France 2 (1996), pp. 79-81.

[13088] J. Le Loeuff, E. Buffetaut, L. Cavin, M. Martin, V. Martin, and H. Tong. An armored titanosaurid sauropod from the Late Cretaceous of southern France and the occurrence of osteoderms in the Titanosauridae. English. Vol. 10. Aspects of Sauropod Paleobiology. GAIA. 1995, pp. 155-159.

[13089] J. Le Loeuff, E. Buffetaut, G. Cuny, Y. Laurent, M. Ouaja, C. Souillat, D. Srarfi, and H. Tong. Mesozoic continental vertebrates of Tunisia. English. Karlsruhe, 2000.

[13090] J. Le Loeuff and E. Buffetaut. “The evolution of Late Cretaceous non-marine vertebrate fauna in Europe". English. In: Sixth Symposium on Mesozoic Terrestrial Ecosystems and Biota, Short Papers (1995), pp. 181-184.

[13091] J. Le Loeuff, C. Gourrat, P. Landry, L. Hautier, R. Liard, C. Souillat, E. Buffetaut, and R. Enay. "Late Jurassic sauropod footprint sites of southern Jura (France)". English. In: Kaupia 14 (2005), pp. 27-31.

[13092] J. Le Loeuff, C. Gourrat, P. Landry, L. Hautier, R. Liard, C. Souillat, E. Buffetaut, and R. Enay. “A Late Jurassic sauropod tracksite from Southern Jura (France)". English. In: Comptes Rendus Palevol 5 (2006), pp. 705-709. DOI: 10.1016/j.crpv.2006.01.007.

[13093] J. Le Loeuff, M. G. Lockley, C. Meyer, and J. -P. Petit. “Discovery of a thyreophoran trackway in the Hettangian of central France". French. In: Comptes Rendus de l'Académie des Sciences á Paris, Sciences de la Terre et des Planétes 328 (1999), pp. 215-219.

[13094] J. Le Loeuff, E. Métais, D. B. Dutheil, J. L. Rubino, E. Buffetaut, F. Lafont, L. Cavin, F. Moreau, H. Tong, C. Blanpied, and A. Sbeta. "An Early Cretaceous vertebrate assemblage from the Cabao Formation of NW Libya". English. In: Geological Magazine 147.5 (2010), pp. 750-759. DOI: 10.1017/ S0016756810000178.

[13095] J. Le Loeuff and E. Métais. New stratigraphical data on North African spinosaurs. English. Aix en Provence, 2010. 
[13096] J. Le Loeuff, T. Saenyamoon, C. Souillat, V. Suteethorn, and E. Buffetaut. Mesozoic vertebrate footprints of Thailand and Laos. English. Vol. 315. Late Palaeozoic and Mesozoic Ecosystems in SE Asia. The Geological Society of London, Special Publication. 2009, pp. 245-254. DOI: 10.1144/SP315.17.

[13097] J. Le Loeuff, S. Suteethorn, and E. Buffetaut. "A new sauropod dinosaur from the Albian of Le Havre (Normandy, France)". English. In: Oryctos 10 (2013), pp. 23-30.

[13098] J. Le Loeuff, V. Suteethorn, and C. Souillat. "Tracks in the Triassic: new vertebrate footprints from Thailand". English. In: 6th Meeting of the European Association of Vertebrate Palaeontologists, Spisská Nová Ves. Abstracts (2008), pp. 58-59.

[13099] J. Le Menn and N. Spjeldnaes. “Un nouveau crinode Dimeocrinitidae (Camerata, Diplobathrida) de l'Ordovicien supérieur du Maroc: Rosfacrinus robustus nov. gen., nov. sp." French. In: Geobios 29.3 (1996), pp. 341-351.

[13100] J. Le Renard. "Sur la position systématique des Gastropoda Éocénes du bassin de Paris classés Parvisipho et Siphonalia". English. In: Cossmanniana 3 (1995), pp. 57-64.

[13101] J. Le Renard and J.-M. Pacaud. "Revision des mollusques paleogenes du Bassin de Paris. 5 - Commentaires sur l'index général des espéces". English. In: Cossmanniana 4 4.1-2 (1997), pp. 25-28.

[13102] J. Le Renard and J.-M. Pacaud. “Révision des Mollusques Paléogénes du Bassin de Paris. II - Liste des Références primaries des espécies". French. In: Cossmanniana 3.3 (1995), pp. 65-132.

[13103] J. Le Renard, B. Sabelli, and M. Taviani. “On Candinia (Sacoglossa: Juliidae), a new fossil genus of bivalved Gastropods". English. In: Journal of Paleontology 70.2 (1996), pp. 230-235.

[13104] J. P. Le Roux, D. M. Olivares, S. N. Nielsen, N. D. Smith, H. Middleton, J. Fenner, and S. E. Ishman. "Bay sedimentation as controlled by regional crustal behaviour, local tectonics and eustatic sealevel changes: Coquimbo Formation (Miocene-Pliocene), Bay of Tongoy, central Chile". English. In: Sedimentary Geology 184 (2006), pp. 133-153.

[13105] K. Le Verger, F. Solé, and S. Ladevéze. "Description of a new species of Cynodictis Bravard \& Pomel, 1850 (Carnivora, Mammalia) from the Quercy Phosphorites with comments on the use of skull morphology for phylogenetics". English. In: Geodiversitas 42.16 (2020), pp. 239-255.

[13106] L. G. Leahey, R. E. Molnar, K. Carpenter, L. M. Witmer, and S. W. Salisbury. “Cranial osteology of the ankylosaurian dinosaur formerly known as Minmi sp. (Ornithischia: Thyreophora) from the Lower Cretaceous Allaru Mudstone of Richmond, Queensland, Australia". English. In: PeerJ 3 (2015), e1475:1-47. DOI: 10.7717/peerj.1475.

[13107] L. G. Leahey and S. W. Salisbury. “First evidence of ankylosaurian dinosaurs (Ornithischia: Thyreophera) from the mid-Cretaceous (late Albian-Cenomanian) Winton Formation of Queensland, Australia". English. In: Alcheringa 37.2 (2013), pp. 249-257. DOI: 10.1080/03115518.2013.743703.

[13108] M. G. Leakey and C. Feibel. "Lothagam: a record of faunal change in the late Miocene of East Africa". English. In: Journal of Vertebrate Paleontology 16.3 (1996), pp. 556-570.

[13109] M. G. Leakey, P. S. Ungar, and A. Walker. "A new genus of large primate from the late Oligocene of Lothidok, Turkana District, Kenya". English. In: Journal of Human Evolution 28.6 (1995), pp. 519 531.

[13110] L. A. Leal, S. A. K. Azevedo, A. W. A. Kellner, and A. A. S. Da Rosa. "A new early dinosaur (Sauropodomorpha) from the Caturrita Formation (Late Triassic), Paraná Basin, Brazil". In: Zootaxa 690 (2004), pp. 1-24.

[13111] H. Leanza, A. Zeiss, A. Cione, W. C. Dullo, E. Flugel, J. I. Carate-Zubillaga, and Z. Gasparini. “Upper Jurassic Lithographic Limestones from Argentina (Neuquen Basin): Stratigraphy and Fossils". English. In: Facies 22 (1990), pp. 169-186.

[13112] H. A. Leanza. "A new species of Steinmanella Crickmay (Bivalvia-Trigonioida) from the Lower Cretaceous of the Neuquen Basin, Argentina". Spanish. In: Revista Geologica de Chile 25.1 (1998), pp. 57-67. 
[13113] H. A. Leanza, S. Apesteguia, F. E. Novas, and M. S. de la Fuente. “Cretaceous terrestrial beds from the Neuquen Basin (Argentina) and their tetrapod assemblages". English. In: Cretaceous Research 25 (2004), pp. 61-87.

[13114] Z. M. A. Leao, R. K. P. Kikuchi, L. X. C. Dutra, and M. D. M. Oliveira. “The status of eastern Brazil coral reefs during the last 5000 years". English. In: Proceedings of the 10th International Coral Reef Symposium (2006), pp. 959-968.

[13115] Z. M. A. Leao and R. K. P. Kikuchi. “A relic coral fauna threatened by global changes and human activities, eastern Brazil". English. In: Marine Pollution Bulletin 51 (2005), pp. 599-611.

[13116] J. M. Leardi and D. Pol. "The rst crocodyliform from the Chubut Group (Chubut Province, Argentina) and its phylogenetic position within basal Mesoeucrocodylia". English. In: Cretaceous Research 30 (2009), pp. 1376-1386. DOI: 10.1016/j.cretres.2009.08.002.

[13117] J. M. Leardi, D. Pol, and Z. Gasparini. “New Patagonian baurusuchids (Crocodylomorpha;Notosuchia) from the Bajo de la Carpa Formation (Upper Cretaceous; Neuquén, Argentina): New evidences of the early sebecosuchian diversification in Gondwana". English. In: Comptes Rendus Palevol 8.1 (2018), e54275. DOI: 10.1016/j.crpv.2018.02.002.

[13118] O. A. Lebedev. "A new specimen of Helicoprion Karpinsky, 1899 from Kazakhstanian Cisurals and a new reconstruction of its tooth whorl position and function". English. In: Acta Zoologica 90 (2009), pp. 171-182.

[13119] O. A. Lebedev. "A new tetrapod Jakubsonia livnensis from the Early Femennian (Devonian) of Russia and palaeoecological remarks in the Late Devonian tetrapod habitats". English. In: Acta Universitatis Latviensis, Series Earth and Environment Sciences 679 (2004), pp. 79-98.

[13120] A. R. H. LeBlanc, A. K. Brar, W. May, and R. R. Reisz. "Multiple tooth-rowed captorhinids from the early Permian fissure fills of the Bally Mountain Locality of Oklahoma". English. In: Vertebrate Anatomy Morphology Palaeontology 1 (2015), pp. 35-49.

[13121] A. R. H. LeBlanc, M. W. Caldwell, and N. Bardet. "A new mosasaurine from the Maastrichtian (Upper Cretaceous) phosphates of Morocco and its implications for mosasaurine systematics". English. In: Journal of Vertebrate Paleontology 32.1 (2012), pp. 82-104.

[13122] D. A. Leckie, C. Singh, J. Bloch, M. Wilson, and J. Wall. "An anoxic event at the Albian-Cenomanian boundary: the Fish Scale Marker Bed, northern Alberta, Canada". In: Palaeogeography, Palaeoclimatology, Palaeoecology 92 (1992), pp. 139-166.

[13123] A. Lecuona, M. D. Ezcurra, and R. B. Irmis. "Revision of the early crocodylomorph Trialestes romeri (Archosauria, Suchia) from the lower Upper Triassic Ischigualasto Formation of Argentina: one of the oldest-known crocodylomorphs". English. In: Papers in Palaeontology 2.4 (2016), pp. 585622.

[13124] C. Lecuyer, P. Grandjean, F. Paris, M. Robardet, and D. Robineau. "Deciphering temperature and salinity from biogenic phosphates: the 6180 of coexisting fishes and mammals of the Middle Miocene sea of western France". English. In: Palaeogeography, Palaeoclimatology, Palaeoecology 126.1 (1996), pp. 61-74.

[13125] B.-S. Lee and K.-S. Seo. “Conodonts from the Hwajeol Formation (Upper Cambrian) in the Seokgaejae area, southeast margin of the Taebaeksan Basin". English. In: Geosciences Journal 12.3 (2008), pp. 233-242. DOI: 10.1007/s12303-008-0024-7.

[13126] D. E. Lee, J. M. Bannister, J. I. Raine, and J. G. Conran. “Euphorbiaceae: Acalyphoideae fossils from early Miocene New Zealand: Mallotus-Macaranga leaves, fruits, and inflorescence with in situ Nyssapollenites endobalteus pollen". English. In: Review of Palaeobotany and Palynology 163 (2010), pp. 127-138. DOI: 10.1016/j.revpalbo.2010.10.002.

[13127] D. E. Lee, J. M. Bannister, and J. K. Lindqvist. "Late Oligocene - Early Miocene leaf macrofossils confirm a long history of Agathis in New Zealand". English. In: New Zealand Journal of Botany 45.4 (2007), pp. 565-578. DOI: 10.1080/00288250709509739. 
[13128] D. E. Lee and J. H. Robinson. "Kakanuiella (gen. nov.) and Thecidellina: Cenozoic and Recent thecideide brachiopods from New Zealand". English. In: Journal of the Royal Society of New Zealand 33.1 (2003), pp. 341-361.

[13129] D. E. Lee, J. Scholz, and D. P. Gordon. "Paleoecology of a Late Eocene Mobile Rockground Biota from North Otago, New Zealand". English. In: Palaios 12.6 (1997), pp. 568-581. DOI: 10.2307 / 3515412.

[13130] D.-C. Lee. “Late Ordovician Trilobites from the Xiazhen Formation in Zhuzhai, Jiangxi Province, China". English. In: Acta Palaeontologica Polonica 58.4 (2013), pp. 855-882. DOI: 10.4202/app.2010. 0036.

[13131] J.-H. Lee, B. F. Dattilo, S. Mrozek, J. F. Miller, and R. Riding. "Lithistid sponge-microbial reefs, Nevada, USA: Filling the late Cambrian 'reef gap'". English. In: Palaeogeography, Palaeoclimatology, Palaeoecology (2019). DOI: 10.1016/j.palaeo.2019.02.003.

[13132] K. G. Lee, W. I. Ausich, and T. W. Kammer. "Crinoids from the Nada Member of the Borden Formation (Lower Mississippian) in eastern Kentucky". English. In: Journal of Paleontology 79.2 (2005), pp. 337-355.

[13133] M. Lee, R. J. Elias, S. -J. Choh, and D. -J. Lee. “Disorientation of corals in late Ordovician lime mudstone: A case". English. In: Palaeogeography, Palaeoclimatology, Palaeoecology (2019). DOI: 10. 1016/j.palaeo.2019.01.027.

[13134] M. S. Y. Lee. "A taxonomic revision of pareiasaurian reptiles: implications for Permian terrestrial paleoecology". English. In: Modern Geology 21 (1997), pp. 231-298.

[13135] M. S. Y. Lee, C. E. Gow, and J. W. Kitching. "Anatomy and relationships of the pareiasaur Pareiasuchus nasicornis from the Upper Permian of Zambia". English. In: Palaeontology 40.2 (1997), pp. 307-335.

[13136] M. S. Y. Lee, M. N. Hutchinson, T.H. worthy, M. Archer, A. J. D. Tennyson, J. P. Worthy, and R. P. Scofield. "Miocene skinks and geckos reveal long-term conservatism of New Zealand's lizard fauna". English. In: Biology Letters (2009). DOI: 10.1098/rsbl.2009.0440.

[13137] M. S. Y. Lee and J. D. Scanlon. "The Cretaceous marine squamate Mesoleptos and the origin of snakes". English. In: Bulletin of the Natural History Museum: Zoology 68.2 (2002), pp. 131-142.

[13138] S. Lee, Y.-N. Lee, A. Chinsamy, J. Lü, R. Barsbold, and K. Tsogtbaatar. “A new baby oviraptorid dinosaur (Dinosauria: Theropoda) from the Upper Cretaceous Nemegt Formation of Mongolia". English. In: PLoS ONE 14 (2019), e0210867:1-25. DOI: 10.1371/journal.pone.0210867.

[13139] S. Lee, J.-Y. Park, Y. -N. Lee, S. -H. Kim, J. Lü, R. Barsbold, and K. Tsogtbaatar. “A new alvarezsaurid dinosaur from the Nemegt Formation of Mongolia". English. In: Scientific Reports 9 (2019), 15493:112.

[13140] S. Lee, G. R. Shi, H. Park, and J. I. Tazawa. “Antitropicality and convergent evolution: a case study of Permian neospiriferine brachiopods". English. In: Palaeontology 59 (2016), pp. 109-138.

[13141] S. M. Lee, D. K. Choi, and G. R. Shi. "Pennsylvanian brachiopods from the Geumcheon-Jangseong Formation, Pyeongan supergroup, Taebaeksan basin, Korea". English. In: Journal of Paleontology 84 (2010), pp. 417-443.

[13142] S. W. Lee. “New Lower Cretaceous basal mantodean (Insecta) from the Crato Formation (NE Brazil)". English. In: Geologica Carpathica 65 (2014).

[13143] S. W. Lee. "Taxonomic diversity of cockroach assemblages (Blattaria, Insecta) of the Aptian Crato Formation (Cretaceous, NE Brazil)". English. In: Geologica Carpathica 67 (2016), pp. 433-450.

[13144] S.-B. Lee, B. Lefebvre, and D. K. Choi. "Morphometric analysis of Tremadocian (earliest Ordovician) kirkocystid mitrates (Echinodermata, Stylophora) from the Taebaeksan Basin, Korea". English. In: Geobios 37 (2004), pp. 731-748. DOI: 10.1016/j.geobios.2003.05.012.

[13145] S. B. Lee, B. Lefebvre, and D. K. Choi. “Latest Cambrian Cornutes (Echinodermata: Stylophora) From the Taebaeksan Basin, Korea". In: Journal of Paleontology 79.1 (2005), pp. 139-151. 
[13146] Y.-N. Lee. "A new nodosaurid ankylosaur (Dinosauria: Ornithschia) from the Paw Paw Formation (late Albian) of Texas". English. In: Journal of Vertebrate Paleontology 16.2 (1996), pp. 232-245.

[13147] Y.-N. Lee, J. H. Hutchison, and K. -H. Chang. "The first Mesozoic turtle from South Korea". English. In: Cretaceous Research 30 (2009), pp. 1287-1292. DOI: 10.1016/j.cretres.2009.07.004.

[13148] Y.-N. Lee, H. Ichishima, and D. K. Choi. "First Record of a Platanistoid Cetacean from the Middle Miocene of South Korea". English. In: Journal of Vertebrate Paleontology 32.1 (2012), pp. 231-234.

[13149] Y.-N. Lee. "Bird and dinosaur footprints in the Woodbine Formation (Cenomanian), Texas". In: Cretaceous Research 18 (1997), pp. 849-864.

[13150] Y.-N. Lee. "The Early Cretaceous pterodactyloid pterosaur $<\mathrm{i}>$ Coloborhynchus $</ \mathrm{i}>$ from North America". In: Palaeontology 37.4 (1994), pp. 755-763.

[13151] Y.-N. Lee. "Dinosaur bones and eggs in South Korea". English. In: Memoir of the Fukui Prefectural Dinosaur Museum 2 (2003), pp. 113-121.

[13152] Y.-N. Lee. "The Archosauria from the Woodbine Formation (Cenomanian) in Texas". English. In: Journal of Paleontology 71.6 (1997), pp. 1147-1156.

[13153] Y.-N. Lee. "The First Cyprinid Fish and Small Mammal Fossils". English. In: Journal of Vertebrate Paleontology 24.2 (2004), pp. 489-493.

[13154] Y.-N. Lee, Y. Azuma, H. -J. Lee, M. Shibata, and J. Lü. “The first pterosaur trackways from Japan”. English. In: Cretaceous Research 31 (2010), pp. 263-273. DOI: 10.1016/j.cretres.2009.11.001.

[13155] Y.-N. Lee, R. Barsbold, P. J. Currie, Y. Kobayashi, H. -J. Lee, P. Godefroit, F. Escuillié, and T. Chinzorig. "Resolving the long-standing enigmas of a giant ornithomimosaur Deinocheirus mirificus". English. In: Nature 515.7526 (2014), pp. 257-260. DOI: 10.1038/nature13874.

[13156] Y.-N. Lee and M. Huh. "Manus-only sauropod tracks in the Uhangri Formation (Upper Cretaceous), Korea and their paleobiological implications". English. In: Journal of Paleontology 76.3 (2002), pp. 558-564.

[13157] Y.-N. Lee and L. L. Jacobs. “The platacanthomyine rodent Neocometes from the Miocene of South Korea and its paleobiogeographical implications". English. In: Acta Palaeontologica Polonica 55 (2010), pp. 581-586. DOI: 10.4202/app.2010.0013.

[13158] Y.-N. Lee and H.-J. Lee. “A sauropod trackway in Donghae-Myeon, Goseong County, South Gyeongsang province, Korea and its paleobiological implications of Uhangri manus-only sauropod tracks". English. In: Journal of the Paleontological Society of Korea 22.1 (2006), pp. 1-14.

[13159] Y.-N. Lee, H.-J. Lee, J. Lü, and Y. Kobayashi. “New pterosaur tracks from the Hasandong Formation (Lower Cretaceous) of Hadong County, South Korea". English. In: Cretaceous Research 29 (2008), pp. 345-353. DOI: 10.1016/j.cretres.2007.05.004.

[13160] Y.-N. Lee, M. J. Ryan, and Y. Kobayashi. "The first ceratopsian dinosaur from South Korea". English. In: Naturwissenschaften (2010). DOI: 10.1007/s00114-010-0739-y.

[13161] Y.-N. Lee, S.-Y. Yang, S. -J. Seo, K. -S. Baek, M. -S. Yi, D. -J. Lee, E. -J. Park, and S. -W. Han. “Distribution and paleobiological significance of dinosaur tracks from the Jindong Formation (Albian) in Kosong County, Korea". English. In: Paleontological Society of Korea Special Publication 4 (2000), pp. 1-12.

[13162] Y.-N. Lee, K.-M. Yu, and C. B. Wood. "A review of vertebrate faunas from the Gyeongsang Supergroup (Cretaceous) in South Korea". English. In: Palaeogeography, Palaeoclimatology, Palaeoecology 165 (2001), pp. 357-373.

[13163] Y.-U. Lee and J.-H. Song. "[The stratigraphy and depositional environments of the Cretaceous Gurye Basin, Jeollanamdo, Korea]". other. In: Journal of the Geological Society of Korea 43.3 (2007), pp. 265-279.

[13164] B. Lefebvre. "A new mitrate (Echinodermata, Stylophora) from the Tremadoc of Shropshire (England) and the origin of the Mitrocystitida". English. In: Journal of Paleontology 74.5 (2000), pp. 890906. DOI: 10.1666/0022-3360(2000)074<0890:ANMESF>2.0.CO;2. 
[13165] B. Lefebvre, N. Allaire, T. E. Guensburg, A. W. Hunter, K. Kourass, E. L. O. Martin, E. Nardin, F. Noailles, B. Pittet, C. D. Sumrall, and S. Zamora. "Palaeoecological aspects of the diversification of echinoderms in the Lower Ordovician of central Anti-Atlas, Morocco". English. In: Palaeogeography, Palaeoclimatology, Palaeoecology 460 (2016), pp. 97-121. DOI: 10.1016/j.palaeo.2016.02.039.

[13166] B. Lefebvre and J. C. Gutierrez-Marco. "New Ordovician mitrocystitidan mitrates (Echinodermata, Stylophora) from the Central Iberian zone (Spain)". English. In: Neues Jahrbuch für Geologie und Paläontologie, Abhandlungen 227.1 (2003), pp. 39-61.

[13167] B. Lefebvre and R. Lerosey-Aubril. "Laurentian origin of solutan echinoderms: new evidence from the Guzhangian (Cambrian Series 3) Weeks Formation of Utah, USA". English. In: Geological Magazine 155.5 (2018), pp. 1190-1204. DOI: 10.1017/S0016756817000152.

[13168] F. Lefebvre, T. Bourgoin, and A. Nel. "New Cixiidae and Achilidae fossils from Middle Eocene Baltic amber (Hemiptera: Fulgoromorpha)". English. In: Annales de la Société Entomologique de France 43 (2007), pp. 37-43.

[13169] F. Lefebvre, B. Vincent, D. Azar, and A. Nel. "The oldest beetle of the Euaesthetinae (Staphylinidae) from Early Cretaceous Lebanese amber". English. In: Cretaceous Research 26 (2005), pp. 207211.

[13170] C. Lefevre, D. G. Corbett, D. West, and D. Siegel-Causey. "A zooarchaeological study at Buldir Island, Western Aleutians, Alaska". English. In: Arctic Anthropology 34.2 (1997), pp. 118-131.

[13171] U. Lefévre, A. Cau, A. Cincotta, D. -Y. Hu, A. Chinsamy, F. Escuillié, and P. Godefroit. "A new Jurassic theropod from China documents a transitional step in the macrostructure of feathers". English. In: The Science of Nature 104 (2017), p. 74. DOI: 10.1007/s00114-017-1496-y.

[13172] U. Lefevre, D. Hu, F. Escuillie, G. Dyke, and P. Godefroit. "A new long-tailed basal bird from the Lower Cretaceous of north-eastern China". English. In: Biological Journal of the Linnean Society 113 (2014), pp. 790-804.

[13173] A. Legalov. "New genus and four new species of the subfamily Eccoptarthrinae from Middle Upper Jurassic (Coleoptera: Nemonychidae)". English. In: Studies and Reports, Taxonomical Series 6 (2010), pp. 171-178.

[13174] A. A. Legalov. "Review of curculionoid beetles of the genus Arnoldibelus Leg. from the Jurassic of Kazakhstan (Coleoptera: Nemonychidae)". English. In: Paleontological Journal 44.6 (2010), pp. 654656.

[13175] A. A. Legalov. "The first record of anthribid beetle from the Jurassic of Kazakhstan (Coleoptera: Anthribidae)". English. In: Paleontological Journal 45.6 (2011), pp. 629-633.

[13176] A. A. Legalov. "Phylogeny of the family Nemonychidae (Coleoptera) with descriptions of new taxa". English. In: Euroasian Entomological Journal 9 (2010), pp. 457-473.

[13177] A. A. Legalov. "Checklist of Mesozoic Curculionoidea (Coleoptera) with description of new taxa". English. In: Baltic Journal of Coleopterology 10 (2010), pp. 71-101.

[13178] A. A. Legalov. "Contribution to the knowledge of the Mesozoic Curculionoidea (Coleoptera)". English. In: Amurian Zoological Journal 1 (2009), pp. 283-295.

[13179] A. A. Legalov. "New Obrieniidae from the Jurassic of Kazakhstan (Coleoptera, Obrienioidea)". English. In: Paleontological Journal 46 (2012), pp. 73-78.

[13180] A. A. Legalov. "New curculionoid beetles (Coleoptera: Curculionoidea) from the Baltic amber". English. In: Paleontological Journal 46 (2012), pp. 262-272.

[13181] A. A. Legalov. "A new weevil genus of the tribe Metrioxenini (Coleoptera: Belidae) in Eocene Baltic amber". English. In: Historical Biology 24 (2012), pp. 213-217.

[13182] A. A. Legalov. "New and little known weevils (Coleoptera: Curculionoidea) from the Paleogene and Neogene". English. In: Historical Biology 25 (2013), pp. 59-80.

[13183] A. A. Legalov. "Review of the family Anthribidae (Coleoptera) from the Jurassic of Karatau: subfamily Protoscelinae. Genus Protoscelis Medvedev". English. In: Paleontological Journal 47 (2013), pp. 292-302. 
[13184] A. A. Legalov. "A New Tribe of the Subfamily Cretonemonychinae (Coleoptera, Nemonychidae) from the Middle Eocene of the Green River". English. In: Paleontological Journal 47 (2013), pp. 410413.

[13185] A. A. Legalov. "The oldest Brentidae and Curculionidae (Coleoptera: Curculionoidea) from the Aptian of Bon-Tsagaan". English. In: Historical Biology 26 (2014), pp. 6-15.

[13186] A. A. Legalov. “New Nemonychidae, Brentidae and Curculionidae (Coleoptera: Curculionoidea) from the Turonian of Kzyl-Dzhar (Kazakhstan)". English. In: Historical Biology 26 (2014), pp. 675689.

[13187] A. A. Legalov. "First record of the weevil subfamily Nanophyinae (Coleoptera, Brentidae) from the Eocene of the Green River, United States". English. In: Paleontological Journal 49 (2015), pp. 399 401.

[13188] A. A. Legalov. "Fossil Mesozoic and Cenozoic weevils (Coleoptera, Obrienioidea, Curculionoidea)". English. In: Paleontological Journal 49 (2015), pp. 1442-1513.

[13189] A. A. Legalov. "A new genus of seed beetles (Coleoptera, Chrysomelidae, Bruchinae) in Baltic amber". English. In: Paleontological Journal 50 (2016), pp. 73-77.

[13190] A. A. Legalov. "Two new genera and four new species of fossil weevils (Coleoptera: Curculionoidea) in Baltic amber". English. In: Entomologica Fennica 27 (2016), pp. 57-69.

[13191] A. A. Legalov. "New weevils (Curculionidae) in Baltic amber". English. In: Paleontological Journal 50 (2016), pp. 970-985.

[13192] A. A. Legalov. “A new weevil, Burmorhinus georgei gen. et sp. nov. (Coleoptera; Curculionidae) from the Cretaceous Burmese amber". English. In: Cretaceous Research 84 (2017), pp. 13-17.

[13193] A. A. Legalov. "A new tribe of the subfamily Cyladinae (Coleoptera, Brentidae) in the Miocene of Germany". English. In: Paleontological Journal 52 (2018), pp. 35-38.

[13194] A. A. Legalov. "New weevils (Coleoptera, Curculionoidea) from the Eocene of the Green River, United States: part 1". English. In: Paleontological Journal 52 (2018), pp. 294-302.

[13195] A. A. Legalov. "New weevils (Coleoptera, Curculionoidea) from the Eocene of the Green River, United States: part 2". English. In: Paleontological Journal 52 (2018), pp. 421-428.

[13196] A. A. Legalov. "New auger beetle (Coleoptera; Bostrichidae) from mid-Cretaceous Burmese amber". English. In: Cretaceous Research 92 (2018), pp. 210-213.

[13197] A. A. Legalov. "Two new weevil tribes (Coleoptera: Curculionoidea) from Burmese amber". English. In: Historical Biology 32 (2018), pp. 128-136.

[13198] A. A. Legalov. "First record of a fungus weevil (Coleoptera; Anthribidae) from the Upper Cretaceous Arzamazovskaya Formation, Primorsky Krai, Russian Far East". English. In: Cretaceous Research 106.104246 (2019). DOI: 10.1016/j.cretres.2019.104246.

[13199] A. A. Legalov. "New species of weevils (Coleoptera, Curculionidae) in Dominican amber". English. In: Paleontological Journal 53 (2019), pp. 511-521. DOI: 10.1134/S003103011905006X.

[13200] A. A. Legalov. "A review of the Curculionoidea (Coleoptera) from European Eocene ambers". English. In: Geosciences 10.16 (2019). DOI: 10.3390/geosciences10010016.

[13201] A. A. Legalov. "Two new weevil genera of the family Brentidae (Coleoptera) in Baltic amber". English. In: Entomologica Fennica 29 (2018), pp. 161-168.

[13202] A. A. Legalov. "A new genus of the tribe Curculionini (Coleoptera: Curculionidae) from Baltic amber". English. In: Paleontological Journal 53 (2019), pp. 1036-1039. DOI: 10.1134/S0031030119100095.

[13203] A. A. Legalov, D. Azar, and A. G. Kirejtshuk. "A new weevil (Coleoptera; Nemonychidae; Oropsini trib. nov.) from Lower Cretaceous Lebanese amber". English. In: Cretaceous Research 70 (2016), pp. 111-116.

[13204] A. A. Legalov and A. Bukejs. "Succinapion telnovi n. gen. et n. sp. of the tribe Kalcapiini (Coleoptera: Brentidae: Apioninae) in Baltic amber". English. In: Historical Biology 26 (2014), pp. 603-607. 
[13205] A. A. Legalov and A. Bukejs. "A new species of the genus Archaeocallirhopalus Legalov (Coleoptera: Curculionidae, Entiminae) in Baltic amber". English. In: Entomologica Fennica 26 (2015), pp. 25-29.

[13206] A. A. Legalov and A. Bukejs. "A new genus of the tribe Ceutorhynchini (Coleoptera: Curculionidae) in Baltic amber". English. In: Entomologica Fennica 29 (2018), pp. 185-190.

[13207] A. A. Legalov and A. Bukejs. "New findings of weevils (Coleoptera, Curculionioidea) in Baltic amber". English. In: Baltic Journal of Coleopterology 18 (2018), pp. 179-183.

[13208] A. A. Legalov and J. Háva. “The first record of subfamily Polycaoninae (Coleoptera; Bostrichidae) from mid-Cretaceous Burmese amber". English. In: Cretaceous Research 116.104620 (2020). DOI: 10.1016/j.cretres.2020.104620.

[13209] A. A. Legalov and E. A. Jarzembowski. "First record of a weevil (Coleoptera: Nemonychidae) from the Lower Cretaceous (Wealden) of southern England". English. In: Cretaceous Research 82 (2017), pp. 104-108.

[13210] A. A. Legalov, A. G. Kirejtshuk, and A. Nel. “New and little known weevils (Coleoptera: Curculionoidea) from the Paleocene of Menat (France)". English. In: Comptes Rendus Palevol 16 (2017), pp. 248-256.

[13211] A. A. Legalov, A. G. Kirejtshuk, and A. Nel. "The oldest genus of the subfamily Sagrinae (Coleoptera: Chrysomelidae) from the Paleocene of Menat (France)". English. In: Comptes Rendus Palevol 18 (2019), pp. 178-185. DOI: 10.1016/j.crpv.2018.10.003.

[13212] A. A. Legalov, A. G. Kirejtshuk, and B. A. Anokhin. “The oldest seed beetle (Coleoptera; Chrysomelidae: Bruchinae) from Upper Cretaceous amber of northern Myanmar with description of new tribe, genus and species". English. In: Cretaceous Research 107.104283 (2019). DOI: 10.1016/j.cretres. 2019.104283.

[13213] A. A. Legalov, A. G. Kirejtshuk, and A. Nel. “New weevils (Coleoptera, Curculionoidea) from the earlymost Eocene Oise amber". English. In: Paleontological Journal 53 (2019), pp. 729-751. DOI: 10.1134/S0031030119070049.

[13214] A. A. Legalov, V. Y. Nazarenko, and E. E. Perkovsky. "A new genus of fungus weevils (Coleoptera: Anthribidae) in Rovno amber". English. In: Fossil Record 21 (2018), pp. 207-212.

[13215] A. A. Legalov, V. Y. Nazarenko, and E. E. Perkovsky. "A new species of the genus Homocloeus Jordan (Coleoptera: Anthribidae) in Miocene Mexican amber". English. In: Paleontological Journal 53 (2019), pp. 56-61. DOI: 10.1134/S0031030119010040.

[13216] A. A. Legalov, V. Y. Nazarenko, and E. E. Perkovsky. “New weevils (Coleoptera: Curculionidae) from Rovno amber". English. In: Paleontological Journal 53 (2019), pp. 1045-1059. DOI: 10.1134 / S0031030119100101.

[13217] A. A. Legalov and G. Poinar. "A new species of the genus Anthonomus Germar (Curculionidae) in Mexican amber". English. In: Paleontological Journal 50 (2016), pp. 986-990.

[13218] A. A. Legalov and G. Poinar. "A new species of the weevil genus Anthonomus Germar, 1817 (Coleoptera: Curculionidae) in Dominican amber". English. In: Paleontological Journal 54 (2020), pp. 385-388. DOI: 10.1134/S0031030120040085.

[13219] A. A. Legalov and G. O. Poinar. "Two new species and new findings of Curculionoidea (Insecta: Coleoptera) in Baltic amber". English. In: Ukrainian Journal of Ecology 10 (2020), pp. 357-364.

[13220] A. A. Legalov and M. J. Poschmann. "New genus of the tribe Ceutorhynchini (Coleoptera: Curculionidae) from the late Oligocene of Enspel, southwestern Germany, with a remark on the role of weevils in the ancient food web". English. In: Fossil Record 23 (2020), pp. 197-204. DOI: 10.5194/fr23-197-2020.

[13221] L. J. Legendre, D. Rubilar-Rogers, G. M. Musser, S. N. Davis, R. A. Otero, A. O. Vargas, and J. A. Clarke. "A giant soft-shelled egg from the Late Cretaceous of Antarctica". English. In: Nature Research (2020), pp. 1-5. DOI: 10.1038/s41586-020-2377-7.

[13222] D. Legg. "Multi-segmented arthropods from the Middle Cambrian of British Columbia(Canada)". English. In: Journal of Paleontology 87.3 (2013), pp. 493-501. 
[13223] D. A. Legg. "A new marrellid arthropod from the Ordovician of Wales". English. In: Acta Palaeontologica Polonica 61.3 (2016), pp. 617-619. DOI: 10.4202/app.00246.2016.

[13224] D. Lehman and J. K. Pope. “Upper Ordovician tempestites from Swatara Gap, Pennsylvania: depositional processes affecting the sediments and paleoecology of the fossil faunas". In: Palaios 4 (1990), pp. 553-564.

[13225] T. M. Lehman. "A horned dinosaur from the El Picacho Formation of West Texas, and review of ceratopsian dinosaurs from the American Southwest". English. In: Journal of Paleontology 70.3 (1996), pp. 494-508.

[13226] T. M. Lehman. "New data on the ceratopsian dinosaur Pentaceratops sternbergii Osborn from New Mexico". English. In: Journal of Paleontology 67.2 (1993), pp. 279-288.

[13227] T. M. Lehman. "Pachycephalosauridae from the San Carlos and Aguja Formations (Upper Cretaceous) of West Texas, and observations of the frontoparietal dome". English. In: Journal of Vertebrate Paleontology 30.3 (2010), pp. 786-798.

[13228] T. M. Lehman and K. Barnes. "Champsosaurus (Diapsida: Choristodera) from the Paleocene of West Texas: Paleoclimatic Implications". English. In: Journal of Paleontology 84.2 (2010), pp. 341345.

[13229] T. M. Lehman and S. Chatterjee. "Depositional setting and vertebrate biostratigraphy of the Triassic Dockum Group of Texas". English. In: Journal of Earth Systems Science 114.3 (2005), pp. 325351.

[13230] T. M. Lehman and A. B. Coulson. "A juvenile specimen of the sauropod dinosaur Alamosaurus sanjuanensis from the Upper Cretaceous of Big Bend National Park, Texas". English. In: Journal of Paleontology 76.1 (2002), pp. 156-172.

[13231] T. M. Lehman and S. L. Tomlinson. "Terlinguachelys fischbecki, a new genus and species of sea turtle (Chelonioidea: Protostegidae) from the Upper Cretaceous of Texas". English. In: Journal of Paleontology 78.6 (2004), pp. 1163-1178.

[13232] T. M. Lehman and S. L. Wick. "Chupacabrachelys complexus, n. gen. n. sp. (Testudines: Bothremydidae), from the Aguja Formation (Campanian) of West Texas". English. In: Journal of Vertebrate Paleontology 30.6 (2010), pp. 1709-1725.

[13233] T. M. Lehman and S. L. Wick. “Tyrannosauroid dinosaurs from the Aguja Formation (Upper Cretaceous) of Big Bend National Park, Texas". English. In: Earth and Environmental Science Transactions of the Royal Society of Edinburgh 103 (2013), pp. 1-15.

[13234] T. M. Lehman, S. L. Wick, and J. R. Wagner. "Hadrosaurian dinosaurs from the Maastrichtian Javelina Formation, Big Bend National Park, Texas". English. In: Journal of Paleontology 90.2 (2016), pp. 333-356. DOI: 10.1017/jpa.2016.48.

[13235] T. M. Lehman, S. L. Wick, A. B. Brink, and T. A. Shiller II. "Stratigraphy and vertebrate fauna of the lower shale member of the Aguja Formation (lower Campanian) in West Texas". English. In: Cretaceous Research 99 (2019), pp. 291-314. DOI: 10.1016/j.cretres.2019.02.028.

[13236] J. Lehmann. Integrated stratigraphy and palaeoenvironment of the Cenomanian-Lower Turonian (Upper Cretaceous) of Northern Westphalia, North Germany. 1999.

[13237] J. Lehmann, R. Hoffmann, H. G. Owen, and W. Beckert. “Cephalopoden aus unterkreidezeitlichen Geschieben der Region um Wolgast-Hohendorf, Vorpommern". German. In: Archiv für Geschiebekunde 7 (2016), pp. 401-530.

[13238] J. Lehmann, M. W. Maisch, C. Baudouin, and A. Salfinger-Maisch. “Origin and evolutionary history of Anglonautilus (Nautilida, Cymatoceratidae) and a new species from the lower Aptian of Spain". English. In: Cretaceous Research 72 (2017), pp. 66-80.

[13239] J. Lehmann, A. Mosavinia, and M. Wilmsen. "Parahoplitid ammonites and narrowing down the Aptian/Albian boundary interval in northern Iran". English. In: Cretaceous Research 94 (2019), pp. 207-228. DOI: 10.1016/j.cretres.2018.10.004. 
[13240] J. Lehmann, H. G. Owen, and W. Beckert. "A new ammonite fauna from NE Germany - evidence for an Early Albian cooling and the initial transgression in the Danish-Polish Trough". English. In: Neues Jahrbuch für Geologie und Paläontologie, Abhandlungen 268 (2013), pp. 199-235.

[13241] J. Lehmann, K. A. Tröger, and H. Owen. "Ammonites and associated macrofauna from the early Late Albian of the Zippelsförde 1/64 core, NE-Germany". English. In: Acta Geologica Polonica 58.4 (2008), pp. 437-453.

[13242] T. Lehmann. "Plio-Pleistocene aardvarks (Mammalia, Tubulidentata) from East Africa". English. In: Fossil Record 11.2 (2008), pp. 67-81.

[13243] T. Lehmann, P. Vignaud, A. Likius, and M. Brunet. "A new species of Orycteropodidae (Mammalia, Tubulidentata) in the Mio-Pliocene of northern Chad". English. In: Zoological Journal of the Linnean Soceity 143.1 (2005), pp. 109-131.

[13244] T. Lehmann, P. Vignaud, H. T. Mackaye, and M. Brunet. "A fossil aardvark (Mammalia, Tubulidentata) from the lower Pliocene of Chad". English. In: Journal of African Earth Sciences 40 (2004), pp. 201-217.

[13245] D. Lehnert, M. Keller, and D. Bordonaro. “Early Ordovician conodonts from the southern Cuyania terrane (Mendoza Province, Argentina)". English. In: Palaeontologia Polonica 58 (1998), pp. 47-65.

[13246] O. Lehnert, S. M. Bergström, J. L. Benedetto, and N. E. Vaccari. "First record of Lower Silurian conodonts from South America: biostratigraphic and palaeobiogeographic implications of Llandovery conodonts in the Precordillera of Argentina". English. In: Geological Magazine 136.2 (1999), pp. 119-131. DOI: 10.1017/S0016756899002290.

[13247] O. Lehnert and M. Keller. Posicion estratigrafica de los arrecifes Arenigianos en la Precordillera Argentina. Spanish. 1993.

[13248] D. J. Lehrmann. "Early Triassic calcimicrobial mounds and biostromes of the Nanpanjiang basin, south China". English. In: Geology 27.4 (1999), pp. 359-362.

[13249] X. J. Lei, W. M. Zhou, M. L. Wan, H. B. Wei, and B. Wang. "A new scorpion from a Permian peat swamp in Inner Mongolia, China". English. In: Proceedings of the Geologists' Association 131 (2020), pp. 160-167. DOI: 10.1016/j.pgeola.2020.02.0060016-7878.

[13250] E. G. Leigh and S. J. Wright. Barro Colorado Island and Tropical Biology. 1990.

[13251] R. R. Leinfelder. “A modern-type Kimmeridgian reef (Ota Limestone, Portugal): implications for Jurassic reef models". In: Facies 26 (1992), pp. 11-34.

[13252] R. R. Leinfelder, M. Krautter, M. Nose, M. M. Ramalho, and W. Werner. "Siliceous sponge facies from the Upper Jurassic of Portugal". English. In: Neues Jahrbuch für Geologie und Paläontologie, Abhandlungen 189 (1993), pp. 199-254.

[13253] M. B. Leite. "Stratigraphy and mammalian paleontology of the Ash Hollow Formation (upper Miocene) on the north shore of Lake McConaughy, Keith County, Nebraska". English. In: Contributions to Geology, University of Wyoming 28.1 (1990), pp. 1-29.

[13254] E. Lekkas, G. Danamos, E. Skourtsos, and D. Sakellariou. "Position of the Middle Triassic Tyros Beds in the Gavrovo-Tripolis Unit (Rhodes Island, Dodecanese, Greece)". English. In: Geologica Carpathica 53.1 (2002), pp. 37-44.

[13255] V. L. Leleshus. "Permian tabulates from Afghanistan and the Pamirs". English. In: Coral Research Bulletin 5 (1997), pp. 191-195.

[13256] V. L. Leleshus. “Liauria und Gundarina, zwei neue Korallen-Gattungen aus dem Perm des DarvazGebirges in Tadshikistan". German. In: Senckenbergiana Lethaea 73 (1993), pp. 31-35.

[13257] J. Leloux. "Numerical distribution of Santonian to Danian corals (Scleractinia, Octocorallia) of southern Limburg, the Netherlands". English. In: Geologie en Mijnbouw 78 (1999), pp. 191-195.

[13258] J. Leloux. "Columactinastraea anthonii sp. nov. (Scleractinia, Astrocoeniina), a new coral species from the Maastrichtian (Upper Cretaceous) of The Netherlands". English. In: Scripta Geologica 126 (2003), pp. 185-201. 
[13259] J. Leloux. “Notes on taxonomy and taphonomy of two Upper Maastrichtian (Upper Cretaceous) scleractinian corals from Limburg, The Netherlands". English. In: Scripta Geologica 127 (2004), pp. 313-339.

[13260] J. Leloux. Type specimens of Maastrichtian fossils in the National Museum of Natural History, Leiden. English. 2002.

[13261] J. Leloux and F. P. Wesselingh. “Types of Cenozoic Mollusca from Java in the Martin Collection of Naturalis". English. In: NNM Technical Bulletin 11 (2009), pp. 1-765.

[13262] M. S. Leman, N. Ramli, S. Mohamed, and C. Molujin. "The discovery of Late Permian (early Changshingian) brachiopods from Penjom, Pahang Darul Makmur". English. In: Geological Society of Malaysia Bulletin 48 (2004), pp. 91-95.

[13263] A. K. Lemke. “Great Lakes Rangifer and Paleoindians: Archaeological and Paleontological Caribou Remains from Michigan". English. In: PaleoAmerica 1.3 (2015), pp. 276-283.

[13264] G. M. LeMoine and C. M. Darwent. "The walrus and the carpenter: Late Dorset ivory working in the High Arctic". English. In: Journal and Archaeological Science 25 (1998), pp. 73-83.

[13265] A. C. Lenz. "A Silurian sponge-inarticulate brachiopod life? association". English. In: Journal of Paleontology 67.1 (1993), pp. 138-139.

[13266] A. C. Lenz and A. Kozowska. "New and unusual upper Llandovery graptolites from Arctic Canada". English. In: Acta Palaeontologica Polonica 52.3 (2007), pp. 489-502.

[13267] N. D. Leonard, K. J. Welsh, J. -X. Zhao, L. D. Nothdurft, G. E. Webb, J. Major, Y. Feng, and G. J. Price. "Mid-Holocene sea-level and coral reef demise: U-Th dating of subfossil corals in Moreton Bay, Australia". English. In: The Holocene (2013), pp. 1-12.

[13268] G. Leonardi. Annotated Atlas of South America Tetrapod Footprints (Devonian to Holocene) with an Appendix on Mexico and Central America. English. República Federativa do Brasil, Ministério de Minas e Energia, Secretaria de Minas e Metalurgia, Companhia de Pesquisa de Recursos Minerais, Braslia. 1994, pp. 1-248.

[13269] G. Leonardi. "I dinosauri d'Italia e delle aree adiacenti [The dinosaurs of Italy and adjacent areas]". Italian. In: Dinosauri in Italia. Le Orme Giurassiche dei Lavini di Marco (Trentino) e Gli Altri Resti Fossili Italiani. Roma: Accademia Editoriale, 2000, pp. 275-295.

[13270] G. Leonardi. "Vertebrate ichnology in Italy". English. In: Studi Trentini di Scienze Naturali, Acta Geologica 83 (2008), pp. 213-221.

[13271] G. Leonardi and I.d.S. Carvalho. Icnofósseis da Bacia do Rio do Peixe, PB: o mais marcante registro de pegadas de dinossauros do Brasil [Ichnofossils of the Rio do Peixe Basin, PB: the most remarkable record of dinosaur tracks from Brazill. Portugese. C. Schobbenhaus, D. d. A. Campos, E. T. Queiroz, M. Winge, \& M. Berbert-Born (eds.), Stios Geológicos e Paleontológicos do Brasil. SIGEP, Brasilia. 2002, pp. 101-111.

[13272] G. Leonardi and I.d.S. Carvalho. Jazigo icnofossilfero do Ouro - Araraquara (SP) [Ichnofossiliferous grave of Ouro - Araraquara (SP)]. Portugese. Stios Geológicos e Paleontológicos do Brasil. SIGEP, Brasilia. 2002, pp. 39-48.

[13273] G. Leonardi and M. F. C. Dos Santos. "New dinosaur tracksites from the Sousa Lower Cretaceous Basin (Paraba, Brasil)". English. In: Studi Trentini di Scienze Naturali, Acta Geologica 81 (2006), pp. 521.

[13274] G. Leonardi and P. Mietto. Le piste liassiche di dinosauri dei Lavini di Marco [The Liassic dinosaur trackways of Lavini di Marco]. Italian. In G. Leonardi \& P. Mietto (eds.), Dinosauri in Italia. Accademia Editoriale, Roma. 2000, pp. 169-246.

[13275] F. Leone, A. Ferretti, W. Hammann, A. Loi, G. L. Pillola, and E. Serpagli. "Outline of the postSardic Ordovician sequence in south-westem Sardinia". English. In: Giornale di Geologia 60 (1998), pp. 39-56.

[13276] T. B. Leonova. "Permian ammonoids: classification and phylogeny". English. In: Paleontological Journal 36.Suppl 1 (2002), pp. 1-114. 
[13277] T. B. Leonova. "Correlation of the Kazanian of the Volga-Urals with the Roadian of the global Permian scale". English. In: Palaeoworld 16 (2007), pp. 246-253.

[13278] T. B. Leonova. "Classification of the late Paleozoic family Medlicottiidae Karpinsky (Ammonoidea)". English. In: Paleontological Journal 53 (2019), pp. 354-365. DOI: 10.1134/S0031030119040075.

[13279] T. B. Leonova and M. S. Boiko. "New data on the taxonomy and distribution of the Early Permian genus Cardiella (Ammonoidea)". English. In: Paleontological Journal 34 (2000), pp. 258-262.

[13280] T. B. Leonova, R. V. Kutygin, and O. P. Shilovsky. "New data on the composition and evolution of the Permian superfamily Popanocerataceae (Ammonoidea)". English. In: Paleontological Journal 39.5 (2005), pp. 476-486.

[13281] T. B. Leonova, Mohd Shafeea Leman, and G. R. Shi. "Discovery of an Early Permian (late Sakmarian) ammonoid from Langkawi Island, Malaysia". English. In: Alcheringa 23 (1999), pp. 277281.

[13282] T. B. Leonova and O. P. Shilovsky. "Evolution of the Permian family Spirolegoceratidae (Goniatitida, Ammonoidea)". English. In: Paleontological Journal 41.1 (2007), pp. 28-38.

[13283] B. A. LePage, B. Beauchamp, H. W. Pfefferkorn, and J. Utting. “Late Early Permian plant fossils from the Canadian High Arctic: a rare paleoenvironmental/climatic window in northwest Pangea". In: Palaeogeography, Palaeoclimatology, Palaeoecology 191 (2003), pp. 345-372.

[13284] Y. Lepage, G. Cuny, and A. Desquesne. "Premiére découverte d'Acrodus nobilis Agassiz, 1838, dans le Sinémurien du Cotentin (Normandie, France)". French. In: Bulletin Sciences et Géologie Normandes 3 (2011), pp. 7-13.

[13285] Y. Lepage and J. Guyader. “Le renouvellement des dents chez Liopleurodon macromerus (Phillips) 1871 : un exemple descriptif havrais (Normandie, France)". French. In: Bulletin de la Société Géologique de Normandie et des Amis du Muséum du Havre 94.1 (2007), pp. 9-23.

[13286] A. J. Lerner, S. G. Lucas, and C. F. Mansky. "The earliest paleolimulid and its attributed ichnofossils from the Lower Mississippian (Tournaisian) Horton Bluff Formation of Blue Beach, Nova Scotia, Canada". English. In: Neues Jarbuch für Geologie und Paläontologie, Abhandlungen 280 (2016), pp. 193-214. DOI: 10.1127/njgpa/2016/0575.

[13287] A. J. Lerner, S. G. Lucas, and M. Lockley. "First fossil horseshoe crab (Xiphosurida) from the Triassic of North America". English. In: Neues Jarbuch für Geologie und Paläontologie, Abhandlungen 286 (2017), pp. 289-302. DOI: 10.1127/njgpa/2017/0702.

[13288] R. Lerosey-Aubril. “The late Palaeozoic trilobites of Iran and Armenia and their palaeogeographical significance". English. In: Geological Magazine 149.6 (2012), pp. 1023-1045. DOI: 10.1017 / S0016756812000179.

[13289] R. Lerosey-Aubril and L. Angiolini. “Permian trilobites from Antalya Province, Turkey, and enrollment in late Palaeozoic trilobites". English. In: Turkish Journal of Earth Sciences 18 (2009), pp. 427448.

[13290] R. Lerosey-Aubril and R. Feist. "Late ontogeny and hypostomal condition of a new cyrtosymboline trilobite from the Famennian of Morocco". English. In: Palaeontology 49.5 (2006), pp. 10531068.

[13291] R. Lerosey-Aubril, R. Feist, and B. D. E. Chatterton. “The ontogeny and systematics of the otarionine rilobites Otarionella from the Devonian of the Montagne Noire, France and the Maider, Morocco". English. In: Geological Magazine 145.1 (2008), pp. 55-71.

[13292] R. Lerosey-Aubril, X.-J. Zhu, and J. Ortega-Hernandez. "The Vicissicaudata revisited - insights from a new aglaspidid arthropod with caudal appendages from the Furongian of China". English. In: Scientific Reports 7.1 (2017), pp. 1-18.

[13293] R. A. B. Leschen and B. E. Rhode. "A new genus and species of large extinct Ulodidae (Coleoptera) from New Zealand". English. In: New Zealand Entomologist 25 (2002), pp. 57-64. 
[13294] S. V. Leshchinskiy, A. V. Faingerts, A. V. Voronkevich, E. N. Mashchensko, and A. O. Averianov. Predvaritel'nye rezul'taty izucheniy mestonakhozhdenii Shestakovskogo kompleksa rannemelovykh pozvonochnykh [Preliminary results of the investigation of the Shestakovo localities of Early Cretaceous vertebrates]. Russian. Vol. 2. Materialy Regional'noy Konferentsii Geologov Sibiri Dal'nego Vostoka i Severo-Vostoka Rossii. Gala Press, Tomsk. 2000, pp. 363-366.

[13295] S. A. Leslie. "Apparatus Architecture of Belodina (Conodonta): Interpretations Based on Fused Clusters of Belodina compressa (Branson and Mehl, 1933) from the Middle Ordovician (Turinian) Plattin Limestone of Missouri and Iowa". English. In: Journal of Paleontology 71.5 (1997), pp. 921926.

[13296] P. J. Lespérance and D. Desbiens. "Selected Ordovician trilobites from the Lake St. John District of Quebec and their bearing on systematics". English. In: Paleontological Society Memoir 42 (1995), pp. 1-19.

[13297] G. Lessa, C. Cartelle, H. de Farias, and P. R. Gonçalves. "Novos achados de mamiferos carnivoros do Pleistoceno final-Holoceno em grutas calcarias do Estado da Bahia". Portugese. In: Acta Geologica Leopoldensia 21.46/47 (1998), pp. 157-169.

[13298] E. J. Lessner, M. R. Stocker, N. D. Smith, A. H. Turner, R. B. Irmis, and S. J. Nesbitt. “A new rauisuchid (Archosauria, Pseudosuchia) from the Upper Triassic (Norian) of New Mexico increases the diversity and temporal range of the clade". English. In: PeerJ 4 (2016), e2336.

[13299] S. Leszczynski, B. Kolodziej, D. Bassi, E. Malata, and M. A. Gasinski. “Origin and resedimentation of rhodoliths in the Late Paleocene flysch of the Polish Outer Carpathians". English. In: Facies 58 (2012), pp. 367-387.

[13300] U. B. Leu and H. Sulser. "Fossile Brachiopoden aus der Sammlung von Johann Jakob Scheuchzer (1672-1733) auf dem Hintergrund der frühneuzeitlichen Paläontologie". German. In: Eclogae Geologicae Helvetiae 93 (2000), pp. 517-530.

[13301] E. J. Leven. "Lower Permian fusulinids from the vicinity of Ankara (Turkey)". English. In: Rivista Italiana di Paleontologia e Stratigrafia 101 (1995), pp. 235-248.

[13302] E. J. Leven and M. N. Gorgij. “First record of Gzhelian and Asselian fusulinids from the Vazhnan Formation (Sanandaj-Sirgan zone of Iran)". English. In: Stratigraphy and Geological Correlation 19 (2011), pp. 486-501.

[13303] E. J. Leven and M. N. Gorgij. "Bolorian and Kubergandian stages of the Permian in the SanandajSirjan zone of Iran". English. In: Stratigraphy and Geological Correlation 16 (2008), pp. 455-466.

[13304] E. J. Leven, S. V. Naugolnykh, and M. N. Gorgij. “New findings of Permian marine and terrestrial fossils in central Iran (the Kalmard block) and their significance for correlation of the Tethyan, Uralian, and west European scales". English. In: Rivista Italiana di Paleontologia e Stratigrafia 117 (2011), pp. 355-374.

[13305] E. Y. Leven, M. Gaetani, and S. Schroeder. "New findings of Permian fusulinids and corals from western Karakorum and E Hindu Kush (Pakistan)". English. In: Rivista Italiana di Paleontologia e Stratigrafia 113 (2007), pp. 151-165.

[13306] E. Y. Leven and M. H. Gorgij. “Gzhelian fusulinids first discovered in central Iran”. English. In: Stratigraphy and Geological Correlation 14 (2006), pp. 19-29.

[13307] E. Y. Leven and M. N. Gorgij. “Fusulinids of the Khan formation (Kalmard region, eastern Iran) and some problems of their paleobiogeography". English. In: Russian Journal of Earth Sciences 9.ES1004 (2007), pp. 1-10.

[13308] E. Y. Leven and M. N. Gorgij. "Section of Permian deposits and fusulinids in the Halvan Mountains, Yazd Province, central Iran". English. In: Stratigraphy and Geological Correlation 17 (2009), pp. 155-172.

[13309] M. Levera and C. A. McRoberts. "Carninan/Norian Halobiids from Pizzo Modello succession (Sicani Mountains, Sicily)". English. In: Berichte der Geologischen Bundesanstalt 76 (2008), pp. 20-22. 
[13310] D. N. Lewis, S. K. Donovan, and P. Sawforn. "Fossil echinoderms from the Carboniferous Limestone sea defence blocks at Barton-on-sea, Hampshire, southern England". In: Proceedings of the Geologists' Association 114.3 (2003), pp. 307-317.

[13311] D. N. Lewis, S. K. Donovan, P. Crabb, and D. J. Gladwell. "A field guide to the Silurian Echinodermata of the British Isles: Part 1 - Eleutherozoa and Rhombifera". English. In: Scripta Geologica 134 (2007), pp. 27-59.

[13312] E. K. Lewis and A. N. Drinnan. "The Miocene conifer flora of Balcombe Bay, Victoria, Australia". English. In: Australia. Australian Systematic Botany 26 (2013), pp. 145-155. DOI: 10.1071/SB11031.

[13313] M. Lewis, M. Pacher, and A. Turner. "The larger Carnivora of the West Runton Freshwater Bed". English. In: Quaternary International 228 (2010), pp. 116-135. DOI: 10.1016/j.quaint.2010.06.022.

[13314] R. E. Lewis and D. Grimaldi. "A Pulicid Flea in Miocene Amber from the Dominican Republic (Insecta: Siphonaptera: Pulicidae)". English. In: American Museum Novitates 3205 (1997), pp. 1-9.

[13315] C. Li. "First record of protorosaurid reptile (Order Protorosauria) from the Middle Triassic of China". English. In: Acta Geologica Sinica 77 (2003), pp. 419-423.

[13316] C. Li. “Ichthyosaur from Guizhou, China”. English. In: Chinese Science Bulletin 44.14 (1999), pp. 13291333.

[13317] C. Li, N. C. Fraser, O. Rieppel, and X. -C. Wu. "A Triassic stem turtle with an edentulous beak". English. In: Nature 560 (2018), pp. 476-479. DOI: 10.1038/s41586-018-0419-1.

[13318] C. Li, N. C. Fraser, O. Rieppel, L. -J. Zhao, and L. -T. Wang. "A new diapsid from the Middle Triassic of southern China". English. In: Journal of Paleontology 91.6 (2017), pp. 1306-1312.

[13319] C. Li, D.-Y. Jiang, L. Cheng, X. -C. Wu, and O. Rieppel. "A new species of Largocephalosaurus (Diapsida: Saurosphargidae), with implications for the morphological diversity and phylogeny of the group". English. In: Geological Magazine (2013). DOI: 10.1017/S001675681300023X.

[13320] C. Li, J. Meng, and Y. Wang. "Dawsonolagus antiquus, A Primitive Lagomorph from the Eocene Arshanto Formation, Nei Mongol, China". English. In: Bulletin of Carnegie Museum of Natural History 39 (2007), pp. 97-110.

[13321] C. Li, O. Rieppel, and M. C. LaBarbara. "A Triassic aquatic protorosaur with an extremely long neck". English. In: Science 305 (2004), p. 1931.

[13322] C. Li, O. Rieppel, X. -C. Wu, L. -J. Zhao, and L. -T. Wang. "A new Triassic marine reptile from southwestern China". English. In: Journal of Vertebrate Paleontology 31.2 (2011), pp. 303-312.

[13323] C. Li and O. Rieppel. "A new cyamodontid placodont from Triassic of Guizhou, China". English. In: Chinese Science Bulletin 47.5 (2002), pp. 403-407.

[13324] C. Li, Y. Wang, Y. Hu, and J. Meng. "A new species of Gobiconodon (Triconodonta, Mammalia) and its implication for the age of Jehol Biota". English. In: Chinese Science Bulletin 48.11 (2003), pp. 1129-1134. DOI: 10.1360/02wd0134.

[13325] C. Li, X.-C. Wu, Y. -N. Cheng, T. Sato, and L. Wang. "An unusual archosaurian from the marine Triassic of China". English. In: Naturwissenschaften 93.4 (2006), pp. 200-206. DOI: 10.1007/s00114006-0097-y.

[13326] C. Li, X.-C. Wu, L. -J. Zhao, T. Sato, and L. -T. Wang. “A new archosaur (Diapsida, Archosauriformes) from the marine Triassic of China". English. In: Journal of Vertebrate Paleontology 32.5 (2012), pp. 1064-1081. DOI: $10.1080 / 02724634.2012 .694383$.

[13327] C. Li, X. C. Wu, O. Rieppel, L. T. Wang, and L. J. Zhao. "An ancestral turtle from the Late Triassic of southwestern China". English. In: Nature 456 (2008), pp. 497-501.

[13328] C. Li, X.-C. Wu, L. -J. Zhao, S. J. Nesbitt, M. R. Stocker, and L. -T. Wang. "A new armored archosauriform (Diapsida: Archosauromorpha) from the marine Middle Triassic of China, with implications for the diverse life styles of archosauriforms prior to the diversification of Archosauria". English. In: The Science of Nature 103.11-12 (2016). DOI: 10.1007/s00114-016-1418-4. 
[13329] C. Li, X.-C. Wu, and S. Rufolo. "A new crocodyloid (Eusuchia: Crocodylia) from the Upper Cretaceous of China". English. In: Cretaceous Research 94 (2019), pp. 25-39. DOI: 10.1016/j.cretres.2018. 09.015 .

[13330] C. Li, L. J. Zhao, and L. T. Wang. "A new species of Macrocnemus (Reptilia: Protorosauria) from the Middle Triassic of southwestern China and its palaeogeographical implication". English. In: Science in China Series D: Earth Sciences 50.11 (2007), pp. 1601-1605. DOI: 10.1007/s11430-007-01185.

[13331] C.-S. Li and D. Edwards. "Demersatheca Li and Edwards, gen. nov., a new genus of early land plants from the Lower Devonian, Yunnan province, China". In: Review of Palaeobotany and Palynology 93 (1996), pp. 77-88.

[13332] C.-S. Li and D. Edwards. "A new microphyllous plant from the Lower Devonian of Yunnan Province, China". In: American Journal of Botany 84 (1997), pp. 1441-1448.

[13333] C.-S. Li and D. Edwards. "A re-investigation of Halle's Drepanophycus spinaeformis Gopp. from the Lower Devonian of Yunnan Province, southern China". In: Botanical Journal of the Linnean Society 118 (1995), pp. 163-192.

[13334] C.-S. Li and F. M. Hueber. “Cervicornus wenshanensis, gen. et sp. nov, a Pragian (Early Devonian) plant with forked leaves from Yunnan, China". In: Review of Palaeobotany and Palynology 109 (2000), pp. 113-119.

[13335] C. S. Li. "Minarodendron cathaysiense (gen. et comb. nov.), A lycopod from the late Middle Devonian of Yunnan, China". In: Palaeontographica Abteilung B 220 (1990), pp. 97-117.

[13336] C. S. Li, F. M. Hueber, and C. L. Hotton. "A neotype for Drepanophycus spinaeformis Goppert 1852". In: Canadian Journal of Botany 78 (2000), pp. 889-902.

[13337] C.-K. Li, T. Setoguchi, Y. -Q. Wang, Y. -M. Hu, and Z. -L. Chang. "The first record of eupantotherian (Theria, Mammalia) from the late Early Cretaceous of western Liaoning, China". English. In: Vertebrata PalAsiatica 43.4 (2005), pp. 245-255.

[13338] C.-K. Li, Y.-Q. Wang, Z. -Q. Zhang, F. -Y. Mao, and J. Meng. “A new mimotonidan Mina hui (Mammalia, Glires) from the Middle Paleocene of Qianshan, Anhui, China". English. In: Vertebrata PalAsiatica 54.2 (2016), pp. 121-136.

[13339] C.-Y. Li, J.-Y. Hsiao, and C. -H. Yang. "Fossil Woods of Taxodiaceae From the Kungkuan Tuff (Early Miocene) of Northern Taiwan". English. In: Bulletin of National Museum of Natural Science 12 (1999), pp. 41-48. DOI: 10.6693/CAR.1999.12.3.

[13340] C.-Y. Li, C.-M. Wang, J. -Y. Hsiao, and C. -H. Yang. "Two fossil Dicotyledonous woods from the Kungkuan Tuff (Early". English. In: Collection and Research 16 (2003), pp. 71-78.

[13341] D. Li, Y. Azuma, M. Fujita, Y. -N. Lee, and Y. Arakawa. “A preliminary report on two new vertebrate track sites including dinosaurs from the Early Cretaceous Hekou Group, Gansu province, China". English. In: Journal of the Paleontological Society of Korea 22.1 (2006), pp. 29-49.

[13342] D. Li, M. A. Norell, K. -Q. Gao, N. D. Smith, and P. J. Makovicky. “A longirostrine tyrannosauroid from the Early Cretaceous of China". English. In: Proceedings of the Royal Society B: Biological Sciences (2009). DOI: 10.1098/rspb.2009.0249.

[13343] D. Li, C. Peng, H. You, M. C. Lamanna, J. D. Harris, K. J. Lacovara, and J. Zhang. "A large therizinosauroid (Dinosauria: Theropoda) from the Early Cretaceous of northwestern China". English. In: Acta Geologica Sinica 81.4 (2007), pp. 539-549.

[13344] D.-Q. Li, L.-D. Xing, M. G. Lockley, A. Romilio, J. -T. Yang, and L. -F. Li. “The first theropod tracks from the Middle Jurassic of Gansu, northwest China: new and rare evidence of quadrupedal progression in theropod dinosaurs". English. In: Journal of Palaeogeography 8 (2019), 10:1-11. DOI: 10.1186/s42501-019-0028-4.

[13345] D.-q. Li, H.-1. You, and Z. -p. Zhang. "A new specimen of Suzhousaurus megatherioides (Dinosauria: Therizinosauroidea) from the Early Cretaceous of northwestern China". English. In: Canadian Journal of Earth Sciences 45 (2008), pp. 769-779. DOI: 10.1139/E08-21. 
[13346] D.-Q. Li, C.-F. Zhou, L. Li, J. -T. Yang, and M. Rabi. “The sinemydid turtle Ordosemys from the Lower Cretaceous Mengyin Formation of Shandong, China and its implication for the age of the Luohandong Formation of the Ordos Basin". English. In: PeerJ 7 (2019), e6229:1-23. DOI: 10.7717/ peerj.6229.

[13347] F. Li, G. Peng, Y. Yong, S. Jiang, and D. Huang. "A new carnosaur from the Late Jurassic of Qianwei, Sichuan, China". Chinese. In: Acta Geologica Sinica 83.9 (2009), pp. 1203-1210.

[13348] G. Li and L. E. Holmer. "Early Cambrian lingulate brachiopods from the Shaanxi Province, China". English. In: Geologiska Föreningens i Stockholm Förhandlingar 126.2 (2004), pp. 193-211.

[13349] G. Li and Z.-X. Luo. "A Cretaceous symmetrodont therian with some monotreme-like postcranial features". English. In: Nature 439 (2006), pp. 195-200.

[13350] G. Li, M. Steiner, X. Zhu, A. Yang, H. Wang, and B. D. Erdtmann. "Early Cambrian metazoan fossil record of South China: Generic diversity and radiation patterns". English. In: Palaeogeography, Palaeoclimatology, Palaeoecology 254 (2007), pp. 229-249. DOI: 10.1016/j.palaeo.2007.03.017.

[13351] G. Li and S. Xiao. "Tannuolina and Micrina (Tannuolinidae) from the Lower Cambrian of eastern Yunnan, south China, and their scleritome reconstruction". English. In: Journal of Paleontology 78.5 (2004), pp. 900-913. DOI: 10.1666/0022-3360(2004)078<0900:tamtft>2.0.co;2.

[13352] G. Li, X. Zhao, A. Gubanov, M. Zhu, and L. Na. "Early Cambrian mollusc Watsonella crosbyi: a potential GSSP index fossil for the base of the Cambrian stage 2". English. In: Acta Geologica Sinica (English Edition) 85.2 (2011), pp. 309-319.

[13353] G. Li, M. Zhu, M. Steiner, and Q. Yi. “Skeletal faunas from the Qiongzhusian of southern Shaanxi: biodiversity and lithofacies-biofacies links in the Lower Cambrian carbonate settings". English. In: Progress in natural science 14.1 (2004).

[13354] G. X. Li and J. Y. Chen. "Early Cambrian cap-shaped lathamellids: their microstructures and systematics". Chinese. In: Acta Palaeontologica Sinica 31.4 (1992), pp. 459-471.

[13355] G. X. Li, M. Steiner, M. Y. Zhu, and X. Zhao. "Early Cambrian eodiscoid trilobite Hupeidiscus orientalis from South China: ontogeny and implications for affinities of Mongolitubulus-like sclerites". English. In: Bulletin of Geosciences 87.1 (2012), pp. 159-169.

[13356] G.-Q. Li and M. V. H. Wilson. "The discovery of heterotidinae (Teleostei: Osteoglossidae) from the Paleocene Paskapoo Formation of Alberta, Canada". English. In: Journal of Vertebrate Paleontology 16.2 (1996), pp. 198-209.

[13357] H. Li, B. Tian, E. L. Taylor, and T. N. Taylor. "Foliar Anatomy of Gigantonoclea guizhouensis (Gigantopteridales) from the Upper Permian of Guizhou Province, China". English. In: American Journal of Botany 81.6 (1994), pp. 678-689. DOI: 10.1002/j.1537-2197.1994.tb15502.x.

[13358] H. Y. Li, S. Bai, X. M. Lu, W. W. Zhang, B. Wang, and X. Y. Liu. “Taxonomic notes on dustywings of Aleuropteryginae (Insecta, Neuroptera, Coniopterygidae) from the mid-Cretaceous Burmese amber". English. In: Cretaceous Research 98 (2019), pp. 122-135. DOI: 10.1016/j.cretres.2019.02.008.

[13359] H. Y. Li and X. Y. Liu. "A new genus and species of Dipteromantispidae (Insecta: Neuroptera) from Cretaceous Burmese amber". Chinese. In: Acta Palaeontologica Sinica 59 (2020), pp. 100-108.

[13360] H. Y. Li, D. Zhuo, B. Wang, and X. Y. Liu. "New dipteromantispids (Insecta: Neuroptera: Dipteromantispidae) from mid-Cretaceous Myanmar amber". English. In: Cretaceous Research 116.104579 (2020). DOI: 10.1016/j.cretres.2020.104579.

[13361] J. Li. "Fossil reptiles from Zhaili member, Hedi Formation, Yuanqu, Shanxi". Chinese. In: Vertebrata PalAsiatica 29.4 (1991), pp. 276-285.

[13362] J. Li. "Fossil reptiles from Hetaoyuan Formation, Xichuan, Henan". Chinese. In: Vertebrata PalAsiatica 29.3 (1991), pp. 190-203.

[13363] J. Li, Z. Li, Y. Zhang, Z. Zhou, Z. Bai, L. Zhang, and T. Ba. “A new species of Cathayornis from the Lower Cretaceous of Inner Mongolia, China and its stratigraphic significance". English. In: Acta Geologica Sinica 82.6 (2008), pp. 1115-1123. 
[13364] J. Li, M. G. Lockley, Y. Zhang, S. Hu, M. Matsukawa, and Z. Bai. “An important ornithischian tracksite in the Early Jurassic of the Shenmu region, Shaanxi, China". English. In: Acta Geologica Sinica 86.1 (2012), pp. 1-10.

[13365] J. Li, Y. M. Luo, Y. Wang, G. F. Xu, and Z. H. Ma. “A new discovery of Colobodus Agassiz, 1844 (Colobodontidae) from the Carnian (Upper Triassic) of Guizhou, South China". English. In: Acta Geologica Sinica 93 (2019), pp. 1967-1968. DOI: 10.1111/1755-6724.13832.

[13366] J. Li, X. Wu, and X. Li. "New material of Hsisosuchus chungkingensis from Sichuan, China". Chinese. In: Vertebrata PalAsiatica 32.2 (1994), pp. 107-126.

[13367] J. X. Li, X. D. Zhao, Y. P. Gao, B. Wang, and C. T. Xiao. “Cockroach Stavba jarzembowskii sp. nov. (Blattaria: Liberiblattindae) from mid-Cretaceous Burmese amber". English. In: Cretaceous Research 115.104531 (2020). DOI: 10.1016/j.cretres.2020.104531.

[13368] J.-J. Li, M. Bater, B. -L. Hu, and L. -H. Gao. "A new type of dinosaur tracks from Lower Cretaceous of Chabu, Otog Qi, Inner Mongolia". English. In: Acta Palaeontologica Sinica 45.2 (2006), pp. 221234.

[13369] J.-J. Li, J.-C. Lü, and B. -K. Zhang. “A new Lower Cretaceous sinopteroid pterosaur from western Liaoning, China". Chinese. In: Acta Palaeontologica Sinica 42.3 (2003), pp. 442-447.

[13370] J.-L. Li. "The most primitive lower tetrapod fauna in China". English. In: Science in China Series D: Earth Sciences 44.1 (2001), pp. 47-51. DOI: 10.1007/BF02906884.

[13371] J.-L. Li, J. Liu, and O. Rieppel. “A new species of Lariosaurus (Sauropterygia: Nothosauridae) from Triassic of Guizhou, southwest China". English. In: Vertebrata PalAsiatica 40.2 (2002), pp. 122-126.

[13372] J.-L. Li, Y. Wang, Y. -Q. Wang, and C. -K. Li. “A new family of primitive mammal from the Mesozoic of western Liaoning, China [in Chinese]." Chinese. In: Chinese Science Bulletin 45 (2000), pp. 2545-2549.

[13373] K. Li, C.-Y. Yang, J. Liu, and Z. -X. Wang. "[A new sauropod from the Lower Jurassic of Huili, Sichuan, China]". Chinese. In: Vertebrata PalAsiatica 48.3 (2010), pp. 185-202.

[13374] L. Li, G. Keller, and W. Stinnesbeck. “The Late Campian and Maastrichtian in northwestern Tunisia: palaeoenvironmental inferences from lithology, macrofauna and benthic formainifera". In: Cretaceous Research 20 (1999), pp. 231-252.

[13375] L. Li, Y. Duan, D. Hu, L. Wang, S. Cheng, and L. Hou. “New Eoenantiornithid Bird from the Early Cretaceous Jiufotang Formation of Western Liaoning, China". English. In: Acta Geologica Sinica (English Edition) 80.1 (2006), pp. 38-41.

[13376] L. Li and S. Hou. "Discovery of a new bird (Enantiornithines) from Lower Cretaceous in western Liaoning, China". Chinese. In: Journal of Jilin University (Earth Science Edition) 41.3 (2011), pp. 759 763.

[13377] L. Li, D.-y. Hu, Y. Duan, E. E. Gong, and L-.h. Hou. “Alethoalaornithidae fam. nov.: a new family of enantiornithine bird from the Lower Cretaceous of western Liaoning". English. In: Acta Palaeontologica Sinica 46.3 (2007), pp. 365-372.

[13378] L. Li, D. Janussen, R. Zhan, and J. Reitner. “Oldest known fossil of Rossellids (Hexactinellida, Porifera) from the Ordovician-Silurian transition of Anhui, South China". English. In: Palaeontologische Zeitschrift 93.4 (2019), pp. 559-566. DOI: 10.1007/s12542-019-00452-3.

[13379] L. Li, W. G. Joyce, and J. Liu. "The first soft-shelled turtle from the Jehol Biota of China". English. In: Journal of Vertebrate Paleontology 35.2 (2015), e909450. DOI: 10.1080/02724634.2014.909450.

[13380] L. Li, X. Ni, X. Lu, and Q. Li. "First record of Cricetops rodent in the Oligocene of southwestern China". English. In: Historical Biology (2016). DOI: 10.1080/08912963.2016.1196686.

[13381] L. Li, C. K. Shih, C. Wang, and D. Ren. "A new fossil scorpionfly (Insecta: Mecoptera: Holcorpidae) with extremely elongate male genitalia from northeastern China". English. In: Acta Geologica Sinica 91 (2017), pp. 797-805.

[13382] L. Li, H. Tong, W. Gu, and J. Liu. "A new trionychid turtle from the Early Cretaceous of Heilongjiang Province, Northeastern China". English. In: Cretaceous Research 56 (2015), pp. 155-160. 
[13383] L. Li, H. Tong, K. Wang, S. Chen, and X. Xu. “Lindholmemydid turtles (Cryptodira: Testudinoidea) from the Late Cretaceous of Shandong Province, China". English. In: Annales de Paléontologie 99 (2013), pp. 243-259. DOI: 10.1016/j.annpal.2013.07.003.

[13384] L. Li, J. Wang, X. Zhang, and S. Hou. "A new enantiornithine bird from the Lower Cretaceous Jiufotang Formation in Jinzhou area, western Liaoning Province, China". English. In: Acta Geologica Sinica 5 (2012), pp. 1039-1044.

[13385] L. Li, J.-Q. Wang, and S. -L. Hou. "A new ornithurine bird (Hongshanornithidae) from the Jiufotang Formation of Chaoyang, Liaoning, China". Chinese. In: Vertebrata PalAsiatica 49.2 (2011), pp. 195-200.

[13386] L. F. Li, D. S. Kopylov, C. K. Shih, and D. Ren. “The first record of Ichneumonidae (Insecta: Hymenoptera) from the Upper Cretaceous of Myanmar". English. In: Cretaceous Research 70 (2016), pp. 157-162.

[13387] L. F. Li, A. P. Rasnitsyn, C. K. Shih, and D. Ren. "Anomopterellidae restored, with two new genera and its phylogeny in Evanioidea (Hymenoptera)". English. In: PLoS One 8.12 (2013), e82587.

[13388] L. F. Li, A. P. Rasnitsyn, C. K. Shih, and D. Ren. “A new genus and species of Praeaulacidae (Hymenoptera: Evanioidea) from Upper Cretaceous Myanmar amber". English. In: Cretaceous Research 55 (2015), pp. 19-24.

[13389] L. F. Li, A. P. Rasnitsyn, C. C. Labandeira, C. K. Shih, and D. Ren. "Phylogeny of Stephanidae (Hymenoptera: Apocrita) with a new genus from Upper Cretaceous Myanmar amber". English. In: Systematic Entomology 42 (2017), pp. 194-203.

[13390] L. F. Li, A. P. Rasnitsyn, C. K. Shih, and D. Ren. “The Mesozoic family Mesoserphidae and its phylogeny (Hymenoptera: Apocrita: Proctotrupoidea)". English. In: Journal of Systematic Palaeontology 15 (2016), pp. 617-639.

[13391] L. F. Li, A. P. Rasnitsyn, C. K. Shih, C. C. Labandeira, M. Buffington, D. Q. Li, and D. Ren. “Phylogeny of Evanioidea (Hymenoptera, Apocrita), with descriptions of new Mesozoic species from China and Myanmar". English. In: Systematic Entomology 43 (2018), pp. 810-842.

[13392] L. F. Li, A. P. Rasnitsyn, C. K. Shih, D. Q. Li, and D. Ren. “Two new rare wasps (Hymenoptera: Apocrita: Panguidae and Burmusculidae) from mid-Cretaceous amber of northern Myanmar". English. In: Cretaceous Research 109.104220 (2019). DOI: 10.1016/j.cretres.2019.104220.

[13393] L. F. Li, A. P. Rasnitsyn, C. K. Shih, D. Q. Li, and D. Ren. “A new species and diagnostic characters for Panguidae (Hymenoptera, Panguoidea)". English. In: Cretaceous Research 115.104563 (2020). DOI: $10.1016 /$ j.cretres.2020.104563.

[13394] L. F. Li, C. K. Shih, and D. Ren. "New fossil evaniids (Hymenoptera, Evanioidea) from the Yixian Formation of western Liaoning, China". English. In: Cretaceous Research 47 (2014), pp. 48-55.

[13395] L. F. Li, C. K. Shih, and D. Ren. “Two new wasps (Hymenoptera: Stephanoidea: Ephialtitidae) from the Middle Jurassic of China". English. In: Acta Geologica Sinica 87 (2013), pp. 1486-1494.

[13396] L. F. Li, C. K. Shih, and D. Ren. “Two new species of Nevania (Hymenoptera: Evanioidea: Praeaulacidae: Nevaniinae) from the Middle Jurassic of China". English. In: Alcheringa 39 (2014), pp. 140-147.

[13397] L. F. Li, C. K. Shih, and D. Ren. “New fossil Praeaulacinae wasps (Insecta: Hymenoptera: Evanioidea: Praeaulacidae) from the Middle Jurassic of China". English. In: Zootaxa 3814 (2014), pp. 432442.

[13398] L. F. Li, C. K. Shih, and D. Ren. “Revision of Anomopterella Rasnitsyn, 1975 (Insecta, Hymenoptera, Anomopterellidae) with two new Middle Jurassic species from northeastern China". English. In: Geologica Carpathica 65 (2014), pp. 365-374.

[13399] L. F. Li and C. K. Shih. "Two new fossil wasps (Insecta: Hymenoptera: Apocrita) from northeastern China". English. In: Journal of Natural History 49 (2015), pp. 829-840.

[13400] L. F. Li, C. K. Shih, A. P. Rasnitsyn, and D. Ren. "New fossil ephialtitids elucidating the origin and transformation of the propodeal-metasomal articulation in Apocrita (Hymenoptera)". English. In: BMC Evolutionary Biology 15.45 (2015), pp. 1-17. 
[13401] L. F. Li, C. K. Shih, and D. Ren. "New fossil helorid wasps (Hymenoptera, Proctotrupoidea) from the Early Cretaceous of China". English. In: Alcheringa 41 (2017), pp. 474-486.

[13402] L. F. Li, C. K. Shih, A. P. Rasnitsyn, D. Q. Li, and D. Ren. "A new wasp of Myanmarinidae (Hymenoptera: Stephanoidea) from the mid-Cretaceous Myanmar amber". English. In: Cretaceous Research 86 (2018), pp. 33-40.

[13403] L. F. Li, C. K. Shih, D. Q. Li, and D. Ren. “New fossil species of Ephialtitidae and Baissidae (Hymenoptera, Apocrita) from the mid-Mesozoic of northeastern China". English. In: Alcheringa 43 (2019), pp. 568-579. DOI: 10.1080/03115518.2019.1601767.

[13404] L.-G. Li, D.-Q. Li, H. -L. You, and P. Dodson. “A new titanosaurian sauropod from the Hekou Group (Lower Cretaceous) of the Lanzhou-Minhe Basin, Gansu Province, China". English. In: PLoS ONE 9.1 (2014), e85979:1-22. DOI: 10.1371/journal.pone.0085979.

[13405] P. Li, Z. Cheng, and J. Li. "A new species of Dicynodon from Upper Permian of Sunan, Gansu, with remarks on related strata". English. In: Vertebrata PalAsiatica 38 (2000), pp. 147-156.

[13406] P. Li and Y.-Q. Wang. "Newly discovered Schlosseria magister (Lophialetidae, Perissodactyla, Mammalia) skulls from central nei mongol, china". English. In: Vertebrata PalAsiatica 48.2 (2010), pp. 119-132.

[13407] P.-P. Li, K.-Q. Gao, L. -H. Hou, and X. Xu. "A gliding lizard from the Early Cretaceous of China". English. In: Proceedings of the National Academy of Sciences 104.13 (2007), pp. 5507-5509. DOI: 10. 1073/pnas.0609552104.

[13408] Q. Li. “A New Parasemionotid-Like Fish from the Lower Triassic of Jurong, Jiangsu Province, South China". English. In: Palaeontology 52.2 (2009), pp. 369-384.

[13409] Q. Li. "New material of Bamalambda from Chijiang Basin in Jiangxi, China". Chinese. In: Vertebrata PalAsiatica 43.4 (2005), pp. 325-329.

[13410] Q. Li. “Middle Eocene cricetids (Rodentia, Mammalia) from the Erlian Basin, Nei Mongol, China". English. In: Vertebrata PalAsiatica 50.3 (2012), pp. 237-244.

[13411] Q. Li. "New materials of Sianodon from Shaanxi, China". English. In: Vertebrata PalAsiatica 41.3 (2003), pp. 203-210.

[13412] Q. Li. "Brachyscirtetes tomidai, a new Late Miocene dipodid (Rodentia, Mammalia) from Siziwang Qi, central Nei Mongol, China". English. In: Historical Biology 28.1-2 (2016), pp. 35-42. DOI: 10.1080/08912963.2014.996218.

[13413] Q. Li, J. A. Clarke, K. -Q. Gao, C. -F. Zhou, Q. Meng, D. Li, L. D'Alba, and M. D. Shawkey. "Melanosome evolution indicates a key physiological shift within feathered dinosaurs". English. In: Nature 507 (2014), pp. 350-353. DOI: 10.1038/nature12973.

[13414] Q. Li, Y.-X. Gong, and Q. -Q. Wang. "New dipodid rodents from the Late Eocene of Erden Obo (Nei Mongol, China)". English. In: Historical Biology (2016). DOI: 10.1080/08912963.2016.1232406.

[13415] Q. Li, Y. Li, and W. Kiessling. "Early Ordovician sponge-Calathium-microbial reefs on the Yangtze Platform margin of the South China Block". English. In: gff (2014).

[13416] Q. Li, Y. Li, and W. Kiessling. "The first sphinctozoan-bearing reef from an Ordovician back-arc basin". English. In: Facies 61.17 (2015). DOI: 10.1007/s10347-015-0444-6.

[13417] Q. Li and J. Meng. "Eocene ischyromyids (Rodentia, Mammalia) from the Erlian Basin, Nei Mongol, China". English. In: Vertebrata PalAsiatica 51.4 (2013), pp. 289-304.

[13418] Q. Li and J. Meng. "Erlianomys combinatus, a primitive myodont rodent from the Eocene Arshanto Formation, Nuhetingboerhe, Nei Mongol, China". English. In: Vertebrata PalAsiatica 48.2 (2010), pp. 133-144.

[13419] Q. Li and J. Meng. "New ctenodactyloid rodents from the Erlian Basin, Nei Mongol, China, and the phylogenetic relationships of Eocene Asian ctenodactyloids". English. In: American Museum Novitates 3828 (2015), pp. 1-58. 
[13420] Q. Li, J. Meng, and Y. Wang. "New Cricetid Rodents from Strata near the Eocene-Oligocene Boundary in Erden Obo Section (Nei Mongol, China)". English. In: PLoS ONE 11.5 (2016), e0156233:117.

[13421] Q. Li and X. Ni. "An early Oligocene fossil demonstrates treeshrews are slowly evolving living fossils". English. In: Scientific Reports 6 (2016), 18627:1-8. DOI: 10.1038/srep18627.

[13422] Q. Li and S. C. Peng. "Huaiaspis, a new Cambrian trilobite genus from northern Anhui". Chinese. In: Acta Palaeontologica Sinica 45.4 (2006), pp. 540-548.

[13423] Q. Li, Y. Q. Wang, F. Y. Mao, and J. Meng. "A new Eocene cylindrodontid rodent from the Erlian Basin (Nei Mongol, China) and its implications for phylogeny and biochronology". English. In: Journal of Vertebrate Paleontology (2019), e1680990:1-10. DOI: 10.1080/02724634.2019.1680990.

[13424] Q. Li, Y.-Q. Wang, and L. Fostowicz-Frelik. "Small mammal fauna from Wulanhuxiu (Nei Mongol, China) implies the Irdinmanhan-Sharamurunian (Eocene) faunal turnover". English. In: Acta Palaeontologica Polonica 61.4 (2016), pp. 759-776. DOI: 10.4202/app.00292.2016.

[13425] Q. H. Li, D. Ren, and Y. J. Wang. "Revision of the gumilline genus Nilionympha with a new species from the Middle Jurassic of China (Neuroptera: Osmylidae)". English. In: Zootaxa 4399 (2018), pp. 146-150.

[13426] Q.-J. Li, Y. Li, K. Steve, Y. Zhang, and X. Deng. "Middle Member Limestone of the Ordovician Meitan Formation in Dongkala, Fenggang, Northern Guizhou, SW China: typical warm marine facies". Chinese. In: Acta Micropalaeontologica Sinica 27.2 (2010), pp. 150-158.

[13427] R. Li, M. G. Lockley, P. J. Makovicky, M. Matsukawa, M. A. Norell, J. D. Harris, and M. Liu. "Behavioral and faunal implications of Early Cretaceous deinonychosaur trackways from China". English. In: Naturwissenschaften (2007). DOI: 10.1007/s00114-007-0310-7.

[13428] R. Li, M. G. Lockley, and M. Liu. "A new ichnotaxon of fossil bird track from the Early Cretaceous Tianjialou Formation (Barremian-Albian), Shandong province, China". English. In: Chinese Science Bulletin 50.11 (2005), pp. 1149-1154. DOI: 10.1360/982004-823.

[13429] R. Li, M. G. Lockley, M. Matsukawa, K. Wang, and M. Liu. "An unusual theropod track assemblage from the Cretaceous of the Zhucheng area, Shandong Province, China". English. In: Cretaceous Research 32 (2011), pp. 422-432. DOI: 10.1016/j.cretres.2010.10.006.

[13430] R. Q. Li, K. Sashida, and Y. Ogawa. "Earliest Cretaceous initial spicule-bearing spherical radiolarians from the Mariana Trench". English. In: Journal of Paleontology 85.1 (2011), pp. 92-101.

[13431] R.-Y. Li and T. Allen. "Llandovery (Early Silurian) orthide brachiopod associations from Anticosti Island, eastern Canada". English. In: Canadian Journal of Earth Sciences 45.2 (2008), pp. 189-201. DOI: $10.1139 / \mathrm{E} 07-044$.

[13432] R. Y. Li and B. Jones. "Communities and paleoecology of Eifelian (mid-Devonian) brachiopods from the Bird Fiord Formation of Arctic Canada". In: Canadian Journal of Earth Sciences 39 (2002), pp. 1485-1503.

[13433] S. Li. "A new species of Brontotheriidae from the Middle Eocene of Junggar Basin, Xinjiang, China". English. In: Vertebrata PalAsiatica 56.1 (2018), pp. 25-44.

[13434] S. Li, C. Kang, and X. Zhang. "Sedimentary environment and trilobites of Lower Cambrian Yuxiansi Formation in Leshan District, Sichuan". Chinese. In: Bulletin of the Chengdu Institute of Geology and Mineral Resources 12 (1990), pp. 37-56.

[13435] S. Li, Y. Y. Lu, B. Wang, J. Li, X. K. Yang, and M. Bai. “+Electrorubesopsinae, a new subfamily from Cretaceous Burmese amber, as the possible sister group of Dynamopodinae (Coleoptera: Scarabaeidae)". English. In: Journal of Systematic Palaeontology 17 (2018), pp. 349-357.

[13436] S. Li, C. K. Shih, C. Wang, H. Pang, and D. Ren. "Forever love: the hitherto earliest record of copulating insects from the Middle Jurassic of China". English. In: PLoS One 8.11 (2013), e78188.

[13437] S. Li, J. Szwedo, D. Ren, and H. Pang. "Fenghuangor imperator gen. et sp. nov. of Fulgoridiidae from the Middle Jurassic of Daohugou biota (Hemiptera: Fulgoromorpha)". English. In: Zootaxa 3094 (2011), pp. 52-62. 
[13438] S. Li, Q. Z. Wang, D. Ren, and Y. Z. Yao. “New genus and species of Empheriidae (Psocodea: Trogiomorpha) from mid-Cretaceous amber of northern Myanmar". English. In: Cretaceous Research 110.104421 (2020). DOI: 10.1016/j.cretres.2020.104421.

[13439] S. Li, Y. Wang, D. Ren, and H. Pang. “Revision of the genus Sunotettigarcta Hong, 1983 (Hemiptera, Tettigarctidae), with a new species from Daohugou, Inner Mongolia, China". English. In: Alcheringa 36 (2012), pp. 501-507.

[13440] S. Li, W. W. Zhang, C. K. Shih, and D. Ren. "A new species of hangingfly (Insecta: Mecoptera: Bittacidae) from the mid-Cretaceous Myanmar amber". English. In: Cretaceous Research 89 (2018), pp. 92-97.

[13441] S. Li, Y. Zhou, X. Yao, and C. Li. "[Study on dinosaur track fossils and footprints reconstruction in Zhucheng area, Shandong Province]". Chinese. In: Geological Review 58.3 (2012), pp. 434-443.

[13442] T. T. Li and D. Ren. "A new fossil genus of Mesosciophilidae (Diptera, Nematocera) with two new species from the Middle Jurassic of Inner Mongolia, China". English. In: Progress in Natural Science 19 (2009), pp. 1837-1841.

[13443] W. Z. Li and S. Z. Shen. "Lopingian (Late Permian) brachiopods around the WuchiapingianChanghsingian boundary at the Meishan sections C and D, Changxing, south China". English. In: Geobios 41 (2008), pp. 307-320.

[13444] W. Z. Li, G. R. Shi, Y. Ariunchimeg, W. H. He, and S. Z. Shen. "Cancrinella and Costatumulus (Brachiopoda) from the Permian of South Mongolia and South China: their morphology, biostratigraphy and distribution". English. In: Geobios 45 (2012), pp. 297-309.

[13445] X. Li, X.-W. Li, S. -H. Jia, and J. Liu. "The Jiyuan tetrapod Fauna of the Upper Permian of China-1. New pareiasaur material and the reestablishment of Honania complicidentata". English. In: Acta Palaeontologica Polonica (2014). DOI: 10.4202/app.00035.2013.

[13446] X. K. Li and D. K. Yeates. "The first Ironomyiidae from mid-Cretaceous Burmese amber provides insights into the phylogeny of Phoroidea (Diptera: Cyclorrhapha)". English. In: Systematic Entomology 44 (2018), pp. 251-261.

[13447] X. R. Li and D. Y. Huang. "A new praying mantis from middle Cretaceous Burmese amber exhibits bilateral asymmetry of forefemoral spination (Insecta: Dictyoptera)". English. In: Cretaceous Research 91 (2018), pp. 269-273.

[13448] X. R. Li and D. Y. Huang. "A new Cretaceous cockroach with heterogeneous tarsi preserved in Burmese amber (Dictyoptera, Blattodea, Corydiidae)". English. In: Cretaceous Research 92 (2018), pp. 12-17.

[13449] X. R. Li and D. Y. Huang. "A new mid-Cretaceous cockroach of stem Nocticolidae and reestimating the age of Corydioidea (Dictyoptera: Blattodea)". English. In: Cretaceous Research 106.104202 (2019). DOI: 10.1016/j.cretres.2019.104202.

[13450] X. R. Li and D. Y. Huang. "A brachypterous cockroach (Dictyoptera: Blattaria: Blattoidea) and its potential relevance to the palaeoenvironment of mid-Cretaceous Myanmar amber locality". English. In: Cretaceous Research 120.104730 (2020). DOI: 10.1016/j.cretres.2020.104730.

[13451] X.-W. Li and J. Liu. “New specimens of pareiasaurs from the Upper Permian Sunjiagou Formation of Liulin, Shanxi and their indication for the taxonomy of Chinese pareiasaurs". English. In: Vertebrata PalAsiatica 51 (2013), pp. 199-204.

[13452] X. X. Li and J. F. Rigby. "Further contributions to the study of the Qubu Flora from southern Xizang (Tibet)". In: The Palaeobotanist 44 (1995), pp. 38-47.

[13453] X. X. Li and G. L. Shen. "A brief review of the Permian macrofloras in southeast Asia and their phytogeographical delimitation". In: Journal of Southeast Asian Earth Sciences 13 (1996), pp. 161170.

[13454] Y. Li, S. Kershaw, and X. Chen. "Biotic structure and morphology of patch reefs from South China (Ningqiang Formation, Telychian, Llandovery, Silurian)". In: Facies 46 (2002), pp. 133-148. 
[13455] Y. Li and S. Kershaw. "Reef Reconstruction after Extinction Events of the Latest Ordovician in the Yangtze Platform, South China". English. In: Facies 48 (2003), pp. 269-284.

[13456] Y. Li, S. Kershaw, and X. Mu. "Ordovician reef systems and settings in South China before the Late Ordovician mass extinction". English. In: Palaeogeography, Palaeoclimatology, Palaeoecology 205 (2004), pp. 235-254.

[13457] Y. Li, X. H. Liu, D. Ren, X. C. Li, and Y. Z. Yao. "First report of Cixiidae insect fossils from the Miocene of the northeastern Tibetan Plateau and their palaeoenvironmental implications". English. In: Alcheringa 41 (2017), pp. 54-60.

[13458] Y. Li, J. Wang, A. J. Shen, and Z. Huang. "Evolutionary significance of the Calathium reef mound from the Yijianfang Formation, Bachu, Xinjiang". Chinese. In: Acta Palaeontologica Sinica 46.3 (2007), pp. 341-348.

[13459] Y. D. Li, Z. H. Liu, E. A. Jarzembowski, Z. W. Yin, D. Y. Huang, and C. Y. Cai. "Early evolution of Cupedidae revealed by a mid-Cretaceous reticulated beetle from Myanmar (Coleoptera: Archostemata)". English. In: Systematic Entomology 44 (2019), pp. 777-786.

[13460] Y. D. Li, E. Tihelka, Z. H. Liu, D. Y. Huang, and C. Y. Cai. "Muonabuntor gen. nov., a new genus of false click beetles from mid-Cretaceous Burmese amber (Coleoptera: Elateroidea: Eucnemidae)". English. In: Palaeoentomology 3 (2020), pp. 399-406.

[13461] Y. D. Li, S. Yamamoto, D. Y. Huang, and C. Y. Cai. “A miniaturized ommatid beetle in midCretaceous Burmese amber (Coleoptera: Archostemata: Ommatidae)". English. In: Papéis Avulsos de Zoologia 60.e20206063 (2020).

[13462] Y. F. Li, W. Huang, H. S. Wang, D. L. Dilcher, X. Tan, T. Li, Y. L. Na, and C. L. Sun. “The first discovery of the easternmost Jehol biota from southeastern Jilin, China". English. In: Acta Geologica Sinica 92 (2018), pp. 1649-1650.

[13463] Y. F. Li, C. L. Sun, T. Li, Y. L. Na, Y. J. Chen, and D. H. Xing. “Solenites (Czekanowskiales) from the late Mesozoic Jehol biota of southeastern Jilin and its paleoclimatic implications". English. In: Acta Geologica Sinica 89 (2015), pp. 1088-1102.

[13464] Y. J. Li, O. Béthoux, H. Pang, and D. Ren. "Early Pennsylvanian Odonatoptera from the Xiaheyan locality (Ningxia, China): new material, taxa, and perspectives". English. In: Fossil Record 16 (2013), pp. 117-139.

[13465] Y. J. Li, G. Han, A. Nel, D. Ren, H. Pang, and X. L. Liu. “A new fossil petalurid dragonfly (Odonata: Petaluroidea: Aktassiidae) from the Cretaceous of China". English. In: Alcheringa 36 (2012), pp. 319322.

[13466] Y. J. Li, A. Nel, D. Ren, B. L. Zhang, and H. Pang. "A new Chinese Mesozoic dragonfly clarifies the relationships between Rudiaeschnidae and Cymatophlebiidae (Odonata: Aeshnoptera)". English. In: Zootaxa 2802 (2011), pp. 51-57.

[13467] Y. J. Li, A. Nel, D. Ren, and H. Pang. "A new damsel-dragonfly from the Lower Cretaceous of China enlightens the systematics of the Isophlebioidea (Odonata: Isophlebioptera: Campterophlebiidae)". English. In: Cretaceous Research 34 (2012), pp. 340-343.

[13468] Y. J. Li, A. Nel, D. Ren, and H. Pang. “New gomphaeschnids and progobiaeshnids from the Yixian Formation in Liaoning Province (China) illustrate the tremendous Upper Mesozoic diversity of the aeshnopteran dragonflies". English. In: Geobios 45 (2012), pp. 339-350.

[13469] Y. J. Li, A. Nel, D. Ren, and H. Pang. "Redescription of the damsel-dragonfly Parafleckium senjituense on the basis of a more complete specimen (Odonata: Isophlebioptera: Campterophlebiidae)". English. In: Zootaxa 3597 (2012), pp. 53-56.

[13470] Y. J. Li, A. Nel, C. K. Shih, D. Ren, and H. Pang. "The first euthemistid damsel-dragonfly from the Middle Jurassic of China (Odonata, Epiproctophora, Isophlebioptera)". English. In: ZooKeys 261 (2013), pp. 41-50. DOI: 10.3897/zookeys.261.4371.

[13471] Y. J. Li, A. Nel, D. Ren, and H. Pang. "A new damsel-dragonfly from the Mesozoic of China with a hook-like male anal angle (Odonata: Isophlebioptera: Campterophlebiidae)". English. In: Journal of Natural History (2013), pp. 1-6. 
[13472] Y. J. Li, A. Nel, D. Ren, B. L. Zhang, and H. Pang. “New discoveries of Neogene hawker dragonflies (Insecta, Odonata, Aeshnidae) from Shandong province in China". English. In: Zoosystema 33 (2011), pp. 577-590.

[13473] Y. J. Li, A. Nel, D. Ren, B. L. Zhang, and H. Pang. “Reassessment of the Jurassic damsel-dragonfly genus Karatawia (Odonata: Campterophlebiidae)". English. In: Zootaxa 3417 (2012), pp. 64-68.

[13474] Y. J. Li, A. Nel, D. Ren, and H. Pang. "A new genus and species of hawker dragonfly of uncertain affinities from the Middle Jurassic of China (Odonata: Aeshnoptera)". English. In: Zootaxa 2927 (2011), pp. 57-62.

[13475] Y. J. Li, D. Ren, M. Pecharová, and J. Prokop. “A new palaeodictyopterid (Insecta: Palaeodictyoptera: Spilapteridae) from the Upper Carboniferous of China supports a close relationship between insect faunas of Quilianshian (northern China) and Laurussia". English. In: Alcheringa 37 (2013), pp. 487-495.

[13476] Y. L. Li, J. Chen, and B. Wang. "New Cretaceous palaeontinids (Insecta, Hemiptera) from northeast China". English. In: Cretaceous Research 95 (2018), pp. 130-137.

[13477] Y. L. Li, E. Jarzembowski, J. Chen, and B. Wang. “New Palaeontinidae (Insecta: Hemiptera) from the Lower Cretaceous of southern England". English. In: Cretaceous Research 95 (2019), pp. 297301. DOI: 10.1016/j.cretres.2018.11.019.

[13478] Y. L. Li, D. Ren, and C. K. Shih. "Two Middle Jurassic hanging-flies (Insecta: Mecoptera: Bittacidae) from northeast China". English. In: Zootaxa 1929 (2008), pp. 38-46.

[13479] Y. L. Li and D. Ren. "Middle Jurassic Bittacidae (Insecta, Mecoptera) from Daohugou, Inner Mongolia, China". Chinese. In: Acta Zootaxonomica Sinica 34 (2009), pp. 560-567.

[13480] Y.X. Li. “Famennian Tentaculitids of China”. English. In: Journal of Paleontology 74.5 (2000), pp. 969 975.

[13481] Y.-X. Li, S.-M. Hu, S. -J. Wang, Y. -X. Zhang, J. Li, K. Xie, and Y. Chen. "Fossil lizards and snakes from the middle Pleistocene of China". English. In: Journal of Vertebrate Paleontology e1631175 (2019), pp. 1-5. DOI: 10.1080/02724634.2019.1631175.

[13482] Y.-X. Li, Y.-X. Zhang, J. Li, Z. -C. Li, and K. Xie. "New fossils of paraceratheres (Perissodactyla, Mammalia) from the Early Oligocene of the Lanzhou Basin, Gansu Province, China". English. In: Vertebrata PalAsiatica 56.4 (2017), pp. 367-381.

[13483] Z. Li, J. Fang, X. Li, S. Ma, and J. Chen. "Mesozoic strata of Chaoshui Basin, northwest China". Chinese. In: Palaeoworld 14 (2002), pp. 49-75.

[13484] Z. Li, Y. C. Hong, and D. Yang. "A new Middle Triassic genus and species of Mylacridae (Blattodea) from China". English. In: Zootaxa 1660 (2007), pp. 53-59.

[13485] Z. Li, Y. Li, X. Xue, W. Li, Y. Zhang, and F. Yang. "A New Fossil Erinaceidae from the Shajingyi Area in the Lanzhou Basin, China". English. In: Acta Geologica Sinica (English Edition) 93.4 (2019), pp. 789-798.

[13486] Z. Li, T. A. Stidham, T. Deng, and Z. Zhou. "Evidence of Late Miocene Peri-Tibetan Aridification From the Oldest Asian Species of Sandgrouse (Aves: Pteroclidae)". English. In: Frontiers in Ecology and Evolution 8 (2020), 59:1-10. DOI: 10.3389/fevo.2020.00059.

[13487] Z. Li, Z. Zhou, M. Wang, and J. A. Clarke. "A new specimen of large-bodied basal enantiornithine Bohaiornis from the Early Cretaceous of China and the inference of feeding ecology in Mesozoic birds". English. In: Journal of Paleontology 88.1 (2014), pp. 99-108.

[13488] Z.-C. Li, Y.-X. Li, Y. -X. Zhang, W. -H. Li, and K. Xie. "Nanpoping fauna of the Lanzhou Basin and its environmental significance". English. In: Science China Earth Sciences 59.6 (2016), pp. 1258-1266.

[13489] Z.-G. Li, D.-Y. Jiang, O. Rieppel, R. Motani, A. Tintori, Z. -Y. Sun, and C. Ji. "A new species of Xinpusaurus (Reptilia, Thalattosauria) from the Ladinian (Middle Triassic) of Xingyi, Guizhou, southwestern China". English. In: Journal of Vertebrate Paleontology 36.6 (2016), e1218340. DOI: 10. 1080/02724634.2016.1218340. 
[13490] F. Y. Liang, W. W. Zhang, and X. Y. Liu. "A new genus and species of the paraneopteran family Archipsyllidae in mid-Cretaceous amber of Myanmar". English. In: Zootaxa 4105 (2016), pp. 483490.

[13491] J. H. Liang, W. L. Huang, and D. Ren. “Graciliblatta bella gen. et sp. n. - a rare carnivorous cockroach (Insecta, Blattida, Raphidiomimidae) from the Middle Jurassic sediments of Daohugou in Inner Mongolia, China". English. In: Zootaxa 3449 (2012), pp. 62-68.

[13492] J. H. Liang, C. K. Shih, and D. Ren. "New Jurassic predatory cockroaches (Blattaria: Raphidiomimidae) from Daohugou, China and Karatau, Kazakhstan". English. In: Alcheringa 42 (2018), pp. 101109.

[13493] J. H. Liang, C. K. Shih, L. X. Wang, and D. Ren. "New cockroaches (Insecta, Blattaria, Fuziidae) from the Middle Jurassic Jiulongshan Formation in northeastern China". English. In: Alcheringa 43 (2019), pp. 441-448. DOI: 10.1080/03115518.2019.1576061.

[13494] J. H. Liang, P. Vranský, D. Ren, and C. Shih. "A new Jurassic carnivorous cockroach (Insecta, Blattaria, Raphidiomimidae) from the Inner Mongolia in China". English. In: Zootaxa 1974 (2009), pp. 17-30.

[13495] J. H. Liang, P. Vranský, and D. Ren. "Variability and symmetry of a Jurassic nocturnal predatory cockroach (Blattida: Raphidiomimidae)". English. In: Revista Mexicana de Ciencias Geológicas 29 (2012), pp. 411-421.

[13496] W. P. Liang. Lengwu Formation of Permian and its Brachiopod Fauna in Zhejiang Province. Chinese. Vol. 2. Geological Memoirs 10. 1990, pp. 1-522.

[13497] X. Liang, S. Wen, D. Yang, S. Zhou, and S. Wu. "Dinosaur eggs and dinosaur egg-bearing deposits (Upper Cretaceous) of Henan Province, China: Occurrences, palaeoenvironments, taphonomy and preservation". English. In: Progress in Natural Science 19.11 (2009), pp. 1587-1601. DOI: 10.1016/j.pnsc.2009.06.012.

[13498] Y. Liang, R.-b. Zhan, and J. Jin. "The oldest known occurrence of the Foliomena fauna in the uppermost Darriwilian (Middle Ordovician) of South China". English. In: Lethaia 47 (2014), pp. 432436. DOI: $10.1111 /$ let.12069.

[13499] Z. L. Liang, Z. H. Qi, J. H. Chen, and F. L. Jia. “Cretodineutus rotundus gen. et sp. nov., the oldest adult whirligig beetle from the Upper Cretaceous of Myanmar (Coleoptera, Gyrinidae, Gyrininae)". English. In: Cretaceous Research 106.104251 (2020). DOI: 10.1016/j.cretres.2019.104251.

[13500] J.-C. Liao and J. I. Valenzuela-Rios. “Givetian and early Frasnian conodonts from the Compte section (Middle-Upper Devonian, Spanish Central Pyrenees)". English. In: Geological Quarterly 52.1 (2008), pp. 1-18.

[13501] W. Liao and J. Xia. "Mesozoic and Cenozoic scleractinian corals from Xizang". Chinese. In: Palaeontologia Sinica 184.31 (1994), pp. 1-252.

[13502] Z. T. Liao and X. J. Wang. "Fossil ophiuroids from Tongziyan Formation (Middle Permian) in Longyan, Fujian". Chinese. In: Acta Palaeontologica Sinica 41.3 (2002), pp. 396-402.

[13503] L. K. Libbey and M. E. Johnson. "Upper Pleistocene Rocky Shores and Intertidal Biotas at Playa La Palmita (Baja California Sur,Mexico)". English. In: Journal of Coastal Research 13.1 (1997), pp. 216225.

[13504] D. K. Lich. “Cosomys primus: a case for stasis". English. In: Paleobiology 16.3 (1990), pp. 384-395.

[13505] A. Lichtig, J. H. Hutchison, and S. G. Lucas. "Additional records of turtles from the Eocene San Jose Formation, San Juan Basin, New Mexico". English. In: Fossil Record 6. New Mexico Museum of Natural History and Science Bulletin 79 (2018), pp. 319-322.

[13506] A. Lichtig and S. G. Lucas. "The trionychid turtle Axestemys montinsana from the Paleocene Nacimiento Formation, San Juan Basin, New Mexico". English. In: Fossil Record 6. New Mexico Museum of Natural History and Science Bulletin 79 (2018), pp. 369-373. 
[13507] A. J. Lichtig, S. E. Jasinski, and S. G. Lucas. “Eocene North American Testudinidae and Geoemydidae (Reptilia, Testudines): A re-evaluation of their alpha taxonomy, ecology and origin". English. In: Proceedings of the 2nd International Electronic Conference on Geosciences (2019), pp. 1-6. DOI: 10.3390/IECG2019-06195.

[13508] A. J. Lichtig and S. G. Lucas. "Paleocene-Eocene turtles of the Piceance Creek Basin, Colorado". English. In: New Mexico Museum of Natural History and Science Bulletin 67 (2015), pp. 145-152.

[13509] A. J. Lichtig and S. G. Lucas. "Turtles of the lower Eocene San Jose Formation, San Juan Basin, New Mexico". English. In: New Mexico Museum of Natural History and Science Bulletin 67 (2015), pp. 161-177.

[13510] A. J. Lichtig and S. G. Lucas. "Turtles of the Eocene Huerfano Formatoin, Raton Basin, Colorado". English. In: New Mexico Museum of Natural History and Science Bulletin 67 (2015), pp. 153-160.

[13511] A. J. Lichtig and S. G. Lucas. "A new species of Neurankylus (Testudines: Baenidae) from the Upper Cretaceous Crevasse Canyon Formation, southern New Mexico, USA". English. In: New Mexico Museum of Natural History and Science Bulletin 74 (2016), pp. 117-119.

[13512] B. S. Lieberman. "Phylogenetic analysis of the Olenellina Walcott, 1890 (Trilobita, Cambrian)". English. In: Journal of Paleontology 75.1 (2001), pp. 96-115. DOI: 10.1666/0022-3360(2001)075<0096: PAOTOW>2.0.CO;2.

[13513] B. S. Lieberman. "Evolution of the trilobite subfamily Proetinae Salter, 1864, and the origin, diversification, evolutionary affinity, and extinction of the Middle Devonian proetid fauna of eastern North America". English. In: Bulletin of the American Museum of Natural History 223 (1994), pp. 1176.

[13514] P. M. Liebig, K. W. Flessa, and T. A. Taylor. “Taphonomic variation despite catastrophic mortality: Analysis of a mass stranding of false killer whales (Pseudorca crassidens), Gulf of California, Mexico". English. In: Palaios 22 (2007), pp. 384-391.

[13515] T. Liebrecht, J. Fortuny, A. Galobart, J. Müller, and P. M. Sander. "A large, multiple-tooth-rowed captorhinid reptile (Amniota: Eureptilia) from the Upper Permian of Mallorca (Balearic Islands, western Mediterranean)". English. In: Journal of Vertebrate Paleontology 37.1 (2017), e1251936. DOI: 10.1080/02724634.2017.1251936.

[13516] G. A. Liggett. "The Beckerdite local biota (early Hemphillian) and the first Tertiary occurrence of a crocodilian from Kansas". English. In: Transactions of the Kansas Academy of Sciences 100.3-4 (1997), pp. 101-108.

[13517] G. A. Liggett. "A review of the dinosaurs from Kansas". In: Transactions of the Kansas Academy of Science 108.1/2 (2005), pp. 1-14.

[13518] G. A. Liggett, K. Shimada, S. C. Bennett, and B. A. Schumacher. “Cenomanian (Late Cretaceous) reptiles from northwestern Russell County, Kansas". English. In: PaleoBios 25 (2005), pp. 9-17.

[13519] F. Lihoreau, J.-R. Boisserie, F. K. Manthi, and S. Ducrocq. "Hippos stem from the longest sequence of terrestrial cetartiodactyl evolution in Africa". English. In: Nature Communications 6.6264 (2015). DOI: $10.1038 /$ ncomms7264.

[13520] F. Lihoreau, S. Ducrocq, P. -O. Antoine, M. Vianey-Liaud, S. Rafaß, G. Garcia, and X. Valentin. "First complete skulls of Elomeryx crispus (Gervais, 1849) and of Protaceratherium albigense (Roman, 1912) from a new Oligocene locality near Moissac (SW France)". English. In: Journal of Vertebrate Paleontology 29.1 (2009), pp. 242-253.

[13521] A. Likius, P. Vignaud, and M. Brunet. “Une nouvelle espéce du genre Bohlinia (Mammalia, Giraffidae) du Miocéne supérieur de Toros-Menalla, Tchad". French. In: Comptes Rendus Palevol 6 (2007), pp. 211-220. DOI: 10.1016/j.crpv.2006.12.003.

[13522] L. Liljedahl. "Yonginella, a new bivalve (Mollusca) from the Silurian of Gotland". English. In: Journal of Paleontology 66.2 (1992), pp. 211-214.

[13523] M. Liljeroth, D. A. T. Harper, H. Carlisle, and A. T. Nielsen. “Ordovician rhynchonelliformean brachiopods from Co. Waterford, SE Ireland: Palaeobiogeography of the Leinster Terrane". English. In: Fossils and Strata 62 (2017), pp. 1-164. 
[13524] J. A. Lillegraven and J. J. Eberle. "Vertebrate faunal changes through Lancian and Puercan time in southern Wyoming". English. In: Journal of Paleontology 73.4 (1999), pp. 691-710.

[13525] J.-D. Lim, L. D. Martin, and R. W. Wilson. "A new species of Leptarctus (Carnivora, Mustelidae) from the late Miocene of Texas". English. In: Journal of Paleontology 75.5 (2001), pp. 1043-1046.

[13526] J.-D. Lim. “The first dolphin fossil from the Miocene of Korea”. English. In: Current Science 89.6 (2005), pp. 939-940.

[13527] J.-D. Lim and L. D. Martin. "A new fossil mustelid from the Miocene of South Dakota, USA". English. In: Naturwissenschaften 89.6 (2002), pp. 270-274. DOI: 10.1007/s00114-002-0315-1.

[13528] J.-D. Lim and D.-S. Miao. “New species of Leptarctus (Carnivora, Mustelidae) from the Miocene of Nebraska, USA". In: Vertebrata PalAsiatica 38.1 (2000), pp. 52-57.

[13529] B. Lin and S. Rodriguez. "Permian rugose corals from south Gansu, northwest China". English. In: Geobios 27.3 (1994), pp. 293-302.

[13530] C.-H. Lin, R. Brzobohaty, D. Nolf, and A. Girone. "Tortonian teleost otoliths from northern Italy: taxonomic synthesis and stratigraphic significance". English. In: European Journal of Taxonomy 322 (2017), pp. 1-44. DOI: 10.5852/ ejt.2017.322.

[13531] C.-H. Lin, D. Nolf, E. Steurbaut, and A. Girone. "Fish otoliths from the Lutetian of the Aquitaine Basin (SW France), a breakthrough in the knowledge of the European Eocene ichthyofauna". English. In: Journal of Systematic Palaeontology 15.11 (2017), pp. 879-907. DOI: 10.1080/14772019.2016. 1246112.

[13532] H. Q. Lin, Z. Y. Sun, A. Tintori, C. Lombardo, D. Y. Jiang, and W. C. Hao. "A new species of Habroichthys Brough, 1939 (Actinopterygii; Peltopleuriformes) from the Pelsonian (Anisian, Middle Triassic) of Yunnan Province, South China". English. In: Neues Jahrbuch für Geologie und Paläontologie, Abhandlungen 262 (2011), pp. 79-89.

[13533] J.-P. Lin. “Taphonomy of naraoiids (Arthropoda) from the Middle Cambrian Kaili Biota, Guizhou Province, South China". English. In: Palaios 21 (2006), pp. 15-25.

[13534] L. Lin, L. Zhu, Y. Pang, and J. Sha. "A new genus of Pergamidiidae (Bivalvia) from the Late Triassic of the Changtai-Gacun area, eastern Qinghai-Xizang Plateau, China". English. In: Journal of Asian Earth Sciences 30 (2007), pp. 108-112. DOI: 10.1016/j.jseaes.2006.08.005.

[13535] M. Y. Lin and M. Bai. "Qitianniu zhihaoi gen. et sp. nov.: The first cerambycid beetle found in Cretaceous Burmese amber (Coleoptera: Chrysomeloidea)". English. In: Cretaceous Research 75 (2017), pp. 173-178.

[13536] Q. Lin, D. Huang, and A. Nel. "A new genus of Chifengiinae (Orthoptera: Ensifera: Prophalangopsidae) from the Middle Jurassic (Jiulongshan Formation) of Inner Mongolia, China". English. In: Comptes Rendus Palevol 7 (2008), pp. 205-209.

[13537] Q. B. Lin. "Late Triassic insect fauna from Toksun, Xinjiang". Chinese. In: Acta Palaeontologica Sinica 31 (1992), pp. 313-335.

[13538] Q. B. Lin. “On Penaphis Lin, 1980 of Cretaceous (Callaphididae, Homoptera) and its coevolutionary relationships". Chinese. In: Acta Palaeontologica Sinica 34 (1995), pp. 194-204.

[13539] Q. B. Lin. "Insecta, II: Jurassic-Early Cretaceous insects". Chinese. In: Paleontological Atlas of Jilin Province. 1992, pp. 417-424.

[13540] Q. B. Lin, D. Y. Huang, and A. Nel. “A new family of Cavilabiata from the Lower Cretaceous Yixian Formation, China (Odonata: Anisoptera)". English. In: Zootaxa 1469 (2007), pp. 59-64.

[13541] Q. B. Lin and D. Y. Huang. "Discovery of Paleocene Prophalangopsidae (Insecta, Orthoptera) in the Jiangtang Basin, Northern Tibet, China". English. In: Alcheringa 30.1 (2006), pp. 97-102.

[13542] Q. B. Lin and D. Y. Huang. "Description of Caenoephemera shangyuanensis gen. nov., sp. nov. (Ephemeroptera) from the Yixian Formation". English. In: The Canadian Entomologist 133 (2001), pp. 747-754. 
[13543] Q. B. Lin and D. Y. Huang. "Revision of Parahagla lamina Lin, 1982 and two new species of Aboilus (Orthoptera: Prophalangopsidae) from the Early-Middle Jurassic of northwest China". English. In: Progress in Natural Science 16.spec issue (2006), pp. 303-307.

[13544] Q. B. Lin and D. Y. Huang. “New Middle Jurassic mayflies (Insecta: Ephemeroptera: Siphlonuridae) from Innger Mongolia, China". English. In: Annales Zoologici 58 (2008), pp. 521-527.

[13545] Q. B. Lin and E. D. Lukashevich. "Proptychopterina (Diptera: Eoptychopteridae) from the Jurassic of northeastern China". English. In: Paleontological Journal 40.3 (2006), pp. 290-294.

[13546] Q. B. Lin, A. Nel, and D. Y. Huang. "The first agetopanorpine mecopteroid insect from Middle Permian of China (Insecta: Mecoptera: Permochoristidae)". English. In: Annales de la Société Entomologique de France 46 (2010), pp. 62-66.

[13547] Q. B. Lin, A. Nel, and D. Y. Huang. "Sinaktassia tangi, a new Chinese Mesozoic genus and species of Aktassiidae (Odonata: Petaluroidea)". English. In: Zootaxa 2359 (2010), pp. 61-64.

[13548] Q. B. Lin, J. F. Petruleviius, D. Y. Huang, A. Nel, and M. S. Engel. "First fossil Calopterygoidea (Odonata: Zygoptera) from southeastern Asia: A new genus and species from the Paleogene of China". English. In: Geobios 43 (2010), pp. 349-353. DOI: 10.1016/j.geobios.2009.11.005.

[13549] Q. B. Lin, J. Szwedo, D. Y. Huang, and A. Stroinski. “Weiwoboidae fam. nov. of 'Higher' Fulgoroidea (Hemiptera: Fulgoromorpha) from the Eocene deposits of Yunnan, China". English. In: Acta Geologica Sinica 84.4 (2010), pp. 751-755.

[13550] Q. B. Lin, S. Zhang, and D. Y. Huang. "Fuxiaeschna hsiufunia gen. nov., spec. nov., a new Lower Cretaceous dragonfly from northwestern China (Aeshnoptera: Rudiaeschnidae)". English. In: Odonatologica 33 (2004), pp. 437-442.

[13551] Q. Q. Lin, L. J. Kong, C. K. Shih, Y. Y. Zhao, and D. Ren. “The latest record of Hexagenitidae (Insecta: Ephemeroptera) with elongated abdominal sternum IX from mid-Cretaceous Myanmar amber". English. In: Cretaceous Research 91 (2018), pp. 140-146.

[13552] Q. Q. Lin, C. K. Shih, Y. Y. Zhao, and D. Ren. "A new genus and species of Prosopistomatidae (Insecta: Ephemeroptera) from mid-Cretaceous Myanmar amber". English. In: Cretaceous Research 84 (2017), pp. 401-406.

[13553] S. Lin, Y. Z. Yao, and D. Ren. "A new scale insect of the extinct family Weitschatidae (Insecta: Hemiptera: Coccomorpha) from mid-Cretaceous Burmese amber”. English. In: Zootaxa 4407 (2018), pp. 427-434.

[13554] T. R. Lin. "Middle Cambrian stratigraphy and trilobite fauna of Taoyuan, NW Hunan". Chinese. In: Acta Palaeontologica Sinica 30.3 (1991), pp. 360-376.

[13555] W. Lin, X. D. Wang, E. Poty, and M. Aretz. "Late Visean to Early Serpukhovian rugose corals from the Yashui Section, Guizhou, South China". English. In: Geologica Belgica 15.4 (2012), pp. 329-339.

[13556] X. D. Lin, C. C. Labandeira, C. K. Shih, C. L. Hotton, and D. Ren. "Life habits and evolutionary biology of new two-winged long-proboscid scorpionflies from mid-Cretaceous Myanmar amber". English. In: Nature Communications 10.1235 (2019). DOI: 10.1038/s41467-019-09236-4.

[13557] X. D. Lin, M. J. H. Shih, C. C. Labandeira, and D. Ren. "New data from the Middle Jurassic of China shed light on the phylogeny and origin of the proboscis in the Mesopsychidae (Insecta: Mecoptera)". English. In: BMC Evolutionary Biology 16.1 (2016), pp. 1-22.

[13558] X. Q. Lin, C. K. Shih, and D. Ren. "Two new species of Mesoplecia (Insecta: Diptera: Protopleciidae) from the late Middle Jurassic of China". English. In: Zootaxa 3838 (2014), pp. 545-556.

[13559] X. Q. Lin, C. K. Shih, and D. Ren. "New fossil mesosciophilids (Diptera: Nematocera) from the Yixian Formation (Lower Cretaceous) of western Liaoning, China". English. In: Cretaceous Research 54 (2015), pp. 86-97.

[13560] X. Q. Lin, C. K. Shih, and D. Ren. "Revision of the genus Epimesoplecia Zhang, 2007 (Diptera, Nematocera, Protopleciidae) with five new species". English. In: ZooKeys 492 (2015), pp. 123-143. 
[13561] Z.-C. Lin, A. T.-S. Lin, and S. -W. Yu. "Fossil seed from the Miocene Shihti Formation of Taiwan". English. In: Terrestrial, Atmospheric and Oceanic Sciences 24.4 (2013), pp. 731-735. DOI: 10.3319/ TAO.2013.03.11.01(TT).

[13562] E. Liñán, M. E. Dies, J. A. Gamez Vintaned, R. Gozalo, E. Mayoral, and F. Muñiz. "Lower Ovetian (Lower Cambrian) trilobites and biostratigraphy of the Pedroche Formation (Sierra de Córdoba, southern Spain)". English. In: Géobios 38 (2005), pp. 365-381.

[13563] O. J. Linares. “Nuevos restos del género Lestodon Gervais, 1855 (Xenarthra, Tardigrada, Mylodontidae), del Mioceno Tardo y Plioceno Temprano de Urumaco (Venezuela), con descripción de dos nuevas especies". English. In: Paleobiologa Neotropical 2 (2004), pp. 1-14.

[13564] O. J. Linares. "Bioestratigrafia de la fauna de mamferos de las Formaciones Socorro, Urumaco y Codore (Mioceno medio - Plioceno temprno)de la región de Urumaco, Falcon, Venezuela". Spanish. In: Paleobiologia Neotropical 1 (2004), pp. 1-26.

[13565] D. R. Lindberg and C. Hedegaard. "A deep waterr patellogastropod from Oligocene water-logged wood of Washington State (Acmaeoidea: Pectinodonta)". English. In: Journal of Molluscan Studies 62 (1996), pp. 299-314.

[13566] D. R. Lindberg and R. L. Squires. “Patellogastropods (Mollusca) from the Eocene Tejon Formation of southern California". English. In: Journal of Paleontology 64.4 (1990), pp. 578-587.

[13567] R. H. Lindemann and P. Karabinos. Dacryoconarid bioevents of the Onondaga Formation and the Marcellus Subgroup, Cherry Valley, New York. English. Guidebooks for fieldtrips in New York and Vermont. 2002, B.7.1-B.7.17.

[13568] R. H. Lindemann and D. A. Melycher. "Tentaculites (Tentaculutoidea) from the Manlius Limestone (Lower Devonian) at Schoharie, New York". In: Journal of Paleontology 71.3 (1997), pp. 360368.

[13569] J. Lindgren. "The first record of Hainosaurus (Reptilia: Mosasauridae) from Sweden". English. In: Journal of Paleontology 79.6 (2005), pp. 1157-1165.

[13570] J. Lindgren. "Cranial osteology of the giant mosasaur Plesiotylosaurus (Squamata, Mosasauridae)". English. In: Journal of Paleontology 83.3 (2009), pp. 448-456.

[13571] J. Lindgren. "Dental and vertebral morphology of the enigmatic mosasaur Dollosaurus (Reptilia, Mosasauridae) from the lower Campanian (Upper Cretaceous) of southern Sweden". English. In: Bulletin of the Geological Society of Denmakr 52 (2005), pp. 17-25.

[13572] J. Lindgren. "First record of Halisaurus (Squamata: Mosasauridae) from the Pacific coast of North America". English. In: PaleoBios 27.2 (2007), pp. 40-47.

[13573] J. Lindgren, M. W. Caldwell, and J. W. Jagt. "New data on the postcranial anatomy of the California mosasaur Plotosaurus bennisoni (Camp, 1942) (Upper Cretaceous: Maastrichtian), and the taxonomic status of P. tuckeri (Camp, 1942)". English. In: Journal of Vertebrate Paleontology 28.4 (2008), pp. 1043-1054.

[13574] J. Lindgren, M. W. Caldwell, T. Konishi, and L. M. Chiappe. “Convergent evolution in aquatic tetrapods: insights from an exceptional fossil mosasaur". English. In: PLoS One 5.8 (2010), e11998. DOI: 10.1371/journal.pone.0011998.

[13575] J. Lindgren, P. J. Currie, M. Siverson, J. Rees, P. Cederström, and F. Lindgren. "The first neoceratopsian dinosaur remains from Europe". English. In: Palaeontology 50.4 (2007), pp. 929-937.

[13576] J. Lindgren, P. J. Currie, J. Rees, M. Siverson, S. Lindström, and C. Alwmark. “Theropod dinosaur teeth from the lowermost Cretaceous Rabekke Formation on Bornholm, Denmark". English. In: Geobios 41 (2008), pp. 253-262. DOI: 10.1016/j.geobios.2007.05.001.

[13577] J. Lindgren, M. J. Everhart, and M. W. Caldwell. “Three-dimensionally preserved integument reveals hydrodynamic adaptations in the extinct marine lizard Ectenosaurus (Reptilia, Mosasauridae)". English. In: PLoS One 6.11 (2011), e27343.

[13578] J. Lindgren and J. W. M. Jagt. "Danish mosasaurs". English. In: Netherlands Journal of Geosciences - Geologie en Mijnbouw 84.3 (2005), pp. 315-320. 
[13579] J. Lindgren, J. Rees, M. Siverson, and G. Cuny. "The first Mesozoic mammal from Scandinavia". English. In: GFF 126 (2004), pp. 325-330.

[13580] J. Lindgren and A. S. Schulp. "New material of Prognathodon (Squamata: Mosasauridae), and the mosasaur assemblage of the Maastrichtian of California, USA". English. In: Journal of Vertebrate Paleontology 30.5 (2010), pp. 1632-1636.

[13581] J. Lindgren and M. Siverson. "Halisaurus sternbergi, a small mosasaur with an intercontinental distribution". English. In: Journal of Paleontology 79.4 (2005), pp. 763-773.

[13582] J. Lindgren and M. Siverson. "The first record of the mosasaur Clidastes from Europe and its palaeogeographical implications". English. In: Acta Palaeontologica Polonica 49.2 (2004), pp. 219234.

[13583] J. Lindgren and M. Siverson. "Tylosaurus ivoensis: a giant mosasaur from the early Campanian of Sweden". English. In: Transactions of the Royal Society of Edinburgh: Earth Sciences 93 (2002), pp. $73-$ 93. DOI: $10.1017 /$ S026359330000033X.

[13584] J. Lindgren, P. Sjövall, R. M. Carney, A. Cincotta, P. Uvdal, S. W. Hutcheson, O. Gustafsson, U. Lefévre, F. Escuillié, J. Heimdal, A. Engdahl, J. A. Gren, B. P. Kear, K. Wakamatsu, J. Yans, and P. Godefroit. "Molecular composition and ultrastructure of Jurassic paravian feathers". English. In: Scientific Reports 5 (2015), 13520:1-13. DOI: 10.1038/srep13520.

[13585] I. D. Lindley. "Tertiary echinoids from Papua New Guinea". English. In: Proceedings of the Linnean Society of New South Wales 123 (2001), pp. 119-139.

[13586] R. M. Lindoso, T.d.S. Marinho, R. M. Santucci, M. A. Medeiros, and I.d.S. Carvalho. "A titanosaur (Dinosauria: Sauropoda) osteoderm from the Alcantara Formation (Cenomanian), São Lus Basin, Northeastern Brazil”. English. In: Cretaceous Research 45 (2013), pp. 43-48. DOI: 10.1016/j.cretres. 2013.07.005.

[13587] R. M. Lindoso, M. A. Medeiros, I. de S. Carvalho, and T. da S. Marinho. "Masiakasaurus-like theropod teeth from the Alcantara Formation, São Lus Basin (Cenomanian), northeastern Brazil". English. In: Cretaceous Research 36 (2012), pp. 119-124. DOI: 10.1016/j.cretres.2012.03.002.

[13588] R. M. Lindoso, M. A. A. Medeiros, I. S. Carvalho, A. A. Pereira, I. D. Mendes, F. V. Iori, E. P. Sousa, S. H. S. Arcanjo, and T. C. M. Silva. "A new rebbachisaurid (Sauropoda: Diplodocoidea) from the middle Cretaceous of northern Brazil”. English. In: Cretaceous Research 104 (2019), 104191:1-15. DOI: 10.1016/j.cretres.2019.104191.

[13589] B. E. K. Lindow and G. J. Dyke. "Bird evolution in the Eocene: climate change in Europe and a Danish fossil fauna". English. In: Biological Reviews (Cambridge) 81.4 (2006), pp. 483-499.

[13590] E. H. Lindsay. "Copemys and the Barstovian/Hemingfordian Boundary". English. In: Journal of Vertebrate Paleontology 15.2 (1995), pp. 357-365.

[13591] E. H. Lindsay, L. J. Flynn, I. U. Cheema, J. C. Barry, K. Downing, A. R. Rajpar, and S. M. Raza. "Will Downs and the Zinda Pir Dome". English. In: Palaeontologia Electronica 8.1 (2005), 19A:1-18.

[13592] E. H. Lindsay and L. J. Flynn. "Late Oligocene and Early Miocene Muroidea of the Zinda Pir Dome". English. In: Historical Biology 28.1-2 (2016), pp. 215-236.

[13593] E. Lindsey and E. Lopez. "Tanque Loma, a new late-Pleistocene megafaunal tar seep locality from southwest Ecuador". English. In: Journal of South American Earth Sciences 57 (2015), pp. 61-82.

[13594] T. Lingham-Soliar. "A new mosasaur Pluridens walkeri from the Upper Cretaceous, Maastrichtian of the Iullemmeden Basin, southwest Niger". English. In: Journal of Vertebrate Paleontology 18.4 (1998), pp. 709-707.

[13595] T. Lingham-Soliar. "Mosasaurs from the Upper Cretacous of Niger". English. In: Palaeontology 34.3 (1991), pp. 653-670.

[13596] T. Lingham-Soliar. "First record of mosasaurs from the Maastrichtian (Upper Cretaceous) of Zaire". English. In: Palaeontologische Zeitschrift 68.1/2 (1994), pp. 259-265. 
[13597] T. Lingham-Soliar. “Anatomy and Functional Morphology of the Largest Marine Reptile Known, Mosasaurus hoffmanni (Mosasauridae, Reptilia) from the Upper Cretaceous, Upper Maastrichtian of the Netherlands". English. In: Philosophical Transactions of the Royal Society of London B: Biological Sciences 347.1320 (1995), pp. 155-180.

[13598] T. Lingham-Soliar, T. Broderick, and A. A. K. Ahmed. "Closely associated theropod trackways from the Jurassic of Zimbabwe". In: Naturwissenschaften 90 (2003), pp. 572-576.

[13599] T. Lingham-Soliar, A. Feduccia, and X. Wang. "A new Chinese specimen indicates that 'protofeathers' in the Early Cretaceous theropod dinosaur Sinosauropteryx are degraded collagen fibres". English. In: Proceedings of the Royal Society of London B (2007).

[13600] M. Linklater. "Past and present coral distribution at the latitudinal limit of reef development, southwest Pacific Ocean". English. PhD thesis. 2016.

[13601] G. Lio, F. L. Agnoln, R. Juarez Valieri, L. Filippi, and D. Rosales. "A new peirosaurid (Crocodilyformes) from the Late Cretaceous (Turonian-Coniacian) of Patagonia, Argentina". English. In: Historical Biology 28.6 (2016), pp. 835-841. DOI: 10.1080/08912963.2015.1043999.

[13602] L. Liping, M. Fortelius, and M. Pickford. "New fossil Suidae from Shanwang, Shandong, China". English. In: Journal of Vertebrate Paleontology 22.1 (2002), pp. 152-163. DOI: 10.1671/0272-4634(2002) 022[0152:NFSFSS]2.0.CO;2.

[13603] T. R. Lipka. The affinities of the enigmatic theropods of the Arundel Clay facies (Aptian), Potomac Formation, Atlantic Coastal Plain of Maryland. English. Vol. 14. Lower and Middle Cretaceous Terrestrial Ecosystems; New Mexico Museum of Natural History and Science Bulletin. 1998, pp. 229-234.

[13604] T. R. Lipka. "Recovery of new dinosaur and other fossils from the Early Cretaceous Arundel Clay facies (Potomac Group) of central Maryland, U.S.A." English. In: Special Publication - The Paleontological Society 8 (1996), p. 241.

[13605] T. R. Lipka, F. Therrien, D. B. Weishampel, H. A. Jamniczky, W. G. Joyce, M. W. Colbert, and D. B. Brinkman. "A new turtle from the Arundel Clay facies (Potomac Formation, Early Cretaceous) of Maryland, USA". English. In: Journal of Vertebrate Paleontology 26.2 (2006), pp. 300-307.

[13606] J. A. Lis, B. Lis, and E. Heiss. "Chilamnestocoris mixtus gen. et spec. nov., the rst burrower bug (Hemiptera: Pentatomoidea: Cydnidae) in Upper Cretaceous Burmese amber". English. In: Cretaceous Research 91 (2018), pp. 257-262.

[13607] J. A. Lis, M. Roca-Cusachs, B. Lis, and S. Jung. "Pullneyocoris dentatus gen. et sp. nov. (Hemiptera: Pentatomoidea: Cydnidae), the third representative of the subfamily Amnestinae from mid-Cretaceous amber of northern Myanmar". English. In: Cretaceous Research 115.104562 (2020). DOI: 10.1016/j. cretres.2020.104562.

[13608] D. V. Lisitsyn. “The first Permian find of the genus Hederella (Bryozoa)". English. In: Paleontological Journal 32.6 (1998), pp. 589-591.

[13609] D. V. Lisitsyn and A. Ernst. "A revision of the Paleozoic bryozoan genera Synocladia and Thamniscus". English. In: Paleontological Journal 38.3 (2004), pp. 285-293.

[13610] A. M. Lister and J. M. McGlade. “The Early Middle Pleistocene vertebrate fauna from Little Oakley, Essex". In: Philosophical Transactions of the Royal Society of London B 328 (1990), pp. 359-385.

[13611] J. J. Liston. "A re-examination of a Middle Jurassic sauropod limb bone from the Bathonian of the Isle of Skye". English. In: Scottish Journal of Geology 40.2 (2004), pp. 119-122.

[13612] J. J. Liston and D. Gendry. “Le Python de Caen, les algues géantes d'Amblie, et austres spécimens perdus de Leedsichthys d'Alexandre Bourienne, Jules Moriére, Eugéne Eudes-Deslongchamps et Alexandre Bigot". French. In: L'Echo des falaises 19 (2015), pp. 17-34.

[13613] M. Liter and D. Prothero. New dromomerycids (Mammalia: Artiodactyla) from the middle Miocene Sharktooth Hill Bonebed, California, and the systematics of the cranioceratinins. English. 2003.

[13614] C. T. S. Little, T. Danelian, R. J. Herrington, and R. M. Haymon. "Early jurassic hydrothermal vent community from the Franciscan Complex, California". English. In: Journal of Paleontology 78.3 (2004), pp. 542-559. 
[13615] S. A. Little, R. A. Stockey, and G. W. Rothwell. “Solenostelopteris skogiae sp. nov. from the Lower Cretaceous of Vancouver Island [Canada]". English. In: Journal of Plant Research 119.5 (2006), pp. 525532.

[13616] S. A. Little, R. A. Stockey, and G. W. Rothwell. "Stramineopteris aureopilosus gen. et sp. nov.: reevaluating the role of vegetative anatomy in the resolution of leptosporangiate fern phylogeny". English. In: International Journal of Plant Sciences 167.3 (2006), pp. 683-694. DOI: 10.1086/501156.

[13617] A. G. Liu, J. J. Matthews, L. R. Menon, D. McIlroy, and M. D. Braiser. "Haootia quadriformis n. gen., n. sp., interpreted as a muscular cnidarian impression from the late Ediacaran period (approx. $560 \mathrm{Ma}) "$. English. In: Proceedings of the Royal Society B 281 (2014). DOI: 10.1098/ rspb. 2014.1202.

[13618] B. Liu, J. K. Rigby, Y. Jiang, and Z. Zhu. "Lower Ordovician lithistid sponges from the eastern Yangtze Gorge area, Hubei, China". English. In: Journal of Paleontology 71.2 (1997), pp. 194-207.

[13619] B. Liu, J. K. Rigby, and Z. Zhu. "Middle Ordovician lithistid sponges from the Bachu-Kalpin area, Xinjiang, northwestern China". English. In: Journal of Paleontology 77.3 (2003), pp. 430-441.

[13620] C. X. Liu, T. P. Gao, C. K. Shih, and D. Ren. "New pelecinid wasps (Hymenoptera: Proctotrupoidea: Pelecinidae) from the Yixian Formation of western Liaoning, China". English. In: Acta Geologica Sinica 85.4 (2011), pp. 749-757.

[13621] C. X. Liu, C. K. Shih, and D. Ren. "The earliest fossil record of the wasp subfamily Pelecininae (Hymenoptera: Proctotrupoidea: Pelecinidae) from the Yixian Formation of China". English. In: Zootaxa 2080 (2009), pp. 47-54.

[13622] D. Liu, L. M. Chiappe, Y. -G. Zhang, A. Bell, Q. -J. Meng, Q. Ji, and X. Wang. “An advanced, new long-legged bird from the Early Cretaceous of the Jehol Group (northeastern China): insights into the temporal divergence of modern birds". English. In: Zootaxa 3884.3 (2014), pp. 253-266.

[13623] D. Liu, L. M. Chiappe, F. Serrano, M. Habib, Y. -G. Zhang, and Q. -J. Meng. “Flight aerodynamics in enantiornithines: Information from a new Chinese Early Cretaceous bird". English. In: PLoS ONE 12.10 (2017), e0184637. DOI: 10.1371/journal.pone.0184637.

[13624] D. Liu, L. M. Chiappe, Y. -G. Zhang, F. J. Serrano, and Q. -J. Meng. "Soft tissue preservation in two new enantiornithine specimens (Aves) from the Lower Cretaceous Huajiying Formation of Hebei Province, China". English. In: Cretaceous Research 95 (2019), pp. 191-207. DOI: 10.1016/j.cretres. 2018.10.017.

[13625] G. Liu and G. Chen. "Late Cenozoic crocodilian fossils from Jiangsu". Chinese. In: Vertebrata PalAsiatica 31.1 (1993), pp. 61-64.

[13626] G. B. Liu, H. Z. Feng, J. X. Wang, T. M. Wu, and Z. H. Zhai. “Early Triassic fishes from Jurong, Jiangsu". Chinese. In: Acta Palaeontologica Sinica 41 (2002), pp. 27-52.

[13627] G. B. Liu and Q. Wang. "New material of Sinohelicoprion from Changxing, Zhejiang Province". Chinese. In: Vertebrata PalAsiatica 32 (1994), pp. 244-248.

[13628] G. B. Liu, C. Z. Yin, X. H. Wang, Y. M. Luo, and S. Y. Wang. “New discovered fishes from Keichousaurusbearing horizon of Late Triassic in Xingyi of Guizhou". Chinese. In: Acta Palaeontologica Sinica 42 (2003), pp. 346-366.

[13629] J. Liu. "A nearly complete skeleton of Ikechosaurus pijiagouensis sp. nov. (Reptilia: Choristodera) from the Jiufotang Formation (Lower Cretaceous) of Liaoning, China". English. In: Vertebrata PalAsiatica 42.2 (2004), pp. 120-129.

[13630] J. Liu. "Parakannemeyeria chengi sp. nov. from Kelamayi Formation of Jimusar, Xinjiang". Chinese. In: Vertebrata PalAsiatica 42 (2004), pp. 77-80.

[13631] J. Liu. "New discoveries from the Sinokannemeyeria-Shansisuchus Assemblage Zone: 1. Kannemeyeriiformes from Shanxi, China". English. In: Vertebrata PalAsiatica 53.1 (2015), pp. 16-28.

[13632] J. Liu. "Yuanansuchus maopingchangensis sp. nov., the second capitosauroid temnospondyl from the Middle Triassic Badong Formation of Yuanan, Hubei, China". English. In: PeerJ 4 (2016), e1903. DOI: $10.7717 /$ peerj.1903. 
[13633] J. Liu. “Taoheodon baizhijuni, gen. et sp. nov. (Anomodontia, Dicynodontoidea), from the upper Permian Sunjiagou Formation of China and its implications". English. In: Journal of Vertebrate Paleontology 40.1 (2020), e1762088. DOI: 10.1080/02724634.2020.1762088.

[13634] J. Liu and F. Abdala. "New discoveries from the Sinokannemeyeria-Shansisuchus Assemblage". English. In: Vertebrata PalAsiatica 53.2 (2015), pp. 123-132.

[13635] J. Liu and F. Abdala. “Therocephalian (Therapsida) and chroniosuchian (Reptiliomorpha) from the Permo-Triassic transitional Guodikeng Formation of the Dalongkou Section, Jimsar, Xinjiang, China". English. In: Vertebrata PalAsiatica 55 (2017), pp. 24-40.

[13636] J. Liu and F. Abdala. "The tetrapod fauna of the upper Permian Naobaogou Formation of China: 1. Shiguaignathus wangi gen. et sp. nov., the first akidnognathid therocephalian from China". English. In: PeerJ 5 (2017), e4150.

[13637] J. Liu, J. Aitchison, Y. Y. Sun, Q. Y. Zhang, C. Y. Zhou, and T. Lv. “New Mixosaurid Ichthyosaur Specimen from the Middle Triassic of SW China: Further Evidence for the Diapsid Origin of Ichthyosaurs". English. In: Journal of Paleontology 85.1 (2011), pp. 32-36. DOI: 10.1666/09-131.1.

[13638] J. Liu and J. C. Aitchison. "Upper Paleocene radiolarians from the Yamdrock melange, south Xizang (Tibet), China". English. In: Micropaleontology 48.1 (2002), pp. 145-154.

[13639] J. Liu and G. S. Bever. "The last diadectomorph sheds light on Late Palaeozoic tetrapod biogeography". English. In: Biology Letters 11 (2015), p. 20150100. DOI: 10.1098/rsbl.2015.0100.

[13640] J. Liu and G. S. Bever. "The tetrapod fauna of the upper Permian Naobaogou Formation of China: a new species of Elginia (Parareptilia, Pareiasauria)". English. In: Papers in Palaeontology 4.2 (2018), pp. 197-209.

[13641] J. Liu, S.-X. Hu, O. Rieppel, D. -Y. Jiang, M. J. Benton, N. P. Kelley, J. C. Aitchison, C. -Y. Zhou, W. Wen, J. -Y. Huang, T. Xie, and T. Lv. "A gigantic nothosaur (Reptilia: Sauropterygia) from the Middle Triassic of SW China and its implication for the Triassic biotic recovery". English. In: Scientific Reports 4 (2014), p. 7142. DOI: 10.1038/srep07142.

[13642] J. Liu, S. Ji, F. Tang, and C. Gao. "A new species of dromaeosaurids from the Yixian Formation of western Liaoning". Chinese. In: Geological Bulletin of China 23.8 (2004), pp. 778-783.

[13643] J. Liu and J.-L. Li. "[A new material of kannemeyerid from Xinjiang and the restudy of Parakannemeyeria brevirostris]". English. In: Vertebrata PalAsiatica 41.2 (2003), pp. 147-156.

[13644] J. Liu, J.-L. Li, and Z. -W. Cheng. "[The Lystrosaurus fossils from Xinjiang and their bearing on the terrestrial Permian-Triassic boundary]". Chinese. In: Vertebrata PalAsiatica 40.4 (2002), pp. 267-275.

[13645] J. Liu, R. Motani, D. -Y. Jiang, S. -X. Hu, J. C. Aitchison, O. Rieppel, M.J. benton, Q. -Y. Zhang, and C. -Y. Zhou. "The first specimen of the Middle Triassic Pharalodon atavus (Ichthyosauria: Mixosauridae) from South China, showing postcranial anatomy and peri-Tethyan distribution". English. In: Palaeontology 56.4 (2013), pp. 849-866. DOI: 10.1111/pala.12021.

[13646] J. Liu, C. L. Organ, M. J. Benton, M. C. Brandley, and J. C. Aitchison. "Live birth in an archosauromorph reptile". English. In: Nature Communications (2017).

[13647] J. Liu and J. Powell. “Osteology of Andescynodon (Cynodontia: Traversodontidae) from the Middle Triassic of Argentina". English. In: American Museum Novitates 3674 (2009), pp. 1-19.

[13648] J. Liu and O. Rieppel. "The second thalattosaur from the Triassic of Guizhou, China". English. In: Vertebrata PalAsiatica 39.2 (2001), pp. 78-87.

[13649] J. Liu, O. Rieppel, D. -Y. Jiang, J. C. Aitchison, R. Motani, Q. -Y. Zhang, C. -Y. Zhou, and Y. -Y. Sun. "A new pachypleurosaur (Reptilia: Sauropterygia) from the lower Middle Triassic of southwestern China and the phylogenetic relationships of Chinese pachypleurosaurs". English. In: Journal of Vertebrate Paleontology 31.2 (2011), pp. 292-302.

[13650] J. Liu, B. Rubidge, and J. Li. "New basal synapsid supports Laurasian origin for therapsids". English. In: Acta Palaeontologica Polonica 54.3 (2009), pp. 393-400. DOI: 10.4202/app.2008.0071. 
[13651] J. Liu, M. Steiner, J. A. Dunlop, H. Keupp, D. Shu, Q. Ou, J. Han, Z. Zhang, and X. Zhang. “An armoured Cambrian lobopodian from China with arthropod-like appendages". English. In: Nature 470.7335 (2011), pp. 526-530.

[13652] J. Liu and H.-D. Sues. "Dentition and tooth replacement of Boreogomphodon (Cynodontia: Traversodontidae) from the Upper Triassic of North Carolina, USA". English. In: Vertebrata PalAsiatica 48 (2010), pp. 169-184.

[13653] J. Liu and Y. Wang. "The first complete mastodonsauroid skull from the Triassic of China: Yuanansuchus laticeps gen. et sp. nov." English. In: Journal of Vertebrate Paleontology 25.3 (2005), pp. 725728.

[13654] J. Liu, L. Xu, S. -H. Jia, H. -Y. Pu, and X. -L. Liu. "The Jiyuan tetrapod fauna of the Upper Permian of China-2. stratigraphy, taxonomical review, and correlation". English. In: Vertebrata PalAsiatica 52.3 (2014), pp. 328-339.

[13655] J. W. Liu, W. W. Zhang, W. Z. Cai, and H. Li. “Two new species of angel insects in mid-Cretaceous Burmese amber (Zoraptera: Zorotypidae)". English. In: Cretaceous Research 90 (2018), pp. 259-264.

[13656] J.-Y. Liu. "Megantereon fossil remains from Renzidong Cave, Fanchang County, Anhui Province". Chinese. In: Vertebrata PalAsiatica 43.2 (2005), pp. 122-134.

[13657] J.-Y. Liu, Q. Wang, Z. -K. Zhao, X. -L. Wang, C. -L. Gao, and C. -Z. Shen. "A parataxonomic revision of spheroolithid eggs from the Upper Cretaceous Quantou Formation in Changtu, Liaoning". Chinese. In: Vertebrata PalAsiatica 51.4 (2013), pp. 278-288.

[13658] J.-Y. Liu and Z.-K. Zhao. "A new oospecies of the dinosaur eggs (Dictyoolithus) from Laiyang, Shandong Province". Chinese. In: Vertebrata PalAsiatica 42.2 (2004), pp. 166-170.

[13659] L. X. Liu, C. K. Shih, and D. Ren. "Two new species of Ptychopteridae and Trichoceridae from the Middle Jurassic of northeastern China (Insecta: Diptera: Nematocera)". English. In: Zootaxa 3501 (2012), pp. 55-62.

[13660] L.-P. Liu. "Eocene suoids (Artiodactyla, Mammalia) from Bose and Yongle basins, China, and the classification and evolution of the Paleogene suoids". English. In: Vertebrata PalAsiatica 39.2 (2001), pp. 115-128.

[13661] L.-P. Liu and X.-S. Huang. "Propterodorz (Hyaenodontidae, Creodonta, Mammalia) from the Middle Eocene of Yuanqu Basin, Shanxi Province". English. In: Vertebrata PalAsiatica 40.2 (2002), pp. 133-138.

[13662] M. Liu, W. H. Lu, and D. Ren. "A new fossil mordellid (Coleoptera: Tenebrionoidea: Mordellidae) from the Yixian Formation of Western Liaoning Province, China". English. In: Zootaxa 1415 (2007), pp. 49-56.

[13663] M. Liu and D. Ren. "First fossil Eccoptarthridae (Coleoptera: Curculionoidea) from the Mesozoic of China". English. In: Zootaxa 1176 (2006), pp. 59-68.

[13664] M. Liu and D. Ren. "New fossil eccoptarthrids (Coleoptera: Curculionoidea) from the Yixian Formation of western Liaoning, China". English. In: Science in China Series D: Earth Sciences 50 (2007), pp. 641-648.

[13665] M. Liu, D. Ren, and J. J. Tan. "New fossil weevils (Coleoptera: Curculionoidea: Nemonychidae) from the Jehol biota of western Liaoning, China". English. In: Annales Zoologici 56 (2006), pp. 605612.

[13666] M. Liu, D. Ren, and C. K. Shih. "A new fossil weevil (Coleoptera, Curculionoidea, Belidae) from the Yixian Formation of western Liaoning, China". English. In: Progress in Natural Science 16 (2006), pp. 885-888.

[13667] M. Liu, Y. Y. Zhao, and D. Ren. “Discovery of three new mordellids (Coleoptera, Tenebrionoidea) from the Yixian Formation of western Liaoning, China". English. In: Cretaceous Research 29 (2008), pp. $445-450$. 
[13668] N. Liu, Y. Y. Zhao, and D. Ren. “Two new fossil species of Itaphlebia (Mecoptera: Nannochoristidae) from Jiulongshan Formation, Inner Mongolia, China". English. In: Zootaxa 2420 (2010), pp. 37-45.

[13669] P. Liu, S. Xiao, C. Yin, C. Zhou, L. Gao, and F. Tang. "Systematic description and phylogenetic affinity of tubular microfossils from the Ediacaran Doushantuo Formation at Weng'an, south China". English. In: Palaeontology 51.2 (2008), pp. 339-366.

[13670] Q. Liu, A. V. Khramov, and H. C. Zhang. "A new species of Kalligramma Walther, 1904 (Insecta, Neuroptera, Kalligrammatidae) from the Middle-Upper Jurassic of Daohugou, Inner Mongolia, China". English. In: Alcheringa 39 (2015), pp. 438-442.

[13671] Q. Liu, A. V. Khramov, H. C. Zhang, and E. A. Jarzembowski. "Two new species of Kalligrammula Handlirsch, 1919 (Insecta, Neuroptera, Kalligrammatidae) from the Jurassic of China and Kazakhstan". English. In: Journal of Paleontology 89 (2015), pp. 405-410.

[13672] Q. Liu, X. M. Lu, Q. Q. Zhang, J. Chen, X. T. Zheng, W. W. Zhang, X. Y. Liu, and B. Wang. “High niche diversity in Mesozoic pollinating lacewings". English. In: Nature Communications 9.3793 (2018), pp. 1-11.

[13673] Q. Liu, H. C. Zhang, B. Wang, Y. Fang, D. R. Zheng, Q. Zhang, and E. A. Jarzembowski. “A new genus of Saucrosmylinae (Insecta, Neuroptera) from the Middle Jurassic of Daohugou, Inner Mongolia, China". English. In: Zootaxa 3736 (2013), pp. 387-391.

[13674] Q. Liu, H. C. Zhang, B. Wang, Y. Fang, D. R. Zheng, Q. Zhang, and E. A. Jarzembowski. "A new saucrosmylid lacewing (Insecta, Neuroptera) from the Middle Jurassic of Daohugou, Inner Mongolia, China". English. In: Alcheringa 38 (2014), pp. 301-304.

[13675] Q. Liu, D. R. Zheng, Q. Zhang, B. Wang, Y. Fang, and H. C. Zhang. “Two new kalligrammatids (Insecta, Neuroptera) from the Middle Jurassic of Daohugou, Inner Mongolia, China". English. In: Alcheringa 39 (2014), pp. 65-69.

[13676] S. L. Liu, C. K. Shih, and D. Ren. “Four new species of hangingflies (Insecta, Mecoptera, Bittacidae) from the Middle Jurassic of northeastern China". English. In: ZooKeys 466 (2014), pp. 77-94.

[13677] S. L. Liu, C. K. Shih, A. Bashkuev, and D. Ren. "New Jurassic hangingflies (Insecta: Mecoptera: Bittacidae) from Inner Mongolia, China". English. In: Zootaxa 4067 (2016), pp. 65-78.

[13678] W. Liu, X. Wu, S. Pei, and C. J. Norton. "Huanglong Cave: A Late Pleistocene human fossil site in Hubei Province, China". English. In: Quaternary International (2009). DOI: 10.1016/j.quaint.2009. 06.017.

[13679] W. X. Liu, P. T. Rühr, and T. Wesener. "A look with mCT technology into a treasure trove of fossils: The first two fossils of the millipede order Siphoniulida discovered in Cretaceous Burmese amber (Myriapoda, Diplopoda)". English. In: Cretaceous Research 74 (2017), pp. 100-108.

[13680] X. Liu, O. Béthoux, X. C. Yin, and D. Ren. "The smallest Palaeodictyoptera (Insecta) discovered at Xiaheyan (Late Carboniferous, China)". English. In: Comptes Rendus Palevol 14 (2015), pp. 346-352.

[13681] X. Liu, Z. Liu, M. Yang, R. Yang, Y. Xiao, and Y. Wang. “A preliminary study on the Devonian Buzhai reefs in southern Guizhou". Chinese. In: Chinese Journal of Geology 39.1 (2004), pp. 92-97.

[13682] X. Liu, G. X. Qiao, Y. Z. Yao, and D. Ren. “New fossil Juraphididae (Hemiptera: Aphidomorpha) from Burmese amber, with phylogeny of the family". English. In: Cretaceous Research 84 (2017), pp. $420-425$.

[13683] X. Liu, G. X. Qiao, Y. Z. Yao, and D. Ren. “A new species of the aphid family Burmitaphididae (Hemiptera: Sternorrhyncha: Aphidomorpha) from Upper Cretaceous Burmese amber". English. In: Alcheringa 43 (2019), pp. 455-460. DOI: 10.1080/03115518.2019.1579367.

[13684] X. H. Liu, Y. Li, Y. Z. Yao, and D. Ren. "A hairy-bodied tettigarctid (Hemiptera: Cicadoidea) from the latest Middle Jurassic of northeast China". English. In: Alcheringa 40 (2016), pp. 383-389.

[13685] X. Y. Liu, H. Aspöck, S. L. Winterton, W. W. Zhang, and U. Aspöck. "Phylogeny of pleasing lacewings (Neuroptera: Dilaridae) with a revised generic classification and description of a new subfamily". English. In: Systematic Entomology 42 (2017), pp. 448-471. 
[13686] X. Y. Liu, X. M. Lu, and W. W. Zhang. "New genera and species of the minute snakeflies (Raphidioptera: Mesoraphidiidae: Nanoraphidiini) from the mid Cretaceous of Myanmar". English. In: Zootaxa 4103 (2016), pp. 301-324.

[13687] X. Y. Liu, X. M. Lu, and W. W. Zhang. "Halteriomantispa grimaldii gen. et sp. nov.: A new genus and species of the family Dipteromantispidae (Insecta: Neuroptera) from the mid-Cretaceous amber of Myanmar". English. In: Zoological Systematics 41 (2016), pp. 165-172.

[13688] X. Y. Liu, X. M. Lu, and W. W. Zhang. "New genera and species of the family Dipteromantispidae (Insecta: Neuroptera) from the Cretaceous amber of Myanmar and New Jersey". English. In: Cretaceous Research 72 (2016), pp. 18-25.

[13689] X. Y. Liu, X. M. Lu, F. Y. Xia, and B. Wang. "First description of female of Haplosialodes liui Huang et al., 2016 (Megaloptera: Sialidae) from Cretaceous Burmese amber". English. In: Zootaxa 4254 (2017), pp. 593-598.

[13690] X. Y. Liu, X. M. Lu, and W. W. Zhang. "Phylogenetic position of Corydasialidae (Insecta: Neuropterida) revisited based on a significant new fossil in Cretaceous amber of Myanmar". English. In: Journal of Systematic Palaeontology 15 (2016), pp. 571-581.

[13691] X. Y. Liu and X. M. Lu. "A remarkable new genus of Cretaceous dustywings (Neuroptera: Coniopterygidae) in amber from northern Myanmar". English. In: Zoological Systematics 42 (2017), pp. 380-389.

[13692] X. Y. Liu, V. N. Makarkin, Q. Yang, and D. Ren. “A remarkable new genus of basal snakeflies (Insecta: Raphidioptera: Priscaenigmatomorpha) from the Early Cretaceous of China". English. In: Cretaceous Research 45 (2013), pp. 306-313.

[13693] X. Y. Liu, D. Ren, and D. Yang. "New transitional fossil snakeflies from China illuminate the early evolution of Raphidioptera". English. In: BMC Evolutionary Biology 14.84 (2014), pp. 1-15.

[13694] X. Y. Liu, G. L. Shi, F. Y. Xia, X. M. Lu, B. Wang, and M. S. Engel. "Liverwort mimesis in a Cretaceous lacewing larva". English. In: Current Biology 28 (2018), pp. 1475-1481.

[13695] X. Y. Liu, Y. J. Wang, C. K. Shih, D. Ren, and D. Yang. "Early evolution and historical biogeography of fishflies (Megaloptera: Chauliodinae): implications from a phylogeny combining fossil and extant taxa". English. In: PLoS One 7.7 (2012), e40345.

[13696] X. Y. Liu, W. W. Zhang, S. L. Winterton, L. C. V. Breitkreuz, and M. S. Engel. “Early morphological specializations for insect-spider associations in Mesozoic lacewings". English. In: Current Biology 26 (2016), pp. 1590-1594.

[13697] Y. Liu, D. Ren, N. D. Sinitshenkova, and C. Shih. "A new Middle Jurassic Stonefly from Daohugou, Inner Mongolia, China (Insecta: Plecoptera)". English. In: Annales Zoologici 56.3 (2006), pp. 549554.

[13698] Y. Liu, T. Shao, H. Zhang, Q. Wang, Y. Zhang, C. Chen, Y. Liang, and J. Xue. “A new scyphozoan form the Cambrian Fortunian Stage of South China". English. In: Palaeontology 60.4 (2017), pp. 511518. DOI: 10.1111 / pala.12306.

[13699] Y. Liu, H. L. Shi, C. Y. Cai, H. B. Liang, and D. Y. Huang. "The first record of Cretaceous ground beetle (Coleoptera: Carabidae: Oodini) from Burmese amber". English. In: Cretaceous Research 52 (2015), pp. 427-430.

[13700] Y. C. Liu, E. Tihelka, S. Yamamoto, Z. W. Yin, D. Y. Huang, L. Tian, and C. Y. Cai. “The first fossil record of the rove beetle subfamily Protopselaphinae (Coleoptera: Staphylinidae) from midCretaceous Burmese amber". English. In: Cretaceous Research 110.104416 (2020). DOI: 10.1016/j. cretres.2020.104416.

[13701] Y. H. Liu, Y. Li, T. Q. Shao, Y. P. Wang, B. Yu, H. P. Han, and J. Yang. “Two new species of protoconulariids from the Early Cambrian in south Shaanxi, China". Chinese. In: Acta Micropalaeontologica Sinica 22.3 (2005), pp. 311-321. 
[13702] Y. H. Liu, E. Tihelka, T. C. McElrath, S. Yamamoto, A. lipiski, B. Wang, D. Ren, and H. Pang. "New minute clubbed beetles (Coleoptera, Monotomidae, Lenacini) from mid-Cretaceous amber of northern Myanmar". English. In: Cretaceous Research 107.104255 (2019). DOI: 10.1016/j.cretres. 2019.104255.

[13703] Y. J. Liu, W. T. Zhang, Y. Z. Yao, and D. Ren. “A new fossil of Necrotauliidae (Insecta: Trichoptera) from the Jiulongshan Formation of China and its taxonomic significance". English. In: PLoS One 9.12 (2014), e114968.

[13704] Y. M. Liu, C. Y. Cai, and D. Y. Huang. "First soldier fly from the mid-Cretaceous Burmese amber (Diptera, Stratiomyidae)". English. In: Cretaceous Research 70 (2016), pp. 142-146.

[13705] Y. M. Liu and D. Y. Huang. "A large new nemestrinid fly from the lower Cretaceous Yixian formation at Liutiaogou, Ningcheng County, Inner Mongolia, NE China". English. In: Cretaceous Research 96 (2018), pp. 107-112.

[13706] Y. M. Liu and D. Y. Huang. "New materials of Nemestrinidae (Diptera: Brachycera) from the midCretaceous Burmese amber". English. In: Cretaceous Research 104.104173 (2019). DOI: 10.1016/j. cretres.2019.07.003.

[13707] Y. S. Liu, D. Ren, and J. Prokop. “Discovery of a new Namurian archaeorthopterid from Ningxia, China (Insecta: Archaeorthoptera)". English. In: Zootaxa 2032 (2009), pp. 63-68.

[13708] Y. S. Liu, D. Ren, N. D. Sinitshenkova, and C. K. Shih. "Three new stoneflies (Insecta: Plecoptera) from the Yixian Formation of Liaoning, China". English. In: Acta Geologica Sinica 82 (2008), pp. 249 256.

[13709] Y. S. Liu, D. Ren, N. D. Sinitshenkova, and C. K. Shih. "The oldest known record of Taeniopterygidae in the Middle Jurassic of Daohugou, Inner Mongolia, China (Insecta: Plecoptera)". English. In: Zootaxa 1521 (2007), pp. 1-8.

[13710] Y. S. Liu and D. Ren. "Two new Jurassic stoneflies (Insecta: Plecoptera) from Daohugou, Inner Mongolia, China". English. In: Progress in Natural Science 18 (2008), pp. 1038-1042.

[13711] Y. S. Liu, C. F. Shi, and D. Ren. "A new lacewing (Insecta: Neuroptera: Grammolingiidae) from the Middle Jurassic of Inner Mongolia, China". English. In: Zootaxa 2897 (2011), pp. 51-56.

[13712] Y. S. Liu, N. D. Sinitshenkova, D. Ren, and C. K. Shih. "Pronemouridae fam. nov. (Insecta: Plecoptera), the stem group of Nemouridae and Notonemouridae, from the Middle Jurassic of Inner Mongolia, China". English. In: Palaeontology 54.4 (2011), pp. 923-933.

[13713] Y. S. Liu, N. D. Sinitshenkova, and D. Ren. "A new genus and species of stonefly (Insecta: Plecoptera) from the Yixian Formation, Liaoning Province, China". English. In: Cretaceous Research 28 (2007), pp. 322-326.

[13714] Y. S. Liu, N. D. Sinitshenkova, and D. Ren. "A revision of the Jurassic stonefly genera Dobbertiniopteryx Ansorge and Karanemoura Sinitshenkova (Insecta: Plecoptera), with the description of new species from the Daohugou locality, China". English. In: Paleontological Journal 43.2 (2009), pp. 183-190.

[13715] Z. H. Liu. "New material of helicoprionid shark from Lianyuan of Hunan". Chinese. In: Vertebrata PalAsiatica 32.2 (1994), pp. 127-133.

[13716] Z. H. Liu, A. lipiski, R. A. B. Leschen, D. Ren, and H. Pang. “The oldest Prionoceridae (Coleoptera: Cleroidea) from the Middle Jurassic of China". English. In: Annales Zoologici 65 (2015), pp. 41-52.

[13717] Z. H. Liu, A. lipiski, J. F. Lawrence, D. Ren, and H. Pang. “Palaeoboganium gen. nov. from the Middle Jurassic of China (Coleoptera: Cucujoidea: Boganiidae): the first cycad pollinators?" English. In: Journal of Systematic Palaeontology 16 (2017), pp. 351-360.

[13718] Z. H. Liu, A. lipiski, D. Ren, and H. Pang. "The first Mesozoic Helotidae (Coleoptera: Cucujoidea)". English. In: Cretaceous Research 96 (2019), pp. 113-119. DOI: 10.1016/j.cretres.2018.12.005.

[13719] Z. H. Liu, A. lipiski, B. Wang, and H. Pang. "The oldest Silvanid beetles from the Upper Cretaceous Burmese amber (Coleoptera, Silvanidae, Brontinae)". English. In: Cretaceous Research 98 (2019), pp. 1-8. DOI: 10.1016/j.cretres.2019.02.002. 
[13720] Z. H. Liu and L. Y. Su. "New discovery of Permian belemnoids in Hunan". Chinese. In: Journal of the Xiangtan Mining Institute 14 (1999), pp. 25-29.

[13721] Z. H. Liu, J. J. Tan, A. lipiski, E. A. Jarzembowski, B. Wang, D. Ren, and H. Pang. “Brochocoleus zhiyuani, a new species of brochocolein beetle (Coleoptera: Ommatidae) from the Cretaceous amber of Myanmar". English. In: Annales Zoologici 67 (2017), pp. 79-85.

[13722] Z. W. Liu, M. S. Engel, and D. A. Grimaldi. "Phylogeny and geological history of the cynipoid wasps (Hymenoptera: Cynipoidea)". English. In: American Museum Novitates 3583 (2007), pp. 148.

[13723] Z. W. Liu and M. S. Engel. "Baltic amber Ibaliidae (Hymenoptera: Cynipoidea): a new genus with implications for the phylogeny and historical biogeography of the family". English. In: Systematic Entomology 35 (2010), pp. 164-171.

[13724] Z.-J. Liu and X. Wang. "A perfect flower from the Jurassic of China”. English. In: Historical Biology (2015). DOI: 10.1080/08912963.2015.1020423.

[13725] J. R. Lively. "A new species of baenid turtle from the Kaiparowits Formation (Upper Cretaceous, Campanian) of southern Utah". English. In: Journal of Vertebrate Paleontology 35.6 (2015), e1009084:116. DOI: $10.1080 / 02724634.2015 .1009084$.

[13726] J. R. Lively. "Baenid turtles of the Kaiparowits Formation (Upper Cretaceous: Campanian) of southern Utah, USA". English. In: Journal of Systematic Palaeontology 14.11 (2016), pp. 891-918. DOI: $10.1080 / 14772019.2015 .1120788$.

[13727] M. Llandres Serrano, R. Vullo, J. Marugan-Lobon, F. Ortega, and A. D. Buscalioni. “An articulated hindlimb of a basal iguanodont (Dinosauria, Ornithopoda) from the Early Cretaceous Las Hoyas Lagerstätte (Spain)". English. In: Geological Magazine 150.3 (2013), pp. 527-576. DOI: 10.1017 / S0016756813000095.

[13728] C. Llompart. "Presencia de icnitas de dinosaurios en el Cretácico superior del margen sur del sinclinal de Tremp (Prov. de Lleida, Cataluña, España) [Presence of dinosaur footprints in the Upper Cretaceous of the southern margin of the Tremp syncline (Lleida prov., Catalonia, Spain]". Spanish. In: Revista Española de Paleontologa 21.1 (2006), pp. 1-14.

[13729] M. Llorens. "Estudio palinológico de la Formación Punta del Barco, Cretácico Inferior (Aptiano) de la provincia de Santa Cruz, Argentina. Descripciones sistemáticas I: esporas monoletes y triletes lisas y cinguladas". English. In: Ameghiniana 45.1 (2008), pp. 153-166.

[13730] M. Llorens. “Estudio palinológico de la Formación Punta del Barco, Cretácico Inferior (Aptiano) de la provincia de Santa Cruz, Argentina: Descripciones sistemáticas II: esporas triletes apiculadas, murornadas, tricrasadas y perinadas. Implicancias paleoecológicas". English. In: Ameghiniana 45.2 (2008), pp. 273-288.

[13731] L. Lloveras, L. Garcia, J. Maroto, J. Soler, and N. Soler. "The bird assemblage from the Middle Palaeolithic level I of Arbreda Cave: A taphonomic story". English. In: Journal of Archaeological Science: Reports 21 (2018), pp. 758-770.

[13732] K. J. Lloyd and J. J. Eberle. "A new talpid from the late Eocene of North America". English. In: Acta Palaeontologica Polonica 53.3 (2008), pp. 539-543.

[13733] K. J. Lloyd and J. J. Eberle. "A late Eocene (Chadronian) mammalian fauna from the White River Formation in Kings Canyon, northern Colorado". English. In: Rocky Mountain Geology 47.2 (2012), pp. 113-132. DOI: 10.2113/gsrocky.47.2.113.

[13734] K. J. Lloyd, M. P. Worley-Georg, and J. J. Eberle. "The Chadronian mammalian fauna of the Florissant Formation, Florissant Fossil Beds National Monument, Colorado". English. In: vol. 435. Paleontology of the Upper Eocene Florissant Formation, Colorado. Boulder, CO: Geological Society of America, 2008, pp. 117-126. DOI: 10.1130/2008.2435(08).

[13735] E. Y. Lobanov and A. R. Glebov. "Stromatoporoids and Tabulata from the Wenlock-Ludlow Boundary of the Eastern Slope of the Urals". English. In: Paleontological Journal 30.3 (1996), pp. 277-283. 
[13736] S. Loboziak and M. Streel. "Late Lower and Middle Devonian miospores from Saudi Arabia". In: Review of Palaeobotany and Palynology 89 (1995), pp. 105-113.

[13737] J. D. Loch. “Trilobite biostratigraphy and correlation of the Kindblade Formation (Lower Ordovician) of Carter and Kiowa Counties, Oklahoma". English. In: Oklahoma Geological Survey Bulletin 149 (2007), pp. 1-154.

[13738] J. D. Loch and J. F. Taylor. “New trilobite taxa from Upper Cambrian microbial reefs in the central Appalachians". English. In: Journal of Paleontology 78.3 (2004), pp. 591-602.

[13739] J. D. Loch and J. F. Taylor. "High-Resolution Biostratigraphy in the Upper Cambrian ore hill Member of Gatesburg Formation, South-Central Pennsylvnia". English. In: Graphic Correlation, SEPM Special Publication 53 (1995).

[13740] M. Lockley, K. Chin, K. Houck, M. Matsukawa, and R. Kukihara. "New interpretations of Ignotornis, the first-reported Mesozoic avian footprints: implications for the paleoecology and behavior of an enigmatic Cretaceous bird". English. In: Cretaceous Research 30 (2009), pp. 1041-1061. DOI: 10.1016/j.cretres.2009.04.001.

[13741] M. Lockley, T. J. Logue, J. J. Moratalla, A. P. Hunt, R. J. Schultz, and J. W. Robinson. “The fossil trackway Pteraichnus is pterosaurian, not crocodilian: implications for the global distribution of pterosaur tracks". English. In: Ichnos 4 (1995), pp. 7-20.

[13742] M. G. Lockley. "A decade of dinosaur tracking at Dinosaur Ridge". English. In: The Mountain Geologist 38.3 (2001), pp. 119-135.

[13743] M. G. Lockley. Pterosaur and bird tracks from a new Late Cretaceous locality in Utah. English. Vol. 991. Vertebrate Paleontology in Utah, Utah Geological Survey Miscellaneous Publications. 1999, pp. 355-359.

[13744] M. G. Lockley. Cretaceous dinosaur-dominated footprints assemblages: their stratigraphic and palaeoecological potential. English. Aspects of Nonmarine Cretaceous Geology. China Ocean Press, Beijing. 1992, pp. 269-282.

[13745] M. G. Lockley. “Tracking the rise of dinosaurs in eastern Utah”. English. In: Canyon Legacy 6 (1990), pp. 2-8.

[13746] M. G. Lockley. "The Moab megatracksite: a preliminary description and discussion of millions of Middle Jurassic tracks in eastern Utah". English. In: Guidebook for Dinosaur Quarries and Tracksites Tour: Western Colorado and Eastern Utah. Grand Junction, Colorado: Grand Junction Geological Society, 1991, pp. 59-65.

[13747] M. G. Lockley. "Observations on the ichnogenus Gwyneddichium and Gwyneddichium-like footprints and trackways from the Upper Triassic of the western United States". English. In: vol. 37. The Triassic-Jurassic Terrestrial Transition. New Mexico Museum of Natural History and Science Bulletin. Albuquerque: New Mexico Museum of Natural History and Science, 2006, pp. 170-175.

[13748] M. G. Lockley. "Putting the best foot forward: a single case of toe extension has general implications for the toe extension concept in theropod dinosaur feet and footprints". English. In: vol. 53. Fossil Record 3. New Mexico Museum of Natural History and Science Bulletin. Albuquerque: New Mexico Museum of Natural History and Science, 2011, pp. 301-305.

[13749] M. G. Lockley. “Theropod- and prosauropod-dominated ichnofaunas from the Navajo-Nugget Sandstone (Lower Jurassic) at Dinosaur National Monument: implications for prosauropod behaviour and ecology". English. In: vol. 53. Fossil Record 3. New Mexico Museum of Natural History and Science Bulletin. Albuquerque: New Mexico Museum of Natural History and Science, 2011, pp. 316-320.

[13750] M. G. Lockley, K. Cart, J. Martin, and A. R. C. Milner. "New theropod tracksites from the Upper Cretaceous Mesaverde Group, western Colorado: implications for ornithomimosaur track morphology". English. In: vol. 53. Fossil Record 3. New Mexico Museum of Natural History and Science Bulletin. Albuquerque: New Mexico Museum of Natural History and Science, 2011, pp. 321329. 
[13751] M. G. Lockley, K. L. Conrad, and M. Paquette. “Distribution and significance of Mesozoic vertebrate trace fossils in Dinosaur National Monument". English. In: University of Wyoming National Park Service Research Center Annual Report 15.16 (1991), pp. 85-90.

[13752] M. G. Lockley, K. L. Conrad, M. Paquette, and A. H. Hamblin. "Late Triassic vertebrate tracks in the Dinosaur National Monument area". English. In: vol. 92-3. Field Guide to Geologic Excursions in Utah and Adjacent Areas of Nevada, Idaho, and Wyoming. Utah Geological Survey Miscellaneous Publication. Salt Late City: Utah Geological Survey, 1992, pp. 383-390.

[13753] M. G. Lockley, V. F. dos Santos, C. A. Meyer, and A. P. Hunt. "A new dinosaur tracksite in the Morrison Formation, Boundary Butte, southeastern Utah". English. In: Modern Geology 23.1-4 (1998), pp. 317-330.

[13754] M. G. Lockley, J. O. Farlow, and C. A. Meyer. Brontopodus and Parabrontopodus ichnogen. nov. and the significance of wide- and narrow-gauge sauropod trackways. English. Vol. 10. Aspects of Sauropod Paleobiology. GAIA. 1995, pp. 135-145.

[13755] M. G. Lockley and J. R. Foster. "Late Cretaceous mammal tracks from North America". English. In: Ichnos 10 (2003), pp. 269-276. DOI: 10.1080/10420940390257923.

[13756] M. G. Lockley and J. R. Foster. “Dinosaur and turtle tracks from the Morrison Formation (Upper Jurassic) of Colorado National Monument, with observations on the taxonomy of vertebrate swim tracks". English. In: vol. 36. Paleontology and Geology of the Upper Jurassic Morrison Formation. New Mexico Museum of Natural History and Science Bulletin. Albuquerque: New Mexico Museum of Natural History and Science, 2006, pp. 193-198.

[13757] M. G. Lockley, J. R. Foster, and A. P. Hunt. "A short summary of dinosaur tracks and other fossil footprints from the Morrison Formation". English. In: The Upper Jurassic Morrison Formation: An Interdisciplinary Study. Modern Geology 23.1-4 (1998), pp. 277-290.

[13758] M. G. Lockley and G. D. Gierlinski. “Diverse vertebrate ichnofaunas containing Anomoepus and other unusual trace fossils from the Lower Jurassic of the western United States: implications for paleoecology and palichnostratigraphy". English. In: vol. 37. The Triassic-Jurassic Terrestrial Transition. New Mexico Museum of Natural History and Science Bulletin. Albuquerque: New Mexico Museum of Natural History and Science, 2006, pp. 176-191.

[13759] M. G. Lockley, G. D. Gierlinski, A. L. Titus, and L. B. Albright. “An introduction to thunderbird footprints at the Flag Point Pictograph-Track Site: preliminary observations on Lower Jurassic theropod tracks from the Vermillion Cliffs area, southwestern Utah". English. In: vol. 37. The Triassic-Jurassic Terrestrial Transition. New Mexico Museum of Natural History and Science Bulletin. Albuquerque: New Mexico Museum of Natural History and Science, 2006, pp. 310-314.

[13760] M. G. Lockley, J. Holbrook, R. Kukihara, and M. Matsukawa. An ankylosaur-dominated dinosaur tracksite in the Cretaceous Dakota Group of Colorado: paleoenvironmental and sequence stratigraphic context. English. Vol. 35. Late Cretaceous Vertebrates from the Western Interior. New Mexico Museum of Natural History and Science Bulletin. 2006, pp. 95-104.

[13761] M. G. Lockley, N. Hook, and A. Taylor. "A brief history of paleontological research and public education on Dinosaur Ridge". English. In: The Mountain Geologist 38.3 (2001), pp. 87-95.

[13762] M. G. Lockley, K. Houck, S. -Y. Yang, M. Matsukawa, and S. -K. Lim. “Dinosaur-dominated footprint assemblages from the Cretaceous Jindong Formation, Hallyo Haesang National Park area, Goseong County, South Korea: evidence and implications". English. In: Cretaceous Research 27.1 (2006), pp. 70-101.

[13763] M. G. Lockley and A. P. Hunt. "A new Late Triassic tracksite from the Sloan Canyon Formation, type section, Cimarron Valley, New Mexico". English. In: The Nonmarine Triassic. New Mexico Museum of Natural History and Science Bulletin 3 (1993), pp. 279-283.

[13764] M. G. Lockley and A. P. Hunt. "A track of the giant theropod dinosaur Tyrannosaurus from close to the Cretaceous/Tertiary boundary, northern New Mexico". English. In: Ichnos 3 (1994), pp. 213218. 
[13765] M. G. Lockley and A. P. Hunt. “Ceratopsid tracks and associated ichnofauna from the Laramie Formation (Upper Cretaceous: Maastrichtian) of Colorado". English. In: Journal of Vertebrate Paleontology 15.3 (1995), pp. 592-614.

[13766] M. G. Lockley, A. P. Hunt, M. Paquette, S. -A. Bilbey, and A. H. Hamblin. "Dinosaur tracks from the Carmel Formation, northeastern Utah: implications for Middle Jurassic paleoecology". English. In: Ichnos 5.4 (1998), pp. 255-267. DOI: 10.1080/10420949809386424.

[13767] M. G. Lockley and A. P. Hunt. "A probable stegosaur track from the Morrison Formation of Utah". English. In: The Upper Jurassic Morrison Formation: An Interdisciplinary Study. Modern Geology 23.1-4 (1998), pp. 331-342.

[13768] M. G. Lockley, K. M. Hups, K. Cart, and S. Gerwe. “A zone of sauropodomorph footprints in the basal Wingate Sandstone (latest Triassic) of western Colorado and eastern Utah: is Eosauropus a common ichnogenus in the region?" English. In: vol. 53. Fossil Record 3. New Mexico Museum of Natural History and Science Bulletin. Albuquerque: New Mexico Museum of Natural History and Science, 2011, pp. 337-343.

[13769] M. G. Lockley, J. Y. Kim, K. S. Kim, S.H. kim, M. Matsukawa, R. Li, J. Li, and S. -Y. Yang. “Minisauripusthe track of a diminutive dinosaur from the Cretaceous of China and South Korea: implications for stratigraphic correlation and theropod foot morphodynamics". English. In: Cretaceous Research 29.1 (2008), pp. 115-130. DOI: 10.1016/j.cretres.2007.04.003.

[13770] M. G. Lockley, J. I. Kirkland, F. L. DeCourten, B. B. Britt, and S. T. Hasiotis. Dinosaur tracks from the Cedar Mountain Formation of eastern Utah: a preliminary report. Vol. 99-1. Vertebrate Paleontology in Utah, Utah Geological Survey Miscellaneous Publication. 1999, pp. 253-257.

[13771] M. G. Lockley, R. Kukihara, and L. Mitchell. New dinosaur and crocodile tracksites from the Cretaceous Dakota Group of the Colorado Front Range, Boulder and Jefferson Counties, Colorado. English. Vol. 35. Late Cretaceous Vertebrates from the Western Interior. New Mexico Museum of Natural History and Science Bulletin. 2006, pp. 89-94.

[13772] M. G. Lockley, J. Li, M. Matsukawa, and R. Li. "A new avian ichnotaxon from the Cretaceous of Nei Mongol, China". English. In: Cretaceous Research 34.1 (2012), pp. 84-93. DOI: 10.1016/j.cretres. 2011.10.006.

[13773] M. G. Lockley, S. G. Lucas, and A. P. Hunt. “Eosauropus, a new name for a Late Triassic track: further observations on the Late Triassic ichnogenus Tetrasauropus and related forms, with notes on the limits of interpretation". English. In: vol. 37. The Triassic-Jurassic Terrestrial Transition. New Mexico Museum of Natural History and Science Bulletin. Albuquerque: New Mexico Museum of Natural History and Science, 2006, pp. 192-198.

[13774] M. G. Lockley, S. G. Lucas, and A. P. Hunt. Dinosaur tracksites in New Mexico: a review. English. Vol. 7. Dinosaurs of New Mexico. New Mexico Museum of Natural History and Science Bulletin. 2000, pp. 9-16.

[13775] M. G. Lockley, S. G. Lucas, A. P. Hunt, and R. Gaston. "Ichnofaunas from the Triassic-Jurassic boundary sequences of the Gateway area, western Colorado: implications for faunal composition and correlations with other areas". English. In: Ichnos 11 (2004), pp. 89-102. DOI: 10.1080 / 10420940490442331.

[13776] M. G. Lockley, S. G. Lucas, and A. P. Hunt. "Evazoum and the renaming of Northern Hemisphere Pseudotetrasauropus: implications for tetrapod ichnotaxonomy at the Triassic-Jurassic boundary". English. In: vol. 37. The Triassic-Jurassic Terrestrial Transition. New Mexico Museum of Natural History and Science Bulletin. Albuquerque: New Mexico Museum of Natural History and Science, 2006, pp. 199-206.

[13777] M. G. Lockley, M. Matsukawa, Y. Sato, M. Polahan, and V. Daorerk. "A distinctive new theropod dinosaur track from the Cretaceous of Thailand: implications for theropod track diversity". English. In: Cretaceous Research 27.1 (2006), pp. 139-145.

[13778] M. G. Lockley, M. Matsukawa, H. Ohira, J. Li, J. L. Wright, D. White, and P. Chen. "Bird tracks from Liaoning Province, China: new insights into avian evolution during the Jurassic-Cretaceous transition". English. In: Cretaceous Research 27 (2006), pp. 33-43. 
[13779] M. G. Lockley, M. Matsukawa, and D. Witt. Giant theropod tracks from the Cretaceous Dakota Group of northeastern New Mexico. English. Vol. 35. Late Cretaceous Vertebrates from the Western Interior. New Mexico Museum of Natural History and Science Bulletin. 2006, pp. 83-87.

[13780] M. G. Lockley, R. T. McCrea, and M. Matsukawa. Ichnological evidence for small quadrupedal ornithischians from the basal Cretaceous of SE Asia and North America: implications for a global radiation. English. Vol. 315. Late Palaeozoic and Mesozoic Ecosystems in SE Asia. The Geological Society of London, Special Publication. 2009, pp. 255-269. DOI: 10.1144/SP315.18.

[13781] M. G. Lockley, C. A. Meyer, and V. F. dos Santos. Trackway evidence for a herd of juvenile sauropods from the Late Jurassic of Portugal. English. Vol. 10. Aspects of Sauropod Paleobiology. GAIA. 1995, pp. 27-35.

[13782] M. G. Lockley, C. A. Meyer, and V. F. Santos. "Megalosauripus and the problematic concept of megalosaur footprints". English. In: GAIA 15 (2000), pp. 313-337.

[13783] M. G. Lockley, C. A. Meyer, H. -J. Siber, and B. Pabst. "Theropod tracks from the Howe Quarry, Morrison Formation, Wyoming". English. In: Modern Geology 23.1-4 (1998), pp. 309-316.

[13784] M. G. Lockley, C. A. Meyer, and J. J. Moratalla. “Therangospodus: trackway evidence for the widespread distribution of a Late Jurassic theropod with well-padded feet". English. In: GAIA 15 (2000), pp. 339-353.

[13785] M. G. Lockley and C. A. Meyer. English. Dinosaur Tracks and Other Fossil Footprints of Europe. Columbia University Press, New York. 2000, pp. 1-323.

[13786] M. G. Lockley and D. L. Mickelson. "Dinosaur and pterosaur tracks in the Summerville and Bluff (Jurassic) beds of eastern Utah and northeastern Arizona". English. In: vol. 48. New Mexico Geological Society, 48th Field Conference, Mesozoic Geology and Paleontology of the Four Corners Region. New Mexico Geological Society Guidebook, 1997, pp. 133-138.

[13787] M. G. Lockley and A. R. C. Milner. "Tetrapod tracksites from the Shinarump Formation (Chinle Group, Upper Triassic) of southwestern Utah". English. In: vol. 37. The Triassic-Jurassic Terrestrial Transition. New Mexico Museum of Natural History and Science Bulletin. Albuquerque: New Mexico Museum of Natural History and Science, 2006, pp. 257-262.

[13788] M. G. Lockley, A. R. C. Milner, D. Slauf, and A. H. Hamlbin. “Dinosaur tracksites from the Kayenta Formation (Lower Jurassic) Desert Tortoise site, Washington County, Utah". English. In: vol. 37. The Triassic-Jurassic Terrestrial Transition. New Mexico Museum of Natural History and Science Bulletin. Albuquerque: New Mexico Museum of Natural History and Science, 2006, pp. 269-275.

[13789] M. G. Lockley, G. Nadon, and P. J. Currie. "A diverse dinosaur-bird footprint assemblage from the Lance Formation, Upper Cretaceous, eastern Wyoming; implications for ichnotaxonomy". English. In: Ichnos 11 (2003), pp. 229-249.

[13790] M. G. Lockley, B. D. Ritts, and G. Leonardi. "Mammal track assemblages from the Early Tertiary of China, Peru, Europe and North America". English. In: Palaios 14 (1999), pp. 398-404.

[13791] M. G. Lockley, A. S. Schulp, C. A. Meyer, G. Leonardi, and D. K. Mamani. “Titanosaurid trackways from the Upper Cretaceous of Bolivia: evidence for large manus, wide-gauge locomotion and gregarious behaviour". In: Cretaceous Research 23 (2002), pp. 383-400.

[13792] M. G. Lockley, A. R. Tedrow, K. C. Chamberlain, N. J. Minter, and J. -D. Lim. "Footprints and invertebrate traces from a new site in the Nugget Sandstone (Lower Jurassic) of Idaho: implications for life in the northern reaches of the great Navajo-Nuggest erg system in the western USA". English. In: vol. 53. Fossil Record 3. New Mexico Museum of Natural History and Science Bulletin. Albuquerque: New Mexico Museum of Natural History and Science, 2011, pp. 344-356.

[13793] M. G. Lockley, D. White, J. I. Kirkland, and V. L. Santucci. "Dinosaur tracks from the Cedar Mountain Formation (Lower Cretaceous), Arches National Park, Utah". English. In: Ichnos 11 (2004), pp. 285-293. DOI: 10.1080/10420940490428742.

[13794] M. G. Lockley, J. L. Wright, and M. Matsukawa. "A new look at Magnoavipes and so-called big bird tracks from Dinosaur Ridge (Cretaceous, Colorado)". English. In: The Mountain Geologist 38.3 (2001), pp. 137-146. 
[13795] M. G. Lockley, J. L. Wright, D. White, M. Matsukawa, J. Li, L. Feng, and H. Li. “The first sauropod footprints from China". English. In: Cretaceous Research 23 (2002), pp. 363-381.

[13796] M. G. Lockley, J. L. Wright, W. Langston Jr., and E. S. West. “New pterosaur track specimens and tracksites in the Late Jurassic of Oklahoma and Colorado: their paleobiological significance and regional ichnological context". English. In: Modern Geology 24 (2001), pp. 179-203.

[13797] M. G. Lockley, S. Y. Yang, M. Matsukawa, F. Fleming, and S. K. Lim. “The track record of Mesozoic birds: evidence and implications". English. In: Philosophical Transactions of the Royal Society of London, Series B: Biological Sciences 336 (1992), pp. 113-134.

[13798] M. G. Lockley, J. A. Smith, and M. R. King. "First reports of turtle tracks from the Williams Fork Formation ('Mesaverde' Group), Upper Cretaceous (Campanian) of western Colorado". English. In: Palaeogeography, Palaeoclimatology, Palaeoecology (2017). DOI: 10.1016/j.cretres.2017.11.001.

[13799] J. A. Lockwood, S. P. Schell, J. K. Wangberg, L. D. DeBrey, W. G. DeBrey, and C. R. Bomar. "Preserved insects and physical condition of Grasshopper Glacier, Carbon County, Montana, USA". English. In: Arctic and Alpine Research 24 (1992), pp. 229-232.

[13800] J. A. Lockwood, C. D. Thompson, L. D. Debrey, C. M. Love, R. A. Nunamaker, and R. E. Pfadt. "Preserved grasshopper fauna of Knife Point Glacier, Fremont County, Wyoming, USA". English. In: Arctic and Alpine Research 23 (1991), pp. 108-114.

[13801] S. T. LoDuca and A. Kramer. "Graptolites from the Wheeler and Marjum Formations (Cambrian, Series 3) of Utah". English. In: Journal of Paleontology 88.2 (2014), pp. 403-410. DOI: 10.1666/12-096.

[13802] M. A. Loewen, R. B. Irmis, J. J. W. Sertich, P. J. Currie, and S. D. Sampson. “Tyrant dinosaur evolution tracks the rise and fall of Late Cretaceous oceans". English. In: PLoS ONE 8.11 (2013), e79420. DOI: 10.1371/journal.pone.0079420.

[13803] M. A. Loewen, S. D. Sampson, E. K. Lund, A. A. Farke, M. C. Aguillón-Martnez, C. A. de Leon, R. A. Rodrguez-de la Rosa, M. A. Getty, and D. A. Eberth. Horned dinosaurs (Ornithischia: Ceratopsia) from the Upper Cretaceous (Campanian) Cerro del Pueblo Formation, Coahuila, Mexico. English. New Perspectives on Horned Dinosaurs: The Royal Tyrrell Museum Ceratopsian Symposium. Indiana University Press, Bloomington. 2010, pp. 99-116.

[13804] A. Löfgren. "The conodont fauna in the Middle Ordovician Eoplacognathus pseudoplanus Zone of Baltoscandia". English. In: Geological Magazine 141.4 (2004), pp. 505-524. DOI: 10.1017/S0016756804009227.

[13805] A. Löfgren, J. E. Repetski, and R. L. Ethington. “Some trans-Iapetus conodont faunal connections in the Tremadocian". English. In: Bollettino della Societá Paleontologica Italiana 37 (1999), pp. 159173.

[13806] D. L. Lofgren, B. M. Gaytan, M. Pastrano, J. E. Rice, and R. L. Zheng. "First record of Kimbetohia campi (Mammalia, Multituberculata) from the Paleocene part of the North Horn Formation, Utah". English. In: Journal of Vertebrate Paleontology 32.5 (2012), pp. 1214-1217.

[13807] D. L. Lofgren, J. A. Greening, C. F. Johnson, S. J. Lewis, and M. A. Torres. Footprints on the sands of time: fossil tracks at the Raymond Alf Museum of Paleontology. English. Making Tracks Across the Southwest: The 2006 Desert Symposium. Zzyzx: California State University, Desert Studies Consortium and LSA Associates, Inc., 2006, pp. 52-62.

[13808] D. L. Lofgren, J. G. Honey, M. C. McKenna, R. L. Zondervan, and E. E. Smith. "Paleocene primates from the Goler Formation of the Mojave Desert in California". English. In: Natural History Museum of Los Angeles County Science Series 41 (2008), pp. 11-28.

[13809] D. L. Lofgren, B. E. Scherer, C. K. Clark, and B. Standhardt. "First record of Stygimys (Mammalia, Multituberculata, Eucosmodontidae) from the Paleocene (Puercan) part of the North Horn Formation, Utah, and a review of the genus". English. In: Journal of Mammalian Evolution 12.1/2 (2005), pp. 77-97.

[13810] V. Lohrmann and M. S. Engel. “The wasp larva's last supper: 100 million years of evolutionary stasis in the larval development of rhopalosomatid wasps (Hymenoptera: Rhopalosomatidae)". English. In: Fossil Record 20 (2017), pp. 239-244. 
[13811] V. Lohrmann, M. Ohl, P. Michalik, J. P. Pitts, L. Jeanneau, and V. Perrichot. “Notes on rhopalosomatid wasps of Dominican and Mexican amber (Hymenoptera: Rhopalosomatidae) with a description of the first fossil species of Rhopalosoma Cresson, 1865". English. In: Fossil Record 22 (2019), pp. 31-44. DOI: 10.5194/fr-22-31-2019.

[13812] V. Lohrmann, Q. Zhang, P. Michalik, J. Blaschke, P. Müller, L. Jeanneau, and V. Perrichot. “+Cretolixon - a remarkable new genus of rhopalosomatid wasps (Hymenoptera: Vespoidea: Rhopalosomatidae) from chemically tested, mid-Cretaceous Burmese (Kachin) amber supports the monophyly of Rhopalosomatinae". English. In: Fossil Record 23 (2020), pp. 215-236. DOI: 10.5194/fr-23215-2020.

[13813] D. Lomax and J. A. Massare. "The first reported Leptonectes (Reptilia: Ichthyosauria) with associated embryos, from Somerset, England". English. In: Paludicola 8.4 (2012), pp. 263-267.

[13814] D. R. Lomax. "An Ichthyosaurus (Reptilia, Ichthyosauria) with gastric contents from Charmouth, England: first report of the genus from the Pliensbachian". English. In: Paludicola 8.1 (2010), pp. $22-$ 36.

[13815] D. R. Lomax. "A new leptonectid ichthyosaur from the Lower Jurassic (Hettangian) of Nottinghamshire, England, UK, and the taxonomic usefulness of the ichthyosaurian coracoid". English. In: Journal of Systematic Palaeontology 15.5 (2017), pp. 387-401. DOI: 10.1080/14772019.2016.1183149.

[13816] D. R. Lomax, P. De la Salle, J. A. Massare, and R. Gallois. "A giant Late Triassic ichthyosaur from the UK and a reinterpretation of the Aust Cliff 'dinosaurian' bones". English. In: PLoS ONE 13.4 (2017), e0194742.

[13817] D. R. Lomax and J. A. Massare. "A new species of Ichthyosaurus from the Lower Jurassic of west Dorset, England, U.K". English. In: Journal of Vertebrate Paleontology e903260 (2015), pp. 1-14. DOI: 10.1080/02724634.2014.903260.

[13818] D. R. Lomax and J. A. Massare. "Two new species of Ichthyosaurus from the lowermost Jurassic (Hettangian) of Somerset, England". English. In: Papers in Palaeontology 3.1 (2017), pp. 1-20. DOI: 10.1002/spp2.1065.

[13819] E. R. Lombard and J. R. Bolt. "Microsaur from the Mississippian of Illinois and a standard format for morphological characters". English. In: Journal of Paleontology 73.5 (1999), pp. 908-923.

[13820] R. E. Lombard and J. R. Bolt. "A new primitive tetrapod, Whatcheeria deltae, from the Lower Carboniferous of Iowa". English. In: Palaeontology 38.3 (1995), pp. 471-494.

[13821] C. Lombardo. "Perleidus altolepis (Actinopterygii, Perleidiformes) from the Kalkschieferzone of Ca' del Frate (N. Italy)". English. In: Geobios 28.Suppl 2 (1995), pp. 211-213.

[13822] C. Lombardo. "Sexual dimorphism in a new species of the actinopterygian Peltopleurus from the Triassic of northern Italy". English. In: Palaeontology 42.4 (1999), pp. 741-760.

[13823] C. Lombardo. "Actinopterygians from the Middle Triassic of Northern Italy and Canton Ticino (Switzerland): Anatomical Descriptions and Nomenclatural Problems". English. In: Rivista Italiana di Paleontologia e Stratigrafia 107.3 (2001), pp. 345-369.

[13824] C. Lombardo. "Caelatichthys gen. n.: a new palaeonisciform from the Middle Triassic of Northern Italy and Canton Ticino (Switzerland)". English. In: Rivista Italiana di Paleontologia e Stratigrafia 108 (2002), pp. 399-414.

[13825] C. Lombardo. "A new basal actinopterygian fish from the Late Ladinian of Monte San Giorgio (Canton Ticino, Switzerland)". English. In: Swiss Journal of Geosciences 106 (2013), pp. 219-230.

[13826] C. Lombardo and F. Brambillasca. "A New perleidiform (Actinopterygii, Osteichthyes) from the Late Triassic of Northern Italy". English. In: Bollettino della Societá Paleontologica Italiana 44.1 (2005), pp. 25-34.

[13827] C. Lombardo, M. Rusconi, and A. Tintori. "New Perleidiform from the Lower Ladinian (Middle Triassic) of the Northern Grigna (Northern Italy)". English. In: Rivista Italiana di Paleontologia e Stratigrafia 114.2 (2008), pp. 263-272. 
[13828] C. Lombardo, Z. Y. Sun, A. Tintori, D. Y. Jiang, and W. C. Hao. "A new species of the genus Perleidus (Actinopterygii: Perleidiformes) from the Middle Triassic of Southern China". English. In: Bollettino della Societá Paleontologica Italiana 50.2 (2011), pp. 75-83.

[13829] C. Lombardo, A. Tintori, and D. Tona. "A new species of Sangiorgioichthys (Actinopterygii, Semionotiformes) from the Kalkschieferzone of Monte San Giorgio (Middle Triassic; Meride, Canton Ticino, Switzerland)". English. In: Bollettino della Societá Paleontologica Italiana 51 (2012), pp. 203-212.

[13830] C. Long and C. Yahnke. "End of the Pleistocene: elk-moose (Cervalces) and caribou (Rangifer) in Wisconsin". English. In: Journal of Mammalogy 92.5 (2011), pp. 1127-1135.

[13831] D. J. Long. "Preliminary List of the Marine Fishes and Other Vertebrate Remains from the Late Pleistocene Palos Verdes Sand Formation at Costa Mesa, Orange County, California". English. In: PaleoBios 15.1 (1993), pp. 9-13.

[13832] D. J. Long. "Sharks from the La Meseta Formation (Eocene), Seymour Island, Antarctic Peninsula". English. In: Journal of Vertebrate Paleontology 12.1 (1992), pp. 11-32.

[13833] D. J. Long. “Late Miocene and Early Pliocene fish assemblages from the north central coast of Chile". English. In: Tertiary Research 14.3 (1993), pp. 117-126. DOI: 10.1016/j.annpal.2012.04.001.

[13834] D. J. Long. "An Eocene wrasse (Perciformes; Labridae) from Seymour Island". English. In: Antarctic Science 4.2 (1992), pp. 235-237.

[13835] D. J. Long, M. A. Murphy, and P. U. Rodda. "A New World occurrence of Notidanodon lanceolatus (Chondrichthyes, Hexanchidae) and comments on hexanchid shark evolution". English. In: Journal of Paleontology 67.4 (1993), pp. 655-659.

[13836] D. J. Long and J. D. Stilwell. "Fish remains from the Eocene of Mount Discovery, East Antarctica". English. In: Paleobiology and Paleoenvironments of Eocene Rocks, McMurdo Sound, East Antarctica. Antarctic Research Series 76 (2000), pp. 349-353.

[13837] J. A. Long. "First dinosaur bones from Western Australia". English. In: The Beagle, Records of the Northern Territory Museum of Arts and Sciences 9.1 (1992), pp. 21-28.

[13838] J. A. Long. "Cretaceous dinosaur ichnofauna from Broome, Western Australia". English. In: The Beagle: Records of the Northern Territory Museum of Arts and Sciences 9.1 (1992), p. 262.

[13839] J. A. Long. "A new genus of fossil coelacanth (Osteichthyes: Coelacanthiformes) from the Middle Devonian of southeastern Australia". English. In: Records of the Western Australian Museum Supplement 57 (1999), pp. 37-53.

[13840] J. A. Long. "Cranial anatomy of two new Late Devonian lungfishes (Pisces: Dipnoi) from Mount Howitt, Victoria". English. In: Records of the Australian Museum 44 (1992), pp. 299-318.

[13841] J. A. Long. "A second incisoscutid arthrodire (Pisces, Placodermi) from the Late Devonian Gogo Formation, Western Australia". English. In: Alcheringa 18.1-2 (1994), pp. 59-69. DOI: 10.1080 / 03115518.1994.9638763.

[13842] J. A. Long, K. S. W. Campbell, and R. E. Barwick. “A new dipnoan genus, Ichnomylax, from the Lower Devonian of Victoria, Australia". English. In: Journal of Vertebrate Paleontology 14.1 (1994), pp. 127-131.

[13843] J. A. Long, B. Choo, and G. C. Young. "A new basal actinopterygian fish from the Middle Devonian Aztec". English. In: Antarctic Science 20.4 (2008), pp. 393-412. DOI: 10.1017/S0954102008001144.

[13844] J. A. Long and A. R. I. Cruickshank. "First record of an Early Cretaceous theropod dinosaur bone from Western Australia". English. In: Records of the Western Australian Museum 18 (1996), pp. 219222.

[13845] J. A. Long and A. R. I. Cruickshank. "Further records of plesiosaurian reptiles of Jurassic and Cretaceous age from Western Australia". English. In: Records of the Western Australian Museum 19 (1998), pp. 47-55.

[13846] J. A. Long and R. E. Molnar. "A new Jurassic theropod dinosaur from Western Australia". In: Records of the Western Australian Museum 19 (1998), pp. 121-129. 
[13847] R. A. Long and P. A. Murry. "Late Triassic (Carnian and Norian) tetrapods from the southwestern United States". English. In: New Mexico Museum of Natural History and Science Bulletin 4 (1995), pp. 1-254.

[13848] N. Longrich. "An ornithurine bird from the Late Cretaceous of Alberta, Canada". English. In: Canadian Journal of Earth Sciences 43.1 (2006), pp. 1-7.

[13849] N. Longrich. "A new, large ornithomimid from the Cretaceous Dinosaur Park Formation of Alberta, Canada: implications for the study of dissociated dinosaur remains". English. In: Palaeontology 51.4 (2008), pp. 983-997. DOI: 10.1111/j.1475-4983.2008.00791.x.

[13850] N. R. Longrich. "An ornithurine-dominated avifauna from the Belly River Group (Campanian, Upper Cretaceous) of Alberta, Canada". English. In: Cretaceous Research 30.1 (2009), pp. 161-177. DOI: 10.1016/j.cretres.2008.06.007.

[13851] N. R. Longrich. "Mojoceratops perifania, a new chasmosaurine ceratopsid from the late Campanian of western Canada". English. In: Journal of Paleontology 84.4 (2010), pp. 681-694. DOI: 10.1666/ 09-114.1.

[13852] N. R. Longrich. "Titanoceratops ouranos, a giant horned dinosaur from the late Campanian of New Mexico". English. In: Cretaceous Research 32 (2011), pp. 264-276. DOI: 10.1016/j.cretres.2010. 12.007.

[13853] N. R. Longrich. "Judiceratops tigris, a new horned dinosaur from the middle Campanian Judith River Formation of Montana". English. In: Bulletin of the Peabody Museum of Natural History 54.1 (2013), pp. 51-65.

[13854] N. R. Longrich. “The horned dinosaurs Pentaceratops and Kosmoceratops from the upper Campanian of Alberta and implications for dinosaur biogeography". English. In: Cretaceous Research 51 (2014), pp. 292-308. DOI: 10.1016/j.cretres.2014.06.011.

[13855] N. R. Longrich. "A ceratopsian dinosaur from the Late Cretaceous of eastern North America, and implications for dinosaur biogeography". English. In: Cretaceous Research 57 (2016), pp. 199-207.

[13856] N. R. Longrich. "A new species of Pluridens (Mosasauridae: Halisaurinae) from the upper Campanian of Southern Nigeria". English. In: Cretaceous Research 64 (2016), pp. 36-44.

[13857] N. R. Longrich, K. Barnes, S. Clark, and L. Millar. “Caenagnathidae from the upper Campanian Aguja Formation of west Texas, and a revision of the Caenagnathinae". English. In: Bulletin of the Peabody Museum of Natural History 54.1 (2013), pp. 23-49.

[13858] N. R. Longrich, B.-A. S. Bhullar, and J. A. Gauthier. "A transitional snake from the Late Cretaceous period of North America". English. In: Nature 488 (2012), pp. 205-208. DOI: 10.1038/nature11227.

[13859] N. R. Longrich, B.-A. S. Bhullar, and J. A. Gauthier. "Mass extinction of lizards and snakes at the Cretaceous-Paleogene boundary". English. In: Proceedings of the National Academy of Sciences 109.52 (2012), pp. 21396-21401. DOI: 10.1073/pnas.1211526110.

[13860] N. R. Longrich, B.-A. S. Bhullar, and J. A. Gauthier. "Correction for Longrich et al, Mass extinction of lizards and snakes at the Cretaceous-Paleogene boundary". English. In: Proceedings of the National Academy of Sciences 110.16 (2013), pp. 6608-6608. DOI: 10.1073/pnas.1303907110.

[13861] N. R. Longrich and P. J. Currie. “Albertonykus borealis, a new alvarezsaur (Dinosauria: Theropoda) from the Early Maastrichtian of Alberta, Canada: implications for the systematics and ecology of the Alvarezsauridae". English. In: Cretaceous Research 30.1 (2009), pp. 239-252. DOI: 10.1016/j. cretres.2008.07.005.

[13862] N. R. Longrich and P. J. Currie. "A microraptorine (Dinosauria-Dromaeosauridae) from the Late Cretaceous of North America". English. In: Proceedings of the National Academy of Sciences (2009). DOI: $10.1073 /$ pnas.0811664106.

[13863] N. R. Longrich, P. J. Currie, and Z. -M. Dong. "A new oviraptorid (Dinosauria: Theropoda) from the Upper Cretaceous of Bayan Mandahu, Inner Mongolia". English. In: Palaeontology 53.5 (2010), pp. 945-960. DOI: 10.1111/j.1475-4983.2010.00968.x. 
[13864] N. R. Longrich, D. M. Martill, and B. Andres. "Late Maastrichtian pterosaurs from North Africa and mass extinction of Pterosauria at the Cretaceous-Paleogene boundary". English. In: PLoS Biology 16.3 (2018), e2001663:1-38.

[13865] N. R. Longrich, X. Pereda Suberbiola, R. A. Pyron, and N. -E. Jalil. “The first duckbill dinosaur (Hadrosauridae: Lambeosaurinae) from Africa and the role of oceanic dispersal in dinosaur biogeography". English. In: Cretaceous Research 120 (2021), p. 104678. DOI: 10.1016/j.cretres.2020. 104678.

[13866] N. R. Longrich, X. Pereda-Suberbiola, N. -E. Jalil, F. Khaldoune, and E. Jourani. "An abelisaurid from the latest Cretaceous (late Maastrichtian) of Morocco, North Africa". English. In: Cretaceous Research 76 (2017), pp. 40-52.

[13867] N. R. Longrich, J. Sankey, and D. Tanke. “Texacephale langstoni, a new genus of pachycephalosaurid (Dinosauria: Ornithischia) from the upper Campanian Aguja Formation, southern Texas, USA". English. In: Cretaceous Research 31 (2010), pp. 274-284. DOI: 10.1016/j.cretres.2009.12.002.

[13868] N. R. Longrich, J. Vinther, R. A. Pyron, D. Pisani, and J. A. Gauthier. "Biogeography of worm lizards (Amphisbaenia) driven by end-Cretaceous mass extinction". English. In: Proceedings of the Royal Society, B 282 (2015), p. 20143034. DOI: 10.1098/rspb.2014.3034.

[13869] L. M. Longridge, E. S. Carter, P. L. Smith, and H. W. Tipper. “Early Hettangian ammonites and radiolarians from the Queen Charlotte Islands, British Columbia and their bearing on the definition of the Triassic-Jurassic boundary". English. In: Palaeogeography, Palaeoclimatology, Palaeoecology 244 (2007), pp. 142-169.

[13870] L. M. Longridge, J. Pálfy, P. L. Smith, and H. W. Tipper. “Middle and late Hettangian (Early Jurassic) ammonites from the Queen Charlotte Islands, British Columbia, Canada". English. In: Revue de Paleobiologie, Geneve 27.1 (2008), pp. 191-248.

[13871] L. M. Longridge, P. L. Smith, and H. W. Tipper. "Late Hettangian (Early Jurassic) ammonites from Taseko Lakes, British Columbia, Canada". English. In: Palaeontology 51 (2008), pp. 367-404.

[13872] L. M. Longridge, P. L. Smith, J. Pálfy, and H. W. Tipper. "Three new species of the Hettangian (Early Jurassic) ammonite Sunrisites from British Columbia, Canada". English. In: Journal of Paleontology 82 (2008), pp. 128-139.

[13873] L. M. Longridge, P. L. Smith, and H. W. Tipper. “The Early Jurassic ammonite Badouxia from British Columbia, Canada". English. In: Palaeontology 49 (2006), pp. 795-816.

[13874] O. Lonsdale and K. Apigian. "Description of the first known fossil representative of the family Tanypezidae (Diptera: Schizophora)". English. In: Tijdschrift voor Entomologie 153 (2010), pp. 213216.

[13875] D. B. Loope. “Dry-season tracks in dinosaur-triggered grainflows”. English. In: Palaios 21 (2006), pp. 132-142.

[13876] C. V. Looy. "The Permian-Triassic Biotic Crisis: collapse and recovery of terrestrial ecosystems". PhD thesis. 2000.

[13877] A. V. Lopatin. "New Early Miocene Zapodidae (Rodentia, Mammalia) from the Aral Formation of the Altynshokysu Locality (North Aral Region)". English. In: Paleontological Journal 33.4 (1999), pp. 429-438.

[13878] A. V. Lopatin. "New early Miocene Aplodontidae and Eomyidae (Rodentia, Mammalia) from the Aral Formation of the Altynshokysu Locality (North Aral Region)". English. In: Paleontological Journal 34.2 (2000), pp. 198-202.

[13879] A. V. Lopatin. “The earliest Hapalodectes (Mesonychia, Mammalia) from the Paleocene of Mongolia". English. In: Paleontological Journal 35.4 (2001), pp. 426-432.

[13880] A. V. Lopatin. “Oligocene and Early Miocene Insectivores (Mammalia) from Western Kazakhstan”. English. In: Paleontological Journal 33.2 (1999), pp. 182-191.

[13881] A. V. Lopatin. "Early Paleogene insectivore mammals of Asia and establishment of the major groups of Insectivora". English. In: Paleontological Journal 40.3 (2006), S205-S405. 
[13882] A. V. Lopatin. "The Skull Structure of Archaeoryctes euryalis sp. nov. (Didymoconidae, Mammalia) from the Paleocene of Mongolia and the Taxonomic Position of the Family". English. In: Paleontological Journal 35.3 (2001), pp. 320-329.

[13883] A. V. Lopatin. "A New Species of Ardynictis (Didymoconidae, Mammalia) from the Middle Eocene of Mongolia". English. In: Paleontological Journal 37.3 (2003), pp. 303-311.

[13884] A. V. Lopatin. “New Oligocene Didymoconidae (Mesonychia, Mammalia) from Mongolia and Kazakhstan". English. In: Paleontological Journal 31.1 (1997), pp. 108-119.

[13885] A. V. Lopatin. "A New Genus of the Erinaceidae (Insectivora, Mammalia) from the Oligocene of Mongolia". English. In: Paleontological Journal 37.6 (2003), pp. 653-664.

[13886] A. V. Lopatin. "A New Genus of the Galericinae (Erinaceidae, Insectivora, Mammalia) from the Middle Eocene of Mongolia". English. In: Paleontological Journal 38.3 (2004), pp. 319-326.

[13887] A. V. Lopatin. "A Zalambdodont Insectivore of the Family Apternodontidae (Insectivora, Mammalia) from the Middle Eocene of Mongolia". English. In: Paleontological Journal 37.2 (2003), pp. 187195.

[13888] A. V. Lopatin. “Late Paleogene Erinaceidae (Insectivora, Mammalia) from the Ergilin Dzo Locality, Mongolia". English. In: Paleontological Journal 39.1 (2005), pp. 85-92.

[13889] A. V. Lopatin. "The Earliest Shrew (Soricidae, Mammalia) from the Middle Eocene of Mongolia". English. In: Paleontological Journal 36.6 (2002), pp. 650-659.

[13890] A. V. Lopatin. “An Oligocene Mole (Talpidae, Insectivora, Mammalia) from Mongolia”. English. In: Paleontological Journal 36.5 (2002), pp. 531-534.

[13891] A. V. Lopatin. "The Largest Asiatic Amphechinus (Erinaceidae, Insectivora, Mammalia) from the Oligocene of Mongolia". English. In: Paleontological Journal 36.3 (2002), pp. 302-306.

[13892] A. V. Lopatin. "The Stratigraphy and Small Mammals from the Aral Formation, the Altynshokysu Locality, Northern Aral Area". English. In: Stratigraphy and Geological Correlation 4.2 (1996), pp. 6579.

[13893] A. V. Lopatin. "The First Finding of Ansomys (Aplodontidae, Rodentia, Mammalia) in the Miocene of Kazakhstan". English. In: Paleontological Journal 31.6 (1997), pp. 667-670.

[13894] A. V. Lopatin. "A Revision of the Early Miocene Lagomorpha (Mammalia) from the North Aral Region". English. In: Paleontological Journal 32.3 (1998), pp. 291-304.

[13895] A. V. Lopatin. "Early Miocene small mammals from the North Aral region (Kazakhstan) with special reference to their biostratigraphic significance". English. In: Paleontological Journal 38.S3 (2004), S217-S323.

[13896] A. V. Lopatin. "New Early Miocene Shrews (Soricidae, Mammalia) from Kazakhstan". English. In: Paleontological Journal 38.2 (2004), pp. 211-219.

[13897] A. V. Lopatin and A. O. Averianov. "Mesozoic mammals of Russia". English. In: 9th International Symposium on Mesozoic Terrestrial Ecosystems and Biota, Abstracts and Proceedings Volume (2006), pp. 67-70.

[13898] A. V. Lopatin and A. O. Averianov. "A new species of Tribosphenomys (Mammalia: Rodentiformes) from the Paleocene of Mongolia". English. In: in Paleogene Mammals, S. G. Lucas, K. E. Zeigler, and P.E. Kondrashov (eds.), New Mexico Museum of Natural History and Science Bulletin 26 (2004), pp. 169-175.

[13899] A. V. Lopatin and A. O. Averianov. "The earliest Asiatic pretribosphenic mammal (Cladotheria, Amphitheriidae) from the Middle Jurassic of Siberia". English. In: Doklady Biological Sciences 417 (2007), pp. 432-434.

[13900] A. V. Lopatin, A. O. Averianov, E. N. Maschenko, and S. V. Leschinskiy. “Early Cretaceous mammals of Western Siberia: 2. Tegotheriidae". English. In: Paleontological Journal 43.4 (2009), pp. 92100. 
[13901] A. V. Lopatin and A. O. Averianov. “Eocene Lagomorpha (Mammalia) of Asia: 2. Strenulagus and Gobiolagus (Strenulagidae)". English. In: Paleontological Journal 40.2 (2006), pp. 198-206.

[13902] A. V. Lopatin and A. O. Averianov. "New Palaeoryctidae (Mammalia) from the Eocene of Kyrgyzstan and Mongolia". English. In: Paleontological Journal 38.5 (2004), pp. 556-562.

[13903] A. V. Lopatin and A. O. Averianov. "A New Stem Placental Mammal from the Early Cretaceous of Mongolia". English. In: Doklady Biological Sciences 478.1 (2018), pp. 8-11.

[13904] A. V. Lopatin and A. O. Averianov. "O nakhodkakh dinozavrov v Krymu [On the findings of dinosaurs in the Crimea]". Russian. In: Izvestiya Vysshikh Uchebnykh Zavedenii, Geologiya i Razvedka 2019.1 (2019), pp. 67-71.

[13905] A. V. Lopatin and P. E. Kondrashov. "Sarcodontinae, a new subfamily of micropternodontid insectivores from the early Paleocene-middle Eocene of Asia". English. In: in Paleogene Mammals, S. G. Lucas, K. E. Zeigler, and P.E. Kondrashov (eds.), New Mexico Museum of Natural History and Science Bulletin 26 (2004), pp. 177-184.

[13906] A. V. Lopatin, E. N. Maschenko, A. O. Averianov, A. S. Rezvyi, P. P. Skutschas, and S. V. Leschinskiy. "Early Cretaceous Mammals from Western Siberia: 1. Tinodontidae". English. In: Paleontological Journal 39.5 (2005), pp. 523-534.

[13907] A. V. Lopatin, E. N. Maschenko, and A. O. Averianov. "A new genus of triconodont mammals from the Early Cretaceous of western Siberia". English. In: Doklady biological Sciences 433 (2010), pp. 282-285. DOI: 10.1134/S0012496610040137.

[13908] A. V. Lopatin and V. S. Zazhigin. “New Brachyericinae (Erinaceidae, Insectivora, Mammalia) from the Oligocene and Miocene of Asia". English. In: Paleontological Journal 37.1 (2003), pp. 62-75.

[13909] R. P. Lopes and J. C. Pereira. "Fossils of Scelidotheriinae Ameghino, 1904 (Xenarthra, Pilosa) in the Pleistocene deposits of Rio Grande do Sul, Brazil". English. In: Gaea: Journal of Geoscience 6.1 (2010), pp. 44-52.

[13910] R. P. Lopes, J. C. Pereira, S. R. Dillenburg, S. H. Tatumi, M. Yee, A. M. Graciano Figueiredo, A. Kinoshita, and O. Baffag. "Late Pleistocene-Holocene fossils from Mirim Lake, Southern Brazil, and their paleoenvironmental significance: I - Vertebrates". English. In: Journal of South American Earth Sciences 100 (2020), p. 102566. DOI: 10.1016/j.jsames.2020.102566.

[13911] R. P. Lopes, L. R. Simone, S. R. Dillenburg, C. L. Schultz, and J. C. Pereira. “A middle Pleistocene marine molluscan assemblage from the Southern coastal plain of Rio Grande do Sul State, Brazil". English. In: Revista Brasileira de Paleontologia 16.3 (2013), pp. 343-360.

[13912] R. P. Lopes and L. R. Simone. “New fossil records of Pleistocene Marine mollusks in Southern Brazil". English. In: Revista Brasileira de Paleontologia 15.1 (2012), pp. 49-56.

[13913] R. P. Lopes and J. C. Pereira. “On the presence of Megatherium Cuvier, 1796 (Xenarthra, Pilosa) in fossiliferous deposits of the Coastal Plain of Southern Brazil". English. In: Revista Brasileira de Paleontologia 22.1 (2019), pp. 38-52. DOI: 10.4072/rbp.2019.1.04.

[13914] G. M. López. "Paleogene faunal assemblage from Antofagasta de la Sierra (Catamarca Province, Argentina)". English. In: Palaeovertebrata 26.1-4 (1997), pp. 61-81.

[13915] G. M. López. "Suniodon catamarcensis gen. et sp. nov. y otros Oldfieldthomasiidae (Notoungulata, Typotheria) del Eoceno de Antofagasta de la Sierra, Catamarca, Argentina". Spanish. In: Actas, VI Congreso Argentino de Paleontologa y Bioestratigrafa, Trelew (1995), pp. 167-172.

[13916] G. M. López. “Primer registro del Orden Astrapotheria en la Formación Divisadero Largo (Mendoza, Argentina)". Spanish. In: Ameghiniana 46.1 (2009), pp. 189-192.

[13917] G. M. López and M. Bond. “Un nuevo Notopithecinae (Notoungulata, Typotheria) del Terciario Inferior de la Puna, Argentina". Spanish. In: Studia Geológica Salmanticensia 31 (1995), pp. 87-99.

[13918] G. M. López, J. N. Gelfo, N. Bauzá, M. Bond, and M. F. Tejedor. "Biochron and diversity of Archaeopithecidae (Mammalia, Notoungulata) and a new genus and species from the Eocene of Patagonia, Argentina". English. In: Ameghiniana 57.2 (2020), pp. 103-116. DOI: 10.5710/ AMGH.18. 01.2020.3291. 
[13919] G. M. López, M. G. Vucetich, A. A. Carlini, M. Bond, M. E. Pérez, M. R. Ciancio, D. J. Pérez, M. Arnal, and A. I. Olivares. "New Miocene mammal assemblages from Neogene Manantiales basin, Cordillera Frontal, San Juan, Argentina". English. In: Cenozoic Geology of the Central Andes of Argentina. Salta: SCS Publisher, 2011, pp. 211-226.

[13920] R. López-Antoñanzas, P. Peláez-Campomanes, J. Prieto, and F. Knoll. “New species of Karydomys (Rodentia) from the Miocene of Chios Island (Greece) and phylogenetic relationships of this rare democricetodontine genus". English. In: Palaeontology 5.1 (2019), pp. 33-45. DOI: 10.1002/spp2. 1224.

[13921] R. L. Lopez-Antonanzas, S. Sen, and G. D. Koufos. “A ctenodactylid rodent (Mammalia: Rodentia) from the Middle Miocene of Chios Island (Greece)". English. In: Geobios 38 (2005), pp. 113-126. DOI: 10.1016/j.geobios.2003.08.006.

[13922] R. L. López-Antoñazas and S. Sen. “New species of Paraphiomys (Rodentia, Thryonomyidae) from the lower Miocene of As-Sarrar, Saudi Arabia". English. In: Palaeontology 48.2 (2005), pp. 223233.

[13923] A. López-Arbarello, T. Bürgin, H. Furrer, and R. Stockar. "New holostean fishes (Actinopterygii: Neopterygii) from the Middle Triassic of the Monte San Giorgio (Canton Ticino, Switzerland)". English. In: PeerJ 4.e2234 (2016), pp. 1-61.

[13924] A. López-Arbarello, T. Bürgin, H. Furrer, and R. Stockar. “Taxonomy and phylogeny of Eosemionotus Stolley, 1920 (Neopterygii: Ginglymodi) from the Middle Triassic of Europe". English. In: Palaeontologia Electronica 22.1.10A (2019), pp. 1-64.

[13925] A. López-Arbarello and L. Codorniú. “Semionotids (Neopterygii, Semionotiformes) from the Lower Cretaceous Lagarcito Formation, San Luis Province, Argentina". English. In: Journal of Vertebrate Paleontology 27.4 (2007), pp. 811-826.

[13926] A. López-Arbarello, E. E. Maxwell, and G. Schweigert. "New halecomorph (Actinopterygii, Neopterygii) from the Nusplingen Lithographic Limestone (Upper Jurassic, Late Kimmeridgian), Germany". English. In: Journal of Vertebrate Paleontology 40.3 (2020), e1771348:1-19. DOI: 10.1080 / 02724634. 2020.1771348.

[13927] A. López-Arbarello, O. W. R. Rauhut, and E. Cerdeño. “The Triassic fish faunas of the Cuyana Basin, Western Argentina". English. In: Palaeontology 53 (2010), pp. 249-276.

[13928] A. López-Arbarello and E. Sfercoa. "New Semionotiform (Actinopterygii, Neopterygii) from the Late Jurassic of Southern Germany". English. In: Journal of Systematic Palaeontology 9 (2009), pp. 197215.

[13929] A. López-Arbarello, R. Stockar, and T. Bürgin. "Phylogenetic relationships of the Triassic Archaeosemionotus Deecke (Halecomorphi, Ionoscopiformes) from the Perledo Fauna". English. In: PLoS One 9.10 (2014), e108665.

[13930] A. López-Arbarello, Z. Y. Sun, E. Sferco, A. Tintori, G. H. Xu, Y. L. Sun, F. X. Wu, and D. Y. Jiang. "New species of Sangiogioichthys Tintori and Lombardo, 2007 (Neopterygii, Semionotiformes) from the Anisian of Luoping (Yunnan Province, South China)". English. In: Zootaxa 2749 (2011), pp. 25-39.

[13931] A. Lopez-Arbarello and L. Wencker. "New callipurbeckiid genus (Ginglymodi: Semionotiformes) from the Tithonian (Late Jurassic) of Canjuers, France". English. In: Palaeontologische Zeitschrift 90 (2016), pp. 543-560. DOI: 10.1007/s12542-016-0312-x.

[13932] A. López-Arbarello and A. M. Zavattieri. "Systematic revision of Pseudobeaconia Bordas, 1944, and Mendocinichthys Whitley, 1953 (Actinopterygii: 'Perleidiformes') from the Triassic of Argentina". English. In: Palaeontology 51.5 (2008), pp. 1025-1052. DOI: 10.1111/j.1475-4983. 2008. 00806.x.

[13933] O. A. López-Conde, M. L. Chavarra-Arellano, and M. Montellano-Ballesteros. “Nonmarine turtles from the Aguja Formation (Late Cretaceous, Campanian) of Chihuahua, Mexico". English. In: Cretaceous Research (2020), p. 102668. 
[13934] O. A. López-Conde, A. Pérez-Garca, M. L. Chavarra-Arellano, and J. Alvarado-Ortega. "A new bothremydid turtle (Pleurodira) from the Olmos Formation (upper Campanian) of Coahuila, Mexico". English. In: Cretaceous Research 119 (2021), p. 104710. DOI: 10.1016/j.cretres.2020.104710.

[13935] O. A. Lopez-Conde, J. Sterli, J. Alvarado-Ortega, and M. Cavarria-Arellano. "A new platychelyid turtle (Pan-Pleurodira) from the Late Jurassic (Kimmeridgian) of Oaxaca, Mexico". English. In: Papers in Palaeontology 3.2 (2017), pp. 161-174. DOI: 10.1002/spp2.1069.

[13936] O. A. López-Conde, J. Sterli, M. L. Chavarra-Arellano, D. B. Brinkman, and M. Montellano-Ballesteros. "Turtles from the Late Cretaceous (Campanian) of El Gallo Formation, Baja California, Mexico". English. In: South American Journal of Earth Sciences 88 (2018), pp. 693-699. DOI: 10.1016/j.jsames. 2018.10.005.

[13937] O. A. Lopez-Conde, J. Sterli, J. Alvarado-Ortega, M. L. Chavarria-Arellano, and H. Porras-Muzquiz. "The first record of Desmatochelys cf. D. lowii from the Late Cretaceous (Campanian)of Coahuila, Mexico". English. In: Journal of South American Earth Sciences (2019). DOI: 10.1016/j.jsames.2019. 05.020.

[13938] J. López-Gappa and L. M. Pérez. "A new genus and species of Chaperiidae (Bryozoa: Cheilostomata) from the early Miocene of Patagonia (Argentina)". English. In: Ameghiniana 56.5 (2019), pp. 422 429. DOI: 10.5710/AMGH.30.08.2019.3281.

[13939] P. López-Guerrero, O. Maridet, Z. Zhang, and G. Daxner-Höck. "A new species of Argyromys (Rodentia, Mammalia) from the Oligocene of the Valley of Lakes (Mongolia): Its importance for palaeobiogeographical homogeneity across Mongolia, China and Kazakhstan". English. In: PLoS ONE 12.3 (2017), e0172733:1-23.

[13940] P. López-Guerrero, O. Maridet, and G. Daxner-Höck. “Cricetidae (Rodentia, Mammalia) from the Oligocene of the Valley of Lakes (Mongolia): the genera Aralocricetodon, Eocricetodon, Bagacricetodon, Witenia and Paracricetodon". English. In: Palaeobiodiversity and Palaeoenvironments 97.1 (2017), pp. 93-109.

[13941] P. López-Guerrero, O. Maridet, and G. Daxner-Höck. “Evolution of the genus Eucricetodon (Rodentia, Mammalia) from the Valley of Lakes (Mongolia): a taxonomical description and update on the stratigraphical distribution". English. In: Palaeobiodiversity and Palaeoenvironments 97.1 (2017), pp. 67-89.

[13942] L. F. Lopez-Jurado and J. A. Mateo. "A new giant land tortoise from the Pliocene of Gran Canaria (Canary Islands)". English. In: Revista Española de Herpetologa 7 (1993), pp. 107-111.

[13943] L. F. López-Jurado, J. A. Mateo, and M. Garca-Márquez. “La tortuga fósil de la isla de Sal (Archipiélago de Cabo Verde)". Spanish. In: Revista Espanola Herpetologica 12 (1998), pp. 111-114.

[13944] N. López-Martnez. "Eggshell sites from the Cretaceous-Tertiary transition in south-central Pyrenees (Spain)". English. In: First International Symposium on Dinosaur Eggs and Babies, Extended Abstracts. Isona i Conda Dellá, 2000, pp. 95-115.

[13945] N. López-Martnez, L. Ardévol, M. E. Arribas, J. Civis, and Á González-Delgado. “The geological record in non-marine environments around the K/T boundary (Tremp Formation, Spain)". English. In: Bulletin de la Société Géologique de France 169.1 (1998), pp. 11-20.

[13946] N. López-Martnez, J. I. Canudo, L. Ardévol, X. Pereda Suberbiola, X. Orue-Etxebarria, G. CuencaBescós, J. I. Ruiz-Omeñaca, X. Murelaga, and M. Feist. "New dinosaur sites correlated with Upper Maastrichtian pelagic deposits in the Spanish Pyrenees: implications for the dinosaur extinction pattern in Europe". In: Cretaceous Research 22.1 (2001), pp. 41-61.

[13947] N. López-Martnez and P. Peláez-Campomanes. "New mammals from south-central Pyrenees (Tremp Formation, Spain) and their bearing on late Paleocene marine-continental correlations." English. In: Bulletin de la Societé Géologique de France 170.5 (1999), pp. 681-696.

[13948] N. López-Martnez and E. Vicens. "A new peculiar dinosaur egg, Sankofa pyrenaica oogen. nov. oosp. nov. from the Upper Cretaceous coastal deposits of the Aren Formation, South-Central Pyrenees, Lleida, Catalonia, Spain". English. In: Palaeontology 55.2 (2012), pp. 325-339. DOI: 10.1111/j. 1475-4983.2011.01114.x. 
[13949] P. López-Mendoza, O. Rojas, P. Mansilla, L. Olivares, and I. Martnez. “Mamferos extintos del Pleistoceno de la Cuenca de Calama (Segunda Región, Chile). Viejas colecciones y nuevos hallazgos". Spanish. In: Treballs del Museu de Geologia de Barcelona 17 (2010), pp. 11-25.

[13950] R. A. Lopez-Perez. "Fossil corals from the Gulf of California, Mexico: still a depauperate fauna but it bears more species than previously thought". English. In: Proceedings of the California Academy of Sciences, 459.12 (2008), pp. 503-519.

[13951] S. López-Torres and Fostowicz-Frelik. "A new Eocene anagalid (Mammalia: Euarchontoglires) from Mongolia and its implications for the group's phylogeny and dispersal". English. In: Scientific Reports 8 (2018), 13955:1-9. DOI: 10.1038/s41598-018-32086-x.

[13952] S. López-Torres and M. T. Silcox. "The European Paromomyidae (Primates, Mammalia): taxonomy, phylogeny, and biogeographic implications". English. In: Journal of Paleontology (2018). DOI: 10.1017/jpa.2018.10.

[13953] S. López-Torres, M. T. Silcox, and P. A. Holroyd. “New omomyoids (Euprimates, Mammalia) from the late Uintan of southern California, USA, and the question of the extinction of the Paromomyidae (Plesiadapiformes, Primates)". English. In: Palaeontologia Electronica 21.3.37A (2018), pp. 1-28.

[13954] A. R. Lord and D. C. Lambourne. "Lower Jurassic ostracods from the western Pontides, Turkey". English. In: Geologica Romana 27 (1991), pp. 381-387.

[13955] E. Loreal, A. Villa, G. Georgalis, and M. Delfino. "Amphibians and reptiles from the late Miocene and early Pliocene of the Ptolemais area (Western Macedonia, Greece)". English. In: Annales de Paléontologie (2020), pp. 1-24. DOI: 10.1016/j.annpal.2020.102407.

[13956] M. Lorente, L. Chornogubsky, and F. J. Goin. "On the existence of non-microbiotherian Australidelphian marsupials (Diprotodontia) in the Eocene of Patagonia". English. In: Palaeontology 59.4 (2016), pp. 533-547. DOI: 10.1111/pala.12241.

[13957] M. Lorente, J. N. Gelfo, and G. M. López. "First skeleton of the notoungulate mammal Notostylops murinus and palaeobiology of Eocene Notostylopidae". English. In: Lethaia 52 (2019), pp. 244-259.

[13958] J. C. Lorenz, G. A. Smith, and S. G. Lucas. "Sedimentary patterns in Pennsylvanian strata at the Kinney Brick Company Quarry, Bernalillo County, New Mexico". English. In: New Mexico Bureau of Mines E Mineral Resources, Bulletin 138 (1992), pp. 13-19.

[13959] H. Löser. "Taxonomy, stratigraphic distribution and palaeobiogeography of the Early Cretaceous coral genus Holocystis". English. In: Revista Mexicana de Ciencias Geológicas 23.3 (2006), pp. 288301.

[13960] H. Löser. "A new solitary coral genus of the suborder Heterocoeniina (Scleractinia) from the Aptian (Cretaceous) of Spain". English. In: Palaeontologische Zeitschrift 82.3 (2008), pp. 279-284.

[13961] H. Löser. "Remarks on the genus Hexasmilia (Scleractinia, Cretaceous) and description of a new species from the Aptian of Spain". English. In: Neues Jahrbuch für Geologie und Paläontologie, Abhandlungen 250.1 (2008), pp. 45-52.

[13962] H. Löser. "Early Cretaceous (Late Valanginian-Aptian) coral faunas from east Africa (Tanzania, Kenya) and revision of the Dietrich collection (Berlin, Germany)". English. In: Palaeontographica Abteilung A 285 (2008), pp. 23-75.

[13963] H. Löser. "Barremian corals from San Antonio Texcala, Puebla, Mexico - A review of the type material of Felix 1891". English. In: Universidad Nacional Autonoma de Mexico, Instituto de Geologia, Boletin 114 (2006), pp. 1-68.

[13964] H. Löser. "The Barremian coral fauna of the Serre de Bleyton mountain range (Drome, SE France)". English. In: Annalen des Naturhistorischen Museums in Wien, Serie A 112 (2010), pp. 575-612.

[13965] H. Löser. "Revision of the Amphiastraeidae from the Monti d'Ocre area (Scleractinia; early Cretaceous)". English. In: Revista italiana di paleontologia e stratigrafia 118.3 (2012), pp. 461-469.

[13966] H. Löser. "Podoseris - a poorly known solitary coral from the Albian of England (Scleractinia)". English. In: Palaeodiversity 5 (2012), pp. 7-11. 
[13967] H. Löser. "Revision of the Early Cretaceous coral genus Felixigyra". English. In: Revista Italiana di Paleontologia e Stratigrafia 116.2 (2010), pp. 189-200.

[13968] H. Löser. "Revision of the coral genera Neocoenia and Helladastraea from the Cretaceous of Greece". English. In: Palaeodiversity 4 (2011), pp. 7-15.

[13969] H. Löser. "Morphology, taxonomy and distribution of the Cretaceous coral genus Aulastraeopora (Late Barremian-Early Cenomanian; Scleractinia)". English. In: Rivista Italiana di Paleontologia e Stratigrafia 114.1 (2008), pp. 19-27.

[13970] H. Löser. "Corals from the Maastrichtian Ocozocoautla Formation (Chiapas, Mexico) - a closer look". English. In: Revista Mexicana de Ciencias Geológicas 29.4 (2012), pp. 534-550.

[13971] H. Löser. "Early evolution of the family Siderastraeidae (Scleractinia; Cretaceous-extant)". English. In: Palaeontologische Zeitschrift 90 (2016), pp. 1-17.

[13972] H. Löser and M. Bilotte. "Taxonomy of a platy coral association from the Late Cenomanian of the southern Corbiéres (Aude, France)". English. In: Annales de Paléontologie 103.1 (2017), pp. 3-17.

[13973] H. Löser and S. Ferry. “Coraux du Barrémien du Sud de la France (Ardéche et Drome)”. French. In: Géobios 39 (2006), pp. 469-489.

[13974] H. Löser, P. Garcia-Barrera, C. C. Mendoza-Rosales, and J. Ortega-Hernández. "Corals from the Early Cretaceous (Barremian - Early Albian) of Puebla (Mexico) - Introduction and Family Stylinidae". English. In: Revista Mexicana de Ciencias Geológicas 30.2 (2013), pp. 385-403.

[13975] H. Löser and W. Liao. "Cretaceous corals from Tibet (China) - stratigraphic and palaeobiogeographic aspects". English. In: Journal of Asian Earth Sciences 19 (2001), pp. 661-667.

[13976] H. Löser and M. Mohanti. "A Cenomanian coral assemblage from southern India". In: Neues Jahrbuch für Geologie und Paläontologie Monatshefte 2004.10 (2004), pp. 577-594.

[13977] H. Löser and J. C. Saldana Villodre. "Colonial Corals from the early Aptian siliciclastic Montlivalta marls of Jumilla (Murcia, Spain)". English. In: Revista Espanola de Paleontologia 23.1 (2008), pp. 1-6.

[13978] H. Löser and J. Sklenar. "The Scleractinian coral genus Glenarea (Bohemian Cretaceous Basin)". English. In: Acta Musei Nationalis Pragae 71.3-4 (2015), pp. 365-376.

[13979] H. Löser, T. A. Stemann, and S. Mitchell. “Oldest scleractinian fauna from Jamaica (Hauterivian, Benbow Inlier)". English. In: Journal of Paleontology 83.3 (2009), pp. 333-349.

[13980] H. Löser, T. Steuber, and C. Löser. "Early Cenomanian coral faunas from Nea Nikopoli (Kozani, Greece; Cretaceous)". English. In: 18.3 (2018).

[13981] H. Löser, L. Vilas, C. Arias, P. A. Ruiz-Ortiz, J. M. Castro, and G. A. De Gea. "An Early Aptian coral fauna from the Prebetic (Southern Spain)". English. In: Spanish Journal of Palaeontology 28.2 (2013).

[13982] H. Löser, W. Werner, and R. Darga. “A Middle Cenomanian coral fauna from the Northern Calcareous Alps (Bavaria, Southern Germany) - new insights into the evolution of Mid-Cretaceous corals". English. In: Zitteliana A 53 (2013), pp. 37-76.

[13983] A. Louchart. "An extinct large thrush (Aves: Turdidae) from the Late Quaternary of Mediterranean Europe". English. In: Neues Jahrbuch für Geologie und Paläontologie, Abhandlungen 233 (2004), pp. 275-296.

[13984] A. Louchart, Y. Haile-Selassie, P. Vignaud, A. Likius, and M. Brunet. "Fossil birds from the Late Miocene of Chad and Ethiopia and zooge- ographical implications". English. In: Oryctos 7 (2008), pp. 147-167.

[13985] A. Louchart, C. Mourer-Chauviré, H. Taisso Mackaye, A. Likius, P. Vignaud, and M. Brunet. “Les oiseaux du Pliocéne inférieur du Djourab, Tchad, Afrique centrale". French. In: Bulletin de la Société Géologique de France 175 (2004), pp. 413-421.

[13986] A. Louchart, N. Tourment, J. Carrier, T. Roux, and C. Mourer-Chauviré. “Hummingbird with modern feathering: an exceptionally well-preserved Oligocene fossil from southern France". English. In: Naturwissenschaften 95.2 (2008), pp. 171-175. 
[13987] L. Lõugas, A. Kriiska, and H. Moora. "Coastal adaptation and marine exploitation of the island Hiiumaa, Estonia, during the stone age with special emphasis on the Kõpu I site". English. In: Landscape and Life. Studies in honour of Urve Miller. 1996, pp. 197-211.

[13988] J. Louis. “Wombats (Vombatidae, Marsupialia) from the Pliocene Chinchilla Sand, southeast Queensland, Australia". English. In: Alcheringa 39.3 (2015), pp. 394-406.

[13989] J. P. Loureiro, P. Correia, A. Nel, and A. Pinto De Jesus. “Lusitaneura covensis n. gen., n. sp., first Caloneurodea from the Carboniferous of Portugal (Insecta: Pterygota: Panorthoptera)". English. In: Annales de la Société Entomologique de France 46 (2010), pp. 242-246.

[13990] W. R. Lourenço. “Premier cas d'un sub-fossile d'araignée appartenant au genre Archaea Koch and Berendt (Archaeidae) dans le copal de Madagascar". French. In: Comptes Rendus de l'Académie des Sciences Paris, Sciences de la Terre et des Planets 330 (2000), pp. 509-512.

[13991] W. R. Lourenço. "About the scorpion fossils from the Cretaceous amber of Myanmar (Burma) with the descriptions of a new family, genus and species". English. In: Acta Biológica Paranaense 41 (2012), pp. 75-87.

[13992] W. R. Lourenço. “A new species of Tityus C. L. Koch, 1836 (subgenus Brazilotityus Lourenço, 2006) from the Dominican amber (Scorpiones: Buthidae)". English. In: Euscorpius - Occasional Publications in Scorpiology 83 (2009), pp. 1-5.

[13993] W. R. Lourenço. “The first scorpion fossil from the Cretaceous amber of France. New implications for the phylogeny of Chactoidea". English. In: Comptes Rendus Palevol 2 (2003), pp. 213-219.

[13994] W. R. Lourenço. “The first scorpion fossil from the Cretaceous amber of Myanmar (Burma). New implications for the phylogeny of Buthoidea". English. In: Comptes Rendues Palevol 1 (2002), pp. 97101.

[13995] W. R. Lourenço. "A remarkable scorpion fossil from the amber of Lebanon. Implications for the phylogeny of Buthoidea". English. In: Comptes Rendus de l'Académie des Sciences Paris, Sciences de la Terre et des Planétes 332 (2001), pp. 641-646.

[13996] W. R. Lourenço. "A new sub-fossil scorpion of the genus Microcharmus Lourenço, 1995 from Malagasy copal (Scorpiones, Microcharmidae)". English. In: Boletn Sociedad Entomológica Aragonesa 44 (2009), pp. 135-137.

[13997] W. R. Lourenço. "Further considerations on scorpions found in Baltic amber, with a description of a new species (Scorpiones: Buthidae)". English. In: Euscorpius - Occasional Publications in Scorpiology 146 (2012), pp. 1-7.

[13998] W. R. Lourenço. "A new species of Tityus C. L. Koch, 1836 (Scorpiones: Buthidae) from Dominican amber". English. In: Euscorpius - Occasional Publications in Scorpiology 156 (2013), pp. 1-5.

[13999] W. R. Lourenço. "Premier cas connu d'un sub-fossile de scorpion dans le copal de Madagascar". French. In: Comptes Rendus de l'Académie des Sciences Paris, Série IIa, Sciences de la Terre et des Planétes 323 (1996), pp. 889-891.

[14000] W. R. Lourenço. "A new species of Chaerilobuthus Lourenço \& Beigel, 2011 from Cretaceous Burmese amber (Scorpiones: Chaerilobuthidae)". English. In: Acta Biológica Paranaense 42 (2013), pp. 1-5.

[14001] W. R. Lourenço. Description of a further species of fossil scorpion in Baltic amber. English. Vol. 3. Beiträge zur Araneologie. 2004, pp. 1886-1889.

[14002] W. R. Lourenço. "A preliminary synopsis on amber scorpions with special reference to Burmite species: an extraordinary development of our knowledge in only 20 years". English. In: ZooKeys 600 (2016), pp. 75-87.

[14003] W. R. Lourenço. "A new genus and three new species of scorpions from Cretaceous Burmese amber (Scorpiones: Chaerilobuthidae: Palaeoeuscorpiidae)". English. In: Arthropoda Selecta 25 (2016), pp. 67-74. 
[14004] W. R. Lourenço. "A new subfamily, genus and species of fossil scorpions from Cretaceous Burmese amber (Scorpiones: Palaeoeuscorpiidae)". English. In: vol. 9. Mesozoic Spiders (Araneae): Ancient Spider Faunas and Spider Evolution, Beiträge zur Araneologie. 2015, pp. 457-464.

[14005] W. R. Lourenço. "Clarification of the familiar status of the genus Palaeoburmesebuthus Lourenço, 2002 from Cretaceous Burmese amber (Scorpiones: Archaeobuthidae: Palaeoburmesebuthinae)". English. In: vol. 9. Mesozoic Spiders (Araneae): Ancient Spider Faunas and Spider Evolution, Beiträge zur Araneologie. 2015, pp. 465-475.

[14006] W. R. Lourenço and A. Beigel. "A new scorpion fossil from the Cretaceous amber of Myanmar (Burma). New phylogenetic implications". English. In: Comptes Rendus Palevol 10 (2011), pp. 635639.

[14007] W. R. Lourenço and A. Beigel. "A new genus and species of Palaeoburmesebuthinae Lourenço, 2015 (Scorpiones: Archaeobuthidae) from Cretaceous amber of Myanmar". English. In: vol. 9. Mesozoic Spiders (Araneae): Ancient Spider Faunas and Spider Evolution, Beiträge zur Araneologie. 2015, pp. 476-480.

[14008] W. R. Lourenço and J. C. Gall. "Fossil scorpions from the Buntsandstein (Early Triassic) of France". English. In: Comptes Rendus Palevol 3 (2004), pp. 369-378.

[14009] W. R. Lourenço and H. Henderickx. "Another new sub-fossil species of scorpion of the genus Palaeogrosphus Lourenço, 2000 from Malagasy copal (Scorpiones: Buthidae)". English. In: Euscorpius - Occasional Publications in Scorpiology 137 (2012), pp. 1-4.

[14010] W. R. Lourenço and W. Weitschat. "A new species of Palaeoananteris Lourenço \& Weitschat, 2001, fossil scorpion from Ukrainian amber (Scorpiones, Buthidae)". English. In: Boletn Sociedad Entomológica Aragonesa 45 (2009), pp. 231-235.

[14011] W. R. Lourenço and W. Weitschat. "New fossil scorpions from the Baltic amber - implications for Cenozoic biodiversity". English. In: Mitteilungen aus dem Geologisch-Paläontologischen Institut der Universität Hamburg 84 (2000), pp. 247-260.

[14012] S. Louwye. “Dinoflagellate cyst biostratigraphy of the upper Miocene Deurne Sands (Diest Formation) of northern Belgium, southern North Sea Basin". English. In: Geological Journal 37 (2002), pp. 55-67.

[14013] S. Louwye and S. De Schepper. "The Miocene-Pliocene hiatus in the southern North Sea Basin (northern Belgium) revealed by dinoflagellate cysts". English. In: Geological Magazine 147.5 (2010), pp. 760-776.

[14014] S. Louwye, R. Marquet, M. Bosselaers, and O. Lambert. "Stratigraphy of an early-middle Miocene sequence near Antwerp in Northern Belgium (Southern North Sea Basin)". English. In: Geologica Belgica 13.3 (2010), pp. 269-284.

[14015] J. Louys, K. Black, M. Archer, S. J. Hand, and H. Godthelp. “Descriptions of koala fossils from the Miocene of Riversleigh, northwestern Queensland and implications for Litokoala (Marsupialia, Phascolarctidae)". English. In: Alcheringa 31.2 (2007), pp. 99-110. DOI: 10.1080/03115510701305082.

[14016] T. S. Lovejoy and R. O. Bierregaard Jr. Central Amazonian Forests and the Minimum Crtical Size of Ecosystems Project. 1990.

[14017] D. Lovelace. Taphonomy and paleoenvironment of a Late Jurassic dinosaur locality in the Morrison Formation of east-central Wyoming. English. 2004.

[14018] D. Lovelace, S. Hartman, and W. R. Wahl. Revised osteology of Supersaurus vivianae. English. 2005.

[14019] D. M. Lovelace. "An Upper Jurassic Morrison Formation fire-induced debris flow: taphonomy and paleoenvironment of a sauropod (Sauropoda: Supersaurus vivianae) locality, east-central Wyoming". English. In: vol. 36. Paleontology and Geology of the Upper Jurassic Morrison Formation. New Mexico Museum of Natural History and Science Bulletin. Albuquerque: New Mexico Museum of Natural History and Science, 2006, pp. 47-56.

[14020] D. M. Lovelace and S. D. Lovelace. "Paleoenvironments and paleoecology of a Lower Triassic invertebrate and vertebrate ichnoassemblage from the Red Peak Formation (Chugwater Group), central Wyoming". English. In: Palaios 27 (2012), pp. 636-657. 
[14021] L. Löwemark and E. Hong. "Schaubcylindrichnus formosus isp. nov. in Miocene Sandstones from northeastern Taiwan". English. In: Ichnos 13.4 (2006), pp. 267-276. DOI: 10.1080/10420940600843757.

[14022] L. Löwemark and M. Nara. "Morphological variability of the trace fossil Schaubcylindrichnus". English. In: Palaeontologia Electronica 16.1 (2013), pp. 1-14.

[14023] L. Löwemark, Y.-C. Zheng, S. Das, C. -P. Yeh, and T. -T. Chen. “A peculiar reworking of Ophiomorpha shafts in the Miocene Nangang Formation, Taiwan". English. In: Geodinamica Acta 28.1-2 (2016), pp. 71-85. DOI: 10.1080/09853111.2015.1035208.

[14024] D. K. Loydell, P. Männik, and V. Nestor. "Integrated biostratigraphy of the lower Silurian of the Aizpute-41 core, Latvia”. English. In: Geological Magazine 140.2 (2003), pp. 205-229. DOI: 10.1017 / S0016756802007264.

[14025] M. C. Lozano Francisco, J. L. Vera Pelaez, and A. Guerra-Merchan. “Arcoida (Mollusca, Bivalvia) del Plioceno de la provincia de Malaga, Espana [Pliocene Arcoida from Malaga, Spain]". Spanish. In: Treballs del Museu de Geologia de Barcelona 3 (1993), pp. 157-188.

[14026] R. P. Lozinsky and R. H. Tedford. "Geology and Paleontology of the Santa Fe Group, Southwestern Albuquerque Basin, Valencia County, New Mexico". English. In: Bulletin of the New Mexico Bureau of Mines and Mineral Research 132 (1991), pp. 1-35.

[14027] P. Lozouet. "Nouvelles espéces de gastéropodes (Mollusca: Gastropoda) de L'Oligocéne et di Miocéne inférieur deAquitaine (sud-ouest de la France)". French. In: Cossmanniana 5.3-4 (1998), pp. 61-102.

[14028] P. Lozouet. “New Pliocéne and Oligocéne Olividae (Mollusca, Gastropoda) from France and the Mediterranean area". English. In: Contr. Tert. Quatern. Geol 29.1-2 (1992), pp. 27-37.

[14029] P. Lozouet. "A new species of Iravadia s.s. (Mollusca, Gastropoda, Iravadiidae) from the late Oligocene of the Aquitaine Basin (southern France). The earliest record of brackishwater Iravadiidae?" English. In: Geodiversitas 25.2 (2003), pp. 237-242.

[14030] P. Lozouet, J.-F. Lesport, and R. Renard. "Révision des Gastropoda (Mollusca) du stratotype de L'Aquitanien (Miocéne inf.) site de Saucats Lariey, Gironde, France". English. In: Cossmanniana 8 (2001), pp. 1-189.

[14031] P. Lozouet and T. Molodtsova. "Filling a gap: The first occurrences of Epiphaxum (Cnidaria: Helioporacea: Lithotelestidae) in the eocene, oligocene and miocene". English. In: Palaeontology 51.1 (2008), pp. 241-250.

[14032] P. Lozouet and P. Renard. "Les Coralliophilidae, Gastropoda de l'Oligocene et du Miocene inferieur d' Aquitaine (Sud-Ouest de la France): systematique et coraux hotes [The Coralliophilidae, Gastropoda from the Oligocene and Lower Miocene of Aquitaine (SW France): systematics and coral hosts]". French. In: Geobios 31.2 (1998), pp. 171-184.

[14033] A. Löfgren. "Conodont faunas from the upper Tremadoc at Brattefors, southcentral Sweden, and reconstruction of the Paltodus apparatus". English. In: G.F.F 119.4 (1997), pp. 257-266. DOI: 10. 1080/11035899709546485.

[14034] H. Lu, D.-Y. Jiang, R. Motani, P. -G. Ni, Z. -Y. Sun, A. Tintori, S. -Z. Xiao, M. Zhou, C. Ji, and W. -F. Fu. "Middle Triassic Xingyi Fauna: Showing turnover of marine reptiles from coastal to oceanic environments". English. In: Palaeoworld 27.1 (2018), pp. 107-116. DOI: 10.1016/j.palwor.2017.05. 005.

[14035] J. Lü. "A new oviraptorosaurid (Theropoda: Oviraptorosauria) from the Late Cretaceous of southern China". English. In: Journal of Vertebrate Paleontology 22.4 (2003), pp. 871-875.

[14036] J. Lü. "A new non-pterodactyloid pterosaur from Qinglong County, Hebei Province of China". English. In: Acta Geologica Sinica 83.2 (2009), pp. 189-199.

[14037] J. Lü. "A baby pterodactyloid pterosaur from the Yixian Formation of Ningcheng, Inner Mongolia, China". English. In: Acta Geologica Sinica 83.1 (2009), pp. 1-8. 
[14038] J. Lü. "A boreopterid pterodactyloid pterosaur from the Early Cretaceous Yixian Formation of Liaoning Province, northeastern China". English. In: Acta Geologica Sinica (English Edition) 84.2 (2010), pp. 241-246.

[14039] J. Lü, L. Xu, Y. Liu, X. Zhang, S. Jia, and Q. Ji. “A new troodontid theropod from the Late Cretaceous of central China, and the radiation of Asian troodontids". English. In: Acta Palaeontologica Polonica 55.3 (2010), pp. 381-388. DOI: 10.4202/app.2009.0047.

[14040] J. Lü, Y. Azuma, T. Wang, S. Li, and S. Pan. "The first discovery of dinosaur footprint from Lufeng of Yunnan province, China". English. In: Memoir of the Fukui Prefectural Dinosaur Museum 5 (2006), pp. 35-39.

[14041] J. Lü, Y. Azuma, Z. Dong, R. Barsbold, Y. Kobayashi, and Y. -N. Lee. "New material of dsungaripterid pterosaurs (Pterosauria: Pterodactyloidea) from western Mongolia and its palaeoecological implications". English. In: Geological Magazine 146 (2009), pp. 690-700.

[14042] J. Lü, Y. Azuma, R. Chen, W. Zheng, and X. Jin. “A new titanosauriform sauropod from the Early Late Cretaceous of Dongyang, Zhejiang Province”. English. In: Acta Geologica Sinica 82.2 (2008), pp. 225-235.

[14043] J. Lü and X. Bo. "A new rhamphorhynchid pterosaur (Pterosauria) from the Middle Jurassic Tiaojishan Formation of western Liaoning, China". English. In: Acta Geologica Sinica 86.5 (2011), pp. 977-983.

[14044] J. Lü, R. Chen, S. L. Brusatte, Y. Zhu, and C. Shen. "A Late Cretaceous diversification of Asian oviraptorid dinosaurs: evidence from a new species preserved in an unusual posture". English. In: Scientific Reports 6 (2016), 35780:1-12. DOI: 10.1038/srep35780.

[14045] J. Lü, P. J. Currie, L. Xu, X. Zhang, H. Pu, and S. Jia. “Chicken-sized oviraptorid dinosaurs from central China and their ontogenetic implications". English. In: Naturwissenschaften 100 (2013), pp. 165-175. DOI: 10.1007/s00114-012-1007-0.

[14046] J. Lü and X. Fucha. "A new pterosaur (Pterosauria) from Middle Jurassic Tiaojishan Formation of western Liaoning, China". English. In: Global Geology 13 (2010), pp. 113-118.

[14047] J. Lü, Y. Gao, L. Xing, Z. Li, and Q. Ji. “A new species of Huaxiapterus (Pterosauria: Tapejaridae) from the Early Cretaceous of western Liaoning, China". English. In: Acta Geologica Sinica 81.5 (2007), pp. 683-687.

[14048] J. Lü and D. W. E. Hone. "A new Chinese anurognathid pterosaur and the evolution of pterosaurian tail lengths". English. In: Acta Palaeontologica Sinica 86.6 (2012), pp. 1317-1325. DOI: 10.1111/17556724.12002 .

[14049] J. Lü and P. Hu. "[Dinosaur remains from Datong Suburb, Shanxi Province]". Chinese. In: Vertebrata PalAsiatica 36.3 (1998), pp. 252-256.

[14050] J. Lü, Q. Ji, Y. Gao, and Z. Li. “A new species of the ankylosaurid dinosaur Crichtonsaurus (Ankylosauridae: Ankylosauria) from the Cretaceous of Liaoning Province, China". English. In: Acta Geologica Sinica 81.6 (2007), pp. 883-897.

[14051] J. Lü and Q. Ji. "New azhdarchid pterosaur from the Early Cretaceous of western Liaoning". English. In: Acta Geologica Sinica 79.3 (2005), pp. 301-307.

[14052] J. Lü and Q. Ji. "A new ornithocheirid from the Early Cretaceous of Liaoning Province, China". English. In: Acta Geologica Sinica 79.2 (2005), pp. 157-163.

[14053] J. Lü, Q. Ji, X. Wei, and Y. Liu. "A new ctenochasmatoid pterosaur from the Early Cretaceous Yixian Formation of western Liaoning, China". English. In: Cretaceous Research 34.1 (2012), pp. 2630. DOI: 10.1016/j.cretres.2011.09.010.

[14054] J. Lü, S. Ji, C. Yuan, Y. Gao, Z. Sun, and Q. Ji. New pterodactyloid pterosaur from the Lower Cretaceous Yixian Formation of Western Liaoning. English. Papers from the 2005 Heyuan International Dinosaur Symposium. Geological Publishing House, Beijing. 2006, pp. 195-203. 
[14055] J. Lü, X. Jin, Y. Sheng, Y. Li, G. Wang, and Y. Azuma. “New nodosaurid dinosaur from the Late Cretaceous of Lishui, Zhejiang Province, China". English. In: Acta Geologica Sinica 81.3 (2007), pp. 344-350.

[14056] J. Lü, X. Jin, D. M. Unwin, L. Zhao, Y. Azuma, and Q. Ji. “A new species of Huaxiapterus (Pterosauria: Pterodactyloidea) from the Lower Cretaceous of western Liaoning, China with comments on the systematics of tapejarid pterosaurs". English. In: Acta Geologica Sinica 80.3 (2006), pp. 315-326.

[14057] J. Lü, Y. Kobayashi, Y. -N. Lee, and Q. Ji. “A new Psittacosaurus (Dinosauria: Ceratopsia) specimen from the Yixian Formation of western Liaoning, China: the first pathological psittacosaurid". English. In: Cretaceous Research 28 (2007), pp. 272-276.

[14058] J. Lü, Y. Kobayashi, T. Li, and S. Zhong. "A new basal sauropod dinosaur from the Lufeng Basin, Yunnan Province, southwestern China". English. In: Acta Geologica Sinica 84.6 (2010), pp. 13361342.

[14059] J. Lü, G. Li, M. Kundrát, Y. -N. Lee, Z. Sun, Y. Kobayashi, C. Shen, F. Teng, and H. Liu. “High diversity of the Ganzhou oviraptorid fauna increased by a new cassowary-like crested species". English. In: Scientific Reports 7.6393 (2017), 6393:1-13. DOI: 10.1038/s41598-017-05016-6.

[14060] J. Lü, S. Li, G. Wang, J. Zhang, and Z. Dong. “New eusauropod dinosaur from Yuanmou of Yunnan province, China". English. In: Acta Geologica Sinica 80.1 (2006), pp. 1-10.

[14061] J. Lü, T. Li, S. Zhong, Y. Azuma, M. Fujita, Z. Dong, and Q. Ji. “New yunnnosaurid dinosaur (Dinosauria, Prosauropoda) From the Middle Jurassic Zhanghe Formation of Yuanmou, Yunnan province of China". English. In: Memoir of the Fukui Prefectural Dinosaur Museum 6 (2007), pp. 1-15.

[14062] J. Lü, T. Li, S. Zhong, Q. Ji, and S. Li. "A new mamenchisaurid dinosaur from the Middle Jurassic of Yuanmou, Yunnan Province, China”. English. In: Acta Geologica Sinica 82.1 (2008), pp. 17-26.

[14063] J. Lü, J. Liu, C. Gao, Q. Meng, and Q. Ji. “New material of pterosaur Sinopterus (Reptilia: Pterosauria) from the Early Cretaceous Jiufotang Formation, Western Liaoning, China". English. In: Acta Geologica Sinica 80.6 (2006), pp. 783-789.

[14064] J. Lu, H. Pu, X. Wei, H. Chang, and M. Kundrat. "A new rhamphorhynchid pterosaur (Pterosauria) from Jurassic deposits of Liaoning Province, China". English. In: Zootaxa 3911.1 (2015), pp. 119129.

[14065] J. Lü, H. Pu, Y. Kobayashi, L. Xu, H. Chang, Y. Shang, D. Liu, Y. -N. Lee, M. Kundrát, and C. Shen. "A new oviraptorid dinosur (Dinosauria: Oviraptorosauria) from the Late Cretaceous of southern China and its paleobiogeographical implicationas". English. In: Scientific Reports 5.11490 (2015), pp. 1-15. DOI: 10.1038/srep11490.

[14066] J. Lü, Y. Tomida, Y. Azuma, Z. Dong, and Y. -N. Lee. “New oviraptorid dinosaur (Dinosauria: Oviraptorosauria) from the Nemegt Formation of southwestern Mongolia". English. In: Bulletin of the National Science Museum, Tokyo, Series C 30 (2004), pp. 95-130.

[14067] J. Lü, D. M. Unwin, X. Jin, Y. Liu, and Q. Ji. “Evidence for modular evolution in a long-tailed pterosaur with a pterodactyloid skull". English. In: Proceedings of the Royal Society B 277 (2010), pp. 383-389. DOI: 10.1098/rspb.2009.1603.

[14068] J. Lü, D. M. Unwin, L. Xu, and X. Zhang. “A new azhdarchoid pterosaur from the Lower Cretaceous of China and its implications for pterosaur phylogeny and evolution". English. In: Naturwissenschften 95 (2008), pp. 891-897. DOI: 10.1007/s00114-008-0397-5.

[14069] J. Lü, D. M. Unwin, D. C. Deeming, X. Jin, Y. Liu, and Q. Ji. “An egg-adult association, gender, and reproduction in pterosaurs". English. In: Science 331.6015 (2011), pp. 321-324. DOI: 10.1126/ science.1197323.

[14070] J. Lü, D. M. Unwin, B. Zhao, C. Gao, and C. Shen. "A new rhamphorhynchid (Pterosauria: Rhamphorhynchidae) from the Middle/Upper Jurassic of Qinglong, Hebei Province, China". English. In: Zootaxa 3158 (2012), pp. 1-19.

[14071] J. Lü, L. Xu, X. Zhang, W. Hu, Y. Wu, S. Jia, and Q. Ji. “A new gigantic sauropod dinosaur with the deepest known body cavity from the Cretaceous of Asia". English. In: Acta Geologica Sinica 81.2 (2007), pp. 167-176. 
[14072] J. Lü, L. Xu, X. Jiang, S. Jia, M. Li, C. Yuan, X. Zhang, and Q. Ji. “A preliminary report on the new dinosaurian fauna from the Cretaceous of the Ruyang Basin, Henan Province of central China". English. In: Journal of the Paleontological Society of Korea 25.1 (2009), pp. 43-56.

[14073] J. Lü, L. Xu, H. Chang, and X. Zhang. "A new darwinopterid pterosaur from the Middle Jurassic of western Liaoning, northeastern China and its ecological implications". English. In: Acta Geologica Sinica 85.3 (2011), pp. 507-514. DOI: 10.1111/j.1755-6724.2011.00444.x.

[14074] J. Lü, L. Xu, H. Pu, X. Zhang, Y. Zhang, S. Jia, H. Chang, J. Zhang, and X. Wei. “A new sauropod dinosaur (Dinosauria, Sauropoda) from the late Early Cretaceous of the Ruyang Basin (central China)". English. In: Cretaceous Research 44 (2013), pp. 202-213. DOI: 10.1016/j.cretres.2013.04.009.

[14075] J. Lü, L. Yi, H. Zhong, and X. Wei. "A new somphospondylan sauropod (Dinosauria, Titanosauriformes) from the Late Cretaceous of Ganzhou, Jiangxi Province of southern China". English. In: Acta Geologica Sinica (English Edition) 87.3 (2013), pp. 678-685.

[14076] J. Lü, L. Yi, H. Zhong, and X. Wei. “A new oviraptorosaur (Dinosauria: Oviraptorosauria) from the Late Cretaceous of southern China and its palaeoecological implications". English. In: PLoS One 8.11 (2013), e80557:1-14. DOI: 10.1371/journal.pone.0080557.

[14077] J. Lü, L. Yi, S. L. Brusatte, L. Yang, H. Li, and L. Chen. "A new clade of Asian Late Cretaceous long-snouted tyannosaurids". English. In: Nature Communications 5.1 (2014), 3788:1-10. DOI: 10. 1038/ncomms4788.

[14078] J. Lü and C. Yuan. "New tapejarid pterosaur from western Liaoning, China”. English. In: Acta Geologica Sinica 79.4 (2005), pp. 453-458.

[14079] J. Lu and M. Zhu. "An onychodont fish (Osteichthyes, Sarcopterygii) from the Early Devonian of China, and the evolution of the Onychodontiformes". English. In: Proceedings of the Royal Society B 277 (2010), pp. 293-299.

[14080] J. Lu, M. Zhu, J. A. Long, W. -J. Zhao, T. J. Senden, L. -T. Jia, and T. Qiao. “The earliest known stemtetrapod from the Lower Devonian of China". English. In: Nature Communications 3.1160 (2012).

[14081] J.-C. Lü, H.-Y. Pu, L. Xu, Y. -H. Wu, and X. -F. Wei. “Largest toothed pterosaur skull from the Early Cretaceous Yixian Formation of western Liaoning, China, with comments on the family Boreopteridae". English. In: Acta Geological Sinica 86.2 (2012), pp. 287-293. DOI: 10.1111/j.17556724.2012.00658.x.

[14082] J.-C. Lü. “A new pterosaur: Beipiaopterus chenianus, gen. et sp. nov. (Reptilia: Pterosauria) from western Liaoning Province of China". English. In: Memoir of the Fukui Prefectural Dinosaur Museum 2 (2003), pp. 153-160.

[14083] J.-C. Lü and S. L. Brusatte. "A large, short-armed, winged dromaeosaurid (Dinosauria: Theropoda) from the Early Cretaceous of China and its implications for feather evolution". English. In: Scientific Reports 5 (2015), p. 11775. DOI: 10.1038/srep11775.

[14084] J.-c. Lü, R.-j. Chen, Y. Azuma, W. -j. Zheng, I. Tanaka, and X. -s. Jin. “New pterosaur tracks from the early Late Cretaceous of Dongyang City, Zhejiang Province, China". English. In: Acta Geoscientica Sinica 31.suppl. 1 (2010), pp. 46-48.

[14085] J.-C. Lü, X.-H. Fucha, and J. -M. Chen. "A new scaphognathine pterosaur from the Middle Jurassic of western Liaoning, China". English. In: Acta Geoscientica Sinica 31.2 (2010), pp. 263-266.

[14086] J.-C. Lü, C.-L. Gao, J. -Y. Liu, Q. -J. Meng, and Q. Ji. “New material of the pterosaur Eopteranodon from the Early Cretaceous Yixian Formation, western Liaoning, China". English. In: Geological Bulletin of China 25.5 (2006), pp. 565-571.

[14087] J.-c. Lü, S.-a. Ji, and Z. -m. Dong. "An Upper Cretaceous lizard with a lower temporal arcade". English. In: Naturwissenschaften 95.7 (2008), pp. 663-669.

[14088] J.-C. Lü, Y. Kobayashi, and Z. -G. Li. "A new species of Ikechosaurus (Reptilia: Choristodera) from the Jiufutang Formation (Early Cretaceous) of Chifeng City, Inner Mongolia". English. In: Bulletin de l'Institut Royal des Sciences Naturelles de Belgique, Sciences de la Terre 69 (1999), pp. 37-47. 
[14089] J.-C. Lu, Q.-J. Meng, B. -P. Wang, D. .Liu, C. -Z. Shen, and Y. -G. Zhang. "Short note on a new anurognathid pterosaur with evidence of perching behaviour from Jianchang of Liaoning Province, China". English. In: vol. 455. Geological Society of London Special Publications. London: Geological Society, 2017, pp. 95-104. DOI: 10.1144/SP455.16.

[14090] J.-c. Lü, L. Xu, S. -h. Jia, X. -1. Zhang, J. -m. Zhang, L. -l. Yang, H. -l. You, and Q. Ji. “A new gigantic sauropod dinosaur from the Cretaceous of Ruyang, Henan, China". English. In: Geological Bulletin of China 28.1 (2009), pp. 1-10.

[14091] J.-C. Lü, L. Xu, H. -L. Chang, S. -H. Jia, J. M. Zhang, D. -S. Gao, Y. -Y. Zhang, C. -J. Zhang, and F. Ding. "A new alvarezsaurid dinosaur from the Late Cretaceous Qiupa Formation of Luanchuan, Henan Province, central China". English. In: China Geology 1 (2018), pp. 28-35.

[14092] J.-C. Lü and B.-K. Zhang. “A new oviraptorid (theropod: Oviraptorosauria) from the Upper Cretaceous of the Nanxiong Basin, Guangdong province of southern China". English. In: Acta Palaeontologica Sinica 44.3 (2005), pp. 412-422.

[14093] L. Lu. "[A new paddlefish from the Upper Jurassic of northeast China]". Chinese. In: Vertebrata PalAsiatica 32.2 (1994), pp. 134-142.

[14094] L. Lu, C. Y. Cai, and D. Y. Huang. "The earliest oxyteline rove beetle in amber and its systematic implications (Coleoptera: Staphylinidae: Oxytelinae)". English. In: Cretaceous Research 69 (2017), pp. $169-177$.

[14095] X. Lu, X. Ni, L. Li, and Q. Li. "Two New Mylagaulid Rodents from the Early Miocene of China". English. In: PLoS ONE 11.e0159445 (2016), pp. 1-17. DOI: 10.1371/journal.pone.0159445.

[14096] X. M. Lu, J. H. Hu, B. Wang, W. W. Zhang, M. Ohl, and X. Y. Liu. “New antlions (Insecta: Neuroptera: Myrmeleontidae) from the mid-Cretaceous of Myanmar and their phylogenetic implications". English. In: Journal of Systematic Palaeontology 17 (2019), pp. 995-1012. DOI: 10.1080 / 14772019.2018.1517132.

[14097] X. M. Lu, B. Wang, M. Ohl, and X. Y. Liu. "The first green lacewing (Insecta: Neuroptera: Chrysopidae) from the mid-Cretaceous amber of Myanmar". English. In: Zootaxa 4399 (2018), pp. 563-570.

[14098] X. M. Lu, B. Wang, S. Y. Yang, and X. Y. Liu. "Early evolution of Nemopteridae illuminated with the first and oldest thread-winged lacewing in Cretaceous amber". English. In: Systematic Entomology 44 (2019), pp. 262-272.

[14099] X. M. Lu, B. Wang, W. W. Zhang, M. Ohl, M. S. Engel, and X. Y. Liu. “Cretaceous diversity and disparity in a lacewing lineage of predators (Neuroptera: Mantispidae)". English. In: Proceedings of the Royal Society B 287.20200629 (2020). DOI: 10.1098/rspb.2020.0629.

[14100] X. M. Lu, F. Y. Xia, U. Aspöck, and X. Y. Liu. “Taxonomic notes on Cretarophalis patrickmuelleri Wichard, 2017 (Insecta: Neuroptera: Nevrorthidae) from the mid-Cretaceous of Myanmar, and its phylogenetic significance". English. In: Zootaxa 4370 (2018), pp. 591-600.

[14101] X. M. Lu, W. W. Zhang, and X. Y. Liu. "New long-proboscid lacewings of the mid-Cretaceous provide insights into ancient plant-pollinator interactions". English. In: Scientific Reports 6.25382 (2016), pp. 1-12.

[14102] X. M. Lu, W. W. Zhang, and X. Y. Liu. “Discovery of the family Babinskaiidae (Insecta: Neuroptera) in mid-Cretaceous amber from Myanmar". English. In: Cretaceous Research 71 (2016), pp. 14-23.

[14103] X. M. Lu, W. W. Zhang, M. Ohl, and X. Y. Liu. "The first moth lacewing (Insecta: Neuroptera: Ithonidae) from the mid-Cretaceous amber of Myanmar". English. In: Cretaceous Research 78 (2017), pp. 78-83.

[14104] X. M. Lu, W. W. Zhang, M. Ohl, and X. Y. Liu. "New genus and species of silky lacewing (Insecta: Neuroptera: Psychopsidae) from the mid-Cretaceous Burmese amber". English. In: Zootaxa 4291 (2017), pp. 373-383.

[14105] X. M. Lu, W. W. Zhang, B. Wang, M. S. Engel, and X. Y. Liu. "A new and diverse paleofauna of the extinct snakefly family Baissopteridae from the mid-Cretaceous of Myanmar (Raphidioptera)". English. In: Organisms Diversity \& Evolution 20 (2020), pp. 565-595. DOI: 10.1007 / s13127-02000455-y. 
[14106] Y. Lu, Y. Z. Yao, and D. Ren. "Two new genera and species of fossil true bugs (Hemiptera: Heteroptera: Pachymeridiidae) from northeastern China". English. In: Zootaxa 2835 (2011), pp. 4152.

[14107] Y. H. Lu and Z. L. Zhu. "Trilobites from the Middle Cambrian Hsuchuangian stage of Zhangxia, Changqing county, Shandong province". Chinese. In: Acta Palaeontologica Sinica 40.3 (2001), pp. 279 293.

[14108] Y. N. Lu, X. Y. Liu, and D. Ren. "First record of the fossil snakefly genus Mesoraphidia (Insecta: Raphidioptera: Mesoraphidiidae) from the Middle Jurassic of China, with description of a new species". English. In: Zootaxa 3999 (2015), pp. 560-570.

[14109] Y. Y. Lu, R. E. Nie, C. K. Shih, D. Ren, X. K. Yang, and M. Bai. “New Scarabaeoidea (Coleoptera) from the Lower Cretaceous Yixian Formation, western Liaoning Province, China: elucidating the systematics of Mesozoic Hybosoridae". English. In: Cretaceous Research 86 (2018), pp. 53-59.

[14110] S. H. Lubkin. "Paracupes svitkoi (Coleoptera: Cupedidae), a new species from the Cretaceous of New Jersey". English. In: Acta Zoologica Cracoviensia 46.Suppl (2003), pp. 189-194.

[14111] S. H. Lubkin and M. S. Engel. "Permocoleus, New Genus, the First Permian Beetle (Coleoptera) from North America". English. In: Annals of the Entomological Society of America 98 (2005), pp. $73-$ 76.

[14112] S. G. Lucas. Fossil mammals and the Paleocene/Eocene series boundary in Europe, North America, and Asia. English. Late Paleocene-Early Eocene Biotic and Climatic Events in the Marine and Terrestrial Records. 1998, pp. 451-500.

[14113] S. G. Lucas. "Pathological aetosaur armor from the Upper Triassic of Germany". English. In: Stuttgarter Beiträge zur Naturkunde Serie B (Geologie und Paläontologie) 281 (2000), pp. 1-6.

[14114] S. G. Lucas. The beginning of the age of dinosaurs in Wyoming. English. Vol. 44. Wyoming Geological Association Guidebook. 1994, pp. 105-113.

[14115] S. G. Lucas. "Late Pleistocene mammals from El Hatillo, Panama". English. In: Revista Geológica de América Central 50 (2014), pp. 139-151.

[14116] S. G. Lucas. "Fossil mammals and the age of the Changxindian Formation, Northeastern China". English. In: Palaeo Vertebrata 25.2-4 (1996), pp. 133-140.

[14117] S. G. Lucas. "Eocene mammals from the Liguanqiao Basin, Henan, China, and the boundary between the Bumbanian and Arshantan land-mammal ages". English. In: New Mexico Museum of Natural History and Science Bulletin 26 (2004), pp. 221-226.

[14118] S. G. Lucas. "Gobiatherium (Mammalia: Dinocerata) from the middle Eocene of Asia: Taxonomy and biochronological significance". English. In: Palaeontologische Zeitschrift 74.4 (2001), pp. 591600.

[14119] S. G. Lucas. "Vertebrate biostratigraphy and biochronology of the upper Paleozoic Dunkard Group, Pennsylvania-West Virginia-Ohio, USA". English. In: International Journal of Coal geology 119 (2013), pp. 79-87. DOI: 10.1016/j.coal.2013.04.007.

[14120] S. G. Lucas. "A new amynodontid (Mammalia, Perissodactyla) from the Eocene Clarno Formation, Oregon, and its biochronological signifi cance". English. In: PaleoBios 26.2 (2006), pp. 7-20.

[14121] S. G. Lucas. "A new dicynodont from the Triassic of Brazil and the tetrapod biochronology of the Brazilian Triassic". English. In: New Mexico Museum of Natural History and Science Bulletin 21 (2002), pp. 131-141.

[14122] S. G. Lucas. "Late Cenozoic fossil mammals from the Chapala rift basin, Jalisco, Mexico". English. In: New Mexico Museum of Natural History and Science Bulletin 44 (2008), pp. 39-49.

[14123] S. G. Lucas, R. H. Aguilar, and J. A. Spielmann. "Stegomastodon (Mammalia, Proboscidea) from the Pliocene of Jalisco, Mexico and the species-level taxonomy of Stegomastodon". English. In: New Mexico Museum of Natural History and Science, Bulletin 53, 2011, pp. 517-553.

[14124] S. G. Lucas, G. E. Alvarado, and E. Vega. "The Pleistocene Mammals of Costa Rica". English. In: Journal of Vertebrate Paleontology 17.2 (1997), pp. 413-427. 
[14125] S. G. Lucas and B. U. Bayshashov. "The giant rhinoceros Paraceratherium from the late Oligocene at Aktau Mountain, southeastern Kazakhstan, and its biochronological significance". English. In: Neues Jahrbuch für Geologie und Paläontologie, Monatshefte 1996.H9 (1996), pp. 539-548.

[14126] S. G. Lucas, E. S. Bray, R. J. Emry, and K. F. Hirsch. "Dinosaur eggshell and the CretaceousPaleogene boundary in the Zaysan Basin, eastern Kazakhstan". English. In: Journal of Stratigraphy 36.2 (2012), pp. 417-435.

[14127] S. G. Lucas and S. M. Cather. Stratigraphy of the Paleogene Chuska Sandstone, New Mexico-Arizona. English. New Mexico Geological Society Guidebook, 54th Field Conference, Geology of the Zuni Plateau. 2003, pp. 389-395.

[14128] S. G. Lucas and R. J. Emry. "The entelodont Brachyhyops (Mammalia, Artiodactyla) from the Upper Eocene of Flagstaff Rim, Wyoming". English. In: New Mexico Museum of Natural History and Science Bulletin 26 (2004), pp. 97-100.

[14129] S. G. Lucas, R. J. Emry, and B. U. Bayshashov. “Eocene Perissodactyla from the Shinzhaly River, eastern Kazakhstan". English. In: Journal of Vertebrate Paleontology 17.1 (1997), pp. 235-246.

[14130] S. G. Lucas and R. J. Emry. "Biochronological significance of Amynodontidae (Mammalia, Perissodactyla) from the Paleogene of Kazakhstan". English. In: Journal of Paleontology 70.4 (1996), pp. 691-696.

[14131] S. G. Lucas, R. J. Emry, and P. A. Tleuberdina. "Franconictis (Mammalia: Carnivora) from the Late Oligocene Of eastern Kazakstan". English. In: Proceedings of the Biological Society of Washington 111.3 (1998), pp. 504-510.

[14132] S. G. Lucas and R. J. Emry. "Early record of indricothere (Mammalia, Perissodactyla, Hyracodontidae) from the Aral Sea region of western Kazakhstan". English. In: Proceedings of the Biological Society of Washington 109.2 (1996), pp. 391-396.

[14133] S. G. Lucas and R. J. Emry. "Eocene Pantolesta from the Zaysan Basin, Kazakstan". English. In: New Mexico Museum of Natural History and Science Bulletin 26 (2004), pp. 227-230.

[14134] S. G. Lucas and R. J. Emry. "Late Eocene entelodonts (Mammalia, Artiodactyla) from Inner Mongolia, China". English. In: Proceedings of the Biological Society of Washington 109.2 (1996), pp. 397405.

[14135] S. G. Lucas, R. J. Emry, and B. U. Bayshahov. "Zaisanamynodon, a Late Eocene amynodontid (Mammalia, Perissodactyla) from Kazakhstan and China". English. In: Tertiary Research 17.1+2 (1996), pp. 51-58.

[14136] S. G. Lucas and R. J. Emry. "Taxonomy and biochronological significance of Paraentelodon, a giant entelodont (Mammalia, Artiodactyla) from the late Oligocene of Eurasia". English. In: Journal of Vertebrate Paleontology 19.1 (1999), pp. 160-168.

[14137] S. G. Lucas and J. W. Estep. "Permian, Triassic, and Jurassic stratigraphy, biostratigraphy, and sequence stratigraphy in the Sierra del Alamo Muerto, Sonora, Mexico". English. In: Geological Society of America Special Paper 340 (1999), pp. 271-286.

[14138] S. G. Lucas and J. W. Estep. "Pennsylvanian Selachians from the Cerros de Amado, Central New Mexico". English. In: New Mexico Museum of Natural History and Science Bulletin 16 (2000), pp. 2128.

[14139] S. G. Lucas and J. W. Estep. “The late Albian ammonite Engonoceras from southwest New Mexico". English. In: New Mexico Geology 20 (1998), pp. 78-82.

[14140] S. G. Lucas and C. A. Ferguson. Upper Cretaceous dinosaur footprints from Grant County, New Mexico. English. New Mexico Geological Society Guidebook, 63rd Field Conference, Warm Springs Region. 2012, pp. 499-502.

[14141] S. G. Lucas, D. L. Fillmore, and E. L. Simpson. "Amphibian Body Impressions from the Mississippian of Pennsylvania, USA”. English. In: Ichnos 17.3 (2010), pp. 172-176. DOI: 10.1080/10420940. 2010.502488. 
[14142] S. G. Lucas, S. E. Foss, and M. C. Mihlbacher. "Achaenodon (Mammalia, Artiodactyla) from the Eocene Clarno Formation, Oregon, and the Age of the Hancock Quarry Local Fauna". English. In: in Paleogene Mammals, S. G. Lucas, K. E. Zeigler, and P.E. Kondrashov (eds.), New Mexico Museum of Natural History and Science Bulletin 26 (2004), pp. 89-95.

[14143] S. G. Lucas, R. Garcia, E. Espinoza, G. E. Alvarado, L. H. de Mendoza, and E. Vega. “The fossil mammals of Nicaragua". English. In: New Mexico Museum of Natural History and Science Bulletin 44 (2008), pp. 417-429.

[14144] S. G. Lucas and C. M. González-León. "Ichthyosaurs from the Upper Triassic of Sonora and the biochronology of Triassic ichthyosaurs". English. In: Geological Society of America Special Paper 301 (1995), pp. 17-20.

[14145] S. G. Lucas and S. K. Harris. “Taxonomic and biochronological significance of specimens of the Triassic dicynodont Dinodontosaurus Romer 1943 in the Tübingen collection". English. In: Palaeontologische Zeitschrift 70 (1996), pp. 603-622.

[14146] S. G. Lucas, S. K. Harris, J. A. Spielmann, D. S. Berman, A. C. Henrici, A. B. Heckert, K. E. Zeigler, and L. F. Rinehart. Early Permian Vertebrate Assemblage and its Biostratigraphic Significance, Arroyo del Agua, Rio Arriba County, New Mexico. English. New Mexico Geological Society, 56th Field Conference Guidebook, Geology of the Chama Basin. 2005, pp. 288-296.

[14147] S. G. Lucas, A. B. Heckert, and A. P. Hunt. Probably turtle from the Upper Triassic of east-central New Mexico. 2000.

[14148] S. G. Lucas and A. B. Heckert. "Theropod dinosaurs and the Early Jurassic age of the Moenave Formation, Arizona-Utah, USA". English. In: Neues Jahrbuch für Geologie und Paläontologie Monatshefte 2001.7 (2001), pp. 435-448.

[14149] S. G. Lucas, A. B. Heckert, and R. M. Sullivan. "Cretaceous dinosaurs in New Mexico". English. In: Dinosaurs of New Mexico. New Mexico Museum of Natural History and Science Bulletin 17 (2000), pp. 83-90.

[14150] S. G. Lucas and A. B. Heckert. Upper Triassic dinosaur track from Fort Wingate, New Mexico. English. Vol. 21. In A. B. Heckert \& S. G. Lucas (eds.), Upper Triassic Stratigraphy and Paleontology. New Mexico Museum of Natural History and Science Bulletin. 2002, pp. 245-247.

[14151] S. G. Lucas and A. B. Heckert. Distribution, age and correlation of Cretaceous fossil vertebrates from Arizona. English. Vol. 29. In A. B. Heckert \& S. G. Lucas (eds.), Vertebrate Paleontology in Arizona. New Mexico Museum of Natural History and Science Bulletin. 2005, pp. 105-110.

[14152] S. G. Lucas, A. B. Heckert, and L. Rinehart. A giant skull, ontogenetic variation and taxonomic validity of the Late Triassic phytosaur Parasuchus. English. Vol. 41. The Global Triassic, New Mexico Museum of Natural History and Science Bulletin. 2007, pp. 222-228.

[14153] S. G. Lucas, A. B. Heckert, and N. Hotton III. The rhynchosaur Hyperodapedon from the Upper Triassic of Wyoming and its global biochronological significance. English. Vol. 21. Upper Triassic Stratigraphy and Paleontology, New Mexico Museum of Natural History and Science Bulletin. 2002, pp. 149156.

[14154] S. G. Lucas and A. B. Heckert. Skull of the dicynodont Placerias from the Upper Triassic of Arizona. English. Vol. 21. Upper Triassic Stratigraphy and Palaeontology, New Mexico Museum of Natural History and Science Bulletin. 2002, pp. 127-130.

[14155] S. G. Lucas and A. B. Heckert. Triassic stratigraphy in the Lucero Uplift, Cibola, Valencia and Socorro Counties, New Mexico. English. Vol. 45. New Mexico Geological Society Guidebook, 45th Field Conference, Mogollon Slope, West-Central New Mexico and East-Central Arizona. 1994, pp. 241254.

[14156] S. G. Lucas, A. B. Heckert, and A. P. Hunt. A new species of the aetosaur Typothorax (Archosauria: Stagonolepididae) from the Upper Triassic of east-central New Mexico. English. Vol. 21. Upper Triassic Stratigraphy and Paleontology, New Mexico Museum of Natural History and Science Bulletin. 2002, pp. 221-233. 
[14157] S. G. Lucas, A. B. Heckert, and R. Kahle. Postcranial anatomy of Angistorhinus, a Late Triassic phytosaur from West Texas. English. Vol. 21. Upper Triassic Stratigraphy and Paleontology, New Mexico Museum of Natural History and Science Bulletin. 2002, pp. 157-164.

[14158] S. G. Lucas and A. B. Heckert. Stratigraphy and correlation of Triassic strata around the Nacimiento and Jemez uplifts, northern New Mexico. English. Vol. 47. New Mexico Geological Society Guidebook, 47th Field Conference, Jemez Mountains Region. 1996, pp. 199-204.

[14159] S. G. Lucas, A. B. Heckert, J. D. Harris, D. Seegis, and R. Wild. "Mammal-like tooth from the Upper Triassic of Germany". English. In: Journal of Vertebrate Paleontology 21.2 (2001), pp. 397-399.

[14160] S. G. Lucas, A. B. Heckert, and L. H. Tanner. "Arizona's Jurassic fossil vertebrates and the age of the Glen Canyon Group". English. In: Vertebrate Paleontology in Arizona. New Mexico Museum of Natural History and Science Bulletin 29 (2005), pp. 95-104.

[14161] S. G. Lucas and A. B. Heckert. "Biochronological significance of Triassic nonmarine tetrapod records from marine strata". English. In: Albertiana 24 (2000), pp. 27-32.

[14162] S. G. Lucas, L. T. Holbrook, and R. J. Emry. "Isectolophus (Mammalia, Perissodactyla) from the Eocene of the Zaysan Basin, Kazakstan and its biochronological significance". English. In: Journal of Vertebrate Paleontology 23.1 (2003), pp. 238-243.

[14163] S. G. Lucas, L. T. Holbrook, and R. J. Emry. "The lophialetid ceratomorph Eoletes (Mammalia) from the Eocene of the Zaysan Basin, Kazakstan". English. In: Proceedings of the Biological Society of Washington 114.4 (2001), pp. 988-992.

[14164] S. G. Lucas, A. P. Hunt, and M. G. Lockley. Dinosaur footprint from the Upper Triassic Rock Point Formation of the Chinle Group, Canyonlands National Park. English. Vol. 1. In V. L. Santucci \& L. McClelland (eds.), National Park Service Natural Resources Publication Office Technical Report NPS/NRPO/NRTR-95/16. National Park Service Paleontological Research Volume. 1995, pp. 5859.

[14165] S. G. Lucas and A. P. Hunt. Dinosaur tracks from the Upper Cretaceous Menefee Formation, west-central New Mexico. English. Vol. 35. Late Cretaceous Vertebrates from the Western Interior. New Mexico Museum of Natural History and Science Bulletin. Albuquerque: New Mexico Museum of Natural History and Science, 2006, pp. 79-81.

[14166] S. G. Lucas and A. P. Hunt. "A dicynodont from the Upper Triassic of New Mexico and its biochronological significance". English. In: New Mexico Museum of Natural History and Science Bulletin 3 (1993), pp. 321-325.

[14167] S. G. Lucas, A. P. Hunt, and J. A. Spielmann. A new aetosaur from the Upper Triassic (Adamanian: Carnian) of Arizona. English. Vol. 40. Triassic of the American West, New Mexico Museum of Natural History and Science Bulletin. 2007, pp. 241-247.

[14168] S. G. Lucas and A. P. Hunt. "A review of Triassic labyrinthodont amphibians from China". English. In: Geobios 26 (1993), pp. 121-128.

[14169] S. G. Lucas, A. R. Hunt, and R. Kahle. "Late Triassic vertebrates from the Dockum Formation near Otis Chalk, Howard County, Texas". English. In: New Mexico Geological Society Guidebook, 44th Field Conference, Carlsbad Region, New Mexico and West Texas (1993).

[14170] S. G. Lucas, H. Klein, M. G. Lockley, J. A. Spielmann, G. D. Gierlinski, A. P. Hunt, and L. H. Tanner. "Triassic-Jurassic stratigraphic distribution of the theropod footprint ichnogenus Eubrontes". English. In: vol. 37. The Triassic-Jurassic Terrestrial Transition. New Mexico Museum of Natural History and Science Bulletin. Albuquerque: New Mexico Museum of Natural History and Science, 2006, pp. 86-93.

[14171] S. G. Lucas, E. G. Kordikova, and R. J. Emry. Upper Cretaceous-Paleocene stratigraphy and vertebrate paleontology in the Zaysan Basin, Kasakhstan. English. 1995.

[14172] S. G. Lucas, B. S. Kues, J. W. Estep, and C. M. González-León. “Permian-Triassic boundary at El Antimonio, Sonora, Mexico". English. In: Revista Mexicana de Ciencias Geológicas 14.2 (1997), pp. $149-154$. 
[14173] S. G. Lucas, B. S. Kues, and C. M. Conzález-León. Paleontology of the Upper Cretaceous Cabullona Group, northeastern Sonora. English. Vol. 301. Studies on the Mesozoic of Sonora and Adjacent Areas. Geological Society of America Special Paper. 1995, pp. 143-165.

[14174] S. G. Lucas and A. J. Lerner. Lower Pennsylvanian invertebrate ichnofossils from the Union Chapel Mine, Alabama: A preliminary assessment. English. Vol. 1. Alabama Paleontological Society Monograph. 2005, pp. 147-152.

[14175] S. G. Lucas, A. J. Lerner, A. R. C. Milner, and M. G. Lockley. “Lower Jurassic invertebrate ichnofossils from a clastic lake margin, Johnson Farm, southwestern Utah". English. In: vol. 37. The Triassic-Jurassic Terrestrial Transition. New Mexico Museum of Natural History and Science Bulletin. Albuquerque: New Mexico Museum of Natural History and Science, 2006, pp. 128-136.

[14176] S. G. Lucas, C. Lewis, W. R. Dickinson, and A. B. Heckert. The Late Cretaceous Tucson Mountains dinosaur. English. Vol. 29. In A. B. Heckert \& S. G. Lucas (eds.), Vertebrate Paleontology in Arizona. New Mexico Museum of Natural History and Science Bulletin. 2005, pp. 111-113.

[14177] S. G. Lucas, M. G. Lockley, A. P. Hunt, and L. H. Tanner. "Biostratigraphic significance of tetrapod footprints from the Triassic-Jurassic Wingate Sandstone on the Colorado Plateau". English. In: vol. 37. The Triassic-Jurassic Terrestrial Transition. New Mexico Museum of Natural History and Science Bulletin. Albuquerque: New Mexico Museum of Natural History and Science, 2006, pp. 109-117.

[14178] S. G. Lucas and Z. Luo. "Adelobasileus from the Upper Triassic of west Texas: the oldest mammal". English. In: Journal of Vertebrate Paleontology 13.3 (1993), pp. 309-334.

[14179] S. G. Lucas, G. H. Mack, and J. W. Estep. "The ceratopsian dinosaur Torosaurus from the Upper Cretaceous McRae Formation, Sierra County, New Mexico". English. In: vol. 49. New Mexico Geological Society, 49th Field Conference, Las Cruces Country II. New Mexico Geological Society Guidebook. Albuquerque: New Mexico Geological Society, 1998, pp. 223-227.

[14180] S. G. Lucas and G. S. Morgan. "The oldest Mammut (Mammalia: Proboscidea) from New Mexico". English. In: New Mexico Geology 21.1 (1999), pp. 10-12.

[14181] S. G. Lucas, L. F. Rinehart, and A. B. Heckert. “Glyptops (Testudines, Pleurosternidae) from the Upper Jurassic Morrison Formation, New Mexico". English. In: vol. 36. Paleontology and Geology of the Upper Jurassic Morrison Formation. New Mexico Museum of Natural History and Science Bulletin. Albuquerque: New Mexico Museum of Natural History and Science, 2006, pp. 97-99.

[14182] S. G. Lucas, L. F. Rinehart, K. Krainer, J. A. Spielmann, and A. B. Heckert. "Taphonomy of the Lamy amphibian quarry: A Late Triassic bonebed in New Mexico, U.S.A." English. In: Palaeogeography, Palaeoclimatology, Palaeoecology 298 (2010), pp. 388-398. DOI: 10.1016/j.palaeo.2010.10.025.

[14183] S. G. Lucas, L. F. Rinehart, A. B. Heckert, A. P. Hunt, and J. A. Spielmann. "Rotten Hill: A Late Triassic bonebed in the Texas Panhandle, USA". English. In: vol. 72. New Mexico Museum of Natural History and Science Bulletin. 2016.

[14184] S. G. Lucas and R. R. Schoch. "Triassic temnospondyl biostratigraphy, biochronology and correlation of the German Bundsandstein and North American Moenkopi Formation". English. In: Lethaia 35 (2002), pp. 97-106.

[14185] S. G. Lucas and R. A. Smartt. "Late Pleistocene peccary from northwestern New Mexico". English. In: Southwestern Naturalist 40.3 (1995), pp. 293-296.

[14186] S. G. Lucas, J. A. Spielmann, R. M. Sullivan, and C. Lewis. Late Cretaceous crocodylians from the San Juan Basin, New Mexico. English. Vol. 35. Late Cretaceous Vertebrates from the Western Interior. New Mexico Museum of Natural History and Science Bulletin. 2006, pp. 249-252.

[14187] S. G. Lucas, J. A. Spielmann, J. I. Kirkland, J. R. Foster, and R. M. Sullivan. A juvenile hadrosaurine from the middle Campanian (Late Cretaceous) interval of the Mancos Shale, western Colorado. English. Vol. 35. Late Cretaceous Vertebrates from the Western Interior. New Mexico Museum of Natural History and Science Bulletin. 2006, pp. 281-292. 
[14188] S. G. Lucas, J. A. Spielmann, A. O. Ivanov, L. F. Rinehart, and K. Krainer. "Petalodont chondrichthyan teeth from the Pennsylvanian-Permian Horquilla Formation, Big Hatchet Mountains, New Mexico". English. In: Fossil Record 3. New Mexico Museum of Natural History and Science Bulletin 53 (2011), pp. 110-114.

[14189] S. G. Lucas, J. A. Spielmann, and A. P. Hunt. "A new doswelliid archosauromorph from the Upper Triassic of West Texas". English. In: vol. 61. New Mexico Museum of Natural History and Science Bulletin. 2013, pp. 382-388.

[14190] S. G. Lucas, J. A. Spielmann, and L. F. Rinehart. "Juvenile skull of the phytosaur Redondasaurus from the Upper Triassic of New Mexico, and phytosaur ontogeny". English. In: New Mexico Museum of Natural History and Science Bulletin 61 (2013), pp. 389-400.

[14191] S. G. Lucas and R. M. Sullivan. "The sauropod dinosaur Alamosaurus from the Upper Cretaceous of the San Juan Basin, New Mexico." English. In: New Mexico Museum of Natural History and Science Bulletin 17 (2000), pp. 147-156.

[14192] S. G. Lucas and R. M. Sullivan. "A new crocodilian from the upper Cretaceous of the San Juan Basin, New Mexico". English. In: Neues Jahrbuch für Geologie und Paläontologie Monatshefte 2003.2 (2003), pp. 109-119.

[14193] S. G. Lucas and R. M. Sullivan. "Stratigraphy and vertebrate biostratigraphy across the CretaceousTertiary boundary, Betonnie Tsosie Wash, San Juan Basin, New Mexico". English. In: Dinosaurs of New Mexico. New Mexico Museum of Natural History and Science Bulletin 17 (2000), pp. 95-104.

[14194] S. G. Lucas, R. M. Sullivan, and A. P. Hunt. Re-evaluation of Pentaceratops and Chasmosaurus (Ornithischia: Ceratopsidae) in the Upper Cretaceous of the Western Interior. English. Vol. 35. Late Cretaceous Vertebrates from the Western Interior. New Mexico Museum of Natural History and Science Bulletin. 2006, pp. 367-370.

[14195] S. G. Lucas and R. M. Sullivan. Denazinemys, a new name for some Late Cretaceous turtles from the Upper Cretaceous of the San Juan Basin, New Mexico. English. Vol. 35. Late Cretaceous Vertebrates from the Western Interior. New Mexico Museum of Natural History and Science Bulletin. 2006, pp. 223-227.

[14196] S. G. Lucas, R. M. Sullivan, S. E. Jasinski, and T. L. Ford. Hadrosaur footprints from the Upper Cretaceous Fruitland Formation, San Juan Basin, New Mexico, and the ichnotaxonomy of large ornithopod footprints. English. Vol. 53. Fossil Record 3. New Mexico Museum of Natural History and Science Bulletin. Albuquerque: New Mexico Museum of Natural History and Science, 2011, pp. 357-362.

[14197] S. G. Lucas and R. M. Sullivan. "Tetrapod footprints from the Upper Triassic Passaic Formation near Graterford, Montgomery County, Pennsylvania". English. In: vol. 37. The Triassic-Jurassic Terrestrial Transition. New Mexico Museum of Natural History and Science Bulletin. Albuquerque: New Mexico Museum of Natural History and Science, 2006, pp. 251-256.

[14198] S. G. Lucas, D. G. Taylor, J. Guex, L. H. Tanner, and K. Krainer. "The proposed global stratotype section and point for the base of the Jurassic system in the New York Canyon area, Nevada, USA". English. In: New Mexico Museum of Natural History and Science Bulletin 40 (2007), pp. 139-168.

[14199] S. G. Lucas, D. P. Whistler, and H. M. Wagner. “Giant entelodont (Mammalia, Artiodactyla) from the Early Miocene of southern California". English. In: Contributions in Science, Natural History Museum of Los Angeles County 466 (1997), pp. 1-9.

[14200] S. G. Lucas and T. E. Williamson. In: New Mexico Museum of Natural History Bulletin 2 (1993).

[14201] S. G. Lucas and T. E. Williamson. In: New Mexico Museum of Natural History Bulletin 2 (1993).

[14202] S. G. Lucas, T. E. Williamson, and J. Sobus. "Plio-Pleistocene stratigraphy, paleoecology, and mammalian biochronology, Tijeras Arroyo, Albuquerque area, New Mexico". English. In: New Mexico Geology 15.1 (1993), pp. 1-8.

[14203] S. G. Lucas, T. E. Williamson, J. W. Estep, A. P. Hunt, and O. J. Anderson. Jurassic fossil vertebrates from New Mexico. Vol. 60. The Continental Jurassic. Museum of Northern Arizona Bulletin. 1996, pp. 235-241. 
[14204] S. G. Lucas, K. E. Ziegler, A. B. Heckert, and A. P. Hunt. Upper Triassic stratigraphy and biostratigraphy, Chama Basin, north-central New Mexico. English. Vol. 24. In K. E. Ziegler, A. B. Heckert, \& S. G. Lucas (eds.), Paleontology and Geology of the Upper Triassic (Revueltian) Snyder Quarry, New Mexico. New Mexico Museum of Natural History and Science Bulletin. 2003, pp. 15-39.

[14205] S. G. Lucas, K. E. Ziegler, and A. B. Heckert. Invertebrate paleontology of the Upper Triassic Snyder Quarry, Chinle Group, Chama Basin, New Mexico. English. Vol. 24. In K. E. Ziegler, A. B. Heckert, \& S. G. Lucas (eds.), Paleontology and Geology of the Upper Triassic (Revueltian) Snyder Quarry, New Mexico. New Mexico Museum of Natural History and Science Bulletin. 2003, p. 63.

[14206] V. Luccisano, J. Sudre, and F. Lihoreau. "Revision of the Eocene artiodactyls (Mammalia, Placentalia) from Aumelas and Saint-Martin-de-Londres (Montpellier limestones, Hérault, France) questions the early European artiodactyl radiation". English. In: Journal of Systematic Palaeontology 18.19 (2020), pp. 1631-1656. DOI: 10.1080/14772019.2020.1799253.

[14207] D. A. A. Lucena and G. A. R. Melo. “Chrysidid wasps (Hymenoptera: Chrysididae) from Cretaceous Burmese amber: Phylogenetic affinities and classification". English. In: Cretaceous Research 89 (2018), pp. 279-291.

[14208] S. O. Lucero, F. L. Agnolin, R. E. Obredor, R. F. Lucero, M. M. Cenizo, and L. L. de los Reyes. "Una nueva especie del genero Ctenomys (Mammalia; Rodentia) del Plioceno tardio - Pleistoceno medio del sudeste de la provincia de Buenos Aires, Argentina". Spanish. In: Studia Geologica Salmanticensia 44.2 (2008), pp. 163-175.

[14209] V. A. Luchinina. "Reef frameworks on the Siberian Platform through the Vendian-Cambrian boundary". English. In: Russian Geology and Geophysics 40.12 (1999), pp. 1753-1762.

[14210] L. Luci. "Encrusting pattern and life habit of Mesozoic trigonoids; a case study of Steinmanella quintucoensis (Weaver) from the Early Cretacous of Argentinia". English. In: Lethaia 43 (2010), pp. 529-544.

[14211] L. Luci, R. M. Garberoglio, and D. G. Lazo. "Serpulids and other calcareous tube-dwelling encrusting polychaetes from the Early Cretaceous Agrio Formation (Neuquen Basin, Argentina)". English. In: Geobios 46.3 (2013), pp. 213-224.

[14212] J. A. Ludtke and D. R. Prothero. "Taxonomic revision of the Middle Eocene (Uintan-Duchesnean) protoceratid Leptoreodon (Mammalia: Artiodactyla)". English. In: vol. 26. Paleogene Mammals. Albuquerque, NM: New Mexico Museum of Natural History and Science, 2004, pp. 101-112.

[14213] R. Ludvigsen and B. D. E. Chatterton. "The peculiar Ordovician trilobite Hypodicranotus from the Whittaker Formation, District of Mackenzie". In: Canadian Journal of Earth Sciences 28.4 (1991), pp. 616-622.

[14214] R. Ludvigsen and R. P. Tripp. "Silurian trilobites from the northern Yukon Territory". In: Life Sciences Contributions, Royal Ontario Museum 153 (1990), pp. 1-59.

[14215] Á H. Luján, M. Chroust, A. eranský, J. Fortuny, M. Mazuch, and M. Ivanov. "First record of Diplocynodon ratelii Pomel, 1847 from the early Miocene site of Tuimice (Most Basin, Northwest Bohemia, Czech Republic)". English. In: Comptes Rendus Palevol 18.7 (2019), pp. 877-889. DOI: 10.1016/j.crpv.2019.04.002.

[14216] A. H. Lujan, M. Delfino, J. M. Robles, and D. M. Alba. "The Miocene tortoise Testudo catalaunica Bataller, 1926, and a revised phylogeny of extinct species of genus Testudo (Testudines: Testudinidae)". English. In: Zoological Journal of the Linnean Society (2016), pp. 1-31. DOI: 10.1111 / zoj. 12414.

[14217] A. H. Lujan, D. deMiguel, M. Ivanov, J. Madurell-Malapeira, S. Jovells-Vaque, and I. CasanovasVilar. Paleoherpetofauna from the Early Miocene Locality of Les Cases de la Valenciana (Catalonia, Spain). English. 2017.

[14218] E. Lukashevich, J. Ansorge, W. Krzemiski, and E. Krzemiska. “Revision of Eoptychopterinae (Diptera: Eoptychopteridae)". English. In: Polskie Pismo Entomologiczne 67 (1998), pp. 311-343.

[14219] E. D. Lukashevich. "New Eoptychopteridae (Diptera: Psychodomorpha) from the Jurassic of Asia". English. In: Paleontological Journal 27.1A (1993), pp. 103-122. 
[14220] E. D. Lukashevich. "Five new species of Eoptychopteridae (Diptera) from the Mesozoic of Asia". English. In: Acta Geologica Hispanica 35.1-2 (2000), pp. 25-30.

[14221] E. D. Lukashevich. "New nematocerans (Insecta: Diptera) from the Late Jurassic of Mongolia". English. In: Paleontological Journal 45.6 (2011), pp. 620-628.

[14222] E. D. Lukashevich. "New chaoborids from the Mesozoic of Mongolia (Diptera: Chaoboridae)". English. In: Paleontological Journal 30 (1996), pp. 551-558.

[14223] E. D. Lukashevich. "A phantom midge (Diptera: Chaoboridae) from Cretaceous Taimyr amber". English. In: Paleontological Journal 33 (1999), pp. 57-60.

[14224] E. D. Lukashevich. "New Bibionomorpha (Insecta: Diptera) from the Jurassic of Asia". English. In: Paleontological Journal 46 (2012), pp. 273-287.

[14225] E. D. Lukashevich. "Pupae of Mesozoic Oryctochlus Kalugina, 1985 (Chironomidae: Podonominae), with description of two new species". English. In: Fauna Norvegica 31 (2012), pp. 159-165.

[14226] E. D. Lukashevich. "Phantom midges (Diptera: Chaoboridae) from Burmese amber". English. In: Bulletin of the Natural History Museum, Geology Series 56 (2000), pp. 47-52.

[14227] E. D. Lukashevich. "A revision of the genus Eoptychopterina (Diptera: Eoptychopteridae)". English. In: Paleontological Journal 38 (2004), pp. 294-306.

[14228] E. D. Lukashevich. "First pupae of the Eoptychopteridae and Ptychopteridae from the Mesozoic of Siberia (Insecta: Diptera)". English. In: Paleontological Journal 29.1 (1995), pp. 164-171.

[14229] E. D. Lukashevich. "Limoniidae (Diptera) in the Upper Jurassic of Shar Teg, Mongolia". English. In: Zoosymposia 3 (2009), pp. 131-154.

[14230] E. D. Lukashevich. "Review of the fossil record of Bittacomorphinae (Diptera: Ptychopteridae)". English. In: Zootaxa 4661 (2019), pp. 566-578.

[14231] E. D. Lukashevich. "Rare nematoceran dipterans (Insecta: Diptera) from the Khasurty locality, Transbaikalia". English. In: Paleontological Journal 54 (2020), pp. 600-612. DOI: 10.1134/S0031030120060040.

[14232] E. D. Lukashevich and A. Arillo. "New Eoptychoptera (Insecta: Diptera, Ptychopteridae) from the Lower Cretaceous of Spain". English. In: Cretaceous Research 58 (2016), pp. 254-264.

[14233] E. D. Lukashevich and D. Azar. "First Eoptychopteridae (Insecta: Diptera) from the Early Cretaceous Lebanese amber". English. In: Acta Zoologica Cracoviensia 46.Suppl (2003), pp. 195-204.

[14234] E. D. Lukashevich and V. A. Blagoderov. "Review of Mesozoic Perissommatidae (Insecta: Diptera)". English. In: Zootaxa 4718 (2020), pp. 481-496.

[14235] E. D. Lukashevich, R. A. Coram, and E. A. Jarzembowski. "New true flies (Insecta: Diptera) from the Lower Cretaceous of southern England". English. In: Cretaceous Research 22 (2001), pp. 451460.

[14236] E. D. Lukashevich and D. A. Grimaldi. "Eoptychopteridae (Insecta: Diptera) in Cretaceous amber from Myanmar". English. In: Studia Dipterologica 10 (2004), pp. 359-366.

[14237] E. D. Lukashevich, D. Y. Huang, and Q. B. Lin. "Rare families of lower Diptera (Hennigmatidae, Blephariceridae, Perissommatidae) from the Jurassic of China". English. In: Studia Dipterologica 13 (2006), pp. 127-143.

[14238] E. D. Lukashevich and W. Krzemiski. "New Jurassic Tanyderidae (Diptera) from Asia with first find of larvae". English. In: Zoosymposia 3 (2009), pp. 155-172.

[14239] E. D. Lukashevich, A. A. Oprzhiboro, F. Marchal-Papier, and L. Grauvogel-Stamm. "The oldest occurrence of immature Diptera (Insecta), Middle Triassic, France". English. In: Annales de la Société Entomologique de France 46.1-2 (2010), pp. 4-22.

[14240] E. D. Lukashevich, M. Pepinelli, and D. C. Currie. "A new family and genus of Mesozoic Simulioidea (Insecta: Diptera)". English. In: Journal of Systematic Palaeontology 18 (2019), pp. 213-231. DOI: 10. 1080/14772019.2019.1588796.

[14241] E. D. Lukashevich and A. A. Przhiboro. "New Chironomidae (Diptera) with elongate proboscises from the Late Jurassic of Mongolia". English. In: ZooKeys 130 (2011), pp. 307-322. 
[14242] E. D. Lukashevich and A. A. Przhiboro. “Pupae of Mesozoic Jurochlus Kalugina, 1985 (Diptera: Chironomidae), with description of four new species". English. In: Zootaxa 3478 (2012), pp. 434452.

[14243] E. D. Lukashevich and A. A. Przhiboro. "A new tribe of Diamesinae (Diptera: Chironomidae) from the Lower Cretaceous of Mongolia". English. In: Cretaceous Research 52 (2015), pp. 562-569.

[14244] E. D. Lukashevich and A. A. Przhiboro. "A new genus of Chironomidae (Insecta: Diptera) from the Lower Cretaceous of Mongolia". English. In: Paleontological Journal 52 (2018), pp. 1401-1407.

[14245] E. D. Lukashevich and G. C. Ribeiro. "Mesozoic fossils and the phylogeny of Tipulomorpha (Insecta: Diptera)". English. In: Journal of Systematic Palaeontology 17 (2018), pp. 635-652.

[14246] E. D. Lukashevich and D. E. Shcherbakov. "A new Triassic family of Diptera from Australia". English. In: Proceedings of the First International Palaeoentomological Conference (1999), pp. 81-89.

[14247] E. D. Lukashevich and D. E. Shcherbakov. "A first find of net-winged midges (Blephariceridae, Diptera) in the Mesozoic". English. In: Neues Jahrbuch für Geologie und Paläontologie, Monatshefte 1997 (1997), pp. 639-646.

[14248] A. Lukeneder. "Late Valanginian ammonoids: Mediterranean and Boreal elements - Implications on sea-level controlled migration (Ebenforst Syncline; Northern Calcareous Alps; Upper Austria)". English. In: Austrian Journal of Earth Sciences 95/96 (2004), pp. 46-59.

[14249] A. Lukeneder. "Taphonomy and stratigraphy of Early Cretaceous ammonoid mass occurrences (Late Valanginian; Northern Calcareous Alps; Upper Austria)". English. In: Austrian Journal of Earth Sciences 98 (2005), pp. 34-51.

[14250] A. Lukeneder. "Barremian ammonoids from Serre de Bleyton (Drome, SE France)". English. In: Annalen des Naturhistorischen Museums in Wien, Serie A 112 (2010), pp. 613-626.

[14251] A. Lukeneder. "The ecological significance of solitary coral and bivalve epibionts on Lower Cretaceous (Valangianian-Aptian) ammonoids from the Italian Dolomites". English. In: Acta Geologica Polonica 58.4 (2008), pp. 425-436.

[14252] A. Lukeneder. "The Karsteniceras level: Dysoxic ammonoid beds within the Early Cretaceous (Barremian, Northern Calcareous Alps, Austria)". English. In: Facies 49.1 (2003), pp. 87-100.

[14253] A. Lukeneder. "Shell accumulation of the brachiopod Pygope catulloi Pictet, 1867 (Lower Valanginian; Northern Calcareous Alps, Upper Austria): palaeoecological implications". English. In: Annalen des Naturhistorischen Museums in Wien, Serie A 103 (2002), pp. 143-159.

[14254] A. Lukeneder and D. Rehakova. "Lower Cretaceous Section of the Ternberg Nappe (Northern Calcareous Alps, Upper Austria): facies-changes, biostratigraphy and paleoecology". English. In: Geologica Carpathica 55.3 (2004), pp. 227-237.

[14255] A. Lukeneder and K. Tanabe. "In situ finds of aptychi in the Barremian of the Alpine Lower Cretaceous (Northern Calcareous Alps, Upper Austria)". In: Cretaceous Research 23 (2002), pp. 15-24.

[14256] S. Lukeneder and A. Lukeneder. "A new ammonoid fauna from the Carnian (Upper Triassic) Kasimlar Formation of the Taurus Mountains (Anatolia, Turkey)". English. In: Palaeontology 57 (2014), pp. 357-396.

[14257] V. Y. Lukin. "New species of syringoporids from Eifelian deposits of the subpolar Ural Mountains". English. In: Paleontological Journal 40.4 (2006), pp. 369-374.

[14258] M. Lukowiak, A. Pisera, and J. Schloegel. "Bathyal sponges from the late Early Miocene of the Vienna Basin (central Paratethys, Slovakia)". English. In: Paläontologische Zeitschrift 88 (2014), pp. $263-$ 277.

[14259] C. A. Luna and M. C. Prieto. Los fosiles de la Formacion Lagunilla del Plata (Pleistoceno tardio) Provincia de Cordoba, Argentina. Spanish. 2013.

[14260] E. K. Lund, P. M. O'Connor, M. A. Loewen, and Z. A. Jinnah. "A new centrosaurine ceratopsid, Machairoceratops cronusi gen et sp. nov., from the Upper Sand Member of the Wahweap Formation (Middle Campanian), southern Utah". English. In: PLoS ONE 11.5 (2016), e0154403:1-21. DOI: 10.1371/journal.pone.0154403. 
[14261] R. Lund and C. Poplin. “The Rhadinichthyids (paleoniscoid actinopterygians) from the Bear Gulch limestone of Montana (USA, Lower Carboniferous)". English. In: Journal of Vertebrate Paleontology 17.3 (1997), pp. 466-486.

[14262] J. Lundberg. "Freshwater Fishes and their paleobiotic implicatios". English. In: Vertebrate Paleontology in the Neotropics. The Miocene Fauna from La Venta, Colombia. Washington and London: Smithsonian Institution Press, 1997, pp. 67-91.

[14263] J. Lundberg and B. Chernoff. “A Miocene Fossil of the Amazonian Fish Arapaima (Teleostei, Arapaimidae) from the Magdalena River Region of Colombia - Biogeographic and Evolutionary Implications". English. In: Biotropica 24.1 (1992), pp. 2-14.

[14264] J. G. Lundberg. "Brachyplatystoma promagdalena, new species, a fossil goliath catfish (Siluriformes: Pimelodidae) from the Miocene of Colombia, South America". English. In: Neotropical Ichthyology 3.4 (2005), pp. 597-605.

[14265] J. G. Lundberg and O. A. Aguilera. "The late Miocene Phractocephalus catfish (Siluriformes: Pimelodidae) from Urumaco, Venezuela: additional specimens and reinterpretation as a distinct species". English. In: Neotropical Ichthyology 1.2 (2003), pp. 97-109.

[14266] E. L. Lundelius, V. M. Bryant, R. Mandel, K. J. Thies, and A. Thoms. "The first occurrence of a toxodont (Mammalia, Notoungulata) in the United States". English. In: Journal of Vertebrate Paleontology 33.1 (2013), pp. 229-232. DOI: 10.1080/02724634.2012.711405.

[14267] E. L. Lundelius Jr. "The Avenue Local Fauna, Late Pleistocene vertebrates from terrace deposits at Austin, Texas". English. In: Annales Zoologici Fennici 28 (1992), pp. 329-340.

[14268] C. H. Luo, T. Jiang, B. Wang, and C. T. Xiao. "A new species of Burmissus (Hemiptera: Fulgoromorpha: Mimarachnidae) from mid-Cretaceous Burmese amber". English. In: Cretaceous Research 110.104417 (2020). DOI: 10.1016/j.cretres.2020.104417.

[14269] C. H. Luo, T. Jiang, J. Szwedo, B. Wang, and C. T. Xiao. "A new genus and species of Perforissidae (Hemiptera: Fulgoromorpha) from mid-Cretaceous Kachin amber". English. In: Cretaceous Research 114.104518 (2020). DOI: 10.1016/j.cretres.2020.104518.

[14270] C. H. Luo, T. Jiang, J. Szwedo, B. Wang, and C. T. Xiao. "A new planthopper family Katlasidae fam. nov. (Hemiptera: Fulgoromorpha: Fulgoroidea) from mid-Cretaceous Kachin amber". English. In: Cretaceous Research 115.104532 (2020). DOI: 10.1016/j.cretres.2020.104532.

[14271] C. H. Luo, C. P. Xu, and E. A. Jarzembowski. “Enervipraeala nigra gen. et sp. nov., a umenocoleid dictyopteran (Insecta) from mid-Cretaceous Kachin amber". English. In: Cretaceous Research 119.104702 (2020). DOI: 10.1016/j.cretres.2020.104702.

[14272] J. Y. Luo, P. Baa, and Q. Xie. "Allocephalocorinae, a new subfamily of Enicocephalidae, based on Allocephalocoris zhengi gen. et sp. nov., in mid-Cretaceous amber from northern Myanmar (Insecta: Hemiptera)". English. In: Cretaceous Research 118.104628 (2020). DOI: 10.1016/j.cretres. 2020.104628.

[14273] K. L. Luo. “Upper Middle-Upper Cambrian trilobites of Hancheng area, Shaanxi”. Chinese. In: Acta Palaeontologica Sinica 40.3 (2001), pp. 371-387.

[14274] X.-Z. Luo, Q.-J. Meng, D. M. Grossnickle, D. Lui, A. I. Neander, Y. -G. Zhang, and Q. Ji. “New evidence for mammaliaform ear evolution and feeding adaptation in a Jurassic ecosystem". English. In: Nature 548 (2017), pp. 326-329. DOI: 10.1038/nature23483.

[14275] Z. Luo. "Variability of Dental Morphology and the Relationships of the Earliest Arctocyonid Species". English. In: Journal of Vertebrate Paleontology 11.4 (1991), pp. 452-471.

[14276] Z. Luo and D. R. Ketten. "CT Scanning and Computerized Reconstructions of the Inner Ear of Multituberculate Mammals". English. In: Journal of Vertebrate Paleontology 11.2 (1991), pp. 220-228.

[14277] Z. Luo, S. G. Lucas, J. Li, and S. Zhen. "A new specimen of Morganucodon oehleri (Mammalia, Triconodonta) from the Liassic Lower Lufeng Formation of Yunnan, China". English. In: Neues Jahrbuch für Geologie und Paläontologie Monatshefte 1995.11 (1995), pp. 671-680. 
[14278] Z. Luo and K. Marsh. "Petrosal (periotic) and inner ear of a Pliocene kogiine whale (Kogiinae, Odontoceti): Implications on relationships and hearing evolution of toothed whales". English. In: Journal of Vertebrate Paleontology 16.2 (1996), pp. 328-348.

[14279] Z. Luo and A. Sun. "Oligokyphus (Cynodontia: Tritylodontidae) from the Lower Lufeng Formation (Lower Jurassic) of Yunnan, China". English. In: Journal of Vertebrate Paleontology 13.4 (1993), pp. 477-482.

[14280] Z. Luo and X.-C. Wu. The small tetrapods of the Lower Lufeng Formation, Yunnan, China. English. In the Shadow of the Dinosaurs: Early Mesozoic Tetrapods. Cambridge University Press, Cambridge. 1994, pp. 251-270.

[14281] Z.-X. Luo, P. Chen, G. Li, and M. Chen. "A new eutriconodont mammal and evolutionary development in early mammals". English. In: Nature 446 (2007), pp. 288-293.

[14282] Z.-X. Luo, A. W. Crompton, and A. -L. Sun. "A new mammaliaform from the Early Jurassic and evolution of mammalian characteristics". English. In: Science 292 (2001), pp. 1535-1540.

[14283] Z.-X. Luo, Q. Ji, J. R. Wible, and C. -X. Yuan. "An Early Cretaceous tribosphenic mammal and metatherian evolution". English. In: Science 302 (2003), pp. 1934-1939.

[14284] Z.-X. Luo, Q. Ji, and C. -X. Yuan. "Convergent dental adaptations in pseudo-tribosphenic and tribosphenic mammals". English. In: Nature 450 (2007), pp. 93-97. DOI: 10.1038/nature06221.

[14285] Z.-X. Luo, Q.-J. Meng, Q. Ji, Y. -G. Zhang, and A. I. Neander. “Evolutionary development in basal mammaliaforms as revealed by a docodontan". English. In: Science 347.6223 (2015), pp. 760-764.

[14286] Z.-X. Luo and J. R. Wible. "A Late Jurassic digging mammal and early mammalian diversification". English. In: Science 308 (2005), pp. 103-107.

[14287] Z.-X. Luo, C.-X. Yuan, Q. -J. Meng, and Q. Ji. "A Jurassic eutherian mammal and divergence of marsupials and placentals". English. In: Nature 476 (2011), pp. 442-445. DOI: 10.1038/nature10291.

[14288] R. Lupia, P. S. Herendeen, and J. A. Keller. "A new fossil flower and associated coprolites: evidence for angiosperm-insect interactions in the Santonian (Late Cretaceous) of Georgia, U.S.A." English. In: International Journal of Plant Sciences 163.4 (2002), pp. 675-686.

[14289] R. Lupia, H. Schneider, G. M. Moeser, K. M. Pryer, and P. R. Crane. “Marsileaceae sporocarps and spores from the Late Cretaceous of Georgia". In: International Journal of Plant Sciences 161 (2000).

[14290] H. Lutz. "Systematische und palökologische Untersuchungen an Insekten aus dem Mittel-Eozän der Grube messel bei Darmstadt". German. In: Courier Forschungsinstitut Senckenberg 124 (1990), pp. 1-165.

[14291] R. L. Lyman. "Prehistoric Seal and Sea-Lion Butchering on the Southern Northwest Coast". English. In: American Antiquity 57.2 (1992), pp. 246-261.

[14292] S. Lynch, M. R. SánchezVillagra, and A. Balcarcel. "Description of a fossil camelid from the Pleistocene of Argentina, and a cladistic analysis of the Camelinae". English. In: Swiss Journal of Palaeontology 139 (2020), 5:1-17. DOI: 10.1186/s13358-020-00208-6.

[14293] S. C. Lynch and J. F. Parham. "The first report of hard-shelled sea turtles (Cheloniidae sensu lato) from the". English. In: PaleoBios 23.3 (2003), pp. 21-35.

[14294] B. C. Lyngdoh, R. P. Tiwari, and R. P. Kachhara. "Miocene Molluscan biosratigraphy of the Garo Hills, Meghalaya, India". English. In: Journal of the Paleontological Society of India 44 (1999), pp. 5567.

[14295] W. G. Lyons and M. A. Snyder. "New genera and species of Peristerniinae (Gastropoda: Fasciolariidae) from the Caribbean Region, with comments on the fasciolariid fauna of Bermuda". English. In: The Veliger 50.3 (2008), pp. 225-240.

[14296] G. A. Lyras, A. A. E. van der Geer, and L. Rook. “Body size of insular carnivores: evidence from the fossil record". English. In: Journal of Biogeography 37.6 (2010), pp. 1007-2021. DOI: 10.1111/j.13652699.2010.02312.x. 
[14297] T. R. Lyson and W. G. Joyce. "A new baenid turtle from the Upper Cretaceous (Maastrichtian) Hell Creek Formation of North Dakota and a preliminary taxonomic review of Cretaceous Baenidae". English. In: Journal of Vertebrate Paleontology 30.2 (2010), pp. 394-402.

[14298] T. R. Lyson and W. G. Joyce. "A new species of Palatobaena (Testudines: Baenidae) and a maximum parsimony and Bayesian phylogenetic analysis of Baenidae". English. In: Journal of Paleontology 83.3 (2009), pp. 457-470.

[14299] T. R. Lyson and W. G. Joyce. "A revision of Plesiobaena (Testudines: Baenidae) and an assessment of baenid ecology across the K/T boundary". English. In: Journal of Paleontology 83.6 (2009), pp. 833-853.

[14300] T. R. Lyson and W. G. Joyce. "Cranial anatomy and phylogenetic placement of the enigmatic turtle Compsemys victa Leidy, 1856". English. In: Journal of Paleontology 85.4 (2011), pp. 789-801. DOI: 10.1666/10-081.1.

[14301] T. R. Lyson, W. G. Joyce, G. E Knauss, and D. A. Pearson. “Boremys (Testudines, Baenidae) from the latest Cretaceous and early Paleocene of North Dakota: an 11 million year range extension and an additional K/T survivor". English. In: Journal of Vertebrate Paleontology 31.4 (2011), pp. 729-737. DOI: $10.1080 / 02724634.2011 .576731$.

[14302] T. R. Lyson, W. G. Joyce, S. G. Lucas, and R. M. Sullivan. "A new baenid turtle from the early Paleocene (Torrejonian) of New Mexico and a species-level phylogenetic analysis of Baenidae". English. In: Journal of Paleontology (2016). DOI: 10.1017/jpa.2016.47.

[14303] T. R. Lyson, W. G. Joyce, and J. J. W. Sertich. “A new chelydroid turtle, Lutemys warreni, gen. et sp. nov., from the Upper Cretaceous (Campanian) Kaiparowits Formation of southern Utah". English. In: Journal of Vertebrate Paleontology 37.6 (2017), e1390672. DOI: 10.1080/02724634.2017.1390672.

[14304] T. R. Lyson, I. M. Miller, A. D. Bercovici, K. Weissenburger, A. J. Fuentes, W. C. Clyde, J. W. Hagadorn, M. J. Butrim, K. R. Johnson, R. F. Fleming, R. S. Barclay, S. A. Maccracken, B. Lloyd, G. P. Wilson, D. W. Krause, and S. G. B. Chester. "Exceptional continental record of biotic recovery after the Cretaceous-Paleogene mass extinction". English. In: Science eaay2268 (2019), pp. 1-12. DOI: $10.1126 /$ science.aay2268.

[14305] T. R. Lyson, J. L. Sayler, and W.G. joyce. "A new Baenid turtle, Saxochelys Gilberti, gen. et sp. nov., from the uppermost Cretaceous (Maastrichtian) Hell Creek Formation: Sexual Dimorphism and Spatial Niche Partitioning within the most speciose group of Late Cretaceous turtles". English. In: Journal of Vertebrate Paleontology e1662428 (2019), pp. 1-18. DOI: 10.1080/02724634.2019.1662428.

[14306] Y. N. Lyu, D. Ren, and X. Y. Liu. "Systematic revision of the fossil snakefly family Baissopteridae (Insecta: Raphidioptera) from the Lower Cretaceous of China, with description of a new genus and three new species". English. In: Cretaceous Research 80 (2017), pp. 13-26.

[14307] Y. N. Lyu, D. Ren, and X. Y. Liu. "Review of the fossil snakefly family Mesoraphidiidae (Insecta: Raphidioptera) in the Middle Jurassic of China, with description of a new species". English. In: Alcheringa 41 (2017), pp. 403-412.

[14308] Y. N. Lyu, D. Ren, and X. Y. Liu. "A remarkable new genus of the snakefly family Mesoraphidiidae (Insecta: Raphidioptera) from the Lower Cretaceous of China, with description of a new species". English. In: Cretaceous Research 89 (2018), pp. 119-125.

[14309] Y. N. Lyu, R. R. Shen, Y. J. Wang, D. Ren, and X. Y. Liu. "The snakefly family Mesoraphidiidae (Insecta: Raphidioptera) from the Lower Cretaceous Yixian Formation, China: systematic revision and phylogenetic implications". English. In: Journal of Systematic Palaeontology 18 (2020), pp. 17431768. DOI: $10.1080 / 14772019.2020 .1807629$.

[14310] G. Y. Lyubarsky and E. E. Perkovsky. "The first Eocene species of the genus Cryptophagus (Coleoptera, Clavicornia, Cryptophagidae)". English. In: Vestnik Zoologii 46.1 (2012), e36-e40.

[14311] G. Y. Lyubarsky and E. E. Perkovsky. "New species of Stilbus (Coleoptera, Clavicornia, Phalacridae) from the late Eocene Rovno amber". English. In: Vestnik Zoologii 45.2 (2011), e47-e50.

[14312] G. Y. Lyubarsky and E. E. Perkovsky. "The first Eocene species of the genus Micrambe (Coleoptera, Clavicornia, Cryptophagidae)". English. In: Vestnik Zoologii 44.3 (2010), e37-e40. 
[14313] G. Y. Lyubarsky and E. E. Perkovsky. "A new genus of Erotylidae from Eocene amber (Coleoptera: Clavicornia)". English. In: Russian Entomological Journal 21 (2012), pp. 35-38.

[14314] G. Y. Lyubarsky and E. E. Perkovsky. "Fourth contribution on late Eocene amber silken fungus beetles: a new Baltic amber species of Atomaria (Coleoptera, Clavicornia, Cryptophagidae)". English. In: Vestnik Zoologii 47.3 (2013), e63-e66.

[14315] G. Y. Lyubarsky and E. E. Perkovsky. “Third contribution on Rovno amber silken fungus beetles: a new Eocene species of Cryptophagus (Coleoptera, Clavicornia, Cryptophagidae)". English. In: ZooKeys 130 (2011), pp. 255-261.

[14316] G. Y. Lyubarsky and E. E. Perkovsky. "New species of the genus Nganasania from Upper Cretaceous of Taymyr (Coleoptera: Cryptophagidae)". English. In: Russian Entomological Journal 23 (2014), pp. 191-194.

[14317] G. Y. Lyubarsky and E. E. Perkovsky. "New genus Microticus from Upper Cretaceous of Taymyr (Coleoptera: Cryptophagidae), oldest silken fungus beetle with sexually dimorphic tarsal formula". English. In: Russian Entomological Journal 24 (2015), pp. 61-66.

[14318] G. Y. Lyubarsky and E. E. Perkovsky. "A new genus, Neolitochropus (Coleoptera: Cucujoidea: Phalacridae), from the Upper Eocene Bitterfeld amber". English. In: Russian Entomological Journal 25 (2016), pp. 249-253.

[14319] G. Y. Lyubarsky, E. E. Perkovsky, and V. I. Alekseev. "The first record of the subfamily Xenoscelinae (Coleoptera, Erotylidae) from the Baltic amber". English. In: Paleontological Journal 50 (2016), pp. 963-969.

[14320] G. Y. Lyubarsky and E. E. Perkovsky. "New genus Ennoticus from the Upper Cretaceous of Taimyr (Coleoptera: Cryptophagidae)". English. In: Paleontological Journal 51 (2017), pp. 191-195.

[14321] G. Y. Lyubarsky and E. E. Perkovsky. "Serramorphus, a new genus of Erotylidae from Eocene amber (Coleoptera: Clavicornia) from late Eocene Bitterfeldian amber". English. In: Russian Entomological Journal 26 (2017), pp. 37-40.

[14322] G. Y. Lyubarsky and E. E. Perkovsky. "Xenophagus, a new genus of pleasing fungus beetles (Coleoptera: Erotylidae) from Baltic amber". English. In: Russian Entomological Journal 26 (2017), pp. 147-150.

[14323] G. Y. Lyubarsky and E. E. Perkovsky. "Microzavaljus, a second extinct genus of pleasing fungus beetles (Coleoptera: Erotylidae) from Bitterfeld Amber". English. In: Russian Entomological Journal 27 (2018), pp. 271-276.

[14324] G. Y. Lyubarsky and E. E. Perkovsky. "First species of Atomaria (Coleoptera: Clavicornia: Cryptophagidae) from Bitterfeld amber and several notes on Miocene and Cretaceous Cryptophagidae". English. In: Russian Entomological Journal 27 (2018), pp. 381-385.

[14325] G. Y. Lyubarsky and E. E. Perkovsky. “First species of Ephistemus (Coleoptera: Clavicornia: Cryptophagidae) from Baltic amber". English. In: Russian Entomological Journal 28 (2019), pp. 54-57.

[14326] G. Y. Lyubarsky and E. E. Perkovsky. "Spaniophagus, first new Eocene genus of silken fungus beetle from Baltic amber (Coleoptera: Clavicornia: Cryptophagidae)". English. In: Russian Entomological Journal 28 (2019), pp. 263-268.

[14327] G. Y. Lyubarsky and E. E. Perkovsky. “Olibrolitus, new genus of shining flower beetles (Coleoptera, Cucujoidea, Phalacridae) from Bitterfeld and Baltic amber". English. In: Paleontological Journal 54 (2020), pp. 143-148. DOI: 10.1134/S0031030120020070.

[14328] G. Y. Lyubarsky and E. E. Perkovsky. "First Rovno amber species of the genus Telmatophilus (Coleoptera: Clavicornia: Cryptophagidae) from Veselukha floodplain". English. In: Invertebrate Zoology 17 (2020), pp. 25-35.

[14329] L.-T. Ma, D.-Y. Jiang, O. Rieppel, R. Motani, and A. Tintori. "A new pistosauroid (Reptilia, Sauropterygia) from the late Ladinian Xingyi marine reptile level, southwestern China". English. In: Journal of Vertebrate Paleontology 35.1 (2015), e881832. DOI: 10.1080/02724634.2014.881832. 
[14330] X.-P. Ma, Y.-L. Sun, W.-C. Hao, and W.-H. Liao. “Rugose corals and brachiopods across the FrasnianFamennian boundary in central Hunan, South China". In: Acta Palaeontologica Polonica 47.2 (2002), pp. 373-396.

[14331] X. Ma, V. Ebbighausen, and R. T. Becker. "Desquamatia and related atrypid brachiopods from the Frasnian (Upper Devonian) of Bergisches Land, Germany". English. In: Canadian Journal of Earth Sciences 45 (2008), pp. 121-134.

[14332] X. Y. Ma and G. H. Xu. "A new ionoscopiform fish (Holostei: Halecomorphi) from the Middle Triassic (Anisian) of Yunnan, China". English. In: Vertebrata PalAsiatica 55 (2017), pp. 162-176.

[14333] X.-P. Ma, G. Li, F. Gao, Y. -L. Sun, and L. Zheng. “New early Pleistocene mammalian materials from Zhongdian, Yunnan Province, China". English. In: Vertebrata PalAsiatica 42.3 (2004), pp. 246258.

[14334] Y. M. Ma, C. K. Shih, D. Ren, and Y. J. Wang. "A new genus of lance lacewings from the Middle Jurassic of Inner Mongolia, China". English. In: Acta Palaeontologica Polonica 65 (2020), pp. 363-369. DOI: 10.4202/app.00691.2019.

[14335] A. Maas, G. Mayer, R. M. Kristensen, and D. Waloszek. "A Cambrian micro-lobopodian and the evolution of arthropod locomotion and reproduction". English. In: Chinese Science Bulletin 52 (2007), pp. 3385-3392. DOI: 10.1007/s11434-007-0515-3.

[14336] A. Maas, D. Waloszek, J. T. Haug, and K. J. Müller. “A possible larval roundworm from the Cambrian 'Orsten' and its bearing on the phylogeny of Cycloneuralia". English. In: Memoir of the Association of Australasian Palaeontologists 34 (2007), pp. 499-519.

[14337] A. Maas and D. Waloszek. "Cambrian Derivatives of the Early Arthropod Stem Lineage, Pentastomids, Tardigrades and Lobopodians - An 'Orsten' Perspective". English. In: Zoologischer Anzeiger 240 (2001), pp. 451-459.

[14338] M. C. Maas, S. T. Hussain, J. J. M. Leinders, and J. G. M. Thewissen. "A new isectolophid tapiromorph (Perissodactyla, Mammalia) from the early Eocene of Pakistan". English. In: Journal of Paleontology 75.2 (2001), pp. 407-417.

[14339] M. C. Maas and M. O'Leary. "Evolution of molar enamel microstructure in North American Notharctidae (primates)". English. In: Journal of Human Evolution 31 (1996).

[14340] M. C. Maas, J. G. M. Thewissen, S. Sen, N. Kazanci, and J. Kappelman. “Enigmatic new ungulates from the early middle Eocene of Central Anatolia, Turkey". English. In: Journal of Vertebrate Paleontology 21.3 (2001), pp. 578-590.

[14341] C. R. Macadam and A. J. Ross. "A new species of mayfly, Maccaffertium annae sp. nov. (Ephemeroptera: Heptageniidae) from Mexican amber (Miocene)". English. In: Boletn de la Sociedad Geológica Mexicana 68 (2016), pp. 1-5.

[14342] L. Macaluso, J. E. Martin, L. Del Favero, and M. Delfino. "Revision of the crocodilians from the Oligocene of Monteviale, Italy, and the diversity of European eusuchians across the EoceneOligocene boundary". English. In: Journal of Vertebrate Paleontology (2019), e1601098:1-13. DOI: 10.1080/02724634.2019.1601098.

[14343] F. Macchioni, P. L. Smith, and H. W. Tipper. "Late early Sinemurian (early Jurassic) Ammonites from the Taseko Lakes map area, British Columbia". English. In: Palaeontology 49 (2006), pp. 557583.

[14344] F. Macchioni, P. L. Smith, and H. W. Tipper. “A new early Sinemurian (Jurassic) ammonite species from the Taseko Lakes map area, British Columbia, Canada". English. In: Journal of Paleontology 79 (2005), pp. 790-795.

[14345] M. MacDougall and R. R. Reisz. "The first record of a nyctiphruretid parareptile from the Early Permian of North America, with a discussion of parareptilian temporal fenestration". English. In: Zoological Journal of the Linnean Society 172 (2014), pp. 616-630.

[14346] M. J. MacDougall, S. P. Modesto, and R. R. Reisz. "A new reptile from the Richards Spur Locality, Oklahoma, USA, and patterns of Early Permian parareptile diversification". English. In: Journal of Vertebrate Paleontology 36.5 (2016), e1179641. DOI: 10.1080/02724634.2016.1179641. 
[14347] M. J. MacDougall and R. Reisz. "A new parareptile (Parareptilia, Lanthanosuchoidea) from the Early Permian of Oklahoma". English. In: Journal of Vertebrate Paleontology 32.5 (2012), pp. 10181026. DOI: $10.1080 / 02724634.2012 .679757$.

[14348] B. J. MacFadden. "Three-toed browsing horse Anchitherium clarencei from the early Miocene (Hemingfordian) Thomas Farm, Florida". English. In: Bulletin of the Florida Museum of Natural History 43.3 (2001), pp. 79-109.

[14349] B. J. MacFadden. "North American Miocene Land Mammals from Panama". English. In: Journal of Vertebrate Paleontology 26.3 (2006), pp. 720-734.

[14350] B. J. MacFadden. "Three-Toed Browsing Horse Anchitherium (Equidae) From the Miocene of Panama". English. In: Journal of Vertebrate Paleontology 83.3 (2009), pp. 489-492. DOI: 10.1666/08155.1.

[14351] B. J. MacFadden, F. Anaya, and J. Argollo. "Magnetic polarity stratigraphy of Inchasi: a Pliocene mammal-bearing locality from the Bolivian Andes deposited just before the Great American Interchange". English. In: Earth and Planetary Science Letters 114.2-3 (1993), pp. 229-241.

[14352] B. J. MacFadden, J. I. Bloch, H. Evans, D. A. Foster, G. S. Morgan, A. Rincon, and A. R. Wood. "Temporal Calibration and Biochronology of the Centenario Fauna, Early Miocene of Panama". English. In: The Journal of Geology 122.2 (2014), pp. 113-135. DOI: 10.1086/675244.

[14353] B. J. MacFadden, J. D. Bryant, and P. A. Mueller. "Sr-isotopic, paleomagnetic, and biostratigraphic calibration of horse evolution: evidence from the Miocene of Florida". English. In: Geology 19.3 (1991), pp. 242-245.

[14354] B. J. MacFadden and O. Carranza-Castafieda. "Cranium of Dinohippus mexicanus (Mammalia: Equidae) from the Early Pliocene (Latest Hemphillian) of Central Mexico, and the origin of Equus". English. In: Bulletin of the Florida Museum of Natural History 43.5 (2002), pp. 163-185.

[14355] B. J. MacFadden and T. E. Cerling. "Mammalian Herbivore Communities, Ancient Feeding Ecology, and Carbon Isotopes: A 10 Million-Year Sequence from the Neogene of Florida". English. In: Journal of Vertebrate Paleontology 16.1 (1996), pp. 103-115.

[14356] B. J. MacFadden and P. Higgins. Middle Miocene land mammals from Panama: evidence for the age of the Neotropical rainforest. English. 2003.

[14357] B. J. MacFadden and P. Higgins. "Ancient ecology of 15-million-year-old browsing mammals within C3 plant communities of Panama". English. In: Oecologia 140 (2004), pp. 169-182.

[14358] B. J. MacFadden, D. S. Jones, N. A. Jud, J. W. Moreno, G. S. Morgan, R. W. Portell, V. J. Perez, S. M. Moran, and A. R. Wood. "Integrated Chronology, Flora and Faunas, and Paleoecology of the Alajuela Formation, Late Miocene of Panama". English. In: PLoS One 12.1 (2017), e0170300. DOI: 10.1371/journal.pone.0170300.

[14359] B. J. MacFadden, M. X. Kirby, A. Rincon, C. Montes, S. Moron, N. Strong, and C. Jaramillo. “Extinct peccary Cynorca occidentale (Tayassuidae, Tayassuinae) from the Miocene of Panama and correlations to North America". English. In: Journal of Paleontology 84.2 (2010), pp. 288-298.

[14360] B. J. MacFadden and G. S. Morgan. "New oreodont (Mammalia, Artiodactyla) from the late Oligocene (early Arikareean) of Florida". English. In: Bulletin of the American Museum of Natural History 279 (2003), pp. 368-396.

[14361] B. J. MacFadden, G. S. Morgan, D. S. Jones, and A. F. Rincon. “Gomphothere proboscidean (Gomphotherium) from the late Neogene of Panama". English. In: Journal of Paleontology 89.2 (2015), pp. 360-365. DOI: 10.1017/jpa.2014.31.

[14362] D. A. B. MacFarlan. "Mesozoic stratigraphy of the Marokopa area, southwest Auckland, New Zealand". English. In: New Zealand Journal of Geology and Geophysics 41 (1998), pp. 297-310.

[14363] D. A. B. MacFarlan. "Middle and Late Jurassic terebratulides from New Zealand". English. In: Palaeoworld 25 (2016), pp. 467-495.

[14364] D. A. B. MacFarlan. "Early Jurassic terebratulide brachiopods from Zealandia". English. In: Rivista Italiana di Paleontologia e Stratigrafia 125 (2019), pp. 551-586. 
[14365] D. A. B. MacFarlan and J. D. Campbell. “Zeilleria spiculata, a new terebratulide brachiopod from the latest Triassic-earliest Jurassic of New Zealand". English. In: Journal of the Royal Society of New Zealand 33.1 (2003), pp. 213-221.

[14366] E. B. Machado, L. S. Avilla, W. R. Nava, D. A. Campos, and A. W. A. Kellner. "A new titanosaur sauropod from the Late Cretaceous of Brazil". English. In: Zootaxa 3701.3 (2013), pp. 301-321.

[14367] E. B. Machado, D.d.A. Campos, J. O. Calvo, and A. W. A. Kellner. "A new abelisauroid from the Upper Cretaceous of Brazil". English. In: Revista Mexicana de Ciencias Geologicas 30.2 (2013), pp. 446-452.

[14368] G. P. Machado, J. Alvarado-Ortega, L. P. Machado, and P. M. Brito. “Teoichthys brevipina, sp. nov., a new ophiopsid fish (Halecomorphi, Ionoscopiformes) from the Lower Cretaceous Tlayúa Formation, Central Mexico". English. In: Journal of Vertebrate Paleontology 33.2 (2013), pp. 482-487.

[14369] R. J. P. Machado, A. V. L. Freitas, and G. C. Ribeiro. "A new giant species of the remarkable extinct family Kalligrammatidae (Insecta: Neuroptera) from the Lower Cretaceous Crato Formation of Brazil". English. In: Cretaceous Research 120.104724 (2020). DOI: 10.1016/j.cretres.2020.104724.

[14370] M. Machalski. “Oster life positions and shell beds from the Upper Jurassic of Poland". English. In: Acta Palaeontologica Polonica 43.4 (1998), pp. 609-634.

[14371] M. Machalski, J. W. M. Jagt, R. W. Dortangs, E. W. A. Mulder, and A. Radwaski. “Campanian and Maastrichtian mosasaurid reptiles from central Poland". English. In: Acta Palaeontologica Polonica 48.3 (2003), pp. 397-408.

[14372] M. Machalski, J. W. M. Jagt, A. S. Alekseev, and E. A. Jagt-Yazykova. "Terminal Maastrichtian ammonites from Turkmenistan, central Asia". English. In: Acta Palaeontologica Polonica 57 (2012), pp. 729-735.

[14373] M. Machalski, J. W. M. Jagt, N. H. Landman, and J. Uberna. "First record of the North American scaphitid ammonite Discoscaphites iris from the upper Maastrichtian of Libya". English. In: Neues Jahrbuch für Geologie und Paläontologie, Abhandlungen 254 (2009), pp. 373-378.

[14374] M. Machalski and M. Wilmsen. "Taxonomy and taphonomy of Cenomanian (Upper Cretaceous) nautilids from Annopol, Poland". English. In: Acta Geologica Polonica 65 (2015), pp. 495-506.

[14375] I. G. Macintyre and W. H. Adey. "Buck Island Bar, St. Croix, USVI: a reef that cannot catch up with sea level". English. In: Atoll Research Bulletin 336 (1990), pp. 1-7.

[14376] I. G. Macintyre and R. B. Aronson. "Diving into the Past: Scuba and the Temporal Dimension of Coral Reefs". English. In: Smithsonian Contributions to the Marine Sciences 39 (2013).

[14377] I. G. Macintyre, P. W. Glynn, and J. Cortes. "Holocene reef history in the eastern Pacific: mainland Costa Rica, Cano Island, Cocos Island, and Galapagos Islands". English. In: Proceedings of the 7th International Coral Reef Symposium 2 (1992), pp. 1174-1184.

[14378] I. G. Macintyre, M. A. Toscano, and J. Lundberg. “Complex environmental patterns and Holocene sea-level changes controlling reef histories along northeastern St. Croix, USVI". English. In: Atoll Research Bulletin 556 (2008), pp. 1-25.

[14379] E. Maciunas, J. G. Conran, J. M. Bannister, R. Paull, and D. E. Lee. “Miocene Astelia (Asparagales: Asteliaceae) macrofossils from southern New Zealand". English. In: Australian Systematic Botany 24 (2011), pp. 19-31.

[14380] W. P. MacKay. "Anochetus brevidentatus, new species, a second fossil Odontomachiti ant (Hymenoptera: Formicidae)". English. In: Journal of the New York Entomological Society 99 (1991), pp. 138 140.

[14381] H. T. Mackaye, M. Brunet, and P. Tassy. "Selenetherium kolleensis nov. gen. nov. sp.: un nouveau Proboscidea (Mammalia) dans le Pliocéne tchadien". French. In: Geobios 38.6 (2005), pp. 765-777. DOI: 10.1016/j.geobios.2003.09.010.

[14382] H. T. Mackaye, Y. Coppens, P. VIgnaud, F. Lihoreau, and M. Brunet. "De nouveaux restes de Primelephas dans le Mio-Pliocéne du Nord du Tchad et révision du genre Primelephas". French. In: Comptes Rendus Palevol 7.4 (2008), pp. 227-236. DOI: 10.1016/j.crpv.2008.03.007. 
[14383] A. C. Macken and E. H. Reed. "Late Quaternary Small Mammal Faunas of the Naracoorte Caves World Heritage Area". English. In: Transactions of the Royal Society of South Australia 137.1 (2013), pp. 53-67.

[14384] D. MacKinnon, S. S. Beus, and D. L. Lee. "Brachiopod fauna of the Kokoamu Greensand (Oligocene), New Zealand". English. In: New Zealand Journal of Geology and Geophysics 36 (1993), pp. 327-347.

[14385] D. I. MacKinnon and T. N. Smirnova. "Scanning electron microscopy study of Cretaceous brachiopods of the new family Praeargyrothecidae: implications for megathyroid systematics and terebratulide phylogeny". English. In: Journal of Paleontology 69.4 (1995), pp. 670-685.

[14386] B. Mackness. "On the identity of Euowenia robusta De Vis, 1891 with a description of a new zygomaturine genus". English. In: Alcheringa 34 (2010), pp. 455-469. DOI: 10.1080/03115511003793488.

[14387] B. Mackness. “On the identity of 'Kolopsis' watutense (Anderson, 1937) (Diprotodontidae, Marsupialia) and the New Guinean diprotodontid radiation". English. In: Alcheringa (2012), pp. 1-10. DOI: $10.1080 / 03115518.2012 .701488$.

[14388] B. Mackness. "Anhinga malagurala, a new pygmy darter from the Early Pliocene Bluff Downs Local Fauna, North-eastern Queensland". English. In: Emu 95 (1995), pp. 265-271.

[14389] B. Mackness, K. H. Black, and G. P. Price. “Occurrence of Euowenia grata (De Vis, 1887) (Diprotodontidae, Marsupialia) from the Pliocene Spring Park Local Fauna, northeastern Queensland". English. In: Alcheringa 39.2 (2015), pp. 164-174.

[14390] B. S. Mackness and M. Archer. "A new petauroid possum (Marsupialia, Pseudocheiridae) from the Pliocene Bluff Downs Local Fauna, northern Queensland". English. In: Alcheringa 25.4 (2008), pp. 439-444. DOI: 10.1080/03115510108619233.

[14391] B. S. Mackness, J. E. Cooper, C. Wilkinson, and D. Wilkinson. "Palaeopathology of a crocodile femur from the Pliocene of eastern Australia". English. In: Alcheringa 34 (2010), pp. 515-521.

[14392] S. E. MacLeod and L. V. Hills. "Conformable Late Jurassic (Oxfordian) to Early Cretaceous Strata, northern Bowser Basin, British Columbia: a sedimentological and paleontological model". In: Canadian Journal of Earth Sciences 27 (1990), pp. 989-998.

[14393] A. J. Macneil and B. Jones. "Sequence stratigraphy of a Late Devonian ramp-situated reef system in the Western Canada Sedimentary Basin: dynamic responses to sea-level change and regressive reef development". English. In: Sedimentology 53 (2006), pp. 321-359. DOI: 10.1111/j.1365-3091. 2005.00767.x.

[14394] M. Macphail and D. J. Cantrill. "Age and implications of the Forest Bed, Falkland Islands, southwest Atlantic Ocean: Evidence from fossil pollen and spores". English. In: Palaeogeography, Palaeoclimatology, Palaeoecology 240 (2006), pp. 602-629. DOI: 10.1016/j.palaeo.2006.03.010.

[14395] M. Macphail, R. J. Carpenter, A. Iglesias, and P. Wilf. “First Evidence for Wollemi Pine-type Pollen (Dilwynites: Araucariaceae) in South America". English. In: PLoS ONE 8.7 (2013), pp. 1-8. DOI: 10.1371/journal.pone.0069281.

[14396] M. K. Macphail. "Neogene environments in Australia, 1: re-evaluation of microfloras associated with important Early Pliocene marsupial remains at Grange Burn, southwest Victoria". English. In: Review of Palaeobotany and Palynology 92 (1996), pp. 307-328.

[14397] M. K. Macphail, R. S. Hill, S. M. Forsyth, and P. M. Wells. "A Late Oligocene Early Miocene cool climate flora in Tasmania". English. In: Alcheringa 15.2 (1991), pp. 87-106. DOI: 10.1080 / 03115519108619011.

[14398] R. D. E. MacPhee. "Morphology, adaptations, and relationships of Plesiorycteropus, and a diagnosis of a new order of eutherian mammals". English. In: Bulletin of the American Museum of Natural History 220 (1994), pp. 1-214.

[14399] R. D. E. MacPhee, M. A. Iturralde-Vinent, and E. S. Gaffney. “Domo de Zaza, an Early Miocene vertebrate locality in south-central Cuba, with notes on the tectonic evolution of Puerto Rico and the Mona Passage". English. In: American Museum Novitates 3394 (2003), pp. 1-42. 
[14400] R. D. E. MacPhee and M. Reguero. "Reinterpretation of a Middle Eocene record of Tardigrada (Pilosa, Xenarthra, Mammalia) from La Meseta Formation, Seymour Island, West Antarctica". English. In: American Museum Novitates 3689 (2010), pp. 1-21. DOI: 10.1206/703.1.

[14401] R. D. E. MacPhee, R. Singer, and M. Diamond. "Late Cenozoic Land Mammals from Grenada, Lesser Antilles Island-Arc". English. In: American Museum Novitates 3302 (2000), pp. 1-20.

[14402] R. D. E. MacPhee and A. R. Wyss. "Oligo-Miocene vertebrates from Puerto Rico, with a catalog of localities". English. In: American Museum Novitates 2965 (1990), pp. 1-45.

[14403] O. Macsotay and I. Olivares. "Algunas esponjas fosiles de Venezuela. Descripcion de Discocoelia winkleri nueva especie (Porifera: Faretronida) del Oligoceno Tardio". Spanish. In: Bol. Inst. Oceanogr. Venezuela 46.2 (2007), pp. 161-173.

[14404] P. Maddaleni. "I coralli di Russiz nel Collio orientale (Luteziano inferiore, Gorizia, Italia nordorientale) [The corals of Russiz in the eastern Collio (Early Lutetian, Gorizia, NE Italy)]". Italian. In: Gortania - Atti del Museo Friulano di Storia Naturale 19 (1997), pp. 61-84.

[14405] C. T. Madden and W. W. Dalquest. "The Last Rhinoceros in North America". English. In: Journal of Vertebrate Paleontology 10.2 (1990), pp. 266-267.

[14406] R. H. Madden. "A new Toxodontid Notoungulate". English. In: Vertebrate Paleontology in the Neotropics. The Miocene fauna of La Venta, Colombia. Smithsonian Institution Press, 1997, pp. 335354.

[14407] H. C. Maddin, D. C. Evans, and R. R. Reisz. "An Early Permian varanodontine varanopid (Synapsida: Eupelycosauria) from the Richards Spur locality, Oklahoma". English. In: Journal of Vertebrate Paleontology 26.4 (2006), pp. 957-966. DOI: 10.1671/0272-4634(2006)26[957:aepvvs]2.0.co;2.

[14408] H. C. Maddin, N. B. Fröbisch, D. C. Evans, and A. R. Milner. "Reappraisal of the Early Permian amphibamid Tersomius texensis and some referred material". English. In: Comptes Rendus Palevol 12 (2013), pp. 447-461. DOI: 10.1016/j.crpv.2013.06.007.

[14409] H. C. Maddin, A. Mann, and B. Hebert. "Varanopid from the Carboniferous of Nova Scotia reveals evidence of parental care in amniotes". English. In: Nature Ecology and Evolution 4 (2020), pp. 5056. DOI: 10.1038/s41559-019-1030-z.

[14410] H. C. Maddin, C. A. Sidor, and R. R. Reisz. "Cranial Anatomy of Ennatosaurus tecton (Synapsida: Caseidae) from the Middle Permian of Russia and the Evolutionary Relationships of Caseidae". English. In: Journal of Vertebrate Paleontology 28.1 (2008), pp. 160-180.

[14411] B. J. Mader and J. P. Alexander. "Megacerops kuwagatarhinus n. sp., an Unusual Brontothere (Mammalia, Perissodactyla) with Distally Forked Horns". English. In: Journal of Paleontology 69.3 (1995), pp. 581-587.

[14412] A. Madi, P.-A. Bourque, and L. Mamet. “Depth-related ecological zonation of a Carboniferous carbonate ramp: upper Viséan of Béchar Basin, western Algeria". In: Facies 35 (1996), pp. 59-80.

[14413] A. A. Madison. "New Brachiopod Subfamily Anechophragmiinae (Strophomenida) from the Ordovician of the Leningrad Region". English. In: Paleontological Journal 47.1 (2013), pp. 23-35. DOI: 10.1134/S0031030113010061.

[14414] A. A. Madison. "To the Revision of the Upper Ordovician Bilobia Cooper (Strophomenida, Brachiopoda)". English. In: Paleontological Journal 51.4 (2017), pp. 368-373. DOI: 10.1134/S0031030117040062.

[14415] M. C. Madozzo-Jaén. "Systematic and phylogeny of Prodolichotis prisca (Caviidae, Dolichotinae) from the Northwest of Argentina (late Miocene-early Pliocene): Advances in the knowledge of the evolutionary history of maras". English. In: Comptes Rendus Palevol 18 (2019), pp. 33-50. DOI: 10.1016/j.crpv.2018.07.003.

[14416] M. C. Madozzo-Jaén, M. E. Pérez, C. I. Montalvo, and R. L. Tomassini. "Systematic review of Neocavia from the Neogene of Argentina: Phylogenetic and evolutionary implications". English. In: Acta Palaeontologica Polonica 63.2 (2018), pp. 241-260. DOI: 10.4202/app.00464.2018. 
[14417] M. C. Madozzo-Jaén and M. E. Pérez. “The most ancient caviine rodent (Hystricognathi, Cavioidea) comes from the late Miocene of Northwest Argentina (South America)" ${ }^{\prime \prime}$ English. In: Historical Biology 29.3 (2017), pp. 376-383. DOI: 10.1080/08912963.2016.1166360.

[14418] J. H. Madsen Jr. and S. P. Welles. "Ceratosaurus (Dinosauria, Theropoda): a revised osteology". English. In: Utah Geological Survey, Miscellaneous Publications 00-2 (2000), pp. 1-80.

[14419] J. Madurell-Malapeira, D. M. Alba, and S. Moya-Sola. “Carnivora from the late Early Pleistocene of Cal Guardiola (Terrassa, Vallés-Penedés Basin, Catalonia, Spain)". English. In: Journal of Paleontology 83.6 (2009), pp. 969-974. DOI: 10.1666/09-054.1.

[14420] J. Madurell-Malapeira, J. M. Robles, I. Casanovas-Vilar, P. Obrado, and D. M. Alba. "The scimitartoothed cat Machairodus aphanistus (Carnivora: Felidae) in the Vallés-Penedés Basin (NE Iberian Peninsula)". English. In: Comptes Rendus Palevol 13.7 (2014), pp. 569-585. DOI: 10.1016/j.crpv.2014. 05.001 .

[14421] D. Madzia. "The first non-avian theropod from the Czech Republic". English. In: Acta Palaeontologica Polonica 59.4 (2014), pp. 855-962. DOI: 10.4202/app.2012.0111.

[14422] D. Madzia, C. A. Boyd, and M. Mazuch. "A basal ornithopod dinosaur from the Cenomanian of the Czech Republic". English. In: Journal of Systematic Palaeontology 16.11 (2018), pp. 967-979. DOI: 10.1080/14772019.2017.1371258.

[14423] A. M. Maga and R. M. D. Beck. "Skeleton of an unusual, cat-sized marsupial relative (Metatheria: Marsupialiformes) from the middle Eocene (Lutetian: 44-43 million years ago) of Turkey". English. In: PLoS One 12 (2017), e0181712:1-74. DOI: 10.1371/journal.pone.0181712.

[14424] F. A. Magalhaes, R. G. Garri, C. H. Tosi, S. Siciliano, S. Chellappa, and F. J. L. Silva. “First confirmed record of Feresa attenuata (Delphinidae) for the Northern Brazilian Coast". English. In: Biota Neotropica 7.2 (2007), pp. 313-318.

[14425] I. L. F. Magalhaes, G. H. F. Azevedo, P. Michalik, and M. J. Ramrez. “The fossil record of spiders revisited: implications for calibrating trees and evidence for a major faunal turnover since the Mesozoic". English. In: Biological Reviews 95 (2020), pp. 184-217. DOI: 10.1111/brv.12559.

[14426] I. Magallanes, J. F. Parham, G. -P. Santos, and J. Velez-Juarbe. "A new tuskless walrus from the Miocene of Orange County, California, with comments on the diversity and taxonomy of odobenids". English. In: PeerJ 6 (2018), e5708. DOI: 10.7717/ peerj.5708.

[14427] S. Magallon, P. S. Herendeen, and P. R. Crane. “Androdecidua endressii gen. et sp. nov., from the Late Cretaceous of Georgia (United States): further floral diversity in Hamamelioideae (Hamamelidaceae)". In: International Journal of Plant Sciences 162.4 (2001), pp. 963-983.

[14428] S. Magallon-Puebla, P. S. Herendeen, and P. K. Endress. "Allonia decandra: Floral remains of the tribe Hamamelideae (Hamamelidaceae) from Campanian strata of southeastern USA". In: Plant Systematics and Evolution 202 (1996), pp. 177-198.

[14429] S. Magallon-Puebla, P. S. Herendeen, and P. R. Crane. “Quadriplatanus georgianus gen. et sp. nov.: staminate and pistillate platanaceous flowers from the Late Cretaceous (Coniacian-Santonian) of Georgia, U.S.A." In: International Journal of Plant Sciences 158.3 (1997), pp. 373-394.

[14430] S. Magallon-Puebla, P. S. Herendeen, and P. K. Endress. "Allonia decandra: floral remains of the tribe Hamamelideae (Hamamelidaceae) from Campanian strata of southeastern USA". In: Plant Systematics and Evolution 202 (1996), pp. 177-198.

[14431] S. Maganuco. "New dinosaur bones from the Dinosaur Provincial Park (Alberta, Canada) expedition of 1922". English. In: Atti della Societá Italiana di Scienze Naturali e del Museo Civico di Storia Naturale di Milano 145.1 (2004), pp. 69-77.

[14432] S. Maganuco, A. Cau, and G. Pasini. "First description of theropod remains from the Middle Jurassic (Bathonian) of Madagascar". English. In: Atti della Societá Italiana di Scienze Naturali e del Museo Civico di Storia Naturale di Milano 146.2 (2005), pp. 165-202.

[14433] S. Maganuco, A. Cau, and G. Pasini. "New information on the abelisaurid pedal elements from the Late Cretaceous of NW Madagascar (Mahajanga Basin)". English. In: Atti della Societá Italiana di Scienze Naturali e del Museo Civico di Storia Naturale di Milano 149.2 (2008), pp. 239-252. 
[14434] S. Maganuco, A. Cau, C. Dal Sasso, and G. Pasini. "Evidence of large theropods from the Middle Jurassic of the Mahajanga Basin, NW Madagascar, with implications for ceratosaurian peal ungual evolution". English. In: Atti della Societá Italiana di Scienze Naturali e del Museo Civico di Storia Naturale di Milano 148.2 (2007), pp. 261-271.

[14435] S. Maganuco, C. Dal Sasso, and G. Pasini. "A new large predatory archosaur from the Middle Jurassic (Bathonian) of Madagascar". English. In: Atti della Societá Italiana di Scienze Naturali e del Museo Civico di Storia Naturale di Milano 147.1 (2006), pp. 19-51.

[14436] S. Maganuco and G. Pasini. "A new specimen of trematosaurian temnospondyl from the Lower Triassic of NW Madagascar, with remarks on palatal anatomy and taxonomic affinities". English. In: Atti della Societa Italiana di Scienze Naturali e del Museo Civico di Storia Naturale di Milano 150 (2009), pp. 91-112.

[14437] S. Maganuco, G. Pasini, and M. Auditore. "A revision of the short-faced stereospondyls Mahavisaurus dentatus and Lyrosaurus australisfrom the Lower Triassic of Madagascar: cranial anatomy, ontogenetic remarks, palaeoecology and rhytidosteid phylogeny". English. In: Memorie della Societá Italiana di Scienze Naturali e del Museo Civico di Storia Naturale di Milano 39 (2014), pp. 1-64.

[14438] S. Maganuco, J. S. Steyer, G. Pasini, M. Boulay, S. Lorrain, A. Beneteau, and M. Auditore. “An exquisite specimen of Edingerella madagascariensis (Temnospondyli) from the Lower Triassic of NW Madagascar; cranial anatomy, phylogeny, and restorations". English. In: Memorie della Societa Italiana di Scienze Naturali e del Museo Civico di Storia Naturale di Milano 36 (2009), pp. 1-72.

[14439] K. C. Maguire and P. A. Holroyd. "Pleistocene vertebrates of Silicon Valley (Santa Clara County, California)". English. In: PaleoBios 33 (2016), pp. 1-14.

[14440] K. C. Maguire, J. X. Samules, and M. D. Schmitz. "The fauna and chronostratigraphy of the middle Miocene Mascall type area, John Day Basin, Oregon, USA". English. In: PaleoBios 35 (2018), pp. 151.

[14441] F. Mahammed, E. Läng, L. Mami, L. Mekahli, M. Benhamou, B. Bouterfa, A. Kacemi, S. A. Chérief, H. Chaouati, and P. Taquet. "The 'Giant of Ksour', a Middle Jurassic sauropod dinosaur from Algeria". English. In: Comptes Rendus Palevol 4 (2005), pp. 707-714.

[14442] M. Mahboubi, M. Bessedik, L. Belkebir, M. Adaci, H. Hebib, M. Bensalah, C. Mammeri, B. Mansour, and M. E. H. Mansouri. "Premiére découverte d'empreintes de pas de dinosaures dans le Crétacé inférieur de la region d'El Bayadh (Algérie) [First discovery of dinosaur footprints in the Lower Cretaceous of the El Bayadh region (Algeria)]". English. In: Bulletin du Service Géologique National 18.2 (2007), pp. 127-139.

[14443] H. K. Maheshwari. "Provincialism in Gondwana floras". English. In: The Palaeobotanist. Four decades of Indian Palaeobotany 40 (1991), pp. 101-127.

[14444] A. Maheu and A. Nel. "A new fossil booklouse (Psocodea: Troctomorpha: Amphientometae: Manicapsocidae) from the mid-Cretaceous amber of northern Myanmar". English. In: Cretaceous Research 106.104222 (2019). DOI: 10.1016/j.cretres.2019.104222.

[14445] A. Maheu and A. Nel. "The oldest representative of the bombyliid bee fly in the earliest Eocene French amber". English. In: Acta Palaeontologica Polonica 65 (2020), pp. 81-83. DOI: 10.4202/app. 00657.2019.

[14446] M. S. Mahmoud and A.-R. M. Moawad. "Jurassic-Cretaceous (Bathonian to Cenomanian) palynology and stratigraphy of the West Tiba-1 borehole, northern Western Desert, Egypt". English. In: Journal of African Earth Sciences 30 (2000), pp. 401-416. DOI: 10.1016/S0899-5362(00)00026-9.

[14447] S. Maho, B. M. Gee, and R. R. Reisz. "A new varanopid synapsid from the early Permian of Oklahoma and the evolutionary stasis in this clade". English. In: Royal Society Open Science 6.10 (2019), p. 191297. DOI: $10.1098 /$ rsos.191297.

[14448] D. H. Mai. "Contribution to the flora of the middle Oligocene Calau Beds in Brandenberg, Germany". In: Review of Palaeobotany and Palynology 101 (1998), pp. 43-70.

[14449] D. H. Mai. "Palaeocarpological investigations in the Villafranchian (Pliocene) of Italy". In: Bollettino Museo Regionale di Scienze Naturali 13.2 (1995), pp. 407-437. 
[14450] S. C. R. Maidment and P. M. Barrett. "A new specimen of Chasmosaurus belli (Ornithischia: Ceratopsidae), a revision of the genus, and the utility of postcrania in the taxonomy and systematics of ceratopsid dinosaurs". English. In: Zootaxa 2963 (2011), pp. 1-17.

[14451] S. C. R. Maidment, D. B. Norman, P. M. Barrett, and P. Upchurch. "Systematics and phylogeny of Stegosauria (Dinosauria: Ornithischia)". English. In: Journal of Systematic Palaeontology 6.4 (2008), pp. 367-407. DOI: $10.1017 /$ S1477201908002459.

[14452] S. C. R. Maidment, T. J. Raven, D. Ouarhache, and P. M. Barrett. "North Africa's first stegosaur: implications for Gondwanan thyreophoran dinosaur diversity". English. In: Gondwana Research 77 (2020), pp. 82-97. DOI: 10.1016/j.gr.2019.07.007.

[14453] S. C. R. Maidment and G. Wei. "A review of the Late Jurassic stegosaurs (Dinosauria, Stegosauria) from the People's Republic of China". English. In: Geological Magazine 143.5 (2006), pp. 621-634.

[14454] S. C. R. Maidment, G. Wei, and D. B. Norman. "Re-description of the postcranial skeleton of the Middle Jurassic stegosaur Huayangosaurus taibaii". English. In: Journal of Vertebrate Paleontology 26.4 (2006), pp. 944-956.

[14455] S. C. R. Maidment, D. C. Woodruff, and J. R. Horner. "A new specimen of the ornithischian dinosaur Hesperosaurus mjosi from the Upper Jurassic Morrison Formation of Montana, U.S.A., and implications for growth and size in Morrison stegosaurs". English. In: Journal of Vertebrate Paleontology 38.1 (2018), e1406366:1-22. DOI: 10.1080/02724634.2017.1406366.

[14456] G. Maier. English. African Dinosaurs Unearthed: The Tendaguru Expeditions. Indiana University Press, Bloomington. 2003, pp. 1-380.

[14457] S. Maillet, C. Dojen, and B. Milhau. "Stratigraphical distribution of Givetian ostracods in the typearea of the Fromelennes Formation (Fromelennes, Ardennes, France) and their relationship to global events". English. In: Bulletin of Geosciences 88.4 (2013), pp. 865-892.

[14458] M. Mainelli. "The rudist Mathesia tertiicolloquiirudistarum n. gen., n. sp. in the Upper Aptian of Serra Sbregavitelli, Matese, South Apennines, Italy". English. In: Revista Mexicana de Ciencias Geologicas 12.2 (1995), pp. 201-210.

[14459] M. Mainelli. "Durania montislacostae n. sp. in the Upper Cenomanian of La Costa Mountain (Matese-Italy)". English. In: Geologica Romana 28 (1992), pp. 79-85.

[14460] M. Mainelli. "Apricardia manuelae n. sp. in the lower Turonian of northeastern Matese (south Apennines), Italy". English. In: Revista Mexicana de Ciencias Geologicas 12.2 (1995), pp. 195-200.

[14461] H. M. Maisch, M. A. Becker, B. W. Raines, and J. A. Chamberlain. "Chondrichthyans from the Tallahatta-Lisbon Formatino contact (Middle Eocene), Silas, Choctaw County, Alabama". English. In: Paludicola 9.4 (2014), pp. 183-2009.

[14462] H. M. Maisch, M. A. Becker, and M. L. Griffiths. "Chondrichthyans from the Lower Clayton Limestone Unit of the Midway Group (Paleocene) near Malvern, Arkansas, USA, with comments on the K/Pg boundary". English. In: Palaeontologische Zeitschrift 94 (2020), pp. 561-593. DOI: 10.1007/ s12542-019-00494-7.

[14463] H. M. Maisch, M. A. Becker, and B. H. Raines. "Osteichthyans from the Tallahatta-Lisbon Formation Contact (middle Eocene-Lutetian) Pigeon Creek, Conecuh-Covington Counties, Alabama with Comments on Transatlantic Occurrences in the Northern Atlantic Ocean Basin". English. In: PalArch's Journal of Vertebrate Palaeontology 13.3 (2016), pp. 1-22.

[14464] M. Maisch, C. S. Vega, and R. R. Schoch. "No dicynodont in the Keuper - a reconsideration of the occurrence of aff. Dinodontosaurus in the Middle Triassic of Southern Germany". English. In: Palaeodiversity 2 (2009), pp. 271-278.

[14465] M. W. Maisch. "Phylogeny, systematics, and origin of the Ichthyosauria - the state of the art". English. In: Palaeodiversity 3 (2010), pp. 151-214.

[14466] M. W. Maisch. “Revision der gattung Stenopterygius Jaekel, 1904 emend. von Huene, 1922 (Reptilia: Ichthyosauria) aus dem unteren Jura Westeuropas". German. In: Palaeodiversity 1 (2008), pp. 227-271. 
[14467] M. W. Maisch. “Observations on Karoo and Gondwana vertebrates. part 6. A new rhachiocephalid dicynodont (Therapsida) from the Upper Permian of the Ruhuhu Basin (Tanzania)". English. In: Neues Jahrbuch für Geologie und Paläontologie 273.3 (2005), pp. 313-355.

[14468] M. W. Maisch. "A well preserved skull of Cymatosaurus (Reptilia: Sauropterygia) from the uppermost Buntsandstein (Middle Triassic) of Germany". English. In: Neues Jahrbuch für Geologie und Paläontologie-Abhandlungen 272.2 (2014), pp. 213-224. DOI: 10.1127/0077-7749/2014/0407.

[14469] M. W. Maisch and J. Ansorge. "The Liassic ichthyosaur Stenopterygius cf. quadriscissus from the Lower Toarcian of Dobbertin (northeastern Germany) and some considerations on Lower Toarcian marine reptile palaeobiogeography". English. In: Palaeontologische Zeitschrift 78.1 (2004), pp. 161171.

[14470] M. W. Maisch and D. Blomeier. “Filling the gap - an ichthyosaur (Reptilia: Ichthyosauria) from the Middle Triassic Botneheia Formation of Svalbard". English. In: Neues Jarbuch fur geologie und Palaeontologie Abhandlung 254.3 (2009), pp. 379-384.

[14471] M. W. Maisch and A. Hungerbühler. "Revision of Temnodontosaurus nuertingensis (v. Huene, 1931) a large ichthyosaur from the Lower Pliensbachian (Lower Jurassic) of Nürtingen, South Western Germany". English. In: Stuttgarter Beiträge zur Naturkunde, Serie B (Geologie und Paläontologie) 248 (1997), pp. 1-11.

[14472] M. W. Maisch and A. Hungerbühler. "New Evidence for a Discrete Supratemporal Bone in the Jurassic Ichthyosaur Temnodontosaurus". English. In: Historical Biology 15.4 (2001), pp. 335-345. DOI: 10.1080/08912960127806.

[14473] M. W. Maisch, D.-Y. Jiang, W. -C. Hao, Y. -L. Sun, Z. -Y. Sun, and H. Stohr. “A well-preserved skull of Qianichthyosaurus zhoui Li, 1999 (Reptilia: Ichthyosauria) from the Upper Triassic of China and the phylogenetic position of the Toretocnemidae". English. In: Neues Jahrbuch für Geologie und Paläontologie Abhandlungen 248 (2008), pp. 257-266.

[14474] M. W. Maisch and M. Kapitzke. “A presumably marine phytosaur (Reptilia: Archosauria) from the pre-planorbis beds (Hettangian) of England". English. In: Neues Jahrbuch für Geologie und Paläontologie, Abhandlungen 257.3 (2010), pp. 373-379.

[14475] M. W. Maisch and J. Lehmann. "A new basal omphalosaurid from the Middle Triassic of Germany". English. In: Neues Jahrbuch für Geologie und Paläontologie Monatshefte 9 (2002), pp. 513-525.

[14476] M. W. Maisch and A. T. Matzke. "Theropods (Dinosauria, Saurischia) from the Middle Jurassic Toutunhe Formation of the southern Junggar Basin, NW China". In: Paläontologische Zeitschrift 77.2 (2003), pp. 281-292.

[14477] M. W. Maisch, A. T. Matzke, F. Grossmann, H. Stöhr, H. -U. Pfretzschner, and G. Sun. “The first haramiyoid mammal from Asia". In: Naturwissenschaften 92 (2005), pp. 403-44.

[14478] M. W. Maisch, A. T. Matzke, and G. Sun. "A new dsungaripteroid pterosaur from the Lower Cretaceous of the southern Junggar Basin, north-west China". English. In: Cretaceous Research 25 (2004), pp. 625-634.

[14479] M. W. Maisch and A. T. Matzke. "The braincase of Phantomosaurus neubigi (Sander, 1997), an unusual ichthyosaur from the Middle Triassic of Germany". English. In: Journal of Vertebrate Paleontology 26.3 (2006), pp. 598-607.

[14480] M. W. Maisch and A. T. Matzke. “Observations on Triassic ichthyosaurs. Part VIII. A redescription of Phalarodon major (von Huene, 1916) and the composition and phylogeny of the Mixosauridae". English. In: Neues Jahrbuch fur Geologie und Palaontologie, Abhandlungen 220.3 (2001), pp. 431-447.

[14481] M. W. Maisch and A. T. Matzke. “Observations on Triassic ichthyosaurs. Part IX. The first associated skeletal remains of Merriamosaurus n. g. (Ichthyosauria, Lower Triassic) and their bearing on the systematic position of the Omphalosauria". English. In: Neues Jahrbuch fur Geologie und Palaontologie, Abhandlungen 226.1 (2002), pp. 59-94.

[14482] M. W. Maisch and A. T. Matzke. "Observations on Triassic ichthyosaurs. Part XII. A new Early Triassic ichthyosaur genus from Spitzbergen". English. In: Neues Jahrbuch fur Geologie und Palaontologie, Abhandlungen 229.3 (2003), pp. 317-338. 
[14483] M. W. Maisch and A. T. Matzke. “The Ichthyosauria”. English. In: Stuttgarter Beitrage zur Naturkunde, Serie B (Geologie und Palaontologie) 298 (2000), pp. 1-159.

[14484] M. W. Maisch and A. T. Matzke. "The cranial osteology of the Middle Triassic ichthyosaur Contectopalatus from Germany". English. In: Palaeontology 44.6 (2001), pp. 1127-1156.

[14485] M. W. Maisch, A. T. Matzke, and G. E. Sun. "A new sinemydid turtle (Reptilia: Testudines) from the Lower Cretaceous of the Junggar Basin (NW-China)". English. In: Neues Jahrbuch für Geologie und Paläontologie, Monatshefte 2003.12 (2003), pp. 705-722.

[14486] M. W. Maisch and A. T. Matzke. "Temnospondyl amphibians from the Jurassic of the Southern Junggar Basin (NW China)". English. In: Palaeontologische Zeitschrift 79.2 (2005), pp. 285-301.

[14487] M. W. Maisch, A. T. Matzke, and G. Sun. "A new tritylodontid from the Upper Jurassic Shishugou Formation of the Junggar Basin (Zinjiang, NW china)". English. In: Journal of Vertebrate Paleontology 24.3 (2004), pp. 649-656.

[14488] M. W. Maisch, A. T. Matzke, and H. Stohr. "Sunosuchus (Archosauria, Crocodyliformes) from the Toutunhe Formation (Middle Jurassic) of the Southern Junggar Basin (Xinjiang, NW-China)". English. In: Geobios 36 (2003), pp. 391-400.

[14489] M. W. Maisch, A. T. Matzke, and G. Sun. “A relict trematosauroid (Amphibia: Temnospondyli) from the Middle Jurassic of the Junggar Basin (NW China)". English. In: Naturwissenschaften 91 (2004), pp. 589-593.

[14490] M. W. Maisch and A. T. Matzke. “The turtle Xinjiangchelys radiplicatoides BRINKMAN et al., 2013 (Reptilia: Testudines) from the Lower Qigu Formation (Upper Jurassic) of Liuhuanggou, Xinjiang, People's Republic of China". English. In: Palaeodiversity 7 (2014), pp. 133-147.

[14491] M. W. Maisch and A. T. Matzke. "Sungeodon kimkraemerae n. gen. n. sp., the oldest kannemeyeriiform (Therapsida, Dicynodontia) and its implications for the early diversification of large herbivores after the P/T boundary". English. In: Neues Jahrbuch für Geologie und Paläontologie - Abhandlungen 272.1 (2014), pp. 1-12. DOI: 10.1127/0077-7749/2014/0394.

[14492] M. W. Maisch and A. T. Matzke. "Observations on Triassic ichthyosaurs. Part I: Structure of the palate and mode of tooth implantation in Mixosaurus cornalianus (Bassani, 1886)". English. In: Neues Jahrbuch für Geologie und Paläontologie 1997.12 (1997), pp. 717-732.

[14493] M. W. Maisch and A. T. Matzke. "A new hybodontid shark (Chondrichthyes, Hybodontiformes) from the Lower Jurassic Posidonienschiefer Formation of Dotternhausen, SW Germany". English. In: Neues Jahrbuch für Geologie und Paläontologie, Abhandlungen 280 (2016), pp. 241-257.

[14494] M. W. Maisch, A. T. Matzke, and T. Rathgeber. "Re-evaluation of the enigmatic archosaur Dyoplax arenaceus O. Fraas, 1867 from the Schilfsandstein (Stuttgart Formation, lower Carnian, Upper Triassic) of Stuttgart, Germany". English. In: Neues Jahrbuch für Geologie und Paläontologie - Abhandlungen 267.3 (2013), pp. 353-362. DOI: 10.1127/0077-7749/2013/0317.

[14495] M. W. Maisch and A. T. Matzke. "First record of the ammonite genus Graefenbergites (Perisphinctoidea: Passendorferiinae) from the late Oxfordian of the Swabian Alb (SW Germany)". English. In: Palaeodiversity 11 (2018), pp. 167-172.

[14496] M. W. Maisch and A. T. Matzke. "First record of a eusauropod (Dinosauria: Sauropoda) from the Upper Jurassic Qigu-Formation (southern Junggar Basin, China), and a reconsideration of Late Jurassic sauropod diversity in Xinjiang". English. In: Neues Jahrbuch für Geologie und Paläontologie Abhandlungen 291.1 (2019), pp. 109-117. DOI: 10.1127/njgpa/2019/0792.

[14497] M. W. Maisch, X.-R. Pan, Z. -Y. Sun, T. Cai, D. -P. Zhang, and J. -L. Xie. “Cranial osteology of Guizhouicthyosaurus tangae (Reptilia: Ichthyosauria) from the Upper Triassic of China". English. In: Journal of Vertebrate Paleontology 26.3 (2006), pp. 588-597.

[14498] M. W. Maisch and A. G. Reisdorf. "Evidence for the longest stratigraphic range of a post-Triassic Ichthyosaur: a Leptonectes tenuirostris from the Pliensbachian (Lower Jurassic) of Switzerland". English. In: Geobios 39 (2006), pp. 491-505. 
[14499] M. W. Maisch, A. G. Reisdorf, R. Schlatter, and A. Wetzel. “A large skull of Ichthyosaurus (Reptilia: Ichthyosauria) from the Lower Sinemurian (Lower Jurassic) of Frick (NW Switzerland)". English. In: Swiss Journal of Geoscience 101 (2008), pp. 617-627.

[14500] M. W. Maisch and A. Salfinger-Maisch. "First record of the lytoceratid Protetragonites Hyatt, 1900 (Cephalopoda: Ammonoidea) from the Upper Jurassic of southwestern Germany". English. In: Neues Jahrbuch für Geologie und Paläontologie, Abhandlungen 280 (2016), pp. 183-192.

[14501] M. W. Maisch. "A new basal lystrosaurid dicynodont from the Upper Permian of South Africa". English. In: Palaeontology 45.2 (2002), pp. 343-359.

[14502] J. Maisey, R. Miller, and S. Turner. "The braincase of the chondrichthyan Doliodus from the Lower Devonian Campbellton formation of New Brunswick, Canada". English. In: Acta Zoologica 90 (2009), pp. 109-122.

[14503] J. G. Maisey. "Some observations on Denaea fournieri (Chondrichthyes, Symmoriiformes) from the Lower Carboniferous of Belgium". English. In: Acta Geologica Polonica 58.2 (2008), pp. 185-190.

[14504] J. G. Maisey. "A new clupeomorph fish from the Santana Formation (Albian) of NE Brazil". English. In: American Museum Novitates 3076 (1993), pp. 1-15.

[14505] J. G. Maisey and J. M. Moody. "A Review of the Problematic Extinct Teleost Fish Araripichthys, with a Description of a New Species from the Lower Cretaceous of Venezuela". English. In: American Museum Novitates 3324 (2001), pp. 1-27.

[14506] K. Majer. "Rhadalinae from the Baltic Amber". English. In: Deutsche Entomologische Zeitschrift 45.2 (1998), pp. 255-264.

[14507] M. R. Majidifard. "Late Bajocian-Bathonian ammonites from northeast Iran". English. In: Acta Palaeontologica Romaniae 11 (2015), pp. 25-41.

[14508] C. P. Majors. "Preliminary Report on a Late Pleistocene Vertebrate Assemblage From Bonita, San Diego County, California". English. In: PaleoBios 15.4 (1993), pp. 63-77.

[14509] L. Makadi. "A new polyglyphanodontine lizard (Squamata: Borioteiioidea) from the Late Cretacoues Tharkut locality (Santonian, Hungary)". English. In: Cretaceous Research 46 (2013), pp. 166176.

[14510] L. Makádi. "Bicuspidon aff. hatzegiensis (Squamata: Scincomorpha: Teiidae) from the Upper Cretaceous Csehbanya Formation (Hungary, Bakony Mts)". English. In: Acta Geologica Hungarica 49.4 (2006), pp. 373-385. DOI: 10.1556/AGeol.49.2006.4.5.

[14511] L. Makadi. “The first known chamopsiid lizard (Squamata) from the Upper Cretaceous of Europe (Csehbanya Formation; Hungary, Bakony Mts)". English. In: Annales de Paleontologie 99 (2013), pp. 261-274. DOI: 10.1016/j.annpal.2013.07.002.

[14512] L. Makádi, M. W. Caldwell, and A. Osi. "The first freshwater mosasauroid (Upper Cretaceous, Hungary) and a new clade of basal mosasauroids". English. In: PLoS ONE 7.12 (2012), e51781. DOI: 10.1371 /journal.pone.0051781.

[14513] L. Makadi and R. L. Nydam. "A new durophagous scincomorphan lizard genus from the Late Cretaceous Iharkut locality (Hungary, Bakony Mts)". English. In: Palaeontologische Zeitschrift 89.4 (2015), pp. 925-941. DOI: $10.1007 /$ s12542-014-0253-1.

[14514] V. N. Makarkin. “Upper Cretaceous Neuroptera from Russia and Kazakhstan”. English. In: Annales de la Société Entomologique de France 30.3 (1994), pp. 283-292.

[14515] V. N. Makarkin. "Fossil Neuroptera of the Lower Cretaceous of Baisa, east Siberia. Part 3. Chrysopidae (Insecta)". English. In: Spixiana 20 (1997), pp. 107-118.

[14516] V. N. Makarkin. "Baissoleon cretaceus gen. and sp. nov. Fossil Neuroptera from the Lower Cretaceous of Baisa, east Siberia. 2. Nymphitidae". English. In: Annales de la Société Entomologique de France 26.1 (1990), pp. 125-126.

[14517] V. N. Makarkin. "A new fossil genus and species of Osmylidae from the Lower Cretaceous of east Siberia". English. In: Deutsche Entomologische Zeitschrift 37 (1990), pp. 101-103. 
[14518] V. N. Makarkin. "Fossil Neuroptera of the Lower Cretaceous of Baisa, east Siberia. Part 5. Mantispidae". English. In: Russian Entomological Journal 5 (1996), pp. 91-93.

[14519] V. N. Makarkin. "New psychopsoid Neuroptera from the Early Cretaceous of Baissa, Transbaikalia”. English. In: Annales de la Société Entomologique de France 46 (2010), pp. 254-261.

[14520] V. N. Makarkin. "Miocene insects (Neuroptera) from the northern Caucasus and Sikhote-Alin". English. In: Paleontological Journal 25.1 (1991), pp. 55-65.

[14521] V. N. Makarkin. "A new fossil green lacewing (Neuroptera: Chrysopidae) from the Eocene Tadushi Formation, eastern Sikhote-Alin". English. In: Far Eastern Entomologist 272 (2014), pp. 1-7.

[14522] V. N. Makarkin. "Fossil Neuroptera from the Lower Cretaceous of Baisa, east Siberia. Part 6. Mesithonidae (Insecta)". English. In: Neues Jahrbuch für Geologie und Paläontologie, Monatshefte 1999.12 (1999), pp. 705-712.

[14523] V. N. Makarkin. "Fossil Neuroptera of the Lower Cretaceous of Baisa, east Siberia. Part 4: Psychopsidae". English. In: Beiträge zur Entomologie 47 (1997), pp. 489-492.

[14524] V. N. Makarkin. "A new fossil genus of Osmylidae (Neuroptera) from the Early Cretaceous of Baissa, Transbaikalia". English. In: Far Eastern Entomologist 278 (2014), pp. 8-12.

[14525] V. N. Makarkin. "A new genus of the mantispid-like Paraberothinae (Neuroptera: Berothidae) from Burmese amber, with special consideration of its probasitarsus spine-like setation". English. In: Zootaxa 4007 (2015), pp. 327-342.

[14526] V. N. Makarkin. “Enormously long, siphonate mouthparts of a new, oldest known spongillafly (Neuroptera, Sisyridae) from Burmese amber imply nectarivory or hematophagy". English. In: Cretaceous Research 65 (2016), pp. 126-137.

[14527] V. N. Makarkin. "An interesting new genus of Berothinae (Neuroptera: Berothidae) from the early Eocene Green River Formation, Colorado". English. In: Zootaxa 4226 (2017), pp. 594-600.

[14528] V. N. Makarkin. "New taxa of unusual Dilaridae (Neuroptera) with siphonate mouthparts from the mid-Cretaceous Burmese amber". English. In: Cretaceous Research 74 (2017), pp. 11-22.

[14529] V. N. Makarkin. “A remarkable new genus of Protosmylinae (Neuroptera: Osmylidae) from late Eocene Florissant, Colorado". English. In: Zootaxa 4268 (2017), pp. 581-587.

[14530] V. N. Makarkin. “Oldest new genus of Myrmeleontidae (Neuroptera) from the Eocene Green River Formation". English. In: Zootaxa 4337 (2017), pp. 540-552.

[14531] V. N. Makarkin. "A new species of Haploberotha (Neuroptera: Berothidae) from mid-Cretaceous Burmese amber". English. In: Cretaceous Research 90 (2018), pp. 375-381.

[14532] V. N. Makarkin. "The first mantidfly (Neuroptera: Mantispidae) from the Early Eocene Green River Formation". English. In: Bulletin of the Peabody Museum of Natural History 60 (2019), pp. 111119. DOI: $10.3374 / 014.060 .0202$.

[14533] V. N. Makarkin, S. B. Archibald, and J. D. Oswald. “New Early Eocene brown lacewings (Neuroptera: Hemerobiidae) from western North America". English. In: The Canadian Entomologist 135 (2003), pp. 637-653.

[14534] V. N. Makarkin and S. B. Archibald. "A new genus and first Cenozoic fossil record of moth lacewings (Neuroptera: Ithonidae) from the Early Eocene of North America". English. In: Zootaxa 2063 (2009), pp. 55-63.

[14535] V. N. Makarkin and S. B. Archibald. "Family affinity of the genus Palaeopsychops Andersen with description of a new species from the Early Eocene of British Columbia, Canada (Neuroptera: Polystoechotidae)". English. In: Annals of the Entomological Society of America 96.3 (2003), pp. 171180.

[14536] V. N. Makarkin and S. B. Archibald. "A diverse new assemblage of green lacewings (Insecta, Neuroptera, Chrysopidae) from the early Eocene Okanagan Highlands, western North America". English. In: Journal of Paleontology 87 (2013), pp. 123-146. 
[14537] V. N. Makarkin and S. B. Archibald. "An unusual new fossil genus probably belonging to the Psychopsidae (Neuroptera) from the Eocene Okanagan Highlands, western North America". English. In: Zootaxa 3838 (2014), pp. 385-391.

[14538] V. N. Makarkin and S. B. Archibald. "A revision of the late Eocene snakeflies (Raphidioptera) of the Florissant Formation, Colorado, with special reference to the wing venation of the Raphidiomorpha". English. In: Zootaxa 3784 (2014), pp. 401-444.

[14539] V. N. Makarkin, S. B. Archibald, and J. E. Jepson. "The oldest Inocelliidae (Raphidioptera) from the Eocene of western North America". English. In: The Canadian Entomologist 151 (2019), pp. 521-530.

[14540] V. N. Makarkin and C. Gröhn. "The first unusual Hemerobiidae (Neuroptera) from mid-Cretaceous Burmese amber". English. In: Cretaceous Research 106.104206 (2020). DOI: 10.1016/j.cretres.2019. 104206.

[14541] V. N. Makarkin, S. W. Heads, and S. Wedmann. "Taxonomic study of the Cretaceous lacewing family Babinskaiidae (Neuroptera: Myrmeleontoidea: Nymphidoidae), with description of new taxa". English. In: Cretaceous Research 78 (2017), pp. 149-160.

[14542] V. N. Makarkin and A. V. Khramov. "A new fossil species of snakeflies (Raphidioptera: Mesoraphidiidae) from the Late Cretaceous of Kazakhstan, with notes on Turonian Neuropterida". English. In: Cretaceous Research 52 (2015), pp. 407-415.

[14543] V. N. Makarkin and J. Kupryjanowicz. "A New Mantispid-Like Species of Rhachiberothinae (Neuroptera: Berothidae) from Baltic Amber, with a Critical Review of the Fossil Record of the Subfamily". English. In: Acta Palaeontologica Sinica 84.4 (2010), pp. 655-664.

[14544] V. N. Makarkin and F. Menon. "First record of fossil rapismatid-like Ithonidae (Insecta, Neuroptera) from the Lower Cretaceous Crato Formation of Brazil". English. In: Cretaceous Research 28 (2007), pp. 743-753.

[14545] V. N. Makarkin and F. Menon. "New species of the Mesochrysopidae (Insecta, Neuroptera) from the Crato Formation of Brazil (Lower Cretaceous), with taxonomic treatment of the family". English. In: Cretaceous Research 26 (2005), pp. 801-812.

[14546] V. N. Makarkin and M. Ohl. "An important new fossil genus of Berothinae (Neuroptera: Berothidae) from Baltic amber". English. In: Zootaxa 3946 (2015), pp. 401-415.

[14547] V. N. Makarkin and E. E. Perkovsky. "Rophalis relicta Hagen (Neuroptera, Nevrorthidae) in the Late Eocene Rovno amber, with a discussion of the taxonomic status of the genus". English. In: Denisia 26 (2009), pp. 137-144.

[14548] V. N. Makarkin and E. E. Perkovsky. "An interesting new species of Sisyridae (Neuroptera) from the Upper Cretaceous Taimyr amber". English. In: Cretaceous Research 63 (2016), pp. 170-176.

[14549] V. N. Makarkin and E. E. Perkovsky. "A new species of Glaesoconis Meinander (Neuroptera: Coniopterygidae) from the Santonian Taimyr amber". English. In: Cretaceous Research 75 (2017), pp. 120-124.

[14550] V. N. Makarkin and E. E. Perkovsky. "New Coniopterygidae (Neuroptera) from the upper Cenomanian Nizhnyaya Agapa amber, northern Siberia". English. In: Cretaceous Research 93 (2019), pp. 107-113. DOI: 10.1016/j.cretres.2018.09.006.

[14551] V. N. Makarkin, E. E. Perkovsky, and C. Gröhn. “Neotype designation and re-description of Prolachlanius resinatus (Hagen) (Neuroptera, Hemerobiidae) from Baltic amber, with the first record of the species from Rovno amber". English. In: Zootaxa 4688 (2019), pp. 57-70.

[14552] V. N. Makarkin, D. Ren, and Q. Yang. "Two new species of Kalligrammatidae (Neuroptera) from the Jurassic of China, with comments on venational homologies". English. In: Annals of the Entomological Society of America 102 (2009), pp. 964-969.

[14553] V. N. Makarkin and A. H. Staniczek. "A new large-sized genus of Babinskaiidae (Neuroptera: Myrmeleontoidea: Nymphidoidae) from mid-Cretaceous Burmese amber". English. In: Cretaceous Research 104.104196 (2019). DOI: 10.1016/j.cretres.2019.104196. 
[14554] V. N. Makarkin and S. Wedmann. "First record of the genus Sympherobius (Neuroptera: Hemerobiidae) from Baltic amber". English. In: Zootaxa 2078 (2009), pp. 55-62.

[14555] V. N. Makarkin, S. Wedmann, and T. Weiterschan. "First record of a fossil larva of Hemerobiidae (Neuroptera) from Baltic amber". English. In: Zootaxa 3417 (2012), pp. 53-63.

[14556] V. N. Makarkin, S. Wedmann, and T. Weiterschan. "First record of the family Ithonidae (Neuroptera) from Baltic amber". English. In: Zootaxa 3796 (2014), pp. 385-393.

[14557] V. N. Makarkin, S. Wedmann, and T. Weiterschan. "A new genus of Hemerobiidae (Neuroptera) from Baltic amber, with a critical review of the Cenozoic Megalomus-like taxa and remarks on the wing venation variability of the family". English. In: Zootaxa 4179 (2016), pp. 345-370.

[14558] V. N. Makarkin, S. Wedmann, and S. W. Heads. "A systematic reappraisal of Araripeneuridae (Neuroptera: Myrmeleontoidea), with description of new species from the Lower Cretaceous Crato Formation of Brazil". English. In: Cretaceous Research 84 (2018), pp. 600-621.

[14559] V. N. Makarkin, S. Wedmann, and T. Weiterschan. "The first green lacewings from the late Eocene Baltic amber". English. In: Acta Palaeontologica Polonica 63 (2018), pp. 527-537.

[14560] V. N. Makarkin, Q. Yang, and D. Ren. "Two new species of Sinosmylites Hong (Neuroptera, Berothidae) from the Middle Jurassic of China, with notes on Mesoberothidae". English. In: ZooKeys 130 (2011), pp. 199-215.

[14561] V. N. Makarkin, Q. Yang, Y. Y. Peng, and D. Ren. “A comparative overview of the neuropteran assemblage of the Lower Cretaceous Yixian Formation (China), with description of a new genus of Psychopsidae (Insecta: Neuroptera)". English. In: Cretaceous Research 35 (2012), pp. 57-68.

[14562] V. N. Makarkin, Q. Yang, and D. Ren. "A new Cretaceous family of enigmatic two-winged lacewings (Neuroptera)". English. In: Fossil Record 16 (2013), pp. 67-75.

[14563] V. N. Makarkin, Q. Yang, C. F. Shi, and D. Ren. "The presence of the recurrent veinlet in the Middle Jurassic Nymphidae (Neuroptera): a unique character condition in Myrmeleontoidea". English. In: ZooKeys 325 (2013), pp. 1-20.

[14564] V. N. Makarkin, Q. Yang, and D. Ren. "A new basal osmylid neuropteran insect from the Middle Jurassic of China linking Osmylidae to the Permian-Triassic Archeosmylidae". English. In: Acta Palaeontologica Polonica 59 (2014), pp. 209-214.

[14565] K. V. Makarov. "New data on the larvae of the Jurassic Carabomorpha (Coleoptera, Adephaga)". English. In: Paleontological Journal 29.1 (1995), pp. 167-171.

[14566] K. V. Makarov and E. E. Perkovsky. "Smallest and oldest false skin beetle: Paleobiphyllus ponomarenkoi gen. et sp. nov. (Coleoptera: Cleroidea: Biphyllidae) from Santonian Taimyr amber, northern Russia". English. In: Cretaceous Research 106.104238 (2019). DOI: 10.1016/j.cretres.2019. 104238.

[14567] Y. Makhlouf, B. Lefebvre, E. Nardin, A. Nedjari, and C. R. C. Paul. “The diploporite blastozoan Lepidocalix pulcher from the Middle Ordovician of northern Algeria: Taxonomic revision and palaeoecological implications". English. In: Acta Palaeontologica Polonica 62.2 (2017), pp. 299-310. DOI: 10.4202/app.00286.2016.

[14568] P. J. Makovicky, S. Apestegua, and F. L. Agnoln. "The earliest dromaeosaurid theropod from South America". English. In: Nature 437 (2005), pp. 1007-1011.

[14569] P. J. Makovicky, S. Apesteguia, and F. A. Gianechini. "A new coelurosaurian theropod from the La Buitrera fossil locality of Ro Negro, Argentina". English. In: Fieldiana: Life and Earth Sciences 5 (2012), pp. 90-98. DOI: 10.3158/2158-5520-5.1.90.

[14570] P. J. Makovicky, B. M. Kilbourne, R. W. Sadleir, and M. A. Norell. “A new basal ornithopod (Dinosauria, Ornithischia) from the Late Cretaceous of Mongolia". English. In: Journal of Vertebrate Paleontology 31.3 (2011), pp. 626-640. DOI: 10.1080/02724634.2011.557114.

[14571] P. J. Makovicky, D. Li, K. -Q. Gao, M. Lewin, G. M. Erickson, and M. A. Norell. “A giant ornithomimosaur from the Early Cretaceous of China". English. In: Proceedings of the Royal Society B: Biological Sciences (2009). DOI: 10.1098/rspb.2009.0236. 
[14572] P. J. Makovicky, M. A. Norell, J. M. Clark, and T. Rowe. “Osteology and relationships of Byronosaurus jaffei (Theropoda: Troodontidae)". In: American Museum Novitates 3402 (2003), pp. 132.

[14573] P. J. Makovicky and M. A. Norell. "A partial ornithomimid braincase from Ukhaa Tolgod (Upper Cretaceous, Mongolia)". English. In: American Museum Novitates 3247 (1998), pp. 1-16.

[14574] P. J. Makovicky and M. A. Norell. "Yamaceratops dorngobiensis, a new primitive ceratopsian (Dinosauria: Ornithischia) from the Cretaceous of Mongolia". English. In: American Museum Novitates 3530 (2006), pp. 1-42.

[14575] G. Makranczy, S. Yamamoto, and M. S. Engel. "Description of a Cretaceous amber fossil putatively of the tribe Coprophilini (Coleoptera, Staphylinidae, Oxytelinae)". English. In: ZooKeys 782 (2018), pp. 81-94.

[14576] M. C. Malabarba, F. Abdala, F. E. Weiss, and P. A. Perez. "New data on the late Permian vertebrate fauna of Posto Queimado, Rio do Rasto Formation, southern Brazil". English. In: Revista Brasileira de Paleontologia 6 (2003), pp. 49-54.

[14577] M. C. Malabarba and J. G. Lundberg. "A fossil loricariid catfish (Siluriformes: Loricarioidea) from the Taubaté Basin, eastern Brazil". English. In: Neotropical Ichthyology 5.3 (2007), pp. 263-270.

[14578] M. C. Malabarba, L. R. Malabarba, and C. Del Papa. “Gymnogeophagus eocenicus, n. sp. (Perciformes: Cichlidae), an Eocene Cichlid from the Lumbrera Formation in Argentina". English. In: Journal of Vertebrate Paleontology 30.2 (2010), pp. 341-350.

[14579] M. C. Malabarba, O. Zuleta, and C. D. Papa. "Proterocara argentina, a New Fossil Cichlid from the Lumbrera Formation, Eocene of Argentina". English. In: Journal of Paleontology 26.2 (2006), pp. 267-275.

[14580] E. Malafaia, P. Dantas, F. Ortega, F. Escaso, J. M. Gasulla, B. Ribeiro, F. Barriga, I. Gromicho, M. Garca-Oliva, G. Ramalheiro, J. Santamara, N. L. Pimentel, C. Moniz, and A.M.G.d. Carvalho. Análisis preliminar de la diversidad faunstica en el yacimiento de Andrés (Jurásico Superior. Pombal, Portugal) [Preliminary analysis of faunal diversity in the Andrés locality (Upper Jurassic. Pombal, Portugal)]. Spanish. 2006.

[14581] E. Malafaia, J. M. Gasulla, F. Escaso, i. Narváez, J. L. Sanz, and F. Ortega. “A new spinosaurid theropod (Dinosauria: Megalosauroidea) from the late Barremian of Vallibona, Spain: Implications for spinosaurid diversity in the Early Cretaceous of the Iberian Peninsula". English. In: Cretaceous Research (2019). DOI: 10.1016/j.cretres.2019.104221.

[14582] E. Malafaia, P. Mocho, F. Escaso, and F. Ortega. "A new carcharodontosaurian theropod from the Lusitanian Basin: evidence of allosauroid sympatry in the European Late Jurassic". English. In: Journal of Vertebrate Paleontology 40.1 (2020), e1768106:1-8. DOI: 10.1080/02724634.2020.1768106.

[14583] E. Malafaia, F. Ortega, B. Silva, F. Escaso, and P. Dantas. Un nuevo ejemplar de Allosauroidea (Dinosauria: Tetanurae) del Jurásico Superior de Valmitão (Lourinhã, Portugal) [A new specimen of Allosauroidea (Dinosauria: Tetanurae) from the Upper Jurassic of Valmitão (Lourinhã, Portugal)]. Spanish. 2008.

[14584] E. Malafaia, F. Ortega, F. Escaso, P. Dantas, N. Pimentel, J. M. Gasulla, B. Ribeiro, F. Barriga, and J. L. Sanz. "Vertebrate fauna at the Allosaurus fossil-site of Andres (Upper Jurassic), Pombal, Portugal". English. In: Journal of Iberian Geology 36.2 (2010), pp. 193-204. DOI: 10.5209/rev_JIGE.2010. v36.n2.7.

[14585] E. Malafaia, F. Ortega, F. Escaso, and B. Silva. “New evidence of Ceratosaurus (Dinosauria: Theropoda) from the Late Jurassic of the Lusitanian Basin, Portugal". English. In: Historical Biology 27.7 (2015), pp. 938-946.

[14586] D. V. Malakhov. “Giant pliosaur (Reptilia; Sauropterygia) from the Late Jurassic of Kazakhstan and some remarks on the systematics of Pliosauridae". English. In: Russian Journal of Hepetology 6.3 (1999), pp. 241-246.

[14587] D. V. Malakhov. "The earliest known record of Mioproteus (Caudata; Proteidae) from the Middle Miocene of Central Kazakhstan". English. In: Biota 4 (2003), pp. 67-72. 
[14588] N. Malchus, V. Dhondt, and K. -A. Tröger. "Upper Cretaceous bivalves from the Glauconie de Lonzee near Gembloux (SE Belgium)". English. In: Sciences de la Terre 64 (1994), pp. 109-149.

[14589] N. Malchus, J. M. Pons, and R. Salas. "Rudist distribution in the Lower Aptian shallow platform of La Mola de Xert, Eastern Iberian Range, NE Spain". English. In: Revista Mexicana de Ciencias Geologicas 12.2 (1995), pp. 224-235.

[14590] O. Malchyk and M. Machalski. "First record of Epicymatoceras vaelsense (Nautilida) from the Maastrichtian white chalk of northern Denmark". English. In: Bulletin of the Geological Society of Denmark 66 (2018), pp. 229-235.

[14591] C. J. Maldonado and G. O. Poinar. "Reuteroscopus Carvalhoi n. sp., a new fossil plant bug (Heteroptera: Miridae: Phylinae)". English. In: Proceedings of the Entomological Society of Washington 97 (1995), pp. 346-349.

[14592] J. Maldonado Capriles and G. O. Poinar. "Stomatomiris, a new fossil mirid genus in Dominican amber (Heteroptera: Miridae)". English. In: Caribbean Journal of Science 31 (1995), pp. 281-283.

[14593] J. Maldonado Capriles, J. A. Santiago-Blay, and G. O. Poinar. “Apicrenus fossilis gen. \& sp. n. (Heteroptera: Reduviidae: Apiomerinae) from Dominican amber (lower Oligocene-upper Eocene)". English. In: Entomologica Scandinavica 24 (1993), pp. 139-142.

[14594] J. Maldonado Capriles, J. A. Santiago-Blay, and G. O. Poinar. "Paleoploiariola venosa, a new fossil Emesinae (Heteroptera: Reduviidae) genus and species from Dominican amber". English. In: Journal of the Agricultural University of Puerto Rico 77 (1993), pp. 95-100.

[14595] J. Maldonado Capriles, J. A. Santiago-Blay, and G. O. Poinar. “Paralienates hyalinus n. gen. and n. sp. (Enicocephalidae: Heteroptera): fossil gnat bug from Dominican amber (lower Oligoceneupper Eocene)". English. In: Journal of the Agricultural University of Puerto Rico 80 (1996), pp. 4754 .

[14596] J. Malec and G. Racki. "Givetian and Frasnian ostracod associations from the Holy Cross Mountains". English. In: Acta Palaeontologica Polonica 37.2-4 (1992), pp. 359-384.

[14597] J. Maletz. "Middle Devonian dendroid graptolites from the Brilon Reef area (Rheinisches Schiefergebirge, Germany)". English. In: Paläontologische Zeitschrift 80.3 (2006), pp. 221-229.

[14598] J. Maletz. “The Lower Ordovician graptolites Didymograptus balticus Tullberg and D. protobalticus Monsen". English. In: Norsk Geologisk Tidsskrift 76 (1996), pp. 107-114.

[14599] J. Maletz and D. L. Bruton. "The Middle Ordovician Proventocitum procerulum radiolarian assemnblage of Spitsbergen and its biostratigraphic correlation". English. In: 51.5 (2008), pp. 11811200.

[14600] J. Maletz and S. O. Egenhoff. "Late Tremadoc to early Arenig graptolite faunas of southern Bolivia and their implications for a worldwide biozonation". English. In: Lethaia 34.1 (2001), pp. 47-62. DOI: $10.1080 / 002411601300068279$.

[14601] J. Maletz and T. Servais. "Upper Ordovician graptolites from the Brabant Massif, Belgium”. English. In: Geobios 31.1 (1998), pp. 21-37.

[14602] J. M. Malinky. "Ordovician and Silurian hyoliths and gastropods reassigned from the Hyolitha from the Girvan District, Scotland". English. In: Journal of Paleontology 77.4 (2003), pp. 625-645.

[14603] J. M. Malinky. "Cambrian Hyolitha from Northeast Canada: reappraisal of the Hyolith orders Camerothecida and Diplothecida". English. In: Journal of Paleontology 64.4 (1990), pp. 587-595.

[14604] J. M. Malinky. "Permian Hyolithida from Australia: the last of the hyoliths?" English. In: Journal of Paleontology 83.1 (2009), pp. 147-152.

[14605] J. M. Malinky. “First occurrence of Orthotheca Novák, 1886 (Hyolitha, Early Devonian) in North America". English. In: Journal of Paleontology 83.4 (2009), pp. 588-596. DOI: 10.1666/08-164R.1.

[14606] J. M. Malinky. “Cambrian Hyolitha and problematica from West Laurentian North America: taxonomy and palaeobiogeography". English. In: Alcheringa 38.3 (2014), pp. 338-363. DOI: 10.1080 / 03115518.2014.874715. 
[14607] J. M. Malinky and V. Berg-Madsen. "A revision of Holm's Early and early Mid Cambrian hyoliths of Sweden". English. In: Palaeontology 42.1 (1999), pp. 25-65.

[14608] J. M. Malinky and P. H. Heckel. "Paleoecology and taphonomy of faunal assemblages in gray core (offshore) shales in Midcontinent Pennsylvanian cyclothems". English. In: Palaios 13.4 (1998), pp. 311-334. DOI: 10.1043/0883-1351(1998)013<0311:PATOFA>2.0.CO;2.

[14609] J. M. Malinky and C. B. Skovsted. "Hyoliths and small shelly fossils from the Lower Cambrian of NorthEast Greenland". English. In: Acta Palaeontologica Polonica 49.4 (2004), pp. 551-578.

[14610] M. S. Malkani. "Pakistani Titanosauria: are armoured dinosaurs?" English. In: Geological Bulletin University of Preshawar 36 (2003), pp. 85-91.

[14611] M. S. Malkani. "Biodiversity of saurischian dinosaurs from the latest Cretaceous Park of Pakistan". English. In: Journal of Applied and Emerging Sciences 1.3 (2006), pp. 108-140.

[14612] M. S. Malkani. "First diagnostic fossils of Late Cretaceous crocodyliform (Mesoeucrocodylia, Reptilia) from Vitakri area, Barkhan District, Balochistan, Pakistan". English. In: Contribution to Geology of Pakistan. Proceedings of 5th Pakistan Geological Congress 2004, Pakistan Museum of Natural History, Islamabad. National Geological Society of Pakistan (2007), pp. 241-260.

[14613] M. S. Malkani. "Trackways evidence of a sauropod dinosaurs confronted by a theropod found from Middle Jurassic Samana Suk Limestone of Pakistan". English. In: Sindh University Research Journal (Science Series) 39.1 (2007), pp. 1-14.

[14614] M. S. Malkani. "First Jurassic dinosaur fossils found from Kirthar Range, Khuzdar District, Balochistan, Pakistan". English. In: Geological Bulletin, University of Peshawar 36 (2003), pp. 73-83.

[14615] M. S. Malkani. "First rostrum of carnivorous Vitakridrinda (Abelisaurid Theropod Dinosaur) found from the latest Cretaceous Dinosaur Beds (Vitakri) Member of PAB formation, Alam Kali Kakor Locality of Vitakri area, Barkhan District, Balochistan, Pakistan". English. In: Sindh University Research Journal (Science Series) 38.2 (2006), pp. 7-26.

[14616] M. S. Malkani. "Recently discovered basilosaurid, baluchithere rhinoceros, horses, sea cow, proboscidean, eucrocodile, pterosaurs, plesiosaur, fishes, invertebrates and wood fossils, tracks and trackways of dinosaurs from Pakistan; comparison of recognized four titanosaur taxa of IndoPakistan with Madagascar". English. In: Open Journal of Geology 9.12 (2019), pp. 919-955. DOI: 10.4236/ojg.2019.912098.

[14617] M. S. Malkani, M. S. I. Dhantor, A. Latif, and H. M. Saeed. "New remains of Basilosauridae-the giant basal whale, and baluchithere-the giant rhinoceros discovered from Balochistan Province (Pakistan)". English. In: Sindh University Research Journal (Science Series) 45.A-1 (2013), pp. 177188.

[14618] L. Mallada. "Contribución a la taxonoma y bioestratigrafa de los rudistas del Cretácico superior en el Prepirineo aragonés". Portugese. In: (1998).

[14619] J. C. Mallon and D. B. Brinkman. "Basilemys morrinensis, a new species of nanhsiungchelyid turtle from the Horseshoe Canyon Formation (Upper Cretaceous) of Alberta, Canada". English. In: Journal of Vertebrate Paleontology 38.2 (2018), e1431922:1-11. DOI: 10.1080/02724634.2018.1431922.

[14620] J. C. Mallon, D. C. Evans, T. T. Tokaryk, and M. L. Currie. "First pachycephalosaurid (Dinosauria: Ornithischia) from the Frenchman Formation (upper Maastrichtian) of Saskatchewan, Canada". English. In: Cretaceous Research 56 (2015), pp. 426-431. DOI: 10.1016/j.cretres.2015.06.005.

[14621] J. C. Mallon, C. J. Ott, P. L. Larson, E. M. Iuliano, and D. C. Evans. "Spiclypeus shipporum gen. et sp. nov., a boldly audacious new chasmosaurine ceratopsid (Dinosauria: Ornithischia) from the Judith River Formation (Upper Cretaceous: Campanian) of Montana, USA". English. In: PLoS ONE 11.5 (2016), e0154218:1-40. DOI: 10.1371/journal.pone.0154218.

[14622] E. N. Malysheva. "A new sphinctozoan species (Porifera), Colospongia lenis sp. nov., from the Upper Permian reefs of Southern Primorye". English. In: Paleontological Journal 52 (2018), pp. 231233. 
[14623] T. Malyshkina. "Late Eocene scyliorhinid sharks from the TransUrals, Russia". English. In: Acta Palaeontologica Polonica 51.3 (2006), pp. 465-475.

[14624] T. P. Malyshkina, E. A. Jagt-Yazykova, V. V. Kolchanov, and M. V. Nazarkin. "First shark record from the Upper Cretaceous of the Kuril Islands, Far East Russia". English. In: Cretaceous Research 115.104551 (2020). DOI: 10.1016/j.cretres.2020.104551.

[14625] H. Malz and M. Poschmann. “Erste SüSSwasser-Limuliden (Arthropoda, Chelicerata) aus dem Rotliegenden der Saar-Nahe-Senke". German. In: Osnabrücker Naturwissenschafliche Mitteilungen 19 (1993), pp. 21-34.

[14626] S. H. Mamay and G. Mapes. "Early Virgilian plant megafossils from the Kinney Brick Company Quarry, Manzanita Mountains, New Mexico". In: New Mexico Bureau of Mines E Mineral Resources Bulletin 138 (1992), pp. 61-85.

[14627] M. Manabe. “The early evolution of the Tyrannosauridae in Asia”. English. In: Journal of Paleontology 73.6 (1999), pp. 1176-1178.

[14628] M. Manabe, Y. Hasegawa, and T. Takahashi. "A hadrosaurid vertebra from the Ashizawa Formation, Futaba Group, Fukushima, Japan". English. In: Bulletin of the Gunma Museum of Natural History 7 (2003), pp. 7-10.

[14629] M. Manabe, T. Tsuijihi, Y. Miyake, and T. Komatsu. "A possible ceratopsid tooth from the Upper Cretaceous of Kyushu, Japan". English. In: Bulletin of the National Museum of Nature and Science, Series C 42 (2017), pp. 29-34.

[14630] I. N. Manankov. "Late Permian Productida (Brachiopoda) from southeastern Mongolia”. English. In: Paleontological Journal 32 (1998), pp. 486-492.

[14631] I. N. Manankov. "New spiriferids (Brachiopoda) from the Middle-Late Permian of northeastern Mongolian boreal basin". English. In: Paleontological Journal 53 (2019), pp. 611-615. DOI: 10.1134/ S0031030119060054.

[14632] I. N. Manankov. "New species of Early Permian brachiopods and biostratigraphy of the boreal basin of Mongolia". English. In: Paleontological Journal 38.4 (2004), pp. 366-372.

[14633] M. O. Mancenido. "First record of Jurassic nucleatid brachiopods from the southwest Pacific with comments on the global distribution of the group". English. In: Palaeogeography, Palaeoclimatology, Palaeoecology 100 (1993), pp. 189-207.

[14634] S. R. Manchester. "Update on the Megafossil Flora of Florissant, Colorado". In: Denver Museum of Nature and Science 4.1 (2001), p. 137.

[14635] S. R. Manchester. "Leaves and fruits of Aesculus (Sapindales) from the Paleocene of North America". English. In: International Journal of Plant Sciences 162.4 (2001), pp. 985-998.

[14636] S. R. Manchester. "Flowers, fruits, and pollen of Florissantia, an extinct Malvalean genus from the Eocene and Oligocene of western North America". In: American Journal of Botany 79.9 (1992), pp. 996-1008.

[14637] S. R. Manchester. "Leaves and fruits of Davidia (Cornales) from the Paleocene of North America". English. In: Systematic Botany 27 (2002), pp. 368-382.

[14638] S. R. Manchester, M. A. Akhmetiev, and T. M. Kodrul. "Leaves and fruits of Celtis aspera (newberry) comb. nov. (Celtidaceae) from the Paleocene of North America and eastern Asia". In: International Journal of Plant Sciences 163.5 (2002), pp. 725-736.

[14639] S. R. Manchester, Z. Chen, B. Geng, and J. Tao. "Middle Eocene flora of Huadian, Jilin Province, Northeastern China". English. In: Acta Palaeobotanica 45.1 (2005), pp. 3-26.

[14640] S. R. Manchester and Z. D. Chen. "A new genus of Coryloideae (Betulaceae) from the Paleocene of North America". English. In: International Journal of Plant Sciences 159.3 (1998), pp. 522-532.

[14641] S. R. Manchester, P. R. Crane, and L. B. Golovneva. "An extinct genus with affinities to the extant Davida and Camptotheca (Cornales) from the Paleoecene of North America". English. In: International Journal of Plant Sciences 160.1 (1999), pp. 188-207. 
[14642] S. R. Manchester and D. L. Dilcher. "Reproductive and vegetative morphology of Polyptera (Juglandaceae) from the Paleocene of Wyoming and Montana". English. In: American Journal of Botany 84 (1997), pp. 649-663.

[14643] S. R. Manchester and M. J. Donoghue. "Winged fruits of Linnaeeae (Caprifoliaceae) in the Tertiary of western North America: Diplodipelta gen. nov." In: International Journal of Plant Sciences 156.5 (1995), pp. 709-722.

[14644] S. R. Manchester and W. J. Kress. “Fossil bananas (Musaceae): Ensete oregonense sp. nov. from the Eocene of western North America and its phytogeographic significance". In: American Journal of Botany 80.11 (1993), pp. 1264-1272.

[14645] S. R. Manchester. "Fruits and seeds of the Middle Eocene Nut Beds Flora, Clarno Formation, Oregon". In: Palaeontographica Americana 58 (1994), pp. 1-205.

[14646] S. R. Manchester and L. J. Hickey. "Reproductive and vegetative organs of Browniea gen. n. (Nyssaceae) from the Paleocene of North America." English. In: International Journal of Plant Sciences 168.2 (2007), pp. 229-249.

[14647] C. A. Mancina and L. Garca-Rivera. "New genus and species of fossil bat (Chiroptera: Phyllostomidae) from Cuba". English. In: Caribbean Journal of Science 41.1 (2005), pp. 22-27.

[14648] A. Mancinelli. "Acroporella cairensis n. sp. (Dasycladales) from the Barremian of Monte Cairo (southern Latium, Italy)". English. In: Facies 52 (2006), pp. 411-416.

[14649] A. Mancinelli, D. Ferrandes, and B. Coccia. "Norian calcareous Algae from the Matese Mountains (northern Campania, Italy)". In: Facies 50 (2004), pp. 107-112.

[14650] A. Mancosu and J. H. Nebelsick. "The origin and paleoecology of clypeasteroid assemblages from different shelf settings of the Miocene of Sardinia, Italy". English. In: Palaios 30.5 (2015), pp. 373387.

[14651] A. Mancosu and J. H. Nebelsick. "Echinoid assemblages from the early Miocene of Funtanazza (Sardinia): A tool for reconstructing depositional environments along a shelf gradient". English. In: Palaeogeography, Palaeoclimatology, Palaeoecology 454 (2016), pp. 139-160.

[14652] A. Mancosu and J. H. Nebelsick. "Palaeoecology and taphonomy of spatangoid-dominated echinoid assemblages: A case study from the Early-Middle Miocene of Sardinia, Italy". English. In: Palaeogeography, Palaeoclimatology, Palaeoecology 466 (2017), pp. 334-352.

[14653] S. Manda. "Trocholites Conrad, 1938 (Nautiloidea, Tarphycerida) in the Middle Ordovician of the Prague Basin and its palaeobiogeographical significance". English. In: Bulletin of Geosciences 83.3 (2008), pp. 327-334.

[14654] S. Manda. “New Silurian nautiloids Phragmoceras Broderip, 1839, and Tubiferoceras Hedström, 1917, from the Prague Basin (Bohemia)". English. In: Bulletin of Geosciences 82.2 (2007), pp. 119131. DOI: 10.3140/bull.geosci.2007.02.119.

[14655] S. Manda and V. Turek. "Revision of the Pragian Rutoceratoidea Hyatt, 1884 (Nautiloidea, Oncocerida) from the Prague Basin". English. In: Bulletin of Geosciences 84.1 (2009), pp. 127-148.

[14656] L. Mander, R. J. Twitchett, and M. J. Benton. "Palaeoecology of the Late Triassic extinction event in the SW UK". English. In: Journal of the Geological Society, London 165 (2008), pp. 319-332.

[14657] O. Mandic, M. Harzhauser, S. Spezzaferri, and M. Zuschin. "The paleoenvironment of an early Middle Miocene Paratethys sequence in NE Austria with special emphasis on mollusks and foraminifera". English. In: Geobios 24 (2002), pp. 193-206. DOI: 10.1016/S0016-6995(02)00059-1.

[14658] O. Mandic, T. Kurei, T. A. Neubauer, and M. Narzhauser. "Stratigraphic and palaeogeographic significance of lacustrine molluscs from the Pliocene Viviparus beds in central Croatia". English. In: Geologia Croatica 68.3 (2015), pp. 179-207.

[14659] O. Mandic and W. E. Piller. "Pectinid coquinas and their palaeoenvironmental implications - examples from the early Miocene of northeastern Egypt". English. In: Palaeogeography, Palaeoclimatology, Palaeoecology 172 (2001), pp. 171-191. 
[14660] O. Mandic and F. F. Steininger. "Computer-based mollusc stratigraphy - a case study from the Eggenburgian (Lower Miocene) type region (NE Austria)". English. In: Palaeogeography, Palaeoclimatology, Palaeoecology 197 (2003), pp. 263-291.

[14661] M. H. Mandurah. "Paleontological studies on the Neogene (Miocene and Quaternary) carbonate rocks of Rabigh-Ubhur areas, Red Sea coast, Saudia Arabia". English. In: Journal of King Abdulaziz University, Earth Sciences 21.2 (2010), pp. 105-143.

[14662] R. Mane, J. Ribe, J. Magrans, and E. Ferrer. “Ictiologia fossil del Plioce del Baix Llobregat III Els Batoideus (condrictis hipotremats)". English. In: Batalleria 11 (2003), pp. 43-52.

[14663] A. Manegold and J. S. Brink. "Descriptions and palaeoecological implications of bird remains from the Middle Pleistocene of Florisbad, South Africa". English. In: Paläontologische Zeitschrift 85 (2011), pp. 19-32.

[14664] T. Manera de Bianco. Nuevas observaciones acerca de las cascaras de huevo de dinosaurio del Cretácico Superior del Cerro Blanco, Yaminue, Provincia de Ro Negro, Argentina [New observations on the dinosaur eggshells from the Upper Cretaceous of Cerro Blanco, Yaminue, Ro Negro province, Argentina]. Spanish. 2000.

[14665] M. G. Mángano, L. A. Buatois, R. Astini, and A. K. Rindsberg. “Trilobites in early Cambrian tidal flats and the landward expansion of the Cambrian explosion". English. In: Geology (2013).

[14666] G. Mangerud. "Palynostratigraphy of the Permian and lowermost Triassic succession, Finnmark Platform, Barents Sea." In: Review of Palaeobotany and Palynology 82 (1994), pp. 317-349.

[14667] I. J. Maniel and M. S. de la Fuente. "A Review of the Fossil Record of Turtles of the Clade PanChelidae". English. In: Bulletin of the Peabody Museum of Natural History 57.2 (2016), pp. 191-227.

[14668] I. J. Maniel, M. S. de la Fuente, J. Sterli, J. M. Jannello, and J. M. Krause. "New remains of the aquatic turtle Hydromedusa casamayorensis (Pleurodira, Chelidae) from the middle Eocene of Patagonia: taxonomic validation and phylogenetic relationships". English. In: Papers in Palaeontology (2018), pp. 1-29. DOI: 10.1002/spp2.1117.

[14669] I. J. Maniel, M. S. de la Fuente, S. Apesteguia, J. Perez Mayoral, M. L. Sanchez, G. D. Vega, and I. Smales. "Cranial and postcranial remains of a new species of Prochelidella (Testudines: Pleurodira: Chelidae) from 'La Buitrera' (Cenomanian of Patagonia, Argentina), with comments on the monophyly of this extinct chelid genus from southern Gondwana". English. In: Journal of Systematic Palaeontology (2020), pp. 1-23. DOI: 10.1080/14772019.2020.1721579.

[14670] C. Mankiewicz. "Response of reef growth to sea-level changes (Late Miocene, Fortuna Basin, southeastern Spain)". English. In: Palaios 10 (1995), pp. 322-336.

[14671] D. G. Manley and G. Poinar. "A second species of fossil Dasymutilla (Hymenoptera: Mutillidae) from Dominican amber". English. In: The Pan-Pacific Entomologist 75 (1999), pp. 48-51.

[14672] D. G. Manley and G. O. Poinar. “A new species of fossil Dasymutilla (Hymenoptera: Mutillidae) from Dominican amber". English. In: The Pan-Pacific Entomologist 67.3 (1991), pp. 200-205.

[14673] D. G. Manley and G. O. Poinar. "A new specimen of fossil Mutillidae (Hymenoptera) from Dominican amber". English. In: Proceedings of the Entomological Society of Washington 105 (2003), pp. 10691071.

[14674] A. Mann and H. C. Maddin. "Diabloroter bolti, a short-bodied recumbirostran 'microsaur' from the Francis Creek Shale, Mazon Creek, Illinois". English. In: Zoological Journal of the Linnean Society (2019), pp. 1-12. DOI: 10.1093/zoolinnean/zlz025.

[14675] A. Mann, E. J. McDaniel, E. R. McColville, and H. C. Maddin. "Carbonodraco lundi gen et sp. nov., the oldest parareptile, from Linton, Ohio, and new insights into the early radiation of reptiles". English. In: Royal Society Open Science 6.11 (2019). DOI: 10.1098/rsos.191191.

[14676] A. Mann, J. D. Pardo, and H. C. Maddin. "Infernovenator steenae, a new serpentine recumbirostran from the 'Mazon Creek' Lagertätte further clarifies lysorophian origins". English. In: Zoological Journal of the Linnean Society XX (2019), pp. 1-12. 
[14677] A. Mann, D. Rudkin, D. C. Evans, and M. Laflamme. "A large onychodontiform (Osteichthyes: Sarcopterygii) apex predator from the Eifelian-aged Dundee Formation of Ontario, Canada". English. In: Canadian Journal of Earth Sciences 54 (2017), pp. 233-241. DOI: 10.1139/cjes-2016-0119.

[14678] B. Mannai-Tayech. "The lithostratigraphy of Miocene series from Tunisia, revisited". English. In: Journal of African Sciences 54 (2009), pp. 53-61.

[14679] M. Mannani and M. Yazdi. "Late Triassic and Early Cretaceous sedimentary sequences of the northern Isfahan Province (Central Iran): stratigraphy and paleoenvironments". English. In: Boletn de la Sociedad Geológica Mexicana 61.3 (2009), pp. 367-374.

[14680] A. A. Mannering and N. Hiller. "An early Cenozoic neoselachian shark fauna from the South Pacific". English. In: Palaeontology 51.6 (2008), pp. 1341-1365.

[14681] K. Mannermaa. "Bird bones from Jettböle I, a site in the Neolithic Åland archipelago in the northern Baltic". English. In: Acta zoologica cracoviensia 45 (2002), pp. 85-98.

[14682] K. Mannermaa. "Birds in Finnish prehistory". English. In: Fennoscandia Archaeologica 20 (2003), pp. 3-39.

[14683] P. Männik. Distribution of Ordovician and Silurian conodonts. English. Vol. 10. Viki Drill Core. Tallinn: Geological Survey of Estonia, 2010, pp. 21-24.

[14684] P. Männik. "Distribution of Ordovician and Silurian conodonts". English. In: vol. 5. Estonian geological sections: Ruhnu (500) drill core. Tallinn: Geological Survey of Estonia, 2003, pp. 17-23.

[14685] P. Männik, O. K. Bogolepova, A. Põldvere, and A. P. Gubanov. “New data on Ordovician-Silurian conodonts and stratigraphy from the Severnaya Zemlya Archipelago, Russian Arctic". English. In: Geological Magazine 146.4 (2009), pp. 497-516.

[14686] P. Männik, D. K. Loydell, and S. Lubeseder. "Sheinwoodian (Silurian) conodonts and graptolites from NE Anti-Atlas, Morocco". English. In: Lethaia 44 (2010), pp. 410-416.

[14687] P. Männik, D. K. Loydell, V. Nestor, and J. Nolvak. “Integrated Upper Ordovician - lower Silurian biostratigraphy of the Grötlingbo-1 core section, Sweden". English. In: Geologiska Föreningen 137.1 (2015), pp. 226-244.

[14688] P. Männik and K. Makowski. "Silurian conodonts from the Godap core". English. In: Palaeontologia Polonica 58 (1998), pp. 141-151.

[14689] P. Männik, V. V. Menner, R. G. Matukhin, and V. Kurss. "Silurian and Devonian strata on the Severnaya Zemlya and Sedov archipelagos (Russia)". English. In: Geodiversitas 24.1 (2002), pp. 99122.

[14690] P. Männik, A. Põldvere, V. Nestor, T. Kallaste, T. Kiipli, and T. Martma. “The Llandovery - Wenlock boundary interval in west-central continental Estonia: an example from the Suigu (S-3) core section". English. In: Estonian Journal of Earth Sciences 63.1 (2014), pp. 1-17. DOI: 10.3176/ earth. 2014.01.

[14691] P. Männik, O. Tinn, D. K. Loydell, and L. Ainsaar. “Age of the Kalana Lagerstätte, early Silurian, Estonia". English. In: Estonian Journal of Earth Sciences 65.2 (2016), pp. 105-114.

[14692] E. Manning. "An early Oligocene Rhinoceros jaw from the marine Byram Formation of Mississippi". English. In: Mississippi Geology 18.2 (1997), pp. 13-31.

[14693] P. L. Manning, V. M. Egerton, and M. Romano. “A new sauropod dinosaur from the Middle Jurassic of the United Kingdom". English. In: PLoS ONE 10.6 (2015), e0128107:1-7. DOI: 10.1371/ journal.pone.0128107.

[14694] M. A. Mannino, S. Talamo, A. Tagliacozzo, I. Fiore, O. Nehlich, M. Piperno, S. Tusa, C. Collina, R. Di Salvo, V. Schimmenti, and M. P. Richards. "Climate-driven environmental changes around 8,200 years ago favoured increases in cetacean strandings and Mediterranean hunter-gatherers exploited them". English. In: Scientific Reports 5 (2015), p. 16288. DOI: 10.1038/srep16288.

[14695] P. D. Mannion. "A rebbachisaurid sauropod from the Lower Cretaceous of the Isle of Wight, England". English. In: Cretaceous Research 30 (2009), pp. 521-526. DOI: 10.1016/j.cretres.2008.09.005. 
[14696] P. D. Mannion. "A revision of the sauropod dinosaur genus 'Bothriospondylus' with a redescription of the type material of the Middle Jurassic form 'B. madagascariensis". English. In: Palaeontology 53.2 (2010), pp. 277-296. DOI: 10.1111/j.1475-4983.2009.00919.x.

[14697] P. D. Mannion. "A turiasaurian sauropod dinosaur from the Early Cretaceous Wealden Supergroup of the United Kingdom". English. In: PeerJ 7 (2019), e6348:1-14. DOI: 10.7717/peerj.6348.

[14698] P. D. Mannion, R. Allain, and O. Moine. “The earliest known titanosauriform sauropod dinosaur and the evolution of Brachiosauridae". English. In: PeerJ 5 (2017), e3217:1-82. DOI: 10.7717/ peerj. 3217.

[14699] P. D. Mannion and P. M. Barrett. "Additions to the sauropod dinosaur fauna of the Cenomanian (early Late Cretaceous) Kem Kem beds of Morocco: Palaeobiogeographical implications of the mid-Cretaceous African sauropod fossil record". English. In: Cretaceous Research 45 (2013), pp. 49 59. DOI: 10.1016/j.cretres.2013.07.007.

[14700] P. D. Mannion, R. B. J. Benson, M. T. Carrano, J. P. Tennant, J. Judd, and R. J. Butler. “Climate constrains the evolutionary history and biodiversity of crocodylians". English. In: Nature Communications 6 (2015), 8438:1-9. DOI: 10.1038/ncomms9438.

[14701] P. D. Mannion and J. O. Calvo. "Anatomy of the basal titanosaur (Dinosauria, Sauropoda) Andesaurus delgadoi from the mid-Cretaceous (Albian-early Cenomanian) Ro Limay Formation, Neuquén Province, Argentina: implications for titanosaur systematics". English. In: Zoological Journal of the Linnean Society 163 (2011), pp. 155-181.

[14702] P. D. Mannion and A. Otero. "A reappraisal of the Late Cretaceous Argentinean sauropod dinosaur Argyrosaurus superbus, with a description of a new titanosaur genus". English. In: Journal of Vertebrate Paleontology 32.3 (2012), pp. 614-638.

[14703] P. D. Mannion, P. Upchurch, O. Mateus, R. N. Barnes, and M. E. H. Jones. “New information on the anatomy and systematic position of Dinheirosaurus lourinhanensis (Sauropoda: Diplodocoidea) from the Late Jurassic of Portugal, with a review of European diplodocoids". English. In: Journal of Systematic Palaeontology 10.3 (2012), pp. 521-551. DOI: 10.1080/14772019.2011.595432.

[14704] P. D. Mannion, P. Upchurch, R. N. Barnes, and O. Mateus. “Osteology of the Late Jurassic Portuguese sauropod dinosaur Lusotitan atalaiensis (Macronaria) and the evolutionary history of basal titanosauriforms". English. In: Zoological Journal of the Linnean Society 168 (2013), pp. 98-206.

[14705] P. D. Mannion, P. Upchurch, D. Schwarz, and O. Wings. "Taxonomic affinities of the putative titanosaurs from the Late Jurassic Tendaguru Formation of Tanzania: phylogenetic and biogeographic implications for eusauropod dinosaur evolution". English. In: Zoological Journal of the Linnean Society 185.3 (2019), pp. 784-909. DOI: 10.1093/zoolinnean/zly068/5300162.

[14706] L. L. Manske and S. E. Lewis. "Two Fossil Adult Cockroaches (Blattaria) from the Cretaceous of Minnesota". English. In: Journal of Paleontology 64.1 (1990), pp. 159-161.

[14707] C. L. C. Manso and E. J. Andrade. "Equinoides do Turoniano (Cretaceo Superior) de Sergipe, Brasil". Portugese. In: São Paulo, UNESP, Geociencias 27.3 (2008), pp. 319-327.

[14708] J. L. Mansy, F. Debrenne, and A. Y. Zhuravlev. "Calcaires a archaeocyathes du Cambrien inferieur du nord de la Colombie Britannique (Canada), implications paleogeographiques et precisions sur l'extension du continent Americano-Koryakien [Lower Cambrian archaeocyath limestones of northern British Columbia (Canada), paleogeographic implications and precisions on the Americano-Koryakian continent extension]". French. In: Geobios 26.6 (1993), pp. 643-683.

[14709] N. Mantovani. “The genus Tetractinella Bittner 1890: morphology, ultrastructure, and 3D reconstruction". English. In: Rivista Italiana di Paleontologia e Stratigrafia 108.1 (2002), pp. 37-50.

[14710] S. B. Manum, M. N. Bose, R. T. Sayer, and S. Boström. "A nematode (Captivonema cretacea gen. et sp. n.) preserved in a clitellate cocoon wall from the Early Cretaceous". English. In: Zoologica Scripta 23 (1994), pp. 27-31.

[14711] S. B. Manum, M. N. Bose, and J. Os Vigran. "The Jurassic Flora of Andoya, northern Norway". In: Review of Palaeobotany and Palynology 68 (1991), pp. 233-256. 
[14712] C. L. Manz and J. I. Bloch. "Systematics and phylogeny of Paleocene-Eocene Nyctitheriidae (Mammalia, Eulipotyphla?) with description of a new species from the late Paleocene of the Clarks Fork Basin, Wyoming, USA". English. In: Journal of Mammalian Evolution 22 (2015), pp. 307-342. DOI: 10.1007/s10914-014-9284-3.

[14713] E. Manzanares, C. Pla, C. Martnez-Pérez, H. Ferrón, and H. Botella. “Lonchidion derenzii, sp. nov., a new lonchidiid shark (Chondrichthyes, Hybodontiformes) from the Upper Triassic of Spain, with remarks on lonchidiid enameloid". English. In: Journal of Vertebrate Paleontology 37.e1253585 (2017), pp. 1-5.

[14714] A. S. Manzano, J. I. Noriega, and W. Joyce. “The tropical tortoise Chelonoidis denticulata (Testudines: Testudinidae) from the Late Pleistocene of Argentina and its paleoclimatological implications". English. In: Journal of Paleontology 83.6 (2009), pp. 975-980.

[14715] P. C. Manzig, A. W. A. Kellner, L. C. Weinschütz, C. E. Fragoso, C. S. Vega, G. B. Guimarães, L. C. Godoy, A. Liccardo, J. H. Z. Ricetti, and C. M. de Moura. "Discovery of a Rare Pterosaur Bone Bed in a Cretaceous Desert with Insights on Ontogeny and Behavior of Flying Reptiles". English. In: PLoS ONE 9.8 (2014), e100005. DOI: 10.1371/journal.pone.0100005.

[14716] A. Manzuetti, D. Perea, M. Ubilla, and A. Rinderknecht. "First record of Smilodon fatalis Leidy, 1868 (Felidae, Machairodontinae)". English. In: Quaternary Science Reviews 180 (2018), pp. 57-62.

[14717] A. Manzuetti, D. Perea, W. Jones, M. Ubilla, and A. Rinderknecht. "An extremely large sabertooth cat skull from Uruguay (late Pleistocene-early". English. In: Alcheringa (2020). DOI: 10.1080 / 03115518.2019.1701080.

[14718] A. Manzuetti, D. Perea, A. Rinderknecht, and M. Ubilla. "New Canid Remains from Dolores Formation, late Pleistocene-early Holocene, Uruguay". English. In: Journal of Mammalian Evolution 25 (2018), pp. 391-396.

[14719] A. Manzuetti, M. Ubilla, D. Perea, R. I. Vezzosi, A. Rinderknecht, M. Ghizzoni, and W. Jones. "The large American opossum Didelphis (Didelphimorphia, Didelphidae) in the Late Pleistocene of Uruguay, and paleoecological remarks". English. In: Journal of South American Earth Sciences 98 (2020), 102437:1-8.

[14720] F.-Y. Mao, Q. Li, Y. -Q. Wang, and C. -K. Li. “Taizimylus tongi, a new eurymylid (Mammalia, Glires) from the upper Paleocene of Xinjiang, China". English. In: Palaeoworld 26.3 (2017), pp. 519 530. DOI: 10.1016/j.palwor.2016.12.002.

[14721] F.-Y. Mao, Y.-Q. Wang, Q. Li, and X. Jin. "New records of archaic ungulates from the Lower Eocene of Sanshui Basin, Guangdong, China". English. In: Historical Biology (2015). DOI: 10.1080/ 08912963.2015.1034120.

[14722] F.-Y. Mao, Y.-Q. Wang, and J. Meng. “New specimens of the multituberculate mammalian Sphenopsalis from the Paleocene of Inner Mongolia, China: implications for phylogeny and biology of taeniolabidoid multituberculates". English. In: Acta Palaeontologica Polonica 61.2 (2016), pp. 429454.

[14723] F.-Y. Mao and Y.-Q. Wang. "Coryphodontids (Mammalia:Pantodonta) from the Erlian Basin of Nei Mongol, China, and their biostratigraphic implications". English. In: Vertebrata PalAsiatica 50.3 (2012), pp. 258-280.

[14724] Y. Mao, M. S. Engel, D. Ren, and T. P. Gao. "A new species of Astreptolabis in mid-Cretaceous amber from northern Myanmar, with the discovery of the first male of Astreptolabidinae (Dermaptera)". English. In: ZooKeys 911 (2020), pp. 101-112. DOI: 10.3897/zookeys.911.38845.

[14725] Y. Mao, M. S. Engel, Y. Y. Zhao, and D. Ren. "A new genus of labidurid earwigs in mid-Cretaceous amber from northern Myanmar (Dermaptera: Labiduridae)". English. In: Cretaceous Research 111.104447 (2020). DOI: 10.1016/j.cretres.2020.104447.

[14726] Y. Y. Mao, J. P. Lin, C. H. Lin, and W. I. Ausich. “Chinese origin and radiation of the Palaeozoic crinoid family Petalocrinidae". English. In: Palaeoworld 24.4 (2015), pp. 445-453. DOI: 10.1016/j. palwor.2014.12.007. 
[14727] Y. Y. Mao, G. D. Webster, W. I. Ausich, Y. Li, Q. L. Wang, and M. Reich. “A new crinoid fauna from the Taiyuan Formation (early Permian) of Henan, North China". English. In: Journal of Paleontology 92 (2018), pp. 1066-1080.

[14728] R. H. Mapes and T. S. Evans. "The color pattern on a Cretaceous nautiloid from South Dakota". English. In: Journal of Paleontology 69 (1995), pp. 785-786.

[14729] R. H. Mapes, S. Niko, J. Fryda, and A. Nützel. “A newly hatched coiled nautiloid from the Permian of Italy". English. In: Journal of Paleontology 81 (2007), pp. 1118-1121.

[14730] B. Marandat. "Mammiferes de l'Ilerdien moyen (Eocene inferieur) des Corbieres et du Minervois (Bas-Languedoc, France): Systematique, biostratigraphie, correlations". French. In: Palaeovertebrata 20.2-3 (1991), pp. 55-144.

[14731] B. Marandat, S. Adnet, L. Marivaux, A. Martinez, M. Vianey-Liaud, and R. Tabuce. "A new mammalian fauna from the earliest Eocene (Ilerdian) of the Corbiéres (Southern France): palaeobiogeographical implications". English. In: Swiss Journal of Geosciences 105 (2012), pp. 417-434.

[14732] H. Marani and M. T. Dozo. "El cráneo más completo de Eurygenium latirostris Ameghino, 1895 (Mammalia, Notoungulata), un Notohippidae del Deseadense (Oligoceno Tardo) de la Patagonia, Argentina". Spanish. In: Ameghiniana 45.3 (2008), pp. 619-626.

[14733] L. Marchal, E. Guilbert, P. Brisac, and A. Nel. "A new record and a new species of Aradidae fossils (Hemiptera: Heteroptera)". English. In: Zootaxa 2832 (2011), pp. 56-62.

[14734] F. Marchal-Papier, A. Nel, and L. Grauvogel-Stamm. "New Orthoptera (Ensifera, Insecta) from the Triassic of the Vosges (France)". French. In: Acta Geologica Hispanica 35.1-2 (2000), pp. 5-18.

[14735] M. Marchetti, K. Parolin, and B. Sala. "The Biharian fauna from Monte La Mesa (Verona, northeastern Italy)". English. In: Acta Zoologica Cracoviensia 43.1 (2000), pp. 79-105.

[14736] F. Marcolini, G. Bigazzi, F. P. Bonnadonna, E. Centamore, R. Cioni, and G. Zanchetta. “Tephrochronology and tephrostratigraphy of two Pleistocene continental fossiliferous successions from central Italy". English. In: Journal of Quaternary Science 18.6 (2003), pp. 545-556.

[14737] F. Marcolini, F. P. Bonadonna, T. Kotsakis, P. Mazza, and G. Zanchetta. "Preliminary data on the micro- and macromammal remains from Casa Sgherri, Lower Valdarno (Tuscany, Italy)". English. In: Bollettino della Societa Paleontologica Italiana 39.2 (2000), pp. 243-252.

[14738] A. Marcopoulou-Diacantoni. "[Paleoecological observations of the corals reefs of the upper Tortonian between Viannos - Ierapetra provinces (SE Crete)]". other. In: Bulletin of the Geological Society of Greece 34.2 (2001), pp. 495-502.

[14739] A. Marcopoulou-Diacantoni, J. Fountoulis, and E. Lekkas. "Presence de coraux Oligocene (Rupelien) dans le Peloponnese central-occidental (Grece), signification paleoecologique et paleobiogeographique [The occurrence of Oligocene (Rupelian) corals in west-central Peloponnesus (Greece), paleoecological and paleobiogeographic significance]". French. In: Geologie Mediterraneenne 23.1 (1996), pp. 11-25.

[14740] A. Marcopoulou-Diacantoni and G. Kagiouzis. "Otoliths from the lower Pliocene of the section Prassies (Rethymnon, NW-Crete), Systematics - Paleoecology". other. In: Bulletin of the Geological Society of Greece 34 (2001), pp. 577-584.

[14741] A. Marcopoulu-Diacontoni and E. Logos. "The occurrence of the Metaxytherium cuvieri Christol in the Late Miocene Sediments of Sitia, Crete". English. In: Bulletin of the Geological Society of Greece 36 (2004), pp. 764-771.

[14742] C. W. Marean. “Implications of Late Quaternary mammalian fauna from Lukenya Hill (SouthCentral Kenya) for paleoenvironmental change and faunal extinctions". In: Quaternary Research 37 (1992), pp. 239-255.

[14743] C. W. Marean, M. Bar-Matthews, J. Bernatchez, E. Fisher, P. Goldberg, A. I. R. Herries, Z. Jacobs, A. Jerardino, P. Karkanas, T. Minichillo, P. J. Nilssen, E. Thompson, I. Watts, and H. M. Williams. "Early human use of marine resources and pigment in South Africa during the Middle Pleistocene". English. In: Natures 449 (2007), pp. 905-909. 
[14744] C. W. Marean, N. Mudida, and K. E. Reed. "Holocene Paleoenvironmental Change in the Kenyan Central Rift Indicated by Micromammals from Enkapune Ya Muto Rockshelter". English. In: Quaternary Research 41 (1994), pp. 376-389.

[14745] J. Marek, B. Weber, F. Schönian, S. O. Egenhoff, and B. D. Erdtmann. Arenig cephalopods from Bolivia. English. 2000.

[14746] L. Marek, J. M. Malinky, and G. Geyer. "Middle Cambrian fossils from Tizi n"Tichka, the High Atlas, Morocco. Part 2. Hyolitha". In: Journal of Paleontology 71.4 (1997), pp. 638-656.

[14747] S. Marenssi, V. Guler, S. Casado, R. Guerstein, and O. Papú. "Sedimentology and palynology of the Calafate Formation (Maastrichtian), Austral Basin, Southern Patagonia, Argentina". English. In: Cretaceous Research 25 (2004), pp. 907-918. DOI: 10.1016/j.cretres.2004.08.004.

[14748] S. A. Marenssi, M. A. Regeuro, S. N. Santillana, and S. F. Vizcaino. “Eocene land mammals from Seymour Island, Antarctica: palaeobiogeographical implications". English. In: 6.1 (1994), pp. 3-15.

[14749] O. Maridet, G. Daxner-Höck, D. Badamgarav, and U. B. Göhlich. "The eomyid rodents (Mammalia) from the Oligocene and Miocene of the Valley of Lakes (Central Mongolia)". English. In: Palaeontologische Zeitschrift 89 (2015), pp. 207-228.

[14750] O. Maridet, G. Daxner-Höck, D. Badamgarav, and U. B. Göhlich. “New discoveries of Sciurids (Rodentia, Mammalia) from the Valley of Lakes (Central Mongolia)". English. In: Annalen des Naturhistorischen Museums in Wien, Serie A 116 (2014), pp. 271-291.

[14751] O. Maridet, G. Daxner-Höck, P. López-Guerrero, and U. B. Göhlich. “The record of Aplodontidae (Rodentia, Mammalia) in the Oligocene and Miocene of the Valley of Lakes (Central Mongolia) with some comments on the morphologic variability". English. In: Palaeobiodiversity and Palaeoenvironments 97.1 (2017), pp. 25-49.

[14752] O. Maridet, M. Hugueney, and K. Heissig. "New data about the diversity of Early Oligocene eomyids (Mammalia, Rodentia) in Western Europe". English. In: Geodiversitas 32.2 (2010), pp. 221254.

[14753] O. Maridet and X. Ni. "A New Cricetid Rodent from the Early Oligocene of Yunnan, China, and its Evolutionary Implications for Early Eurasian Cricetids". English. In: Journal of Vertebrate Paleontology 33.1 (2013), pp. 185-194.

[14754] O. Maridet, W. Wu, J. Ye, S. Bi, X. Ni, and J. Meng. “Eucricetodon (Rodentia, Mammalia) from the Late Oligocene of the Junggar basin, northern Xinjiang, China". English. In: American Museum Novitates 3665 (2009), pp. 1-21.

[14755] O. Maridet, W.-Y. Wu, J. Ye, S. -D. Bi, X. -J. Ni, and J. Meng. "Early Miocene cricetids (Rodentia) from the Junggar basin (Xinjiang, China) and their biochronological implications". English. In: Geobios 44.5 (2011), pp. 445-459.

[14756] J. Marigó, R. Minwer-Barakat, and S. Moyá-Solá. “New Anchomomyini (Adapoidea, Primates) from the Mazaterón Middle Eocene locality (Almazán Basin, Soria, Spain)". English. In: Journal of Human Evolution 58.2 (2010), pp. 353-361. DOI: 10.1016/j.jhevol.2010.01.011.

[14757] J. Marigó, R. Minwer-Barakat, and S. Moyá-Solá. “New Anchomomys (Adapoidea, Primates) from the Robiacian (Middle Eocene) of northeastern Spain. Taxonomic and evolutionary implications". English. In: Journal of Human Evolution 60.5 (2011), pp. 665-672. DOI: 10.1016/j.jhevol.2010.12.006.

[14758] J. Marigó, R. Minwer-Barakat, S. Moyá-Solá, and S. López-Torres. "First record of Plesiadapiformes (Primates, Mammalia) from Spain". English. In: Journal of Human Evolution 62.3 (2012), pp. 429-433. DOI: 10.1016/j.jhevol.2012.01.002.

[14759] J. Marigó, R. Minwer-Barakat, and S. Moyá-Solá. "Nievesia sossisensis, a new anchomomyin (Adapiformes, Primates) from the early Late Eocene of the southern Pyrenees (Catalonia, Spain)". English. In: Journal of Human Evolution 64.5 (2013), pp. 1-13. DOI: 10.1016/j.jhevol.2012.11.004.

[14760] A. B. Marin, M. R. Gonzalez-Morales, and J. Estevez. "Paleoclimatic inference of the mid-Holocene record of monk seal (Monachus monachus) in the Cantabrian Coast". English. In: Proceedings of the Geologists' Association (2010). 
[14761] L. Marincovich Jr. “Danian Mollusks from the Prince Creek Formation, Northern Alaska, and implications for arctic ocean paleogeography". English. In: Journal of Paleontology Memoir 67.5 (1993), pp. 1-35.

[14762] F. Marinescu and S. Proches. "Serafimea bergeri, new genus and species of weevils (Coleoptera: Curculionidae) from the Romanian Miocene". English. In: Travaux Du Museum d'Histoire Naturelle Grigore Antipa 41 (1999), pp. 465-471.

[14763] T. S. Marinho and C. R. A. Candeiro. “Titanosaur (Dinosauria: Sauropoda) osteoderms from the Maastrichtian of Uberaba, Minas Gerais state, Brazil". English. In: Gondwana Research 8.4 (2005), pp. 473-477.

[14764] T. S. Marinho and I.d.S. Carvalho. "An armadillo-like sphagesaurid crocodyliform from the Late Cretaceous of Brazil". English. In: Journal of South American Earth Sciences 27.1 (2009), pp. 36-41. DOI: 10.1016/j.jsames.2008.11.005.

[14765] T. S. Marinho, F. V. Iori, I. S. Carvalho, and F. M. Vasconcellos. “Gondwanasuchus scabrosus gen. et sp. nov., a new terrestrial predatory crocodyliform (Mesoeucrocodylia: Baurusuchidae) from the Late Cretaceous Bauru Basin of Brazil". English. In: Cretaceous Research 44 (2013), pp. 104-111. DOI: 10.1016/j.cretres.2013.03.010.

[14766] B. Mario, C. Luigi, and D. Piero. "I sirenidi fossili della Provincia di Vibo Valentia". Italian. In: Bollettino del Gruppo Paleontologico Tropeano 7 (2000), pp. 4-10.

[14767] N. Mariotti, R. Weis, M. Falahatgar, H. Parent, and M. Javidan. “Oxfordian belemnites and ammonites from Rostam Kola, Northern East Alborz, North Iran". English. In: Boletn del Instituto de Fisiografa y Geologa 83 (2013).

[14768] L. Marivaux, M. Adaci, M. Bensalah, H. G. Rodrigues, L. Hautier, M.h. Mahboubi, F. Mebrouk, R. Tabuce, and M. Vianey-Liaud. "Zegdoumyidae (Rodentia, Mammalia), stem anomaluroid rodents from the Early to Middle Eocene of Algeria (Gour Lazib, Western Sahara): new dental evidence". English. In: Journal of Systematic Palaeontology 9.4 (2011), pp. 563-588. DOI: 10.1080/14772019.2011. 562555.

[14769] L. Marivaux, S. Adnet, A. J. Altamirano-Sierra, M. Boivin, F. Pujos, A. Ramdarshan, R. SalasGismondi, J. V. Tejada-Lara, and P. -O. Antoine. "Neotropics provide insights into the emergence of New World monkeys: New dental evidence from the late Oligocene of Peruvian Amazonia". English. In: Journal of Human Evolution 97 (2016), pp. 159-175.

[14770] L. Marivaux, S. Adnet, M. Benammi, and R. Tabuce. "Anomaluroid rodents from the earliest Oligocene of Dakhla, Morocco, reveal the long-lived and morphologically conservative pattern of the Anomaluridae and Nonanomaluridae during the Tertiary in Africa". English. In: Journal of Systematic Palaeontology 15.7 (2017), pp. 539-569. DOI: 10.1080/14772019.2016.1206977.

[14771] L. Marivaux, S. Adnet, M. Benammi, R. Tabuce, and J. Yans. "Earliest Oligocene hystricognathous rodents from the Atlantic margin of northwestern Saharan Africa (Dakhla, Morocco): systematic, paleobiogeographical, and paleoenvironmental implications". English. In: Journal of Vertebrate Paleontology 37 (2017), e1357567:1-22.

[14772] L. Marivaux, S. Adnet, A. J. Altamirano-Sierra, F. Pujos, A. Ramdarshan, R. Salas-Gismondi, and J. V. Tejada-Lara. "Dental remains of cebid platyrrhines from the earliest late Miocene of Western Amazonia, Peru: Macroevolutionary implications on the extant capuchin and marmoset lineages". English. In: American Journal of Physical Anthropology 161 (2016), pp. 478-493. DOI: 10.1002 / ajpa. 23052.

[14773] L. Marivaux, P.-O. Antoine, S. R. H. Baqri, M. Benammi, and Y. Chaimanee. "Anthropoid primates from the Oligocene of Pakistan (Bugti Hills): Data on early anthropoid evolution and biogeography". English. In: Proceedings of the National Academy of Sciences 102.24 (2005), pp. 8436-8441. DOI: 10.1073/pnas.0503469102.

[14774] L. Marivaux, M. Benammi, S. Ducrocq, J. -J. Jaeger, and Y. Chaimanee. "A new baluchimyine rodent from the Late Eocene of the Krabi Basin (Thailand): paleobiogeographic and biochronologic implications". English. In: Comptes rendus de l'Académie des Sciences Paris, Sciences de la Terre et des planétes 331 (2000), pp. 427-433. 
[14775] L. Marivaux, L. Bocat, Y. Chaimanee, J. -J. Jaeger, B. Marandat, P. Srisuk, P. Tafforeau, C. Yamee, and J. -L. Welcomme. "Cynocephalid dermopterans from the Palaeogene of South Asia (Thailand, Myanmar and Pakistan): systematic, evolutionary and palaeobiogeographic implications". English. In: Zoologica Scripta 35.4 (2006), pp. 395-420.

[14776] L. Marivaux, Y. Chaimanee, P. Tafforeau, and J. -J. Jaeger. "New strepsirrhine primate from the late Eocene of peninsular Thailand (Krabi Basin)". English. In: American Journal of Physical Anthropology 130 (2006), pp. 425-434.

[14777] L. Marivaux, Y. Chaimanee, C. Yamee, P. Srisuk, and J. -J. Jaeger. “Discovery of Fallomus ladakhensis Nanda \& Sahni, 1998 (Mammalia, Rodentia, Diatomyidae) in the lignites of Nong Ya Plong (Phetchaburi Province, Thailand): systematic, biochronological and paleoenvironmental implications". English. In: Geodiversitas 26.3 (2004), pp. 493-507.

[14778] L. Marivaux, S. Ducrocq, J. -J. Jaeger, B. Marandat, J. Sudre, Y. Chaimanee, S. T. Tun, W. Htoon, and A. N. Soe. "New remains of Pondaungimys anomaluropsis (Rodentia, Anomaluroidea) from the Latest Middle Eocene Pondaung Formation of Central Myanmar". English. In: Journal of Vertebrate Paleontology 25.1 (2005), pp. 214-227.

[14779] L. Marivaux, E. M. Essid, W. Marzougui, H. K. Ammar, S. Adnet, B. Marandat, G. Merzeraud, R. Tabuce, and M. Vianey-Liaud. "A new and primitive species of Protophiomys (Rodentia, Hystricognathi) from the late middle Eocene of Djebel el Kébar, Central Tunisia". English. In: Palaeovertebrata 38.1 (2014), pp. 1-17.

[14780] L. Marivaux, E. M. Essid, W. Marzougui, H. Ammar, S. Adnet, B. Marandat, G. Merzeraud, R. Tabuce, and M. Vianey-Liaud. "A Morphological Intermediate Between Eosimiiform and Simiiform Primates From the Late Middle Eocene of Tunisia: Macroevolutionary and Paleobiogeographic Implications of Early Anthropoids". English. In: American Journal of Physical Anthropology 154 (2014), pp. 387-401.

[14781] L. Marivaux, F. Lihoreau, F. K. Manthi, and S. Ducrocq. "A new basal phiomorph (Rodentia, Hystricognathi) from the late Oligocene of Lokone (Turkana Basin, Kenya)". English. In: Journal of Vertebrate Paleontology 32.3 (2012), pp. 646-657.

[14782] L. Marivaux, R. Salas-Gismondi, J. Tejada, G. Billet, M. Louterbach, J. Vink, J. Bailleul, M. Roddaz, and P. O Antoine. "A platyrrhine talus from the early Miocene of Peru (Amazonian Madre de Dios Sub-Andean Zone)". English. In: Journal of Human Evolution 63 (2012), pp. 696-703.

[14783] L. Marivaux, J. Vélez-Juarbe, G. Merzeraud, F. Pujos, L. W. Viñola López, M. Boivin, H. SantosMercado, E. J. Cruz, A. Grajales, J. Padilla, K. I. Vélez-Rosado, M. Philippon, J. -L. Léticée, P. Münch, and P. -O. Antoine. "Early Oligocene chinchilloid caviomorphs from Puerto Rico and the initial rodent colonization of the West Indies". English. In: Proceedings of the Royal Society B 287 (2020), 20192806:1-10. DOI: 10.1098/rspb.2019.2806.

[14784] L. Marivaux, M. Vianey-Liaud, and J. -L. Welcomme. "Premiére découverte de Cricetidae (Rodentia, Mammalia) oligocénes dans le synclinal sud de Gando (Bugti Hills, Balouchistan, Pakistan)". French. In: Comptes Rendus de l'Académie des Sciences-Series IIA-Earth and Planetary Science 329.11 (1999), pp. 839-844.

[14785] L. Marivaux, M. Vianey-Liaud, J. -L. Welcomme, and J. -J. Jaegar. "The role of Asia in the origin and diversification of hystricognathous rodents". English. In: Zoologica Scripta 31.3 (2002), pp. 225239.

[14786] L. Marivaux, J.-L. Welcomme, S. Ducrocq, and J. -J. Jaeger. “Oligocene sivaladapid primate from the Bugti Hills (Balochistan, Pakistan) bridges the gap between Eocene and Miocene adapiform communities in southern Asia." English. In: Journal of Human Evolution 42 (2002), pp. 379-388.

[14787] L. Marivaux, J.-L. Welcomme, P. -O. Antoine, G. Metais, I. M. Baloch, M. Benammi, Y. Chaimanee, S. Ducrocq, and J. -J. Jaeger. "A fossil lemur from the Oligocene of Pakistan." English. In: Science 294 (2001), pp. 587-591.

[14788] L. Marivaux and J.-L. Welcomme. "New diatomyid and baluchimyine rodents from the Oligocene of Pakistan (Bugti Hills, Balochistan): systematic and paleobiogeographic implications". English. In: Journal of Vertebrate Paleontology 23.2 (2003), pp. 420-434. 
[14789] H. W. Markewich, C. M. Hacke, and P. F. Huddlestun. “Emergent Pliocene and Pleistocene sediments of southeastern Georgia: an anomalous, fossil-poor, clastic section". English. In: SEPM Special Publication 48 (1992), pp. 173-189.

[14790] A. K. Markova. “The sequence of Early Pleistocene small-mammal faunas from the South Russian Plain." English. In: Quartärpaläontologie 1990 (1990), pp. 131-151.

[14791] Z. Markovi, H. de Bruijn, A. A. van de Weerd, and W. Wessels. “Deperetomys (Rodentia, Muridae) from the Oligocene of Serbia and Bosnia and Herzegovina". English. In: Palaeobiodiversity and Palaeoenvironments (2019). DOI: 10.1007/s12549-019-00389-0.

[14792] Z. Markovi, W. Wessels, A. A. van de Weerd, and H. de Bruijn. "Pseudocricetodontinae (Mammalia, Rodentia) from the Paleogene of south-east Serbia". English. In: Palaeobiodiversity and Palaeoenvironments (2019). DOI: 10.1007/s12549-019-00373-8.

[14793] Z. Markovi, W. Wessels, A. A. van de Weerd, and H. de Bruijn. "On a new diatomyid (Rodentia, Mammalia) from the Paleogene of south-east Serbia, the first record of the family in Europe". English. In: Palaeobiodiversity and Palaeoenvironments 98.3 (2018), pp. 459-469. DOI: 10.1007/s12549017-0301-4.

[14794] A. E. Marks and A. Mohammed-Ali. The Late Prehistory of the Eastern Sahel. 1991.

[14795] J. Marmi, A. H. Luján, V. Riera, R. Gaete, O. Oms, and Á Galobart. "The youngest species of Polysternon: A new bothremydid turtle from the uppermost Maastrichtian of the southern Pyrenees". English. In: Cretaceous Research 35 (2012), pp. 133-142.

[14796] J. Marmi, B. Vila, and A. Galobart. "Solemys (Chelonii, Solemydidae) remains from the Maastrichtian of Pyrenees: evidence for a semi-aquatic lifestyle". English. In: Cretaceous Research 30 (2009), pp. 1307-1312. DOI: 10.1016/j.cretres.2009.07.008.

[14797] R. Marquet. "The Neogene Bivalvia (Heterodonta and Anomalodesmata) and Scaphopoda from Kallo and Doel (Oost Vlaanderen, Belgium)". English. In: Palaeontos 6 (2005), pp. 1-142.

[14798] R. Marquet. "A study of some Neogene European species of Seilinae (Cerithiopsidae, Gastropoda)". English. In: Bulletin de l'Institut royal des Sciences naturelles de Belgique, Sciences de la Terre 71 (2001), pp. 195-208.

[14799] R. Marquet and H. H. Dijkstra. "Pliocene species of Aequipecten (Mollusca, Bivalvia, Pectinidae) from the North Sea Basin". English. In: Contributions to Tertiary and Quaternary Geology 37.3-4 (2000), pp. 39-55.

[14800] R. Marquet and H. H. Dijkstra. "Neogene species of Pseudamussium (Mollusca, Bivalvia, Pectinidae) from Belgium". English. In: Contributions to tertiary and quaternary geology 36.1-4 (1999), pp. $45-57$.

[14801] A. Márquez-Aliaga, K. Budurov, and V. Martnez. "Registro de conodontos del Triásico Medio en un nautiloideo de Espejeras (Alicante, España) [Middle Triassic conodonts record in a nautiloid from Espejeras (Alicante, Spain)]”. Spanish. In: Coloquios de Paleontologa 48 (1996), pp. 76-83.

[14802] A. Marquez-Aliaga, S. Damborenea, J. J. Gomez, and A. Goy. "Bivalves from the Triassic-Jurassic transition in northern Spain (Asturias and western Basque-Cantabrian Basin)". English. In: Ameghiniana 47.2 (2010), pp. 185-205.

[14803] A. Marquez-Aliaga, C. C. Emig, and J. M. Brito. "Triassic lingulide brachiopods from the Iberian Range (Spain)". In: Géobios 32.6 (1999), pp. 815-821.

[14804] A. Marquez-Aliaga, N. Klein, M. Reolid, P. Plasencia, J. A. Villena, and C. Martinez-Perez. "An enigmatic marine reptile, Hispaniasaurus cranioelongatus (gen. et sp. nov.) with nothosauroid affinities from the Ladinian of the Iberian Range (Spain)". English. In: Historical Biology (2017), pp. 1-11. DOI: 10.1080/08912963.2017.1359264.

[14805] A. Marquez-Aliaga and S. Ros. "Associations of bivalves of Iberian Peninsula (Spain): Ladinian". English. In: Albertiana 28 (2003), pp. 85-83. 
[14806] R. Marquina, A. Fagoaga, V. D. Crespo, F. J. Ruiz-Sánchez, S. Bailon, C. M. Hernández, and B. Galván. "Amphibians and squamate reptiles from the stratigraphic unit $\mathrm{Xb}$ of El Salt (Middle Palaeolithic; Alcoy, Spain): palaeoenvironmental and palaeoclimatic implications". English. In: Spanish Journal of Palaeontology 32.2 (2017), pp. 291-312.

[14807] G. Marramá, A. Engelbrecht, G. Carnevale, and J. Kriwet. English. In: Historical Biology 31.2 (2019), pp. 102-116. DOI: 10.1080/08912963.2017.1341503.

[14808] G. Marramá, C. Lombardo, A. Tintori, and G. Carnevale. "Redescription of Perleidus (Osteichthyes, Actinopterygii) from the Early Triassic of northwestern Madagascar". English. In: Rivista Italiana di Paleontologia e Stratigrafia 123 (2017), pp. 219-242.

[14809] G. Marrama, O. Schultz, and J. Kriwet. "A new Miocene skate from the Central Paratethys (Upper Austria): the first". English. In: Journal of Systematic Palaeontology (2018), pp. 1-24. DOI: 10.1080 / 14772019.2018.1486336.

[14810] G. Marrama' and G. Carnevale. "Eoalosa janvieri gen. et sp. nov., a new clupeid fish (Teleostei," English. In: PalZ 92 (2018), pp. 107-120. DOI: 10.1007/s12542-017-0378-0.

[14811] A. D. Marsh. “A new record of Dromomeron romeri Irmis et al., 2007 (Lagerpetidae) from the Chinle Formation of Arizona, U.S.A." English. In: PaleoBios 35 (2018), pp. 1-8.

[14812] A. D. Marsh and T. B. Rowe. "A comprehensive anatomical and phylogenetic evaluation of Dilophosaurus wetherilli (Dinosauria, Theropoda) with descriptions of new specimens from the Kayenta Formation of northern Arizona". English. In: Journal of Paleontology 94.Memoir 78 (2020), pp. 1-103. DOI: 10.1017/jpa.2020.14.

[14813] L. G. Marshall. "Fossil Marsupialia from the type Friasian Land Mammal Age (Miocene), Alto Rio Cisnes, Aisen, Chile". English. In: Revista Geológica de Chile 17.1 (1990), pp. $19-55$.

[14814] L. G. Marshall, P. Salinas, and M. Suarez. “Astrapotherium sp. (Mammalia, Astrapotheriidae) from Miocene strata along the Quepuca river, Central Chile". English. In: Revista Geologica de Chile 17.2 (1990), pp. 215-223.

[14815] L. G. Marshall and P. Salinas Z. The Lorenzo Sundt collection of Pleistocene mammals from Ulloma, Bolivia in the Museo Nacional de Historia Natural, Santiago, Chile. English. Vol. 12. Fósiles y Facies de Bolivia - Vol. I Vertebrados 3-4. 1991, pp. 685-692.

[14816] L. G. Marshall and P. Salinas Z. "Vertebrados continentales del Mioceno inferior de Magallanes, Chile". Spanish. In: Anales del Instituto de la Patagonia, Serie Ciencias Naturales 19.1 (1990), pp. 27-38.

[14817] L. G. Marshall and T. Sempere. The Eocene to Pleistocene vertebrates of Bolivia and their stratigraphic context: a review. English. Vol. 12. Fósiles y Facies de Bolivia - Vol. 1 Vertebrados (Revista Ténica de YPFB) 3-4. 1991, pp. 631-652.

[14818] P. Marshall. "Theropod dinosaur and other footprints from the Valtos Sandstone Formation (Bathonian, Middle Jurassic) of the Isle of Skye". English. In: Scottish Journal of Geology 41.2 (2005), pp. 97104.

[14819] S. A. Marshall, M. Buck, J. H. Skevington, and D. Grimaldi. “A revision of the family Syringogastridae (Diptera: Diopsoidea)". English. In: Zootaxa 1996 (2009), pp. 1-80.

[14820] C. A. Marsicano. "Otuminisaurus limensis Rusconi, 1948: a problematic temnospondyl amphibian from the Triassic of Argentina". English. In: Journal of Vertebrate Paleontology 16.4 (1996), pp. 785786.

[14821] C. A. Marsicano, N. S. Domnanovich, and A. C. Mancuso. "Dinosaur origins: evidence from the footprint record". English. In: Historical Biology 19.1 (2007), pp. 83-91. DOI: 10.1080/08912960600866920.

[14822] C. A. Marsicano, E. Latimer, B. Rubidge, and R. M. H. Smith. "The Rhinesuchidae and early history of the Stereospondyli (Amphibia: Temnospondyli) at the end of the Palaeozoic". English. In: Zoological Journal of the Linnean Society (2017).

[14823] S. Marsili. "Analisi Sistematica, Paleoecologica e Paleogeografica della Selaciofauna Plio-Pleistocenica del Mediterraneo". Italian. PhD thesis. 2006. 
[14824] S. Marsili, G. Carnevale, E. Danese, G. Bianucci, and W. Landini. “Early Miocene vertebrates from Montagna della Maiella, Italy". English. In: Annales de Paleontologie 93 (2007), pp. 27-66.

[14825] J. C. A. Marsola, J. S. Bittencourt, R. J. Butler, A. A. S. Da Rosa, J. M. Sayão, and M. C. Langer. "A new dinosaur with theropod affinities from the Late Triassic Santa Maria Formation, south Brazil". English. In: Journal of Vertebrate Paleontology 38.5 (2019), e1531878. DOI: 10.1080/02724634. 2018.1531878.

[14826] T. Marss and P. Y. Gagnier. "A new chondrichthyan from the Wenlock, Lower Silurian, of BaillieHamilton Island, the Canadian Arctic". English. In: Journal of Vertebrate Paleontology 21.4 (2001), pp. 693-701.

[14827] T. Marss and V. Karatajute-Talimaa. “Ordovician and Lower Silurian thelodonts from Severnaya Zemlya Archipelago (Russia)". English. In: Geodiversitas 24.2 (2002), pp. 381-404.

[14828] T. Märss and C. G. Miller. "Thelodonts and distribution of associated conodonts from the Llandoverylowermost Lochkovian of the Welsh Borderland". English. In: Palaeontology 47.5 (2004), pp. 12111265.

[14829] T. Martens, D. S. Berman, A. C. Henrici, and S. S. Sumida. The Bromacker Quarry - the Most Important Locality of Lower Permian Terrestrial Vertebrate Fossils Outside of North America. English. Vol. 30. The Nonmarine Permian. New Mexico Museum of Natural History and Science Bulletin. 2005, pp. 214-215.

[14830] S. Martha and P. D. Taylor. "A new Western European Cretaceous Bryozoan genus from the Early Cenomanian radiation of Neocheilostomes". English. In: Papers in Palaeontology 2.2 (2016), pp. 311321.

[14831] S. O. Martha, K. Matsuyama, P. D. Taylor, and J. Scholz. “On rediscovered types of Santonian cheilostome bryozoans described by Ehrhard Voigt $(1924,1930)$ from the Subhercynian Cretaceous Basin and its surroundings". English. In: Palaeontologische Zeitschrift 89.4 (2015), pp. 689-706. DOI: 10.1007/s12542-014-0252-2.

[14832] S. O. Martha and P. D. Taylor. “The oldest erect cheilostome bryozoan: Jablonskipora gen. nov. from the upper Albian of south-west England". English. In: Papers in Palaeontology (2017). DOI: 10.1002/spp2.1097.

[14833] S. O. Martha, P. D. Taylor, and W. L. Rader. "Early Cretaceous cyclostome bryozoans from the early to middle Albian of". English. In: Journal of Paleontology 93 (2019), pp. 244-259. DOI: 10.1017/ jpa.2018.79.

[14834] M. Mart Mus, T. Palacios, and S. Jensen. "Size of the earliest mollusks: did small helcionellids grow to become large adults?" English. In: Geology 36.2 (2008), pp. 175-178.

[14835] D. M. Martill. "First pterosaur remains from the Exu Formation (Cretaceous) of the Araripe Basin, Brazil". English. In: Zitteliana B 28 (2008), pp. 243-248.

[14836] D. M. Martill. "A new pterodactyloid pterosaur from the Santana Formation (Cretaceous) of Brazil”. English. In: Cretaceous Research 32.2 (2011), pp. 236-243. DOI: 10.1016/j.cretres.2010.12.008.

[14837] D. M. Martill. "An ichthyosaur with preserved soft tissue from the Sinemurian of southern England". English. In: Palaeontology 38.4 (1995), pp. 897-903.

[14838] D. M. Martill. “First occurrence of the pterosaur Coloborhynchus (Pterosauria, Ornithocheiridae) from the Wessex Formation (Lower Cretaceous) of the Isle of Wight, England". English. In: Proceedings of the Geologists' Association (2015). DOI: 10.1016/j.pgeola.2015.03.004.

[14839] D. M. Martill and M. J. Barker. "A paper nautilus (Octopoda, Argonauta) from the Miocene Pakhna Formation of Cyprus". English. In: Palaeontology 49.5 (2006), pp. 1035-1041.

[14840] D. M. Martill, D. J. Batten, and D. K. Loydell. "A new specimen of the thyreophoran dinosaur cf. $<\mathrm{i}>$ Scelidosaurus $</ \mathrm{i}>$ with soft tissue preservation". In: Palaeontology 43.3 (2000), pp. 549-559.

[14841] D. M. Martill, G. Chong D., and R. Pardo. "A new pycnodont (Pisces, Actincopterygii) from the Jurassic of Chile". English. In: Neueus Jahrbuch für Geologie und Paläontologie Monatshefte 1998.8 (1998), pp. 485-493. 
[14842] D. M. Martill, A. R. I. Cruickshank, E. Frey, P. G. Small, and M. Clarke. “A new crested maniraptoran dinosaur from the Santana Formation (Lower Cretaceous) of Brazil". In: Journal of the Geological Society, London 153 (1996), pp. 5-8.

[14843] D. M. Martill, P. J. A. Del Strother, and F. Gallien. "Acanthorhachis, a new genus of shark from the Carboniferous (Westphalian) of Yorkshire, England". English. In: Geological Magazine 151 (2014), pp. 517-533.

[14844] D. M. Martill and S. Etches. "A new monofenestratan pterosaur from the Kimmeridge Clay Formation (Kimmeridgian, Upper Jurassic) of Dorset, England". English. In: Acta Palaeontologica Polonica 58.2 (2013), pp. 285-294.

[14845] D. M. Martill and J. B. M. Filgueira. "A new feather from the Lower Cretaceous of Brazil". English. In: Palaeontology 37.3 (1994), pp. 483-487.

[14846] D. M. Martill, E. Frey, and R. M. Sadaqah. “The first dinosaur from the Hashemite Kingdom of Jordan". English. In: Neues Jahrbuch für Geologie und Paläontologie Monatshefte 1996.3 (1996), pp. 147154.

[14847] D. M. Martill, E. Frey, M. Green, and M. E. Green. “Giant pterosaurs from the Lower Cretaceous of the Isle of Wight". English. In: Neues Jahrbuch für Geologie und Paläontologie, Monatshefte 1996 (1996), pp. 672-683.

[14848] D. M. Martill, E. Frey, G. C. Diaz, and C. M. Bell. "Reinterpretation of a Chilean pterosaur and the occurrence of Dsungaripteridae in South America". English. In: Geological Magazine 137.1 (2000), pp. 19-25.

[14849] D. M. Martill and E. Frey. "Colour patterning preserved in Lower Cretaceous birds and insects: the Crato Formation of N. E. Brazil". English. In: Neues Jahrbuch für Geologie und Paläontologie Monatshefte 1995.2 (1995), pp. 118-128.

[14850] D. M. Martill and S. Hutt. "Possible baryonychid dinosaur teeth from the Wessex Formation (Lower Cretaceous, Barremian) of the Isle of Wight, England". English. In: Proceedings of the Geologists' Association 107 (1996), pp. 81-84.

[14851] D. M. Martill, N. Ibrahim, P. M. Brito, L. Baider, S. Zhouri, R. Loveridge, D. Naish, and R. Hing. "A new Plattenkalk Konservat Lagerstätte in the Upper Cretaceous of Gara Sbaa, south-eastern Morocco". English. In: Cretaceous Research 32 (2011), pp. 433-446.

[14852] D. M. Martill and N. Ibrahim. "An unusual modification of the jaws in cf. Alanqa, a mid-Cretaceous azhdarchid pterosaur from the Kem Kem beds of Morocco". English. In: Cretaceous Research 53 (2015), pp. 59-67.

[14853] D. M. Martill, N. Ibrahim, and S. Bouaziz. "A giant pterosaur in the Early Cretaceous (Albian) of Tunisia". English. In: Journal of African Earth Sciences (2018). DOI: 10.1016/j.jafrearsci.2018.05.008.

[14854] D. M. Martill and D. Naish. "Cranial crest development in the azhdarchoid pterosaur Tupuxuara, with a review of the genus and tapejarid monophyly". English. In: Palaeontology 49.4 (2006), pp. 925-941.

[14855] D. M. Martill and A. Nel. "A new dragonfly from the Crato Formation (Lower Cretaceous, Aptian) of N.E. Brazil". English. In: Neues Jahrbuch für Geologie und Paläontologie, Monatshefte 1996 (1996), pp. 279-292.

[14856] D. M. Martill, M. O'Sullivan, and C. Newman. "A possible azhdarchid pterosaur (Pterosauria, Azhdarchidae) in the Durlston Formation (Early Cretaceous, Berriasian) of southern England". English. In: Cretaceous Research 43 (2013), pp. 26-39.

[14857] D. M. Martill, R. Smith, D. M. Unwin, A. Kao, J. McPhee, and N. Ibrahim. "A new tapejarid (Pterosauria, Azhdarchoidea) from the mid-Cretaceous Kem Kem beds of Takmout, southern Morocco". English. In: Cretaceous Research 112 (2020), p. 104424. DOI: 10.1016/j.cretres.2020.104424.

[14858] D. M. Martill, H. Tischlinger, and N. R. Longrich. "A four-legged snake from the Early Cretaceous of Gondwana”. English. In: Science 349 (2015), pp. 416-419. 
[14859] D. M. Martill, D. M. Unwin, N. Ibrahim, and N. Longrich. “A new edentulous pterosaur from the Cretaceous Kem Kem beds of south eastern Morocco". English. In: Cretaceous Research 84 (2018), pp. 1-12. DOI: 10.1016/j.cretres.2017.09.006.

[14860] D. M. Martill, S. U. Vidovic, C. Howells, and J. R. Nudds. "The oldest Jurassic dinosaur: a basal neotheropod from the Hettangian of Great Britain". English. In: PLoS ONE 11.1 (2016), e0145713:138. DOI: 10.1371 /journal.pone.0145713.

[14861] D. M. Martill and M. P. Witton. "Catastrophic failure in a pterosaur skull from the Cretaceous Santana Formation of Brazil". English. In: Zitteliana B 28 (2008), pp. 175-183.

[14862] A. J. Martin. "Dinosaur burrows in the Otway Group (Albian) of Victoria, Australia, and their relation to Cretaceous polar environments". English. In: Cretaceous Research 30 (2009), pp. 12231237. DOI: $10.1016 /$ j.cretres.2009.06.003.

[14863] A. J. Martin and N. D. Pyenson. Behavioral significance of vertebrate trace fossils from the Union Chapel site. English. Vol. 1. Alabama Paleontological Society Monograph. 2005, pp. 59-73.

[14864] A. J. Martin, T. H. Rich, M. Hall, P. Vickers-Rich, and G. Vazquez-Prokopec. "A polar dinosaurtrack assemblage from the Eumeralla Formation (Albian), Victoria, Australia". English. In: Alcheringa 36 (2012), pp. 171-188. DOI: 10.1080/03115518.2011.597564.

[14865] A. R. Martin, V. M. F. da Silva, and P. R. Rothery. "Does radio tagging affect the survival of reproduction of small cetaceans?" English. In: Marine Mammal Science 22.1 (2006), pp. 17-24.

[14866] E. L. O. Martin, M. Vidal, D. Vizcano, R. Vaucher, P. Sansjofre, B. Lefebvre, and J. Destombes. “Biostratigraphic and palaeoenvironmental controls on the trilobite associations from the Lower Ordovician Fezouata Shale of the central Anti-Atlas, Morocco". English. In: Palaeogeography, Palaeoclimatology, Palaeoecology 460 (2016), pp. 142-154. DOI: 10.1016/j.palaeo.2016.06.003.

[14867] J. E. Martin. "New material of the Late Cretaceous globidontan Acynodon iberoccitanus (Crocodylia) from southern France". English. In: Journal of Vertebrate Paleontology 27.2 (2007), pp. 362-372.

[14868] J. E. Martin. "A North American Hainosaurus (Squamata: Mosasauridae) from the Late Cretaceous of southern South Dakota". English. In: Geological Society of America Special Paper 427 (2007), pp. 199-207.

[14869] J. E. Martin. “A new species of the durophagous mosasaur Globidens (Squamata: Mosasauridae) from the Late Cretaceous Pierre Shale Group of central South Dakota, USA". English. In: Geological Society of America Special Paper 427 (2007), pp. 177-198.

[14870] J. E. Martin. "Juvenile marine reptiles from the Late Cretaceous of the Antarctic Peninsula and their relationships to other such occurrences in Central South Dakota and Belgium". English. In: Proceedings of the South Dakota Academy of Science 81 (2002), pp. 53-57.

[14871] J. E. Martin. "A new species of Diplocynodon (Crocodylia, Alligatoroidea) from the Late Eocene of the Massif Central, France, and the evolution of the genus in the climatic context of the Late Palaeogene". English. In: Geological Magazine 147.4 (2010), pp. 596-610.

[14872] J. E. Martin. "A sebecosuchian in a middle Eocene karst with comments on the dorsal shield in Crocodylomorpha". English. In: Acta Palaeontologica Polonica 60.3 (2015), pp. 673-680.

[14873] J. E. Martin. "New material of the ziphodont mesoeucrocodylian Iberosuchus from the Eocene of Languedoc, southern France". English. In: Annales de Paléontologie 102 (2016), pp. 135-144.

[14874] J. E. Martin. "The taxonomic content of the genus Gavialis from the Siwalik Hills of India and Pakistan". English. In: Papers in Palaeontology 5.3 (2019), pp. 483-497. DOI: 10.1002/spp2.1247.

[14875] J. E. Martin, P.-O. Antoine, V. Perrier, J. -L. Welcomme, G. Metais, and L. Marivaux. “A large crocodyloid from the Oligocene of the Bugti Hills, Pakistan". English. In: Journal of Vertebrate Paleontology (2019), e1671427:1-8. DOI: 10.1080/02724634.2019.1671427.

[14876] J. E. Martin and E. Buffetaut. "Crocodilus affuvelensis Matheron, 1869 from the Late Cretaceous of southern France: a reassessment". English. In: Zoological Journal of the Linnean Society 152 (2008), pp. 567-580. 
[14877] J. E. Martin, E. Buffetaut, W. Naksri, K. Lauprasert, and J. Claude. “Gavialis from the Pleistocene of Thailand and its relevance for drainage connections from India to Java". English. In: PLoS One 7.9 (2012), e44541. DOI: 10.1371/journal.pone.0044541.

[14878] J. E. Martin, J. A. Case, J. W. M. Jagt, A. S. Schulp, and E. W. A. Mulder. “A new European marsupial indicates a Late Cretaceous high-latitude transatlantic dispersal route". English. In: Journal of Mammalian Evolution 12.3/4 (2005), pp. 495-511.

[14879] J. E. Martin and A. Cordes-Person. "A new species of the diving bird Baptornis (Ornithurae, Hesperonithiformes) from the lower Pierre Shale Group (Upper Cretaceous) of southwestern South Dakota". English. In: Geological Society of America Special Paper 427 (2007), pp. 227-237.

[14880] J. E. Martin and F. de Lapparent de Broin. "A miniature notosuchian with multicuspid teeth from the Cretaceous of Morocco". English. In: Journal of Vertebrate Paleontology (2016), e1211534:1-17. DOI: 10.1080/02724634.2016.1211534.

[14881] J. E. Martin and M. Delfino. "Recent advances in the comprehension of the biogeography of Cretaceous European eusuchians". English. In: Palaeogeography, Palaeoclimatology, Palaeoecology 293 (2010), pp. 406-418. DOI: 10.1016/j.palaeo.2009.10.021.

[14882] J. E. Martin, M. Delfino, G. Garcia, P. Godefroit, S. Berton, and X. Valentin. “New specimens of Allodaposuchus precedens from France: intraspecific variability and the diversity of European Late Cretaceous eusuchians". English. In: Zoological Journal of the Linnean Society 176.3 (2016), pp. 607631. DOI: $10.1111 /$ zoj.12331.

[14883] J. E. Martin, M. Delfino, and T. Smith. “Osteology and affinities of Dollo's goniopholidid (Mesoeucrocodylia) from the Early Cretaceous of Bernissart, Belgium". English. In: Journal of Vertebrate Paleontology 36.6 (2016), e1222534:1-27. DOI: 10.1080/02724634.2016.1222534.

[14884] J. E. Martin, V. Fischer, P. Vincent, and G. Suan. "A longirostrine Temnodontosaurus (Ichthyosauria) with comments on Early Jurassic ichthyosaur niche partitioning and disparity". English. In: Palaeontology 55.5 (2012), pp. 995-1005. DOI: 10.1111/j.1475-4983.2012.01159.x.

[14885] J. E. Martin and J. E. Fox. "Stomach contents of Globidens, a shell-crushing mosasaur (Squamata), from the Late Cretaceous Pierre Shale Group, Big Bend area of the Missouri River, central South Dakota". English. In: Geological Society of America Special Paper 427 (2007), pp. 167-176.

[14886] J. E. Martin and M. Gross. “Taxonomic clarification of Diplocynodon POMEL, 1847 (Crocodilia) from the Miocene of Styria, Austria". English. In: Neues Jahrbuch für Geologie und Paläontologie Abhandlungen 261.2 (2011), pp. 177-193.

[14887] J. E. Martin, M. N. Hutchinson, R. Meredith, J. A. Case, and N. S. Pledge. "The oldest genus of scincid lizard (Squamata) from the Tertiary Etadunna Formation of South Australia". English. In: Journal of Herpetology 38.2 (2004), pp. 180-187. DOI: 10.1670/25-03A.

[14888] J. E. Martin and K. Lauprasert. "A new primitive alligatorine from the Eocene of Thailand: relevance of Asiatic members to the radiation of the group". English. In: Zoological Journal of the Linnean Society 158 (2010), pp. 608-628.

[14889] J. E. Martin, K. Lauprasert, E. Buffetaut, R. Liard, and V. Suteethorn. “A large pholidosaurid from the Phu Kradung Formation of north-eastern Thailand". English. In: Palaeontology (2013), pp. 113. DOI: $10.1111 /$ pala.12086.

[14890] J. E. Martin, K. Lauprasert, H. Tong, V. Suteethorn, and E. Buffetaut. “An Eocene tomistomine from peninsular Thailand". English. In: Annales de Paléontologie 105.3 (2019), pp. 245-253. DOI: 10.1016/j.annpal.2019.03.002.

[14891] J. E. Martin, M. Rabi, and Z. Csiki. "Survival of Theriosuchus (Mesoeucrocodylia: Atoposauridae) in a Late Cretaceous archipelago: a new species from the Maastrichtian of Romania". English. In: Naturwissenschaften 97 (2010), pp. 845-854. DOI: 10.1007/s00114-010-0702-y.

[14892] J. E. Martin, M. Rabi, Z. Csiki-Sava, and S. Vasile. “Cranial morphology of Theriosuchus sympiestodon (Mesoeucrocodylia, Atoposauridae) and the widespread occurrence in the Late Cretaceous of Europe". English. In: Journal of Paleontology 88.3 (2014), pp. 444-456. 
[14893] J. E. Martin, R. Sarr, and L. Hautier. "A dyrosaurid from the Paleocene of Senegal”. English. In: Journal of Paleontology 93.2 (2019), pp. 343-358. DOI: 10.1017/jpa.2018.77.

[14894] J. E. Martin, J. F. Sawyer, M. Reguero, and J. A. Case. "Occurrence of a young elasmosaurid plesiosaur skeleton from the Late Cretaceous (Maastrichtian) of Antarctica". English. In: U.S. Geological Survey and The National Academies Short Research Paper 66 (2007), pp. 1-4. DOI: 10.3133/of20071047.srp066.

[14895] J. E. Martin, T. Smith, F. de Lapparent de Broin, F. Escuillié, and M. Delfino. "Late Palaeocene eusuchian remains from Mont de Berru, France, and the origin of the alligatoroid Diplocynodon". English. In: Zoological Journal of the Linnean Society 172 (2014), pp. 867-891.

[14896] J. E. Martin, S. Suteethorn, K. Lauprasert, H. -Y. Tong, E. Buffetaut, R. Liard, C. Salaviale, U. Deesri, V. Suteethorn, and J. Claude. "A new freshwater teleosaurid from the Jurassic of northeastern Thailand". English. In: Journal of Vertebrate Paleontology 38.6 (2018), e1549059. DOI: 10.1080 / 02724634.2018.1549059.

[14897] J. M. Martn and J. C. Braga. "Eocene to Pliocene coralline algae in the Queensland Plateau (northeastern Australia)". English. In: Proceedings of the Ocean Drilling Program, Scientific Results 133 (1993).

[14898] J. P. Martin. “The Girvanella-like remains from Messinian marine deposits (Sardinia, Italy): Lagerstätten paradigm for microbial biota?" English. In: Annales de Paléontologie 96 (2010), pp. 33-50.

[14899] J. W. R. Martin, C. A. Walker, H. C. Bonser, and G. J. Dyke. "A new species of large auk from the Pliocene of Belgium". English. In: Oryctos 3 (2000), pp. 53-60.

[14900] L. D. Martin. "A new miniature saber-toothed nimravid from the Oligocene of Nebraska". English. In: Annales Zoologici Fennici 28 (1992), pp. 341-348.

[14901] L. D. Martin, J. P. Babiarz, V. L. Naples, and J. Hearst. "Three ways to be a saber-toothed cat". English. In: Naturwissenschaften 87 (2000), pp. 41-44.

[14902] L. D. Martin, E. N. Kurochkin, and T. T. Tokaryk. "A new evolutionary lineage of diving birds from the Late Cretaceous of North America and Asia". English. In: Palaeoworld 21 (2012), pp. 5963.

[14903] L. D. Martin and J.-D. Lim. "New insectivores from the Early Miocene of Nebraska, USA and the Hemingfordian faunal exchange". English. In: Mammalian Biology 69.3 (2004), pp. 202-209.

[14904] L. D. Martin and J.-D. Lim. "New information on the hesperornithiform radiation". English. In: Proceedings of the 5th Symposium of the Society of Avian Paleontology and Evolution, Beijing, 1-4 June 2000. Beijing: Science Press, 2002, pp. 165-174.

[14905] M. Martin, G. Cuny, and J. M. Mazin. "Rostres de Saurichthys (Saurichthyiformes, Saurichthyidae) en trois dimensions dans le Trias Moyen d'Israël". French. In: Geobios 24 (1991), pp. 183-186.

[14906] M. W. Martin, D. V. Grazhdankin, S. A. Bowring, D. A. D. Evans, M. A. Fedonkin, and J. L. Kirschvink. "Age of Neoproterozoic bilatarian body and trace fossils, White Sea, Russia: implications for metazoan evolution". English. In: Science 288 (2000), pp. 841-845.

[14907] R. A. Martin. "A new middle Pleistocene species of Microtus (Pedomys) from the southern United States, with comments on the taxonomy and early evolution of Pedomys and Pitymys in North America". English. In: Journal of Vertebrate Paleontology 15.1 (1995), pp. 171-186.

[14908] R. A. Martin, L. Duobinis-Gray, and C. P. Crockett. "A new species of early Pleistocene Synaptomys (Mammalia, Rodentia) from Florida and its relevance to southern bog lemming origins". In: 23.4 (2003), pp. 917-936.

[14909] R. A. Martin, H. T. Goodwin, and J. O. Farlow. "Late Neogene (late Hemphillian) rodents from the Pipe Creek Sinkhole, Grant County, Indiana". English. In: Journal of Vertebrate Paleontology 22.1 (2002), pp. 137-151.

[14910] R. A. Martin, F. Marcolini, and F. Grady. "The Early Pleistocene Hamilton Cave muskrats and a review of muskrat size change through the Late Neogene". English. In: Paludicola 7.2 (2009), pp. 61-66. 
[14911] R. A. Martin and R. H. Prince. "Variation and evolutionary trends in the dentition of late Pleistocene Microtus pennsylvanicus from three levels in Bell Cave, Alabama". English. In: Historical Biology 4 (1990), pp. 117-129.

[14912] R. A. Martin, A. Tesakov, J. Agusti, and K. Jonston. "Orcemys, un nouveau genre de rongeur arvicolidé du Pléistocéne inférieur du bassin de Cadix-Baza, Espagne méridionale". English. In: Comptes Rendus Palevol (2017). DOI: 10.1016/j.crpv.2017.06.006.

[14913] S. Martin and K. J. McNamara. "First record of a neolampadoid echinoid from the Paleogene of Western Australia". English. In: Records of the Western Australian Museum 22 (2004), pp. 213-217.

[14914] S. K. Martin. "A new protorhyphid fly (Insecta: Diptera: Protorhyphidae) from the Lower Jurassic of the Perth Basin, Western Australia". English. In: Alavesia 2 (2008), pp. 253-257.

[14915] S. K. Martin. "Early Jurassic coleopterans from the Mintaja insect locality, Western Australia". English. In: Acta Geologica Sinica 84 (2010), pp. 925-953.

[14916] S. K. Martin. "Early Jurassic cockroaches (Blattodea) from the Mintaja insect locality, Western Australia". English. In: Alavesia 3 (2010), pp. 55-72.

[14917] S. K. Martin, L. I. Skidmore, and J. D. Stilwell. "A first record of Cretaceous aphids (Hemiptera, Sternorrhyncha, Aphidomorpha) in Australia, from the Lower Cretaceous Koonwarra Fossil Bed, Victoria". English. In: Zootaxa 4137 (2016), pp. 95-107.

[14918] T. Martin. "New stem-lineage representatives of Zatheria (Mammalia) from the Late Jurassic of Portugal". English. In: Journal of Vertebrate Paleontology 22.2 (2002), pp. 332-348. DOI: 10.1671/02724634(2002)022[0332:NSLROZ]2.0.CO;2.

[14919] T. Martin, A. O. Averianov, and H. -U. Pfretzschner. "Palaeoecology of Middle to Late Jurassic vertebrate assemblages from the Fergana and Junggar Basins (Central Asia)". English. In: 9th International Symposium on Mesozoic Terrestrial Ecosystems and Biota, Abstracts and Proceedings Volu (2006), pp. 76-79.

[14920] T. Martin and A. O. Averianov. "Mammals from the Middle Jurassic Balabansai Formation of the Fergana Depression, Kyrgyzstan". English. In: Journal of Vertebrate Paleontology 30.3 (2010), pp. 855-871.

[14921] T. Martin, A. O. Averianov, and H. -U. Pfretzschner. "Mammals from the Late Jurassic Qigu Formation in the southern Junggar Basin, Xinjiang, northwest China". English. In: Palaeobiodiversity and Palaeoenvironments 90.3 (2010), pp. 295-319. DOI: 10.1007/s12549-010-0030-4.

[14922] T. Martin and A. O. Averianov. "A new docodont (Mammalia) form the Middle Jurassic of Kyrgyzstan, Central Asia". English. In: Journal of Vertebrate Paleontology 24.1 (2004), pp. 195-201.

[14923] T. Martin and A. O. Averianov. "A previously unrecognised group of Middle Jurassic triconodontan mammals from Central Asia". English. In: Naturwissenschaften 94 (2007), pp. 43-48.

[14924] T. Martin, A. O. Averianov, J. A. Schultz, A. H. Schwemann, and O. Wings. "Late Jurassic multituberculate mammals from Langenberg Quarry (Lower Saxony, Germany) and palaeobiogeography of European Jurassic multituberculates". English. In: Historical Biology (2019). DOI: 10.1080 / 08912963.2019.1650274.

[14925] T. Martin, E. Buffetaut, and H. Tong. "A Late Cretaceous eutherian mammal from southwestern France". English. In: Palaeontologische Zeitschrift 89.3 (2015), pp. 535-544. DOI: 10.1007/s12542-0140231-7.

[14926] T. Martin, J. Marugán-Lobón, R. Vullo, H. Martn-Abad, Z. -X. Luo, and A. D. Buscalioni. “A Cretaceous eutriconodont and integument evolution in early mammals". English. In: Nature 526 (2015), pp. 380-384.

[14927] V. Martin, E. Buffetaut, and V. Suteethorn. "A new genus of sauropod dinosaur from the Sao Khua Formation (Late Jurassic or Early Cretaceous) of northeastern Thailand". In: Compte Rendus de l'Academie des Sciences, Paris, série IIa 319 (1994), pp. 1085-1092. 
[14928] V. Martin, E. Buffetaut, and V. Suteethorn. "Jurassic sauropod dinosaurs of Thailand: a preliminary report". English. In: International Symposium on Biostratigraphy of Mainland Southeast Asia: Facies $\mathcal{E}$ Paleontology, 31 January-5 February 1993, Chang Mai, Thailand (1993), pp. 415-425.

[14929] V. Martin, J. Le Loeuff, and E. Buffetaut. "A sauropod dinosaur in the Middle Albian of Pargnysur-Saulx (Meuse, Eastern France)". English. In: Revue de Paleobiologie Spec.7 (1993), pp. 119-124.

[14930] E. Martin Suarez and M. Freudenthal. "Castromys, a new genus of Muridae (Rodentia) from the Late Miocene of Spain." English. In: Scripta Geologica 106 (1994), pp. 11-34.

[14931] E. Martn Suárez and M. Freudenthal. "Muridae (Rodentia) from the Lower Turolian of Crevillente (Alicante, Spain)". English. In: Scripta Geologica 103 (1993), pp. 65-118.

[14932] E. Martn Suárez, M. Freudenthal, and J. Agust. "Micromammals from the Middle Miocene of the Granada Basin (Spain)". English. In: Geobios 26.3 (1993), pp. 377-387.

[14933] A. Martn-Algarra, N. Solé de Porta, and A. Márquez Aliaga. "Nuevos datos sobre la estratigrafa, paleontologá y procedencia paleogeográfica del Triásico de las escamas del Corredor del Boyar (Cordillera Bética Occidental)". Spanish. In: Cuadernos de geologa ibérica [Journal of Iberian Geology] 19 (1995), pp. 279-307.

[14934] B. Martin-Garin, B. Lathuiliere, J. Geister, E. H. Chellai, and V. Huault. “Geology, facies model and coral associations of the Late Jurassic reef complex at Cape Ghir (Atlantic High Atlas, Morocco)". English. In: Comptes Rendus Geoscience 339 (2007), pp. 65-74.

[14935] L. Martin-Medrano and P. Garcia-Barrera. Fossil Ophiuroids of Mexico. English. Vol. 24. Topics in Geobiology. Dordrecht: Springer, 2006, pp. 115-131.

[14936] L. Martin-Medrano, B. Thuy, and P. Garcia-Barrera. "New Albian (Early Cretaceous) ophiuroids from Tlayua Quarry, Puebla, Mexico". English. In: Palaeontology 52.1 (2009), pp. 83-94.

[14937] V. Martin-Rolland. "Les sauropodes chinois [The Chinese sauropods]". French. In: Revue Paléobiologie, Genéve 18.1 (1999), pp. 287-315.

[14938] E. Martin-Silverstone, M. P. Witton, V. M. Arbour, and P. J. Currie. "A small azhdarchoid pterosaur from the latest Cretaceous, the age of flying giants". English. In: Royal Society Open Science 3 (2016), 160333:1-15.

[14939] E. Martn-Suárez, N. Bendala, and M. Freudenthal. “Archaeodesmana baetica, sp. nov. (Mammalia, Insectivora, Talpidae) from the Mio-Pliocene transition of the Granada Basin, southern Spain". English. In: Journal of Vertebrate Paleontology 21.3 (2001), pp. 547-554.

[14940] R. C. Martindale, D. J. Bottjer, and F. A. Corsetti. "Platy coral patch reefs from eastern Panthalassa (Nevada, USA): Unique reef construction in the Late Triassic". English. In: Palaeogeography, Palaeoclimatology, Palaeoecology 313-314 (2012), pp. 41-58.

[14941] W. Martindale. "Calcified epibionts as palaeoecological tools: examples from the Recent and Pleistocene reefs of Barbados". English. In: Coral Reefs 11 (1992), pp. 167-177.

[14942] A. Martinelli. "On the postcanine dentition of Pascualgnathus polanskii Bonaparte (Cynodontia, Traversodontidae) from the Middle Triassic of Argentina". English. In: Geobios (2010). DOI: 10. 1016/j.geobios.2010.03.006.

[14943] A. Martinelli, M. de la Fuente, and F. Abdala. "Diademodon tetragonus Seeley, 1894 (Therapsida: Cynodontia) in the Triassic of South America and its biostratigraphic implications". English. In: Journal of Vertebrate Paleontology 29.3 (2009), pp. 852-862.

[14944] A. Martinelli and A. M. Forasiepi. "Late Cretaceous vertebrates from Bajo de Santa Rosa (Allen Formation), Ro Negro province, Argentina, with the description of a new sauropod dinosaur (Titanosauridae)". English. In: Revista del Museo Argentino de Ciencias Naturales, nuevo serie 6.2 (2004), pp. 257-305.

[14945] A. G. Martinelli. "New cranial remains of the bizarre notosuchid Comahuesuchus brachybuccalis (Archosauria, Crocodyliformes) from the Late Cretaceous of Ro Negro Province (Argentina)". English. In: Ameghiniana 40.4 (2003), pp. 559-572. 
[14946] A. G. Martinelli, M. Bento Soares, and R. R. Schoch. “Owenettids and procolophonids from the lower Keuper shed new light on the diversity of parareptiles in the German Middle Triassic". English. In: Journal of Paleontology 90.1 (2016), pp. 92-101. DOI: 10.1017/jpa.2016.26.

[14947] A. G. Martinelli, S. Bogan, F. L. Angolin, L. C. B. Riberio, C. L. Cavellani, M. L. F. Ferraz, and V. P. A. Teixeira. "First fossil record of amiid fishes (Halecomorphi, Amiiformes, Amiidae) from the Late Cretaceous of Uberaba, Minas Gerais State, Brazil". English. In: Alcheringa 37 (2013), pp. 105-113.

[14948] A. G. Martinelli, J. F. Bonaparte, C. L. Schultz, and R. Rubert. "A new tritheledontid (Therapsida, Eucynodontia) from the Late Triassic of Rio Grande do Sul (Brazil) and its phylogenetic relationships among carnivorous non-mammalian eucynodonts". English. In: Ameghiniana 42.1 (2005), pp. 191-208.

[14949] A. G. Martinelli, T. da Silva Marinho, L. S. Filippi, L. C. B. Ribeiro, M. L. da Fonseca Ferraz, C. L. Cavellani, and V. de Paula Antunes Teixeira. "Cranial bones and atlas of titanosaurs (Dinosauria, Sauropoda) from Late Cretaceous (Bauru Group) of Uberaba, Minas Gerais State, Brazil”. English. In: Journal of South American Earth Sciences (2015). DOI: 10.1016/j.jsames.2015.02.009.

[14950] A. G. Martinelli, E. Eltink, A. A. S. Da-Rosa, and M. C. Langer. "A new cynodont from the Santa Maria Formation, South Brazil, improves Late Triassic probainognathian diversity". English. In: Papers in Palaeontology 3.3 (2017), pp. 401-423.

[14951] A. G. Martinelli, J. A. Escobar, H. Francischini, L. Kerber, R. T. Müller, R. Rubert, C. L. Schultz, and Á A. S. DaRosa. "New record of a stahleckeriid dicynodont (Therapsida, Dicynodontia) from the Late Triassic of southern Brazil and biostratigraphic remarks on the Riograndia Assemblage Zone". English. In: Historical Biology (2020). DOI: 10.1080/08912963.2020.1850715.

[14952] A. G. Martinelli, P. Fonseca Ferraz, G. Cardoso Cunha, and I. Cardoso Cunha. "First record of Eremotherium laurillardi (Lund, 1842) (Mammalia, Xenarthra, Megatheriidae) in the Quaternary of Uberaba, Triangulo Mineiro (Minas Gerais State), Brazil". English. In: Journal of South American Earth Sciences 37 (2012), pp. 202-207.

[14953] A. G. Martinelli, H. Francischini, P. C. Dentzien-Dias, M. Soares, and C. L. Schultz. "The oldest archosauromorph from South America: postcranial remains from the Guadalupian (mid-Permian) Rio do Rasto Formation (Paraná Basin), southern Brazil". English. In: Historical Biology 29.1 (2017), pp. 76-84. DOI: 10.1080/08912963.2015.1125897.

[14954] A. G. Martinelli, A. C. Garrido, A. M. Forasiepi, E. R. Paz, and Y. Gurovich. “Notes on fossil remains from the Early Cretaceous Lohan Cura Formation, Neuquén Province, Argentina". English. In: Gondwana Research 11 (2007), pp. 537-552.

[14955] A. G. Martinelli, C. F. Kammerer, T. P. Melo, V. D. Paes Neto, A. M. Ribeiro, A. A. S. Da-Rosa, C. L. Schultz, and M. B. Soares. "The African cynodont Aleodon (Cynodontia, Probainognathia) in the Triassic of southern Brazil and its biostratigraphic significance". English. In: PLoS ONE 12.6 (2017), e0177948. DOI: 10.1371/journal.pone.0177948.

[14956] A. G. Martinelli, T. S. Marinho, F. V. Iori, and L. C. B. Ribeiro. “The first Caipirasuchus (Mesoeucrocodylia, Notosuchia) from the Late Cretaceous of Minas Gerais, Brazil: new insights on sphagesaurid anatomy and taxonomy". English. In: PeerJ 6 (2018), e5594:1-70.

[14957] A. G. Martinelli and D. F. Pais. "A new baurusuchid crocodyliform (Archosauria) from the Late Cretaceous of Patagonia (Argentina)”. English. In: Comptes Rendus Palevol 7 (2008), pp. 371-381. DOI: 10.1016/j.crpv.2008.05.002.

[14958] A. G. Martinelli, D. Riff, and R. P. Lopes. "Discussion about the occurrence of the genus Aeolosaurus Powell 1987 (Dinosauria, Titanosauria) in the Upper Cretaceous of Brazil". English. In: Gaea - Journal of Geoscience 7.1 (2011), pp. 34-40.

[14959] A. G. Martinelli and G. W. Rougier. "On Chaliminia musteloides (Eucynodontia: Tritheledontidae) from the Late Triassic of Argentina, and a phylogeny of Ictidosauria". English. In: Journal of Vertebrate Paleontology 27 (2007), pp. 442-460. 
[14960] A. G. Martinelli, J. J. W. Sertich, A. C. Garrido, and A. M. Praderio. "A new peirosaurid from the Upper Cretaceous of Argentina: Implications for specimens referred to Peirosaurus torminni Price (Crocodyliformes: Peirosauridae)". English. In: Cretaceous Research 37 (2012), pp. 191-200.

[14961] A. G. Martinelli, M. B. Soares, and C. Schwanke. "Two New Cynodonts (Therapsida) from the Middle-Early Late Triassic of Brazil and Comments on South American Probainognathians". English. In: PLoS ONE 11.10 (2016), e0162945. DOI: 10.1371/journal.pone.0162945.

[14962] A. G. Martinelli and E. I. Vera. "Achillesaurus manzzonei, a new alvarezsaurid theropod (Dinosauria) from the Late Cretaceous Bajo de la Carpa Formation, Ro Negro Province, Argentina". English. In: Zootaxa 1582 (2007), pp. 1-17.

[14963] C. Martinez, M. A. Gandolfo, and N. R. Cuneo. "Angiosperm leaves and cuticles from the uppermost Cretaceous of Patagonia, biogeographic implications and atmospheric paleo-CO2 estimates". English. In: Cretaceous Research 89 (2018), pp. 107-118. DOI: 10.1016/j.cretres.2018.03.015.

[14964] J.-N. Martinez. Un fauna de mamiferos continentales del Pleistoceno Superior en el valle del rio Chira (Norte del Peru); datos preliminares. Spanish. 2001.

[14965] J.-N. Martinez and J. Jacay. Evolucion Sedimentologica y Paleontologica del paleodelta del Chira (Departamento de Piura) durante el Pleistoceno: Datos preliminares Sedimentologic and Paleontologic evolution of the paleodelta of the Chira (Piura department) during the Pleistocene: Preliminaries datum. Spanish. 2000.

[14966] P. Martnez. "Hallan en Argüero un nuevo yacimiento con tres rastros de huellas de dinosaurio [A new locality with three trackways of dinosaur footprints is found in Argüero]". Spanish. In: La Nueva España 78.25721 (2014), p. 16.

[14967] R. Martinez. "Chilean teenagers find trove of whale fossils". English. In: Reuters (2007).

[14968] R. Martnez and A. Grauges. "Nautlidos del Aptiense Inferior (Cretácico Inferior) de la Subcuenca de Oliete, Cordillera Ibérica oriental (Teruel, España)". Spanish. In: Revista Española de Paleontologa 21 (2006), pp. 15-27.

[14969] R. D. Martnez. “Notohypsilophodon comodorensis gen. et sp. nov. un Hypsilophodontidae (Ornitischia: Ornithopoda) del Cretácico Superior de Chubut, Patagonia central, Argentina [Notohypsilophodon comodorensis gen. et sp. nov., a Hypsilophodontidae (Ornithischia: Ornithopoda) from the Upper Cretaceous of Chubut, central Patagonia, Argentina]". Spanish. In: Acta Geologica Leopoldensia 21.46/47 (1998), pp. 119-135.

[14970] R. D. Martnez, O. Giménez, J. Rodrguez, M. Luna, and M. C. Lamanna. "An articulated specimen of the basal titanosaurian (Dinosauria: Sauropoda) Epachthosaurus sciuttoi from the early Late Cretaceous Bajo Barreal Formation of Chubut province, Argentina". English. In: Journal of Vertebrate Paleontology 24.1 (2004), pp. 107-120.

[14971] R. D. Martnez, F. E. Novas, and A. Ambrosio. "Abelisaurid remains (Theropoda, Ceratosauria) from southern Patagonia". English. In: Actas I del Congreso Ltinoamericano de Paleontologa de Vertebrados. Ameghiniana 41.4 (2004), pp. 577-585.

[14972] R. D. Martnez and F. E. Novas. "Aniksosaurus darwini gen. et sp. nov., a new coelurosaurian theropod from the early Late Cretaceous of central Patagonia, Argentina". English. In: Revista del Museo Argentino de Ciencias Naturales, nuevo serie 8.2 (2006), pp. 243-259.

[14973] R. D. F. Martnez, M. C. Lamanna, F. E. Novas, R. C. Ridgley, G. A. Casal, J. E. Martnez, J. R. Vita, and L. M. Witmer. "A basal lithostrotian titanosaur (Dinosauria: Sauropoda) with a complete skull: implications for the evolution and paleobiology of Titanosauria". English. In: PLoS ONE 11.4 (2016), e0151661:1-82.

[14974] R. N. Martnez. “Adeopapposaurus mognai, gen. et sp. nov. (Dinosauria: Sauropodomorpha), with comments on adaptations of basal Sauropodomorpha". English. In: Journal of Vertebrate Paleontology 29.1 (2009), pp. 142-164. DOI: 10.1671/039.029.0102.

[14975] R. N. Martnez and O. A. Alcober. "A basal sauropodomorph (Dinosauria: Saurischia) from the Ischigualasto Formation (Triassic, Carnian) and the early evolution of Sauropodomorpha". English. In: PLoS ONE 4.2 (e4397) (2009), pp. 1-12. DOI: 10.1371/journal.pone.0004397. 
[14976] R. N. Martnez, O. A. Alcober, and D. Pol. "A new protosuchid crocodyliform (Pseudosuchia, Crocodylomorpha) from the Norian Los Colorados Formation, northwestern Argentina". English. In: Journal of Vertebrate Paleontology 38.4 (2018), e1491047:1-12.

[14977] R. N. Martnez, C. Apaldetti, O. A. Alcober, C. E. Colombi, P. C. Sereno, E. Fernandez, P. Santi Malnis, G. A. Correa, and D. Abelin. "Vertebrate succession in the Ischigualasto Formation". English. In: vol. 32. Basal Sauropodomorphs and the Vertebrate Fossil Record of the Ischigualasto Formation (Late Triassic: Carnian-Norian) of Argentina. Society of Vertebrate Paleontology Memoir 12. Journal of Vertebrate Paleontology 6 (s1). 2013, pp. 10-30. DOI: 10.1080/02724634.2013.818546.

[14978] R. N. Martnez, C. Apaldetti, and D. Abelin. "Basal sauropodomorphs from the Ischigualasto Formation". English. In: vol. 32. Basal Sauropodomorphs and the Vertebrate Fossil Record of the Ischigualasto Formation (Late Triassic: Carnian-Norian) of Argentina. Society of Vertebrate Paleontology Memoir 12. Journal of Vertebrate Paleontology 6 (s1). Society of Vertebrate Paleontology, 2013, pp. 51-69. DOI: 10.1080/02724634.2013.819361.

[14979] R. N. Martinez, C. Apaldetti, C. E. Colombi, A. Praderio, E. Fernandez, P. S. Malnis, G. A. Correa, D. Abelin, and O. Alcober. "A new sphenodontian (Lepidosauria: Rhynchocephalia) from the Late Triassic of Argentina and the early origin of the herbivore opisthodontians". English. In: Proceedings of the Royal Society B 280.1772 (2013), pp. 20132057-1-20132057-7. DOI: 10.1098/ rspb. 2013.2057.

[14980] R. N. Martnez, C. Apaldetti, G. A. Correa, and D. Abeln. “A Norian lagerpetid dinosauromorph from the Quebrada del Barro Formation, northwestern Argentina". English. In: Ameghiniana 53.1 (2016), pp. 1-13. DOI: 10.5710/AMGH.21.06.2015.2894.

[14981] R. N. Martnez, C. Apaldetti, G. Correa, C. E. Colombi, E. Fernández, P. S. Malnis, A. Praderio, D. Abeln, L. G. Benegas, A. Aguilar-Cameo, and O. A. Alcober. "A new Late Triassic vertebrate assemblage from northwestern Argentina". English. In: Ameghiniana 52.4 (2015), pp. 379-390. DOI: 10.5710/AMGH.27.04.2015.2889.

[14982] R. N. Martinez and C. Apaldetti. "A late Norian-Rhaetian coelophysid neotheropod (Dinosauria, Saurischia) from the Quebrada del Barro Formation, northwestern Argentina". English. In: Ameghiniana 54.5 (2017), pp. 448-505. DOI: 10.5710/AMGH.09.04.2017.3065.

[14983] R. N. Martinez, E. Fernandez, and O. A. Alcober. "A new non-mammaliaform eucynodont from the Carnian-Norian Ischigualasto Formation, Northwestern Argentina". English. In: Revista Brasileira de Paleontologia 16.1 (2013), pp. 61-76. DOI: 10.4072/rbp.2013.1.05.

[14984] R. N. Martinez and C. A. Forster. "The skull of Probelesodon sanjuanensis, sp. nov., from the Late Triassic Ischigualasto Formation of Argentina". English. In: Journal of Vertebrate Paleontology 16.2 (1996), pp. 285-291.

[14985] R. N. Martinez, C. L. May, and C. A. Forster. “A new carnivorous cynodont from the Ischigualasto Formation (Late Triassic, Argentina), with comments on eucynodont phylogeny". English. In: Journal of Vertebrate Paleontology 16.2 (1996), pp. 271-284.

[14986] R. N. Martinez, P. C. Sereno, O. A. Alcober, C. E. Colombi, P. R. Renne, I. P. Montañez, and B. S. Currie. "A basal dinosaur from the dawn of the dinosaur era in southwestern Pangaea". English. In: Science 331.6014 (2011), pp. 206-210. DOI: 10.1126/science.1198467.

[14987] S. Martinez, C. J. del Rio, and D. E. Pérez. "A brittle star bed from the Miocene of Patagonia, Argentina". English. In: Lethaia 43 (2010), pp. 1-9.

[14988] S. Martinez, V. Reichler, and R. Mooi. "A New Species of Abertella (Echinoidea: Scutellina) from the Gran Bajo del Gualicho Formation (Late Early Miocene-Early Middle Miocene), Ro Negro Province, Argentina". English. In: Journal of Paleontology 79.6 (2005), pp. 1229-1233.

[14989] M. Martinez-Cáceres and C. Muizon. "A new basilosaurid (Cetacea, Pelagiceti) from the Late Eocene to Early Oligocene Otuma Formation of Peru". English. In: Comptes Rendus Palevol 10 (2011), pp. 517-526. 
[14990] X. Martnez-Delclós. "Insectos del Cretácico inferior de Santa Maria de Meiá (Lleida): colleción Llus Mariá Vidal i Carreras". Spanish. In: Treballs del Museu de Geologia de Barcelona 1 (1990), pp. $91-$ 116.

[14991] X. Martnez-Delclós. “Blátidos (Insecta, Blattodea) del Cretácico Inferior de España. Familias Mesoblattinidae, Blattulidae y Poliphagidae". Spanish. In: Boletn Geológico y Minero 104 (1993), pp. 516-538.

[14992] X. Martnez-Delclós, A. Nel, and Y. A. Popov. "Systematics and functional morphology of Iberonepa romerali n. gen. and sp., Belostomatidae from the Spanish Lower Cretaceous (Insecta, Heteroptera)". English. In: Journal of Paleontology 69 (1995), pp. 496-508.

[14993] X. Martnez-Delclós and A. Nel. "Los Gomphidae (Insecta, Odonata, Anisoptera) del Cretácico Inferior de España". Spanish. In: Revista Española de Paleontologa 9 (1994), pp. 176-184.

[14994] X. Martnez-Delclós and A. Nel. "Discovery of a new Protomyrmeleontidae in the Upper Jurassic from Germany (Odonatoptera: Archizygoptera)". English. In: Archaeopteryx 14 (1996), pp. 67-73.

[14995] J. L. Martnez-Daz, M. C. Aguillon-Martnez, J. Luque, and F. J. Vega. "Paleocene decapod Crustacea from northeastern Mexico: Additions to biostratigraphy and diversity". English. In: Journal of South American Earth Sciences 74 (2017), pp. 67-82. DOI: 10.1016/j.jsames.2017.01.005.

[14996] B. Martinez-Navarro. Revision sistematica de la fauna de macromamiferos del yacimiento de Venta Micena (Orce, Granada, Espana). Spanish. in Gibert, J. ed., Proyecto Orce-Cueva Victoria (1988-1992): Presencia humana en el Pleistoceno inferior de Granada y Murcia. Ayuntamiento de Orce, Granada, Spain. 1992, pp. 21-85.

[14997] B. Martinez-Navarro. “The skull of Orce: parietal bones or frontal bones?" In: Journal of Human Evolution 43 (2002), pp. 265-270.

[14998] B. Martinez-Navarro, M. Belmaker, and O. Bar-Yosef. "The large carnivores from 'Ubeidiya (early Pleistocene, Israel): biochronological and biogeographical implications". English. In: Journal of Human Evolution 56 (2009), pp. 514-524. DOI: 10.1016/j.jhevol.2009.02.004.

[14999] R. Martini, D. Vachard, L. Zaninetti, S. Cirilli, J. J. Cornee, B. Lathuiliere, and M. Villeneuve. "Sedimentology, stratigraphy, and micropalaeontology of the Upper Triassic reefal series in Eastern Sulawesi (Indonesia)". English. In: Palaeogeography, Palaeoclimatology, Palaeoecology 128 (1997), pp. 157-174.

[15000] R. Martini, L. Zaninetti, B. Lathuilliére, S. Cirilli, J. -J. Cornée, and M. Villeneuve. “Upper Triassic carbonate deposits of Seram (Indonesia): palaeogeographic and geodynamic implications". In: Palaeogeography, Palaeoclimatology, Palaeoecology 206.1-2 (2004), pp. 75-102.

[15001] A. W. Martinius and N. Molenaar. "A coral-mollusc (Goniaraea-Crassatella) dominated hardground community in a siliciclastic-carbonate sandstone (the lower Eocene Roda Formation, southern Pyrenees, Spain)". English. In: Palaios 6.2 (1991), pp. 142-155.

[15002] R. L. Martino. "Limnopus Trackways from the Conemaugh Group (Late Pennsylvanian), Southern West Virginia". English. In: Journal of Palentology 65.6 (1991), pp. 957-972.

[15003] R. G. Martins-Neto. “Um novo genero e duas novas espécies de Tridactylidae (Insecta, Orthopteridea) na Formação Santana (Cretáceo Inferior do nordeste do Brasil)". Portugese. In: Anais da Academia Brasileira de Ciencias 62 (1990), pp. 51-59.

[15004] R. G. Martins-Neto. “Neurópteros (Insecta, Planipennia) da Formação Santana (Cretáceo Inferior), Bacia do Araripe, nordeste do Brasil - IX - primeiros resultados da composição da fauna e descrição de novos táxons". Portugese. In: Acta Geologica Leopoldensia 17.39 (1994), pp. 269-288.

[15005] R. G. Martins-Neto. “New Mayflies (Insecta, Ephemeroptera) from the Santana Formation (Lower Cretaceous), Araripe Basin, Northeastern Brazil". English. In: Revista Española de Paleontologia 11 (1996), pp. 177-192.

[15006] R. G. Martins-Neto. "Novos registros de paleontindeos (Insecta, Hemiptera) na Formação Santana (Cretáceo Inferior), Bacia do Araripe, nordeste do Brasil". Portugese. In: Acta Geologica Leopoldensia 21.46/47 (1998), pp. 69-74. 
[15007] R. G. Martins-Neto. "A new genus of the family Locustopsidae (Insecta, Caelifera) in the Santana Formation (Lower Cretaceous, northeast Brazil)". English. In: Revista Española de Paleontologia 13 (1998), pp. 133-138.

[15008] R. G. Martins-Neto. “Conan barbarica n. gen. et n. sp. (Insecta, Coleoptera, Coptoclavidae) - uma gigantesca larva da Formação Santana, Bacia do Araripe (Cretáceo Inferior)". Portugese. In: Geociencias 17 (1998), pp. 109-114.

[15009] R. G. Martins-Neto. "New Orthoptera Stenopelmatoidea and Hagloidea (Ensifera) from the Santana Formation (Lower Cretaceous, Northeast Brazil) with description of new taxa". English. In: Gaea 3 (2007), pp. 3-8.

[15010] R. G. Martins-Neto. "Systematics of the Caelifera (Insecta, Orthopteroidea) from the Santana Formation, Araripe Basin (Lower Cretaceous, northeast Brazil), with a description of new genera and species". English. In: Acta Zoologica Cracoviensia 46.Suppl (2003), pp. 205-228.

[15011] R. G. Martins-Neto. “New Neuroptera from Crato Formation, Lower Cretaceous, Araripe Basin, northeast Brazil". English. In: Gaea 1 (2005), pp. 5-10.

[15012] R. G. Martins-Neto. "A New Subfamily of Ensifera (Insecta, Grylloidea) from the Santana Formation (Lower Cretaceous), Araripe Basin, NE Brazil". English. In: Proceedings of the First International Palaeoentomological Conference (1999), pp. 91-97.

[15013] R. G. Martins-Neto. “Neurópteros (Insecta, Planipennia) da Formação Santana (Cretáceo Inferior) Bacia do Araripe, Nordeste do Brasil. VI - Ensaio filogenético das espécies do genero Blittersdorffia Martins-Neto and Vulcano, com descrição de nova espécie". Portugese. In: Acta Geologica Leopoldensia 13.31 (1990), pp. 3-12.

[15014] R. G. Martins-Neto. “Complementos ao estudo sobre os Ensifera (Insecta, Orthopteroidea) da Formação Santana, Cretáceo Inferior do nordeste do Brasil". Portugese. In: Revista Brasileira de Entomologia 39 (1995), pp. 321-345.

[15015] R. G. Martins-Neto. "Araripelocustidae, fam. n. uma nova famlia de gafanhotos (Insecta, Caelifera) da Formação Santana, Cretáceo Inferior do Nordeste do Brasil". Portugese. In: Revista Brasileira de Entomologia 39 (1995), pp. 311-319.

[15016] R. G. Martins-Neto. "Primeiro registro de Dermaptera (Insecta, Orthopteromorpha) na Formação Santana (Cretáceo Inferior), Bacia do Araripe, nordeste do Brasil". Portugese. In: Revista Brasileira de Entomologia 34 (1990), pp. 775-784.

[15017] R. G. Martins-Neto. “A Paleoentomofauna da Formação Tremembé (Bacia de Taubaté) Oligoceno do Estado de São Paulo: novos Hemiptera, Hymenoptera, Coleoptera, Auchenorrhyncha e Lepidoptera". Portugese. In: Revista Universidade Guarulhos - Série Geociencias 3.6 (1998), pp. 58-70.

[15018] R. G. Martins-Neto. “Dpteros (Insecta) da Formação Tremembé, Bacia de Taubaté, Oligoceno do Estado de São Paulo. III - Famlia Tabanidae". Portugese. In: Acta Geologica Leopoldensia 20.44 (1997), pp. 51-57.

[15019] R. G. Martins-Neto. “A paleoentomofauna da Formação Tremembé (Bacia do Taubaté), Oligoceno do Estado de São Paulo: descripção de novos lepidópteros (Insecta)". Portugese. In: Acta Geologica Leopoldensia 21.46/47 (1998), pp. 75-82.

[15020] R. G. Martins-Neto. "Review of some Insecta from Mesozoic and Cenozoic Brazilian deposits with descriptions of new taxa". English. In: Acta Geologica Leopoldensia 24.52/53 (2001), pp. 115-124.

[15021] R. G. Martins-Neto. “Neurópteros (Insecta, Planipennia) da Formação Santana (Cretáceo Inferior), Bacia do Araripe, Nordeste do Brasil. X - descrição de novos táxons (Chrysopidae, Babinskaiidae, Myrmeleontidae, Ascalaphiidae e Psychopsidae)". Portugese. In: Revista da Universidade de Guarulhos, Ciencias Exatas e Tecnológicas 2.4 (1997), pp. 68-83.

[15022] R. G. Martins-Neto. “Neurópteros (Insecta, Planipennia) da Formação Santana (Cretáceo Inferior), Bacia do Araripe, Nordeste do Brasil - XI - descrição de novos táxons de Myrmeleontidae (Palaeoleontinae e Pseudonymphinae)". Portugese. In: Revista da Universidade de Guarulhos, Ciencias Biológicas e da Saúde 3.5 (1998), pp. 38-42. 
[15023] R. G. Martins-Neto. “New genus and new species of Lepidoptera (Insecta, Eolepidopterigidae) from Santana Formation (Lower Cretaceous, northeast Brazil)". English. In: Boletim do 5 Simposio sobre o Cretaceo do Brasil (1999), pp. 531-535.

[15024] R. G. Martins-Neto. “The Santana Formation paleoentomofauna reviewed. Part 1 - Neuropteroida (Neuroptera and Raphidioptera): systematic and phylogeny, with description of new taxa". English. In: Acta Geologica Lepolodensia 25.55 (2002), pp. 35-66.

[15025] R. G. Martins-Neto. “A paleoentomofauna da formação Tremembé (Bacia de Taubaté) Oligoceno do estado de São Paulo: descrição de novos hempteros (Insecta)". Portugese. In: Revista Universidade Guarulhos - Geociencias 2.6 (1997), pp. 66-69.

[15026] R. G. Martins-Neto. "The family Locustopsidae (Insecta, Caelifera) in the Santana Formation (Lower Cretaceous, northeast Brazil). I - description of two new species of the genus Locustopsis Handlirsch and three new species of the genus Zessinia n. gen." English. In: I Simpósio Sobre a Bacia do Araripe e Bacias Interiores do Nordeste. 1990, pp. 277-291.

[15027] R. G. Martins-Neto. "New Baissogryllidae and Gryllidae (Insecta, Ensifera) from Santana Formation, Araripe Basin (Lower Cretaceous, northeast Brazil)". English. In: Historia Natural (Segunda Serie) 1.6 (2002), pp. 31-35.

[15028] R. G. Martins-Neto, C. Brauckmann, O. F. Gallego, and M. J. Carmona. “The Triassic insect fauna from Argentina. - Blattoptera, Glosselytrodea, Miomoptera, Auchenorrhyncha, and Coleoptera from the Los Rastros Formation (Bermejo Basin), Los Chañares locality (La Rioja Province)". English. In: Clausthaler Geowissenschaften 5 (2006), pp. 1-9.

[15029] R. G. Martins-Neto and E. B. Caldas. "Sobre a ocorrencia de Latiscutella santosi Pinto e Ornellas 1974 (Insecta, Heteroptera) na Formação Santana, Cretáceo Inferior do nordeste do Brasil”. Portugese. In: Acta Geologica Leopoldensia 17.39 (1994), pp. 263-268.

[15030] R. G. Martins-Neto and E. B. Caldas. “Efemeras escavadoras (Insecta, Ephemeroptera, Ephemeropidea) na Formaçáo Santana (Cretáceo inferior), bacia do Araripe Nordeste do Brasil: descriçáo de tres novos generos e trees novas espécies (ninfas)". Portugese. In: I Simpósio Sobre a Bacia do Araripe e Bacias Interiores do Nordeste (1990), pp. 265-275.

[15031] R. G. Martins-Neto, C. de Oliveira Assis, and L. V. Tassi. “New Blattoptera from Early Cretaceous of Santana Formation (Araripe Basin, NE Brazil) and a review of Arariplebatta Mendes, 2000". English. In: Gaea 6.1 (2010), pp. 9-13.

[15032] R. G. Martins-Neto, O. F. Gallego, and A. M. Zavattieri. "A new Triassic insect fauna from Cerro Bayo, Potrerillos (Mendoza Province, Argentina) with descriptions of new taxa (Insecta: Blattoptera and Coleoptera)". English. In: Alcheringa 31 (2007), pp. 199-213. DOI: 10.1080/03115510701305173.

[15033] R. G. Martins-Neto, O. F. Gallego, and R. N. Melchor. “The Triassic insect fauna from South America (Argentina, Brazil and Chile): a checklist (except Blattoptera and Coleoptera) and descriptions of new taxa". English. In: Acta Zoologica Cracoviensia 46.Suppl (2003), pp. 229-256.

[15034] R. G. Martins-Neto, O. F. Gallego, and A. M. Zavattieri. “The Triassic insect fauna from Argentina: Coleoptera, Hemiptera and Orthoptera from the Potrerillos Formation, south of cerro Cacheuta, Cuyana basin". English. In: Alavesia 2 (2008), pp. 47-58.

[15035] R. G. Martins-Neto, O. F. Gallego, and A. C. Mancuso. "The Triassic insect fauna from Argentina. Coleoptera from the Los Rastros Formation (Bermejo Basin), La Rioja Province". English. In: Ameghiniana 43.3 (2006), pp. 1-20.

[15036] R. G. Martins-Neto and O. F. Gallego. "Review of Dysmorphoptilidae Handlirsch (Hemiptera: Cicadomorpha) from the Argentinean Triassic, with description of a new subfamily, and a new species". English. In: Polish Journal of Entomology 75 (2006), pp. 185-197.

[15037] R. G. Martins-Neto, O. F. Gallego, C. Brauckmann, and J. L. Cruz. "A review of the South American Palaeozoic entomofauna part I: the Ischnoneuroidea and Cacurgoidea, with description of new taxa". English. In: African Invertebrates 48 (2007), pp. 87-101. 
[15038] R. G. Martins-Neto and O. F. Gallego. "The Triassic insect fauna from Argentina. Blattoptera and Coleoptera from the Ischichuca Formation (Bermejo Basin), La Rioja Province". English. In: Ameghiniana 46 (2009), pp. 361-372.

[15039] R. G. Martins-Neto and O. F. Gallego. "The Triassic insect fauna from Argentina. IV. Glosselytrodea and complements on Auchenorrhyncha". English. In: Acta Geologica Leopoldensia 24.52/53 (2001), pp. 105-114.

[15040] R. G. Martins-Neto and J. C. Kucera-Santos. “Um novo genero e nova espécie de mutuca (Insecta, Diptera, Tabanidae) da Formação Santana (Cretáceo Inferior), Bacia do Araripe, Nordeste do Brasil". Portugese. In: Acta Geologica Leopoldensia 17.39 (1994), pp. 289-297.

[15041] R. G. Martins-Neto, J. C. Kucera-Santos, F. R. M. Vieira, and L. M. C. Fragoso. "Nova espécie de borboleta (Lepidoptera: Nymphalidae: Satirynae) da Formação Tremembé, Oligoceno do Estado de São Paulo". Portugese. In: Acta Geologica Leopoldensia 16.37 (1993), pp. 5-15.

[15042] R. G. Martins-Neto, A. Mancuso, and O. F. Gallego. “The Triassic Insect Fauna from Argentina. Blattoptera from the Los Rastros Formation (Bermejo Basin), La Rioja Province". English. In: Ameghiniana 42.4 (2005), pp. 1-21.

[15043] R. G. Martins-Neto, A. C. Melo, and F. Prezoto. "A new species of wasp (Symphyta, Sepulcidae) from the Santana Formation (Lower Cretaceous, Northeast Brazil)". English. In: Journal of the Entomological Research Society 9 (2007), pp. 1-6.

[15044] R. G. Martins-Neto and M. Mendes. "The Fonseca Formation paleoentomofauna (Fonseca Basin, Oligocene of Minas Gerais state, Brazil) with description of new taxa". English. In: Acta Geologica Leopoldensia 25.55 (2002), pp. 27-33.

[15045] R. G. Martins-Neto and A. Nel. “Un nouveau fossile de Raphidioptére de la formation Santana, Crétacé inférieur du Brésil (Neuropteroidea, Raphidioptera)". French. In: Bulletin de la Société Entomologique de France 97 (1993), pp. 425-428.

[15046] R. G. Martins-Neto and M. Pesenti. “The first fossil Termitidae (Isoptera) from the Oligocene of South America: the Entre-Córregos Formation of the Aiuruoca Basin, Minas Gerais, Brazil". English. In: Journal of the Entomological Research Society 8.3 (2006), pp. 63-68.

[15047] R. G. Martins-Neto, C. Ribeiro-Júnior, and F. Prezoto. “New fossils (Isoptera: Hodotermitidae), from the Santana Formation (Lower Cretaceous, Araripe Basin, northeast Brazil), with descriptions of new taxa including a new subfamily". English. In: Sociobiology 47 (2006), pp. 125-134.

[15048] R. G. Martins-Neto and V. Z. Rodrigues. “New Neuroptera (Insecta, Osmylidae and Mesochrysopidae) from the Santana Formation, Lower Cretaceous of northeast Brazil”. English. In: Gaea 5.1 (2009), pp. 15-20.

[15049] R. G. Martins-Neto and V. Z. Rodrigues. "New neuropteran insects (Osmylidae, Palaeoleontidae, Araripeneuridae and Psychopsidae) from the Santana Formation, Early Cretaceous NE Brazil". English. In: Gaea 6 (2010), pp. 1-8.

[15050] R. G. Martins-Neto and R. Rohn. "Primeiro registro de inseto na Formação Rio do Rasto, Bacia do Paraná, com descrição de novo táxon". Portugese. In: Geociencias 15 (1996), pp. 243-251.

[15051] R. G. Martins-Neto and L. V. Tassi. "The Orthoptera (Ensifera) from the Santana formation (Early Cretaceous, northeast Brazil): A statistical and paleoecological approach, with description of new taxa". English. In: Zootaxa 2080 (2009), pp. 21-37.

[15052] R. G. Martins-Neto and M. A. Vulcano. “Primeiro registro de Raphidioptera (Neuropteroidea) na Formação Santana (Cretáceo Inferior), Bacia do Araripe, nordeste do Brasil". Portugese. In: Revista Brasileira de Entomologia 34 (1990), pp. 241-249.

[15053] R. G. Martins-Neto and M. A. Vulcano. “Neurópteros (Insecta, Planipennia) da Formação Santana (Cretáceo Inferior), Bacia do Araripe, nordeste do Brasil. III. Superfamlia Mantispoidea". Portugese. In: Revista Brasileira de Entomologia 34 (1990), pp. 619-625. 
[15054] R. G. Martins-Neto and M. A. Vulcano. “Neurópteros (Insecta, Planipennia) da Formação Santana (Cretáceo Inferior), Bacia do Araripe, Nordeste do Brasil. VIII - descrição de novos taxa de Myrmeleontidae, Ascalaphidae e Nemopteridadae". Portugese. In: Revista da Universidade de Guarulhos, Ciencias Biológicas e da Saúde 2.5 (1997), pp. 64-81.

[15055] D. Marty, J. Ayer, D. Becker, J. -P. Berger, J. -P. Billon-Bruyat, L. Braillard, W. A. Hug, and C. A. Meyer. "Late Jurassic dinosaur tracksites of the Transjurane highway (Canton Jura, NW Switzerland): overview and measures for their protection and valorisation". English. In: Bulletin für Angewandte Geologie 12.1 (2007), pp. 75-89.

[15056] D. Marty, M. Belvedere, C. A. Meyer, P. Mietto, G. Paratte, C. Lovis, and B. Thüring. "Comparative analysis of Late Jurassic sauropod trackways from the Jura Mountains (NW Switzerland) and the central High Atlas Mountains (Morocco): implications for sauropod ichnotaxonomy". English. In: Historical Biology 22.1-3 (2010), pp. 109-133. DOI: 10.1080/08912960903503345.

[15057] D. Marty, W. A. Hug, A. Iberg, L. Cavin, C. A. Meyer, and M. G. Lockley. "Preliminary report on the Courtedoux dinosaur tracksite from the Kimmeridgian of Switzerland". English. In: Ichnos 10.2 (2003), pp. 209-219.

[15058] D. Marty and C. A. Meyer. From sauropods to cycads— the Late Jurassic terrestrial record of the Swiss Jura Mountains. English. 2012.

[15059] D. Marty, C. A. Meyer, M. Belvedere, J. Ayer, and K. L. Schäfer. "Rochefort-Les Grattes: an Early Tithonian dinosaur tracksite from the Canton Neuchatel, Switzerland". English. In: Revue de Paléobiologie 32.2 (2013), pp. 373-384.

[15060] K. V. Martynova, M. Olmi, P. Müller, and E. E. Perkovsky. "Description of the first sclerogibbid wasp (Hymenoptera: Sclerogibbidae) from Burmese (Myanmar) amber and its phylogenetic significance". English. In: Journal of Systematic Palaeontology 17 (2019), pp. 1571-1583. DOI: 10.1080 / 14772019.2018.1551250.

[15061] K. V. Martynova and E. E. Perkovsky. “Two new genera of cuckoo wasps (Chrysididae: Amiseginae) from Rovno and Baltic ambers". English. In: Paleontological Journal 51 (2017), pp. 382-390.

[15062] K. V. Martynova, E. E. Perkovsky, M. Olmi, and D. V. Vasilenko. "New records of Upper Eocene chrysidoid wasps (Hymenoptera: Chrysidoidea) from basins of Styr and Stokhod rivers (Rovno amber)". English. In: Paleontological Journal 53 (2019), pp. 998-1023. DOI: 10.1134/S0031030119100125.

[15063] K. V. Martynova, Q. Zhang, M. Olmi, P. Müller, and E. E. Perkovsky. "Revision of the genus Dryinus Latreille (Hymenoptera: Dryinidae) from mid-Cretaceous Kachin (Myanmar) amber". English. In: Cretaceous Research 106.104217 (2019). DOI: 10.1016/j.cretres.2019.104217.

[15064] J. W. Martz. “Lithostratigraphy, chemostratigraphy, and vertebrate biostratigraphy of the Dockum Group (Upper Triassic), of southern Garza County, West Texas. Unpublished PhD thesis, Texas Tech University". English. PhD thesis. 2008, pp. 1-504.

[15065] J. W. Martz and B. J. Small. "Tecovasuchus chatterjeei, a new aetosaur (Archosauria: Stagonolepididae) from the Tecovas Formation (Carnian, Upper Triassic) of Texas". English. In: Journal of Vertebrate Paleontology 26.2 (2006), pp. 308-320.

[15066] J. W. Martz and B. J. Small. “Non-dinosaurian dinosauromorphs from the Chinle Formation (Upper Triassic) of the Eagle Basin, northern Colorado: Dromomeron romeri (Lagerpetidae) and a new taxon, Kwanasaurus williamparkeri (Silesauridae)". English. In: PeerJ 7 (2019), e7551:1-71. DOI: $10.7717 /$ peerj.7551.

[15067] Y. M. Marusik and D. Penney. "A survey of Baltic amber Theridiidae (Araneae) inclusions, with descriptions of six new species". English. In: Arthropoda Selecta, Special Issue 1 (2004), pp. 201-208.

[15068] Y. M. Marusik, E. E. Perkovsky, and K. Y. Eskov. "First records of spiders (Arachnida: Aranei) from Sakhalinian amber with description of a new species of the genus Orchestina Simon, 1890". English. In: Far Eastern Entomologist 367 (2018), pp. 1-9.

[15069] F. G. Marx, M. E. J. Bosselaers, and S. Louwye. "A new species of Metopocetus (Cetacea, Mysticeti, Cetotheriidae) from the Late Miocene of the Netherlands". English. In: PeerJ 4 (2016), e1572. DOI: $10.7717 /$ peerj.1572. 
[15070] F. G. Marx, M. R. Buono, A. R. Evans, R. E. Fordyce, M. Reguero, and D. P. Hocking. “Gigantic mysticete predators roamed the Eocene Southern Ocean". English. In: Antarctic Science 31.2 (2019), pp. 98-104. DOI: 10.1017/S095410201800055X.

[15071] F. G. Marx, A. Collareta, A. Gioncada, K. Post, O. Lambert, E. Bonaccorsi, M. Urbina, and G. Bianucci. "How whales used to filter: exceptionally preserved baleen in a Miocene cetotheriid". English. In: Journal of Anatomy (2017). DOI: 10.1111/joa.12622.

[15072] F. G. Marx, E. M. G. Fitzgerald, and R. E. Fordyce. "Like phoenix from the ashes: How modern baleen whales arose from a fossil dark age". English. In: Acta Palaeontologica Polonica 64.2 (2019), pp. 231-238. DOI: 10.4202/app.00575.2018.

[15073] F. G. Marx and R. E. Fordyce. "Baleen boom and bust: a synthesis of mysticete phylogeny, diversity and disparity". English. In: Royal Society Open Science 2 (2015), p. 140434. DOI: 10.1098/rsos.140434.

[15074] F. G. Marx and N. Kohno. "A new Miocene baleen whale from the Peruvian desert". English. In: Royal Society Open Science 3.10 (2016), p. 160542.

[15075] F. G. Marx, O. Lambert, and C. de Muizon. "A new Miocene baleen whale from Peru deciphers the dawn of cetotheriids". English. In: Royal Society Open Science 4 (2017), p. 170560. DOI: 10.1098/ rsos.170560.

[15076] F. G. Marx, T. Park, E. M. G. Fitzgerald, and A. R. Evans. "A Miocene pygmy right whale fossil from Australia". English. In: PeerJ 6 (2018), e5025. DOI: 10.7717/peerj.5025.

[15077] F. G. Marx, K. Post, M. Bosselaers, and D. K. Munsterman. "A large Late Miocene cetotheriid (Cetacea, Mysticeti) from the Netherlands clarifies the status of Tranatocetidae". English. In: PeerJ 7 (2019), e6426. DOI: 10.7717 / peerj.6426.

[15078] F. G. Marx, C.-H. Tsai, and R. E. Fordyce. "A new Early Oligocene toothed 'baleen' whale (Mysticeti: Aetiocetidae) from western North America: one of the oldest and the smallest". English. In: Royal Society Open Science 2.12 (2015), p. 150476. DOI: 10.1098/rsos.150476.

[15079] T. Maryanska and M. A. Shishkin. "New cyclotosaurid (Amphibia: Temnospondyli) from the Middle Triassic of Poland and some problems of interrelationships of capitosauroids". English. In: Prace Muzeum Ziemi 43 (1996), pp. 53-83.

[15080] M. Marzola, O. Mateus, N. H. Shubin, and L. B. Clemmensen. “Cyclotosaurus naraserluki, sp. nov., a new Late Triassic cyclotosaurid (Amphibia, Temnospondyli) from the Fleming Fjord Formation of the Jameson Land Basin (East Greenland)". English. In: Journal of Vertebrate Paleontology 37.2 (2017), e1303501. DOI: 10.1080/02724634.2017.1303501.

[15081] G. Mas. “Comunicació preliminar sobre la freqüéncia de grans Cetacis (Mammalia) al Pliocé mitjá - superior de la conca sedimentária de Palma (Illes Balears). Implicacions paleoambientals". Portugese. In: Soc. Hist. Nat. Balears (2004), pp. 63-67.

[15082] G. Mas and M. T. Antunes. "Preséncia de Tomistoma cf. lusitanica (Vianna i Moraes, 1945) (Reptilia: Crocodylia) al Burdigaliá inferior de Mallorca (Illes Balears, Mediterránia occidental). Implicacions paleoambientals". Spanish. In: Bollet de la Societat d'História Natural de les Balears 51 (2014), pp. 131-146.

[15083] G. Mas, M. Bisconti, E. Torres-Roig, J. Juárez, and J. Sacarés. “L'última balena del Messiniá. Primera cita d'un cetaci misticet relacionat amb la Crisi de Salinitat Messiniana de la Mediterránia". Spanish. In: Jornades de Medi Ambient de les Illes Balears VII.3 (2018), pp. 112-115.

[15084] G. Mas, A. Maillard, J. A. Alcover, J. J. Fornos, P. Bover, and E. Torres-Roig. “Terrestrial colonization of the Balearic Islands: New evidence". English. In: Geological Society America Bulletin 46.6 (2018), pp. 527-530. DOI: 10.1130/G40260.1.

[15085] E. N. Maschenko and A. V. Lopatin. "First record of an Early Cretaceous triconodont mammal from Siberia". English. In: Bulletin de l'Institute Royal des Sciences Naturelles de Belgique, Sciences de la Terre 68 (1998), pp. 233-236.

[15086] E. N. Maschenko and A. V. Lopatin. "A new Early Cretaceous mammal from Western Siberia". English. In: Doklady Biological Sciences 386 (2002), pp. 475-477. 
[15087] Y. Mashimo, P. Müller, H. Pohl, and R. G. Beutel. “The hairy beast - Zorotypus hirsutus sp. n., an unusual new species of Zoraptera (Insecta) from Burmese amber". English. In: Zootaxa 4508 (2018), pp. 562-568.

[15088] Y. Mashimo, P. Müller, and R. G. Beutel. “Zorotypus pecten, a new species of Zoraptera (Insecta) from mid-Cretaceous Burmese amber". English. In: Zootaxa 4651 (2019), pp. 565-577.

[15089] F. Masini, T. Giannini, L. Abbazzi, F. Fanfani, M. Delfino, L. C. Maul, and D. Torre. "A latest Biharian small vertebrate fauna from the lacustrine succession of San Lorenzo (Sant'Arcangelo Basin, Basilicata, Italy)". In: Quaternary International 131 (2005), pp. 79-93.

[15090] L. Masner, N. F. Johnson, and A. D. Polaszek. "Redescription of Archaeoscelio Brues and description of three new genera of Scelionidae (Hymenoptera): a challenge to the definition of the family". English. In: American Museum Novitates 3550 (2007), pp. 1-24.

[15091] M. Masrour, L. Ladel, and F. Pérez-Lorente. "New theropod and prosauropod ichnites from Issiln-Aït Arbi (Lower Jurassic, Central High Atlas, Morocco)". English. In: Geogaceta 57 (2015), pp. 5558.

[15092] M. Masrour, F. Pérez-Lorente, S. Ferry, N. Içame, and D. Grosheny. "First dinosaur tracks from the Lower Cretaceous of the western High Atlas". English. In: Geogaceta 53 (2013), pp. 33-36.

[15093] J. A. Massare and J. M. Callaway. “Cymbospondylus (Ichthyosauria: Shastasauridae) from the Lower Triassic Thaynes Formation of southeastern Idaho". English. In: Journal of Vertebrate Paleontology 14.1 (1994), pp. 139-141.

[15094] J. A. Massare and D. R. Lomax. "An Ichthyosaurus breviceps collected by Mary Anning: new information on the species". English. In: Geological magazine (2013), pp. 1-8. DOI: 10.1017/S0016756813000241.

[15095] J. A. Massare and H. A. Young. "Gastric contents of an ichthyosaur from the Sundance Formation (Jurassic) of Central Wyoming". English. In: Paludicola 5.1 (2005), pp. 20-27.

[15096] F. Massari, C. Neri, P. Pittau, D. Fontana, and C. Stefani. "Sedimentology, palynostratigraphy and sequence stratigraphy of a continental to shallow-marine rift-related succession: Upper Permian of the eastern Southern Alps (Italy)". In: Mem. Sci. Geol. 46 (1994), pp. 119-234.

[15097] J.-P. Masse, M. Gallo Maresca, and E. Luperto Sinni. Albian rudist faunas from southern Italy: taxonomic, biostratigraphic, and palaeobiogeographic aspects. 1998.

[15098] J. P. Masse. "Systématique, stratigraphie et paléobiogéographie du genre Lovetchenia (Requieniidae) du Crétacé inférieur méditerranéen. [Taxonomy, stratigraphy and palaeobiogeography of the Lovetehenia genus (Requieniidae) from the Mediterranean Early Cretaceous]". French. In: Geobios 26.6 (1993), pp. 699-708.

[15099] J. P. Masse, J. Beltramo, J. Martinez-Reyes, and A. Arnaud-Vanneau. Revision of Albian polyconitid and monopleurid rudist bivalves from the New World. English. Vol. 87. Cretaceous rudists and carbonate platforms: environmental feedback, SEPM Special Publication. 2007, pp. 221-230.

[15100] J. P. Masse, J. Borgomano, and S. Al Maskiry. "A platform-to-basin transition for lower Aptian carbonates (Shuaiba Formation) of the northeastern Jebel Akhdar (Sultanate of Oman)". English. In: Sedimentary Geology 119 (1998), pp. 297-309.

[15101] J. P. Masse, A. Chartrousse, and J. Borgomano. “The Lower Cretaceous (Upper Barremian-Lower Aptian) caprinid rudists from Northern Oman". English. In: Géobios 22 (1998), pp. 211-223.

[15102] J. P. Masse, M. Fenerci-Masse, and S. Ozer. "Late Aprian rudist faunas from the Zonguldak region, western Black Sea, Turkey (taxonomy, biostratigraphy, palaeoenvironment and palaeobiogeography)". In: Cretaceous Research 23 (2002), pp. 523-536.

[15103] J. P. Masse, M. Fenerci-Masse, T. Korbar, and I. Velic. “Lower Aptian rudist faunas (Bivalvia, Hippuritoidea) from Croatia". English. In: Geologia Croatica 57.2 (2004), pp. 117-137.

[15104] J. P. Masse and M. Fenerci-Masse. "Debrunia, a new Barremian genus of petalodontid Monopleuridae (Bivalvia, Hippuritoidea) from the Mediterranean region". English. In: Palaeontology 52.6 (2009), pp. 1363-1372. 
[15105] J. P. Masse, C. Gourrat, D. Orbette, and D. Schmuck. "Hauterivian rudist faunas of southern Jura (France)". English. In: Geobios, Memoire Special 22 (1998), pp. 225-233.

[15106] J. P. Masse, E. Morycowa, and M. Fenerci-Masse. "Valanginian-Hauterivian scleractinian coral communities from the Marseille region (SE France)". English. In: Cretaceous Research 30 (2009), pp. 178-192.

[15107] J. P. Masse and E. Morycowa. “Les scleractiniaires hydnophoroides du Cretace inferieur (BarremienAptien inferieur) de Provence (S.E. de la France), systematique, stratigraphie et paleobiogeographie [Early Cretaceous (Barremian-Early Aptian) hydnophoroid Scleractinia from Provence (S.E. France), systematic paleontology, stratigraphy and paleobiogeography]". French. In: Geobios 27.4 (1994), pp. 433-448.

[15108] J. P. Masse and A. Uchman. "New biostratigraphic data on the Early Cretaceous platform carbonates of the Tatra Mountains, Western Carpathians, Poland". English. In: Cretaceous Research 18 (1997), pp. 713-729.

[15109] J.-P. Masse, J. Borgomano, and S. Al Maskiry. "Stratigraphy and tectonosedimentary evolution of a late Aptian-Albian carbonate margin: the northeastern Jebel Akhdar (Sultanate of Oman)". In: Sedimentary Geology 113 (1997), pp. 269-280.

[15110] G. Masselot and A. Nel. "Pseudokageronia thomasi gen. nov., sp. nov. from the Upper Miocene of Murat (France) [Ephemeroptera: Heptageniidae]". English. In: Ephemera 1 (1999), pp. 61-73.

[15111] M. Masseti. "Deer and dwarf elephants of the Dodecanese. The Holocene redefinition of the faunal ecosystems of Rhodes and other nearby islands". English. In: Conservation and presentation of the cultural and natural heritage of the large islands of the Mediterranean. Proceedings of the International Symposium, Rhodes, 2005. Ministry of Culture, Archaeological Institute of Aegean Studies. Athens: Foundation Anastasios G. Leventis, 2006, pp. 113-122.

[15112] T. Massonne, D. Vasilyan, M. Rabi, and M. Böhme. "A new alligatoroid from the Eocene of Vietnam highlights an extinct Asian clade independent from extant Alligator sinensis". English. In: PeerJ 7 (2019), e7562:1-60. DOI: 10.7717/ peerj.7562.

[15113] A. Mastandrea, F. Muto, C. Neri, C. A. Papazzoni, E. Perri, and F. Russo. “Deep-water coral banks: an example from the Calcare di Mendicino (Upper Miocene, Northern Calabria, Italy)". English. In: Facies 47 (2002), pp. 27-42.

[15114] A. Mastandrea and F. Russo. "Microstructure and Diagenesis of Calcified Demosponges from the Upper Triassic of the Northeastern Dolomites (Italy)". In: Journal of Paleontology 69.3 (1995), pp. 416-431.

[15115] B. Mastrantonio and C. Schultz. "The braincase of Prestosuchus chiniquensis (Archosauria: Suchia)". English. In: Geological Society Special Publications 379 (2013), pp. 425-440.

[15116] N. J. Mateer, P. Wycisk, L. L. Jacobs, M. Brunet, P. Luger, M. A. Arush, F. Hendriks, T. WEissbrod, G. Gvirtzman, E. Mbede, A. Dina, R. T. J. Moody, G. Weigelt, H. A. El-Nakhal, J. Hell, and J. Stets. "Correlation of nonmarine Cretaceous strata of Africa and the Middle East". In: Cretaceous Research 13 (1992), pp. 273-318.

[15117] I. Mateus, H. Mateus, M. T. Antunes, O. Mateus, P. Taquet, V. Ribeiro, and G. Manuppella. “Couvée, oeufs et embryons d'un Dinosaure Théropode du Jurassique supérieur de Lourinhã (Portugal)". French. In: Comptes Rendus de l'Académie des Sciences á Paris, Sciences de la Terre et des Planétes 325 (1997), pp. 65-70.

[15118] O. Mateus. "Lourinhanosaurus antunesi, a new Upper Jurassic allosauroid (Dinosauria: Theropoda) from Lourinhã, Portugal”. English. In: Memórias da Academia de Ciencias de Lisboa 37 (1998), pp. 111124.

[15119] O. Mateus and M. T. Antunes. “Draconyx loureiroi, a new camptosauridae (Dinosauria, Ornithopoda) from the Late Jurassic of Lourinhã, Portugal". English. In: Annales de Paléontologie 87.1 (2001), pp. 61-73.

[15120] O. Mateus and M. T. Antunes. "A new dinosaur tracksite in the Lower Cretaceous of Portugal". English. In: Ciencias da Terra 15 (2003), pp. 253-262. 
[15121] O. Mateus, R. J. Butler, S. L. Brusatte, J. H. Whiteside, and J. S. Steyer. “The first phytosaur (Diapsida, Archosauriformes) from the Late Triassic of the Iberian Peninsula". English. In: Journal of Vertebrate Paleontology 34.4 (2014), pp. 970-975.

[15122] O. Mateus, G. J. Dyke, N. Motchurova-Dekova, G. D. Kamenov, and P. Ivanov. "The rst record of a dinosaur from Bulgaria". English. In: Lethaia 43.1 (2010), pp. 88-94. DOI: 10.1111/j.15023931.2009.00174.x.

[15123] O. Mateus, L. Jacobs, M. Polcyn, A. S. Schulp, D. P. Vineyard, A. B. Neto, and M. T. Antunes. “The oldest African eucryptodiran turtle from the Cretaceous of Angola". English. In: Acta Palaeontologica Polonica 54.4 (2009), pp. 581-588. DOI: 10.4202/app.2008.0063.

[15124] O. Mateus, S. C. R. Maidment, and N. A. Christiansen. "A new long-necked 'sauropod-mimic' stegosaur and the evolution of the plated dinosaurs". English. In: Proceedings of the Royal Society B: Biological Sciences 276 (2009), pp. 1815-1821. DOI: 10.1098/rspb.2008.1909.

[15125] O. Mateus, P. D. Mannion, and P. Upchurch. "Zby atlanticus, a new turiasaurian sauropod (Dinosauria, Eusauropoda) from the Late Jurassic of Portugal". English. In: Journal of Vertebrate Paleontology 34.3 (2014), pp. 618-634.

[15126] O. Mateus, M. Marzola, A. S. Schulp, L. L. Jacobs, M. J. Polcyn, V. Pervov, A. O. Goncalves, and M. L. Morais. "Angolan ichnosite in a diamond mine shows the presence of a large terrestrial mammaliamorph, a crocodylomorph, and sauropod dinosaurs in the Early Cretaceous of Africa". English. In: Palaeogeography, Palaeoclimatology, Palaeoecology 471 (2017), pp. 220-232. DOI: 10.1016/ j.palaeo.2016.12.049.

[15127] O. Mateus and J. Milán. First records of crocodyle and pterosaur tracks in the Upper Jurassic of Portugal. English. Vol. 51. Crocodyle tracks and traces. New Mexico Museum of Natural History and Science, Bulletin. 2010, pp. 83-87.

[15128] O. Mateus and J. Milán. "A diverse Upper Jurassic dinosaur ichnofauna from central-west Portugal". English. In: Lethaia 43 (2010), pp. 245-257. DOI: 10.1111/j.1502-3931.2009.00190.x.

[15129] O. Mateus, J. Milán, M. Romano, and M. A. Whyte. “New finds of stegosaur tracks from the Upper Jurassic Lourinhã Formation, Portugal". English. In: Acta Palaeontologica Polonica 56.3 (2011), pp. 651-658. DOI: 10.4202/app.2009.0055.

[15130] O. Mateus, M. J. Polcyn, L. L. Jacobs, R. Arujo, A. S. Schulp, J. Marinheiro, B. Pereira, and D. P. Vineyard. "Cretaceous amniotes from Angola: dinosaurs, pterosaurs, mosasaurs, plesiosaurs, turtles". English. In: Actas de V Jornadas Internacionales sobre Paleontologia de Dinosaurios y su Entorno, Salas de los Infantes, Burgos (2012), pp. 71-105.

[15131] O. Mateus, E. Puértolas-Pascual, and P. M. Callapez. "A new eusuchian crocodylomorph from the Cenomanian (Late Cretaceous) of Portugal reveals novel implications on the origin of Crocodylia". English. In: Zoological Journal of the Linnean Society 186.2 (2019), pp. 501-528. DOI: 10.1093/zoolinnean/ zly064/5232234.

[15132] O. Mateus, A. Walen, and M. T. Antunes. "The large theropod fauna of the Lourinhã Formation (Portugal) and its similarity to that of the Morrison Formation, with a description of a new species of Allosaurus". English. In: vol. 36. Paleontology and Geology of the Upper Jurassic Morrison Formation. New Mexico Museum of Natural History and Science Bulletin. Albuquerque: New Mexico Museum of Natural History and Science, 2006, pp. 123-129.

[15133] O. M. Mateus, L. L. Jacobs, A. S. Schulp, M. L. Polcyn, T. S. Tavares, A. B. Neto, M. L. Morais, and M. T. Antunes. "Angolatitan adamastor, a new sauropod dinosaur and the first record from Angola". English. In: Anais da Academia Brasileira de Ciencias 83.1 (2011), pp. 221-233.

[15134] S. D. Matheos and S. M. Morsch. "Geochemistry and paleoecological aspects of coral-bearing limestones from the Late Jurassic at the southern end of the Sierra de la Vaca Muerta, Neuquen Basin, Argentina". English. In: Neues Jahrbuch für Geologie und Paläontologie, Abhandlungen 181 (1990), pp. 159-169. 
[15135] J. C. Mathews, S. L. Brusatte, S. A. Williams, and M. D. Henderson. “The first Triceratops bonebed and its implications for gregarious behavior". English. In: Journal of Vertebrate Paleontology 29.1 (2009), pp. 286-290. DOI: 10.1671/039.029.0126.

[15136] J. C. Mathews and K. E. Samonds. "A juvenile subfossil crocodylian from Anjohibe Cave, Northwestern Madagascar". English. In: PeerJ 4 (2016), e2296:1-30. DOI: 10.7717/peerj.2296.

[15137] S. C. Mathur, S. D. Gaur, R. S. Loyal, A. Tripathi, R. P. Tripathi, and A. Gupta. “Occurrence of magnetite spherules in the Maastrichtian bone bed sedimentary sequence of Fatehgarh Formation, Barmer basin, India". English. In: Current Science 89.7 (2005), pp. 1259-1268.

[15138] S. K. Mathur, S. C. Mathur, and R. S. Loyal. "First microvertebrate assemblage from the Fatehgarh Formation (Cretaceous), Barmer district, western Rajasasthan". English. In: Journal of the Geological Society of India 67 (2006), pp. 759-769.

[15139] U. B. Mathur and D. K. Pandey. "Radiocarbon Dates of Corals, Gastropods and Foraminifers from Saurashtra Peninsula, Gujarat and their implications for Sea level Studies". English. In: Journal Geological Society of India 60 (2002), pp. 303-308.

[15140] V. K. Mathur and D. K. Srivastava. "Record of terminal Neoproterozoic Ediacaran fossils from Krol Group, Nigalidhar Syncline, Sirmaur District, Himachal Pradesh, India". English. In: Journal of the Geological Society of India 64 (2004), pp. 231-232.

[15141] T. Matsubara. "Molluscan fauna of the Miocene Maéjima Formation in Maéjima Island, Okayama Prefecture, southwest Japan". English. In: Paleontological Research 6.2 (2002), pp. 127-145.

[15142] T. Matsubara, H. Kurita, and H. Matsuo. "Eocene Mollusca from the Tainohata Formation in Kobe City, southwest Japan". English. In: Paleontological Research 14.2 (2010), pp. 119-144. DOI: 10.2517/ 1342-8144-14.2.119.

[15143] T. Matsubara and H. Ugai. "Paleoecology and Taxonomy of Middle Eocene Molluscs from the Shiratake Formation on Takeshima lsland, Amakusa lslands, Southwest Japan". English. In: Goshoura Cretaceous Museum 7 (2006), pp. 1-17.

[15144] K. Matsui and B. Beaty. Juvenile specimen reveals unexpected dental morphology of early desmostylians. English. 2019.

[15145] K. Matsui and S. Kawabe. "The Oldest Record of Paleoparadoxia from the Northwest Pacific with an Implication on the Early Evolution of Paleoparadoxiinae (Mammalia: Desmostylia)". English. In: Paleontological Research 19.3 (2015), pp. 251-265. DOI: 10.2517/2015PR007.

[15146] K. Matsui, Y. Kimura, M. Nagata, H. Inose, K. Ikeda, B. L. Beatty, H. Obayashi, T. Hirata, S. Otoh, T. Shinmura, S. Agematsu, and K. Sashida. "A long-forgotten 'dinosaur' bone from a museum cabinet, uncovered to be". English. In: Royal Society Open Science 5 (2018), p. 172441. DOI: 10.1098/ rsos.172441.

[15147] M. Matsukawa and M. Fukui. "Hauterivian-Barremian marine molluscan fauna from the Tetori Group in Japan and late Mesozoic marine transgressions in East Asia". English. In: Cretaceous Research 30 (2009), pp. 615-631. DOI: 10.1016/j.cretres.2008.12.003.

[15148] M. Matsukawa, T. Hamuro, T. Mizukami, and S. Fujii. "First trackway evidence of gregarious dinosaurs from the Lower Cretaceous Tetori Group of eastern Toyama prefecture, central Japan". English. In: Cretaceous Research 18 (1997), pp. 603-619.

[15149] M. Matsukawa, K. Koarai, M. Fukui, K. Suzuki, Y. Ogawa, S. Kikukawa, M. Kometani, and T. Hamuro. "A gigantic ammonite from the Upper Jurassic Arimine Formation of the Tetori Group, Japan". English. In: Bulletin of the Tateyami Caldera Sabo Museum 9 (2008), pp. 1-10.

[15150] M. Matsukawa, M. G. Lockley, and A. P. Hunt. “Three age groups of ornithopods inferred from footprints in the mid-Cretaceous Dakota Group, eastern Colorado, North America". English. In: Palaeogeography, Palaeoclimatology, Palaeoecology 147 (1999), pp. 39-51.

[15151] M. Matsukawa, M. G. Lockley, and J. Li. "Cretaceous terrestrial biotas of East Asia, with special reference to dinosaur-dominated ichnofaunas: towards a synthesis". English. In: Cretaceous Research 27.1 (2006), pp. 3-21. 
[15152] M. Matsukawa and I. Obata. “Dinosaurs and sedimentary environments in the Japanese Cretaceous: a contribution to dinosaur facies in Asia based on molluscan palaeontology and stratigraphy". English. In: Cretaceous Research 15.1 (1994), pp. 101-125. DOI: 10.1006/cres.1994.1005.

[15153] M. Matsukawa, K. Shibata, R. Kukihara, K. Koarai, and M. G. Lockley. "Review of Japanese dinosaur track localities: implications for ichnotaxonomy, paleogeography and stratigraphic correlation". English. In: Ichnos 12.3 (2005), pp. 201-222. DOI: 10.1080/10420940591009231.

[15154] R. Matsumoto, E. Buffetaut, F. Escuillie, S. Hervet, and S. E. Evans. "New material of the choristodere Lazarussuchus (Diapsida, Choristodera) from the Paleocene of France". English. In: Journal of Vertebrate Paleontology 33.2 (2013), pp. 319-339.

[15155] R. Matsumoto, L. Dong, Y. Wang, and S. E. Evans. "The first record of a nearly complete choristodere (Reptilia: Diapsida) from the". English. In: Journal of Systematic Palaeontology (2019). DOI: 10.1080/14772019.2018.1494220.

[15156] R. Matsumoto, S. E. Evans, and M. Manabe. “The choristoderan reptile Monjurosuchus from the Early Cretaceous of Japan". English. In: Acta Palaeontologica Polonica 52.2 (2007), pp. 329-350.

[15157] R. Matsumoto and S. E. Evans. "Choristoderes and the freshwater assemblages of Laurasia". English. In: Journal of Iberian Geology 36.2 (2010), pp. 253-274.

[15158] R. Matsumoto and S. E. Evans. "The first record of albanerpetontid amphibians (Amphibia: Albanerpetontidae) from East Asia". English. In: PLoS ONE 13.1 (2018), e0189767:1-58.

[15159] R. Matsumoto, M. Manabe, and S. E. Evans. “The first record of a long-snouted chrositodere (Reptilia, Diapsida) from the Early Cretaceous of Isihikawa Prefecture, Japan". English. In: Historical Biology 27.5 (2014), pp. 583-594. DOI: 10.1080/08912963.2014.898296.

[15160] R. Matsumoto, S. Suzuki, K. Tsogtbaatar, and S. E. Evans. "New material of the enigmatic reptile Khurendukhosaurus (Diapsida: Choristodera) from Mongolia". English. In: Naturwissenschaften 96 (2009), pp. 233-242. DOI: 10.1007/s00114-008-0469-6.

[15161] T. Matsumoto, M. Nemoto, and C. Suzuki. "Gigantic ammonites from the Cretaceous Futaba Group of Fukushima Prefecture". English. In: Transactions and Proceedings of the Paleontological Society of Japan, N.S. 157 (1990), pp. 366-381.

[15162] T. Matsumoto, T. Nishida, and S. Toshimitsu. "Early Cenomanian (Cretaceous) ammonoids Utaturiceras and Graysonites from Hokkaido, North Japan". English. In: Bulletin of the Geological Survey of Japan 54 (2003), pp. 131-159.

[15163] T. Matsumoto and S. K. Skwarko. "Cretaceous ammonites from south-central Papua New Guinea". English. In: AGSO Journal of Australia Geology \& Geophysics 14 (1993), pp. 411-433.

[15164] T. Matsumoto and S. K. Skwarko. "Ammonites of the Cretaceous Ieru Formation, western Papua New Guinea”. English. In: BMR Journal of Australian Geology \& Geophysics 12 (1991), pp. 245-262.

[15165] A. Matsuoka. "Faunal composition of earliest Cretaceous (Berriasian) radiolaria from the Mariana Trench in the western Pacific". In: News of Osaka Microplaleontologists, Special Volume 11 (1998), pp. 165-187.

[15166] A. Matsuoka. "Early Jurassic Radiolarians from the Nanjo Massif in the Mino Terrane, central Japan. Part 1. Tricolocapsa, Stichocapsa, and Minocapsa, n. gen". English. In: Transactions and Proceedings of the Paleontological Society of Japan, N.S. 161 (1991), pp. 720-738.

[15167] A. Matsuoka. "Toarcian (Early Jurassic) radiolarian fauna from the Nanjo Massif in the Mino Terrane, central Japan". English. In: News of Osaka Micropaleontologists, Special Volume 13 (2004), pp. 69-87.

[15168] A. Matsuoka, K. Kobayashi, T. Nagahashi, Q. Yang, Y. Wang, and Q. Zeng. Early Middle Jurassic (Aalenian) radiolarian fauna from the Xialu chert in the Yarlung Zango Suture Zone, southern Tibet. English. in Metcalfe, I., Smith, J.M.B., Morwood, M., and Davidson, I., eds., Faunal and floral migrations and evolution in SE Adia-Australia: Lisse, A.A. Balkema. 2001, pp. 105-110. 
[15169] H. Matsuoka. "The Late Pleistocene fossil birds of the central and southern Ryukyu Islands, and their zoogeographical implications for the Recent avifauna of the archipelago". English. In: Tropics 10 (2000), pp. 165-188.

[15170] H. Matsuoka and Y. Hasegawa. "Birds around the Minatogawa Man: the Late Pleistocene avian fossil assemblage of the Minatogawa Fissure, southern part of Okinawa Island, Central Ryukyu Islands, Japan". English. In: Bulletin of the Gunma Museum of Natural History 22 (2018), pp. 1-21.

[15171] H. Matsuoka, S. Isaji, Y. Hasegawa, I. Yamaguchi, and T. Takada. "A new dinosaur track locality in the Tetori Group of Mekko-dani ravine, Oguchi, Ishikawa, Japan". Japanese. In: Bulletin of the Gunma Museum of Natural History 5 (2001), pp. 39-48.

[15172] H. Matsuoka, Y. Koda, K. Ono, and Y. Hasegawa. "Pseudodontorn fossils from Japan, with preliminary observations on the maxilla specimen from the Lower Oligocene Iwaki Formation, Fukushima, Japan". Japanese. In: Bulletin of the Gunma Museum of Natural History 7 (2003), pp. 47-59.

[15173] H. Matsuoka, N. Kusuhashi, T. Takada, and T. Setogushi. "A clue to the Neocomian vertebrate fauna: initial results from the Kuwajima Kaseki-kabe (Tetori Group) in Shiramine, Ishikawa, central Japan". English. In: Memoirs of the Faculty of Science, Kyoto University, Series of Geology and Mineralogy 59.1 (2002), pp. 33-45.

[15174] H. Matsuoka, N. Kusuhashi, and I. J. Corfe. "A new Early Cretaceous tritylodontid (Synapsida, Cynodontia, Mammaliamorpha) from the Kuwajima Formation (Tetori Group) of central Japan". English. In: Journal of Vertebrate Paleontology 36.4 (2016), e1112289:1-16. DOI: 10.1080 / 02724634. 2016.1112289.

[15175] H. Matsuoka, H. Nakajima, Y. Takakuwa, and Y. Hasegawa. "Preliminary note on the Miocene flightless swan from the Haraichi Formation, Tomioka Group of Annaka, Gunma, Japan". English. In: Bulletin of the Gunma Museum of Natural History 5 (2001), pp. 1-8.

[15176] H. Matsuoka, F. Sakakura, and F. Ohe. "A Miocene pseudodontorn (Pelecaniformes : Pelagornithidae) from the Ichishi Group of Misato, Mie Prefecture, Central Japan". English. In: Paleontological Research 2.4 (1998), pp. 246-252.

[15177] N. Matsuura and K. Nagasaw. "Fossil cetaceans from the distribution area of the Omma Formation in Kanazawa, Ishikawa Prefecture, Japan”. English. In: Nihonaki Cetology 10 (2000), pp. 3747.

[15178] L. C. Matten and T. I. Fine. “Telangium schweitzeri sp. nov.: A Gymnosperm Pollen Organ from the Upper Devonian of Ireland". In: Palaeontographica Abteilung B 232 (1994), pp. 15-33.

[15179] R. Matteucci. "Drifted Nautilus shells from the Bajuni Islands (southern Somali coast of Indian Ocean)". English. In: Journal of Mediterranean Earth Sciences 7 (2015), pp. 35-50.

[15180] R. Matteucci and A. Russo. "The Middle Eocene siliceous sponges from Val di Chiampo (Lessini Mountains, northern Italy)". English. In: Museologia Scientifica e Naturalistica, Volume Speciale (2005), pp. 51-62.

[15181] J. V. Matthews, J. A. Westgate, L. Ovenden, L. D. Carter, and T. Fouch. "Stratigraphy, fossils, and age of sediments at the upper pit of the Lost Chicken gold mine: new information on the late Pliocene environment of east central Alaska". English. In: Quaternary Research 60 (2003), pp. 9-18.

[15182] N. Matthews, M. D. Wegweiser, and B. Breithaupt. Caught in Dante's inferno-studying dinosaur tracks near This Side of Hell Quarry, Wyoming. English. 2003.

[15183] S. G. Mattingly, K. C. Beard, P. M. C. Coster, M. J. Salem, Y. Chaimanee, and J. -J. Jaegar. "A new carnivoraform from the early Oligocene of Libya: Oldest known record of Carnivoramorpha in Africa". English. In: Journal of African Earth Sciences 172 (2020), p. 103994. DOI: 10.1016/j.jafrearsci. 2020.103994.

[15184] S. G. Mattingly, O. Sanisidro, and K. C. Beard. "A new species of Carpolestes (Mammalia, Plesiadapoidea) from the late Paleocene of southern Wyoming: assessing changes in size and shape during the evolution of a key anatomical feature". English. In: Historical Biology (2017). DOI: 10. 1080/08912963.2017.1328509. 
[15185] S. Mattioli and D. P. Domning. "An annotated list of extant skeletal material of Steller's Sea Cow (Hydrodamalis gigas) (Sirenia: Dugongidae) from the Commander Islands". English. In: Aquatic Mammals 32.3 (2006), pp. 273-288.

[15186] A. T. Matzke. "An almost complete juvenile specimen of the cheloniid turtle Ctenochelys stenoporus (Hay, 1905) from the Upper Cretaceous Niobrara Formation of Kansas, USA". English. In: Palaeontology 50.3 (2007), pp. 669-691.

[15187] A. T. Matzke and M. W. Maisch. "The first aetosaurid archosaur from the Trossingen Plateosaurus Quarry (Upper Triassic, Germany)". English. In: Neues Jahrbuch für Geologie und Paläontologie, Abhandlungen 262.3 (2011), pp. 354-357. DOI: 10.1127/0077-7749/2011/0203.

[15188] A. T. Matzke, M. W. Maisch, H. -U. Pfretzschner, G. Sun, and H. Stöhr. "A new basal sinemydid turtle (Reptilia: Testudines) from the Lower Cretaceous Tugulu Group of the Junggar Basin (NW China)". English. In: Neues Jahrbuch für Geologie und Paläontologie, Monatshefte 2004.3 (2004), pp. 151-167.

[15189] A. T. Matzke, M. W. Maisch, G. Sun, H. -U. Pfretzschner, and H. Stöhr. "A new xinjiangchelyid turtle (Testudines, Eucryptodira) from the Jurassic Qigu Formation of the southern Junggar Basin, Xinjiang, North-West China". English. In: Palaeontology 47.5 (2004), pp. 1267-1299.

[15190] R. Matzke-Karasz and W. Witt. “Ostracods of the Paratethyan Neogene Klç and Yalakdere formations near Yalova (Izmit Province, Turkey)". English. In: Zitteliana A 45 (2005), pp. 115-133.

[15191] A. Mauko and B. Florjancic. "Dinosaur footprints in the upper Turonian-Coniacian limestone in the Krnica Bay (NE Istria, Croatia)". English. In: Geologija 46.1 (2003), pp. 93-100.

[15192] B. M. Mauro and V. Giuseppe. "Nuove specie di Gasteropodi del Piacenziano di rio Crevalese, Castell'Arquato (Piacenza, Italia)". Italian. In: Bollettino Malacologico 41.1-4 (2005), pp. 1-22.

[15193] L. R. Mautino and L. M. Anzótegui. "Palinologa de la Formación Chiquimil (Mioceno superior) en Vallecito, provincia de Catamarca, Argentina. Parte I. Esporas: Especies nuevas". Spanish. In: Ameghiniana 35.2 (1998), pp. 227-233.

[15194] L. R. Mautino and L. M. Anzótegui. “Esporas del Mioceno y retrabajadas del Mesozoico en la Formación Chiquimil, Vallecito, provincia de Catamarca". Spanish. In: Ameghiniana 37.1 (2000), pp. 13-22.

[15195] L. R. Mautino and L. M. Anzótegui. "Palinologa de la Formación Chiquimil (Mioceno Superior), en Ro Vallecito, provincia de Catamarca, Argentina. Parte 2. Polen". Spanish. In: Ameghiniana 39.3 (2002), pp. 257-270.

[15196] L. R. Mautino and L. M. Anzótegui. "Palinologa de la Formación Chiquimil (Mioceno Superior), en Ro Vallecito, provincia de Catamarca, Argentina. Parte 3. Polen". Spanish. In: Ameghiniana 39.3 (2002), pp. 271-284.

[15197] F. Mavridis, L. Kormazopoulou, A. Papadea, O. Apostolikas, D. Yamaguchi, Z. Tankosic, G. Kotzamani, K. Trantalidou, P. Karkanas, Y. Maniatis, K. Papagianni, and D. Lambropoulos. "Anonymous Cave Of Schisto At Keratsini, Attika: A Preliminary Report On A Diachronic Cave Occupation From The Pleistocene/Holocene Transition To The Byzantine Times". English. In: Stable Places and Changing Perceptions: Cave Archaeology in Greece. Oxford: Archaeopress, Publishers of British Archaeological Reports, 2013, pp. 248-284.

[15198] T. Mavrinskaya and L. Slavik. “Correlation of Early Devonian (Lochkovian-early Pragian) conodont faunas of the South Urals (Russia)". English. In: Bulletin of Geosciences 88.2 (2013), pp. 283296.

[15199] J. R. Mawdsley. "A New Species of the Genus Strotocera Schenkling (Coleoptera: Cleridae: Tillinae) From the Baltic Amber". English. In: Psyche 100.1-2 (1993), pp. 77-81.

[15200] R. Mawson and J. A. Talent. "Conodont faunas from sequences on or marginal to the Anakie Inlier (Central Queensland, Australia) in relation to Devonian transgressions". English. In: Bulletin of Geosciences 78.4 (2003), pp. 335-358. 
[15201] E. E. Maxwell. “Generic reassignment of an ichthyosaur from the Queen Elizabeth Islands, Northwest Territories, Canada". English. In: Journal of Vertebrate Paleontology 30.2 (2010), pp. 403-415.

[15202] E. E. Maxwell. "First Middle Jurassic record of Saurichthyidae (Actinopterygii)". English. In: PalZ 90 (2016), pp. 287-291.

[15203] E. E. Maxwell. “Redescription of the 'lost' holotype of Suevoleviathan integer (Bronn, 1844) (Reptilia: Ichthyosauria)". English. In: Journal of Vertebrate Paleontology 38.2 (2018), e1439833. DOI: 10. 1080/02724634.2018.1439833.

[15204] E. E. Maxwell, S. Alexander, G. Bechly, K. Eck, E. Frey, K. Grimm, J. Kovar-Eder, G. Mayr, N. Micklich, M. Rasser, A. Roth-Nebelsick, R. B. Salvador, R. R. Schoch, G. Schweigert, W. Stinnesbeck, K. Wolf-Schwenninger, and R. Zeigler. "The Rauenberg fossil Lagerstätte (Baden-Württemberg, Germany): A window into early Oligocene marine and coastal ecosystems of Central Europe". English. In: Palaeogeography, Palaeoclimatology, Palaeoecology 463 (2016), pp. 238-260. DOI: 10.1016/ j.palaeo.2016.10.002.

[15205] E. E. Maxwell and M. W. Caldwell. "First record of live birth in Cretaceous ichthyosaurs: closing an 80 million year gap". English. In: Proceedings of the Royal Society of London B 270 (2003), S104S107.

[15206] E. E. Maxwell and M. W. Caldwell. "A new genus of ichthyosaur from the Lower Cretaceous of western Canada". English. In: Palaeontology 49.5 (2006), pp. 1043-1052.

[15207] E. E. Maxwell, D. Dick, S. Padilla, and M. L. Parra. "A new ophthalmosaurid ichthyosaur from the Early Cretaceous of Colombia". English. In: Papers in Palaeontology (2015). DOI: 10.1002/spp2.1030.

[15208] E. E. Maxwell and P. S. Druckenmiller. "A small ichthyosaur from the Clearwater Formation (Alberta, Canada) and a discussion of the taxonomic utility of the pectoral girdle". English. In: Palaeontologische Zeitschrift 85 (2011), pp. 457-463.

[15209] E. E. Maxwell, M. S. Fernández, and R. R. Schoch. "First diagnostic marine reptile remains from the Aalenian (Middle Jurassic): a new ichthyosaur from southwestern Germany". English. In: PLoS ONE 7.8 (2012), e41692. DOI: 10.1371/journal.pone.0041692.

[15210] E. E. Maxwell and B. P. Kear. "Postcranial Anatomy of Platypterygius americanus (Reptilia: Ichthyosauria) from the Cretaceous of Wyoming". English. In: Journal of Vertebrate Paleontology 30.4 (2010), pp. 10591068.

[15211] E. E. Maxwell and A. López-Arbarello. “A new species of the deep-bodied actinopterygian Dapedium from the Middle Jurassic (Aalenian) of southwestern Germany". English. In: PeerJ 6 (2018), e5033.

[15212] E. E. Maxwell and R. C. Martindale. "New Saurorhynchus (Actinopterygii: Saurichthyidae) material from the Early Jurassic of Alberta, Canada". English. In: Canadian Journal of Earth Sciences 54 (2017), pp. 714-719.

[15213] E. E. Maxwell and S. Stumpf. "Revision of Saurorhynchus (Actinopterygii: Saurichthyidae) from the Early Jurassic of England and Germany". English. In: European Journal of Taxonomy 321 (2017), pp. 1-29.

[15214] P. Maxwell and R. E. Fordyce. Fresh Each Day: Beach Road, a spectacular new North Otago Fossil Locality. English. 2000.

[15215] P. A. Maxwell. “Eocene Mollusca from the vicinity of McCulloch's Bridge, Waihao River, South Canterbury, New Zealand: Paleoecology and systematics". In: New Zealand Geological Survey Paleontological Bulletin 65 (1992), pp. 1-280.

[15216] P. A. Maxwell. “The Volutid genera Athleta and Lyria (Mollusca: Gastropoda) in the New Zealand Cenozoic". English. In: Journal of the Royal Society of New Zealand 33.1 (2003), pp. 363-394. DOI: 10.1080/03014223.2003.9517735.

[15217] S. J. Maxwell, B. C. Congdon, and T. L. Rymer. "A New Species of Paraseraphs (Gastropoda, Seraphsidae) from the Priabonian White Limestone Formation of Jamaica". English. In: Paleontological Journal 52.12 (2018), pp. 1371-1373. DOI: 10.1134/S0031030118120122. 
[15218] W. D. Maxwell and J. H. Ostrom. “Taphonomy and paleobiological implications of TenontosaurusDeinonychus associations". English. In: Journal of Vertebrate Paleontology 15.4 (1995), pp. 707-712.

[15219] A. May. "Paleoecology of upper Eifelian and lower Givetian coral limestones in the northwestern Sauerland (Devonian; Rhenish Massif)". English. In: Facies 26 (1992), pp. 103-116.

[15220] A. May. “Die Fossilführung des Mitteldevons im Raum Attendorn-Olpe (West-Sauerland; Rechtsrheinisches Schiefergebirge) [Middle Devonian fossils of the Attendorn-Olpe area (western Sauerland; Rhenish Massif]". German. In: Geologie und Paläontologie in Westfalen 60 (2003), pp. 47-79.

[15221] A. May. "Revision of the Silurian and Devonian stromatoporoids of Bohemia described by Pocta (1894)". English. In: Journal of the Czech Geological Society 44.1-2 (1999), pp. 167-180.

[15222] A. May. "Zur Fossilführung des Ohler Schiefers (Devon: Eifelium) im West-Sauerland (Rheinisches Schiefergebirge) [Fossils of the Ohler Schiefer (Devonian, Eifelian) in the western Sauerland (Eastern Rhenish Massif)]". German. In: Dortmunder Beiträge zur Landeskunde 27 (1993), pp. 109122.

[15223] A. May. “Die Stromatoporen-Fauna des Mitteldevons von Zentral-Böhmen [Middle Devonian stromatoporoids from central Bohemia]". German. In: Münstersche Forschungen zur Geologie und Palaeontologie 86 (1999), pp. 121-134.

[15224] A. May. “Thamnopora und verwandte ästige tabulate Korallen aus dem Emsium bis Unter-Eifelium von Asturien (Devon; Nord-Spanien) [Thamnopora and related ramose tabulate corals from the Emsian to the Lower Eifelian of Asturias (Devonian; Spain)]". German. In: Geologica et Palaeontologica 27 (1993), pp. 73-101.

[15225] A. May. Lower Devonian stromatoporoids of the Sierra Morena (Southern Spain) and their palaeogeographic affinities. English. Vol. 17. Hubmann, B. \& Piller, W.E. (Eds.): Fossil Corals and Sponges. Proceedings of the 9 th international Symposium on Fossil Cnidaria and Porifera. - Österreichische Akademie der Wissenschaften, Schriftenreihe der Erdwissenschaftlichen Kommissionen. 2007, pp. 139-151.

[15226] A. May. “Die Stromatoporen des Devons und Silurs von Zentral-Böhmen (Tschechische Republik) und ihre Kommensalen [Devonian and Silurian stromatoporoids from central Bohemia (Czech Republic) and their commensal organisms]". German. In: Zitteliana, B 25 (2005), pp. 117-250.

[15227] A. May. "Corals (Anthozoa, Tabulata and Rugosa) and chaetetids (Porifera) from the Devonian of the Semara area (Morocco) at the Museo Geominero (Madrid, Spain), and their biogeographic significance". English. In: Bulletin de l'Institut Scientifique 30 (2008), pp. 1-12.

[15228] A. May. "Radiastraea (Anthozoa, Rugosa) from the Emsian and Eifelian (Devonian) of Aviados, northern Spain". English. In: Bulletin of Geosciences 81.3 (2006), pp. 151-162.

[15229] A. May, M. L. Pohler, C. E. Brett, and H. P. Schönlaub. "Lower Devonian reef biota from the Carnic Alps, Austria: implications for biogeography". English. In: Berichte des Institutes für Erdwissenschaften der Karl-Franzens-Universität Graz 9 (2004), pp. 256-257.

[15230] A. May and S. Rodrguez. "Pragian (Lower Devonian) stromatoporoids and rugose corals from Zújar (Sierra Morena, southern Spain)". English. In: Geologica Belgica 15.4 (2012), pp. 226-235.

[15231] M. L. May and F. L. Carle. "Pamita hannahdaltonae gen. nov., sp. nov. from Baltic amber (Odonata: Amphipterygida)". English. In: International Journal of Odonatology 8 (2005), pp. 213-221.

[15232] S. R. May. "The Lapara Creek Fauna: Early Clarendonian of south Texas, USA". English. In: Palaeontologia Electronica 22.1.15 (2019), pp. 1-129.

[15233] S. R. May, M. O. Woodburne, E. H. Lindsay, L. B. Albright III, A. Sarna-Wojcicki, E. Wan, and E. B. Wahl. "Geology and mammalian paleontology of the Horned Toad Hills, Mojave Desert, California, USA". English. In: Palaeontologia Electronica 13.3 (2011), 28A.

[15234] W. May, A. K. Huttenlocker, J. D. Pardo, J. Benca, and B. J. Small. “New Upper Pennsylvanian armored dissorophid records (Temnospondyli, Dissorophoidea) from the U.S. midcontinent and the stratigraphic distributions of dissorophids". English. In: Journal of Vertebrate Paleontology 31.4 (2011), pp. 907-912. DOI: 10.1080/02724634.2011.582532. 
[15235] E. L. Mayer, A. Hubbe, L. Kerber, P. M. Haddad-Martim, and W. Neves. "Taxonomic, biogeographic, and taphonomic reassessment of a large extinct species of paca from the Quaternary of Brazil". English. In: Acta Palaeontologica Polonica 61.4 (2016), pp. 743-758.

[15236] E. Mayoral, E. Liñán, J. A. Gámez Vintaned, F. Muñiz, and R. Gozalo. "Stranded jellyfish in the lowermost Cambrian (Corduban) of Spain". English. In: Revista española de paleontologa 19.2 (2004), pp. 191-198.

[15237] G. Mayr. "A skull of a new pelecaniform bird from the Middle Eocene of Messel, Germany". English. In: Acta Palaeontologica Polonica 47.3 (2002), pp. 507-512.

[15238] G. Mayr. “Old World fossil record of modern-type hummingbirds". English. In: Science 304 (2004), pp. 861-864.

[15239] G. Mayr. “Caprimulgiform birds from the Middle Eocene of Messel (Hessen, Germany)”. English. In: Journal of Vertebrate Paleontology 19.3 (1999), pp. 521-532.

[15240] G. Mayr. "A specimen of Eocuculus Chandler, 1999 (Aves, ? Cuculidae) from the early Oligocene of France". English. In: Geobios 39.6 (2006), pp. 865-872.

[15241] G. Mayr. "A chicken-sized crane precursor from the early Oligocene of France". English. In: Naturwissenschaften 92 (2005), pp. 389-393.

[15242] G. Mayr. "A new specimen of the tiny Middle Eocene bird Gracilitarsus mirabilis (new family: Gracilitarsidae)". English. In: The Condor 103.1 (2001), pp. 78-84.

[15243] G. Mayr. "A new trogon from the Middle Oligocene of Céreste, France”. English. In: The Auk 116.2 (1999), pp. 427-434.

[15244] G. Mayr. "The birds from the Paleocene fissure filling of Walbeck (Germany)". English. In: Journal of Vertebrate Paleontology 27.2 (2007), pp. 394-408.

[15245] G. Mayr. "The earliest fossil record of a modern-type piciform bird from the late Oligocene of Germany". English. In: Journal of Ornithology 142.1 (2001), pp. 2-6.

[15246] G. Mayr. "A new mousebird (Coliiformes: Coliidae) from the Oligocene of Germany". English. In: Journal of Ornithology 141.1 (2000), pp. 85-92.

[15247] G. Mayr. "A new Eocene swift-like bird with a peculiar feathering”. English. In: Ibis 145.3 (2003), pp. 382-391.

[15248] G. Mayr. "New trogons from the early Tertiary of Germany". English. In: Ibis 147.3 (2005), pp. 512518.

[15249] G. Mayr. “Tiny hoopoe-like birds from the Middle Eocene of Messel (Germany)". English. In: The Auk 117.4 (2000), pp. 964-970.

[15250] G. Mayr. "A tiny barbet-like bird from the Lower Oligocene of Germany: the smallest species and earliest substantial fossil record of the Pici (woodpeckers and allies)". English. In: The Auk 122.4 (2005), pp. 1055-1063.

[15251] G. Mayr. "First substantial Middle Eocene record of the Lithornithidae (Aves): A postcranial skeleton from Messel (Germany)". English. In: Annales de Paléontologie 94.1 (2008), pp. 29-37.

[15252] G. Mayr. "Phylogenetic affinities of the enigmatic avian taxon Zygodactylus based on new material from the early Oligocene of France". English. In: Journal of Systematic Palaeontology 6.3 (2008), pp. 333-344.

[15253] G. Mayr. "A skull of the giant bony-toothed bird Dasornis (Aves: Pelagornithidae) from the Lower Eocene of the Isle of Sheppey". English. In: Palaeontology 51.5 (2008), pp. 1107-1116.

[15254] G. Mayr. "A new eocene Chascacocolius-like mousebird (Aves: Coliiformes) with a remarkable gaping adaptation". English. In: Organisms Diversity \& Evolution 5.3 (2005), pp. 167-171.

[15255] G. Mayr. "A rail (Aves, Rallidae) from the early Oligocene of Germany". English. In: Ardea 94.1 (2006), pp. 23-31.

[15256] G. Mayr. "A Fluvioviridavis-like bird from the Middle Eocene of Messel, Germany". English. In: Canadian Journal of Earth Sciences 42.11 (2005), pp. 2021-2037. 
[15257] G. Mayr. "A new cypselomorph bird from the middle Eocene of Germany and the early diversification of avian aerial insectivores". English. In: Condor 107.2 (2005), pp. 342-352.

[15258] G. Mayr. "A new avian species with tubercle-bearing cervical vertebrae from the Middle Eocene of Messel (Germany)". English. In: Records of the Australian Museum 62 (2010), pp. 21-28.

[15259] G. Mayr. Paleogene Fossil Birds. English. Berlin: Springer-Verlag, 2009, pp. 1-262. DOI: 10.1007/9783-540-89628-9.

[15260] G. Mayr. "A new Paleogene procellariiform bird from western North America". English. In: Neues Jahrbuch für Geologie und Paläontologie 275.1 (2015), pp. 11-17. DOI: 10.1127/njgpa/2015/0445.

[15261] G. Mayr. "New species of Primozygodactylus from Messel and the ecomorphology and evolutionary significance of early Eocene zygodactylid birds (Aves, Zygodactylidae)". English. In: Historical Biology 29.7 (2017), pp. 875-884. DOI: 10.1080/08912963.2016.1261135.

[15262] G. Mayr. "A new species of Plesiocathartes (Aves: ?Leptosomidae) from the middle Eocene of Messel, Germany". English. In: PaleoBios 22.1 (2002), pp. 10-20.

[15263] G. Mayr. "Avian feet, crocodilian food and the diversity of larger birds in the early Eocene of Messel". English. In: Palaeobiodiversity and Palaeoenvironments 96.4 (2016), pp. 601-609. DOI: 10. 1007/s12549-016-0243-2.

[15264] G. Mayr. "An osprey (Aves: Accipitridae: Pandioninae) from the early Oligocene of Germany". English. In: Senckenbergiana lethaea 86.1 (2006), pp. 93-96.

[15265] G. Mayr. "Pumiliornis tessellatus n. gen. n. sp., a new enigmatic bird from the Middle Eocene of Grube Messel (Hessen, Germany)". English. In: Courier Forschungsinstitut Senckenberg 216 (1999), pp. 75-83.

[15266] G. Mayr. "The world's smallest owl, the earliest unambiguous charadriiform bird, and other avian remains from the early Eocene Nanjemoy Formation of Virginia (USA)". English. In: Paläontologische Zeitschrift 90 (2016), pp. 747-763.

[15267] G. Mayr. "New remains of the Eocene Prophaethon and the early evolution of tropicbirds (Phaethontiformes)". English. In: Ibis 157 (2015), pp. 54-67.

[15268] G. Mayr. "A cormorant from the late Oligocene of Enspel, Germany (Aves, Pelecaniformes, Phalacrocoracidae)". English. In: Senckenbergian laethaea 81.2 (2001), pp. 329-333.

[15269] G. Mayr. "A small representative of the Phalacrocoracoidea (cormorants and anhingas) from the Late Oligocene of Germany". English. In: The Condor 109 (2007), pp. 929-942.

[15270] G. Mayr. "A dwarf species of the Phalacrocoracoidea". English. In: Ibis 151 (2009), pp. 392-395.

[15271] G. Mayr. "Charadriiformbirds from the early Oligoceneof C6reste(France)and theMiddle Eoceneof Messel (Hessen,Germany)". English. In: Geobios 33.5 (2000), pp. 625-636.

[15272] G. Mayr. "A new family of Eocene zygodactyl birds". English. In: Senckenbergiana lethaea 78.1/2 (1998), pp. 199-209.

[15273] G. Mayr, H. Alvarenga, and J. Clarke. "An Elaphrocnemuslike landbird and other avian remains from the late Paleocene of Brazil". English. In: Acta Palaeontologica Polonica 56.4 (2011), pp. 679684.

[15274] G. Mayr, H. Alvarenga, and C. Mourer-Chauviré. “Out of Africa: fossils shed light on the origin of the hoatzin, an iconic Neotropic bird". English. In: Naturwissenschaften 98 (2011), pp. 961-966. DOI: 10.1007/s00114-011-0849-1.

[15275] G. Mayr, S. B. Archibald, G. W. Kaiser, and R. W. Mathewes. "Early Eocene (Ypresian) birds from the Okanagan Highlands, British Columbia (Canada) and Washington State (USA)". English. In: Canadian Journal of Earth Sciences 56 (2019), pp. 803-813. DOI: 10.1139/cjes-2018-0267.

[15276] G. Mayr and M. Daniels. "A new short-legged landbird from the early Eocene of Wyoming and contemporaneous European sites". English. In: Acta Palaeontologica Polonica 46.3 (2001), pp. 393402. 
[15277] G. Mayr, V. L. De Pietri, and R. P. Scofield. "A new fossil from the mid-Paleocene of New Zealand reveals an unexpected diversity of world's oldest penguins". English. In: Naturwissenschaften 104.34 (2017), pp. 1-6. DOI: 10.1007/s00114-017-1441-0.

[15278] G. Mayr, V. L. De Pietri, L. Love, A. A. Mannering, and R. P. Scofield. "A well-preserved new mid-Paleocene penguin (Aves, Sphenisciformes) from the Waipara Greensand in New Zealand". English. In: Journal of Vertebrate Paleontology 37.6 (2017), e1398169:1-19. DOI: 10.1080 / 02724634. 2017.1398169.

[15279] G. Mayr, V. L. De Pietri, R. P. Scofield, and T. Smith. "A fossil heron from the early Oligocene of Belgium: the earliest temporally well-constrained record of the Ardeidae". English. In: Ibis 161 (2019), pp. 79-90. DOI: 10.1111/ibi.12600.

[15280] G. Mayr, V. L. De Pietri, L. Love, A. Mannering, and R. P. Scofield. “Leg bones of a new penguin species from the Waipara Greensand add to the diversity of very large-sized Sphenisciformes in the Paleocene of New Zealand". English. In: Alcheringa 44.1 (2020), pp. 194-201. DOI: 10.1080 / 03115518.2019.1641619.

[15281] G. Mayr, V. L. De Pietri, L. Love, A. Mannering, and R. P. Scofield. “Oldest, smallest and phylogenetically most basal pelagornithid, from the early Paleocene of New Zealand, sheds light on the evolutionary history of the largest flying birds". English. In: Papers in Palaeontology 7.1 (2021), pp. 217-233. DOI: 10.1002 /spp2.1284.

[15282] G. Mayr, V. L. de Pietri, L. Love, A. A. Mannering, J. J. Bevit, and R. P. Scofield. "First complete wing of a stem group sphenisciform from the Paleocene of New Zealand sheds light on the evolution of the penguin fipper". English. In: Diversity 12 (2020), pp. 1-13. DOI: 10.3390/d12020046.

[15283] G. Mayr and V. L. De Pietri. "Earliest and first Northern Hemispheric hoatzin fossils substantiate Old World origin of a Neotropic endemic". English. In: Naturwissenschaften 101 (2014), pp. 143148. DOI: $10.1007 /$ s00114-014-1144-8.

[15284] G. Mayr, P. D. Gingerich, and T. Smith. "Skeleton of a new owl from the early Eocene of North America (Aves, Strigiformes) with an accipitrid-like foot morphology". English. In: Journal of Vertebrate Paleontology (2020), e1769116:1-15. DOI: 10.1080/02724634.2020.1769116.

[15285] G. Mayr, J. L. Goedert, and S. A. McLeod. "Partial Skeleton of a Bony-Toothed Bird from the Late Oligocene/Early Miocene of Oregon (USA) and the Systematics of Neogene Pelagornithidae". English. In: Journal of Paleontology 87.5 (2007), pp. 922-929. DOI: 10.1666/13-025.

[15286] G. Mayr and J. L. Goedert. "New Late Eocene and Oligocene Remains of the Flightless, PenguinLike Plotopterids (Aves, Plotopteridae) from Western Washington State, U.S.A." English. In: Journal of Vertebrate Paleontology 36.4 (2016), e1163573. DOI: 10.1080/02724634.2016.1163573.

[15287] G. Mayr and J. L. Goedert. “Oligocene and Miocene albatross fossils from Washington State (USA) and the evolutionary history of North Pacific Diomedeidae". English. In: The Auk 134 (2017), pp. 659-671. DOI: 10.1642/AUK-17-32.1.

[15288] G. Mayr and J. L. Goedert. "First record of a tarsometatarsus of Tonsala hildegardae (Plotopteridae) and other avian remains from the late Eocene/early Oligocene of Washington State (USA)". English. In: Geobios 51 (2018), pp. 51-59. DOI: 10.1016/j.geobios.2017.12.006.

[15289] G. Mayr, J. L. Goedert, and S. A. McLeod. "Partial Skeleton of a Bony-Toothed Bird from the Late Oligocene/Early Miocene of Oregon (USA) and the Systematics of Neogene Pelagornithidae". English. In: Journal of Paleontology 87.5 (2013), pp. 922-929. DOI: 10.1666/13-025.

[15290] G. Mayr, C. J. Hazevoet, P. Dantas, and M. Cachao. “A sternum of a very large bony-toothed bird (Pelagornithidae) from the Miocene of Portugal". English. In: Journal of Vertebrate Paleontology 28.3 (2008), pp. 762-769.

[15291] G. Mayr, S. Hervet, and E. Buffetaut. “On the diverse and widely ignored Paleocene avifauna of Menat (Puy-de-Dome, France): new taxonomic records and unusual soft tissue preservation". English. In: Geological Magazine (2018). DOI: 10.1017/S0016756818000080.

[15292] G. Mayr and C. W. Knopf. "A stem lineage representative of buttonquails from the Lower Oligocene of Germany - fossil evidence for a charadriiform origin of the Turnicidae". English. In: Ibis (2007). 
[15293] G. Mayr, T. Lechner, and M. Böhme. “The large-sized darter Anhinga pannonica (Aves, Anhingidae) from the late Miocene hominid Hammerschmiede locality in Southern Germany". English. In: PLoS One 15.5 (2020), e0232179. DOI: 10.1371/journal.pone.0232179.

[15294] G. Mayr and A. Manegold. "New specimens of the earliest European passeriform bird". English. In: Acta Palaeontologica Polonica 51.2 (2006), pp. 315-323.

[15295] G. Mayr and C. Mourer-Chauviré. "Rollers (Aves: Coraciiformes s.s.) from the Middle Eocene of Messel (Germany) and the Upper Eocene of the Quercy (France)". English. In: Journal of Vertebrate Paleontology 20.3 (2000), pp. 533-546.

[15296] G. Mayr and C. Mourer-Chauviré. “Osteology and systematic position of the Eocene Primobucconidae (Aves, Coraciiformes sensu stricto), with first records from Europe". English. In: Journal of Systematic Palaeontology 2.1 (2004), pp. 1-12.

[15297] G. Mayr and M. Pavia. "On the true affinities of Chenornis graculoides Portis, 1884, and Anas lignitifila Portis, 1884-an albatross and an unusual duck from the Miocene of Italy". English. In: Journal of Vertebrate Paleontology 34.4 (2014), pp. 914-923. DOI: 10.1080/02724634.2013.821076.

[15298] G. Mayr, D. S. Peters, G. Plodowski, and O. Vogel. "Bristle-like integumentary structures at the tail of the horned dinosaur $<i>$ Psittacosaurus</i>". In: Naturwissenschaften 89 (2002), pp. 361-365.

[15299] G. Mayr, D. S. Peters, and S. Rietschel. "Petrel-like birds with a peculiar foot morphology from the Oligocene of Germany and Belgium (Aves: Procellariiformes)". English. In: Journal of Vertebrate Paleontology 22.3 (2002), pp. 667-676.

[15300] G. Mayr, M. Poschmann, and M. Wuttke. "A nearly complete skeleton of the fossil galliform bird Palaeortyx from the late Oligocene of Germany". English. In: Acta Ornithologica 41.2 (2006), pp. 129-135.

[15301] G. Mayr, R. S. Rana, A. Sahni, and T. Smith. "Oldest fossil avian remains from the Indian subcontinental plate". English. In: Current Science 92.9 (2007), pp. 1266-1269.

[15302] G. Mayr and D. Rubilar-Rogers. “Osteology of a new giant bony-toothed bird from the Miocene of Chile, with a revision of the taxonomy of Neogene Pelagornithidae". English. In: Journal of Vertebrate Paleontology 30.5 (2010), pp. 1313-1330.

[15303] G. Mayr and R. P. Scofield. "First diagnosable non-sphenisciform bird from the early Paleocene of New Zealand". English. In: Journal of the Royal Society of New Zealand 44.1 (2014), pp. 48-56. DOI: 10.1080/03036758.2013.863788.

[15304] G. Mayr, R. P. Scofield, V. L. De Pietri, and A. J. D. Tennyson. “A Paleocene penguin from New Zealand substantiates multiple origins of gigantism in fossil Sphenisciformes". English. In: Nature Communication 8 (2017), p. 1927. DOI: 10.1038/s41467-017-01959-6.

[15305] G. Mayr and R. Smith. "A new record of the Prophaethontidae (Aves: Pelecaniformes) from the Middle Eocene of Belgium". In: Bulletin de l'Institut Royal des Sciences Naturelles de Belgique 72 (2002), pp. 135-138.

[15306] G. Mayr and R. Smith. "Ducks, rails, and limicoline waders (Aves: Anseriformes, Gruiformes, Charadriiformes) from the lowermost Oligocene of Belgium". English. In: Geobios 34.5 (2001), pp. 547-561.

[15307] G. Mayr and T. Smith. "Bony-toothed birds (Aves: Pelagornithidae) from the middle Eocene of Belgium". English. In: Palaeontology 53.2 (2010), pp. 365-376.

[15308] G. Mayr and T. Smith. "New Paleocene bird fossils from the North Sea Basin in Belgium and France". English. In: Geologica Belgica 22.1-2 (2019), pp. 35-46.

[15309] G. Mayr and T. Smith. "A diverse bird assemblage from the Ypresian of Belgium furthers knowledge of early Eocene avifaunas of the North Sea Basin". English. In: Neus Jahrbuch fur Geologie und Palaontologie, Abhandlungen 291.3 (2019), pp. 253-281. DOI: 10.1127/njgpa/2019/0801.

[15310] G. Mayr and T. Smith. "A fossil albatross from the early Oligocene of the North Sea Basin". English. In: The Auk 129.1 (2012), pp. 87-95. 
[15311] G. Mayr and A. J. D. Tennyson. “A small, narrow-beaked albatross from the Pliocene of New Zealand demonstrates a higher past diversity in the feeding ecology of the Diomedeidae". English. In: Ibis (2019). DOI: 10.1111/ibi.12757.

[15312] G. Mayr, J. Yang, E. de Bast, C. -S. Li, and T. Smith. "A Strigogyps-like bird from the middle Paleocene of China with an unusual grasping foot". English. In: Journal of Vertebrate Paleontology 33.4 (2013), pp. 895-901.

[15313] G. Mayr and E. A. Zvonok. “Middle Eocene Pelagornithidae and Gaviiformes (Aves) from the Ukrainian Paratethys". English. In: Palaeontology 54.6 (2011), pp. 1347-1359.

[15314] G. Mayr and E. A. Zvonok. "A new genus and species of Pelagornithidae with well-preserved pseudodentition and further avian remains from the middle Eocene of the Ukraine". English. In: Journal of Vertebrate Paleontology 32.4 (2012), pp. 914-925.

[15315] A. V. Mazaev. "Permian gastropods from the Kulogory Formation of the northern Moscow Syneclise". English. In: Paleontological Journal 40.4 (2006), pp. 391-403.

[15316] A. V. Mazaev. "Middle and Upper Carboniferous gastropods from the central part of the Russian Plate: part 1. Euomphalacea". English. In: Ruthenica 4.1 (1994), pp. 21-33.

[15317] A. V. Mazaev. "Middle and Upper Carboniferous gastropods from the central part of the Russian Plate: part 2. Platyceratidae". English. In: Ruthenica 6.2 (1996), pp. 85-106.

[15318] A. V. Mazaev. "A new genus of Fissurelloidei (Gastropoda) from the Upper Carboniferous of Moscow Basin: the oldest known example of the suborder". English. In: Ruthenica 8.1 (1998), pp. 13-15.

[15319] A. V. Mazaev. "Middle and Upper Carboniferous gastropods from the central part of the Russian Plate. Part 3. Microdomatidae and Anomphalidae". English. In: Ruthenica 7.2 (1997), pp. 91-110.

[15320] A. V. Mazaev. “The gastropod genus Stegocoelia Donald, 1889 (Murchisoniidae) from the Middle and Upper Carboniferous of the central part of the Russian Plate". English. In: Ruthenica 12.2 (2001), pp. 137-151.

[15321] A. V. Mazaev. "Anetshelloida, a new rostroconch order (Mollusca: Rostroconchia)". English. In: Paleontological Journal 46.2 (2012), pp. 121-131. DOI: 10.1134/S0031030112020074.

[15322] A. V. Mazaev. "Pennsylvanian gastropods of the suborders Murchisoniina Cox et Knight, 1960 and Sinuspirina Mazaev subordo nov. from the central regions of the Russian Platform: Morphology, taxonomy, and phylogeny". English. In: Paleontological Journal 45.12 (2011), pp. 1533-1599. DOI: 10.1134/s003103011112001x.

[15323] A. V. Mazaev. "The family Orthonemidae (Gastropoda) from the Middle and Upper Carboniferous of the central part of the Russian Plate". English. In: Ruthenica 13.2 (2003), pp. 89-100.

[15324] A. V. Mazaev. "Middle Permian rostroconchs of the Kazanian stage of the East European Platform". English. In: Paleontological Journal 49.3 (2015), pp. 238-249. DOI: 10.1134/S0031030115030089.

[15325] A. V. Mazaev. "Upper Kazanian (Middle Permian) gastropods of the Volga-Urals Region". English. In: Paleontological Journal 49.8 (2015), pp. 869-986. DOI: 10.1134/S0031030115080018.

[15326] A. V. Mazaev. "Evolution of the genus Baylea (Gastropoda) in the Kazan paleobasin (Middle Permian, Volga-Ural Region)". English. In: Paleontological Journal 50.6 (2016), pp. 585-600. DOI: 10.1134/S0031030116060101.

[15327] A. V. Mazaev. “The development of the genus Biarmeaspira (Gastropoda) in the Kazanian Paleobasin (Middle Permian, Volga-Urals Region)". English. In: Paleontological Journal 51 (2017), pp. 223-232.

[15328] A. V. Mazaev. "The role of fetalization in the morphogenesis of Kazanian gastropods (Middle Permian, Volga-Urals Region)". English. In: Paleontological Journal 51 (2017), pp. 357-367.

[15329] A. V. Mazaev. "Early Kazanian (Middle Permian) gastropods". English. In: Paleontological Journal 52 (2018), pp. 796-827. 
[15330] A. V. Mazaev. "The Order Anetshelloida (Mollusca, Rostroconchia): Origin, Patterns, Mechanisms". English. In: Paleontological Journal 52.13 (2018), pp. 1480-1489. DOI: 10.1134/S0031030118130099.

[15331] A. V. Mazaev. "A new species of the genus Bellazona (Gastropoda) from the Early Permian reef limestones of Shakhtau". English. In: Paleontological Journal 53 (2019), pp. 252-256. DOI: 10.1134/ S0031030119070062.

[15332] A. V. Mazaev. "A new genus Perakella gen. nov. (Gastropoda) from the Lower Permian reef limestone of Shakh-Tau". English. In: Paleontological Journal 53 (2019), pp. 341-345. DOI: 10.1134 / S0031030119040087.

[15333] A. V. Mazaev. "Morphology and systematics of the late Paleozoic gastropods Deseretospira Gordon and Yochelson and Termihabena gen. nov." English. In: Paleontological Journal 53 (2019), pp. 455464. DOI: $10.1134 /$ S0031030119050083.

[15334] A. V. Mazaev. "New late Paleozoic gastropod genus Alanstukella gen. nov. (Trochonematidae)". English. In: Paleontological Journal 54 (2020), pp. 332-338. DOI: 10.1134/S0031030120040097.

[15335] J. M. Mazin and G. M. King. "The first dicynodont from the Late Permian of Malagasy". English. In: Palaeontology 34.4 (1991), pp. 837-842.

[15336] J. M. Mazin and P. M. Sander. "Palaeobiogeography of the Early and Late Triassic ichthyopterygia". English. In: Paleontologia Lombarda 2 (1993), pp. 93-107.

[15337] J.-M. Mazin, J.-P. Billon-Bruyat, J. Pouech, and P. Hantzpergue. “The Purbeckian site of Chervesde-Cognac (Berriasian, Early Cretaceous, southwest France): a continental ecosystem accumulated in an evaporitic littoral depositional environment". English. In: 9th International Symposium on Mesozoic Terrestrial Ecosystems and Biota, Abstracts and Proceedings Volume (2006), pp. 84-88.

[15338] J.-M. Mazin and J.-P. Billon-Bruyat. "Le gisement paléontologique de Cherves-de-Cognac [The paleontological locality of Cherves-de-Cognac]". English. In: Pour La Science 293 (2002), pp. 30-31.

[15339] J.-M. Mazin, J.-P. Billon-Bruyat, and K. Padian. "First record of a pterosaur landing trackway". English. In: Proceedings of the Royal Society B: Biological Sciences 276 (2009), pp. 3881-3886. DOI: 10.1098/rspb.2009.1161.

[15340] J.-M. Mazin, P. Hantzpergue, J. -P. Bassoullet, G. Lafaurie, and P. Vignaud. “Le gisement de Crayssac (Tithonien inferieur, Quercy, Lot, France): decouverte de pistes de dinosaures en place et premier bilan ichnologique [The Crayssac site (lower Tithonian, Quercy, Lot, France): discovery of dinosaur trackways in situ and first ichnological results]". French. In: Comptes Rendus de l'Academie des Sciences, Paris IIa 321 (1997), pp. 417-424.

[15341] J.-M. Mazin, P. Hantzpergue, G. Lafaurie, and P. Vignaud. “Des pistes de ptérosaures dans le Tithonien de Crayssac (Quercy, France) [Pterosaur trackways from the Tithonian of Crayssac (Quercy, France)]". French. In: Comptes Rendus de l'Academie des Sciences, Paris, série IIa 321 (1995), pp. 417-424.

[15342] J.-M. Mazin, P. Hantzpergue, and J. Pouech. “The dinosaur tracksite of Loulle (early Kimmeridgian; Jura, France)". English. In: Geobios 49.3 (2016), pp. 211-228. DOI: 10.1016/j.geobios.2016.01. 018.

[15343] D. Mazurek. "The Tommotian phase of the Early Cambrian Agronomic Revolution in the carbonate mud environment of central Siberia". English. In: Lethaia (2013).

[15344] P. Mazza and M. Rustoni. "The fossil bear from Seneze (Southern France)". In: Atti Della Accademia Nazionale dei Lincei, Classe di Scienze Fisiche, Matematiche e Naturali, Rendiconti Lincei, Serie 9 (Rend. Fisc. Acc. Lincei) 5.1 (1994), pp. 17-26.

[15345] D. L. Mazzanti and C. A. Quintana. "Asociación cultural con fauna extinguida en el sitio arqueologico Cueva Tixi, provincia de Buenos Aires, Argentina". Spanish. In: Revista Espanola de Anthropologia Americana 27 (1997), pp. 11-21.

[15346] L. A. Mazzarolo and D. S. Amorim. "Cratomyia macrorrhyncha, a Lower Cretaceous brachyceran fossil from the Santana Formation, Brazil, representing a new species, genus and family of the Stratiomyiomorpha (Diptera)". English. In: Insect Systematics E Evolution 31 (2000), pp. 91-102. 
[15347] M. Mazzini, V. Borselli, E. Cioppi, and G. Napoleone. “Poggiorosso: un importante arrichimento delle faune villafranchiane a vertebrati del Valdarno Superiore, di eta prossima al limite PlioPleistocene". Italian. In: Bollettino della Societa Paleontologica Italiana 39.3 (2000), pp. 381-388.

[15348] S. J. Mazzullo. "Late Pliocene to Holocene platform evolution in northern Belize, and comparison with coeval deposits in southern Belize and the Bahamas". English. In: Sedimentology 53 (2006), pp. 1015-1047.

[15349] N. E. B. McAdams and J. M. Adrain. "Heckethornia, a new genus of dimeropygid trilobites from the Lower Ordovician (Ibexian; Tulean and Blackhillsian) of the Great Basin, western USA". English. In: Canadian Journal of Earth Sciences 46 (2009), pp. 875-914.

[15350] W. P. McCafferty. "Insects from the Santana Formation, Lower Cretaceous of Brazil. Chapter 2: Ephemeroptera". English. In: Bulletin of the American Museum of Natural History 195 (1990), pp. 20 50.

[15351] W. P. McCafferty and J. A. Santiago-Blay. "A new Cretaceous mayfly from Burmese amber (Ephemeroptera: Australiphemeridae)". English. In: Entomological News 119 (2008), pp. 492-496.

[15352] J. McCall, B. Rosen, and J. Darrell. "Carbonate deposition in accretionary prism settings: Early Miocene coral limestones and corals of the Makran Mountain Range in southern Iran". In: Facies 31 (1994), pp. 141-178.

[15353] A. J. McCarthy, B. Jasin, and N. S. Haile. "Middle Jurassic radiolarian chert, Indarung, Padang District, and its implications for the tectonic evolution of western Sumatra, Indonesia". English. In: Journal of Asian Earth Scienses 19 (2001), pp. 31-44.

[15354] J. A. McCartney, E. M. Roberts, 1. Tapanila, and M. A. O’Leary. “Large palaeophiid and nigerophiid snakes from Paleogene Trans-Saharan Seaway deposits of Mali". English. In: Acta Palaeontologica Polonica 63.2 (2018), pp. 207-220. DOI: 10.4202/app.00442.2017.

[15355] J. A. McCartney and E. R. Seiffert. "A late Eocene snake fauna from the Fayum Depression, Egypt". English. In: Journal of Vertebrate Paleontology 36.1 (2016), e1029580. DOI: 10.1080 / 02724634.2015. 1029580.

[15356] J. A. McCartney, N. J. Stevens, and P. M. O'Connor. “The Earliest Colubroid-Dominated Snake Fauna from Africa: Perspectives from the Late Oligocene Nsungwe Formation of Southwestern Tanzania". English. In: PLoS ONE 9.3 (2014), e90415. DOI: 10.1371/journal.pone.0090415.

[15357] L. M. E. McCobb and M. G. Bassett. “Machaeridians from the Lower Silurian (Llandowery, Telychian) of Shorpshire, England". English. In: Journal of Paleontology 82.6 (2008), pp. 1207-1214.

[15358] L. M. E. McCobb, P. D. McDermott, and A. W. Owen. "The taphonomy of a trilobite fauna from an uppermost Katian echinoderm Lagerstäatte in South West Wales". English. In: Fossils and Strata (2018). DOI: 10.1111/let.12265.

[15359] L. M. E. McCobb and L. E. Popov. "Late Ordovician trilobites from the Mayatas Formation, Atansor area, north-central Kazakhstan". English. In: Earth and Environmental Science Transactions of the Royal Society of Edinburgh 107 (2017), pp. 33-52. DOI: 10.1017/S1755691017000068.

[15360] M. E. McColloch, E. H. Gilmour, and E. M. Snyder. “The order Fenestrata (Bryozoa) of the Toroweap Formation (Permian), Southern Nevada". English. In: Journal of Paleontology 68.4 (1994), pp. 746762.

[15361] K. M. McComas and J. J. Eberle. "A new earliest Paleocene (Puercan) arctocyonid mammal from the Fort Union Formation, Great Divide Basin, Wyoming, and its phylogenetic position among early condylarths". English. In: Journal of Systematic Palaeontology 14.6 (2016), pp. 445-459. DOI: 10.1080/14772019.2015.1066886.

[15362] R. D. McCord. "An Arizona titanosaurid sauropod and revision of the Late Cretaceous Adobe Canyon fauna". English. In: Journal of Vertebrate Paleontology 17.3 (1997), pp. 620-622.

[15363] R. D. McCord, G. McCullough, B. J. Tegowski, J. -P. Hodnett, and R. Scarborough. “Ongoing research in the Late Cretaceous Fort Crittenden Formation, southeastern Arizona: the non-dinosaurian vertebrate fauna". English. In: vol. 8. Southwest Paleontological Symposium - Proceedings 2001. Mesa Southwest Museum Bulletin. Mesa: Mesa Southwest Museum, 2001, pp. 65-71. 
[15364] T. McCormick and R. A. Fortey. “The most widely distributed trilobite species: Ordovician $<$ i $>$ Carolinites genacinaca</i>". English. In: Journal of Paleontology 73.2 (1999), pp. 202-218. DOI: 10.1017/S0022336000027724.

[15365] R. T. McCrea. "Dinosaur footprints in the Lower Cretaceous (Albian) Gates Formation of Alberta, Canada: their use in palaeobiology and palaeoenvironmental interpretation". English. In: Y.-N. Lee (ed.), 2000 International Dinosaur Symposium for Kosong County in Korea. Paleontological Society of Korea Special Publication 4 (2000), pp. 169-178.

[15366] R. T. McCrea. "Fossil tracks from Tumbler Ridge: a brief history of collaboration between amateurs and academics". English. In: Alberta Palaeontological Society, Seventh Annual Symposium (2003), pp. 41-46.

[15367] R. T. McCrea, L. G. Buckley, J. O. Farlow, M. G. Lockley, P. J. Currie, N. A. Matthews, and S. G. Pemberton. "A 'terror of tyrannosaurs': the first trackways of tyrannosaurids and evidence of gregariousness and pathology in Tyrannosauridae". English. In: PLoS ONE 9.7 (2014), e103613:113. DOI: 10.1371 /journal.pone.0103613.

[15368] R. T. McCrea, L. G. Buckley, A. G. Plint, P. J. Currie, J. W. Haggart, C. W. Helm, and S. G. Pemberton. "A review of vertebrate track-bearing formations from the Mesozoic and earliest Cenozoic of western Canada with a description of a new theropod ichnospecies and reassignment of an avian ichnogenus". English. In: vol. 62. Fossil Footprints of Western North America. New Mexico Museum of Natural History and Science Bulletin. Albuquerque: New Mexico Museum of Natural History and Science, 2014, pp. 5-94.

[15369] R. T. McCrea and L. G. Buckley. "A dinosaur track site from the Elk Valley coal district". English. In: Marrella 20 (2005), pp. 19-20.

[15370] R. T. McCrea and L. G. Buckley. “Excavating British Columbia's first dinosaurs and other palaeontological projects in the Tumbler Ridge area". English. In: Alberta Palaeontological Society, Eighth Annual Symposium (2004), pp. 24-33.

[15371] R. T. McCrea and P. J. Currie. A preliminary report on dinosaur tracksites in the Lower Cretaceous (Albian) Gates Formation near Grande Cache, Alberta. English. Vol. 14. Lower and Middle Cretaceous Terrestrial Ecosystems, New Mexico Museum of Natural History and Science Bulletin. 1998, pp. 155-162.

[15372] R. T. McCrea, P. J. Currie, and S. G. Pemberton. Vertebrate ichnology. English. Dinosaur Provincial Park: A Spectacular Ancient Ecosystem Revealed. Indiana University Press, Bloomington. 2005, pp. 405-416.

[15373] R. T. McCrea, D. H. Tanke, L. G. Buckley, M. G. Lockley, J. O. Farlow, L. Xing, N. A. Matthews, C. W. Helm, S. G. Pemberton, and B. H. Breithaupt. "Vertebrate ichnopathology: pathologies inferred from dinosaur tracks and trackways from the Mesozoic". English. In: Ichnos 22.3-4 (2015), pp. 235-260. DOI: 10.1080/10420940.2015.1064408.

[15374] M. L. McCrossin. New species of bushbaby from the Middle Miocene of Maboko Island, Kenya. 1992.

[15375] W. N. McCuen, A. S. Ishimori, and R. W. Boessenecker. "A new specimen of Xiphiorhynchus cf. $X$. aegyptiacus (Istiophoriformes, Xiphioidei, Xiphiidae) and Billfish Diversity in the Oligocene of South Carolina". English. In: Vertebrate Anatomy Morphology Palaeontology 8 (2020), pp. 98-104.

[15376] P. D. McDermott and C. R. Paul. "Coronate echinoderms from the Ordovician of the Llanddowror area, South Wales". English. In: Geological Journal 50.2 (2015), pp. 173-188. DOI: 10.1002/gj.2540.

[15377] P. D. McDermott and C. R. C. Paul. “Ateleocystites? lansae sp. nov. (Mitrata, Anomalocystitidae) from the Upper Ordovician of South Wales". English. In: Geological Journal 52.1 (2017), pp. 1-13. DOI: $10.1002 /$ gj.2712.

[15378] A. T. McDonald, P. M. Barrett, and S. D. Chapman. “A new basal iguanodont (Dinosauria: Ornithischia) from the Wealden (Lower Cretaceous) of England". English. In: Zootaxa 2569 (2010), pp. 1-43.

[15379] A. T. McDonald, E. Esplez, L. Mampel, J. I. Kirkland, and L. Alcalá. "An unusual new basal iguanodont (Dinosauria: Ornithopoda) from the Lower Cretaceous of Teruel, Spain". English. In: Zootaxa 3595 (2012), pp. 61-76. 
[15380] A. T. McDonald, J. I. Kirkland, D. D. DeBlieux, S. K. Madsen, J. Cavin, A. R. C. Milner, and L. Panzarin. "New basal iguanodonts from the Cedar Mountain Formation of Utah and the evolution of thumb-spiked dinosaurs". English. In: PLoS One 5.11 (2010), e14075:1-35. DOI: 10.1371/journal. pone.0014075.

[15381] A. T. McDonald, D. G. Wolfe, and J. I. Kirkland. "A new basal hadrosauroid (Dinosauria: Ornithopoda) from the Turonian of New Mexico". English. In: Journal of Vertebrate Paleontology 30.3 (2010), pp. 799-812.

[15382] A. T. McDonald and D. G. Wolfe. "A new nodosaurid ankylosaur (Dinosauria: Thyreophora) from the Upper Cretaceous Menefee Formation of New Mexico". English. In: PeerJ 6.e5435 (2018). DOI: 10.7717 / peerj.5435.

[15383] H. G. McDonald. "Gravigrade xenarthrans from the early Pleistocene Leisey Shell Pit 1A, Hillsborough County, Florida". English. In: Bulletin of the Florida Museum of Natural History 37.11 (1995).

[15384] H. G. McDonald. "Second Record of the Badger Taxidea taxus (Schreber) from the Pleistocene of Kentucky and Its Paleoecological Implications". English. In: Smithsonian Contributions to Paleobiology 93 (2002), pp. 77-82.

[15385] H. G. McDonald, L. D. Agenbroad, and C. Manganaro Haden. "Late Pleistocene mylodont sloth Paramylodon harlani (Mammalia: Xenarthra) from Arizona". English. In: Southwestern Naturalist 49.2 (2004), pp. 229-238.

[15386] H. G. McDonald and O. Carranza-Castañeda. "Increased xenarthran diversity of the Great American Biotic Interchange: a new genus and species of ground sloth (Mammalia, Xenarthra, Megalonychidae) from the Hemphillian (late Miocene) of Jalisco, Mexico". English. In: Journal of Paleontology 91.5 (2017), pp. 1069-1082. DOI: 10.1017/jpa.2017.45.

[15387] H. G. McDonald, J. C. Chatters, and T. J. Gaudin. "A new genus of megalonychid ground sloth (Mammalia, Xenarthra) from the late Pleistocene of Quintana Roo, Mexico". English. In: Journal of Vertebrate Paleontology 37.3 (2017), e1307206:1-14.

[15388] H. G. McDonald, C. R. Harington, and G. De Iulis. "The Ground Sloth,ăMegalonyx, from Pleistocene Deposits of the Old Crow Basin, Yukon, Canada". English. In: Arctic 53.3 (2000), pp. 213220.

[15389] H. G. McDonald, W. E. Miller, and T. H. Morris. “Taphonomy and significance of Jefferson's ground sloth (Xenarthra: Megalonychidae) from Utah". English. In: Western North American Naturalist 61.1 (2001), pp. 64-77.

[15390] H. G. McDonald and C. Muizon. “The cranial anatomy of Thalassocnus (Xenarthra, Mammalia), a derived nothrothere from the Neogene of the Pisco Formation (Peru)". English. In: Journal of Vertebrate Paleontology 22.2 (2002), pp. 349-365.

[15391] H. G. McDonald and D. Perea. “The large Scelidothere Catonyx tarijensis (Xenarthra, Mylodontidae) from the Pleistocene of Uruguay". English. In: Journal of Vertebrate Paleontology 22.3 (2002), pp. 677-683.

[15392] H. G. McDonald, A. D. Rincon, and T. J. Gaudin. “A New Genus of Megalonychid Sloth (Mammalia, Xenarthra) from the Late Pleistocene (Lujanian) of Sierra De Perija, Zulia State, Venezuela". English. In: Journal of Vertebrate Paleontology 33.5 (2013), pp. 1226-1238. DOI: 10.1080 / 02724634. 2013.764883.

[15393] H. G. McDonald and S. L. Dávila. "Mammoths in Central America: New records from Guatemala”. English. In: Quaternary International 443 (2017), pp. 122-128. DOI: 10.1016/j.quaint.2016.12.018.

[15394] J. N. McDonald and G. E. Lammers. “Bison antiquus from Kenora, Ontario, and Notes on the Evolution of North American Holocene Bison". English. In: Smithsonian Contributions to Paleobiology 93 (2002), pp. 83-97.

[15395] J. N. McDonald and C. E. Ray. "Records of musk oxen form the Atlantic Coastal Plain of North America". English. In: The Mosasaur 5 (1993), pp. 1-18. 
[15396] B. McFeeters. “Bone Taxon B: reevaluation of a supposed small theropod dinosaur from the midCretaceous of Morocco". English. In: Kirtlandia 58 (2013), pp. 38-41.

[15397] B. McFeeters, M. J. Ryan, C. Schroder-Adams, and T. M. Cullen. "A new ornithomimid theropod from the Dinosaur Park Formation of Alberta, Canada". English. In: Journal of Vertebrate Paleontology 36 (2016), e1221415:1-20. DOI: 10.1080/02724634.2016.1221415.

[15398] B. McFeeters, M. J. Ryan, S. Hinic-Frlog, and C. Schröder-Adams. “A reevaluation of Sigilmassasaurus brevicollis (Dinosauria) from the Cretaceous of Morocco". English. In: Canadian Journal of Earth Sciences 50.6 (2013), pp. 636-649. DOI: 10.1139/cjes-2012-0129.

[15399] A. J. McGowan, A. B. Smith, and P. D. Taylor. "Faunal diversity, heterogeneity and body size in the Early Triassic: testing post-extinction paradigms in the Virgin Limestone of Utah, USA". English. In: Australian Journal of Earth Sciences 56 (2009), pp. 859-872.

[15400] C. Mcgowan. "A new species of Shastasaurus (Reptilia: Ichthyosauria) from the Triassic of British Columbia: the most complete exemplar of the genus". English. In: Journal of Vertebrate Paleontology 14.2 (1994), pp. 168-179.

[15401] C. McGowan. "The taxonomic status of the Late Triassic ichthyosaur Grendelius mordax: a preliminary report". English. In: Journal of Vertebrate Paleontology 17.2 (1997), pp. 428-430.

[15402] C. McGowan. "Temnodontosaurus risor is a juvenile of T. platyodon (Reptilia: Ichthyosauria)". English. In: Journal of Vertebrate Paleontology 14.4 (1994), pp. 472-479.

[15403] C. McGowan. "A new specimen of Excalibosaurus from the English Lower Jurassic". English. In: Journal of Vertebrate Paleontology 23.4 (2003), pp. 950-956.

[15404] C. McGowan and A. C. Milner. "A new Pliensbachian Ichthyosaur from Dorset, England". English. In: Palaeontology 42.5 (1999), pp. 761-768.

[15405] G. McGowan and S. E. Evans. "Albanerpetontid amphibians from the Cretaceous of Spain". English. In: Nature 373 (1995), pp. 143-145.

[15406] G. J. McGowan. "The development and function of the atlanto-axial joint in albanerpetontid amphibians". English. In: Journal of Herpetology 32.1 (1998), pp. 116-122.

[15407] A. McGrath, F. Anaya, and D. Croft. "New Proterotheriids From the Middle Miocene of Quebrada Honda, Bolivia, and Body Size and Diversity Trends in Proterotheriid and Macraucheniid Litopterns (Mammalia)". English. In: Ameghiniana 57.2 (2020), pp. 159-188. DOI: 10.5710/ AMGH. 03.03.2020.3268.

[15408] A. J. McGrath, F. Anaya, and D. A. Croft. "Two new macraucheniids (Mammalia: Litopterna) from the late middle Miocene (Laventan South American Land Mammal Age) of Quebrada Honda, Bolivia". English. In: Journal of Vertebrate Paleontology 38.3 (2018), e1461632. DOI: 10.1080/02724634. 2018.1461632.

[15409] A. J. McGrath, J. J. Flynn, and A. R. Wyss. “Proterotheriids and macraucheniids (Litopterna: Mammalia) from the Pampa Castillo Fauna, Chile (early Miocene, Santacrucian SALMA) and a new phylogeny of Proterotheriidae". English. In: Journal of Systematic Palaeontology 18.9 (2020), pp. 717738. DOI: $10.1080 / 14772019.2019 .1662500$.

[15410] G. A. Mchedlidze. "The short preliminary information on the Metekhi vertebrate site (Late Oligocene)". English. In: Problems of Paleobiology 3 (2008), pp. 129-133.

[15411] J. B. McHugh. "Paleohistology and histovariability of the Permian stereospondyl Rhinesuchus". English. In: Journal of Vertebrate Paleontology 34.1 (2014), pp. 59-68. DOI: 10.1080 / 02724634.2013. 787429.

[15412] A. P. McIntosh, K. Shimada, and M. J. Everhart. “Late Cretaceous marine vertebrate fauna from the Fairport Chalk Member of the Carlile Shale in southern Ellis County, Kansas, U.S.A." English. In: Transactions of the Kansas Academy of Science 119 (2016), pp. 222-230. DOI: 10.1660/062.119.0214.

[15413] G. E. O. McIntosh. “Devonian cladid crinoids: families Glossocrinidae Goldring, 1923, and Rutkowskicrinidae new family". English. In: Journal of Paleontology 75.4 (2001), pp. 783-807. 
[15414] J. S. Mcintosh, W. P. Coombs, and D. A. Russell. "A new diplodocid sauropod (Dinosauria) from Wyoming, U.S.A." English. In: Journal of Vertebrate Paleontology 12.2 (1992), pp. 158-167.

[15415] E. E. McIver. “The paleoenvironment of Tyrannosaurus rex from southwestern Saskatchewan, Canada". English. In: Canadian Journal of Earth Sciences 39 (2002), pp. 207-221.

[15416] E. E. McIver and J. F. Basinger. "Flora of the Ravenscrag Formation (Paleocene), Southwestern Saskatchewan, Canada". In: Palaeontographica Canadiana 10 (1993), pp. 1-85.

[15417] E. E. McIver. "An early Chamaecyparis (Cupressaceae) from the Late Cretaceous of Vancouver Island, British Columbia, Canada". In: Canadian Journal of Botany 72.12 (1994).

[15418] I. J. McKay. “Cretaceous Promecognathinae (Coleoptera: Carabidae): a new genus, phylogenetic reconstruction and zoogeography". English. In: Biological Journal of the Linnean Society 44 (1991), pp. 1-12.

[15419] P. J. McKeever and H. Haubold. "Reclassification of Vertebrate Trackways from the Permian of Scotland and Related Forms from Arizona and Germany". English. In: Journal of Paleontology 70.6 (1996), pp. 1011-1022.

[15420] R. C. McKellar and B. D. E. Chatterton. "Early and Middle Devonian Phacopidae (Trilobita) of southern Morocco". English. In: Palaeontographica Canadiana 28 (2009), pp. 1-109.

[15421] R. C. McKellar and M. S. Engel. "The serphitid wasps (Hymenoptera: Proctotrupomorpha: Serphitoidea) of Canadian Cretaceous amber". English. In: Systematic Entomology 36 (2011), pp. 192208.

[15422] R. C. McKellar and M. S. Engel. "A new thorny lacewing (Neuroptera: Rhachiberothidae) from Canadian Cretaceous amber". English. In: Journal of the Kansas Entomological Society 82.2 (2009), pp. 114-121.

[15423] R. C. McKellar and M. S. Engel. “New Stigmaphronidae and Megaspilidae (Hymenoptera: Ceraphronoidea) from Canadian Cretaceous amber". English. In: Cretaceous Research 32 (2011), pp. $794-$ 805.

[15424] R. C. McKellar and M. S. Engel. "First Mesozoic Microphysidae (Hemiptera): a new genus and species in Late Cretaceous amber from Canada". English. In: The Canadian Entomologist 143 (2011), pp. 349-357.

[15425] R. C. McKellar and M. S. Engel. “The first Mesozoic Leptopodidae (Hemiptera: Heteroptera: Leptopodomorpha), from Canadian Late Cretaceous amber". English. In: Historical Biology 26 (2014), pp. 702-709.

[15426] R. C. McKellar and M. S. Engel. "New bethylid and chrysidid wasps (Hymenoptera: Chrysidoidea) from Canadian Late Cretaceous amber". English. In: Paläontologische Zeitschrift 88 (2014), pp. 433-451. DOI: 10.1007/s12542-013-0208-y.

[15427] R. C. McKellar, J. R. N. Glasier, and M. S. Engel. “New ants (Hymenoptera: Formicidae: Dolichoderinae) from Canadian Late Cretaceous amber". English. In: Bulletin of Geosciences 88 (2013), pp. 583594.

[15428] R. C. McKellar, J. R. N. Glasier, and M. S. Engel. “A new trap-jawed ant (Hymenoptera: Formicidae: Haidomyrmecini) from Canadian Late Cretaceous amber". English. In: The Canadian Entomologist 145 (2013), pp. 454-465.

[15429] R. C. McKellar, E. Jones, M. S. Engel, R. Tappert, A. P. Wolfe, K. Muehlenbachs, P. Cockx, E. B. Koppelhus, and P. J. Currie. "A direct association between amber and dinosaur remains provides paleoecological insights". English. In: Scientific Reports 9.17916 (2019), pp. 1-7.

[15430] R. C. McKellar, D. S. Kopylov, and M. S. Engel. "Ichneumonidae (Insecta: Hymenoptera) in Canadian Late Cretaceous amber". English. In: Fossil Record 16 (2013), pp. 217-227.

[15431] M. C. McKenna. "Plagiomenids (Mammalia: ?Dermoptera) from the Oligocene of Oregon, Montana, and South Dakota, and middle Eocene of northwestern Wyoming." English. In: Geological Society of America Special Paper 243 (1990), pp. 211-234. 
[15432] M. C. McKenna and S. K. Bell. English. Classification of Mammals Above the Species Level. 1997, pp. 1-640.

[15433] M. C. McKenna, Z. Kielan-Jaworowska, and J. Meng. "Earliest eutherian mammal skull, from the Late Cretaceous (Coniacian) of Uzbekistan". English. In: Acta Palaeontologica Polonica 45.1 (2000), pp. 1-54.

[15434] M. C. McKenna and D. L. Lofgren. "Mimotricentes tedfordi, a new arctocyonid from the late Paleocene of California". English. In: Bulletin of the American Museum of Natural History 279 (2003), pp. 632-643.

[15435] M. C. McKenna and J. Meng. "A primitive relative of rodents from the Chinese Paleocene". English. In: Journal of Vertebrate Paleontology 21.3 (2001), pp. 565-572.

[15436] M. C. McKenna, A. R. Wyss, and J. J. Flynn. "Paleogene Pseudoglyptodont Xenarthrans from Central Chile and Argentine Patagonia". English. In: American Museum Novitates 3536 (2006), pp. 118.

[15437] S. M. S. McLachlan, G. W. Kaiser, and N. R. Longrich. "Maaqwi cascadensis: A large, marine diving bird (Avialae: Ornithurae) from the Upper Cretaceous of British Columbia, Canada". English. In: PLos One 12.12 (2017), e0189473. DOI: 10.1371/journal.pone.0189473.

[15438] R. B. McLaughlin. "Cyclotella jonesii, a new diatom species from Pliocene deposits at Chiloquin, Oregon, USA". English. In: Diatom Research 7.1 (1992), pp. 95-101.

[15439] W. N. F. McLaughlin, S. S. B. Hopkins, and M. D. Schmitz. "A new late Hemingfordian vertebrate fauna from Hawk Rim, Oregon, with implications for biostratigraphy and geochronology". English. In: Journal of Vertebrate Paleontology e1201095 (2016), pp. 1-21. DOI: 10.1080 / 02724634.2016. 1201095.

[15440] R. S. McLean. Phillipsastreid corals from the Frasnian (Upper Devonian) of western Canada: taxonomy and biostratigraphic significance. English. NRC Press. 2005, pp. 1-109.

[15441] S. A. McLeod and L. G. Barnes. "A new genus and species of Eocene protocetid archaeocete whale (Mammalia, Cetacea) from the Atlantic Coastal plain". English. In: Science Series, Natural History Museum of Los Angeles County 41 (2008), pp. 73-98.

[15442] S. McLoughlin. “Late Permian Plant Megafossils from the Bowen Basin, Queensland, Australia: Part 1". In: Palaeontographica Abteilung B 228 (1992), pp. 105-149.

[15443] S. McLoughlin. "Late Permian plant megafossils from the Bowen Basin, Queensland, Australia: Part 3". In: Palaeontographica Abteilung B 231 (1994), pp. 31-62.

[15444] S. McLoughlin, R. J. Carpenter, G. J. Jordan, and R. S. Hill. “Seed ferns survived the end-Cretaceous mass extinction in Tasmania". English. In: American Journal of Botany 95.4 (2008), pp. 465-471. DOI: 10.3732/ajb.95.4.465.

[15445] S. McLoughlin, R. J. Carpenter, and C. Pott. "Ptilophyllum muelleri (Ettingsh.) comb. nov. from the Oligocene of Australia: Last of the Bennettitales?" English. In: International Journal of Plant Sciences 172.4 (2011), pp. 574-585.

[15446] S. McLoughlin, A. N. Drinnan, and A. C. Rozefelds. "A Cenomanian Flora from the Winton Formation, Eromanga Basin, Queensland, Australia". In: Memoirs of the Queensland Museam 38.1 (1995), pp. 273-313.

[15447] S. McLoughlin and A. N. Drinnan. "A Middle Jurassic Flora from the Walloon Coal Measures, Mutdapilly, Queensland, Australia". In: Memoirs of the Queensland Museam 38.1 (1995), pp. 257272.

[15448] S. McLoughlin, S. Lindstrom, and A. N. Drinnan. “Gondwanan floristic and sedimentological trends during the Permian-Triassic transition: new evidence from the Amery Group, northern Prince Charles Mountains, East Antarctica". In: Antarctic Science 9.3 (1997), pp. 281-298.

[15449] S. McLoughlin, A.-M. P. Tosolini, N. S. Nagalingum, and A. N. Drinnan. "Early Cretaceous (Neocomian) flora and fauna of the Lower Strzelecki Group, Gippsland Basin, Victoria". In: Memoirs of the Association of Australasian Palaeontologists 26 (2002), pp. 1-144. 
[15450] M. A. S. McMenamin. "Early Cambrian sponge spicules from the Cerro Clemente and Cerro Rajón, Sonora, México". English. In: Geologica Acta 6.4 (2008), pp. 363-367.

[15451] M. A. S. McMenamin. "Cambrian Chordates and Vetulicolians". English. In: Geosciences 3.354 (2019), pp. 1-24. DOI: 10.3390/geosciences9080354.

[15452] M. A. S. McMenamin, F. Debrenne, and A. Y. Zhuravlev. “Early Cambrian Appalachian archaeocyaths: further age constraints from the fauna of New Jersey and Virginia, USA". English. In: Geobios 33.6 (2000), pp. 693-708.

[15453] M. A. S. McMenamin. Homo tsaichangensis and Gigantopithecus. English. Homo tsaichangensis and Gigantopithecus. South Hadley: Meanma Press, 2015, pp. 1-12.

[15454] G. C. McNamara. “The Wyandotte Local Fauna: A New, Dated, Pleistocene Vertebrate Fauna from Northern Queensland". English. In: Memoirs of the Queensland Museum 28 (1990), pp. 285-297.

[15455] K. J. McNamara. "A new genus of marsupiate spatangoid echinoid from the Miocene of South Australia". English. In: Records of the South Australian Museum 26 (1992), pp. 139-147.

[15456] K. J. McNamara, G. M. Philip, and P. D. Kruse. "Tertiary brissid echinoids of southern Australia". English. In: Alcheringa 10.1 (2008), pp. 55-84.

[15457] K. J. McNamara and G. W. Kendrick. “Cenozoic Molluscs and Echinoids of Barrow Island, Western Australia". English. In: Records of the Western Australian Museum Supplement 51 (1994).

[15458] M. E. McNamara, V. Saranathan, E. R. Locatelli, H. Noh, D. E. G. Briggs, P. J. Orr, and H. Cao. "Cryptic iridescence in a fossil weevil generated by single diamond photonic crystals". English. In: Journal of the Royal Society Interface 11.20140736 (2014), pp. 1-8. DOI: 10.1098/rsif.2014.0736.

[15459] P. E. McNeil. "Mammoth steps: an overview of the fauna of Wally's Beach (DhPg-8), a late Pleistocene locality from southwestern Alberta". English. In: GeoCanada 2010 - Working with the Earth (2010).

[15460] B. W. McPhee, R. B. J. Benson, J. Botha-Brink, E. M. Bordy, and J. N. Choiniere. "A Giant Dinosaur from the Earliest Jurassic of South Africa and the Transition to Quadrupedality in Early Sauropodomorphs". English. In: Current Biology 28 (2018), pp. 1-9.

[15461] B. W. McPhee, M. F. Bonnan, A. M. Yates, J. Neveling, and J. N. Choiniere. "A new basal sauropod from the pre-Toarcian Jurassic of South Africa: evidence of niche-partitioning at the sauropodomorphsauropod boundary?" English. In: Scientific Reports 5 (2015), 13224:1-12. DOI: 10.1038/srep13224.

[15462] B. W. McPhee, J. N. Choiniere, A. M. Yates, and P. A. Viglietti. "A second species of Eucnemesaurus Van Hoepen, 1920 (Dinosauria, Sauropodomorpha): new information on the diversity and evolution of the sauropodomorph fauna of South Africa's lower Elliot Formation (latest Triassic)". English. In: Journal of Vertebrate Paleontology 35.5 (2015), e980504:1-24. DOI: 10.1080/02724634.2015. 980504.

[15463] B. W. McPhee, P. D. Mannion, W. J. de Klerk, and J. N. Choiniere. “High diversity in the sauropod dinosaur fauna of the Lower Cretaceous". English. In: Cretaceous Research 59 (2016), pp. 228-248. DOI: 10.1016/j.cretres.2015.11.006.

[15464] B. W. McPhee, P. Upchurch, P. D. Mannion, C. Sullivan, R. J. Butler, and P. M. Barrett. "A revision of Sanpasaurus yaoi Young, 1944 from the Early Jurassic of China, and its relevance to the early evolution of Sauropoda (Dinosauria)". English. In: PeerJ 4 (2016), e2578:1-41. DOI: 10.7717/ peerj. 2578.

[15465] J. McPhee, N. Ibrahim, A. Kao, D. M. Unwin, R. Smith, and D. M. Martill. "A new ?chaoyangopterid (Pterosauria: Pterodactyloidea) from the Cretaceous Kem Kem beds of southern Morocco". English. In: Cretaceous Research 110 (2020), p. 104410. DOI: 10.1016/j.cretres.2020.104410.

[15466] C. McRoberts. "Systematics and paleobiogeography of Late Triassic Gryphaea (Bivalvia) from the North American Cordillera". English. In: Journal of Paleontology 66.1 (1992), pp. 28-39.

[15467] C. McRoberts, L. Krystyn, and A. Shea. "Rhaetian (Late Triassic) Monotis (Bivalvia: Pectinoida) from the eastern Northern Calcareous Alps (Austria) and the end-Norian crisis in pelagic faunas". English. In: Palaeontology 51.3 (2008), pp. 721-735. 
[15468] C. A. McRoberts. "Late Triassic (Norian-Rhaetian) bivalves from the Antimonio Formation, northwestern Sonora, Mexico". In: Revista Mexicana de Ciencias Geológicas 14.2 (1997), pp. 167-177.

[15469] C. A. McRoberts. "A primitive Halobia (Bivalvia: Halobioidea) from the Triassic of Northeast British Columbia". In: Journal of Paleontology 74.4 (2000), pp. 599-603.

[15470] C. A. McRoberts. "Systematics and biostratigraphy of halobiid bivalves from the Martin Bridge Formation (Upper Triassic), Northeast Oregon". English. In: Journal of Paleontology 67.2 (1993), pp. 198-210.

[15471] C. A. McRoberts. "Late Triassic Bivalvia (Chiefly Halobiidae and Monotidae) from the Pardonet Formation, Williston Lake Area, Northeastern British Columbia, Canada". English. In: Journal of Paleontology 85.4 (2011), pp. 613-664. DOI: 10.1666/10-051.1.

[15472] C. A. McRoberts and R. B. Blodgett. "Late Triassic (Norian) mollusks from the Taylor Mountains quadrangle, southwestern Alaska". English. In: United States Geological Survey Professional Paper 1662 (2000), pp. 55-67.

[15473] C. A. McRoberts, L. Krystyn, and M. Hautmann. "Macrofaunal response to the end Triassic mass extinction in the West-Tethyan Kössen Basin, Austria". English. In: Palaios 27 (2012), pp. 607-616.

[15474] C. A. McRoberts and N. D. Newell. "Marine Myalinidae (Bivalvia: Pterioida) from the Permian of West Texas". English. In: American Museum Novitates 3469 (2005), pp. 1-15.

[15475] C. A. McRoberts and N. D. Newell. "A new Permian myalinid genus, Elversella, of west Texas". In: American Museum Novitates 3311 (2001), pp. 1-5.

[15476] C. A. McRoberts and N. D. Newell. "A new transitional myalinid bivalve from the Lower Permian of west Texas". In: Palaeontology 40.2 (1997), pp. 487-495.

[15477] C. A. McRoberts, C. R. Newton, and A. Allasinaz. "End-triassic bivalve extinction: Lombardian alps, Italy". In: Historical Biology 9 (1995), pp. 297-317.

[15478] J. A. Meachen. "A new species of Hemiauchenia (Artiodactyla, Camelidae) from the late Blancan of Florida". English. In: Bulletin of the Florida Museum of Natural History 45.4 (2005), pp. 435-447.

[15479] A. J. Mead. "Enamel hypoplasia in Miocene rhinoceroses (Teleoceras) from Nebraska; evidence of severe physiological stress". English. In: Journal of Vertebrate Paleontology 19.2 (1999), pp. 391-397.

[15480] J. I. Mead. "Scolecophidia (Serpentes) of the late Oligocene and early Miocene, North America, and a fossil history overview". English. In: Geobios 46 (2013), pp. 225-231.

[15481] J. I. Mead, J. M. Arroyo-Cabrales, and S. L. Swift. “Late Pleistocene Mammuthus and Cuvieronius (proboscidea) from Térapa, Sonora, Mexico". English. In: Quaternary Science Reviews 223 (2019), pp. 1-11.

[15482] J. I. Mead, A. Baez, S. L. Swift, M. C. Carpenter, M. Hollenshead, N. J. Czaplewski, D. W. Steadman, J. Bright, and J. Arroyo-Cabrales. "Tropical marsh and savanna of the late Pleistocene in northeastern Sonora, Mexico". English. In: Southwestern Naturalist 51.2 (2006), pp. 226-239.

[15483] J. I. Mead, R. Cubero, A. L. Valerio Zamora, S. L. Swift, C. Laurito, and L. D. Gómez. “PlioPleistocene Crocodylus (Crocodylia) from southwestern Costa Rica". English. In: Studies on Neotropical Fauna and Environment 41.1 (2006), pp. 1-7.

[15484] J. I. Mead and F. Grady. “Ochotona (Lagomorpha) from late Quaternary cave deposits in eastern North America". English. In: Quaternary Research 45.1 (1996), pp. 93-101.

[15485] J. I. Mead, D. Moscato, B. W. Schubert, C. Jin, G. Wei, C. Sun, and L. Zheng. "Early Pleistocene snake (Squamata, Reptilia) skeleton from Renzidong Cave, Anhui, China". English. In: Historical Biology 28.1-2 (2016), pp. 208-214. DOI: 10.1080/08912963.2015.1023719.

[15486] J. I. Mead and B. W. Schubert. “Extinct Pterygoboa (Boidae, Erycinae) from the latest Oligocene and early Miocene of Florida". English. In: Southeastern Naturalist 12.2 (2013), pp. 427-438.

[15487] J. I. Mead, A. E. Spiess, and K. D. Sobolik. "Skeleton of Extinct North American Sea Mink (Mustela macrodon)". English. In: Quaternary Research 53 (2000), pp. 247-262. DOI: 10.1006/qres.1999.2109. 
[15488] J. I. Mead, D. W. Steadman, S. H. Bedford, C. J. Bell, and M. Spriggs. “New Extinct Mekosuchine Crocodile from Vanuatu, South Pacific". English. In: Copeia 2002.3 (2002), pp. 632-641.

[15489] J. I. Mead and D. W. Steadman. "Late Pleistocene snakes (Squamata: Serpentes) from Abaco, The Bahamas". English. In: Geobios 50 (2017), pp. 431-440. DOI: 10.1016/j.geobios.2017.09.001.

[15490] J. I. Mead, S. L. Swift, R. S. White, H. G. McDonald, and A. Baez. “Late Pleistocene (Rancholabrean) glyptodont and pampathere (Xenarthra, Cingulata) from Sonora, Mexico". English. In: Revista Mexicana de Ciencias Geológicas 24.3 (2007), pp. 439-449.

[15491] J. I. Mead and L. H. Taylor. "New species of Sinocapra (Bovidae, Caprinae) from the lower Pliocene Panaca Formation, Nevada, USA". English. In: Palaeontologia Electronica 8.1.11A (2005), pp. 1-10.

[15492] J. I. Mead, J. Wilkins, and P. W. Collins. "Late Quaternary chorus frog (Pseudacris) from the Channel Islands," English. In: Southern California Academy of Sciences 117.1 (2018), pp. 52-63. DOI: 10. 3160/soca-117-01-52-63.1.

[15493] J. Meco, H. Guillou, J. -C. Carracedo, A. Lomoschitz, A. -J. G. Ramos, and J. -J. Rodriguez-Yanez. "The maximum warmings of the Pleistocene world climate recorded in the Canary Islands". English. In: Palaeogeography, Palaeoclimatology, Palaeoecology 185 (2002), pp. 197-210.

[15494] M. A. Medeiros. "Large theropod teeth from the Eocenomanian of northeastern Brazil and the occurrence of Spinosauridae". English. In: Revista Brasileira de Paleontologia 9.3 (2006), pp. 333-338.

[15495] M. A. Medeiros and L. S. Avilla. Revisão sistemática dos dinossauros saurópodes da Formação Alcantara (Cenomaniano), Maranhão, Brasil [Systematic revision of the sauropod dinosaurs of the Alcantara Formation (Cenomanian), Maranhão, Brazil]. Portugese. 2005.

[15496] M. A. Medeiros and C. L. Schultz. "A fauna dinossauriana da Laje do Coringa, Cretáceo Médio do nordeste do Brasil [The dinosaurian fauna of Laje do Coringa, middle Cretaceous of northeastern Brazil]". Portugese. In: Arquivos do Museu Nacional, Rio de Janeiro 60.3 (2002), pp. 155-162.

[15497] J. Mederos, Y. N. Wang, S. Duque-Valero, and M. Campeny. “A new fossil species of Trentepohlia (Diptera, Limoniidae) from the Dominican Miocene". English. In: Zoosystema 42 (2020), pp. 583592. DOI: 10.5252 / zoosystema2020v42a29.

[15498] T. Medin, B. Martinez-Navarro, F. Rivals, J. Madurell-Malapeira, S. Ros-Montoya, M. -P. Espigares, B. Figueirido, L. Rook, and P. Palmqvist. "Late Villafranchian Ursus etruscus and other large carnivorans from the Orce sites (Guadix-Baza basin, Andalusia, southern Spain): Taxonomy, biochronology, paleobiology, and ecogeographical context". English. In: Quaternary International 431 (2017), pp. 20-41.

[15499] F. A. Medina and A. C. Riccardi. "Tuberosciponoceras: a new dimorphic ammonoid genus from the Upper Albian of Patagonia, Argentina". English. In: Palaeontologische Zeitschrift 81.2 (2007), pp. 123-130.

[15500] F. A. Medina and A. C. Riccardi. “Desmoceratidae, Silesitidae and Kossmaticeratidae (Ammonitida) from the Upper Aptian-Albian of Patagonia (Argentina)". English. In: Revue de Paleobiologie, Geneve 24.1 (2005), pp. 251-286.

[15501] T. J. Meehan and L. D. Martin. "Emended genus description and a new species of Hypisodus (Artiodactyla: Ruminantia: Hypertragulidae)". English. In: in Paleogene Mammals, S. G. Lucas, K. E. Zeigler, and P.E. Kondrashov (eds.), New Mexico Museum of Natural History and Science Bulletin 26 (2004), pp. 137-143.

[15502] T. J. Meehan and L. D. Martin. "New leptictids (Mammalia: Insectivora) from the Early Oligocene of Nebraska, USA". English. In: Neues Jahrbuch für Geologie und Paläontologie - Abhandlungen 256.1 (2010), pp. 99-107.

[15503] T. J. Meehan and L. D. Martin. “New large leptictid insectivore from the Late Paleogene of South Dakota, USA". English. In: Acta Palaeontologica Polonica 57.3 (2012), pp. 509-518.

[15504] T. J. Meehan and R. W. Wilson. "New viverravids from the Torrejonian (Middle Paleocene) of Kutz Canyon, New Mexico and the oldest skull of the order Carnivora". English. In: Journal of Paleontology 76.6 (2002), pp. 1091-1101. 
[15505] J. G. Meert, A. S. Gibsher, N. M. Levashova, W. C. Grice, G. D. Kamenov, and A. B. Ryabinin. "Glaciation and $770 \mathrm{Ma}$ (?) Ediacara fossils from the Lesser Karatau Microcontinent, Kazakhstan". English. In: Gondwana Research (2010).

[15506] D. Megirian. "A new species of Quinkana Molnar (Eusuchia: Crocodylidae) from the Miocene Camfield Beds of northern Australia". English. In: The Beagle, Records of the Museums and Art Galleries of the Northern Territory 11 (1994), pp. 145-166.

[15507] D. Megirian. "Meiolania brevicollis sp. nov. (Testudines: Meiolaniidae): a new horned turtle from the Australian Miocene". English. In: Alcheringa 16.2 (1992), pp. 93-106.

[15508] D. Megirian, P. F. Murray, and P. Willis. "A new crocodile of the gavial ecomorph morphology from the Miocene of Northern Australia". English. In: The Beagle, Records of the Northern Territory Museum of Arts and Sciences 8.1 (1991), pp. 135-158.

[15509] A. D. Meglei, K. Shimada, and J. I. Kirkland. "Fossil vertebrates from the middle Graneros Shale (Upper Cretaceous: middle Cenomanian) in southeastern Nebraska". English. In: Transactions of the Kansas Academy of Science 116 (2013), pp. 129-135. DOI: 10.1660/062.116.0304.

[15510] D. Mehl and F. T. Fürsich. "Middle Jurassic Porifera from Kachchh, western India". English. In: Palaeontologische Zeitschrift 71 (1997), pp. 19-33.

[15511] D. Mehl, J. K. Rigby, and S. R. Holmes. "Hexactinellid sponges from the Silurian-Devonian Roberts Mountains Formation in Nevada and hypotheses of hexactine-stauractine origin". English. In: Geology Studies Brigham Young University 39 (1993), pp. 101-124.

[15512] D. Mehl, M. Wuttke, and R. Kott. “Beiträge zur Spongien-Fauna des Hunsrückschiefers (II). Beschreibung eines neuen Kieselschammes (Hexactinellida, Rossellimorpha, fam., gen. et sp. indet)". German. In: Magyar Allami Foldtani Intezet Evi Jelentese 1997.2 (1997), pp. 79-92.

[15513] R. C. Mehrotra, R. P. Tiwari, and B. I. Mazumder. "Nypa megafossils from the Tertiary sediments of Northeast India". English. In: Geobios 36 (2003), pp. 83-92. DOI: 10.1016/S0016-6995(02)00107-9.

[15514] H. J. M. Meijer and R. Awe Due. "A new species of giant marabou stork (Aves: Ciconiiformes) from the Pleistocene of Liang Bua, Flores (Indonesia)". English. In: Zoological Journal of the Linnean Society 160.4 (2010), pp. 707-724.

[15515] H. J. M. Meijer, R. A. Due, T. Sutikna, Jatmiko Saptomo W., S. Wasisto, M. W. Tocheri, and G. Mayr. "Late Pleistocene songbirds of Liang Bua (Flores, Indonesia); the first fossil passerine fauna described from Wallacea". English. In: PeerJ 5 (2017), e3676.

[15516] H. J. M. Meijer, J. Louys, and S. O'Connor. "First record of avian extinctions from the Late Pleistocene and Holocene of Timor Leste". English. In: Quaternary Science Reviews 203 (2009), pp. 170184. DOI: 10.1016/j.quascirev.2018.11.005.

[15517] H. J. M. Meijer, J. Louys, and S. O'Connor. "First record of avian extinctions from the Late Pleistocene and Holocene of Timor Leste". English. In: Quaternary Science Reviews 203 (2019), pp. 170184.

[15518] H. J. M. Meijer, T. Sutikna, E. W. Saptomo, Jatmiko Due R.A., S. Wasisto, H. F. James, M. J. Morwood, and M. W. Tocheri. "Late Pleistocene-Holocene non-passerine avifauna of Liang Bua (Flores, Indonesia)". English. In: Journal of Vertebrate Paleontology 33 (2013), pp. 877-894.

[15519] P. Mein and L. Ginsburg. "Les mammiferes du gisement miocene inferieure de Li Mae Long, Thailande; Systematique biostratigraphie et paleoenvironment". French. In: Geodiversitas 19.4 (1997), pp. 783-844.

[15520] P. Mein, E. Martn Suárez, and J. Agust. “Progonomys Schaub, 1938 and Huerzelerimys gen. nov. (Rodentia); their evolution in Western Europe". English. In: Scripta Geologica 103 (1993), pp. 41-64.

[15521] P. Mein and E. Martn-Suárez. “Galerix iberica sp. nov. (Erinaceidae, Insectivora, Mammalia) from the Late Miocene and Early Pliocene of the Iberian Peninsula." English. In: Geobios 26.6 (1993), pp. 723-730.

[15522] P. Mein and M. Pickford. "Rodentia (other than Pedetidae) from the Orange River deposits, Namibia". English. In: Memoirs of the Geological Survey of Namibia 19 (2003), pp. 147-160. 
[15523] P. Mein and M. Pickford. "Insectivora from Arrisdrift, a basal middle Miocene locality in southern Namibia". English. In: Memoirs of the Geological Survey of Namibia 19 (2003), pp. 143-146.

[15524] P. Mein and M. Pickford. "Fossil bat (Microchiroptera, Mammalia) from Arrisdrift, Namibia". English. In: Memoirs of the Geological Survey of Namibia 19 (2003), pp. 115-117.

[15525] C. Meister, K. Alazouma, J. Lang, B. Mathey, and A. Pascal. “Nouvelles données sur les ammonites du Niger oriental (Ténéré, Afrique occidentale) dans le cadre de la transgression du CénomanienTuronien". French. In: Geobios 27 (1994), pp. 189-219.

[15526] C. Meister, K. Alzouma, J. Lang, and B. Mathey. "Les ammonites du Niger (Afrique occidentale) et la transgression Transsaharienne au cours du Cénomanien-Turonien". French. In: Geobios 25 (1992), pp. 55-100.

[15527] C. Meister and J. Blau. "Pliensbachian ammonites from the Central Apennines, Italy (Acquasparta section) - a revision of Fischer's collection and new data". English. In: Neues Jahrbuch für Geologie und Paläontologie 273.3 (2014), pp. 253-275. DOI: 10.1127/0077-7749/2014/0430.

[15528] C. Meister, J. Blau, J. -L. Dommergues, R. Schlatter, R. Schmidt-Effing, and K. Burk. “Ammonites from the Lower Jurassic (Sinemurian) of Tenango de Doria (Sierra Madre Oriental, Mexico). Part IV: Biostratigraphy, palaeobiogeography and taxonomic addendum." English. In: Revue de Paléobiologie 24.1 (2005), pp. 365-384.

[15529] C. Meister, J. L. Dommergues, and R. B. Rocha. "Ammonites from the Apoderoceras beds (Early Pliensbachian) in São Pedro de Muel (Lusitanian basin, Portugal)". English. In: Bulletin of Geosciences 87 (2012), pp. 407-430.

[15530] C. Meister, J. L. Dommergues, C. Dommergues, N. Lachkar, and K. El Hariri. “Les ammonites du Pliensbachien du jebel Bou Rharraf (Haut Atlas oriental, Maroc)". French. In: Geobios 44 (2011), 117.e1-117.e60.

[15531] C. Meister, P. Maurizot, and J. A. Grant-Mackie. "Early Jurassic (Hettangian - Sinemurian) Ammonites from New Caledonia (French Overseas Territory, Western Pacific)". English. In: Paleontological Research 14.2 (2010), pp. 85-118. DOI: 10.2517/1342-8144-14.2.085.

[15532] C. Meister, M. Mbina Mounguengui, and J. Lang. “Les ammonites du Cénomano-Turonien du bassin cotier nord-gabonais: systématique et intéret paléogéographique pour la liaison TéthysAtlantique Sud". French. In: Revue de Paléobiologie, Genéve 22 (2003), pp. 341-355.

[15533] C. Meister, J. Schlögl, and M. Rakús. "Sinemurian ammonites from Male Karpaty Mts., Western Carpathians, Slovakia. Part 1: Phylloceratoidea, Lytoceratoidea, Schlotheimiidae". English. In: Neues Jahrbuch für Geologie und Paläontologie - Abhandlungen 259.1 (2011), pp. 25-88. DOI: 10. 1127/0077-7749/2010/0105.

[15534] P. Mejia-Velazquez, S. R. Manchester, and C. Jaramillo. Floristic reconstruction of two Lower Cretaceous sections from Peru during the period of early angiosperm diversification and their climatic implications. English. Tokyo, 2012.

[15535] P. J. Mejia-Velazquez, D. L. Dilcher, C. A. Jaramillo, L. B. Fortini, and S. R. Manchester. “Palynological composition of a Lower Cretaceous South American tropical sequence: Climatic implications and diversity comparisons with other latitudes". English. In: American Journal of Botany 99 (2012), pp. 1819-1827. DOI: 10.3732/ajb.1200135.

[15536] M. S. Mekawy. "Taphonomy of Aptian-Albian Beds in the Gebel Mistan, Maghara Area, Northern Sinai, Egypt". English. In: Earth Science and Climatic Change 4.2 (2013).

[15537] R. N. Melchor, R. Buchwaldt, and S. Bowring. "A Late Eocene date for Late Triassic bird tracks". English. In: Nature 495 (2013), E1-E2. DOI: 10.1038/nature11931.

[15538] R. N. Melchor and S. de Valais. "A review of Triassic tetrapod track assemblages from Argentina". English. In: Palaeontology 49.2 (2006), pp. 355-379.

[15539] R. N. Melchor and W. A. S. Sarjeant. "Small Amphibian and Reptile Footprints from the Permian Carapacha Basin, Argentina". English. In: Ichnos 11 (2004), pp. 57-78. DOI: 10.1080/10420940490428814. 
[15540] R. N. Melchor and S. N. Cesari. "Algunos elementos paleofloristicos de la formacion carapacha (Permico inferior), Provincia de la Pampa, Republica Argentina". Spanish. In: Ameghiniana 28 (1991), pp. 347-352.

[15541] K. H. Meldahl and A. H. Cutler. "Neotectonics and taphonomy; Pleistocene molluscan shell accumulations in the northern Gulf of California". English. In: Palaios 7.2 (1992), pp. 187-197.

[15542] D. J. Meldrum. “New Fossil Platyrrhine Tali from the Early Miocene of Argentina". English. In: American Journal of Physical Anthropology 83.4 (1990), pp. 403-418. DOI: 10.1002/ajpa.1330830402.

[15543] D. J. Meldrum, J. G. Fleagle, and R. F. Kay. "Partial humeri of two Miocene Colombian primates". English. In: American Journal of Physical Anthropology 81.3 (1990), pp. 413-422.

[15544] D. J. Meldrum and R. F. Kay. "Nuciruptor rubricae, a new pitheciin seed predator from the Miocene of Colombia". English. In: American Journal of Physical Anthropology 102.3 (1997), pp. 407427.

[15545] D. J. Meldrum and R. F. Kay. "Postcranial skeleton of Laventan Platyrrhines". English. In: Vertebrate Paleontology in the Neotropics. The Miocene fauna of La Venta, Colombia. Smithsonian Institution Press, 1997, pp. 459-472.

[15546] D. L. Melendi, L. H. Scafati, and W. Volkheimer. "Palynostratigraphy of the Paleogene Huitrera Formation in N-W Patagonia, Argeyesina". English. In: Neues Jahrbuch für Geologie und. Paläoyeslogie, Abhandlungen 228 (2003), pp. 205-273.

[15547] M. Melero Rubio and F. Pérez-Lorente. “Huellas en las obras. Reconocimiento y estudio de huellas fósiles de dinosaurio en las obras de la presa de Enciso (La Rioja. España) [Footprints in the works. Recognition and study of fossil dinosaur footprints in the works of the Enciso dam (La Rioja. Spain)]". Spanish. In: Zuba 29 (2011), pp. 31-60.

[15548] L. M. Melinkova. "A new genus of Bradoriidae (Crustacea) from the Cambrian of Northern Eurasia". In: 34.2 (2000), pp. 180-185.

[15549] R. Melis and M. R. Palombo. "Mammuthus lamarmorae (Major, 1883) remains in the pre-Tyrrhenian deposits of San Giovanni in Sinis (Western Sardinia, Italy)". English. In: The World of Elephants International Congress, Rome (2001), pp. 481-485.

[15550] B. Meller, A. G. Ponomarenko, D. V. Vasilenko, T. C. Fischer, and B. Aschauer. "First beetle elytra, abdomen (Coleoptera) and a mine trace from Lunz (Carnian, Late Triassic, Lunz-am-See, Austria) and their taphonomic and evolutionary aspects". English. In: Palaeontology 54.1 (2011), pp. 97-110.

[15551] L. H. C. Mello, F. T. Mello, and M. H. Zucon. "A new species of Gervillia Defrance (Bivalvia, Bakevelliidae) from the Aptian-Albian transition of Sergipe, Brazil". English. In: Revista Brasileira de Paleontologia 10.1 (2007), pp. 63-69.

[15552] G. Melnikova. "Monstroseris, a new Upper Triassic Scleractinian Coral from Iran". English. In: Acta Palaeontologica Polonica 34.1 (1989), pp. 71-74.

[15553] G. K. Melnikova. "The Early Jurassic fauna from the Gurumdy and Mynhajir zones of the east Pamirs". English. In: Doklady Earth Sciences 407 (2006), pp. 171-174.

[15554] G. K. Melnikova and E. Roniewicz. "The Middle Triassic scleractinia-like coral Furcophyllia from the Pamir Mountains". English. In: Acta Palaeontologica Polonica 52.2 (2007), pp. 401-406.

[15555] G. K. Melnikova, E. Roniewicz, and H. Loeser. “New microsolenid genus Eocomoseris (Scleractinia, Early Lias-Cenomanian)". English. In: Annales Societatis Geologorum Poloniae 63.3 (1993), pp. 3-12.

[15556] G. K. Melnikova and E. Roniewicz. "On a new stylophyllid genus, Pamirophyllum (Scleractinia, Upper Triassic)". English. In: Acta Palaeontologica Polonica 35.1-2 (1990), pp. 85-90.

[15557] G. K. Melnikova and E. Roniewicz. "Early Jurassic corals of the Pamir Mountains - a new TriassicJurassic transitional fauna". English. In: Geologica Belgica 15.4 (2012), pp. 376-381.

[15558] G. K. Melnikova and E. Roniewicz. "Early Jurassic corals with dominating solitary growth forms from the Kasamurg Mountains, Central Asia". English. In: Palaeoworld 26.1 (2017), pp. 124-148. 
[15559] G. K. Melnikova. "New Triassic Colonial Scleractinians from the Southeastern Pamirs". In: Paleontological Journal 30.2 (1996), pp. 128-134.

[15560] S. I. Melnitsky. "Archaeotinodes ivanovi sp. nov., a new fossil species of Ecnomidae (Insecta: Trichoptera) from the Baltic amber". English. In: Paleontological Journal 47 (2013), pp. 407-409.

[15561] S. I. Melnitsky. "A new caddisfly of the fossil genus Archaeotinodes (Insecta: Trichoptera: Ecnomidae) from the Baltic amber". English. In: Paleontological Journal 43 (2009), pp. 296-299.

[15562] S. I. Melnitsky and V. D. Ivanov. "New species of caddisflies (Insecta: Trichoptera) from the Rovno amber, Eocene of Ukraine". English. In: Paleontological Journal 44.3 (2010), pp. 303-311.

[15563] S. I. Melnitsky and V. D. Ivanov. “Seven new species of caddisflies (Insecta: Trichoptera) from the Rovno amber (Eocene of Ukraine)". English. In: Paleontological Journal 47 (2013), pp. 283-291.

[15564] S. I. Melnitsky and V. D. Ivanov. "Three new caddisflies species of the fossil genus Archaeotinodes (Insecta: Trichoptera: Ecnomidae) from the Baltic Amber". English. In: Zootaxa 3635 (2013), pp. 261-268.

[15565] S. I. Melnitsky and V. D. Ivanov. “New species of caddisflies (Insecta: Trichoptera) from the Paleogene resins of Europe". English. In: Paleontological Journal 50 (2016), pp. 69-72.

[15566] S. I. Melnitsky and V. D. Ivanov. “New species of caddisflies (Insecta, Trichoptera) from the Rovno Amber". English. In: Zoosymposia 10 (2016), pp. 278-291.

[15567] S. I. Melnitsky and V. D. Ivanov. “New species of caddisflies (Insecta: Trichoptera) from V.A. Gusakov collection". English. In: Paleontological Journal 53 (2019), pp. 506-510. DOI: 10.1134 / S0031030119050095.

[15568] G. A. R. Melo and D. A. A. Lucena. "†Chrysobythidae, a new family of chrysidoid wasps from Cretaceous Burmese amber (Hymenoptera, Aculeata)". English. In: Historical Biology 32 (2019), pp. 1143-1155. DOI: 10.1080/08912963.2019.1570184.

[15569] T. P. Melo, F. Abdala, and M. B. Soares. "The Malagasy cynodont Menadon besairiei (Cynodontia; Traversodontidae) in the Middle-Upper Triassic of Brazil". English. In: Journal of Vertebrate Paleontology (2015), e1002562. DOI: 10.1080/02724634.2014.1002562.

[15570] T. P. Melo, A. G. Martinelli, and M. B. Soares. “A new gomphodont cynodont (Traversodontidae) from the Middle-Late Triassic Dinodontosaurus Assemblage Zone of the Santa Maria Supersequence, Brazil". English. In: Palaeontology 60.4 (2017), pp. 571-582. DOI: 10.1111/pala.12302.

[15571] M. Melou. "Brachiopodes articules de la coupe de l'ile de Rosan (Crozon, Finistere); formation des tufs et calcaires de Rosan (Caradoc-Ashgill)". French. In: Géobios 23.5 (1990), pp. 539-579.

[15572] D. J. Meltzer, D. H. Mann, and J. M. LaBelle. "A Bison antiquus from Archuleta Creek, Folsom, New Mexico". English. In: Current Research in the Pleistocene 21 (2004), pp. 107-109.

[15573] Q. L. Men, Z. K. Hu, and D. Mu. "New species of Lebania (Diptera: Limoniidae) from midCretaceous amber of northern Myanmar". English. In: Cretaceous Research 104.104183 (2019). DOI: 10.1016/j.cretres.2019.07.013.

[15574] Q. L. Men, Z. K. Hu, and L. Y. Xu. “The first representative of Espanoderus and one new species of Similinannotanyderus (Diptera: Tanyderidae) from mid-Cretaceous amber of northern Myanmar". English. In: Cretaceous Research 111.104442 (2020). DOI: 10.1016/j.cretres.2020.104442.

[15575] Q. L. Men and Z. K. Hu. “A new species of Brachypremna (Diptera: Tipulidae) from Dominican amber, with a key of the genus to all fossil species". English. In: Zoological Systematics 45 (2020), pp. 236-240.

[15576] Q. L. Men and S. Podenas. "A new genus of Limoniidae (Diptera: Tipuloidea) from the midCretaceous Burmese amber". English. In: Cretaceous Research 126.104915 (2021). DOI: 10.1016/j. cretres.2021.104915.

[15577] L. F. Mendes. "Some Zygentoma (Nicoletiidae, Ateluridae) from the Neotropics, with description of one new Metrinura species". English. In: Revue Suisse de Zoologie 104 (1997), pp. 795-806. 
[15578] L. F. Mendes. "Second contribution to the study of the Dominican Republic amber Zygentoma (Insecta): family Lepismatidae". English. In: The Canadian Entomologist 130 (1998), pp. 899-904.

[15579] L. F. Mendes. "First contribution to the study of the Dominican amber Zygentoma (Insecta). Family Ateluridae". English. In: Pedobiologia 41 (1997), pp. 40-43.

[15580] L. F. Mendes and G. Poinar. "Description of two new fossil Zygentoma from Mexico and the Dominican Republic". English. In: Soil Organisms 85 (2013), pp. 1-9.

[15581] L. F. Mendes and G. O. Poinar. "A new fossil Nicoletiidae (Zygentoma, Apterygota) in Dominican amber". English. In: Proceedings of the Entomological Society of Washington 106 (2004), pp. 102-109.

[15582] L. F. Mendes and G. O. Poinar. "A new fossil silverfish (Zygentoma: Insecta) in Mesozoic Burmese amber". English. In: European Journal of Soil Biology 44 (2008), pp. 491-494.

[15583] L. F. Mendes and J. Wunderlich. "New data on thysanurans preserved in Burmese amber (Microcoryphia and Zygentoma Insecta)". English. In: Soil Organisms 85 (2013), pp. 11-22.

[15584] M. Mendes. "Novas baratas (Insecta, Blattodea) da Formação Santana, Cretáceo Inferior do nordeste do Brasil". Portugese. In: Revista da Universidade de Guarulhos, Série Geociencias 5.6 (2000), pp. 2535.

[15585] M. Mendes and L. A. Coelho. “Novas baratas (Insecta, Blattodea, Blattidae) da Formação Santana, Cretáceo Inferior, nordeste do Brasil". Portugese. In: Paleontologia: Cenários de Vida. 2007, pp. 449-457.

[15586] M. Mendes, F. I. B. de Oliveira, and S. Limaverde. "Um novo genero e duas novas espécies de Pergidae (Insecta, Hymenoptera) na Formação Fonseca (Bacia de Fonseca, Paleógeno) Minas Gerais, Brasil". Portugese. In: Revista de Geologia 28 (2015), pp. 27-36.

[15587] M. Mendes, S. M. O. Lopes de Vasconcelos, and F. I. Bezerra de Oliveira. "A new fossil stick grasshopper (Proscopioidea: Proscopiidae) from the Crato Formation of Brazil". English. In: Anuário do Instituto de Geociencias - UFRJ 42 (2019), pp. 437-443.

[15588] A. H. Méndez, F. E. Novas, and S. Chatterjee. "An abelisaurid humerus from the Upper Cretaceous of India". English. In: Palaeontologische Zeitschrift 83.3 (2010), pp. 421-425. DOI: 10.1007/s12542010-0055-z.

[15589] I. Méndez-Bedia, F. Soto, and E. Fernández-Martnez. "Devonian reef types in the Cantabrian Mountains (NW Spain) and their faunal composition". English. In: Courier Forschungsinstitut Senckenberg 172.2 (1994), pp. 161-183.

[15590] M. C. Menegazzo, R. J. Bertini, and F. F. Manzini. "A new turtle from the Upper Cretaceous Bauru Group of Brazil, updated phylogeny and implications for age of the Santo Anastacio Formation". English. In: Journal of South American Earth Sciences 58 (2015), pp. 18-32. DOI: 10.1016/j.jsames. 2014.12.008.

[15591] J. Meng. "A New Species of Didymoconidae and Comments on Related Locality and Stratigraphy". English. In: Vertebrata PalAsiatica 28.3 (1990), pp. 206-217.

[15592] J. Meng, G. J. Bowen, J. Ye, P. L. Koch, S. Ting, Q. Li, and X. Jin. “Gomphos elkema (Glires, Mammalia) from the Erlian Basin: evidence for the early Tertiary Bumbanian Land Mammal Age in Nei-Mongol, China". English. In: 3425 (2004), pp. 1-24.

[15593] J. Meng, Y. Hu, Y. Wang, X. Wang, and C. Li. "A Mesozoic gliding mammal from northeastern China". English. In: Nature 444 (2006), pp. 889-893.

[15594] J. Meng, Y. Hu, and C. Li. “Gobiolagus (Lagomorpha, Mammalia) from Eocene Ula Usu, Inner Mongolia, and Comments on Eocene Lagomorphs of Asia". English. In: Palaeontologia Electronica 8.1 (2005), 7A:1-23.

[15595] J. Meng and Y.-M. Hu. "Lagomorphs from the Yihesubu late Eocene of Nei Mongol (Inner Mongolia)". English. In: Vertebrata PalAsiatica 42.4 (2004), pp. 261-275.

[15596] J. Meng, Y.-M. Hu, Y. -Q. Wang, and C. -K. Li. "A new triconodont (Mammalia) from the Early Cretaceous Yixian Formation of Liaoning, China". English. In: Vertebrata PalAsiatica 43.1 (2005), pp. 1-10. 
[15597] J. Meng and B. P. Kraatz. “A new species of Gomphos (Glires, Mammalia) from the Eocene of the Erlian Basin, Nei Mongol, China". English. In: American Museum Novitates 3670 (2009), pp. 1-11.

[15598] J. Meng, C. Li, X. Ni, Y. Wang, and K. C. Beard. "A new Eocene rodent from the Lower Arshanto Formation in the Nuhetingboerhe (Camp Margetts) area, Inner Mongolia". English. In: American Museum Novitates 3569 (2007), pp. 1-18.

[15599] J. Meng and C.-K. Li. “New rodents from the earliest Eocene of Nei Mongol, China”. English. In: Vertebrata PalAsiatica 48.4 (2010), pp. 390-401.

[15600] J. Meng, X.-J. Ni, C. -K. Li, K. C. Beard, D. L. Gebo, Y. -Q. Wang, and H. -J. Wang. “New material of Alagomyidae (Mammalia, Glires) from the late Paleocene Subeng locality, Inner Mongolia". English. In: American Museum Novitates 3597 (2007), pp. 1-29.

[15601] J. Meng, Y. Wang, and C. Li. “Transitional mammalian middle ear from a new Cretaceous Jehol eutriconodont". English. In: Nature 472 (2011), pp. 181-185. DOI: 10.1038/nature09921.

[15602] J. Meng, W.-Y. Wu, and J. Ye. "A new species of Advenimus (Rodentia, Mammalia) from the Eocene of northern Junggar Basin of Xinjiang, China". English. In: Vertebrata PalAsiatica 39.3 (2001), pp. 185-196.

[15603] J. Meng, W.-Y. Wu, J. Ye, and S. -D. Bi. “Two petrosals of gliriform mammals from Late Oligocene of Tieersihabahe, Xinjiang Uygur Autonomous Region, China". English. In: Vertebrata PalAsiatica 39.1 (2001), pp. 43-53.

[15604] J. Meng, A. R. Wyss, M. R. Dawson, and R. -J. Zhai. "Primitive fossil rodent from Inner Mongolia and its implications for mammalian phylogeny". English. In: Nature 370 (1994), pp. 134-136.

[15605] J. Meng, A. R. Wyss, Y. Hu, Y. Wang, G. J. Bowen, and P. L. Koch. “Glires (Mammalia) from the Late Paleocene Bayan Ulan Locality of Inner Mongolia". English. In: American Museum Novitates 3473 (2005), pp. 1-25.

[15606] J. Meng, J. Ye, and X. -S. Huang. "Eocene mammals from the Bayan Ulan of Nei Mongol (Inner Mongolia) and comments on related stratigraphy". English. In: Vertebrata PalAsiatica 37.3 (1999), pp. 165-174.

[15607] J. Meng, R.-J. Zhai, and A. R. Wyss. “The late Paleocene Bayan Ulan fauna of Inner Mongolia, China". English. In: Bulletin of Carnegie Museum of Natural History 34 (1998), pp. 148-185.

[15608] Q.-J. Meng, D. M. Grossnickle, D. Liu, Y. -G. Zhang, A. I. Neander, Q. Ji, and Z. -X. Luo. “New gliding mammaliaforms from the Jurassic". English. In: Nature 548 (2017), pp. 291-296. DOI: 10. 1038/nature23476.

[15609] Q.-J. Meng, Q. Ji, Y. -G. Zhang, D. Liu, D. M. Grossnickle, and Z. -X. Luo. "An arboreal docodont from the Jurassic and mammaliaform ecological diversification". English. In: Science 347.6223 (2015), pp. 764-768.

[15610] X. M. Meng and D. Ren. "Late Jurassic prophalangopsids from northeast China (Orthoptera, Prophalangopsidae, Chifengiinae)". Chinese. In: Acta Zootaxonomica Sinica 31.2 (2006), pp. 282288.

[15611] X. M. Meng, D. Ren, and L. M. Li. "New prophalangopsid fossils from Liaoning, China (Orthoptera, Prophalangopsidae, Chifengiinae)". Chinese. In: Acta Zootaxonomica Sinica 31.4 (2006), pp. 752-757.

[15612] Z. Meng, Y. B. Wang, A. Woods, W. Liao, and G. S. Li. “Deep shelf biostrome of Late Permian in South China and its implications for the adaptability of calcisponges to water depth". English. In: Palaeogeography, Palaeoclimatology, Palaeoecology 401 (2014), pp. 132-141.

[15613] J. J. Menier, A. Nel, A. Waller, and G. De Ploëg. “A new fossil ichneumon wasp from the Lowermost Eocene amber of Paris Basin (France), with a checklist of fossil Ichneumonoidea s. 1. (Insecta: Hymenoptera: Ichneumonidae: Metopiinae)". English. In: Geologica Acta 2.1 (2004), pp. 83-94.

[15614] J. L. Menn and P. A. Jaouen. “Nouvelles espéces d'Ancyrocrinus et d'Ammonicrinus, crinodes á pédoncule spécialisé du Dévonien armoricain (Brest, France)". French. In: Comptes Rendus Palevol 2.3 (2003), pp. 205-212. DOI: 10.1016/S1631-0683(03)00043-5. 
[15615] A. Mennad, R. Tabuce, G. Guinot, R. Sarr, M. Benyoucef, M. Bensalah, H. Cappetta, A. Charriére, and $\mathrm{M}$. Adaci. "Découverte d'une nouvelle faune d'age cénomanien dans la région de Forthassa (Atlas saharien occidental, Algérie): Implications biostratigraphiques et paléoenvironnementales". French. In: Annales de Paléontologie 106.102355 (2020). DOI: 10.1016/j.annpal.2019.05. 005.

[15616] B. Mennecart. “The European Ruminants during the Microbunodon Event (MP28, Latest Oligocene): Impact of Climate Changes and Faunal Event on the Ruminant Evolution". English. In: PLoS ONE 10.2 (2015), e0116830:1-28.

[15617] B. Mennecart, M. Aiglstorfer, U. B. Göhlich, and G. Daxner-Höck. “On the oldest Mongolian moschids (Mammalia, Ruminantia) and the early moschid evolution". English. In: Palaeontologia Electronica 22.5.23 (2019), pp. 1-17.

[15618] B. Mennecart, D. Becker, and J. -P. Berger. "Iberomeryx minor (Mammalia, Artiodactyla) from the Early Oligocene of Soulce (Canton Jura, NW Switzerland): systematics and palaeodiet". English. In: Swiss Journal of Geosciences 104.S1 (2011), S115-S132.

[15619] B. Mennecart, D. Geraads, N. Spassov, and I. Zagorchev. "Discovery of the oldest European ruminant in the late Eocene of Bulgaria: Did tectonics influence the diachronic development of the Grande Coupure?" English. In: Palaeogeography, Palaeoclimatology, Palaeoecology 498 (2018), pp. 1-8. DOI: 10.1016/j.palaeo.2018.01.011.

[15620] B. Mennecart and G. Métais. "Mosaicomeryx gen. nov., a ruminant mammal from the Oligocene of Europe and the significance of 'gelocids'". English. In: Journal of Systematic Palaeontology 13.7 (2015), pp. 581-600.

[15621] B. Mennecart, P. Radovi, and Z. Markovi. "New data on the earliest European ruminant (Mammalia, Artiodactyla): A revision of the fossil mandible from Rusce in the Pinja basin (late Eocene, Southeastern Serbia)". English. In: Palaeontologia Electronica 21.3 (2018), 38A:1-12.

[15622] B. Mennecart, L. Scherler, F. Hiard, D. Becker, and J. P. Berger. "Large mammals from Rickenbach (Switzerland, reference locality MP29, Late Oligocene): biostratigraphic and palaeoenvironmental implications". English. In: Swiss Journal of Palaeontology 131 (2012), pp. 161-181.

[15623] B. Mennecart, B. Yerly, P. -O. Mojon, C. Angelone, O. Maridet, M. Böhme, and C. Pirkenseer. "A new Late Agenian (MN2a, Early Miocene) fossil assemblage from Wallenried (Molasse Basin, Canton Fribourg, Switzerland)". English. In: Palaeontologische Zeitschrift 90 (2016), pp. 101-123. DOI: $10.1007 / \mathrm{s} 12542-015-0275-3$.

[15624] F. Menon. "New record of Tettigarctidae (Insecta, Hemiptera, Cicadoidea) from the Lower Cretaceous of Brazil". English. In: Zootaxa 1087 (2005), pp. 53-58.

[15625] F. Menon. "Higher systematics of scorpions from the Crato Formation, Lower Cretaceous of Brazil". English. In: Palaeontology 50 (2007), pp. 185-195.

[15626] F. Menon, S. W. Heads, and D. M. Martill. “New Palaeontinidae (Insecta: Cicadomorpha) from the Lower Cretaceous Crato Formation of Brazil". English. In: Cretaceous Research 26 (2005), pp. 837844.

[15627] F. Menon and S. W. Heads. "New species of Palaeontinidae (Insecta: Cicadomorpha) from the Lower Cretaceous Crato Formation of Brazil". English. In: Stuttgarter Beiträge zur Naturkunde Serie B (Geologie und Paläontologie) 357 (2005), pp. 1-11.

[15628] F. Menon and V. N. Makarkin. "New fossil lacewings and antlions (Insecta, Neuroptera) from the Lower Cretaceous Crato Formation of Brazil". English. In: Palaeontology 51.1 (2008), pp. 149-162.

[15629] F. Menon, R. G. Martins-Neto, and D. M. Martill. "A new Lower Cretaceous nymphid (Insecta, Neuroptera, Nymphidae) from the Crato Formation of Brazil". English. In: Gaea 1 (2005), pp. 1115.

[15630] F. Menon, D. Penney, P. A. Selden, and D. M. Martill. “A new fossil scolopendromorph centipede from the Crato Formation of Brazil". English. In: Bulletin of the British Myriapod and Isopod Group 19 (2003), pp. 62-66. 
[15631] B. Ménouret. "Gisements paléontologiques á mammiféres ou empreintes de pas de mammiféres du Parc naturel régional du Luberon". English. In: Courrier scientifique du Parc naturel régional du Luberon et de la Réserve de biosphére Luberon-Lure 12 (2014), pp. 56-74.

[15632] B. Ménouret, J.-J. Chateauneuf, D. Nury, and S. Peigné. “Aubenas-les-Alpes, a forgotten Oligocene mammalian site in Provence". English. In: Annales de Paléontologie 101 (2015), pp. 241-250.

[15633] B. Ménouret and C. Guérin. “Diaceratherium massiliae nov. sp. des argiles oligocénes de SaintAndré et Saint-Henri á Marseille et de Les Milles prés d'Aix-en-Provence (SE de la France), premier grand Rhinocerotidae brachypode européen". French. In: Geobios 42 (2009), pp. 293-327.

[15634] A. H. Meor Hakif and L. C. Peng. "Early Devonian graptolites and tentaculitids in northwest Peninsular Malaysia and a revision of the Devonian-Carboniferous stratigraphy of the region". English. In: Alcheringa 37 (2013), pp. 49-63.

[15635] M. Mergl. "The hexactinellid sponge Cyathophycus from the Lower Ordovician Klabava Formation of the Prague Basin, Czech Republic". English. In: Bulletin of Geosciences 83.2 (2008), pp. 233236.

[15636] M. Mergl. “Lingulate and craniate brachiopods from the top of the Králuv Dvur Formation (latest Katian) and their contribution to palaeogeography". English. In: Sbornk Národnho Muzea V Praze. Rada B, Prrodn vedy 68.1/2 (2012), pp. 35-46.

[15637] M. Mergl. "Earliest occurrence of the Hirnantia Fauna in the Prague Basin (Czech Republic)". English. In: Bulletin of Geosciences 86.861 (2011), pp. 63-70.

[15638] M. Mergl. "Lingulate brachiopods across the Kaák Event”. English. In: Bulletin of Geosciences 94.2 (2019). DOI: 10.3140/bull.geosci.1740.

[15639] M. Mergl. "The late Emsian association of weakly plicate brachiopods from Hamar Laghdad (Tafilalt, Morocco) and their ecology". English. In: 290.1-3 (2018), pp. 153-182. DOI: 10.1127 / njgpa / 2018/0775.

[15640] M. Mergl. "Linguliformean and craniiformean brachiopods of the Ordovician (Tenice to Dobrotivá Formations) of the Barrandian, Bohemia". English. In: Acta Musei Nationalis Pragae, Series B, Natural History 58.1-2 (2002), pp. 1-82.

[15641] M. Mergl and O. Elicki. "Cambrian lingulid and acrotretid brachiopods from the Iglesiente area (Campo Pisano Formation, southwestern Sardinia)". English. In: Rivista Italiana di Paleontologia e Stratigrafia 110.3 (2004), pp. 581-589.

[15642] M. Mergl, G. Geyer, and A. El Attari. “The billingsellid genus Saccogonum (Brachiopoda) from the Moroccan Cambrian and its significance for the regional geology and stratigraphy". English. In: Neues Jahrbuch fur Geologie und Palaontologie Abhandlungen 209.3 (1998), pp. 273-293.

[15643] M. Mergl and V. Kordule. "New Middle Cambrian lingulate brachiopods from the Skryje-Týøovice area (Central Bohemia, Czech Republic)". English. In: Bulletin of Geosciences 83.1 (2008), pp. 11-22. DOI: 10.3140/bull.geosci.2008.01011.

[15644] M. Mergl and D. Massa. “Devonian and Lower Carboniferous brachiopods and bivalves from western Libya". In: Biostratigraphie du Paleozoique 12 (1992), pp. 1-115.

[15645] M. Mergl and R. J. Prokop. “Lower Ordovician cystoids (Rhombifera, Diploporita) from the Prague Basin (Czech Republic)". English. In: Bulletin of Geosciences 81.1 (2006), pp. 1-15.

[15646] M. Mergl and P. Slehoferová. "Middle Cambrian inarticulate brachiopods from Central Bohemia". English. In: Sbornk geologickych vd, Paleontologie 31 (1990), pp. 9-46.

[15647] M. Mergl and S. Zamora. "New and revised occurrences of rhynchonelliformean brachiopods from the middle Cambrian of the Iberian Chains, NE Spain". English. In: Bulletin of Geosciences 83.3 (2012), pp. 571-586.

[15648] X. Mérit and M. Mérit. “Problongos baudiliensis genus novus \& species nova: un nouveau Lépidoptére fossile découvert dans la diatomite du miocéne supérieur de Saint-Bauzile (Ardéche, F-07) (Lepidoptera, Geometridae, Ennominae)". French. In: Lépidoptéres 17.39 (2008), pp. 29-33. 
[15649] D. Merle. "Premiére étude taphonomique de la prédation affectant de grands mollusques benthiques dans l'Eocene de Gan (Pyrénées-Atlantiques, France)". French. In: Comptes Rendus de l'Academie des Sciences, Serie II. Sciences de la Terre et des Planétes 330.3 (2000), pp. 217-220.

[15650] D. Merle. "Nucellopsis (Gastropoda, Muricidae), a new genus from the paralic domain of the European Palaeogene". English. In: Comptes Rendus Palevol 4.1-2 (2005), pp. 177-189. DOI: 10.1016/ j.crpv.2004.11.005.

[15651] D. Merle, J.-P. Baut, L. Ginsburg, C. Sagne, S. Hervet, R. -P. Carriol, M. -T. Vénec-Peyré, M. M. Blanc-Valleron, C. Mourer-Chauviré, D. Arambol, and P. Viette. "Découverte d'une faune de vertébrés dans l'Oligocéne inférieur de Vayres-sur-Essone (bassin de Paris, France): biodiversité et paléoenvironnement". English. In: Comptes Rendus Palevol 1.2 (2002), pp. 111-116.

[15652] D. Merle, J. Pacaud, G. Metais, A. Bartolini, R. A. Lashari, I. Brohi, S. H. Solangi, L. Marivaux, and J. -L. Welcomme. "Volutidae (Mollusca: Gastropoda) of the Lakhra Formation (Earliest Eocene, Sindh, Pakistan): systematics, biostratigraphy and paleobiogeography". English. In: Zootaxa 3826.1 (2014), pp. 101-138.

[15653] D. Merle and J. M. Pacaud. "The Early Paleogene muricids (Mollusca, Neogastropoda) from the Oiching beds (Haunsberg area, Salzburg, Austria): revision and addition to the knowledge of the evolution of the Paleocene and Lower Eocene Foirieria". English. In: Mitteilungen der Bayerischen Staatssammlung für Paläontologie und historische Geologie 42 (2002), pp. 3-14.

[15654] D. Merle and J.-M. Pacaud. "New species of Eocithara Fischer, 1883 (Mollusca, Gastropoda, Harpidae) from the Early Paleogene with phylogenetic analysis of the Harpidae". English. In: Geodiversitas 26.1 (2003), pp. 61-87.

[15655] A. Mermighis and A. Marcopoulou-Diacantoni. "La faune á rudistes, poriféres et scléractiniaires du Crétacé superieur du mont Ptoon (Béotie septentrionale, Gréce continentale) [The fauna with rudists, porifers and corals of upper Cretaceous of mount Ptoon (Northern Beotia, central Greece)]". French. In: Revue de Paléobiologie 23.1 (2004), pp. 313-353.

[15656] D. Mertmann and V. Jacobshagen. “Upper Olenekian (Spathian) ammonoids from Chios (Lower Triassic, Greece): Taxonomy and stratigraphic position". English. In: Rivista Italiana di Paleontologia e Stratigrafia 109.3 (2003), pp. 417-447.

[15657] D. A. A. Mertz. "Phylogeny, diversity, and ecology of the ammonoid superfamily Acanthoceratoidea through the Cenomanian and Turonian". English. PhD thesis. 2017, pp. 1-111.

[15658] V. Mesa and D. Perea. "First record of theropod and ornithopod tracks and detailed description of sauropod trackways from the Tacuarembó Formation (Late Jurassic-?Early Cretaceous) of Uruguay". English. In: Ichnos 22.2 (2015), pp. 109-121. DOI: 10.1080/10420940.2015.1030075.

[15659] M. V. Mesquita. “Cretaraneus martinsnetoi n. sp. (Araneoide) da Formação Santana, Cretáceo Inferior da Bacia do Araripe". Portugese. In: Revista Universidade Guarulhos - Série Geociencias 1.3 (1996), pp. 24-31.

[15660] L. G. Mészáros. "Kordosia, a new genus for some Late Miocene Amblycoptini shrews (Mammalia, Insectivora)". English. In: Neues Jahrbuch für Geologie un Paläontologie 1997.2 (1997), pp. 65-78.

[15661] G. Métais. "New basal selenodont artiodactyls from the Pondaung Formation (late middle Eocene, Myanmar) and the phylogenetic relationships of early ruminants". English. In: Annals of Carnegie Museum 75.1 (2006), pp. 51-67.

[15662] G. Métais, E. Albayrak, P. -O. Antoine, O. Erdal, L. Karadenizli, N. Oyal, G. Saraç, Y. Büyükmeriç, and S. Sen. "Oligocene ruminants from the Kzlrmak Formation, Çankr-Çorum Basin, Central Anatolia, Turkey". English. In: Palaeontologia Electronica 19.3 (2016), 37A:1-23.

[15663] G. Métais, P.-O. Antoine, L. Marivaux, J. -L. Welcomme, and S. Ducrocq. "New artiodactyl ruminant mammal from the late Oligocene of Pakistan". English. In: Acta Palaeontologica Polonica 48.3 (2003), pp. 375-382. 
[15664] G. Métais, P.-O. Antoine, S. R. H. Baqri, M. Benammi, J. -Y. Crochet, D. de Franceschi, L. Marivaux, and J. -L. Welcomme. "New remains of the enigmatic cetartiodactyl Bugtitherium grandincisivum Pilgrim, 1908, from the upper Oligocene of the Bugti Hills (Balochistan, Pakistan)". English. In: Naturwissenschaften 93.7 (2006), pp. 348-355. DOI: 10.1007/s00114-006-0112-3.

[15665] G. Métais, M. Benammi, Y. Chaimanee, J. J. Jaeger, T. Tun, T. Thein, and S. Ducrocq. “Discovery of new ruminant dental remains from the middle Eocene Pondaung Formation (Myanmar): reassessment of the phylogenetic position of Indomeryx". English. In: Comptes Rendus de l'Academie des Sciences, Serie II. Sciences de la Terre et des planetes 330 (2000), pp. 805-811.

[15666] G. Metais, Y. Chaimanee, J. -J. Jaeger, and S. Ducrocq. “New remains of primitive ruminants from Thailand: evidence of the early evolution of the Ruminantia in Asia." English. In: Zoologica Scripta 30.4 (2001), pp. 231-248.

[15667] G. Métais, Y. Chaimanee, J. -J. Jaeger, and S. Ducrocq. “Eocene bunoselenodont Artiodactyla from southern Thailand and the early evolution of Ruminantia in South Asia". English. In: Naturwissenschaften 94.6 (2007), pp. 493-498. DOI: 10.1007/s00114-007-0218-2.

[15668] G. Métais, P. M. Coster, J. R. Kappelman, A. Licht, F. Ocakolu, M. H. Taylor, and K. C. Beard. "Eocene metatherians from Anatolia illuminate the assembly of an island fauna during Deep Time". English. In: PLoS One 13 (2018), e0206181:1-20. DOI: 10.1371/journal.pone.0206181.

[15669] G. Métais, O. Erdal, k. Erturaç, and K. C. Beard. "Tarsal morphology of the pleuraspidotheriid mammal Hilalia from the middle Eocene of Turkey". English. In: Acta Palaeontologica Polonica 62 (2017). DOI: 10.4202/app.00314.2016.

[15670] G. Metais, J. Guo, and K. C. Beard. "A new small dichobunid artiodactyl from Shanghuang (MIddle Eocene, eastern China): Implications for the early evolution of proto-selenodonts in Asia". English. In: Bulletin of the Carnegie Museum of Natural History 36 (2004), pp. 177-195.

[15671] G. Métais, B. Mennecart, and G. Roohi. "A new assemblage of stem pecoran ruminants from the Oligocene Chitarwata Formation, Bugti Hills, Baluchistan, Pakistan: Paleoenvironmental and paleobiogeographic implications". English. In: Journal of Asian Earth Sciences 136 (2017), pp. 40-49.

[15672] G. Metais, T. Qi, J. Guo, and C. Beard. "A new bunoselenodont artiodactyl from the Middle Eocene of China and the early record of selenodont artiodactyls in Asia". English. In: Journal of Vertebrate Paleontology 25.4 (2005), pp. 994-997.

[15673] G. Métais, S. Sen, K. Sözeri, S. Peigné, and B. Varol. "Late Paleogene terrestrial fauna and paleoenvironments in Eastern Anatolia: New insights from the Kagzman-Tuzluca Basin". English. In: Journal of Asian Earth Sciences 107 (2015), pp. 96-109.

[15674] G. Métais and S. Sen. "First occurrence of Palaeotheriidae (Perissodactyla) from the late-middle Eocene of eastern Thrace (Greece)". English. In: Comptes Rendus Palevol 16 (2017), pp. 382-396.

[15675] G. Métais, A. N. Soe, and S. Ducrocq. "A new basal tapiromorph (Perissodactyla, Mammalia) from the middle Eocene of Myanmar". English. In: Geobios 39 (2006), pp. 513-519.

[15676] G. Métais, A. N. Soe, L. Marivaux, and K. C. Beard. "Artiodactyls from the Pondaung Formation (Myanmar): new data and reevaluation of the South Asian Faunal Province during the Middle Eocene". English. In: Naturwissenschaften 94 (2007), pp. 759-768.

[15677] G. Métais, J.-L. Welcomme, and S. Ducrocq. "New lophiomerycid ruminants from the Oligocene of the Bugti Hills (Balochistan, Pakistan)". English. In: Journal of Vertebrate Paleontology 29.1 (2009), pp. 231-241.

[15678] S. J. Metcalf, R. F. Vaughan, M. J. Benton, J. Cole, M. J. Simms, and D. L. Dartnall. "A new Bathonian (Middle Jurassic) microvertebrate site, within the Chipping Norton Limestone Formation at Honsleasow Quarry, Gloucestershire". English. In: Proceedings of the Geologists' Association 103 (1992), pp. 321-342.

[15679] S. J. Metcalf and R. J. Walker. A new Bathonian microvertebrate locality in the English Midlands. English. In the Shadow of the Dinosaurs: Early Mesozoic Tetrapods, edited by N. C. Fraser and H.-D. Sues. Cambridge University Press, Cambridge. 1994, pp. 322-331. 
[15680] L. S. Metodiev. “New data about the Ammonite genus Pseudolioceras Buckman, 1889 (Harpoceratinae, Ammonitina) from the Toarcian of the Balkan Mountains (Bulgaria)". English. In: Comptes rendus de L'Académie bulgare des Sciences 59 (2006), pp. 757-762.

[15681] L. S. Metodiev. "The Ammonite zones of the Toarcian in Bulgaria - New evidence, subzonation and correlation with the standard zones and subzones in North-Western Europe". English. In: Comptes rendus de l'Acaemie bulgare des Sciences 61 (2008), pp. 87-132.

[15682] W. Mette. "Middle to Upper Jurassic sedimentary sequences and marine biota of the early Indian Ocean (SW Madagascar): some biostratigraphic, palaeoecologic and palaeobiogeographic conclusions". English. In: Journal of African Earth Sciences 38 (2004), pp. 331-342.

[15683] W. Mette, A. Elsler, and C. Korte. "Palaeoenvironmental changes in the Late Triassic (Rhaetian) of the Northern Calcareous Alps: Clues from stable isotopes and microfossils". English. In: Palaeogeography, Palaeoclimatology, Palaeoecology 350-352 (2012), pp. 62-72.

[15684] M. H. M. Metwally. "Maastrichtian scleractinian corals from the Western flank of the Oman Mountains, U.A.E. and their paleoecological significance". English. In: Neues Jahrbuch für Geologie und Paläontologie Monatshefte 6 (1996), pp. 375-388.

[15685] M. A. Metz and M. E. Irwin. "Revision of Lindneria Kröber, with the description of two new genera Insulatitan and Ambradolon, a fossil from Dominican amber (Diptera: Therevidae: Therevinae)". English. In: Annals of the Entomological Society of America 93 (2000), pp. 977-1018.

[15686] R. A. Metzger. "Conodont biostratigraphy of the scotch grove and Laporte City Formations (Late Llandovery- early Wenlock; Silurian) in eastern Iowa". English. In: Bulletin 369369 (2005), pp. 93104.

[15687] L. M. V. Meunier and H. C. E. Larsson. "Revision and phylogenetic affinities of Elosuchus (Crocodyliformes)". English. In: Zoological Journal of the Linnean Society 179.1 (2016), pp. 169-200. DOI: 10. 1111/zoj.12448.

[15688] L. M. V. Meunier and H. C. E. Larsson. "Trematochampsa taqueti as a nomen dubium and the crocodyliform diversity of the Upper Cretaceous In Beceten Formation of Niger". English. In: Zoological Journal of the Linnean Society 182.3 (2018), pp. 659-680.

[15689] W. Mey. "On the systematic position of Baltimartyria Skalski, 1995 and description of a new species from Baltic amber (Lepidoptera, Micropterigidae)". English. In: ZooKeys 120 (2011), pp. 331342.

[15690] W. Mey, W. Wichard, P. Müller, and B. Wang. “The blueprint of the Amphiesmenoptera - Tarachoptera, a new order of insects from Burmese amber (Insecta, Amphiesmenoptera)". English. In: Fossil Record 20 (2017), pp. 129-145.

[15691] W. Mey, W. Wichard, P. Müller, E. Ross, and A. Ross. "New taxa of Tarachoptera from Burmese amber (Insecta, Amphiesmenoptera)". English. In: Cretaceous Research 90 (2018), pp. 154-162.

[15692] W. Mey, W. Wichard, P. Müller, and B. Wang. "Descriptions of two new species of Tarachoptera from Burmese amber (Insecta, Amphiesmenoptera: Tarachoptera)". English. In: Contributions to Entomology 70 (2020), pp. 181-188.

[15693] S. V. Meyen. "Permian conifers of Western Angaraland". In: Review of Palaeobotany and Palynology 96 (1997), pp. 351-447.

[15694] C. A. Meyer, E. D. Frey, B. Thuring, W. Etter, and W. Stinnesbeck. “Dinosaur tracks from the Late Cretaceous Sabinas Basin (Mexico)". English. In: Kaupia 14 (2005), pp. 41-45.

[15695] C. A. Meyer and M. Hauser. New sauropod and theropod tracksites from the Upper Jurassic megatracksite of northern Switzerland. English. Vol. 10. Aspects of Sauropod Paleobiology. GAIA. 1995, pp. 49-55.

[15696] C. A. Meyer and A. P. Hunt. "The first stegosaurian dinosaur (Ornithischia: Thyreophora) from the Upper Jurassic of Switzerland". English. In: Neues Jahrbuch für Geologie und Paläontologie Monatshefte 1998.3 (1998), pp. 141-145.

[15697] C. A. Meyer and A. P. Hunt. "The first pterosaur from the Late Jurassic of Switzerland: evidence for the largest Jurassic flying animal". English. In: Oryctos 2 (1999), pp. 111-116. 
[15698] C. A. Meyer, M. G. Lockley, J. W. Robinson, and V. F. dos Santos. A comparison of well-preserved sauropod tracks from the Late Jurassic of Portugal and the western United States: evidence and implications. English. Vol. 10. Aspects of Sauropod Paleobiology. GAIA. 1995, pp. 57-64.

[15699] C. A. Meyer and J. G. Pittman. A comparison between the Brontopodus ichnofacies of Portugal, Switzerland and Texas. English. Vol. 10. Aspects of Sauropod Paleobiology. GAIA. 1995, pp. 125-133.

[15700] C. A. Meyer and B. Thüring. Mind the Middle Jurassic gap-bone versus track record in dinosaurs. English. 2005.

[15701] C. A. Meyer and B. Thüring. "Dinosaurs of Switzerland". English. In: Comptes Rendus Palevol 2 (2003), pp. 103-117. DOI: 10.1016/S1631-0683(03)00005-8.

[15702] C. A. Meyer and B. Thüring. "The first iguanodontid dinosaur tracks from the Swiss Alps (Schrattenkalk Formation, Aptian)". English. In: Ichnos 10.2-4 (2003), pp. 221-228. DOI: 10.1080/10420940390256186.

[15703] D. L. Meyer and W. I. Ausich. "Morphologic variation within and among populations of the camerate crinoid Agaricocrinus (Lower Mississippian, Kentucky and Tennessee): Breaking the spell of the mushroom". In: Journal of Paleontology 71.5 (1997), pp. 896-917.

[15704] D. L. Meyer and T. Oji. "Eocene Crinoids from Seymour Island, Antarctic Peninsula: Paleobiogeographic and Paleoecologic Implications". English. In: Journal of Paleontology 67.2 (1993), pp. 250257.

[15705] H. W. Meyer and S. R. Manchester. “The Oligocene Bridge Creek flora of the John Day Formation, Oregon". English. In: University of California Publications in Geological Sciences 141 (1997), pp. 1-195.

[15706] B. Meyer-Berthaud and P. Gerrienne. "Aarabia, a new Early Devonian vascular plant from Africa (Morocco)". In: Review of Palaeobotany and Palynology 116 (2001), pp. 39-53.

[15707] B. Meyer-Berthaud and N. P. Rowe. "A Lower Carboniferous plant assemblage from Thuringia (Germany): compressions". In: Review of Palaeobotany and Palynology 97 (1997), pp. 361-379.

[15708] B. Meyer-Berthaud, S. E. Scheckler, and J. Bousquet. "The development of Archaeopteris: New evolutionary characters from the structural analysis of an Early Famennian trunk form southeast Morocco". In: American Journal of Botany 87.4 (2000), pp. 456-468.

[15709] B. Meyer-Berthaud and W. E. Stein. "A reinvestigation of Stenomyelon from the late Tournaisian of Scotland". In: International Journal of Plant Sciences 156.6 (1995), pp. 863-895.

[15710] P. Meylan and E. S. Gaffney. "Sinaspideretes is not the oldest trionychid turtle". English. In: Journal of Vertebrate Paleontology 12.2 (1992), pp. 257-259.

[15711] P. A. Meylan. Pleistocene amphibians and reptiles from the Leisey Shell Pit, Hillsborough County, Florida. 1995.

[15712] P. A. Meylan. "Skeletal morphology and relationships of the Early Cretaceous side-necked turtle, Araripemys barretoi (Testudines: Pelomedusoides: Araripemydidae), from the Santana Formation of Brazil". English. In: Journal of Vertebrate Paleontology 16.1 (1996), pp. 20-33. DOI: 10.1080 / 02724634.1996.10011280.

[15713] P. A. Meylan, E. S. Gaffney, and D. de Almeida Campos. “Caninemys, a New Side-Necked Turtle (Pelomedusoides: Podocnemididae) from the Miocene of Brazil". English. In: American Museum Novitates 3634 (2009), pp. 1-26.

[15714] P. A. Meylan, R. T. J. Moody, C. A. Walker, and S. D. Chapman. “Sandownia harrisi, a highly derived trionychoid turtle (Testudines: Cryptodira) from the Early Cretaceous of the Isle of Wight, England". English. In: Journal of Vertebrate Paleontology 20.3 (2000), pp. 522-532.

[15715] P. A. Meylan and W. Sterrer. "Hesperotestudo (Testudines: Testudinidae) from the Pleistocene of Bermuda, with comments on the phylogenetic position of the genus". English. In: Zoological Journal of the Linnean Society 128 (2000), pp. 51-76. DOI: 10.1006/zjls.1998.0199.

[15716] P. A. Meylan, B. S. Weig, and R. Wood. "Fossil soft-shelled turtles of the Lake Turkana Basin,Africa". English. In: Copeia 1 (1990), pp. 508-528. 
[15717] A. Mezga and Z. Bajraktarevic. "Cenomanian dinosaur tracks on the islet of Fenoliga in southern Istria, Croatia". English. In: Cretaceous Research 20 (1999), pp. 735-746.

[15718] A. Mezga, D. Buckovic, and F. Santak. "New dinosaur tracksite in the Late Jurassic of Kirmenjak quarry (Istria)". English. In: Rivista Italiana di Paleontologia e Stratigrafia 123.3 (2017), pp. 443-454.

[15719] A. Mezga, C. A. Meyer, B. C. Tesovic, Z. Bajraktarevic, and I. Gusic. "The first record of dinosaurs in the Dalmatian part (Croatia) of the Adriatic-Dinaric carbonate platform (ADCP)". English. In: Cretaceous Research 27 (2006), pp. 735-742.

[15720] A. Mezga, B. C. Tesovic, and Z. Bajraktarevic. "First record of dinosaurs in the Late Jurassic of the Adriatic-Dinaridic carbonate platform (Croatia)". English. In: Palaios 22.2 (2007), pp. 188-199.

[15721] C. Mezzabotta. "Cricetid and arvicolid rodents of the California wash local fauna, late Blancan of the san Pedro Valley, Arizona". English. In: Palaeovertebrata 26.1-4 (1997), pp. 189-218.

[15722] D. Michailidis, G. E. Konidaris, A. Athanassiou, E. Panagopoulou, and K. Harvati. "The ornithological remains from Marathousa 1 (Middle Pleistocene; Megalopolis Basin, Greece)". English. In: Quaternary International 497 (2018), pp. 85-94.

[15723] D. Michailidis, S. Roussiakis, and G. Theodorou. Palaeoavian remains from the Late Miocene localities of Pikermi, Chomateri and Kerassiá; palaeoecological implications. English. 2010.

[15724] J. Michel, G. Doitteau, H. Hebib, P. Lozouet, and L. Villier. “Biodiversity structure of an exceptionally preserved Aquitanian bivalve assemblage (Meilhan, SW France)". English. In: Neues Jahrbuch für Geologie und Paläontologie 265.2 (2012), pp. 113-130.

[15725] P. Michel and L. Wengler. Le site paleontologique et archeologique de DoukkalaII:premier jalon en Afrique du Nord dun comportement humain assimilable a un charongnage controle et actif. French. 1993.

[15726] V. Michelsen. “Oldest authentic record of a fossil calyptrate fly (Diptera): a species of Anthomyiidae from early Cenozoic Baltic amber". English. In: Studia Dipterologica 7 (2000), pp. 11-18.

[15727] V. Michelsen. "First reliable record of a fossil species of Anthomyiidae (Diptera), with comments on the definition of recent and fossil clades in phylogenetic classification". English. In: Biological Journal of the Linnean Society 58 (1996), pp. 441-451.

[15728] C. D. Michener and G. Poinar. "The known bee fauna of the Dominican amber". English. In: Journal of the Kansas Entomological Society 69 (1996), pp. 353-361.

[15729] D. Michez, T. D. Meulemeester, P. Rasmont, A. Nel, and S. Patiny. "New fossil evidence of the early diversification of bees: Paleohabropoda oudardi from the French Paleocene (Hymenoptera, Apidae, Anthophorini)". English. In: Zoologica Scripta 38.2 (2009), pp. 171-181.

[15730] D. Michez, A. Nel, J. J. Menier, and P. Rasmont. "The oldest fossil of a melittid bee (Hymenoptera: Apiformes) from the early Eocene of Oise (France)". English. In: Zoological Journal of the Linnean Society 150 (2007), pp. 701-709.

[15731] D. L. Mickelson, M. G. Lockley, J. Bishop, and J. Kirkland. “A new pterosaur tracksite from the Jurassic Summerville Formation, near Ferron, Utah". English. In: Ichnos 11 (2004), pp. 125-142.

[15732] D. L. Mickelson, A. C. R. Milner, D. DeBlieux, and J. L. McGuire. “The oldest known Early Triassic fossil vertebrate footprints in North America, from Zion National Park, Utah". English. In: New Mexico Museum of Natural History and Science Bulletin 34 (2006), pp. 141-144.

[15733] K. E. Mickle. “The early actinopterygian fauna of the Manning Canyon Shale Formation (Upper Mississippian, Lower Pennsylvanian) of Utah, USA". English. In: Journal of Vertebrate Paleontology 31.5 (2011), pp. 962-980.

[15734] K. E. Mickle and K. Bader. "A new platysomid from the Upper Carboniferous of Kansas (USA) and remarks on the systematics of deep-bodied lower actinopterygians". English. In: Acta Zoologica 90.Suppl 1 (2009), pp. 211-219.

[15735] K. E. Mickle, R. Lund, and E. D. Grogan. “Three new palaeoniscoid fishes from the Bear Gulch limestone (Serpukhovian, Mississippian) of Montana (USA) and the relationships of lower actinopterygians". English. In: Geodiversitas 31.3 (2009), pp. 623-668. 
[15736] N. Micklich. Emergency excavation in the Grube Unterfeld (Frauenweiler) clay pit (Oligocene, Rupelian: Baden-Wurttemberg, S. Germany): New records and palaeoenvironmental information. English. 2011.

[15737] N. Micklich and L. H. Hildebrandt. “Emergency excavation in the Grube (Unterfeld) Frauenweiler clay pit (Oligocene Rupelian; Baden-Wurttemberg, S Germany): New records and palaeoenvironmental informatino". English. In: Kaupia 17 (2010), pp. 3-21.

[15738] N. R. Micklich, J. C. Tyler, G. D. Johnson, E. Swidnicka, and A. F. Bannikov. “First fossil records of the tholichthys larval stage of butterfly fishes (Perciformes, Chaetodontidae), from the Oligocene of Europe". English. In: Palaeontologische Zeitschrift 83 (2009), pp. 479-497. DOI: 10.1007/ s12542009-0031-7.

[15739] M. D. Middleton and E. W. Dewar. "New mammals from the early Paleocene Littleton fauna (Denver Formation, Colorado)". English. In: New Mexico Museum of Natural History and Science Bulletin 26 (2004), pp. 59-80.

[15740] P. Mietto, S. Manfrin, N. Preto, P. Gianolla, L. Krystyn, and G. Roghi. “Proposal of the Global Stratotype Section and Point (GSSP) for the base of the Ladinian Stage (MIddle Triassic): GSSP at the base of the Avisianum Subzone (FAD of Aplococeras avisianum) in the Bagolino section (Southern Alps, NE Italy)". In: Albertiana 28 (2003), pp. 26-34.

[15741] P. Mietto and S. Manfrin. "Systematic paleontology, in Selected ammonoid fauna from Prati Di Stuores/Stuores Wiesen and related sections across the Ladinian-Carnian boundary (southern Alps, Italy)". English. In: Rivista Italiana di Paleontologia e Stratigrafia 114 (2008), pp. 377-429.

[15742] P. Mietto, S. Manfrin, N. Preto, and P. Gianolla. "Selected ammonoid fauna from Prati Di Stuores/Stuores Wiesen and related sections across the Ladinian-Carnian boundary (southern Alps, Italy)". English. In: Rivista Italiana di Paleontologia e Stratigrafia 114 (2008), pp. 377-429.

[15743] P. Mietto, G. Roghi, and R. Zorzin. “Le impronte di dinosauri liassici dei Monti Lessini Veronesi [The Liassic dinosaur tracks from the Veronese Monti Lessini]". Italian. In: Bollettino del Museo Civico di Storia Naturale di Verona. Geologia Paleontologia Preistoria 24 (2000), pp. 55-72.

[15744] G. S. Miguel, M. Aurell, B. Badenas, V. Martinez, B. Caline, C. Pabian-Goyheneche, J. P. Rolando, and N. Grasseau. "Facies heterogeneity of a Kimmeridgian carbonate ramp (Jabaloyas, eastern Spain): a combined outcrop and 3D geomodelling analysis". English. In: Journal of Iberian Geology 39.2 (2013), pp. 233-252.

[15745] C. Miguel Chaves, F. Ortega, and A. Perez-Garcia. "A new placodont from the Upper Triassic of Spain provides new insights on the acquisition of the specialized skull of Henodontidae". English. In: Papers in Palaeontology 4.4 (2018), pp. 567-576. DOI: 10.1002/spp2.1218.

[15746] M. C. Mihlbachler. "Species taxonomy, phylogeny, and biogeography of the Brontotheriidae (Mammalia: Perissodactyla)". English. In: Bulletin of the American Museum of Natural History 311.1 (2008), pp. 1-475. DOI: 10.1206/0003-0090(2008)501.

[15747] M. C. Mihlbachler. “Eubrontotherium clarnoensis, a new genus and species of brontothere (Brontotheriidae, Perissodactyla) from the Hancock Quarry, Clarno Formation, Wheeler County, Oregon". English. In: PaleoBios 27.1 (2007), pp. 19-30.

[15748] M. C. Mihlbachler and T. A. Deméré. "A New Species of Brontotheriidae (Perissodactyla, Mammalia) from the Santiago Formation (Duchesnean, Middle Eocene) of Southern California". English. In: Proceedings of the San Diego Society of Natural History 41 (2009), pp. 1-36.

[15749] M. C. Mihlbachler and T. A. Deméré. "Phylogenetic status of Metarhinus pater (Brontotheriidae: Perissodactyla) from Southern California and species variation in Metarhinus from the middle Eocene of North America". English. In: Journal of Vertebrate Paleontology 30.4 (2010), pp. 1229-1244. DOI: $10.1080 / 02724634.2010 .483568$.

[15750] M. C. Mihlbachler, S. G. Lucas, R. J. Emry, and B. Bayshashov. "A new brontothere (Brontotheriidae, Perissodactyla, Mammalia) from the Eocene of the Ily Basin of Kazakstan and a phylogeny of Asian horned brontotheres". English. In: American Museum Novitates 3439 (2004), pp. 1-43. 
[15751] M. C. Mihlbachler, F. Rivals, N. Solounias, and G. M. Semprebon. “Dietary Change and Evolution of Horses in North America". English. In: Science 331 (2011), pp. 1178-1181. DOI: 10.1126/science. 1196166.

[15752] M. C. Mihlbachler and J. X. Samuels. "A small-bodied species of Brontotheriidae from the middle Eocene Nut Beds of the Clarno Formation, John Day Basin, Oregon". English. In: Journal of Paleontology 90.6 (2016), pp. 1233-1244. DOI: 10.1017/jpa.2016.61.

[15753] I. Mijan. "Hallazgos de restos fosiles de Hyperoodon sp. (Cetacea, Ziphiidae) en las costas gallegas (NO Espana)". English. In: Revista de Biologia Marina y Oceanografia 42.3 (2007), pp. 253-260.

[15754] I. Miján, S. Louwye, and O. Lambert. "A new Beneziphius beaked whale from the ocean floor off Galicia, Spain and biostratigraphic reassessment of the type species". English. In: Acta Palaeontologica Polonica 62.1 (2017), pp. 2111-220. DOI: 10.4202/app.00309.2016.

[15755] K. Mikhailov. "Eggs of theropods and protoceratopsian dinosaurs from the Cretaceous of Mongolia and Kazakhstan". English. In: Paleontological Journal 28 (1994), pp. 101-120.

[15756] K. Mikhailov, K. Sabath, and S. Kurzanov. Eggs and nests from the Cretaceous of Mongolia. English. Dinosaur Eggs and Babies, Cambridge University Press, Cambridge. 1994, pp. 88-115.

[15757] K. E. Mikhailov. "Eggs and eggshells of dinosaurs and birds from the Cretaceous of Mongolia". English. In: The Age of Dinosaurs in Russia and Mongolia. Cambridge: Cambridge University Press, 2000, pp. 560-572.

[15758] K. E. Mikhailov. “Classification of fossil eggshells of amniotic vertebrates". English. In: Acta Palaeontologica Polonica 36.2 (1991), pp. 193-238.

[15759] K. E. Mikhailov. "Bird eggs in the Upper Cretaceous of Mongolia". English. In: Paleontological Journal 30.1 (1996), pp. 114-116.

[15760] K. E. Mikhailov. "New genera of fossil eggs from the Upper Cretaceous of Mongolia”. English. In: Paleontological Journal 30.2 (1996), pp. 246-248.

[15761] P. M. Miklas-Tempfer. "The Miocene herpetofaunas of Grund (Caudata; Chelonii, Sauria, Serpentes) and Mühlbach am Manhartsberg (Chelonii, Sauria, Amphisbaenia, Serpentes), Lower Austria". English. In: Annalen des Naturhistorischen Museums in Wien 104.A (2003), pp. 195-235.

[15762] I. Mikó, T. van de Kamp, C. Trietsch, J. M. Ulmer, M. Zuber, T. Baumbach, and A. R. Deans. "A new megaspilid wasp from Eocene Baltic amber (Hymenoptera: Ceraphronoidea), with notes on two non-ceraphronoid families: Radiophronidae and Stigmaphronidae". English. In: PeerJ 6 (2018), e5174.

[15763] R. Mikulas, J. Valicek, and M. Szabad. "New finds of ichnofossils from the Middle Cambrian of the Barrandian area (Czech Republic)". English. In: Bulletin of the Czech Geological Survey 77.1 (2002), pp. 55-59.

[15764] V. Mikuz. "The new findings of dolphin in Slovenia from Middle Miocene beds near Bela Cerkev in Lower Carniola". In: Razprave Dissertationes 44.1 (2003), pp. 163-173.

[15765] V. Mikuz. "Whale vertebra from Miocene beds in Turje near Dol pri Hrastniku, Slovenia”. other. In: Geologija 41 (1999), pp. 117-125.

[15766] V. Mikuz. "The whale vertebra from Middle Miocene - Badenianbeds between Doinja Stara vas and Dobruska vas near Skocjan, Slovenia". English. In: Razprave 47.2 (2006), pp. 51-63.

[15767] V. Mikuz. "Navtilid iz srednjeeocenskih plasti pri Grdoselu v Istri na Hrvakem". other. In: Geologija 52 (2009), pp. 33-43.

[15768] V. Mikuz. "Ramenonoci iz Miocenskih skladov blizu entilja v Skovenskih goricah". other. In: Folia Biologica et Geologica 52 (2011), pp. 29-46.

[15769] V. Mikuz and M. Bartol. "A new cephalopod find in the Eocene beds near Grdoselo in Istria, Croatia". English. In: Geologija 55 (2012), pp. 263-270.

[15770] V. Mikuz and J. Pavsic. "The dolphin Champsodelphis? carniolicus from Janezeva Gorca Hill in Bizeljsko, Slovenia". other. In: Razprave XLVI.1 (2005), pp. 133-151. 
[15771] J. Milán, M. Avanzini, L. B. Clemmensen, J. C. Garca-Ramos, and L. Piñuela. “Theropod foot movemenr recorded by Late Triiassic, Early Jurassic and Late Jurassic fossil footprints". English. In: vol. 37. The Triassic-Jurassic Terrestrial Transition. New Mexico Museum of Natural History and Science Bulletin. Albuquerque: New Mexico Museum of Natural History and Science, 2006, pp. 352-364.

[15772] J. Milán and G. Gierlinski. "A probable thyreophoran (Dinosauria, Ornithischia) footprint from the Upper Triassic of southern Sweden". English. In: Bulletin of the Geological Society of Denmark 51 (2004), pp. 71-75.

[15773] J. Milán, B. E. K. Lindow, and B. W. Lauridsen. “Bite traces in a turtle carapace fragment from the middle Danian (Lower Paleocene) bryozoan limestone, Faxe, Denmark". English. In: Bulletin of the Geological Society of Denmark 59 (2011), pp. 61-67.

[15774] J. Milán and D. B. Loope. "Preservation and erosion of theropod tracks in eolian deposits: examples from the Middle Jurassic Entrada Sandstone, Utah, U.S.A." English. In: Journal of Geology 115.4 (2007), pp. 375-386.

[15775] J. Milán, D. B. Loope, and R. G. Bromley. “Crouching theropod and Navahopus sauropodomorph tracks from the Early Jurassic Navaho Sandstone of USA". English. In: Acta Palaeontologica Polonica 53.2 (2008), pp. 197-205.

[15776] J. Milán and O. Mateus. “Fra strandbred til museum på syv dage - Historien om et Gigantisk Dinosaur Fodspor [From beach to museum in seven days - history of a gigantic dinosaur footprint]". other. In: Varv 3 (2003), pp. 8-14.

[15777] D. C. Mildenhall, E. M. Kennedy, D. E. Lee, U. Kaulfuss, and J. M. Bannister. "Palynology of the early Miocene Foulden Maar, Otago, New Zealand: Diversity following destruction". English. In: Review of Palaeobotany and Palynology 204 (2014), pp. 27-42. DOI: 10.1016/j.revpalbo.2014.02.003.

[15778] M. Miler and J. Pavsic. “Triassic and Jurassic beds in Krim Mountain area (Slovenia)". English. In: Geologija 51.1 (2008), pp. 87-99.

[15779] S. Milito. "A survey of fossils and geology of Red Rock Canyon Open Space, Colorado Springs, Colorado". English. In: The Mountain Geologist 47.1 (2010), pp. 1-14.

[15780] J. Milkovsky. "Middle Miocene birds of Devinska Nova Ves, Slovakia". English. In: Acta Society Zoologica Bohemia 68 (2004), pp. 21-24.

[15781] P. R. Millener. “The history of the Chatham Islands' bird fauna of the last 7000 years - a chronicle of change and extinction". English. In: Avian Paleontology at the Close of the 20th Century: Proceedings of the 4th International Meeting of the Society of Avian Paleontology and Evolution, Washington, D.C, 4-7 June 1996. Smithsonian Contributions to Paleobiology 89 (1999), pp. 85-109.

[15782] B. B. Miller, R. W. Graham, A. V. Morgan, N. G. Miller, W. D. McCoy, D. F. Palmer, A. J. Smith, and J. J. Pilny. "A biota associated with Matuyama-age sediments in west-central Illinois". English. In: Quaternary Research 41 (1994), pp. 350-365.

[15783] C. G. Miller. "Ostracode and conodont distribution across the Ludlow/Pridoli boundary (Silurian) of Wales and the welsh borderland". English. In: British Library Supplementary Publication 38.3 (1995), pp. 341-384.

[15784] C. G. Miller, M. Richter, and D. A. Do Carmo. "Fish and ostracod remains from the Santos Basin (Cretaceous to Recent), Brazil". English. In: Geological Journal 37 (2002), pp. 297-316.

[15785] E. R. Miller, B. R. Benefit, M. L. McCrossin, J. M. Plavcan, M. G. Leakey, A. N. El-Barkooky, M. A. Hamdan, M. K. Abdel Gawad, S. M. Hassan, and E. L. Simons. "Systematics of early and middle Miocene Old World monkeys". English. In: Journal of Human Evolution 57 (2009), pp. 195-211. DOI: 10.1016/j.jhevol.2009.06.006.

[15786] E. R. Miller, D. T. Rasmussen, and E. L. Simons. "Fossil storks (Ciconiidae) from the Late Eocene and Early Miocene of Egypt". English. In: The Ostrich 68.1 (1997), pp. 23-26.

[15787] K. B. Miller and M. Balke. "The unusual occurrence of aquatic beetles in amber, Copelatus aphroditae Balke, n. sp. and C. predaveterus Miller, n. sp (Coleoptera: Dytiscidae: Copelatinae)". English. In: Proceedings of the Entomological Society of Washington 105 (2003), pp. 809-815. 
[15788] K. B. Miller and S. H. Lubkin. "Calicovatellus petrodytes, a new genus and species of primitive vatelline diving beetle (Coleoptera: Dytiscidae: Hydroporinae: Vatellini) from the Miocene Barstow Formation, southern California, USA". English. In: Journal of Paleontology 75 (2001), pp. 890894.

[15789] R. Miller and J. McGovern. "Late-glacial marine invertebrate macrofossilsfrom Point Lepreau, New Brunswick". English. In: Atlantic Geology 33 (1997), pp. 217-221.

[15790] R. F. Miller. "New records and AMS radiocarbon dates on Quaternary Walrus (Odobenus rosmarus) from New Brunswick". English. In: Geographie Physique et Quaternaire 51.1 (1997), pp. 107111.

[15791] R. F. Miller, C. R. Harington, and R. Welch. “A giant beaver (Castoroides ohioensis Foster) fossil from New Brunswick, Canada". English. In: Atlantic Geology 36 (2000), pp. 1-5.

[15792] R. R. Miller. "New records of postglacial walrus and a review of Quaternary marine mammals in New Brunswick". English. In: Atlantic Geology 26.1 (1990), pp. 97-107.

[15793] W. Miller. “Checklist of megafossils from the James City Formation (Lower Pleistocene) at Johnson Point, Craven County, North Carolina". English. In: Tulane Studies in Geology and Paleontology 22 (1990), pp. 93-100.

[15794] W. E. Miller. "A Rhynchotherium skull and mandible from Southeastern Arizona". English. In: BYU Geology Studies 36 (1990), pp. 57-68.

[15795] W. E. Miller and O. Carranza-Castaneda. "Late Tertiary Canids from Central Mexico". English. In: Journal of Paleontology 72.3 (1998), pp. 546-556. DOI: 10.1017/S002233600002432X.

[15796] J. Millet and W. Kiessling. "First record of coralline demosponges in the Pleistocene: implications for reef ecology". English. In: Coral Reefs 28 (2009), pp. 867-870. DOI: 10.1007/s00338-009-0549-x.

[15797] J. Millet and A. Nel. "A new myrmeleontoid genus from the Crato Formation of Northeast Brazil (Lower Cretaceous) (Insecta: Neuroptera: Palaeoleontidae)". English. In: Zootaxa 2353 (2010), pp. 49 54.

[15798] A. C. Milner. “Theropod dinosaurs of the Purbeck Limestone Group, southern England". English. In: In A. R. Milner \& D. J. Batten (eds.), Life and Environments in Purbeck Times. Special Papers in Palaeontology 68 (2002), pp. 191-201.

[15799] A. C. Milner. "The astopod amphibian from the Viséan of East Kirkton, West Lothian, Scotland". English. In: Transactions of the Royal Society of Edinburgh: Earth Sciences 84 (1994), pp. 363-368. DOI: $10.1017 /$ S0263593300006167.

[15800] A. C. Milner and W. Lindsay. "Postcranial remains of Buphetes and their bearing on the relationships of the Baphetidae (=Loxommatidae)". English. In: Zoological Journal of the Linnean Society 122 (1998), pp. 211-235. DOI: 10.1111/j.1096-3642.1998.tb02530.x.

[15801] A. C. Milner, A. R. Milner, and S. A. Walsh. "A new specimen of Baphetes from Nyrany, Czech Republic and the intrinsic relationships of the Baphetidae". English. In: Acta Zoologica 90 (2009), pp. 318-334. DOI: 10.1111/j.1463-6395.2008.00340.x.

[15802] A. R. Milner. "The turtles of the Purbeck Limestone Group of Dorset, southern England". English. In: Palaeontology 47.6 (2004), pp. 1441-1467. DOI: 10.1111/j.0031-0239.2004.00418.x.

[15803] A. R. Milner. "Turtles". English. In: Palaeontological Association Field Guide to Fossils 14 (2011), pp. 295-304.

[15804] A. R. Milner, B. G. Gardiner, N. C. Fraser, and M. A. Taylor. "Vertebrates from the Middle Triassic Otter Sandstone Formation of Devon". English. In: Palaeontology 33.4 (1990), pp. 873-892.

[15805] A. R. Milner, J. Klembara, and O. Dostál. “A zatrachydid temnospondyl from the Lower Permian of the Boskovice Furrow in Moravia (Czech Republic)". English. In: Journal of Vertebrate Paleontology 27.3 (2007), pp. 711-715. DOI: 10.1671/0272-4634(2007)27[711:AZTFTL]2.0.CO;2.

[15806] A. R. Milner and S. E. K. Sequeira. "The temnospondyl amphibians from the Viséan of East Kirkton, West Lothian, Scotland". English. In: Transactions of the Royal Society of Edinburgh: Earth Sciences 84 (1994), pp. 331-361. DOI: 10.1017/S0263593300006155. 
[15807] A. R. Milner and S. E. K. Sequeira. "A cochleosaurid temnospondyl amphibian from the Middle Pennsylvanian of Linton, Ohio, U.S.A." English. In: Zoological Journal of the Linnean Society 122 (1998), pp. 261-290. DOI: 10.1111/j.1096-3642.1998.tb02532.x.

[15808] A. R. C. Milner, J. I. Kirkland, and S. Z. Spears. Colorado Plateau Coring Project (CPCP) workshop 2007. Field trip, November 15, 2007. English. 2007, pp. 1-24.

[15809] A. R. C. Milner and J. I. Kirkland. "Preliminary review of the Early Jurassic (Hettangian) freshwater Lake Dixie fish fauna in the Whitmore Point Member, Moenave Formation in southwest Utah". English. In: vol. 37. The Triassic-Jurassic Terrestrial Transition. New Mexico Museum of Natural History and Science Bulletin. Albuquerque: New Mexico Museum of Natural History and Science, 2006, pp. 510-521.

[15810] A. R. C. Milner, M. G. Lockley, and S. B. Johnson. "The story of the St. George Dinosaur Discovery Site at Johnson Farm: an important new Lower Jurassic dinosaur tracksite from the Moenave Formation of southwestern Utah". English. In: vol. 37. The Triassic-Jurassic Terrestrial Transition. New Mexico Museum of Natural History and Science Bulletin. Albuquerque: New Mexico Museum of Natural History and Science, 2006, pp. 329-345.

[15811] A. R. C. Milner, M. G. Lockley, and J. I. Kirkland. "A large collection of well-preserved theropod dinosaur swim tracks from the Lower Jurassic Moenave Formation, St. George, Utah". English. In: vol. 37. The Triassic-Jurassic Terrestrial Transition. New Mexico Museum of Natural History and Science Bulletin. Albuquerque: New Mexico Museum of Natural History and Science, 2006, pp. 315-328.

[15812] A. R. C. Milner and M. G. Lockley. History, geology and paleontology: St. George Dinosaur Discovery Site at Johnson Farm, Utah. English. Making Tracks Across the Southwest: The 2006 Desert Symposium. Zzyzx: California State University, Desert Studies Consortium and LSA Associates, Inc., 2006, pp. 35-48.

[15813] A. R. C. Milner, G. C. Vice, J. D. Harris, and M. G. Lockley. Dinosaur tracks from the Upper Cretaceous Iron Springs Formation, Iron County, Utah. English. Vol. 35. Late Cretaceous Vertebrates from the Western Interior. New Mexico Museum of Natural History and Science Bulletin. 2006, pp. 105113.

[15814] A. R. Milner. “The tail of Microbrachis (Tetrapoda; Microsauria)”. English. In: Lethaia 41.3 (2008), pp. 257-261.

[15815] X. Min, H. Hua, L. Liu, B. Sun, Z. Cui, T, and Jiang. "Phosphatized Epiphyton from the terminal Neoproterozoic and its significance". English. In: Precambrian Research (2019). DOI: 10.1016 / j. precamres.2019.105358.

[15816] A. V. Minikh. "Late Permian Discordichthyiformes (Osteichthyes) from European Russia". English. In: Paleontological Journal 40.5 (2006), pp. 564-571.

[15817] B. Minjin. "An Oligocene sciurid from the Hsanda Gol Formation, Mongolia”. English. In: Journal of Vertebrate Paleontology 24.3 (2004), pp. 753-756.

[15818] L. Minkina. "Archeopsammoporus balticus gen. nov., sp. nov. (Coleoptera: Scarabaeidae: Aegialiinae), a new extinct genus and species from Baltic amber". English. In: Studies and Reports, Taxonomical Series 16 (2020), pp. 451-460.

[15819] A. R. Miño-Boilini. "Additions to the knowledge of the ground sloth Catonyx tarijensis (Xenarthra, Pilosa) in the Pleistocene of Argentina". English. In: Paläontologische Gesellschaft 90 (2016), pp. 173-183.

[15820] A. R. Miño-Boilini, A. A. Carlini, J. O. Chiesa, N. P. Lucero, and A. E. Zurita. “First record of Scelidodon chiliense (Lydekker) (Phyllophaga, Scelidotheriinae) from the Lujanian stage (Late Pleistocene, early Holocene) of Argentina". English. In: Neues Jahrbuch fur Geologie und PalaontologieAbhandlungen 253.2-3 (2009), pp. 373-381. DOI: 10.1127/0077-7749/2009/0253-0373.

[15821] A. R. Miño-Boilini and A. A. Carlini. "The Scelidotheriinae Ameghino, 1904 (Phyllophaga, Xenarthra) from the Ensenadan-Lujanian Stage/Ages (Early Pleistocene to Early-Middle PleistoceneEarly Holocene) of Argentina". English. In: Quarternary International 210 (2009), pp. 93-101. 
[15822] A. R. Miño-Boilini, M. G. De Los Reyes, A. E. Zurita, M. J. Arrouy, and D. G. Poiré. “Pliocene Scelidotheriinae (Xenarthra, Tardigrada) from the Pampean region of Argentina: Morphology, chronology, and comments on the diversity of the subfamily". English. In: Comptes Rendus Palevol 18 (2019), pp. 325-334. DOI: 10.1016/j.crpv.2019.01.005.

[15823] A. R. Miño-Boilini, R. L. Tomassini, and V. H. Contreras. "First record of Scelidotheriinae Ameghino (Xenarthra, Mylodontidae) from the Chasicoan Stage/Age (late Miocene) of Argentina". English. In: Estudios Geológicos 70.1 (2014), e007. DOI: 10.3989/egeol.41551.291First.

[15824] E. Minwegen. “Die Biokonstruktionen im Pennsylvanium des Kantabrischen Gebirges (Nordspanien) [Pennsylvanian bioconstructions of the Cantabrian Mountains (Northern Spain)]". German. In: Kölner Forum für Geologie und Paläontologie 9 (2001), pp. 1-139.

[15825] R. Minwer-Barakat, A. Badiola, J. Marigo, and S. Moya-Sola. "First record of the genus Microchoerus (Omomyidae, Primates) in the western Iberian Peninsula and its palaeobiogeographic implications". English. In: Journal of Human Evolution 65.3 (2013), pp. 313-321.

[15826] R. Minwer-Barakat, A. Garca-Alix, E. Martn Suárez, and M. Freudenthal. "Blarinoides aliciae sp. nov., a new Soricidae (Mammalia, Lipotyphla) from the Pliocene of Spain." English. In: C.R. Palevol 6 (2007), pp. 281-289. DOI: 10.1016/j.crpv.2007.03.001.

[15827] R. Minwer-Barakat, J. Marigó, and S. Moyá-Solá. “A New Species of Pseudoloris (Omomyidae, Primates) from the Middle Eocene of Sant Jaume de Frontanyá (Eastern Pyrenees, Spain)". English. In: American Journal of Physical Anthropology 143 (2010), pp. 92-99. DOI: 10.1002/ajpa.21297.

[15828] R. Minwer-Barakat, J. Marigó, and S. Moyá-Solá. "Pseudoloris cuestai, a New Microchoerine (Primates, Omomyidae) from the Middle Eocene of the Iberian Peninsula". English. In: Journal of Vertebrate Paleontology 32.2 (2012), pp. 407-418. DOI: 10.1080/02724634.2012.643330.

[15829] R. Minwer-Barakat, J. Marigo, and S. Moya-Sola. “Necrolemur anadoni, a new species of Microchoerinae (Omomyidae, Primates) from the Middle Eocene of Sant Jaume de Frontany a (Pyrenees, Northeastern Spain)". English. In: American Journal of Physical Anthropology 158 (2015), pp. 730-744.

[15830] R. Minwer-Barakat, J. Marigo, and S. Moya-Sola. "On the determination of the Microchoerus (Omomyidae, Primates) remains from Sant Cugat de Gavadons (Late Eocene, Ebro Basin, NE Spain)". English. In: American Journal of Physical Anthropology 160 (2016), pp. 162-168.

[15831] R. Minwer-Barakat, J. Marigó, J. Femenias-Gual, L. Costeur, S. De Esteban-Trivigno, and S. Moyá Solá. "Microchoerus hookeri nov. sp., a new late Eocene European microchoerine (Omomyidae, Primates): New insights on the evolution of the genus Microchoerus". English. In: Journal of Human Evolution 102 (2017), pp. 42-66.

[15832] P. S. Minyuk and Y. B. Gladenkov. "Magnetostratigraphy of Paleogene Deposits in Kamchatka". English. In: Stratigraphy and Geological Correlation 15.1 (2007), pp. 100-111.

[15833] G. V. Mirantsev and Yu.A. Arendt. "A new anobasicrinid (Crinoidea, Cladida) from the Upper Carboniferous of the Moscow Region". English. In: Paleontological Journal 47.5 (2013), pp. 470-479. DOI: 10.1134/S0031030113050092.

[15834] L. R. Miron, A. E. B. Pavanatto, F. A. Pretto, R. T. Müller, S. Dias-da-Silva, and L. Kerber. "Siriusgnathus niemeyerorum (Eucynodontia: Gomphodontia): the youngest South American traversodontid?" English. In: Journal of South American Earth Sciences (2019). DOI: 10.1016/j.jsames.2019. 102394.

[15835] A. A. Mironenko and M. A. Rogov. "First direct evidence of ammonoid ovoviviparity". English. In: Lethaia 49 (2016), pp. 245-260.

[15836] K. Mirsa, A. K. Jauhri, S. Kishore, and S. K. Singh. "Calcareous algae from the Lakadong Formation of the South Shillong Plateau, NE India". English. In: Revue Paleobiologie 21.2 (2002), pp. 717-734.

[15837] P. K. Mirsa, A. K. Jauhri, R. P. Tiwari, S. Kishore, Ajay Pratap Singh, and S. K. K=Singh. “Coralline algae from the Prang Formation (middle-late Eocene) of the Lumshnong area, Jaintia Hills, Meghalaya". English. In: Journal Geological Society of India 78 (2011), pp. 355-364. 
[15838] P. K. Mirsa, A. K. Jauhri, S. K. Singh, and S. Kishore. "Coralline algae from the Fulra Limestone (middle Eocene) of Kachchh, Gujarat, western India". English. In: Journal Geological Society of India 67 (2006), pp. 495-502.

[15839] U. K. Mishra and S. Sen. "Dinosaur bones from Meghalaya". English. In: Current Science 80.8 (2001), pp. 1053-1056.

[15840] V. P. Mishra, D. K. Mehrotra, A. C. Pande, and MD. Amjad Ali. "A Teleostean Fish from the Lower Triassic of Chamba, Himachal Pradesh". English. In: Journal of the Palaeontological Society of India 35 (1990), pp. 73-76.

[15841] M. Misik. “Pieninia oblonga- Skeletal parts or endoparasites of Keratosa sponges?" English. In: Geologica Carpathica 49.6 (1998), pp. 401-407.

[15842] P. C. Misra, A. K. Jauhri, S. K. Singh, S. Kishore, and A. Chowdhury. "Coralline algae from the Oligocene of Kachchh, Gujarat, India". English. In: Journal of The Palaeontological Society of India 46 (2001), pp. 59-76.

[15843] P. K. Misra, S. Kishore, S. K. Singh, and A. K. Jauhri. "Rhodophycean Algae from the Lower Cretaceous of the Cauvery Basin, South India". English. In: Journal geological society of India 73 (2009), pp. 325-334.

[15844] P. Missiaen, G. Escarguel, J. -L. Hartenberger, and T. Smith. “A large new collection of Palaeostylops from the Paleocene of the Flaming Cliffs area (Ulan-Nur Basin, Gobi Desert, Mongolia), and an evaluation of the phylogenetic affinities of Arctostylopidae (Mammalia, Gliriformes)". English. In: Geobios 45 (2012), pp. 311-322.

[15845] P. Missiaen and P. D. Gingerich. "New early Eocene tapiromorph perissodactyls from the Ghazij Formation of Pakistan, with implications for mammalian biochronology in Asia". English. In: Acta Palaeontologica Polonica 57.1 (2012), pp. 21-34.

[15846] P. Missiaen and P. D. Gingerich. "New Basal Perissodactyla (Mammalia) From The Lower Eocene Ghazij Formation of Pakistan". English. In: Contributions from the Museum of Paleontology, University of Michigan 32.9 (2014), pp. 139-160.

[15847] P. Missiaen, G. F. Gunnell, and P. D. Gingerich. New Brontotheriidae (Mammalia, Perissodactyla) from the early and middle Eocene of Pakistan with implications for mammalian Paleobiogeography. English. Vol. 85. Journal of Paleontology 4. 2011, pp. 665-677.

[15848] P. Missiaen, F. Quesnel, C. Dupuis, J. -Y. Storme, and T. Smith. “The earliest Eocene mammal fauna of the Erquelinnes Sand Member near the French-Belgian border". English. In: Geologica Belgica 16.4 (2013), pp. 262-273.

[15849] P. Missiaen and T. Smith. "The Gashatan (late Paleocene) mammal fauna from Subeng, Inner Mongolia". English. In: Acta Palaeontologica Polonica 53.3 (2008), pp. 357-378.

[15850] P. Missiaen and T. Smith. "A new Paleocene nyctitheriid insectivore from Inner Mongolia (China) and the origin of Asian nyctitheriids". English. In: Acta Palaeontologica Polonica 50.3 (2005), pp. 513522.

[15851] P. Missiaen, F. Solé, E. De Bast, J. Yang, C. -S. Li, and T. Smith. “A new species of Archaeoryctes from the Middle Paleocene of China and the phylogenetic diversification of Didymoconidae". English. In: Geologica Belgica 16.4 (2013), pp. 245-253.

[15852] S. Missoni, H. J. Gawlick, H. Suzuki, and V. Diersche. “Die paläogeographische Stellung des Watzmann Blockes in den Berchtesgadener Kalkalpen - Neuergebnisse auf der Basis der Analyse der Trias- und Jura-Entwicklung". German. In: Journal of Alpine Geology - Mitt. Ges. Geol. Bergbaustud. Österreich 47 (2005), pp. 169-209.

[15853] B. Mistiaen. “Dendropora explicita Michelin, 1846 et D. briceae nov. sp. (Tabulata) dans leur localite-type du Boulonnais. Presence du genre en Afghanistan". French. In: Geobios 24.2 (1991), pp. 141-155.

[15854] S. F. Mitchel. "Exceptionally well-preserved silicified hippuritid rudist bivalves from the lower Maastrichtian of Puerto Rico". English. In: Carnets de Geologie 20.18 (2020). DOI: 10.2110/ carnets. 2020.2018 . 
[15855] C. Mitchell, E. D. Brussa, and J. Maletz. "A mixed Isograptid-Didymograptid Graptolite assemblage from the Middle Ordovician of West Gondwana (NW Bolivia): implications for Graptolite Paleoecology". English. In: Journal of Paleontology 82.6 (2008), pp. 1114-1126.

[15856] C. E. Mitchell, X. Chen, S. M. Bergström, Y. -D. Zhang, Z. H. Wang, B. D. Webby, and S. C. Finney. "Definition of a global boundary stratotype for the Darriwilian Stage of the Ordovician System". English. In: Episodes 20.3 (1997), pp. 158-166.

[15857] E. D. Mitchell. A new edentulous cetacean with short, arched rostrum from Late Oligocene rocks of Santa Barbara County, California. 1996.

[15858] J. S. Mitchell, A. B. Heckert, and H. -D. Sues. “Grooves to tubes: evolution of the venom delivery system in a Late Triassic reptile". English. In: Naturwissenschaften 97 (2010), pp. 1117-1121. DOI: 10.1007/s00114-010-0729-0.

[15859] S. F. Mitchell. "The Cretaceous crinoid Uintacrinus socialis from Jamaica and its significance for global correlation". English. In: Geological Magazine 146.6 (2009), pp. 937-940.

[15860] S. F. Mitchell. "A new rudist bivalve Curtocaprina clabaughikinsorum gen. et sp. nov. from the Middle Albian of Texas and its bearing on the origin of the Ichthyosarcolitidae Douville". English. In: Caribbean Journal of Earth Science 45 (2013), pp. 85-89.

[15861] S. F. Mitchell. "Stratigraphy of the Guinea Corn Formation (Upper Cretaceous) at its type locality in the Rio Minho between Grantham and Guinea Corn, northern Clarendon, Jamaica". English. In: The Journal of the Geological Society of Jamaica 33 (1999), pp. 1-12.

[15862] S. F. Mitchell. "A new rudist from the Santonian of Jamaica". English. In: Caribbean Journal of Earth Science 40 (2009), pp. 15-20.

[15863] S. F. Mitchell. "Palaeoecology of corals and rudists in mixed volcaniclastic carbonate small-scale rhythms (Upper Cretaceous, Jamaica)". English. In: Palaeogeography, Palaeoclimatology, Palaeoecology 186 (2002), pp. 237-259.

[15864] S. F. Mitchell, G. C. Gunter, and R. Ramsook. Paleoecology of the Maastrichtian rudist Biradiolites in Jamaica. English. Vol. 87. Cretaceous rudists and carbonate platforms: environmental feedback, SEPM Special Publication. 2007, pp. 81-94.

[15865] S. F. Mitchell and G. C. Gunter. "First record of the rudist bivalve Mitrocaprina tschoppi (Palmer) from the Maastrichtian of Jamaica". English. In: Caribbean Journal of Science 40.3 (2004), pp. 392396.

[15866] S. F. Mitchell, R. K. Pickerill, and T. A. Stemann. “The Port Morant Formation (Upper Pleistocene, Jamaica): high resolution sedimentology and paleoenvironmental analysis of a mixed carbonate clastic lagoonal succession". English. In: Sedimentary Geology 144 (2001), pp. 291-306.

[15867] S. F. Mitchell and R. Ramsook. "Rudist bivalve assemblages from the Back Rio Grande Formation (Creaceous: Campanian) of Jamaica and their stratigraphic significance". English. In: Cretaceous Research 30 (2009), pp. 307-321. DOI: 10.1016/j.cretres.2008.07.009.

[15868] S. F. Mitchell, T. Stemann, D. Blissett, I. Brown, W. O’Brian Ebanks, G. Gunter, D. J. Miller, A. G. M. Pearson, B. Wilson, and W. A. Young. "Late Maastrichtian rudist and coral assemblages from the Central Inlier, Jamaica: towards an event stratigraphy for shallow-water Caribbean limestones". In: Cretaceous Research 25 (2004), pp. 499-507.

[15869] P. G. Mitov, J. A. Dunlop, and D. Penney. “A new species of Lacinius in amber (Arachnida: Opiliones)". English. In: Fossil Record 18 (2015), pp. 37-42.

[15870] V. V. Mitta. “Genus Oraniceras (Parkinsoniidae, Ammonoidea) from the lower Bathonian of southern European Russia". English. In: Paleontological Journal 49 (2015), pp. 595-601.

[15871] V. V. Mitta. “On the phylogeny of early Cardioceratidae (Ammonoidea) and Cadoceratinae from central Russia at the Bathonian-Callovian boundary". English. In: Paleontological Journal 50 (2016), pp. 358-368.

[15872] V. V. Mitta. "The ammonoid genus Spiroceras (Spiroceratidae, Ammonoidea) from the Upper Bajocian of the northern Caucasus". English. In: Paleontological Journal 51 (2017), pp. 133-142. 
[15873] V. V. Mitta. “The genus Keppleritiana gen. nov. (Stephanoceratidae, Ammonoidea) from the Upper Bajocian of the northern Caucasus". English. In: Paleontological Journal 51 (2017), pp. 247-257.

[15874] V. V. Mitta. “On some Rarecostites (Parkinsoniidae, Ammonoidea) from the upper Bajocian Parkinsoni zone of the northern Caucasus". English. In: Paleontological Journal 51 (2017), pp. 464-479.

[15875] V. V. Mitta, Yu.N. Savelieva, A. A. Fedorova, and O. V. Shurekova. “Ammonites, Microfauna, and Palynomorphs from the Lower Part of the Upper Bajocian Parkinsoni Zone of the Basin of the Bolshoi Zelenchuk River, Northern Caucasus". English. In: Stratigraphy and Geological Correlation 26.5 (2018), pp. 552-570. DOI: 10.1134/S0869593818050040.

[15876] T. Miyashita, M. I. Coates, R. Farrar, P. Larson, P. L. Manning, R. A. Wogelius, N. P. Edwards, J. Anné, U. Bergmann, A. R. Palmer, and P. J. Currie. "Hagfish from the Cretaceous Tethys Sea and a reconciliation of the morphological-molecular conflict in early vertebrate phylogeny". English. In: Proceedings of the National Academy of Science, U.S.A 116.6 (2019), pp. 2146-2151. DOI: 10.1073/ pnas.1814794116.

[15877] K. Miyata. "New species of Trogosus (Tillodontia, Mammalia) from the Green River Basin, Wyoming". English. In: Journal of Vertebrate Paleontology 27.3 (2007), pp. 661-675.

[15878] K. Miyata. “New material of Asian Trogosus (Tillodontia, Mammalia) from the Akasaki Formation, Kumamoto Prefecture, Japan". English. In: Journal of Vertebrate Paleontology 27.1 (2007), pp. 176-188.

[15879] K. Miyata, Y. Azuma, and M. Shibata. "New mammalian specimens from the Lower Cretaceous Kitadani Formation, Tetori Group, Fukui, Japan". English. In: Historical Biology 28.1-2 (2016), pp. 139150.

[15880] K. Miyata and Y. Tomida. "A new tillodont from the early Middle Eocene of Japan and its implication to the subfamily Trogosinae (Tillodontia: Mammalia)". English. In: Paleontological Research 2.1 (1998), pp. 53-66.

[15881] K. Miyata and Y. Tomida. “Trogosus-like tillodont (Tillodontia, Mammalia) from the early Middle Eocene of Japan". English. In: Paleontological Research 2.3 (1998), pp. 193-198.

[15882] K. Miyata, Y. Tomida, K. C. Beard, G. F. Gunnell, H. Ugai, and K. Hirose. "Eocene mammals from the Akasaki and Nakakoshiki formations, western Kyushu, Japan: Preliminary work and correlation with Asian Land Mammal Ages". English. In: Vertebrata PalAsiatica 49.1 (2011), pp. 5368.

[15883] T. Miyata, Y. Maeda, E. Matsumoto, Y. Matsushima, P. Rodda, A. Sugimura, and H. Kayanne. "Evidence for a Holocene high sea-level stand, Vanua Levu, Fiji". English. In: Quaternary Research 33 (1990), pp. 352-359.

[15884] N. Miyazaki and W. F. Perrin. "Rough-toothed dolphin Steno bredanensis (Lesson, 1828)". English. In: Handbook of marine mammals, Volume 5: The first book of dolphins. Academic Press, 1994, pp. 1-21.

[15885] S. Miyazaki. "A new Pliocene fur seal from Tozawa-mura, Yamagata Prefecture, northern Japan". English. In: International Geological Conference Abstracts 30 (1996), p. 138.

[15886] S. Miyazaki, H. Horikawa, N. Kohno, K. Hirota, M. Kimura, Y. Hasegawa, Y. Tomida, L. G. Barnes, and C. E. Ray. "Summary of the fossil record of pinnipeds of Japan, and comparisons with that from the eastern North Pacific". English. In: The Island Arc 3 (1995), pp. 361-372.

[15887] J. Mlikovsky. “Taxonomic identity of Eostega lebedinskyi LAMBRECHT, 1929 (Aves) from the middle Eocene of Romania". English. In: Annalen des Naturhistorischen Museums in Wien 109.A (2007), pp. 19-27.

[15888] J. Mlikovsky. Cenozoic Birds of the World. English. Praha: Ninox Press, 2002, pp. 1-417.

[15889] J. Mo and E. Buffetaut. "A sauropod dorsal vertebra from the Middle Jurassic of Guangxi, China". English. In: Journal of Science and Technology MSU 31.1 (2012), pp. 1-8.

[15890] J. Mo, C. Huang, S. Xie, and E. Buffetaut. "A megatheropod tooth from the Early Cretaceous of Fusui, Guangxi, Southern China". English. In: Acta Geologica Sinica 88.1 (2014), pp. 6-12. 
[15891] J. Mo, K. Wang, S. Chen, P. Wang, and X. Xu. "A new titanosaurian sauropod from the Late Cretaceous strata of Shandong Province". Chinese. In: Geological Bulletin of China 36.9 (2017), pp. 15011504.

[15892] J. Mo, W. Wang, Z. Huang, X. Huang, and X. Xu. "A basal titanosauriform from the Early Cretaceous of Guangxi, China". English. In: Acta Geologica Sinica 80.4 (2006), pp. 486-489.

[15893] J. Mo, X. Xu, and E. Buffetaut. "A new eusauropod dinosaur from the Lower Cretaceous of Guangxi Province, southern China". English. In: Acta Geologica Sinica 84.6 (2010), pp. 1328-1335.

[15894] J. Mo, Z. Zhao, W. Wang, and X. Xu. "The first hadrosaurid dinosaur from southern China". English. In: Acta Geologica Sinica 81.4 (2007), pp. 550-554.

[15895] J. Mo, F. Zhou, G. Li, Z. Huang, and C. Cao. “A new Carcharodontosauria (Theropoda) from the Early Cretaceous of Guangxi, Southern China". English. In: Acta Geologica Sinica 88.4 (2014), pp. 1051-1059.

[15896] J.-Y. Mo, X. Xu, and S. E. Evans. "The evolution of the lepidosaurian lower temporal bar: new perspectives from the Late Cretaceous of South China". English. In: Proceedings of the Royal Society of London B, Biological Sciences 277 (2010), pp. 331-336. DOI: 10.1098/rspb.2009.0030.

[15897] J.-Y. Mo, X. Xu, and S. E. Evans. “A large predatory lizard (Platynota, Squamata) from the Late Cretaceous of South China". English. In: Journal of Systematic Palaeontology 10.2 (2012), pp. 333339. DOI: $10.1080 / 14772019.2011 .588254$.

[15898] J.-Y. Mo, C.-L. Huang, Z. -R. Zhao, W. Wang, and X. Xu. “A new titanosaur (Dinosauria: Sauropoda) from the Late Cretaceous of Guangxi, China". Chinese. In: Vertebrata PalAsiatica 46.2 (2008), pp. 147156.

[15899] P. Mocho, A. Pérez-Garca, M. Martn Jiménez, and F. Ortega. "New remains from the Spanish Cenomanian shed light on the Gondwanan origin of European Early Cretaceous titanosaurs". English. In: Cretaceous Research 95 (2019), pp. 164-190. DOI: 10.1016/j.cretres.2018.09.016.

[15900] P. Mocho, R. Royo-Torres, and F. Ortega. "A new macronarian sauropod from the Upper Jurassic of Portugal". English. In: Journal of Vertebrate Paleontology (2019), e1578782:1-23. DOI: 10.1080 / 02724634.2019.1578782.

[15901] P. Mocho, R. Royo-Torres, E. Malafaia, F. Escaso, and F. Ortega. "A preliminary evaluation of Diplodocidae record from the Upper Jurassic of Lusitanian Basin (W, Portugal)". English. In: IV Congresso Jovens Investigadores em Geociencias, LEG 2014, Pólo de Estremoz da Universidade de Évora. Livro de Actas (2014), pp. 85-88.

[15902] E. L. Mockford and A. N. Garca Aldrete. "A new genus and two new species, one extant and one fossil, in the family Troctopsocidae (Psocodea: 'Psocoptera': Troctomorpha: Amphientometae: Electrentomoidea)". English. In: Zootaxa 3869 (2014), pp. 159-164.

[15903] E. L. Mockford, C. Lienhard, and K. Yoshizawa. "Revised classification of Psocoptera from Cretaceous amber, a reassessment of published information". English. In: Insecta Matsumurana 69 (2013), pp. 1-26.

[15904] M. Moczydowska and K. E. Nagovitsin. "Ediacaran radiation of organic-walled microbiota recorded in the Ura Formation, Patom Uplift, East Siberia". English. In: Precambrian Research 198-199 (2012), pp. 1-24.

[15905] M. Moczydlowska, G. Vidal, and V. A. Rudavskaya. “Neoproterozoic (Vendian) Phytoplankton from the Sieberian Platform, Yakutia". English. In: Palaeontology 36.3 (1993), pp. 395-521.

[15906] S. Modesto, V. J. Flear, M. M. Dilney, and R. R. Reisz. "A large moradisaurine tooth plate from the Lower Permian of Texas and its biostratigraphic implications". English. In: 36.6 (2016), e1221832. DOI: $10.1080 / 02724634.2016 .1221832$.

[15907] S. Modesto, B. Rubidge, I. Visser, and J. Welman. "A new basal dicynodont from the Upper Permian of South Africa". English. In: Palaeontology 46 (2003), pp. 211-223. 
[15908] S. Modesto, B. Rubidge, and J. Welman. "The most basal anomodont therapsid and the primacy of Gondwana in the evolution of anomodonts". English. In: Proceedings of the Royal Society B 266 (1999), pp. 331-337.

[15909] S. Modesto, B. Rubidge, and J. Welman. "The most basal anomodont therapsid and the primacy of Gondwana in the evolution of the anomodonts". English. In: The Royal Society 266 (1999), pp. 331337.

[15910] S. P. Modesto. “Noteosaurus africanus Broom is a nomen dubium". English. In: Journal of Vertebrate Paleontology 16.1 (1996), pp. 172-174.

[15911] S. P. Modesto and J. Botha-Brink. "Evidence of a second, large archosauriform reptile in the Lower Triassic Katberg Formation of South Africa". English. In: Journal of Vertebrate Paleontology 28.3 (2008), pp. 914-917.

[15912] S. P. Modesto and R. R. Reisz. "An Enigmatic New Diapsid Reptile from the Upper Permian of Eastern Europe". English. In: Journal of Vertebrate Paleontology 22.4 (2002), pp. 851-855.

[15913] S. P. Modesto and R. R. Reisz. "Taxonomic status of Edaphosaurus raymondi Case". English. In: Journal of Paleontology 64.6 (1990), pp. 1049-1051.

[15914] S. P. Modesto, B. S. Rubidge, and J. Welman. "A new dicynodont therapsid from the lowermost Beaufort Group, Upper Permian of South Africa". English. In: Canadian Journal of Earth Sciences 39.12 (2002), pp. 1555-1765. DOI: 10.1139/e02-091.

[15915] S. P. Modesto, D. Scott, and R. R. Reisz. "A new small captorhinid reptile from the lower Permian of Oklahoma and resource partitioning among small captorhinids in the Richards Spur fauna". English. In: Papers in Palaeontology 4.2 (2018), pp. 293-307.

[15916] S. P. Modesto, D. M. Scott, and R. R. Reisz. "A new parareptile with temporal fenestration from the Middle Permian of South Africa". English. In: Canadian Journal of Earth Sciences 46.1 (2009), pp. 9-20. DOI: 10.1139/E09-001.

[15917] S. P. Modesto, D. M. Scott, and R. R. Reisz. "Arthropod remains in the oral cavities of fossil reptiles support inference of early insectivory". English. In: Biology Letters 5.6 (2009), pp. 838-840. DOI: 10.1098/rsbl.2009.0326.

[15918] S. P. Modesto, D. M. Scott, J. Botha-Brink, and R. R. Reisz. "A new and unusual procolophonid parareptile from the Lower Triassic Katberg Formation of South Africa". English. In: Journal of Vertebrate Paleontology 30.3 (2010), pp. 715-723.

[15919] S. P. Modesto, D. M. Scott, M. J. MacDougall, H. -D. Sues, D. C. Evans, and R. R. Reisz. “The oldest parareptile and the early diversification of reptiles". English. In: Proceedings of the Royal Society B 282 (2015), p. 20141912.

[15920] S. P. Modesto and R. M. H. Smith. "A new Late Permian captorhinid reptile: a first record from the South African Karoo". English. In: Journal of Vertebrate Paleontology 21.3 (2001), pp. 405-409.

[15921] S. P. Modesto, H.-D. Sues, and R. Damiani. "A new Triassic procolophonoid reptile and its implications for procolophonoid survivorship during the Permo-Triassic extinction event". English. In: Proceedings of the Royal Society of London, Series B 268 (2001), pp. 2047-2052.

[15922] S. P. Modesto and H.-D. Sues. "The skull of the Early Triassic archosauromorph reptile Prolacerta broomi and its phylogenetic significance". English. In: Zoological Journal of the Linnean Society 140 (2004), pp. 335-351.

[15923] S. P. Modesto, R. J. Damiani, and H. -D. Sues. "A reappraisal of Coletta seca, a basal procolophonoid reptile from the Lower Triassic of South Africa". English. In: Palaeontology 45.5 (2002), pp. 883-895.

[15924] S. P. Modesto, R. J. Damiani, J. Neveling, and A. M. Yates. “A new Triassic owenettid parareptile and the mother of mass extinctions". English. In: Journal of Vertebrate Paleontology 23.3 (2003), pp. 715-719.

[15925] P. J. Modreski. "Geochemical and mineralogical studies of dinosaur bone from the Morrison Formation at Dinosaur Ridge". English. In: The Mountain Geologist 38.3 (2001), pp. 111-118. 
[15926] T. L. Modzalevskaya. "Silurian and Devonian brachiopods from Severnaya Zemlya (Russian Arctic)". English. In: Geodiversitas 25.1 (2003), pp. 73-107.

[15927] T. L. Modzalevskaya and L. E. Popov. "Earliest Silurian articulate brachiopods from central Kazakhstan". English. In: Acta Palaeontologica Polonica 40.4 (1995), pp. 399-426.

[15928] P. W. Moerdijk. "Mactromeris polynyma (Stimpson, 1860) (Mollusca, Matricidae) from the Upper Pliocene of the Netherlands and Belgium". English. In: Cainozoic Research 2.1-2 (2003), pp. 135-137.

[15929] H. V. Moghadam and C. R. C. Paul. “Trace fossils of the Jurassic, Blue Lias, Lyme Regis, Southern England". English. In: Ichnos 7.4 (2000), pp. 283-306.

[15930] I. M. Moghaddam, P. Shams, and M. P. N. Shirazi. "Systematic of Albian - Cenomanian Gastropods and Bivalves from the Kazhdumi Formation, Zagros Basin". English. In: Journal of Sciences, Islamic Republic of Iran 27.3 (2016), pp. 237-252.

[15931] D. M. Mohabey. "A new oospecies, Megaloolithus matleyi, from the Lameta Formation (Upper Cretaceous) of Chandrapur district, Maharashtra, India, and general remarks on the palaeoenvironment and nesting behaviour of dinosaurs". In: Cretaceous Research 17 (1996), pp. 183-196.

[15932] D. M. Mohabey. "Systematics of Indian Upper Cretaceous dinosaur and chelonian eggshells". English. In: Journal of Vertebrate Paleontology 18.2 (1998), pp. 348-362.

[15933] D. M. Mohabey. Late Cretaceous (Maastrichtian) nests, eggs, and dung mass (coprolites) of sauropods (titanosaurs) from India. English. Thunder-Lizards: The Sauropodomorph Dinosaurs. Indiana University Press, Bloomington. 2005, pp. 466-490.

[15934] D. M. Mohabey. "Indian dinosaur eggs: a review". English. In: Journal of the Geological Society of India 58.6 (2001), pp. 479-508.

[15935] D. M. Mohabey. "Dinosaur eggs and dung (fecal mass) from Late Cretaceous of central India: dietary implications". English. In: Geological Survey of India Special Publication 64 (2001), pp. 605615.

[15936] D. M. Mohabey, J. J. Head, and J. A. Wilson. "A new species of the snake Madtsoia from the Upper Cretaceous of India and its paleobiogeographic implications". English. In: Journal of Vertebrate Paleontology 31.3 (2011), pp. 588-595. DOI: 10.1080/02724634.2011.560220.

[15937] M. Mohammadi, A. Ernest, and M. Yazdi. "The First Study of Bryozoans from the Geirud Formation in Central Alborz". English. In: Geo Sciences 18.70 (2008), pp. 166-173.

[15938] M. Mohanti and S. C. Srivastava. “Oligocene reefal environment of Kutch Basin (western India) with implications of the Mediterranean connection". In: Géologie Méditerranéenne 21.3-4 (1994), pp. 127-129.

[15939] Mohd Shafeea Leman. "The significance of Upper Permian brachiopods from Merapoh area, northwest Pahang”. English. In: Geological Society of Malaysia Bulletin 35 (1994), pp. 113-121.

[15940] Mohd Shafeea Leman and M. Sone. "A Permian phillipsiid trilobite from peninsular Malaysia". English. In: Geosciences Journal 6 (2002), pp. 125-129.

[15941] M. Mohibullah, T. R. A. Vandenbroucke, M. Williams, J. D. Floyd, T. Meidla, J. A. Zalasiewicz, and D. J. Siveter. "Late Ordovician (Sandbian) ostracods from the Ardwell Farm Formation, SW Scotland". English. In: Scottish Journal of Geology 47 (2011), pp. 57-66.

[15942] B. Mohr and M. Bernardes de Oliveira. "Endressinia brasiliana, a Magnolialean Angiosperm from the Lower Cretaceous Crato Formation (Brazil)". English. In: International Journal of Plant Sciences 165.6 (2004), pp. 1121-1133.

[15943] B. A. R. Mohr, M. E. C. Bernardes-de-Oliveira, and D. W. Taylor. "Pluricarpellatia, a nymphaealean angiosperm from the Lower Cretaceous of northern Gondwana, Crato Formation, Brazil". English. In: Taxon 57.4 (2008), pp. 1147-1158.

[15944] B. A. R. Mohr and H. Eklund. "Araripia florifera, a magnoliid angiosperm from the Lower Cretaceous Crato Formation (Brazil)". English. In: Review of Palaeobotany and Palynology 126 (2003), pp. 279-292. 
[15945] W. Mohrig and F. Röschmann. "Sciarid flies from Dominican amber (Diptera, Sciaridae)". English. In: Beiträge zur Entomologie 55 (2005), pp. 319-361.

[15946] P. Moisan, E. Abad, B. Bomfleur, and H. Kerp. “A Late Triassic flora from Gomero (Santa Juana Formation), Chile". English. In: Neues Jahrbuch für Geologie und Paläontologie-Abhandlungen 258.1 (2010), pp. 89-106. DOI: 10.1127/0077-7749/2010/0087.

[15947] P. Moissette, J. J. Cornee, F. Quilleviere, H. Zibrowius, E. Koskeridou, and G. E. Lopez-Otalvaro. "Pleistocene (Calabrian) deep-water corals and associated biodiversity in the eastern Mediterranean (Karpathos Island, Greece)". English. In: Journal of Quaternary Science 32.7 (2017), pp. 923933. DOI: $10.1002 /$ jqs.2966.

[15948] P. Moissette, E. Koskeridou, J. -J. Cornee, F. Guillocheau, and C. Lecuyer. "Spectacular preservation of seagrasses and seagrass-associated communities from the Pliocene of Rhodes, Greece". English. In: Palaios 22.2 (2007), pp. 200-211.

[15949] P. Moix, S. Gorican, and J. Marcoux. "First evidence of Campanian radiolarians in Turkey and implications for the tectonic setting of the Upper Antalya Nappes". English. In: Cretaceous Research 30 (2009), pp. 952-960.

[15950] D. Mol, K. Post, J. W. F. Reumer, J. van der Plicht, J. de Vos, B. van Geel, G. van Reenen, J. P. Pals, and J. Glimmerveen. "The Eurogeul-first report of the palaeontological, palynological and archaeological investigations of this part of the North Sea". English. In: Quaternary International 142-143 (2006), pp. 178-185.

[15951] J. M. Molina, L. O’Dogherty, J. Sandoval, and J. A. Vera. "Jurassic radiolarites in a Tethyan continental margin (Subbetic, southern Spain): palaeobatymetric and biostratigraphic considerations". English. In: Palaeogeography, Palaeoclimatology, Palaeoecology 150 (1999), pp. 309-330.

[15952] J. M. Molina, M. Reolid, and E. Mattioli. “Thin-shelled bivalve (filament) buildup of the Aalenianlowest". English. In: Geogaceta 61 (2017), pp. 31-34.

[15953] F. Molina-Olmedo, V. S. Ferreira, M. A. Branham, and M. A. Ivie. “The description of Prototrichalus gen. nov. and three new species from Burmese amber supports a mid-Cretaceous origin of the Metriorrhynchini (Coleoptera, Lycidae)". English. In: Cretaceous Research 111.104452 (2020). DOI: 10.1016/j.cretres.2020.104452.

[15954] L. Moliner, F. Olóriz, and A. B. Villaseñor. "Ataxioceras (Ataxioceras) lopeztichae Cantú-Chapa, 1991: updating the systematic and palaeobiogeographic interpretation". English. In: Palaeontologia Electronica 19.2.19A (2016), pp. 1-16.

[15955] F. H. Mollen. "A new middle Eocene species of Premontreia (Elasmobranchii, Scyliorhinidae) from Vlaam-Brabant, Belgium". English. In: Geologica Belgica 11 (2008), pp. 123-131.

[15956] F. H. Mollen. "A partial rostrum of the porbeagle shark Lamna nasus (Lamniformes, Lamnidae) from the Miocene of the North Sea Basin and the taxonomic importance of rostral morphology in extinct sharks". English. In: Geologica Belgica 13.1-2 (2010), pp. 61-76.

[15957] R. E. Molnar. Avian tibiotarsi from the Early Cretaceous of Lightning Ridge, New South Wales. Vol. 15. Proceedings of the Second Gondwana Dinosaur Symposium, Y. Tomida, T. H. Rich and P. VickersRich (eds.), National Science Museum Monographs. 1999, pp. 197-209.

[15958] R. E. Molnar. "Preliminary report on a new ankylosaur from the Early Cretaceous of Queensland, Australia". English. In: Memoirs of the Queensland Museum 39.3 (1996), pp. 653-668.

[15959] R. E. Molnar. "Observations on the Australian ornithopod dinosaur, Muttaburrasaurus". In: Memoirs of the Queensland Museum 39.3 (1996), pp. 639-652.

[15960] R. E. Molnar. "Sauropod (Saurischia: Dinosauria) material from the Early Cretaceous Griman Creek Formation of the Surat Basin, Queensland, Australia". English. In: Alcheringa 35.2 (2011), pp. 303-307. DOI: 10.1080/03115518.2010.533975.

[15961] R. E. Molnar. "Taphonomic observations on eastern Australian Cretaceous sauropods". English. In: Alcheringa 34.3 (2010), pp. 421-429. DOI: 10.1080/03115518.2010.497258. 
[15962] R. E. Molnar, A. L. Angriman, and Z. Gasparini. "An Antarctic Cretaceous theropod". English. In: Memoirs of the Queensland Museum 39.3 (1996), pp. 669-674.

[15963] R. E. Molnar and H. T. Clifford. "Gut contents of a small ankylosaur". English. In: Journal of Vertebrate Paleontology 20.1 (2000), pp. 194-196.

[15964] R. E. Molnar, I. Obata, M. Tanimoto, and M. Matsukawa. “A tooth of Fukuiraptor aff. F. kitadaniensis from the Lower Cretaceous Sebayashi Formation, Sanchu Cretaceous, Japan". English. In: Bulletin of Tokyo Gakugei University, Division of Natural Sciences 61 (2009), pp. 105-117.

[15965] R. E. Molnar and M. Pole. "A Miocene crocodilian from New Zealand". English. In: Alcheringa 21 (1997), pp. 65-70.

[15966] R. E. Molnar and R. A. Thulborn. "An incomplete pterosaur skull from the Cretaceous of northcentral Queensland, Australia". English. In: Arquivos do Museu Nacional, Rio de Janeiro 65.4 (2007), pp. 461-470.

[15967] R. E. Molnar, J. Wiffen, and B. Hayes. "A probable theropod bone from the latest Jurassic of New Zealand". English. In: New Zealand Journal of Geology and Geophysics 41 (1998), pp. 145-148.

[15968] R. E. Molnar and J. Wiffen. "A Late Cretaceous polar dinosaur fauna from New Zealand". In: Cretaceous Research 15 (1994), pp. 689-706.

[15969] R. E. Molnar and J. Wiffen. "A presumed titanosaurian vertebra from the Late Cretaceous of North Island, New Zealand". English. In: Arquivos do Museu Nacional, Rio de Janeiro 65.4 (2007), pp. 505510.

[15970] R. E. Molnar and P. M. A. Willis. New crocodyliform material from the Early Cretaceous Griman Creek Formation, at Lightning Ridge, New South Wales. Crocodilian Biology and Evolution, G. C. Gridd, F. Seebacher, and C. E. Franklin (eds.), Surrey Beatty \& Sons, Chipping Norton, England. 2000, pp. 75-82.

[15971] R. E. Molnar, T. Worthy, and P. M. A. Willis. “An extinct Pleistocene endemic mekosuchine crocodylian from Fiji". English. In: Journal of Vertebrate Paleontology 22.3 (2002), pp. 612-628.

[15972] S. V. Moloshnikov. “Oredezhosteus, a New Psammosteid Genus (Heterostraci, Psammosteiformes) from the Lower Frasnian (Upper Devonian) of the Main Devonian Field". English. In: Paleontological Journal 43.2 (2009), pp. 197-200.

[15973] S. V. Moloshnikov. "Psammosteiforms (Agnatha, Heterostraci) from the Lower Frasnian of the Mikhailovskii Mine, Kursk Region, Russia". English. In: Paleontological Journal 41.5 (2007), pp. 8488.

[15974] S. V. Moloshnikov. "New Data on Late Devonian Bothriolepidid Placoderms (Pisces, Antiarchi) from Tuva". English. In: Paleontological Journal 43.5 (2009), pp. 558-568. DOI: 10.1134/S0031030109050128.

[15975] I. I. Molostovskaya. “Ostracodes from the Upper Permian Khivach Formation in Kolyma-Omolon Basin". English. In: Paleontological Journal 44.3 (2010), pp. 282-286.

[15976] P. Monaco, A. Baldanza, R. Bizzarri, F. Famiani, M. Lezzerini, and F. Sciuto. “Ambergris cololites of Pleistocene sperm whales from central Italy and description of the new ichnogenus and ichnospecies Ambergrisichnus alleronae". English. In: Palaeontologia Electronica 17.2.29A (2014), pp. 1-20.

[15977] P. Monaco and A. Garassino. "Burrows and body fossil of decapod crustaceans in the Calcari Grigi, lower Jurassic, Trento platform (Italy)". English. In: Geobios 34.3 (2001), pp. 291-301. DOI: 10.1016/S0016-6995(01)80077-2.

[15978] S. Monari. "A new genus and species of fimbriid bivalve from the Kimmeridgian of the western Pontides, Turkey, and the phylogeny of the Jurassic Fimbriidae". English. In: Palaeontology 46.5 (2003), pp. 857-884.

[15979] S. Monari. "I bivalvi giurassici dell'Appennino umbro-marchigiano". Italian. In: Studi Geologici Camerti, Volume Speciale: Biostratigrafia dell'Italia (1994), pp. 157-187. 
[15980] S. Monari, M. Valentini, and M. A. Conti. “Earliest Jurassic patellogastropod, vetigastropod, and neritimorph gastropods from Luxembourg with considerations on the Triassic-Jurassic faunal turnover". English. In: Acta Palaeontologica Polonica 56 (2011), pp. 349-384.

[15981] M. Monbaron, D. A. Russell, and P. Taquet. "Atlasaurus imelakei n.g., n.sp., a brachiosaurid-like sauropod from the Middle Jurassic of Morocco". English. In: Comptes Rendus de l'Académie des Sciences á Paris, Sciences de la Terre et des Planétes 329 (1999), pp. 519-526.

[15982] C. Monnet, P. Brack, H. Bucher, and H. Rieber. "Ammonoids of the middle/late Anisian boundary (Middle Triassic) and the transgression of the Prezzo Limestone in eastern Lombardy-Giudicarie (Italy)". English. In: Swiss Journal of Geosciences 101 (2008), pp. 61-84.

[15983] C. Monnet, H. Bucher, M. Wasmer, and J. Guex. "Revision of the genus Acrochordiceras Hyatt, 1877 (Ammonoidea, Middle Triassic): morphology, biometry, biostratigraphy, and intra-specific variability". English. In: Palaeontology 53.5 (2010), pp. 961-996.

[15984] C. Monnet and H. Bucher. "New Middle and Late Anisian (Middle Triassic) Ammonoid Faunas From Northwestern Nevada(USA): Taxonomy and Biochronology". English. In: Fossils and Strata 52 (2005), pp. 1-121.

[15985] C. Monnet, H. Bucher, A. Brayard, and J. F. Jenks. “Globacrochordiceras gen. nov. (Acrochordiceratidae, late Early Triassic) and its significance for stress-induced evolutionary jumps in ammonoid lineages (cephalopods)". English. In: Fossil Record 16 (2013), pp. 197-215.

[15986] S. Monninger and E. Frey. Humming birds and sea cows at the foothills of Kraichgau: A unique fossile assemblage in the Reingraben near Karlsruhe. English. 2008.

[15987] M. Monostori. “Ostracod evidence of the Carnian salinity crisis in the Balaton Highland, Hungary". English. In: Neues Jahrbuch fur Geologie und Palaeontologie 193 (1994), pp. 311-331.

[15988] M. Monostori. "Pliensbachian ostracod fauna from condensed limestones of the Bakony Mts. (Transdanubian Central Range, Hungary)". English. In: Fragmenta Mineralogica et Palaeontologica 18 (1996), pp. 31-61.

[15989] K. A. Monsch. "Revision of the scombroid fishes from the Cenozoic of England". English. In: Transactions of the Royal Society of Edinburgh: Earth Sciences 95 (2004), pp. 445-489. DOI: 10.1017/ S0263593300001164.

[15990] K. A. Monsch and A. F. Bannikov. "New taxonomic synopses and revision of the scombroid fishes (Scombroidei, Perciformes), including billfishes, from the Cenozoic of territories of the former USSR". English. In: Earth and Environmental Science Transactions of the Royal Society of Edinburgh 102.4 (2011), pp. 253-300. DOI: 10.1017/S1755691011010085.

[15991] K. A. Monsch, H. L. Fierstine, and R. E. Weems. "Taxonomic revision and stratigraphic provenance of '十Histiophorus rotundus' Woodward 1901 (Teleostei, Perciformes)". English. In: Journal of Vertebrate Paleontology 25.2 (2005), pp. 274-279.

[15992] L. F. Montaggioni, G. Cabioch, N. Thouveny, N. Frank, T. Sato, and A. M. Semah. "Revisiting the Quaternary development history of the western New Caledonian shelf system: from ramp to barrier reef". English. In: Marine Geology 280 (2011), pp. 57-75.

[15993] L. F. Montaggioni and G. Faure. "Response of reef coral communities to sea-level rise: a Holocene model from Mauritius (western Indian Ocean)". English. In: Sedimentology 44 (1997), pp. 10531070.

[15994] M. Montagna, J. T. Haug, L. Strada, C. Haug, M. Felber, and A. Tintori. “Central nervous system and muscular bundles preserved in a 240 million year old giant bristletail (Archaeognatha: Machilidae)". English. In: Scientific Reports 7.46016 (2017), pp. 1-9.

[15995] M. Montagna, L. Strada, P. Dioli, and A. Tintori. “The Middle Triassic Lagerstätte of Monte San Giorgio reveals the oldest lace bugs (Hemiptera: Tingidae): Archetingis ladinica gen. n. sp. n". English. In: Rivista Italiana di Paleontologia e Stratigrafia 124 (2018), pp. 35-44. 
[15996] C. I. Montalvo, F. J. Fernández, M. S. Bargo, R. L. Tomassini, and A. Mehl. “First record of a Late Holocene fauna associated with an ephemeral fluvial sequence in La Pampa Province, Argentina. Taphonomy and paleoenvironment". English. In: Journal of South American Earth Sciences 76 (2017), pp. 225-237.

[15997] C. I. Montalvo, R. N. Melchor, G. Visconti, and E. Cerdeño. "Vertebrate taphonomy in loesspalaeosol deposits: A case study from the late Miocene of Central Argentina". English. In: Geobios 41 (2008), pp. 133-143.

[15998] C. I. Montalvo, A. R. Miño-Boilini, R. Sostillo, E. Cerdeño, M. C. Cardonatto, and R. A. Bonini. "The Scelidotheriinae Proscelidodon gracillimus (Xenarthra: Mylodontidae) from the Cerro Azul Formation (late Miocene), Argentina: Ontogenetic variability and taxonomy". English. In: Journal of South American Earth Sciences (2020), p. 102754. DOI: 10.1016/j.jsames.2020.102754.

[15999] C. I. Montalvo, R. L. Tomassini, R. Sostillo, E. Cerdeño, D. H. Verzi, G. Visconti, A. Folguera, and G. I. Schmidt. "A chasicoan (late miocene) vertebrate assemblage from cerro azul formation, central Argentina. Geomorphological and biochronological considerations". English. In: Journal of South American Earth Sciences (2019). DOI: 10.1016/j.jsames.2019.102218.

[16000] C. I. Montalvo, R. L. Tomassini, and R. Sostillo. "Leftover prey remains: a new taphonomic mode from the Late Miocene Cerro Azul Formation of Central Argentina". English. In: Lethaia 49 (2016), pp. 219-230. DOI: 10.1111/let.12140.

[16001] C. I. Montalvo and M. Bond. “Un notoungulatade la Formacion Vaca Mahuida (Eoceno), Provincia de la Pampa, Argentina". Spanish. In: Asociacion Paleontologica Argentina, Publicacion Especial 5 (1998), pp. 55-60.

[16002] S. Montanari, J. Louys, and G. J. Price. "Pliocene paleoenvironments of southeastern Queensland, Australia inferred from stable isotopes of marsupial tooth enamel". English. In: PLoS One 2013(E66221) (2013). DOI: 10.1371/journal.pone.0066221.

[16003] F. C. Montefeltro, M. C. Langer, and C. L. Schultz. “Cranial anatomy of a new genus of hyperodapedontine rhynchosaur (Diapsida, Archosauromorpha) from the Upper Triassic of southern Brazil". English. In: Earth and Environmental Science Transactions of the Royal Society of Edinburgh 101 (2010), pp. 27-52. DOI: 10.1017/S1755691010009060.

[16004] F. C. Montefeltro, H. C. E. Larsson, and M. C. Langer. "A New Baurusuchid (Crocodyliformes, Mesoeucrocodylia) from the Late Cretaceous of Brazil and the Phylogeny of Baurusuchidae". English. In: PLoS One 6.7 (2011), e21916. DOI: 10.1371/journal.pone.0021916.

[16005] F. C. Montefeltro, H. C. E. Larsson, M. A. G. França, and M. C. Langer. "A new neosuchian with Asian affinities from the Jurassic of northeastern Brazil". English. In: Naturwissenschaften 100.9 (2013), pp. 835-841. DOI: 10.1007/s00114-013-1083-9.

[16006] F. C. Montefeltro, C. R. Laurini, and M. C. Langer. "Multicusped crocodyliform teeth from the Upper Cretaceous (São José do Rio Preto Formation, Bauru Group) of São Paulo, Brazil". English. In: Cretaceous Research 30 (2009), pp. 1279-1286. DOI: 10.1016/j.cretres.2009.07.003.

[16007] M. Montellano. "Mammalian fauna of the Judith River Formation (Late Cretaceous, Judithian), northcentral Montana". In: University of California Publications in Geological Sciences 136 (1992), pp. 1-115.

[16008] M. Montellano, R. C. Fox, and C. S. Scott. "Species Composition of the Late Cretaceous Eutherian Mammal Paranyctoides Fox". English. In: Canadian Journal of Earth Sciences (2013). DOI: 10.1139/ cjes-2012-0184.

[16009] M. Montellano, J. A. Hopson, and J. M. Clark. "Late Early Jurassic mammaliaforms from Huizachal Canyon, Tamaulipas, Mexico". English. In: Journal of Vertebrate Paleontology 28.4 (2008), pp. 11301143.

[16010] M. Montellano-Ballesteros. "New vertebrate locality of late Hemphillian age in Teocaltiche, Jalisco, Mexico". English. In: Revista Mexicana de Ciencias Geologicas 14.1 (1997), pp. 84-90.

[16011] M. Montellano-Ballesteros. "New Cuvieronius finds from the Pleistocene of central Mexico". English. In: Journal of Paleontology 76.3 (2002), pp. 578-583. 
[16012] M. Montellano-Ballesteros. "A titanosaurid sauropod from the Upper Cretaceous of Chihuahua, Mexico". In: Revista Mexicana de Ciencias Geológicas 20.2 (2003), pp. 160-164.

[16013] M. Montellano-Ballesteros, R. Hernández-Rivera, G. Álvarez-Reyes, P. Andrade-Ramos, and L. Martn-Medrano. Discovery of Late Cretaceous vertebrate local faunas in northern Mexico. 2000.

[16014] M. Montellano-Ballesteros, A. D. Rincon, and A. Solorzano. "Record of tayassuids in ?Late Pliocene to Quaternary deposits in Venezuela". English. In: Revista brasileira de Paleontologia 17.2 (2014), pp. 169-182. DOI: 10.4072/rbp.2014.2.05.

[16015] C. Montenat, P. Barrier, and P. Ott D'Estevou. “The Vigny limestones: a record of Paleocene (Danian) tectonic-sedimentary events in the Paris Basin". English. In: Sedimentology 49 (2002), pp. 421440.

[16016] H. Montgomery. "Deposition and emplacement of Permian reefs in Sierra Plomosa, Chihuahua, Mexico". English. In: Revista Mexicana de Ciencias Geologicas 21.2 (2004), pp. 236-246.

[16017] H. Montgomery and S. Clark. "Paleoecology of the Gaddis Site in the Upper Cretaceous Aguja Formation, Terlingua, Texas". English. In: Palaios 31 (2016), pp. 341-357. DOI: 10.2110/ palo.2015. 099.

[16018] D. S. Monti. "Morphometrics of Leptoplastides marianus (Hoek) (Trilobita, Olenidae) from the Tremadocian of north-western Argentina: taxonomic implications". English. In: Journal of Systematic Palaeontology 16.3 (2018), pp. 179-197.

[16019] P. Montoya, M. T. Alberdi, L. J. Barbadillo, J. van der Made, J. Morales, X. Murelaga, E. Penalver, F. Robles, A. R. Bustos, A. Sanchez, B. Sanchiz, D. Soria, and Z. Szyndlar. "Une faune tres diversifee du Pleistocene inferieur de la Sierra de Quibas (province de Murcia, Espagne)". French. In: Comptes Rendus de L'Academie des Sciences Serie II Fasicule A - Sciences de la Terre et des Planetes 332 (2001), pp. 387-393.

[16020] G. Montoya-Sanhueza, K. Moreno, R. Bobe, M. T. Carrano, M. Garca, and A. Corgne. "Peltephilidae and Mesotheriidae (Mammalia) from late Miocene strata of Northern Chilean Andes, Caragua". English. In: Journal of South American Earth Sciences 75 (2017), pp. 51-65.

[16021] O. Montreuil, F. Génier, and A. Nel. "Lobateuchus, un nouveau genre de bousier fossile du nord de la France (Coleoptera : Scarabaeidae, Scarabaeinae)". English. In: Annales de la Société Entomologique de France 46 (2010), pp. 164-167.

[16022] R. T. J. Moody and P. J. C. Suttcliffe. “The Cretaceous deposits of the Iullemmeden Basin of Niger, central West Africa". English. In: Cretaceous Research 12 (1991), pp. 137-157.

[16023] R. Mooi, S. A. Martinez, C. J. Del Rio, and M. I. Feijo Ramos. "Late Oligocene-Miocene nonlunulate sand dollars of South America:" English. In: Zootaxa 4369.3 (2018), pp. 301-326.

[16024] E. J. Moore. "Tertiary marine pelecypods of California and Baja California: Crassatellidae through Pharidae". English. In: United States Geological Survey Professional Paper 1228.F (2003), pp. 1-107.

[16025] J. G. Moore, D. A. Clague, K. R. Ludwig, and R. K. Mark. "Subsidence and volcanism of the Haleakala Ridge, Hawaii". English. In: Journal of Volcanology and Geothermal Research 42 (1990), pp. 273-284.

[16026] P. R. Moore and Y. Aita. "A Jurassic chert-limestone-spilite association near Eketahuna, North Island, New Zealand. Appendix: Middle Jurassic radiolaria from Eketahuna, North Island, New Zealand". English. In: Journal of The Royal Society of New Zealand 25.2 (1995), pp. 99-114.

[16027] R. A. Moore and B. S. Lieberman. "Preservation of early and Middle Cambrian soft-bodied arthropods from the Pioche Shale, Nevada, USA". English. In: Palaeogeography, Palaeoclimatology, Palaeoecology 277 (2009), pp. 57-62.

[16028] C. L. Mora. "Ictiofauna de la Formacion Punta Judas, Mioceno Medio, Provincia de Puntarenas, Costa Rica". English. In: Brensia 62 (2004), pp. 57-74.

[16029] H. Moraes-Santos, J. Bocquentin Villanueva, and P. M. Toledo. “New remains of a gavialoid crocodilian from the late Oligocene-early Miocene of the Pirabas Formation, Brazil". English. In: Zoological Journal of the Linnean Society 163 (2011), S132-S139. 
[16030] J. Morales and M. Pickford. "Giant bunodont Lutrinae from the Mio-Pliocene of Kenya and Uganda". English. In: Estudios Geologicos 61.3-6 (2005), pp. 233-246.

[16031] J. Morales, M. Pickford, and D. Soria. “New carnivoran material (Creodonta, Carnivora and Incertae sedis) from the Early Miocene of Napak, Uganda". English. In: Paleontological Research 11.1 (2007), pp. 71-84. DOI: 10.2517/1342-8144(2007)11[71:NCMCCA]2.0.CO;2.

[16032] J. Morales, M. Pickford, and M. J. Salesa. “Creodonta and Carnivora from the Early Miocene of the Northern Sperrgebiet, Namibia". English. In: Memoir of the Geological Survey of Namibia 20 (2008), pp. 291-310.

[16033] J. Morales, M. Pickford, D. Soria, and S. Fraile. “New Viverrinae (Carnivora: Mammalia) from the basal Middle Miocene of Arrisdrift, Namibia". English. In: Palaeontologia africana 37 (2001), pp. 99 102.

[16034] J. Morales, M. Pickford, D. Soria, and S. Fraile. "New carnivores from the basal Middle Miocene of Arrisdrift, Namibia". English. In: Eclogae geologicae Helvetiae 91 (1998), pp. 27-40.

[16035] J. Morales, M. Pickford, S. Fraile, M. J. Salesa, and D. Soria. "Creodonta and Carnivora from Arrisdrift, early Middle Miocene of southern Namibia". English. In: Memoir of the Geological Survey of Namibia 19 (2003), pp. 177-194.

[16036] J. Morales and M. Pickford. "New Hyaenodonts (Ferae, Mammalia) from the early Miocene of Napak (Uganda), Koru (Kenya) and Grillental (Namibia)". English. In: Fossil Imprint 73.3-4 (2017), pp. 332-359.

[16037] J. Morales, M. Pickford, and A. Valenciano. "Systematics of African Amphicyonidae, with descriptions of new material from Napak (Uganda) and Grillental (Namibia)". English. In: Journal of Iberian Geology 42.2 (2016), pp. 131-150. DOI: 10.5209/rev_JIGE.2016.v42.n2.5196.

[16038] J. Morales, D. Soria, and M. Pickford. "New stem giraffoid ruminants from the early and middle Miocene of Namibia". English. In: Geodiversitas 21.2 (1999), pp. 229-253.

[16039] M. Morales and M. A. Shiskin. “A re-assessment of Parotosuchus africanus (Broom), a capitosauroid temnospondyl amphibian from the Triassic of South Africa". English. In: Journal of Vertebrate Paleontology 22.1 (2002), pp. 1-11.

[16040] J. V. Morales Perez and A. Sanchis Serra. "The Quaternary fossil record of the genus Testudo in the Iberian Peninsula. Archaeological implications and diachronic distribution in the western Mediterranean". English. In: Journal of Archaeological Science 36 (2009), pp. 1152-1162. DOI: 10. 1016/j.jas.2008.12.019.

[16041] P. Morales-Ortega, G. González-Barba, and E. H. Nava-Sánchez. "New Eocene bivalves from Bateque Formation, Baja California Sur, Mexico". English. In: Paleontologa Mexicana 5.1 (2016), pp. 1-19.

[16042] J. J. Moratalla, J. Garca-Mondéjar, V. F. dos Santos, M. G. Lockley, J. L. Sanz, and S. Jiménez. Sauropod trackways from the Lower Cretaceous of Spain. English. Vol. 10. Aspects of Sauropod Paleobiology. GAIA. 1995, pp. 75-83.

[16043] J. J. Moratalla, J. Hernán, and S. Jiménez. “Los Cayos dinosaur tracksite: an overview on the Lower Cretaceous ichno-diversity of the Cameros Basin (Cornago, La Rioja province, Spain)". English. In: Ichnos 10 (2003), pp. 229-240. DOI: 10.1080/10420940390255547.

[16044] J. J. Moratalla and J. Hernan. “Turtle and pterosaur tracks from the Los Cayos dinosaur tracksite, Cameros Basin (Cornago, La Rioja, Spain): tracking the Lower Cretaceous Biodiversity". English. In: Revista Española de Paleontologa 24.1 (2009), pp. 59-77.

[16045] J. J. Moratalla and J. Hernán. “Los Cayos S y D: dos afloramientos con icnitas de saurópodos, terópodos y ornitópodos en el Cretácico inferior del área de Los Cayos (Cornago, La Rioja, España) [Los Cayos S and D: two sites with sauropod, theropod and ornithopod tracks from the Lower Cretaceous of the Los Cayos area (Cornago, La Rioja, Spain)]". Spanish. In: Estudios Geológicos 64.2 (2008), pp. 161-173. DOI: 10.3989/egeol.08642.043. 
[16046] J. D. Moreau, V. Perrichot, D. Neraudeau, and P. Tafforeau. "100-million-year-old ant-conifer associates inside French amber: a fortuitous or ecological association?" English. In: Lethaia 53 (2020), pp. 546-552. DOI: 10.1111/let.12375.

[16047] J.-D. Moreau, E. Fara, D. Néraudeau, and G. Gand. "New Hettangian tracks from the Causses Basin (Lozére, southern France) complement the poor fossil record of earliest Jurassic crocodylomorphs in Europe". English. In: Historical Biology 31.3 (2019), pp. 341-352. DOI: 10.1080/08912963. 2017.1370587.

[16048] J.-D. Moreau, D. Néraudeau, R. Vullo, D. Abit, B. Mennecart, and J. Schnyder. "Late Jurassic dinosaur footprints from Chassiron-La Moreliére (Oléron Island, western France)". English. In: Palaeobiodiversity and Palaeoenvironments 97.4 (2017), pp. 773-789. DOI: 10.1007/s12549-017-0282-3.

[16049] M.-G. Moreau, H. Bucher, A.-M. Bodergat, and J. Guex. “Pliensbachian magnetostratigraphy: new data from Paris Basin (France)". English. In: Earth and Planetary Science Letters 203 (2002), pp. 755767.

[16050] E. Morel, D. Edwards, and M. Iniguez Rodriguez. "The first record of Cooksonia from South America in Silurian rocks of Bolivia". In: Geological Magazine 132 (1995), pp. 449-452.

[16051] E. M. Morel. “El Triasico del Cerro Cacheuta, Mendoza (Argentina). Parte 1: Geologia, contenido paleofloristico y cronoestratigrafia". Spanish. In: Ameghiniana 31.2 (1994), pp. 161-176.

[16052] J. F. Moreno, A. J. W. Hendy, L. Quiroz, N. Hoyos, D. S. Jones, V. Zapata, S. Zapata, G. A. Ballen, E. Cadena, A. L. Cardenas, J. D. Carrillo, D. Delgado-Sierra, J. Escobar, J. I. Martinez, C. Martinez, C. Montes, J. Moreno, N. Perez, R. Sanchez, C. Suarez, and M. C. Valle. “Revised stratigraphy of Neogene strata in the Cocinetas Basin, La Guajira, Colombia". English. In: Swiss Journal of Paleontology (2015).

[16053] K. Moreno and M. J. Benton. "Occurence of sauropod dinosaur tracks in the Upper Jurassic of Chile (redescription of Iguanodonichnus frenki)". English. In: Journal of South American Earth Sciences 20 (2005), pp. 253-257.

[16054] K. Moreno, N. Blanco, and A. Tomlinson. "Nuevas huellas de dinosaurios del Jurásico Superior en el norte de Chile [New dinosaur footprints from the Upper Jurassic of northern Chile]". Spanish. In: Ameghiniana 41.4 (2004), pp. 535-543.

[16055] M. Moreno-Azanza, J. I. Canudo, and J. M. Gasca. Primera evidencia de fragmentos de cáscara de huevo en el Valanginiense-Hauteriviense (Cretácico Inferior) de la Cordillera Ibérica (Zaragoza, España) [First evidence of eggshell fragments in the Valanginian-Hauterivian (Lower Cretaceous) of the Iberian Cordillera (Zaragoza, Spain)]. English. 2007.

[16056] M. Moreno-Azanza, J. I. Canudo, and J. M. Gasca. “Unusual theropod eggshells from the Early Cretaceous Blesa Formation of the Iberian Range, Spain". English. In: Acta Palaeontologica Polonica 59.4 (2014), pp. 843-854. DOI: 10.4202/app.2012.0069.

[16057] J. W. Moreno-Bernal, J. Head, and C. A. Jaramillo. "Fossil crocodilians from the High Guajira Peninsula of Colombia: Neogene faunal change in northernmost South America". English. In: Journal of Vertebrate Paleontology 36 (2016), e1110586:1-17.

[16058] G. S. Morgan. "Mammalian biochronology and marine-nonmarine correlations in the Neogene of Florida". In: Neogene of Florida and adjacent regions; proceedings of the Third Bald Head Island conference on Coastal plains geology. Special Publication, Florida Geological Survey 37 (1993), pp. 55-66.

[16059] G. S. Morgan. Miocene and Pliocene marine mammal faunas from the Bone Valley Formation of central Florida. Vol. 29. Contributions in Marine Mammal Paleontology Honoring Frank C. Whitmore Jr., Proceedings of the San Diego Society of Natural History. 1994, pp. 239-268.

[16060] G. S. Morgan. "Late Quaternary fossil vertebrates from the Cayman Islands". English. In: The Cayman Islands: Natural History and Biogeography. Dordrecht, The Netherlands: Kluwer Academic Publishers, 1994, pp. 465-508.

[16061] G. S. Morgan. "Late Rancholabrean mammals from south- ernmost Florida, and the Neotropical influence in Florida Pleistocene faunas". English. In: Smithsonian Contributions to Paleobiology 93 (2002), pp. 15-38. 
[16062] G. S. Morgan, N. A. Albury, R. Rmoli, P. Lehman, A. L. Rosenberger, and S. B. Cooke. “The Cuban Crocodile (Crocodylus rhombifer) from Late Quaternary Underwater Cave Deposits in the Dominican Republic". English. In: American Museum Novitates 3916 (2018), pp. 1-56.

[16063] G. S. Morgan and N. A. Albury. "The Cuban crocodile (Crocodylus rhombifer) from late Quaternary fossil deposits in the Bahamas and Cayman Islands". English. In: Bulletin of the Florida Museum of Natural History 52.3 (2013), pp. 161-236.

[16064] G. S. Morgan and N. J. Czaplewski. "A new bat (Chiroptera: Natalidae) from the early Miocene of Florida, with comments on natalid phylogeny". English. In: Journal of Mammalogy 84.2 (2003), pp. 729-752.

[16065] G. S. Morgan, R. Franz, and R. I. Crombie. "The Cuban Crocodile, Crocodylus rhombifer, from Late Quaternary Fossil Deposits on Grand Cayman". English. In: Caribbean Journal of Science 29.34 (1993), pp. 153-164.

[16066] G. S. Morgan and R. C. Hulbert Jr. “Overview of the geology and vertebrate biochronology of the Leisey Shell Pit Local Fauna, Hillsborough County, Florida". English. In: Bulletin of the Florida Museum of Natural History 37.1 (1995).

[16067] G. S. Morgan, E. B. Lander, C. Cikoski, R. M. Chamberlain, D. W. Lowe, and L. Peters. “The oreodont Merychyus major major (Mammalia: Artiodactyla: Oreodontidae) from the Miocene Popotosa Formation, Bosque del Apache National Wildlife Refuge, Socorro County, central New Mexico". English. In: New Mexico Geology 31.4 (2009), pp. 91-103.

[16068] G. S. Morgan and S. G. Lucas. "Radioisotopically calibrated oreodonts (Mammalia: Artiodactyla) from the late Oligocene of southwestern New Mexico". English. In: Journal of Vertebrate Paleontology 23.2 (2003), pp. 471-473.

[16069] G. S. Morgan and L. F. Rinehart. "Late Pleistocene (Rancholabrean) mammals from fissure deposits in the Jurassic Todilto Formation, White Mesa mine, Sandoval County, north-central New Mexico". English. In: New Mexico Geology 29.2 (2007), pp. 39-51.

[16070] G. S. Morgan and K. L. Seymour. "Fossil history of the panther (Puma concolor) and the cheetahlike cat (Miracinonyx inexpectatus) in Florida". English. In: Bulletin of the Florida Museum of Natural History 40.2 (1997), pp. 177-219.

[16071] G. S. Morgan and J. A. White. "Small mammals (Insectivora, Lagomorpha, and Rodentia) from the early Pleistocene (early Irvingtonian) Leisey Shell Pit Local Fauna, Hillsborough County, Florida". English. In: Bulletin of the Florida Museum of Natural History 37.13 (1995).

[16072] G. S. Morgan and S. G. Lucas. "The sabertooth cat Smilodon fatalis (Mammalia: Felidae) from a Pleistocene (Rancholabrean) site in the Pecos River valley of southeastern New Mexico/southwestern Texas". English. In: New Mexico Geology 23.4 (2001), pp. 130-133.

[16073] G. S. Morgan, B. J. MacFadden, and M. Martinez. "Quaternary gomphotheres (Mammalia: Proboscidea: Gomphotheriidae) from the continental shelf, Pearl Islands, Panama". English. In: Quaternary International 392 (2016), pp. 335-348. DOI: 10.1016/j.quaint.2015.11.003.

[16074] J. K. Morgan and N. H. Morgan. “A New Species of Capromeryx (Mammalia: Artiodactyla) from the Taunton Local Fauna of Washington, and the Correlation with Other Blancan Faunas of Washington and Idaho". English. In: Journal of Vertebrate Paleontology 15.1 (1995), pp. 160-170.

[16075] H. S. Morgans. "Lower and Middle Jurassic woods of the Cleveland Basin ( North Yorkshire), England". In: Palaeontology 42.2 (1999), pp. 303-328.

[16076] H. Mori, P. S. Druckenmiller, and G. M. Erickson. "A new Arctic hadrosaurid from the Prince Creek Formation (lower Maastrichtian) of northern Alaska". English. In: Acta Palaeontologica Polonica 60.1 (2016), pp. 15-32. DOI: 10.4202/app.00152.2015.

[16077] H. Mori, F. G. Marx, N. Kohno, H. Nakaya, and H. Akazaki. "Enigmatic humerus of an archaic Oligocene-Miocene neo- cete from Miyazaki Prefecture, Kyushu, Japan". English. In: Paleontological Research 21.3 (2017), pp. 207-214. DOI: 10.2517/2016PR026. 
[16078] L. Moritz and T. Wesener. "Symphylella patrickmuelleri sp. nov. (Myriapoda: Symphyla): The oldest known Symphyla and first fossil record of Scolopendrellidae from Cretaceous Burmese amber". English. In: Cretaceous Research 84 (2017), pp. 258-263.

[16079] L. Moritz and T. Wesener. "The first known fossils of the Platydesmida - an extant American genus in Cretaceous amber from Myanmar (Diplopoda: Platydesmida: Andrognathidae)". English. In: Organisms Diversity \& Evolution 19 (2019), pp. 423-433. DOI: 10.1007/s13127-019-00408-0.

[16080] K. Moriya and H. Hirano. "Cretaceous stratigraphy in the Chikubetsu area, Hokaido". English. In: Journal of the Geological Society of Japan 107.3 (2001), pp. 199-214.

[16081] M. Morlo. "New remains of Barbourofelidae (Mammalia, Carnivora) from the Miocene of Southern Germany: implications for the history of barbourofelid migrations". English. In: Beiträge zur Paläontologie 30 (2006), pp. 339-346.

[16082] M. Morlo. “Carnivoren aus dem Unter-Miozän des Mainzer Beckens". German. In: Senckenbergiana Lethaea 76.1/2 (1996), pp. 193-249.

[16083] M. Morlo, K. Bastl, W. Wu, and S. F. K. Schaal. "The first species of Sinopa (Hyaenodontida, Mammalia) from outside of North America: implications for the history of the genus in the Eocene of Asia and North America". English. In: Palaeontology 57.1 (2014), pp. 111-125.

[16084] M. Morlo and G. F. Gunnell. "New species of Limnocyon (Mammalia, Creodonta) from the Bridgerian (middle Eocene)". English. In: Journal of Vertebrate Paleontology 25.1 (2005), pp. 251-255.

[16085] M. Morlo and G. F. Gunnell. “Small Limnocyonines (Hyaenodontidae, Mammalia) From the Bridgerian Middle Eocene of Wyoming: Thinocyon, Prolimnocyon, And Iridodon, New Genus". English. In: Contributions from the Museum of Paleontology, University of Michigan 31.2 (2003), pp. 43-78.

[16086] M. Morlo, E. R. Miller, and A. N. El-Barkooky. "Creodonta and Carnivora from Wadi Moghra, Egypt". English. In: Journal of Vertebrate Paleontology 27.1 (2007), pp. 145-159.

[16087] M. Morlo and E. R. Miller. “New Amphicyonids (Mammalia, Carnivora) from Moghra, Early Miocene, Egypt". English. In: Geodiversitas 41.1 (2019), pp. 731-745. DOI: 10.5252/geodiversitas2019v41a21.

[16088] M. Morlo and D. Nagel. "New Didymoconidae (Mammalia) from the Oligocene of Central Mongolia and first information on the tooth eruption sequence of the family". English. In: Neues Jahrbuch für Geologie und Paläontologie. Abhandlungen 223.1 (2002), pp. 123-144.

[16089] A. Moro. "Stratigraphy and paleoenvironments of rudist biostromes in the Upper Cretaceous (Turonian-upper Santonian) limestones of southern Istria, Croatia". In: Palaeogeography, Palaeoclimatology, Palaeoecology 131 (1997), pp. 113-131.

[16090] A. Moro, V. Cosovic, J. B. Dokmanovic, and J. Dokmanovic. “Taxonomy of rudists from the Campanian transgressive sediments of Brasljevica, Donje Oresje and Sv. Martin, Northern Croatia". English. In: Turkish Journal of Earth Sciences 19 (2010), pp. 613-633. DOI: 10.3906/yer-0901-12.

[16091] A. Moro, P. W. Skelton, and V. Cosovic. "Palaeoenvironmental setting of rudists in the Upper Cretaceous (Turonian-Maastrichtian) Adriatic Carbonate Platform (Croatia), based on sequence stratigraphy". English. In: Cretaceous Research 23 (2002), pp. 489-508.

[16092] M. Moros, W. Lempke, A. Kuijpers, R. Endler; J. B. ensen, O. Bennike, and F. Gingele. “Regressions and transgressions of the Baltic Basin reflected by a new high-resolution deglacial and postglacial lithostratigraphy for Arkona Basin sediments (western Baltic Sea)". English. In: Boreas 31.2 (2002), pp. 151-162.

[16093] I. P. Morozova. "New Early Permian bryozoans of eastern Australia". English. In: Paleontological Journal 38.4 (2004), pp. 381-392.

[16094] I. P. Morozova and D. V. Lisitsyn. "A Revision of Bryozoans from the Stratotype Sections of the Gzhelian Stage (Upper Carboniferous)." In: Paleontologicheskiy Zhurnal 2002.6 (2002), pp. 63-72.

[16095] D. A. Morris, M. L. Augee, D. Gillieson, and J. Head. "Analysis of a late Quaternary deposit and small mammal fauna from Nettle Cave, Jenolan, New South Wales". English. In: Proceedings of the Linnean Society of New South Wales 117 (1997), pp. 135-161. 
[16096] N. J. Morris, J. M. Dickins, and K. Astafieva-Urbaitis. “Upper Palaeozoic Anomalodesmatan Bivalvia". English. In: Bulletin of the British Museum of Natural History (Geology) 47.1 (1991), pp. 51100.

[16097] S. C. Morris and J. S. Peel. "A new Helcionelloid mollusk from the Middle Cambrian Burgess Shale, Canada". English. In: Journal of Paleontology 87.6 (2013), pp. 1067-1070.

[16098] S. F. Morris and J. S. H. Collins. "Neogene crabs from Brunei, Sabah, and Sarawak". English. In: Bulletin of the British Museum of Natural History 47.1 (1991), pp. 1-33.

[16099] K. Morrison, G. J. Dyke, and L. M. Chiappe. “Cretaceous fossil birds from Hornby Island (British Columbia)". English. In: Canadian Journal of Earth Sciences 42 (2005), pp. 2097-2101. DOI: 10.1139/ E05-081.

[16100] T. Mors. "Biostratigraphy and paleoecology of continental Tertiary vertebrate faunas in the Lower Rhine Embayment (NW-Germany)". English. In: Netherlands Journal of Geosciences 81.2 (2002), pp. 177-183.

[16101] T. Mors, F. Hocht, and B. Wutzler. "Die erst Wirbeltierfauna aus der miozanen Braunkohle der Niederrheinischen Bucht (Ville-Schichten, Tagebau Hambach) [The first vertebrate fauna from the Miocene Ville Series of the Lower Rhine Embayment (Hambach open cast mine, western Germany)]". German. In: Paläontologische Zeitschrift 74.1/2 (2000), pp. 145-170.

[16102] T. Mörs and D. C. Kalthoff. "A new species of Karydomys (Rodentia, Mammalia) and a systematic re-evaluation of this rare Eurasian Miocene hamster". German. In: Palaeontology 47.6 (2004), pp. 1387-1405.

[16103] T. Mörs, M. Reguero, and D. Vasilyan. "First fossil frog from Antarctica: implications for Eocene high latitude climate conditions and Gondwanan cosmopolitanism of Australobatrachia". English. In: Scientific Reports 10 (2020), 5051:1-11. DOI: 10.1038/s41598-020-61973-5.

[16104] S. M. Morsch. “Les Scléractiniaires jurassiques (Bajocien) d'Argentine (Bassin de Neuquén). Systématique". French. In: Géobios 29.6 (1996), pp. 671-706.

[16105] S. M. Morsch. "Corales (Scleractinia) de la extremidad sur de la Sierra de la Vaca Muerta, Formacion La Manga (Oxfordiano), Provincia del Neuquen, Argentina [Corals (Scleractinia) from the southern end of Sierra de la Vaca Muerta, La Manga Formation (Oxfordian), Neuquen, Argentina]". Spanish. In: Ameghiniana 27 (1990), pp. 19-28.

[16106] E. M. Morschhauser, D. J. Varricchio, C. Gao, J. Liu, Z. Wang, X. Cheng, and Q. Meng. “Anatomy of the Early Cretaceous bird Rapaxavis pani, a new species from Liaoning Province, China". English. In: Journal of Vertebrate Paleontology 29.2 (2009), pp. 545-554. DOI: 10.1671/039.029.0210.

[16107] M. Morsilli, F. R. Bosellini, L. Pomar, P. Hallock, and M. Aurell. C. A. Papazzoni. “Mesophotic coral buildups in a prodelta setting (Late Eocene, southern Pyrenees, Spain): a mixed carbonatesiliciclastic system". English. In: Sedimentology 59 (2012), pp. 766-794.

[16108] M. J. Morwood, P. Brown, . Jatmiko, T. Sutikna, E. Wahyu Saptomo, K. E. Westaway, Rokus Awe Due, R. G. Roberts, T. Maeda, S. Wasisto, and T. Djubiantono. "Further evidence for small-bodied hominins from the Late Pleistocene of Flores, Indonesia". English. In: 437 (2005), pp. 1012-1017.

[16109] M. J. Morwood, R. P. Soejono, R. G. Roberts, T. Sutikna, C. S. M. Turney, K. E. Westaway, W. J. Rink, J. -x. Zhao, G. D. van den Bergh, Rokus Awe Due, D. R. Hobbs, M. W. Moore, M. I. Bird, and L. K. Fifield. "Archaeology and age of a new hominin from Flores in eastern Indonesia". English. In: Nature 431 (2004), pp. 1087-1091.

[16110] E. Morycowa. "On a new rhipidogyrin genus, Diplocoeniella (Scleractinia, Lower Cretaceous)". English. In: Annales Societatis Geologorum Poloniae 67 (1997), pp. 297-305.

[16111] E. Morycowa. “Corals from the Tithonian carbonate complex in the Dabrowa Tarnowska-Szczucin area (Polish Carpathian Foreland)". English. In: Annales Societatis Geologorum Poloniae 82 (2012), pp. 1-38.

[16112] E. Morycowa. "Supplemental data on Triassic (Anisian) corals from Upper Silesia (Poland)". English. In: Annales Societatis Geologorum Poloniae 87.5 (2018), pp. 37-45. 
[16113] E. Morycowa and D. Decrouez. “Description de quelques coraux des Calcaires Urgoniens du domaine delphino-helvetique (Bornes, Haute-Savoie, France) [Description of corals from Urgonian limestones of the Delphino-Helvetic Zone (Bornes, Haute-Savoie, France)]". French. In: Revue de Paleobiologie 12.1 (1993), pp. 203-215.

[16114] E. Morycowa and A. Marcopoulou-Diacantoni. "Albian corals from the Subpelagonian Zone of Central Greece (Agrostylia, Parnassos region)". English. In: Annales Societatis Geologorum Poloniae 72 (2002), pp. 1-65.

[16115] E. Morycowa and J. P. Masse. “Les scléractiniaires du Barrémien-Aptien inférieur de Provence (SE de la France) [The Barremian-Early Aptian Scleractinia from Provence (SE France)]". French. In: Géobios 31.6 (1998), pp. 725-766.

[16116] E. Morycowa and J. P. Masse. "Lower Cretaceous Microsolenina (Scleractinia) from Provence (southern France)". English. In: Annales Societatis Geologorum Poloniae 79 (2009), pp. 97-140.

[16117] E. Morycowa, J. P. Masse, C. Arias, and L. Vilas. “Montlivaltia multiformis Toula (Scleractinia) from the Aptian of the Prebetic Domain (SE Spain)". English. In: Revista Espanola de Paleontologia 16.1 (2001), pp. 131-144.

[16118] E. Morycowa and J.-P. Masse. “Actinaraeopsis ventosiana, A new scleractinian species from the lower cretaceous of Provence (SE France)". English. In: Annales Societatis Geologorum Poloniae 77 (2007), pp. 141-145.

[16119] E. Morycowa and M. Misik. "Upper Jurrasic shallow-water scleractinian corals from the Pieniny Klippen Belt (Western Carpathians/Slovakia)". English. In: Geologica Carpathica 56.5 (2005), pp. 415432.

[16120] E. Morycowa and B. Olszewska. "Foraminiferal assemblage in the coral-bearing limestones of the Vratec area (Pieniny Klippen Belt, Western Carpathians, Slovakia)". English. In: Geologica Carpathica 64.1 (2013), pp. 63-69.

[16121] P. Morzadec, F. Paris, Y. Plusquellec, P. -R. Rachebouef, and M. Weyant. La limite LochkovienPraguien (Devonien inferieur) dans le Massif armoricain: especes index et correlations. French. 1991.

[16122] A. Mosavinia, J. Lehmann, and M. Wilmsen. "Late Albian ammonites from the Aitamir Formation (Koppeh Dagh, northeast Iran)". English. In: Cretaceous Research 50 (2014), pp. 72-88.

[16123] A. Mosavinia and M. Wilmsen. "Cenomanian Acanthoceratoidea (Cretaceous Ammonoidea) from the Koppeh Dagh, NE Iran: taxonomy and stratigraphic implications". English. In: Acta Geologica Polonica 61 (2011), pp. 175-192.

[16124] A. Mosavinia, M. Wilmsen, A. A. Aryai, M. R. Chahida, and J. Lehmann. "Mortoniceratinae (Ammonitina) from the upper Albian (Cretaceous) of the Atamir Formation, Koppeh Dagh mountains, NE Iran". English. In: Neues Jahrbuch für Geologie und Paläontologie, Abhandlungen 246 (2007), pp. 83-95.

[16125] A. Mosavinia and M. Wilmsen. “Cenomanian Turrilitidae (Cretaceous heteromorph ammonites) from the Koppeh Dagh, northeast Iran: Taxonomy and stratigraphic implications". English. In: Cretaceous Research 78 (2017), pp. 113-126.

[16126] M. Moser. “Plateosaurus engelhardti Meyer, 1837 (Dinosauria: Sauropodomorpha) aus dem Feuerletten (Mittelkeuper; Obertrias) von Bayern". German. In: Zitteliana B 24 (2003), pp. 1-188.

[16127] M. Moser, U. B. Mathur, F. T. Fürsich, D. K. Pandey, and N. Mathur. “Oldest camarasauromorph sauropod (Dinosauria) discovered in the Middle Jurassic (Bajocian) of the Khadir Island, Kachchh, western India". English. In: Paläontologische Zeitschrift 80.1 (2006), pp. 34-51.

[16128] M. Moser and R. Schoch. "Revision of the type material and nomenclature of Mastodonsaurus giganteus (Jaeger) (Temnospondyli) from the Middle Triassic of Germany". English. In: Palaeontology 50.5 (2007), pp. 1245-1266. DOI: 10.1111/j.1475-4983.2007.00705.x.

[16129] A. G. Moseyko, A. G. Kirejtshuk, and A. Nel. “New genera and new species of leaf beetles (Coleoptera: Polyphaga: Chrysomelidae) from lowermost Eocene French amber". English. In: Annales de la Société Entomologique de France 46 (2010), pp. 116-123. 
[16130] A. G. Moseyko and A. G. Kirejtshuk. "On the taxonomic position of new taxa of the subfamily Eumolpinae (Coleoptera, Chrysomelidae) from Baltic amber". English. In: Terrestrial Arthropod Reviews 6 (2013), pp. 163-172.

[16131] D. K. Moss and S. R. Westrop. "Systematics of some Late Ordovician encrinurine trilobites from Laurentian North America". English. In: Journal of Paleontology 88.6 (2014), pp. 1095-1119. DOI: 10.1666/13-159.

[16132] Z. K. Mossadegh, J. Parker, E. Gischler, W. Oschmann, D. Blakeway, and A. Eisenhauer. “Palaeoecology of well-preserved coral communities in a siliciclastic environment from the Late Pleistocene (MIS 7), Kish Island, Persian Gulf (Iran): the development of low-relief reef frameworks (biostromes) in increasingly restricted environments". English. In: International Journal of Earth Sciences 102 (2013), pp. 545-570. DOI: 10.1007/s00531-012-0802-3.

[16133] C. Möstel, M. Schorr, and G. Bechly. "A new stem-coenagrionoid genus of damselflies (Odonata: Zygoptera) from mid-Cretaceous Burmese amber". English. In: Zootaxa 4243 (2017), pp. 177-186.

[16134] H. Mostler and K. Krainer. "Neue Ophiuren aus Liassischen Slope-Sedimenten der nördlischen Kalkalpen in der Ungebung von Lofer (Salzburg)". German. In: GeologischPaläontologische Mitteilungen Innsbruck 19 (1993), pp. 29-47.

[16135] M. B. Mostovski. “New Species of the Genus Mesosolva Hong, 1983 (Diptera, Archisargidae) from the Jurassic of Kazakhstan and Mongolia". English. In: The Continental Jurassic 60 (1996), pp. 329332.

[16136] M. B. Mostovski. "A Revision of the Nemestrinid Flies (Diptera, Nemestrinidae) Described by Rohdendorf, and a Description of New Taxa of the Nemestrinidae from the Upper Jurassic of Kazakhstan". English. In: Paleontological Journal 32.4 (1998), pp. 369-375.

[16137] M. B. Mostovski. "On an interesting find of a brachycerous fly (Diptera, Brachycera) in the Jurassic of Kazakhstan". English. In: Paleontological Journal 33 (1999), pp. 406-408.

[16138] M. B. Mostovski. “Contributions to the study of fossil snipe-flies (Diptera: Rhagionidae). The genus Palaeobolbomyia". English. In: Paleontological Journal 34.Suppl 3 (2000), S360-S366.

[16139] M. B. Mostovski. "A brief review of brachycerous flies (Diptera, Brachycera) in the Mesozoic, with descriptions of some curious taxa". English. In: Proceedings of the First International Palaeoentomological Conference (1999), pp. 103-110.

[16140] M. B. Mostovski. “Contributions to the Study of Fossil Snipe Flies (Diptera: Rhagionidae): The Genus Protorhagio". English. In: Paleontological Journal 42.1 (2008), pp. 75-80.

[16141] M. B. Mostovski. "New taxa of Ironomyiidae (Diptera, Phoromorpha) from the Cretaceous of Siberia and Mongolia". English. In: Paleontological Journal 30 (1995), pp. 318-331.

[16142] M. B. Mostovski. "A new species of phoromorph dipteran (Diptera, Phoromorpha) from the Upper Cretaceous of eastern Siberia". English. In: Paleontological Journal 30 (1996), pp. 436-439.

[16143] M. B. Mostovski. “On knowledge of fossil flies of the superfamily Archisargoidea (Diptera, Brachycera)". English. In: Paleontological Journal 31.1 (1997), pp. 72-78.

[16144] M. B. Mostovski. "Curious Phoridae (Insecta, Diptera) found mainly in Cretaceous ambers". English. In: Estudios del Museo de Ciencias Naturales de Alava 14.2 (1999), pp. 231-242.

[16145] M. B. Mostovski. "New Mesozoic Platypezidae (Diptera) and the main directions of evolution of the family". English. In: Paleontological Journal 29.2 (1995), pp. 130-146.

[16146] M. B. Mostovski. "To the knowledge of Archisargoidea (Diptera, Brachycera). Families Eremochaetidae and Archisargidae". English. In: Russian Entomological Journal 5 (1996), pp. 117-124.

[16147] M. B. Mostovski and E. A. Jarzembowski. "The First Brachycerous Flies (Diptera: Rhagionidae) from the Lower Jurassic of Gondwana". English. In: Paleontological Journal 34.Suppl 3 (2000), S367S369.

[16148] M. B. Mostovski, E. A. Jarzembowski, and R. A. Coram. "Horseflies and Athericids (Diptera: Tabanidae, Athericidae) from the Lower Cretaceous of England and Transbaikalia". English. In: $\mathrm{Pa}$ leontological Journal 37.2 (2003), pp. 162-169. 
[16149] M. B. Mostovski, E. A. Jarzembowski, R. A. Coram, and J. Ansorge. “Curious snipe-flies (Diptera: Rhagionidae) from the Purbeck of Dorset, The Wealden of the Weald and the Lower Cretaceous of Spain and Transbaikalia". English. In: Proceedings of the Geologists' Association 111 (2000), pp. 153160.

[16150] M. B. Mostovski and X. Martnez-Delclós. "New Nemestrinoidea (Diptera: Brachycera) from the Upper Jurassic - Lower Cretaceous of Eurasia, taxonomy, and palaeobiology". English. In: Entomological Problems 31.2 (2000), pp. 137-148.

[16151] R. Motani. "Phylogeny of the Ichthyopterygia". English. In: Journal of Vertebrate Paleontology 19.3 (1999), pp. 473-496.

[16152] R. Motani, D. Y. Jiang, A. Tintori, O. Rieppel, and G. B. Chen. "Terrestrial origin of viviparity in Mesozoic marine reptiles indicated by Early Triassic embryonic fossils". English. In: PLoS One 9.2 (2014), e88640.

[16153] R. Motani, D.-Y. Jiang, A. Tintori, Y. -L. Sun, W. -C. Hao, A. Boyd, S. Hinic-Frlog, L. Schmitz, J. -Y. Shin, and Z. -Y. Sun. "Horizons and assemblages of Middle Triassic marine reptiles from Panxian. Guizhou, China". English. In: Journal of Vertebrate Paleontology 28.3 (2008), pp. 900-903.

[16154] R. Motani, D.-Y. Jiang, G. -B. Chen, A. Tintori, O. Rieppel, C. Ji, and J. -D. Huang. “A basal ichthyosauriform with a short snout from the Lower Triassic of China". English. In: Nature 517 (2015), pp. 485-488. DOI: 10.1038/nature13866.

[16155] R. Motani, N. Minoura, and T. Ando. "Ichthyosaurian relationships illuminated by new primitive skeletons from Japan". English. In: Nature 393 (1998), pp. 255-257.

[16156] R. Motani and H. You. "The forefin of Chensaurus chaoxianensis (Ichthyosauria) shows delayed mesopodial ossification". English. In: Journal of Paleontology 72.1 (1998), pp. 133-136.

[16157] R. Motani, H. You, and C. McGowan. "Eel-like swimming in the earliest ichthyosaurs". English. In: Nature 382 (1996), pp. 347-348.

[16158] N. Motchurova and E. T. Ruggiero. "First occurence of the brachiopod family Erymnariidae Cooper in the upper Cretaceous of southern Italy". English. In: Palaeontology 43.1-3 (2000), pp. 173-197. DOI: $10.1111 / 1475-4983.00123$.

[16159] D. Mothé and L. Avilla. "Mythbusting evolutionary issues on South American Gomphotheriidae (Mammalia: Proboscidea)". English. In: Quaternary Science Reviews 110 (2015), pp. 23-35. DOI: 10. 1016/j.quascirev.2014.12.013.

[16160] D. Mothé, L. S. Avilla, D. Zhao, G. Xie, and B. Sun. "A new Mammutidae (Proboscidea, Mammalia) from the Late Miocene of Gansu Province, China". English. In: Anais da Academia Brasileira de Ciencias 88.1 (2016), pp. 65-74. DOI: 10.1590/0001-3765201520150261.

[16161] D. Mothé, L. dos Santos Avilla, L. Asevedo, L. Borges-Silva, M. Rosas, R. Labarca-Encina, R. Souberlich, E. Soibelzon, J. L. Roman-Carrion, S. D. Ros, A. D. Rincon, and G. Cardoso de Oliveira. "Sixty years after 'The mastodonts of Brazil': The state of the art of South American proboscideans (Proboscidea, Gomphotheriidae)". English. In: Quaternary International 443 (2017), pp. 52-64. DOI: 10.1016/j.quaint.2016.08.028.

[16162] H. Moths, K. Thiede, and N. Thiede. "Zahnwalreste aus dem Sternberger Gestein (Eochattium, Oligozän) von Norddeutschland". English. In: Der Geschiebesammler 37.2 (2004), pp. 71-79.

[16163] M. J. Motta, F. L. Agnolin, F. B. Egli, and F. E. Novas. “New theropod dinosaur from the Upper Cretaceous of Patagonia sheds light on the paravian radiation in Gondwana". English. In: The Science of Nature 107 (2020), p. 24. DOI: 10.1007/s00114-020-01682-1.

[16164] M. J. Motta, A. M. Aranciaga Rolando, S. Rozadilla, F. L. Agnolin, N. R. Chimento, F. Brissón Egli, and F. E. Novas. "New theropod fauna from the Upper Cretaceous (Huincul Formation) of northwestern Patagonia, Argentina". English. In: vol. 71. Cretaceous Period: Biotic Diversity and Biogeography. New Mexico Museum of Natural History and Science Bulletin. Albuquerque: New Mexico Museum of Natural History and Science, 2016, pp. 231-253. 
[16165] B. Mottequin. "Late Middle Frasnian to Early Famennian (Late Devonian) strophomenid, orthotetid, and athyridid brachiopods from southern Belgium". English. In: Journal of Paleontology 82.6 (2008), pp. 1052-1073.

[16166] B. Mottequin and G. Sevastopulo. "Predatory boreholes in Tournaisian (Lower Carboniferous) spiriferid brachiopods". English. In: Lethaia 42 (2009), pp. 274-282.

[16167] M. Mõtus and Y. Zaika. "The oldest heliolitids from the early Katian of the East Baltic region". English. In: GFF A Scandinavian Journal of Earth Sciences 134.3 (2012), pp. 225-234. DOI: 10.1080 / 11035897.2012.721805.

[16168] M. A. Motus. "Tabulate corals from the Lower Silurian of Jamtland (Sweden)". English. In: GFF 126.4 (2004), pp. 339-352.

[16169] M. A. Motus and E. Klaamann. "The halysitid coral genera Halysites and Cystihalysites from Gotland, Sweden". English. In: GFF 121.2 (1999), pp. 81-90.

[16170] M. A. Motus and O. Sandstrom. "Cystihalysites sp. and its significance to biostratigraphy and event stratigraphy in the Ludlow (Late Silurian) of Gotland, Sweden". English. In: GFF 127.4 (2005), pp. 269-272.

[16171] C. J. Mou and C. L. Liu. "Permian bivalves from the area of Guangzhou". Chinese. In: Acta Scientiarum Naturalium Universitatis Sunyatseni 32 (1993), pp. 101-108.

[16172] Y. Mou. "A New Arvicoline Species (Rodentia: Cricetidae) from the Pliocene Panaca Formation, Southeast Nevada". English. In: Journal of Vertebrate Paleontology 17.2 (1997), pp. 376-383.

[16173] P. O. J. Mouchet. "A new sauropods printsite from the Upper Jurassic of northern Switzerland (Kimmeridgian; Montbautier, Kt. Bern)". English. In: Revue de Paléobiologie 12.2 (1993), pp. 345349.

[16174] J. F. Moura, F. Góis, F. C. Galliari, and M. A. Fernandes. “Zootaxa”. English. In: 4661.3 (2019), pp. 401-444.

[16175] D. A. Moura-Júnior, S. M. Scheffler, F. F. F. Moreira, A. Nel, and G. Mejdalani. "First record of a shore bug (Insecta, Hemiptera, Saldidae) from Gondwana". English. In: Journal of Paleontology 95 (2020), pp. 133-140. DOI: 10.1017/jpa.2020.61.

[16176] C. Mourer-Chauviré. "A large owl from the Paleocene of France". English. In: Palaeontology 37.2 (1994), pp. 339-348.

[16177] C. Mourer-Chauvire. "Influence de l'homme prehistorique sur la repartition de certains oiseaux marins: L'exemple du grand pingouin Pinguinus impennis". English. In: 67.4 (1999), pp. 273-279.

[16178] C. Mourer-Chauvire. “Une nouvelle famille de perroquets (Aves: Psittaciformes) dans l’Éocéne Supérieur des phosphorites du Quercy, France". English. In: Geobios 14 (1992), pp. 169-177.

[16179] C. Mourer-Chauvire and M. T. Antunes. "Presence du grand pingouin, Pinguinus impennis (Aves, Charadriiformes) dans le Pleistocene du Portugal". French. In: Geobios 24.2 (1991), pp. 201-205.

[16180] C. Mourer-Chauviré, D. Berthet, and M. Hugueney. English. In: Senckenbergiana lethaea 84.1/2 (2004), pp. 303-315.

[16181] C. Mourer-Chauviré, R. Bour, S. Ribes, and F. Moutou. "The avifauna of Réunion Island (Mascarene Islands) at the time of the arrival of the first Europeans". English. In: Smithsonian Contributions to Paleobiology 89 (1999), pp. 1-38.

[16182] C. Mourer-Chauviré, R. Bour, and S. Ribes. "The taxonomic identity of Circus alphonsi (Newton \& Gadow 1893), the extinct harrier from Mauritius". English. In: Ibis 146 (2004), pp. 168-172.

[16183] C. Mourer-Chauviré and E. Bourdon. "The Gastornis (Aves, Gastornithidae) from the Late Paleocene of Louvois (Marne, France)". English. In: Swiss Journal of Palaeontology 135 (2016), pp. 327341.

[16184] C. Mourer-Chauvire and D. Geraads. "The Struthionidae and Pelagornithidae (Aves: Struthioniformes, Odontopterygiformes) from the late Pliocene of Ahl Al Oughlam, Morocco". English. In: Oryctos 7 (2008), pp. 169-194. 
[16185] C. Mourer-Chauviré, M. Philippe, S. Guillard, and M. Meyssonnier. "Presence of the Northern Bald Ibis Geronticus eremita (L.) during the". English. In: Ibis 148 (2006), pp. 820-823.

[16186] C. Mourer-Chauvire, R. Tabuce, M. Mahboubi, M. Adaci, and M. Bensalah. "A Phororhacoid bird from the Eocene of Africa". English. In: Naturwissenschaften 98 (2011), pp. 815-823.

[16187] F. A. Mourgues. "Advances in ammonite biostratigraphy of the marine Atacama basin (Lower Cretaceous), northern Chile, and its relationship with the Neuquen basin, Argentina". English. In: Journal of South American Earth Sciences 17 (2004), pp. 3-10.

[16188] F. A. Mourgues, L. G. Bulot, and C. Frau. “The Valanginian Olcostephaninae Haug, 1910 (Ammonoidea) from the Andean Lower Cretaceous Chañarcillo Basin, Northern Chile". English. In: Andean Geology 42 (2015), pp. 213-236.

[16189] A. A. Mourik, R. H. B. Fraaije, G. J. van der Zwaan, and U. Scheer. "The burrowing shrimp, Protocallianassa faujasi (Crustacea, Decapoda, Thalassinoidea), from the lower Campanian at Dulmen, Germany". English. In: Bulletin of the Mizunami Fossil Museum 32 (2005), pp. 1-12.

[16190] M. J. Mourlam and M. J. Orliac. "Protocetid (Cetacea, Artiodactyla) bullae and petrosals from the middle Eocene locality of Kpogamé, Togo: new insights into the early history of cetacean hearing". English. In: Journal of Systematic Palaeontology (2017). DOI: 10.1080/14772019.2017.1328378.

[16191] L. D. Mouro, A. C. S. Fernandes, D. W. Rogerio, and V. M. Fonseca. “First Articulated Sponge from the Paleozoic of Brazil, and a New Organization of the Order Hemidiscosa". English. In: Journal of Paleontology 88.1 (2014), pp. 171-178.

[16192] E. Moussavian and J. Kuss. “Typification and status of Lithothamnium aschersoni Schwager, 1883 (Corallinaceae, Rhodophyta) from Paleocene limestones of Egypt. A contribution to the synonmy and priority of the genera Archaeolithothamnium Rothpletz and Sporolithon Heydrich". English. In: Berliner geowiss. Abh 120.2 (1990), pp. 929-942.

[16193] E. Moussavian and A. Vecsei. "Paleocene reef sediments from the Maiella carbonate platform, Italy". In: Facies 32 (1995), pp. 213-222.

[16194] B. M. Moussavou. "Bivalves (Mollusca) from the Coniacian-Santonian Anguille Formation from Cap Esterias, Northern Gabon, with notes on paleoecology and paleobiogeography". English. In: Geodiversitas 37.3 (2015), pp. 315-324.

[16195] S. Moyá-Solá, M. Köhler, D. M. Alba, I. Casanovas-Vilar, and J. Galindo. “Pierolapithecus catalaunicus, a new Middle Miocene great ape from Spain". English. In: Science 306 (2004), pp. 1339-1344. DOI: 10.1126 /science.1103094.

[16196] S. Moya-Sola and M. Köhler. "Middle Bartonian locality with Anchomomys (Adapidae, Primates) in the Spanish Pyrenees: Preliminary report". English. In: Folia Primatologica 60 (1993), pp. 158-163.

[16197] S. MoyáSolá, M. Köhler, and D. Alba. "Egarapithecus narcisoi, a new genus of Pliopithecidae (Primates, Catarrhini) from the Late Miocene of Spain". English. In: American Journal of Physical Anthropology 114 (2001), pp. 312-324.

[16198] A. E. Moyer, W. Zheng, E. A. Johnson, M. C. Lamanna, D. -q. Li, K. J. Lacovara, and M. H. Schweitzer. "Melanosomes or microbes: testing an alternative hypothesis for the origin of microbodies in fossil feathers". English. In: Scientific Reports 4.4233 (2014), pp. 1-9. DOI: 10.1038 / srep04233.

[16199] L. Mu, Y. D. Zakharov, W. Z. Li, and S. Z. Shen. “Early Induan (Early Triassic) cephalopods from the Daye Formation at Guiding, Guizhou Province, south China". English. In: Journal of Paleontology 81 (2007), pp. 858-872.

[16200] P. Muchez, W. Viaene, J. Bouckaert, R. Conil, M. Dusar, E. Poty, P. Soille, and N. Vandenberghe. "The occurrence of a microbial buildup at Poederlee (Campine Basin, Belgium): biostratigraphy, sedimentology, early diagenesis and significance for Early Warnantian paleogeography". English. In: Annales de la Societe Geologique de Belgique 113.2 (1990), pp. 329-339.

[16201] S. N. Mude and P. Kundal. "Additional Coralline Algae from the Lower Miocene to Late Holocene Sediments of the Porbandar Group, Gujarat". English. In: Journal Geological Society of India 79 (2012), pp. 69-76. 
[16202] A. Mudroch, U. Richter, and M. Reich. "The dinosaur digs in the Keuper of Halberstadt: a second reconnaissance". English. In: 9th International Symposium on Mesozoic Terrestrial Ecosystems and Biota, Abstracts and Proceedings Volume (2006), pp. 93-95.

[16203] A. Mudroch, U. Richter, U. Joger, R. Kosma, O. Idé, and A. Maga. “Didactyl tracks of paravian theropods (Maniraptora) from the ?Middle Jurassic of Africa". English. In: PLoS One 6.2 (2011), e14642:1-10. DOI: 10.1371/journal.pone.0014642.

[16204] B. D. Mueller and W. G. Parker. A new species of Trilophosaurus (Diapsida: Archosauromorpha) from the Sonsela Member (Chinle Formation) of Petrified Forest National Park, Arizona. English. Vol. 62. A Century of Research at Petrified Forest National Park, 1906-2006: Geology and Paleontology. Museum of Northern Arizona Bulletin. 2006, pp. 119-125.

[16205] P. Mueller and G. Hahn. "Edrioasteroidea from the Seifen Formation of the Westerwald, Rhenish Slate Mountains (Lower Devonian, Germany), part 2: Sumrallia rseiberti gen. et sp. nov." English. In: PalZ 91.4 (2017), pp. 629-639. DOI: 10.1007/s12542-017-0356-6.

[16206] I. J. Mueller-Töwe. "Anatomy, phylogeny, and palaeoecology of the basal thalattosuchians (Mesoeucrocodylia) from the Liassic of Central Europe". English. PhD thesis. 2006.

[16207] I. J. Mueller-Towe, T. A. Kjeldahl-Vallon, J. Milan, L. H. Vallon, G. Theodorou, J. Lindgren, S. J. Roussiakis, and R. G. Bromley. "First chelonian eggs and carapace fragments from the Pliocene of Rhodes, Greece". English. In: Neues Jahrbuch für Geologie und Paläontologie 262.3 (2011), pp. 309322. DOI: $10.1127 / 0077-7749 / 2011 / 0201$.

[16208] A. M. Muftah. "Distichoplax biserialis (Dietrich) from Sirt Basin, Libya". English. In: Journal of Science and Its Applications 4.1 (2010), pp. 85-92.

[16209] D. R. Muhs, H. M. Kelsey, G. H. Miller, G. L. Kennedy, J. F. Wheland, and G. W. Mcinelly. “Age Estimates and Uplift Rates for Late Pleistocene Marine Terraces: Southern Oregon Portion of the Cascadia Forearc". English. In: Journal of Geophysical Research 95.B5 (1990), pp. 6685-6698.

[16210] D. R. Muhs, K. R. Simmons, and B. Steinke. "Timing and warmth of the Last Interglacial period: new U-series evidence from Hawaii and Bermuda and a new fossil compilation for North America". English. In: Quaternary Science Reviews 21 (2002), pp. 1355-1383.

[16211] D. R. Muhs, K. R. Simmons, R. R. Schumann, and R. B. Halley. "Sea-level history of the past two interglacial periods: new evidence from U-series dating of reef corals from south Florida". English. In: Quaternary Science Reviews 30 (2011), pp. 570-590.

[16212] L. A. Muir and J. P. Botting. "Graptolite faunas and monaxonid demosponges of the Cyrtograptus lundgreni event (Late Wenlock, Silurian) interval from the Orange district, New South Wales". English. In: Alcheringa 31 (2007), pp. 375-395.

[16213] J. Muirhead. "A specialised thylacinid, Thylacinus macknessi, (Marsupialia: Thylacinidae) from Miocene deposits of Riversleigh, northwestern Queensland". English. In: Australian Mammalogy 15 (1992), pp. 67-76.

[16214] J. Muirhead. "Two new early Miocene thylacines from Riversleigh, northwestern Queensland". English. In: Memoirs of The Queensland Museum 41 (1997), pp. 367-377.

[16215] J. Muirhead, L. Dawson, and M. Archer. "Perameles bowensis, a new species of Perameles (Peramelemorphia, Marsupialia) from Pliocene faunas of Bow and Wellington Caves, New South Wales". English. In: Proceedings of The Linnean Society of New South Wales 117 (1997), pp. 163-174.

[16216] J. Muirhead and S. Filan. "Yarala burchfieldi, a Plesiomorphic Bandicoot (Marsupialia, Peramelemorphia) from Oligo- Miocene Deposits of Riversleigh, Northwestern Queensland". English. In: Journal of Paleontology 69.1 (1995), pp. 127-134.

[16217] J. Muirhead and S. Wroe. “A new genus and species, Badjcinus turnbulli (Thylacinidae: Marsupialia), from the Late Oligocene of Riversleigh, Northern Australia, and an investigation of thylacinid philogeny". English. In: Journal of Vertebrate Paleontology 18.3 (1998), pp. 612-626.

[16218] C. Muizon. "Walrus-like feeding adaptation in a new cetacean from the Pliocene of Peru". In: Nature 365 (1993), pp. 745-748. 
[16219] C. Muizon. "A new Ziphiidae (Cetacea) from the Early Miocene of Washington State (USA) and phylogenetic analysis of the major groups of odontocetes". English. In: Bulletin du Museum National d'Histoire Naturelle. 4e Serie. Section C. Sciences de la Terre. Paleontologie, Geologie, Mineralogie 12.3-4 (1990), pp. 279-326.

[16220] C. Muizon, G. Billet, C. Argot, S. Ladeveze, and F. Goussard. "Alcidedorbignya inopinata, a basal pantodont (Placentalia, Mammalia) from the early Palaeocene of Bolivia: anatomy, phylogeny and palaeobiology". English. In: Geodiversitas 37.4 (2015), pp. 397-634.

[16221] C. Muizon, D. P. Domning, and M. Parrish. "Dimorphic tusks and adaptive strategies in a new species of walrus-like dolphin (Odobenocetopsidae) from the Pliocene of Peru". English. In: C. R. Academie des Sciences, Paris, Sciences de la terre et des planets 329 (1999), pp. 449-455.

[16222] C. Muizon, H. G. McDonald, R. Salas, and M. Urbina. "A new early species of the aquatic sloth Thalassocnus (Mammalia, Xenarthra) from the late Miocene of Peru". English. In: Journal of Vertebrate Paleontology 23.4 (2003), pp. 886-894.

[16223] C. Muizon and H. G. McDonald. "An aquatic sloth from the Pliocene of Peru". English. In: Nature 375 (1995), pp. 224-227.

[16224] C. Muizon, H. G. McDonald, R. Salas, and M. Urbina. "The youngest species of the aquatic sloth Thalassocnus and a reassesment of the relationships of the nothrothere sloths (Mammalia: Xenarthra)". English. In: Journal of Vertebrate Paleontology 24.2 (2004), pp. 387-397.

[16225] C.d. Muizon. "Marsupial skulls from the Deseadan (late Oligocene) of Bolivia and phylogenetic analysis of the Borhyaenoidea (Marsupialia, Mammalia)". English. In: Geobios 32.3 (1999), pp. 483509. DOI: 10.1016/S0016-6995(99)80022-9.

[16226] D. Mukherjee, S. Bardhan, and D. Ghosh. "Significance of new species of Cryptorhynchia (Brachiopoda) from the Middle Jurassic of Kutch,India". English. In: Alcheringa 26 (2002), pp. 209-231.

[16227] D. Mukherjee and S. Ray. "A new Hyperodapedon (Archosauromorpha, Rhynchosauria) from the upper Triassic of India: implications for rhynchosaur phylogeny". English. In: Palaeontology 57.6 (2015), pp. 1241-1276.

[16228] D. Mukherjee and S. Ray. "Taphonomy of an Upper Triassic vertebrate bonebed: A new rhynchosaur (Reptilia; Archosauromorpha) accumulation from India". English. In: Palaeogeography, Palaeoclimatology, Palaeoecology 333-334 (2012), pp. 75-91.

[16229] R. N. Mukherjee and D. P. Sengupta. “New capitosaurid amphibians from the Triassic Denwa Formation of the Satpura Gondwana Basin, central India". English. In: Ameghiniana 22 (1998), pp. 317-327.

[16230] E. W. A. Mulder. "Ein Elasmosaurierzahn aus der oberen Kreide des St. Pietersberges bei Maastricht, Siid-Limburg, Niederlande". German. In: Palaeontologische Zeitschrift 64.1/2 (1990), pp. 145151.

[16231] E. W. A. Mulder. "Transatlantic latest Cretaceous mosasaurs (Reptilia, Lacertilia) from the Maastrichtian type area and New Jersey". English. In: Geologie en Mijnbouw 78 (1999), pp. 281-300.

[16232] E. W. A. Mulder, N. Bardet, P. Godefroit, and J. W. M. Jagt. “Elasmosaur remains from the Maastrichtian type area, and a review of latest Cretaceous elasmosaurs (Reptilia, Plesiosauroidea)". English. In: Bulletin de l'Institut Royal des Sciences Naturalles de Belgique, Sciences de la Terre 70 (2000), pp. 161-178.

[16233] E. W. A. Mulder, P. Formanoy, W. B. Gallagher, J. W. M. Jagt, and A. S. Schulp. "The first North American record of Carinodens belgicus (Squamata, Mosasauridae) and correlation with the youngest in situ examples from the Maastrichtian type area: palaeoecological implications". English. In: Netherlands Journal of Geosciences - Geologie En Mijnbouw 92.2-3 (2013), pp. 145-152. DOI: 10.1017/ S001677460000007X.

[16234] E. W. A. Mulder and R. H. B. Fraaije. "New records of Early Cretaceous iguanodontian dinosaur remains from the Dutch sector of the North Sea". English. In: Neues Jahrbuch für Geologie und Paläontologie Abhandlungen 282.3 (2016), pp. 271-277. DOI: 10.1127/njgpa/2016/0618. 
[16235] E. W. A. Mulder, J. W. M. Jagt, and A. S. Schulp. "Another record of a hadrosaurid dinosaur from the Maastrichtian type area (The Netherlands, Belgium): Seeley (1883) revisited". English. In: Bulletin de l'Institut Royal des Sciences Naturelles de Belgique, Sciences de la Terre 75 (2005), pp. 201206.

[16236] E. W. A. Mulder, J. W. M. Jagt, M. M. M. Kuypers, H. H. G. Peeters, and P. Rompen. “Preliminary observations on the stratigraphic distribution of Late Cretaceous marine and terrestrial reptiles from the Maastrichtian type area (SE Netherlands, NE Belgium)". English. In: Oryctos 1 (1998), pp. 55-64.

[16237] E. W. A. Mulder, M. M. M. Kuyper, J. W. M. Jagt, and H. H. G. Peeters. “A new late Maastrichtian hadrosaurid dinosaur record from northeast Belgium". English. In: Neues Jahrbuch für Geologie und Paläontologie Monatshefte 1997.6 (1997), pp. 339-347.

[16238] E. W. A. Mulder and H. Mai. “The oldest tylosaurine mosasaur (Reptilia; Lacertilia) from the Late Cretaceous of Belgium: Hermann von Meyer (1860) revisited". English. In: Geologie en Mijnbouw 78 (1999), pp. 207-213.

[16239] K. M. Muldoon, B. E. Crowley, L. R. Godfrey, A. Rasoamiaramanana, A. Aronson, J. Jernvall, P. C. Wright, and E. L. Simons. "Early Holocene fauna from a new subfossil site: A first assessment from Christmas River, south central Madagascar". English. In: Madagascar Conservation \& Development 7.1 (1992), pp. 23-29.

[16240] K. M. Muldoon and G. F. Gunnell. “Omomyid primates (Tarsiiformes) from the Early Middle Eocene at South Pass, Greater Green River Basin, Wyoming". English. In: Journal of Human Evolution 43.4 (2002), pp. 479-511.

[16241] A. Müller and C. Diedrich. "Selachier (Pisces, Chondrichthyes) aus dem Cenomanium von Ascheloh am Teutoburger Wald (Nordrhein-Westfalen, NW-Deutschland)". German. In: Geologie und Paläontologie in Westfalen 20 (1991), pp. 1-105.

[16242] D. Muller. "Neue Funde unserer Mitglieder: Ichthyosaurierwirbel”. German. In: Arbeitskreis Paläontologie Hannover 18.3 (1990), pp. 66-67.

[16243] H. Muller. "Zur Altersfrage und Faunenführung der Briloner Schiefer im nordöstlichen Sauerland (Mitteldevon, Rheinisches Schiefergebirge)". German. In: Geologisches Jahrbüch, Reihe D: Mineralogie, Petrographie, Geochemie, und Lagerstättenkunde 95 (1990), pp. 7-42.

[16244] J. Müller. "The anatomy of Askeptosaurus italicus from the Middle Triassic of Monte San Giorgio and the interrelationships of thalattosaurs (Reptilia, Diapsida)". English. In: Canadian Journal of Earth Sciences 42 (2005), pp. 1347-1367.

[16245] J. Müller, D. S. Berman, A. C. Henrici, T. Martens, and S. S. Sumida. “The Basal Reptile Thuringothyris mahlendorffae (Amniota: Eureptilia) from the Lower Permian of Germany". English. In: Journal of Paleontology 80.4 (2006), pp. 726-739.

[16246] J. Müller, C. A. Hipsley, J. J. Head, N. Kardjilov, A. Hilger, M. Wuttke, and R. R. Reisz. “Eocene lizard from Germany reveals amphisbaenian origins". English. In: Nature 473 (2011), pp. 364-367. DOI: $10.1038 /$ nature09919.

[16247] J. Müller, J.-L. Li, and R. R. Reisz. "A new bolosaurid parareptile, Belebey chengi sp. nov., from the Middle Permian of China and its paleogeographic significance". English. In: Naturwissenschaften 95.12 (2008), pp. 1169-1174.

[16248] J. Müller and C. Mödden. "A Fossil Leaf-Toed Gecko from the Oppenheim/Nierstein Quarry (Lower Miocene, Germany)". English. In: Journaolf Herpetology 135.3 (2001), pp. 529-532.

[16249] J. Müller and R. R. Reisz. "An early captorhinid reptile (Amniota, Eureptilia) from the Upper Carboniferous of Hamilton, Kansas". English. In: Journal of Vertebrate Paleontology 25.3 (2005), pp. 561568.

[16250] J. Müller, S. Renesto, and S. E. Evans. "The marine diapsid reptile Endennasaurus from the Upper Triassic of Italy". English. In: Palaeontology 48 (2005), pp. 15-30. 
[16251] J. Müller, E. Roberts, E. Naylor, and N. Stevens. "A fossil Gekkotan (Squamata) from the late Oligocene Nsungwe Formation, Rukwa Rift Basin, Tanzania". English. In: Journal of Herpetology 52.2 (2018), pp. 223-227. DOI: 10.1670/17-123.

[16252] P. Muller. "New decapods from the Miocene of Hungary- with remarks about their enviroment". English. In: Foldtani Kozlony 136.1 (2006).

[16253] P. Müller. “Revision der Gattung Cystispina (Trilobita; Unter-Karbon)”. English. In: Geologica et Palaeontologica 42 (2008), pp. 55-70.

[16254] P. Muller and J. S. H. Collins. "Late Eocene Coral-Associated Decapods (Crustacea) From Hungary". English. In: Contributions to Tertiary and Quaternary Geology 28.2-3 (1991), pp. 47-92.

[16255] R. T. Müller. "A new theropod dinosaur from a peculiar Late Triassic assemblage of southern Brazil". English. In: Journal of South American Earth Sciences (2020), p. 103026. DOI: 10.1016/j. jsames.2020.103026.

[16256] R. T. Müller, M. Belén von Baczko, J. B. Desojo, and S. J. Nesbitt. "The first ornithosuchid from Brazil and its macroevolutionary and phylogenetic implications for Late Triassic faunas in Gondwana". English. In: Acta Palaeontologica Polonica 65.1 (2020), pp. 1-10. DOI: 10.4202/app.00652.2019.

[16257] R. T. Müller, A. A. S. da Rosa, L. R. da Silva, A. S. S. Aires, C. P. Pacheco, A. E. B. Pavanatto, and S. Dias-da-Silva. "Wachholz, a new exquisite dinosaur-bearing fossiliferous site from the Upper Triassic of southern Brazil". English. In: Journal of South American Earth Sciences 61 (2015), pp. 120128.

[16258] R. T. Müller, M. C. Langer, A. S. S. Aires, and S. Dias-da-Silva. “New dinosauriform (Ornithodira, Dinosauromorpha) record from the Upper Triassic of southern Brazil". English. In: Paleontological Research 18.2 (2014), pp. 118-121. DOI: 10.2517/2014PR012.

[16259] R. T. Müller, M. C. Langer, S. F. Cabreira, and S. Dias-da-Silva. "The femoral anatomy of Pampadromaeus barberenai based on a new specimen from the Upper Triassic of Brazil". English. In: Historical Biology (2015).

[16260] R. T. Müller, M. C. Langer, and S. Dias-da-Silva. “An exceptionally preserved association of complete dinosaur skeletons reveals the oldest long-necked sauropodomorphs". English. In: Biology Letters 14 (2018), 20180633:1-5. DOI: 10.1098/rsbl.2018.0633.

[16261] S. P. Müller, J. A. Dunlop, U. Kotthoff, J. U. Hammel, and D. Harms. “The oldest short-tailed whipscorpion (Schizomida): A new genus and species from the Upper Cretaceous amber of northern Myanmar". English. In: Cretaceous Research 106.104227 (2019). DOI: 10.1016/j.cretres.2019.104227.

[16262] G. Multer, E. Gischler, J. Lundberg, K. R. Simmons, and E. A. Shinn. "Key Largo Limestone Revisited: Pleistocene Shelf-edge Facies, Florida Keys, USA". English. In: Facies 46 (2002), pp. 229 272.

[16263] D. J. C. Mundy. Microbialite-sponge-bryozoan-coral framestones in Lower Carboniferous (Late Visean) buildups of northern England (UK). Vol. 17. in: Embry, A.F., Beauchamp, B., Glass, D.J. (eds): Pangea: Global Environments and Resources. Canadian Society of Petroleum Geologists Memoir. 1994, pp. 713-729.

[16264] F. Muñiz, Z. Belaústegui, A. Toscano, S. Ramirez- Cruzado, and J. A. Gámez Vintaned. “New ichnospecies of Linichnus Jacobsen \& Bromley, 2009". English. In: Ichnos (2020). DOI: 10.1080 / 10420940.2020.1744585.

[16265] H. Munk. "A preliminary report on Late Cretaceous herptiles within or near Bryce Canyon National Park, Utah". English. In: In V. L. Santucci \& L. McClelland (eds.), National Park Service Geologic Resources Division Technical Report NPS/NRGRD/GRDTR-98/01. National Park Service Paleontological Research Volume 3 (1998), pp. 41-44.

[16266] W. Munk and H.-P. Sues. “Gut contents of Parasaurus (Pareiasauria) and Protorosaurus (Archosauromorpha) from the Kupferschiefer (Upper Permian) of Hessen, Germany". English. In: Palaeontologische Zeitschrift 67.1/2 (1993), pp. 169-176. 
[16267] T. J. Munson and J. S. Jell. “Llandovery rugose corals from the Quinton Formation, Broken River Province, northeast Queensland". In: Memoirs of the Association of Australasian Palaeontologists 21 (1999), pp. 1-65.

[16268] D. Munyikwa and M. A. Raath. "Further material of the ceratosaurian dinosaur Syntarsus from the Elliot Formation (Early Jurassic) of South Africa". In: Palaeontologia Africana 35 (1999), pp. 5559.

[16269] J. Muona. “Eucnemidae and Throscidae from Baltic amber (Coleoptera)". English. In: Entomologische Blatter 89 (1993), pp. 15-45.

[16270] J. Muona. “Throscidae (Coleoptera) relationships, with descriptions of new fossil genera and species". English. In: Zootaxa 4576 (2019), pp. 521-543.

[16271] M. Murakami. First record of a pontoporiid cetacean (Odontoceti: Inioidea) from the late Miocene of Chiba, Japan. English. 2012.

[16272] M. Murakami. "A new extinct inioid (Cetacea, Odontoceti) from the upper Miocene Senhata Formation, Chiba, central Japan: the first record of Inioidea from the North Pacific Ocean". English. In: Paleontological Research 20.3 (2016), pp. 207-225. DOI: 10.2517/2015PR031.

[16273] M. Murakami, R. Hirayama, Y. Hikida, and H. Hirano. "A theropod dinosaur (Saurischia: Maniraptora) from the Upper Cretaceous Yezo Group of Hokkaido, northern Japan". English. In: Paleontological Research 12.4 (2008), pp. 421-425.

[16274] M. Murakami and Y. Koda. "The first Pliocene albireonid (Cetacea, Delphinoidea) periotic from the western North Pacific and paleobiogeographic signifcance of fossil delphinoid ear bones of Na-arai Formation of Choshi, Chiba, central Japan". English. In: Japan Cetology 23 (2013), pp. 1320.

[16275] M. Murakami, C. Shimada, Y. Hikida, and H. Hirano. "A new basal porpoise, Pterophocaena nishinoi (Cetacea, Odontoceti, Delphinoidea), from the Upper Miocene of Japan and its phylogenetic relationships". English. In: Journal of Vertebrate Paleontology 32.5 (2012), pp. 1157-1171.

[16276] M. Murakami, C. Shimada, Y. Hikida, and H. Hirano. "Two new extinct basal phocoenids (Cetacea, Odontoceti, Delphinoidea), from the Upper Miocene Koetoi Formation of Japan and their phylogenetic significance". English. In: Journal of Vertebrate Paleontology 32.5 (2012), pp. 11472-1185.

[16277] M. Murakami, C. Shimada, Y. Hikidad, Y. Soedae, and H. Hirano. "Eodelphis kabatensis, a new name for the oldest true dolphin Stenella kabatensis Horikawa, 1977 (Cetacea, Odontoceti, Delphinidae), from the upper Miocene of Japan, and the phylogeny and paleobiogeography of Delphinoidea". English. In: Journal of Vertebrate Paleontology 34.3 (2014), pp. 491-511. DOI: 10.1080 / 02724634.2013.816720.

[16278] M. Murakami, C. Shimada, Y. Hikida, and H. Hirano. "Asymmetrical Basal Delphinoid Skull from the Upper Lower Miocene Yamato Formation of Hokkaido, Northern Japan: Implications on Evolution Of Cranial Asymmetry and Symmetry in Odontoceti". English. In: Paleontological Research 18.3 (2014), pp. 134-149. DOI: 10.2517/2014PR013.

[16279] M. Murakami, C. Shimada, Y. Hikida, and H. Hirano. "New fossil remains from the Pliocene Koetoi Formation of northern Japan provide insights into growth rates and the vertebral evolution of porpoises". English. In: Acta Palaeontologica Polonica 60.1 (2015), pp. 97-111. DOI: 10.4202/app. 2012.0127.

[16280] D. J. E. Murdock, P. C. J. Donoghue, S. Bengtson, and F. Marone. “Ontogeny and microstructure of the enigmatic Cambrian tommotiid Sunnaginia Missarzhevsky, 1969". English. In: Palaeontology (2012), pp. 1-16.

[16281] D. J. E. Murdock, S. E. Gabbott, and M. A. Purnell. "The impact of taphonomic data on phylogenetic resolution: Helenodora inopinata (Carboniferous, Mazon Creek Lagerstätte) and the onychophoran stem lineage". English. In: BMC Evolutionary Biology 16.19 (2016), pp. 1-14.

[16282] X. Murelaga, B. Azanza, and H. Astibia. "Restos de quelonios del Mioceno medio del área de Tarazona de Aragón (Cuenca del Ebro, Aragón, España)". Spanish. In: Estudios Geológicos 62.1 (2006), pp. 205-212. 
[16283] X. Murelaga and J. I. Canudo. “Descripción de los restos de quelonios del Maastrichtiense superior de Aren y Serraduy (Huesca) [Description of chelonian remains from the Upper Maastrichtian of Aren and Seraduy (Huesca)]". English. In: Geogaceta 38 (2005), pp. 51-54.

[16284] X. Murelaga, F. Garcia Garmilla, and X. Pereda-Suberbiola. "Primeros restos de vertebrados del Cretácico superior de Quecedo de Valdivielso (Burgos): First vertebrate remains from the Upper Cretaceous of Quecedo de Valdivielso (Burgos)". Spanish. In: Geogaceta 37 (2005), pp. 195-198.

[16285] X. Murelaga, F. Lapparent de Broin, X. Pereda Xuberbiola, and H. Astibia. "Two new chelonian species from the Lower Miocene of the Ebro Basin (Bardenas Reales of Navarre)". English. In: Comptes Rendus de l'Academie des Sciences Series IIA Earth and Planetary Science 328.6 (1999), pp. 423429.

[16286] X. Murelaga, X. Pereda Xuberbiola, F. Lapparent de Broin, J. C. Rage, S. Duffaud, H. Astibia, and A. Badiola. "Amphibians and reptiles from the Early Miocene of the Bardenas Reales of Navarre (Ebro Basin, Iberian Peninsula)". English. In: Geobios 35 (2002), pp. 347-365.

[16287] P. C. Murphey and R. H. Dunn. "Hemiacodon engardae, a new species of omomyid primate from the earliest Uintan Turtle Bluff Member of the Bridger Formation, southwestern Wyoming, USA". English. In: Journal of Human Evolution 57.2 (2009), pp. 123-130.

[16288] P. C. Murphey and T. S. Kelly. “Mammals from the earliest Uintan (middle Eocene) Turtle Bluff Member, Bridger Formation, southwestern Wyoming, USA, Part 2: Apatotheria, Lipotyphla, Carnivoramorpha, Condylartha, Dinocerata, Perissodactyla and Artiodactyla". English. In: Palaeontologia Electronica 20.2.29A (2017).

[16289] P. C. Murphey, T. S. Kelly, K. R. Chamberlain, K. Tsukui, and W. C. Clyde. "Mammals from the earliest Uintan (middle Eocene) Turtle Bluff Member, Bridger Formation, southwestern Wyoming," English. In: Palaeontologia Electronica 21.2.25A (2018), pp. 1-52.

[16290] P. C. Murphey, L. L. Torick, E. S. Bray, R. Chandler, and E. Evanoff. “Taphonomy, Fauna, and Depositional Environment of the Omomys Quarry, an Unusual Accumulation From the Bridger Formation (Middle Eocene) of Southwestern Wyoming (USA)". English. In: Eocene Biodiversity: Unusual Occurrences and Rarely Sampled Habitats. Kluwer Academic/Plenum Publishers, 2001, pp. 361-402. DOI: 10.1007/978-1-4615-1271-4_15.

[16291] M. A. Murphy, P. U. Rodda, and P. G. Embree. “A new heteromorph ammonite from the Barremian (Cretaceous) of California". English. In: Journal of Paleontology 69.6 (1995), pp. 1179-1182. DOI: $10.1017 /$ S0022336000038166.

[16292] A. M. Murray. "A new Paleocene genus and species of percopsid, Massamorichthys wilsoni (Paracanthopterygii) from Joffre Bridge, Alberta, Canada". English. In: Journal of Vertebrate Paleontology 16.4 (1996), pp. 642-652.

[16293] A. M. Murray. "A new Eocene citharinoid fish (Ostariophysi: Characiformes) from Tanzania". English. In: Journal of Vertebrate Paleontology 23.3 (2003), pp. 501-507.

[16294] A. M. Murray, T. Argyriou, S. Cote, and L. MacLatchy. "The fishes of Bukwa, Uganda, a lower Miocene (Burdigalian) locality of East Africa". English. In: Journal of Vertebrate Paleontology 37.3 (2017). DOI: 10.1080/02724634.2017.1324460.

[16295] A. M. Murray and I. Hogör. "An early Oligocene elopiform fish from a new locality in Eastern Anatolia, Turkey". English. In: Journal of Vertebrate Paleontology 32.2 (2012), pp. 296-303. DOI: 10. 1080/02724634.2012.648248.

[16296] A. M. Murray, M. G. Newbrey, A. G. Neuman, and D. B. Brinkman. “New articulated osteoglossomorph from Late Cretaceous freshwater deposits (Maastrichtian, Scollard Formation) of Alberta, Canada". English. In: Journal of Vertebrate Paleontology (2016), pp. 1-14. DOI: 10.1080 / 02724634. 2016.1120737.

[16297] A. M. Murray, E. L. Simons, and Y. S. Attia. "A new clupeid fish (Clupeomorpha) from the Oligocene of Fayum, Egypt, with notes on some other fossil clupeomorphs". English. In: Journal of Vertebrate Paleontology 25.2 (2005), pp. 300-308. 
[16298] A. M. Murray and J. G. M. Thewissen. "Eocene actinopterygian fishes from Pakistan, with a description of a new genus and species of channid (Channiformes)". English. In: Journal of Vertebrate Paleontology 28.14 (2008), pp. 41-52. DOI: 10.1671/0272-4634(2008)28[41:EAFFPW]2.0.CO;2.

[16299] A. M. Murray and M. V. H. Wilson. "A new Late Cretaceous macrosemiid fish (Neopterygii, Halecostomi) from Morocco, with temporal and geographical range extensions for the family". English. In: Palaeontology 52.2 (2009), pp. 429-440.

[16300] A. M. Murray and M. V. H. Wilson. "Four new basal acanthomorph fishes from the Late Cretaceous of Morocco". English. In: Journal of Vertebrate Paleontology 34.1 (2014), pp. 34-48. DOI: 10.1080/02724634.2013.791693.

[16301] A. M. Murray and M. V. H. Wilson. “A new Palaeocene genus and species of percopsiform (Teleostei: Paracanthopterygii) from the Paskapoo Formation, Smoky Tower, Alberta". English. In: Canadian Journal of Earth Sciences 33 (1996), pp. 429-438.

[16302] A. M. Murray, H. L. You, and C. Peng. "A New Cretaceous Osteoglossomorph Fish from Gansu Province, China". English. In: Journal of Vertebrate Paleontology 30.2 (2010), pp. 322-332.

[16303] A. M. Murray, D. K. Zelenitsky, D. B. Brinkman, and A. G. Neuman. “Two new Palaeocene osteoglossomorphs from Canada, with a reassessment of the relationships of the genus +Joffrichthys, and analysis of diversity from articulated versus microfossil material". English. In: Zoological Journal of the Linnean Society (2018), pp. 1-8.

[16304] L. K. Murray, C. J. Bell, M. T. Dolan, and J. I. Mead. "Late Pleistocene fauna from the southern Colorado Plateau, Navajo County, Arizona". English. In: The Southwestern Naturalist 50.3 (2005), pp. 363-374.

[16305] M. S. Murray. "Prehistoric use of ringed seals: a zooarchaeological study from Arctic Canada". English. In: Environmental Archaeology 10 (2005), pp. 19-38.

[16306] P. Murray and D. Megirian. "Two new genera and three new species of Thylacinidae (Marsupialia) from the Miocene of the Northern Territory, Australia". English. In: The Beagle, Records of the Museums and Arl Galleries of the Northern Terrilory 16 (2000), pp. 145-162.

[16307] P. F. Murray. "The postcranial skeleton of the Miocene kangaroo, Hadronomas puckridgi Woodburne (Marsupialia, Macropodidae)". English. In: Alcheringa 19.1-2 (1995), pp. 119-170.

[16308] P. F. Murray and D. Megirian. "The Pwerte Marnte Marnte Local Fauna: a new vertebrate assemblage of presumed Oligocene age from the Northern Territory of Australia". English. In: Alcheringa 30.1 (2006), pp. 211-228. DOI: 10.1080/03115510609506864.

[16309] P. A. Murry and R. E. Kirby. A new hybodont shark from the Chinle and Bull Canyon formations, Arizona, Utah and New Mexico. English. Vol. 21. Upper Triassic Stratigraphy and Paleontology, New Mexico Museum of Natural History and Science Bulletin. 2002, pp. 87-106.

[16310] P. A. Murry, D. A. Winkler, and L. L. Jacobs. "An azhdarchid pterosaur humerus from the Lower Cretaceous Glen Rose Formation of Texas". English. In: Journal of Paleontology 65.1 (1991), pp. 167170.

[16311] B. Musavu Moussavou. "Albian bivalves from Madiela Formation in north Gabonese coastal basin". English. In: BSGF - Earth Sciences Bulletin 190.5 (2019), pp. 1-8. DOI: 10.1051/bsgf/2019006.

[16312] B. Musavu Moussavou. "Systematics, palaeoecology and taphonomy of Turonian oysters from the northern Gabon Coastal Basin”. English. In: Geodiversitas 39 (2017), pp. 213-224.

[16313] B. Musavu Moussavou and R. Mabicka Obame. "Taxonomy and paleoecology of Albian Madiela Formation gastropods, Gabonese coastal basin: N'Toum quarry section". English. In: Bulletin de la Société Géologique de France 186 (2015), pp. 35-42.

[16314] B. Musavu Moussavou and W. L. B. Mougola. "Bivalves et gastéropodes du Turonien du port d'Owendo dans le bassin cotier nord gabonais". French. In: Revue Sciences de la Vie, de la Terre et Agronomie du CAMES 4 (2016), pp. 26-35. 
[16315] B. Musavu Moussavou, S. M. Ndong Ondo, and M. M’Voubou. "Turonian bivalves from the Coastal Basin of Gabon, South of Libreville". English. In: Bulletin de l'Institut Scientifique, Rabat, Section Sciences de la Terre 35 (2013), pp. 1-8.

[16316] B. Musavu Moussavou, S. M. Ndong Ondo, and M. M’Voubou. “Les gastéropodes du Turonien de la coupe de Belle-vue 3 dans la région de Libreville Sud ausein du bassin cotier gabonais". French. In: Revue de Paléobiologie, Genéve 33 (2014), pp. 419-429.

[16317] B. Musavu Moussavou and M. Ngnibome Angoue. "Turonian gastropods from the Coastal Basin of Gabon: Gabon store section, South of Libreville". English. In: Bulletin de l'Institut Scientifique, Rabat, Section Sciences de la Terre 36 (2014), pp. 19-26.

[16318] B. Musavu Moussavou, U. G. Yakouya-Moubamba, A. C. Ayeng Eyeghe, and M. A. Mamidi. "Nouvelles données sur les macro-invertébrés du Turonien de la région de Libreville (bassin cotier nord-gabonais)". French. In: Annales de Paléontologie 103 (2017), pp. 283-292.

[16319] B. Musavu-Moussavou, T. Danelian, F. Baudin, R. Coccioni, and F. Fröhlich. "The Radiolarian biotic response during OAE2. A high resolution study across the Bonarelli Level at Bottaccione (Gubbio, Italy)". English. In: Revue de Micropaléontologie 50.3 (2007), pp. 253-287.

[16320] A. D. Muscente and W. D. Allmon. "Revision of the hydroid Plumalina Hall, 1858 in the Silurian and Devonian of New York". English. In: Journal of Paleontology 87.4 (2013), pp. 710-725. DOI: $10.1666 / 12-125$.

[16321] G. Muscio and F. M. D. Vecchia. "Reperti di odontoceti miocenici nelle collezioni del Museo Friulano di Storia Naturale (Udine)". English. In: Museologia Scientifica Memorie 13 (2014), pp. 56-58.

[16322] G. Musser and J. A. Clarke. "An Exceptionally Preserved Specimen From the Green River Formation Elucidates Complex". English. In: Frontiers in Ecology and Evolution 8.559929 (2020), pp. 1-18. DOI: 10.3389 /fevo.2020.559929.

[16323] H. A. Mustafa, G. R. Case, and I. S. Zalmout. "A new selachian fauna from the Wadi Umm Ghudran Formation (Late Creteceous) - Central Jordan”. English. In: N.Jb.Geol.Paläont.Abh 226.3 (2002), pp. 419-444.

[16324] P. Musteikis. "Silurian Brachiopod communities in the section of the Vilkaviskis-129 boring". Russian. In: Geologija 12.1991 (1991), pp. 47-65.

[16325] P. Musteikis and L. R. M. Cocks. "Strophomenide and orthotetide Silurian brachiopods from the Baltic region, with particular reference to Lithuanian boreholes". English. In: Acta Palaeontologica Polonica 49.3 (2004), pp. 455-482.

[16326] P. Musteikis and T. L. Modzalevskaya. "Some Silurian Brachiopods from Lithuania and their Palaeobiogeographical significance". English. In: Palaeontology 45.3 (2002), pp. 595-626.

[16327] G. E. Mustoe. "Eocene Bird, Reptile, and Mammal Tracks from the Chuckanut Formation, Northwest Washington". English. In: Palaios 17 (2002), pp. 403-413.

[16328] G. E. Mustoe, C. R. Harington, and R. E. Morlan. "Cedar Hollow, an Early Holocene faunal site from Whidbey Island, Washington". English. In: Western North American Naturalist 65.4 (2005), pp. 429-440.

[16329] R. J. Mutter. "Re-assessment of the genus Helmolepis Stensio 1932 (Actinopterygii: Platysiagidae) and the evolution of Platysiagids in the Early-Middle Triassic". English. In: Eclogae Geologicae Helvetiae 98 (2005), pp. 271-280.

[16330] R. J. Mutter, K. deBlanger, and A. G. Neuman. "Elasmobranchs from the Lower Triassic Sulphur Mountain Formation near Wapiti Lake (BC, Canada)". English. In: Zoological Journal of the Linnean Society 149 (2007), pp. 309-337.

[16331] R. J. Mutter and A. B. Heckert. "Re-investigation of enigmatic fish bones known as colobodontid/perleidid toothplates from the Upper Triassic Chinle Group (southwestern U.S.A.)" English. In: vol. 37. The Triassic-Jurassic Terrestrial Transition. New Mexico Museum of Natural History and Science Bulletin. Albuquerque: New Mexico Museum of Natural History and Science, 2006, pp. 530-542. 
[16332] R. J. Mutter and A. G. Neuman. "An enigmatic chondrichthyan with Paleozoic affinities from the Lower Triassic of western Canada". English. In: Acta Palaeontologica Polonica 51.2 (2006), pp. 271282.

[16333] R. J. Mutter and A. G. Neuman. "Recovery from the end-Permian extinction event: Evidence from Lilliput Listracanthus". English. In: Palaeogeography, Palaeoclimatology, Palaeoecology 284 (2009), pp. 22-28.

[16334] R. J. Mutter and A. G. Neuman. New eugeneodontid sharks from the Lower Triassic Sulphur Mountain Formation of western Canada. English. Vol. 295. Fishes and the Break-up of Pangaea. Geological Society, London, Special Publication. 2008, pp. 9-41.

[16335] R. J. Mutter and H. Rieber. "Pyknotylacanthus spathianus gen et sp nov, a new ctenacathoid from the Early Triassic of Bear Lake (Idaho, USA)". English. In: Revista Brasileira de Paleontologia 8.2 (2005), pp. 139-148.

[16336] J. Mutterlose, M. Mecklenbeck, and S. Rückheim. “Die Floren- und Faunenverteilung im UnterHauterive (Unter-Kreide) der Tongruben Heisterholz (NRW)". German. In: Geol. Paläont. Westf. 58 (2001), pp. 5-31.

[16337] H. Mutvei. "Connecting ring structure and its significance for classification of the orthoceratid cephalopods". English. In: Acta Palaeontologica Polonica 47.1 (2002), pp. 157-168.

[16338] H. Mutvei. "Siphuncular structure in Ordovician endocerid cephalopods". English. In: Acta Palaeontologica Polonica 42.3 (1997), pp. 375-390.

[16339] P. Muzzopappa. “Calyptocephalella (Anura, Australobatrachia) remains from Ro Santa Cruz (EarlyMiddle Miocene, Santa Cruz Formation), Santa Cruz Province, Argentina". English. In: vol. 19. Early-Middle Miocene Paleontology in the Ro Santa Cruz, Southern Patagonia, Argentina. 130 years since Ameghino, 1887 2. Publicacion Electronica de la Asociacion Paleontologica Argentina, 2019, pp. 48-54. DOI: 10.5710/PEAPA.27.06.2019.282.

[16340] P. Muzzopappa, A. G. Martinelli, J. P. Garderes, and G. W. Rougier. “Exceptional avian pellet from the Paleocene of Patagonia and description of its content: a new species of calyptocephalellid (Neobatrachia) anuran". English. In: Papers in Palaeontology (2020). DOI: 10.1002/spp2.1333.

[16341] E. V. Mychko. "A new species of trilobites from Sakmarian reefs of Bashkortostan". English. In: Paleontological Journal 46 (2012), pp. 44-48.

[16342] E. V. Mychko. "Revision of trilobites of the genus Paraphillipsia Tumanskaya from the Permian olistoliths of Crimea". English. In: Paleontological Journal 46 (2012), pp. 575-582. DOI: 10.1134 / S003103011206007X.

[16343] E. V. Mychko and O. V. Savchuk. "A new brachymetopid trilobite from the Early Permian Shakhtau reef complex of the southwestern Urals, Bashkortostan, Russia". English. In: Zootaxa 4555.3 (2019), pp. 346-358.

[16344] E. V. Mychko and K. K. Tarasenko. "The first finding of Basilosauridae (Mammalia: Cetacea)". English. In: Paleontological Journal 54.3 (2020), pp. 311-318.

[16345] R. Myczynski and M. Iturralde-Vinent. "The Late Lower Albian Invertebrate Fauna of the Ro Hatillo Formation of Pueblo Viejo, Dominican Republic". English. In: Caribbean Journal of Science 41.4 (2005), pp. 782-796.

[16346] T. Myers, K. Crosby, M. Archer, and M. Tyler. “The Encore Local Fauna, a late Miocene assemblage from Riversleigh, northwestern Queensland". English. In: Memoirs of the Association of Australian Paleontologists 25 (2001), pp. 147-154.

[16347] T. J. Myers and M. Archer. "Kuterintja ngama (Marsupiala, Ilariidae); a revised systematic analysis based on material from the late Oligocene of Riversleigh, northwestern Queensland". English. In: Memoirs of the Queensland Museum 41.2 (1997), pp. 379-392.

[16348] T. S. Myers. "A new ornithocheiroid pterosaur from the Upper Cretaceous (Cenomanian-Turonian) Eagle Ford Group of Texas”. English. In: Journal of Vertebrate Paleontology 30.1 (2010), pp. 280-287. 
[16349] T. S. Myers. "Earliest occurrence of the Pteranodontidae (Archosauria: Pterosauria) in North America: new material from the Austin Group of Texas". English. In: Journal of Paleontology 84 (2010), pp. 1071-1081.

[16350] T. S. Myers. "First North American occurrence of the toothed pteranodontoid pterosaur Cimoliopterus". English. In: Journal of Vertebrate Paleontology 25 (2015), e1014904. DOI: 10.1080/02724634. 2015.1014904.

[16351] T. S. Myers, M. J. Polcyn, O. Mateus, D. P. Vineyard, A. O. Goncalves, and L. J. Jacobs. “A new durophagous stem cheloniid turtle from the lower Paleocene of Cabinda, Angola". English. In: Papers in Palaeontology 4.2 (2018), pp. 161-176. DOI: 10.1002/spp2.1100.

[16352] G. Mynhardt and T. K. Philips. "A third new genus and species of spider beetle, Okamninus annae n. gen., n. sp. (Coleoptera: Ptinidae), from Dominican amber". English. In: Palaeodiversity 6 (2013), pp. 23-28.

[16353] A. Myrcha, P. Jadwiszczak, C. P. Tambussi, J. I. Noriega, A. Gazdzicki, A. Tatur, and R. A. del Valle. "Taxonomic revision of Eocene Antarctic penguins based on tarsometatarsal morphology". English. In: Polish Polar Research 23.1 (2002), pp. 5-46.

[16354] A. Myrcha, A. Tatur, and R. Del Valle. "A new species of fossil penguin from Seymour Island, West Antarctica". English. In: Alcheringa 14.3 (1990), pp. 195-205.

[16355] A. C. Myrick. "Thecachampsa antiqua (Leidy, 1852) (Crocodylidae: Thoracosaurinae) from fossil marine deposits at Lee Creek Mine, Aurora, North Carolina, USA". English. In: Smithsonian Contributions to Paleobiology 90 (2001), pp. 219-225.

[16356] P. M. Myrow. “Neoproterozoic rocks of the Newfoundland Avalon Zone”. English. In: Precambrian Research 73 (1995), pp. 123-136.

[16357] K. S. Myrvold, J. Milan, and J. A. Rasmussen. “Two new finds of turtle remains from the Danian and Selandian (Paleocene) deposits of Denmark with evidence of predation by crocodilians and sharks". English. In: Bulletin of the Geological Society of Denmark 66 (2018), pp. 211-218.

[16358] N. V. Myshkina and A. V. Zhuravlev. "A New Genus of Frasnian Polygnathid Conodonts". English. In: Paleontological Journal 39.1 (2005), pp. 57-61.

[16359] J. Myskowiak, D. Azar, and A. Nel. "The first fossil hilarimorphid fly (Diptera: Brachycera)". English. In: Gondwana Research 35 (2016), pp. 192-197.

[16360] J. Myskowiak, F. Escuillié, and A. Nel. "A new Osmylidae (Insecta, Neuroptera) from the Lower Cretaceous Crato Formation in Brazil". English. In: Cretaceous Research 54 (2015), pp. 27-33.

[16361] J. Myskowiak, R. Garrouste, and A. Nel. "A new genus and species of micro bee fly from the Earliest Eocene French amber (Diptera: Mythicomyiidae: Psiloderoidinae)". English. In: Zootaxa 4114 (2016), pp. 583-586.

[16362] J. Myskowiak, R. Garrouste, and A. Nel. "Eodromyia pumilio gen. et sp. nov., a new empidoid fly from the earliest Eocene amber of France (Diptera: Hybotidae: Tachydromiinae)". English. In: Zootaxa 4379 (2018), pp. 279-286.

[16363] J. Myskowiak, D. Y. Huang, D. Azar, C. Y. Cai, R. Garrouste, and A. Nel. “New lacewings (Insecta, Neuroptera, Osmylidae, Nymphidae) from the Lower Cretaceous Burmese amber and Crato Formation in Brazil". English. In: Cretaceous Research 59 (2016), pp. 214-227.

[16364] J. Myskowiak and A. Nel. "A new genus and species of ibis fly in the Lowermost Eocene amber of Oise (France) (Diptera: Athericidae)". English. In: Zootaxa 3869 (2014), pp. 372-382.

[16365] J. Myskowiak and A. Nel. “New antlion species (Insecta, Neuroptera, Palaeoleontidae) from the Lower Cretaceous Crato Formation in northeastern Brazil". English. In: Cretaceous Research 59 (2016), pp. 278-284.

[16366] J. Myskowiak, J. M. Pouillon, and A. Nel. "The oldest record of the grylloblattodean family Euryptilonidae discovered in the Late Carboniferous of France". English. In: Comptes Rendus Palevol 14 (2015), pp. 1-4. 
[16367] A. Mørk, G. Elvebakk, A. W. Forsberg, M. W. Hounslow, H. A. Nakrem, J. O. Vigran, and W. Weitschat. "The type section of the Vikinghøgda Formation: a new Lower Triassic unit in central and eastern Svalbard". In: Polar Research 18.1 (1999), pp. 51-82.

[16368] M. Nabozhenko, A. Kirejtshuk, and O. Merkl. "Yantaroxenos colydioides gen. et sp. nov. (Tenebrionidae, Lagriinae) from Baltic amber". English. In: Annales Zoologici 66 (2016), pp. 563-566.

[16369] M. Nabozhenko and A. Kirejtshuk. "The oldest opatrine terrestrial darkling beetle (Coleoptera: Tenebrionidae: Tenebrioninae) from the Paleocene of Menat (France)". English. In: PalZ 91 (2017), pp. 307-313.

[16370] M. V. Nabozhenko, A. Bukejs, and D. Telnov. "Gonialaenini, a new tribe of Lagriinae (Coleoptera: Tenebrionidae) from Eocene Baltic amber". English. In: Zootaxa 4565 (2019), pp. 253-260.

[16371] M. V. Nabozhenko, H. L. Chang, L. Xu, H. Y. Pu, and S. H. Jia. "A new species of comb-clawed beetle (Coleoptera: Tenebrionidae: Alleculinae) from the Lower Cretaceous of Yixian (China, Liaoning province)". English. In: Paleontological Journal 49 (2015), pp. 1420-1423.

[16372] M. V. Nabozhenko and I. A. Chigray. "New and little known species of Alleculini (Coleoptera: Tenebrionidae: Alleculinae): extinst from Eocene Baltic Amber and extant from Lebanon". English. In: Caucasian Entomological Bulletin 14 (2018), pp. 171-176.

[16373] M. V. Nabozhenko and A. G. Kirejtshuk. "Cryptohelops menaticus - a new genus and species of the tribe Helopini (Coleoptera: Tenebrionidae) from the Palaeocene of Menat (France)". English. In: Comptes Rendus Palevol 13 (2014), pp. 65-71.

[16374] M. V. Nabozhenko and A. G. Kirejtshuk. “The oldest Tenebrionidae (Coleoptera) of the subfamily Diaperinae and the tribe Scaphidemini from the Paleocene of Menat (France)". English. In: Acta Zoologica Academiae Scientiarum Hungaricae 66 (2020), pp. 23-33.

[16375] M. V. Nabozhenko, E. E. Perkovsky, and L. S. Chernei. "A new species of the genus Nalassus Mulsant (Coleoptera: Tenebrionidae: Helopini) from the Baltic amber". English. In: Paleontological Journal 50 (2016), pp. 947-952.

[16376] K. Nadein and E. Perkovsky. "New taxa of Chrysomelidae (Insecta: Coleoptera) from Rovno amber, Late Eocene". English. In: Acta Geologica Sinica 84 (2010), pp. 772-782.

[16377] K. S. Nadein, E. E. Perkovsky, and A. G. Moseyko. “New late Eocene Chrysomelidae (Insecta: Coleoptera) from Baltic, Rovno and Danish ambers". English. In: Papers in Palaeontology 2 (2016), pp. 117-137.

[16378] K. S. Nadein and E. E. Perkovsky. "A new tribe of Galerucinae leaf beetle (Insecta: Coleoptera: Chrysomelidae) from the Upper Cretaceous Taimyr amber". English. In: Cretaceous Research 84 (2017), pp. 97-106.

[16379] K. S. Nadein and E. E. Perkovsky. "Small and common: the oldest tropical Chrysomelidae (Insecta: Coleoptera) from the lower Eocene Cambay amber of India". English. In: Alcheringa 43 (2019), pp. 597-611. DOI: 10.1080/03115518.2019.1622780.

[16380] K. Nagasawa and Y. Mitani. "A humpback whale, Megaptera novaeangliae (Borowski, 1781), from the Pleistocene Kioroshi Formation of Inba-mura, Chiba Prefecture, central Japan". English. In: Paleontological Research 8.3 (2004), pp. 155-165.

[16381] P. Nagel. "New fossil paussids from Dominican amber with notes on the phylogenetic systematics of the paussine complex (Coleoptera: Carabidae)". English. In: Systematic Entomology 22 (1997), pp. 345-362.

[16382] J. Nagel-Myers, M. R. W. Amler, and R. T. Becker. "Vetupraeca n. gen. and Mucopraeca n. gen. (Cryptodonta, Bivalvia): a reappraisal of Late Devonian bivalves from the Hercynian Facies". English. In: Journal of Paleontology 82.6 (2008), pp. 1150-1160. DOI: 10.1666/07-138.1.

[16383] D. W. Nagorsen and G. Keddie. "Late Pleistocene mountain goats (Oreamnos americanus) from Vancouver Island: biogeographic implications". English. In: Journal of Mammalogy 81.3 (2000), pp. 666-675. 
[16384] M. Nagrodski, K. Shimada, and B. A. Schumacher. "Marine vertebrates from the Hartland Shale (Upper Cretaceous: Upper Cenomanian) in southeastern Colorado, USA". English. In: Cretaceous Research 37 (2012), pp. 76-88. DOI: 10.1016/j.cretres.2012.03.007.

[16385] D. Naish. "A small, unusual theropod (Dinosauria) femur from the Wealden Group (Lower Cretaceous) of the Isle of Wight, England". English. In: Neues Jahrbuch für Geologie und Paläontologie Monatshefte 2000.4 (2000), pp. 217-234.

[16386] D. Naish. "A definitive allosauroid (Dinosauria; Theropoda) from the Lower Cretaceous of East Sussex". English. In: Proceedings of the Geologists' Association 114 (2003), pp. 319-326.

[16387] D. Naish, G. Dyke, A. Cau, F. Escuillié, and P. Godefroit. "A gigantic bird from the Upper Cretaceous of Central Asia". English. In: Biology Letters 2012.8 (2012), pp. 97-100. DOI: 10.1098/rsbl. 2011.0683.

[16388] D. Naish, D. M. Martill, and E. Frey. "Ecology, systematics, and biogeographic relationships of dinosaurs, including a new theropod, from the Santana Formation (?Albian, Early Cretaceous) of Brazil". In: Historical Biology 2004 (2004), pp. 1-14.

[16389] D. Naish, D. M. Martill, D. Cooper, and K. A. Stevens. "Europe's largest dinosaur? A giant brachiosaurid cervical vertebra from the Wessex Formation (Early Cretaceous) of southern England". In: Cretaceous Research 25.6 (2004), pp. 787-795.

[16390] D. Naish and D. M. Martill. "Dinosaurs of Great Britain and the role of the Geological Society of London in their discovery: basal Dinosauria and Saurischia". English. In: Journal of the Geological Society, London 164 (2007), pp. 493-510.

[16391] D. Naish and D. M. Martill. "Dinosaurs of Great Britain and the role of the Geological Society of London in their discovery: Ornithischia". English. In: Journal of the Geological Society, London 165 (2008), pp. 613-623.

[16392] D. Naish, M. Simpson, and G. Dyke. "A new small-bodied azhdarchoid pterosaur from the Lower Cretaceous of England and its implications for pterosaur anatomy, diversity and phylogeny". English. In: PLoS One 8.3 (2013), e58451.

[16393] D. Naish and S. C. Sweetman. "A tiny maniraptoran dinosaur in the Lower Cretaceous Hastings Group: evidence from a new vertebrate-bearing locality in south-east England". English. In: Cretaceous Research 32 (2011), pp. 464-471. DOI: 10.1016/j.cretres.2011.03.001.

[16394] T. Nakagawa. "Miocene tropical sandy and rocky bottom molluscan assemblages of the Shimo Formation, Uchiura Group, Fukui Prefecture, Central Japan". English. In: Bulletin of the Mizunami Fossil Museum 35 (2009), pp. 127-151.

[16395] T. Nakagawa and Y. Sowa. "Crocodilian tooth from the Miocene Uchiura Group, in the western part of Fukui Prefecture, Central Japan". Japanese. In: Bulletin of the Mizunami Fossil Museum 37 (2011), pp. 189-191.

[16396] Y. Nakajima and R. R. Schoch. “The first temnospondyl amphibian from Japan”. English. In: Journal of Vertebrate Paleontology 31.5 (2011), pp. 1154-1157.

[16397] H. Nakamine and S. Yamamoto. "A new genus and species of thorny lacewing from Upper Cretaceous Kuji amber, northeastern Japan (Neuroptera, Rhachiberothidae)". English. In: ZooKeys 802 (2018), pp. 109-120.

[16398] H. Nakamine, S. Yamamoto, and Y. Takahashi. "Hidden diversity of small predators: new thorny lacewings from mid-Cretaceous amber from northern Myanmar (Neuroptera: Rhachiberothidae: Paraberothinae)". English. In: Geological Magazine 157 (2020), pp. 1149-1175. DOI: 10.1017/S0016756820000205.

[16399] E. Nakano, Y. Takahashi, H. Aiba, and T. Sato. "Cicada fossil from Nasushiobara city, Tochigi Prefecture". English. In: Bulletin of Tokyo Gakugei University, Division of Natural Sciences 70 (2018), pp. 55-61.

[16400] M. Nakatsukasa, M. Takai, and T. Setoguchi. "Functional morphology of the postcranium and locomotor behavior of Neosaimiri fieldsi, a Saimiri-like Middle Miocene platyrrhine". English. In: American Journal of Physical Anthropology 102.4 (1997), pp. 515-544. 
[16401] K. Nakazawa. "Permian bivalves from the H. S. Lee Formation, Malaysia”. English. In: Paleontological Research 6.1 (2002), pp. 67-72.

[16402] K. Nakazawa. "Permian bivalves from West Spitsbergen, Svalbard Islands, Norway". English. In: Paleontological Research 3.1 (1999), pp. 1-17.

[16403] K. Nakazawa. “Uppermost Permian bivalve fossils from the southern Kitakami Mountains”. Japanese. In: Earth Science (Chikyu Kagaku) 52 (1998), pp. 51-54.

[16404] K. Nakazawa. "Minute bivalve fossils from the Permian Akasaka Limestone, Central Japan, (Appendix) Description of a new species of Pernopecten". Japanese. In: Earth Science (Chikyu Kagaku) 61 (2007), pp. 187-201.

[16405] K. Nakazawa, R. L. Batten, S. Suzuki, and H. Uwada. "Permian and Triassic molluscan fossils from the Maizuru Zone, Okayama City, southwest Japan". Japanese. In: Okayama University Earth Science Reports 15 (2008), pp. 1-8.

[16406] T. Nakazawa. "Carboniferous reef succession of the Panthalassan open-ocean setting: Example from Omi Limestone, Central Japan”. In: Facies 44 (2001), pp. 183-210.

[16407] T. Nakazawa, T. Igawa, K. Ueno, and M. Fujikawa. "Middle Permian sponge-microencruster reefal facies in the mid-Panthalassan Akiyoshi atoll carbonates: observations on a limestone slab". English. In: Facies 61 (2015). DOI: 10.1007/s10347-015-0443-7.

[16408] H. A. Nakrem. "Bryozoans from the Lower Permian Voringen Member (Kapp Starostin Formation), Spitsbergen, Svalbard". English. In: Norsk Polarinstitutt Skrifter 196 (1994), pp. 1-93.

[16409] H. A. Nakrem. "Middle Carboniferous to Early Permian bryozoans from Spitsbergen". English. In: Acta Palaeontologica Polonica 39 (1994), pp. 45-116.

[16410] H. A. Nakrem, B. Baejowski, and A. Gadzicki. "Lower Permian bryozoans from southern and central Spitsbergen, Svalbard". English. In: Acta Palaeontologica Polonica 54 (2009), pp. 677-698.

[16411] H. A. Nakrem and A. Ernst. Arcticoporidae fam. nov. (Bryozoa, Trepostomata) from the Lower Triassic of Ellesmere Island (Canada) with remarks on some other Triassic bryozoans. English. 14th International Bryozoology Association Conference Volume. 2008, pp. 143-152.

[16412] H. A. Nakrem and A. Mork. "New early Triassic Bryozoa (Trepostomata) from Spitsbergen, with some remarks on the stratigraphy of the investigated horizons". In: Geological Magazine 128.2 (1991), pp. 129-140.

[16413] R. Nalin, D. Basso, and F. Massari. "Pleistocene coralline algal build-ups (corallige'ne de plateau) and associated bioclastic deposits in the sedimentary cover of Cutro marine terrace (Calabria, southern Italy)". English. In: Geological Society, London, Special Publications 255 (2006), pp. 11-22.

[16414] K. S. Nam. "Taxonomy and ecological implications of stonefly (Order: Plecoptera) nymphs from the Late Triassic Amisan Formation in the Boryeong region, Korea". other. In: Journal of the Korean Earth Science Society 38 (2017), pp. 293-302.

[16415] K. S. Nam and J. H. Kim. "Occurrence of the fossil Mesopsyche dobrokhotovae in the Late Triassic Amisan Formation, Nampo Group, Korea and its geological implication". other. In: Journal of the Korean Earth Science Society 35 (2014), pp. 161-167.

[16416] K. S. Nam and J. H. Kim. "Reconstruction and paleoecological implications of dragonfly Hemeroscopus baissicus Pritykina, 1977 (Hemeroscopidae) from the Lower Cretaceous Jinju Formation in the Jinju Area, Korea". other. In: Journal of the Geological Society of Korea 52 (2016), pp. 105-112.

[16417] K. S. Nam, Y. Wang, D. Ren, J. H. Kim, and J. Szwedo. "An extraordinary palaeontinid from the Triassic of Korea and its significance". English. In: Scientific Reports 7.40691 (2017), pp. 1-6. DOI: $10.1038 /$ srep40691.

[16418] K.-S. Nam and M. V. Nazarkin. “Fossil Prowfish, Zaprora koreana, sp. nov. (Pisces, Zaproridae), from the Neogene of South Korea". English. In: Journal of Vertebrate Paleontology 38.e1514616 (2019), pp. 1-5. DOI: 10.1080/02724634.2018.1514616.

[16419] A. C. Nanda and A. Sahni. "Oligocene vertebrates from Ladakh Molasse group, Ladakh: palaeobiogeographic implications". English. In: Journal of Himalayan Geology 1 (1990), pp. 1-10. 
[16420] A. C. Nanda and A. Sahni. "Ctenodactyloid rodent assemblage from Kargil Formation, Ladakh Molasse Group". English. In: Geobios 31.4 (1998), pp. 533-544.

[16421] G. M. Narbonne. "New Ediacaran fossils from the Mackenzie Mountains, northwestern Canada". In: Journal of Paleontology 68.3 (1994), pp. 411-416.

[16422] G. M. Narbonne. "Modular construction of early Ediacaran complex life forms". English. In: Science 305 (2004), pp. 1141-1144.

[16423] G. M. Narbonne and J. G. Gehling. "Life after snowball: The oldest complex Ediacaran fossils". English. In: Geology 31.1 (2003), pp. 27-30.

[16424] G. M. Narbonne, M. Laflamme, C. Greentree, and P. Trusler. "Reconstructing a lost world: Ediacaran rangeomorphs from Spaniard's Bay, Newfoundland". English. In: Journal of Paleontology 83.4 (2009), pp. 503-523.

[16425] G. Narboone and J. Aitken. "Ediacaran fossils from the Sekwi Brock Area, Mackenzie Mountains, Northwestern Canada". In: Palaeontology 33.4 (1990), pp. 945-980.

[16426] E. Nardin. "New specimens of Lingulocystis Thoral, 1935 (Eocrinoidea, Blastozoa) from the Arenig (Lower Ordovician) of Montagne noire (southern France): Intraspecific morphological variability, stratigraphic, and palaeoecological implications". English. In: Annales de Paléontologie 93.3 (2007), pp. 199-214. DOI: 10.1016/j.annpal.2007.06.004.

[16427] E. Nardin, E. Almazán-Vásquez, and B. E. Buitrón-Sánchez. "First report of Gogia (Eocrinoidea, Echinodermata) from the Early-Middle Cambrian of Sonora (Mexico), with biostratigraphical and palaeoecological comments". English. In: Geobios 42 (2009), pp. 233-242. DOI: 10.1016/j.geobios. 2008.10.003.

[16428] E. Nardin and J. Bohatý. "A new pleurocystitid blastozoan from the Middle Devonian of the Eifel (Germany) and its phylogenetic importance". English. In: Acta Palaeontologica Polonica 58.3 (2013), pp. 533-544. DOI: 10.4202/app.2011.0116.

[16429] E. Nardin, B. Lefebvre, O. Fatka, M. Nohejlová, L. Kaika, M. Sinágl, and M. Szabad. “Evolutionary implications of a new transitional blastozoan echinoderm from the middle Cambrian of the Czech Republic". English. In: Journal of Paleontology 91.4 (2017), pp. 672-684. DOI: 10.1017/jpa.2016.157.

[16430] K. Narkiewicz and P. Bultynck. "Conodont biostratigraphy of shallow marine Givetian deposits from the Radom-Lublin area, SE Poland". English. In: Geological Quarterly 51.4 (2007), pp. 419-442.

[16431] I. Narváez, C. A. Brochu, F. Escaso, A. Pérez-Garca, and F. Ortega. “New Crocodyliforms from Southwestern Europe and Definition of a Diverse Clade of European Late Cretaceous Basal Eusuchians". English. In: PLoS ONE 10.11 (2015), e0140679:1-34. DOI: 10.1371/journal.pone.0140679.

[16432] I. Narváez, C. A. Brochu, F. Escaso, A. Perez-Garca, and F. Ortega. “New Spanish Late Cretaceous eusuchian reveals the synchronic and sympatric presence of two allodaposuchids". English. In: Cretaceous Research 65 (2016), pp. 112-125.

[16433] P. L. Narváez, N. Mego, and M. B. Prámparo. "Cretaceous cicatricose spores from north and central-western Argentina. Taxonomic and biostratigraphic discussion". English. In: Palynology 37 (2012), pp. 1-15. DOI: 10.1080/01916122.2012.762062.

[16434] P. L. Narváez and I. F. Sabino. "Palynology of the Las Curtiembres Formation (Late Cretaceous, Salta Group Basin), Las Conchas Creek area, northwestern Argentina". English. In: Ameghiniana 45.2 (2008), pp. 473-482.

[16435] J. S. O. Nascimento, É V. Oliveira, and J. L. L. Silva. “Taxonomy and paleoenvironmental inferences from fossil vertebrates of". English. In: Journal of South American Earth Sciences 99 (2020), 102491:112.

[16436] P. M. Nascimento and H. Zaher. "A new species of Baurusuchus (Crocodyliformes, Mesoeucrocodylia) from the Upper Cretaceous of Brazil, with the first complete postcranial skeleton described for the family Baurusuchidae". English. In: Papéis Avulsos de Zoologia 50.21 (2010), pp. 323361. 
[16437] N. L. Nasif. “Nuevo material de Eumysopinae (Echimyidae, Rodentia) de la formacion Andalhuala (Terciario superior), Valle de Santa maria, provincia de Catamarca, Argentina". Spanish. In: Ameghiniana 35.1 (1998), pp. 3-6.

[16438] N. L. Nasif, G. I. Esteban, and P. E. Ortiz. “Novedoso hallazgo de egagrópilas en el Mioceno tardo, Formación Andalhuala, provincia de Catamarca, Argentina". Spanish. In: Serie correlación geológica 22.2 (2009).

[16439] N. L. Nasif, S. Musalem, and E. Cerdeño. "A new toxodont from the late Miocene of Catamarca, Argentina, and a phylogenetic analysis of the Toxodontidae". English. In: Journal of Vertebrate Paleontology 30.3 (2000), pp. 591-600.

[16440] T. T. Nath, P. Yadagiri, and A. K. Moitra. "First record of armoured dinosaur from the Lower Jurassic Kota Formation, Pranhita-Godavari Valley, Andhra Pradesh". English. In: Journal of the Geological Society of India 59.6 (2002), pp. 575-577.

[16441] S. V. Naugolnykh. "Permian floral assemblages of Kozhim section (Pechora Fore-Ural), their age and taxonomic composition". English. In: GEOS. Abstracts and proceedings, Vakhrameev memorial conference (1996), pp. 49-54.

[16442] S. V. Naugolnykh. "Vetlugospermum and Vetlugospermaceae: A new genus and family of peltasperms from the Lower Triassic of Moscow syneclise (Russia)". English. In: Geobios 45 (2012), pp. 451-462. DOI: 10.1016/j.geobios.2011.10.009.

[16443] S. V. Naugolnykh. "Upper Permian flora of Vjazniki (European part of Russia), its Zechstein appearance, and the nature of the Permian/Triassic extinction". English. In: New Mexico Museum of Natural History and Science Bulletin 30 (2005), pp. 226-242.

[16444] S. V. Naugolnykh. "Lower Kungurian shallow-water lagoon biota of middle Cis-Urals, Russia: towards paleoecological reconstruction". English. In: Global Geology 20 (2017), pp. 1-13. DOI: 10. 3969/j.issn.1673-9736.2017.01.0.

[16445] W. R. Nava and A. G. Martinelli. "A new squamate lizard from the Upper Cretaceous Adamantina Formation (Bauru Group), São Paulo State, Brazil". English. In: Anais da Academia Brasileira de Ciencias 83.1 (2011), pp. 291-299.

[16446] C. Navarrete, G. Casal, and R. Martnez. "Drusilasaura deseadensis gen. et sp. nov., un nuevo titanosaurio (Dinosauria-Sauropoda), de la Formacon Bajo Barreal, Cretácico Superior del norte de Santa Cruz, Argentina [Drusilasaura deseadensis gen. et sp. nov., a new titanosaur (DinosauriaSauropoda), from the Bajo Barreal Formation, Upper Cretaceous of the north of Santa Cruz, Argentina]". Spanish. In: Revista Brasileira de Paleontologia 14.1 (2011), pp. 1-14. DOI: 10.4072 / rbp. 2011.1.01.

[16447] V. Navarro, M. Reolid, J. M. Molina, and P. A. Ruiz-Ortiz. "Slope breccias colonized by bivalves and serpulids during the Middle Jurassic (Subbetic, SE Spain)". English. In: Facies 54 (2008), pp. 403415.

[16448] D. Navarro-Santillan, F. Sour-Tovar, and E. Centeno-Garca. "Lower Mississippian (Osagean) brachiopods from the Santiago Formation, Oaxaca, Mexico: stratigraphic and tectonic implications". English. In: Journal of South American Earth Sciences 15.3 (2002), pp. 327-336.

[16449] B. G. Naylor and R. C. Fox. "A new ambystomatid salamander, Dicamptodon antiquus n.sp., from the Paleocene of Alberta, Canada". English. In: Canadian Journal of Earth Sciences 30 (1993), pp. 814818.

[16450] V. Y. Nazarenko, A. A. Legalov, and E. E. Perkovsky. “A new species of the genus Caulophilus Woll. (Coleoptera: Curculionidae: Cossoninae) from the Rovno amber". English. In: Paleontological Journal 45.3 (2011), pp. 287-290.

[16451] V. Y. Nazarenko and E. E. Perkovsky. "A new genus and species of dryophthorid weevils (Coleoptera, Dryophthoridae: Stromboscerinae) from the Rovno amber". English. In: Paleontological Journal 43.9 (2009), pp. 1097-1100. 
[16452] V. Y. Nazarenko and E. E. Perkovsky. "A new species of Derelomine weevils (Coleoptera, Curculionidae, Curculioninae: Acalyptini) from the Rovno amber". English. In: Paleontological Journal 50 (2016), pp. 991-996.

[16453] M. V. Nazarkin. "The fossil viperfish Chauliodus testa sp. nov. (Stomiiformes: Stomiidae) from the Neogene of western Sakhalin, Russia". English. In: Paleontological Journal 48.3 (2014), pp. 317-325.

[16454] M. V. Nazarkin. “Fossil Bristlemouth Cyclothone mukhachevae sp. nov. (Stomiiformes: Gonostomatidae) from the Neogene of Western Sakhalin, Russia". English. In: Paleontological Journal 49.2 (2015), pp. 162-175.

[16455] M. V. Nazarkin. "Cenozoic fossil fishes of the extinct alepisauroid family Polymerichthyidae from the Sakhalin Island, Russia". English. In: Acta Palaeontologica Polonica 61.4 (2016), pp. 829-829. DOI: 10.4202/app.00247.2016.

[16456] M. V. Nazarkin. “Tubesnout Aulichthys miocaenicus sp. nov. from the Miocene of Sakhalin Island (Russia): the First Reliable Fossil Record for the Family Aulorhynchidae". English. In: Paleontological Journal 53.5 (2019), pp. 522-529.

[16457] M. V. Nazarkin and A. F. Bannikov. "Fossil mackerel (Actinopterygii: Scombridae: Scomber) from". English. In: Zoosystemica Rossica 23.1 (2014), pp. 158-163.

[16458] M. V. Nazarkin and G. Carnevale. "A Miocene Pearleye, Benthalbella praecessor, sp. nov. (Teleostei, Aulopiformes), from Sakhalin Island, Russia: The First Known Skeletal". English. In: Journal of Vertebrate Paleontology 38.e1511992 (2019), pp. 1-12. DOI: 10.1080/02724634.2018.1511992.

[16459] M. V. Nazarkin and T. P. Malyshkina. "The first reliable record of selachians from the Neogene deposits of Sakhalin Island". English. In: Zoosystemica Rossica 21.1 (2012), pp. 180-184.

[16460] M. V. Nazarkin and L. A. Nesov. "A new species of Myctophidae from Miocene deposits of Karaginskiy Island (Bering Sea)". English. In: Journal of Ichthyology 35.8 (1995), pp. 24-32.

[16461] D. A. Nazaruddin and A. R. Othman. “Geoheritage Conservation of Paleontological Sites in Aring Area, Gua Musang District, Kelantan, Malaysia". English. In: International Journal on Advanced Science, Engineering and Information Technology 4.1 (2014), pp. 14-19.

[16462] T. Neagu and P. Cirnaru. "Lower Aptian agglutinated foraminifera from the Southern Dobrogea and SE part of the Moesian Platform". English. In: Acta Palaeontologica Romaniae 4 (2004), pp. 277297.

[16463] E. H. Nearns and M. A. Branham. "A new species of Plectromerus Haldeman (Coleoptera: Cerambycidae) from Dominican amber with notes on the fossil Plectromerus tertiarius Vitali". English. In: Zootaxa 1088 (2005), pp. 17-24.

[16464] J. Nebelsick, D. Bassi, and K. Drobne. "Microfacies analysis and palaeoenvironmental interpretation of Lower Oligocene, shallow-water carbonates (Gornji Grad beds, Slovenia)". In: Facies 43 (2000), pp. 157-176.

[16465] J. H. Nebelsick, D. Bassi, and J. Lempp. “Tracking paleoenvironmental changes in coralline algaldominated carbonates of the Lower Oligocene Calcareniti di Castelgomberto formation (Monti Berici, Italy)". English. In: Facies 59 (2013), pp. 133-148.

[16466] J. M. Neenan, N. Klein, and T. M. Scheyer. "European origin of placodont marine reptiles and the evolution of crushing dentition in Placodontia". English. In: Nature Communications (2013). DOI: $10.1038 /$ ncomms2633.

[16467] J. M. Neenan and T. M. Scheyer. "New specimen of Psephoderma alpinum (Sauropterygia, Placodontia) from the Late Triassic of Schesaplana Mountain, Graubünden, Switzerland". English. In: Swiss Journal of Geosciences 107.2-3 (2014), pp. 349-357. DOI: 10.1007/s00015-014-0173-9.

[16468] M. H. Negra, B. H. Purser, and A. M'Rabet. Sedimentation, diagenesis and syntectonic erosion of Upper Cretaceous rudist mounds in central Tunisia. English. Vol. 23. in C. L. V. Monty, D. W. J. Bosence, P. H. Bridges and B. R. Pratt, eds., Carbonate mud-mounds. Special Publication of the International Association of Sedimentologists. 1995, pp. 401-419. 
[16469] M. H. Negra and M. F. Zagrarni. Upper Cretaceous tempestites in rudist-rich facies, Tunisia. English. Vol. 87. Cretaceous rudists and carbonate platforms: environmental feedback, SEPM Special Publication. 2007, pp. 45-56.

[16470] F. R. Negri and J. Ferigolo. "Urumacotheriinae, Nova Subfamlia de Mylodontidae (Mammalia, Tardigrada) do Mioceno Superior-Plioceno, América do Sul". English. In: Revista Brasileira de Paleontologia 7.2 (2004), pp. 281-288.

[16471] O. P. Negrobov and O. V. Selivanova. "A new species of the genus Amesorhaga (Diptera, Dolichopodidae) from the Baltic amber". English. In: Paleontological Journal 37 (2003), pp. 280-286.

[16472] R. H. Nehm. "Neogene paleontology in the northern Dominican Republic. Part 21. The Genus Prunum (Gastropoda: Marginellidae)". English. In: Bulletins of American Paleontology 359 (2001), pp. 1-46.

[16473] L. V. Nekhorosheva. "Paleozoic bryozoa from Severnaya Zemlya (Russian Arctic)". English. In: Geodiversitas 24 (2002), pp. 317-327.

[16474] A. Nel. "A new Odonata family from the Jurassic of central Asia (Odonata: Epiproctophora)". English. In: Journal of Natural History 43.1-2 (2009), pp. 57-64.

[16475] A. Nel. "Redescription de la Libellule fossile du Jurassique supérieur ? Malmagrion eichstaettense (Hagen, 1862) (Odonatoptera, Odonata, Archizygoptera)". French. In: Bulletin de la Société Entomologique de France 96.5 (1991), pp. 433-442.

[16476] A. Nel. "New and poorly known Cenozoic sawflies of France (Hymenoptera, Tenthredinoidea, Pamphilioidea)". English. In: Deutsche Entomologische Zeitschrift 2 (2004), pp. 253-269.

[16477] A. Nel. "Oldest records of Bombyliidae: Phthiriinae and Mythicomyiidae: Glabellulinae from the Lowermost Eocene amber of France (Diptera: Bombylioidea)". English. In: European Journal of Entomology 103.1 (2006), pp. 109-114.

[16478] A. Nel. “The oldest bee fly in the French Paleocene (Diptera: Bombyliidae)". English. In: Comptes Rendus Palevol 7 (2008), pp. 401-405.

[16479] A. Nel. "Oldest representatives of the Sphecidae: Trypoxylini in the early Eocene French amber (Insecta: Hymenoptera)". English. In: Comptes Rendus Palevol 4 (2005), pp. 17-24.

[16480] A. Nel. "Descriptions et révisions de trois Siricidae fossiles du Cénozoque (Hymenoptera)". French. In: Bulletin de la Société Entomologique de France 96.3 (1991), pp. 247-253.

[16481] A. Nel. “Nouveaux insectes neuroptérodes fossiles de l'Oligocéne de France (Neuroptera et Megaloptera)". French. In: Bulletin du Muséum National d'Histoire Naturelle. Section C, Sciences de la Terre, Paléontologie, Géologie, Minérologie 12 (1991), pp. 327-349.

[16482] A. Nel. "Essai de révision des Berytidae fossiles (Heteroptera, Pentatomorpha)". French. In: Bulletin du Muséum National d'Histoire Naturelle. Section C, Sciences de la Terre, Paléontologie, Géologie, Minérologie 14 (1992), pp. 275-287.

[16483] A. Nel. "Nouveaux Raphidioptéres fossiles du Cénozoque de France et d'Espagne". French. In: École Pratique des Hautes Études, Biologie et Évolution des Insectes 6 (1993), pp. 99-108.

[16484] A. Nel. “Un nouvel odonate fossile du miocéne de Bellver de Cerdana (Espagne) (Odonata, Libellulidae)". French. In: Entomologica Gallica 2 (1991), pp. 129-130.

[16485] A. Nel. "Nouveaux Tingidae fossiles du Cénozoque de France (Heteroptera)". French. In: École Pratique des Hautes Études, Biologie et Évolution des Insectes 5 (1992), pp. 97-104.

[16486] A. Nel. "Un Tettigarctidae fossile du Lias européen (Cicadomorpha, Cicadoidea, Tettigarctidae)". French. In: École Pratique des Hautes Études, Biologie et Évolution des Insectes 9 (1996), pp. 83-94.

[16487] A. Nel. "Le premier représentant fossile du genre Ibalia dans le Miocéne supérieur du Cantal (France) (Hymenoptera, Cynipoidea)". French. In: Bulletin de la Société Entomologique de France 101 (1996), pp. 141-143.

[16488] A. Nel. "A new Mesozoic-aged rhagionemestriid fly (Diptera: Nemestrinoidea) from China". English. In: Zootaxa 2645 (2010), pp. 49-54. 
[16489] A. Nel, V. Albouy, C. Caussanel, and C. Jamet. "Réflexion paléo-entomologique sur la systématique des Dermaptéres. Quatre nouveaux forficules fossiles de l'Oligocéne de Provence (France)". French. In: Bulletin de la Société Entomologique de France 99 (1994), pp. 253-266.

[16490] A. Nel, C. Aria, R. Garrouste, and A. Waller. "Evolution and palaeosynecology of the Mesozoic earwigs (Insecta: Dermaptera)". English. In: Cretaceous Research 33 (2012), pp. 189-195.

[16491] A. Nel and A. Arillo. “The first Baltic amber dysagrionine damselfly (Odonata: Zygoptera: Thaumatoneuridae: Dysagrioninae)". English. In: Annales de la Société Entomologique de France 42 (2006), pp. 179-182.

[16492] A. Nel, A. Arillo, and X. Martnez-Delclós. "New fossil Odonata (Insecta) from the upper Miocene of France and Spain (Anisoptera and Zygoptera)". English. In: Neues Jahrbuch für Geologie und Paläontologie, Abhandlungen 199 (1996), pp. 167-219.

[16493] A. Nel, A. Arillo, and V. M. Ortuño. “New western Palaearctic Cenozoic Odonata (Zygoptera and Anisoptera)". English. In: Bulletin de la Société Entomologique de France 102 (1997), pp. 265-270.

[16494] A. Nel and F. Auvray. "The oldest Vespinae from the Paleocene of Menat (France) (Hymenoptera: Vespidae)". English. In: Zootaxa 1344 (2006), pp. 59-62.

[16495] A. Nel, D. Azar, X. Martnez-Delclós, and E. Makhoul. “A new Upper Cretaceous species of Chresmoda from Lebanon - a latest representative of Chresmodidae (Insecta: Polyneoptera inc. sed. ) : first record of homeotic mutations in the fossil record of insects". English. In: European Journal of Entomology 101 (2004), pp. 145-151.

[16496] A. Nel, D. Azar, and S. Hervet. "A new rhopalosomatid wasps in the Paleocene of France (Hymenoptera)". English. In: Annales de la Société Entomologique de France 46 (2010), pp. 211-215.

[16497] A. Nel and D. Azar. "The oldest parasitic Scelionidae: Teleasinae (Hymenoptera: Platygastroidea)". English. In: Polskie Pismo Entomologiczne 74 (2005), pp. 333-338.

[16498] A. Nel, D. Azar, and D. Y. Huang. "A new Middle Jurassic Chinese fossil clarifies the systematic composition of the Heterophlebioptera (Odonata: Trigonoptera)". English. In: Alcheringa 39 (2014), pp. 130-134.

[16499] A. Nel, G. Bechly, and X. Martnez-Delclós. "A new genus and species of Aeschnidiidae (Insecta: Odonata: Anisoptera) from the Solnhofen Limestone, Upper Jurassic, Germany". English. In: Senckenbergiana Lethaea 76 (1996), pp. 175-179.

[16500] A. Nel, G. Bechly, X. Martinz-Delclos, and G. Fleck. "A new family of Anisoptera from the Upper Jurassic of Karatau in Kazakhstan (Insecta: Odonata: Juragomphidae n. fam)". English. In: Stuttgarter Beiträge zur Naturkunde Serie B (Geologie und Paläontologie) 314 (2001), pp. 1-9.

[16501] A. Nel, G. Bechly, R. Garrouste, B. Pohl, and F. Escuillié. “A new extraordinary neuropterid family from the Lower Cretaceous Crato Formation of Brazil: a new insect order? (Insecta, Neuropterida)". English. In: Cretaceous Research 26 (2005), pp. 845-852.

[16502] A. Nel, G. Bechly, E. Jarzembowski, and X. Martnez-Delclós. "A revision of the fossil petalurid dragonflies (Insecta: Odonata: Anisoptera: Petalurida)". English. In: Paleontologia Lombarda 10 (1998), pp. 1-68.

[16503] A. Nel, G. Bechly, X. Delclós, and D. Y. Huang. “New and poorly known Mesozoic damseldragonflies (Odonata: Isophlebioidea: Campterophlebiidae, Isophlebiidae)". English. In: Palaeodiversity 2 (2009), pp. 209-232.

[16504] A. Nel, G. Bechly, J. Prokop, O. Béthoux, and G. Fleck. "Systematics and evolution of Paleozoic and Mesozoic damselfly-like Odonatoptera of the Protozygopteran grade". English. In: Journal of Paleontology 86.1 (2012), pp. 81-104.

[16505] A. Nel, G. Bechly, and X. Martnez-Delclós. "A new fossil dragonfly from the Upper Jurassic in Germany (Odonata, Anisoptera, Protolindeniidae)". English. In: Revue Française d'Entomologie (N.S.) 23 (2001), pp. 257-261. 
[16506] A. Nel, O. Béthoux, G. Bechly, X. Martinez-Delclos, and F. Papier. “The Permo-Triassic Odonatoptera of the Protodonate grade (Insecta: Odonatoptera)". English. In: Annales de la Société Entomologique de France 37.4 (2001), pp. 501-525.

[16507] A. Nel and P. Blot. "Paléoentomologie de la paléotufiére éocéne de Sézanne (Marne, France) (Insecta Odonata, Trichoptera, Hemiptera, Diptera)". French. In: Entomologica Gallica 2.1 (1990), pp. 26-31.

[16508] A. Nel and E. Bourguet. "Termite of the early Eocene amber of France (Isoptera: Mastotermitidae, Kalotermitidae)". English. In: Neues Jahrbuch für Geologie und Paläontologie, Monatshefte 2006 (2006), pp. 101-115.

[16509] A. Nel and P. Brisac. "Découverte du premier Calopteryx fossile du Miocéne de l'Ardéche (Odonata, Calopterygidae)". French. In: Bulletin de la Société Entomologique de France 99.1 (1994), pp. 27-30.

[16510] A. Nel and D. Coty. “A fossil dung midge in Mexican amber (Diptera: Scatopsidae)". English. In: Palaeontologia Electronica 19.2.22A (2016), pp. 1-6.

[16511] A. Nel, G. de Plöeg, J. Dejax, D. Duthiel, D. de Franceschi, E. Gheerbrant, M. Godinot, S. Hervet, J. -J. Menier, M. Augé, G. Bignot, C. Cavagnetto, S. Duffaud, J. Gaudant, S. Hua, A. Jossang, F. de Lapparent de Broin, J. -P. Pozzi, J. -C. Paicheler, F. Beuchet, and J. -C. Rage. “Un gisement sparnacien exceptionnel á plantes, arthropodes et vertébrés (Éocéne basal, MP7): Le Quesnoy (Oise, France)". French. In: Comptes Rendus de l'Académie des Sciences - Series IIA - Earth and Planetary Science 329.1 (1999), pp. 65-72.

[16512] A. Nel and G. De Ploeg. "New fossil bee flies (Diptera: Bombylioidea) in the Lowermost Eocene amber of the Paris Basin". English. In: Geologica Acta 2.1 (2004), pp. 57-65.

[16513] A. Nel, G. de Ploëg, and V. Perrichot. "The first ibis fly in mid-Cretaceous amber of France (Diptera: Athericidae)". English. In: Zootaxa 3768 (2014), pp. 591-595.

[16514] A. Nel, X. Delclos, and A. Hutin. "Mesozoic chrysopid-like Planipennia: a phylogenetic approach (Insecta: Neuroptera)". English. In: Annales de la Société Entomologique de France 41 (2005), pp. 2969.

[16515] A. Nel and E. Delfosse. "A new Chinese Mesozoic stick insect". English. In: Acta Palaeontologica Polonica 56.2 (2011), pp. 429-432.

[16516] A. Nel, E. Delfosse, T. Robillard, and J. F. Petruleviius. “An early winged crown group stick insect from the Early Eocene amber of France (Insecta, Phasmatodea)". English. In: Systematic Entomology 35 (2010), pp. 340-346.

[16517] A. Nel, R. A. DePalma, and M. S. Engel. "A possible hemiphlebiid damselfly in Late Cretaceous amber from South Dakota (Odonata: Zygoptera)". English. In: Transactions of the Kansas Academy of Science 113 (2010), pp. 231-234.

[16518] A. Nel, M. S. Engel, J. Huang, L. B. Jia, T. Su, and T. Wappler. “Leaf-mimicking katydids from the Middle Miocene of Yunnan, southwestern China (Orthoptera: Tettigoniidae)". English. In: PalZ 94 (2020), pp. 255-261. DOI: 10.1007/s12542-019-00488-5.

[16519] A. Nel and F. Escuillé. "A new dragonfly from the Lower Cretaceous of Brazil". English. In: Palaeontology 37.4 (1994), pp. 923-930.

[16520] A. Nel and F. Escuillé. “Découverte d'un nouveau genre de Sieblosiidae dans le Miocéne supérieur de l'Ardéche (France) (Odonata, Zygoptera, Lestoidea, Sieblosiidae)". French. In: Nouvelle Revue d'Entomologie (N.S.) 10 (1993), pp. 233-242.

[16521] A. Nel, F. Escuillie, and R. Garrouste. "A new scoliid wasp in the Early Cretaceous Crato Formation in Brazil (Hymenoptera: Scoliidae)". English. In: Zootaxa 3717 (2013), pp. 395-400.

[16522] A. Nel, G. Fleck, R. Garrouste, G. Gand, J. Lapeyrie, S. M. Bybee, and J. Prokop. “Revision of Permo-Carboniferous griffenflies (Insecta: Odonatoptera: Meganisoptera) based upon new species and redescription of selected poorly known taxa from Eurasia". English. In: Palaeontographica Abteilung A 289.4-6 (2009), pp. 89-121. 
[16523] A. Nel and G. Fleck. "A new genus and species of Sieblosiidae from the Middle Miocene of Germany (Odonata: Epiproctophora)". English. In: Zootaxa 3582 (2012), pp. 64-68.

[16524] A. Nel and G. Fleck. "Dragonflies and damselflies (Insecta: Odonata) from the Late Eocene of the Isle of Wight". English. In: Earth and Environmental Science Transactions of the Royal Society of Edinburgh 104 (2014), pp. 283-306.

[16525] A. Nel, G. Fleck, G. Garcia, B. Gomez, P. Ferchaud, and X. Valentin. “New dragonflies from the lower Cenomanian of France enlighten the timing of the odonatan turnover at the Early - Late Cretaceous boundary". English. In: Cretaceous Research 52 (2015), pp. 108-117.

[16526] A. Nel, G. Gand, and J. Garric. "A new family of Odonatoptera from the continental Upper Permian: The Lapeyriidae (Lodéve Basin, France)". English. In: Geobios 32.1 (1999), pp. 63-72.

[16527] A. Nel, G. Gand, G. Fleck, O. Bethoux, J. Lapeyrie, and J. Garric. "Saxonagrion minutus nov. gen. et sp., The oldest Damselfly from the Upper Permian of France (Odonatoptera, Panodonata, Saxonagrionidae nov. fam)". English. In: Geobios 32.6 (1999), pp. 883-888.

[16528] A. Nel, G. Gand, J. Garric, and J. Lapeyrie. “The first recorded Protozygopteran Insects from the Upper Permian of France". English. In: Palaeontology 42.1 (1999), pp. 83-97.

[16529] A. Nel, R. Garrouste, and P. Roques. "A new griffenfly genus from the Late Carboniferous of northern France (Odonatoptera: Meganeuridae)". English. In: Insect Systematics E Evolution 39 (2008), pp. 231-239.

[16530] A. Nel, R. Garrouste, and J. Prokop. “The first African Anthracoptilidae (Insecta: Paoliida) near the Permian-Triassic boundary in Kenya". English. In: Zootaxa 3925 (2015), pp. 145-150.

[16531] A. Nel, R. Garrouste, and C. Daugeron. "Two new long-legged flies in the Santonian amber of France (Diptera: Dolichopodidae)". English. In: Cretaceous Research 69 (2016), pp. 1-5.

[16532] A. Nel, M. Gross, and M. S. Engel. "First fossil occurrence of the jewel damselflies (Odonata: Chlorocyphidae): a new species from the Late Miocene of Styria, Austria". English. In: Annales de la Société Entomologique de France 53 (2017), pp. 280-285.

[16533] A. Nel and M. Henrotay. “Les Chrysopidae Mésozoques. État actuel des connaissances. Description d'un nouveau genre et nouvelle espéce dans le Jurassique inférieur (Lias) (Insecta: Neuroptera)". French. In: Annales de la Société Entomologique de France 30 (1994), pp. 295-318.

[16534] A. Nel and M. Henrotay. "Les Protomyrmeleontidae (Odonatoptera, Odonata, Archizygoptera stat. rest.): état actuel des connaissances". French. In: Annales de Paléontologie 78 (1992), pp. 1-47.

[16535] A. Nel and D. Y. Huang. "A new Mesozoic Chinese genus of aeshnopteran dragonflies (Odonata: Anisoptera: Progobiaeshnidae)". English. In: Comptes Rendus Palevol 9 (2010), pp. 141-145.

[16536] A. Nel, D. Y. Huang, and Q. B. Lin. "A new genus of isophlebioid damsel-dragonflies with calopterygidlike wing shape from the Middle Jurassic of China (Odonata: Isophlebioidea: Campterophlebiidae)". English. In: European Journal of Entomology 105 (2008), pp. 783-787.

[16537] A. Nel and D. Y. Huang. "First Chinese Cymatophlebiidae from the Middle Jurassic of Inner Mongolia (Odonata: Anisoptera: Aeshnoptera)". English. In: Palaeodiversity 2 (2009), pp. 199-204.

[16538] A. Nel and D. Y. Huang. "A new genus and species of damsel-dragonfly (Odonata: Stenophlebiidae) from the Lower Cretaceous of Inner Mongolia, China". English. In: Cretaceous Research 56 (2015), pp. 421-425.

[16539] A. Nel and D. Y. Huang. "A new family of 'libelluloid' dragonflies from the Middle Jurassic of Daohugou, northeastern China (Odonata: Anisoptera: Cavilabiata)". English. In: Alcheringa 39 (2015), pp. 525-529.

[16540] A. Nel and E. Jarzembowski. "New fossil Sisyridae and Nevrorthidae (Insecta: Neuroptera) from Eocene Baltic amber and Upper Miocene of France". English. In: European Journal of Entomology 94 (1997), pp. 287-294.

[16541] A. Nel and E. A. Jarzembowski. “Description and revison of some dragonflies ('Anisozygoptera') from the Lower Cretaceous of England (Odonata : Stenophlebiidae , Campterophlebiidae? , Epiophlebiidae , Euthemistidae)". English. In: Cretaceous Research 17 (1996), pp. 87-96. 
[16542] A. Nel and E. A. Jarzembowski. "New protomyrmeleontid dragonflies from the Lower Cretaceous of southern England (Insecta, Odonata, Archizygoptera)". English. In: Cretaceous Research 19 (1998), pp. 393-402.

[16543] A. Nel and E. A. Jarzembowski. "Fossil damselflies and dragonflies (Insecta: Odonata) from the late Upper Eocene of southern England". English. In: Proceedings of the Geologists' Association 110 (1999), pp. 193-201.

[16544] A. Nel and E. A. Jarzembowski. "New lacewings from the Insect Bed (late Eocene) of the Isle of Wight (Neuroptera: Nemopteridae, Chrysopidae, Hemerobiidae)". English. In: Earth and Environmental Science Transactions of the Royal Society of Edinburgh 110 (2019), pp. 397-403. DOI: 10.1017/ S1755691018000476.

[16545] A. Nel, W. Krzemiski, and J. Szwedo. "Elektroeuphaea gen. n., the oldest representative of the modern Epallaginae from Eocene Baltic amber (Odonata: Zygoptera: Epallagidae)". English. In: Insect Systematics \& Evolution 44 (2013), pp. 129-140.

[16546] A. Nel, J. Lapeyrie, and R. Garrouste. "The first European representative of the South American family Xenopteraidae (Insecta: Megasecoptera) discovered in the Guadalupian of Lodéve (France)". English. In: Alcheringa 43 (2019), pp. 436-440. DOI: 10.1080/03115518.2019.1597162.

[16547] A. Nel, F. Marchal-Papier, O. Béthoux, and J. C. Gall. "A stick insect-like from the Triassic of the Vosges (France) (pre-Tertiary Phasmatodea)". English. In: Annales de la Société Entomologique de France 40.1 (2004), pp. 31-36.

[16548] A. Nel, V. Marie, and S. SchmeiSSner. "Revision of the Lower Mesozoic dragonfly family Triassolestidae Tillyard, 1918 (Odonata: Epiproctophora)". English. In: Annales de Paléontologie 88 (2002), pp. 189-214.

[16549] A. Nel and X. Martnez-Delclós. “Nuevos Zygoptera y Anisoptera (Insecta: Odonata) en el Cretacico inferior de Espana". Spanish. In: Estudios Geológicos 49 (1993), pp. 351-359.

[16550] A. Nel, X. Martnez-Delclós, J. C. Paicheler, and M. Henrotay. “Les Anisozygoptera fossiles Phylogenie et classification (Odonata)". French. In: Martinia 3 (1993), pp. 1-311.

[16551] A. Nel, X. Martnez-Delclós, F. Escuillé, and P. Brisac. "Les Aeshnidae fossiles: Etat actuel des connaissances (Odonata, Anisoptera)". French. In: Neues Jahrbuch für Geologie und Paläontologie, Abhandlungen 194.2/3 (1994), pp. 143-186.

[16552] A. Nel, X. Martnez-Delclós, F. Papier, and J. Oudard. "New Tertiary Fossil Odonata from France (Sieblosiidae, Lestidae, Coenagrionidae, Megapodagrionidae, Libellulidae)". English. In: Deutsche Entomologische Zeitschrift 44.2 (1997), pp. 231-258.

[16553] A. Nel, X. Martnez-Delclós, A. Arillo, and E. Peñalver. "A review of the European fossil species of the bee Apis". English. In: Palaeontology 42 (1999), pp. 243-285.

[16554] A. Nel, X. Martnez-Delclós, and D. Azar. “A new ensign-fly from the Lower-Middle Miocene Dominican amber (Hymenoptera, Evaniidae)". English. In: Bulletin de la Société Entomologique de France 107 (2002), pp. 217-221.

[16555] A. Nel and X. Martnez-Delclós. "Essai de Révision des Aeschnidioidea (Insecta, Odonata, Anisoptera)". French. In: Cahiers de Paléontologie 1993 (1993), pp. 7-99.

[16556] A. Nel, J. Menier, G. De Ploeg, G. Hodebert, and L. Danvin. "Eosialis, a new aldery genus in French Lowermost Eocene amber (Insecta, Megaloptera, Sialidae)". English. In: Geobios 35 (2002), pp. 313-319.

[16557] A. Nel, J. J. Menier, A. Waller, G. Hodebert, and G. de Ploëg. “New fossil spongilla-flies from the lowermost Eocene amber of France (Insecta, Neuroptera, Sisyridae)". English. In: Geodiversitas 25 (2003), pp. 109-117.

[16558] A. Nel, J. J. Menier, and G. De Plöeg. "The oldest representative of Trichomyiinae from the lowermost Eocene amber of the Paris basin (France) (Diptera: Psychodidae)". English. In: Annales de la Société Entomologique de France 38 (2002), pp. 247-252. 
[16559] A. Nel, J. Nel, and C. Balme. “Un nouveau Lépidoptére Satyrinae fossile de l'Oligocéne du Sud-Est de la France (Insecta, Lepidoptera, Nymphalidae)". French. In: Linneana Belgica 14 (1993), pp. 20 36.

[16560] A. Nel, P. Nel, R. Krieg-Jacquier, J. M. Pouillon, and R. Garrouste. "Exceptionally preserved insect fossils in the Late Jurassic lagoon of Orbagnoux (Rhone Valley, France)". English. In: PeerJ 2.e510 (2014), pp. 1-16. DOI: 10.7717 / peerj.510.

[16561] A. Nel, D. Neraudeau, V. Perrichot, V. Girard, and B. Gomez. “A new dragonfly family from the Upper Cretaceous of France". English. In: Acta Palaeontologica Polonica 53.1 (2008), pp. 165-168.

[16562] A. Nel and J. C. Paicheler. "Les Lestoidea (Odonata, Zygoptera) fossiles: Un inventaire critique". French. In: Annales de Paléontologie 80.1 (1994), pp. 1-59.

[16563] A. Nel and J. C. Paicheler. "Les Odonata fossiles: état actuel des connaissances. Huitiéme partie: Les Calopterygoidea fossiles (Odonata, Zygoptera)". French. In: Bulletin de la Societe Entomologique de France 97.4 (1993), pp. 381-396.

[16564] A. Nel and J. C. Paicheler. "Les Gomphidae fossiles, un inventaire critique (Odonata: Gomphidae)". French. In: Annales de la Société Entomologique de France 30 (1994), pp. 55-77.

[16565] A. Nel and J. C. Paicheler. “Les Isoptera fossiles. État actuel des connaissances, implications paléoécologiques et paléoclimatologiques (Insecta, Dictyoptera)". French. In: Cahiers de Paléontologie 1993 (1993), pp. 102-179.

[16566] A. Nel and J. C. Paicheler. "Les Heteroptera aquatiques fossiles, état actuel des connaissances (Heteroptera: Nepomorpha et Gerromorpha)". French. In: Entomologica Gallica 3 (1992), pp. 159182.

[16567] A. Nel and J. C. Paicheler. "Les Heteroptera aquatiques fossiles, état actuel des connaissances (Heteroptera: Nepomorpha et Gerromorpha) (suite)". French. In: Entomologica Gallica 4 (1993), pp. 15-21.

[16568] A. Nel and J. C. Paicheler. "Les Heteroptera aquatiques fossiles, état actuel des connaissances (Heteroptera: Nepomorpha et Gerromorpha) (suite et fin)". French. In: Entomologica Gallica 4 (1993), pp. 79-89.

[16569] A. Nel and J. C. Paicheler. "Les Libellulidae fossiles. Un inventaire critique (Odon., Anisoptera, Libelluloidea)". English. In: Entomologica Gallica 4 (1993), pp. 166-190.

[16570] A. Nel and M. Papazian. "Les Coenagrionoidea fossiles de l'Oligocéne du sud-est de la France (Zygoptera: Platycnemididae, Coenagrionidae)". French. In: Odonatologica 19 (1990), pp. 251-262.

[16571] A. Nel, F. Papier, L. Grauvogel-Stamm, and J. C. Gall. Voltzialestes triasicus gen. nov., sp. nov., le premier Odonata Protozygoptera du Trias inférieur des Vosges (France). French. Vol. 5. Paleontologia Lombarda. 1997, pp. 25-36.

[16572] A. Nel, G. Perrault, V. Perrichot, and D. Néraudeau. "The oldest ant in the Lower Cretaceous amber of Charente-Maritime (SW France) (Insecta: Hymenoptera: Formicidae)". English. In: Geologica Acta 2.1 (2004), pp. 23-29.

[16573] A. Nel, Z. Perreau, and G. Doitteau. "The oldest representative of the modern snipe fly genus Symphoromyia (Diptera: Rhagionidae)". English. In: Zootaxa 4196 (2016), pp. 144-150.

[16574] A. Nel, V. Perrichot, and D. Azar. "New and poorly known fossil Coniopterygidae in Cretaceous and Cenozoic ambers (Insecta: Neuroptera)". English. In: Annales Zoologici 55 (2005), pp. 1-7.

[16575] A. Nel, V. Perrichot, C. Daugeron, and D. Néraudeau. "A new Microphorites in the Lower Cretaceous amber of the southwest of France (Diptera: Dolichopodidae, Microphorinae)". English. In: Annales de la Société Entomologique de France 40 (2004), pp. 23-29.

[16576] A. Nel, V. Perrichot, and D. Néraudeau. "The oldest trigonalid wasp in the Late Albian amber of Charente-Maritime (SW France) (Hymenoptera, Trigonalidae)". English. In: Eclogae Geologicae Helvetiae 96 (2003), pp. 503-508. 
[16577] A. Nel, V. Perrichot, D. Azar, and D. Néraudeau. “New Rhachiberothidae (Insecta: Neuroptera) in Early Cretaceous and Early Eocene ambers from France and Lebanon". English. In: Neues Jahrbuch für Geologie und Paläontologie, Abhandlungen 235 (2005), pp. 51-85.

[16578] A. Nel and J. Petruleviius. "New Palaeogene bees from Europe and Asia". English. In: Alcheringa 27 (2003), pp. 277-293. DOI: 10.1080/03115510308619108.

[16579] A. Nel and J. F. Petruleviius. "A new genus and species of damsel-dragonfly from the Early Liassic of Germany (Odonata, Liassophlebiidae)". English. In: Bulletin de la Société Entomologique de France 110.2 (2005), pp. 185-188.

[16580] A. Nel, J. F. Petruleviius, G. Gentilini, and X. Martnez-Delclós. "Phylogenetic analysis of the Cenozoic family Sieblosiidae (Insecta: Odonata), with description of new taxa from Russia, Italy and France". English. In: Geobios 38 (2005), pp. 219-233.

[16581] A. Nel, J. F. Petruleviius, and X. Martnez-Delclós. “New Mesozoic Protomyrmeleontidae (Insecta: Odonatoptera: Archizygoptera) from Asia with a new phylogenetic analysis". English. In: Journal of Systematic Palaeontology 3.2 (2005), pp. 187-201.

[16582] A. Nel and J. F. Petruleviius. "Afrotropical and Nearctic genera of Odonata in the French Oligocene: biogeographic and paleoclimatic implications (Insecta: Calopterygidae, Aeshnidae)". English. In: Annales de la Société Entomologique de France 46.1-2 (2010), pp. 228-236.

[16583] A. Nel, J. F. Petruleviius, and M. Henrotay. "New Early Jurassic sawflies from Luxembourg: the oldest record of Tenthredinoidea (Hymenoptera: Symphyta)". English. In: Acta Palaeontologica Polonica 49.2 (2004), pp. 283-288.

[16584] A. Nel, J. F. Petruleviius, and E. A. Jarzembowski. "New fossil Odonata from the European Cenozoic (Insecta: Odonata: Thaumatoneuridae, Aeshnidae, Idionychidae, Libellulidae)". English. In: Neues Jahrbuch für Geologie und Paläontologie, Abhandlungen 235.3 (2005), pp. 343-380.

[16585] A. Nel and Y. A. Popov. "The oldest known fossil Hydrometridae from the Lower Cretaceous of Brazil (Heteroptera: Gerromorpha)". English. In: Journal of Natural History 34 (2000), pp. 23152322.

[16586] A. Nel and M. J. Poschmann. "A new stem Orthoptera (Archaeorthoptera: Oedischioidea) from the Early Permian of the Saar-Nahe basin, southwest Germany". English. In: Geobios 63 (2020), pp. 47-52. DOI: 10.1016/j.geobios.2020.10.001.

[16587] A. Nel, M. J. Poschmann, and S. Wedmann. "New dragonflies and damselflies (Odonata) from the late Oligocene of Enspel (Rhineland-Palatinate, SW Germany)". English. In: Palaeontologia Electronica 23.3.a59 (2020), pp. 1-24.

[16588] A. Nel and J. M. Pouillon. "The third skimmer dragonfly species from the Lower Cretaceous (Aptian) Crato Formation in NE Brazil (Odonata, Cavilabiata, Araripelibellulidae)". English. In: Cretaceous Research 115.104565 (2020). DOI: 10.1016/j.cretres.2020.104565.

[16589] A. Nel, J. Prokop, G. De Ploeg, and J. Millet. “New Psocoptera (Insecta) from the lowermost Eocene Amber of Oise, France". English. In: Journal of Systematic Palaeontology 3.4 (2005), pp. 371-391.

[16590] A. Nel and J. Prokop. "New fossil gall midges from the earliest Eocene French amber (Insecta, Diptera, Cecidomyiidae)". English. In: Geodiversitas 28.1 (2006), pp. 37-54.

[16591] A. Nel, J. Prokop, and A. J. Ross. “New genus of leaf-mimicking katydids (Orthoptera: Tettigoniidae) from the Late Eocene-Early Oligocene of France and England". English. In: Comptes Rendus Palevol 7 (2008), pp. 211-216.

[16592] A. Nel, J. Prokop, P. Nel, P. Grandcolas, D. Y. Huang, P. Roques, E. Guilbert, O. Dostál, and J. Szwedo. "Traits and evolution of wing venation pattern in paraneopteran insects". English. In: Journal of Morphology 273 (2012), pp. 480-506.

[16593] A. Nel and J. Prokop. “New fossil Scelionidae (Insecta: Hymenoptera) in early Paleogene amber from eastern Moravia (Czech Republic) and northern France". English. In: Polskie Pismo Entomologiczne 74 (2005), pp. 339-347. 
[16594] A. Nel and J. Prokop. “New Paleogene Scatopsidae (Diptera: Nematocera) in amber from the Czech Republic and France". English. In: Acta Societatis Zoologicae Bohemicae 68 (2004), pp. 91-98.

[16595] A. Nel, J. Prokop, P. Grandcolas, R. Garrouste, J. Lapeyrie, F. Legendre, L. N. Anisyutkin, and A. G. Kirejtshuk. "The beetle-like Palaeozoic and Mesozoic roachoids of the so-called umenocoleoid lineage (Dictyoptera: Ponopterixidae fam. nov.)" English. In: Comptes Rendus Palevol 13 (2014), pp. 545-554.

[16596] A. Nel, P. Roques, P. Nel, J. Prokop, and J. S. Steyer. “The earliest holometabolous insect from the Carboniferous: a crucial innovation with delayed success (Insecta Protomeropina Protomeropidae)". English. In: Annales de la Société Entomologique de France 43.3 (2007), pp. 349-355.

[16597] A. Nel, P. Roques, P. Nel, A. A. Prokin, T. Bourgoin, J. Prokop, J. Szwedo, D. Azar, L. DesutterGrandcolas, T. Wappler, R. Garrouste, D. Coty, D. Y. Huang, M. S. Engel, and A. G. Kirejtshuk. "The earliest known holometabolous insects". English. In: Nature 503 (2013), pp. 257-261.

[16598] A. Nel, P. Roques, J. Prokop, and R. Garrouste. “A new, extraordinary'damselfly-like' Odonatoptera from the Pennsylvanian of the Avion locality in Pas-de-Calais, France (Insecta: 'Exopterygota')". English. In: Alcheringa 43 (2019), pp. 241-245. DOI: 10.1080/03115518.2018.1489561.

[16599] A. Nel and R. Roy. "Revision of the fossil mantid and ephemerid species described by Piton from the Palaeocene of Menat (France) (Mantodea: Chaeteessidae, Mantidae; Ensifera: Tettigonioidea)". English. In: European Journal of Entomology 93 (1996), pp. 223-234.

[16600] A. Nel, Y. Séméria, and R. G. Martins-Neto. “Un Raphidioptera fossile du Cretace inferieur du Bresil (Neuropteroidea)". French. In: Neuroptera International 6.1 (1990), pp. 27-37.

[16601] A. Nel, N. Simov, V. Bozukov, and M. Marinov. “New dragonflies and damselflies from Middle Miocene deposits in SW Bulgaria (Insecta: Odonata)". English. In: Palaeontologia Electronica 19.3.35A (2016), pp. 1-13.

[16602] A. Nel and J. Skartveit. "Occurrence of the genus Hesperinus Walker (Diptera, Hesperinidae) in the Oligocene of France". English. In: Studia Dipterologica 18 (2012), pp. 85-89.

[16603] A. Nel and A. Waller. "The first fossil Compsocidae from Cretaceous Burmese amber (Insecta, Psocoptera, Troctomorpha)". English. In: Cretaceous Research 28 (2007), pp. 1039-1041.

[16604] A. Nel, A. Waller, and G. de Ploég. "The oldest fossil Tingidae from the lowermost Eocene amber of the Paris Basin (Heteroptera: Cimicomorpha: Tingoidea)". English. In: Geologica Acta 2 (2004), pp. 37-43.

[16605] A. Nel, A. Waller, and G. De Ploeg. "The oldest fossil piesmatid bug in the Lowermost Eocene amber of the Paris Basin (Heteroptera: Lygaeoidea: Piesmatidae)". English. In: Geologica Acta 2.1 (2004), pp. 45-50.

[16606] A. Nel, A. Waller, and G. De Ploeg. "The oldest palm bug in the Lowermost Eocene amber of the Paris Basin (Heteroptera: Cimicomorpha: Thaumastocoridae)". English. In: Geologica Acta 2.1 (2004), pp. 51-55.

[16607] A. Nel, A. Waller, and G. De Ploeg. "An aulacid wasp in the Lowermost Eocene amber from the Paris Basin (Hymenoptera: Aulacidae)". English. In: Geologica Acta 2.1 (2004), pp. 67-74.

[16608] A. Nel, A. Waller, V. Albouy, J. -J. Menier, and G. De Plöeg. “New fossil earwigs from the lowermost Eocene amber of Paris basin (France) (Insecta, Dermaptera, family incertae sedis)". English. In: Geodiversitas 25.1 (2003), pp. 119-129.

[16609] A. Nel, A. Waller, and G. O. Poinar. "The first fossil Myopsocidae (Psocoptera) in Dominican amber". English. In: Zootaxa 1349 (2006), pp. 63-68.

[16610] A. Nel, A. Waller, G. Hodebert, and G. De Plöeg. "An ensign-fly in the lowermost Eocene amber from the Paris basin (Hymenoptera: Evaniidae)". English. In: Annales de la Société Entomologique de France 38 (2002), pp. 263-269.

[16611] A. Nel and R. Weis. "A new Early Jurassic damselfly from the Grand Duchy of Luxembourg (Odonata: Campterophlebiidae)". English. In: Alcheringa 41 (2017), pp. 378-382. 
[16612] A. Nel, M. Zarbout, G. Barale, and M. Philippe. “Liassotettigarcta africana sp. n. (Auchenorrhyncha: Cicadoidea: Tettigarctidae), the first Mesozoic insect from Tunisia". English. In: European Journal of Entomology 95 (1998), pp. 593-598.

[16613] P. Nel, D. Azar, and A. Nel. "A new 'primitive' family of thrips from Early Cretaceous Lebanese amber (Insecta, Thysanoptera)". English. In: Cretaceous Research 28 (2007), pp. 1033-1038.

[16614] P. Nel, D. Azar, J. Prokop, P. Roques, G. Hodebert, and A. Nel. "From Carboniferous to Recent: wing venation enlightens evolution of thysanopteran lineage". English. In: Journal of Systematic Palaeontology 10 (2012), pp. 385-399.

[16615] P. Nel, E. Peñalver, D. Azar, G. Hodebert, and A. Nel. "Modern thrips families Thripidae and Phlaeothripidae in Early Cretaceous amber (Insecta: Thysanoptera)". English. In: Annales de la Société Entomologique de France 46 (2010), pp. 154-163.

[16616] P. Nel, A. P. Retana-Salazar, D. Azar, A. Nel, and D. Y. Huang. "Redefining the Thripida (Insecta: Paraneoptera)". English. In: Journal of Systematic Palaeontology 12 (2014), pp. 865-878. DOI: 10.1080/ 14772019.2013.841781.

[16617] P. Nel, A. R. Schmidt, C. Bässler, and A. Nel. “Fossil thrips of the family Uzelothripidae suggest 53 million years of morphological and ecological stability". English. In: Acta Palaeontologica Polonica 58 (2013), pp. 609-614.

[16618] A. Nelms, A. P. McIntosh, and K. Shimada. "Fossil fishes from the Jetmore Chalk Member (Lower Turonian) of the Upper Cretaceous Greenhorn Limestone in north-central Kansas". English. In: Transactions of the Kansas Academy of Science 117 (2014), pp. 245-252.

[16619] M. D. Nelson and M. D. Uhen. "First occurrence of a squalodelphinid (Cetacea, Odontoceti) from the early Miocene of Washington State". English. In: Journal of Vertebrate Paleontology (2018). DOI: 10.1080/02724634.2017.1428197.

[16620] M. D. Nelson and M. D. Uhen. "A new platanistoid, Perditicetus yaconensis gen." English. In: Journal of Systematic Paleontology (2020). DOI: 10.1080/14772019.2020.1783379.

[16621] M. E. Nelson and D. M. Miller. "A Pliocene record of the giant marmot, Paenemarmota sawrockensis, in northern Utah". English. In: Contributions to Geology, University of Wyoming 28.1 (1990), pp. 31-37.

[16622] P. G. Nemkov. "A New Wasp Genus of the Tribe Gorytini from the Oligocene of the Primor'skiy Region". English. In: Paleontological Journal 24.4 (1990), pp. 123-125.

[16623] I. Nengo, P. Tafforeau, G. C. Gilbert, J. G. Fleagle, E. R. Miller, C. Feibel, D. L. Fox, J. Feinberg, K. D. Pugh, C. Berruyer, S. Mana, Z. Engle, and F. Spoor. "New infant cranium from the African Miocene sheds light on ape evolution". English. In: Nature 548 (2017), pp. 169-174.

[16624] I. O. Nengo and T. C. Rae. "New hominoid fossils from the early Miocene site of Songhor, Kenya". English. In: Journal of Human Evolution 23.5 (1992), pp. 423-429.

[16625] D. Néraudeau, R. Allain, V. Perrichot, B. Videt, F. de Lapparent de Broin, F. Guillocheau, M. Philippe, J. -C. Rage, and R. Vullo. "Découverte d'un dépot paralique á bois fossiles, ambre insectifére et restes d'Iguanodontidae (Dinosauria, Ornithopoda) dans le Cénomanien inférieur de Fouras (Charente-Maritime, Sud-Ouest de la France)". French. In: Comptes Rendus Palevol 2 (2003), pp. 221-230.

[16626] D. Néraudeau, R. Allain, M. Ballévre, D. J. Batten, E. Buffetaut, J. P. Colin, M. P. Dabard, V. Daviero-Gomez, A. El Albani, B. Gomez, D. Grosheny, J. Le Loeuff, A. Leprince, C. Martn-Closas, E. Masure, J. -M. Mazin, M. Phillipe, J. Pouech, H. Tong, J. F. Tournepiche, and R. Vullo. "The Hautevarian-Barremian lignitic bone bed of Angeac (Charente, south-west France): stratigraphical, palaeobiological and palaeogeographical implications". English. In: Cretaceous Research 37.1 (2012), pp. 1-14. DOI: 10.1016/j.cretres.2012.01.006.

[16627] D. Néraudeau and G. Breton. "Astérides du Cénomanien de Charente-Maritime (SW France)". French. In: Géobios 26.1 (1993), pp. 105-120. 
[16628] D. Néraudeau and P. Courville. "Cenomanian and Turonian echinoids from Nigeria". English. In: Geobios 30.6 (1997), pp. 835-847.

[16629] D. Néraudeau, A. Crame, and M. Kooser. "Upper Cretaceous echinoids from James Ross Basin, Antarctica". English. In: Géobios 33.4 (2000), pp. 455-466.

[16630] D. Néraudeau, B. David, and M. S. Al-Muallem. "The Cretaceous echinoids from central Saudi Arabia". English. In: Neues Jahrbuch für Geologie und Paläontologie, Abhandlungen 197 (1995), pp. 399424.

[16631] D. Néraudeau and P. Moreau. "Paléoécologie et paléobiogéographie des faunes d'échinides du Cénomanien nord-aquitain (Charente-Maritime, France)". French. In: Géobios 22.3 (1996), pp. 293324.

[16632] D. Neraudeau, V. Perrichot, J. -P. Colin, V. Girard, B. Gomez, F. Guillocheau, E. Masure, D. Peyrot, F. Tostain, B. Videt, and R. Vullo. "A new amber deposit from the Cretaceous (uppermost Albianlowermost". English. In: Cretaceous Research 29 (2008), pp. 925-929. DOI: 10.1016/j.cretres.2008.05. 009.

[16633] D. Néraudeau, R. Vullo, B. Gomez, V. Perrichot, and B. Videt. "Stratigraphie et paléontologie (plantes, vertébrés) de la série paralique Albien terminal-Cénomanien basal de Tonnay-Charente (Charente-Maritime, France) [Stratigraphy and palaeontology (plants, vertebrates) of the paralic deposits from the uppermost Albian-lower Cenomanian of Tonnay-Charente (Charente-Maritime, France)]". French. In: Comptes Rendus Palevol 4 (2005), pp. 79-93. DOI: 10.1016/j.crpv.2004.11.008.

[16634] E. A. Nesbitt. "Paleoecological anlaysis of molluscan assemblages from the Middle Eocene Cowlitz Formation, southwestern Washington". English. In: Journal of Paleontology 69.6 (1995), pp. 10601073.

[16635] E. A. Nesbitt. “Cenozoic Marine Formations of Washington and Oregon: an annotated catalogue". English. In: PaleoBios 35 (2018), pp. 1-20.

[16636] E. A. Nesbitt. "A novel trophic relationship between cassid gastropods and mysticete whale carcasses". English. In: Lethaia 38 (2005), pp. 17-25. DOI: 10.1080/00241160510013132.

[16637] E. A. Nesbitt. "Marine fauna of the middle Eocene Tukwila Formation, King County". English. In: Washington Geology 26.1 (1998), pp. 13-19.

[16638] S. J. Nesbitt. The Moenkopi Formation along the Little Colorado River in eastern Arizona. English. Vol. 9. Guidebook to the Triassic Formations of the Colorado Plateau in northern Arizona, Mesa Southwest Museum Bulletin. 2005, pp. 13-23.

[16639] S. J. Nesbitt. The tetrapod fauna of the Moenkopi Formation in northern Arizona. English. Vol. 9. Guidebook to the Triassic Formations of the Colorado Plateau in northern Arizona, Mesa Southwest Museum Bulletin. 2005, pp. 25-32.

[16640] S. J. Nesbitt. “Arizonasaurus and its implications for archosaur divergence". English. In: Proceedings of the Royal Society of London B (supplement, Biology Letters) 270 (2003), S234-S237.

[16641] S. J. Nesbitt. "Osteology of the Middle Triassic pseudosuchian archosaur Arizonasaurus babbitti". English. In: Historical Biology 17 (2005), pp. 19-47.

[16642] S. J. Nesbitt. "A new archosaur from the upper Moenkopi Formation (Middle Triassic) of Arizona and its implications for rauisuchian phylogeny and diversification". English. In: Neues Jahrbuch für Geologie und Paläontologie Monatshefte 2005.6 (2005), pp. 332-346.

[16643] S. J. Nesbitt. "A preliminary report on new vertebrate fossil sites, including a microsite from the Holbrook Member of the Moenkopi Formation, Holbrook, Arizona". English. In: Mesa Southwest Museum Bulletin 7 (2000), pp. 17-30.

[16644] S. J. Nesbitt. "The early evolution of archosaurs: relationships and the origin of major clades". English. In: Bulletin of the American Museum of Natural History 353 (2011), pp. 1-292.

[16645] S. J. Nesbitt and K. D. Angielczyk. "New evidence of large dicynodonts in the upper Moenkopi Formation (Middle Triassic) of northern Arizona". English. In: PaleoBios 22.2 (2002), pp. 10-17. 
[16646] S. J. Nesbitt, P. M. Barrett, S. Werning, C. A. Sidor, and A. J. Charig. "The oldest dinosaur? A Middle Triassic dinosauriform from Tanzania". English. In: Biology Letters 9.1 (2013), pp. 1-5. DOI: 10.1098/rsbl.2012.0949.

[16647] S. J. Nesbitt and R. J. Butler. "Redescription of the archosaur Parringtonia gracilis from the Middle Triassic Manda beds of Tanzania, and the antiquity of Erpetosuchidae". English. In: Geological Magazine (2012). DOI: 10.1017/S0016756812000362.

[16648] S. J. Nesbitt, R. J. Butler, and D. J. Gower. "A new archosauriform (Reptilia: Diapsida) from the Manda beds (Middle Triassic) of southwestern Tanzania". English. In: PLoS ONE 8 (2013), e72753. DOI: 10.1371/journal.pone.0072753.

[16649] S. J. Nesbitt, R. J. Butler, M. D. Ezcurra, P. M. Barrett, M. R. Stocker, K. D. Angielczyk, R. M. H. Smith, C. A. Sidor, G. Niedwiedzki, A. G. Sennikov, and A. J. Charig. "The earliest bird-line archosaurs and the assembly of the dinosaur body plan". English. In: Nature 544.27 (2017), pp. 484487. DOI: $10.1038 /$ nature22037.

[16650] S. J. Nesbitt and S. Chatterjee. "Late Triassic dinosauriforms from the Post Quarry and surrounding areas, west Texas, USA". English. In: Neues Jahrbuch für Geologie und Paläontologie Abhandlungen 249.2 (2008), pp. 143-156.

[16651] S. J. Nesbitt, J. A. Clarke, A. H. Turner, and M. A. Norell. “A small alvarezsaurid from the Eastern Gobi Desert offers insight into evolutionary patterns in the Alvarezsauroidea". English. In: Journal of Vertebrate Paleontology 31.1 (2011), pp. 144-153. DOI: 10.1080/02724634.2011.540053.

[16652] S. J. Nesbitt and J. A. Clarke. "The anatomy and taxonomy of the exquisitely preserved Green River Formation (Early Eocene) lithornithids (Aves) and the relationships of Lithornithidae". English. In: Bulletin of the American Museum of Natural History 406 (2016), pp. 1-91.

[16653] S. J. Nesbitt, R. K. Denton, M. A. Loewen, S. L. Brusatte, N. D. Smith, A. H. Turner, J. I. Kirkland, A. T. McDonald, and D. G. Wolfe. "A mid-Cretaceous tyrannosauroid and the origin of North American end-Cretaceous dinosaur assemblages". English. In: Nature Ecology \& Evolution 3.6 (2019), pp. 892-899. DOI: 10.1038/s41559-019-0888-0.

[16654] S. J. Nesbitt and M. D. Ezcurra. “The early fossil record of dinosaurs in North America: A new neotheropod from the base of the Upper Triassic Dockum Group of Texas". English. In: Acta Palaeontologica Polonica 60.3 (2015), pp. 513-526. DOI: 10.4202/app.00143.2014.

[16655] S. J. Nesbitt, R. B. Irmis, and W. G. Parker. "A critical re-evaluation of the Late Triassic dinosaur taxa of North America". English. In: Journal of Systematic Palaeontology 5.2 (2007), pp. 209-243.

[16656] S. J. Nesbitt, R. B. Irmis, W. G. Parker, N. D. Smith, A. H. Turner, and T. Rowe. "Hindlimb osteology and distribution of basal dinosauromorphs from the Late Triassic of North America". English. In: Journal of Vertebrate Paleontology 29.2 (2009), pp. 498-516. DOI: 10.1671/039.029.0218.

[16657] S. J. Nesbitt, R. B. Irmis, S. G. Lucas, and A. P. Hunt. "A giant crocodylomorph from the Upper Triassic of New Mexico". English. In: Palaeontologische Zeitschrift 79 (2005), pp. 471-478.

[16658] S. J. Nesbitt, S. G. Lucas, and R. R. Schoch. "A new, large archosauriform from the Anton Chico Member of the upper Moenkopi Formation (Middle Triassic), east-central New Mexico, USA". English. In: Neues Jahrbuch für Geologie und Paläontologie Abhandlungen 239.2 (2006), pp. 289-311.

[16659] S. J. Nesbitt and M. A. Norell. "Extreme convergence in the body plans of an early suchian (Archosauria) and ornithomimid dinosaurs (Theropoda)". English. In: Proceedings of the Royal Society of London B (2006).

[16660] S. J. Nesbitt, C. A. Sidor, R. B. Irmis, K. D. Angielczyk, R. M. H. Smith, and L. A. Tsuji. “Ecologically distinct dinosaurian sister group shows early diversification of Ornithodira". English. In: Nature 464 (2010), pp. 95-98. DOI: 10.1038/nature08718.

[16661] S. J. Nesbitt, C. A. Sidor, K. D. Angielczyk, R. M. H. Smith, and L. A. Tsuji. "A new archosaur from the Manda beds (Anisian, Middle Triassic) of southern Tanzania and its implications for character state optimizations at Archosauria and Pseudosuchia". English. In: Journal of Vertebrate Paleontology 34.6 (2014), pp. 1357-1382. DOI: 10.1080/02724634.2014.859622. 
[16662] S. J. Nesbitt, N. D. Smith, R. B. Irmis, A. H. Turner, A. Downs, and M. A. Norell. “A complete skeleton of a Late Triassic saurischian and the early evolution of dinosaurs". English. In: Science 326 (2009), pp. 1530-1533. DOI: 10.1126/science.1180350.

[16663] S. J. Nesbitt and M. R. Stocker. "The vertebrate assemblage of the Late Triassic Canjilon Quarry (northern New Mexico, USA), and the importance of apomorphy-based assemblage comparisons". English. In: Journal of Vertebrate Paleontology 28.4 (2008), pp. 1063-1072. DOI: 10.1671 / 0272-463428.4.1063.

[16664] S. J. Nesbitt, M. R. Stocker, B. J. Small, and A. Downs. “The osteology and relationships of Vancleavea campi (Reptilia: Archosauriformes)". English. In: Zoological Journal of the Linnean Society 157 (2009), pp. 814-864. DOI: 10.1111/j.1096-3642.2009.00530.x.

[16665] S. J. Nesbitt and R. L. Whatley. "The first discovery of a rhynchosaur from the upper Moenkopi Formation (Middle Triassic) of northern Arizona". In: PaleoBios 24.3 (2004), pp. 1-10.

[16666] V. Nesin and O. Kovalchuk. "A new species of jerboa (Mammalia, Rodentia, Allactaga) from the late Miocene of Ukraine". English. In: Palaeontologia Electronica 20.2 (2017), 25A-1-10.

[16667] L. A. Nessov. Dinozavri severnoi Yevrazii: Novye dannye o sostave kompleksov, ekologii i paleobiogeografii [Dinosaurs of northern Eurasia: new data about assemblages, ecology, and paleobiogeography]. Russian. Institute for Scientific Research on the Earth's Crust, St. Petersburg State University, St. Petersburg. 1995, pp. 1-156.

[16668] L. A. Nessov. “On some Mesozoic turtles of the Fergana Depression (Kyrgyzstan) and Dzhungar Alatau Ridge (Kazakhstan)". English. In: Russian Journal of Herpetology 2.2 (1995), pp. 134-141.

[16669] L. A. Nessov, Z. Kielan-Jaworowska, J. Hurum, A. O. Averianov, P. V. Fedorov, D. O. Potapov, and M. Froyland. "First Jurassic mammals from Kyrgyzstan". English. In: Acta Palaeontologica Polonica 39.3 (1994), pp. 315-326.

[16670] L. A. Nessov and A. A. Yarkov. "Gesperornisy v Rossii [Hesperornithiforms in Russia]". Russian. In: Russian Journal of Ornithology 2.1 (1993), pp. 37-54.

[16671] L. A. Nessov, V. I. Zhegallo, and A. O. Averianov. "A new locality of Late Cretaceous snakes, mammals and other vertebrates in Africa (western Libya)". English. In: Annales de Paléontologie 84.3-4 (1998), pp. 265-275.

[16672] M. K. Nestell and C. H. Stevens. "Mixed Tethyan and McCloud Belt rugose corals and fusulinids in an Upper Triassic conglomerate, central Oregon". English. In: Journal of Paleontology 87 (2013), pp. 909-921.

[16673] H. Nestor. "Community structure and succession of Baltoscandian Early Palaeozoic stromatoporoids". English. In: Proceedings of the Estonian Academy of Sciences 48.3 (1999), pp. 123-139.

[16674] H. Nestor. "Telychian (lower Silurian) Stromatoporoids from the Charlestown Inlier, co. Mayo, Ireland". English. In: Irish Journal of Earth Sciences 17 (1999), pp. 115-121.

[16675] H. Nestor, R. Einasto, P. Männik, and V. Nestor. "Correlation of lower-middle Llandovery sections in central and southern Estonia and sedimentation cycles of lime muds". English. In: Proceedings of the Estonian Academy of Sciences, Geology 52.1 (2003), pp. 3-27.

[16676] T. A. Neubauer, O. Mandic, M. Harzhauser, and H. Hrvatovic. "A new Miocene lacustrine mollusc fauna of the Dinaride Lake System and its palaeobiogeographic, palaeoecologic and taxonomic implications". English. In: Palaeontology 56.1 (2013), pp. 129-156. DOI: 10.1111/j.1475-4983.2012. 01171.x.

[16677] E. Neubert and D. van Damme. "Palaeogene continental molluscs of Oman". English. In: Contribution to Natural History 20 (2012), pp. 1-28.

[16678] A. G. Neuman and D. B. Brinkman. Fishes of the fluvial beds. English. Dinosaur Provincial Park: A Spectacular Ancient Ecosystem Revealed. Indiana University Press, Bloomington. 2005, pp. 167185. 
[16679] A. G. Neuman and R. J. Mutter. "Helmolepis cyphognathus, sp. nov., a new platysiagid actinopterygian from the Lower Triassic Sulphur Mountain Formation (British Columbia, Canada)". English. In: Canadian Journal of Earth Sciences 42 (2005), pp. 25-36.

[16680] B. E. E. Neuman. "The new early Palaezoic rugose coral genera Eurogrewingkia gen. nov. and Fosselasma gen. nov." English. In: Proc. Estonian Acad. Sci. Geol 52.4 (2003), pp. 199-212.

[16681] R. B. Neuman. "Famatinorthis cf. turneri Levy and Nullo, 1973 (Brachiopoda, Orthida) from the Shin Brook Formation (Ordovician, Arenig) in Maine". English. In: Journal of Paleontology 71.5 (1997), pp. 812-815.

[16682] R. B. Neuman. "Late Ordovician (Ashgill) Foliomena Fauna Brachiopods from Northeastern Maine". English. In: Journal of Paleontology 68.6 (1994), pp. 1218-1234. DOI: 10.1017/S0022336000034211.

[16683] R. B. Neuman, D. L. Bruton, and J. P. Projeta Jr. “Fossils from the Ordovician 'Upper Hovin Group' (Caradoc - Ashgill), Trondheim Region, Norway". English. In: Norges geologiske undersokelse Bulletin 432 (1997), pp. 25-58.

[16684] C. Neumann. "The mode of life and paleobiogeography of the genus Douvillaster Lambert (Echinoidea: Spatangoida) as first recorded in the Lower Cretaceous (Albian) of Spain". In: Berliner geowissenschaftliche Abhandlungen E18 (1996), pp. 257-265.

[16685] C. Neumann, J. W. M. Jagt, and R. W. J. M. van der Ham. "Rare Campanian echinoids from the Höver and Misburg (Hannover area, Lower Saxony, Germany)". In: Mitteilungen des Museums für Naturkunde Berlin, Geowissenschaftliche Reihe 5 (2002), pp. 121-139.

[16686] C. Neumann. "Pentasteria sp., ein Kammseestern (Astropectinidae) aus dem Unter-Hauterive von Engelbostel". German. In: Arbeitskreis Paläontologie Hannover 38 (2010), pp. 35-40.

[16687] C. Neumann and H. Hess. "Coulonia parva n. sp., a new species of Astropectinidae (Asteroidea; Echinodermata) from the Santonian (Upper Cretaceous) of Sierra de Montsech (Southern Pyrenees, Spain)". English. In: Paläontologische Zeitschrift 75.1 (2001), pp. 7-11.

[16688] F. Neuweiler. "Development of Albian microbialites and microbialite reefs at marginal platform areas of the Vasco-Cantabrian Basin (Soba reef area, Cantabria, N.Spain)". English. In: Facies 29 (1993), pp. 231-250.

[16689] F. Neuweiler, M. Mehdi, and M. Wilmsen. "Facies of Liassic sponge mounds, Central High Atlas, Morocco". In: Facies 44 (2001), pp. 243-264.

[16690] J. Neveling, B. S. Rubidge, and P. J. Hancox. "A lower Cynognathus Assemblage Zone fossil from the Katberg Formation (Beaufort Group, South Africa)". English. In: South African Journal of Science 95 (1999), pp. 555-556.

[16691] J. P. Neves, L. E. Anelli, M. A. Pagani, and M. G. Simões. "Late Palaeozoic South American pectinids revised: biostratigraphical and palaeogeographical implications". English. In: Alcheringa 38 (2014), pp. 281-295.

[16692] J. P. Neves, L. E. Anelli, and M. S. Simões. “Early Permian post-glacial bivalve faunas of the Itararé Group, Paraná Basin, Brazil: Paleoecology and biocorrelations with South American intraplate basins". English. In: Journal of South American Earth Sciences 52 (2014), pp. 203-233.

[16693] M. G. Newbrey and M. A. Bozek. "A new species of Joffrichthys (Teleostei: Osteoglossidae) from the Sentinel Butte Formation, (Paleocene) of North Dakota, USA". English. In: Journal of Vertebrate Paleontology 20.1 (2000), pp. 12-20.

[16694] M. G. Newbrey, A. M. Murray, D. B. Brinkman, M. V. H. Wilson, and A. G. Neuman. “A new articulated freshwater fish (Clupeomorpha, Ellimmichthyiformes) from the Horseshoe Canyon Formation, Maastrichtian, of Alberta, Canada". English. In: Canadian Journal of Earth Sciences 47 (2010), pp. 1183-1196. DOI: 10.1139/E10-041.

[16695] N. D. Newell. "A new limoid bivalve from the Texas Middle Permian". English. In: American Museum Novitates 3264 (1999), pp. 1-6.

[16696] N. D. Newell and D. W. Boyd. "Pectinoid bivalves of the Permian-Triassic crisis". In: Bulletin of the American Museum of Natural History 227 (1995), pp. 1-95. 
[16697] N. D. Newell and D. W. Boyd. "A new Lower Triassic Permophorus from the central Rocky Mountains". In: American Museum Novitates 3263 (1999), pp. 1-565.

[16698] M. J. Newman, R. G. Davidson, J. L. Den Blaauwen, and C. J. Burrow. “The Early Devonian Acanthodian $<\mathrm{i}>$ Euthacanthus gracilis $</ \mathrm{i}>$ from the Midland Valley of Scotland". English. In: Scottish Journal of Geology 47 (2011), pp. 101-111.

[16699] M. J. Newman and J. L. Den Blaauwen. "Developmental anomalies on the skull of the Scottish Middle Devonian lungfish Pinnalongus saxoni". English. In: Scottish Journal of Geology 46 (2010), pp. 85-88. DOI: 10.1144/0036-9276/01-402.

[16700] K. Ngasawa, K. Mori, and K. Shindo. "A dredged fossil rostrum of Mesoplodon with boring shell burrows from the ocean bottom off the Midway Islands in the North Pacific Ocean". Japanese. In: Journal of Fossil Research 38.1 (2005), pp. 12-16.

[16701] V. Ngo-Muller, M. S. Engel, R. Garrouste, J. M. Pouillon, and A. Nel. "The first predatory dance fly of the subfamily Ocydromiinae with specialized, raptorial legs in mid-Cretaceous amber from Myanmar (Diptera: Hybotidae)". English. In: Cretaceous Research 119.104697 (2020). DOI: 10.1016/ j.cretres.2020.104697.

[16702] V. Ngo-Muller, R. Garrouste, J. M. Pouillon, and A. Nel. "A new species of the long-legged fly genus Microphorites in Burmese amber (Dolichopodidae: Microphorinae)". English. In: Cretaceous Research 107.104284 (2020). DOI: 10.1016/j.cretres.2019.104284.

[16703] V. Ngo-Muller, R. Garrouste, J. M. Pouillon, and A. Nel. "A new micropterigid moth from the 'mid'-Cretaceous Burmese amber (Insecta: Lepidoptera)". English. In: Cretaceous Research 109.104375 (2020). DOI: 10.1016/j.cretres.2020.104375.

[16704] V. Ngo-Muller, R. Garrouste, and A. Nel. "Small but important: a piece of mid-Cretaceous Burmese amber with a new genus and two new insect species (Odonata: Burmaphlebiidae \& 'Psocoptera': Compsocidae)". English. In: Cretaceous Research 110.104405 (2020). DOI: 10.1016/j j.cretres.2020. 104405.

[16705] V. Ngo-Muller, R. Garrouste, J. M. Pouillon, J. Douteau, and A. Nel. "A new Babinskaiidae from the 'mid'-Cretaceous Burmese amber (Insecta, Neuroptera, Myrmeleontoidea)". English. In: Cretaceous Research 113.104478 (2020). DOI: 10.1016/j.cretres.2020.104478.

[16706] V. Ngo-Muller, C. Jouault, R. Garrouste, and A. Nel. "Potential new evidences of bee fly parasitoidism on ground-dwelling insects in mid-Cretaceous Burmese amber (Diptera: Bombyliidae)". English. In: Cretaceous Research 114.104524 (2020). DOI: 10.1016/j.cretres.2020.104524.

[16707] M.-L. Nguyen. "Palaeoenvironment inferred from stable isotopes of archaeological Crassostrea gigas shells unearthed from Tainan Science Park, Taiwan since middle Holocene". English. PhD thesis. 2018.

[16708] M. Nguyen Duy-Jacquemin and D. Azar. “The oldest records of Polyxenida (Myriapoda, Diplopoda): new discoveries from the Cretaceous ambers of Lebanon and France". English. In: Geodiversitas 26 (2004), pp. 631-641.

[16709] P. G. Ni, A. Tintori, Z. Y. Sun, and D. Y. Jiang. "A new specimen of Birgeria liui (Osteichthyes, Actinopterygii) from the Longobardian (Ladinian, Middle Triassic) of Xingyi, Guizhou Province, South China". English. In: Research \& Knowledge 3.2 (2017), pp. 55-58.

[16710] X. Ni, K. C. Beard, J. Meng, Y. Wang, and D. L. Gebo. “Discovery of the first early Cenozoic euprimate (Mammalia) from Inner Mongolia". English. In: American Museum Novitates 3571 (2007), pp. 1-11.

[16711] X. Ni, D. L. Gebo, M. Dagosto, J. Meng, P. Tafforeau, J. J. Flynn, and K. C. Beard. “The oldest known primate skeleton and early haplorhine evolution". English. In: Nature 498 (2013), pp. 60-64.

[16712] X. Ni, Q. Li, L. Li, and K. C. Beard. “Oligocene primates from China reveal divergence between African and Asian primate evolution". English. In: Science 352.6286 (2016), pp. 673-677.

[16713] X. Ni, Q. Li, T. A. Stidham, L. Li, X. Lu, and J. Meng. "A late Paleocene probable metatherian (?deltatheroidan) survivor of the Cretaceous mass extinction". English. In: Scientific Reports 6 (2016), 38547:1-9. DOI: 10.1038/srep38547. 
[16714] X. Ni, J. Meng, K. C. Beard, D. L. Gebo, Y. Wang, and C. Li. “A new tarkadectine primate from the Eocene of Inner Mongolia, China: Phylogenetic and biogeographic implications". English. In: Proceedings of the Royal Society B (Biological Sciences) (2009). DOI: 10.1098/rspb.2009.0173.

[16715] X. Ni and Z. Qiu. "Tupaiine tree shrews (Sandentia, Mammalia) from the Yuanmou Lufengpithecus locality of Yunnan, China". English. In: Swiss Journal of Palaeontology 131 (2012), pp. 51-60.

[16716] X.-J. Ni, Y.-Q. Wang, Y. -M. Hu, and C. -K. Li. "A euprimate skull from the early Eocene of China". English. In: Nature 427 (2004), pp. 65-68.

[16717] C. S. C. Nicholl, P. D. Mannion, and P. M. Barrett. "Sauropod dinosaur remains from a new Early Jurassic locality in the Central High Atlas of Morocco". English. In: Acta Palaeontologica Polonica 63.1 (2018), pp. 147-157. DOI: 10.4202/app.00425.2017.

[16718] C. S. C. Nicholl, J. P. Rio, P. D. Mannion, and M. Delfino. "A re-examination of the anatomy and systematics of the tomistomine crocodylians from the Miocene of Italy and Malta". English. In: Journal of Systematic Palaeontology 18.22 (2020), pp. 1853-1889. DOI: 10.1080 / 14772019.2020. 1855603.

[16719] E. L. Nicholls. “Note on the occurence of the marine turtle Desmatochelys (Reptilia: Chelonioidea) from the upper Cretaceous of Vancouver Island". English. In: Canadian Journal of Earth Science 29.2 (1992), pp. 377-380.

[16720] E. L. Nicholls and D. Brinkman. "New thalattosaurs (Reptilia: Diapsida) from the Triassic Sulphur Mountain Formation of Wapiti Lake, British Columbia". English. In: Journal of Paleontology 67.2 (1993), pp. 263-278.

[16721] E. L. Nicholls and D. Brinkman. "A new specimen of Utatsusaurus (Reptilia: Ichthyosauria) from the Lower Triassic". English. In: Canadian Journal of Earth Sciences 30 (1993), pp. 486-490. DOI: 10.1139/e93-037.

[16722] E. L. Nicholls, D. B. Brinkman, and X. -C. Wu. "A new archosaur from the Upper Triassic Pardonet Formation of British Columbia". In: Canadian Journal of Earth Sciences 35 (1998), pp. 1134-1142.

[16723] E. L. Nicholls and M. Manabe. "Giant ichthyosaurs of the Triassic - a new species of Shonisaurus from the Pardonet Formation (Norian: Late Triassic) of British Columbia". English. In: Journal of Vertebrate Paleontology 24.4 (2004), pp. 838-849.

[16724] E. L. Nicholls and M. Manabe. "A new genus of ichthyosaur from the Late Triassic Pardonet Formation of British Columbia: bridging the Triassic-Jurassic gap". English. In: Canadian Journal of Earth Sciences 38 (2001), pp. 983-1002.

[16725] E. L. Nicholls and D. Meckert. "Marine reptiles from the Nanaimo Group (Upper Cretaceous) of Vancouver Island". English. In: Canadian Journal of Earth Sciences 39.11 (2002), pp. 1591-1603.

[16726] E. L. Nicholls, T. T. Tokaryk, and L. V. Hills. "Cretaceous marine turtles from the Western Interior Seaway of Canada". English. In: Canadian Journal of Earth Sciences 27.10 (1990), pp. 1288-1298.

[16727] E. L. Nicholls, C. Wei, and M. Manabe. "New material of Qianichthyosaurus Li, 1999 (Reptilia, Ichthyosauria) from the Late Triassic of southern China, and implications for the distribution of Triassic icthyosaurs". English. In: Journal of Vertebrate Paleontology 22.4 (2002), pp. 759-765.

[16728] P. Nicholson, C. Woodruff, J. Harrison, and C. Heck. A sirenian from the Maadi Formation (Upper Eocene) from the catacombs of Anubis at Saqqara (Egypt). English. 2014.

[16729] L. Nicoli. "The presence of Lepidobatrachus (Anura, Ceratophryidae) in the Neogene of La Pampa Province, Argentina". English. In: Ameghiniana 54.6 (2017), pp. 700-705. DOI: 10.5710/ AMGH.08. 06.2017.3064.

[16730] R. S. Nicoll. "Seximembrate apparatus structure of the Late Cambrian coniform conodont Teridontus nakamurai from the Chatsworth Limestone, Georgina Basin, Queensland". English. In: AGSO Journal of Australian Geology and Geophysics 15.3 (1994), pp. 367-379.

[16731] A. Nicora and I. P. Silva. "Paleogene shallow-water larger foraminifers from holes 714A and 715A, Leg 115, Indian Ocean". English. In: Proceedings of the Ocean Drilling Program, Scientific Results 115 (1990), pp. 381-393. 
[16732] U. Nicosia and M. Loi. "Triassic footprints from Lerici (La Spezia, northern Italy)". English. In: Ichnos 10 (2003), pp. 127-140. DOI: 10.1080/10420940390256203.

[16733] U. Nicosia, M. Marino, N. Mariotti, C. Muraro, S. Panigutti, F. M. Petti, and E. Sacchi. “The Late Cretaceous dinosaur tracksite near Altamura (Bari, southern Italy). II - Apulosauripus federicianus new ichnogen. and new ichnosp." English. In: Geologica Romana 35 (1999), pp. 237-247.

[16734] V. Nidergas, J. Hadrava, R. Garrouste, J. Prokop, T. Schubnel, and A. Nel. “The first pipizine hoverfly from the Oligocene of Céreste, France". English. In: Acta Palaeontologica Polonica 63 (2018), pp. 539-548.

[16735] B. Niebuhr. "Das Campan (höhere Ober-Kreide) der Lehrter Westmulde bei Hannover". German. In: Arbeitskreis Paläontologie Hannover (2005), pp. 5-14.

[16736] B. Niebuhr, M. Taherpour Khalil Abad, M. Wilmsen, J. Noorbakhsh Razmi, A. A. Aryaei, and A. Ashouri. "First record of late Campanian ammonites from the Abderaz Formation of the Koppeh Dagh, northeastern Iran”. English. In: Cretaceous Research 58 (2016), pp. 202-222.

[16737] G. Niedwiedzki. "A Late Triassic dinosaur-dominated ichnofauna from the Tomanová Formation of the Tatra Mountains, Central Europe". English. In: Acta Palaeontologica Polonica 56.2 (2011), pp. 291-300.

[16738] G. Niedzwiedzki and M. Bojanowski. "A supposed eupelycosaur body impression from the Early Permian of the Intra-Sudetic Basin, Poland". English. In: Ichnos 19 (2012), pp. 150-155. DOI: 10. 1080/10420940.2012.702549.

[16739] G. Niedzwiedzki, P. Gorzelak, and T. Sulej. “Bite traces on dicynodont bones and the early evolution of large terrestrial predators". English. In: Lethaia 44 (2011), pp. 87-92. DOI: 10.1111/j.15023931.2010.00227.x.

[16740] G. Niedzwiedzki and G. Pienkowski. "A dinosaur track association from the Early Jurassic deltaic deposits of Podole near Opatów, Poland". English. In: Geological Quarterly 48.4 (2004), pp. 333-338.

[16741] G. Niedzwiedzki, T. Sulej, and J. Dzik. "A large predatory archosaur from the Late Triassic of Poland". English. In: Acta Palaeontologica Polonica 57.2 (2012), pp. 267-276. DOI: 10.4202/app.2010. 0045 .

[16742] C. M. Nield, R. Damiani, and A. Warren. "A short-snouted trematosauroid (Tetrapoda, Temnospondyli) from the Early Triassic of Australia: the oldest known trematosaurine". English. In: Alcheringa 30 (2006), pp. 263-271.

[16743] A. T. Nielsen. "Trilobite systematies, biostratigraphy and palaeoecology of the Lower Ordovician Komstad Limestone and Huk Forrnations, southern Scandinavia". English. In: Fossils and Strata 38 (1995), pp. 1-374.

[16744] S. N. Nielsen. “The genus Olivancillaria (Gastropoda: Olividae) in the Miocene of Chile: rediscovery of a senior synonym and description of a new species". English. In: The Nautilus 118.2 (2004), pp. 88-92.

[16745] S. N. Nielsen. "Exilia alanbeui, a new species from the Neogene of central Chile: the first record of Exilia (Gastropoda: Ptychatractidae) from South America". English. In: The Nautilus 119.4 (2005), pp. 153-156.

[16746] S. N. Nielsen. “Cenozoic Strombidae, Aporrhaidae, and Struthiolariidae (Gastropoda: Stromboidea) from Chile: their significance to the interpretation of southeast pacific biogeography and climate". English. In: Journal of Paleontology 79.6 (2005), pp. 1120-1130.

[16747] S. N. Nielsen. "A new Pliocene mollusk fauna from Mejillones, northern Chile". English. In: Paläontologische Zeitschrift 87.1 (2013), pp. 33-66.

[16748] S. N. Nielsen. "The Triassic Santa Juana Formation at the lower Biobo River, south central Chile". English. In: Journal of South American Earth Sciences 19 (2005), pp. 547-562. DOI: 10.1016/j.jsames. 2005.06.002. 
[16749] S. N. Nielsen, K. Bandel, and B. Kröger. "Palaeobiogeographical provenance, taphonomy, and mode of life of Aturia cubaensis (Cephalopoda, Nautiloidea) from Cainozoic deposits of Chile". English. In: Geobios 42 (2009), pp. 73-88.

[16750] S. N. Nielsen and T. J. DeVries. "Tertiary Xenophoridae (Gastropoda) of western South America". English. In: The Nautilus 116.3 (2002), pp. 71-78.

[16751] S. N. Nielsen and A. Encinas. “The genus Struthiochenopus (Gastropoda, Aporrhaidae): neu Miocene records from southern Chile". English. In: Journal of Paleontology 88.1 (2014), pp. 152159.

[16752] S. N. Nielsen, D. Frassinetti, and K. Bandel. Miocene Vetigastropoda and Neritimorpha (Mollusca, Gastropoda) of central Chile. 2004.

[16753] S. N. Nielsen and D. Frassinetti. “New and little known species of Pseudolividae (Gastropoda) from the Tertiary of Chile". English. In: The Nautilus 117.3 (2003), pp. 91-96.

[16754] S. N. Nielsen and C. Salazar. "Eutrephoceras subplicatum (Steinmann, 1895) is a junior synonym of Eutrephoceras dorbignyanum (Forbes in Darwin, 1846) (Cephalopoda, Nautiloidea) from the Maastrichtian Quiriquina Formation of Chile". English. In: Cretaceous Research 32.6 (2011), pp. 833840.

[16755] S. N. Nielson and C. Valdovinos. "Early Pleistocene mollusks of the Tubul Formation, southcentral Chile". English. In: The Nautilus 122.4 (2008), pp. 201-216.

[16756] A. M. Nieves-Rivera, A. C. Ruiz-Yantin, and M. D. Gottfried. "New record of the lamnid shark Carcharodon megalodon from the Middle Miocene of Puerto Rico". English. In: Caribbean Journal of Science 39.2 (2003), pp. 223-227.

[16757] I. F. Nikitin and L. E. Popov. "Strophomenid and triplesiid brachiopods from an Upper Ordovician carbonate mound in central Kazakhstan". English. In: Alcheringa 20 (1996), pp. 1-20.

[16758] I. F. Nikitin, L. E. Popov, and M. G. Bassett. "Late Ordovician brachiopods from the Selety river basin, north Central Kazakhstan". English. In: Acta Palaeontologica Polonica 48.1 (2003), pp. 39-54.

[16759] I. F. Nikitin, L. E. Popov, and L. E. Holmer. "Late Ordovician brachiopod assemblage of HibernoSalairian type from central Kazakhstan". English. In: Geologiska Föreningens i Stockholm Förhandlingar 118.2 (1996), pp. 83-96.

[16760] O. I. Nikitina, L. E. Popov, R. B. Neuman, M. G. Bassett, and L. E. Holmer. "Mid Ordovician (Darriwilian) brachiopods of South Kazakhstan". English. In: vol. 25. Studies in Palaeozoic palaeontology. Cardiff: National Museum of Wales Geological Series, 2006, pp. 145-222.

[16761] N. B. Nikitsky. "New species of the genus Orchesia Latr. from the Upper Eocene (Coleoptera, Tenebrionoidea)". English. In: Paleontological Journal 45.5 (2011), pp. 559-562.

[16762] N. B. Nikitsky. “New taxa of the beetles Melandryidae (Coleoptera, Tenebrionoidea) from the Upper Cretaceous". English. In: Paleontological Journal 36 (2002), pp. 504-507.

[16763] S. Niko. "Middle Carboniferous orthoconic cephalopods from the Omi Limestone Group, Central Japan". In: Paleontological Research 5.2 (2001), pp. 115-120.

[16764] S. Niko. "Auloporid Tabulate Corals from the Lower Permian Ryozensan Limestone, Shiga Prefecture". English. In: Bulletin of the National Science Museum, Series C 27.1, 2 (2001), pp. 15-23.

[16765] S. Niko. "Sakmarian (Early Permian) Tabulate Corals from the Mizuyagadani Formation, Gifu Prefecture". English. In: Bulletin of the National Science Museum, Series C 27.1, 2 (2001), pp. 25-32.

[16766] S. Niko. "Late Silurian Auloporids (Coelenterata: Tabulata) from the Hitoegane Formation, Gifu Prefecture". English. In: Bulletin of the National Science Museum, Series C 27.3, 4 (2001), pp. 63-71.

[16767] S. Niko. "Devonian Auloporid Tabulate Corals from the Fukuji Formation, Gifu Prefecture". English. In: Bulletin of the National Science Museum, Series C 27.3, 4 (2001), pp. 73-88.

[16768] S. Niko. "Wuchiapingian (Late Permian) Tabulate Corals from the Maizuru Group in the Yakuno Area, Kyoto Prefecture". English. In: Bulletin of the National Science Museum, Series C 31 (2005), pp. 31-38. 
[16769] S. Niko. "Ludlow (Late Silurian) Pachyporid Tabulate Corals from the Suberidani Group, Tokushima Prefecture". English. In: Bulletin of the National Science Museum, Series C 29 (2003), pp. 9-18.

[16770] S. Niko. "Devonian Coenitid Tabulate Corals from the Fukuji Formation, Gifu Prefecture". English. In: Bulletin of the National Science Museum, Series C 29 (2003), pp. 19-24.

[16771] S. Niko. "Mandulapora jimboi, a New Species of Early Permian Coral (Tabulata: Auloporida) from the Nakadaira Formation, Miyagi Prefecture". English. In: Bulletin of the National Science Museum, Series C 28 (2002), pp. 31-35.

[16772] S. Niko. "Redescription of the Ordovician Cephalopod Genus Centroonoceras Kobayashi, 1934". English. In: Journal of Paleontology 79.5 (2005), pp. 1028-1030.

[16773] S. Niko. "Revision of an Ordovician Cephalopod Ormoceras yokoyamai (Kobayashi, 1927)". English. In: Paleontological Research 6.1 (2002), pp. 121-124.

[16774] S. Niko. "Isorthoceras wahlenbergi, a new Late Ordovician cephalopod from the Boda Limestone of Dalarna, Sweden". English. In: Paleontological Research 12.2 (2007), pp. 195-198.

[16775] S. Niko. "Yakunopora mabutii, a new species of tabulate coral from the Permian Iwaizaki Limestone, Miyagi Prefecture, Japan". English. In: Bulletin of the National Museum of Nature and Science, Series C 41 (2015), pp. 25-28.

[16776] S. Niko and M. Ehiro. "Permian orthoconic cephalopods of the Ochiai Formation in the southern Kitakami Mountains, northeast Japan”. English. In: Paleontological Research 6 (2002), pp. 385-389.

[16777] S. Niko and M. Ehiro. "Trematoceras watanabei, a new orthoconic nautiloid species from the Middle Triassic Fukkoshi Formation, Miyagi Prefecture, Northeast Japan". English. In: Bull. Tohoku Univ. Museum 19 (2020), pp. 1-6.

[16778] S. Niko, Y. Ibaraki, and J. Tazawa. "Devonian tabulate corals from pebbles in Mesozoic conglomerate, Kotaki, Niigata Prefecture, central Japan. Part 1: Favositina". English. In: Science Reports of Niigata University (Geology) 29 (2014), pp. 53-66.

[16779] S. Niko and R. H. Mapes. "Trigonoceratid nautilids from the Early Carboniferous Imo Formation of Arkansas, Midcontinent North America". English. In: Paleontological Research 11.3 (2007), pp. 293-303. DOI: 10.2517/1342-8144(2007)11[293:TNFTEC]2.0.CO;2.

[16780] S. Niko and R. H. Mapes. "Early Carboniferous trigonoceratid nautilids from the Pitkin Formation of Arkansas, Midcontinent North America". English. In: Paleontological Research 9.3 (2005), pp. 233-241.

[16781] S. Niko and R. H. Mapes. “Coiled nautiloids from the Lower Carboniferous Fayetteville Formation in Arkansas, midcontinent North America". English. In: Paleontological Research 20 (2016), pp. 717.

[16782] S. Niko and R. H. Mapes. "Late Carboniferous coiled nautiloids from the Lost Branch Formation of Oklahoma, midcontinent North America". English. In: Paleontological Research 20 (2016), pp. 7379.

[16783] S. Niko and R. H. Mapes. "Tainoceratid and liroceratid nautilids from the upper Mississippian Imo Formation of Arkansas, midcontinent North America". English. In: Paleontological Research 21 (2017), pp. 178-182.

[16784] S. Niko, T. Nishida, and K. Nakazawa. "Orthoconic cephalopods from the Lower Permian Atahoc Formation in East Timor". English. In: Paleontological Research 4.2 (2000), pp. 83-88.

[16785] S. Niko and T. Nishida. "A new pseudorthoceratid cephalopod from the Kazanian (middle Late Permian) of Japan". English. In: Paleontological Research 4 (2000), pp. 53-55.

[16786] S. Niko, T. Nishida, and T. Hamada. "Aktastioceras nishikawai n sp, a first Permian bactritoid cephalopod from Japan”. English. In: Journal of Paleontology 67 (1993), pp. 314-316.

[16787] S. Niko and T. Ozawa. "Late Gzhelian (Carboniferous) to early Asselian (Permian) non-ammonoid cephalopods from the Taishaku Limestone Group, Southwest Japan." In: Paleontological Research 1.1 (1997), pp. 47-54. 
[16788] S. Niko, A. Pillevuit, and T. Nishida. “Early Late Permian (Wordian) non-ammonoid cephalopods from the Hamrat Duru Group, central Oman Mountains". English. In: Transactions and Proceedings of the Paleontological Society of Japan, N.S. 183 (1996), pp. 522-527.

[16789] S. Niko and Y. Senzai. "Stratigraphy of the Devonian Kamianama Formation in the Kuzuryu LakeIse River area, Fukui Prefecture and Its Favositid Coral Fauna". English. In: Bulletin of the National Museum of Nature and Science SERIES C 36 (2010), pp. 31-59.

[16790] S. Niko, M. Sone, and M. S. Leman. “A new Permian species of Mooreoceras (Cephalopoda: Orthocerida) from northwestern peninsular Malaysia". English. In: Proceedings of the Japan Academy, Series B 81.8 (2005), pp. 329-333.

[16791] S. Niko, S. Suzuki, and E. Taguchi. "Madrepora mitsukurii, a new Miocene species of scleractinia coral from the Katsuta Group in the Tsuyama area, Okayama Prefecture, Southwest Japan". English. In: Bulletin of the Akioshi-dai Museum of Natural History 51 (2016), pp. 5-8.

[16792] S. Niko, N. Yamagiwa, and H. Sugimura. "Late Carboniferous Corals from the Oboradani Formation, Fukui Prefecture." In: Bulletin of the National Science Museum, Series C (Geology E Paleontology) 23.1, 2 (1997), pp. 35-49.

[16793] S. V. Nikolaeva and B. I. Bogoslovsky. "On the occurrence of Famennian ammonoids in the northern Caucasus". English. In: Paleontological Journal 39 (2005), pp. 465-475.

[16794] S. V. Nikolaeva, I. A. Kim, F. A. Salimova, F. S. Karimova, and V. A. Konovalova. "The discovery of Eifelian ammonoids in the central Kyzylkum Desert (Aristantau Mountains, Uzbekistan)". English. In: Paleontological Journal 51 (2017), pp. 233-246.

[16795] S. V. Nikolaeva and V. A. Konovalova. “New Late Viséan and early Serpukhovian ammonoids in the Verkhnyaya Kardailovka Section (eastern slope of the South Urals)". English. In: Paleontological Journal 51 (2017), pp. 715-726.

[16796] S. V. Nikolaeva, A. B. Kuzmichev, and V. A. Aristov. “On Frasnian ammonoids of the New Siberian Islands". English. In: Paleontological Journal 43 (2009), pp. 134-141.

[16797] G. V. Nikolajev. “On the Mesozoic taxa of scarabaeoid beetles of the Family Hybosoridae (Coleoptera: Scarabaeoidea)". English. In: Paleontological Journal 44.6 (2010), pp. 649-653.

[16798] G. V. Nikolajev. "A new genus of the Subfamily Anaidinae (Coleoptera, Scarabaeoidea, Hybosoridae) from the Mesozoic of Transbaikalia". English. In: Paleontological Journal 44.2 (2010), pp. 192194.

[16799] G. V. Nikolajev. "Lamellicorn beetle species (Coleoptera, Scarabaeidae) with multistriate elytra from the Lower Cretaceous Baisa locality, Transbaikalia". English. In: Paleontological Journal 30 (1996), pp. 217-224.

[16800] G. V. Nikolajev. "A new subfamily of lamellicorn beetles (Coleoptera, Scarabaeoidea) from the Lower Cretaceous of Transbaikalia and Mongolia, and its position within the superfamily". English. In: Paleontological Journal 34 (2000), pp. 426-428.

[16801] G. V. Nikolajev. "New subfamily of the stag beetles (Coleoptera: Scarabaeoidea: Lucanidae) from the Mesozoic of Mongolia, and its position in the system of the superfamily". English. In: Paleontological Journal 34.Suppl 3 (2000), S327-S330.

[16802] G. V. Nikolajev. "New species of scarabaeoid beetles from the family Glaresidae (Coleoptera: Scarabaeoidea) from the Cretaceous of Transbaikalia". English. In: Paleontological Journal 43 (2009), pp. $425-427$.

[16803] G. V. Nikolajev. "To possible assignment of a new genus of lamellicorn beetles from the Lower Cretaceous of Mongolia to the subfamily Pleocominae (Coleoptera, Scarabaeidae)". English. In: Paleontological Journal 36 (2002), pp. 279-282.

[16804] G. V. Nikolajev. "A new subfamily of lamellicorn beetles (Coleoptera, Scarabaeidae) from the Lower Cretaceous of Transbaykalia and its phylogenetic relationships". English. In: Paleontological Journal 29.2 (1995), pp. 185-191. 
[16805] G. V. Nikolajev. "Taxonomic criteria and generic composition of Mesozoic lamellicorn beetles (Coleoptera, Scarabaeidae)". English. In: Paleontological Journal 26.1 (1992), pp. 96-111.

[16806] G. V. Nikolajev. "Mezozoyskiy etap v evolyutsii podsemeystva Aclopinae (Coleoptera, Scarabaeidae)". Russian. In: Tethys Entomological Research 10 (2004), pp. 33-46.

[16807] G. V. Nikolajev. "Materialy k sistematike plastinchatousykh zhukov podsemeistva Hybosorinae (Coleoptera, Scarabaeidae) s vydeleniem novoi triby dlya chetyrekh monotipichnykh podov iz Yuzhnoi Ameriki i opistniem novykh taksonov iz nizhnego mela Zabaikal'ya". Russian. In: Tethys Entomological Research 1 (1999), pp. 173-182.

[16808] G. V. Nikolajev. "Novyy rod triby Hybosorini (Coleoptera, Scarabaeidae) iz Mezozoya Azii”. Russian. In: Tethys Entomological Research 11 (2005), pp. 27-28.

[16809] G. V. Nikolajev. "Nakhodka grebenchatousogo zhuka (Coleoptera, Lucanidae) v verkhnem Mele Kazakhstana". Russian. In: Selevinia 1 (1993), pp. 89-92.

[16810] G. V. Nikolajev. "Materialy k sistematike podsemeystva Ochodaeinae (Coleoptera, Scarabaeidae)". Russian. In: Zoologicheskii Zhurnal 74.8 (1995), pp. 72-82.

[16811] G. V. Nikolajev. "A new genus and species of the family Trogidae (Coleoptera: Scarabaeoidea) from the Lower Cretaceous of Mongolia". Russian. In: Caucasian Entomological Bulletin 5 (2009), pp. $179-182$.

[16812] G. V. Nikolajev. “Novyy rod plastinchatousykh zhukov (Coleoptera, Scarabaeidae) iz nizhnemelovogo mestonakhozhdeniya Baisa v Zabaykal'e". Russian. In: Biologicheskie Nauki Kazakhstana 1 (2005), pp. 117-120.

[16813] G. V. Nikolajev. "On the discovery of the genus Penichrolucanus Deyrolle, 1863 (Coleoptera: Lucanidae: Figulinae) from the Lower Cretaceous of Transbaikalia". Russian. In: Caucasian Entomological Bulletin 6 (2010), pp. 25-26.

[16814] G. V. Nikolajev. "A new genus of the family Glaphyridae (Coleoptera: Scarabaeoidea) from the Mesozoic of China". Russian. In: Caucasian Entomological Bulletin 11 (2015), pp. 19-23.

[16815] G. V. Nikolajev. "About raising the status of the subfamily Eremazinae (Coleoptera: Scarabaeoidea: Scarabaeidae) with description of new taxa from the Mesozoic of China". Russian. In: Caucasian Entomological Bulletin 11 (2015), pp. 297-302.

[16816] G. V. Nikolajev. “On the systematic position of the new scarab beetles genus (Coleoptera: Scarabaeoidea: Ochodaeidae) from the Mesozoic of China". Russian. In: Euroasian Entomological Journal 14 (2015), pp. 21-26.

[16817] G. V. Nikolajev and D. Ren. “The oldest species of the genus Glaphyrus Latr. (Coleoptera: Scarabaeoidea: Glapyridae) from the Mesozoic of China". English. In: Paleontological Journal 45.2 (2011), pp. 179182.

[16818] G. V. Nikolajev and D. Ren. "New genus of the subfamily Geotrupinae (Coleoptera: Scarabaeoidea: Geotrupindae) from the Jehol Biota". English. In: Acta Geologica Sinica 84.4 (2010), pp. 673-675.

[16819] G. V. Nikolajev and D. Ren. "The earliest known species of the genus Pleocoma LeConte (Coleoptera, Scarabaeoidea, Pleocomidae) from the Mesozoic of China". English. In: Paleontological Journal 46 (2012), pp. 495-498.

[16820] G. V. Nikolajev and D. Ren. "A new Glaphyridae genus (Coleoptera: Scarabaeidae) from the Yixian Formation". English. In: Caucasian Entomological Bulletin 9 (2013), pp. 62-64.

[16821] G. V. Nikolajev and D. Ren. "The oldest fossil Ochodaeidae (Coleoptera: Scarabaeoidea) from the Middle Jurassic of China". English. In: Zootaxa 2553 (2010), pp. 65-68.

[16822] G. V. Nikolajev and D. Ren. "A new fossil Lucanidae subfamily (Coleoptera) from the Mesozoic of China". Russian. In: Caucasian Entomological Bulletin 11 (2015), pp. 15-18.

[16823] G. V. Nikolajev and D. Ren. "A second species of the fossil genus Cretohypna Yan, Nikolajev et Ren (Coleoptera: Glaphyridae) from the Mesozoic of China". Russian. In: Euroasian Entomological Journal 14 (2015), pp. 142-143. 
[16824] G. V. Nikolajev, B. Wang, Y. Liu, and H. C. Zhang. “Stag beetles from the Mesozoic of Inner Mongolia, China (Scarabaeoidea: Lucanidae)". English. In: Acta Palaeontologica Sinica 50 (2011), pp. 4147.

[16825] G. V. Nikolajev, B. Wang, and H. C. Zhang. "A new fossil genus of the family Glaphyridae (Coleoptera: Scarabaeoidea) from the Lower Cretaceous Yixian Formation". English. In: Zootaxa 2811 (2011), pp. 47-52.

[16826] G. V. Nikolajev, B. Wang, Y. Liu, and H. C. Zhang. "First record of Mesozoic Ceratocanthinae (Coleoptera: Hybosoridae)". English. In: Acta Palaeontologica Sinica 49 (2010), pp. 443-447.

[16827] G. V. Nikolajev, B. Wang, and H. Zhang. "On the systematic position of a new genus of beetles from the Mesozoic of China in the superfamily Scarabaeoidea (Coleoptera)". Russian. In: Caucasian Entomological Bulletin 10 (2014), pp. 219-222.

[16828] G. V. Nikolajev, B. Wang, and H. Zhang. "A new genus of the family Hybosoridae (Coleoptera, Scarabaeoidea) from the Yixian Lower Cretaceous Formation in China". Russian. In: Euroasian Entomological Journal 11 (2012), pp. 503-506.

[16829] G. V. Nikolayev. "The taxonomic placement in the subfamily Aphodiinae (Coleoptera, Scarabaeidae) of the new genus of Lower Cretaceous scarab beetles from Transbaykal". English. In: Paleontological Journal 27.1A (1993), pp. 1-8.

[16830] V. Nikolov, P. Pavlishina, M. Yaneva, D. Dochev, R. Konyovska, and L. Hristova. "Late Cretaceous dinosaur remains and other tetrapod fauna from the vicinity of Tran town (Western Srednogorie)". English. In: Review of the Bulgarian Geological Society 79.3 (2018), pp. 99-100.

[16831] V. Nikolov, M. Yaneva, D. Dochev, R. Konyovska, I. Sergeeva, and L. Hristova. "Bone histology reveals the first record of titanosaur (Dinosauria: Sauropoda) from the Late Cretaceous of Bulgaria". English. In: Palaeontologia Electronica 23.1 (2020), A10:1-38.

[16832] P. A. Nikolsky and V. V. Titov. "Libralces gallicus (Cervidae, Mammalia) from the Upper Pliocene of the North East Azov Region". In: Paleontological Journal 36.1 (2002), pp. 87-93.

[16833] I. Nilsson, G. Mangerud, and A. Mørk. "Permian stratigraphy of the Svalis Dome south-western Barents Sea". In: Norsk Geologisk Tidsskrift 76 (1996), pp. 127-146.

[16834] Y. Nishioka and C. Vidthayanon. "First occurrence of Duboisia (Bovidae, Artiodactyla, Mammalia) from Thailand". English. In: Fossil Record 21 (2018), pp. 291-299.

[16835] Z. J. Niu, L. Y. Ma, and B. F. Zeng. "Late Permian brachiopod faunas from Wuli Group of Geladangdong Mountain area in the source region of the Yangtze region". Chinese. In: Acta Geoscientia Sinica 24.4 (2003), pp. 343-348.

[16836] K. C. Nixon and W. L. Crepet. "Late Cretaceous fossil flowers of Ericalean affinity". In: American Journal of Botany 80.6 (1993), pp. 616-623.

[16837] F. Noailles, B. Lefebvre, and L. Kasicka. "A probable case of heterochrony in the solutan Dendrocystites Barrande, 1887 (Echinodermata: Blastozoa) from the Upper Ordovician of the Prague Basin (Czech Republic) and a revision of the family Dendrocystitidae Bassler, 1938". English. In: Bulletin of Geosciences 89.3 (2014), pp. 451-476. DOI: 10.3140/bull.geosci.1475.

[16838] P. J. Noble and J. Maletz. "Radiolaria from the Telychian (Llandovery, Early Silurian) of Dalarna, Sweden”. English. In: Micropaleontology 46.3 (2000), pp. 265-275.

[16839] P. H. Nobre and I.d.S. Carvalho. "Adamantinasuchus navae: A new Gondwanan Crocodylomorpha (Mesoeucrocodylia) from the Late Cretaceous of Brazil". English. In: Gondwana Research 10 (2006), pp. 370-378. DOI: 10.1016/j.gr.2006.05.008.

[16840] P. H. Nobre, I.d.S. Carvalho, F.M.d. Vasconcellos, and W. R. Nava. “Mariliasuchus robustus, um Novo Crocodylomorpha (Mesoeucrocodylia) da Bacia Bauru, Brasil [Mariliasuchus robustus, a new Crocodylomorpha (Mesoeucrocodylia) from the Bauru Basin, Brazil]". Spanish. In: Anuário do Instituto de Geociencias 30.1 (2007), pp. 38-49. 
[16841] T. Nobuhara, D. Onda, T. Sato, H. Aosawa, T. Ishimura, Tsunogai Akira Ijiri, N. Kikuchi, Y. Kondo, and S. Kiel. "Mass occurrence of the enigmatic gastropod Elmira in the Late Cretaceous Sada Limestone seep deposit in southwestern Shikoku, Japan". English. In: Palaeontologische Zeitschrift 90 (2016), pp. 701-722.

[16842] T. Nobuhara and T. Tanaka. "Palaeoecology of Akebiconcha kawamurai (Bivalvia: Vesicomyidae) from the Pliocene Tamari Silt Formation in the Kakegawa area, central Japan". English. In: Palaeogeography, Palaeoclimatology, Palaeoecology 102 (1993), pp. 27-40.

[16843] H. Noda, H. Nakagawa, N. Doi, and Y. Kikuchi. "First occurrence of Eocene nautilids from the Miyaragawa Formation in Ishigaki-jima Island the Ryukyus, southwest Japan". English. In: Bulletin of the National Science Museum, Tokyo, Series C 27 (2001), pp. 89-100.

[16844] Y. A. Noda and K. Hoyanagi. "Molluscan fauna from the Miocene Meshikuni Formation on Rebun Island, Northern Hokkaido". English. In: Transactions and Proceedings of the Paleontological Society of Japan, N.S. 172 (1993), pp. 311-327.

[16845] L. F. Noé, D. T. J. Smith, and D. I. Walton. "A new species of Kimmeridgian pliosaur (Reptilia; Sauropterygia) and its bearing on the nomenclature of Liopleurodon macromerus". English. In: Proceedings of the Geologists' Association 115 (2004), pp. 13-24.

[16846] M. Nohejlová, E. Nardin, O. Fatka, L. Kaika, and M. Szabad. “Morphology, palaeoecology and phylogenetic interpretation of the Cambrian echinoderm Vyscystis (Barrandian area, Czech Republic)". English. In: Journal of Systematic Palaeontology (2019). DOI: 10.1080 / 14772019 . 2018. 1541485.

[16847] K. Nojima and J. Itoigawa. "Tomistominae gen. et sp. indet. (Crocodylia: Crocodylidae) from the Lower Yage Formation (Middle Pleistocene) in Hamamatsu City, Shizuoka Prefecture, Japan". English. In: Bulletin of the Mizunami Fossil Museum 43 (2017), pp. 35-46.

[16848] S. C. Nolan, P. W. Skelton, B. P. Clissold, and J. D. Smewing. Maastrichtian to early Tertiary stratigraphy and palaeogeography of the Central and Northern Oman Mountains. English. Vol. 49. In A. H. F. Robertson, M. P. Searle, \& A. C. Ries (eds.), The Geology and Tectonics of the Oman Region. Geological Society Special Publication. 1990, pp. 495-519.

[16849] D. Nolf and S. Bajpai. "Marine middle Eocene fish otoliths from India and Java". English. In: Bulletin de I'lnstitut Royal des Sciences Naturelles de Belgique, Sciences de la Terre 62 (1992), pp. 195221.

[16850] D. Nolf and R. Brzobohaty. "Fish otoliths from the Late Oligocene (Eger and Kiscell Formations) in the Eger area (northeastern Hungary)". English. In: Bulletin de l'Institut Roayal des Sciences Naturells de Belgique 64 (1994), pp. 225-252.

[16851] J. Nõlvak. "A new chitinozoan species from the Upper Ordovician of the East Baltic". English. In: Estonian Journal of Earth Sciences 56.1 (2007), pp. 63-64.

[16852] T. Nomokonova, R. J. Losey, O. I. Gorlunova, A. G. Novikov, and A. J. Weber. "A 9,000 Year History of Seal Hunting on Lake Baikal, Siberia: The Zooarchaeology of Sagan-Zaba II". English. In: PLoS One 10.5 (2015), e0128314. DOI: 10.1371/journal.pone.0128314.

[16853] M. A. Norell, J. M. Clark, R. Barsbold, and L. M. Chiappe. Oviraptorid and dromaeosaurids and their association with presumed theropod nests. English. 1994.

[16854] M. A. Norell, J. M. Clark, A. H. Turner, P. J. Makovicky, R. Barsbold, and T. Rowe. “A new dromaeosaurid theropod from Ukhaa Tolgod (Ömnögov, Mongolia)". English. In: American Museum Novitates 3545 (2006), pp. 1-25.

[16855] M. A. Norell, J. M. Clark, and J. H. Hutchison. “The Late Cretaceous alligatoroid Brachychampsa montana (Crocodylia): new material and putative relationships". English. In: American Museum Novitates 3116 (1994), pp. 1-26.

[16856] M. A. Norell and J. A. Clarke. "Fossil that fills a critical gap in avian evolution". In: Nature 409 (2001), pp. 181-184. 
[16857] M. A. Norell and K. de Queiroz. "The earliest iguanine lizard (Reptilia: Squamata) and its bearing on iguanine phylogeny". English. In: American Museum Novitates 2997 (1991), pp. 1-16.

[16858] M. A. Norell and K. Gao. "Braincase and phylogenetic relationships of Estesia mongoliensis from the Late Cretaceous of the Gobi Desert and the recognition of a new clade of lizards". English. In: American Museum Novitates 3211 (1997), pp. 1-25.

[16859] M. A. Norell, K.-Q. Gao, and J. Conrad. “A New Platynotan Lizard (Diapsida: Squamata) from the Late Cretaceous Gobi Desert (Ömnögov), Mongolia". English. In: American Museum Novitates 3605 (2007), pp. 1-22.

[16860] M. A. Norell and S. H. Hwang. "A troodontid dinosaur from Ukhaa Tolgod (Late Cretaceous Mongolia)". In: American Museum Novitates 3446 (2004), pp. 1-9.

[16861] M. A. Norell, P. J. Makovicky, and J. M. Clark. "A new troodontid theropod from Ukhaa Tolgod, Mongolia". In: Journal of Vertebrate Paleontology 20.1 (2000), pp. 7-11.

[16862] M. A. Norell and P. J. Makovicky. "Important features of the dromaeosaur skeleton: information from a new specimen". English. In: American Museum Novitates 3215 (1997), pp. 1-28.

[16863] M. A. Norell and P. J. Makovicky. "Important features of the dromaeosaur skeleton II: information from newly collected specimens of Velociraptor mongoliensis". English. In: American Museum Novitates 3282 (1999), pp. 1-45.

[16864] B. S. Norford. "Stratigraphy and biostratigraphy of the Advance Formation, a new upper Middle Ordovician unit, northern Rocky Mountains, British Columbia". English. In: Geological Survey of Canada Bulletin 491 (1996), pp. 5-19.

[16865] J. I. Noriega and F. L. Agnolin. "El registro paleontológico de las Aves del Mesopo- tamiense (Formación Ituzaingó; Mioceno tardo- Plioceno) de la provincia de Entre Ros, Argentina". English. In: INSUGEO, Miscelánea 17.2 (2008), pp. 271-290.

[16866] J. I. Noriega, A. L. Cione, and F. G. Acenolaza. "Shark tooth marks on Miocene balaenopterid cetacean bones from Argentina". English. In: Neues Jahrbuch fur Geologie und Palaontologie 245.2 (2007), pp. 185-192.

[16867] J. I. Noriega and G. Cladera. "First record of an extinct marabou stork in the Neogene of South America". English. In: Acta Palaeontologica Polonica 53.4 (2008), pp. 593-600.

[16868] J. I. Noriega, E. A. Jordan, R. I. Vezzosi, and J. I. Areta. “A New Species of Opisthodactylus Ameghino, 1891 (Aves, Rheidae), from the Late Miocene of Northwestern Argentina, with Implications for the Paleobiogeography and Phylogeny of Rheas". English. In: Journal of Vertebrate Paleontology 37.1 (2017), e1278005. DOI: 10.1080/02724634.2017.1278005.

[16869] J. I. Noriega and C. P. Tambussi. “New material of Cayaoa bruneti TONNI, an Early Miocene anseriform (Aves) from Patagonia, Argentina". English. In: Neues Jahrbuch für Geologie und Paläontologie 249.3 (2008), pp. 271-280. DOI: 10.1127/0077-7749/2008/0249-0271.

[16870] D. B. Norman. "A taxonomy of iguanodontians (Dinosauria: Ornithopoda) from the lower Wealden Group (Cretaceous: Valanginian) of southern England". English. In: Zootaxa 2489 (2010), pp. 4766.

[16871] D. B. Norman. "On the taxonomy and diversity of Wealden iguanodontian dinosaurs (Ornithischia: Ornithopoda)". English. In: Revue de Paléobiologie 32.2 (2013), pp. 385-404.

[16872] D. B. Norman. "On the history, osteology, and systematic position of the Wealden (Hastings group) dinosaur Hypselospinus fittoni (Iguanodontia, Styracosterna)". English. In: Zoological Journal of the Linnean Society in press (2014).

[16873] A. L. Norrbom. "New genera of Tephritidae (Diptera) from Brazil and Dominican amber, with phylogenetic analysis of the tribe Ortalotrypetini". English. In: Insecta Mundi 8 (1994), pp. 1-15.

[16874] A. W. Norris, T. T. Uyeno, P. Sartenaer, and P. G. Telford. "Brachiopod and conodont faunas from the uppermost Williams Island Formation and lower Long Rapids Formation (Middle and Upper Devonian), Moose River Basin, northern Ontario". In: Geological Survey of Canada Bulletin 434 (1992), pp. 1-133. 
[16875] C. A. Norris. "The cranium of Bunomeryx (Artiodactyla: Homacodontidae) from the Upper Eocene Uinta deposits of Utah and its implications for tylopod systematics". In: Journal of Vertebrate Paleontology 19.4 (1999), pp. 742-751.

[16876] C. A. Norris. "The cranium of Leptotragulus, a hornless protoceratid (Artiodactyla: Protoceratidae) from the MIddle Eocene of North America". In: Journal of Vertebrate Paleontology 20.2 (2000), pp. 341-348.

[16877] C. A. Norris and D. L. Harrison. "Mammalian periotic bones from the Eocene deposits at Hordle, Hampshire". In: Acta Palaeontologica Polonica 41.1 (1998), pp. 69-77.

[16878] M. Nose, D. U. Schmid, and R. R. Leinfelder. "Significance of microbialites, calcimicrobes, and calcareous algae in reefal framework formation from the Silurian of Gotland, Sweden". English. In: Sedimentary Geology 192 (2006), pp. 243-265.

[16879] S. Nosotti and O. Rieppel. "Eusaurosphargis dalsassoi n. gen. n. sp., a new, unusual diapsid reptile from the Middle Triassic of Besano (Lombardy, N Italy)". English. In: Memoire della Societa Italiana di Scienze Naturali e del Museo Civico di Storia Naturale di Milano 31.3 (2003), pp. 1-33.

[16880] W. Nothdurft and J. Smith. The Lost Dinosaurs of Egypt. English. 2002, pp. 1-239.

[16881] C. R. Noto, S. K. Drumheller, T. L. Adams, and A. H. Turner. “An Enigmatic Small Neosuchian Crocodyliform from the Woodbine Formation of Texas". English. In: The Anatomical Record 303.4 (2020), pp. 801-812. DOI: 10.1002 /ar.24174.

[16882] A. Noubhani and H. Cappetta. "Révision des Rhombodontidae (Neoselachii, Batomorphi) des bassins á phosphate du Maroc". French. In: Palaeovertebrata 23 (1994), pp. 1-49.

[16883] J. Nouri, I. Daz-Martnez, and F. Pérez-Lorente. "Tetradactyl footprints of an unknown affinity theropod dinosaur from the Upper Jurassic of Morocco". English. In: PLoS One 6.12 (2011), e26882:17. DOI: $10.1371 /$ journal.pone.0026882.

[16884] M. J. Novacek, I. Ferrusqua-Villafranca, J. J. Flynn, A. R. Wyss, and M. A. Norell. “Wasatchian (early Eocene) mammals and other vertebrates from Baja California, Mexico : the Lomas Las Tetas de Cabra fauna". English. In: Bulletin of the American Museum of Natural History 208 (1991), pp. 188.

[16885] M. J. Novacek, G. W. Rougier, J. R. Wible, M. C. McKenna, D. Dashzeveg, and I. Horovitz. “Epipubic bones in eutherian mammals from the Late Cretaceous of Mongolia". English. In: Nature 389 (1997), pp. 483-486.

[16886] P. M. Novack-Gottshall. "Comparative geographic and environmental diversity dynamics of gastropods and bivalves during the Ordovician Radiation (M.S. thesis, University of Cincinnati)". English. PhD thesis. 1999, pp. 1-191.

[16887] P. M. Novack-Gottshall and A. I. Miller. "Taxonomic richness and abundance of Late Ordovician gastropods and bivalves in mollusc-rich strata of the Cincinnati Arch". English. In: Palaios 18 (2003), pp. 559-571.

[16888] V. Novák and J. Háva. “Amberophlus niger gen. nov and sp. nov. of the tribe Cteniopodini Solier, 1835 (Coleoptera: Tenebrionidae: Alleculinae) from Baltic amber". English. In: Folia Heyrovskyana, Series A 27.2 (2019), pp. 128-131.

[16889] F. E. Novas. "Alvarezsauridae, Cretaceous basal birds from Patagonia and Mongolia". English. In: Memoirs of the Queensland Museum 39.3 (1996), pp. 675-702.

[16890] F. E. Novas. "Megaraptor namunhuaiquii, gen. et sp. nov., a large-clawed, Late Cretaceous theropod from Patagonia". In: Journal of Vertebrate Paleontology 18.1 (1998), pp. 4-9.

[16891] F. E. Novas. "Anatomy of Patagonykus puertai (Theropoda, Avialae, Alvarezsauridae), from the Late Cretaceous of Patagonia". English. In: Journal of Vertebrate Paleontology 17.1 (1997), pp. 137166.

[16892] F. E. Novas, F. L. Agnoln, and C. A. Scanferla. "New enantiornithine bird (Aves, Ornithothoraces) from the Late Cretaceous of NW Argentina". English. In: Comptes Rendus Palevol 9 (2010), pp. 499 503. 
[16893] F. E. Novas, F. L. Agnolin, S. Rozadilla, A. M. Aranciaga-Rolando, F. Brisson-Egli, M. J. Motta, M. Cerroni, M. D. Ezcurra, A. G. Martinelli, J. S. D'Angelo, and G. Alvarez-Herrera. "Paleontological discoveries in the Chorrillo Formation (upper Campanian-lower Maastrichtian, Upper Cretaceous), Santa Cruz Province, Patagonia, Argentina". English. In: Revista del Museo Argentino de Ciencias Naturales, Nueva Serie 21.2 (2019), pp. 217-293.

[16894] F. E. Novas, L. C. Borges Ribeiro, and I.d.S. Carvalho. "Maniraptoran theropod ungual from the Marlia Formation (Upper Cretaceous), Brazil". English. In: Revista del Museo Argentino de Ciencias Naturales, nuevo serie 7.1 (2005), pp. 31-36.

[16895] F. E. Novas, A. V. Cambiaso, and A. Ambrosio. "A new basal iguanodontian (Dinosauria, Ornithischia) from the Upper Cretaceous of Patagonia". English. In: Ameghiniana 41.1 (2004), pp. 7582.

[16896] F. E. Novas, I.d.S. Carvalho, L. C. B. Ribeiro, and A. H. Méndez. "First abelisaurid bone remains from the Maastrichtian Marlia Formation, Bauru Basin, Brazil". English. In: Cretaceous Research 29.4 (2008), pp. 625-635. DOI: 10.1016/j.cretres.2008.01.010.

[16897] F. E. Novas, S. Chatterjee, D. K. Rudra, and P. M. Datta. Rahiolisaurus gujaratensis, n. gen. n. sp., a new abelisaurid theropod from the Late Cretaceous of India. English. New Aspects of Mesozoic Biodiversity. Lecture Notes in Earth Sciences 132. Springer-Verlag, Berlin. 2010, pp. 45-62. DOI: 10.1007/978-3642-10311-7_3.

[16898] F. E. Novas, S. de Valais, P. A. Vickers-Rich, and T. H. Rich. "A large Cretaceous theropod from Patagonia, Argentina, and the evolution of carcharodontosaurids". English. In: Naturwissenschaften 92 (2005), pp. 226-230.

[16899] F. E. Novas, M. D. Ezcurra, and F. L. Agnoln. "Humerus of a basal abelisauroid theropod from the Late Cretaceous of Patagonia". English. In: Revista del Museo Argentino de Ciencias Naturales, nuevo serie 8.1 (2006), pp. 63-68.

[16900] F. E. Novas, M. D. Ezcurra, and A. Lecuona. “Orkoraptor burkei nov. gen. et sp., a large theropod from the Maasdtrichtian Pari Aike Formation, southern Patagonia, Argentina". English. In: Cretaceous Research 29.3 (2008), pp. 468-480. DOI: 10.1016/j.cretres.2008.01.001.

[16901] F. E. Novas, M. D. Ezcurra, S. Chatterjee, and T. S. Kutty. "New dinosaur species from the Upper Triassic Upper Maleri and Lower Dharmaram formations of Central India". English. In: Earth and Environmental Science Transactions of the Royal Society of Edinburgh 101 (2011), pp. 333-349. DOI: 10.1017/S1755691011020093.

[16902] F. E. Novas, M. D. Ezcurra, F. L. Agnolin, D. Pol, and R. Ortz. "New Patagonian Cretaceous theropod sheds light about the early radiation of Coelurosauria". English. In: Revista del Museo Argentino de Ciencias Naturales, nuevo serie 14.1 (2012), pp. 57-81.

[16903] F. E. Novas, M. Fernández, Z.B.d. Gasparini, J. M. Lirio, H. J. Nuñez, and P. Puerta. “Lakumasaurus antarcticus, n. gen. et sp., a new mosasaur (Reptilia, Squamata) from the Upper Cretaceous of Antarctica". English. In: Ameghiniana 39.2 (2002), pp. 245-249.

[16904] F. E. Novas, M. Kundrat, F. L. Agnolin, M. D. Ezcurra, P. E. Ahlberg, M. P. Isasi, A. Arriagada, and P. Chafrat. "A new large pterosaur from the Late Cretaceous of Patagonia". English. In: Journal of Vertebrate Paleontology 32.6 (2012), pp. 1447-1452. DOI: 10.1080/02724634.2012.703979.

[16905] F. E. Novas, D. F. Pais, D. Pol, I.d.S. Carvalho, A. Scanferla, A. Mones, and M. S. Riglos. “Bizarre notosuchian crocodyliform with associated eggs from the Upper Cretaceous of Bolivia". English. In: Journal of Vertebrate Paleontology 29.4 (2009), pp. 1316-1320. DOI: 10.1671/039.029.0409.

[16906] F. E. Novas and D. Pol. "New evidence on deinonychosaurian dinosaurs from the Late Cretaceous of Patagonia". In: Nature 433 (2005), pp. 858-861.

[16907] F. E. Novas, D. Pol, J. I. Canale, J. D. Porfiri, and J. O. Calvo. “A bizarre Cretaceous theropod dinosaur from Patagonia and the evolution of Gondwanan dromaeosaurids". English. In: Proceedings of the Royal Society B (2008). DOI: 10.1098/rspb.2008.1554.

[16908] F. E. Novas and P. F. Puerta. "New evidence concerning avian origins from the Late Cretaceous of Patagonia". In: Nature 387 (1997), pp. 390-392. 
[16909] F. E. Novas, L. Salgado, J. O. Calvo, and F. L. Agnoln. “Giant titanosaur (Dinosauria, Sauropoda) from the Late Cretaceous of Patagonia". English. In: Revista del Museo Argentino de Ciencias Naturales, nuevo serie 7.1 (2005), pp. 37-41.

[16910] F. E. Novas, L. Salgado, M. Suárez, F. L. Agnoln, M. D. Ezcurra, N. R. Chimento, R. de la Cruz, M. P. Isasi, A. O. Vargas, and D. Rubilar-Rogers. "An enigmatic plant-eating theropod from the Late Jurassic period of Chile". English. In: Nature 522.7556 (2015), pp. 331-334. DOI: 10.1038 / nature14307.

[16911] A. Novello, C. Blondel, and M. Brunet. "Feeding behavior and ecology of the Late Oligocene Moschidae (Mammalia, Ruminantia) from La Milloque (France): Evidence from dental microwear analysis". English. In: Comptes Rendus Palevol 9 (2010), pp. 471-478.

[16912] I. V. Novikov, V. R. Lozovsky, M. A. Shishkin, and M. G. Minikh. “Novyy gorizont v nizhnem triase Vostochno-Yevropeyskoy platformy [A new horizon in the Lower Triassic of the East European Platform]". Russian. In: Doklady Akademii Nauk SSSR 315.2 (1990), pp. 453-456.

[16913] I. V. Novikov. "Novye Dannye po Prokolofoninam SSSR [New data on Procolophonines of the USSR]". Russian. In: Paleontologicheskii Zhurnal 1991.2 (1991), pp. 73-85.

[16914] I. V. Novikov. "New data on trematosauroid labyrinthodonts of Eastern Europe: 2. Trematosaurus galae sp. nov.: cranial morphology". English. In: Paleontological Journal 44.4 (2010), pp. 94-104.

[16915] I. V. Novikov. "New data on trematosauroid labyrinthodonts of Eastern Europe: 4. Genus Benthosuchus Efremov, 1937". English. In: Paleontological Journal 46.4 (2012), pp. 68-79.

[16916] I. V. Novikov. "New Data on Trematosauroid Labyrinthodonts of Eastern Europe: 3. Qantas samarensis gen. et sp. nov." English. In: Paleontological Journal 46.2 (2012), pp. 177-186. DOI: 10.1134 / S0031030112020098.

[16917] I. V. Novikov. “New Data on Trematosauroid Labyrinthodonts of Eastern Europe: 1. Genus Inflectosaurus Shishkin, 1960". English. In: Paleontological Journal 41.2 (2007), pp. 167-174.

[16918] I. V. Novikov. "New tempospondyl amphibians from the basal Triassic of the Obshchii Syrt Highland, Eastern Europe". English. In: Paleontological Journal 50.3 (2016), pp. 297-310.

[16919] I. V. Novikov, D. S. Aristov, and I. D. Sukacheva. "Paleontological characterization of the Triassic deposits of the Korotaikha Depression (Northern Cis-Urals)". English. In: Paleontological Journal 53 (2019), pp. 752-756. DOI: 10.1134/S0031030119070074.

[16920] I. V. Novikov and A. N. Orlov. "Novye Dannye po Rannetriasovym Pozvonochnym o. Kolguev [New Data on Early Triassic Vertebrates on the Kolguyev Island]". Russian. In: Paleontologicheskii Zhurnal 1992.1 (1992), pp. 133-136.

[16921] I. V. Novikov, M. A. Shishkin, and V. K. Golubev. Permian and Triassic anthracosaurs from Eastern Europe. English. The Age of Dinosaurs in Russia and Mongolia. Cambridge University Press, Cambridge. 2000, pp. 60-70.

[16922] I. V. Novikov and M. A. Shishkin. "Triassic chroniosuchians (Amphibia, Anthracosauromorpha) and the evolution of trunk dermal scutes in bystrowianids". English. In: Paleontological Journal 34.2 (2000), S165-S178.

[16923] I. V. Novikov and M. A. Shishkin. "New Middle Triassic labyrinthodonts from the Pechora Urals". English. In: Paleontological Journal 26 (1992), pp. 92-102.

[16924] I. V. Novikov and H.-D. Sues. “Cranial osteology of Kapes (Parareptilia: Procolophonidae) from the Lower Triassic of Orenburg Province, Russia". English. In: Neues Jahrbuch für Geologie und Paläontologie, Abhandlungen 232.2 (2004), pp. 267-281.

[16925] N. M. Novo and J. G. Fleagle. "New specimens of platyrrhine primates from Patagonia (Pinturas Formation, Early Miocene)". English. In: Ameghiniana 52.3 (2015), pp. 367-372. DOI: 10.5710 / AMGH.22.01.2015.2887.

[16926] N. M. Novo, M. F. Tejedor, M. E. Pérez, and J. M. Krause. "New primate locality from the early Miocene of Patagonia, Argentina". English. In: American Journal of Physical Anthropology 164 (2017), pp. 861-867. DOI: 10.1002/ajpa.23309. 
[16927] N. M. Novo, M. F. Tejedor, and L. R. González-Ruiz. “Previously unknown fossil platyrrhines (Primates) of Patagonia from the Tournouër collection at the Muséum national d'Histoire naturelle, Paris". English. In: Geodiversitas 40.22 (2018), pp. 529-535. DOI: 10.5252/geodiversitas2018v40a22.

[16928] V. Novokshonov. “Der älteste Vertreter der Meropeidae (Mecoptera, Insecta)”. German. In: Paläontologische Zeitschrift 69 (1995), pp. 149-152.

[16929] V. Novokshonov and E. Novokshonova. “Okolpania favorabilis n. sp. (Planipennia; Neuroptera: Permithonidae) aus dem unteren Perm des Urals". German. In: Paläontologische Zeitschrift 71 (1997), pp. 89-90.

[16930] V. G. Novokshonov. "Die interessante Bittacidenreste (Mecoptera Insecta) aus dem Jura von Eurasien". German. In: Russian Entomological Journal 2.1 (1993), pp. 57-62.

[16931] V. G. Novokshonov. Russian. Rannyaya Evolyutsiya Skorpionnits (Insecta: Panorpida). Moscow: Nauka, 1997, pp. 1-140.

[16932] V. G. Novokshonov. "New fossil insects (Insecta: Hypoperlida, Panorpida, Ordinis Incertis) from the Chekarda Locality". English. In: Paleontological Journal 33 (1999), pp. 52-56.

[16933] V. G. Novokshonov. "Scorpionflies of the Family Liassophilidae from the Triassic of Ukraine". English. In: Paleontological Journal 36.4 (2002), pp. 380-382.

[16934] V. G. Novokshonov. "New Triassic Scorpionflies (Insecta, Mecoptera)". English. In: Paleontological Journal 31.6 (1997), pp. 628-635.

[16935] V. G. Novokshonov. "New Fossil Insects from the Kungurian of the Middle Urals". English. In: Paleontological Journal 29.3 (1995), pp. 76-85.

[16936] V. G. Novokshonov. "The First Mecopteroids (Insecta: Papilionidea = Mecopteroidea) and the Origin of Scorpionflies (Panorpida = Mecoptera), with Description of a Legless Eruciform Larva from the Lower Permian of Tshekarda". English. In: Paleontological Journal 38.2 (2004), pp. 204-213.

[16937] V. G. Novokshonov. "Some Mesozoic scorpionflies (Insecta: Panorpida=Mecoptera) of the families Mesopsychidae, Pseudopolycentropodidae, Bittacidae, and Permochoristidae". English. In: Paleontological Journal 31.1 (1997), pp. 65-71.

[16938] V. G. Novokshonov. “New insects (Insecta: Hypoperlida, Mischopterida, Jurinida) from the Lower Permian of the Middle Urals". Russian. In: Paleontological Journal 32 (1998), pp. 46-53.

[16939] V. G. Novokshonov. "New Taxa of Fossil Insects from the Lower Permian of the Middle Urals". Russian. In: Paleontological Journal 31 (1997), pp. 383-388.

[16940] V. G. Novokshonov. “New Fossil Insects (Insecta: Grylloblattida, Caloneurida, Hypoperlida?, Ordinis Incertis) from the Kungurian Beds of the Middle Urals". English. In: Paleontological Journal 32.4 (1998), pp. 362-368.

[16941] V. G. Novokshonov. "New Fossil Insects (Insecta: Grylloblattida, Ordinis Incertis) from the Lower Permian of the Middle Urals". English. In: Paleontological Journal 34 (2000), pp. 513-518.

[16942] V. G. Novokshonov. "New Palaeomanteida=Miomoptera from the Lower Permian of Tshekarda". English. In: Paleontological Journal 34.Suppl 3 (2000), S303-S308.

[16943] V. G. Novokshonov. "New and little known Permian scorpion flies (Insecta, Mecoptera = Panorpida) of the family Agetopanorpidae from Perm and Arkhangel'sk oblasts". English. In: Paleontological Journal 27.1A (1993), pp. 70-89.

[16944] V. G. Novokshonov. “Caddis flies (Insecta, Trichoptera, Microptysmatidae)". English. In: Paleontological Journal 27.1A (1993), pp. 90-102.

[16945] V. G. Novokshonov. "New insects (Insecta) from the Lower Permian of Chekarda (central Urals)". English. In: Paleontological Journal 27.1A (1993), pp. 172-178.

[16946] V. G. Novokshonov. "Permian Scorpion Flies (Insecta, Panorpida) of the Families Kaltanidae, Permochoristidae and Robinjohnidae". English. In: Paleontological Journal 28.1 (1994), pp. 79-95. 
[16947] V. G. Novokshonov. "Scorpion Flies of the Family Permochoristidae, the Closest Common Ancestors of Extant Scorpion Flies (Insecta, Panorpida-Mecoptera)". Russian. In: Zoologicheskii Zhurnal 73.7-8 (1994), pp. 58-70.

[16948] V. G. Novokshonov. “Tshekhosara improvida n. gen., n. sp. (Insecta; Grylloblattida: Megakhosaridae) aus dem unteren Perm des Urals". German. In: Paläontologische Zeitschrift 72 (1998), pp. 6566.

[16949] V. G. Novokshonov. "New enigmatic insects (Insecta: Hypoperlidea?: Sojanopteridae) from the Upper Permian of northern Russia". English. In: Paleontological Journal 36 (2002), pp. 48-49.

[16950] V. G. Novokshonov. "New and little-known representatives of the family Hypoperlidae (Insecta: Hypoperlida)". English. In: Paleontological Journal 35 (2001), pp. 40-44.

[16951] V. G. Novokshonov. "New Triassic scorpionflies (Insecta, Mecoptera) from Kyrgyzstan”. English. In: Paleontological Journal 35 (2001), pp. 281-288.

[16952] V. G. Novokshonov. "Permian scorpion flies (Insecta, Panorpida) of the family Permochoristidae". English. In: Paleontological Journal 29.1 (1995), pp. 84-99.

[16953] V. G. Novokshonov. "Caddis flies of the genus Kamopanorpa (Trichoptera, Microptysmatidae) from the Kungurian of Chekarda (Perm District)". English. In: Paleontological Journal 26.3 (1992), pp. 136-141.

[16954] V. G. Novokshonov. “Eine neue Notoptere aus dem unteren Perm des Urals (Insecta: Grylloblattida, Lemmatophoridae)". German. In: Neues Jahrbuch für Geologie und Paläontologie, Monatshefte 1999.11 (1999), pp. 641-646.

[16955] V. G. Novokshonov. "Orthobittacus polymitus sp. n. und Asiathauma sajsagulis gen. et sp. n., zwei fossile Mecoptera-Arten aus dem Jura von Kasachstan und Kirgisien". German. In: Russian Entomological Journal 5 (1996), pp. 94-96.

[16956] V. G. Novokshonov. “Mückenhafte (Mecoptera Bittacidae) aus dem Jura, Kreide und Paläogen von Eurasien und ihre phylogenetischen Beziehungen". German. In: Russian Entomological Journal 2 (1993), pp. 75-86.

[16957] V. G. Novokshonov and D. S. Aristov. “New Taxa of Hypoperlids (Insecta: Hypoperlida) from the Upper Permian of the Arkhangelsk Region". English. In: Paleontological Journal 38.1 (2004), pp. 6066.

[16958] V. G. Novokshonov and D. S. Aristov. "New and little-known Permian insects (Insecta: Grylloblattida; Orthoptera) from the Chekarda locality, central Ural Mountains". English. In: Paleontological Journal 36 (2002), pp. 644-649.

[16959] V. G. Novokshonov and D. S. Aristov. "Grilloblattidy roda Sylvaella (Insecta; Grylloblattida: Sylbaphlebiidae) iz nizhney Permi Urala". Russian. In: Vestnik Permskogo Universiteta, Geologiya 3 (1999), pp. 109-114.

[16960] V. G. Novokshonov, V. D. Ivanov, and I. D. Sukacheva. “New Jurassic caddis flies (Insecta, Phryganeida=Trichoptera) from Siberia and Mongolia". English. In: Paleontological Journal 29.4 (1995), pp. 157-163.

[16961] V. G. Novokshonov, V. V. Ivanov, and D. S. Aristov. "New insects from the Late Permian of the Ural Mountains". English. In: Paleontological Journal 36 (2002), pp. 157-160.

[16962] V. G. Novokshonov and N. N. Pan'kov. "A new aquatic insect larva (Plecopteroidea) from the Lower Permian of the Urals". English. In: Neues Jahrbuch für Geologie und Paläontologie, Monatshefte 1999.4 (1999), pp. 193-198.

[16963] V. G. Novokshonov and A. P. Rasnitsyn. "A new enigmatic group of insects (Psocidea, Tshekarcephalidae) from Tshekarda (Lower Permian of the middle Urals)". English. In: Paleontological Journal 34.Suppl 3 (2000), S284-S287.

[16964] V. G. Novokshonov, A. J. Ross, E. Cook, W. Krzemiski, and A. Soszyska-Maj. "A new family of scorpionflies (Insecta; Mecoptera) from the Lower Cretaceous of England". English. In: Cretaceous Research 62 (2016), pp. 44-51. 
[16965] V. G. Novokshonov and S. Y. Storozhenko. "New genus of the family Sojanoraphidiidae (Grylloblattida) from the Lower Permian of Ural". English. In: Far Eastern Entomologist 33 (1996), pp. 14.

[16966] V. G. Novokshonov, I. D. Sukacheva, and D. S. Aristov. “An Early Triassic scorpionfly (Panorpida = Mecoptera) of the Vologda Region". English. In: Paleontological Journal 38.Suppl 2 (2004), S214S215.

[16967] V. G. Novokshonov and I. D. Sukacheva. "Fossil Scorpionflies of the Suborder Paratrichoptera (Insecta: Mecoptera)". English. In: Paleontological Journal 35 (2001), pp. 173-182.

[16968] V. G. Novokshonov and I. D. Sukacheva. "New genus of caddis flies (Insecta; Trichoptera = Phryganeida) from the Upper Permian of Kazakhstan". English. In: Paleontological Journal 27.1A (1993), pp. 166-168.

[16969] V. G. Novokshonov and I. D. Sukatsheva. "New Jurassic scorpionflies of the families Orthophlebiidae and Nannochoristidae (Insecta: Mecoptera) from Mongolia and Transbaikalia". English. In: Paleontological Journal 37 (2003), pp. 501-506.

[16970] V. G. Novokshonov and R. Willmann. "On the morphology of Asthenohymen uralicum (Insecta; Diaphanopterida: Asthenohymenidae) from the Lower Permian of the Urals". English. In: Paleontological Journal 33 (1999), pp. 539-545.

[16971] V. G. Novokshonov and L. V. Zhuzhgova. "Palaeomantis laeta n. sp., the third representative of the genus Palaeomantis (Insecta: Miomoptera, Palaeomanteidae) from the Lower Permian of Chekarda (Ural)". English. In: Neues Jahrbuch für Geologie und Paläontologie, Monatshefte 2002.6 (2002), pp. 373-376.

[16972] V. G. Novokshonov and L. V. Zhuzhgova. "Discussion of the System and Phylogeny of the Order Palaeomanteida (=Miomoptera) with Description of New Representatives of the Genus Permosialis Mart. from the Late Permian of Kirov Region and Triassic of Kyrgyzstan". English. In: Paleontological Journal 38.2 (2004), pp. 173-184.

[16973] V. N. Novokshonov. "Novye setchatokrylye (Neuroptera) iz verkhnego Mela Azii". Russian. In: Novosti Faunistiki i Sistematiki 1990 (1990), pp. 63-68.

[16974] E. A. Novokshonova. "A new species of Hypoperlidae (Insecta, Hypoperlida) from the Lower Permian of the middle Urals". English. In: Paleontological Journal 32 (1998), pp. 503-504.

[16975] A. Nowinski. “Late Carboniferous to early Permian Tabulata from Spitsbergen”. English. In: Palaeontologia Polonica 51 (1991), pp. 3-74.

[16976] A. Nowinski. "Tabulate corals from the Givetian and Frasnian of the Holy Cross Mountains and Silesian Upland". English. In: Acta Palaeontologica Polonica 37 (1992), pp. 183-216.

[16977] A. Nowinski. "A new trachypsammiid cnidarian from the Late Permian of Spitsbergen". English. In: Polish Polar Research 18 (1997), pp. 159-169.

[16978] M. J. Ntamak-Nida, B. Ketchemen-Tandia, R. V. Ewane, J. P. Lissock, and P. Courville. “Nouvelles données sur les Mollusques et autres macro-organismes campaniens de Sikoum (Centre-Est du sous bassin de Douala-Cameroun): intérets bio-chronologiques et paléo-écologiques". French. In: Africa Geoscience Review 13.4 (2006), pp. 385-394.

[16979] A. Nuetzel. "Racheliella, a new mathildoid gastropod genus (Gastropoda, lower Heterobranchia) from the Late Triassic St. Cassian Formation (N Italy)". English. In: Neues Jahrbuch für Geologie und Paläontologie - Abhandlungen 287.2 (2018).

[16980] C. Núñez-Lahuerta, J. Galán, V. Sauqué, R. Rabal-Garcés, and G. Cuenca-Bescós. “Avian remains from new Upper Pleistocene and Holocene sites in the Spanish Pyrenees". English. In: Quaternary International 481 (2018), pp. 123-134.

[16981] J. F. Nunn. “A new tridactyl footprint impression in Durlston Bay, Swanage". English. In: Proceedings of the Dorset Natural History and Archaeological Society 111 (1990), pp. 133-134.

[16982] P. D. Nunn. "Significance of emerged Holocene corals around Ovalau and Moturiki islands, Fiji, southwest Pacific". English. In: Marine Geology 163 (2000), pp. 345-351. 
[16983] D. K. Nurgaliev, V. V. Silantiev, and S. V. Nikolaeva. Type and reference sections of the Middle and Upper Permian of the Volga and Kama River Regions: A Field Guidebook of XVIII International Congress on Carboniferous and Permian. English. Kazan: Kazan University Press, 2015, pp. 1-208.

[16984] A. Nützel. "A new Early Triassic gastropod genus and the recovery of gastropods from the Permian/Triassic extinction". English. In: Acta Palaeontologica Polonica 50.1 (2005), pp. 19-24.

[16985] A. Nützel. "A review of the Triassic gastropod genus Kittliconcha Bonarelli, 1927 - implications for the phylogeny of Caenogastropoda". English. In: Zitteliana A50 (2010), pp. 9-24.

[16986] A. Nützel. "Two new caenogastropod genera from the Late Triassic Cassian Formation". English. In: Zitteliana 47 (2007), pp. 53-58.

[16987] A. Nützel, B. Aghababalou, and B. Senowbari-Daryan. "Gastropods from the Norian (Late Triassic) Nayband Formation near Natanz (Iran)". English. In: Bulletin of Geosciences 87 (2012), pp. 5365.

[16988] A. Nützel, R. B. Blodgett, and G. D. Stanley. "Late Triassic gastropods from the Martin Bridge Formation (Wallowa Terrane) of northeastern Oregon and their paleogeographic significance". English. In: Neues Jahrbuch für Geologie und Paläontologie, Abhandlungen 228.1 (2003), pp. 83-100.

[16989] A. Nützel and D. H. Erwin. “Battenizyga, a new Early Triassic gastropod genus with a discussion of the caenogastropod evolution at the Permian/Triassic boundary". English. In: Paläontologische Zeitschrift 76.1 (2002), pp. 21-27.

[16990] A. Nützel and D. H. Erwin. "New Late Triassic gastropods from the Wallowa Terrane (Idaho) and their biogeographic significance". English. In: Facies 45 (2001), pp. 87-92.

[16991] A. Nützel and D. H. Erwin. "Late Triassic (late Norian) gastropods from the Wallowa Terrane (Idaho, USA)". English. In: Paläontologische Zeitschrift 78.2 (2004), pp. 361-416.

[16992] A. Nützel and D. L. Geiger. "A new scissurelloid genus and species (Mollusca, Gastropoda) from the Late Triassic Cassian Formation". English. In: Paläontologische Zeitschrift 80.3 (2006), pp. 277283.

[16993] A. Nützel, A. Hamedani, and B. Senowbari-Daryan. "Some Late Triassic gastropods from the Nayband Formation in central Iran". English. In: Facies 48 (2003), pp. 127-134.

[16994] A. Nützel and A. Kaim. "Diversity, palaeoecology and systematics of a marine fossil assemblage from the Late Triassic Cassian Formation at Settsass Scharte, N Italy". English. In: Paläontologische Zeitschrift 88 (2014), pp. 405-431. DOI: 10.1007/s12542-013-0205-1.

[16995] A. Nützel, A. Kaim, and E. Gradinaru. "Middle Triassic (Anisian, Bithynian) gastropods from North Dobrogea (Romania) and their significance for gastropod recovery from the end-Permian mass extinction event". English. In: Papers in Palaeontology 4 (2018), pp. 477-512.

[16996] A. Nützel and C. Ketwetsuriya. "Systematic palaeontology, in Permian gastropods from the Tak Fa Limestone, Nakhon Sawan, northern Thailand". English. In: Bulletin of Geosciences 91 (2016), pp. 481-513.

[16997] A. Nützel and W. Kiessling. "Gastropoden aus dem Amaltheenton (oberes Pliensbachium) von Kalchreuth". German. In: Geologische Blätter von Nordost-Bayern 70 (1997), pp. 381-414.

[16998] A. Nützel and R. H. Mapes. "Larval and juvenile gastropods from a Carboniferous black shale: palaeoecology and implications for the evolution of the Gastropoda". English. In: Lethaia 34.2 (2001), pp. 143-162.

[16999] A. Nützel and K. Nakazawa. "Permian (Capitanian) gastropods from the Akasaka Limestone (Gifu Prefecture, Japan)". English. In: Journal of Systematic Palaeontology 10 (2012), pp. 103-169.

[17000] A. Nützel, H. Z. Pan, and D. H. Erwin. "New taxa and some taxonomic changes of latest Permian gastropod fauna from China". English. In: Documenta Naturae 145 (2002), pp. 1-7.

[17001] A. Nützel and H.-Z. Pan. "Late Paleozozoic evolution of the Caenogastropoda: larval shell morphology and implications for the Permian/Triassic mass extinction event". English. In: Journal of Paleontology 79.6 (2005), pp. 1175-1188. 
[17002] A. Nützel and C. Schulbert. "Facies of two important Early Triassic gastropod lagerstatten: implications for diversity patterns in the aftermath of the end-Permian mass extinction". English. In: Facies 51 (2005), pp. 480-500.

[17003] A. Nützel and B. Senowbari-Daryan. "Gastropods from the Late Triassic (Norian-Rhaetian) Nayband Formation of central Iran". English. In: Beringeria 23 (1999), pp. 93-132.

[17004] A. Nützel, D. Ware, H. Bucher, M. Hautmann, G. Roohi, K. Ur-Rehman, and A. Yaseen. “An Early Triassic (Dienerian) microgastropod assemblage from the Salt Range, Pakistan and its implication for gastropod recovery from the end-Permian mass extinction". English. In: Bulletin of Geosciences 93 (2018), pp. 56-70.

[17005] C. N. Nwojiji, P. Osterloff, A. Okoro, and P. O. Ukeri. "Palynostratigraphy and Age of the Sequence Penetrated by the Kolmani River 1 Well in the Gongola Basin, Northern Benue Trough, Nigeria". English. In: Journal of Geosciences and Geomatics 1.1 (2013), pp. 15-21.

[17006] T. Nyborg, A. Garassino, and G. Slak. “Eonomus californianus n. gen., n. sp. (Crustacea, Brachyura, Cymonomidae) from the Eocene Llajas Formation, California (USA)". English. In: Neues Jahrbuch für Geologie und Paläontologie-Abhandlungen 286.2 (2017), pp. 189-193.

[17007] T. Nyborg and A. Garassino. "A new genus of slipper lobster (Crustacea: Decapoda: Scyllaridae) from the Eocene of California and Oregon (USA)". English. In: Neues Jahrbuch für Geologie und Paläontologie - Abhandlungen 283.3 (2017), pp. 309-316. DOI: 10.1127/njgpa/2017/0644.

[17008] T. Nyborg and A. Garassino. "New fossil squat lobsters (Crustacea: Anomura: Munididae) from the Eastern Pacific". English. In: Palaeodiversity 8 (2015), pp. 95-101.

[17009] T. Nyborg and A. Garassino. “New Neogene species of Tymolus STIMPSON, 1858 (Decapoda, Brachyura, Cyclodorippidae) from the eastern Pacific". English. In: Neus Jahrbuch fur Geologie und Palaontologie, Abhandlungen 296'.1-2 (2020), pp. 167-174.

[17010] T. Nyborg, B. Nyborg, A. Garassino, and F. J. Vega. “New occurrences of fossil Macrocheira (Brachyura, Inachidae) from the North Eastern Pacific". English. In: Paleontologia Mexicana 5.2 (2016), pp. 123135.

[17011] T. Nyborg, G. E. Phillips, B. V. Bakel, and F. J. Vega. “A new genus and species of raninoid crab from the Upper". English. In: 91 (2017), pp. 291-298. DOI: 10.1007/s12542-017-0373-5.

[17012] T. Nyborg and F. J. Vega. “Three new fossil species of Lopihomastix (Decapoda: Blepharipodidae) from the Cenozoic of Washington". English. In: Journal of Crustacean Biology 28.2 (2008), pp. 361369.

[17013] T. Nyborg, F. J. Vega, and H. F. Filkorn. "First described species of Costacopluma (Crustacea: Brachyura: Retroplumidae) from the Pacific slope, Paleocene of California, USA". English. In: Boletin de la Sociedad Geologica Mexicana 61.2 (2009), pp. 203-209.

[17014] T. G. Nyborg, R. E. Berglund, and J. L. Goedert. “A New Crab From The Late Eocene Hoko River Formation, Olympic Peninsula, Washington: The Earliest Record Of Euphylax (Decapoda: Portunidae)". English. In: Journal of Paleontology 77.2 (2003), pp. 323-330. DOI: 10.1666/0022-3360(2003) 077<0323:ANCFTL>2.0.CO;2.

[17015] R. L. Nydam. "A new taxon of helodermatid-like lizard from the Albian-Cenomanian of Utah". English. In: Journal of Vertebrate Paleontology 20.2 (2000), pp. 285-294.

[17016] R. L. Nydam. "Lizards of the Mussentuchit Local Fauna (Albian-Cenomanian boundary) and comments on the evolution of the Cretaceous lizard fauna of North America". English. In: Journal of Vertebrate Paleontology 22.3 (2002), pp. 645-660.

[17017] R. L. Nydam. "Polyglyphanodontinae (Squamata: Teiidae) from the medial and Late Cretaceous: new taxa from Utah, U.S.A. and Baja California del Norte, Mexico". English. In: Utah Geological Survey Miscellaneous Publication 99-1 (1999), pp. 303-317.

[17018] R. L. Nydam. "Dakotaseps gen. nov., a replacement name for the lizard genus Dakotasaurus Nydam 2013, a junior homonym of the ichnotaxon Dakotasaurus Branson and Mehl 1932". English. In: Zootaxa 3900.1 (2014), p. 150. 
[17019] R. L. Nydam, M. W. Caldwell, and F. Fanti. “Borioteiioidean lizard skulls from Kleskun Hil (Wapiti Formation; upper Campanian), west-central Alberta, Canada". English. In: Journal of Vertebrate Paleontology 30.4 (2010), pp. 1090-1099.

[17020] R. L. Nydam, D. J. Chure, and S. E. Evans. "Schillerosaurus gen. nov., a replacement name for the lizard genus Schilleria Evans and Chure, 1999 a junior homonym of Schilleria Dahl, 1907". English. In: Zootaxa 3734.1 (2013), pp. 99-100.

[17021] R. L. Nydam and R. L. Cifelli. "A new teiid lizard from the Cedar Mountain Formation (AlbianCenomanian boundary) of Utah". English. In: Journal of Vertebrate Paleontology 22.2 (2002), pp. 276285.

[17022] R. L. Nydam and R. L. Cifelli. "Lizards from the Lower Cretaceous (Aptian-Albian) Antlers and Clovery formations". English. In: Journal of Vertebrate Paleontology 22.2 (2002), pp. 286-298.

[17023] R. L. Nydam, J. G. Eaton, and J. T. Sankey. "New taxa of transversely-toothed lizards (Squamata: Scincomorpha) and new information on the evolutionary history of teiids". English. In: Journal of Paleontology 81.3 (2007), pp. 538-549.

[17024] R. L. Nydam and B. M. Fitzpatrick. "The occurrence of Contogenys-like lizards in the Late Cretaceous and Early Tertiary of the Western Interior of the U.S.A." English. In: Journal of Vertebrate Paleontology 29.3 (2009), pp. 677-701. DOI: 10.1671/039.029.0331.

[17025] R. L. Nydam, J. A. Gauthier, and J. J. Chiment. "The mammal-like teeth of the Late Cretaceous lizard Peneteius aquilonius Estes 1969 (Squamata, Teiidae)". English. In: Journal of Vertebrate Paleontology 20.3 (2000), pp. 628-631.

[17026] R. L. Nydam, T. B. Rowe, and R. L. Cifelli. “Lizards and snakes of the Terlingua local fauna (Late Campanian), Aguja Formation, Texas, with comments on the distribution of paracontemporaneous squamates throughout the Western Interior of North America". English. In: Journal of Vertebrate Paleontology 33.5 (2013), pp. 1081-1099.

[17027] R. L. Nydam and G. E. Voci. "Teiid-like scincomorphan lizards from the Late Cretaceous (Campanian) of southern Utah". English. In: Journal of Herpetology 41.2 (2007), pp. 211-219.

[17028] E. Nye, S. Feist-Burkhardt, D. J. Horne, A. J. Ross, and J. E. Whittaker. "The palaeoenvironment associated with a partial Iguanodon skeleton from the Upper Weald Clay (Barremian, Early Cretaceous) at Smokejacks Brickworks (Ockley, Surrey, UK), based on palynomorphs and ostracods". English. In: Cretaceous Research 29.3 (2008), pp. 417-444. DOI: 10.1016/j.cretres.2008.01.004.

[17029] B. O'Conner. "Seven New Radiolarian Species from the Oligocene of New Zealand". English. In: Micropaleontology 40.4 (1994), pp. 337-350.

[17030] J. O'Connor, X. Zheng, L. Dong, X. Wang, Y. Wang, X. Zhang, and Z. Zhou. "Microraptor with ingested lizard suggests non-specialized digestive function". English. In: Current Biology 29 (2019), pp. 1-7. DOI: $10.1016 /$ j.cub.2019.06.020.

[17031] J. K. O'Connor, A. O. Averianov, and N. V. Zelenkov. “A confuciusornithiform (Aves, Pygostylia)like tarsometatarsus from the Early Cretaceous of Siberia and a discussion of the evolution of avian hind limb musculature". English. In: Journal of Vertebrate Paleontology 34.3 (2014), pp. 647656.

[17032] J. K. O'Connor, K.-Q. Gao, and L. M. Chiappe. “A new ornithuromorph (Aves: Ornithothoraces) bird from the Jehol Group indicative of higher-level diversity". English. In: Journal of Vertebrate Paleontology 30.2 (2010), pp. 311-321.

[17033] J. K. O'Connor, D.-Q. Li, M. C. Lamanna, M. Wang, J. D. Harris, J. Atterholt, and H. -L. You. "A new Early Cretaceous enantiornithine (Aves, Ornithothoraces) from northwestern China with elaborate tail ornamentation". English. In: Journal of Vertebrate Paleontology 36.1 (2016), e1054035:113. DOI: $10.1080 / 02724634.2015 .1054035$.

[17034] J. K. O'Connor, C. Sun, X. Xu, X. Wang, and Z. Zhou. “A new species of Jeholornis with complete caudal integument". English. In: Historical Biology 24.1 (2012), pp. 29-41. DOI: 10.1080/08912963. 2011.552720. 
[17035] J. K. O'Connor, M. Wang, and H. Hu. “A new ornithuromorph (Aves) with an elongate rostrum from the Jehol Biota, and the early evolution of rostralization in birds". English. In: Journal of Vertebrate Paleontology 14.11 (2016), pp. 939-948. DOI: 10.1080/14772019.2015.1129518.

[17036] J. K. O'Connor, X. Wang, L. M. Chiappe, C. Gao, Q. Meng, X. Cheng, and J. Liu. “Phylogenetic support for a specialized clade of Cretaceous enantiornithine birds with information from a new species". English. In: Journal of Vertebrate Paleontology 29.1 (2009), pp. 188-204. DOI: 10.1671 / 039. 029.0121.

[17037] J. K. O'Connor, X.-L. Wang, X. -T. Zheng, H. Hu, X. -M. Zhang, and Z. -H. Zhou. “An enantiornithine with a fan-shaped tail, and the evolution of the rectricial complex in early birds". English. In: Current Biology 26 (2016), pp. 114-119.

[17038] J. K. O'Connor, Y.-G. Zhang, L. M. Chiappe, Q. -J. Meng, Q. -G. Li, and D. Liu. “A new enantiornithine from the Yixian Formation with the first recognized avian enamel specialization". English. In: Journal of Vertebrate Paleontology 33.1 (2013), pp. 1-12. DOI: 10.1080/02724634.2012.719176.

[17039] P. M. O'Connor and C. A. Forster. "A Late Cretaceous (Maastrichtian) avifauna from the Maevarano Formation, Madagascar". English. In: Journal of Vertebrate Paleontology 30.4 (2010), pp. 11781201.

[17040] P. M. O'Connor, M. D. Gottfried, N. J. Stevens, E. M. Roberts, S. Ngasala, S. Kapilima, and R. Chami. "A new vertebrate fauna from the Cretaceous Red Sandstone Group, Rukwa Rift Basin, southwestern Tanzania". English. In: Journal of African Earth Sciences 44 (2006), pp. 277-288.

[17041] P. M. O'Connor, D. W. Krause, N. J. Stevens, J. R. Groenke, R. D. E. MacPhee, D. C. Kalthoff, and E. M. Roberts. "A new mammal from the Turonian-Campanian (Upper Cretaceous) Galula Formation, southwestern Tanzania". English. In: Acta Palaeontologica Polonica 64.1 (2019), pp. 6584.

[17042] P. M. O'Connor, J. J. W. Sertich, N. J. Stevens, E. M. Roberts, M. D. Gottfried, T. L. Hieronymus, Z. A. Jinnah, R. Ridgely, S. E. Ngasala, and J. Temba. "The evolution of mammal-like crocodyliforms in the Cretaceous Period of Gondwana". English. In: Nature 466 (2010), pp. 748-751. DOI: 10.1038 /nature09061.

[17043] P. M. O'Connor, J. J. W. Sertich, and F. K. Manthi. “A pterodactyloid pterosaur from the Upper Cretaceous Lapurr sandstone, West Turkana, Kenya". English. In: Anais da Academia Brasileira de Ciencias 83.1 (2011), pp. 309-315.

[17044] P. M. O'Connor, A. H. Turner, J. R. Groenke, R. N. Felice, R. R. Rogers, D. W. Krause, and L. J. Rahantarisoa. "Late Cretaceous bird from Madagascar reveals unique development of beaks". English. In: Nature (2020). DOI: 10.1038/s41586-020-2945-x.

[17045] L. O'Dogherty. "Biochronology an Paleontology of Mid-Cretaceous Radiolarians from Northern Apennines (Italy) and Betic Cordillera (Spain)". English. In: Memoires de Geologie (Lausanne) 21 (1994), pp. 1-415.

[17046] L. O'Dogherty, M. Bill, S. Gorican, P. Dumitrica, and H. Masson. “Bathonian radiolarians from an ophiolitic mélange of the Alpine Tethys (Gets Nappe, Swiss-French Alps)". English. In: Micropaleontology 51.6 (2006), pp. 425-485.

[17047] L. O'Dogherty and H. J. Gawlick. "Pliensbachian radiolarians in Teltschengraben (Northern Calcareous Alps, Austria): a keystone in reconstructing the Early Jurassic evolution of the Tethys". English. In: Stratigraphy 5.1 (2008), pp. 63-81.

[17048] J. P. O'Gorman. “The oldest elasmosaurs (Sauropterygia, Plesiosauria) from Antarctica, Santa Marta Formation (upper Coniacian? Santonian-upper Campanian) and Snow Hill Island Formation (upper Campanian-lower Maastrichtian), James Ross Island". English. In: Polar Research 31.11090 (2012), pp. 1-10. DOI: 10.3402/polar.v31i0.11090.

[17049] J. P. O'Gorman. “A small body sized non-aristonectine elasmosaurid (Sauropterygia," English. In: Ameghiniana 53.3 (2016), pp. 245-268. 
[17050] J. P. O'Gorman, Z. Gasparini, and L. Salgado. “Postcranial morphology of Aristonectes (Plesiosauria, Elasmosauridae) from the Upper Cretaceous of Patagonia and Antarctica". English. In: Antarctic Science 25.1 (2013), pp. 71-82.

[17051] J. P. O'Gorman, E. B. Olivero, and D. A. Cabrera. "Gastroliths associated with a juvenile elasmosaur (Plesiosauria, Elasmosauridae) from the Snow Hill Formation (upper Campanian-lower Maastrichtian), Vega Island, Antarctica". English. In: Alcheringa 36.4 (2012), pp. 531-541.

[17052] J. P. O'Gorman, R. A. Otero, and N. Hiller. "A new record of an aristonectine elasmosaurid (Sauropterygia, Plesiosauria) from the Upper Cretaceous of New Zealand: implications for the Mauisaurus haasti Hector, 1874 hypodigm". English. In: Alcheringa 38.4 (2014), pp. 504-512.

[17053] J. P. O'Gorman, K. M. Panzeri, M. S. Fernández, S. Santillana, J. J. Moly, and M. Reguero. “A new elasmosaurid from the upper Maastrichtian López de Bertodano Formation: new data on weddellonectian diversity". English. In: Alcheringa 42.4 (2018), pp. 575-586. DOI: 10.1080/03115518.2017. 1339233.

[17054] J. P. O'Gorman, L. Salgado, E. B. Olivero, and S. A. Marenssi. “Vegasaurus molyi, gen. et sp. nov. (Plesiosauria, Elasmosauridae), from the Cape Lamb Member (lower maastrichtian) of the Snow Hill Island Formation, Vega Island, Antarctica, and remarks on Wedellian Elasmosauridae". English. In: Journal of Vertebrate Paleontology 35.3 (2015), e931285:1-21.

[17055] J. P. O'Gorman, S. Santillana, R. Otero, and M. Reguero. “A giant elasmosaurid (Sauropterygia; Plesiosauria) from Antarctica: New information on elasmosaurid body size diversity and aristonectine evolutionary scenarios". English. In: Cretaceous Research 102 (2019), pp. 37-58.

[17056] J. P. O'Gorman and A. N. Varela. “The oldest lower Upper Cretaceous plesiosaurs (Reptilia, Sauropterygia) from Southern Patagonia, Argentina". English. In: Ameghiniana 47.4 (2010), pp. 447-459.

[17057] F. R. O'Keefe. "A cladistic analysis and taxonomic revision of the Plesiosauria (Reptilia: Sauropterygia)". English. In: Acta Zoologica Fennica 213 (2001), pp. 1-63.

[17058] F. R. O'Keefe. “On the cranial anatomy of the polycotylid plesiosaurs, including new material of Polycotylus latipinnis, Cope, from Alabama". English. In: Journal of Vertebrate Paleontology 24.2 (2004), pp. 326-340.

[17059] F. R. O'Keefe. "Preliminary description and phylogenetic position of a new plesiosaur (Reptilia: Sauropterygia) from the Toarcian of Holzmaden, Germany". English. In: Journal of Paleontology 78.5 (2004), pp. 973-988.

[17060] F. R. O'Keefe. “Cranial anatomy and taxonomy of Dolichorhynchops bonneri new combination, a polycotylid (Sauropteryga: Plesiosauria) from the Pierre Shale of Wyoming and South Dakota". English. In: Journal of Vertebrate Paleontology 28.3 (2008), pp. 664-676.

[17061] F. R. O'Keefe and L. M. Chiappe. "Viviparity and K-selected life history in a Mesozoic marine Plesiosaur (Reptilia, Sauropterygia". English. In: Science 333.870 (2011), pp. 870-873. DOI: 10.1126/ science.1205689.

[17062] F. R. O'Keefe, C. A. Sidor, H. C. E. Larsson, A. Maga, and O. Ide. “The Vertebrate Fauna of the Upper Permian of Niger - III, Morphology and Ontogeny of the Hindlimb of Moradisaurus grandis (Reptilia, Captorhinidae)". English. In: Journal of Vertebrate Paleontology 25.2 (2005), pp. 309-319.

[17063] F. R. O’Keefe, H. P. Street, J. P. Cavigelli, J. J. Socha, and R. D. O'Keefe. “A plesiosaur containing an ichthyosaur embryo as stomach contents from the Sundance Formation of the Bighorn Basin, Wyoming". English. In: Journal of Vertebrate Paleontology 29.4 (2009), pp. 1306-1310.

[17064] F. R. O'Keefe and H. P. Street. “Osteology of the cryptocleidoid plesiosaur Tatenectes laramiensis, with comments on the taxonomic status of the Cimoliasauridae". English. In: Journal of Vertebrate Paleontology 29.1 (2009), pp. 48-57.

[17065] F. R. O'Keefe, H. P. Street, B. C. Wilhelm, C. D. Richards, and H. Zhu. "A new skeleton of the cryptoclidid plesiosaur Tatanectes laramiensis reveals a novel body shape among plesiosaurs". English. In: Journal of Vertebrate Paleontology 31.2 (2011), pp. 330-339. 
[17066] F. R. O'Keefe and W. Wahl. “Current taxonomic status of the plesiosaur Pantosaurus striatus from the Upper Jurassic Sundance Formation, Wyoming". English. In: Paludicola 4.2 (2003), pp. 37-46.

[17067] F. R. O'Keefe and W. Wahl Jr. "Current taxonomic status of the plesiosaur Pantosaurus striatus from the Upper Jurassic Sundance Formation, Wyoming". English. In: Paludicola 4.2 (2003), pp. 3746.

[17068] S. O'Keefe, T. Pike, and G. O. Poinar. “Palaeoleptochromus schaufussi (gen. nov., sp. nov.), a new antlike stone beetle (Coleoptera, Scydmaenidae) from Canadian Cretaceous amber". English. In: The Canadian Entomologist 129 (1997), pp. 379-385.

[17069] S. T. O'Keefe. "Revision of the Neotropical genus Leptochromus Motschulsky (Coleoptera: Scydmaenidae)". English. In: Systematic Entomology 27 (2002), pp. 211-234.

[17070] M. A. O'Leary. "Morphology of the humerus of Hapalodectes (Mammalia, Mesonychia)". English. In: American Museum Novitates 3242 (1998), pp. 1-6.

[17071] M. A. O'Leary, M. L. Bouare, K. Heilbronn, R. V. Hill, J. McCartney, J. A. Sessa, F. Sissoko, L. Tapanila, E. Wheeler, and E. M. Roberts. "Stratigraphy and Paleobiology of the Upper Cretaceous - Lower Paleogene Sediments from the Trans-Saharan Seaway in Mali". English. In: Bulletin of the American Museum of Natural History 436 (2019), pp. 1-177.

[17072] M. A. O'Leary, E. M. Roberts, J. J. Head, F. Sissoko, and M. L. Bouare. “Titanosaurian (Dinosauria: Sauropoda) remains from the Continental Intercalaire of Mali". English. In: Journal of Vertebrate Paleontology 24.4 (2004), pp. 923-930.

[17073] M. A. O'Leary, E. M. Roberts, M. Bouare, F. Sissoko, and L. Tapanila. "Malian Paenungulata (Mammalia: Placentalia): New African Afrotheres from the early Eocene". English. In: Journal of Vertebrate Paleontology (2006).

[17074] M. A. O'Leary and K. D. Rose. "New mesonychian dentitions from the Paleocene of the Bighorn Basin, Wyoming". English. In: Annals of Carnegie Museum 64.2 (1995), pp. 147-172.

[17075] M. A. O'Leary and K. D. Rose. "Postcranial Skeleton of the Early Eocene Mesonychid Pachyaena (Mammalia: Mesonychia)". English. In: Journal of Vertebrate Paleontology 15.2 (1995), pp. 401-430.

[17076] M. A. O'Leary, R. Sarr, R. Malou, E. H. Sow, C. Lepre, and R. V. Hill. “A New Fossil Amiid from the Eocene of Senegal and the Persistence of Extinct Marine Amiids after the Cretaceous-Paleogene Boundary". English. In: Copeia 2012.4 (2012), pp. 603-608. DOI: 10.1643/CI-11-130.

[17077] J. A. O'Sullivan. "A new species of Archaeohippus (Mammalia, Equidae) from the Arikareean of central Florida". English. In: Journal of Vertebrate Paleontology 23.4 (2003), pp. 877-885.

[17078] M. O'Sullivan, D. M. Martill, and D. Groocock. "A pterosaur humerus and scapulocoracoid from the Jurassic Whitby Mudstone Formation, and the evolution of large body size in early pterosaurs". English. In: Proceedings of the Geologists' Association (2013). DOI: 10.1016/j.pgeola.2013.03.002.

[17079] M. O'Sullivan and D. M. Martill. "Evidence for the presence of Rhamphorhynchus (Pterosauria: Rhamphorhynchinae) in the Kimmeridge Clay of the UK". English. In: Proceedings of the Geologist's Association 126.3 (2015), pp. 390-401.

[17080] T. Obada. "Associatia de vertebrate din punctul fosilifer Sarmatian mediu Otovasca (Mun. Chisinau) si importanta oor biostratigraphfica". other. In: Buletin tiinific. Revist de Etnografie, tiinele Naturii i Muzeologie 30.43 (2019), pp. 112-120.

[17081] R. G. Oberprieler, L. G. Ashman, M. Frese, and A. lipiski. "The first elateroid beetles (Coleoptera: Polyphaga: Elateroidea) from the Upper Jurassic of Australia". English. In: Zootaxa 4147 (2016), pp. 177-191.

[17082] R. G. Oberprieler and S. K. Oberprieler. “Talbragarus averyi gen. et sp. n., the first Jurassic weevil from the southern hemisphere (Coleoptera: Curculionoidea: Nemonychidae)". English. In: Zootaxa 3478 (2012), pp. 256-266.

[17083] S. K. Oberprieler, W. Krzemiski, J. Hinde, and D. K. Yeates. "First crane fly from the Upper Jurassic of Australia (Diptera: Limoniidae)". English. In: Zootaxa 4021 (2015), pp. 178-186. 
[17084] S. K. Oberprieler, A. P. Rasnitsyn, and D. J. Brothers. "The first wasps from the Upper Jurassic of Australia (Hymenoptera: Evanioidea, Praeaulacidae)". English. In: Zootaxa 3503 (2012), pp. 47-54.

[17085] S. K. Oberprieler and D. K. Yeates. "Calosargus talbragarensis new species: the first brachyceran fly from the Jurassic of Australia (Diptera, Archisargidae)". English. In: Journal of Paleontology 86.4 (2012), pp. 641-645.

[17086] S. K. Oberprieler and D. K. Yeates. “Notoatherix antiqua gen. et sp. nov., first fossil water snipe fly from the Late Jurassic of Australia (Diptera: Athericidae)". English. In: Zootaxa 3866 (2014), pp. 138-144.

[17087] F. C. Ocampo. "Procoilodes adrastus Ocampo, a New Genus and Species of Miocene Hybosorid in Amber from the Dominican Republic (Coleoptera: Scarabaeoidea: Hybosoridae)". English. In: The Coleopterists Bulletin 56.1 (2002), pp. 123-126.

[17088] F. C. Ocampo. "Phylogenetic analysis of the scarab family Hybosoridae and monographic revision of the new world subfamily Anaidinae (Coleoptera: Scarabaeoidea)". English. In: Bulletin of the University of Nebraska State Museum 19 (2006), pp. 13-177.

[17089] G. S. Odin. "The Campanian-Maastrichtian stage boundary". English. In: Development in Palaeontology and Stratigraphy 19 (2001), pp. 1-881.

[17090] G. S. Odin and W. A. Cobban. "Europe-America connection; palaeontological identification of some ammonites from Tercis les Bains (Landes, France)". English. In: Developments in Palaeontology and Stratigraphy 19 (2001), pp. 483-486.

[17091] G. S. Odin and A. V. Dhondt. "Inoceramid bivalves in the Campanian-Maastrichtian of Tercis les Bains (Landes, France)". English. In: Developments in Palaeontology and Stratigraphy 19 (2001), pp. 452-461.

[17092] G. S. Odin and A. V. Dhondt. "Bivalve shells in the Campanian-Maastrichtian of Tercis les Bains (Landes, France)". English. In: Developments in Palaeontology and Stratigraphy 19 (2001), pp. $462-$ 469.

[17093] V. K. Odnosum and E. E. Perkovsky. "New species of the tumbling flower beetle genus Glipostena (Insecta: Coleoptera: Mordellidae) from Rovno amber". English. In: Paleontological Journal 43.9 (2009), pp. 1095-1096.

[17094] V. K. Odnosum and E. E. Perkovsky. "The first Eocene tumbling beetle of the genus Isotrilophus (Insecta: Coleoptera: Mordellidae) from the Green River Formation (Colorado, United States)". English. In: Paleontological Journal 50 (2016), pp. 609-611.

[17095] S. Oezer. "Rudist bearing upper Cretaceous metamorphic sequences of the Menderes Massif (Western Turkey)". English. In: Geobios 22 (1998), pp. 235-249.

[17096] S. Oezer and F. Ahmad. "Cenomanian-Turonian rudist (bivalvia) lithosomes from NW of Jordan". English. In: Journal of African Earth Sciences 107 (2015), pp. 119-133.

[17097] S. Oezer and A.-S. ElSorogy. "New record of Durania cornupastoris (rudist) from the Campanian of". English. In: Journal of African Earth Sciences 129 (2017), pp. 380-389. DOI: 10.1016/j.jafrearsci. 2017.01.014.

[17098] V. V. Ogar. "New data on the Carboniferous corals of the Donets Basin". English. In: Palaeoworld 19 (2010), pp. 284-293.

[17099] V. V. Ogar. "Carboniferous buildups in the Donets Basin (Ukraine)". English. In: Geologica Belgica 15.4 (2012), pp. 340-349.

[17100] K. Ogasawara, K. Hisada, and N. Kitada. "Early Miocene Calyptogena from the Aokiyama Formation, Hota Group, Boso Peninsula, Japan". English. In: Annual Report of the Institute of Geoscience, the University of Tsukuba 20 (1994), pp. 33-37.

[17101] A. Ogawa, Y. Takahashi, and T. Fujita. "New wheel microfossils of Ophiocistioidea and Holothuroidea (Echinodermata) from Japan". English. In: 15 (2019), pp. 106-114.

[17102] L. V. Ogienko. “New Late Cambrian trilobites from the Daldyn-Alakit Region of Yakutia (Kuraspoides planus Zone)". In: Paleontological Journal 33.6 (1999), pp. 620-626. 
[17103] T. Ohashi and P. M. Barrett. "A new ornithischian dinosaur from the Lower Cretaceous Kuwajima Formation of Japan". English. In: Journal of Vertebrate Paleontology 29.3 (2009), pp. 748-757. DOI: 10.1671/039.029.0306.

[17104] T. Ohashi and Y. Hasegawa. "New Species of Plotopteridae (Aves) from the Oligocene Ashiya Group of Northern Kyushu, Japan". English. In: Paleontological Research 24.4 (2020), pp. 285-297. DOI: $10.2517 / 2020$ PR005.

[17105] T. Ohashi, A. Prieto-Marquéz, Y. Hasegawa, Y. Koda, Y. Taketani, and M. Nemoto. “Hadrosauroid remains from the Coniacian (Late Cretaceous) Futaba Group, northeastern Japan". English. In: Bulletin of the Kitakyushu Museum of Natural History and Human History, Series A 13 (2015), pp. 1-6.

[17106] S. Ohde, M. Greaves, T. Masuzawa, H. A. Buckley, R.v. Woesik, P. A. Wilson, P. A. Pirazzoli, and H. Elderfield. "The chronology of Funafuti Atoll: revisiting an old friend". English. In: Proceedings of the Royal Society A 458 (2002), pp. 2289-2306.

[17107] M. Ohl. "The First Fossil Representative of the Wasp Genus Dolichurus, with a Review of Fossil Ampulicidae (Hymenoptera: Apoidea)". English. In: Journal of the Kansas Entomological Society 77.4 (2004), pp. 332-342.

[17108] M. Ohl. "Eine neue Bethylidae der Gattung Lytopsenella Kieffer 1911 aus dem Baltischen Bernstein (Hymenoptera: Chrysidoidea)". German. In: Paläontologische Zeitschrift 69 (1995), pp. 409416.

[17109] M. Ohl and D. J. Bennett. "A new genus and species of apoid wasps from Saxonian amber (Hymenoptera: Apoidea: Crabronidae)". English. In: Denisia 26 (2009), pp. 145-150.

[17110] W. Ohmert. "Radiolarien-Faunen und Obergrenze der Amden-Formation (Coniacium-Santonium) im Tölzer Helvetikum (Oberbayern) [Radiolarian fauna and upper boundary of the Amden Formation (Coniacian-Santonian) in the Tölz Helvetikum (Upper Bavaria)]". German. In: Zitteliana A 46 (2006), pp. 3-40.

[17111] W. Ohmert, V. Allia, and C. Arias et al. “Die Grenzziehung Unter-/Mitteljura (Toarcium/Aalenium) bei Wittnau und Fuentelsaz [Determinig the boundary between Toarcium/Aalenium near Wittnau and Fuentelsaz]". German. In: Informationen Geologisches Landesamt Baden-Württemberg 8 (1996), pp. 1-52.

[17112] M. Ohtaka, Y. Aita, and T. Sakai. "Middle Triassic radiolarian biostratigraphy of the bedded chert in the Minowa quarry, Kuzuu Town, Ashio Mountains". Japanese. In: News of Osaka Micropaleontologists, Special Volume 11 (1998), pp. 95-113.

[17113] M. Oishi, H. Fujii, and S. Tagusari. "Pliocene cetaceans from Shiriuchi-machi, Hachinohe City, Northeast Japan (Part 2)". Japanese. In: Research report of the Fossil Hachinohe Whales, Hachinohe Children's Science Museum 2 (2001), pp. 7-22.

[17114] M. Oishi and Y. Hasegawa. "A list of fossil cetaceans in Japan". English. In: The Island Arc 3 (1995), pp. 493-505.

[17115] M. Oishi and Y. Hasegawa. "Diversity of Pliocene mysticetes from eastern Japan". English. In: The Island Arc 3 (1995), pp. 436-452.

[17116] Y. Oiso. New land mammal locality of middle Miocene (Colloncuran) age from Nazareno, southern Bolivia. English. Vol. 12. Fósiles y Facies de Bolivia - Vol. 1 Vertebrados (Revista Ténica de YPFB) 3-4. 1991, pp. 653-672.

[17117] T. Oji, M. Kanoh, S. Toshimitsu, and M. Tashiro. "Nielsenicrinus japonicus New Species (Echinodermata: Crinoidea) from the Late Cretaceous of Japan and Its Paleobiogeographic Implications". English. In: Journal of Paleontology 30.6 (1996), pp. 964-968.

[17118] T. Oji and R. J. Twitchett. "The oldest post-Paleozoic crinoid and Permian-Triassic origins of the Articulata (Echinodermata)". English. In: Zoological Science 32 (2015), pp. 211-215.

[17119] Y. Okan and I. Hosgor. "Early Eocene (middle-late Cuisian) Molluscs Assemblage from the Harpactocarcinid Beds, in the Yoncal Formation of the Çankr Basin, Central Anatolia, and Implications for Tethys Paleogeography". English. In: Geological Bulletin of Turkey 52.1 (2009). 
[17120] Y. Okan and I. Hosgor. "The Ampullinid Gastropod Globularia (Swainson 1840) from the late Thanetian-early Ilerdian Kirkkavak formation (Polatli-Ankara) of the Tethyan realm". English. In: Turkish Journal of Earth Sciences 17 (2008), pp. 758-801.

[17121] A. I. Okay and D. Altiner. "Uppermost Triassic limestone in the Karakaya Complex - stratigraphic and tectonic significance". English. In: Turkish Journal of Earth Sciences 13 (2004), pp. 187-199.

[17122] A. I. Okay, O. Sahintürk, and H. Yakar. "Stratigraphy and tectonics of the Pulur (Bayburt) region in the Eastern Pontides". In: Bulletin of the Mineral Research and Exploration 119 (1997), pp. 1-24.

[17123] Y. Okazaki. "A new genus and species of carnivorous dinosaur from the Lower Cretaceous Kwanmon Group, northern Kyushu". In: Bulletin of the Kitakyushu Museum of Natural History 11 (1992), pp. 87-90.

[17124] Y. Okazaki. “A new mysticete form the upper Oligocene Ashiya Group, Kyushu, Japan and its significance to mysticete evolution". English. In: Bulletin of the Kitakyushu Museum of Natural History and Human History Series A (Natural History) 10 (2012), pp. 129-152.

[17125] Y. Okazaki and N. Kitamura. "The first discovery of a pterosaur from the Cretaceous Mifune Group, Kyushu, Japan". English. In: Bulletin of the Kitakyushu Museum of Natural History 15 (1996), pp. 133-136.

[17126] K. Okumura and Y. Yamagishi. "Molluscan fauna from the Late Miocene Hatsuse Formation in the Miura Peninsula, Kanagawa Prefecture, Japan". English. In: Transactions and Proceedings of the Paleontological Society of Japan, N.S. 165 (1992), pp. 1009-1023.

[17127] T. Okutaini. English. In: Marine mollusks of Japan (2000), pp. 1-1173.

[17128] C. Okuyucu. "Systematics and biostratigraphic notes of the upper Moscovian-upper Gzhelian fusulinid foraminifers from the Anatolian Platform in the Southern Turkey". English. In: Geologica Balcanica 38 (2009), pp. 35-51.

[17129] C. Okuyucu and M. C. Goncuoglu. "Middle-late Asselian (Early Permian) fusulinid fauna from the post-Variscan cover in NW Anatolia (Turkey): Biostratigraphy and geological implications". English. In: Geobios 43 (2010), pp. 225-240.

[17130] A. O. Ola-Buraimo and O. A. Boboye. "Palynological Investigation of the Albian to Lower Cenomanian Bima Formation, Bornu Basin, Nigeria". English. In: World Applied Sciences Journal 12.7 (2011), pp. 1026-1033.

[17131] A. E. Oleinik. "Eocene gastropods of western Kamchatka - implications for high-latitude north Pacific biostratigraphy and biogeography". In: Palaeogeography, Palaeoclimatology, Palaeoecology 166 (2001), pp. 121-140.

[17132] E. Olempska. "Silicified shallow-water ostracodes from the Early Carboniferous of South China". English. In: Acta Palaeontologica Polonica 44.4 (1999), pp. 383-436.

[17133] E. Olempska. "The Late Devonian Upper Kellwasser Event and entomozoacean ostracods in the Holy Cross Mountains, Poland". In: Acta Palaeontologica Polonica 47.2 (2002), pp. 247-266.

[17134] E. Olempska and J. Blaszyk. “Ostracods from the Permian of Spitsbergen”. English. In: Polish Polar Research 17 (1996), pp. 3-20.

[17135] C. Oliva, A. E. Zurita, A. Dondas, and G. J. Scillato-Yané. “Los Glyptodontinae (Xenarthra, Glyptodontidae) del Piso/Edad Chapadmalalense (Plioceno tardo): revisión y aportes a su conocimiento". Spanish. In: Revista Mexicana de Ciencias Geológicas 27.1 (2010), pp. 112-120.

[17136] A. I. Olivares and D. H. Verzi. "Systematics, phylogeny and evolutionary pattern of the hystricognath rodent Eumysops (Echimyidae) from the Plio-Pleistocene of southern South America". English. In: 27.8 (2015), pp. 1042-1061. DOI: 10.1080/08912963.2014.929672.

[17137] A. I. Olivares, D. H. Verzi, V. H. Contreras, and L. Pessoa. "A new Echimyidae (Rodentia, Hystricomorpha) from the late Miocene of southern South America". English. In: Journal of Vertebrate Paleontology 37.1 (2017), e1239204. DOI: 10.1080/02724634.2017.1239204. 
[17138] I. Olivares and H. Severeyn. "Registro preliminar de corales escleractinios hermatipicos del Cenozoico y su ocurrencia actual, en areas costeras del estado Falcon, Venezuela". Spanish. In: Ciencia 8.2 (2000), pp. 145-154.

[17139] S. Olive, A. Pradel, C. Martinez-Pérez, P. Janvier, J. C. Lamsdell, P. Gueriau, N. Rabet, P. DuranleauGagnon, A. L. Cardenas-Rozo, P. A. Zapata Ramirez, and H. Botella. “New insights into Late Devonian vertebrates and associated fauna from the Cuche Formation (Floresta Massif, Colombia)". English. In: Journal of Vertebrate Paleontology (2019), pp. 1-18. DOI: 10.1080/02724634.2019.1620247.

[17140] C. E. M. Oliveira, R. M. Santucci, M. B. Andrade, V. J. Fulfaro, J. A. F. Baslio, and M. J. Benton. "Crocodylomorph eggs and eggshells from the Adamantina Formation (Bauru Group), Upper Cretaceous of Brazil". English. In: Palaeontology 54.2 (2011), pp. 309-321.

[17141] E. V. Oliveira and L. P. Bergqvist. "A new Paleocene armadillo (Mammalia, Dasypodoidea) from the Itabora Basin, Brazil". English. In: Asociación Paleontológica Argentina, Publicación Especial 5 (1998), pp. 35-40.

[17142] E. V. Oliveira, A. M. Franca Barreto, and R. Alves. "Aspectos sistemáticos, paleobiogeográficos e paleoclimáticos dos mamferos quaternáros de Fazenda Nova, PE, nordeste do Brasil". Portugese. In: Gaea - Journal of Geoscience 5.2 (2009), pp. 75-85. DOI: 10.4013/gaea.2009.52.04.

[17143] E. V. Oliveira and F. J. Goin. "A reassessment of bunodont metatherians from the Paleogene of Itaborai (Brazil): Systematics and the age of the Itaborian SALMA". English. In: Revista Brasileira de Paleontologia 14.2 (2011), pp. 105-136.

[17144] E. V. Oliveira and F. J. Goin. "A new species of Gaylordia Paula Couto (Mammalia, Metatheria) from Itabora, Brazil". English. In: Revista Brasileira de Paleontologia 18.1 (2015), pp. 97-108. DOI: 10.4072/rbp.2015.1.07.

[17145] E. V. Oliveira, T. Lindner Dutra, and F. Zeltzer. "Megaterideos ( Mammalia , Xenarthra ) do Quaternarlo de Cacapava do Sul, Rio Grande do Sul , com consideracoes sobre a flora associada". English. In: Geologia Colombiana 27 (2002), pp. 77-86.

[17146] E. V. Oliveira and J. C. Pereira. "Intertropical cingulates (Mammalia, Xenarthra) from the Quaternary of Southern Brazil: Systematics and paleobiogeographical aspects". English. In: Revista Brasileira de Paleontologia 12.3 (2009), pp. 167-178.

[17147] E. V. Oliveira, K. O. Porpino, and A. F. Barreto. “On the presence of Glyptotherium in the Late Pleistocene of Northeastern Brazil, and the status of Glyptodon and Chlamydotherium. Paleobiogeographic implications". English. In: Neues Jahrbuch für Geologie und Paläontologie - Abhandlungen 258.3 (2010), pp. 353-363. DOI: 10.1127/0077-7749/2010/0116.

[17148] E. V. Oliveira, P. Villa Nova, F. J. Goin, and L. S. Avilla. “A new hyladelphine marsupial (Didelphimorphia, Didelphidae) from cave deposits of northern Brazil”. English. In: Zootaxa 3041 (2011), pp. 51-62.

[17149] E. V. Oliveira, N. Zimicz, and F. J. Goin. "Taxonomy, affinities, and paleobiology of the tiny metatherian mammal Minusculodelphis, from the early Eocene of South America". English. In: The Science of Nature 103 (2016). DOI: 10.1007/s00114-015-1331-2.

[17150] É V. Oliveira, F. J. Prevosti, and J. C. Pereira. "Protocyon troglodytes (Lund) (Mammalia, Carnivora) in the Late Pleistocene of Rio Grande do Sul and their paleoecological significance". English. In: Revista Brasileira de Paleontologia 8.3 (2005), pp. 215-220.

[17151] G. R. Oliveira and A. W. A. Kellner. "Rare hatchling specimens of Araripemys Price, 1973 (Testudines, Pelomedusoides, Araripemydidae) from the Crato Formation, Araripe Basin". English. In: Journal of South American Earth Sciences 79 (2017), pp. 137-142. DOI: 10.1016/j.jsames.2017.07. 014.

[17152] G. R. Oliveira and A. W. A. Kellner. "A new side-necked turtle (Pleurodira, Pelomedusoides) from the Santana". English. In: Zootaxa 1425 (2007), pp. 53-61.

[17153] G. R. Oliveira, A. A. F. Saraiva, H. de Paula Silva, J. A. F. G. de Andrade, and A. W. A. Kellner. "First turtle from the Ipubi Formation (Early Cretaceous), Santana Group, Araripe Basin, Brazil". English. In: Revista Brasileira de Paleontologia 14.1 (2011), pp. 61-66. 
[17154] I.d.S. Oliveira, M. Bai, H. Jahn, V. Gross, C. Martin, J. U. Hammel, W. W. Zhang, and G. Mayer. "Earliest onychophoran in amber reveals Gondwanan migration patterns". English. In: Current Biology 26 (2016), pp. 2594-2601.

[17155] T.V.de. Oliveira, A. G. Martinelli, and M. B. Soares. "New information about Irajatherium hernandezi Martinelli, Bonaparte, Schultz \& Rubert 2005 (Eucynodontia, Tritheledontidae) from the upper triassic (Caturrita Formation, Parana Basin) of Brazil". English. In: Palaeontologische Zeitschrift 85 (2011), pp. 67-82.

[17156] T.V.de. Oliveira, M. B. Soares, and C. L. Schultz. “Trucidocynodon riograndensis gen. nov. et sp. nov. (Eucynodontia), a new cynodont from the Brazilian Upper Triassic (Santa Maria Formation)". English. In: Zootaxa 2382 (2010), pp. 1-71.

[17157] A. Oliver and G. Daxner-Höck. "Large-sized species of Ctenodactylidae from the Valley of Lakes (Mongolia): An update on dental morphology, biostratigraphy, and paleobiogeography". English. In: Palaeontologia Electronica 20.1 (2017), 1A:1-22.

[17158] W. A. Oliver, J. E. Sorauf, and C. E. Brett. "A Unique Occurrence of Endophyllum (Rugose Coral; Devonian) in Eastern North America: An Ecological and Biogeographical Puzzle". English. In: Journal of Paleontology 70.1 (1996), pp. 46-56.

[17159] A. M. Olivera, W. J. Zinsmeister, and S. G. Parma. "Peonza: New Gastropod Genus from the Middle Tertiary of Patagonia and Chile". English. In: Journal of Paleontology 68.2 (1994), pp. 279286.

[17160] E. B. Olivero. Asociaciones de amonites de la formacion Santa Marta (Cretacio Tardio), Isla James Ross, Antartida. Spanish. Geologia de la Isla James Ross. 1992, pp. 47-75.

[17161] E. B. Olivero and N. Maluman. "Mesozoic-Cenozoic stratigraphy of the Fuegian Andes, Argentina". English. In: Geologica Acta 6.1 (2008), pp. 5-18.

[17162] E. B. Olivero, D. R. Martinioni, and F.J. MUSSEL. Upper Cretaceous sedimentology and biostratigraphy of western Cape Lamb (Vega Island, Antarctica). Implications of sedimentary cycles and evolution of the basin. English. Geologia de la Isla James Ross. 1992, pp. 47-166.

[17163] C. Olivier, B. Battail, S. Bourquin, C. Rossignol, J. -S. Steyer, and N. -E. Jalil. “New dicynodonts (Therapsida, Anomodontia) from near the Permo-Triassic boundary of Laos: implications for dicynodont survivorship across the Permo-Triassic mass extinction and the paleobiogeography of Southeast Asian blocks". English. In: Journal of Vertebrate Paleontology (2019). DOI: 10.1080 / 02724634.2019.1584745.

[17164] N. Olivier, C. Carpentier, B. Martin-Garin, B. Lathuiliére, C. Gaillard, S. Ferry, P. Hantzpergue, and J. Geister. "Coral-microbialite reefs in pure carbonate versus mixed carbonate-siliciclastic depositional environments: the example of the Pagny-sur-Meuse section (Upper Jurassic, northeastern France)". In: Facies 50.2 (2004), pp. 229-255.

[17165] N. Olivier, P. Hantzpergue, C. Gaillard, B. Pittet, R. Leinfelder, D. U. Schmid, and W. Werner. "Microbialite morphology, structure and growth: a model of the Upper Jurassic reefs of the Chay Peninsula (Western France)". In: Palaeogeography, Palaeoclimatology, Palaeoecology 193.3-4 (2003), pp. 383-404.

[17166] N. Olivier, B. Lathuiliere, and P. Thiry-Bastien. "Growth models of Bajocian coral-microbialite reefs of Chargey-les-Port (eastern France): palaeoenvironmental interpretations". English. In: Facies 52 (2006), pp. 113-127.

[17167] N. Olivier, B. Martin-Garin, C. Colombié, J. J. Cornée, F. Giraud, J. Schnyder, B. Kabbachi, and K. Ezaidi. "Ecological succession evidence in an Upper Jurassic coral reef system (Izwarn section, High Atlas, Morocco)". English. In: Geobios 45.6 (2012), pp. 555-572.

[17168] N. Olivier, B. Pittet, W. Werner, P. Hantzpergue, and C. Gaillard. "Facies distribution and coralmicrobialite reef development on a low-energy carbonate ramp (Chay Peninsula, Kimmeridgian, western France)". English. In: Sedimentary Geology 205 (2008), pp. 14-33.

[17169] M. Olmi. "Dryinids and embolemids in amber (Hymenoptera Dryinidae et Embolemidae)". English. In: Redia 78 (1995), pp. 253-271. 
[17170] M. Olmi. “New fossil Dryinidae from Baltic and Lebanese amber (Hymenoptera Chrysidoidea)". English. In: Frustula Entomologica 21 (2000), pp. 48-67.

[17171] M. Olmi. “New oriental and neotropic Dryinidae (Hymenoptera Chrysidoidea)”. English. In: Frustula Entomologica 20 (1998), pp. 152-167.

[17172] M. Olmi. “New Embolemidae and Dryinidae (Hymenoptera Chrysidoidea)”. English. In: Frustula Entomologica 20 (1998), pp. 30-118.

[17173] M. Olmi. "A new fossil dryinid in amber from the Dominican Republic: Harpactosphecion scheveni n. sp. (Hymenoptera Dryinidae)". English. In: Frustula Entomologica 26-27 (2005), pp. 15-19.

[17174] M. Olmi. "A revision of the world Sclerogibbidae (Hymenoptera Chrysidoidea)". English. In: Frustula Entomologica, Nuova Serie 26-27 (2005), pp. 46-193.

[17175] M. Olmi and G. Bechly. "New parasitic wasps from Baltic amber (Insecta: Hymenoptera: Dryinidae)". English. In: Stuttgarter Beiträge zur Naturkunde Serie B (Geologie und Paläontologie) 306 (2001), pp. 158.

[17176] M. Olmi and A. Guglielmino. "Revision of fossil species of Dryinus belonging to lamellatus group, with description of a new species (Hymenoptera, Dryinidae)". English. In: ZooKeys 130 (2011), pp. 505-514.

[17177] M. Olmi, A. Guglielmino, and M. Vollaro. "Revision of fossil species of Dryinus belonging to constans group, with description of a new species (Hymenoptera: Dryinidae)". English. In: Zootaxa 2981 (2011), pp. 43-55.

[17178] M. Olmi and A. Guglielmino. "A contribution to the knowledge of Dryinidae from Late Eocene Baltic amber (Hymenoptera: Chrysidoidea), with description of new subfamily," English. In: Zootaxa 3351 (2012), pp. 15-26.

[17179] M. Olmi, E. E. Perkovsky, K. V. Martynova, M. Contarini, C. Bückle, and A. Guglielmino. “An important intermediate step in the evolution of pincer wasps: an extraordinary new type of chela from mid-Cretaceous Burmese amber (Hymenoptera, Dryinidae)". English. In: Cretaceous Research 111.104420 (2020). DOI: 10.1016/j.cretres.2020.104420.

[17180] M. Olmi, A. P. Rasnitsyn, and A. Guglielmino. "The first record of Embolemidae (Hymenoptera Chrysidoidea) in the Rovno Amber (Upper Eocene) of Ukraine: a male of Ampulicomorpha succinalis Brues". English. In: Paleontological Journal 45.1 (2011), pp. 73-76.

[17181] M. Olmi, A. P. Rasnitsyn, and A. Guglielmino. "Revision of rock fossils of Dryinidae and Embolemidae (Hymenoptera: Chrysidoidea)". English. In: Zootaxa 2499 (2010), pp. 21-38.

[17182] M. Olmi, A. P. Rasnitsyn, D. J. Brothers, and A. Guglielmino. "The first fossil Embolemidae (Hymenoptera: Chrysidoidea) from Burmese amber (Myanmar) and Orapa kimberlitic deposits (Botswana) and their phylogenetic significance". English. In: Journal of Systematic Palaeontology 12 (2014), pp. 623635.

[17183] M. Olmi, Z. F. Xu, and A. Guglielmino. “Descriptions of new fossil taxa of Dryinidae (Hymenoptera: Chrysidoidea) from Burmese amber (Myanmar)". English. In: Acta Entomologica Musei Nationalis Pragae 54 (2014), pp. 703-714.

[17184] F. Oloriz, M. Reolid, and F. J. Rodriguez-Tovar. “A Late Jurassic carbonate ramp colonized by sponges and benthic microbial communities (External Prebetic, Southern Spain)". English. In: Palaios 18 (2003), pp. 528-545.

[17185] F. Olóriz and A. B. Villaseñor. "Ceratosphinctes (Ammonitina, Kimmeridgian) in Mexico: from rare but typical inhabitant of west-Tethyan epioceanic and epicontinental waters to a geographically widespread ammonite genus". English. In: Geobios 39.2 (2006), pp. 255-266.

[17186] F. Olóriz, A. B. Villaseñor, C. Gonzalez-Arreola, and G. E. G. Westermann. “Ammonite Biostratigraphy and Correlations in the Upper Jurassic-Lowermost Cretaceous La Caja Formation of NorthCentral Mexico (Sierra de Catorce, San Luis de Potos)". English. In: Advancing Research on Living and Fossil Cephalopods. New York: Springer US, 1999, p. 550. DOI: 10.1007/978-1-4615-4837-9_31. 
[17187] S. L. Olroyd, C. A. Sidor, and K. D. Angielczyk. "New materials of the enigmatic dicynodont Abajudon kaayai (Therapsida, Anomodontia) from the lower Madumabisa Mudstone Formation, middle Permian of Zambia". English. In: Journal of Vertebrate Paleontology (2018).

[17188] P. E. Olsen. Paleontology and paleoenvironments of Early Jurassic age strata in the Walter Kidde Dinosaur Park (New Jersey, USA). English. In J. E. B. Baker (ed.), Field Guide and Proceedings of the Twelfth Annual Meeting of the Geological Association of New Jersey. Geological Association of New Jersey, William Patterson College. 1995, pp. 156-190.

[17189] P. E. Olsen and P. Huber. "The oldest Late Triassic footprint assemblage from North America (Pekin Formation, Deep River basin, North Carolina, USA)". English. In: Southeastern Geology 38.2 (1998), pp. 77-90.

[17190] P. E. Olsen and P. Huber. Stop 3: Triangle Brick Quarry. English. TRIBI: Triassic Basin Initiative, Abstracts with Programs and Field Trip Guidebook, Duke University, Durham. 1997, pp. 22-29.

[17191] P. E. Olsen and E. C. Rainforth. The Early Jurassic ornithischian dinosaurian ichnogenus Anomoepus. English. The Great Rift Valleys of Pangea in Eastern North America, Volume 2: Sedimentology, Stratigraphy, and Paleontology. New York: Columbia University Press, 2003, pp. 314-368.

[17192] E. C. Olson. "An Eryopid (Amphibia: Labyrinthodontia) from the Fort Sill Fissures, Lower Permian, Oklahoma". English. In: Journal of Vertebrate Paleontology 11.1 (1991), pp. 130-132.

[17193] S. L. Olson. "A new diminutive species of shearwater of the genus Calonectris (Aves: Procellariidae) from the Middle Miocene Calvert Formation of Chesapeake Bay". English. In: Proceedings of the Biological Society of Washington 122.4 (2009), pp. 466-470.

[17194] S. L. Olson. Part 6. Early Eocene Birds from Eastern North America: A Faunule from the Nanjemoy Formation of Virginia. English. Virginia Division of Mineral Resources Publication 152. 1999, pp. 123132.

[17195] S. L. Olson. "A giant Presbyornis (Aves: Anseriformes) and other birds from the Paleocene Aquia Formation of Maryland and Virginia". English. In: Proceedings of the Biological Society of Washington 107.3 (1994), pp. 429-435.

[17196] S. L. Olson. "A fossil of the Great Auk (Penguinus impennis) from Middle Pleistocene deposits on Bermuda". English. In: Atlantic Seabirds 5.2 (2003), pp. 81-84.

[17197] S. L. Olson. "First fossil record of a finfoot (Aves: Heliornithidae) and its biogeographical significance". English. In: 116.3 (2003), pp. 732-736.

[17198] S. L. Olson. "The Fossil Record of the Genus Mycteria (Ciconiidae) in North America". English. In: The Condor 93.4 (1991), pp. 1004-1006.

[17199] S. L. Olson. "A new species of small owl of the genus Aegolius (Aves: Strigidae) from Quaternary deposits on Bermuda". English. In: Proceedings of the Biological Society of Washington 125.2 (2012), pp. $97-105$.

[17200] S. L. Olson. "Fossil red-shouldered hawk in the Bahamas: Calohierax quadratus Wetmore synonymized with Buteo lineatus (Gmelin)". English. In: Proceedings of the Biological Society of Washington 113.1 (2000), pp. 298-301.

[17201] S. L. Olson. “A new species of pelican (Aves: Pelecanidae) from the Lower Pliocene of North Carolina and Florida". English. In: Proceedings of the Biological Society of Washington 112.3 (1999), pp. 503-509.

[17202] S. L. Olson. "Fossil woodpeckers from Bermuda with the description of a new species of Colaptes (Aves: Picidae)". English. In: Proceedings of the Biological Society of Washington 126 (2013), pp. 17-24.

[17203] S. L. Olson. "A new genus and species of buteonine hawk from Quaternary deposits in Bermuda (Aves: Accipitridae)". English. In: Proceedings of the Biological Society of Washington 121 (2008), pp. 130-141.

[17204] S. L. Olson. "The fossil record and history of doves on Bermuda (Aves: Columbidae)". English. In: Proceedings of the Biological Society of Washington 124 (2011), pp. 1-6. 
[17205] S. L. Olson. "A new species of shearwater of the genus Calonectris (Aves: Procellariidae) from a middle Pleistocene deposit on Bermuda". English. In: Proceedings of the Biological Society of Washington 121 (2008), pp. 398-409.

[17206] S. L. Olson. "History, morphology, and fossil record of the extinct Puerto Rican parakeet Psittacara maugei Souancé". English. In: The Wilson Journal of Ornithology 127 (2015), pp. 1-12.

[17207] S. L. Olson. "A late Pliocene occurrence of the thick-billed murre (Alcidae: Uria lomvia) on St. George Island, Pribilofs, Alaska". English. In: Paleontological Journal 47 (2013), pp. 1365-1368.

[17208] S. L. Olson. "The anseriform relationships of Anatalavis Olson and Parris (Anseranatidae), with a new species from the Lower Eocene London Clay". English. In: Smithsonian Contributions to Paleobiology 89 (1999), pp. 231-243.

[17209] S. L. Olson. "A new family of primitive landbirds from the early Eocene Green River Formation of Wyoming". English. In: vol. 36. Papers in avian paleontology honoring Pierce Brodkorb. Los Angeles: Natural History Museum of Los Angeles County, 1992, pp. 127-136.

[17210] S. L. Olson. "A new genus and species of unusual tern (Aves: Laridae: Anoinae) from the Middle Miocene Calvert Formation of Virginia". English. In: Proceedings of the Biological Society of Washington 124.4 (2011), pp. 270-279. DOI: 10.2988/11-16.1.

[17211] S. L. Olson. "A trans-Atlantic record of the fossil tropicbird Heliadornis ashbyi (Aves: Phaethontidae) from the Miocene of Belgium". English. In: Proceedings of the Biological Society of Washington 110.4 (1997), pp. 624-628.

[17212] S. L. Olson and H. M. F. Alvarenga. "A new genus of small teratorn from the Middle Tertiary of the Taubaté Basin, Brazil (Aves: Teratornithidae)". English. In: Proceedings of the Biological Society of Washington 115.4 (2002), pp. 701-705.

[17213] S. L. Olson and Y. Hasegawa. "A new genus and two new species of gigantic Plotopteridae from Japan (Aves: Pelecaniformes)". English. In: Journal of Vertebrate Paleontology 16.4 (1996), pp. 742 751.

[17214] S. L. Olson and P. J. Hearty. "Probable extirpation of a breeding colony of short-tailed albatross (Phoebastria albatrus) on Bermuda by Pleistocene sea-level rise". English. In: Proceedings of the National Academy of Sciences 100 (2003), pp. 12825-12829.

[17215] S. L. Olson and H. F. James. "Descriptions of Thirty-Two New Species of Birds from the Hawaiian Islands: Part I. Non-Passeriformes". English. In: Ornithological Monographs 45 (1991), pp. 1-88.

[17216] S. L. Olson and P. Jouventin. "A new species of small flightless duck from Amsterdam Island, southern Indian Ocean (Anatidae: Anas)". English. In: The Condor 98 (1996), pp. 1-9.

[17217] S. L. Olson and E. J. Maz López. "New evidence of Ara autochthones from an archeological site in". English. In: Caribbean Journal of Science 44 (2008), pp. 215-222.

[17218] S. L. Olson and H. Matsuoka. "New specimens of the early Eocene frigatebird Limnofregata (Pelecaniformes: Fregatidae), with the description of a new species". English. In: Zootaxa 1046 (2005), pp. 1-15.

[17219] S. L. Olson, G. K. Pregill, and W. B. Hilgartner. "Studies on Fossil and Extant Vertebrates from San Salvador (Watling's) Island, Bahamas". English. In: Smithsonian Contributions to Zoology 508 (1990), pp. 1-24.

[17220] S. L. Olson and P. C. Rasmussen. "Miocene and Pliocene birds from the Lee Creek Mine, North Carolina". English. In: Smithsonian Contributions to Paleobiology 90 (2001), pp. 233-365.

[17221] S. L. Olson and W. Suárez. "A fossil cranium of the Cuban macaw Ara tricolor (Aves: Psittacidae) from Villa Clara Province, Cuba". English. In: Caribbean Journal of Science 44 (2008), pp. 287-290.

[17222] S. L. Olson and W. Suárez. "Bare-throated tiger-heron (Tigrisoma mexicanum) from the Pleistocene of Cuba: a new subfamily for the West Indies". English. In: Waterbirds 31 (2008), pp. 285288.

[17223] S. L. Olson and W. Suárez. "A new generic name for the Cuban Bare-legged Owl Gymnoglaux lawrencii Sclater and Salvin”. English. In: Zootaxa 1960 (2008), pp. 67-68. 
[17224] S. L. Olson and D. B. Wingate. "A new species of large flightless rail of the Rallus longirostris/elegans complex (Aves: Rallidae) from the late Pleistocene of Bermuda". English. In: Proceedings of the Biological Society of Washington 114.2 (2001), pp. 509-516.

[17225] S. L. Olson and D. B. Wingate. "A new species of towhee (Aves: Emberizidae: Pipilo) from Quaternary deposits on Bermuda". English. In: Proceedings of the Biological Society of Washington 125 (2012), pp. 85-96.

[17226] S. L. Olson and D. B. Wingate. “A new species of night-heron (Ardeidae: Nyctanassa) from Quaternary deposits on Bermuda". English. In: Proceedings of the Biological Society of Washington 119 (2006), pp. 326-337.

[17227] S. L. Olson and D. B. Wingate. "Two new species of flightless rails (Aves: Rallidae) from the Middle Pleistocene crane fauna of Bermuda". English. In: Proceedings of the Biological Society of Washington 113 (2000), pp. 356-368.

[17228] S. L. Olson and A. C. Ziegler. "Remains of land birds from Lisianski Island, with observations on the terrestrial avifauna of the northwestern Hawaiian Islands". English. In: Pacific Science 49 (1995), pp. 111-125.

[17229] S. L. Olson. "Evidence of a large albatross in the Miocene of Argentina (Aves: Diomedeidae)". English. In: Proceedings of the Biological Society of Washington 97.4 (1990), pp. 741-743.

[17230] T. D. Olszewski and M. E. Patzkowsky. "T.D. Olszewski"s Ph.D. - Penn State University". English. PhD thesis. 1999.

[17231] L. Omana and C. González Arreola. “Late Jurassic (Kimmeridgian) larger benthic Foraminifera from Santiago Coatepec, SE Puebla, Mexico". English. In: Geobios 41.6 (2008), pp. 799-817.

[17232] K. Omoto. "Radiocarbon ages of beach rocks and late Holocene sea-level changes in the southern part of the Nansei Islands, southwest of Japan". English. In: Radiocarbon 43.2B (2001), pp. 887-898.

[17233] A. M. Omran, H. A. Soliman, and M. S. Mahmoud. “Early Cretaceous palynology of three boreholes from northern Western Desert (Egypt)". English. In: Review of Palaeobotany and Palynology 66 (1990), pp. 293-312.

[17234] A. Omura, Y. Maeda, T. Kawana, F. P. Siringan, and R. D. Berdin. “U-series dates of Pleistocene corals and their implications to the paleo-sea levels and the vertical displacement in the central Philippines". English. In: Quaternary International 115-116 (2004), pp. 3-13.

[17235] T. Onoue, T. Nikaido, L. R. Zamoras, and A. Matsuoka. "Preservation of larval bivalve shells in a radiolarian chert in the Late Triassic (Early Norian) interval of th Malaypa Sound Group, Calamian Island, western Philippines". English. In: Marine Micropaleonology 79 (2011), pp. 58-65.

[17236] T. Onoue and H. Sano. "Triassic mid-oceanic sedimentation in Panthalassa Ocean: Sambosan accretionary complex, Japan". English. In: Island Arc 16.1 (2007), pp. 173-190.

[17237] T. Onoue and G. D. Stanley. "Sedimentary facies from Upper Triassic reefal limestone of the Sambosan accretionary complex in Japan: mid-ocean patch reef development in the Panthalassa Ocean". English. In: Facies 54 (2008), pp. 529-547.

[17238] T. Onoue and H. Tanaka. "Late Triassic bivalves from Sambosan accretionary complex, southwest Japan, and their biogeographic implications". English. In: Paleontological Research 9.1 (2005), pp. 15-25.

[17239] W. Opitz. "Arawakis poinari Opitz, New Genus, New Species, A New Fossil Checkered Beetle in Dominican Amber (coleoptera: Cleridae: Clerinae) and Review of the Historical References of Fossil Cleridae". English. In: The Coleopterists Bulletin 61.3 (2007), pp. 339-350.

[17240] M. Orchard. “Late Triassic (Norian) conodonts from Peru”. English. In: Palaeontographica Abteilung A 233 (1994), pp. 203-208.

[17241] M. J. Orchard, E. S. Carter, S. G. Lucas, and D. G. Taylor. "Rhaetian (Upper Triassic) conodonts and radiolarians from New York Canyon, Nevada, USA". English. In: Albertiana 35 (2007), pp. 5965. 
[17242] J. D. Orcutt and S. S. B. Hopkins. “The Canid Fauna of the Juntura Formation (Late Clarendonian), Oregon". English. In: Journal of Vertebrate Paleontology 31.3 (2011), pp. 700-706. DOI: 10.1080 / 02724634.2011.558147.

[17243] M. P. J. Oreska, M. T. Carrano, and K. M. Dzikiewicz. “Vertebrate paleontology of the Cloverly Formation (Lower Cretaceous), I: faunal composition, biogeographic relationships, and sampling". English. In: Journal of Vertebrate Paleontology 33.2 (2013), pp. 264-292. DOI: 10.1080/02724634.2012. 717567.

[17244] J. Orihuela, L. W. Viñola López, and T. E. Macrini. "First cranial endocasts of early Miocene sirenians (Dugongidae) from the West Indies". English. In: Journal of Vertebrate Paleontology (2019), e1584565. DOI: $10.1080 / 02724634.2019 .1584565$.

[17245] C. Oriozabala, J. Sterli, and L. Gonzalez Ruiz. "Morphology of the mid-sized tortoises (Testudines: Testudinidae) from the Middle Miocene of Northwestern Chubut". English. In: Ameghiniana 55.1 (2018), pp. 30-54. DOI: 10.5710/AMGH.18.05.2017.3078.

[17246] C. Oriozabala, J. Sterli, and M. S. de la Fuente. "New species of the long-necked chelid Yaminuechelys from the Upper Cretaceous (Campanian-Maastrichtian) of Chubut, Argentina". English. In: Cretaceous Research 106 (2020), 104197:1-11. DOI: 10.1016/j.cretres.2019.104197.

[17247] M. Orliac, F. Guy, Y. Chaimanee, J. -J. Jaegar, and S. Ducrocq. “New remains of Egatochoerus jaegeri (Mammalia, Suoidea) from the late Eocene of Peninsular Thailand". English. In: Palaeontology 54.6 (2011), pp. 1323-1335.

[17248] M. J. Orliac, P.-O. Antoine, and F. Duranthon. “The Suoidea (Mammalia, Artiodactyla), exclusive of Listriodontinae, from the early Miocene of Béon 1 (Montréal-du-Gers, Sw France, MN4)". English. In: Geodiversitas 28.4 (2006), pp. 685-718.

[17249] M. J. Orliac, P.-O. Antoine, G. Roohi, and J. -L. Welcomme. "Suoidea (Mammalia, Cetartiodactyla) from the early Oligocene of the Bugti Hills, Balochistan, Pakistan". English. In: Journal of Vertebrate Paleontology 30.4 (2010), pp. 1300-1305.

[17250] M. J. Orliac and S. Ducrocq. “Eocene raoellids (Mammalia, Cetartiodactyla) outside the Indian Subcontinent: palaeogeographical implications". English. In: Geological Magazine 149.1 (2012), pp. 8092.

[17251] O. Orlov-Labkovsky. "Permian Fusulinids (Foraminifera) of the Subsurface of Israel: Taxonomy and Biostratigraphy". English. In: Revista Española de Micropaleontologa 36.3 (2004), pp. 389-406.

[17252] D. Ormezzano and A. Lanzetti. "I cetacei fossili del Museo Regionale di Scienze Naturali di Torino". English. In: Museologia Scientifica Memorie 13 (2014), pp. 18-24.

[17253] F. Ortega, A. D. Buscalioni, and Z. Gasparini. "Reinterpretation and new denomination of Atacisaurus crassiproratus (Middle Eocene; Issel, France) as cf. Iberosuchus (Crocodylomorpha, Metasuchia)". English. In: Geobios 29.3 (1996), pp. 353-364.

[17254] F. Ortega, F. Escaco, and J. L. Sanz. "A bizarre, humped Carcharodontosauria (Theropoda) from the Lower Cretaceous of Spain". English. In: Nature 467 (2010), pp. 203-206. DOI: 10.1038/nature09181.

[17255] F. Ortega, Z. Gasparini, A. D. Buscaloni, and J. O. Calvo. “A new species of Araripesuchus (Crocodylomorpha, Mesoeucrocodylia) from the Lower Cretaceous of Patagonia (Argentina)". English. In: Journal of Vertebrate Paleontology 20.1 (2000), pp. 57-76.

[17256] F. Ortega, J. J. Moratalla, A. G. Buscalioni, J. S. Sanz, S. Jiménez, and J. Valbuena. “Sobre la presencia de un cocodrilo fósil (Crocodylomorpha: Neosuchia: Goniopholis sp.) en la Cuenca de Cameros (Cretácico inferior: Vadillos-San Román de Cameroa, La Rioja)". Spanish. In: Zuba 14 (1996), pp. 113-120.

[17257] G. E. Ortega, E. Brussa, and R. Astini. “Nuevos hallazgos de graptolitos en la Formacion Yerba Loca y su implicancia estratigrafica, Precordillera de San Juan Argentina". Spanish. In: Ameghiniana 28.1-2 (1991), pp. 163-178. 
[17258] J. Ortega-Blanco, D. J. Bennett, X. Delclós, and M. S. Engel. “A Primitive Aphidiine Wasp in Albian Amber from Spain and a Northern Hemisphere Origin for the Subfamily (Hymenoptera: Braconidae: Aphidiinae)". English. In: Journal of the Kansas Entomological Society 82.4 (2009), pp. 273282.

[17259] J. Ortega-Blanco, S. Chatzimanolis, H. Singh, and M. S. Engel. "The oldest fossil of the subfamily Osoriinae (Coleoptera: Staphylinidae), from Eocene Cambay amber (India)". English. In: The Coleopterists Bulletin 67 (2013), pp. 304-308.

[17260] J. Ortega-Blanco, X. Declós, and M. S. Engel. “The Wasp Family Embolemidae in Early Cretaceous Amber from Spain (Hymenoptera: Chrysidoidea)". English. In: Journal of the Kansas Entomological Society 84.1 (2011), pp. 36-42.

[17261] J. Ortega-Blanco, X. Declós, and M. S. Engel. “A Protorhyssaline Wasp in Early Cretaceous Amber from Spain (Hymenoptera: Braconidae)". English. In: Journal of the Kansas Entomological Society 84.1 (2011), pp. 51-57.

[17262] J. Ortega-Blanco, X. Delclós, and M. S. Engel. “Diverse stigmaphronid wasps in Early Cretaceous amber from Spain (Hymenoptera: Ceraphronoidea: Stigmaphronidae)". English. In: Cretaceous Research 32 (2011), pp. 762-773.

[17263] J. Ortega-Blanco, X. Delclós, E. Peñalver, and M. S. Engel. "Serphitid wasps in Early Cretaceous amber from Spain (Hymenoptera: Serphitidae)". English. In: Cretaceous Research 32 (2011), pp. 143154.

[17264] J. Ortega-Blanco and M. S. Engel. “Bethylidae from Early Cretaceous Spanish amber (Hymenoptera: Chrysidoidea)". English. In: Journal of the Kansas Entomological Society 86 (2013), pp. 264-276.

[17265] J. Ortega-Blanco, R. C. McKellar, and M. S. Engel. “Diverse scelionid wasps from Early Cretaceous Álava amber, Spain (Hymenoptera: Platygastroidea)". English. In: Bulletin of Geosciences 89 (2014), pp. 553-571.

[17266] J. Ortega-Blanco, E. Peñalver, X. Declós, and M. S. Engel. "False fairy wasps in Early Cretaceous amber from Spain (Hymenoptera: Mymarommatoidea)". English. In: Palaeontology 54.3 (2011), pp. 511-523.

[17267] J. Ortega-Blanco, A. P. Rasnitsyn, and X. Delclos. "A New Family of Ceraphronoid Wasps form Early Cretaceous Álava Amber". English. In: Acta Palaeontologica Polonica 55.2 (2010), pp. 265-276.

[17268] J. Ortega-Blanco, A. P. Rasnitsyn, and X. Delclós. "First record of anaxyelid woodwasps (Hymenoptera: Anaxyelidae) in Lower Cretaceous Spanish amber". English. In: Zootaxa 1937 (2008), pp. 39-50.

[17269] J. Ortega-Blanco, H. Singh, and M. S. Engel. "First amber fossil Rhysipolini (Hymenopera: Braconidae): a new genus and species in early Eocene Cambay amber". English. In: Acta Entomologica Musei Nationalis Pragae 52 (2012), pp. 585-594.

[17270] J. Ortega-Hernandez, S. J. Braddy, J. B. Jago, and P. W. Baillie. "A new aglaspidid arthropod from the Upper Cambrian of Tasmania". English. In: Palaeontology 53.5 (2010), pp. 1065-1976.

[17271] J. Ortega-Hernandez, R. Lerosey-Aubril, C. Kier, and E. Bonino. “A rare non-trilobite artiopodan from the Guzhangian (Cambrian Series 3) Weeks Formation konservat-lagerstatte in Utah, USA". English. In: Palaeontology (2014). DOI: 10.1111/pala.12136.

[17272] P. E. Ortiz, D. A. Garca López, M. J. Babot, U. F. J. Pardiñas, P. J. A. Muruaga, and J. P. Jayat. “Exceptional Late Pliocene microvertebrate diversity in northwestern Argentina reveals a marked small mammal turnover". English. In: Palaeogeography, Palaeoclimatology, Palaeoecology 361-362 (2012), pp. 21-37. DOI: 10.1016/j.palaeo.2012.07.012.

[17273] P. E. Ortiz, D. A. Garcia-Lopez, M. C. Madozzo Jaen, and G. I. Esteban. "Sntesis actualizada del registro paleontológico pleistoceno en el Noroeste argentino". English. In: Mioceno al Pleistoceno del centro y norte de Argentina. 2019, pp. 574-605.

[17274] P. E. Ortiz and J. P. Jayat. "Primer registro fósil para dos especies de sigmodontinos (Rodentia, Cricetidae) endémicas del extremo sur de las Yungas de Argentina". Spanish. In: Ameghiniana 50.6 (2013), pp. 598-604. 
[17275] P. E. Ortiz, J. P. Jayat, and S. J. Steppan. “A New fossil phyllotine Rodentia Sigmodontinae from the late Pliocene in the Andes of northern Argentina". English. In: Journal of Vertebrate Paleontology 32.6 (2012), pp. 1429-1441.

[17276] P. E. Ortiz, J. P. Jayat, N. L. Nasif, P. Teta, and A. Haber. “Roedores del Holoceno tardo de la Puna de Atacama, sitio arqueológico Tebenquiche Chico, Catamarca, Argentina". Spanish. In: Archaeofauna 21 (2012), pp. 249-266.

[17277] P. E. Ortiz, J. P. Jayat, and U. F. J. Pardinas. “Roedores y Marsupiales en Torno Al Lmite Pleistoceno/Holoceno en Catamarca, Argentina: Extinciones y Evolución Ambiental". English. In: Ameghiniana 48.3 (2011), pp. 336-357. DOI: 10.5710/AMGH.v48i3(355).

[17278] P. E. Ortiz, J. P. Jayat, F. Barbiere, M. M. Sampietro Vattuone, and J. L. Pena Monne. “Evolution of small mammal communities during the late Quaternary in a middle-altitude valley of Northwestern Argentina". English. In: Ameghiniana 56 (2019), pp. 153-186. DOI: 10.5710/ AMGH.11.02.2019. 3241.

[17279] P. E. Ortiz, U. F. J. Pardiñas, and S. J. Steppan. “A New Fossil Phyllotine (Rodentia: Muridae) from Northwestern Argentina and Relationships of Reithrodon Group". English. In: Journal of Mammalogy 81.1 (2000), pp. 37-51.

[17280] E. Ortiz-Caballero, E. Jiménez-Hidalgo, and V. M. Bravo-Cuevas. “A new species of the gopher Gregorymys (Rodentia, Geomyidae) from the". English. In: Journal of Paleontology (2020). DOI: 10. 1017/jpa.2020.64.

[17281] L. Ortlieb, T. DeVries, and A. Diaz. "Occurrence de Chione broggi (Pilsbry \& Olsson, 1943) (Pelecypoda) en depositos litorales cuaternarios del sur del Peru: implicaciones paleoceanograficas". Spanish. In: Boletn de la Sociedad Geológica de Perú 81 (1990), pp. 127-134.

[17282] L. Ortlieb, C. Zazo, J. L. Goy, C. Dabrio, and J. Machare. “Pampa del Palo: an anomalous composite marine terrace on the uprising coast of southern Peru". English. In: Journal of South American Earth Sciences 9.5/6 (1996), pp. 367-379.

[17283] V. Ortuño and A. Arillo. "Nuevos Heteroptera (Insecta) del Mioceno de Izarra (Álava, España)". Spanish. In: Estudios del Museo de Ciencias Naturales de Álava 12 (1997), pp. 17-23.

[17284] V. M. Ortuño and A. Arillo. "Discovery of the genus Ernobius Thomson (Coleoptera: Anobiidae) from the Oligocene of Izarra, Alava, Spain". English. In: The Coleopterists Bulletin 51.1 (1997), pp. 71-73.

[17285] V. M. Ortuño and A. Arillo. "Fossil carabids from Baltic amber -II - A new subgenus of Bembidion Latreille 1802 (Coleoptera: Carabidae: Bembidiini)". English. In: Annales de la Société Entomologique de France 46 (2010), pp. 189-192.

[17286] V. M. Ortuño and A. Arillo. "La entomofauna del Mioceno superior de la depresión ceretana (Lleida, NE de España). Coleópteros I". Spanish. In: Boletn Geológico y Minero 106 (1995), pp. 407414.

[17287] V. M. Ortuño and A. Arillo. “Presencia del género Dicerca (Coleoptera, Buprestidae) en el Mioceno superior de la depresión ceretana (Lleida, NE de España)". Spanish. In: Acta Geologica Hispanica 35 (2000), pp. 189-193.

[17288] V. M. Ortuño and A. Arillo. "Presencia del género Geocoris en el Oligoceno de Izarra (Alava, España). Descripción de G. monserrati sp. nov. (Heteroptera, Lygaeidae)". Spanish. In: Nouvelle Revue d'Entomologie, Nouvelle Série 14 (1997), pp. 359-363.

[17289] V. M. Ortuño and A. Arillo. "Fossil carabids from Baltic amber - I - A new species of the genus Calathus Bonelli, 1810 (Coleoptera: Carabidae: Pterostichinae)”. English. In: Zootaxa 2239 (2009), pp. 55-61.

[17290] V. M. Ortuño and A. Arillo. "Fossil carabids from Baltic amber - III - Tarsitachys bilobus Erwin, 1971 an interesting fossil ground beetle from Baltic amber (Coleoptera: Carabidae: Trechinae): Redescription and comments on its taxonomic placement". English. In: Zootaxa 4027 (2015), pp. 578586. 
[17291] D. V. Osadchaya and D. V. Kotelnikov. "Archaeocyathids from the Atdabanian (Lower Cambrian) of the Altay-Sayan Foldbelt, Russia". English. In: Geodiversitas 20.1 (1998), pp. 5-18.

[17292] A. Osi. "The first dinosaur remains from the Upper Cretaceous of Hungary (Csehbánya Formation, Bakony Mts)". In: Géobios 37 (2004), pp. 749-753.

[17293] A. Osi. "Hungarosaurus tormai, a new ankylosaur (Dinosauria) from the Upper Cretaceous of Hungary". English. In: Journal of Vertebrate Paleontology 25.2 (2005), pp. 370-383.

[17294] A. Osi. “Cranial osteology of Iharkutosuchus makadii, a Late Cretaceous basal eusuchian crocodyliform from Hungary". English. In: Neues Jahrbuch für Geologie und Paläontologie - Abhandlungen 248.3 (2008), pp. 279-299.

[17295] A. Osi, S. Apesteguia, and M. Kowalewski. "Non-avian theropod dinosaurs from the early Late Cretaceous of central Europe". English. In: Cretaceous Research 31.3 (2010), pp. 304-320. DOI: 10. 1016/j.cretres.2010.01.001.

[17296] A. Osi, E. R. Bodor, L. Makádi, and M. Rabi. "Vertebrate remains from the Upper Cretaceous (Santonian) Ajka Coal Formation, western Hungary". English. In: Cretaceous Research 57 (2015), pp. 228-238. DOI: 10.1016/j.cretres.2015.04.014.

[17297] A. si, G. Botfalvai, E. Prondvai, Z. Hajdu, G. Czirják, Z. Szentesi, E. Pozsgai, A. E. Götz, L. Makádi, D. Csengdi, and K. Sebe. "First report of Triassic vertebrate assemblages from the Villány Hills (southern Hungary)". English. In: Central European Geology 56 (2013), pp. 297-335.

[17298] A. Osi and E. Buffetaut. "Additional non-avian theropod and bird remains from the early Late Cretaceous (Santonian) of Hungary and a review of the European abelisauroid record". English. In: Annales de Paléontologie 97 (2011), pp. 34-49. DOI: 10.1016/j.annpal.2011.07.001.

[17299] A. Osi, E. Buffetaut, and E. Prondvai. "New pterosaurian remains from the Late Cretaceous (Santonian) of Hungary (Iharkút, Csehbánya Formation)". English. In: Cretaceous Research 32 (2011), pp. 456-463. DOI: 10.1016/j.cretres.2011.01.011.

[17300] A. Osi, R. J. Butler, and D. B. Weishampel. "A Late Cretaceous ceratopsian dinosaur from Europe with Asian affinities". English. In: Nature 465 (2010), pp. 466-468. DOI: 10.1038/nature09019.

[17301] A. Osi, J. M. Clark, and D. B. Weishampel. "First report on a new basal eusuchian crocodyliform with multicusped teeth from the Upper Cretaceous (Santonian) of Hungary". English. In: Neues Jahrbuch für Geologie und Paläontologie - Abhandlungen 243.2 (2007), pp. 169-177.

[17302] A. si, Z. Csiki-Sava, and E. Prondvai. "A sauropod tooth from the Santonian of Hungary and the European Late Cretaceous 'sauropod hiatus'". English. In: Scientific Reports 7 (2017), 3261:1-8. DOI: 10.1038/s41598-017-03602-2.

[17303] A. Osi and I. Fozy. "A maniraptoran (Theropoda, Dinosauria) sacrum from the Upper Cretaceous of the Hateg Basin (Romania) - in search of the los pterosaurs of Baron Franz Nopcsa". English. In: Neues Jahrbuch für Geologie und Paläontologie Abhandlungen 246.2 (2007), pp. 173-181. DOI: 10. 1127/0077-7749/2007/0246-0173.

[17304] A. Osi, C.-M. Jianu, and D. B. Weishampel. Dinosaurs from the Upper Cretaceous of Hungary. English. In A. Petculescu \& E. Stiuca (eds.), Advances in Vertebrate Paleontology: Hen to Panta. Romanian Academy, Emil Racovita Institute of Speleology, Bucarest. 2003, pp. 117-120.

[17305] A. Osi, J. Pálfy, L. Makádi, Z. Szentesi, P. Gulyás, M. Rabi, G. Botfalvai, and K. Hips. “Hettangian (Early Jurassic) dinosaur tracksites from the Mecsek Mountains, Hungary". English. In: Ichnos 18 (2011), pp. 79-94.

[17306] A. Osi, X. Pereda-Suberbiola, and T. Foldes. "Partial skull and endocranial cast of the ankylosaurian dinosaur Hungarosaurus from the Late Cretaceous of Hungary: implications for locomotion". English. In: Palaeontologia Electronica 17.1 (2014), pp. 1-18.

[17307] A. Osi, E. Prondvai, R. Butler, and D. B. Weishampel. "Phylogeny, histology and inferred body size evolution in a new rhabdodontid dinosaur from the Late Cretaceous of Hungary". English. In: PLoS ONE 7.9 (2012), e44318. DOI: 10.1371/journal.pone.0044318. 
[17308] A. Osi and E. Prondvai. "Sympatry of two ankylosaurs (Hungarosaurus and cf. Struthiosaurus) in the Santonian of Hungary". English. In: Cretaceous Research 44 (2013), pp. 58-63.

[17309] A. si and E. Prondvai. "Forgotten pterosaurus in Hungarian collections: first description of Rhamphorhynchus and Pterodactylus specimens". English. In: Neues Jahrbuch für Geologie und Paläontologie - Abhandlungen 252.2 (2009), pp. 167-180.

[17310] A. si, M. Rabi, and L. Makádi. “An enigmatic crocodyliform tooth from the bauxites of western Hungary suggests hidden mesoeucrocodylian diversity in the Early Cretaceous European archipelago". English. In: PeerJ 3 (2015), e1160:1-17.

[17311] A. Osi, D. B. Weishampel, and C. M. Jianu. "First evidence of azhdarchid pterosaurs from the Late Cretaceous of Hungary". English. In: Acta Palaeontologica Polonica 50.4 (2005), pp. 777-787.

[17312] A. Osi, M. T. Young, A. Galacz, and M. Rabi. "A new large-bodied thalattosuchian crocodyliform from the Lower Jurassic (Toarcian) of Hungary, with further evidence of the mosaic acquisition of marine adaptations in Metriorhynchoidea". English. In: PeerJ (2018). DOI: 10.7717/peerj.4668.

[17313] L. Osiková. "Mollusca of Neogene in the area around Velké Blovice and their ecological aspects". other. PhD thesis. 2010.

[17314] H. Osmólska. "An unusual theropod dinosaur from the Late Cretaceous Nemegt Formation of Mongolia". In: Acta Palaeontologica Polonica 41.1 (1996), pp. 1-38.

[17315] H. Osmólska, S. Hua, and E. Buffetaut. "Gobiosuchus kielanae (Protosuchia) from the Late Cretaceous of Mongolia: anatomy and relationships". English. In: Acta Palaeontologica Polonica 42.2 (1997), pp. 257-289.

[17316] Á Ossó. “New species of Kromtitis Müller, 1984 (Decapoda: Brachyura: Dynomenidae)”. English. In: Palaeontologia Electronica 22.2.47A (2019), pp. 1-9.

[17317] A. Ossó and D. Clements. English. In: Paleontologa Mexicana 5.2 (2016), pp. 137-145.

[17318] A. Ossó, J. L. Domnguez, and P. Artal. "Pyreneplax basaensis new genus, new species (Decapoda, Brachyura, Vultocinidae) from the Priabonian (Late Eocene) of the Pyrenees of Huesca (Aragón, Spain), and remarks on the genus Lobonotus A. Milne-Edwards, 1863". English. In: Treb. Mus. Geol. Barcelona 20 (2014), pp. 33-43.

[17319] A. Ossó, C. Gagnaison, and J. Bailleul. “First report of Early Eocene Decapods in Morocco: description of a new genus and a new species of Carpiliidae (Decapoda: Brachyura) with remarks on its paleobiogeography". English. In: Geodiversitas 42.4 (2020), pp. 47-56. DOI: 10.5252/geodiversitas2020v42a4. http://geodiversitas.com/42/4.

[17320] A. Osso-Morales, P. Artal, and F. J. Vega. "New crabs (Crustacea, Decapoda) from the Upper Cretaceous (Campanian) of the Moyenne Moulouya, northeast Morocco". English. In: Revista Mexicana de Ciencias Geologias 27.2 (2010), pp. 213-224.

[17321] J. H. Ostrom and J. S. McIntosh. Marsh's Dinosaurs: The Collections from Como Bluff. Yale University Press, New Haven. 1999, pp. 1-388.

[17322] J. H. Ostrom and P. Wellnhofer. Triceratops: an example of flawed systematics. Dinosaur Systematics: Perspectives and Approaches, Cambridge University Press, Cambridge. 1990, pp. 245-254.

[17323] J. A. Oswald and D. W. Steadman. "Late Pleistocene passerine birds from Sonora, Mexico". English. In: Palaeogeography, Palaeoclimatology, Palaeoecology 301 (2011), pp. 56-63.

[17324] J. A. Oswald and D. W. Steadman. "The late Quaternary bird community of New Providence, Bahamas". English. In: The Auk 135 (2018), pp. 359-377.

[17325] J. D. Oswald. "Insects from the Santana Formation, Lower Cretaceous, of Brazil. Chapter 8: Raphidioptera". English. In: Bulletin of the American Museum of Natural History 195 (1990), pp. 154-163.

[17326] J. D. Oswald. “The Brown Lacewing Genus Notiobiella (Neuroptera: Hemerobiidae) from Dominican Amber". English. In: Journal of the New York Entomological Society 107.4 (1999), pp. 297303. 
[17327] Y. Ota and J. Chappell. "Holocene sea-level rise and coral reef growth on a tectonically rising coast, Huon Peninsula, Papua New Guinea". English. In: Quaternary International 55 (1999), pp. 51-59.

[17328] J. Otava, J. Hladil, P. Petrova, and S. Hladilova. “Nalezy Badenskych fosili v jeskyni Svazna Studna, Moravsky Kras - dusledky pro speleogenesi [Finds of Badenian fossils in the cave Svazna Studna, Moravian Karst - implications for speleogenesis]". other. In: Geologicke Vyzkumy na Morave ve Slezsku v r. 2002 (2003), pp. 25-26.

[17329] A. Otero. "The appendicular skeleton of Neuquensaurus, a Late Cretaceous saltasaurine sauropod from Patagonia, Argentina". English. In: Acta Palaeontologica Polonica 55.3 (2010), pp. 399-426. DOI: 10.4202/app.2009.0099.

[17330] A. Otero, J. I. Canale, A. Haluza, and J. O. Calvo. "New titanosaur with unusual haemal arches from the Upper Cretaceous of Neuquén Province, Argentina". English. In: Ameghiniana 48.4 (2011), pp. 655-661.

[17331] A. Otero, E. Krupandan, D. Pol, A. Chinsamy, and J. Choiniere. "A new basal sauropodiform from South Africa and the phylogenetic relationships of basal sauropodomorphs". English. In: Zoological Journal of the Linnean Society 174 (2015), pp. 589-634. DOI: 10.1111/zoj.12247.

[17332] A. Otero and M. Reguero. “Dinosaurs (Reptilia, Archosauria) at Museo de La Plata, Argentina: annotated catalogue of the type material and Antarctic specimens". English. In: Palaeontologia Electronica 16.1 (2013), 3T:1-24.

[17333] O. Otero, G. Garcia, X. Valentin, F. Lihoreau, F. K. Manthi, and S. Ducrocq. "A glimpse at the ectotherms of the earliest fauna from the East African Rift (Lokone, late Oligocene of Kenya)". English. In: Journal of Vertebrate Paleontology (2017), e1312691:1-8. DOI: 10.1080 / 02724634.2017. 1312691.

[17334] O. Otero, A. Likius, P. Vignaud, and M. Brunet. "A new polypterid fish: Polypterus faraou sp. nov. (Cladistia, Polypteridae) from the Late Miocene, Toros-Menalla, Chad". English. In: Zoological Journal of the Linnean Society 146 (2006), pp. 227-237.

[17335] O. Otero, A. Pinton, H. Cappetta, S. Adnet, X. Valentin, M. Salem, and J. -J. Jaeger. "A Fish Assemblage from the Middle Eocene from Libya (Dur At-Talah) and the Earliest Record of Modern African Fish Genera". English. In: PLoS One 10.12 (2015), e0144358. DOI: 10.1371 / journal.pone. 0144358.

[17336] R. A. Otero. “Taxonomic reassessment of Hydralmosaurus as Styxosaurus: new insights on the elasmosaurid neck evolution throughout the Cretaceous". English. In: PeerJ 4 (2016), e1777:1-60. DOI: $10.7717 /$ peerj.1777.

[17337] R. A. Otero. “Tortugas fosiles en Chile (Testudines): primeras perspectivas de un registro aun escaso". Spanish. In: Publicación Ocasional del Museo Nacional de Historia Natural, Chile 63 (2015), pp. 189-207.

[17338] R. A. Otero. “Loancorhynchus catrillancai gen. et”. English. In: PeerJ 7.e6671 (2019). DOI: 10.7717/ peerj.6671.

[17339] R. A. Otero and J. P. O'Gorman. "Identification of the first postcranial skeleton of Aristonectes Cabrera (Plesiosauroidea, Elasmosauridae) from the upper Maastrichtian of the south-eastern Pacific, based on a bivariate graphic analysis". English. In: Cretaceous Research 41 (2013), pp. 86-89. DOI: 10.1016/j.cretres.2012.11.001.

[17340] R. A. Otero, J. P. O'Gorman, N. Hiller, F. R. O'Keefe, and R. E. Fordyce. “Alexandronectes zealandiensis gen. et sp. nov., a new aristonectine plesiosaur from the lower Maastrichtian of New Zealand". English. In: Journal of Vertebrate Paleontology 36.2 (2016), e1054494:1-14. DOI: 10.1080 / 02724634.2015.1054494.

[17341] R. A. Otero, J. P. O'Gorman, W. L. Moisley, M. Terezow, and J. A. W. McKee. “A juvenile Tuarangisaurus keyesi Wiffen and Moisley 1986 (Plesiosauria, Elasmosauridae) from the Upper Cretaceous of New Zealand, with remarks on its skull ontogeny". English. In: Cretaceous Research 85 (2018), pp. 214-231. 
[17342] R. A. Otero, J. F. Parham, S. Soto-Acuña, P. Jimenez-Huidobro, and D. Rubilar-Rogers. “Marine reptiles from Late Cretaceous (early Maastrichtian) deposits in Algarrobo, central Chile". English. In: Cretaceous Research 35 (2012), pp. 124-132.

[17343] R. A. Otero, S. Soto-Acuña, and D. Rubilar-Rogers. "Presence of the elasmosaurid plesiosaur Mauisaurus in the Maastrichtian (Late Cretaceous) of central Chile". English. In: Acta Palaeontologica Polonica 55.2 (2010), pp. 361-364.

[17344] R. A. Otero, S. Soto-Acuña, and D. Rubilar-Rogers. "A postcranial skeleton of an elasmosaurid plesiosaur from the Maastrichtian of central Chile, with comments on the affinities of Late Cretaceous plesiosauroids from the Weddellian Biogeographic Province". English. In: Cretaceous Research 37 (2012), pp. 89-99.

[17345] R. A. Otero, S. Soto-Acuna, A. O. Vargas, D. Rubilar-Rogers, R. E. Yury-Yanez, and C. S. Gutstein. "Additions to the diversity of elasmosaurid plesiosaurs from the Upper Cretaceous of Antarctica". English. In: Gondwana Research (2013). DOI: 10.1016/j.gr.2013.07.016.

[17346] R. A. Otero, S. Soto-Acuña, F. R. O'Keefe, J. P. O'Gorman, W. Stinnesbeck, M. E. Suárez, D. RubilarRogers, C. Salazar, and L. A. Quinzio-Sinn. "Aristonectes quiriquinensis sp. nov., a new highly derived elasmosaurid from the upper Maastrichtian of central Chile". English. In: Journal of Vertebrate Paleontology 34.1 (2014), pp. 100-125. DOI: 10.1080/02724634.2013.780953.

[17347] R. A. Otero, S. Soto-Acuña, A. O. Vargas, and D. Rubilar-Rogers. “A new postcranial skeleton of an elasmosaurid plesiosaur from the Upper Cretaceous of central Chile and reassessment of Cimoliasaurus andium Deecke". English. In: Cretaceous Research 50 (2014), pp. 318-331. DOI: 10. 1016/j.cretres.2014.05.008.

[17348] R. A. Otero, S. Soto-Acuna, and R. E. Yury-Yanez. "Primer registro de tortugas y cocodrilos en el Eoceno de Magallanes, extremo sur de Chile". Spanish. In: Actas del XIII Congreso Geológico de Chile. Antofagasta (2012), pp. 722-724.

[17349] R. A. Otero, S. Soto-Acuna, D. Rubilar-Rogers, and C. S. Gutstein. "Kaikaifilu hervei gen. et sp. nov., a new large mosasaur (Squamata, Mosasauridae) from the upper Maastrichtian of Antarctica". English. In: Cretaceous Research 70 (2017), pp. 209-225. DOI: 10.1016/j.cretres.2016.11.002.

[17350] R. A. Otero and S. Soto-Acuña. "New chondrichthyans from Bartonian-Priabonian levels of Ro de Las Minas". English. In: Andean Geology 42.2 (2015), pp. 268-283. DOI: 10.5027/andgeoV42n2-a06.

[17351] R. A. Otero, S. Soto-Acuña, C. Salazar, and J. L. Oyarzún. "New elasmosaurids (Sauropterygia, Plesiosauria) from the Late Cretaceous of the Magallanes Basin, Chilean Patagonia: Evidence of a faunal turnover during the Maastrichtian along the Weddellian Biogeographic Province". English. In: Andean Geology 42.2 (2015), pp. 237-267.

[17352] R. A. Otero and S. Soto-Acuña. “Wunyelfia maulensis gen. et sp. nov., a new basal aristonectine (Plesiosauria," English. In: Cretaceous Research 118 (2021), p. 104651. DOI: 10.1016/j.cretres.2020. 104651.

[17353] R. A. Otero, M. E. Suarez, and J. P. le Roux. "First record of elasmosaurid plesiosaurs (Sauropterygia: Plesiosauria) in upper levels of the Dorotea Formation, Late Cretaceous (Maastrichtian), Puerto Natales, Chilean Patagonia". English. In: Andean Geology 36.2 (2009), pp. 342-350.

[17354] A. R. Othman. "Fosil moluska Trias Akhir dari kawasan Binjui, Kedah [Late Triassic Molluscan Fossils from Binjui Area, Kedah]". other. In: Newsletter of the Geological Society of Malaysia 38.2 (2012), pp. 27-34.

[17355] A. R. Othman and Mohd Shafeea Leman. "Middle Triassic ammonoid fossils from Aring, Kelantan, Malaysia". other. In: Bulletin of the Geological Society of Malaysia 56 (2010), pp. 53-59.

[17356] H. Otsuka. "Fossil deer from the Tokuno island, Ryukyu Islands, Southwest Japan". Japanese. In: Journal of National Museum of Science (Japan) 23 (1990), pp. 185-196.

[17357] R. L. Otto. "Descriptions of two new elateroid beetles (Coleoptera: Eucnemidae, Elateridae) from Burmese amber". English. In: Insecta Mundi 702 (2019), pp. 1-6. 
[17358] E. G. Ottone, M. Monti, C. A. Marsicano, M. S. de la Fuente, M. Naipauer, R. Armstrong, and A. C. Mancuso. "A new Late Triassic age for the Puesto Viejo Group (San Rafael depocenter, Argentina): SHRIMP UePb zircon dating and biostratigraphic correlations across southern Gondwana". English. In: Journal of South African Earth Sciences 56 (2014), pp. 186-199.

[17359] E. G. Ottone and G. B. Garcia. "Algunos elementos megafloristicos de la Formacion Santa Maxima, Paleozoico Superior, Argentina". Spanish. In: Ameghiniana 27 (1990), pp. 311-316.

[17360] O. Ouroumova, K. Shimada, and J. I. Kirkland. "Fossil marine vertebrates from the Blue Hill Shale Member (Middle Turonian) of the Upper Cretaceous Carlile Shale in northeastern Nebraska". English. In: Transactions of the Kansas Academy of Science 119 (2016), pp. 211-221. DOI: 10.1660/062. 119.0213.

[17361] M. Ourribane, E. H. Chellai, and D. Zaghbib-Turki. “Role des microbialites et des micro-encroutants dans la lithification recifale: exemples du Jurassique superieur de l'Atlas maghrebin (Maroc et Tunisie) [The role of microbialites and micro-encrusters in the reef lithification: examples from the Upper Jurassic of the Maghrebian Atlas (Morocco and Tunisia)]". French. In: Comptes Rendus de l'Academie des Sciences, Serie II. Sciences de la Terre et des Planetes 330.6 (2000), pp. 407-414.

[17362] D. Ouvrard, D. Burckhardt, D. Azar, and D. Grimaldi. "Non-jumping plant-lice in Cretaceous amber (Hemiptera: Sternorrhyncha: Psylloidea)". English. In: Systematic Entomology 35 (2010), pp. $172-180$.

[17363] D. Ouvrard, D. Burckhardt, and D. Greenwalt. "The oldest jumping plant-louse (Hemiptera: Sternorrhyncha) with comments on the classification and nomenclature of the Palaeogene Psylloidea". English. In: Acta Musei Moraviae, Scientiae Biologicae 98.2 (2013), pp. 21-33.

[17364] H. Ouyang and Y. Ye. "The first mamenchisaurian skeleton with complete skull: Mamenchisaurus youngi". English. In: Sichuan Science and Technology Press, Chengdu (2002), pp. 1-111.

[17365] J. R. Ovando-Figueroa, J. A. Moreno-Bedmar, K. P. Minor, M. Franco-Rubio, A. Oviedo, P. Patarroyo, and E. Robert. "Ammonite taxonomy and biostratigraphy for the upper Aptian-lower Albian (Lower Cretaceous) of Cerro Chino, Chihuahua State, northeast Mexico". English. In: Cretaceous Research 82 (2018), pp. 109-137.

[17366] D. J. Over and S. C. Ruppel. “Woodford conodonts and biostratigraphy (upper Devonian-Carboniferous) in the subsurface of eastern New Mexico and Texas". English. In: Stratigraphy 8.4 (2011), pp. 271279.

[17367] A. Oviedo, J. M. Pons, and Y. Pichardo-Barron. "Stratigraphical distribution of the Hippuritid Rudists in the Upper Cretaceous of central Mexico". English. In: 4th European Meeting on the Palaeontology and Stratigraphy of Latin America (2007).

[17368] M. Ovtcharova, H. Bucher, U. Schaltegger, T. Galfetti, A. Brayard, and J. Guex. "New Early to Middle Triassic U-Pb ages from South China: Calibration with ammonoid biochronozones and implications for the timing of the Triassic biotic recovery". English. In: Earth and Planetary Science Letters 243.3-4 (2006), pp. 463-475. DOI: 10.1016/j.epsl.2006.01.042.

[17369] A. W. Owen, D. L. Bruton, J. F. Bockelie, and T. G. Vockelie. The Ordovician successions of the Oslo region, Norway. English. Norges Geologiske Undersolelse Special Publication 4. 1990, pp. 1-54.

[17370] A. W. Owen and D. L. Bruton. "The only known cyclopygid-'atheloptic' trilobite fauna from North America: the upper Ordovician fauna of the Pyle Mountain Argillite and its palaeoenvironmental significance". English. In: Geological Magazine 149.6 (2012), pp. 964-988.

[17371] A. W. Owen and M. A. Parkes. “Trilobite faunas of the Duncannon Group: Caradoc stratigraphy, environments and palaeobiogeography of the Leinster Terrane, Ireland". English. In: Palaeontology 43.2 (2000), pp. 219-269.

[17372] E. F. Owen and E. P. F. Rose. "Early Jurassic brachiopods from Gibraltar, and their Tethyan affinities". English. In: Palaeontology 40 (1997), pp. 497-513.

[17373] H. G. Owen and J. Mutterlose. "Late Albian ammonites from offshore Suriname: implications for biostratigraphy and palaeobiogeography”. English. In: Cretaceous Research 27 (2006), pp. 717-727. 
[17374] M. Owen, S. Warsina, and J. H. Shergold. "Pacoota Sandstone macrofossil locality index". English. In: Bureau of Mineral Resources, Geology and Geophysics Bulletin 237 (1991), pp. 77-93.

[17375] P. R. Owen. "Description of a new late Miocene American badger (Taxidiinae) utilizing highresolution X-ray computed tomography". English. In: Palaeontology 49.5 (2006), pp. 999-1011. DOI: 10.1111/j.1475-4983.2006.00590.x.

[17376] P. R. Owen, C. J. Bell, and E. M. Mead. "Fossils, Diet, and Conservation of Black-Footed Ferrets (Mustela nigripes)". English. In: Journal of Mammalogy 81.2 (2000), pp. 422-433.

[17377] R. M. Owens. "The stratigraphical distribution and extinctions of Permian trilobites". English. In: Special Papers in Palaeontology 70 (2003), pp. 377-397.

[17378] R. M. Owens. "Late Ordovician and early Silurian Proetida (Trilobita) from North-Western and Central Europe". English. In: Palaeontology 47.3 (2004), pp. 557-578.

[17379] R. M. Owens and M. G. Bassett. "Catalogue of Type, Figured and Cited Fossils in the National Museum of Wales: Supplement 1971-1994". English. In: National Museum Wales. Geological Series 12 (1995), pp. 1-250.

[17380] R. M. Owens and R. A. Fortey. "Silicified Upper Ordovician trilobites from Pai-Khoi, arctic Russia". English. In: Palaeontology 52.6 (2009), pp. 1209-1220.

[17381] R. M. Owens and W. Hammann. "Proetide triolobites from the Cystoid Limestone (Ashgill) of NW Spain, and the suprageneric classification of related forms". English. In: Palaeontologische Zeitschrift 64.3/4 (1990), pp. 221-244.

[17382] R. M. Owens, O. Ivanova, I. Kim, L. E. Popov, and R. Feist. “Lower and Middle Devonian trilobites from southern Uzbekistan". English. In: AAP Memoir 39 (2010), pp. 211-244.

[17383] K. Oyama, H. Nishimoto, and A. Naruse. "New fossil molluscs indicating tropical sea elements from the miocene Bihoku Group, southwest Honshu, Japan: Part 2 Description of Cancilla hirosei n. sp., with notes on some molluscs from the Bihoku Group of Shobara City, Hiroshima Prefecture". In: Bulletin of the Mizunami Fossil Museum 21 (1994), pp. 19-28.

[17384] N. Oyama and H. Maeda. "Madygella humioi sp. nov. from the Upper Triassic Mine Group, southwest Japan: the oldest record of a sawfly (Hymenoptera: Symphyta) in east Asia". English. In: Paleontological Research 24 (2020), pp. 64-71. DOI: 10.2517/2019PR005.

[17385] C. W. Oyen and R. W. Portell. "Diversity patterns and biostratigraphy of Cenozoic echinodems from Florida". English. In: Palaeogeography, Palaeoclimatology, Palaeoecology 166 (2001), pp. 193-218.

[17386] K. Ozaki. Late Miocene and Pliocene Floras in Central Honshu, Japan. Bulletin of Kanagawa Prefectural Museam Natural Science Special Issue. 1991, pp. 1-244.

[17387] T. Ozawa, K. Inoue, and S. Tomida. "Early to Middle Miocene molluscan fossils from the Megami and Ebie limestones in Shizuoka Prefecture and their implications for the formation of a Miocene coral-algal reef within the Japanese faunal realm". English. In: Transactions and Proceedings of the Paleontological Society of Japan, N.S. 179 (1995), pp. 175-183.

[17388] T. Ozawa and S. Tomida. “Occurrence of Aturia coxi (Cephalopoda: Nautilida) from the uppermost Miocene of Japan and its implication for Late Miocene marine climate in the northwestern Pacific". English. In: Journal of Paleontology 70.5 (1996), pp. 795-798.

[17389] S. Ozer. "Presence of rudist bearing limestone blocks derived from the Arabian Platform in Gevas (Van) ophiolite". English. In: Bulletin of the Mineral Research and Exploration 114 (1992), pp. 75-82.

[17390] S. Ozer. "Two new species of canaliculate rudists (Dictyoptychidae) from southeastern Turkey". English. In: Geobios 38 (2005), pp. 235-245.

[17391] S. Ozer and M. Fenerci. "Two new species of Caprinidae from the Bayburt area (Eastern Black Sea, Turkey)". English. In: Bulletin of the Mineral Research and Exploration 115 (1993), pp. 15-21.

[17392] R. Özkan, N. Nazik, A. Munnecke, D. G. Saydam Demiray, E. Schindler, T. Aydin Özbek, E. eker Zor, I. Yilmaz, R. Brocke, R. H. Sancay, V. Wilde, and M. N. Yalçn. “Givetian/Frasnian (Middle/Upper Devonian) transition in the eastern Taurides, Turkey". English. In: Turkish Journal of Earth Sciences 28 (2019), pp. 207-231. DOI: 10.3906/yer-1804-20. 
[17393] P. Ozsvárt. "Five new species of the benthic Foraminifera from the Hungarian Paleogene Basin". English. In: Fragmenta Palaeontologica Hungarica 21 (2003), pp. 1-4.

[17394] P. Ozsvart. "Middle Eocene foraminifer, mollusc and ostracod fauna from the Csordakut Basin (Gerecse Mountains, Hungary): palaeoenvironments recorded in a transgressive sequence". English. In: Annales Universitatis Scientiarum Budapestinensis, Sectio Geologica 32 (1999), pp. 73-135.

[17395] P. Ozsvárt and S. Kovács. “Revised Middle and Late Triassic radiolarian ages for ophiolite mélanges: implications for the geodynamic evolution of the northern part of the early Mesozoic Neotethyan subbasins". English. In: Bulletin de la Société Géologique de France 183.4 (2012), pp. 273-286.

[17396] L. Ozvoldova. "Middle Jurassic radiolarian assemblages from radiolarites of the silica nappe (Slovak Karst, Western Carpathians)". English. In: Geologica Carpathica 49.4 (1998), pp. 289-296.

[17397] L. Ozvoldova and L. Frantova. "Jurassic radiolarites from the eastern part of the Pieniny Klippen Belt". English. In: Geologica Carpathica 48 (1997), pp. 49-61.

[17398] L. Ozvoldova, J. Jablonsky, and L. Frantova. “Upper Jurassic radiolarites of the Czertezic succession and comparison with the Kysuca succession in the east-slovak part of the Pieniny Klippen belt (Western Carpathians, Slovakia)". English. In: Geologica carpathica 51.2 (2000), pp. 109-119.

[17399] J. P. O'Gorman, P. Bona, M. de los Reyes, M. E. Raffi, and M. Reguero. “A non-aristonectine plesiosaur from Antarctica reveals new data on the". English. In: Alcheringa (2020). DOI: 10.1080 / 03115518.2020.1824261.

[17400] J. P. O'Gorman and Z. Gasparini. "A new Pliosaurus species (Sauropterygia, Plesiosauria) from the Upper". English. In: Journal of Paleontology 92.2 (2018), pp. 240-253. DOI: 10.1017/jpa.2017.82.

[17401] J. P. O'Gorman, L. Salgado, I. A. Cerda, and Z. Gasparini. “First record of gastroliths associated with elasmosaur remains from La Colonia Formation (Campanian-Maastrichtian), Chubut, Patagonia Argentina, with comments on the probable depositional palaeoenvironment of the source of the gastroliths". English. In: Cretaceous Research 40 (2013), pp. 212-217.

[17402] M. A. O'Leary, E. M. Roberts, M. Bouare, F. Sissoko, and L. Tapanila. “Malian Paenungulata (Mammalia: Placentalia): New African Afrotheres from the Early Eocene". English. In: Journal of Vertebrate Paleontology 26.4 (2006), pp. 981-988.

[17403] R. K. Pabian and W. J. Rushlau. "Taphonomic Analysis and Systematic Descriptions of Some Late Pennsylvanian and Early Permian Crinoids from Southeastern Nebraska, Eastern Kansas and Southwestern Iowa". English. In: Geological Survey Papers 20 (2002).

[17404] J.-M. Pacaud and D. Ledon. “Révision des Mollusques de l'Éocéne de Blaye (Gironde). 4. Description d'une espéce nouvelle de Pachycrommium (Gastropoda, Caenogastropoda, Ampullinidae). Notes taxonomiques et nomenclaturales sur quelques Ampullinidae avec la description de trois espéces nouvelles". French. In: Bulletin de la Société Linnéenne de Bordeaux 42.2 (2014), pp. 193-198.

[17405] J.-M. Pacaud. “Nouveautés nomenclaturales et taxinomiques introduites par Alcide d'Orbigny dans le Prodrome $(1850,1852)$ pour les espéces du Paléocéne et de l'Éocéne". French. In: Geodiversitas 29.1 (2007), pp. 17-85.

[17406] J.-M. Pacaud. "Sur les spécimens types et figurés des taxons relatifs á Gisortia (s.str.) coombii (Sowerby in Dixon, 1850) (Gastropoda, Cypraeoidea)". English. In: Cossmanniana 12.1-4 (2008), pp. 1-45.

[17407] J.-M. Pacaud. http://coldb.mnhn.fr/catalognumber/mnhn/f/j11867. English. Muséum national d'Histoire naturelle, Paris (France) Collection: Paleontology (F). 2012.

[17408] J.-M. Pacaud and B. Caze. “Une espéce nouvelle de Rostellariidae (Mollusca, Gastropoda, Littorinimorpha) dans le Lutétien (Éocéne moyen) du bassin de Paris. Redécouverte du matériel type de Hippochrenes fissura (Coquebert de Montbret \& Brongniart, 1793)". French. In: Cossmanniana 13 (2011), pp. 21-31.

[17409] J.-M. Pacaud and M. Harzhauser. "Jponsia, Moniquia et Eginea, trois nouveaux genres de Pachychilidae (Gastropoda, Caenogastropoda) du Paléogéne européen". French. In: Annales Museusem Historie naturales Nice 27 (2012), pp. 105-153. 
[17410] J. M. Pacaud. “Description des rhyncholites des Nautiles (Mollusca, Cephalopoda) du Paléogéne des bassins de Paris et d'Aquitaine et des Corbiéres (France)". French. In: Geodiversitas 32 (2010), pp. 121-156.

[17411] J. M. Pacaud. “Terebellomimus quaggiottoi n. gen., n. sp. (Mollusca, Gastropoda, Littorinimorpha, Rostellariidae) du Lutétien inférieur (Éocéne moyen) du Vicentin (Italie)". English. In: Geodiversitas 30.4 (2008), pp. 721-729.

[17412] J. M. Pacaud. “Le genre Bouryia Cossmann, 1888 (Gastropoda: Littorinimorpha: Pomatiopsidae ?) des sables thanétiens (Paléocéne) du bassin de Paris". English. In: Cossmanniana 13 (2011), pp. 310.

[17413] J. M. Pacaud. "Maralsenia, un nouveau genre de Pseudolividae (Gastropoda, Muricoidea) du Paléogéne inférieur des régions nord-africaine et sud-américaine". English. In: Bulletin de l'Institut Scientifique 31 (2009), pp. 1-7.

[17414] J. M. Pacaud and D. Ledon. “Révision des Mollusques de l'Éocéne de Blaye (Gironde). 2. Description de trois espéces nouvelles de Cypraeoidea (Gastropoda, Caenogastropoda)". English. In: Bulletin de la Société Linnéenne de Bordeaux 147.40 (2012), pp. 1-11.

[17415] J. M. Pacaud and A. Leroy. “Nouvelles espéces de Terebellopsis Leymerie, 1846 (Mollusca, Gastropoda, Strombidae) de l'Éocéne inférieur des Bassins de Paris et d'Aquitaine". English. In: Revue de Paléobiologie, Genéve 25.2 (2006), pp. 633-641.

[17416] J. M. Pacaud, D. Merle, and J. Pons. “Nouvelles espéces d'Ancillariinae (Mollusca: Gastropoda: Olividae) du Paléogéne des bassins de Paris et d'Aquitaine". English. In: Cossmanniana 15 (2013), pp. 27-73.

[17417] J. M. Pacaud and S. Tracey. "The occurrence of the genus Fusulculus Bouchet \& Vermeij (Gastropoda, Pseudolividae) in the Eocene of England, with a description of two new species". English. In: Tertiary Research 20 (2000), pp. 53-58.

[17418] J.-M. Pacaud. "First fossil records of the Recent Ovulid genus Pseudocypraea Schilder, 1927 (Mollusca, Gastropoda) with description of a new species". English. In: Geodiversitas 25.3 (2003), pp. 451462.

[17419] J.-M. Pacaud. “Un nouveau genre d'Hydrobiidae (Gastropoda, Prosobranchia) du Paléogéne du Bassin de Paris". English. In: Cossmanniana 4.1-2 (1997), pp. 1-14.

[17420] J.-M. Pacaud. "Révision des mollusques du Danien (Paléocéne inférieur) du Bassin de Paris. 1. Gastropoda : Patellogastropoda et Vetigastropoda (pro parte)". French. In: Geodiversitas 26.4 (2004), pp. 577-629.

[17421] J.-M. Pacaud and J. Le Renard. “Révision des Mollusques Paléogénes du Bassin de Paris. IV - Liste systématique actualisée". English. In: Cossmanniana 3.4 (1995), pp. 155-187.

[17422] J.-M. Pacaud, D. Merle, and J. -C. Meyer. “La faune danienne de Vigny (Val-d'Oise, France): importance pour l'étude de la diversification des mollusques au début du Tertiaire". French. In: Comptes Rendus de l'Académie des Sciences,Sciences de la Terre et des Planétes, Paris, série II a 330.12 (2000), pp. 867-873.

[17423] J.-M. Pacaud and K. I. Schnetler. "Revision of the gastropod family Pseudolividae from the Paleocene of West Greenland and Denmark". English. In: Bulletin of the Geological Society of Denmark 46 (1999), pp. 53-67.

[17424] C. Pacheco, R. T. Muller, M. Langer, F. A. Pretto, L. Kerber, and S. Dias da Silva. "Gnathovorax cabreirai: a new early dinosaur and the origin and initial radiation of predatory dinosaurs". English. In: PeerJ 7.e7963 (2019). DOI: 10.7717/peerj.7963.

[17425] C. P. Pacheco, E. Eltink, R. T. Müller, and S. Dias-da-Silva. “A new Permian temnospondyl with Russian affinities from South America, the new family Konzhukoviidae, and the phylogenetic status of Archegosauroidea". English. In: Journal of Systematic Palaeontology 15.3 (2017), pp. 241256. DOI: 10.1080/14772019.2016.1164763. 
[17426] C. P. Pacheco, A. G. Martinelli, A. E. B. Pavanatto, M. B. Soares, and S. Dias-da-Silva. "Prozostrodon brasiliensis, a probainognathian cynodont from the Late Triassic of Brazil: second record and improvements on its dental anatomy". English. In: Historical Biology 30.4 (2018), pp. 475-485. DOI: 10.1080/08912963.2017.1292423.

[17427] J. F. Pachut and R. J. Cuffey. "Stratigraphic and Geographic Bryozoan Abundance Gradients in the Calcareous Shales of the Wreford Megacyclothem (Lower Permian, Kansas)". In: The University of Kansas Paleontological Contributions New Series 10 (1999), pp. 1-17.

[17428] S. R. Packer and M. B. Hart. "Coniacian-Santonian Radiolaria from the Upper Cretaceous of Bornholm, Denmark: A preliminary investigation". English. In: Bulletin of the Geological Society of Denmark 52.2 (2005), pp. 141-157.

[17429] G. H. Packham, G. M. Philip, and T. C. T. Hubble. "Late Silurian or Early Devonian corals from the continental slope off southern New South Wales". English. In: Alcheringa 30 (2006), pp. 33-42.

[17430] K. Padian. "The ornithischian form genus Revueltosaurus from the Petrified Forest of Arizona (Late Triassic: Norian; Chinle Formation)". English. In: Journal of Vertebrate Paleontology 10.2 (1990), pp. 268-269.

[17431] K. Padian, A. J. de Ricqles, and J. R. Horner. "Bone histology determines identification of a new fossil taxon of pterosaur (Reptilia: Archosauria)". English. In: Comptes Rendus de l'Academie des Science, Serie II 320 (1995), pp. 77-84.

[17432] K. Padian and M. Smith. "New light on Late Cretaceous pterosaur material from Montana". English. In: Journal of Vertebrate Paleontology 12 (1992), pp. 87-92.

[17433] K. Padian and R. Wild. "Studies of Liassic Pterosauria, I. The holotype and referred specimens of the Liassic pterosaur Dorygnathus banthensis (Theodori) in the Petrefaktensammlung Banz, northern Bavaria". English. In: Palaeontographica Abteilung A 225 (1992), pp. 59-77.

[17434] A. Padilla, J. J. Eberle, M. D. Gottfried, A. R. Sweet, and J. H. Hutchison. "A Sand Tiger SharkDominated Fauna from the Eocene Arctic Greenhouse". English. In: Journal of Vertebrate Paleontology 34.6 (2014), pp. 1307-1316. DOI: 10.1080/02724634.2014.880446.

[17435] M. A. Pagani. “Los bivalvos carboniferos y permicos de la Patagonia (Chubut, Argentina). Parte III: Familias Mytilidae, Pterineidae, Limidae, Leptochondriidae, Etheripectinidae, Euchondriidae y Streblochondriidae". Spanish. In: Ameghiniana 42.3 (2005), pp. 579-596.

[17436] M. A. Pagani. "Los bivalvos carboniferos y permicos de Patagonia (Chubut, Argentina). Parte V: Familias Trigoniidae, Permophoridae, Cardiniidae, Crassatellidae, Pholadomyidae, Sanguinolitidae y Megadesmidae. Conclusiones". Spanish. In: Ameghiniana 43.3 (2006), pp. 539-556.

[17437] M. A. Pagani. "Los bivalvos carboniferos y permicos de Patagonia (Chubut, Argentina). Parte IV: familias Aviculopectinidae, Deltopectinidae y Schizodidae". Spanish. In: Ameghiniana 43.2 (2006), pp. 461-476.

[17438] M. A. Pagani. "Bivalvos del Permico inferior de la Formacion Bonete, Sierras Australes (provincia de Buenos Aires, Argentina)". Spanish. In: Ameghiniana 37 (2000), pp. 301-320.

[17439] M. A. Pagani, S. E. Damborenea, M. O. Mancenido, and S. M. Ferrari. "New early Jurassic decapod crustacean from Patagonia (Chubut Province), Argentina". English. In: Palaeontologische Zeitschrift 85 (2011), pp. 143-154.

[17440] M. A. Pagani, N. Sabattini, and M. F. Tortello. "A new Species of Hyolitha from the Late Cambrian of Northwestern Argentina". English. In: INSUGEO, Serie Correlación Geológica 19 (2005), pp. 169 176.

[17441] D. Pagnac. "Scaphohippus, a new genus of horse (Mammalia: Equidae) from the Barstow Formation of California". English. In: Journal of Mammalian Evolution 13.1 (2006), pp. 37-61. DOI: 10.1007/s10914-005-9002-2.

[17442] D. Pagnac. “New camels (Mammalia: Artiodactyla) from the Barstow Formation (middle Miocene), San Bernardino County, California". English. In: PaleoBios 25.2 (2005), pp. 19-13. 
[17443] D. C. Pagnac. "Additions to the Vertebrate Faunal Assemblage of the Middle Miocene Fort Randall Formation in the Vicinity of South Bijou Hill, South Dakota, USA". English. In: The Mountain Geologist 49.1 (2012), pp. 19-34.

[17444] J. L. A. Paijmans, R. Barnett, M. T. P. Gilbert, M. L. Z. Mendoza, J. W. F. Reumer, J. D. Vos, G. D. Zazula, D. Nagel, G. F. Baryshnikov, J. A. Leonard, N. Rohland, M. V. Westbury, A. Barlow, and M. Hofreiter. "Evolutionary History of Saber-Toothed Cats Based on Ancient Mitogenomics". English. In: Current Biology 27.21 (2017), pp. 3330-3336. DOI: 10.1016/j.cub.2017.09.033.

[17445] I. S. Paik. "Bone chip-filled burrows associated with bored dinosaur bone in floodplain paleosols of the Cretaceous Hasandong Formation, Korea". In: Palaeogeography, Palaeoclimatology, Palaeoecology 157 (2000), pp. 213-225.

[17446] I. S. Paik, H. J. Kim, J. D. Lim, M. Huh, and H. I. Lee. “Diverse tooth marks on an adult sauropod bone from the Early Cretaceous, Korea: implications in feeding behaviour of theropod dinosaurs". English. In: Palaeogeography, Palaeoclimatology, Palaeoecology 309 (2011), pp. 342-346. DOI: 10.1016/ j.palaeo.2011.07.002.

[17447] I. S. Paik, H. J. Kim, and M. Huh. "Dinosaur egg deposits in the Cretaceous Gyeongsang Supergroup, Korea: diversity and paleobiological implications". English. In: Journal of Asian Earth Sciences 56 (2012), pp. 135-146. DOI: 10.1016/j.jseaes.2012.05.006.

[17448] iii Pajak A.F., E. Scott, and C. J. Bell. “A review of the biostratigraphy of Pliocene and Pleistocene sediments in the Elsinore Fault Zone, Riverside County, California". English. In: PaleoBios 17.2-4 (1996), pp. 28-49.

[17449] S. Palamarczuk and V. Barreda. "Palinologa del Paleogeno tardo-Neógeno temprano, pozo Aries x-1, plataforma Continental Argentina, Tierra del Fuego". Spanish. In: Ameghiniana 37.2 (2000), pp. 221-234.

[17450] L. Palazzesi and V. Barreda. "Primer registro palinológico de la Formación Puerto Madryn, Mioceno de la provincia de Chubut, Argentina". Spanish. In: Ameghiniana 41.3 (2004), pp. 355-362.

[17451] L. Palazzesi and V. D. Barreda. "Palazzesi, L. and Barreda, V. 2012. Fossil pollen records reveal a late rise of open-habitat ecosystems in Patagonia". English. In: Nature Communications (2012). DOI: $10.1038 /$ ncomms2299.

[17452] A. Palci and M. W. Caldwell. "Vestigial forelimbs and axial elongation in a 95 million-year-old non-snake squamate". English. In: Journal of Vertebrate Paleontology 27.1 (2007), pp. 1-7.

[17453] A. Palci and M. W. Caldwell. "Redescription of Acteosaurus tommasinii von Meyer, 1860, and a discussion of evolutionary trends within the clade Ophidiomorpha". English. In: Journal of Vertebrate Paleontology 30.1 (2010), pp. 94-108.

[17454] A. Palci, M. W. Caldwell, and C. A. Papazzoni. "A new genus and subfamily of mosasaurs from the Upper Cretaceous of northern Italy". English. In: Journal of Vertebrate Paleontology 33.3 (2013), pp. 599-612.

[17455] A. Palci, M. W. Caldwell, C. A. Papazzoni, and E. Forniciari. "Mosasaurine mosasaurs (Squamata, Mosasauridae) from northern Italy". English. In: Journal of Vertebrate Paleontology 34.3 (2014), pp. 549-559.

[17456] L. Palencia, E. Peñalver, C. E. Prieto, and F. J. Poyato-Ariza. “First fossil harvestmen (Arachnida: Opiliones) from Spain and notes on the fossil record of Opiliones". English. In: Palaeontologia Electronica 22.1.5A (2019), pp. 1-18.

[17457] J. Palfy. "The Pelsonian brachiopod fauna of the Balaton Highland". In: Geologica Hungarica, Series Palaeontologica 55 (2003), pp. 139-158.

[17458] J. Pálfy, A. Demény, J. Haas, E. S. Carter, Á Görög, D. Halász, A. Oravecz-Scheffer, M. Hetényi, E. Márton, M. J. Orchard, P. Ozsvárt, I. Veto, and N. Zajzon. “Triassic-Jurassic boundary events inferred from integrated stratigraphy of the Csövár section, Hungary". English. In: Palaeogeography, Palaeoclimatology, Palaeoecology 244 (2007), pp. 11-33. 
[17459] J. Pálfy and L. Dosztály. A New Marine Triassic-Jurassic Boundary Section in Hungary. English. Vol. 6. GeoResearch Forum. 2000, pp. 173-180.

[17460] J. Pálfy and K. L. Schmidt. "Biostratigraphic and facies studies of the Telkwa Formation (Lower Jurassic)," English. In: Current Research, Geological Survey of Canada 1994.E (1994), pp. 29-38.

[17461] J. Palfy, P. L. Smith, and J. K. Mortensen. "A U-Pb and 40Ar/39Ar time scale for the Jurassic". English. In: Canadian Journal of Earth Sciences 37.6 (2000), pp. 923-944.

[17462] J. Pálfy, P. L. Smith, J. K. Mortensen, and R. M. Friedman. "Integrated ammonite biochronology and U-Pb geochronometry from a basal Jurassic section in Alaska". English. In: Geological Society America Bulletin 111.10 (1999), pp. 1537-1549.

[17463] G. Pallini, S. Elmi, and F. Gasparri. "Late Toarcian - Late Aalenian ammonites assemblage from Mt. Magaggiaro (Western Sicily, Italy)”. English. In: Geologica Romana 37 (2004), pp. 1-66.

[17464] R. M. Palma and M. P. Angeleri. "Early Cretaceous serpulid limestones: Chachao Formation, Neuquen basin, Argentina". English. In: Facies 27 (1992), pp. 175-178.

[17465] R. M. Palma, D. A. Kietzmann, S. Adamonis, and J. Lopez Gomez. "Oxfordian reef architecture of the La Manga Formation, Neuquen Basin, Mendoza Province, Argentina". English. In: Sedimentary Geology 221 (2009), pp. 127-140.

[17466] R. M. Palma and S. G. Lanes. "Shell Bed Stacking Patterns in the Chachao Formation (Early Valanginian) in Malargue Area, Mendoza Province, Neuquen Basin, Argintina". In: Carbonates and Evaporites 16.2 (2001), pp. 168-180.

[17467] S. C. Palma-Heldt, F. J. Fernandoy, I. Quezada, and M. A. Leppe. Registro palinológico de Cabo Shirreff, Isla Livingstone, nueva localidad para el Mesozoico de las Shetland del Sur. Spanish. 2004.

[17468] A. R. Palmer. "Terminal Early Cambrian extinction of the Olenellina: documentation from the Pioche Formation, Nevada". In: Journal of Paleontology 72.4 (1998), pp. 650-672.

[17469] A. R. Palmer. "Stratotype boundary of the Steptoean Stage, McGill Nevada". In: Laurentai 99: V field conference of the Cambrian Stage Subdivision Working Group, International Subcomission on Cambrian Stratigraphy (1999), pp. 22-23.

[17470] A. R. Palmer. "Ruin Wash, Chief Range Nevada". In: Laurentia 99: V field conference of the Cambrian Stage Subdivision Working Group, International Subcomission on Cambrian Stratigraphy (1999), pp. 2425.

[17471] A. R. Palmer. "Oak Springs Summit section, type locality for the base of the Delamaran Stage". In: Laurentia 99: $V$ field conference of the Cambrian Stage Subdivision Working Group, International Subcomission on Cambrian Stratigraphy (1999), pp. 26-28.

[17472] A. R. Palmer and A. J. Rowell. "Early Cambrian trilobites from the Shackleton Limestone of the Central Mountains". English. In: Journal of Paleontology Memoir 69.6 (1995), pp. 1-28.

[17473] P. Palmqvist, J. A. Perez-Claros, J. Gibert, and J. L. Santamaria. "Comparative morphometric study of a human phalanx from the lower Pleistocene site at Cueva Victoria (Murcia, Spain), by means of Fourier analysis, shape co-ordinates of landmarks, principal and relative warps". In: Journal of Archaeological Science 23 (1996), pp. 95-107.

[17474] M. R. Palombo, M. Zedda, and R. T. Melis. "A New Elephant Fossil from the Late Pleistocene of Alghero:" English. In: Comptes Rendus Palevol 16 (2017), pp. 841-849.

[17475] C. Pålsson. "Middle-Upper Ordovician trilobites and stratigraphy along the Kyrkbacken rivulet in the Rostånga area, southern Sweden". English. In: Examensarbeten i geologi vid Lunds Universitet 20.63 (1995), pp. 1-26.

[17476] A. Pan, B. Jacobs, and E. Currano. "Dioscoreaceae fossils from the late Oligocene and Miocene Ethiopia". English. In: Botanical Journal of the Linnean Society 175 (2014), pp. 17-28. DOI: 10.1111/ boj.12150.

[17477] B. Pan, G. A. Brock, C. B. Skovsted, M. J. Betts, T. P. Topper, and G. Li. "<i>Paterimitra pyramidalis </i $>$ Laurie, 1986, the first tommotiid discovered from the early Cambrian of North China". English. In: Gondwana Research 63 (2018), pp. 179-185. DOI: 10.1016/j.gr.2018.05.014. 
[17478] H. Pan. “Namurian (Lower Carboniferous) gastropod assemblages from Ningxia, China”. In: Journal of Paleontology 71.4 (1997), pp. 599-609.

[17479] H.-Z. Pan and D. H. Erwin. "Gastropods from the Permian of Guangxi and Yunnan Provinces, South China". English. In: Journal of Paleontology Memoir 56 (2002), pp. 1-49. DOI: 10.1666/00223360(2002)76[1:GFTPOG]2.0.CO;2.

[17480] H. Z. Pan, D. H. Erwin, A. Nützel, and X. S. Zhu. “Jiangxispira, a new gastropod genus from the Early Triassic of China with remarks on the phylogeny of the Heterostropha at the Permian/Triassic boundary". English. In: Journal of Paleontology 77.1 (2003), pp. 44-49.

[17481] H.-Z. Pan and S.-Z. Shen. "Late Permian (Lopingian) Gastropods from the Qubuerga Formation at the Qubu Section in the Mt. Everest (Qomolangma) Region, Southern Tibet (Xizang), China". English. In: Journal of Paleontology 82.5 (2008), pp. 1038-1042.

[17482] H. Z. Pan and A. G. Cook. "Early Devonian gastropods from Zhusilenghaierhan region, Western Inner Mongolia, China". In: Journal of Paleontology 77.1 (2003), pp. 31-43.

[17483] T. Y. Pan, C. V. Murray-Wallace, A. Dosseto, and R. P. Bourman. “The last interglacial (MIS 5e) sea level highstand from a tectonically stable far-field setting, Yorke Peninsula, southern Australia". English. In: Marine Geology 398 (2018), pp. 126-136. DOI: 10.1016/j.margeo.2018.01.012.

[17484] X. X. Pan, H. L. Chang, D. Ren, and C. K. Shih. "The first fossil buprestids from the Middle Jurassic Jiulongshan Formation of China (Coleoptera: Buprestidae)". English. In: Zootaxa 2745 (2011), pp. 53-62.

[17485] Y. Pan, J. Sha, F. T. Fürsich, Y. Wang, X. Zhang, and X. Yao. “Dynamics of the lacustrine fauna from the Early Cretaceous Yixian Formation, China: implications of volcanic and climatic factors". English. In: Lethaia 45.3 (2011), pp. 299-314. DOI: 10.1111/j.1502-3931.2011.00284.x.

[17486] Y. H. Pan, S. X. Hu, J. G. Sha, Q. Y. Zhang, Y. Q. Wang, C. Y. Zhou, W. Wen, J. Y. Huang, and T. Xie. "Early Triassic bivalves from the Feixianguan Formation in Xingyi, Guizhou and the Ximatang Formation in Qiubei, Yunnan (southern China)". English. In: Palaeoworld 23 (2014), pp. 143-154.

[17487] X. Panadés I Blas, R. S. Loyal, H. H. Schleich, and E. Llinás Agrasar. "Pristichampsine cranial remains from the basal redbed facies of the Subathu Formation (Himachal Pradesh, India) and some palaeobiographical remarks". English. In: PalArch 3.1 (2004), pp. 1-7.

[17488] E. Panagopoulou, V. Tourloukis, N. Thompson, A. Athanassiou, G. Tsartsidou, G. E. Konidaris, D. Giusti, P. Karkanas, and K. Harvati. "Marathousa 1: a new Middle Pleistocene archaeological site from Greece". English. In: Antiquity 343 (2015).

[17489] G. Panasc, D. J. Varricchio, and R. Hirayama. "New occurrence of Neurankylus sp. (Testudines: Paracryptodiria: Baenidae) in the Upper Cretaceous Frontier Formation of south western Montana (USA)". English. In: Cretaceous Research (2019). DOI: 10.1016/j.cretres.2019.104318.

[17490] A. L. Panchen and T. R. Smithson. "The pelvic girdle and hind limb of Crassigyrinus scoticus (Lydekker) from the Scottish Carboniferous and the origin of the tetrapod pelvic skeleton". English. In: Transactions of the Royal Society of Edinburgh 81 (1990), pp. 31-44. DOI: 10.1017/S0263593300005113.

[17491] E. Panciroli, R. B. J. Benson, and S. Walsh. "The dentary of Wareolestes rex (Megazostrodontidae): A new specimen from Scotland and implications for morganucodontan tooth replacement". English. In: Papers in Palaeontology 3.3 (2017), pp. 373-386. DOI: 10.1002/spp2.1079.

[17492] E. Panciroli, S. Walsh, N. C. Fraser, S. L. Brusatte, and I. Corfe. "A reassessment of the postcanine dentition and systematics of the tritylodontid Stereognathus (Cynodontia, Tritylodontidae, Mammaliamorpha), from the Middle Jurassic of the United Kingdom". English. In: Journal of Vertebrate Paleontology 37.5 (2017), e1351448:1-20.

[17493] B. Pandey and D. B. Pathak. "Biostratigraphic implication of Olcostephanus Neumayr, 1875 (Ammonoidea) from the Lower Cretaceous Giumal Formation, Spiti Valley, Tethys Himalaya, India". English. In: Cretaceous Research 70 (2017), pp. 244-251.

[17494] D. K. Pandey, F. Ahmad, and F. T. Fürsich. “Middle Jurassic scleractinian corals from northwestern Jordan". English. In: Beringeria 27 (2000), pp. 3-29. 
[17495] D. K. Pandey, T. Bahadur, and U. B. Mathur. "Stratigraphic distribution and depositional environment of the Chaya Formation along the northwestern coast of Saurashtra Peninsula, western India". English. In: Journal of the Geological Society of India 69 (2007), pp. 1215-1230.

[17496] D. K. Pandey, F. T. Fürsich, M. Gameil, and W. S. Ayoub-Hannaa. “Aspidiscus cristatus (Lamarck) from the Cenomanian of Wadi Quseib, East Sinai, Egypt". English. In: Journal of the Palaeontological Society of India 56.1 (2011), pp. 29-37.

[17497] D. K. Pandey and F. T. Fürsich. “Jurassic corals of east-central Iran”. In: Beringeria 32 (2003), pp. 1138.

[17498] D. K. Pandey and F. T. Fürsich. "Jurassic corals from the Shemshak Formation of the Alborz Mountains, Iran". English. In: Zitteliana A 46 (2006), pp. 41-74.

[17499] D. K. Pandey and F. T. Fürsich. "Jurassic corals from the southern Tunisia". English. In: Zitteliana A45 (2005), pp. 3-34.

[17500] D. K. Pandey, F. T. Fürsich, R. Baron-Szabo, and M. Wilmsen. "Lower Cretaceous corals from the Koppeh Dagh, NE-Iran". English. In: Zitteliana A47 (2007), pp. 3-52.

[17501] D. K. Pandey, F. T. Fürsich, and R. Baron-Szabo. "Jurassic corals from the Jaisalmer Basin, western Rajasthan, India". English. In: Zitteliana A 48/49 (2009), pp. 13-37.

[17502] D. K. Pandey and B. Lathuiliere. "Variability in Epistreptophyllum from the Middle Jurassic of Kachchh, western India: an open question for the taxonomy of Mesozoic scleractinian corals". English. In: Journal of Paleontology 71.4 (1997), pp. 564-577.

[17503] D. K. Pandey, B. Lathuiliere, F. T. Fürsich, and S. Kuldeep. "The oldest Jurassic cyathophorid coral (Scleractinia) from siliciclastic environments of the Kachchh Basin, western India". English. In: Palaeontologische Zeitschrift 76.2 (2002), pp. 347-356.

[17504] D. K. Pandey, U. B. Mathur, R. Singh, and T. Bahadur. "Late Pleistocene Coral-Algal Sediments of Chaya Formation of Mithapur area, Jamnagar, Gujarat". English. In: Journal Geological Society of India 61 (2003), pp. 195-201.

[17505] D. K. Pandey and R. Singh. "Early Pliocene - Holocene Favia from the northern and northwestern coastal areas of Saurashtra Peninsula, western India". English. In: Journal of the Palaeontological Society of India 55.2 (2010), pp. 107-120.

[17506] J. M. Pandolfi. “Limited membership in Pleistocene reef coral assemblages from the Huon Peninsula, Papua New Guinea: constancy during global change". In: Paleobiology 22.2 (1996), pp. 152176.

[17507] J. M. Pandolfi. "Geomorphology of the uplifted Pleistocene atoll at Henderson Island, Pitcairn Group". English. In: Biological Journal of the Linnean Society 56 (1995), pp. 63-77.

[17508] J. M. Pandolfi. "A new, extinct Pleistocene reef coral from the Montastraea annularis species complex". English. In: Journal of Paleontology 81.3 (2007), pp. 472-482.

[17509] J. M. Pandolfi. "Community structure of Pleistocene coral reefs of Curacao, Netherlands Antilles". English. In: Ecological Monographs 71.1 (2001), pp. 49-67.

[17510] J. M. Pandolfi and J. B. C. Jackson. "Ecological persistence interrupted in Caribbean coral reefs". English. In: Ecology Letters 9 (2006), pp. 818-826.

[17511] J. M. Pandolfi and J. B. C. Jackson. Broad-scale patterns in Pleistocene coral reef communities from the Caribbean: implications for ecology and management. English. Vol. 192. Geological approaches to coral reef ecology. Ecological Studies. 2007, pp. 201-236.

[17512] J. M. Pandolfi, G. Llewellyn, and J. B. C. Jackson. "Pleistocene reef environments, constituent grains, and coral community structure: Curacao, Netherlands Antilles". English. In: Coral Reefs 18 (1999), pp. 107-122.

[17513] J. M. Pandolfi, A. W. Tudhope, G. Burr, J. Chappell, E. Edinger, M. Frey, R. Steneck, C. Sharma, A. Yeates, M. Jennions, H. Lescinsky, and A. Newton. "Mass mortality following disturbance in Holocene coral reefs from Papua New Guinea". English. In: Geology 34.11 (2006), pp. 949-952. 
[17514] L. Pandolfi. "Persiatherium rodleri, gen. et sp. nov. (Mammalia, Rhinocerotidae) from the upper Miocene of Maragheh (northwestern Iran)". English. In: Journal of Vertebrate Paleontology (2015). DOI: 10.1080/02724634.2015.1040118.

[17515] L. Pandolfi. "New insights into the Oligocene Rhinocerotoidea (Mammalia, Perissodactyla) from Northwestern Italy". English. In: Annales de Paléontologie 101 (2015), pp. 67-73.

[17516] L. Pandolfi, G. Carnevale, L. Costeur, L. Del Favero, M. Fornasiero, E. Ghezzo, L. Maiorini, P. Mietto, P. Piras, L. Rook, G. Sansalone, and T. Kotsakis. "Reassessing the earliest Oligocene vertebrate assemblage of Monteviale (Vicenza, Italy)". English. In: Journal of Systematic Palaeontology 15.2 (2017), pp. 83-127.

[17517] Q. Pang, Z. Cheng, J. Yang, M. Xie, C. Zhu, and J. Luo. "The preliminary report on Late Cretaceous dinosaur fauna expeditions in Tianzhen, Shanxi". In: Journal of Hebei College of Geology 19.3-4 (1996), pp. 227-235.

[17518] Q. Pang and Z. Cheng. "A new ankylosaur of Late Cretaceous from Tianzhen, Shanxi”. English. In: Progress in Natural Science 8.3 (1998), pp. 326-334.

[17519] Q. Pang and Z. Cheng. "A new family of sauropod dinosaur from the Upper Cretaceous of Tianzhen, Shanxi province, China". English. In: Acta Geologica Sinica 74.2 (2000), pp. 117-125.

[17520] K. M. Panzeri, S. G. Cavalli, N. A. Muñoz, and A. L. Cione. "Metaceratodus baibianorum, a new dipnoan species from the Upper Cretaceous of southern South America supported by traditional and geometric morphometric analyses". English. In: Journal of Vertebrate Paleontology 40.2 (2020), e1769640:1-14. DOI: 10.1080/02724634.2020.1769640.

[17521] A. Paolillo and O. J. Linares. “Nuevos cocodrilos Sebecosuchia del Cenozoico Suramericano (Mesosuchia: Crocodylia)". Spanish. In: Paleobiologia Neotropical 3 (2007), pp. 1-25.

[17522] F. Paolucci, M. S. Fernández, M. R. Buono, and J. I. Cuitiño. "'Aulophyseter' rionegrensis (Cetacea: Odontoceti: Physeteroidea) from the Miocene of Patagonia (Argentina): a reappraisal". English. In: 192 (2021), pp. 1293-1332. DOI: 10.1093/zoolinnean/zlaa137.

[17523] I. Paparella, E. E. Maxwell, A. Cipriani, S. Roncace, and M. W. Caldwell. "The first ophthalmosaurid ichthyosaur from the Upper Jurassic of the Umbrian-Marchean Apennines (Marche, Central Italy)". English. In: Geological Magazine 154.4 (2017), pp. 837-858.

[17524] I. Paparella, A. Palci, U. Nicosia, and M. W. Caldwell. "A new fossil marine lizard with soft tissues from the Late Cretaceous of southern Italy". English. In: Royal Society Open Science 5 (2018), 172411:1-27.

[17525] F. Papier and L. Grauvogel-Stamm. "Les Blattodea du Trias: le genre Voltziablatta n. gen. du Buntsandstein supérieur des Vosges (France)". French. In: Palaeontographica Abteilung A 235.4-6 (1995), pp. 141-162.

[17526] F. Papier, L. Grauvogel-Stamm, and A. Nel. "Subioblatta undulata n. sp., une nouvelle blatte (Subioblattidae Schneider) du Buntsandstein supérieur (Anisien) des Vosges (France). Morphologie, systématique et affinités". French. In: Neues Jahrbuch für Geologie und Paläontologie, Monatshefte 1994 (1994), pp. 277-290.

[17527] F. Papier, A. Nel, L. Grauvogel-Stamm, and J. Gall. "La plus ancienne sauterelle Tettigoniidae, Orthoptera (Trias, NE France): mimetisme ou exaptation?" French. In: Paläontologische Zeitschrift 71.1/2 (1997), pp. 71-77.

[17528] F. Papier and A. Nel. "Les Subioblattidae (Blattodea, Insecta) du Trias d'Asie Centrale". French. In: Paläontologische Zeitschrift 74.4 (2001), pp. 533-542.

[17529] J. Pappas, R. Moses, and B. O'Grady. Taxonomic diversity of a Maastrichtian age microfaunal locality in the Little Cottonwood Draw, Carbon County, Montana. English. 2005.

[17530] O. H. Papú. "Nueva microflora de edad maastichtiana en la localidad de Calmu-Co, sur de Mendoza, Argentina". Spanish. In: Ameghiniana 39.4 (2002), pp. 415-426. 
[17531] M. E. Páramo. "Posicion sistematica de un reptil marino con base en los restos fosiles encontrados en capas del Cretacico superior en Yaguara (Huila)". Spanish. In: Revista de la Academia Colombiana de Ciencias Exactas, Fsicas y Naturales 19.72 (1994), pp. 63-80.

[17532] M. E. Páramo-Fonseca. "Yaguarasaurus columbianus (Reptilia, Mosasauridae), a primitive mosasaur from the Turonian (Upper Cretaceous) of Colombia". English. In: Historical Biology 14 (2000), pp. 121-131.

[17533] M. E. Páramo-Fonseca. "Mosasauroids from Colombia". English. In: Bulletin de la Societe Geologique de France 182.2 (2011), pp. 103-109.

[17534] M. E. Páramo-Fonseca. “Eonatator coellensis nov. sp. (Squamata: Mosasauridae), a new species from the Upper Cretaceous of Colombia". Spanish. In: Revista de la Academia Colombiana de Ciencias 37.145 (2013), pp. 499-518.

[17535] M. E. Páramo-Fonseca, C. D. Benavides-Cabra, and I. E. Gutiérrez. "A new large pliosaurid from the Barremian (Lower Cretaceous) of Sáchica, Boyacá, Colombia". English. In: Earth Sciences Research Journal 22.4 (2018), pp. 223-238.

[17536] M. E. Páramo-Fonseca, M. Gómez-Pérez, L. F. Noé, and F. Etayo-Serna. “Stenorhynchosaurus munozi, gen. et sp. nov. a new pliosaurid from the Upper Barremian (Lower Cretaceous) of Villa de Leiva, Colombia, South America". English. In: Revista de la Academia Colombiana de Ciencias Exactas, Fsicas y Naturales 40.154 (2016), pp. 84-103.

[17537] M. E. Paramo-Fonseca, J. P. O'Gorman, Z. Gasparini, S. Padilla, and M. L. Parra-Ruge. “A new late Aptian elasmosaurid from the Paja Formation, Villa de Leiva, Colombia". English. In: Cretaceous Research 99 (2019), pp. 30-40.

[17538] U. F. J. Pardiñas. “New data on Scapteromys hershkovitzi Reig, 1994 (Rodentia: Cricetidae) from the Pliocene of Argentina". English. In: Ameghiniana 50.6 (2013), pp. 593-597.

[17539] U. F. J. Pardiñas. "Un nuevo sigmodontino (Mammalia: Rodentia) del Plioceno de Argentina y consideraciones sobre". Spanish. In: Revista Chilena de Historia Natural 70 (1997), pp. 543-555.

[17540] U. F. J. Pardinas, F. J. Prevosti, D. Voglino, and M. Cenizo. "A controversial unit within the argentine neogene: the Irenean fauna". English. In: Ameghiniana 54.6 (2017), pp. 655-680. DOI: 10.5710/ AMGH.24.04.2017.3080.

[17541] J. D. Pardo, R. Holmes, and J. S. Anderson. "An enigmatic braincase from Five Points, Ohio (Westphalian D) further supports a stem tetrapod position for aistopods". English. In: Earth and Environmental Science Transactions of the Royal Society of Edinburgh (2018), pp. 1-10. DOI: 10.1017 / S1755691018000567.

[17542] J. D. Pardo, A. K. Huttenlocker, B. J. Small, and M. A. Gorman II. "The cranial morphology of a new genus of lungfish (Osteichthyes: Dipnoi) from the Upper Jurassic Morrison Formation of North America". English. In: Journal of Vertebrate Paleontology 30.5 (2010), pp. 1352-1359.

[17543] J. D. Pardo, A. K. Huttenlocker, and B. J. Small. “An exceptionally preserved transitional lungfish from the Lower Permian of Nebraska, USA, and the origin of modern lungfishes". English. In: PLoS One 9.9 (2014), e108542.

[17544] J. D. Pardo, B. J. Small, and A. K. Huttenlocker. "Stem caecilian from the Triassic of Colorado sheds light on the origins of Lissamphibia". English. In: Proceedings of the National Academy of Sciences (2017). DOI: 10.1073/pnas.1706752114.

[17545] M. Pardo. "Reporte de un nuevo ejemplar de Granastrapotherium snorki en el Valle superior del Magdalena, Desierto de la Tatacoa, Huila, Colombia". Spanish. In: Revista Academia Colombiana de Ciencias 34.131 (2010), pp. 253-256.

[17546] M. Pardo. “Reporte del hallazgo de un cráneo de Stegomastodon waringi (Holland, 1920) juvenil (MAMMALIA, PROBOSCIDEA) en zona rural del municipio de de Turbaná, Bolivar, Colombia". Spanish. In: Revista Academia Colombiana de Ciencias 36.139 (2012), pp. 203-210. 
[17547] M. Pardo-Jaramillo. “Reporte del hallazgo de restos de Hilarcotherium sp. (Mammalia, Astrapotheria) y de material asociado en una nueva localidad fosilfera del valle inferior del Magdalena, ciénaga de Zapatosa, Cesar, Colombia". Spanish. In: Revista de la Academia Colombiana de Ciencias Exactas, Fsicas y Naturales 42.164 (2018), pp. 280-286.

[17548] J. Pardo-Pérez, E. Frey, W. Stinnesbeck, M. S. Fernández, L. Rivas, C. Salazar, and M. Leppe. “An ichthyosaurian forefin from the Lower Cretaceous Zapata Formation of southern Chile: implications for morphological variability within Platypterygius". English. In: Palaeobiodiversity and Palaeoenvironments 92 (2012), pp. 287-294. DOI: 10.1007/s12549-012-0074-8.

[17549] R. Paredes, M. J. Comas-Rengifo, and L. V. Duarte. “Moluscos bivalves da Formação de Água de Madeiros (Sinemuriano superior) da Bacia Lusitanica (Portugal)". Portugese. In: Comunicações Geológicas 100.Especial I (2013), pp. 21-27.

[17550] R. Paredes, M. J. Comas-Rengifo, L. V. Duarte, and A. Goy. "Braquiópodes do Sinemuriano superior da região de S. Pedro de Moel e de Peniche (Bacia Lusitanica, Portugal)". Portugese. In: Comunicações Geológicas 100.Especial I (2013), pp. 29-35.

[17551] H. Parent. "The Middle Tithonian (Upper Jurassic) Ammonoid fauna of Canadon de los Alazanes, Southern Neuquen-Mendoza Basin, Argentina". English. In: Boletin del Instituto de Fisiografia y Geologia 71.1-2 (2001), pp. 19-38.

[17552] H. Parent. "Oxfordian and late Callovian ammonite faunas and biostratigraphy of the NeuquenMendoza and Tarapaca Basins (Jurassic, Ammonoidea, Western South-America)". English. In: Boletin del Instituto de Fisiografia y Geologia 76.1-2 (2006), pp. 1-70.

[17553] H. Parent. "Upper Bathonian and lower Callovian ammonites from Chacay Melehué (Argentina)”. English. In: Acta Palaeontologica Polonica 43 (1998), pp. 69-130.

[17554] H. Parent, A. C. Garrido, G. Schweigert, and A. Scherzinger. "The Tithonian ammonite fauna and stratigraphy of Picun Leufu, southern Neuquen Basin, Argentina". English. In: Revue de Paleobiologie 30.1 (2011), pp. 45-104.

[17555] H. Parent, A. C. Garrido, G. Schweigert, and A. Scherzinger. "Andean Lower Tithonian (Picunleufuense Zone) ammonites and aptychus from Estancia Maria Juana, Southern Neuquén Basin, Argentina". English. In: Boletn del Instituto de Fisiografa y Geologa 83.27 (2013), pp. 27-34.

[17556] H. Parent and A. C. Garrido. "The ammonite fauna of the La Manga Formation (Late CallovianEarly Oxfordian) of Vega de la Veranada, Neuquén Basin, Argentina". English. In: Neues Jahrbuch für Geologie und Paläontologie, Abhandlungen 275.2 (2015), pp. 163-217.

[17557] H. Parent, G. Melendez, and M. Falahatgar. "Oxfordian ammonites from Rostam Kola, northern East Alborz, North Iran". English. In: Neues Jahrbuch für Geologie und Paläontologie, Abhandlungen 263.2 (2012), pp. 133-142.

[17558] H. Parent, G. Schweigert, and G. Melendez. “Oxfordian perisphinctid ammonites from Chacay Melehue, Argentina". English. In: Palaeontologische Zeitschrift 80.4 (2006), pp. 307-324.

[17559] H. Parent, R. Weis, N. Mariotti, M. Falahatgar, G. Schweigert, and M. Javidan. "Middle Jurassic belemnites and ammonites (Cephalopoda) from Telma-Dareh, northern Iran". English. In: Rivista Italiana di Paleontologia e Stratigrafia 119.2 (2013), pp. 163-174.

[17560] M. Parente. "Dasycladales from the Upper Maastrichtian of Salento Peninsula (Puglia, Southern Italy)". English. In: Facies 36 (1997), pp. 91-122.

[17561] J. F. Parham. "A reassessment of the referral of sea turtle skulls to the genus Osteopygis (Late Cretaceous, New Jersey, USA)". English. In: Journal of Vertebrate Paleontology 25.1 (2005), pp. 7177.

[17562] J. F. Parham, R. P. Hilton, and E. S. Gohre. "The oldest turtle from California and other new records of Late Cretaceous sea turtles from the Chico Formation". English. In: PaleoBios 23.1 (2003), pp. 2428.

[17563] J. F. Parham and J. H. Hutchison. "A new eucryptodiran turtle from the Late Cretaceous of North America (Dinosaur Provincial Park, Alberta, Canada)". English. In: Journal of Vertebrate Paleontology 23.4 (2003), pp. 783-798. 
[17564] J. F. Parham, R. A. Otero, and M. E. Suárez. "A sea turtle skull from the Cretaceous of Chile with comments on the taxonomy and biogeography of Euclastes (formerly Osteopygis)". English. In: Cretaceous Research 49 (2014), pp. 181-189.

[17565] J. F. Parham, M. E. Outerbirdge, B. L. Stuart, D. B. Wingate, H. Erlenkeuser, and T. J. Papenfuss. "Introduced delicacy or native species? A natural origin of Bermudian terrapins supported by fossil and genetic data". English. In: Biology Letters 2008.4 (2008), pp. 216-219. DOI: 10.1098/ rsbl. 2007.0599.

[17566] J. F. Parham and N. D. Pyenson. "New sea turtle from the Miocene of Peru and iterative evolution of feeding ecomorphologies since the Cretaceous". English. In: Journal of Paleontology 84.2 (2010), pp. 231-247.

[17567] J. F. Parham and T. A. Stidham. "Late Cretaceous sea turtles from the Chico Formation of California". In: PaleoBios 19.3 (1999), pp. 1-7.

[17568] P. R. Parham, Y. Saito, N. Sapon, R. Suriadi, and N. A. Mohtar. “Evidence for ca. 7-ka maximum Holocene transgression on the Peninsular Malaysia east coast". English. In: Journal of Quaternary Science 29.5 (2014), pp. 414-422. DOI: 10.1002/jqs.2714.

[17569] F. Parisi and F. Fanti. "A new fossil species of the extinct tribe Mimoplatycini Kazantsev, 2013 (Coleoptera Cantharidae)". English. In: Annales de Paléontologie 105 (2019), pp. 119-122. DOI: 10. 1016/j.annpal.2019.04.002.

[17570] F. Parisi and F. Fanti. "A new fossil Malthodes Kiesenwetter, 1852 from the Eocene Baltic amber (Coleoptera Cantharidae)". English. In: Zootaxa 4652 (2019), pp. 189-195.

[17571] F. Parisi and F. Fanti. “On the first Silis Charpentier, 1825 from Baltic amber (Coleoptera, Cantharidae)". English. In: Fossil Record 22 (2019), pp. 119-123. DOI: 10.5194/fr-22-119-2019.

[17572] E.-J. Park, S.-Y. Yank, and P. J. Currie. Early Cretaceous dinosaur teeth of Korea. English. Vol. 4. 2000 International Dinosaur Symposium for Kosong County in Korea. Paleontological Society of Korea Special Publication. 2000, pp. 85-98.

[17573] J.-Y. Park, S. E. Evans, and M. Huh. “The first lizard fossil (Reptilia: Squamata) from the Mesozoic of South Korea". English. In: Cretaceous Research 55 (2015), pp. 292-302.

[17574] L. E. Park and K. F. Downing. "Paleoecology of an exceptionally preserved arthropod fauna from lake deposits of the Miocene Barstow Formation, Southern California, U.S.A." English. In: Palaios 16.2 (2001), pp. 175-184.

[17575] T. Park, E. M. G. Fitzgerald, and A. R. Evans. “Ultrasonic hearing and echolocation in the earliest toothed whales". English. In: Biology Letters 12.4 (2016). DOI: 10.1098/rsbl.2016.0060.

[17576] T. Park, E. M. G. Fitzgerald, S. J. Gallagher, E. Tomkins, and T. Allan. “New Miocene fossils and the history of penguins in Australia". English. In: PLoS One 11.4 (2016), e0153915. DOI: 10.1371/ journal.pone.0153915.

[17577] T. Y. Park, Y. H. Kim, and K. S. Nam. "Preliminary research on the aquatic coleopteran, Coptoclava from the Early Cretaceous Jinju Formation". other. In: Journal of the Geological Society of Korea 49 (2013), pp. 617-624.

[17578] T. Y. S. Park, K. S. Nam, and P. A. Selden. "A diverse new spider (Araneae) fauna from the Jinju Formation, Cretaceous (Albian) of Korea". English. In: Journal of Systematic Palaeontology 17 (2019), pp. 1051-1077. DOI: 10.1080/14772019.2018.1525441.

[17579] T.-Y. Park, J.-H. Kihm, and D. K. Choi. “Late Middle Cambrian (Cambrian Series 3) Trilobite Faunas from the Lowermost Part of the Sesong Formation, Korea and Their Correlation with North China". English. In: Journal of Paleontology 87.6 (2013), pp. 991-1003.

[17580] T.-Y. Park, J. Woo, D. -J. Lee, D. -C. Lee, S. Lee, Z. Han, S. K. Chough, and D. K. Choi. “A stemgroup cnidarian described from the mid-Cambrian of China and its significance for cnidarian evolution". English. In: Nature communications (2011). 
[17581] J. Parker. "Emergence of a superradiation: pselaphine rove beetles in mid-Cretaceous amber from Myanmar and their evolutionary implications". English. In: Systematic Entomology 41 (2016), pp. 541566.

[17582] J. Parker and D. A. Grimaldi. "Specialized myrmecophily at the ecological dawn of modern ants". English. In: Current Biology 24 (2014), pp. 2428-2434.

[17583] P. Parker, J. T. Harvey, J. M. Maniscalco, and S. Atkinson. “Pupping-site fidelity among individual Steller sea lions (Eumetopias jubatus) at Chiswell Island, Alaska". English. In: Canadian Journal of Zoology 86 (2008), pp. 826-833.

[17584] W. Parker and R. B. Irmis. "Advances in Late Triassic vertebrate paleontology based on new material from Petrified Forest National Park, Arizona". English. In: Vertebrate Paleontology in Arizona, New Mexico Museum of Natural History and Science Bulletin 29 (2005), pp. 45-58.

[17585] W. G. Parker. "A new species of the Late Triassic aetosaur Desmatosuchus (Archosauria: Pseudosuchia)". English. In: Comptes Rendus Palevol 4 (2005), pp. 327-340.

[17586] W. G. Parker. Faunal review of the Upper Triassic Chinle Formation of Arizona. English. Vol. 11. Vertebrate Paleontology of Arizona, Mesa Southwest Museum Bulletin. 2005, pp. 34-54.

[17587] W. G. Parker. "Revised phylogenetic analysis of the Aetosauria (Archosauria: Pseudosuchia); assessing the effects of incongruent morphological character sets". English. In: PeerJ 4 (2016), e1583.

[17588] W. G. Parker. "Osteology of the Late Triassic aetosaur Scutarx deltatylus (Archosauria: Pseudosuchia)". English. In: PeerJ 4 (2016), e2411.

[17589] W. G. Parker, R. B. Irmis, S. J. Nesbitt, J. W. Martz, and L. S. Browne. “The Late Triassic pseudosuchian Revueltosaurus callenderi and its implications for the diversity of early ornithischian dinosaurs". English. In: Proceedings of the Royal Society B 272 (2005), pp. 963-969.

[17590] W. G. Parker and R. B. Irmis. A new species of the Late Triassic phytosaur Pseudopalatus (Archosauria: Pseudosuchia) from Petrified Forest National Park, Arizona. English. Vol. 62. A Century of Research at Petrified Forest National Park, 1906-2006: Geology and Paleontology. Museum of Northern Arizona Bulletin. 2006, pp. 126-143.

[17591] W. G. Parker and J. W. Martz. "Using positional homology in aetosaur (Archosauria: Pseudosuchia) osteoderms to evaluate the taxonomic status of Lucasuchus hunti". English. In: Journal of Vertebrate Paleontology 30.4 (2010), pp. 1100-1108. DOI: 10.1080/02724634.2010.483536.

[17592] W. G. Parker, M. R. Stocker, and R. B. Irmis. "A new desmatosuchine aetosaur (Archosauria: Suchia) from the Upper Triassic Tecovas Formation (Dockum Group) of Texas". English. In: Journal of Vertebrate Paleontology 28.3 (2008), pp. 692-701. DOI: 10.1671/0272-4634(2008)28[692:ANDAAS] 2.0.CO;2.

[17593] M. A. Parkes. “The brachiopods of the Duncannon Group (Middle-Upper Ordovician) of southeast Ireland". English. In: Bulletin of the Natural History Museum (Geology) 50.2 (1994), pp. 105-174.

[17594] M. A. Parkes. "Silurian (Telychian) fossil assemblages from the Charlestown Inlier, County Mayo". English. In: Irish Journal of Earth Sciences 12 (1993), pp. 27-40.

[17595] P. Y. Parkhaev and Y. Demidenko. "Zooproblematica and mollusca from the Lower Cambrian Meishucun section (Yunnan, China) and taxonomy and systematics of the Cambrian small shelly fossils of China". English. In: Paleontological Journal 44.8 (2010), pp. 883-1161. DOI: 10.1134 / s0031030110080010.

[17596] P.Yu. Parkhaev. "Siphonoconcha-A new class of Early Cambrian bivalved organisms". In: Paleontological Journal 32.1 (1998), pp. 1-15.

[17597] P.Yu. Parkhaev. "Malacofauna of the Lower Cambrian Bystraya Formation of Eastern Transbaikalia". In: Paleontological Journal 38.6 (2004), pp. 590-608.

[17598] P.Yu. Parkhaev. "Trenella bifrons: a new helcionelloid mollusck from the Lower Cambrian of South Australia". In: Paleontological Journal 35.6 (2001), pp. 585-588.

[17599] P.Yu. Parkhaev. "On the Genus Auricullina Vassiljeva, 1998 and Shell Pores of the Cambrian Helcionelloid Mollusks". English. In: Paleontological Journal 40.1 (2006), pp. 20-32. 
[17600] P.Yu. Parkhaev. "Two new species of the Cambrian helcionelloid mollusks from the northern part of the Siberian Platform". English. In: Paleontological Journal 39.6 (2005), pp. 615-619.

[17601] S. G. Parma and S. Casadio. "Upper Cretaceous-Paleocene Echinoids from Northern Patagonia, Argentina". English. In: Journal of Paleontology 79.6 (2005), pp. 1072-1087.

[17602] P. W. Parmalee and R. W. Graham. "Additional records of the giant beaver, Castoroides, from the Mid-South: Alabama, Tennessee, and South Carolina". English. In: Smithsonian Contribution to Paleobiology 93 (2002), pp. 65-71.

[17603] V. Parmar, G. V. R. Prasad, and D. Kumar. "The first multituberculate mammal from India". English. In: Naturwissenschaften (2013). DOI: 10.1007/s00114-013-1047-0.

[17604] D. Parmley and J. A. Holman. "Nebraskophis Holman from the Late Eocene of Georgia (USA), the oldest known North American colubrid snake". In: Acta Zoologica Cracoviensia 46.1 (2003), pp. 1-8.

[17605] D. Parmley. "Frogs in Hemphillian deposits of Nebraska, with the description of a new species of Bufo". English. In: Journal of Herpetology 26.3 (1992), pp. 274-281.

[17606] D. Parmley, R. Chandler, and L. Chandler. “Turtles of the early Pleistocene Santa Fe River 1B locality". English. In: Georgia Journal of Science 77.2 (2019), pp. 1-19.

[17607] D. Parmley, R. Chandler, and L. Chandler. "Fossil Frogs of the Late Clarendonian (Late Miocene) Pratt Slide Local Fauna of Nebraska, with the Description of a New Genus". English. In: Journal of Herpetology 49.1 (2015), pp. 143-149. DOI: 10.1670/13-171.

[17608] D. Parmley and D. J. Cicimurri. "First record of a chimaeroid fish from the Eocene of the southeastern United States". English. In: Journal of Paleontology 79.6 (2005), pp. 1219-1221.

[17609] D. Parmley and D. J. Cicimurri. "Late Eocene Sharks of the Hardie Mine Local Fauna of Wilkinson County, Georgia". English. In: Georgia Journal of Science 61.3 (2003), pp. 153-179.

[17610] D. Parmley, J. Clark, and A. J. Mead. "Amphiuma (Caudata: Amphiumidae) from the Pleistocene Clark Quarry local fauna of coastal Georgia". English. In: Georgia Journal of Science 65.2 (2007), pp. 76-81.

[17611] D. Parmley and M. DeVore. "Palaeopheid snakes from the Late Eocene Hardie Mine local fauna of central Georgia". English. In: Southeastern Naturalist 4.4 (2005), pp. 703-722.

[17612] D. Parmley and J. A. Holman. "Hemphillian (late Miocene) snakes from Nebraska, with comments on Arikareean through Blancan snakes of midcontinental North America". English. In: Journal of Vertebrate Paleontology 15.1 (1995), pp. 79-95.

[17613] D. Parmley and J. A. Holman. "Earliest Fossil Record of a Pigmy Rattlesnake (Viperidae: Sistrurus Garman)". English. In: Journal of Herpetology 41.1 (2007), pp. 141-144.

[17614] D. Parmley and K. B. Hunter. "Fossil snakes of the Clarendonian (late Miocene) Pratt Slide local fauna of Nebraska, with the description of a new natricine colubrid". English. In: Journal of Herpetology 44.4 (2010), pp. 526-543. DOI: 10.1670/09-248.1.

[17615] D. Parmley, J. H. Hutchison, and J. F. Parham. "Diverse turtle fauna from the Late Eocene of Georgia including the oldest records of aquatic testudinoids in southeastern North America". English. In: Journal of Herpetology 40.3 (2006), pp. 343-350.

[17616] D. Parmley and D. L. Peck. "Amphibians and reptiles of the late Hemphillian White Cone local fauna, Navajo County, Arizona”. English. In: Journal of Vertebrate Paleontology 22.1 (2002), pp. 175178.

[17617] D. Parmley and D. Walker. "Snakes of the Pliocene Taunton local fauna of Adams County, Washington with the description of a new colubrid". English. In: Journal of Herpetology 37.2 (2003), pp. 235-244.

[17618] H. Pärnaste. "The earliest encrinurid trilobites from the east Baltic and their taxonomic interest". English. In: Palaeontology 49.1 (2006), pp. 155-170. DOI: 10.1111/j.1475-4983.2005.00535.x.

[17619] H. Pärnaste. "The early Ordovician trilobite distribution and zonation of the East Baltic". English. In: Proceedings of the Estonian Academy of Sciences, Geology 55.2 (2006), pp. 109-127. 
[17620] H. Pärnaste, J. Bergström, and Z. -y. Zhou. "High resolution trilobite stratigraphy of the LowerMiddle Ordovician Öland Series of Baltoscandia". English. In: Geological Magazine 150.3 (2013), pp. 509-518. DOI: 10.1017/S0016756812000908.

[17621] J. Párraga and A. Prieto-Márquez. "Pareisactus evrostos, a new basal iguanodontian (Dinosauria: Ornithopoda) from the Upper Cretaceous of southwestern Europe". English. In: Zootaxa 4555.2 (2019), pp. 247-258.

[17622] J. Parrilla-Bel, M. T. Young, M. Moreno-Azanza, and J. I. Canudo. “The first metriorhynchid crocodylomorph from the Middle Jurassic of Spain, with implications for evolution of the subclade Rhacheosaurini". English. In: PLoS ONE 8.1 (2013), e54275. DOI: 10.1371/journal.pone.0054275.

[17623] D. C. Parris and E. Daeschler. "Pleistocene turtles of Port Kennedy Cave (late Irvingtonian), Montgomery County, Pennsylvania". In: Journal of Paleontology 69.3 (1995), pp. 563-568.

[17624] D. C. Parris, J. L. Dobie, and A. B. McPherson. "A fossil marine turtle from east central Louisiana". English. In: Texas Journal of Science 52.3 (2000), pp. 230-234.

[17625] D. C. Parris and B. S. Grandstaff. "An oreodont of Miocene age from Slim Buttes, Harding County, South Dakota". English. In: Proceedings of the South Dakota Academy of Science 82 (2003), pp. 61-65.

[17626] D. C. Parris, B. S. Grandstaff, and W. B. Gallagher. "A lungfish (dipnoan) from the Upper Cretaceous of New Jersey". English. In: The Mosasaur 7 (2004), pp. 65-68.

[17627] D. C. Parris, J. P. Schein, E. B. Daeschler, E. S. Gilmore, J. C. Poole, and R. A. Pellegrini. “Two halves make a Holotype: two hundred years between discoveries". English. In: Proceedings of the National Academy of Sciences 163.1 (2014), pp. 85-89. DOI: 10.1635/053.163.0105.

[17628] J. M. Parrish. Small fossil vertebrates from the Chinle Formation (Upper Triassic) of southern Utah. Vol. 99-1. Vertebrate Paleontology in Utah, Utah Geological Survey Miscellaneous Publication. 1999, pp. 44-50.

[17629] J. M. Parrish. "A new specimen of an early crocodylomorph (cf. Sphenosuchus sp.) from the Upper Triassic Chinle Formation of Petrified Forest National Park, Arizona". English. In: Journal of Vertebrate Paleontology 11 (1991), pp. 198-212.

[17630] L. A. Parry, G. D. Edgecombe, D. Sykes, and J. Vinther. "Jaw elements in Plumulites bengtsoni confirm that machaeridians are extinct armoured scaleworms". English. In: Proceedings of the Royal Society B: Biological Sciences 286.1907 (2019), pp. 1-8.

[17631] R. L. Parsley. "Aristocystites, a Recumbent Diploporid (Echinodermata) from the Middle and Late Ordovician of Bohemia, SSR". English. In: Journal of Paleontology 64.2 (1990), pp. 278-293. DOI: 10.1017/S0022336000018436.

[17632] R. L. Parsley and J. C. Gutierrez-Marco. "Stylophorans in middle Arenig shallow water siliciclastics:" English. In: Bulletin of Geosciences 80.3 (2005), pp. 182-192.

[17633] R. L. Parsley and R. J. Prokop. "Functional morphology and paleoecology of some sessile Middle Cambrian echinoderms from the Barrandian region of Bohemia". English. In: Bulletin of Geosciences 79.3 (2004), pp. 147-156.

[17634] R. L. Parsley, R. J. Prokop, and K. Derstler. "Kirkocystid ankyroids (Stylophora: Echinodermata) from the Sarka Formation (Ordovician) of Bohemia". English. In: Bulletin of Geosciences 75.1 (2000), pp. 37-48.

[17635] R. L. Parsley and C. D. Sumrall. “New recumbent echinoderm genera from the Bois d'Arc Formation: Lower Devonian (Lochkovian) of Coal County, Oklahoma". English. In: Journal of Paleontology 81.6 (2007), pp. 1486-1493. DOI: 10.1666/04-072.1.

[17636] R. L. Parsley and Y.-L. Zhao. "Long stalked eocrinoids in the basal Middle Cambrian Kaili Biota, Taijiang County, Guizhou Province, China". English. In: Journal of Paleontology 80.6 (2006), pp. 10581071.

[17637] W. L. Parsons and K. M. Parsons. "A new ankylosaur (Dinosauria: Ankylosauria) from the Lower Cretaceous Cloverly Formation of central Montana". English. In: Canadian Journal of Earth Sciences 46 (2009), pp. 721-738. DOI: 10.1139/E09-45. 
[17638] D. Pas, A.-C. Da Silva, M. R. Dital, and F. Boulvain. “Sedimentology of a Mid-Late Ordovician carbonate mud-mound complex from the Katmandu nappe in Central Nepal". English. In: Journal of Asian Earth Sciences 42.3 (2011), pp. 452-467.

[17639] A. D. Pasch and K. C. May. First occurrence of a hadrosaur (Dinosauria) from the Matanuska Formation (Turonian) in the Talkeetna Mountains of south-central Alaska. English. In J. G. Clough \& F. Larson (eds.), Short Notes on Alaska Geology 1997. Professional Report 118: Recent Research on Alaska Geology. 1997, pp. 99-109.

[17640] C. Pascual, J. I. Canudo, N. Hernández, J. L. Barco, and D. Castanera. "First record of stegosaur dinosaur tracks in the Lower Cretaceous (Berriasian) of Europe (Oncala group, Soria, Spain)". English. In: Geodiversitas 34.2 (2012), pp. 297-312. DOI: 10.5252/g2012n2a4.

[17641] R. Pascual, M. Archer, E. O. Jaureguizar, J. L. Prado, H. Godthelp, and S. Hand. “First discovery of monotremes in South America". English. In: Nature 356 (1992), pp. 704-706.

[17642] R. Pascual, M. Archer, E. O. Jaureguizar, J. L. Prado, H. Godthelp, and S. J. Hand. The first nonAustralian monotreme: an early Paleocene South American platypus (Monotremata, Ornithorhynchidae). English. Platypus and Echidnas. Royal Zoological Society of New South Wales. 1992, pp. 1-14.

[17643] R. Pascual, A. A. Carlini, M. Bond, and F. J. Goin. "Mamferos Cenozoicos". Spanish. In: vol. II-11. Geologa y Recursos Naturales de Santa Cruz. Relatorio del XVř Congreso Geológico Argentino. Buenos Aires: El Calafate, 2002, pp. 1-12.

[17644] R. Pascual, F. J. Goin, P. Gonzalez, A. Ardolino, and P. F. Puerta. “A highly derived docodont from the Patagoinan Late Cretaceous: evolutionary implications for Gondwanan mammals". English. In: Geodiversitas 23.3 (2000), pp. 395-414.

[17645] R. Pascual, F. J. Goin, E. Ortiz-Jaureguizar, and A. A. Carlini. "The first gnathic remains of Sudamerica: implications for gondwanathere relationships". English. In: Journal of Vertebrate Paleontology 19.2 (1999), pp. 373-382.

[17646] C. Pascual Arribas and E. Sanz Pérez. "Huellas de pterosaurios en el Grupo Oncala (Soria, España). Pteraichnus palaciei-saenzi nov. ichnosp. [Pterosaur tracks in the Oncala Group (Soria, Spain). Pteraichnus palaciei-saenzi nov. ichnosp.]" Spanish. In: Estudios Geológicos 56 (2000), pp. $73-$ 100.

[17647] C. Pascual Arribas and E. Sanz Pérez. “Icnitas de dinosaurios en Valdelavilla (Soria, España) [Dinosaur tracks in Valdelavilla (Soria, Spain)]". Spanish. In: Estudios Geológicos 56 (2000), pp. 4161.

[17648] C. Pascual-Arribas and N. Hernández-Medrano. "Nuevas huellas de estegosáuridos en el TitonienseBerriasiense de la Cuenca de Cameros (Formación Magaña) [New tracks of stegosaurids in the Tithonian-Berriasian of the Cameros Basin (Magaña Formation)]". Spanish. In: Revista de la Sociedad Geológica de España 28.2 (2015), pp. 15-27.

[17649] D. I. Pashchenko, I. T. Kuzmin, A. G. Sennikov, P. P. Skutschas, and M. B. Efimov. “On the Finding of Neosuchians (Neosuchia, Crocodyliformes) in the Middle Jurassic (Bathonian) Deposits of the Moscow Region". English. In: Paleontological Journal 52.5 (2018), pp. 550-562.

[17650] J. C. Pashin and F. R. Ettensohn. Paleoecology and sedimentology of the dysaerobic Bedford fauna (Late Devonian), Ohio and Kentucky (USA). English. 1992.

[17651] G. Pasini and A. Garassino. "A new phyllosoma form (Decapoda, ?Palinuridae) from the Late Cretaceous (Cenomanian) of Lebanon". English. In: Atti della Societá Italiana di Scienze Naturali e del Museo Civico di Storia Naturale in Milano 150.1 (2009), pp. 21-28.

[17652] G. Pasini and A. Garassino. "First record of Maja squinado (Herbst, 1788) (Decapoda, Brachyura, Majidae) from the Pliocene of Masserano, Biella (Piemonte, NW Italy)". English. In: Atti della Societá Italiana di Scienze Naturali e del Museo Civico di Storia Naturale in Milano 150.1 (2009), pp. 1320.

[17653] G. Pasini and A. Garassino. "A new raninoid crab (Decapoda, Brachyura, Raninidae) from the early Oligocene (late Rupelian) of Italy". English. In: Natural History Sciences. Atti Soc. it. Sci. nat. Museo civ. Stor. nat. Milano 4.1 (2017), pp. 87-96. DOI: 10.4081/nhs.2017.323. 
[17654] G. Pasini, A. Garassino, T. Nyborg, S. G. Dunbar, and R. H. B. Faaije. “In situ hermit crab (Anomura, Paguroidea) from the Oligocene Pysht Formation, Washington, USA". English. In: Neues Jahrbuch für Geologie und Paläontologie 295.1 (2020), pp. 17-22. DOI: 10.1127/njgpa/2020/0865.

[17655] J. Pakeviius. "Pecularities of the lithology and fauna of the early Katian (Ordovician) in the Lithuanian facies zone". English. In: Geologija. Geografija 2.2 (2016), pp. 49-61.

[17656] J. Pakeviius and L. Hints. "New Early Katian species of Leptestiidae and Hesperorthidae (Brachiopoda) from Lithuania". English. In: Estonian Journal of Earth Sciences 65.2 (2016), pp. 75-84.

[17657] G. Pasnik. "Fossils of Staphylinidae from Baltic amber: a new genus and three new species (Insecta, Coleoptera, Staphylinidae)". English. In: Senckenbergiana Biologica 85 (2005), pp. 97-100.

[17658] G. Pasnik and D. Kubisz. "A new genus and new species of Staphylinidae (Coleoptera) from Baltic amber". English. In: European Journal of Entomology 99 (2002), pp. 353-361.

[17659] M. Passalia, S. Archangelsky, E. Romero, and G. Cladera. "A new early angiosperm leaf from the Anfiteatro de Ticó Formation (Aptian), Santa Cruz Province, Argentina". English. In: Revista del Museo Argentino de Ciencias Naturales 5.2 (2003), pp. 245-252.

[17660] M. G. Passalia. “Nuevos registros para la flora cretácica descripta por Halle (1913) en lago San Martn, Santa Cruz, Argentina". Spanish. In: 44.3 (2007), pp. 565-595.

[17661] M. G. Passalia. "A mid-Cretaceous flora from the Kachaike Formation, Patagonia, Argentina". English. In: Cretaceous Research 28 (2007), pp. 830-840. DOI: 10.1016/j.cretres.2006.12.006.

[17662] M. G. Passalia, G. Del Fueyo, and S. Archangelsky. “An Early Cretaceous zamiaceous cycad of South West Gondwana: Restrepophyllum nov. gen. from Patagonia, Argentina". English. In: Review of Palaeobotany and Palynology 161 (2010), pp. 137-150. DOI: 10.1016/j.revpalbo.2010.04.001.

[17663] M. G. Passalia, M. B. Prámparo, J. O. Calvo, and S. Heredia. "Primer registro de hojas de angiospermas en el Grupo Neuquén (Turoniano tardo-Coniaciano temprano), Lago Barreales, Argentina [First record of angiosperm leaves in the Neuquén Group (late Turonian-early Coniacian), Lago Barreales, Argentina]". Spanish. In: Ameghiniana 45.1 (2008), pp. 233-239.

[17664] L. Passoni and J. H. A. van Konijnenburg-van Cittert. "New taxa of fossil Carnian plants from Mount Pora (Bergamasc Alps, Northern Italy)." In: Review of Palaeobotany and Palynology 123 (2003), pp. 321-346.

[17665] R. Patel, R. S. Rana, and P. A. Selden. “An orb-weaver spider (Araneae, Araneidae) from the early Eocene of India". English. In: Journal of Paleontology 93 (2019), pp. 98-104. DOI: 10.1017/jpa.2018.71.

[17666] R. P. Patel, D. Lenz, A. C. Kitchener, J. Fickel, D. W. Forster, and A. Wilting. "Threatened but understudied: supporting conservation by understanding the genetic structure of the flat-headed cat". English. In: Conservation Genetics 18 (2017), pp. 1423-1433. DOI: 10.1007/s10592-017-0990-2.

[17667] J. R. Paterson and G. A. Brock. "Early Cambrian trilobites from Angorichina, Flinders Ranges, South Australia, with a new assemblage from the Pararaia bunyerooensis zone". English. In: Journal of Paleontology 81.1 (2007), pp. 116-142.

[17668] J. R. Paterson, D. C. Garca-Bellido, J. B. Jago, J. G. Gehling, M. S. Y. Lee, and G. D. Edgecombe. “The Emu Bay Shale Konservat-Lagerstätte: a view of Cambrian life from East Gondwana". English. In: Journal of the Geological Society 173 (2016), pp. 1-11. DOI: 10.1144/jgs2015-083.

[17669] J. R. Paterson, J. B. Jago, J. G. Gehling, D. C. Garca-Bellido, G. D. Edgecombe, and M. S. Y. Lee. "Early Cambrian arthropods from the Emu Bay Shale Lagerstätte, South Australia". English. In: Advances in Trilobite Research. Instituto Geologico y Minero de Espana, 2008, pp. 319-325.

[17670] J. R. Paterson and J. R. Laurie. "Late Cambrian trilobites from the Dolodrook River limestones, eastern Victoria, Australia". English. In: Memoirs of the Association of Australasian Palaeontologists 30 (2004), pp. 83-111.

[17671] R. Paterson, J. X. Samuels, N. Rybczynski, M. J. Ryan, and H. C. Maddin. "The earliest mustelid in North America". English. In: Zoological Journal of the Linnean Society 188 (2020), pp. 1318-1339. DOI: 10.1093/zoolinnean/zlz091. 
[17672] D. B. Pathak. "Ammonoid stratigraphy of the Spiti Shale Formation in Spiti Himalaya, India". English. In: Journal of the Geological Society of India 50 (1997), pp. 191-200.

[17673] D. B. Pathak. "Jurassic/Cretaceous boundary in the Spiti Himilaya, India". English. In: Journal of the Paleontological Society of India 52.1 (2007), pp. 51-57.

[17674] S. Patiny, M. S. Engel, P. Vanmarsenille, and D. Michez. "A new record of Thaumastobombus andreniformis Engel 2001 in Eocene amber (Hymenoptera: Apidae)". English. In: Annales de la Société Entomologique de France 43.4 (2007), pp. 505-508.

[17675] R. Patnaik. "New murids and gerbellids (Rodentia, Mammalia) from Pliocene Siwalik sediments of India". English. In: Palaeovertebrata 26.1-4 (1997), pp. 129-165.

[17676] R. L. Paton. "Elasmobranch fishes from the Viséan of East Kirkton, West Lothian, Scotland". English. In: Transactions of the Royal Society of Edinburgh: Earth Sciences 84 (1994), pp. 329-330. DOI: 10.1017/S0263593300006143.

[17677] R. L. Paton, T. R. Smithson, and J. A. Clack. "An amniote-like skeleton from the Early Carboniferous of Scotland". English. In: Nature 398 (1999), pp. 508-513.

[17678] T. R. Paton, R. L. Freeman, B. F. Dattilo, and C. D. Sumrall. “Edrioasteroids on corals: Taphonomic feedback and sedimentary processescontrol the ecology of a Late Ordovician (Katian: Cincinnatian,Richmondian) community in central Kentucky, USA". English. In: Palaeogeography, Palaeoclimatology, Palaeoecology 537 (2020). DOI: 10.1016/j.palaeo.2019.109447.

[17679] E. L. Patrick, D. I. Whiteside, and M. J. Benton. "A new crurotarsan archosaur from the Late Triassic of South Wales". English. In: Journal of Vertebrate Paleontology 39.3 (2019), e1645147. DOI: 10.1080/02724634.2019.1645147.

[17680] M. E. Patzkowsky. Gradient analysis of Middle Ordovician brachiopod biofacies: Biostratigraphic, biogeographic, and Macroevolutionary Implications. 1995.

[17681] M. E. Patzkowsky and S. M. Holland. "Biofacies Replacement in a Sequence Stratigraphic Framework: Middle and Upper Ordovician of the Nashville Dome, Tennessee, USA". English. In: Palaios 14.4 (1999), pp. 301-317. DOI: 10.2307/3515459.

[17682] C. R. C. Paul. "Prokopius, a new name for Hippocystis sculptus Prokop, 1965, and the status of the genus Hippocystis Bather, 1919 (Echinodermata; Diploporita)". English. In: Bulletin of Geosciences 93.3 (2018), pp. 337-346. DOI: 10.3140/bull.geosci.1697.

[17683] C. R. C. Paul, A. J. Boucot, S. K. Donovan, R. Zhan, and W. Tansathien. "Primitive stalked echinoderms from the Middle Ordovician (Darriwilian) of Bang Song Tho, Kanchanaburi, western Thailand". English. In: Geological Magazine 156.1 (2019), pp. 147-171. DOI: 10.1017/S0016756817000826.

[17684] C. R. C. Paul, S. F. Mitchell, J. D. Marshall, P. N. Leary, A. S. Gale, A. M. Duane, and P. W. Ditchfield. "Palaeoceanographic events in the Middle Cenomanian of northwest Europe". English. In: Cretaceous Research 15 (1994), pp. 707-738.

[17685] C. R. C. Paul and S. V. Rozhnov. "Revision of Scoliocystis (Rhombifera: Echinoencrinitidae) and related cystoid genera". English. In: Paleontological Journal 50.3 (2016), pp. 255-275. DOI: 10.1134/ S0031030116030059.

[17686] G. S. Paul. "A revised taxonomy of the iguanodont dinosaur genera and species". English. In: Cretaceous Research 29.2 (2008), pp. 192-216. DOI: 10.1016/j.cretres.2007.04.009.

[17687] A. Paulina Carabajal, J. I. Canale, and A. Haluza. "New rebbachisaurid cranial remains (Sauropoda, Diplodocoidea) from the Cretaceous of Patagonia, Argentina, and the first endocranial description for a South American representative of the clade". English. In: Journal of Vertebrate Paleontology (2016), e1167067:1-9. DOI: 10.1080/02724634.2016.1167067.

[17688] A. Paulina-Carabajal and R. A. Coria. "An unusual theropod frontal from the Upper Cretaceous of north Patagonia". English. In: Alcheringa 39 (2015).

[17689] A. Paulina-Carabajal and L. Salgado. “Un basicráneo de titanosaurio (Dinosauria, Sauropoda) del Cretácico Superior del norte de Patagonia: descripción y aportes al conocimiento del odo interno de los dinosaurios". Portugese. In: Ameghiniana 44.1 (2007), pp. 109-120. 
[17690] V. E. Pauliv, E. V. Dias, and F. A. Sedor. "A new species of sphenacanthid (Chondrichthyes, Elasmobranchii) from the Rio do Rasto Formation (Paraná basin), southern Brazil". English. In: Revista Brasileira de Paleontologia 15 (2012), pp. 243-250.

[17691] R. Paull and R. S. Hill. “Libocedrus Macrofossils from Tasmania (Australia)”. English. In: International Journal of Plant Sciences 170.3 (2009), pp. 381-399.

[17692] V. Paumard, P. Zuckmeyer, R. Boichard, J. Bourget, J. Borgomano, T. Maurin, and J. -N. Ferry. "Evolution of Late Oligocene - Early Miocene attached and isolated carbonate platforms in a volcanic ridge context (Maldives type), Yadana field, offshore Myanmar". English. In: Marine and Petroleum Geology 81 (2017), pp. 361-387.

[17693] M. Paunovic. “Mesocetus aff. agrami (Mysticeti, Cetotheriidae) iz srednjomicenskih naslaga sjeverne bosne". other. In: Rad Hrvatske Akademiji Znanosti i Umjetnosti Prirodne Znanosti 26 (1993), pp. 1-11.

[17694] A. E. B. Pavanatto, A. T. S. Da-Rosa, R. Temp-Müller, L. Roberto-da-Silva, A. M. Ribeiro, A. G. Martinelli, and S. Dias-da-Silva. "Bortolin site, a new fossiliferous locality in the Triassic (Ladinian/Carnian) of southern Brazil". English. In: Revista Brasileira de Paleontologia 23.2 (2020), pp. 123-137. DOI: 10.4072/rbp.2020.2.04.

[17695] A. E. B. Pavanatto, R. T. Müller, A. A. S. Da-Rosa, and S. Dias-da-Silva. "New information on the postcranial skeleton of Massetognathus ochagaviae". English. In: Historical Biology 28.7 (2015), pp. 978-989. DOI: 10.1080/08912963.2015.1070148.

[17696] A. E. B. Pavanatto, F. A. Pretto, L. Kerber, R. T. Müller, Á A. S. Da-Rosa, and S. Dias-da-Silva. "A new Upper Triassic cynodont-bearing fossiliferous site from southern Brazil, with taphonomic remarks and description of a new traversodontid taxon". English. In: Journal of South American Earth Sciences 88 (2018), pp. 179-196. DOI: 10.1016/j.jsames.2018.08.016.

[17697] G. Pavia. "Lissoceras monachum (Gemmellaro), a ghost Ammonitida of the Tethyan Bathonian". English. In: Bollettino della Societá Paleontologica Italiana 45.2-3 (2007), pp. 217-226.

[17698] M. Pavia. "The evolution dynamics of the Strigiformes in the Mediterranean islands with the description of Aegolius martae n. sp. (Aves, Strigidae)". English. In: Quaternary International 182 (2008), pp. 80-89.

[17699] M. Pavia. "A new large barn owl (Aves, Strigiformes, Tytonidae) from the Middle Pleistocene of Sicily, Italy, and its taphonomical significance". English. In: Geobios 37 (2004), pp. 631-641.

[17700] M. Pavia. "The Middle Pleistocene avifauna of Spinagallo Cave (Sicily, Italy): preliminary report". English. In: Smithsonian Contributions to Paleobiology 89 (1999), pp. 125-127.

[17701] M. Pavia and C. Bedetti. "The late Pleistocene fossil avian remains from Grotta dei Fiori, Carbonia (SW Sardinia, Italy)". English. In: Bolletino della Societá Paleontologica Italiana 42 (2003), pp. 163-169.

[17702] M. Pavia, C. Bedetti, and L. Carrera. "A new Middle Pleistocene bird assemblage from Cava di Breccia di Casal Selce (Ponte Galeria, Rome, Italy)". English. In: Avocetta 42 (2018), pp. 31-38.

[17703] M. Pavia and C. Bedetti. "The presence of Harlequin duck Histrionicus histrionicus (Linnaeus 1758) in the Middle Pleistocene of Italy". English. In: Journal of Ornithology 154 (2013), pp. 875-878.

[17704] M. Pavia and G. Insacco. "The fossil bird associations from the early Middle Pleistocene of the Ragusa province (SE Sicily, Italy)”. English. In: Bollettino della Societá Paleontologica Italiana 52 (2013), pp. 157-165.

[17705] P. Pavlakis, A. Fistani, and N. Symeonidis. "New Evidence of Middle Pleistocene mammal fauna from the Perama Cave (Ioannina, Greece)". other. In: Bulletin of the Speleological Society of Greece 21 (1993), pp. 340-360.

[17706] P. P. Pavlakis. Plio-Pleistocene Hippopotamidae from the Upper Semliki. 1990.

[17707] T. Pawellek, S. Adnet, H. Cappetta, E. Metais, M. Salem, M. Brunet, and J. -J. Jaeger. “Discovery of an earliest Pliocene relic tropical fish fauna in a newly detected cliff section (Sabratah Basin, NW Libya)". English. In: Neues Jahrbuch for Geologie und Palaontologie Abhandlungen 266.2 (2012), pp. 93-114. 
[17708] K. Pawley. "The Postcranial Skeleton of Trimerorhachis insignis Cope, 1878 (Temnospondyli: Trimerorhachidae): A Plesiomorphic Temnospondyl from the Lower Permian of North America". English. In: Journal of Paleontology 81.5 (2007), pp. 873-894.

[17709] J. L. Payne, M. Summers, B. L. Rego, D. Altiner, Y. Yu, J. Wei, and D. J. Lehrmann. "Early and Middle Triassic trends in diversity, evenness, and size of foraminifers on a carbonate platform in south China: Implications for tempo and mode of biotic recovery from the end-Permian mass extinction". English. In: Paleobiology 37.3 (2011), pp. 409-425.

[17710] C. E. Payri and G. Cabioch. "The systematics and significance of coralline red algae in the rhodolith sequence of the Amedee 4 drill core (southwest New Caledonia)". English. In: Palaeogeography, Palaeoclimatology, Palaeoecology 204 (2004), pp. 187-208.

[17711] B. A. Payseur, H. H. Covert, C. J. Vinyard, and M. Dagosto. “New body mass estimates for Omomys carteri, a middle Eocene primate from North America". English. In: American Journal of Physical Anthropology 109 (1999), pp. 41-52.

[17712] E. R. Paz, A. Kramarz, and M. Bond. "Mesotheriid (Mammalia, Notoungulata) remains from the Colhuehuapian beds (early Miocene) of Chinchinales Formation, Ro Negro Province, Argetina". English. In: Ameghiniana 48.2 (2011), pp. 264-269.

[17713] P. J. Pazos, D. G. Lazo, M. A. Tunik, C. A. Marsicano, D. E. Fernández, and M. B. Aguirre-Urreta. "Paleoenvironmental framework of dinosaur tracksites and other ichnofossils in Early Cretaceous mixed siliciclastic-carbonate deposits in the Neuquén Basin, northern Patagonia (Argentina)". English. In: Gondwana Research 22 (2012), pp. 1125-1140. DOI: 10.1016/j.gr.2012.02.003.

[17714] H. Pearce. "A Study of the Bioherms of the Early Ordovician Garden City Formation and a Literature Review of Early Ordovician Organic Buildups". English. PhD thesis. 2012.

[17715] D. A. Pearson, T. Schaefer, K. R. Johnson, D. J. Nichols, and J. P. Hunter. Vertebrate biostratigraphy of the Hell Creek Formation in southwestern North Dakota and northwestern South Dakota. English. Vol. 361. The Hell Creek Formation and the Cretaceous-Tertiary Boundary in the Northern Great Plains: An Integrated Continental Record of the End of the Cretaceous, Geological Society of America Special Paper. 2002, pp. 145-167.

[17716] G. A. Pearson. "Late Pleistocene megafaunal deposits on the isthmus of Panama and their paleoenvironmental implications". English. In: Caribbean Journal of Science 41.1 (2005), pp. 1-13.

[17717] M. Pecharová, J. Prokop, and D. Ren. “Early Pennsylvanian aykhalids from Xiaheyan, northern China and their palaeogeographical significance (Insecta: Megasecoptera)". English. In: Comptes Rendus Palevol 14 (2015), pp. 613-624.

[17718] M. Pecharová and J. Prokop. “The morphology of mouthparts, wings and genitalia of Paleozoic insect families Protohymenidae and Scytohymenidae reveals new details and supposed function". English. In: Arthropod Structure \& Development 47 (2018), pp. 117-129.

[17719] M. Pecharová, D. Ren, and J. Prokop. “A new palaeodictyopteroid (Megasecoptera: Brodiopteridae) from the Early Pennsylvanian of northern China reveals unique morphological traits and intra-specific variability". English. In: Alcheringa 39 (2015), pp. 236-249.

[17720] M. Pecharová, N. D. Sinitshenkova, and J. Prokop. "On the morphology of the Late Paleozoic insect families Bardohymenidae and Aspidothoracidae (Palaeodictyopterida: Megasecoptera)". English. In: Arthropod Structure \& Development 55.100916 (2020). DOI: 10.1016/j.asd.2020.100916.

[17721] J. Peckmann, E. Gischler, W. Oschmann, and J. Reitner. “An Early Carboniferous seep community and hydrocarbon-derived carbonates from the Harz Mountains, Germany". English. In: Geology 29.3 (2001), pp. 271-274.

[17722] J. Peckmann, J. L. Goedert, V. Thiel, W. Michaelis, and J. Reitners. "A comprehensive approach to the study of methane-seep deposits from the Lincoln Creek Formation," English. In: Sedimentology 49 (2002), pp. 855-873. DOI: 10.1046/j.1365-3091.2002.00474.x.

[17723] J. Peckmann, S. Kiel, M. R. Sandy, D. G. Taylor, and J. L. Goedert. "Mass occurrences of the brachiopod Halorella in Late Triassic methane-seep deposits, eastern Oregon". English. In: Journal of Geology 119 (2011), pp. 207-220. 
[17724] J. Peckmann, C. T. S. Little, F. Gill, and J. Reitner. "Worm tube fossils from the Hollard Mound hydrocarbon-seep deposit, Middle Devonian, Morocco: Palaeozoic seep-related vestimentiferans?" English. In: Palaeogeography, Palaeoclimatology, Palaeoecology 227 (2005), pp. 242-257.

[17725] J. Peckmann, V. Thiel, W. Michaelis, P. Clari, C. Gaillard, L. Martire, and J. Reitner. “Cold seep deposits of Beauvoisin (Oxfordian, southeastern France) and Marmorito (Miocene, northern Italy): microbially induced authigenic carbonates". English. In: International Journal of Earth Sciences 88 (1999), pp. 60-75.

[17726] A. E. H. Pedder and M. A. Murphy. "Lochkovian Rugosa of Nevada". In: Geological Society of America Special Paper 321 (1997), pp. 341-385.

[17727] A. E. H. Pedder and M. A. Murphy. "Emsian (Lower Devonian) Rugosa of Nevada: revision of systematics and stratigraphic ranges, and reassessment of faunal provincialism". English. In: Journal of Paleontology 78.5 (2004), pp. 838-865.

[17728] T. E. Pedernera, E. G. Ottone, A. C. Mancuso, and C. A. Benavente. "Syn-Eruptive taphoflora from the Agua de la Zorra Formation (Upper Triassic) Cuyana Basin, Mendoza, Argentina." English. In: Andean Geology 46.3 (2019), pp. 604-628. DOI: 10.5027/andgeoV46n3-3228.

[17729] K. R. Pedersen, P. R. Crane, A. N. Drinnan, and E. M. Friis. "Fruits from the mid-Cretaceous of North America with pollen grains of the Clavatipollenites type". English. In: Grana 30 (1991), pp. 577-590.

[17730] K. R. Pedersen, E. M. Friis, C. R. Crane, and A. N. Drinnan. "Reproductive structures of an extinct platanoid from the Early Cretaceous (latest Albian) of eastern North America". In: Review of Palaeobotany and Palynology 80 (1994), pp. 291-303.

[17731] K. R. Pedersen, E. M. Friis, and P. R. Crane. "Pollen organs and seeds with Decussosporites Brenner from Lower Cretaceous Potomac Group sediments of eastern USA". In: Grana 32 (1993), pp. 273-289.

[17732] M. Pedersen and C. M. Ø Rasmussen. "The glacially induced Middle Ordovician rise of the Plectambonitoidea (Brachiopoda) and the phylogenetic placement of the Baltic genus Ukoa". English. In: Palaeogeography, Palaeoclimatology, Palaeoecology 534 (2019). DOI: 10.1016/j.palaeo.2019.109319.

[17733] M. Pedley. "Miocene reef facies of the pelagian region (Central Mediterranean)". English. In: SEPM Concepts in Sedimentology and Paleontology 5 (1996), pp. 247-259.

[17734] B. R. Peecook, C. A. Sidor, S. J. Nesbitt, R. M. H. Smith, J. S. Steyer, and K. D. Angielczyk. “A new silesaurid from the upper Ntawere Formation of Zambia (Middle Triassic) demonstrates the rapid diversification of Silesauridae (Avemetatarsalia, Dinosauriformes)". English. In: Journal of Vertebrate Paleontology 33.5 (2013), pp. 1127-1137. DOI: 10.1080/02724634.2013.755991.

[17735] B. R. Peecook and C. A. Sidor. "The first dinosaur from Washington State and a review of Pacific Coast dinosaurs from North America". English. In: PLoS ONE 10.5 (2015), e0127792:1-15. DOI: 10.1371/journal.pone.0127792.

[17736] B. R. Peecook, R. M. H. Smith, and C. A. Sidor. "A novel archosauromorph from Antarctica and an updated review of a high-latitude vertebrate assemblage in the wake of the end-Permian mass extinction". English. In: Journal of Vertebrate Paleontology (2019). DOI: 10.1080 / 02724634.2018. 1536664.

[17737] B. R. Peecook, J. S. Steyer, N. J. Tabor, and R. M. H. Smith. “Updated Geology and Vertebrate Paleontology of the Triassic Ntawere Formation of Northeastern Zambia, with Special Emphasis on the Archosauromorphs". English. In: Society of Vertebrate Paleontology Memoir 37.6 supp. (2017), pp. 8-38.

[17738] B. R. Peecook, J. A. Wilson, R. Hernandez-Rivera, M. Montellano-Ballesteros, and G. P. Wilson. "First tyrannosaurid remains from the Upper Cretaceous El Gallo Formation of Baja California, Mexico". English. In: Acta Palaeontologica Polonica 59.1 (2014), pp. 71-80.

[17739] J. S. Peel. "Salpingostomatiform and related bellerophontacean gastropods from Greenland and the Baltic region". English. In: Grønlands Geologiske Undersøgelse Bulletin 161 (1991), pp. 67-116. 
[17740] J. S. Peel. "Gastropods from the Carboniferous (Namurian) of Congleton Edge, Cheshire, UK". English. In: Papers in Palaeontology 2.3 (2016), pp. 399-438. DOI: 10.1002/spp2.1047.

[17741] J. S. Peel. "Feeding behaviour of a new worm (Priapulida) from the Sirius Passet Lagerstätte (Cambrian Series 2, Stage 3) of North Greenland (Laurentia)". English. In: Palaeontology 60.6 (2017), pp. 795-805. DOI: $10.1111 /$ pala.12316.

[17742] J. S. Peel. “Bobellis oliveri gen. et sp. nov. from the Silurian of North Greenland (Laurentia) and the systematic position of pycnomphaline gastropods". English. In: Bulletin of Geosciences 94.2 (2019). DOI: $10.3140 /$ bull.geosci.1743.

[17743] J. S. Peel. "The Dala thumb: shell morphology and failed predation in Pollicina cyathina (Gastropoda) from the Ordovician of Dalarna, Sweden". English. In: G F F (2020). DOI: 10.1080 / 11035897.2020.1728374.

[17744] J. S. Peel. “The oldest palaeoloricate mollusc (Cambrian Series 2, Stage 4; North Greenland) and its bearing on aculiferan evolution". English. In: Bulletin of Geosciences 95.2 (2020), pp. 127-144. DOI: 10.3140/bull.geosci.1779.

[17745] J. S. Peel and L. Jeppsson. "The problematic fossil Jinonicella from the Lower Silurian of Gotland". English. In: Gff 128.1 (2006), pp. 39-42. DOI: 10.1080/11035890601281039.

[17746] J. S. Peel and C. B. Skovsted. "Problematic cap-shaped fossils from the Lower Cambrian of NorthEast Greenland". English. In: Paläontologische Zeitschrift 79.4 (2005), pp. 461-470. DOI: 10.1007 / BF02988372.

[17747] R. V. Pegas, M. E. C. Leal, and A. W. A. Kellner. “A Basal Tapejarine (Pterosauria; Pterodactyloidea; Tapejaridae) from the Crato Formation, Early Cretaceous of Brazil". English. In: Plos One (2016). DOI: $10.1371 /$ journal.pone.0162692.

[17748] R. V. Pegas, M. E. C. Leal, and J. Damgaard. "A surprisingly derived hydrometrid (Hemiptera, Gerromorpha) from the Crato Formation, Early Cretaceous of Brazil". English. In: Historical Biology 30 (2017), pp. 1094-1101.

[17749] T. V. Pegel. "Evolution of trilobite biofacies in Cambrian basins of the Siberian Platform". English. In: Journal of Paleontology 74.6 (2000), pp. 1000-1019.

[17750] F. Pei and W.-m. Feng. "Discovery of the molluscan fauna from the Lower Cambrian Xinji Formation of Zhuyang, Lingbao of Henan". Chinese. In: Journal of Stratigraphy 29 (2005), pp. 458-461.

[17751] R. Pei, M. A. Norell, D. E. Barta, G. S. Bever, M. Pittman, and X. Xu. "Osteology of a new Late Cretaceous troodontid specimen from Ukhaa Tolgod, Ömnögovi Aimag, Mongolia". English. In: American Museum Novitates 3889 (2017), pp. 1-47.

[17752] S. Peigné. "Systematic review of European Nimravinae (Mammalia, Carnivora, Nimravidae) and the phylogenetic relationships of Palaeogene Nimravidae". English. In: Zoologica Scripta 32.3 (2003), pp. 199-229.

[17753] S. Peigné. "A primitive nimravine skull from the Quercy fissures, France: implications for the origin and evolution of Nimravidae (Carnivora)". English. In: Zoological Journal of the Linnean Society 132 (2001), pp. 401-410.

[17754] S. Peigné. "A new species of Eofelis (Carnivora: Nimravidae) from the Phosphorites of Quercy, France". English. In: Comptes Rendus de l'Académie des Sciences - Series IIA - Earth and Planetary Science 330.9 (2000), pp. 653-658.

[17755] S. Peigné and M. Brunet. “Une nouvelle espéce du genre Eusmilus (Carnivora: Nimravidae) de l'Oligocéne (MP 22) d'Europe". French. In: Geobios 34.6 (2001), pp. 657-672.

[17756] S. Peigne, Y. Chaimanee, J. -J. Jaeger, V. Suteethorn, and S. Ducrocq. “Eocene nimravid carnivorans from Thailand". English. In: Journal of Vertebrate Paleontology 20.1 (2000), pp. 157-163. DOI: 10. 1671/0272-4634(2000)020[0157:ENCFT]2.0.CO;2.

[17757] S. Peigné, Y. Chaimanee, C. Yamee, P. Srisuk, B. Marandat, and J. -J. Jaeger. "A new member of the Mustelida (Mammalia: Carnivora) from the Paleogene of southern Asia". English. In: Journal of Vertebrate Paleontology 26.3 (2006), pp. 788-793. 
[17758] S. Peigné, Y. Chaimanee, C. Yamee, B. Marandat, P. Srisuk, and J. -J. Jaeger. "An astonishing example of convergent evolution toward carnivory: Siamosorex debonisi n. gen., n. sp. (Mammalia, Lipotyphla, Soricomorpha, Plesiosoricidae) from the latest Oligocene of Thailand". English. In: Geodiversitas 31.4 (2009), pp. 973-992.

[17759] S. Peigne, L. de Bonis, A. Likius, H. T. Mackaye, P. Vignaud, and M. Brunet. "A new machairodontine (Carnivora, Felidae) from the Late Miocene hominid locality of TM 266, Toros-Menalla, Chad". English. In: Comptes Rendus Palevol 4 (2005), pp. 243-253.

[17760] S. Peigné and L. de Bonis. "The genus Stenoplesictis Filhol (Mammalia, Carnivora) from the Oligocene deposits of the Phosphorites of Quercy, France". English. In: Journal of Vertebrate Paleontology 19.3 (1999), pp. 566-575.

[17761] S. Peigné, L. de Bonis, A. Likius, H. T. Mackaye, P. Vignaud, and M. Brunet. “The earliest modern mongoose (Carnivora, Herpestidae) from Africa (late Miocene of Chad)". English. In: Naturwissenschaften 92 (2005), pp. 287-292. DOI: 10.1007/s00114-005-0626-0.

[17762] S. Peigné, M. Morlo, Y. Chaimanee, S. Ducrocq, S. T. Tun, and J. -J. Jaeger. “New discoveries of hyaenodontids (Creodonta, Mammalia) from the Pondaung Formation, middle Eocene, Myanmarpaleobiogeographic implications". English. In: Geodiversitas 29.3 (2007), pp. 441-458.

[17763] S. Peigné, M. J. Salesa, M. Antón, and J. Morales. "Ailurid carnivoran mammal Simocyon from the late Miocene of Spain and the systematics of the genus." English. In: Acta Palaeontologica Polonica 50.2 (2005), pp. 219-238.

[17764] S. Peigné, M. J. Salesa, M. Antón, and J. Morales. "A new amphicyonine (Carnivora, Amphicyonidae) from the upper Miocene of Batallones-1, Madrid, Spain". English. In: Palaeontology 51.4 (2008), pp. 943-965. DOI: 10.1111/j.1475-4983.2008.00788.x.

[17765] S. Peigné, M. Vianey-Liaud, T. Pélissié, and B. Sigé. “Valbro : un nouveau site á vertébrés de l'Oligocéne inférieur (MP22) de France (Quercy). I - Contexte géologique ; Mammalia : Rodentia, Hyaenodontida, Carnivora [Valbro: A new site of vertebrates from the early Oligocene (MP22) of France (Quercy). I - Geological context; Mammalia: Rodentia, Hyaenodontida, Carnivora]". French. In: Annales de Paléontologie 100.1 (2014), pp. 1-45. DOI: 10.1016/j.annpal.2013.11.002.

[17766] J. Peinado, A. Nel, and A. Waller. "A dryinid wasp in Early Eocene amber from the Paris basin (Hymenoptera: Dryinidae)". English. In: Zootaxa 1168 (2006), pp. 31-41.

[17767] A. Peirano, P. Kruzic, and G. Mastronuzzi. "Growth of Mediterranean reef of Cladocora caespitosa (L.) in the Late Quaternary and climate inferences". English. In: Facies 55 (2009), pp. 325-333.

[17768] A. Peirano, C. Morri, C. N. Bianchi, J. Aguirre, F. Antonioli, C. Calzetta, L. Carobene, G. Mastronuzzi, and P. Orru. "The Mediterranean coral Cladocora caespitosa: a proxy for past climate fluctuations?" English. In: Global and Planetary Change 40 (2004), pp. 195-200.

[17769] P. Pelaez-Campomanes. "Valdecollares: a rodent fauna from the lower Oligocene of the Loranca Basin (Cuenca, Spain)". English. In: Proceedings Koninklijke Nederlandse Akademie van Wetenschappen 98.3 (1995), pp. 265-289.

[17770] P. Peláez-Campomanes. "Mammalian faunas from the Paleogene of the Sierra Palomera (Teruel, Spain)". English. In: Journal of Paleontology 74.2 (2000), pp. 336-348.

[17771] P. Peláez-Campomanes. “Upper Eocene rodents from the Almazan basin (Soria, Spain)”. English. In: Eclogae Geologicae Helvetiae 89.3 (1996), pp. 1363-1385.

[17772] P. Peláez-Campomanes. "Primates and rodents from the middle Eocene of Casa Ramon (Huesca, Spain)". English. In: Proceedings Koninklijke Nederlandse Akademie van Wetenschappen 98.3 (1995), pp. 291-312.

[17773] P. Pelaez-Campomanes and R. Daams. "Middle Miocene rodents from Paalar, Anatolia, Turkey". English. In: Acta Palaeontologica Polonica 47.1 (2002), pp. 125-132.

[17774] P. Pelaez-Campomanes, F. Gökta, T. Kaya, P. Joniak, M. Bilgin, S. Mayda, and L. W. van den Hoek Ostende. "Gördes: a new early Miocene micromammal assemblage from western Anatolia". English. In: Palaeobiodiversity and Palaeoenvironments 99.4 (2019), pp. 639-653. DOI: 10.1007/s12549018-0346-z. 
[17775] P. Peláez-Campomanes and N. López-Martnez. "Strange Eocene rodents from Spain". English. In: Palaeovertebrata 25.2-4 (1996), pp. 323-338.

[17776] P. Peláez-Campomanes, N. López-Martnez, M. A. Alvarez Sierra, and R. Daams. "The earliest mammal of the European Paleocene: the multituberculate Hainina." English. In: Journal of Paleontology 74.4 (2000), pp. 701-711.

[17777] C. Pella and A. Nel. "A hawker dragonfly (Odonata: Liupanshaniidae) from the Lower Cretaceous Crato Formation, northeastern Brazil". English. In: Cretaceous Research 116.104559 (2020). DOI: 10. 1016/j.cretres.2020.104559.

[17778] G. Pelzer. "Sedimentologie und palynologie der Wealden-Fazies im Hannoverschen Bergland [Sedimentology and palynology of the Wealden facies in the Hannover region]". German. In: Courier Forschungsinstitut Senckenberg 207 (1998), 1-211, A1-27.

[17779] S. G. Pemberton and J. P. A. Magwood. "A Unique Occurrence of Bergaueria in the Lower Cambrian Gog Group near Lake Louise, Alberta". English. In: Journal of Paleontology 64.3 (1990), pp. 436440.

[17780] E. Peñalver and A. Arillo. "A new species of the family Hybotidae in the Lower Cretaceous amber of El Caleyu (Asturias, Spain); Alavesia prietoi n. sp." English. In: Alavesia 1 (2007), pp. 63-68.

[17781] E. Peñalver and A. Arillo. "Primer registro fósil del género Acantholyda (Insecta: Hymenoptera: Pamphiliidae), Mioceno inferior de Ribesables (España)". Spanish. In: Revista Española de Paleontologia 17 (2002), pp. 73-81.

[17782] E. Peñalver, A. Arillo, X. Delclós, D. Peris, D. A. Grimaldi, S. R. Anderson, P. C. Nascimbene, and R. Pérez-de la Fuente. "Parasitised feathered dinosaurs as revealed by Cretaceous amber assemblages". English. In: Nature Communications 8.1924 (2017), pp. 1-13.

[17783] E. Peñalver and M. Baena. "Primer registro fósil del género Dicyphus (Insecta: Hemiptera: Miridae); Mioceno Inferior de Teruel (España)". Spanish. In: Revista Española de Paleontologa 15 (2000), pp. 49-56.

[17784] E. Peñalver, M. S. Engel, and D. A. Grimaldi. "Fig wasps in Dominican amber (Hymenoptera: Agaonidae)". English. In: American Museum Novitates 3541 (2006), pp. 1-16.

[17785] E. Peñalver and M. S. Engel. "Two wasp families rare in the fossil record (Hymenoptera): Perilampidae and Megaspilidae from the Miocene of Spain". English. In: American Museum Novitates 3540 (2006).

[17786] E. Peñalver, F. M. Fontal-Cazalla, and J. Pujade-Villar. “Palaeogronotoma n. gen. from the Miocene of Spain, the first Tertiary fossil record of the subfamily Eucoilinae (Hymenoptera: Figitidae)". English. In: Geodiversitas 35 (2013), pp. 643-653.

[17787] E. Peñalver and V. Garca-Gimeno. “Otroacizzia soriae sp. nov., a new Miocene psyllid (Insecta, Hemiptera, Psyllidae) from Dominican amber". English. In: Estudios Geológicos 62.1 (2006), pp. 199204.

[17788] E. Peñalver and D. Grimaldi. "Assemblages of mammalian hair and blood-feeding midges (Insecta: Diptera: Psychodidae: Phlebotominae) in Miocene amber". English. In: Transactions of the Royal Society of Edinburgh: Earth Sciences 96 (2006), pp. 177-195.

[17789] E. Peñalver, D. A. Grimaldi, and X. Delclos. "Early Cretaceous spider web with its prey". English. In: Science 312 (2006), p. 1761.

[17790] E. Peñalver and D. A. Grimaldi. "New data on Miocene butterflies in Dominican Amber (Lepidoptera: Riodinidae and Nymphalidae) with the description of a new nymphalid". English. In: American Museum Novitates 3519 (2006), pp. 1-17.

[17791] E. Peñalver and D. A. Grimaldi. "Latest occurrences of the Mesozoic family Elcanidae (Insecta: Orthoptera), in Cretaceous amber from Myanmar and Spain". English. In: Annales de la Société Entomologique de France 46 (2010), pp. 88-99. 
[17792] E. Peñalver, C. C. Labandeira, E. Barrón, X. Delclós, P. Nel, A. Nel, P. Tafforeau, and C. Soriano. "Thrips pollination of Mesozoic gymnosperms". English. In: Proceedings of the National Academy of Sciences 109 (2012), pp. 8623-8628.

[17793] E. Peñalver and X. Martnez-Delclós. "Insectos del Mioceno inferior de Ribesalbes (Castellón, España). Hymenoptera". Spanish. In: Treballs del Museu de Geologia de Barcelona 9 (2000), pp. 97-153.

[17794] E. Peñalver, A. Nel, and X. Martnez-Delclós. "New Nothochrysinae from the spanish Miocene (Neuroptera, Chrysopidae)". English. In: Bulletin de la Société Entomologique de France 100.5 (1995), pp. 481-487.

[17795] E. Peñalver, A. Nel, and X. Martnez-Delclós. "Insectos del Mioceno inferior de Ribesalbes (Castellón, España). Paleoptera y Neoptera poli- y paraneoptera". Spanish. In: Treballs del Museu de Geologia de Barcelona 5 (1996), pp. 15-95.

[17796] E. Peñalver and P. Nel. "Hispanothrips from Early Cretaceous Spanish amber, a new genus of the resurrected family Stenurothripidae (Insecta: Thysanoptera)". English. In: Annales de la Société Entomologique de France 46 (2010), pp. 138-147.

[17797] E. Peñalver, J. Ortega-Blanco, and X. Delclós. “Mesozoic Evaniidae (Insecta: Hymenoptera) in Spanish amber: reanalysis of the phylogeny of the Evanioidea". English. In: Acta Geologica Sinica 84 (2010), pp. 809-827.

[17798] E. Peñalver and J. Szwedo. “Perforissidae (Hemiptera: Fulgoroidea) from the Lower Cretaceous San Just amber (Eastern Spain)". English. In: Alavesia 3 (2010), pp. 97-103.

[17799] E. Peñalver and P. Wegierek. "A new genus and species of the family Tajmyraphididae (Hemiptera: Sternorrhyncha) in Early Cretaceous amber from Peñacerrada I (Spain)". English. In: Alavesia 2 (2008), pp. 187-192.

[17800] B. Peng, C. Liu, Z. . Li, Y. Ma, J. Cao, W. Zhang, and X. Zhang. "Evolution of the Carboniferous Reef in Eastern Qaidam Basin and its". English. In: Acta Geologica Sinica 91.1 (2017), pp. 349-350.

[17801] D. Peng, Y. Hong, and Z. Zhang. "Namurian insects (Diaphanopterodea) from Qilianshan Mountains, China". English. In: Geological Bulletin of China 24.3 (2005), pp. 219-234.

[17802] G. Peng. “Jurassic ornithopod Agilisaurus louderbacki (Ornithopoda: Fabrosauridae) from Zigong, Sichuan, China". Chinese. In: Vertebrata PalAsiatica 30.1 (1992), pp. 39-53.

[17803] G. Peng, Y. Ye, Y. Gao, C. Shu, and S. Jiang. A new camarasaurid from the Middle Jurassic, Xiashaximiao Formation in Dashanpu, China. Chinese. Jurassic Dinosaur Faunas in Zigong. 2005, pp. 81-85.

[17804] G.-Z. Peng. "[A Late Jurassic Protosuchian Sichuanosuchus huidongensis from Zigong, Sichuan Province]". Chinese. In: Vertebrata PalAsiatica 34.4 (1996), pp. 269-278.

[17805] G.-Z. Peng and C.-K. Shu. "A new species of Hsisosuchus from the Late Jurassic of Zigong, Sichuan, China". Chinese. In: Vertebrata PalAsiatica 43.4 (2005), pp. 312-324.

[17806] J. Peng. "A new genus of Proterosuchia from Lower Triassic of Shaanxi, China". Chinese. In: Vertebrata PalAsiatica 29 (1991), pp. 95-107.

[17807] J. Peng, H. Feng, X. Fu, Y. Zhao, and 1. Yao. "New bradoriid arthropods from the Early Cambrian Balang Formation of eastern Guizhou, south China". English. In: Acta Geologica Sinica 84.1 (2010), pp. 56-68.

[17808] J. Peng, A. P. Russell, and D. B. Brinkman. “Vertebrate microsite assemblages (exclusive of mammals) from the Foremost and Oldman Formations of the Judith River Group (Campanian) of southeastern Alberta: an illustrated guide". English. In: Provincial Museum of Alberta, Natural History Occasional Paper 25 (2001), pp. 1-54.

[17809] J. Peng, J. L. Yuan, Y. L. Zhao, and R. J. Yang. "Discovery of trilobite genus Zhenbaspis from the Lower Cambrian Niutitang biota at Heishapo, Songlin, Zunyi, Guizhou, China". Chinese. In: Acta Palaeontologica Sinica 43.3 (2004), pp. 407-415.

[17810] J.-H. Peng and D. B. Brinkman. "New material of Xinjiangchelys (Reptilia: Testudines) from the Late Jurassic Qigu Formation (Shishugou Group) of the Pingfengshan locality, Junggar Basin, Xinjiang". English. In: Canadian Journal of Earth Sciences 30.10-11 (1994), pp. 2013-2026. 
[17811] N. Peng, Y. Liu, H. Kuang, X. Jiang, and H. Xu. “Stratigraphy and geochronology of vertebrate fossil-bearing Jurassic strata from Linglongta, Jianchang county, western Liaoning, northeastern China". English. In: Acta Geologica Sinica 86.6 (2012), pp. 1326-1339.

[17812] S. Peng. "New material of Songtaoia (Trilobita, Tremadoc) from Northwestern Hunan, China". English. In: Neues Jahrbuch für Geologie und Paläontologie, Abhandlungen 180.1 (1990), pp. 97-115.

[17813] S. Peng. “Tremadoc stratigraphy and trilobite faunas of northwestern Hunan. 1: Trilobites from the Nantsinkwan Formation of the Yangtze Platform". English. In: Beringeria 2 (1990), pp. 3-53.

[17814] S. Peng, N. C. Hughes, N. A. Heim, B. K. Sell, X. Zhu, P. M. Myrow, and S. K. Parcha. "Cambrian Trilobites from the Parahio and Zanskar Valleys, Indian Himalaya". English. In: Journal of Paleontology Memoir 83.sp71 (2009), pp. 1-95. DOI: 10.1666/08-129.1.

[17815] S. Peng and R. A. Robison. "Agnostid biostratigraphy across the Middle-Upper Cambrian boundary in Hunan, China". In: Journal of Paleontology Memoir 53 (2000).

[17816] S. C. Peng, L. E. Babcock, J. X. Zuo, H. L. Lin, X. J. Zhu, X. F. Yang, Y. P. Qi, G. Bagnoli, and L. W. Wang. "Proposed GSSP for the base of Cambrian Stage 9, coinciding with the first appearance of Agnostotes orientalis, at Duibian, Zhejiang, China". English. In: Science in China, D Earth Sciences 52.4 (2009), pp. 434-451.

[17817] S. C. Peng, L. E. Babcock, J. X. Zuo, H. L. Lin, X. J. Zhu, X. F. Yang, R. A. Robison, Y. P. Qi, G. Bagnoli, and Y. Chen. "The Global Boundary Stratotype Section and Point (GSSP) of the Guzhangian Stage (Cambrian) in the Wuling Mountains, northwestern Hunan, China". English. In: Episodes 32.1 (2009), pp. 41-55.

[17818] S. C. Peng, X. F. Yang, and N. C. Hughes. “The oldest known stalk-eyed trilobite, Parablackwelderia Kobayashi, 1942 (Damesellinae, Cambrian), and its occurence in Shandong, China". English. In: Journal of Paleontology 82.4 (2008), pp. 842-850.

[17819] Y. Peng and G. R. Shi. "New Early Triassic Lingulidae (Brachiopoda) genera and species from South China". English. In: Alcheringa 32 (2008), pp. 149-170.

[17820] Y. Y. Peng, V. N. Makarkin, X. D. Wang, and D. Ren. “A new fossil silky lacewing genus (Neuroptera, Psychopsidae) from the Early Cretaceous Yixian Formation of China". English. In: ZooKeys 130 (2011), pp. 217-228.

[17821] Y. Y. Peng, V. N. Makarkin, Q. Yang, and D. Ren. “A new silky lacewing (Neuroptera: Psychopsidae) from the Middle Jurassic of Inner Mongolia, China". English. In: Zootaxa 2663 (2010), pp. 5967.

[17822] Y. Y. Peng, V. N. Makarkin, and D. Ren. "Diverse new Middle Jurassic Osmylopsychopidae (Neuroptera) from China shed light on the classification of psychopsoids". English. In: Journal of Systematic Palaeontology 14 (2016), pp. 261-295.

[17823] P. Penkalski. “A new ankylosaurid from the late Cretaceous Two Medicine Formation of Montana, USA". English. In: Acta Palaeontologica Polonica (2014). DOI: 10.4202/app.2012.0125.

[17824] P. Penkalski. "Revised systematics of the armoured dinosaur Euoplocephalus and its allies". English. In: Neues Jahrbuch für Geologie und Paläontologie Abhandlungen 287.3 (2018), pp. 261-306. DOI: 10.1127/njgpa/2018/0717.

[17825] P. Penkalski and T. Tumanova. "The cranial morphology and taxonomic status of Tarchia (Dinosauria: Ankylosauridae) from the Upper Cretaceous of Mongolia". English. In: Cretaceous Research 70 (2017), pp. 117-127.

[17826] D. Penney. "Advances in the taxonomy of spiders in Miocene amber from the Dominican Republic (Arthropoda: Araneae)". English. In: Palaeontology 44 (2001), pp. 987-1009.

[17827] D. Penney. “Miocene spiders in Dominican amber (Oonopidae, Mysmenidae)". English. In: Palaeontology 43 (2000), pp. 343-357.

[17828] D. Penney. "Spiders in Upper Cretaceous amber from New Jersey (Arthropoda: Araneae)". English. In: Palaeontology 45.4 (2002), pp. 709-724. DOI: 10.1111/1475-4983.00256. 
[17829] D. Penney. “New spiders in Upper Cretaceous amber from New Jersey in the American Museum of Natural History (Arthropoda: Araneae)". English. In: Palaeontology 47.2 (2004), pp. 367-375.

[17830] D. Penney. "A new fossil oonopid spider in lowermost Eocene amber from the Paris Basin, with comments on the fossil spider assemblage". English. In: African Invertebrates 48.1 (2007), pp. 71-75.

[17831] D. Penney. "A new deinopoid spider from Cretaceous Lebanese amber". English. In: Acta Palaeontologica Polonica 48.4 (2003), pp. 569-574.

[17832] D. Penney. "Afrarchaea grimaldii, a new species of Archaeidae (Araneae) in Cretaceous Burmese amber". English. In: The Journal of Arachnology 31 (2003), pp. 122-130.

[17833] D. Penney. "The fossil spider family Lagonomegopidae". English. In: The Journal of Arachnology 33 (2005), pp. 439-444.

[17834] D. Penney. "First fossil Filistatidae: a new species of Misionella in Miocene amber from the Dominican Republic". English. In: The Journal of Arachnology 33 (2005), pp. 93-100.

[17835] D. Penney. "First Caribbean Floricomus (Araneae: Linyphiidae), a new fossil species in Miocene Dominican Republic amber. A new synonymy for the extant North American fauna". English. In: Geologica Acta 3.1 (2005), pp. 59-64.

[17836] D. Penney. "Cretaceous Canadian amber spider and the palpimanoidean nature of lagonomegopids". English. In: Acta Palaeontologica Polonica 49 (2004), pp. 579-584.

[17837] D. Penney. "A new genus and species of Pisauridae (Araneae) in Cretaceous Burmese amber". English. In: Journal of Systematic Palaeontology 2 (2004), pp. 141-145.

[17838] D. Penney. "Fossil oonopid spiders in Cretaceous ambers from Canada and Myanmar". English. In: Palaeontology 49 (2006), pp. 229-235.

[17839] D. Penney. "The oldest lagonomegopid spider, a new species in Lower Cretaceous amber from Álava, Spain". English. In: Geologica Acta 4 (2006), pp. 377-382.

[17840] D. Penney. "The oldest fossil pholcid and selenopid spiders (Araneae) in lowermost Eocene amber from the Paris basin, France". English. In: The Journal of Arachnology 34 (2007), pp. 592-598.

[17841] D. Penney. "A new spider family record for Hispaniola-a new species of Plectreurys (Araneae: Plectreuridae) in Miocene Dominican amber". English. In: Zootaxa 3144 (2009), pp. 65-68.

[17842] D. Penney. "Tertiary neotropical Hersiliidae (Arthropoda, Araneae) with new combinations for the extant fauna and comments on historical biogeography of the family". English. In: Palaeontology 49 (2006), pp. 899-906.

[17843] D. Penney. "A fossil ray spider (Araneae: Theridiosomatidae) in Cretaceous amber from Vendée, France". English. In: Paleontological Contributions 10 (2014), pp. 5-8.

[17844] D. Penney, M. Dierick, V. Cnudde, B. Masschaele, J. Vlassenbroeck, L. Van Hoorebeke, and P. Jacobs. "First fossil Micropholcommatidae (Araneae), imaged in Eocene Paris amber using X-ray computed tomography". English. In: Zootaxa 1623 (2007), pp. 47-53.

[17845] D. Penney, N. L. Evenhuis, and D. I. Green. "A new species of Proceroplatus Edwards (Diptera: Keroplatidae) in Miocene amber from the Dominican Republic". English. In: Zootaxa 3686 (2013), pp. 593-599.

[17846] D. Penney, D. I. Green, A. McNeil, R. S. Bradley, Y. M. Marusik, P. J. Withers, and R. F. Preziosi. “A new species of Craspedisia (Araneae: Theridiidae) in Miocene Dominican amber, imaged using X-ray computed tomography". English. In: Paleontological Journal 46 (2012), pp. 583-588.

[17847] D. Penney, A. McNeil, D. I. Green, R. S. Bradley, J. E. Jepson, P. J. Withers, and R. F. Preziosi. “Ancient Ephemeroptera-Collembola symbiosis fossilized in amber predicts contemporary phoretic associations". English. In: PLoS One 7.10 (2012), e47651.

[17848] D. Penney, A. McNeil, D. I. Green, R. Bradley, Y. M. Marusik, P. J. Withers, and R. F. Preziosi. "A new species of anapid spider (Araneae: Araneoidea, Anapidae) in Eocene Baltic amber, imaged using phase contrast X-ray computed micro-tomography". English. In: Zootaxa 2742 (2011), pp. 60-66. 
[17849] D. Penney and V. M. Ortuño. “Oldest true orb-weaving spider (Araneae: Araneidae)”. English. In: Biology Letters 2 (2006), pp. 447-450.

[17850] D. Penney and P. A. Selden. "First fossil Huttoniidae (Arthropoda: Chelicerata: Araneae) in Late Cretaceous Canadian amber". English. In: Cretaceous Research 27 (2006), pp. 442-446.

[17851] D. Penney, C. Wadsworth, D. I. Green, S. L. Kennedy, R. F. Preziosi, and T. A. Brown. “Extraction of inclusions from (sub)fossil resins, with description of a new species of stingless bee (Hymenoptera: Apidae: Meliponini) in Quaternary Colombian copal". English. In: Paleontological Contributions 7 (2013), pp. 1-6.

[17852] A. H. Pentland, S. F. Poropat, T. R. Tischler, T. Sloan, R. A. Elliott, H. A. Elliott, J. A. Elliott, and D. A. Elliott. "Ferrodraco lentoni gen. et sp. nov., a new ornithocheirid pterosaur from the Winton Formation (Cenomanian-lower Turonian) of Queensland, Australia". English. In: Scientific Reports 9.13454 (2019). DOI: 10.1038/s41598-019-49789-4.

[17853] M. Pepinelli and D. C. Currie. "The identity of giant black flies (Diptera: Simuliidae) in Baltic amber: insights from large-scale photomicroscopy, micro-CT scanning and geometric morphometrics". English. In: Zoological Journal of the Linnean Society 181 (2017), pp. 846-866.

[17854] D. J. Peppe, J. M. Erickson, and L. J. Hickey. "Fossil Leaf Species from the Fox Hills Formation (Upper Creataceous: North Dakota, USA) and their Paleographic Significance". English. In: Journal of Paleontology 81.3 (2007), pp. 550-567.

[17855] D. J. Peppe, L. J. Hickey, I. M. Miller, and W. A. Green. "A morphotype catalogue, floristic analysis and stratigraphic description of the Aspen Shale flora Cretaceous-Albian) of Southwestern Wyoming". English. In: Bulletin of the Peabody Museum of Natural History 49.2 (2008), pp. 181-208.

[17856] R. A. Peppers. "Palynology of the Lost Branch Formation of Kansas-new insights on the major floral transition at the Middle-Upper Pennsylvanian boundary". In: Review of Palaeobotany and Palynology 98 (1997), pp. 223-246.

[17857] L. Perales-Gogenola, J. Elorza, J. I. Canudo, and X. Pereda-Suberbiola. "Taphonomy and palaeohistology of ornithischian dinosaur remains from the Lower Cretaceous bonebed of La Cantalera (Teruel, Spain)". English. In: Cretaceous Research 98 (2019), pp. 316-334. DOI: 10.1016/j.cretres.2019. 01.024 .

[17858] S. H. Peralta. Nuevas graptofaunas de la Formacion La Cantera, Sierra de Villicum, Precordillera Oriental de San Juan, Argentina. Spanish. 1990.

[17859] S. H. Peralta. La Formacion Gualcamayo en la Sierra de Villicum: sus Graptolitos y fauna asociadas. Spanish. 1995.

[17860] I. Percival. "Late Ordovician articulate brachiopods from central New South Wales, Australia". English. In: Memoir of the Association of Australasian Palaeontologists 11 (1991), pp. 107-177.

[17861] I. G. Percival. "Late Ordovician Strophomenide and Pentameride Brachiopods from central New South Wales". English. In: Proceedings of the Linnean Society of New South Wales 130 (2009), pp. 157178.

[17862] I. G. Percival, B. D. Webby, and J. W. Pickett. “Ordovician (Bendigonian, Darriwilian to Gisbornian) faunas from the northern Molong Volcanic Belt of central New South Wales". English. In: Alcheringa 25 (2001), pp. 211-250.

[17863] I. G. Percival, A. J. Wright, R. S. Nicoll, and M. A. Hamedi. "Martellia and associated Middle Ordovician brachiopods from the Katkoyeh Formation, east-central Iran". English. In: Memoirs of the Association of Australasian Palaeontologists 37 (2009), pp. 315-325.

[17864] I. G. Percival, Y. Y. Zhen, D. J. Pogson, and O. D. Thomas. "The Upper Ordovician Kenyu Formation in the Boorowa District, Southeastern New South Wales". English. In: Proceedings of the Linnean Society of New South Wales 129 (2008), pp. 197-204.

[17865] I. G. Percival, Y. Y. Zhen, J. E. Simes, and R. A. Cooper. "Furongian (late Cambrian) brachiopods and associated conodonts from the Takaka Terrane in the Springs Junction - Maruia area, South Island, New Zealand". English. In: Memoirs of the Association of Australasian Palaeontologists 45 (2014), pp. 55-70. 
[17866] D. Perea. "Nuevos Dasypodidae fósiles de Uruguay". Spanish. In: Revista Chilena de Historia Natural 66 (1993), pp. 149-154.

[17867] D. Perea. “Pseudoplohophorus absolutus n. sp. (Xenarthra, Glyptodontidae), variabilidad en Sclerocaliptynae y redefinición de una biozona del Mioceno Superior de Uruguay". Spanish. In: Ameghiniana 42.1 (2005), pp. 175-190.

[17868] D. Perea. “Nothrotherium cf. N. maquinense (Xenarthra, Tardigrada) en la Formación Sopas (Pleistoceno tardo de Uruguay)". Spanish. In: Revista SUG 14 (2007), pp. 5-9.

[17869] D. Perea, M. Soto, G. Verolavsky, S. Martinez, and M. Ubilla. "A Late Jurassic fossil assemblage in Gondwana: biostratigraphy and correlations of the Tacuarembo Formation, Parana Basin, Uruguay". English. In: Journal of South American Earth Sciences 28 (2009), pp. 168-179.

[17870] D. Perea, M. Soto, J. Sterli, V. Mesa, P. Torino, G. Roland, and J. Da Silva. “Tacuarembemys kusterae, gen. et sp. nov., a new Late Jurassic-?earliest Cretaceous continental turtle from western Gondwana". English. In: Journal of Vertebrate Paleontology 34.6 (2014), pp. 1329-1341.

[17871] D. Perea, P. Toriño, and M. R. Ciancio. "La presencia del Xenartro Palaeopeltis inornatus Ameghino, 1894, en la Formación Fray Bentos (Oligoceno Tardo), Uruguay". English. In: Ameghiniana 51.3 (2014), pp. 254-258. DOI: 10.5710/AMGH.18.03.2014.1861.

[17872] D. Perea, M. Ubilla, and A. Rojas. "First report of theropods from the Tacuarembó Formation (Late Jurassic-Early Cretaceous), Uruguay". English. In: Alcheringa 27 (2003), pp. 79-83.

[17873] X. Pereda Suberbiola, N. Bardet, M. Iarochéne, B. Bouya, and M. Amaghzaz. "The first record of a sauropod dinosaur from the Late Cretaceous phosphates of Morocco". In: Journal of African Earth Sciences 40 (2004), pp. 81-88.

[17874] X. Pereda Suberbiola, N. Bardet, S. Jouve, M. Iarochéne, B. Bouya, and M. Amaghzaz. A new azhdarchid pterosaur from the Late Cretaceous phosphates of Morocco. English. Vol. 217. Evolution and Palaeobiology of Pterosaurs. Geological Society, London, Special Publications. 2003, pp. 79-90.

[17875] X. Pereda Suberbiola, P. M. Galton, J. I. Ruiz-Omeñaca, and J. I. Canudo. “Dermal spines of stegosaurian dinosaurs from the Lower Cretaceous (Hauterivian-Barremian) of Galve (Teruel, Aragón, Spain)". English. In: Geogaceta 38 (2005), pp. 35-38.

[17876] X. Pereda Suberbiola, M. Meijide, F. Torcida, J. Welle, C. Fuentes, L. A. Izquierdo, D. Montero, G. Pérez, and V. Urién. "Espinas dermicas del dinosaurio anquilosaurio Polacanthus en las facies Weald de Salas de los Infantes (Burgos, España) [Dermal spines of the ankylosaurian dinosaur Polacanthus in the Weald facies of Salas de los Infantes (Burgos, Spain)]". Spanish. In: Estudios Geológicos 55 (1999), pp. 267-272.

[17877] X. Pereda Suberbiola, X. Murelaga, J. I. Baceta, J. C. Corral, A. Badiola, and H. astibia. “Nuevos restos fosiles de vertebrados continentales en el Cretacico Superior de Alava (Region Vasco-Cantabrica): sistematica y posicion estratigrafica". Spanish. In: Geogaceta 26 (1999), pp. 79-82.

[17878] X. Pereda Suberbiola and J. I. Ruiz-Omeñaca. “Un dinosaurio sauropódo (Titanosauria) en el Cretácico superior de Cubilla, Soria (España) [A sauropod dinosaur (Titanosauria) in the Upper Cretaceous of Cubilla, Soria (Spain)]". Spanish. In: Geogaceta 30 (2001), pp. 175-178.

[17879] X. Pereda Suberbiola, J. I. Ruiz-Omeñaca, J. Ullastre, and A. Masriera. "Primera cita de un dinosaurio hadrosaurio en el Cretácico Superior del Prepirineo oriental (Peguera, provincia de Barcelona) [First notice of a hadrosaurian dinosaur in the Upper Cretaceous of the eastern Pyrénées (Peguera, Barcelona province]". Spanish. In: Geogaceta 34 (2003), pp. 195-198.

[17880] X. Pereda Suberbiola, J. I. Ruiz-Omeñaca, J. M. Hernández, and V. Pujalte. "Primera cita de un dinosaurio ornitópodo en el Cretácico Inferior (Berriasiense) del SO de la Cuenca Vasco-Cantábrica (Palencia, España) [First note of an ornithopod dinosaur in the Lower Cretaceous (Berriasian) of SW Vasco-Cantabrian Basin (Palencia, Spain)". Spanish. In: Revista de la Sociedad Geológica de España 19.3-4 (2006), pp. 219-231.

[17881] X. Pereda Suberbiola, J. I. Ruiz-Omeñaca, and J. I. Canudo. "Los primeros descubrimientos de dinosaurios ibéricos [The first discoveries of Iberian dinosaurs]". Spanish. In: Naturaleza Aragonesa 17 (2006), pp. 4-10. 
[17882] X. Pereda Suberbiola, F. Torcida, L. A. Izquierdo, P. Huerta, D. Montero, and G. Pérez. “First rebbachisaurid dinosaur (Sauropoda, Diplodocoidea) from the early Cretaceous of Spain: palaeobiogeographical implications". In: Bulletin de la Societé Géologique de France 2003.5 (2003), pp. 471-479.

[17883] X. Pereda-Suberbiola, H. Asibia, X. Murelaga, J. J. Elzorza, and J. J. Gomez-Alday. "Taphonomy of the Late Cretaceous dinosaur-bearing beds of the Lano Quarry (Iberian Peninsula)". In: Palaeogeography, Palaeoclimatology, Palaeoecology 157 (2000), pp. 247-275.

[17884] X. Pereda-Suberbiola, J. I. Canudo, P. Cruzado-Caballero, J. L. Barco, N. López-Martnez, O. Oms, and J. I. Ruiz-Omeñaca. "The last hadrosaurid dinosaurs of Europe: a new lambeosaurine from the uppermost Cretaceous of Aren (Huesca, Spain)". English. In: Comptes Rendus Palevol 8 (2009), pp. 559-572. DOI: 10.1016/j.crpv.20009.05.002.

[17885] X. Pereda-Suberbiola, P. M. Galton, H. Mallison, and F. E. Novas. "A plated dinosaur (Ornithischia, Stegosauria) from the Early Cretaceous of Argentina, South America: an evaluation". English. In: Alcheringa 37.1 (2013), pp. 65-78.

[17886] X. Pereda-Suberbiola, F. Knoll, J. I. Ruiz-Omenaca, J. Company, and D. Torcida Fernandez-Baldor. "Reassessment of Prejanopterus curvirostris, a basal pterodactyloid pterosaur from the Early Cretaceous of Spain". English. In: Acta Geological Sinica 86.6 (2012), pp. 1389-1401.

[17887] X. Pereda-Suberbiola, A. Pérez-Garca, J. C. Corral, X. Murelaga, G. Martin, J. Larrañaga, N. Bardet, A. Berreteaga, and J. Company. "First dinosaur and turtle remains from the latest Cretaceous shallow marine deposits of Albaina (Lano quarry, Iberian Peninsula)". English. In: Competes Rendus Palevol 14.6 (2015), pp. 471-482.

[17888] X. Pereda-Suberbiola, J. I. Ruiz-Omeñaca, F. Torcida Fernández-Baldor, M. W. Maisch, P. Huerta, R. Contreras, L. Á Izquierdo, D. Montero Huerta, V. Urién Montero, and J. Welle. "A tall-spined ornithopod dinosaur from the Early Cretaceous of Salas de los Infantes (Burgos, Spain)". English. In: Comptes Rendus Palevol 10 (2011), pp. 551-558. DOI: 10.1016/j.crpv.2011.04.003.

[17889] C. M. Peredo and N. D. Pyenson. "Salishicetus meadi, a new aetiocetid from the late Oligocene of Washington State and implications for feeding transitions in early mysticete evolution". English. In: Royal Society Open Science 5.4 (2018), p. 172336. DOI: 10.1098/rsos.172336.

[17890] C. M. Peredo, N. D. Pyenson, C. D. Marshall, and M. D. Uhen. "Tooth loss precedes the origin of baleen in whales". English. In: Current Biology 28 (2018), pp. 1-9. DOI: 10.1016/j.cub.2018.10.047.

[17891] C. M. Peredo and M. D. Uhen. "A new basal chaeomysticete (Mammalia: Cetacea) from the Late Oligocene Pysht Formation of Washington, USA". English. In: Papers in Palaeontology 2.4 (2016), pp. 533-554. DOI: 10.5061/dryad.3sm6t.

[17892] A. A. Pereira and M. A. Medeiros. "A new sclerorhynchiform (Elsamobranchii) from the middle Cretaceous of Brazil". English. In: Revista Brasileira De Paleontologia 11.3 (2008), pp. 207-212.

[17893] E. Pereira and M. Salotti. "Cyrnolutra castiglionis, une nouvelle forme de loutre (Mustelidae, Lutrinae), dans un depot du Pleistocene moyen Casiglione 3CG (Oletta, Haute-Corse)". English. In: Comptes Rendus Academie de Science Paris Sciences de la Terre et des planetes 331.1 (2000), pp. 45-52.

[17894] J. C. Pereira, R. P. Lopes, and L. Kerber. "New remains of Late Pleistocene mammals from the Chu Creek, Southern Brazil". English. In: Revista Brasileira De Paleontologia 15.2 (2012), pp. 228-239.

[17895] S. Pereira, C. Marques da Silva, M. Pires, and A. Abreu Sá. "The oldest brachymetopid trilobite record from the European peri-Gondwana". English. In: Bulletin of Geosciences 90.3 (2015).

[17896] T. M. Pereira Ferreira, E. L. Mayer, J. Ferigolo, J. Pereira, and A. M. Ribeiro. “Pampatherium humboldtii (Lund, 1839) (Xenarthra, Cingulata) of the Southern Brazilian Quaternary: cranial anatomy and taxonomic remarks". English. In: Revista Brasileira de Paleontologia 21.2 (2018), pp. 158-174.

[17897] A. Perejon, M. Fröhler, T. Bechstädt, E. Moreno-Eiris, and M. Boni. "Archaeocyathan assemblages from the Gonnesa Group, Lower Cambrian (Sardinia, Italy) and their sedimentologic context". English. In: Bollettino della Societa Paleontologica Italiana 39.3 (2000), pp. 257-291.

[17898] A. Pereswiet-Soltan. "First record of serotine bat Eptesicus serotinus (Chiroptera: Vespertilionidae) from Early-Middle Holocene in southern Europe (Boeotia - Greece)". English. In: Hystrix, the Italian Journal of Mammalogy (2016), pp. 1-3. DOI: 10.4404/hystrix-27.2-11712. 
[17899] C. Peretto, J. Arnaud, J. Moggi-Cecchi, G. Manzi, and S. Nomade. "A human deciduous tooth and new 40Ar/39Ar dating results from the Middle Pleistocene archaeological site of Isernia La Pineta, Southern Italy". English. In: Plos One 10.10 (2015), pp. 1-19.

[17900] D. Pérez. "The earliest fossil record of the poorly known family Condylocardiidae from Argentina". English. In: Andean Geology 46.2 (2019), pp. 433-443. DOI: 10.5027/andgeoV46n2-3130.

[17901] D. Pérez, M. Alvarez, and M. B. Santelli. Reassessment of Neovenericor Rossi de Garca, Levy E Franchi, 1980 (Bivalvia: Carditidae) using a geometric morphometric approach, and revision of planicostate carditids from Argentina. English. Vol. 41. Alcheringa 1. 2016, pp. 112-123. DOI: 10.1080 / 03115518.2016. 1196436.

[17902] D. Pérez, C. del Ro, and S. Nielsen. "Sistemática y filogenia del género Ameghinomya Ihering, 1907 (Bivalvia: Chioninae) del Cenozoico de Argentina y Chile". Spanish. In: Ameghiniana 50.3 (2013), pp. 354-374. DOI: 10.5710/AMGH.30.04.2013.594.

[17903] D. E. Perez, B. Hierro, G. O. Dominici, and D. Otte. “New Eumastacid Grasshopper Taxa (Orthoptera: Eumastacidae: Episactinae) from Hispaniola, Including a Fossil New Genus and Species from Dominican Amber". English. In: Journal of Orthoptera Research 6 (1997), pp. 139-151.

[17904] E. Pérez, M. Aberhan, R. Reyes, and A. von Hillebrandt. “Early Jurassic Bivalvia of northern Chile. Part III. Order Trigonioida". English. In: Beringeria 39 (2008), pp. 51-102.

[17905] E. Perez, M. R. Cooper, and V. Covacevich. "Aptian ammonite-based age for the Pabellon Formation, Atacama region, northern Chile". English. In: Revista Geologica de Chile 17.2 (1990), pp. 181185.

[17906] E. Pérez and R. Reyes. “Presencia de Maoritrigonia Fleming, 1962 (Bivalvia; Minetrigoniidae) en el Triasico Superior de Sudamerica: descripcion de dos especies nuevas". Spanish. In: Revista Geológica de Chile 21 (1994), pp. 105-117.

[17907] E. Pérez, R. Reyes, and S. E. Damborenea. “El género Groeberella Leanza, 1993 y Groeberellidae nov.(Bivalvia; Trigonioida) del Jurásico de Chile y Argentina". Spanish. In: Revista Geológica de Chile 22 (1995), pp. 143-157.

[17908] L. M. Perez, A. L. Cione, M. Cozzuol, and A. N. Varela. “A sperm whale (Cetacea: Physeteroidea) from the Parana Formation (Late Miocene) of Entre Rios, Argentina. Environment and taphonomy". English. In: Ameghiniana 48.4 (2011), pp. 648-654.

[17909] L. M. Pérez, J. I. Cuitiño, A. N. Varela, and N. A. Muñoz. “Diplodon cf. colhuapiensis (Bivalvia, Hyriidae) in the Santa Cruz Formation (Early-Middle Miocene) at the Ro Santa Cruz, Patagonia, Argentina. Stratigraphic and paleoenvironmental considerations". English. In: vol. 19. EarlyMiddle Miocene Paleontology in the Ro Santa Cruz, Southern Patagonia, Argentina. 130 years since Ameghino, 1887 2. Publicacion Electronica de la Asociacion Paleontologica Argentina, 2019, pp. 34-47. DOI: 10.5710/PEAPA.16.07.2019.283.

[17910] M. A. Pérez, M. Arnal, M. Boivin, M. G. Vucetich, A. Candela, F. Busker, and B. Mamani Quispe. "New caviomorph rodents from the late Oligocene of Salla, Bolivia: taxonomic, chronological, and biogeographic implications for the Deseadan faunas of South America". English. In: Journal of Systematic Palaeontology (2018). DOI: 10.1080/14772019.2018.1471622.

[17911] M. E. Pérez. "A new rodent (Cavioidea, Hystricognathi) from the middle Miocene of Patagonia, mandibular homologies, and the origin of the crown group Cavioidea sensu stricto". English. In: Journal of Vertebrate Paleontology 30.6 (2010), pp. 1848-1859. DOI: 10.1080/02724634.2010.522432.

[17912] M. E. Pérez, C. M. Deschamps, and M. G. Vucetich. “Diversity, phylogeny and biogeography of the South American 'Cardiomyine' rodents (Hystricognathi, Caviodea) with a description of the two new species". English. In: Papers in Palaeontology 4.1 (2018), pp. 1-19.

[17913] M. E. Pérez, M. Krause, and M. G. Vucetich. "A new species of Chubutomys (Rodentia, Hystricognathi) from the late Oligocene of Patagonia and its implications on the early evolutionary history of Cavioidea sensu stricto". English. In: Geobios 45.6 (2012), pp. 573-580. DOI: 10.1016/j.geobios. 2012.06.001. 
[17914] M. E. Pérez, M. C. Vallejo-Pareja, J. D. Carrillo, and C. Jaramillo. “A new Pliocene capybara (Rodentia, Caviidae) from northern South America (Guajira, Colombia), and its implications for the Great American Biotic Interchange". English. In: Journal of Mammalian Evolution 24.1 (2017), pp. 111-125. DOI: 10.1007/s10914-016-9356-7.

[17915] M. E. Pérez and M. G. Vucetich. “A new Extinct Genus of Cavioidea (Rodentia, Hystricognathi) from the Miocene of Patagonia (Argentina) and the Evolution of Cavoid Mandibular Morphology". English. In: Journal of Mammalian Evolution 18.3 (2011), pp. 163-183. DOI: 10.1007/ s10914011-9154-1.

[17916] M. E. Pérez, M. G. Vucetich, and A. Kramarz. "The first Eocardiidae (Rodentia) in the Colhuehuapian (Earky Miocene) of Bryn Gwyn (Northern Chubut, Argentina) and the early evolution of the peculiar cavioid rodents". English. In: Journal of Vertebrate Paleontology 30.2 (2010), pp. 528-534. DOI: $10.1080 / 02724631003618223$.

[17917] M. E. Pérez and M. G. Vucetich. “A revision of the fossil genus Phanomys Ameghino, 1887 (Rodentia, Hystricognathi, Cavioidea) from the early Miocene of Patagonia (Argentina) and the acquisition of euhypsodonty in Cavioidea sensu stricto". English. In: Paläontologische Zeitschrift 86.2 (2011), pp. 187-204. DOI: 10.1007/s12542-011-0120-2.

[17918] M. E. Pérez and M. G. Vucetich. “Asteromys punctus Ameghino (Rodentia, Hystricognathi Cavioidea) from the Late Oligocene of Patagonia (Argentina) and the Early Evolution of Cavioidea Sensu stricto". English. In: Ameghiniana 49.1 (2012), pp. 118-125.

[17919] V. J. Perez, C. Pimiento, and A. Hendy. “Late Miocene chondrichthyans from Lago Bayano, Panama: Functional diversity, environment and biogeography". English. In: Journal of Paleontology 91.3 (2017), pp. 512-547. DOI: 10.1017/jpa.2017.5.

[17920] C. M. Pérez Ben, R. O. Gómez, and A. M. Báez. "Intraspecific morphological variation and its implications in the taxonomic status of 'Bufo pisanoi,' a Pliocene anuran from eastern Argentina". English. In: Journal of Vertebrate Paleontology 34.4 (2014), pp. 767-773.

[17921] A. Pérez Garca, F. Mees, and T. Smith. "Shell anatomy of the African Paleocene bothremydid turtle Taphrosphys congolensis and systematic implications within Taphrosphyini". English. In: Historical Biology (2018). DOI: 10.1080/08912963.2018.1497023.

[17922] A. Pérez Garcia, B. Sánchez Chillón, and F. Ortega. “Aportaciones de José Royo y Gómez al conocimiento sobre los dinosaurios de España [Contributions of José Royo y Gómez to the knowledge of the dinosaurs of Spain]". Spanish. In: Paleolusitana 1 (2009), pp. 339-364.

[17923] V. Perez Loinaze, S. Archangelsky, and G. Cladera. “Palynostratigraphic study of the Early Cretaceous Ro Mayer and Kachaike formations at the Quebrada El Moro Section, Austral Basin, southwestern Argentina". English. In: Cretaceous Research 34 (2011), pp. 161-171. DOI: 10.1016/j.cretres. 2011.10.015.

[17924] J. A. Pérez Valera. “Ammonoideos y bioestratigrafa del Triásico Medio (Anisiense superior-Ladiniense) en la sección de Calasparra (sector oriental de la Cordillera Bética, Murcia, España)". Spanish. In: Coloquios de Paleontologa 55 (2005), pp. 125-161.

[17925] R. Pérez-de la Fuente, X. Delclós, E. Peñalver, and A. Arillo. “Biting midges (Diptera: Ceratopogonidae) from the Early Cretaceous El Soplao amber (N Spain)". English. In: Cretaceous Research 32 (2011), pp. 750-761.

[17926] R. Pérez-de la Fuente, X. Delclós, E. Peñalver, M. Speranza, J. Wierzchos, C. Ascaso, and M. S. Engel. "Early evolution and ecology of camouflage in insects". English. In: Proceedings of the National Academy of Sciences 109 (2012), pp. 21414-21419.

[17927] R. Pérez-de la Fuente, X. Delclós, E. Peñalver, and M. S. Engel. “A new dustywing (Neuroptera: Coniopterygidae) from the Early Cretaceous amber of Spain". English. In: Palaeoentomology 2 (2019), pp. 279-288.

[17928] R. Pérez-de la Fuente, M. S. Engel, D. Azar, and E. Peñalver. "The hatching mechanism of 130million-year-old insects: an association of neonates, egg shells and egg bursters in Lebanese amber". English. In: Palaeontology 62 (2018), pp. 547-559. 
[17929] R. Pérez-de la Fuente, M. S. Engel, X. Delclós, and E. Peñalver. “Straight-jawed lacewing larvae (Neuroptera) from Lower Cretaceous Spanish amber, with an account on the known amber diversity of neuropterid immatures". English. In: Cretaceous Research 106.104200 (2020). DOI: 10.1016/j. cretres.2019.104200.

[17930] R. Pérez-de la Fuente, S. W. Heads, I. A. Hinojos-Daz, and M. S. Engel. "The first record of Protogryllinae from the Jurassic of India (Orthoptera: Protogryllidae)". English. In: Journal of the Kansas Entomological Society 85.1 (2012), pp. 53-58.

[17931] R. Pérez-de la Fuente, C. Hoffeins, and J. Rohacek. "A new Acartophthalmites Hennig from Eocene Baltic amber (Diptera, Acalyptratae)". English. In: ZooKeys 737 (2018), pp. 125-139.

[17932] R. Pérez-de la Fuente, A. Nel, E. Peñalver, and X. Delclós. "A new Early Cretaceous snakefly (Raphidioptera: Mesoraphidiidae) from El Soplao amber (Spain)". English. In: Annales de la Société Entomologique de France 46 (2010), pp. 108-115.

[17933] R. Pérez-de la Fuente, E. Peñalver, X. Delclós, and M. S. Engel. "Snakefly diversity in Early Cretaceous amber from Spain (Neuropterida, Raphidioptera)". English. In: ZooKeys 204 (2012), pp. 140.

[17934] R. Pérez-de la Fuente, E. Peñalver, and J. Ortega-Blanco. "A new species of the diverse Cretaceous genus Cretevania Rasnitsyn, 1975 (Hymenoptera: Evaniidae) from Spanish amber". English. In: Zootaxa 3514 (2012), pp. 70-78.

[17935] R. Pérez-de la Fuente, E. Peñalver, D. Azar, and M. S. Engel. “A soil-carrying lacewing larva in Early Cretaceous Lebanese amber". English. In: Scientific Reports 8.16663 (2018), pp. 1-12.

[17936] R. Pérez-de la Fuente and E. Peñalver. "A mantidfy in Cretaceous Spanish amber provides insights into the evolution of integumentary specialisations on the raptorial foreleg". English. In: Scientific Reports 9.13248 (2019), pp. 1-16.

[17937] R. Pérez-de la Fuente, E. Peñalver, and M. S. Engel. “Beaded lacewings (Neuroptera: Berothidae) in amber from the Lower Cretaceous of Spain". English. In: Cretaceous Research 119.104705 (2020). DOI: 10.1016/j.cretres.2020.104705.

[17938] R. Pérez-de la Fuente, V. Perrichot, J. Ortega-Blanco, X. Delclós, and M. S. Engel. “Description of the male of Megalava truncata Perrichot (Hymenoptera: Megalyridae) in Early Cretaceous amber from El Soplao (Spain)". English. In: Zootaxa 3274 (2012), pp. 29-35.

[17939] R. Pérez-de la Fuente, E. E. Saupe, and P. A. Selden. “New lagonomegopid spiders (Araneae: +Lagonomegopidae) from Early Cretaceous Spanish amber". English. In: Journal of Systematic Palaeontology 11 (2013), pp. 531-553.

[17940] A. Pérez-Garca. "High diversity of pancryptodiran turtles in the Lower Cretaceous of Europe". English. In: Cretaceous Research 36 (2012), pp. 67-82. DOI: 10.1016/j.cretres.2012.02.004.

[17941] A. Pérez-Garca. "The European Lower Cretaceous Chitracephalus dumonii (Testudines: Cryptodira) and the diversity of a poorly known lineage of turtles". English. In: Acta Palaeontologica Polonica 57.3 (2012), pp. 575-588. DOI: 10.4202/app.2011.0065.

[17942] A. Pérez-Garca. "Berruchelus russelli, gen. et sp. nov., a paracryptodiran turtle from the Cenozoic of Europe". English. In: Journal of Vertebrate Paleontology 32.3 (2012), pp. 545-556.

[17943] A. Pérez-Garca. "Revision of the poorly known Dorsetochelys typocardium, a relatively abundant pleurosternid turtle (Paracryptodira) in the Early Cretaceous of Europe". English. In: Cretaceous Research 49 (2014), pp. 152-162.

[17944] A. Pérez-Garca. "Revision of the British record of Tropidemys (Testudines, Plesiochelyidae) and recognition of its presence in the Late Jurassic of Portugal". English. In: Journal of Iberian Geology 41.1 (2015), pp. 11-20.

[17945] A. Pérez-Garca. "New data on the poorly-known Late Jurassic European turtles Thalassemys and Enaliochelys and description of a new basal eucryptodiran taxon". English. In: Iberian Journal of Geology 41.1 (2015), pp. 21-30. 
[17946] A. Pérez-Garca. "Largest shell of a basal eucryptodiran turtle reveals Late Jurassic Thalassemys hugii in the British record". English. In: Comptes Rendus Palevol 14 (2015), pp. 555-561. DOI: 10. 1016/j.crpv.2015.06.003.

[17947] A. Pérez-Garca. "A new turtle confirms the presence of Bothremydidae (Pleurodira) in the Cenozoic of Europe and expands the biostratigraphic range of Foxemydina". English. In: The Science of Nature 103.50 (2016), pp. 1-14. DOI: 10.1007/s00114-016-1375-y.

[17948] A. Pérez-Garca. "A new turtle taxon (Podocnemidoidea, Bothremydidae) reveals the oldest known dispersal event of the crown Pleurodira from Gondwana to Laurasia". English. In: Journal of Systematic Palaeontology 15.9 (2017), pp. 709-731.

[17949] A. Pérez-Garca. "The Iberian fossil record of turtles: an update". English. In: Journal of Iberian Geology (2017), pp. 1-37. DOI: 10.1007/s41513-017-0016-4.

[17950] A. Pérez-Garca. "New information and establishment of a new genus for the Egyptian Paleogene". English. In: Historical Biology 31.3 (2019), pp. 383-392. DOI: 10.1080/08912963.2017.1374383.

[17951] A. Pérez-Garca. "Analysis of the Iberian Aragonian record of Paleotestudo, and refutation of the validity of the Spanish 'Testudo catalaunica' and the French 'Paleotestudo canetotiana'". English. In: Spanish Journal of Palaeontology 31.2 (2017), pp. 321-340.

[17952] A. Pérez-Garca. “The African Aptian Francemys gadoufaouaensis gen. et sp. nov.: new data on". English. In: Cretaceous Research 102 (2019), pp. 112-126. DOI: 10.1016/j.cretres.2019.06.003.

[17953] A. Pérez-Garca. "A new member of Taphrosphyini (Pleurodira, Bothremydidae) from the Maastrichtian of Niger". English. In: Journal of African Earth Sciences 158 (2019), 103548:1-8. DOI: 10. 1016/j.jafrearsci.2019.103548.

[17954] A. Pérez-Garca. "Surviving the Cretaceous-Paleogene mass extinction event: A terrestrial stem turtle in the Cenozoic of Laurasia". English. In: Scientific Reports 10 (2020), p. 1489.

[17955] A. Pérez-Garcia. "A new bothremydid turtle (Pleurodira) from the Upper Cretaceous (Cenomanian) of Madagascar". English. In: Cretaceous Research (2020). DOI: 10.1016/j.cretres.2020.104645.

[17956] A. Pérez-Garca. “A European Cenozoic 'Macrobaenid': New Data about the Paleocene Arrival of Several Turtle Lineages to Europe". English. In: Journal of Vertebrate Paleontology (2020), e1795874:110. DOI: $10.1080 / 02724634.2020 .1795874$.

[17957] A. Pérez-Garca. "First evidence of a bothremydid turtle (crown Pleurodira) in the middle Cretaceous of Castile and Leon (Spain)". English. In: Journal of Iberian Geology (2020), pp. 1-6. DOI: 10.1007/s41513-020-00146-9.

[17958] A. Pérez-Garca, M. T. Antunes, F. Barroso-Barcenilla, P. M. Callapez, M. Segura, A. F. Soares, and A. Torices. "A bothremydid from the middle Cenomanian of Portugal identified as one of the oldest pleurodiran turtles in Laurasia". English. In: Cretaceous Research 78 (2017), pp. 61-70.

[17959] A. Pérez-Garca, N. Bardet, M. A. Fregenal-Martnez, M. Martn-Jiménez, P. Mocho, I. Narváez, A. Torices, R. Vullo, and F. Ortega. "Cenomanian vertebrates from Algora (central Spain): new data on the establishment of the European Upper Cretaceous continental faunas". English. In: Cretaceous Research 115 (2020), p. 104566. DOI: 10.1016/j.cretres.2020.104566.

[17960] A. Perez-Garcia, J. M. Brandao, P. M. Callapez, L. Machado, E. Malafaia, F. Ortega, and V. F. Santos. "The oldest turtle from Portugal corresponding to the only pre-Kimmeridgian plesiochelyid (basal Eucryptodira) recognized at the generic level". English. In: Historical Biology (2017), pp. 1-9. DOI: 10.1080/08912963.2017.1330889.

[17961] A. Pérez-Garca and S. Chapman. "Identification of Podocnemididae (Pleurodira) in the British record by the first specimen of the coastal Eocenochelus recognized outside Continental Europe". English. In: Proceedings of the Geologists' Association 128.5-6 (2017), pp. 757-763. DOI: 10.1016/j. pgeola.2017.06.001.

[17962] A. Pérez-Garca, A. Cobos, and R. Royo-Torres. "The oldest evidence of a dortokid turtle (stem Pleurodira) from the uppermost Hauterivian-basal Barremian El Castellar Formation (Teruel, Spain)". English. In: Journal of Iberian Geology (2017). 
[17963] A. Pérez-Garca and V. Codrea. "New insights on the anatomy and systematics of Kallokibotion Nopcsa, 1923, the enigmatic uppermost Cretaceous basal turtle (stem Testudines) from Transylvania". English. In: Zoological Journal of the Linnean Society 182.2 (2017), pp. 419-443.

[17964] A. Pérez-Garca, M. S. de la Fuente, and F. Ortega. "A new freshwater basal eucryptodiran turtle from the Early Cretaceous of Spain". English. In: Acta Palaeontologica Polonica 57.2 (2012), pp. 285298. DOI: 10.4202/app.2011.0031.

[17965] A. Pérez-Garca, F. de Lapparent de Broin, and X. Murelaga. "The Erymnochelys group of turtles (Pleurodira, Podocnemididae) in the Eocene of Europe: New taxa and paleobiogeographical implications". English. In: Palaeontologia Electronica 20.1.14A (2017), pp. 1-28.

[17966] A. Pérez-Garca, E. Esplez, L. Mampel, and L. Alcalá. "A new European Albian turtle that extends the known stratigraphic range of the Pleurosternidae (Paracryptodira)". English. In: Cretaceous Research 55 (2015), pp. 74-83. DOI: 10.1016/j.cretres.2015.02.007.

[17967] A. Perez-Garcia, E. Espilez, L. Mampel, and L. Alcala. "A new basal turtle represented by the two most complete skeletons of Helochelydridae in Europe". English. In: Cretaceous Research (2019), pp. 1-55. DOI: 10.1016/j.cretres.2019.104291.

[17968] A. Pérez-Garca, J. M. Gasulla, and F. Ortega. "A new species of Brodiechelys (Testudines, PanCryptodira) from the Early Cretaceous of Spain: Systematic and palaeobiogeographic implications". English. In: Acta Palaeontologica Polonica 59.2 (2014), pp. 333-342. DOI: 10.4202/app.2012. 0059 .

[17969] A. Pérez-Garca and F. Lapparent de Broin. "A new species of Neochelys (Chelonii, Podocnemididae) from the Ypresian (Early Eocene) of the South of France". English. In: Comptes Rendus Palevol 12 (2013), pp. 269-277. DOI: 10.1016/j.crpv.2013.05.011.

[17970] A. Pérez-Garca and F. Lapparent de Broin. "New insights into the anatomy and systematic of 'Papoulemys' laurenti, a representative of Neochelys (Chelonii, Podocnemididae) from the early Eocene of the south of France". English. In: Palaeontologische Zeitschrift 89 (2015), pp. 901-923. DOI: $10.1007 / \mathrm{s} 12542-015-0259-3$.

[17971] A. Pérez-Garca and X. Murelaga. "Galvechelone lopezmartinezae gen. et sp. nov. a new cryptodiran turtle in the Lower Cretaceous of Europe". English. In: Palaeontology 55.5 (2012), pp. 937-944. DOI: $10.1111 / j .1475-4983.2012 .01154 . x$.

[17972] A. Pérez-Garca and X. Murelaga. "Larachelus morla, gen. et sp. nov., a new member of the littleknown European Early Cretaceous record of stem cryptodiran turtles". English. In: Journal of Vertebrate Paleontology 32.6 (2012), pp. 1293-1302. DOI: 10.1080/02724634.2012.694592.

[17973] A. Pérez-Garca and X. Murelaga. “Camerochelys vilanovai gen. et sp. nov., a new pan-cryptodiran turtle in the Early Cretaceous of the Iberian Range (Spain)". English. In: Cretaceous Research 41 (2013), pp. 143-149. DOI: 10.1016/j.cretres.2012.12.002.

[17974] A. Pérez-Garca and X. Murelaga. “Tortugas del Cretácico Inferior de la Cuenca Vasco-Cantábrica: el registro Hauteriviense-Barremiense de Vega de Pas (Cantabria) [Turtles from the Lower Cretaceous of the Basque-Cantabrian Basin: the Hauterivian-Barremian record from Vega de Pas (Cantabria)]". Spanish. In: Geogaceta 55 (2014), pp. 79-82.

[17975] A. Pérez-Garca, X. Murelaga, J. A. Torres, L. I. Viera, and F. -R. Sáez-Benito. “Tortugas del Cretácico Inferior (Hauteriviense-Barremiense) de La Rioja (Cuenca de Cameros, España) [Turtles from the Lower Cretaceous (Hauterivian-Barremian) of La Rioja (Cameros Basin, Spain)]". Spanish. In: Geogaceta 48 (2010), pp. 87-90.

[17976] A. Pérez-Garca, X. Murelaga, J. Cardiel Lalueza, A. Badiola, and E. Daz-Berenguer. "Presence of several clades of continental turtles in the Lutetian (Middle Eocene) of the Sobrarbe Formation (Ainsa Basin, South-Central Pyrenees, Northeast Spain)". English. In: Geologica Belgica 16.4 (2013), pp. 311-319.

[17977] A. Perez-Garcia and X. Murelaga. "Las tortugas del Vallesiense superior del Cerro de los Batallones (Madrid, España): nuevos datos sobre el escasamente conocido género Paleotestudo". Spanish. In: Ameghiniana 50.3 (2013), pp. 335-353. DOI: 10.5710/AMGH.16.01.2013.585. 
[17978] A. Perez-Garcia, X. Murelaga, C. Liesau, A. Morales, L. Llorente Rodriguez, and A. Daza Perez. "Estudio preliminar de los quelonios del yacimiento calcoltico (Holoceno) de Camino de las Yeseras (Madrid, España)". Spanish. In: Geogaceta 50.2 (2011), pp. 189-192.

[17979] A. Pérez-Garca and F. Ortega. "A new eucryptodiran turtle from the Early Cretaceous Jiufotang Formation of western Liaoning, China". English. In: Journal of Vertebrate Paleontology 31.1 (2011), pp. 60-69.

[17980] A. Pérez-Garca, F. Ortega, and X. Murelaga. "A new genus of Bothremydidae (Chelonii, Pleurodira) in the Cretaceous of southwestern Europe". English. In: Geobios 45 (2012), pp. 219-229. DOI: 10.1016/j.geobios.2011.03.001.

[17981] A. Pérez-Garca, F. Ortega, and X. Murelaga. “Ampliación de la distribución geográfica y temporal de Elochelys convenarum (Chelonii, Bothremydidae) en el Cretácico Superior de la Pennsula Ibérica". Portugese. In: Ameghiniana 47.3 (2010), pp. 307-315.

[17982] A. Pérez-Garca, F. Ortega, Z. Murelaga, and P. Dantas. "Plesiochelys sp. (Testudines, Eucryptodira) de la Fm. Freixial (Jurásico Superior) en Ulsa (Torres Vedras, Portugal)". Spanish. In: Palaeontologica Nova. SEPAZ 8 (2008), pp. 331-344.

[17983] A. Pérez-Garca and F. Ortega. "A new species of the turtle Hylaeochelys (Eucryptodira) outside its known geographic and stratigraphic ranges of distribution". English. In: Comptes Rendus Palevol 13.3 (2014), pp. 183-188.

[17984] A. Pérez-Garca, F. Ortega, and E. Jimenez Fuentes. "Taxonomy, systematics, and diversity of the European oldest testudinids". English. In: Zoological Journal of the Linnean Society 177 (2016), pp. 648-675. DOI: $10.1111 /$ zoj.12381.

[17985] A. Pérez-Garca and F. Ortega. "Identification of the French Upper Cretaceous bothremydid turtle Foxemys mechinorum in the Spanish record". English. In: Geobios 51.3 (2018), pp. 211-217. DOI: 10.1016/j.geobios.2018.04.002.

[17986] A. Pérez-Garca, F. Ortega, A. Bolet, F. Escaso, A. Houssaye, J. Martnez-Salanova, C. de Miguel Chaves, P. Mocho, I. Narváez, M. Segura, A. Torices, D. Vidal, and J. L. Sanz. "A review of the upper Campanian vertebrate site of Armuña (Segovia Province, Spain)". English. In: Cretaceous Research 57 (2016), pp. 591-623. DOI: 10.1016/j.cretres.2015.08.008.

[17987] A. Pérez-Garca, R. Royo-Torres, and A. Cobos. “A new European Late Jurassic pleurosternid (Testudines, Paracryptodira) and a new hypothesis of paracryptodiran phylogeny". English. In: Journal of Systematic Palaeontology 13.4 (2015), pp. 351-369.

[17988] A. Pérez-Garca, T. Scheyer, and X. Murelaga. "The turtles from the uppermost Jurassic and Early Cretaceous of Galve (lberian Range, Spain): anatomical, systematic, biostratigraphic and palaeobiogeographical implications". English. In: Cretaceous Research 44 (2013), pp. 64-82.

[17989] A. Pérez-Garca and T. Smith. "Identification of the African-European Erymnochelys group (Pleurodira, Podocnemididae) in the Belgian fossil record: first finding of Eocenochelus eremberti outside its type locality". English. In: Fossil Record 20 (2017), pp. 245-251.

[17990] A. Perez-Garcia and T. Smith. "Systematics and diversity of the giant soft-shelled turtles (Cryptodira, Trionychidae) from the earliest Eocene of Belgium". English. In: Geobios (2020). DOI: 10. 1016/j.geobios.2020.07.006.

[17991] A. Pérez-Garca and E. Vlachos. "New generic proposal for the European Neogene large testudinids (Cryptodira) and the first phylogenetic hypothesis for the medium and large representatives of the European Cenozoic record". English. In: Zoological Journal of the Linnean Society 172 (2014), pp. 653-719. DOI: 10.1111/zoj.12183.

[17992] A. Pérez-Garca, E. Vlachos, and P. Mocho. "The westernmost records of extinct large European tortoises: the presence of Titanochelon (Testudinidae) in the Miocene of Portugal". English. In: Historical Biology 29.6 (2017), pp. 854-861.

[17993] A. Pérez-Garca, E. Vlachos, and A. Arribas. "The last giant continental tortoise of Europe: A survivor in the Spanish Pleistocene site of Fonelas P-1". English. In: Palaeogeography, Palaeoclimatology, Palaeoecology 470 (2017), pp. 30-39. 
[17994] A. Pérez-Garca, E. Vlachos, and X. Murelaga. "A large testudinid with African affinities in the post-Messinian (lower Pliocene) record of southeastern Spain". English. In: Palaeontology (2020), pp. 1-16. DOI: $10.1111 /$ pala.12468.

[17995] D. E. Perez-Gelabert. “Further characterization of Paleomastacris ambarinus Perez et al. (Orthoptera: Eumastacidae) from Dominican amber". English. In: Proceedings of the Entomological Society of Washington 104 (2002), pp. 330-334.

[17996] A. Pérez-Huerta, C. Chonglakmani, and A. Chitnarin. "Permian brachiopods from new localities in northeast Thailand: implications for paleobiogeographic analysis". English. In: Journal of Asian Earth Sciences 30 (2007), pp. 504-517.

[17997] A. Perez-Huerta and N. D. Sheldon. "Pennsylvanian sea level cycles, nutrient availability and brachiopod paleoecology". English. In: Palaeogeography, Palaeoclimatology, Palaeoecology 230 (2006), pp. 264-279.

[17998] A. Perez-Lopez, A. C. Lopez-Garrido, A. Marquez-Aliaga, C. S. de Galdeano, and F. J. GarciaTortosa. "Ladinian carbonates of the Cabo Cope Unit (Betic Cordillera, SE Spain): a Tethys-Malaguide palaeogeographic gateway". In: Facies 48 (2003), pp. 1-7.

[17999] F. Pérez-Lorente. "La distribución de yacimientos y de tipos de huellas de dinosaurios en la Cuenca de Cameroa (La Rioja, Burgos, Soria, España) [The distribution of localities and types of dinosaur footprints in the Cameros Basin (La Rioja, Burgos, Soria, Spain)]". Spanish. In: Zubia Monográfico 14 (2002), pp. 191-210.

[18000] F. Pérez-Lorente, G. Cuenca-Bescos, M. Aurell, J. I. Canudo, A. R. Soria, and J. I. Ruiz-Omeñaca. "Las Cerradicas tracksite (Berriasian, Galve, Spain): growing evidence for quadrupedal ornithopods". English. In: Ichnos 5 (1997), pp. 109-120.

[18001] F. Pérez-Lorente, F. Guillén-Mondejar, and A. del Ramo. “Primeras icnitas de dinosaurio en Murcia (Albiense de Yecla) [First dinosaur footprints in Murcia (Albian of Yecla)]". Spanish. In: Geogaceta 39 (2006), pp. 147-150.

[18002] F. Pérez-Lorente, M. Hadri, and M. Boutakiout. "Primeras icnitas de dinosaurio en sur del Alto Atlas Central. Carixiense (Formación de Arhbalou, Goulmima, Marruecos) [First dinosaur footprints in the southern Central High Atlas. Carixian (Arhbalou Formation, Goulmima, Morroco)]". Spanish. In: Geogaceta 40 (2006), pp. 159-162.

[18003] F. Pérez-Lorente and A. Jiménez Vela. “Barranco de Valdegutiérrez: un nuevo gran yacimiento de huellas de dinosaurio en La Rioja (España) [Barranco de Valdegutiérrez: a new large dinosaur footprint locality in La Rioja (Spain)]". Spanish. In: Zubia Monográfico 18-19 (2007), pp. 9-20.

[18004] F. Pérez-Lorente and M. M. Romero-Molina. “Nuevas icnitas de dinosaurios terópodos y saurópodos en Galve y Miravete de la Sierra (Teruel. España) [New theropod and sauropod dinosaur footprints in Galve and Miravete de la Sierra (Teruel. Spain)]". Spanish. In: Geogaceta 30 (2001), pp. 115-118.

[18005] B. P. Pérez-Moreno, J. L. Sanz, A. D. Buscalioni, J. J. Moratalla, F. Ortega, and D. Rasskin-Gutman. "A unique multitoothed ornithomimosaur from the Lower Cretaceous of Spain". In: Nature 370 (1994), pp. 363-367.

[18006] B. P. Pérez-Moreno, J. L. Sanz, J. Sudre, and B. Sigé. "A theropod dinosaur from the Lower Cretaceous of southern France". English. In: Dinosaurs and Other Fossil Reptiles of Europe, Second Georges Cuvier Symposium, Montbéliard. Revue de Paléobiologie, Volume spéciale 7 (1994), pp. 173-188.

[18007] J. A. Pérez-Valera, F. Barroso-Barcenilla, A. Goy, and F. Pérez-Valera. "Nautiloids from the Muschelkalk facies of the Southiberian Triassic (Betic Cordillera, southern Spain)". English. In: Journal of Systematic Palaeontology 15 (2016), pp. 171-191.

[18008] K. S. Perfilieva, D. A. Dubovikoff, and G. M. Dlussky. “Miocene ants (Hymenoptera, Formicidae) from Crimea". English. In: Paleontological Journal 51 (2017), pp. 391-401.

[18009] E. Peri, A. Collareta, G. Insacco, and G. Bianucci. "An Inticetus-like (Cetacea, Odontoceti) cheek tooth from the Pietra Leccese (Miocene, Southern Italy)". English. In: Fossilia 2018 (2018), pp. 3335 . 
[18010] E. Peri, A. Collareta, and G. Bianucci. "A new record of Physeteroidea from the Upper Miocene of the Pietra leccese (southern Italy): systematics, paleoecology and taphonomy of a fossil macroraptorial sperm whale". English. In: Rivista Italiana di Paleontologia e Stratigrafia 126.3 (2020), pp. 751769.

[18011] F. A. Perini, P. G. Guedes, C. R. M. Neto, M. P. A. Fracasso, K. B. Cardoso, D. Duha, and L. O. Salles. "Carnivores (Mammalia, Carnivora) from the Quaternary of Serra da Bodoquena, Mato Grosso do Sul, Brazil". English. In: Arquivos do Museu Nacional, Rio de Janeiro 67.1-2 (2009), pp. 119-128.

[18012] F. A. Perini, E. R. Nascimento, and M. A. Cozzuol. "A new species of Trichechus Linnaeus, 1758 (Sirenia, Trichechidae), from the upper Pleistocene of southwestern Amazonia, and the evolution of Amazonian manatees". English. In: Journal of Vertebrate Paleontology (2020), e1697882. DOI: 10. 1080/02724634.2019.1697882.

[18013] D. Peris. "Early Cretaceous origin of pollen-feeding beetles (Insecta: Coleoptera: Oedemeridae)". English. In: Cladistics 33 (2017), pp. 268-278.

[18014] D. Peris, S. Chatzimanolis, and X. Delclós. "Diversity of rove beetles (Coleoptera: Staphylinidae) in Early Cretaceous Spanish amber". English. In: Cretaceous Research 48 (2014), pp. 85-95.

[18015] D. Peris, S. R. Davis, M. S. Engel, and X. Delclós. “An evolutionary history embedded in amber: reflection of the Mesozoic shift in weevil-dominated (Coleoptera: Curculionoidea) faunas". English. In: Zoological Journal of the Linnean Society 171 (2014), pp. 534-553.

[18016] D. Peris, X. Delclós, C. Soriano, and V. Perrichot. "The earliest occurrence and remarkable stasis of the family Bostrichidae (Coleoptera: Polyphaga) in Cretaceous Charentes amber". English. In: Palaeontologia Electronica 17.1.14A (2014), pp. 1-8.

[18017] D. Peris and X. Delclós. "Fossil Monotomidae (Coleoptera: Polyphaga) from Laurasian Cretaceous amber". English. In: Organisms Diversity \& Evolution 15 (2015), pp. 333-342.

[18018] D. Peris and F. Fanti. "Molliberus albae gen. et sp. nov., the oldest Laurasian soldier beetle (Coleoptera: Cantharidae) from the Lower Cretaceous Spanish amber". English. In: Cretaceous Research 91 (2018), pp. 263-268.

[18019] D. Peris and J. Háva. “New species from Late Cretaceous New Jersey amber and stasis in subfamily Attageninae (Insecta: Coleoptera: Dermestidae)". English. In: Journal of Paleontology 90 (2016), pp. 491-498.

[18020] D. Peris and J. Jelnek. "Syninclusions of two new species of short-winged flower beetle (Coleoptera: Kateretidae) in mid-Cretaceous Kachin amber (Myanmar)". English. In: Cretaceous Research 106.104264 (2019). DOI: 10.1016/j.cretres.2019.104264.

[18021] D. Peris, J. Kolibá, and X. Delclós. “Cretamerus vulloi gen. et sp. nov., the oldest bark-gnawing beetle (Coleoptera: Trogossitidae) from Cretaceous amber". English. In: Journal of Systematic Palaeontology 12 (2014), pp. 879-891. DOI: 10.1080/14772019.2013.853108.

[18022] D. Peris, R. Kundrata, X. Delclós, B. Mähler, M. A. Ivie, J. Rust, and C. C. Labandeira. “Unlocking the mystery of the mid-Cretaceous Mysteriomorphidae (Coleoptera:" English. In: Scientific Reports 10.16854 (2020). DOI: 10.1038/s41598-020-73724-7.

[18023] D. Peris, G. Y. Lyubarsky, and E. E. Perkovsky. “A new genus of silken-fungus beetle (Coleoptera: Cryptophagidae) from the Spanish Cretaceous amber". English. In: Cretaceous Research 78 (2017), pp. 191-195.

[18024] D. Peris, C. A. Maier, A. Sánchez-Garca, and X. Delclós. “The oldest known riffle beetle (Coleoptera: Elmidae) from Early Cretaceous Spanish amber". English. In: Comptes Rendus Palevol 14 (2015), pp. 181-186.

[18025] D. Peris, T. K. Philips, and X. Delclós. “Ptinid beetles from the Cretaceous gymnosperm-dominated forests". English. In: Cretaceous Research 52 (2015), pp. 440-452.

[18026] D. Peris and E. Ruzzier. "A new tribe, new genus, and new species of Mordellidae (Coleoptera: Tenebrionoidea) from the Early Cretaceous amber of Spain". English. In: Cretaceous Research 45 (2013), pp. 1-6. 
[18027] D. Peris, M. M. Solórzano Kraemer, E. Peñalver, and X. Delclós. “New ambrosia beetles (Coleoptera: Curculionidae: Platypodinae) from Miocene Mexican and Dominican ambers and their paleobiogeographical implications". English. In: Organisms Diversity \& Evolution 15 (2015), pp. 527-542.

[18028] D. Peris, M. M. Solórzano Kraemer, S. M. Smith, and A. I. Cognato. “Eoplatypus jordali gen.n. et sp.n., the first described Platypodinae (Coleoptera: Curculionidae) from Baltic amber". English. In: Arthropod Systematics \& Phylogeny 75 (2017), pp. 185-194.

[18029] D. Peris, M. K. Thayer, and D. Néraudeau. “Oldest Omaliini (Coleoptera: Staphylinidae: Omaliinae) discovered in the opaque Cretaceous amber of Charentes". English. In: Annals of the Entomological Society of America 107 (2014), pp. 902-910.

[18030] E. E. Perkovsky. “The first find of leiodid tribe Scotocryptini (Coleoptera: Leiodidae: Leiodinae) in fossil resin (Dominican amber)". English. In: Paleontological Journal 34.Suppl 3 (2000), S331-S332.

[18031] E. E. Perkovsky. "Pervyy Eotsenovyy predstavitel roda Ipelates (Coleoptera, Agyrtidae) iz baltiyskogo yantarya". English. In: Vestnik Zoologii 39.1 (2005), pp. 59-61.

[18032] E. E. Perkovsky. "On the Find of Adult Micromalthus (Coleoptera, Micromalthidae) in Dominican Amber". English. In: Paleontological Journal 41 (2007), pp. 626-628.

[18033] E. E. Perkovsky. “On finding a single-clawed aphid, Germaraphis ungulata (Homoptera, Aphidinea), in a syninclusion with the ant Monomorium mayrianum (Hymenoptera, Formicidae) in the Saxonian amber". English. In: Paleontological Journal 43 (2009), pp. 1006-1007.

[18034] E. E. Perkovsky. “First occurence of syninclusion of ants Lasius schiefferdeckeri Mayr (Hymenoptera: Formicidae) and aphids Germaraphis ungulata Heie (Homoptera: Aphidinea) in amber (Klesov)". English. In: Russian Entomological Journal 17 (2008), pp. 207-208.

[18035] E. E. Perkovsky. "Occurrence of ant (Hymenoptera, Formicidae) and aphid (Homoptera, Aphidinea) syninclusions in Saxonian and Rovno ambers". English. In: Paleontological Journal 40 (2006), pp. 190192.

[18036] E. E. Perkovsky. "Novyy pozdnejurskiy rod i vid Leiodinae (Coleoptera, Leiodidae) iz Mongolii”. Russian. In: Vestnik Zoologii 33 (1999), pp. 77-79.

[18037] E. E. Perkovsky. "A new species of Micromalthidae (Coleoptera) from the Rovno amber: 1. Adult morphology". English. In: Paleontological Journal 50 (2016), pp. 293-296.

[18038] E. E. Perkovsky. "Rovno amber caddisflies (Insecta, Trichoptera) from different localities, with information about three new sites". English. In: Vestnik Zoologii 51 (2017), pp. 15-22.

[18039] E. E. Perkovsky, K. Y. Eskov, and Y. M. Marusik. "First record of Atypidae (Araneae) in Rovno Amber". English. In: Acta Arachnologica 67 (2018), pp. 13-17.

[18040] E. E. Perkovsky and Z. A. Fedotova. "New gall midge taxa of the subfamilies Porricondylinae and Lasiopterinae (Diptera, Cecidomyiidae) from the Rovno amber". English. In: Paleontological Journal 42.2 (2008), pp. 166-175.

[18041] E. E. Perkovsky and Z. A. Fedotova. “New Species of Gall Midges (Diptera, Cecidomyiidae) from Rovno Amber: Subfamily Lestremiinae, Tribes Micromyiini and Peromyiini". English. In: Paleontological Journal 38.4 (2004), pp. 396-406.

[18042] E. E. Perkovsky and Z. A. Fedotova. "Rovnodiplosis eduardi gen. et sp. nov., the first record of a fossil gall midge of the supertribe Mycodiplosidi (Diptera, Cecidomyioidea, Cecidomyiidae) in the Late Eocene of the Rovno amber". English. In: Paleontological Journal 50 (2016), pp. 1027-1032.

[18043] E. E. Perkovsky and Z. A. Fedotova. "The second Cretaceous gall midge genus of the tribe Diallactiini (Diptera, Cecidomyiidae) from the Late Cretaceous Burmese amber". English. In: Vestnik Zoologii 51 (2017), pp. 117-124.

[18044] E. E. Perkovsky and G. Y. Lyubarsky. "Fifth contribution on silken fungus beetles from Late Eocene amber: a second Baltic amber species of Atomaria (Coleoptera: Clavicornia: Cryptophagidae)". English. In: Russian Entomological Journal 23 (2014), pp. 41-44.

[18045] E. E. Perkovsky and V. N. Makarkin. "First confirmation of spongillaflies (Neuroptera: Sisyridae) from the Cretaceous". English. In: Cretaceous Research 56 (2015), pp. 363-371. 
[18046] E. E. Perkovsky and V. N. Makarkin. “A new species of Succinoraphidia Aspöck \& Aspöck, 2004 (Raphidioptera: Raphidiidae) from the late Eocene Rovno amber, with venation characteristics of the genus". English. In: Zootaxa 4576 (2019), pp. 570-580.

[18047] E. E. Perkovsky and V. N. Makarkin. "A new species of Sympherobius Banks (Neuroptera: Hemerobiidae) from the late Eocene Rovno amber". English. In: Palaeoentomology 3 (2020), pp. 196-203.

[18048] E. E. Perkovsky, K. V. Martynova, T. Mita, M. Olmi, Y. Zheng, P. Müller, Q. Zhang, F. Gantier, and V. Perrichot. "A golden age for ectoparasitoids of Embiodea: Cretaceous Sclerogibbidae (Hymenoptera, Chrysidoidea) from Kachin (Myanmar), Charentes (France) and Choshi (Japan) ambers". English. In: Gondwana Research 87 (2020), pp. 1-22. DOI: 10.1016/j.gr.2020.06.004.

[18049] E. E. Perkovsky, M. B. Mostovsky, and H. Henderickx. "New records of the dipteran genera Triphleba (Phoridae) and Prosphyracephala (Diopsidae) in Rovno and Baltic ambers". English. In: Vestnik Zoologii 49 (2015), pp. 245-250.

[18050] E. E. Perkovsky and V. K. Odnosum. "A new species of the scraptiid beetle genus Anaspis (Insecta: Coleoptera: Scraptiidae) from the Baltic and Rovno amberas (Upper Eocene of eastern Europe)". English. In: Paleontological Journal 43.9 (2009), pp. 1092-1094.

[18051] E. E. Perkovsky and V. K. Odnosum. "A new species of tumbling flower beetles of the genus Mordellaria (Insecta: Coleoptera: Mordellidae) from the Baltic amber". English. In: Paleontological Journal 47 (2013), pp. 177-179.

[18052] E. E. Perkovsky, M. Olmi, P. Müller, and K. V. Martynova. "A review of the genus Hybristodryinus Engel, 2005 (Hymenoptera, Dryinidae) from mid-Cretaceous Burmese amber, with a discussion on its phylogenetic significance". English. In: Cretaceous Research 99 (2019), pp. 169-189. DOI: 10.1016/ j.cretres.2019.01.023.

[18053] E. E. Perkovsky and M. Olmi. "Discovery of the first pincer wasp (Hymenoptera, Dryinidae) from Rovno amber". English. In: Zootaxa 4457 (2018), pp. 296-304.

[18054] E. E. Perkovsky, M. Olmi, P. Müller, L. Capradossi, D. V. Vasilenko, and A. Guglielmino. “A review of the Palaeoanteoninae (Hymenoptera: Dryinidae), with description of the first species from midCretaceous Kachin (Myanmar) amber and comments on its phylogenetic significance". English. In: Cretaceous Research 116.104582 (2020). DOI: 10.1016/j.cretres.2020.104582.

[18055] E. E. Perkovsky and A. P. Rasnitsyn. "First records of Scolebythidae and Chrysididae (Hymenoptera, Chrysidoidea) in Rovno amber". English. In: Vestnik Zoologii 47.2 (2013), e14-e19.

[18056] E. E. Perkovsky and E. B. Sukhomlin. "New late Eocene blackflies (Diptera, Simuliidae) from the Rovno Amber (Ukraine)". English. In: Paleontological Journal 49 (2015), pp. 608-614.

[18057] E. E. Perkovsky and E. B. Sukhomlin. "A new species of Hellichiella (Diptera: Simuliidae) with 11-segmented antenna from the Eocene". English. In: Israel Journal of Entomology 46 (2016), pp. 79 86.

[18058] E. E. Perkovsky and E. B. Sukhomlin. "The first record of Late Cretaceous blackflies (Diptera: Simuliidae) in Asia (Yantardakh, Taimyr)". English. In: Paleontological Journal 50 (2016), pp. 9971000.

[18059] E. E. Perkovsky, E. B. Sukhomlin, and N. V. Zelenkov. "An unexpectedly abundant new genus of black flies (Diptera, Simuliidae) from Upper Cretaceous Taimyr amber of Ugolyak, with discussion of the early evolution of birds at high latitudes". English. In: Cretaceous Research 90 (2018), pp. 80-89.

[18060] E. E. Perkovsky and D. V. Vasilenko. "Evolution of tropical termites in early Paleogene with description of a new species of Stylotermitidae (Isoptera) from Rovno amber (late Eocene of Ukraine)". English. In: Invertebrate Zoology 17 (2020), pp. 231-246.

[18061] E. E. Perkovsky and P. Wegierek. "Oldest amber species of Palaeoaphididae (Hemiptera) from Baikura (Taimyr amber)". English. In: Cretaceous Research 80 (2017), pp. 56-60.

[18062] A. Perle, L. M. Chiappe, R. Barsbold, J. M. Clark, and M. A. Norell. "Skeletal morphology of Mononykus olecranus (Theropoda: Avialae) from the Late Cretaceous of Mongolia". English. In: American Museum Novitates 3105 (1994), pp. 1-29. 
[18063] A. Perle, M. A. Norell, L. M. Chiappe, and J. M. Clark. "Flightless bird from the Cretaceous of Mongolia". English. In: Nature 362 (1993), pp. 623-626.

[18064] A. Perle, M. A. Norell, L. M. Chiappe, and J. M. Clark. "Correction: Flightless bird from the Cretaceous of Mongolia". English. In: Nature 363 (1993), p. 188.

[18065] A. Perrard, D. Grimaldi, and J. M. Carpenter. “Early lineages of Vespidae (Hymenoptera) in Cretaceous amber". English. In: Systematic Entomology 42 (2017), pp. 379-386.

[18066] A. Perrard, A. Nel, and J. M. Carpenter. "A new paper wasp from Late Eocene of France (Hymenoptera: Vespidae: Polistinae)". English. In: Zootaxa 3753 (2014), pp. 542-548.

[18067] M. Perreau. "Description of a new genus and two new species of Leiodidae (Coleoptera) from Baltic amber using phase contrast synchrotron X-ray microtomography". English. In: Zootaxa 3455 (2012), pp. 81-88.

[18068] M. Perreau. “Archaeocerus uenoi n. gen. n. sp. (Coleoptera Leiodidae Catopocerinae) from Albian/Cenomanian age amber of Myanmar". English. In: Zootaxa 4638 (2019), pp. 595-600.

[18069] M. Perreau. "Cretaciella sorianoae gen. et sp. nov. (Coleoptera, Leiodidae, Cholevinae, Oritocatopini), anophthalmic species from Albian amber of the Escucha Formation". English. In: Geosciences 9.521 (2019). DOI: 10.3390/geosciences9120521.

[18070] M. Perreau and P. Tafforeau. "Virtual dissection using phase-contrast X-ray synchrotron microtomography: reducing the gap between fossils and extant species". English. In: Systematic Entomology 36 (2011), pp. 573-580.

[18071] R. T. Perreault and J. S. Buckeridge. "Paleogene Verrucidae (Cirripedia: Verrucomorpha) of North America, with descriptions of three new species". English. In: Zootaxa 4712.1 (2019), pp. 34-50.

[18072] E. Perri, M. Borrelli, M. P. Bernasconi, L. GindreChanu, A. Spadafora, and S. Critelli. “Microbialdominated carbonate depositional systems: a biosedimentary and stratigraphic reconstruction in the Late Triassic of Western Tethys (northern Calabria, Italy)". English. In: Facies 65.31 (2019).

[18073] V. Perrichot. "Long-tailed wasps (Hymenoptera: Megalyridae) from Cretaceous and Paleogene European amber". English. In: Paleontological Contributions 1 (2009), pp. 1-35.

[18074] V. Perrichot. "New maimetshid wasps in Cretaceous amber from Myanmar (Insecta: Hymenoptera)". English. In: Annales de Paléontologie 99 (2013), pp. 67-77.

[18075] V. Perrichot. "A new species of the Cretaceous ant Zigrasimecia based on the worker caste reveals placement of the genus in the Sphecomyrminae (Hymenoptera: Formicidae)". English. In: Myrmecological News 19 (2014), pp. 165-169.

[18076] V. Perrichot. "A new species of Baikuris (Hymenoptera: Formicidae: Sphecomyrminae) in midCretaceous amber from France". English. In: Cretaceous Research 52 (2015), pp. 585-590.

[18077] V. Perrichot, P. O. Antoine, R. Salas-Gismondi, J. J. Flynn, and M. S. Engel. "The genus Macroteleia Westwood in Middle Miocene amber from Peru (Hymenoptera, Platygastridae s.l., Scelioninae)". English. In: ZooKeys 426 (2014), pp. 119-127.

[18078] V. Perrichot, D. Azar, D. Neraudeau, and A. Nel. “New Psocoptera in the Early Cretaceous amber of SW France and Lebanon (Insecta: Psocoptera: Trogiomorpha)". English. In: Geological Magazine 140 (2003), pp. 669-683.

[18079] V. Perrichot and J. C. Beaucournu. "First extinct genus of a flea (Siphonaptera: Pulicidae) in Miocene amber from the Dominican Republic". English. In: Zootaxa 3438 (2012), pp. 54-61.

[18080] V. Perrichot, M. S. Engel, A. Nel, P. Tafforeau, and C. Soriano. "New earwig nymphs (Dermaptera: Pygidicranidae) in mid-Cretaceous amber from France". English. In: Cretaceous Research 32 (2011), pp. 325-330.

[18081] V. Perrichot and M. S. Engel. “A new micropterous species of Embolemus Westwood from Baltic amber (Hymenoptera: Embolemidae)". English. In: Annales de Paléontologie 97 (2011), pp. 1-7.

[18082] V. Perrichot and M. S. Engel. "Early Cretaceous snakefly larvae in amber from Lebanon, Myanmar, and France (Raphidioptera)". English. In: American Museum Novitates 3598 (2007), pp. 1-11. 
[18083] V. Perrichot and M. S. Engel. "Youngest occurrence of the genus Microphorites (Diptera: Dolichopodidae): a new species in Late Cretaceous Vendean amber". English. In: Paleontological Contributions 10 (2014), pp. 30-33.

[18084] V. Perrichot, R. Garrouste, D. Azar, D. Néraudeau, and A. Nel. "A new genus of dustywings (Neuroptera: Coniopterygidae) in Late Cretaceous Vendean amber". English. In: Paleontological Contributions 10 (2014), pp. 25-29.

[18085] V. Perrichot, L. Marion, D. Néraudeau, R. Vullo, and P. Tafforeau. “The early evolution of feathers: fossil evidence from Cretaceous amber of France". English. In: Proceedings of the Royal Society B: Biological Sciences 275.1639 (2008), pp. 1197-1202. DOI: 10.1098/rspb.2008.0003.

[18086] V. Perrichot, A. Nel, and W. Krzemiski. "A new crane fly (Diptera: Limoniidae) from the Cretaceous amber of France". English. In: Alavesia 1 (2007), pp. 75-80.

[18087] V. Perrichot, A. Nel, and D. Néraudeau. “A new, enigmatic, evaniomorphan wasp in the Albian amber of France (Insecta: Hymenoptera)". English. In: Journal of Systematic Palaeontology 2 (2004), pp. 159-162.

[18088] V. Perrichot, A. Nel, and D. L. J. Quicke. “New braconid wasps from French Cretaceous amber (Hymenoptera, Braconidae): synonymization with Eoichneumonidae and implications for the phylogeny of Ichneumonoidea". English. In: Zoologica Scripta 38 (2009), pp. 79-88.

[18089] V. Perrichot, A. Nel, and D. Néraudeau. "Gerromorphan bugs in Early Cretaceous French amber (Insecta: Heteroptera): first representatives of Gerridae and their phylogenetic and palaeoecological implications". English. In: Cretaceous Research 26 (2005), pp. 793-800.

[18090] V. Perrichot and A. Nel. "A new betyline wasp in Cretaceous amber from France (Hymenoptera: Diapriidae)". English. In: Alavesia 2 (2008), pp. 203-209.

[18091] V. Perrichot, A. Nel, and D. Néraudeau. "Two new wedge-shaped beetles in Albo-Cenomanian ambers of France (Coleoptera: Ripiphoridae: Ripiphorinae)". English. In: European Journal of Entomology 101 (2004), pp. 577-581.

[18092] V. Perrichot, A. Nel, E. Guilbert, and D. Néraudeau. "Fossil Tingoidea (Heteroptera: Cimicomorpha) from French Cretaceous amber, including Tingidae and a new family, Ebboidae". English. In: Zootaxa 1203 (2006), pp. 57-68.

[18093] V. Perrichot, A. Nel, and D. Néraudeau. "Schizopterid Bugs (Insecta: Heteroptera) in Mid-cretaceous Ambers From France and Myanmar (Burma)". English. In: Palaeontology 50.6 (2007), pp. 13671374.

[18094] V. Perrichot, A. Nel, D. Néraudeau, S. Lacau, and T. Guyot. "New fossil ants in French Cretaceous amber (Hymenoptera: Formicidae)". English. In: Naturwissenschaften 95 (2007), pp. 91-97.

[18095] V. Perrichot and A. Nel. "Eocene bethylid wasps from French amber (Hymenoptera: Bethylidae)". English. In: Neues Jahrbuch für Geologie und Paläontologie, Abhandlungen 248 (2008), pp. 91-101.

[18096] V. Perrichot and D. Neraudeau. "Reptile skin remains in the Cretaceous amber of France". English. In: Comptes Rendus Palevol 4 (2005), pp. 47-51. DOI: 10.1016/j.crpv.2004.11.009.

[18097] V. Perrichot, D. Néraudeau, D. Azar, J. J. Menier, and A. Nel. “A new genus and species of fossil mole cricket in the Lower Cretaceous amber of Charente-Maritime, SW France (Insecta: Orthoptera: Gryllotalpidae)". English. In: Cretaceous Research 23 (2002), pp. 307-314.

[18098] V. Perrichot, J. Ortega-Blanco, R. C. McKellar, X. Delclós, D. Azar, A. Nel, P. Tafforeau, and M. S. Engel. "New and revised maimetshid wasps from Cretaceous ambers (Hymenoptera, Maimetshidae)". English. In: ZooKeys 130 (2011), pp. 421-453.

[18099] V. Perrichot and E. E. Perkovsky. "A new species of maimetshid wasp (Insecta: Hymenoptera) in Siberian Cretaceous amber". English. In: Annales de Paléontologie 102 (2016), pp. 213-217.

[18100] V. Perrichot, B. Wang, and M. S. Engel. "Extreme morphogenesis and ecological specialization among Cretaceous basal ants". English. In: Current Biology 26 (2016), pp. 1468-1472. 
[18101] V. Perrichot, B. Wang, and P. Barden. “New remarkable hell ants (Formicidae: Haidomyrmecinae stat. nov.) from mid-Cretaceous amber of northern Myanmar". English. In: Cretaceous Research 109.104381 (2020). DOI: 10.1016/j.cretres.2020.104381.

[18102] V. Perrier, J. M. C. Vannier, P. R. Racheboeuf, S. Charbonnier, D. Chabard, and D. Sotty. “Syncarid crustaceans from the Montceau Lagerstätte (Upper Carboniferous; France)". English. In: Palaeontology 49 (2006), pp. 647-672. DOI: 10.1111/j.1475-4983.2006.00553.x.

[18103] M. Perrilliat and A. Cristin. "Late Paleocene Cancellariidae (Gastropoda: Neogastropoda) from Baja California, Mexico". English. In: Boletn de la Sociedad Geológica Mexicana 68.1 (2016), pp. 105109.

[18104] M. C. Perrilliat. "Bivalvos y gasterópodos de la formacion Ferrotepec (Mioceno Medio) de Michoacan". Spanish. In: Paleontologia Mexicana 60 (1992), pp. 1-48.

[18105] M. C. Perrilliat. "Bivalvos de la Formación Tuxpan (Mioceno Medio), Estado de Veracruz, México". English. In: Revista Mexicana de Ciencias Geológicas 11.2 (1994), pp. 232-242.

[18106] M. C. Perrilliat. "Late Paleocene Architectonicidae (Gastropoda: Heterobranchia) from Baja California, Mexico". English. In: Revista Mexicana de Ciencias Geológicas 30.1 (2013), pp. 178-185.

[18107] M. C. Perrilliat, F. Ahmad, and F. J. Vega. “Upper Cretaceous (Cenomanian-Turonian) bivalves from northern Jordan, Middle East". English. In: Revista Mexicana de Ciencias Geologicas 23.1 (2006), pp. 96-106.

[18108] M. C. Perrilliat and P. Flores-Guerrero. "Moluscos de la Formación Agueguexquite (Plioceno inferior) de Coatzacoalcos, Veracruz, México". English. In: Revista Mexicana de Ciencias Geológicas 28.3 (2011), pp. 379-397.

[18109] M. C. Perrilliat, F. J. Vega, and R. Corona. "Early Maastrictian mollusca from the Mexcala formation of the state of Guerro, southern Mexico". In: Journal of Paleontology 74.1 (2000), pp. 7-24.

[18110] M. D. Perrilliat, J. Avendano, F. J. Vega, and J. Solé. “Lower Eocene Gastropods from El Bosque Formation, Central Chiapas, Mexico". English. In: The Veliger 48.3 (2006), pp. 151-169.

[18111] M.d.C. Perrilliat. "Fossil gastropods from the Late Paleocene Sepultura Formation, Baja California, Mexico". English. In: Neues Jahrbuch für Geologie und Palaeontologie - Abhandlungen 268.2 (2013), pp. 127-148. DOI: 10.1127/0077-7749/2013/0323.

[18112] M.d.C. Perrilliat, J. Avendaño, and F. J. Vega. "Middle Eocene Cypraeoideans from the San Juan Formation, Chiapas, southern Mexico". English. In: Revista Mexicana de Ciecnias Geológicas 20.1 (2003), pp. 41-51.

[18113] M.d.C. Perrilliat, F. J. Vega, and M. A. Coutiño. "Miocene mollusks from the Simojovel area in Chiapas, southwestern Mexico". English. In: Journal of South American Earth Sciences 30 (2010), pp. 111-119. DOI: 10.1016/j.jsames.2010.04.005.

[18114] M. D. C. Perrilliat and F. J. Vega. "Early Eocene Ostreids from the Adjuntas Formation, Difunta Group, northeastern Mexico". In: Tulane Studies in Geology and Paleontology 26 (1994), pp. 15-25.

[18115] C. Perrin. "Changes of palaeozonation patterns within Miocene coral reefs, Gebel Abu Shaar, Gulf of Suez, Egypt". In: Lethaia 33 (2000), pp. 253-268.

[18116] C. T. Perry. "Macroboring of Pleistocene Coral Communities, Falmouth Formation, Jamaica". English. In: Palaios 15 (2000), pp. 483-491.

[18117] C. T. Perry, S. G. Smithers, R. C. Roche, and J. Wassenburg. "Recurrent patterns of coral community and sediment facies development through successive phases of Holocene inner-shelf reef growth and decline". English. In: Marine Geology 289 (2011), pp. 60-71. DOI: 10.1016/j.margeo. 2011.09.012.

[18118] F. A. Perry. "And the results are... (Fossils salvaged during development of the Graham Quarry, Scotts Valley)". English. In: Monterey Bay Paleontological Society Bulletin 4.3 (2000). 
[18119] J. M. Perry, R. F. Kay, S. F. Vizcano, and M. S. Bargo. “Oldest known cranium of a juvenile New World monkey (Early Miocene, Patagonia, Argentina): Implications for the taxonomy and the molar eruption pattern of early platyrrhines". English. In: Journal of Human Evolution 74 (2014), pp. 67-81. DOI: 10.1016/j.jhevol.2014.03.009.

[18120] T. Perry. “Whale fossil found at San Diego Zoo". English. In: Los Angeles Times (2010).

[18121] T. M. Peryt, P. Raczynski, D. Peryt, K. Chódek, and K. Miklajewski. “Sedimentary history and biota of the Zechstein Limestone (Permian, Wuchiapingian) of the Jablonna Reef in Western Poland". English. In: Annales Societatis Geologorum Poloniae 86 (2016), pp. 379-413.

[18122] F. Pesci, A. Collareta, C. Tinelli, and G. Bianucci. "First record of Monodontidae (Cetacea, Odontoceti) in the Mediterranean Basin from the Pliocene sands of Arcille (Grosseto, Tuscany, Italy)". English. In: Fossilia 2018 (2018), pp. 37-39.

[18123] M. D. Pesquero, M. T. Alberdi, and L. Alcalá. "New species of Hipparion from La Roma 2 (Late Vallesian; Teruel Spain): a study of the morphological and biometric variability of Hipparion primigenium." English. In: Journal of Paleontology 80.2 (2006), pp. 343-356.

[18124] E. A. Pessagno and D. M. Hull. "Upper Jurassic (Oxfordian) Radiolaria from the Sula Islands (East Indies): Thier taxonomic, biostratigraphic, chronostratigraphic, and paleobiogeographic significance". In: Micropaleontology 48.3 (2002), pp. 229-256.

[18125] E. A. Pessagno Jr., C. D. Blome, D. M. Hull, and W. M. Six. "Jurassic radiolaria from the Josephine ophiolite and overlying strata, Smith River subterrane (Klamath Mountains), northwestern California and southwestern Oreg". English. In: Micropaleontology 39 (1993), pp. 93-166.

[18126] A. M. M. Peters and H. J. Monteiro. "A small sperm whale (Cetacea, Odontoceti, Physeteridae) from the Miocene of Antwerp". English. In: Deinsea 11 (2005), pp. 87-101.

[18127] D. S. Peters. "Messelastur gratulator n. gen. n. spec., ein Greifvogel as der Grube Messel (Aves: Accipitridae)". German. In: Courier Forschungsinstitut Senckenberg 170 (1994), pp. 3-9.

[18128] J. Peters. "Late Pleistocene hunter-gatherers at Ishango (eastern Zaire): the faunal evidence". English. In: Revue de Paléobiologie 9.1 (1990), pp. 73-112.

[18129] M. E. Peters, M. E. J. Bosselaers, K. Post, and J. W. F. Reumer. "A Miocene leatherback turtle from the Westerschelde (The Netherlands) with possible cetacean bite marks: identification, taphonomy and cladistics". English. In: Cainozoic Research 19.2 (2019), pp. 121-133.

[18130] S. E. Peters. "Evenness, richness and the Cambrian-Paleozoic faunal transition in North America: an assemblage-level perspective". English. PhD thesis. 2003, pp. 1-279.

[18131] S. E. Peters and K. B. Bork. "Species-abundance models: an ecological approach to inferring paleoenvironment and resolving paleoecological change in the Waldron Shale (Silurian)". In: Palaios 14 (1999), pp. 234-245.

[18132] W. L. Peters and J. G. Peters. Discovery of a new genus of Leptophlebiidae: Leptophlebiinae (Ephemeroptera) in Cretaceous amber from New Jersey. English. Studies on Fossils in Amber, with Particular Reference to the Cretaceous of New Jersey. Leiden: Backhuys Publishers, 2000, pp. 127-131.

[18133] J. E. Peterson, R. P. Scherer, and K. M. Huffman. "Methods of microvertebrate sampling and their influences on taphonomic interpretations". English. In: Palaios 28.2 (2011), pp. 81-88. DOI: 10.2110/ palo.2010.p10-080r.

[18134] J.-M. Petillon. "First evidence of a whale-bone industry in the western European Upper Paleolithic: Magdalenian artifacts from Isturitz (Pyrenees-Atlantiques, France)". English. In: Journal of Human Evolution 54 (2008), pp. 720-726.

[18135] A. V. Petrov and E. E. Perkovsky. "New species of bark beetles from the Rovno amber (Insecta: Coleoptera: Scolytidae)". English. In: Paleontological Journal 42.4 (2008), pp. 406-408.

[18136] A. V. Petrov and E. E. Perkovsky. "A new genus and species of Scolytinae (Coleoptera: Curculionidae) from the Rovno amber". English. In: Paleontological Journal 52 (2018), pp. 164-167. 
[18137] A. V. Petrov and V. V. Zherikhin. "Fossil bark beetles of the genus Scolytus from the Neogene of France (Coleoptera: Curculionidae: Scolytinae)". English. In: Paleontological Journal 34.Suppl 3 (2000), S344-S346.

[18138] A. V. Petrov and V. V. Zherikhin. "A new species of bark beetles of the genus Hylesinus (Insecta: Coleoptera: Scolytidae) from the Oligocene of France". English. In: Paleontological Journal 38 (2004), pp. 187-189.

[18139] S. Petrova, E. Mehmed, I. Mollov, D. Georgiev, and I. Velcheva. “Molluscs (Mollusca: Gastropoda, Bivalvia) from The Upper Eocene of Perunika Village (East Rhodopes, Bulgaria) - Preliminary Results". English. In: Acta Zoologica Bulgarica 4 (2012), pp. 233-236.

[18140] M. Petrucci, A. Cipullo, B. Martinez-Navarro, L. Rook, and R. Sardella. "The late Villafranchian (Early Pleistocene) carnivores (Carnivora, Mammalia) from Pirro Nord (Italy)". English. In: Palaeontographica Abteilung A 298.1-6 (2013), pp. 113-145. DOI: 10.1127/pala/298/2013/113.

[18141] J. Petruleviius. "A new pentatomoid bug from the Ypresian of Patagonia, Argentina". English. In: Acta Palaeontologica Polonica 61 (2016), pp. 863-868.

[18142] J. F. Petruleviius. "A plant hopper (Nogodinidae) from the upper Palaeocene of Argentina: systematics and taphonomy". English. In: Palaeontology 48.2 (2005), pp. 299-308.

[18143] J. F. Petruleviius. "A panorpoid (Insecta: Mecoptera) from the lower Eocene of Patagonia, Argentina". English. In: Journal of Paleontology 83 (2009), pp. 994-997.

[18144] J. F. Petruleviius. "Phylogenetic and biogeographical remarks on Thyridates (Mecoptera: Bittacidae), with the first fossil record of the taxon". English. In: Acta Zoologica Cracoviensia 46.Suppl (2003), pp. 257-265.

[18145] J. F. Petruleviius. “A new Synlestidae damselfly (Insecta: Odonata: Zygoptera) from the early Eocene of Nahuel Huapi Este, Patagonia, Argentina". English. In: Arquivos Entomolóxicos 14 (2015), pp. 287-294.

[18146] J. F. Petruleviius. "A new burmagomphid dragonfly from the Eocene of Patagonia, Argentina". English. In: Acta Palaeontologica Polonica 62 (2017), pp. 779-783.

[18147] J. F. Petruleviius. "A new malachite damselfly (Synlestidae: Odonata) from the Eocene of Patagonia, Argentina". English. In: Life: The Excitement of Biology 6 (2018), pp. 36-43.

[18148] J. F. Petruleviius. "First argiolestid damselfly (Odonata: Zygoptera) from the late Palaeocene of Northwest Argentina". English. In: Palaeoentomology 3.6 (2020), pp. 541-545.

[18149] J. F. Petruleviius, D. Azar, and A. Nel. “A new thorny lacewing (Insecta: Neuroptera: Rhachiberothidae) from the Early Cretaceous amber of Lebanon". English. In: Acta Geologica Sinica 84 (2010), pp. 828-833.

[18150] J. F. Petruleviius and P. R. Gutiérrez. “New basal Odonatoptera (Insecta) from the lower Carboniferous (Serpukhovian) of Argentina". English. In: Arquivos Entomolóxicos 16 (2016), pp. 341-358.

[18151] J. F. Petruleviius, D. Y. Huang, and A. Nel. “A new genus and species of damsel-dragonfly (Odonata: Isophlebioidea: Campterophlebiidae) in the Middle Jurassic of Inner Mongolia, China". English. In: Acta Geologica Sinica 85.4 (2011), pp. 733-738.

[18152] J. F. Petruleviius, D. Y. Huang, and D. Ren. "A new hangingfly (Insecta: Mecoptera: Bittacidae) from the Middle Jurassic of Inner Mongolia, China". English. In: African Invertebrates 48.1 (2007), pp. $145-152$.

[18153] J. F. Petruleviius and E. A. Jarzembowski. “The first hangingfly (Insecta: Mecoptera: Bittacidae) the Cretaceous of Europe". English. In: Journal of Paleontology 78.6 (2004), pp. 1198-1201.

[18154] J. F. Petruleviius and A. Nel. "Austroperilestidae, a new family of damselflies from early Eocene of Argentina (Insecta: Odonata). Phylogenetic relationships within Odonata". English. In: Journal of Paleontology 79.4 (2005), pp. 658-662.

[18155] J. F. Petruleviius, A. Nel, and J. F. Voisin. "A new genus and species of darner dragonfly (Aeshnidae: Odonata) from the lower Eocene of Laguna del Hunco, Patagonia, Argentina". English. In: Annales de la Société Entomologique de France 46 (2010), pp. 271-275. 
[18156] J. F. Petruleviius and A. Nel. "First Cordulephyidae dragonfly in America: A new genus and species from the Paleogene of Argentina (Insecta: Odonata)". English. In: Comptes Rendus Palevol 8 (2009), pp. 385-388.

[18157] J. F. Petruleviius and A. Nel. "A new libelluloid dragonfly (Insecta: Odonata: Italoansida) from the late Paleocene of Argentina". English. In: Geobios 36 (2003), pp. 401-406.

[18158] J. F. Petruleviius and A. Nel. "Recognition of the first fossil lestoid damselfly in South America (Insecta: Zygoptera): biogeographic and phylogenetic remarks". English. In: Journal of Paleontology 78.4 (2004), pp. 798-801.

[18159] J. F. Petruleviius and A. Nel. "A new damselfly family from the Upper Palaeocene of Argentina". English. In: Palaeontology 47.1 (2004), pp. 109-116.

[18160] J. F. Petruleviius, A. Nel, J. Rust, G. Bechly, and D. Kohls. “New Paleogene Epallagidae (Insecta: Odonata) recorded in North America and Europe. Biogeographic implications". English. In: Alavesia 1 (2007), pp. 15-25.

[18161] J. F. Petruleviius and A. Nel. "A new libelluloid dragonfly from late Paleocene deposits in Argentina (Odonata: Italoansida)". English. In: European Journal of Entomology 99 (2002), pp. 485-489.

[18162] J. F. Petruleviius and A. Nel. "Frenguelliidae, a new family of dragonflies from the earliest Eocene of Argentina (Insecta: Odonata): phylogenetic relationships within Odonata". English. In: Journal of Natural History 37 (2003), pp. 2909-2917.

[18163] J. F. Petruleviius and A. Nel. "New Palaeomacromiid dragonflies from the Upper Paleocene of Argentina". English. In: Palaeontology 45.4 (2002), pp. 751-758.

[18164] J. F. Petruleviius, A. Nel, and J. Muzón. "A new Libelluloid family from the Upper Paleocene of Argentina". English. In: Palaeontology 42.4 (1999), pp. 677-682.

[18165] J. F. Petruleviius and A. Nel. “Oldest Petalurid dragonfly (Insecta: Odonata): a Lower Cretaceous specimen from south Patagonia, Argentina". English. In: Cretaceous Research 24 (2003), pp. 31-34.

[18166] J. F. Petruleviius, A. Nel, and A. S. Sallenave. "Recent genus Notonecta (Insecta: Heteroptera: Notonectidae) in the Lower Cretaceous of San Luis, Argentina: Palaeoecological implications". English. In: Annales de la Société Entomologique de France 46 (2010), pp. 247-253.

[18167] J. F. Petruleviius, A. Nel, D. de Franceschi, C. Goillot, P. O. Antoine, R. Salas-Gismondi, and J. J. Flynn. "First fossil blood sucking Psychodidae in South America: a sycoracine moth fly (Insecta: Diptera) in the middle Miocene Amazonian amber". English. In: Insect Systematics E Evolution 42 (2011), pp. 87-96.

[18168] J. F. Petruleviius and A. Nel. "A new Frenguelliidae (Insecta: Odonata) from the early Eocene of Laguna del Hunco, Patagonia, Argentina". English. In: Zootaxa 3616 (2013), pp. 597-600.

[18169] J. F. Petruleviius and Y. A. Popov. "First fossil record of Discocephalinae (Insecta, Pentatomidae): a new genus from the middle Eocene of Ro Pichileufú, Patagonia, Argentina". English. In: ZooKeys 422 (2014), pp. 23-33.

[18170] J. F. Petruleviius and D. Ren. "A new species of Orthophlebiidae (Insecta: Mecoptera) from the Middle Jurassic of Inner Mongolia, China". English. In: Revue de Paléobiologie, Genéve, Vol. spéc 11 (2012), pp. 311-315.

[18171] J. F. Petruleviius, A. N. Varela, A. Iglesias, A. B. Zamuner, and D. G. Poiré. “First Cenomanian record of insects in the southern Hemisphere, with Perforissidae (Fulgoroidea) and Cupedidae (Coleoptera) from southern Patagonia, Argentina". English. In: Cretaceous Research 51 (2014), pp. 174185.

[18172] J. F. Petruleviius, T. Wappler, S. Wedmann, J. Rust, and A. Nel. “New megapodagrionid Damselflies (Odonata: Zygoptera) from the Paleogene of Europe". English. In: Journal of Paleontology 82.6 (2008), pp. 1173-1181.

[18173] J. F. Petruleviius, T. Wappler, A. Nel, and J. Rust. "The diversity of Odonata and their endophytic ovipositions from the Upper Oligocene Fossillagerstätte of Rott (Rhineland, Germany)". English. In: ZooKeys 130 (2011), pp. 67-89. 
[18174] M. Petruzzelli. "Gli speleologi e la tutela del patrimonio naturale, Es i siti ad orme di dinosauro [Speleologists and the protection of natural patrimony, e.g. dinosaur footprint sites]". Italian. In: vol. Atti. Spelaion2012, Convegno nazionale di Speleologia italiana e racuno regionale Pugliese. Riassunti della Giornata pugliese di studi sul carsismo e la speleologia Spelaion 2012. 2012.

[18175] M. Petruzzelli, A. Iannone, and R. La Perla. "Le orme di dinosauro in Puglia: emergenze da proteggere [Dinosaur footprints in Puglia: emergencies to protect]". Italian. In: vol. Atti. Criticitá geologiche del territorio pugliese: metodi di studio ed esempi, Giornata Scientifica. Bari: Dipartimento di Scienze della Terra e Geoambientali, Universitá di Bari, 2011.

[18176] A. Petter and F. K. Jouffroy. Fiber type population in limb muscles of Microcebus murinus. 1993.

[18177] F. M. Petti, M. Bernardi, P. Ferretti, R. Tomasoni, and M. Avanzini. “Dinosaur tracks in a marginal marine environment: the Coste dell'Anglone ichnosite (Early Jurassic, Trento Platform, NE Italy)". English. In: Italian Journal of Geosciences 130.1 (2011), pp. 27-41. DOI: 10.3301/IJG.2010.19.

[18178] F. M. Petti, S. D’Orazi Porchetti, M. A. Conti, U. Nicosia, G. Perugini, and E. Sacchi. “Theropod and sauropod footprints in the Early Cretaceous (Aptian) Apenninic Carbonate Platform (Esperia, Lazio, central Italy): a further constraint on the palaeogeography of the central-Mediterranean area". English. In: Studi Trentini di Scienze Naturali, Acta Geologica 83 (2008), pp. 323-334.

[18179] E. J. Petuch. "New ecphoras (Gastropoda: Thaididae: Ecphorinae) from the Calvert Formation of Maryland (Langhian Miocene)". English. In: The Nautilus 106.2 (1992), pp. 68-71.

[18180] E. J. Petuch. "A new gastropod fauna from an Oligocene back-reef lagoonal environment in west central Florida." English. In: The Nautilus 110.4 (1997), pp. 122-138.

[18181] C. Peybernes, J. Chablais, and R. Martini. “Upper Triassic (Ladinian?-Carnian) reef biota from the Sambosan Accretionary Complex, Shikoku, Japan". English. In: Facies 61.20 (2015). DOI: 10.1007 / s10347-015-0446-4.

[18182] K. Peyer, J. G. Carter, H. -D. Sues, S. E. Novak, and P. E. Olsen. “A new suchian archosaur from the Upper Triassic of North Carolina". English. In: Journal of Vertebrate Paleontology 28.2 (2008), pp. 363-381.

[18183] K. Peyer, S. Charbonnier, R. Allain, É Läng, and R. Vacant. "A new look at the Late Jurassic Canjuers conservation Lagerstätte (Tithonian, Var, France)". English. In: Comptes Rendus Palevol 13.5 (2014), pp. 403-420. DOI: 10.1016/j.crpv.2014.01.007.

[18184] E. Peyre, C. Guerin, N. Guidon, and Y. Coppens. "Des restes humains pleistocenes dans la grotte du Garrincho, Piaui, Bresil". French. In: C. R. Acad. Sci. Paris, Sciences de la terre et des planetes 327 (1998), pp. 335-360.

[18185] C. Peyre de Fabrégues and R. Allain. "Kholumolumo ellenbergerorum, gen. et sp. nov., a new early sauropodomorph from the lower Elliot Formation (Upper Triassic) of Maphutseng, Lesotho". English. In: Journal of Vertebrate Paleontology e1732996 (2020), pp. 1-32. DOI: 10.1080/02724634.2019. 1732996.

[18186] C. Peyre de Fabrégues, S. Bi, H. Li, G. Li, L. Yang, and X. Xu. “A new species of earlydiverging Sauropodiformes from the Lower Jurassic Fengjiahe Formation of Yunnan province, China". English. In: Scientific Reports 10 (2020), 10961:1-17. DOI: 10.1038/s41598-020-67754-4.

[18187] D. Peyrot, D. Jolly, and E. Barron. “Apport de données palynologiques á la reconstruction paléoenvironnementale de l'Albo-Cénomanien des Charentes (Sud-Ouest de la France)". English. In: Comptes Rendus Palevol 4 (2005), pp. 151-165. DOI: 10.1016/j.crpv.2004.11.016.

[18188] G. Peyrotty. "Sedimentology, biostratigraphy and diagenesis of Upper Triassic". English. PhD thesis. 2020.

[18189] G. Peyrotty, H. Ueda, C. Peybernes, R. Rettori, and R. Martini. “Upper Triassic shallow-water carbonates from the Naizawa Accretionary Complex, Hokkaido (Japan): New insights from Panthalassa". English. In: Palaeogeography, Palaeoclimatology, Palaeoecology (2020). DOI: 10.1016/j.palaeo. 2020.109832. 
[18190] L. H. Peza and J. Zitt. Urgonian (Early Cretaceous) echinoids of the Mirdita zone (Southern Albania). 2002.

[18191] H. U. Pfretzschner. “Ein weiteres Exemplar von Lethe? corbieri Nel 1993 (Lepidoptera, Satyridae) aus dem Unter-Oligozän von Céreste (Süd-Frankreich)". German. In: Paläontologische Zeitschrift 72 (1998), pp. 59-64.

[18192] H. U. Pfretzschner, T. Martin, M. W. Maisch, A. T. Matzke, and G. Sun. “A new docodont mammal from the Late Jurassic of the Junggar Basin in Northwest China". English. In: Acta Palaeontologica Polonica 50.4 (2005), pp. 799-808.

[18193] J. Philip and E. Jaillard. "Revision of the Upper Cretaceous rudists from northwestern Peru". English. In: Journal of South American Earth Sciences 17 (2004), pp. 39-48.

[18194] J. Philip and J. P. Platel. “Nouvelles espéces de Torreites du Campanien du Haushi-Huqf, Sultanat d'Oman". English. In: Geobios 22 (1998), pp. 283-294.

[18195] J. Philip and J.-P. Platel. "Monopilarites a new rudist genus from the Upper Cenomanian of the Haushi-Huqf massif". French. In: Geobios 22 (1998), pp. 269-282.

[18196] M. Philippe, F. Thevenard, G. Barale, S. Ferry, and G. Guignard. "Middle Bathonian floras and phytocoenoses of France." In: Palaeogeography, Palaeoclimatology, Palaeoecology 143 (1998), pp. 135158.

[18197] T. K. Philips and G. Mynhardt. "Description of Electrognostus intermedius, the first spider beetle from Dominican amber with implications on spider beetle phylogeny (Coleoptera Ptinidae)". English. In: Entomapeiron (P.S.) 4 (2011), pp. 37-51.

[18198] T. L. Phillips and W. A. DiMichele. "A Transect through a Clastic-swamp to Peat-swamp Ecotene in the Springfield Coal, Middle Pennsylvanian Age of Indiana, USA". In: Palaios 13 (1998), pp. 113128.

[18199] C. J. Phipps, B. J. Axsmith, T. N. Taylor, and E. L. Taylor. “Gleichenipteris antarcticus gen. et sp. nov. from the Triassic of Antarctica". In: Review of Palaeobotany and Palynology 108 (2000), pp. 75-83.

[18200] A. E. Piacentini Pinheiro, P. V. L. G. C. Pereira, R. G. de Souza, A. S. Brum, R. T. Lopes, A. S. Machado, L. P. Bergqvist, and F. M. Simbras. "Reassessment of the enigmatic crocodyliform Goniopholis paulistanus Roxo, 1936: Historical approach, systematic, and description by new materials". English. In: PLoS ONE 13.8 (2018), e0199984:1-45. DOI: 10.1371/journal.pone.0199984.

[18201] R. Pian, M. Archer, and S. J. Hand. "A New, Giant Platypus, Obdurodon tharalkooschild, sp. nov. (Monotremata, Ornithorhynchidae), from the Riversleigh World Heritage Area, Australia". English. In: Journal of Vertebrate Paleontology 33.6 (2013), pp. 1255-1259. DOI: 10.1080 / 02724634. 2013.782876.

[18202] D. S. Piazza, F. L. Agnolin, and S. Lucero. "First record of a macroraptorial sperm whale (Cetacea, Physeteroidea) from the Miocene of Argentina". English. In: Revista Brasileira de Paleontologia 21.3 (2018), pp. 276-280. DOI: 10.4072/rbp.2018.3.09.

[18203] V. Piazza, L. V. Duarte, J. Renaudie, and M. Aberhan. "Reductions in body size of benthic macroinvertebrates as a". English. In: Paleobiology 45.2 (2019), pp. 296-316. DOI: 10.1017/pab.2019.11.

[18204] V. Piazza, O. Hammer, and R. Jattiot. "New late Smithian (Early Triassic) ammonoids from the Lusitaniadalen Member, Vikinghøgda Formation". English. In: Norwegian Journal of Geology 97 (2017), pp. 105-117.

[18205] V. Piazza, C. V. Ullmann, and M. Aberhan. "Temperature-related body size change of marine benthic macroinvertebrates across the Early Toarcian Anoxic Event". English. In: Scientific Reports 10 (2020), p. 4675. DOI: 10.1038/s41598-020-61393-5.

[18206] M. B. J. Picasso, R. S. De Mendoza, and J. N. Gelfo. "A seedsnipe (Aves, Charadriiformes, Thinocoridae) from the Ensenadan Age/Stage (early-middle Pleistocene) of Buenos Aires, Argentina". English. In: Historical Biology 31 (2019), pp. 363-370. DOI: 10.1080/08912963.2017.1370647. 
[18207] J. Pickett and Y. Plusquellec. "Eponges siliceuses du Dévonien supérieur de la Rade de Brest (France)[Siliceous sponges in the Upper Devonian of Rade de Brest (France)]". French. In: Geobios 31.6 (1998), pp. 715-723.

[18208] J. Pickett and S. Pohler. “The Alaskan Devonian sphinctozoan Hormospongia (Porifera) in eastern Australia". English. In: Alcheringa 17 (1993), p. 158.

[18209] J. Pickett and W. S. Wu. "The succession of Early Carboniferous coral faunas in eastern Australia and China". English. In: Alcheringa 14 (1990), pp. 89-108.

[18210] J. W. Pickett. "Tournaisian corals and conodonts from the Slaughterhouse Creek area, New South Wales, Australia". English. In: Courier Forschungsinstitut Senckenberg 172 (1994), pp. 51-67.

[18211] J. W. Pickett. “A Late Devonian xiphosuran from near Parkes, New South Wales". English. In: Memoirs of the Association of Australasian Palaeontologists 15 (1993), pp. 279-287.

[18212] J. W. Pickett, M. K. Macphail, A. D. Partridgec, and M. S. Poled. “Middle Miocene palaeotopography at Little Bay, near Maroubra, New South Wales". English. In: Australian Journal of Earth Sciences: An International Geoscience Journal of the Geological Society of Australia 44.4 (1997), pp. 509518. DOI: $10.1080 / 08120099708728330$.

[18213] M. Pickford. Evidence for an arid climate in western Uganda during the middle Miocene. 1992.

[18214] M. Pickford. "Decouverte de Kenyapotamus en Tunisie". French. In: Annales de Paleontologie 76.4 (1990), pp. 277-283.

[18215] M. Pickford. "Revision des suides de la formation de Beglia (Tunisie)". French. In: Annales de Paleontologie 76.2 (1990), pp. 133-141.

[18216] M. Pickford. "Crocodiles from the Beglia Formation, Middle/Late Miocene Boundary, Tunisia, and their significance for Saharan palaeoclimatology". In: Annales de Paleontologie 86.1 (2000), pp. 59-67.

[18217] M. Pickford. "Suidae and hippopotamidae from the Middle Miocene of Kipsaraman, Kenya and other sites in East Africa". English. In: Palaeontological Research 11.1 (2007), pp. 85-105.

[18218] M. Pickford. "A new suiform (Artiodactyla, Mammalia) from the Early Miocene of East Africa". English. In: Comptes Rendu Palevol 6.3 (2007), pp. 221-229. DOI: 10.1016/j.crpv.2006.11.002.

[18219] M. Pickford. “Orycteropus (Tubulidentata, Mammalia) from Langebaanweg and Baard's Quarry, Early Pliocene of South Africa". English. In: Comptes Rendus Palevol 4 (2005), pp. 715-726. DOI: 10.1016/j.crpv.2005.06.001.

[18220] M. Pickford. "Revision of the Early Miocene Hyracoidea (Mammalia) of East Africa". English. In: Comptes Rendus Palevol 3 (2004), pp. 675-690.

[18221] M. Pickford. "Middle Miocene vertebrate fauna from Pemba Island, Tanzania”. English. In: South African Journal of Science 104 (2008), pp. 231-237.

[18222] M. Pickford. "Revision of the Mio-Pliocene bunodont otter-like mammals of the Indian Subcontinent". English. In: Estudios Geologicos 63.1 (2007), pp. 83-127.

[18223] M. Pickford. "Minute species of Orycteropus from the early Middle Miocene at Arrisdrift, Namibia". English. In: Memoirs of the Geological Survey of Namibia 19 (2003), pp. 195-198.

[18224] M. Pickford. "A new genus of Tayassuidae (Mammalia) from the middle Miocene of Uganda and Kenya". English. In: Annales de Paléontologie 84.3-4 (1998), pp. 275-285.

[18225] M. Pickford. "Fossil hyraxes (Hyracoidea: Mammalia) from the Late Miocene and Plio-Pleistocene of Africa, and the phylogeny of the Procaviidae". English. In: Palaeontologia Africana 41 (2005), pp. 141-161.

[18226] M. Pickford. "A new species of Crocodile from Early and Middle Miocene deposits of the lower Orange River Valley, Namibia, and the origins of the Nile Crocodile (Crocodylus niloticus)". English. In: Memoir Geological Survey, Namibia 19 (2003), pp. 51-65. 
[18227] M. Pickford. "Late Cenozoic crocodiles (Reptilia: Crocodylidae) from the Western Rift, Uganda". English. In: Geology and Palaeobiology of the Albertine Rift Valley, UgandaZaire, Vol. II: Palaeobiology. Orléans: CIFEG, 1994, pp. 137-155.

[18228] M. Pickford. "New Proboscidea from the Miocene strata in th elower Orange River Valley, Namibia". English. In: Memoir of the Geological Survey of Namibia 19 (2003), pp. 207-256.

[18229] M. Pickford. "Large ungulates from the basal Oligocene of Oman: 1 - Embrithopoda". English. In: Spanish Journal of Palaeontology 30.1 (2015), pp. 33-42.

[18230] M. Pickford. "Bothriogenys (Anthracotheriidae) from the Bartonian of Eoridge, Namibia". English. In: Communications of the Geological Survey of Namibia 16 (2015), pp. 215-222.

[18231] M. Pickford. "Chrysochloridae (Mammalia) from the Lutetian (Middle Eocene) of Black Crow, Namibia". English. In: Communications of the Geological Survey of Namibia 16 (2015), pp. 105-113.

[18232] M. Pickford. "Late Eocene Chrysochloridae (Mammalia) from the Sperrgebiet, Namibia". English. In: Communications of the Geological Survey of Namibia 16 (2015), pp. 153-193.

[18233] M. Pickford. "Late Eocene Lorisiform Primate from Eocliff, Sperrgebiet, Namibia". English. In: Communications of the Geological Survey of Namibia 16 (2015), pp. 194-199.

[18234] M. Pickford. "New Titanohyracidae (Hyracoidea: Afrotheria) from the Late Eocene of Namibia". English. In: Communications of the Geological Survey of Namibia 16 (2015), pp. 200-214.

[18235] M. Pickford. "Late Eocene Potamogalidae and Tenrecidae (Mammalia) from the Sperrgebiet, Namibia". English. In: Communications of the Geological Survey of Namibia 16 (2015), pp. 114-152.

[18236] M. Pickford. "Anthracotheres from the Oligocene of Aubenas-les-Alpes, France". English. In: Annales de Paléontologie 102 (2016), pp. 243-260.

[18237] M. Pickford. "Tiny Tenrecomorpha (Mammalia) from the Eocene of Black Crow, Namibia". English. In: Communications of the Geological Survey of Namibia 21 (2019), pp. 15-25.

[18238] M. Pickford. "New Chrysochloridae (Mammalia) from the middle Eocene of Black Crow, Namibia". English. In: Communications of the Geological Survey of Namibia 21 (2019), pp. 40-47.

[18239] M. Pickford. "Adapisoriculidae from the Southern Hemisphere". English. In: Communications of the Geological Survey of Namibia 21 (2019), pp. 26-31.

[18240] M. Pickford. "Tufamyidae, a new family of hystricognath rodents from the Palaeogene and Neogene of the Sperrgebiet, Namibia". English. In: Communications of the Geological Survey of Namibia 19 (2018), pp. 71-109.

[18241] M. Pickford. "Early and middle Miocene Anthracotheriidae (Mammalia, Artiodactyla) from the Sperregebiet, Namibia". English. In: Memoirs of the Geological Survey of Namibia 19 (2003), pp. 283289.

[18242] M. Pickford. "Two new rodents (Rodentia, Mammalia) from the late middle Eocene of Eocliff, Namibia". English. In: Communications of the Geological Survey of Namibia 22 (2020), pp. 21-46.

[18243] M. Pickford, Y. S. Attia, and M. S. Abd el Ghany. "Discovery of Prolibytherium magnieri Arambourg, 1961 (Artiodactyla, Climacoceratidae) in Egypt". English. In: Geodiversitas 23.4 (2001), pp. 647652.

[18244] M. Pickford, L. Gabunia, P. Mein, J. Morales, and B. Azanza. “The middle Miocene mammalian site of Belometchetskaya, North Caucasus: an important biostratigraphic link between Europe and China". English. In: Geobios 33.2 (2000), pp. 257-267.

[18245] M. Pickford and S. S. Gupta. "New specimen of Conohyus indicus (Lydekker, 1884) (Mammalia: Suidae) from the base of the Late Miocene, Jammu, India". English. In: Annales de Paléontologie 87.4 (2001), pp. 271-281.

[18246] M. Pickford, P. Mein, and B. Senut. Fossiliferous Neogene karst fillings in Angola,Botswana and Namibia. 1994. 
[18247] M. Pickford and J. Morales. "A tubulidentate suiform lineage (Tayassuidae, Mammalia) from the Early Miocene of Spain". English. In: Comptes Rendus de l'Academie des Sciences, Serie II. Sciences de la Terre et des Planetes 237.4 (1998), pp. 285-290.

[18248] M. Pickford and J. Morales. "Basal middle Miocene Listriodontinae (Suidae, Artiodactyla) from Madrid," English. In: Spanish Journal of Palaeontology 31.2 (2016), pp. 369-406.

[18249] M. Pickford, B. Senut, P. Mein, D. Gommery, J. Morales, D. Soria, M. Nieto, and J. Ward. "Preliminary results of new excavations at Arrisdrift, middle Miocene of southern Namibia". English. In: Comptes rendus de l'Académie des sciences. Série IIa, Sciences de la Terre et des Planetes/Earth \& Planetary Sciences 322.11 (1996), pp. 991-996.

[18250] M. Pickford and B. Senut. Palaeobiology of the Albertine rift valley,Uganda-Zaire. Vol. II. In:Geol. and palaeobiology of the Albertine rift valley,B.Senut. 1994, pp. 9-26.

[18251] M. Pickford and B. Senut. "Cainozoic mammals from coastal Namaqualand, South Africa". English. In: Paleontologia Africana 34 (1997), pp. 199-217.

[18252] M. Pickford and B. Senut. "Geology and Palaeobiology of the Central and Southern Namib Desert, Southwestern Africa, Volume 1: Geology and History of Study". English. In: Geological Survey of Namibia, Memoire 18 (2000), pp. 1-155.

[18253] M. Pickford, B. Senut, D. Gommery, and E. Musiime. "New Catarrhine fossils from Moroto II, Early Middle Miocene (ca 17.5 Ma) Uganda". English. In: Comptes Rendus Palevol 2.8 (2003), pp. 649 662.

[18254] M. Pickford, B. Senut, J. Morales, P. Mein, and I. M. Sanchez. "Mammalia from the Lutetian of Namibia". English. In: Memoir of the Geological Survey of Namibia 20 (2008), pp. 465-514.

[18255] M. Pickford, H. Thomas, S. Sen, J. Roger, E. Gheerbrant, and Z. Al-Sulaimani. "Early Oligocene Hyracoidea (Mammalia) from Thaytiniti and Taqah, Dhofar Province, Sultanate of Oman". English. In: Comptes Rendus de l'Académie des Sciences de Paris 318 (1994), pp. 1385-1400.

[18256] M. Pickford, H. Wanas, and H. Soliman. "Indications for a humid climate in the Western Desert of Egypt 11-10 Myr ago: evidence from Galagidae (Primates, Mammalia)". English. In: Comptes Rendus Palevol 5.8 (2006), pp. 935-943.

[18257] R. Pidal. “A Lower Devonian (Emsian) species of the genus Bactrocrinites (Crinoidea): Bactrocrinites robustus n. sp. (Cantabrian Mountains, NW Spain)". English. In: Revista Española de Paleontologa 23.2 (2008), pp. 267-271.

[18258] G. Piekowski and G. Niedwiedzki. "Pterosaur tracks from the early Kimmeridgian intertidal deposits of Wierzbica, Poland". English. In: Geological Quarterly 49.3 (2005), pp. 339-346.

[18259] G. Pienkowski. "Dinosaur nesting ground from the Early Jurassic fluvial deposits, Holy Cross Mountains (Poland)". English. In: Geological Quarterly 42.4 (1998), pp. 461-476.

[18260] G. Pienkowski, P. Branski, D. K. Pandey, J. Schlögl, M. Alberti, and F. T. Fürsich. “Dinosaur footprints from the Thaiat ridge and their palaeoenvironmental background, Jaisalmer Basin, Rajastan, India". English. In: Volumina Jurassica 13.1 (2015), pp. 17-26. DOI: 10.5604/17313708.1148553.

[18261] G. Pienkowski, M. E. Popa, and A. Kedzior. "Early Jurassic sauropod footprints of the Southern Carpathians, Romania: palaeobiological and palaeogeographical significance". English. In: Geological Quarterly 53.4 (2009), pp. 461-470.

[18262] S. E. Pierce and M. J. Benton. "Pelagosaurus typus Bronn, 1841 (Mesoeucrocodylia: Thalattosuchia) from the Upper Lias (Toarcian, Lower Jurassic) of Somerset, England". English. In: Journal of Vertebrate Paleontology 26.3 (2006), pp. 621-635. DOI: 10.1671/0272-4634(2006)26[621:PTBMTF]2. $0 . \mathrm{CO} ; 2$.

[18263] S. E. Pierce and M. W. Caldwell. "Redescription and phylogenetic position of the Adriatic (Upper Cretaceous; Cenomanian) dolichosaur Pontosaurus lesinensis (Kornhuber, 1873)". English. In: Journal of Vertebrate Paleontology 24.2 (2004), pp. 373-386. 
[18264] V. Pieroni and A. Nützel. "Rasatomaria gentilii gen. n. n. sp. - a new Middle Triassic pleurotomarioid gastropod genus and species from Rasa di Varese (San Salvatore Formation, southern Alps)". English. In: Rivista Italiana di Paleontologia e Stratigrafia 120 (2014), pp. 281-286.

[18265] B. J. Pierson, S. Aspinall, and K. Al-Mehsin. Fossil whale skeleton in Abu Dhabi's coastal sabkha. English. 2008.

[18266] C. Pietsch and D. J. Bottjer. "Ecological recovery dynamics of the benthic and pelagic fauna in response to extreme temperature events and low oxygen environments developed during the Early Triassic". English. PhD thesis. 2015.

[18267] T. W. Pietsch and G. Carnevale. "A New Genus and Species of Anglerfish (Teleostei: Lophiiformes: Lophiidae) from the Eocene of Monte Bolca, Italy". English. In: Copeia 2011.1 (2011), pp. 64-71.

[18268] G. Piga, A. Santos-Cubedo, A. Brunetti, M. Piccinini, A. Malgosa, E. Napolitano, and S. Enzo. “A multi-technique approach by XRD, XRF, FT-IR to characterize the diagenesis of dinosaur bones from Spain". English. In: Palaeogeography, Palaeoclimatology, Palaeoecology 310.1-2 (2011), pp. 92107. DOI: $10.1016 /$ j.palaeo.2011.05.018.

[18269] J. S. Pigati, D. R. Muhs, and J. P. McGeehin. "On the importance of stratigraphic control for vertebrate fossil sites in". English. In: Quaternary Research 443 (2017), pp. 129-139. DOI: 10.1016/j. quaint.2016.07.015.

[18270] K. B. Pigg. "Anatomically preserved Glossopteris foliage from the central Transantarctic Mountains". English. In: Review of Palaeobotany and Palynology 66 (1990), pp. 105-127. DOI: 10.1016/00346667(90)90030-M.

[18271] K. B. Pigg and R. A. Stockey. "Platanaceous plants from the Paleocene of Alberta, Canada". In: Review of Palaeobotany and Palynology 70 (1991), pp. 125-146.

[18272] C. S. G. Pillai, K. K. Appukuttan, and P. Kaladharan. “Occurence of submerged Pleistocene stony corals and marine molluscs at Vazhakala near Cochin and their significance on sea level changes". English. In: Indian Journal of Marine Sciences 28 (1999), pp. 96-98.

[18273] D. D. L. Pillai, N. D. J. Cook, and H. J. Campbell. "Permian ammonoids from the Greville Formation, Upkerora valley, Southland". English. In: New Zealand Journal of Geology and Geophysics 340 (1991), pp. 365-372.

[18274] J. Pillet. "Les Gastéropodes de l'Ordovicien moyen en Anjou". French. In: Bulletin de la Société des études scientifiques d'Anjour 7 (1992), pp. 1-60.

[18275] G. L. Pillola and D. Zoboli. “I cetacei fossili del Museo Sardo di Geologia e Paleontologia Domenico Lovisato (Cagliari)". Italian. In: Museologia Scientifica Memorie 13 (2014), pp. 124-126.

[18276] C. Pimiento and M. Balk. The extinct giant shark Carcharocles megalodon: A model for understanding deep-time body size trends of marine apex predators. English. 2015.

[18277] C. Pimiento, D. J. Ehret, B. J. MacFadden, and G. Hubbell. "Ancient Nursery Area for the Extinct Giant Shark Megalodon from the Miocene of Panama". English. In: PloS One 5.5 (2010), pp. 1-9.

[18278] C. Pimiento, G. González-Barba, A. J. W. Hendy, C. Jaramillo, B. J. MacFadden, C. Montes, S. C. Suarez, and M. Shippritt. "Early Miocene chondrichthyans from the Culebra Formation Panama A window into marine vertebrate faunas before closure the Central American Seaway". English. In: Journal of South American Earth Sciences 42 (2013), pp. 159-170.

[18279] C. Pimiento, G. González-Barba, D. J. Ehret, B. J. MacFadden, A. J. W. Hendy, and C. Jaramillo. "Sharks and Rays (Chondrichthyes, Elasmobranchii) from the late Miocene Gatun Formation of Panama". English. In: Journal of Paleontology 87.5 (2013), pp. 755-774. DOI: 10.1666/12-117.

[18280] J. D. Pinard, R. Weis, P. Neige, N. Mariotti, and A. Di Cencio. "Belemnites from the Upper Pliensbachian and the Toarcian (Lower Jurassic) of Tournadous (Causses, France)". English. In: Neues Jahrbuch für Geologie und Paläontologie, Abhandlungen 273 (2014), pp. 155-177.

[18281] M. G. Pincemaille-Quillevere, E. Buffetaut, and F. Quillevere. “Description ostéologique de l'arriérecrane de Rhabdodon (Dinosauria, Euornithopoda) et implications phylogénetiques [Osteological description of the braincase of Rhabdodon (Dinosauria, Euornithopoda) and phylogenetic implications]". English. In: Bulletin de la Société Géologique de France 177.2 (2006), pp. 97-104. 
[18282] G. Pineiro, C. Marsicano, C. Goso, and E. Morosi. “Temnospondyl diversity of the Permian-Triassic Colonia Orozco Local Fauna (Buena Vista Formation) of Uruguay". English. In: Revista Brasileira de Paleontologia 10.3 (2007), pp. 169-180.

[18283] G. Pineiro, A. Ramos, and C. Marsicano. "A rhinesuchid-like temnospondyl from the PermoTriassic of Uruguay". English. In: Comptes Rendus Palevol 11 (2012), pp. 65-78. DOI: 10.1016/j. crpv.2011.07.007.

[18284] G. Pineiro, A. Rojas, and M. Ubilla. "A new procolophonoid (Reptilia, Parareptilia) from the Upper Permian of Uruguay". English. In: Journal of Vertebrate Paleontology 24.4 (2004), pp. 814-821.

[18285] P. Pinero, J. Agusti, O. Oms, I. Fierro, P. Montoya, S. Mansino, F. Ruiz-Sanchez, D. M. Alba, M. T. Alberdi, H. -A. Blain, C. Laplana, J. van der Made, A. V. Mazo, J. Morales, X. Murelaga, A. PerezGarcia, F. Perez-Valera, J. A. Perez-Valera, P. Sevilla, J. M. Soria, and G. Romero. “Early Pliocene continental vertebrate Fauna at Puerto de la Cadena (SE Spain) and its bearing on the marinecontinental correlation of the Late Neogene of Eastern Betics". English. In: Palaeogeography, Palaeoclimatology, Palaeoecology (2017).

[18286] A. E. P. Pinheiro, R. J. Bertini, M.B.d. Andrade, and R. G. M. Neto. "A new specimen of Stratiotosuchus maxhechti (Baurusuchidae, Crocodyliformes) from the Adamantina Formation (Upper Cretaceous), Southeastern Brazil". English. In: Revista Brasileira de Paleontologia 11.1 (2008), pp. 37-50. DOI: 10.4072/rbp.2008.1.04.

[18287] A. E. P. Pinheiro, D. C. Fortier, D. Pol, D. A. Campos, and L. P. Bergqvist. "A new Eocaiman (Alligatoridae, Crocodylia) from the Itaborai Basin, Paleogene of Rio de Janeiro, Brazil". English. In: Historical Biology 25.3 (2013), pp. 327-337. DOI: 10.1080/08912963.2012.705838.

[18288] F. Pinheiro, A. E. Q. de Figueiredo, P. C. Dentzien-Dias, D. C. Fortier, C. I. Schultz, and M. S. S. Viana. "Planohybodus marki sp. nov., a new fresh-water hybodontid shark from the Early Cretaceous of northeastern Brazil". English. In: Cretaceous Research 41 (2013), pp. 210-216. DOI: 10.1016/ j.cretres.2012.12.005.

[18289] F. L. Pinheiro, D. C. Fortier, C. L. Schultz, J. Artur, F. G. De Andrade, and R. A. M. Bantim. "New information on Tupandactylus imperator, with comments on the relationships of Tapejaridae (Pterosauria)". English. In: Acta Palaeontologica Polonica 56.3 (2011), pp. 567-580. DOI: 10.4202/ app.2010.0057.

[18290] F. L. Pinheiro, M. A. G. França, M. B. Lacerda, R. J. Butler, and C. L. Schultz. “An exceptional fossil skull from South America and the origins of the archosauriform radiation". English. In: Scientific Reports 6 (2016), p. 22817.

[18291] K. Pinilla, N. Sabattini, and J. Hlebszevitsch. "Nuevos gastrópodos del Pérmico inferior de la Formación Mojón de Hierro, provincia del Chubut, Argentina". Spanish. In: Ameghiniana 44.2 (2007), pp. 399-405.

[18292] K. Pinilla and N. Sabattini. "Una nueva especie de Retispira Knight (Gastropoda, Bellerophontoidea) del Pérmico Inferior en la provincia del Chubut, Argentina". Portugese. In: Ameghiniana 50.4 (2013), pp. 379-388.

[18293] M. K. Pinilla, N. M. Sabattini, M. F. Tortello, and G. F. Aceñolaza. “A new species of Strepsodiscus Knight (Gastropoda, Bellerophontoidea) from the Upper Cambrian of Argentina". English. In: Neues Jahrbuch für Geologie und Paläontologies Abhandlungen 248.2 (2008), pp. 217-223. DOI: 10.1127/ 0077-7749/2008/0248-0217.

[18294] S. Pinkert, G. Bechly, and A. Nel. "First record of hawker dragonflies from Eocene Baltic amber (Odonata: Anisoptera: Gomphaeschnidae)". English. In: Zootaxa 4272 (2017), pp. 263-275.

[18295] S. Pinkert, A. Nel, and D. Y. Huang. "A new hawker dragonfly from the Middle Jurassic of China (Odonata: Aeshnoptera)". English. In: Comptes Rendus Palevol 16 (2017), pp. 378-381.

[18296] M. Pino, M. Hoffmeister, X. N Harris, and R. Labarca. "The late Pleistocene Pilauco site, Osorno, south-central Chile". English. In: Quatenary International 229 (2013), pp. 3-12. 
[18297] J. D. Pinsof. "A Cranium of Bison alaskensis (Mammalia: Artiodactyla: Bovidae) and Comments on Fossil Bison Diversity in the American Falls Area, Southeastern Idaho". English. In: Journal of Vertebrate Paleontology 11.4 (1991), pp. 509-514.

[18298] J. D. Pinsof and J. Echols. "A late Pleistocene (Sangamonian) vertebrate fauna from eastern Texas". English. In: Texas Journal of Science 49.1 (1997), pp. 3-22.

[18299] I. D. Pinto. "A new Lower Cretaceous Blattoid Insect from Argentina". English. In: Pesquisas 17.1-2 (1990), pp. 11-14.

[18300] I. D. Pinto. "Rigattoptera ornellasae n. g. n. sp., a new fossil insect from the Carboniferous of Argentina". English. In: Neues Jahrbuch für Geologie und Paläontologie, Monatshefte 1996.1 (1996), pp. 43-47.

[18301] I. D. Pinto. "Pemian Insects from Paraná Basin, South Brazil VI. Homoptera-3. Fulgoringruidae". English. In: Pesquisas 17.1-2 (1990), pp. 3-6.

[18302] I. D. Pinto. "New Upper Carboniferous palaeodictyopteran insect from Piedra Shotle Formation, Argentina". English. In: Pesquisas em Geociencias 19 (1992), pp. 55-58.

[18303] I. D. Pinto. "A new species of palaeodictyopteran Insecta from Piedra Shotle Formation, Upper Carboniferous, Argentina". English. In: Pesquisas em Geociencias 21 (1995), pp. 107-111.

[18304] I. D. Pinto. “Carboniferous insects from Argentina V Narkeminidae Pinto et Ornellas, 1991 - Ordo Paraplecoptera". English. In: Anais da Academia Brasileira de Ciencias 64 (1992), pp. 289-292.

[18305] I. D. Pinto. "Sphecorydaloides lucchesei, a new Carboniferous megasecopteran Insecta from Argentina". English. In: Pesquisas 21.2 (1994), pp. 85-89.

[18306] I. D. Pinto. "A new Upper Carboniferous paraplecopteran insect from south Brazil". English. In: Pequisas 17 (1990), pp. 7-10.

[18307] I. D. Pinto and K. Adami-Rodrigues. "Velisoptera taschi nov. gen., nov. sp. a Carboniferous insect from Bajo de Velis, Argentina". English. In: Pesquisas 24.1/2 (1997), pp. 47-52.

[18308] I. D. Pinto and K. Adami-Rodrigues. "A new Upper Carboniferous insect from Itararé Subgroup, Paraná Basin, Brazil". English. In: Pesquisas 22 (1995), pp. 53-57.

[18309] I. D. Pinto and M. Mendes. "A second upper Paleozoic blattoid (Insecta) from Betancourt, Chubut Province, Argentina". English. In: Revista Brasileira de Paleontologia 4 (2002), pp. 45-50.

[18310] I. D. Pinto, G. Piñeiro, and M. Verde. "First Permian insects from Uruguay". English. In: Pesquisas 27.1 (2000), pp. 89-96.

[18311] I. D. Pinto and F. A. Sedor. "A new Upper Carboniferous blattoid from Mafra Formation, Itarare Group, Parana Basin, Brazil". English. In: Pesquisas 27.2 (2000), pp. 45-48.

[18312] S. Pinto, M. C. Cabral, and L. V. Duarte. "Preliminary data on the ostracod fauna from the Lower Toarcian of Peniche". English. In: Ciencias da Terra (UNL) 16 (2007), pp. 37-43.

[18313] L. Piñuela, J. C. Garcia-Ramos, and J. I. Ruiz-Omeñaca. Evidence of pterosaur tracks in the Late Jurassic of Asturias. English. 2007.

[18314] K. J. Piper. “Early Pleistocene mammals from the Nelson Baylocal fauna, Portland, Victoria, Australia". English. In: Journal of Vertebrate Paleontology 27.2 (2007), pp. 492-503. DOI: 10.1671/02724634(2007)27[492:EPMFTN]2.0.CO;2.

[18315] K. J. Piper, E. M. G. Fitzgerald, and T. H. Rich. "Mesozoic to early Quaternary mammal faunas of Victoria, South-East Australia". English. In: Palaeontology 49.6 (2006), pp. 1237-1262.

[18316] R. Pipik and P. Holec. "Pannonian ostracods (Crustacea, Ostracoda) and vertebrates (Chordata, Vertebrata) from loam pit of the brick yard in Borský Svätý Jur". other. In: Min. Slov 30 (1998), pp. 185-194.

[18317] P. Piras and A. D. Buscalioni. "Diplocynodon muelleri comb. nov., an Oligocene diplocynodontine alligatoroid from Catalonia (Ebro Basin, Lleida Province, Spain)". English. In: Journal of Vertebrate Paleontology 26.3 (2006), pp. 608-620. 
[18318] P. Piras and T. Kotsakis. "A new gavialid from the Early Miocene of south-eastern Pakistan (Preliminary Report)". English. In: Rendiconti Societa Paleontologica Italiana 2 (2005), pp. 201-207.

[18319] P. A. Pirazzoli, U. Radtke, W. S. Hantoro, C. Jouannic, C. T. Hoang, C. Causse, and M. Borel Best. "A one million-year-long sequence of marine terraces on Sumba Island, Indonesia". English. In: Marine Geology 109 (1993), pp. 221-236.

[18320] P. A. Pirazzoli, J. L. Reyss, M. Fontugne, A. Haghipour, A. Hilgers, H. U. Kasper, H. Nazari, F. Preusser, and U. Radtke. "Quaternary coral-reef terraces from Kish and Qeshm Islands, Persian Gulf: new radiometric ages and tectonic implications". English. In: Quaternary International 120 (2004), pp. 15-27.

[18321] R. Pires, H. C. Neves, and A. A. Karamanlidis. "The critically endangered Mediterranean monk seal Monachus monachus in the archipelago of Madeira: priorities for conservation". English. In: Oxyx 42.2 (2008), pp. 278-285.

[18322] A. Pisera. "New species of lithistid sponges from the Paleogene of the Ukraine". English. In: Zoosystema 22.2 (2000), pp. 285-298.

[18323] A. Pisera. "Miocene reefs of the Paratethys: a review". English. In: SEPM Concepts in Sedimentology and Paleontology 5 (1996), pp. 97-104.

[18324] A. Pisera. "Upper Jurassic siliceous sponges from the Swabian Alb: taxonomy and paleoecology". English. In: Palaeontologia Polonica 57 (1997), pp. 3-216.

[18325] A. Pisera and M. A. Bitner. "The sponge genus Brachiaster (Pachastrellidae, Demospongiae) and its first known fossil representative, from the Late Eocene of southwestern Australia". English. In: Alcheringa 31.4 (2007), pp. 365-373.

[18326] A. Pisera and A. Bodzioch. "Middle Triassic lyssacinosan sponges from Upper Silesia (southern Poland), and the history of hexactinosan and lychniscosan sponges". English. In: Acta Geologica Polonica 41 (1991), pp. 193-207.

[18327] A. Pisera and P. Busquets. "Eocene siliceous sponges from the Ebro Basin (Catalonia, Spain)". English. In: Géobios 35.3 (2002), pp. 321-346.

[18328] A. Pisera, M. Cachao, and C. M. da Silva. "Siliceous sponge spicules from the Miocene Mem Moniz Marls (Portugal) and their environmental significance". English. In: Rivista Italiana di Paleontologia e Stratigrafia 112.2 (2006), pp. 287-299.

[18329] A. Pisera, R. Manconi, P. A. Siver, and A. P. Wolfe. "The sponge genus Ephydatia from the highlatitude middle Eocene: environmental and evolutionary significance". English. In: Palaeontologische Zeitschrift 90 (2016), pp. 673-680. DOI: 10.1007/s12542-016-0328-2.

[18330] A. Pisera, J. K. Rigby, and K. G. Bylund. “Lower Triassic hexactinellid sponges from the Confusion Range, western Utah". English. In: Brigham Young University Geology Studies 41 (1996), pp. 139-148.

[18331] V. G. Pitana and A. M. Ribeiro. "Novos materiais de Propraopus Ameghino, 1881 (Mammalia, Xenarthra, Cingulata) do Pleistoceno final, Rio Grande do Sul, Brasil". Spanish. In: GAEA Journal of Geoscience 3.2 (2007), pp. 60-67.

[18332] R. L. Pitman, A. L. Van Helden, P. B. Best, and A. Pym. "Shepherd's beaked whale (Tasmacetus shepherdi): Information on appearance and biology based on strandings and at-sea observations". English. In: Marine Mammal Science 22.3 (2006), pp. 744-755.

[18333] W. D. Pitt and L. J. Pitt. "A new species of Enaeta (Gastropoda: Volutidae) from the Mio-Pliocene of northwestern Ecuador". In: Tulane Studies in Geology and Paleontology 28 (1995), pp. 123-126.

[18334] W. D. Pitt and L. J. Pitt. "Nassarius (Mollusca: Neogastropoda) from the Neogene of northwestern Ecuador". In: Tulane Studies in Geology and Paleontology 29 (1997), pp. 135-150.

[18335] W. D. Pitt and L. J. Pitt. "Naticidae (Mollusca: Mesogastropoda) from the Neogene of northwestern Ecuador". In: Tulane Studies in Geology and Paleontology 25.4 (1992), pp. 109-138.

[18336] V. V. Pitulko and A. K. Kasparov. "Ancient Arctic Hunters: Material Culture and Survival Strategy". English. In: Arctic Anthropology 33.1 (1996), pp. 1-36. 
[18337] C. Pla, A. Márquez-Aliaga, and H. Botella. "The Chondrichthyan Fauna from the Middle Triassic (Ladinian)of the Iberian Range (Spain)". English. In: Journal of Vertebrate Paleontology 33 (2013), pp. 770-785.

[18338] A. R. Plant, I. Shamshev, and E. Perkovsky. "A new species of Hemerodromia Meigen (Diptera: Empididae: Hemerodromiinae) from Late Eocene Rovno Amber". English. In: Studia Dipterologica 18 (2011), pp. 79-84.

[18339] J. P. Platel. "The Turonian rudist-bearing carbonate platforms of the Charentes and Perigord areas, Aquitaine Basin (France)". English. In: Geobios, Memoire special 22 (1998), pp. 295-311.

[18340] B. F. Platt and S. T. Hasiotis. "Newly discovered sauropod dinosaur tracks with skin and footpad impressions from the Upper Jurassic Morrison Formation, Bighorn Basin, Wyoming, U.S.A." English. In: Palaios 21 (2006), pp. 249-261.

[18341] N. H. Platt and C. A. Meyer. "Dinosaur footprints from the Lower Cretaceous of northern Spain: their sedimentological and palaeoecological context". English. In: Palaeogeography, Palaeoclimatology, Palaeoecology 86 (1991), pp. 321-333.

[18342] J.-C. Plaziat and C. Perrin. "Multikilometer-sized reefs built by foraminifera (Solenomeris) from the early Eocene of the Pyrenean domain (S. France, N.Spain): Palaeoecologic relations with coral reefs". In: Palaeogeography, Palaeoclimatology, Palaeoecology 96 (1992), pp. 195-231.

[18343] N. Pledge. "The upper fossil fauna of the Henschke fossil cave, Naracoorte, South Australia". English. In: Memoirs of the Queensland Museum 28.1 (1990), pp. 247-262.

[18344] N. S. Pledge. "A new species of early Oligocene cetacean from Port Wilunga, South Australia". English. In: Memoirs of the Queensland Musuem 51.1 (2005), pp. 123-133.

[18345] N. S. Pledge. First record of fossil sirenians in southern Australia. English. 1992.

[18346] N. S. Pledge. "The Telford Cetothere (Cetacea: Mysticeti)". English. In: Transactions of the Royal Society of South Australia 13.4 (2010), pp. 158-163.

[18347] N. S. Pledge. "Sirenians in southern Australia - first fossil record". English. In: Alcheringia SI 1 (2006), pp. 295-305.

[18348] N. S. Pledge. "A new koala (Marsupialia : Phascolarctidae) from the late Oligocene Etadunna Formation, Lake Eyre Basin, South Australia". English. In: Australian Mammalogy 32 (2010), pp. 79 86. DOI: 10.1071/AM09014.

[18349] N. S. Pledge. A New Species of Muramura Pledge (Wynyardiidae: Marsupialia) from the Middle Tertiary of the Callabonna Basin, Northeastern South Australia. English. Vol. 279. Bulletin of the American Museum of Natural History. American Museum of Natural History. 2003, pp. 541-555. DOI: 10. 1206/0003-0090(2003)279<0541:C>2.0.CO;2.

[18350] N. S. Pledge, A. R. Milnes, R. P. Bourman, and N. F. Alley. "Fossil shark teeth from upland Fleurieu Peninsula, South Australia: evidence for previously unknown Tertiary marine sediments". English. In: Mesa Journal 76.1 (2015), pp. 67-73.

[18351] F. Pleijel, G. W. Rouse, and J. M. C. Vannier. "Carboniferous fireworms (Amphinomida: Annelida), with a discussion of species taxa in palaeontology". English. In: Invertebrate Systematics 18 (2004), pp. 693-700. DOI: 10.1071/IS04003.

[18352] M. Plenicar and B. Jurkovsek. “Rudisti iz cenomanijskih bioherm Hrusice in Nanosa [Rudists from the Cenomanian bioherms of Hrusica and Nanos, Slovenia]". other. In: Geologija 42 (2000), pp. 69 116.

[18353] M. Plenicar and B. Jurkovsek. "Rudists from the Santonian-Campanian bioherm near the spring of the Lijak Brook (SW Slovenia)". English. In: Razprave Slovenska Akademija Znanosti in Umetnosti, Razred za Naravoslovne Vede, IV 41.1 (2000), pp. 51-79.

[18354] G. Ples, A. Oprisa, I. I. Bucur, E. Sasaran, C. V. Mircescu, G. Oltean, and R. G. Iacob. “The centralwestern Getic Carbonate Platform: Upper Jurassic to Lower Cretaceous biostratigraphy and sedimentary evolution of the Cioclovina-Bnia sector (Southern Carpathians, Romania)". English. In: Facies 65.32 (2019). DOI: 10.1007/s10347-019-0574-3. 
[18355] R. E. Plotnick. “Habitat of Llandoverian-Lochkovian eurypterids". English. In: Paleocommunities - a case study from the Silurian and Lower Devonian. Cambridge: Cambridge University Press, 1999, pp. 106-136.

[18356] V. V. Plotnikov, E. N. Maschenko, I. S. Pavlov, A. V. Protopopov, G. G. Boeskorov, and E. A. Petrova. "New data on trunk morphology in the woolly mammoth, Mammuthus primigenius (Blumenbach)". English. In: 49.2 (2015), pp. 200-210.

[18357] S. Podenas. "Paradelphomyia (Diptera, Limoniidae) from the Baltic amber". English. In: Acta Zoologica Lituanica: Biodiversity 9 (1999), pp. 107-110.

[18358] S. Podenas. "New Cheilotrichia crane flies (Diptera, Limoniidae) from Baltic amber". English. In: Mitteilungen aus dem Geologisch-Paläontologischen Institut der Universität Hamburg 83 (1999), pp. 239-248.

[18359] S. Podenas. "New species of fossil mosquitoes (Diptera, Culicidae) from the Baltic amber". English. In: Acta Zoologica Lituanica, Biodiversity 9 (1999), pp. 111-114.

[18360] S. Podenas. "Rhabdomastix Crane Flies (Diptera: Limoniidae) in Baltic Amber (Eocene)". English. In: Proceedings of the Academy of Natural Sciences of Philadelphia 155 (2006), pp. 41-66.

[18361] S. Podenas. "Dicranoptycha crane flies (Diptera: Limoniidae) from Baltic amber (Eocene)". English. In: Transactions of the American Entomological Society 130 (2004), pp. 457-462.

[18362] S. Podenas. "New species of Tricyphona crane flies (Diptera: Pediciidae) from Baltic amber (Eocene)". English. In: Proceedings of the Academy of Natural Sciences of Philadelphia 151 (2001), pp. 31-39.

[18363] S. Podenas. "First phantom crane flies (Diptera, Ptychopteridae) from Baltic amber (Eocene)". English. In: Proceedings of the Academy of Natural Sciences of Philadelphia 156 (2007), pp. 195-198.

[18364] S. Podenas. "A new subgenus for Trentepohlia crane flies (Diptera Limoniidae) with elongated mouth parts, from Baltic amber (Eocene)". English. In: Proceedings of the Academy of Natural Sciences of Philadelphia 153 (2003), pp. 67-71.

[18365] S. Podenas. "Dactylolabis Crane Flies (Diptera: Limoniidae) in Baltic Amber (Eocene)". English. In: Proceedings of the Academy of Natural Sciences of Philadelphia 153 (2003), pp. 49-65.

[18366] S. Podenas. "Idiocera Dale, 1842 (Diptera, Limoniidae) from Baltic amber (Eocene)". English. In: Transactions of the American Entomological Society 132.3/4 (2006), pp. 419-425.

[18367] S. Podenas. "First Fossil Dolichopeza Curtis, 1825 (Diptera: Tipulidae), from Baltic Amber (Eocene)". English. In: Proceedings of the Academy of Natural Sciences of Philadelphia 153 (2003), pp. 73-75.

[18368] S. Podenas. “Trentepohlia Bigot, 1854, crane flies (Diptera, Limoniidae) From Baltic amber (Eocene)". English. In: Bulletin de la Société Neuchateloise des Sciences Naturelles 128 (2005), pp. 145-154.

[18369] S. Podenas. "A New Species of Diogma Edwards, 1938 (Diptera, Cylindrotomidae) from Baltic Amber (Eocene)". English. In: Transactions of the American Entomological Society 126.1 (2000), pp. 103107.

[18370] S. Podenas. "Trichoceridae (Diptera) from Baltic amber (Eocene) in the collection of the Muséum d'Histoire Naturelle, Neuchatel, Switzerland". English. In: Bulletin de la Société Neuchateloise des Sciences Naturelles 124 (2001), pp. 131-147.

[18371] S. Podenas. "First Rhipidia Meigen, 1818 (Diptera, Limoniidae) from Baltic amber (Eocene)". English. In: Bulletin de la Société Neuchateloise des Sciences Naturelles 126 (2003), pp. 97-100.

[18372] S. Podenas. "New Dactylolabis Osten Sacken, 1860 (Diptera, Limoniidae) from Baltic Amber (Eocene)". English. In: Mitteilungen aus dem Geologisch-Paläontologischen Institut der Universität Hamburg 89 (2005), pp. 117-128.

[18373] S. Podenas. "First fossil Eloeophila Rondani, 1856 (Diptera, Limoniidae) from Baltic amber (Eocene)". English. In: Mitteilungen aus dem Geologisch-Paläontologischen Institut der Universität Hamburg 87 (2003), pp. 125-130.

[18374] S. Podenas. "New species of Helius crane flies (Diptera: Limoniidae) from Baltic amber (Eocene)". English. In: Mitteilungen aus dem Geologisch-Paläontologischen Institut der Universität Hamburg 86 (2002), pp. 229-238. 
[18375] S. Podenas. “New Thaumastoptera Mik, 1896 (Diptera, Limoniidae) from the Jordan amber (Lower Cretaceous)". English. In: Mitteilungen aus dem Geologisch-Paläontologischen Institut der Universität Hamburg 84 (2000), pp. 237-240.

[18376] S. Podenas. "Ormosia Rondani crane flies (Diptera, Limoniidae) from the Baltic amber". English. In: Acta Zoologica Lituanica 9 (1999), pp. 183-200.

[18377] S. Podenas and G. O. Poinar. "New crane flies (Diptera: Tipulidae, Limoniidae) from Dominican and Mexican amber". English. In: Proceedings of the Entomological Society of Washington 103.4 (2001), pp. 863-878.

[18378] S. Podenas and G. O. Poinar. "New crane flies (Diptera: Limoniidae) from Dominican amber". English. In: Proceedings of the Entomological Society of Washington 101 (1999), pp. 595-610.

[18379] S. Podenas, G. O. Poinar, and R. Milki. "New crane flies (Diptera: Limoniidae) from Lebanese amber". English. In: Proceedings of the Entomological Society of Washington 103 (2001), pp. 433-436.

[18380] S. Podenas and G. O. Poinar. "New short-palped crane flies (Diptera: Limoniidae) from Mexican amber". English. In: Proceedings of the Entomological Society of Washington 114 (2012), pp. 347-371.

[18381] S. Podenas and G. O. Poinar. "New crane flies (Diptera: Limoniidae) from Burmese amber". English. In: Proceedings of the Entomological Society of Washington 111 (2009), pp. 470-492.

[18382] S. Podenas and T. Weiterschan. "Two new species of short palped crane flies (Diptera, Limoniidae) from Baltic amber". English. In: Transactions of the American Entomological Society 137 (2011), pp. 149-155.

[18383] T. Podhalanska and W. Trela. "Stratigraphy and sedimentary record of the Lower Silurian succession in the". English. In: Acta Palaeontologica Sinica 46.Suppl. (2007), pp. 397-401.

[18384] L. Podstrelená and H. Sendi. “Cratovitisma Bechly, 2007 (Blattaria: Umenocoleidae) recorded in Lebanese and Myanmar ambers". English. In: Palaeontographica Abteilung A 310 (2018), pp. 121129.

[18385] H. Pohl, J. Batelka, J. Prokop, P. Müller, M. I. Yavorskaya, and R. G. Beutel. “A needle in a haystack: Mesozoic origin of parasitism in Strepsiptera revealed by first definite Cretaceous primary larva (Insecta)". English. In: PeerJ 6 (2018), e5943.

[18386] H. Pohl, R. G. Beutel, and R. Kinzelbach. "Protoxenidae fam. nov. (Insecta, Strepsiptera) from Baltic amber - a 'missing link' in strepsipteran phylogeny". English. In: Zoologica Scripta 34.1 (2005), pp. 57-69.

[18387] H. Pohl and R. G. Beutel. “†Kinzelbachilla ellenbergeri - a new ancestral species, genus and family of Strepsiptera (Insecta)". English. In: Systematic Entomology 41 (2016), pp. 287-297.

[18388] H. Pohl, J. U. Hammel, A. Richter, and R. G. Beutel. "The first fossil free-living late instar larva of Strepsiptera (Insecta)". English. In: Arthropod Systematics \& Phylogeny 77 (2019), pp. 125-140.

[18389] H. Pohl and R. Kinzelbach. "First record of a female stylopid (Strepsiptera: ? Mymecolacidae) parasite of a prionomyrmecine ant (Hymenoptera: Formicidae) in Baltic amber". English. In: Insect Systematics \& Evolution 32 (2001), pp. 143-146.

[18390] H. Pohl and R. Kinzelbach. "Neufunde von Fächerflüglern aus dem Baltischen und Dominikanischen Bernstein (Strepsiptera: Bohartillidae \& Myrmecolacidae)". German. In: Mitteilungen aus dem Geologisch-Paläontologischen Institut der Universität Hamburg 78 (1995), pp. 197-209.

[18391] A. Pohle and C. Klug. “Early and Middle Devonian cephalopods from Hamar Laghdad (Tafilalt, Morocco) and remarks on epicoles and cameral deposits". English. In: 290.1-3 (2018), pp. 203-240. DOI: $10.1127 /$ njgpa/2018/0776.

[18392] S. Pohler. "Paleoecology, biostratigraphy and paleogeography of Favositidae (Tabulata) from the Emsian to Middle Devonian Tamworth Group (New South Wales, Australia)". English. In: Senckenbergiana lethaea 81.1 (2001), pp. 91-109.

[18393] S. M. Pohler. "Favositidae (Tabulata) from Emsian to Middle Devonian limestones of the". English. In: Palaontologische Zeitschrift 76.1 (2002), pp. 1-19. 
[18394] S. M. L. Pohler, D. Brühl, and B. Mestermann. "Struves Mud Mound am Weinberg - carbonate buildup-Fazies im otomari-Intervall, Hillesheimer Mulde, Eifel [Struve's mud mound from the Weinberg Quarry - carbonate buildup facies within the otomari interval, Hillesheim syncline, Eifel Hills]". German. In: Senckenbergiana lethaea 79.1 (1999), pp. 13-29.

[18395] S. M. L. Pohler. "Devonian carbonate buildup facies in an intra-oceanic island arc (Tamworth Belt, New South Wales, Australia)". In: Facies 39 (1998), pp. 1-34.

[18396] G. Poinar. "A rhabdocoel turbellarian (Platyhelminthes, Typhloplanoida) in Baltic amber with a review of fossil and sub-fossil platyhelminths". English. In: Invertebrate Biology 122.4 (2003), pp. 308-312.

[18397] G. Poinar. "Cascoplecia insolitis (Diptera: Cascopleciidae), a new family, genus, and species of flower-visiting, unicorn fly (Bibionomorpha) in Early Cretaceous Burmese amber". English. In: Cretaceous Research 31 (2010), pp. 71-76.

[18398] G. Poinar. “A Cretaceous palm bruchid, Mesopachymerus antiqua, n. gen., n. sp. (Coleptera: Bruchidae: Pachymerini) and biogeographical implications". English. In: Proceedings of the Entomological Society of Washington 107.2 (2005), pp. 392-397.

[18399] G. Poinar. "Vetuformosa buckleyi n. gen., n. sp. (Ephemeroptera: Baetidae; Vetuformosinae n. subfam.), a new subfamily of mayflies in Early Cretaceous Burmese amber". English. In: Historical Biology 23 (2011), pp. 369-374.

[18400] G. Poinar. "Palaeocryptorhynchus burmanus, a new genus and species of Early Cretaceous weevils (Coleoptera: Curculionidae) in Burmese amber". English. In: Cretaceous Research 30 (2009), pp. 587-591.

[18401] G. Poinar. "Mesophyletis calhouni (Mesophyletinae), a new genus, species, and subfamily of early cretaceous weevils (Coleoptera: Curculionoidea: Eccoptarthridae) in burmese amber". English. In: Proceedings of the Entomological Society of Washington 108 (2006), pp. 878-884.

[18402] G. Poinar. "Fossil onychophorans from Dominican and Baltic amber: Tertiapatus dominicanus n. g., n. sp. (Tertiapatidae n. fam.) and Succinipatopsis balticus n. g., n. sp. (Succinipatopsidae n. fam.) with a proposed classification of the subphylum Onychophora". English. In: Invertebrate Biology 119 (2000), pp. 104-109.

[18403] G. Poinar. "Heydenius araneus n. sp. (Nematoda: Mermithidae), a parasite of a fossil spider, with an examination of helminths from extant spiders (Arachnida: Araneae)". English. In: Invertebrate Biology 119.4 (2000), pp. 388-393.

[18404] G. Poinar. "Leptoconops nosopheris sp. n. (Diptera: Ceratopogonidae) and Paleotrypanosoma burmanicus gen. n., sp. n. (Kinetoplastida: Trypanosomatidae), a biting midge - trypanosome vector association from the Early Cretaceous". English. In: Memórias do Instituto Oswaldo Cruz 103.5 (2008), pp. 468-471.

[18405] G. Poinar. "Palaeosiro burmanicum n. gen., n. sp., a fossil Cyphophthalmi (Arachnida: Opiliones: Sironidae) in early Cretaceous Burmese amber". English. In: vol. 12. Advances in Arachnology and Developmental Biology. Papers dedicated to Prof. Dr. Boidar uric. Belgrade: Institute of Zoology, 2008, pp. 267-274.

[18406] G. Poinar. "Paleotrichius dominicanus n. gen., n. sp. (Coleoptera; Cetoniidae), a flower beetle in Dominican amber". English. In: Historical Biology 23 (2011), pp. 109-113.

[18407] G. Poinar. "A walking stick, Clonistria dominicana n. sp. (Phasmatodea: Diapheromeridae) in Dominican amber". English. In: Historical Biology 23 (2011), pp. 223-226.

[18408] G. Poinar. “Dominibrentus leptus, n. gen., n. sp. (Curculionoidea, Brentidae, Cyphagoginae, Dominibrentini, n. tribe), a straight-snouted weevil in Dominican amber". English. In: Historical Biology 21 (2009), pp. 51-55.

[18409] G. Poinar. "Fossil palm flowers in Dominican and Mexican amber". English. In: Botanical Journal of the Linnean Society 138 (2002), pp. 57-61. DOI: 10.1046/j.1095-8339.2002.00010.x. 
[18410] G. Poinar. "Fossil palm flowers in Dominican and Baltic amber". English. In: Botanical Journal of the Linnean Society 139.4 (2002), pp. 361-367. DOI: 10.1046/j.1095-8339.2002.00052.x.

[18411] G. Poinar. “Stenaspidiotus microptilus n. gen., n. sp. (Coleoptera: Chrysomelidae: Chrysomelinae) in Dominican amber, with evidence of tachinid (Diptera: Tachinidae) oviposition". English. In: Historical Biology 25 (2013), pp. 101-105.

[18412] G. Poinar. “Discoclavata dominicana n. gen., n. sp., (Coleoptera: Bostrichidae) and Lissantauga epicrana n. gen., n. sp. (Coleoptera: Ecumenidae) in Dominican amber". English. In: Historical Biology 25 (2013), pp. 107-113.

[18413] G. Poinar. "Paleoeuglossa melissiflora gen. n., sp. n. (Euglossinae: Apidae), fossil orchid bees in Dominican amber". English. In: Journal of the Kansas Entomological Society 71 (1998), pp. 29-34.

[18414] G. Poinar. "Palaeomyia burmitis (Diptera: Phlebotomidae), a new genus and species of Cretaceous sand flies with evidence of blood-sucking habits". English. In: Proceedings of the Entomological Society of Washington 106 (2004), pp. 598-605.

[18415] G. Poinar. "Culex malariager, n. sp. (Diptera: Culicidae) from Dominican amber: the first fossil mosquito vector of Plasmodium". English. In: Proceedings of the Entomological Society of Washington 107 (2005), pp. 548-553.

[18416] G. Poinar. "Feroseta priscus (Neuroptera: Mantispidae), a new genus and species of mantidflies in Dominican amber". English. In: Proceedings of the Entomological Society of Washington 108 (2006), pp. 411-417.

[18417] G. Poinar. "Lutzomyia adiketis sp. n. (Diptera: Phlebotomidae), a vector of Paleoleishmania neotropicum sp. n. (Kinetoplastida: Trypanosomatidae) in Dominican amber". English. In: Parasites $\mathcal{E}$ Vectors 1.22 (2008), pp. 1-8. DOI: 10.1186/1756-3305-1-22.

[18418] G. Poinar. "Fossil Trigonalidae and Vespidae (Hymenoptera) in Baltic amber". English. In: Proceedings of the Entomological Society of Washington 107 (2005), pp. 55-63.

[18419] G. Poinar. "Panstrongylus hispaniolae sp. n. (Hemiptera: Reduviidae: Triatominae), a new fossil triatomine in Dominican amber, with evidence of gut flagellates". English. In: Palaeodiversity 6 (2013), pp. 1-8.

[18420] G. Poinar. "Pulchellaranea pedunculata n. gen., n. sp. (Araneae: Araneidae), a new genus of spiders with a review of araneid spiders in Cenozoic Dominican amber". English. In: Historical Biology 27 (2015), pp. 103-108.

[18421] G. Poinar. "First fossil record of nematode parasitism of ants; a 40 million year tale". English. In: Parasitology 125 (2002), pp. 457-459.

[18422] G. Poinar. "Fossil evidence of phorid parasitism (Diptera: Phoridae) by allantonematid nematodes (Tylenchida: Allantonematidae)". English. In: Parasitology 127 (2003), pp. 589-592.

[18423] G. Poinar. "A new genus of fleas with associated microorganisms in Dominican amber". English. In: Journal of Medical Entomology 52 (2015), pp. 1234-1240.

[18424] G. Poinar. "A sphere-forming scarab beetle (Ceratocanthinae: Hybosoridae) in Dominican amber". English. In: Historical Biology 28 (2016), pp. 433-437.

[18425] G. Poinar. "Beetles with orchid pollinaria in Dominican and Mexican amber". English. In: American Entomologist 62 (2016), pp. 172-177.

[18426] G. Poinar. "A new family of aphids (Hemiptera: Aphidoidea) in mid-Cretaceous Myanmar amber". English. In: Cretaceous Research 75 (2017), pp. 7-10.

[18427] G. Poinar. "A new genus and species of aphids, Tanyaulus caudisetula gen. et sp. nov. (Hemiptera: Aphidoidea: Burmitaphidae) in mid-Cretaceous Myanmar amber". English. In: Cretaceous Research 82 (2017), pp. 36-39.

[18428] G. Poinar. "A gilled mushroom, Gerontomyces lepidotus gen. et sp. nov. (Basidiomycota: Agaricales), in Baltic amber". English. In: Fungal Biology 120 (2016), pp. 1090-1093. 
[18429] G. Poinar. "A primitive triatomine bug, Paleotriatoma metaxytaxa gen. et sp. nov. (Hemiptera: Reduviidae: Triatominae), in mid-Cretaceous amber from northern Myanmar". English. In: Cretaceous Research 93 (2018), pp. 90-97.

[18430] G. Poinar. "A new genus of moths (Lepidoptera: Gracillarioidea: Douglasiidae) in Myanmar amber". English. In: Historical Biology 31 (2017), pp. 898-902.

[18431] G. Poinar. “Discoscapidae fam. nov. (Hymenoptera: Apoidea), a new family of stem lineage bees with associated beetle triungulins in mid-Cretaceous Burmese amber". English. In: Palaeodiversity 12 (2020), pp. 1-9.

[18432] G. Poinar. "Pygmy mole crickets (Orthoptera: Tridactylidae) in Dominican and Burmese amber". English. In: Historical Biology 32 (2018), pp. 238-243.

[18433] G. Poinar. "A new genus of terrestrial isopods (Crustacea: Oniscidea: Armadillidae) in Myanmar amber". English. In: Historical Biology 32 (2020), pp. 583-588. DOI: 10.1080/08912963.2018.1509964.

[18434] G. Poinar and A. Ballerio. "Remarks on some Ceratocanthinae (Coleoptera: Hybosoridae) in Dominican amber". English. In: Zootaxa 4286 (2017), pp. 125-128.

[18435] G. Poinar, G. Bechly, and R. Buckley. "First record of Odonata and a new subfamily of damselflies from Early Cretaceous Burmese amber". English. In: Palaeodiversity 3 (2010), pp. 15-22.

[18436] G. Poinar and A. J. Boucot. "Evidence of intestinal parasites of dinosaurs". English. In: Parasitology 133 (2006), pp. 245-249.

[18437] G. Poinar and A. Brown. “The first fossil streblid bat fly, Enischnomyia stegosoma n. g., n. sp. (Diptera: Hippoboscoidea: Streblidae)". English. In: Systematic Parasitology 81 (2012), pp. 79-86.

[18438] G. Poinar and A. Brown. "New genera and species of jumping ground bugs (Hemiptera: Schizopteridae) in Dominican and Burmese amber, with a description of a meloid (Coleoptera: Meloidae) triungulin on a Burmese specimen". English. In: Annales de la Société Entomologique de France 50 (2015), pp. 372-381.

[18439] G. Poinar and A. Brown. "A new genus of leafhoppers (Hemiptera: Cicadellidae) in mid-Cretaceous Myanmar amber". English. In: Historical Biology 32 (2017), pp. 160-163.

[18440] G. Poinar and A. Brown. "Dating the co-evolution between bees and beetle triungulins (Coleoptera: Cleridae) to the mid-Cretaceous". English. In: Biosis: Biological Systems 1 (2020), pp. 2-7.

[18441] G. Poinar and A. E. Brown. "New Aphidoidea (Hemiptera: Sternorrhyncha) in Burmese amber". English. In: Proceedings of the Entomological Society of Washington 107 (2005), pp. 835-845.

[18442] G. Poinar and A. E. Brown. "Anchineus dolichobothris, a new genus and species of Early Cretaceous weevils (Curculionoidea: Coleoptera) in Burmese amber". English. In: Proceedings of the Entomological Society of Washington 111 (2009), pp. 263-270.

[18443] G. Poinar and A. E. Brown. "Descriptions of a broad-nosed weevil (Eudiagogini: Curculionidae) and false ladybird beetle (Nilionini: Nilionidae) in Dominican amber". English. In: Historical Biology 23 (2011), pp. 231-235.

[18444] G. Poinar and A. E. Brown. “Eugnamptus proterus, n. sp. (Coleoptera: Curculionoidea : Rhynchitidae), a tooth-nosed snout beetle in mexican amber". English. In: Proceedings of the Entomological Society of Washington 109 (2007), pp. 880-885.

[18445] G. Poinar and A. E. Brown. "A new genus of primitive crane flies (Diptera: Tanyderidae) in Cretaceous Burmese amber, with a summary of fossil tanyderids". English. In: Proceedings of the Entomological Society of Washington 106 (2004), pp. 339-345.

[18446] G. Poinar and A. E. Brown. "A new subfamily of Cretaceous antlike stone beetles (Coleoptera: Scydmaenidae: Hapsomelinae) with an extra leg segment". English. In: Proceedings of the Entomological Society of Washington 106 (2004), pp. 789-796.

[18447] G. Poinar and A. E. Brown. "A new genus of hard ticks in Cretaceous Burmese amber (Acari: Ixodida: Ixodidae)". English. In: Systematic Parasitology 54 (2003), pp. 199-205. 
[18448] G. Poinar and A. E. Brown. "Pantostictus burmanicus, a new genus and species of Cretaceous beetles (Coleoptera: Hydrophiloidea: Histeridae) in Burmese amber". English. In: Proceedings of the Entomological Society of Washington 111 (2009), pp. 38-46.

[18449] G. Poinar and A. E. Brown. "A new whip spider (Arachnida: Amblypygi), Phrynus mexicana, is described from Mexican amber". English. In: vol. 3. Beiträge zur Araneologie. 2004, pp. 1881-1885.

[18450] G. Poinar and A. E. Brown. “The enigmatic Dacochile microsoma Poinar \& Brown: Tanyderidae or Bruchomyiinae?" English. In: Zootaxa 1162 (2006), pp. 19-31.

[18451] G. Poinar, A. E. Brown, and A. A. Legalov. "First record of the genus Pseudopilolabus Legalov, 2003 (Coleoptera: Attelabidae) in Dominican amber". English. In: Fossil Record 19 (2016), pp. 1116.

[18452] G. Poinar and A. E. Brown. “Toad bugs (Hemiptera: Gelastocoridae) in Myanmar amber". English. In: Cretaceous Research 63 (2016), pp. 39-44.

[18453] G. Poinar and A. E. Brown. "An exotic insect Aethiocarenus burmanicus gen. et sp. nov. (Aethiocarenodea ord. nov., Aethiocarenidae fam. nov.) from mid-Cretaceous Myanmar amber". English. In: Cretaceous Research 72 (2016), pp. 100-104.

[18454] G. Poinar and A. E. Brown. "Furcalabratum burmanicum gen. et sp. nov., a short-winged flower beetle (Coleoptera: Kateretidae) in mid-Cretaceous Myanmar amber". English. In: Cretaceous Research 84 (2017), pp. 240-244.

[18455] G. Poinar and R. Buckley. “Doratomantispa burmanica n. gen., n. sp. (Neuroptera: Mantispidae), a new genus of mantidflies in Burmese amber". English. In: Historical Biology 23 (2011), pp. 169178.

[18456] G. Poinar and R. Buckley. "Palaeoleptus burmanicus n. gen., n. sp., an Early Cretaceous shore bug (Hemiptera: Palaeoleptidae n. fam.) in Burmese amber". English. In: Cretaceous Research 30 (2009), pp. 1000-1004.

[18457] G. Poinar and R. Buckley. "Predatory behaviour of the social orb-weaver spider, Geratonephila burmanica n. gen., n. sp. (Araneae: Nephilidae) with its wasp prey, Cascoscelio incassus n. gen., n. sp. (Hymenoptera: Platygastridae) in Early Cretaceous Burmese amber". English. In: Historical Biology 24 (2012), pp. 519-525.

[18458] G. Poinar and R. Buckley. "Nematode (Nematoda: Mermithidae) and hairworm (Nematomorpha: Chordodidae) parasites in Early Cretaceous amber". English. In: Journal of Invertebrate Pathology 93 (2006), pp. 36-41.

[18459] G. Poinar, A. Bukejs, and A. A. Legalov. "First records of weevils (Coleoptera: Curculionidae) in Quaternary Colombian copal". English. In: Revista Colombiana de Entomologia 43 (2017), pp. 85-90.

[18460] G. Poinar and F. Fanti. "New fossil soldier beetles (Coleoptera: Cantharidae) in Burmese, Baltic and Dominican amber". English. In: Palaeodiversity 9 (2016), pp. 1-7.

[18461] G. Poinar and F. Fanti. "A new fossil soldier beetle (Coleoptera: Cantharidae) of the genus Cacomorphocerus Schaufuss, 1892 from Baltic amber". English. In: Palaeodiversity 12 (2019), pp. 99 105.

[18462] G. Poinar, A. V. Gorochov, and R. Buckley. “Longioculus burmensis, n. gen., n. sp. (Orthoptera: Elcanidae) in Burmese amber". English. In: Proceedings of the Entomological Society of Washington 109 (2007), pp. 649-655.

[18463] G. Poinar and J. Háva. "New Dermestidae (Coleoptera) from Dominican amber". English. In: Palaeodiversity 8 (2015), pp. 1-11.

[18464] G. Poinar and E. Heiss. “New Termitaphididae and Aradidae (Hemiptera) in Mexican and Dominican amber". English. In: Palaeodiversity 4 (2011), pp. 51-62.

[18465] G. Poinar and E. Heiss. "Minysporops dominicanus gen. n., sp. n. (Hemiptera: Pentatomoidea: Megarididae), a megaridid in Dominican amber". English. In: Historical Biology 25 (2013), pp. 95100 . 
[18466] G. Poinar, H. Kerp, and H. Hass. "Palaeonema phyticum gen. n., sp. n. (Nematoda: Palaeonematidae fam. n.), a Devonian nematode associated with early land plants". English. In: Nematology 10 (2008), pp. 9-14.

[18467] G. Poinar, A. G. Kirejtshuk, and R. Buckley. “Pleuroceratos burmiticus n. gen., n. sp. (Coleoptera: Silvanidae) from Early Cretaceous Burmese amber". English. In: Proceedings of the Entomological Society of Washington 110 (2008), pp. 250-257.

[18468] G. Poinar and G. Kritsky. "Morphological conservatism in the foreleg structure of cicada hatchlings, Burmacicada protera n. gen., n. sp. in Burmese amber, Dominicicada youngi n. gen., n. sp. in Dominican amber and the extant Magicicada septendecim (L.) (Hemiptera: Cicadidae)". English. In: Historical Biology 24 (2012), pp. 461-466.

[18469] G. Poinar, G. Kritsky, and A. Brown. "Minyscapheus dominicanus n. gen., n. sp. (Hemiptera: Cicadidae), a fossil cicada in Dominican amber". English. In: Historical Biology 24 (2012), pp. 329333.

[18470] G. Poinar, J. P. Lachaud, A. Castillo, and F. Infante. "Recent and fossil nematode parasites (Nematoda: Mermithidae) of Neotropical ants". English. In: Journal of Invertebrate Pathology 91 (2006), pp. 19-26.

[18471] G. Poinar, A. A. Legalov, and A. E. Brown. "Brachycamacina, a new subtribe of the tribe Naupactini (Coleoptera: Curculionidae Entiminae) in Dominican amber". English. In: Palaeontologia Electronica 16.3.24A (2013), pp. 1-9.

[18472] G. Poinar and A. A. Legalov. "First record of the genus Baris Germar, 1817 (Coleoptera: Curculionidae), in Dominican amber". English. In: Fossil Record 18 (2015), pp. 31-35.

[18473] G. Poinar and A. A. Legalov. "New Apioninae (Coleoptera: Brentidae) in Dominican amber". English. In: Historical Biology 27 (2015), pp. 134-157.

[18474] G. Poinar and A. A. Legalov. "New species of the subfamily Cossoninae (Coleoptera: Curculionidae) in Dominican amber". English. In: Historical Biology 27 (2015), pp. 491-502.

[18475] G. Poinar and A. A. Legalov. "New species of the genera Dryophthorus Germ. and Stenommatus Woll. (Coleoptera: Dryophthoridae) in Dominican amber". English. In: Historical Biology 27 (2015), pp. 508-513.

[18476] G. Poinar and A. A. Legalov. "New Curculioninae (Coleoptera: Curculionidae) in Dominican amber". English. In: Palaeontologia Electronica 18.1.13A (2015), pp. 1-15.

[18477] G. Poinar and A. A. Legalov. “Two new species of the genus Rhynchitobius Sharp, 1889 (Coleoptera: Rhynchitidae) in Dominican amber". English. In: Annales de la Société Entomologique de France 51 (2015), pp. 70-77.

[18478] G. Poinar and A. A. Legalov. “New Anthribidae (Coleoptera: Curculionoidea) in Dominican and Mexican ambers". English. In: Palaeontologia Electronica 19.2.24A (2016), pp. 1-38.

[18479] G. Poinar and A. A. Legalov. "Five new species from the subfamily Entiminae (Coleoptera: Curculionidae) in Dominican amber". English. In: Palaeontologia Electronica 20.2.21A (2017), pp. 1-13.

[18480] G. Poinar and A. A. Legalov. “Two new species of the genus Anchonus Schoenherr, 1825 (Coleoptera: Curculionidae: Molytinae) in Dominican amber". English. In: Palaeontologia Electronica 22.3.59 (2019), pp. 1-10.

[18481] G. Poinar and J. C. Miller. "First fossil record of endoparasitism of adult ants (Formicidae: Hymenoptera) by Braconidae (Hymenoptera)". English. In: Annals of the Entomological Society of America 95 (2002), pp. 41-43.

[18482] G. Poinar and S. R. Shaw. "Megalyra baltica Poinar and Shaw n. sp (Hymenoptera : Megalyridae), a long-tailed wasp from Baltic amber". English. In: Zootaxa 1478 (2007), pp. 65-68.

[18483] G. Poinar and S. R. Shaw. "Endoparasitism of a Cretaceous adult weevil by a euphorine wasp (Hymenoptera: Braconidae)". English. In: Neues Jahrbuch für Geologie und Paläontologie, Abhandlungen 282 (2016), pp. 109-113. 
[18484] G. Poinar, Y. N. Su, and A. E. Brown. "A new genus of crickets (Orthoptera: Gryllidae) in midCretaceous Myanmar amber". English. In: Biosis: Biological Systems 1 (2020), pp. 33-38.

[18485] G. Poinar and D. B. Thomas. "A stink bug, Edessa protera sp. n. (Pentatomidae: Edessinae) in Mexican amber". English. In: Historical Biology 24 (2012), pp. 207-211.

[18486] G. Poinar and F. E. Vega. "A lacewing bug, Paleoanomala aptenus gen. et sp. nov. (Hemiptera: Tingidae), in mid-Cretaceous Burmese amber". English. In: Biosis: Biological Systems 1 (2020), pp. 6571.

[18487] G. Poinar, F. E. Vega, and S. A. Schneider. "A mid-Cretaceous female scale insect (Hemiptera: Sternorrhyncha: Coccomorpha) in Burmese amber". English. In: Zootaxa 4810 (2020), pp. 511-512.

[18488] G. Poinar and F. E. Vega. “A new genus of cylindrical bark beetle (Coleoptera: Zopheridae: Colydiinae) in mid-Cretaceous Burmese amber". English. In: Biosis: Biological Systems 1 (2020), pp. 134140.

[18489] G. Poinar, T. J. Zavortink, and A. Brown. "Priscoculex burmanicus n. gen. et sp. (Diptera: Culicidae: Anophelinae) from mid-Cretaceous Myanmar amber". English. In: Historical Biology 32 (2019), pp. 1157-1162. DOI: 10.1080/08912963.2019.1570185.

[18490] G. O. Poinar. "Description of an early Cretaceous termite (Isoptera: Kalotermitidae) and its associated intestinal protozoa, with comments on their co-evolution". English. In: Parasites $\mathcal{E}$ Vectors 2.12 (2009), pp. 1-17.

[18491] G. O. Poinar. “A snail-killing fly, Dominimyza tanyacaena n. gen., n. sp. (Diptera: Sciomyzidae) in Dominican amber". English. In: Historical Biology 26 (2014), pp. 428-432.

[18492] G. O. Poinar. "A fossil stalk-winged damselfly, Diceratobasis worki spec. nov., from Dominican Amber, with possible ovipositional behavior in tank bromeliads (Zygoptera: Coenagrionidae)". English. In: Odonatologica 25.4 (1996), pp. 381-385.

[18493] G. O. Poinar. "Praecoris dominicana gen. n., sp. n. (Hemiptera: Reduviidae: Holoptilinae) from Dominican amber, with an interpretation of past behaviour based on functional morphology". English. In: Entomologica Scandinavica 22 (1991), pp. 193-199.

[18494] G. O. Poinar. "A fossil palm bruchid, Caryobruchus dominicanus sp. n. (Pachymerini: Bruchidae) in Dominican amber". English. In: Entomologica Scandinavica 30 (1999), pp. 219-224.

[18495] G. O. Poinar. "First fossil soft ticks, Ornithodoros antiquus n. sp. (Acari: Argasidae) in Dominican amber with evidence of their mammalian host". English. In: Experientia 51 (1995), pp. 384-387.

[18496] G. O. Poinar. "Heydenius brownii sp. n. (Nematoda: Mermithidae) parasitising a planthopper (Homoptera: Achilidae) in Baltic amber". English. In: Nematology 3 (2001), pp. 753-757.

[18497] G. O. Poinar. "New fossil nematodes in Dominican and Baltic amber". English. In: Nematology 14 (2012), pp. 483-488.

[18498] G. O. Poinar. English. The Evolutionary History of Nematodes: As Revealed in Stone, Amber and Mummies. Leiden: Brill, 2011, pp. 1-429.

[18499] G. O. Poinar. "Meloe dominicanus n. sp. (Coleoptera: Meloidae) phoretic on the bee Proplebeia dominicana (Hymenoptera: Apidae) in Domincan amber". English. In: Proceedings of the Entomological Society of Washington 111 (2009), pp. 145-150.

[18500] G. O. Poinar. "A mermithid nematode, Cretacimermis aphidophilus sp. n. (Nematoda: Mermithidae), parasitising an aphid (Hemiptera: Burmitaphididae) in Myanmar amber: a 100 million year association". English. In: Nematology 19 (2017), pp. 509-513.

[18501] G. O. Poinar, B. Archibald, and A. Brown. "New amber deposit provides evidence of early Paleogene extinctions, paleoclimates, and past distributions". English. In: The Canadian Entomologist 131 (1999), pp. 171-177.

[18502] G. O. Poinar, A. E. Brown, and A. A. Legalov. "A new weevil tribe, Mekorhamphini trib. nov. (Coleoptera, Ithyceridae) with two new genera in Burmese amber". English. In: Biological Bulletin of the Bogdan Chmelnitskiy Melitopol State Pedagogical University 6 (2016), pp. 157-164. 
[18503] G. O. Poinar, A. E. Brown, and A. A. Legalov. “A new weevil, Aepyceratus hyperochus gen. et sp. nov., Aepyceratinae subfam. nov., (Coleoptera; Nemonychidae) in Burmese amber". English. In: Cretaceous Research 77 (2017), pp. 75-78.

[18504] G. O. Poinar, A. E. Brown, and A. A. Legalov. "A new weevil, Periosomerus tanyorhynchus gen. et sp. nov. (Coleoptera; Ithyceridae) in mid-Cretaceous Burmese amber". English. In: Cretaceous Research 104.104195 (2019). DOI: 10.1016/j.cretres.2019.104195.

[18505] G. O. Poinar and J. W. Brown. "A new fossil tortricid (Lepidoptera: Tortricidae) from Dominican amber". English. In: Entomologica Scandinavica 24 (1993), pp. 25-29.

[18506] G. O. Poinar and R. Buckley. "Compluriscutula vetulum (Acari: Ixodida: Ixodidae), a new genus and species of hard tick from Lower Cretaceous Burmese amber". English. In: Proceedings of the Entomological Society of Washington 110 (2008), pp. 445-450.

[18507] G. O. Poinar and R. Buckley. "Evidence of mycoparasitism and hypermycoparasitism in Early Cretaceous amber". English. In: Mycological Research 111 (2007), pp. 503-506.

[18508] G. O. Poinar and D. C. Currie. "Mermithid nematode (Nematoda: Mermithidae) parasites of a fossil black fly (Diptera: Simuliidae) in Baltic amber". English. In: Nematology 22 (2020), pp. 655658. DOI: $10.1163 / 15685411-00003328$.

[18509] G. O. Poinar and B. N. Danforth. "A fossil bee from Early Cretaceous Burmese amber". English. In: Science 314 (2006), p. 614.

[18510] G. O. Poinar and J. T. Doyen. “A fossil termite bug, Termitaradus protera sp.n. (Hemiptera: Termitaphididae), from Mexican amber". English. In: Entomologica Scandinavica 23 (1992), pp. 89-93.

[18511] G. O. Poinar and C. A. Edwards. "First description of a fossil symphylan, Scutigerella dominicana sp. n. (Scutigerellidae: Symphyla), in Dominican amber". English. In: Experientia 51 (1995), pp. 391-393.

[18512] G. O. Poinar, K. G. A. Hamilton, and A. E. Brown. "Prisciba, n. gen., and two new species of fossil froghoppers (Hemiptera: Cercopoidea: Clastopteridae) in Dominican amber". English. In: Historical Biology 26 (2014), pp. 1-5.

[18513] G. O. Poinar and J. T. Huber. "A new genus of fossil Mymaridae (Hymenoptera) from Cretaceous amber and key to Cretaceous mymarid genera". English. In: ZooKeys 130 (2011), pp. 461-472.

[18514] G. O. Poinar and A. A. Legalov. “Bicalcasura maculata n. gen., n. sp. (Curculionoidea: Dryophthoridae) with a list of weevils described from Dominican amber". English. In: Historical Biology 26 (2014), pp. 449-453.

[18515] G. O. Poinar and A. A. Legalov. "New Cryptorhynchinae (Coleoptera: Curculionidae) in Dominican amber". English. In: Historical Biology 26 (2014), pp. 502-534.

[18516] G. O. Poinar and A. A. Legalov. "New species of the subfamily Conoderinae (Coleoptera: Curculionidae) in Dominican amber". English. In: Historical Biology 26 (2014), pp. 556-562.

[18517] G. O. Poinar and A. A. Legalov. "Pleurambus strongylus n. gen., n. sp. (Coleoptera: Belidae) in Dominican amber". English. In: Historical Biology 26 (2014), pp. 670-674.

[18518] G. O. Poinar and C. Ricci. "Bdelloid rotifers in Dominican amber: evidence for parthenogenetic continuity". English. In: Experientia 48 (1992), pp. 408-410.

[18519] G. O. Poinar and J. A. Santiago-Blay. "Paleodoris lattini gen. n., sp. n., a fossil palm bug (Hemiptera: Thaumastocoridae, Xylastodorinae) in Dominican amber, with habits discernible by comparative functional morphology". English. In: Entomologica Scandinavica 28 (1997), pp. 307-310.

[18520] G. O. Poinar and R. Singer. "Upper Eocene gilled mushroom from the Dominican Republic". English. In: Science 248 (1990), pp. 1099-1101.

[18521] G. O. Poinar and L. A. Stange. "A new antlion from Dominican amber (Neuroptera: Myrmeleontidae)". English. In: Experientia 52 (1996), pp. 383-386.

[18522] G. O. Poinar and R. Szadziewski. "Corethrella andersoni (Diptera: Corethrellidae), a new species from Lower cretaceous Burmese amber". English. In: Proceedings of the Entomological Society of Washington 109 (2007), pp. 155-159. 
[18523] G. O. Poinar, F. E. Vega, and A. A. Legalov. "New subfamily of ambrosia beetles (Coleoptera: Platypodidae) from mid-Cretaceous Burmese amber". English. In: Historical Biology 32 (2018), pp. 137-142.

[18524] G. O. Poinar and J. F. Voisin. "A Dominican amber weevil, Velatis dominicana gen. n., sp. n. and key to the genera of the Anchonini (Molytinae, Curculionidae)". English. In: Nouvelle Revue d'Entomologie, Nouvelle Série 19 (2003), pp. 373-381.

[18525] G. O. Poinar, T. J. Zavortink, T. Pike, and P. A. Johnston. "Paleoculicis minutus (Diptera: Culicidae) n. gen., n. sp., from Cretaceous Canadian amber, with a summary of described fossil mosquitoes". English. In: Acta Geologica Hispanica 35 (2000), pp. 119-128.

[18526] G. P. Poinar, A. Acra, and F. Acra. "Earliest fossil nematode (Mermithidae) in Cretaceous Lebanese amber". English. In: Fundamental and Applied Nematology 17 (1994), pp. 475-477.

[18527] J. Pojeta Jr., D. J. Eernisse, R. D. Hoare, and M. D. Henderson. “Echinociton dufoei: a new spiny Ordovician chiton". English. In: Journal of Paleontology 77.4 (2003), pp. 646-654.

[18528] J. Pojeta Jr., J. F. Taylor, and G. Darrough. “Matthevia (Polyplacophora) invades the Ordovician: the first reported post-Cambrian occurrence". English. In: Journal of Paleontology 79.5 (2005), pp. 10211027. DOI: 10.1666/0022-3360(2005)079[1021:MPITOT]2.0.CO;2.

[18529] J. Pojeta Jr., M. J. Vendrasco, and G. Darrough. "Upper Cambrian chitons (Mollusca, Polyplacophora) from Missouri, USA". English. In: Bulletins of American Paleontology 379 (2010), pp. 1182.

[18530] J. Pojeta Jr. "Claudeonychia babini nov. gen. et nov. sp. of Ordovician ambonychiid palecypods from Cincinnati, Ohio, USA". English. In: Geobios Mémoire Spécial 20 (1997), pp. 433-436.

[18531] J. Pojeta Jr. and C. A. Stott. “Nucularcidae: a new family of palaeotaxodont Ordovician pelecypods (Mollusca) from North America and Australia". English. In: Canadian Journal of Earth Sciences 44.10 (2007), pp. 1479-1501. DOI: 10.1139/E07-028.

[18532] C. Pol, A. D. Buscalioni, J. Carballeira, V. Francés, N. López Martnez, B. Marandat, J. J. Moratalla, J. L. Sanz, B. Sigé, and J. Villatte. "Reptiles and mammals from the Late Cretaceous new locality Quintanilla del Coco (Burgos Province, Spain)". English. In: Neues Jahrbuch für Geologie und Paläontologie Abhandlungen 184.3 (1992), pp. 279-314.

[18533] D. Pol. "New remains of Sphagesaurus huenei (Crocodylomorpha: Mesoeucrocodylia) from the Late Cretaceous of Brazil". English. In: Journal of Vertebrate Paleontology 23.4 (2003), pp. 817-831.

[18534] D. Pol. "Postcranial remains of Notosuchus terrestris (Archosauria: Crocodyliformes) from the upper Cretaceous of Patagonia, Argentina". English. In: Ameghiniana 42.1 (2005), pp. 21-38.

[18535] D. Pol and S. Apestegua. “New Araripesuchus remains from the early Late Cretaceous (CenomanianTuronian) of Patagonia". English. In: American Museum Novitates 3940 (2005), pp. 1-38.

[18536] D. Pol and Z. B. de Gasparini. "Skull anatomy of DAKOSAURUS ANDINIENSIS (Thalattosuchia: Crocodylomorpha) and the phylogenetic position of Thalattosuchia". English. In: Journal of Systematic Palaeontology (2009).

[18537] D. Pol, A. Garrido, and I. A. Cerda. "A new sauropodomorph dinosaur from the Early Jurassic of Patagonia and the origin and evolution of the sauropod-type sacrum". English. In: PLoS One 6.1(e14572) (2011), pp. 1-24. DOI: 10.1371/journal.pone.0014572.

[18538] D. Pol, S. Ji, J. M. Clark, and L. M. Chiappe. "Basal crocodyliforms from the Lower Cretaceous Tugulu Group (Xinjiang, China), and the phylogenetic position of Edentosuchus". English. In: Cretaceous Research 25.2004 (2004), pp. 603-622.

[18539] D. Pol, J. M. Leardi, A. Lecuona, and M. Krause. "Postcranial anatomy of Sebecus icaeorhinus (Crocodyliformes, Sebecidae) from the Eocene of Patagonia". English. In: Journal of Vertebrate Paleontology 32.2 (2012), pp. 328-354.

[18540] D. Pol, P. M. Nascimento, A. B. Carvalho, C. Riccomini, R. A. Pires-Domingues, and H. Zaher. "A new notosuchian from the Late Cretaceous of Brazil and the phylogeny of advanced notosuchians". English. In: PLoS One 9.4 (2014), e93105. 
[18541] D. Pol and M. A. Norell. “A new gobiosuchid crocodyliform taxon from the Cretaceous of Mongolia". English. In: American Museum Novitates 3458 (2004), pp. 1-31.

[18542] D. Pol and M. A. Norell. "A New Crocodyliform from Zos Canyon, Mongolia". English. In: American Museum Novitates 3445 (2004), pp. 1-36.

[18543] D. Pol and J. E. Powell. “A new sebecid mesoeucrocodylian from the Rio Loro Formation (Palaeocene) of north-western Argentina". English. In: Zoological Journal of the Linnean Society 163 (2011), S7-S36.

[18544] D. Pol and J. E. Powell. "Skull anatomy of Mussaurus patagonicus (Dinosauria: Sauropodomorpha) from the Late Triassic of Patagonia". English. In: Historical Biology 19.1 (2007), pp. 125-144.

[18545] D. Pol, J. Ramezani, K. Gomez, J. L. Carballido, A. Paulina Carabajal, O. W. M. Rauhut, I. H. Escapa, and N. R. Cúneo. "Extinction of herbivorous dinosaurs linked to Early Jurassic global warming event". English. In: Proceedings of the Royal Society of London B 287 (2020), 20202310:1-7. DOI: $10.1098 / \mathrm{rspb} .2020 .2310$.

[18546] D. Pol, O. W. M. Rauhut, and M. Becerra. "A Middle Jurassic heterodontosaurid dinosaur from Patagonia and the evolution of heterodontosaurids". English. In: Naturwissenschaften 98 (2011), pp. 369-379.

[18547] D. Pol and O. W. M. Rauhut. “A Middle Jurassic abelisaurid from Patagonia and the early diversification of theropod dinosaurs". English. In: Proceedings of the Royal Society of London, B 279 (2012), pp. 3170-3175. DOI: $10.1098 / \mathrm{rspb} .2012 .0660$.

[18548] D. Pol, O. W. M. Rauhut, A. Lecuona, J. M. Leardi, X. Xu, and J. M. Clark. "A new fossil from the Jurassic of Patagonia reveals the early basicranial evolution and the origins of Crocodyliformes". English. In: Biological Reviews 88.4 (2013), pp. 862-872. DOI: 10.1111/brv.12030.

[18549] D. Pol, A. H. Turner, and M. A. Norell. "Morphology of the Late Cretaceous crocodylomorph Shamosuchus djadochtaensis and a discussion of neosuchian phylogeny as related to the origin of Eusuchia". English. In: Bulletin of the American Museum of Natural History 324 (2009), pp. 1-103.

[18550] M. J. Polcyn and G. L. Bell. "Russellosaurus coheni n. gen., n. sp., a 92 million-year-old mosasaur from Texas (USA), and the definition of the parafamily Russellosaurina". English. In: Netherlands Journal of Geosciences — Geologie en Mijnbouw 84.3 (2005), pp. 321-333.

[18551] M. J. Polcyn and M. J. Everhart. “Description and phylogenetic analysis of a new species of Selmasaurus (Mosasauridae: Plioplatecarpinae) from the Niobrara Chalk of Western Kansas". English. In: Proceedings of the second Mosasaur Meeting (2008), pp. 13-28.

[18552] M. J. Polcyn, L. L. Jacobs, A. S. Schulp, and O. Mateus. “The North African Mosasaur Globidens phosphaticus from the Maastrichtian of Angola". English. In: Historical Biology 22.1-3 (2010), pp. 175185.

[18553] M. J. Polcyn, J. Lindgren, N. Bardet, D. Cornelissen, L. Verding, and A. S. Schulp. “Description of new specimens of Halisaurus arambourgi Bardet \& Pereda Suberbiola, 2005 and the relationships of Halisaurinae". English. In: Bulletin de la Société Géologique de France 183.2 (2012), pp. 123-136.

[18554] M. J. Polcyn, J. V. Rogers II, Y. Kobayashi, and L. L. Jacobs. “Computed tomography of an Anolis lizard in Dominican amber: systematic, taphonomy, biogeographic, and evolutionary implications". English. In: Palaeontologia Electronica 5.1 (2002).

[18555] M. J. Polcyn, E. Tchernov, and L. L. Jacobs. "The Cretaceous biogeography of the Eastern Mediterranean with a description of a new basal mosasauroid from 'Ein Yabrud, Israel". English. In: in Y. Tomida, T.H. Rich and P. Vickers-Rich, eds., Proceedings of the Second Gondwanan Dinosaur Symposium. National Science Museum Monographs, Tokyo, Japan. 15 (1999), pp. 259-290.

[18556] M. J. Polcyn, D. A. Winkler, L. L. Jacobs, and K. Newman. Fossil occurrences and structural disturbance in the Triassic Chinle Formation at North Stinking Springs Mountain near St. Johns, Arizona. English. Vol. 21. Upper Triassic Stratigraphy and Paleontology, New Mexico Museum of Natural History and Science Bulletin. 2002, pp. 43-49.

[18557] M. Pole. “Eocene Vegetation from Hasties, North-eastern Tasmania”. English. In: Australian Systematic Botany 5.4 (1992), pp. 431-475. DOI: 10.1071/SB9920431. 
[18558] M. Pole. "Paleocene plant macrofossils from Kakahu, south Canterbury, New Zealand". English. In: Journal of the Royal Society of New Zealand 27.3 (1997), pp. 371-400.

[18559] M. Pole. "Miocene broad-leaved Podocarpus from Foulden Hills, New Zealand". English. In: Alcheringa 17 (1993), pp. 173-177.

[18560] M. Pole. "Plant macrofossils from the Foulden Hills Diatomite (Miocene), Central Otago, New Zealand". English. In: Journal of the Royal Society of New Zealand 26 (1996), pp. 1-39.

[18561] M. Pole. "Ecology of Paleocene \& Eocene vegetation at Kakahu, South Canterbury, New Zealand". English. In: Palaeontologia Electronica (2010), pp. 14-29.

[18562] M. Pole and V. Vajda. "A new terrestrial Cretaceous-Paleogene site in New Zealand turnover in macroflora confirmed by palynology". English. In: Cretaceous Research 30 (2009), pp. 917-938. DOI: 10.1016/j.cretres.2009.02.007.

[18563] M. S. Pole. "Early Eocene Dispersed Cuticles and Mangrove to Rainforest vegetation at StrahanRegatta Point, Tasmania". English. In: Palaeontologia Electronica 10.3 (2007), pp. 1-66.

[18564] M. S. Pole, R. S. Hill, N. Green, and M. K. Macphail. “The Oligocene Berwick Quarry Flora Rainforest in a Drying Environment". English. In: Australian Systematic Botany 6.5 (1993), pp. 399427. DOI: $10.1071 /$ SB9930399.

[18565] M. S. Pole and M. K. Macphail. "Eocene Nypa from Regatta Point, Tasmania”. English. In: Review of Palaeobotany and Palynology 92.1-2 (1996), pp. 55-67. DOI: 10.1016/0034-6667(95)00099-2.

[18566] M. Polechová. "Bivalves from the Middle Ordovician árka Formation (Prague Basin, Czech Republic)". English. In: Bulletin of Geosciences 88.2 (2013), pp. 427-461.

[18567] M. Polechová. "The youngest representatives of the genus Ribeiria Sharpe, 1853 from the late Katian of the Prague Basin (Bohemia)". English. In: Estonian Journal of Earth Sciences 64.1 (2015), 84Ü-90. DOI: 10.3176/earth.2015.15.

[18568] V. I. Poletaev. "Donispirifer and Tegulispirifer - New Middle to Late Carboniferous Spiriferids from Eurasia." In: Paleontologicheskiy Zhurnal 2000.3 (2000), pp. 50-57.

[18569] J. T. Polhemus. "North American Mesozoic aquatic Heteroptera (Insecta, Naucoroidea, Nepoidea) from the Todilto Formation, New Mexico". English. In: New Mexico Museum of Natural History and Science Bulletin 16 (2000), pp. 29-40.

[18570] A. A. Polilov and E. E. Perkovsky. “New Species of Late Eocene Feather-Winged Beetles (Coleoptera, Ptiliidae) from the Rovno and Baltic Amber". English. In: Paleontological Journal 38.6 (2004), pp. $664-$ 668.

[18571] G. G. Politis and P. G. Messineo. “The Campo Laborde site: New evidence for the Holocene survival of Pleistocene megafauna in the Argentine Pampas". English. In: Quaternary International 191.1 (2008), pp. 98-114.

[18572] G. G. Politis and M. C. Salemme. Pre-Hispanic mammal exploitation and hunting strategies in the eastern Pampa subregion of Argentina. English. 1990.

[18573] S. Polkowsky. “Das Sternberger Gestein un seine Artenzahl - Stand 1994”. English. In: Archiv fur Geschiebekunde 1.10 (1994), pp. 605-614.

[18574] B. P. Polley and R. R. Reisz. “A new Lower Permian trematopid (Temnospondyli: Dissorophoidea) from Richards Spur, Oklahoma". English. In: Zoological Journal of the Linnean Society 161 (2011), pp. 789-815.

[18575] J. R. Pollitt, S. J. Braddy, and J. A. Dunlop. "The phylogenetic position of the extinct arachnid order Phalangiotarbida Haase, 1890, with reference to the fauna from the Writhlington Geological Nature Reserve (Somerset, UK)". English. In: Transactions of the Royal Society of Edinburgh: Earth Sciences 94 (2003), pp. 243-259.

[18576] S. G. Pollock, D. A. T. Harper, and D. M. Rohr. "Late Ordovician nearshore faunas and depositional environments, northwestern Maine". English. In: Journal of Paleontology 68.5 (1994), pp. 925937. 
[18577] P. D. Polly. "Hyaenodontidae (Creodonta, Mammalia) from the Early Eocene Four Mile Fauna and their biostratigraphic implications". English. In: PaleoBios 14.4 (1993), pp. 1-10.

[18578] P. D. Polly. "The skeleton of Gazinocyon vulpeculus gen. et. comb nov. and the cladistic relationships of Hyaenodontidae (Eutheria, Mammalia)". English. In: Journal of Vertebrate Paleontology 16.2 (1996), pp. 303-319. DOI: 10.1080/02724634.1996.10011318.

[18579] P. D. Polly. “Ancestry and Species Definition in Paleontology: A Stratocladistic Analysis of PaleoceneEocene Viverravidae (Mammalia, Carnivora) from Wyoming". English. In: Contributions from the Museum of Paleontology, University of Michigan 30.1 (1997), pp. 1-53.

[18580] L. Pomar, W. C. Ward, and D. G. Green. "Upper Miocene reef complex of the Llucmajor area, Mallorca, Spain". English. In: SEPM Concepts in Sedimentology and Paleontology 5 (1996), pp. 191225.

[18581] F. Pomoni, H. Drinia, and N. Tsaparas. "Palaeoecological and sedimentological characteristics of the Lower Tortonian scleractinian reef corals of Gavdos Island, southern Greece". English. In: Geobios 46.3 (2013), pp. 233-241.

[18582] F. A. Pomoni, V. Tselepidis, W. Yuan, and L. Min. "Lithofacies palaeogeography and biostratigraphy of the lowermost horizons of the Middle Triassic Hallstatt Limestones (Argolis Peninsula, Greece)". English. In: Journal of Palaeogeography 2.3 (2013), pp. 252-274. DOI: 10.3724 / SP.J.1261. 2013.00030.

[18583] A. Ponomarenko and X. Martnez-Delclós. "New beetles (Insecta: Coleoptera) from the Lower Cretaceous of Spain". English. In: Acta Geologica Hispanica 35 (2000), pp. 47-52.

[18584] A. G. Ponomarenko. "New Triassic Beetles (Coleoptera) from Northern European Russia". English. In: Paleontological Journal 42.6 (2008), pp. 600-606.

[18585] A. G. Ponomarenko. "A New Beetle Species of the Genus Taldycupes (Taldycupedidae, Coleoptera) from the Permian of the Tunguska River Basin". English. In: Paleontological Journal 40.3 (2006), pp. 295-296.

[18586] A. G. Ponomarenko. "New beetles (Insecta, Coleoptera) from Vyazniki Locality, terminal Permian of European Russia". English. In: Paleontological Journal 45.4 (2011), pp. 414-422.

[18587] A. G. Ponomarenko. "Two new species of Mesozoic dysticoid beetles from Asia". English. In: Paleontological Journal 27.1A (1993), pp. 182-191.

[18588] A. G. Ponomarenko. “New alderflies (Megaloptera: Parasialidae) and glosselytrodeans (Glosselytrodea: Glosselytridae) from the Permian of Mongolia". English. In: Paleontological Journal 34.Suppl 3 (2000), pp. 309-311.

[18589] A. G. Ponomarenko. "New beetles of the family Cupedidae from the Mesozoic of Mongoloa. Ommatini, Mesocupedini, Priacmini". English. In: Paleontological Journal 31 (1997), pp. 389-399.

[18590] A. G. Ponomarenko. "New beetles from the Permian of european Russia". English. In: Paleontological Journal 34.Suppl 3 (2000), S312-S316.

[18591] A. G. Ponomarenko. "The first beetles (Permosynidae, Coleoptera) from the upper Tatarian of European Russia". English. In: Paleontological Journal 37 (2003), pp. 170-173.

[18592] A. G. Ponomarenko. "Beetles (Insecta, Coleoptera) of the Late Permian and Early Triassic". English. In: Paleontological Journal 38.Suppl 2 (2004), S185-S196.

[18593] A. G. Ponomarenko. "New Mesozoic cupedid beetles from Mongolia: Brochocoleini and Notocupedini". English. In: Paleontological Journal 28 (1994), pp. 102-115.

[18594] A. G. Ponomarenko. "On the Types of Mesozoic Archostematan Beetles (Insecta, Coleoptera, Archostemata) in the Natural History Museum, London". English. In: Paleontological Journal 40.1 (2006), pp. 90-99.

[18595] A. G. Ponomarenko. "Beetles of the family Cupedidae from the Lower Cretaceous locality of Semen, Transbaikalia". English. In: Paleontological Journal 34.Suppl 3 (2000), S317-S322. 
[18596] A. G. Ponomarenko. "A new beetle species of the genus Brochocoleus (Coleoptera, Cupedidae) from the Turonian of Kazakhstan". English. In: Paleontological Journal 33 (1999), pp. 272-273.

[18597] A. G. Ponomarenko. "Supposed alderfly larva (Insecta, Megaloptera) from the Jurassic locality Shar-Teg, southwestern Mongolia". English. In: Paleontological Journal 46 (2012), pp. 378-382.

[18598] A. G. Ponomarenko. Nizhnemelovye verblyudki Zabaykal'ya. Russian. Mezozoyskie Nasekomye i Ostrakody Azii. 1993, pp. 60-80.

[18599] A. G. Ponomarenko. “On some Neuroptera (Insecta) from Upper Jurassic Solnhofen Limestone". English. In: Annals of the Upper Silesian Museum, Entomology 12 (2003), pp. 87-100.

[18600] A. G. Ponomarenko. "New beetles (Insecta, Coleoptera) from the Nedubrovo locality, terminal Permian or basal Triassic of European Russia". English. In: Paleontological Journal 49 (2015), pp. 39 50.

[18601] A. G. Ponomarenko. “New beetles (Insecta, Coleoptera) from the Lower Triassic of European Russia". English. In: Paleontological Journal 50 (2016), pp. 286-292.

[18602] A. G. Ponomarenko. "New beetles (Insecta, Coleoptera) from the upper Vyatkian Aristovo locality, European Russia". English. In: Paleontological Journal 52 (2018), pp. 620-630.

[18603] A. G. Ponomarenko, D. S. Aristov, A. S. Bashkuev, Y. M. Gubin, A. V. Khramov, E. D. Lukashevich, Y. A. Popov, L. N. Pritykina, S. M. Sinitsa, N. D. Sinitshenkova, I. D. Sukatsheva, D. V. Vassilenko, and E. V. Yan. "Upper Jurassic Lagerstätte Shar Teg, southwestern Mongolia". English. In: Paleontological Journal 48 (2014), pp. 1573-1682.

[18604] A. G. Ponomarenko and A. S. Bashkuev. "First Triassic record of the beetle family Permocupedidae (Insecta: Coleoptera): a peculiar example of a Lazarus taxon". English. In: PalZ 92 (2018), pp. 587-591.

[18605] A. G. Ponomarenko, R. A. Coram, and E. A. Jarzembowski. “New beetles (Insecta: Coleoptera) from the Berriasian Purbeck Limestone Group, Dorset, UK". English. In: Cretaceous Research 26 (2005), pp. 277-281.

[18606] A. G. Ponomarenko and M. B. Mostovski. “New beetles (Insecta: Coleoptera) from the Late Permian of South Africa". English. In: African Invertebrates 46 (2005), pp. 253-260.

[18607] A. G. Ponomarenko, A. A. Prokin, and A. S. Bashkuev. “Coptoclavid beetles (Insecta: Coleoptera: Adephaga) from the Triassic of Lower Franconia, Germany". English. In: Paleontological Journal 49 (2015), pp. 1334-1345.

[18608] A. G. Ponomarenko and D. Ren. “First Record of Notocupes (Coleoptera: Cupedidae) In Locality Daohugou, Middle Jurassic of Inner Mongolia, China". English. In: Annales Zoologici 60.2 (2010), pp. 169-171.

[18609] A. G. Ponomarenko and D. E. Shcherbakov. "New lacewings (Neuroptera) from the terminal Permian and basal Triassic of Siberia". English. In: Paleontological Journal 38.Suppl 2 (2004), pp. 197203.

[18610] A. G. Ponomarenko and A. N. Volkov. “Ademosynoides asiaticus Martynov, 1936, the earliest known member of an extant beetle family (Insecta, Coleoptera, Trachypachidae)". English. In: Paleontological Journal 47 (2013), pp. 601-606.

[18611] A. G. Ponomarenko, E. V. Yan, and D. Y. Huang. "New beetles (Coleoptera) from the terminal Middle Permian of China". English. In: Paleontological Journal 48 (2014), pp. 191-200.

[18612] A. G. Ponomarenko, E. V. Yan, O. D. Strelnikova, and R. G. Beattie. “The first finding of an asiocoleid beetle (Coleoptera: Asiocoleidae) in the Upper Permian Belmont Insect Beds, Australia, with descriptions of a new genus and species". English. In: Israel Journal of Entomology 50 (2020), pp. 1-9. DOI: 10.5281/zenodo.3954477.

[18613] E. S. Ponomarenko, E. O. Statsenko, and M. N. Urazaeva. "A hydrozoan interpretation of Palaeoaplysina (enigmatic organisms) based on the canal arrangement and structure". English. In: Paleontological Journal 48 (2014), pp. 118-123. 
[18614] J. M. Pons, J. Gallemi, R. Höfling, and E. Moussavian. “Los Hippurites del Barranc del Raco, microfacies y fauna asociada (Maastrichtiense Superior, sur de la provincia de Valencia) [Hippuritids from Barranc del Raco, microfacies and associated fauna (Upper Maastrichtian, southern Valencia)]". Spanish. In: Cuadernos de Geologia Iberica 18 (1994), pp. 271-307.

[18615] J. M. Pons, J. H. Schroeder, R. Höfling, and E. Moussavian. “Upper Cretaceous rudist assemblages in northern Somalia". English. In: Geologica Romana 28 (1992), pp. 219-241.

[18616] J. M. Pons and G. Sirna. "Upper Cretaceous rudists distribution in the Mediterranean Tethys: comparison between platforms from Spain and South Central Italy". English. In: Geologica Romana 28 (1992), pp. 341-349.

[18617] J. M. Pons, E. Vicens, Y. Pichardo, J. Aguilar, A. Oviedo, G. Alencaster, and P. Garcia-Barrera. “A new Early Campanian rudist fauna from San Luis Potosi in Mexico and its taxonomic stratigraphic significance". English. In: Journal of Paleontology 84.5 (2010), pp. 974-995.

[18618] A. C. Pont and C. J. B. de Carvalho. "Three species of Muscidae (Diptera) from Dominican amber". English. In: Studia Dipterologica 4 (1997), pp. 173-181.

[18619] I. Poole and J. E. Francis. "The first record of fossil atherospermataceous wood from the upper Cretaceous of Antarctica". In: Review of Palaeobotany and Palynology 107 (1999), pp. 97-107.

[18620] I. Poole, R. J. Hunt, and D. J. Cantrill. "A fossil wood flora from King George Island: ecological implications for an Antarctic Eocene vegetation". In: Annals of Botany 88.1 (2001), pp. 33-54.

[18621] I. Poole, A. M. W. Mennega, and D. J. Cantrill. "Valdivian ecosystems in the Late Cretaceous and Early Tertiary of Antarctica: further evidence from myrtaceous and eucryphiaceous fossil wood". In: Review of Palaeobotany and Palynology 124 (2003), pp. 9-27.

[18622] M. E. Popa. "Early Jurassic land flora of the Getic Nappe". PhD thesis. 2000.

[18623] M. V. Popa, A. Duma, and A. Scan. "Badenian gastropods from the collections of the Mure County Museum". English. In: Analele Stiintifice ale Universitatii Al. I. Cuza din Iasi Seria Geologie 60.2 (2014), pp. 5-30.

[18624] E. J. Popham. "Insects from the Santana Formation, Lower Cretaceous, of Brazil. Chapter 4: Dermaptera". English. In: Bulletin of the American Museum of Natural History 195 (1990), pp. 69-75.

[18625] C. Poplin and R. Lund. "Two new deep-bodied palaeoniscoid actinopterygians from Bear Gulch (Montana, USA, Lower Carboniferous)". English. In: Journal of Vertebrate Paleontology 20.3 (2000), pp. 428-449.

[18626] C. Poplin, D. Sotty, and P. Janvier. “Un Myxinode (Craniata, Hyperotreti) dans le KonservatLagerstätte Carbonifére supérieur d Montceau-les-Mines (Allier, France)". English. In: C. R. Acad. Sci. Paris Sciences de la Terre et des planetes 332 (2001), pp. 345-350.

[18627] C. M. Poplin and R. Lund. "Two Carboniferous fine-eyed palaeoniscoids (Pisces, Actinopterygii) from Bear Gluch (USA)". English. In: Journal of Paleontology 76.6 (2002), pp. 1014-1028.

[18628] A. M. Popov and Y. D. Zakharov. "Olenekian brachiopods from the Kamenushka River basin, South Primorye: new data on the brachiopod recovery after the end-Permian mass extinction". English. In: Paleontological Journal 51 (2017), pp. 735-745.

[18629] A. V. Popov. "A new species of the genus Epijuresanites (Ammonoidea) from the Permian of PaiKhoi". English. In: Paleontological Journal 39 (2005), pp. 17-18.

[18630] A. V. Popov and L. F. Kusina. The earliest Goniatitina (Ammonoidea) from the south Urals. 1997.

[18631] E. V. Popov, M. J. Johns, and S. Suntok. "A new genus of chimaerid fish (Holocephali, Chimaeridae) from the upper Oligocene Sooke Formation of British Columbia, Canada". English. In: Journal of Vertebrate Paleontology (2020), e1772275. DOI: 10.1080/02724634.2020.1772275.

[18632] L. Popov, L. E. Holmer, A. J. Rowell, and J. S. Peel. “Early Cambrian brachiopods from north Greenland". In: Palaeontology 40.2 (1997), pp. 337-354.

[18633] L. Popov, J. Nolvak, and L. E. Holmer. "Late Ordovician lingulate brachiopods from Estonia". English. In: Palaeontology 37.3 (1994), pp. 627-650. 
[18634] L. E. Popov, V. Hairapetian, D. H. Evans, M. Ghobadi Pour, L. E. Holmer, and C. Baars. “Review of the Ordovician stratigraphy and fauna of the Anarak Region in Central Iran". English. In: Acta Geologica Polonica 65.4 (2015), pp. 403-435. DOI: 10.1515/agp-2015-0019.

[18635] L. E. Popov. "Late Ordovician linguliformean microbrachiopods from north-central Kazakhstan". English. In: Alcheringa 24 (2000), pp. 257-275.

[18636] L. E. Popov, L. R. M. Cocks, and I. F. Nikitin. “Upper Ordovician brachiopods from the Anderken Formation, Kazakhstan: their ecology and systematics". English. In: Bulletin of the Natural History Museum, Geology Series 58.1 (2002), pp. 13-79.

[18637] L. E. Popov and L. R. M. Cocks. "Late Ordovician brachiopods from the Chingiz Terrane, Kazakhstan, and their palaeogeography". English. In: Journal of Systematic Palaeontology 12.6 (2014), pp. 687-758. DOI: 10.1080/14772019.2013.837844.

[18638] L. E. Popov and L. R. M. Cocks. "Late Ordovician brachiopods from the Dulankara formation of the Chu-ili range, Kazakhstan: their systematics, palaeoecology and palaeobiogeography". English. In: Palaeontology 49.2 (2006), pp. 247-283. DOI: 10.1111/j.1475-4983.2006.00544.x.

[18639] L. E. Popov and L. R. M. Cocks. “The radiation of early Silurian spiriferide brachiopods, with new taxa from the Llandovery of Iran". English. In: Alcheringa 37 (2013), pp. 558-564. DOI: 10.1080 / 03115518.2013.828254.

[18640] L. E. Popov and L. R. M. Cocks. "The World's second oldest strophomenoid-dominated benthic assemblage in the first Dapingian (Middle Ordovician) brachiopod fauna identified from Iran". English. In: Journal of Asian Earth Sciences 140 (2017), pp. 1-12. DOI: 10.1016/j.jseaes.2017.03.007.

[18641] L. E. Popov, E. Egerquist, and L. E. Holmer. "Earliest ontogeny of Middle Ordovician rhynchonelliform brachiopods (Clitambonitoidea and Polytoechioidea): implications for brachiopod phylogeny". English. In: Lethaia 40 (2007), pp. 85-96.

[18642] L. E. Popov, E. V. A. Egerquist, and M. A. Zuykov. “Ordovician (Arenig-Caradoc) syntrophiidine brachiopods from the east Baltic region". English. In: Palaeontology 48.4 (2005), pp. 739-761. DOI: 10.1111/j.1475-4983.2005.00487.x.

[18643] L. E. Popov, M. Ghobadi Pour, M. R. Kebriah-Ee Zadeh, and S. Shahbeik. "First record of silicified Cambrian (Furongian) rhynchonelliform brachiopods from the Mila Formation, Alborz Range, Iran". English. In: Memoirs of the Association of Australasian Palaeontologists 42 (2011), pp. 193-207.

[18644] L. E. Popov, L. E. Holmer, and V. Ju. Gorjansky. "Middle Cambrian lingulate brachiopods from the Tarbagatay Range, Kazakhstan". English. In: Acta Palaeontologica Polonica 41.3 (1996), pp. 299 317.

[18645] L. E. Popov, L. E. Holmer, and V. J. Gorjansky. "Late Ordovician and Early Silurian trimerellide brachiopods from Kazakhstan". English. In: Journal of Paleontology 71.4 (1997), pp. 584-598.

[18646] L. E. Popov, M. R. Kebriaee-Zadeh, and M. Ghobadi Pour. “Emergence of the Saucrorthis Fauna in the Middle Ordovician of northern Iran". English. In: Australasian Palaeontological Memoirs 49 (2016), pp. 485-514.

[18647] L. E. Popov, I. F. Nitikin, and L. R. M. Cocks. "Late Ordovician brachiopods from the Otar Member of the Chu-Ili Range, south Kazakhstan". English. In: Palaeontology 43.5 (2000), pp. 833-870.

[18648] L. E. Popov, M. G. Pour, M. G. Bassett, and M. Kebria-ee. “Billengsellide and orthide brachiopods: new insights into earliest Ordovician evolution and biogeography from northern Iran". English. In: Palaeontology 52.1 (2009), pp. 35-52.

[18649] L. E. Popov, M. G. Pour, and M. Hosseini. "Early to Middle Ordovician lingulate brachiopods from the Lashkarak Formation, Eastern Alborz Mountains, Iran”. English. In: Alcheringa 32 (2008), pp. 1-35.

[18650] L. E. Popov, O. Vinn, and O. I. Nikitina. "Brachiopods of the redefined family Tritoechiidae from the Ordovician of Kazakhstan and South Urals". English. In: Geobios 34.2 (2001), pp. 131-155. DOI: 10.1016/S0016-6995(01)80057-7. 
[18651] L. Y. Popov and Y. A. Tikhonov. "Early Cambrian Brachiopods from Southern Kirgizia”. In: Paleontological Journal 24.3 (1990), pp. 30-44.

[18652] L. E. Popov, J. C. W. Cope, and I. F. Nikitin. "A new Ordovician rostroconch mollusc from Kazakhstan". English. In: Alcheringa 27.3 (2004), pp. 173-179.

[18653] L. E. Popov, J. E. R. Ebbestad, A. Mambetov, and F. Kh. Apayarov. "A low diversity shallow water lingulid brachiopodgastropod association from the Upper Ordovician of Kyrgyz Range". English. In: Acta Palaeontologica Polonica 52.1 (2007), pp. 27-40.

[18654] L. E. Popov, L. E. Holmer, and J. F. Miller. "Lingulate brachiopods from the Cambrian-Ordovician boundary beds of Utah". English. In: Journal of Paleontology 76.2 (2002), pp. 211-228.

[18655] L. E. Popov, I. F. Nikitin, and E. V. Sokiran. “The earliest atrypides and athyridides (Brachiopoda) from the Ordovician of Kazakhstan". English. In: Palaeontology 42.4 (1999), pp. 625-661.

[18656] L. Y. Popov, R. B. Blodgett, and A. V. Anderson. "First occurrence of the genus Bicarinatina (Brachiopoda, Inarticulata) from the Middle Devonian in North America (Alaksa)". English. In: Journal of Paleontology 68.6 (1994), pp. 1214-1218.

[18657] S. V. Popov, I. A. Gontsharova, P. I. Nikolov, and B. Studencka. "Bivalve Molluscs from the Badenian of Northwestern Bulgaria". English. In: Paleontological Journal 30.2 (1996), pp. 157-166.

[18658] S. V. Popov, E. K. Sychevskaya, M. A. Akhmet'ev, N. I. Zaporohets, and L. A. Golovina. "Stratigraphy of the Maikop Group and Pteropoda Beds in Northern Azerbaijan". English. In: Stratigraphy and Geological Correlation 16.6 (2008), pp. 664-677.

[18659] Y. A. Popov. "A New Genus of Emesinae from Dominican Amber (Heteroptera: Reduviidae)". English. In: Acta Zoologica Cracoviensia 35.3 (1993), pp. 435-443.

[18660] Y. A. Popov. "Jurassic bugs (Hemiptera: Heteroptera) from the Museum of Natural History in Vienna". English. In: Annalen des Naturhistorischen Museums in Wien, Serie A 94 (1992), pp. 7-14.

[18661] Y. A. Popov. "The first record of a fossil water bug from the Lower Jurassic of Poland (Heteroptera: Nepomoprha: Belostomatidae)". English. In: Polskie Pismo Entomologiczne 65 (1996), pp. 101-105.

[18662] Y. A. Popov. "Pavlostysia wunderlichi gen. nov. and sp. nov., the first fossil spider-web bug (Hemiptera: Heteroptera: Cimicomorpha: Plokiophilidae) from the Baltic Eocene amber". English. In: Acta Entomologica Musei Nationalis Pragae 48.2 (2008), pp. 497-502.

[18663] Y. A. Popov. "Bugs, Cimicina, in Pozdne-Mezozoyskie Nasekomye Vostochnogo Zabaykal'ya". Russian. In: vol. 239. Akademiya Nauk SSSR, Trudy Paleontologicheskogo Instituta. 1990, pp. 20 39.

[18664] Y. A. Popov. "New microphysids (Heteroptera, Cimicomorpha, Microphysidae) of the Baltic Eocene amber from the collection of Ernst Heiss". English. In: Denisia 19 (2006), pp. 571-579.

[18665] Y. A. Popov. "New flower bugs from Baltic and Ukrainian amber (Heteroptera: Anthocoridae, Lyctocorinae)". English. In: Mitteilungen aus dem Geologisch-Paläontologischen Institut der Universität Hamburg 87 (2003), pp. 183-202.

[18666] Y. A. Popov. "Some fossil Reduviidae in Baltic amber (Heteroptera: Cimicomorpha, Reduviidae)". English. In: Mitteilungen aus dem Geologisch-Paläontologischen Institut der Universität Hamburg 87 (2003), pp. 159-170.

[18667] Y. A. Popov. "Fossil piesmatids from Baltic amber (Heteroptera: Pentatomomorpha, Piesmatidae)". English. In: Mitteilungen aus dem Geologisch-Paläontologischen Institut der Universität Hamburg 85 (2001), pp. 211-220.

[18668] Y. A. Popov. "Water measurers from the Baltic amber (Heteroptera: Gerromorpha, Hydrometridae)". English. In: Mitteilungen aus dem Geologisch-Paläontologischen Institut der Universität Hamburg 79 (1996), pp. 211-221.

[18669] Y. A. Popov. “New microphysids (Heteroptera: Cimicomorpha, Microphysidae) from Baltic amber and taxonomy of this family". English. In: Prace Muzeum Ziemi 47 (2004), pp. 97-107. 
[18670] Y. A. Popov. "A new notion on the heteropterofauna (Insecta: Hemiptera, Heteroptera) from the Pliocene of Willershausen (N Germany)". English. In: Paläontologische Zeitschrift 81 (2007), pp. 429 439.

[18671] Y. A. Popov. "Alumeda solorzanokraemerae sp. nov. from the Miocene Mexican amber (Hemiptera: Heteroptera, Reduviidae, Emesinae)". English. In: Boletn de la Sociedad Geológica Mexicana 68 (2016), pp. 23-27.

[18672] Y. A. Popov. "A new family of anthocoroid hemipterans (Hemiptera: Heteroptera, Cimicomorpha) from Cretaceous Taimyr amber". English. In: Paleontological Journal 50 (2016), pp. 406-411.

[18673] Y. A. Popov and D. Chlond. "The first fossil record of the Emesinae genus Emesopsis Uhler (Hemiptera: Heteroptera, Reduviidae) from Eocene Baltic amber". English. In: Zootaxa 4039 (2015), pp. 566-574.

[18674] Y. A. Popov, W. R. Dolling, and P. E. S. Whalley. “British Upper Triassic and Lower Jurassic Heteroptera and Coleorrhyncha (Insecta: Hemiptera)". English. In: Genus 5.4 (1994), pp. 307-347.

[18675] Y. A. Popov and V. B. Golub. "A new tribe, genus and four species of lace bugs (Hemiptera: Heteroptera: Tingidae) from the Upper Cretaceous of southwestern Kazakhstan". English. In: Paleontological Journal 53 (2019), pp. 155-164. DOI: 10.1134/S0031030119010088.

[18676] Y. A. Popov and E. Heiss. "Grimaldinia pronotalis n. gen., n. sp. from Mid-Cretaceous Burmese Amber (Hemiptera: Heteroptera, Leptopodidae, Leptosaldinae)". English. In: Zootaxa 3878 (2014), pp. $444-450$.

[18677] Y. A. Popov and E. Heiss. "A remarkable fossil leptosaldine bug from Mid-Cretaceous Burmese amber (Hemiptera: Heteroptera: Leptopodomorpha: Leptopodidae)". English. In: Zootaxa 4137 (2016), pp. 233-238.

[18678] Y. A. Popov, A. Herczek, and J. Brozek. “The first fossil Dufoureillini (Hemiptera: Heteroptera: Anthocoridae: Lyctocorinae) from the Eocene Baltic Amber". English. In: Zootaxa 2760 (2011), pp. 5360.

[18679] Y. A. Popov, A. Herczek, and I. Kania. "One more microphysid from the Eocene Baltic amber (Heteroptera: Cimicomorpha, Microphysidae)". English. In: Genus 19 (2008), pp. 611-617.

[18680] Y. A. Popov, A. Herczek, and J. Brozek. “Brachypictritus ribesi n. gen., n. sp., a new fossil Cardiastethini (Hemiptera: Heteroptera: Anthocoridae) from the Eocene Baltic amber". English. In: Heteropterus Revista de Entomologa 11.2 (2011), pp. 323-327.

[18681] Y. A. Popov and A. Herczek. "Cylapopsallops kerzhneri gen.et sp. n. - a new peculiar mirid from Baltic amber (Heteroptera: Miridae: Psallopinae)". English. In: Russian Entomological Journal 15.2 (2006), pp. 187-188.

[18682] Y. A. Popov and A. Herczek. "A new peculiar minute bug (Hemiptera, Heteroptera, Cimicomorpha, Microphysidae) from the Eocene Baltic amber". English. In: Denisia 26 (2009), pp. 151-154.

[18683] Y. A. Popov and A. Herczek. "The first Isometopinae from Baltic amber (Insecta: Heteroptera, Miridae)". English. In: Mitteilungen aus dem Geologisch-Paläontologischen Institut der Universität Hamburg 73 (1992), pp. 241-258.

[18684] Y. A. Popov and A. Herczek. "Another new plant bug from Baltic amber (Heteroptera: Miridae: Cylapinae)". English. In: Annals of the Upper Silesian Museum, Entomology 12 (2003), pp. 111-116.

[18685] Y. A. Popov and A. Herczek. "A new flower bug (Hemiptera: Heteroptera, Anthocoridae) from the Baltic amber". English. In: Prace Muzeum Ziemi 46 (2001), pp. 55-58.

[18686] Y. A. Popov and A. Herczek. "Metoisops punctatus sp. n., the second representative of the fossil genus Metoisops from Baltic amber (Heteroptera: Miridae: Isometopinae)". English. In: Annals of the Upper Silesian Museum, Entomology, Supplement 1 (1993), pp. 51-56.

[18687] Y. A. Popov, B. Kosmowska-Ceranowicz, A. Herczek, and J. Kupryjanowicz. “Review of true bugs (Insecta: Hemiptera, Heteroptera) from the amber collection of the Museum of the Earth of PAS in Warsaw with some remarks on heteropteran insects from Eocene European amber". English. In: Polish Journal of Entomology 80 (2011), pp. 699-728. 
[18688] Y. A. Popov, J. Rust, and C. Brauckmann. “Insect remains (Hemiptera: Belostomatidae; Coleoptera) from the Upper Jurassic (Kimmeridgian) of Nettelstedt (Wiehengebirge, NW Germany)". German. In: Neues Jahrbuch für Geologie und Paläontologie Monatshefte 2000.2 (2000), pp. 83-92.

[18689] Y. A. Popov and W. Weitschat. “Emesites voigti n. gen. n. sp. - the first Emesina (Insecta: Heteroptera, Reduviidae) from the Borneo amber". English. In: Mitteilungen aus dem Geologisch-Paläontologischen Institut der Universität Hamburg 89 (2005), pp. 173-178.

[18690] Yu.A. Popov and D. E. Shcherbakov. “Mesozoic Peloridioidea and their ancestors (Insecta: Hemiptera, Coleorrhyncha)". English. In: Geologica et Palaeontologica 25 (1991), pp. 215-235.

[18691] I. M. Popova, P. O. Baumgartner, A. N. Filippov, and A. I. Khanchuk. "Jurassic and Early Cretaceous Radiolaria of the Lower Amurian Terrane: Khabarovsk region, Far East of Russia". English. In: The Island Arc 8.4 (1999), pp. 491-522.

[18692] I. Popova-Goll, V. Vishnevskaya, and P. O. Baumgartner. “Upper Cretaceous (Santonian-Campanian) radiolarians from Voronesh Anticline, southwestern Russia". English. In: Micropaleontology 51.1 (2005), pp. 1-37.

[18693] J. D. Porfiri and J. D. Calvo. A new record of an ornithopod dinosaur from the Upper Cretaceous of Neuquén, Patagonia, Argentina. English. 2002.

[18694] J. D. Porfiri, J. O. Calvo, and D. dos Santos. “A new small deinonychosaur (Dinosauria: Theropoda) from the Late Cretaceous of Patagonia, Argentina". English. In: Anais da Academia Brasileira de Ciencias 83.1 (2011), pp. 109-116.

[18695] J. D. Porfiri, R. D. Juárez Valieri, D. D. D. Santos, and M. C. Lamanna. “A new megaraptoran theropod dinosaur from the Upper Cretaceous Bajo de la Carpa Formation of northwestern Patagonia". English. In: Cretaceous Research 89 (2018), pp. 302-319. DOI: 10.1016/j.cretres.2018.03.014.

[18696] J. D. Porfiri, F. E. Novas, J. O. Calvo, F. L. Agnoln, M. D. Ezcurra, and I. A. Cerda. “Juvenile specimen of Megaraptor (Dinosauria, Theropoda) shedsălightăabout tyrannosauroid radiation". English. In: Cretaceous Research 51.1 (2014), pp. 35-55. DOI: 10.1016/j.cretres.2014.04.007.

[18697] S. F. Poropat. “Carl Wiman's sauropods: The Uppsala Museum of Evolution's collection”. English. In: GFF (Geologiska Foreningen) 135.1 (2013), pp. 104-119.

[18698] S. F. Poropat, L. Kool, P. Vickers-Rich, and T. H. Rich. "Oldest meiolaniid turtle remains from Australia: evidence from the Eocene Kerosene Creek Member of the Rundle Formation, Queensland". English. In: Alcheringa 41.2 (2017), pp. 231-239. DOI: 10.1080/03115518.2016.1224441.

[18699] S. F. Poropat, P. D. Mannion, P. Upchurch, S. A. Hocknull, B. P. Kear, M. Kundrát, T. R. Tischler, T. Sloan, G. H. K. Sinapius, J. A. Elliott, and D. A. Elliott. "New Australian sauropods shed light on Cretaceous dinosaur palaeobiogeography". English. In: Scientific Reports 6 (2016), 34467:1-12.

[18700] S. F. Poropat, P. D. Mannion, P. Upchurch, T. R. Tischler, T. Sloan, G. H. K. Sinapius, J. A. Elliott, and D. A. Elliott. "Osteology of the wide-hipped titanosaurian sauropod dinosaur Savannasaurus elliottorum from the Upper Cretaceous Winton Formation of Queensland, Australia". English. In: Journal of Vertebrate Paleontology 40.3 (2020), e1786836:1-36. DOI: 10.1080/02724634.2020.1786836.

[18701] S. F. Poropat, J. P. Nair, C. E. Syme, P. D. Mannion, P. Upchurch, S. A. Hocknull, A. G. Cook, T. R. Tischler, and T. Holland. "Reappraisal of Austrosaurus mckillopi Longman, 1933 from the Allaru Mudstone of Queensland, Australia's first named Cretaceous sauropod dinosaur". English. In: Alcheringa (2017). DOI: 10.1080/03115518.2017.1334826.

[18702] K. O. Porpino, J. C. Fernicola, and L. P. Bergqvist. "A new cingulate (Mammalia: Xenarthra), Pachyarmatherium brasiliense sp. nov., from the Late Pleistocene of northeastern Brazil". English. In: Journal of Vertebrate Paleontology 29.3 (2009), pp. 881-893.

[18703] K. O. Porpino, M. F. Santos, and L. P. Bergqvist. “Registros de mamferos fósseis no Lajedo de Soledade, Apodi, Rio Grande do Norte, Brasil". Portugese. In: Revista Brasileira de Paleontologia 7.3 (2004), pp. 349-358.

[18704] H. G. Porras-Múzquiz, S. Chaterjee, and T. M. Lehmann. "The carinate bird Ichthyornis from the Upper Cretaceous of Mexico". English. In: Cretaceous Research 51 (2014), pp. 148-152. 
[18705] L. B. Porro, R. J. Butler, P. M. Barrett, S. Moore-Fay, and R. L. Abel. “New heterodontosaurid specimens from the Lower Jurassic of southern Africa and the early ornithischian dinosaur radiation". English. In: Earth and Environmental Science Transactions of the Royal Society of Edinburgh 101 (2011), pp. 351-366.

[18706] R. W. Portell and J. S. H. Collins. "A new species of Montezumella (Crustacea: Decapoda: Cheiragonidae) from the upper Eocene Ocala Limestone of Florida". English. In: Proceedings of the Biological Society of Washington 115.3 (2002), pp. 594-599.

[18707] R. W. Portell and S. K. Donovan. “Campanile trevorjacksoni sp. nov.y (Mollusca: Gastropoda) from the Eocene of Jamaica: at last, a name for the first fossil used in intercontinental biostratigraphic correlation (de la Beche 1827)". English. In: Geological Journal 43 (2008), pp. 542-551. DOI: 10.1002/gj.1128.

[18708] R. W. Portell, G. Hubbell, S. Donovan, D. A. T. Harper, and R. Pickerill. "Miocene sharks in the Kendeace and Grand Bay formations of Carriacou, The Grenadines, Lesser Antilles". English. In: Caribbean Journal of Science 44.3 (2008), pp. 279-286.

[18709] R. W. Portell, G. L. Polites, and G. W. Schmelz. "Mollusca: Shoal River Formation (Middle Miocene". English. In: Florida Fossil Invertebrates 9 (2006), pp. 1-52.

[18710] R. W. Portell, R. L. Turner, and J. L. Beerenson. “Occurrence of the Atlantic Ghost Crab Ocypode quadrata from the Upper Pleistocene to Holocene Anastasia Formation of Florida". English. In: Journal of Crustacean Biology 23.3 (2003), pp. 712-722.

[18711] R. W. Portell, K. S. Schindler, and G. S. Morgan. “The Pleistocene molluscan fauna from Leisley Shell Pit 1, Hillsborough County, Florida". English. In: Florida Geological Survey Special Publication 36: Plio-Pleistocene stratigraphy and paleontology of southern Florida (1992).

[18712] M. Poschmann. “Ein fossiler Skorpion aus dem Oberkarbon (Westfalium C) des Saar-Nahe-Beckens (SW-Deutschland)". German. In: Mitteilungen der Pollichia 94 (2009), pp. 5-10.

[18713] M. Poschmann. "Sea scorpions (Chelicerata, Eurypterida) from the Lower Devonian (Siegenian) of the Lahrbach Valley/Westerwald area (SW Germany, Rhineland-Palatinate)". English. In: Palaeontologische Zeitschrift 89 (2015), pp. 783-793.

[18714] M. Poschmann. "Pelmatozoan rooting grounds from the Early Devonian (late Emsian) Heckelmann Mill FossilLagerstätte (Lahn Syncline, RhinelandPalatinate, SWGermany): morphological, palaeoenvironmental and taphonomic aspects". English. In: (2019). DOI: 10.1007 / s12542-01900454-1.

[18715] M. Poschmann, L. I. Anderson, and J. A. Dunlop. “Chelicerate arthropods, including the oldest phalangiotarbid arachnid, from the Early Devonian (Siegenian) of the Rhenish Massif, Germany". English. In: Journal of Paleontology 79 (2005), pp. 110-124.

[18716] M. Poschmann, J. A. Dunlop, C. Kamenz, and G. Scholtz. “The Lower Devonian scorpion Waeringoscorpio and the respirstory nature of its filamentous structures, with the description of a new species from the Westerwald area, Germany". English. In: Paläontologische Zeitschrift 82 (2008), pp. 418436.

[18717] M. Poschmann and J. A. Dunlop. “Trigonotarbid arachnids from the Lower Devonian (Siegenian) of Bürdenbach (Lahrbach Valley, Westerwald area, Rhenish Slate Mountains, Germany)". English. In: Paläontologische Zeitschrift 85 (2011), pp. 433-447.

[18718] M. Poschmann and J. A. Dunlop. “Trigonotarbid arachnids from the Lower Devonian (Lower Emsian) of Alken an der Mosel (Rhineland-Palatinate, SW Germany)". English. In: Paläontologische Zeitschrift 84 (2010), pp. 467-484.

[18719] M. Poschmann and J. A. Dunlop. "Reassessing Devonotarbus, a phalangiotarbid arachnid from the Lower Devonian (Siegenian and Emsian) of the Rheinisches Schiefergebirge (SW Germany)". English. In: Paläontologische Zeitschrift 86 (2012), pp. 377-387.

[18720] M. Poschmann, J. A. Dunlop, O. Béthoux, and J. Galtier. “Carboniferous arachnids from the Graissessac Basin, Central Massif, France”. English. In: PalZ 90 (2016), pp. 33-48. 
[18721] R. Posenato. “Anisian (Middle Triassic) bivalves from the Dolomites (Italy)". English. In: Neues Jahrbuch für Geologie und Paläontologie, Abhandlungen 247.1 (2008), pp. 93-115.

[18722] R. Posenato. "The Athyridoids of the transitional beds between Bellerophon and Werfen Formations (uppermost Permian, southern Alps, Italy)". English. In: Rivista Italiana di Paleontologia e Stratigrafia 107.2 (2001), pp. 197-226.

[18723] R. Posenato. "Latest Changhsingian orthotetid brachiopods in the Dolomites (southern Alps, Italy): ecological opportunists at the peak of the end-Permian mass extinction". English. In: Journal of Paleontology 85.1 (2011), pp. 58-68.

[18724] R. Posenato. "Survival patterns of macrobenthic marine assemblages during the end-Permian mass extinction in the western Tethys (Dolomites, Italy)". English. In: Palaeogeography, Palaeoclimatology, Palaeoecology 280 (2009), pp. 150-167.

[18725] R. Posenato. "Marine biotic events in the Lopingian succession and latest Permian extinction in the Southern Alps (Italy)". English. In: Geological Journal 45 (2010), pp. 195-215.

[18726] R. Posenato. “The gen. Comelicania Frech, 1901 (Brachiopoda) from the southern Alps: morphology and classification". English. In: Rivista Italiana di Paleontologia e Stratigrafia 104.1 (1998), pp. 4368.

[18727] R. Posenato. “Opisoma excavatum Boehm, a Lower Jurassic photosymbiotic alatoform-chambered bivalve". English. In: Lethaia 46 (2013), pp. 424-437.

[18728] R. Posenato. "Bivalves and other macrobenthic fauna from the Ladinian Muschelkalk of Punta del Lavatoio (Alghero, SW Sardinia)". English. In: Rendiconti della Societá Paleontologica Italiana 1 (2002), pp. 185-196.

[18729] R. Posenato, L. E. Holmer, and H. Prinoth. “Adaptive strategies and environmental significance of lingulid brachiopods across the late Permian extinction". English. In: Palaeogeography, Palaeoclimatology, Palaeoecology 399 (2014), pp. 373-384.

[18730] R. Posenato and A. Ietto. "Late Triassi Megalodontidae from Northern Calabria (Italy)". English. In: Rivista Italiana di Paleontologia e Stratigraphia 101.3 (1995), pp. 325-340.

[18731] R. Posenato and M. Morsilli. “New species of Peregrinella (Brachiopoda) from the Lower Cretaceous of the Gargano Promontory (southern Italy)". English. In: Cretaceous Research 20 (1999), pp. 641-654.

[18732] R. Posenato, P. Pelikan, and K. Hips. “Bivalves and brachiopods near the Permian-Triassic boundary in the Bukk Mountains (Balvany-North section, northern Hungary)". English. In: Rivista Italiana di Paleontologia e Stratigrafia 111.2 (2005), pp. 215-232.

[18733] R. Posenato and H. Prinoth. "Orizzonti a nautiloidi e a brachiopodi della formazione a Bellerophon (Permiano Superiore) in Val Gardena (Dolomiti) [Nautiloidea and brachiopoda horizons in the Upper Permian Bellerophon Formation in the Gardena Valley (Dolomites)]". Italian. In: Geo.Alp 1 (2004), pp. 71-86.

[18734] R. Posenato and H. Prinoth. "Discovery of Paratirolites from the Bellerophon Formation (Upper Permian, Dolomites, Italy)". English. In: Rivista Italiana di Paleontologia e Stratigrafia 105 (1999), pp. 129-134.

[18735] R. Posenato, D. Sciunnach, and E. Garzanti. "First report of Claraia (Bivalvia) in the Servino Formation (Lower Triassic) of the Western Orobic Alps, Italy". English. In: Rivista Italiana di Paleontologia e Stratigraphia 102.2 (1996), pp. 201-210.

[18736] K. Post. “Laat-pleistocene zeezoogdieren van de Nederlandse kustwteren”. English. In: Grondboor E Hamer 6 (1999), pp. 126-130.

[18737] K. Post. "A Weischelian marine mammal assemblage from the southern North Sea". English. In: Deinsea 11 (2005), pp. 21-27.

[18738] K. Post. "Raadsels uit de Noordzee". other. In: Cranium 24.2 (2007), pp. 31-38.

[18739] K. Post and M. Bosselaer. “Late Pliocene occurrence of Hemisyntrachelus (Odontoceti, Delphinidae) in the southern North Sea". English. In: Deinsea 11 (2005), pp. 29-45. 
[18740] K. Post and M. Bosselaers. “Cetacean fossils from a 1961 expedition at the Schelde estuary, province of Zeeland, The Netherlands". English. In: Cainozoic Research 17.1 (2017), pp. 11-21.

[18741] K. Post and J. K. Jensen. “On diamonds, a mammal fossil from the Faroe Islands, and the northernmost occurrence of fossil beaked whales". English. In: Cranium November (2013), pp. 19-21.

[18742] K. Post and E. J. O. Kompanje. "A new dolphin (Cetacea, Delphinidae) from the Plio-Pleistocene of the North Sea". English. In: Deinsea 14 (2010), pp. 1-12.

[18743] K. Post and T. Lammerse. "NMR 9991-14005, ofwel de vondst van een perioticum van De". English. In: Afzettingen Wtkg 38.2 (2017), pp. 28-32.

[18744] K. Post, S. Louywe, and O. Lambert. "Scaldiporia vandokkumi, a new pontoporiid (Mammalia, Cetacea, Odontoceti) from the Late Miocene to earliest Pliocene of the Westerschelde estuary (The Netherlands)". English. In: PeerJ 5 (2017), :e3991. DOI: 10.7717/peerj.3991.

[18745] K. Post and J. W. F. Reumer. "History and future of paleontological surveys in the Westerschelde Estuary (Province of Zeeland, the Netherlands)". English. In: Deinsea 16 (2016), pp. 1-9.

[18746] A. W. Potter. "The Ordovician brachiopod genus Bimuria from the eastern Klamath Mountains, northern California". English. In: Journal of Paleontology 64.2 (1990), pp. 200-213.

[18747] A. W. Potter. "Middle and Late Ordovician brachiopods from the eastern Klamath Mountains, northern California". English. In: Palaeontographica Abteilung A 212.1-6 (1990), pp. 31-158.

[18748] R. Potts. "Variables versus models of early Pleistocene hominid land use". In: Journal of Human Evolution 27 (1994), pp. 7-24.

[18749] R. Potts, A. K. Behrensmeyer, and P. Ditchfield. "Paleolandscape variation and Early Pleistocene hominid activities: Members 1 and 7, Olorgesailie Formation, Kenya". In: Journal of Human Evolution 37 (1999), pp. 747-788.

[18750] R. Potts, A. K. Behrensmeyer, A. Deino, P. Ditchfield, and J. Clark. "Small mid-Pleistocene hominin associated with East African Acheulean technology". English. In: Science 305 (2004), pp. 75-78.

[18751] R. Potts and A. Deino. Mid-Pleistocene change in large mammal faunas of East Africa. 1995.

[18752] E. Poty and E. Chevalier. “Late Frasnian phillipsastreid biostromes in Belgium”. English. In: vol. 275. Geological Society, London, Special Publications. 2007, pp. 143-161.

[18753] J. Pouech, J.-M. Mazin, and J. -P. Billon-Bruyat. "Microvertebrate biodiversity from Cherves-deCognac (Lower Cretaceous, Berriasian: Charente, France)". English. In: 9th International Symposium on Mesozoic Terrestrial Ecosystems and Biota, Abstracts and Proceedings Volume (2006), pp. 96100.

[18754] J. M. Pouillon and A. Nel. "The oldest representative of the modern clade Aeshnodea from the Lower Cretaceous Crato Formation, Araripe Basin, NE Brazil (Odonata: Anisoptera)". English. In: Cretaceous Research 116.104580 (2020). DOI: 10.1016/j.cretres.2020.104580.

[18755] J. M. Pouillon and A. Nel. "Revision of the Early Cretaceous mydid Cretomydas santanensis (Diptera: Mydidae)". English. In: Cretaceous Research 116.104604 (2020). DOI: 10.1016 / j.cretres. 2020.104604.

[18756] N. Poulakakis, M. Mylonas, P. Lymberakis, and Ch. Fassoulas. "Origin and taxonomy of the fossil elephants of the island of Crete (Greece): problems and perspectives". English. In: Palaeogeography, Palaeoclimatology, Palaeoecology 186 (2002), pp. 163-183.

[18757] M. G. Pour, M. Ghavidel-Syooki, J. J. Álvaro, L. E. Popov, and M. H. Ehsani. “First reported Late Ordovician trilobites from the High Zagros Ranges, Iran: A biogeographical link between Gondwanan Chinese and Mediterranean faunas". English. In: Geobios 48 (2015), pp. 351-369.

[18758] M. G. Pour and L. E. Popov. "Silicified Middle Cambrian trilobites from Kyrgystan". English. In: Palaeontology 52.5 (2009), pp. 1039-1056.

[18759] A. W. Poust. "First report of fossil turtle eggshell west of the Colorado Plateau". English. In: Historical Biology 29.4 (2017), pp. 473-479. DOI: 10.1080/08912963.2016.1189911. 
[18760] A. W. Poust. "Expanding the geographic and geochronologic range of early pinnipeds: New specimens of Enaliarctos from Northern California and Oregon". English. In: Acta Palaeontologica Polonica (2018). DOI: 10.4202/app.00399.2017.

[18761] A. W. Poust and R. W. Boessenecker. "Mandibles of the sea lion Proterozetes ulysses from the middle Pleistocene Port Orford Formation of Oregon". English. In: Journal of Vertebrate Paleontology 37.3 (2017), e1317637. DOI: 10.1080/02724634.2017.1317637.

[18762] S. Pouyet. "Les bryozoaires cheilostomes du Néogéne bétique (SE Espagne)". French. In: Revista Española de Paleontologa 15.2 (2000), pp. 181-202.

[18763] L. Povilauskas. "Palinologa de la Formación Monte Chico (Cretácico Tardo) de la Provincia de Santa Cruz, Argentina: Esporas". Spanish. In: Revista Brasileira de Paleontologia 14.3 (2011), pp. 255268. DOI: 10.4072/rbp.2011.3.05.

[18764] L. Povilauskas. "Palinologa de la Formación Monte Chico (Cretácico Tardo) de la Provincia de Santa Cruz, Argentina: Gimnospermas". English. In: Revista Brasileira de Paleontologia 15.1 (2012), pp. 85-94. DOI: 10.4072/rbp.2012.1.07.

[18765] L. Povilauskas. "Palinologa de Angiospermas de la Formación Monte Chico (Cretácico Superior) de la Provincia de Santa Cruz, Argentina". Spanish. In: Revista Brasileira de Paleontologia 16.1 (2013), pp. 115-126. DOI: 10.4072/rbp.2013.1.09.

[18766] L. Povilauskas, V. Barreda, and S. Marenssi. "Polen y esporas de la Formación La Irene (Maastrichtiano), sudoeste de la provincia de Santa Cruz, Argentina: primeros resultados". Spanish. In: Geobios 41 (2008), pp. 819-831. DOI: 10.1016/j.geobios.2008.07.002.

[18767] L. K. Povilauskas. "Palinologa del entorno cretácico/paleógeno del SO de la provincia de Santa Cruz: significado estratigráfico y paleoambiental". Spanish. PhD thesis. La Plata, 2010, p. 391.

[18768] C. L. Powell, R. W. Boessenecker, N. A. Smith, R. J. Fleck, S. J. Carlson, J. R. Allen, D. J. Long, A. M. Sarna-Wojcicki, and R. B. Guruswami-Naidu. "Geology and Paleontology of the Late Miocene Wilson Grove Formation at Bloomfield Quarry, Sonoma County, California". English. In: Scientific Investigations Report 2019.5021 (2019), pp. 1-77. DOI: 10.3133/sir20195021.

[18769] C. L. Powell and D. L. Geiger. "Two new Miocene limpets (Fissurellidae) from southern California, with notes on other fossil occurrences of the family in northwestern North America". English. In: PaleoBios 36.46304 (2019), pp. 1-7.

[18770] C. L. Powell and D. Stevens. "Age and paleoenvironmental significance of mega-invertebrates from the San Pedro Formation in the Coyote Hills, Fullerton and Buena Park, Orange County, Southern California". English. In: United States Geological Survey Open File Report 319 (2000), pp. 183.

[18771] J. E. Powell. "Revision of South American titanosaurid dinosaurs: palaeobiological, palaeobiogeographical and phylogenetic aspects". English. In: Records of the Queen Victoria Museum Launceston 111 (2003), pp. 1-173.

[18772] J. E. Powell, M. J. Babot, D. A. Garca López, M. V. Deraco, and C. Herrera. “Eocene vertebrates of northwest Argentina: annotated list". English. In: Cenozoic Geology of the Central Andes of Argentina. SCS Publisher, 2011, pp. 349-370.

[18773] J. H. Powell, A. Nicora, M. C. Perri, R. Rettori, R. Posenato, M. H. Stephenson, A. Masri, L. M. Borlenghi, and V. Gennari. "Lower Triassic (Induan to Olenekian) conodonts, foraminifera and bivalves from the Al Mamalih area, Dead Sea, Jordan: constraints on the P-T boundary". English. In: Rivista Italiana di Paleontologia e Stratigrafia 125 (2019), pp. 147-181.

[18774] C. L. Powell II, L. B. Grant, and S. W. Conkling. "Paleoecologic analysis and age of a late Pleistocene fossil assemblage from Upper Newport Bay, Newport Beach, Orange County, California". English. In: The Veliger 47.3 (2005), pp. 183-192.

[18775] F. Poyato-Ariza. "Polazzodus, gen. nov., A New Pycnodont Fish from the Late Cretaceous of Northeastern Italy". English. In: Journal of Vertebrate Paleontology 30.3 (2010), pp. 650-664. DOI: $10.1080 / 02724631003762955$. 
[18776] F. J. Poyato-Ariza. "Ichthyemidion, a new genus for the elopiform fish Anaethalion vivaldi, from the Early Cretaceous of Spain: phylogenetic comments". English. In: Comptes rendus de l'Académie des sciences. Série 2. Sciences de la terre et des planétes 320.2 (1995), pp. 133-139.

[18777] F. J. Poyato-Ariza. "A new Early Cretaceous Gonorynchiform fish (Teleostei: Ostariophysi) from Las Hoyas (Cuenca, Spain)". English. In: Occassional papers of the Museum of Natural History, The University of Kansas, Lawrence, Kansas 164 (1994), pp. 1-37.

[18778] F. J. Poyato-Ariza and D. D. Bermúdez-Rochas. "New Pycnodont Fish (Arcodonichthys pasiegae gen. et sp. nov.) from the Early Cretaceous of the Basque-Cantabrian Basin, Northern Spain". English. In: Journal of Vertebrate Paleontology 29.1 (2007), pp. 271-275.

[18779] F. J. Poyato-Ariza, M. A. Lopez-Horgue, and F. Garca-Garmilla. "A new early Cretaceous clupeomorph fish from the Arratia Valley, Basque Country, Spain". English. In: Cretaceous Research 21 (2000), pp. 571-585.

[18780] F. J. Poyato-Ariza and S. Wenz. "Naiathaelon okkidion nov. gen. nov. sp. (Teleostei, Elopomorpha) from the early Tithonian of Canjuers (Var, France)". English. In: Geobios 16 (1993), pp. 157-166. DOI: 10.1016/S0016-6995(94)80030-8.

[18781] J. Poyato-Ariza and S. E. K. Wenz. “Akromystax tilmachiton Gen. Et Sp. Nov., a New Pycnodontid Fish from the Lebanese Late Cretaceous of Haqel and En Nammoura". English. In: Journal of Vertebrate Paleontology 25.1 (2005), pp. 27-45.

[18782] A. Pradel, M. Langer, J. G. Maisey, D. Geffard-Kuriyama, P. Cloetens, P. Janvier, and P. Tafforeau. "Skull and brain of a 300-million-year-old chimaeroid fish revealed by synchrotron holotomography". English. In: Proceedings of the National Academy of Sciences 106 (2009), pp. 5224-5228.

[18783] A. Pradel, J. G. Maisey, P. Tafforeau, R. H. Mapes, and J. Mallatt. "A Palaeozoic shark with osteichthyanlike branchial arches". English. In: Nature 509 (2014), pp. 608-611.

[18784] A. Pradel, I. J. Sansom, P. -Y. Gagnier, R. Cespedes, and P. Janvier. "The tail of the Ordovician fish Scabambaspis". English. In: Biology Letters 3 (2007), pp. 72-75.

[18785] A. Pradel, P. Tafforeau, J. G. Maisey, and P. Janvier. "A New Paleozoic Symmoriiformes (Chondrichthyes) from the Late Carboniferous of Kansas (USA) and Cladistic Analysis of Early Chondrichthyans". English. In: PLoS One 6.9 (2011), e24938.

[18786] J. L. Prado, M. T. Alberdi, and M. A. Reguero. "El registro mas antiguo de Hippidion Owen, 1869 (Mammalia, Perissodactyla) en America del Sur". Spanish. In: Estudios Geológicos 54 (1998), pp. 8591.

[18787] J. L. Prado, E. Cerdeño, and S. Roig-Juñet. “The giant rodent Chapalmatherium from the Pliocene of Argentina: new remains and taxonomic remarks on the family Hydrochoeridae". English. In: Journal of Vertebrate Paleontology 18.4 (1998), pp. 788-798.

[18788] J. L. Prado and E. Cerdeño. "Los mamferos pliocenos de la fauna local Quequén Grande (Provincia de Buenos Aires, Argentina)". English. In: Estudios Geológicos 54 (1998), pp. 75-83.

[18789] J. L. Prado, J. Chiesa, G. Tognelli, E. Cerdeño, and E. Strasser. “Los mamiferos de la Formacion Rio Quinto (Plioceno), provincia de San Luis (Argentina). Aspectos bioestratigraficos, zoogeograficos y paleoambientales". Spanish. In: Estudios Geologicos 54 (1998), pp. 153-160.

[18790] M. B. Prámparo. "Lower Cretaceous palynoflora of the La Cantera Formation, San Luis Basin: correlation with other Cretaceous palynofloras of Argentina". English. In: Cretaceous Research 15 (1994), pp. 193-203.

[18791] M. B. Prámparo, A. L. Cione, and B. González Riga. "Sharks (Neoselachii) and palynomorphs from Mendoza (Argentina): new evidence of the Late Cretaceous Atlantic marine transgression." English. In: Alcheringa 38.2 (2013), pp. 177-189.

[18792] G. V. R. Prasad and S. Bajpai. “Agamid lizards from the Early Eocene of western India: oldest Cenozoic lizards from South Asia". English. In: Palaeontologia Electronica 11.1 (2008).

[18793] G. V. R. Prasad and M. Godinot. "Eutherian tarsal bones from the Late Cretaceous of India". In: Journal of Paleontology 68.4 (1994), pp. 892-902. 
[18794] G. V. R. Prasad, J. J. Jaeger, A. Sahni, E. Gheerbrant, and C. K. Khajuria. “Eutherian mammals from the Upper Cretaceous (Maastrichtian) inter-trappean beds of Naskal, Andhra Pradesh, India". English. In: Journal of Vertebrate Paleontology 14.2 (1994), pp. 260-277.

[18795] G. V. R. Prasad and F.d. Lapparent de Broin. "Late Cretaceous crocodile remains from Naskal (India): comparisons and biogeographic affinities". English. In: Annales de Paléontologie 88 (2002), pp. 19-71.

[18796] G. V. R. Prasad and B. K. Manhas. "A new docodont mammal from the Jurassic Kota Formation of India". English. In: Palaeontologia Electronica 10.2 (2007), 7A-1-7A-11.

[18797] G. V. R. Prasad and B. K. Manhas. "A new symmetrodont mammal from the Lower Jurassic Kota Formation, Pranhita-Godavari Valley, India". English. In: Geobios 30.4 (1997), pp. 563-572.

[18798] G. V. R. Prasad and B. K. Manhas. "Triconodont mammals from the Jurassic Kota Formation of India". English. In: Geodiversitas 24.2 (2002), pp. 445-464.

[18799] G. V. R. Prasad and J. C. Rage. "Amphibians and squamates from the Maastrichtian of Naskal, India". English. In: Cretaceous Research 16 (1995), pp. 95-107.

[18800] G. V. R. Prasad, O. Verma, A. Sahni, D. W. Krause, A. Khosla, and V. Parmar. "A new Late Cretaceous gondwanatherian mammal from central India". English. In: Proceedings of the Indian National Science Academy 73.1 (2007), pp. 17-24.

[18801] G. V. R. Prasad, O. Verma, A. Sahni, V. Parmar, and A. Khosla. “A Cretaceous hoofed mammal from India". English. In: Science 318 (2007), p. 937.

[18802] G. V. R. Prasad, O. Verma, E. Gheerbrant, A. Goswami, A. Khosla, V. Parmar, and A. Sahni. First mammal evidence from the Late Cretaceous of India for biotic dispersal between India and Africa at the KT transition. English. Vol. 9. Comptes Rendus Palevol. 2010, pp. 63-71.

[18803] G. V. R. Prasad, O. Verma, J. J. Flynn, and A. Goswami. “A new Late Cretaceous vertebrate fauna from the Cauvery Basin, South India: implications for Gondwanan paleobiogeography". English. In: Journal of Vertebrate Paleontology 33.6 (2013), pp. 1260-1268.

[18804] K. A. Prassack. "Lontra weiri, sp. nov., a Pliocene River Otter (Mammalia, Carnivora, Mustelidae, Lutrinae) from the Hagerman Fossil Beds (Hagerman Fossil Beds National Monument), Idaho, U.S.A." English. In: Journal of Vertebrate Paleontology 36.4 (2016), e1149075. DOI: 10.1080/02724634. 2016.1149075.

[18805] A. E. Pratt. "Taphonomy of the large vertebrate fauna from the Thomas Farm locality (Miocene, Hemingfordian), Gilchrist County, Florida". English. In: Bulletin of the Florida State Museum, Biological Sciences 35.2 (1990).

[18806] A. E. Pratt and R. C. Hulbert Jr. "Taphonomy of the terrestrial mammals of Leisey Shell Pit 1A, Hillsborough County, Florida". English. In: Bulletin of the Florida Museum of Natural History 37.7 (1995).

[18807] B. R. Pratt. "Probable predation on Upper Cambrian trilobites and its relevance for the extinction of soft-bodied Burgess Shale-type animals". In: Lethaia 31 (1998), pp. 73-88.

[18808] B. R. Pratt. “Trilobites of the Marjuman and Steptoean stages (Upper Cambrian), Rabbitkettle Formation, southern Mackenzie Mountains, northwest Canada". English. In: Palaeontographica Canadiana 9 (1992), pp. 1-109.

[18809] B. R. Pratt and O. L. Bordonaro. "Early Middle Cambrian Trilobites from La Laja Formation Cerro El Molle Precordillera of western Argentina. Journal of Paleontology, 88(5):906-924". English. In: (2014).

[18810] A. Preat, S. Blockmans, L. Capette, V. Dumoulin, and B. Mamet. "Microfacies d'une lentille biohermale a la limite Eifelien/Givetien (Fondry des Chiens, Nismes, bord sud du synclinorium de Dinant) [Microfacies of a biohermal lens at the Eifelian/Givetian transition (Fondry des Chiens, Nismes, southern border of the Dinant Basin]". French. In: Geologica Belgica 10 (2007), pp. 3-25. 
[18811] W. F. Precht, K. J. P. Deslarzes, H. L. Hickerson, G. P. Schmahl, M. F. Nuttall, and R. B. Aronson. "Back to the future: The history of acroporid corals at the Flower Garden Banks, Gulf of Mexico, USA". English. In: Marine Geology 349 (2014), pp. 152-161.

[18812] G. K. Pregill, R. I. Crombie, D. W. Steadman, L. K. Gordon, F. W. Davis, and W. B. Hilgartner. "Living and late Holocene fossil vertebrates and the vegetation of the Cockpit Country, Jamaica". English. In: Atol Research Bulletin 353 (1991), pp. 1-19.

[18813] G. K. Pregill and D. W. Steadman. "The prehistory and biogeography of terrestrial vertebrates on Guam, Mariana Islands". English. In: Diversity and Distributions 15 (2009), pp. 983-996.

[18814] G. K. Pregill and D. W. Steadman. "Fossil vertebrates from Palau, Micronesia: a resource assessment". English. In: Micronesica 33 (2000), pp. 137-152.

[18815] W. V. Preiss. "The Adelaide Geosyncline of South Australia and its significance in Neoproterozoic continental reconstruction". English. In: Precambrian Research 100 (2000), pp. 21-63.

[18816] M. A. Prentice and G. O. Poinar. "Three Species of Trypoxylon Latreille from Dominican Amber (Hymenoptera: Sphecidae)". English. In: Journal of the Kansas Entomological Society 66.3 (1993), pp. 280-291.

[18817] M. A. Prentice and G. O. Poinar. “Fossil scolebythids (Hymenoptera: Scolebythidae) from Lebanese and Dominican Amber". English. In: Proceedings of the Entomological Society of Washington 98 (1996), pp. 802-811.

[18818] F. A. Pretto, M. C. Langer, and C. L. Schultz. “A new dinosaur (Saurischia: Sauropodomorpha) from the Late Triassic of Brazil provides insights on the evolution of sauropodomorph body plan". English. In: Zoological Journal of the Linnean Society 185.2 (2019), pp. 388-416. DOI: 10.1093/ zoolinnean/zly028/5003418.

[18819] F. A. Pretto, C. L. Schultz, and M. C. Langer. "New dinosaur remains from the Late Triassic of southern Brazil (Candelária Sequence, Hyperodapedon Assemblage Zone)". English. In: Alcheringa 39 (2015), pp. 264-273.

[18820] R. Prevec, R. A. Gastaldo, J. Neveling, S. B. Reid, and C. V. Looy. "An autochthonous glossopterid flora with latest Permian palynomorphs and its depositional setting in the Dicynodon Assemblage Zone of the southern Karoo Basin, South Africa". English. In: 292 (2010), pp. 391-408. DOI: 10. 1016/j.palaeo.2010.03.052.

[18821] E. Previtera. "Taphonomic analysis of saurischian dinosaurs from the Plottier Formation (Upper Cretaceous), Mendoza, Argentina". English. In: Andean Geology 46.2 (2019), pp. 345-367. DOI: 10. 5027/andgeoV46n2-3161.

[18822] E. Previtera and B. González Riga. “Vertebrados cretácicos de la Formación Loncoche en CalmuCo, Mendoza, Argentina". Spanish. In: Ameghiniana 45.2 (2008), pp. 349-359.

[18823] E. Previtera and B. J. González Riga. “Vertebrados cretácicos de la Formación Loncoche en CalmuCo, Mendoza, Argentina [Cretaceous vertebrates from the Loncoche Formation in Calmu-Co, Mendoza, Argentina]". Spanish. In: Ameghiniana 45.2 (2008), pp. 349-359.

[18824] F. J. Prevosti and B. S. Ferrero. "A Pleistocene giant river otter from Argentina: Remarks on the fossil record and phylogenetic analysis". English. In: Journal of Vertebrate Paleontology 28.4 (2008), pp. 1171-1181.

[18825] F. J. Prevosti, G. M. Gasparini, and M. Bond. “On the systematic position of a specimen previously assigned to Carnivora from the Pliocene of Argentina and its implications for the Great American Biotic Interchange". English. In: Neues Jahrbuch fur Geologie und Palaontologie-Abhandlungen 242.1 (2006), pp. 133-144.

[18826] F. J. Prevosti, F. M. Martin, and M. Massone. “First record of Smilodon Lund (Felidae, Machairodontinae) in Tierra del Fuego Island (Chile)". English. In: Ameghiniana 50.6 (2013), pp. 605-610.

[18827] F. J. Prevosti, J. I. Noriega, C. M. Garca Esponda, and B. S. Ferrero. "Primer registro de Dusicyon gymnocercus (Fisher, 1814) (Carnivora: Canidae) en el Pleistoceno de Entre Ros (Argentina)". Spanish. In: Revista Española de Paleontologa 20.2 (2005), pp. 159-167. 
[18828] F. J. Prevosti and U. F. J. Pardinas. "Comment on The oldest South American Cricetidae (Rodentia) and Mustelidae (Carnivora): Late Miocene faunal turnover in central Argentina and the Great American Biotic Interchange by D. H. Verzi and C. I. Montalvo [Palaeogeography, Palaeoclimatology, Palaeoecology 267 (2008) 284-291]". English. In: Palaeogeography, Palaeoclimatology, Palaeoecology 280 (2009), pp. 543-547.

[18829] F. J. Prevosti and A. D. Rincón. "A new fossil canid assemblage from the late Pleistocene of Northern South America: the canids of the Inciarte asphalt pit (Zulia, Venezuela), fossil record and biogeography". English. In: Journal of Paleontology 81.5 (2007), pp. 1053-1065.

[18830] F. J. Prevosti, L. H. Soibelzon, A. Prieto, M. San Román, and F. Morello. "The Southernmost bear: Pararctotherium (Carnivora, Ursidae, Tremarctinae) in the latest Pleistocene of Southern Patagonia, Chile". English. In: Journal of Vertebrate Paleontology 23.3 (2003), pp. 709-712.

[18831] F. J. Prevosti, E. P. Tonni, and J. C. Bidegain. "Stratigraphic range of the large canids (Carnivora, Canidae) in South America, and its relevance to quaternary biostratigraphy". English. In: Quaternary International 210 (2009), pp. 76-81. DOI: 10.1016/j.quaint.2009.06.034.

[18832] F. J. Prevosti, M. Ubilla, and D. Perea. "Large extinct canids from the Pleistocene of Uruguay: systematic, biogeographic and paleoecological remarks". English. In: Historical Biology 21.1-2 (2009), pp. 79-89.

[18833] G. J. Price. “Taxonomy and palaeobiology of the largest-ever marsupial, Diprotodon Owen, 1838 (Diprotodontidae, Marsupialia)". English. In: Zoological Journal Linnean Society 153 (2008), pp. 369397.

[18834] G. J. Price and S. A. Hocknull. “Invictokoala monticola gen. et sp. nov. (Phascolarctidae, Marsupialia), a Pleistocene plesiomorphic koala holdover from Oligocene ancestors". English. In: Journal of Systematic Palaeontology 9.2 (2011), pp. 327-335.

[18835] G. J. Price, J.-X. Zhao, Y. -X. Feng, and S. A. Hocknull. “New Records of Plio-Pleistocene Koalas from Australia: Palaeoecological and Taxonomic Implications". English. In: Records of the Australian Museum 61 (2009), pp. 39-48. DOI: 10.3853/j.0067-1975.61.2009.1518.

[18836] G. J. Prideaux. Systematics and evolution of the sthenurine kangaroos. English. Vol. 146. UC Publications in Geological Sciences, University of California Press. 2004, pp. 1-623.

[18837] G. J. Prideaux and R. H. Tedford. “Tjukuru wellsi, gen. et sp. nov., a lagostrophine kangaroo (Diprotodontia, Macropodidae) from the Pliocene (Tirarian) of northern South Australia". English. In: Journal of Vertebrate Paleontology 32.3 (2012), pp. 717-721. DOI: 10.1080/02724634.2012.652323.

[18838] G. J. Prideaux and N. M. Warburton. “A new Pleistocene tree-kangaroo (Diprotodontia: Macropodidae) from the Nullarbor Plain of southcentral Australia". English. In: Journal of Vertebrate Paleontology 28.2 (2008), pp. 463-478. DOI: 10.1671/0272-4634(2008)28[463:ANPTDM]2.0.CO;2.

[18839] P. A. Pridmore, T. H. Rich, P. Vickers-Rich, and P. P. Gambaryan. "A tachyglossid-like humerus from the Early Cretaceous of south-eastern Australia". English. In: Journal of Mammalian Evolution 12.3/4 (2005), pp. 359-378. DOI: 10.1007/s10914-005-6959-9.

[18840] J. Prieto. “The Middle Miocene mole Desmanodon crocheti sp. nov. (Talpidae, Mammalia): the last representative of the genus in the North Alpine foreland basin". English. In: Palaeontologische Zeitschrift 84.2 (2010), pp. 217-225. DOI: 10.1007/s12542-009-0038-0.

[18841] J. Prieto and M. Böhme. "Heissigia bolligeri gen. et sp. nov.: a new enigmatic dormouse (Gliridae, Rodentia) from the Miocene of the Northern Alpine Foreland Basin." English. In: Neues Jahrbuch für Geologie und Paläontologie Abhandlungen 245.3 (2007), pp. 301-307.

[18842] J. Prieto, M. Böhme, H. Maurer, K. Heissig, and H. A. Abdul Aziz. "Biostratigraphy and sedimentology of the Fluviatile Untere Serie (Early and Middle Miocene) in the central part of the North Alpine Foreland Basin: implications for palaeoenvironment and climate". English. In: International Journal of Earth Sciences 98 (2009), pp. 1767-1791. DOI: 10.1007/s00531-008-0331-2.

[18843] J. Prieto, L. W. Van Den Hoek Ostende, J. Hr, and L. Kordos. "The Middle Miocene insectivores from Hasznos (Hungary, Nógrád County)". English. In: Palaeobiodiversity and Palaeoenvironments 95.3 (2015), pp. 431-451. DOI: 10.1007/s12549-015-0193-0. 
[18844] A. Prieto-Márquez. “Glishades ericksoni, a new hadrosauroid (Dinosauria: Ornithopoda) from the Late Cretaceous of North America". English. In: Zootaxa 2452 (2010), pp. 1-17.

[18845] A. Prieto-Marquez. "The braincase and skull of Gryposaurus notabilis (Dinosauria, Hadrosauridae), with a taxonomic revision of the genus". English. In: Journal of Vertebrate Paleontology 30.3 (2010), pp. 838-854.

[18846] A. Prieto-Marquez. “Skeletal morphology of Kritosaurus navajovius (Dinosauria: Hadrosauridae) from the Late Cretaceous of the North American south-west, with an evaluation of the phylogenetic systematics and biogeography of Kritosaurini". English. In: Journal of Systematic Palaeontology (2013).

[18847] A. Prieto-Márquez. “Cranial and appendicular ontogeny of Bactrosaurus johnsoni, a hadrosauroid dinosaur from the Late Cretaceous of northern China". English. In: Palaeontology 54.4 (2011), pp. 773-792. DOI: 10.1111/j.1475-4983.2011.01053.x.

[18848] A. Prieto-Marquez, M. Bolortsetseg, and J. R. Horner. "A diminutive deinonychosaur (Dinosauria: Theropoda) from the Early Cretaceous of Oosh (Ovorkhangai, Mongolia)". English. In: Alcheringa 36.1 (2012), pp. 117-136. DOI: 10.1080/03115518.2011.590401.

[18849] A. Prieto-Márquez, G. M. Erickson, and J. A. Ebersole. "A primitive hadrosaurid from southeastern North America and the origin and early evolution of 'duck-billed' dinosaurs". English. In: Journal of Vertebrate Paleontology 36.2 (2016), e1054495:1-10. DOI: 10.1080/02724634.2015.1054495.

[18850] A. Prieto-Márquez, V. Fondevilla, A. G. Sellés, J. R. Wagner, and A. Galobart. “Adynomosaurus arcanus, a new lambeosaurine dinosaur from the Late Cretaceous Ibero-Armorican Island of the European archipelago". English. In: Cretaceous Research 96 (2019), pp. 19-37. DOI: 10.1016/j.cretres. 2018.12.002.

[18851] A. Prieto-Márquez, R. Gaete, A. Galobart, and L. Ardévol. “A Richardoestesia-like theropod tooth from the Late Cretaceous foredeep, south-central Pyrenees, Spain". English. In: Eclogae Geologicae Helveticae 93 (2001), pp. 497-501.

[18852] A. Prieto-Márquez, R. Gaete, G. Rivas, Á Galobart, and M. Boada. “Hadrosauroid dinosaurs from the Late Cretaceous of Spain: Pararhabdodon isonensis revisited and Koutalisaurus kohlerorum, gen. et. sp. nov." English. In: Journal of Vertebrate Paleontology 26.4 (2006), pp. 929-943.

[18853] A. Prieto-Márquez and S. Gutarra. "The 'duck-billed' dinosaurs of Careless Creek (Upper Cretaceous of Montana, USA), with comments on hadrosaurid ontogeny". English. In: Journal of Paleontology 90.1 (2016), pp. 133-146. DOI: 10.1017/jpa.2016.42.

[18854] A. Prieto-Márquez and C. I. Serrano Brañas. "Latirhinus uitstlani, a 'broad-nosed' saurolophine hadrosaurid (Dinosauria, Ornithopoda) from the late Campanian (Cretaceous) of northern Mexico". English. In: Historical Biology 24.6 (2012), pp. 607-619. DOI: 10.1080/08912963.2012.671311.

[18855] A. Prieto-Marquez, F. M. D. Vecchia, R. Gaete, and A. Galobart. “Diversity, relationships, and biogeography of the lambeosaurine dinosaurs from the European archipelago, with description of the new aralosaurin Canardia garonnensis". English. In: PLoS One 8.7 (2013), e69835:1-44. DOI: 10.1371/journal.pone.0069835.

[18856] A. Prieto-Marquez and J. R. Wagner. "A new species of saurolophine hadrosaurid dinosaur from the Late Cretaceous of the Pacific Coast of North America". English. In: Acta Palaeontologica Polonica 58.2 (2013), pp. 255-268.

[18857] A. Prieto-Márquez, J. R. Wagner, and T. Lehman. "An unusual 'shovel-billed' dinosaur with trophic specializations from the early Campanian of Trans-Pecos Texas, and the ancestral hadrosaurian crest". English. In: Journal of Systematic Palaeontology 18.6 (2020), pp. 461-498.

[18858] A. Prieto-Márquez, D. B. Weishampel, and J. R. Horner. “The dinosaur Hadrosaurus foulkii, from the Campanian of the East Coast of North America, with a reevaluation of the genus". English. In: Acta Palaeontologica Polonica 51.1 (2006), pp. 77-98.

[18859] T. Prikryl and G. Carnevale. "Miocene bristlemouths (Teleostei: Stomiiformes: Gonostomatidae) from the Makrilia Formation, Ierapetra, Crete". English. In: Comptes Rendus Palevol 16.3 (2017), pp. 266-277. DOI: 10.1016/j.crpv.2016.11.004. 
[18860] T. Pikryl and G. Carnevale. "An Oligocene tubeshoulder (Teleostei, Alepocephaliformes) from the Central Paratethys (Czech Republic): the first skeletal record for the family Platytroctidae". English. In: Journal of Vertebrate Paleontology (2020), e1719123. DOI: 10.1080/02724634.2019.1719123.

[18861] T. Pikryl, I. Kania, and W. Krzeminski. "Synopsis of fossil fish fauna from the Hermanowa locality (Rupelian; Central Paratethys; Poland): current state of knowledge". English. In: Swiss Journal of Geoscience (2016). DOI: 10.1007/s00015-016-0216-5.

[18862] H. Prinoth and R. Posenato. "Late Permian nautiloids from the Bellerophon Formation of the Dolomites (Italy)". English. In: Palaeontographica Abteilung A 282 (2007), pp. 135-165.

[18863] P. Prinz-Grimm. “Triassische Korallen der südlichen Zentral-Anden”. German. In: Geologica et Palaeontologica 29 (1995), pp. 233-243.

[18864] A. C. Pritchard, J. A. Gauthier, M. Hanson, G. S. Bever, and B. -A. S. Bhullar. "A tiny Triassic saurian from Connecticut and the early evolution of the diapsid feeding apparatus". English. In: Nature Communications 9 (2018), p. 1213.

[18865] A. C. Pritchard, J. A. McCartney, D. W. Krause, and N. J. Kley. "New snakes from the Upper Cretaceous (Maastrichtian) Maevarano Formation, Mahajanga Basin, Madagascar". English. In: Journal of Vertebrate Paleontology 34.5 (2014), pp. 1080-1093.

[18866] A. C. Pritchard and S. J. Nesbitt. "A bird-like skull in a Triassic diapsid reptile increases heterogeneity of the morphological and phylogenetic radiation of Diapsida". English. In: Royal Society Open Science 4 (2017), p. 170499.

[18867] A. C. Pritchard, A. H. Turner, E. R. Allen, and M. A. Norell. "Osteology of a North American Goniopholidid (Eutretauranosuchus delfsi) and Palate Evolution in Neosuchia". English. In: American Museum Novitates 3783 (2013), pp. 1-56.

[18868] A. C. Pritchard, A. H. Turner, R. B. Irmis, S. J. Nesbitt, and N. D. Smith. “Extreme Modification of the Tetrapod Forelimb in a Triassic Diapsid Reptile". English. In: Current Biology 26.20 (2016), pp. 2779-2786. DOI: 10.1016/j.cub.2016.07.084.

[18869] L. N. Pritykina. "Isophlebiid Dragonflies from the Late Mesozoic of Eastern Transbaikalia (Odonata: Isophlebiidae)". English. In: Paleontological Journal 40.6 (2006), pp. 636-645.

[18870] C. J. Proctor. "Arthropleurids from the Westphalian D of Writhlington Geological Nature Reserve, Somerset". English. In: Proceedings of the Geologists' Association 109 (1998), pp. 93-98.

[18871] A. Prokin, D. Ren, and M. Fikáek. "New Mesozoic water scavenger beetles from the Yixian Formation in China (Coleoptera: Hydrophiloidea)". English. In: Annales Zoologici 60 (2010), pp. 173179.

[18872] A. A. Prokin. "New water scavenger beetles (Coleoptera: Hydrophilidae) from the Mesozoic of Mongolia". English. In: Paleontological Journal 43 (2009), pp. 660-663.

[18873] A. A. Prokin, K. V. Makarov, A. G. Ponomarenko, and A. S. Bashkuev. "New beetle larvae (Coleoptera: Coptoclavidae, Caraboidea, Polyphaga) from the Upper Triassic of Germany". English. In: Russian Entomological Journal 22 (2013), pp. 259-274.

[18874] A. A. Prokin, P. N. Petrov, B. Wang, and A. G. Ponomarenko. "New fossil taxa and notes on the Mesozoic evolution of Liadytidae and Dytiscidae (Coleoptera)". English. In: Zootaxa 3666 (2013), pp. 137-159.

[18875] A. A. Prokin and A. G. Ponomarenko. "The first record of crawling water beetles (Coleoptera, Haliplidae) in the Lower Cretaceous of Mongolia". English. In: Paleontological Journal 47 (2013), pp. 89-93.

[18876] A. A. Prokin, A. G. Ponomarenko, and A. G. Kirejtshuk. “Description of a larva of Kargalarva permosialis gen. et sp. nov. (Coleoptera: Schizophoromorpha) from the Kargala fossil site". English. In: Paleontological Journal 53 (2019), pp. 282-286. DOI: 10.1134/S0031030119030110.

[18877] A. A. Prokin and D. Ren. "New species of variegated mud-loving beetles (Coleoptera: Heteroceridae) from Mesozoic deposits of China". English. In: Paleontological Journal 45.3 (2011), pp. 284286. 
[18878] A. A. Prokin and D. Ren. "New Mesozoic diving beetles (Coleoptera, Dytiscidae) from China". English. In: Paleontological Journal 44.5 (2010), pp. 526-533.

[18879] A. M. Prokofiev. "A New Genus of the Family Amblypteridae (Osteichthyes: Actinopterygii) from the Lower Permian of Eastern Europe". English. In: Paleontological Research 9.1 (2005), pp. 79-84.

[18880] A. M. Prokofiev. "An interesting new palaeoniscoid actinopterygian (Osteichthyes) from the lower Permian of Southwestern Kazakhstan". English. In: Paleontological Research 9.1 (2005), pp. 85-92.

[18881] A. M. Prokofiev. "A remarkable new paleoniscoid fish (Osteichthyes: Actinopterygii) from the Lower Carboniferous of Tuva Republic (Russia)". English. In: Paleontological Research 8.2 (2004), pp. 109-114.

[18882] A. M. Prokofiev. "Oligocene eel from the Frauenweiler site (Germany)". English. In: Journal of Ichthyology 52.1 (2012), pp. 11-18. DOI: 10.1134/S0032945212010109.

[18883] J. Prokop. "An immature stonefly from Lower Miocene of the Blina mine in northern Bohemia (Plecoptera: Perlidae)". English. In: Acta Societatis Zoologicae Bohemicae 66 (2002), pp. 239-239.

[18884] J. Prokop, M. Dehon, D. Michez, and M. S. Engel. “An Early Miocene bumble bee from northern Bohemia (Hymenoptera, Apidae)". English. In: ZooKeys 710 (2017), pp. $43-63$.

[18885] J. Prokop, F. R. Fernandes, J. Lapeyrie, and A. Nel. “Discovery of the first lacewings (Neuroptera: Permithonidae) from the Guadalupian of the Lodéve Basin (southern France)". English. In: Geobios 48 (2015), pp. 263-270.

[18886] J. Prokop and M. Fikáek. "Early Oligocene insect fauna from Seifhennersdorf (Saxony, Germany)”. English. In: Acta Musei Nationalis Pragae Series B - Historia Naturalis 63 (2007), pp. 205-213.

[18887] J. Prokop, G. Fleck, and A. Nel. “New dragonflies from the Lower Miocene (Ottnangian/Karpatian) of the Cypris Shale in western Bohemia (Odonata: Libellulidae)". English. In: Neues Jahrbuch für Geologie und Paläontologie, Monatshefte 2003.9 (2003), pp. 561-576.

[18888] J. Prokop, R. Garrouste, and A. Nel. "A new permopsocidan genus and species from the Late Permian of Australia (Insecta: Acercaria: Psocidiidae)". English. In: Zootaxa 4147 (2016), pp. 589592.

[18889] J. Prokop, W. Krzemiski, E. Krzemiska, and D. Wojciechowski. “Paoliida, a putative stem-group of winged insects: Morphology of new taxa from the Upper Carboniferous of Poland". English. In: Acta Palaeontologica Polonica 57 (2012), pp. 161-173. DOI: 10.4202/app.2010.0064.

[18890] J. Prokop, W. Krzemiski, E. Krzemiska, T. Hornschemeyer, J. M. Ilger, C. Brauckmann, P. Grandcolas, and A. Nel. "Late Palaeozoic Paoliida is the sister group of Dictyoptera (Insecta: Neoptera)". English. In: Journal of Systematic Palaeontology 12 (2014), pp. 601-622.

[18891] J. Prokop and J. Kukalová-Peck. "New insects from the earliest Permian of Carrizo Arroyo (New Mexico, USA) bridging the gap between the Carboniferous and Permian entomofaunas". English. In: Insect Systematics \& Evolution 48 (2017), pp. 493-511.

[18892] J. Prokop, A. Nel, and A. Tenny. “On the phylogenetic position of the palaeopteran Syntonopteroidea (Insecta: Ephemeroptera), with a new species from the Upper Carboniferous of England". English. In: Organisms Diversity \& Evolution 10 (2010), pp. 331-340. DOI: 10.1007/s13127-010-0022-2.

[18893] J. Prokop and A. Nel. "New griffenfly, Bohemiatupus elegans from the Late Carboniferous of western Bohemia in the Czech Republic (Odonatoptera: Meganisoptera: Meganeuridae)". English. In: Annales de la Société Entomologique de France 46 (2010), pp. 183-188.

[18894] J. Prokop and A. Nel. "Merlax bohemicus gen. n., sp. n., a new fossil dragonfly from the Lower Miocene of northern Bohemia (Odonata: Aeshnidae)". English. In: European Journal of Entomology 97 (2000), pp. 427-431.

[18895] J. Prokop and A. Nel. "New Middle Permian palaeopteran insects from Lodéve Basin in southern France (Ephemeroptera, Diaphanopterodea, Megasecoptera)". English. In: ZooKeys 130 (2011), pp. $41-55$. 
[18896] J. Prokop and A. Nel. “New fossil record Gerridae (Heteroptera: Gerromorpha) from the Early Oligocene diatomite in the Czech Republic". English. In: Acta Societatis Zoologicae Bohemicae 71 (2007), pp. 15-19.

[18897] J. Prokop and A. Nel. "An enigmatic Palaeozoic stem-group: Paoliida, designation of new taxa from the Upper Carboniferous of the Czech Republic (Insecta: Paoliidae, Katerinkidae fam. n)". English. In: African Invertebrates 48 (2007), pp. 77-86.

[18898] J. Prokop and A. Nel. “Tertiary termite from the Blina mine locality in northern Bohemia (Isoptera: Hodotermitidae)". English. In: Klapalekiana 35 (1999), pp. 141-144.

[18899] J. Prokop and A. Nel. "New fossil Aculeata from the Oligocene of the eské Stedoho Mts. and the Lower Miocene of the Most Basin in northern Czech Republic (Hymenoptera: Apidae, Vespidae)". English. In: Acta Musei Nationalis Pragae, Series B, Natural History 59 (2003), pp. 163-171.

[18900] J. Prokop and A. Nel. "New Tertiary dragonflies from Lower Oligocene of the eské stedohoi Mts and Lower Miocene of the Most Basin in the Czech Republic (Odonata: Anisoptera)". English. In: Acta Societatis Zoologicae Bohemicae 66 (2002), pp. 141-150.

[18901] J. Prokop and A. Nel. "New scuttle flies from early Paleogene amber in eastern Moravia, Czech Republic (Diptera: Phoridae)". English. In: Studia Dipterologica 12 (2005), pp. 13-22.

[18902] J. Prokop, A. Nel, J. Hájek, and M. Bubk. "First record of a fossil beetle (Coleoptera, Haliplidae) from the basal Paleocene flysch sediments in the Magura unit (outer Western Carpathians, Moravia)". English. In: Geologica Carpathica 55 (2004), pp. 469-473.

[18903] J. Prokop, A. Nel, M. S. Engel, M. Pecharová, and T. Hörnschemeyer. "New Carboniferous fossils of Spilapteridae enlighten postembryonic wing development in Palaeodictyoptera". English. In: Systematic Entomology 41 (2016), pp. 178-190.

[18904] J. Prokop, M. Pecharová, and A. Nel. "New Cenozoic dragonflies from the Most Basin and Stredohori Complex volcanic area (Czech Republic, Germany)". English. In: Journal of Natural History 50 (2016), pp. 2311-2326.

[18905] J. Prokop, M. Pecharová, A. Nel, M. Grey, and T. Hörnschemeyer. “A remarkable insect from the Pennsylvanian of the Joggins Formation in Nova Scotia, Canada: insights into unusual venation of Brodiidae and nymphs of Megasecoptera". English. In: Journal of Systematic Palaeontology 15 (2017), pp. 1051-1065.

[18906] J. Prokop, M. Pecharová, R. Garrouste, R. Beattie, I. C. Chintauan-Marquier, and A. Nel. “Redefining the extinct orders Miomoptera and Hypoperlida as stem acercarian insects". English. In: BMC Evolutionary Biology 17.205 (2017), pp. 1-20.

[18907] J. Prokop, M. Pecharová, E. A. Jarzembowski, and A. J. Ross. "New palaeodictyopterans from the Late Carboniferous of the UK (Insecta: Palaeodictyopterida)". English. In: Earth and Environmental Science Transactions of the Royal Society of Edinburgh 107 (2018), pp. 99-107.

[18908] J. Prokop, T. Prikryl, O. Dostal, and A. Nel. “Oligaeschna kvaceki sp. nov., a new fossil dragonfly (Odonata: Aeshnidae) from the middle Oligocene sediments of Northern Moravia (Western Carpathians)". English. In: Geologica Carpathica 58.2 (2007), pp. 181-184.

[18909] J. Prokop and D. Ren. "New significant fossil insects from the Upper Carboniferous of Ningxia in northern China (Palaeodictyoptera, Archaeorthoptera)". English. In: European Journal of Entomology 104 (2007), pp. 267-275.

[18910] J. Prokop, P. Roques, and A. Nel. "New non-holometabolous insects from the Pennsylvanian of the Avion locality in Pas-de-Calais, France (Insecta: 'Exopterygota')". English. In: Alcheringa 38 (2014), pp. 155-169.

[18911] J. Prokop, R. Smith, E. A. Jarzembowski, and A. Nel. "New homoiopterids from the Late Carboniferous of England (Insecta: Palaeodictyoptera)". English. In: Comptes Rendus Palevol 5 (2006), pp. 867-873.

[18912] J. Prokop, J. Szwedo, J. Lapeyrie, R. Garrouste, and A. Nel. “New Middle Permian insects from Salagou Formation of the Lodéve Basin in southern France (Insecta: Pterygota)". English. In: Annales de la Société Entomologique de France 51 (2015), pp. 14-51. 
[18913] J. Prokop, Z. Tippeltová, P. Roques, and A. Nel. "A new genus and species of Breyeriidae and wings of immature stages from the Upper Carboniferous, Nord-Pas-de-Calais, France (Insecta: Palaeodictyoptera)". English. In: Insect Systematics \& Evolution 44 (2013), pp. 117-128.

[18914] J. Prokop, K. D. WeiSS, R. P. Dechambre, and A. Nel. “Early Permian insects from Saar-Nahe Basin of Odernheim town site, Rheinland-Pfalz in Germany (Insecta, Grylloblattida, Blattinopseida)". English. In: Geodiversitas 34 (2012), pp. 271-281.

[18915] R. J. Prokop. “Carpocrinus chlupaci sp. n. and Bouskacrinus solus gen. et sp. n. (Echinodermata, Crinoidea) from the Konprusy Limestone (Lower Devonian, Pragian) of the Barrandian area, Czech Republic". English. In: Journal of the National Museum (Prague), Natural History Series 180.9 (2011), pp. 127-131.

[18916] R. J. Prokop and V. Petr. "Survey of echinoderms and a new ophiocistioid Branzoviella talpa gen. et sp. n. (Echinodermata, Ophiocistioidea) in the Lower Devonian, Lochkov Formation of the Barrandian area, Czech Republic". English. In: Bulletin of the Czech Geological Survey 77.3 (2002), pp. 237-240.

[18917] R. J. Prokop and V. Petr. "Plasiacystis mobilis, gen. et sp. n., a strange carpoid (Echinodermata, ?Homoiostelea: Soluta) in the Bohemian Ordovician (Czech Republic)". English. In: Acta Musei Nationalis Pragae, Series B, Natural History 59.3-4 (2004), pp. 151-162.

[18918] E. L. Prosorovskaya. Facies control of Jurassic brachiopods: examples from central Asia. English. Brachiopods: proceedings of the third International Brachiopod Symposium. Rotterdam (Balkema). 1996, pp. 215-220.

[18919] V. A. Prosorovsky. “The Urgonian facies of Central Asia”. English. In: Cretaceous Research 11 (1990), pp. 253-260.

[18920] J. Pross, L. Contreras, P. K. Bijl, D. R. Greenwood, S. M. Bohaty, S. Schouten, J. A. Bendle, U. Röhl, L. Tauxe, J. I. Raine, C. E. Huck, T. van de Flierdt, S. S. R. Jamieson, C. E. Stickley, B. van de Schootbrugge, C. Escutia, H. Brinkhuis, and Integrated Ocean Drilling Program. "Persistent neartropical warmth on the Antarctic continent during the early Eocene epoch". English. In: Nature 488 (2012), pp. 73-77. DOI: 10.1038/nature11300.

[18921] D. R. Prothero. "Systematics of the musk deer (Artiodactyla: Moschidae: Blastomerycinae) from the Miocene of North America". English. In: vol. 44. Neogene Mammals. Albuquerque: New Mexico Museum of Natural History and Science Bulletin, 2008, pp. 207-223.

[18922] D. R. Prothero. The Evolution of North American Rhinoceroses. English. Cambridge: University of Cambridge Press, 2005, pp. 1-218.

[18923] D. R. Prothero. "The Early Evolution of the North American Peccaries (Artiodactyla: Tayassuidae)". English. In: Papers on Geology, Vertebrate Paleontology, and Biostratigraphy in Honor of Michael O. Woodburne (Museum of Northern Arizona Bulletin 65). 2009, pp. 509-541.

[18924] D. R. Prothero. "Systematics of the Musk Deer (Artiodactyla: Moschidae: Blastomerycinae) From the Miocene of Nevada". English. In: New Mexico Museum of Natural History and Science, Bulletin 53 (2011), pp. 610-615.

[18925] D. R. Prothero. "Evolution of the Early Miocene Hesperhyine Peccaries". English. In: New Mexico Museum of Natural History and Science Bulletin 67 (2015), pp. 235-255.

[18926] D. R. Prothero. "A new genus of hesperhyine peccary (Artiodactyla: Tayassuidae) from the late Oligocene of Oregon". English. In: New Mexico Museum of Natural History and Science Bulletin 74 (2016), pp. 205-211.

[18927] D. R. Prothero, K. E. Campbell, B. L. Beatty, and C. D. Frailey. “New late Miocene dromomerycine artiodactyl from Amazon Basin: implications for interchange dynamics". English. In: Journal of Paleontology 88.3 (2014), pp. 434-443. DOI: 10.1666/13-022.

[18928] D. R. Prothero and J. Grenader. "A New Primitive Species of the Flat-Headed Peccary Platygonus (Tayassuidae, Artiodactyla, Mammalia) from the Late Miocene of the High Plains". English. In: Journal of Paleontology 86.6 (2012), pp. 1021-1031. DOI: 10.1666/12-050R.1. 
[18929] D. R. Prothero, T. S. Kelly, K. J. McCardell, and E. L. Wilson. “Magnetostratigraphy, Biostratigraphy, and Tectonic Rotation of the Miocene Caliente Formation, Ventura County, California". English. In: vol. 44. Neogene Mammals. Albuquerque, NM: New Mexico Museum of Natural History and Science, 2008, pp. 255-272.

[18930] D. R. Prothero, M. R. Liter, L. G. Barnes, X. Wang, E. Mitchell, S. McLeod, D. P. Whistler, R. H. Tedford, and C. Ray. "Land mammals from the middle Miocene Sharktooth Hill Bonebed, Kern County, California". English. In: New Mexico Museum of Natural History and Science Bulletin 44 (2008), pp. 299-314.

[18931] D. R. Prothero and M. R. Liter. "Systematics of the dromomerycines and aletomerycines (Artiodactyla: Palaeomerycidae) from the Miocene and Pliocene of North America". English. In: vol. 44. Neogene Mammals. Albuquerque: New Mexico Museum of Natural History and Science Bulletin, 2008, pp. 273-298.

[18932] D. R. Prothero and A. Pollen. "New Late Miocene Fossil Peccaries From California and Nebraska". English. In: Kirtlandia 58 (2013), pp. 42-53.

[18933] D. R. Prothero and D. L. Rasmussen. "New giant rhinoceros from the Arikareean (OligoceneMiocene) of Montana, South Dakota and Wyoming". English. In: New Mexico Museum of Natural History and Science Bulletin 44 (2008), pp. 323-330.

[18934] D. R. Prothero and F. Sanchez. "Magnetic stratigraphy of the upper Eocene Florissant Formation, Teller County, Colorado". English. In: New Mexico Museum of Natural History and Science Bulletin 26 (2004), pp. 145-149.

[18935] D. R. Prothero and C. C. Swisher III. Magnetostratigraphy and geochronology of the terrestrial EoceneOligocene transition in North America. In: Prothero, D. R. and W. A. Berggren, eds. Eocene-Oligocene Climatic and Biotic Evolution. Princeton University Press, Princeton, N. J. 1992, pp. 46-73.

[18936] P. Provini, Z.-H. Zhou, and F. -C. Zhang. "A new species of the basal bird Sapeornis from the Early Cretaceous of Liaoning, China". English. In: Vertebrata PalAsiatica 47.3 (2009), pp. 194-207.

[18937] S. B. Pruss, J. L. Payne, and D. J. Bottjer. "Placunopsis bioherms; the first metazoan buildups following the end-Permian mass extinction". English. In: Palaios 22.1 (2007), pp. 17-23.

[18938] S. B. Pruss, E. F. Smith, O. Leadbetter, R. Z. Nolan, M. Hicks, and D. A. Fike. "Palaeoecology of the archaeocyathan reefs from the lower Cambrian Harkless Formation, southern Nevada, western United States and carbon isotopic evidence for their demise". English. In: Palaeogeography, Palaeoclimatology, Palaeoecology (2019). DOI: 10.1016/j.palaeo.2019.109389..

[18939] A. Psczólkowski and R. Myczyñski. “Ammonite-supported microfossil and nannoconid stratigraphy of the Tithonian-Hauterivian limestones in selected sections of the Branisko Succession, Pieniny Klippen Belt (Poland)". English. In: Studia Geologica Polonica 123 (2004), pp. 133-197.

[18940] T. Ptaszyski and G. Niedwiedzki. "Late Permian vertebrate tracks from the Tumlin Sandstone, Holy Cross Mountains, Poland". English. In: Acta Palaeontologica Polonica 49.2 (2004), pp. 289-320.

[18941] H. Pu, Y. Kobayashi, J. Lu, Y. Wu, H. Chang, J. Zhang, and S. Jia. “An unusual basal therizinosaur with an ornithischian dental arrangement from northeastern China". English. In: PLOS ONE 8.5 (2013), e63423.

[18942] H. Pu, D. K. Zelenitsky, J. Lü, P. J. Currie, K. Carpenter, L. Xu, E. B. Koppelhus, S. Jia, L. Xiao, H. Chuang, T. Li, M. Kundrát, and C. Shen. "Perinate and eggs of a giant caenagnathid dinosaur from the Late Cretaceous of central China". English. In: Nature Communications 8 (2017), 14952:1-9. DOI: $10.1038 /$ ncomms14952.

[18943] T. M. Puckett. "New Ostracoda species from an Upper Cretaceous oyster reef, northern Gulf Coastal Plain, U.S.A." English. In: Journal of Paleontology 68.6 (1994), pp. 1321-1335.

[18944] G. G. Puebla, M. B. Prámparo, and M. A. Gandolfo. "Aquatic ferns from the Upper Cretaceous Loncoche Formation," English. In: Plant Systematics and Evolution 301.2 (2015), pp. 577-588. DOI: 10.1007/s00606-014-1096-7. 
[18945] G. G. Puebla, B. A. Vento, and M. B. Prámparo. “An aquatic angiosperm of the Late Cretaceous, Mendoza Province, central-western Argentina: its phylogenetic position in Araceae". English. In: Historical Biology (2019), pp. 1-9. DOI: 10.1080/08912963.2019.1687696.

[18946] E. Puértolas, J. I. Canudo, and P. Cruzado-Caballero. "A new crocodylian from the late Maastrichtian of Spain: Implications for the initial radiation of crocodyloids". English. In: PLoS One 6.6 (2011), e20011:1-12. DOI: 10.1371/journal.pone.0020011.

[18947] E. Puértolas-Pascual, J. I. Canudo, and M. Moreno-Azanza. “The eusuchian crocodylomorph Allodaposuchus subjuniperus sp. nov., a new species from the latest Cretaceous (upper Maastrichtian) of Spain". English. In: Historical Biology 26.1 (2013), pp. 91-109. DOI: 10.1080 / 08912963.2012. 763034.

[18948] E. Puértolas-Pascual, J. I. Canudo, and L. M. Sender. "New material from a huge specimen of Anteophthalmosuchus cf. escuchae (Goniopholididae) from the Albian of Andorra (Teruel, Spain): Phylogenetic implications". English. In: Journal of Iberian Geology 41.1 (2015), pp. 41-56.

[18949] E. Puértolas-Pascual and O. Mateus. "A three-dimensional skeleton of Goniopholididae from the Late Jurassic of Portugal: implications for the Crocodylomorpha bracing system". English. In: Zoological Journal of the Linnean Society (2019). DOI: 10.1093/zoolinnean/zlz102/5610606.

[18950] E. L. Pueyo, A. Munoz, C. Laplana, and J. M. Pares. “The Last Appearance Datum of Hipparion in Western Europe: magnetostratigraphy along the Pliocene-Pleistocene boundary in the Villarroya Basin (Northern Spain)". English. In: International Journal of Earth Sciences 105 (2015), pp. 22032220.

[18951] P. K. Pufahl and N. P. James. “Monospecific Pliocene oyster buildups, Murray Basin, South Australia: Brackish water end member of the reef spectrum". English. In: Palaeogeography, Palaeoclimatology, Palaeoecology 233.1-2 (2006), pp. 11-33.

[18952] A. T. Pugh, C. J. Schröder-Adams, E. S. Carter, J. O. Herrle, J. Galloway, J. W. Haggart, J. L. Andrews, and K. Hatsukanoc. "Cenomanian to Santonian radiolarian biostratigraphy, carbon isotope stratigraphy and paleoenvironments of the Sverdrup Basin, Ellef Ringnes Island, Nunavut, Canada". English. In: Palaeogeography, Palaeoclimatology, Palaeoecology 413 (2014), pp. 101-122.

[18953] I. Pujana. A new Lower Jurassic radiolarian from the Neuquén Basin, central west Argentina. English. 1996.

[18954] I. Pujana and P. G. Quilty. "High latitude, late Campanian (Cretaceous) Radiolaria from offshore south-eastern Tasmania". English. In: Alcheringa 26 (2002), pp. 249-260.

[18955] R. R. Pujana, C. Panti, J. I. Cuitiño, J. L. Garca Massini, and S. L. Mirabelli. "A new megaflora (fossil woods and leaves) from the Miocene of southwestern Patagonia". English. In: Ameghiniana 52.3 (2015), pp. 350-366.

[18956] R. R. Pujana, S. N. Santillana, and S. A. Marenssi. "Conifer fossil woods from the La Meseta Formation (Eocene of Western Antarctica): Evidence of Podocarpaceae-dominated forests". English. In: Review of Palaeobotany and Palynology 200 (2014), pp. 122-137. DOI: 10.1016/j.revpalbo.2013.09.001.

[18957] F. Pujos. "Megatherium celendinense sp. nov. from the pleistocene of the Peruvian Andes and the phylogenetic relationships of Megatheriines". English. In: Palaeontology 49.2 (2006), pp. 285-306.

[18958] F. Pujos. "Scelidodon Chiliensis (Xenarthra, Mammalia) du Pléistocéne terminal de Pampa de los Fósiles". Spanish. In: Quaternaire 11.3-4 (2000), pp. 197-206.

[18959] F. Pujos, A. M. Albino, P. Baby, and J. L. Guyot. "Presence of the extinct lizard Paradracaena (Teiidae) in the Middle Miocene of the Peruvian Amazon". English. In: Journal of Vertebrate Paleontology 29.2 (2009), pp. 594-598.

[18960] F. Pujos, A. Candela, C. I. Galli, B. L. Coira, M. A. Reguero, M. De Los Reyes, and M. A. Abello. "The Scelidotheriine proscelidodon (Xenarthra: Mylodontidae) from the late Miocene of Maimará (northwestern Argentina, Jujuy province)". English. In: Ameghiniana 49.4 (2012), pp. 668-674. DOI: 10.5710/AMGH.20.11.2012.593. 
[18961] F. Pujos, G. De Iuliis, and B. M. Quispe. “Hiskatherium saintandrei, gen. et sp. nov.: An Unusual Sloth from the Santacrucian of Quebrada Honda (Bolivia) and an Overview of Middle Miocene, Small Megatherioids". English. In: Journal of Vertebrate Paleontology 31.5 (2011), pp. 1131-1149.

[18962] F. Pujos and G. De Iuliis. "Late Oligocene Megatherioidea fauna (Mammalia: Xenarthra) from Salla-Luribay (Bolivia): new data on basal sloth radiation and Cingulata-Tardigrada split". English. In: Journal of Vertebrate Paleontology 27.1 (2007), pp. 132-144.

[18963] F. Pujos, G. de Iuliis, C. Argot, and L. Werdelin. "A peculiar climbing Megalonychidae from the Pleistocene of Peru and its implication for sloth history". English. In: Zoological Journal of the Linnean Society 149 (2007), pp. 179-235.

[18964] F. Pujos, G. De Iuliis, B. M. Quispe, and R. A. Flores. "Lakukullus anatisrostratus, gen. et sp. nov., a new massive nothrotheriid sloth (Xenarthra, Pilosa) from the middle Miocene of Bolivia". English. In: Journal of Vertebrate Paleontology 34.5 (2014), pp. 1243-1248. DOI: 10.1080/02724634.2014.849716.

[18965] F. Pujos, G. De Iuliis, B. Mamani Quispe, S. Adnet, R. Andrade Flores, G. Billet, M. FernandezMonescillo, L. Marivaux, P. Munch, M. B. Pramparo, and P. O. Antoine. "A new nothrotheriid xenarthran from the early Pliocene of Pomata-Ayte (Bolivia): new insights into the caniniformmolariform transition in sloths". English. In: Zoological Journal of the Linnean Society 178 (2016), pp. 679-712. DOI: $10.1111 /$ zoj.12429.

[18966] F. Pujos and R. Salas. "A systematic reassessment and paleogeographic review of fossil Xenarthra from Peru". English. In: Bulletin de l'institut Francais d'Études Andines 33 (2004), pp. 331-377.

[18967] F. Pujos and R. Salas. “A new species of Megatherium (Mammalia: Xenarthra: Megatheriidae) from the Pleistocene of Sacaco and Tres Ventanas, Peru". English. In: Palaeontology 47.3 (2004), pp. 579-604.

[18968] F. Pujos, R. Salas-Gismondi, G. Baby, P. Baby, C. Goillot, J. Tejada, and P. O. Antoine. “Implication of the presence of Megathericulus (Xenarthra: Tardigrada: Megatheriidae) in the Laventan of Peruvian Amazonia". English. In: Journal of Systematic Palaeontology 11.8 (2013), pp. 1-19. DOI: 10.1080/14772019.2012.743488.

[18969] F. Pujos and R. Salas-Gismondi. "Predation of the giant Miocene caiman Purussaurus on a mylodontid ground sloth in the wetlands of proto-Amazonia". English. In: Biology Letters 16 (2020), 20200239:1-6.

[18970] W. J. Pulawski, A. P. Rasnitsyn, D. J. Brothers, and S. B. Archibald. "New genera of Angarosphecinae: Cretosphecium from Early Cretaceous of Mongolia and Eosphecium from Early Eocene of Canada (Hymenoptera: Sphecidae)". English. In: Journal of Hymenoptera Research 9.1 (2000), pp. 3440.

[18971] T. A. Punina. "Stratigraphic levels of Triassic limestones of the South Sikhote-Alin (on the basis of coral study)". English. In: Memoires de Geologie (Lausanne) 30 (1997), pp. 155-174.

[18972] T. A. Punina. "Classification and correlation of Triassic limestones in Sikhote-Alin on the basis of corals". English. In: in J. M. Dickins, Z. Yang, H. Yin, S. G. Lucas, S. K. Acharyya, eds., Late Palaeozoic and Early Mesozoic Circum-Pacific events and their global correlation. World and Regional Geology 10 (1997), pp. 186-192.

[18973] C. Puntener, J. Anquetin, and J. -P. Billon-Bruyat. “Thalassemys bruntrutana n. sp., a new coastal marine turtle from the Late Jurassic of Porrentruy (Switzerland), and the paleobiogeography of the Thalassemydidae". English. In: PeerJ 3:e1282 (2015), pp. 1-28. DOI: 10.7717/peerj.1282.

[18974] C. Puntener, J. Anquetin, and J. -P. Billon-Bruyat. "The comparative osteology of Plesiochelys bigleri n. sp., a new coastal marine turtle from the Late Jurassic of Porrentruy (Switzerland)". English. In: PeerJ (2017). DOI: 10.7717/ peerj.3482.

[18975] C. Püntener, J. Anquetin, and J. -P. Billon-Bruyat. "New material of Eurysternidae (Thalassochelydia, Pan-Cryptodira) from the Kimmeridgian of the Swiss Jura Mountains". English. In: Palaeovertebrata 43.1-e2 (2020), pp. 1-14. 
[18976] C. Puntener, J.-P. Billon-Bruyat, L. Bocat, J. -P. Berger, and W. G. Joyce. “Taxonomy and phylogeny of the turtle Tropidemys langii Rutimeyer, 1873, based on new specimens from the Kimmeridgian of the Swiss Jura Mountains". English. In: Journal of Vertebrate Paleontology 34.2 (2014), pp. 353-374.

[18977] R. W. Purdy. "Chondrichthyan fishes from the Paleocene of South Carolina". English. In: Transactions of the American Philosophical Society 88.4 (1998), pp. 122-146.

[18978] R. W. Purdy, V. P. Schneider, S. P. Applegate, J. H. McLellan, R. L. Meyer, and B. H. Slaughter. “The Neogene sharks, rays, and bony fishes from Lee Creek Mine, Aurora, North Carolina". English. In: Smithsonian Contributions to Paleobiology 90 (2001), pp. 71-202.

[18979] V. I. Pushkin and L. E. Popov. "Two enigmatic bryozoans from the Middle Ordovician of the East Baltic". English. In: Palaeontology 48.5 (2005), pp. 1065-1074.

[18980] V. I. Pushkin and L. E. Popov. "Early Ordovician Bryozoans from North - Western Russia". English. In: Palaeontology 42.1 (1999), pp. 171-189.

[18981] V. Puthz. "Stenus Latreille, 1797 aus dem Baltischen Bernstein nebst Bemerkungen über andere fossile Stenus-Arten (Coleoptera, Staphylinidae)". German. In: Entomologische Blätter 106 (2010), pp. 265-287.

[18982] P. V. Putshkov and Y. A. Popov. “Collarhamphus mixtus n. gen. n. sp. - the first Collartidina (Heteroptera: Reduviidae, Emesinae) from the Baltic amber". English. In: Mitteilungen aus dem Geologisch-Paläontologischen Institut der Universität Hamburg 78 (1995), pp. 179-187.

[18983] P. V. Putshkov and Y. A. Popov. "The first find of Microphysidae from the Rovno amber (Heteroptera, Cimicomorpha)". English. In: Annals of the Upper Silesian Museum, Entomology 12 (2003), pp. 81-86.

[18984] A. Pütz, C. Hernando, and I. Ribera. "A new genus of Limnichidae (Coleoptera) from Baltic amber". English. In: Insect Systematics \& Evolution 35 (2004), pp. 329-334.

[18985] I. Puura and L. E. Holmer. "Lingulate brachiopods from the Cambrian-Ordovician boundary beds in Sweden". English. In: Geologiska Föreningens i Stockholm Förhandlingar 115.3 (1993), pp. 215-237. DOI: $10.1080 / 11035899309452754$.

[18986] N. D. Pyenson, J. A. Goldbogen, and R. E. Shadwick. "Mandible allometry in extant and fossil Balaenopteridae (Cetacea: Mammalia): the largest vertebrate skeletal element and its role in rorqual lunge feeding". English. In: Biological Journal of the Linnean Society 108 (2013), pp. 586-599.

[18987] N. D. Pyenson, C. S. Gutstein, J. F. Parham, J. P. Le Roux, C. C Chavarra, H. Little, A. Metallo, V. Rossi, A. M. Valenzuela-Toro, J. Velez-Juarbe, C. M. Santelli, D. R. Rogers, M. A. Cozzuol, and M. E. Suárez. "Repeated mass strandings of Miocene marine mammals from Atacama Region of Chile point to sudden death at sea". English. In: Proceedings of the Royal Society B 281.1781 (2014), p. 20133316. DOI: $10.1098 / \mathrm{rspb} .2013 .3316$.

[18988] N. D. Pyenson and D. M. Haasi. "Miocene whale-fall from California demostrates that cetacean size did not determine the evolution of modern whale-fall communities". English. In: Biology Letters (2007). DOI: 10.1098/rsbl.2007.0342.

[18989] N. D. Pyenson and E. Hoch. "Tortonian pontoporiid odontocetes from the eastern North Seas". English. In: Journal of Vertebrate Paleontology 27.3 (2007), pp. 757-762.

[18990] N. D. Pyenson, J. Velez-Juarbe, C. S. Gutstein, H. Little, D. Vigil, and A. O’Dea. “Isthminia panamensis, a new fossil inioid (Mammalia, Cetacea) from the Chagres Formation of Panama and the evolution of 'river dolphins' in the Americas". English. In: PeerJ 3 (2015), e1227. DOI: 10.7717 / peerj.1227.

[18991] L. J. Pyle and C. R. Barnes. "Conodonts from a platform-to-basin transect, Lower Ordovician to Lower Silurian, northeastern British Columbia, Canada". English. In: Journal of Paleontology 77.1 (2003), pp. 146-171.

[18992] L. J. Pyle and C. R. Barnes. “Taxonomy, Evolution, and Biostratigraphy of Conodonts: from the Kechika Formation, Skoki Formation, and Road River Group (Upper Cambrian to Lower Silurian)". English. In: (2002), pp. 1-227. 
[18993] L. J. Pyle and C. R. Barnes. “Conodonts from the Kechika Formation and Road River Group (Lower to Upper Ordovician) of the Cassiar Terrane, northern British Columbia". English. In: Canadian Journal of Earth Sciences 38 (2001), pp. 1387-1401. DOI: 10.1139/cjes-38-10-1387.

[18994] G.-Q. Qi, C.-K. Ho, and C. -H. Chang. "The Pleistocene Fossil Suids From Chochen, Tainan, Southwestern Taiwan". English. In: Bulletin of the National Museum of Natural Science 12 (1999), pp. 3340.

[18995] T. Qi. "A New Genus, Ulania, of Hyracodontidae (Perissodactyla, Mammalia)". English. In: Vertebrata PalAsiatica 28.3 (1990), pp. 218-227.

[18996] T. Qi. "A new species of Gigantamynodon from Yunnan Province". Chinese. In: Vertebrata PalAsiatica 30.3 (1992), pp. 229-232.

[18997] T. Qi and K. C. Beard. "Late Eocene sivaladapid primate from Guangxi Zhuang Autonomous Region, People's Republic of China." English. In: Journal of Human Evolution 35 (1998), pp. 211220.

[18998] T. Qi and K. C. Beard. "Nanotitan shanghuangensis, gen. et sp. nov.: The smallest known brontothere (Mammalia: Perissodactyla)". English. In: Journal of Vertebrate Paleontology 16.3 (1996), pp. 578-581.

[18999] T. Qi, L. Wu, and Q. Zhang. "Discovery of Protitan (Perissodactyla, Brototheriidae) from Late Eocene Tukhum beds, Neimongol". English. In: Vertebrata PalAsiatica 30.2 (1992), pp. 162-167.

[19000] T. Qi, G. Zong, and Y. Wang. “Discovery of Lushilagus and Miacis in Jiangsu and its zoogeographical significance". In: Vertebrata PalAsiatica 29.1 (1991), pp. 59-63.

[19001] W. Qi and C. W. Stearn. "Stromatoporoids from the Slave Point Formation (Givetian) at Evie Lake, northeastern British Columbia, Canada". English. In: Acta Scientiarum Naturalium Universitatis Pekinensis 29.6 (1993), pp. 715-728.

[19002] M.-p. Qian, Y. Jiang, R. Chen, Y. -g. Jiang, Y. -j. Zhang, and G. -f. Xin. “Late Cretaceous troodontid eggs from Tiantai, Zhejiang". Chinese. In: Acta Palaeontologica Sinica 47.2 (2008), pp. 248-255.

[19003] M.-p. Qian, Z.-y. Zhang, Y. Jiang, Y. -g. Jiang, Y. -j. Zhang, R. Chen, and G. -f. Xing. “[Cretaceous therizinosaurs in Zhejiang of eastern China]". Chinese. In: Journal of Geology 36.4 (2012), pp. 337348. DOI: 10.3969/j.issn.1764-3636.2012.04.337.

[19004] Y. Qian, Y.-S. Xie, and T. -G. He. "Hyoliths of the Lower Cambrian Chiungchussuan Stage in south Shaanxi Province". English. In: Acta Palaeontologica Sinica 40.1 (2001), pp. 31-43.

[19005] Y. Qian, G. Z. Yin, and B. Xiao. "Opercula of hyoliths and operculum-like fossils from the Lower Cambrian Yuertus Formation, Xinjiang". Chinese. In: Acta Micropalaeontologica Sinica 17.4 (2000), pp. 404-415.

[19006] Y. Qian, M. Y. Zhu, T. G. He, and Z. W. Jiang. "New investigation of Precambrian-Cambrian boundary sections in eastern Yunnan". Chinese. In: Acta Micropalaeontologica Sinica 13.3 (1996), pp. 225-240.

[19007] T. Qiao and M. Zhu. "A new Early Devonian lungfish from Guangxi, China, and its palaeogeographic significance". English. In: Alcheringa 39.3 (2015), pp. 428-437. DOI: 10.1080/03115518.2015. 1015819.

[19008] T. Qiao and M. Zhu. "A new tooth-plated lungfish from the Middle Devonian of Yunnan, China, and its phylogenetic relationships". English. In: Acta Zoologica 90.1 (2009), pp. 236-252.

[19009] X. Qiao, C. K. Shih, and D. Ren. "Three new species of aneuretopsychids (Insecta: Mecoptera) from the Jehol Biota, China". English. In: Cretaceous Research 36 (2012), pp. 146-150.

[19010] X. Qiao, C. K. Shih, and D. Ren. "Two new Middle Jurassic species of orthophlebiids (Insecta: Mecoptera) from Inner Mongolia, China". English. In: Alcheringa 36 (2012), pp. 467-472.

[19011] X. Qiao, C. K. Shih, J. F. Petruleviius, and D. Ren. "Fossils from the Middle Jurassic of China shed light on morphology of Choristopsychidae (Insecta, Mecoptera)". English. In: ZooKeys 318 (2013), pp. 91-111. 
[19012] Z. Qin, J. Clark, J. Choiniere, and X. Xu. "A new alvarezsaurian theropod from the Upper Jurassic Shishugou formation of western China". English. In: Scientific Reports 9 (2019), 11727:1-14. DOI: 10.1038/s41598-019-48148-7.

[19013] L. Qiu, Y. C. Liu, Z. Q. Wang, and Y. L. Che. “The first blattid cockroach (Dictyoptera: Blattodea) in Cretaceous amber and the reconsideration of purported Blattidae". English. In: Cretaceous Research 109.104359 (2020). DOI: 10.1016/j.cretres.2019.104359.

[19014] L. Qiu, Z. Q. Wang, and Y. L. Che. “A new corydiid cockroach with large holoptic eyes in Upper Cretaceous Burmese amber (Blattodea: Corydiidae: Euthyrrhaphinae)". English. In: Cretaceous Research 96 (2019), pp. 179-183. DOI: 10.1016/j.cretres.2018.12.018.

[19015] L. Qiu, Z. Q. Wang, and Y. L. Che. "First record of Blattulidae from mid-Cretaceous Burmese amber (Insecta: Dictyoptera)". English. In: Cretaceous Research 99 (2019), pp. 281-290. DOI: 10.1016/ j.cretres.2019.03.011.

[19016] T. F. Qiu, Y. Y. Lu, W. W. Zhang, S. Wang, Y. X. Yang, and M. Bai. “Electraesalopsis beuteli gen. \& sp. nov., the first lucanid beetle from the Cretaceous Burmese amber (Coleoptera: Scarabaeoidea)". English. In: Zoological Systematics 42 (2017), pp. 390-394.

[19017] Z. Qiu. The Chinese Neogene mammalian biochronology - its correlation with the European Neogene mammal zonation. In E.H. Lindsay, V. Fahlbusch and P. Mein, eds., European Neogene Mammal Chronology. Plenum Press, New York. 1990, pp. 527-556.

[19018] Z. Qiu and G. Storch. “The early Pliocene Micromammalian Fauna of Bilike, Inner Mongolia, China (Mammalia: Lipotyphla, Chiroptera, Rodentia, Lagomorpha)". English. In: Senckenbergiana lethaea 80.1 (2000), pp. 173-229.

[19019] Z. Qiu and B. Wang. "Paracerathere Fossils of China". English. In: Palaeontologia Sinica, New Series C 193.29 (2007), pp. 1-396.

[19020] Z. Qiu, B. Wang, and J. Xie. "Mid-Tertiary chalicothere (Perissodactyla) fossils from Lanzhou, Gansu, China". English. In: Vertebrata PalAsiatica 36.4 (1998), pp. 297-318.

[19021] Z. Qiu and J. Xie. "A new species of Aprotodon (Perissodactyla, Rhinocerotidae) from Lanzhou Basin, Gansu, China". English. In: Vertebrata PalAsiatica 35.4 (1997), pp. 250-267.

[19022] Z.-X. Qiu, B.-Y. Wang, and T. Deng. "Indricotheres (Perissodactyla, Mammalia) from Oligocene in Linxia Basin, Gansu, China". Chinese. In: Vertebrata PalAsiatica 42.3 (2004), pp. 177-192.

[19023] Z.-X. Qiu, B.-Y. Wang, and T. Deng. "Mammal fossils from Yagou, Linxia Basin, Gansu, and related stratigraphic problems". Chinese. In: Vertebrata PalAsiatica 42.4 (2004), pp. 276-296.

[19024] Z.-X. Qiu and B.-Y. Wang. "Allacerops (Rhinoceroroidea, Perissodactyla), its discovery in China and its systematic position". English. In: Vertebrata PalAsiatica 37.1 (1999), pp. 48-61.

[19025] Z.-x. Qiu, J.-y. Xie, and Y. Defa. "Discovery of Late Miocene Agriotherium from Jiegou, Gansu, and its taxonomic implications". Chinese. In: Vertebrata PalAsiatica 29.4 (1991), pp. 286-295.

[19026] T. Q. Qu, Z. W. Yin, D. Y. Huang, and C. Y. Cai. "First Mesozoic brachypsectrid beetles in midCretaceous amber from northern Myanmar (Coleoptera: Elateroidea: Brachypsectridae)". English. In: Cretaceous Research 106.104190 (2019). DOI: 10.1016/j.cretres.2019.07.020.

[19027] A. B. Quadros, P. Chafrat, and H. Zaher. "A New Teiid Lizard of the Genus Callopistes Gravenhorst, 1838". English. In: Journal of Vertebrate Paleontology 38.4 (2018), pp. 1-19. DOI: 10.1080 / 02724634.2018.1484754.

[19028] F. Quaglio, R. J. Whittle, A. Gazdzicki, and M. G. Simoes. “A new fossil Adamussium (Bivalvia: Pectinidae) from Antarctica". English. In: Polish polar research 31.4 (2010), pp. 291-302.

[19029] M. E. Quattrocchio, C. M. Deschamps, C. A. Zavala, S. C. Grill, and A. M. Borromei. "Geology of the area of Baha Blanca, Darwin's view and the present knowledge: A story of 10 million years". English. In: Revista de la Asociación Geológica Argentina 64.1 (2009), pp. 137-146. 
[19030] M. E. Quattrocchio, M. A. Martnez, A. Carpinelli Pavisich, and W. Volkheimer. “Early Cretaceous palynostratigraphy, palynofacies and palaeoenvironments of well sections in northeastern Tierra del Fuego, Argentina". English. In: Cretaceous Research 27 (2006), pp. 584-602. DOI: 10.1016 / j. cretres.2005.11.012.

[19031] R. Quer and J. Agusti. "A new genus of rodents (Remyidae, Mammalia) from the Iberian Eocene". English. In: Palaeontology 53.1 (2010), pp. 53-58.

[19032] P. Quéreilhac. "La sous-famille des Taramelliceratinae (Ammonitina, Haploceratoidea, Oppeliidae) de l'Oxfordien Moyen et Supérieur (Zone á Plicatilis, Sous-zone á Berrense) du Nord de la Vienne, France (Province subméditerranéenne)". French. In: Carnets de Géologie (Notebook on Geology) (2009).

[19033] P. Quereilhac and Y. Guinot. "Les Marnes á theoi de Pamproux (Deux-Sévres, France), Sous-Zone á Antecedens (Oxfordien moyen, Zone á Plicatilis): diversité des faunes et découverte de nouvelles espéces d'ammonites [The Theoi Marls of Pamproux (Deux-Sévres department, France), Antecedens Sub-zone (Middle Oxfordian, Plicatilis Zone): faunal diversity and discovery of new ammonite species]". French. In: Carnets de géologie (Notebook on Geology) CG2011_M01 (2011), pp. 3161.

[19034] P. Quilodran and J. Yanez. Descripcion preliminar de una nueva especie de cetaceo fosil (Odontoceti, Pontoporiidae) en el Mioceno de la Formacion Bahia Inglesa, Tercera Region, Chile. Spanish. 2000.

[19035] P. G. Quilty, J. M. Lirio, and D. Jillett. "Stratigraphy of the Pliocene Sarrsdal Formation, Marine Plain, Vestfold Hills, East Antarctica". English. In: Antarctic Science 12.2 (2000), pp. 205-216.

[19036] P. G. Quilty, C. V. Murray-Wallace, and J. M. Whitehead. "Austrochlamys heardensis (Fleming, 1957) (Bivalvia: Pectinidae) from Central Kerguelen Plateau, Indian Ocean: palaeontology and possible tectonic significance". English. In: Antarctic Science 16 (2004), pp. 329-338.

[19037] L. Quinn, S. H. Williams, D. A. T. Harper, and E. N. K. Clarkson. "Late Ordovician foreland basin fill: Long Point Group of onshore western Newfoundland". English. In: Bulletin of Canadian Petroleum Geology 47.1 (1999), pp. 63-80.

[19038] S. I. Quiñones, M. De los Reyes, A. E. Zurita, F. Cuadrelli, A. R. Miño-Boilini, and D. G. Poiré. "Neosclerocalyptus Paula Couto (Xenarthra, Glyptodontidae) in the late Pliocene-earliest Pleistocene of the Pampean region (Argentina): Its contribution to the understanding of evolutionary history of Pleistocene glyptodonts". English. In: Journal of South American Earth Sciences 103 (2020), 102701:1-20.

[19039] S. I. Quiñones, A. R. Miño-Boilini, A. E. Zurita, S. A. Contreras, C. A. Luna, A. M. Candela, M. Camacho, M. D. Ercoli, N. Sols, and D. Brandoni. "New records of Neogene Xenarthra (Mammalia) from eastern Puna (Argentina): diversity and biochronology". English. In: Journal of Paleontology 93.6 (2019), pp. 1258-1275. DOI: 10.1017/jpa.2019.64.

[19040] C. Quintana. "El roedor Dolicavia minuscula (Caviomorpha, Caviidae) del Plioceno Superior de a provincia de Buenos Aires, Argentina". Spanish. In: Historia Animalium 3 (1997), pp. 55-71.

[19041] C. A. Quintana. "Roedores Cricetidos del Sanandresense (Plioceno tardio) de la provincia de Buenos Aires". Spanish. In: Mastozoologa Neotropical 9.2 (2002), pp. 263-275.

[19042] C. A. Quintana. "Diversidad y relaciones sistematicas de Chasicomys Pascual, 1967 (Rodentia, Octodontoidea) del Mioceno de Argentina". Spanish. In: Boletn de la Sociedad Española de Historia Natural 90.1-4 (1995), pp. 51-58.

[19043] J. Quintana, M. Köhler, and S. Moyá-Solá. “Nuralagus rex, gen. et sp. nov., an endemic insular giant rabbit from the Neogene of Minorca (Balearic Islands, Spain)". English. In: Journal of Vertebrate Paleontology 31 (2011), pp. 231-240.

[19044] S. A. Quiroz-Barroso and M. Del Carmen Perrilliat. "Pennsylvanian bivalves from the Ixaltepec formation, Mexico". In: Journal of Paleontology 72.6 (1998), pp. 1011-1024.

[19045] S. A. Quiroz-Barroso, J. Pojeta, F. Sour-Tovar, and S. Morales-Soto. “Pseudomulceodens: a Mississippian rostroconch from Mexico". In: Journal of Paleontology 74.6 (2000), pp. 1184-1186. 
[19046] S. A. Quiroz-Barroso, F. Sour-Tovar, and E. Centeno-Garca. “Gasterópodos y bivalvos cisuralianos (Pérmico inferior) de Otlamalacatla, Hidalgo, México". Spanish. In: Revista Mexicana de Ciencias Geológicas 29 (2012), pp. 158-178.

[19047] M. A. Raath. "Earliest evidence of dinosaurs from central Gondwana". English. In: Memoirs of the Queensland Museum 39.3 (1996), pp. 703-709.

[19048] M. A. Raath. Morphological variation in small theropods and its meaning in systematics: evidence from Syntarsus rhodesiensis. Dinosaur Systematics: Perspectives and Approaches, Cambridge University Press, Cambridge. 1990, pp. 91-105.

[19049] M. A. Raath, J. W. Kitching, R. W. Shone, and G. J. Rossouw. “Dinosaur tracks in Triassic Molteno sediments: the earliest evidence for dinosaurs in South Africa?" English. In: Palaeontologia africana 27 (1990), pp. 89-95.

[19050] M. A. Raath, P. M. Oesterlen, and J. W. Kitching. "First record of Triassic Rhynchosauria (Reptilia: Diapsida) from the Lower Zambezi Valley, Zimbabwe". English. In: Palaeontologia Africana 29 (1992), pp. 1-10.

[19051] I. Rabano. “Trilobites del Museo Geominero; I, Platypeltoides magrebiensis n. sp., Asaphina, Nileidae, del Ordovicico inferior del Anti-Atlas central, Marruecos". Spanish. In: Boletin Geologico y Minero 101.1 (1990), pp. 21-27.

[19052] I. Rabano, J. C. Gutiérrez-Marco, and D. C. Garca-Bellido. “A remarkable illaenid trilobite from the Middle Ordovician of Morocco". English. In: Bulletin of Geosciences 89.2 (2014), pp. 365-374. DOI: 10.3140/bull.geosci.1467.

[19053] G. Rabeder. “Dinosorex (Insectivora, Mammalia) aus dem Miozän von Österreich." German. In: Geologische und Paläontologische Mitteilungen Innsbruck 23 (1998), pp. 117-126.

[19054] M. Rabi, K. Bastl, G. Botfalvai, Z. Evanics, and S. Peigné. "A new carnivoran fauna from the late Oligocene of Hungary". English. In: Palaeobiodiversity and Palaeoenvironments 98.3 (2018), pp. 509521.

[19055] M. Rabi and N. Sebk. “A revised Eurogondwana model: Late Cretaceous notosuchian crocodyliforms and other vertebrate taxa suggest the retention of episodic faunal links between Europe and Gondwana during most of the Cretaceous". English. In: Gondwana Research 28.3 (2015), pp. 11971211. DOI: 10.1016/j.gr.2014.09.015.

[19056] M. Rabi, V. B. Sukhanov, V. N. Egorova, I. Danilov, and W. G. Joyce. “Osteology, relationships, and ecology of Annemys (Testudines, Eucryptodira) from the Late Jurassic of Shar Teg, Mongolia, and phylogenetic definitions for Xinjiangchelyidae, Sinemydidae, and Macrobaenidae". English. In: Journal of Vertebrate Paleontology 34.2 (2014), pp. 327-352.

[19057] M. Rabi, H. Tong, and G. Botfalvai. "A new species of the side-necked turtle Foxemys (Pelomedusoides: Bothremydidae) from the Late Cretaceous of Hungary and the historical biogeography of the Bothremydini". English. In: Geological Magazine 149.4 (2012), pp. 662-674. DOI: 10.1017/ S0016756811000756.

[19058] M. Rabi, M. Vremir, and H. Tong. "Preliminary Overview of Late Cretaceous Turtle Diversity in Eastern Central Europe (Austria, Hungary, and Romania)". English. In: Morphology and Evolution of Turtles. 2013, pp. 307-336. DOI: 10.1007/978-94-007-4309-0_19.

[19059] M. Rabi, C.-F. Zhou, O. Wings, S. Ge, and W. G. Joyce. "A new xinjiangchelyid turtle from the Middle Jurassic of Xinjiang, China and the evolution of the basipterygoid process in Mesozoic turtles". English. In: BMC Evolutionary Biology 13.203 (2013), pp. 1-28. DOI: 10.1186/1471-2148-13203.

[19060] D. Rabrenovic, N. Vasic, J. Mitrovic-Petrovic, V. Radulovic, B. Radulovic, and D. Sreckovic-Batocanin. "The middle Cenomanian basal series of Planinica, Western Serbia". English. In: Geoloshki Anali Balkanskoga Poluostrva = Annales Geologiques de la Peninsule Balkanique 64 (2002), pp. 13-43.

[19061] D. Rabu, J. J. Chauvel, M. P. Dabard, T. P. Fletcher, and G. L. Pillola. "Présence de Tommotien (Cambrien inférieur) á Saint-Pierre et Miquelon". French. In: Comptes Rendus de l'Académie Sciences Paris, Série II 317 (1993), pp. 379-386. 
[19062] A. Racco, J. C. Fernicola, M. S. Bargo, S. F. Vizcano, and G. De Iuliis. “On the type of Schismotherium fractum Ameghino, 1887 (Xenarthra, Folivora, Megatherioidea) from the early Miocene Santa Cruz Formation (Santa Cruz Province, Argentina)". English. In: Ameghiniana 55.1 (2018), pp. 117-125. DOI: 10.5710/AMGH.18.07.2017.3109.

[19063] P. R. Racheboeuf. Lower Silurian to Lower Devonian communities from the Armorican Massif (western France) and Artois (northern France). Paleocommunities-a case study from the Silurian and Lower Devonian. 1999, pp. 260-270.

[19064] P. R. Racheboeuf. "Valloisella lievinensis n. g. n. sp.: nouveau xiphosure carbonifére du Nord de la France". English. In: Neues Jahrbuch für Geologie und Paläontologie, Monatshefte 1992.6 (1992), pp. 336-342. DOI: 10.1127 /njgpm/1992/1992/336.

[19065] P. R. Racheboeuf, P. Copper, and F. Alvarez. "Planalvus (Brachiopoda, Athyridida) from the Lower Devonian of the Armorican Massif, Northwest France". English. In: Journal of Paleontology 68.3 (1994), pp. 451-460. DOI: 10.2307/1306195.

[19066] P. R. Racheboeuf and H. R. Feldman. "Chonetacean Brachiopods of the Pink Chonetes Zone, Onondaga Limestone (Devonian, Eifelian), Central New York". English. In: American Museum Novitates 2982 (1990), pp. 1-16.

[19067] P. R. Racheboeuf, R. Gourvennec, M. Deynoux, and D. Brice. “The Devonian of the Hodh area (Islamic Republic of Mauritania): paleontology and stratigraphy". English. In: Journal of Paleontology 78.1 (2004), pp. 98-110.

[19068] P. R. Racheboeuf, J. T. Hannibal, and J. M. C. Vannier. "A new species of the diplopod Amynilyspes (Oniscomorpha) from the Stephanian lagerstätte of Montceau-les-Mines, France". English. In: Journal of Paleontology 78 (2004), pp. 221-229.

[19069] P. R. Racheboeuf, T. E. Moore, and R. B. Blodgett. “A new species of Dyoros (Brachiopoda: Chonetoidea) from Nevada (United States) and stratigraphic implications for the Pennsylvanian and Permian Antler Overlap assemblage". English. In: Géobios 37 (2004), pp. 382-394.

[19070] P. R. Racheboeuf, J. M. C. Vannier, and L. I. Anderson. “A new three-dimensionally preserved xiphosuran chelicerate from the Montceau-les-Mines Lagerstätte (Carboniferous, France)". English. In: Palaeontology 45 (2002), pp. 125-174. DOI: 10.1111/1475-4983.00230.

[19071] P. R. Racheboeuf and M. Villeneuve. “Une faune Malvino-Cafre de Brachiopodes Siluriens du Bassin Bove (Guinee, Ouest de l'Afrique)". French. In: Geologica et Palaeontologica 26 (1992), pp. 111.

[19072] P. R. Racheboeuf and Amos F.C. "Revision and Reassignment of Strophomena cornuta Hall, 1843 (Brachiopoda, Silurian) to Strophochonetes Muir-Wood, 1962". English. In: Journal of Paleontology 71.5 (1997), pp. 816-819.

[19073] P. R. Racheboeuf, P. Janvier, T. H. Phuong, J. M. C. Vannier, and W. Shang-Qi. "Lower Devonian vertebrates, arthropods and brachiopods from northern Vietnam". English. In: Géobios 38 (2005), pp. 533-551.

[19074] R. A. Racicot, R. W. Boessenecker, S. A. F. Darroch, and J. H. Geisler. "Evidence for convergent evolution of ultrasonic hearing in toothed whales (Cetacea: Odontoceti)". English. In: Biology Letters 15 (2019), pp. 1-6. DOI: 10.1098/rsbl.2019.0083.

[19075] R. A. Racicot, T. A. Deméré, B. L. Beatty, and R. W. Boessenecker. “Unique feeding morphology in a new prognathous extinct porpoise from the Pliocene of California". English. In: Current Biology (2014). DOI: 10.1016/j.cub.2014.02.031.

[19076] G. Racki. "Brachiopod assemblages in the Devonian Kowala Formation of the Holy Cross Mountains". English. In: Acta Palaeontologica Polonica 37 (1992), pp. 297-357.

[19077] A. Radchenko. "New species of extinct ant genus Eocenomyrma Dlussky et Radchenko (Hymenoptera: Formicidae: Myrmicinae) from the Baltic amber". English. In: Annales Zoologici 70 (2020), pp. 109-111. DOI: 10.3161/00034541ANZ2020.70.1.005. 
[19078] A. Radchenko, G. Dlussky, and G. W. Elmes. "The Ants of the Genus Myrmica (Hymenoptera, Formicidae) from Baltic and Saxonian Amber (Late Eocene)". English. In: Journal of Paleontology 81.6 (2007), pp. 1494-1501.

[19079] A. Radchenko and G. M. Dlussky. "Boltonidris gen. nov., the first extinct Stenammini ant genus (Hymenoptera, Formicidae) from the late Eocene Rovno amber". English. In: Annales Zoologici 62 (2012), pp. 627-631.

[19080] A. Radchenko and G. M. Dlussky. "Bilobomyrma new genus, a new extinct ant genus (Hymenoptera, Formicidae) from the late Eocene European ambers". English. In: Journal of Paleontology 87 (2013), pp. 1060-1066.

[19081] A. Radchenko and G. M. Dlussky. "New species of the extinct ant genus Stigmomyrmex Mayr and designation of the neotype of Stiphromyrmex robustus (Mayr) (Hymenoptera: Formicidae: Myrmicinae)". English. In: Annales Zoologici 67 (2017), pp. 773-780.

[19082] A. Radchenko, G. M. Dlussky, and K. Perfilieva. “A new extinct ant genus (Hymenoptera: Formicidae: Myrmicinae) from the Late Eocene Rovno amber - a putative ancestor of the Leptothorax genus group". English. In: Myrmecological News 27 (2018), pp. 111-117.

[19083] A. Radchenko and G. M. Dlussky. "New species of the extinct ant genus Enneamerus Mayr (Hymenoptera, Formicidae) and designation of the neotype of E. reticulatus". English. In: Asian Myrmecology 9 (2017), e009012.

[19084] A. Radchenko and G. M. Dlussky. "First record of the ant genus Crematogaster (Hymenoptera: Formicidae) from the late Eocene European ambers". English. In: Annales Zoologici 69 (2019), pp. 417-421. DOI: 10.3161/00034541ANZ2019.69.2.008.

[19085] A. Radchenko, G. M. Dlussky, and C. Gröhn. "New extinct species of the ant genus Carebara (Hymenoptera: Formicidae) from the late Eocene European ambers". English. In: Annales Zoologici 69 (2019), pp. 609-616. DOI: 10.3161/00034541ANZ2019.69.3.010.

[19086] A. G. Radchenko and G. M. Dlussky. "First record of fossil species of the genus Tetramorium (Hymenoptera, Formicidae)". English. In: Vestnik Zoologii 49 (2015), pp. 311-316.

[19087] A. G. Radchenko and G. M. Dlussky. "Further data on the extinct ant genus Eocenomyrma (Hymenoptera, Formicidae)". English. In: Vestnik Zoologii 50 (2016), pp. 395-406.

[19088] A. G. Radchenko and G. M. Dlussky. "Ants of the genus Fallomyrma Dlussky et Radchenko (Hymenoptera, Formicidae, Myrmicinae) from late Eocene European ambers". English. In: Paleontological Journal 52 (2018), pp. 155-163.

[19089] A. G. Radchenko and G. M. Dlussky. "Two new fossil species of the ant genus Pristomyrmex Mayr (Hymenoptera: Formicidae) from the Rovno and Bitterfeld ambers". English. In: Annales Zoologici 68 (2018), pp. 251-258.

[19090] A. G. Radchenko and G. M. Dlussky. "A new species of the extinct ant genus Electromyrmex (Hymenoptera, Formicidae)". English. In: Vestnik Zoologii 52 (2018), pp. 361-366.

[19091] A. G. Radchenko and E. E. Perkovsky. "Monomorium kugleri n. sp., a new fossil ant species (Hymenoptera: Formicidae: Myrmicinae) from the late Eocene Rovno amber (Ukraine)". English. In: Israel Journal of Entomology 39 (2009), pp. 99-103.

[19092] A. G. Radchenko and E. E. Perkovsky. “The ant Aphaenogaster dlusskyana sp. nov. (Hymenoptera, Formicidae) from the Sakhalin amber - the earliest described species of an extant genus of Myrmicinae". English. In: Paleontological Journal 50 (2016), pp. 936-946.

[19093] A. G. Radchenko and E. E. Perkovsky. "First record of fossil ant species Eocenomyrma rugosostriata (Mayr) (Hymenoptera: Formicidae) from the Rovno amber". English. In: Russian Entomological Journal 27 (2018), pp. 285-288.

[19094] A. G. Radchenko and E. E. Perkovsky. "New finds of the fossil ant genus Prionomyrmex Mayr (Hymenoptera, Formicidae, Myrmeciinae) in Late Eocene European amber". English. In: Paleontological Journal 54 (2020), pp. 617-626. DOI: 10.1134/S0031030120060088. 
[19095] T. A. Radenbaugh and F. K. McKinney. "Comparison of the structure of a Mississippian and a Holocene pen shell assemblage". English. In: Palaios 13.1 (1998), pp. 52-69.

[19096] J. Radley and S. Hutt. "The Isle of Wight sauropod". English. In: Earth Science and Conservation 33 (1993), pp. 10-12.

[19097] J. D. Radley. "Stratigraphy, palaeontology and palaeoenvironment of the Wessex Formation (Wealden Group, Lower Cretaceous) at Yaverland, Isle of Wight, southern England". English. In: Proceedings of the Geologists' Association 105 (1994), pp. 199-208.

[19098] J. D. Radley. "Type, figured and cited specimens in the Museum of Isle of Wight Geology (Isle of Wight, England)". English. In: The Geological Curator 6.5 (1996), pp. 187-193.

[19099] R. Radoii. “Trinocladus divnae and Montiella filipovici - a new species (Dasycladales, green algae) from the Upper Cretaceous of the Mountain Patrik (Mirdita Zone)". English. In: Annales Géologiques de la Péninsule Balkanique 67 (2006), pp. 65-87.

[19100] C. Radulesco and P. Samson. "The Plio-Pleistocene mammalian succession of the Oltet Valley, Dacic Basin, Romania". In: Quatarpalaontologie 8 (1990), pp. 225-232.

[19101] C. Radulesco and P. Samson. Traces d'activite humaine a la limite Pliocene/Pleistocene dans le bassin Dacique (Roumanie). French. Les Premiers Europeens. Edition du comite des Travaux Historiques et Scientifiques (CTHS). Paris, 1991, pp. 203-207.

[19102] C. Radulesco and P.-M. Samson. "Pliocene and Early Pleistocene arvicolids (Rodentia, Mammalia) of the Dacic Basin, Romania." In: Acta Zoologica Cracoviensia 39.1 (1996), pp. 401-406.

[19103] C. Radulescu, P. Enciu, and A. Petculescu. "On the presence of Prolagurus and Allophaiomys in the Dacic Basin". In: Travaux de l'Institut de Speologie 'Emole Racovitza' 36 (2000), pp. 119-133.

[19104] B. Radulovic, N. Motchurova-Dekova, and V. Radulovic. "New Barremian rhynchonellide brachiopod genus from Serbia and the shell microstructure of Tetrarhynchiidae". English. In: Acta Palaeontologica Polonica 52 (2007), pp. 761-782.

[19105] V. Radulovic and N. Motchurova-Dekova. "The rhynchonellide brachiopod Cyclothyris? globata (Arnaud, 1877) from the Santonian-Campanian of Pannonides, Carpatho-Balkanides and Dinarides (southeastern Europe)". English. In: Geological Annals of the Balkan Peninsula 64 (2001), pp. 107135.

[19106] V. Radulovi and D. Rabrenovi. "Brachiopods from the Klaus Beds of the Yugoslavian CarpathoBalkanides". English. In: Mesozoic Brachiopods of Alpine Europe. Budapest: Hungarian Geological Society, 1993, pp. 113-126.

[19107] V. Radulovic, D. U. Urosevic, and N. Banjac. “Upper Triassic brachiopods from the Yugoslavian Carpatho-Balkanides (Stara Planina)". English. In: Senckenbergiana lethaea 72 (1992), pp. 61-76.

[19108] U. Radwanska. "A new echinoid from the Eocene La Meseta Formation of Seymour Island, Antarctic Peninsula". English. In: Palaeontologia Polonica 55 (1996), pp. 117-125.

[19109] U. Radwanska. "Lower Kimmeridgian echinoids of Poland". English. In: Acta Geologica Polonica 49.4 (1999), pp. 287-364.

[19110] A. Radwanski. “Triassic brittlestar beds of Poland: a case of Aspidurella ludeni (v. Hagenow, 1846) and Arenorbis squamosus (E. Picard, 1858)". other. In: Acta geologica Polonica 52.4 (2002), pp. 395410.

[19111] A. Radwanski, M. Górka, and A. Wysocka. "Middle Miocene coralgal facies at Maksymivka near Ternopil (Ukraine): a preliminary account". English. In: Acta Geologica Polonica 56.1 (2006), pp. 89103.

[19112] A. Radwanski and E. Roniewicz. "Kolonie korali z muszlowcow ostrygowych i oolitow dolnego kimerydu Malogoszcza [Coral lumps in Early Kimmeridgian oyster shellbeds and oolites of Malogoszcz]". other. In: Tomy Jurajskie 3 (2005), pp. 97-107. 
[19113] A. Radwanski and H. Summesberger. "A new species of inarticulate brachiopods, Discinisca zapfei sp. n., from the Upper Triassic Zlambach Formation (Northern Calcareous Alps, Austria), and a discussion of other Triassic disciniscans". English. In: Annalen des Naturhistorischen Museums in Wien, A 102 (2001), pp. 109-129.

[19114] S. Radzevicius, A. Spiridonov, and A. Brazauskas. “Integrated middle-upper Homerian (Silurian) stratigraphy of the Vidukle-61 well, Lithuania". English. In: Gff 136.1 (2014), pp. 218-222. DOI: 10.1080/11035897.2013.866976.

[19115] S. Radzeviius, A. Spiridonov, A. Brazauskas, D. Dankina, A. Rimkus, G. Bikauskas, D. Kaminskas, T. Meidla, and L. Ainsaar. "Integrated stratigraphy, conodont turnover and palaeoenvironments of the upper Wenlock and Ludlow in the shallow marine succession of the Vilkavikis-134 core (Lithuania)". English. In: Newsletters on Stratigraphy 49.2 (2016), pp. 321-336. DOI: 10.1127 / nos / 2016/0074.

[19116] S. Radzeviius, A. Spiridonov, A. Brazauskas, A. Norkus, T. Meidla, and L. Ainsaar. “Upper Wenlock d13C chemostratigraphy, conodont biostratigraphy and palaeoecological dynamics in the Ledai-179 drill core (Eastern Lithuania)". English. In: Estonian Journal of Earth Sciences 63.4 (2014), pp. 293-299. DOI: 10.3176/earth.2014.33.

[19117] L. Ragaini, G. Bianucci, G. Cantalamessa, G. Valleri, and W. Landini. "Paleoecology and paleobiogeography of fossil mollusks from Isla Isabela (Galapagos, Ecuador)". English. In: Journal of South American Earth Sciences 15 (2002), pp. 381-389.

[19118] L. Ragaini, C. di Celma, and G. Cantalamessa. “Warm-water mollusc assemblages from northern Chile (Mejillones Peninsula): new evidence for permanent El Nino-like conditions during Pliocene warmth?" English. In: Journal of the Geological Society 165 (2008), pp. 1075-1084.

[19119] J. Rage. "Squamates (Reptilia) from the Upper Cretaceous of Lano (Basque Country, Spain)". In: Estudios del Museo de Ciencias Naturales de Alava 14.1 (1999), pp. 121-133.

[19120] J.-C. Rage, L. G. Marshall, and M. Gayet. "Enigmatic Caudata (Amphibia) from the Upper Cretaceous of Gondwana". English. In: Géobios 26.5 (1993), pp. 515-519.

[19121] J.-C. Rage and A. Richter. "A snake from the Lower Cretaceous (Barremian) of Spain: the oldest known snake". English. In: Neues Jahrbuch für Geologie und Paläontologie, Monatshefte 1994.9 (1994), pp. 561-565.

[19122] J. C. Rage and M. Augé. "Amphibians and squamate reptiles from the lower Eocene of Silveirinha (Portugal)". English. In: Ciencias da Terra 15 (2003), pp. 103-116.

[19123] J. C. Rage and M. Auge. "Squamates from the Cainozoic of the western part of Europe. A review". English. In: Revue de Paleobiologie 7 (1993), pp. 199-216.

[19124] J. C. Rage and S. Hossini. "Les Amphibians du Miocene moyen de Sansan". English. In: Memoires du Museum national d'Histoire naturelle 183 (2000), pp. 177-217.

[19125] J. C. Rage and G. V. R. Prasad. "New snakes from the Late Cretaceous (Maastrichtian) of Naskal, India." In: Neues Jahrbuch für Geologie und Paläontologie, Abhandlungen 187.1 (1992), pp. 83-97.

[19126] J.-C. Rage. "Fossil snakes from the Palaeocene of São José de Itabora, Brazil. Part II. Boidae". English. In: Palaeovertebrata 30.3-4 (2001), pp. 111-150.

[19127] J.-C. Rage. "Fossil snakes from the Palaeocene of São José de Itabora, Brazil. Part I. Madtsoiidae, Aniliidae". English. In: Palaeovertebrata 27.3-4 (1998), pp. 109-144.

[19128] J.-C. Rage. "Squamate reptiles from the early Miocene of Arrisdrift (Namibia)". English. In: vol. 19. Geology and Palaeobiology of the central and southern Namib. Vol. 2: Palaeontology of the Orange River valley, Namibia. Memoir of the Geological Survey of Namibia (Ministry of Mines and Energy, Windhoek). 2003, pp. 43-50.

[19129] J.-C. Rage. Squamate reptiles from the early Paleocene of the Tiupampa area (Santa Luca Formation), Bolivia. Suárez-Soruco, R. (ed.), Fósiles y facies de Bolivia. Vol. 1. Vertebrados. Revista Técnica de Yacimientos Petrolferos Fiscales Bolivianos. 1991, pp. 503-508. 
[19130] J.-C. Rage. “Oldest Bufonidae (Amphibia, Anura) from the Old World: a bufonid from the Paleocene of France". English. In: Journal of Vertebrate Paleontology 23.2 (2003), pp. 462-463.

[19131] J.-C. Rage. "Fossil snakes from the Palaeocene of São José de Itabora, Brazil. Part III. Ungaliophiinae, booids incertae sedis, and Caenophidia. Summary, update and discussion of the snake fauna from the locality". English. In: Palaeovertebrata 36.1-4 (2008), pp. 37-73.

[19132] J.-C. Rage. "Squamate reptiles from the Lower Miocene of the Sperrgebiet, Namibia". English. In: Geology and palaeobiology of the northern Sperrgebiet, Namibia. Memoir of the Geological Survey of Namibia (Ministry of Mines and Energy, Windhoek) 20 (2008), pp. 93-103.

[19133] J.-C. Rage. "The lower vertebrates from the Eocene and Oligocene of the Phosphorites du Quercy (France): an overview". English. In: Strata 1.13 (2006), pp. 161-173.

[19134] J.-C. Rage. “Mesozoic and Cenozoic squamates of Europe". English. In: Palaeobiodiversity and Palaeoenvironments 93 (2013), pp. 517-534.

[19135] J.-C. Rage and M. Augé. "Squamate reptiles from the middle Eocene of Lissieu (France). A landmark in the middle Eocene of Europe". English. In: Geobios 43.2 (2010), pp. 253-268. DOI: 10.1016/ j.geobios.2009.08.00.

[19136] J.-C. Rage and M. Augé. “Valbro: A new site of vertebrates from the early Oligocene (MP 22) of France (Quercy). III - Amphibians and squamates". English. In: Annales de Paléontologie 101.1 (2015), pp. 29-41. DOI: 10.1016/j.annpal.2014.10.002.

[19137] J.-C. Rage and S. Bailon. "Amphibians and squamate reptiles from the late early Miocene (MN 4) of Béon 1 (Montréal-du-Gers, southwestern France)". English. In: Geodiversitas 27.3 (2005), pp. 413441.

[19138] J.-C. Rage, S. Bajpai, J. G. M. Thewissen, and B. N. Tiwari. "Early Eocene snakes from Kutch, western India, with a review of the Palaeophiidae." In: Geodiversitas 25.4 (2003), pp. 695-716.

[19139] J.-C. Rage, E. Buffetaut, H. Buffetaut-Tong, Y. Chaimanee, S. Ducrocq, J. -J. Jaeger, and V. Suteethorn. "A colubrid snake in the late Eocene of Thailand: the oldest known Colubridae (Reptilia, Serpentes)". English. In: Comptes Rendus de l'Académie des Sciences, Paris. Série 2314 (1992), pp. 1085-1089.

[19140] J.-C. Rage and H. Cappetta. "Vertebrates from the Cenomanian, and the geological age of the Draa Ubari fauna (Libya)". English. In: Annales de Paléontologie 88 (2002), pp. 79-84.

[19141] J.-C. Rage and I. G. Danilov. "A new Miocene fauna of snakes from eastern Siberia, Russia. Was the snake fauna largely homogenous in Eurasia during the Miocene". English. In: Comptes Rendus Palevol 7.6 (2008), pp. 383-390. DOI: 10.1016/j.crpv.2008.05.004.

[19142] J.-C. Rage and D. Dutheil. "Amphibians and squamates from the Cretaceous (Cenomanian) of Morocco". English. In: Palaeontographica Abteilung A 285 (2008), pp. 1-22.

[19143] J.-C. Rage and F. Escuillié. “Un nouveau serpent bipéde du Cénomanien (Crétacé). Implications phylétiques." French. In: Comptes Rendus á l' Académie des Sciences, Paris, Sciences de la Terre et des Planétes 330 (2000), pp. 513-520.

[19144] J.-C. Rage, A. Folie, R. S. Rana, H. Singh, K. D. Rose, and T. Smith. "A diverse snake fauna from the early Eocene of Vastan Lignite Mine, Gujarat, India". English. In: Acta Palaeontologica Polonica 53.3 (2008), pp. 391-403.

[19145] J.-C. Rage and L. Ginsburg. Amphibians and squamates from the early Miocene of Li Mae Long, Thailand: the richest and most diverse herpetofauna from the Cainozoic of Asia. 1997.

[19146] J.-C. Rage, S. G. Gupta, and G. V. R. Prasad. “Amphibians and squamates from the Neogene Siwalik beds of Jammu and Kashmir, India". In: Paläontologische Zeitschrift 75 (2001), pp. 197-205.

[19147] J.-C. Rage, G. Métais, A. Bartolini, I. A. Brohi, R. A. Lashari, L. Marivaux, D. Merle, and S. H. Solangi. "First report of the giant snake Gigantophis (Madtsoiidae) from the Paleocene of Pakistan: Paleobiogeographic implications". English. In: Geobios 47 (2014), pp. 147-153. 
[19148] J.-C. Rage, R. Vullo, and D. Néraudeau. “The mid-Cretaceous snake Simoliophis rochebrunei Sauvage, 1880 (Squamata: Ophidia) from its type area (Charentes, southwestern France): Redescription, distribution, and palaeoecology". English. In: Cretaceous Research 58 (2016), pp. 234253. DOI: $10.1016 /$ j.cretres.2015.10.010.

[19149] J.-C. Rage and C. Werner. "Mid-Cretaceous (Cenomanian) snakes from Wadi Abu Hashim, Sudan: The earliest snake assemblage." In: Palaeontologia Africana 35 (1999), pp. 85-110.

[19150] A. H. Rahiminejad, M. Yazdi, and A. R. Ashouri. "Miocene scleractinian corals from a mixed siliciclastic-carbonate system: Bakhtiari succession, Zagros Basin (central-western Iran)". English. In: Alcheringa: An Australasian Journal of Palaeontology 35.4 (2010), pp. 571-592.

[19151] I. A. Rahman, J. R. Thompson, D. E. Briggs, D. J. Siveter, and M. D. Sutton. “A new ophiocistioid with soft-tissue preservation from the Silurian Herefordshire Lagerstätte, and the evolution of the holothurian body plan". English. In: Proceedings of the Royal Society B: Biological Sciences 286.1900 (2019), pp. 1-7. DOI: 10.1098/rspb.2018.2792yad.c71qf48.

[19152] I. A. Rahman, S. Zamora, and G. Geyer. "The oldest stylophoran echinoderm: a new Ceratocystis from the middle Cambrian of Germany". English. In: Palaeontologische Zeitschrift 84 (2010), pp. 227-237.

[19153] I. A. Rahman and S. Zamora. “The oldest cinctan carpoid (stem-group Echinodermata), and the evolution of the water vascular system". English. In: Zoological Journal of the Linnean Society 157.2 (2009), pp. 420-432. DOI: 10.1111/j.1096-3642.2008.00517.x.

[19154] S. Rahmat, F. Muniz, A. Toscano, R. Esperante, and I. Koretsky. "First European record of Homiphoca (Phocidae: Monachinae: Lobodontini) and its bearing on the paleobiogeography of the genus". English. In: Historical Biology (2018). DOI: 10.1080/08912963.2018.1507030.

[19155] S. J. Rahmat, I. A. Koretsky, J. E. Osborne, and A. A. Alford. “New Miocene Monachinae from the western shore of the Chesapeake Bay (Maryland, USA)". English. In: Vestnik zoologii 51.3 (2017), pp. 221-242. DOI: 10.1515/vzoo-2017-0029.

[19156] P. Raia and S. Meiri. “The Island Rule in Large Mammals: Paleontology Meets Ecology". English. In: Evolution 60.8 (2006), pp. 1731-1742.

[19157] M. S. Raigemborn, S. D. Matheos, V. Krapovickas, S. F. Vizcaino, M. S. Bargo, R. F. Kay, J. C. Fernicola, and L. Zapata. "Paleoenvironmental reconstruction of the coastal Monte Leon and Santa Cruz formations (Early Miocene) at Rincon del Buque, Southern Patagonia: A revisited locality". English. In: Journal of South American Earth Sciences 60 (2015), pp. 31-55. DOI: 10.1016/j.jsames. 2015.03.001.

[19158] R. J. Raine and M. P. Smith. "Sequence Stratigraphy of the Scottish Laurentian Margin and Recognition of the Sauk Megasequence". English. In: The Great American Carbonate Bank: The Geology and Economic Resources of the Cambrian-Ordovician Sauk Megasequence of Laurentia. Tulsa: AAGP and Shell, 2012, pp. 575-596.

[19159] S. Rak, J. Kalvoda, and F. X. Devuyst. "New Mississippian trilobite association from the Brno vicinity and its significance (Moravian Karst), Czech Republic)". English. In: Geologica Carpathica 63.3 (2012), pp. 181-190.

[19160] Rak, J. OrtegaHernández, and D. A. Legg. "A revision of the Late Ordovician marrellomorph arthropod Furca bohemica from Czech Republic". English. In: Acta Palaeontologica Polonica 58.3 (2013), pp. 615-628. DOI: 10.4202/app.2011.0038.

[19161] N. Rakshit, M. S. Bhat, S. Ray, and P. M. Datta. "First report of dinosaurian claws from the Late Triassic of India". English. In: Palaeoworld 27 (2018), pp. 179-187. DOI: 10.1016/j.palwor.2018.01. 001.

[19162] M. Rakús. “Lower Liassic (Hettangian) ammonites from Zlambach Graben near Bad Goisern, Upper Austria". English. In: Abhandlungen der Geologischen Bundesanstalt 56 (1999), pp. 329-341.

[19163] M. Rakús and J. Guex. "Les ammonites du jurassique inférieur et moyen de la dorsal tunisienne". French. In: Mémoires de Géologie (Lausanne) 39 (2002), pp. 1-149. 
[19164] B. Ramassamy. “Description of a new long-snouted beaked whale from the Late Miocene of Denmark: evolution of suction feeding and sexual dimorphism in the Ziphiidae (Cetacea: Odontoceti)". English. In: Zoological Journal of the Linnean Society 178 (2016), pp. 381-409. DOI: 10.1111/zoj. 12418.

[19165] B. Ramassamy, O. Lambert, A. Collareta, M. Urbina, and G. Bianucci. “Description of the skeleton of the fossil beaked whale Messapicetus gregarius: searching potential proxies for deep-diving abilities". English. In: Fossil Record 21 (2018), pp. 11-323. DOI: 10.5194/fr-21-11-2018.

[19166] B. Ramassamy and H. Lauridsen. "A new specimen of Ziphiidae (Cetacea, Odontoceti) from the late Miocene of Denmark with morphological evidence for suction feeding behaviour". English. In: Royal Society Open Science 6.10 (2019), p. 191347. DOI: 10.1098/rsos.191347.

[19167] J. L. Ramrez and S. R. S. Cevallos-Ferriz. "A diverse assemblage of Anacardiaceae from Oligocene sediments, Tepexi de Rodriguez, Puebla, Mexico". English. In: American Journal of Botany 89 (2002), pp. 535-545.

[19168] L. C. Ramrez and C. P. Alonso. "Bradysia aliciae sp. nov. (Diptera: Sciaridae) del Pleistoceno de Buenos Aires, Argentina". Spanish. In: Revista de la Sociedad Entomológica Argentina 73 (2014), pp. 81-83.

[19169] L. C. Ramrez and C. P. Alonso. “Two late Pleistocene members of the white-grub complex, one of the most destructive insect pests of turfgrasses". English. In: Revista Brasileira de Paleontologia 19 (2016), pp. 531-536.

[19170] L. C. Ramrez, R. Carrara, V. A. Silvestro, and G. E. Flores. "First fossil assemblage of darkling beetles (Coleoptera: Tenebrionidae) from Buenos Aires, Argentina: evidence of dry climate during the Late Pleistocene in the humid Pampas". English. In: Annales Zoologici 66 (2016), pp. 643-652.

[19171] L. C. Ramrez, J. Corsolino, and O. Di Iorio. “First fossil record of parasitic flat-bark beetle (Coleoptera: Passandridae) from the Eocene of Patagonia, Argentina". English. In: Ameghiniana 53 (2016), pp. 160 169.

[19172] L. C. Ramrez and M. C. Michat. "First fossil predaceous diving beetle from the Late Pleistocene of Buenos". English. In: Ameghiniana 53 (2016), pp. 512-516.

[19173] L. C. Ramirez, J. Negre, and C. P. Alonso. "First record of fossil insects from the middle Holocene of Tierra del Fuego, Argentina". English. In: Ameghiniana 54.6 (2017), pp. 713-719. DOI: 10.5710/ AMGH.23.06.2017.3073.

[19174] F. V. Ramirez Rozzi, F. d’Errico, and M. A. Zarate. “Le site paléo-indien de Piedra Museo (Patagonie). Sa contribution au débat sur le premier peuplement du continent amérlcaln". French. In: Comptes Rendus de l'Académie des Sciences Series IIA Earth and Planetary Science 331.4 (2000), pp. 311318.

[19175] A. A. Ramrez-Velasco, M. Benammi, A. Prieto-Marquez, J. Alvarado Ortega, and R. HernándezRivera. "Huehuecanauhtlus tiquichensis, a new hadrosauroid dinosaur (Ornithischia: Ornithopoda) from the Santonian (Late Cretaceous) of Michoacán, Mexico". English. In: Canadian Journal of Earth Sciences 49 (2012), pp. 379-395. DOI: 10.1139/E11-062.

[19176] C. N. Ramos. "An Irvingtonian species of Brachylagus (mammalia: Lagomorpha) from Porcupine Cave, Park County, Colorado". English. In: Great Basin Naturalist 59.2 (1999), pp. 151-159.

[19177] M. S. Ramos, E. E. Perkovsky, A. P. Rasnitsyn, and C. O. Azevedo. “Revision of Bethylinae fossils (Hymenoptera: Bethylidae) from Baltic, Rovno and Oise amber, with comments on the Tertiary fauna of the subfamily". English. In: Neues Jahrbuch für Geologie und Paläontologie, Abhandlungen 271 (2014), pp. 203-228.

[19178] A. Ramovs. "Cordevolski greben na Menini [The Cordevolian reef on the Menina, Kamnik-Savinja Alps, Slovenia]". other. In: Geologija 35 (1992), pp. 73-80.

[19179] A. Ramovs and S. Gorican. "Late Anisian-Early Ladinian radiolarians and conodonts from Smarna Gora near Ljubljana, Slovenia". English. In: Razprave Slovenska Akademija Znanosti in Umetnosti, Razred za Naravosloone Vede 36.9 (1995), pp. 179-221. 
[19180] R. S. Rana. “Alligatorine teeth from the Deccan intertrappean beds near Rangapur, Andhra-Pradesh, India: further evidence of Laurasiatic elements". English. In: Current Science 59 (2000), pp. 49-51.

[19181] R. S. Rana. "Palaeontology and palaeoecology of the Intertrappean (Cretaceous-Tertiary transition) beds of the peninsular India". English. In: Journal of the Palaeontological Society of India 35 (1990), pp. 105-120.

[19182] R. S. Rana, M. Augé, A. Folie, K. D. Rose, K. Kumar, L. Singh, A. Sahni, and T. Smith. "High diversity of acrodontan lizards in the early Eocene Vastan lignite mine of India". English. In: Geologica Belgica 16.4 (2013), pp. 290-301.

[19183] R. S. Rana, K. Kumar, G. Escarguel, A. Sahni, K. D. Rose, T. Smith, H. Singh, and L. Singh. “An ailuravine rodent from the lower Eocene Cambay Formation at Vastan, western India, and its palaeobiogeographic implications". English. In: Acta Palaeontologica Polonica 53.1 (2008), pp. 1-14.

[19184] R. S. Rana, K. Kumar, H. Singh, and K. D. Rose. "Lower vertebrates from the Late PalaeoceneEarliest Eocene Akli Formation, Giral Lignite Mine, Barmer District, western India". English. In: Current Science 89.9 (2005), pp. 1606-1613.

[19185] R. S. Rana, K. Kumar, R. S. Loyal, A. Sahni, K. D. Rose, and J. Mussel. "Selachians from the Early Eocene Kapurdi Formatino (Fuller's Earth), Barmer District, Rajathan". English. In: Journal of the Geological Society of INdia 67 (2006), pp. 509-522.

[19186] R. S. Rana and K. K. Sati. “Late Cretaceous-Palaeocene crocodilians from the Deccan Trap-associated sedimentary sequences of peninsular India". English. In: Journal of the Palaeontological Society of India 45 (2000), pp. 123-136.

[19187] R. S. Rana, H. Singh, A. Sahni, K. D. Rose, and P. K. Sarswati. "Early Eocene chiropterans from a new mammalian assemblage (Vastan Lignite Mine, Gujarat, western peninsular margin): Oldest known bats from Asia". English. In: Journal of the Palaeontological Society of India 50.1 (2005), pp. 93100.

[19188] R. S. Rana and G. P. Wilson. "New Late Cretaceous mammals from the Intertrappean beds of Rangapur, India and paleobiogeographic framework". English. In: Acta Palaeontologica Polonica 48.3 (2003), pp. 331-348.

[19189] A. F. Randazzo, M. Kosters, D. S. Jones, and R. W. Portell. "Paleoecology of shallow-marine carbonate environments, middle Eocene of Peninsular Florida". English. In: Sedimentary Geology 66 (1990), pp. 1-11.

[19190] J. C. Rando, J. A. Alcover, S. L. Olson, and H. Pieper. “A new species of extinct scops owl (Aves: Strigiformes: Strigidae: Otus) from São Miguel Island (Azores Archipelago, North Atlantic Ocean)". English. In: Zootaxa 3647 (2013), pp. 343-357.

[19191] J. C. Rando, M. López, and B. Segu. “A new species of extinct flightless passerine (Emberizidae: Emberiza) from the Canary Islands". English. In: The Condor 101 (1999), pp. 1-13.

[19192] J. C. Rando, H. Pieper, S. L. Olson, F. Pereira, and J. A. Alcover. "A new extinct species of large bullfinch (Aves: Fringillidae: Pyrrhula) from Graciosa Island (Azores, North Atlantic Ocean)". English. In: Zootaxa 4282 (2017), pp. 567-583.

[19193] J. C. Rando, H. Pieper, J. A. Alcover, and S. L. Olson. “A new species of extinct fossil scops owl (Aves: Strigiformes: Strigidae: Otus) from the Archipelago of Madeira (North Atlantic Ocean)". English. In: Zootaxa 3182 (2012), pp. 29-42.

[19194] B. D. Rankin. “New pantolestids (Mammalia, Eutheria) from the late Paleocene (late middle Tiffanian) Roche Percée local fauna, southeastern Saskatchewan, Canada". English. In: Journal of Paleontology 88.6 (2014), pp. 1199-1211.

[19195] B. D. Rankin. “New late Paleocene (late middle Tiffanian) mammals from the Roche Percée local fauna, south-eastern Saskatchewan, Canada". English. In: Journal of Systematic Palaeontology 16.5 (2018), pp. 361-393. DOI: 10.1080/14772019.2017.1296498.

[19196] B. D. Rankin and P. A. Holroyd. "Aceroryctes dulcis, a new palaeoryctid (Mammalia, Eutheria) from the early Eocene of the Wasatch Formation of southwestern Wyoming, USA". English. In: Canadian Journal of Earth Sciences 51 (2014), pp. 919-926. DOI: 10.1139/cjes-2014-0101. 
[19197] R. I. Rao and M. F. Tortello. “Tremadoc conodonts and trilobites from the Cardonal Formation, Incamayo Creek, Salta Province, northwestern Argentina". English. In: Proceedings of the Sixth European Conodont Symposium (ECOS VI)- Paleontologia Polonica 58 (1998), pp. 31-45.

[19198] I. Raselli and J. Anquetin. "Novel insights into the morphology of Plesiochelys bigleri from the early Kimmeridgian of Northwestern Switzerland". English. In: bioRxiv preprint (2019), pp. 1-32. DOI: $10.1101 / 582700$.

[19199] K. Rashidi and B. Senowbari-Daryan. "Dasycladales from the Permian Jamal Formation of the Shotori Mountains, NE Iran, Part 1: Imperiella Elliott and Süssli, Nanjinoporella Mu and Elliott, Tabasoporella nov. gen., and Pseudotabasoporella nov. gen". English. In: Facies 56 (2010), pp. 111137.

[19200] K. Rashidi and B. Senowbari-Daryan. "Sponges from a section of the Upper Triassic Nayband Formation, northeast of Esfahan, central Iran". English. In: Annalen des Naturhistorischen Museums Wien A 113 (2011), pp. 309-371.

[19201] L. L. Rasia, R. A. Bonini, and A. M. Candela. "Nuevos registros de Lagostomus Brookes, 1828 (Rodentia, Chinchillidae) en el Mioceno tardo de Argentina y su importancia bioestratigráfica". Spanish. In: Andean Geology 47.2 (2020). DOI: 10.5027/andgeoV47n2-3270.

[19202] L. L. Rasia and A. M. Candela. "Systematic and biostratigraphic significance of a chinchillid rodent from tre Pliocene of eastern Argentina". English. In: Acta Palaeontologica Polonica 58.2 (2013), pp. 241-254. DOI: 10.4202/app.2011.0041.

[19203] L. L. Rasia and A. M. Candela. "Lagostomus telenkechanum, sp. nov., a new lagostomine rodent (Caviomorpha, Chinchillidae) from the Arroyo Chasicó Formation (late Miocene; Buenos Aires Province, Argentina)". English. In: Journal of Vertebrate Paleontology 37.1 (2017), e1239205. DOI: 10. 1080/02724634.2017.1239205.

[19204] L. L. Rasia and A. M. Candela. "Systematic revision of the vizcachas (Rodentia, Caviomorpha, Chinchillidae) from the Chapadmalal Formation, late Pliocene of Buenos Aires Province, Argentina". English. In: Ameghiniana 54.1 (2017), pp. 50-69. DOI: 10.5710/AMGH.01.09.2016.3012.

[19205] C. M. O. Rasmussen, J. O. R. Ebbestad, and D. A. T. Harper. "Unravelling a Late Ordovician pentameride (Brachiopoda) hotspot from the Boda Limestone, Siljan district, central Sweden". English. In: Geologiska Föreningens Förhandlingar 132.3-4 (2010), pp. 133-152.

[19206] C. M. O. Rasmussen, D. A. T. Harper, and R. B. Blodgett. "Late Ordovician brachiopods from west-central Alaska: systematics, ecology and palaeobiogeography". English. In: Fossils and Strata 58 (2012), pp. 1-103.

[19207] C. M. O. Rasmussen and D. A. T. Harper. "Resolving early Mid-Ordovician (Kundan) bioevents in the East Baltic based on brachiopods". English. In: Geobios 41 (2008), pp. 533-542.

[19208] D. Rasmussen and E. Simons. "The oldest Egyptian Hyracoids (Mammalia: Pliohyracidae): New species of Saghatherium and Thyrohyrax from the Fayum". English. In: Neues Jahrbuch fur Geologie und Palaontologie, Abhandlungen 182 (1991), pp. 187-209.

[19209] D. T. Rasmussen. “The phylogenetic position of Mahgarita stevensi: protoanthropoid or lemuroid?" English. In: International Journal of Primatology 11.5 (1990).

[19210] D. T. Rasmussen. "A new Middle Eocene omomyine primate from the Uinta Basin, Utah". English. In: Journal of Human Evolution 31 (1996).

[19211] D. T. Rasmussen, A. R. Friscia, M. Gutierrez, J. Kappelman, E. R. Miller, S. Muteti, D. Reynoso, J. B. Rossie, T. L. Spell, N. J. Tabor, E. Gierlowski-Kordesch, B. F. Jacobs, B. Kyongo, M. Macharwas, and F. Muchemi. "Primitive Old World monkey from the earliest Miocene of Kenya and the evolution of cercopithecoid bilophodonty". English. In: Proceedings of the National Academy of Sciences 116.13 (2019), pp. 6051-6056. DOI: 10.1073/pnas.1815423116.

[19212] D. T. Rasmussen, M. Gagnon, and E. L. Simons. “Taxeopody in the carpus and tarsus of Oligocene Pliohyracidae (Mammalia: Hyracoidea) and the phyletic position of Hyraxes". English. In: Proceedings of the National Academy of Sciences 87.12 (1990), pp. 4688-4691. 
[19213] D. T. Rasmussen and M. Gutierrez. “A Mammalian Fauna from the Late Oligocene of Northwestern Kenya". English. In: Palaeontographica Abteilung A 288.1-3 (2009), pp. 1-52.

[19214] D. T. Rasmussen, M. Pickford, P. Mein, B. Senut, and G. C. Conroy. "Earliest known procaviid hyracoid from the late Miocene of Namibia". English. In: Journal of Mammalogy 77.3 (1996), pp. 745754.

[19215] D. T. Rasmussen, M. Shekelle, S. L. Walsh, and B. O. Riney. “The dentition ofăDyseolemur, and comments on the use of the anterior teeth in primate systematics". English. In: Journal of Human Evolution 29.4 (1995), pp. 301-320.

[19216] D. T. Rasmussen and E. L. Simons. "Ecomorphological diversity among Paleogene hyracoids (Mammalia): a new cursorial browser from the Fayum, Egypt". English. In: Journal of Vertebrate Paleontology 20.1 (2000), pp. 167-176.

[19217] D. T. Rasmussen, E. L. Simons, F. Hertel, and A. Judd. "Hindlimb of a giant terrestrial bird form the upper Eocene, Fayum, Egypt". English. In: Palaeontology 44.2 (2001), pp. 325-337.

[19218] J. A. Rasmussen. "Conodont biostratigraphy and taxonomy of the Ordovician shelf margin deposits in the Scandinavian Caledonides". English. In: Fossils and Strata 48 (2001), pp. 1-179.

[19219] E. L. Rasmusson Simons and G. A. Buckley. “New material of Trematochampsa oblita (Crocodyliformes, Trematochampsidae) from the Late Cretaceous of Madagascar". English. In: Journal of Vertebrate Paleontology 29.2 (2009), pp. 599-604. DOI: 10.1671/039.029.0224.

[19220] A. Rasnitsyn. "New hymenopterans of the genus Baissa (Gasteruptiidae s.l.) from Early Cretaceous Buryatia and Mongolia". Russian. In: Vestnik Zoologii 1991.1 (1991), pp. 78-79.

[19221] A. P. Rasnitsyn. "New hymenopteran insects (Insecta: Vespida) from the Lower or Middle Jurassic of India". English. In: Paleontological Journal 42.1 (2008), pp. 81-85.

[19222] A. P. Rasnitsyn. "Archaescoliinae, an extinct subfamily of scoliid wasps (Insecta: Vespida = Hymenoptera: Scoliidae)". English. In: Journal of Hymenoptera Research 2 (1993), pp. 85-96.

[19223] A. P. Rasnitsyn. "New genus and two new species of the Lower Cretaceous Digger Wasps from Spain (Hymenoptera: Sphecidae, Angarosphecinae)". English. In: Acta Geologica Hispanica 35.1-2 (2000), pp. 55-58.

[19224] A. P. Rasnitsyn. "Strashila incredibilis, a new enigmatic mecopteroid insect with possible siphonapteran affinities from the Upper Jurassic of Siberia". English. In: Psyche 99 (1992), pp. 323-333.

[19225] A. P. Rasnitsyn. "Hymenopterous insects (Insecta: Vespida) in the Upper Jurassic deposits of Shar Teg, SW Mongolia". English. In: Russian Entomological Journal 17 (2008), pp. 299-310.

[19226] A. P. Rasnitsyn. An extremely primitive aculeate wasp in the Cretaceous amber from New Jersey (Vespida: ? Sierolomorphidae). English. Studies on Fossils in Amber, with Particular Reference to the Cretaceous of New Jersey. Leiden: Backhuys Publishers, 2000, pp. 327-332.

[19227] A. P. Rasnitsyn. “Early Cretaceous evanimorphous hymenopteran families Stigmaphronidae and Cretevaniidae and the subfamily Kotujellitinae (Gasteruptiidae)". English. In: Paleontological Journal 25.4 (1991), pp. 172-179.

[19228] A. P. Rasnitsyn. "New Late Jurassic Representatives of the Family Mesoserphidae (Vespida, Proctotrupoidea)". English. In: Paleontological Journal 28.2 (1994), pp. 141-147.

[19229] A. P. Rasnitsyn. Novye taksony sepulek (Vespida: Sepulcidae). Russian. Mezozoyskie Nasekomye i Ostrakody Azii. 1993, pp. 80-99.

[19230] A. P. Rasnitsyn. "Tertiary sawflies of the tribe Xyelini (Insecta: Vespida=Hymenoptera: Xyelidae) and their relationship to the Mesozoic and modern faunas". English. In: Contributions in Science, Natural History Museum of Los Angeles County 450 (1995), pp. 1-14.

[19231] A. P. Rasnitsyn. “Taxonomy and morphology of Dasyleptus Brongniart, 1885, with description of a new species (Insecta: Machilida: Dasyleptidae)". English. In: Russian Entomological Journal 8 (1999), pp. 145-154. 
[19232] A. P. Rasnitsyn. "New Early Cretaceous Embolemidae (Vespida = Hymenoptera: Chrysidoidea)". English. In: Memoirs of the Entomological Society of Washington 17 (1996), pp. 183-187.

[19233] A. P. Rasnitsyn and J. Ansorge. "Two new Lower Cretaceous hymenopterous insects (Insecta: Hymenoptera) from Sierra del Montsec, Spain". English. In: Acta Geologica Hispanica 35 (2000), pp. 59-64.

[19234] A. P. Rasnitsyn and J. Ansorge. “New Early Cretaceous hymenopterous insects (Insecta: Hymenoptera) from Sierra del Montsec (Spain)". English. In: Paläontologische Zeitschrift 74.3 (2000), pp. 335-341.

[19235] A. P. Rasnitsyn, J. Ansorge, and H. C. Zhang. "Ancestry of the orussoid wasps, with description of three new genera and species of Karatavitidae (Hymenoptera = Vespida: Karatavitoidea stat. nov.)" English. In: Insect Systematics \& Evolution 37 (2006), pp. 179-190.

[19236] A. P. Rasnitsyn, J. Ansorge, and W. Zessin. "New hymenopterous insects (Insecta: Hymenoptera) from the lower Toarcian (Lower Jurassic) of Germany". English. In: Neues Jahrbuch für Geologie und Paläontologie, Abhandlungen 227 (2003), pp. 321-342.

[19237] A. P. Rasnitsyn and D. S. Aristov. "New Eoblattida (Insecta) from the Permian of Russia”. English. In: Russian Entomological Journal 19.1 (2010), pp. 13-20.

[19238] A. P. Rasnitsyn and D. S. Aristov. "Two new Insects from the Upper Permian (Tatarian) of Belmont, New South Wales, Australia (Insecta: Hypoperlida: Anthracoptilidae=Permarrhaphidae; Grylloblattida: Sylvaphlebiidae)". English. In: Paleontological Journal 38.Suppl 2 (2004), S158-S163.

[19239] A. P. Rasnitsyn, D. S. Aristov, A. V. Gorochov, J. M. Rowland, and N. D. Sinitshenkova. Important new insect fossils from Carrizo Arroyo and the Permo-Carboniferous faunal boundary. English. Vol. 25. Carboniferous-Permian transition, New Mexico Museum of Natural History and Science Bulletin. 2004, pp. 215-246.

[19240] A. P. Rasnitsyn and D. S. Aristov. "New fossil insects (Insecta: Caloneurida, Hypoperlida, Palaeomanteida, Jurinida) from the Middle and Upper Permian of European Russia". English. In: Paleontological Journal 47 (2013), pp. 678-704.

[19241] A. P. Rasnitsyn, H. H. Basibuyuk, and D. L. J. Quicke. “A basal chalcidoid (Insecta: Hymenoptera) from the earliest Cretaceous or latest Jurassic of Mongolia". English. In: Insect Systematics \& Evolution 35 (2004), pp. 123-135.

[19242] A. P. Rasnitsyn and D. J. Brothers. "Two new hymenopteran fossils from the mid-Cretaceous of southern Africa (Hymenoptera: Jurapriidae, Evaniidae)". English. In: African Invertebrates 48.1 (2007), pp. 193-202.

[19243] A. P. Rasnitsyn and D. J. Brothers. "New genera and species of Maimetshidae (Hymenoptera: Stephanoidea s. 1. ) from the Turonian of Botswana, with comments on the status of the family". English. In: African Invertebrates 50.1 (2009), pp. 191-204.

[19244] A. P. Rasnitsyn and D. J. Brothers. "The first plumalexiid wasp (Hymenoptera: Chrysidoidea, Plumalexiidae) from the mid-Cretaceous Burmese amber". English. In: Cretaceous Research 115.104568 (2020). DOI: 10.1016/j.cretres.2020.104568.

[19245] A. P. Rasnitsyn, E. A. Jarzembowski, and A. J. Ross. “Wasps (Insecta: Vespida = Hymenoptera) from the Purbeck and Wealden (Lower Cretaceous) of southern England and their biostratigraphical and palaeoenvironmental significance". English. In: Cretaceous Research 19 (1998), pp. 329-391.

[19246] A. P. Rasnitsyn and V. A. Krassilov. "First find of pollen grains in the gut of Permian insects". English. In: Paleontological Journal 30 (1996), pp. 484-490.

[19247] A. P. Rasnitsyn and V. A. Krassilov. "Pollen in the gut contents of fossil insects as evidence of coevolution". English. In: Paleontological Journal 30 (1996), pp. 716-722.

[19248] A. P. Rasnitsyn and V. A. Krassilov. "The first documented occurrence of phyllophagy in preCretaceous insects: leaf tissues in the gut of Upper Jurassic insects from southern Kazakhstan". English. In: Paleontological Journal 34 (2000), pp. 301-309. 
[19249] A. P. Rasnitsyn and X. Martnez-Delclós. “Wasps (Insecta: Vespida = Hymenoptera) from the Early Cretaceous of Spain". English. In: Acta Geologica Hispanica 35 (2000), pp. 65-95.

[19250] A. P. Rasnitsyn and X. Martnez-Delclós. "New Cretaceous Scoliidae (Vespida=Hymenoptera) from the Lower Cretaceous of Spain and Brazil". English. In: Cretaceous Research 20 (1999), pp. 767-772.

[19251] A. P. Rasnitsyn and C. D. Michener. "Miocene fossil bumble bee from the Soviet Far East with comments on the chronology and distribution of fossil bees (Hymenoptera: Apidae)". English. In: Annals of the Entomological Society of America 84.6 (1991), pp. 583-589.

[19252] A. P. Rasnitsyn and C. Öhm-Kühnle. "Three new female Aptenoperissus from mid-Cretaceous Burmese amber (Hymenoptera, Stephanoidea, Aptenoperissidae): Unexpected diversity of paradoxical wasps suggests insular features of source biome". English. In: Cretaceous Research 91 (2018), pp. $168-175$.

[19253] A. P. Rasnitsyn and C. Öhm-Kühnle. “New serphitoid wasp Supraserphites draculi gen. et sp. nov. in Burmese amber (Hymenoptera, Serphitidae: Supraserphitinae)". English. In: Cretaceous Research 99 (2018), pp. 46-50.

[19254] A. P. Rasnitsyn and C. Öhm-Kühnle. "Revision of the Cretaceous Proctotrupomorpha (Insecta: Hymenoptera) of Australia". English. In: Cretaceous Research 100 (2019), pp. 91-96. DOI: 10.1016/j. cretres.2019.03.017.

[19255] A. P. Rasnitsyn, G. Poinar, and A. E. Brown. "Bizzare wingless parasitic wasp from mid-Cretaceous Burmese amber (Hymenoptera, Ceraphronoidea, Aptenoperissidae fam. nov.)" English. In: Cretaceous Research 69 (2016), pp. 113-118.

[19256] A. P. Rasnitsyn, W. J. Pulawski, and X. Martnez-Delclós. "Cretaceous digger wasps of the new genus Bestiola Pulawski and Rasnitsyn (Hymenoptera: Sphecidae: Angarosphecinae)". English. In: Journal of Hymenoptera Research 8 (1999), pp. 23-34.

[19257] A. P. Rasnitsyn, E. A. Sidorchuk, H. C. Zhang, and Q. Zhang. “Dipterommatidae, a new family of parasitic wasps (Hymenoptera: Mymarommatoidea) in mid-Cretaceous Burmese amber: the first case of morphological diptery in flying Hymenoptera". English. In: Cretaceous Research 104.104193 (2019). DOI: 10.1016/j.cretres.2019.104193.

[19258] A. P. Rasnitsyn, I. D. Sukacheva, and D. S. Aristov. "Permian insects of the Vorkuta Group in the Pechora basin, and their stratigraphic implications". English. In: Paleontological Journal 39 (2005), pp. 404-416.

[19259] A. P. Rasnitsyn and D. E. van Dijk. “The first Gondwanan Epimastax from the Lopingian of KwaZulu-Natal, South Africa (Insecta: Palaeomanteida=Miomoptera: Permosialidae)". English. In: African Invertebrates 52.1 (2011), pp. 207-209.

[19260] A. P. Rasnitsyn and H. Zhang. "Early evolution of Apocrita (Insecta, Hymenoptera) as indicated by new findings in the Middle Jurassic of Daohugou, Northeast China". English. In: Acta Geologica Sinica 84.4 (2010), pp. 834-873.

[19261] A. P. Rasnitsyn and H. Zhang. "A new family, Daohugoidae fam. n, of siricomorph hymenopteran (Hymenoptera=Vespida) from the Middle Jurassic of Daohugou in Inner Mongolia (China)". English. In: Proceedings of the Russian Entomological Society 75.1 (2004), pp. 12-16.

[19262] A. P. Rasnitsyn, H. C. Zhang, and B. Wang. "Bizarre fossil insects: web-spinning sawflies of the genus Ferganolyda (Vespida, Pamphilioidea) from the Middle Jurassic of Daohugou, Inner Mongolia, China". English. In: Palaeontology 49.4 (2006), pp. 907-916.

[19263] A. P. Rasnitsyn and V. V. Zherikhin. "First fossil chewing louse from the Lower Cretaceous of Baissa, Transbaikalia (Insecta, Pediculida=Phthiriaptera, Saurodectidae fam n)" English. In: Russian Entomological Journal 8.4 (1999), pp. 253-255.

[19264] M. W. Rasser and W. E. Piller. “Application of neontological taxonomie concepts to Late Eocene coralline algae (Rhodophyta) of the Austrian Molasse Zone". English. In: Journal of Micropalaeontology 18 (1999), pp. 67-80. 
[19265] M. W. Rasser, C. Scheibner, and M. Mutti. “A paleoenvironmental standard section for Early Ilerdian tropical carbonate factories (Corbieres, France; Pyrenees, Spain)". English. In: Facies 51.1-4 (2005), pp. 218-232.

[19266] B. C. Ratcliffe and F. C. Ocampo. "Tyrannasorus rex Ratcliffe and Ocampo, a new genus and species of Miocene hybosorid in amber from the Dominican Republic (Coleoptera: Scarabaeoidea: Hybosoridae)". English. In: The Coleopterists Bulletin 55.3 (2001), pp. 351-355.

[19267] B. C. Ratcliffe, D. M. Smith, and D. Erwin. “Oryctoantiquus borealis, new genus and species from the Eocene of Oregon, U.S.A., the world's oldest fossil dynastine and largest fossil scarabaeid (Coleoptera: Scarabaeidae: Dynastinae)". English. In: The Coleopterists Bulletin 59.1 (2005), pp. 127135.

[19268] K. T. Ratcliffe. Brachiopod assemblages from the Much Wenlock Limestone Formation of England and Wales. Paleocommunities-a case study from the Silurian and Lower Devonian. 1999, pp. 399-407.

[19269] R. Rateau, C. Gagnaison, and V. Gelot. “Un Metaxytherium medium (Mammalia, Sirenia) attaque par des requins dans les fauluns miocenes de Channay-sur-lathan (37, France)". French. In: Symbioses 23 (2009), pp. 68-79.

[19270] R. Ratkevich. “New Cretaceous brachiosaurid dinosaur, Sonorasaurus thompsoni gen. et sp. nov., from Arizona". English. In: Journal of the Arizona-Nevada Academy of Science 31.1 (1998), pp. 71-82.

[19271] V. A. Ratter and J. C. W. Cope. "New Silurian Neotaxodont Bivalves from South Wales and their phylogenetic significance". English. In: Palaeontology 41.5 (1998), pp. 975-991.

[19272] L. A. Raubeson and P. G. Gensel. “Upper Cretaceous conifer leaf fossils from the Black Creek Formation with an assessment of affinitiesusing principal components analysis". In: Botanical Gazette 152.3 (1991), pp. 380-391.

[19273] O. W. M. Rauhut. "Herbivorous dinosaurs from the Late Jurassic (Kimmeridgian) of Guimarota, Portugal". In: Proceedings of the Geologists' Association 112 (2001), pp. 275-283.

[19274] O. W. M. Rauhut. The dinosaur fauna from the Guimarota mina. Guimarota-A Jurassic Ecosystem, Verlag Dr. Friedrich Pfeil, München. 2000, pp. 75-82.

[19275] O. W. M. Rauhut. "A dinosaur fauna from the Late Cretaceous (Cenomanian) of northern Sudan". In: Palaeontologia Africana 35 (1999), pp. 61-84.

[19276] O. W. M. Rauhut. "Osteology and relationships of a new theropod dinosaur from the Middle Jurassic of Patagonia". In: Palaeontology 48.1 (2005), pp. 87-110.

[19277] O. W. M. Rauhut. "Post-cranial remains of 'coelurosaurs' (Dinosauria, Theropoda) from the Late Jurassic of Tanzania". In: Geological Magazine 142.1 (2005), pp. 97-107.

[19278] O. W. M. Rauhut. "A dentary of Patagosaurus (Sauropoda) from the Middle Jurassic of Patagonia". English. In: Ameghiniana 40.3 (2003), pp. 425-432.

[19279] O. W. M. Rauhut. "A tyrannosauroid dinosaur from the Upper Jurassic of Portugal". English. In: Palaeontology 46.5 (2003), pp. 903-913.

[19280] O. W. M. Rauhut. "Dinosaur teeth from the Barremian of Uña, province of Cuenca, Spain". English. In: Cretaceous Research 23 (2002), pp. 255-263.

[19281] O. W. M. Rauhut. "A reappraisal of a putative record of abelisauroid theropod dinosaur from the Middle Jurassic of England". English. In: Proceedings of the Geologists' Association 123 (2012), pp. 779-786. DOI: 10.1016/j.pgeola.2012.05.008.

[19282] O. W. M. Rauhut. "Theropod dinosaurs from the Late Jurassic of Tendaguru (Tanzania)". English. In: Special Papers in Palaeontology 86 (2011), pp. 195-239. DOI: 10.1111/j.1475-4983.2011.01084.x.

[19283] O. W. M. Rauhut. “Artikulierte Rückenwirbel eines Sauropoden aus dem mittleren(?) Jura von Marokko [Articulated vertebrae of a sauropod from the Middle (?) Jurassic of Morocco]". German. In: Freunde der Bayerischen Staatssammlung für Paläontologie und Historische Geologie München e.v., Jahresbericht 2014 und Mitteilungen 43 (2015), pp. 45-51. 
[19284] O. W. M. Rauhut, J. L. Carballido, and D. Pol. “A diplodocid sauropod dinosaur from the Late Jurassic Cañadón Calcáreo Formation of Chubut, Argentina". English. In: Journal of Vertebrate Paleontology 35.5 (2015), e982798:1-8. DOI: 10.1080/02724634.2015.982798.

[19285] O. W. M. Rauhut, G. Cladera, P. Vickers-Rich, and T. H. Rich. “Dinosaur remains from the Lower Cretaceous of the Chubut Group, Argentina". English. In: Cretaceous Research 24 (2003), pp. 487497.

[19286] O. W. M. Rauhut and R. Fechner. "Early development of the facial region in a non-avian theropod dinosaur". English. In: Proceedings of the Royal Society of London B 272 (2005), pp. 1179-1183. DOI: 10.1098/rspb.2005.3071.

[19287] O. W. M. Rauhut, C. Foth, H. Tischlinger, and M. A. Norell. “Exceptionally preserved juvenile megalosauroid theropod dinosaur with filamentous integument from the Late Jurassic of Germany". English. In: Proceedings of the National Academy of Sciences 29 (2012), pp. 11746-11751. DOI: 10.1073 /pnas.1203238109.

[19288] O. W. M. Rauhut, C. Foth, and H. Tischlinger. "The oldest Archaeopteryx (Theropoda: Avialiae): a new specimen from the Kimmeridgian/Tithonian boundary of Schamhaupten, Bavaria". English. In: PeerJ 6 (2018), e4191. DOI: 10.7717/ peerj.4191.

[19289] O. W. M. Rauhut, A. M. Heyng, A. López-Arbarello, and A. Hecker. “A new rhynchocephalian from the Late Jurassic of Germany with a dentition that is unique amongst tetrapods". English. In: PLoS ONE 7.10 (2012), e46839:1-9. DOI: 10.1371/journal.pone.0046839.

[19290] O. W. M. Rauhut, F. M. Holwerda, and H. Furrer. "A derived sauropodiform dinosaur and other sauropodomorph material from the Late Triassic of Canton Schaffhausen, Switzerland". English. In: Swiss Journal of Geosciences 113 (2020), 8:1-54.

[19291] O. W. M. Rauhut, T. R. Hübner, and K. -P. Lanser. “A new megalosaurid theropod dinosaur from the late Middle Jurassic (Callovian) of north-western Germany: Implications for theropod evolution and faunal turnover in the Jurassic". English. In: Palaeontologia electronica 19.2 (2016), 2A:165 .

[19292] O. W. M. Rauhut and A. Hungerbühler. "A review of European Triassic theropods". In: GAIA 15 (2000), pp. 75-88.

[19293] O. W. M. Rauhut, A. López-Arbarello, M. Röper, and M. Rothgaenger. "Vertebrate fossils from the Kimmeridgian of Brunn: the oldest fauna from the Solnhofen Archipelago (Late Jurassic, Bavaria, Germany)". English. In: Zitteliana 89 (2017), pp. 305-329.

[19294] O. W. M. Rauhut, T. Martin, E. Ortz-Jaureguizar, and P. Puerta. “A Jurassic mammal from South America". English. In: Nature 416 (2002), pp. 165-168.

[19295] O. W. M. Rauhut, L. Piñuela, D. Castanera, J. -C. Garca-Ramos, and I. Sánchez Cela. “The largest European theropod dinosaurs: remains of a gigantic megalosaurid and giant theropod tracks from the Kimmeridgian of Asturias, Spain". English. In: PeerJ 6 (2018), e4963:1-34. DOI: 10.7717/ peerj. 4963.

[19296] O. W. M. Rauhut and D. Pol. “A theropod dinosaur from the Late Jurassic Cañadón Calcáreo Formation of central Patagonia, and the evolution of the theropod tarsus". English. In: Ameghiniana 54 (2017), pp. 506-538. DOI: 10.5710/AMGH.12.10.2017.3105.

[19297] O. W. M. Rauhut and D. Pol. "Probable basal allosauroid from the early Middle Jurassic Cañadón Asfalto Formation of Argentina highlights phylogenetic uncertainty in tetanuran theropod dinosaurs". English. In: Scientific Reports 9 (2019), p. 18826. DOI: 10.1038/s41598-019-53672-7.

[19298] O. W. M. Rauhut, K. Remes, R. Fechner, G. Cladera, and P. Puerta. “Discovery of a short-necked sauropod dinosaur from the Late Jurassic period of Patagonia". In: Nature 435 (2005), pp. 670-672.

[19299] O. W. M. Rauhut and M. Röper. "Brückenechsen aus dem oberen Jura von Brunn (Oberpfalz)". German. In: Freunde der Bayerischen Staatssammlung für Paläontologie und Historische Geologie e.V., Jahresbericht und Mitteilungen 41 (2013), pp. 55-72. 
[19300] O. W. M. Rauhut, H. Tischlinger, and C. Foth. "A non-archaeopterygid avialan theropod from the Late Jurassic of southern Germany". English. In: eLife 8.e43789 (2019). DOI: 10.7554/eLife.43789.

[19301] O. W. M. Rauhut and C. Werner. “First record of the family Dromaeosauridae (Dinosauria: Theropoda) in the Cretaceous of Gondwana (Wadi Milk Formation, northern Sudan)". In: Paläontologische Zeitschrift 69.3/4 (1995), pp. 475-489.

[19302] O. W. M. Rauhut and X. Xu. “The small theropod dinosaurs Tugulusaurus and Phaedrolosaurus from the Early Cretaceous of Xinjiang, China". In: Journal of Vertebrate Paleontology 25.1 (2005), pp. 107-118.

[19303] A. Ravel, M. Adaci, M. Bensalah, A. -L. Charruault, E. M. Essid, H. K. Ammar, W. Marzougui, M. Mahboubi, F. Merbrouk, G. Merzeraud, M. Vianey-Liaud, R. Tabuce, and L. Marvaux. “Origine et radiation initiale des chauves-souris modernes : nouvelles découvertes dans l'Éocène d'Afrique du Nord". French. In: Geodiversitas 38.3 (2016), pp. 355-434. DOI: 10.5252/g2016n3a3.

[19304] A. Ravel, M. Adaci, M. Bensalah, M. Mahboubi, F. Mebrouk, E. M. Essid, W. Marzougui, H. K. Ammar, A. -L. Charruault, R. Lebrun, R. Tabuce, M. Vianey-Liaud, and L. Marivaux. “New philisids (Mammalia, Chiroptera) from the Early-Middle Eocene of Algeria and Tunisia: new insight into the phylogeny, palaeobiogeography and palaeoecology of the Philisidae". English. In: (2014).

[19305] A. Ravel, L. Marivaux, R. Tabuce, M. Ben Haj Ali, E. L. Essid, and M. Vianey-Liaud. “A new large philisid (Mammalia, Chiroptera, Vespertilionoidea) from the late early Eocene of Chambi, Tunisia". English. In: Palaeontology 55.5 (2012), pp. 1035-1041.

[19306] R. J. Raven, P. A. Jell, and R. A. Knezour. "Edwa maryae gen. et sp. nov. in the Norian Blackstone Formation of the Ipswich Basin—the first Triassic spider (Mygalomorphae) from Australia". English. In: Alcheringa 39 (2015), pp. 259-263.

[19307] N. J. Rawlence, A. Kardamaki, L. J. Easton, A. J. D. Tennyson, R. P. Scofield, and J. M. Waters. "Ancient DNA and morphometric analysis reveal extinction and replacement of New Zealand's unique black swans". English. In: Proceedings of the Royal Society B 284 (2017), p. 20170876.

[19308] P. F. Rawson and M. B. Aguirre-Urreta. "Lower Cretaceous ammonites from the Neuquén Basin, Argentina: The Hauterivian genus Spitidiscus". English. In: Cretaceous Research 33 (2012), pp. 97105. DOI: $10.1016 /$ j.cretres.2011.09.004.

[19309] D. C. Ray and A. T. Thomas. "Carbonate depositional environments, sequence stratigraphy and exceptional skeletal preservation in the Much Wenlock Limestone Formation (Silurian) of Dudley, England". English. In: Palaeontology 50.1 (2007), pp. 197-222.

[19310] S. Ray. "Lystrosaurus (Therapsida, Dicynodontia) from India: taxonomy, relative growth and cranial dimorphism". English. In: Journal of Systematic Palaeontology 3.2 (2005), pp. 203-221.

[19311] S. Ray. "A New Late Triassic Traversodontid Cynodont (Therapsida, Eucynodontia) from India". English. In: Journal of Vertebrate Paleontology 35 (2015), e930472. DOI: 10.1080 / 02724634.2014. 930472.

[19312] S. Ray and S. Bandyopadhyay. "Late Permian vertebrate community of the Pranhita-Godavari valley, India". English. In: Journal of Asian Earth Sciences 21.6 (2003), pp. 643-654.

[19313] J. P. Raynal, J. P. Texier, D. Geraads, and F. Z. Sbihi-Alaoui. “Un nouveau gisement paleontologique plio-pleistocene en Afrique du Nord: Ahl al Oughlam (ancienne carriere Deprez) a Casablanca (Maroc)". French. In: C. R. Acad. Sci. Paris, Serie II 310 (1990), pp. 315-320.

[19314] J. P. Raynal, D. Geraads, L. Magoga, A. El Hajraoui, J. P. Texier, D. Lefevre, and F. Z. Sbihi-Alaoui. "La Grotte des Rhinoceros (Carriere Oulad Hamida 1, anciennement Thomas III, Casablanca), nouveau site acheuleen du Maroc atlantique". French. In: Comptes Rendues de l'Academie des Sciences Paris, Series II 316 (1993), pp. 1477-1483.

[19315] J. P. Raynal, D. Lefevre, D. Geraads, and M. El Graoui. “Contribution du site paleontologique de Lissasfa (Casablanca, maroc) a une nouvelle interpretation du Mio-Pliocene de la Meseta". French. In: Comptes Rendues de l'Academie des Sciences, Paris, Sciences de la terre et des planetes 329 (1999), pp. 617-622. 
[19316] R. J. Rayner, B. P. Moon, and J. C. Masters. "The Makapansgat australopithecine environment". English. In: Journal of Human Evolution 24 (1993), pp. 219-231.

[19317] R. J. Rayner and S. B. Waters. "A Cretaceous crane-fly (Diptera: Tipulidae): 93 million years of stasis". English. In: Zoological Journal of the Linnean Society 99 (1990), pp. 309-318.

[19318] H. Razak and L. Kocsis. "Late Miocene Otodus (Megaselachus) megalodon from Brunei Darussalam: Body length estimation and habitat reconstruction". English. In: Neues Jahrbuch für Geologie und Paläotologie, Abhandlungen 288 (2018), pp. 299-306.

[19319] A. A. Razumovskiy, A. Y. Ivantsov, I. A. Novikov, and A. V. Korochantsev. "Kuckaraukia multituberculata: A vew Vendian fossil from the Basa Formation of the Asha Group in the South Urals". English. In: Paleontological Journal 49.5 (2015), pp. 449-456. DOI: 10.1134/S0031030115050111.

[19320] N. L. Razzolini, M. Belvedere, D. Marty, G. Paratte, C. Lovis, M. Cattin, and C. A. Meyer. "Megalosauripus transjuranicus ichnosp. nov. A new Late Jurassic theropod ichnotaxon from NW Switzerland and implications for tridactyl dinosaur ichnology and ichnotaxomy". English. In: PLoS ONE 12.7 (2017), e0180289:1-42. DOI: 10.1371/journal.pone.0180289.

[19321] N. L. Razzolini, O. Oms, D. Castanera, B. Vila, V. F. dos Santos, and Á Galobart. “Ichnological evidence of megalosaurid dinosaurs crossing Middle Jurassic tidal flats". English. In: Scientific Reports 6.31494 (2016), pp. 1-15. DOI: 10.1038/srep31494.

[19322] A.-C. Rebelo, M. W. Rasser, R. Riosmena-Rodriguez, A. I. Neto, and S. P. Avila. "Rhodolith forming coralline algae in the Upper Miocene of Santa Maria Island (Azores, NE Atlantic): a critical evaluation". English. In: Phytotaxa 190.1 (2014), pp. 370-382.

[19323] S. Reboulet. "L'évolution des ammonites du Valanginien-Hauterivien inférieur du bassin Vocontien et de la plate-form Provençale (sud-est de la France): relations avec la stratigraphie séquentielle et implications biostratigraphiques". French. In: Documents des Laboratoires de Géologie Lyon 137 (1996), pp. 1-371.

[19324] S. Reboulet, F. Atrops, S. Ferry, and A. Schaaf. "Renouvellement des ammonites en fosse Vocontienne a la limite Valanginien-Hauterivien [Ammonite turnover in the Vocontian trough at the Valanginian-Hauterivian boundary]". French. In: Géobios 25.4 (1992), pp. 469-476.

[19325] O. Redkozubov, E. Syromyatnikova, A. Gnetneva, and I. Danilov. "First reliable records of the genus Chersine (Testudines: Testudinidae) from the Pliocene of Moldova". English. In: Historical Biology 1.10 (2020). DOI: 10.1080/08912963.2020.1846531.

[19326] E. H. Reed. “In Situ Taphonomic Investigation of Pleistocene Large Mammal”. English. In: Helictite 39.1 (2006), pp. 5-15.

[19327] E. H. Reed and S. J. Bourne. "Pleistocene fossil vertebrate sites of the South East region of South Australia". English. In: Transactions of the Royal Society of South Australia 124.2 (2000), pp. 61-90.

[19328] E. H. Reed and S. J. Bourne. "Pleistocene fossil vertebrate sites of the South East region of South Australia II". English. In: Transactions of the Royal Society of South Australia 133.1 (2009), pp. 30-40. DOI: $10.1080 / 03721426.2009 .10887108$.

[19329] E. K. E. Reed, J. W. Kitching, F. E. Grine, W. L. Jungers, and L. Sokoloff. “Proximal femur of Australopithecus africanus from Member 4, Makapansgat, South Africa". English. In: American Journal of Physical Anthropology 92.1 (1993), pp. 1-15.

[19330] A. J. Rees, A. T. Thomas, M. Lewis, H. E. Hughes, and P. Turner. "The Cambrian of SW Wales: Towards a United Avalonian Stratigraphy". English. In: Geological Society of London 42 (2014). DOI: 10.1144/M42.

[19331] J. Rees. "Neoselachian shark and ray teeth from the Valanginian, Lower Cretaceous, of Wawal, Central Poland". English. In: Palaeontology 48.2 (2005), pp. 209-221.

[19332] J. Rees. "An Early Cretaceous scincomorph lizard dentary from Bornholm, Denmark". English. In: Bulletin of the Geological Society of Denmark 48 (2000), pp. 105-109.

[19333] J. Rees. "Early Jurassic selachians from the Hasle Formation on Bornholm, Denmark". English. In: Acta Palaeontologica Polonica 43.3 (1998), pp. 439-452. 
[19334] J. Rees. "A new Pliensbachian (Early Jurassic) neoselachian shark fauna from southern Sweden". English. In: Acta Palaeontologica Polonica 45.4 (2000), pp. 407-424.

[19335] J. Rees. “Neoselachian Sharks from the Callovian-Oxfordian (Jurassic) of Ogrodzieniec Zawiercie Region, Southern Poland". English. In: Palaeontology 53.4 (2010), pp. 887-902.

[19336] J. Rees. "Palaeoecological implications of neoselachian shark teeth from the Bathonian (Middle Jurassic) ore-bearing clays atnGnaszyn, Kraków-Silesia Homocline, Poland". English. In: Acta Palaeontologica Polonica 62.3 (2012), pp. 397-402. DOI: 10.2478/v10263-012-0022-y.

[19337] J. Rees. "Shark fauna and depositional environment of the earliest Cretaceous Vitabäck Clays at Eriksdal, southern Sweden". English. In: Earth and Environmental Science Transactions of the Royal Society of Edinburgh 93 (2002), pp. 59-71.

[19338] J. Rees and S. E. Evans. "Amphibian remains from the lower Cretaceous of Sweden; the first Scandanavian record of the enigmatic group Albanerpetontidae". English. In: GFF (formerly Geologiska Foreningens i Stockholm Forhandlingar) 124.2 (2002), pp. 87-91.

[19339] J. Rees, J. Lindgren, and S. E. Evans. "Amphibians and small reptiles from the Berriasian Rabekke Formation on Bornholm, Denmark". English. In: GFF 127 (2005), pp. 233-238.

[19340] J. Rees and J. Lindgren. "Aquatic birds from the Upper Cretaceous (lower Campanian) of Sweden and the biology and distribution of hesperornithiforms". English. In: Palaeontology 48.6 (2005), pp. 1321-1329.

[19341] P. M. Rees and C. J. Cleal. "Lower Jurassic floras from Hope Bay and Botany Bay, Antarctica". English. In: Special Papers in Palaeontology 72 (2004), pp. 5-90.

[19342] L. L. N. Reeve, R. B. Reeve, and P. L. Cleghorn. The Hawaiian Monk Seal in Traditional Hawaiian Culture. English. National Oceanic and Atmospheric Administration. 2013.

[19343] S. Reguant. "Un nivel de concentracion de briozoos en el Cuisiense inferior de Esdolomada (Formacion Murillo, Valle de Isabena) [Level of bryozoan concentration in the lower Cuisian of Esdolomada (Murillo Formation, Isabena Valley)]". Spanish. In: Geogaceta 24 (1998), pp. 255-258.

[19344] M. A. Reguero, A. M. Candela, and R. N. Alonso. "Biochronology and biostratigraphy of the Uqua Formation (Pliocene- early Pleistocene, NW Argentina) and its significance in the Great American Biotic Interchange". English. In: Journal of South American Earth Sciences 23 (2007), pp. 1-16. DOI: 10.1016/j.jsames.2006.09.005.

[19345] M. A. Reguero and A. M. Candela. "Late cenozoic mammals from the northwest of Argentina". English. In: Cenozoic geology of the Central Andes of Argentina. Salta: INCE (Instituto Cenozoico), 2011, pp. 411-426.

[19346] M. A. Reguero, A. M. Candela, C. I. Galli, R. Bonini, and D. Voglino. “A new hypsodont notoungulate (Hegetotheriidae, Pachyrukhinae) from the late Miocene of the Eastern Cordillera, Salta province, northwest of Argentina". English. In: Andean Geology 42.1 (2015), pp. 56-70. DOI: 10.5027/andgeoV42n1-a04.

[19347] M. A. Reguero and P. V. Castro. “Un nuevo Trachytheriinae (Mammalia, Notoungulata) del Deseadense (Oligoceno tardAo) de Patagonia, Argentina: implicancias en la filogenia, biogeografAa y bioestratigrafAa de los Mesotheriidae". Spanish. In: Andean Geology 31.1 (2004), pp. 45-64.

[19348] M. A. Reguero and E. Cerdeño. “New late Oligocene Hegetotheriidae (Mammalia, Notoungulata) from Salla, Bolivia". English. In: Journal of Vertebrate Paleontology 25.3 (2005), pp. 674-684.

[19349] M. A. Reguero, D. A. Croft, J. J. Flynn, and A. R. Wyss. "Small archaeohyracids from Chubut Province, Argentina and central Chile: implications for trans-Andean temporal correlation". English. In: Fieldiana: Geology (New Series) 48 (2003), pp. 1-17.

[19350] M. A. Reguero, D. C. Croft, G. M. Lopez, and R. N. Alonso. “Eocene archaeohyracids (Mammalia: Notoungulata: Hegetotheria) from the Puna, northwest Argentina". English. In: Journal of South American Earth Sciences 26 (2008), pp. 225-233. 
[19351] M. A. Reguero, M. T. Dozo, and E. Cerdeño. “A poorly known rodent-like mammal (Pachyrukhinae, Hegetotheriidae, Notoungulata) from the Deseadan (Late Oligocene) of Argentina. Paleoecology, biogeography, and radiation of the rodentlike ungulates in South America". English. In: Journal of Paleontology 81.6 (2007), pp. 1301-1307.

[19352] M. A. Reguero, S. A. Marenssi, and S. N. Santillana. "Weddellian marine/coastal vertebrates diversity from a basal horizon (Ypresian, Eocene) of the Cucullaea I Allomember, La Meseta formation, Seymour (Marambio) Island, Antarctica". English. In: 19.3 (2012), pp. 275-284.

[19353] M. A. Reguero, S. A. Marenssi, and S. N. Santillana. "Antarctic Peninsula and South America (Patagonia) Paleogene terrestrial faunas and environments: biogeographic relationships". English. In: Palaeogeography, Palaeoclimatology, Palaeoecology 179 (2002), pp. 189-210.

[19354] M. A. Reguero, C. Tambussi, T. Mors, M. Buono, S. Marenssi, and S. Santillana. Vertebrates from the basal horizons (Ypresian to Lutetian) of the Cucullaea I Allomember, La Meseta Formation, Seymour (Marambio) Island, Antarctica. English. 2011.

[19355] M. A. Reguero, M. Ubilla, and D. Perea. "A new species of Eopachyrucos (Mammalia, Notoungulata, Interatheriidae) from the Late Oligocene of Uruguay". English. In: Journal of Vertebrate Paleontology 23.2 (2003), pp. 445-457. DOI: 10.1671/0272-4634(2003)023[0445:ANSOEM]2.0.CO;2.

[19356] U. Rehfeld and G. Ernst. “Hydrozoan build-ups of Millepora irregularis sp. nov. and fungiid coral meadows of Cunnolites Alloiteau (Anthozoa) - palaeoecological and palaeoceanographical implications for the Upper Cretaceous of north Cantabria (northern Spain)". In: Facies 39 (1998), pp. 125-138.

[19357] U. Rehfeld and A. W. Janssen. "Development of Phosphatized Hardgrounds in the Miocene Globigerina Limestone of the Maltese Archipelago, Including a Description of Gamopleura melitensis sp. nov. (Gastropoda, Euthecosomata)". English. In: Facies 33 (1995), pp. 91-106.

[19358] C. D. Reich, T. D. Hickey, K. L. DeLong, R. Z. Poore, and J. C. Brock. "Holocene core logs and site statistics for modern patch-reef cores: Biscayne National Park, Florida". English. In: USGS Open-File Report 1246 (2009), pp. 1-26.

[19359] M. Reich. “Holothuriensklerite (Echinodermata) aus dem Oligozän (Rupelium) Norddeutschlands". German. In: Neues Jahrbuch für Geologie und Paläontologie, Abhandlungen 224.1 (2002), pp. 97113.

[19360] M. Reich. "Holothurien (Echinodermata) aus der Oberkreide des Ostseeraumes: teil. 5. Molpadiidae J. Müller, 1859". German. In: Neues Jahrbuch für Geologie une Paläontologie, Abhandlungen 229.2 (2003), pp. 231-253.

[19361] M. Reich. "Holothurien (Echinodermata) aus Kelloway-Geschieben (Dogger: Callovium)". German. In: Geschiebekunde aktuell 20.2/3 (2004), pp. 55-68.

[19362] M. Reich. "Pravuscucumis deeckei paragen. et parasp. nov. (Echinodermata: Holothuroidea) aus dem Turonium des Ostseegebietes". German. In: Geschiebekunde aktuell 17.2/3 (2001), pp. 97-106.

[19363] M. Reich. "Linguaserra spandeli sp nov (Echinodermata: Ophiocistioidea) from the Late Permian (Zechstein) of Thuringia, Germany". English. In: Annales de Paléontologie 93 (2007), pp. 317-330.

[19364] M. Reich. “über Achistrum huckei (Frizzell \& Hexline 1956) [Holothuroidea, Echinodermata] aus der Unterkreide von Bartin (Hinterpommern)". German. In: Greifswalder Geowissenschaftliche Beiträge 6 (1999), pp. 383-391.

[19365] M. Reich. "The oldest synallactid sea cucumber (Echinodermata: Holothuroidea: Aspidochirotida)". English. In: Palaeontologische Zeitschrift (2010).

[19366] M. Reich and H. Mostler. "Gillocystis (Echinodermata) aus dem Unter-Karbon Afganistans". German. In: Neues Jarhbuch für Geologie und Paläontologie, Monatshefte 2002.10 (2002), pp. 588-596.

[19367] M. Reich, J. Sprinkle, B. Lefebvre, G. E. Rössner, and S. Zamora. "The first Ordovician cyclocystoid (Echinodermata) from Gondwana and its morphology, paleoecology, taphonomy, and paleogeography". English. In: Journal of Paleontology 91.4 (2017), pp. 735-754. DOI: 10.1017/jpa.2017.7. 
[19368] M. Reich, T. R. Stegemann, I. M. Hausmann, V. J. Roden, and A. Nützel. “The youngest ophiocistoid: a first Palaeozoic-type echinoderm group representative from the Mesozoic". English. In: Palaeontology 61 (2018), pp. 803-811.

[19369] M. Reich, L. Villier, and M. Kutscher. The echinoderms of the Rügen White Chalk (Maastrichtian, Germany). English. Echinoderms. München, London: Taylor \& Francis Group, 2004, pp. 495-501.

[19370] M. Reich and F. Wiese. “Apodid sea cucumbers (Echinodermata: Holothuroidea) from the Upper Turonian of the Isle of Wolin, NW Poland". English. In: Cretaceous Research 31 (2010), pp. 350-363.

[19371] S. Reich. "Gastropod Associations as a Proxy for Seagrass Vegetation in a Tropical, Carbonate Setting (San Salvador, Bahamas)". English. In: Palaios 29.9 (2014), pp. 467-482.

[19372] M. Reichel, C. L. Schultz, and M. B. Soares. “A new traversodontid cynodont (Therapsida, Eucynodontia) from the Middle Triassic Santa Maria Formation of Rio Grande do Sul, Brazil". English. In: Palaeontology 52 (2009), pp. 229-250.

[19373] B. Reichenbacher and M. Boehme. Fish remains (otoliths, teeth) from the Miocene of Chios (Greece) new. English. 2004.

[19374] V. A. Reichler. “Estratigrafa y paleontologa del Cenozoico marino del Gran Bajo y Salinas del Gualicho, Argentina y descripción de 17 especies nuevas". English. In: Andean Geology 37.1 (2010), pp. 177-219.

[19375] C. M. Reid. “Permian Bryozoa of Tasmania and New South Wales: systematics and their use in Tasmanian biostratigraphy". English. In: Association of Australasian Palaeontologists, Memoir 28 (2003), pp. 1-133.

[19376] C. M. Reid. "Stratigraphy, paleontology, and tectonics of Lower Miocene rocks in the Waipatiki/Mangatuna area, southern Hawke's Bay, New Zealand". English. In: New Zealand Journal of Geology and Geophysics 41 (1998), pp. 115-131.

[19377] C. M. Reid. "Large sediment encrusting trepostome bryozoans from the Permian of Tasmania, Australia". English. In: Bryozoan Studies 2010. Lecture Notes in Earth Sciences 143 (2012), pp. 225237.

[19378] M. Reid, A. W. Hunter, W. L. Taylor, and E. M. Bordy. "A new genus of Protasteridae (Ophiuridea) from the Lower Devonian Bokkeveld Group of South Africa". English. In: Palaeontologia africana 53 (2019), pp. 66-74.

[19379] O. A. Reig and C. A. Quintana. "Fossil ctenomyine rodents of the genus Eucelophorus (Caviomorpha: Octodontidae) from the Pliocene and early Pleistocene of Argentina". English. In: Ameghiniana 29.4 (1992), pp. 363-380.

[19380] H. P. Reike. “Neue Arten und Anmerkungen zu Latridiidae (Coleoptera) aus Baltischem Bernstein". German. In: Latridiidae 9 (2012), pp. 7-23.

[19381] H. P. Reike, V. I. Alekseev, C. Gröhn, T. Arlt, and I. Manke. "First extinct species of the genus Holoparamecus (Coleoptera: Merophysiidae: Holoparamecinae) from Eocene amber deposits". English. In: Studies and Reports, Taxonomical Series 16 (2020), pp. 241-255.

[19382] H. P. Reike, A. Bukejs, T. Arlt, N. Kardjilov, and I. Manke. "Phase-contrast synchrotron microtomography reveals the internal morphology of a new fossil species of the Corticaria-sylvicolagroup (Coleoptera: Latridiidae)". English. In: Zootaxa 4242 (2017), pp. 578-590.

[19383] H.-P. Reike, V. I. Alekseev, and A. Bukejs. "Dieneremia rueckeri, a new genus and species of minute brown scavenger beetle from Baltic amber, with notes on other fossil Latridiidae (Coleoptera: Cucujoidea)". English. In: Zootaxa 3686 (2013), pp. 381-388.

[19384] C. K. Reimann and F. Strauch. “Ein Hippopotamus-Schädel aus dem Pliozän von Elis (Peloponnes, Griechenland)". German. In: Neues Jahrbuch für Geologie und Paläontologie 249.2 (2008), pp. 203-222.

[19385] C. Reinhold. "Guild structure and aggradation pattern of Messinian Porites patch reefs: ecological succession and external environmental control (San Miguel de Salinas Basin, SE Spain)". English. In: Sedimentary Geology 97 (1995), pp. 157-175. 
[19386] K. R. Reis and A. M. Garong. “Late Quaternary terrestrial vertebrates from Palawan Islad, Philippines". English. In: Palaeogeography, Palaeoclimatology, Palaeoecology 171 (2001), pp. 409-421. DOI: 10.1016/S0031-0182(01)00256-5.

[19387] K. R. Reis and D. W. Steadman. "Archaeology of Trants, Montserrat. Part 5. Prehistoric avifauna". English. In: Annals of Carnegie Museum 68 (1999), pp. 275-287.

[19388] A. G. Reisdorf, M. W. Maisch, and A. Wetzel. "First record of the leptonectid ichthyosaur Eurhinosaurus longirostris from the Early Jurassic of Switzerland and its stratigraphic framework". English. In: Swiss Journal of Geoscience 104 (2011), pp. 211-224. DOI: 10.1007/s00015-011-0069-x.

[19389] S. Reiss, U. Scheer, S. Sachs, and B. P. Kear. "Filling the biostratigraphical gap: first choristoderan from the Lower-mid Cretaceous interval of Europe". English. In: Cretaceous Research (2018). DOI: 10.1016/j.cretres.2018.12.009.

[19390] R. R. Reisz. “Oromycter, a New Caseid from the Lower Permian of Oklahoma”. English. In: Journal of Vertebrate Paleontology 25.4 (2005), pp. 905-910.

[19391] R. R. Reisz, V. Barkas, and D. Scott. "A New Early Permian Bolosaurid Reptile from the Richards Spur Dolese Brothers Quarry, near Fort Sill, Oklahoma". English. In: Journal of Vertebrate Paleontology 22.1 (2002), pp. 23-28.

[19392] R. R. Reisz and D. W. Dilkes. “Archaeovenator hamiltonensis, a new varanopid (Synapsida: Eupelycosauria) from the Upper Carboniferous of Kansas". English. In: Canadian Journal of Earth Sciences 40.4 (2003), pp. 667-678.

[19393] R. R. Reisz and D. W. Dilkes. "The taxonomic position of Anningia megalops, a small amniote from the Permian of South Africa". English. In: Canadian Journal of Earth Sciences 29.7 (1992), pp. 16051608. DOI: 10.1139 /e92-126.

[19394] R. R. Reisz, D. C. Evans, H. -D. Sues, and D. Scott. “Embryonic skeletal anatomy of the sauropodomorph dinosaur Massospondylus from the Lower Jurassic of South Africa". English. In: Journal of Vertebrate Paleontology 30.6 (2010), pp. 1653-1665.

[19395] R. R. Reisz and J. Fröbisch. "The oldest caseid synapsid from the Late Pennsylvanian of Kansas, and the evolution of herbivory in terrestrial vertebrates". English. In: PLoS One 9.4 (2014), e94518. DOI: 10.1371/journal.pone.0094518.

[19396] R. R. Reisz, T. D. Huang, E. M. Roberts, S. Peng, C. Sullivan, K. Stein, A. R. H. LeBlanc, D. Shieh, R. Chang, C. Chiang, C. Yang, and S. Zhong. "Embryology of Early Jurassic dinosaur from China with evidence of preserved organic remains". English. In: Nature 496 (2013), pp. 210-214. DOI: 10.1038/nature11978.

[19397] R. R. Reisz, N. I. Krupina, and M. M. Smith. "Dental histology in Ichnomylax karatajae sp. nov., an Early Devonian dipnoan from the Taymir Peninsula, Siberia, with a discussion on petrodentine". English. In: Journal of Vertebrate Paleontology 24.1 (2004), pp. 18-25.

[19398] R. R. Reisz and M. Laurin. "The reptile Macroleter, the first vertebrate evidence for correlation of Upper Permian continental strata of North America and Russia". English. In: Geological Society America Bulletin 113.9 (2001), pp. 1229-1233.

[19399] R. R. Reisz, A. R. H. LeBlanc, C. A. Sidor, D. Scott, and W. May. "A new captorhinid reptile from the Lower Permian of Oklahoma showing remarkable dental and mandibular convergence with microsaurian tetrapods". English. In: The Science of Nature 102.9-10 (2015), p. 50. DOI: 10.1007 / s00114-015-1299-y.

[19400] R. R. Reisz, J. Liu, J. -L.Li, and J. Müller. "A new captorhinid reptile, Gansurhinus qingtoushanensis, gen. et sp. nov., from the Permian of China". English. In: Naturwissenschaften 98.5 (2011), pp. 435-441. DOI: 10.1007/s00114-011-0793-0.

[19401] R. R. Reisz, M. J. MacDougall, and S. P. Modesto. “A new species of the parareptile genus Delorhynchus, based on articulated skeletal remains from Richards Spur, Lower Permian of Oklahoma". English. In: Journal of Vertebrate Paleontology 34.5 (2014), pp. 1033-1043. 
[19402] R. R. Reisz, H. C. Maddin, J. Fröbisch, and J. Falconnet. “A new large caseid (Synapsida, Caseasauria) from the Permian of Rodez (France), including a reappraisal of Casea rutena Sigogneau-Russell \& Russell, 1974". English. In: Geodiversitas 33.2 (2011), pp. 227-246.

[19403] R. R. Reisz and S. P. Modesto. “Heleosaurus scholtzi from the Permian of South Africa: a Varanopid Synapsid, not a Diapsid Reptile". English. In: Journal of Vertebrate Paleontology 27.3 (2007), pp. 734-739.

[19404] R. R. Reisz and S. P. Modesto. "Archerpeton anthracos from the Joggins Formation of Nova Scotia: a microsaur, not a reptile". English. In: Canadian Journal of Earth Sciences 33.5 (1996), pp. 703-709.

[19405] R. R. Reisz, S. P. Modesto, and D. M. Scott. "A new Early Permian reptile and its significance in early diapsid evolution". English. In: Proceedings of the Royal Society B 278 (2011), pp. 3731-3737. DOI: $10.1098 / \mathrm{rspb} .2011 .1537$.

[19406] R. R. Reisz, R. R. Schoch, and J. S. Anderson. “The armoured dissorophid Cacops from the Early Permian of Oklahoma and the exploitation of the terrestrial realm by amphibians". English. In: Naturwissenschaften 96 (2009), pp. 789-796.

[19407] R. R. Reisz and D. Scott. “Owenetta kitchingorum, sp. nov., a small parareptile (Procolophonia: Owenettidae) from the Lower Triassic of South Africa". English. In: Journal of Vertebrate Paleontology 22.2 (2002), pp. 244-256.

[19408] R. R. Reisz and L. A. Tsuji. "An articulated skeleton of Varanops with bite marks: the oldest known evidence of scavenging among terrestrial vertebrates". English. In: Journal of Vertebrate Paleontology 26.4 (2006), pp. 1021-1023.

[19409] R. R. Reisz, H. Wilson, and D. Scott. “Varanopseid Synapsid Skeletal Elements from Richards Spur, a Lower Permian Fissure Fill Near Fort Sill, Oklahoma". English. In: Oklahoma Geology Notes 57.5 (1997), pp. 160-170.

[19410] J. Reitner, N. Langsford, and P. Kruse. “An unusual ferruginous-calcitic Frutexites microbialite community from the lower Cambrian of the Flinders Ranges, South Australia". English. In: Palaeontologische Zeitschrift 91.1 (2017), pp. 1-3. DOI: 10.1007/s12542-017-0342-z.

[19411] J. Reitner, M. Wilmsen, and F. Neuweiler. “Cenomanian/Turonian sponge microbialite deep-water hardground community (Liencres, northern Spain)". English. In: Facies 32 (1995), pp. 203-212.

[19412] K. Remes. "A second Gondwanan diplodocid dinosaur from the Upper Jurassic Tendaguru Beds of Tanzania, East Africa". English. In: Palaeontology 50.3 (2007), pp. 653-667.

[19413] K. Remes. "Taxonomy of Late Jurassic diplodocid sauropods from Tendaguru (Tanzania)". English. In: Fossil Record 12.1 (2009), pp. 23-46. DOI: 10.1002/mmng.200800008.

[19414] K. Remes, F. Ortega, I. Fierro, U. Joger, R. Kosma, J. M. M. Ferrer, Project PALDES, Niger Project SNHM, O. A. Ide, and A. Maga. "A new basal sauropod dinosaur from the Middle Jurassic of Niger and the early evolution of Sauropoda". English. In: PLoS One 4.9 (2009), e6924:1-13. DOI: 10.1371/journal.pone.0006924.

[19415] A. Remia and M. Taviani. "Shallow-buried Pleistocene Madrepora-dominated coral mounds on a muddy continental slope, Tuscan Archipelago, NE Tyrrhenian Sea". In: Facies 50.3-4 (2005), pp. 419-425.

[19416] J. A. Remy. "Plagiolophus huerzeleri, une nouvelle espéce de Palaeotheriidae (Perissodactyla, Mammalia) d'Oligocéne inférieur (Rupélien, MP 23) á Murs (Vaucluse, France)". English. In: Geobios 33.4 (2000), pp. 489-503.

[19417] J. A. Remy. “Une faunule de vertébrés sous la base de grés de Celas (Eocéne supérieur) á St-Dezery (Gard)". French. In: Palaeovertebrata 23.1-4 (1994), pp. 211-216.

[19418] J. A. Remy. “Les Périssodactyles (Mammalia) du gisement Bartonien supérieur de Robiac (Éocéne moyen du Gard, Sud de la France)". French. In: Palaeovertebrata 39.1 (2015), e1:1-98.

[19419] J. A. Remy, G. Krasovec, and B. Marandat. "A new species of Propalaeotherium (Palaeotheriidae, Perissodactyla, Mammalia) from the Middle Eocene locality of Aumelas (Hérault, France)". English. In: Palaeovertebrata 40.2 (2016). 
[19420] J. A. Remy, G. Krasovec, É Lopez, B. Marandat, and F. Lihoreau. “The Palaeotheriidae (Equoidea, Perissodactyla, Mammalia) from the Eocene fauna of Aumelas (Hérault department, France)". English. In: Geodiversitas 41.13 (2019), pp. 525-585.

[19421] J. A. Remy and F. Fournier. "Mammiféres fossiles des grés de Célas (Eocéne supérieur du Gard): découvertes récentes". English. In: Bulletin de la Société d'étude des sciences naturelles de Nmes et Gard 64 (2003), pp. 18-30.

[19422] D. Ren. Insecta. Chinese. Faunae and stratigraphy of Jurassic-Cretaceous in Beijing and the adjacent areas. 1995, pp. 47-121.

[19423] D. Ren. "A new lacewing family (Neuroptera) from the Middle Jurassic of Inner Mongolia, China". English. In: Entomologica Sinica 9.12 (2002), pp. 53-67.

[19424] D. Ren. "Late Jurassic Brachycera from northeastern China (Insecta: Diptera)". English. In: Acta Zootaxonomica Sinica 23 (1998), pp. 65-82.

[19425] D. Ren. "First record of fossil crickets (Orthoptera: Trigonidiidae) from China". English. In: Entomologica Sinica 5 (1998), pp. 101-105.

[19426] D. Ren. "Studies on the late Mesozoic snake-flies of China (Raphidoiptera: Baissopteridae, Mesoraphidiidae, Alloraphidiidae)". Chinese. In: Acta Zootaxonomica Sinica 22 (1997), pp. 172-188.

[19427] D. Ren. "First discovery of fossil bittacids from China". Chinese. In: Acta Geologica Sinica 67 (1993), pp. 376-381.

[19428] D. Ren. "Studies on Late Jurassic scorpion-flies from northeast China (Mecoptera: Bittacidae, Orthophlebiidae)". English. In: Acta Zootaxonomica Sinica 22 (1997), pp. 75-85.

[19429] D. Ren. "Two new Late Jurassic genera of kalligrammatids from Beipiao, Liaoning (Neuroptera, Kalligramatidae)". English. In: Acta Zootaxonomica Sinica 28 (2003), pp. 105-109.

[19430] D. Ren. "First record of fossil stick-insects from China (Phasmatodea: Hagiphasmatidae fam. nov.) with analysis of some palaeobiological features". English. In: Acta Zootaxonomica Sinica 22 (1997), pp. 268-281.

[19431] D. Ren and D. S. Aristov. “A new species of Plesioblattogryllus Huang, Nel et Petrulevicius (Grylloblattida: Plesioblattogryllidae) from the Middle Jurassic of China". English. In: Paleontological Journal 45.3 (2011), pp. 273-274.

[19432] D. Ren, M. S. Engel, and W. Lu. "New giant lacewings from the Middle Jurassic of Inner Mongolia, China (Neuroptera: Polystoechotidae)". English. In: Journal of the Kansas Entomological Society 75.3 (2002), pp. 188-193.

[19433] D. Ren and M. S. Engel. "Aetheogrammatidae, A New Family of Lacewings from the Mesozoic of China (Neuroptera: Myrmeleontiformia)". English. In: Journal of the Kansas Entomological Society 81.3 (2008), pp. 161-167.

[19434] D. Ren and M. S. Engel. "A split-footed lacewing and two epiosmylines from the Jurassic of China (Neuroptera)”. English. In: Annales Zoologici 57.2 (2007), pp. 211-219.

[19435] D. Ren and M. S. Engel. "A second antlion from the Mesozoic of northeastern China (Neuroptera: Myrmeleontidae)". English. In: Alavesia 2 (2008), pp. 183-186.

[19436] D. Ren and Z. Guo. "Three new genera and three new species of dragonflies from the late Jurassic of Northeast China". English. In: Entomologica Sinica 3.2 (1996), pp. 95-105.

[19437] D. Ren and Z. Guo. "A new genus and two new species of short-horned flies of Upper Jurassic from Northeast China (Diptera: Eremochaetidae)". English. In: Entomologica Sinica 2.4 (1995), pp. 300-307.

[19438] D. Ren and Z. G. Guo. “On the new fossil genera and species of Neuroptera (Insecta) from the Late Jurassic of northeast China". English. In: Acta Zootaxonomica Sinica 21 (1996), pp. 461-479.

[19439] D. Ren and W. Krzemiski. "Eoptychopteridae (Diptera) from the Middle Jurassic of China". English. In: Annales Zoologici 52 (2002), pp. 207-210. 
[19440] D. Ren, C. C. Labandeira, J. A. Santiago-Blay, A. Rasnitsyn, C. K. Shih, A. Bashkuev, M. A. V. Logan, C. L. Hotton, and D. Dilcher. "A probable pollination mode before angiosperms: Eurasian long-proboscid scorpionflies". English. In: Science 326 (2009), pp. 840-847.

[19441] D. Ren, J. Y. Liu, and X. D. Cheng. "A new hemeroscopid dragonfly from the Lower Cretaceous of Northeast China (Odonata: Hemeroscopidae)". English. In: Acta Entomologica Sinica 46.5 (2003), pp. 622-628.

[19442] D. Ren, V. N. Makarkin, and Q. Yang. “A new fossil genus of Mesochrysopidae (Neuroptera) from the Early Cretaceous Yixian Formation of China". English. In: Zootaxa 2523 (2010), pp. 50-56.

[19443] D. Ren and V. N. Makarkin. "Ascalochrysidae - a new lacewing family from the Mesozoic of China (Insecta: Neuroptera: Chrysopoidea)". English. In: Cretaceous Research 30 (2009), pp. 1217-1222.

[19444] D. Ren and X. M. Meng. "New Jurassic protaboilins from China (Orthoptera: Prophalangopsidae, Protaboilinae)". Chinese. In: Acta Zootaxonomica Sinica 31.3 (2006), pp. 513-519.

[19445] D. Ren, A. Nel, and J. Prokop. "New early griffenfly, Sinomeganeura huangheensis from the Late Carboniferous of northern China (Meganisoptera: Meganeuridae)". English. In: Insect Systematics E Evolution 38 (2008), pp. 223-229.

[19446] D. Ren and J. D. Oswald. “A new genus of kalligrammatid lacewings from the Middle Jurassic of China (Neuroptera: Kalligrammatidae)". English. In: Stuttgarter Beiträge zur Naturkunde Serie B (Geologie und Paläontologie) 317 (2002), pp. 1-8.

[19447] D. Ren, C. K. Shih, and C. C. Labandeira. "A well-preserved aneuretopsychid from the Jehol Biota of China (Insecta, Mecoptera, Aneuretopsychidae)". English. In: ZooKeys 129 (2011), pp. 17-28.

[19448] D. Ren and C. K. Shih. "The first discovery of fossil eomeropids from China (Insecta, Mecoptera)". English. In: Acta Zootaxonomica Sinica 30.2 (2005), pp. 275-280.

[19449] D. Ren and J. Tan. "A new cupedid genus (Coleoptera: Archostemata: Cupedidae) from Jehol Biota of western Liaoning, China". English. In: Annales Zoologici (Warszawa) 56.3 (2006), pp. 457-464.

[19450] D. Ren, J. J. Tan, and S. Q. Ge. "New fossil ommatid (Coleoptera: Archostemata: Ommatidae) from Jehol biota of western Liaoning, China". English. In: Progress in Natural Science 16 (2006), pp. 639643.

[19451] D. Ren and J. Yin. “New 'Osmylid-Like' Fossil Neuroptera from the Middle Jurassic of Inner Mongolia, China". English. In: Journal of the New York Entomological Society 111.1 (2003), pp. 1-11.

[19452] D. Ren, J. Yin, and W. Dou. "Late Jurassic Palaeontinids (Homoptera; Auchenorrhyncha) from Hebei and Liaoning Provinces in China". English. In: Entomologia Sinica 5.3 (1998), pp. 222-232.

[19453] D. Ren, J. C. Yin, and W. X. Dou. "New planthoppers and froghoppers from the Late Jurassic of northeast China (Homoptera: Auchenorrhyncha)". English. In: Acta Zootaxonomica Sinica 23 (1998), pp. 281-288.

[19454] D. Ren and J. C. Yin. "A new Middle Jurassic species of Epiosmylus from Inner Mongolia, China (Neuroptera: Osmylidae)". Chinese. In: Acta Zootaxonomica Sinica 27 (2002), pp. 274-277.

[19455] D. Ren and J. C. Yin. "A new genus and new species of lacewings in the Jurassic of China (Neuroptera: Myrmeleontoidea)". English. In: Acta Zootaxonomica Sinica 27 (2002), pp. 269-273.

[19456] D. Ren, H. Z. Zhu, and Y. Q. Lu. "New discovery of Early Cretaceous fossil insects from Chifeng City, Inner Mongolia". Chinese. In: Acta Geoscientia Sinica 1995.4 (1995), pp. 432-438.

[19457] M. Y. Ren, W. T. Zhang, C. K. Shih, and D. Ren. "A new earwig (Dermaptera: Pygidicranidae) from the Upper Cretaceous Myanmar amber". English. In: Cretaceous Research 74 (2017), pp. 137-141.

[19458] M. Y. Ren, W. T. Zhang, C. K. Shih, and D. Ren. "Earwig nymphs (Dermaptera) from the midCretaceous amber of Myanmar". English. In: Cretaceous Research 90 (2018), pp. 382-390.

[19459] X.-X. Ren, J.-D. Huang, and H. -L. You. "The second mamenchisaurid dinosaur from the Middle Jurassic of Eastern China". English. In: Historical Biology (2018). DOI: 10.1080 / 08912963.2018. 1515935 . 
[19460] X.-X. Ren, T. Sekiya, T. Wang, Z. -W. Yang, and H. -L. You. “A revision of the referred specimen of Chuanjiesaurus anaensis Fang et al., 2000: a new early branching mamenchisaurid sauropod from the Middle Jurassic of China". English. In: Historical Biology (2020). DOI: 10.1080 / 08912963.2020. 1747450 .

[19461] A. J. Renaut, R. J. Damiani, A. M. Yates, and P. J. Hancox. "A taxonomic note concerning a dicynodont (Synapsida: Anomodontia) from the Middle Triassic of East Africa". English. In: Palaeontologia africana 39 (2003), pp. 93-94.

[19462] W. Renema, V. Warter, V. Novak, J. R. Young, N. Marshall, and F. Hasibuan. “Ages of Miocene Fossil Localities In The Northern Kutai Basin (east Kalimantan, Indonesia)". English. In: Palaios 30 (2015), pp. 26-39.

[19463] S. Renesto. "A Cretaceous plesiosaur remain (Reptilia, Sauropterygia) from the Argille Varicolori of Varzi (Pavia, Lombardy, Northern Italy)". In: Rivista Italiana di Paleontologia e Stratigrafia 99.1 (1993), pp. 101-106.

[19464] S. Renesto. "Bird-like head on a chameleon body: new specimens of the enigmatic diapsid reptile Megalancosaurus from the Late Triassic of Northern Italy". English. In: Rivista Italiana di Paleontologia e Stratigrafia 106 (2000), pp. 157-180.

[19465] S. Renesto. "An isolated sternum of Eudimorphodon (Reptilia, Pterosauria) from the Norian (Late Triassic) of the Bergamo Prealps (Lombardy, northern Italy)". English. In: Rivista Italiana di Paleontologia e Stratigrafia 99 (1993), pp. 415-422.

[19466] S. Renesto. "A new prolacertiform reptile from the Late Triassic of northern Italy". English. In: Rivista Italiana di Paleontologia e Stratigrafia 100.2 (1994), pp. 285-306.

[19467] S. Renesto. "Remains of a juvenile phytosaur from the Late Triassic of northern Italy". English. In: Revisita Italiana di Paleontologia e Stratigrafia 114.1 (2008), pp. 155-160.

[19468] S. Renesto. "A sphenodontid from the Norian (Late Triassic) of Lombardy (northern Italy): a preliminary note". English. In: Modern Geology 20 (1995), pp. 149-158.

[19469] S. Renesto. "A new specimen of Tanystropheus (Reptilia Protorosauria) from the Middle Triassic of Switzerland and the ecology of the genus". English. In: Rivista Italiana di Paleontologia e Stratigrafia 111.3 (2005), pp. 377-394.

[19470] S. Renesto. "A new specimen of Nothosaurus from the latest Anisian (Middle Triassic) Besano formation (Grenzbitumenzone) of Italy". English. In: Rivista Italiana di Paleontologia e Stratigrafia 116.2 (2010), pp. 145-160.

[19471] S. Renesto and G. Binelli. "Vallesaurus cenensis Wild 1991, a drepanosaurid (Retilia, Diapsida) from the Late Triassic of northern Italy". English. In: Rivista Italiana di Paleontologia e Stratigrafia 112 (2006), pp. 77-94.

[19472] S. Renesto, G. Binelli, and H. Hagdorn. "A new pachypleurosaur from the Middle Triassic Besano Formation of Northern Italy". English. In: Neues Jahrbuch für Geologie und Paläontologie - Abhandlungen 271.2 (2014), pp. 151-168. DOI: 10.1127/0077-7749/2014/0382.

[19473] S. Renesto and F. M. Dalla Vecchia. "A revision of Langobardisaurus rossii Bizzarini and Muscio, 1995 from the Late Triassic of Friuli (Italy)". English. In: Rivista Italiana di Paleontologia e Stratigrafia 113 (2007), pp. 191-201.

[19474] S. Renesto and F. M. Dalla Vecchia. "The unusual dentition and feeding habits of the prolacertiform reptile Langobardisaurus (Late Triassic, northern Italy)". English. In: Journal of Vertebrate Paleontology 20 (2000), pp. 622-627.

[19475] S. Renesto, F. M. Dalla Vecchia, and D. Peters. "Morphological evidence for bipedalism in the Late Triassic prolacertiform reptile Langobardisaurus". English. In: Senckenbergiana Lethaea 82 (2002), pp. 95-106.

[19476] S. Renesto and N. C. Fraser. "Drepanosaurid (Reptilia: Diapsida) remains from a Late Triassic infilling at Cromhall Quarry (Avon, Great Britain)". English. In: Journal of Vertebrate Paleontology 23.3 (2003), pp. 703-705. 
[19477] S. Renesto, E. Gozzi, and A. Tintori. "Archosaur (possibly theropod) teeth from the Norian (Late Triassic) of Lombardy (Northern Italy)". English. In: Neues Jahrbuch für Geologie und Paläontologie Monatshefte 2005.9 (2005), pp. 529-546.

[19478] S. Renesto and E. Kustatscher. "A coelacanth fish from the Anisian (Middle Triassic) of the Dolomites". English. In: Rivista Italiana di Paleontologia e Stratigrafia 125 (2019), pp. 343-353.

[19479] S. Renesto and C. Lombardo. "Structure of the tail of a phytosaur (Reptilia, Archosauria) from the Norian (Late Triassic) of Lombardy (northern Italy)". English. In: Revista Italiana di Paleontologia e Stratigrafia 105.1 (1999), pp. 135-144.

[19480] S. Renesto and A. Paganoni. "A phytosaur skull from the Norian (Late Triassic) of Lombardy (northern Italy)". English. In: Revista Italiana di Paleontologia e Stratigrafia 104.1 (1998), pp. 115-122.

[19481] S. Renesto and V. Pieroni. "Middle Triassic vertebrate remains from Rasa Village (Varese, northern Italy)". English. In: New Mexico Museum of Natural History and Science Bulletin 61 (2013), pp. 485488.

[19482] S. Renesto and R. Posenato. "A new lepidosauromorph reptile from the Middle Triassic of the Dolomites (Northern Italy)". English. In: Italian Journal of Paleontology and Stratigraphy 109 (2003), pp. 463-474.

[19483] S. Renesto and R. Stockar. "Exceptional preservation of embryos in the actinopterygian Saurichthys from the Middle Triassic of Monte San Giorgio, Switzerland". English. In: Swiss Journal of Geosciences 102 (2009), pp. 323-330.

[19484] S. Renesto and R. Stockar. "First record of a coelacanth fish from the Middle Triassic Meride Limestone of Monte San Giorgio (Canton Ticino, Switzerland)". English. In: Rivista Italiana di Paleontologia e Stratigrafia 124 (2018), pp. 639-653.

[19485] S. C. Renesto, J. A. Spielmann, and S. G. Lucas. “The oldest record of drepanosaurids (Reptilia, Diapsida) from the Late Triassic (Adamanian Placerias Quarry, Arizona, USA) and the stratigraphic range of the Drepanosauridae". English. In: Neues Jahrbuch für Paläontologie und Geologie, Abhandlungen 252.3 (2009), pp. 315-325.

[19486] G. W. Renz. "Late Ordovician (Caradocian) radiolarians from Nevada". In: Micropaleontology 36.4 (1990), pp. 367-377.

[19487] J. Reolid, M. Reolid, C. Betzler, S. Lindhorst, M. G. Wiesner, and N. Lahajnar. “Upper Pleistocene coldwater corals from the Inner Sea of the Maldives: taphonomy and environment". English. In: 63.8 (2017). DOI: $10.1007 /$ s10347-016-0491-7.

[19488] M. Reolid, J. M. Molina, H. Löser, V. Navarro, and P. A. Ruiz-Ortiz. “Coral biostromes of the Middle Jurassic from the Subbetic (Betic Cordillera, southern Spain): facies, coral taxonomy, taphonomy, and palaeoecology". English. In: Facies 55 (2009), pp. 575-593.

[19489] M. T. Reolid and J. M. Molina. "Record of Carcharocles megalodon in the Eastern Guadalquivir Basin (Upper Miocene, South Spain)". English. In: Estudios geológicos 71.2 (2015). DOI: 10.3989/ egeol.15712.

[19490] C. A. Repenning. "Allophaiomys and the age of the Olyor Suite, Krestovka sections, Yakutia". English. In: United States Geological Survey Bulletin 2037.4 (1992), pp. 1-95.

[19491] C. A. Repenning and E. M. Brouwers. "Late Pliocene-early Pleistocene ecologic changes in the Arctic Ocean borderland". English. In: United States Geological Survey Bulletin 2036.3 (1992), pp. 137.

[19492] J. E. Repetski, J. D. Loch, and R. L. Ethington. “Conodonts and biostratigraphy of the Lower Ordovician Roubidoux Formation in and near the Ozark National Scenic Riverways, southeastern Missouri". English. In: Paleontological Research 3 (1998), pp. 109-115.

[19493] Y. S. Repin. "New Bivalves from the Jurassic of Iran”. English. In: Paleontological Journal 42.3 (2008), pp. 243-250. DOI: 10.1134/S0031030108030040.

[19494] Y. S. Repin. "New taxa of Jurassic bivalve mollusks from Iran”. English. In: Paleontological Journal 47 (2013), pp. 562-569. 
[19495] Yu.S. Repin, S. V. Meledina, and S. N. Alexeev. "Phylloceratids (Ammnonoidea) from the Lower Jurassic of Northeastern Asia." In: Paleontological Journal 32.5 (1998), pp. 461-473.

[19496] L. N. Repina, E. V. Romanenko, E. S. Fedjanina, and T. V. Pegel. "Trilobites from the Lower and Lowermost middle Cambrian of the Kiya river reference section (Kuznetsk, Alatau)". English. In: Annales de Paléontologie 85.1 (1999), pp. 3-56.

[19497] L. E. Requeta Loza, N. Hernández Medrano, and F. Pérez-Lorente. “La Pellejera: descripción y aportaciones. heterocronía y variabilidad de un yacimiento con huellas de dinosaurio de La Rioja (España) [La Pellejera: description and contributions: heterochrony and variability of a dinosaur footprint locality from La Rioja (Spain)]". Spanish. In: Zubia Monográfico 18-19 (2007), pp. 21-114.

[19498] V. Reshetov, N. Spassov, and B. Baishashov. "Tenisia gen. nov.: taxonomic revaluation of the asian Oligocene rhinocerotoid Eggysodon turgacum (Borissiak, 1915) (Mammalia, Perissodactlya, Hyracodontidae)". English. In: Géobios 26.6 (1993), pp. 715-722.

[19499] G. J. Retallack. "Early Triassic therapsid footprints from the Sydney Basin, Australia”. English. In: Alcheringa 20 (1996), pp. 301-314.

[19500] J. W. F. Reumer. "Pliocene vertebrate loclaity of Calta, Ankara, Turkey. 3. Insectivores". English. In: Geodiversitas 20.3 (1998), pp. 353-358.

[19501] J. W. F. Reumer. "The insectivorous mammals (Marsupialia: Didelphidae; Insectivora: Nyctitheriidae; Chiroptera) from the early Oligocene of Balm, Switzerland". English. In: Eclogae Geologicae Helvetiae 87.3 (1994), pp. 1029-1035.

[19502] J. W. F. Reumer. “Insectivora (Mammalia: Soricidae, Talpidae) from the Late Pliocene of Frechen, Germany". English. In: Deinsea 2 (1995), pp. 9-15.

[19503] J. W. F. Reumer, T. H. Mens, and K. Post. "New fnds of giant raptorial sperm whale teeth (Cetacea, Physeteroidea) from the Westerschelde Estuary (province of Zeeland, the Netherlands)". English. In: Deinsea 17 (2017), pp. 32-38.

[19504] J. W. F. Reumer, L. Rook, K. Van Der Borg, K. Post, D. Mol, and J. De Vos. “Late Pleistocene survival of the saber-toothed cat Homotherium in Northwestern Europe". English. In: Journal of Vertebrate Paleontology 23.1 (2002), pp. 260-262.

[19505] M. Reuter, F. R. Bosellini, A. F. Budd, S. Coric, W. E. Piller, and M. Harzhauser. “High coral reef connectivity across the Indian Ocean is revealed". English. In: Coral Reefs (2019). DOI: 10.1007 / s00338-019-01830-8.

[19506] M. Reuter, T. C. Brachert, and K. F. Kroeger. "Diagenesis of growth bands in fossil scleractinian corals: identification and modes of preservation". English. In: Facies 51 (2005), pp. 146-159.

[19507] M. Reuter, T. C. Brachert, A. Böcker, and J. S. Klaus. “An unusual Pocillopora reef from the Late Miocene of Hispaniola". English. In: Coral Reefs (2011). DOI: 10.1007/s00338-011-0728-4.

[19508] M. Reuter, W. E. Piller, M. Harzhauser, O. Mandic, B. Berning, F. Rögl, A. Krog, M. -P. Aubry, U. Wielandt-Schuster, and A. Hamedani. "The Oligo/Miocene Qom Formation (Iran): evidence for an early Burdigalian restriction of the Tethyan Seaway and closure of its Iranian gateways". English. In: International Journal of Earth Sciences 98 (2009), pp. 627-650.

[19509] M. Reuter, W. E. Piller, M. Harzhauser, A. Kroh, F. Rögl, and S. Coric. "The Quilon Limestone, Kerala Basin, India: an archive for Miocene Indo-Pacific seagrass beds". English. In: Lethaia (2010).

[19510] M. Reuter, W. E. Piller, M. Harzhauser, A. Kroh, F. Rogl, and S. Coric. "The Quilon Limestone, Kerala Basin, India: an archive for Miocene Indo-Pacific seagrass beds". English. In: Lethaia 44 (2011), pp. 76-86.

[19511] M. Reuter, W. E. Piller, and C. Erhart. "A Middle Miocene carbonate platform under silici-volcaniclastic sedimentation stress (Leitha Limestone, Styrian Basin, Austria) — Depositional environments, sedimentary evolution and palaeoecology". English. In: Palaeogeography, Palaeoclimatology, Palaeoecology 350-352 (2012), pp. 198-211. 
[19512] M. Reuter, W. E. Piller, M. Harzhauser, and A. Kroh. “Cyclone trends constrain monsoon variability during late Oligocene sea level highstands (Kachchh Basin, NW India)". English. In: Climate of the Past 9 (2013), pp. 2101-2115.

[19513] M. Reuter, T. Wiedl, and W. E. Piller. "Parascolymia (Scleractinia: Lobophylliidae) in the Central Paratethys Sea (Vienna Basin, Austria) and its possible biogeographic implications". English. In: PLOS one 10.7 (2015), e0132243. DOI: 10.1371/journal.pone.0132243.

[19514] G. Rey, R. Royo-Torres, and L. Alcalá. “Nuevos restos de dinosaurios estiracosternos en el Albiense de la Cordillera Ibérica [New styracosternan dinosaur remains from the Albian of the Iberian Range]". Spanish. In: Geogaceta 63 (2018), pp. 83-86.

[19515] J. Reyes-Abril, E. Villas, and J. C. Gutiérrez-Marco. “Orthid brachiopods from the Middle Ordovician of the Central Iberian Zone, Spain". English. In: Acta Palaeontologica Polonica 55.2 (2010), pp. 285-308.

[19516] N. Reynaud Savioz and P. Morel. "La faune de Nadaouiyeh An Askar (Syrie centrale, Pléistocéne moyen): aperçu et perspectives". French. In: Revue de Paléobiologie 10 (2005), pp. 31-35.

[19517] R. E. Reynolds. Jurassic tracks in California. English. Making Tracks Across the Southwest: The 2006 Desert Symposium. Zzyzx: California State University, Desert Studies Consortium and LSA Associates, Inc., 2006, pp. 19-24.

[19518] V. H. Reynoso. "A 'beaded' sphenodontian (Diapsida: Lepidosauria) from the Early Cretaceous of central Mexico". English. In: Journal of Vertebrate Paleontology 17 (1997), pp. 52-59. DOI: 10.1080 / 02724634.1997.10010953.

[19519] V. H. Reynoso. "An unusual aquatic sphenodontian (Reptilia: Diapsida) from the Tlayua Formation (Albian), central Mexico". English. In: Journal of Paleontology 74 (2000), pp. 133-148.

[19520] V. H. Reynoso. "Huehuecuetzpali mixtecus gen. et sp. nov: a basal squamate (Reptilia) from the Early Cretaceous of Tepexi de Rodrguez, Central México". English. In: Philosophical Transactions of the Royal Society of London B, Biological Sciences 353 (1998), pp. 477-500.

[19521] V. H. Reynoso and G. Callison. "A new scincomorph lizard from the Early Cretaceous of Puebla, México". English. In: Zoological Journal of the Linnean Society 130 (2000), pp. 183-212.

[19522] V.-H. Reynoso. “A Middle Jurassic Sphenodon-like sphenodontian (Diapsida: Lepidosauria) from Huizachal Canyon, Tamaulipas, Mexico". English. In: Journal of Vertebrate Paleontology 16.2 (1996), pp. 210-221.

[19523] V.-H. Reynoso. "Possible evidence of a venom apparatus in a Middle Jurassic sphenodontian from the Huizachal red beds of Tamaulipas, Mexico". English. In: Journal of Vertebrate Paleontology 25.3 (2005), pp. 646-654.

[19524] V.-H. Reynoso. "Research on fossil amphibians and reptiles in Mexico, from 1869 to early 2004 (including marine forms but excluding pterosaurs, dinosaurs, and obviously, birds)". English. In: vol. 24. Studies on Mexican Paleontology. 2006, pp. 209-231.

[19525] V.-H. Reynoso and J. M. Clark. "A dwarf sphenodontian from the Jurassic La Boca Formation of Tamaulipas, Mexico". English. In: Journal of Vertebrate Paleontology 18 (1998), pp. 333-339.

[19526] V.-H. Reynoso and M. Montellano-Ballesteros. "A new giant turtle of the genus Gopherus (Chelonia: Testudinidae) from the Pleistocene of Tamaulipas, México, and a review of the phylogeny and biogeography of gopher tortoises". English. In: Journal of Vertebrate Paleontology 24.4 (2004), pp. 822-837.

[19527] J. Rheinheimer. “Neue fossile Rüsselkäfer (Coleoptera: Curculionidae) aus dem Eozän des Baltischen Bernsteins und der Grube Messel bei Darmstadt". German. In: Stuttgarter Beiträge zur Naturkunde Serie B (Geologie und Paläontologie) 365 (2007), pp. 1-24.

[19528] P. D. Rhinehart, A. J. Mead, and D. Parmley. “Eocene Terrestrial Mammals From Central Georgia”. English. In: Georgia Journal of Science 77.2 (2019), pp. 1-9.

[19529] S. Riamon, N. Tourment, and A. Louchart. "The earliest Tyrannida (Aves, Passeriformes), from the Oligocene of France". English. In: Scientific Reports 10 (2020), 9776:1-14. 
[19530] A. M. Ribeiro, C. J. Drehmer, S. de C. Francisco, and P. C. Simones Lopes. "Pleistocene skull remains of Pontoporia blainvillei (Cetacea, Pontoporiidae) from the coast plain of Rio Grande do Sul State, Brazil, and the relationship of pontoporids". English. In: Revista Universidade Guarulhos Geociencias 3.6 (1998), pp. 71-77.

[19531] A. M. Ribeiro, R. H. Madden, F. R. Negri, L. Kerber, A. Schmaltz-Hsiou, and K. A. Rodrigues. "Mamferos fósiles y biocronologa en el suroeste de la Amazonia, Brasil". Spanish. In: Asociación Paleontológica Argentina, Publicación Especial 14 (2013), pp. 207-221.

[19532] G. C. Ribeiro. "A new fossil Helius (Diptera: Limoniidae) from Burmese amber". English. In: Studia Dipterologica 9 (2003), pp. 403-408.

[19533] G. C. Ribeiro and W. Krzemiski. "New information on Limoniidae (Diptera: Tipulomorpha) from the Lower Cretaceous Santana Formation (northeastern Brazil)". English. In: Polskie Pismo Entomologiczne 69 (2000), pp. 451-457.

[19534] G. C. Ribeiro and E. D. Lukashevich. "New Leptotarsus from the Early Cretaceous of Brazil and Spain: the oldest members of the family Tipulidae (Diptera)". English. In: Zootaxa 3753 (2014), pp. 347-363.

[19535] G. C. Ribeiro, D. Santos, and R. C. R. Nicolau. "A new species of Leptotarsus (Diptera: Tipulidae) from the Lower Cretaceous Crato Formation of Brazil". English. In: Cretaceous Research 56 (2015), pp. 244-249.

[19536] G. Ribeiro de Oliveira and A. W. A. Kellner. "Note on a plastron (Testudines, Pleurodira) from the Lower Cretaceous Crato Member, Santana Formation, Brazil". English. In: Arquivos do Museu Nacional, Rio de Janeiro 63.3 (2005), pp. 523-528.

[19537] A. C. Riccardi, S. E. Damborenea, M. O. Mancenido, and S. C. Ballent. "Hettangian and Sinemurian (Lower Jurassic) biostratigraphy of Argentina". English. In: Journal of South American Earth Sciences 4.3 (1991), pp. 159-170.

[19538] A. C. Riccardi, S. E. Damborenea, M. O. Mancenido, and M. P. Iglesia Llanos. "The Triassic/Jurassic boundary in the Andes of Argentina". English. In: Rivista Italiana di Paleontologia e Stratigrafia 110.1 (2004), pp. 69-76.

[19539] C. Ricci, B. Lathuiliere, and G. Rusciadelli. "Coral communities, zonation and paleoecology of an Upper Jurassic reef complex (Ellipsactinia Limestones, central Apennines, Italy)". English. In: Rivista Italiana di Paleontologia e Stratigrafia 124.3 (2018), pp. 433-508.

[19540] C. Ricci, G. Rusciadelli, G. Della Porta, A. Lanfranchi, F. Jadoul, and B. Lathuiliére. “Sedimentary evolution of a coral-, microbialites- and debris-rich Upper Jurassic reef (upper Tithonian, eastern Sardinia, Italy)". English. In: Sedimentary Geology 376 (2018). DOI: 10.1016/j.sedgeo.2018.07.010.

[19541] T. Rich, K. Piper, D. Pickering, and S. Wright. "Further Ektopodontidae (Phalangeroidea, Mammalia) from southwestern Victoria". English. In: Alcheringia 30.1 (2006), pp. 133-140. DOI: 10.1080/ 03115510608619349.

[19542] T. Rich and P. Vickers-Rich. "Protoceratopsian? ulnae from Australia". In: Records of the Queen Victoria Museum Launceston 113 (2003), pp. 1-12.

[19543] T. H. Rich, R. A. Gangloff, and W. R. Hammer. "Polar dinosaurs". English. In: Encyclopedia of Dinosaurs. New York: Academic Press, 1997, pp. 562-573.

[19544] T. H. Rich, P. V. Rich, B. E. Wagstaff, J. R. C. M. Mason, T. F. Flannery, M. Archer, R. E. Molnar, and J. A. Long. Two possible chronological anomalies in the Early Cretaceous tetrapod assemblages of southeastern Australia. English. Aspects of Nonmarine Cretaceous Geology. China Ocean Press, Beijing. 1992, pp. 165-176.

[19545] T. H. Rich and P. Vickers-Rich. "Neoceratopsians and ornithomimosaurs: dinosaurs of Gondwana origin?" In: National Geographic Research and Exploration 10.1 (1994), pp. 129-131.

[19546] T. H. Rich, P. Vickers-Rich, O. Gimenez, R. Cúneo, P. Puerta, and R. Vacca. A new sauropod dinosaur from Chubut province, Argentina. English. Vol. 15. Proceedings of the Second Gondwanan Dinosaur Symposium, National Science Museum Monographs. 1999, pp. 61-84. 
[19547] T. H. Rich and P. Vickers-Rich. The Hypsilophodontidae from southeastern Australia. English. Vol. 15. Proceedings of the Second Gondwanan Dinosaur Symposium, National Science Museum Monographs. 1999, pp. 167-180.

[19548] T. H. Rich, P. Vickers-Rich, M. Fernandez, and S. Santillana. A probable hadrosaur from Seymour Island, Antarctic Peninsula. English. Vol. 15. Proceedings of the Second Gondwanan Dinosaur Symposium, National Science Museum Monographs. 1999, pp. 219-222.

[19549] T. H. Rich and P. Vickers-Rich. English. A Century of Australian Dinosaurs. Queen Victoria Museum and Art Gallery and Monash Science Centre, Monash University. 2003, pp. 1-124.

[19550] T. H. Rich, P. Vickers-Rich, A. Constantine, T. F. Flannery, L. Kool, and N. van Klaveren. “A tribosphenic mammal from the Mesozoic of Australia". English. In: Science 278 (1997), pp. 14381442.

[19551] T. H. Rich, P. A. Vickers-Rich, T. F. Flannery, B. P. Kear, D. J. Cantrill, P. Komarower, L. Kool, D. Pickering, P. Trusler, S. Morton, N. A. Van Klaveren, and E. M. G. Fitzgerald. "An Australian multituberculate and its palaeobiogeographic implications". English. In: Acta Palaeontologica Polonica 54.1 (2009), pp. 1-6.

[19552] T. H. Rich, P. J. Vickers-Rich, F. E. Novas, R. Cuneo, P. Puerta, and R. Vacca. "Theropods from the Middle Cretaceous Chubut Group of the San Jorge Sedimentary Basin, central Patagonia. A preliminary note". In: GAIA 15 (1998), pp. 111-115.

[19553] A. E. Richards, P. L. Gibbard, and M. E. Pettit. "The sedimentology and palaeoecology of the Westleton Member of the Norwich Crag Formation (Early Pleistodene) at Thorigton, Suffolk, England". English. In: Geological Magazine 136.4 (1999), pp. 453-464.

[19554] G. D. Richards and M. L. McCrossin. "A new species of Antilocapra from the late Quaternary of California". English. In: Géobios 24.5 (1991), pp. 623-635. DOI: 10.1016/0016-6995(91)80027-W.

[19555] R. L. Richards and W. D. Turnbull. "Giant short-faced bear (Arctodus simus yukonensis) remains from Fulton County, northern Indiana". English. In: Fieldiana: Geology (New Series) 30 (1995), pp. 134.

[19556] D. R. Richmond and N. Murphy. Stratigraphy, sedimentology, and depositional facies of the Morrison Formation 5ES Quarry of central Montana. English. 2020. DOI: 10.1130/abs/2020AM-351193.

[19557] D. R. Richmond and K. L. Stadtman. "Sedimentology of a Ceratosaurus site in the San Rafael Swell, Emery County, Utah". English. In: Brigham Young University Geology Studies 41 (1996), pp. 117124.

[19558] A. Richter. “Der problematische Lacertilier Ilerdaesaurus (Reptilia, Squamata) aus der UnterKreide von Una und Galve (Spanien)". German. In: Berliner Geowissenschaftliche Abhandlungen Reihe E 13 (1994), pp. 135-161.

[19559] A. Richter. "Lacertilia aus der Unteren Kreide von Una und Galve (Spanien) und Anoual (Marokko)". German. In: Berliner Geowissenschaftliche Abhandlungen Reihe E 14 (1994), pp. 1-147.

[19560] A. Richter, O. Wings, H. -U. Pfretzchner, and T. Martin. "Late Jurassic Squamata and possible Choristodera from the Junggar Basin, Xinjiang, Northwest China". English. In: Palaeobiodiversity and Palaeoenvironments 90.3 (2010), pp. 275-282.

[19561] U. Richter, A. Mudroch, and L. G. Buckley. "Isolated theropod teeth from the Kem Kem Beds (Early Cenomanian) near Taouz, Morocco". English. In: Palaeontologische Zeitschrift (2013). DOI: 10.1007/s12542-012-0153-1.

[19562] T. C. Rick, R. L. DeLong, J. M. Erlandson, T. J. Braje, T. L. Jones, J. E. Arnold, M. R. Des Lauriers, W. R. Hildebrandt, D. J. Kennett, R. L. Vellanoweth, and T. A. Wake. "Where were the northern elephant seals? Holocene archaeology and biogeography of Mirounga angustirostris". English. In: The Holocene 21.7 (2011), pp. 1159-1166.

[19563] T. C. Rick, R. L. DeLong, J. M. Erlandson, T. J. Braje, T. L. Jones, D. J. Kennett, T. A. Wake, and P. L. Walker. "A trans-Holocene archaeological record of Guadalupe fur seals (Arctocephalus townsendi) on the California coast". English. In: Marine Mammal Science 25.2 (2009), pp. 487-502. DOI: $10.1111 / j .1748-7692.2008 .00273 . x$. 
[19564] R. B. Rickards, P. W. Baillie, and J. B. Jago. “An Upper Cambrian (Idamean) dendroid assemblage from near Smithton, northwestern Tasmania". English. In: Alcheringa 14.3 (1990), pp. 207-232. DOI: 10.1080/03115519008619056.

[19565] R. B. Rickards and M. J. Garratt. "Pridoli graptolites from the Humevale Formation at Ghin Ghin and Cheviot, Victoria, Australia". English. In: Proceedings of the Yorkshire Geological Society 48.1 (1990), pp. 41-46.

[19566] R. B. Rickards, R. A. Parkes, and A. J. Wright. "Llandovery (Early Silurian) graptolites from the Quidong Basin, NSW". English. In: Proceedings of the Linnean Society of New South Wales 126 (2005), pp. 143-152.

[19567] J. B. Riding and J. A. Crame. “Aptian to Coniacian (Early-Late Cretaceous) palynostratigraphy of the Gustav Group, James Ross Basin, Antarctica". English. In: Cretaceous Research 23 (2002), pp. 739-760. DOI: 10.1006/cres.2002.1024.

[19568] R. Riding. "Solenopora is a chaetetid sponge, not an alga". English. In: Palaeontology 47.1 (2004), pp. 117-122.

[19569] R. Riding and S. Barkham. "Temperate water Shamovella from the Lower Permian of West Timor, Indonesia". English. In: Alcheringa 23 (1999), pp. 21-29.

[19570] R. Riding, J. M. Martin, and J. C. Braga. "Coral-stromatolite reef framework, upper Miocene, Almeria, Spain". English. In: Sedimentology 38.5 (1991), pp. 799-818.

[19571] R. Riding and A. Y. Zhuravlev. "Structure and diversity of oldest sponge-microbe reefs: Lower Cambrian, Aldan River, Siberia". English. In: Geology 23.7 (1995), pp. 649-652.

[19572] A. Riedel. "A new tribe, genus and species of Nemonychidae from Baltic amber (Coleoptera: Curculionoidea: Nemonychidae: Cimberidinae)". English. In: Insect Systematics \& Evolution 41 (2010), pp. 29-38.

[19573] A. Riedel, T. Dos Santos Rolo, A. Cecilia, and T. Van de Kamp. "Sayrevilleinae Legalov, a newly recognised subfamily of fossil weevils (Coleoptera, Curculionoidea, Attelabidae) and the use of synchrotron microtomography to examine inclusions in amber". English. In: Zoological Journal of the Linnean Society 165 (2012), pp. 773-794.

[19574] B. Riegl and W. E. Piller. "Biostromal Coral Facies-A Miocene Example from the Leitha Limestone (Austria) and its Actualistic Interpretation". In: Palaios 15.5 (2000), pp. 399-413.

[19575] W. Riegraf and G. Moosleitner. "Barremian rhyncholites (Lower Cretaceous Ammonoidea: calcified upper jaws) from the Serre de Bleyton (Département Drome, SE France)". English. In: Annalen des Naturhistorischen Museums in Wien, Serie A 112 (2010), pp. 627-658.

[19576] O. Rieppel. "Corosaurus alcovensis Case and the phylogenetic interrelationships of Triassic stemgroup Sauropterygia". English. In: Zoological Journal of the Linnean Society 124 (1998), pp. 1-41.

[19577] O. Rieppel. "The sauropterygian genera Chinchenia, Kwangsisaurus, and Sanchiaosaurus from the Lower and Middle Triassic of China". English. In: Journal of Vertebrate Paleontology 19.2 (1999), pp. 321-337.

[19578] O. Rieppel. "The systematic status of Hanosaurus hupehensis (Reptilia, Sauropterygia) from the Triassic of China". English. In: Journal of Vertebrate Paleontology 18.3 (1998), pp. 545-557.

[19579] O. Rieppel. "The status of the sauropterygian reptile Partanosaurus zitteli Skuphos from the Middle Triassic of the Austrian Alps, with comments on Microleptosaurus schlosseri Skuphos". English. In: Paläontologische Zeitschrift 70.3/4 (1996), pp. 567-577.

[19580] O. Rieppel. "Variation of cranial characters in Cymatosaurus 'gracilis' Schrammen 1899 (Reptilia, Sauropterygia), and its implications for systematics". English. In: Palaeontologische Zeitschrift 73.3/4 (1999), pp. 369-375.

[19581] O. Rieppel. "The status of the sauropterygian reptile Nothosaurus juvenilis from the Middle Triassic of Germany". English. In: Palaeontology 37.4 (1995), pp. 733-745.

[19582] O. Rieppel. "Paraplacodus and the phylogeny of the Placodontia". English. In: Zoological Journal of the Linnean Society 130 (2000), pp. 365-359. DOI: 10.1006/zjls.2000.0232. 
[19583] O. Rieppel. "Revision of the sauropterygian reptile genus Cymatosaurus v. Fritsch, 1894, and the relationships of Germanosaurus Nopcsa, 1928, from the Middle Triassic of Europe". English. In: Fieldiana: Geology, new series 36 (1997), pp. 1-36.

[19584] O. Rieppel. "The braincases of Simosaurus and Nothosaurus: monophyly of the Nothosauridae (Reptilia: Sauropterygia)". English. In: Journal of Vertebrate Paleontology 14.1 (1994), pp. 9-23.

[19585] O. Rieppel. “Osteology of Simosaurus gaillardoti and the relationships of stem-group Sauropterygia". English. In: Fieldiana: Geology, new series 28 (1994), pp. 1-85.

[19586] O. Rieppel. "The status of the sauropterygian reptile genera Ceresiosaurus, Lariosaurus, and Silvestrosaurus from the Middle Triassic of Europe". English. In: Fieldiana: Geology, new series 38 (1998), pp. 1-46.

[19587] O. Rieppel. “The genus Placodus: systematics, morphology, paleobiogeography, and paleobiology". English. In: Fieldiana: Geology, new series 31 (1995), pp. 1-44.

[19588] O. Rieppel. "The cranial anatomy of Placochelys placodonta Jaekel, 1902, and a review of the Cyamodontoidea (Reptilia, Placodonta)". English. In: Fieldiana: Geology, new series 45 (2001), pp. 1104.

[19589] O. Rieppel. "A new species of Tanystropheus (Reptilia: Protorosauria) from the Middle Triassic of Makhtesh Ramon, Israel". English. In: Neues Jahrbuch für Geologie und Paläontologie - Abhandlungen 221.2 (2001), pp. 271-287.

[19590] O. Rieppel. “A new species of Nothosaurus (Reptilia: Sauropterygia) from the Upper Muschelkalk (Lower Ladinian) of southwestern Germany". English. In: Palaeontographica Abteilung A 263 (2001), pp. 137-161.

[19591] O. Rieppel. "Status of the Pachypleurosauroid Psilotrachelosaurus toeplitschi Nopcsa (Reptilia, Sauropterygia), from the Middle Triassic of Austria". English. In: Fieldiana: Geology, new series (1993), pp. 1-17.

[19592] O. Rieppel. "The dermal armor of the cyamodontoid placodonts (Reptilia, Sauropterygia): morphology and systematic value". English. In: Fieldiana Geology: New Series 46 (2002), pp. 1-41.

[19593] O. Rieppel and L. Grande. “A well-preserved fossil amphiumid (Lissamphibia: Caudata) from the Eocene Green River Formation of Wyoming". English. In: Journal of Vertebrate Paleontology 18.4 (1998), pp. 700-708.

[19594] O. Rieppel and L. Grande. "The anatomy of the fossil varanid lizard Saniwa ensidens Leidy, 1870, based on a newly discovered complete skeleton". English. In: Journal of Paleontology 81.4 (2007), pp. 643-665.

[19595] O. Rieppel and H. Hagdorn. "A skull of Cyamodus kuhnschnyderi Nosotti \& Pinna 1993, from the Muschelkalk of Wassonne (Alsace, France)". English. In: Palaeontologische Zeitschrift 73.3/4 (1999), pp. 377-383.

[19596] O. Rieppel and H. Hagdorn. "Fossil reptiles from the Spanish Muschelkalk (MontRal and Alcover, Province Tarragona)". English. In: Historical Biology 13 (1998), pp. 77-97. DOI: 10.1080 / 08912969809386575.

[19597] O. Rieppel, D.-Y. Jiang, N. C. Fraser, W. -C. Hao, R. Motani, Y. -L. Sun, and Z. -Y. Sun. “Tanystropheus cf. T. longbardicus from the early Late Triassic of Guizhou Province, southwestern China". English. In: Journal of Vertebrate Paleontology 30.4 (2010), pp. 1082-1089.

[19598] O. Rieppel, R. Kindlimann, and H. Bucher. A new fossil fish fauna from the Middle Triassic (Anisian) of north-western Nevada. English. Mesozoic Fishes - Systematics and Paleoecology. 1996, pp. 501-512.

[19599] O. Rieppel and K. Lin. "Pachypleurosaurs (Reptilia: Sauropterygia) from the Lower Muschelkalk, and a review of the Pachypleurosauroidea". English. In: Fieldiana: Geology, new series 32 (1995), pp. $1-44$.

[19600] O. Rieppel, J. Liu, and H. Bucher. "The first record of a thalattosaur reptile from the Late Triassic of southern China (Guizhou Province, PR China)". English. In: Journal of Vertebrate Paleontology 20.3 (2000), pp. 507-514. 
[19601] O. Rieppel, J. Liu, and C. Li. "A new species of the thalattosaur genus Anshunsaurus (Reptilia: Thalattosauria) from the Middle Triassic of Guizhou Province, southwestern China". English. In: Vertebrata PalAsiatica 44.4 (2006), pp. 285-296.

[19602] O. Rieppel, J.-M. Mazin, and E. Tchernov. "Speciation along rifting continental margins: a new nothosaur from the Negev (Israel)". English. In: Comptes rendus de l'Académie des Sciences Série IIA, Sciences de la Terre et des planétes 326 (1997), pp. 991-997.

[19603] O. Rieppel and R. Wernburg. "A new species of the sauropterygian Cymatosaurus from the Lower Muschelkalk of Thuringia, Germany". English. In: Palaeontology 41.4 (1998), pp. 575-589.

[19604] O. Rieppel and R. Wild. "A revision of the genus Nothosaurus (Reptilia: Sauropterygia) from the Germanic Triassic, with comments on the status of Conchiosaurus clavatus". English. In: Fieldiana: Geology, new series 34 (1996), pp. 1-82.

[19605] D. Riff and O. A. Aguilera. “The world's largest gharials Gryposuchus: description of G. croizati n. sp. (Crocodylia, Gavialidae) from the Upper Miocene Urumaco Formation, Venezuela". English. In: Paläontologische Zeitschrift 82.2 (2008), pp. 178-195.

[19606] S. Rigal, P. V. Kirch, and T. H. Worthy. "New prehistoric avifaunas from the Gambier Group, French Polynesia". English. In: Palaeontologia Electronica 21.3.4A (2018), pp. 1-35.

[19607] J. K. Rigby and R. Keyes. “Wewokella costata new species, a large heteractinid calcareous sponge from the Upper Mississippian Hartselle Sandstone in northeastern Alabama". English. In: Journal of Paleontology 72.1 (1998), pp. 1-6.

[19608] J. K. Rigby. “Well-preserved specimens of the sponges Gondekia (Heteractinida) and Pseudohydnoceras (Hexactinellida), Middle Devonian of New York State". English. In: Journal of Paleontology 68.4 (1994), pp. 727-734.

[19609] J. K. Rigby. "The new Devonian (Givetian) heteractinid sponge Gondekia from Ontario, Canada, and evolution of the astraeospongiids and eiffeliids". English. In: Journal of Paleontology 65.1 (1991), pp. 38-44.

[19610] J. K. Rigby. "The hexactinellid sponge Cyathophycus from the Lower-Middle Ordovician Vinini Formation Of central Nevada". English. In: Journal of Paleontology 69.3 (1995), pp. 409-416.

[19611] J. K. Rigby and Y. Albi. “An Upper Miocene hexactinellid xponge from the Puente Shale, Orange County, California". English. In: Journal of Paleontology 70.6 (1996), pp. 908-913.

[19612] J. K. Rigby and G. L. Bell. "A new hexactinellid sponge from the Reef Trial Member of the Upper Guadalupian Bell Canyon Formation, Guadalupe Mountains National Park, Texas". English. In: Journal of Paleontology 79.1 (2005), pp. 200-204.

[19613] J. K. Rigby and G. L. Bell. "Sponges from the Reef Trail Member of the Upper Guadalupian (Permian) Bell Canyon Formation, Guadalupe Mountains National Park, Texas". English. In: Journal of Paleontology 80.5 (2006), pp. 1-42.

[19614] J. K. Rigby, G. L. Bell, and K. Thompson. "Hexactinellid and associated sponges from the upper Reef Trail Member of the Bell Canyon Formation, southern Guadalupe Mountains National Park, Texas". English. In: Journal of Paleontology 81.6 (2007), pp. 1241-1256.

[19615] J. K. Rigby, R. B. Blodgett, and N. K. Anderson. “Emsian (Early Late Devonian) sponges from west-central and south-central Alaska". English. In: Journal of Paleontology 83.2 (2009), pp. 293298.

[19616] J. K. Rigby, R. B. Blodgett, and B. B. Britt. “Ordovician sponges from west-central and eastcentral Alaska and western Yukon Territory, Canada". English. In: Bulletin of Geosciences 83.2 (2008), pp. 153-168.

[19617] J. K. Rigby and D. W. Boyd. "Sponges from the Park City Formation (Permian) of Wyoming". English. In: Journal of Paleontology 78.1 (2004), pp. 71-76.

[19618] J. K. Rigby and B. D. E. Chatterton. "New Middle Silurian hexactinellid sponge from the Mackenzie Mountains, Northwest Territories, Canada". English. In: Journal of Paleontology 68.2 (1994), pp. 218-223. 
[19619] J. K. Rigby and S. B. Church. "A new Middle Cambrian Hexactinellid, Ratcliffespongia wheeleri, from western Utah and skeletal structure of Ratcliffespongia". In: Journal of Paleontology 64.3 (1990), pp. 331-334.

[19620] J. K. Rigby, S. B. Church, and N. K. Anderson. "Middle Cambrian sponges from the Drum Mountains and House Range in western Utah". English. In: Journal of Paleontology 84.1 (2010), pp. 6678.

[19621] J. K. Rigby and S. B. Church. "Wewokella and other sponges from the Pennsylvanian Minturn Formation of north-central Colorado". English. In: Journal of Paleontology 67.6 (1993), pp. 909-916.

[19622] J. K. Rigby and C. R. Clemont. "Demosponges and hexactinellid sponges from the Lower Devonian Ross Formation of west-central Tennessee". In: Journal of Paleontology 69.2 (1995), pp. 211231.

[19623] J. K. Rigby and A. Desrochers. "Lower and Middle Ordovician lithistid demosponges from the Mingan Islands, Gulf of St. Lawrence, Quebec, Canada". English. In: Journal of Paleontology Memoir 69.4 (1995), pp. 1-35.

[19624] J. K. Rigby, P. Embree, and M. Murphy. "An unusual Upper Cretaceous (Santonian) hexactinellid sponge from the Great Valley sequence, western Sacramento Valley, northern California". English. In: Journal of Paleontology 70.5 (1996), pp. 713-717.

[19625] J. K. Rigby, J. Fan, W. Zhang, S. Wang, and X. Zhang. "Sphinctozoan and Inozoan Sponges from the Permian Reefs of South China". In: BYU Geology Studies 40 (1994), pp. 43-109.

[19626] J. K. Rigby, J. S. Fan, and N. Han. “Upper Permian silicified sponges from central Guangxi and western Hubei, south China". English. In: Journal of Paleontology 69.2 (1995), pp. 232-250.

[19627] J. K. Rigby and J. L. Goedert. "Fossil sponges from a localized cold-seep limestone in Oligocene rocks of the Olympic Peninsula, Washington". English. In: Journal of Paleontology 70.6 (1996), pp. 900 908.

[19628] J. K. Rigby, L. F. Gunther, and F. Gunther. "The first occurrence of the Burgess Shale demosponge Hazelia palmata Walcott, 1920, in the Cambrian of Utah". English. In: Journal of Paleontology 71.6 (1997), pp. 994-997.

[19629] J. K. Rigby, J. C. Gutierrez-Marco, M. Robardet, and J. M. Picarra. "First articulated Silurian sponges from the Iberian Peninsula (Spain and Portugal)". In: Journal of Paleontology 71.4 (1997), pp. 554-563.

[19630] J. K. Rigby and X. G. Hou. "Lower Cambrian demosponges and hexactinellid sponges from Yunnan, China". English. In: Journal of Paleontology 69.6 (1995), pp. 1009-1019.

[19631] J. K. Rigby and P. Jamison. "Lithistid Sponges from the Late Ordovician Fish Haven Dolomite, Bear River Range, Cache County, Utah". In: Journal of Paleontology 68.4 (1994), pp. 722-725.

[19632] J. K. Rigby and P. A. Johnston. "An unusually large Aulocopella winnipegensis and associated demosponges from the Upper Ordovician Beaverfoot Formation, southeastern British Columbia". English. In: Canadian Journal of Earth Sciences 41 (2004), pp. 939-947.

[19633] J. K. Rigby, S. M. Karl, R. B. Blodgett, and J. F. Baichtal. “Ordovician sphinctozoan sponges from Prince of Wales Island, southeastern Alaska". English. In: Journal of Paleontology 79.5 (2005), pp. 862870.

[19634] J. K. Rigby, B. J. Kessel, B. D. Ritts, and S. J. Friedman. "A new Ordovician chiastoclonellid sponge from Inner Mongolia, China". English. In: Journal of Paleontology 80.4 (2006), pp. 775-779.

[19635] J. K. Rigby and R. Keyes Jr. "First report of hexactinellid dictyosponges and other sponges from the upper Mississippian Bangor Limestone, northwestern Alabama". In: Journal of Paleontology 64.6 (1990), pp. 886-897.

[19636] J. K. Rigby, G. A. Linder, and C. H. Stevens. "A new occurrence of the Hydrozoan Radiotrabeculopora reticulata Fan, Rigby, and Zhang, 1991 in the Permian of California". English. In: Journal of Paleontology 78.2 (2004), pp. 410-413. 
[19637] J. K. Rigby, B. J. Maher, and Q. J. Browne. "New Hexactinellids from the Siluro-Devonian of the Snake Mountains, Elko County, Nevada, and a new locality for Gabelia". In: Journal of Paleontology 65.5 (1991), pp. 709-714.

[19638] J. K. Rigby and B. J. Maher. "Age of the hexactinellid beds of the Roberts Mountains Formation, Snake Mountains, Nevada, and additions to the Silurian sponge fauna". English. In: Journal of Paleontology 69.6 (1995), pp. 1020-1029.

[19639] J. K. Rigby and W. L. Manger. "Morrowan lithistid demosponges and hexactinellids from the Ozark Mountains of northwestern Arkansas". English. In: Journal of Paleontology 68.4 (1994), pp. $734-$ 746.

[19640] J. K. Rigby, J. T. McCleary, and B. B. Britt. "A new demospongiid sponge from the Permian Park City Formation near Park City, Utah, USA". English. In: Neues Jahrbuch für Geologie und Paläontologie, Abhandlungen 245.2 (2007), pp. 153-158.

[19641] J. K. Rigby, M. G. McKinzie, and B. B. Britt. “Pennsylvanian sponges from thr Graford Formation, Wise County, Texas". English. In: Journal of Paleontology 82.3 (2008), pp. 492-510.

[19642] J. K. Rigby and M. Mohanti. “The first reported Middle Eocene sponge from India; a Raphidonema from the Fulra Limestone Formation, Kutch, India". English. In: Journal of Paleontology 64.4 (1990), pp. 510-514.

[19643] J. K. Rigby and M. Mohanti. "A new hexactinellid sponge from the Eocene of Kutch, India". English. In: Journal of Paleontology 67.6 (1993), pp. 917-922.

[19644] J. K. Rigby and D. J. C. Mundy. “Lower Carboniferous sponges from the Craven Reef Belt of North Yorkshire". English. In: Proceedings of the Yorkshire Geological Society 53.2 (2000), pp. 119-128.

[19645] J. K. Rigby, J. L. Nelson, and B. S. Norford. "Silurian hexactinellid sponges from northern British Columbia, Canada". English. In: Journal of Paleontology 72.2 (1998), pp. 202-220.

[19646] J. K. Rigby, M. H. Nitecki, C. M. Soja, and R. B. Blodgett. “Silurian aphrosalpingid sphinctozoans from Alaska and Russia". English. In: Acta Palaeontologica Polonica 39.4 (1994), pp. 341-391.

[19647] J. K. Rigby, A. Pisera, T. T. Wrzolek, and G. Racki. “Upper Devonian sponges from the Holy Cross Mountains, central Poland". English. In: Palaeontology 44.3 (2001), pp. 447-488.

[19648] J. K. Rigby, A. W. Potter, and N. K. Anderson. "Ordovician sponges from the Montgomery Limestone, Taylorsville area, northern Sierra Nevada, California, USA". English. In: Bulletin of Geosciences 83.3 (2008), pp. 299-310.

[19649] J. K. Rigby, D. M. Rohr, R. B. Blodgett, and B. B. Britt. "Silurian sponges and some associated fossils from the Heceta Limestone, Prince of Wales Island, Southeastern Alaska". English. In: Journal of Paleontology 82.1 (2008), pp. 91-101.

[19650] J. K. Rigby and B. Senowbari-Daryan. “Upper Permian inozoid, demospongid, and hexactinellid sponges from Djebel Tebaga, Tunisia". In: University of Kansas Paleontological Contributions, New Series 7 (1996), pp. 1-130.

[19651] J. K. Rigby, B. Senowbari-Daryan, and A. Hamedani. "First reported occurrence of wewokellid sponges (Calcarea, Heteractinida) from the Permian of central Iran". English. In: Facies 51 (2005), pp. 533-538.

[19652] J. K. Rigby and B. Senowbari-Daryan. "First hexactinellid sponge reported from the Upper Triassic Nayband Formation of central Iran". English. In: Journal of Paleontology 81.6 (2007), pp. 1538-1542.

[19653] J. K. Rigby and B. Senowbari-Daryan. “Gigantospongia, new genus, the largest known Permian sponge, Capitan Limestone, Guadalupe Mountains, New Mexico". English. In: Journal of Paleontology 70 (1996), pp. 347-355.

[19654] J. K. Rigby and C. C. Smith. "Microscleres of a Paleocene Geodia from western Alabama". English. In: Journal of Paleontology 66.3 (1992), pp. 406-413.

[19655] J. K. Rigby and P. von Bitter. "Sponges and associated fossils from the Pennsylvanian Carbondale Formation of northwestern Illinois". English. In: Journal of Paleontology 79.3 (2005), pp. 460-468. 
[19656] J. K. Rigby, J. A. Waters, C. G. Maples, N. G. Lane, Z. T. Liao, and L. J. Liu. “Hexactinellid and calcareous sponges from the Pennsylvanian (Moscovian) Dikanre Formation from Xinjiang-Uygur Autonomous Region, NW China". English. In: Journal of Paleontology 73.3 (1999), pp. 380-388.

[19657] K. F. Rijsdijk, J. P. Hume, F. Bunnik, F. B. V. Florens, C. Baider, B. Shapiro, J. van der Plicht, A. Janoo, O. Griffiths, L. W. van den Hoek Ostende, H. Cremer, T. Vernimmen, P. G. B. De Louw, A. Bholah, S. Saumtally, N. Porch, J. Haile, M. Buckley, M. Collins, and E. Gittenberger. “Mid-Holocene vertebrate bone Concentration-Lagerstätte on oceanic island Mauritius provides a window into the ecosystem of the dodo (Raphus cucullatus)". English. In: Quaternary Science Reviews 28 (2009), pp. 14-24.

[19658] J. Rikkinen and G. O. Poinar. "A new species of Phyllopsora (Lecanorales, lichen-forming Ascomycota) from Dominican amber, with remarks on the fossil history of lichens". English. In: Journal of Experimental Botany 59.5 (2008), pp. 1007-1011.

[19659] T. R. Riley, J. A. Crame, M. R. A. Thomson, and D. J. Cantrill. “Late Jurassic (KimmeridgianTithonian) macrofossil assemblage from Jason Peninsula, Graham Land: evidence for a significant northward extension of the Latady Formation". In: Antarctic Science 9.4 (1997), pp. 434-442.

[19660] A. D. Rincón. “New remains of Mixotoxodon larensis Van Frank 1957 (Mammalia: Notoungulata) from Mene de Inciarte Tar Pit, north-western Venezuela". English. In: Interciencia 36.12 (2011), pp. 894-899.

[19661] A. D. Rincón, M. T. Alberdi, and J. L. Prado. “Nuevo registro de Equus (Amerhippus) santaeelenae (Mammalia, Perissodactyla) del pozo de asfalto de Inciarte (Pleistoceno Superior), estado Zulia, Venezuela". Spanish. In: Ameghiniana 43.3 (2006), pp. 529-538.

[19662] A. D. Rincón, N. J. Czaplewski, M. Montellano-Ballesteros, and M. Benammi. "New species of Postcopemys (Cricetidae: Rodentia) from the early Pliocene of Lago de Chapala, Jalisco, Mexico". English. In: The Southwestern Naturalist 61.2 (2016), pp. 108-118.

[19663] A. D. Rincón, H. G. McDonald, A. Solórzano, M. Núñez Flores, and D. Ruiz-Ramoni. “A new enigmatic Late Miocene mylodontoid sloth from northern South America". English. In: Royal Society Open Science 2.2 (2015), 140256:1-13. DOI: 10.1098/rsos.140256.

[19664] A. D. Rincón and H. G. McDonald. "Reexamination of the Relationship of Pseudoprepotherium Hoffstetter, 1961, to the Mylodont Ground Sloths (Xenarthra) from the Miocene of Northern South America". English. In: Revista Geológica de América Central 63 (2020), pp. 1-20.

[19665] A. D. Rincón, G. E. Parra, F. J. Prevosti, M. T. Alberdi, and C. J. Bell. "A preliminary assessment of the mammalian fauna from the Pliocene-Pleistocene El Breal de Orocual locality, Monagas state, Venezuela". English. In: Museum of Northern Arizona Bulletin 64 (2009), pp. 593-620.

[19666] A. D. Rincón, F. J. Prevosti, and G. E. Parra. “New saber-toothed cat records (Felidae: Machairodontinae) for the Pleistocene of Venezuela, and the Great American Biotic Interchange". English. In: Journal of Vertebrate Paleontology 31.2 (2011), pp. 468-478. DOI: 10.1080/02724634.2011.550366.

[19667] A. D. Rincón, B. J. Shockey, F. Anaya, and A. Solórzano. “Palaeothentid Marsupials of the Salla Beds of Bolivia (Late Oligocene): Two New Species and Insights into the Post-Eocene Radiation of Palaeothentoids". English. In: Journal of Mammalian Evolution 22.4 (2015), pp. 455-471. DOI: 10. 1007/s10914-015-9295-8.

[19668] A. D. Rincón, A. Solórzano, M. Benammi, P. Vignaud, and H. G. McDonald. "Chronology and geology of an Early Miocene mammalian assemblage in North of South America, from Cerro La Cruz (Castillo Formation), Lara State, Venezuela: implications in the changing course of Orinoco River hypothesis". English. In: Andean Geology 41.3 (2014), pp. 507-528.

[19669] A. D. Rincón, A. Solórzano, H. G. McDonald, and M. Núñez Flores. "Baraguatherium takumara, Gen. et sp. nov., the earliest Mylodontoid Sloth (Early Miocene) from Northern South America". English. In: Journal of Mammalian Evolution 24.2 (2016), pp. 179-191. DOI: 10.1007 / s10914-0169328-y. 
[19670] A. D. Rincon, A. Solorzano, O. Macsotay, H. G. McDonald, and M. Nunez-Flores. "A new Miocene vertebrate assemblage from the Rio Yuca Formation (Venezuela) and the northernmost record of typical Miocene mammals of high latitude (Patagonian) affinities in South America". English. In: Geobios 49 (2016), pp. 395-405. DOI: 10.1016/j.geobios.2016.06.005.

[19671] A. D. Rincón, A. Solórzano, H. G. McDonald, and M. Montellano-Ballesteros. "Two new megalonychid sloths (Mammalia: Xenarthra) from the Urumaco Formation (late Miocene), and their phylogenetic affinities". English. In: Journal of Systematic Palaeontology 17.5 (2019), pp. 409-421. DOI: $10.1080 / 14772019.2018 .1427639$.

[19672] A. D. Rincon and M. Stuccchi. "Premer registro de la familia Pelagornithidae (Aves: Pelecaniformes) para Venezuela". English. In: Boletin Sociedad Venezolana Espeleologica 37 (2003), pp. 2730.

[19673] A. D. Rincón, A. L. Valerio, and C. Laurito. “First fossil record of a Megatheriidae-Megatheriinae in the Early Hemphillian (Late Miocene) from San Gerardo de Limoncito, Curré Formation, Costa Rica". English. In: Revista Geológica de América Central 62 (2020), pp. 1-24.

[19674] A. D. Rincon and R. White. "Los Xenarthra Cingulata del Pleistoceno Tardio (Lujanense) de Cerro Mision, Estado Falcon, Venezuela". Spanish. In: Boletn de la Sociedad Venezolana de Espeleologa 41 (2007), pp. 2-12.

[19675] A. D. Rincón, R. S. White, and H. G. McDonald. "Late Pleistocene cingulates (Mammalia: Xenarthra) from Mene de Inciarte tar pits, Sierra de Perijá, western Venezuela". English. In: Journal of Vertebrate Paleontology 28.1 (2008), pp. 197-207.

[19676] A. F. Rincon, J. I. Bloch, B. J. Macfadden, and C. Jaramillo. "First Central American record of Anthracotheriidae (Mammalia, Bothriodontidae) from the early Miocene of Panama". English. In: Journal of Vertebrate Paleontology 33.2 (2013), pp. 421-433.

[19677] A. F. Rincon, J. I. Bloch, C. Suarez, B. J. MacFadden, and C. A. Jaramillo. “New floridatragulines (Mammalia, Camelidae) from the early Miocene Las Cascadas Formation, Panama". English. In: Journal of Vertebrate Paleontology 32.2 (2012), pp. 456-475.

[19678] A. F. Rincón, J. I. Bloch, B. J. MacFadden, and C. A. Jaramillo. “New early Miocene Protoceratids (Mammalia, Artiodactyla) from Panama". English. In: Journal of Vertebrate Paleontology 35.5 (2015), e970688. DOI: $10.1080 / 02724634.2015 .970688$.

[19679] A. D. Rincón R. “A first record of the Pleistocene saber-toothed cat Smilodon populator Lund, 1842 (Carnivora: Felidae: Machairodontinae) from Venezuela." English. In: Ameghiniana 43.2 (2006), pp. 499-501.

[19680] A. D. Rincón R. “Los Mamferos fósiles del Pleistoceno de la Cueva del Zumbador (Fa. 116), Estado Falcón, Venezuela". Spanish. In: Boletn de la Sociedad Venezolana de Espeleologa 37 (2003), pp. 18-26.

[19681] A. D. Rincón R. “Quirópteros subfósiles presentes en los depósitos de guano de la Cueva de los Murciélagos, Isla de Toas, Estado Zulia, Venezuela". Spanish. In: Anartia 13 (2001), pp. 18-13.

[19682] A. D. Rincón R. “Algunos resultados preliminares de la expedición a Cerro Pintado 1997, Zu.16 Cueva de los Huesos (Sierra de Perijá, Venezuela)". Spanish. In: Boletin de la Sociedad Venezolana de Espeleologa 34 (2000), pp. 44-46.

[19683] A. Rinderknecht and R. E. Blanco. "The largest fossil rodent". English. In: Proceedings of The Royal Society B 275 (2008), pp. 923-928. DOI: 10.1098/rspb.2007.1645.

[19684] A. Rinderknecht, E. Bostelmann, D. Perea, and G. Lecuona. "A new genus and species of Mylodontidae (Mammalia: Xenarthra) from the late Miocene of Southern Uruguay, with comments on the systematics of Mylodontinae". English. In: Journal of Vertebrate Paleontology 30.3 (2010), pp. 899-910. DOI: 10.1080/02724631003757997.

[19685] A. Rinderknecht, E. Bostelmann, and M. Ubilla. “New genus of giant Dinomyidae (Rodentia: Hystricognathi: Caviomorpha) from the late Miocene of Uruguay". English. In: Journal of Mammalogy 92.1 (2011), pp. 169-178. 
[19686] A. Rinderknecht, E. Bostelmann, and M. Ubilla. "Making a giant rodent: cranial anatomy and ontogenetic development in the genus Isostylomeys (Mammalia, Hystricognathi, Dinomyidae)". English. In: Journal of Systematic Palaeontology 16.3 (2018), pp. 245-261. DOI: 10.1080 / 14772019. 2017.1285360.

[19687] A. Rinderknecht, D. Perea, and H. G McDonald. “A New Mylodontinae (Mammalia, Xenarthra) from the Camacho Formation (Late Miocene), Uruguay". English. In: Journal of Vertebrate Paleontology 27.3 (2007), pp. 744-747.

[19688] A. Rinderknecht, M. Ubilla, A. Manzuetti, P. Torino, and D. Perea. "First record of Tetrastylus Ameghino, 1886 (Rodentia; Dinomyidae) from the Upper Miocene of Uruguay". English. In: Revista Brasileira de Paleontologia 22.1 (2019), pp. 30-37. DOI: 10.4072/rbp.2019.1.03.

[19689] A. K. Rindsberg and D. C. Kopaska-Merkel. Treptichnus and Arenicolites from the Steven C. Minkin Paleozoic Footprint Site (Langsettian, Alabama, USA). English. Vol. 1. Alabama Paleontological Society Monograph. 2005, pp. 121-141.

[19690] A. K. Rindsberg and A. J. Martin. "Arthrophycus in the Silurian of Alabama (USA) and the problem of compound trace fossils". English. In: Palaeogeography, Palaeoclimatology, Palaeoecology 192 (2003), pp. 187-219. DOI: 10.1016/S0031-0182(02)00685-5.

[19691] L. F. Rinehart, S. G. Lucas, and A. B. Heckert. An early brachyuran (Malacostraca: Decapoda) from the Upper Triassic Snyder Quarry, Petrified Forest Formation, north-central New Mexico. English. Vol. 24. In K. E. Ziegler, A. B. Heckert, \& S. G. Lucas (eds.), Paleontology and Geology of the Upper Triassic (Revueltian) Snyder Quarry, New Mexico. New Mexico Museum of Natural History and Science Bulletin. 2003, p. 67.

[19692] L. F. Rinehart, S. G. Lucas, A. B. Heckert, J. A. Spielmann, and M. D. Celeskey. "The paleobiology of Coelophysis bauri (Cope) from the Upper Triassic (Apachean) Whitaker quarry, New Mexico, with detailed analysis of a single quarry block". English. In: New Mexico Museum of Natural History and Science Bulletin 45 (2009), pp. 1-260.

[19693] L. F. Rinehart, S. G. Lucas, and J. A. Spielmann. "Bite marks on tetrapod bones from the Upper Triassic Chinle Group representing a new ichnogenus". English. In: vol. 37. The Triassic-Jurassic Terrestrial Transition. New Mexico Museum of Natural History and Science Bulletin. Albuquerque: New Mexico Museum of Natural History and Science, 2006, pp. 160-163.

[19694] L. F. Rinehart, S. G. Lucas, and R. R. Schoch. "Eocyclotosaurus appetolatus, a new cyclotosaurid amphibian from the Middle Triassic (Perovkan) Moenkopi Formation of New Mexico, U.S.A." English. In: Journal of Vertebrate Paleontology 35.3 (2015), e929140. DOI: 10.1080 / 02724634.2014. 929140.

[19695] C. L. Ringor, A. Omura, and Y. Maeda. "Last interglacial sea level changes deduced from coral reef terraces in southwest Bohol, central Philippines". English. In: Quaternary Research 43.6 (2004), pp. 401-416.

[19696] J. P. Rio and P. D. Mannion. "The osteology of the giant snake Gigantophis garstini from the upper Eocene of North Africa and its bearing on the phylogenetic relationships and biogeography of Madtsoiidae". English. In: Journal of Vertebrate Paleontology 37.4 (2017), e1347179:1-20. DOI: 10. 1080/02724634.2017.1347179.

[19697] J. P. Rio, P. D. Mannion, E. Tschopp, J. E. Martin, and M. Delfino. “Reappraisal of the morphology and phylogenetic relationships of the alligatoroid crocodylian Diplocynodon hantoniensis from the late Eocene of the United Kingdom". English. In: Zoological Journal of the Linnean Society 188 (2020), pp. 579-629. DOI: 10.1093/zoolinnean/zlz034/5525732.

[19698] M. Rios, I. M. Sanchez, and J. Morales. "A new giraffid (Mammalia, Ruminantia, Pecora) from the late Miocene of Spain, and the evolution of the sivathere-samothere lineage". English. In: PLoS ONE 12.e0185378 (2017), pp. 1-59. DOI: 10.1371/journal.pone.0185378.

[19699] S. D. Rios Diaz. Una nueva localidad de vertebrados cuaternarios en Puerto Pinasco, Dpto. de Presidente Hayes, Republica del Paraguay. Spanish. 2013. 
[19700] B. Riou. “Lyristes renei, n. sp., cigale fossile du Miocéne ardéchois (Homoptera Cicadidae)". French. In: Travaux de l'École Pratique des Hautes Études, Biologie et Évolution des Insectes $7 / 8$ (1995), pp. $73-$ 76.

[19701] B. Riou and A. Nel. “Nouveaux Odonates fossiles du Miocéne supérieur de l'Ardéche (Odonata: Sieblosiidae, Lestidae, Libellulidae, Corduliidae et Aeshnidae)". French. In: Travaux de l'École Pratique des Hautes Études, Biologie et Évolution des Insectes 7/8 (1995), pp. 125-144.

[19702] F. Riquelme, J. Alvarado-Ortega, M. Ramos-Aria, M. Hernández, I. Le Dez, T. A. Lee-Whiting, and J. L. Ruvalcaba-Sil. "A fossil stemmiulid millipede (Diplopoda: Stemmiulida) from the Miocene amber of Simojovel, Chiapas, Mexico". English. In: Historical Biology 26 (2014), pp. 415-427.

[19703] F. Riquelme, M. Hernández-Patricio, A. Martnez-Dávalos, M. Rodrguez-Villafuerte, M. MontejoCruz, J. Alvarado-Ortega, J. L. Ruvalacaba-Sil, and L. Zúñiga-Mijangos. "Two flat-backed polydesmidan millipedes from the Miocene Chiapas-amber Lagerstätte, Mexico". English. In: PLoS One 9.8 (2014), e105877.

[19704] F. Riquelme and M. Hernández-Patricio. "The millipedes and centipedes of Chiapas amber". English. In: Check List 14.4 (2018), pp. 637-646.

[19705] F. Riquelme and M. Menéndez-Acuña. “Miocene spider Maevia eureka nov. sp. (Araneae: Salticidae)". English. In: PeerJ 5.e3614 (2017), pp. 1-15.

[19706] F. Riquelme, M. Montejo-Cruz, B. Luna-Castro, and L. Zuñiga-Mijangos. “Fossil jumping-bristletail from the Chiapas amber: Neomachilellus (Praeneomachilellus) ezetaelenensis sp. nov. (Microcoryphia: Meinertellidae)". English. In: Neues Jahrbuch für Geologie und Paläontologie, Abhandlungen 275 (2015), pp. 93-106.

[19707] F. Riquelme, D. F. Piedra-Jiménez, V. Córdova-Tabares, and B. Luna-Castro. "A new chernetid pseudoscorpion from the Miocene Chiapas - amber Lagerstätte, Mexico". English. In: Canadian Journal of Earth Sciences 51 (2014), pp. 902-908.

[19708] F. Riquelme, G. Villegas-Guzmán, E. González-Santillán, V. Córdova-Tabares, O. F. Francke, D. Piedra-Jiménez, E. Estrada-Ruiz, and B. Luna-Castro. "New fossil scorpion from the Chiapas amber lagerstätte". English. In: PLoS One 10.8 (2015), e0133396.

[19709] J. Ristevski, A. M. Yates, G. J. Price, R. E. Molnar, V. Weisbecker, and S. W. Salisbury. “Australia's prehistoric 'swamp king': revision of the Plio-Pleistocene crocodylian genus Pallimnarchus de Vis, 1886". English. In: PeerJ 8 (2020), e10466:1-98. DOI: 10.7717/peerj.10466.

[19710] J. Ristevski, M. T. Young, M. B. de Andrade, and A. K. Hastings. “A new species of Anteophthalmosuchus (Crocodylomorpha, Goniopholididae) from the Lower Cretaceous of the Isle of Wight, United Kingdom, and a review of the genus". English. In: Cretaceous Research 84 (2018), pp. 340 383.

[19711] A. Ritchie and G. D. Edgecombe. "An odontogriphid from the Upper Permian of Australia". English. In: Palaeontology 44.5 (2001), pp. 861-874.

[19712] S. M. Ritter and T. H. Morris. "Oldest and lowest latitudinal occurence of Palaeoaplysina: Middle Pennsylvanian Ely Limestone, Burbank Hills, Utah". English. In: Palaios 12.4 (1997), pp. 397-401.

[19713] M. M. Rivadeneira and E. R. Carmona. "A Late Pleistocene macrobenthic assemblage in Caleta Patillos, northern Chile: paleoecological and paleobiogeographical interpretations". English. In: Revista Geologica de Chile 35.1 (2008), pp. 163-173.

[19714] H. Rivera-Sylva, E. Frey, F. J. Palomino-Sánchez, J. R. Guzmán-Gutiérrez, and J. A. Oritz-Mendieta. "Preliminary report on a Late Cretaceous vertebrate fossil assemblage in northwestern Coahuila, Mexico". English. In: Boletn de la Sociedad Geológica Mexicana 61.2 (2009), pp. 239-244.

[19715] H. E. Rivera-Sylva, G. Carbot-Chanona, R. Vivas-González, L. Nava-Rodrguez, and F. CabralValdéz. "The first crocodyliforms remains from La Parrita locality, Cerro del Pueblo Formation (Campanian), Coahuila, Mexico". English. In: Boletn de la Sociedad Geológica Mexicana 71.3 (2019), pp. 727-739. 
[19716] H. E. Rivera-Sylva, K. Carpenter, and F. J. Aranda-Manteca. "Late Cretaceous nodosaurids (Ankylosauria: Ornithischia) from Mexico". English. In: Revista Mexicana de Ciencias Geológicas 28.3 (2011), pp. 371-378.

[19717] H. E. Rivera-Sylva and L. Espinosa-Arrubarrena. "Remains of a diplodocid (Sauropoda: Flagellicaudata) from the Otlaltepec Formation Middle Jurassic (Bathonian-Callovian) from Puebla, Mexico". English. In: Paleontologa Mexicana 9.2 (2020), pp. 145-150.

[19718] H. E. Rivera-Sylva and B. Espinosa-Chávez. "Ankylosaurid (Dinosauria: Thyreophora) osteoderms from the Upper Cretaceous Cerro de Pueblo Formation of Coahuila, Mexico". English. In: Carnets de Géologie/Notebooks on Geology Letter.2006/02 (2006), pp. 1-5.

[19719] H. E. Rivera-Sylva, E. Frey, J. R. Guzmán-Gutiérrez, F. Palomino-Sánchez, and W. Stinnesbeck. “A Deinosuchus riograndensis (Eusuchia: Alligatoroidea) from Coahuila, North Mexico". English. In: Revista Mexicana de Ciencias Geológicas 28.2 (2011), pp. 267-274.

[19720] H. E. Rivera-Sylva, E. Frey, W. Stinnesbeck, G. Carbot-Chanona, I. E. Sanchez-Uribe, and J. R. Guzman-Gutierrez. "Paleodiversity of Late Cretaceous Ankylosauria from Mexico and their". English. In: Swiss Journal of Palaeontology 137.1 (2018), pp. 83-93.

[19721] H. E. Rivera-Sylva, E. Frey, W. Stinnesbeckc, J. R. Guzmán-Gutiérrez, and A. H. González-González. "Mexican ceratopsids: considerations on their diversity and biogeography". English. In: Journal of South American Earth Sciences 75 (2017), pp. 66-73.

[19722] H. E. Rivera-Sylva, E. D. Frey, A. S. Schulp, C. A. Meyer, B. Thüring, W. Stinnesbeck, and V. Vanhecke. "Late Campanian theropod trackways from Porvenir de Jalpa, Coahuila, Mexico". English. In: Palaeovertebrata 41.2 (2018), e1:1-6.

[19723] H. E. Rivera-Sylva, R. Rodrguez-de la Rosa, and J. A. Ortiz-Mendieta. A review of the dinosaurian record from Mexico. English. Vol. 24. Studies on Mexican Paleontology; Topics in Geobiology. 2006, pp. 233-248.

[19724] M. Rivero and O. Arredondo. "Paralouatta varonai, a new Quaternary platyrrhine from Cuba". English. In: Journal of Human Evolution 21 (1991), pp. 1-11.

[19725] Y. Rizal, Y. Zaim, and Y. Iriani. "Preliminary study of Late Tertiary fossil whale from Surade, South Sukabumi- West Jawa". English. In: Bulletin Geologi 37.1 (2005), pp. 29-34.

[19726] A. Rõõmusoks. “Ordovician strophomenoid brachiopods of northern Estonia". English. In: Fossilia Baltica 3 (2004), pp. 1-150.

[19727] A. Rõõmusoks. "Trilobites of the Genus Toxochasmops from the Ordovician of Estonia". English. In: Proceedings of the Estonian Academy of Sciences, Geology 47.3 (1998), pp. 173-194.

[19728] A. J. Robert, P. S. Druckenmiller, G. -P. Saetre, and J. H. Hurum. “A new Upper Jurassic ophthalmosaurid ichthyosaur from the Slottsmøya Member, Agardhfjellet Formation of central Spitsbergen". English. In: PLoS One 9.8 (2014), pp. 1-24. DOI: 10.1371/journal.pone.0103152.

[19729] E. Robert and L. G. Bulot. "Albian ammonite faunas from Peru: The genus Neodeshaesites Casey, 1964". English. In: Journal of Paleontology 79.3 (2005), pp. 611-618.

[19730] E. Robert, J.-L. Latil, and L. G. Bulot. "Albian ammonite faunas from South America : the genus Tegoceras Hyatt, 1903". English. In: Revue de Paléobiologie 28.1 (2009), pp. 43-51.

[19731] E. Robert, A. Samaniego-Pesqueira, J. A. Moreno-Bedmar, and C. M. González-León. “Aptian and Albian (Early Cretaceous) ammonites from Lampazos and the Bisbee groups (Sonora State, northwest Mexico)". English. In: Cretaceous Research 86 (2018), pp. 1-23.

[19732] L. Roberto-da-Silva, J. B. Desojo, S. F. Cabreira, A. S. S. Aires, R. T. Mueller, C. P. Pacheco, and S. Dias-da-Silva. "A new aetosaur from the Upper Triassic of the Santa Maria Formation, southern Brazil". English. In: Zootaxa 3764.3 (2014), pp. 240-278.

[19733] A. J. Roberts, P. S. Druckenmiller, B. Cordonnier, L. L. Delsett, and J. H. Hurum. "A new plesiosaurian from the Jurassic-Cretaceous transitional interval of the Slottsmøya Member (Volgian), with insights into the cranial anatomy of cryptoclidids using computed tomography". English. In: PeerJ 8 (2020), e8652. DOI: 10.7717 / peerj. 8652. 
[19734] E. M. Roberts, R. R. Rogers, and B. Z. Foreman. “Continental insect borings in dinosaur bone: examples from the Late Cretaceous of Madagascar and Utah". English. In: Journal of Paleontology 81.1 (2007), pp. 201-208.

[19735] J. Roberts and P. A. Jell. “Early Middle Cambrian (Ordian) Brachiopods of the Coonigan Formation, Western New-South-Wales". English. In: Alcheringa 14.3-4 (1990), pp. 257-309.

[19736] K. Roberts, M. Bassarova, and M. Archer. “Oligo-Miocene ringtail possums of the genus Paljara (Pseudocheiridae: Marsupialia) from Queensland, Australia". English. In: Geobios 41.6 (2008), pp. 833-844.

[19737] K. K. Roberts, M. Archer, S. J. Hand, and H. Godthelp. “New genus and species of extinct Miocene ringtail possums (Marsupialia: Pseudocheiridae)". English. In: American Museum Novitates 3560 (2007), pp. 1-15.

[19738] R. G. Roberts. “Thermoluminescence dating of a 50,000-year-old human occupation site in northern Australia". English. In: Nature 345.6271 (1990), pp. 153-156.

[19739] N. Robin, O. Béthoux, E. Sidorchuk, Y. Y. Cui, Y. N. Li, D. Germain, A. King, F. Berenguer, and D. Ren. "A Carboniferous mite on an insect reveals the antiquity of an inconspicuous interaction". English. In: Current Biology 26 (2016), pp. 1376-1382.

[19740] N. Robin, C. D'Haese, and P. Barden. "Fossil amber reveals springtails' longstanding dispersal by social insects". English. In: BMC Evolutionary Biology 19.213 (2019). DOI: 10.1186/s12862-019-15296.

[19741] N. Robin, B. W. M. Van Bakel, M. M. Blanc-Valleron, P. Y. Noël, L. Lemaire, and S. Charbonnier. "First fossil crabs (Crustacea, Decapoda, Brachyura) from the Kerguelen Islands (Miocene) with exceptionally preserved gills". English. In: Journal of Paleontology 92 (2018), pp. 466-477.

[19742] C. Robinet, J. A. Remy, Y. Laurent, L. Danilo, and F. Lihoreau. “A new genus of Lophiodontidae (Perissodactyla, Mammalia) from the early Eocene of La Borie (Southern France) and the origin of the genus Lophiodon Cuvier, 1822". English. In: Geobios 48 (2015), pp. 25-38.

[19743] C. Robins, C. E. Schweitzer, and R. M. Feldmann. “The Oldest Munididae (Decapoda: Anomura: Galatheoidea) from Ernstbrunn, Austria (Tithonian)". English. In: Annals of Natural History Museum (2012), pp. 289-300.

[19744] C. M. Robins, R. M. Feldmann, and C. E. Schweitzer. "Nine new genera and 24 new species of the Munidosidae (Decapoda: Anomura: Galatheoidea) from the Jurassic Ernstbrunn Limestone of Austria, and notes on fossil numidopsid classification". English. In: Annals of Natural History Museum A (2013), pp. 115-251.

[19745] C. M. Robins, R. M. Feldmann, and C. E. Schweitzer. "Clarification of the South American genus Austromunida Schweitzer \& Feldmann, 2000 (Crustacea: Decapoda: Anomura), with the establishment of a new species". English. In: Annalen des Naturhistorischen Museums in Wien, Serie A 114 (2012), pp. 301-306.

[19746] J. H. Robinson. "Early Miocene brachiopods of the Waitemata and Waitakere groups, Auckland". English. In: New Zealand Journal of Geology and Geophysics 60 (2017), pp. 2-22.

[19747] J. H. Robinson and D. E. Lee. "A shallow, warm-water calcitic molluscan fauna from an Early Oligocene seamount, North Otago, New Zealand". English. In: New Zealand Journal of Geology and Geophysics 54.1 (2011), pp. 135-147. DOI: 10.1080/00288306.2011.537612.

[19748] J. L. Robinson, M. J. Thomas, and S. W. Heads. "A fossil caddisfly (Insecta: Trichoptera) from the Eocene of Colorado". English. In: Zootaxa 4403 (2018), pp. 389-394.

[19749] P. Robinson. "Myrmekomomys, a new genus of Micromomyine (Mammalia, ?Microsyopidae) from the lower Eocene rocks of the Powder River Basin, Wyoming". English. In: Contributions to Geology, University of Wyoming 30.1 (1994), pp. 85-90.

[19750] P. Robinson and L. D. Ivy. "Paromomyidae (?Dermoptera) from the Powder River Basin, Wyoming and a discussion of microevolution in closely related species". English. In: Contributions to Geology, University of Wyoming 30.1 (1994), pp. 91-116. 
[19751] P. Robinson and D. G. Kron. "Koniaryctes, a new genus of apternodontid insectivore from lower Eocene rocks of the Powder River basin, Wyoming". English. In: Contributions to Geology, University of Wyoming 32.2 (1998), pp. 187-190.

[19752] P. Robinson and B. A. Williams. "Species diversity, tooth size, and shape of Haplomylus (Condylarthra, Hyopsodontidae) from the Powder River Basin, northeastern Wyoming". English. In: Contributions to Geology, University of Wyoming 31.2 (1997), pp. 59-78.

[19753] R. A. Robison. "Revision of the middle Cambrian trilobite Agnostus acadicus Hartt". English. In: Journal of Paleontology 69.2 (1995), pp. 302-307.

[19754] J. M. Robles, D. M. Alba, S. Moya-Sola, I. Casanovas-Vilar, J. Galindo, C. Rotgers, S. Almecija, and R. Carmona. "New craniodental remains of Trocharion Albanense Major, 1903 (Carnivora, Mustelidae), from the Vallés-Penedés Basin (middle to late Miocene, Barcelona, Spain)". English. In: Journal of Vertebrate Paleontology 30.2 (2010), pp. 547-562.

[19755] S. P. Robson and B. R. Pratt. "Cambrian and Ordovician linguliform brachiopods from the Shallow Bay Formation (Cow Heard Group), Western Newfoundland". In: Journal of Paleontology 75.2 (2001), pp. 241-260.

[19756] S. P. Robson and G. A. Young. "Late Ordovician conulariids from Manitoba, Canada". English. In: Journal of Paleontology 87.5 (2013), pp. 775-785. DOI: 10.1666/12-0370.

[19757] S. V. Robson, N. A. Famoso, E. B. Davis, and S. S. B. Hopkins. "First mesonychid from the Clarno Formation (Eocene) of Oregon, USA". English. In: Palaeontologia Electronica 22.2 (2019), 35:1-13.

[19758] S. P. Robson, G. S. Nowlan, and B. R. Pratt. "Middle to Upper Cambrian linguliformean brachiopods from the Deadwood Formation of subsurface Alberta and Saskatchewan, Canada". In: Journal of Paleontology 77.2 (2003), pp. 201-211.

[19759] Z. Roec and L. A. Nessov. "Cretaceous anurans from Central Asia”. English. In: Palaeontographica Abteilung A 226 (1993), pp. 1-54.

[19760] Z. Roek. "A new specimen of Eopelobates (Anura: Pelobatidae) from the Tertiary near Bonn (Germany) and the problem of E. anthracinus- E. bayeri relations". English. In: Paläontologische Zeitschrift 69.1-2 (1995), pp. 283-287.

[19761] Z. Roek. “The Late Cretaceous frog Gobiates from Central Asia: its evolutionary status and possible phylogenetic relationships". English. In: Cretaceous Research 29 (2008), pp. 577-591.

[19762] L. S. G. Rocha, T. O. Burt, C. A. de Mello-Patiu, and J. H. Skevington. "The first Stylogaster Macquart, 1835 (Diptera: Conopidae) fossil, from Oligo-Miocene Dominican amber, and some phylogenetic and biogeographic considerations". English. In: Fossil Record 18 (2015), pp. 119-125.

[19763] R. C. Roche, C. T. Perry, K. G. Johnson, K. Sultana, S. G. Smithers, and A. A. Thompson. “MidHolocene coral community data as baselines for understanding contemporary reef ecological states". English. In: Palaeogeography, Palaeoclimatology, Palaeoecology 299 (2011), pp. 159-167.

[19764] P. U. Rodda, M. A. Murphy, and C. Schuchman. “The nautilid Eucymatoceras (Mollusca: Cephalopoda) in the Lower Cretaceous of northern California". English. In: The Veliger 36 (1993), pp. 265-269.

[19765] P. U. Rodda and M. A. Murphy. "Two occurrences of the genus Pictetia (Early Cretaceous, Albian, Ammonoidea) in California". English. In: Journal of Paleontology 66.3 (1992), pp. 435-439. DOI: 10. 1017/S0022336000033989.

[19766] A. L. Rode and B. S. Lieberman. "Using GIS to unlock the interactions between biogeography, environment, and evolution in middle and Late Devonian brachiopods and bivalves". English. In: Palaeogeography, Palaeoclimatology, Palaeoecology 211.3-4 (2004), pp. 345-359.

[19767] A. L. Rode, B. S. Lieberman, and A. J. Rowell. "A new Early Cambrian bradoriid (Arthropoda) from East Antarctica". In: Journal of Paleontology 77.4 (2003), pp. 691-697.

[19768] A. S. L. Rodrigues, A. Charpentier, D. Bernal-Casasola, A. Gardeisen, C. Nores, J. A. Pis Millán, K. McGrath, and C. F. Speller. "Forgotten Mediterranean calving grounds of grey and North Atlantic right whales: evidence from Roman archaeological records". English. In: Proceedings of the Royal Society B 285.20180961 (2018), pp. 1-9. DOI: 10.1098/rspb.2018.0961. 
[19769] P. Rodrigues, B. Ferigolo, and J. Ferigolo. “Osteopatologias e alteracoes dentarias em Otaria byronia (Pinnipedia, Otariidae) de costa do Rio Grande do Sul, Brasil". Portugese. In: Iheringia, Serie Zoologia 94.2 (2004), pp. 117-122.

[19770] P. H. Rodrigues, F. J. Prevosti, J. Ferigolo, and A. M. Ribeiro. “Novos materials de Carnivora para o Pleistoceno do estado do Rio Grande do Sul, Brasil. New Pleistocene Carnivora data from Rio Grande do Sul State, Brazil". Portugese. In: Revista Brasileira de Paleontologia 7.1 (2004), pp. 77-86.

[19771] T. Rodrigues, S. Jiang, X. Cheng, X. Wang, and A. W. A. Kellner. "A new toothed pteranodontoid (Pterosauria, Pterodactyloidea) from the Jiufotang Formation (Lower Cretaceous, Aptian) of China and comments on Liaoningopterus gui Wang and Zhou, 2003". English. In: Historical Biology 27.6 (2015), pp. 782-795.

[19772] T. Rodrigues and A. W. A. Kellner. "Note on the pterosaur material described by Woodward from the Reconcavo Basin, Lower Cretaceous, Brazil". English. In: Revista Brasileira de Paleontologia 13.2 (2010), pp. 159-164. DOI: 10.4072/rbp.2010.2.08.

[19773] T. Rodrigues and A. W. A. Kellner. "New pterosaur specimens from the Kem Kem beds (Upper Cretaceous, Cenomanian) of Morocco". English. In: Revista Italiana di Paleontologia e Stratigrafia 117.1 (2011), pp. 149-160.

[19774] T. Rodrigues and A. W. A. Kellner. “Taxonomic review of the Ornithocheirus complex (Pterosauria) from the Cretaceous of England". English. In: ZooKeys 308 (2013), pp. 1-112. DOI: 10.3897/ zookeys. 308.5559 .

[19775] J. Rodriguez, C. Waichert, C. D. Von Dohlen, G. Poinar, and J. P. Pitts. “Eocene and not Cretaceous origin of spider wasps: fossil evidence from amber". English. In: Acta Palaeontologica Polonica 61 (2016), pp. 89-96.

[19776] J. Rodriguez, C. Waichert, C. D. von Dohlen, and J. P. Pitts. “The geological record and phylogeny of spider wasps (Hymenoptera: Pompilidae): A revision of fossil species and their phylogenetic placement". English. In: PLoS One 12.10 (2017), e0185379.

[19777] S. Rodriguez. "Development of coral reef-facies during the Visean at Los Santos de Maimona, SW Spain". English. In: Geological Society Special Publication 107 (1996), pp. 145-152.

[19778] S. Rodrguez, M. E. Arribas, S. Falces, E. Moreno-Eiris, and J. A. de la Pena. "The Siphonodendron Limestone of the Los Santos de Maimona Basin: development of an extensive reef-flat during the Visean in Ossa Morena, SW Spain". English. In: Courier Forschungsinstitut Senckenberg 172 (1994), pp. 203-214.

[19779] S. Rodriguez and J. M. Hernando. “Description of Espielia columellata gen. and sp. nov. (Rugosa) from the Sierra del Castillo Unit (upper Visean, Cordoba, SW Spain)". English. In: Geobios 38 (2005), pp. 553-561.

[19780] S. G. Rodriguez, L. H. Soibelzon, S. Rodrigues, C. C. Morgan, C. Bernardes, L. Avilla, and E. Lynch. "First record of Procyon cancrivorus (G. Cuvier, 1798) (Carnivora, Procyonidae) in stratigraphic context in the Late Pleistocene of Brazil". English. In: Journal of South American Earth Sciences 45 (2013), pp. 1-5.

[19781] R. Rodrguez Brizuela and A. F. Taube. "Estratigrafa y mamferos fósiles de la Formación Toro Negro (Neógeno), Departamento Vinchina, noroeste de la provincia de La Rioja, Argentina". English. In: Ameghiniana 43.2 (2006), pp. 257-262.

[19782] R. Rodrguez-Cañero, A. Martn-Algarra, G. N. Sarmiento, and P. Navas-Parejo. “First Late Ordovician conodont fauna in the Betic Cordillera". English. In: Tera Nova 22.5 (2010), pp. 330-340. DOI: 10.1111/j.1365-3121.2010.00954.x.

[19783] R. A. Rodriguez-de la Rosa. Pterosaur tracks from the latest Campanian Cerro del Pueblo Formation of southeastern Coahuila, Mexico. English. Vol. 217. Evolution and Palaeobiology of Pterosaurs. Geological Society, London, Special Publications. 2003, pp. 275-282.

[19784] R. A. Rodrguez-de la Rosa, M. C. Aguillón-Martnez, and J. López-Espinoza. “The fossil record of vertebrate tracks in Mexico". English. In: Ichnos 11 (2004), pp. 27-37. 
[19785] R. A. Rodriguez-de la Rosa and S. R. S. Cevallos-Ferriz. "Vertebrates of the El Pelillal locality (Campanian, Cerro del Pueblo Formation), southeastern Coahuila, Mexico". English. In: Journal of Vertebrate Paleontology 18.4 (1998), pp. 751-764.

[19786] R. A. Rodriguez-de la Rosa and S. R. S. Cevallos-Ferriz. "Upper Cretaceous Zingiberalean fruits with in situ seeds from Southeastern Coahuila, Mexico". English. In: International Journal of Plant Sciences 155.6 (1994), pp. 786-805.

[19787] R. A. Rodrguez-de la Rosa, J. R. Guzmán-Guitérrez, and C. Ortega-Hurtado de Mendoza. “A new occurrence of Toxodonts in the Pleistocene of México". English. In: Current Research in the Pleistocene 28 (2011), pp. 29-30.

[19788] M. Rodriguez-Martinez, R. Cózar, R. Mas, and S. Rodriguez. Upper Viséan Saccamminopsis-sponge microbial mud mounds, Sierra de la Estrella, southwestern Spain. English. Vol. 78. Permo-Carboniferous carbonate platforms and reefs. SEPM Special Publication. 2003, pp. 189-200.

[19789] R. Rodriguez-Canero and A. Martin-Algarra. "Frasnian-Famennian crisis in the Malaguide Complex (Betic". English. In: Terra Nova (2013). DOI: 10.1111/ter.12068.

[19790] L. J. Roe. "Phylogenetic and ecological significance of Channidae (Osteichthyes, Teleostei) from the early Eocene Kuldana Formation of Kohat, Pakistan". English. In: Contributions from the Museum of Paleontology, University of Michigan 28.5 (1991), pp. 93-100.

[19791] M. A. Roeder. "A fossil fish fauna from the Upper Eocene Mission Valley Formation at the Lake Miramar Filtration Plant, San Diego, San Diego County, California". English. In: Pacific section SEPM 68 (1991), pp. 179-180.

[19792] H. W. Roehler. "Revised stratigraphic nomenclature for the Wasatch and Green River formations of Eocene age, Wyoming, Utah, and Colorado". English. In: United States Geological Survey Professional Paper 1506-B (1991), B1-B38.

[19793] H. W. Roehler. "Godiva Rim Member; a new stratigraphic unit of the Green River Formation in Southwest Wyoming and Northwest Colorado". English. In: United States Geological Survey Professional Paper 1506-C (1991), pp. C1-C17.

[19794] J. Rofes, P. Bover, G. Cuenca-Bescós, and J. A. Alcover. "Nesiotites rafelinensis sp. nov., the earliest shrew (Mammalia, Soricidae) from the Balearic Islands, Spain". English. In: Palaeontologia Electronica 15.1;8A (2012), pp. 1-12.

[19795] N. S. Rogalla and M. R. W. Amler. "Revision der Familie Pseudobigaleaidae Hoare, Mapes \& Yancey, 2002 (Mollusca; Rostroconchia)". German. In: Paläontologische Zeitschrift 80.2 (2006), pp. 167208.

[19796] N. S. Rogalla and M. R. W. Amler. "Revision der Familie Hippocardiidae Pojeta \& Runnegar, 1976 (Mollusca, Rostroconchia)". German. In: Paläontologische Zeitschrift 80.3 (2006), pp. 238-276.

[19797] S. Roger, Ph. Munich, J. J. Cornee, J. P. Saint Martin, G. Feraud, S. Pestrea, G. Conesa, and A. Ben Moussa. "40Ar/39Ar dating of the pre-evaporitic Messinian marine sequences of the Melilla Basin (Morocco); a proposal for some biosedimentary events as isochrons around the Alboran Sea". In: Earth and Planetary Science Letters 179 (2000), pp. 101-113.

[19798] K. L. Rogers, C. A. Repenning, F. G. Luiszer, and R. D. Benson. “Geologic history, stratigraphy, and paleontology of SAM Cave, north-central New Mexico". English. In: New Mexico Geology 22.4 (2000), pp. 89-117.

[19799] R. R. Rogers. Taphonomy of three dinosaur bone beds in the Upper Cretaceous Two Medicine Formation of Northwestern Monana: evidence for drought-related mortality. 1991.

[19800] R. R. Rogers. "Non-marine borings in dinosaur bones from the Upper Cretaceous Two Medicine Formation, northwestern Montana". In: Journal of Vertebrate Paleontology 12.4 (1992), pp. 527-531.

[19801] R. R. Rogers, A. B. Arcucci, F. Abdala, P. C. Sereno, C. A. Forster, and C. L. May. "Paleoenvironment and taphonomy of the Chanares Formation tetrapod assemblage (Middle Triassic), northwestern Argentina: spectacular preservation in volcanogenic concretions". English. In: Palaios 16 (2001), pp. 461-481. 
[19802] R. R. Rogers, D. W. Krause, and K. Curry Rogers. "Cannibalism in the Madagascan dinosaur Majungatholus atopus". In: Nature 422 (2003), pp. 515-518.

[19803] R. R. Rogers, D. W. Krause, K. Curry Rogers, A. H. Rasoamiaramanana, and L. Rahantarisoa. “Paleoenvironment and paleoecology of Majungasaurus crenatissimus (Theropoda: Abelisauridae) from the Late Cretaceous of Madagascar". English. In: In S. D. Sampson \& D. W. Krause (eds.), Majungasaurus crenatissimus (Theropoda: Abelisauridae) from the Late Cretaceous of Madagascar. Society of Vertebrate Paleontology Memoir 8. Journal of Vertebrate Paleontology 27.2, suppl. (2007), pp. 21-31.

[19804] R. R. Rogers, D. W. Krause, S. C. Kast, M. S. Marshall, L. Rahantarisoa, C. R. Robins, and J. J. W. Sertich. "A new, richly fossiliferous member comprised of tidal deposits in the Upper Cretaceous Maevarano Formation, northwestern Madagascar". English. In: Cretaceous Research 44 (2013), pp. 12 29.

[19805] J. V. I. I. Rogers. "Pachycheilosuchus trinquei, a new procoelous crocodyliform from the Lower Cretaceous (Albian) Glen Rose Formation of Texas". English. In: Journal of Vertebrate Paleontology 23.1 (2003), pp. 128-145.

[19806] J. V. I. I. Rogers. “A complete crocodiloid egg from the Lower Cretaceous (Albian) Glen Rose Formation, central Texas". English. In: Journal of Vertebrate Paleontology 20.4 (2000), pp. 780-783.

[19807] G. Roghi, E. Kustatscher, and J. H. A. Van Konijnenburg-van Cittert. "Late Triassic Plants from the Julian Alps (Italy)". English. In: Bollettino della Scietá Paleontologica Italiana 45.1 (2006), pp. 133-140.

[19808] M. A. Rogov, A. A. Mironenko, A. V. Guzhov, E. M. Tesakova, M. A. Ustinova, Y. A. Shurupova, N. G. Zverkov, M. S. Archangelsky, A. S. Shmakov, and E. E. Baraboshkin. "Jurassic deposits of the southern part of the Moscow syneclyse and their fauna". English. In: Transactions of the Geological Institute (2017).

[19809] M. A. Rogov, A. Wierzbowski, and E. Shchepetova. "Ammonite assemblages in the Lower to Upper Kimmeridgian boundary interval (Cymodoce to Mutabilis zones) of Tatarstan (central European Russia) and their correlation importance". English. In: Neues Jahrbuch für Geologie und Paläontologie 285.2 (2017), pp. 161-185.

[19810] J. Roháek. "Reliquantha eocena sp. nov., first Tertiary representative of an extant genus of Anthomyzidae (Diptera)". English. In: Acta Entomologica Musei Nationalis Pragae 54 (2014), pp. 773784.

[19811] J. Roháek. “New amber fossil Anthomyzidae (Diptera): an unexpected Eocene diversity". English. In: Journal of Systematic Palaeontology 11 (2013), pp. 431-473.

[19812] J. Rohacek. "The second species of Acartophthalmites from Baltic amber (Eocene), with notes on the relationships of the genus (Diptera: Acalyptrata)". English. In: Acta Entomologica Musei Nationalis Pragae 56 (2016), pp. 409-422.

[19813] J. Roháek. "Protanthomyza grimaldii sp. nov., a further member of the extinct subfamily Protanthomyzinae (Diptera, Anthomyzidae) from Baltic amber". English. In: ZooKeys 973 (2020), pp. 115. DOI: 10.3897 / zookeys.973.51435.

[19814] J. Roháek. “Taxonomic limits, phylogeny and higher classification of Anthomyzidae (Diptera), with species regard to fossil record". English. In: European Journal of Entomology 95 (1998), pp. 141177.

[19815] U. Röhl, T. Dumont, U. von Rad, R. Martini, and L. Zaninetti. “Upper Triassic Tethyan Carbonates off Northwest Australia (Wombat Plateau, ODP Leg 122)". English. In: Facies 25 (1991), pp. 211252. DOI: $10.1007 /$ BF02536760.

[19816] D. M. Rohr. "Middle Ordovician carrier shell Lytospira (Mollusca, Gastropoda) from Alaska". English. In: Journal of Paleontology 67.6 (1993), pp. 959-962.

[19817] D. M. Rohr. “Ordovician (Whiterockian) gastropods of Nevada, Part 2". English. In: Journal of Paleontology 70.1 (1996), pp. 56-63.

[19818] D. M. Rohr. “Ordovician (Whiterockian) gastropods of Nevada: Bellerophontoidea, Macluritoidea, Euomphaloidea". English. In: Journal of Paleontology 68.3 (1994), pp. 473-486. 
[19819] D. M. Rohr, R. B. Blodgett, and W. M. Furnish. "Maclurina manitobensis (Whiteaves) (Ordovician Gastropoda): The largest known Paleozoic gastropod". English. In: Journal of Paleontology 66.6 (1992), pp. 880-884.

[19820] D. M. Rohr, R. B. Blodgett, and J. Frýda. "New Silurian muchisoniid gastropods from Alaska and a review of the genus Coelocaulus". English. In: Short notes on Alaska geology 2003, Division of Geological and Geophysical Surveys Professional Report 120 (2003), pp. 88-93.

[19821] D. M. Rohr and R. B. Blodgett. "Palliseria (Middle Ordovician Gastropoda) from east-central Alaska and its stratigraphic and biogeographic significance". English. In: Journal of Paleontology 68.3 (1994), pp. 674-675.

[19822] D. M. Rohr, R. B. Blodgett, and J. Frýda. "Silurian Gastropoda from Southeastern and West-Central Alaska". English. In: Journal of Paleontology 82.3 (2008), pp. 604-611.

[19823] D. M. Rohr and R. B. Blodgett. "Silurian Gastropoda from the Alexander terrane, southeast Alaska". English. In: Geological Society of America Special Paper 442 (2008), pp. 51-61. DOI: 10.1130 / 2008. 442(03).

[19824] D. M. Rohr, R. B. Blodgett, and J. Baichtal. "Scaphopoda from the Alexander Terrane, Southeast Alaska: The first occurrence of Scaphopoda in the Silurian". English. In: Palaeoworld 15 (2006), pp. 211-215.

[19825] D. M. Rohr, W. D. Boyce, and E. A. Measures. "The Middle Ordovician mollusk Archinacella from the Table Point Formation (Table Head Group), western Newfoundland". English. In: Newfoundland Department of Mines and Energy, Report 08.1 (2008), pp. 93-99.

[19826] D. M. Rohr, W. D. Boyce, and E. A. Measures. “The rostroconch mollusc Euchasma Billings, 1865 from the Lower Ordovician Catoche Formation, western Newfoundland". English. In: Newfoundland Department of Mines and Energy, Report 08.1 (2008), pp. 79-91.

[19827] D. M. Rohr, W. D. Boyce, and I. Knight. "Ordovician gastropods from Western Newfoundland". English. In: Current Research (2003) Newfoundland Department of Mines and Energy Geological Survey 2003 (2003), pp. 127-136.

[19828] D. M. Rohr, M. Fix, and G. Darrough. "Life association of shell and operculum of Ceratopea Ulrich 1911 (Ordovician; Gastropoda)". English. In: Journal of Paleontology 78.1 (2004), pp. 218-220.

[19829] D. M. Rohr and J. Frýda. "A new Ordovician gastropod and operculum from the Czech Republic". English. In: Journal of Paleontology 75.2 (2001), pp. 461-462.

[19830] D. M. Rohr, J. Frýda, and R. B. Blodgett. "Alaskadiscus, a new bellerophontoidean gastropod from the Upper Ordovician of the York and Farewell terranes of Alaska". In: Short notes on Alaska geology 2003, Division of Geological and Geophysical Surveys Professional Report 120 (2003), pp. 95-99.

[19831] D. M. Rohr and A. P. Gubanov. "Macluritid opercula (Gastropoda) from the Middle Ordovician of Sibera and Alaska". English. In: Journal of Paleontology 71.3 (1997), pp. 394-400.

[19832] D. M. Rohr, D. A. T. Harper, S. Stouge, and J. L. Christiansen. “Ordovician Gastropoda from Northeast Greenland". English. In: Bulletin of Geosciences 90.4 (2015), pp. 795-805. DOI: 10.3140 / bull.geosci.1566.

[19833] D. M. Rohr and R. A. Johns. "First occurence of Oriostoma (Gastropoda) from the Middle Ordovician". In: Journal of Paleontology 64.5 (1990), pp. 732-735.

[19834] D. M. Rohr, E. A. Measures, W. D. Boyce, and I. Knight. "Ongoing studies of Late Cambrian and Early Ordovician gastropods of western Newfoundland". English. In: Current Research (2000) Newfoundland Department of Mines and Energy Geological Survey, Report 2000.1 (2000), pp. 241-250.

[19835] D. M. Rohr, E. A. Measures, W. D. Boyce, and I. Knight. “Euomphalopsis and Polhemia (Gastropoda) from the Lower Ordovician Catoche Formation, western Newfoundland". English. In: Current Research (2002) Newfoundland Department of Mines and Energy Geological Survey, Report 2002 2002.2 (2002), pp. 265-275. 
[19836] D. M. Rohr and E. A. Measures. “Middle Ordovician (Whiterockian) gastropods of western Newfoundland: Macluritoidea and Euomphaloidea". English. In: Journal of Paleontology 75.2 (2001), pp. 284-294.

[19837] D. M. Rohr, E. A. Measures, and W. D. Boyce. "Middle Ordovician (Whiterockian) gastropods from the Table Point formation, western Newfoundland". English. In: Current Research (2004) Newfoundland Department of Mines and Energy Geological Survey 2004.1 (2004), pp. 225-234.

[19838] D. M. Rohr, E. A. Measures, W. D. Boyce, and I. Knight. “Early Ordovician gastropods of the Barbace Cove Member (Boat Harbour Formation) and Catoche Formation, western Newfoundland". English. In: Current Research (2001) Newfoundland Department of Mines and Energy Geological Survey, Report 20012001.1 (2001), pp. 113-126.

[19839] D. M. Rohr, B. S. Norford, and E. L. Yochelson. "Stratigraphically significant Early and Middle Ordovician gastropod occurrences, Western and Northwestern Canada". English. In: Journal of Paleontology 69.6 (1995), pp. 1047-1053.

[19840] D. M. Rohr and E. L. Yochelson. "An unusual new Bellerophontacean Gastropod from the Ordovician (Whiterockian) of Nevada". English. In: Journal of Paleontology 64.6 (1990), pp. 956-960.

[19841] D. M. Rohr and E. L. Yochelson. "Life association of shell and operculum of Middle Ordovician gastropod Maclurites". English. In: Journal of Paleontology 73.6 (1999), pp. 1078-1080.

[19842] A. Rojas, M. Demicheli, and S. A. Martnez. "Taphonomy of the Late Pleistocene marine molluscan assemblages from Uruguay". English. In: Neues Jahrbuch für Geologie und Paläontologie - Abhandlungen 289.2 (2018), pp. 217-235. DOI: 10.1127/njgpa/2018/0757.

[19843] R. Rojas, M. Iturralde-Vinent, and P. W. Skelton. "Stratigraphy, composition and age of Cuban rudist-bearing deposits". English. In: Revista Mexicana de Ciencias Geologicas 12.2 (1995), pp. 272291.

[19844] W. D. I. Rolfe, G. P. Durant, A. E. Fallick, A. J. Hall, D. J. Large, A. C. Scott, T. R. Smithson, and G. M. Walkden. An early terrestrial biota preserved by Visean vulcanicity in Scotland. English. Vol. 244. Volcanism and Fossil Biotas. Geological Society of America Special Paper. 1990, pp. 13-24.

[19845] Y. Rollot, T. R. Lyson, and W. G. Joyce. "A Description of the Skull of Eubaena cephalica (Hay, 1904) and New Insights into the Cranial Circulation and Innervation of Baenid Turtles". English. In: Journal of Vertebrate Paleontology e1474886 (2018), pp. 1-11. DOI: 10.1080/02724634.2018.1474886.

[19846] C. Romano, T. Argyriou, L. J. Krumenacker, and The Paris Biota Team. “Chondrichthyan teeth from the Early Triassic Paris Biota (Bear Lake County, Idaho, USA)". English. In: Geobios 54 (2019), pp. 63-70. DOI: 10.1016/j.geobios.2019.04.001.

[19847] C. Romano and W. Brinkmann. "A new specimen of the hybodont shark Palaeobates polaris with three-dimensionally preserved Meckel's cartilage from the Smithian (Early Triassic) of Spitsbergen". English. In: Journal of Vertebrate Paleontology 30.6 (2010), pp. 1673-1683. DOI: 10.1080 / 02724634.2010.521962.

[19848] C. Romano, J. F. Jenks, R. Jattiot, T. M. Scheyer, K. G. Bylund, and H. Bucher. “Marine Early Triassic Actinopterygii from Elko County (Nevada, USA): implications for the Smithian equatorial vertebrate eclipse". English. In: Journal of Paleontology 91 (2017), pp. 1025-1046.

[19849] C. Romano, I. Kogan, J. Jenks, I. Jerjen, and W. Brinkmann. "Saurichthys and other fossil fishes from the late Smithian (Early Triassic) of Bear Lake County (Idaho, USA), with a discussion of saurichthyid palaeogeography and evolution". English. In: Bulletin of Geosciences 87 (2012), pp. 543-570.

[19850] C. Romano, A. López-Arbarello, D. Ware, J. F. Jenks, and W. Brinkmann. "Marine Early Triassic Actinopterygii from the Candelaria Hills (Esmeralda County, Nevada, USA)". English. In: Journal of Paleontology 93 (2019), pp. 971-1000. DOI: 10.1017/jpa.2019.18.

[19851] C. Romano, D. Ware, T. Brühwiler, H. Bucher, and W. Brinkmann. "Marine Early Triassic Osteichthyes from Spiti, Indian Himalayas". English. In: Swiss Journal of Palaeontology 135 (2016), pp. 275-294. 
[19852] M. Romano. “Trilobites from the Ordovician of Portugal". English. In: Palaeontology 34.2 (1991), pp. 329-355.

[19853] M. Romano, P. Citton, A. Cipriani, and S. Fabbi. "First report of hybodont shark from the Toarcian Rosso Ammonitico Formation of Umbria-Marche Apennine (Polino area, Terni, Central Italy)". English. In: Italian Journal of Geosciences 137 (2018), pp. 151-159.

[19854] M. Romano, R. Manni, E. Venditti, U. Nicosia, and A. Cipriani. “First occurrence of a Tylosaurinae mosasaur from the Turonian of the Central Apennines, Italy". English. In: Cretaceous Research 96 (2019), pp. 196-209. DOI: 10.1016/j.cretres.2019.01.001.

[19855] M. Romano and U. Nicosia. "Alierasaurus ronchii, gen. et sp. nov., a caseid from the Permian of Sardinia, Italy". English. In: Journal of Vertebrate Paleontology 34.4 (2014), pp. 900-913. DOI: 10. 1080/02724634.2014.837056.

[19856] M. Romano and A. W. Owen. "Early Caradoc Trilobites of Eastern Ireland and their paleogeographical significance". In: Palaeontology 36.3 (1993), pp. 681-720.

[19857] M. Romano and M. A. Whyte. "Jurassic dinosaur tracks and trackways of the Cleveland Basin, Yorkshire: preservation, diversity and distribution". English. In: Proceedings of the Yorkshire Geological Society 54.3 (2003), pp. 185-215.

[19858] P. S. R. Romano and S. A. K. Azevedo. "Morphometric analysis of the Upper Cretaceous Brazilian side-necked turtle Bauruemys elegans (Suarez, 1969) (Pleurodira, Podocnemididae)". English. In: Arquivos do Museu Nacional, Rio de Janeiro 65.4 (2007), pp. 395-402.

[19859] P. S. R. Romano, V. Gallo, R. R. C. Ramos, and L. Antonioli. “Atolchelys lepida, a new side-necked turtle from the Early Cretaceous of Brazil and the age of crown Pleurodira". English. In: Biology Letters 10.20140290 (2014). DOI: 10.1098/rsbl.2014.0290.

[19860] P. S. R. Romano, G. R. Oliveira, S. A. K. Azevedo, A. W. A. Kellner, and D. de Almeida Campos. "New Information about Pelomedusoides (Testudines: Pleurodira) from the Cretaceous of Brazil". English. In: Morphology and Evolution of Turtles. 2013, pp. 261-275. DOI: 10.1007 /978-94-0074309-0_16.

[19861] P. R. Romo de Vivar Martnez, M. Montellano Ballesteros, and D. Garca Alcántara. “Primer registro de la Familia Albanerpetontidae (Lissamphibia) en la formación El Gallo (Campaniano, Cretácico Superior), Baja California, México [First record of the family Albanerpetontidae (Lissamphibia) in the El Gallo Formation (Campanian, Upper Cretaceous), Baja California, Mexico)". Spanish. In: Boletn de la Sociedad Geológica Mexicana 68.3 (2016), pp. 571-580.

[19862] A. Ronchi, E. Sacchi, M. Romano, and U. Nicosia. "A huge caseid pelycosaur from northwestern Sardinia and its bearing on European Permian stratigraphy and palaeobiogeography". English. In: Acta Palaeontologica Polonica 56.4 (2011), pp. 723-738.

[19863] A. Ronchi and A. Tintori. "First amphibian find in Early Permian from Sardinia (Italy)". English. In: Rivista Italiana di Paleontologia e Stratigrafia 103.1 (1997), pp. 29-38.

[19864] H. Rong, Y. Jiao, Y. Wang, L. Wu, and R. Wang. "Distribution and geologic significance of Girvanella within the Yijianfang Ordovician reef complexes in the Bachu area, West Tarim Basin, China". English. In: Facies (2013).

[19865] J. Rong, J. Jin, R. -b. Zhan, and J. Bergström. “The earliest known Stegerhynchus (Rhynchonellida, Brachiopoda) from the Hirnantian strata (uppermost Ordovician) at Borenshult, Östergötland, Sweden". English. In: G F F 130 (2008), pp. 21-30.

[19866] J. Rong, X. Wei, R. Zhan, and Y. Wang. "A deep water shelly fauna from the uppermost Ordovician in northwestern Hunan, South China and its paleoecological implications". English. In: Science China Earth Sciences 61.6 (2018), pp. 730-744. DOI: 10.1007/s11430-017-9165-y.

[19867] J.-Y. Rong, K. P. Aung, R. -B. Zhan, B. Huang, D. A. T. Harper, D. Chen, H. -H. Zhou, and X. L. Zhang. "The latest Ordovician Hirnantia brachiopod Fauna of Myanmar: Significance of new data from the Mandalay Region". English. In: Palaeoworld 28 (2019). DOI: 10.1016/j.palwor.2019. 07.002 . 
[19868] J.-Y. Rong, X. Chen, and D. A. T. Harper. “The latest Ordovician Hirnantia Fauna (Brachiopoda) in time and space". English. In: Lethaia 35 (2002), pp. 231-249.

[19869] J.-y. Rong, D. A. T. Harper, R. -b. Zhan, and R. -y. Li. "Kassinella-Christiania Associations in the early Ashgill Foliomena brachiopod fauna of South China". English. In: Lethaia 27 (1994), pp. 1928.

[19870] J.-Y. Rong and R.-Y. Li. “A silicified Hirnantia Fauna (latest Ordovician brachiopods) from Guizhou, Southwest China". English. In: Journal of Paleontology 73.5 (1999), pp. 831-849. DOI: 10.2307 / 1306843.

[19871] J.-Y. Rong and R.-B. Zhan. "Surviving the end-Ordovician extinctions: evidence from the earliest Silurian brachiopods of northeastern Jiangxi and western Zhejiang provinces, East China". English. In: Lethaia 39.1 (2006), pp. 39-48. DOI: 10.1080/00241160500443164.

[19872] J.-y. Rong, R.-b. Zhan, and D. A. T. Harper. "Late Ordovician (Caradoc-Ashgill) Brachiopod Faunas with Foliomena Based on Data from China". English. In: Palaios 14 (1999), pp. 412-431.

[19873] Y.-F. Rong. "Restudy of Regalerpeton weichangensis (Amphibia: Urodela) from the Lower Cretaceous of Hebei, China". English. In: Vertebrata PalAsiatica 56.2 (2018), pp. 121-136.

[19874] E. Roniewicz. "Upper Triassic Solitary Corals from the Gosaukamm and other North Alpine Regions". In: Sitzungsberichte Österreichische Akademie der Wissenschaften, mathematisch-naturwissenschaftliche Klasse, Abteilung I 202 (1995), pp. 3-41.

[19875] E. Roniewicz. "Kimmeridgian-Valanginian reef corals from the Moesian Platform from Bulgaria". English. In: Annales Societatis Geologorum Poloniae 78 (2008), pp. 91-134.

[19876] E. Roniewicz. "Early Norian (Triassic) corals from the Northern Calcareous Alps, Austria, and the intra-Norian faunal turnover". English. In: Acta Palaeontologica Polonica 56.2 (2011), pp. 401-428.

[19877] E. Roniewicz, G. W. Mandl, O. Ebli, and H. Lobitzer. “Early Norian scleractinian corals and microfacies data of the Dachstein Limestone of Feisterscharte, southern Dachstein Plateau (Northern Calcareous Alps, Austria)". English. In: Jahrbuch der Geologischen Bundesanstalt 147 (2007), pp. 577594.

[19878] E. Roniewicz and J. Michalik. “Carnian corals from the Malé Karpaty Mountains, western Carpathians, Slovakia". English. In: Geologica Carpathica 53.3 (2002), pp. 149-157.

[19879] E. Roniewicz and J. Michalk. "Rhaetian Scleractinian Corals in the Western Carpathians". In: Geologica Carpathica 49.6 (1998), pp. 391-399.

[19880] E. Roniewicz and J. Michalik. "A New Triassic scleractinian coral from the High Tatra Mountains (Western Carpathians, Czecho-Slovakia)". English. In: Geologica Carpathica 42.3 (1991), pp. 157162.

[19881] E. Roniewicz and G. D. Stanley. "Middle Triassic cnidarians from the New Pass Range, central Nevada". English. In: Journal of Paleontology 72.2 (1998), pp. 246-256.

[19882] E. Roniewicz and G. D. Stanley. "Noriphyllia, a new Tethyan Late Triassic coral genus". English. In: Palaeontologische Zeitschrift 83 (2009), pp. 467-478.

[19883] E. Roniewicz and G. D. Stanley. "Upper Triassic corals from Nevada, western North America, and the implications for paleoecology and paleogeography". English. In: Journal of Paleontology 87 (2013), pp. 934-964.

[19884] E. Roniewicz, J. D. Stanley Jr., F. Da Costa Monteiro, and J. A. Grant-Mackie. “Late Triassic (Carnian) corals from Timor-Leste (East Timor): their identity, setting, and biogeography". English. In: Alcheringa 29.2 (2005), pp. 287-303.

[19885] E. Roniewicz and J. Stolarski. "Miocene Scleractinia from the Holy Cross Mountains, Poland; II, Archaecoeniina, Astraeina, and Fungiina". In: Acta Geologica Polonica 41.1-2 (1991), pp. 69-83.

[19886] D. L. Rook, J. P. Hunter, D. A. Pearson, and A. Bercovici. "Lower jaw of the Early Paleocene mammal Alveugena and its interpretation as a transitional fossil". English. In: Journal of Paleontology 84.6 (2010), pp. 1217-1225. DOI: 10.1666/10-054.1. 
[19887] L. Rook, M. Delfino, and M. Sami. “I vertebrati fossili della cava del Monticino di Brisighella: una finestra sui". Italian. In: Memorie dell'Istituto Italiano di Speleologia 28 (2015), pp. 79-100.

[19888] L. Rook, B. Martinez-Navarro, and F. Clark-Howell. "Occurrence of Theropithecus sp. in the Late Villafranchian of Southern Italy and implication for Early Pleistocene 'out of Africa' dispersals." In: Journal of Human Evolution 47 (2004), pp. 267-277.

[19889] A. Rõõmusoks. "Some Brachiopod Genera of the Subfamily Strophomeninae from the Ordovician of Estonia". English. In: Proceedings of the Estonian Academy of Sciences, Geology 199342.3 (1993), pp. 110-117.

[19890] A. Rõõmusoks. “The new trilobite genus Valdariops from the Harju Series (Upper Ordovician) of Estonia". English. In: Proceedings of the Estonian Academy of Sciences, Geology 49 (2000), pp. 28-42.

[19891] S. Ros-Montoya, B. Martinez-Navarro, M. -P. Espigares, A. Guerra-Merchan, J. M. Garcia-Aguilar, P. Pinero, A. Rodriguez-Rueda, J. Agusti, O. Oms, and P. Palmqvist. "A new Ruscinian site in Europe: Baza-1 (Baza basin, Andalusia, Spain)". English. In: Comptes Rendus Palevol (2017).

[19892] I. Rosales, D. Mehl, P. A. Fernandez-Mendiola, and J. Garcia-Mondejar. "An unusual poriferan community in the Albian of Islares (north Spain): palaeoenvironmental and tectonic implications". English. In: Palaeogeography, Palaeoclimatology, Palaeoecology 119 (1995), pp. 47-61.

[19893] F. Röschmann and W. Mohrig. "Beiträge zur Kenntnis fossiler Trauermücken aus Sächsischem Bernstein. Teil II. Drei neue Sciariden aus Tertiär-Harzen des Bitterfelder Braunkohlereviers (Insecta, Diptera, Sciaridae)". German. In: Paläontologische Zeitschrift 69 (1995), pp. 153-166.

[19894] F. Röschmann and W. Mohrig. “Die Trauermücken des Sächsischen Bernsteins aus dem Untermiozän von Bitterfeld/Deutschland (Diptera, Sciaridae)". German. In: Deutsche Entomologische Zeitschrift 42 (1995), pp. 17-54.

[19895] F. Röschmann and W. Mohrig. "Einschlüsse fossiler Trauermücken (Diptera, Sciaridae) in Baltischem Bernstein aus Kollektionen des Deutschen Entomologischen Institutes Eberswalde". German. In: Beiträge zur Entomologie 44 (1994), pp. 403-408.

[19896] J. Rose, B. S. P. Moorlock, and R. J. O. Hamblin. "Pre-Anglican fluvial and coastal deposits in Eastern England; lithostratigraphy and palaeoenvironments". English. In: Quaternary Internationat 79 (2001), pp. 5-22.

[19897] K. D. Rose. "Anterior dentition and relationships of the early Eocene omomyidsăArapahovius advenaăandăTeilhardina demissa, sp. nov". English. In: Journal of Human Evolution 28 (1995).

[19898] K. D. Rose. “Postcranial skeleton of Eocene Leptictidae (Mammalia), and its implications for behavior and relationships". In: Journal of Vertebrate Paleontology 19.2 (1999), pp. 355-372.

[19899] K. D. Rose. "Part 7. Fossil Mammals from the Early Eocene Fisher/Sullivan Site". English. In: Virginia Division of Mineral Resources Publication 152 (1999), pp. 133-138.

[19900] K. D. Rose. "Land-mammals from the Late Paleocene Aquia Formation: The first early Cenozoic mammals from Maryland". English. In: Proceedings of the Biological Society of Washington 113.4 (2000), pp. 855-863.

[19901] K. D. Rose. "New marsupial from the early Eocene of Virginia". English. In: Journal of Paleontology 84.3 (2010), pp. 561-565.

[19902] K. D. Rose and T. M. Bown. “A new plesiadapiform (Mammalia: Plesiadapiformes) from the early Eocene of the Bighorn Basin, Wyoming". English. In: Annals of Carnegie Museum 65.3 (1996), pp. 305-321.

[19903] K. D. Rose, S. G. B. Chester, R. H. Dunn, D. M. Boyer, and J. I. Bloch. "New fossils of the oldest North American euprimate Teilhardina brandti (Omomyidae) from the Paleocene-Eocene Thermal Maximum". English. In: American Journal of Physical Anthropology 146 (2011), pp. 281-305. DOI: 10.1002/ajpa.21579.

[19904] K. D. Rose, A. E. Chew, R. H. Dunn, M. J. Kraus, H. C. Fricke, and S. P. Zack. "Earliest Eocene mammalian fauna from the Paleocene-Eocene Thermal Maximum at Sand Creek Divide, southern Bighorn Basin, Wyoming". English. In: University of Michigan Papers on Paleontology 36 (2012), pp. 1-122. 
[19905] K. D. Rose, V. B. DeLeon, P. Missiaen, R. S. Rana, A. Sahni, L. Singh, and T. Smith. “Early Eocene lagomorph (Mammalia) from Western India and the early diversification of Lagomorpha". English. In: Proceedings of the Royal Society B 275 (2008), pp. 1203-1208.

[19906] K. D. Rose, R. H. Dunn, K. Kumar, J. M. G. Perry, K. A. Prufrock, R. S. Rana, and T. Smith. “New fossils from Tadkeshwar Mine (Gujarat, India) increase primatediversity from the early Eocene Cambay Shale". English. In: Journal of Human Evolution 122 (2018), pp. 93-107. DOI: 10.1016/j. jhevol.2018.05.006.

[19907] K. D. Rose, J. J. Eberle, and M. C. McKenna. "Arcticanodon dawsonae, a primitive new palaeanodont from the lower Eocene of Ellesmere Island, Canadian High Arctic". English. In: Canadian Journal of Earth Sciences 41 (2004), pp. 757-763.

[19908] K. D. Rose, L. T. Holbrook, R. S. Rana, K. Kumar, K. E. Jones, H. E. Ahrens, P. Missiaen, A. Sahni, and T. Smith. "Early Eocene fossils suggest that the mammalian order Perissodactyla originated in India". English. In: Nature Communications 5 (2014), 5570:1-9.

[19909] K. D. Rose, L. T. Holbrook, K. Kumar, R. S. Rana, H. E. Ahrens, R. H. Dunn, A. Folie, K. E. Jones, and T. Smith. "Anatomy, Relationships, and Paleobiology of Cambaytherium (Mammalia, Perissodactylamorpha, Anthracobunia) from the lower Eocene of western India". English. In: Journal of Vertebrate Paleontology 39.Supp. 1 (2020), pp. 1-147. DOI: 10.1080/02724634.2020.1761370.

[19910] K. D. Rose, L. Krishtalka, and R. K. Stucky. "Revision of the Wind River faunas, early Eocene of central Wyoming. Part 11. Palaeanodonta (Mammalia)". English. In: Annals of Carnegie Museum 60.1 (1991), pp. 63-82.

[19911] K. D. Rose, K. Kumar, R. S. Rana, A. Sahni, and T. Smith. "New Hypsodont Tillodont (Mammalia, Tillodontia) from the Early Eocene of India". English. In: Journal of Paleontology 87.5 (2013), pp. 842 853. DOI: $10.1666 / 13-027$.

[19912] K. D. Rose and S. G. Lucas. "An early Paleocene palaeanodont (Mammalia, ?Pholidota) from New Mexico, and the origin of Palaeanodonta". In: Journal of Vertebrate Paleontology 20.1 (2000), pp. 139156.

[19913] K. D. Rose, R. S. Rana, A. Sahni, and T. Smith. "A new adapoid primate from the early Eocene of India". English. In: Contributions from the Museum of Paleontology, University of Michigan 31.14 (2007), pp. 379-385.

[19914] K. D. Rose, R. S. Rana, A. Sahni, K. Kumar, P. Missiaen, L. Singh, and T. Smith. "Early Eocene primates from Gujarat, India". English. In: Journal of Human Evolution 56.4 (2009), pp. 366-404. DOI: 10.1016/j.jhevol.2009.01.008.

[19915] K. D. Rose, R. S. Rana, A. Sahni, K. Kumar, L. Singh, and T. Smith. "First tillodont from India: Additional evidence for an early Eocene faunal connection between Europe and India?" English. In: Acta Palaeontologica Polonica 54.2 (2009), pp. 351-355.

[19916] K. D. Rose, T. Smith, R. S. Rana, A. Sahni, H. Sing, P. Missiaen, and A. Folie. “Early Eocene (Ypresian) continental vertebrate assemblage from India, with description of a new anthracobunid (Mammalia, Tethytheria)". English. In: Journal of Vertebrate Paleontology 26.1 (2006), pp. 219-225.

[19917] A. L. Rosenberger, W. C. Hartmg, and R. G. Wolff. "Szalatavus attricuspis, an early platyrrhine primate". English. In: Folia Primatologica 56.4 (1991), pp. 225-233. DOI: 10.1159/000156552.

[19918] A. L. Rosenberger, T. Setoguchi, and W. C. Hertwig. "Laventiana annectens, new genus and species: fossil evidence for the origins of callitrichine New World monkeys". English. In: Proceedings of the National Academy of Sciences 88.6 (1991), pp. 2137-2140.

[19919] A. J. Ross. "A review of the Carboniferous fossil insects from Scotland". English. In: Scottish Journal of Geology 46 (2010), pp. 157-168.

[19920] A. J. Ross. “The Blattodea (cockroaches), Mantodea (praying mantises) and Dermaptera (earwigs) of the Insect Limestone (late Eocene), Isle of Wight, including the first record of Mantodea from the UK". English. In: Earth and Environmental Science Transactions of the Royal Society of Edinburgh 110 (2019), pp. 301-311. DOI: 10.1017/S1755691018000440. 
[19921] A. J. Ross, M. A. Coutiño José, and A. Nel. “The first records of coenagrionid damselflies (Odonata: Zygoptera: Coenagrionidae: Neoerythromma sp. and Nehalennia sp.) from Mexican Amber (Miocene)". English. In: Boletn de la Sociedad Geológica Mexicana 68 (2016), pp. 81-86.

[19922] A. J. Ross, G. D. Edgecombe, N. D. Clark, C. E. Bennett, V. Carrió, R. Contreras-Izquierdo, and B. Crighton. "A new terrestrial millipede fauna of earliest Carboniferous (Tournaisian) age from southeastern Scotland helps fill 'Romer's Gap'". English. In: Earth and Environmental Science Transactions of The Royal Society of Edinburgh (2018). DOI: 10.1017/S1755691018000142.

[19923] A. J. Ross and M. S. Engel. "The first diplatyid earwig in Tertiary amber (Dermaptera: Diplatyidae): a new species from Miocene Mexican amber". English. In: Insect Systematics \& Evolution 44 (2013), pp. 157-166.

[19924] A. J. Ross, C. J. T. Mellish, B. Crighton, and P. V. York. "A catalogue of the collections of Mexican amber at the Natural History Museum, London and National Museums Scotland, Edinburgh, UK". English. In: Boletn de la Sociedad Geológica Mexicana 68 (2016), pp. 45-55.

[19925] A. J. Ross and P. V. York. "A list of type and figured specimens of insects and other inclusions in Burmese amber". English. In: Bulletin of the Natural History Museum, Geology Series 56 (2000), pp. 11-20.

[19926] C. F. Ross, H.-D. Sues, and W. J. de Klerk. "Lepidosaurian remains from the Lower Cretaceous Kirkwood Formation of South Africa". English. In: Journal of Vertebrate Paleontology 19.1 (1999), pp. 21-27.

[19927] D. J. Ross. "Sedimentology and depositional profile of a mid-Cretaceous shelf edge reef complex, Nahal Ha'mearot, northwestern Israel". English. In: Sedimentary Geology 79 (1992), pp. 161-172.

[19928] E. S. Ross. "EMBIA contributions to the biosystematics of the insect order Embidiina. Part 5. A review of the family Anisembiidae with descriptions of new taxa". English. In: Occasional Papers of the California Academy of Sciences 154 (2003), pp. 1-123.

[19929] M. R. Ross and D. E. Fastovsky. "Trans-Atlantic correlations of Upper Cretaceous marine sediments; the Mid-Atlantic (USA) and Maastricht (Netherlands) regions". English. In: Northeastern Geology and Environmental Sciences 28.1 (2006), pp. 34-44.

[19930] T. J. Rossbach and J. G. Carter. "Molluscan biostratigraphy of the lower River Bend Formation at Martin Marietta Quarry, New Bern, North Carolina". English. In: Journal of Paleontology 65.1 (1991), pp. 80-118.

[19931] M. R. Rossi-Santos and L. L. Wedekin. "Evidence of bottom contact behavior by estuarine dolphins (Sotalia guianensis) on the eastern coast of Brazil". English. In: Aquatic Mammals 32.2 (2006), pp. 140-144.

[19932] J. B. Rossie and L. MacLatchy. "A new pliopithecoid genus from the early Miocene of Uganda". English. In: Journal of Human Evolution 50.5 (2006), pp. 568-586.

[19933] R. Rossler and C. Brauckmann. “Der erste Arachnidenfund im Paläozoikum der Alpen: Aphantomartus pustulatus (Scudder 1884) aus dem ältesten Ober-Karbon (mittleres bis oberes Namurium A) von Nötsch (Österreich)". German. In: Jahrbuch der Geologischen Bundesanstalt 142 (2000), pp. 227234.

[19934] R. Rössler, J. A. Dunlop, and J. W. Schneider. “A redescription of some poorly known Rotliegend arachnids from the Lower Permian (Asselian) of the Ilfeld and Thuringian Forest Basins, Germany". English. In: Paläontologische Zeitschrift 77 (2003), pp. 417-427.

[19935] T. Rossman, M. Rauhe, and F. Ortega. "Studies on Cenozoic crocodiles: 8. Bergisuchus dietrichbergi Kuhn (Sebecosuchia: Bergisuchidae n. fam.) from the Middle Eocene of Germany, some new systematic and biological conclusions". English. In: Paläontologische Zeitschrift 74.3 (2000), pp. 379392.

[19936] T. Rossmann. "Studien an Mesosauriern (Amniota inc sed: Mesosauridae): 2 Neue Erkenntnisse zur Anatomie, mit Berücksichtigung der Taxonomie von Mesosaurus pleurogaster (Seeley)". German. In: Senckenbergiana lethaea 80.1 (2000), pp. 13-28. 
[19937] T. Rossmann. "Studien an Mesosauriern (Amniota inc sed, Mesosauridae): 3 Neue Aspekte zur Anatomie, Erhaltung und Paläoökologie aufgrund der Exemplare im Paläontologischen Institut der Universität Zürich. [Studies on mesosaurs (Amniota inc sed, Mesosauridae): 3 New aspects on the anatomy, preservation and palaeoecology, based on the specimens from the Palaeontological Institute of the University of Zurich]". German. In: Neues Jahrbuch für Geologie und Paläontologie, Abhandlungen 224.2 (2002), pp. 197-221.

[19938] T. Rossmann. "Studies on Cenozoic crocodiles: 10. First evidence of a tomistomid crocodilian (Eusuchia: Tomistomidae) from the Middle Eocene (Geiseltalian, MP 11) of Grube Messel, Germany". English. In: Neues Jahrbuch für Geologie und Paläontologie, Monatshefte 2002.3 (2002), pp. 129-146.

[19939] T. Rossmann and M. W. Maisch. “Das Mesosaurier-Material in der Bayerischen Staatssammlung für Paläontologie und Historische Geologie: Übersicht und neue Erkenntnisse". German. In: Mitteilungen der Bayerischen Staatssammlung für Paläontologie und Historische Geologie 39 (1999), pp. 6983.

[19940] A. Rosso and R. Sanfilippo. "Bryozoans and serpuloideans in skeletobiont communities from the Pleistocene of Sicily: spatial utilisation and competitive interactions". English. In: Annali dell'Universitá degli Studi di Ferrara Museologia Scientifica e Naturalistica (2005).

[19941] B. Roth. "Tropical 'physiognomy' of a land snail faunule from the Eocene of southern California [USA]". English. In: Malacologia 33 (1991), pp. 281-288.

[19942] F. Roth and K. Hoedemakers. "The Marine Gram Formation at Gram, Denmark: Late Miocene Geology and Palaeontology". English. In: Palaeontos 7 (2005), pp. 1-189.

[19943] J. Rothecker and J. E. Storer. "The Marsupials of the Lac Pelletier Lower Fauna, Middle Eocene (Duchesnean) of Saskatchewan". English. In: Journal of Vertebrate Paleontology 16.4 (1996), pp. 770774.

[19944] G. W. Rothwell and R. A. Stockey. "Combining characters of Pteridaceae and tree ferns: Pterisorus radiata gen. et sp. nov., a permineralized Lower Cretaceous filicalean with radial sori". English. In: International Journal of Plant Sciences 167.3 (2006), pp. 695-701. DOI: 10.1086/501035.

[19945] G. W. Rothwell and R. A. Stockey. “The Role of Hydropteris pinnata gen. et. sp. nov. In Reconstructing the cladistics of Heterosporous Ferns". English. In: American Journal of Botany 81.4 (1994), pp. 479-492.

[19946] T. Rothwell. "Chapter 12: New felid material from the Ulaan Tologoi Locality, Loh Formation (early Miocene) of Mongolia". English. In: Bulletin of the American Museum of Natural History 285.1 (2004), pp. 157-165.

[19947] T. M. Rothwell. “A Partial Skeleton of Pseudaelurus (Carnivora: Felidae) from the Nambé Member of the Tesuque Formation, Española Basin, New Mexico". English. In: American Museum Novitates 3342 (2001), pp. 1-31. DOI: 10.1206/0003-0082(2001)342<0001:APSOPC>2.0.CO;2.

[19948] G. W. Rougier, S. Apestegua, and L. C. Gaetano. "Highly specialized mammalian skulls from the Late Cretaceous of South America". English. In: Nature 479 (2011), pp. 98-102. DOI: 10.1038 / nature10591.

[19949] G. W. Rougier, L. Chornogubsky, S. Casadio, N. P. Arango, and A. Giallombardo. "Mammals from the Allen Formation, Late Cretaceous, Argentina". English. In: Cretaceous Research 30 (2009), pp. 223-238. DOI: 10.1016/j.cretres.2008.07.006.

[19950] G. W. Rougier, B. M. Davis, and M. J. Novacek. “A deltatheroidan mammal from the Upper Cretaceous Baynshiree Formation, eastern Mongolia”. English. In: Cretaceous Research 52 (2015), pp. 167177. DOI: $10.1016 /$ j.cretres.2014.09.009.

[19951] G. W. Rougier, M. S. de la Fuente, and A. B. Arcucci. "Late Triassic turtles from South America”. English. In: Science 268 (1995), pp. 855-858.

[19952] G. W. Rougier, A. M. Forasiepi, R. V. Hill, and M. Novacek. "New mammalian remains from the Late Cretaceous La Colonia Formation, Patagonia, Argentina". English. In: Acta Palaeontologica Polonica 54.2 (2009), pp. 195-212. DOI: 10.4202/app.2006.0026. 
[19953] G. W. Rougier, A. Garrido, L. Gaetano, P. F. Puerta, C. Corbitt, and M. J. Novacek. “First Jurassic triconodont from South America". English. In: American Museum Novitates 3580 (2007), pp. 1-17.

[19954] G. W. Rougier, S. Isaji, and M. Manabe. "Early Cretaceous mammals from the Kuwajima Formation (Tetori Group), Japan, and a reassessment of triconodont phylogeny". English. In: Annals of Carnegie Museum 76.2 (2007), pp. 73-115.

[19955] G. W. Rougier, Q. Ji, and M. J. Novacek. "A new symmetrodont mammal with fur impressions from the Mesozoic of China". English. In: Acta Geologica Sinica 77.1 (2003), pp. 7-14.

[19956] G. W. Rougier, A. G. Martinelli, A. M. Forasiepi, and M. J. Novacek. “New Jurassic Mammals from Patagonia, Argentina: A Reappraisal of Australosphenidan Morphology and Interrelationships". English. In: American Museum Novitates 3566 (2007), pp. 1-54.

[19957] G. W. Rougier, M. J. Novacek, and D. Dashzeveg. "A new multituberculate from the Late Cretaceous locality Ukhaa Tolgod, Mongolia. Considerations on multituberculate interrelationships". English. In: American Museum Novitates 3191 (1997), pp. 1-26.

[19958] G. W. Rougier, M. J. Novacek, M. C. McKenna, and J. R. Wible. “Gobiconodonts from the Early Cretaceous of Oshih (Ashile), Mongolia". English. In: American Museum Novitates 3348 (2001), pp. 1-30. DOI: 10.1206/0003-0082(2001)348<0001:GFTECO>2.0.CO;2.

[19959] G. W. Rougier, A. S. Sheth, K. Carpenter, L. Appella-Guiscafre, and B. M. Davis. "A new species of Docodon (Mammaliaformes: Docodonta) from the Upper Jurassic Morrison Formation and a reassessment of selected craniodental characters in basal mammaliaforms". English. In: Journal of Mammalian Evolution (2014). DOI: 10.1007/s10914-014-9263-8.

[19960] G. W. Rougier, A. S. Sheth, B. K. Spurlin, M. Bolortsetseg, and M. J. Novacek. “Craniodental anatomy of a new Late Cretaceous multituberculate mammal from Udan Sayr, Mongolia". English. In: Palaeontologia Polonica 67 (2016), pp. 197-248.

[19961] G. W. Rougier, J. R. Wible, and M. J. Novacek. "Implications of Deltatheridium specimens for early marsupial history". English. In: Nature 396.6710 (1998), pp. 459-463.

[19962] G. W. Rouse, S. K. Goffredi, and R. C. Vrijenhoek. "Osedax: Bone-eating marine worms with dwarf males". English. In: Science 305 (2004), pp. 668-671.

[19963] S. Roussiakis, A. Athanassiou, D. Michailidis, V. Mitsopoulou, C. Solomos, and G. Theodorou. Remarks on new proboscidean remains from the classical Late Miocene locality of Pikermi and their associated fauna. English. 2014.

[19964] S. J. Roussiakis and G. E. Theodorou. "Carnivora from the Late Miocene of Kerassiá (Northern Euboea, Greece)". English. In: Deinsea. Distribution and Migration of Tertiary Mammals in Eurasia. A Volume in Honour of Hans de Bruijn 10 (2003), pp. 469-497.

[19965] M. Roux, B. Cahuzac, and K. Sztrakos. "Les paléoenvironnements éocénes á crinodes pédonculés des marnes de Miretrain (Angoumé, SW France): interprétations paléobathymétriques". French. In: Compte Rendus Geoscience 338 (2006), pp. 262-271.

[19966] N. P. Rowe. “The Gymonosperm Archaeopteridium tschermakii and an associated glandular fructification from the upper Visean drybrook sandstone of Great Britain". In: Palaeontology 35.4 (1992), pp. 875-900.

[19967] N. P. Rowe and J. Galtier. "A Lower Carboniferous plant assemblage from La Serre (Montagne Noire, France), 2. Gymnosperms". In: Review of Palaeobotany and Palynology 63 (1990), pp. 91-115.

[19968] T. Rowe, R. L. Cifelli, T. M. Lehman, and A. Weil. “The Campanian Terlingua local fauna, with a summary of other vertebrates from the Aguja Formation, Trans-Pecos Texas". In: Journal of Vertebrate Paleontology 12.4 (1992), pp. 472-493.

[19969] T. Rowe and J. Gauthier. Ceratosauria. English. The Dinosauria. University of California Press, Berkeley. 1990, pp. 151-168.

[19970] T. B. Rowe, H.-D. Sues, and R. R. Reisz. "Dispersal and diversity in the earliest North American sauropodomorph dinosaurs, with a description of a new taxon". English. In: Proceedings of the Royal Society B 278 (2011), pp. 1044-1053. DOI: 10.1098/rspb.2010.1867. 
[19971] S. M. Rowland, V. A. Luchinina, I. V. Korovnikov, D. P. Sipin, A. I. Tarletskov, and A. V. Fedoseev. "Biostratigraphy of the Vendian-Cambrian Sukharikha River section, northwestern Siberian Platform". English. In: Canadian Journal of Earth Sciences 35.4 (1998), pp. 339-352.

[19972] K. Roy. "Effects of the Mesozoic Marine Revolution on the Taxonomic, Morphologic, and Biogeographic Evolution of a Group: Aporrhaid Gastropods During the Mesozoic". English. In: Paleobiology 20.3 (1994), pp. 274-296.

[19973] R. Royo-Torres, L. Alcalá, and A. Cobos. “A new specimen of the Cretaceous sauropod Tastavinsaurus sanzi from El Castellar (Teruel, Spain), and a phylogenetic analysis of the Laurasiformes". English. In: Cretaceous Research 34.1 (2012), pp. 61-83. DOI: 10.1016/j.cretres.2011.10.005.

[19974] R. Royo-Torres and J. I. Canudo. “El dinosaurio saurópodo (Aptiense, Cretacico Inferior) de Peñarroya de Tastavins (Teruel) [The sauropod dinosaur (Aptian, Lower Cretaceous) from Peñarroya de Tastavins (Teruel)]". Spanish. In: Actas de Las I Jornadas Internacionales Sobre Paleontologa de Dinosaurios y Su Entorno, Salas de Los Infantes, Burgos, Spain, September 1999. Colectivo ArqueológicoPaleontológico de Salas, C.A.S. (2001), pp. 417-425.

[19975] R. Royo-Torres and A. Cobos. "Presencia en Riodeva (Teruel) de la mayor vértebra caudal (Dinosauria, Sauropoda) de Europa [Presence in Riodeva of the largest caudal vertebra (Dinosauria, Sauropoda) in Europe]". Spanish. In: Geogaceta 38 (2005), pp. 23-26.

[19976] R. Royo-Torres, A. Cobos, and L. Alcalá. "A giant European dinosaur and a new sauropod clade". English. In: Science 314 (2006), pp. 1925-1927.

[19977] R. Royo-Torres, A. Cobos, A. Aberasturi, E. Esplez, I. Fierro, A. González, L. Luque, L. Mampel, and L. Alcalá. "Riodeva sites (Teruel, Spain) shedding light to European sauropod phylogeny". English. In: Geogaceta 41 (2007), pp. 183-186.

[19978] R. Royo-Torres, A. Cobos, P. Mocho, and L. Alcalá. “Origin and evolution of turiasaur dinosaurs set by means of a new 'rosetta' specimen from Spain". English. In: Zoological Journal of the Linnean Society 191.1 (2021), pp. 201-227. DOI: 10.1093/zoolinnean/zlaa091.

[19979] R. Royo-Torres, C. Fuentes, M. Meijide, F. Meijide-Fuentes, and M. Meijide-Fuentes. "A new Brachiosauridae sauropod dinosaur from the Lower Cretaceous of Europe (Soria Province, Spain)". English. In: Cretaceous Research 80 (2017), pp. 38-55. DOI: 10.1016/j.cretres.2017.08.012.

[19980] R. Royo-Torres and J. I. Ruiz-Omeñaca. The pubis of Aragosaurus ischiaticus Sanz, Buscalioni, Casanovas $\mathcal{E}$ Santafé, 1987, a camarasaurid sauropod from the Upper Hauterivian (Lower Cretaceous) of Galve, Teruel, Spain. English. Albarracin, 1999.

[19981] R. Royo-Torres, P. Upchurch, P. D. Mannion, R. Mas, A. Cobos, F. Gascó, L. Alcalá, and J. L. Sanz. "The anatomy, phylogenetic relationships, and stratigraphic position of the Tithonian-Berriasian Spanish sauropod dinosaur Aragosaurus ischiaticus". English. In: Zoological Journal of the Linnean Society 171.3 (2014), pp. 623-655. DOI: 10.1111/zoj.12144.

[19982] R. Royo-Torres, P. Upchurch, J. I. Kirkland, D. D. DeBlieux, J. R. Foster, A. Cobos, and L. Alcalá. "Descendants of the Jurassic turiasaurs from Iberia found refuge in the Early Cretaceous of western USA". English. In: Scientific Reports 7 (2017), 14311:1-12. DOI: 10.1038/s41598-017-14677-2.

[19983] S. Rozadilla, F. L. Agnolin, F. E. Novas, A. M. Aranciaga Rolando, M. J. Motta, J. M. Lirio, and M. P. Isasi. "A new ornithopod (Dinosauria, Ornithischia) from the Upper Cretaceous of Antarctica and its palaeobiogeographical implications". English. In: Cretaceous Research 57 (2016), pp. 311-324. DOI: 10.1016/j.cretres.2015.09.009.

[19984] A. C. Rozefelds, D. C. Christophel, and N. F. Alley. "Tertiary occurrence of the fern Lygodium (Schizaeaceae) in Australia and New Zealand". English. In: Memoirs of The Queensland Museum 32 (1992), pp. 203-222.

[19985] A. C. Rozefelds, A. Warren, A. Whitfield, and S. Bull. "New evidence of large Permo-Triassic dicynodonts (Synapsida) from Australia". English. In: Journal of Vertebrate Paleontology 31.5 (2011), pp. 1158-1162. 
[19986] J. G. Rozen. "A new species of the bee Heterosarus from Dominican amber (Hymenoptera: Andrenidae; Panurginae)". English. In: Journal of the Kansas Entomological Society, Supplement 69 (1996), pp. 346-352.

[19987] A. G. Rozenbaum, D. Shaked Gelband, M. Stein, H. K. Mienis, and R. Rabinovich. “First evidence of ancient deer (cervid) in the late Miocene Bira Formation, Northern Israel". English. In: PLoS ONE 12.e0185268 (2017), pp. 1-16. DOI: 10.1371/journal.pone.0185268.

[19988] S. V. Rozhnov. "Reinterpretation of Baltic Ordovician Heckerites multistellatus, Rozhnov, 1987 as a possible paracrinoid based on new material". English. In: Zoosymposia 7 (2012), pp. 306-316.

[19989] S. V. Rozhnov. On the Paracrinoid-like Echinoderms Achradocystites Volborth, 1870 and Heckerites Rozhnov, 1987 from the Ordovician of Baltica. English. Instituto Geologico y Minero de Espana. 2015, pp. 147-150.

[19990] S. V. Rozhnov. "Elgaecrinus uralicus gen. et sp. nov., a new crotalocrinitid (Crinoidea," English. In: Estonian Journal of Earth Sciences 67.1 (2018), pp. 12-18. DOI: 10.3176/earth.2017.23.

[19991] S. V. Rozhnov. "Carpozoan Echinoderms from the Middle Cambrian (Mayaktakh Formation) of Siberia (Lower Reaches of the Lena River)". English. In: Paleontological Journal 40.3 (2006), pp. 266275. DOI: $10.1134 /$ S0031030106030063.

[19992] S. V. Rozhnov. "Aboral nervous system in two Ordovician crinoids: Reconstruction and comparison of Baltic Pentamerocrinus Jaekel and Grammocrinus Eichwald". English. In: Paleontological Journal 50.2 (2016), pp. 163-173.

[19993] S. V. Rozhnov and P. V. Federov. "A New Cryptocrinid Genus (Eocrinoidea, Echinodermata) from the Bioherm-related Volkhov Facies (Late Arenigian, Ordovician), Leningrad Region". Russian. In: Paleontologicheskiy Zhurnal 6 (2001), pp. 42-49.

[19994] M. Rubel. "Silurian brachiopods Dictyonellida, Strophomenida, Productida, Orthotetida, Protorthida and Orthida from Estonia". English. In: Fossilia Baltica 4 (2011), pp. 1-65.

[19995] M. Rubel, O. Hints, P. Männik, T. Meidla, V. Nestor, L. Sarv, and I. Sibul. "Lower Silurian biostratigraphy of the Viirelaid core, western Estonia". English. In: Estonian Journal of Earth Sciences 56.4 (2007), pp. 193-204.

[19996] M. Rubel and L. Popov. "Brachiopods of the subfamily Atelelasmatinae (Clitambonitacea) from the Arenig, Ordovician, of the Baltic klint area". English. In: Proceedings of the Estonian Academy of Sciences. Geology 43.4 (1994), pp. 192-202.

[19997] D. Ruberti. "Facies analysis of an Upper Cretaceous high-energy rudist-dominated carbonate ramp (Matese Mountains, central-southern Italy): subtidal and peritidal cycles". In: Sedimentary Geology 113 (1997), pp. 81-110.

[19998] D. Ruberti, G. Carannante, L. Simone, G. Sirna, and M. Sirna. Sedimentary processes and biofacies of Late Cretaceous low-energy carbonate ramp systems (southern Italy). English. Vol. 87. Cretaceous rudists and carbonate platforms: environmental feedback, SEPM Special Publication. 2007, pp. 5770.

[19999] B. S. Rubidge. "The cranial morphology of a new species of the genus Eodicynodon (Therapsida, Dicynodontia)". English. In: Navorsinge van die Nasionale Museum Bloemfontein 7.2 (1990), pp. 2942.

[20000] B. S. Rubidge. "Australosyodon, the first primitive anteosaurid dinocephalian from the Upper Permian of Gondwana". English. In: Palaeontology 37.3 (1994), pp. 579-594.

[20001] B. S. Rubidge. "A new primitive dinocephalian mammal-like reptile from the Permian of southern Africa". English. In: Palaeontology 34 (1991), pp. 547-559.

[20002] B. S. Rubidge and J. A. Hopson. "A new anomodont therapsid from South Africa and its bearing on the ancestry of Dicynodontia". English. In: South African Journal of Science 86 (1990), pp. 43-45.

[20003] B. S. Rubidge, G. M. King, and J. P. Hancox. "The Postcranial Skeleton of the Earliest Dicynodont Synapsid Eodicynodon from the Upper Permian of South Africa". English. In: Palaeontology 37.2 (1994), pp. 397-408. 
[20004] B. S. Rubidge, S. P. Modesto, C. A. Sidor, and J. Welman. “Eunotosaurus africanus from the EccaBeaufort contact in Northern Cape Province, South Africa - implications for Karoo Basin development". English. In: South African Journal of Science 95.11/12 (1999), pp. 553-556.

[20005] B. S. Rubidge, C. A. Sidor, and S. P. Modesto. "A new burnetiamorph (Therapsida: Biarmosuchia) from the Middle Permian of South Africa". English. In: Journal of Paleontology 80.4 (2006), pp. 740 749.

[20006] B. S. Rubidge and C. A. Sidor. "On the Cranial Morphology of the Basal Therapsids Burnetia and Proburnetia (Therapsida: Burnetiidae)". English. In: Journal of Vertebrate Paleontology 22.2 (2002), pp. 257-267.

[20007] B. S. Rubidge and J. A. van den Heever. "Morphology and systematic position of the dinocephalian Styracocephalus platyrhynchus". English. In: Lethaia 30 (1997), pp. 157-168.

[20008] D. Rubilar-Rogers, K. Moreno, N. Blanco, and J. O. Calvo. "Theropod dinosaur trackways from the Lower Cretaceous of the Chacarilla Formation, Chile". English. In: Revista Geologica de Chile 35.1 (2008), pp. 175-184.

[20009] D. Rubilar-Rogers, R. A. Otero, R. E. Yury-Yáñez, A. O. Vargas, and C. S. Gutstein. “An overview of the dinosaur fossil record from Chile". English. In: Journal of South American Earth Sciences 37 (2012), pp. 242-255. DOI: 10.1016/j.jsames.2012.03.003.

[20010] N. Ruckert-Ulkumen, Th. Kowalke, R. Matzke-Karasz, W. Witt, and E. Yigitbas. "Biostratigraphy of the Paratethyan Neogene at Yalova (Izmit-Province, NW-Turkey)". English. In: Newsletters on Stratigraphy 42 (2006), pp. 43-68.

[20011] N. Ruckert-Ulkumen and E. Yigitbas. "Pharyngeal Teeth, Lateral Ethmoids, and Jaw Teeth of Fishes and Additional Fossils From the Late Miocene (Late Khersonian / Early Maeotian) of Eastern Paratethys (Yalova, Near Istanbul, Turkey)". English. In: Turkish Journal of Earth Sciences 16 (2007), pp. 211-224.

[20012] D. M. Rudkin, R. P. Tripp, and R. Ludvigsen. “The Ordovician trilobite genus Hemiarges (Lichidae: Trochurinae) from North American and Greenland". English. In: New York State Museum Bulletin 481 (1994), pp. 289-306.

[20013] D. M. Rudkin, G. A. Young, and G. S. Nowlan. “The oldest horseshoe crab: a new xiphosurid from Late Ordovician Konservat-Lagerstätten deposits, Manitoba, Canada". English. In: Palaeontology 51 (2008), pp. 1-9. DOI: 10.1111/j.1475-4983.2007.00746.x.

[20014] P. Rudra and S. Bardhan. "Status of Trigonia ventricosa (Bivalvia) from the Upper Jurassic-Lower Cretaceous of Kutch, western India: Kitchin's unfinished synthesis". English. In: Cretaceous Research 27 (2006), pp. 611-628.

[20015] M. Ruecklin, H. Lelievre, and C. Klug. "Placodermi from the Early Devonian Kess-Kess mounds of Hamar Laghdad, Southern Morocco". English. In: 290.1-3 (2018), pp. 301-306. DOI: 10.1127 / njgpa/2018/0780.

[20016] D. R. Ruez. "Mammalian taphonomy of the Early Irvingtonian (Late Pliocene) Inglis 1C Fauna (Citrus County, Florida)". English. In: Southeastern Geology 41.3 (2002), pp. 159-168.

[20017] D. R. Ruez Jr. "Early Irvingtonian (latest Pliocene) rodents from Inglis 1C, Citrus County, Florida”. English. In: Journal of Vertebrate Paleontology 21.1 (2001), pp. 153-171.

[20018] D. R. Ruez Jr. “Late Pleistocene (Rancholabrean) records of the harvest mouse (Reithrodontomys) in Florida". English. In: Florida Scientist 63.3 (2000), pp. 182-190.

[20019] D. R. Ruez Jr. "Mammalian taphonomy of the early Irvingtonian (late Pliocene) Inglis 1C fauna (Citrus County, Florida)". English. In: Southeastern Geology 41.3 (2002), pp. 159-168.

[20020] D. R. Ruez Jr. "Earliest record of Palaeolama (Mammalia, Camelidae) with comments on Palaeolama guanajuatensis". English. In: Journal of Vertebrate Paleontology 25.3 (2005), pp. 741-744.

[20021] D. R. Ruez Jr. and C. J. Bell. “First Pleistocene jumping mouse (Zapus, Zapodinae, Rodentia) from Utah". English. In: Western North American Naturalist 64.4 (2004), pp. 439-444. 
[20022] T. Rüffer and V. Zamparelli. "Facies and biota of Anisian to Carnian carbonate platforms in the Northern Calcareous Alps (Tyrol and Bavaria)". In: Facies 37 (1997), pp. 115-136.

[20023] E. T. Ruggiero. "Zeilleria laboniae (Greco) From the Sinemurian of Longobucco (Southern Italy)". English. In: Mesozoic Brachiopods of Alpine Europe. Budapest: Hungarian Geological Society, 1993, pp. 133-141.

[20024] L. C. Ruiz and M. E. Quatrocchio. “Srivastavapollenites exoticus no. gen. et. sp. de la Formación Pedro Luro (Paleoceno), Cuenca del Colorado, Argentina". Spanish. In: Ameghiniana 30.3 (1993), pp. 311-315.

[20025] P. G. Ruiz, M. S. Fernández, M. Talevi, J. M. Leardi, and M. A. Reguero. “A new Plotosaurini mosasaur skull from the upper Maastrichtian of Antarctica. Plotosaurini paleogeographic occurrences". English. In: Cretaceous Research 103 (2019), 104166:1-11. DOI: 10.1016/j.cretres.2019.06.012.

[20026] J. I. Ruiz-Omeñaca. Dientes de ornitópodos extraños en el Barremiense inferior (Cretácico Inferior) de Teruel (Cordillera Ibérica, España) [Strange ornithopod teeth from the lower Barremian (Lower Cretaceous) of Teruel (Iberian Range, Spain)]. Spanish. Karlsruhe, 2000.

[20027] J. I. Ruiz-Omeñaca. “Delapparentia turolensis nov. gen et sp., un nuevo dinosaurio iguanodontoideo (Ornithischia: Ornithopoda) en el Cretácico Inferior de Galve [Delapparentia turolensis nov. gen et sp., a new iguanodontoid dinosaur(Ornithischia: Ornithopoda) from the Lower Cretaceous of Galve (Spain)]". Spanish. In: Estudios Geológicos 67.1 (2011), pp. 83-110.

[20028] J. I. Ruiz-Omeñaca, J. I. Canudo, and G. Cuenca-Bescós. Dientes de dinosaurios ornitópodos en el Barremiense superior de Castellote y Mas de las Matas (Teruel) [Ornithopod dinosaur teeth in the Upper Barremian of Castellote and Mas de las Matas (Teruel)]. Spanish. Tomo Estraordinario, 125 Aniversario de la RSEHN. Real Sociedad Española de Historia Natural, Madrid. 1996, pp. 315-319.

[20029] J. I. Ruiz-Omeñaca and J. I. Canudo. “Un nuevo dinosaurio terópodo (Prodeinodon sp.) en el Cretácio Inferior de La Cantalera (Teruel) [A new theropod dinosaur (Prodeinodon sp.) from the Lower Cretaceous of La Cantalera (Teruel, Spain)]". English. In: Geogaceta 34 (2003), pp. 111-114.

[20030] J. I. Ruiz-Omeñaca and J. I. Canudo. “Pleurocoelus valdensis Lydekker 1889 (Saurischia, Sauropoda) en el Cretácico Inferior (Barremiense) de la Pennsula Ibérica [Pleurocoelus valdensis Lydekker 1889 (Saurischia, Sauropoda) in the Lower Cretaceous (Barremian) of the Iberian Peninsula]". Spanish. In: Geogaceta 38 (2005), pp. 43-45.

[20031] J. I. Ruiz-Omeñaca, J. I. Canudo, and G. Cuenca-Bescós. "Primera evidencia de un área de alimentación de dinosaurios herbvoros en el Cretácico Inferior de España (Teruel) [First evidence of a feeding area of herbivorous dinosaurs in the Lower Cretaceous of Spain (Teruel)]". Spanish. In: Monografias de la Academia de Ciencias Exactas, Fisicas, Quimicas y Naturales de Zaragoza 10 (1997), pp. $1-48$.

[20032] J. I. Ruiz-Omeñaca, J. I. Canudo, and P. Infante. Presencia de un posible alosáurido (Dinosauria: Theropoda) en el Cretácico Inferior (Barremiense inferior) de La Maca 3 (Galve, Teruel) [Presence of a possible allosaurid (Dinosauria: Theropoda) in the Lower Cretaceous (lower Barremian) of La Maca 3 (Galve, Teruel)]. Spanish. 2005.

[20033] J. I. Ruiz-Omeñaca, J. I. Canudo, M. Aurell, B. Bádenas, J. L. Barco, G. Cuenca-Bescós, and J. Ipas. "Estado de las investigaciones sobre los vertebrados del Jurásico Superior y Cretácico Interior de Galve (Teruel) [State of the investigations into the vertebrates of the Upper Jurassic and Lower Cretaceous of Galve (Teruel)]". Spanish. In: Estudios Geológicos 60 (2004), pp. 179-202.

[20034] J. I. Ruiz-Omeñaca, J. I. Canudo, L. Piñuela, and J. C. Garca-Ramos. Dientes de dinosaurios carnvorous (Saurischia: Theropoda) del Jurásico Superior de Asturias [Teeth of carnivorous dinosaurs (Saurischia: Theropoda) from the Upper Jurassic of Asturias]. English. 2007.

[20035] J. I. Ruiz-Omeñaca, J. I. Canudo, and G. Cuenca-Bescós. “Sobre las especies de Iguanodon (Dinosauria, Ornithischia) encontradas en el Cretácico inferior de España [On the species of Iguanodon (Dinosauria, Ornithischia) found in the Lower Cretaceous of Spain]". Spanish. In: Geogaceta 24 (1998), pp. 275-278. 
[20036] J. I. Ruiz-Omeñaca, J. I. Canudo, G. CUenca-Bescós, P. Cruzado-Caballero, J. M. Gasca, and M. Moreno-Azanza. "A new basal ornithopod dinosaur from the Barremian of Galve, Spain". English. In: Comptes Rendus Palevol 11 (2012), pp. 435-444. DOI: 10.1016/j.crpv.2012.06.001.

[20037] J. I. Ruiz-Omeñaca, J. I. Canudo, and G. Cuenca-Bescós. “Primeros restos de reptiles voladores (Pterosauria: Pterodactyloidea) en el Barremiense superior (Cretacico inferior) de Vallipón (Castellote, Teruel) [First remains of flying reptiles (Pterosauria: Pterodactyloidea) in the upper Barremian (Lower Cretaceous) of Vallipón (Castellote, Teruel)]". Spanish. In: Mas de las Matas 17 (1998), pp. 225-249.

[20038] J. I. Ruiz-Omeñaca, J. I. Canudo, and G. Cuenca-Bescós. “Los dinosaurios del Jurásico y del Cretácico de la Cordillera Ibérica aragonesa [The Jurassic and Cretaceous dinosaurs of the Aragonese Iberian Cordillera]". English. In: Actas del I Encuentro Nacional de Estudios sobre la Cordillera Ibérica (ciencias de la naturaleza). Veruela-Tarazona, Spain: Moreno Twose, 2002, pp. 119-130.

[20039] J. I. Ruiz-Omeñaca and J. I. Canudo. “Dinosaurios (Saurischia, Ornithischia) en el Barremiense (Cretácico Inferior) de la pennsula Ibérica [Dinosaurs (Saurischia, Ornithischia) in the Barremian (Lower Cretaceous) of the Iberian peninsula]". English. In: Dinosaurios y Otros Reptiles Mesozóicos de España. Logroño, Spain: Instituto de Estudios Riojanos, 2003, pp. 269-312.

[20040] J. I. Ruiz-Omeñaca, J. M. Canudo, and G. Cuenca-Bescós. “Vallipón, el yacimiento con vertebrados continentales del Cretácico Inferior más completo de Europe [Vallipón, the most complete locality with Lower Cretaceous continental vertebrates in Europe]". Spanish. In: El Masino (2003).

[20041] J. I. Ruiz-Omeñaca and G. Cuenca-Bescós. Ornithopod dinosaurs from the Early Cretaceous of the Iberian peninisula (Spain and Portugal). English. 2004.

[20042] J. I. Ruiz-Omeñaca, X. Pereda Suberbiola, J. Company, and M. Belinchón. “Dientes de arcosaurios (Crocodyliformes, Theropoda) del Jurásico Superior de Buñol (Valencia) [Archosaurian teeth (Crocodyliformes, Theropoda) from the Late Jurassic of Buñol (Valencia)]". Spanish. In: Geogaceta 48 (2010), pp. 79-82.

[20043] J. I. Ruiz-Omeñaca, X. Pereda Suberbiola, L. Piñuela, and J. C. Garca Ramos. "First evidence of stegosaurs (Dinosauria: Thyreophora) in the Vega Formation, Kimmeridgian, Asturias, N Spain". English. In: Geogaceta 53 (2013), pp. 37-40.

[20044] J. I. Ruiz-Omeñaca and X. Pereda-Suberbiola. “Un documento inédito de Royo y Gómez sobre los dinosaurios del Levante [An unpublished document by Royo y Gómez on the dinosaurs of Levante]". Spanish. In: Temas Geologico-Mineros ITGE 26 (1999), pp. 111-112.

[20045] J. I. Ruiz-Omeñaca, L. Piñuela, and J. C. Garca-Ramos. “Una vértebra de un pequeño ornitópodo (Dinosauria: Ornithischia) del Kimmeridgiense (Formación Lastres) de Tazones (Villaviciosa, Asturias) [A vertebra from a small ornithopod (Dinosauria: Ornithischia) from the Kimmeridgian (Lastres Formation) of Tazones (Villaviciosa, Asturias)]". Spanish. In: Geogaceta 42 (2007), pp. 8186.

[20046] J. I. Ruiz-Omeñaca, L. Piñuela, and J. C. Garca-Ramos. "Nuevos restos de ornitópodo (Ornithischia: Ankylopollexia) del Jurásico Superior de Tazones, Asturias (Formación Tereñes) [New ornithopod remains (Ornithischia: Ankylopollexia) from the Upper Jurassic of Tazones, Asturias (Tereñes Formation)]". Spanish. In: Geogaceta 45 (2008), pp. 59-62.

[20047] J. I. Ruiz-Omeñaca, L. Piñuela, and J. C. Garca-Ramos. “El primer diente de ornitópodo del Jurásico Superior de España (Asturias) [The first ornithopod tooth from the Late Jurassic of Spain (Asturias)]". Spanish. In: Geogaceta 48 (2010), pp. 83-86.

[20048] J. I. Ruiz-Omeñaca, L. Piñuela, and J. C. Garca-Ramos. "Dakosaurus sp. (Thalattosuchia: Metriorhynchidae) en el Kimmeridgiense de Colunga (Asturias)". Spanish. In: Comunicaciones del V Congreso del Jurásico de España 5 (2010), pp. 193-199.

[20049] J. I. Ruiz-Omeñaca, L. Piñuela, and J. C. Garca-Ramos. "Primera descripción de dientes de dinosaurios terópodos en la Formación Tereñes (Kimmeridgiense), Asturias [First description of theropod dinosaur teeth in the Tereñes Formation (Kimmeridgian), Asturias]". Spanish. In: Geogaceta 52 (2012), pp. 177-180. 
[20050] J. I. Ruiz-Omeñaca and A. Santos Cubedo. “Un húmero de iguanodóntido (Ornithischia: Ornithopoda) del Cretácico inferior (Aptiense) de Morella (Castellón, España) [An iguanodontid (Ornithischia: Ornithopoda) humerus from the Lower Cretaceous (Aptian) of Morella (Castellón, Spain)]". Spanish. In: Geogaceta 24 (1998), pp. 279-282.

[20051] D. Ruiz-Ramoni, M. Montellano-Ballesteros, A. D. Rincón, A. Solórzano, and G. Guzmán. “Presence of Amphimachairodus coloradensis (Cook, 1922) (Felidae: Machairodontinae) in the Neogene of Hidalgo, Central Mexico". English. In: Journal of South American Earth Sciences 100 (2020), 102550:1-11.

[20052] D. Ruiz-Ramoni, A. D. Rincón, A. Solórzano, and S. Moyá-Solá. “The first fossil Platyrrhini (Primates: Anthropoidea) from Venezuela: A capuchin monkey from the Plio-Pleistocene of El Breal de Orocual". English. In: Journal of Human Evolution 105 (2017), pp. 127-131.

[20053] D. Ruiz-Ramoni, A. D. Rincón, and M. Montellano-Ballesteros. “Taxonomic revision of a Machairodontinae (Felidae) from the Late Hemphillian". English. In: Historical Biology (2019). DOI: 10.1080 / 08912963.2019.1583750.

[20054] F. J. Ruiz-Sánchez, J. I. Lacomba-Andueza, M. Freudenthal, and M. A. Álvarez-Sierra. "A new species of Vasseuromys (Gliridae, Mammalia) from the Upper Oligocene of the Ebro Basin (Spain)". English. In: Palaeontologische Zeitschrift 88 (2014), pp. 73-84.

[20055] F. J. Ruiz-Sánchez, X. Murelaga, M. Freudenthal, J. C. Larrasoaña, and M. Garcés. “Vasseuromys rambliensis sp. nov. (Gliridae, Mammalia) from the Ramblian (Lower Miocene) of the Tudela Formation (Ebro basin, Spain)". English. In: Palaeontologia Electronica 15.1.4a (2012), pp. 1-16.

[20056] J. P. Rule, J. W. Adams, F. G. Marx, A. R. Evans, A. J. D. Tennyson, R. P. Scofield, and E. M. G. Fitzgerald. "First monk seal from the Southern Hemisphere rewrites the evolutionary history of true seals". English. In: Proceedings of the Royal Society B 287 (2020), p. 20202318. DOI: 10.1098/rspb. 2020.2318

[20057] J. P. Rule, J. W. Adams, D. S. Rovinsky, D. P. Hocking, A. R. Evans, and E. M. G. Fitzgerald. “A new large-bodied Pliocene seal with unusual". English. In: Royal Society Open Science 7 (2020), pp. 1-32. DOI: $10.1098 /$ rsos.201591.

[20058] J. P. Rule, J. W. Adaws, and E. M. G. Fitzgerald. “Colonization of the ancient southern oceans by small-sized Phocidae: new evidence from Australia". English. In: Zoological Journal of the Linnean Society (2020). DOI: 10.1093/zoolinnean/zlaa075.

[20059] J. P. Rule, D. P. Hocking, and E. M. G. Fitzgerald. “Pliocene monachine seal (Pinnipedia: Phocidae) from Australia constrains timing of pinniped turnover in the Southern Hemisphere". English. In: Journal of Vertebrate Paleontology (2020), e1734015. DOI: 10.1080/02724634.2019.1734015.

[20060] V. Rull. "Palaeofloristic and palaeovegetational changes across the Paleocene/Eocene boundary in northern South America". English. In: Review of Palaeobotany and Palynology 107 (1999), pp. 8395.

[20061] V. Rull. "Middle Eocene Mangroves and Vegetation Changes in the Maracaibo Basin, Venezuela”. English. In: Palaios 13.3 (1998), pp. 287-296.

[20062] K. Rumbucher. "Hemerobiidae (Insecta, Planipennia), eine bisher noch nicht entdeckte Familie der Santana Formation aus der brasilianischen Unterkreide". German. In: Bericht der Naturforschenden Gesellschaft Augsburg 55 (1995), pp. 46-61.

[20063] M. Rummel. “Mixocricetodon dehmi n. gen., n. sp., ein neuer Cricetide (Rodentia, Mammalia) aus dem Mittelmiozän von Süddeutschland". German. In: Mitteilungen der Bayerische Staatssammlung für Paläontologie und historische Geologie 37 (1997), pp. 75-93.

[20064] M. Rummel. "Ein neuer Cricetodon aus dem Miozän von Petersbuch bei Eichstätt". German. In: Stuttgarter Beiträge zur Naturkunde B 311 (2001), pp. 1-6.

[20065] B. T. Rumsey, A. A. Klompmaker, and R. W. Portell. "Paleobiogeography of the fossil box crab Calappilia (Brachyura: Calappidae) with a new species from the Eocene-Oligocene of Florida". English. In: Journal of Crustacean Biology 36.3 (2016), pp. 329-337. DOI: 10.1163/1937240X-00002422. 
[20066] B. Runnegar and J. Pojeta Jr. "The earliest bivalves and their Ordovician descendants". English. In: American Malacological Bulletin 9.2 (1992), pp. 117-122.

[20067] C. Runnels and T. H. van Andel. "The Lower and Middle Paleolithic of Thessaly, Greece". English. In: Journal of Field Archaeology 20 (1993), pp. 299-317.

[20068] G. Rusciadelli, C. Ricci, and B. Lathuiliére. "The Ellipsactinia Limestones of the Marsica area (Central Apennines): A reference zonation model for Upper Jurassic Intra-Tethys reef complexes". English. In: Sedimentary Geology 233 (2011), pp. 69-87.

[20069] A. W. A. Rushton, L. R. M. Cocks, and R. A. Fortey. “Upper Cambrian trilobites and brachiopods from Severnaya Zemlya, Arctic Russia, and their implications for correlation and biogeography". English. In: Geological Magazine 139.3 (2002), pp. 281-290.

[20070] D. A. Russell. "Jurassic marine reptiles from Cape Grassy, Melville Island, Arctic Canada". English. In: Geological Survey of Canada Bulletin 450 (1993), pp. 195-201.

[20071] D. A. Russell and Z.-M. Dong. "The affinities of a new theropod from the Alxa Desert, Inner Mongolia, People's Republic of China". English. In: Canadian Journal of Earth Sciences 30.10-11 (1994), pp. 2107-2127.

[20072] D. A. Russell and Z.-M. Dong. "A nearly complete skeleton of a new troodontid dinosaur from the Early Cretaceous of the Ordos Basin, Inner Mongolia, People's Republic of China". English. In: Canadian Journal of Earth Sciences 30.10-11 (1994), pp. 2163-2173.

[20073] D. A. Russell and X.-J. Zhao. "New psittacosaur occurrences in Inner Mongolia". In: Canadian Journal of Earth Sciences 33.4 (1996), pp. 637-648.

[20074] D. A. Russell and Z. Zheng. "A large mamenchisaurid from the Junggar Basin, Xinjiang, People's Republic of China". English. In: Canadian Journal of Earth Sciences 30.10-11 (1994), pp. 2082-2095.

[20075] M. P. Russell. "Modern Death Assemblages and Pleistocene Fossil Assemblages in Open Coast High Energy Environments, San Nicolas Island, California". English. In: Palaios 6.2 (1991), pp. 179191.

[20076] F. Russo, A. Mastandrea, M. Stefani, and C. Neri. “Carbonate facies dominated by syndepositional cements: a key component of Middle Triassic platforms. The Marmolada case history (Dolomites, Italy)". English. In: Facies 42 (2000), pp. 211-226.

[20077] F. Russo, C. Neri, A. Mastandrea, and A. Baracca. "The mud mound nature of the Cassian platform margins of the Dolomites. A case history: The Cipit boulders from Punta Grohmann (Sasso Piatto Massif, Northern Italy)". In: Facies 36 (1997), pp. 25-36.

[20078] J. Russo, O. Mateus, M. Marzola, and A. Balbino. "Two new ootaxa from the late Jurassic: The oldest record of crocodylomorph eggs, from the Lourinhã Formation, Portugal". English. In: PLOS one (2017). DOI: 10.1371/journal.pone.0171919.

[20079] J. Rust. “Oldest known pteroplistine cricket and other Gryllidae (Orthoptera) from the Paleogene Fur and Ølst Formations of Denmark". English. In: Entomologica Scandinavica 30 (1999), pp. 35-45.

[20080] J. Rust. “Insekten aus der Fur-Formation von Dänemark (Moler, ob. Paleozän/unt. Eozän?). 3. Hymenoptera". German. In: Meyniana 42 (1990), pp. 25-45.

[20081] J. Rust and N. M. Andersen. "Giant ants from the Paleogene of Denmark with a discussion of the fossil history and early evolution of ants (Hymenoptera: Formicidae)". English. In: Zoological Journal of the Linnean Society 125 (1999), pp. 331-348.

[20082] J. Rust, J. F. Petruleviius, and A. Nel. “The first damselflies from the lowermost Eocene of Denmark, with a description of a new subfamily (Odonata, Zygoptera, Dysagrionidae)". English. In: Palaeontology 51 (2008), pp. 709-713.

[20083] J. J. Rustán, D. Balseiro, B. Waisfeld, R. D. Foglia, and N. E. Vaccari. “Infaunal molting in Trilobita and escalatory responses against predation". English. In: Geology 39.5 (2011), pp. 495-498.

[20084] M. Rustioni, P. Mazza, A. Azzaroli, G. Boscagli, F. Cozzini, E. Di Vito, M. Masseti, and A. Pisano. "Miocene vertebreate remains from Scontrone, National Park of Abruzzi, Central Italy". English. In: Rendiconti Lincei. Scienze fisiche e naturali 3.3 (1992), pp. 227-237. 
[20085] M. Ruta. "First record of the mitrate Barrandeocarpus from England". English. In: Paläontologische Zeitschrift 71.1/2 (1997), pp. 97-105.

[20086] M. Ruta. "A new stylophoran echinoderm, Juliaecarpus milnerorum, from the late Ordovician Upper Ktaoua Formation of Morocco". English. In: Bulletin of the Natural History Museum of London (Geology) 55.2 (1999), pp. 47-79.

[20087] M. Ruta and P. A. Jell. "Two new anomalocystitid mitrates from the Lower Devonian Humevale Formation of Central Victoria". English. In: Memoirs of the Queensland Museum 43.1 (1999), pp. 399422.

[20088] M. Ruta and P. A. Jell. "Protocytidium Gen. Nov., a new anomalocystitid mitrate from the Victorian latest Ordovician and evolution of the Allanicytidiidae". English. In: Memoirs of the Queensland Museum 43.1 (1999), pp. 353-376.

[20089] D. Ruiková, A. Nel, and J. Prokop. “New dustywings (Neuroptera, Coniopterygidae) from midCretaceous amber of Myanmar reveal spectacular diversity". English. In: ZooKeys 827 (2019), pp. 139-152.

[20090] M. J. Ryan. "A new basal centrosaurine ceratopsid from the Oldman Formation, southeastern Alberta". English. In: Journal of Paleontology 81.2 (2007), pp. 376-396.

[20091] M. J. Ryan, P. J. Currie, J. D. Gardner, M. K. Vickaryous, and J. M. Lavigne. “Baby hadrosaurid material associated with an unusually high abundance of Troodon teeth from the Horseshoe Canyon Formation, Upper Cretaceous, Alberta, Cananda". English. In: Gaia 15 (2000), pp. 123-133.

[20092] M. J. Ryan, D. C. Evans, P. J. Currie, C. M. Brown, and D. Brinkman. “New leptoceratopsids from the Upper Cretaceous of Alberta, Canada". English. In: Cretaceous Research 35.1 (2012), pp. 69-80. DOI: $10.1016 /$ j.cretres.2011.11.018.

[20093] M. J. Ryan, D. C. Evans, and K. M. Shepherd. "A new ceratopsid from the Foremost Formation (middle Campanian) of Alberta". English. In: Canadian Journal of Earth Sciences 49 (2012), pp. 12511262. DOI: 10.1139 /e2012-056.

[20094] M. J. Ryan, D. C. Evans, P. J. Currie, and M. A. Lowman. "A new chasmosaurine from northern Laramidia expands fill disparity in ceratopsid dinosaurs". English. In: Naturwissenchaften 101 (2014), pp. 505-512. DOI: 10.1007/s00114-014-1183-1.

[20095] M. J. Ryan, R. Holmes, and A. P. Russell. "A revision of the late Campanian centrosaurine ceratopsid genus Styracosaurus from the Western Interior of North America". English. In: Journal of Vertebrate Paleontology 27.4 (2007), pp. 944-962.

[20096] M. J. Ryan, R. Holmes, J. Mallon, M. Loewen, and D. C. Evans. "A basal ceratopsid (Centrosaurinae: Nasutoceratopsini) from the Oldman Formation (Campanian) of Alberta, Canada". English. In: Canadian Journal of Earth Sciences 54 (2017), pp. 1-14. DOI: 10.1139/cjes-2016-0110.

[20097] M. J. Ryan, A. P. Russell, D. A. Eberth, and P. J. Currie. “The taphonomy of a Centrosaurus (Ornithischia: Ceratopsidae) bone bed from th Dinosaur Park Formation (Upper Campanian), Alberta, Canada, with comments on cranial ontogeny". In: Palaios 16 (2001), pp. 482-506.

[20098] M. J. Ryan and A. P. Russell. "A new centrosaurine ceratopsid from the Oldman Formation of Alberta and its implications for centrosaurine taxonomy and systematics". English. In: Canadian Journal of Earth Sciences 42 (2005), pp. 1369-1387.

[20099] N. Rybczynski, M. R. Dawson, and R. H. Tedford. "A semi-aquatic Arctic mammalian carnivore from the Miocene epoch and origin of Pinnipedia". English. In: Nature 458 (2009), pp. 1021-1024.

[20100] J. R. Rylaarsdam, B. L. Varban, A. G. Plint, L. G. Buckley, and R. T. McCrea. “Middle Turonian dinosaur paleoenvironments in the Upper Cretaceous Kaskapau Formation, northeast British Columbia". English. In: Canadian Journal of Earth Sciences 43 (2006), pp. 631-652.

[20101] O. V. Ryzhkova. "New bugs of the family Archegocimicidae (Hemiptera: Heteroptera) from the Upper Jurassic of Mongolia". English. In: Paleontological Journal 45.5 (2011), pp. 546-551. 
[20102] O. V. Ryzhkova. "New saldoid bugs of the family Enicocoridae (Hemiptera: Heteroptera: Leptopodomorpha) from the Lower Cretaceous of Mongolia". English. In: Paleontological Journal 46 (2012), pp. 485-494.

[20103] O. V. Ryzhkova. "New saldoid bug of the family Archegocimicidae (Hemiptera: Heteroptera: Leptopodomorpha) from the Middle Jurassic of eastern Siberia". English. In: Paleontological Journal 47 (2013), pp. 180-184.

[20104] O. V. Ryzhkova. “New Saldidae-Enicocorinae (Heteroptera: Leptopodomorpha) from the Lower Cretaceous of Siberia and Mongolia". English. In: Paleontological Journal 49 (2015), pp. 153-161.

[20105] O. V. Ryzhkova and R. A. Coram. "Archegocimicidae (Insecta: Heteroptera) from the Purbeck Limestone Group (Lower Cretaceous: Berriasian) of southern England". English. In: Cretaceous Research 61 (2016), pp. 199-208.

[20106] B. Rzebik-Kowalska. "Insectivora (Mammalia) from the Miocene of Belchatow in Poland. I. Metacodontidae: Plesiosorex Pomel, 1854". English. In: Acta zoologica Cracoviensia 36.2 (1993), pp. 267274.

[20107] B. Rzebik-Kowalska. “Insectivora (Mammalia) from the Miocene of Belchatow in Poland. II. Soricidae Fischer von Waldheim, 1817". In: Acta zoologica Cracoviensia 37.1 (1994), pp. 137-155.

[20108] B. Rzebik-Kowalska. "Insectivora (Mammalia) from the Miocene of Belchatow, Poland. III. Dimylidae Schlosser, 1887". In: Acta zoologica Cracoviensia 39.1 (1996), pp. 447-468.

[20109] B. Rzebik-Kowalska. "Pliocene and Pleistocene Insectivora (mammalia) of Poland. VII. Soricidae: Mafia Reumer, 1984, Sulimskia Reumer, 1984 and Paenelimnoecus Baudelot, 1972". In: Acta Zoologia Cracoviensia 33.14 (1990), pp. 303-327.

[20110] B. Rzebik-Kowalska. “Pliocene and Pleistocene Insectivora (Mammalia) of Poland. VIII. Soricidae: Sorex Linnaeus, 1758, Neomys Kaup, 1829, Macroneomys Fejfar, 1966, Paenelimnoecus Baudelot, 1972 and Soricidae indeterminata." In: Acta Zoologica Cracoviensia 34.2 (1991), pp. 323-424.

[20111] B. Rzebik-Kowalska. "Pliocene and Pleistocene Insectivora (Mammalia) of Poland. VI. Soricidae: Deinsdorfia Heller, 1963 and Zelceina Sulimski, 1962". In: Acta Zoologica Cracoviensia 33.4 (1990), pp. $45-77$.

[20112] M. A. Rzhonsnitskaya, B. P. Markovskii, Y. A. Yudina, and E. V. Sokiran. “Late Frasnian Atrypida (Brachiopoda) from the South Urals, South Timan and Kuznetsk Basin (Russia)". English. In: Acta Palaeontologica Polonica 43.2 (1998), pp. 305-344.

[20113] A. A. Sá, C. Meireles, and J. C. Gutiérrez-Marco. "Reappraisal of the Ordovician stratigraphy and paleontology of Trás-os-Montes (Central Iberian Zone, NE Portugal)". English. In: Ordovician from the Andes. Tucumán: Universidad Nacional de Tucumán, 2003, pp. 131-136.

[20114] K. Sabath. "Upper Cretaceous amniotic eggs from the Gobi Desert". English. In: Acta Palaeontologica Polonica 36.2 (1991), pp. 151-192.

[20115] N. Sabattini, A. C. Riccardi, and M. A. Pagani. "Cisuralian cephalopods from Patagonia, Argentina". English. In: Journal of Paleontology 80.6 (2006), pp. 1142-1151.

[20116] S. Saber, J. J. W. Sertich, H. M. Sallam, K. A. Ouda, P. M. O'Connor, and E. R. Seiffert. “An enigmatic crocodyliform from the Upper Cretaceous Quseir Formation, central Egypt". English. In: Cretaceous Research 90 (2018), pp. 174-184.

[20117] M. Sabol and P. Holec. "Temporal and spatial distribution of Miocene mammals in the western Carpatians (Slovakia)". English. In: Geologica Carpathica 53.4 (2002), pp. 269-279.

[20118] M. Sabol and M. Kovac. "Badenian palaeoenvironment, faunal succesion and biostratigraphy: A case study from Northern Vienna Basin, Devinska Nova Ves-Bonanza site (Western Carpathians, Slovakia)". English. In: Beitrage zur Palaontologie 30 (2006), pp. 415-425.

[20119] M. Sabol, D. Persico, and E. Troco. "First fossil record of leopard-like felid (Panthera cf. pardus) from alluvial deposits of the Po River in northern Italy". English. In: Quaternary International 436 (2017), pp. 192-200. DOI: 10.1016/j.quaint.2016.12.036. 
[20120] E. Sacchi, M. A. Conti, S. D. Porchetti, A. Logoluso, U. Nicosia, G. Perugina, and F. M. Petti. “Aptian dinosaur footprints from the Apulian platform (Bisceglie, southern Italy) in the framework of periadriatic ichnosites". English. In: Palaeogeography, Palaeoclimatology, Palaeoecology 271 (2009), pp. 104-116. DOI: 10.1016/j.palaeo.2008.09.018.

[20121] V. Sach. “Einmal Miozän und zurück - Zeitreise am Maurerkopf bei Edelbeuren". German. In: Oberschwaben Naturnah 2010 (2010), pp. 41-45.

[20122] S. Sachs. “Erster Nachweis eines gepanzerten Dinosauriers (Reptilia, Ornithischia, Thyreophora) aus der Unterkreide (Berrias) von Gronau in Westfalen". German. In: Neues Jahrbuch für Geologie und Paläontologie Monatshefte 1997.1 (1997), pp. 56-64.

[20123] S. Sachs. Mesozoische Reptilien aus Nordrhein-Westfalen [Mesozoic reptiles from Nordrhein-Westfalen]. German. 1997.

[20124] S. Sachs. “Tuarangisaurus australis sp. nov. (Plesiosauria: Elasmosauridae) from the Lower Cretaceous of Northeastern Queensland, with additional notes on the phylogeny of the Elasmosauridae". English. In: Memoirs of the Queensland Museum 50.2 (2005), pp. 425-440.

[20125] S. Sachs. "First record of a mosasaur (Reptilia: Squamata) in der Oberkreide Mitteldeutschlands". English. In: Abhandlungen und Berichte aus dem Museum Heineanum 7 (2006), pp. 1-7.

[20126] S. Sachs and J. A. Grant-Mackie. "An ichthyosaur fragment from the Cretaceous of Northland, New Zealand". English. In: Journal of the Royal Society of New Zealand 33.1 (2003), pp. 307-314.

[20127] S. Sachs and J. J. Hornung. "Juvenile ornithopod (Dinosauria: Rhabdodontidae) remains from the Upper Cretaceous (lower Campanian, Gosau Group) of Muthmannsdorf (Lower Austria)". English. In: Géobios 39 (2006), pp. 415-425.

[20128] S. Sachs and J. J. Hornung. “Ankylosaur remains from the Early Cretaceous (Valanginian) of northwestern Germany". English. In: PLoS One 8.4 (2013), e60571:1-7. DOI: 10.1371/ journal.pone. 0060571.

[20129] S. Sachs, J. J. Hornung, and B. P. Kear. "A new basal elasmosaurid (Sauropterygia: Plesiosauria) from the Lower Cretaceous of Germany". English. In: Journal of Vertebrate Paleontology 37 (2017), e1301945. DOI: 10.1080/02724634.2017.1301945.

[20130] S. Sachs and B. P. Kear. "A rare new Pliensbachian plesiosaurian from the Amaltheenton Formation of Bielefeld in northwestern Germany". English. In: Alcheringa (2017). DOI: 10.1080/03115518. 2017.1367419.

[20131] S. Sachs, U. Scheer, and M. Rabi. "Reste von protostegiden Meeresschildkröten aus dem Cenomanium (Oberkreide) des Kassenberges (Mülheim an der Ruhr, Westdeutschland)". German. In: Berichte des Naturwissenschaftlichen Vereins für Bielefeld und Umgegend 54 (2016), pp. 32-43.

[20132] S. Sachs, M. T. Young, P. Abel, and H. Mallison. "A new species of the metriorhynchid crocodylomorph Cricosaurus from the Upper Jurassic of southern Germany". English. In: Acta Palaeontologica Polonica 64.2 (2019), pp. 343-356. DOI: 10.4202/app.00541.2018.

[20133] K. Sada, Y. Takata, and Y. Oho. Radiolarian faunas discovered from the Permian Yoshii Group in Okayama Prefecture, western Japan. English. Centenary of Japanese Micropaleontology. 1992, pp. 383-387.

[20134] W. Sadeddin and M. Al-Tamimi. "Two new holothurian sclerite genera from the Late Cretaceous of Jordan". English. In: Journal of Applied Sciences 6.11 (2006), pp. 2426-2431.

[20135] D. Sadki. "Proposition de la region de Rich (Haut-Atlas central marocain) comme stratotype auxiliaire submediterranen pour la limite Aalenien Bajocien". French. In: Geobios 17 (1994), pp. 431440.

[20136] G. Sadlok and Z. Wawrzyniak. "Upper Triassic vertebrate tracks from Kraków-Czstochowa upland, southern Poland". English. In: Annales Societatis Geologorum Poloniae 83 (2013), pp. 105-111.

[20137] H. Saegusa. "A partial skeleton of Paleoparadoxia from San-yama, Ogano-cho, Saitama Prefecture, central Japan”. English. In: Nature and Human Activities 7 (2002), pp. 1-25.

[20138] H. Saegusa. "Dwarf Stegolophodon from the Miocene of Japan Passengers on sinking boats". English. In: Quaternary International 182 (2008), pp. 49-62. 
[20139] H. Saegusa and T. Ikeda. "A new titanosauriform sauropod (Dinosauria: Saurischia) from the Lower Cretaceous of Hyogo, Japan”. English. In: Zootaxa 3848.1 (2014), pp. 1-66.

[20140] H. Saegusa, S. Tanaka, and T. Ikeda. "[Preliminary observations on the dinosaur teeth from the Lower Cretaceous Sasayama Group in Tamba City, Hyogo Prefecture and addtional notes on the pneumaticity of the postcranial skeleton of Tamba sauropod]". Japanese. In: Journal of Fossil Research 42.2 (2010), pp. 52-65.

[20141] H. Saegusa and Y. Tomida. "Titanosauriform teeth from the Cretaceous of Japan". English. In: Anais da Academia Brasileira de Ciencias 83.1 (2011), pp. 247-265.

[20142] C. Saenger, A. L. Cohen, D. W. Oppo, and D. Hubbard. "Interpreting sea surface temperature from strontium/calcium ratios in". English. In: Paleoceanography 23.3 (2008), pp. 1-11. DOI: 10. 1029/2007PA001572.

[20143] K. P. Saether, C. T. S. Little, and K. A. Campbell. "A new fossil provannid gastropod from Miocene hydrocarbon seep deposits, East Coast Basin, North Island, New Zealand". English. In: Acta Palaeontologica Polonica 55.3 (2010), pp. 507-517. DOI: 10.4202/app.2009.1112.

[20144] N. Sagawa, T. Nakamori, and Y. Iryu. "Pleistocene reef development in the southwest Ryukyu Islands, Japan". English. In: Palaeogeography, Palaeoclimatology, Palaeoecology 175 (2001), pp. 303323.

[20145] B. S. Sageman and C. R. Bina. “Diversity and Species Abundance Patterns in Late Cenomanian Black Shale Biofacies, Western Interior, U.S." In: Palaios 12 (1997), pp. 449-466.

[20146] C. Sagne. "Halitherium taulannense, nouveau sirenien (Sirenia, Mammalia) de l'Eocene superieur provenant du domaine Nord-Tethysien (Alpes-de-Haute-Provence, France)". English. In: Comptes Rendus de l'Academie des Sciences, Serie II. Sciences de la Terre et des Planetes 333 (2001), pp. 471-476.

[20147] M. Sagri, E. Abbate, A. Azzaroli, M. L. Balestrieri, M. Benvenuti, P. Bruni, M. Fazzuoli, G. Ficcarelli, M. Marcucci, M. Papini, G. Pavia, V. Reale, L. Rook, and T. W. Tecle. "New data on the Jurassic and Neogene sedimentation in the Danakil Horst and northern Afar Depression, Eritrea". English. In: Mémoires du Muséum National d'Histoire Naturelle 177 (1998), pp. 193-214.

[20148] L. Sahakyan, T. Grigoryan, A. Ara, E. Zakrevskaya, Z. Stepanyan, and A. Hayrapetyan. “Upper Eocene-Lower Oligocene Shaghap reef (Armenia): composition and paleoenvironment". English. In: Proceedings NAS RA, Earth Sciences 73 (2020).

[20149] A. Sahni and A. Khosla. Paleobiological, taphonomical and paleoenvironmental aspects of Indian Cretaceous sauropod nesting sites. English. Vol. 10. Aspects of Sauropod Paleobiology. GAIA. 1995, pp. 215-223.

[20150] A. Sahni, S. K. Tandon, A. Jolly, S. Bajpai, A. Sood, and S. Srinivasan. Upper Cretaceous dinosaur eggs and nesting sites from the Deccan volcano-sedimentary province of peninsular India. English. Dinosaur Eggs and Babies. Cambridge: Cambridge University Press, 1994, pp. 204-226.

[20151] M. Sahnouni, D. Hadjouis, J. van der Made, A. -e.-K. Derradji, A. Canals, M. Medig, H. Belahrech, Z. Harichane, and M. Rabhi. "Further research at the Oldowan site of Ain Hanech, North-eastern Algeria". English. In: Journal of Human Evolution 43.6 (2002), pp. 925-937. DOI: 10.1006/jhev.2002. 0608.

[20152] L. K. Saila. "A new species of the sphenodontian reptile Clevosaurus from the Lower Jurassic of South Wales". English. In: Palaeontology 48.4 (2005), pp. 817-832.

[20153] L. K. Säilä. “The Osteology and Affinities of Anomoiodon liliensterni, a Procolophonid Reptile from the Lower Triassic Buntsandstein of Germany". English. In: Journal of Vertebrate Paleontology 28.4 (2008), pp. 1199-1205.

[20154] L. K. Saila. "Alpha taxonomy of the Russian Permian procolophonoid reptiles". English. In: Acta Palaeontologica Polonica 54.4 (2009), pp. 599-608.

[20155] J. P. Saint Martin. "Implications de la presence de mud-mound microbiens au Messinien (Sicile, Italie) [Implications of the presence of microbial mud-mounds in Messinian deposits (Sicily, Italy)]". French. In: Comptes rendus de l'Academie des Sciences, Serie 2a: Sciences de la Terre et des planetes 332 (2001), pp. 527-534. 
[20156] J. P. Saint Martin, G. Conesa, and J. J. Cornee. "A new type of Messinian composite microbialitic build-up (Salemi, Sicily, Italy)”. English. In: Sedimentary Geology 106 (1996), pp. 51-63.

[20157] J. P. Saint Martin and S. Pestrea. "Les constructions a serpules et microbialites du sarmatien de Moldavie [Sarmatian serpulid-microbialite reefs from Moldavia]". French. In: Acta Palaeontologica Romaniae 2 (1999), pp. 463-469.

[20158] J.-P. Saint Martin. "Messinian coral reefs of western Orania, Algeria". English. In: SEPM Concepts in Sedimentology and Paleontology 5 (1996), pp. 239-246.

[20159] J.-P. Saint Martin. "Les formations recifales coralliennes du Miocene superieur d'Algerie et du Maroc [Upper Miocene coral reef formations from Algeria and Morocco]". French. In: Memoires du Museum National d'Histoire Naturelle de Paris, C 56 (1990), pp. 1-373.

[20160] J.-P. Saint Martin and J. J. Cornee. “The Messinian reef complex of Melilla, northeastern Rif, Morocco". English. In: SEPM Concepts in Sedimentology and Paleontology 5 (1996), pp. 227-237.

[20161] J.-P. Saint Martin, D. Merle, J. J. Cornee, S. Filipescu, S. Saint Martin, and I. I. Bucur. “Les constructions coralliennes du Badenien (Miocene moyen) de la bordure occidentale de la depression de Transylvanie (Roumanie) [Badenian (Middle Miocene) coral build-ups of the western border of the Transylvanian Basin (Romania)]". French. In: Comptes Rendus Palevol 6 (2007), pp. 37-46.

[20162] J.-P. Saint Martin, P. Müller, P. Moissette, and A. Dulai. "Coral microbialite environment in a Middle Miocene reef of Hungary". In: Palaeogeography, Palaeoclimatology, Palaeoecology 160 (2000), pp. 179-191.

[20163] P. A. Saint-Andre and G. De Iuliis. "The smallest and most ancient representative of the genus Megatherium Cuvier, 1796 (Xenarthra, Tardigrada, Megatheriidae), from the Pliocene of the Bolivian Altiplano". English. In: Geodiversitas 23.4 (2001), pp. 625-645.

[20164] P. A. Saint-André, F. Pujos, C. Cartelle, G. De Iuliis, T. J. Gaudin, H. G. McDonald, and B. Mamani Quispe. “Nouveaux paresseux terrestres (Mammalia, Xenarthra, Mylodontidae) du Néogéne de l'Altiplano bolivien". French. In: Geodiversitas 32.2 (2010), pp. 255-306. DOI: 10.5252/g2010n2a4.

[20165] N. Saita, S. Komukai, and M. Oishi. "A small fossil whale from the Tatsunokuchi Formation (uppermost Miocene to Lower Pliocene) of Sendai City, Northeast Japan: Its occurrence, age and paleontological signi cance". English. In: Bulletin of the Tohoku University Museum 10 (2011), pp. 135146.

[20166] E. T. Saitta. “Evidence for sexual dimorphism in the plated dinosaur Stegosaurus mjosi (Ornithischia, Stegosauria) from the Morrison Formation (Upper Jurassic) of western USA". English. In: PLoS ONE 10.4 (2015), e0123503:1-20. DOI: 10.1371/journal.pone.0123503.

[20167] R. Sakagami and S. Kawabe. "Endocranial anatomy of the ceratopsid dinosaur Triceratops and interpretations of sensory and motor function". English. In: PeerJ (2020), pp. 1-19. DOI: 10.7717/ peerj. 9888 .

[20168] S. Sakagami. “Upper Paleozoic bryozoans from the Lake Titicaca region, Bolivia, Part 2. Systematic paleontology". English. In: Transactions and Proceedings of the Paleontological Society of Japan, N.S. 180 (1995), pp. 261-281.

[20169] S. Sakagami. “Upper Paleozoic bryozoans from the Lake Titicaca region, Bolivia, Part 1. Introductory remarks, stratigraphy and systematic paleontology". English. In: Transactions and Proceedings of the Paleontological Society of Japan, N.S. 180 (1995), pp. 226-260.

[20170] S. Sakagami. "Middle Permian bryozoa from Irian Jaya, Indonesia". English. In: Bulletin of the National Science Museum, Tokyo, Series C 26.3,4 (2000), pp. 139-168.

[20171] S. Sakagami. "Permian bryozoans from some localities in the Khao Hin Kling area near Phetchabun, north-central Thailand". English. In: Bulletin of the Kitakyushu Museum of Natural History 18 (1999), pp. 77-103.

[20172] S. Sakagami. "Permian bryozoans from the Lihuirco-Quisuar Route near Abancay, Peru". English. In: Bulletin of the National Science Museum, Tokyo, Series C 30 (2004), pp. 55-88. 
[20173] S. Sakagami and A. Pillevuit. "Permian bryozoans from the exotic formations in Oman". English. In: Paleontological Research 1.3 (1997), pp. 200-224.

[20174] S. Sakagami and H. Sakai. "Fossil bryozoans from the Lower Gondwana Sisne Formation, Nepal lesser Himalayas". English. In: Transactions and Proceedings of the Paleontological Society of Japan, N.S. 162 (1991), pp. 761-766.

[20175] S. Sakagami, D. Sciunnach, and E. Garzanti. "Late Paleozoic and Triassic bryozoans from the Tethys Himalaya (N India, Nepal and S Tibet)". English. In: Facies 52 (2006), pp. 279-298.

[20176] S. Sakagami and A. Sugimura. "Upper Permian bryozoans from the Akiyoshi Limestone Group". English. In: Bulletin of the Akiyoshi-Dai museum of Natural History 35 (2000), pp. 1-20.

[20177] N. Sakakura. "Taphonomy of bivalve assemblages in the upper part of the Paleogene Ashiya Group, southwestern Japan". English. In: Paleontological Research 6.1 (2002), pp. 101-120.

[20178] K. Sakamoto and T. Uyeno. "Paralichthys yamanai, a new middle Miocene lefteye flatfish from Tottori, Japan". English. In: Bulletin of the Natural Science Museum, Tokyo, Series C 19.1 (1993), pp. 19.

[20179] K. Sakamoto and T. Uyeno. "An Oligocene record of a flatfish from the Kiwado Formation, Yamaguchi Prefecture, Japan". English. In: Bulletin of the Natural Science Museum, Tokyo, Series C 23.1,2 (1997), pp. 51-59.

[20180] T. Sakumoto, K. Seto, and K. Takayasu. “Fossil cephalopods from the Middle Miocene Fujina Formation of southwest Japan and its paleoenvironmental significance". Japanese. In: Earth Science (Chikyu Kagaku) 50 (1996), pp. 408-413.

[20181] K. Sakurai, M. Kimura, and T. A. Katoh. "New penguin-like bird (Pelecaniformes; Plotopteridae) from the Late Oligocene Tokoro Formation, northeastern Hokkaido". English. In: Oryctos 7 (2008), pp. 83-94.

[20182] B. Sala. “Dinaromys allegranzii n. sp. (Mammalia, Rodentia) from Rivoli Veronese (northeastern Italy) in a Villanyian association". In: Acta Zoologica Cracoviensia 39.1 (1996), pp. 469-472.

[20183] M. Salak and H. L. Lescinsky. "Spygoria zappania new genus and species, a Cloudina-like biohermal metazoan from the Lower Cambrian of central Nevada". In: Journal of Paleontology 73.4 (1999), pp. 571-576.

[20184] Y. Salama, M. Grammer, S. Saber, S. El-Shazly, and G. Abdel-Gawad. "Sequence Stratigraphy and Rudist Facies Development of the Upper". English. In: Acta geologica sinica 92.1 (2018), pp. 286310.

[20185] Y. Salama and S. Oezer. "Durania cornupastoris rudist from the Turonian of El-Hassana Dome (Abu Roash area), Egypt: Systematic palaeontology and palaeoecology". English. In: Journal of African Earth Sciences (2019). DOI: 10.1016/j.jafrearsci.2019.02.002.

[20186] Y. F. Salama, G. I. Abdel-Gawad, S. G. Saber, S. H. El-Shazly, G. M. Grammer, and S. Oezer. "Chemostratigraphy of the Cenomanian-Turonian shallow-water carbonate: new correlation for the rudist levels from north Sinai, Egypt". English. In: Arabian Journal of Geosciences 9.755 (2016). DOI: $10.1007 / \mathrm{s} 12517-016-2775-1$.

[20187] M. Salamon, R. Niedzwiedzki, and R. Walter. "New data on Middle Triassic echinoderms from the Sudetes Mountains". English. In: Geological Quaterly 47.2 (2003), pp. 133-138.

[20188] M. A. Salamon. "A new prospect in crinoid (Crinoidea, Echinodermata) research: An example from the Lower Jurassic of Montenegro". English. In: Carnets de Geologie 19.12 (2019), pp. 211-220. DOI: $10.4267 / 2042 / 70491$.

[20189] M. A. Salamon. "Early Cretaceous (Valanginian) sea lilies (Echinodermata, Crinoidea)". English. In: Swiss Journal of Geosciences 102.1 (2009), pp. 77-88. DOI: 10.1007/s00015-009-1312-6.

[20190] M. A. Salamon, W. I. Ausich, T. Brachaniec, B. J. Pachno, and P. Gorzelak. “Uncovering the hidden diversity of Mississippian crinoids (Crinoidea, Echinodermata) from Poland". English. In: PeerJ - Life and Environment - Paleontology and Evolutionary Science 8.e10641 (2020). DOI: 10.7717 / peerj. 10641. 
[20191] M. A. Salamon and A. Boczarowski. “The first record of Aspiduriella (Ophiuroidea) in the Upper Muschelkalk of Poland". In: Geological Quarterly 47.3 (2003), pp. 307-310.

[20192] M. A. Salamon, M. K. Eagle, and R. Niedzwiedzki. "A new ceratite record from Upper Silesia (Poland)". In: Geological Quarterly 47 (2003), pp. 281-287.

[20193] M. A. Salamon, A. Gajerski, P. Gorzelak, and M. ukowiak. "A new plicatocrinid crinoid, Tetracrinus jagti, from the Cenomanian". English. In: Neues Jahrbuch für Geologie und Paläontologie, Abhandlungen 245.2 (2007), pp. 179-183. DOI: 10.1127/0077-7749/2007/0245-0179.

[20194] M. A. Salamon, P. Gorzelak, N. M. Hanken, H. E. Riise, and B. Ferré. “Crinoids from Svalbard in the aftermath of the endPermian mass extinction". English. In: Polish Polar Research: The Journal of Committee on Polar Research of Polish Academy of Sciences 36.3 (2015), pp. 225-238. DOI: 10.1515/ popore-2015-0015.

[20195] M. A. Salamon, R. Niedwiedzki, R. Lach, T. Brachaniec, and P. Gorzelak. “Ophiuroids discovered in the Middle Triassic hypersaline environment". English. In: PLoS One 7.11 (2012), e49798.

[20196] M. A. Salamon and M. Zaton. "Mass-occurrence of articulated skeletons of Middle Triassic ophiuroids from the Upper Silesia and their Taphonomical implications (southern Poland)". other. In: Przeglad Geologiczny 52.10 (2004), pp. 997-1001.

[20197] L. Salari, K. F. Achino, M. Gatta, C. Petronio, M. F. Rolfo, L. Silvestri, and L. Pandolfi. “The wolf from Grotta Mora Cavorso (Simbruini mountains, Latium) within the evolution of Canis lupus L., 1758 in the Quaternary of Italy". English. In: Palaeogeography, Palaeoclimatology, Palaeoecology 476 (2017), pp. 90-105. DOI: 10.1016/j.palaeo.2017.03.023.

[20198] M. J. Salas, J. J. Rustán, and A. F. Sterren. “Lower and Middle Devonian Malvinokaffric ostracods from the Precordillera Basin of San Juan, Argentina". English. In: Journal of South American Earth Sciences 45 (2013), pp. 56-68.

[20199] R. Salas, J. Sánchez, and C. Chacaltana. "A new Pre-Deseadan Pyrothere (Mammalia) from northern Peru and the wear facets of molariform teeth of Pyrotheria". English. In: Journal of Vertebrate Paleontology 26.3 (2006), pp. 760-769.

[20200] R. Salas, M. Stucchi, and T. J. Devries. "The Presence of Plio-Pleistocene Paleolama sp. (Artiodactyla: Camelidae) on the southern coast of Peru". English. In: Boletn del Instituto francés de Estudios Andinos 32.2 (2003), pp. 347-359.

[20201] R. Salas-Gismondi, P.-O. Antoine, P. Baby, S. Brusset, M. Benammi, N. Espurt, D. de Franceschi, F. Pujos, J. Tejada, and M. Urbina. "Middle Miocene crocodiles from the Fitzcarrald Arch, Amazonian Peru". English. In: Cuadernos del Museo Geominero 8 (2007), pp. 355-360.

[20202] R. Salas-Gismondi, J. J. Flynn, P. Baby, J. V. Tejada-Lara, F. P. Wesselingh, and P. -O. Antoine. "A Miocene hyperdiverse crocodylian community reveals peculiar trophic dynamics in protoAmazonian mega-wetlands". English. In: Proceedings of the Royal Society of London, Series B 282 (2015), p. 20142490. DOI: 10.1098/rspb.2014.2490.

[20203] R. Salas-Gismondi, J. J. Flynn, P. Baby, J. V. Tejada-Lara, J. Claude, and P. -O. Antoine. “A New 13 Million Year Old Gavialoid Crocodylian from Proto-Amazonian Mega-Wetlands Reveals Parallel Evolutionary Trends in Skull Shape Linked to Longirostry". English. In: PLoS ONE 11.4 (2016), e0152453:1-29. DOI: 10.1371/journal.pone.0152453.

[20204] R. Salas-Gismondi, J. W. Moreno-Bernal, T. M. Scheyer, M. R. Sánchez-Villagra, and C. Jaramillo. "New Miocene Caribbean gavialoids and patterns of longirostry in crocodylians". English. In: Journal of Systematic Palaeontology 17.12 (2019), pp. 1049-1075. DOI: 10.1080 / 14772019.2018. 1495275.

[20205] C. Salazar, W. Stinnesbeck, and L. A. Quinzio-Sinn. "Ammonites from the Maastrichtian (Upper Cretaceous) Quiriquina Formation in central Chile". English. In: Neues Jahrbuch für Geologie und Paläontologie, Abhandlungen 257 (2010), pp. 181-236.

[20206] C. Salazar, W. Stinnesbeck, and D. Rubilar-Roggers. "The largest Menuites fresvillensis (Seunes, 1890) (Ammonoidea, Pachydiscidae) from the Maastrichtian Quiriquina Formation, Chila". English. In: Boletn del Museo Nacional de Historia Natural, Chile 62 (2013), pp. 31-40. 
[20207] C. Salazar and W. Stinnesbeck. "Tithonian-Berriasian ammonites from the Baños del Flaco Formation, central Chile". English. In: Journal of Systematic Palaeontology 14 (2016), pp. 149-182.

[20208] C. A. Salazar Soto. "The Jurassic-Cretaceous Boundary (Tithonian - Hauterivian) in the Andean Basin of Central Chile: Ammonites, Bio- and Sequence Stratigraphy and Palaeobiogeography". English. In: (2012).

[20209] A. B. Salberg, T. Hang, and K. T. Nilssen. "Estimation of hooded seal (Cystophora cristata) pup production in the Greenland Sea pack ice during the 2005 whelping season". English. In: Polar Biology 31 (2008), pp. 867-878.

[20210] M. A. F. Sales, A. Liparini, M. B. de Andrade, P. R. L. Aragão, and C. L. Schultz. "The oldest South American occurrence of Spinosauridae (Dinosauria, Theropoda)". English. In: Journal of South American Earth Sciences 74 (2017), pp. 83-88. DOI: 10.1016/j.jsames.2016.10.005.

[20211] M. J. Salesa, M. Antón, G. Siliceo, M. D. Pesquero, J. Morales, and L. Alcalá. “A non-aquatic otter (Mammalia, Carnivora, Mustelidae) from the Late Miocene (Vallesian, MN 10) of La Roma 2 (Alfambra, Teruel, Spain): systematics and". English. In: Zoological Journal of the Linnean Society 169 (2013), pp. 448-482. DOI: 10.1111/zoj.12063.

[20212] M. J. Salesa, M. Antón, J. Morales, and S. Peigné. "Systematics and phylogeny of the small felines (Carnivora, Felidae) from the Late Miocene of Europe: a new species of Felinae from the Vallesian of Batallones (MN 10, Madrid, Spain)". English. In: Journal of Systematic Palaeontology 10.1 (2012), pp. 87-102. DOI: 10.1080/14772019.2011.566584.

[20213] M. J. Salesa, I. M. Sanchéz, and J. Morales. "Presence of the Asian horse Sinohippus in the Miocene of Europe". English. In: Acta Palaeontologica Polonica 49.2 (2004), pp. 189-196.

[20214] L. Salgado, S. Apestegua, and S. Heredia. "A new specimen of Neuquensaurus australis, a Late Cretaceous saltasaurine titanosaur from North Patagonia". English. In: Journal of Vertebrate Paleontology 25.3 (2005), pp. 623-634.

[20215] L. Salgado and C. Azpilicueta. "Un nuevo saltasaurino (Sauropoda, Titanosauridae) de la provincia de Ro Negro (Formación Allen, Cretácico Superior), Patagonia, Argentina [A new saltasaurine (Sauropoda, Titanosauridae) from Ro Negro province (Allen Formation, Upper Cretaceous), Patagonia, Argentina". Spanish. In: Ameghiniana 37.3 (2000), pp. 259-264.

[20216] L. Salgado and J. F. Bonaparte. “Un nuevo saurópodo Dicraeosauridae, Amargasaurus cazaui gen. et sp. nov., de la Formación La Amarga, Neocomiano de la provincia del Neuquén, Argentina [Amargasaurus cazaui gen. et sp. nov., a new dicraeosaurid sauropod from the La Amarga Formation, Neocomian of Neuquén province, Argentina]". Spanish. In: Ameghiniana 28.3-4 (1991), pp. 333-346.

[20217] L. Salgado, J. I. Canudo, A. C. Garrido, J. I. Ruiz-Omeñaca, R. A. Coria, M. S. de la Fuente, J. L. Barco, and R. Bollati. "Upper Cretaceous vertebrates from El Anfiteatro area, Ro Negro, Patagonia, Argentina". English. In: Cretaceous Research 30.3 (2009), pp. 767-784. DOI: 10.1016/j.cretres.2009. 01.001 .

[20218] L. Salgado, J. I. Canudo, A. C. Garrido, M. Moreno-Azanza, L. C. A. Martnez, R. A. Coria, and J. M. Gasca. "A new primitive neornithischian dinosaur from the Jurassic of Patagonia with gut contents". English. In: Scientific Reports 7 (2017), 42778:1-10. DOI: 10.1038/srep42778.

[20219] L. Salgado, I.d.S. Carvalho, and A. C. Garrido. "Zapalasaurus bonapartei, un nuevo saurópodo de La Formación La Amarga (Cretacico Inferior), noroeste de Patagonia, Provincia de Neuquén, Argentina [Zapalasaurus bonapartei, a new sauropod from the La Amarga Formation (Lower Cretaceous), northwestern Patagonia, Neuquén province, Argentina]". Spanish. In: Géobios 39 (2006), pp. 695-707.

[20220] L. Salgado and I. S. Carvalho. “Uberabatitan ribeiroi, a new titanosaur from the Marlia Formation (Bauru Group, Upper Cretaceous), Minas Gerais, Brazil”. English. In: Palaeontology 51.4 (2008), pp. 881-901. DOI: 10.1111/j.1475-4983.2008.00781.x. 
[20221] L. Salgado and R. A. Coria. "El genero Aeolosaurus (Sauropoda, Titanosauridae) en la Formacion Allen (Campaniano-Maastrichtiano) de la Provincia de Rio Negro, Argentina [The genus Aeolosaurus (Sauropoda, Titanosauridae) in the Allen Formation (Campanian-Maastrichtian) of Rio Negro Province, Argentina]". Spanish. In: Ameghiniana 30.2 (1993), pp. 119-128.

[20222] L. Salgado, R. A. Coria, and S. E. Heredia. “New materials of Gasparinisaura cincosaltensis (Ornithischia, Ornithopoda) from the Upper Cretaceous of Argentina". English. In: Journal of Paleontology 71.5 (1997), pp. 933-940.

[20223] L. Salgado and R. A. Coria. “Barrosasaurus casamiquelai gen. et sp. nov., a new titanosaur (Dinosauria, Sauropoda) from the Anacleto Formation (Late Cretaceous: early Campanian) of Sierra Barrosa (Neuquén, Argentina)". English. In: Zootaxa 2222 (2009), pp. 1-16.

[20224] L. Salgado, R. A. Coria, A. B. Arcucci, and L. M. Chiappe. “Restos de Alvarezsauridae (Theropoda, Coelurosauria) en la Formación Allen (Campaniano-Maastrictiano), en Salitral Ojo de Agua, Provincia de Ro Negro, Argentina". Spanish. In: Andean Geology 36.1 (2009), pp. 67-80.

[20225] L. Salgado, R. A. Coria, C. M. Magalhaes Ribeiro, A. Garrido, R. Rogers, M. E. Simon, A. B. Arcucci, K. Curry Rogers, A. Paulina Carabajal, S. Apesteguia, M. Fernandez, R. A. Garcia, and M. Talevi. "Upper Cretaceous dinosaur nesting sites of Rio Negro (Salitral Ojo de Agua and Salinas de Trapalco-Salitral de Santa Rosa), northern Patagonia, Argentina". English. In: Cretaceous Research 28 (2007), pp. 392-404. DOI: 10.1016/j.cretres.2006.06.007.

[20226] L. Salgado, R. de la Cruz, M. Suárez, M. S. Fernández, Z. B. Gasparini, S. Palma-Heldt, and M. Fanning. "First Late Jurassic dinosaur bones from Chile". English. In: Journal of Vertebrate Paleontology 28.2 (2008), pp. 529-534.

[20227] L. Salgado and Z. Gasparini. "Reappraisal of an ankylosaurian dinosaur from the Upper Cretaceous of James Ross Island (Antarctica)". English. In: Geodiversitas 28.1 (2006), pp. 119-135.

[20228] L. Salgado, F. E. Novas, M. Suarez, R. de la Cruz, M. Isasi, D. Rubilar-Rogers, and A. O. Vargas. "Late Jurassic sauropods in Chilean Patagonia". English. In: Ameghiniana 52.4 (2015), pp. 418-429. DOI: 10.5710/AMGH.07.05.2015.2883.

[20229] L. Salgado, A. Parras, and Z. Gasparini. "Un plesiosaurio de cuello corto (Plesiosauroidea, Polycotylidae) del Cretácico Superior del norte de Patagonia". Portugese. In: Ameghiniana 44.2 (2007), pp. 349-358.

[20230] H. D. Salih and Y. K. Abdullah. "Microfossils and carbonate microfacies of Sinjar Formation, west of Sulaimaniyah city, Kurdistan region, NE Iraq". English. In: Iraqi Bulletin of Geology and Mining 5.2 (2009), pp. 13-28.

[20231] P. Salinas, L. G. Marshall, and P. Sepúlveda. Vertebrados continentales del Paleozoico y Mesozoico de Chile [Continental vertebrates of the Paleozoic and Mesozoic of Chile]. Spanish. 1991.

[20232] P. Salinas, P. Sepúlveda, and L. G. Marshall. "Hallazgo de restos oseos de dinosaurios (saurópodos) en la Formación Pajonales (Cretácico Superior), Sierra de Almeyda, Región de Antofagasta, Chile: implicancia cronológica [Discovery of skeletal remains of dinosaurs (sauropods) in the Pajonales Formation (Upper Cretaceous), Sierra de Almeyda, Antofagasta Region, Chile: chronological implications]". Spanish. In: 6e Congreso Geológico Chileño, Viña del Mar. Resumenes Expandidos. Servicio Nacional de Geologa y Mineria, Chile (1991), pp. 534-537.

[20233] F. M. Salinas-Marquez, L. G. Barnes, J. G. Flores-Trujillo, and F. J. Aranda-Manteca. “Una especie de delfn fósil (Cetacea; Delphinoidea; Kentriodontoidae) del Mioceno Medio de Baja California". English. In: Boletin de la Sociedad Geologica Mexicana 66.1 (2014), pp. 145-164.

[20234] S. W. Salisbury. Theropod teeth from the Lower Cretaceous (Albian-Cenomanian) Winton Formation, Central-Western Queensland, Australia. English. 2003.

[20235] S. W. Salisbury. "Crocodilians from the Lower Cretaceous (Berriasian) Purbeck Limestone Group of Dorset, southern England". English. In: Special Papers in Palaeontology 68 (2002), pp. 121-144.

[20236] S. W. Salisbury, E. Frey, D. M. Martill, and M. -C. Buchy. "A new crocodilian from the Lower Cretaceous Crato of north-eastern Brazil". English. In: Palaeontographica. Abteilung A, Palaozoologie - Stratigraphie 270.1-3 (2003), pp. 3-47. 
[20237] S. W. Salisbury, R. E. Molnar, E. Frey, and P. M. A. Willis. “The origin of modern crocodyliforms: new evidence from the Cretaceous of Australia". English. In: Proceedings of the Royal Society B 273 (2006), pp. 2439-2448. DOI: 10.1098/rspb.2006.3613.

[20238] S. W. Salisbury and D. Naish. Crocodilians. English. English Wealden fossils. 2011, pp. 305-369.

[20239] S. W. Salisbury, A. Romilio, M. C. Herne, R. T. Tucker, and J. P. Nair. “The Dinosaurian Ichnofauna of the Lower Cretaceous (Valanginian-Barremian) Broome Sandstone of the Walmadany Area (James Price Point), Dampier Peninsula, Western Australia". English. In: Society of Vertebrate Paleontology Memoir 16. Journal of Vertebrate Paleontology 36.6, suppl. (2016), pp. 1-152. DOI: 10.1080/02724634.2016.1269539.

[20240] S. W. Salisbury, P. M. A. Willis, S. Peitz, and P. M . Sander. “The crocodilian Goniopholis simus from the Lower Cretaceous of north-western Germany". English. In: Special Papers in Palaeontology 60 (1999), pp. 121-148.

[20241] S. W. Salisbury and P. M. A. Willis. "A new crocodylian from the early Eocene of south-eastern Queensland and a preliminary investigation of the phylogenetic relationships of crocodyloids". English. In: Alcheringa 20 (1996), pp. 179-226.

[20242] M. A. Sallaberry, R. E. Yury-Yanez, R. A. Otero, S. Soto-Acuna, and T. G. Torres. “Eocene birds from the western margin of southernmost South America". English. In: Journal of Paleontology 84.6 (2010), pp. 1061-1070.

[20243] H. M. Sallam, E. Gorscak, P. M. O'Connor, I. A. El-Dawoudi, S. El-Sayed, S. Saber, M. A. Kora, J. J. W. Sertich, E. R. Seiffert, and M. C. Lamanna. “New Egyptian sauropod reveals Late Cretaceous dinosaur dispersal between Europe and Africa". English. In: Nature Ecology \& Evolution 2.3 (2018), pp. 445-451. DOI: 10.1038/s41559-017-0455-5.

[20244] H. M. Sallam, E. R. Seiffert, and E. L. Simons. "A highly derived anomalurid rodent (Mammalia) from the earliest Late Eocene of Egypt". English. In: Palaeontology 53.4 (2010), pp. 803-813.

[20245] H. M. Sallam, E. R. Seiffert, E. L. Simons, and C. Brindley. "A large-bodied anomaluroid rodent from the earliest late Eocene of Egypt: phylogenetic and biogeographic implications". English. In: Journal of Vertebrate Paleontology 30.5 (2010), pp. 1579-1593.

[20246] H. M. Sallam, E. R. Seiffert, and E. L. Simons. “A basal phiomorph (Rodentia, Hystricognathi) from the late Eocene of the Fayum Depression, Egypt". English. In: Swiss Journal of Palaeontology 131.2 (2012), pp. 283-301.

[20247] H. M. Sallam and E. R. Seiffert. "New phiomorph rodents from the latest Eocene of Egypt, and the impact of Bayesian clock-based phylogenetic methods on estimates of basal hystricognath relationships and biochronology". English. In: PeerJ 4 (2016), e1717:1-53. DOI: 10.7717/ peerj.1717.

[20248] H. M. Sallam, E. R. Seiffert, M. E. Steiper, and E. L. Simons. "Fossil and molecular evidence constrain scenarios for the early evolutionary and biogeographic history of hystricognathous rodents". English. In: Proceedings of the National Academy of Sciences 106.39 (2009), pp. 16722-16727.

[20249] H. M. Sallam, E. R. Seiffert, and E. L. Simons. “Craniodental Morphology and Systematics of a New Family of Hystricognathous Rodents (Gaudeamuridae) from the Late Eocene and Early Oligocene of Egypt". English. In: PLoS ONE 6.2 (2011), e16525:1-29.

[20250] H. M. Sallam and E. R. Seiffert. "Revision of Oligocene 'Paraphiomys' and an origin for crown Thryonomyoidea (Rodentia: Hystricognathi: Phiomorpha) near the Oligocene-Miocene boundary in Africa". English. In: Zoological Journal of the Linnean Society (2019). DOI: 10.1093 / zoolinnean / zlz148/5691033.

[20251] H. M. Sallam, A. H. Sileem, E. R. Miller, and G. F. Gunnell. “Deciduous dentition and dental eruption sequence of Bothriogenys fraasi (Anthracotheriidae, Artiodactyla) from the Fayum Depression, Egypt". English. In: Palaeontologia Electronica 19.3 (2016), 38A:1-20.

[20252] F. Saller, S. Renesto, and F. M. Dalla Vecchia. "First record of Langobardisaurus (Diapsida, Protorosauria) from the Norian (Late Triassic) of Austria, and a revision of the genus". English. In: Neues Jahrbuch für Geologie und Paläontologie-Abhandlungen 268.1 (2013), pp. 83-95. DOI: 10.1127 / 0077-7749/2013/0319. 
[20253] L. O. Salles, C. Cartelle, P. G. Guedes, P. C. Boggiani, A. Janoo, and C. A. M. Russo. “Quaternary mammals from Serra do Bodoquena, Mato Grosso do Sul, Brazil". English. In: Boletim do Museu Nacional 521 (2006), pp. 1-12.

[20254] L. O. Salles, G. S. Carvalho, M. Weksler, F. L. Sicuro, F. Abreu, A. R. Camardella, P. G. Guedes, L. S. Avilla, E. A. P. Abrantes, V. Sahate, and I. S. A. Costa. "Fauna de mamferos do Quaternário de Serra da Mesa (Goiás, Brasil)". Portugese. In: Publicações Avulsas do Museu Nacional 78 (1999), pp. 1-15.

[20255] L. O. Salles, F. A. Perini, C. R. Moraes Neto, F. Lencastre Sicuro, J. Arroyo-Cabrales, P. Gonçalves Guedes, F. V. Laureano, E. M. Calvo, L. F. B. Oliveira, J. L. P. Cordeiro, V. A. Pérez-Crespo, P. Morales-Puente, L. J. S. Anjos, F. B. Pontual, K. R. Costa, and C. M. S. Freitas Fariasd. "A Puma concolor (Carnivora: Felidae) in the Middle-Late Holocene landscapes of the Brazilian Northeast (Bahia): submerged cave deposits and stable isotopes". English. In: Geobios (2020). DOI: 10.1016/j. geobios.2020.06.007.

[20256] L. O. Salles, F. A. Perini, P. M. Toledo, P. T. Guedes, R. R. C. Ramos, N. M. Strikis, L. F. B. Oliveira, G. S. Hofmann, E. M. Calvo, and T. W. Stafford Jr. "A new record of a Scelidotheriine ground sloth (Xenarthra, Mylodontidae) from Central Brazil: Quaternary cave stratigraphy, taxonomy and stable isotopes". English. In: Palaeogeography, Palaeoclimatology, Palaeoecology 461 (2016), pp. 253260.

[20257] M. Salotti, S. Bailon, M. -F. Bonifay, J. -Y. Courtois, J. -N. Dubois, J. Ferrandini, J. -C. La Milza, C. Mourer-Chauvire, J. -B. Popelard, Y. Quinif, A. -M. Real-Testud, C. Miniconi, E. Pereira, and C. Persiani. "Castiglione 3, un nouveau remplissage fosilifere d'age Pleistocene moyen dans le karst de la region d'Oletta (Haute-Corse)". French. In: Comptes Rendus de l'Academie des Sciences, Paris, Serie IIa 324 (1997), pp. 67-74.

[20258] R. B. Salvador, M. Pipperr, B. Reichenbacher, and M. W. Rasser. "Early Miocene continental gastropods from new localities of the Molasse Basin in southern Germany". English. In: Palaeontologische Zeitschrift 90 (2016), pp. 469-491.

[20259] R. B. Salvador, M. W. Rasser, and O. Höltke. "Fossil gastropods from Miocene Lake Randeck Maar and its hinterland (SW Germany)". English. In: Neues Jahrbuch für Geologie und Paläontologie, Abhandlungen 277.3 (2015), pp. 251-273.

[20260] B. Salvat, J. Trondle, and J. Letourneux. "Pleistocene mollusc assemblage in the slightly raised atoll lagoon". English. In: Paläontologische Gesellschaft (2018). DOI: 10.1007/s12542-018-0401-0.

[20261] E. Samankassou. Upper Carboniferous-Lower Permian buildups of the Carnic Alps, Austria-Italy. Vol. 78. Permo-Carboniferous carbonate platforms and reefs. SEPM Special Publication. 2003, pp. 201-217.

[20262] E. Samankassou. "Internal structure and depositional environment of Late Carboniferous mounds from the San Emiliano Formation, Carmenes Syncline, Cantabrian Mountains, northern Spain". English. In: Sedimentary Geology 145 (2001), pp. 235-252.

[20263] A. Samathi, P. Chanthasit, and P. M. Sander. "Two new basal coelurosaurian theropod dinosaurs from the Lower Cretaceous Sao Khua Formation of Thailand". English. In: Acta Palaeontologica Polonica 64.2 (2019), pp. 239-260. DOI: 10.4202/app.00540.2018.

[20264] B. S. Sambou, R. Sarr, L. Hautier, H. Cappetta, and S. Adnet. “The selachian fauna (sharks and rays) of the phosphate series of Ndendouri-Ouali Diala (Matam, Western Senegal): Dating and paleoenvironmental interests". English. In: Neus Jahrbuch fur Geologie und Palaontologie, Abhandlungen 283.2 (2017), pp. 205-219.

[20265] K. E. Samonds, B. E. Crowley, T. R. N. Rasolofomanana, M. C. Andriambelomanana, H. T. Andrianavalona, T. N. Ramihangihajason, R. Rakotozandry, Z. B. Nomenjanahary, M. T. Irwin, N. A. Wells, and L. R. Godfrey. "A new late Pleistocene subfossil site (Tsaramody, Sambaina basin, central Madagascar) with implications for the chronology of habitat and megafaunal community change on Madagascar's Central Highlands". English. In: Journal of Quaternary Science (2019), pp. 1-19. DOI: $10.1002 /$ jqs.3096. 
[20266] K. E. Samonds, R. A. Ernat, T. Andrianvalona, and D. P. Domning. “New Miocene sirenians from Nosy Makamby, northwestern Madagascar". English. In: Journal of Vertebrate Paleontology (2019), e1570223. DOI: $10.1080 / 02724634.2019 .1570223$.

[20267] K. E. Samonds and R. E. Fordyce. “The first pre-Pleistocene cetacean from Madagascar, western Indian Ocean". English. In: Journal of African Earth Sciences 151 (2019), pp. 41847-188. DOI: 10. 1016/j.jafrearsci.2018.12.015.

[20268] K. E. Samonds and I. S. Zalmout. "Eotheroides lambondrano, new middle Eocene sea cow (Mammalia, Sirenia) from the Mahajanga Basin, northwestern Madagascar". English. In: Journal of Vertebrate Paleontology 29.4 (2009), pp. 1233-1243.

[20269] S. D. Sampson. "Two new horned dinosaurs from the upper Cretaceous Two Medicine Formation of Montana; with a phylogenetic analysis of the Centrosaurinae (Ornithischia: Ceratopsidae)". In: Journal of Vertebrate Paleontology 14.5 (1995), pp. 743-760.

[20270] S. D. Sampson. Two new horned dinosaurs (Ornithischia: Ceratopsidae) from the Upper Cretaceous Two Medicine Formation, Montana, USA. English. 1994.

[20271] S. D. Sampson, M. T. Carrano, and C. A. Forster. "A bizarre predatory dinosaur from the Late Cretaceous of Madagascar". English. In: Nature 409 (2001), pp. 504-506.

[20272] S. D. Sampson, D. W. Krause, P. Dodson, and C. A. Forster. "The premaxilla of $<\mathrm{i}>$ Majungasaurus $</ \mathrm{i}>$ (Dinosauria: Theropoda), with implications for Gondwanan paleobiogeography". In: Journal of Vertebrate Paleontology 16.4 (1996), pp. 601-605.

[20273] S. D. Sampson, M. A. Loewen, A. A. Farke, E. M. Roberts, C. A. Forster, J. A. Smith, and A. L. Titus. "New horned dinosaurs from Utah provide evidence for intracontinental dinosaur endemism". English. In: PLoS One 5.9 (2010), e12292:1-12. DOI: 10.1371/journal.pone.0012292.

[20274] S. D. Sampson, E. K. Lund, M. A. Loewen, A. A. Farke, and K. E. Clayton. "A remarkable shortsnouted horned dinosaur from the Late Cretaceous (late Campanian) of southern Laramidia". English. In: Proceedings of the Royal Society B: Biological Sciences 280 (2013), p. 20131186. DOI: 10. 1098/rspb.2013.1186.

[20275] S. D. Sampson, L. M. Witmer, C. A. Forster, D. W. Krause, P. M. O'Connor, P. Dodson, and F. Ravoavy. "Predatory dinosaur remains from Madagascar: implications for the Cretaceous biogeography of Gondwana". In: Science 280 (1998), pp. 1048-1051.

[20276] S. D. Sampson and M. A. Loewen. “Tyrannosaurus rex from the Upper Cretaceous (Maastrichtian) North Horn Formation of Utah: biogeographic and paleoecologic implications". English. In: Journal of Vertebrate Paleontology 25.2 (2005), pp. 469-472. DOI: 10.1671 / 0272 - 4634(2005) 025[0469: TRFTUC]2.0.CO;2.

[20277] S. Samson, A. R. Palmer, R. A. Robison, and D. T . Secor. "Biogeographical significance of Cambrian trilobites from the Carolina slate belt". English. In: Geological Society America Bulletin 102 (1990), pp. 1459-1470.

[20278] C. Samtleben and A. Munnecke. "Reefmounds im unteren Wenlock auf Gotland: Beispiele früher Korallenriffe [Reef mounds in the Lower Wenlockian of Gotland: examples of early coral reefs]". German. In: Meyniana 51 (1999), pp. 77-94.

[20279] J. X. Samuels, K. E. Bredehoeft, and S. C. Wallace. "A new species of Gulo from the Early Pliocene Gray Fossil Site (Eastern United States); rethinking the evolution of wolverines". English. In: PeerJ 6 (2018), e4648. DOI: $10.7717 /$ peerj. 4648.

[20280] J. X. Samuels and J. Cavin. "The Earliest Known Fisher (Mustelidae), a New Species From the Rattlesnake Formation of Oregon". English. In: Journal of Vertebrate Paleontology 33.2 (2013), pp. 448454. DOI: $10.1080 / 02724634.2013 .722155$.

[20281] J. X. Samuels and W. W. Korth. "The first Eocene rodents from the Pacific Northwest, USA". English. In: Palaeontologia Electronica 20.2.24A (2017), pp. 1-17.

[20282] J. X. Samuels, J. A. Meachem-Samuels, and P. A. Gensler. "The first mid-Blancan occurrence of Agriotherium (Ursidae) in North America: a record from Hagerman Fossil Beds National Monument, Idaho". English. In: Journal of Paleontology 83.4 (2009), pp. 597-603. 
[20283] C. San Vicente and J. Cartanyá. “A new mysid (Crustacea, Mysida) from the Ladinian Stage (Middle Triassic) of Conca de Barberá (Catalonia, NE Iberian Peninsula)". English. In: Journal of Paleontology 91 (2017), pp. 968-980.

[20284] I. M. Sánchez, J. L. Cantalapiedra, M. Ros, V. Quiralte, and J. Morales. "Systematics and Evolution of the Miocene Three-Horned Palaeomerycid Ruminants (Mammalia, Cetartiodactyla)". English. In: PLoS One 10.12 (2015), e0143034. DOI: 10.1371/journal.pone.0143034.

[20285] T. M. Sanchez. “Una fauna de bivalvos en la Formacion Santa Gertrudis (Ordovicico) de la Provincia de Salta (Argentina)". Spanish. In: Ameghiniana 23.3-4 (1990), pp. 131-139.

[20286] T. M. Sanchez. "New late Ordovician (Early Caradoc) Bivalves from the Sierra De Villicum (Argentine Precordillera)". English. In: Journal of Paleontology 73.1 (1999), pp. 66-76.

[20287] T. M. Sanchez. "Additional Mollusca (Bivalvia and Rostroconchia) from the Suri Formation, Early Ordovician (Arenig), western Argentina". English. In: Journal of Paleontology 71.6 (1997), pp. 10461053.

[20288] T. M. Sánchez. "Moluscos bivalvos de la Formación Molles (Arenigiano medio), sierra de Famatina, Argenitna". Spanish. In: Ameghiniana 38.2 (2001), pp. 185-193.

[20289] T. M. Sánchez. "New Bivalvia and Rostroconchia from the Early Ordovician (Late Tremadoc - Middle Arenig) of northwestern Argentina". English. In: Journal of Paleontology 79.3 (2005), pp. 532541.

[20290] T. M. Sánchez. “The oldest record of Rostroconchia (Mollusca) from western Gondwana (Cordillera Oriental, northwestern Argentina)". English. In: Ameghiniana 37.3 (2000), pp. 265-269.

[20291] T. M. Sánchez. "Rostroconchia (Mollusca, Diasoma) en la formación San Juan (Ordovco temprano), Precordillera Argentina". Spanish. In: Ameghiniana 35.3 (1998), pp. 345-347.

[20292] T. M. Sánchez and C. Babin. "Lower Ordovician bivalves from southern Bolivia: paleobiogeographic affinities". English. In: Ameghiniana 42.3 (2005), pp. 559-566.

[20293] T. M. Sanchez and N. E. Vaccari. “Ucumariidae new family (Bivalvia, Anomalodesmata), and other bivalves from the Early Ordovician (Tremadoc) of northwestern Argentina". English. In: Ameghiniana 40 (2003), pp. 415-424.

[20294] T. M. Sanchez, B. G. Waisfeld, and B. A. Toro. "Silurian and Devonian molluscan bivalves from precordillera region, western Argentina". English. In: Journal of Paleontology 69.5 (1995), pp. 869 885.

[20295] T. M. Sanchez, B. G. Waisfeld, and J. L. Benedetto. "Lithofacies, taphonomy, and brachiopod assemblages in the Silurian of western Argentina: A review of Malvinokaffric Realm communities". English. In: Journal of South American Earth Sciences 4.4 (1991), pp. 307-329.

[20296] F. Sanchez-Beristain and J. Reitner. "Palaeoecology of new fossil associations from the Cipit boulders, St. Cassian Formation (Ladinian-Carnian, Middle-Upper Triassic; Dolomites, NE Italy)". English. In: Palaeontologische Zeitschrift 90.2 (2016), pp. 243-269.

[20297] A. Sánchez-Garca, A. Arillo, and A. Nel. "The first water measurers from the Lower Cretaceous amber of Spain (Heteroptera, Hydrometridae, Heterocleptinae)". English. In: Cretaceous Research 57 (2016), pp. 111-121.

[20298] A. Sánchez-Garca, X. Delclós, M. S. Engel, G. J. Bird, V. Perrichot, and E. Peñalver. “Marsupial brood care in Cretaceous tanaidaceans". English. In: Scientific Reports 7.4390 (2017), pp. 1-10.

[20299] A. Sánchez-Garca and M. S. Engel. "Springtails from the Early Cretaceous amber of Spain (Collembola: Entomobryomorpha), with an annotated checklist of fossil Collembola". English. In: American Museum Novitates 3862 (2016), pp. 1-47.

[20300] A. Sánchez-Garca and M. S. Engel. "Long-term stasis in a diverse fauna of Early Cretaceous springtails (Collembola: Symphypleona)". English. In: Journal of Systematic Palaeontology 15 (2016), pp. 513-537.

[20301] A. Sánchez-Garca, A. Nel, A. Arillo, and M. M. Solórzano Kraemer. "The semi-aquatic pondweed bugs of a Cretaceous swamp". English. In: PeerJ 5.e3760 (2017), pp. 1-32. 
[20302] A. Sánchez-Garca, E. Peñalver, R. Pérez-de la Fuente, and X. Delclós. "A rich and diverse tanaidomorphan (Crustacea: Tanaidacea) assemblage associated with Early Cretaceous resin-producing forests in North Iberia: palaeobiological implications". English. In: Journal of Systematic Palaeontology 13 (2015), pp. 645-676.

[20303] A. Sánchez-Garca, E. Peñalver, G. J. Bird, V. Perrichot, and X. Delclós. "Palaeobiology of tanaidaceans (Crustacea: Peracarida) from Cretaceous ambers: extending the scarce fossil record of a diverse peracarid group". English. In: Zoological Journal of the Linnean Society 178 (2016), pp. 492-522.

[20304] A. Sánchez-Garca, E. Peñalver, X. Delclós, and M. S. Engel. "Jumping bristeltails (Insecta, Archaeognatha) from the Lower Cretaceous amber of Lebanon". English. In: Papers in Palaeontology 5 (2019), pp. 679-697. DOI: 10.1002/spp2.1261.

[20305] A. Sánchez-Garca, E. Peñalver, X. Delclós, and M. S. Engel. “Early Cretaceous termites in amber from northern Spain (Isoptera)". English. In: Cretaceous Research 110.104385 (2020). DOI: 10.1016/j. cretres.2020.104385.

[20306] B. Sánchez-Hernández, M. J. Benton, and D. Naish. “Dinosaurs and other fossil vertebrates from the Late Jurassic and Early Cretaceous of the Galve area, NE Spain". English. In: Palaeogeography, Palaeoclimatology, Palaeoecology 249 (2007), pp. 180-215. DOI: 10.1016/j.palaeo.2007.01.009.

[20307] B. Sánchez-Hernández and M. J. Benton. "Filling the ceratosaur gap: a new ceratosaurian theropod from the Early Cretaceous of Spain". English. In: Acta Palaeontologica Polonica 59.3 (2014), pp. 581600. DOI: 10.4202/app.2011.0144.

[20308] B. Sánchez-Hernández, A. G. Przewieslik, and M. J. Benton. "A reassessment of the Pteraichnus ichnospecies from the Early Cretaceous of Soria Province, Spain". English. In: Journal of Vertebrate Paleontology 29.2 (2009), pp. 487-497. DOI: 10.1671/039.029.0205.

[20309] A. Sanchez-Marco. "Implications of the avian fauna for palaeoecology in the Early Pleistocene of the Iberian Peninsula". In: Journal of Human Evolution 37 (1999), pp. 375-388.

[20310] A. Sanchez-Marco. "A paleospecies of Alca (Aves: Charadriiformes) in the Pliocene of Spain". English. In: Neus Jahrbuch fur Palaeontologie 2003.5 (2003), pp. 314-320.

[20311] M. R. Sánchez-Villagra, R. J. Asher, A. D. Rincón, A. A. Carlini, P. Meylan, and R. W. Purdy. “New faunal reports for the Cerro La Cruz locality (lower Miocene), north-western Venezuela". English. In: Special Papers in Palaeontology 71 (2004), pp. 105-112.

[20312] M. R. Sánchez-Villagra, W. Brinkmann, and R. Lozsán. “The Paleozoic and Mesozoic vertebrate record of Venezuela: an overview, summary of previous discoveries and report of a mosasaur from the La Luna Formation (Cretaceous)". English. In: Palaeontologische Zeitschrift 82.2 (2008), pp. 113124.

[20313] M. R. Sanchez-Villagra, R. J. Burnham, D. C. Campbell, R. M. Feldmann, E. S. Gaffney, R. S. Kay, R. Lozsan, R. Purdy, and J. G. M. Thewissen. "A new near-shore marine fauna and flora from the early Neogene of northwestern Venezuela". In: Journal of Paleontology 74.5 (2000), pp. 957-968.

[20314] M. R. Sanchez-VIllagra, Z. Gasparini, B. Lozsan, J. M. Moody, and M. D. Uhen. “New discoveries of vertebrates from a near-shore marine fauna from the Early Miocene of northwestern Venezuela". English. In: Palaeontolgische Zeitschrift 75 (2001), pp. 227-232.

[20315] M. R. Sanchez-Villagra and R. F. Kay. "A skull of Proargyrolagus, the oldest argyrolagid (late Oligocene Salla Beds, Bolivia), with brief comments concerning its paleobiology". English. In: Journal of Vertebrate Paleontology 17.4 (1997), pp. 717-724.

[20316] M. R. Sánchez-Villagra, R. F. Kay, and F. Anaya-Daza. “Cranial anatomy and palaeobiology of the Miocene marsupial Hondalagus altiplanensis and a phylogeny of argyrolagids". English. In: Palaeontology 43.2 (2000), pp. 287-301. DOI: 10.1111/1475-4983.00127.

[20317] M. R. Sanchez-Villagra and T. M. Scheyer. "Fossil turtles from the Northern Noetropics: the Urumaco Sequence fauna and finds from other localities in Venezuela and Colombia". English. In: Urumaco and Venezuelan paleontology 9. Bloomington, IN: Indiana University Press, 2010, pp. 173191. 
[20318] M. R. Sánchez-Villagra, E. R. Seiffert, T. Martin, E. L. Simons, G. F. Gunnell, and Y. Attia. “Enigmatic new mammals from the late Eocene of Egypt". English. In: Palaeontologische Zeitschrift 81.4 (2007), pp. 406-415.

[20319] F. SánchezBeristain and J. Reitner. "Four new fossil associations identified in the Cipit boulders from the St. Cassian Formation (Ladinian-Carnian; Dolomites, NE Italy)". English. In: Palaeontologische Zeitschrift (2017).

[20320] B. Sanchiz, M. Alcobendas, and H. H. Schleich. "Evidence of Seasonal Growth in Extinct Oligocene Palaeobatrachid Anurans". English. In: Copeia 1994.1 (1994), pp. 232-233.

[20321] P. M. Sander. The Norian Plateosaurus bonebeds of central Europe and their taphonomy. 1992.

[20322] P. M. Sander. “Cymbospondylus (Shastasauridae: Ichthyosauria) from the Middle Triassic of Spitsbergen: filling a paleobiogeographic gap". English. In: Journal of Paleontology 66.2 (1992), pp. 332337.

[20323] P. M. Sander. “Ichthyosauria: their diversity, distribution and phylogeny”. English. In: Palaeontologische Zeitschrift 74.1/2 (2000), pp. 1-35.

[20324] P. M. Sander and H. Boucher. "On the presence of Mixosaurus (Ichthyopterygia: Reptilia) in the Middle Triassic of Nevada". English. In: Journal of Paleontology 64.1 (1990), pp. 161-164.

[20325] P. M. Sander and C. Faber. "The Triassic marine reptile Omphalosaurus: osteology, jaw anatomy, and evidence for ichthyosaurian affinities". English. In: Journal of Vertebrate Paleontology 23.4 (2003), pp. 799-816.

[20326] P. M. Sander and C. Faber. "New finds of Omphalosaurus and a review of Triassic ichthyosaur paleobiogeography". English. In: Palaeontologische Zeitschrift 72.1/2 (1998), pp. 149-162.

[20327] P. M. Sander, N. Klein, P. C. H. Albers, C. Bickelmann, and H. Winkelhorst. "Postcranial morphology of a basal Pistosauroidea (Sauropterygia) from the Lower Muschelkalk of Winterswijk, The Netherlands". English. In: Palaeontologische Zeitschrift 88 (2014), pp. 55-71. DOI: 10.1007/ s12542013-0181-5.

[20328] P. M. Sander, O. Mateus, T. Laven, and N. Knótschke. “Bone histology indicates insular dwarfism in a new Late Jurassic sauropod dinosaur". English. In: Nature 441 (2006), pp. 739-741.

[20329] P. M. Sander and C. Meyer. "A labyrinthodont jaw fragment from the marine Triassic of the Alps". English. In: Neues Jahrbuch für Geologie und Paläontologie, Monatshefte 1991.4 (1991), pp. 222-232.

[20330] P. M. Sander, C. Peitz, J. Gallemi, and R. Cousin. “Dinosaurs nesting on a red beach?" English. In: Comptes Rendus de l'Académie des Sciences, Paris: Sciences de la Terre et des Planétes 327 (1998), pp. 67-74.

[20331] P. M. Sander, O. C. Rieppel, and H. Bucher. "A new pistosaurid (Reptilia: Sauropterygia) from the Middle Triassic of Nevada and its implications for the origin of the plesiosaurs". English. In: Journal of Vertebrate Paleontology 17.3 (1997), pp. 526-533.

[20332] P. M. Sander, O. C. Rieppel, and H. Bucher. "A new marine vertebrate fauna from the Middle Triassic of Nevada". English. In: Journal of Paleontology 68.3 (1994), pp. 676-680.

[20333] A. E. Sanders. "Additions to the Pleistocene Mammal Faunas of South Carolina, North Carolina, and Georgia". English. In: American Philosophical Society (2002), pp. 1-152.

[20334] A. E. Sanders and L. G. Barnes. "Paleontology of the Late Oligocene Ashley and Chandler Bridge Formations of South Carolina, 2: Micromysticetus rothauseni, a primitive cetotheriid mysticete (Mammalia: Cetacea)". In: Smithsonian Contributions to Paleobiology 93 (2002), pp. 271-293.

[20335] A. E. Sanders and L. G. Barnes. "Paleontology of the Late Oligocene Ashley and Chandler Bridge Formations of South Carolina, 3: Eomysticetidae, a new family of primitive mysticetes (Mammalia: Cetacea)". In: Smithsonian Contributions to Paleobiology 93 (2002), pp. 313-356.

[20336] A. E. Sanders and J. H. Geisler. "A new basal odontocete from the upper Rupelian of South Carolina, U.S.A., with contributions to the systematics of Xenorophus and Mirocetus (Mammalia, Cetacea)". English. In: Journal of Vertebrate Paleontology (2015), e890107. DOI: 10.1080 / 02724634. 2014.890107. 
[20337] A. E. Sanders and M. P. Katuna. Proposal for revision of the stratigraphic nomenclature of the Santee Limestone (Eocene) of South Carolina, U.S.A. English. 2000.

[20338] D. Sanders. "Burrow-mediated carbonate dissolution in rudist biostromes (Aurisina, Italy): implications for taphonomy in tropical, shallow subtidal carbonate environments". In: Palaeogeography, Palaeoclimatology, Palaeoecology 168.1-2 (2001), pp. 39-74.

[20339] D. Sanders. "Rudist biostromes on the margin of an isolated carbonate platform: The Upper Cretaceous of Montagna della Maiella, Italy". English. In: Eclogae geologicae Helvetiae 89.2 (1996), pp. 845-871.

[20340] D. Sanders. “The Upper Cretaceous near Maurach (Tyrol, Austria)". English. In: Geologisch-Paläontologische Mitteilungen Innsbruck Band 21 (1996).

[20341] D. Sanders and R. Baron-Szabo. "Palaeoecology of solitary corals in soft-substrate habitats: the example of Cunnolites (upper Santonian, Eastern Alps)". English. In: Lethaia 41 (2008), pp. 1-14.

[20342] D. Sanders and R. C. Baron-Szabo. “Coral-rudist bioconstructions in the Upper Cretaceous Haidach section (Northern Calcaerous Alps, Austria)". In: Facies 36 (1997), pp. 69-90.

[20343] D. Sanders, G. Keller, F. Schlagintweit, and M. Studeny. "Cretaceous-Paleocene transition along a rocky carbonate shore: implications for the Cretaceous-Paleocene boundary event in shallow platform environments and correlation to the deep sea". English. In: vol. 544. Mass Extinctions, Volcanism, and Impacts: New Developments. Geological Society of America Special Paper. 2020, pp. 137-163. DOI: 10.1130/2019.2544(06).

[20344] M. T. Sanders, J. Bardin, M. Benzaggagh, and F. Cecca. “Early Toarcian (Jurassic) belemnites from northeastern Gondwana (South Riffian ridges, Morocco)". English. In: Paläontologische Zeitschrift 89 (2015), pp. 51-62.

[20345] M. T. Sanders, D. Merle, and L. Villier. “The molluscs of the Faluniére of Grignon (Middle Lutetian, Yvelines, France): quantification of lithification bias and its impact on the biodiversity assessment of the Middle Eocene of Western Europe". English. In: Geodiversitas 37.3 (2015), pp. 345-365. DOI: $10.5252 / \mathrm{g} 2015 \mathrm{n} 3 \mathrm{a} 4$.

[20346] W. Sanders, J. Kappelman, and D. T. Rasmussen. "New largebodied mammals from the late Oligocene site of Chilga, Ethiopia." English. In: Acta Palaeontologica Polonica 49.3 (2004), pp. 365-392.

[20347] W. J. Sanders. Fossil Proboscidea from the Pliocene Lusso Beds of the Western Rift,Zaire. 1990.

[20348] W. J. Sanders. “Oldest record of Stegodon (Mammalia: Proboscidea)”. English. In: 19.4 (1999), pp. 793-797.

[20349] W. J. Sanders and E. R. Miller. "New proboscideans from the early Miocene of Wadi Mogahara, Egypt". English. In: Journal of Vertebrate Paleontology 22.2 (2002), pp. 388-404.

[20350] W. J. Sanders, W. Nemec, M. Aldinucci, N. E. Janbu, and M. Ghinassi. "Latest evidence of Palaeoamasia (Mammalia, Embrithopoda) in Turkish Anatolia". English. In: Journal of Vertebrate Paleontology 34.5 (2014), pp. 1155-1164.

[20351] A. C. Sandford. "Palaeogeographic setting of a deep-water trilobite fauna from the Early Devonian (Pragian) of the Upper Yarra, central Victoria. Phacopidae of Victoria, Part 3". English. In: Alcheringa 28 (2004), pp. 113-128.

[20352] W. J. Sando. Coralliferous carbonate shelves of Mississippian age, west side of Antler Orogen, central Nevada. 1993.

[20353] J. Sandoval, A. Linares, and M. H. Henriques. “The Middle Jurassic genus Riccardiceras (Otoitidae, Ammonitina) in the Westernmost Tethys: Betic Cordillera and Lusitanian Basin". English. In: Revue de Paléobiologie 19 (2000), pp. 29-44.

[20354] O. Sandström and S. Kershaw. "Reef biostromes and related facies from the middle Silurian of Gotland, Sweden". PhD thesis. 2000, pp. 1-11.

[20355] M. R. Sandy. "Triassic-Jurassic articulate brachiopods from the Pucara Group, central Peru, and description of the brachidial net in the spiriferid Spondylospira". English. In: Palaeontographica Abteilung A 233 (1994), pp. 99-126. 
[20356] M. R. Sandy. “Cretaceous brachiopods from James Ross Island, Antarctic Peninsula, and their paleobiogeographic affinities". English. In: Journal of Paleontology 65.3 (1991), pp. 396-411.

[20357] M. R. Sandy. "Early Cretaceous brachiopods from Mexico and their paleobiogeographic significance". English. In: Journal of Paleontology 64.6 (1990), pp. 942-956.

[20358] M. R. Sandy. "A New Early Cretaceous Articulate Brachiopod from the Northwest Territories, Canda, and Its Paleobiogeographic Significance". English. In: Journal of Paleontology 64.3 (1990), pp. 367-372.

[20359] M. R. Sandy and F. Aly. "A southern Tethyan brachiopod fauna from the Late Triassic of the United Arab Emirates". English. In: Geobios 33.5 (2000), pp. 561-567.

[20360] M. R. Sandy and R. B. Blodgett. "Early Jurassic spiriferid brachiopods from Alaska and their paleogeographic significance". English. In: PaleoBios 33.3 (2000), pp. 319-328.

[20361] M. R. Sandy and R. B. Blodgett. Peregrinella (Brachiopoda; Rhynchonellida) from the Early Cretaceous, Wrangellia Terrane, Alaska. English. Brachiopods. 1996, pp. 239-242.

[20362] M. R. Sandy, D. A. T. Harper, S. K. Donovan, and D. J. Miller. "A Late Cretaceous terebratulid brachiopod from Jamaica, and its significance for Mesozoic brachiopod palaeobiogeography and evolution". English. In: Proceedings of the Geologists Association 108 (1997), pp. 201-207.

[20363] M. R. Sandy, K. Hryniewicz, O. Hammer, H. A. Nakrem, and C. T. S. Little. “Brachiopods from the Late Jurassic-Early Cretaceous hydrocarbon seep deposits, central Spitsbergen, Svalbard". English. In: Zootaxa 3884.6 (2014), pp. 501-532.

[20364] M. R. Sandy, M. A. Murphy, and P. U. Rodda. “Dzirulina (Brachiopoda; Terebratellidina) from California, U.S.A.-Additional record of an Early Cretaceous transatlantic brachiopod genus". English. In: Journal of Paleontology 69.5 (1995), pp. 838-845. DOI: 10.1017/S0022336000035514.

[20365] M. R. Sandy, R. L. Squires, and R. Demetrion. “Middle Eocene Terebratulide Brachiopods from the Bateque Formation, Baja California Sur, Mexico". English. In: Journal of Paleontology 69.1 (1995), pp. $45-51$.

[20366] M. R. Sandy and G. D. Stanley Jr. "Late Triassic brachiopods from the Luning Formation, Nevada, and their palaeobiogeographical significance". English. In: Palaeontology 36 (1993), pp. 439-480.

[20367] M. Saneyoshi, M. Watabe, T. Tsubamoto, K. Tsogtbaatar, T. Chinzorig, and S. Suzuki. "Report of the HMNS-MPC Joint Paleontological Expedition in 2007". English. In: Hayashibara Museum of Natural Sciences Research Bulletin 3 (2010), pp. 19-28.

[20368] A. Sanfilippo, A. Hakyemez, and U. K. Tekin. "Biostratigraphy of Late Paleocene- Middle Eocene radiolarians and foraminifera from Cyprus". English. In: Micropaleontology 49.1-2 (2003), pp. 4764.

[20369] R. Sanfilippo, A. Reitano, G. Insacco, and A. Rosso. "A new tubeworm of possible serpulid affinity from the Permian of Sicily". English. In: Acta Palaeontologica Polonica 61.3 (2016), pp. 621-626. DOI: 10.4202/app.00209.2015.

[20370] R. Sanfilippo, A. Rosso, A. Reitano, A. Viola, and G. Insacco. “New serpulid polychaetes from the Permian of western Sicily". English. In: Acta Palaeontologica Polonica 63 (2018), pp. 579-584.

[20371] R. Sanfilippo, A. Rosso, A. Reitano, and G. Insacco. "First record of sabellid and serpulid polychaetes from the Permian of Sicily". English. In: Acta Palaeontologica Polonica 62 (2017), pp. 2538.

[20372] A. C. Sanford and D. J. Holloway. “Early Silurian phacopide trilobites from central Victoria, Australia". English. In: Memoirs of Museum Victoria 63.2 (2008), pp. 215-255.

[20373] J. Sankey, J. Biewer, J. Basuga, F. Palacios, H. Wagner, and D. Garber. “The giant, spike-toothed salmon, Oncorhynchus rastrosus and the Proto-Tuolumne River (early Pliocene) of central California". English. In: PaleoBios 33 (2016), pp. 1-16.

[20374] J. T. Sankey. Vertebrate paleontology and magnetostratigraphy, upper Aguja Formation (late Campanian), Big Bend National Park, Texas. English. 1998. 
[20375] J. T. Sankey. “Late Campanian southern dinosaurs, Aguja Formation, Big Bend, Texas". English. In: Journal of Paleontology 75.1 (2001), pp. 208-215.

[20376] J. T. Sankey. Turtles of the upper Aguja Formation (late Campanian), Big Bend National Park, Texas. English. Vol. 35. Late Cretaceous Vertebrates from the Western Interior. New Mexico Museum of Natural History and Science Bulletin. 2006, pp. 235-243.

[20377] J. T. Sankey. Faunal composition and significance of high-diversity, mixed bonebeds containing Agujaceratops mariscalensis and other dinosaurs, Aguja Formation (Upper Cretaceous), Big Bend, Texas. English. New Perspectives on Horned Dinosaurs: The Royal Tyrrell Museum Ceratopsian Symposium. Indiana University Press, Bloomington. 2010, pp. 520-537.

[20378] J. T. Sankey, B. R. Standhardt, and J. A. Schiebout. Theropod teeth from the Upper Cretaceous (CampanianMaastrichtian), Big Bed National Park, Texas. English. The Carnivorous Dinosaurs. Indiana University Press, Bloomington. 2005, pp. 127-152.

[20379] H. Sano, K. Horibo, and Y. Kumamoto. “Tubiphytes-Archaeolithoporella-Girvanella reefal facies in Permian buildup, Mino Terrane, central Japan". English. In: Sedimentary Geology 68 (1990), pp. 293-306.

[20380] H. Sano, K. Kuwahara, A. Yao, and S. Agematsu. "Stratigraphy and age of the Permian-Triassic boundary siliceous rocks of the Mino terrane in the Mt. Funabuseyama area, central Japan". English. In: Paleontological Research 16.2 (2012), pp. 124-145. DOI: 10.2517/1342-8144-16.2.124.

[20381] S. Sano. "Litho- and biofacies of Early Cretaceous rudist-bearing carbonate sediments in northeastern Japan". In: Sedimentary Geology 99 (1995), pp. 179-189.

[20382] S. Sano, Y. Iba, P. W. Skelton, J. Masse, Y. M. Aguilar, and T. Kase. “The evolution of canaliculate rudists in the light of a new canaliculate polyconitid rudist from the Albian of the central Pacific". English. In: Palaeontology (2014), pp. 1-12. DOI: 10.1111/pala.12096.

[20383] S.-I. Sano. “Discovery of a coral-rudist buildup in the Miyako Group, Northeast Japan”. In: Transactions and Proceedings of the Palaeontological Society of Japan, New Series 162 (1991), pp. 794-800.

[20384] S.-i. Sano and A. Yabe. "Fauna and flora of Early Cretaceous Tetori Group in central Japan: the clues to revealing the evolution of Cretaceous terrestrial ecosystem in Asia". English. In: Palaeoworld 26 (2017), pp. 253-267. DOI: 10.1016/j.palwor.2016.10.004.

[20385] I. J. Sansom. “Late Triassic (Rhaetian) conodonts and ichthyoliths from Chile”. English. In: Geological Magazine 137.2 (2000), pp. 129-135.

[20386] I. J. Sansom and D. K. Elliott. "A thelodont from the Ordovician of Canada". English. In: Journal of Vertebrate Paleontology 22.4 (2002), pp. 867-870.

[20387] I. J. Sansom, C. G. Miller, A. Heward, N. S. Davies, G. A. Booth, R. A. Fortey, and F. Paris. “Ordovician fish from the Arabian Peninsula". English. In: Palaeontology 52.2 (2009), pp. 337-342.

[20388] I. J. Sansom and M. P. Smith. "Late Ordovician vertebrates from the Bighorn Mountains of Wyoming". English. In: Palaeontology 48.1 (2005), pp. 31-48.

[20389] I. J. Sansom, M. P. Smith, M. M. Smith, and P. Turner. "Astraspis, the anatomy and histology of an Ordovician fish". English. In: Palaeontology 40.3 (1997), pp. 625-643.

[20390] J. Santiago-Blay and G. O. Poinar. "Millipeds from Dominican amber, with the description of two new species (Diplopoda: Siphonophoridae) of Siphonophora". English. In: Annals of the Entomological Society of America 85 (1992), pp. 363-369.

[20391] J. A. Santiago-Blay, V. Fet, M. E. Soleglad, and S. R. Anderson. “A new genus and subfamily of scorpions from Lower Cretaceous Burmese amber (Scorpiones: Chaerilidae)". English. In: Revista Ibérica de Aracnologa 9 (2004), pp. 3-14.

[20392] J. A. Santiago-Blay, V. Fet, M. E. Soleglad, and P. R. Craig. "The second Cretaceous scorpion specimen from Burmese amber (Arachnida: Scorpiones)". English. In: Journal of Systematic Palaeontology 2 (2004), pp. 147-152. 
[20393] J. A. Santiago-Blay and G. O. Poinar. "First scorpion (Buthidae: Centruroides) from Mexican amber (Lower Miocene to Upper Oligocene)". English. In: The Journal of Arachnology 21 (1993), pp. 147-151.

[20394] C.d. Santisteban, A. Santos-Cubedo, and B. Poza. "Revisión de la sección del yacimiento del Mas de la Chimenea Alta (Formación Arcillas de Morella, Castellón) y significado en el contexto paleoambiental [Revision of the Mas de la Chimenea Alta fossil site section (Formación Arcillas de Morella, Castellón) and its significance in the paleoenvironmental context]". Spanish. In: Geogaceta 51 (2012), pp. 67-70.

[20395] C.d. Santisteban, M. Suñer, and B. Vila. "El yacimiento de icnitas de dinosaurios de Cañada Paris, Alpuente, Valencia [The dinosaur tracksite of Cañada Paris, Alpuente, Valencia]". English. In: vol. Actas. IV Jornadas Internacionales sobre Paleontologa de Dinosaurios y su Entorno. Salas de los Infantes: Colectivo Arqueológico-Paleontológico Salense, 2009, pp. 301-309.

[20396] C.d. Santisteban, B. Vila, and M. Suñer. "Huellas de dinosaurios conservadas en materiales del cortejo transgresivo en cauces encajados. Jurásico superior y Cretácico inferior de Alpuente, Valencia [Dinosaur footprints preserved in deposits of the transgressive systems tract in incised valleys. Upper Jurassic and Lower Cretaceous of Alpuente, Valencia ]". Spanish. In: Geogaceta 42 (2007), pp. 79-82.

[20397] N. Santodomingo. Miocene reef-coral diversity of Indonesia: unlocking the murky origins of the Coral Triangle. English. UU Department of Earth Sciences. 2014.

[20398] A. Santos, E. J. Mayoral, C. M. da Silva, M. Cachao, M. E. Johnson, and B. G. Baarli. “Miocene intertidal zonation on a volcanically active shoreline: Porto Santo in the Madeira Archipelago, Portugal". English. In: Lethaia 44 (2011), pp. 26-32.

[20399] G.-P. Santos, J. F. Parham, and B. L. Beatty. “New data on the ontogeny and senescence of Desmostylus (Desmostylia, Mammalia)". English. In: Journal of Vertebrate Paleontology (2016), e1078344. DOI: 10.1080/02724634.2016.1078344.

[20400] J. C. R. Santos, A. Rancy, and J. Ferigolo. “Octodontobradyinae, uma nova subfamilia de Orophodontidae (Edentata, Tardigrada) do Mioceno superior-Plioceno do estado do Amazonas, Brasil". Spanish. In: Ameghiniana 30.3 (1993), pp. 255-264.

[20401] M. F. A. Santos, I. Mattos, J. R. M. Mermudes, S. M. Scheler, and P. Reyes-Castillo. “A new passalid fossil (Insecta: Coleoptera) from the Santana Formation (Crato Member, Lower Cretaceous), Araripe basin, NE Brazil: paleoecologic and paleobiogeographic implications". English. In: Cretaceous Research 118.104664 (2020). DOI: 10.1016/j.cretres.2020.104664.

[20402] M. F. A. Santos, J. R. M. Mermudes, and V. M. M. Fonseca. “A specimen of Curculioninae (Curculionidae, Coleoptera) from the Lower Cretaceous, Araripe Basin, north-eastern Brazil”. English. In: Palaeontology 54.4 (2011), pp. 807-814.

[20403] V. F. Santos. "Dinosaur tracks in the southwest Algarve Basin”. English. In: Comunicações Geológicas 103.Especial 1 (2016), pp. 117-120.

[20404] V. F. Santos. "Dinosaur tracksites in the Middle Jurassic of Maciço Calcário Estremenho (westcentral Portugal): a geoheritage to be enhanced". English. In: Comunicações Geológicas 103.Especial 1 (2016), pp. 55-58.

[20405] V. F. Santos, P. Caetano, and A. Pólvora. "Sesimbra Geocircuit and dinosaur tracksites". English. In: Comunicações Geológicas 103.Especial 1 (2016), pp. 153-158.

[20406] V. F. Santos, J. J. Moratalla, and R. Royo-Torres. "New sauropod trackways from the Middle Jurassic of Portugal". English. In: Acta Palaeontologica Polonica 54.3 (2009), pp. 409-422. DOI: 10.4202 / app.2008.0049.

[20407] A. Santos-Cubedo, B. Poza, and C.d. Santisteban. “Un poco de tierra...un mundo Cretácico: el yacimiento BMG de Portell (Barremiense superior, Castellón) [A handful of land...a Cretaceous world: the BMG site from Portell (upper Barremian, Castellón, Spain)]". Spanish. In: Geogaceta 63 (2018), pp. 91-94. 
[20408] R. M. Santucci and A.C.d. Arruda-Campos. "A new sauropod (Macronaria, Titanosauria) from the Adamantina Formation, Bauru Group, Upper Cretaceous of Brazil and the phylogenetic relationships of Aeolosaurini". English. In: Zootaxa 3085 (2011), pp. 1-33.

[20409] R. M. Santucci and R. J. Bertini. "A new titanosaur from western São Paulo State, Upper Cretaceous Bauru Group, south-east Brazil". English. In: Palaeontology 49.1 (2006), pp. 59-66.

[20410] R. M. Santucci and R. J. Bertini. “Distribuição paleogeográfica e biocronológica dos titanossauros (Saurischia, Sauropoda) do Grupo Bauru, Cretáceo Superior do sudeste Brasileiro [Paleogeographic and biochronologic distribution of titanosaurs (Saurischia, Sauropoda) from the Bauru Group, Upper Cretaceous of southeastern Brazil]". Portugese. In: Revista Brasileira de Geosciencias 31.3 (2001), pp. 307-314.

[20411] R. M. Santucci and R. J. Bertini. "A large sauropod titanosaur from Peirópolis, Bauru Group, Brazil”. English. In: Neues Jahrbuch für Geologie und Paläontologie Monatshefte 2006.6 (2006), pp. 344360.

[20412] V. L. Santucci. The Yellowstone paleontological survey. English. Vol. 98-1. Yellowstone Center for Resources, National Park Service, YCR-NR. 1998, pp. 1-51.

[20413] V. L. Santucci, A. P. Hunt, T. Nyborg, and J. P. Kenworthy. “Additional fossil vertebrate tracks in National Park Service Areas". English. In: vol. 34. Fossils from Federal Lands. New Mexico Museum of Natural History and Science Bulletin. 2006, pp. 152-158.

[20414] V. L. Santucci and J. I. Kirkland. An Overview of National Park Service Paleontological Resources from the Parks and Monuments in Utah. English. Vol. 28. Utah Geological Association Publication 28 (third edition). 2010, pp. 589-623.

[20415] J. L. Sanz. "Yacimientos ibéricos de dinosaurios [Iberian dinosaur localities]". Spanish. In: Dinosaurios: Los Señores del Pasado [Dinosaurs: The Lords of the Land]. Barcelona: Martnez Roca, 2000, pp. 267-299.

[20416] J. L. Sanz, L. M. Chiappe, B. P. Pérez-Moreno, A. D. Buscalioni, J. J. Moratalla, F. Ortega, and F. J. Poyato-Ariza. "An Early Cretaceous bird from Spain and its implications for the evolution of avian flight". In: Nature 382 (1996), pp. 442-445.

[20417] J. L. Sanz, L. M. Chiappe, and A. D. Buscalioni. “The osteology of Concornis lacustris (Aves: Enantiornithes) from the Lower Cretaceous of Spain and a reexamination of its phylogenetic relationships". English. In: American Museum Novitates 3133 (1995), pp. 1-23.

[20418] J. L. Sanz, L. M. Chiappe, Y. Fernández-Jalvo, F. Ortega, B. Sánchez-Chillón, F. J. Poyato-Ariza, and B. P. Pérez-Moreno. “An Early Cretaceous pellet”. English. In: Nature 409 (2001), pp. 998-999.

[20419] J. L. Sanz, L. M. Chiappe, B. P. Pérez-Moreno, J. J. Moratalla, F. Hernández-Carrasquilla, A. D. Buscalioni, F. Ortega, F. J. Poyato-Ariza, D. Rasskin-Gutman, and X. Martnez-Delciós. "A nestling bird from the Lower Cretaceous of Spain: implications for avian skull and neck evolution". English. In: 276 (1997), pp. 1543-1546.

[20420] J. Sanz-Lopez, S. Blanco-Ferrera, L. C. Sanchez de Posada, and S. Garcia-Lopez. “Serpukhovian conodonts from Northern Spain and their biostratigraphic application". English. In: Palaeontology 50.4 (2007), pp. 1-22.

[20421] V. P. Sapelnikov, O. V. Bogoyavlenskaya, L. I. Mizens, and V. P. Shuysky. Silurian and Early Devonian benthic communities of the Ural-Tien Shan region. Paleocommunities-a case study from the Silurian and Lower Devonian. 1999, pp. 510-544.

[20422] V. P. Sapelnikov, M. P. Snigireva, A. Z. Bikbayev, and L. I. Mizens. "Zonal subdivision of EarlyMiddle Devonian reef deposits of the Urals based on conodonts and brachiopods". English. In: Courier Forschungsinstitut Senckenberg 182 (1995), pp. 399-419.

[20423] G. Sarac. "Turkiye omurgali fosil yataklari". other. In: MTA (Maden Tetkik ve Arama Genel Müdürlügü) Derleme Rapor 10609 (2003). 
[20424] R. J. Sardella, D. Berté, D. A. Iurino, M. Cherin, and A. Tagliacozzo. “The wolf from Grotta Romanelli (Apulia, Italy) and its implications in the evolutionary history of Canis lupus in the Late Pleistocene of Southern Italy". English. In: Quaternary International 328-329 (2014), pp. 179-195. DOI: 10.1016/j.quaint.2013.11.016.

[20425] K. A. Sardi and C. Merigo. "Erignathus barbatus (Bearded Seal) vagrant in Massachusetts". English. In: Northeastern Naturalist 13.1 (2006), pp. 39-42.

[20426] B. Sari and S. Ozer. “Upper Cretaceous stratigraphy of the Bey Daglari carbonate platform, Korkuteli area (western Taurides, Turkey)". In: Turkish Journal of Earth Sciences 11.1 (2002), pp. 3959.

[20427] B. Sari and S. Ozer. "Upper Cretaceous rudist biostratigraphy of the Bey Daglari Carbonate Platform, Western Taurides, SW Turkey". English. In: Geobios 42 (2009), pp. 359-380.

[20428] V. Sargül. "New basal dinosauromorph records from the Dockum Group of Texas, USA". English. In: Palaeontologia Electronica 19.2 (2016), 21A.

[20429] V. Sargül. "New theropod fossils from the Upper Triassic Dockum Group of Texas, USA, and a brief overview of the Dockum theropod diversity". English. In: PaleoBios 34 (2017), pp. 1-18.

[20430] V. Sarigul, F. Agnolin, and S. Chatterjee. "Description of a multitaxic bone assemblage from the Upper Triassic Post Quarry of Texas (Dockum Group), including a new small basal dinosauriform taxon". English. In: Historia Natural 8.1 (2018), pp. 5-24.

[20431] W. A. S. Sarjeant, J. B. Delair, and M. G. Lockley. "The footprints of Iguanodon: a history and taxonomic study". English. In: Ichnos 6.3 (1998), pp. 183-202.

[20432] S. Sarkar. "The Enigmatic Paleocene-Eocene coralline Distichoplax: Approaching the structural complexities, ecological affinities and extinction hypotheses". English. In: Marine Micropaleontology 139 (2018), pp. 72-83. DOI: 10.1016/j.marmicro.2017.12.001.

[20433] S. Sarkar. "Thanetian-Ilerdian coralline algae and benthic foraminifera from northeast India: microfacies analysis and new insights into the Tethyan perspective". English. In: Lethaia 48 (2015), pp. 13-28.

[20434] S. Sarkar. "Calcareous algal-rich carbonate sediments from Assam shelf, N-E India: an overview of the palaeoenvironmental implications". English. In: Petroleum Geosciences: Indian Contexts. Springer Geology, 2015, pp. 175-189.

[20435] S. Sarkar. "Ecostratigraphic implications of a Late Paleocene shallow-marine benthic community from the Jaintia Hills, Meghalaya, NE India". English. In: Journal of Earth System Science 129.10 (2020). DOI: 10.1007/s12040-019-1257-8.

[20436] S. Sarkar, A. K. Ghosh, and M. Kumar. "Recognition of algal rich facies from the Umlatdoh Limestone of Shella Formation, Jaintia Group, Meghalaya". English. In: The palaeobotanist 60 (2011), pp. 315-321.

[20437] S. Sarkar and G. M. N. Rao. "Coralline red algae from late Palaeocene-earliest Eocene carbonates". English. In: Carbonates and Evaporites (2018). DOI: 10.1007/s13146-018-0422-5.

[20438] D. K. Sarko, D. P. Domning, L. Marino, and R. L. Reep. "Estimating body size of fossil sirenians". English. In: Marine Mammals Science 26.4 (2010), pp. 937-959.

[20439] A. Sarma and A. K. Ghosh. "A new record of calcareous algae from Shella Formation (Jaintia Group) of South Jaintia Hills, Meghalaya, India". English. In: Current Science 90.9 (2006).

[20440] G. N. Sarmiento, D. Fernández-Remolar, and M. C. Göncüoglu. "Cambrian small shelly fossils from the Çal Tepe Formation, Taurus Mountains, Turkey". English. In: Coloquios de Paleontologa 52 (2001), pp. 117-134.

[20441] P. Sartenaer. "Restatement of Terebratula orbignyana de Verneuil, 1850 on the basis of the original collection". English. In: Bulletin de l'Institut royal des Sciences naturelles de Belgique, Sciences de la Terre, supplement 74 (2004), pp. 81-88.

[20442] C. Sarti and A. Larnzetti. “I cetacei fossili del Museo Geologico Giovanni Capellini dell’Università di Bologna". Italian. In: Museologia Scientifica Memorie 13 (2014), pp. 70-78. 
[20443] M. Sarti, A. Russo, and F. R. Bosellini. “Rhaetian strata, Wombat Plateau: analysis of fossil communities as a key to paleoenvironmental change". English. In: Proceedings of the Ocean Drilling Program, Scientific Results 122 (1992), pp. 181-195.

[20444] L. C. Sarzetti, C. C. Labandeira, and J. F. Genise. "A leafcutter bee trace fossil from the Middle Eocene of Patagonia, Argentina, and a review of Megachilid (Hymenoptera) ichnology". English. In: Palaeontology 51.4 (2008), pp. 933-941. DOI: 10.1111/j.1475-4983.2008.00787.x.

[20445] K. Sasaki, A. Omura, K. Murakami, N. Sagawa, and T. Nakamori. "Interstadial coral reef terraces and relative sea-level changes during marine oxygen isotope stages 3-4, Kikai Island, central Ryukyus, Japan". English. In: Quaternary International 120 (2004), pp. 51-64.

[20446] K. Sasaki, A. Omura, T. Miwa, Y. Tsuji, H. Matsuda, T. Nakamori, Y. Iryu, T. Yamada, Y. Sato, and H. Nakagawa. "230Th/234U and $14 \mathrm{C}$ dating of a lowstand coral reef beneath the insular shelf off Irabu Island, Ryukyus, southwestern Japan". English. In: Island Arc 15 (2006), pp. 455-467.

[20447] L. Sasaran, S. Oezer, and E. Sasaran. "Description of Pseudosabinia klinghardti and some species of Pseudopolyconites (rudist bivalves) from the Late Cretaceous shallow-marine deposits from the Rosia Basin, Apuseni Mountains, Romania: Systematic palaeontology, biostratigraphy, and palaeobiogeography". English. In: Cretaceous Research 43 (2013), pp. 59-69.

[20448] K. Sashida, S. Adachi, H. Igo, N. Nakornsri, and A. Ampornmaha. "Middle to Upper Permian and Middle Triassic radiolarians from eastern Thailand". English. In: Science Reports of the Institute of Geoscience University of Tsukuba, Section B: Geological Sciences 18 (1997), pp. 1-17.

[20449] K. Sashida, H. Igo, S. Adachi, K. Ueno, Y. Kajiwara, N. Nakornsri, and A. Sardsud. “Late Permian to Middle Triassic radiolarian faunas from northern Thailand". English. In: Journal of Paleontology 74.5 (2000), pp. 789-811.

[20450] K. Sashida, Y. Kamata, S. Adachi, and Munasri. "Middle Triassic Radiolarians from West Timor, Indonesia". English. In: Journal of Paleontology 73.5 (1999), pp. 765-786.

[20451] K. Sashida, Munasri, S. Adachi, and Y. Kamata. "Middle Jurassic radiolarian fauna from Rotti Island, Indonesia". In: Journal of Asian Earth Sciences 17.4 (1999), pp. 561-572.

[20452] K. Sashida and S. Salyapongse. "Permian radiolarian faunas from Thailand and their paleogeographic significance". English. In: Journal of Asian Earth Sciences 20 (2002), pp. 691-701.

[20453] K. Sashida and H. Uematsu. "Late Jurassic radiolarians from the Torinosu-type limestone embedded in the Early Cretaceous Hinodani Formation of the northern Shimanto Terrane, Shikoku, Japan". English. In: Science Reports of the Institute of Geoscience, University of Tsukuba. Section B: Geological Sciences 17 (1996), pp. 39-69.

[20454] S. Sassaroli and F. Venturi. "Early Toarcian (post-OAE) Hildoceratinae (Ammonitina) fauna from the Marchean Apennines (Italy)". English. In: Revue de Paléobiologie, Genéve 31 (2012), pp. 85-114.

[20455] S. Sassaroli and F. Venturi. "The genus Pseudolillia (Maubeuge, 1949) (Ammonitina, Grammoceratinae) in the upper Toarcian of the Central Apennines (Cingoli, Macerata, Italy)". English. In: Bollettino della Societá Paleontologica Italiana 44 (2005), pp. 231-236.

[20456] S. Sassaroli and F. Venturi. “Cingolites n. gen., a new lower Toarcian Hildoceratinae (Ammonitina) from the Marchean Apennines (Cingoli, Macerata, Italy)". English. In: Bollettino della Societá Paleontologica Italiana 49 (2010), pp. 97-118.

[20457] T. Sato. "Terminonatator ponteixensis, a new elasmosaur (Reptilia: Sauropterygia) from the Upper Cretaceous of Saskatchewan". English. In: Journal of Vertebrate Paleontology 23.1 (2003), pp. 89-103.

[20458] T. Sato. "A new polycotylid plesiosaur (Reptilia: Sauropterygia) from the Upper Cretaceous Bearpaw Formation in Saskatchewan, Canada". English. In: Journal of Paleontology 79.5 (2005), pp. 969-980.

[20459] T. Sato, D. A. Eberth, E. L. Nicholls, and M. Manabe. "Plesiosaurian remains from non-marine to paralic sediments". English. In: Dinosaur Provincial Park: A Spectacular Ancient Ecosystem Revealed. 2005, pp. 249-276.

[20460] T. Sato, Y. Hasegawa, and M. Manabe. "A new elasmosaurid plesiosaur from the Upper Cretaceous of Fukushima, Japan”. English. In: Palaeontology 49.3 (2006), pp. 467-484. 
[20461] T. Sato, M. Sato, S. Kobayashi, and Aizu Fossil Research Group. “A fossil balaenopterid whale from the Upper Miocene Shiotsubo Formation in Takasato, Kitakata City, Fukushima Prefecture, northeast Japan". English. In: Chikyu Kagaku 64 (2010), pp. 23-28.

[20462] T. Sato and G. W. Storrs. "An early polycotylid plesiosaur (Reptilia: Sauropterygia) from the Cretaceous of Hokkaido, Japan". English. In: Journal of Paleontology 74.5 (2000), pp. 907-914.

[20463] T. Sato and X.-C. Wu. "A new Jurassic pliosaur from Melville Island, Canadian Arctic Archipelago". English. In: Canadian Journal of Earth Sciences 45 (2008), pp. 303-320. DOI: 10.1139/R08-003.

[20464] T. Sato, X.-C. Wu, A. Tirabasso, and P. Bloskie. "Braincase of a polycotylid plesiosaur (Reptilia: Sauropterygia) from the Upper Cretaceous of Manitoba, Canada". English. In: Journal of Vertebrate Paleontology 31.2 (2011), pp. 313-329.

[20465] T. Sato and T. Yamada. “A new Oxfordian (Late Jurassic) ammonite assemblage from the Arimine Formation (Tetori Group) in the Arimine area, southeastern Toyama Prefecture, northern Central Japan". English. In: Bulletin of the National Museum of Nature and Science, Series C, Geology and Paleontology 40 (2014), pp. 21-55.

[20466] T. Sato and T. Yamada. "Early Tithonian (Late Jurassic) Ammonite Parapallasiceras newly discovered from the Itoshiro Subgroup (Tetori Group) in the Hida Belt, northern Central Japan". English. In: Proceedings of the Japan Academy 81.7] (2005), pp. 267-272. DOI: 10.2183/pjab.81.267.

[20467] T. Sato, L.-J. Zhao, X. -C. Wu, and C. Li. "A new specimen of the Triassic pistosauroid Yunguisaurus, with implications for the origin of Plesiosauria (Reptilia, Sauropterygia)". English. In: Palaeontology (2013). DOI: 10.1111/pala.12048.

[20468] T. Sato, L.-J. Zhao, X. -C. Wu, and C. Li. "A new specimen of the Triassic pistosauroid Yunguisaurus, with implications for the origins of Plesiosauria (Reptilia, Sauropterygia)". English. In: Palaeontology 57.1 (2014), pp. 55-76.

[20469] Y. Sato and T. Uyeno. "Sardinella miyanoshitaensis, a new clupeid fish from the middle Miocene Tottori Group, Tottori Prefecture, Japan". English. In: Bulletin of the Natural Science Museum, Tokyo, Series C 25.3,4 (1999), pp. 129-141.

[20470] L. Satour, A. Lauriat-Rage, L. Belkebir, and M. Bessedik. "Biodiversity and taphonomy of bivalve assemblages of the Pliocene of Algeria (Bas Chelif Basin)". English. In: Arabian Journal of Geosciences 7.12 (2013), pp. 1-14.

[20471] A. K. Satterley. "Sedimentology of the Upper Triassic reef complex at the Hochkönig Massif (Northern Calcareous Alps, Austria)". English. In: Facies 30 (1994), pp. 119-150.

[20472] R. A. Sattler. "Large mammals in Lower Rampart Cave 1, Alaska: interspecific utilization of an eastern Beringian cave". English. In: Geoarchaeology 12.6 (1997), pp. 657-688.

[20473] K. Satyanarayana, D. K. Dasgupta, A. Dave, and K. K. Das. "Record of skeletal remains of dinosaur from early Middle Jurassic of Kuar Bet, Kutch, Gujarat". English. In: Current Science 77.5 (1999), pp. 639-641.

[20474] T. Saucéde and D. Néraudeau. "An 'Elvis' echinoid, Nucleopygus (Jolyclypus) jolyi, from the Cenomanian of France: phylogenetic analysis, sexual dimorphism and neotype designation". English. In: Cretaceous Research 27.4 (2006), pp. 542-554.

[20475] T. Saucéde, E. Vennin, E. Fara, N. Olivier, and The Paris Biota Team. "A new holocrinid (Articulata) from the Paris Biota (Bear Lake County, Idaho, USA) highlights the high diversity of Early Triassic crinoids". English. In: Geobios 54 (2019), pp. 45-53. DOI: 10.1016/j.geobios.2019.04.003.

[20476] L. R. Saul and W. P. Popenoe. "Additions to Pacific slope Turonian Gastropoda". English. In: The Veliger 36.4 (1993), pp. 351-388.

[20477] L. R. Saul and R. L. Squires. "Cretaceous trichotropid gastropods from the Pacific slope of North America: Possible pathways to calyptraeid morphology". English. In: The Nautilus 122.3 (2008), pp. 115-142. 
[20478] L. R. Saul and R. L. Squires. "New Cretaceous cerithiform gastropods from the Pacific Slope of North America". English. In: Journal of Paleontology 77.3 (2003), pp. 442-453. DOI: 10.1017 / S0022336000044164.

[20479] L. R. Saul and R. L. Squires. “Volutoderminae (Gastropoda: Volutidae) of Coniacian through Maastrichtian age from the North American Pacific Slope". English. In: Journal of Paleontology 82.2 (2008), pp. 213-237. DOI: 10.1666/06-010.1.

[20480] L. R. Saul, R. L. Squires, and J. L. Goedert. "A new genus of cryptic lucinid? bivalve from Eocene cold seeps and turbidite-influenced mudstone, western Washington". English. In: Journal of Paleontology 70.5 (1996), pp. 788-794.

[20481] W. B. Saunders, V. N. Shimansky, and O. V. Amitrov. "Clarification of Nautilus praepompilius Shimansky from the Late Eocene of Kazakhstan". English. In: Journal of Paleontology 70.4 (1996), pp. 609-611.

[20482] E. E. Saupe, R. Pérez-de la Fuente, P. A. Selden, X. Delclós, P. Tafforeau, and C. Soriano. “New Orchestina Simon, 1882 (Araneae: Oonopidae) from Cretaceous ambers of Spain and France: first spiders described using phase-contrast X-ray synchrotron microtomography". English. In: Palaeontology 55 (2012), pp. 127-143.

[20483] E. E. Saupe and P. A. Selden. "First fossil Mecysmaucheniidae (Arachnida, Chelicerata, Araneae), from Lower Cretaceous (uppermost Albian) amber of Charente-Maritime, France". English. In: Geodiversitas 31 (2009), pp. 49-60.

[20484] E. E. Saupe, P. A. Selden, and D. Penney. “First fossil Molinaranea Mello-Leitão, 1940 (Araneae: Araneidae), from middle Miocene Dominican amber, with a phylogenetic and palaeobiogeographical analysis of the genus". English. In: Zoological Journal of the Linnean Society 158 (2010), pp. 711725.

[20485] L. A. Sava. "The molluscan and brachiopod fauna of the Late Cretaceous Pierre Shale (Baculites compressus/Baculites cuneatus biozones) near Kremmling, Colorado". English. PhD thesis. 2007, pp. 1-111.

[20486] N. M. Savage. "Middle Devonian conodonts from the Wadleigh Limestone, southeastern Alaska". English. In: Journal of Paleontology 69.3 (1995), pp. 540-555.

[20487] N. M. Savage and M. Baxter. "Late Devonian (Frasnian) brachiopods from the Wadleigh Limestone, Southeastern Alaska". In: Journal of Paleontology 69.6 (1995), pp. 1029-1046.

[20488] N. M. Savage and E. H. Goodwin. "The internal features of some Paleozoic rhynchonellid brachiopods". In: Journal of Paleontology 72.3 (1998), pp. 437-441.

[20489] R. J. G. Savage, D. P. Domning, and J. G. M. Thewissen. "Fossil Sirenia of the West Atlantic and Caribbean region. V. The most primitive known sirenian, Prorastomus sirenoides Owen, 1855". In: Journal of Vertebrate Paleontology 14.3 (1994), pp. 427-449.

[20490] E. Savazzi. “Constructional morphology of strombid gastropod". English. In: Lethaia 24.3 (1991), pp. 311-331. DOI: $10.1111 /$ j.1502-3931.1991.tb01482.x.

[20491] A. R. Savinetsky, N. K. Kiseleva, and B. F. Khassanov. "Dynamics of sea mammal and bird populations of the Bearing Sea region over the last several millennia". English. In: Palaeogeography, Palaeoclimatology, Palaeoecology 209 (2004), pp. 335-352.

[20492] A. Savorelli, F. Masini, P. P. A. Mazza, M. A. Rossi, and S. Agostini. “New species of Deinogalerix (Mammalia, Eulipotyphla) from the late Miocene of Scontrone (Abruzzo, central Italy)". English. In: Palaeontologia Electronica 20.1 (2017), 16A-1-26.

[20493] B. B. Saw, M. Schlaich, M. C. Pöppelreiter, M. Ramkumar, P. Lunt, J. A. Gamez Vintaned, and S. H. Ali. "Facies, depositional environments, and anatomy of the Subis buildup". English. In: Facies 65.28 (2019). DOI: 10.1007/s10347-019-0571-6.

[20494] J. V. M. Saw, A. W. Hunter, K. G. Johnson, and A. H. B. A. Rahman. "Pliocene corals from the Togopi Formation of the Dent Peninsula, Sabah, northeastern Borneo, Malaysia". English. In: Alcheringa: An Australasian Journal of Palaeontology (2019). DOI: 10.1080/03115518.2018.1510978. 
[20495] J. Sawada, N. K. Thuy, and N. A. Tuan. "Faunal remains at Man Bac". English. In: Terra Australis 33 (2011), pp. 105-116.

[20496] H. Sawamura, M. Kimura, L. G. Barnes, and H. Furusawa. "Late Oligocene Cetacea from Ashorocho, Hokkaido, Japan; The fauna and its ecologic implications". English. In: The Paleontological Society Special Publication 8 (1996), p. 342.

[20497] J. Sawoniewicz and J. Kupryjanowicz. “Evaniella eocenica sp. nov. from the Baltic amber (Hymenoptera: Evaniidae)". English. In: Acta Zoologica Cracoviensia 46.Suppl (2003), pp. 267-270.

[20498] G. T. Sawyer. "Coprolites of the Black Mingo Group (Paleocene) of the South Carolina". English. In: Transactions of the American Philosophical Society 88.4 (1998), pp. 221-228.

[20499] C. Sayar and L. R. M. Cocks. “A new Late Ordovician Hirnantia brachiopod fauna from NW Turkey, its biostratigraphical relationships and palaeogeographical setting". English. In: Geological Magazine 150.3 (2013), pp. 479-496. DOI: 10.1017/S0016756812000520.

[20500] L. Scafati, D. L. Melendi, and W. Volkheimer. "A Danian subtropical lacustrine palynobiota from South America (Bororó Formation, San Jorge Basin, Patagonia - Argentina)". English. In: Geological Acta 7.1-2 (2009), pp. 35-61. DOI: 10.1344/105.000000270.

[20501] D. J. Scager, H.-J. Ahrens, F. E. Dieleman, L. W. van den Hoek Ostende, J. de Vos, and J. W. F. Reumer. "The Kor \& Bot collection revisited, with a biostratigraphic interpretation of the Early Pleistocene Oosterschelde Fauna (Oosterschelde Estuary, the Netherlands)". English. In: Deinsea 17 (2017), pp. 16-31.

[20502] A. Scanferla, F. Agnolin, F. E. Novas, M. de la Fuente, E. Bellosi, A. M. Baez, and A. Cione. “A vertebrate assemblage of Las Curtiembres Formation (Upper Cretaceous) of northwestern Argentina". English. In: Revista del Museo Argentino de Ciencias Naturales, new series 13.2 (2011), pp. 195-204.

[20503] A. Scanferla, H. Zaher, F. E. Novas, C. de Muizon, and R. Cespedes. "A New Snake Skull from the Paleocene of Bolivia Sheds Light on the Evolution of Macrostomatans". English. In: PLoS ONE 8.3 (2013), e57583. DOI: 10.1371/journal.pone.0057583.

[20504] J. D. Scanlon. "A new large madtsoiid snake from the Miocene of the Northern Territory". In: The Beagle, Records of the Northern Territory Museum of Arts and Sciences 9.1 (1992), pp. 49-60.

[20505] J. D. Scanlon. “Australia's oldest known snakes: Patagoniophis, Alamitophis, and Cf. Madtsoia (Squamata: Madtsoiidae) from the Eocene of Queensland." English. In: Memoirs of the Queensland Museum 51.1 (2005), pp. 215-235.

[20506] J. D. Scanlon. "Nanowana gen. nov., small madtsoiid snakes from the Miocene of Riversleigh: sympatric species with divergently specialised dentition." English. In: Memoirs of the Queensland Museum 41.2 (1997), pp. 393-412.

[20507] J. D. Scanlon. "Skull of the large non-macrostomatan snake Yurlunggur from the Australian OligoMiocene." English. In: Nature 439 (2006), pp. 839-842.

[20508] J. D. Scanlon. "Montypythonoides: the Miocene snake Morelia riversleighensis (Smith \& Plane, 1985) and the geographical origin of pythons". English. In: Memoirs of the Association of Australasian Palaeontologists 25 (2001), pp. 1-35.

[20509] J. D. Scanlon. “Cranial morphology of the Plio-Pleistocene giant madtsoiid snake Wonambi naracoortensis". English. In: Acta Palaeontologica Polonica 50.1 (2005), pp. 139-180.

[20510] J. D. Scanlon. "First records from Wellington Caves, New South Wales, of the extinct madtsoiid snake Wonambi naracoortensis Smith, 1976". English. In: Proceedings of the Linnean Society of New South Wales 115 (1995), pp. 233-238.

[20511] J. D. Scanlon and M. S. Y. Lee. “The Pleistocene serpent Wonambi and the early evolution of snakes." In: Nature 403 (2000), pp. 416-420.

[20512] J. D. Scanlon, M. S. Y. Lee, and M. Archer. “Mid-Tertiary elapid snakes (Squamata, Colubroidea) from Riversleigh, northern Australia: early steps in a continent-wide adaptive radiation". English. In: Geobios 36.5 (2003), pp. 573-601. DOI: 10.1016/S0016-6995(03)00056-1. 
[20513] J. D. Scanlon and B. S. Mackness. "A new giant python from the Pliocene Bluff Downs Local Fauna of Northeastern Queensland". In: Alcheringa 25 (2002), pp. 425-437.

[20514] F. Scarabino, S. Martinez, C. J. Del Rio, A. E. Olenik, H. H. Comacho, and W. J. Zinsmeister. “Two new species of Adelomelon Dall, 1906 (Gastropoda: Volutidae) from the Tertiary of Patagonia (Argentina)". English. In: Journal of Paleontology 78.5 (2004), pp. 914-919.

[20515] A. G. Scarbrough and G. O. Poinar. "Upper Eocene robber flies of the genus Ommatius (Diptera: Asilidae) in Dominican Amber". English. In: Insecta Mundi 6.1 (1992), pp. 13-18.

[20516] S. Scarpetta. "The earliest known occurrence of Elgaria (Squamata: Anguidae) and a minimum age for crown Gerrhonotinae: Fossils from the Split Rock Formation, Wyoming, USA". English. In: Palaeontologia Electronica 21.1.1FC (2018), pp. 1-8.

[20517] S. G. Scarpetta. "The first known fossil Uma: ecological evolution and the origins of North American fringe-toed lizards". English. In: BMC Evolutionary Biology 19.178 (2019), pp. 1-22. DOI: 10. 1186/s12862-019-1501-5.

[20518] D. Scarpioni, G. Dellabella, B. Dell'Angelo, J. W. Huntley, and M. Sosso. “Middle Miocene conoidean gastropods from western Ukraine (Paratethys): Integrative taxonomy, palaeo-climatogical and palaeobiogeographical implications". English. In: Acta Palaeontologica Polonica 61.2 (2016), pp. 327344.

[20519] D. Scarponi and G. Della Bella. "Molluschi marini del Plio-Pleistocene dell'Emilia-Romagna e della Toscana, Conoidea, Vol. 1 - Drilliidae e Turridae". Italian. In: Universitá di Bologna, Museo geologico Giovanni Capellini (2003), pp. 1-89.

[20520] R. A. Scasso, J. M. McArthur, C. J. del Rio, S. Martinez, and M. F. Thirlwall. "87Sr/86Sr Late Miocene age of fossil molluscs in the 'Entrerriense' of the Valdes Peninsula (Chubut, Argentina)". English. In: Journal of South American Earth Sciences 14 (2001), pp. 319-329.

[20521] S. Schaal. "Palaeopython fischeri n. sp. (Serpentes: Boidae), eine Riesenschlange aus dem Eozän (MP 11) von Messel". German. In: CFS Courier Forschungsinstitut Senckenberg 252 (2004), pp. 35-45.

[20522] M. Schädel and G. Bechly. "First record of Anisoptera (Insecta: Odonata) from mid-Cretaceous Burmese amber". English. In: Zootaxa 4103 (2016), pp. 537-549.

[20523] M. Schädel and T. S. Lechner. "Two new dragonflies (Odonata: Anisoptera) from the Miocene of Carinthia (Austria)". English. In: Zootaxa 4243 (2017), pp. 153-164.

[20524] M. Schädel, P. Müller, and J. T. Haug. “Two remarkable fossil insect larvae from Burmese amber suggest the presence of a terminal filum in the direct stem lineage of dragonflies and damselflies (Odonata)". English. In: Rivista Italiana di Paleontologia e Stratigrafia 126 (2020), pp. 13-35.

[20525] M. Schädel, V. Perrichot, and J. T. Haug. "Exceptionally preserved cryptoniscium larvae - morphological details of rare isopod crustaceans from French Cretaceous Vendean amber". English. In: Palaeontologia Electronica 22.3 .71 (2019), pp. 1-46.

[20526] P. Schäfer, R. J. Cuffey, and A. R. Young. “New trepostome bryozoa from the Early Triassic (Smithian/Spathian) of Nevada". In: Paläonotologische Zeitschrift 77.2 (2003), pp. 323-340.

[20527] P. Schäfer, B. Senowbari-Daryan, and A. Hamedani. "Stenolaemate bryozoans from the Upper Triassic (Norian-Rhaetian) Nayband Formation, Central Iran". English. In: Facies 49 (2003), pp. 135150.

[20528] A. Schafhauser, S. Götz, R. Baron-Szabo, and W. Stinnesbeck. "Depositional environment of coralrudist associations in the Upper Cretaceous Cardenas Formation (central Mexico)". In: Geologica Croatica 56.2 (2003), pp. 187-198.

[20529] G. Schairer and V. Schlampp. "Ammoniten aus dem Ober-Oxfordium von Gräfenberg/Ofr. (BimammatumZone, Hypselum-Subzone, semimammatum-Horizont)". German. In: Zitteliana A 43 (2003), pp. 1743.

[20530] G. Schairer, K. Seyed-Emami, F. T. Fürsich, B. Senowbari-Daryan, S. A. Aghanabati, and M. R. Majidifard. "Stratigraphy, facies analysis and ammonite fauna of the Qal'eh Dokhtar Formation (Middle-Upper Jurassic) at the type locality west of Boshrouyeh (east-central Iran)". English. In: Neues Jahrbuch für Geologie und Paläontologie, Abhandlungen 216.1 (2000), pp. 35-66. 
[20531] R. Schallreuter, I. Hinz-Schallreuter, and T. Suttner. "New Ordovician ostracodes from Himalaya and their palaeobiological and palaeogeographical implications". English. In: Revue de micropaléontologie 51 (2008), pp. 191-204.

[20532] W. Schatz. "Revision of the subgenus Daonella (Arzelella) (Halobiidae; Middle Triassic)". In: Journal of Paleontology 78.2 (2004), pp. 300-316.

[20533] W. Schatz. "Revision der Untergattung Daonella (Pichlerella) (Bivalvia, Ladin)". German. In: Eclogae Geologicae Helvetiae 94 (2001), pp. 389-398.

[20534] G. Schaumberg. "Neue Informationen zu Menaspis armata Ewald". German. In: Paläontologische Zeitschrift 66.3/4 (1992), pp. 311-329.

[20535] G. Schaumberg, D. M. Unwin, and S. Brandt. "New information on the anatomy of the Late Permian gliding reptile Coelurosauravus". English. In: Palaeontologische Zeitschrift 81.2 (2007), pp. 160-173.

[20536] W. Schawaller. “The first Mesozoic pseudoscorpion, from Cretaceous Canadian amber". In: Palaeontology 34.4 (1991), pp. 971-976.

[20537] W. Schawaller. "New species and records of Prostomis Latreille, including the first fossil records from Baltic amber and a checklist of the species (Coleoptera: Prostomidae)". English. In: Stuttgarter Beiträge zur Naturkunde Serie A (Biologie) 650 (2003), pp. 1-11.

[20538] W. Schawaller, W. A. Shear, and P. M. Bonamo. "The first Paleozoic pseudoscorpions (Arachnida, Pseudoscorpiones)". English. In: American Museum Novitates 3009 (1991), pp. 1-17.

[20539] W. Schedl. "Nachweis eines Männchens von Eodiprion sp. aus dem baltischen Bernstein (Hymenoptera: Symphyta: Diprionidae)". German. In: Berichte des Naturwissenschaftlich-Medizinischen Vereins in Innsbruck 95 (2008), pp. 77-80.

[20540] W. Schedl. "Eidonomische und taxonomische Beschreibung einer Diprionidae aus dem baltischen Bernstein (Hymenoptera: Symphyta: Diprionidae)". German. In: Zeitschrift der Arbeitsgemeinschaft Österreichischer Entomologen 59 (2007), pp. 65-69.

[20541] W. Schedl. "Eine Orussidae aus dem baltischen Bernstein (Hymenoptera: Symphyta)". German. In: Zeitschrift der Arbeitsgemeinschaft Österreichischer Entomologen 63 (2011), pp. 33-36.

[20542] C. Scheibner, M. W. Rasser, and M. Mutti. “The Campo section (Pyrenees, Spain) revisited: implications for changing benthic carbonate assemblages across the Paleocene-Eocene boundary". English. In: Palaeogeography, Palaeoclimatology, Palaeoecology 248 (2007), pp. 145-168.

[20543] U. Scheller and J. Wunderlich. "First description of a fossil pauropod, Eopauropus balticus n. gen. n. sp. (Pauropoda: Pauropodidae), in Baltic amber". English. In: Mitteilungen aus dem GeologischPaläontologischen Institut der Universität Hamburg 85 (2001), pp. 221-227.

[20544] U. Scheller and J. Wunderlich. "Two fossil symphylan species, Scutigerella baltica n. sp. and Hanseniella baltica n. sp. (Tracheata, Scutigerellidae), in Baltic amber". English. In: Stuttgarter Beiträge zur Naturkunde Serie B (Geologie und Paläontologie) 351 (2004), pp. 1-11.

[20545] R. Schellhorn, D. Schwarz-Wings, M. W. Maisch, and O. Wings. "Late Jurassic Sunosuchus (Crocodylomorpha, Neosuchia) from the Qigu Formation in the Junggar Basin (Xinjiang, China)". English. In: Fossil Record 12.1 (2009), pp. 59-69.

[20546] G. Schellmann and U. Radtke. "A revised morpho- and chronostratigraphy of the Late and Middle Pleistocene coral reef terraces on Southern Barbados (West Indies)". English. In: Earth-Science Reviews 64 (2004), pp. 157-187.

[20547] M. Schemm-Gregory. "Leonispirifer leonensis gen. et sp. nov., a rare delthyridoid spiriferid brachiopod from northern Spain (Brachiopoda, Lower Devonian)". English. In: Palaeontologische Zeitschrift 84 (2010), pp. 345-364.

[20548] M. Schemm-Gregory and M. H. Henriques. "New data on internal morphology of exceptionally preserved Nannirhynchia pygmaea (Morris, 1847) from the Lusitanian Basin (Brachiopoda, Early Jurassic, Portugal)". English. In: Fossil Record 15 (2012), pp. 77-83. 
[20549] C. S. Scherer, J. Ferigolo, and A. M. Ribeiro. “Contribution to the knowledge of Hemiauchenia paradoxa (Artiodactyla, Camelidae) from the Pleistocene of southern Brazil". English. In: Revista Brasileira de Paleontologia 10.1 (2007), pp. 35-52.

[20550] C. S. Scherer, V. G. Pitana, and A. M. Ribeiro. "Proterotheriidae and Macraucheniidae (Litopterna, Mammalia) from the Pleistocene of Rio Grande do Sul State, Brazil". English. In: Revista Brasileira de Paleontologia 12.3 (2009), pp. 231-246. DOI: 10.4072/rbp.2009.3.06.

[20551] L. Scherler, D. Becker, and J. -P. Berger. “Tapiridae (Perissodactyla, Mammalia) of the Swiss Molasse Basin during the Oligocene-Miocene transition". English. In: Journal of Vertebrate Paleontology 31.2 (2011), pp. 479-496.

[20552] L. Scherler, F. Lihoreau, and D. Becker. “To split or not to split Anthracotherium? A phylogeny of Anthracotheriinae (Cetartiodactyla: Hippopotamoidea) and its palaeobiogeographical implications". English. In: Zoological Journal of the Linnean Society 185.2 (2019), pp. 487-510. DOI: 10.1093/ zoolinnean/zly052/5093183.

[20553] R. Scherreiks. "Platform margin and oceanic sedimentation in a divergent and convergent plate setting (Jurassic, Pelagonian Zone, NE Evvoia, Greece)". English. In: International Journal of Earth Sciences 89 (2000), pp. 90-107.

[20554] B. Scherzer and D. Varricchio. Taphonomy of a juvenile lambeosaur bonebed from the Two Medicine Formation of Montana. English. 2005.

[20555] B. A. Scherzer and D. J. Varricchio. "Taphonomy of a juvenile lambeosaurine bonebed from the Two Medicine Formation (Campanian) of Montana, United States". English. In: Palaios 25.12 (2010), pp. 780-795. DOI: 10.2110/palo.2009.p09-143r.

[20556] A. Scherzinger, H. Parent, and G. Schweigert. "A new species of the ammonite genus Physodoceras Hyatt". English. In: Boletn del Instituto de Fisiografa y Geologa 88 (2018), pp. 11-24.

[20557] A. Scherzinger and G. Schweigert. "Xenosphinctes n. gen. (Ataxioceratidae, Lithacoceratinae), a new rare ammonite genus from the Lower Tithonian (Hybonotum Zone) of SW Germany". English. In: Volumina Jurassica 15 (2017), pp. 155-160.

[20558] A. Scherzinger and G. Schweigert. "The ammonite genera Gravesia Salfeld and Pseudogravesia Hantzpergue in the Tithonian of S Germany and their correlation value with Western Europe". English. In: Proceedings of the Geologists' Association 127 (2016), pp. 288-296.

[20559] T. Scheyer, M. Delfino, N. Klein, N. Bunbury, F. Fleischer-Dogley, and D. M. Hansen. “Trophic interactions between larger crocodylians and giant tortoises on Aldabra Atoll, Western Indian Ocean, during the Late Pleistocene". English. In: Royal Society Open Science 5.171800 (2018), pp. 115. DOI: $10.1098 /$ rsos.171800.

[20560] T. M. Scheyer. "New interpretation of the postcranial skeleton and overall body shape of the placodont Cyamodus hildegardis Peyer, 1931 (Reptilia, Sauropterygia)". English. In: Palaeontologica Electronica 13.2 (2010), 15A.

[20561] T. M. Scheyer, O. A. Aguilera, M. Delfino, D. C. Fortier, A. A. Carlini, R. Sánchez, J. D. CarrilloBriceño, L. Quiroz, and M. R. Sánchez-Villagra. "Crocodylian diversity peak and extinction in the late Cenozoic of the northern Neotropics". English. In: Nature Communications 4 (2013), 1907:1-9. DOI: $10.1038 /$ ncomms2940.

[20562] T. M. Scheyer and J. Anquetin. "Bone histology of the Middle Jurassic turtle shell remains from Kirtlington, Oxfordshire, England". English. In: Lethaia 41 (2008), pp. 85-96.

[20563] T. M. Scheyer and M. Delfino. “The late Miocene caimanine fauna (Crocodylia: Alligatoroidea) of the Urumaco Formation, Venezuela". English. In: Palaeontologia Electronica 19.3 (2016), 48A:1-57.

[20564] T. M. Scheyer, J. R. Hutchinson, O. Strauss, M. Delfino, J. D. Carrillo-Briceño, R. Sánchez, and M. R. Sánchez-Villagra. "Giant extinct caiman breaks constraint on the axial skeleton of extant crocodylians". English. In: eLife 8 (2019), e49972:1-19. DOI: 10.7554/eLife.49972.

[20565] T. M. Scheyer, T. Möhrs, and E. Einarsson. "First record of soft-shelled turtles (Cryptodira, Trionychidae) from the Late Cretaceous of Europe". English. In: Journal of Vertebrate Paleontology 32.5 (2012), pp. 1027-1032. DOI: 10.1080/02724634.2012.685036. 
[20566] T. M. Scheyer, J. M. Neenan, T. Bodogan, H. Furrer, C. Obrist, and M. Plamodon. “A new, exceptionally preserved juvenile specimen of Eusaurosphargis dalsassoi (Diapsida) and implications for Mesozoic marine diapsid phylogeny". English. In: Scientific Reports 7 (2017), p. 4406. DOI: 10.1038/s41598-017-04514-x.

[20567] T. M. Scheyer, A. G. Neuman, and D. B. Brinkman. "A large marine eosauropterygian reptile with affinities to nothosauroid diapsids from the Early Triassic of British Columbia, Canada". English. In: Acta Palaeontologica Polonica 64.4 (2019), pp. 745-755. DOI: 10.4202/app.00599.2019.

[20568] M. I. Schiaffini, F. J. Prevosti, B. S. Ferrero, and J. I. Noriega. "A Late Pleistocene Guloninae (Carnivora, Mustelidae) from South". English. In: Journal of South American Earth Sciences 78 (2017), pp. 141-149.

[20569] T. A. Schiappa, N. T. Hemmesch, C. Spinosa, and W. W. Nassichuk. "Cisuralian ammonoid genus Uraloceras in North America". English. In: Journal of Paleontology 79.2 (2005), pp. 366-377.

[20570] T. A. Schiappa, C. Spinosa, and W. S. Snyder. "Nevadoceras, a new Early Permian adrianitid (Ammonoidea) from Nevada". English. In: Journal of Paleontology 69.6 (1995), pp. 1073-1079.

[20571] J. A. Schiebout. “The Fort Polk Miocene terrestrial microvertebrate sites compared to those from East Texas". English. In: Texas Journal of Science 49.1 (1997), pp. 23-32.

[20572] J. A. Schiebout. Paleofaunal survey, collecting, processing, and documentation at two locations on Fort Polk, Louisiana. U.S. Army Corps of Engineers, Fort Worth District; Contract No. DACW63-90-D0008, Delivery Order 13 [No sponsoring agency report number given]. 1997, pp. 1-92.

[20573] J. A. Schiebout. "Fossil vertebrates from the Castor Creek Member, Fleming Formation, western Louisiana". English. In: Transactions - Gulf Coast Association of Geological Societies 44 (1994), pp. 675680.

[20574] T. A. Schiller II, H. G. Porras-Muzquiz, and T. M. Lehman. "Sabinosuchus coahuilensis, a new dyrosaurid crocodyliform from the Escondido Formation (Maastrichtian) of Coahuila, Mexico". English. In: Journal of Vertebrate Paleontology 36.6 (2016), e1222586:1-9.

[20575] M. K. Schimmel, M. Kowalewski, and B. P. Coffey. "Traces of predation/parasitism recorded in Eocene brachiopods from the Castle Hayne Limestone, North Carolina, USA". English. In: Lethaia 45 (2012), pp. 274-289. DOI: 10.1111/j.1502-3931.2011.00281.x.

[20576] T. Schindler, K. Nungesser, A. Mueller, and K. I. Grimm. “Die Alzey-Formation der klassichen Lokalitat Wlschberg bei Waldbockelheim (Rupelium, Oligozan, Mainzer Becken) - Ergebnisse neuer Grabungen". English. In: Jahresberichte un Mitteilungen des Oberrheinischen Geologischen Vereines 91 (2009), pp. 37-87.

[20577] F. Schlagintweit. "Consinocodium japonicum ENDO, 1961 from the Upper Jurassic of the Northern Calcareous Alps of Austria : not a siphonous green alga, but a coralline sponge". English. In: Revue de Paléobiologie, Genéve 24.2 (2005), pp. 533-540.

[20578] F. Schlagintweit. "Murania reitneri n. sp., a new sclerosponge from the Upper Jurassic of the Northern Calcareous Alps (Plassen Formation, Austria and Germany)". English. In: Austrian Journal of Earth Sciences 95/96 (2004), pp. 37-45.

[20579] F. Schlagintweit. “Iberopora bodeuri Granier \& Berthou 2002 (incertae sedis) from the Plassen Formation (Kimmeridgian-Berrasian) of the Tethyan Realm". English. In: Geologica Croatica 57.1 (2004), pp. 1-13.

[20580] F. Schlagintweit. “Cryptobiotic foraminifera from the Paleocene Kambuhel Formation (northern calcareous Alps, Austria)". English. In: Studia Universitatis Bades-Bolyai, Geollogia 50.1-2 (2005), pp. 13-17.

[20581] F. Schlagintweit and H.-J. Gawlick. "Sarsteinia babai n. gen., n. sp., a new problematic sponge (Inozoa?) from the Late Jurassic of the Northern Calcareous Alps, Austria". English. In: Rivista Italiana di Paleontologie e Stratigrafia 112.2 (2006), pp. 251-260.

[20582] F. Schlagintweit, L. Svabenicka, and H. Lobitzer. "An occurrence of Paleocene reefal limestone in the Zwieselalm Formation of Gosau (Upper Austria)". English. In: Beitrage zur Geologie des Salzkammerguts. Erkudok Institut Museam Gmunden, 2003, pp. 173-180. 
[20583] T. Schlemmermeyer and E. M. Cancello. “New fossil termite species: Dolichorhinotermes dominicanus from Dominican amber (Isoptera, Rhinotermitidae, Rhinotermitinae)". English. In: Papéis Avulsos de Zoologia 41 (2000), pp. 303-311.

[20584] G. Schliephake. "Fossil Thrips (Thysanoptera, Insecta) of the Baltic (North- and Baltic Sea) and Saxonian (Bitterfeldian) Tertiary Amber from the Collections of Hoffeins". English. In: Deutsche Entomologische Zeitschrift 46.1 (1999), pp. 83-100.

[20585] G. Schliephake. "Fossile Thysanoptera (Insecta) aus dem Baltischen Bernstein". German. In: Mitteilungen aus dem Geologisch-Paläontologischen Institut der Universität Hamburg 87 (2003), pp. 171182.

[20586] G. Schliephake. "Beitrag zur Kenntnis fossiler Fransenflügler (Thysanoptera) aus dem Bernstein des Tertiär des Bitterfelder Raumes (3. Beitrag: Thripidae, Panchaetothripinae)". German. In: Entomologische Nachrichten und Berichte 41 (1997), pp. 66-67.

[20587] G. Schliephake. “Fossile Thysanoptera im Baltischen Bernstein aus Kiesgruben westlich von Sarstedt (Niedersachsen)". German. In: Entomologische Nachrichten und Berichte 47 (2003), pp. 179-181.

[20588] J. Schlögl, R. Chirat, V. Balter, M. Joachimski, N. Hudackova, and F. Quillévéré. “Aturia from the Miocene Paratethys: An exceptional window on nautilid habitat and lifestyle". English. In: Palaeogeography, Palaeoclimatology, Palaeoecology 308 (2011), pp. 330-338.

[20589] T. Schlueter, G. Picho-Olarker, and T. Kreuser. "A review of some neglected Karoo grabens of Uganda". In: Journal of African Earth Sciences 17.4 (1993), pp. 415-428.

[20590] M. Schluter, T. Steuber, and M. Parente. “Chronostratigraphy of Campanian-Maastrichtian platform carbonates and rudist associations of Salento (Apulia, Italy)". English. In: Cretaceous Research 29 (2008), pp. 100-114.

[20591] M. Schluter, T. Steuber, M. Parente, and J. Mutterlose. “Evolution of a Maastrichtian-Paleocene tropical shallow-water carbonate platform (Qalhat, NE Oman)". English. In: Facies 54 (2008), pp. 513527.

[20592] T. Schlüter. “Moltenia rieki n. gen., n. sp. (Hymenoptera: Xyelidae?), a tentative sawfly from the Molteno Formation (Upper Triassic), South Africa". English. In: Paläontologische Zeitschrift 74.1/2 (2000), pp. 75-78.

[20593] T. Schlüter. "Eocene insects from a Maar Lagerstätte at Mahenge, northern Tanzania”. English. In: Entomologia Generalis 37 (2018), pp. 375-392.

[20594] T. Schlüter, R. Kohring, and H. J. Gregor. "Dragonflies preserved in transparent gypsum crystals from the Messinian (Upper Miocene) of Alba, northern Italy". English. In: Acta Zoologica Cracoviensia 46.Suppl (2003), pp. 373-379.

[20595] R. Schmeisser McKean. "A new species of polycotylid plesiosaur (Reptilia: Sauropterygia) from the Lower Turonian of Utah: Extending the stratigraphic range of Dolichorhynchops". English. In: Cretaceous Research 34 (2012), pp. 184-199.

[20596] D. U. Schmid and W. Werner. "Sobralispongia densespiculata, a new coralline sponge from the Upper Jurassic of Portugal". English. In: Geobios 38 (2005), pp. 653-666.

[20597] A. R. Schmidt, S. Jancke, E. E. Lindquist, E. Ragazzi, G. Roghi, P. C. Nascimbene, K. Schmidt, T. Wappler, and D. A. Grimaldi. "Arthropods in amber from the Triassic Period". English. In: Proceedings of the National Academy of Sciences 109 (2012), pp. 14796-14801.

[20598] A. R. Schmidt, U. Kaulfuss, J. M. Bannister, V. Baranov, C. Beimforde, N. Bleile, A. Borkent, A. Busch, J. G. Conran, M. S. Engel, M. Harvey, E. M. Kennedy, P. H. Kerr, E. Kettunen, A. P. Kiecksee, F. Lengeling, J. K. Lindqvist, M. Maraun, D. C. Mildenhall, V. Perrichot, and J. Rikkinen. “Amber inclusions from New Zealand". English. In: Gondwana Research 56 (2018), pp. 135-146.

[20599] A. R. Schmidt, V. Perrichot, M. Svojtka, K. B. Anderson, K. H. Belete, R. Bussert, H. Dörfelt, S. Jancke, B. Mohr, E. Mohrmann, P. C. Nascimbene, A. Nel, P. Nel, E. Ragazzi, G. Roghi, E. E. Saupe, K. Schmidt, H. Schneider, P. A. Selden, and N. Vávra. "Cretaceous African life captured in amber". English. In: Proceedings of the National Academy of Sciences 107 (2010), pp. 7329-7334. 
[20600] G. I. Schmidt and E. Cerdeño. “Los ungulados nativos (Litopterna y Notoungulata: Mammalia) del Mesopotamiense (Mioceno tardo) de Entre Ros, Argentina". Spanish. In: El Neógeno de la Mesopotamia argentina 14 (2013), pp. 145-152.

[20601] G. I. Schmidt, E. Cerdeño, and S. Hernández del Pino. "Macraucheniidae and Proterotheriidae (Mammalia, Litopterna) from Quebrada Fiera (Late Oligocene), Mendoza Province, Argentina". English. In: Andean Geology 46.2 (2019), pp. 368-382.

[20602] G. I. Schmidt, J. M. Diederle, F. Góis, E. R. Vallone, J. Tarquini, M. A. Fernández Osuna, M. G. Gottardi, and D. Brandoni. "New vertebrates from the Late Miocene of Entre Ros Province, Argentina: diversity, age, and paleoenvironment". English. In: Journal of South American Earth Sciences 101 (2020), 102618:1-11.

[20603] G. I. Schmidt and B. S. Ferrero. “Taxonomic reinterpretation of Theosodon hystatus Cabrera and Kraglievich, 1931 (Litopterna, Macraucheniidae ) and phylogenetic relationships of the family". English. In: Journal of Vertebrate Paleontology 34.5 (2014), pp. 1231-1238.

[20604] G. I. Schmidt, S. Hernández Del Pino, N. Muñoz, and M. Fernández. “Litopterna (Mammalia) From the Santa Cruz Formation (Early-Middle Miocene) At the Ro Santa Cruz, Southern Argentina". English. In: vol. 19. Early-Middle Miocene Paleontology in the Ro Santa Cruz, Southern Patagonia, Argentina. 130 years since Ameghino, 1887 2. Publicación Electrónica de la Asociación Paleontológica Argentina, 2019, pp. 170-192. DOI: 10.5710/PEAPA.13.08.2019.290.

[20605] G. I. Schmidt, C. I. Montalvo, R. Sostillo, and E. Cerdeño. “Proterotheriidae (Mammalia, Litopterna) from the Cerro Azul Formation (late Miocene), La Pampa Province, Argentina". English. In: Journal of South American Earth Sciences 83 (2018), pp. 165-177.

[20606] G. I. Schmidt, M. A. Reguero, and J. I. Noriega. “Notoungulata y Litopterna en el Plioceno de Entre Ros, Argentina". Spanish. In: Paleontologia y dinosaurios desde America Latina. Editorial de la Universidad Nacional de Cuyo, 2008, pp. 223-234.

[20607] J. Schmidt. “On the Eocene age of Limodromus Motschulsky, 1850, with description of L. hoffeinsorum sp. n. from Baltic Amber (Coleoptera: Carabidae: Platynini)". English. In: Zootaxa 3974 (2015), pp. 573-581.

[20608] J. Schmidt, I. Belousov, and P. Michalik. "X-ray microscopy reveals endophallic structures in a new species of the ground beetle genus Trechus Clairville, 1806 from Baltic amber (Coleoptera, Carabidae, Trechini)". English. In: ZooKeys 614 (2016), pp. 113-127.

[20609] J. Schmidt and A. Faille. "Confirmation of occurrence of Trechus Clairville, 1806 in the Baltic amber forests, with description of a flightless edaphic species, and remarks on Trechoides Motschulsky, 1856 (Coleoptera: Carabidae: Trechini)". English. In: Zootaxa 4028 (2015), pp. 539-550.

[20610] J. Schmidt, T. Göpel, and K. Will. "Description of the first flightless platynine ground beetle preserved in Baltic amber (Coleoptera: Carabidae)". English. In: Zootaxa 4318 (2017), pp. 110-122.

[20611] J. Schmidt, H. Hoffmann, and P. Michalik. "Blind life in the Baltic amber forests: description of an eyeless species of the ground beetle genus Trechus Clairville, 1806 (Coleoptera: Carabidae: Trechini)". English. In: Zootaxa 4083 (2016), pp. 431-443.

[20612] J. Schmidt and P. Michalik. "The ground beetle genus Bembidion Latreille in Baltic amber: Review of preserved specimens and first $3 \mathrm{D}$ reconstruction of endophallic structures using X-ray microscopy (Coleoptera, Carabidae, Bembidiini)". English. In: ZooKeys 662 (2017), pp. 101-126.

[20613] J. Schmidt, S. Scholz, and D. H. Kavanaugh. “Unexpected findings in the Eocene Baltic amber forests: ground beetle fossils of the tribe Nebriini (Coleoptera: Carabidae)". English. In: Zootaxa 4701 (2019), pp. 350-370.

[20614] R. Schmidt-Effing and T. Aguilar. "Dos fósiles notables de la Formación Punta Carballo". Spanish. In: Revista Geológica de América Central 39 (2008), pp. 117-120.

[20615] N. Schmidt-Kittler, N. Vianey-Liaud, and L. Marivaux. “6. The Ctenodactylidae (Rodentia, Mamalia)". English. In: Annalen des Naturhistorischen Museums in Wien, Serie A 108A (2007), pp. 173215. 
[20616] H. Schmied, T. Wappler, and J. Kolibá. “A new bark-gnawing beetle (Coleoptera, Trogossitidae) from the middle Eocene of Europe, with a checklist of fossil Trogossitidae". English. In: Zootaxa 1993 (2009), pp. 17-26.

[20617] M. R. Schmitt, A. G. Martinelli, T. P. Melo, and M. B. Soares. "On the occurrence of the traversodontid Massetognathus ochagaviae (Synapsida, Cynodontia) in the early late Triassic Santacruzodon Assemblage Zone (Santa Maria Supersequence, southern Brazil): Taxonomic and biostratigraphic implications". English. In: Journal of South American Earth Sciences 93 (2019), pp. 36-50.

[20618] L. Schmitz. "The taxonomic status of Mixosaurus nordenskioeldii (Ichthyosauria)". English. In: Journal of Vertebrate Paleontology 25.4 (2005), pp. 983-985. DOI: 10.1671 / 0272-4634(2005)025[0983: TTSOMN]2.0.CO;2.

[20619] L. Schmitz, P. M. Sander, G. W. Storrs, and O. Rieppel. “New Mixosauridae (Ichthyosauria) from the Middle Triassic of the Augusta Moutnains (Nevada, USA) and their implications for mixosaur taxonomy". English. In: Palaeontographica Abteilung A 270 (2004), pp. 133-162.

[20620] U. Schmolcke. "Holocene environmental changes and the seal (Phocidae) fauna of the Baltic Sea: coming, going and staying". English. In: Mammal Review 38.4 (2008), pp. 231-246.

[20621] T. Schnabel. "A fossil Triloba species from Macedonia and its relationships to the recent species of the genus (Gastropoda: Pulmonata: Clausiliidae)". English. In: Archiv für Molluskenkunde: International Journal of Malacology 141 (2012), pp. 35-42.

[20622] C. Schneider and C. Neumann. "Die Echiniden aus dem Mittelsanton von Lengede". German. In: Arbeitskreis Paläontologie Hannover 34 (2006), pp. 67-83.

[20623] C. L. Schneider. "Community paleoecology of the Pennsylvanian Winchell Formation, northcentral Texas". PhD thesis. 2003.

[20624] C. L. Schneider, J. Sprinkle, and D. Ryder. "PENNSYLVANIAN (LATE CARBONIFEROUS) ECHINOIDS FROM THE WINCHELL FORMATION, NORTH-CENTRAL TEXAS, USA". English. In: Journal of Paleontology 79.4 (2005), pp. 745-762.

[20625] J. Schneider and R. Werneburg. "Neue Spiloblattinidae (Insecta, Blattodea) aus dem Oberkaron und Unterperm von Mitteleuropa sowie die Biostratigraphie des Rotliegend". German. In: Veröffentlichungen des Naturhistorischen Museums Schleusingen 7/8 (1993), pp. 31-52.

[20626] J. W. Schneider, S. G. Lucas, and J. M. Rowland. The Blattida (Insecta) fauna of Carrizo Arroyo, New Mexico-Biostratigraphic link between marine and nonmarine Pennsylvanian/Permian boundary profiles. English. Vol. 2. Carboniferous-Permian transition, New Mexico Museum of Natural History and Science Bulletin. 2004, pp. 247-262.

[20627] K. A. Schneider and W. I. Ausich. "Paleoecology of framebuilders in Early Silurian reefs (Brassfield Formation, southwestern Ohio)". In: Palaios 17.3 (2002), pp. 237-248.

[20628] S. Schneider. "The bivalve fauna from the Ortenburg Marine Sands in the well-core StraSS (Early Miocene; SE Germany) - taxonomy, stratigraphy, paleoecology, and paleogeography". English. In: Paläontologische Zeitschrift 82.4 (2008), pp. 402-417.

[20629] S. Schneider, B. Berning, M. A. Bitner, R. -P. Carriol, M. Jaeger, J. Kriwet, A. Kroh, and W. Werner. "A parautochthonous shallow marine fauna from the Late Burdigalian (early Ottnangian) of Gurlarn (Lower Bavaria, SE Germany): Macrofaunal inventory and paleoecology". English. In: Neues Jahrbuch für Geologie und Paläontologie 254.1-2 (2009), pp. 63-103.

[20630] S. Schneider and K. Heissig. "An early seal (Mammalia, Pinnipedia) from the Middle Miocene (Langhian) of Miste (The Netherlands)". English. In: Scripta Geologica 129 (2005), pp. 151-158.

[20631] S. Schneider, M. Jäger, A. Kroh, A. Mitterer, B. Niebuhr, R. Vodráka, M. Wilmsen, C. J. Wood, and K. Zágorek. "Silicified sea life - Macrofauna and palaeoecology of the Neuburg Kieselerde Member (Cenomanian to Lower Turonian Wellheim Formation, Bavaria, southern Germany)". English. In: Acta Geologica Polonica 63.4 (2013), pp. 555-610.

[20632] S. Schneider and O. Mandic. "Middle Ottnangian (late Burdigalian) mollusks from the Rott Valley (SE Germany): the ultimate marine fauna of the Western Paratethys". English. In: Paläontologische Zeitschrift 88 (2014), pp. 375-403. 
[20633] S. Schneider, W. Witt, and E. Yigitbas. “Ostracods and bivalves from an Upper Pleistocene (Tyrrhenian) marine terrace near Altinova (Izmit Province, Turkey)". English. In: Zitteliana 45 (2005), pp. 87-114.

[20634] V. P. Schneider and H. L. Fierstine. "Fossil tuna vertebrae punctured by istiophorid billfishes". English. In: Journal of Vertebrate Paleontology 24.1 (2004), pp. 253-255. DOI: 10.1671/22.1.

[20635] K. I. Schnetler. “The Selandian (Paleocene) mollusc fauna from Copenhagen, Denmark: the Poul Harder 1920 collection". In: Geology of Denmark Survey Bulletin 37 (2001), pp. 1-85.

[20636] K. I. Schnetler. "Eoatlanta ravni nov. sp. (Mollusca: Gastropoda, ?Hipponicidae) from the Danian (early Paleocene) of Faxe, Denmark". English. In: Cainozoic Research 10.1-2 (2013), pp. 3-7.

[20637] K. I. Schnetler and C. Beyer. A Late Oligocene (Chattian B) Molluscan Fauna from the Coastal Cliff at Mogenstrup, North of Skive, Jutland, Denmark. 1990.

[20638] K. I. Schnetler and C. Heilmann-Clausen. "The molluscan fauna of the Eocene Lillebælt clay, Denmark". English. In: Cainozoic Research 8.1-2 (2011), pp. 41-99.

[20639] K. I. Schnetler and P. Lozouet. "A new genus and species of the Mesozoic superfamily Porcellioidea (Mollusca: Vetigastropoda) from the Danian (early Paleocene) of Faxe, Denmark". English. In: Cainozoic Research 9.1 (2012), pp. 3-7.

[20640] K. I. Schnetler and R. E. Petit. "Revision of the gastropod family Cancellariidae from the Danian (Early Paleocene) of Fakse, Denmark". English. In: Cainozoic Research 4.1-2 (2006), pp. 97-108.

[20641] K. I. Schnetler and R. E. Petit. "Revision of the gastropod family Cancellariidae from the Paleocene of Nuussuaq, West Greenland". English. In: Cainozoic Research 7.1-2 (2010), pp. 3-26.

[20642] R. Schoch and A. R. Milner. Stereospondyli. English. Vol. 3B. Handbuch der Paläoherpetologie Encyclopedia of Paleoherpetology. 2000, pp. 1-203.

[20643] R. M. Schoch. "Late Paleocene land-mammals from the Williamsburg Formation (Black Mingo Group) of South Carolina". English. In: Transactions of the American Philosophical Society 88.4 (1998), pp. 229-245.

[20644] R. R. Schoch. "Osteology of the small archosaur Aetosaurus from the Upper Triassic of Germany". English. In: Neues Jahrbuch für Paläontologie und Geologie, Abhandlungen 246 (2007), pp. 1-35.

[20645] R. R. Schoch. "The status and osteology of two new cyclotosaurid amphibians from the Upper Moenkopi Formation of Arizona (Amphibia: Temnospondyli; Middle Triassic)". English. In: Neues Jahrbuch für Geologie und Paläontologie Abhandlungen 216.3 (2000), pp. 387-411.

[20646] R. R. Schoch. "Comparative osteology of Mastodonsaurus giganteus (Jaeger, 1828) from the Middle Triassic (Lettenkeuper: Longobardian) of Germany (Baden-Württemberg, Bayern, Thüringen)". English. In: Stuttgarter Beiträge zur Naturkunde Serie B (Geologie und Paläontologie) 278 (1999), pp. 1170.

[20647] R. R. Schoch. "A new stereospondyl from the German Middle Triassic, and the origin of the Metoposauridae". English. In: Zoological Journal of the Linnean Society 152 (2008), pp. 79-113.

[20648] R. R. Schoch. "A new capitosaur amphibian from the Upper Lettenkeuper (Triassic: Ladinian) of Kupferzell (Southern Germany)". English. In: Neues Jahrbuch für Geologie und Paläontologie 203.2 (1997), pp. 239-272.

[20649] R. R. Schoch. "New archosauriform remains from the German Lower Keuper". English. In: Neues Jahrbuch für Geologie und Paläontologie Abhandlungen 260 (2011), pp. 87-100. DOI: 10.1127 / 0077 7749/2011/0133.

[20650] R. R. Schoch. "How diverse is the temnospondyl fauna in the Lower Triassic of southern Germany?" English. In: Neues Jahrbuch für Geologie und Paläontologie Abhandlungen 261 (2011), pp. 4960.

[20651] R. R. Schoch. "A dicynodont mandible from the Triassic of Germany forms the first evidence of large herbivores in the Central European Carnian". English. In: Neues Jahrbuch für Geologie und Paläontologie Abhandlungen 263 (2012), pp. 119-123. 
[20652] R. R. Schoch. "First evidence of the branchiosaurid temnospondyl Leptorophus in the Early Permian of the Saar-Nahe Basin (SW Germany)". English. In: Neues Jahrbuch für Geologie und Paläontologie Abhandlungen 272.2 (2014), pp. 225-236. DOI: 10.1127/0077-7749/2014/0401.

[20653] R. R. Schoch. "The temnospondyl Parotosuchus nasutus (v. Meyer, 1858) from the Early Triassic Middle Buntsandstein of Germany". English. In: Palaeodiversity 11 (2018), pp. 107-126.

[20654] R. R. Schoch, M. Fastnacht, J. Fichter, and T. Keller. "Anatomy and relationships of the Triassic temnospondyl Sclerothorax". English. In: Acta Palaeontologica Polonica 52.1 (2007), pp. 117-136.

[20655] R. R. Schoch, A. R. Milner, and H. Hellrung. "The last trematosaurid amphibian Hyperokynodon keuperinus revisited". English. In: Stuttgarter Beiträge zur Naturkunde Serie B (Geologie und Paläontologie 321 (2002), pp. 1-9.

[20656] R. R. Schoch, A. R. Milner, and F. Witzmann. "Skull morphology and phylogenetic relationships of a new middle Triassic plagiosaurid temnospondyl from Germany, and the evolution of plagiosaurid eyes". English. In: Palaeontology (2014), pp. 1-14. DOI: 10.1111/pala.12101.

[20657] R. R. Schoch, S. Nesbitt, J. Müller, S. G. Lucas, and J. A. Boy. "The reptile assemblage from the Moenkopi Formation (Middle Triassic) of New Mexico". English. In: Neues Jahrbuch für Geologie und Paläontologie, Abhandlungen 255 (2010), pp. 345-369. DOI: 10.1127/0077-7749/2009/0030.

[20658] R. R. Schoch and B. S. Rubidge. "The amphibamid Micropholis from the Lystrosaurus Assemblage Zone of South Africa". English. In: Journal of Vertebrate Paleontology 25.3 (2005), pp. 502-522.

[20659] R. R. Schoch and H.-D. Sues. "A new archosauriform reptile from the Middle Triassic (Ladinian) of Germany". English. In: Journal of Systematic Palaeontology 12.1 (2014), pp. 113-131. DOI: 10.1080/ 14772019.2013.781066.

[20660] R. R. Schoch and H.-D. Sues. "A Middle Triassic stem-turtle and the evolution of the turtle body plan". English. In: Nature (2015). DOI: 10.1038/nature14472.

[20661] R. R. Schoch and H.-D. Sues. "A new dissorophid temnospondyl from the Lower Permian of north-central Texas". English. In: Comptes Rendus Palevol 12 (2013), pp. 437-445.

[20662] R. R. Schoch and H.-D. Sues. "A new lepidosauromorph reptile from the Middle Triassic (Ladinian) of Germany and its phylogenetic relationships". English. In: Journal of Vertebrate Paleontology 38 (2018), e1444619.

[20663] R. R. Schoch, S. Voigt, and M. Buchwitz. "A chroniosuchid from the Triassic of Kyrgyzstan and analysis of chroniosuchian relationships". English. In: Zoological Journal of the Linnean Society 160 (2010), pp. 515-530.

[20664] R. R. Schoch and S. Voigt. "A dvinosaurian temnospondyl from the Carboniferous-Permian boundary of Germany sheds light on dvinosaurian phylogeny and distribution". English. In: Journal of Vertebrate Paleontology 39.1 (2019), e1577874. DOI: 10.1080/02724634.2019.1577874.

[20665] R. R. Schoch and R. Werneburg. "The Triassic labyrinthodonts from Germany". English. In: Zentralblatt für Geologie und Paläontologie Teil I 7-8 (1999), pp. 629-650.

[20666] R. R. Schoch and F. Witzmann. "Osteology and relationships of the temnospondyl genus Sclerocephalus". English. In: Zoological Journal of the Linnean Society 157 (2009), pp. 135-168.

[20667] R. R. Schoch and F. Witzmann. "The temnospondyl Glanochthon from the Lower Permian Meisenheim Formation of Germany". English. In: Special Papers in Palaeontology 81 (2009), pp. 121-136. DOI: $10.1111 / j .1475-4983.2009 .00868 . x$.

[20668] R. S. Schoch. "A complete trematosaurid amphibian from the Middle Triassic of Germany". English. In: Journal of Vertebrate Paleontology 26.1 (2006), pp. 29-43.

[20669] R. S. Schoch. "A trematosauroid temnospondyl from the Middle Triassic of Jordan". English. In: Fossil Record 14.2 (2011), pp. 119-127.

[20670] A. Scholz, M. Aberhan, and C. M. León. "Early Jurassic bivalves of the Antimonio terrane (Sonora, NW Mexico): Taxonomy, biogeography, and paleogeographic implications". English. In: Geological Society of America Special Paper 442 (2008), pp. 269-312. 
[20671] A. Scholz, G. Schweigert, and G. Dietl. "Bivalves from the Nusplingen Lithographic Limestone (Upper Jurassic, southern Germany)". English. In: Palaeodiversity 1 (2008), pp. 111-131.

[20672] H. Scholz. "Taxonomie der Muschelfauna aus dem Oberjura von Hildesheim (N-Deutschland)[Taxonomy of Upper Jurassic Bivalves from Hildesheim (Northern Germany)]". German. In: Beringeria 35 (2005), pp. 3-52.

[20673] A. Schomann and A. Solodovnikov. "A new genus of Staphylinidae (Coleoptera) from the Lower Cretaceous: the first fossil rove beetles from the southern hemisphere". English. In: Systematic Entomology 37 (2012), pp. 379-386.

[20674] H. P. Schönlaub, C. Corradini, M. G. Corriga, and A. Ferretti. “Chrono-, litho- and conodont biostratigraphy of the Rauchkofel Boden Section (Upper Ordovician-Lower Devonian), Carnic Alps, Austria". English. In: Newsletters on Stratigraphy (2017). DOI: 10.1127/nos/2017/0391.

[20675] H. P. Schönlaub, M. Attrep, K. Boeckelmann, R. Dreesen, R. Feist, A. Feininger, G. Hahn, P. Klein, D. Korn, R. Kratz, M. Magaritz, C. J. Orth, and J. -M. Schramm. “The Devonian/Carboniferous Boundary in the Carnic Alps (Austria) - A Multidisciplinary Approach". In: Jahrbuch der Geologischen Bundesanstalt 135.1 (1992), pp. 57-98.

[20676] S. Schouten. "De wervels van Basilosauridae: een overzicht van en een vergelijking met raadselachtige vondsten uit de Noordzee". other. In: Cranium 28.2 (2011), pp. 17-25.

[20677] F. R. Schram, Y.-B. Shen, R. Vonk, and R. S. Taylor. “The First Fossil Stenopodidean". English. In: Crustaceana 73.2 (2000), pp. 235-242.

[20678] E. Schrank. "Pollen and spores from the Tendaguru Beds, Upper Jurassic and Lower Cretaceous of southeast Tanzania: palynostratigraphical and paleoecological implications". English. In: Palynology 34.1 (2010), pp. 3-42.

[20679] E. Schrank and M. S. Mahmoud. "Barremian angiosperm pollen and associated palynomorphs from the Dakhla Oasis Area, Egypt". In: Palaeontology 45.1 (2002), pp. 33-56.

[20680] F. Schrenk, T. G. Bromage, C. G. Betzler, U. Ring, and Y. M. Juwayeyi. “Oldest Homo and Pliocene biogeography of the Malawi Rift". English. In: Nature 365 (1993), pp. 833-836.

[20681] S. Schröder. "Stratigraphie und Systematik rugoser Korallen aus dem Givetium und Unter-Frasnium des Rheinischen Schiefergebirges (Sauerland/Bergisches Land) [Stratigraphy and systematics of rugose corals from the Givetian and Lower Frasnian of the Rheinisches Schiefergebirge (Sauerland/Bergisches Land)]". German. In: Zitteliana B 25 (2005), pp. 39-116.

[20682] S. Schröder. "Colonial Rugosa from the Early Devonian (Pragian) of the Zeravshan Range, Tajikistan". English. In: Alcheringa 31 (2007), pp. 121-151.

[20683] S. Schröder and M. Kazmierczak. “The Middle Devonian coral reef of Ouihlane (Morocco) - New data on the geology and rugose coral fauna". English. In: Geologica et Palaeontologica 33 (1999), pp. 93-115.

[20684] S. Schröder and F. Soto. "Lower Devonian (Emsian) rugose corals from the Cantabrian Mountains, northern Spain". English. In: Acta Palaeontologica Polonica 48.4 (2003), pp. 547-558.

[20685] S. Schroeder and V. L. Leleshus. "First records of Givetian and Frasnian (Devonian) Rugosa from the Pamir Mountains, Tadjikistan". English. In: Alcheringa 26 (2002), pp. 127-142.

[20686] S. Schroeder and C. Salerno. "Korallenfauna und Fazies givetischer Kalksteinabfolgen (Cuerten/Dreimühlen-Formation) der Dollendorfer Mulde (Devon, Rheinisches Schiefergebirge/Eifel)". English. In: Senckenbergiana lethaea 81.1 (2001), pp. 111-133.

[20687] A. E. Schrøder, B. W. Lauridsen, and F. Surlyk. “Ecophenotypic asymmetry in the middle Danian brachiopod Obliquorhynchia flustracea caused by adaption to attachment on the coral Dendrophyllia candelabrum". English. In: Lethaia 51.1 (2018), pp. 86-95.

[20688] B. W. Schubert, J. C. Chatters, J. Arroyo-Cabrales, J. X. Samuels, L. H. Soibelzon, F. J. Prevosti, C. Widga, A. Nava, D. Rissolo, and P. L. Erreguerena. "Yucatán carnivorans shed light on the Great American Biotic Interchange". English. In: Biology Letters 15.5 (2019), 20190148:1-6. 
[20689] B. W. Schubert, R. W. Graham, H. G. McDonald, E. C. Grimm, T. W. Stafford, and Jr. “Latest Pleistocene paleoecology of Jefferson's ground sloth (Megalonyx jeffersonii) and elk-moose (Cervalces scotti) in northern Illinois". English. In: Quaternary Research 61 (2004), pp. 231-240.

[20690] B. W. Schubert and J. E. Kaufmann. "A partial short-faced bear skeleton from an Ozark cave with comments on the paleobiology of the species". English. In: Journal of Cave and Karst Studies 65.2 (2003), pp. 101-110.

[20691] B. W. Schubert and S. C. Wallace. "Late Pleistocene giant short-faced bears, mammoths, and large carcass scavenging in the Saltville Valley of Virginia, USA". English. In: Boreas 38 (2009), pp. 482 492. DOI: $10.1111 / \mathrm{j} .1502-3885.2009 .00090$.

[20692] C. Schubert. "Pleistocene marine terraces of la Blanquilla island, Venezuela, and their diagenesis". English. In: Proceedings, Third International Coral Reef Symposium 2 (1997), pp. 149-154.

[20693] J. K. Schubert and D. J. Bottjer. “Aftermath of the Permian-Triassic mass extinction event: Paleoecology of Lower Triassic carbonates in the western USA". In: Palaeogeography, Palaeoclimatology, Palaeoecology 116 (1995), pp. 1-39.

[20694] T. Schubnel, L. Desutter-Grandcolas, R. Garrouste, S. Hervet, and A. Nel. "Paleocene of Menat Formation, France, reveals an extraordinary diversity of orthopterans and the last known survivor of a Mesozoic Elcanidae". English. In: Acta Palaeontologica Polonica 65 (2020), pp. 371-385. DOI: 10.4202/app.0676.2019.

[20695] T. Schubnel and A. Nel. "New Paleogene mantises from the Oise amber and their evolutionary importance". English. In: Acta Palaeontologica Polonica 64 (2019), pp. 779-786. DOI: 10.4202 / app. 00628.2019.

[20696] T. Schubnel, L. Perdu, P. Roques, R. Garrouste, and A. Nel. “Two new stem-stoneflies discovered in the Pennsylvanian Avion locality, Pas-de-Calais, France (Insecta: 'Exopterygota')". English. In: Alcheringa 43 (2019), pp. 430-435. DOI: 10.1080/03115518.2019.1569159.

[20697] T. Schubnel, D. Roberts, P. Roques, R. Garrouste, L. Desutter-Grandcolas, and A. Nel. "Moscovian fossils shed light on the enigmatic polyneopteran families Cacurgidae and Eoblattidae (Insecta: 'Eoblattida', Archaeorthoptera)". English. In: Journal of Systematic Palaeontology 18 (2019), pp. 499 511. DOI: 10.1080/14772019.2019.1627595.

[20698] C. Schulbert. "Die Ammonitenfauna und Stratigraphie der Tongrube Mistelgau bei Bayreuth (Oberfranken)". German. In: Beihefte zu den Berichten der Naturwissenschaftlichen Gesellschaft Bayreuth e.V 4 (2001), pp. 1-183.

[20699] C. Schulbert and A. Nützel. "Gastropods from the Early/Middle Jurassic transition of Franconia (southern Germany)". English. In: Bulletin of Geosciences 88 (2013), pp. 723-778.

[20700] I. Schülke. "Rioultina deisteriensis (Struckmann) from the Heersumer Schichten (Brachiopoda, Thecideidina, Middle Oxfordian, northwestern Germany)". English. In: Neues Jahrbuch für Geologie und Paläontologie, Monatshefte 8 (1997), pp. 465-476.

[20701] I. Schülke and C. Helm. "A new thecideidinid species (Brachiopoda, Spiriferida) from the Late Jurassic (Oxfordian) of northwestern Germany". English. In: Neues Jahrbuch für Geologie und Paläontologie, Monatshefte 5 (2000), pp. 257-270.

[20702] M. Schülke. "Eine neue Art der Gattung Bolitobius Leach in Samouelle aus dem Baltischen Bernstein (Col., Staphylinidae, Tachyporinae)". German. In: Entomologische Nachrichten und Berichte 44 (2000), pp. 101-103.

[20703] A. S. Schulp, A. O. Averianov, A. A. Yarkov, F. A. Trikolidi, and J. W. M. Jagt. "First record of the Late Cretaceous durophagous mosaasaur Carinodens belgicus (Squamata, Mosasauridae) from Volgogradskaya Oblast (Russia) and Crimea (Ukraine)". English. In: Russian Journal of Herpetology 213.3 (2006), pp. 175-180.

[20704] A. S. Schulp, N. Bardet, and B. Bouya. "A new species of the durophagous mosasaur Carinodens (Squamata, Mosasauridae) and additional material of Carinodens belgicus from the Maastrichtian phosphates of Morocco". English. In: Netherlands Journal of Geosciences 88.3 (2009), pp. 161-167. 
[20705] A.S. Schulp and W. A. Brokx. "Maastrichtian sauropod footprints from the Fumanya site, Berguedá, Spain". In: Ichnos 6.4 (1999), pp. 239-250.

[20706] A. S. Schulp, S. S. Hanna, A. F. Hartman, and J. M. W. Jagt. "A Late Cretaceous theropod caudal vertebra from the Sultanate of Oman". English. In: Cretaceous Research 21 (2000), pp. 851-856.

[20707] A. S. Schulp, J. W. M. Jagt, and F. Fonken. "New material of the mosasaur Carinodens belgicus from the Upper Cretaceous of the Netherlands". English. In: Journal of Vertebrate Paleontology 24.3 (2004), pp. 744-747.

[20708] A. S. Schulp, P. M. O'Connor, D. B. Weishampel, A. R. Al Sayigh, A. Al-Harthy, J. W. M. Jagt, and A. F. Hartman. "Ornithopod and sauropod dinosaur remains from the Maastrichtian Al-Khod Conglomerate, Sultanate of Oman". English. In: SQU Journal for Science 13 (2008), pp. 27-32.

[20709] A. S. Schulp, M. J. Polcyn, O. Mateus, L. L. Jacobs, and M. L. Morais. “A new species of Prognathodon (Squamata, Mosasauridae) from the Maastrichtian of Angola, and the affinities of the mosasaur genus Liodon". English. In: Proceedings of the Second Mosasaur Meeting (2008), pp. 1-12.

[20710] S. Schulte, E. Davaud, and R. Wernli. "Les bioconstructions a foraminiferes de l'Urgonien du massif du Haut-Giffre (Hte Savoie, France) [Urgonian foraminiferal bioconstructions from the HautGiffre Massif (Haute-Savoie, France)]". French. In: Bulletin de la Societe Geologique de France 164.5 (1993), pp. 675-682.

[20711] C. L. Schultz, M. C. Langer, and F. C. Montefeltro. "A new rhynchosaur from south Brazil (Santa Maria Formation) and rhynchosaur diversity patterns across the Middle-Late Triassic boundary". English. In: Palaeontologische Zeitschrift 90 (2016), pp. 593-609.

[20712] O. Schultz. "An Anglerfish, Lophius (Osteichthyes, Euteleostei, Lophiidae), from the Leitha Limestone (Badenian, Middle Miocene) of the Vienna Basin, Austria (Central Paratethys)". English. In: Beitrage Paläontologie 30 (2006), pp. 427-435.

[20713] O. Schultz. "A triggerfish (Osteichthyes: Balistidae: Balistes) from the Badenian (Middle Miocene) of the Vienna and the Styrian Basin (Central Paratethys)". English. In: Annalen des Naturhistorischen Museums in Wien. Serie A für Mineralogie und Petrographie, Geologie und Paläontologie, Anthropologie und Prähistorie 106 (2004), pp. 345-369.

[20714] O. Schultz, R. Brzobohatý, and O. Kroupa. "Fish teeth from the Middle Miocene of Kienberg at Mikulov, Czech Republic, Vienna Basin". English. In: Annalen des Naturhistorischen Museums in Wien 112 (2010), pp. 489-506.

[20715] T. R. Schultz. “The fungus-growing ant genus Apterostigma in Dominican amber". English. In: Memoirs of the American Entomological Institute 80 (2007), pp. 425-436.

[20716] H. Schultze and R. R. West. "An Eugeneodontid Elasmobranch from the Late Paleozoic of Kansas". English. In: Journal of Paleontology 70.1 (1996), pp. 162-165.

[20717] H. P. Schultze. "A new acanthodian from the Pennsylvanian of Utah, U.S.A. and the distribution of otoliths in gnathostomes". English. In: Journal of Vertebrate Paleontology 10.1 (1990), pp. 49-58.

[20718] H. P. Schultze. "Melanognathus, a primitive dipnoan from the Lower Devonian of the Canadian Arctic and the interrelationships of Devonian dipnoans". English. In: Journal of Vertebrate Paleontology 21.4 (2001), pp. 781-794.

[20719] H. P. Schultze and R. Cloutier. "Comparison of the Escuminac Formation ichthyofauna with other late Givetian/early Frasnian ichthyofaunas". English. In: Devonian Fishes and Plants of Miguasha, Quebec, Canada. Munich: Verlag, 1996, pp. 348-368.

[20720] H.-P. Schultze. "A new long-headed dipnoan (Osteichthyes) from the Middle Devonian of Iowa, USA". English. In: Journal of Vertebrate Paleontology 12.1 (1992), pp. 42-58.

[20721] H.-P. Schultze. "A porolepiform rhipidistian from the Lower Devonian of the Canadian Arctic". English. In: Mitteilungen aus dem Museum fur Naturkunde Berlin, Geowissenschaften Reihe 3 (2000), pp. 99-109. 
[20722] H.-P. Schultze and J. W. Reed. "A tristichopterid sarcopterygian fish from the upper Middle Devonian of Nevada". English. In: Historical Biology 24.4 (2012), pp. 425-440. DOI: 10.1080/08912963. 2012.673599.

[20723] B. Schumacher and G. Liggett. The dinosaurs of Picket Wire Canyonlands, a glimpse into the Morrison basin of southeastern Colorado. English. 2004.

[20724] B. A. Schumacher. "A new polycotylid plesiosaur (Reptilia; Sauropterygia) from the Greenhorn Limestone (Upper Cretaceous; lower upper Cenomanian), Black Hills, South Dakota". English. In: Geological Society of America Special Paper 427 (2007), pp. 133-146.

[20725] B. A. Schumacher. "On the skull of a pliosaur (Plesiosauria; Pliosauridae) from the Upper Cretaceous (early Turonian) of the North American Western Interior". English. In: Transactions of the Kansas Academy of Science 111.3/4 (2008), pp. 203-218.

[20726] B. A. Schumacher. "A 'woollgari-zone mosasaur' (Squamata; Mosasauridae) from the Carlile Shale (Lower Middle Turonian) of central Kansas and the stratigraphic overlap of early mosasaurs and pliosaurid plesiosaurs". English. In: Transactions of the Kansas Academy of Science 114.1-2 (2011), pp. 1-14.

[20727] B. A. Schumacher, K. Carpenter, and M. J. Everhart. "A new Cretaceous pliosaurid (Reptilia, Plesiosauria) from the Carlile Shale (Middle Turonian) of Russell County, Kansas". English. In: Journal of Vertebrate Paleontology 33.3 (2013), pp. 613-628. DOI: 10.1080/02724634.2013.722576.

[20728] B. A. Schumacher and M. J. Everhart. "A stratigraphic and taxonomic review of plesiosaurs from the old Fort Benton Group of central Kansas: a new assessment of old records". English. In: Paludicola 5.2 (2005), pp. 33-54.

[20729] B. A. Schumacher and J. E. Martin. "Polycotylus latipinnis Cope (Plesiosauria, Polycotylidae), a nearly complete skeleton from the Niobrara Formation (Early Campanian) of southwestern South Dakota". English. In: Journal of Vertebrate Paleontology 36.1 (2016), e1031341:1-15.

[20730] K. K. Schumaker and A. J. Kihm. "Multituberculates from the Medicine Pole Hills Local Fauna (Chadronian) of Bowman, County, North Dakota". English. In: Paludicola 6.1 (2006), pp. 9-21.

[20731] D. Schumann. "Upper Cretaceous rudist and stromatoporid associations of Central Oman (Arabian Peninsula)". In: Facies 32 (1995), pp. 189-202.

[20732] H. Schumann. “Eine neue Glabellula-Art aus dem Sächsischen Bernstein (Diptera, Bombyliidae)". German. In: Deutsche Entomologische Zeitschrift 38 (1991), pp. 79-84.

[20733] F. Schuster. "Early Miocene corals and associated sediments of the northwestern Gulf of Suez,Egypt". English. In: Courier Forschungsinstitut Senckenberg 239 (2002), pp. 57-81.

[20734] F. Schuster. "Oligocene scleractinian corals from Doutsiko (Mesohellenic Basin, northwestern Greece)”. English. In: Courier Forschungsinstitut Senckenberg 239 (2002), pp. 83-127.

[20735] F. Schuster. “Early Miocene scleractinian corals from the Qom and Asmari formations (central and southwest Iran)". English. In: Courier Forschungsinstitut Senckenberg 239 (2002), pp. 129-161.

[20736] F. Schuster. "Scleractinian corals from the Oligocene of the Qom Formation (Esfahan-Sirjan forearc basin, Iran)". English. In: Courier Forschungsinstitut Senckenberg 239 (2002), pp. 5-55.

[20737] F. Schuster and U. Wielandt. "Oligocene and Early Miocene coral faunas from Iran: palaeoecology and palaeobiogeography". In: International Journal of Earth Sciences 88.3 (1999), pp. 571-581.

[20738] W. A. Schutt Jr. and N. B. Simmons. "Morphology and Homology of the Chiropteran Calcar, with Comments on the Phylogenetic Relationships of Archaeopteropus". English. In: Journal of Mammalian Evolution 5.1 (1998), pp. 1-32.

[20739] A. Schwardt. "Revision der Wortheniella-Gruppe (Archaeogastropoda) der Cassianer Schichten (Trias, Dolomiten) [Revision of the Wortheniella group (Archaeogastropoda) from the Cassian Formation (Triassic, Dolomites)]". German. In: Annalen des Naturhistorischen Museums in Wien, A 94 (1992), pp. 23-57.

[20740] H. L. Schwartz and K. Manley. "Geology and stratigraphy of the Seismosaurus locality, Sandoval County, New Mexico". English. In: New Mexico Geology 14.2 (1992), pp. 25-30. 
[20741] J. H. Schwartz, V. T. Long, N. L. Cuong, L. T. Kha, and I. Tattersall. “A review of the Pleistocene hominoid fauna of the Socialist Republic of Vietnam (excluding Hylobatidae)". English. In: $A n-$ thropological Paper of the American Museum of Natural History 76 (1995), pp. 1-23.

[20742] J. H. Schwartz, T. H. Vu, L. C. Nguyen, K. T. Le, and I. Tattersall. "A diverse hominoid fauna from the late middle Pleistocene breccia cave of Tham Khuyen, Socialist Republic of Vietnam". English. In: Anthropological Papers of the American Museum of Natural History 73 (1994), pp. 1-11.

[20743] L. R. S. Schwartz. "A new species of bandicoot from the Oligocene of northern Australia and implications of badnicoots for correlating Australian Tertiary mammal fauna". English. In: Palaeontology 49.5 (2006), pp. 991-998.

[20744] L. R. S. Schwartz. "Miralinidae (Marsupialia: Phalangeroidea) from northern Australia, including the youngest occurrence of the family". English. In: Alcheringa 30.2 (2006), pp. 343-350. DOI: 10. $1080 / 03115510608619321$.

[20745] L. R. S. Schwartz and D. Megirian. “A New Species of Nambaroo (Marsupialia; Macropodoidea) from the Miocene Camfield Beds of Northern Australia with Observations on the Phylogeny of the Balbarinae". English. In: Journal of Vertebrate Paleontology 24.3 (2004), pp. 668-675.

[20746] D. Schwarz. "A new species of Goniopholis from the Upper Jurassic of Portugal". English. In: Palaeontology 45.1 (2002), pp. 185-208.

[20747] D. Schwarz and R. Fechner. "The first dentary of Lisboasaurus (Crocodylomorpha, ?Mesoeucrocodylia) from the Lower Cretaceous (Barremian) of Uña, Cuenca Province, Spain". English. In: Journal of Vertebrate Paleontology 28.1 (2008), pp. 264-268.

[20748] D. Schwarz and R. Fechner. “Lusitanisuchus, a new generic name for Lisboasaurus mitracostatus (Crocodylomorpha: Mesoeucrocodylia), with a description of new remains from the Upper Jurassic (Kimmeridgian) and Lower Cretaceous (Berriasian) of Portugal". English. In: Canadian Journal of Earth Sciences 41 (2004), pp. 1259-1271.

[20749] D. Schwarz, P. D. Mannion, O. Wings, and C. A. Meyer. "Re-description of the sauropod dinosaur Amanzia (Ornithopsis/Cetiosauriscus) greppini n. gen. and other vertebrate remains from the Kimmeridgian (Late Jurassic) Reuchenette Formation of Moutier, Switzerland". English. In: Swiss Journal of Geosciences 113 (2020), 2:1-48.

[20750] D. Schwarz, M. Raddatz, and O. Wings. "Knoetschkesuchus langenbergensis gen. nov. sp. nov., a new atoposaurid crocodyliform from the Upper Jurassic Langenberg Quarry (Lower Saxony, northwestern Germany), and its relationships to Theriosuchus". English. In: PLoS ONE 12.2 (2017), e0160617:1-47.

[20751] D. Schwarz and S. W. Salisbury. "A new species of Theriosuchus (Atoposauridae, Crocodylomorpha) from the Late Jurassic (Kimmeridgian) of Guimarota, Portugal”. English. In: Géobios 38 (2005), pp. 779-802.

[20752] D. Schwarz-Wings, N. Klein, C. Neumann, and U. Resch. "A new partial skeleton of Alligatorellus (Crocodyliformes) associated with echinoids from the Late Jurassic (Tithonian) lithographic limestone of Kelheim, S-Germany". English. In: Fossil Record 14.2 (2011), pp. 195-205.

[20753] D. Schwarz-Wings, J. Milán, and P. Gravesen. "A new eusuchian (Crocodylia) tooth from the Early or Middle Paleocene, with a description of the Early-Middle Paleocene boundary succession at Gemmas Allé, Copenhagen, Denmark". English. In: Bulletin of the Geological Society of Denmark 62 (2014), pp. 17-26.

[20754] D. Schwarz-Wings, J. Rees, and J. Lindgren. “Lower Cretaceous Mesoeucrocodylians from Scandinavia (Denmark and Sweden)". English. In: Cretaceous Research 30 (2009), pp. 1345-1355.

[20755] W. Schwarzhans. "Fish otoliths from the Paleocene of Denmark". English. In: Geological Survey of Denmark and Greenland Bulletin 2 (2003), pp. 1-94.

[20756] W. Schwarzhans. "The otoliths from the middle Eocene of Osteroden near Bramsche, north-western Germany". English. In: Neues Jahrbuch für Geologie und Paläontologie 244.3 (2007), pp. 299-369. DOI: 10.1127/0077-7749/2007/0244-0299. 
[20757] W. Schwarzhans and A. Bratischko. "The otoliths from the middle Paleocene of Luzanivka (Cherkasy district, Ukraine)". English. In: Neues Jahrbuch für Geologie und Paläontologie, Abhandlungen 261.1 (2011), pp. 83-110.

[20758] W. Schwarzhans, T. Mörs, A. Engelbrecht, M. Reguero, and J. Kriwet. "Before the freeze: otoliths from the Eocene of Seymour Island, Antarctica, reveal dominance of gadiform fishes (Teleostei)". English. In: Journal of Systematic Palaeontology 15.2 (2017), pp. 147-179. DOI: 10.1080 / 14772019. 2016.1151958.

[20759] W. Schwarzhans, F. Ohe, and Y. Ando. “An Early Oligocene fish-fauna from Japan reconstructed from otoliths". English. In: Zitteliana 90 (2017), pp. 3-26.

[20760] G. Schweigert, G. Dietl, M. Kapitzke, J. Rieter, and R. Hugger. "Libellen aus dem Nusplinger Plattenkalk (Oberjura, Ober-Kimmeridgium, Württemberg)". German. In: Stuttgarter Beiträge zur Naturkunde Serie B (Geologie und Paläontologie) 236 (1996), pp. 1-12.

[20761] G. Schweigert and G. Dietl. “Ein fossiler HundertfüSSler (Chilopoda, Geophilida) aus dem Nusplinger Plattenkalk (Oberjura, Südwestdeutschland)". German. In: Stuttgarter Beiträge zur Naturkunde Serie B (Geologie und Paläontologie) 254 (1997), pp. 1-11.

[20762] G. Schweigert and W. Ernst. "First record of a polychelid lobster (Crustacea: Decapoda: Coleiidae) from the Sinemurian (Early Jurassic) of Germany". English. In: Neues Jahrbuch für Geologie und Paläontologie, Abhandlungen 263 (2012), pp. 35-42.

[20763] G. Schweigert, R. Fraaije, P. Havlik, and A. Nützel. "New Early Jurassic hermit crabs from Germany and France". English. In: Journal of Crustacean Biology 33 (2013), pp. 802-817.

[20764] G. Schweigert and F. A. Wittler. "First record of a polychelid lobster (Crustacea: Decapoda: Coleiidae) from the Pliensbachian (Early Jurassic) of Germany". English. In: Boletn de la Sociedad Geológica Mexicana 65 (2013), pp. 219-223.

[20765] C. Schweitzer and R. M. Feldmann. “Earliest known Porcellanidae (Decapoda: Anomura: Galatheoidea) (Jurassic: Tithonian)". English. In: Neues Jahrbachfur Geologieurd Palaontologie Abhandlungen (2010). DOI: $10.0027 / 0077-7749 / 2010 / 0096$.

[20766] C. E. Schweitzer. "The Trapeziidae and Domeciidae (Decapoda: Brachyura: Xanthoidea) in the fossil record and a new Eocene genus from Baja California Sur, Mexico". English. In: Journal of Crustacean Biology 25.4 (2005), pp. 625-636.

[20767] C. E. Schweitzer, P. Artal, B. van Bakel, J. W. M. Jagt, and H. Karasawa. "Revision of the genus Titanocarcinus (Decapoda: Brachyura: Xanthoidea) with two new genera and one new species". English. In: Journal of Crustacean Biology 27.2 (2007), pp. 278-295.

[20768] C. E. Schweitzer and R. M. Feldmann. "Differentiation of the fossil Hexapodidae Miers, 1886 (Decapoda: Brachyura) from similar forms". In: Journal of Paleontology 75.2 (2001), pp. 330-345.

[20769] C. E. Schweitzer, R. M. Feldmann, G. Gonzales-Barba, and F. J. Vega. “New crabs from the Eocene and Oligocene of Baja California Sur, Mexico and an assessment of the evolutionary and paleobiogeographic implications of Mexican fossil decapods". English. In: Memoir (The Paleontological Society) 59 (2002), pp. 1-43.

[20770] C. E. Schweitzer, R. M. Feldmann, and P. D. Gingerich. "New Decapoda (Crustacea) from the middle and late Eocene of Pakistan and a revision of Lobonotus A. Milne Edwards, 1864". English. In: University of Michigan Contributions from the Musuem of Paleontology 31.4 (2004), pp. 89-118.

[20771] C. E. Schweitzer, R. M. Feldmann, S. Marenssi, and D. A. Waugh. "Remarkably preserved annelid worms from the La Meseta Formation (Eocene), Seymour Island, Antarctica". English. In: Palaeontology 48.1 (2005), pp. 1-13.

[20772] C. E. Schweitzer and R. M. Feldmann. "New Eocene decapods (Thalassinidea and Brachyura) from Southern California". English. In: Journal of Crustacean Biology 22 (2002), pp. 938-967.

[20773] C. E. Schweitzer, R. M. Feldmann, A. Encinas, and M. Suarez. "New Cretaceous and Eocene Callianassoidea (Thalassinidea, Decapoda) from Algarrobo, Chile". English. In: Journal of Crustacean Biology 26.1 (2006), pp. 73-81. 
[20774] C. E. Schweitzer, R. M. Feldmann, G. Gonzalez-Barba, and V. Cosovic. “New Decapoda (Anomura, Brachyura) from the Eocene Bateque and Tepetate Formations, Baja California Sur, Mexico". English. In: Bulletin of the Mizunami Fossil Museum 33 (2006), pp. 21-45.

[20775] C. E. Schweitzer, R. M. Feldmann, G. Gonzalez-Barba, and V. Cosovic. “Decapod crustaceans (Brachyura) from the Eocene Tepetate Formation, Baja California Sur, Mexico". English. In: Annals of Carnegie Museum 76.1 (2007), pp. 1-14.

[20776] C. E. Schweitzer, R. M. Feldmann, and I. Lazar. “Decapods from Jurassic (Oxfordian) sponge megafacies of Dobrogea, Romania and reconsideration of Nodoprosopon Beurlen, 1928". English. In: Neues Jahrbuch fur Palaontologie Abhandlungen 244.1 (2007), pp. 99-113.

[20777] C. E. Schweitzer and R. M. Feldmann. "New Eocene hydrocarbon seep decapod crustacean (Anomura: Galatheidae: Shinkaiinae) and its paleobiology". English. In: Journal of Paleontology 82.5 (2008), pp. 1021-1029.

[20778] C. E. Schweitzer and R. M. Feldmann. "Revision of the genus Laeviprosopon Glaessner, 1933 (Decapoda: Brachyura: Homolodromioidea: Prosopidae) including 2 new species". English. In: Neues Jahrbuch fur Geologie und Palaontologie Abhandlung 250.3 (2008), pp. 273-285.

[20779] C. E. Schweitzer and R. M. Feldmann. "Revision of the Prosopinae sensu Glaessner, 1969 (Crustacea: Decapoda: Brachyura) including four new families, four new genera, and five new species". English. In: Annalen des Naturhistorischen Museums in Wien, Serie A 110 (2009), pp. 55-121.

[20780] C. E. Schweitzer and R. M. Feldmann. "New species of Longodromitidae Schweitzer and Feldmann, 2009, from the Ernstbrunn Formation, Late Jurassic (Tithonian), Austria". English. In: Annalen des Naturhistorischen Museums in Wien, Serie A 111 (2009), pp. 207-224.

[20781] C. E. Schweitzer and R. M. Feldmann. "Revision of Gabriella Collins et al., 2006 (Decapoda: Brachyura: Homolodromioidea: Tanidromitidae) with new Jurassic species". English. In: Neues Jahrbuch für Geologie und Paläontologie Abhandlungen 252.1 (2009), pp. 1-16.

[20782] C. E. Schweitzer and R. M. Feldmann. "A new classification for some Jurassic Brachyura (Crustacea: Decapoda: Brachyura: Homolodromioidea): families Goniodromitidae Beurlen, 1932 and Tanidromitidae new family". English. In: Senckenbergiana lethaea 87.2 (2008), pp. 119-156.

[20783] C. E. Schweitzer, R. M. Feldmann, and I. Lazar. "Fossil Crustacea (excluding Cirripedia and Ostracoda) in the University of Bucharest Collections, Romania, including two new species". English. In: Bulletin of the Mizunami Fossil Museum 35 (2009), pp. 1-14.

[20784] C. E. Schweitzer and R. M. Feldmann. "Revision of the genus Cyclothyreus Remes, 1895 (Decapoda: Brachyura: Dromiodea)". English. In: Neues Jahrbuch fur Geologie und Palaontologie, Abhandlungen 253.2-3 (2009), pp. 357-372.

[20785] C. E. Schweitzer and R. M. Feldmann. "New fossil Brachyura (Decapoda: Homoildea, Dorippoidea, Carpilioidea) from the United Kingdom". English. In: Bulletin of the Mizunami Fossil Museum 37 (2011), pp. 1-11.

[20786] C. E. Schweitzer, R. M. Feldmann, J. Fam, W. A. Hessin, S. W. Hetrick, T. G. Nyborg, and R. L. M. Ross. Cretaceous and Eocene Decapod Crustaceans from Southern Vancouver Island, British Columbia Canada. English. NRC Research Press. 2003, pp. 1-66.

[20787] C. E. Schweitzer and R. M. Feldmann. "First notice of the Chirostylidae (Decapoda) in the fossil record and new Tertiary Galatheidae (Decapoda) from the Americas". English. In: Bulletin of the Mizunami Fossil Museum 27 (2000), pp. 147-165.

[20788] C. E. Schweitzer and R. M. Feldmann. "New Cretaceous and Tertiary decapod crustaceans from western North America". English. In: Bulletin of the Mizunami Fossil Museum 28 (2001), pp. 173210.

[20789] C. E. Schweitzer, R. M. Feldmann, S. X. Hu, J. Y. Huang, C. Y. Zhou, Q. Y. Zhang, W. Wen, and T. Xie. "Penaeoid Decapoda (Dendrobranchiata) from the Luoping biota (Middle Triassic) of China: systematics and taphonomic framework". English. In: Journal of Paleontology 88 (2014), pp. 457474. 
[20790] C. E. Schweitzer, R. M. Feldmann, and G. L. Stringer. “Neozanthopsis americana (Decapoda, Brachyura, Carpilioidea) from the Middle Eocene Cane River Formation of Louisiana, USA, and associated teleost otoliths". English. In: Scripta Geologica 147 (2014), pp. 163-183.

[20791] C. E. Schweitzer and R. M. Feldmann. "Re-evaluation of the Cancridae Latreille, 1902 (Decapoda: Brachyura) including three new genera and three new species". English. In: Contributions to Zoology 69.4 (2000), pp. 223-250.

[20792] C. E. Schweitzer, R. M. Feldmann, A. B. Tucker, and R. E. Berglund. "Eocene decapod crustaceans from Pulali Point, Washington". English. In: Annals of the Carnegie Museum 69.1 (2000), pp. 23-67.

[20793] C. E. Schweitzer and R. M. Feldmann. "New fossil portunids from Washington, USA, and Argentina and a re-evaluation of generic and family relationships within the Portunoidea Rafinesque, 1815 (Decapoda: Brachyura)". English. In: Journal of Paleontology 74.4 (2000), pp. 636-653.

[20794] C. E. Schweitzer, R. M. Feldmann, V. Cosovic, R. L. M. Ross, and D. A. Waugh. "New Cretaceous and Eocene decapoda (Astacidea, Thalassinidea, Brachyura) from British Columbia, Canada". English. In: Annals of Carnegie Museum 77.4 (2009), pp. 403-423.

[20795] C. E. Schweitzer and R. M. Feldmann. "New species of calappid crabs from Western North American and reconsideration of the Calappidae sensu lato". English. In: Journal of Paleontology 74.2 (2000), pp. 230-246.

[20796] C. E. Schweitzer, G. González-Barba, R. M. Feldmann, and D. A. Waugh. “Decapoda (Thalassinidea and Paguroidea) from the Eocene Bateque and Tepetate formations, Baja California Sur, Mexico: Systematics, cuticle microstructure, and paleoecology". English. In: Annals of Carnegie Museum 74.4 (2005), pp. 275-293. DOI: 10.2992/0097-4463(2005)74[275:DTAPFT]2.0.CO;2.

[20797] C. E. Schweitzer, M. Iturralde-Vinent, J. L. Hetler, and J. Velez-Juarbe. “Oligocene and Miocene decapods (Thalassinidea and Brachyura) from the Caribbean". English. In: Annals of Carnegie Museum 75.2 (2006), pp. 111-136.

[20798] C. E. Schweitzer and H. Karasawa. "Revision of Amydrocarcinus and Palaeograpsus (Decapoda: Brachyura: Xanthoidea) with definition of three new genera". In: Paleontological Research 8.1 (2004), pp. 71-86.

[20799] C. E. Schweitzer, C. F. R. Odumodu, and R. M. Feldmann. "New Eocene Crabs from Nigeria (Decapoda: Brachyura: Heterotremata)". English. In: Annals of Carnegie Museum 84.1 (2016), pp. 59-73. DOI: 10.2992/007.084.0107.

[20800] C. E. Schweitzer, A. M. Shirk, V. Cosovic, Y. Okan, R. M. Feldmann, and I. Hosgor. "New species of Harpactocarcinus from the Tethyan Eocene and their paleoecological setting". English. In: Journal of Paleontology 81.5 (2007), pp. 1091-1100.

[20801] C. E. Schweitzer, J. Velez-Juarbe, M. Martiniez, A. Hull, R. M. Feldmann, and H. Santos. “New Cretaceous and Cenozoic Decapoda (Crustacea: Thalassinidea, Brachyura) from Puerto Rico, United States Territory". English. In: Bulletin of the Mizunami Fossil Museum 34 (2008), pp. 1-15.

[20802] C. E. Schweitzer Hopkins, E. W. Salva, and R. M. Feldmann. "Re-evaluation of the genus Xanthosia Bell, 1863 (Decapoda: Brachyura: Xanthidae) and description of two new species from the Cretaceous of Texas". English. In: Journal of Paleontology 73.1 (1999), pp. 77-90.

[20803] L. Schwermann and P. M. Sander. “Osteologie und Phylogenie von Westphaliasaurus simonsensii: Ein neuer Plesiosauride (Sauropterygia) aus dem Unteren Jura (Pliensbachium) von Sommersell (Kreis Höxter), Nordrhein-Westfalen, Deutschland". German. In: Geologie und Paläontologie in Westfalen 79 (2011), pp. 1-60.

[20804] D. R. Schwimmer. "First mastodont remains from the Chattahoochee River valley in western Georgia, with implications for the age of adjacent stream terraces". English. In: Georgia Journal of Science 49 (1991), pp. 81-86.

[20805] D. R. Schwimmer, G. E. Hooks, and B. Johnson. "Revised taxonomy, age, and geographic range of the large lamniform shark Cretodus semplicatus". English. In: Journal of Vertebrate Paleontology 22.3 (2002), pp. 704-707. DOI: 10.1671/0272-4634(2002)022[0704:RTAAGR]2.0.CO;2. 
[20806] D. R. Schwimmer, A. E. Sanders, B. R. Erickson, and R. E. Weems. "A Late Cretaceous dinosaur and reptile assemblage from South Carolina, USA". English. In: Transactions of the American Philosophical Society 105.2 (2015), pp. 1-157.

[20807] D. R. Schwimmer, J. D. Steward, and G. D. Williams. "Giant fossil coelacanths of the Late Cretaceous in the eastern United States". English. In: Geology 22 (1994), pp. 503-506.

[20808] D. R. Schwimmer, G. D. Williams, J. L. Dobie, and W. G. Siesser. "Late Cretaceous dinosaurs from the Blufftown Formation in western Georgia and eastern Alabama". English. In: Journal of Paleontology 67.2 (1993), pp. 288-296.

[20809] G. J. Scillato-Yané and A. A. Carlini. "Nuevos Xenarthra del Friasense (Mioceno medio) de Argentina". Spanish. In: Studia geologica salmanticensia 34 (1998), pp. 43-67.

[20810] G. J. Scillato-Yané, F. Góis, A. E. Zurita, A. A. Carlini, L. R. González-Ruiz, C. M. Krmpotic, C. Oliva, and M. Zamorano. "Los cingulata (Mammalia, Xenarthra) del Conglomerado Osfero (Mioceno tardo) de la Formación Ituzaingó de Entre Ros, Argentina". Spanish. In: El Neógeno de la Mesopotamia argentina 14 (2013), pp. 118-134.

[20811] L. Sciscio, E. M. Bordy, M. Abrahams, F. Knoll, and B. W. McPhee. “The first megatheropod tracks from the Lower Jurassic upper Elliot Formation, Karoo Basin, Lesotho". English. In: PLoS ONE 12.10 (2017), e0185941:1-28. DOI: 10.1371/journal.pone.0185941.

[20812] F. Sciuto, A. Rosso, R. Sanfilippo, and R. Maniscalco. "New faunistic data on the Pleistocene environmental evolution of the south-western edge of the Hyblean Plateau (SE Sicily)". English. In: Notebooks on Geology 15.5 (2015).

[20813] J. C. Sciutto and R. D. Martnez. “Un nuevo yacimiento fosilfero de la Formación Bajo Barreal (Cretacico Tardio) y su fauna de saurópodos [A new fossiliferous locality in the Bajo Barreal Formation (Late Cretaceous) and its sauropod fauna]". Spanish. In: Naturalia Patagonica, Ciencias de la Tierra 2 (1994), pp. 27-47.

[20814] T. P. Scoffin and M. D. A. Le Tissier. "Late Holocene sea level and reef-flat progradation, Phuket, south Thailand". English. In: Coral Reefs 17 (1998), pp. 273-276.

[20815] R. P. Scofield, N. Hiller, and A. A. Mannering. "A fossil diving petrel (Aves: Pelecanoididae) from the mid-Miocene of North Canterbury, New Zealand". English. In: Records of the Canterbury Museum 20 (2006), pp. 65-71.

[20816] R. P. Scofield, T. H. Worthy, and A. J. D. Tennyson. "A Heron (Aves: Ardeidae) from the Early Miocene St Bathans Fauna of Southern New Zealand". English. In: Records of the Australian Museum 62 (2010), pp. 89-104.

[20817] A. G. Scott. "Sub-fossil spiders from Holocene peat cores". English. In: The Journal of Arachnology 31 (2003), pp. 1-7.

[20818] C. Scott. New multituberculates (Mammalia, Allotheria) from the late Paleocene of Alberta, Canada, and the evolution of multituberculates in western Canada. English. 2003.

[20819] C. S. Scott. "Late Torrejonian (middle Paleocene) mammals from south central Alberta, Canada". English. In: Journal of Paleontology 77.4 (2003), pp. 745-768.

[20820] C. S. Scott. "A new species of the ptilodontoiid multituberculate Prochetodon (Mammalia, Allotheria) from the Paleocene Paskapoo Formation of Alberta, Canada". English. In: Canadian Journal of Earth Sciences 41.2 (2004), pp. 237-246.

[20821] C. S. Scott. "A new erinaceid (Mammalia, Insectivora) from the Late Paleocene of western Canada". English. In: Canadian Journal of Earth Sciences 43.11 (2006), pp. 1695-1709.

[20822] C. S. Scott. "New cyriacotheriid pantodonts (Mammalia, Pantodonta) from the Paleocene of Alberta, Canada, and the relationships of Cyriacotheriidae". English. In: Journal of Paleontology 84.2 (2010), pp. 197-215. DOI: 10.1666/09-109R.1.

[20823] C. S. Scott. "Eudaemonema webbi sp. nov. (Mammalia, Mixodectidae) from the late Paleocene of western Canada: the youngest known mixodectid". English. In: Canadian Journal of Earth Sciences 47.12 (2010), pp. 1451-1462. DOI: 10.1139/E10-074. 
[20824] C. S. Scott. "Horolodectidae: a new family of unusual eutherians (Mammalia: Theria) from the Palaeocene of Alberta, Canada". English. In: Zoological Journal of the Linnean Society 185.2 (2019), pp. 431-458. DOI: 10.1093 /zoolinnean/zly040/5078608.

[20825] C. S. Scott, R. C. Fox, and G. P. Youzwyshyn. "New earliest Tiffanian (late Paleocene) mammals from Cochrane 2, southwestern Alberta, Canada". English. In: Acta Palaeontologica Polonica 47.4 (2002), pp. 691-704.

[20826] C. S. Scott and R. C. Fox. "Windows on the evolution of Picrodus (Plesiadapiformes: Primates): morphology and relationships of a species complex from the Paleocene of Alberta". English. In: Journal of Paleontology 79.4 (2005), pp. 635-657.

[20827] C. S. Scott and D. W. Krause. "Multituberculates (Mammalia, Allotheria) from the earliest Tiffanian (late Paleocene) Douglass Quarry, eastern Crazy Mountains Basin, Montana". English. In: Contributions from the Museum of Paleontology, University of Michigan 31.10 (2006), pp. 211-243.

[20828] C. S. Scott, D. N. Spivak, and A. R. Sweet. "First mammals from the Paleocene Porcupine Hills Formation of southwestern Alberta, Canada". English. In: Canadian Journal of Earth Sciences 50 (2013), pp. 355-378.

[20829] C. S. Scott, M. W. Webb, and R. C. Fox. "Horolodectes sunae, an enigmatic mammal from the late Paleocene of Alberta, Canada". English. In: Journal of Paleontology 80.5 (2006), pp. 1009-1025.

[20830] C. S. Scott, A. Weil, and J. M. Theodor. "A new, diminutive species of Catopsalis (Mammalia, Multituberculata, Taeniolabidoidea) from the early Paleocene of southwestern Alberta, Canada". English. In: Journal of Paleontology 92.5 (2018), pp. 896-910. DOI: 10.1017/jpa.2018.2.

[20831] E. Scott and S. M. Cox. “Arctodus simus (Cope, 1879) from Riverside County, California”. English. In: PaleoBios 15.2 (1993), pp. 27-36.

[20832] E. Scott, R. W. Graham, T. W. Stafford Jr., and L. D. Martin. On the validity of Equus laurentius Hay, 1913. English. 2003.

[20833] R. W. Scott. “Cretaceous rudists of Guatemala”. English. In: Revista Mexicana de Ciencias Geologicas 12.2 (1995), pp. 294-306.

[20834] R. W. Scott. Key bivalves of the Lower Albian Glen Rose Formation, Texas, U.S.A. English. Vol. 87. Cretaceous rudists and carbonate platforms: environmental feedback, SEPM Special Publication. 2007, pp. 247-252.

[20835] R. W. Scott and H. F. Filkorn. Barremian-Albian rudist zones, U.S. Gulf Coast. English. Vol. 87. Cretaceous rudists and carbonate platforms: environmental feedback, SEPM Special Publication. 2007, pp. 167-180.

[20836] R. W. Scott and R. E. Hinote. Barremian-Early Aptian rudists, Sligo Formation, Texas, U.S.A. English. Vol. 87. Cretaceous rudists and carbonate platforms: environmental feedback, SEPM Special Publication. 2007, pp. 237-246.

[20837] R. W. Scott, A. M. Molineux, H. Löser, and E. A. Mancini. Lower Albian sequence stratigraphy and coral buildups: Glen Rose Formation, Texas, U.S.A. English. Vol. 87. Cretaceous rudists and carbonate platforms: environmental feedback, SEPM Special Publication. 2007, pp. 181-191.

[20838] R. W. Scott and M. Weaver. “Ontogeny and functional morphology of a lower Cretaceous caprinid Rudist; Bivalvia, Hippuritoida". English. In: Turkish Journal of Earth Sciences 19 (2010), pp. 527-542.

[20839] R. W. Scott, C. Whitney, R. Hojnacki; W. Yulin, and X. Lai. "Albian rudist biostratigraphy (Bivalvia), Comanche shelf to shelf margin, Texas". English. In: Carnets de Géologie 16.21 (2016).

[20840] L. J. Scriven and R. S. Hill. "Macrofossil Casuarinaceae: their Identification and the Oldest Macrofossil Record, Gymnostoma antiquum sp. nov., from the Late Paleocene of New South Wales, Australia". English. In: Australian Systematic Botany 8.6 (1995), pp. 1035-1053. DOI: 10.1071/SB9951035.

[20841] C. T. Scrutton and E. N. K. Clarkson. "A new Scleractinian-like Coral from the Ordovician of the Southern Uplands, Scotland”. English. In: Palaeontology 34.1 (1991), pp. 179-194.

[20842] P. L. Sealey and S. G. Lucas. Exceptionally preserved invertebrate fauna from the Upper Cretaceous Paguate Member of the Dakota Formation, Rio Puerco Valley, Sandoval county, New Mexico. 2000. 
[20843] P. L. Sealey and S. G. Lucas. “Turonian ammonites from the Upper Cretaceous D-Cross Member of the Mancos Shale, Puertecito, Socorro County, New Mexico". English. In: New Mexico Museum of Natural History and Science Bulletin 53 (2011), pp. 363-369.

[20844] P. L. Sealey and S. G. Lucas. “Upper Cretaceous (Turonian) ammonites from the Carlile Member and reference area of the Juana Lopez Member of the Mancos Shale, eastern side of the San Juan Basin, La Ventana, Sandoval County, New Mexico". English. In: New Mexico Museum of Natural History and Science Bulletin 53 (2011), pp. 370-379.

[20845] P. L. Sealey and S. G. Lucas. "First record of the Cenomanian (Cretaceous) ammonite Pachydesmoceras maroccanum from North America". English. In: Neues Jahrbuch für Geologie und Paläontologie, Abhandlungen 283 (2017), pp. 77-84.

[20846] O.-G. Sebe, S. Crasquin, and E. Grdinaru. "Early and middle Anisian (Triassic) deep-water ostracods (Crustacea) from North Dobrogea (Romania)". English. In: Revue de Paléobiologie, Genéve 32 (2013), pp. 509-529.

[20847] R. Secord. "Paleocene mammalian biostratigraphy of the Carbon Basin, southeastern Wyoming, and age constraints on local phases of tectonism". English. In: Rocky Mountain Geology 33.1 (1998), pp. 119-154. DOI: 10.2113/33.1.119.

[20848] R. Secord. The Y2K Quarry, a new diverse latest Tiffanian (late Paleocene) mammalian assemblage from the Fort Union Formation in the northern Bighorn Basin, Wyoming. English. 2002.

[20849] R. Secord. "The Tiffanian Land-Mammal Age (middle and late Paleocene) in the northern Bighorn Basin, Wyoming". English. In: University of Michigan Papers on Paleontology 35 (2008), pp. 1-192.

[20850] R. Secord, P. D. Gingerich, and J. I. Bloch. "Mylanodon rosei, a new metacheiromyid (Mammalia, Palaeanodonta) from the late Tiffanian (late Paleocene) of northwestern Wyoming". English. In: Contributions from the Museum of Paleontology, University of Michigan 30.15 (2002), pp. 385-399.

[20851] F. A. Sedor and R. C. da Silva. "Prmeiro registro des pegadas de Mesosauridae (Amniota, Sauropsida) na Formacao Irati (Permiano Superior da Bacia do Parana) do estado de goias, Brasil". English. In: Revista Brasileira de Paleontologia 7.2 (2004), 269'-274.

[20852] F. A. Sedor and J. Ferigolo. "A coluna vertebral de Brazilosaurus sanpauloensis Shikama e Ozaki, 1966 da Formação Irati, Permiano da Bacia do Paraná (Brasil) (Proganosauria, Mesosauridae)". Portugese. In: Acta Biológica Paranaense, Curitiba 30.1-4 (2001), pp. 151-173.

[20853] F. A. Sedor, E. V. Oliveira, D. D. Silva, L. A. Fernandes, R. F. Cunha, A. M. Ribeiro, and E. V. Dias. "A New South American Paleogene Land Mammal Fauna, Guabirotuba Formation (Southern Brazil)". English. In: Journal of Mammalian Evolution 24 (2017), pp. 39-55.

[20854] J. Seeling and P. Bengtson. "The bivalve Pinna cretacea (Schlotheim, 1813)from the Cretaceous of Brazil". English. In: Acta Palaeontologica Polonica 48.3 (2003), pp. 475-480.

[20855] J. Seeling and P. Bengtson. "Cenomanian oysters from the Sergipe Basin, Brazil”. English. In: Creatceaous Research 20 (1999), pp. 747-765.

[20856] J. Seeling and P. Bengtson. "The Late Cretaceous bivalve Didymotis Gerhardt, 1987 from Sergipe Brazil". English. In: Paläontologische Zeitschrift 77.1 (2003), pp. 153-160.

[20857] B. Segui. "A new species of Pica (Aves: Corvidae) from the Plio-Pleistocene of Mallorca, Balearic Islands (Western Mediterranean)." English. In: Geobios 34.3 (2001), pp. 339-347.

[20858] B. Segu, C. Mourer-Chauviré, and J. A. Alcover. “Upper Pleistocene and Holocene fossil avifauna from Moleta cave (Mallorca, Balearic Islands)". English. In: Bollet de la Societat d'História Natural de les Balears 40 (1997), pp. 223-252.

[20859] B. Segui, J. Quintana, J. J. Fornos, and J. A. Alcover. “A new fulmarine petrel (Aves: Procellariiformes) from the upper Miocene of the western Mediterranean". English. In: Palaeontology 44.5 (2001), pp. 933-948.

[20860] E. R. Seiffert. “The oldest and youngest records of afrosoricid placentals from the Fayum Depression of northern Egypt". English. In: Acta Palaeontologica Polonica 55.4 (2010), pp. 599-616. 
[20861] E. R. Seiffert, D. M. Boyer, J. G. Fleagle, G. F. Gunnell, C. P. Heesy, J. M. G. Perry, and H. M. Sallam. "New adapiform primate fossils from the late Eocene of Egypt". English. In: Historical Biology (2017). DOI: 10.1080/08912963.2017.1306522.

[20862] E. R. Seiffert, S. Nasir, A. Al-Harthy, J. R. Groenke, B. P. Kraatz, N. J. Stevens, and A. R. Al-Sayigh. "Diversity in the later Paleogene proboscidean radiation: a small barytheriid from the Oligocene of Dhofar Governorate, Sultanate of Oman". English. In: Naturwissenschaften 99 (2012), pp. $133-$ 141.

[20863] E. R. Seiffert, J. M. G. Perry, E. L. Simons, and D. M. Boyer. “Convergent evolution of anthropoidlike adaptations in Eocene adapiform primates". English. In: Nature 461 (2009), pp. 1118-1121. DOI: $10.1038 /$ nature08429.

[20864] E. R. Seiffert, E. L. Simons, and Y. Attia. "Fossil evidence for an ancient divergence of lorises and galagos". English. In: Nature 422 (2003), pp. 421-424.

[20865] E. R. Seiffert and E. L. Simons. “Widanelfarasia, a diminutive placental from the late Eocene of Egypt". English. In: Proceedings of the National Academy of Sciences 97.6 (2000), pp. 2646-2651.

[20866] E. R. Seiffert, E. L. Simons, W. C. Clyde, J. B. Rossie, Y. Attia, T. M. Bown, P. Chatrath, and M. E. Mathison. "Basal anthropoids from Egypt and the antiquity of Africa's higher primate radiation". English. In: Science 310 (2005), pp. 300-304.

[20867] E. R. Seiffert, E. L. Simons, T. M. Ryan, T. M. Bown, and Y. Attia. "New remains of Eocene and Oligocene Afrosoricida (Afrotheria) from Egypt, with implications for the origin(s) of afrosoricid zalambdodonty". English. In: Journal of Vertebrate Paleontology 27.4 (2007), pp. 963-972.

[20868] E. R. Seiffert, E. L. Simons, D. M. Boyer, J. M. G. Perry, T. M. Ryan, and H. M. Sallam. “A fossil primate of uncertain affinities from the earliest late Eocene of Egypt". English. In: Proceedings of the National Academy of Sciences 107.21 (2010), pp. 9712-9717.

[20869] E. R. Seiffert and E. L. Simons. "Last of the oligopithecids? A dwarf species from the youngest primate-bearing level of the Jebel Qatrani Formation, northern Egypt". English. In: Journal of Human Evolution 64 (2013), pp. 211-215.

[20870] E. R. Seiffert, M. F. Tejedor, J. G. Fleagle, N. M. Novo, F. M. Cornejo, M. Bond, D. de Vries, and K. E. Campbell Jr. "A parapithecid stem anthropoid of African origin in the Paleogene of South America". English. In: Science 368 (2020), pp. 194-197.

[20871] K. Seike, Y. Shiino, and Y. Suzuki. "Crininicaminus giberti isp. nov.: tubular trace fossil armored with crinoid stem plates from the Upper Permian Kamiyasse Formation, northeastern Japan". English. In: Spanish Journal of Palaeontology 29 (2014), pp. 45-50.

[20872] W. M. Seiler and M. A. Chan. "A wet interdune dinosaur trampled surface in the Jurassic Navajo Sandstone, Coyote Buttes, Arizona: rare preservation of Multiple track types and tail traces". English. In: Palaios 23.10 (2008), pp. 700-710. DOI: 10.2110/palo.2007.p07-082r.

[20873] C. Sein. "A New Stegolophodon (Proboscidea, Mammalia) from the Irrawaddy Formation of Myanmar". English. In: Open Journal of Geology 10 (2020), pp. 863-873. DOI: 10.4236/ ojg. 2020. 108039.

[20874] T. Sekiya. "[A new prosauropod dinosaur from Lower Jurassic in Lufeng of Yunnan]". Chinese. In: Global Geology 29.1 (2010), pp. 6-15.

[20875] T. Sekiya and Z. Dong. “A new juvenile specimen of Lufengosaurus huenei Young, 1941 (Dinosauria: Prosauropoda) from the Lower Jurassic Lower Lufeng Formation of Yunnan, southwest China". English. In: Acta Geologica Sinica (English Edition) 84.1 (2010), pp. 11-21. DOI: 10.1111/j. 1755-6724.2010.00165.x.

[20876] P. A. Selden. "First fossil mesothele spider, from the Carboniferous of France". English. In: Revue Suisse de Zoologie hors série (1996), pp. 585-596.

[20877] P. A. Selden. "Lower Cretaceous spiders from the Sierra de Montsech, north-east Spain”. English. In: Palaeontology 33 (1990), pp. 257-285. 
[20878] P. A. Selden. "Eocene spiders from the Isle of Wight with preserved respiratory structures". In: Palaeontology 44.4 (2001), pp. 695-729.

[20879] P. A. Selden. "First British Mesozoic spider, from Cretaceous amber of the Isle of Wight, southern England". English. In: Palaeontology 45 (2002), pp. 973-983.

[20880] P. A. Selden. "Missing links between Argyroneta and Cybaeidae revealed by fossil spiders". English. In: The Journal of Arachnology 30 (2002), pp. 189-200.

[20881] P. A. Selden. "A theridiosomatid spider from the Early Cretaceous of Russia". English. In: Bulletin of the British Arachnological Society 15 (2010), pp. 69-78.

[20882] P. A. Selden. "Revision of the fossil ricinuleids". English. In: Transactions of the Royal Society of Edinburgh: Earth Sciences 83 (1992), pp. 595-634.

[20883] P. A. Selden. "Spiders (Arachnida: Araneae) from the Insect Limestone (Bembridge Marls, Late Eocene) of the Isle of Wight, southern England". English. In: Earth and Environmental Science Transactions of the Royal Society of Edinburgh 104 (2014), pp. 275-282.

[20884] P. A. Selden. "A new spider (Araneae: Haplogynae: Plectreuridae) from the Cretaceous fossilLagerstätte of El Montsec, Spain". English. In: The Journal of Arachnology 42 (2014), pp. 16-23.

[20885] P. A. Selden, H. M. Anderson, and J. M. Anderson. "A review of the fossil record of spiders (Araneae) with special reference to Africa, and description of a new specimen from the Triassic Molteno Formation of South Africa". English. In: African Invertebrates 50 (2009), pp. 105-116.

[20886] P. A. Selden, J. M. Anderson, H. M. Anderson, and N. C. Fraser. "Fossil araneomorph spiders from the Triassic of South Africa and Virginia". English. In: The Journal of Arachnology 27 (1999), pp. 401-414.

[20887] P. A. Selden and R. G. Beattie. "A spider fossil from the Jurassic Talbragar fossil fish bed of New South Wales". English. In: Alcheringa 37 (2013), pp. 203-208.

[20888] P. A. Selden, F. C. Casado, and M. V. Mesquita. "Mygalomorph spiders (Araneae: Dipluridae) from the Lower Cretaceous Crato Lagerstätte, Araripe basin, north-east Brazil". English. In: Palaeontology 49 (2006), pp. 817-826.

[20889] P. A. Selden and J. A. Dunlop. "The first fossil spider (Araneae: Palpimanoidea) from the Lower Jurassic (Grimmen, Germany)". English. In: Zootaxa 3894 (2014), pp. 161-168.

[20890] P. A. Selden, J. A. Dunlop, and L. Simonetto. "A fossil whip-scorpion (Arachnida: Thelyphonida) from the Carboniferous of the Carnic alps (Friuli, NE Italy)". English. In: Rivista Italiana di Paleontologia e Stratigrafia 122 (2016), pp. 7-12.

[20891] P. A. Selden, J. A. Dunlop, G. Giribet, W. W. Zhang, and D. Ren. “The oldest armoured harvestman (Arachnida: Opiliones: Laniatores), from Upper Cretaceous Myanmar amber". English. In: Cretaceous Research 65 (2016), pp. 206-212.

[20892] P. A. Selden and J. Gall. "A Triassic mygalomorph spider from the northern Vosges, France". In: Palaeontology 35.1 (1992), pp. 211-235.

[20893] P. A. Selden and D. Huang. "The oldest haplogyne spider (Araneae: Plectreuridae), from the Middle Jurassic of China". English. In: Naturwissenschaften 97.5 (2010), pp. 449-459. DOI: 10.1007 / s00114-010-0649-z.

[20894] P. A. Selden, D. Y. Huang, and D. Ren. "Palpimanoid spiders from the Jurassic of China". English. In: The Journal of Arachnology 36 (2008), pp. 306-321.

[20895] P. A. Selden, D. Y. Huang, and R. J. Garwood. “New spiders (Araneae: Palpimanoidea) from the Jurassic Yanliao Biota of China". English. In: Journal of Systematic Palaeontology 18 (2019), pp. 137185. DOI: $10.1080 / 14772019.2019 .1584831$.

[20896] P. A. Selden and U. Kaulfuss. "Fossil arachnids from the earliest Miocene Foulden Maar fossilLagerstätte, New Zealand". English. In: Alcheringa 43 (2019), pp. 165-169. DOI: 10.1080/03115518. 2018.1450446. 
[20897] P. A. Selden, J. C. Lamsdell, and L. Qi. "An unusual euchelicerate linking horseshoe crabs and eurypterids, from the Lower Devonian (Lochkovian) of Yunnan, China". English. In: Zoologica Scripta 44 (2015), pp. 645-652. DOI: 10.1111/zsc.12124.

[20898] P. A. Selden, K. S. Nam, S. H. Kim, and H. J. Kim. "A fossil spider from the Cretaceous of Korea”. English. In: Journal of Paleontology 86 (2012), pp. 1-6.

[20899] P. A. Selden and D. Penney. "A fossil spider (Araneae: Pisauridae) of Eocene age from Horsefly, British Columbia, Canada". English. In: Contributions to Natural History 12 (2009), pp. 1269-1282.

[20900] P. A. Selden and D. Penney. "Lower Cretaceous spiders (Arthropoda: Arachnida: Araneae) from Spain". English. In: Neues Jahrbuch für Geologie und Paläontologie, Monatshefte 2003 (2003), pp. 175192.

[20901] P. A. Selden and G. L. Pillola. "A trigonotarbid arachnid from the Upper Carboniferous of the San Giorgio basin, Sardinia". English. In: Rivista Italiana di Paleontologia e Stratigrafia 115 (2009), pp. 269-274.

[20902] P. A. Selden, D. Ren, and C. K. Shih. "Mesozoic cribellate spiders (Araneae: Deinopoidea) from China". English. In: Journal of Systematic Palaeontology 14 (2015), pp. 49-74.

[20903] P. A. Selden, D. E. Shcherbakov, J. A. Dunlop, and K. Y. Eskov. “Arachnids from the Carboniferous of Russia and Ukraine, and the Permian of Kazakhstan". English. In: Paläontologische Zeitschrift 88 (2014), pp. 297-307.

[20904] P. A. Selden and W. A. Shear. "The first mesozoic Solifugae (Arachnida), from the Cretaceous of Brazil, and a redescription of the Palaeozoic Solifuge". In: Palaeontology 39.3 (1996), pp. 583-604.

[20905] P. A. Selden, W. A. Shear, and P. M. Bonamo. "A spider and other arachnids from the Devonian of New York, and reinterpretations of Devonian Araneae". English. In: Palaeontology 34 (1991), pp. 241-281.

[20906] P. A. Selden, C. K. Shih, and D. Ren. “A golden orb-weaver spider (Araneae: Nephilidae: Nephila) from the Middle Jurassic of China". English. In: Biology Letters (2011). DOI: 10.1098/rsbl.2011.0228.

[20907] P. A. Selden, C. K. Shih, and D. Ren. "A giant spider from the Jurassic of China reveals greater diversity of the orbicularian stem group". English. In: Naturwissenschaften 100 (2013), pp. 11711181.

[20908] P. A. Selden, L. Simonetto, and G. Marsiglio. “An effaced horseshoe crab (Arthropoda: Chelicerata: Xiphosura) from the Upper Carboniferous of the Carnic Alps (Friuli, NE Italy)". English. In: Rivista Italiana di Paleontologia e Stratigrafia 125 (2019), pp. 333-342.

[20909] P. A. Selden and Y. N. Wang. "Fossil spiders (Araneae) from the Eocene Green River Formation of Colorado". English. In: Arthropoda Selecta 23 (2014), pp. 207-219.

[20910] P. A. Selden and T. Wappler. "A new spider (Arachnida: Araneae) from the Middle Eocene Messel Maar, Germany". English. In: Palaeoentomology 2 (2019), pp. 596-601.

[20911] P. A. Selden, W. W. Zhang, and D. Ren. "A bizarre armoured spider (Araneae: Tetrablemmidae) from Upper Cretaceous Myanmar amber". English. In: Cretaceous Research 66 (2016), pp. 129-135.

[20912] A. G. Sellés, A. Blanco, B. Vila, J. Marmi, F. J. LópezSoriano, S. Llácer, J. Frigola, M. Canals, and A. Galobart. "A small Cretaceous crocodyliform in a dinosaur nesting ground and the origin of sebecids". English. In: Scientific Reports 10 (2020), 15293:1-11. DOI: 10.1038/s41598-020-71975-y.

[20913] A. G. Sellés, A. M. Bravo, X. Delclós, F. Colombo, X. Mart, J. Ortega-Blanco, C. Parellada, and Á Galobart. "Dinosaur eggs in the Upper Cretaceous of the Coll de Nargó area, Lleida Province, south-central Pyrenees, Spain: Oodiversity, biostratigraphy and their implications". English. In: Cretaceous Research 40.1 (2013), pp. 10-20.

[20914] A. G. Sellés and B. Vila. "Re-evaluation of the age of some dinosaur localities from the southern Pyrenees by means of megaloolithid oospecies". English. In: Journal of Iberian Geology 41.1 (2015), pp. 125-139. 
[20915] A. G. Sellés, B. Vila, and Á Galobart. "Spheroolithus europaeus, oosp. nov. (Late Maastrichtian, Catalonia), the youngest oological record of hadrosauroids in Eurasia". English. In: Journal of Vertebrate Paleontology 34.3 (2014), pp. 725-729. DOI: 10.1080/02724634.2013.819360.

[20916] V. Semeniuk. "New Pleistocene and Holocene stratigraphic units in the Yalgorup Plain area, southern Swan Costal Plain". English. In: Journal of the Royal Society of Western Australia 78 (1995), pp. 6779.

[20917] Y. Séméria and A. Nel. "Paleochrysopa monteilsensis gen. et sp. nov., a new fossil of Chrysopidae from the Upper Eocene Formation of Monteils (France), with a review of known chrysopid fossils (Insecta: Neuroptera)". English. In: Advances in Neuropterology. Proceedings of the Third International Symposium on Neuropterology (1990), pp. 27-32.

[20918] K. Sen. "A new rauisuchian archosaur from the Middle Triassic of India". English. In: Palaeontology 48.1 (2005), pp. 185-196.

[20919] K. Sen. "Pamelaria dolichotrachela, a new prolacertid reptile from the Middle Triassic of India". English. In: Journal of Asian Earth Sciences 21 (2003), pp. 663-681.

[20920] S. Sen. "Pliocene vertebrate locality of Calta, Ankara, Turkey. 4. Rodentia and Lagomorpha". In: Geodiversitas 20.3 (1998), pp. 359-378.

[20921] S. Sen. "Rodents and insectivores from the Upper Miocene of Molayan, Afghanistan". English. In: Palaeontology 44.5 (2001), pp. 913-932.

[20922] S. Sen. "Early Pliocene porcupine (Mammalia, Rodentia) from Perpignan, France: a new systematic study". English. In: Geodiversitas 23.2 (2001), pp. 303-312.

[20923] S. Sen, P.-O. Antoine, B. Varol, T. Ayyildiz, and K. Sözeri. "Giant rhinoceros Paraceratherium and other vertebrates from Oligocene and middle Miocene deposits of the Kazman-Tuzluca Basin, Eastern Turkey". English. In: Naturwissenschaften 98 (2011), pp. 407-423. DOI: 10.1007/ s00114-0110786-z.

[20924] S. Sen, G. Bouvrain, and D. Geraads. "Pliocene vertebrate locality of Calta, Ankara, Turkey. 12. Paleoecology, biogeography and biochronology". In: Geodiversitas 20.3 (1998), pp. 497-510.

[20925] S. Sen, L. de Bonis, N. Dalfes, D. Geraads, J. J. Jaeger, and J. M. Mazin. "Premiere decouverte d'un site a mammiferes pleistocenes dans une fissure karstique en Anatolie centrale". French. In: Comptes Rendus de l'Academie des Sciences, Paris, Serie II 313 (1991), pp. 127-132.

[20926] S. Sen, F. Fack, G. Métais, and E. Moissenet. "A late Miocene mammalian fauna from Olba in the Sarriot'n Depression, eastern Spain". English. In: Paläontologische Zeitschrift 89 (2015), pp. 545-562.

[20927] M. V. A. Sena, R. C. L. P. Andrade, R. A. M. Bantim, J. M. Sayão, J. A. Barbosa, and G. R. Oliveira. "New dyrosaurid remains (Crocodyliformes, Mesoeucrocodylia) from the". English. In: Revista Brasileira de Paleontologia 20.3 (2017), pp. 345-354.

[20928] H. Sendi and D. Azar. "New aposematic and presumably repellent bark cockroach from Lebanese amber". English. In: Cretaceous Research 72 (2016), pp. 13-17.

[20929] H. Sendi, J. Hinkelman, L. Vranská, T. Kúdelová, M. Kúdela, M. Zuber, T. van de Kamp, and P. Vranský. "Roach nectarivory, gymnosperm and earliest flower pollination evidence from Cretaceous ambers". English. In: Biologia 75 (2020), pp. 1613-1630. DOI: 10.2478/s11756-019-00412-x.

[20930] H. Sendi, P. Vranský, L. Podstrelená, J. Hinkelman, T. Kúdelová, M. Kúdela, L. Vidlika, X. Y. Ren, and D. L. J. Quicke. "Nocticolid cockroaches are the only known dinosaur age cave survivors". English. In: Gondwana Research 82 (2020), pp. 288-298. DOI: 10.1016/j.gr.2020.01.002.

[20931] F. Sénégas and J. Michaux. "Boltimys broomi gen. nov. (Rodentia, Mammalia), nouveau Muridae d'affinité incertaine du Pliocéne inférieur d'Afrique du Sud". French. In: Comptes Rendus de l'Académie des Sciences - Series IIA - Sciences de la Terre et des planétes 330 (2000), pp. 521-525.

[20932] D. P. Sengupta. "Chigutisaurid temnospondyls from the Late Triassic of India and a review of the Family Chigutisauridae". English. In: Palaeontology 38.2 (1995), pp. 313-339.

[20933] D. S. Sengupta. "Triassic temnospondyls of the Pranhita-Godavari basin, India". English. In: Journal of Asian Earth Sciences 21 (2003), pp. 655-662. 
[20934] H. Senkowiczowa and E. Popiel-Barczyk. "Some Terebratulida (Brachiopoda) from the Muschelkalk sediments in the Holy Cross Mts". English. In: Geological Quarterly 40.3 (1996), pp. 443-466.

[20935] A. G. Sennikov. "New tanystropheids (Reptilia: Archosauromorpha) from the Triassic of Europe". English. In: Paleontological Journal 45.1 (2011), pp. 90-104.

[20936] A. G. Sennikov. "The first ctenosauriscid (Reptilia: Archosauromorpha) from the Lower Triassic of Eastern Europe". English. In: Paleontological Journal 46.5 (2012), pp. 499-511.

[20937] A. G. Sennikov. "The evolution of the postcranial skeleton in archosaurs in connection with new finds of the Rauisuchidae in the Early Triassic of Russia". English. In: Paleontological Journal 33.6 (1999), pp. 648-659.

[20938] A. G. Sennikov. “Discovery of a primitive sauropterygian from the Lower Triassic of the Donskaya Luka (Don Basin) and the Range of Triassic marine reptiles in Russia". English. In: Paleontological Journal 35.3 (2001), pp. 301-309.

[20939] A. G. Sennikov. "[The first Middle Triassic proterosuchid from eastern Europe]". Russian. In: Doklady RAN 336 (1994), pp. 659-661.

[20940] A. G. Sennikov. "A new specialized prolacertilian (Reptilia: Archosauromorpha) from the Lower Triassic of the Orenburg Region". English. In: Paleontological Journal 39.2 (2005), pp. 199-209.

[20941] A. G. Sennikov. "New data on the rauisuchids of Eastern Europe". English. In: Paleontological Journal 3 (1990), pp. 1-12.

[20942] A. G. Sennikov. "[An enigmatic reptile from the Upper Permian of the Volga River Basin]". Russian. In: Paleontologicheskii Zhurnal 1997.1 (1997), pp. 95-103.

[20943] A. G. Sennikov. “Oldest proterosuchids from the Triassic of eastern Europe". Russian. In: Doklady Akademii Nauk 326 (1992), pp. 896-899.

[20944] A. G. Sennikov and M. S. Arkhangelsky. "On a typical Jurassic sauropterygian from the Upper Triassic of Wilczek Land (Franz Josef Land, Arctic Russia)". English. In: Paleontological Journal 44.5 (2010), pp. 567-572.

[20945] A. G. Sennikov and V. K. Golubev. "Vyazniki Biotic Assemblage of the Terminal Permian". English. In: Paleontological Journal 40.suppl. 4 (2006), S475-S481.

[20946] N. V. Sennikov, E. V. Lykova, O. T. Obut, T. Yu. Tolmacheva, and N. G. Izokh. “The new Ordovician stage standard as applied to the stratigraphic units of the western Altai-Sayan Folded Area". English. In: Russian Geology and Geophysics 55 (2014), pp. 971-988. DOI: 10.1016/j.rgg.2014.07.005.

[20947] N. V. Sennikov, O. T. Obut, E. V. Lykova, A. V. Timokhin, T. V. Gonta, R. A. Khabibulina, T. A. Shcherbanenko, and T. P. Kipriyanova. Ordovician Sedimentary Basin and Paleobiotas of the Gorny Altai. English. Novosibirsk: SB RAS, 2019, pp. 1-183.

[20948] B. Senowbari and M. Link. "Bicoelia corticifera, a new inozoid sponge from the Upper Triassic". English. In: Turkish Journal of Earth Sciences 23 (2014), pp. 575-579.

[20949] B. Senowbari-Daryan. "Upper Triassic Reefs and Reef communities of Iran”. In: Göttinger Arbeiten zur Geologie und Paläontologie, Sb 2 (1996), pp. 299-304.

[20950] B. Senowbari-Daryan. "Mesozoic sponges of the Pucara Group, Peru". English. In: Palaeontographica Abteilung A 233 (1994), pp. 57-74.

[20951] B. Senowbari-Daryan. "Peronidellen (Schwämme) der Trias und Beschreibung von Peronidella iranica n. sp. aus der Obertrias (Nor-Rhät) des Iran und von Österreich". German. In: Jahrbuch der Geologischen Bundesanstalt 143.1 (2003), pp. 63-72.

[20952] B. Senowbari-Daryan. "Micropaleontology of Limestone Beds within the Shotori Dolomite (Triassic) of Kuh-e Nayband, Tabas Area, East-Central Iran". In: Facies 48 (2003), pp. 115-126.

[20953] B. Senowbari-Daryan. "Die systematische Stellung der thalamiden Schwämme und ihre Bedeutung in der Erdgeschichte". German. In: Münchener Geowissenschaftliche Abhandlungen, Reihe A 21 (1990), pp. 5-326. 
[20954] B. Senowbari-Daryan. “Hypercalcified sphinctozoan sponges from Upper Triassic (Norian-Rhaetian) reefs of the Nayband Formation (Central and Northeast Iran)". English. In: Jahrbuch der Geologischen Bundesanstalt 145.2 (2005), pp. 171-277.

[20955] B. Senowbari-Daryan. "Segmentierte Schwämme (Sphinctozoen) aus der Obertrias (Nor) des TaurusGebirges (S-Türkei) [Upper Triassic (Norian) segmented sponges (Sphinctozoa) from the Taurus Mountains (Southern Turkey)]". German. In: Abhandlungen der Geologischen Bundesanstalt 50 (1994), pp. 415-446.

[20956] B. Senowbari-Daryan. “Inozoide Schwämme aus obertriassischen (Nor-Rhät) Riffen der NaybandFormation (NE und Zentraliran) [Inozoid sponges from Upper Triassic (Norian-Rhaetian) reefs of the Nayband Formation (NE and central Iran)]". German. In: Senckenbergiana lethaea 85.2 (2005), pp. 261-299.

[20957] B. Senowbari-Daryan. “Coralline Schwämme aus dem norisch-rhätischen Dachstein-Riff des Gosaukammes (Nördliche Kalkalpen, Österreich) [Coralline sponges from the Norian-Rhaetian Dachstein Reef of the Gosaukamm (Northern Calcareous Alps, Austria)]". German. In: Jahrbuch der Geologischen Bundesanstalt 149 (2009), pp. 111-166.

[20958] B. Senowbari-Daryan. "Enoplocoelia? gosaukammensis - ein neuer thalamider Schwamm aus den obertriadischen Riffkalken des Gosaukammes (Nördliche Kalkalpen, Österreich) [Enoplocoelia? gosaukammensis - a new thalamid sponge from the Upper Triassic reef limestones of the Gosaukamm (Northern Calcareous Alps, Austria)]". German. In: Jahrbuch der Geologischen Bundesanstalt 137.4 (1994), pp. 669-674.

[20959] B. Senowbari-Daryan and F. Amirhassankhani. "Chambered hexactinellid sponges from Upper Triassic (Norian-Rhaetian?) reefs of Nayband Formation in central Iran". English. In: Rivista Italiana di Paleontologia e Stratigrafia 118 (2012), pp. 247-260.

[20960] B. Senowbari-Daryan and F. Amirhassankhani. “Lovcenipora iranica nov. sp., an unusually large chaetetid sponge from the Upper Triassic (Howz-e Khan member, Nayband Formation) of northeast Iran". English. In: Zitteliana A 53 (2013), pp. 15-22.

[20961] B. Senowbari-Daryan, M. Bernecker, L. Krystyn, and M. Siblik. “Carnian reef biota from a megabreccia of the Hawasina complex (Al Aqil, Oman)". In: Rivista Italiana di Paleontologia e Stratigrafia 105.3 (1999), pp. 327-342.

[20962] B. Senowbari-Daryan and M. Bernecker. "Amblysiphonella agahensis nov. sp., and Musandamia omanica nov. gen., nov. sp. (Porifera) from the Upper Triassic of Oman". English. In: Zitteliana A 50 (2010), pp. 3-7.

[20963] B. Senowbari-Daryan, A. H. Caruthers, and G. D. Stanley Jr. "The First Upper Triassic Silicified Hypercalcified Sponges from the Alexander Terrane, Gravina Island and Keku Strait, Southeast Alaska". English. In: Journal of Paleontology 82.2 (2008), pp. 344-350.

[20964] B. Senowbari-Daryan, P. di Stefano, and B. Abate. Hypercalcified sponges from the Upper Triassic (Norian-Rhaetian) reefs of Sicily. English. Vol. 10. Qauderni del Museo Geologico G.G. Gemmellaro. 2015.

[20965] B. Senowbari-Daryan, F. T. Fürsich, and K. Rashidi. "Sponges from the Jurassic of the Shotori MountainsPart III. Endostoma Roemer, Eudea Lamouroux, Pareudea Étallon, Preperonidella Finks \& Rigby, Polyendostoma Roemer, Seriespongia n. gen., and Iniquispongia n. gen". English. In: Revue de Paléobiologie, Genéve 39.1 (2020), pp. 265-301. DOI: 10.5281/zenodo.3936171.

[20966] B. Senowbari-Daryan and A. Hamadani. “Obertriadische (Nor) Dasycladaceen aus der NaybandFormation vom Zentraliran". German. In: Revue Paléobiologie 19.1 (2000), pp. 97-121.

[20967] B. Senowbari-Daryan and H. Hamadani. "Thalamid Sponges from the Upper Triassic (NorianRhaetian) Nayband Formation near Wali Abad, SE Abadeh, Central Iran. (Contribution to Triassic Paleontology of Iran 4)". In: Rivista Italiana di Paleontologia e Stratigrafia 105.1 (1999), pp. 79-100.

[20968] B. Senowbari-Daryan, A. Hamedani, and K. Rashidi. "Sponges from the Permian of Hambast Mountains, south of Abadeh, central Iran". English. In: Facies 53.4 (2007), pp. 575-614. 
[20969] B. Senowbari-Daryan and A. Hamedani. "First report of the occurrence of Amblysiphonella (thalamid sponge) in Permian of Iran and description of A. iranica n. sp. from central Iran". English. In: Revue de Paléobiologie, Genéve 21 (2002), pp. 795-801.

[20970] B. Senowbari-Daryan and R. Ingavat-Helmcke. "Sponge assemblage of some Upper Permian reef limestones from Phrae province (Northern Thailand)". In: Geologija 36 (1994), pp. 5-59.

[20971] B. Senowbari-Daryan, S. Kovács, and F. Velledits. "Sponges from the Middle Triassic reef limestone of the Aggtelek Karst (NE Hungary)". English. In: Geologica Carpathica 62 (2011), pp. 397412.

[20972] B. Senowbari-Daryan and M. Link. "Filograna (colonial serpulid worm tubes) from Upper Triassic (Norian) reef boulders of Taurus Mts. (southern Turkey)". English. In: Facies 51 (2005), pp. 454459.

[20973] B. Senowbari-Daryan, M. Link, and I. Isintek. "Calcareous algae from the Triassic (Anisian reef boulders and Norian reef limestones) of Karaburun, western Turkey". English. In: Facies 52 (2006), pp. $129-148$.

[20974] B. Senowbari-Daryan, M. Link, and I. Isintek. "Filograna minor nov. sp. (worm tube) from the Middle Triassic (Anisian) reef boulders of the Karaburun Peninsula, western Turkey". English. In: Turkish Journal of Earth Sciences 16 (2007), pp. 381-389.

[20975] B. Senowbari-Daryan, M. Link, and D. C. Garcia-Bellido. "Fanthalamia kadiri nov. sp., a new sphinctozoan sponge from the Triassic (Carnian) of Turkey". English. In: Studia Universitatis BabesBolyai, Geologia 48.2 (2003), pp. 125-131.

[20976] B. Senowbari-Daryan and M. Link. "Solenoporaceen aus den obertriassischen (Nor) Riffkalken des Taurusgebirges (Antalya-Gebiet, Südtürkei) [Upper Triassic (Norian) solenoporaceans from the reef limestones of the Taurus Mountains (Antalya, southern Turkey)]". German. In: Palaeontologische Zeitschrift 79.4 (2005), pp. 409-427.

[20977] B. Senowbari-Daryan and M. Link. "A new thalamid sponge from the Upper Triassic reef limestones of the Antalya region (Turkey)". English. In: Acta Geologica Hungarica 41.3 (1998), pp. 343354.

[20978] B. Senowbari-Daryan and M. Link. “Desmekalamos fuersichi nov. gen., nov. sp., ein Mikroröhrchen (Cyanophyceen?) aus den norischen Riffkalken des Taurus-Gebirges (Trias, Südtürkei) [Desmekalamos fuersichi nov. gen., nov. sp., a microtube (Cyanophycea?) from the Norian reef limestones of Taurus Mountains (Triassic, southern Turkey)]". German. In: Beringeria 37 (2007), pp. 181-188.

[20979] B. Senowbari-Daryan and M. Link. "Hypercalcified segmented sponges (sphinctozoans) from the Upper Triassic (Norian) reef boulders of Taurus Mountains (southern Turkey)". English. In: Facies 57.4 (2011), pp. 663-693.

[20980] B. Senowbari-Daryan and M. Link. "Hypercalcified inozoan sponges from the Norian reef carbonates of Turkey". English. In: Revue de Paléobiologie, Genéve 35.1 (2016), pp. 279-339.

[20981] B. Senowbari-Daryan, M. Link, and P. Riedel. “Colospongia cribrifera nov. sp. and Parastylothalamia minima nov. sp." English. In: Revue de Paleobiologie, Geneve 34.1 (2015), pp. 1-9.

[20982] B. Senowbari-Daryan, D. Matarangas, and M. Vartis-Matarangas. "Norian-Rhaetian reefs in Argolis Peninsula, Greece". In: Facies 34 (1996), pp. 77-82.

[20983] B. Senowbari-Daryan and F. Maurer. “Upper Triassic (Norian) hypercalcified sponges from the Musandam Peninsula (United Arab Emirates and Oman)". English. In: Facies 54 (2008), pp. 433460.

[20984] B. Senowbari-Daryan, K. Rashidi, and A. Hamedani. "Sponge assemblage from the Permian reefal limestones of Kuh-e Bagh-e Vang, Shotori Mountains (eastern Iran)". English. In: Geologica Carpathica 56.5 (2005), pp. 381-406.

[20985] B. Senowbari-Daryan, K. Rashidi, and A. Hamedani. "Two Permian sphinctozoan sponges from the Shotori Mountains (eastern Iran)". English. In: Geologica Carpathica 57.6 (2006), pp. 427-432. 
[20986] B. Senowbari-Daryan, K. Rashidi, and H. Bettollah. "Hypercalcified sponges from a small reef within the Norian-Rhaetian Nayband Formation near Yazd, central Iran". English. In: Rivista Italiana di Paleontologia e Stratigrafia 117.2 (2011), pp. 269-281.

[20987] B. Senowbari-Daryan and M. F. Ridd. "Two new Triassic sphinctozoan sponge species from near Kantang, Trnag Province, southern Thailand". English. In: Palaeontologische Zeitschrift 82.3 (2008), pp. 254-261.

[20988] B. Senowbari-Daryan and J. K. Rigby. "First report of Lercaritubus in North America, from the Permian Capitan Limestone, Guadalupe Mountains, New Mexico". English. In: Journal of Paleontology 70 (1996), pp. 22-26.

[20989] B. Senowbari-Daryan and J. K. Rigby. "Brachiopod mounds not sponge reefs, Permian CapitanTansill Formations, Guadalupe Mountains, New Mexico". English. In: Journal of Paleontology 70 (1996), pp. 697-701.

[20990] B. Senowbari-Daryan and J. K. Rigby. "Hikorocodium Endo is not an alga but an inozoid sponge". English. In: Canadian Journal of Earth Sciences 44 (2007), pp. 149-154.

[20991] B. Senowbari-Daryan and J. K. Rigby. "Three additional thalamid sponges from the Upper Permian reefs of Djebel Tebaga (Tunisia)". In: Journal of Paleontology 65.4 (1991), pp. 623-629.

[20992] B. Senowbari-Daryan, K. Seyed-Emami, and A. Aghanabati. "Some Inozoid sponges from Upper Triassic (Norian-Rhaetian) Nayband Formation of Central Iran". In: Rivista Italiana di Paleontologia e Stratigrafia 103.3 (1997), pp. 293-322.

[20993] B. Senowbari-Daryan and G. D. Stanley. "Late Triassic thalamid sponges from Nevada". English. In: Journal of Paleontology 66 (1992), pp. 183-193.

[20994] B. Senowbari-Daryan and G. D. Stanley. “Neoguadalupia oregonensis new species: Reappearance of a Permian sponge genus in the Upper Triassic Wallowa terrane, Oregon". English. In: Journal of Paleontology 72.2 (1998), pp. 221-224.

[20995] B. Senowbari-Daryan, G. D. Stanley, and T. Onoue. "Upper Triassic (Carnian) reef biota from the Sambosan Accretionary Complex, Kyushu, Japan". English. In: Facies 58 (2012), pp. 671-684.

[20996] B. Senowbari-Daryan and G. D. Stanley Jr. "Lower Jurassic marine carbonate deposits in central Peru: stratigraphy and paleontology". English. In: Palaeontographica Abteilung A 233 (1994), pp. 4356.

[20997] B. Senowbari-Daryan, G. D. Stanley Jr., and C. Gonzalez-Leon. "A new Triassic sponge from the Antimonio terrane, Sonora, Mexico". English. In: Journal of South American Earth Sciences 14 (2001), pp. 447-452.

[20998] B. Senowbari-Daryan, H. Torabi, and K. Rashidi. “New solenoporaceans from Upper Triassic (Norian-Rhaetian) reef limestones in central Iran". English. In: Geologica Croatica 61 (2008), pp. 135157.

[20999] B. Senowbari-Daryan and T. E. Yancey. "A sphinctozoan sponge from the Late Triassic (Norian) of the United Arab Emirates". English. In: Journal of Paleontology 81.5 (2007), pp. 1128-1131.

[21000] B. Senowbari-Daryan and V. Zamparelli. "Upper Triassic Sphinctozoan sponges from Northern Calabria (Southern Italy)". In: Rivista Italiana di Paleontologia e Stratigrafia 105.1 (1999), pp. 145154.

[21001] B. Senowbari-Daryan and V. Zamparelli. “Upper Triassic (Norian-Rhaetian) new thalamid sponges from northern Calabria (southern Italy)". English. In: Studia Universitatis Babes-Bolyai, Geologia 48.2 (2003), pp. 113-124.

[21002] B. Senowbari-Daryan and V. Zamparelli. "Triassic hamimedaceans: new genera and species from the Alps, Sicily and southern Apennines". English. In: Revista Espanola de Micropaleontologia 37.1 (2005), pp. 141-169.

[21003] B. Senowbari-Daryan and H. Zankl. "First chambered hexactinellid sponge from the Upper Triassic Dachstein Reef Limestone (Hoher Göll, Northern Calcareous Alps)". English. In: Jahrbuch der Geologischen Bundesanstalt A 150 (2010), pp. 389-392. 
[21004] B. Senowbari-Daryan, R. Zühlke, T. Bechstädt, and E. Flügel. “Anisian (Middle Triassic) buildups of the northern Dolomites (Italy): The recovery of reef communities after the Permian/Triassic crisis". In: Facies 28 (1993), pp. 181-256.

[21005] S. Senqupta, M. Ezcurra, and S. Bandyopadhyay. "A new horned and long-necked herbivorous stem-archosaur from the Middle Triassic of India". English. In: Scientific Reports 7.8366 (2017). DOI: 10.1038/s41598-017-08658-8.

[21006] P. Senter, J. I. Kirkland, D. D. DeBlieux, S. Madsen, and N. Toth. “New dromaeosaurids (Dinosauria: Theropoda) from the Lower Cretaceous of Utah, and the evolution of the dromaeosaurid tail". English. In: PLoS ONE 7.5 (2012), e36790. DOI: 10.1371/journal.pone.0036790.

[21007] P. Senter, J. I. Kirkland, J. Bird, and J. A. Bartlett. "A new troodontid theropod dinosaur from the Lower Cretaceous of Utah". English. In: PLoS ONE 5.12 (2010), e14329. DOI: 10.1371/journal.pone. 0014329.

[21008] P. Senter, J. I. Kirkland, and D. D. DeBlieux. "Martharaptor greenriverensis, a new theropod dinosaur from the Lower Cretaceous of Utah". English. In: PLoS ONE 7.8 (2012), e43911:1-12. DOI: 10.1371/journal.pone.0043911.

[21009] K. S. Seo, H. Y. Lee, and R. L. Ethington. "Early Ordovician conodonts from the Dumugol Formation in the Baegunsan Syncline, eastern Yeongweol and Samcheog areas, Kangweon-Do, Korea". English. In: Journal of Paleontology 68.3 (1994), pp. 599-616. DOI: 10.1017/S0022336000025944.

[21010] F. Seoane and E. Cerdeño. "First Extra-Patagonian Record of Asmodeus Ameghino (Notoungulata, Homalodotheriidae) in the Late Oligocene of Mendoza Province, Argentina". English. In: Ameghiniana 51.5 (2014), pp. 373-384.

[21011] F. D. Seoane, E. Cerdeño, and H. Singleton. "Re-assessment of the Oligocene genera Prosotherium and Propachyrucos (Hegetotheriidae, Notoungulata)". English. In: Comptes Rendus Palevol 18.6 (2019), pp. 643-662. DOI: 10.1016/j.crpv.2019.07.001.

[21012] J. J. Sepkoski. unpublished data. English. 2000.

[21013] S. E. K. Sequeira and M. I. Coates. “Reassessment of Cladodus neilsoni Traquair: a primitive shark from the Lower Carboniferous of East Kilbridge, Scotland". English. In: Palaeontology 43.1 (2000), pp. 153-172. DOI: 10.1111/1475-4983.00122.

[21014] J. Serangeli, T. V. Kolfschoten, B. M. Starkovichm, and I. Verheijen. “The European saber-toothed cat (Homotherium latidens) found in the Spear Horizon at Schöningen (Germany)". English. In: 89 (2015), pp. 172-180.

[21015] R. Serbet and R. A. Stockey. "Taxodiaceous pollen cones from the Upper Cretaceous (Horshoe Canyon Formation) of Drumheller, Alberta, Canada". In: Review of Palaeobotany and Palynology 70 (1991), pp. 67-76.

[21016] R. Serbet and G. W. Rothwell. "Anatomically preserved ferns from the Late Cretaceous of western North America. II. Blechnaceae and Dryopteridaceae". English. In: International Journal of Plant Sciences 167.3 (2006), pp. 703-709.

[21017] R. Serbet and G. W. Rothwell. "Anatomically preserved ferns from the Late Cretaceous of western North America: Dennstaedtiaceae". English. In: International Journal of Plant Sciences 164.6 (2003), pp. 1041-1051.

[21018] F. Seredszus and W. Wichard. "Fossil chironomids (Insecta, Diptera) in Baltic amber". English. In: Palaeontographica Abteilung A 279 (2007), pp. 49-91.

[21019] F. Seredszus and W. Wichard. "Overview and descriptions of fossil non-biting midges in Baltic amber (Diptera: Chironomidae)". English. In: Studia Dipterologica 17 (2010), pp. 121-129.

[21020] F. Seredszus and W. Wichard. "Buchonomyiinae (Diptera, Chironomidae) im Baltischen Bernstein". German. In: Studia Dipterologica 9 (2003), pp. 393-402.

[21021] P. C. Sereno. "Taxonomy, morphology, masticatory function and phylogeny of heterodontosaurid dinosaurs". English. In: Zookeys 226 (2012), pp. 1-225. DOI: 10.3897/zookeys.226.2840. 
[21022] P. C. Sereno. "Early Cretaceous ornithomimosaurs (Dinosauria: Coelurosauria) from Africa". English. In: Ameghiniana 54.5 (2017), pp. 576-616. DOI: 10.5710/AMGH.23.10.2017.3155.

[21023] P. C. Sereno and A. B. Arcucci. "Dinosaurian precursors from the Middle Triassic of Argentina: Marasuchus lilloensis, gen. nov". English. In: Journal of Vertebrate Paleontology 14.1 (1994), pp. 5373.

[21024] P. C. Sereno and A. B. Arcucci. "Dinosaurian precursors from the Middle Triassic of Argentina: Lagerpeton chanarensis". English. In: Journal of Vertebrate Paleontology 13.4 (1994), pp. 385-399.

[21025] P. C. Sereno, A. L. Beck, D. B. Dutheil, B. Gado, H. C. E. Larsson, G. H. Lyon, J. D. Marcot, O. W. M. Rauhut, R. W. Sadleir, C. A. Sidor, D. D. Varricchio, G. P. Wilson, and J. A. Wilson. A long-snouted predatory dinosaur from Africa and the evolution of spinosaurids. English. 1998.

[21026] P. C. Sereno, A. L. Beck, D. B. Dutheil, H. C. E. Larsson, G. H. Lyon, B. Moussa, R. W. Sadleir, C. A. Sidor, D. J. Varricchio, G. P. Wilson, and J. A. Wilson. "Cretaceous sauropods from the Sahara and the uneven rate of skeletal evolution among dinosaurs". In: Science 286 (1999), pp. 1342-1347.

[21027] P. C. Sereno and S. L. Brusatte. "Basal abelisaurid and carcharodontosaurid theropods from the Lower Cretaceous Elrhaz Formation of Niger". English. In: Acta Palaeontologica Polonica 53.1 (2008), pp. 15-46.

[21028] P. C. Sereno, D. B. Dutheil, M. Iarochene, H. C. E. Larsson, G. H. Lyon, P. M. Magwene, C. A. Sidor, D. J. Varricchio, and J. A. Wilson. "Predatory dinosaurs from the Sahara and Late Cretaceous faunal differentiation". English. In: Science 272 (1996), pp. 986-991.

[21029] P. C. Sereno and S. J. ElShafie. A New Long-Necked Turtle, Laganemys tenerensis (Pleurodira: Araripemydidae), from the Elrhaz Formation (Aptian-Albian) of Niger. English. Morphology and Evolution of Turtles. 2013, pp. 215-250. DOI: 10.1007/978-94-007-4309-0_14.

[21030] P. C. Sereno, C. A. Forster, R. R. Rogers, and A. M. Monetta. "Primitive dinosaur skeleton from Argentina and the early evolution of Dinosauria". English. In: Nature 361 (1993), pp. 64-66.

[21031] P. C. Sereno, E. A. A. Garcea, H. Jousse, C. M. Stojanowski, J. -F. Saliége, A. Maga, O. A. Ide, K. J. Knudson, A. M. Mercuri, T. W. Stafford Jr., T. G. Kaye, C. Giraudi, I. Massamba N'siala, E. Cocca, H. M. Moots, D. B. Dutheil, and J. P. Stivers. "Lakeside cemeteries in the Sahara: 5000 years of Holocene population and environmental change". English. In: PLoS ONE 3.8 (2008), e2995. DOI: 10.1371/journal.pone.0002995.

[21032] P. C. Sereno and H. C. E. Larsson. "Cretaceous crocodyliformes from the Sahara". English. In: ZooKeys 28 (2009), pp. 1-143. DOI: 10.3897/zookeys.28.325.

[21033] P. C. Sereno, R. N. Martnez, J. A. Wilson, D. J. Varricchio, O. A. Alcober, and H. C. E. Larsson. "Evidence for avian intrathoracic air sacs in a new predatory dinosaur from Argentina". English. In: PLoS ONE 3.9 (2008), e3303:1-20. DOI: 10.1371/journal.pone.0003303.

[21034] P. C. Sereno and F. E. Novas. "The skull and neck of the basal theropod Herrerasaurus ischigualastensis". English. In: Journal of Vertebrate Paleontology 13.4 (1994), pp. 451-476.

[21035] P. C. Sereno and C. Rao. "Early evolution of avian flight and perching: new evidence from the Lower Cretaceous of China". English. In: Science 255 (1992), pp. 845-848.

[21036] P. C. Sereno, C. A. Sidor, H. C. E. Larsson, and B. Gado. “A new notosuchian from the Early Cretaceous of Niger". English. In: Journal of Vertebrate Paleontology 23.2 (2003), pp. 477-482.

[21037] P. C. Sereno, L. Tan, S. L. Brusatte, H. J. Kriegstein, X. Zhao, and K. Cloward. “Tyrannosaurid skeletal design first evolved at small body size". English. In: Science (2009). DOI: 10.1126/science. 1177428.

[21038] P. C. Sereno and R. Wild. "Procompsognathus: theropod, thecodont or both?" English. In: Journal of Vertebrate Paleontology 12.4 (1992), pp. 435-458.

[21039] P. C. Sereno, J. A. Wilson, H. C. E. Larsson, D. B. Dutheil, and H. -D. Sues. “Early Cretaceous dinosaurs from the Sahara". English. In: Science 266.5183 (1994), pp. 267-271.

[21040] P. C. Sereno, J. A. Wilson, and J. L. Conrad. "New dinosaurs link southern landmasses in the midCretaceous". English. In: Proceedings of the Royal Society of London B 271.1546 (2004), pp. 1325-1330. 
[21041] P. C. Sereno, X. Zhao, L. Brown, and L. Tan. “New psittacosaurid highlights skull enlargement in horned dinosaurs". English. In: Acta Palaeontologica Polonica 52.2 (2007), pp. 275-284.

[21042] P. C. Sereno, X. Zhao, and L. Tan. "A new psittacosaur from Inner Mongolia and the parrot-like structure and function of the psittacosaur skull". English. In: Proceedings of the Royal Society B: Biological Sciences 277.1679 (2010), pp. 199-209. DOI: 10.1098/rspb.2009.0691.

[21043] T. A. Sergi and E. E. Perkovsky. "Latridius usovae, a new species of the minute brown scavenger beetles (Coleoptera, Latridiidae) from Rovno amber". English. In: Vestnik Zoologii 48 (2014), pp. 319-324.

[21044] T. A. Sergi, E. E. Perkovsky, and H. P. Reike. "Revelieria groehni - a new species of minute brown scavenger beetles (Coleoptera, Latridiidae) from Baltic amber". English. In: Vestnik Zoologii 47.6 (2013), e43-e48.

[21045] D. Serjeantson. "The Great Auk and the Gannet: a Prehistoric Perspective on the Extinction of the Great Auk". English. In: International Journal of Osteoarchaeology 11 (2001), pp. 43-55.

[21046] J. Serra-Kiel, E. Mató, E. Saula, A. Travé, C. Ferrández-Canadell, P. Busquets, J. M. Samsó, J. Tosquella, A. A. Barnolas, G. Álvarez Pérez, J. Franqués, and J. Romero. “An inventory of the marine and transitional Middle/Upper Eocene deposits of the Southeastern Pyrenean Foreland Basin (NE Spain)". English. In: Geologica Acta 1.2 (2003), pp. 201-229.

[21047] M. Serran, N. Centeno, N. Weiler, and J. G. Otero. "Massive death of pinnipeds 1200 years ago: Taphonomic history of the Lobos site (Golfo Nuevo, Patagonia, Argentina)". English. In: Quaternary International 183.1 (2008), pp. 135-142.

[21048] C. I. Serrano-Brañas, B. Espinosa-Chávez, S. A. Maccracken, C. Gutiérrez-Blando, C. de LeónDávilae, and J. F. Ventura. "Paraxenisaurus normalensis, a large deinocheirid ornithomimosaur from the Cerro del Pueblo Formation (Upper Cretaceous), Coahuila, Mexico". English. In: Journal of South American Earth Sciences 101 (2020), p. 102610. DOI: 10.1016/j.jsames.2020.102610.

[21049] C. I. Serrano-Brañas, R. Hernández-Rivera, E. Torres-Rodrguez, and B. Espinosa Chávez. A natural hadrosaurid endocast from the Cerro del Pueblo Formation (Upper Cretaceous) of Coahuila, Mexico. English. Vol. 35. Late Cretaceous Vertebrates from the Western Interior. New Mexico Museum of Natural History and Science Bulletin. 2006, pp. 317-321.

[21050] C. I. Serrano-Brañas, E. Torres-Rodrguez, P. C. R. Luna, I. Gonzalez, and C. Gonzalez-Leon. “Tyrannosaurid teeth from the Lomas Coloradas Formation, Cabullona Group (Upper Cretaceous) Sonora, México". English. In: Cretaceous Research 49 (2014), pp. 163-171.

[21051] C. I. Serrano-Brañas, E. Torres-Rodrguez, P. C. Reyes-Luna, I. González-Ramrez, and C. GonzálezLeón. "A new ornithomimid dinosaur from the Upper Cretaceous Packard Shale formation (Cabullona Group) Sonora, México". English. In: Cretaceous Research 58.1 (2016), pp. 49-62. DOI: 10. 1016/j.cretres.2015.08.013.

[21052] A. Serrano-Martnez, F. Knoll, I. Narváez, and F. Ortega. "Brain and pneumatic cavities of the braincase of the basal alligatoroid Diplocynodon tormis (Eocene, Spain)". English. In: Journal of Vertebrate Paleontology 39.1 (2019), e1572612:1-11. DOI: 10.1080/02724634.2019.1572612.

[21053] A. Serrano-Martnez, D. Vidal, L. Sciscio, F. Ortega, and F. Knoll. "Isolated theropod teeth from the Middle Jurassic of Niger and the early dental evolution of Spinosauridae". English. In: Acta Palaeontologica Polonica 61.2 (2016), pp. 403-415. DOI: 10.4202/app.00101.2014.

[21054] D. J. Serratos, P. Druckenmiller, and R. B. J. Benson. “A new elasmosaurid (Sauropterygia, Plesiosauria) from the Bearpaw Shale (Late Cretaceous, Maastrichtian) of Montana demonstrates multiple evolutionary reductions of neck length within Elasmosauridae". English. In: Journal of Vertebrate Paleontology 37.2 (2017), e1278608.

[21055] J. J. W. Sertich and M. A. Loewen. "A new basal sauropodomorph dinosaur from the Lower Jurassic Navajo Sandstone of southern Utah". English. In: PLoS One 5.3 (2010), e9789. DOI: 10.1371 / journal.pone.0009789. 
[21056] J. J. W. Sertich and P. M. O'Connor. "A new crocodyliform from the middle Cretaceous Galula Formation, southwestern Tanzania". English. In: Journal of Vertebrate Paleontology 34.3 (2014), pp. 576596.

[21057] C. Sesé and J. Morales. "Late Aragonian mammal sites of Cuesta del Rey (Duero Basin, Burgos, Spain)". English. In: Spanish Journal of Palaeontology 32.1 (2017), pp. 63-78.

[21058] J. A. Sessa. “The Dynamics of Rapid, Asynchronous Biotic Turnover in the Middle Devonian Appalachian Basin of New York". English. PhD thesis. 2003.

[21059] J. A. Sessa, T. J. Bralower, M. E. Patzkowsky, J. C. Handley, and L. C. Ivany. "Environmental and biological controls on the diversity and ecology of Late Cretaceous through early Paleogene marine ecosystems in the US Gulf Coastal Plain". English. In: Paleobiology 38.2 (2012), pp. 218-239.

[21060] J. A. Sessa, P. M. Callapez, P. A. Dinis, and A. J. W. Hendy. “Paleoenvironmental and paleobiogeographical implications of a Middle Pleistocene mollusc assemblage from the marine terraces of Baa das Pipas, southwest Angola". English. In: Journal of Paleontology 87.6 (2013), pp. 1016-1040.

[21061] J. A. Sessa, M. E. Patzkowsky, and T. J. Bralower. "Impact of lithification on the diversity, size distribution, and recovery dynamics of marine invertebrate assemblages". English. In: Geology 37.2 (2009), pp. 115-118. DOI: 10.1130/G25286A.1.

[21062] E. Setiyabudi. "An Early Pleistocene giant tortoise (Reptilia ; Testudines ; Testudinidae) from the Bumiayu area, Central Java, Indonesia". English. In: Journal of Fossil Research 42.1 (2009), pp. 1-11.

[21063] E. Setiyabudi, I. Kurniawan, H. Insani, and A. Takahashi. "Late Pleistocene Fossil Record of Cuora amboinensis (Testudines: Geoemydidae) from the Wajak Site, East Java, Indonesia, and Its Paleozoogeographic and Archeozoological Implications". English. In: Paleontological Research 25.1 (2020), pp. 25-31. DOI: $10.2517 / 2020$ PR007.

[21064] E. Setiyabudi, A. Takahashi, and Y. Kaifu. "First Certain Fossil Record of Orlitia borneensis (Testudines: Geoemydidae)". English. In: Current Herpetology 35.2 (2016), pp. 75-82.

[21065] T. Setoguchi, T. Tsubamoto, H. Hanamura, and K. Hachiya. "An early Late Cretaceous mammal from Japan, with reconsideration of the evolution of tribosphenic molars". English. In: Paleontological Research 3.1 (1999), pp. 18-28.

[21066] B. Seuss, A. Nützel, R. H. Mapes, and T. E. Yancey. “Facies and fauna of the Pennsylvanian Buckhorn Asphalt Quarry deposit: a review and new data on an important Palaeozoic fossil Lagerstätte with aragonite preservation". English. In: Facies 55 (2009), pp. 609-645.

[21067] B. Seuss, B. Senowbari-Daryan, A. Nützel, S. Dittrich, and J. Neubauer. "A chaetetid sponge assemblage from the Desmoinesian (upper Moscovian) Buckhorn Asphalt Quarry Lagerstätte in Oklahoma, USA". English. In: Rivista Italiana di Paleontologia e Stratigrafia 120.1 (2014), pp. 3-26.

[21068] G. D. Sevastopulo. "The early ontogeny of blastoids". English. In: Geological Journal 6.40 (2005), pp. 351-362. DOI: 10.1002/gj.1009.

[21069] J. evk, W. Krzemiski, and K. Skibiska. “Intriguing and beautiful: Adamacrocera adami gen. et sp. nov. from the Upper Cretaceous amber of Myanmar represents a new subfamily of Keroplatidae (Diptera: Bibionomorpha)". English. In: Insects 11.552 (2020). DOI: 10.3390/insects11090552.

[21070] P. Sevilla. "Rhinolophoidea (Chiroptera, Mammalia) from the upper Oligocene of Carrascosa del Campo (Central Spain)". English. In: Geobios 23.2 (1990), pp. 173-188.

[21071] L. Seward, S. D. Chapman, and A. P. Currant. "A catalogue of British Pleistocene birds identified by Colin JO Harrison and stored in the Natural History Museum, London, (Department of Palaeontology)". English. In: Historical Biology 18.2 (2006), pp. 235-254.

[21072] I. I. Sey and E. D. Kalacheva. "Lower Berriasian of Southern Primorye (Far East Russia) and the problem of Boreal-Tethyan correlation". In: Palaeogeography, Palaeoclimatology, Palaeoecology 150.12 (1999), pp. 49-63.

[21073] K. Seyed-Emami, F. T. Fürsich, M. Wilmsen, M. R. Majidifard, and A. Shekarifard. "Upper Triassic (Norian) cephalopods from the Ekrasar Formation (Shemshak Group) of northern Alborz, Iran". English. In: Rivista Italiana di Paleontologia e Stratigrafia 115 (2009), pp. 189-198. 
[21074] K. Seyed-Emami and M. Wilmsen. "Leymeriellidae (Cretaceous ammonites) from the lower Albian of Esfahan and Khur (Central Iran)". English. In: Cretaceous Research 60 (2016), pp. 78-90.

[21075] K. Seyed-Emami, A. Raoufian, and H. Zand-Moghadam. "Late Bajocian and Bathonian (Middle Jurassic) ammonites from the". English. In: 288.2 (2018), pp. 183-203. DOI: 10.1127/njgpa/2018/ 0732.

[21076] L. J. Seyfullah, E. Kustatscher, and W. A. Taylor. “The first discovery of in situ Verrucosisporites applanatus spores from the Middle Triassic flora from Bromsgrove (Worcestershire, UK)". English. In: Review of Palaeobotany and Palynology 197 (2013), pp. 15-25. DOI: 10.1016/j.revpalbo.2013.04.004.

[21077] K. L. Seymour. "Pleistocene vertebrates from the pre-late Wisconsinan Mill Creek site, St. Clair County, Michigan". English. In: Michigan Academician 36 (2004), pp. 181-211.

[21078] K. L. Seymour. "Perusing Talara: overview of the late Pleistocene fossils from the tar seeps of Peru". English. In: La Brea and Beyond: The Paleontology of Asphalt-Preserved Biotas. Los Angeles: Natural History Museum of Los Angeles County, 2015, pp. 97-110.

[21079] J. Sha, H. Cai, C. He, Z. Gu, J. Jiang, D. Yin, X. Zhao, Z. Liu, and B. Jiang. "Studies on the Early Cretaceous Longzhaogou and Jixi Groups of eastern Heilongjiang, northeast China, and their bearing on the age of supposedly Jurassic strata in eastern Asia". English. In: Journal of Asian Earth Sciences 20.2002 (2002), pp. 141-150.

[21080] J. Sha and F. T. Fursich. "Biostratigraphy of the Upper Jurassic-Lower Cretaceous bivalves Buchia and Aucellina of eastern Heilongjiang, northeast China". English. In: Geol. Mag. 130.4 (1993), pp. 533-542.

[21081] J. Sha and J. A. Grant-Mackie. "Late Permian to Miocene bivalve assemblages from Hohxil, QinghaiXizang Plateau, China". English. In: Journal of the Royal Society of New Zealand 26.4 (1996), pp. 429 455.

[21082] J. Sha, M. Matsukawa, H. Cai, B. Jiang, M. Ito, C. He, and Z. Gu. "The Upper Jurassic-Lower Cretaceous of eastern Heilongjiang, northeast China: stratigraphy and regional basin history". In: Cretaceous Research 24.6 (2003), pp. 715-728.

[21083] J. Sha, P. L. Smith, and F. T. Fursich. "Jurassic Ostreoida (Bivalvia) from China (Tanggula Mountains, Quinghai-Xizang Plateau) and their paleobiogeographic context". In: Journal of Paleontology 76.3 (2002), pp. 431-446.

[21084] M. N. Shaaban, H. M. Holail, M. A. El-Askary, and M. A. Rashed. "Environment and diagenesis of an Upper Cretaceous bioclastic oyster limestone bed, Red Sea Coast, Egypt". English. In: Facies 33 (1995), pp. 121-128.

[21085] Y. Shaked, A. Agnon, B. Lazar, S. Marco, U. Avner, and M. Stein. "Large earthquakes kill coral reefs at the north-west Gulf of Aqaba". English. In: Terra Nova 16 (2004), pp. 133-138.

[21086] Y. Shaked, B. Lazar, S. Marco, M. Stein, and A. Agnonb. "Late Holocene events that shaped the shoreline at the northern Gulf of Aqaba recorded by a buried fossil reef". English. In: Israel Journal of Earth Sciences 58 (2011), pp. 355-368.

[21087] H.-Y. Shan, Y.-N. Cheng, and X. -C. Wu. "The first fossil skull of Alligator sinensis from the Pleistocene, Taiwan, with a paleogeographic implication of the species". English. In: Journal of Asian Earth Sciences 69 (2013), pp. 17-25.

[21088] H.-Y. Shan, K.-Y. Wei, and C. -Y. Huang. "Morphometric Study of the Benthic Foraminiferal Clade Gaudryina". English. In: Collection and Research 19 (2006), pp. 35-47. DOI: 10.6693/CAR.2006.19.6.

[21089] H.-Y. Shan, X.-C. Wu, Y. -N. Cheng, and T. Sato. "A new tomistomine (Crocodylia) from the Miocene of Taiwan". English. In: Canadian Journal of Earth Sciences 46 (2009), pp. 529-555.

[21090] L. J. Shang, O. Béthoux, and D. Ren. "New stem-Phasmatodea from the Middle Jurassic of China". English. In: European Journal of Entomology 108 (2011), pp. 677-685.

[21091] Q. Shang, G. Cuny, and L. Chen. "Early Middle Jurassic vertebrate microremains from the Three Gorges area, southern China". English. In: Historical Biology 20.2 (2008), pp. 87-99. DOI: 10.1080/ 08912960701616935. 
[21092] Q.-H. Shang. "A new species of Nothosaurus from the early Middle Triassic of Guizhou, China". English. In: Vertebrata PalAsiatica 44.3 (2006), pp. 237-249.

[21093] Q.-H. Shang and C. Li. "On the occurrence of the ichthyosaur Shastasaurus in the Guanling biota (Late Triassic), Guizhou, China". English. In: Vertebrata PalAsiatica 47.3 (2009), pp. 178-193.

[21094] Q.-H. Shang and C. Li. "A new small-sized eosauropterygian (Diapsida: Sauropterygia) from the Middle Triassic of Luoping, Yunnan, southwestern China". English. In: Vertebrata PalAsiatica 53.4 (2015), pp. 265-280.

[21095] Q.-H. Shang, X.-C. Wu, and C. Li. "A new eosauropterygian from Middle Triassic of eastern Yunnan Province, southwestern China". English. In: Vertebrata PalAsiatica 49.2 (2011), pp. 155-171.

[21096] T. T. Shang, X. L. Wang, L. X. Zhang, and J. Chen. "A tiny yuripopovinid true bug (Hemiptera, Pentatomomorpha) from Cenomanian Burmese amber". English. In: Cretaceous Research 114.104534 (2020). DOI: $10.1016 /$ j.cretres.2020.104534.

[21097] S. Shao, L. Li, Y. Yang, and C. -F. Zhou. "Hyperphalangy in a new sinemydid turtle from the Early Cretaceous Jehol Biota". English. In: PeerJ 6 (2018), e5371:1-21.

[21098] M. D. Shapiro and F. A. Jenkins. "A cynodont from the Upper Triassic of East Greenland: tooth replacement and double-rootedness". English. In: Bulletin of the Museum of Comparative Zoology 156 (2001), pp. 49-58.

[21099] R. S. Shapiro and J. K. Rigby. "First occurrence of an in situ anthaspidellid sponge in a dendrolite mound (Upper Cambrian; Great Basin, USA)". In: Journal of Paleontology 78.4 (2004), pp. 645-650.

[21100] J. Sharifi, S. N. Raisossadat, M. Mortazavi Mehrizi, and M. Motamedalshariati. "Albian and Cenomanian ammonites of the eastern margin of the Lut block (East Iran)". English. In: Carnets de Géologie 16 (2016), pp. 591-613.

[21101] N. Sharma, R. K. Kar, A. Agarwal, and R. Kar. "Fungi in dinosaurian (Isisaurus) coprolites from the Lameta Formation (Maastrichtian) and its reflection on food habit and environment". English. In: Micropaleontology 51.1 (2005), pp. 73-82.

[21102] A. V. Shavrin and S. Yamamoto. “Unexpected palaeodiversity of omaliine rove beetles in Eocene Baltic amber (Coleoptera, Staphylinidae, Omaliinae)". English. In: ZooKeys 863 (2019), pp. 35-83.

[21103] A. V. Shavrin and S. Yamamoto. "A remarkable new species of the rove beetle genus Anthobium Leach, 1819 from Eocene Baltic amber (Coleoptera, Staphylinidae, Omaliinae)". English. In: ZooKeys 973 (2020), pp. 89-101. DOI: 10.3897/zookeys.973.53940.

[21104] C.-L. Shaw. “Fossil Polygonaceous Palynomorphs of Taiwan”. English. In: Taiwania 43.1 (1998), pp. 27-32. DOI: 10.6165/tai.1998.43(1).27.

[21105] F. C. Shaw. "Telephina and other trilobites from the Pratt Ferry Beds, Ordovician of Alabama, U.S.A." English. In: Journal of Paleontology 88.3 (2014), pp. 545-555. DOI: 10.1666/12-137.

[21106] F. C. Shaw. "Ordovician trinucleid trilobites of the Prague Basin, Czech Republic". English. In: Paleontological Society Memoir 40 (1995), pp. 1-23.

[21107] F. C. Shaw and T. E. Bolton. “Ordovician trilobites from the Romaine and Mingan Formations (Ibexian-Late Whiterockian), Mingan Islands, Quebec". English. In: Journal of Paleontology 85.3 (2011), pp. 406-441.

[21108] D. E. Shcherbakov. "New and little-known families of Hemiptera Cicadomorpha from the Triassic of Central Asia-early analogs of treehoppers and planthoppers". English. In: Zootaxa 2836 (2011), pp. 1-26.

[21109] D. E. Shcherbakov. "Extinct four-winged precoccids and the ancestry of scale insects and aphids (Hemiptera)". English. In: Russian Entomological Journal 16 (2007), pp. 47-62.

[21110] D. E. Shcherbakov. “Mesozoic Velocipedinae (Nabidae s. 1.) and Ceresopseidae (Reduvioidea), with notes on the phylogeny of Cimicomorpha (Heteroptera)". English. In: Russian Entomological Journal 16 (2007), pp. 401-414. 
[21111] D. E. Shcherbakov. "The most primitive whiteflies (Hemiptera; Aleyrodidae; Bernaeinae subfam. nov.) from the Mesozoic of Asia and Burmese amber, with an overview of Burmese amber hemipterans". English. In: Bulletin of the Natural History Museum, Geology Series 56 (2000), pp. 2937.

[21112] D. E. Shcherbakov. "The earliest find of Tropiduchidae (Homoptera: Auchenorrhyncha), representing a new tribe, from the Eocene of Green River, USA, with notes on the fossil record of higher Fulgoroidea". English. In: Russian Entomological Journal 15 (2006), pp. 315-322.

[21113] D. E. Shcherbakov. "Review of the fossil and extant genera of the cicada family Tettigarctidae (Hemiptera: Cicadoidea)". English. In: Russian Entomological Journal 17 (2008), pp. 343-348.

[21114] D. E. Shcherbakov. "Mesozoic spider mimics - Cretaceous Mimarachnidae fam. n. (Homoptera: Fulgoroidea)". English. In: Russian Entomological Journal 16.3 (2007), pp. 259-264.

[21115] D. E. Shcherbakov. "An extraordinary new family of Cretaceous planthoppers (Homoptera: Fulgoroidea)". English. In: Russian Entomological Journal 16.2 (2007), pp. 139-154.

[21116] D. E. Shcherbakov. "More on Mesozoic Membracoidea (Homoptera)". English. In: Russian Entomological Journal 21 (2012), pp. 15-22.

[21117] D. E. Shcherbakov. "Permian ancestors of Hymenoptera and Raphidioptera". English. In: ZooKeys 358 (2013), pp. 45-67.

[21118] D. E. Shcherbakov. "A new subfamily of Mesozoic Hylicellidae (Homoptera: Cicadomorpha)". English. In: Russian Entomological Journal 21 (2012), pp. 441-444.

[21119] D. E. Shcherbakov. "The earliest true bugs and aphids from the Middle Triassic of France (Hemiptera)". English. In: Russian Entomological Journal 19 (2010), pp. 179-182.

[21120] D. E. Shcherbakov. "Permian and Triassic ancestors of webspinners (Embiodea)". English. In: Russian Entomological Journal 24 (2015), pp. 187-200.

[21121] D. E. Shcherbakov. "First record of the Cretaceous family Mimarachnidae (Homoptera: Fulgoroidea) in amber". English. In: Russian Entomological Journal 26 (2017), pp. 389-392.

[21122] D. E. Shcherbakov. "The earliest fully brachypterous auchenorrhynchan from Cretaceous Burmese amber (Homoptera: Fulgoroidea: Jubisentidae)". English. In: Russian Entomological Journal 29 (2020), pp. 6-11.

[21123] D. E. Shcherbakov. "New Homoptera from the Early Cretaceous of Buryatia with notes on the insect fauna of Khasurty". English. In: Russian Entomological Journal 29 (2020), pp. 127-138.

[21124] D. E. Shcherbakov and D. Azar. "A new subfamily of Trichoceridae (Diptera: Tipulomorpha) from Early Cretaceous Lebanese amber". English. In: Zootaxa 4563 (2019), pp. 311-324.

[21125] D. E. Shcherbakov, E. D. Lukashevich, and V. A. Blagoderov. “Triassic Diptera and initial radiation of the order". English. In: International Journal of Dipterological Research 6.2 (1995), pp. 75-115.

[21126] D. E. Shcherbakov, V. N. Makarkin, D. S. Aristov, and D. V. Vasilenko. "Permian insects from the Russky Island, South Primorye". English. In: Russian Entomological Journal 18.1 (2009), pp. 7-16.

[21127] D. E. Shcherbakov, T. Timm, A. B. Tzetlin, O. Vinn, and A. Y. Zhuravlev. "A probable oligochaete from an Early Triassic Lagerstätte of the southern Cis-Urals and its evolutionary implications". English. In: Acta Palaeontologica Polonica 65 (2020), pp. 219-233. DOI: 10.4202/app.00704.2019.

[21128] D. E. Shcherbakov and P. Wegierek. "Creaphididae, a new and the oldest aphid family from the Triassic of middle Asia". English. In: Psyche 98 (1991), pp. 81-85.

[21129] W. A. Shear. "Gigantocharinus szatmaryi, a new trigonotarbid arachnid from the Late Devonian of North America (Chelicerata, Arachnida, Trigonotarbida)". English. In: Journal of Paleontology 74.1 (2000), pp. 25-31.

[21130] W. A. Shear, A. J. Jeram, and P. A. Selden. "Centiped legs (Arthropoda, Chilopoda, Scutigeromorpha) from the Silurian and Devonian of Britain and the Devonian of North America". English. In: American Museum Novitates 3231 (1998), pp. 1-16. 
[21131] W. A. Shear, P. A. Selden, and J. C. Gall. “Millipedes from the Grés á Voltzia, Triassic of France, with comments on Mesozoic millipedes (Diplopoda: Helminthomorpha: Eugnatha)". English. In: International Journal of Myriapodology 1 (2009), pp. 1-13.

[21132] S. L. Sheffield, W. I. Ausich, and C. D. Sumrall. "Late Ordovician (Hirnantian) diploporitan fauna of Anticosti Island, Quebec, Canada: implications for evolutionary and biogeographic patterns". English. In: Canadian Journal of Earth Sciences 55.1 (2018), pp. 1-7. DOI: 10.1139/ cjes-2017-0160.

[21133] S. L. Sheffield and C. D. Sumrall. "The phylogeny of the Diploporita: a polyphyletic assemblage of blastozoan echinoderms". English. In: Journal of Paleontology 93.3 (2019). DOI: 10.1017/jpa.2019.2.

[21134] B. Shen, S. Xiao, L. Dong, C. Zhou, and J. Liu. "Problematic macrofossils from Ediacaran successions in the North China and Chaidam Blocks: implications for their evolutionary roots and biostratigraphic significance". English. In: Journal of Paleontology 81.6 (2007), pp. 1396-1411.

[21135] C. Shen, J. Lü, S. Liu, M. Kundrát, S. L. Brusatte, and H. Gao. “A new troodontid dinosaur from the Lower Cretaceous Yixian Formation of Liaoning Province, China". English. In: Acta Geologica Sinica (English Edition) 91.3 (2017), pp. 763-780. DOI: 10.1111/1755-6724.13307.

[21136] C. C. Shen, F. P. Siringan, K. Lin, C. F. Dai, and S. Y. Gong. "Sea-level rise and coral-reef development of northwestern Luzon since 9.9 ka". English. In: Palaeogeography, Palaeoclimatology, Palaeoecology 292 (2010), pp. 465-473.

[21137] C.-z. Shen, B. Zhao, C. -1. Gao, J. -c. Lü, and M. Kundrát. “A new troodontid dinosaur (Liaoningvenator curriei gen. et sp. nov.) from the Early Cretaceous Yixian Formation in western Liaoning Province". English. In: Acta Geoscientica Sinica 38.3 (2017), pp. 359-371.

[21138] J-w. Shen and T. Kawamura. "Guadalupian algae-sponge reefs in siliciclastic environments - the reefs at Lengwu (South China) compared with the reef at Iwaizaki (Japan)". In: Facies 45 (2001), pp. 137-156.

[21139] J. Shen, G. E. Webb, and H. Qing. "Microbial mounds prior to the Frasnian-Famennian mass extinctions, Hantang, Guilin, South China". English. In: Sedimentology 57 (2010), pp. 1615-1639.

[21140] J. W. Shen, T. Kawamura, and W. R. Yang. “Upper Permian coral reef and colonial rugose corals Hunan, South China". English. In: Facies 39 (1998), pp. 35-66.

[21141] J. W. Shen and H. L. Xu. "Microbial carbonates as contributors to Upper Permian (GuadalupianLopingian) biostromes and reefs in carbonate platform setting, Ziyun County, south China". English. In: Palaeogeography, Palaeoclimatology, Palaeoecology 218 (2005), pp. 217-238.

[21142] J.-W. Shen and G. E. Webb. “Famennian (Upper Devonian) calcimicrobial (Renalcis) reef at Miaomen, Guilin, Guangxi, South China". In: Palaeogeography, Palaeoclimatology, Palaeoecology 204 (2004), pp. 373394.

[21143] J.-W. Shen and G. E. Webb. “Metazoan-microbial framework fabrics in a Mississippian (Carboniferous) coral-sponge-microbial reef, Monto, Queensland, Australia". English. In: Sedimentary Geology 178.1-2 (2005), pp. 113-133.

[21144] J.-w. Shen, C.-m. Yu, and H. -m. Bao. "A Late Devonian (Famennian) Renalcis-Epihphyton reef at Zhaijian, Guilin, South China". In: Facies 37 (1997), pp. 195-210.

[21145] J.-w. Shen and C.-m. Yu. “Middle Devonian (Givetian) coral-stromatoporoid reef at Yanshan, north of Guilin, Guangxi, South China". In: Acta Palaeontologica Sinica 35.6 (1996), pp. 686-701.

[21146] J.-W. Shen and S.-L. Zhang. A Late Devonian (Frasnian) Coral-Bafflestone Reef at Houshan in Guilin, South China. 1997.

[21147] S. Shen and Y. Jin. "Brachiopods from the Permian-Triassic boundary beds at the Selong Xishan section, Xizang (Tibet), China". English. In: Journal of Asian Earth Sciences 17 (1999), pp. 547-559.

[21148] S. Shen and G. Shi. "Permianella (Brachiopoda) from the Upper Permian of Transcaucasia". English. In: Science reports of Niigata University (Geology) 12 (1997), pp. 19-27.

[21149] S. Z. Shen, N. W. Archbold, G. R. Shi, and Z. Q. Chen. "Permian brachiopods from the Selong Xishan Section, Xizang (Tibet), China. Part 1: Stratigraphy, Strophomenida, Productida and Rhynchonellida". English. In: Geobios 33.6 (2000), pp. 725-752. 
[21150] S. Z. Shen, N. W. Archbold, G. R. Shi, and Z. Q. Chen. "Permian brachiopods from the Selong Xishan Section, Xizang (Tibet), China. Part 2: Palaeobiogeographical and palaeoecological implications, Spiriferida, Athyridida and Terebratulida". English. In: Geobios 34.2 (2001), pp. 157-182.

[21151] S. Z. Shen, C. Q. Cao, Y. Zhang, W. Li, G. R. Shi, Y. Wang, Y. Wu, K. Ueno, C. M. Henderson, X. Wang, H. Zhang, and J. Chen. "End-Permian mass extinction and palaeoenvironmental changes in Neotethys: Evidence from an oceanic carbonate section in southwestern Tibet". English. In: Global and Planetary Change 73 (2010), pp. 3-14.

[21152] S. Z. Shen and M. E. Clapham. "Wuchiapingian (Lopingian, Late Permian) brachiopods from the Episkopi Formation of Hydra Island, Greece". English. In: Palaeontology 52.4 (2009), pp. 713-743.

[21153] S. Z. Shen, B. C. Fan, C. Zhang, and X. P. Zhang. "A new species of permianellids (Brachiopoda): taxonomic and palaeoecologic significance". English. In: Geobios 27.4 (1994), pp. 477-485.

[21154] S. Z. Shen, X. L. He, and G. R. Shi. "Biostratigraphy and correlation of several Permian-Triassic boundary sections in southwestern China". English. In: Journal of Southeast Asian Earth Sciences 12.1-2 (1995), pp. 19-30.

[21155] S. Z. Shen and X. L. He. "Changhsingian brachiopod faunas from Guiding, Guizhou". Chinese. In: Acta Palaeontologica Sinica 33 (1994), pp. 440-454.

[21156] S. Z. Shen, Y. G. Jin, Y. Zhang, and E. A. Weldon. "Permian brachiopod genera on type species of China". English. In: Phanerozoic Brachiopod Genera of China. Beijing: Science Press, 2017, pp. 651-881.

[21157] S. Z. Shen, L. Mu, and Y. D. Zakharov. "Roadoceras (Permian Ammonoidea) from the Qubuerga Formation in the Mt Everest area in southern Tibet". English. In: Gondwana Research 7 (2004), pp. 863-869.

[21158] S. Z. Shen, J. Ramezani, J. Chen, C. -Q. Cao, D. H. Erwin, H. Zhang, L. Xiang, S. D. Schoepfer, C. M. Henderson, Q. -F. Zheng, S. A. Bowring, Y. Wang, X. -H. Li, X. -D. Wang, D. -X. Yuan, Y. -C. Zhang, L. Mu, J. Wang, and Y. S. Wu. "A sudden end-Permian mass extinction in South China". English. In: Geological Society of America (2019).

[21159] S. Z. Shen, G. R. Shi, and N. W. Archbold. "A Wuchiapingian (Late Permian) brachiopod fauna from an exotic block in the Indus-Tsangpo Suture Zone, southern Tibet, and its palaeobiogeographical and tectonic implications". English. In: Palaeontology 46.2 (2003), pp. 225-256.

[21160] S. Z. Shen, G. R. Shi, and K. Y. Zhu. "Early Permian Brachiopods of Gondwana affinity from the Dingjiazhai Formation of the Baoshan Block, western Yunnan, China". English. In: Rivista Italiana di Paleontologia e Stratigrafia 106.3 (2000), pp. 263-282.

[21161] S. Z. Shen, G. R. Shi, and Z. Fang. "Permian brachiopods from the Baoshan and Simao Blocks in Western Yunnan, China". English. In: Journal of Asian Earth Sciences 20 (2002), pp. 665-682.

[21162] S. Z. Shen and G. R. Shi. “Lopingian (Late Permian) brachiopods from South China. Part 1. Orthotetida, Orthida and Rhynchonellida". English. In: Bulletin of the Tohoku University Museum 6 (2007), pp. 1-102.

[21163] S. Z. Shen and G. R. Shi. "Latest Guadalupian brachiopods from the Guadalupian/Lopingian boundary GSSP section at Penglaitan in Laibin, Guangxi, south China and implications for the timing of the pre-Lopingian crisis". English. In: Palaeoworld 18 (2008), pp. 152-161.

[21164] S. Z. Shen, D. L. Sun, and G. R. Shi. "A biogeographically mixed late Guadalupian (late Middle Permian) brachiopod fauna from an exotic limestone block at Xiukang in Lhaze county, Tibet". English. In: Journal of Asian Earth Sciences 21 (2003), pp. 1125-1137.

[21165] S. Z. Shen, T. R. Sun, Y. C. Zhang, and D. X. Yuan. “An upper Kungurian/lower Guadalupian (Permian) brachiopod fauna from the South Qiangtang Block in Tibet and its palaeobiogeographical implications". English. In: Palaeoworld 25 (2016), pp. 519-538.

[21166] S. Z. Shen, J. Tazawa, and G. R. Shi. “Carboniferous and Permian Rugosochonetidae (Brachiopoda) from West Spitsbergen". English. In: Alcheringa 29 (2005), pp. 241-256. 
[21167] S. Z. Shen, J. Tazawa, and Y. Miyake. “A Kungurian (Early Permian) Panthalassan brachiopod fauna from Hatahoko in the Mino Belt, central Japan". English. In: Journal of Paleontology 85.3 (2011), pp. 553-566.

[21168] S. Z. Shen, J. I. Tazawa, and G. R. Shi. "Peltichia Jin and Liao, 1981 (Enteletidae, Brachiopoda) from Asia: taxonomy, biostratigraphy, and paleobiogeography". English. In: Journal of Paleontology 73.1 (1999), pp. 49-62.

[21169] S. Z. Shen and J. I. Tazawa. "Two permianellids (Brachiopoda) from the Middle Permian of the southern Kitakami Mountains, northeast Japan". English. In: Paleontological Research 1 (1997), pp. 285290.

[21170] S. Z. Shen and J. I. Tazawa. "Pararigbyella and Dicystoconcha (Lyttoniidina, Brachiopoda) from the Middle Permian (Wordian) of Japan". English. In: Paleontological Research 18 (2014), pp. 245249.

[21171] S. Z. Shen and Y. C. Zhang. "Earliest Wuchiapingian (Lopingian, Late Permian) brachiopods in southern Hunan, south China: implications for the pre-Lopingian crisis and onset of Lopingian recovery/radiation". English. In: Journal of Paleontology 82.5 (2008), pp. 924-937.

[21172] S.-Z. Shen, N. W. Archbold, and G. R. Shi. “A Lopingian (Late Permian) brachiopod fauna from the Qubuerga Formation at Shengmi in the Mount Qomolangma Region of southern Xizang (Tibet), China". In: Journal of Paleontology 75.2 (2001), pp. 274-283.

[21173] S.-Z. Shen, T. A. Grunt, and Y. -G. Jin. "A comparative study of Comelicaniidae Merla, 1930 (Brachiopoda: Athyridida) from the Lopingian (Late Permian) of South China and Transcaucasia in Azerbaijan and Iran". English. In: Journal of Paleontology 78.5 (2004), pp. 884-899.

[21174] S.-Z. Shen, G. R. Shi, and N. W. Archbold. “Lopingian (Late Permian) brachiopods from the Qubuerga Formation at the Qubu section in the Mt. Qomolangma region, southern Tibet (Xizang), China". English. In: Palaeontographica Abteilung A 268.1-3 (2003), pp. 49-101.

[21175] S. Z. Shen and N. Archbold. "Chonetoidea (Brachiopoda) from the Lopingian (Late Permian) of South China". English. In: Alcheringa 25 (2002), pp. 327-349.

[21176] S. Z. Shen, J. I. Tazawa, and T. Ono. "Scacchinella (Productida, Brachiopoda) from the Lower Permian of Akasaka, Mino Belt, central Japan, with a review of its world distribution". English. In: Science Reports, Niigata University (Geology) 21 (2006), pp. 19-30.

[21177] Y.-B. Shen, R. S. Taylor, and F. R. Schram. “A new spelaegriphacean (Crustacea: Peracarida) from the Upper Jurassic of China". English. In: Contributions to Zoology 68.1 (1998), pp. 13-35.

[21178] C. Shena, C. Wu, C. F. Dai, and S. Y. Gong. "Variable uplift rate through time: Holocene coral reef and neotectonics of". English. In: Journal of Asian Earth Sciences 156 (2018), pp. 201-206.

[21179] H. M. E. Shepherd, G. D. Stanley, and F. Amirhassankhani. "Norian to Rhaetian scleractinian corals in the Ferdows patch reef (Nayband Formation, east central Iran)". English. In: Journal of Paleontology 86 (2012), pp. 801-812.

[21180] J. H. Shergold, O. Bordonaro, and E. Linan. "Late Cambrian Agnostoid trilobites from Argentina". English. In: Palaeontology 38.2 (1995), pp. 241-257.

[21181] J. H. Shergold, R. Feist, and D. Vizcaino. “Early Late Cambrian trilobites of Australo-Sinian aspect from the Montagne Noire, Southern France". English. In: Palaeontology 43.4 (2000), pp. 599-632.

[21182] C. E. Sherman, C. H. Fletcher, K. H. Rubin, K. R. Simmons, and W. A. Adey. "Sea-level and reef accretion history of Marine Oxygen Isotope Stage 7 and late Stage 5 based on age and facies of submerged late Pleistocene reefs, Oahu, Hawaii". English. In: Quaternary Research 81 (2014), pp. 138150.

[21183] B. Sherzer. "A possible physeteroid (Cetacea: Odontoceti) from the Yorba Member of the Puente Formation, Orange County, California". English. In: PaleoBios 34 (2017), pp. 11-12.

[21184] A. A. Shevyrev. "Triassic ammonoids of the northwest Caucasus". Russian. In: Rossiyskaya Akademiya Nauk, Trudy Paleontologicheskogo Instituta 264 (1995), pp. 1-174. 
[21185] A. A. Shevyrev. "Ammonoidei i Khronostratigrafiya Triasa". Russian. In: Akademiya Nauk SSSR, Trudy Paleontologicheskogo Instituta 241 (1990), pp. 1-179.

[21186] C. F. Shi, O. Béthoux, C. K. Shih, and D. Ren. “Guyiling jianboni gen. et sp.n., an antlion-like lacewing, illuminating homologies and transformations in Neuroptera wing venation". English. In: Systematic Entomology 37 (2012), pp. 617-631.

[21187] C. F. Shi, V. N. Makarkin, Q. Yang, S. B. Archibald, and D. Ren. “New species of Nymphites Haase (Neuroptera: Nymphidae) from the Middle Jurassic of China, with a redescription of the type species of the genus". English. In: Zootaxa 3700 (2013), pp. 393-410.

[21188] C. F. Shi, M. Ohl, J. Wunderlich, and D. Ren. “A remarkable new genus of Mantispidae (Insecta, Neuroptera) from Cretaceous amber of Myanmar and its implications on raptorial foreleg evolution in Mantispidae". English. In: Cretaceous Research 52 (2015), pp. 416-422.

[21189] C. F. Shi, Y. J. Wang, Q. Yang, and D. Ren. “Chorilingia (Neuroptera: Grammolingiidae): a new genus of lacewings with four species from the Middle Jurassic of Inner Mongolia, China". English. In: Alcheringa 36 (2012), pp. 309-318.

[21190] C. F. Shi, Y. J. Wang, and D. Ren. "New species of Grammolingia Ren, 2002 from the Middle Jurassic of Inner Mongolia, China (Neuroptera: Grammolingiidae)". English. In: Fossil Record 16 (2013), pp. 171-178.

[21191] C. F. Shi, S. L. Winterton, and D. Ren. "Phylogeny of split-footed lacewings (Neuroptera, Nymphidae), with descriptions of new Cretaceous fossil species from China". English. In: Cladistics 31 (2015), pp. 455-490.

[21192] C. F. Shi, Q. Yang, and D. Ren. “Two new fossil lacewing species from the Middle Jurassic of Inner Mongolia, China (Neuroptera: Grammolingiidae)". English. In: Acta Geologica Sinica 85 (2011), pp. 482-489.

[21193] C. F. Shi, Q. Yang, S. L. Winterton, H. Pang, and D. Ren. "Stem-group fossils of Symphrasinae shed light on early evolution of Mantispidae (Insecta, Neuroptera)". English. In: Papers in Palaeontology 6 (2020), pp. 143-154. DOI: 10.1002/spp2.1265.

[21194] C. F. Shi, Q. Yang, C. K. Shih, C. C. Labandeira, H. Pang, and D. Ren. "Cretaceous mantid lacewings with specialized raptorial forelegs illuminate modification of prey capture (Insecta: Neuroptera)". English. In: Zoological Journal of the Linnean Society 190 (2020), pp. 1054-1070. DOI: 10.1093 / zoolinnean/zlaa096.

[21195] G. F. Shi, C. K. Shih, and D. Ren. "A new genus with two new species of mesosciophilids from the Middle Jurassic of China (Diptera: Nematocera: Mesosciophilidae)". English. In: Journal of Natural History 49 (2015), pp. 1147-1158.

[21196] G. F. Shi, Y. Zhu, C. K. Shih, and D. Ren. "A new axymyiid genus with two new species from the Middle Jurassic of China (Diptera: Nematocera: Axymyiidae)". English. In: Acta Geologica Sinica 87 (2013), pp. 1228-1234.

[21197] G. R. Shi and N. W. Archbold. "Permian brachiopod faunal sequence of the Shan-Thai terrane: biostratigraphy, palaeobiogeographical affinities and plate tectonic/palaeoclimatic implications". English. In: Journal of Southeast Asian Earth Sciences 11.3 (1995), pp. 177-187.

[21198] G. R. Shi, Z. Q. Chen, and N. R. Hai. "Permophricodothyris Pavlova, 1965 (Brachiopoda, Spiriferida) from the Permian of south China: its morphology, biostratigraphy and distribution". English. In: Paläontologische Zeitschrift 76.2 (2002), pp. 369-383.

[21199] G. R. Shi, Z. J. Fang, and N. W. Archbold. "An Early Permian brachiopod fauna of Gondwanan affinity from the Baoshan block, western Yunnan, China". English. In: Alcheringa 20 (1996), pp. 81101.

[21200] G. R. Shi, Mohd Shafeea Leman, and B. K. Tan. "Early Permian brachiopods from the Singa Formation of Langkawi Island, northwestern Peninsular Malaysia: biostratigraphical and biogeographical implications". English. In: Proceedings of the International Conference on Stratigraphy and Tectonic Evolution of Southeast Asia and the South Pacific (1997), pp. 62-72. 
[21201] G. R. Shi, L. Raksaskulwong, and H. J. Campbell. “Early Permian brachiopods from central and northern peninsular Thailand". English. In: Carboniferous and Permian of the World. Canadian Society of Petroleum Geologists Memoir 19 (2001), pp. 596-608.

[21202] G. R. Shi and S. Shen. "A biogeographically mixed, Middle Permian brachiopod fauna from the Baoshan Block, western Yunnan, China". In: Palaeontology 44.2 (2001), pp. 237-258.

[21203] G. R. Shi, S. Shen, and L. Zhan. "A Guadalupian-Lopingian (Middle to Late Permian) brachiopod fauna from the Juripu Formation in the Yarlung-Zangbo suture zone, southern Tibet, China". English. In: Journal of Paleontology 77.6 (2003), pp. 1053-1068.

[21204] G. R. Shi, S. Shen, and J. -I. Tazawa. "Middle Permian (Guadalupian) brachiopods from the Xiujimqinqi area, Inner Mongolia, northeast China, and their palaeobiogeographical and palaeogeographical significance". English. In: Paleontological Research 6.3 (2002), pp. 285-297.

[21205] G. R. Shi, S. Z. Shen, H. J. Campbell, and L. Raksaskulwong. A Meekella-dominated Early Permian brachiopod assemblage from central Peninsular Thailand. English. Contributions to the Geology and Palaeontology of Gondwana in Honour of Helmut Wopfner. 2001, pp. 441-451.

[21206] G. R. Shi and S.-Z. Shen. "A Changhsingian (Late Permian) brachiopod fauna from Son La, northwest Vietnam". In: Journal of Asian Earth Sciences 16.5-6 (1998), pp. 501-511.

[21207] G. R. Shi and S.-Z. Shen. "A Late Permian brachiopod fauna from Selong, Southern Xizang (Tibet), China". English. In: Proceedings of the Royal Society of Victoria 109.1 (1997), pp. 37-56.

[21208] G. R. Shi and J. Tazawa. "Rhynchopora and Blasispirifer (Brachiopoda) from the Middle Permian of the Hida Gaien Belt, central Japan, and their paleobiogeographical significance". In: Journal of Geological Society of Japan 107.12 (2001), pp. 755-761.

[21209] G. R. Shi and J. B. Waterhouse. "Early Permian brachiopods from Perak, west Malaysia”. English. In: Journal of Southeast Asian Earth Sciences 6 (1991), pp. 25-39.

[21210] G. R. Shi, J. B. Waterhouse, and S. Lee. "Early Permian brachiopods from the Pebbley Beach Formation, southern Sydney Basin, southeastern Australia". English. In: Alcheringa 44 (2020), pp. 411429. DOI: $10.1080 / 03115518.2020 .1810773$.

[21211] G. R. Shi and J. B. Waterhouse. "Lower Permian brachiopods and molluscs from the upper Jungle Creek Formation, northern Yukon Territory, Canada". English. In: Geological Survey of Canada Bulletin 424 (1996), pp. 1-241.

[21212] X. Shi and R. E. Grant. "Jurassic rhynchonellids: internal structures and taxonomic revisions". English. In: Smithsonian Contributions to Paleobiology 73 (1993), pp. 1-190.

[21213] X. Q. Shi, Y. Y. Zhao, C. K. Shih, and D. Ren. "New fossil helorid wasps (Insecta, Hymenoptera, Proctotrupoidea) from the Jehol Biota, China". English. In: Cretaceous Research 41 (2013), pp. 136142.

[21214] X. Q. Shi, Y. Y. Zhao, C. K. Shih, and D. Ren. “New fossil mesoserphid wasps (Insecta, Hymenoptera, Proctotrupoidea) from the Jehol Biota, China". English. In: Zootaxa 3710 (2013), pp. 591599.

[21215] X. Q. Shi, Y. Y. Zhao, C. K. Shih, and D. Ren. “Two new species of Archaeohelorus (Hymenoptera, Proctotrupoidea, Heloridae) from the Middle Jurassic of China". English. In: ZooKeys 369 (2014), pp. 49-59.

[21216] Y. K. Shi, H. Huang, X. C. Jin, and X. N. Yang. "Early Permian fusulinids from the Baoshan Block, western Yunnan, China and their paleobiogeographic significance". English. In: Journal of Paleontology 85 (2011), pp. 489-501.

[21217] Y. K. Shi, X. C. Jin, H. Huang, and X. N. Yang. "Permian Fusulinids from the Tengchong Block, Western Yunnan, China". English. In: Journal of Paleontology 82.1 (2008), pp. 118-127.

[21218] M. Shibata and Y. Azuma. "New basal hadrosauroid (Dinosauria: Ornithopoda) from the Lower Cretaceous Kitadani Formation, Fukui, central Japan". English. In: Zootaxa 3914.4 (2015), pp. 421440 . 
[21219] M. Shibata, P. Jintasakul, and Y. Azuma. "A new iguanodontian dinosaur from the Lower Cretaceous Khok Kruat Formation, Nakon Ratchasima in northeastern Thailand". English. In: Acta Geologica Sinica (English Edition) 85.5 (2011), pp. 969-976. DOI: 10.1111/j.1755-6724.2011.00230.x.

[21220] M. Shibata, P. Jintasakul, Y. Azuma, and H. -L. You. "A new basal hadrosauroid dinosaur from the Lower Cretaceous Khok Kruat Formation in Nakhon Ratchasima Province, Northeastern Thailand". English. In: PLoS One 10(.12 (2015), e0145904. DOI: 10.1371/journal.pone.0145904.

[21221] T. F. Shibata and T. Oji. "Kiimetra miocenica, a new genus and species of the family Calometridae (Echinodermata : Crinoidea) from the Middle Miocene of southwestern Japan". English. In: Journal of Paleontology 81.2 (2007), pp. 397-404. DOI: 10.1666/0022-3360(2007)81[397:KMANGA]2.0.CO;2.

[21222] N. Shigehara, M. Takai, R. F. Kay, A. K. Aung, A. N. Soe, S. T. Tun, T. Tsubamoto, and T. Thein. "The upper dentition and face of Pondaungia cotteri from central Myanmar". English. In: Journal of Human Evolution 43.2 (2002), pp. 143-166.

[21223] J. Shigeno, K. Fujita, Y. Azuma, M. Goto, A. Kano, M. Jige, M. Shibata, and T. Kawai. "[Paleoenvironment of the Akaiwa Subgroup of the Tetori Group based on pedogenic sediments and sedimentary facies in the Kamiichi and Tateyama area, Toyama Prefecture]". Japanese. In: Memoir of the Fukui Prefectural Dinosaur Museum 3 (2004), pp. 1-22.

[21224] Y. Shigeta. "Morewites, a new Campanian (Late Cretaceous) heteromorph ammonoid genus from Hokkaido, Japan". English. In: Paleontological Research 18.1 (2014), pp. 1-5. DOI: 10.2517/2014PR001.

[21225] Y. Shigeta. "A new species of Tanabeceras (Ammonoidea, Gaudryceratidae) from the lowest Cenomanian of Hokkaido, Japan". English. In: Paleontological Research 17 (2013), pp. 312-316.

[21226] Y. Shigeta, M. Izukura, T. Nishimura, and Y. Tsutsumi. "Middle and late Campanian (Late Cretaceous) ammonoids from the Urakawa area, Hokkaido, northern Japan". English. In: Paleontological Research 20 (2016), pp. 322-366.

[21227] Y. Shigeta and M. Izukura. "Discovery of the middle Campanian (Late Cretaceous) Soya Fauna ammonoids in the Hidaka area, Hokkaido, Japan". English. In: The Bulletin of the Hobetsu Museum 33 (2018), pp. 11-25.

[21228] Y. Shigeta, T. Komatsu, D. H. Nguyen, T. H. Dang, and N. Iwakiri. "Discovery of the Middle Triassic ammonoid Balatonites in the Quy Lang Formation, Thanh Hoa Province, central Vietnam". English. In: Paleontological Research 14.4 (2010), pp. 244-249.

[21229] Y. Shigeta, T. Komatsu, T. Maekawa, and H. T. Dang. “Olenekian (Early Triassic) stratigraphy and fossil assemblages in northeastern Vietnam". English. In: National Museum of Nature and Science Monographs 45 (2014), pp. 1-309.

[21230] Y. Shigeta and T. Kumagae. "Churkites, a trans-Panthalassic Early Triassic ammonoid genus from South Primorye, Russian far east". English. In: Paleontological Research 19 (2015), pp. 219-236.

[21231] Y. Shigeta and T. Kumagae. "Spathian (late Olenekian, Early Triassic) ammonoids from the Artyom area, South Primorye, Russian far east and implications for the timing of the recovery of the oceanic environment". English. In: Paleontological Research 20 (2016), pp. 48-60.

[21232] Y. Shigeta and Y. Nakajima. "Discovery of the early Spathian (late Olenekian, Early Triassic) ammonoid Tirolites in the Hiraiso Formation, South Kitakami Belt, northeast Japan". English. In: Paleontological Research 21 (2017), pp. 37-43.

[21233] Y. Shigeta and H. D. Nguyen. "Cephalopods". English. In: vol. 45. Olenekian (Early Triassic) stratigraphy and fossil assemblages in northeastern Vietnam. National Museum of Nature and Science Monographs. 2014, pp. 65-167.

[21234] Y. Shigeta, T. Nishimura, and K. Nifuku. "Middle and late Maastrichtian (latest Cretaceous) ammonoids from the Akkeshi Bay area, eastern Hokkaido, northern Japan and their biostratigraphic implications". English. In: Paleontological Research 19 (2015), pp. 107-127.

[21235] Y. Shigeta and T. Nishimura. "A new species of Anagaudryceras (Ammonoidea, Gaudryceratidae) from the lowest Maastrichtian of Hokkaido, Japan". English. In: Paleontological Research 18 (2014), pp. 176-185. 
[21236] Y. Shigeta and T. Nishimura. "A new species of Gaudryceras (Ammonoidea, Gaudryceratidae) from the lowest Maastrichtian of Hokkaido, Japan and its biostratigraphic implications". English. In: Paleontological Research 17 (2013), pp. 47-57.

[21237] Y. Shigeta, Y. D. Zakharov, H. Maeda, and A. M. Popov. The Lower Triassic System in the Abrek Bay area, south Primorye, Russia. English. Vol. 38. National Museum of Nature and Science Monographs. 2009, pp. 1-218.

[21238] Y. Shigeta and Y. D. Zakharov. Systematic Paleontology: Cephalopods. English. Vol. 38. The Lower Triassic System in the Abrek Bay area, south Primorye, Russia. 2009, pp. 44-140.

[21239] C. K. Shih, F. Dong, I. Kania, L. X. Liu, W. Krzemiskic, and D. Ren. “A new species of Tipulidae (Diptera) from the Lower Cretaceous Yixian Formation of Liaoning, China - evolutionary implications". English. In: Cretaceous Research 54 (2015), pp. 98-105.

[21240] C. K. Shih, H. Feng, C. X. Kiu, Y. Y. Zhao, and D. Ren. "Morphology, phylogeny, evolution, and dispersal of pelecinid wasps (Hymenoptera: Pelecinidae) over 165 million years". English. In: Annals of the Entomological Society of America 103.6 (2010), pp. 875-885.

[21241] C. K. Shih, H. Feng, and D. Ren. “New fossil Heloridae and Mesoserphidae wasps (Insecta, Hymenoptera, Proctotrupoidea) from the Middle Jurassic of China". English. In: Annals of the Entomological Society of America 104 (2011), pp. 1334-1348.

[21242] C. K. Shih, C. X. Liu, and D. Ren. "The earliest fossil record of pelecinid wasps (Insecta: Hymenoptera: Proctotrupoidea: Pelecinidae) from Inner Mongolia, China". English. In: Annals of the Entomological Society of America 102 (2009), pp. 20-38.

[21243] C. K. Shih, X. Qiao, C. C. Labandeira, and D. Ren. "A new mesopsychid (Mecoptera) from the Middle Jurassic of northeastern China". English. In: Acta Geologica Sinica 87 (2013), pp. 1235-1241.

[21244] C. K. Shih, X. G. Yang, C. C. Labandeira, and D. Ren. "A new long-proboscid genus of Pseudopolycentropodidae (Mecoptera) from the Middle Jurassic of China and its plant-host specializations". English. In: ZooKeys 130 (2011), pp. 281-297.

[21245] M. J. H. Shih, L. F. Li, and D. Ren. "Application of geometric morphometric analyses to confirm two new species of Karatavitidae (Hymenoptera: Karatavitoidea) from northeastern China". English. In: Alcheringa 41 (2017), pp. 499-508.

[21246] P. J. M. Shih, L. F. Li, D. Q. Li, and D. Ren. “Application of geometric morphometric analyses to confirm three new wasps of Evaniidae (Hymenoptera: Evanioidea) from mid-Cretaceous Myanmar amber". English. In: Cretaceous Research 109.104249 (2019). DOI: 10.1016/j.cretres.2019.104249.

[21247] Y. Shiino. "Middle Permian echinoconchoide brachiopod Vediproductus in the Kamiyasse area, Southern Kitakami Mountains, northeast Japan". English. In: Paleontological Research 13.3 (2009), pp. 251-258.

[21248] Y. Shiino and Y. Suzuki. "Articulatory and musculatory systems in a Permian concavo-convex brachiopod Waagenoconcha imperfecta Prendergast, 1935 (Productida, Brachiopoda)". English. In: Paleontological Research 11.3 (2007), pp. 265-275.

[21249] K. Shimada. "Ichthyosaur (Reptilia: Ichthyosauria) vertebra from the Kiowa Shale (Lower Cretaceous: Upper Albian), Clark County, Kansas". English. In: Transactions of the Kansas Academy of Science 99.1/2 (1996), pp. 39-44.

[21250] K. Shimada. "Mesozoic origin for megamouth shark (Lamniformes: Megachasmidae)". English. In: Journal of Vertebrate Paleontology 27 (2007), pp. 512-516.

[21251] K. Shimada. "Selachians from the Fort Hays Limestone Member of the Niobrara Chalk (Upper Cretaceous), Ellis County, Kansas". English. In: Transactions of the Kansas Academy of Science 99 (1996), pp. 1-15.

[21252] K. Shimada. "New anacoracid shark from upper Cretaceous Niobrara Chalk of western Kansas, U.S.A." English. In: Journal of Vertebrate Paleontology 28 (2008), pp. 1189-1194. DOI: 10.1671/02724634-28.4.1189. 
[21253] K. Shimada. "Marine vertebrates from the Blue Hill Shale Member of the Carlile Shale (Upper Cretaceous: Middle Turonian) in Kansas". English. In: New Mexico Museum of Natural History and Science Bulletin 35 (2006), pp. 165-175.

[21254] K. Shimada and G. L. Bell Jr. "Coniasaurus Owen, 1850 (Reptilia: Squamata), from the Upper Cretaceous Niobrara Chalk of western Kansas". English. In: Journal of Paleontology 80.3 (2006), pp. 589-593.

[21255] K. Shimada, R. E. Chandler, O. Lok Tao Lam, T. Tanaka, and D. J. Ward. “A new elusive otodontid shark (Lamniformes:" English. In: Historical Biology 29.5 (2017), pp. 704-714. DOI: 10.1080 / 08912963.2016.1236795.

[21256] K. Shimada and D. J. Cicimurri. "The oldest record of the Late Cretaceous anacoracid shark Squalicorax pristodontus (Agassiz), from the Western Interior, with comments on Squalicorax phylogeny". English. In: New Mexico Museum of Natural History and Science Bulletin 35 (2006), pp. 177184.

[21257] K. Shimada and M. J. Everhart. "A new large Late Cretaceous lamniform shark from North America, with comments on the taxonomy, paleoecology, and evolution of the genus Cretodus". English. In: Journal of Vertebrate Paleontology 39 (2019), e1673399. DOI: 10.1080/02724634.2019.1673399.

[21258] K. Shimada, M. J. Everhart, R. Decker, and P. D. Decker. “A new skeletal remain of the durophagous shark, Ptychodus mortoni, from the Upper Cretaceous of North America: an indication of gigantic body size". English. In: Cretaceous Research 31 (2010), pp. 249-254. DOI: 10.1016/j.cretres.2009.11. 005.

[21259] K. Shimada and M. J. Everhart. "Ptychodus mammillaris (Elasmobranchii) and Enchodus cf. E. shumardi (Teleostei) from the Fort Hays Limestone Member of the Niobrara Chalk (Upper Cretaceous) in Ellis County, Kansas". English. In: Transactions of the Kansas Academy of Science 106 (2003), pp. 171-176.

[21260] K. Shimada, K. Ewell, and M. J. Everhart. "The first record of the lamniform shark genus, Johnlongia, from the Niobrara Chalk (Upper Cretaceous), western Kansas". English. In: Transactions of the Kansas Academy of Science 107 (2004), pp. 131-135.

[21261] K. Shimada and G. E. Hooks III. "Shark-bitten protostegid turtles from the Upper Cretaceous Mooreville Chalk, Alabama". English. In: Journal of Paleontology 78.1 (2004), pp. 205-210. DOI: 10. 1666/0022-3360(2004)078<0205:SPTFTU>2.0.CO;2.

[21262] K. Shimada and N. Inuzuka. "Desmostylian tooth remains from the Miocene Tokigawa Group at Kuzubukuro, Saitama, Japan". English. In: Transactions and Proceedings of the Palaeontological Society of Japan 175 (1994), pp. 553-577.

[21263] K. Shimada and D. J. Martin. "Fossil fishes from the basal Greenhorn Limestone (Upper Cretaceous, Late Cenomanian) in Russell County, Kansas". English. In: Fort Hays Studies, Special Issue 2 (2008), pp. 89-103.

[21264] K. Shimada and M. Nagrodski. "Occurrence of the fossil lamniform shark, Cretoxyrhina mantelli, from the Upper Cretaceous Hartland Shale, central Kansas". English. In: Transactions of the Kansas Academy of Science 113 (2010), pp. 235-236. DOI: 10.1660/062.113.0313.

[21265] K. Shimada, J. A. Parkin, J. M. Palermo, and B. A. Schumacher. Late Cretaceous marine vertebrates from the basal Greenhorn Limestone in southeastern Colorado. English. 2003.

[21266] K. Shimada and D. C. Parris. "A long-snouted Late Cretaceous crocodyliform, Terminonaris cf. T. browni, from the Carlile Shale (Turonian) of Kansas". English. In: Transactions of the Kansas Academy of Science 110.1/2 (2007), pp. 107-115.

[21267] K. Shimada, E. V. Popov, M. Siversson, B. J. Welton, and D. J. Long. "A new clade of putative plankton-feeding sharks from the Upper Cretaceous of Russia and the United States". English. In: Journal of Vertebrate Paleontology 35.5 (2015), e981335. DOI: 10.1080/02724634.2015.981335.

[21268] K. Shimada, C. K. Rigsby, and S. H. Kim. "Partial skull of Late Cretaceous durophagous shark, Ptychodus occidentalis (Elasmobranchii: Ptychodontidae), from Nebraska, U.S.A." English. In: Journal of Vertebrate Paleontology 29 (2009), pp. 336-349. DOI: 10.1671/039.029.0226. 
[21269] K. Shimada, B. A. Schumacher, J. A. Parkin, and J. M. Palermo. “Fossil marine vertebrates from the lowermost Greenhorn Limestone (Upper Cretaceous: Middle Cenomanian) in southeastern Colorado". English. In: Journal of Paleontology 80.sp 63 (2006), pp. 1-45.

[21270] K. Shimada, B. J. Welton, and D. J. Long. “A new fossil megamouth shark (Lamniformes, Megachasmidae) from the Oligocene-Miocene of the western United States". English. In: Journal of Vertebrate Paleontology 34.2 (2014), pp. 281-290. DOI: 10.1080/02724634.2013.803975.

[21271] K. Shimada and T. K. Ystesund. "A dolichosaurid lizard, Coniasaurus cf. C. crassidens, from the Upper Cretaceous Carlile Shale in Russell County, Kansas". English. In: Transactions of the Kansas Academy of Science 110.3/4 (2007), pp. 236-242.

[21272] T. Shimaguchi. "A desmostylian coxal bone from the Middle Miocene of Shiomizaki, Fukaura Town, Aomori Prefecture, Northeast Japan". English. In: Journal of Fossil Research 41.1 (2008), pp. 41-45.

[21273] V. N. Shimanskiy. "Permian nonammonoid cephalopods from the Pamirs". English. In: Paleontological Journal 30.4 (1996), pp. 396-400.

[21274] V. N. Shimanskiy. "Permskie Nautilida Pamira". Russian. In: Byulleten Moskovskogo Obshchestva Ispytatelei Prirody, Otdel Geologicheskiy 67 (1992), pp. 77-84.

[21275] V. N. Shimanskiy. "Permian bactritoids of the Pamir". English. In: Paleontological Journal 27.3 (1993), pp. 153-160.

[21276] V. N. Shimanskiy. "Verkhnepaleozoyskiye nautiloida severnykh rayonov SSSR". Russian. In: Byulleten Moskovskogo Obshchestva Ispytatelei Prirody, Otdel Geologicheskiy 65 (1990), pp. 60-74.

[21277] J. Y. Shin. "A new species of Edaphodon (Chondrichthyes: Holocephali) from the Upper Cretaceous Haslam Formation, Vancouver Island, British Columbia, Canada". English. In: Journal of Vertebrate Paleontology 30 (2010), pp. 1012-1018.

[21278] T. Shinamura, M. Oishi, and M. Shiba. "Fragmental mandibles of mysticete cetaceans from the Upper Pliocene of Kakegawa, Shizuoka Prefecture, Central Japan". Japanese. In: Scientific Reports of the Museum of Tokai University 9 (2008), pp. 1-9.

[21279] T. Shintani. "Orthotetoids from the Lower Permian (Sakmarian) of the Nagaiwa-Sakamotozawa area, South Kitakami Belt, northeast Japan". English. In: Science Reports, Niigata University (Geology) 26 (2011), pp. 73-90.

[21280] B. K. Shipps, C. M. Peredo, and N. D. Pyenson. "Borealodon osedax, a new stem mysticete (Mammalia, Cetacea) from the Oligocene of Washington State and its implications for fossil whale-fall communities". English. In: Royal Society Open Science 6.182168 (2019), pp. 1-20. DOI: 10.1098/rsos. 182168.

[21281] F. Shiraishi and A. Kano. "Composition and spatial distribution of microencrusters and microbial crusts in Upper Jurassic-Lowermost Cretaceous reef limestone (Torinosu Limestone, southwest Japan)". English. In: Facies 50 (2004), pp. 217-227.

[21282] F. Shirmohammad, P. L. Smith, R. G. Anderson, and V. J. McNicoll. "The Jurassic succession at Lisadele Lake (Tulsequah map area, British Columbia, Canada) and its bearing on the tectonic evolution of the Stikine terrane". English. In: Volumina Jurassica 11 (2011), pp. 43-60.

[21283] M. A. Shishkin. "Tungussogyrinus; a relict neotenic dissorophoid (Amphibia, Temnospondyli) from the Permo-Triassic of Siberia". English. In: Paleontological Journal 32.5 (1998), pp. 521-531.

[21284] M. A. Shishkin and I. V. Novikov. "Relict anthracosaurs in the early Mesozoic of Eastern Europe". English. In: Transactions (Doklady) of the U.S.S.R. Academy of Sciences: Earth Science Sections 326 (1992), pp. 219-223.

[21285] M. A. Shishkin, I. V. Novikov, and J. Fortuny. "New Bystrowianid Chroniosuchians (Amphibia, Anthracosauromorpha) from the Triassic of Russia and Diversification of Bystrowianidae". English. In: Paleontological Journal 48.5 (2014), pp. 512-522. 
[21286] M. A. Shishkin, B. S. Rubidge, and J. W. Kitching. “A new lydekkerinid (Amphibia, Temnospondyli) from the lower Triassic of South Africa: implications for evolution of the early capitosauroid cranial pattern". English. In: Philosophical Transactions of the Royal Society of London B 351 (1996), pp. 1635-1659.

[21287] M. A. Shishkin and B. S. Rubidge. "A relict rhinesuchid (Amphibia: Temnospondyli) from the Lower Triassic of South Africa". English. In: Palaeontology 43.4 (2000), pp. 653-670.

[21288] M. A. Shishkin, B. S. Rubidge, J. Hanox, and J. Welman. "Re-evaluation of Kestrosaurus Haughton, a capitosaurid temnospondyl amphibian from the Upper Beaufort Group of South Africa". English. In: Russian Journal of Herpetology 11.2 (2004), pp. 121-138.

[21289] M. A. Shishkin and T. Sulej. "The Early Triassic temnospondyls of the Czatkowice 1 tetrapod assemblage". English. In: Palaeontologia Polonica 65 (2009), pp. 31-77.

[21290] A. A. Shkolin. "New species of the ammonoid genus Juresanites from the Lower Permian of the southern Urals". English. In: Paleontological Journal 26.4 (1992), pp. 88-92.

[21291] A. Shmakov. "Thrips (Insecta: Thysanoptera) from the Insect Limestone (Bembridge Marls, Late Eocene) of the Isle of Wight, UK". English. In: Earth and Environmental Science Transactions of the Royal Society of Edinburgh 104 (2014), pp. 317-325.

[21292] A.S. Shmakov. "The oldest members of the families Aeolothripidae and Thripidae (Insecta: Thysanoptera) from the Lower Cretaceous of Transbaikalia". English. In: Paleontological Journal 43.4 (2009), pp. 428432.

[21293] A. S. Shmakov. “The Jurassic thrips Liassothrips crassipes (Martynov, 1927) and its taxonomic position in the Order Thysanoptera (Insecta)". English. In: Paleontological Journal 42 (2008), pp. 4752.

[21294] A. S. Shmakov and E. E. Perkovsky. "Thrips (Thysanoptera, Insecta) from the Rovno amber, Eocene of Ukraine". English. In: Paleontological Journal 43.6 (2009), pp. 669-674.

[21295] B. J. Shockey. "Two new notoungulates (Family Notohippidae) from the Salla Beds of Bolivia (Deseadan: Late Oligocene): systematics and functional morphology". English. In: Journal of Vertebrate Paleontology 17.3 (1997), pp. 584-599.

[21296] B. J. Shockey. “New leontinidids (Class Mammalia, Order Notoungulata, Family Leontiniidae) from the Salla beds of Bolivia (Deseadan, Late Oligocene)". English. In: Bulletin of the Florida Museum of Natural History 45.4 (2005), pp. 249-260.

[21297] B. J. Shockey. "New Early Diverging Cingulate (Xenarthra: Peltephilidae) from the Late Oligocene of Bolivia and Considerations Regarding the Origin of Crown Xenarthra". English. In: Bulletin of the Peabody Museum of Natural History 58.2 (2017), pp. 371-396.

[21298] B. J. Shockey and F. Anaya. Postcranial osteology of mammals from Salla, Bolivia (Late Oligocene): form, function, and phylogenetic implications. English. Mammalian evolutionary morphology: a tribute to Frederick S. Szalay. 2008, pp. 135-157.

[21299] B. J. Shockey and F. Anaya. "Grazing in a new late Oligocene Mylodontid Sloth and a Mylodontid radiation as a component of the Eocene-Oligocene faunal turnover and the early spread of grasslands/savannas in South America". English. In: Journal of Mammalian Evolution 18 (2011), pp. 101115. DOI: $10.1007 / \mathrm{s} 10914-010-9147-5$.

[21300] B. J. Shockey and F. Anaya-Daza. "Pyrotherium macfaddeni, sp. nov. (late Oligocene, Bolivia) and the pedal morphology of pyrotheres". English. In: Journal of Vertebrate Paleontology 24.2 (2004), pp. 481-488.

[21301] B. J. Shockey, G. Billet, and R. Salas-Gismondi. "A new species of Trachytherus (Notoungulata: Mesotheriidae) from the late Oligocene (Deseadan) of Southern Peru and the middle latitude diversification of early diverging mesotheriids". English. In: Zootaxa 4111.5 (2016), pp. 565-583.

[21302] B. J. Shockey, J. J. Flynn, D. A. Croft, P. Gans, and A. R. Wyss. “New leontiniid Notoungulata (Mammalia) from Chile and Argentina: comparative anatomy, character analysis, and phylogenetic hypotheses". English. In: American Museum Novitates 3737 (2012), pp. 1-64. 
[21303] B. J. Shockey, R. S. Gismondi, P. Gans, A. Jeong, and J. J. Flynn. “Paleontology and geochronology of the Deseadan (late Oligocene) of Moquegua, Peru". English. In: American Museum Novitates 3668 (2009), pp. 1-24. DOI: 10.1206/662.1.

[21304] B. J. Shockey, R. Hitz, and M. Bond. "Paleogene notoungulates from the Amazon Basin of Peru". English. In: Natural History Museum of Los Angeles County, Science Series 40 (2004), pp. 61-69.

[21305] B. J. Shockey, R. Salas, R. Quispe, A. Flores, E. J. Sargis, J. Acosta, A. Pino, N. J. Jarica, and M. Urbina. "Discovery of Deseadan fossils in the upper Moquegua Formation (late Oligocene - ?early Miocene) of southern Peru". English. In: Journal of Vertebrate Paleontology 26.1 (2006), pp. 205-208.

[21306] B. J. Shockey, R. Salas-Gismondi, P. Baby, J. -L. Guyot, M. C. Baltazar, L. Huamán, A. Clack, M. Stucchi, F. Pujos, J. M. Emerson, and J. J. Flynn. "New Pleistocene Cave Faunas of the Andes of Central Perú: Radiocarbon Ages and the Survival of Low Latitude, Pleistocene DNA". English. In: Palaeontologia Electronica 12.3 (2009), 15A:1-15.

[21307] F. W. Shockley. “Discolomopsis dominicana, a new genus and species of Endomychidae (Coleoptera) from Dominican amber". English. In: Insecta Mundi 20 (2006), pp. 211-214.

[21308] F. W. Shockley and V. I. Alekseev. "Glesirhanis bercioi, a new genus and species from Baltic amber (Coleoptera: Endomychidae: Leiestinae) with a checklist and nomenclatural notes regarding fossil Endomychidae". English. In: Zootaxa 3755 (2014), pp. 391-400.

[21309] F. W. Shockley and D. Greenwalt. "Ptenidium kishenehnicum (Coleoptera: Ptiliidae), a New Fossil Described from the Kishenehn Oil Shales, with a Checklist of Previously Known Fossil Ptiliids". English. In: Proceedings of the Entomological Society of Washington 115.2 (2013), pp. 173-181.

[21310] S. Shome, S. Bardhan, and S. De. "Record of Tithopeltoceras Arkell (Ammonoidea) from the late Tithonian of Kutch, India: its stratigraphic and paleobiogeographic significance". English. In: Journal of Paleontology 79 (2005), pp. 619-624.

[21311] R. A. Short, S. C. Wallace, and L. G. Emmert. "A new species of Teleoceras (Mammalia, Rhinocerotidae) from the Late Hemphillian of Tennessee". English. In: Bulletin of the Florida Museum of Natural History 56.5 (2019), pp. 183-260.

[21312] J. Shoshani, R. C. Walter, M. Abraha, S. Berhe, P. Tassy, W. J. Sanders, G. H. Marchant, Y. Libsekal, T. Ghirmai, and D. Zinner. "A proboscidean from the late Oligocene of Eritrea, a missing link between early Elephantiformes and Elephantimorpha, and biogeographic implications". English. In: Proceedings of the National Academy of Sciences 103.46 (2006), pp. 17296-17301.

[21313] E. S. Shpinev. "New data on Carboniferous xiphosurans (Xiphosura, Chelicerata) of the Donets Coal Basin". English. In: Paleontological Journal 52 (2018), pp. 271-283.

[21314] E. S. Shpinev and D. V. Vasilenko. "First fossil xiphosuran (Chelicerata, Xiphosura) egg clutch from the Carboniferous of Khakassia". English. In: Paleontological Journal 52 (2018), pp. 400-404. DOI: $10.1134 /$ S0031030118040111.

[21315] D. Shu, S. Conway Morris, X. -L. Zhang, L. Chen, Y. Li, and J. Han. "A pipiscid-like fossil from the Lower Cambrian of south China". English. In: Nature 400 (1999), pp. 746-749.

[21316] D. Shu, H.-L. Luo, S. Conway Morris, X. -L. Zhang, S. -X. Hu, L. Chen, J. Han, M. Zhu, Y. Li, and L. -Z. Chen. "Lower Cambrian vertebrates from south China". English. In: Nature 402 (1999), pp. $42-46$.

[21317] D.-G. Shu, L. Chen, J. Han, and X. -L. Zhang. "An Early Cambrian tunicate from China”. English. In: Nature 411 (2001), pp. 472-473.

[21318] D.-G. Shu, S. Conway Morris, J. Han, Y. Li, X. -L. Zhang, H. Hua, Z. -F. Zhang, J. -N. Liu, J. -F. Guo, Y. Yao, and K. Yasui. "Lower Cambrian Vendobionts from China and Early Diploblast Evolution". English. In: Science 312 (2006).

[21319] D.-G. Shu, S. Conway Morris, J. Han, Z. -F. Zhang, and J. -N. Liu. “Ancestral echinoderms from the Chengjiang deposits of China”. English. In: Nature 430 (2002), pp. 422-428. DOI: 10.1038 / nature02648. 
[21320] N. H. Shubin, A. W. Crompton, H. -D. Sues, and P. E. Olsen. “New fossil evidence on the sistergroup of mammals and early Mesozoic faunal distributions". English. In: Science 251 (1991), pp. 10631065.

[21321] N. H. Shubin and F. A. Jenkins. "An Early Jurassic jumping frog". English. In: Nature 377 (1995), pp. 49-52.

[21322] N. H. Shubin, P. E. Olsen, and H. -D. Sues. Early Jurassic small tetrapods from the McCoy Brook Formation of Nova Scotia, Canada. English. In N. C. Fraser \& H.-D. Sues (eds.), In the Shadow of the Dinosaurs: Early Mesozoic Tetrapods. Cambridge University Press, Cambridge. 1994, pp. 242250.

[21323] N. Shuji and M. Fujikawa. "Gertholites haikawai, a new Early Carboniferous species of pachyporid tabulate coral from the Akiyoshi Limestone Group, Yamaguchi Prefecture". English. In: Bulletin of the Akiyoshi-dai Museum of Natural History 51 (2016), pp. 1-4.

[21324] U. K. Shukla and R. Srivastava. "Lizard eggs from Upper Cretaceous Lameta Formation of Jabalpur, central India, with interpretation of depositional environments of the nest-bearing horizon". English. In: Cretaceous Research 29 (2008), pp. 674-686. DOI: 10.1016/j.cretres.2008.02.003.

[21325] N. I. Shulgina, M. D. Burdykina, V. A. Basov, and N. Arhus. “Distribution of ammonites, foraminifera and dinoflagellate cysts in the Lower Cretaceous reference sections of the Khatanga Basin, and Boreal Valanginian biogeography". English. In: Cretaceous Research 15.1 (1994), pp. 1-16.

[21326] E. Shute, G. J. Prideaux, and T. H. Worthy. "Taxonomic review of the late Cenozoic megapodes (Galliformes: Megapodiidae) of Australia". English. In: Royal Society Open Science 4 (2017), p. 170233. DOI: $10.1098 /$ rsos.170233.

[21327] M. Siblik. "A contribution to the brachiopod fauna of the Oberrhaetkalk (Northern Calcareous Alps, Tyrol-Salzburg)". English. In: Jahrbuch der geologischen Bundesanstalt 141.1 (1998), pp. 73-95.

[21328] M. Siblik. "New data on the Hettangian brachiopod fauna of the Northern Calcareous Alps (Austria, Bavaria)". In: Abhandlungen der geologischen Bundesanstalt 56.2 (1999), pp. 419-438.

[21329] M. Siblik. "Lower Liassic brachiopods from the Steinplatte-Kammerkoehral area near Waidring (Northern Calcareous Alps, Salzburg)". In: Jahrbuch der geologischen Bundesanstalt 136.4 (1993), pp. 965-982.

[21330] M. Siblik. "The Brachiopod Fauna of the Wetterstein Limestone of the Raxalpe (Austria)". In: Jahrbuch der geologischen Bundesanstalt 137.2 (1994), pp. 365-381.

[21331] M. Siblik. "Carnian spire-bearing brachiopods from the Slovak Karst (SE Slovakia)". In: Slovak Geological Magazine 4.2 (1998), pp. 121-136.

[21332] M. Siblik. On Carnian brachiopods of the Gaisberg near Kirchberg in Tirol (Northern Calcareous Alps, Tyrol). 1999.

[21333] M. Siblik. "A Jurassic brachiopod fauna from the Mitterwand area near Hallstatt (Upper Austria)". English. In: Jahrbuch der Geologischen Bundensanstalt 148.1 (2008), pp. 59-87.

[21334] M. Siblk. “Bericht 2008 über Untersuchungen von Brachiopoden in den Raibler Schichten auf Blatt 65 Mondsee". English. In: Jahrbuch der Geologischen Bundesanstalt 148 (2008), pp. 276-277.

[21335] M. Siblik and G. Bryda. "Brachiopods from the Upper Triassic reef habitats of the Northern Calcareous Alps (Dachstein Limestone, Hochschwab, Austria)". English. In: Rivista Italiana di Paleontologia e Stratigrafia 111.3 (2005), pp. 413-437.

[21336] M. Siblk, I. Szente, R. Mikulas, and H. Lobitzer. "An invertebrate faunula in the Kössen beds of Starnkogel (Bad Ischl, Upper Austria)". English. In: Abhandlungen der Geologischen Bundesanstalt 65 (2010), pp. 57-64.

[21337] M. K. Siddiq, M. A. Khan, K. Mahmood, M. A. Babar, and M. Akhtar. "Some new remains of Hexaprotodon (Mammalia, Hippopotamidae) from the Pinjor Formation of Sardhok, Pakistan". English. In: Science International 28.3 (2016), pp. 2581-2584. 
[21338] P. J. A. Siddiqui, A. Ali, K. Bromfield, P. Iqbal, and N. Shoaib. “Identification of fossil corals inhabiting an uplifted area of Ras Gunz near Jiwani, Balochistan, Pakistan". English. In: Pakistan Journal of Zoology 43.3 (2011), pp. 523-537.

[21339] C. Sidor, M. Miller, and J. Isbell. "Tetrapod Burrows From the Triassic of Antarctica". English. In: Journal of Vertebrate Paleontology 28.2 (2008), pp. 277-284. DOI: 10.1671 / 0272-4634(2008) 28[277: TBFTTO]2.0.CO;2.

[21340] C. A. Sidor. "The first biarmosuchian from the upper Madumabisa Mudstone Formation (Luangwa Basin) of Zambia". English. In: Palaeontologia Africana 49 (2015), pp. 1-7.

[21341] C. A. Sidor. "The naris and palate of Lycaenodon longiceps (Therapsida: Biarmosuchia), with comments on their early evolution in the Therapsida". English. In: Journal of Paleontology 77.5 (2003), pp. 977-984.

[21342] C. A. Sidor, K. D. Angielczyk, D. M. Weide, R. M. H. Smith, S. J. Nesbitt, and L. A. Tsuji. “Tetrapod fauna of the lowermost Usili Formation (Songea Group, Ruhuhu Basin) of southern Tanzania, with a new burnetiid record". English. In: Journal of Vertebrate Paleontology 30.3 (2010), pp. 696703.

[21343] C. A. Sidor, K. D. Angielczyk, R. M. H. Smith, A. K. Goulding, S. J. Nesbitt, B. R. Peecook, J. S. Steyer, and S. Tolan. "Tapinocephalids (Therapsida: Dinocephalia) from the Permian Madumabisa Mudstone Formation (Lower Karoo, Mid-Zambezi Basin) of southern Zambia". English. In: Journal of Vertebrate Paleontology 34 (2014), pp. 980-986.

[21344] C. A. Sidor, D. C. Blackburn, and B. Gado. "The vertebrate fauna of the Upper Permian of Niger - II, Preliminary description of a new pareiasaur". English. In: Palaeontologia Africana 39 (2003), pp. $45-52$.

[21345] C. A. Sidor, R. Damiani, and W. R. Hammer. "A new Triassic temnospondyl from Antarctica and a review of Fremouw Formation biostratigraphy". English. In: Journal of Vertebrate Paleontology 28.3 (2008), pp. 656-663.

[21346] C. A. Sidor and P. J. Hancox. "Elliotherium kersteni, a new tritheledontid from the lower Elliot Formation (Upper Triassic) of South Africa". English. In: Journal of Paleontology 80.2 (2006), pp. 333342.

[21347] C. A. Sidor, J. A. Hopson, and A. W. Keyser. "A New Burnetiamorph Therapsid from the Teekloof Formation, Permian of South Africa". English. In: Journal of Vertebrate Paleontology 24.4 (2004), pp. 938-950.

[21348] C. A. Sidor and J. A. Hopson. "Cricodon metabolus (Cynodontia: Gomphodontia) from the Triassic Ntawere Formation of northeastern Zambia: patterns of tooth replacement and a systematic review of the Trirachodontidae". English. In: Journal of Vertebrate Paleontology 37.Sup. 1 (2018), pp. 39-64.

[21349] C. A. Sidor and B. S. Rubidge. "Herpetoskylax hopsoni, a new biarmosuchian (Therapsida: Biarmosuchia) from the Beaufort Group of South Africa". English. In: Amniote Paleobiology: Perspectives on the Evolution of Mammals, Birds, and Reptiles. Chicago: The University of Chicago Press, 2006, pp. 76-113.

[21350] C. A. Sidor and R. M. H. Smith. "A Second Burnetiamorph Therapsid from the Permian Teekloof Formation of South Africa and its Associated Fauna". English. In: Journal of Vertebrate Paleontology 27.2 (2007), pp. 420-430.

[21351] C. A. Sidor and R. M. H. Smith. "A new galesaurid (Therapsida: Cyndontia) from the Lower Triassic of South Africa". English. In: Palaeontology 47 (2004), pp. 535-556.

[21352] C. A. Sidor, R. M. H. Smith, A. K. Huttenlocker, and B. R. Peecook. "New Middle Triassic tetrapods from the upper Fremouw Formation of Antarctica and their depositional setting". English. In: 34 (2014), pp. 793-801.

[21353] C. A. Sidor, J. S. Steyer, and R. Damiani. "Parotosuchus (Temnospondyli: Mastodonsauridae) from the Triassic of Antarctica". English. In: Journal of Vertebrate Paleontology 27.1 (2007), pp. 232-235. 
[21354] C. A. Sidor, J. S. Steyer, and W. R. Hammer. "A new capitosauroid temnospondyl from the Middle Triassic upper Fremouw Formation of Antarctica". English. In: 34 (2014), pp. 539-548.

[21355] C. A. Sidor and J. Welman. "A second specimen of Lemurosaurus pricei (Therapsida: Burnetiamorpha)". English. In: Journal of Vertebrate Paleontology 23.3 (2003), pp. 631-642.

[21356] E. Sidorchuk and M. Bertrand. “New fossil labidostomatids (Acari: Labidostomatidae) from Eocene amber and presence of an apustulate species in Europe". English. In: Acarologia 53 (2013), pp. 2539.

[21357] E. A. Sidorchuk and P. B. Klimov. "Redescription of the mite Glaesacarus rhombeus (Koch \& Berendt, 1854) from Baltic amber (Upper Eocene): evidence for female-controlled mating". English. In: Journal of Systematic Palaeontology 9 (2011), pp. 183-196.

[21358] E. A. Sidorchuk and R. A. Norton. "The fossil mite family Archaeorchestidae (Acari, Oribatida) I: redescription of Strieremaeus illibatus and synonymy of Strieremaeus with Archaeorchestes". English. In: Zootaxa 2993 (2011), pp. 34-58.

[21359] E. A. Sidorchuk and R. A. Norton. "The fossil mite family Archaeorchestidae (Acari, Oribatida) II: redescription of Plategeocranus sulcatus and family-group relationships". English. In: Zootaxa 3051 (2011), pp. 14-40.

[21360] E. A. Sidorchuk and R. A. Norton. "Redescription of the fossil oribatid mite Scutoribates perornatus, with implications for systematics of Unduloribatidae (Acari: Oribatida)". English. In: Zootaxa 2666 (2010), pp. 45-67.

[21361] E. A. Sidorchuk, V. Perrichot, and E. E. Lindquist. “A new fossil mite from French Cretaceous amber (Acari: Heterostigmata: Nasutiacaroidea superfam. nov.), testing evolutionary concepts within the Eleutherengona (Acariformes)". English. In: Journal of Systematic Palaeontology 14 (2016), pp. 297-317.

[21362] E. A. Sidorchuk, A. R. Schmidt, E. Ragazzi, G. Roghi, and E. E. Lindquist. "Plant-feeding mite diversity in Triassic amber (Acari: Tetrapodili)". English. In: Journal of Systematic Palaeontology 13 (2015), pp. 129-151.

[21363] H. Siegmund. "The Ocruranus-Eohalobia group of small shelly fossils from Lower Cambrian of Yunnan, China - Sigmund 1997". In: Lethaia 30 (1997), pp. 285-291.

[21364] B. Sigé, M. Archer, J. -Y. Crochet, H. Godthelp, S. Hand, and R. Beck. “Chulpasia and Thylacotinga, late Paleocene-earliest Eocene trans-Antarctic Gondwanan bunodont marsupials: New data from Australia". English. In: Geobios 42 (2009), pp. 813-823.

[21365] B. Sigé, M. Hugueney, J. -Y. Crochet, S. Legendre, C. Mourer-Chauviré, J. -C. Rage, and R. SimonCoinçon. "Baraval, nouvelle faune de l'Oligocéne inférieur de l'Oligocéne inférieur (MP 22) des Phosphorites du Quercy. Apport á la signification chronologique des remplissages karstiques". French. In: Bulletin de la Société d'Histoire naturelle de Toulouse 134 (1998), pp. 85-90.

[21366] B. Sigé, T. Sempere, R. F. Butler, L. G. Marshall, and J. -Y. Crochet. “Age and stratigraphic reassessment of the fossil-bearing Laguna Umayo red mudstone unit, SE Peru, from regional stratigraphy, fossil record, and paleomagnetism". English. In: Geobios 37 (2004), pp. 771-794.

[21367] B. Sigé and G. Storch. “Un nouveau Saturninia (Nyctitheriidae, Lipotyphla, Mammalia) de l'assise OK (Oberkohle, MP 14) du bassin lignitifére du Geiseltal (Eocéne moyen supérieur d'Allemagne)". English. In: Senckenbergiana lethaea 81.2 (2001), pp. 343-346.

[21368] B. Sigé, H. Thomas, S. Sen, E. Gheerbrant, J. Roger, Z, and Al-Sulaimani. “Les chiroptéres de Taqah (Oligocéne inférieur, Sultanat d'Oman): Premier inventaire systématique". English. In: Munchner geowissenschaftliche Abhandlungen 26 (1994), pp. 35-48.

[21369] D. Sigogneau-Russell. "First evidence of Multituberculata (Mammalia) in the Mesozoic of Africa". In: Neues Jahrbuch für Geologie und Paläontologie Monatshefte 1991.H2 (1991), pp. 119-125.

[21370] D. Sigogneau-Russell. "Docodonts from the British Mesozoic". English. In: Acta Palaeontologica Polonica 48.3 (2003), pp. 357-374. 
[21371] D. Sigogneau-Russell. “Hypomylos phelizoni nov. gen. nov. sp., une étape précoce de l'évolution de la molaire tribosphénique (Crétacé basal du Maroc)". French. In: Geobios 25.2 (1992), pp. 389393.

[21372] D. Sigogneau-Russell. "Two possibly aquatic triconodont mammals from the Early Cretaceous of Morocco". English. In: Acta Palaeontologica Polonica 40.2 (1995), pp. 149-162.

[21373] D. Sigogneau-Russell. "Decouverte du premier mammifere tribosphenique du Mesozoique africain". French. In: Comptes-rendus de l'Academie des Sciences de Paris, serie II 313 (1991), pp. 1635-1640.

[21374] D. Sigogneau-Russell. "Nouveaux Mammiferes theriens du Cretace inferieur du Maroc". French. In: Comptes-Rendus de l'Academis des Sciences du Paris, series II 313 (1991), pp. 279-285.

[21375] D. Sigogneau-Russell. “Reevaluation des Peramura (Mammalia, Cladotheria) sur la base de nouveaux specimens de Cretace inferieur d'Angleterre et du Maroc". French. In: Geodiversitas 21.1 (1999), pp. 93-127.

[21376] D. Sigogneau-Russell. "Further data and reflexions on the tribosphenid mammals (Tribotheria) from the Early Cretaceous of Morocco". English. In: Bull Mus natl Hist nat, Paris, 4 ser 16.2-4 (1995), pp. 291-312.

[21377] D. Sigogneau-Russell. “Discovery of a Late Jurassic Chinese mammal in the Upper Bathonian of England". English. In: Comptes Rendus de l'Académie des Sciences de la Terre et des Planetes 327 (1998), pp. 571-576.

[21378] D. Sigogneau-Russell and P. Ensom. "Thereuodon (Theria, Symmetrodonta) from the Lower Cretaceous of North Africa and Europe, and a brief review of symmetrodonts". English. In: Cretaceous Research 19 (1998), pp. 445-470.

[21379] D. Sigogneau-Russell, S. E. Evans, J. F. Levine, and D. A. Russell. “The Early Cretaceous microvertebrate locality of Anoual, Morocco: a glimpse at the small vertebrate assemblages of Africa". English. In: Lower and Middle Cretaceous Terrestrial Ecosystems, New Mexico Museum of Natural History and Science Bulletin 14 (1998), pp. 177-181.

[21380] D. Sigogneau-Russell and G. Hahn. Late Triassic microvertebrates from central Europe. English. In N. C. Fraser \& H.-D. Sues (eds.), In the Shadow of the Dinosaurs: Early Mesozoic Tetrapods. Cambridge University Press, Cambridge. 1994, pp. 197-213.

[21381] D. Sigogneau-Russell and R. Hahn. "Reassessment of the late Triassic symmetrodont mammal Woutersia". English. In: Acta Palaeontologica Polonica 40.3 (1995), pp. 245-260.

[21382] D. Sigogneau-Russell, J. J. Hooker, and P. C. Ensom. "The oldest tribosphenic mammal from Laurasia (Purbeck Limestone Group, Berriasian, Cretaceous, UK) and its bearing on the 'dual origin' of Tribosphenida". English. In: Comptes-Rendus de l'Academie des Sciences, Paris, Sciences de la Terres et des planetes 333 (2001), pp. 141-147.

[21383] D. Sigogneau-Russell, M. Monbaron, and E. de Kaenel. “Nouvelles données sur le gisement á mammiféres Mésozoques du Haut-Atlas Marocain”. French. In: Géobios 23.4 (1990), pp. 461-483.

[21384] T. Sigurdsen, A. K. Huttenlocker, S. P. Modesto, T. B. Rowe, and R. Damiani. "Reassessment of the morphology and paleobiology of the therocephalian Tetracynodon darti (Therapsida), and the phylogenetic relationships of Baurioidea". English. In: Journal of Vertebrate Paleontology 32.5 (2012), pp. 1113-1134.

[21385] V. V. Silantiev and M. N. Urazaeva. “Hypoanthraconaia: a new genus of non-marine bivalve molluscs from the Early Permian of Far East Russia". English. In: Palaeontologische Zeitschrift 91 (2017), pp. 71-84. DOI: 10.1007/s12542-016-0334-4.

[21386] V. V. Silantiev, M. N. Urazaeva, and V. K. Golubev. The Nonmarine Bivalve Permianaia gen. nov., the Last Member of Naiaditidae from the Terminal Permian the East European Platform. English. Vol. 52. Paleontological Journal 7. 2018, pp. 777-790. DOI: 10.1134/S0031030118070109.

[21387] M. T. Silcox, J. I. Bloch, D. M. Boyer, and P. Houde. "Cranial anatomy of Paleocene and Eocene Labidolemur kayi (Mammalia: Apatotheria), and the relationships of the Apatemyidae to other mammals". English. In: Zoological Journal of the Linnean Society 160 (2010), pp. 773-825. 
[21388] M. T. Silcox, D. W. Krause, M. C. Maas, and R. C. Fox. "New specimens of Elphidotarsius russelli (Mammalia, ?Primates, Carpolestidae) and a revision of plesiadapoid relationships". English. In: Journal of Vertebrate Paleontology 21.1 (2001), pp. 132-152.

[21389] M. T. Silcox, K. D. Rose, and S. L. Walsh. "New specimens of picromomyids (Plesiadapiformes, Primates) with description of a new species of Alveojunctus". English. In: Annals of Carnegie Museum 71.1 (2002), pp. 1-12.

[21390] A. H. Sileem, H. M. Sallam, A. G. A. Hewaidy, E. R. Miller, and G. F. Gunnell. "A new anthracothere (Artiodactyla) from the early Oligocene, Fayum, Egypt, and the mystery of African 'Rhagatherium' solved". English. In: Journal of Paleontology 90.1 (2016), pp. 170-181.

[21391] G. Siliceo, M. J. Salesa, M. Antón, M. F. G. Monescillo, and J. Morales. "Promegantereon ogygia (Felidae, Machairodontinae, Smilodontini) from the Vallesian (late Miocene, MN 10) of Spain: morphological and functional differences in two noncontemporary populations". English. In: Journal of Vertebrate Paleontology 34.2 (2014), pp. 407-418. DOI: 10.1080/02724634.2013.812099.

[21392] M. B. Silva Lacerda, L. G. Souza, L. S. Lobo, C. E. G. R. Schaefer, and P. S. R. Romano. “New outcrop with vertebrate remains from Solimões Formation (Eocene-Pliocene), Southern Solimões Basin, Acre State, Northern Brazil". English. In: Journal of South American Earth Sciences 101 (2020), 102588:1-14. DOI: 10.1016/j.jsames.2020.102588.

[21393] G. Silvestri, F. R. Bosellini, and J. H. Nebelsick. "Microtaphofacies analysis of Lower Oligocene turbid-water coral assemblages". English. In: Palaios 26 (2011), pp. 805-820.

[21394] S. M. Silvestri and M. J. Szajna. "Biostratigraphy of vertebrate footprints in the Late Triassic section of the Newark Basin, Pennsylvania: reassessment of stratigraphic ranges". English. In: The Nonmarine Triassic. New Mexico Museum of Natural History and Science Bulletin 3 (1993), pp. 439445.

[21395] A. Simeone and X. Navarro. "Human exploitation of seabirds in coastal southern Chile during the mid-Holocene". English. In: Revista Chilena de Historia Natural 75 (2002), pp. 423-431.

[21396] N. B. Simmons, K. L. Seymour, J. Habersetzer, and G. F. Gunnell. “Primitive Early Eocene bat from Wyoming and the evolution of flight and echolocation". English. In: Nature 451 (2008), pp. 818821. DOI: $10.1038 /$ nature06549.

[21397] N. B. Simmons, E. R. Seiffert, and G. F. Gunnell. “A New Family of Large Omnivorous Bats (Mammalia, Chiroptera) from the Late Eocene of the Fayum Depression, Egypt, with Comments on Use of the Name Eochiroptera". English. In: American Museum Novitates 3857 (2016), pp. 1-43.

[21398] M. Simms, C. T. S. Little, and B. R. Rosen. "Corals not serpulids: mineralized colonial fossils in the Lower Jurassic marginal facies of South Wales". In: Proceedings of the Geologists' Association 113.1 (2002), pp. 31-36.

[21399] M. J. Simms. "Crinoids from the Chambara Formation, Pucara Group, Central Peru". English. In: Palaeontographica Abteilung A 233 (1994), pp. 169-175.

[21400] M. G. Simões and L. E. Anelli. “Taxonomic position of Guiratingia mendesi (Megadesmidae) and the evolution of Permian endemic bivalve fauna of the Paraná basin, Brazil". English. In: Revista Brasileira de Paleontologia 13 (2010), pp. 167-174.

[21401] M. G. Simões, L. E. Anelli, and J. M. David. “Othonella araguaiana (Bivalvia, Megadesmidae) from the Corumbata Formation (Midlle Permian), eastern margin of the Paraná Basin: systematic, evolutionary and biostratigraphic significances". English. In: Revista do Instituto Geociencias - USP 10 (2010), pp. 45-55.

[21402] M. G. Simões, J. M. David, L. E. Anelli, C. Klein, S. A. Matos, V. B. Guerrini, and L. V. Warren. "The Permian Tiaraju bivalve assemblage, Passa Dois Group, southern Brazil: biostratigraphic and paleobiogeographic significance". English. In: Brazilian Journal of Geology 47 (2017), pp. 209224.

[21403] M. G. Simões, L. H. C. de Mello, F. F. Torello, and R. P. Ghilardi. “Tambaquyra gen. n. (Bivalvia, Anomalodesmata), Formação Serra Alta (Neopermiano), Grupo Passa Dois, Bacia do Paraná, Brasil". Portugese. In: Revista Universidade de Guarulhos, Serie Geosciencias 6 (2000), pp. 11-19. 
[21404] M. G. Simoes and M. Kowalewski. "Shell beds as paleoecological puzzles: a case study from the Upper Permian of the Parana Basin, Brazil". In: Facies 38 (1998), pp. 175-196.

[21405] M. G. Simóes, A. C. Marques, L. H. Cruz de Mello, and L. E. Anneli. "Phylogenetic analysis of the genera of the extinct family Megadesmidae (Bivalvia, Anomalodesmata), with remarks on its paleoecology and taxonomy". English. In: Journal of Comparative Biology 2.2 (1997), pp. 75-90.

[21406] M. G. Simões, S. A. Matos, L. E. Anelli, R. Rohn, L. V. Warren, and J. M. David. "A new Permian bivalve-dominated assemblage in the Rio do Rasto Formation, Parana Basin, Brazil: Faunal turnover driven by regional-scale environmental changes in a vast epeiric sea". English. In: Journal of South American Earth Sciences 64 (2015), pp. 14-26.

[21407] M. G. Simões, J. P. Neves, L. E. Anelli, and L. C. Weinschütz. "Permian bivalves of the Taciba Formation, Itararé Group, Paraná Basin, and their biostratigraphic significance". English. In: Revista do Instituto de Geociencias - USP 12 (2012), pp. 71-82.

[21408] M. G. Simões, F. Quaglio, L. V. Warren, L. E. Anelli, P. Stone, C. Riccomini, C. H. Grohmann, and M. A. C. Chamani. "Permian non-marine bivalves of the Falkland Islands and their palaeoenvironmental significance". English. In: Alcheringa 36 (2012), pp. 543-554.

[21409] T. R. Simões, M. W. Caldwell, and A. W. A. Kellner. "A new Early Cretaceous lizard species from Brazil, and the phylogenetic position of the oldest known South American squamates". English. In: Journal of Systematic Palaeontology 13.7 (2015), pp. 601-614. DOI: 10.1080/14772019.2014.947342.

[21410] T. R. Simoes, M. W. Caldwell, R. L. Nydam, and P. Jimenez-Huidobro. “Osteology, phylogeny, and functional morphology of two Jurassic lizard species and the early evolution of scansoriality in geckoes". English. In: Zoological Journal of the Linnean Society (2016), pp. 1-26. DOI: 10.1111/zoj. 12487.

[21411] T. R. Simões, E. Wilner, M. W. Caldwell, L. C. Weinschütz, and A. W. A. Kellner. “A stem acrodontan lizard in the Cretaceous of Brazil revises early lizard evolution in Gondwana". English. In: Nature Communications 6 (2015), 8149:1-8. DOI: 10.1038/ncomms9149.

[21412] D. J. Simon, D. J. Varricchio, Z. Jin, and S. F. Robison. “Microstructural overlap of Macroelongatoolithus eggs from Asia and North America expands the occurrence of colossal oviraptorosaurs". English. In: Journal of Vertebrate Paleontology 38.6 (2019), e1553046:1-16. DOI: 10.1080 / 02724634. 2018.1553046.

[21413] E. Simon. "Upper Campanian brachiopods from the Mons Basin (Hainaut, Belgium): the brachiopod assemblage from the Belemnitella mucronata Zone". English. In: Bulletin De L'Institut Royal Des Sciences Naturelles de Belgique, Sciences De La Terre 70 (2000), pp. 129-160.

[21414] E. Simon. "A reappraisal of some large late Maastrichtian brachiopods from Kunrade (southern Limburg, The Netherlands)". English. In: Bulletin de l'Institut Royal des Sciences Naturelles de Belgique, Sciences de la Terre 74.Suppl (2004), pp. 121-137.

[21415] E. Simon. "A new Late Maastrichtian rhynchonellide brachiopod from the Kunrade Limestone facies near Maastricht (southern Limburg, The Netherlands)". English. In: Bulletin de l'Institut Royal des Sciences Naturelles de Belgique, Sciences de la Terre 73 (2003), pp. 137-148.

[21416] E. Simon. "Maastrichtian brachiopods from Ciply: palaeoecological and stratigraphical significance". English. In: Bulletin de l'Institut Royal des Sciences Naturelles de Belgique, Sciences de la Terre 68 (1998), pp. 181-232.

[21417] E. Simon. "A late Maastrichtian species of Gisilina (Brachiopoda, Chlidonophoridae) from the Maastricht area (The Netherlands, Belgium) first illustrated by Faujas de Saint-Fond". English. In: Bulletin de l'Institut Royal des Sciences Naturelles de Belgique, Sciences de la Terre 77 (2007), pp. 131140.

[21418] E. Simon. "New Lower Maastrichtian megathyridid brachiopods from the phosphatic chalk of Ciply (Mons, Belgium)". English. In: Bulletin van het Koninklijk Belgisch Institut voor Natuurwetenschappen, Aardwetenschappen 62 (1992), pp. 121-138. 
[21419] E. Simon. “New Lower Maastrichtian brachiopods (Gulpen Formation, Vijlen Member) from southern Limburg (The Netherlands)". English. In: Bulletin de l'Institut Royal des Sciences Naturelles de Belgique, Sciences de la Terre 75 (2005), pp. 127-165.

[21420] E. Simon and N. Motchurova-Dekova. "New representatives of the genus Septatoechia Lobatscheva \& Titova, 1977 (Brachiopoda, Rhynchonellida, Tetrarhynchiidae) from the Maastrichtian of Western Europe". English. In: Bulletin De L'Institut Royal Des Sciences Naturelles De Belgique(Bulletin Van Het Konikluk Belgisch Instituut Voor Natuurwetenschappen) 80 (2010), pp. 171-186.

[21421] E. Simon and E. F. Owen. "A first step in the revision of the genus Cretirhynchia Pettitt, 1950". English. In: Bulletin de l'Institut Royal des Sciences Naturelles de Belgique, Sciences de la Terre 71 (2001), pp. 53-118.

[21422] E. Simón, L. Salgado, and J. O. Calvo. "A new titanosaur sauropod from the Upper Cretaceous of Patagonia, Neuquén Province, Argentina". English. In: Ameghiniana 55.1 (2018), pp. 1-29. DOI: 10.5710/AMGH.01.08.2017.3051.

[21423] E. Simon and D. ya. "New fossil taxa of Monophlebidae (Sternorrhyncha: Coccoidea) from Baltic amber". English. In: European Journal of Entomology 111 (2015), pp. 381-388.

[21424] M. E. Simon and A. W. A. Kellner. "New sphenodontid (Lepidosauria, Rhynchocephalia, Eilenodontinae) from the Candeleros Formation, Cenomanian of Patagonia, Argentina". English. In: Boletim do Museu Nacional, Geologia, nova série 68 (2003), pp. 1-12.

[21425] R. V. Simon, C. A. Sidor, K. D. Angielczyk, and R. M. H. Smith. "First record of a tapinocephalid (Therapsida: Dinocephalia) from the Ruhuhu Formation (Songea Group) of southern Tanzania". English. In: Journal of Vertebrate Paleontology 30.4 (2010), pp. 1289-1293.

[21426] L. A. Simonarson, K. S. Petersen, and S. Funder. "Molluscan palaeontology of the Pliocene-Pleistocene Kap Kobenhavn Formation, North Greenland". English. In: Meddelelser om Gronland, Geoscience 36 (1998), pp. 1-104.

[21427] L. Simone, G. Carannante, D. Ruberti, M. Sirna, G. Sirna, A. Laviano, and M. Tropeano. “Development of rudist lithosomes in the Coniacian-Lower Campanian carbonate shelves of centralsouthern Italy: high-energy vs low-energy settings". English. In: Palaeogeography, Palaeoclimatology, Palaeoecology 200 (2003), pp. 5-29.

[21428] G. Simonpietri, J. Philip, and J. P. Platel. "Etude statistique des espéces de Vaccinites (Hippuritacea, Hippuritidae) du Campanien du Sultanat d'Oman". French. In: Geobios 31 (1998), pp. 313329.

[21429] E. L. Simons. "Diversity in the early Tertiary anthropoidean radiation in Africa". English. In: Proceedings of the National Academy of Sciences 89 (1992), pp. 10743-10747.

[21430] E. L. Simons. "Discovery of the Smallest Fayum Egyptian Primates (Anchomomyini, Adapidae)". English. In: Proceedings of the National Academy of Sciences 94.1 (1997), pp. 180-184.

[21431] E. L. Simons. "The cranium of Parapithecus grangeri, an Egyptian Oligocene anthropoidean primate". English. In: Proceedings of the National Academy of Sciences 98 (2001), pp. 7892-7897.

[21432] E. L. Simons. "Crania of Apidium: primitive anthropoidean (Primates, Parapithecidae) from the Egyptian Oligocene". English. In: American Museum Novitates 3124 (1995), pp. 1-10.

[21433] E. L. Simons, L. R. Godfrey, W. L. Jungers, P. S. Chatrath, and J. Ravaoarisoa. “A new species of Mesopropithecus (Primates, Palaeopropithecidae) from northern Madagascar". English. In: International Journal of primatology 16.4 (1995), pp. 653-682.

[21434] E. L. Simons, P. A. Holroyd, and T. M. Bown. "Early Tertiary elephant-shrews from Egypt and the origin of the Macroscelidea". English. In: Proceedings of the National Academy of Sciences 88 (1991), pp. 9734-9737.

[21435] E. L. Simons, D. T. Rasmussen, and P. D. Gingerich. "New cercamoniine adapid from Fayum, Egypt". English. In: Journal of Human Evolution 29.6 (1995), pp. 577-589. 
[21436] E. L. Simons, E. R. Seiffert, P. S. Chatrath, and Y. Attia. “Earliest record of a parapithecid anthropoid from the Jebel Qatrani Formation, northern Egypt". English. In: Folia Primatologica 72 (2001), pp. 316-331.

[21437] T. J. Simonsen, D. L. Wagner, and M. Heikkilä. “Ghosts from the past: a review of fossil Hepialoidea (Lepidoptera)". English. In: PeerJ 7.e7982 (2019). DOI: 10.7717/peerj.7982.

[21438] E. L. Simpson, H. F. Malenda, M. Needle, H. L. Hilbert-Wolf, A. Steullet, K. Boling, M. C. Wizevich, and S. E. Tindall. Upper Cretaceous dinosaur tracks from the upper and capping sandstone members of the Wahweap Formation, Grand Staircase-Escalante National Monument, Utah, U.S.A. English. Vol. 53. Fossil Record 3. New Mexico Museum of Natural History and Science Bulletin. Albuquerque: New Mexico Museum of Natural History and Science, 2011, pp. 380-385.

[21439] H. J. Sims, P. S. Herendeen, and P. R. Crane. "New genus of fossil Fagaceae from the Santonian (Late Cretaceous) of central Georgia, U.S.A". In: International Journal of Plant Sciences 159.2 (1998), pp. 391-404.

[21440] H. J. Sims, P. S. Herendeen, R. Lupia, R. A. Christopher, and P. R. Crane. "Fossil flowers with Normapolles pollen from the Upper Cretaceous of southeastern North America". English. In: Review of Palaeobotany and Palynology 106 (1999), pp. 131-151.

[21441] S. A. Simutnik. "A new genus of encyrtid wasps (Hymenoptera, Chalcidoidea, Encyrtidae) from Late Eocene Rovno Amber (Ukraine)". Russian. In: Vestnik Zoologii 36 (2002), pp. 99-102.

[21442] S. A. Simutnik. "The first record of Encyrtidae (Hymenoptera, Chalcidoidea) from the Sakhalin amber". English. In: Paleontological Journal 48 (2014), pp. 621-623.

[21443] S. A. Simutnik. "A new fossil genus of Encyrtidae (Hymenoptera: Chalcidoidea) from Late Eocene Danish amber". English. In: Russian Entomological Journal 24 (2015), pp. 73-75.

[21444] S. A. Simutnik. "Description of two new monotypical genera of encyrtid wasps (Hymenoptera, Chalcidoidea: Encyrtidae), based on males from the Middle Eocene Sakhalin Amber". English. In: Entomological Review 95 (2015), pp. 937-940.

[21445] S. A. Simutnik and E. E. Perkovsky. "A description of the encyrtid male (Hymenoptera, Chalcidoidea, Encyrtidae) with archaic structure of metasoma from Rovno amber". English. In: Vestnik Zoologii 40 (2006), pp. 283-286.

[21446] S. A. Simutnik, E. E. Perkovsky, and A. V. Gumovsky. "Review of the late Eocene Encyrtidae (Hymenoptera, Chalcidoidea) with a description of the first fossil genus with filum spinosum". English. In: Paleontological Journal 48 (2014), pp. 65-73.

[21447] S. A. Simutnik and E. E. Perkovsky. "Rovnosoma gen. nov. (Hymenoptera, Chalcidoidea, Encyrtidae) from the late Eocene Rovno Amber". English. In: Paleontological Journal 49 (2015), pp. 3638.

[21448] S. A. Simutnik and E. E. Perkovsky. "Protocopidosoma gen. nov. (Hymenoptera, Chalcidoidea, Encyrtidae) from the late Eocene Danish amber". English. In: Paleontological Journal 51 (2017), pp. 288-290.

[21449] S. A. Simutnik and E. E. Perkovsky. "Dencyrtus gen. nov. (Hymenoptera, Chalcidoidea, Encyrtidae) from the late Eocene Danish amber". English. In: Paleontological Journal 52 (2018), pp. 290293.

[21450] S. A. Simutnik and E. E. Perkovsky. “Trjapitzion Simutnik, gen. n. (Hymenoptera, Chalcidoidea: Encyrtidae), a new genus of encyrtid wasps from the late Eocene Rovno amber". Russian. In: Entomologicheskoe Obozrenie 97 (2018), pp. 537-542.

[21451] S. A. Simutnik and E. E. Perkovsky. "Archaeocercus gen. nov. (Hymenoptera, Chalcidoidea, Encyrtidae) from Late Eocene Rovno Amber". English. In: Zootaxa 4441 (2018), pp. 543-548.

[21452] S. A. Simutnik, E. E. Perkovsky, and D. V. Vasilenko. "Efesus trufanovi Simutnik gen. et sp.n. (Hymenoptera: Chalcidoidea: Encyrtidae) from late Eocene Danish amber". English. In: Russian Entomological Journal 29 (2020), pp. 298-302. 
[21453] S. A. Simutnik, E. E. Perkovsky, and D. V. Vasilenko. “First record of Leptoomus janzeni Gibson (Hymenoptera, Chalcidoidea) from Rovno amber". English. In: Journal of Hymenoptera Research 80 (2020), pp. 137-145. DOI: 10.3897/jhr.80.58882.

[21454] B. J. Sinclair. "Proclinopyga ulrichi sp. nov.: the first fossil aquatic dance fly of the subfamily Clinocerinae (Diptera: Empididae)". English. In: Bonn Zoological Bulletin 57.1 (2010), pp. 85-89.

[21455] B. J. Sinclair and C. Hoffeins. “New fossil species of Ragas Walker (Diptera: Empididae) in Baltic amber (Tertiary, Eocene)". English. In: Bonn Zoological Bulletin 62 (2013), pp. 92-99.

[21456] N. P. Singh, A. M. Jukar, R. Patnaik, K. M. Sharma, N. A. Singh, and Y. P. Singh. "The first specimen of Deinotherium indicum (Mammalia, Proboscidea, Deinotheriidae) from the late Miocene of Kutch, India". English. In: Journal of Paleontology 94.4 (2020), pp. 788-795. DOI: 10.1017/jpa.2020.3.

[21457] S. K. Singh, S. Kishore, P. K. Mirsa A. K. Jauhri, and Anjali Gupta. "Middle Eocene calcareous algae from the southwestern Kachchh, Gujarat". English. In: Journal Geological Society of India 75 (2010), pp. 749-759.

[21458] T. Singh and N. W. Archbold. "Brachiopoda from the Early Permian of the eastern Himalaya". English. In: Alcheringa 17 (1993), pp. 55-75.

[21459] N. D. Sinitshenkova. "New Stoneflies of the Family Palaeonemouridae from the Upper Permian of Udmurtiya and the Orenburg Region (Insecta: Perlida = Plecoptera)". English. In: Paleontological Journal 38.Suppl 2 (2004), S164-S172.

[21460] N. D. Sinitshenkova. New Jersey amber mayflies: the first North American Mesozoic members of the order (Insecta; Ephemeroptera). English. Studies on fossils in amber, with particular reference to the Cretaceous of New Jersey. Leiden: Backhuys Publishers, 2000, pp. 111-125.

[21461] N. D. Sinitshenkova. “New Mesozoic Mayflies from Transbaikal and Mongolia”. English. In: Paleontological Journal 25.1 (1991), pp. 116-119.

[21462] N. D. Sinitshenkova. “New stoneflies (Insecta: Perlida = Plecoptera) from the late Mesozoic locality Khasurty, Transbaikalia". English. In: Paleontological Journal 45.5 (2011), pp. 552-558.

[21463] N. D. Sinitshenkova. "The Oldest Known Record of an Imago of Nemouridae (Insecta: Perlida = Plecoptera) in the Late Mesozoic of Eastern Transbaikalia". English. In: Paleontological Journal 39.1 (2005), pp. 38-40.

[21464] N. D. Sinitshenkova. "New Late Mesozoic mayflies from the Shar-Teeg Locality, Mongolia (Insecta, Ephemerida=Ephemeroptera)". English. In: Paleontological Journal 36.3 (2002), pp. 270-276.

[21465] N. D. Sinitshenkova. Dva novykh vida nasekomykh (Insecta: Dictyoneurida=Palaeodictyoptera, Perlida=Plecoptera) iz pozdnei Permi yuzhnoi Mongolii. Russian. Vol. 41. Novye Taksony Iskopaemykh Bespozvonochnykh Mongolii, Sovmestnaya Rossiisko-Mongol'skaya Paleontologicheskaya Ekspeditsiya. 1992, pp. 98-101.

[21466] N. D. Sinitshenkova. "New stoneflies (Insecta: Perlida=Plecoptera) from Eocene Rovno amber, Ukraine". English. In: Paleontological Journal 43.6 (2009), pp. 664-668.

[21467] N. D. Sinitshenkova. “The first fossil prosopistomatid mayfly from Burmese amber (Ephemeroptera; Prosopistomatidae)". English. In: Bulletin of the Natural History Museum, Geology Series 56.1 (2000), pp. 25-28.

[21468] N. D. Sinitshenkova. "The first European Cretaceous stonefly (Insecta, Perlida = Plecoptera)". English. In: Cretaceous Research 19 (1998), pp. 317-321.

[21469] N. D. Sinitshenkova. "A new mayfly species of the extant genus Neoephemera from the Eocene of North America (Insecta: Ephemerida = Ephemeroptera: Neoephemeridae)". English. In: Paleontological Journal 33 (1999), pp. 403-405.

[21470] N. D. Sinitshenkova. “New Mesozoic stoneflies from Asia”. English. In: Paleontological Journal 24.3 (1990), pp. 62-70.

[21471] N. D. Sinitshenkova. "New Upper Mesozoic Stoneflies from Central Transbaikalia (Insecta, Perlida=Plecoptera)". English. In: Paleontological Journal 32.2 (1998), pp. 167-173. 
[21472] N. D. Sinitshenkova. "New mayflies from the upper Mesozoic Transbaikalian locality Chernovskie Kopi (Insecta: Ephemerida = Ephemeroptera)". English. In: Paleontological Journal 34 (2000), pp. 68 74.

[21473] N. D. Sinitshenkova. "A review of Triassic mayflies, with a description of new species from western Siberia and Ukraine (Ephemerida = Ephemeroptera)". English. In: Paleontological Journal 34.Suppl 3 (2000), S275-S283.

[21474] N. D. Sinitshenkova. “New mayflies (Insecta: Ephemerida = Ephemeroptera) from the intertrappean deposits of the Tunguska Basin, Siberia". English. In: Paleontological Journal 47 (2013), pp. 8488.

[21475] N. D. Sinitshenkova. "New mayflies (Insecta: Ephemerida = Ephemeroptera) from the Upper Permian locality of Isady, northern European Russia". English. In: Paleontological Journal 47 (2013), pp. 162-165.

[21476] N. D. Sinitshenkova. “Mayflies. Ephemerida, in Pozdne-Mezozoyskie Nasekomye Vostochnogo Zabaykal'ya". Russian. In: vol. 239. Akademiya Nauk SSSR, Trudy Paleontologicheskogo Instituta. 1990, pp. 14-20.

[21477] N. D. Sinitshenkova. “New late Mesozoic stoneflies from Shara-Teeg, Mongolia (Insecta: PerlidaPlecoptera)". English. In: Paleontological Journal 29.4 (1995), pp. 93-104.

[21478] N. D. Sinitshenkova. "New upper Mesozoic stone flies from Yakutia (Insecta: Perlida = Plecoptera)". English. In: Paleontological Journal 26.3 (1992), pp. 43-55.

[21479] N. D. Sinitshenkova. "Stoneflies. Perlida, in Pozdne-Mezozoyskie Nasekomye Vostochnogo Zabaykal'ya". Russian. In: vol. 239. Akademiya Nauk SSSR, Trudy Paleontologicheskogo Instituta. 1990, pp. 207210.

[21480] N. D. Sinitshenkova. "New mayflies (Insecta: Ephemerida = Ephemeroptera) from the Upper Mesozoic locality of Khasurty, western Transbaikalia". English. In: Paleontological Journal 51 (2017), pp. 280-287.

[21481] N. D. Sinitshenkova. "New stoneflies of the suborder Nemourina Newman, 1853 (Insecta: Perlida = Plecoptera) from the Middle Permian deposits of the Kostovaty locality, Udmurtia, Russia". English. In: Paleontological Journal 52 (2018), pp. 1374-1380.

[21482] N. D. Sinitshenkova. "New stoneflies of the suborder Perlina Latreille, 1802 (Insecta: Perlida = Plecoptera) from the Middle Permian of the Kostovaty locality in Udmurtia, Russia". English. In: Paleontological Journal 52 (2018), pp. 1583-1592.

[21483] N. D. Sinitshenkova. "New species of Mischopterida = Megasecoptera (Insecta) from the Permian deposits of the Vorkuta Basin". English. In: Paleontological Journal 53 (2019), pp. 52-55. DOI: 10. 1134/S003103011901009X.

[21484] N. D. Sinitshenkova. "New dictyoneuridans (Insecta: Dictyoneurida Handlirsch = Palaeodictyoptera Goldenberg) from the Permian deposits of the Vorkuta basin". English. In: Paleontological Journal 54 (2020), pp. 126-131. DOI: 10.1134/S0031030120020136.

[21485] N. D. Sinitshenkova and D. S. Aristov. "New Permian Stoneflies of the Family Palaeonemouridae (Insecta: Perlida = Plecoptera) from the Isady Locality". English. In: Paleontological Journal 44 (2010), pp. 49-52.

[21486] N. D. Sinitshenkova and D. S. Aristov. “The biggest fossil mayfly (Insecta: Ephemerida=Ephemeroptera) from the Upper Permian locality of Isady, northern European Russia". English. In: Far Eastern Entomologist 255 (2012), pp. 8-10.

[21487] N. D. Sinitshenkova and D. S. Aristov. "The latest member of the order Mischopterida = Megasecoptera (Insecta) from the Upper Permian Isady locality". English. In: Paleontological Journal 47 (2013), pp. 704-705.

[21488] N. D. Sinitshenkova, D. S. Aristov, P. Wegierek, and D. ya. "New mayfly genera from the Middle Triassic of Poland and their evolutionary and paleogeographic implications (Ephemerida: Litophlebiidae, Vogesonymphidae)". English. In: Zootaxa 3949 (2015), pp. 281-288. 
[21489] N. D. Sinitshenkova and R. A. Coram. "The first mayfly from the Lower Cretaceous of southern England (Insecta: Ephemerida=Ephemeroptera)". English. In: Cretaceous Research 23 (2002), pp. 461-463.

[21490] N. D. Sinitshenkova, F. Marchal-Papier, L. Grauvogel-Stamm, and J. C. Gall. "The Ephemeridea (Insecta) from the Gres a Voltzia (early Middle Triassic) of the Vosges (NE France)". English. In: Paläontologische Zeitschrift 79.3 (2005), pp. 377-397.

[21491] N. D. Sinitshenkova, G. Y. Ponomareva, and D. S. Aristov. "A new megasecopteran species of the genus Aspidothorax Brongniart, 1893 (Insecta: Mischopterida = Megasecoptera: Aspidothoracidae) from the Middle Permian of Perm region, Russia". English. In: Paleontological Journal 54 (2020), pp. 273-278. DOI: 10.1134/S0031030120030144.

[21492] N. D. Sinitshenkova and D. V. Vassilenko. "The latest record of mayflies of the family Protereismatidae Sellards (Ephemerida $=$ Ephemeroptera) and a new species of the family Misthodotidae in the Upper Permian of Europe". English. In: Paleontological Journal 46 (2012), pp. 61-65.

[21493] L. Sirkin, B. J. Szabo, G. Padilla-Arredondo, S. Pedrin-Aviles, and E. Diaz-Rivera. “Uranium-series ages of marine terraces, La Paz Peninsula, Baja California Sur, Mexico". English. In: Coral Reefs 9 (1990), pp. 25-30.

[21494] M. Siverson. "Revision of the Danian cow sharks, sand tiger sharks, and goblin sharks (Hexanchidae, Odontaspididae, and Mitsukurinidae) from southern Sweden". English. In: Journal of Vertebrate Paleontology 15.1 (1995), pp. 1-12.

[21495] M. Siverson. "Sharks from the mid-Cretaceous Gearle Siltstone, Southern Carnarvon Basin, Western Australia". English. In: Journal of Vertebrate Paleontology 17.3 (1997), pp. 453-465.

[21496] M. Siverson. "Late Cretaceous Paraorthacodus (Palaeospinacidae, Neoselachii) from Sweden". English. In: Journal of Paleontology 66 (1992), pp. 994-1001.

[21497] M. Siverson. "Biology, dental morphology and taxonomy of lamniform sharks from the Campanian of the Kristianstad Basin, Sweden". English. In: Palaeontology 35 (1992), pp. 519-554.

[21498] M. Siverson. "Maastrichtian squaloid shaks from southern Sweden". English. In: Palaeontology 36 (1993), pp. 1-19.

[21499] M. Siverson. "A new large lamniform shark from the uppermost Gearle Siltstone (Cenomanian, Late Cretaceous) of Western Australia". English. In: Transactions of the Royal Society of Edinburgh: Earth Sciences 90 (1999), pp. 49-66. DOI: 10.1017/S0263593300002509.

[21500] M. Siverson. "Lamniform sharks of the mid Cretaceous Alinga Formation and Beedagong Claystone, Western Australia". English. In: Palaeontology 39 (1996), pp. 813-849.

[21501] M. Siverson. "Revision of Cretorectolobus (Neoselachii) and description of Cederstroemia n. gen., a Cretaceous carpet shark (Orectolobiformes) with a cutting dentition". English. In: Journal of Paleontology 69 (1995), pp. 974-979.

[21502] M. Siverson and H. Cappetta. "A skate in the lowermost Maastrichtian of southern Sweden". English. In: Palaeontology 44 (2001), pp. 431-445. DOI: 10.1111/1475-4983.00186.

[21503] M. Siverson and J. Lindgren. "Late Cretaceous sharks Cretoxyrhina and Cardabiodon from Montana, USA". English. In: Acta Palaeontologica Polonica 50 (2005), pp. 301-314.

[21504] M. Siverson, D. J. Ward, J. Lindgren, and L. S. Kelley. “Mid-Cretaceous Cretoxyrhina (Elasmobranchii) from Mangyshlak, Kazakhstan and Texas, USA". English. In: Alcheringa 37 (2013), pp. 87104. DOI: $10.1080 / 03115518.2012 .709440$.

[21505] M. Siversson, T. D. Cook, H. E. Ryan, D. K. Watkins, N. J. Tatarnic, P. J. Downes, and M. G. Newbrey. "Anacoracid sharks and calcareous nannofossil stratigraphy of the mid-Cretaceous 'upper' Gearle Siltstone and Haycock Marl in the lower Murchison River area, Western Australia". English. In: Alcheringa 43 (2018), pp. 85-113. DOI: 10.1080/03115518.2018.1462401.

[21506] M. Siversson, T. D. Cook, P. Cederström, and H. E. Ryan. “Early Campanian (Late Cretaceous) squatiniform and synechodontiform selachians from the Åsen locality, Kristianstad Basin, Sweden". English. In: Mesozoic Biotas of Scandinavia and its Arctic Territories. Geological Society, London, Special Publications 434 (2015), pp. 251-275. DOI: 10.1144/SP434.9. 
[21507] M. Siversson, J. Lindgren, M. G. Newbrey, P. Cederström, and T. D. Cook. “Cenomanian-Campanian (Late Cretaceous) mid-palaeolatitude sharks of Cretalamna appendiculata type". English. In: Acta Palaeontologica Polonica 60 (2015), pp. 339-384. DOI: 10.4202/app.2012.0137.

[21508] M. Siversson and M. Machalski. "Late late Albian (Early Cretaceous) shark teeth from Annopol, Poland". English. In: Alcheringa 41 (2017), pp. 433-463. DOI: 10.1080/03115518.2017.1282981.

[21509] D. J. Siveter, D. E. G. Briggs, M. D. Sutton, and S. C. Joomun. "A Silurian myodocope with preserved soft-parts: cautioning the interpretation of the shell-based ostracod record". English. In: Proceedings of the Royal Society of London B: Biological Sciences 280.1752 (2013), p. 20122664. DOI: 10.1098/rspb.2012.2664.

[21510] D. J. Siveter, R. A. Fortey, X. -J. Zhu, and Z. -Y. Zhou. "A three-dimensionally preserved aglaspidid euarthropod with a calcitic cuticle from the Ordovician of China". English. In: Geological Magazine 155.7 (2017), pp. 1427-1441.

[21511] D. J. Siveter and A. W. A. Rushton. “An ostracod-like-arthropod with appendages preserved from the lower Ordovician of England". English. In: Lethaia 28 (1995), pp. 299-307.

[21512] D. J. Siveter, M. D. Sutton, and D. E. G. Briggs. "An ostracode crustacean with soft parts from the Lower Silurian". English. In: Science 302 (2003), pp. 1749-1751.

[21513] D. J. Siveter, G. Tanaka, Ú C. Farrell, M. J. Martin, and D. E. G. Briggs. “Exceptionally preserved 450-million-year-old Ordovician ostracods with brood care". English. In: Current Biology 24 (2014), pp. 1-6. DOI: $10.1016 /$ j.cub.2014.02.040.

[21514] U. Sivhed, M. Erlström, J. A. Bojesen-Koefoed, and A. Löfgren. “Upper Ordovician carbonate mounds on Gotland, central Baltic Sea: distribution, composition and reservoir characteristics". English. In: Journal of Petroleum Geology 27.2 (2004), pp. 115-140.

[21515] J. Skartveit. "Fossil Hesperinidae and Bibionidae from Baltic amber (Diptera: Bibionoidea)". English. In: Studia Dipterologica 15 (2009), pp. 3-42.

[21516] J. Skartveit and G. Bechly. "First record of the march fly genus Plecia (Diptera: Bibionidae) in Dominican amber". English. In: Neues Jahrbuch für Geologie und Paläontologie, Abhandlungen 269 (2013), pp. 97-100.

[21517] J. Skartveit, F. Grimsson, and T. Wappler. "Bibionidae (Diptera) from the late Miocene of Hrútagil (Mókollsdalur), Iceland". English. In: PalZ 91 (2017), pp. 195-205.

[21518] J. Skartveit and A. Nel. "Fossil Bibionidae (Diptera: Bibionomorpha) from the late Oligocene of Bes-Konak, Anatolia, Turkey". English. In: Zootaxa 3329 (2012), pp. 51-63.

[21519] J. Skartveit and A. Nel. "Revision of fossil Bibionidae (Insecta: Diptera) from French Oligocene deposits". English. In: Zootaxa 4225 (2017), pp. 1-83.

[21520] P. E. Skelley. “The genus Dacne Latreille (Coleoptera: Erotylidae) in tropical America”. English. In: Insecta Mundi 17 (2003), pp. 111-117.

[21521] P. E. Skelley. "A new species of Dacne Latreille from Dominican amber, with a key and checklist to the known species of Dacne (Erotylidae: Dacninae)". English. In: Annales Zoologici 47 (1997), pp. 49-53.

[21522] P. W. Skelton and G. M. A. El-Asa'ad. "A new canaliculate rudist bivalve from the Aruma Formation of central Saudi Arabia". In: Geologica Romana 28 (1992), pp. 105-117.

[21523] P. W. Skelton, E. Gili, E. Vicens, and A. Obrador. "The growth fabric of gregarious elevators (hippuritids) in a Santonian carbonate platform in the southern Central Pyrenees". In: Palaeogeography, Palaeoclimatology, Palaeoecology 119 (1995), pp. 107-126.

[21524] K. Skibiska, W. Krzemiski, and R. A. Coram. "Discovery of the most ancient member of family Tanyderidae (Diptera) from the Lower Jurassic (Sinemurian) of England". English. In: Zootaxa 3857 (2014), pp. 125-130.

[21525] K. Skibiska. “Nannotanyderinae: A new subfamily of Tanyderidae (Diptera)”. English. In: Palaeontologia Electronica 19.3.56A (2016), pp. 1-16. 
[21526] K. Skibiska and W. Krzemiski. “Nannotanyderus kubekovensis sp. nov. (Diptera: Tanyderidae) from the Middle Jurassic of Kubekovo (Russia)". English. In: Annales Zoologici 63 (2013), pp. 409412.

[21527] K. Skibiska and W. Krzemiski. "New species of the genus Similinannotanyderus (Tanyderidae, Diptera) from the Myanmar amber". English. In: Cretaceous Research 90 (2018), pp. 56-59.

[21528] K. Skibiska, W. Krzemiski, and A. Arillo. “The first Tanyderidae (Diptera) from Lower Cretaceous Álava amber (Spain)". English. In: Historical Biology 31 (2017), pp. 872-878.

[21529] M. Skinner, D. I. Whiteside, and M. J. Benton. "Late Triassic island dwarfs? Terrestrial tetrapods of the Ruthin fissure (South Wales, UK) including a new genus of procolophonid". English. In: Proceedings of the Geologists' Association 131.5 (2020), pp. 535-561. DOI: 10.1016/j.pgeola.2020.04. 005.

[21530] J. Sklenár, T. Ko, and M. Jäger. "Late Turonian polychaete communities recorded in the hemipelagic sediments of the Bohemian Cretaceous Basin (Teplice Formation, Ohe and Dresden districts)". English. In: Bulletin of Geosciences 88.3 (2013), pp. 675-695.

[21531] J. Sklenar and E. Simon. "Brachiopod Gyrosoria Cooper, 1973- a comparative palaeoecological, stratigraphical and taxonomical study". English. In: Bulletin of Geosciences 84.3 (2009), pp. 437464.

[21532] S. Skoczen. "New records of Parascalops, Neurotrichus and Condylura (Talpinae, Insectivora) from the Pliocene of Poland." English. In: Acta Theriologica 38.2 (1993), pp. 125-137.

[21533] J. E. Skog and D. L. Dilcher. "A new species of Marsilea from the Dakota Formation in central Kansas". In: American Journal of Botany 79.9 (1992), pp. 982-988.

[21534] J. E. Skog and D. L. Dilcher. "Lower vascular plants of the Dakota Formation in Kansas and Nebraska, USA". English. In: Review of Palaeobotany and Palynology 80 (1994), pp. 1-18.

[21535] S. Skompski, P. Luczyjski, D. Drygant, and W. Kozlowski. "High-energy sedimentary events in lagoonal successions of the Upper Silurian of Podolia, Ukraine". English. In: Facies 54 (2008), pp. 277-296. DOI: 10.1007/s10347-007-0133-1.

[21536] S. Skompski, M. Paszkowski, M. Krobicki, K. Kokovin, D. Korn, A. Tomas, and T. Wezolek. “Depositional setting of the Devonian/Carboniferous biohermal Bol'shaya Nadota carbonate complex, Subpolar Urals". In: Acta Geologica Polonica 51.3 (2001), pp. 217-235.

[21537] E. Skourtsos, D. Vachard, A. Zambetakis-Lekkas, R. Martini, and L. Zaninetti. "Late Wuchiapingian (Late Dzhulfian, early Late Permian) limestone olistolites within the Tertiary flysch of Glypia Unit (Mount Parnon, central-eastern Peloponnesus, Greece)". English. In: Comptes Rendus Geoscience 334 (2002), pp. 925-931.

[21538] C. Skovsted. "Mobergellans (Problematica) from the Cambrian of Greenland, Siberia and Kazakhstan". English. In: Paläontologische Zeitschrift 77.2 (2003), pp. 429-443.

[21539] C. Skovsted and L. Holmer. "The Early Cambrian (Botomian) stem group brachiopod Mickwitzia from Northeast Greenland". English. In: Acta Palaeontologica Polonica 48.1 (2003), pp. 1-20.

[21540] C. B. Skovsted. "Mollusc fauna of the Early Cambrian Bastion Formation of North-East Greenland". In: Bulletin of the Geological Society of Denmark 51.1 (2004), pp. 11-37.

[21541] C. B. Skovsted. "Small shelly fossils from the basal Emigrant Formation (Cambrian, uppermost Dyeran Stage) of Split Mountain, Nevada". English. In: Canadian Journal of Earth Sciences 43.4 (2006), pp. 487-496. DOI: 10.1139/E05-119.

[21542] C. B. Skovsted. "Small shelly fauna from the upper Lower Cambrian Bastion and Ella Island Formations, North-East Greenland". English. In: Journal of Paleontology 80.6 (2006), pp. 1087-1112.

[21543] C. B. Skovsted. "Unusually preserved Salterella from the Lower Cambrian Forteau Formation of Newfoundland". English. In: Geologiska Föreningens i Stockholm Förhandlingar 125.1 (2003), pp. 1722. 
[21544] C. B. Skovsted, U. Balthasar, G. A. Brock, and J. R. Paterson. "The tommotiid Camenella reticulosa from the early Cambrian of South Australia: Morphology, scleritome reconstruction, and phylogeny". English. In: Acta Palaeontologica Polonica 54.3 (2009), pp. 525-540. DOI: 10.4202/app. 2008.0082.

[21545] C. B. Skovsted, G. A. Brock, and J. R. Paterson. "Bivalved arthropods from the Lower Cambrian Mernmerna Formation, Arrowie Basin, South Australia, and their implications for identification of Cambrian 'small shelly fossils'". English. In: Memoirs of the Association of Australasian Palaeontologists 32 (2006), pp. 7-41.

[21546] C. B. Skovsted, G. A. Brock, A. Lindström, J. S. Peel, J. R. Paterson, and M. K. Fuller. "Early Cambrian record failed durophagy and shell repair in an epibenthic mollusc". English. In: Biological Letters (2007).

[21547] C. B. Skovsted, G. A. Brock, J. R. Paterson, L. E. Holmer, and G. E. Budd. “The scleritome of Eccentrotheca from the Lower Cambrian of South Australia: Lophophorate affinities and implications for tommotiid phylogeny". English. In: Geology 36.2 (2008), pp. 171-174.

[21548] C. B. Skovsted, G. A. Brock, and T. P. Topper. "Sclerite fusion in the problematic early Cambrian spine-like Stoibostrombus from South Australia". English. In: Bulletin of Geosciences 86.3 (2011), pp. 651-658.

[21549] C. B. Skovsted, G. A. Brock, and T. P. Topper. "First occurrence of a new Ocruranus-like helcionelloid mollusc from the lower Cambrian of East Gondwana". English. In: Gondwana Research 22 (2012), pp. 256-261.

[21550] C. B. Skovsted, S. Clausen, J. J. Álvaro, and D. Ponlevé. “Tommotiids from the early Cambrian (Series 2, Stage 3) of Morocco and the evolution of the tannuolinid scleritome and setigerous shell structures in stem group brachiopods". English. In: Palaeontology 57.1 (2014), pp. 171-192. DOI: 10.1111/pala.12060.

[21551] C. B. Skovsted and L. E. Holmer. "The Lower Cambrian brachiopod Kyrshabaktella and associated shelly fossils from the Harkless Formation, southern Nevada". English. In: Geologiska Föreningens i Stockholm Förhandlingar 128.4 (2006), pp. 327-337.

[21552] C. B. Skovsted and L. E. Holmer. "Early Cambrian brachiopods from north-east Greenland". In: Palaeontology 48.2 (2005), pp. 325-345.

[21553] C. B. Skovsted, I. Knight, U. Balthasar, and W. D. Boyce. "Depth related brachiopod faunas from the lower Cambrian Forteau Formation of southern Labrador and western Newfoundland, Canada". English. In: Palaeontologia Electronica 20.3.54A (2017), pp. 1-52. DOI: 10.26879/775.

[21554] C. B. Skovsted and J. S. Peel. "Small shelly fossils from the argillaceous facies of the Lower Cambrian Forteau Formation of western Newfoundland". English. In: Acta Palaeontologica Polonica 52.4 (2007), pp. 729-748.

[21555] C. B. Skovsted, J. S. Peel, and C. J. Atkins. "The problematic fossil Triplicatella from the Early Cambrian of Greenland, Canada and Siberia". English. In: Canadian Journal of Earth Sciences 41 (2004), pp. 1273-1283. DOI: 10.1139/e04-066.

[21556] C. B. Skovsted and J. S. Peel. "The problematic fossil Mongolitubulus from the Lower Cambrian of Greenland". English. In: Bulletin of the Geological Society of Denmark 48 (2001), pp. 135-147.

[21557] C. B. Skovsted and J. S. Peel. "Early Cambrian brachiopods and other shelly fossils from the basal Kinzers Formation of Pennsylvania". English. In: Journal of Paleontology 84.4 (2010), pp. 754-762. DOI: $10.1666 / 09-123.1$.

[21558] C. B. Skovsted and J. S. Peel. "Hyolithellus in life position from the Lower Cambrian of north Greenland". English. In: Journal of Paleontology 85.1 (2011), pp. 37-47.

[21559] P. Skutschas. "Mesozoic amphibians from Siberia, Russia". English. In: 9th International Symposium on Mesozoic Terrestrial Ecosystems and Biota, Abstracts and Proceedings Volume (2006), pp. 123-126.

[21560] P. P. Skutschas. "New specimens of albanerpetontid amphibians from the Upper Cretaceous of Uzbekistan". English. In: Acta Palaeontologica Polonica 52.4 (2007), pp. 819-821. 
[21561] P. P. Skutschas. "A choristoderan reptile from the Lower Cretaceous of Transbaikalia, Russia". English. In: Neues Jahrbuch für Geologie und Paläontologie Abhandlungen 247.1 (2008), pp. 63-78. DOI: 10.1127/0077-7749/2008/0247-0063.

[21562] P. P. Skutschas. "Re-evaluation of Mynbulakia Nesov, 1981 (Lissamphibia: Caudata) and description of a new salamander genus from the Late Cretaceous of Uzbekistan". English. In: Journal of Vertebrate Paleontology 29.3 (2009), pp. 659-664. DOI: 10.1671/039.029.0326.

[21563] P. P. Skutschas. "Anuran remains from the Early Cretaceous of Transbaikalia, Russia". English. In: Russian Journal of Herpetology 10.3 (2003), pp. 213-216.

[21564] P. P. Skutschas and Y. M. Gubin. "A new salamander from the late Paleocene-early Eocene of Ukraine". English. In: Acta Palaeontologica Polonica 57.1 (2012), pp. 135-148.

[21565] P. P. Skutschas and V. V. Kolchanov. "Anurans (Amphibia: Anura) from the Upper Cretaceous (Santonian-lower Campanian) Bostobe Formation of northeastern Aral Sea region, Kazakhstan". English. In: Palaeoworld 26 (2017), pp. 202-208. DOI: 10.1016/j.palwor.2016.01.006.

[21566] P. P. Skutschas, V. V. Kolchanov, A. O. Averianov, T. Martin, R. Schellhorn, P. N. Kolosov, and D. D. Vitenko. "A new relict stem salamander from the Early Cretaceous of Yakutia, Siberian Russia". English. In: Acta Palaeontologica Polonica 63 (2018). DOI: 10.4202/app.00498.2018.

[21567] P. P. Skutschas and S. A. Krasnolutskii. "A new genus and species of basal salamanders from the Middle Jurassic of western Siberia, Russia". English. In: Proceedings of the Zoological Institute of the Russian Academy of Sciences 315.2 (2011), pp. 167-175.

[21568] P. P. Skutschas, S. V. Leschinskiy, A. S. Rezvyi, A. V. Fayngertz, and S. A. Krasnolutskii. “Remains of Salamanders from the Middle Jurassic of the Krasnoyarsk territory". Russian. In: Modern Paleontology: Classical and Newest Methods. Paleontological Institute RAS. Moscow, 2005, pp. 121124.

[21569] P. P. Skutschas, V. D. Markova, V. V. Kolchanov, A. O. Averianov, T. Martin, R. Schellhorn, P. N. Kolosov, D. V. Grigoriev, D. D. Vitenko, E. M. Obraztsova, and I. G. Danilov. “Basal turtle material from the Lower Cretaceous of Yakutia (Russia) filling the gap in the Asian record". English. In: Cretaceous Research (2020), pp. 1-14. DOI: 10.1016/j.cretres.2019.07.016.

[21570] P. P. Skutschas, V. D. Markova, E. A. Boitsova, S. V. Leshchinskiy, S. V. Ivantsov, E. N. Maschenko, and A. O. Averianov. "The first dinosaur egg from the Lower Cretaceous of Western Siberia, Russia". English. In: Historical Biology 31 (2019), pp. 836-844. DOI: 10.1080/08912963.2017.1396322.

[21571] P. P. Skutschas, T. Martin, and S. Ge. “The co-occurrence of non-lissamphibian temnospondyls and salamanders in the Late Jurassic of the southern Junggar Basin (Xinjiang autonomous region, NW China)". English. In: Proceedings of the Zoological Institute RAS 313.2 (2009), pp. 143-148.

[21572] P. P. Skutschas, T. Martin, and S. A. Krasnolutskii. "First Jurassic frog from Siberia, Russia". English. In: Journal of Vertebrate Paleontology 36 (2016), e1101376:1-3.

[21573] K. E. Slack, C. M. Jones, T. Ando, G. L. Harrison, R. E. Fordyce, U. Arnason, and D. Penny. “Early penguin fossils, plus mitochondrial genomes, calibrate avian evolution". English. In: Molecular Biology and Evolution 23.6 (2006), pp. 1144-1155.

[21574] M. Sladic-Trifunovic. "On the Senonian rudist-bearing sediments in Yugoslavia”. English. In: Geobios, Memoire Special 22 (1998), pp. 371-384.

[21575] B. J. Slater, M. Reolid, R. Schouten, and M. J. Benton. “A new Late Jurassic turtle from Spain: phylogenetic implications, taphonomy and palaeoecology". English. In: Palaeontology 54.6 (2011), pp. 1393-1414.

[21576] J. A. Slater and R. M. Baranowski. “Discocoris dominicanus, a new species of palm bug from Dominican amber (Heteroptera: Thaumastocoridae)". English. In: Florida Entomologist 83 (2000), pp. 349-353.

[21577] L. Slavik and P. Carls. "Post-Lau Event (lateLudfordian, Silurian) recovery of conodont faunas of Bohemia". English. In: Bulletin of Geosciences 87.4 (2012), pp. 815-832. 
[21578] L. Slavk, P. Carls, J. Hladil, and L. Koptková. "Subdivision of the Lochkovian Stage based on conodont faunas from the stratotype area (Prague Synform, Czech Republic)". English. In: Geological Journal 47 (2012), pp. 616-631.

[21579] L. Slavik, J. Kriz, and P. Carls. "Reflection of the mid-Ludfordian Lau Event in conodont faunas of Bohemia". English. In: Bulletin of Geosciences 85.3 (2010), pp. 395-414.

[21580] B. J. Small. "The occurrence of Aetosaurus in the Chinle Formation (Late Triassic, USA) and its biostratigraphic significance". English. In: Neues Jahrbuch für Geologie und Paläontologie Monatshefte 1998 (1998), pp. 285-296.

[21581] B. J. Small and J. W. Martz. "A new aetosaur from the Upper Triassic Chinle Formation of the Eagle Basin, Colorado, USA". English. In: vol. 379. Anatomy, Phylogeny, and Palaeobiology of Early Archosaurs and their Kin. Geological Society, London, Special Publications. 2013, pp. 393412.

[21582] B. J. Small. "A new procolophonid from the Upper Triasic of Texas, with a description of tooth replacement and implantation". English. In: Journal of Vertebrate Paleontology 17.4 (1997), pp. 674678.

[21583] R. A. Smartt, S. G. Lucas, and D. J. Hafner. “The giant bison (Bison latifrons) from the Middle Rio Grande Valley of New Mexico". English. In: Southwestern Naturalist 36.1 (1991), pp. 136-137.

[21584] M. Smelror, R. M. Cocks, A. Mork, B. E. E. Neuman, and H. A. Nakrem. "Upper Ordovician Lower Silurian strata and biota from offshore South Norway". English. In: Norsk Geologisk Tidsskrift 77 (1997), pp. 251-268.

[21585] K. Smettan. “Bivalven, Gastropoden und Serpuliden aus den Branderfleckschichten (Cenoman) der Fahrenbergmulde (Nördliche Kalkalpen, Bayern): Taxonomie und Palökologie [Bivalves, gastropods and serpulids from the Branderfleck Formation (Cenomanian) of Fahrenbergmulde (Bavarian Alps): taxonomy and palaeoecology]". German. In: Zitteliana 21 (1997), pp. 99-158.

[21586] L. mdová. "Cryptic bark cockroach (Blattinae: Bubosa poinari gen. et sp.nov.) from mid-Cretaceous amber of northern Myanmar". English. In: Cretaceous Research 109.104383 (2020). DOI: 10.1016/j. cretres.2020.104383.

[21587] L. mdová and X. J. Lei. “The earliest amber-recorded type cockroach family was aposematic (Blattaria: Blattidae)". English. In: Cretaceous Research 72 (2017), pp. 189-199.

[21588] T. M. Smiley, C. A. Sidor, A. Maga, and O. Ide. "The Vertebrate Fauna of the Upper Permian of Niger. VI. First Evidence of a Gorgonopsian Therapsid". English. In: Journal of Vertebrate Paleontology 28.2 (2008), pp. 543-547.

[21589] D. Smiri, D. Japundi, N. Gaberek, D. Aljinovi, N. Prlj-imi, K. Krizmani, U. Barudija, and I. Pavi. "First record of the upper Illyrian ammonoid subzone marker Reitziites reitzi in the Karst Dinarides". English. In: Mining-Geology-Petroleum Engineering Bulletin 35.2 (2020), pp. 75-84.

[21590] T. N. Smirnova. "The Lower Kazanian (Upper Permian) terebratulid assemblage of the Family Beecheriidae fam. nov. (Brachiopoda) from the east of the Russian Platform". English. In: Paleontological Journal 38.2 (2004), pp. 166-171.

[21591] T. N. Smirnova. "New Late Hauterivian Terebratulids from the southwestern Crimea”. Russian. In: Paleontologicheskiy Zhurnal 6 (2001), pp. 34-41.

[21592] T. N. Smirnova. "Permian terebratulids of Eurasia: morphology, systematics, and phylogeny". English. In: Paleontological Journal 41.7 (2007), pp. 707-813.

[21593] T. N. Smirnova. "Systematics and phylogeny of the Late Permian terebratulids (Brachiopoda) from Darvaz". English. In: Paleontological Journal 35.2 (2001), pp. 140-151.

[21594] T. N. Smirnova. “A new genus and revision of known species of early Kazanian (Upper Permian) terebratulids from the eastern Russian platform". English. In: Paleontological Journal 38.4 (2004), pp. 373-380. 
[21595] T. N. Smirnova. “New Upper Permian Superfamily Compositelasmatoidea (Brachiopoda, Terebratulida) from the East of the Russian Platform: The specificity of ontogenetic transformations". English. In: Paleontological Journal 40.1 (2006), pp. 66-74.

[21596] T. N. Smirnova. "The ontogeny of the late Permian terebratulids of the Family Beecheriidae Smirnova (Brachiopoda)". English. In: Paleontological Journal 43.2 (2009), pp. 142-152.

[21597] T. N. Smirnova. "Late Mesozoic Brachiopods of the Caspian Depression and the Russian Platform". English. In: Paleontological Journal 26.1 (1992), pp. 25-35.

[21598] T. N. Smirnova. “Early Cretaceous Rhynchonellids of Dagestan: System, Morphology, Stratigraphic and Paleobiogeographic Significance". English. In: Paleontological Journal 46.11 (2012), pp. 11971296.

[21599] T. N. Smirnova and E. Y. Baraboshkin. “Valanginian-Lower Hauterivian brachiopod assemblages of the area between rivers Kacha and Bodrak (South-West Crimea)". Russian. In: Stratigraphy and Geological Correlation 12.2 (2004), pp. 48-63.

[21600] T. N. Smirnova and T. A. Grunt. "New Permian brachiopods of the Order Terebratulida from southwestern Darvaz, the northern Pamirs: 1. Superfamilies Centronelloidea Waagen, 1882 and Dielasmatoidea Schuchert, 1913". In: Paleontological Journal 36.5 (2002), pp. 480-489.

[21601] T. N. Smirnova and T. A. Grunt. "New Permian brachiopods of the Order Terebratulida from the southwestern Darvaz (northern Pamirs): 3. Superfamily Loboidothyroidea". In: Paleontological Journal 37.2 (2003), pp. 138-144.

[21602] T. N. Smirnova and T. A. Grunt. "New Permian brachiopods of the Order Terebratulida from the southwestern Darvaz (northern Pamirs): 2. Superfamily Terebratuloidea Gray, 1840". In: Paleontological Journal 37.1 (2003), pp. 24-30.

[21603] T. N. Smirnova and D. I. MacKinnon. "Apodosia, an enigmatic new genus of micromorphic brachiopod from the Cretaceous of Crimea, Ukraine, and the Jurassic of England". English. In: Journal of Paleontology 69.4 (1995), pp. 686-692.

[21604] T. N. Smirnova, A. A. Madison, and N. K. Esaulova. “New Lower Kazanian (Upper Permian) Terebratulids (Brachiopoda) from the Northeastern Russian Platform: Family Dielasmatidae Schuchert, 1913". English. In: Paleontological Journal 38 (2004), pp. 39-44.

[21605] T. N. Smirnova and E. A. Zhegallo. "Shell microstructure of Kabanoviella obliterata Lahusen (Brachiopoda, Rhynchonellidae) from the Upper Hauterivian of Ulyanovsk Region". English. In: $\mathrm{Pa}$ leontological Journal 52 (2018), pp. 394-399.

[21606] T. N. Smirnova and E. A. Zhegallo. "Shell Microstructure in Representatives of the Genus Lingulipora Girty from the Frasnian (Upper Devonian) Deposits of Southern Timan". English. In: Paleontological Journal 54 (2020), pp. 501-507. DOI: 10.1134/S0031030120050135.

[21607] A. B. Smith. "Echinoids from the Jurassic Oxford Clay of England". English. In: Palaeontology 38.4 (1995), pp. 743-755.

[21608] A. B. Smith. "British Jurassic regular echinoids. Part 1, Introduction, Cidaroida, Echinothurioida, Aspidodiadematoida and Pedinoida". English. In: Monograph of the Palaeontographical Society 169.644 (2015), pp. 1-67.

[21609] A. B. Smith and L. Anzalone. "Loriolella, a key taxon for understanding the early evolution of irregular echinoids". In: Palaeontology 43.2 (2000), pp. 303-324.

[21610] A. B. Smith and P. Bengtson. "Cretaceous echinoids from north-eastern Brazil". English. In: Fossils and Strata 31 (1991), pp. 1-88.

[21611] A. B. Smith and J. A. Crame. "Echinoderm faunas from the Lower Cretaceous (Aptian-Albian) of Alexander Island, Antarctica". English. In: Palaeontology 55.2 (2012), pp. 305-325. DOI: 10.1111/j. 1475-4983.2012.01129.x.

[21612] A. B. Smith and J. Gallemi. "Middle Triassic holothurians from northern Spain". In: Palaeontology 34.1 (1991), pp. 49-76. 
[21613] A. B. Smith, J. Gallem, C. H. Jeffery, G. Ernst, and P. D. Ward. “Late Cretaceous-early Tertiary echinoids from northern Spain: implications for the Cretaceous-Tertiary extinction event". English. In: Bulletin of the Natural History Museum, London (Geology) 55.2 (1999), pp. 81-137.

[21614] A. B. Smith and N. T. J. Hollingworth. "Tooth structure and phylogeny of the Upper Permian echinoid Miocidaris keyserlingi". English. In: Proceedings of the Yorkshire Geological Society 48 (1990), pp. 47-60.

[21615] A. B. Smith and P. A. Jell. "Cambrian edrioasteroids from Australia and the origin of starfishes". English. In: Memoirs of the Queensland Museum 28.2 (1990), pp. 715-778.

[21616] A. B. Smith and P. A. Jell. "A new cornute carpoid from the Upper Cambrian (Idamean) of Queensland". English. In: Memoirs of the Queensland Museum 43.1 (1999), pp. 341-350.

[21617] A. B. Smith, N. J. Morris, A. S. Gale, and B. R. Rosen. "Late Cretaceous (Maastrichtian) echinoidmollusc-coral assemblages and palaeoenvironments from a Tethyan carbonate platform succession, northern Oman Mountains". English. In: Palaeogeography, Palaeoclimatology, Palaeoecology 119 (1995), pp. 155-168.

[21618] A. B. Smith and J. J. Savill. "Bromidechinus, a new Ordovician echinozoan (Echinodermata), and its bearing on the early history of echinoids". English. In: Transactions of the Royal Society of Edinburgh 92 (2001), pp. 137-147.

[21619] A. B. Smith and S. Zamora. "Cambrian spiral-plated echinoderms from Gondwana reveal the earliest pentaradial body plan". English. In: Proceedings of the Royal Society B: Biological Sciences 280.1765 (2013). DOI: 10.1098/rspb.2013.1197.

[21620] A. S. Smith. "Plesiosaurs from the Pliensbachian (Lower Jurassic) of Bornholm, Denmark". English. In: Journal of Vertebrate Paleontology 28.4 (2008), pp. 1213-1217.

[21621] A. S. Smith. "Rare ichthyosaur and plesiosaur material from the Lower Jurassic of Ireland". English. In: Irish Journal of Earth Sciences 28 (2010), pp. 47-52.

[21622] A. S. Smith. "The back-to-front plesiosaur Cryptoclidus (Apractocleidus) aldingeri from the Kimmeridgian of Milne Land, Greenland". English. In: Bulletin of the Geological Society of Denmark 55 (2007), pp. 1-7.

[21623] A. S. Smith, R. Araujo, and O. Mateus. "A new plesiosauroid from the Toarcian (Lower Jurassic) of Alhadas, Portugal". English. In: Acta Palaeontologica Polonica 57.2 (2012), pp. 257-266. DOI: 10. 4202/app.2011.0023.

[21624] A. S. Smith and R. Araújo. "Thaumatodracon wiedenrothi, a morphometrically and stratigraphically intermediate new rhomaleosaurid plesiosaurian from the Lower Jurassic (Sinemurian) of Lyme Regis". English. In: Palaeontographica Abteilung A 308.4-6 (2017), pp. 89-125.

[21625] A. S. Smith and G. J. Dyke. “The skull of the giant predatory pliosaur Rhomaleosaurus cramptoni: implications for plesiosaur phylogenetics". English. In: Naturwissenschaften 95 (2008), pp. 975-980.

[21626] A. S. Smith and J. D. Radley. "A marine reptile fauna from the Early Jurassic Saltford Shale (Blue Lias Formation) of Central England". English. In: Proceedings of the Yorkshire Geological Society 56.4 (2007), pp. 253-260.

[21627] B. D. Smith, G. Braulik, S. Strindberg, B. Ahmed, and R. Mansur. “Abundance of Irrawaddy dolphins (Orcaella brevirostris) and Ganges River dolphin (Platanista gangetica gangetica) estimated using concurrent counts made by independent teams in waterways of the Sundarabans Mangrove Forest in Bangladesh". English. In: Marine Mammal Science 22.3 (2006), pp. 527-547.

[21628] D. K. Smith, E. R. Allen, R. K. Sanders, and K. L. Stadtman. "A new specimen of Eutretauranosuchus (Crocodyliformes; Goniopholididae) from Dry Mesa, Colorado". English. In: Journal of Vertebrate Paleontology 30.5 (2010), pp. 1466-1477.

[21629] D. K. Smith, D. R. Richmond, and P. J. Bybee. Morphological variation in a large specimen of Allosaurus fragilis, Upper Jurassic Morrison Formation, eastern Utah. Vol. 99-1. Vertebrate Paleontology in Utah, Utah Geological Survey Miscellaneous Publication. 1999, pp. 135-141. 
[21630] D. M. Smith, M. A. Gorman, J. D. Pardo, and B. J. Small. “First fossil Orthoptera from the Jurassic of North America". English. In: Journal of Paleontology 85.1 (2011), pp. 102-105.

[21631] D. R. Smith and G. O. Poinar. "Sawflies (Hymenoptera: Argidae) from Dominican amber". English. In: Entomological News 103.4 (1992), pp. 117-124.

[21632] E. T. Smith. "Early Cretaceous chelids from Lightning Ridge, New South Wales". English. In: Alcheringa 34 (2010), pp. 375-384. DOI: 10.1080/03115518.2010.488117.

[21633] E. T. Smith and B. P. Kear. Spoochelys ormondea gen. et sp. nov., an Archaic Meiolaniid-Like Turtle from the Early Cretaceous of Lightning Ridge, Australia. English. Morphology and Evolution of Turtles. 2013, pp. 121-146. DOI: 10.1007/978-94-007-4309-0_9.

[21634] H. F. Smith, J. H. Hutchison, K. E. B. Townsend, B. Adrian, and D. Jager. "Morphological variation, phylogenetic relationships, and geographic distribution of the Baenidae (Testudines), based on new specimens from the Uinta Formation (Uinta Basin), Utah (USA)". English. In: PLoS ONE 12.7 (2017), e0180574. DOI: 10.1371/journal.pone.0180574.

[21635] J. B. Smith and F. M. Dalla Vecchia. "An abelisaurid (Dinosauria: Theropoda) tooth from the Lower Cretaceous Chicla Formation of Libya". English. In: Journal of African Earth Sciences 46 (2006), pp. 240-244.

[21636] J. B. Smith, M. C. Lamanna, K. J. Lacovara, P. Dodson, J. R. Smith, J. C. Poole, R. Giegengack, and Y. Attia. "A giant sauropod dinosaur from an Upper Cretaceous mangrove deposit in Egypt". In: Science 292 (2001), pp. 1704-1706.

[21637] J. B. Smith and M. C. Lamanna. "An abelisaurid from the Late Cretaceous of Egypt: implications for theropod biogeography". English. In: Naturwissenschaften 93/11 (2006), pp. 242-245.

[21638] J. B. Smith, M. C. Lamanna, A. S. Askar, K. A. Bergig, S. O. Tshakreen, M. M. Abugares, and D. T. Rasmussen. "A large abelisauroid theropod dinosaur from the Early Cretaceous of Libya". English. In: Journal of Paleontology 84.5 (2010), pp. 927-934.

[21639] K. Smith. New Basilosaurus specimens. English. 2020.

[21640] K. Smith, N. Czaplewski, and R. L. Cifelli. "Middle Miocene carnivorans from the Monarch Mill Formation, Nevada". English. In: Acta Palaeontologica Polonica 61.1 (2016), pp. 231-252. DOI: 10. 4202/app.00111.2014.

[21641] K. Smith, L. Maul, F. Flemming, R. Barkai, and A. Gopher. “The microvertebrates of Qesem Cave: A comparison of the two concentrations". English. In: Quaternary International (2015), pp. 1-13. DOI: 10.1016/j.quaint.2015.04.047.

[21642] K. M. Smith, A. Hastings, and R. M. Bebej. Evolution, dispersal, and habitat preference of Basilosaurus (Mammalia: Cetacea) in the southeastern United States: New evidence from the Eocene of southwest Georgia. English. 2013.

[21643] K. S. Smith. "First Record of Leptodontomys (Rodenta: Eomyidae) in the Clarendonian (Miocene) of the Southern Great Plains". English. In: Proceedings of the Oklahoma Academy of Sciences 85 (2005), pp. 47-53.

[21644] K. T. Smith. "A diverse new assemblage of late Eocene squamates (Reptilia) from the Chadron Formation of North Dakota, U.S.A." English. In: Palaeontologia Electronica 9.2 (2006), pp. 1-44.

[21645] K. T. Smith. "A new lizard assemblage from the earliest Eocene (zone Wa0) of the Bighorn Basin, Wyoming, USA: biogeography during the warmest interval of the Cenozoic". English. In: Journal of Systematic Palaeontology 7.3 (2009), pp. 299-358.

[21646] K. T. Smith. "New constraints on the evolution of the snake clades Ungaliophiinae, Loxocemidae and Colubridae (Serpentes), with comments on the fossil history of erycine boids in North America". English. In: Zoologischer Anzeiger 252.2 (2013), pp. 157-182. DOI: 10.1016/j.jcz.2012.05.006.

[21647] K. T. Smith. "The Evolution of Mid-latitude Faunas during the Eocene: Late Eocene Lizards of the Medicine Pole Hills Reconsidered". English. In: Bulletin of the Peabody Museum of Natural History 52.1 (2011), pp. 3-105. 
[21648] K. T. Smith. "Eocene lizards of the clade Geiseltaliellus from Messel and Geiseltal, Germany, and the early radiation of Iguanidae (Reptilia: Squamata)". English. In: Bulletin of the Peabody Museum of Natural History 50.2 (2009), pp. 219-306. DOI: 10.3374/014.050.0201.

[21649] K. T. Smith. “The long-term history of dispersal among lizards in the early Eocene: new evidence from a microvertebrate assemblage in the Bighorn Basin of Wyoming, USA". English. In: Palaeontology 54.6 (2011), pp. 1243-1270. DOI: 10.1111/j.1475-4983.2011.01107.x.

[21650] K. T. Smith. "Acrodont iguanians (Squamata) from the middle Eocene of the Huadian Basin of Jilin Province, China, with a critique of the taxon Tinosaurus". English. In: Vertebrata PalAsiatica 49.1 (2011), pp. 69-84.

[21651] K. T. Smith, B.-A. S. Bhullar, and P. A. Holroyd. "Earliest African record of the Varanus stemclade (Squamata: Varanidae) from the early Oligocene of Egypt". English. In: Journal of Vertebrate Paleontology 28.3 (2008), pp. 909-913. DOI: 10.1671/0272-4634(2008)28[909:EAROTV]2.0.CO;2.

[21652] K. T. Smith and M.-C. Buchy. "A new aigialosaur (Squamata: Anguimorpha) with soft tissue remains from the Upper Cretaceous of Nuevo León, Mexico". English. In: Journal of Vertebrate Paleontology 28.1 (2008), pp. 85-94.

[21653] K. T. Smith and J. A. Gauthier. "Early Eocene lizards of the Wasatch Formation near Bitter Creek, Wyoming: diversity and paleoenvironment during an interval of global warming". English. In: Bulletin of the Peabody Museum of Natural History 54.2 (2013), pp. 135-230. DOI: 10.3374/014.054. 0205.

[21654] M. M. Smith, A. Riley, G. J. Fraser, C. Underwood, M. Welten, J. Kriwet, C. Pfaff, and Z. Johanson. "Early development of rostrum saw-teeth in a fossil ray tests classical theories of the evolution of vertebrate dentitions". English. In: Proceedings of the Royal Society B 282 (2015), p. 20151628. DOI: 10.1098/rspb.2015.1628.

[21655] M. M. Smith, I. J. Sansom, and P. Smith. "Diversity of the dermal skeleton in Ordovician to Silurian vertebrate taxa from North America: Histology, skeletogenesis and relationships". English. In: Geobios 19 (1995), pp. 65-70.

[21656] M. R. Smith. "Nectocaridid ecology, diversity, and affinity: early origin of a cephalopod-like body plan". English. In: Paleobiology 39.2 (2013), pp. 297-321. DOI: 10.1666/12029.

[21657] M. R. Smith and N. J. Butterfield. "A new view on Nematothallus: Coralline Red Algae from the Silurian of Gotland". English. In: Palaeontology 56.Part 2 (2013), pp. 345-357.

[21658] M. R. Smith and J.-B. Caron. "Primitive soft-bodied cephalopods from the Cambrian". English. In: Nature 465 (2010), pp. 469-472.

[21659] M. R. Smith. "An Ordovician nectocaridid hints at an endocochleate origin of Cephalopoda". English. In: Journal of Paleontology (2019). DOI: 10.1017/jpa.2019.57.

[21660] N. A. Smith. "Taxonomic revision and phylogenetic analysis of the flightless Mancallinae (Aves, Pan-Alcidae)". English. In: ZooKeys 91 (2011), pp. 1-116.

[21661] N. A. Smith. "A New Species of Auk (Charadriiformes, Pan-Alcidae) from the Miocene of Mexico". English. In: The Condor 115.1 (2013), pp. 77-83. DOI: 10.1525/cond.2012.120066.

[21662] N. A. Smith. "The fossil record and phylogeny of the auklets (Pan-Alcidae, Aethiini)". English. In: Journal of Systematic Palaeontology 12.2 (2014), pp. 217-236. DOI: 10.1080/14772019.2012.742147.

[21663] N. A. Smith, R. W. Boessenecker, D. Long, and C. Powell. A new marine vertebrate assemblage from the Wilson Grove Formation at Bloomfield Quarry (Late Miocene), Sonoma County, California. English. 2017.

[21664] N. A. Smith and J. A. Clarke. "An alphataxonomic revision of extinct and extant razorbills (Aves, Alcidae): A combined morphometric and phylogenetic approach". English. In: Ornithological Monographs 72.1 (2011), pp. 1-61.

[21665] N. A. Smith and G. Mayr. "Earliest northeastern Atlantic Ocean basin record of an auk (Charadriiformes, Pan-Alcidae): fossil remains from the Miocene of Germany". English. In: Journal of Ornithology 154 (2013), pp. 775-782. DOI: 10.1007/s10336-013-0943-6. 
[21666] N. A. Smith, S. L. Olson, and J. A. Clarke. "First Atlantic record of the puffin Cerorhinca (Aves, Alcidae) from the Pliocene of North Carolina". English. In: Journal of Vertebrate Paleontology 27.4 (2007), pp. 1039-1042.

[21667] N. A. Smith, T. A. Stidham, and J. S. Mitchell. "The First Fossil Owl (Aves, Strigiformes) From the Paleogene of Africa". English. In: Diversity 12 (2020), 163:1-12. DOI: 10.3390/d12040163.

[21668] N. D. Smith, L. Grande, and J. A. Clarke. "A new species of Threskiornithidae-like bird (Aves, Ciconiiformes) from the Green River Formation (Eocene) of Wyoming". English. In: Journal of Vertebrate Paleontology 33.2 (2013), pp. 363-381. DOI: 10.1080/02724634.2012.722898.

[21669] N. D. Smith, P. J. Makovicky, C. A. Sidor, and W. R. Hammer. "A kannemeyeriiform (Synapsida: Dicynodontia) occipital plate from the Middle Triassic upper Fremouw Formation of Antarctica". English. In: Journal of Vertebrate Paleontology (2020), e1829634. DOI: 10.1080/02724634.2020.1829634.

[21670] N. D. Smith and D. Pol. "Anatomy of a basal sauropodomorph dinosaur from the Early Jurassic Hanson Formation of Antarctica". English. In: Acta Palaeontologica Polonica 52.4 (2007), pp. 657674.

[21671] P. M. Smith, G. A. Brock, and J. R. Paterson. "Shelly fauna from the Cambrian (Miaolingian, Guzhangian) Shannon Formation and the SPICE event in the Amadeus Basin, Northern Territory". English. In: Alcheringa 44.1 (2020), pp. 1-24. DOI: 10.1080/03115518.2019.1660405.

[21672] R. Smith. "Présence du genre Eotalpa (Mammalia, Talpidae) dans l'Oligocéne inférieur de Belgique (Formation de Borgloon, MP 21)". French. In: Bulletin de l'Institut royal des Sciences naturelles de Belgique, Sciences de la Terre 77 (2007), pp. 159-165.

[21673] R. Smith. "Palaeosinopa russelli (Mammalia, Pantolesta), une espece nouvelle du Membre de Dormaal, proche de la limite Paleocene-Eocene". French. In: Bulletin de l'Institut Royal des Sciences Naturelles de Belgique 67 (1997), pp. 153-159.

[21674] R. Smith. "Insectivores (Mammalia) from the earliest Oligocene (MP 21) of Belgium". English. In: Netherlands Journal of Geosciences/Geologie en Mijnbouw 83.3 (2004), pp. 187-192.

[21675] R. Smith. "Les pantolestides (Mammalia, Pantolesta) de l'Eocene inferieur de Premontre (Aisne, France)". French. In: Palaeovertebrata 30.1-2 (2001), pp. 11-35.

[21676] R. Smith. "Les vertébrés terrestres de l'Oligocéne inférieur de Belgique (Formation de Borgloon, MP 21): inventaire et interprétation des données actuelles". French. In: Coloquios de Paleontologa 1 (2003), pp. 647-657.

[21677] R. Smith and J. J. Hooker. "Sur la présence de dents de mammiféres (Creodonta, Perissodactyla) prés de la limite Paléocéne-Eocéne á Hoegaarden, Belgique". French. In: Palaeovertebrata 25.2-4 (1996), pp. 115-124.

[21678] R. E. Smith, D. M. Martill, A. Kao, S. Zouhri, and N. Longrich. “A long-billed, possible probefeeding pterosaur (Pterodactyloidea: ?Azhdarchoidea) from the mid-Cretaceous of Morocco, North Africa". English. In: Cretaceous Research (2020), p. 104643. DOI: 10.1016/j.cretres.2020.104643.

[21679] R. M. H. Smith. Vertebrate taphonomy of late Permian floodplain deposits in the Southwestern Karoo Basin of South Africa. 1993.

[21680] R. M. H. Smith and S. E. Evans. "An Aggregation of Juvenile Youngina from the Beaufort Group, Karoo Basin, South Africa". English. In: Palaeontologia Africana 32 (1995), pp. 45-49.

[21681] R. M. H. Smith, B. S. Rubidge, and C. A. Sidor. "A new burnetiid (Therapsida: Biarmosuchia) from the Upper Permian of South Africa and its biogeographic implications". English. In: Journal of Vertebrate Paleontology 26 (2006), pp. 331-343.

[21682] R. M. H. Smith, C. A. Sidor, N. J. Tabor, and J. S. Steyer. "Sedimentology and vertebrate taphonomy of the Moradi Formation of northern Niger: A Permian wet desert in the tropics of Pangaea". English. In: Palaeogeography, Palaeoclimatology, Palaeoecology 440 (2015), pp. 128-141. DOI: 10.1016/j.palaeo.2015.08.032. 
[21683] R. M. H. Smith and R. Swart. "Changing fluvial environments and vertebrate taphonomy in response to climatic drying in a mid-Triassic rift valley fill: the Omingonde Formation (Karoo Supergroup) of central Namibia". English. In: Palaios 17 (2002), pp. 249-267.

[21684] S. D. Smith, W. S. Persons, and L. Xing. "A tyrannosaur trackway at Glenrock, Lance Formation (Maastrichtian), Wyoming". English. In: Cretaceous Research 61.1 (2016), pp. 1-4. DOI: 10.1016/j. cretres.2015.12.020.

[21685] S. M. Smith, C. J. Sprain, W. A. Clemens, D. L. Lofgren, P. R. Renne, and G. P. Wilson. “Early mammalian recovery after the end-Cretaceous mass extinction: A high-resolution view from McGuire Creek area, Montana, USA". English. In: Geological Society America Bulletin (2018). DOI: 10.1130 / B31926.

[21686] S. Y. Smith, G. W. Rothwell, and R. A. Stockey. “Cyathea cranhamii sp. nov. (Cyatheaceae), anatomically preserved tree fern sori from the Lower Cretaceous of Vancouver Island, British Columbia". English. In: American Journal of Botany 90 (2003), pp. 755-760.

[21687] S. Y. Smith and R. A. Stockey. "Aroid seeds from the Middle Eocene Princeton Chert (Keratosperma allenbyense, Araceae): comparisons with extant Lasioideae". In: International Journal of Plant Sciences 164.2 (2003), pp. 239-250.

[21688] S. Y. Smith and R. A. Stockey. "Permineralized pine cones from the Cretaceous of Vancouver Island, British Columbia". English. In: International Journal of Plant Sciences 163.1 (2002), pp. 185196.

[21689] S. Y. Smith and R. A. Stockey. "A new species of Pityostrobus (Pinaceae) from the Lower Cretaceous of California and its bearing on the evolution of Pinaceae". English. In: International Journal of Plant Sciences 162.3 (2001), pp. 669-681.

[21690] T. Smith. "Leptacodon dormaalensis (Mammalia, Lipotyphla), un nyctithere primitif de la transition Paleocene-Eocene de Belgique." French. In: Belgian Journal of Zoology 126.2 (1996), pp. 153167.

[21691] T. Smith. "Presence du genre Wyonycteris (Mammalia, Lipotyphla) a la limite Paleocene-Eocene en Europe." French. In: Comptes rendus de l'Academie des Sciences, Paris (Ser. IIa) 321 (1995), pp. $923-$ 930.

[21692] T. Smith, J. I. Bloch, S. G. Strait, and P. D. Gingerich. "New species of Macrocranion (Mammalia, Lipotyphla) from the earliest Eocene of North America and its biogeographic implications". English. In: Contributions from the Museum of Paleontology, University of Michigan 30.14 (2002), pp. 373384.

[21693] T. Smith, V. A. Codrea, A. Sasaran, J. Van Itterbeeck, P. Bultynck, Z. Csiki, P. Dica, C. Farcas, A. Folie, G. Garcia, and P. Godefroit. "A new exceptional vertebrate site from the Late Cretaceous of the Hateg Basin (Romania)". English. In: Studia Universitatis Babes-Bolyai, Geologia, Special Issue 1 (2002), pp. 321-330.

[21694] T. Smith, C. Dupuis, A. Folie, F. Quesnel, J. -Y. Storme, P. Iacumin, J. Riveline, P. Missiaen, S. Ladevéze, and J. Yans. "A new terrestrial vertebrate site just after the Paleocene-Eocene boundary in the Mortemer Formation of Upper Normandy, France". English. In: Comptes Rendus Palevol 10 (2011), pp. 11-20.

[21695] T. Smith, D.-Y. Guo, and Y. Sun. "A new species of Kryptobaatar (Multituberculata): the first Late Cretaceous mammal from Inner Mongolia (P. R. China)". In: Bulletin de l'Institut Royal des Sciences Naturelles de Belgique, Science de la Terre 71.supplement (2001), pp. 29-501.

[21696] T. Smith, K. Kumar, R. S. Rana, A. Folie, F. Solé, C. Noiret, T. Steeman, A. Sahni, and K. D. Rose. "New early Eocene vertebrate assemblage from western India reveals a mixed fauna of European and Gondwana affinities". English. In: Geoscience Frontiers 7.6 (2016), pp. 969-1001. DOI: 10.1016/ j.gsf.2016.05.001. 
[21697] T. Smith, F. Quesnel, G. De Plöeg, D. De Franceschi, G. Métais, E. De Bast, F. Solé, A. Folie, A. Boura, J. Claude, C. Dupuis, C. Gagnaison, A. Iakovleva, J. Martin, F. Maubert, J. Prieur, E. Roche, J. -Y. Storme, R. Thomas, H. Tong, J. Yans, and E. Buffetaut. “First Clarkforkian Equivalent Land Mammal Age in the Latest Paleocene Basal Sparnacian Facies of Europe: Fauna, Flora, Paleoenvironment and (Bio)stratigraphy". English. In: PLoS ONE 9.1 (2014), e86229:1-19. DOI: 10.1371/ journal.pone.0086229.

[21698] T. Smith, R. S. Rana, P. Missiaen, K. D. Rose, A. Sahni, H. Singh, and L. Singh. "High bat (Chiroptera) diversity in the Early Eocene of India". English. In: Naturwissenschaften 94.12 (2007), pp. 1003-1009. DOI: 10.1007/s00114-007-0280-9.

[21699] T. Smith and R. Smith. "Terrestrial mammals as biostratigraphic indicators in upper Paleocenelower Eocene marine deposits of the southern North Sea Basin". English. In: Geological Society of America Special Paper 369 (2003), pp. 513-520.

[21700] T. Smith and R. Smith. "A new genus of miacid carnivoran from the earliest Eocene of Europe and North America". English. In: Acta Palaeontologica Polonica 55.4 (2010), pp. 761-764.

[21701] T. Smith and R. Smith. "The creodonts (Mammalia, Ferae) from the Paleocene-Eocene transition in Belgium (Tienen Formation, MP7)”. English. In: Belgian Journal of Zoology 131.2 (2001), pp. 117135.

[21702] T. Smith and R. Smith. "A land micro-mammal fauna from the Early Eocene marine Egem deposits (NP12, Belgium) and the first occurrence of the peradectid marsupial Armintodelphys outside North America". English. In: Geologica Belgica 16.4 (2013), pp. 302-310.

[21703] T. Smith, F. Solé, P. Missiaen, R. S. Rana, and K. Kumar. "First early Eocene tapiroid from India and its implication for the paleobiogeographic origin of perissodactyls". English. In: Palaeovertebrata 39.2 (2015), pp. 1-9.

[21704] T. Smith, J. Van Itterbeeck, and P. Missiaen. “Oldest plesiadapiform (Mammalia, Proprimates) from Asia and its palaeobiogeographical implications for faunal interchange with North America". English. In: Comptes Rendus Palevol 3 (2004), pp. 43-52.

[21705] T. R. Smithson. "Eldeceeon rolfei, a new reptiliomorph from the Visean of East Kirkton, West Lothian, Scotland". English. In: Transactions of the Royal Society of Edinburgh: Earth Sciences 84 (1993), pp. 377-382. DOI: $10.1017 /$ S0263593300006180.

[21706] T. R. Smithson, M. A. Browne, S. J. Davies, J. E. Marshall, D. Millward, S. A. Walsh, and J. A. Clack. "A New Mississippian Tetrapod from Fife, Scotland and its Environmental Context". English. In: Papers in Palaeontology (2017), pp. 1-11. DOI: 10.1002/spp2.1086.

[21707] T. R. Smithson and J. A. Clack. “Tetrapod appendicular skeletal elements from the Early Carboniferous of Scotland". English. In: Comptes Rendus Palevol 12 (2013), pp. 405-417. DOI: 10.1016/j.crpv. 2013.06.006.

[21708] T. R. Smithson and J. A. Clack. “A new tetrapod from Romer's Gap reveals an early adaptation for walking". English. In: Earth and Environmental Science Transactions of the Royal Society of Edinburgh 108 (2018), pp. 89-97. DOI: 10.1017/S1755691018000075.

[21709] T. R. Smithson, K. R. Richards, and J. A. Clack. "Lungfish diversity in Romer's Gap: reaction to the end-Devonian". English. In: Palaeontology 59.1 (2016), pp. 29-44. DOI: 10.1111/pala.12203.

[21710] T. R. Smithson and W. D. I. Rolfe. "Westlothiana gen. nov.: naming the earliest known reptile". English. In: Scottish Journal of Geology 26 (1990), pp. 137-138. DOI: 10.1144/sjg26020137.

[21711] O. P. Smyshlyaeva. "A new species of Euflemingites Spath (Ammonoidea) from the Lower Triassic of southern Primorye". English. In: Paleontological Journal 44.2 (2010), pp. 125-128.

[21712] O. P. Smyshlyaeva and Y. D. Zakharov. "New representatives of the family Melagathiceratidae (Ammonoidea) from the Lower Triassic of south Primorye". English. In: Paleontological Journal 46 (2012), pp. 142-147.

[21713] O. P. Smyshlyaeva and Y. D. Zakharov. "New members of the family Flemingitidae (Ammonoidea) from the Lower Triassic of south Primorye". English. In: Paleontological Journal 47 (2013), pp. 247255. 
[21714] O. P. Smyshlyaeva and Y. D. Zakharov. "New Lower Triassic ammonoids from South Primorye". English. In: Paleontological Journal 49 (2015), pp. 111-120.

[21715] O. P. Smyshlyaeva, Y. D. Zakharov, A. M. Popov, L. G. Bondarenko, and I. V. Borisov. "Stratigraphic Subdivisions of the Lower Triassic of South Primorye Region, Article 3: First Findings of Euflemingites prynadai and Shimanskyites shimanskyi (Ammonoidea) in the SMID Section". English. In: Russian Journal of Pacific Geology 12 (2018), pp. 469-486. DOI: 10.1134/S1819714018060088.

[21716] P. B. Snetkov. "Vertebrae of the sea snake Palaeophis nessovi Averianov (Acrochordoidea, Palaeophiidae) from the Eocene of Western Kazakhstan and phylogenetic analysis of the Superfamily Acrochordoidea". English. In: Palaeontological Journal 45.3 (2011), pp. 305-313.

[21717] P. B. Snetkov and A. F. Bannikov. "Vertebrae of sea snakes from the Eocene of the Crimea". English. In: Palaeontological Journal 44.6 (2010), pp. 698-700.

[21718] J. M. K. Sniderman. "Early Pleistocene vegetation change in upland south-eastern Australia". English. In: Journal of Biogeography 38.8 (2011), pp. 1456-1470. DOI: 10.1111/j.1365-2699.2011.02518.x.

[21719] J. M. K. Sniderman, G. J. Jordan, and R. M. Cowling. "Fossil evidence for a hyperdiverse sclerophyll flora under a non-Mediterranean-type climate". English. In: Proceedings of the National Academy of Sciences 110.9 (2013), pp. 3423-3428. DOI: 10.1073/pnas.1216747110.

[21720] A. W. Snoke and P. J. Noble. “Ammonite-radiolarian assemblage, Tobago Volcanic Group, Tobago, West Indies-Implications for the evolution of the Great Arc of the Caribbean". English. In: Geological Society America Bulletin 113 (2001), pp. 256-264.

[21721] E. M. Snyder and E. H. Gilmour. "New fenestrate Bryozoa of the Gerster Limestone (Permian), Medicine Range, northeastern Nevada". English. In: Journal of Paleontology 80.5 (2006), pp. 867888.

[21722] K. S. So, G. K. Won, K. S. Han, C. P. Xu, B. Wang, and Y. Fang. “The first Orthoptera (Insecta) from the Lower Cretaceous of Democratic People's Republic of Korea". English. In: Cretaceous Research 108.104336 (2020). DOI: 10.1016/j.cretres.2019.104336.

[21723] M. B. Soares. "A taphonomic model for the Mesosauridae assemblage of the Irati Formation (Paraná Basin, Brazil)". English. In: Geologica Acta 1.4 (2003), pp. 349-361.

[21724] M. B. Soares, F. Abdala, and C. Bertoni-Machado. "A sectorial toothed cynodont (Therapsida) from the Triassic Santa Cruz do Sul fauna, Santa Maria Formation, Southern Brazil". English. In: Geodiversitas 33 (2011), pp. 265-278.

[21725] M. B. Soares, A. G. Martinelli, and T. V. de Oliveira. "A new prozostrodontian cynodont (Therapsida) from the Late Triassic Riograndia Assemblage Zone (Santa Maria Supersequence) of Southern Brazil". English. In: Anais da Academia Brasileira de Ciencias 86.4 (2014), pp. 1673-1691.

[21726] M. B. Soares, C. L. Schultz, and B. I. D. Horn. "New information on Riograndia guaibensis Bonaparte, Ferigolo \& Ribeiro, 2001 (Eucynodontia, Tritheledontidae) from the Late Triassic of southern Brazil: anatomical and biostratigraphic implications". English. In: Anais da Academia Brasileira de Ciencias 83.1 (2011), pp. 329-354.

[21727] I. H. Sobbe, G. J. Price, and R. A. Knezour. "A ziphodont crocodile from the late Pleistocene King Creek catchment, Darling Downs, Queensland". English. In: Memoirs of the Queensland Museum Nature 56.2 (2013), pp. 601-606.

[21728] T. Sobczyk and M. J. Kobbert. "Die Psychidae des baltische Bernsteins". German. In: Nota Lepidopterologica 32 (2009), pp. 13-22.

[21729] E. S. Sobolev. "Novye vidy sveriutykh Nautiloidey iz srednego i verkhnego Triasa Sibiri". Russian. In: News on Paleontology and Stratigraphy 1 (1998), pp. 133-151.

[21730] E. S. Sobolev, I. V. Budnikov, A. G. Klets, and V. S. Grinenko. “Late Bashkirian Amminoids and Nautiloids from Western Verkhoyansk Region". In: Paleontological Journal 32.5 (1998), pp. 13-25.

[21731] G. Sobral, T. R. Simões, and R. R. Schoch. "A tiny new Middle Triassic stem lepidosauromorph from Germany: implications for the early evolution of lepidosauromorphs and the Vellberg fauna". English. In: Scientific Reports 10.2273 (2020). DOI: 10.1038/s41598-020-58883-x. 
[21732] A. N. Soe, O. Chavasseau, Y. Chaimanee, C. Sein, J. -J. Jaeger, X. Valentin, and S. Ducrocq. “New remains of Siamotherium pondaungensis (Cetartiodactyla, Hippopotamoidea) from the Eocene of Pondaung, Myanmar: Paleoecologic and phylogenetic implications". English. In: Journal of Vertebrate Paleontology 37 (2017), e1270290:1-10.

[21733] K. L. Soehn, T. Märss, M. W. Caldwell, and M. V. H. Wilson. "New and biostratigraphically useful thelodonts from the Silurian of the Mackenzie Mountains, Northwest Territories, Canada". English. In: Journal of Vertebrate Paleontology 21.4 (2001), pp. 651-659.

[21734] I. G. Sohn and L. S. Kornicker. "Ostracoda from the Late Permian of Greece (Thaumatocyprididae and Polycopidae)". English. In: Smithsonian Contributions to Paleobiology 87 (1998), pp. 1-34.

[21735] J. C. Sohn, C. Labandeira, D. Davis, and C. Mitter. "An annotated catalog of fossil and subfossil Lepidoptera (Insecta: Holometabola) of the world". English. In: Zootaxa 3286 (2012), pp. 1-132.

[21736] J. C. Sohn, G. S. Nam, S. W. Choi, and D. Ren. “New fossils of Elateridae (Insecta, Coleoptera) from Early Cretaceous Jinju Formation (South Korea) with their implications to evolutionary diversity of extinct Protagrypninae". English. In: PLoS One 14.e0225502 (2019). DOI: 10.1371/journal.pone. 0225502.

[21737] E. Soibelzon, L. S. Avilla, and M. Castro. "The cingulates (Mammalia: Xenarthra) from the late Quaternary of northern Brazil: Fossil records, paleoclimates and displacements in America". English. In: Quaternary International 377 (2015), pp. 118-125. DOI: 10.1016/J.QUAINT.2015.02.052.

[21738] L. H. Soibelzon. "First description of milk teeth of fossil South American procyonid from the lower Chapadmalalan (Late Miocene-Early Pliocene) of Farola Monte Hermoso, Argentina: paleoecological considerations". English. In: Paläontologische Zeitschrift 85 (2011), pp. 83-89. DOI: 10.1007/s12542-010-0073-xSHORT.

[21739] L. H. Soibelzon, M. M. Cenizo, F. J. Prevosti, E. Soibelzon, and V. B. Tartarini. “Dos nuevos registros de Dusicyon Hamilton-Smith, 1839 (Canidae, Mammalia) en el Plioceno y Pleistoceno de la region pampeana (Argentina). Aspectos sistematicos, tafonomicos y bioestratigraficos". Spanish. In: $V$ Congreso Uruguayo de Geologia (2007), pp. 1-15.

[21740] L. H. Soibelzon, M. De los Reyes, J. Tarquini, D. E. Tineod, D. G. Poiréd, G. Gonzáleze, and G. D. Vergani. "First record of a fossil procyonid (Cyonasua cf. C. pascuali), Mammalia, Procyonidae) in Bolivia, Tariqua Fm., Late Miocene". English. In: Journal of South American Earth Sciences 99 (2020), 102492:1-6.

[21741] L. H. Soibelzon and A. D. Rincón. "The fossil record of the short-faced bears (Ursidae, Tremarctinae) from Venezuela. Systematic, biogeographic, and paleoecological implications". English. In: Neues Jahrbuch für Geologie und Paläontologie Abhandlungen 244 (2007), pp. 287-298. DOI: 10.1127/ 0077-7749/2007/0244-0287.

[21742] L. H. Soibelzon, A. Rinderknecht, J. Tarquini, and R. Ugalde. "First record of fossil procyonid (Mammalia, Carnivora) from Uruguay". English. In: Journal of South American Earth Sciences 92 (2019), pp. 368-373. DOI: 10.1016/j.jsames.2019.03.024.

[21743] L. H. Soibelzon, M. R. Romero, D. Huziel Aguilar, and V. B. Tartarini. “A Blancan (Pliocene) shortfaced bear from El Salvador and its implications for Tremarctines in South America". English. In: Neues Jahrbuch für Geologie und Paläontologie - Abhandlungen 250.1 (2008), pp. 1-8.

[21744] L. H. Soibelzon and B. W. Schubert. "The Largest Known Bear, Arctotherium angustidens, from the Early Pleistocene Pampean Region of Argentina: With a Discussion of Size and Diet Trends in Bears". English. In: Journal of Paleontology 85.1 (2011), pp. 69-75.

[21745] C. M. Soja and R. Riding. "Silurian microbial associations from the Alexander Terrane, Alaska". English. In: Journal of Paleontology 67.5 (1993), pp. 728-738.

[21746] C. M. Soja, B. White, A. Antoshkina, S. Joyce, L. Mayhew, B. Flynn, and A. Gleason. "Development and decline of a Silurian stromatolite reef complex, Glacier Bay National Park, Alaska". English. In: Palaios 15 (2000), pp. 273-292. 
[21747] B. Sokac and T. Grgasovic. "Asterocalculus heraki n. gen., n. sp., a new calcareous alga (Gymnocodiaceae) from the Upper Triassic Hauptdolomite of Zumberak, north Croatia". English. In: Facies 38 (1998), pp. 197-206.

[21748] E. V. Sokiran. "Frasnian-Famennian extinction and recovery of rhynchonellid brachiopods from the East European Platform". English. In: Acta Palaeontologica Polonica 47.2 (2002), pp. 339-354.

[21749] A. V. Sokolov and E. E. Perkovsky. "The first Eocene species of Bacanius (Coleoptera: Histeridae: Dendrophilinae) from Rovno amber". English. In: Russian Entomological Journal 29 (2020), pp. 157160.

[21750] F. Soldati and M. V. Nabozhenko. "Asida groehni sp. nov., the first and the oldest fossil representative of the subfamily Pimeliinae from Eocene Baltic amber (Coleoptera: Tenebrionidae: Asidini)". English. In: Annales Zoologici 67 (2017), pp. 555-559.

[21751] F. Solé. "New carnivoraforms from the early Eocene of Europe and their bearing on the evolution of the Carnivoraformes". English. In: Palaeontology 57.5 (2014), pp. 963-978.

[21752] F. Solé. "New proviverrine genus from the Early Eocene of Europe and the first phylogeny of Late Palaeocene-Middle Eocene hyaenodontidans (Mammalia)". English. In: Journal of Systematic Palaeontology 11.4 (2013), pp. 375-398.

[21753] F. Solé, E. Amson, M. Borths, D. Vidalenc, M. Morlo, and K. Bastl. “A New Large Hyainailourine from the Bartonian of Europe and Its Bearings on the Evolution and Ecology of Massive Hyaenodonts (Mammalia)". English. In: PLoS ONE 10.9 (2015), e0135698:1-55.

[21754] F. Solé, E. De Bast, J. Yang, C. -S. Li, and T. Smith. “The first species of Hapalodectes (Mesonychia, Mammalia) from the middle Paleocene of China (Qianshan Basin, Anhui Province) sheds light on the initial radiation of hapalodectids". English. In: Palaeontology 60.3 (2017), pp. 433-449. DOI: 10.1111/pala.12293.

[21755] F. Solé, E. M. Essid, W. Marzougui, R. Temani, H. K. Ammar, M. Mahboubi, L. Marivaux, M. Vianey-Liaud, and R. Tabuce. "New fossils of Hyaenodonta (Mammalia) from the Eocene localities of Chambi (Tunisia) and Bir el Ater (Algeria), and the evolution of the earliest African hyaenodonts". English. In: Palaeontologia Electronica 19.3 (2016), 41A:1-23.

[21756] F. Solé, J. Falconett, and D. Vidalenc. "New fossil Hyaenodonta (Mammalia, Placentalia) from the Ypresian and Lutetian of France and the evolution of the Proviverrinae in southern Europe". English. In: Palaeontology 58.6 (2015), pp. 1049-1072.

[21757] F. Solé, J. Falconnet, and L. Yves. “New proviverrines (Hyaenodontida) from the early Eocene of Europe; phylogeny and ecological evolution of the Proviverrinae". English. In: Zoological Journal of the Linnean Society 171 (2014), pp. 878-917.

[21758] F. Solé, E. Gheerbrant, M. Amaghzaz, and B. Bouya. "Further evidence of the African antiquity of hyaenodontid ('Creodonta', Mammalia) evolution". English. In: Zoological Journal of the Linnean Society 156 (2009), pp. 827-846.

[21759] F. Solé, E. Gheerbrant, and M. Godinot. "Sinopaninae and Arfianinae (Hyaenodontida, Mammalia) from the Early Eocene of Europe and Asia; evidence for dispersal in Laurasia around the Paleocene/Eocene boundary and for an unnoticed faunal turnover in Europe". English. In: Geobios 46 (2013), pp. 313-327.

[21760] F. Solé, E. Gheerbrant, and M. Godinot. "New data on the Oxyaenidae from the Early Eocene of Europe; biostratigraphic, paleobiogeographic and paleoecologic implications". English. In: Palaeontologia Electronica 14.2 (2011), 13A:1-41.

[21761] F. Solé, E. Gheerbrant, and M. Godinot. "The miacids (Carnivoraformes, Mammalia) from the Early Eocene locality of Le Quesnoy (MP7, France); first occurrence of Vassacyon in Europe". English. In: Comptes Rendus Palevol 12 (2013), pp. 191-202.

[21762] F. Solé, M. Godinot, Y. Laurent, A. Galoyer, and T. Smith. “The European Mesonychid Mammals: Phylogeny, Ecology, Biogeography, and Biochronology". English. In: Journal of Mammalian Evolution 25 (2018), pp. 339-379. DOI: 10.1007/s10914-016-9371-8. 
[21763] F. Solé, J. Lhuillier, M. Adaci, M. Bensalah, M. Mahboubi, and R. Tabuce. “The hyaenodontidans from the Gour Lazib area (?Early Eocene, Algeria): implications concerning the systematics and the origin of the Hyainailourinae and Teratodontinae". English. In: Journal of Systematic Palaeontology 12.3 (2014), pp. 303-322.

[21764] F. Solé, B. Marandat, and F. Lihoreau. "The hyaenodonts (Mammalia) from the French locality of Aumelas (Hérault), with possible new representatives from the late Ypresian". English. In: Geodiversitas 42.13 (2020), pp. 185-214.

[21765] F. Solé and B. Mennecart. "A large hyaenodont from the Lutetian of Switzerland expands the body mass range of the European mammalian predators during the Eocene". English. In: Acta Palaeontologica Polonica 64.2 (2019), pp. 275-290. DOI: 10.4202/app.00581.2018.

[21766] F. Solé, T. Smith, E. De Bast, V. Codrea, and E. Gheerbrant. "New carnivoraforms from the latest Paleocene of Europe and their bearing on the origin and radiation of Carnivoraformes (Carnivoramorpha, Mammalia)". English. In: Journal of Vertebrate Paleontology 36.2 (2016), e1082480:1-19.

[21767] F. Solé, T. Smith, R. Tabuce, and B. Marandat. "New dental elements of the oldest proviverrine mammal from the early Eocene of Southern France support possible African origin of the subfamily". English. In: Acta Palaeontologica Polonica 60.3 (2015), pp. 527-538.

[21768] R. Soler-Gijón and J. J. Moratalla. "Fish and tetrapod trace fossils from the Upper Carboniferous of Puertollano, Spain". English. In: Palaeogeography, Palaeoclimatology, Palaeoecology 171.1-2 (2001), pp. 1-28. DOI: 10.1016/S0031-0182(01)00257-7.

[21769] A. Solis-Añorve, G. González-Barba, and R. Hernández-Rivera. "Description of a new toothed mysticete from the Late Oligocene of San Juan de La Costa, B.C.S., México". English. In: Journal of South American Earth Science 89 (2019), pp. 337-346. DOI: 10.1016/j.jsames.2018.11.015.

[21770] A. Solodovnikov, Y. L. Yue, S. Tarasov, and D. Ren. "Extinct and extant rove beetles meet in the matrix: Early Cretaceous fossils shed light on the evolution of a hyperdiverse insect lineage (Coleoptera: Staphylinidae: Staphylininae)". English. In: Cladistics 29 (2013), pp. 360-403.

[21771] R. V. Solomina. "Brachiopods of the family Licharewiidae in northeastern Russia". English. In: Paleontological Journal 35.4 (2001), pp. 379-386.

[21772] A. A. Solomon, V. A. Codrea, M. Venczel, and G. Grellet-Tinner. "A new species of large-sized pterosaur from the Maastrichtian of Transylvania (Romania)". English. In: Cretaceous Research 110 (2020), p. 104316.

[21773] A. Solorzano, A. Encinas, A. Kramarz, G. Carrasco, G. Montoya-Sanhueza, and R. Bobe. “Late early Miocene caviomorph rodents from Laguna del Laja ( 37ř S), Cura-Malln Formation, southcentral Chile". English. In: Journal of South American Earth Sciences 102 (2020), p. 102658. DOI: 10. 1016/j.jsames.2020.102658.

[21774] A. Solórzano, A. Encinas, R. Bobe, R. Maximiliano, and G. Carrasco. “The Early to late Middle Miocene mammalian assemblages from the Cura-Malln Formation, at Lonquimay, southern Central Andes, Chile ( 38řS): Biogeographical and paleoenvironmental implications". English. In: Journal of South American Earth Sciences 96.102319 (2019), pp. 1-18.

[21775] A. Solórzano, M. Núñez-Flores, and A. D. Rincón. “Gryposuchus (Crocodylia, Gavialoidea) from the early Miocene of Venezuela". English. In: Paläontologische Zeitschrift 92.1 (2018), pp. 121-129. DOI: $10.1007 / \mathrm{s} 12542-017-0383-3$.

[21776] A. Solorzano and A. D. Rincon. "The earliest record (early Miocene) of a bony-toothed bird from South America and a reexamination of Venezuelan pelagornithids". English. In: Journal of Vertebrate Paleontology 35.6 (2015), e995188. DOI: 10.1080/02724634.2014.995188.

[21777] A. Solórzano, A. D. Rincón, G. M. Cidade, M. Núñez-Flores, and L. Sánchez. “Lower Miocene alligatoroids (Crocodylia) from the Castillo Formation, northwest of Venezuela". English. In: Palaeobiodiversity and Palaeoenvironments 99.2 (2019), pp. 241-259. DOI: 10.1007/s12549-018-0332-5.

[21778] M. Solórzano Kraemer and W. Mohrig. "Schwenckfeldina archoica sp. nov. (Diptera, Sciaridae) from the middle Miocene Mexican amber". English. In: Alavesia 1 (2007), pp. 105-108. 
[21779] M. M. Solórzano Kraemer. “The first fossil Paussine (Coleoptera: Carabidae) from Mexican amber". English. In: Paläontologische Zeitschrift 80 (2006), pp. 107-111.

[21780] M. M. Solórzano Kraemer. "Systematic, palaeoecology, and palaeobiogeography of the insect fauna from Mexican amber". English. In: Palaeontographica Abteilung A 282 (2007), pp. 1-133.

[21781] M. M. Solórzano Kraemer and B. V. Brown. “Dohrniphora (Diptera: Phoridae) from the Miocene Mexican and Dominican ambers with a paleobiological reconstruction". English. In: Insect Systematics E Evolution 49 (2018), pp. 299-327.

[21782] M. M. Solórzano Kraemer and J. M. Cumming. "New genera of brachyceran flies (Diptera: Xylomyidae and Apsilocephalidae sensu auctorum) from mid-Cretaceous Hukawng Valley Burmese amber". English. In: Palaeoentomology 2 (2019), pp. 251-261.

[21783] M. M. Solórzano Kraemer and N. L. Evenhuis. “The first keroplatid (Diptera: Keroplatidae) species from the Lower Eocene amber of Vastan, Gujarat, India". English. In: Zootaxa 1816 (2008), pp. 5760.

[21784] M. M. Solórzano Kraemer and A. Nel. "First recorded evidence in the fossil record of snipe flies (Diptera: Rhagionidae) in Cretaceous amber, France". English. In: Cretaceous Research 30 (2009), pp. 1367-1375.

[21785] M. M. Solórzano Kraemer, V. Perrichot, B. V. Brown, P. Tafforeau, and C. Soriano. “A new species of the Cretaceous genus Prioriphora (Diptera: Phoridae) in French amber". English. In: Systematic Entomology 36 (2011), pp. 561-588.

[21786] M. M. Solórzano Kraemer, V. Perrichot, C. Soriano, and J. Damgaard. "Fossil water striders in Cretaceous French amber (Heteroptera: Gerromorpha: Mesoveliidae and Veliidae)". English. In: Systematic Entomology 39 (2014), pp. 590-605.

[21787] M. M. Solórzano Kraemer and J. F. Petruleviius. “A new planthopper (Insecta: Hemiptera: Nogodinidae) from Chiapas amber, middle Miocene of Mexico". English. In: Geobios 40 (2007), pp. 827832.

[21788] M. M. Solórzano Kraemer, B. J. Sinclair, and J. M. Cumming. "Five new species of Tachydromiinae (Diptera: Empididae s.l.) from New World Tertiary ambers". English. In: Zootaxa 1010 (2005), pp. 37-52.

[21789] M. M. Solórzano Kraemer and R. Wagner. "The first psychodid (Diptera: Psychodidae: Phlebotominae) species from the Lower Eocene amber of Vastan, Gujarat, India". English. In: Zootaxa 2152 (2009), pp. 63-68.

[21790] M. M. Solórzano-Kraemer, X. Delclós, E. Peñalver, and B. J. Sinclair. “New genus and first record of Hybotinae (Diptera: Empidoidea: Hybotidae) in middle Miocene Dominican amber". English. In: Novitates Caribaea 15 (2020), pp. 1-8.

[21791] I. Somerville, P. Strogen, and A. Somerville. “Upper Visean platform carbonates and buildups in the Kingscourt Outlier,Ireland". English. In: Prace Panstwowego Instytutu Geologicznego 157.2 (1997), pp. 143-152.

[21792] I. D. Somerville. "Biostratigraphy and biofacies of Upper Carboniferous-Lower Permian rugose coral assemblages from the Isfjorden area, central Spitsbergen". English. In: Boletin de la Real Sociedad Espanola de Historia Natural, Seccion Geologica 92 (1997), pp. 365-380.

[21793] I. D. Somerville, P. Cozar, and S. Rodrguez. Late Viséan rugose coral faunas from south-eastern Ireland: composition, depositional setting and palaeoecology of Siphonodendron biostromes. 2003.

[21794] I. D. Somerville, N. A. H. Pickard, P. Strogen, and G. L. Jones. “Early to mid-Visean shallow water platform buildups, north Co. Dublin, Ireland". English. In: Geological Journal 27 (1992), pp. 151172.

[21795] I. D. Somerville and S. Rodriguez. "A new genus and species of colonial rugose coral from the Late Tournaisian (Waulsortian) mud-mounds in Ireland: its ecological associations and depositional setting". English. In: Palaeoworld 19 (2010), pp. 414-425. 
[21796] I. D. Somerville, S. Rodriguez, I. Said, and P. Cozar. "Mississippian coral assemblages from Tabainout mud-mound complex, Khenifra area, central Morocco". English. In: Geologica Belgica 15.4 (2012), pp. 308-316.

[21797] I. D. Somerville, P. Strogen, and G. L. Jones. "Biostratigraphy of Dinantian limestones and associated volcanic rocks in the Limerick Syncline, Ireland". English. In: Geological Journal 27 (1992), pp. 201-220.

[21798] I. D. Somerville, P. Strogen, and G. L. Jones. “Mid-Dinantian Waulsortian buildups in the Dublin Basin, Ireland". English. In: Sedimentary Geology 79 (1992), pp. 91-116.

[21799] R. Sommer and R. Benecke. "Post-glacial history of the European seal fauna on the basis of subfossil records". English. In: Beitrage zur Archaeozoologie un prahistorischen Anthropologie 4 (2003), pp. 16-28.

[21800] M. Sone. “A new species of the rare neritopsid gastropod Magnicapitatus from the Guadalupian (Middle Permian) of East Thailand (the Indochina Terrane)". English. In: Alcheringa 34.1 (2010), pp. 1-6. DOI: 10.1080/03115510903277709.

[21801] M. Sone, C. Chonglakmani, and A. Chitnarin. "Middle Permian productidine brachiopods from central Thailand (the Indochina terrane) with paleobiogeographic implications". English. In: Journal of Paleontology 83.5 (2009), pp. 804-810.

[21802] M. Sone, I. Metcalfe, and M. S. Leman. "Palaeobiogeographic implications of Middle Permian brachiopods from Johore (Peninsular Malaysia)". English. In: Geological Magazine 140.5 (2003), pp. 523-538.

[21803] M. Sone and Mohd Shafeea Leman. "Some mid-Permian fossils from Felda Mayam, Central Peninsular Malaysia". English. In: Proceedings of the Annual Geological Congress of Malaysia (2000), pp. 143149.

[21804] M. Sone, Mohd Shafeea Leman, and G. R. Shi. "Middle Permian brachiopods from central Peninsular Malaysia - faunal affinities between Malaysia and west Cambodia". English. In: Journal of South American Earth Sciences 19 (2001), pp. 177-194.

[21805] M. Sone and Mohd Shafeea Leman. "Permian linoproductioid brachiopod Permundaria from Bera South, Peninsular Malaysia". English. In: Journal of Paleontology 79.3 (2005), pp. 601-606.

[21806] M. Sone, Mohd Shafeea Leman, and M. Ehiro. "Middle Permian cephalopods from central peninsular Malaysia: implications for faunal migration through the southern Tethys". English. In: Journal of Asian Earth Sciences 19 (2001), pp. 805-814.

[21807] M. Sone, Mohd Shafeea Leman, and I. Metcalfe. "Triassic nautiloid Sibyllonautilus from Gua Bama, peninsular Malaysia and its regional stratigraphic implications". English. In: Alcheringa 28 (2004), pp. 477-483.

[21808] T. Song, J. Tong, L. Tian, D. Chu, and Y. Huang. “Taxonomic and ecological variations of PermianTriassic transitional bivalve communities from the littoral clastic facies in southwestern China". English. In: Palaeogeography, Palaeoclimatology, Palaeoecology 519 (2018), pp. 108-123. DOI: 10.1016/ j.palaeo.2018.02.027.

[21809] Z. S. Song, G. H. Xu, A. P. Liang, J. Szwedo, and T. Bourgoin. "Still greater disparity in basal planthopper lineage: A new planthopper family Yetkhatidae (Hemiptera, Fulgoromorpha, Fulgoroidea) from mid-Cretaceous Myanmar amber". English. In: Cretaceous Research 101 (2019), pp. 4760. DOI: 10.1016/j.cretres.2019.03.023.

[21810] T. Sonoda, R. Hirayama, Y. Okazaki, and H. Ando. "A new species of the genus Adocus (Adocidae, Testudines) from the Lower Cretaceous of Southwest Japan". English. In: Paleontological Research 19.1 (2015), pp. 26-32. DOI: 10.2517/2014PR026.

[21811] E. Sontag and R. Szadziewski. “Biting midges (Diptera: Ceratopogonidae) in Eocene Baltic amber from the Rovno region (Ukraine)". English. In: Polish Journal of Entomology 80 (2011), pp. 779-800. 
[21812] R. B. Sookias, C. Böhmer, and J. A. Clack. “Redescription and Phylogenetic Analysis of the Mandible of an Enigmatic Pennsylvanian (Late Carboniferous) Tetrapod from Nova Scotia, and the Lability of Meckelian Jaw Ossification". English. In: PLoS ONE 9.10 (2014), e109717. DOI: 10.1371/journal. pone.0109717.

[21813] J. E. Sorauf. "Late Devonian (Famennian) rugose coral fauna of the Percha Shale of southwestern New Mexico". In: Journal of Paleontology 66.5 (1992), pp. 730-749.

[21814] J. E. Sorauf. "Permian corals of Timor (Rugosa and Tabulata): history of collection and study". In: Alcheringa 28.1 (2004), pp. 157-183.

[21815] J. E. Sorauf. "Skeletal Microstructure, Geochemistry, and Organic Remnants in Cretaceous ScleractinianCorals: Santonian Gosau Beds of Gosau, Austria". English. In: Journal of Paleontology 73.6 (1999), pp. 1029-1041.

[21816] J. E. Sorauf and P. J. Harries. "Rotatory colonies of the corals Siderastrea radians and Solenastraea ssp. (Cnidaria, Scleractinia), from the Plesitocene Bermont Formation, south Florida, USA". English. In: Palaeontology 52.1 (2009), pp. 111-126.

[21817] J. E. Sorauf and M. Savarese. "A Lower Cambrian coral from South Australia". In: Palaeontology 38.4 (1995), pp. 757-770.

[21818] S. Sorbi. "New record of Metaxytherium (Mammalia, Sirenia) from the lower Miocene of Manosque (Provence, France)". English. In: Geodiversitas 30.2 (2008), pp. 433-444.

[21819] S. Sorbi, D. P. Domning, S. C. Vaiani, and G. Bianucci. "Metaxytherium subapenninum (Bruno, 1839) (Mammalia, Dugongidae), the latest sirenian of the Mediterranean Basin". English. In: Journal of Vertebrate Paleontology 32.3 (2012), pp. 686-707.

[21820] C. Sorbini, G. Bianucci, and M. Baldassarri. "La balena fossile di Montopoli in Val d'Arno (Pisa)". Italian. In: Museologia Scientifica Memorie 13 (2014), pp. 90-92.

[21821] C. Sorbini and J. C. Tyler. "Review of the fossil file fishes of the family Monacanthidae (Tetraodontiformes), Pliocene and Pleistocene of Europe, with a new genus, Frigocanthus, and two new species related to the recent Aluterus". English. In: Bolletino del Museo Civico di Storia Naturale de Verona 28 (2004), pp. 41-76.

[21822] A. M. Sörensen, S. Floris, and F. Surlyk. "Late Cretaceous scleractinian corals from the rocky shore of Ivö Klack, southern Sweden, including some of the northernmost zooxanthellate corals". English. In: Cretaceous Research 32 (2011), pp. 259-263.

[21823] C. Soriano. "First record of the family Belidae (Insecta, Coleoptera) in amber. New genus and species from the uppermost Albian amber of France". English. In: Geodiversitas 31 (2009), pp. 99104.

[21824] C. Soriano and X. Delclos. "New cupedid beetles from the Lower Cretaceous of Spain and the palaeogeography of the family". English. In: Acta Palaeontologica Polonica 51 (2006), pp. 185-200.

[21825] C. Soriano, V. G. Gratshev, and X. Delclos. "New Early Cretaceous weevils (Insecta, Coleoptera, Curculionoidea) from El Montsec, Spain". English. In: Cretaceous Research 27 (2006), pp. 555-564.

[21826] C. Soriano, A. G. Kirejtshuk, and X. Delclós. "The Mesozoic Laurasian family Parandrexidae (Insecta: Coleoptera:, new species from the Lower Cretaceous of Spain". English. In: Comptes Rendus Palevol 5 (2006), pp. 779-784.

[21827] C. Soriano, D. Pollock, D. Néraudeau, A. Nel, and P. Tafforeau. "First fossil record of polypore fungus beetles from Lower Cretaceous amber of France". English. In: Acta Palaeontologica Polonica 59 (2014), pp. 941-946.

[21828] C. Soriano, A. G. Ponomarenko, and X. Delclós. "Coptoclavid beetles (Coleoptera: Adephaga) from the Lower Cretaceous of Spain: A new feeding strategy in beetles". English. In: Palaeontology 50.2 (2007), pp. 525-536.

[21829] M. Sosso, M. Larosa, B. Dell'Angelo, A. Bonfitto, and S. Schiaparelli. "Nuovi record di Mareleptopoma minor (Almera \& Bofill, 1898) (Gastropoda: Pickworthiidae) per il Pliocene Italiano". Italian. In: Notiziario S.I.M. Supplemento al Bollettino Malacologico 26.1-8 (2008), pp. 13-16. 
[21830] R. Sostillo, E. Cerdeno, and C. I. Montalvo. "Taxonomic implications of a large sample of Tremacyllus (Hegetotheriidae: Pachyrukhinae) from the late Miocene Cerro Azul formation of La Pampa, Argentina". English. In: Ameghiniana 55.4 (2018), pp. 407-422.

[21831] R. Sostillo, C. I. Montalvo, and D. H. Verzi. "A New Species of Reigechimys (Rodentia, Echimyidae) from the Late Miocene of Central Argentina and the Evolutionary Pattern of the Lineage". English. In: Ameghiniana 51.4 (2014), pp. 284-294. DOI: 10.5710/AMGH.24.04.2014.2741.

[21832] A. Soszyska-Maj, K. Kope, P. Müller, C. Gröhn, and W. Krzemiski. “Cretaceous inclusions in Burmese amber throw a new light on the evolution of the Meropeidae (Mecoptera)". English. In: Cretaceous Research 79 (2017), pp. 191-198.

[21833] A. Soszyska-Maj, K. Krzemiski, K. Kope, and R. A. Coram. "Phylogenetic relationships within the relict family Eomeropidae (Insecta, Mecoptera) based on the oldest fossil from the Early Jurassic (Sinemurian) of Dorset, southern England". English. In: Journal of Systematic Palaeontology 14 (2016), pp. 1025-1031.

[21834] A. Soszyska-Maj and W. Krzemiski. "Family Panorpodidae (Insecta, Mecoptera) from Baltic amber (upper Eocene): new species, redescription and palaeogeographic remarks of relict scorpionflies". English. In: Zootaxa 3636 (2013), pp. 489-499.

[21835] A. Soszyska-Maj and W. Krzemiski. "New representative of the family Panorpodidae (Insecta, Mecoptera) from Eocene Baltic Amber with a key to fossil species of genus Panorpodes". English. In: Palaeontologia Electronica 18.2.33A (2015), pp. 1-7.

[21836] A. Soszyska-Maj, W. Krzemiski, K. Kope, Y. Z. Cao, and D. Ren. "Large Jurassic scorpionflies belonging to a new subfamily of the family Orthophlebiidae (Mecoptera)". English. In: Annales Zoologici 68 (2018), pp. 85-92.

[21837] A. Soszyska-Maj, W. Krzemiski, K. Kope, Y. Z. Cao, and D. Ren. “New Middle Jurassic fossils shed light on the relationship of recent Panorpoidea (Insecta, Mecoptera)". English. In: Historical Biology 32 (2019), pp. 1081-1097. DOI: 10.1080/08912963.2018.1564747.

[21838] M. Sotnikova and P. Nikolskiy. "Systematic position of the cave lion Panthera spelaea (Goldfuss) based on cranial and dentalc haracters". English. In: Quaternary International 142-143 (2006), pp. 218-228. DOI: 10.1016/j.quaint.2005.03.019.

[21839] M. Sotnikova and L. Rook. "Dispersal of the Canini (Mammalia, Canidae: Caninae) across Eurasia during the Late Miocene to Early Pleistocene". English. In: Quaternary International 212 (2010), pp. 86-97. DOI: 10.1016/j.quaint.2009.06.008.

[21840] M. Sotnikova and V. Titov. "Carnivora of the Tamanian faunal unit (the Azov Sea area)". English. In: Quaternary International 201 (2009), pp. 43-52. DOI: 10.1016/j.quaint.2008.05.019.

[21841] M. V. Sotnikova, V. S. Baigusheva, and V. V. Titov. "Carnivores of the Khapry faunal assemblage and their stratigraphic implications". In: Stratigraphy and Geological Correlation 10.4 (2002), pp. 6278.

[21842] M. V. Sotnikova and I. V. Foronova. "First Asian record of Panthera (Leo) fossilis (Mammalia, Carnivora, Felidae) in the Early Pleistocene of Western Siberia, Russia". English. In: Integrative Zoology 9.4 (2014), pp. 517-530. DOI: 10.1111/1749-4877.12082.

[21843] M. V. Sotnikova and I. A. Vislobokova. "Pleistocene Mammals from Lakhuti, Southern Tadjikistan, U.S.S.R." In: Quatarpalaontologie, Berlin 8 (1990), pp. 237-244.

[21844] M. V. Sotnikova, A. E. Dodonov, and A. V. Pen'kov. “Upper Cenozoic bio-magnetic stratigraphy of Central Asian mammalian localities". In: Palaeogeography, Palaeoclimatology, Palaeoecology 133 (1997), pp. 243-258.

[21845] E. Soto, C. Sesé, A. Pérez-Gonzalez, and M. Santonja. Mammal fauna with Elephas (Palaeoloxodon) antiquus from the lower levels of Ambrona (Soria, Spain). English. The World of Elephants - International Congress, Rome 2001. 2001, pp. 607-610.

[21846] M. Soto and D. Perea. "A ceratosaurid (Dinosauria, Theropoda) from the Late Jurassic-Early Cretaceous of Uruguay". English. In: Journal of Vertebrate Paleontology 28.2 (2008), pp. 439-444. 
[21847] M. Soto and D. Perea. “Late Jurassic lungfishes (Dipnoi) from Uruguay, with comments on the systematics of Gondwanan ceradontiforms". English. In: Journal of Vertebrate Paleontology 30.4 (2010), pp. 1049-1058.

[21848] M. Soto, D. Perea, and A. Cambiaso. "First sauropod (Dinosauria: Saurischia) remains from the Guichón Formation, Late Cretaceous of Uruguay". English. In: Journal of South American Earth Sciences 33 (2012), pp. 68-79.

[21849] M. Soto, D. Perea, and P. Torino. “New remains of Priohybodus aramourgi (Hybodontiformes: Hybodontidae) from Late Jurassic-earliest Cretaceous deposits in Uruguay". English. In: Cretaceous Research 35 (2012), pp. 118-123.

[21850] M. Soto, D. Pol, and D. Perea. "A new specimen of Uruguaysuchus aznarezi (Crocodyliformes: Notosuchia) from the middle Cretaceous of Uruguay and its phylogenetic relationships". English. In: Zoological Journal of the Linnean Society 163 (2011), S173-S198.

[21851] M. Soto, P. Toriño, and D. Perea. “A large sized megalosaurid (Theropoda, Tetanurae) from the late Jurassic of Uruguay and Tanzania". English. In: Journal of South American Earth Science 98 (2020), p. 102458.

[21852] M. Soto, P. Toriño, and D. Perea. “Ceratosaurus (Theropoda, Ceratosauria) teeth from the Tacuarembó Formation (Late Jurassic, Uruguay)". English. In: Journal of South American Earth Sciences 103 (2020), p. 102781.

[21853] S. Soto - Acuña, R. A. Otero, and D. Rubilar-Rogers. Un nuevo ejemplar de Metriorhynchus casamiquelai Gasparini y Chong, 1977 (Crocodylomorpha: Thalattosuchia) del Caloviano de Sierra de Moreno, Spanish. 2012.

[21854] R. Souberlich and M. S. de la Fuente. Primer registro de Chelonoidis sp. (Testudines: Testudinidae) en el Pleistoceno de Paraguay. Spanish. 2011.

[21855] F. Sour-Tovar, F. Alvarez, and M. L. M. Chacon. "Lower Mississippian (Osagean) spire-bearing brachiopods from Canon de la Peregrina, north of Ciudad Victoria, Tamaulipas, northeastern Mexico". English. In: Journal of Paleontology 79.3 (2005), pp. 469-485.

[21856] F. Sour-Tovar, J. W. Hagadorn, and T. Huitron-Rubio. “Ediacaran and Cambrian index fossils from Sonora, Mexico". English. In: Palaeontology 50.1 (2007), pp. 169-175.

[21857] F. Sour-Tovar, A. Pérez-Huerta, S. A. Quiroz-Barroso, and E. Centeno-Garcia. "Braquiopodos y trilobite del Permico Inferior del noroeste del Estado de Hidalgo, Mexico". Spanish. In: Revista Mexicana de Ciencias Geologicas 22 (2005), pp. 24-35.

[21858] F. Sour-Tovar, S. A. Quiroz-Barroso, and S. P. Applegate. "Presence of Helicoprion (Chondrichthyes, Elasmobranchii) in the Permian Patlanoaya Formation, Puebla, Mexico". English. In: Journal of Paleontology 74.2 (2000), pp. 363-366.

[21859] F. Sour-Tovar, S. A. Quiroz-Barroso, J. Quiroz-Barragán, M. A. Torres-Martnez, and S. GonzálezMora. "Presencia de Anisopyge perannulata y Ditomopyge cf. D. whitei (Trilobita, Proetidae) en el Pérmico (Guadalupiano medio) de la Formación Las Delicias, Coahuila, norte de México". Spanish. In: Paleontologa Mexicana 5 (2016), pp. 103-109.

[21860] S. H. M. Sousa, D. Rossetti, T. R. Fairchild, L. Burone, M. M. Mahiques, and P. Tibana. "Microfacies and sequence stratigraphy of the Amapá Formation, Late Paleocene to Early Eocene, Foz do Amazonas Basin, Brazil". English. In: Palaeogeography, Palaeoclimatology, Palaeoecology 280 (2009), pp. 440-455.

[21861] M. Soussi, G. Niedwiedzki, M. Taanda, D. Dród, T. Sulej, K. Boukhalfa, J. Mermer, and B. Baejowski. "Middle Triassic (Anisian-Ladinian) Tejra red beds and Late Triassic (Carnian) carbonate sedimentary records of southern Tunisia, Saharan Platform: Biostratigraphy, sedimentology and implication on regional stratigraphic correlations". English. In: Marine and Petroleum Geology 79 (2017), pp. 222-256. DOI: 10.1016/j.marpetgeo.2016.10.019.

[21862] D. A. Southwood. "New bryozoan taxa from the Upper Permian Zechstein reef in NE England". English. In: Proceedings of the Yorkshire Geological Society 48 (1990), pp. 33-40. 
[21863] R. G. Souza, R. G. Figueiredo, S. A. K. Azevedo, D. Riff, and A. W. A. Kellner. “Systematic revision of Sarcosuchus hartti (Crocodyliformes) from the Reconcavo Basin (Early Cretaceous) of Bahia, north-eastern Brazil". English. In: Zoological Journal of the Linnean Society (2019). DOI: 10.1093 / zoolinnean/zlz057/5546069.

[21864] R. G. Souza, D. Riff, J. P. de Souza-Filho, and A. W. A. Kellner. "Revisiting Gryposuchus jessei Gürich, 1912 (Crocodylia: Gavialoidea): specimen description and comments on the genus". English. In: Zootaxa 4457.1 (2018), pp. 167-178.

[21865] J. Souza Bittencourt, T. Rodrigues Simoes, M. W. Caldwell, and M. C. Langer. "Discovery of the oldest South American fossil lizard illustrates the cosmopolitanism of early South American squamates". English. In: Nature Communications Biology 3.201 (2020), pp. 1-11. DOI: 10.1038 / s42003020-0926.

[21866] J. P. Souza-Filho, E. Guilherme, P. M. Toledo, I. S. Carvalho, F. R. Negri, A. A. R. Maciente, G. M. Cidade, M. B. S. Lacerda, and L. G. Souza. “On a new Melanosuchus species (Alligatoroidea: Caimaninae) from Solimões". English. In: Zootaxa 4894.4 (2020), pp. 561-593.

[21867] J. P. Souza-Filho, R. G. Souza, A. S. Hsiou, D. Riff, E. Guilherme, F. R. Negri, and G. M. Cidade. “A new caimanine (Crocodylia, Alligatoroidea) species from the Solimões Formation of Brazil and the phylogeny of Caimaninae". English. In: Journal of Vertebrate Paleontology 39 (2019), e1528450:124. DOI: $10.1080 / 02724634.2018 .1528450$.

[21868] W. Souza-Lima and C. L. deCastro Manso. "The first record record of the comatulid crinoid Sievertsella Radwaska, 2003 and its implications for the Miocene of the Bragança-Viseu Basin, Brazil”. English. In: Acta Geologica Polonica 67.3 (2017), pp. 425-432.

[21869] H. Sozbilir. "Revised stratigraphy and facies analysis of Paleocene-Eocene supra-allochthonous sediments (Denizli, SW Turkey) and their tectonic significance". English. In: Turkish Journal of Earth Sciences 11 (2002), pp. 87-112.

[21870] D. R. Sparling. "Conodonts from the Middle Devonian Plum Brook Shale of north-central Ohio". In: Journal of Paleontology 69.6 (1995), pp. 1123-1138.

[21871] T. Spasojevic, G. R. Broad, A. M. R. Bennett, and S. Klopfstein. “Ichneumonid parasitoid wasps from the Early Eocene Green River Formation: five new species and a revision of the known fauna (Hymenoptera, Ichneumonidae)". English. In: PalZ 92 (2018), pp. 35-63.

[21872] T. Spasojevic, S. Wedmann, and S. Klopfstein. "Seven remarkable new fossil species of parasitoid wasps (Hymenoptera, Ichneumonidae) from the Eocene Messel Pit". English. In: PLoS One 13.6 (2018), e0197477.

[21873] N. Spassov. "A new Late Villafranchian locality of vertebrate fauna - Slivnitsa (Bulgaria) and the carnivore dispersal events in Europe on the Pliocene/Pleistocene boundary". English. In: Historia naturalis bulgarica 9 (1998), pp. 101-113.

[21874] N. Spassov and D. Geraads. "A New Felid from the Late Miocene of the Balkans and the Contents of the Genus Metailurus Zdansky, 1924 (Carnivora, Felidae)". English. In: Journal of Mammalian Evolutino 22 (2015), pp. 45-56. DOI: 10.1007/s10914-014-9266-5.

[21875] N. Spassov, D. Geraads, L. Hristova, G. N. Markov, B. Garevska, and R. Garevski. "The late Miocene mammal faunas of the Republic of Macedonia (FYROM)". English. In: Palaeontographica Abteilung A 311.1-6 (2018), pp. 1-85. DOI: 10.1127/pala/2018/0073.

[21876] N. Spassov, D. Geraads, L. Hristova, G. N. Markov, G. Merceron, T. Tzankov, K. Stoyanov, M. Bohme, and A. Dimitrova. "A hominid tooth from Bulgaria: The last pre-human hominid of continental Europe". English. In: Journal of Human Evolution 62.1 (2012), pp. 138-145. DOI: 10.1016/j. jhevol.2011.10.008.

[21877] M. Spaulding, J. J. Flynn, and R. K. Stucky. "A new basal Carnivoramorphan (Mammalia) from the 'Bridger B' (Black's Fork member, Bridger Formation, Bridgerian Nalma, middle Eocene) of Wyoming, USA". English. In: Palaeontology 53.4 (2010), pp. 815-832. DOI: 10.1111/j.1475-4983. 2010.00963.x. 
[21878] P. S. Spencer and M. S. Y. Lee. "A Juvenile Elginia and Early Growth in Pareiasaurs". English. In: Journal of Paleontology 74.6 (2000), pp. 1191-1195. DOI: 10.1666 / 0022-3360(2000) 074<1191: AJEAEG>2.0.CO;2.

[21879] P. S. Spencer and G. W. Storrs. "A re-evaluation of small tetrapods from the Middle Triassic Otter Sandstone Formation of Devon, England". English. In: Palaeontology 45.3 (2002), pp. 447-467.

[21880] R. A. Spicer, A. Ahlberg, A. B. Herman, S. P. Kelley, M. I. Raikevich, and P. M. Rees. “Palaeoenvironment and ecology of the middle Cretaceous Grebenka flora of northeastern Asia". In: Palaeogeography, Palaeoclimatology, Palaeoecology 184 (2002), pp. 65-105.

[21881] R. A. Spicer and A. B. Herman. "The Albian-Cenomanian flora of the Kukpowruk River, western North Slope, Alaska: stratigraphy, palaeofloristics, and plant communities". In: Cretaceous Research 22 (2001), pp. 1-40.

[21882] R. A. Spicer and J. T. Parrish. "Latest Cretaceous woods of the central North Slope, Alaska". In: Palaeontology 33.1 (1990), pp. 225-242.

[21883] J. A. Spielmann, A. P. Hunt, S. G. Lucas, and A. B. Heckert. "Revision of Redondasuchus (Archosauria: Aetosauria) from the Upper Triassic Redonda Formation, New Mexico, with description of a new species". English. In: vol. 37. The Triassic-Jurassic Terrestrial Transition, New Mexico Museum of Natural History and Science Bulletin. Albuquerque: New Mexico Museum of Natural History and Science, 2006, pp. 583-587.

[21884] J. A. Spielmann, S. G. Lucas, and A. B. Heckert. Tetrapod fauna of the Upper Triassic (Revueltian) Owl Rock Formation, Chinle Group, Arizona. English. Vol. 41. The Global Triassic, New Mexico Museum of Natural History and Science Bulletin. 2007, pp. 371-383.

[21885] J. A. Spielmann, S. G. Lucas, and A. P. Hunt. "The vertebrate macrofauna of the Upper Triassic (Apachean) Redonda Formation, east-central New Mexico". English. In: vol. 37. The TriassicJurassic Terrestrial Transition. New Mexico Museum of Natural History and Science Bulletin. Albuquerque: New Mexico Museum of Natural History and Science, 2006, pp. 502-509.

[21886] J. A. Spielmann, S. G. Lucas, A. B. Heckert, L. F. Rinehart, and H. R. Richards III. “Redescription of Spinosuchus caseanus (Archosauromorpha: Trilophosauridae) from the Upper Triassic of North America". English. In: Palaeodiversity 2 (2009), pp. 283-313.

[21887] J. A. Spielmann, S. G. Lucas, and K. Krainer. “Early Permian (Wolfcampian) marine invertebrate assemblage from the Hueco Group, Shalem Colony Formation, Dona Ana Mountains, New Mexico". English. In: New Mexico Museum of Natural History and Science Bulletin 31 (2005), pp. 170173.

[21888] J. A. Spielmann, S. G. Lucas, A. P. Hunt, and A. B. Heckert. "Reinterpretation of the holotype of Malerisaurus langstoni, a diapsid reptile from the Upper Triassic Chinle Group of New Mexico". English. In: vol. 37. The Triassic-Jurassic Terrestrial Transition. New Mexico Museum of Natural History and Science Bulletin. Albuquerque: New Mexico Museum of Natural History and Science, 2006, pp. 543-547.

[21889] J. A. Spielmann, S. G. Lucas, L. F. Rinehart, and A. B. Heckert. “The Late Triassic archosauromorph Trilophosaurus". English. In: New Mexico Museum of Natural History and Science Bulletin 43 (2008), pp. 1-177.

[21890] J. A. Spielmann and S. G. Lucas. “Tetrapod fauna of the Upper Triassic Redonda formation, EastCentral New Mexico: the characteristic assemblage of the Apachean land-vertebrate faunachron". English. In: New Mexico Museum of Natural History and Science, Bulletin 55 (2012), pp. 1-119.

[21891] J. A. Spielmann, S. G. Lucas, and P. Huber. "New record of Spinosuchus caseanus (Archosauromorpha: Trilophosauridae) from the Late Triassic (Adamanian) of West Texas". English. In: New Mexico Museum of Natural History and Science Bulletin 61 (2013), pp. 573-576.

[21892] F. Spindler. "The basal Sphenacodontia: Systematic revision and evolutionary implications". English. PhD thesis. Freiberg, 2015, p. 385. 
[21893] F. Spindler, S. Voigt, and J. Fischer. "Edaphosauridae (Synapsida, Eupelycosauria) from Europe and their relationship to North American representatives". English. In: Palaeontologische Zeitschrift (2019), pp. 1-29. DOI: 10.1007/s12542-019-00453-2.

[21894] F. Spindler, R. Werneburg, J. W. Schneider, L. Luthardt, V. Annacker, and R. RöSSler. "First arboreal 'pelycosaurs' (Synapsida: Varanopidae) from the early Permian Chemnitz Fossil Lagerstätte, SE Germany, with a review of varanopid phylogen". English. In: Palaeontologische Zeitschrift 92 (2018), pp. 315-364.

[21895] C. Spinosa and W. W. Nassichuk. "The Permian ammonoid Demarezites Ruzhencev from the Phosphoria Formation, Idaho". English. In: Journal of Paleontology 68 (1994), pp. 1036-1040.

[21896] N. Spjeldnaes and P. Moissette. "Celleporid (bryozoan) thickets from the Upper Pliocene of the island of Rhodes, Greece". English. In: Cool-Water carbonates. Tulsa: SEPM Special Publication, 1997, pp. 263-270.

[21897] F. Spoor, M. G. Leakey, P. N. Gathogo, F. H. Brown, S. C. Antón, I. McDougall, C. Kiarie, F. K. Manthi, and L. N. Leakey. "Implications of new early Homo fossils from Ileret, east of Lake Turkana, Kenya". English. In: Nature 448 (2007), pp. 688-691.

[21898] J. Sprinkle and D. Collins. "New eocrinoids from the Burgess Shale, southern British Columbia, Canada, and the Spence Shale, northern Utah, USA". English. In: Canadian Journal of Earth Sciences 43 (2006), pp. 303-322. DOI: 10.1139/E05-107.

[21899] J. Sprinkle and T. E. Guensburg. "Origin of echinoderms in the Paleozoic evolutionary fauna: the role of substrates". English. In: Palaios 10 (1995), pp. 437-453.

[21900] J. Sprinkle and C. D. Sumrall. "New edrioasterine and astrocystitid (Echinodermata: Edrioasteroidea) from the Ninemile Shale (Lower Ordovician), central Nevada". English. In: Journal of Paleontology 89.2 (2015), pp. 346-352. DOI: 10.1017/jpa.2014.29.

[21901] J. Sprinkle and C. D. Sumrall. "New parablastoids from the western United States". English. In: The University of Kansas Paleontological Contributions 16 (2008), pp. 1-14.

[21902] J. Sprinkle and G. P. Wahlman. "New echinoderms from the Early Ordovician of west Texas". English. In: Journal of Paleontology 68.2 (1994), pp. 324-338. DOI: 10.2307/1306073.

[21903] J. Sprinkle and J. A. Waters. "New ridged, conical, fissiculate blastoid from the Permian of Timor". English. In: Journal of Paleontology 87 (2013), pp. 1071-1076.

[21904] C. D. Sproat and J. Jin. "Evolution of the Late Ordovician plaesiomyid brachiopod lineage in Laurentia". English. In: Canadian Journal of Earth Sciences 50.7 (2013), pp. 872-894. DOI: 10.1139/ cjes-2013-0022.

[21905] R. L. Squires. "Additions to the Eocene megafossil fauna of the Llajas Formation, Simi Valley, southern California". English. In: Contributions in Science (Natural History Museum of Los Angeles County) 489 (2001), pp. 1-40.

[21906] R. L. Squires. "West Coast North America record of the Paleogene marine stromboid gastropod Rimella and paleobiogeography of the genus". English. In: Journal of Paleontology 87.5 (2013), pp. 826-841. DOI: 10.1666/13-018.

[21907] R. L. Squires. "New Paleogene Siliquariid and Vermetid Gastropods from the Pacific Coast of Southwestern North America". English. In: The Veliger 33.3 (1990), pp. 286-292.

[21908] R. L. Squires. "Northeast Pacific Upper Cretaceous and Paleocene Glycymeridid Bivalves". English. In: Journal of Paleontology 84.5 (2010), pp. 895-917. DOI: 10.1666/09-130.1.

[21909] R. L. Squires. "A new genus of Cretaceous margaritine gastropod (Turbinidae) from the northeastern Pacific Ocean". English. In: The Nautilus 125.3 (2011), pp. 137-149.

[21910] R. L. Squires. "Macropaleontology of Eocene marine rocks, upper Sespe Creek area, Ventura County, southern California". English. In: SEPM (Society for Sedimentary Geology) Pacific Section 74 (1994), pp. 39-56.

[21911] R. L. Squires. "New Paleogene Fimbria (Mollusca: Bivalvia) from the Pacific coast of southwestern North America". English. In: Journal of Paleontology 64 (1990), pp. 552-556. 
[21912] R. L. Squires. "Taxonomy and Distribution of the Buccinid Gastropod Brachysphingus from Uppermost Cretaceous and Lower Cenozoic Marine Strata of the Pacific Slope of North America". English. In: Journal of Paleontology 71.5 (1997), pp. 847-861.

[21913] R. L. Squires. "Molluscan Paleontology of the Lower Eocene Maniobra Formation, Orocopia Mountains, Southern California". English. In: vol. 68. Eocene Geologic History San Diego Region, Pacific Section SEPM. 1991, pp. 217-226.

[21914] R. L. Squires. “New Early Eocene Species of Arca s.s. (Mollusca: Bivalvia) from Southern California". English. In: The Veliger 34.1 (1991), pp. 67-72.

[21915] R. L. Squires. "Revision of Eocene warm-water cassid gastropods from coastal southwestern North America: implications for paleobiogeographic distribution and faunal-turnover". English. In: $\mathrm{Pa}$ leoBios 36 (2019), pp. 1-22.

[21916] R. L. Squires. "Paleocene and Eocene oysters from the West Coast of the United States: Revision of named species and recognition of new species". English. In: Contributions in Science 526 (2018), pp. 1-29.

[21917] R. L. Squires. “Upper Paleocene to Lower Eocene (Meganos Stage) Marine Megafossils in the Uppermost Santa Susana Formation, Simi Valley, Southern California". English. In: Contributions in Science, Los Angeles County Museum 479 (1999), pp. 1-38.

[21918] R. L. Squires. "Middle Eocene brackish-marine mollusks from the Matilija Sandstone at Matilija Hot Springs, Ventura County, Southern California". English. In: Contributions in Science, Los Angeles County Museum 480 (1999), pp. 1-30.

[21919] R. L. Squires. "A New Middle Eocene potamidid gastropod from brackish-marine deposits, Southern California". English. In: The Veliger 34.4 (1991), pp. 354-359.

[21920] R. L. Squires. "The gastropod Philine bisculptata Hanna, 1927, from the Eocene of Southern California, belongs in the neritid genus Otostoma d'Archiac, 1859". English. In: The Veliger 38.2 (1995), pp. 176-180.

[21921] R. L. Squires. "New reports of the large gastropod Campanile from the Paleocene and Eocene of the Pacific Coast of North America". English. In: The Nautilus 36.4 (1993), pp. 323-331.

[21922] R. L. Squires and T. A. Deméré. "A Middle Eocene marine molluscan assemblage form the usually nonmarine Friars Formation, San Diego County, California". English. In: Pacific Section SEPM 68 (1991), pp. 181-188.

[21923] R. L. Squires and R. Demetrion. “New Early Eocene Marine Gastropods from Baja California Sur, Mexico". In: Journal of Paleontology 64.1 (1990), pp. 99-103.

[21924] R. L. Squires and R. Demetrion. "New Eocene Marine Bivalves from Baja California Sur, Mexico". English. In: Journal of Paleontology 64.3 (1990), pp. 382-391.

[21925] R. L. Squires and R. A. Demetrion. Paleontology of the Eocene Bateque Formation, Baja California Sur, Mexico. 1992.

[21926] R. L. Squires and R. A. Demetrion. "A New Species of the Oligopygoid Echinoid Haimea from the Lower Eocene of Baja California Sur, Mexico". English. In: Journal of Paleontology 68.4 (1994), pp. 846-851.

[21927] R. L. Squires and J. L. Goedert. "Macropaleontology of the Eocene Crescent Formation in the Little River Area, Southern Olympic Peninsula, Washington". English. In: Contributions in Science (Natural History Museum of Los Angeles County) 444 (1994), pp. 1-32.

[21928] R. L. Squires, J. L. Goedert, and K. L. Kaler. "Paleontology and stratigraphy of Eocene rocks at Pulali Point, Jefferson County, Olympic Peninsula, Washington". English. In: (1992).

[21929] R. L. Squires and J. L. Goedert. “New Species of Middle Eocene Gastropods from the Northern Doty Hills, Southwestern Washington". English. In: The Veliger 38.3 (1995), pp. 254-269.

[21930] R. L. Squires, J. L. Goedert, and S. R. Benham. "Protoconch of the Rare Ovulid Gastropod Cypraeogemmula warnerae Effinger, 1938, from the Eocene of Western Washington". English. In: The Veliger 39.2 (1996), pp. 136-141. 
[21931] R. L. Squires and J. L. Goedert. “Eocene megafossils from the Needles-Gray Wolf lithic assemblage of the Easter Core Rocks, Olympic Peninsula, Washington". English. In: Washington Geology 25.4 (1997), pp. 25-29.

[21932] R. L. Squires and J. L. Goedert. "A new species of Thalassomerita? (Gastropoda: Neritidae?) from a Middle Eocene cold-seep carbonate in the Humptulips Formation, Western Washington". English. In: The Veliger 39.3 (1996), pp. 270-272.

[21933] R. L. Squires and J. L. Goedert. "New Late Eocene mollusks from localized limestone deposits formed by subduction-related methane seeps, Southwestern Washington". English. In: Journal of Paleontology 65.3 (1991), pp. 412-416. DOI: 10.1017/S0022336000030389.

[21934] R. L. Squires and J. L. Goedert. "An extant species of Leptochiton (Mollusca: Polyplacophora) in Eocene and Oligocene cold-seep limestones, Olympic Peninsula, Washington". English. In: The Veliger 38.1 (1995), pp. 47-53.

[21935] R. L. Squires and J. L. Goedert. "A new species of the volutid gastropod Fulgoraria (Musashia) from the Oligocene of Washington". English. In: The Veliger 37.4 (1994), pp. 400-409.

[21936] R. L. Squires and J. L. Goedert. "New species of small to minute gastropods of Early Eocene age from the Crescent Formation, Black Hills, Southwest Washington". English. In: The Veliger 39.3 (1996), pp. 226-240.

[21937] R. L. Squires, J. L. Goedert, and S. R Benham. "First fossil record of the pteropod Limacina from the Pacific Coast of North America". English. In: Bulletin of the Southern California Academy of Sciences 98.2 (1999), pp. 80-89.

[21938] R. L. Squires and M. P. Gring. "Late Eocene chemosynthetic? bivalves from suspect cold seeps, Wagonwheel Mountain, central California". English. In: Journal of Paleontology 70.1 (1996), pp. 6373.

[21939] R. L. Squires and G. L. Kennedy. "Additions to the Late Paleocene Molluscan Fauna from the Santa Monica Mountains, Los Angeles County. Southern California". English. In: The Veliger 41.2 (1998), pp. 157-171.

[21940] R. L. Squires and L. R. Saul. "Uncommon Cretaceous naticiform gastropods from the Pacific Slope of North America". English. In: The Velliger 47.1-2 (2004), pp. 21-37.

[21941] R. L. Squires and L. R. Saul. "Additions and refinements to Aptian to Santonian (Cretaceous) Turritella (Mollusca: Gastropoda) from the Pacific Slope of North America". English. In: The Veliger 48.1 (2006), pp. 46-60.

[21942] R. L. Squires and L. R. Saul. "New Late Cretaceous (Santonian and Campanian) gastropods from California and Baja California, Mexico". English. In: The Nautilus 119.4 (2005), pp. 133-148.

[21943] R. L. Squires and L. R. Saul. "New information on Late Cretaceous, Paleocene, and Eocene neritid gastropods from the North American Pacific slope". English. In: The Veliger 45.4 (2002), pp. 177192.

[21944] R. L. Squires and L. R. Saul. "Cretaceous opine bivalves from the pacific slope of North America and palaeobiogeography of subfamily Opinae Chavan, 1969". English. In: Palaeontology 52.6 (2009), pp. 1311-1347. DOI: 10.1111/j.1475-4983.2009.00905.x.

[21945] R. L. Squires and L. R. Saul. "New late Cretaceous (Campanian and Maastrichtian) marine gastropods from California". English. In: Journal of Paleontology 77.1 (2003), pp. 50-63. DOI: 10.1017/ S0022336000043419.

[21946] R. L. Squires and L. R. Saul. "New Late Cretaceous gastropods from the Pacifc slope of North America". English. In: Journal of Paleontology 75.1 (2001), pp. 46-65. DOI: 10.1017/S0022336000031905.

[21947] R. L. Squires and L. R. Saul. "Late Cretaceous occurrence on the Pacific slope of North America of the melanopsid gastropod genus Boggsia Olsson, 1929". English. In: The Veliger 40 (1997), pp. 193202.

[21948] R. L. Squires and L. R. Saul. "Paleocene pareorine turritellid gastropods from the Pacific slope of North America". English. In: The Nautilus 121.1 (2007), pp. 1-16. 
[21949] R. L. Squires and L. R. Saul. “Review of bivalve genus Plicatula from Cretaceous and Lower Cenozoic strata of California and Baja California". English. In: 71.2 (1997), pp. 287-298.

[21950] R. L. Squires and L. R. Saul. "A new species of Otostoma (Gastropoda: Neritidae) from Near the Cretaceous/Tertiary boundary at Dip Greek, Lake Nacimiento, California". English. In: The Veliger 36.3 (1993), pp. 259-264.

[21951] R. L. Squires and L. R. Saul. “A new genus of aporrhaid gastropod from upper Paleocene rocks in southern California". English. In: The Veliger 44.3 (2001), pp. 327-330.

[21952] R. L. Squires and L. R. Saul. "The buccinid gastropod Deussenia from Upper Cretaceous strata of California". English. In: The Veliger 43.2 (2000), pp. 118-125.

[21953] J. Sremac. “Zona Neoschwagerina craticulifera u Srednjem Velebitu [Neoschwagerina craticulifera zone of the Velebit Mountains (Croatia)]". other. In: Geologija 34 (1991), pp. 7-55.

[21954] J. Sremac, B. Jurkovek, D. Aljinovi, and T. Kolar-Jurkovek. “Equatorial Palaeotethys as the last sanctuary for late Permian metazoan". English. In: Palaeogeography, Palaeoclimatology, Palaeoecology 454 (2016), pp. 91-100.

[21955] K. Srinivasan and K. R. Walker. "Sequence stratigraphy of an intrashelf basin carbonate ramp to rimmed platform transition: Maryville Limestone (Middle Cambrian), southern Appalachians". In: Geological Society America Bulletin 105 (1993), pp. 883-896.

[21956] V. Srinivasan. "Conifers from the PUddledock locality (Potomac Group, Early Cretaceous) in eastern North America". In: Review of Palaeobotany and Palynology 89 (1995), pp. 257-286.

[21957] A. K. Srivastava, N. K. Kandwal, S. K. Humane, S. S. Humane, P. Kundal, and N. Khare. “Record of calcareous algae from the Lameta Formation: a new insight". English. In: Arabian Journal of Geosciences (2018). DOI: 10.1007/s12517-017-3333-1.

[21958] D. K. Srivastava, D. K. Pandey, A. Alberti, and F. T. Fürsich. “Record of Advenaster Hess, 1955 (Asteroidea) from the Bathonian Patcham Formation of Kala Jhar in Habo Dome, Kachchh Basin, India". English. In: Journal of the Palaeontological Society of India 55.1 (2010), pp. 65-69.

[21959] G. Srivastava and R. C. Mehrotra. "First Fossil Record of Alphonsea Hk. f. \& T. (Annonaceae) from the Late Oligocene Sediments of Assam, India and Comments on Its Phytogeography". English. In: Plos One 8.1 (2013), e53177. DOI: 10.1371/journal.pone.0053177.

[21960] G. P. Srivastava, M. Shukla, P. Kumar, M. Kumar, and A. Prakash. “Record of pillbug (Armadillidium) and millipede (Polyxenus) remains from the resin lumps of Warkalli Formation (upper Tertiary), Kerala coast”. English. In: Journal of the Geological Society of India 67 (2006), pp. 715-719.

[21961] P. Sroka and A. Nel. “New species of Compsocidae (Insecta, Psocodea) from Cretaceous Burmese amber". English. In: Zootaxa 4320 (2017), pp. 597-600.

[21962] P. Sroka, A. H. Staniczek, and B. C. Kondratieff. “'Rolling' stoneflies (Insecta: Plecoptera) from mid-Cretaceous Burmese amber". English. In: PeerJ 6 (2018), e5354.

[21963] P. Sroka and A. H. Staniczek. "Retention of cervical and abdominal gills in the adult of a new fossil stonefly (Insecta, Plecoptera, Petroperlidae) from mid-Cretacous Burmese amber". English. In: Cretaceous Research 107.104277 (2019). DOI: 10.1016/j.cretres.2019.104277.

[21964] E. M. St. Clair, D. M. Boyer, J. I. Bloch, and D. W. Krause. "First records of a triisodontine mammal, Goniacodon levisanus, in the late Paleocene of the Northern Great Plains, North America". English. In: Journal of Vertebrate Paleontology 30.2 (2010), pp. 604-608.

[21965] C. J. Stadum and K. L. Finger. "Paleontology and stratigraphy of the Miocene Saddleback Valley Limestone, Orange County, Southern California". English. In: Contributions in Science, Natural History Museum of Los Angeles County 524 (2016), pp. 31-49.

[21966] K. Staesche, H. V. Karl, and U. Staesche. "Fossile Schildkroten aus der Turkei". German. In: vol. 98. Fossile Schildkroten aus drei Kontinenten. Hannover: Geologisches Jahrbuch, 2007, pp. 91-149.

[21967] B. Stahl and D. Parris. "The complete dentition of Edaphodon mirificus (Chondrichthyes: Holocephali) from a single individual". English. In: Journal of Paleontology 78.2 (2004), pp. 388-392. 
[21968] C. L. Staines and G. A. Samuelson. "A new Sceloenopla (Coleoptera, Chrysomelidae, Hispinae) from Dominican amber". English. In: Deutsche Entomologische Zeitschrift 47 (2000), pp. 61-63.

[21969] A. R. Staker. "The earliest known dinosaur trackers of Zion National Park, Utah". English. In: vol. 37. The Triassic-Jurassic Terrestrial Transition. New Mexico Museum of Natural History and Science Bulletin. Albuquerque: New Mexico Museum of Natural History and Science, 2006, pp. 137139.

[21970] S. Stamberg. “New discoveries of palaeoniscoid fishes and other fauna and flora from the northern region of Boskovice Furrow, Czech Republic". In: Journal of the Czech Geological Society 42.1-2 (1997), pp. 111-120.

[21971] S. Stamberg. "Actinopterygian fishes from the new Lower Permian locality of the Krkonose Piedmont Basin". English. In: Journal of the Czech Geological Society 47.3-4 (2002), pp. 147-154.

[21972] R. Stanford, M. G. Lockley, C. Tucker, S. J. Godfrey, and S. M. Stanford. "A diverse mammaldominated, footprint assemblage from wetland deposits in the Lower Cretaceous of Maryland". English. In: Scientific Reports 8.1 (2018), 741:1-12. DOI: 10.1038/s41598-017-18619-w.

[21973] R. Stanford, R. E. Weems, and M. G. Lockley. “A new dinosaur ichnotaxon from the Lower Cretaceous Patuxent Formation of Maryland and Virginia". English. In: Ichnos 11 (2004), pp. 251-259.

[21974] R. Stanford, D. B. Weishampel, and V. B. Deleon. "The first hatchling dinosaur reported from the eastern United States: Propanoplosaurus marylandicus (Dinosauria: Ankylosauria) from the Early Cretaceous of Maryland, U.S.A." English. In: Journal of Paleontology 85.5 (2011), pp. 916-924. DOI: 10.1666/10-113.1.

[21975] N. A. Stanich, G. W. Rothwell, and R. A. Stockey. "Phylogenetic diversification of Equisetum (Equisetales) as inferred from Lower Cretaceous species of British Columbia, Canada". English. In: American Journal of Botany 96 (2009), pp. 1289-1299.

[21976] A. H. Staniczek. "New fossil mayflies from Dominican amber (Insecta: Ephemeroptera: Leptophlebiidae: Atalophlebiinae)". English. In: Stuttgarter Beiträge zur Naturkunde Serie B (Geologie und Paläontologie) 341 (2003), pp. 1-22.

[21977] A. H. Staniczek, G. Bechly, and R. J. Godunko. “Coxoplectoptera, a new fossil order of Palaeoptera (Arthropoda: Insecta), with comments on the phylogeny of the stem group of mayflies (Ephemeroptera)". English. In: Insect Systematics \& Evolution 42 (2011), pp. 101-138.

[21978] A. H. Staniczek and G. Bechly. "First fossil record of the mayfly family Baetiscidae from Baltic amber (Insecta: Ephemeroptera)". English. In: Stuttgarter Beiträge zur Naturkunde Serie B (Geologie und Paläontologie) 322 (2002), pp. 1-11.

[21979] A. H. Staniczek and R. J. Godunko. "Revision of fossil Metretopodidae (Insecta: Ephemeroptera) in Baltic amber - Part 1: Type specimens of hitherto described fossil species of Siphloplecton Clemens, 1915 and Metretopus Eaton, 1901; with description of four new fossil species of Siphloplecton". English. In: Palaeodiversity 5 (2012), pp. 57-87.

[21980] A. H. Staniczek and R. J. Godunko. “Revision of fossil Metretopodidae (Insecta: Ephemeroptera) in Baltic amber - Part 2: Description of a new species of Metretopus Eaton, 1901". English. In: Historical Biology 27 (2015), pp. 861-867.

[21981] A. H. Staniczek and R. J. Godunko. "Revision of fossil Metretopodidae (Insecta: Ephemeroptera) in Baltic amber - Part 3: Description of two new species of Siphloplecton Clemens, 1915, with notes on the re-discovered lectotype of Siphloplecton macrops (Pictet-Baraban \& Hagen, 1856)". English. In: Zootaxa 4103 (2016), pp. 1-24.

[21982] A. H. Staniczek, R. J. Godunko, and W. Krzemiski. "A new fossil mayfly species of the genus Borinquena Traver, 1938 (Insecta: Ephemeroptera: Leptophlebiidae: Atalophlebiinae) from Miocene Dominican amber". English. In: Annales Zoologici 67 (2017), pp. 113-119.

[21983] A. H. Staniczek, R. J. Godunko, and N. J. Kluge. "Fossil record of the mayfly family Ephemerellidae (Insecta: Ephemeroptera), with description of new species and first report of Ephemerellinae from Baltic amber". English. In: Journal of Systematic Palaeontology 16 (2017), pp. 1319-1335. 
[21984] G. D. Stanley. "Coral microatolls from the Triassic of Nevada: oldest scleractinians examples". English. In: Coral Reefs 24 (2005), p. 247.

[21985] G. D. Stanley and T. Onoue. "Upper Triassic reef corals from the Sambosan Accretionary Complex, Kyushu, Japan". English. In: Facies 61.1 (2015), pp. 1-27.

[21986] G. D. Stanley and P. K. Swart. "Evolution of the coral-zooxanthellae symbiosis during the Triassic: A geochemical approach". English. In: Paleobiology 21 (1995), pp. 179-199.

[21987] G. D. Stanley, T. E. Yancey, and H. M. E. Shepherd. "Giant Upper Triassic bivalves of Wrangellia, Vancouver Island, Canada". English. In: Canadian Journal of Earth Sciences 50 (2013), pp. 142-147.

[21988] G. D. Stanley and J. M. Yarnell. New paleontological investigations of Triassic carbonate rocks in the Upper Chulitna District (Chulitna Terrane), southcentral Alaska. English. Vol. 120. Short Notes on Alaska Geology 2003. Professional Report of the Division of Geological and Geophysical Surveys Alaska. 2003, pp. 109-116.

[21989] G. D. Stanley Jr. and C. McRoberts. "A coral reef in the Telkwa Range, British Columbia: the earliest Jurassie example". English. In: Canadian Journal of Earth Sciences 30 (1993), pp. 819-831.

[21990] G. D. Stanley Jr. “Upper Triassic corals from Peru”. English. In: Palaeontographica Abteilung A 233 (1994), pp. 75-98.

[21991] G. D. Stanley Jr. “Upper Triassic spongiomorph and coral association dredged off the northwestern Australian shelf". English. In: AGSO Journal of Australian Geology E Geophysics 15.1 (1994), pp. 126-133.

[21992] G. D. Stanley Jr. “A Triassic sponge from Vancouver Island: possible holdover from the Cambrian". English. In: Canadian Journal of Earth Sciences 35 (1998), pp. 1037-1043.

[21993] G. D. Stanley Jr. and L. Beauvais. "Middle Jurassic corals from the Wallowa terrane, west-central Idaho". English. In: Journal of Paleontology 64.3 (1990), pp. 352-362.

[21994] G. D. Stanley Jr. and L. Beauvais. "Corals from an Early Jurassic coral reef in British Columbia: refuge on an oceanic island reef". English. In: Lethaia 27 (1994), pp. 35-47.

[21995] G. D. Stanley Jr., C. Gonzalez-Leon, M. R. Sandy, B. Senowbari-Daryan, P. Doyle, M. Tamura, and D. H. Erwin. "Upper Triassic invertebrates from the Antimonio Formation, Sonora, Mexico". English. In: The Paleontological Society Memoir 36 (1994), pp. 1-33.

[21996] G. D. Stanley Jr. and C. M. Gonzalez-Leon. "New Late Triassic scleractinian corals from the Antimonio Formation, northwestern Sonora, Mexico". English. In: Revista Mexicana de Ciencias Geologicas 14 (1997), pp. 202-207.

[21997] G. D. Stanley Jr. and B. Senowbari-Daryan. “Upper Triassic reef fauna from the Quesnel terrane, central British Columbia, Canada". In: Journal of Paleontology 73.5 (1999), pp. 787-802.

[21998] G. D. Stanley Jr. and J. P. Zonneveld. “The occurrence of the hydrozoan genus Cassianastraea from Upper Triassic (Carnian) rocks of Williston Lake, British Columbia, Canada". English. In: Journal of Paleontology 85.1 (2011), pp. 29-31.

[21999] D. Starck and L. M. Anzotegui. "The late Miocene climatic change - persistence of a climatic signal through the orogenic stratigraphic record in northwestern Argentina". English. In: Journal of South American Earth Sciences 14 (2001), pp. 763-774.

[22000] W. Starega. "Baltic amber harvestmen (Opiliones) from Polish collections". English. In: Annales Zoologici 52 (2002), pp. 601-604.

[22001] B. P. Stark and D. L. Lentz. “Dominiperla antigua (Plecoptera: Perlidae), the first stonefly from Dominican amber". English. In: Journal of the Kansas Entomological Society 65 (1992), pp. 93-96.

[22002] B. M. Starkovich. "Intensification of small game resources at Klissoura Cave 1 (Peloponnese, Greece) from the Middle Paleolithic to Mesolithic". English. In: Quaternary International 264 (2012), pp. 17-31. DOI: 10.1016/j.quaint.2011.10.019.

[22003] B. M. Starkovich. "Paleolithic subsistence strategies and changes in site use at Klissoura Cave 1 (Peloponnese, Greece)". English. In: Journal of Human Evolution 111 (2017), pp. 63-84. DOI: 10. 1016/j.jhevol.2017.04.005. 
[22004] Y. I. Starobogatov and A. V. Mazaev. "A new genus Novlepatella (Gastropoda), and some problems of taxonomy of Paleozoic limpets". English. In: Ruthenica 9.2 (1999), pp. 87-90.

[22005] A. Stathakopoulos and B. Riegl. "Geomorphology and Paleoecology of Holocene Coral Reefs from the SE Florida Shelf". English. In: RieglNational Coral Reef Institute, Nova Southeastern University Oceanographic Center (2014).

[22006] D. W. Steadman. "Doves (Columbidae) and cuckoos (Cuculidae) from the early Miocene of Florida". English. In: Bulletin of the Florida Museum of Natural History 48.1 (2008), pp. 1-16.

[22007] D. W. Steadman. "Late Pleistocene birds from Kingston Saltpeter Cave, southern Appalachian Mountains, Georgia". English. In: Bulletin of the Florida Museum of Natural History 45.4 (2005), pp. 231-248.

[22008] D. W. Steadman. "Extinct and extirpated birds from Aitutaki and Atiu, southern Cook Islands". English. In: Pacific Science 45 (1991), pp. 325-347.

[22009] D. W. Steadman. "Bird bones from the To'aga site: prehistoric loss of seabirds and megapodes". English. In: University of California Archaeological Research Facility, Contributions 51 (1994), pp. 217228.

[22010] D. W. Steadman. "Extinct and extirpated birds from Rota, Mariana Islands". English. In: Micronesica 25 (1992), pp. 71-84.

[22011] D. W. Steadman. "The prehistory of vertebrates, especially birds, on Tinian, Aguiguan, and Rota, Northern Mariana Islands". English. In: Micronesica 31 (1999), pp. 319-345.

[22012] D. W. Steadman. "A new species of gull (Laridae : Larus) from an archaeological site on Huahine, Society Islands". English. In: Proceedings of The Biological Society of Washington 115 (2002), pp. 1-17.

[22013] D. W. Steadman. "A new species of extinct parrot (Psittacidae: Eclectus) from Tonga and Vanuatu, South Pacific". English. In: Pacific Science 60 (2006), pp. 137-145.

[22014] D. W. Steadman. "An extinct species of tooth-billed pigeon (Didunculus) from the Kingdom of Tonga, and the concept of endemism in insular landbirds". English. In: Journal of Zoology 268 (2006), pp. 233-241.

[22015] D. W. Steadman. "Biogeography of Tongan birds before and after human impact". English. In: Proceedings of the National Academy of Sciences 90 (1993), pp. 818-822.

[22016] D. W. Steadman, N. A. Albury, J. I. Mead, J. A. Soto-Centeno, and J. Franklin. "Holocene vertebrates from a dry cave on Eleuthera Island, Commonwealth of The Bahamas". English. In: The Holocene 28 (2018), pp. 806-813.

[22017] D. W. Steadman, R. Franz, G. S. Morgan, N. A. Albury, B. Kakuk, K. Broad, S. E. Franz, K. Tinker, M. P. Pateman, T. A. Lott, D. M. Jarzen, and D. L. Dilcher. “Exceptionally well preserved late Quaternary plant and vertebrate fossils from a blue hole on Abaco, The Bahamas". English. In: Proceedings of the National Academy of Sciences 104.50 (2007), pp. 19897-19902.

[22018] D. W. Steadman and W. B. Hilgartner. "A new species of extinct barn owl (Aves: Tyto) from Barbuda, Lesser Antilles". English. In: Avian Paleontology at the Close of the 20th Century: Proceedings of the 4th International Meeting of the Society of Avian Paleontology and Evolution, Washington, D.C, 4-7 June 1996. Smithsonian Contribution to Paleobiology 89 (1999), pp. 75-83.

[22019] D. W. Steadman and M. Intoh. "Biogeography and prehistoric exploitation of birds from Fais Island, Yap State, Federated States of Micronesia". English. In: Pacific Science 48 (1994), pp. 116135.

[22020] D. W. Steadman and P. V. Kirch. "Prehistoric extinction of birds on Mangaia, Cook Islands, Polynesia". English. In: Proceedings of the National Academy of Sciences 87 (1990), pp. 9605-9609.

[22021] D. W. Steadman, W. T. Kirchgasser, and D. M. Pelkey. "A late Pleistocene white whale (Delphinapterus Leucas) from Champlain Sea sediments in northern New York". English. In: New York State Museum Bulletin 481 (1994), pp. 339-345.

[22022] D. W. Steadman and J. I. Mead. "A late Pleistocene Bird community at the northern edge of". English. In: The American Midland Naturalist 163 (2010), pp. 423-441. 
[22023] D. W. Steadman, J. R. Morris, and N. A. Wright. “A new species of late Pleistocene rail (Aves: Rallidae) from Abaco, the Bahamas". English. In: Paleontological Journal 47 (2013), pp. 1355-1364.

[22024] D. W. Steadman, J. A. Oswald, and A. D. Rincón. “The diversity and biogeography of late Pleistocene birds from the lowland Neotropics". English. In: Quaternary Research 83 (2015), pp. 555564.

[22025] D. W. Steadman and D. S. Pahlavan. "Extinction and biogeography of birds on Huahine, Society Islands, French Polynesia". English. In: Geoarchaeology 7 (1992), pp. 449-483.

[22026] D. W. Steadman, D. S. Pahlavan, and P. V. Kirch. "Extinction, biogeography, and human exploitation of birds on Tikopia and Anuta, Polynesian outliers in the Solomon Islands". English. In: Bishop Museum Occasional Papers 30 (1990), pp. 118-153.

[22027] D. W. Steadman, A. Plourde, and D. V. Burley. "Prehistoric butchery and consumption of birds in the Kingdom of Tonga, south Pacific". English. In: Journal of Archaeological Science 29 (2002), pp. 571-584.

[22028] D. W. Steadman and B. Rolett. "A chronostratigraphic analysis of landbird extinction on Tahuata, Marquesas Islands". English. In: Journal of Archaeological Science 23 (1996), pp. 81-94.

[22029] D. W. Steadman and O. M. Takano. "A late-Holocene bird community from Hispaniola: Refining the chronology of vertebrate extinction in the West Indies". English. In: The Holocene 23 (2013), pp. 936-944.

[22030] D. W. Steadman and O. M. Takano. "A new genus and species of heron (Aves: Ardeidae) from the late Miocene of Florida". English. In: Bulletin of the Florida Museum of Natural History 55.9 (2019), pp. 174-186.

[22031] D. W. Steadman and O. M. Takano. "A new extinct species of Snipe (Aves: Scolopacidae: Gallinago) from the West Indies". English. In: Zootaxa 4109 (2016), pp. 345-358.

[22032] D. W. Steadman, M. P. Tellkamp, and T. A. Wake. "Prehistoric exploitation of birds on the Pacific coast of Chiapas, Mexico". English. In: The Condor 105 (2003), pp. 572-579.

[22033] D. W. Steadman, J. P. White, and J. Allen. "Prehistoric birds from New Ireland, Papua New Guinea: extinctions on a large Melanesian island". English. In: Proceedings of the National Academy of Sciences 96 (1999), pp. 2563-2568.

[22034] D. W. Steadman, T. H. Worthy, A. J. Anderson, and R. Walter. "New species and records of birds from prehistoric sites on Niue, southwest Pacific". English. In: The Wilson Bulletin 112 (2000), pp. $165-186$.

[22035] C. W. Stearn. "Stromatoporoids from the Devonian (Eifelian to Lowest Frasnian) of Manitoba, Canada". In: Journal of Paleontology 70.2 (1996), pp. 196-217.

[22036] C. W. Stearn. "Stromatoporoids from the allochthonous reef facies of the Stuart Bay Formation (Lower Devonian), Bathurst Island, arctic Canada". English. In: Journal of Paleontology 64.4 (1990), pp. $493-510$.

[22037] C. W. Stearn. "Devonian stromatoporoid fauna of the Bent Horn oilfield, Cameron Island, Northwest Territories". English. In: Canadian Journal of Earth Sciences 35.1 (1998), pp. 16-22.

[22038] F. Stebner, H. Singh, J. Rust, and D. A. Grimaldi. "Lygistorrhinidae (Diptera: Bibionomorpha: Sciaroidea) in early Eocene Cambay amber". English. In: PeerJ 5.e3313 (2017), pp. 1-25.

[22039] F. Stebner and M. M. Solórzano Kraemer. "Systematic and palaeoecology of Psychodidae (Insecta: Diptera) from Miocene Mexican amber". English. In: Palaeontographica Abteilung A 303 (2014), pp. 1-21.

[22040] F. Stebner, M. M. Solórzano Kraemer, S. Ibáñez-Bernal, and R. Wagner. "Moth flies and sand flies (Diptera: Psychodidae) in Cretaceous Burmese amber". English. In: PeerJ 3.e1254 (2015), pp. 1-34.

[22041] F. Stebner, R. Szadziewski, and B. Wang. "Biting midges (Diptera: Ceratopogonidae) in Fushun amber reveal further biotic links between Asia and Europe during the Eocene". English. In: Palaeontologia Electronica 19.3.31A (2016), pp. 1-9. 
[22042] F. Stebner, R. Szadziewski, P. T. Rühr, H. Singh, J. U. Hammel, G. M. Kvifte, and J. Rust. “A fossil biting midge (Diptera: Ceratopogonidae) from early Eocene Indian amber with a complex pheromone evaporator". English. In: Scientific Reports 6.34352 (2016), pp. 1-6.

[22043] F. Stebner, R. Szadziewski, H. Singh, S. Gunkel, and J. Rust. “Biting midges (Diptera: Ceratopogonidae) from Cambay amber indicate that the Eocene fauna of the Indian subcontinent was not isolated". English. In: PLoS One 12.1 (2017), e0169144.

[22044] R. Stecher. "A new Triassic pterosaur from Switzerland (Central Austroalpine, Grisons), Raeticodactylus filisurensis gen. et sp. nov". English. In: Swiss Journal of Geosciences 101.1 (2008), pp. 185201. DOI: $10.1007 /$ s00015-008-1252-6.

[22045] L. Steel, D. M. Martill, D. M. Unwin, and J. D. Winch. "A new pterodactyloid pterosaur from the Wessex Formation (Lower Cretaceous) of the Isle of Wight, England". English. In: Cretaceous Research 26 (2005), pp. 686-698.

[22046] L. Steel and M. O'Sullivan. "A Scottish pterosaur in London: the first record of Pterosauria from the Upper Jurassic (Kimmeridgian) of Eathie (Ross and Cromarty), Scotland". English. In: Historical Biology 27.6 (2015), pp. 723-728.

[22047] T. E. Steele and R. G. Klein. "The Middle and Later Stone Age faunal remains from Diepkloof Rock Shelter, Western Cape, South Africa". English. In: Journal of Archaeological Science (2013). DOI: 10.1016/j.jas.2013.01.001.

[22048] M. Steeman. "The extinct baleen whale fauna from the Miocene-Pliocene of Belgium and the diagnostic cetacean ear bones". English. In: Journal of Systematic Palaeontology 8.1 (2010), pp. 63-80.

[22049] M. E. Steeman. "A new baleen whale from the Late Miocene of Denmark and early mysticete hearing". English. In: Palaeontology 52.5 (2009), pp. 1169-1190.

[22050] C. Stefan. "Barstovian (Miocene) beavers from Stewart Valley, Nevada, and a discussion of the genus Monosaulax based on tooth morphology". English. In: PaleoBios 21.1 (2001), pp. 1-14.

[22051] C. M. Stefanic, J. H. Nestler, E. R. Seiffert, and A. H. Turner. “New crocodylomorph material from the Fayum Depression, Egypt, including the first occurrence of a sebecosuchian in African late Eocene deposits". English. In: Journal of Vertebrate Paleontology 39.6 (2019), e1729781:1-10. DOI: 10.1080/02724634.2019.1729781.

[22052] I. Stefanovic. "Note on the first fossil remains of a whale from northern Bosnia". English. In: Annales Geologiques de la Peninsule Balkanique 71 (2010), pp. 127-137.

[22053] M. Steffen and C. Harington. "Giant short-face bear (Arctodus simus) from late Wisconsinan deposits at Cowichan Head, Vancouver Island,British Columbria". English. In: Canadian Journal of Earth Sciences 47.8 (2010), pp. 1029-1036. DOI: 10.1139/E10-018.

[22054] M. Stein, M. Archer, and S. J. Hand. "Dwarfism and feeding behaviours in Oligo-Miocene crocodiles from Riversleigh, northwestern Queensland, Australia". English. In: Acta Palaeontologica Polonica 61.1 (2016), pp. 135-142.

[22055] M. Stein, S. J. Hand, and M. Archer. "A new crocodile displaying extreme constriction of the mandible, from the late Oligocene of Riversleigh, Australia". English. In: Journal of Vertebrate Paleontology 36 (2016), e1179041:1-9. DOI: 10.1080/02724634.2016.1179041.

[22056] M. Stein and J. S. Peel. "Perissopyge (Trilobita) from the lower Cambrian (Series 2, Stage 4) of North America and Greenland". English. In: GFF 130 (2008), pp. 71-78.

[22057] M. Stein, D. Waloszek, A. Maas, J. T. Haug, and K. J. Muller. "The stem crustacean Oelandocaris oelandica re-visited". English. In: Acta Palaeontologica Polonica 53 (2008), pp. 461-484.

[22058] M. Stein, G. J. Wasserburg, P. Aharon, J. H. Chen, Z. R. Chu, A. Bloom, and J. Chappell. “TIMS U-series dating and stable isotopes of the last interglacial event in Papua New Guinea". English. In: Geochimica et Cosmochimica Acta 57 (1993), pp. 2541-2554.

[22059] M. Steiner, G. Li, Y. Qian, and M. Zhu. "Lower Cambrian Small Shelly Fossils of northern Sichuan and southern Shaanxi (China), and their biostratigraphic importance". English. In: Geobios 37 (2004), pp. 259-275. 
[22060] M. Steiner, G. Li, Y. Qian, M. Zhu, and B. -D. Erdtmann. “Neoproterozoic to early Cambrian small shelly fossil assemblages and a revised biostratigraphic correlation of the Yangtze Platform (China)". English. In: Palaeogeography, Palaeoclimatology, Palaeoecology 254 (2007), pp. 67-99.

[22061] M. Steiner, M. Zhu, Y. Zhao, and B. -D. Erdtmann. "Lower Cambrian Burgess Shale-type fossil associations of South China". English. In: Palaeogeography, Palaeoclimatology, Palaeoecology 220 (2005), pp. 129-152.

[22062] M. Steinová. "Probable ancestral type of actinodont hinge in the Ordovician bivalve Pseudocyrtodonta Pfab,1934". English. In: Bulletin of Geosciences 82.2 (2012), pp. 333-346.

[22063] T. A. Stemann. "Reef corals of the White Limestone Group of Jamaica". English. In: Cainozoic Research 3.1-2 (2003), pp. 83-107.

[22064] L. Stemmerik, P. A. Larson, G. B. Larssen, A. Mork, and B. T. Simonsen. “Depositional evolution of Lower Permian Palaeoaplysina build-ups, Kapp Duner Formation, Bjornoya, Arctic Norway". English. In: Sedimentary Geology 92 (1994), pp. 161-174.

[22065] E. Stensland, I. Carlen, A. Sarblad, A. Bignert, and P. Berggren. “Population size, distribution, and behavior of Indo-Pacific bottlenose (Tursips aduncus) and humpback (Sousa chinensis) dolphins off the south coast of Zanzibar". English. In: Marine Mammal Science 22.3 (2006), pp. 667-682.

[22066] S. R. Stenzel and N. P. James. "Shallow-water stromatactis mud-mounds on a Middle Ordovician foreland basin platform, western Newfoundland". English. In: in C. L. V. Monty, D. W. J. Bosence, P. H. Bridges, B. R. Pratt, eds., Carbonate mud-mounds, Special Publication of the International Association of Sedimentologists 23 (1995), pp. 127-149.

[22067] S. J. Steppan. "A new species of Holochilus (Rodentia: Sigmodontinae) from the middle Pleistocene of Bolivia and its phylogenetic significance". English. In: Journal of Vertebrate Paleontology 16.3 (1996), pp. 522-530.

[22068] J. Sterli. "A new, nearly complete stem turtle from the Jurassic of South America with implications for turtle evolution". English. In: Biology Letters 4.3 (2008), pp. 286-289.

[22069] J. Sterli. "A Review of the Fossil Record of Gondwanan Turtles of the Clade Meiolaniformes". English. In: Bulletin of the Peabody Museum of Natural History 56.1 (2015), pp. 21-45.

[22070] J. Sterli and M. S. de la Fuente. "A new turtle from the La Colonia Formation (CampanianMaastrichtian), Patagonia, Argentina, with remarks on the evolution of the vertebral column in turtles". English. In: Palaeontology 54.1 (2011), pp. 63-78. DOI: 10.1111/j.1475-4983.2010.01002.x.

[22071] J. Sterli and M. S. de la Fuente. "Re-description and evolutionary remarks on the Patagonian horned turtle Niolamia argentina Ameghino, 1899 (Testudinata, Meiolaniidae)". English. In: Journal of Vertebrate Paleontology 31.6 (2011), pp. 1210-1229.

[22072] J. Sterli and M. S. de la Fuente. “New evidence from the Palaeocene of Patagonia (Argentina) on the evolution and palaeo-biogeography of Meiolaniformes (Testudinata, new taxon name)". English. In: Journal of Systematic Palaeontology 11.7 (2013), pp. 835-852. DOI: 10.1080 / 14772019. 2012.708674.

[22073] J. Sterli, M. S. de la Fuente, and I. A. Cerda. "A new species of meiolaniform turtle and a revision of the Late Cretaceous Meiolaniformes of South America". English. In: Ameghiniana 50.2 (2013), pp. 240-256.

[22074] J. Sterli, M. S. de la Fuente, and J. M. Krause. "A new turtle from the Palaeogene of Patagonia (Argentina) sheds new light on the diversity and evolution of the bizarre clade of horned turtles (Meiolaniidae, Testudinata)". English. In: Zoological Journal of the Linnean Society 174 (2015), pp. 519-548.

[22075] J. Sterli and M. S. de la Fuente. "Cranial and post-cranial remains and phylogenetic relationships of the Gondwanan meiolaniform turtle Peligrochelys walshae from the Paleocene of Chubut, Argentina". English. In: Journal of Paleontology 93.4 (2019), pp. 798-821. DOI: 10.1017/jpa.2019.11.

[22076] J. Sterli, R. N. Martnez, I. A. Cerda, and C. Apaldetti. "Appearances can deceptive: bizarre shell microanatomy and histology in a new Triassic turtle (Testudinata) from Argentina at the dawn of turtles". English. In: Papers in Palaeontology (2020), pp. 1-36. DOI: 10.1002/spp2.1334. 
[22077] A. F. Sterren. "Moluscos bivalvos en la Formacion Rio del Penon (Carbonifero Tardio-Permico Temprano), provincia de La Rioja, Argentina". Spanish. In: Ameghiniana 37.4 (2000), pp. 421-438.

[22078] A. F. Sterren. "Bivalvos carbonferos de la Formación La Capilla en el área de Las Cambachas, provincia de San Juan, Argentina". Spanish. In: Ameghiniana 42.1 (2005), pp. 209-219.

[22079] T. Steuber. "Cretaceous rudists of Boeotia, Central Greece". English. In: Special Papers in Palaeontology 61 (1999), pp. 5-229.

[22080] T. Steuber. “Turonian-Campanian Plagioptychidae (Mollusca: Hippuritoidea) of Gosau-type rudist formations of the Alps (Austria)". English. In: Annales Naturhist. Museum Wien 106.A (2004), pp. 103-121.

[22081] T. Steuber. "Strontium isotope stratigraphy of Cretaceous hippuritid rudist bivalves: rates of morphological change and heterochronic evolution". English. In: Palaeogeography, Palaeoclimatology, Palaeoecology 200 (2003), pp. 221-243. DOI: 10.1016/S0031-0182(03)00452-8.

[22082] T. Steuber and M. Bachmann. "Upper Aptian-Albian rudist bivalves from northern Sinai, Egypt". English. In: Palaeontology 45.4 (2002), pp. 725-749.

[22083] T. Steuber, S. Ozer, M. Schlüter, and B. Sari. “Description of Paracaprinula syriaca Piveteau (Hippuritoidea, Plagioptychidae) and a revised age of ophiolite obduction on the African-Arabian Plate in southeastern Turkey". English. In: Cretaceous Research 30 (2009), pp. 41-48.

[22084] T. Steuber, M. Parente, M. Hagmaier, A. Immenhauser, B.v.d. Kooij, and G. Frijia. Latest Maastrichtian species-rich rudist associations of the Apulian margin of Salento (S Italy) and the Ionian Islands (Greece). English. Vol. 87. Cretaceous rudists and carbonate platforms: environmental feedback, SEPM Special Publication. 2007, pp. 151-157.

[22085] T. Steuber, C. Yilmaz, and H. Löser. "Growth rates of Early Campanian rudists in a siliciclasticcalcareous setting (Pontid Mts., north-central Turkey)". English. In: Geobios, Memoire special 22 (1998), pp. 385-401.

[22086] I. M. Stevanovic-Walls. “A paleontological study of an Early Pennsylvanian forest preserved above the Blue Creek Coal seam, Pottsville, Formation, Northwestern Alabama". PhD thesis. 2001, pp. 198.

[22087] C. H. Stevens. "Fasciculate rugose corals from Gzhelian and lower Permian strata, Pequop Mountains, northeast Nevada". English. In: Journal of Paleontology 82.6 (2008), pp. 1190-1200.

[22088] C. H. Stevens. "New occurrences of Permian corals from the McCloud belt in western North America". English. In: Palaeontologia Electronica 12.2-6A (2009), pp. 1-16.

[22089] C. H. Stevens. "New Early Permian colonial rugose corals from the central Cordilleran miogeocline, U.S.A." English. In: Journal of Paleontology 84.3 (2010), pp. 529-537.

[22090] C. H. Stevens. "New species of the Early Permian ceriod coral Kleopatrina from northwest Chihuahua, Mexico". English. In: Journal of Paleontology 69 (1995), pp. 1176-1179.

[22091] C. H. Stevens. "Permian colonial rugose corals from the Wrangellian terrane in Alaska". English. In: Journal of Paleontology 82 (2008), pp. 1043-1050.

[22092] C. H. Stevens. "A giant Permian fusulinid from east-central Alaska with comparisons of all giant fusulinids in western North America". English. In: Journal of Paleontology 69.5 (1995), pp. 805-812.

[22093] C. H. Stevens, V. I. Davydov, and D. Bradley. "Permian Tethyan Fusulinina from the Kenai Peninsula, Alaska". English. In: Journal of Paleontology 71.6 (1997), pp. 985-994.

[22094] C. H. Stevens and C. A. Ross. "Fusulinids from piston cores, Northwind Ridge, Amerasia Basin, Arctic Ocean". English. In: Journal of Paleontology 71 (1997), pp. 357-360.

[22095] C. H. Stevens and P. Stone. "New Permian durhaminid cerioid corals from east-central California". English. In: Journal of Paleontology 83.6 (2009), pp. 946-953.

[22096] C. H. Stevens and P. Stone. "New Permian fusulinids from Conglomerate Mesa, southeastern Inyo Mountains, east-central California". English. In: Journal of Paleontology 83.1 (2009), pp. 9-29. 
[22097] C. H. Stevens and P. Stone. "The Pennsylvanian-Early Permian Bird Spring carbonate shelf, southeastern California: fusulinid biostratigraphy, paleogeographic evolution, and tectonic implications". English. In: Geological Society of America Special Paper 429 (2007), pp. 1-82.

[22098] G. R. Stevens. “The ammonite genus Harpoceras (Early Jurassic) in New Zealand". English. In: New Zealand Journal of Geology and Geophysics 50 (2007), pp. 377-386.

[22099] G. R. Stevens. "Dactylioceratidae (Cephalopoda, Ammonoidea) from the Early Jurassic of New Zealand". English. In: New Zealand Journal of Geology and Geophysics 51 (2008), pp. 317-330.

[22100] M. S. Stevens. "Osteology, Systematics, and Relationships of Earliest Miocene Mesocyon venator (Carnivora: Canidae)". English. In: Journal of Vertebrate Paleontology 11.1 (1991), pp. 45-66.

[22101] M. S. Stevens and J. B. Stevens. "Carnivora (Mammalia, Felidae, Canidae, Mustelidae) from the earliest Hemphillian Screw Bean Local Fauna, Big Bend National Park, Brewster County, Texas". English. In: Bulletin of the American Museum of Natural History 279 (2003), pp. 177-211.

[22102] N. J. Stevens, P. A. Holroyd, E. M. Roberts, and P. O'Connor. "Kahawamys mbeyaensis (n. gen., n. sp.) (Rodentia: Thryonomyoidea) from the Late Oligocene Rukwa Rift Basin, Tanzania". English. In: Journal of Vertebrate Paleontology 29.2 (2009), pp. 631-634.

[22103] N. J. Stevens, P. M. O'Connor, and E. M. Roberts. “A hyracoid from the late Oligocene Red Sandstone Group of Tanzania, Rukwalorax jinokitana". English. In: Journal of Vertebrate Paleontology 29.3 (2009), pp. 972-975.

[22104] N. J. Stevens, P. M. O'Connor, M. D. Gottfried, E. M. Roberts, S. Ngasala, and M. R. Dawson. "Metaphiomys (Rodentia: Phiomyidae) from the Paleogene of southwestern Tanzania". English. In: Journal of Paleontology 80.2 (2006), pp. 407-409.

[22105] N. J. Stevens, P. M. Ot'Connor, M. D. Gottfried, E. M. Roberts, and S. Ngasala. “An Anthropoid Primate Humerus from the Rukwa Rift Basin, Paleogene of Southwestern Tanzania". English. In: Journal of Vertebrate Paleontology 25.4 (2005), pp. 986-989. DOI: 10.1671/ 0272-4634(2005)025[0986: AAPHFT]2.0.CO;2.

[22106] N. J. Stevens, E. R. Seiffert, P. M. O'Connor, E. M. Roberts, M. D. Schmitz, C. Krause, E. Gorscak, S. Ngasala, T. L. Hieronymus, and J. Temu. "Palaeontological evidence for an Oligocene divergence between Old World monkeys and apes". English. In: Nature 497 (2013), pp. 611-614.

[22107] W. N. Stevens, K. M. Claeson, and N. J. Stevens. "Alestid (Characiformes: Alestidae) fishes from the late Oligocene Nsungwe Formation, Rukwa Rift Basin, of Tanzania". English. In: Journal of Vertebrate Paleontology 36.e1180299 (2016). DOI: 10.1080/02724634.2016.1180299.

[22108] J. H. Stewart, R. Amaya-Martnez, R. G. Stamm, B. R. Wardlaw, G. D. Stanley Jr., and C. H. Stevens. "Stratigraphy and regional significance of Mississippian to Jurassic rocks in Sierra Santa Teresa, Sonora, Mexico". In: Revista Mexicana de Ciencias Geológicas 14.2 (1997), pp. 115-135.

[22109] J. R. Stewart. "Sea-birds from coastal and non-coastal, archaeological and natural Pleistocene deposits or not all unexpected deposition is of human origin". English. In: Acta zoologica cracoviensia 45 (2002), pp. 167-178.

[22110] J. R. Stewart, S. Aspinall, M. Beech, P. Fenberg, P. Hellyer, N. Larkin, S. W. Lokier, F. G. Marx, M. Meyer, R. Miller, P. S. Rainbow, J. D. Taylor, J. E. Whittaker, K. Al-Mehsin, and C. J. Strohmenger. "Biotically constrained palaeoenvironmental conditions of a mid-Holocene intertidal lagoon on the southern shore of the Arabian Gulf: evidence associated with a whale skeleton at Musaffah, Abu Dhabi, UAE". English. In: Quaternary Science Reviews 30.25-26 (2011), pp. 3675-3690.

[22111] K. M. Stewart. Fossil fish from the Upper Semiliki. 1990.

[22112] S. E. Stewart and A. W. Owen. "Probing the deep shelf: a Lagerstätte from the Upper Ordovician of Girvan, southwestern Scotland". English. In: Lethaia 41.5 (2008), pp. 139-146.

[22113] S. J. Stewart. "Distribution and palaeoecology of Ordovician bivalves and gastropods from Girvan, SW Scotland". English. In: Earth and Environmental Science Transactions of the Royal Society of Edinburgh 102.3 (2011), pp. 145-158. DOI: 10.1017/S175569101201002X. 
[22114] J. S. Steyer. "A revision of the early Triassic capitosaurs (Stegocephali, Stereospondyli) from Madagascar, with remarks on their comparative ontogeny". English. In: Journal of Vertebrate Paleontology 23.3 (2003), pp. 544-555. DOI: 10.1671/1740.

[22115] J. S. Steyer, R. Damiani, C. A. Sidor, F. R. O'Keefe, H. C. E. Larsson, A. Maga, and O. Ide. “The Vertebrate Fauna of the Upper Permian of Niger. IV. Nigerpeton ricqlesi (Temnospondyli: Cochleosauridae), and the Edopoid Colonization of Gondwana". English. In: Journal of Vertebrate Paleontology 26.1 (2006), pp. 18-28.

[22116] J. S. Steyer and R. Damiani. "A giant brachyopoid temnospondyl from the Upper Triassic or Lower Jurassic of Lesotho". English. In: Bulletin de la Societe Geologique de France 176.3 (2005), pp. 243-248.

[22117] J.-S. Steyer, S. Sanchez, P. J. Debriette, A. M. F. Valli, F. Escuille, B. Pohl, R. -P. Dechambre, R. Vacant, C. Spence, and G. de Ploëg. "A new vertebrate Lagerstätte from the Lower Permian of France (Franchesse, Massif Central): palaeoenvironmental implications for the Bourbon-l'Archambault basin". English. In: Bulletin de la Société géologique de France 183.6 (2012), pp. 509-515.

[22118] T. Stidham, R. Patnaik, K. Krishan, B. Singh, A. Ghosh, A. Singla, and S. S. Kotla. "The first darter (Aves: Anhingidae) fossils from India (late Pliocene)". English. In: PLoS ONE 12.e0177129 (2017), pp. 1-16. DOI: 10.1371/journal.pone.0177129.

[22119] T. A. Stidham. "New skull material of Osteodontornis orri (Aves: Pelagornithidae) from the Miocene of California". English. In: PaleoBios 24.2 (2004), pp. 7-12.

[22120] T. A. Stidham. "A new species of Limnofregata (Pelecaniformes: Fregatidae) from the Early Eocene Wasatch Formation of Wyoming: implications for palaeoecology and palaeobiology". English. In: Palaeontology 58.2 (2015), pp. 239-249.

[22121] T. A. Stidham. "The first fossil of the Congo peafowl (Galliformes: Afropavo)". English. In: South African Journal of Science 104 (2008), pp. 511-512.

[22122] T. A. Stidham. "The carpometacarpus of the Pliocene turkey Meleagris leopoldi (Galliformes: Phasianidae) and the problem of morphological variability in turkeys". English. In: PaleoBios 30.1 (2011), pp. 13-17.

[22123] T. A. Stidham and J. J. Eberle. "The palaeobiology of high latitude birds from the early Eocene greenhouse of Ellesmere Island, Arctic Canada". English. In: Scientific Reports 6.20912 (2016), pp. 18. DOI: $10.1038 /$ srep20912.

[22124] T. A. Stidham, P. A. Holroyd, G. F. Gunnell, R. L. Ciochon, T. Tsubamoto, N. Egi, and M. Takai. “An ibis-like bird (Aves: cf. Threskiornithidae) from the late middle Eocene of Myanmar". English. In: Contributions from the Museum of Paleontology, University of Michigan 31.7 (2005), pp. 179-184.

[22125] T. A. Stidham, K. Krishan, B. Singh, A. Ghosh, and R. Patnaik. "A Pelican Tarsometatarsus (Aves: Pelecanidae) from the Latest Pliocene Siwaliks of India". English. In: PLoS One 9.11 (2014), e11210.

[22126] T. A. Stidham, D. Lofgren, A. A. Farke, M. Paik, and R. Choi. "A lithornithid (Aves: Palaeognathae) from the Paleocene (Tiffanian) of southern California". English. In: PaleoBios 31.1 (2014), pp. 1-7.

[22127] T. A. Stidham and X.-J. Ni. "Large anseriform (Aves: Anatidae: Romainvilliinae?) fossils from the Late Eocene of Xinjiang, China". English. In: Vertebrata PalAsiatica 52 (2014), pp. 98-111.

[22128] T. A. Stidham and J. A. Stidham. "A new Miocene band-winged grasshopper (Orthoptera: Acrididae) from Nevada". English. In: Annals of the Entomological Society of America 93 (2000), pp. 405407.

[22129] T. A. Stidham, K. E. B. Townsend, and P. A. Holroyd. "Evidence for Wide Dispersal in a Stem Galliform". English. In: Diversity 12.90 (2020), pp. 1-13. DOI: 10.3390/d12030090.

[22130] T. A. Stidham, X. Wang, Q. Li, and X. Ni. "A shelduck coracoid (Aves: Anseriformes: Tadorna) from the arid early Pleistocene of the Qinghai-Tibetan Plateau, China". English. In: Palaeontologia Electronica 18.2.24A (2010), pp. 1-10.

[22131] T. A. Stidham and N. V. Zelenkov. "North American-Asian aquatic bird dispersal in the Miocene: evidence from a new species of diving duck (Anseriformes: Anatidae) from North America (Nevada) with affinities to Mongolian taxa". English. In: Alcheringa 41 (2016). DOI: 10.1080/03115518.2016. 1224439. 
[22132] A. L. Stigall and J. H. Hartman. "A new spinicaudatan genus (Crustacea: 'Conchostraca') from the Late Cretaceous of Madagascar". English. In: Palaeontology 51.5 (2008), pp. 1053-1067. DOI: 10.1111/j.1475-4983.2008.00799.x.

[22133] A. L. Stigall, R. E. Plotnick, and L. E. Park Boush. "The first Cenozoic spinicaudatans from North America". English. In: Journal of Paleontology 91.3 (2017), pp. 467-476. DOI: 10.1017/jpa.2017.15.

[22134] F. Stiller. "Early Jurassic shallow-marine bivalves from Xiaping, southern Hunan, China". English. In: Palaeontographica Abteilung A 274.1-2 (2006), pp. 1-70.

[22135] F. Stiller. "An early isocrinid sea lily from the middle to late Anisian boundary (Middle Triassic) of south-west China - evidence for a far-east Tethyan origin of the family Isocrinidae". English. In: Palaeontology 54.6 (2011), pp. 1415-1433.

[22136] F. Stiller and H. Bucher. “Anisian ammonoids from Qingyan, southwestern China: biostratigraphical implications for the age of the Qingyan Formation". English. In: Swiss Journal of Geosciences 101 (2008), pp. 547-562.

[22137] F. Stiller and J. Chen. "New Mysidiellidae (Bivalvia) from the Anisian (Middle Triassic) of Qingyan, south-west China". English. In: Palaeontology 49.1 (2006), pp. 213-227.

[22138] F. Stiller and J. Chen. "Eophilobryoidella sinoanisica new genus and species, an early Philobryid bivalve from the upper Anisian (middle Triassic) of Qingyan, southwestern China". English. In: Journal of Paleontology 78.2 (2004), pp. 414-419. DOI: 10.1666/0022-3360(2004)078.

[22139] J. D. Stilwell. "Tectonic and palaeobiogeographic significance of the Chatham Islands, South Pacific, Late Cretaceous fauna". English. In: Palaeogeography, Palaeoclimatology, Palaeoecology 136 (1997), pp. 97-119.

[22140] J. D. Stilwell. “New Early Paleocene Mollusca from the Wangaloa Formation of South Island, New Zealand". English. In: Journal of Paleontology 67.3 (1993), pp. 360-369.

[22141] J. D. Stilwell. "Macropalaeontology of the Trochocyathus-Trematotrochus band (Paleocene/Eocene boundary), Dilwyn Formation, Otway Basin, Victoria". English. In: Alcheringa 27 (2003), pp. 245275.

[22142] J. D. Stilwell. "A rare, late Paleocene molluscan faunule from the Kings Park Formation, Perth Basin, Western Australia". English. In: Alcheringa 29.2 (2005), pp. 331-340.

[22143] J. D. Stilwell, C. P. Consoli, R. Sutherland, S. Salisbury, T. H. Rich, P. A. Vickers-Rich, P. J. Currie, and G. J. Wilson. "Dinosaur sanctuary on the Chatham Islands, southwest Pacific: first record of theropods from the K-T boundary Takatika Grit". English. In: Palaeogeography, Palaeoclimatology, Palaeoecology 230 (2006), pp. 243-250.

[22144] J. D. Stilwell, R. E. Fordyce, and P. J. Rolfe. "Paleocene isocrinids (Echinodermata: Crinoidea) from the Kauru Formation, South Island, New Zealand". English. In: Journal of Paleontology 68.1 (1994), pp. 135-141.

[22145] J. D. Stilwell and S. J. Gallagher. "Biostratigraphy and macroinvertebrate palaeontology of the petroleum-rich Belfast Mudstone (Sherbrook Group, uppermost Turonian to mid-Santonian), Otway Basin, southeastern Australia". English. In: Cretaceous Research 30 (2009), pp. 873-884.

[22146] J. D. Stilwell and A. Grebneff. "Records of Nautiloidea (Mollusca: Cephalopoda) across the CretaceousTertiary boundary in Otago and Chatham Islands, New Zealand". English. In: New Zealand Journal of Geology and Geophysics 39 (1996), pp. 83-91.

[22147] J. D. Stilwell and R. A. Henderson. "Description and paleobiogeographic significance of a rare Cenomanian molluscan faunule from Bathurst Island, northern Australia". English. In: Journal of Paleontology 76.3 (2002), pp. 447-471.

[22148] J. D. Stilwell, J. J. Vitacca, and C. Mays. "South polar greenhouse insects (Arthropoda: Insecta: Coleoptera) from the mid-Cretaceous Tupuangi Formation, Chatham Islands, eastern Zealandia". English. In: Alcheringa 40 (2016), pp. 502-508.

[22149] J. D. Stilwell and W. J. Zinsmeister. "Molluscan Systematics and Biostratigraphy". English. In: Antarctic Research Series, AGU 55 (1992). 
[22150] C. M. Stimpson. "Raptor and owl bone from Niah Caves, Sarawak: identifications and morphological variation in the humerus and tarsometatarsus of selected raptors". English. In: International Journal of Osteoarchaeology 19 (2009), pp. 476-490.

[22151] B. L. Stinchcomb. Chronister vertebrate site. English. In D. Hoffman, B. L. Stinchcomb, and J. R. Palmer (eds.), Association of Missouri Geologists, 53rd Annual Meeting and Field Trips, Sikeston. Association of Missouri Geologists. 2006, pp. 5-8.

[22152] B. L. Stinchcomb and N. A. Angeli. "New Cambrian and Lower Ordovician monoplacophorans from the Ozark Uplift, Missouri". In: Journal of Paleontology 76.6 (2002), pp. 965-974.

[22153] B. L. Stinchcomb and G. Darrough. "Some molluscan problematica from the Upper Cambrian Lower Ordovician of the Ozark uplift". English. In: Journal of Paleontology 69.1 (1995), pp. 52-65.

[22154] M. C. Stiner, G. Arsebuk, and F. C. Howell. "Cave bears and paleolithic artifacts in Yarimburgaz Cave, Turkey: Dissecting a palimpsest". In: Geoarchaeology 11.4 (1996), pp. 279-327.

[22155] M. C. Stiner and N. D. Munro. "On the evolution of diet and landscape during the Upper Paleolithic through Mesolithic at Franchthi Cave (Peloponnese, Greece)". English. In: Journal of Human Evolution 60 (2011), pp. 618-636. DOI: 10.1016/j.jhevol.2010.12.005.

[22156] S. R. Stinnesbeck, E. Frey, J. Avles Olgun, W. Stinnesbeck, P. Zell, H. Mallison, A. González González, E. Aceves Núñez, A. Velázquez Morlet, A. Terrazas Mata, M. Benavente Sanvicente, F. Hering, and C. Rojas Sandoval. "Xibalbaonyx oviceps, a new megalonychid ground sloth (Folivora, Xenarthra) from the Late Pleistocene of the Yucatán Peninsula, Mexico, and its paleobiogeographic significance". English. In: Paläontologische Zeitschrift 91 (2017), pp. 245-271.

[22157] S. R. Stinnesbeck, E. Frey, and W. Stinnesbeck. "New insights on the paleogeographic distribution of the Late Pleistocene ground sloth genus Xibalbaonyx along the Mesoamerican Corridor". English. In: Journal of South American Earth Sciences 85 (2018), pp. 108-120.

[22158] S. R. Stinnesbeck, W. Stinnesbeck, E. Frey, J. Aviles Olgun, and A. H. González González. “Xibalbaonyx exinferis n. sp. (Megalonychidae), a new Pleistocene ground sloth from the Yucatán Peninsula, Mexico". English. In: Historical Biology (2020). DOI: 10.1080/08912963.2020.1754817.

[22159] S. R. Stinnesbeck, W. Stinnesbeck, E. Frey, J. Avilés Olgun, C. Rojas Sandoval, A. Velázquez Morlet, and A. H. González. "Panthera balamoides and other Pleistocene felids from the submerged caves of Tulum, Quintana Roo, Mexico". English. In: Historical Biology 32.7 (2018), pp. 930-939. DOI: 10.1080/08912963.2018.1556649.

[22160] W. Stinnesbeck, E. Frey, L. Rivas, J. P. Pérez, M. L. Cartes, C. S. Soto, and P. Z. Lobos. “A Lower Cretaceous ichthyosaur graveyard in deep marine slope channel deposits at Torres del Paine National Park, southern Chile". English. In: Geological Society of America Bulletin (2014). DOI: 10.1130/ B30964.1.

[22161] W. Stinnesbeck, C. Ifrim, H. Schmidt, A. Rindfleisch, M. -C. Buchy, E. Frey, A. H. GonzálezGonzález, F. J. Vega, L. Cavin, G. Keller, and K. T. Smith. "A new lithographic limestone deposit in the Upper Cretaceous Austin Group at El Rosario, county of Múzquiz, Coahuila, northeastern Mexico". English. In: Revista Mexicana de Ciencias Geológicas 22 (2005), pp. 401-418.

[22162] J. H. Stitt. "Trilobites from the Cedarina dakotaensis zone, lowermost part of the Deadwood Formation, (Marjuman Stage, Upper Cambrian), Black Hills South Dakota". In: Journal of Paleontology 72.6 (1998), pp. 1030-1046.

[22163] J. H. Stitt and P. J. Perfetta. “Trilobites, Biostratigraphy, and Lithostratigraphy of the Crepicephalus and Aphelaspis zones, Lower Deadwood formation (Marjuman and Steptoean Stages, Upper Cambrian), Black Hills, South Dakota". English. In: Journal of Paleontology 74.2 (2000), pp. 199_ 223.

[22164] J. H. Stitt and W. M. Straatmann. "Trilobites from the upper part of the Deadwood Formation (Upper Franconian and Trempealeauan stages, Upper Cambrain), Black Hills, SOuth Dakota". In: Journal of Paleontology 71.1 (1997), pp. 86-102.

[22165] C. W. Stock. "Lower Devonian (Lochkovian) Stromatoporoidea from the Coeymans Formation of Central New York". In: Journal of Paleontology 71.4 (1997), pp. 539-553. 
[22166] C. W. Stock. "Lower Devonian (Lochkovian) Stromatoporoidea from the Manlius Formation of New York". In: Journal of Paleontology 65.6 (1991), pp. 897-911.

[22167] R. Stockar. "Fossil coralline algae from the Paleocene Montorfano Member type-section (Tabiago Formation, northern Italy)". English. In: Eclogae Geologicae Helvetiae 93 (2000), pp. 409-427.

[22168] R. Stockar and E. Kustatscher. "The Ladinian flora from the Cassina Beds (Meride Limestone, Monte San Giorgio, Switzerland): Preliminary results". English. In: Rivista Italiana die Paleontologia e Stratigrafia 116.2 (2010), pp. 173-188.

[22169] R. Stockar and S. Renesto. "Co-occurrence of Neusticosaurus edwardsii and N. peyeri (Reptilia) in the Lower Meride Limestone (Middle Triassic, Monte San Giorgio)". English. In: Swiss Journal of Geosciences 104 (2011), S167-S178.

[22170] M. R. Stocker. "A new taxon of phytosaur (Archosauria: Pseudosuchia) from the Late Triassic (Norian) Sonsela Member (Chinle Formation) in Arizona, and a critical reevaluation of Leptosuchus Case, 1922". English. In: Palaeontology 53 (2010), pp. 997-1022.

[22171] M. R. Stocker. “A new phytosaur (Archosauriformes, Phytosauria) from the Lot's Wife beds (Sonsela Member) within the Chinle Formation (Upper Triassic) of Petrified Forest National Park, Arizona". English. In: Journal of Vertebrate Paleontology 32.3 (2012), pp. 573-586. DOI: 10.1080 / 02724634.2012.649815.

[22172] M. R. Stocker. “A new taxonomic arrangement for Paleorhinus scurriensis". English. In: Earth and Environmental Science Transactions of the Royal Society of Edinburgh 103 (2013). DOI: 10.1017 / S1755691013000340.

[22173] M. R. Stocker and E. C. Kirk. "The first amphisbaenians from Texas, with notes on other squamates from the middle Eocene Purple Bench locality". English. In: Journal of Vertebrate Paleontology e1094081 (2016), pp. 1-15. DOI: 10.1080/02724634.2016.1094081.

[22174] M. R. Stocker, S. J. Nesbitt, K. E. Criswell, W. G. Parker, L. M. Witmer, T. B. Rowe, R. Ridgely, and M. A. Brown. "A Dome-Headed Stem Archosaur Exemplifies Convergence among Dinosaurs and Their Distant Relatives". English. In: Current Biology 26.19 (2016), pp. 2674-2680.

[22175] R. A. Stockey, G. L. Hoffman, and G. W. Rothwell. "The fossil monocot Limnobiophyllum scutatum: resolving the phylogeny of Lemnaceae". In: American Journal of Botany 84.3 (1997), pp. 355368.

[22176] R. A. Stockey and G. W. Rothwell. "Distinguishing angiophytes from the earliest angiosperms: A Lower Cretaceous (Valanginian-Hauterivian) fruit-like reproductive structure". English. In: American Journal of Botany 96.1 (2009), pp. 323-335.

[22177] R. A. Stockey, G. W. Rothwell, and S. A. Little. "Relationships among fossil and living Dipteridaceae: Anatomically preserved Hausmannia from the Lower Cretaceous of Vancouver Island". English. In: International Journal of Plant Sciences 167.3 (2006), pp. 649-663. DOI: 10.1086/503268.

[22178] R. A. Stockey and G. W. Rothwell. "The aquatic angiosperm Trapago angulata from the Upper Cretaceous (Maastrichtian) St. Mary River Formation of Southern Alberta". English. In: International Journal of Plant Sciences 158.1 (1997), pp. 83-94.

[22179] R. A. Stockey, G. W. Rothwell, and K. R. Johnson. “Cobbania corrugata gen. et comb. nov. (Araceae): a floating aquatic monocot from the Upper Cretaceous of western North America". English. In: American Journal of Botany 94.4 (2007), pp. 609-624.

[22180] R. A. Stockey and S. Y. Smith. "A new species of Millerocaulis (Osmundaceae) from the Lower Cretaceous of California". English. In: International Journal of Plant Sciences 161.1 (2000), pp. 159166.

[22181] R. A. Stockey and N. J. P. Wiebe. "Lower Cretaceous conifers from Apple Bay, Vancouver Island: Picea-like leaves, Midoriphyllum piceoides gen. et sp. nov. (Pinaceae)". English. In: Botany 86.7 (2008), pp. 649-657.

[22182] P. Stoev, L. Moritz, and T. Wesener. "Dwarfs under dinosaur legs: a new millipede of the order Callipodida (Diplopoda) from Cretaceous amber of Burma". English. In: ZooKeys 841 (2019), pp. 79 96. 
[22183] S. Stöhr, J. W. M. Jagt, and A. A. Klompmaker. “Ophiura paucilepis, a new species of brittlestar (Echinodermata, Ophiuroidea) from the Pliocene of the southern North Sea Basin". English. In: Swiss Journal of Palaeontology 130 (2011), pp. 113-121.

[22184] J. Stolarski. "Miocene Scleractinia from the Holy Cross Mountains, Poland; I, Caryophyliidae, Flabellidae, Dendrophyliidae, and Micrabaciidae". In: Acta Geologica Polonica 41.1-2 (1991), pp. 3767.

[22185] J. Stolarski. “Paleogene corals from Seymour Island, Antarctic Peninsula”. English. In: Palaeontologia Polonica 55 (1996), pp. 51-63.

[22186] J. Stolarski. "Conopora (Stylasteridae, Hydrozoa) from the Eocene of Seymour Island". English. In: Antarctic Science 10.4 (1998), pp. 487-492.

[22187] J. Stolarski. “On Cretaceous Stephanocyathus (Scleractinia) from the Tatra Mountains". English. In: Acta Palaeontologica Polonica 35 (1990), pp. 31-39.

[22188] J. Stolarski, A. Meibom, R. Przenioslo, and M. Mazur. "A Cretaceous scleractinian coral with a calcitic skeleton". English. In: Science 318 (2007), pp. 92-94.

[22189] J. Stolarski and A. Russo. "Microstructural diversity of the stylophyllid (Scleractinia) skeleton". In: Acta Palaeontologica Polonica 47.4 (2002), pp. 651-666.

[22190] J. Stolarski and M. Taviani. "Oligocene scleractinian corals from CRP-3 drillhole, McMurdo Sound (Victoria Land Basin, Antarctica)". English. In: Terra Antartica 8.3 (2001), pp. 1-4.

[22191] J. Stolarski and A. Vertino. "First Mesozoic record of the scleractinian Madrepora from the Maastrichtian siliceous limestones of Poland". English. In: Facies 53 (2007), pp. 67-78.

[22192] J. Stolarski, H. Zibrowius, and H. Löser. "Antiquity of the scleractinian-sipunculan symbiosis". English. In: Acta Palaeontologica Polonica 46.3 (2001), pp. 309-330.

[22193] P. Stone, M. R. A. Thomson, and A. W. A. Rushton. "An Early Cambrian archaeocyath-trilobite fauna in limestone erratics from the Upper Carboniferous Fitzroy Tillite Formation, Falkland Islands". English. In: Transactions of the Royal Society of Edinburgh 102 (2011), pp. 201-225.

[22194] A. P. Storari, T. Rodrigues, A. A. F. Saraiva, and F. F. Salles. “Unmasking a gap: A new oligoneuriid fossil (Ephemeroptera: Insecta) from the Crato Formation (upper Aptian), Araripe Basin, NE Brazil, with comments on Colocrus McCafferty". English. In: PLoS One 15.e0240365 (2020). DOI: 10.1371/journal.pone.0240365.

[22195] R. Storc. "The Late Cretaceous brittle star Ophiosmilax? alternatus from Europe and northern Africa". English. In: Géobios 37 (2004), pp. 395-401.

[22196] R. Storc. "The ophiuroid Amphiura? plana in nearhore settings of the Bohemian Cretaceous basin (Czech Republic)". English. In: Geologica Carpathica 55.1 (2004), pp. 37-41.

[22197] R. Storc. "Ophiuroid remains from the nearshore environments of the Bohemian Cretaceous basin (Cenomanian - Turonian boundary interval). A preliminary report." English. In: Vestnik Ceského geologického ustavu [Bulletin of the Czech Geological Survey] 72.2 (1997), pp. 171-174.

[22198] R. Storc and J. Zitt. "Late Turonian ophiuroids (Echinodermata) from the Bohemian Cretaceous Basin, Czech Republic". English. In: Bulletin of Geosciences 83.2 (2008), pp. 123-140.

[22199] G. Storch. "Skeletal remains of a diminutive primate from the Paleocene of Germany". English. In: Naturwissenschaften 95 (2008), pp. 927-930.

[22200] G. Storch and T. Dahlmann. "Desmanella rietscheli, ein neuer Talpide aus dem Obermiozän von Dorn-Dürkheim 1, Rheinhessen (Mammalia, Lipotyphla)". German. In: Carolinea 58 (2000), pp. 6569.

[22201] G. Storch and D. Dashzeveg. "Zaraalestes russelli, a new tupaiodontine erinaceid (Mammalia, Lipotyphla) from the Middle Eocene of Mongolia". English. In: Geobios 30.3 (1997), pp. 437-445.

[22202] G. Storch, B. Engesser, and M. Wuttke. "Oldest fossil record of gliding in rodents". English. In: Nature 379.439 (1996), pp. 439-441. 
[22203] G. Storch and O. Fejfar. Gundersheim-Findling, a Ruscinian rodent fauna of Asian affinities from Germany. In E.H. Lindsay, V. Fahlbusch and P. Mein, eds., European Neogene Mammal Chronology, Plenum Press, New York. 1990, pp. 405-412.

[22204] G. Storch and Z. Qiu. "First complete heterosoricine shrew: A new genus and species from the Miocene of China". English. In: Acta Palaeontologica Polonica 49.3 (2004), pp. 357-363.

[22205] G. Storch and Z. Qiu. "Insectivores (Mammalia: Erinaceidae, Soricidae, Talpidae) from the Lufeng hominoid locality, Late Miocene of China". English. In: Geobios 24.5 (1991), pp. 601-621.

[22206] G. Storch, B. Sigé, and J. Habersetzer. “Tachypteron franzeni n. gen., n. sp., earliest emballonurid bat from the Middle Eocene of Messel (Mammalia, Chiroptera)". English. In: Palaeontologische Zeitschrift 76.2 (2002), pp. 189-199.

[22207] P. Storch and R. Feist. "Lowermost Silurian Graptolites of Montagne Noire, France". English. In: Journal of Paleontology 82.5 (2008), pp. 938-956.

[22208] P. Storch, S. Manda, L. Slavk, and Z. Tasáryová. “Wenlock-Ludlow boundary interval revisited: new insights from the offshore facies of the Prague Synform, Czech Republic". English. In: Canadian Journal of Earth Sciences 53.7 (2016), pp. 666-673.

[22209] P. Storch, C. E. Mitchell, S. C. Finney, and M. J. Melchin. “Uppermost Ordovician (upper KatianHirnantian) graptolites of north-central Nevada, USA". English. In: Bulletin of Geosciences 86.2 (2011), pp. 301-386.

[22210] J. E. Storer. "The mammals of the Gryde Local Fauna, Frenchman Formation (Maastrichtian: Lancian), Saskatchewan". In: Journal of Vertebrate Paleontology 11.3 (1991), pp. 350-369.

[22211] J. E. Storer. "Tachylagus, a New Lagomorph from the Lac Pelletier Lower Fauna (Eocene: Duchesnean) of Saskatchewan". English. In: Journal of Vertebrate Paleontology 12.2 (1992), pp. 230-235.

[22212] J. E. Storer. "Multituberculates of the Lac Pelletier Lower Fauna, Late Eocene (Duchesnean), of Saskatchewan". In: Canadian Journal of Earth Sciences 30 (1993), pp. 1613-1617.

[22213] J. E. Storer. "Additions to the mammalian paleofauna of Saskatchewan". In: Modern Geology 18.4 (1993), pp. 475-487.

[22214] J. E. Storer. "A latest Chadronian (Late Eocene) mammalian fauna from the Cypress Hills, Saskatchewan". English. In: Canadian Journal of Earth Sciences 31 (1994).

[22215] J. E. Storer. "Small mammals of the Kealey Springs local fauna (early Arikareean; late Oligocene) of Saskatchewan". English. In: Paludicola 3.4 (2002), pp. 105-133.

[22216] J. E. Storer. “A Middle Pleistocene (late Irvingtonian) mammalian fauna from Thistle Creek, Klondike Goldfields region of Yukon Territory, Canada". English. In: Paludicola 4.4 (2004), pp. 137-150.

[22217] J. E. Storer. "A new species of Mustela (Mammalia; Carnivora; Mustelidae) from the Fort Selkirk fauna (Early Pleistocene) of Yukon Territory, Canada". English. In: Paludicola 4.4 (2004), pp. 151155.

[22218] J. E. Storer and H. N. Bryant. "Biostratigraphy of the Cypress Hills Formation (Eocene to Miocene), Saskatchewan: equid types (Mammalia: Perissodactyla) and associated faunal assemblages". In: Journal of Paleontology 67.4 (1993), pp. 660-669.

[22219] R. W. Storer. "A new Pliocene grebe from Lee Creek deposits". English. In: Smithsonian Contributions to Paleobiology 90 (2001), pp. 227-231.

[22220] A. J. Storey. "Late Silurian trilobite palaeobiology and biodiversity". English. PhD thesis. 2012, pp. 1-389.

[22221] S. Storozhenko. “New Triassic Mesorthopteridae (Insecta, Plecopteroidea, Grylloblattida)". English. In: Spixiana 19.1 (1996), pp. 115-127.

[2222] S. Storozhenko. “New Triassic grylloblattids from Kirghizia (Insecta, Grylloblattida)”. English. In: Spixiana 17.1 (1994), pp. 27-35.

[22223] S. Storozhenko. "Permian fossil insects of north-east Europe: new and little-known Ideliidae (Insecta, Plecopteroidea, Grylloblattida)". English. In: Entomologica Fennica 3 (1992), pp. 21-39. 
[22224] S. Y. Storozhenko. "New Upper Carboniferous grylloblattids (Insecta, Grylloblattida) from Siberia". English. In: Far Eastern Entomologist 26 (1996), pp. 18-20.

[2225] S. Y. Storozhenko. "Classification of the Order Grylloblattida (Insecta), with description of new taxa". English. In: Far Eastern Entomologist 42 (1997), pp. 1-20.

[22226] S. Y. Storozhenko. "A new family of Triassic grylloblattids from central Asia (Insecta, Grylloblattida)". English. In: Spixiana 15.1 (1992), pp. 67-73.

[2227] S. Y. Storozhenko. “Upper Permian Grylloblattid Insects from Eastern Kazakhstan”. English. In: Paleontological Journal 25.2 (1991), pp. 137-142.

[22228] S. Y. Storozhenko. “New Permian and Mesozoic Insects (Insecta, Grylloblattida: Blattogryllidae, Geinitziidae) from Asia". English. In: Paleontological Journal 24.4 (1990), pp. 53-61.

[22229] S. Y. Storozhenko. "Permian fossil insects of North-East Europa: revision of the family Atactophlebiidae". English. In: Deutsche Entomologische Zeitschrift 37.4-5 (1990), pp. 407-412.

[22230] S. Y. Storozhenko. Novye iskopaemye grilloblattidovye nasekomye (Insecta: Grylloblattida) iz Mongolii. Russian. Vol. 41. Novye Taksony Iskopaemykh Bespozvonochnykh Mongolii, Sovmestnaya RossiiskoMongol'skaya Paleontologicheskaya Ekspeditsiya. 1992, pp. 122-129.

[22231] S. Y. Storozhenko. "New Mesozoic Grylloblattid insects (Grylloblattida) from Central Asia". English. In: Paleontological Journal 26.1 (1992), pp. 85-95.

[22232] S. Y. Storozhenko. Reviziya semeystva Megakhosaridae (Grylloblattida). Russian. Mezozoyskie Nasekomye i Ostrakody Azii. 1993, pp. 100-112.

[22233] S. Y. Storozhenko. "Permian fossil insects of north-east Europe: new Liomopterids (Grylloblattida, Liomopteridae and Phenopteridae)". English. In: Deutsche Entomologische Zeitschrift 39 (1992), pp. 209-220.

[22234] S. Y. Storozhenko. “New Triassic grylloblattids of the family Ideliidae (Plecopteroidea, Grylloblattida)". English. In: Russian Entomological Journal 5 (1996), pp. 13-19.

[22235] S. Y. Storozhenko. "Permian fossil insects of north-east Europe: new Atactophlebiidae, Ideliidae and Megakhosaridae (Grylloblattida)". English. In: Zoosystematica Rossica 3 (1994), pp. 49-52.

[22236] S. Y. Storozhenko and D. S. Aristov. "New genus of the family Liomopteridae (Insecta: Grylloblattida) from Lower Permian of Russia". English. In: Far Eastern Entomologist 76 (1999), pp. 6-8.

[22237] S. Y. Storozhenko and D. S. Aristov. "Review of the Paleozoic and Mesozoic families Megakhosaridae and Blattogryllidae (Insecta: Grylloblattida)". English. In: Far Eastern Entomologist 271 (2014), pp. 1-28.

[22238] S. Y. Storozhenko and V. G. Novokshonov. "Revision of the Permian family Sojanoraphidiidae (Grylloblattida)". English. In: Russian Entomological Journal 3 (1995), pp. 37-39.

[22239] S. Y. Storozhenko and P. Vranský. "New fossil family of the order Grylloblattida (Insecta: Plecopteroidea) from Asia". English. In: Far Eastern Entomologist 19 (1995), pp. 1-4.

[22240] G. W. Storrs. "Fossil vertebrate faunas of the British Rhaetian (latest Triassic)". English. In: Zoological Journal of the Linnean Society 112 (1994), pp. 217-259.

[22241] G. W. Storrs. "An examination of Plesiosauria (Diapsida: Sauropterygia) from the Niobrara Chalk (Upper Cretaceous) of Central North America". English. In: Paleontological Contributions of the University of Kansas 11 (1999), pp. 1-15.

[22242] G. W. Storrs. Morphological and taxonomic clarification of the genus Plesiosaurus. English. Ancient Marine Reptiles. 1997, pp. 145-190.

[22243] G. W. Storrs. "A juvenile specimen of ? Plesiosaurus sp. from the Lias (Lower Jurassic, Pliensbachian) near Charmouth, Dorset, England". English. In: Proceedings of the Dorsal Archaelogical and Natural History Society 116 (1995), pp. 71-76.

[22244] G. W. Storrs. "Late Miocene-Early Pliocene crocodilian fauna of Lothagam, southwest Turkana Basin, Kenya". English. In: Lothagam: The Dawn of Humanity in Eastern Africa. New York: Columbia University Press, 2003, pp. 137-159. 
[22245] G. W. Storrs. "Anatomy and relationships of Corosaurus alcovensis (Diapsida: Sauropterygia) and the Triassic Alcova Limestone of Wyoming". English. In: Bulletin of the Peabody Museum of Natural History 44 (1991), pp. 1-151.

[22246] G. W. Storrs. “Dinosaur hunt-the saga of a Yale expedition”. English. In: Discovery 22.2 (1991), pp. 10-18.

[22247] G. W. Storrs. "Note on a second occurrence of thalattosaur remains (Reptilia: Neodiapsida) in British Columbia". English. In: Canadian Journal of Earth Science 28 (1991), pp. 2065-2068.

[22248] G. W. Storrs, S. E. Oser, and M. Aull. "Further analysis of a Late Jurassic dinosaur bone-bed from the Morrison Formation of Montana, USA, with a computed three-dimensional reconstruction". English. In: Earth and Environmental Science Transactions of the Royal Society of Edinburgh 103 (2013), pp. 1-16.

[22249] G. W. Storrs and M. A. Taylor. "Cranial anatomy of a new plesiosaur genus from the lowermost Lias (Rhaetian/Hettangian) of Street, Somerset, England". English. In: Journal of Vertebrate Paleontology 16.3 (1996), pp. 403-420.

[22250] C. A. Stott and J. Jin. “The earliest known Kinnella, an orthide brachiopod from the Upper Ordovician of Manitoulin Island, Ontario, Canada". English. In: Acta Palaeontologica Polonica 53.3 (2007), pp. 535-546.

[22251] S. Stouge. "Middle Ordovician (late Dapingian-Darriwilian) conodonts from the Cow Head Group and Lower Head Formation, western Newfoundland, Canada". English. In: Canadian Journal of Earth Sciences 49 (2012), pp. 59-90. DOI: 10.1139/E11-057.

[22252] S. Stouge and A. T. Nielsen. "An integrated biostratigraphical analysis of the Volkhov-Kunda (Lower Ordovician) succession at Fågelsång, Scania, Sweden". English. In: Bulletin of the Geological Society of Denmark 50 (2003), pp. 75-94.

[22253] S. Stouge and J. A. Rasmussen. “Upper Ordovician conodonts from Bornholm and possible migration routes in the Palaeotethys Ocean". English. In: Bulletin of the Geological Society of Denmark 43.1 (1996), pp. 54-67.

[22254] J. B. Stout. "New early Pleistocene Alligator (Eusuchia: Crocodylia) from Florida bridges a". English. In: Zootaxa 4868.1 (2020), pp. 41-60.

[22255] L. Strada, M. Montagna, and A. Tintori. "A new genus and species of the family Trachypachidae (Coleoptera, Adephaga) from the upper Ladinian (Middle Triassic) of Monte San Giorgio". English. In: Rivista Italiana di Paleontologia e Stratigrafia 120 (2014), pp. 183-190.

[22256] S. G. Strait. New mammalian fossils from the earliest Eocene (Wa-0), Bighorn Basin, Wyoming. English. 2003.

[22257] S. G. Strait, P. A. Holroyd, C. A. Denvir, and B. D. Rankin. "Early Eocene (Wasatchian) rodent assemblages from the Washakie Basin, Wyoming". English. In: PaleoBios 33 (2016), pp. 1-28.

[22258] A. Strapasson, F. L. Pinheiro, and M. B. Soares. “On a New Stereospondylomorph Temnospondyl from the Middle-Late Permian of Southern Brazil". English. In: Acta Palaeontologica Polonica 60.4 (2015), pp. 843-855. DOI: 10.4202/app.00059.2014.

[22259] J. M. C. Stratford, C. A. Landis, S. R. Owen, E. H. Gilmour, M. E. McColloch, and H. J. Campbell. "Stratigraphy of the lower Maitai Group at West Dome, Southland, New Zealand". English. In: Journal of the Royal Society of New Zealand 34 (2004), pp. 267-293.

[22260] O. D. Strelnikova. "New cupedids (Insecta: Coleoptera, Cupedidae) from the Lower Cretaceous of Buryatia". English. In: Paleontological Journal 53 (2019), pp. 292-299. DOI: 10.1134/S0031030119030146.

[22261] O. D. Strelnikova and A. P. Rasnitsyn. "A preliminary study of the respiratory and alimentory systems of the Early Cretaceous flea Saurophthirus longipes Ponomarenko, 1976 (Insecta, ?Aphaniptera, Saurophthiridae)". English. In: Far Eastern Entomologist 327 (2016), pp. 1-7.

[22262] O. D. Strelnikova, E. V. Yan, and D. V. Vasilenko. "A new agyrtid beetle (Coleoptera, Agyrtidae) from the Lower Cretaceous Khasurty locality". English. In: Paleontological Journal 54 (2020), pp. 627631. DOI: $10.1134 /$ S003103012006009X. 
[22263] J. Strelow, M. M. Solórzano Kraemer, S. Ibáñez-Bernal, and J. Rust. “First fossil horsefly (Diptera: Tabanidae) in Miocene Mexican amber". English. In: Paläontologische Zeitschrift 87 (2013), pp. 437444.

[22264] M. Streng, A. D. Butler, J. S. Peel, R. J. Garwood, and J. -B. Caron. "A new family of Cambrian rhynchonelliformean brachiopods (Order Naukatida) with an aberrant coral-like morphology". English. In: Palaeontology 59.2 (2016), pp. 269-293.

[22265] M. Streng and G. Geyer. "Middle Cambrian Bradoriida (Arthropoda) from the Franconian Forest, Germany, with a review of the bradoriids described from West Gondwana and a revision of material from Baltica". English. In: Palaeontologische Zeitschrift 93 (2019), pp. 567-591. DOI: 10.1007/ s12542-019-00448-z.

[22266] M. Streng and L. E. Holmer. "New and poorly known acrotretid brachiopods (Class Lingulata) from the Cedaria-Crepicephalus zone (late Middle Cambrian) of the Great Basin, USA". English. In: Géobios 39 (2006), pp. 125-153.

[22267] M. Streng, B. B. Mellbin, E. Landing, and J. D. Keppie. "Linguliform brachiopods from the terminal Cambrian and lowest Ordovician of the Oaxaquia Microcontinent (southern Mexico)". English. In: Journal of Paleontology 85.1 (2011), pp. 122-155.

[22268] M. Streng and C. B. Skovsted. "A new mobergellan (small shell fossils) from the early Middle Cambrian of Morocco and its significance". English. In: Paläontologische Zeitschrift 80.3 (2006), pp. 209-220.

[22269] C. Strganac. "Terrestrial mammal fossils from the Wildcat Creek Beds (Paleogene), Tieton River Area, south-central Washington, USA". English. In: Palaeontologia Electronica 14.3 (2011).

[22270] C. B. Stringer, J. C. Finlayson, R. N. E. Barton, Y. Fernandez-Jalvo, I. Caceres, R. C. Sabin, E. J. Rhodes, A. P. Currant, J. Rodriguez-Vidal, F. Giles-Pacheco, and J. A. Riquelme-Cantal. "Neanderthal exploitation of marine mammals in Gibraltar". English. In: Proceedings of the National Academy of Sciences 105.38 (2008), pp. 14319-14324.

[22271] G. L. Stringer. "Late Pleistocene-early Holocene teleostean otoliths from a Mississippi River mudlump". English. In: Journal of Vertebrate Paleontology 12.1 (1992), pp. 33-41.

[22272] G. L. Stringer. "Changes in the Sciaenidae during the Eocene/Oligocene as indicated by otoliths in the central Gulf Coast". English. In: Abstracts with Programs - Geological Society of America 14.3 (2011), pp. 7-7.

[22273] G. L. Stringer. "Otolith-based fishes form the Bowden Shell Bed (Pliocene) of Jamaica: Systematics and Palaeoecology". English. In: Contributions to Tertiary and Quaternary Geology 35.1-4 (1998), pp. 147-160.

[22274] G. L. Stringer. "46-million-year-old marine fossils from the Cane River Site, North-Central Louisiana". English. In: Louisiana Geological Survey Public Information Series 10 (2002), pp. 1-7.

[22275] G. L. Stringer. “Evidence and implications of marine invertebrate settlement on Eocene otoliths from the Moodys Branch Formation of Montgomery Landing (Louisiana, U.S.A.)" English. In: Cainozoic Research 16.1 (2016), pp. 3-12.

[22276] G. L. Stringer and M. Henry. "First report of the Cretaceous shark Squalicorax from Louisiana". English. In: Mississippi Geology 17.2 (1996), pp. 40-42.

[22277] G. L. Stringer and L. King. "Late Eocene shark coprolites from the Yazoo Clay in northeastern Louisiana". English. In: Bulletin - New Mexico Museum of Natural History and Science 57 (2012), pp. 275-309.

[22278] P. Strogen, G. L. Jones, and I. D. Somerville. "Stratigraphy and sedimentology of Lower Carboniferous (Dinantian) boreholes from west county Meath, Ireland". English. In: Geological Journal 25 (1990), pp. 103-137.

[22279] A. Stroinski. "Pochazoides szwedoi n. sp. from the East African copal (Hemiptera: Fulgoromorpha: Ricaniidae)". English. In: Genus 18 (2007), pp. 345-349. 
[22280] A. Stroinski and J. Szwedo. “Tonacatecutlius gibsoni gen. and sp. nov. from the Oligocene/Miocene Mexican amber (Hemiptera: Fulgoromorpha: Nogodinidae)". English. In: Annales Zoologici 50 (2000), pp. 341-345.

[22281] A. Stroinski and J. Szwedo. "Yuripopoverus africanus gen. et sp. n. from East African copal (Hemiptera: Fulgoromorpha: Ricaniidae)". English. In: Polish Journal of Entomology 80 (2011), pp. 679-688.

[22282] A. Stroinski and J. Szwedo. "Thionia douglundbergi sp. nov. from the Miocene Dominican amber (Hemiptera: Fulgoromorpha: Issidae) with notes on extinct higher planthoppers". English. In: Annales Zoologici 58 (2008), pp. 529-536.

[22283] A. Stroinski and J. Szwedo. "Abraracourcix curvivenatus n. gen. n. sp. from the Lowermost Eocene Oise amber (Hemiptera: Fulgoromorpha: Ricaniidae)". English. In: Annales de la Société Entomologique de France 47 (2011), pp. 480-486.

[22284] A. Stroinski and J. Szwedo. "The oldest known Lophopidae planthopper (Hemiptera: Fulgoromorpha) from the European Palaeocene". English. In: Geobios 45 (2012), pp. 413-420.

[22285] A. Stroinski and J. Szwedo. "An overview of Fulgoromorpha and Cicadomorpha in east African copal (Hemiptera)". English. In: Denisia 4 (2002), pp. 57-66.

[22286] C. Strömberg. "The conodont genus Ctenognathodus in the Silurian of Gotland, Sweden". English. PhD thesis. Lund, 1997.

[22287] C. R. C. Strong, M. W. Caldwell, T. Konishi, and A. Palci. "A new species of longirostrine plioplatecarpine mosasaur (Squamata:" English. In: Journal of Systematic Palaeontology (2020). DOI: 10.1080/14772019.2020.1818322.

[22288] D. L. Strusz and I. G. Percival. "Silurian (Wenlock) brachiopods from the Quidong district, southeastern New South Wales, Australia". English. In: Australasian Palaeontological Memoirs 51 (2018), pp. 81-129.

[22289] A. J. Stuart. Insularity and Quaternary vertebrate faunas in Britain and Ireland. In R. C. Preece, ed., Island Britain: a Quaternary perspective. Geological Society Special Publication No. 96, London. 1995, pp. 111-125.

[22290] A. J. Stuart and A. M. Lister. "The mammalian faunas of Pakefield/Kessingland and Corton, Suffolk, UK: evidence for a new temperate episode in the British early Middle Pleistocene." In: Quaternary Science Reviews 20 (2001), pp. 1677-1692.

[22291] J. Stuart, L. D. Sulerzhitsky, L. A. Orlova, Y. V. Kuzmin, and A. M. Lister. "The latest woolly mammoths (Mammuthus primigenius Blumenbach) in Europe and Asia: a review of the current evidence". English. In: Quaternary Science Reviews 21 (2002), pp. 1559-1569.

[22292] M. Stucchi. “Una nueva especie de Spheniscus (Aves: Spheniscidae) de la Formacion Pisco, Peru”. Spanish. In: Boletim de la Sociedad Geologica del Peru 94 (2002), pp. 17-24.

[22293] M. Stucchi. "Los Piqueros (Aves: Sulidae) de la Formacion Pisco, Peru”. English. In: Boletin de la Sociedad Geologica de Peru 95 (2003), pp. 75-91.

[22294] M. Stucchi and S. D. Emslie. "A new condor (Ciconiiformes, Vulturidae) from the late Miocene/early Pliocene Pisco Formation, Peru". English. In: Condor 107.1 (2005), pp. 107-113.

[22295] M. Stucchi, S. D. Emslie, R. M. Varas-Malca, and M. Urbina-Schmitt. "A new late Miocene condor (Aves, Cathartidae) from Peru and the origin of South American condors". English. In: Journal of Vertebrate Paleontology (2015), e972507. DOI: 10.1080/02724634.2015.972507.

[22296] M. Stucchi and M. Urbina. "Ramphastosula (aves, Sulidae): a new genus from the early Pliocene of the Pisco Formation, Peru". English. In: Journal of Vertebrate Paleontology 24.4 (2004), pp. 974978.

[22297] M. Stucchi, M. Urbina, and A. Giraldo. “Una nueva especie de Spheniscidae del Mioceno Tardio de la Formacion Pisco, Peru". English. In: Bulletin de la Institute Frances etudes Andines 32.2 (2003), pp. 361-375. 
[22298] M. Stucchi, R. M. Varas-Malca, and M. Urbina-Schmitt. "New Miocene sulid birds from Peru and considerations on their Neogene fossil record in the Eastern Pacific Ocean". English. In: Acta Palaeontologica Polonica 61.2 (2016), pp. 417-427. DOI: 10.4202/app.00170.2015.

[22299] R. K. Stucky and H. H. Covert. "A new genus and species of early Eocene (Ypresian) Artiodactyla (Mammalia), Gagadon minimonstrum, from Bitter Creek, Wyoming, U.S.A." English. In: Journal of Vertebrate Paleontology 34.3 (2014), pp. 731-736. DOI: 10.1080/02724634.2013.827580.

[22300] R. K. Stucky and T. G. Hardy. "A new large, hypercarnivorous oxyaenid (Mammalia, Creodonta) from the middle Eocene of the Wind River Formation, Natrona County, Wyoming". English. In: Bulletin of Carnegie Museum of Natural History 39 (2007), pp. 57-65.

[22301] R. K. Stucky and L. Krishtalka. "Revision of the Wind River Faunas, Early Eocene of Central Wyoming. Part 10. Bunophorus (Mammalia, Artiodactyla)". English. In: Annals of Carnegie Museum 59.2 (1990), pp. 149-171.

[22302] B. Studencka. "Middle Miocene bivalve faunas from the carbonate deposits of Poland (Central Paratethys)". English. In: Geologie Mediterraneenne 11.1-2 (1994), pp. 137-145.

[22303] B. Studencka. "A new species of genus Panopea (Bivalvia) from King George Island, Antarctica". English. In: Polish polar research 12.3 (1991), pp. 363-368.

[22304] B. Studencka and M. Jasionowski. "Bivalves from the Middle Miocene reefs of Poland and Ukraine: A new approach to Badenian/Sarmatian boundary in the Paratethys". English. In: Acta Geologica Polonica 61.1 (2011), pp. 79-114.

[22305] G. A. Stukalina. “The Late Permian crinoids from Primorye, Transcaucasia, and North Caucasus". In: Paleontological Journal 33.2 (1999), pp. 139-146.

[22306] J. H. Stuke. "Eine neue Gattung der Conopidae aus dem Baltischen Bernstein (Diptera: Conopidae)". German. In: Beiträge zur Entomologie 55 (2005), pp. 313-318.

[22307] J. H. Stuke. “Eine neue Blasenkopffliege der Gattung Palaeomyopa Meunier aus dem Baltischen Bernstein (Diptera: Conopidae)". German. In: Studia Dipterologica 10 (2003), pp. 91-96.

[22308] S. Stumpf. "A new genus and species of extinct ground shark, +Diprosopovenator hilperti, gen. et sp. nov. (Carcharhiniformes, +Pseudoscyliorhinidae, fam. nov.), from the Upper Cretaceous of Germany". English. In: Journal of Vertebrate Paleontology 39.2 (2019), e1593185. DOI: 10.1080 / 02724634.2019.1593185.

[22309] S. Stumpf, J. Ansorge, and W. Krempien. "Gravisaurian sauropod remains from the marine late Early Jurassic (Lower Toarcian) of North-Eastern Germany". English. In: Geobios 48 (2015), pp. 271279.

[22310] S. Stumpf, J. Ansorge, C. Pfaff, and J. Kriwet. "Early Jurassic diversification of pycnodontiform fishes (Actinopterygii, Neopterygii) after the end-Triassic extinction event: evidence from a new genus and species, Grimmenodon aureum". English. In: Journal of Vertebrate Paleontology 37 (2017), e1344679.

[22311] S. Stumpf and J. Kriwet. "A new Pliensbachian elasmobranch (Vertebrata, Chondrichthyes) assemblage from Europe, and its contribution to the understanding of late Early Jurassic elasmobranch diversity and distributional patterns". English. In: PalZ 93 (2019), pp. 637-658. DOI: 10. 1007/s12542-019-00451-4.

[22312] C. F. Sturm. "Description of a New Genus and Species of Scallop (Mollusca: Bivalvia: Pectinidae) from the Upper Cenozoic of North Carolina". English. In: Annals of Carnegie Museum 80.1 (2011), pp. $43-48$.

[22313] H. Sturm. "Erstnachweis fischchenartiger Insekten (Zygentoma, Insecta) für das Mesozoikum (Untere Kreide, Brasilien)". German. In: Senekenbergiana Lethaea 78 (1998), pp. 135-140.

[22314] H. Sturm and L. F. Mendes. "Two new species of Nicoletiidae (Zygentoma, Apterygota, Insecta) in Dominican amber". English. In: American Museum Novitates 3226 (1998), pp. 1-11. 
[22315] H. Sturm and G. O. Poinar. "Cretaceomachilis libanensis, the oldest known bristle-tail of the family Meinertellidae (Machiloidea, Archaeognatha, Insecta) from the Lebanese amber". English. In: Deutsche Entomologische Zeitschrift 45 (1998), pp. 43-48.

[22316] T. Stuwe. "Erstfunde von Ophiuren (Schlangensterne) im Obercampanium des öslischen Münsterland." German. In: Geologie und Paläontologie in Westfalen 56 (2000), pp. 67-77.

[22317] D. D. Stynder. “The impact of medium-sized canids on a seal bone assemblage from Dunefield Midden, West Coast, South Africa". English. In: South African Archaeological Bulletin 63 (2008), pp. 159-163.

[22318] D. D. Stynder, J. Moggi-Cecchi, L. R. Berger, and J. E. Parkington. "Human mandibular incisors from the late Middle Pleistocene locality of Hoedjiespunt 1, South Africa". English. In: Journal of Human Evolution 41 (2001), pp. 369-383.

[22319] P. tys. "A fossil head of an enicocephalomorphan (Hemiptera: Heteroptera) from England revisited: Identity of the first fossil species of Enicocephalidae from Europe". English. In: European Journal of Entomology 107 (2010), pp. 455-460.

[22320] D. Su, X. Yuan, and S. Deng. "Discovery of Palaeoniscinotus in China". English. In: Vertebrata PalAsiatica 35.3 (1997), pp. 161-169.

[22321] D.-Z. Su. "A new palaeoniscoid fish from the Upper Triassic of Zichang, northern Shaanxi". Chinese. In: Vertebrata PalAsiatica 37.4 (1999), pp. 263-267.

[22322] Y. Su, Z. J. Zhang, and Y. C. Hong. "Two new ancient griffenflies (Insecta: Odonatoptera) from the Namurian of Ningxia, China". English. In: Insect Systematics \& Evolution 43 (2012), pp. 1-10.

[22323] Y. T. Su, C. Y. Cai, and D. Y. Huang. "Revision of Phryssonotus burmiticus (Diplopoda, Polyxenida, Synxenidae) in mid-Cretaceous amber from Myanmar". English. In: Cretaceous Research 93 (2019), pp. 216-224. DOI: 10.1016/j.cretres.2018.09.002.

[22324] C. Suarez, A. Forsiepi, F. J. Goin, and C. Jaramillo. "Insights into the Neotropics prior to the Great American Biotic Interchange: new evidence of mammalian predators from the Miocene of northern Colombia". English. In: Journal of Vertebrate Paleontology 36.1 (2016), e1029581. DOI: 10.1080 / 02724634.2015.1029581.

[22325] C. A. Suarez, P. P. Flaig, G. A. Ludvigson, L. A. González, R. Tian, H. Zhou, P. J. McCarthy, D. A. Van der Kolk, and A. R. Fiorillo. "Reconstructing the paleohydrology of a cretaceous Alaskan paleopolar coastal plain from stable isotopes of bivalves". English. In: Palaeogeography, Palaeoclimatology, Palaeoecology 441 (2016), pp. 339-351.

[22326] C. A. Suarez, M. B. Suarez, D. O. Terry Jr., and D. E. Grandstaff. "Rare earth element geochemistry and taphonomy of the Early Cretaceous Crystal Geyser Dinosaur Quarry, east-central Utah". English. In: Palaios 22 (2007), pp. 500-512. DOI: 10.2110/palo.2005.p05-126r.

[22327] M. E. Suárez and H. Cappetta. "Sclerorhynchid teeth (Neoselachii, Sclerorhynchidae) from the Late Cretaceous of the Quiriquina Formation, central Chile". English. In: Revista Geológica de Chile 31.1 (2004), pp. 89-103.

[22328] M. E. Suarez and R. A. Otero. "Nuevos hallazgos de vertebrados marinos en el CampanianoMaastrichtiano de Loanco, VII Región". Spanish. In: Actas del I Simposio Paleontología en Chile. Santiago (2008), pp. 78-82.

[22329] W. Suárez and S. Daz-Franco. "A new fossil bat (Chiroptera: Phyllostomatidae) from a Quaternary cave deposit in Cuba". English. In: Caribbean Journal of Science 39.3 (2003), pp. 371-377.

[22330] W. Suarez and S. D. Emslie. "New fossil material with a redescription of the extinct condor Gymnogyps varonai (Arredondo, 1971) from the Quaternary of Cuba (Aves, Vulturidae)". English. In: Proceedings of the Biological Society of Washington 116.1 (2003), pp. 29-37.

[22331] A. Suarez-Bilbao, N. Garcia-Ibaibarriaga, A. Arrizabalaga, M. -J. IriarteChiapusso, and X. Murelaga. "Paleoenvironmental and paleoclimatic approach to the upper Pleistocene". English. In: Ameghiniana 54 (2017), pp. 641-654. DOI: 10.5710/AMGH.13.04.2017.3083. 
[22332] L. S. Subas and A. Arillo. "Oribatid mite fossils from the Upper Devonian of South Mountain, New York and the Lower Carboniferous of County Antrim, Northern Ireland (Acariformes, Oribatida)". English. In: Estudios del Museo de Ciencias Naturales de Álava 17 (2002), pp. 93-106.

[22333] Y. A. Suchkova and V. K. Golubev. "A New Primitive Therocephalian (Theromorpha) from the Middle Permian of Eastern Europe". English. In: Paleontologicheskii Zhurnal 53.3 (2019), pp. 305314.

[22334] Y. A. Suchkova and V. K. Golubev. "A New Permian Therocephalian (Therocephalia, Theromorpha) from the Sundyr Assemblage of Eastern Europe". English. In: Paleontologicheskii Zhurnal 4 (2019), pp. 87-92.

[22335] D. R. Suchy and C. W. Stearn. "Lower Silurian reefs and post-reef beds of the Attawapiskat Formation, Hudson Bay Platform, northern Ontario". English. In: Canadian Journal of Earth Sciences 30.3 (1992), pp. 575-590.

[22336] D. R. Suchy and R. R. West. “Chaetetid buildups in a Westphalian (Desmoinesian) cyclothem in southeastern Kansas". English. In: Palaios 16 (2001), pp. 425-443.

[22337] M. N. Sudar, Y. L. Chen, T. Kolar-Jurkovsek, B. Jurkovsek, D. Jovanovic, and M. B. Forel. “Lower Triassic (Olenekian) microfauna from Jadar block (Guevo Mt., NW Serbia)". English. In: Annales Géologiques de la Péninsule Balkanique 75 (2014), pp. 1-15.

[22338] W. H. Südkamp. "An atypical fauna in the Lower Devonian Hunsrück Slate of Germany". English. In: Palaeontologische Zeitschrift 81.2 (2007), pp. 181-204.

[22339] J. Sudre and J. Erfurt. "Les artiodactyles du gisement yprésien terminal de Premontre (Aisne, France)". French. In: Palaeovertebrata 25.2-4 (1996), pp. 391-414.

[22340] J. Sudre, J.-J. Jaeger, B. Sige, and M. Vianey-Liaud. "Nouvelles donnes sur les Condylarthres du Thanetien et de $1^{\prime} Y$ presien du bassin d'Ouarzazate (Maroc) [New data about the Thanetian and Ypresian Condylarthres of Ouarzazate basin (Morocco)]". French. In: Geobios 26.5 (1993), pp. 609615.

[22341] J. Sudre and G. Lecomte. "Relations et position systématique du genre Cuisitherium Sudre et al., 1983, le plus dérivé des artiodactyles d l'Éocéne inférieur d'Europe". English. In: Geodiversitas 22.3 (2000), pp. 415-432.

[22342] H.-D. Sues, A. J. Fitch, and R. L. Whatley. "A new rhynchosaur (Reptilia, Archosauromorpha) from the Upper Triassic of eastern North America". English. In: 40.2 (2020), e1771568:1-10. DOI: 10.1080/02724634.2020.1771568.

[22343] H.-D. Sues and P. E. Olsen. "A new procolophonid and a new tetrapod of uncertain, possibly procolophonian affinities from the Upper Triassic of Virginia". In: Journal of Vertebrate Paleontology 13.3 (1993), pp. 282-286.

[22344] H.-D. Sues, R. R. Schoch, G. Sobral, and R. B. Irmis. "A new archosauriform reptile with distinctive teeth from the Middle Triassic (Ladinian) of Germany". English. In: Journal of Vertebrate Paleontology (2020). DOI: 10.1080/02724634.2020.1764968.

[22345] H.-D. Sues, J. A. Hopson, and N. H. Shubin. "Affinities of Scalenodontoides plemmyridon Hopson, 1984 (Synapsida: Cynodontia) from the Upper Triassic of Nova Scotia". English. In: Journal of Vertebrate Paleontology 12.2 (1992), pp. 168-171.

[22346] H.-D. Sues, P. E. Olsen, and J. G. Carter. "A Late Triassic traversodont cynodont from the Newark Supergroup of North Carolina". English. In: Journal of Vertebrate Paleontology 19 (1999), pp. 351354.

[22347] H. D. Sues and W. Munk. "A remarkable assemblage of terrestrial tetrapods from the Zechstein (Upper Permian: Tatarian) near Korbach (northwestern Hesse)". English. In: Palaeontologische Zeitschrift 70.1/2 (1996), pp. 213-223.

[22348] H.-D. Sues. "A remarkable new armored archosaur from the Upper Triassic of Virginia". English. In: Journal of Vertebrate Paleontology 12 (1992), pp. 142-149. 
[22349] H.-D. Sues. "An unusual new archosauromorph reptile from the Upper Triassic Wolfville Formation of Nova Scotia". English. In: Canadian Journal of Earth Sciences 40 (2003), pp. 635-649.

[22350] H.-D. Sues. “On Chirostenotes, a Late Cretaceous oviraptorosaur (Dinosauria: Theropoda) from western North America". English. In: Journal of Vertebrate Paleontology 17.4 (1997), pp. 698-716.

[22351] H.-D. Sues and A. Averianov. "A new basal hadrosauroid dinosaur from the Late Cretaceous of Uzbekistan and the early radiation of duck-billed dinosaurs". English. In: Proceedings of the Royal Society B: Biological Sciences 276.1667 (2009), pp. 2549-2555. DOI: 10.1098/rspb.2009.0229.

[22352] H.-D. Sues and A. Averianov. "Enigmatic teeth of small theropod dinosaurs from the Upper Cretaceous (Cenomanian-Turonian) of Uzbekistan". English. In: Canadian Journal of Earth Sciences 50 (2013), pp. 306-314.

[22353] H.-D. Sues and A. Averianov. “Dromaeosauridae (Dinosauria: Theropoda) from the Bissekty Formation (Upper Cretaceous: Turonian) of Uzbekistan and the phylogenetic position of Itemirus medullaris Kurzanov, 1976". English. In: Cretaceous Research 51 (2014), pp. 225-240.

[22354] H.-D. Sues, A. Averianov, R. C. Ridgely, and L. M. Witmer. "Titanosauria (Dinosauria, Sauropoda) from the Upper Cretaceous (Turonian) Bissekty Formation of Uzbekistan". English. In: Journal of Vertebrate Paleontology 35.1 (2015), e889145. DOI: 10.1080/02724634.2014.889145.

[22355] H.-D. Sues and D. Baird. "Procolophonidae (Reptilia: Parareptilia) from the Upper Triassic Wolfville Formation of Nova Scotia, Canada". English. In: Journal of Vertebrate Paleontology 18.3 (1998), pp. 525532.

[22356] H.-D. Sues, J. M. Clark, and F. A. Jenkins Jr. A review of the Early Jurassic tetrapods from the Glen Canyon Group of the American Southwest. In the Shadow of the Dinosaurs: Early Mesozoic Tetrapods, N. C. Fraser and H.-D. Sues (eds.), Cambridge University Press. 1994, pp. 284-294.

[22357] H.-D. Sues, J. B. Desojo, and M. D. Ezcurra. "Doswelliidae: a clade of unusual armoured archosauriforms from the Middle and Late Triassic". English. In: vol. 379. Anatomy, Phylogeny and Palaeobiology of Early Archosaurs and their Kin. Geological Society, London, Special Publications. 2013. DOI: 10.1144/SP379.13.

[22358] H.-D. Sues, E. Frey, D. M. Martill, and D. M. Scott. " $<i>$ Irritator challengeri $</ i>$, a spinosaurid (Dinosauria: Theropoda) from the Lower Cretaceous of Brazil". In: Journal of Vertebrate Paleontology 22.3 (2002), pp. 535-547.

[22359] H.-D. Sues, S. J. Nesbitt, D. S. Berman, and A. C. Henrici. “A late-surviving basal theropod dinosaur from the latest Triassic of North America". English. In: Proceedings of the Royal Society B 278 (2011), pp. 3459-3464. DOI: 10.1098/rspb.2011.0410.

[22360] H.-D. Sues, P. E. Olsen, J. G. Carter, and D. M. Scott. "A new crocodylomorph archosaur from the Upper Triassic of North Carolina". English. In: Journal of Vertebrate Paleontology 23.2 (2003), pp. 329-343.

[22361] H.-D. Sues, P. E. Olsen, and P. A. Kroehler. Small tetrapods from the Upper Triassic of the Richmond basin (Newark Supergroup), Virginia. In the Shadow of the Dinosaurs: Early Mesozoic Tetrapods, N. C. Fraser and H.-D. Sues (eds.), Cambridge University Press. 1994, pp. 161-170.

[22362] H.-D. Sues and P. E. Olsen. "Triassic vertebrates of Gondwanan aspect from the Richmond Basin of Virginia". In: Science 249 (1990), pp. 1020-1023.

[22363] H.-D. Sues, P. E. Olsen, D. M. Scott, and P. S. Spencer. “Cranial osteology of Hypsognathus fenneri, a latest Triassic procolophonid reptile from the Newark Supergroup of Eastern North America". English. In: Journal of Vertebrate Paleontology 20.2 (2000), pp. 275-284.

[22364] H.-D. Sues and R. R. Reisz. "First record of the early Mesozoic sphenodontian Clevosaurus (Lepidosauria: Rhynchocephalia) from the Southern Hemisphere". English. In: Journal of Paleontology 69.1 (1995), pp. 123-126.

[22365] H.-D. Sues, R. R. Reisz, S. Hinic, and M. A. Raath. "On the skull of Massospondylus carinatus Owen, 1854 (Dinosauria: Sauropodomorpha) from the Elliot and Clarens Formations (Lower Jurassic) of South Africa". In: Annals of Carnegie Museum 73.4 (2004), pp. 239-257. 
[22366] H.-D. Sues and R. R. Reisz. "Anatomy and Phylogenetic Relationships of Sclerosaurus armatus (Amniota: Parareptilia) from the Buntsandstein (Triassic) of Europe". English. In: Journal of Vertebrate Paleontology 28.4 (2008), pp. 1031-1042.

[22367] H.-D. Sues and R. R. Schoch. "Reassessment of cf. Halticosaurus orbitoangulatus from the Upper Triassic (Norian) of Germany - a pseudosuchian, not a dinosaur". English. In: Zoological Journal of the Linnean Society 168 (2013), pp. 859-872.

[22368] H.-D. Sues and R. R. Schoch. "First record of Colognathus (?Amniota) from the Middle Triassic of Europe". English. In: Journal of Vertebrate Paleontology 33.4 (2013), pp. 998-1002.

[22369] H.-D. Sues, N. H. Shubin, and P. E. Olsen. "A new sphenodontian (Lepidosauria: Rhynchocephalia) from the McCoy Brook Formation (Lower Jurassic) of Nova Scotia, Canada". English. In: Journal of Vertebrate Paleontology 14.3 (1994), pp. 327-340.

[22370] H.-D. Sues, N. H. Shubin, P. E. Olsen, and W. W. Amarel. "On the cranial structure of a new protosuchid (Archosauria: Crocodyliformes) from the McCoy Brook Formation (Lower Jurassic) of Nova Scotia, Canada". English. In: Journal of Vertebrate Paleontology 16.1 (1996), pp. 34-41.

[22371] Y. Sugamori. "Late Permian radiolarians from the Ajima Formation of the Ultra-Tamba Terrane in the Sasayama area, southwest Japan". English. In: Palaeoworld 20 (2011), pp. 158-165. DOI: 10. 1016/j.palwor.2011.05.004.

[22372] K. Sugiyama. “Lower and Middle Triassic radiolarians from Mt. Kinkazan, Gifu Prefecture, central Japan". English. In: Transactions and Proceedings of the Paleontological Society of Japan, N.S. 167 (1992), pp. 1180-1223.

[22373] T. Sugiyama and K. Nagai. "Reef facies and paleoecology of reef-building corals in the lower part of the Akiyoshi Limestone Group (Carboniferous), southwest Japan". English. In: Courier Forschungsinstitut Senckenberg 172 (1994), pp. 231-240.

[22374] I. D. Sukacheva. "New fossil caddis flies (Trichoptera) from the Shar-Teg locality in Mongolia". English. In: Paleontological Journal 34.Suppl 3 (2000), S347-S351.

[22375] I. D. Sukacheva. "New Mesozoic scorpion flies (Nannochoristidae, Mecoptera) from Yakutia". English. In: Paleontological Journal 27.1A (1993), pp. 169-171.

[22376] I. D. Sukacheva. “Oldest Polycentropodidae (Trichoptera) from Mongolia”. English. In: Paleontological Journal 27.1A (1993), pp. 192-196.

[22377] I. D. Sukacheva and A. P. Rasnitsyn. "Jurassic insects (Insecta) from the Sai-Sagul locality (Kyrgyzstan, southern Fergana)". English. In: Paleontological Journal 38 (2004), pp. 182-186.

[22378] I. D. Sukacheva and D. V. Vasilenko. “Caddisflies (Insecta, Trichoptera) from the Upper Mesozoic Chernovskie Kopi locality (Transbaikalia): Part 1. Imago". English. In: Paleontological Journal 52 (2018), pp. 535-540.

[22379] I. D. Sukatcheva. "The first record of Dicosmoecinae from the Cenozoic of the Russian Far East with a brief global overview of fossil Limnephilidae (Insecta: Trichoptera)". English. In: Paleontological Journal 51 (2017), pp. 53-58.

[22380] I. Sukatsheva, R. Beattie, and M. B. Mostovski. "Permomerope natalensis sp. n. from the Lopingian of South Africa, and a redescription of the type species of Permomerope (Trichoptera: Protomeropidae)". English. In: African Invertebrates 48.2 (2007), pp. 245-251.

[22381] I. D. Sukatsheva. "Caddis-flies (Insecta: Trichoptera) from the Insect Limestone (Bembridge Marls, Late Eocene) of the Isle of Wight, UK". English. In: Earth and Environmental Science Transactions of the Royal Society of Edinburgh 104 (2014), pp. 327-333.

[22382] I. D. Sukatsheva. "The family Phryganeidae (Insecta, Trichoptera) from the Mesozoic and Cenozoic of Asia (with a brief worldwide overview of the fossil caddisfly fauna)". English. In: Paleontological Journal 50 (2016), pp. 396-405.

[22383] I. D. Sukatsheva and D. S. Aristov. "New caddisflies of the suborder Protomeropina (Insecta: Trichoptera) from the Permian of Russia". English. In: Paleontological Journal 47 (2013), pp. 741751. 
[22384] I. D. Sukatsheva and D. S. Aristov. "New insects (Insecta: Trichoptera, Eoblattida) from the Lower Permian of Russia". English. In: Paleontological Journal 51 (2017), pp. 374-381.

[22385] I. D. Sukatsheva and D. S. Aristov. "New caddisflies (Insecta, Trichoptera) of the families Vitimotauliidae and Philopotamidae from the Khasurty locality (Lower Cretaceous, Russia) with a brief review of the world fossil fauna". English. In: Paleontological Journal 54 (2020), pp. 375-384. DOI: 10.1134/S0031030120040139.

[22386] I. D. Sukatsheva, V. D. Ivanov, S. I. Melnitsky, and D. S. Aristov. “Caddisflies (Insecta: Trichoptera) from the Middle Miocene of the Stavropol Region, Russia". English. In: Paleontological Journal 52 (2018), pp. 1593-1609.

[22387] I. D. Sukatsheva and E. A. Jarzembowski. "Fossil caddisflies (Insecta: Trichoptera) from Early Cretaceous of southern England II". English. In: Cretaceous Research 22 (2001), pp. 685-694.

[22388] I. D. Sukatsheva and V. G. Novokshonov. "A new family of Scorpionflies from the Mesozoic of Yakutia (Insecta: Mecoptera, Sibiriothaumatidae fam. nov.)" English. In: Paleontological Journal 32 (1998), pp. 596-597.

[22389] I. D. Sukatsheva, S. Szalma, P. Vranský, B. Chalupová, M. Golej, E. Labajová, and M. mrecková. "Caddis-fly (Insecta: Trichoptera) from the Badenian volcano-sedimentary succession (western Carpathians, Slovakia)". English. In: Geologica Carpathica 57 (2006), pp. 531-534.

[22390] I. D. Sukatsheva and D. V. Vasilenko. "New caddisflies of the family Dysoneuridae (Insecta: Trichoptera) and larval cases (Incertae Familiae) from the Lower Cretaceous of Transbaikalia". English. In: Paleontological Journal 53 (2019), pp. 499-505. DOI: 10.1134/S0031030119050125.

[22391] I. D. Sukatsheva and D. V. Vasilenko. "New caddisflies (Insecta, Trichoptera) of the Philopotamidae family from the Middle Jurassic of Siberia (Kubekovo locality)". English. In: Paleontological Journal 54 (2020), pp. 53-58. DOI: 10.1134/S0031030120010104.

[22392] I. D. Sukatsheva and D. V. Vassilenko. "New taxa of caddisflies (Insecta, Trichoptera) with reduced forewing venation from the Mesozoic of Asia". English. In: Paleontological Journal 47 (2013), pp. 7783.

[22393] I. D. Sukatsheva and D. V. Vassilenko. “Caddisflies from Chernovskie Kopi (Jurassic/Cretaceous of Transbaikalia)". English. In: Zoosymposia 5 (2011), pp. 434-438.

[22394] V. B. Sukhanov. "An archaic turtle, Heckerochelys romani gen. et sp. nov. from the Middle Jurassic of Moscow region, Russia". English. In: Fossil Turtle Researc 1 (2006), pp. 112-118.

[22395] V. B. Sukhanov, I. G. Danilov, and E. V. Syromyatnikova. “The description and phylogenetic position of a new nanhsiungchelyid turtle from the Late Cretaceous of Mongolia". English. In: Acta Palaeontologica Polonica 53.4 (2008), pp. 601-614.

[22396] V. B. Sukhanov, I. G. Danilov, and P. Narmandakh. "A new lindholmemydid turtle (Testudines: Linholmemydidae) from the Bayn Shire Formation (Late Cretaceou) of Mongolia". English. In: Russian Journal of Herpetology 6.2 (1999), pp. 147-152.

[22397] T. Sulej. "A new rauisuchian reptile (Diapsida: Archosauria) from the Late Triassic of Poland". English. In: Journal of Vertebrate Paleontology 25.1 (2005), pp. 78-86.

[22398] T. Sulej. "Species discrimination of the Late Triassic temnospondyl amphibian Metoposaurus diagnosticus". English. In: Acta Palaeontologica Polonica 47.3 (2002), pp. 535-546.

[22399] T. Sulej. "The skull of an early Late Triassic aetosaur and the evolution of the stagonolepidid archosaurian reptiles". English. In: Zoological Journal of the Linnean Society 158 (2010), pp. 860-881.

[22400] T. Sulej, R. Bronowicz, M. Talanda, and G. Niedwiedzki. "A new dicynodont-archosaur assemblage from the Late Triassic (Carnian) of Poland". English. In: Earth and Environmental Science Transactions of the Royal Society of Edinburgh 101 (2011), pp. 261-269. DOI: 10.1017/S1755691011020123.

[22401] T. Sulej and F. Majer. "The temnospondyl amphibian Cyclotosaurus from the Upper Triassic of Poland". English. In: Palaeontology 48.1 (2005), pp. 157-170. 
[22402] T. Sulej and G. Niedwiedzki. "A new large capitosaur temnospondyl amphibian from the Early Triassic of Poland". English. In: Acta Palaeontologica Polonica 58.1 (2011), pp. 65-75. DOI: 10.4202/ app.2011.0025.

[22403] T. Sulej, G. Niedwiedzki, and R. Bronowicz. "A new Late Triassic vertebrate fauna from Poland with turtles, aetosaurs, and coelophysoid dinosaurs". English. In: Journal of Vertebrate Paleontology 32.5 (2012), pp. 1033-1041. DOI: 10.1080/02724634.2012.694384.

[22404] T. Sulej, G. Niedwiedzki, M. Taanda, D. Dród, and E. Hara. “A new early Late Triassic nonmammaliaform eucynodont from Poland". English. In: Historical Biology (2018).

[22405] T. Sulej and G. Niedwiedzki. "An elephant-sized Late Triassic synapsid with erect limbs". English. In: Science 363 (2019), pp. 78-80. DOI: 10.1126/science.aal4853.

[22406] C. Sullivan and R. R. Reisz. "First record of Seymouria (Vertebrata: Seymouriamorpha) from Early Permian fissure fills at Richards Spur, Oklahoma". English. In: Canadian Journal of Earth Sciences 36.8 (1999), pp. 1257-1266.

[22407] C. Sullivan, R. R. Reisz, and W. J. May. "Large dissorophoid skeletal elements from the Lower Permian Richards Spur fissures, Oklahoma, and their paleoecological implications". English. In: Journal of Vertebrate Paleontology 20.3 (2000), pp. 456-461.

[22408] C. Sullivan, Y. Wang, D. W. E. Hone, X. Xu, and F. Zhang. "The vertebrates of the Jurassic Daohugou biota of northeastern China". English. In: Journal of Vertebrate Paleontology 34.2 (2014), pp. 243280.

[22409] N. B. Sullivan, P. I. McLaughlin, P. Emsbo, J. E. Barrick, and W. R. Premo. "Identification of the late Homerian Mulde Excursion at the base of the Salina Group (Michigan Basin, USA)". English. In: Lethaia 49.4 (2016), pp. 591-603. DOI: 10.1111/let.12168.

[22410] R. M. Sullivan. "Paleocene Caudata and Squamata from Gidley and Silberling quarries, Montana". English. In: Journal of Vertebrate Paleontology 11.3 (1991), pp. 293-301.

[22411] R. M. Sullivan. A juvenile Ornithomimus antiquus (Dinosauria: Theropoda: Ornithomimosauria), from the Upper Cretaceous Kirtland Formation (De-na-zin Member), San Juan Basin, New Mexico. English. New Mexico Geological Society Guidebook, 48th Field Conference, Mesozoic Geology and Paleontology of the Four Corners Region. 1997, pp. 249-254.

[22412] R. M. Sullivan. “Prenocephale edmontonensis (Brown and Schlaikjer) new comb. and P. brevis (Lambe) new comb. (Dinosauria: Ornithischia: Pachycephalosauria) from the Upper Cretaceous of North America". English. In: New Mexico Museum of Natural History and Science Bulletin 17 (2000), pp. 177-190.

[22413] R. M. Sullivan. "Revision of the dinosaur Stegoceras Lambe (Ornithischia, Pachycephalosauridae)". English. In: Journal of Vertebrate Paleontology 23.1 (2003), pp. 181-207.

[22414] R. M. Sullivan. “Nodocephalosaurus kirtlandensis, gen. et sp. nov., a new ankylosaurid dinosaur (Ornithischia: Ankylosauria) from the Upper Cretaceous Kirtland Formation (Upper Campanian) San Juan Basin, New Mexico". English. In: Journal of Vertebrate Paleontology 19.1 (1999), pp. 126139.

[22415] R. M. Sullivan. Saurornitholestes robustus, n. sp. (Theropoda: Dromaeosauridae) from the Upper Cretaceous Kirtland Formation (De-na-zin Member), San Juan Basin, New Mexico. English. Vol. 35. Late Cretaceous Vertebrates from the Western Interior. New Mexico Museum of Natural History and Science Bulletin. 2006, pp. 253-256.

[22416] R. M. Sullivan. A taxonomic review of the Pachycephalosauridae (Dinosauria: Ornithischia). English. Vol. 35. Late Cretaceous Vertebrates from the Western Interior. New Mexico Museum of Natural History and Science Bulletin. 2006, pp. 348-365.

[22417] R. M. Sullivan, M. Auge, E. Wille, and R. Smith. "A new glyptosaurine lizard from the earliest Eocene of Dormaal, Belgium". English. In: Bulletin de la Societe Geologique de France 183.6 (2012), pp. 627-633. 
[22418] R. M. Sullivan and M. Augé. “Redescription of the holotype of Placosaurus rugosus gervais 18481852 (Squamata, Anguidae, Glyptosaurinae) from the Eocene of France and a revision of the genus". English. In: Journal of Vertebrate Paleontology 26.1 (2006), pp. 127-132. DOI: 10.1671/02724634(2006)26[127:ROTHOP]2.0.CO;2.

[22419] R. M. Sullivan and G. E. Bennett. A juvenile Parasaurolophus (Ornithischia: Hadrosauridae) from the Upper Cretaceous Fruitland Formation of New Mexico. Vol. 17. New Mexico Museum of Natural History and Science Bulletin. 2000, pp. 215-220.

[22420] R. M. Sullivan and L. Dong. "Stenoplacosaurus mongoliensis, a new generic name for Placosaurus". English. In: New Mexico Museum of Natural History and Science Bulletin 79 (2018), pp. 691-694.

[22421] R. M. Sullivan and R. Estes. A reassessment of the fossil Tupinambinae. English. Vertebrate Paleontology in the Neotropics; the Miocene fauna of La Venta, Columbia. 1997.

[22422] R. M. Sullivan and D. W. Fowler. New specimens of the rare ankylosaurid dinosaur Nodocephalosaurus kirtlandensis (Ornithischia: Ankylosauridae) from the Upper Cretaceous Kirtland Formation (De-na-zin Member), San Juan Basin, New Mexico. English. Vol. 35. Late Cretaceous Vertebrates from the Western Interior. New Mexico Museum of Natural History and Science Bulletin. 2006, pp. 259-261.

[22423] R. M. Sullivan and D. W. Fowler. Navajodactylus boerei, n. gen., n. sp. (Pterosauria, ? Azhdarchidae) from the Upper Cretaceous Kirtland Formation (upper Campanian) of New Mexico. English. Fossil Record 3. New Mexico Museum of Natural History and Science Bulletin. Albuquerque: New Mexico Museum of Natural History and Science, 2011, pp. 393-404.

[22424] R. M. Sullivan, S. E. Jasinski, M. Guenther, and S. G. Lucas. The first lambeosaurin (Dinosauria, Hadrosauridae, Lambeosaurinae) from the Upper Cretaceous Ojo Alamo Formation (Naashoibito Member), San Juan Basin, New Mexico. English. Fossil Record 3. New Mexico Museum of Natural History and Science Bulletin. 2011, pp. 405-417.

[22425] R. M. Sullivan, S. E. Jasinski, and M. P. A. Van Tomme. "A new caenagnathid Ojoraptorsaurus boerei, n. gen., n. sp. (Dinosauria, Oviraptorosauria), from the Upper Cretaceous Ojo Alamo Formation (Naashoibito Member), San Juan Basin, New Mexico". English. In: Fossil Record 3. New Mexico Museum of Natural History and Science Bulletin. Albuquerque: New Mexico Museum of Natural History and Science, 2011, pp. 418-428.

[22426] R. M. Sullivan, S. E. Jasinski, and S. G. Lucas. "Re-assessment of Late Campanian (Kirtlandian) turtles from the Upper Cretaceous Fruitland and Kirtland formations, San Juan Basin, New Mexico, USA". English. In: Morphology and Evolution of Turtles. 2012, pp. 337-387. DOI: 10.1007/97894-007-4309-0_20.

[22427] R. M. Sullivan and S. G. Lucas. "Palaeoscincosaurus middletoni, new genus and species (Squamata: ?Scincidae) from the early Paleocene (Puercan) Denver Formation, Colorado". English. In: Journal of Vertebrate Paleontology 16.4 (1996), pp. 666-672.

[22428] R. M. Sullivan and S. G. Lucas. "Brachychampsa montana Gilmore (Crocodylia, Alligatoroidea) from the Kirtland Formation (upper Campanian), San Juan Basin, New Mexico". English. In: Journal of Vertebrate Paleontology 23.4 (2003), pp. 832-841.

[22429] R. M. Sullivan and S. G. Lucas. "Eucoelophysis baldwini, a new theropod dinosaur from the Upper Triassic of New Mexico, and the status of the original types of Coelophysis". English. In: Journal of Vertebrate Paleontology 19.1 (1999), pp. 81-90.

[22430] R. M. Sullivan and S. G. Lucas. The pachycephalosaurid dinosaur Stegoceras validum from the Upper Cretaceous Fruitland Formation, San Juan Basin, New Mexico. English. Vol. 35. Late Cretaceous Vertebrates from the Western Interior. New Mexico Museum of Natural History and Science Bulletin. 2006, pp. 329-330.

[22431] R. M. Sullivan and S. G. Lucas. A new chasmosaurine (Ceratopsidae, Dinosauria) from the Upper Cretaceous Ojo Alamo Formation (Naashoibito Member), San Juan Basin, New Mexico. English. New Perspectives on Horned Dinosaurs: The Royal Tyrrell Museum Ceratopsian Symposium. Indiana University Press, Bloomington. 2010, pp. 169-180. 
[22432] R. M. Sullivan, S. G. Lucas, S. E. Jasinski, and D. H. Tanke. “An unusual sacral neural spine osteopathy of a chasmosaurine (Dinosauria: Ceratopsidae) from the Upper Cretaceous Kirtland Formation (Hunter Wash Member), San Juan Basin, New Mexico". English. In: vol. 53. Fossil Record 3. New Mexico Museum of Natural History and Science Bulletin. Albuquerque: New Mexico Museum of Natural History and Science, 2011, pp. 484-488.

[22433] R. M. Sullivan, S. G. Lucas, and S. E. Jasinski. "Preliminary observations on a skull of the amiid fish Melvius, from the Upper Cretaceous Kirtland Formation, San Juan Basin, New Mexico". English. In: vol. 53. Fossil Record 3. New Mexico Museum of Natural History and Science Bulletin. Albuquerque: New Mexico Museum of Natural History and Science, 2011, pp. 475-483.

[22434] R. M. Sullivan and S. G. Lucas. "Charles Hazelius Sternberg and his San Juan Basin Cretaceous dinosaur collections: correspondence and photographs (1920-1925)". English. In: vol. 53. Fossil Record 3. New Mexico Museum of Natural History and Science Bulletin. Albuquerque: New Mexico Museum of Natural History and Science, 2011, pp. 429-471.

[22435] R. M. Sullivan, S. G. Lucas, A. Heckert, and A. P. Hunt. "The type locality of Coelophysis, a Late Triassic dinosaur from north-central New Mexico (USA)". English. In: Paläontologische Zeitschrift 70.1/2 (1996), pp. 245-255.

[22436] R. M. Sullivan, K. Randall, M. Hendricks, and W. E. Kochanov. “The Graterford dinosaurs: tracking Triassic travelers". English. In: Pennsylvania Geology 25.4 (1994), pp. 2-9.

[22437] R. M. Sullivan, D. H. Tanke, and B. M. Rothschild. An impact fracture in an ornithomimid (Ornithomimosauria:Dinosauria) metatarsal from the upper Cretaceous (late Campanian) of New Mexico. New Mexico Museum of Natural History and Science Bulletin. 2000, pp. 109-111.

[22438] R. M. Sullivan and T. E. Williamson. "A new skull of Parasaurolophus (Dinosauria: Hadrosauridae) from the Kirtland Formation of New Mexico and a revision of the genus." English. In: New Mexico Museum of Natural History and Science Bulletin 15 (1999), pp. 1-52.

[22439] H. Sulser. "Arzonella exotica n. g. n. sp., a new brachiopod of indeterminate systematic position from the Lower Liassic (Broccatello) of Arzo (Southern Alps of Switzerland) : a short note". English. In: Eclogae Geologicae Helvetiae 97 (2004), pp. 423-428.

[22440] H. Sulser. "Revision des Brachiopoden Ornithella (Delmontanella subgen. n.) delmontana (Oppel) aus dem unteren Malm des nordwestlichen Schweizer Jura". German. In: Eclogae Geologicae Helvetiae 88.3 (1995), pp. 723-741.

[22441] H. Sulser and J. G. Friebe. "Brachiopods from the Plattenwald Bed (Albian, Cretaceous) of the Helvetic Alps of Vorarlberg (Austria)". English. In: Eclogae Geologicae Helvetiae 95.3 (2002), pp. 415427.

[22442] H. Sulser and H. Furrer. "Dimerelloid rhynchonellide brachiopods in the Lower Jurassic of the Engadine (Canton Graubünden, National Park, Switzerland)". English. In: Swiss Journal of Geosciences 101 (2008), pp. 203-222.

[22443] H. Sulser, D. Garcia-Ramso, P. Kursteiner, and U. Menkveld-Gfeller. "Taxonomy and palaeoecology of brachiopods from the South-Helvetic zone of the Faneren region (Lutetian, Eocene, NE Switzerland)". English. In: Swiss Journal of Geosciences 103 (2010), pp. 257-272.

[22444] H. Sulser and C. Meyer. "Taxonomy and paleoecology of terebratulid brachiopods (Sellithyris subsella-group) from the Late Jurassic of northwestern Switzerland". English. In: Eclogae Geologicae Helvetiae 91.3 (1998), pp. 439-451.

[22445] S. S. Sumida, J. Dodick, A. Metcalf, and G. Albright. "Reiszorhinus olsoni, a New Single-ToothRowed Captorhinid Reptile from the Lower Permian of Texas". English. In: Journal of Vertebrate Paleontology 30.3 (2010), pp. 704-714. DOI: 10.1080/02724631003758078.

[22446] H. Summesberger. "Ammoniten aus dem Turon (Oberkreide) der Nördlichen Kalkalpen (Österreich)". German. In: Annalen des Naturhistorischen Museums in Wien, Serie A 94 (1992), pp. 103-133.

[22447] H. Summesberger. "Pseudophyllites latus (Marshal), Ammonoidea, aus der Sandkalkbank der Hochmoosschichten (Obersanton; Gosau, Österreich)". German. In: Annalen des Naturhistorischen Museums in Wien, Serie A 94 (1992), pp. 97-101. 
[22448] C. D. Sumrall. "The Systematics and Ontogeny of Pyrgopostibulla belli, a New Edrioasteroid (Echinodermata) from the Lower Devonian of New York". English. In: Journal of Paleontology 80.1 (2006), pp. 187-192.

[22449] C. D. Sumrall. "First definite record of Permian edrioasteroids: Neoisorophusella maslennikovi $n$ sp from the Kungurian of northeast Russia". English. In: Journal of Paleontology 83.6 (2009), pp. 990993.

[22450] C. D. Sumrall and F. J. Gahn. "Morphological and systematic reinterpretation of two enigmatic edrioasteroids (Echinodermata) from Canada". English. In: Canadian Journal of Earth Sciences 43.4 (2006), pp. 497-507.

[22451] C. D. Sumrall, S. Heredia, C. M. Rodrguez, and A. I. Mestre. "The first report of South American edrioasteroids and the paleoecology and ontogeny of rhenopyrgid echinoderms". English. In: Acta Palaeontologica Polonica 58.4 (2013), pp. 763-776. DOI: 10.4202/app.2011.0108.

[22452] C. D. Sumrall and G. A. Schumacher. "Cheirocystis fultonensis, a new glyptocystitoid rhombiferan from the Upper Ordovician of the Cincinnati Arch - comments on cheirorinid ontogeny". English. In: Journal of Paleontology 76.5 (2002), pp. 843-851. DOI: 10.1666/0022-3360(2002)076<0843: CFANGR>2.0.CO;2.

[22453] C. D. Sumrall, J. Sprinkle, and T. E. Guensburg. "Systematics and paleoecology of Late Cambrian echinoderms from the western United States". In: Journal of Paleontology 71.6 (1997), pp. 1091-1109.

[22454] C. D. Sumrall, J. Sprinkle, and R. M. Bonem. "An edrioasteroid-dominated echinoderm assemblage from a lower Pennsylvanian marine conglomerate in Oklahoma". English. In: Journal of Paleontology 80.2 (2006), pp. 229-244. DOI: 10.1666/0022-3360(2006)080[0229:AEEAFA]2.0.CO;2.

[22455] C. D. Sumrall and J. Sprinkle. "Ponticulocarpus, a new cornute-grade stylophoran from the Middle Cambrian Spence Shale of Utah". English. In: Journal of Paleontology 73.5 (1999), pp. 886-891.

[22456] C. D. Sumrall and J. Sprinkle. "Plating and pectinirhombs of the Ordovician rhombiferan Plethoschisma". English. In: Journal of Paleontology 69.4 (1995), pp. 772-779.

[22457] C. D. Sumrall, J. Sprinkle, and T. E. Guensberg. “Comparison of flattened blastozoan echinoderms: Insights from the new Early Ordovician eocrinoid Haimacystis rozhnovi". English. In: Journal of Paleontology 75.5 (2011), pp. 985-992.

[22458] C. D. Sumrall, J. Sprinkle, S. Pruss, and S. Finnegan. “Cardiocystella, a new cornute stylophoran from the Upper Cambrian Whipple Cave Formation, eastern Nevada, USA". English. In: Journal of Paleontology 83.2 (2009), pp. 307-312.

[22459] C. D. Sumrall and S. Zamora. "Ordovician edrioasteroids from Morocco: faunal exchanges across the Rheic Ocean". English. In: Journal of Systematic Palaeontology 9.3 (2011), pp. 425-454. DOI: 10. 1080/14772019.2010.499137.

[22460] D. Sun and W. Xia. "Identification of the Guadalupian-Lopingian boundary in the Permian in a bedded chert sequence, south China". English. In: Palaeogeography, Palaeoclimatology, Palaeoecology 236 (2006), pp. 272-289.

[22461] G. Sun, D. L. Dilcher, S. Zheng, and Z. Zhou. "In Search of the First Flower: A Jurassic Angiosperm, Archaefructus, from Northeast China". English. In: Science 282 (1998), pp. 1692-1695.

[22462] G. Sun, Q. Ji, D. L. Dilcher, S. Zheng, K. C. Nixon, and X. Wang. “Archaefructaceae, a New Basal Angiosperm Family". English. In: Science 296 (2002), pp. 899-904.

[22463] H. C. Sun, Y. P. Gao, X. D. Zhao, B. Wang, and C. T. Xiao. "A new species of the Meropeidae (Insecta: Mecoptera) from mid-Cretaceous Myanmar amber". English. In: Cretaceous Research 116.104570 (2020). DOI: 10.1016/j.cretres.2020.104570.

[22464] J. Sun and J. Chen. "New material of shore bug subfamily Leptosaldinae in mid-Cretaceous Kachin amber from northern Myanmar (Heteroptera, Leptopodomorpha)". English. In: Cretaceous Research 106.104205 (2020). DOI: 10.1016/j.cretres.2019.104205. 
[22465] J. H. Sun, D. Ren, and C. K. Shih. "Middle Jurassic Nannochoristidae fossils from Daohugou, Inner Mongolia in China (Insecta, Mecoptera)". Chinese. In: Acta Zootaxonomica Sinica 32 (2007), pp. 405-411.

[22466] J. H. Sun, D. Ren, and C. K. Shih. "Middle Jurassic Mesopanorpodidae from Daohugou, Inner Mongolia, China (Insecta, Mecoptera)". Chinese. In: Acta Zootaxonomica Sinica 32 (2007), pp. 865874.

[22467] N. Sun, R. J. Elias, S. -J. Choh, D. -C. Lee, X. -L. Wang, and D. -J. Lee. “Morphometrics and palaeoecology of the coral Agetolites from the Xiazhen Formation (Upper Ordovician), Zhuzhai, South China". English. In: Alcheringa: An Australasian Journal of Palaeontology (2016). DOI: 10.1080/ 03115518.2016.1111071.

[22468] X. Sun and R. S. Nicoll. Cambro-Ordovician conodont biostratigraphy and thermal maturation of the eastern Warburton Basin, South Australia. English. PESA Eastern Australasian Basins Symposium II. Adelaide: Petroleum Exploration Society of Australia, 2004, pp. 725-734.

[22469] X. L. Sun and Y. C. Hong. "Midtriassic species of Mesopanorpodidae (Insecta, Mecoptera) from Shaanxi, China". English. In: Acta Zootaxonomica Sinica 36.1 (2011), pp. 26-28.

[22470] Z. Sun, W. Hao, Y. Sun, and D. Jiang. "Silicified Anisian (Middle Triassic) spiriferinid brachiopods from Guizhou, South China". English. In: Acta Palaeontologica Polonica 54 (2009), pp. 61-68.

[22471] Z. Sun, M. W. Maisch, W. -C. Hao, and D. Jiang. "A Middle Triassic thalattosaur (Reptilia: Diapsida) from Yunnan (China)". English. In: Neues Jahrbuch fur Geologie und Palaontologie Monatshefte 4 (2005), pp. 193-206.

[22472] Z. Sun, A. Tintori, D. Jiang, C. Lombardo, M. Rusconi, W. Hao, and Y. Sun. "A New Perleidiform (Actinopterygii, Osteichthyes) from the Middle Anisian (Middle Triassic) of Yunnan, South China". English. In: Acta Geologica Sinica 83.3 (2009), pp. 460-470.

[22473] Z. Y. Sun, C. Lombardo, A. Tintori, D. Y. Jiang, W. C. Hao, Y. L. Sun, and H. Q. Lin. “Fuyuanperleidus dengi Geng et al., 2012 (Osteichthyes, Actinopterygii) from the Middle Triassic of Yunnan Province, south China". English. In: Rivista Italiana di Paleontologia e Stratigrafia 118 (2012), pp. 359373.

[22474] Z. Y. Sun, C. Lombardo, A. Tintori, and D. Y. Jiang. "A new species of Altisolepis (Peltopleuriformes, Actinopterygii) from the Middle Triassic of southern China". English. In: Journal of Vertebrate Paleontology 35 (2015), e909819.

[22475] Z. Y. Sun and P. G. Ni. “Revision of Kyphosichthys grandei Xu \& Wu, 2012 from the Middle Triassic of Yunnan Province, South China: implications for phylogenetic interrelationships of ginglymodian fishes". English. In: Journal of Systematic Palaeontology 16 (2017), pp. 67-85.

[22476] Z. Y. Sun, A. Tintori, C. Lombardo, D. Y. Jiang, W. C. Hao, Y. L. Sun, F. X. Wu, and M. Rusconi. "A New Species of the Genus Colobodus Agassiz, 1844 (Osteichthyes, Actinopterygii) From the Pelsonian (Anisian, Middle Triassic) of Guizhou, South China". English. In: Rivista Italiana di Paleontologia e Stratigrafia 144.3 (2008), pp. 363-376.

[22477] Z. Y. Sun, A. Tintori, D. Y. Jiang, and R. Motani. “A new perleidid from the Spathian (Olenekian, Early Triassic) of Chaohu, Anhui Province, China". English. In: Rivista Italiana di Paleontologia e Stratigrafia 119 (2013), pp. 275-285.

[22478] Z. Y. Sun, A. Tintori, C. Lombardo, and D. Y. Jiang. “New miniature neopterygians from the Middle Triassic of Yunnan Province, South China". English. In: Neues Jahrbuch für Geologie und Paläontologie, Abhandlungen 282 (2016), pp. 135-156.

[22479] Z. Y. Sun, A. Tintori, Y. Z. Xu, C. Lombardo, P. G. Ni, and D. Y. Jiang. “A new non-parasemionotiform order of the Halecomorphi (Neopterygii, Actinopterygii) from the Middle Triassic of Tethys". English. In: Journal of Systematic Palaeontology 15 (2016), pp. 223-240.

[22480] Z.-Y. Sun, W.-C. Hao, M. W. Maisch, H. -U. Pfretzschner, and D. -Y. Jiang. “A lariosaur (Reptilia: Sauropterygia) from the Middle Triassic (Ladinian) Gejiu Formation of Yunnan, China". English. In: Neues Jahrbuch fur Geologie und Palaontologie Monatshefte 7 (2005), pp. 431-448. 
[22481] F. A. Sundberg. "Redescription of Alokistocare subcoronatum (Hall and Whitfield, 1877), the type species of Alokistocare, and the status of Alokistocaridae Resser, 1939B (Ptychopariida: Trilobita, Middle Cambrian)". English. In: Journal of Paleontology 73.6 (1999), pp. 1126-1143.

[22482] F. A. Sundberg. "Corynexochida and Ptychopariida (Trilobita, Arthropoda) of the Ehmaniella biozone (Middle Cambrian), Utah and Nevada". English. In: Contributions in Science 446 (1994), pp. 1137.

[22483] F. A. Sundberg, R. Kurkewicz, and D. L. Rooks. "Wujiajiania Sutherlandi fauna (Elvinia biozone, Paibian Stage, Furongian Series- Upper Cambrian) from the Emigrant Formation, Nevada". English. In: Journal of Paleontology 81.4 (2007), pp. 794-796.

[22484] F. A. Sundberg and L. B. McCollum. "Ptychoparid trilobites of the Lower-Middle Cambrian boundary interval, Pioche Shale, southeastern Nevada". In: Journal of Paleontology 74.4 (2000), pp. 604630.

[22485] F. A. Sundberg and L. B. McCollum. “Oryctocephalids (Corynexochida: Trilobita) of the LowerMiddle Cambrian boundary interval from California and Nevada". English. In: Journal of Paleontology 77.6 (1997), pp. 1065-1090.

[22486] F. A. Sundberg and L. B. McCollum. "Trilobites of the lower Middle Cambrian Poliella denticulata biozone (new) of southeastern Nevada". In: Journal of Paleontology 77.2 (2003), pp. 331-359.

[22487] F. A. Sundberg and L. B. McCollum. "Early and Mid Cambrian Trilobites from the Outer-shelf Deposits of Nevada and California, USA". English. In: Palaeontology 46.5 (2003), pp. 945-986.

[22488] F. A. Sundberg, Y. L. Zhao, J. L. Yuan, and J. Lin. “Detailed trilobite biostratigraphy across the proposed GSSP for stage 5 (Middle Cambrian boundary) at the Wuliu-Zengjiayan section, Guizhou, China". English. In: Bulletin of Geosciences 86.3 (2011), pp. 423-464.

[22489] D. Sunderlin. "The flora, fauna, and sediments of the Mount Dall Conglomerate (Farewell Terrane, Alaska, USA)". English. In: Geological Society of America Special Paper 442 (2008), pp. 133-150.

[22490] M. Suñer, B. Poza, B. Vila, and A. Santos-Cubedos. "Sntesis del registro fósil de dinosaurios en el Este de la Pennsula Ibérica [Synthesis of the fossil record of dinosaurs in the eastern Iberian Peninsula]". Spanish. In: Palaeontologica Nova 8 (2008), pp. 397-420.

[22491] M. Suñer, C.d. Santisteban, and A. Galobart. "Nuevos restos de Theropoda del Jurásico superiorCretácico inferior de la comarca de Los Serranos (Valencia) [New remains of Theropoda from the Upper Jurassic-Lower Cretaceous of the Los Serranos region (Valencia)]". Spanish. In: Revista Española de Paleontologa 10 (2005), pp. 93-99.

[22492] K. Suraprasit, Y. Chaimanee, H. Bocherens, O. Chavasseau, and J. -J. Jaeger. "Systematics and phylogeny of middle Miocene Cervidae (Mammalia) from Mae Moh Basin (Thailand) and a paleoenvironmental estimate using enamel isotopy of sympatric herbivore species". English. In: Journal of Vertebrate Paleontology 34.1 (2014), pp. 179-194.

[22493] K. Suraprasit, J.-J. Jaegar, Y. Chaimanee, O. Chavasseau, C. Yamee, P. Tian, and S. Panha. “The Middle Pleistocene vertebrate fauna from Khok Sung (Nakhon Ratchasima, Thailand): biochronological and paleobiogeographical implications". English. In: ZooKeys 613 (2016), pp. 1-157. DOI: 10.3897 /zookeys.613.8309.

[22494] M. V. Surkov, M. J. Benton, R. J. Twitchett, V. P. Tverdokhlebov, and A. J. Newell. “First occurrence of footprints of large therapsids from the Upper Permian of European Russia". English. In: Palaeontology 50.3 (2007), pp. 641-652.

[22495] F. Surlyk, J. Milán, and N. Noe-Nygaard. "Dinosaur tracks and possible lungfish aestivation burrows in a shallow coastal lake; lowermost Cretaceous, Bornholm, Denmark". English. In: Palaeogeography, Palaeoclimatology, Palaeoecology 267 (2008), pp. 292-304. DOI: 10.1016/j.palaeo.2008.07. 004.

[22496] D. Surmik. "Hemilopas mentzeli, an enigmatic marine reptile from the Middle Triassic of Poland revisited". English. In: Neues Jahrbuch für Geologie und Paläontologie-Abhandlungen 282.2 (2016), pp. 209-223. DOI: 10.1127/njgpa/2016/0614. 
[22497] D. Surmik, B. M. Rothschild, M. Dulski, and K. Janiszewska. “Two types of bone necrosis in the Middle Triassic Pistosaurus longaevus bones: the results of integrated studies". English. In: Royal Society Open Science 4.7 (2017), p. 170204. DOI: 10.1098/rsos.170204.

[22498] D. R. Sussman. "The erethizontid fossil from the Uqua formation of Argentina should not be referred to the genus Erethizon". English. In: Journal of South American Earth Sciences 31 (2011), pp. 475-478. DOI: 10.1016/j.jsames.2011.02.016.

[22499] O. E. Sutcliffe, D. A. T. Harper, A. A. Salem, R. J. Whittington, and J. Craig. “The development of an atypical Hirnantia-brachiopod Fauna and the onset of glaciation in the late Ordovician of Gondwana". English. In: Earth and Environmental Science Transactions of the Royal Society of Edinburgh 92.1 (2001), pp. 1-14. DOI: 10.1017/S0263593300000018.

[22500] S. Suteethorn, J. Le Loeuff, E. Buffetaut, V. Suteethorn, C. Talubmook, and C. Chonglakmani. A new skeleton of Phuwiangosaurus sirindhornae (Dinosauria, Sauropoda) from NE Thailand. English. Vol. 315. Late Palaeozoic and Mesozoic Ecosystems in SE Asia. The Geological Society of London, Special Publication. 2009, pp. 189-215.

[22501] S. Suteethorn, J. L. Loeuff, E. Buffetaut, V. Suteethorn, and K. Wongko. "First evidence of a mamenchisaurid dinosaur from the Late Jurassic/Early Cretaceous Phu Kradung Formation of Thailand". English. In: Acta Palaeontologica Polonica 58.3 (2013), pp. 459-469.

[22502] P. K. Sutherland. "Ardmosteges orchamus new genus, new species, in the Early Pennsylvanian of Oklahoma - possible ancestor to the richthofenoid brachiopods". English. In: The Paleontological Society Memoir 46 (1996), pp. 1-25.

[22503] T. J. Suttner. "Conodont Stratigraphy, Facies-Related Distribution Patterns and Stable Isotopes (Carbon and Oxygen)of the Uppermost Silurian to Lower Devonian Seewarte Section(Carnic Alps, Carinthia, Austria)". English. In: Abhandlungen der Geologischen Bundesanstalt 59 (2007), pp. 1-111.

[22504] T. J. Suttner. “Lower Devonian conodonts of the Baron von Kottwitz Quarry (Southern Burgenland, Austria)". English. In: Palaeontographica Americana 62 (2009).

[22505] T. J. Suttner and A. Ernst. "Upper Ordovician bryozoans of the Pin Formation (Spiti Valley, Northern India)". English. In: Palaeontology 50.6 (2007), pp. 1485-1518.

[22506] T. J. Suttner, E. Kido, and A. W. W. Suttner. "Icriodus marieae, a new icriodontid conodont species from the Middle Devonian". English. In: Palaeontologische Zeitschrift 91 (2017), pp. 137-144.

[22507] J. F. Sutton and W. W. Korth. "Rodents (Mammalia) from the Barstovian (Miocene) Anceney local fauna, Montana". English. In: Annals of Carnegie Museum 64.4 (1995), pp. 267-314.

[22508] M. D. Sutton, M. G. Bassett, and L. Cherns. "The type species of Lingulella (Cambrian Brachiopoda)". English. In: Journal of Paleontology 74.3 (2000), pp. 426-438.

[22509] M. D. Sutton, D. E. G. Briggs, and D. J. Siveter. “An exceptionally preserved vermiform mollusc from the Silurian of England". English. In: Nature 410 (2001), p. 461.

[22510] M. D. Sutton, D. E. G. Briggs, and D. J. Siveter. "A three-dimensionally preserved fossil polychaete worm from the Silurian of Herefordshire, England". English. In: Proceedings of the Royal Society of London B 268 (2001), pp. 2355-2363.

[22511] M. D. Sutton, D. E. G. Briggs, D. J. Siveter, and P. J. Orr. "A new arthropod from the Silurian Konservat-Lagerstätte of Herefordshire, UK". English. In: Proceedings of the Royal Society of London B 267 (2000), pp. 1497-1504.

[22512] M. D. Sutton, D. E. G. Briggs, D. J. Siveter, and D. J. Gladwell. "A starfish with three-dimensionally preserved soft parts from the Silurian of England". English. In: Proceedings of the Royal Society, B 272 (2005), pp. 1001-1006.

[22513] G. Suwa, B. Aswfaw, Y. Beyene, T. White, S. Katoh, S. Nagaoka, H. Nakaya, K. Uzawa, P. Renne, and G. WoldeGabriel. The first skull of Australopithecus boisei. 1997.

[22514] G. Suwa, R. T. Kono, S. Katoh, B. Asfaw, and Y. Beyene. "A new species of great ape from the late Miocene epoch in Ethiopia". English. In: Nature 448 (2007), pp. 921-924. DOI: 10.1038/nature06113. 
[22515] G. Suwa, H. Nakaya, B. Asfaw, H. Saegusa, A. Amzaye, R. T. Kono, Y. Beyene, and S. Katoh. "Plio-Pleistocene terrestrial mammal assemblage from Konso, Southern Ethiopia". In: Journal of Vertebrate Paleontology 23.4 (2003), pp. 901-916.

[22516] G. Suwa, T. D. White, and F. Clark Howell. Mandibular postcanine dentition from the Shungura Formation, Ethiopia: Crown morphology, taxonomic allocations and Plio-Pleistocene Hominid Evolution. 1996.

[22517] A. Suzuki. "An Eocene cold-water molluscan assemblage from thr Poronai Formation in the Mikasa area, central Hokkaido, northern Japan". English. In: Earth Science (Chikyu Kagaku) 54 (2000), pp. 363-368.

[22518] H. Suzuki. “Drei neue Radiolarienarten in der Canoptum-Vergesellschaftung aus dem Unterjura des Kanoashi-Komplexes [Three new radiolarian species in the Canoptum assemblage from the Lower Jurassic of the Kanoashi complex, Southwest Japan]". German. In: Neues Jahrbuch für Geologie und Paläontologie Monatshefte 6 (1997), pp. 361-369.

[22519] H. Suzuki, P. Prinz-Grimm, and R. Schmidt-Effing. "Radiolarien aus dem Grenzbereich Hettangium/Sinemurium von Nordperu [Radiolarians from the Hettangian/Sinemurian boundary of northern Peru]". German. In: Palaeontologische Zeitschrift 76.2 (2002), pp. 163-187.

[22520] K. Suzuki and T. Yamamoto. "Histological observation of Paleoparadoxia incisor from the Noto Peninsula, Japan". English. In: International Journal of Oral-Medical Science 9.2 (2010), pp. 154-158.

[22521] N. Suzuki, S. Kojima, H. Kano, S. Yamakita, A. Misaki, M. Ehiro, S. Otoh, T. Kurihara, and M. Aoyama. "Permian radiolarian faunas from chert in the Khabarovsk complex, Far East Russia, and the age of each lithologic unit of the Khabarovsk Complex". English. In: Journal of Paleontology 79.4 (2005), pp. 687-701.

[22522] N. Suzuki and K. B. Ogane. "Paleoceanographic affinities of radiolarian faunas in late Aalenian time (Middle Jurassic) recorded in the Jurassic accretionary complex of Japan". English. In: Journal of Asian Earth Sciences 23 (2004), pp. 343-357.

[22523] S. Suzuki and P. Narmandakh. "Change of the Cretaceous turtle faunas in Mongolia". English. In: Hayashibara Museum of Natural Sciences Research Bulletin 2 (2004), pp. 7-14.

[22524] S. Suzuki and C. Tsogtbaatar. "A catalog of Mongolochelys collected by the HMNS-MPC Joint Paleontological Expedition". English. In: Hayashibara Museum of Natural Sciences Research Bulletin 3 (2010), pp. 119-131.

[22525] S. Suzuki, M. Watabe, and K. Tsogtbaatar. "Report of the HMNS-MPC Joint Paleontological Expedition in 2004". English. In: Hayashibara Museum of Natural Sciences Research Bulletin 3 (2010), pp. 1-9.

[22526] Y. Suzuki. "Revision of the late Ordovician trilobite Holotrachelus punctillosus (Törnquist, 1884) from Dalarna, Sweden". English. In: Acta Palaeontologica Polonica 46.3 (2001), pp. 331-348.

[22527] K. Svana, G. Iliopoulos, and C. Fassoulas. "New sirenian findings from Crete Island". English. In: Bulletin of the Geological Society of Greece 43.2 (2010), pp. 746-753.

[22528] N. K. Swami, S. C. Tripathi, R. Laishram, and A. Dharwadkar. "First record of extinct Paraconularia (Cnidaria, Scyphozoa) from Tethyan sequence (Upper Permian) of Spiti valley, Himachal Himalaya, India". English. In: Palaeontologia Electronica 20.3.42A (2017), pp. 1-6.

[22529] B. A. Swanson, V. L. Santucci, S. K. Madsen, A. S. Elder, and J. P. Kenworthy. "Arches National Park paleontological survey". English. In: Geological Resources Division Technical Report NPS/NRGRD/GRDTR05/01 (2005), pp. 1-36.

[22530] B. A. Swartz. "Devonian actinopterygian phylogeny and evolution based on a redescription of Stegotrachelus finlayi". English. In: Zoological Journal of the Linnean Society 156.4 (2009), pp. 750784. DOI: $10.1111 /$ j.1096-3642.2009.00505.x.

[22531] H. J. Swatland. "Colored Clays in a Groundwater Stream, Correlating Fiber-optic". English. In: Hydrology Current Research 8.3 (2017). DOI: 10.4172/2157-7587.1000283.

[22532] W. C. Sweet. "Conodonts and Biostratigraphy of Upper Ordivician Strata Along a Shelf to Basin Transect in Central Nevada". In: Journal of Paleontology 74.6 (2000), pp. 1148-1160. 
[22533] S. C. Sweetman. "A goibiconodontid (Mammalia, Autriconodonta) from the Early Cretaceous (Barremian) Wessex Formation of the Isle of Wight, southern Britain". English. In: Palaeontology 49.4 (2006), pp. 889-897.

[22534] S. C. Sweetman. "A new species of the plagiaulacoid multituberculate mammal Eobaatar from the Early Cretaceous of southern Britain". English. In: Acta Palaeontologica Polonica 54.3 (2009), pp. 373-384.

[22535] S. C. Sweetman. "A spalacolestine spalacotheriid (Mammalia, Trechnotheria) from the Early Cretaceous (Barremian) of southern England and its bearing on spalacotheriid evolution". English. In: Palaeontology 51.6 (2008), pp. 1367-1385.

[22536] S. C. Sweetman and J. D. Gardner. "A new albanerpetontid amphibian from the Early Cretaceous (Barremian) Wessex Formation of the Isle of Wight, southern England". English. In: Acta Palaeontologica Polonica 58.2 (2013), pp. 269-284. DOI: 10.4202/app.2011.0109.

[22537] S. C. Sweetman and D. M. Martill. "Pterosaurs of the Wessex Formation (Earl Cretaceous, Barremian) of the Isle of Wight, southern England: a review with new data". English. In: Journal of Iberian Geology 36.2 (2010), pp. 225-242.

[22538] S. C. Sweetman, U. Pedreira-Segade, and S. U. Vidovic. "A new bernissartiid crocodyliform from the Lower Cretaceous Wessex Formation (Wealden Group, Barremian) of the Isle of Wight, southern England". English. In: Acta Palaeontologica Polonica 60.2 (2015), pp. 257-268.

[22539] S. C. Sweetman, G. Smith, and D. M. Martill. "Highly derived eutherian mammals from the earliest Cretaceous of southern Britain". English. In: Acata Paleontologica Polonica 62.4 (2017), pp. 657665. DOI: 10.4202 /app.00408.2017.

[22540] S. C. Sweetman and C. J. Underwood. "A Neoselachian shark from the non-marine Wessex Formation (Wealden group: Early Cretaceous, Barremian) of the Isle of Wight, Southern England". English. In: Palaeontology 49.2 (2006), pp. 457-465.

[22541] K. Swen, R. Fraaije, and G. J. Zwaan. "Polymorphy and extinction of the Late Cretaceous burrowing shrimp Protocallianassa faujasi and first record of the genera Corallianassa and Calliax (Crustacea, Decapoda, Thalassinoidea) from the Cretaceous". English. In: Contributions to Zoology 70.2 (2001), pp. 85-98.

[22542] C. S. Swezey and F. T. Dulong. "Some Notes on the Geology of Cave Mountain Cave". English. In: The West Virginia Caver 28.2 (2010), pp. 5-10.

[22543] E. Swierczewska-Gladysz. "Hexactinellid sponges from the Santonian deposits of the Krakow area (southern Poland)". English. In: Annales Societatis Geologorum Poloniae 80 (2010), pp. 253-284.

[22544] E. Swierczewska-Gladysz and A. Jurkowska. "Occurences and paleoecological significance of lyssacinosid sponges in the Upper Cretaceous deposits of southern Poland". English. In: Facies 59 (2013), pp. 763-777.

[22545] N. H. M. Swinburne and J. P. Masse. Early Cretaceous rudist fauna of Allison and Resolution Guyots, Mid-Pacific Mountains. English. Vol. 143. in E. L. Winterer, W. W. Sager, J. V. Firth and J. M. Sinton, eds., Proceedings of the Ocean Drilling Program, Scientific Results. 1995, pp. 3-14.

[22546] R. E. Swisher, S. R. Westrop, and L. Amati. "The Upper Ordovician trilobite Raymondites Sinclair, 1944 in North America". English. In: Journal of Paleontology 89.1 (2015), pp. 110-134. DOI: 10.1017/ jpa.2014.10.

[22547] M. Sykora, L. Ozvoldova, and D. Boorova. “Turonian silicified sediments in the Czorsztyn succession of the Pieniny Klippen Belt (Western Carpathians, Slovakia)". English. In: Geologica Carpathica 48.4 (1997), pp. 243-261.

[22548] M. Sykora, M. Siblik, and J. Sotak. "An Upper Triassic limestone pebble with Spirigera deslongchampsi Suess from the southern part of the western Carpathians, southern Slovakia". English. In: Geologica Carpathica 49.2 (1998), pp. 99-108.

[22549] I. Sylvestrou and D. S. Kostopoulos. "Pseudomeriones megistos nov. sp. (Gerbillinae, Mammalia) from the Latest Miocene of Northern Greece and its phylogenetic relationships". English. In: Geobios 40 (2007), pp. 833-848. DOI: 10.1016/j.geobios.2006.04.007. 
[22550] I. A. Sylvestrou. "[Stratigraphic, Palaeontological and Palaeogeographical study of the NeogeneQuaternary deposits of Katerini basin, Northern Greece]". other. PhD thesis. 2002, pp. 1-370.

[22551] N. Symeonidis, I. Giaourtsakis, R. Seemann, and V. Giannopoulos. "Aivaliki, a New Locality with Fossil Rhinoceroses near Alistrati (Serres, Greece)". English. In: Beiträge zur Paläontologie 30 (2006), pp. 437-451.

[22552] N. K. Symeonidis, E. Kazár, and S. J. Roussiakis. "Shark-toothed dolphin remains (Mammalia, Cetacea, Squalodontidae) from the early Miocene of Greece". English. In: Annalen des Naturhistorischen Museums in Wien 105.A (2004), pp. 307-331.

[22553] N. K. Symeonidis, G. E. Theodorou, and B. Gianopoulos. "[The new species Elephas chaniensis from the submerged Pleistocene deposits of Vamos Cave at Chania, Crete]". other. In: Bulletin of the Speleological Society of Greece 22.2 (2000), pp. 95-108.

[22554] M. F. Symonds and J.-M. Pacaud. "New species of Neritidae (Neritimorpha) from the Ypresian and Bartonian of the Paris and Basse-Loire Basins, France". English. In: Zootaxa 2606 (2010), pp. 55-68.

[22555] G. E. Syrides, K. K. Koliadimou, and G. D. Koufos. "New Neogene molluscan and mammalian sites from Thrace, Greece". English. In: Comptes rendus de l'Académie des sciences. Série 2. Sciences de la terre et des planétes 324.5 (1997), pp. 427-433.

[22556] E. Syromyatnikova, G. L. Georgalis, S. Mayda, T. Kaya, and G. Sarac. "A new early Miocene herpetofauna from Kilcak, Turkey". English. In: Russian Journal of Herpetology 26.4 (2019), pp. 205224.

[22557] E. V. Syromyatnikova. “Turtles of the genus Ferganemys Nessov et Khosatzky, 1977 (Adocidae): shell morphology and phylogenetic position". English. In: Proceedings of the Zoological Institute RAS 315.1 (2011), pp. 38-52.

[22558] E. V. Syromyatnikova. "Palaeobatrachid frog from the late Miocene of Northern Caucasus, Russia". English. In: Palaeontologia Electronica 21.2 (2018), 30A:1-16.

[22559] E. V. Syromyatnikova and I. G. Danilov. "New material and a revision of turtles of the genus Adocus (Adocidae) from the Late Cretaceous of middle Asia and Kazakhstan". English. In: Proceedings of the Zoological Institute RAS 313.1 (2009), pp. 74-94.

[22560] E. V. Syromyatnikova and I. G. Danilov. "New material and phylogenetic position of Adocus bostobensis, a poorly known adocid turtle from the Late Cretaceous of Kazakhstan". English. In: Proceedings of the Zoological Institute RAS 317.2 (2013), pp. 195-201.

[22561] E. V. Syromyatnikova, T. V. Krakhmalnaya, V. M. Chkhikvadze, and I. G. Danilov. “Turtles Protestudo bessarabica from the Late Miocene of Ukraine". Russian. In: Paleontological Magazine 6 (2019), pp. 91-104.

[22562] J. Szabo. “A nomenclatorial revision of Pleurotomaria suessii Hörnes, 1853 and Cyclostomaria Szabó, 1980 (Pleurotomarioidea, Gastropoda)". English. In: Neues Jahrbuch für Geologie und Paläontologie - Abhandlungen 250.2 (2008), pp. 167-176. DOI: 10.1127/0077-7749/2008/0250-0167.

[22563] M. Szabo, G. Botfalvai, L. Kocsis, G. Carnevale, O. Sztano, Z. Evanics, and M. Rabi. “Upper Oligocene marine fishes from nearshore deposits of the Central Paratethys (Máriahalom, Hungary)". English. In: Palaeobiodiversity and Palaeoenvironments (2017). DOI: 10.1007 / s12549- 017 0285-0.

[22564] R. Szadziewski. "Biting midges (Insecta: Diptera: Ceratopogonidae) from Sakhalin amber". English. In: Prace Muzeum Ziemi 41 (1990), pp. 77-82.

[22565] R. Szadziewski. "Biting midges (Diptera: Ceratopogonidae) from Burmese amber, Myanmar". English. In: Journal of Systematic Palaeontology 2 (2004), pp. 115-121.

[22566] R. Szadziewski. "The oldest fossil Corethrellidae (Diptera) from Lower Cretaceous Lebanese amber". English. In: Acta Zoologica Cracoviensia 38 (1995), pp. 177-181.

[22567] R. Szadziewski. "Biting midges (Diptera: Ceratopogonidae) from the Lower Cretaceous amber of Jordan". English. In: Polskie Pismo Entomologiczne 69 (2000), pp. 251-256. 
[22568] R. Szadziewski. “New mosquitoes from Baltic amber (Diptera: Culicidae)". English. In: Polish Journal of Entomology 67 (1998), pp. 233-244.

[22569] R. Szadziewski. "Biting midges (Diptera, Ceratopogonidae) from Miocene Saxonian amber". English. In: Acta Zoologica Cracoviensis 35 (1993), pp. 603-656.

[22570] R. Szadziewski. "The first fossil species in the predaceous midge tribe Sphaeromiini (Diptera: Ceratopogonidae)". English. In: Polskie Pismo Entomologiczne 74 (2005), pp. 363-368.

[22571] R. Szadziewski. "Biting midges from Lower Cretaceous amber of Lebanon and Upper Cretaceous Siberian amber of Taimyr (Dipera, Ceratopogonidae)". English. In: Studia Dipterologica 3 (1996), pp. 23-86.

[22572] R. Szadziewski. "A new species of the predaceous midge genus Metahelea from Baltic amber (Diptera: Ceratopogonidae)". English. In: Polskie Pismo Entomologiczne 67 (1998), pp. 245-253.

[22573] R. Szadziewski. "Biting midges (Diptera: Ceratopogonidae) as indicators of biostratigraphy, ecological reconstructions and identification of amber deposits". English. In: Earth and Environmental Science Transactions of the Royal Society of Edinburgh 107 (2018), pp. 219-230.

[22574] R. Szadziewski and A. Arillo. "The oldest fossil record of the extant subgenus Leptoconops (Leptoconops) (Diptera: Ceratopogonidae)". English. In: Acta Zoologica Cracoviensia 46.Suppl (2003), pp. 271-275.

[22575] R. Szadziewski and A. Arillo. "Biting midges (Diptera : Ceratopogonidae) from the lower Cretaceous Amber from Alava, Spain". English. In: Polskie Pismo Entomologiczne 67 (1998), pp. 291298.

[22576] R. Szadziewski, A. Arillo, A. Urbanek, and E. Sontag. "Biting midges of the extinct genus Protoculicoides Boesel from Lower Cretaceous amber of San Just, Spain and new synonymy in recently described fossil genera (Diptera: Ceratopogonidae)". English. In: Cretaceous Research 58 (2016), pp. 1-9.

[22577] R. Szadziewski, P. Dominiak, E. Sontag, W. Krzemiski, B. Wang, and J. Szwedo. “Haematophagous biting midges of the extant genus Culicoides Latreille (Diptera: Ceratopogonidae) evolved during the mid-Cretaceous". English. In: Zootaxa 4688 (2019), pp. 535-548.

[22578] R. Szadziewski, W. Gika, and E. Sontag. "First descriptions of males from Eocene Baltic Amber in the fossil genus Mantohelea (Diptera: Ceratopogonidae)". English. In: Alavesia 1 (2007), pp. 37-40.

[22579] R. Szadziewski and W. Gika. "A new fossil mosquito, with notes on the morphology and taxonomy of other species reported from Eocene Baltic amber (Diptera: Culicidae)". English. In: Polish Journal of Entomology 80 (2011), pp. 765-777.

[22580] R. Szadziewski and W. Gika. “Gedanoborus kerneggeri, gen. et sp. nov. (Diptera: Chaoboridae) from Eocene Baltic amber". English. In: Insect Systematics \& Evolution 38 (2007), pp. 193-200.

[22581] R. Szadziewski, W. Gika, and A. Urbanek. "A blood sucking biting midge from Upper Cretaceous Burmese amber with a key to the determination of fossil species in the relictual genus Leptoconops Skuse (Diptera: Ceratopogonidae)". English. In: Cretaceous Research 54 (2015), pp. 255-259.

[22582] R. Szadziewski and W. L. Grogan. "Biting midges (Diptera: Ceratopogonidae) from Mexican amber". English. In: Polskie Pismo Entomologiczne 65 (1996), pp. 291-295.

[22583] R. Szadziewski and W. L. Grogan. "Biting midges from Dominican amber. III. Species of the tribes Culicoidini and Ceratopogonini (Diptera: Ceratopogonidae)". English. In: Insecta Mundi 12 (1998), pp. 39-52.

[22584] R. Szadziewski and W. L. Grogan. "Biting midges from Dominican amber. I. A new fossil species of Baeodasymyia (Diptera: Ceratopogonidae)". English. In: Proceedings of the Entomological Society of Washington 96 (1994), pp. 219-229.

[22585] R. Szadziewski and W. L. Grogan. "Biting midges from Dominican amber. II. Species of the tribes Heteromyiini and Palpomyiini (Diptera: Ceratopogonidae)". English. In: Memoirs of the Entomological Society of Washington 18 (1997), pp. 254-260. 
[22586] R. Szadziewski and W. L. Grogan. “Biting midges from Dominican amber. IV. Species of the tribes Dasyheleini and Forcipomyiini (Diptera: Ceratopogonidae)". English. In: Polskie Pismo Entomologiczne 67 (1998), pp. 255-290.

[22587] R. Szadziewski, V. E. Krynicki, and W. Krzemiski. "The latest record of the extinct subfamily Eoptychopterinae (Diptera: Ptychopteridae) from Upper Cretaceous amber of North Carolina". English. In: Cretaceous Research 82 (2017), pp. 147-151.

[22588] R. Szadziewski, W. Krzemiski, and M. Kutscher. “A new species of Corethrella (Diptera, Corethrellidae) from Miocene Saxonian amber". English. In: Acta Zoologica Cracoviensia 37 (1994), pp. 8790.

[22589] R. Szadziewski and G. O. Poinar. "Additional biting midges (Diptera: Ceratopogonidae) from Burmese amber". English. In: Polskie Pismo Entomologiczne 74 (2005), pp. 349-362.

[22590] R. Szadziewski, A. J. Ross, and W. Gika. "Further records of biting midges (Diptera: Ceratopogonidae) from Upper Cretaceous Burmese amber (Myanmar)". English. In: Cretaceous Research 52 (2015), pp. 556-561.

[22591] R. Szadziewski and T. Schlüter. "Biting midges (Diptera: Ceratopogonidae) from Upper Cretaceous (Cenomanian) amber of France". English. In: Annales de la Société Entomologique de France 28 (1992), pp. 73-81.

[22592] R. Szadziewski and E. Sontag. "A new species of Forcipomyia from Paleocene Sakhalin amber (Diptera: Ceratopogonidae)". English. In: Polish Journal of Entomology 82 (2013), pp. 59-62.

[22593] R. Szadziewski, E. Sontag, and P. Dominiak. "A new chironomid with a long proboscis from Eocene Baltic amber (Diptera: Chironomidae: Tanypodinae)". English. In: Annales Zoologici 68 (2018), pp. 601-608.

[22594] R. Szadziewski and E. Sontag. "First male of Corethrella andersoni Poinar \& Szadziewski, 2007 (Diptera: Corethrellidae) from mid-Cretaceous Burmese amber". English. In: Palaeoentomology 1 (2018), pp. 47-50.

[22595] R. Szadziewski, E. Sontag, and B. Bojarski. “First record of the relict Australian genus Meunierohelea in Miocene Dominican amber (Diptera: Ceratopogonidae)". English. In: Annales Zoologici 70 (2020), pp. 285-288. DOI: 10.3161/00034541ANZ2020.70.2.008.

[22596] R. Szadziewski, J. Szwedo, E. Sontag, and B. Wang. "The oldest species of the relic extant genus Mesochria from Eocene Fushun amber of China (Diptera: Anisopodidae: Mycetobiinae)". English. In: Palaeontologia Electronica 19.1.12A (2016), pp. 1-11.

[22597] K. Szawaryn. "Unexpected diversity of whitefly predators in Eocene Baltic amber - new fossil Serangium species (Coleoptera: Coccinellidae)". English. In: Zootaxa 4571 (2019), pp. 270-276.

[22598] K. Szawaryn and J. Kupryjanowicz. "The first fossil Discolomatidae (Coleoptera) from Hispaniola". English. In: PalZ 93 (2019), pp. 593-598. DOI: 10.1007/s12542-019-00467-w.

[22599] K. Szawaryn and J. Szwedo. "Have ladybird beetles and whitefies coexisted for at least 40 Mya?" English. In: PalZ 92 (2018), pp. 593-603.

[22600] K. Szawaryn and W. Tomaszewska. "New and known extinct species of Rhyzobius Stephens, 1829 shed light on the phylogeny and biogeography of the genus and the tribe Coccidulini (Coleoptera: Coccinellidae)". English. In: Journal of Systematic Palaeontology 18 (2020), pp. 1445-1461. DOI: 10. 1080/14772019.2020.1769751.

[22601] K. Szawaryn and W. Tomaszewska. "The first fossil Sticholotidini ladybird beetle (Coleoptera, Coccinellidae) reveals a transition zone through northern Europe during the Eocene". English. In: Papers in Palaeontology 6 (2020), pp. 651-659. DOI: 10.1002/spp2.1321.

[22602] T. Szczygielski and T. Sulej. "Revision of the Triassic European turtles Proterochersis and Murrhardtia (Reptilia, Testudinata, Proterochersidae), with the description of new taxa from Poland and Germany". English. In: Zoological Journal of the Linnean Society 177 (2016), pp. 395-427. DOI: 10.1111 /zoj.12374. 
[22603] T. Szczygielski, D. Tyborowski, and B. Baejowski. "A new pancryptodiran turtle from the Late Jurassic of Poland and palaeobiology of early marine turtles". English. In: Geological Journal (2017).

[22604] I. Szente. "Bivalves from a middle Jurassic submarine high (Bajocian, Som Hill, Bakony Mts, Hungary)". English. In: Hantkeniana 1 (1995), pp. 59-66.

[22605] I. Szente. Bivalvia from the Bathonian (Middle Jurassic) of the Mecsek Mts, Hungary. English. Vol. 30. Annales Univ. Budapest. Sectio Geologica. 1995, pp. 93-109.

[22606] I. Szente. "Bivalve assemblages from the Middle Triassic Muschelkalk of the Mecsek Mts, South Hungary: An overview". English. In: Acta Geologica Hungarica 40.4 (1997), pp. 411-424.

[22607] I. Szente. "Bivalve ecology in the Pliensbachian (Lower Jurassic) of the Bakony". English. In: Fragmenta Mineralogica et Palaeontologica 18 (1996), pp. 19-29.

[22608] I. Szente, H. Lobitzer, and F. Schlagintweit. "A short note on the occurrence of the Upper Triassic oyster Umbrostrea? montiscaprilis (Klipstein, 1843) (Mollusca: Bivalvia) in the northern Alpine Raibl beds of the Schafberg, Salzburg, Austria". English. In: Abhandlungen der Geologischen Bundesanstalt 65 (2010), pp. 27-33.

[22609] I. Szente and A. Vörös. The Pelsonian Bivalvia Fauna of the Balaton Highland. Vol. 55. The Pelsonian Substage on the Balaton Highland (Middle Triassic, Hungary) Geologica Hungarica, series Palaeontologica. 2003, pp. 123-137.

[22610] Z. Szentesi and J. Company. "Late Maastrichtian small-sized herpetofauna from Valencia province, eastern Spain". English. In: Historical Biology 29.1 (2017), pp. 43-52.

[22611] Z. Szentesi and M. Venczel. "An advanced anuran from the Late Cretaceous (Santonian) of Hungary". English. In: Neues Jahrbuch für Geologie und Paläontologie - Abhandlungen 256.3 (2010), pp. 291302.

[22612] Z. Szentesi and M. Venczel. "A new discoglossid frog from the Upper Cretaceous (Santonian) of Hungary". English. In: Cretaceous Research 34 (2012), pp. 327-333.

[22613] G. Sziráki and C. Gröhn. "Presence of two extant genera of dusty lacewings (Neuroptera: Coniopterygidae) in Baltic amber, with remarks on some earlier described fossil taxa". English. In: Folia Historico-Naturalia Musei Matraensis 39 (2015), pp. 63-71.

[22614] M. Szostakiwskyj, J. D. Pardo, and J. S. Anderson. "Micro-CT study of Rhynchonkos stovalli (Lepospondyli, Recumbirostra), with description of two new genera". English. In: PLoS ONE 10 (2015), e0127307. DOI: 10.1371/journal.pone.0127307.

[22615] D. Szcs, C. M. González-León, and J. Pálfy. "Ammonoid biostratigraphy and paleobiogeography of Lower Jurassic". English. In: Journal of South American Earth Sciences 93 (2019), pp. 267-282.

[22616] J. Szulc. "Middle Triassic evolution of the northern peri-Tethys area as influenced by early opening of the Tethys Ocean". In: Annales Societatis Geologorum Poloniae 70 (2000), pp. 1-48.

[22617] C. A. Szumik. "Oligembia vetusta, a new fossil teratembiid (Embioptera) from Dominican amber". English. In: Journal of the New York Entomological Society 102.1 (1994), pp. 67-73.

[22618] C. A. Szumik. "Una nueva especie de Anisembiidae (Insecta, Embioptera) en ámbar dominicano". Spanish. In: Revista Brasileira de Entomologia 42 (1998), pp. 7-8.

[22619] J. Szwedo. "Glisachaemus jonasdamzeni gen. et sp. nov. of Cixiidae from the Eocene Baltic amber (Hemiptera: Fulgoromorpha)". English. In: Alavesia 1 (2007), pp. 109-116.

[22620] J. Szwedo. "First discovery of Neazoniidae (Insecta, Hemiptera, Fulgoromorpha) in the Early Cretaceous amber of Archingeay, SW France". English. In: Geodiversitas 31 (2009), pp. 105-116.

[22621] J. Szwedo. "A new tribe of Dictyopharidae planthoppers from Eocene Baltic amber (Hemiptera: Fulgoromorpha: Fulgoroidea), with a brief review of the fossil record of the family". English. In: Palaeodiversity 1 (2008), pp. 75-85.

[22622] J. Szwedo. "First fossil record of Cedusini in the Eocene Baltic amber with notes on the tribe (Hemiptera: Fulgoromorpha: Derbidae)". English. In: Russian Entomological Journal 15 (2006), pp. 327333. 
[22623] J. Szwedo. "A new genus Waghilde gen. nov. representing a new tribe of the planthopper family Achilidae from the Eocene Baltic amber (Hemiptera: Fulgoromorpha)". English. In: Annales Zoologici 56 (2006), pp. 167-174.

[22624] J. Szwedo. "Nymphs of a new family Neazoniidae fam. n. (Hemiptera: Fulgoromorpha: Fulgoroidea) from the Lower Cretaceous Lebanese amber". English. In: African Invertebrates 48.1 (2007), pp. 127-143.

[22625] J. Szwedo. "The first fossil Bothriocerinae from Eocene Baltic amber with notes on recent taxa (Hemiptera, Fulgoromorpha, Cixiidae)". English. In: Deutsche Entomologische Zeitschrift 49.2 (2002), pp. 197-207.

[22626] J. Szwedo. "The Coleorrhyncha (Insecta: Hemiptera) of the European Jurassic, with a description of a new genus from the Toarcian of Luxembourg". English. In: Volumina Jurassica 9 (2011), pp. 320.

[22627] J. Szwedo. "Notes on Otiocerini with a second record of Derbidae in Eocene Baltic amber (Hemiptera: Fulgoromorpha: Derbidae)". English. In: Insect Systematics \& Evolution 36 (2005), pp. 161-172.

[22628] J. Szwedo. "First fossil Tropiduchidae with a description of a new tribe Jantaritambiini from Eocene Baltic amber (Hemiptera: Fulgoromorpha)". English. In: Annales de la Société Entomologique de France 36 (2000), pp. 279-286.

[22629] J. Szwedo. "Jantarivacanthus kotejai gen. et sp. n. from Eocene Baltic amber, with notes on the Bathysmatophorini and related taxa (Hemiptera: Cicadomorpha: Cicadellidae)". English. In: Polskie Pismo Entomologiczne 74 (2005), pp. 251-276.

[22630] J. Szwedo. “Oliarus kulicka sp. n. from Dominican amber (Hemiptera: Fulgoroidea: Cixiidae)". English. In: Polskie Pismo Entomologiczne 69 (2000), pp. 161-166.

[22631] J. Szwedo. "A new Derbidae planthopper Copallinges chiapasensis gen. et sp. n. (Hemiptera Fulgoromorpha) from Oligocene/Miocene Mexican amber". English. In: Polskie Pismo Entomologiczne 73 (2004), pp. 291-298.

[22632] J. Szwedo. "Autrimpus sambiorum gen. and sp. nov. from Eocene Baltic amber and notes on Mnemosynini stat. nov. (Hemiptera: Fulgoroidea: Cixiidae)". English. In: Annales Zoologici 54 (2004), pp. 567-578.

[22633] J. Szwedo. “Ordralfabetix sirophatanis gen. et sp. n. - the first Lophopidae from the lowermost Eocene Oise amber, Paris Basin, France (Hemiptera: Fulgoromorpha)". English. In: Zootaxa 2822 (2011), pp. 52-60.

[22634] J. Szwedo and J. Ansorge. "The first Mimarachnidae (Hemiptera: Fulgoromorpha) from Lower Cretaceous lithographic limestones of the Sierra del Montsec in Spain". English. In: Cretaceous Research 52 (2015), pp. 390-401.

[22635] J. Szwedo, D. Azar, and K. Ziadé. “The first Progonocimicidae (Insecta: Hemiptera: Coleorrhyncha) from Lower Cretaceous Lebanese amber". English. In: Insect Systematics \& Evolution 42 (2011), pp. 161-177.

[22636] J. Szwedo, D. Azar, and Y. Nohra. "First record of Perforissidae from the Early Cretaceous Lebanese amber (Hemiptera: Fulgoromorpha: Fulgoroidea)". English. In: Insect Evolution in an Amberiferous and Stone Alphabet. Leiden: Brill, 2013, pp. 145-163.

[22637] J. Szwedo, T. Bourgoin, and F. Lefebvre. “New Mnemosynini taxa (Hemiptera, Fulgoromorpha: Cixiidae) from the Palaeogene of France with notes on their early association with host plants". English. In: Zootaxa 1122 (2006), pp. 25-45.

[22638] J. Szwedo and J. Drohojowska. "A swarm of whiteflies - the first record of gregarious behavior from Eocene Baltic amber". English. In: The Science of Nature 103.35 (2016), pp. 1-6.

[22639] J. Szwedo, J. Drohojowska, Y. A. Popov, E. Simon, and P. Wegierek. "Aphids, true hoppers, jumping plant-lice, scale insects, true bugs and whiteflies (Insecta: Hemiptera) from the Insect Limestone (latest Eocene) of the Isle of Wight, UK". English. In: Earth and Environmental Science Transactions of the Royal Society of Edinburgh 110 (2019), pp. 331-396. DOI: 10.1017/S175569101900001X. 
[22640] J. Szwedo, C. Gebicki, and M. Kowalewska. “Microelectrona cladara gen. et. sp. nov.: A new Protodikraneurini from the Eocene Baltic Amber (Hemiptera: Cicadomorpha: Cicadellidae: Typhlocybinae)". English. In: Acta Geologica Sinica 84.4 (2010), pp. 696-704.

[22641] J. Szwedo and C. Gebicki. "Protodikraneura ferraria sp. nov. from the Eocene Baltic amber (Hemiptera: Cicadellidae: Protodikraneurini)". English. In: Alavesia 2 (2008), pp. 177-181.

[22642] J. Szwedo and C. Gebicki. "Ambericarda skalskii gen. et sp. n. from Baltic amber (Homoptera: Cicadellidae)". English. In: Polski Pismo Entomologiczne 67 (1998), pp. 179-184.

[22643] J. Szwedo, J. Lapeyrie, and A. Nel. "Rooting down the aphid's tree - the oldest record of the Aphidomorpha lineage from Palaeozoic (Insecta: Hemiptera)". English. In: Systematic Entomology 40 (2015), pp. 207-213.

[22644] J. Szwedo and A. Nel. "The oldest aphid insect from the Middle Triassic of the Vosges, France". English. In: Acta Palaeontologica Polonica 56 (2011), pp. 757-766.

[22645] J. Szwedo and A. J. Ross. “Cedusa baylissae sp. nov. from Oligocene/Miocene Mexican amber (Hemiptera: Fulgoromorpha: Derbidae)". English. In: Annals of the Upper Silesian Museum, Entomology 12 (2003), pp. 37-46.

[22646] J. Szwedo, A. Stroiski, and Q. B. Lin. “Discovery of a Flatidae planthopper (Hemiptera: Fulgoromorpha) in the Paleocene of northern Tibet and its taxonomic and biogeographic significance". English. In: Geodiversitas 35 (2012), pp. 767-776.

[22647] J. Szwedo and A. Stroiski. "First fossil Pentastirini from Eocene Baltic amber (Hemiptera: Fulgoromorpha: Cixiidae)". English. In: Annales Zoologici 2002 (2002), pp. 173-179.

[22648] J. Szwedo and A. Stroinski. "Austrini - a new tribe of Tropiduchidae planthoppers from the Eocene Baltic amber (Hemiptera: Fulgoromorpha)". English. In: Annales de la Société Entomologique de France 46 (2010), pp. 132-137.

[22649] J. Szwedo and A. Stroinski. “Tainosia quisqueyae gen. and sp. nov. from the Oligocene/Miocene Dominican amber (Hemiptera: Fulgoroidea: Nogodinidae)". English. In: Genus 12 (2001), pp. 2934.

[22650] J. Szwedo and A. Stroinski. "An extraordinary tribe of Tropiduchidae from the Eocene Baltic amber (Hemiptera: Fulgoromorpha: Fulgoroidea)". English. In: Zootaxa 3647 (2013), pp. 371-381.

[22651] J. Szwedo and A. Stroinski. "Ptychogroehnia reducta gen. and sp. nov. of the fossil tribe Ptychoptilini from the Eocene Baltic amber (Hemiptera: Fulgoridea: Achilidae)". English. In: Annales Zoologici 51 (2001), pp. 95-101.

[22652] J. Szwedo, A. Stroinski, and Q. B. Lin. "Tip of the clade on the top of the World-the first fossil Lophopidae (Hemiptera: Fulgoromorpha) from the Palaeocene of Tibet". English. In: The Science of Nature 102 (2015), p. 28. DOI: 10.1007/s00114-015-1277-4.

[22653] J. Szwedo and A. Stroinski. "Who's that girl? A singular Tropiduchidae planthopper from the Eocene Baltic amber (Hemiptera: Fulgoromorpha)". English. In: Palaeontologia Electronica 20.3.60A (2017), pp. 1-20.

[22654] J. Szwedo and T. Wappler. "New planthoppers (Insecta: Hemiptera: Fulgoromorpha) from the middle Eocene Messel maar". English. In: Annales Zoologici 56 (2006), pp. 555-566.

[22655] J. Szwedo, R. Weis, and A. Nel. "A bizarre sternorrhynchan wing from the Lower Jurassic of Luxembourg (Hemiptera: Sternorrhyncha: Pincombeomorpha?)" English. In: Historical Biology 31 (2017), pp. 806-812.

[22656] J. Szwedo and D. ya. “New Fulgoridiidae genus from Upper Jurassic Karatau deposits, Kazakhstan (Hemiptera: Fulgoromorpha: Fulgoroidea)". English. In: Zootaxa 2281 (2009), pp. 40-52.

[22657] Z. Szyndlar. "Vertebrates from the Early Miocene lignite deposits of the opencast mine Oberdorf (Western Styrian Basin, Austria). 3. Reptilia 2: Serpentes". English. In: Annalen des Naturhistorischen Museums in Wien, Serie A: Mineralogie, Petrologie, Geologie, Paläontologie, Archäozoologie, Anthropologie, Prähistorie 99A (1998), pp. 31-38. 
[22658] Z. Szyndlar. "Oligocene snakes of southern Germany." In: Journal of Vertebrate Paleontology 14.1 (1994), pp. 24-37.

[22659] Z. Szyndlar. “The snakes (Reptilia, Serpentes) of the Miocene of Portugal”. English. In: Ciencias da Terra 14 (2000), pp. 359-364.

[22660] Z. Szyndlar. "The Vertebrate Locality Maramena (Macedonia, Greece) at the Turolian-Ruscinian Boundary (Neogene). 4. Serpentes (Squamata, Reptilia)". English. In: Münchner Geowissenschaftliche Abhandlungen (A) 28 (1995), pp. 39-42.

[22661] Z. Szyndlar. "Snake fauna (Reptilia: Serpentes) from the Early/Middle Miocene of Sandelzhausen and Rothenstein 13 (Germany)". English. In: Paläontologische Zeitschrift 83.1 (2009), pp. 55-66. DOI: 10.1007/s12542-009-0009-5.

[22662] Z. Szyndlar. "A review of the fossil Snakes (Reptilia: Serpentes) described by Herman von Meyer". English. In: Neues Jahrbuch für Geologie und Paläontologie, Abhandlungen 203.2 (1997), pp. 211-219.

[22663] Z. Szyndlar. “A Review of Neogene and Quaternary Snakes of Central and Eastern Europe. Part II: Natricinae, Elapidae, Viperidae". English. In: Estudios Geológicos 47.3-4 (1991), pp. 237-266. DOI: 10.3989/egeol.91473-4422.

[22664] Z. Szyndlar. "Early Oligocene to Pliocene Colubridae of Europe: a review". English. In: Bulletin de la Société Géologique de France 183.6 (2012), pp. 661-681. DOI: 10.2113/gssgfbull.183.6.661.

[22665] Z. Szyndlar. "A review of Neogene and Quaternary snakes of Central and Eastern Europe. Part I: Scolecophidia, Boidae, Colubrinae". English. In: Estudios Geológicos 47 (1991), pp. 103-126.

[22666] Z. Szyndlar and W. Böhme. “Die fossilen Schlangen Deutschlands: Geschichte der Faunen und ihrer Erforschung [The fossil Snakes of Germany: History of the Faunas and their Investigation]". German. In: Mertensiella 3 (1993), pp. 381-431.

[22667] Z. Szyndlar and I. Hösgör. "Boine snake Bavarioboa from the Oligocene/Miocene of eastern Turkey with comments on connections between European and Asiatic snake faunas". English. In: Acta Palaeontologica Polonica 57.3 (2012), pp. 667-671. DOI: 10.4202/app.2011.0075.

[22668] Z. Szyndlar and J.-C. Rage. "Non-erycine Booidea from the Oligocene and Miocene of Europe". English. In: (2003), pp. 1-109.

[22669] Z. Szyndlar and H. H. Schleich. "Two species of the genus Eryx (Serpentes: Boidae; Erycinae) from the Spanish Neogene with comments on the past distribution of the genus in Europe". English. In: Amphibia-Reptilia 15.1994 (1994), pp. 233-248. DOI: 10.1163/156853894X00010.

[22670] Z. Szyndlar and H. H. Schleich. "Description of Miocene snake from Petersbuch 2 with comments on the lower and middle Miocene ophidian faunas of southern Germany." In: Stuttgarter Beitrage zur Naturkunde, Series B. Geologie und Palaontologie 192 (1993), pp. 1-47.

[22671] Z. Szyndlar, R. Smith, and J. -C. Rage. “A new dwarf boa (Serpentes, Booidea, 'Tropidophiidae') from the Early Oligocene of Belgium: a case of the isolation of Western European snake faunas". English. In: Zoological Journal of the Linnean Society 152.2 (2008), pp. 393-406.

[22672] Z. Szyndlar and G. A. Zerova. "Neogene cobras of the genus Naja (Serpentes: Elapidae) of East Europe". In: Annalen des Naturhistorischen Museums in Wien 91A (1990), pp. 53-61.

[22673] A. M. Sørensen, E. Håkansson, and L. Stemmerik. "Upper Permian bryozoans of central East Greenland". English. In: Bulletin of the Geological Society of Denmark 56 (2008), pp. 39-51.

[22674] A. M. Sørensen, F. Surlyk, and J. Lindgren. "Food resources and habitat selection of a diverse vertebrate fauna from the upper lower Campanian of the Kristianstad Basin, southern Sweden". English. In: Cretaceous Research 42.1 (2013), pp. 85-92. DOI: 10.1016/j.cretres.2013.02.002.

[22675] M. C. Taberner and D. W. J. Bosence. "An Eocene biodetrital mud-mound from the southern Pyrenean foreland basin, Spain: an ancient analogue for Florida Bay mounds?" English. In: Special Publication International Association of Sedimentologists 23 (1995), pp. 423-437.

[22676] A. C. Taboada. "Dos nuevas especies de Linoproductidae (Brachiopoda) y algunas consideraciones sobre el Neopaleozoico sedimentario de las cercanas de Uspallata, Argentina". Spanish. In: Acta Geologica Lilloana 18.1 (1998), pp. 69-80. 
[22677] A. C. Taboada, A. J. Mory, G. R. Shi, D. W. Haig, and M. K. Pinilla. “An Early Permian brachiopodgastropod fauna from the Calytrix Formation, Barbwire Terrace, Canning Basin, Western Australia". English. In: Alcheringa 39 (2015), pp. 207-223.

[22678] A. C. Taboada, J. P. Neves, L. C. Weinschütz, M. A. Pagani, and M. G. Simões. “Eurydesma-Lyonia fauna (Early Permian) from the Itararé group, Paraná Basin (Brazil): A paleobiogeographic W-E trans-Gondwanan marine connection". English. In: Palaeogeography, Palaeoclimatology, Palaeoecology 449 (2016), pp. 431-44.

[22679] A. C. Taboada and M. A. Pagani. "The coupled occurrence of Cimmeriella-Jakutoproductus (Brachiopoda: Productidina) in Patagonia: implications for Early Permian high to middle paleolatitudinal correlations and paleoclimatic reconstruction". English. In: Geologica Acta 8.4 (2010), pp. 513534.

[22680] A. C. Taboada and G. R. Shi. "Yagonia Roberts (Brachiopoda: Chonetidina) from the Malimán Formation, Lower Carboniferous of western Argentina: palaeobiogeographical implications". English. In: Alcheringa 33 (2009), pp. 223-235.

[22681] A. R. Tabrum and G. Métais. "Pipestoneia douglassi, A New Genus and Species of Selenodont Artiodactyl from the Pipestone Springs Area, Jefferson County, Montana". English. In: Bulletin of Carnegie Museum of Natural History 39 (2007), pp. 83-96. DOI: 10.2992 / 0145-9058(2007)39[83: PDANGA]2.0.CO;2.

[22682] R. Tabuce, S. Adnet, H. Cappetta, A. M. Noubhani, and F. Quillevere. “Aznag (bassin d'Ouarzazate, Maroc), nouvelle localite a selaciens et mammiferes de l'Eocene moyen (Lutetien) d'Afrique". English. In: Bulletin de la societe Geologique du France 2005.176 (2005), pp. 381-400.

[22683] R. Tabuce, M. T. Antunes, R. Smith, and T. Smith. “Dental and tarsal morphology of the European Paleocene/Eocene condylarth mammal Microhyus". English. In: Acta Palaeontologica Polonica 51.1 (2006), pp. 37-52.

[22684] R. Tabuce, M. T. Antunes, and B. Sige. "A new primitive bat from the earliest Eocene of Europe". English. In: Journal of Vertebrate Paleontology 29.2 (2009), pp. 627-630.

[22685] R. Tabuce, J. Clavel, and M. T. Antunes. "A structural intermediate between triisodontids and mesonychians (Mammalia, Acreodi) from the earliest Eocene of Portugal". English. In: Naturwissenschaften 98 (2011), pp. 145-155.

[22686] R. Tabuce, B. Coiffait, P. -E. Coiffait, M. Mahboubi, and J. -J. Jaeger. “A new genus of Macroscelidea (Mammalia) from the Eocene of Algeria: a possible origin for elephant-shrews". English. In: Journal of Vertebrate Paleontology 21.3 (2001), pp. 535-546.

[22687] R. Tabuce, B. Coiffait, M. Mahboubi, and J. -J. Jaeger. "A new species of Bunohyrax (Hyracoidea, Mammalia) from the Eocene of Bir El Ater (Algeria)". French. In: Comptes Rendus de l'Académie des Sciences, Paris, Sciences de la Terre et des Planétes 331 (2000), pp. 61-66.

[22688] R. Tabuce, J.-J. Jaeger, L. Marivaux, M. Salem, A. A. Bilal, M. Benammi, Y. Chaimanee, P. Coster, B. Marandat, X. Valentin, and M. Brunet. "New stem elephant-shrews (Mammalia, Macroscelidea) from the Eocene of Dur At-Talah, Libya". English. In: Palaeontology 55.5 (2012), pp. 945-955. DOI: 10.1111/j.1475-4983.2012.01163.x.

[22689] R. Tabuce, L. Marivaux, M. Adaci, M. Bensalah, J. Hartenberger, M. Mahboubi, F. Mehbrouk, P. Tafforeau, and J. Jaeger. "Early Tertiary mammals from North Africa reinforce the molecular Afrotheria clade". English. In: Proceedings: Biological Sciences 274.1614 (2007), pp. 1159-1166. DOI: 10.1098/rspb.2006.0229.

[22690] R. Tabuce, R. Sarr, S. Adnet, R. Lebrun, F. Lihoreau, J. E. Martin, B. Sambou, M. Thiam, and L. Hautier. "Filling a gap in the proboscidean fossil record: a new genus from the Lutetian of Senegal". English. In: Journal of Paleontology 94.3 (2020), pp. 580-588. DOI: 10.1017/jpa.2019.98.

[22691] R. Tabuce, T. Tortosa, M. Vianey-Liaud, G. Garcia, R. Lebrun, P. Godefroit, and Y. Dutour. "New eutherian mammals from the Late Cretaceous of Aix-en-Provence Basin, south-eastern France". English. In: Zoological Journal of the Linnean Society 169 (2013), pp. 653-672. 
[22692] R. Tabuce, M. Vianey-Liaud, and G. Garcia. "A eutherian mammal in the latest Cretaceous of Vitrolles, southern France". In: Acta Palaeontologica Polonica 49.3 (2004), pp. 347-356.

[22693] L. S. Tackett and D. J. Bottjer. "Paleoecological succession of Norian (Late Triassic) benthic fauna in eastern Panthalassa (Luning and Gabbs Formations, west-central Nevada)". English. In: Palaios 31.4 (2016), pp. 190-202. DOI: 10.2110/palo.2015.070.

[22694] E. Taddei Ruggiero. "Argyrotheca ageriana sp. nov. (Brachiopoda): paleoecology and shell ultrastructure". English. In: Palaeogeography, Palaeoclimatology, Palaeoecology 100 (1993), pp. 217-227.

[22695] E. Taddei Ruggiero and P. Raia. "Bioerosion structures and their distribution on shells of the Lower Pleistocene terebratulid brachiopod Gryphus minor". English. In: Palaeogeography, Palaeoclimatology, Palaeoecology 293 (2010), pp. 157-166.

[22696] E. Taddei Ruggiero and R. Taddei. "I brachiopodi delle Calcareniti di Castro Marina (Lecce)". English. In: Thalassia Salentina 29 suppl. (2006), pp. 301-307.

[22697] P. G. Taghon, E. Bonino, and B. Mottequin. "A new representative of the lichid genus Ohleum (Trilobita) from the Eifelian (Middle Devonian) of southern Belgium". English. In: Geologica Belgica 15.3 (2012), pp. 120-125.

[22698] M. Taglioretti, Á Miño-Boilini, F. Scaglia, and A. Dondas. "Presencia de Proscelidodon patrius (Xenarthra, Scelidotheriinae) en la Formación Chapadmalal (Plioceno Superior), mar del Plata, Buenos Aires, Argentina: Implicancias Bioestratigráficas". English. In: Ameghiniana 51.5 (2014), pp. $420-427$.

[22699] A. Tajika, K. Tschanz, and C. Klug. "New Albian ammonite faunas from Semelenberg (Alpstein, Switzerland) and their paleoecology". English. In: Swiss Journal of Palaeontology 137 (2018), pp. 6576.

[22700] A. Takahashi and Y. Iba. "Early Albian Mytiloides (Inoceramidae, Bivalvia) from the Northwest Pacific: A Pioneering Species for Late Cretaceous Inoceramid Diversification". English. In: Paleontological Research 13.2 (2009), pp. 199-205. DOI: 10.2517/1342-8144-13.2.199.

[22701] A. Takahashi, T. Ikeda, M. Manabe, and Y. Hasegawa. "Freshwater and terrestrial turtle fossils discovered from the Minatogawa man site, southern part of Okinawajima Island, Ryukyu Archipelago, southwestern Japan". Japanese. In: Bulletin of the Gunma Museum of Natural History 22 (2018), pp. 51-58.

[22702] A. Takahashi, T. Kato, and H. Ota. "A new species of the genus Geoemyda (Chelonii: Geoemydidae) from the upper Pleistocene of Tokunoshima Island, the Central Ryukyus, Japan". English. In: Current Herpetology 26.1 (2007), pp. 1-11.

[22703] A. Takahashi, A. Kusaka, and N. Kamezaki. "Skeletal Remains of Mauremys reevesii (Testudines: Geoemydidae) from a Late Medieval Archeological Site in Fukuyama City, Hiroshima Prefecture, Western Japan". English. In: Current Herpetology 38.2 (2019), pp. 160-168.

[22704] A. Takahashi, H. Otsuka, and R. Hirayama. "A new species of Manouria (Testudines: Testudinidae) from the Upper Pleistocene of the Ryukyu Islands, Japan". English. In: Paleontological Research 7.3 (2003), pp. 195-217.

[22705] M. Takahashi, P. R. Crane, and H. Ando. “Fossil Megaspores of Marsileales and Selaginellales from the Upper Coniacian to Lower Santonian (Upper Cretaceous) of the Tamagawa Formation (Kuji Group) in Northeastern Japan". In: International Journal of Plant Sciences 162.2 (2001), pp. 431-439.

[22706] M. Takahashi, P. S. Herendeen, and P. R. Crane. "Lauraceous fossil flower from the Kamikitaba locality (Lower Coniacian; Upper Cretaceous) in northeastern Japan". In: Journal of Plant Reasearch 114 (2001), pp. 429-434.

[22707] Y. Takahashi, M. Sutou, and S. Yamamoto. "The compression mating fossil of sciarid fly (Diptera: Sciaridae) from Shiobara, Tochigi Prefecture, Japan". English. In: Paleontological Research 21 (2017), pp. 288-292.

[22708] M. Takai. "New specimens of Neosaimiri fieldsi from La Venta, Colombia: a middle Miocene ancestor of the living squirrel monkeys". English. In: Journal of Human Evolution 27 (1994), pp. 329360. 
[22709] M. Takai and F. Anaya. "New specimens of the oldest fossil Platyrrhine, Branisella boliviana, from Salla, Bolivia". English. In: American Journal of Physical Anthropology 99 (1996), pp. 301-317.

[22710] M. Takai, F. Anaya, H. Suzuki, N. Shigehara, and T. Setoguchi. "A new Platyrrhine from the Middle Miocene of La Venta, Colombia, and the phyletic position of Callicebinae". English. In: Anthropological Science 109.4 (2001), pp. 289-307.

[22711] M. Takai, T. Nishimura, N. Shigehara, and T. Setoguchi. "Meaning of the Canine Sexual Dimorphism in Fossil Owl Monkey, Aotus dindensis from the Middle Miocene of La Venta, Colombia". English. In: Frontiers of oral biology 13 (2009), pp. 55-59.

[22712] M. Takai, C. Sein, T. Tsubamoto, N. Egi, M. Maung, and N. Shigehara. "A new eosimiid from the latest middle Eocene in Pondaung, central Myanmar". English. In: Anthropological Science 113.1 (2005), pp. 17-25.

[22713] M. Takai, T. Setoguchi, C. Villarroel, A. Cadena, and N. Shigehara. "A New Miocene Molossid Bat from La Venta, Colombia, South America". English. In: Memoirs of the Faculty of Science Kyoto University, Series of Geology and Mineralogy 56.1-2 (1991), pp. 1-9.

[22714] M. Takai, N. Shigehara, A. K. Aung, S. T. Tun, A. N. Soe, T. Tsubamoto, and T. Thein. “A new anthropoid from the latest middle Eocene of Pondaung, central Myanmar". English. In: Journal of Human Evolution 40.5 (2001), pp. 393-409.

[22715] A. Takemura, M. Sakai, S. Sakamoto, R. Aono, S. Takemura, and S. Yamakita. "Earliest Triassic Radiolarians from the ARH and ARF sections on Arrow Rocks, Waipapa Terrane, Northland, New Zealand". English. In: GNS Science Monograph 24 (2007), pp. 97-107.

[22716] M. Takeuchi. "Morphologic study of multicyrtid Nassellaria (Radiolaria) from the Lower Jurassic bedded cherts in the Inuyama Area, Mino Terrane, Central Japan". Japanese. In: News of Osaka Micropaleontologists, Special Volume 12 (2001), pp. 181-189.

[22717] E. J. Talamas and M. L. Buffington. "Fossil Platygastroidea in the National Museum of Natural History, Smithsonian Institution". English. In: Journal of Hymenoptera Research 47 (2015), pp. 1-52.

[22718] E. J. Talamas, N. F. Johnson, M. L. Buffington, and D. Ren. “Archaeoteleia Masner in the Cretaceous and a new species of Proteroscelio Brues (Hymenoptera, Platygastroidea)". English. In: Journal of Hymenoptera Research 56 (2016), pp. 241-261.

[22719] E. J. Talamas, N. F. Johnson, C. K. Shih, and D. Ren. "Proterosceliopsidae: A new family of Platygastroidea from Cretaceous amber". English. In: Journal of Hymenoptera Research 73 (2019), pp. 338. DOI: $10.3897 /$ jhr.73.32256.

[22720] C. Tambussi, M. Ubilla, and D. Perea. "The youngest large carnassial bird (Phorusrhacidae, Phorusrhacinae) from South America (Pliocene-Early Pleistocene of Uruguay)". English. In: Journal of Vertebrate Paleontology 19.2 (1999), pp. 404-406. DOI: 10.1080/02724634.1999.10011154.

[22721] C. P. Tambussi. “Nuevo Anatidae (Aves: Anseriformes) del Plioceno de la región pampeana, Argentina". Spanish. In: Bollet de la Societat d'História Natural de les Balears 41 (1998), pp. 19-25.

[22722] C. P. Tambussi, C. I. Acosta Hospitaleche, M. A. Reguero, and S. A. Marenssi. "Late Eocene penguins from West Antarctica: systematics and biostratigraphy". English. In: Geological Society, London Special Publication 258 (2006), pp. 145-161.

[22723] C. P. Tambussi, F. J. Degrange, R. S. Mendoza, E. Sferco, and S. Santillana. “A stem anseriform from the early Palaeocene of Antarctica provides new key evidence in the early evolution of waterfowl". English. In: Zoological Journal of the Linnean Society 186.3 (2019), pp. 673-700. DOI: 10.1093/zoolinnean/zly085/5281199.

[22724] C. P. Tambussi, M. A. Reguero, S. A. Marenssi, and S. N. Santillana. "Crossvallia unienwillia, a new Spheniscidae (Sphenisciformes, Aves) from the Late Paleocene of Antarctica". English. In: Geobios 38.5 (2005), pp. 667-675.

[22725] C. P. Tambussi and J. I. Noriega. "Registro de Presbiornitidos (Aves, Anseriformes) en sedimentitas de la Formacion Vaca Mahuida, La Pampa, Argentina". Spanish. In: Asociacion Paleontologica Argentina Publicacion Especial 5 (1998), pp. 51-54. 
[22726] E. Tamrat, M. Thouveny, M. Taieb, and N. D. Opdyke. “Revised magnetostratigraphy of the PlioPleistocene sedimentary sequency of the Olduvai Formation (Tanzania)". English. In: Palaeogeography, Palaeoclimatology, Palaeoecology 114 (1995), pp. 273-283.

[22727] M. Tamura and C. McRoberts. "A new species of Myophorigonia from the Upper Triassic Martin Bridge Formation, Wallowa Mountains, Oregon, U.S.A. with reference on the Minetrigoniidae of the Circum-Pacific". English. In: Memoirs of the Faculty of Education, Kumamoto University 42.29 (1993), p. 34.

[22728] M. Tamura and E. Nishimura. "Description of Upper Triassic Kyushutrigonia hachibarensis, new genus and new species with revision of trigonian species from Sambosan Terrane, Japan". English. In: Memoirs of the Faculty of Education Kumamoto University, Natural science 43 (1994), pp. 15-23.

[22729] M. Tamura, Y. Okazaki, and N. Ikegami. "[Occurrence of carnosaurian and herbivorous dinosaurs from upper formation of Mifune Group, Japan]". Japanese. In: Kumamoto Daigaku Kyiku Gakubu kiy. Shizen kagaku 40 (1991), pp. 31-45.

[22730] V. Tamutis, V. I. Alekseev, and A. Bukejs. "A new species of Eupariini from Eocene Baltic amber (Coleoptera: Scarabaeidae: Aphodiinae)". English. In: Zootaxa 4353 (2017), pp. 568-576.

[22731] C. Tan, H. Dai, J. -J. He, F. Zhang, X. -F. Hu, H. -D. Yu, N. Li, G. -B. Wei, G. -Z. Peng, Y. Ye, Q. -N. Zhang, X. -X. Ren, and H. -L. You. "Discovery of Omeisaurus (Dinosauria: Sauropoda) in the Middle Jurassic Shaximiao Formation of Yunyang, Chongqing, China". English. In: Vertebrata PalAsiatica 57.2 (2019), pp. 105-116.

[22732] C. Tan, M. Xiao, H. Dai, X. -F. Hu, N. Li, Q. -Y. Ma, Z. -Y. Wei, H. -D. Yu, C. Xiong, G.-Z. Peng, S. Jiang, X. -X. Ren, and H. -L. You. "A new species of Omeisaurus (Dinosauria: Sauropoda) from the Middle Jurassic of Yunyang, Chongqing, China". English. In: Historical Biology (2020). DOI: 10.1080/08912963.2020.1743286.

[22733] J. J. Tan, D. Y. Huang, and D. Ren. "First record of fossil Mesocupes from China (Coleoptera: Archostemata: Cupedidae)". English. In: Acta Geologica Sinica 81 (2007), pp. 688-696.

[22734] J. J. Tan, D. Ren, and C. K. Shih. "New cupedids from the Middle Jurassic of Inner Mongolia, China (Coleoptera: Archostemata)". English. In: Annales Zoologici 56 (2006), pp. 1-6.

[22735] J. J. Tan, D. Ren, C. K. Shih, and X. K. Yang. "New schizophorid fossils from China and possible evolutionary scenarios for Jurassic archostematan beetles". English. In: Journal of Systematic Palaeontology 11 (2013), pp. 47-62.

[22736] J. J. Tan and D. Ren. “Two exceptionally well-preserved catiniids (Coleoptera: Archostemata: Catiniidae) from the late Mesozoic of northeastern China". English. In: Annals of the Entomological Society of America 100 (2007), pp. 666-672.

[22737] J. J. Tan, D. Ren, and C. K. Shih. "New beetles (Insecta: Coleoptera: Archostemata) from the late Mesozoic of north China". English. In: Annales Zoologici 57 (2007), pp. 231-247.

[22738] J. J. Tan, D. Ren, C. K. Shih, and S. Ge. "New fossil beetles of the family Ommatidae (Coleoptera: Archostemata) from the Jehol Biota of China". English. In: Acta Geologica Sinica 80.4 (2006), pp. 474485.

[22739] J. J. Tan, D. Ren, and C. K. Shih. “First record of fossil Priacma (Coleoptera: Archostemata: Cupedidae) from the Jehol Biota of western Liaoning, China". English. In: Zootaxa 1326 (2006), pp. 5568.

[22740] J. J. Tan and D. Ren. "New fossil Priacmini (Insecta: Coleoptera: Archostemata: Cupedidae) from the Jehol Biota of China". English. In: Journal of Natural History 40 (2006), pp. 2653-2661.

[22741] J. J. Tan, D. Ren, and C. K. Shih. "New ommatids of Ommatinae (Coleoptera: Archostemata: Ommatidae) from the Yixian Formation of Liaoning, China". English. In: Progress in Natural Science 17 (2007), pp. 803-811.

[22742] J. J. Tan, D. Ren, and M. Liu. "New ommatids from the Late Jurassic of western Liaoning, China (Coleoptera: Archostemata)". English. In: Insect Science 12 (2005), pp. 207-216. 
[22743] J. J. Tan and D. Ren. “Ovatocupes: a new cupedid genus (Coleoptera: Archostemata: Cupedidae) from the Jehol biota (Late Jurassic) of western Liaoning, China". English. In: Entomological News 117 (2006), pp. 223-232.

[22744] J. J. Tan, Y. J. Wang, D. Ren, and X. K. Yang. "New fossil species of ommatids (Coleoptera: Archostemata) from the middle Mesozoic of China illuminating the phylogeny of Ommatidae". English. In: BMC Evolutionary Biology 12.113 (2012), pp. 1-19.

[22745] K. Tan and F. Jin. "Re-study on Gymnoichthys inopinatus from Middle Triassic of Luoping, Yunnan, China". Chinese. In: Vertebrata PalAsiatica 51 (2013), pp. 1-16.

[22746] Q.-W. Tan, H. Xing, Y. -G. Hu, L. Tan, and X. Xing. “New hadrosauroid material from the Upper Cretaceous Majiacun Formation of Hubei Province, central China". English. In: Vertebrata PalAsiatica 53.3 (2015), pp. 245-264.

[22747] K. Tanabe. "Early Jurrasic Macrofauna of the Oxygen-Depleted Epicontinental Marin Basin in the Toyora Area, West Japan". English. In: Saito Ho-on Kai Special Publication 3 (1991), pp. 147-161.

[22748] K. Tanabe and Y. Hikida. "Jaws of a new species of Nanaimoteuthis (Coleoidea: Vampyromorphida) from the Turonian of Hokkaido, Japan". English. In: Paleontological Research 14 (2010), pp. 145-150. DOI: 10.2517/1342-8144-14.2.145.

[22749] K. Tanabe, Y. Hikida, and Y. Iba. “Two coleoid jaws from the Upper Cretaceous of Hokkaido, Japan". English. In: Journal of Paleontology 80 (2006), pp. 138-145.

[22750] K. Tanabe, N. H. Landman, R. H. Mapes, and C. J. Faulkner. "Analysis of a Carboniferous embryonic ammonoid assemblege-implications for ammonoid embryology". In: Lethaia 26 (1993), pp. 215-224.

[22751] K. Tanabe, P. Trask, R. Ross, and Y. Hikida. "Late Cretaceous octobrachiate coleoid lower jaws from the north Pacific regions". English. In: Journal of Paleontology 82 (2008), pp. 398-408. DOI: 10.1666/07-029.1.

[22752] G. Tanaka, Y. Miyake, T. Ono, A. H. Yuan, M. Ichida, H. Maeda, and S. Crasquin. “Early Permian (Cisuralian) ostracods from Japan: characteristic ostracod assemblage from a seamount of the Panthalassic Ocean". English. In: Zootaxa 4515 (2018), pp. 1-67.

[22753] G. Tanaka, T. Ono, A. H. Yuan, M. Ichida, and H. Maeda. "Early Permian ostracods from Mugi County, Gifu Prefecture, central Japan". English. In: Paleontological Research 16 (2012), pp. 88-106.

[22754] G. Tanaka, T. Ono, T. Nishimura, and H. Maeda. "Middle Permian ostracods from the Akasaka Limestone, Gifu Prefecture, central Japan". English. In: Paleontological Research 16 (2013), pp. 289306.

[22755] H. Tanaka and T. Nagumo. "Fine structures of Stephanodiscus excentricus Hust. and S. niagarae Ehrenb. from Terrebonne diatomite, Oregon, USA". English. In: Diatom 23 (2007), pp. 105-112.

[22756] K. Tanaka, Y. Kobayashi, D. K. Zelenitsky, F. Therrien, Y. -N. Lee, R. Barsbold, K. Kubota, H. J. Lee, T. Chinzorig, and D. Idersaikhan. "Exceptional preservation of a Late Cretaceous dinosaur nesting site from Mongolia reveals colonial nesting behavior in a non-avian theropod". English. In: Geology 47.9 (2019), pp. 843-847. DOI: 10.1130/g46328.1.

[22757] K. Tanaka, J. Lü, Z. Huang, Y. Kobayashi, D. Huang, and D. K. Zelenitsky. “Statistical approach for classification of dinosaur eggs from the Heyuan Basin at the northeast of Guandong province". English. In: Acta Geologica Sinica 86.2 (2012), pp. 294-303.

[22758] K. Tanaka, D. K. Zelenitsky, T. E. Willamson, A. Weil, and F. Therrien. "Fossil eggshells from the Upper Cretaceous (Campanian) Fruitland Formation, New Mexico". English. In: Historical Biology 23.1 (2011), pp. 41-55. DOI: 10.1080/08912963.2010.499171.

[22759] K. Tanaka, D. K. Zelenitsky, H. Saegusa, T. Ikeda, C. L. DeBuhr, and F. Therrien. “Dinosaur eggshell assemblage from Japan reveals unknown diversity of small theropods". English. In: Cretaceous Research 57 (2016), pp. 350-363. DOI: 10.1016/j.cretres.2015.06.002. 
[22760] T. Tanaka, Y. Kobayashi, K. Kurihara, A. R. Fiorillo, and M. Kano. “The oldest Asian hesperornithiform from the Upper Cretaceous of Japan," English. In: Journal of Systematic Palaeontology 16.8 (2018), pp. 689-709.

[22761] T. Tanaka, Y. Kobayashi, K. Ikuno, T. Ikeda, and H. Saegusa. “A marine hesperornithiform (Avialae: Ornithuromorpha) from the Maastrichtian of Japan: Implications for the paleoecological diversity of the earliest diving birds in the end of the Cretaceous". English. In: Cretaceous Research 113 (2020), p. 104492. DOI: 10.1016/j.cretres.2020.104492.

[22762] Y. Tanaka. "A new and ontogenetically younger specimen of Numataphocoena yamashitai from the upper part of the Horokaoshirarika Formation (lower Pliocene), Numata, Hokkaido, Japan". English. In: Paleontological Research 20.2 (2016), pp. 105-115. DOI: 10.2517/2015PR026.

[22763] Y. Tanaka, J. Abella, G. 1 Aguirre-Fernández, M. Gregori, and R. E. Fordyce. "A new tropical Oligocene dolphin from Montañita/Oló, Santa Elena, Ecuador". English. In: PLoS One 12.12 (2017), e0188380. DOI: 10.1371/journal.pone.0188380.

[22764] Y. Tanaka, T. Ando, and H. Sawamura. "A new species of Middle Miocene baleen whale from the Nupinai Group, Hikatagawa Formation of Hokkaido, Japan". English. In: PeerJ 6 (2018), e4934. DOI: $10.7717 /$ peerj. 4934 .

[22765] Y. Tanaka and R. E. Fordyce. “Fossil dolphin Otekaikea marplesi (Latest Oligocene, New Zealand) expands the morphological and taxonomic diversity of Oligocene cetaceans". English. In: PLoS One 9.9 (2014), e107972. DOI: 10.1371/journal.pone.0107972.

[22766] Y. Tanaka and R. E. Fordyce. "Awamokoa tokarahi, a new basal dolphin in the Platanistoidea (late Oligocene, New Zealand)". English. In: Journal of Systematic Palaeontology (2016). DOI: 10.1080 / 14772019.2016.1202339.

[22767] Y. Tanaka and R. E. Fordyce. "Papahu-like fossil dolphin from Kaikoura, New Zealand, helps to fill the Early Miocene gap in the history of Odontoceti". English. In: New Zealand Journal of Geology and Geophysics 15.5 (2017), pp. 365-386. DOI: 10.1080/00288306.2016.1211540.

[22768] Y. Tanaka and R. E. Fordyce. "A new Oligo-Miocene dolphin from New Zealand: Otekaikea huata expands diversity of the early Platanistoidea". English. In: Palaeontologia Electronica 18.2.23A (2015), pp. 1-71.

[22769] Y. Tanaka, H. Furusawa, and L. G. Barnes. "Fossil herpetocetine baleen whales (Cetacea, Mysticeti, Cetotheriidae) from the lower Pliocene Horokaoshirarika Formation at Numata, Hokkaido, northern Japan". English. In: Paleontological Research 22.4 (2018), pp. 295-306. DOI: 10.2517/2017PR025.

[22770] Y. Tanaka, H. Furusawa, and M. Kimura. "A new member of fossil balaenid (Mysticeti, Cetacea) from the early Pliocene of Hokkaido, Japan". English. In: Royal Society Open Science 7 (2020), p. 192182. DOI: $10.1098 /$ rsos.192182.

[22771] Y. Tanaka and N. Kohno. "A New Late Miocene Odobenid (Mammalia: Carnivora) from Hokkaido, Japan Suggests Rapid Diversification of Basal Miocene Odobenids". English. In: PLoS One (2015). DOI: 10.1371/journal.pone.0131856.

[22772] Y. Tanaka, K. Nagasawa, and Y. Taketani. “A new skull of an early diverging rorqual (Balaenopteridae, Mysticeti, Cetacea) from the late Miocene to early Pliocene of Yamagata, northeastern Japan". English. In: Palaeontologia Electronica 23.1 (2020), pp. 1-27.

[22773] Y. Tanaka, M. Ohara, and T. Kimura. “A Large Fossil Baleen Whale from the Shikiya Formation (Early Middle Miocene) of Wakayama, Japan”. English. In: Paleontological Research 23.3 (2019), pp. 199-207. DOI: 10.2517/2018PR020.

[22774] Y. Tanaka and H. Taruna. "A fin whale from the Holocene (Quaternary) of Osaka City, Japan". English. In: Mammal Study 45.2 (2020), pp. 1-12. DOI: 10.3106/ms2019-0044.

[22775] Y. Tanaka and H. Taruno. "The first cetacean record from the Osaka Group (Middle Pleistocene, Quaternary) in Osaka, Japan". English. In: Paleontological Research 23.2 (2019), pp. 166-173. DOI: 10.2517/2018PR016. 
[22776] Y. Tanaka and H. Taruno. "Balaenoptera edeni skull from the Holocene (Quaternary) of Osaka City, Japan". English. In: Palaeontologia Electronica 20.3.50A (2017), pp. 1-13.

[22777] Y. Tanaka and M. Watanabe. "An early and new member of Balaenopteridae from the upper Miocene of Hokkaido, Japan". English. In: Journal of Systematic Palaeontology (2019). DOI: 10.1080 / 14772019.2018.1532968.

[22778] Y. Tanaka, M. Watanabe, and M. Kimura. “Crown beaked whale fossils from”. English. In: Palaeontologia Electronica 22.2.31A (2019), pp. 1-14.

[22779] S. K. Tandon, J. E. Andrews, A. Sood, and S. Mittal. "Skrinkage and sediment supply control on multiple calcrete profile development: a case study from the Maastrichtian of Central India". English. In: Sedimentary Geology 119 (1998), pp. 25-45.

[22780] S. K. Tandon, A. Sood, J. E. Andrews, and P. F. Dennis. "Palaeoenvironments of the dinosaurbearing Lameta Beds (Maastrichtian), Narmada Valley, central India". English. In: Palaeogeography, Palaeoclimatology, Palaeoecology 117 (1995), pp. 153-184.

[22781] C. F. Tang, C. Shi, S. Wang, and D. Yang. "The first report of Dolichopodidae from mid-Cretaceous amber of northern Myanmar". English. In: Cretaceous Research 104.104179 (2019). DOI: 10.1016/j. cretres.2019.07.009.

[22782] C. M. Tang, D. B. Bottjer, and M. J. Simms. "Stalked crinoids from a Jurassic tidal deposit in western North America". English. In: Lethaia 33 (2000), pp. 46-54.

[22783] D. Tang, Y. Z. Yao, and D. Ren. “New fossil flower bugs (Heteroptera: Cimicomorpha: Cimicoidea: Vetanthocoridae) with uniquely long ovipositor from the Yixian Formation (Lower Cretaceous), China". English. In: Cretaceous Research 56 (2015), pp. 504-509.

[22784] D. Tang, Y. Z. Yao, and D. Ren. "A new species of Vetanthocoridae (Heteroptera: Cimicomorpha) from the Lower Cretaceous of China". English. In: Cretaceous Research 64 (2016), pp. 30-35.

[22785] D. Tang, Y. Z. Yao, and D. Ren. "Phylogenetic position of the extinct insect family Vetanthocoridae (Heteroptera) in Cimiciformes". English. In: Journal of Systematic Palaeontology 15 (2016), pp. 697708.

[22786] F. Tang, X.-M. Kang, Z. -S. Jin, F. Wei, and W. -T. Wu. "A new sauropod dinosaur of Cretaceous from Jingshan, Zhejiang province". In: Vertebrata PalAsiatica 39.4 (2001), pp. 272-281.

[22787] F. Tang, C. Yin, P. Liu, L. Gao, and W. Zhang. "A new diverse macrofossil lagerstätte from the uppermost Ediacaran of southwestern China". English. In: Acta Geologica Sinica 82.6 (2008), pp. 10951103.

[22788] L. Tang and X. Chen. "Late Katian Paraorthograptus pacificus Graptolite Biozone from Xing'an, northern Guangxi, China". English. In: G F F 136.1 (2014), pp. 269-261. DOI: 10.1080 / 11035897. 2014.880508.

[22789] M. Tanimoto. "New find of a sauropod fossil from the Lower Cretaceous Matsuo Group of Toba, Mie Prefecture, southwest Japan". English. In: Lower and Middle Cretaceous Terrestrial Ecosystems, New Mexico Museum of Natural History and Science Bulletin 14 (1998), pp. 201-204.

[22790] M. Tanimoto. "Mosasaur remains from the Upper Cretaceous Izumi Group of southwest Japan". English. In: Netherlands Journal of Geosciences — Geologie en Mijnbouw 84.3 (2005), pp. 373-378.

[22791] M. Tanimoto and C. Suzuki. "[Sauropod teeth (cf. Nemegtosaurus sp.) from the Tamayama Formation (Upper Cretaceous, Santonian), Futaba Group of Iwaki City, Fukushima Prefecture, northeast Japan]". Japanese. In: Research Reports IWAKI Natural History (1997), pp. 1-4.

[22792] M. Tanimoto and S. Tanaka. "[Heteroptychodus sp. (Chondrichthyes) from the Lower Cretaceou Matsuo Group of Arashima, Toba City, Mie Prefecture, southwest Japan]". Japanese. In: Chigakukenkyu 47.1 (1998), pp. 37-40.

[22793] D. Tanke and A. Neuman. "Results of 2006 Royal Tyrrell Museum explorations in the Two Lakes and Kakwa Wildland Provincial Park regions, western Alberta". English. In: Alberta Palaeontological Society, Eleventh Annual Symposium (2007), pp. 55-67. 
[22794] D. H. Tanke and P. J. Currie. "A history of Albertosaurus discoveries in Alberta, Canada". English. In: Canadian Journal of Earth Sciences 47.9 (2010), pp. 1197-1211. DOI: 10.1139/E10-057.

[22795] K. B. Tankersley. "Sheriden: a Clovis cave site in eastern North America". English. In: 12.6 (1997), pp. 713-724.

[22796] K. Tanoue and Y. Okazaki. "The first basal neoceratopsian dinosaur from the Lower Cretaceous Kanmon Group in Kyushu, southwestern Japan". English. In: Paleontological Research 18.2 (2014), pp. 77-81. DOI: 10.2517/2014PR008.

[22797] A. A. Tantawy, G. Keller, T. Adatte, W. Stinnesbeck, A. Kassab, and P. Schulte. "Maastrichtian to Paleocene depositional environment of the Dakhla Formation, Western Desert, Egypt: sedimentology, mineralogy, and integrated micro- and macrofossil biostratigraphies". In: Cretaceous Research 22 (2001), pp. 795-827.

[22798] H.-J. Tao. “A New Miocene Fossil Species Priacanthus Liui (Pisces: Perciformes) From the Nanchung Formation in Chiayi Hsien, Taiwan". English. In: Bulletin of National Museum of Natural Science 4 (1993), pp. 91-100.

[22799] L. Tapanila and J. Pruitt. “Unraveling species concepts for the Helicoprion tooth whorl”. English. In: Journal of Paleontology 87 (2013), pp. 965-983.

[22800] L. Tapanila, E. M. Roberts, M. L. Bouaré, F. Sissoko, and M. A. O'Leary. "Bivalve Borings in Phosphatic Coprolites and Bone, Cretaceous-Paleogene, Northeastern Mali". English. In: Palaios 19.6 (2004), pp. 565-573.

[22801] P. M. Tapia and D. M. Harwood. “Upper Cretaceous diatom biostratigraphy of the Arctic archipelago and northern continental margin, Canada". English. In: Micropaleontology 48.4 (2002), pp. 303-342.

[22802] G. Tapia-Ramrez, A. F. Guzmán, and O. J. Polaco. “Los gonfoterios (Proboscidea, Gomphotheriidae) de Colima, México". Spanish. In: Boletn de la Sociedad Geológica Mexicana 65.3 (2013), pp. 591607.

[22803] P. Taquet. “The dinosaurs of Maghreb: the history of their discovery". English. In: Historical Biology 22.1-3 (2010), pp. 88-99. DOI: 10.1080/08912961003625657.

[22804] P. Taquet and D. A. Russell. "A massively-constructed iguanodont from Gadoufaoua, Lower Cretaceous of Niger". English. In: Annales de Paléontologie 85.1 (1999), pp. 85-96.

[22805] P. Taquet and D. A. Russell. "New data on spinosaurid dinosaurs from the Early Cretaceous of the Sahara". English. In: Comptes Rendus de l'Académie des Sciences á Paris, Sciences de la Terre et des Planétes 327 (1998), pp. 347-353.

[22806] K. K. Tarasenko. "New Genera of Baleen Whales (Cetacea, Mammalia) from the Miocene of the Northern Caucasus and Ciscaucasia: 3. Zygiocetus gen. nov. (Middle Sarmatian, Adygea)". English. In: Paleontological Journal 48.5 (2014), pp. 551-562.

[22807] K. K. Tarasenko and A. V. Lopatin. "New Baleen Whale Genera (Cetacea, Mammalia) from the Miocene of the Northern Caucasus and Ciscaucasia: 1. Kurdalagonus gen. nov. from the MiddleLate Sarmatian of Adygea". English. In: Paleontological Journal 46.5 (2012), pp. 531-542.

[22808] K. K. Tarasenko and A. V. Lopatin. “New Baleen Whale Genera (Cetacea, Mammalia) from the Miocene of the Northern Caucasus and Ciscaucasia: 2. Vampalus gen. nov. from the MiddleLate Miocene of Chechnya and Krasnodar Region". English. In: Palaeontological Journal 46.6 (2012), pp. 620-629. DOI: 10.1134/S003103011206010X.

[22809] K. K. Tarasenko, A. V. Lopatin, and D. B. Startsev. "The first finding of the Late Miocene baleen whales of the genus Zygiocetus (Cetotheriidae, Mysticeti) in Crimea (Melek-Chesme locality, Kerch Peninsula)". English. In: Doklady Biological Sciences 491 (2020), pp. 63-66. DOI: 10.1134/S0012496620020118.

[22810] S. Tarasov, F. Z. Vaz-de-Mello, F. T. Krell, and D. Dimitrov. "A review and phylogeny of Scarabaeine dung beetle fossils (Coleoptera: Scarabaeidae: Scarabaeinae), with the description of two Canthochilum species from Dominican amber". English. In: PeerJ 4.e1988 (2016), pp. 1-35. 
[22811] J. Tarquini, L. H. Soibelzon, R. Salas-Gismondi, and C. de Muizon. “Cyonasua (Carnivora, Procyonidae) from late Miocene of Peru shed light on the early dispersal of carnivorans in South America". English. In: Journal of Vertebrate Paleontology (2020), e1834406:1-9. DOI: 10.1080 / 02724634. 2020.1834406.

[22812] H. Taru. "Inference of foraging and mastication from cranial morphology of Paleoparadoxia tabatai". Japanese. In: Bulletin of the Ashoro Museum of Paleontology 1 (2000), pp. 125-135.

[22813] H. Taru and Y. Hasegawa. "The Plio-Pleistocene fossil mammals from the Kasumi and Tama Hills". English. In: Memoirs of the National Science Museum, Tokyo 38 (2002), pp. 43-56.

[22814] M. Tashiro and K. Takatsuka. "Upper Albian bivalves from the Goshonoura Group". English. In: Memoirs of the Faculty of Science, Kochi University, Series E, Geology 12 (1991), pp. 1-10.

[22815] J. N. Tashman, R. M. Feldmann, C. E. Schweitzer, and B. A. Thiel. "Inferences for grooming behavior drawn from epibionts on early to middle Cenozoic crabs of Oregon and Washington state, USA". English. In: Bulletin of the Mizunami Fossil Museum 44 (2018), pp. 9-22.

[22816] P. Tassy. Fossil proboscideans,Mammalia, from the Western Rift,Uganda. Vol. II. In:Geol. and palaeo. of the Albertine rift valley. 1994, pp. 217-257.

[22817] L. P. Tatarinov. "A new cynodont (Reptilia, Theriodontia) from the Madygen Formation (Triassic) of Fergana, Kyrgyzstan". English. In: Paleontological Journal 39 (2005), pp. 192-198.

[22818] M. K. Tate-Jones, C. M. Peredo, S. S. B. Hopkins, and C. D. Marshall. "The dawn of Desmatophocidae: A new species of basal Desmatophocid seal (Mammalia, Carnivora) from the Miocene of Oregon, U.S.A." English. In: Journal of Vertebrate Paleontology (2020), e1789867. DOI: 10.1080/02724634. 2020.1789867.

[22819] F. Tatzreiter. "Noetlingites strombecki (Griepenkerl, 1860) and the stratigraphical position of". German. In: Mitteilungen der Gesellschaft der Geologie und Bergbaustudenten in Österreich 45 (2001), pp. 143-162.

[22820] A. Tauber, J. Krapovickas, L. E. Cruz, and J. Chiesa. “Estratigrafa, paleontologa y paleoambientes del Plioceno de la provincia de Córdoba". Spanish. In: Opera lilloana 52: Mioceno al Pleistoceno del centro y norte de Argentina 389.417 (2019).

[22821] A. A. Tauber. "Mamferos fósiles y edad de la Formación Salicas (Mioceno tardo) de la sierra de Velasco, La Rioja, Argentina". Spanish. In: Ameghiniana 42.2 (2005), pp. 443-460.

[22822] A. A. Tauber. "Las Caleras, provincia de Córdoba, primer yacimiento fosilfero de origen cárstico de Argentina". English. In: Revista Española de Paleontologa 15.2 (2000), pp. 233-245.

[22823] A. A. Tauber. "Bioestratigrafa de la Formación Santa Cruz (Mioceno Inferior) en el extremo sudeste de la Patagonia". Spanish. In: Ameghiniana 34.4 (1997), pp. 517-529.

[22824] A. A. Tauber. "Los vertebrados de la Formacion Santa Cruz (Mioceno inferior-medio) en el extremo sureste de la Patagonia y su significado paleoecológico". Spanish. In: Revista Espagnola de Paleontologia 14.2 (1999), pp. 173-182.

[22825] A. A. Tauber, C. A. Luna, and M. E. Palacios. "El registro de Necrolestes patagonensis Ameghino, 1891 (Mammalia) de la Formación Santa Cruz (Mioceno), Patagonia Austral". Spanish. In: XVI Congreso Geológico Argentino V (2005), pp. 157-164.

[22826] S. A. S. Tavares, F. R. Branco, and R. M. Santucci. "Theropod teeth from the Adamantina Formation (Bauru Group, Upper Cretaceous), Monte Alto, São Paulo, Brazil". English. In: Cretaceous Research 50 (2014), pp. 59-71.

[22827] L. Taverne. "Libanechelys bultyncki gen. et sp. nov., une nouvelle anguille primitive (Teleostei, Anguilliformes) du Cénomanien marin du Liban". French. In: Bulletin de l'Institut Royal des Sciences Naturelles de Belgique, Sciences de la Terre 74 (2004), pp. 73-87.

[22828] L. Taverne. “Ostéologie et relations de Ligulella (Halecostomi, Ligulelliformes nov. ord.), poisson $\mathrm{du}$ Jurassique moyen de Kisangani (Formation de Stanleyville) en République Démocratique du Congo". French. In: Bulletin van het Koninklijk Belgisch Instituut voor Natuurwetenschappen. Aardwetenschappen $=$ Bulletin de l'Institut Royal des Sciences Naturelles de Belgique. Sciences de la Terre 81 (2011), pp. 213-233. 
[22829] L. Taverne and L. Capasso. "Osteology and relationships of Ceneichthys zambellii gen. and sp. nov. (Teleostei, Pholidophoridae) from the Late Triassic of northern Italy". English. In: Bollettino del Museo Civico di Storia Naturale di Verona, Geologia Paleontologia Preistoria 39 (2015), pp. 13-26.

[22830] L. Taverne and L. Capasso. "Comments on the phylogenetic relationships of Pholidorhynchodon malzannii and Eurycormus speciosus (Teleostei, Pholidophoriformes), two Mesozoic tropical fishes". English. In: Geo-Eco-Trop 40 (2016), pp. 305-316.

[22831] L. Taverne and B. Chanet. “Faugichthys loryi n. gen., n. sp. (Teleostei, Ichthyodectiformes) de l'Albien terminal (Cretace inferieur marin) du vallon de la Fauge (Isere, France) et considerations sur la phylogenie des Ichthyodectidae". French. In: Geodiversitas 22.1 (2000), pp. 23-34.

[22832] L. Taverne and E. Steurbaut. "Osteology and relationships of Luxembourgichthys (Pholidophorus) friedeni gen. nov. (Teleostei, Pholidophoriformes) from the Lower Jurassic of Belgium and the Grand Duchy of Luxembourg". English. In: Geologica Belgica 20 (2017), pp. 53-67.

[22833] L. Taverne, S. Van Simaeys, and E. Steurbaut. “Belgocaranx luypaertsi gen. and sp. nov., a new skeleton-based Carangid Fish from the Boom Clay (Rupelian, Early Oligocene) at Kallo (N. Belgium)". English. In: Bulletin de l'Institute Royal des Scineces Naturelles de Belgique, Sciences de la Terre 76 (2006), pp. 119-130.

[22834] M. Taviani, L. Angeletti, and A. Ceregato. "Chemosynthetic bivalves of the family Solemyidae (bivalvia, protobranchia) in the Neogene of the Mediterranean Basin". English. In: Journal of Paleontology 85.6 (2011), pp. 1067-1076.

[22835] M. Taviani, A. Beu, and C. Lombardo. "Pleistocene macrofossils from CRP-1 Drillhole, Victoria Land Basin, Antarctica". In: Terra Antarctica 5.3 (1998), pp. 485-491.

[22836] M. Taviani, M. Lopez Correa, H. Zibrowius, P. Montagna, M. McCulloch, and M. Ligi. “Last glacial deep-water corals from the Red Sea". English. In: Bulletin of Marine Science 81.3 (2007), pp. 361370.

[22837] M. Taviani, P. Montagna, N. M. A. Rasul, L. Angeletti, and W. Bosworth. "Pleistocene Coral Reef Terraces on the Saudi Arabian Side of the Gulf of Aqaba, Red Sea". English. In: Geological Setting, Palaeoenvironment and Archaeology of the Red Sea (2019). DOI: 10.1007/978-3-319-99408-6_16.

[22838] M. Taviani, B. Sabelli, and F. Candini. "A fossil Cenozoic monoplacophoran". English. In: Lethaia 23.2 (1990), pp. 213-216. DOI: 10.1111/j.1502-3931.1990.tb01361.x.

[22839] M. Taviani, A. Vertino, M. Lopez Correa, A. Savini, B. De Mol, A. Remia, P. Montagna, L. Angeletti, H. Zibrowius, T. Alves, M. Salomidi, B. Ritt, and P. Henry. "Pleistocene to recent scleractinian deep-water corals and coral facies in the eastern Mediterranean". English. In: Facies 57 (2011), pp. 579-603.

[22840] V. A. Tavora, D. F. Goncalves, and T. C. C. Araujo. “Ocorrencia de uma nova especie de escleractineo (Coelenterata) na formacao Pirabas (Eomioceno), estado do Para [Occurrence of a new species of Scleractinia (Coelenterata) in the Pirabas Formation (Eomiocene), Para State]". Portugese. In: Revista Brasileira de Geociencias 32.2 (2002), pp. 231-234.

[22841] D. Taylor, J. Guex, and M. Rakus. "Hettangian and Sinemurian ammonoid zonation for the western Cordillera of North America". English. In: Bulletin de la Société Vaudoise des Sciences Naturelles 87.4 (2001), pp. 381-421. DOI: 10.5169/seals-281409.

[22842] D. G. Taylor. "Late Hettangian-early Sinemurian (Jurassic) ammonite biochronology of the western Cordillera, United States". English. In: Geobios 31 (1998), pp. 467-497.

[22843] D. G. Taylor and J. Guex. "The Triassic/Jurassic System boundary in the John Day Inlier, eastcentral Oregon". English. In: Oregon Geology 64 (2002), pp. 3-28.

[22844] D. W. Taylor, G. J. Brenner, and S. H. Basha. "Scutifolium jordanicum gen. et sp. nov. (Cabombaceae), an aquatic fossil plant from the Lower Cretaceous of Jordan, and the relationships of related leaf fossils to living genera". English. In: American Journal of Botany 95.3 (2008), pp. 340352. 
[22845] G. Taylor, E. M. Truswell, K. G. McQueen, and M. C. Brown. “Early Tertiary palaeogeography, landform evolution, and palaeoclimates of the Southern Monaro, N.S.W., Australia". English. In: Palaeogeography, Palaeoclimatology, Palaeoecology 78.1 - 2 (1990), pp. 109-134. DOI: 10.1016 / 00310182(90)90207-N.

[22846] J. F. Taylor and D. J. Kennedy. “Uppermost Cambrian slope deposits at Highgate Gorge, Vermont: a minor miscorrelation with major consequences for conodont - and trilobite - based chronocorrelation". English. In: Journal of Paleontology 65.5 (1991), pp. 855-863.

[22847] J. F. Taylor, J. D. Loch, and P. J. Perfetta. “Trilobite faunas from Upper Cambrian microbial reefs in the Central Appalachians". In: Journal of Paleontology 73.2 (2000), pp. 326-336.

[22848] J. F. Taylor and J. E. Repetski. "High-resolution trilobite and conodont biostratigraphy across the Cambrian-Ordovician boundary in south-central New Mexico". English. In: Ordovician Odyssey: Short Papers for the Seventh International Symposium on the Ordovician System, Las Vegas, Nevada, USA. Fullerton: Pacific Section for Sedimentary Geology, 1995, pp. 133-136.

[22849] L. D. Taylor, A. O'Dea, T. J. Bralower, and S. Finnegan. "Isotopes from fossil coronulid barnacle shells record evidence of migration in multiple Pleistocene whale populations". English. In: Proceedings of the National Academy of Sciences (2019). DOI: 10.1073/pnas.1808759116.

[22850] M. P. Taylor and D. Naish. "An unusual new neosauropod dinosaur from the Lower Cretaceous Hastings Beds Group of East Sussex, England”. English. In: Palaeontology 50.6 (2007), pp. 15471564. DOI: $10.1111 /$ j.1475-4983.2007.00728.x.

[22851] M. P. Taylor, M. J. Wedel, and R. L. Cifelli. "A new sauropod dinosaur from the Lower Cretaceous Cedar Mountain Formation, Utah, USA". English. In: Acta Palaeontologica Polonica 56.1 (2011), pp. 75-98. DOI: 10.4202/app.2010.0073.

[22852] P. D. Taylor. "Late Cretaceous cheilostome Bryozoans from California and Baja California". English. In: Journal of Paleontology 82.4 (2008), pp. 823-834.

[22853] P. D. Taylor. "Barremian bryozoans from Serre de Bleyton (Drome, SE France)". English. In: $A n-$ nalen des Naturhistorischen Museums in Wien, Serie A 112 (2010), pp. 673-700.

[22854] P. D. Taylor and E. Di Martino. "A brief review of seagrass-associated bryozoans, Recent and fossil". English. In: Studi Trentini di Scienze Naturali 94 (2014), pp. 79-94.

[22855] P. D. Taylor and J. Michalik. "Cyclostome bryozoans from the late Triassic (Rhaetian) of the West Carpathians, Czechoslovakia". In: Neues jahrbuch fuer geologie und palaeontologie 182.3 (1991), pp. 285302.

[22856] P. D. Taylor and M. A. Wilson. "Middle Jurassic bryozoans from the Carmel formation of southwestern Utah". English. In: Journal of Paleontology 73.5 (1999), pp. 816-830.

[22857] P. D. Taylor and P. M. P. Zaborski. “A Late Cenomanian bryozoan biostrome from north-eastern Nigeria". English. In: Cretaceous Research 23.2 (2002), pp. 241-253.

[22858] P. D. Taylor and K. Zagorsek. "Operculate cyclostome bryozoans (Eleidae) from the Bohemian Cretaceous". English. In: Palaeontologische Zeitschrift 85 (2011), pp. 407-432.

[22859] R. S. Taylor. "A new bivalved arthropod from the Early Cambrian Sirius Passet fauna, North Greenland". English. In: Palaeontology 45 (2002), pp. 97-123.

[22860] R. S. Taylor, F. R. Schram, and Y. -B. Shen. "A new upper Middle Triassic shrimp (Crustacea: Lophogastrida) from Guizhou, China, with discussion regarding other fossil mysidaceans". In: Journal of Paleontology 75.2 (2001), pp. 310-318.

[22861] R. S. Taylor, Y. B. Shen, and F. R. Schram. "New pygocephalomorph crustaceans from the Permian of China and their phylogenetic relationships". English. In: Palaeontology 41.5 (1998), pp. 815-834.

[22862] T. N. Taylor and S. E. Scheckler. "Devonian spore ultrastructure: Rhabdosporites". In: Review of Palaeobotany and Palynology 93 (1996), pp. 147-158.

[22863] T. N. Taylor and E. L. Taylor. "Permian plants from the Ellsworth Mountains, West Antarctica". In: Geological Society of America Memoir 170 (1992), pp. 285-294. 
[22864] J. Tazawa. "Kochiproductus and Leptodus (Brachiopoda) from the Middle Permian of the Obama area, south Kitakami belt, northeast Japan". English. In: Science Reports, Niigata University, Series E (Geology) 18 (2003), pp. 25-39.

[22865] J. Tazawa. "Brachiopods from the Upper Permian Tsunemori Formation of the Akiyoshi area, southwest Japan, and their tectonic implications". English. In: Paleontological Research 13 (2009), pp. 65-78.

[22866] J. Tazawa. "A bipolar brachiopod genus Terrakea Booker, 1930 from the Middle Permian of the south Kitakami belt, northeast Japan". English. In: Proceedings of the Royal Society of Victoria 120 (2008), pp. 332-340.

[22867] J. Tazawa and Z. Q. Chen. "Middle Permian brachiopods from the Tumenling Formation in the Wuchang area, southern Heilongjiang, NE China, and their palaeobiogeographical implications". English. In: Journal of Asian Earth Sciences 26 (2006), pp. 327-338.

[22868] J. Tazawa, M. Fujikawa, Y. Zakharov, and S. Hasegawa. "Middle Permian ammonoids from the Takakurayama area, Abukuma Mountains, northeast Japan, and their stratigraphical significance". English. In: Science Reports of Nigata University 20 (2005), pp. 15-27.

[22869] J. Tazawa, S. Shen, and G. R. Shi. "Middle Permian brachiopods from the Dongujimqinqi area, Inner Mongolia, China". English. In: Science Reports, Niigata University, Series E (Geology) 16 (2001), pp. 35-45.

[22870] J. Tazawa and S. Z. Shen. "Middle Permian brachiopods from Hiyomo, Mino Belt, central Japan: their provincial relationships with North America". English. In: Science Reports, Niigata University, Series E 12 (1997), pp. 1-17.

[22871] J. I. Tazawa. "Middle Permian brachiopods from the Moribu area, Hida Gaien Belt, central Japan". English. In: Paleontological Research 5.4 (2001), pp. 283-310.

[22872] J. I. Tazawa. "Permian brachiopods from the Mizukoshi Formation, central Kyushu, SW Japan: systematics, palaeogeography and tectonic implications". English. In: Paleontological Research 12 (2008), pp. 37-61.

[22873] J. I. Tazawa. “Lamnimargus, Megousia, and Eolyttonia (Productida, Brachiopoda) from the Upper Permian (Changhsingian) of the Kawahigashi area, Maizuru Belt, southwest Japan, and their palaeobiogeographical significance". English. In: Science Reports of Niigata University, Series E (Geology) 21 (2006), pp. 1-18.

[22874] J. I. Tazawa. “Brachiopods from the Upper Permian Takakurayama Formation, Abukuma Mountains, northeast Japan". English. In: Science Reports, Niigata University (Geology) 23 (2008), pp. 1353.

[22875] J. I. Tazawa. "Late Permian (Wuchiapingian) brachiopod fauna from Okutadami, central Japan: systematics, palaeobiogeography and tectonic implications". English. In: Paleontological Research 15.3 (2011), pp. 168-180.

[22876] J. I. Tazawa. "Late Permian (Changhsingian) brachiopod fauna from Nabekoshiyama in the Kesennuma area, South Kitakami Belt, northeast Japan". English. In: Science Reports, Niigata University (Geology) 27 (2012), pp. 15-50.

[22877] J. I. Tazawa. "Three new brachiopod species from the middle Permian (Wordian) of the South Kitakami Belt, northeastern Japan". English. In: Paleontological Research 20 (2016), pp. 80-89.

[22878] J. I. Tazawa. “Middle Permian (Wordian) mixed BorealTethyan brachiopod fauna from KamiyasseImo, South Kitakami Belt, Japan". English. In: Science Reports, Niigata University (Geology) 31 (2016), pp. 7-43.

[22879] J. I. Tazawa. "Spinomarginifera and Waagenoconcha (Productida, Brachiopoda) from the middle Permian (Wordian-Capitanian) of the South Kitakami Belt, Japan". English. In: Science Reports, Niigata University (Geology) 32 (2017), pp. 33-56.

[22880] J. I. Tazawa and H. Araki. "Four brachiopod species newly described from the Middle Permian of Kesennuma, South Kitakami Belt, northeast Japan". English. In: Science Reports, Niigata University (Geology) 28 (2013), pp. 1-14. 
[22881] J. I. Tazawa and H. Araki. "Additional brachiopod species from the upper Permian (Changhsingian) of Nabekoshiyama in the Kesennuma area, South Kitakami Belt, northeast Japan". English. In: Science Reports, Niigata University (Geology) 29 (2014), pp. 43-52.

[22882] J. I. Tazawa and H. Araki. "A Boreal-type brachiopod species, Waagenoconcha irginae (Stuckenberg), from the middle Permian (Wordian) of the South Kitakami Belt, Japan". English. In: Journal of the Geological Society of Japan 122 (2016), pp. 155-161.

[22883] J. I. Tazawa and H. Araki. “Middle Permian (Wordian) mixed BorealTethyan brachiopod fauna from Matsukawa, South Kitakami Belt, Japan". English. In: Paleontological Research 21 (2017), pp. $265-$ 287.

[22884] J. I. Tazawa and H. Araki. "Middle Permian (Wordian) brachiopod fauna from Matsukawa, South Kitakami Belt, Japan, Part 2". English. In: Science Reports, Niigata University (Geology) 33 (2018), pp. 9-24.

[22885] J. I. Tazawa and S. Hasegawa. “Anidanthus, Gypospirifer, and Alispiriferella (Brachiopoda) from the upper Permian Mizukoshi Formation, central Kyushu, SW Japan". English. In: Science Reports, Niigata University (Geology) 22 (2007), pp. 1-14.

[22886] J. I. Tazawa and T. Hirota. "Permian brachiopod Eolyttonia from the Katsura Sandstone in the Sakawa area, Kochi Prefecture, southwest Japan". Japanese. In: Earth Science (Chikyu Kagaku) 66 (2012), pp. 225-228.

[22887] J. I. Tazawa, N. Kaneko, C. Suzuki, and S. Hasegawa. "Late Permian (Wuchiapingian) brachiopod fauna from the lower Takakurayama Formation, Abukuma Mountains, northeastern Japan". English. In: Paleontological Research 19 (2015), pp. 33-51.

[22888] J. I. Tazawa and N. Kaneko. “Two Species of Permophricodothyris (Reticularioidea, Brachiopoda) from the Middle Permian, South Kitakami Belt, Japan". English. In: Paleontological Research 20 (2016), pp. 24-30.

[22889] J. I. Tazawa and Y. Miyake. "Late Permian (Changhsingian) brachiopod fauna from Maeda, Ofunato area, South Kitakami belt, NE Japan". English. In: Science Reports, Niigata University (Geology) 26 (2011), pp. 1-22.

[22890] J. I. Tazawa, Y. Miyake, and Y. Okumura. "Cooperina (Productida, Brachiopoda) from the Lower Permian of Japan". English. In: Paleontological Research 17 (2013), pp. 335-338.

[22891] J. I. Tazawa and K. Nakamura. "Early Permian (Kungurian) brachiopods from Nakadaira, South Kitakami Belt, northeastern Japan". English. In: Paleontological Research 19 (2015), pp. 156-177.

[22892] J. I. Tazawa, Y. Okomura, and H. Kojima. "Middle Permian brachiopods from Yamasuge in the Kuzu area, Ashio Mountains, central Japan". English. In: Science Reports, Niigata University (Geology) 25 (2010), pp. 35-49.

[22893] J. I. Tazawa, Y. Okumura, and M. Shimizu. "Permian brachiopods from Yamasuge in the Kuzu area, Ashio Mountains, central Japan, part 2". English. In: Science Reports, Niigata University (Geology) 27 (2012), pp. 51-71.

[22894] J. I. Tazawa, Y. Okumura, Y. Miyake, and T. Mizuhara. "A Kungurian (early Permian) brachiopod fauna from Ogama, Kuzu area, central Japan, and its palaeobiogeographical affinity with the Wolfcampian-Leonardian (early Permian) brachiopod fauna of West Texas, USA". English. In: Paleontological Research 20 (2016), pp. 367-384.

[22895] J. I. Tazawa, T. Ono, and M. Hori. “Two Permian lyttoniid brachiopods from Akasaka, central Japan". English. In: Paleontological Research 2.4 (1998), pp. 239-245.

[22896] J. I. Tazawa and T. Ono. "Permian lyttoniid brachiopod Petasmaia from Akasaka, Mino Belt, central Japan". English. In: Journal of the Geological Society of Japan 119 (2013), pp. 51-55.

[22897] J. I. Tazawa and T. Shintani. "A Permian Boreal-Tethyan mixed brachiopod fauna from the NagaiwaSakamotozawa area, South Kitakami Belt, NE Japan". English. In: Science Reports, Niigata University (Geology) 25 (2010), pp. 51-62. 
[22898] J. I. Tazawa and T. Shintani. “Early Permian (Sakmarian) brachiopods from Kamiyasse, South Kitakami Belt, northeast Japan". English. In: Science Reports, Niigata University (Geology) 29 (2014), pp. 13-41.

[22899] J. I. Tazawa and T. Shintani. "Early Permian (Sakmarian) brachiopods from the Nagaiwa-Sakamotozawa area, South Kitakami belt, northeastern Japan, part 3: Productidina". English. In: Science Reports, Niigata University (Geology) 30 (2015), pp. 39-55.

[22900] V. Tchechmedjieva. "Tirnovimeandra gen. n. (scleractinians) du Barremien de Bulgarie du Nord (Prebalkan central) [Tirnovimeandra n. gen. (Scleractinia) from the Barremian of Northern Bulgaria (central Fore-Balkan)]". French. In: Doklady na Balgarskata Akademia na Naukite 58.3 (2005), pp. 303-306.

[22901] E. Tchernov, L. K. Horwitz, A. Ronen, and A. Lister. "The faunal remains from Evron Quarry in relation to other Lower Paleolithic hominid sites in the Levant". English. In: Quaternary Research 42 (1994), pp. 328-339.

[22902] E. Tchernov, O. Rieppel, H. Zaher, M. J. Polcyn, and L. L. Jacobs. "A fossil snake with limbs." In: Science 287 (2000), pp. 2010-2012.

[22903] P. V. Tchoumatchenco. "Brachiopod thanatocoenoses in the Aalenian, Bajocian and Bathonian of western Bulgaria and their distribution". English. In: Palaeogeography, Palaeoclimatology, Palaeoecology 100 (1993), pp. 159-168.

[22904] R. H. Tedford, L. G. Barnes, and C. E. Ray. "The early Miocene littoral ursoid carnivoran Kolponomos: Systematics and mode of life". English. In: Proceedings of the San Diego Society of Natural History 29 (1994), pp. 11-32.

[22905] R. H. Tedford and C. R. Harington. "An Arctic mammal fauna from the Early Pliocene of North America". English. In: Nature 425.6956 (2003), pp. 388-390. DOI: 10.1038/nature01892.

[22906] R. H. Tedford and N. R. Kemp. Oligocene marsupials of the Geilston Bay local fauna, Tasmania. English. American Museum Novitates 3244. 1998, pp. 1-22.

[22907] R. H. Tedford and J. Martin. "Plionarctos, a tremarctine bear (Ursidae: Carnivora) from western North America". English. In: Journal of Vertebrate Paleontology 21.2 (2001), pp. 311-321.

[22908] R. H. Tedford, X. Wang, and B. E. Taylor. "Phylogenetic Systematics of the North American Fossil Caninae (Carnivora: Canidae)". English. In: Bulletin of the American Museum of Natural History 325 (2009), pp. 1-218. DOI: 10.1206/574.1.

[22909] R. H. Tedford and X. Wang. "Metalopex, a new genus of fox (Carnivora: Canidae: Vulpini) from the late Miocene of western North America". English. In: Natural History Museum of Los Angeles County, Science Series 41 (2008), pp. 273-278.

[22910] A. R. Tedrow. Insectivores from the Orellan-Whitneyan transition at Reva Gap, Slim Buttes, Harding County, South Dakota. English. 1994.

[22911] A. R. Tedrow, J. A. Baskin, and S. F. Robison. "An additional occurrence of the genus Simocyon (Mammalia, Carnivora, Procyonidae) in North America". English. In: Utah Geological Survey Miscellaneous Publication 99-1 (1999), pp. 487-493.

[22912] S. Teichert, W. Woelkerling, and A. Munnecke. "Coralline red algae from the Silurian of Gotland indicate that the order Corallinales (Corallinophycidae, Rhodophyta) is much older than previously thought". English. In: Palaeontology (2019), pp. 1-15. DOI: 10.1111/pala.12418.

[22913] J. V. Tejada-Lara, R. Salas-Gismondi, F. Pujos, P. Baby, M. Benammi, S. Brusset, D. de Franceschi, N. Espurt, M. Urbina, and P. O. Antoine. "Life in the proto-Amazonia: middle Miocene mammals from the Fitzcarrald Arch (Peruvian Amazonia)". English. In: Palaeontology (2015), pp. 1-38. DOI: $10.1111 /$ pala.12147.

[22914] M. F. Tejedor. “New fossil Primate from Chile". English. In: Journal of Human Evolution 44 (2003), pp. 515-520.

[22915] M. F. Tejedor. "Primate canines from the early Miocene Pinturas Formation, Southern Argentina". English. In: Journal of Human Evolution 43 (2002), pp. 127-141. DOI: 10.1006/jhev.2002.0565. 
[22916] M. F. Tejedor. “New Fossil Platyrrhine from Argentina”. English. In: Folia Primatologica 76 (2005), pp. 146-150. DOI: 10.1159/000084377.

[22917] M. F. Tejedor. "Sistemática, evolución y paleobiogeografa de los primates Platyrrhini". Spanish. In: Revista del Museo de La Plata, Sección Zoologa 20.176 (2013), pp. 20-39.

[22918] M. F. Tejedor, N. J. Czaplewski, F. J. Goin, and E. Aragón. “The oldest record of South American bats". English. In: Journal of Vertebrate Paleontology 25.4 (2005), pp. 990-993.

[22919] M. F. Tejedor, F. J. Goin, J. N. Gelfo, G. López, M. Bond, A. A. Carlini, G. J. Scillato-Yané, M. O. Woodburne, L. Chornogubsky, E. Aragón, M. A. Reguero, N. J. Czaplewski, S. Vincon, G. M. Martin, and M. R. Ciancio. "New Early Eocene mammalian fauna from western Patagonia, Argentina". English. In: American Museum Novitates 3638 (2009), pp. 1-43. DOI: 10.1206/577.1.

[22920] M. F. Tejedor, A. L. Rosenberg, and C. Cartelle. "Nueva especie de Alouatta (Primates, Atelinae) del Pleistoceno Tardo de Baha, Brasil". Spanish. In: Ameghiniana 45.1 (2008), pp. 247-251.

[22921] M. F. Tejedor, A. A. Tauber, A. L. Rosenberger, C. C. Swisher III, and M. E. Palacios. “New primate genus from the Miocene of Argentina". English. In: Proceedings of the National Academy of Sciences 103 (2006), pp. 5437-5441.

[22922] U. K. Tekin. "Late Triassic (Late Norian-Rhaetian) radiolarians from the Antalya Nappes, Central Taurides, Southern Turkey". English. In: Rivista Italiana di Paleontologia e Stratigrafia 108.3 (2002), pp. $415-440$.

[22923] U. K. Tekin. "Biostratigraphy and Systematics of late Middle to Late Triassic Radiolarians from the Taurus Mountains and Ankara Region, Turkey". English. In: Geologisch-Paläontologische Mitteilungen Innsbruck 5 (1999), pp. 1-296.

[22924] U. K. Tekin and Y. Bedi. "Ruesticyrtiidae (Radiolaria) from the middle Carnian (Late Triassic) of Köseyahya Nappe (Elbistan, eastern Turkey)". English. In: Geologica Carpathica 58.2 (2007), pp. 153-167.

[22925] U. K. Tekin, M. Cemal Göncüoglu, and N. Turhan. "First evidence of Late Carnian radiolarians from the Izmir-Ankara suture complex, central Sakarya, Turkey: implications for the opening age of the Izmir-Ankara branch of Neo-Tethys". English. In: Geobios 35.1 (2002), pp. 127-135.

[22926] U. K. Tekin. "Lower Jurassic (Hettangian-Sinemurian) radiolarians from the Antalya Nappes, Central Taurids, Southern Turkey". In: Micropaleontology 48.2 (2002), pp. 177-205.

[22927] U. K. Tekin and H. Mostler. "Longobardian (Middle Triassic) Entactinarian and Nassellarian Radiolaria from the Dinarides of Bosnia and Herzegovina". English. In: Journal of Paleontology 79.I (2005), pp. 1-20.

[22928] D. Telnov. "Macratriinae (Coleoptera: Anthicidae) of the Baltic amber". English. In: Latvijas Entomologs 51 (2012), pp. 27-39.

[22929] D. Telnov. "Tomoderinae (Coleoptera: Anthicidae) of the Baltic amber". English. In: Latvijas Entomologs 51 (2012), pp. 3-11.

[22930] D. Telnov. "A new species of Tomoderinae (Coleoptera: Anthicidae) from the Baltic amber". English. In: Latvijas Entomologs 52 (2013), pp. 130-134.

[22931] D. Telnov and A. Bukejs. "Catalogue and composition of fossil Anthicidae and Ischaliidae (Insecta: Coleoptera)". English. In: Palaeontologia Electronica 22.1.18A (2019), pp. 1-27.

[22932] D. Telnov, A. Bukejs, and O. Merkl. “Description of a new fossil Statira Lepeletier et AudinetServille, 1828 (Coleoptera: Tenebrionidae: Lagriinae) from Baltic amber of the Sambian Peninsula". English. In: Zootaxa 4683 (2019), pp. 508-514.

[22933] I. Temkin and J. Pojeta. "Cassiavella galtarae, new species, new genus: a new Permian bivalve and its significance for pterioidean systematics". English. In: Journal of Paleontology 84.6 (2010), pp. 1152-1176. DOI: 10.1666/10-022.1.

[22934] P. M. Tempfer. “The Herpetofauna (Amphibia: Caudata, Anura; Reptilia: Sclerogiossa) of the Upper Miocene Locality Kohfidisch (Burgenland, Austria)". English. In: Beiträge zur Paläontologie von Österreich 29 (2005), pp. 145-253. 
[22935] J. T. Temple and H. J. Wu. “Numerical taxonomy of Encrinurinae (Trilobita): additional species from China and elsewhere". English. In: Transactions of the Royal Society of Edinburgh: Earth Sciences 83 (1990), pp. 209-219. DOI: 10.1017/S0263593300005241.

[22936] H. A. Ten Hove and P. van den Hurk. "A review of recent and fossil serpulid 'reefs'; actuopalaeontology and the 'Upper Malm' serpulid limestones in NW Germany". In: Geologie en Mijnbouw 72 (1993), pp. 23-67.

[22937] J. P. Tennant and P. D. Mannion. "Revision of the Late Jurassic crocodyliform Alligatorellus, and evidence for allopatric speciation driving high diversity in western European atoposaurids". English. In: PeerJ 2 (2014), e599.

[22938] J. P. Tennant, P. D. Mannion, and P. Upchurch. "Evolutionary relationships and systematics of Atoposauridae (Crocodylomorpha: Neosuchia): implications for the rise of Eusuchia". English. In: Zoological Journal of the Linnean Society 177 (2016), pp. 854-936.

[22939] A. J. D. Tennyson, J. H. Cooper, and L. D. Shepherd. “A new species of extinct Pterodroma petrel (Procellariiformes: Procellariidae) from the Chatham Islands, New Zealand". English. In: Bulletin of the British Ornithologists' Club 135 (2015), pp. 267-277.

[22940] A. J. D. Tennyson and A. A. Mannering. "A new species of Pliocene shearwater (Aves: Procellariidae) from New Zealand". English. In: Tuhinga 29 (2018), pp. 1-19.

[22941] A. J. D. Tennyson and P. R. Millener. "Bird extinctions and fossil bones from Mangere Island, Chatham Islands". English. In: Notornis, Supplement 41 (1994), pp. 165-178.

[22942] A. J. D. Tennyson and R. P. Scofield. "Holocene fossil bird remains from subantarctic Macquarie Island". English. In: Proceeding of the 8th International Meeting of the Society of Avian Paleontology and Evolution (2013), pp. 239-251.

[22943] A. J. D. Tennyson, T. H. Worthy, C. M. Jones, R. P. Scofield, and S. J. Hand. “Moa's Ark: Miocene Fossils Reveal the Great Antiquity of Moa (Aves: Dinornithiformes) in Zealandia". English. In: Records of the Australian Museum 62 (2010), pp. 105-114.

[22944] M. Terayama. "Descriptions of new taxa and distribution records of the family Bethylidae (Insecta, Hymenoptera) II. Subfamily Bethylinae and fossil taxa". English. In: Academic Reports, Faculty of Engineering, Tokyo Polytechnic University 27 (2004), pp. 39-52.

[22945] V. A. Tereschenko. "Key to protoceratopoid vertebrae (Ceratopsia, Dinosauria) from Mongolia". English. In: Paleontological Journal 41.2 (2007), pp. 175-188.

[22946] V. S. Tereschenko and V. R. Alifanov. "Bainoceratops efremovi, a new protoceratopid dinosaur (Protoceratopidae, Neoceratopsia) from the Bain-Dzak locality (south Mongolia)". English. In: Paleontological Journal 37.3 (2003), pp. 293-302.

[22947] V. S. Tereschenko and T. Singer. "Structural features of neural spines of the caudal vertebrae of protoceratopoids (Ornithischia: Neoceratopsia)". English. In: Paleontological Journal 47.6 (2013), pp. 618-630. DOI: 10.1134/s0031030113060105.

[22948] F. Terfelt. "Upper Cambrian trilobite biostratigraphy and taphonomy at Kakeled on Kinnekulle, Västergötland, Sweden". English. In: Acta Palaeontologica Polonica 48.3 (2003), pp. 409-416.

[22949] E. Terzea. "Biochronology of the Pleistocene deposits at Betfia (Bihor, Romania)". In: Acta Zoologica Cracovensia 39.1 (1996), pp. 531-540.

[22950] P. Teta, F. J. Pardinas, and P. E. Ortiz. "Posición sistemática de Akodon (Abrothrix) kermacki Y A. (AB.) magnus (Rodentia, Cricetidae) del plio-Pleistoceno del sudeste de Buenos Aires, Argentina". Spanish. In: Revista Brasileira de Paleontologia 17.3 (2014), pp. 405-416. DOI: 10.4072/rbp.2014.3.10.

[22951] O. E. Tetlie. "Two new Silurian species of Eurypterus (Chelicerata: Eurypterida) from Norway and Canada and the phylogeny of the genus". English. In: Journal of Systematic Palaeontology 4.4 (2006), pp. 397-412. DOI: 10.1017/S1477201906001921.

[22952] O. E. Tetlie. "A new Baltoeurypterus (Eurypterida: Chelicerata) from the Wenlock of Norway". English. In: Norwegian Journal of Geology 82 (2002), pp. 37-44. 
[22953] O. E. Tetlie and J. A. Dunlop. "A redescription of the Late Carboniferous eurypterids Adelophthalmus granosus von Meyer, 1853 and A. zadrai Pribyl, 1952". English. In: Fossil Record 8 (2005), pp. 3-12. DOI: $10.1002 / \mathrm{mmng} .200410001$.

[22954] O. E. Tetlie, P. A. Selden, and D. Ren. "A new Silurian eurypterid (Arthropoda: Chelicerata) from China". English. In: Palaeontology 50 (2007), pp. 619-625.

[22955] V. C. Tewari, K. Kumar, K. Lokho, and N. Siva Siddaiah. "Lakadong limestone: Paleocene-Eocene boundary carbonate in Meghalaya, northeastern India". English. In: Current Science 98.1 (2010), pp. 88-95.

[22956] P.-J. Texier, G. Porraz, J. Parkington, J. -P. Rigaud, C. Poggenpoel, C. Miller, C. Tribolo, C. Cartwright, A. Coudenneau, R. Klein, T. Steele, and C. Verna. "A Howiesons Poort tradition of engraving ostrich eggshell containers dated to 60,000 years ago at Diepkloof Rock Shelter, South Africa". English. In: Proceedings of the National Academy of Sciences 107.14 (2010), pp. 6180-6185.

[22957] J. F. Thackeray and V. Watson. A preliminary account of faunal remains from Plovers Lake. 1994.

[22958] T. Thanh, T. D. Duyen, N. H. Hung, and B. P. My. “Discovery of the fossiliferous Cu Brei Formation (Lower Devonian) in the Kon Tum Block (South Viet Nam)". English. In: Journal of Asian Earth Sciences 29 (2007), pp. 127-135.

[22959] H. Thassanapak, Q. L. Feng, J. Grant-Mackie, C. Chonglakmani, and N. Thanee. "Middle Triassic radiolarian faunas from Chiang Dao, Northern Thailand". English. In: Palaeoworld 20 (2011), pp. 179-202. DOI: 10.1016/j.palwor.2010.11.001.

[22960] M. K. Thayer, A. F. Newton, and S. Chatzimanolis. "Prosolierius, a new mid-Cretaceous genus of Solieriinae (Coleoptera: Staphylinidae) with three new species from Burmese amber". English. In: Cretaceous Research 34 (2012), pp. 124-134.

[22961] J. M. Theodor. "Protoreodon walshi, a new species of agriochoerid (Oreodonta, Artiodactyla, Mammalia) from the late Uintan of San Diego County, California". English. In: Journal of Paleontology 73.6 (1999), pp. 1179-1190.

[22962] G. Theodorou. Megalopolis - 112 years after the first excavation by National and Kapodistrian University of Athens (NKUA) - and the Post Lignite era. English. 2014.

[22963] G. Theodorou, A. Athanassiou, S. Roussiakis, and G. Iliopoulos. "Preliminary remarks on the Late Miocene herbivores of Kerassiá (Northern Euboea, Greece)". English. In: Deinsea, Distribution and Migration of Tertiary Mammals in Eurasia. A volume in honour of Hans de Bruijn 10 (2003), pp. 519-530.

[22964] G. Theodorou, Y. Bassiakos, E. Tsakalos, E. Yiannouli, and P. Maniatis. "The use of CT scans and 3D modeling as a powerful tool to assist fossil vertebrate taxonomy". English. In: Digital Heritage. Progress in Cultural Heritage: Documentation, Preservation, and Protection. 7th International Conference, EuroMed 2018, Nicosia, Cyprus 11196 (2018), pp. 79-89.

[22965] G. Theodorou, N. Spjeldnaes, N. M. Hanken, S. E. Lauritzen, E. Velitzelos, A. Athanassiou, and S. Roussiakis. "Description and taphonomic investigations of Neogene Proboscidea from Rhodos, Greece". English. In: Annales Geologiques des Pays Helléniques 38 (2000), pp. 133-156.

[22966] G. Theodorou, N. Symeonidis, and E. Stathopoulou. "Elephas tiliensis n. sp. from Tilos island (Dodecanese, Greece)". English. In: Hellenic Journal of Geosciences 42 (2007), pp. 19-32.

[22967] J. N. Theron, R. B. Rickard, and R. J. Aldridge. “Bedding plane assemblages of Promissum pulchrum, a new giant Ashgill conodont from the Table Mountain Group, South Africa". In: Palaeontology 33.3 (1990), pp. 577-594.

[22968] F. Therrien and D. E. Fastovsky. Paleoenvironment of early theropods, Chinle Formation (Late Triassic), Petrified Forest National Park, Arizona. 2000.

[22969] F. Therrien, D. K. Zelenitsky, A. Quinney, and K. Tanaka. "Dinosaur trackways from the Upper Cretaceous Oldman and Dinosaur Park formations (Belly River Group) of southern Alberta, Canada, reveal novel ichnofossil preservation style". English. In: Canadian Journal of Earth Sciences 52 (2015), pp. 630-641. DOI: 10.1139/cjes-2014-0168. 
[22970] J. G. M. Thewissen, E. M. Williams, and S. T. Hussain. "Skeletons of terrestrial cetaceans and the relationship of whales to artiodactyls". In: Nature 413 (2001), pp. 277-281.

[22971] J. G. M. Thewissen. "Evolution of Paleocene and Eocene Phenacodontidae (Mammalia, Condylarthra)". English. In: University of Michigan Papers on Paleontology 29 (1990), pp. 1-107.

[22972] J. G. M. Thewissen and S. Bajpai. “New Oligocene mustelid from western India”. English. In: Journal of Vertebrate Paleontology 28.2 (2008), pp. 565-567.

[22973] J. G. M. Thewissen and S. Bajpai. “Dental morphology of Remingtonocetidae (Cetacea, Mammalia)". English. In: Journal of Paleontology 75.2 (2001), pp. 463-465.

[22974] J. G. M. Thewissen and S. Bajpai. "New skeletal material of Andrewsiphius and Kutchicetus, two Eocene cetaceans from India". English. In: Journal of Paleontology 83.5 (2009), pp. 635-663.

[22975] J. G. M. Thewissen and S. Bajpai. "A new Miocene sirenian from Kutch, India". English. In: Acta Palaeontologica Polonica 54.1 (2009), pp. 7-13.

[22976] J. G. M. Thewissen and S. T. Hussain. “Attockicetus praecursor, a new remingtonocetid cetacean from marine Eocene sediments of Pakistan." English. In: Journal of Mammalian Evolution 7.3 (2000), pp. 133-146.

[22977] J. G. M. Thewissen, S. T. Hussain, and M. Arif. “Fossil evidence for the origin of aquatic locomotion in archaeocete whales". In: Science 263 (1994), pp. 210-212.

[22978] J. G. M. Thewissen, S. T. Hussain, and M. Arif. "New Kohatius (Omomyidae) from the Eocene of Pakistan". English. In: Journal of Human Evolution 32 (1997), pp. 473-477.

[22979] J. G. M. Thewissen and E. L. Simons. "Skull of Megalohyrax eocaenus (Hyracoidea, Mammalia) from the Oligocene of Egypt". English. In: Journal of Vertebrate Paleontology 21.1 (2001), pp. 98-106.

[22980] J. G. M. Thewissen, E. M. Williams, and S. T. Hussain. “Eocene mammal faunas from northern Indo-Pakistan". English. In: Journal of Vertebrate Paleontology 21.2 (2001), pp. 347-366.

[22981] M. Thierens, E. Browning, H. Pirlet, M. -F. Loutre, B. Dorschel, V. A. I. Huvenne, J. Titschack, C. Colin, A. Foubert, and A. J. Wheeler. "Cold-water coral carbonate mounds as unique palaeoarchives: the Plio-Pleistocene Challenger Mound record (NE Atlantic)". English. In: Quaternary Science Reviews 73 (2013), pp. 14-30.

[22982] D. Thies. "Placoid scales (Chondrichthyes: Elasmobranchii) from the Late Jurassic (Kimmeridgian) of northern Germany". English. In: Journal of Vertebrate Paleontology 15.3 (1995), pp. 463-481.

[22983] D. Thies. "A new species of Palaeospinax (Chondrichthyes, Neoselachii) from the Lower Jurassic Posidonia Shale of southern Germany". English. In: Paläontologische Zeitschrift 66 (1992), pp. 137146.

[22984] D. Thies. "New evidence of Annea and Jurobatos, two rare neoselachians (Pisces, Chondrichthyes) from the Jurassic of Europe". English. In: Belgian Geological Survey, Professional Paper, Elasmobranches et Stratigraphie 264 (1993), pp. 137-146.

[22985] D. Thies and R. B. Hauff. "A new species of Dapedium Leach, 1822 (Actinopterygii, Neopterygii, Semionotiformes) from the Early Jurassic of south Germany". English. In: Palaeodiversity 4 (2011), pp. 185-221.

[22986] D. Thies and S. Turner. "Jurassic Actinopterygian fish from Monto, southeast Queensland". English. In: Alcheringa 25.4 (2001), pp. 381-386.

[22987] D. Thies and J. Vespermann. "Die Mosasaurier des Roemer-Museums in Hildesheim. (The Mosasauridae of the Roemer Museum in Hildesheim)". German. In: Paläontologische Zeitschrift 69.3/4 (1995), pp. 459-465.

[22988] A. L. Thomas, G. M. Henderson, P. Deschamps, Y. Yokoyama, A. J. Mason, E. Bard, B. Hamelin, N. Durand, and G. Camoin. "Penultimate Deglacial Sea-Level Timing from Uranium/Thorium Dating of Tahitian Corals". English. In: Science 324.5931 (2009), pp. 1186-1189.

[22989] D. B. Thomas. "Fossil Cydnidae (Heteroptera) in the Dominican Amber". English. In: Journal of the New York Entomological Society 102.3 (1994), pp. 303-309. 
[22990] D. B. Thomas. "A fossil Empicoris Wolff (Reduviidae: Heteroptera) from Mexican amber with remarks on the phylogenetic status of the fossil genus Alumeda Popov". English. In: Journal of the New York Entomological Society 100 (1992), pp. 535-539.

[22991] D. B. Thomas and D. T. Ksepka. "A history of shifting fortunes for African penguins". English. In: Zoological Journal of the Linnean Society 168 (2013), pp. 207-2019. DOI: 10.1111/zoj.12024.

[22992] D. B. Thomas and D. T. Ksepka. “The Glen Murray fossil penguin from the North Island of New Zealand extends the geographic range of Kairuku". English. In: Journal of the Royal Society of New Zealand 46.3-4 (2016), pp. 200-213. DOI: 10.1080/03036758.2016.1211541.

[22993] F. Thomas. "Cenozoic micropaleontological biostratigraphy of the LASMO/NSR(V)L Cohasset Producer CP1 P-51 well, Scotian Shelf". English. In: Atlantic Geology 30.2 (1994), pp. 113-121.

[22994] H. Thomas, D. Geraads, D. Janjou, D. Vaslet, A. Mesmesh, D. Billiou, H. Bocherens, G. Dobigny, V. Eisenmann, M. Gayet, F. de Lapparent de Broin, G. Petter, and M. Halawani. "First Pleistocene faunas from the Arabian Peninsula: An Nafud desert, Saudi Arabia". English. In: Comptes Rendus Academie des Sciences, Paris, Sciences de la terre et des planetes 326 (1998), pp. 145-152.

[22995] H. Thomas, E. Gheerbrant, and J. -M. Pacaud. "Découverte de squelettes subcomplets de mammiféres (Hyracoidea) dans le Paléogéne d'Afrique (Libye)". French. In: Comptes Rendus Palevol 3 (2004), pp. 209-217.

[22996] H. Thomas, J. Roger, M. Halawani, A. Memesh, P. Lebret, C. Bourdillon, E. Buffeteaut, H. Cappetta, C. Cavelier, D. Dutheil, H. Tong, and D. Vaslet. "Late Paleocene to Early Eocene marine vertebrates from the Uppermost Aruma Formation (northern Saudi Arabia): implications for the K-T transition". In: Comptes Rendus de l'Academie des Sciences, Serie II. Sciences de la Terre et des Planetes 329.12 (1999), pp. 905-912.

[22997] H. Thomas, J. Roger, S. Sen, J. Dejax, M. Schuler, Z. Al-Sulaimani, C. Bourdillon de Griassac, G. Breton, F. de Broin, G. Camoin, H. Cappetta, R. -P. Carriol, C. Cavelier, C. Chaix, J. -Y. Crochet, G. Farjanel, M. Gayet, E. Gheerbrant, A. Lauriat-Rage, D. Noel, M. Pickford, and A. -. "Essai de reconstitution des milieux de sédimentation et de vie des primates anthropoides de l'Oligocene de Taqah (Dhofar, Sultanat d'Oman)". English. In: Bulletin de la Societe géologique de France 162.4 (1991), pp. 713-724.

[22998] H. Thomas, S. Sen, J. Roger, and Z. Al-Sulaimani. “The discovery of Moeripthecus markgrafi Schlosser (Propliopithecidae, Anthropoidea, Primates) in the Ashawq Formation (Early Oligocene of Dhofar Province, Sultanate of Oman)". English. In: Journal of Human Evolution 20 (1991), pp. 3349.

[22999] M. J. Thomas, J. Skejo, and S. W. Heads. "The last batrachideine of Europe: A new genus and species of pygmy grasshopper (Orthoptera: Tetrigidae) from Eocene Baltic amber". English. In: Zootaxa 4686 (2019), pp. 435-445.

[23000] T. M. Thomas, M. C. Granatosky, J. R. Bourque, K. L. Krysko, P. E. Moler, T. Gamble, E. Suarez, E. Leone, K. M. Enge, and J. Roman. "Taxonomic assessment of alligator snapping turtles (Chelydridae: Macrochelys), with the description of two new species from the southeastern United States". English. In: Zootaxa 3786.2 (2014), pp. 141-165.

[23001] J. R. Thomasson, R. J. Zakrzewski, H. E. LaGarry, and D. E. Mergen. “A late Miocene (late early Hemphillian) biota from northwestern Kansas”. English. In: National Geograpic Research 6.2 (1990), pp. 231-244.

[23002] J. R. Thomka, R. D. Lewis, D. Mosher, R. K. Pabian, and P. F. Holterhoff. "Genus-level taphonomic variation within cladid crinoids from the upper Pennsylvanian Barnsdall Formation, Northeastern Oklahoma". English. In: Palaios 26 (2011), pp. 377-389. DOI: 10.2110/palo.2011.p11-001r.

[23003] J. R. Thompson, W. I. Ausich, and L. Smith. "Echinoderms from the Lower Devonian (Emsian) of Bolivia (Malvinokaffric Realm)”. English. In: Journal of Paleontology 87.1 (2013), pp. 166-175. 
[23004] J. R. Thompson, S. X. Hu, Q. Y. Zhang, E. Petsios, L. J. Cotton, J. Y. Huang, C. Y. Zho, W. Wen, and D. J. Bottjer. "A new stem group echinoid from the Triassic of China leads to a revised macroevolutionary history of echinoids during the end-Permian mass extinction". English. In: Royal Society Open Science 5 (2018), p. 171548.

[23005] J. R. Thompson, E. Petsios, E. H. Davidson, E. M. Erkenbrack, F. Gao, and D. J. Bottjer. “Reorganization of sea urchin gene regulatory networks at least 268 million years ago as revealed by oldest fossil cidaroid echinoid". English. In: Scientific Reports 5.15541 (2015), pp. 1-9.

[23006] J. R. Thompson, E. Petsios, and D. J. Bottjer. “A diverse assemblage of Permian echinoids (Echinodermata, Echinoidea) and implications for character evolution in early crown group echinoids". English. In: Journal of Paleontology 91.4 (2017), pp. 767-780. DOI: 10.1017/jpa.2016.158.

[23007] K. S. Thomson, N. S. Shubin, and F. G. Poole. "A problematic early tetrapod from the Mississippian of Nevada". English. In: Journal of Vertebrate Paleontology 18.2 (1998), pp. 315-320. DOI: 10.1080 / 02724634.1998.10011059.

[23008] S. A. Thomson. "A revision of the fossil chelid turtles (Pleurodira) described by C. W. de Vis (1897)". English. In: Memoirs of the Queensland Museum 45 (2000), pp. 593-598.

[23009] S. A. Thomson and B. Mackness. "Fossil turtles from the early Pliocene Bluff Downs Local Fauna, with a description of a new species of Elseya". English. In: Transactions of the Royal Society of South Australia 123 (1999), pp. 101-105.

[23010] T. J. Thomson, R. B. Irmis, and M. A. Loewen. "First occurrence of a tyrannosaurid dinosaur from the Mesaverde Group (Nelsen Formation) of Utah: implications for upper Campanian Laramidian biogeography". English. In: Cretaceous Research 43 (2013), pp. 70-79.

[23011] K. M. Thorn, M. N. Hutchinson, M. Archer, and M. S. Y. Lee. “A new scincid lizard from the Miocene of northern Australia, and the evolutionary history of social skinks (Scincidae: Egerniinae)". English. In: Journal of Vertebrate Paleontology (2019), e1577873. DOI: 10.1080/02724634.2019. 1577873.

[23012] T. Thulborn. "Australia's earliest theropods: footprint evidence in the Ipswich Coal Measures (Upper Triassic) of Queensland". In: GAIA 15 (1998), pp. 301-311.

[23013] T. Thulborn. "Impact of sauropod dinosaurs on lagoonal substrates in the Broome Sandstone (Lower Cretaceous), Western Australia". English. In: PLoS ONE 7.5 (2012), 36208:1-22. DOI: 10. 1371/journal.pone.0036208.

[23014] T. Thulborn and S. Turner. “The Last Dicynodont: An Australian Cretaceous Relict". English. In: Proceeedings of the Royal Society B 270 (2003), pp. 985-993.

[23015] B. Thuy. "Les échinides du Bajocien de Rumelange (Grand-Duché de Luxembourg)". French. In: Ferrantia 36 (2003), pp. 79-123.

[23016] B. Thuy. "Exceptionally well-preserved brittle stars from the Pliensbachian (Early Jurassic) of the French Ardennes". English. In: Palaeontology 54.1 (2011), pp. 215-233.

[23017] B. Thuy, G. Escarguel, and T. Paris Biota Team. "A new brittle star (Ophiuroidea: Ophiodermatina) from the Early Triassic Paris Biota (Bear Lake County, Idaho, USA)". English. In: Geobios 54 (2019), pp. 55-61. DOI: 10.1016/j.geobios.2019.04.004.

[23018] B. Thuy, A. S. Gale, and M. Reich. "A new echinoderm Lagerstätte from the Pliensbachian (Early Jurassic) of the French Ardennes". English. In: Swiss Journal of Palaeontology 130 (2011), pp. 173185.

[23019] B. Thuy, H. Hagdorn, and A. S. Gale. "Paleozoic echinoderm hangovers: waking up in the Triassic". English. In: Geology 45 (2017), pp. 531-534.

[23020] B. Thuy, Y. Ishida, E. Doi, and A. Kroh. "New ophiacanthid brittle stars (Echinodermata: Ophiuroidea) from the Upper Triassic of Japan: first insights into the origin and evolution of an extant deep-sea group". English. In: Journal of Systematic Palaeontology 11 (2013), pp. 515-530. 
[23021] B. Thuy, A. A. Klompmaker, and J. W. M. Jagt. “Late Triassic (Rhaetian) ophiuroides from Winterswijk, the Netherlands; with comments on the systematic position of Aplocoma (Echinodermata, Ophiolepididae)". English. In: Zoosymposia 7 (2012), pp. 163-172.

[23022] B. Thuy and A. Kroh. "Barremian ophiuroids from the Serre de Bleyton (Drome, SE France)". English. In: Annalen des Naturhistorisches Museums in Wien, Serie A 113 (2011), pp. 777-807.

[23023] B. Thuy, M. Kutscher, and B. J. Pachno. "A new brittle star from the early Carboniferous of Poland and its implications on Paleozoic modern-type ophiuroid systematics". English. In: Acta Palaeontologica Polonica 60.4 (2015), pp. 923-929. DOI: 10.4202/app.00093.2014.

[23024] H. Tian, J. J. Gu, F. Huang, H. Zhang, and D. Ren. "A new species of Elcaninae (Orthoptera, Elcanidae) from the Lower Cretaceous Yixian Formation at Liutiaogou, Inner Mongolia, NE China, and its morphological implications". English. In: Cretaceous Research 99 (2019), pp. 275-280. DOI: 10.1016/j.cretres.2019.03.010.

[23025] H. Tian, J. J. Gu, X. C. Yin, and D. Ren. "The first Elcanidae (Orthoptera, Elcanoidea) from the Daohugou fossil bed of northeastern China". English. In: ZooKeys 897 (2019), pp. 19-28.

[23026] V. Tidwell, K. Carpenter, and W. Brooks. "New sauropod from the Lower Cretaceous of Utah, USA". In: Oryctos 2 (1999), pp. 21-37.

[23027] V. Tidwell and K. Carpenter. "Braincase of an Early Cretaceous titanosauriform sauropod from Texas". English. In: Journal of Vertebrate Paleontology 23.1 (2003), pp. 176-180.

[23028] W. D. Tidwell. "Preliminary report on the megafossil flora of the Upper Jurassic Morrison Formation". In: Hunteria 2.8 (1990), pp. 1-11.

[23029] W. D. Tidwell and N. Hebbert. "Species of the Cretaceous tree fern Tempskya from Utah". English. In: International Journal of Plant Sciences 153.3 (1992), pp. 513-528.

[23030] W. D. Tidwell, J. R. Jennings, and S. S. Beus. "A Carboniferous flora from the Surprise Canyon Formation in the Grand Canyon, Arizona". English. In: Journal of Paleontology 66.6 (1992), pp. 10131021.

[23031] A. Tierney, I. Deregnaucourt, J. M. Anderson, P. Tierney, T. Wappler, and O. Béthoux. “The Triassic Mesophlebiidae, a little closer to the crown of the Odonata (Insecta) than other 'triassolestids'". English. In: Alcheringa 44 (2020), pp. 279-285. DOI: 10.1080/03115518.2020.1730964.

[23032] B. H. Tiffney. "Re-Evaluation of the age of the Brandon lignite (Vermont, USA) based on plant megafossils". In: Review of Palaeobotany and Palynology 82 (1994), pp. 299-315.

[23033] B. H. Tiffney. "Fruits and seeds of the Tertiary Brandom Lignite. VII. Sargentodoxa (Sargentodoxaceae)". In: American Journal of Botany 80.5 (1993), pp. 517-523.

[23034] E. Tihelka. "New Mesozoic earwigs from England, with a catalogue of fossil Dermaptera". English. In: Proceedings of the Geologists' Association 130 (2019), pp. 609-611. DOI: 10.1016/j.pgeola. 2019.06.003.

[23035] E. Tihelka, M. S. Engel, D. Y. Huang, and C. Y. Cai. "Mimicry in Cretaceous bugs". English. In: iScience 23.101280 (2020). DOI: 10.1016/j.isci.2020.101280.

[23036] E. Tihelka, D. Y. Huang, and C. Y. Cai. "A new genus and tribe of Cretaceous net-winged beetles from Burmese amber (Coleoptera: Elateroidea: Lycidae)". English. In: Palaeoentomology 2 (2019), pp. 262-270.

[23037] E. Tihelka, D. Y. Huang, and C. Y. Cai. “New data on Ommatidae (Coleoptera) from mid-Cretaceous Burmese amber". English. In: Cretaceous Research 106.104253 (2019). DOI: 10.1016/j.cretres.2019. 104253.

[23038] E. Tihelka, D. Y. Huang, and C. Y. Cai. "Diverse Texas beetles (Coleoptera: Elateroidea: Brachypsectridae) in mid-Cretaceous Burmese amber: sexual dimorphism and palaeoecology". English. In: Palaeoentomology 2 (2019), pp. 523-531.

[23039] E. Tihelka, D. Y. Huang, and C. Y. Cai. "First false darkling beetle from mid-Cretaceous Burmese amber (Coleoptera: Melandryidae)". English. In: Alcheringa 44 (2019), pp. 169-175. DOI: 10.1080/ 03115518.2019.1664635. 
[23040] E. Tihelka, D. Y. Huang, and C. Y. Cai. "A new genus and species of Micromalthidae from Burmese amber (Coleoptera: Archostemata)". English. In: Earth and Environmental Science Transactions of the Royal Society of Edinburgh 111 (2020), pp. 39-46. DOI: 10.1017/S1755691019000185.

[23041] E. Tihelka, D. Y. Huang, and C. Y. Cai. “Trihelota, a new and unusual helotid beetle genus from mid-Cretaceous Burmese amber (Coleoptera: Helotidae)". English. In: Acta Entomologica Musei Nationalis Pragae 60 (2020), pp. 509-516.

[23042] E. Tihelka, D. Y. Huang, and C. Y. Cai. “A new genus of wounded-tree beetles from mid-Cretaceous northern Myanmar amber (Coleoptera: Nosodendridae)". English. In: Cretaceous Research 119.104701 (2020). DOI: 10.1016/j.cretres.2020.104701.

[23043] E. Tihelka, A. D. Smith, D. Y. Huang, and C. Y. Cai. "First member of the New World genus Diceroderes from early Miocene Mexican amber (Coleoptera: Tenebrionidae: Tenebrioninae: Toxicini)". English. In: Journal of South American Earth Sciences 104.102828 (2020). DOI: 10.1016/j.jsames. 2020.102828.

[23044] E. Tihelka, L. Tian, and C. Y. Cai. "A new Devonian harvestman from the Rhynie chert (Arachnida: Opiliones)". English. In: Bulletin of Geosciences 95 (2020), pp. 313-318. DOI: 10.3140 / bull.geosci. 1765.

[23045] J. W. Tilsley and D. Korn. “Chadian (Tournaisian - Viséan, Carboniferous) ammonoids from the Milldale Limestone Formation of the southern Peak District, England". English. In: Proceedings of the Yorkshire Geological Society 57.3-4 (2009), pp. 217-234.

[23046] R. M. Timm, R. M. Salazar, and A. T. Peterson. "Historical distribution of the extinct tropical seal Monachus tropicalis (Carnivora: Phocidae)". English. In: Conservation Biology 11.2 (1997), pp. 549551.

[23047] C. Tinelli, A. Ribolini, G. Bianucci, M. Bini, and W. Landini. "Ground penetrating radar and palaeontology: The detection of sirenian fossil bones under a sunflower field in Tuscany (Italy)". English. In: Comptes Rendus Palevol 11 (2012), pp. 445-454.

[23048] D. E. Tineo, P. Bona, L. M. Pérez, G. D. Vergani, G. González, D. G. Poiré, Z. Gasparini, and P. Legarreta. "Palaeoenvironmental implications of the giant crocodylian Mourasuchus (Alligatoridae, Caimaninae) in the Yecua Formation (late Miocene) of Bolivia". English. In: Alcheringa 39 (2015). DOI: 10.1080/03115518.2015.967162.

[23049] S. Ting, J. A. Schiebout, and J. Zheng. "New records of the pantodont Archaeolambda from the Paleocene of southern China". English. In: Palaeovertebrata 25.2-4 (1996), pp. 125-132.

[23050] S.-Y. Ting, G. J. Bowen, P. L. Koch, W. C. Clyde, Y. -Q. Wang, Y. Wang, and M. C. McKenna. “Biostratigraphic, chemostratigraphic, and magnetostratigraphic study across the Paleocene-Eocene boundary in the Hengyang Basin, Hunan, China". English. In: Geological Society of America Special Paper 369 (2003), pp. 521-535.

[23051] S.-Y. Ting, J. Meng, Q. Li, Y. -Q. Wang, Y. -S. Tong, J. A. Schiebout, P. L. Koch, W. C. Clyde, and G. J. Bowen. “Ganungulatum xincunliense, an artiodactyl-like mammal (Ungulata, Mammalia) from the Paleocene, Chijiang Basin, Jiangxi, China". English. In: Vertebrata PalAsiatica 45.4 (2007), pp. 278-286.

[23052] O. Tinn. "The Ordovician Clitambonitidine Brachiopod Genus Vellamo in Estonia". English. In: Proceedings of the Estonian Academy of Sciences 47.3 (1998), pp. 195-216.

[23053] A. Tintori. "The Actinopterygian fish Prohalecites from the Triassic of Northern Italy". English. In: Palaeontology 33 (1990), pp. 155-174.

[23054] A. Tintori. "Dipteronotus olgiatii n. sp. (Actinopterygii, Perleidiformes) from the Kalksschieferzone of Ca' del Frate (N. Italy) (preliminary note)". English. In: Atti Ticinesi di Scienze della Terra 33 (1990), pp. 191-197.

[23055] A. Tintori. Paralepidotus ornatus (Agassiz 1833-43): A semionotid from the Norian (Late Triassic) of Europe. English. Vol. 1. Mesozoic Fishes - Systematics and Paleoecology. München, Germany: Verlag Dr. Friedrich Pfeil, 1996, pp. 167-179. 
[23056] A. Tintori. "A new species of Saurichthys (Actinopterygii) from the Middle Triassic (early Ladinian) of the northern Grigna mountain (Lombardy, Italy)". English. In: Rivista Italiana di Paleontologia e Stratigrafia 119 (2013), pp. 287-302.

[23057] A. Tintori, J. D. Huang, D. Y. Jiang, Z. Y. Sun, R. Motani, and G. B. Chen. "A new Saurichthys (Actinopterygii) from the Spathian (Early Triassic) of Chaohu (Anhui Province, China)". English. In: Rivista Italiana di Paleontologia e Stratigrafia 120 (2014), pp. 157-164.

[23058] A. Tintori and C. Lombardo. "A new early Semionotidae (Semionotiformes, Actinopterygii) from the upper Ladinian of Monte San Giorgio area (southern Switzerland and norther Italy)". English. In: Rivista Italiana di Paleontologia e Stratigrafia 113.3 (2007), pp. 369-381.

[23059] A. Tintori and C. Lombardo. “Gabanellia agilis gen. n. sp. n. (Actinopterygii, Perleidiformes) from the Calcare di Zorzino of Lombardy (North Italy)". English. In: Rivista Italiana di Paleontologia e Stratigrafia 102.2 (1996), pp. 227-236.

[23060] A. Tintori, C. Lombardo, and E. Kustatscher. “The Pelsonian (Anisian, Middle Triassic) fish assemblage from Monte Prá della Vacca/Kühwiesenkopf (Braies Dolomites, Italy)". English. In: Neues Jahrbuch für Geologie und Paläontologie, Abhandlungen 282 (2016), pp. 181-200.

[23061] A. Tintori and D. Sassi. “Thoracopterus Bronn (Osteichthyes: Actinopterygii): a gliding fish from the Upper Triassic of Europe". English. In: Journal of Vertebrate Paleontology 12.3 (1992), pp. 265283.

[23062] A. Tintori, Z. Y. Sun, C. Lombardo, D. Y. Jiang, Y. L. Sun, and W. C. Hao. "A new basal neopterygian from the Middle Triassic of Luoping county (south China)". English. In: Rivista Italiana di Paleontologia e Stratigrafia 116 (2010), pp. 161-172.

[23063] A. Tintori, Z. Y. Sun, C. Lombardo, D. Y. Jiang, C. Ji, and R. Motani. "A new flying fish from the upper Ladinian (Middle Triassic) of Wusha (Guizhou Province, southern China)". English. In: Gortania 33 (2012), pp. 39-50.

[23064] A. Tintori, Z. Y. Sun, P. G. Ni, C. Lombardo, D. Y. Jiang, and R. Motani. “Oldest stem Teleostei from the late Ladinian (Middle Triassic) of southern China". English. In: Rivista Italiana di Paleontologia e Stratigrafia 121 (2015), pp. 285-296.

[23065] A. Tintori, Z. Y. Sun, C. Lombardo, D. Y. Jiang, Y. L. Sun, M. Rusconi, and W. C. Hao. "New specialized basal neopterygians (Actinopterygii) from Triassic of the Tethys realm". English. In: Geologica Insubrica 10 (2008), pp. 13-20.

[23066] H. Tischlinger and E. Frey. "A new pterosaur with mosaic characters of basal and pterodactyloid pterosauria from the Upper Kimmeridgian of Painten (Upper Palatinate, Germany)". German. In: Archaeopteryx 31 (2013), pp. 1-13.

[23067] J. Tissier, D. Becker, V. Codrea, L. Costeur, C. Frca, A. Solomon, M. Venczel, and O. Maridet. "New data on Amynodontidae (Mammalia, Perissodactyla) from Eastern Europe: Phylogenetic and palaeobiogeographic implications around the Eocene-Oligocene transition". English. In: PLoS ONE 13.4 (2018), e0193774:1-35.

[23068] J. Tissier, J.-C. Rage, R. Boistel, V. Fernandez, N. Pollet, G. Garcia, and M. Laurin. "Synchrotron analysis of a 'mummified' salamander (Vertebrata: Caudata) from the Eocene of Quercy, France". English. In: Zoological Journal of the Linnean Society 177 (2016), pp. 147-164.

[23069] R. Tita. "Commets on the Badenian Fauna (Middle Miocene) from Bahna (Southern Carpathians, Romania)". English. In: Travaux du Museum National d'Histoire Naturelle Grigore Antipa 50 (2007), pp. 543-554.

[23070] V. V. Titov. "Sus (Suidae, Mammalia) from the Upper Pliocene of the Northeastern part of the Azov Region." In: Paleontological Journal 34.2 (2000), pp. 203-210.

[23071] V. V. Titov, A. S. Tesakov, I. G. Danilov, G. A. Danukalova, E. N. Mashchenko, A. V. Panteleev, M. V. Sotnikova, and E. K. Sychevskaya. "The First Representative Vertebrate Fauna from the Late Miocene of Southern European Russia". English. In: Doklady Biological Sciences 411 (2006), pp. 508509. DOI: $10.1134 / \mathrm{S} 001249660606024 \mathrm{X}$. 
[23072] J. Titschak, C. S. Nelson, T. Beck, A. Freiwald, and U. Radtke. "Sedimentary evolution of a Late Pleistocene temperate red algal reef (Coralligene) on Rhodes, Greece: correlation with global sealevel fluctuations". English. In: Sedimentology 55 (2008), pp. 1747-1776.

[23073] A. L. Titus. "The first record of Cancelloceras (Early Pennsylvanian Ammonoidea) from southern Nevada: implications for timing of regional Mid-Carboniferous sea-level fluctuations". English. In: Journal of Paleontology 71 (1997), pp. 158-162.

[23074] A. L. Titus, J. G. Eaton, and J. J. W. Sertich. “Late Cretaceous stratigraphy and vertebrate faunas of the Markagunt, Paunsaugunt, and Kaiparowits plateaus, southern Utah". English. In: Geology of the Intermountain West 3 (2016), pp. 229-291.

[23075] A. L. Titus, D. Korn, J. E. Harrell, and L. L. Lambert. “Late Viséan (late Mississippian) ammonoids from the Barnett Shale, Sierra Diablo Escarpment, Culberson County, Texas, USA". English. In: Fossil Record 18 (2015), pp. 81-104.

[23076] B. N. Tiwari. “A late Eocene Juxia (Perissodactyla, Hyracodontidae) from Liyan Molasse, eastern Ladakh, India". English. In: Journal of the Palaeontological Society of India 48 (2003), pp. 103-113.

[23077] B. N. Tiwari, B. C. Verma, and A. Bhandari. "Record of Prodeinotherium (proboscidea: Mammalia) from mid-tertiary dharmsala group of the Kangra valley, NW Himalaya, India: Biochronologic and palaeobiogeographic implications". English. In: Journal of The Palaeontological Society of India 51 (2006), pp. 93-100.

[23078] B. P. Tiwari. "Neogene palaeontology of the Surma Group, Mizoram, India. 1 - The Arcoida (Mollusca: Bivalvia)". English. In: Journal of the Paleontological Society of India 46 (2001), pp. 147-160.

[23079] M. Tiwari. “Organic-walled microfossils from Chert-phosphorite Member, Tal Formation, PrecambrianCambrian Boundary, India". English. In: Precambrian Research 97 (1999), pp. 99-113.

[23080] M. Tiwari, S. K. Parcha, R. Shukla, and H. Joshi. "Ichnology of the Early Cambrian Tal Group, Mussoorie Syncline, Lesser Himalaya, India". English. In: Journal of Earth System Science 122.6 (2013), pp. 1467-1475.

[23081] M. Tiwari and S. K. Parcha. "Early Cambrian trace fossils from the Tal Formation of the Mussoorie Syncline, India". English. In: Current Science 90.1 (2006), pp. 113-118.

[23082] R. P. Tiwari, G. Barman, and P. P. Satsangi. "Miocene crabs from Mizoram, India”. In: Journal of the Palaeontological Society of India 42 (1997), pp. 127-132.

[23083] R. P. Tiwari and R. P. Kachhara. "Molluscan biostratigraphy of the Tertiary sediments of Mizoram, India". English. In: Journal of the Paleontological Society of India 48 (2003), pp. 65-88.

[23084] M. Tkoc, A. Nel, and J. Prokop. "Discovery of a new species of the Cretaceous genus Microphorites Hennig, 1971 (Diptera: Dolichopodidae s. lat.) in Paleogene amber from eastern Moravia (Czech Republic)". English. In: Insect Systematics \& Evolution 47 (2016), pp. 181-193.

[23085] P. V. Tobias. Olduvai Gorge, Parts I-Iv: The Skulls, Endocasts, and Teeth of Homo Habilis. 1991.

[23086] J. A. Todd and J. S. H. Collins. “Neogene and Quaternary crabs (Crustacea, Decapoda) collected from Costa Rica and Panama by members of the Panama Paleontology Project". English. In: Bulletin of the Mizunami Fossil Museum 32 (2005), pp. 53-85.

[23087] J. A. Todd and K. G. Johnson. “Dissecting a marine snail species radiation (Conoidea: Turridae: Polystira) over 12 million years in the southwestern Caribbean". English. In: Bulletin of Marine Science 89.4 (2013).

[23088] J. A. Todd, P. D. Taylor, and T. A. Favorskaya. “A bioimmured ctenostome bryozoan from the early Cretaceous of the Crimea and the new genus Simplicidium". English. In: Geobios 30.2 (1997), pp. 205-213. DOI: 10.1016/S0016-6995(97)80225-2.

[23089] R. Todesco, M. Wachtler, E. Kustatscher, and M. Avanzini. "Preliminary report on a new vertebrate track and flora site from Piz da peres (Anisian-Illyrian): Olang Dolomites, Northern Italy". English. In: Geo.Alp 5 (2008), pp. 121-137. 
[23090] T. K. Tokaryk. "A partial skeleton of Champsosaurus from the Frenchman Formation (Maastrichtian) of Saskatchewan". English. In: Frenchman Formation Terrestrial Ecosystem Conference, Program, Abstracts of Paper, Workshops and Field Trip. Royal Saskatchewan Museum Contribution to Science 12 (2009), pp. 55-59.

[23091] T. T. Tokaryk. "First evidence of juvenile ceratopsians (Reptilia: Ornithischia) from the Frenchman Formation (late Maastrichtian) of Saskatchewan". English. In: Canadian Journal of Earth Sciences 34 (1997), pp. 1401-1404.

[23092] T. T. Tokaryk. "Baptornis sp. (Aves: Hesperornithiformes) from the Judith River Formation (Campanian) of Saskatchewan, Canada". English. In: Journal of Paleontology 66.6 (1992), pp. 1010-1012.

[23093] T. T. Tokaryk. "A plioplatecarpine mosasaur from the Bearpaw Shale (Upper Cretaceous) of Saskatchewan, Canada". English. In: Modern Geology 18 (1993), pp. 503-509.

[23094] T. T. Tokaryk and H. N. Bryant. "The fauna from the Tyrannosaurus rex excavation, Frenchman Formation (Late Maastrichtian), Saskatchewan". English. In: Summary of Investigations 2004, Volume 1. Saskatchewan Geological Survey, Saskatchewan Industry 1 (2004), pp. 1-12.

[23095] T. T. Tokaryk, S. L. Cumbaa, and J. E. Storer. "Early Late Cretaceous birds from Saskatchewan, Canada: the oldest diverse avifauna known from North America". English. In: Journal of Vertebrate Paleontology 17.1 (1997), pp. 172-176.

[23096] T. Tokiwa, Y. Mori, and H. Suzuki. "Cretaceous radiolarian fossils from the Ryujin Formation of the Shimanto Belt in the Kawabe area, Wakayama Prefecture, southwest Japan". English. In: Journal of Earth and Planetary Sciences 52 (2005), pp. 11-23.

[23097] C. Toland. A sequence stratigraphic reference section for the Tithonian of Lebanon. Vol. 69. Middle East models of Jurassic/Cretaceous carbonate systems. SEPM, Special Publication. 2000, pp. 53-64.

[23098] P. M. Toledo and D. P. Domning. "Fossil Sirenia (Mammalia: Dugongidae) from the Pirabas Formation (Early Miocene), Northern Brazil". English. In: Boletim do Museu Paraense Emlio Goeldi, Série Ciencias da Terra 1.2 (1991), pp. 119-146.

[23099] V. I. Tolkanitz, N. B. Narolsky, and E. E. Perkovsky. "A new species of parasitic wasp of the genus Pherhombus (Hymenoptera, Ichneumonidae, Pherhombinae) from the Rovno amber". English. In: Paleontological Journal 39 (2005), pp. 511-513.

[23100] V. I. Tolkanitz, N. B. Narolsky, and E. E. Perkovsky. "New data of fossil ichneumon wasp Pherombus dolini (Hymenoptera, Ichneumonidae, Pherombinae) from Rovno and Bitterfeld amber". Russian. In: Vestnik Zoologii 39 (2005), p. 78.

[23101] V. I. Tolkanitz and E. E. Perkovsky. "A new species of the genus Paxylommites (Hymenoptera, Ichneumonidae, Hybrizoninae) from Baltic amber". English. In: Paleontological Journal 49 (2015), pp. 391-393.

[23102] V. I. Tolkanitz and E. E. Perkovsky. "First record of the late Eocene ichneumon fly Rasnitsynites tarsalis Kasparyan (Ichneumonidae, Townesitinae) in Ukraine confirms correlation of the upper Eocene Lagerstätten". English. In: Paleontological Journal 52 (2018), pp. 31-34.

[23103] T. Tolmacheva, P. Fedorov, and E. Egerquist. "Conodonts and brachiopods from the Volkhov Stage (Lower Ordovician) microbial mud mound at Putilovo Quarry, north-western Russia". English. In: Bulletin of the Geological Society of Denmark 50.1 (2003), pp. 63-74.

[23104] T. J. Tolmacheva, K. E. Degtyarev, J. Samuelsson, and L. E. Holmer. "Middle Cambrian to Lower Ordovician faunas from the Chingiz Mountain Range, central Kazakhstan". English. In: Alcheringa 32 (2008), pp. 443-463.

[23105] T. J. Tolmacheva, T. N. Koren, L. E. Holmer, L. E. Popov, and E. Raevskaya. “The Hunneberg Stage (Ordovician) in the area east of St. Petersburg," English. In: Paläontologische Zeitschrift 74.4 (2001), pp. 543-561.

[23106] Z. Tolokonnikova. "Bryozoans from the Jurginskaya Formation Famennian, Upper Devonian) of the Tom-Kolyvansk area (Western Siberia, Russia)". English. In: Geologos 16.3 (2010), pp. 139-152. DOI: 10.2478/v10118-009-0009-7. 
[23107] Z. Tolokonnikova. "Permian bryozoans fromătheăNemda horizon (Roadian) ofăSamara Region, Russia". English. In: 94 (2020), pp. 79-92. DOI: 10.1007/s12542-018-00440-z.

[23108] Z. Tolokonnikova, A. Ernst, and H. Yarahmadzahi. "Frasnian bryozoans (Late Devonian) from the Khoshyeilagh Section, Alborz Mountains (northern Iran)". English. In: Palaeontologische Zeitschrift 85 (2011), pp. 393-405.

[23109] S. Tomás, H. Löser, and R. Salas. "Low-light and nutrient-rich coral assemblages in an Upper Aptian carbonate platform of the southern Maestrat Basin (Iberian Chain, eastern Spain)". English. In: Cretaceous Research 29 (2008), pp. 509-534.

[23110] A. Tomasovych. "Linking taphonomy to community-level abundance: insights into compositional fidelity of the Upper Triassic shell concentrations (Eastern Alps)". English. In: Palaeogeography, Palaeoclimatology, Palaeoecology 235 (2006), pp. 355-381.

[23111] A. Tomasovych. "Differential effects of environmental factors on ecology of brachiopods and bivalves during the Late Triassic and Jurassic". English. PhD thesis. 2006, pp. 1-430.

[23112] A. Tomasovych. "Brachiopod and bivalve ecology in the Late Triassic (Alps, Austria): onshoreoffshore replacements caused by variations in sediment and nutrient supply". English. In: Palaios 21 (2006), pp. 344-368.

[23113] A. Tomasovych. "A new Early Jurassic rhynchonellid brachiopod from the western Tethys and implications for the systematics of rhynchonellids from the Triassic-Jurassic boundary". English. In: Journal of Paleontology 80.2 (2006), pp. 212-228.

[23114] L. Tomassetti, F. R. Bosellini, and M. Brandano. "Growth and demise of a Burdigalian coral bioconstruction on a granite rocky substrate (Bonifacio Basin, southeastern Corsica)". English. In: Facies 59.4 (2013), pp. 703-716.

[23115] R. L. Tomassini and C. I. Montalvo. "Taphonomic modes on fluvial deposits of the Monte Hermoso Formation (early Pliocene), Buenos Aires province, Argentina". English. In: Palaeogeography, Palaeoclimatology, Palaeoecology 369 (2013), pp. 282-294.

[23116] R. L. Tomassini, C. I. Montalvo, C. M. Deschamps, and T. Manera. “Biostratigraphy and biochronology of the Monte Hermoso Formation (early Pliocene) at its type locality, Buenos Aires Province, Argentina". English. In: Journal of South American Earth Sciences 48 (2013), pp. 31-42.

[23117] W. Tomaszewska, A. lipiski, M. Bai, W. W. Zhang, and D. Ren. “The oldest representatives of Endomychidae (Coleoptera: Coccinelloidea) from the Upper Cretaceous Burmese amber". English. In: Cretaceous Research 91 (2018), pp. 287-298.

[23118] T. Tomek, Z. M. Bochenski, K. Wertz, and E. Swidnicka. "A new genus and species of a galliform bird from the Oligocene of Poland". English. In: Palaeontologia Electronica 17.3.38A (2014), pp. 1-15.

[23119] A. M. F. Tomescu, G. W. Rothwell, and R. Honegger. "A new genus and species of filamentous microfossil of cyanobacterial affinity from Early Silurian fluvial environments (lower Massanutten Sandstone, Virginia, USA)". English. In: Botanical Journal of the Linnean Society 160 (2009), pp. 284289.

[23120] S. Tomida, H. Akazaki, and T. Kawano. "A janthinid gastropod from Late Neogene Miyazaki Group of Southwestern". English. In: Bulletin of the Mizunami Fossil Museum 39 (2013), pp. 59-63.

[23121] S. Tomida, K. Inoue, M. Kadota, H. Sano, and E. Hosoda. “Tectus sp. aff. pyramis (Born, 1778) (Gastropoda: Trochoidea) from the Middle Miocene Yugashima Group of the Izu Peninsula, Central Japan". English. In: Malacological Society of Japan 75 (2017), pp. 88-92.

[23122] S. Tomida and M. Kadota. "Turbo (Gastropoda: Turbinidae) fossils from the middle Miocene of Izu Peninsula, central Japan, including the description of three new species". English. In: Paleontological Research 18.2 (2014), pp. 67-76. DOI: 10.2517/2014PR007.

[23123] S. Tomida and F. Kitao. "Occurrence of Hartungia (Gastropoda: Janthinidae) from the Tonohama Group, Kochi Prefecture, Japan”. English. In: Bulletin of the Mizunami Fossil Museum 29 (2002), pp. 157-160. 
[23124] S. Tomida and Y. Nakamura. "A new species of Hartungia (Gastropoda: Janthinidae) from late Miocene of Japan". English. In: Bulletin of the Mizunami Fossil Museum 28 (2001), pp. 217-221.

[23125] S. Tomida, Y. Okumura, T. Yamaoka, H. Ohsawa, and N. Hamada. “Occurrence of Aturia (Cephalopoda: Nautilida) from the Miocene Bihoku Group of Hiroshima Prefecture, southwestern Japan". English. In: Bulletin of the Mizunami Fossil Museum 29 (2002), pp. 151-156.

[23126] S. Tomida and K. Tanabe. "A nautilid cephalopod beak from the lower Miocene Ichishi Group, central Japan". English. In: Venus 62 (2004), pp. 141-148.

[23127] Y. Tomida and Y. Lee. "A brief review of the Tertiary mammals from the Korean Peninsula". In: National Science Museum Monographs 24 (2004), pp. 197-206.

[23128] Y. Tomida and T. Ohta. “Discovery of a desmostylian tooth from Kitami City, northeastern Hokkaido, Japan". English. In: Memoirs of the Fukui Prefectural Dinosaur Museum 63 (2007), pp. 57-61.

[23129] Y. Tomida and Y. Tsumura. "A partial skeleton of titanosaurian sauropod from the Early Cretaceous of Toba City, central Japan". English. In: Journal of the Paleontological Society of Korea 22.1 (2006), pp. 217-238.

[23130] K. Tominaga, K. Ueno, and K. Hisada. “Anthracoporella-Palaeoaplysina mound in Upper Carboniferous". English. In: Facies 65.11 (2019). DOI: 10.1007/s10347-019-0555-6.

[23131] S. Tomiya. "A new basal caniform (Mammalia: Carnivora) from the middle Eocene of North America and remarks on the phylogeny of early carnivorans". English. In: PLoS ONE 6.9 (2011), e24146. DOI: 10.1371/journal.pone.0024146.

[23132] S. Tomiya and Z. S. Morris. "Reidentification of late middle Eocene Uintacyon from the Galisteo Formation (New Mexico, U.S.A.) as an early beardog (Mammalia, Carnivora, Amphicyonidae)". English. In: Breviora 567.1 (2020), pp. 1-12. DOI: 10.3099/0006-9698-567.1.1.

[23133] P. Tonarová, M. E. Eriksson, and O. Hints. “A jawed polychaete fauna from the Late Ludlow Kozlowskii event interval in the Prague Basin (Czech Republic)". English. In: Bulletin of Geosciences 87.4 (2012), pp. 713-732. DOI: 10.3140/bull.geosci.1317.

[23134] D. T. Tong and K. V. Stratigraphic units of Viet Nam. English. Hanoi: Vietnam National University Publisher, 2011, pp. 1-553.

[23135] H.-W. Tong, N. Hu, and X.-M. Wang. "New remains of Canis chihliensis from Shanshenmiaozui, a lower Pleistocene site in Yangyuan, Hebei". English. In: Vertebrata PalAsiatica 50.4 (2012), pp. 335360.

[23136] H. Tong. "Pleurodiran turtles from the Eocene of Saint Papoul (Aude), southern France". English. In: Oryctos 1 (1998), pp. 43-53.

[23137] H. Tong. Les Tortues du Cenomanien continental des Kem Kem et leurs implications paleobiogeographiques. French. 2008.

[23138] H. Tong, E. Buffetaut, H. Thomas, J. Roger, M. Halawani, A. Memesh, and P. Lebret. "A new dermochelyid turtle from the late Paleocene-early Eocene of Saudi Arabia". English. In: Comptes Rendu de l'Academie de Sciences, Paris: Sciences de la terre et de planetes 329 (1999), pp. 913-919.

[23139] H. Tong, E. Buffetaut, and V. Suteethorn. "Middle Jurassic turtles from southern Thailand". English. In: Geological Magazine 139.6 (2002), pp. 687-697. DOI: 10.1017 /S0016756802006805.

[23140] H. Tong, E. Buffetaut, V. Suteethorn, S. Suteethorn, G. Cuny, L. Cavin, U. Deesri, J. E. Martin, K. Wongko, W. Naksri, and J. Claude. "Phu Din Daeng, a new Early Cretaceous vertebrate locality on the Khorat Plateau, NE Thailand". English. In: Annales de Paléontologie 105.3 (2019), pp. 223-237. DOI: 10.1016/j.annpal.2019.04.004.

[23141] H. Tong, J. Claude, V. Suteethorn, W. Naksri, and E. Buffetaut. Turtle assemblages of the Khorat Group (Late Jurassic-Early Cretaceous) of NE Thailand and their palaeobiogeographical significance. English. Vol. 315. Late Palaeozoic and Mesozoic Ecosystems in SE Asia. The Geological Society of London, Special Publication. 2009, pp. 141-152. 
[23142] H. Tong, J. Claude, W. Naksri, V. Suteethorn, E. Buffetaut, S. Khansubha, K. Wongko, and P. Yuangdetkla. Basilochelys macrobios n. gen. and n. sp, a large cryptodiran turtle from the Phu Kradung Formation (latest Jurassic-earliest Cretaceous) of the Khorat Plateau, NE Thailand. English. Vol. 315. Late Palaeozoic and Mesozoic Ecosystems in SE Asia. The Geological Society of London, Special Publication. 2009, pp. 153-173.

[23143] H. Tong, J. Claude, C. -S. Li, J. Yang, and T. Smith. “Wutuchelys eocenica n. gen. n. sp., an Eocene stem testudinoid turtle from Wutu, Shandong Province, China". English. In: Geological Magazine (2017), pp. 1-14. DOI: 10.1017/S0016756817000905.

[23144] H. Tong, I. Danilov, Y. Ye, H. Ouyang, and G. -Z. Peng. “Middle Jurassic turtles from the Sichuan Basin, China: a review". English. In: Geological Magazine 149.4 (2012), pp. 675-695. DOI: 10.1017/ S0016756811000859.

[23145] H. Tong, Z. Dong, and T. Wang. "A revision of Xinjiangchelys oshanensis (Ye, 1973), and new material from the Middle Jurassic of Lufeng, Yunnan Province, China". English. In: Bulletin de la Société Géologique de France 186.1 (2015), pp. 43-49. DOI: 10.2113/gssgfbull.186.1.43.

[23146] H. Tong, E. S. Gaffney, and E. Buffetaut. "Foxemys, a new side-necked turtle (Bothremydidae: Pelomedusoides) from the Late Cretaceous of France". English. In: American Museum Novitates 3251 (1998), pp. 1-19.

[23147] H. Tong and R. Hirayama. "A new species of Tasbacka (Testudines: Cryptodira: Cheloniidae) from the Paleocene of the Ouled Abdoun phosphate basin, Morocco". English. In: Neues Jahrbuch für Geologie und Paläontologie Monatshefte 2002.5 (2002), pp. 277-294.

[23148] H. Tong, R. Hirayama, E. Makhoul, and F. Escuillié. "Rhinochelys (Chelonioidea: Protostegidae) from the Late Cretaceous (Cenomanian) of Nammoura, Lebanon". English. In: Atti della Societá italiana di scienze naturali e del museo civico di storia naturale di Milano 147.1 (2006), pp. 113-138.

[23149] H. Tong, R. Hirayama, and J. Tabouelle. "Puppigerus camperi (Testudines: Cryptodira: Cheloniidae) from the Ypresian (Early Eocene) of Ouled Abdoun basin, Morocco". English. In: 183.6 (2012), pp. 635-640. DOI: 10.2113/gssgfbull.183.6.635.

[23150] H. Tong and R. Hirayama. "A new species of Argillochelys (Testudines: Cryptodira: Cheloniidae) from the Ouled Abdoun phosphate basin, Morocco". English. In: Bulletin of the Geological Society of France 179.6 (2008), pp. 623-630.

[23151] H. Tong, S.-A. Ji, and Q. Ji. "Ordosemys (Testudines: Cryptodira) from the Yixian Formation of Liaoning Province, Northeastern China: New Specimens and Systematic Revision". English. In: American Museum Novitates 3438 (2004), pp. 1-20.

[23152] H. Tong, L. Li, and H. Ouyang. "A revision of Sinaspideretes wimani Young \& Chow, 1953 (Testudines: Cryptodira: Trionychoidae) from the Jurassic of the Sichuan Basin, China". English. In: Geological Magazine 151.4 (2014), pp. 600-610. DOI: 10.1017/S0016756813000575.

[23153] H. Tong, L. Li, C. Jie, and L. Yi. "New material of Jiangxichelys ganzhouensis Tong \& Mo, 2010 (Testudines: Cryptodira: Nanhsiungchelyidae) and its phylogenetic and palaeogeographical implications". English. In: Geological Magazine 154.3 (2017), pp. 456-464. DOI: 10.1017/S0016756816000108.

[23154] H. Tong and P. Meylan. Morphology and Relationships of Brachyopsemys tingitana gen. et sp. nov. from the Early Paleocene of Morocco and Recognition of the New Eucryptodiran Turtle Family: Sandownidae. English. Morphology and Evolution of Turtles. 2013, pp. 187-212. DOI: 10.1007/978-94-007-43090_13.

[23155] H. Tong, W. Naksri, E. Buffetaut, V. Suteethorn, S. Suteethorn, U. Deesri, S. Sila, P. Chanthasit, and J. Claude. "A new primitive eucryptodiran turtle from the Upper Jurassic Phu Kradung Formation of the Khorat Plateau, NE Thailand". English. In: Geological Magazine (2014). DOI: 10.1017 / S0016756814000223.

[23156] H. Tong, W. Naksri, E. Buffetaut, S. Suteethorn, V. Suteethorn, P. Chantasit, and J. Claude. “Kalasinemys, a new xinjiangchelyid turtle from the Late Jurassic of NE Thailand". English. In: Geological Magazine (2019), pp. 1-12. DOI: 10.1017/S0016756818000791. 
[23157] H. Tong, L. Xu, E. Buffetaut, X. Zhang, and S. Jia. "A new nanhsiungchelyid turtle from the Late Cretaceous of Neixiang, Henan Province, China". English. In: Annales de Paléontologie 98.4 (2012), pp. 303-314. DOI: 10.1016/j.annpal.2012.08.001.

[23158] H.-Y. Tong and J.-Y. Mo. "Jiangxichelys, a new nanhsiungchelyid turtle from the Late Cretaceous of Ganzhou, Jiangxi Province, China". English. In: Geological Magazine 147.6 (2010), pp. 981-986. DOI: $10.1017 /$ S0016756810000671.

[23159] H.-Y. Tong, L. Li, D. -S. Li, L. -M. Chen, T. Li, S. -H. Yu, G. -S. Yu, X. -Q. Cheng, Y. -L. Di, and J. Claude. "A revision of Anhuichelys Yeh, 1979, the earliest known stem Testudinidae (Testudines: Cryptodira) from the Paleocene of China". English. In: Vertebrata PalAsiatica 54.2 (2016), pp. 156179.

[23160] J. Tong and D. H. Erwin. "Triassic gastropods of the southern Qinling Mountains, China". In: Smithsonian Contributions to Paleobiology 92 (2001), pp. 1-47.

[23161] J. Tong, X. Zhou, D. Erwin, J. Zou, and L. Zhao. "Fossil Fishes from the Lower Triassic of Majiashan, Chaohu, Anhui Province, China". English. In: Journal of Paleontology 80.1 (2006), pp. 146161.

[23162] J.-N. Tong and Z.-L. Lui. “The Middle Triassic stratigraphy and sedimentary paleogeography of South China". In: Albertiana 24 (2000), pp. 37-47.

[23163] T. T. Tong, C. K. Shih, and D. Ren. "A new genus and species of Stenurothripidae (Insecta: Thysanoptera: Terebrantia) from mid-Cretaceous Myanmar amber". English. In: Cretaceous Research 100 (2019), pp. 184-191. DOI: 10.1016/j.cretres.2019.03.005.

[23164] Y. Tong. “Middle Eocene Small Mammals from Liguanqiao Basin of Henan Province and Yuanqu Basin of Shanxi Province, Central China". English. In: Palaeontologica Sinica, New Series C 26 (1997), pp. 1-256.

[23165] Y. Tong and J. Wang. "A New Soricomorph (Mammalia, Insectivora) from the Early Eocene of Wutu Basin, Shandong". English. In: Vertebrata PalAsiatica 31.1 (1993), pp. 19-32.

[23166] Y. Tong and J. Wang. "A new neoplagiaulacid multituberculate (Mammalia) from the Lower Eocene of Wutu Basin, Shandong". English. In: Vertebrata PalAsiatica 32.4 (1994), pp. 275-284.

[23167] Y. Tong and J. Wang. "A new palaeanodont (Mammalia) from the Early Eocene of Wutu Basin, Shandong Province". English. In: Vertebrata PalAsiatica 35.2 (1997), pp. 110-120.

[23168] Y.-S. Tong, J.-W. Wang, and J. Meng. "Olbitherium millenariusum, a new perissodactyl-like archaic ungulate (Mammalia) from the Early Eocene Wutu Formation, Shandong". Chinese. In: Vertebrata PalAsiatica 42.1 (2004), pp. 27-38.

[23169] Y.-S. Tong, J.-W. Wang, and J. -F. Fu. "Yuesthonyx, a new tillodont (mammalia) from the Paleocene of Henan". English. In: Vertebrata PalAsiatica 41.1 (2003), pp. 55-65.

[23170] K. Tongtherm, J. Nabhitabhata, P. Srisuk, T. Nutadhira, and D. Tonnayopas. "New records of nautiloid and ammonoid cephalopod fossils in peninsular Thailand". English. In: Swiss Journal of Palaeontology 135.1 (2016), pp. 153-168. DOI: 10.1007/s13358-015-0108-8.

[23171] W. Tonomori, H. Sawamura, T. Sato, and N. Kohno. "A new Miocene pinniped Allodesmus (Mammalia: Carnivora) from Hokkaido, northern Japan". English. In: Royal Society Open Science 5.5 (2018), p. 172440. DOI: 10.1098/rsos.172440.

[23172] E. K. Toolson and B. S. Kues. “Decapod crustaceans from the Semilla Sandstone Member, Mancos Shale (Upper Cretaceous), north-central New Mexico". English. In: Journal of Paleontology 70.1 (1996), pp. 111-116.

[23173] T. P. Topper, G. A. Brock, C. B. Skovsted, and J. R. Paterson. "Shelly fossils from the lower Cambrian Pararaia bunyerooensis Zone, Flinders Ranges, South Australia". English. In: Memoirs of the Association of Australasian Palaeontologists 37 (2009), pp. 199-246.

[23174] T. P. Topper, L. E. Holmer, C. B. Skovsted, G. A. Brock, U. Balthasar, C. M. Larsson, S. Petterson Stolk, and D. A. T. Harper. "The oldest brachiopods from the lower Cambrian of South Australia". English. In: Acta Palaeontologica Polonica 58.1 (2013), pp. 93-109. 
[23175] T. P. Topper, C. B. Skovsted, G. A. Brock, and J. R. Paterson. “The oldest bivalved arthropods from the early Cambrian of East Gondwana: Systematics, biostratigraphy and biogeography". English. In: Gondwana Research 19 (2011), pp. 310-326.

[23176] F. Torcida, C. Fuentes, L. A. Izquierdo, D. Montero, and V. Urién. “Dientes de dinosaurios terópodos (cf. Baryonyx) en el Weald de Burgos (España) [Teeth of theropod dinosaurs (cf. Baryonyx) in the Weald of Burgos (Spain)]". Spanish. In: Stvdia Geologica Salmanticensia 33 (1997), pp. 59-65.

[23177] F. Torcida Fernández, L. A. Izquierdo Montero, P. Huerta Hurtado, D. Montero Huerta, and G. Pérez Martnez. "Dientes de dinosaurios (Theropoda, Sauropoda), en el Cretácico Inferior de Burgos (España) [Teeth of dinosaurs (Theropoda, Sauropoda), in the Lower Cretaceous of Burgos (Spain)]". Spanish. In: Dinosaurios y Otros Reptiles Mesozoicos en España. Congreso Internacional sobre Dinosaurios y otros Reptiles Mesozoicos en España, Logroño. Rioja: Instituto de Estudios Riojanos, Universidad de La Rioja, 2003, pp. 335-346.

[23178] F. Torcida Fernández-Baldor. "Los dinosaurios de Castilla y León [The dinosaurs of Castilla y León]". Spanish. In: Patrimonio Histórico de Castilla y León 6.23 (2005), pp. 23-34.

[23179] F. Torcida Fernández-Baldor. "Registro de dinosaurios en el sureste de la provincia de Burgos [Register of dinosaurs in the southeast of Burgos province]". Spanish. In: Zuba 14 (1996), pp. 89104.

[23180] F. Torcida Fernández-Baldor, J. I. Canudo, P. Huerta, D. Montero, X. Pereda Suberbiola, and L. Salgado. "Demandasaurus darwini,ăa new rebbachisaurid sauropod from the Early Cretaceous of the Iberian Peninsula". English. In: Acta Palaeontologica Polonica 56.3 (2011), pp. 535-552.

[23181] F. Torcida Fernández-Baldor, J. I. Canudo, P. Huerta, M. Moreno-Azanza, and D. Montero. “Europatitan eastwoodi, a new sauropod from the lower Cretaceous of Iberia in the initial radiation of somphospondylans in Laurasia". English. In: PeerJ 5 (2017), e3409:1-50. DOI: 10.7717/ peerj.3409.

[23182] A. Torices, F. Barroso-Barcenilla, O. Cambra-Moo, and A. Pérez-Garca. "Palaeontological and palaeobiogeographical implications of the new Cenomanian vertebrate site of Algora, Guadalajara, Spain". English. In: Cretaceous Research 37 (2012), pp. 231-239. DOI: 10.1016/j.cretres.2012.04. 004.

[23183] A. Torices, F. Barroso-Barcenilla, O. Cambra-Moo, M. Garca-Oliva, F. Marcos Fernández, J. L. Sanz, and M. Segura. "Estudio preliminar de los dientes de terópodos del Cretácico Superior de Lo Hueco (Fuentes, Cuenca) [Preliminary study of the theropod teeth from the Upper Cretaceous of Lo Hueco (Fuentes, Cuenca)]". English. In: XXIV Jornadas de la Sociedad Española de Paleontologa, 15-18 October 2008. Libro de Resúmenes. Colunga: Museo del Jurásico de Asturias (MUJA), 2008, pp. 209-210.

[23184] A. Torices, P. J. Currie, J. I. Canudo, and X. Pereda-Suberbiola. "Theropod dinosaurs from the Upper Cretaceous of the South Pyrenees Basin of Spain". English. In: Acta Palaeontologica Polonica 60.3 (2015), pp. 611-626. DOI: 10.4202/app.2012.0121.

[23185] A. Torices, J. I. Ruiz-Omeñaca, J. I. Canudo, and N. López-Martnez. "Nuevos datos sobre los dinosaurios terópodos (Saurischia: Theropoda) del Cretácico superior de los Pirineos Sur-Centrales (Huesca y Lleida) [New data on the theropod dinosaurs (Saurischia: Theropoda) from the Upper Cretaceous of the south-central Pyrenées (Huesca and Lleida)]". Spanish. In: Geo-Temas 6.5 (2004), pp. 71-74.

[23186] A. Torices Hernández. “Los dinosaurios terópodos del Cretácico Superior de la Cuenca de Tremp (Pirineos Sur-Centrales, Lleida)". Spanish. In: Coloquios de Paleontologa 53 (2002), pp. 139-146.

[23187] P. Toriño and D. Perea. "New contributions to the systematics of the Plohophorini (Mammalia, Cingulata, Glyptodontidae) from Uruguay". English. In: Journal of South American Earth Sciences 86 (2018), pp. 410-430. DOI: 10.1016/j.jsames.2018.07.006.

[23188] M. A. Tornow and T. A. Arbor. "Apatemyids (Mammalia, Apatotheria) from the middle Chadronian (late Eocene) of Sioux County, Nebraska, USA". English. In: Palaeontologia Electronica 20.1.9A (2017), pp. 1-16. 
[23189] B. A. Toro. “Las zonas de Didymograptus (Didymograptellus) bifidus (Arenigiano medio) y Didymograptus (Corymbograptus) deflexus (Arenigiano inferior) en la Formacion Acoite, Cordillera Oriental, Argentina". Spanish. In: Ameghiniana 31.3 (1994), pp. 209-220.

[23190] B. A. Toro. "Asociaciones de graptolitos del Arenig de la localidad tipo de la Formacion La Alumbrera, Sistema de Famatina, Argentina". English. In: Revista Espanola de Paleontologia 12.1 (1997), pp. 43-51.

[23191] B. A. Toro. “Primer hallazgo de graptolitos del Silúrico (Llandoveriano) en la Cordillera Oriental, Provincia de Jujuy, Argentina". Spanish. In: Ameghiniana 32.4 (1995), pp. 375-384.

[23192] B. A. Toro, S. E. Heredia, N. C. H. Sánchez, and F. Moreno. "Primer registro de conodontes del Ordovcico Medio asociado a graptolitos clave de la Puna occidental, Argentina: perspectivas para una bioestratigrafa y correlación integrada de la Cuenca Andina Central. (First Middle Ordovician conodont record related to key graptolites from the western Puna, Argentina: perspectives for an integrated biostratigraphy and correlation of the Central Andean Basin)". English. In: Andean Geology 47.1 (2020), pp. 144-161. DOI: 10.5027/andgeov47n1-3261.

[23193] B. A. Toro and N. C. Herrera Sánchez. "Stratigraphical distribution of the Ordovician graptolite Azygograptus Nicholson \& Lapworth in the Central Andean Basin (northwestern Argentina and southern Bolivia)". English. In: Comptes Rendus Palevol 18 (2019), pp. 493-507. DOI: 10.1016/j.crpv. 2019.06.002.

[23194] B. A. Toro and J. Maletz. "The Proximal Development in Cymatograptus (Graptoloidea) from Argentina and Its Relevance for the Early Evolution of the Dichograptacea". English. In: Journal of Paleontology 82.5 (2008), pp. 974-983.

[23195] M. Á Torrente, F. J. Verdú, A. Cobos, and L. Alcala. “Diente de un coelurosaurio (Theropoda, Dinosauria) del Barremiense (Cretácico Inferior) de El Castellar (Teruel, España) [A coelurosaurian tooth (Theropoda, Dinosauria) from the Barremian (Lower Cretaceous) of El Castellar (Teruel, Spain)]". Spanish. In: Geogaceta 63 (2018), pp. 79-82.

[23196] C. R. Torres, L. M. Ogawa, M. A. F. Gillingham, B. Ferrari, and M. van Tuinen. "A multi-locus inference of the evolutionary diversification of extant flamingos (Phoenicopteridae)". English. In: BMC Evolutionary Biology 14.36 (2014), pp. 1-9.

[23197] F. Torres De La Cruz, E. Chacon-Baca, and Y. Edith Gomez-Mancha. “A palaeobiological window into the Lower Cretaceous Cupido Formation". English. In: 18.8 (2018), pp. 187-203.

[23198] M. A. Torres-Martnez, D. P. Heredia-Jiménez, S. A. Quiroz-Barroso, P. Navas-Parejo, F. Sour-Tovar, and S. A. Quiroz-Barragán. "A Permian (late Guadalupian) brachiopod fauna from northeast Mexico and their paleobiogeographic affinities". English. In: Journal of South American Earth Sciences 92 (2019), pp. 41-55. DOI: 10.1016/j.jsames.2019.03.002.

[23199] M. A. Torres-Martnez, D. P. HerediaJiménez, F. Sour-Tovar, B. E. BuitrónSánchez, and R. Barragán. "Permian brachiopods from Chiapas, Mexico: new stratigraphical and paleobiogeographical insights". English. In: PalZ 93 (2019), pp. 607-624. DOI: 10.1007/s12542-018-0436-2.

[23200] M. A. Torres-Martnez and F. Sour-Tovar. "Nuevos braquiópodos prodúctidos (Rhynchonelliformea, Strophomenata) del Carbonfero de la región de Nochixtlán, Oaxaca". Spanish. In: Revista Mexicana de Ciencias Geológicas 29.3 (2012), pp. 696-712.

[23201] M. A. Torres-Martnez, F. Sour-Tovar, and R. Barragán. "Permian (Leonardian) brachiopods from Paso Hondo Formation, Chiapas, southern Mexico. Paleobiogeographical implications". English. In: Journal of South American Earth Sciences 71 (2016), pp. 71-81.

[23202] M. A. Torres-Martnez, F. Sour-Tovar, and R. Barragán. "Kukulkanus, a new genus of buxtoniin brachiopod from the Artinskian-Kungurian (Early Permian) of Mexico". English. In: Alcheringa 42 (2018), pp. 268-275.

[23203] M. F. Tortello. "Redescription of a Lotagnostus-Mendoparabolina faunule (Trilobita; late Furongian) from Quebrada San Isidro, Precordillera of Mendoza, Argentina". English. In: Palaeontologische Zeitschrift 92 (2018), pp. 373-386. 
[23204] M. F. Tortello and O. L. Bordonaro. “Cambrian Agnostid trilobites from Mendoza, Argentina: A systematic revision and biostratigraphic implications". English. In: Journal of Paleontology 71.1 (1997), pp. 74-86.

[23205] M. F. Tortello and E. N. K. Clarkson. “Ontogeny, structure and moulting of Parabolina frequens argentina (Kayser) (Trilobita, Olenidae) from the Furongian of northwestern Argentina". English. In: Ameghiniana 45.1 (2008).

[23206] M. F. Tortello and B. Esteban. "La transicion Cambrico-Ordovicico en la Formacion Volcancito (sierra de Famatina, La Rioja, Argentina)". Spanish. In: Ameghiniana 36.4 (1999), pp. 371-387.

[23207] M. F. Tortello and S. B. Esteban. "Lower Ordovician stratigraphy and trilobite faunas from the southern Famatina Range, La Rioja, Argentina". English. In: Special Papers in Palaeontology 70 (2003), pp. 213-239.

[23208] M. F. Tortello and S. B. Esteban. "Early Ordovician trilobites from the Iruya area (Cordillera Oriental, northwestern Argentina) and their stratigraphic significance". English. In: Journal of Paleontology 90.5 (2016), pp. 923-958.

[23209] M. F. Tortello and S. B. Esteban. "Early Ordovician trilobites from the Nazareno area, northwestern Argentina". English. In: Journal of Paleontology 88.5 (2014), pp. 925-947.

[23210] M. F. Tortello, D. Vizcano, and J. J. Álvaro. "Early Ordovician agnostoid trilobites from the southern Motagne Noire, France". English. In: Journal of Paleontology 80.3 (2006), pp. 477-495. DOI: 10. 1666/0022-3360(2006)80[477:EOATFT]2.0.CO;2.

[23211] V. Torti and L. Angiolini. "Middle Triassic Brachiopods from Val Palina, Bergamasc Alps, Italy". English. In: Rivista Italiana di Paleontologia e Stratigrafia 103.2 (1997), pp. 149-172.

[23212] T. Tortosa, E. Buffetaut, N. Vialle, Y. Dutour, E. Turini, and G. Cheylan. "A new abelisaurid dinosaur from the Late Cretaceous of southern France: palaeobiogeographical implications". English. In: Annales de Paléontologie 100.1 (2014), pp. 63-86. DOI: 10.1016/j.annpal.2013.10.003.

[23213] A. Toscano, M. Abad, F. Ruiz, F. Muniz, G. Alvarez, E. Xio-Mara Garcia, and J. A. Caro. “Nuevos restos de Scaldicetus (Cetacea, Odontoceti, Physeteridae) del Mioceno superior, sector occidental de la Cuenca del Guadalquivir (sur de España)". English. In: Revista Mexicana de Ciencias Geologicas 30.2 (2013), pp. 436-445.

[23214] M. A. Toscano and J. Lundberg. "Early Holocene sea-level record from submerged fossil reefs on the south-east Florida margin". English. In: Geology 26.3 (1998), pp. 255-258.

[23215] M. A. Toscano and J. Lundberg. "Submerged Late Pleistocene reefs on the tectonically-stable S.E. Florida margin: high-precision geochronology, stratigraphy, resolution of Substage 5a sea-level elevation, and orbital forcing". English. In: Quaternary Science Reviews 18 (1999), pp. 753-767.

[23216] M. A. Toscano, I. G. Macintyre, and J. Lundberg. "Last interglacial reef limestones, northeastern St. Croix, US Virgin Islands - evidence of tectonic tilting and subsidence since MIS 5.5". English. In: Coral Reefs 31.1 (2012), pp. 27-38.

[23217] A. M. P. Tosolini and M. Pole. "Insect and clitellate annelid traces in mesofossil assemblages from the Cretaceous of Australasia". English. In: Alcheringa 34 (2010), pp. 397-419.

[23218] A.-M. P. Tosolini, S. McLoughlin, and A. N. Drinnan. "Early Cretaceous megaspore assemblages from southeastern Australia". In: Cretaceous Research 23 (2002), pp. 807-844.

[23219] F. Tosti, A. Mastandrea, A. Guido, F. Demasi, F. Russo, and R. Riding. "Biogeochemical and redox record of mid-late Triassic reef evolution in the Italian Dolomites". English. In: Palaeogeography, Palaeoclimatology, Palaeoecology 399 (2014).

[23220] L. T. Toth, R. B. Aronson, S. V. Vollmer, J. W. Hobbs, D. H. Urrego, H. Cheng, I. C. Enochs, D. J. Combosch, R. van Woesik, and I. G. Macintyre. "ENSO Drove 2500-Year Collapse of Eastern Pacific Coral Reefs". English. In: Science 337.81 (2012).

[23221] A. Tourani, N. Benaouiss, G. Gand, S. Bourquin, N. -E. Jalil, J. Broutin, B. Battail, D. Germain, F. Khaldoune, S. Sebban, J. -S. Steyer, and R. Vacant. "Evidence of an Early Triassic age (Olenekian) in Argana Basin (High Atlas, Morocco) based on new chirotherioid traces". English. In: Comptes Rendus Palevol 9 (2010), pp. 201-208. DOI: 10.1016/j.crpv.2010.05.001. 
[23222] V. Tourloukis, N. Thompson, C. Garefalakis, P. Karkanas, G. E. Konidaris, E. Panagopoulou, and K. Harvati. "New Middle Palaeolithic sites from the Mani Peninsula, Southern Greece". English. In: Journal of Field Archaeology (2016), pp. 1-16. DOI: 10.1080/00934690.2015.1125223.

[23223] B. Townsend and D. A. Croft. "Middle Miocene Mesotheriine diversity at Cerdas, Bolivia and a reconstruction of Plesiotypotherium minus". English. In: Palaeontologia Electronica 13.1 (2010), 1A.

[23224] K. E. B. Townsend and D. A. Croft. "Diets of notoungulates from the Santa Cruz Formation, Argentina: new evidence from enamel microwear". English. In: Journal of Vertebrate Paleontology 28.1 (2008), pp. 217-230.

[23225] E. T. Tozer. "Canadian Triassic Ammonoid Faunas". In: Geological Survey of Canada Bulletin 467 (1994), pp. 1-663.

[23226] E. T. Tozer. "Significance of Triassic stage boundaries defined in North America". English. In: Mémoires de Géologie Lausanne 22 (1994), pp. 155-170.

[23227] E. T. Tozer and T. J. Calon. "Triassic ammonoids from Jabal Safra and Wadi Alwa, Oman, and their significance". English. In: In: Robertson, A. H. F., Searle, M. P. E Ries, A. C. (eds) The Geology and Tectonics of the oman Region Geological Society, London, Special Publication 49 (1990), pp. 203-211.

[23228] S. Tracey. Mollusca of the Selsey Formation (Middle Eocene): Conoidea, Turrinae. 1996.

[23229] S. Tracey, J. A. Todd, J. Le Renard, C. King, and M. Goodchild. Distribution of Mollusca in Units S1 to S9 of the Selsey Formation (middle Lutetian), Selsey Peninsula, West Sussex. 1996.

[23230] E. Trajano and H. Ferrarezzi. "A fossil bear from northeastern Brazil, with a phylogenetic analysis of the South American extinct Tremarctinae (Ursidae)". English. In: Journal of Vertebrate Paleontology 14.4 (1995), pp. 552-561.

[23231] J. Trappe. "Stratigraphy, facies distribution and paleogeography of the marine Paleogene from the Western High Atlas, Morocco". English. In: Neues Jahrbuch für Geologie und Paläontologie, Abhandlungen 180.3 (1991), pp. 279-321.

[23232] K. J. Travouillion, Y. Gurovich, R. M. D. Beck, and J. Muirhead. “An exceptionally well-preserved short-snouted bandicoot (Marsupialia; Peramelemorphia) from Riversleigh's Oligo-Miocene deposits, northwestern Queensland, Australia". English. In: Journal of Vertebrate Paleontology 30.5 (2010), pp. 1528-1546. DOI: 10.1080/02724634.2010.501463.

[23233] K. J. Travouillon, M. Archer, and S. J. Hand. “Revision of Wabularoo, an early macropodid kangaroo from mid-Cenozoic deposits of the Riversleigh World Heritage Area, Queensland, Australia". English. In: Alcheringa: An Australasian Journal of Palaeontology 39.2 (2015), pp. 274-286.

[23234] K. J. Travouillon, B. N. Cooke, M. Archer, and S. J. Hand. "Revision of basal macropodids from the Riversleigh World Heritage Area with descriptions of new material of Ganguroo bilamina Cooke, 1997 and a new species". English. In: Palaeontologia Electronica 17.1 (2014), pp. 1-34.

[23235] K. J. Travouillon, S. J. Hand, M. Archer, and K. H. Black. "Earliest modern bandicoot and bilby (Marsupialia, Peramelidae and Thylacomyidae) from the Miocene of Riversleigh World Heritage area, northwestern Queensland, Australia". English. In: Journal of Vertebrate Paleontology 34.2 (2014), pp. 375-382.

[23236] K. J. Travouillon, J. Louys, G. J. Price, M. Archer, S. J. Hand, and J. Muirhead. "A review of the Pliocene bandicoots of Australia, and descriptions of new genus and species". English. In: Journal of Vertebrate Paleontology 37.5 (2017), e1360894. DOI: 10.1080/02724634.2017.1360894.

[23237] K. Travoullion, Y. Gurovich, R. M. D. Beck, and J. Muirhead. “An exceptionally well-preserved short-snouted bandicoot (Marsupialia, Peramelemorphia) from Riversleigh's Oligo-Miocene deposits, northwestern Queensland, Australia". English. In: Journal of Vertebrate Paleontology 30.5 (2010), pp. 1528-1546.

[23238] J. V. Tremblay and S. R. Westrop. "Middle Ordovician (Whiterockian) trilobites from the Sunblood Formation, District of Mackenzie, Canada". English. In: Journal of Paleontology 65.5 (1991), pp. 801824. 
[23239] G. Tresise and W. A. S. Sarjeant. The Tracks of Triassic Vertebrates: Fossil Evidence from North-West England. English. London: The Stationary Office for National Museums \& Galleries on Merseyside, 1997, pp. 1-204.

[23240] E. Trevisani and R. Cestari. Upper Cretaceous rudist bivalves from basinal highs (Venetian Prealps, northern Italy). English. Vol. 87. Cretaceous rudists and carbonate platforms: environmental feedback, SEPM Special Publication. 2007, pp. 71-80.

[23241] C. M. Tribull, P. Barden, and M. Olmi. “Hybristodryinus moutesoe (Hymenoptera, Dryinidae), a new species from mid-Cretaceous Kachin (Burmese) amber". English. In: Cretaceous Research 114.104528 (2020). DOI: $10.1016 /$ j.cretres.2020.104528.

[23242] N. Trif, R. Ciobanu, and V. Codrea. "The first record of the giant shark Otodus megalodon (Agassiz, 1835) from Romania". English. In: Brukenthal. Acta Musei 11.3 (2016), pp. 507-526.

[23243] F. A. Trikolidi and I. V. Novikov. "The First Find of the Dental Plate of the Genus Myliobatis Cuvier (Elasmobranchii: Batomorphii)". English. In: Paleontological Journal 54.2 (2020), pp. 166-170.

[23244] K. Tripalo, S. Japundi, J. Sremac, and M. Bonjak. "First record of Acanthuridae (surgeonfish) from the Miocene deposits of the Medvednica Mt". English. In: Geological Croatica 69.2 (2016), pp. 201204. DOI: 10.4154 /gc.2016.15.

[23245] R. P. Tripp. "Review of the trilobites from the Middle Ordovician Barr Group, Girvan district, Scotland". English. In: Transactions of the Royal Society of Edinburgh: Earth Sciences 84 (1993), pp. 87102.

[23246] R. P. Tripp, D. M. Rudkin, and W. R. Evitt. "Silicified trilobites of the genus Sphaerocoryphe from the Middle Ordovician of Virginia". English. In: Canadian Journal of Earth Sciences 34 (1997), pp. 770-788.

[23247] A. R. Trochim and A. C. Dooley. "Diatom biostratigraphy and paleoecology of vertebrate-bearing Miocene localities in Virginia". English. In: Jeffersoniana 23 (2010), pp. 1-18.

[23248] B. A. Trofimov and F. S. Szalay. "New Cretaceous marsupial from Mongolia and the early radiation of Metatheria". English. In: Proceedings of the National Academy of Sciences 91 (1994), pp. 1256912573.

[23249] K.-A. Tröger, H. Summesberger, and P. Skoumal. "Inoceramidae from the Campanian (Upper Cretaceous) of the Gschliefgraben (Ultrahelvetic, Austria)". In: Beiträge zur Paläontologie 24 (1999), pp. 41-61.

[23250] K.-A. Tröger and W. K. Christensen. “Upper Cretaceous (Cenomanian-Santonian) inoceramid bivalve faunas from the island of Bornholm, Denmark". English. In: Geological Survey of Denmark, DGU Series A 28 (1991), pp. 1-47.

[23251] C. Trögl. “Ein Korallenriff aus dem Oberen Malm südlich von Dollnstein, Mittelfranken”. German. In: Archaeopteryx 18 (2000), pp. 93-100.

[23252] R. Trompette. "Temporal relationship between cratonization and glaciation: The Vendian-early Cambrian glaciation in Western Gondwana". English. In: Palaeogeography, Palaeoclimatology, Palaeoecology 123 (1996), pp. 373-383.

[23253] A. Troncoso, M. Suárez, R. de la Cruz, and S. Palma-Heldt. "Paleoflora de la Formación Ligorio Márquez (XI Región, Chile) en su localidad tipo: sistemática, edad e implicancias paleoclimáticas". English. In: Revista Geológica de Chile 29.1 (2002), pp. 113-135. DOI: 10.4067 / S071602082002000100007.

[23254] G. Tröster. "Neue Arten der Gattung Macropunctum (Insecta, Coleoptera, Elateridae) aus der Olschieferfazies der mitteleozänen Messelformation der Grube Messel bei Darmstadt". German. In: Paläontologische Zeitschrift 68 (1994), pp. 145-162.

[23255] G. Tröster. "An unusual new fossil click-beetle (Coleoptera: Elateridae) from the Middle Eocene of the Grube Messel (Germany)". English. In: Neues Jahrbuch für Geologie und Paläontologie, Monatshefte 1999.1 (1999), pp. 11-20. 
[23256] M. J. Trotteyn, A. B. Arcucci, and T. Raugust. “Proterochampsia: an endemic archosauriform clade from South America". English. In: vol. 379. Anatomy, Phylogeny and Palaeobiology of Early Archosaurs and their Kin. Geological Society, London, Special Publications, 2013.

[23257] M. J. Trotteyn, R. N. Martinez, and O. A. Alcober. "A new proterochampsid Chanaresuchus ischigualastensis (Diapsida, Archosauriformes) in the early Late Triassic Ischigualasto Formation, Argentina". English. In: Journal of Vertebrate Paleontology 32.2 (2012), pp. 485-489.

[23258] L. Trueb, C. F. Ross, and R. M. H. Smith. "A new pipoid anuran from the Late Cretaceous of South Africa". English. In: Journal of Vertebrate Paleontology 25.3 (2005), pp. 533-547.

[23259] C. N. G. Trueman, J. H. Field, J. Dortch, B. Charles, and S. Wroe. "Prolonged coexistence of humans and megafauna in Pleistocene Australia". English. In: Proceedings of the National Academy of Sciences of the United States of America 102.23 (2005), pp. 8381-8385.

[23260] L. Trunko and W. Munk. “Makrofloren aus dem Unterrotliegenden (Unterperm) von Alsenz bei Bad Kreuznach/Rheinland Pfalz". German. In: Carolinea 48 (1990), pp. 21-30.

[23261] E. M. Truswell and M. K. Macphail. "Polar forests on the edge of extinction: what does the fossil spore and pollen evidence from East Antarctica say?." English. In: Australian Systematic Botany 22 (2009), pp. 57-106. DOI: 10.1071/SB08046.

[23262] C. H. Tsai, C. H. Chang, and L. K. Lin. Occurrence of fossil balaenids in Taiwan and its implications for climate change. English. 2012.

[23263] C. H. Tsai, R. E. Fordyce, C. H. Chang, and L. K. Lin. "A Review and Status of Fossil Cetacean Research in Taiwan". English. In: Taiwan Journal of Biodiversity 15.2 (2013), pp. 113-124.

[23264] C. H. Tsai and R. E. Fordyce. "Archaic baleen whale from the Kokoamu Greensand: earbones distinguish a new late Oligocene mysticete (Cetacea: Mysticeti) from New Zealand". English. In: Journal of the Royal Society of New Zealand 46.2 (2016), pp. 117-138. DOI: 10.1080 / 03036758.2016. 1156552.

[23265] C.-H. Tsai and T. Ando. "Niche Partitioning in Oligocene Toothed Mysticetes (Mysticeti: Aetiocetidae)". English. In: Journal of Mammalian Evolution (2015). DOI: 10.1007/s10914-015-9292-y.

[23266] C.-H. Tsai and T. Ando. "Niche partitioning in Oligocene toothed mysticetes (Mysticeti: Aetiocetidae)". English. In: Journal of Mammalian Evolution 23 (2016), pp. 33-41. DOI: 10.1007/s10914-0159292-y.

[23267] C.-H. Tsai and R. W. Boessenecker. "An Early Pleistocene gray whale (Cetacea: Eschrichtiidae) from the Rio Dell Formation of northern California". English. In: Journal of Paleontology 89.1 (2015), pp. 103-109. DOI: 10.1017/jpa.2014.9.

[23268] C.-H. Tsai and R. W. Boessenecker. "The earliest-known fin whale, Balaenoptera physalus, from the Early Pleistocene of northern California, U.S.A". English. In: Journal of Vertebrate Paleontology (2017), e1306536. DOI: 10.1080/02724634.2017.1306536.

[23269] C.-H. Tsai and C.-H. Chang. "A right whale (Mysticeti, Balaenidae) from the Pleistocene of Taiwan". English. In: Zoological Letters 5.37 (2019). DOI: 10.1186/s40851-019-0153-z.

[23270] C.-H. Tsai, A. Collareta, E. M. G. Fitzgerald, F. G. Marx, N. Kohno, M. Bosselaers, G. Insacco, A. Reitano, R. Catanzariti, M. Oishi, and G. Bianucci. "Northern pygmy right whales highlight Quaternary marine mammal interchange". English. In: Current Biology 27 (2017), R1037-R1059.

[23271] C.-H. Tsai, A. Collareta, and M. Bosselaers. "A Pliocene gray whale (Eschrichtius sp.) from the Eastern North Atlantic". English. In: Rivista Italiana di Paleontologia e Stratigrafia 126.1 (2020), pp. 189196.

[23272] C.-H. Tsai, R. E. Fordyce, C. -H. Chang, and L. -K. Lin. "Quaternary fossil gray whales from Taiwan". English. In: Paleontological Research 18.2 (2014), pp. 82-93. DOI: 10.2517/2014PR009.

[23273] C.-H. Tsai and R. E. Fordyce. "The Earliest Gulp-Feeding Mysticete (Cetacea: Mysticeti) from the Oligocene of New Zealand". English. In: Journal of Mammalian Evolution (2015). DOI: 10.1007 / s10914-015-9290-0. 
[23274] C.-H. Tsai and R. E. Fordyce. "A new archaic baleen whale Toipahautea waitaki (early Late Oligocene, New Zealand) and the origins". English. In: Royal Society Open Science 5.4 (2018), p. 172453. DOI: 10.1098/rsos.172453.

[23275] N. Tsaparas and A. Marcopoulou-Diacantoni. "Tortonian Scleractinian Corals from the island of Gavdos (South Greece)". English. In: Revue de Paléobiologie 24.2 (2005), pp. 629-637.

[23276] N. Tsaparas and A. Marcopoulou-Diacantoni. "Otoliths from the Middle to Upper Miocene of the Gavdos Island (South Greece)". English. In: Revue de Paléobiologie 24.2 (2005), pp. 617-628.

[23277] E. Tschopp and O. Mateus. "The skull and neck of a new flagellicaudatan sauropod from the Morrison Formation and its implication for the evolution and ontogeny of diplodocid dinosaurs". English. In: Journal of Systematic Palaeontology 11.7 (2013), pp. 853-888. DOI: 10.1080 / 14772019. 2012.746589.

[23278] E. Tschopp, O. Mateus, and R. B. J. Benson. "A specimen-level phylogenetic analysis and taxonomic revision of Diplodocidae (Dinosauria, Sauropoda)". English. In: PeerJ 3 (2015), e857. DOI: 10.7717 / peerj. 857 .

[23279] E. Tschopp and O. Mateus. “Osteology of Galeamopus pabsti sp. nov. (Sauropoda: Diplodocidae), with implications for neurocentral closure timing, and the cervico-dorsal transition in diplodocids". English. In: PeerJ 5 (2017), e3179:1-126.

[23280] Z. J. Tseng and C.-H. Chang. "A Study of New Material of Crocuta crocuta ultima (Carnivora:" English. In: Collection and Research 20 (2007), pp. 9-19. DOI: 10.6693/CAR.2007.20.2.

[23281] Z. J. Tseng, A. Pacheco-Castro, O. Carranza-Castañeda, J. J. Aranda-Gómez, X. Wang, and H. Troncoso. "Discovery of the fossil otter Enhydritherium terraenovae (Carnivora, Mammalia) in Mexico reconciles a palaeozoogeographic mystery". English. In: 13.20170259 (2017), pp. 1-5. DOI: 10.1098/rsbl.2017.0259.

[23282] Z. J. Tseng, G. T. Takeuchi, and X. Wang. "Discovery of the upper dentition of Barbourofelis whitfordi (Nimravidae, Carnivora) and an evaluation of the genus in California". English. In: Journal of Vertebrate Paleontology 30.1 (2010), pp. 244-254. DOI: 10.1080/02724630903416001.

[23283] Z. J. Tseng, X. Wang, G. J. Slater, G. T. Takeuchi, Q. Li, J. Liu, and G. Xie. "Himalayan fossils of the oldest known pantherine establish ancient origin of big cats". English. In: Proceedings of the Royal Society B 281 (2013). DOI: 10.1098/rspb.2013.2686.

[23284] Z. J. Tseng, X. Wang, and J. D. Stewart. “A new immigrant mustelid (Carnivora, Mammalia) from the middle Miocene Temblor Formation of central California". English. In: PaleoBios 29.1 (2009), pp. 13-23.

[23285] K. A. Tsepelev, E. V. Zinovyev, R. Y. Dudko, S. E. Tshernyshev, and A. A. Legalov. “Carrion beetles (Coleoptera, Silphidae) in Younger Dryas of Chick River (Late Pleistocene of Siberia)". Russian. In: Euroasian Entomological Journal 12 (2013), pp. 27-34.

[23286] S. E. Tshernyshev. "Aploceble (Chalcoaploceble) viridiaeneus Tshernyshev — new subgenus and species of dasytid beetles (Coleoptera, Dasytidae) in Baltic amber". English. In: Euroasian Entomological Journal 11 (2012), pp. 213-218.

[23287] S. E. Tshernyshev. "New taxa of soft-winged flower beetles (Coleoptera, Malachiidae) in Baltic and Rovno amber". English. In: Paleontological Journal 50 (2016), pp. 953-962.

[23288] S. E. Tshernyshev. "New species of malachite beetles (Coleoptera, Dasytidae) in Baltic amber". English. In: Paleontological Journal 53 (2019), pp. 1024-1035. DOI: 10.1134/S0031030119100022.

[23289] S. E. Tshernyshev. "New taxa of soft-winged flower beetles (Coleoptera, Malachiidae) in Baltic amber". English. In: Paleontological Journal 54 (2020), pp. 279-286. DOI: 10.1134/S0031030120030065.

[23290] S. E. Tshernyshev, K. A. Tsepelev, R. Y. Dudko, E. V. Zinovyev, and A. A. Legalov. "Pill beetles (Coleoptera, Byrrhidae) in late Pleistocene deposits in the south of the west Siberia". Russian. In: Euroasian Entomological Journal 12 (2013), pp. 109-119. 
[23291] D. Tshudy and U. Sorhannus. "Jagtia kunradensis, a new genus and species of clawed lobster (Decapoda: Nephropidae) from the Upper Cretaceous (Upper Maastrichtian) Maastricht Formation, the Netherlands". English. In: Journal of Paleontology 74.2 (2000), pp. 224-229.

[23292] K. Tsogtbaatar. "Fossil specimens prepared in Mongolian Paleontological Center 1993-2001". English. In: Hayashibara Museum of Natural Sciences Research Bulletin 2 (2004), pp. 123-128.

[23293] K. Tsogtbaatar, D. B. Weishampel, D. C. Evans, and M. Watabe. “A new hadrosauroid (Dinosauria: Ornithopoda) from the Late Cretaceous Baynshire Formation of the Gobi Desert (Mongolia)". English. In: PLoS ONE 14.4 (2019), e0208480:1-47. DOI: 10.1371/journal.pone.0208480.

[23294] E. Tsoukala. "Quaternary large mammals from the Apidima Caves (Lakonia, S. Peloponnese, Greece". In: Beitraege zur palaeontologie 24 (1999), pp. 207-229.

[23295] E. Tsoukala. "The Pleistocene large mammals from the Agios Georgios Cave, Kilkis (Macedonia, N. Greece)". English. In: Geobios 25.3 (1992), pp. 415-433.

[23296] E. Tsoukala. "Rhinocerotidae from the Late Miocene and Late Pliocene of Macedonia, Greece. A revision of the Neogene - Quaternary Rhinocerotidae of Greece". English. In: Revue de Paléobiologie, Genéve 37.2 (2018), pp. 609-630. DOI: 10.5281/zenodo.2545127.

[23297] E. Tsoukala, A. Batsiokas, K. Chatzopoulou, and G. Lazaridis. “Quaternary mammalian remains from the Kitseli Pothole (Alea, Nemea, Peloponnese)". English. In: Scientific Annals, School of Geology, Aristotle University of Thessaloniki, Special volume 98 (2006), pp. 273-284.

[23298] E. Tsoukala and K. Chatzopoulou. "A New Early Pleistocene (Latest Villafranchian) Site with Mammals in Kalamotó (Mygdonia Basin, Macedonia, Greece) - Preliminary Report". English. In: Mitt. Komm. Quartärforsch. Österr. Akad. Wiss 14 (2005), pp. 213-233.

[23299] E. Tsoukala, K. Chatzopoulou, G. Rabeder, D. Nagel, and G. Withalm. "Paleontological and stratigraphical research in Loutrá Aridéas bear cave". English. In: Scientific Annals, School of Geology Aristotle University of Thessaloniki (AUTH) 98 (2006), pp. 41-67.

[23300] E. Tsoukala and A. Lister. "Remains of straight-tusked elephant, Elephas (Palaeoloxodon) antiquus Falc. \& Caut., 1847 ESR-dated to oxygen isotope Stage 6 from Grevena (W. Macedonia, Greece)". English. In: Bolletino della Societa Paleontologica Italiana 37.1 (1998), pp. 117-139.

[23301] E. Tsoukala and J. K. Melentis. “Deinotherium giganteum Kaup (Proboscidea) from Kassandra peninsula (Chalkidiki, Macedonia, Greece)". English. In: Geobios 27.5 (1994), pp. 633-640.

[23302] E. Tsoukala, D. Mol, S. Pappa, E. Vlachos, W. van Logchem, M. Vaxevanopoulos, and J. Reumer. "Elephas antiquus in Greece: New finds and a reappraisal of older material (Mammalia, Proboscidea, Elephantidae)". English. In: Quaternary International 245 (2011), pp. 339-349. DOI: 10. 1016/j.quaint.2010.10.008.

[23303] E. Tsoukala and D. Mol. “The Proboscidea of the Early Villafranchian site of Milia (Grevena, Macedonia, Greece)". English. In: Quaternary International 406 (2016), pp. 4-24. DOI: 10.1016/j.quaint. 2014.10.026.

[23304] T. Tsubamoto. "Recognition of Microbunodon (Artiodactyla, Anthracotheriidae) from the Eocene of China". English. In: Paleontological Research 14.2 (2010), pp. 161-165.

[23305] T. Tsubamoto, N. Egi, M. Takai, C. Sein, and M. Maung. "Middle Eocene ungulate mammals from Myanmar: A review with description of new specimens". English. In: Acta Palaeontologica Polonica 50.1 (2005), pp. 117-138.

[23306] T. Tsubamoto, N. Egi, M. Takai, Thaung-Htike, and Zin-Maung-Maung-Thein. "A new genus and species of bunodont artiodactyl from the Eocene Pondaung Formation, Myanmar". English. In: Paleontological Research 17.4 (2013), pp. 297-311. DOI: 10.2517/1342-8144-17.4.297.

[23307] T. Tsubamoto, P. A. Holroyd, M. Takai, N. Shigehara, A. K. Aung, T. Thein, A. N. Soe, and S. T. Tun. "Upper premolar dentitions of Deperetella birmanica (Mammalia: Perissodactyla: Deperetellidae) from the Eocene Pondaung Formation, Myanmar". English. In: Paleontological Research 4.3 (2000), pp. 183-189. 
[23308] T. Tsubamoto, Y. Koda, Y. Hasegawa, S. Nabana, and Y. Tomida. "Paleogene mammals from the Iwaki Formation in Japan: Their implications for the geologic age and paleobiogeography of this formation". English. In: Journal of Asian Earth Sciences 108 (2015), pp. 18-32.

[23309] T. Tsubamoto and N. Kohno. "Reappraisal of Brachyodus japonicus, an Oligocene anthracotheriid cetartiodactyl from Japan". English. In: Paleontological Research 15.3 (2011), pp. 115-124.

[23310] T. Tsubamoto, T. Matsubara, S. Tanaka, and H. Saegusa. “Geological age of the Yokawa Formation of the Kobe Group (Japan) on the basis of terrestrial mammalian fossils". English. In: Island Arc 16.3 (2007), pp. 479-492.

[23311] T. Tsubamoto, G. W. Rougier, S. Isaji, M. Manabe, and A. M. Forasiepi. “New Early Cretaceous spalacotheriid symmetrodont mammal from Japan". English. In: Acta Palaeontologica Polonica 49.3 (2004), pp. 329-346.

[23312] T. Tsubamoto, M. Saneyoshi, M. Watabe, K. Tsogtbaatar, and B. Mainbayar. “The Entelodontid Artiodactyl Fauna from the Eocene Ergilin Dzo Formation of Mongolia with Comments on Brachyhyops and the Khoer Dzan Locality". English. In: Paleontological Research 15.4 (2011), pp. 258-268.

[23313] T. Tsubamoto, Z. M. M. Thein, T. Htike, N. Egi, C. Sein, M. Maung, and M. Takai. “Discovery of chalicothere and Dorcabune from the upper part (lower Pleistocene) of the Irrawaddy Formation, Myanmar". English. In: Asian Paleoprimatology 4 (2006), pp. 137-142.

[23314] T. Tsubamoto and K. Tsogtbaatar. "New specimens of anthracotheriid artiodactyls from the Upper Eocene Ergilin Dzo Formation of Mongolia". English. In: Paleontological Research 12.4 (2008), pp. 371-386.

[23315] T. Tsubamoto, K. Tsogtbaatar, M. Saneyoshi, B. Mainbayar, M. Watabe, T. Chinzorig, S. Suzuki, P. Khatanbaatar, S. Ishigaki, and R. Barsbold. "Fossil Evidence of a Mesonychid Mammal from the Upper Eocene Ergilin Dzo Formation, Mongolia". English. In: Paleontological Research 16.2 (2012), pp. 171-174. DOI: 10.2517/1342-8144-16.2.171.

[23316] T. Tsubamoto, K. Tsogtbaatar, T. Chinzorig, B. Mainbayar, N. Egi, M. Saneyoshi, and H. Nishido. “Dental morphology of 'Pterodon sp.' (Mammalia; Hyaenodontidae) described from the Eocene Ergilin Dzo Formation, Mongolia". English. In: Bulletin of Research Institute of Natural Sciences Okayama University of Science 39 (2013), pp. 43-44.

[23317] T. Tsubamoto, S. T. Tun, N. Egi, M. Takai, N. Shigehara, A. N. Soe, A. K. Aung, and T. Thein. "Reevaluation of some ungulate mammals from the Eocene Pondaung Formation, Myanmar". English. In: Paleontological Research 7.3 (2003), pp. 219-243.

[23318] T. Tsubamoto, M. Watabe, and K. Tsogtbaatar. "Hyaenodon chunkhtensis and the hyaenodontid fauna from the upper Eocene Ergilin Dzo Formation of Mongolia". English. In: Journal of Vertebrate Paleontology 28.2 (2008), pp. 559-564.

[23319] T. Tsubamoto, Zin-Maung-Maung-Thein, N. Egi, T. Nishimura, Thaung-Htike, and M. Takai. "A new anthracotheriid artiodactyl from the Eocene Pondaung Formation of Myanmar". English. In: Vertebrata PalAsiatica 49.1 (2011), pp. 85-113.

[23320] T. Tsuihiji, B. Andres, P. M. O'Connor, M. Watabe, K. Tsogtbaatar, and B. Mainbayar. “Gigantic pterosaurian remains from the Upper Cretaceous of Mongolia". English. In: Journal of Vertebrate Paleontology 37.5 (2017), e1361431:1-8. DOI: 10.1080/02724634.2017.1361431.

[23321] T. Tsuihiji, T. Komatsu, M. Manabe, Y. Miyake, M. Aramaki, and H. Sekiguchi. "Theropod tooth from the Upper Cretaceous Himenoura Group in the Koshikijima Islands, southwestern Japan". English. In: Paleontological Research 17.1 (2013), pp. 39-46. DOI: 10.2517/1342-8144-17.1.39.

[23322] T. Tsuihiji, M. Watabe, K. Tsogtbaatar, R. Barsbold, and S. Suzuki. “A tyrannosauroid frontal from the Upper Cretaceous (Cenomanian-Santonian) of the Gobi Desert, Mongolia". English. In: Vertebrata PalAsiatica 50.2 (2012), pp. 102-110.

[23323] T. Tsuihiji, M. Watabe, R. Barsbold, and K. Tsogtbaatar. "A gigantic caenagnathid oviraptorosaurian (Dinosauria: Theropoda) from the Upper Cretaceous of the Gobi Desert, Mongolia". English. In: Cretaceous Research 56.1 (2015), pp. 60-65. DOI: 10.1016/j.cretres.2015.03.007. 
[23324] T. Tsuihiji, L. M. Witmer, M. Watabe, R. Barsbold, K. Tsogtbaatar, S. Suzuki, and P. Khatanbaatar. "New information on the cranial morphology of Avimimus (Theropoda: Oviraptorosauria)". English. In: Journal of Vertebrate Paleontology 37.4 (2017), e1347177:1-12. DOI: 10.1080/02724634.2017. 1347177.

[23325] L. A. Tsuji. "Mandaphon nadra gen. et sp. nov., a new procolophonid from the Manda Beds of Tanzania". English. In: Journal of Vertebrate Paleontology 37.6 (Supp.) (2018), pp. 80-87.

[23326] L. A. Tsuji and J. Müller. "A Re-evaluation of Parasaurus geinitzi, the first named pareiasaur (Amniota, Parareptilia)". English. In: Canadian Journal of Earth Sciences 45.10 (2008), pp. 1111-1121.

[23327] L. A. Tsuji, J. Müller, and R. R. Reisz. “Microleter mckinzieorum gen. et sp. nov. from the Lower Permian of Oklahoma: the basalmost parareptile from Laurasia". English. In: Journal of Systematic Palaeontology 8.2 (2010), pp. 245-255. DOI: 10.1080/14772010903461099.

[23328] L. A. Tsuji, G. Sobral, and J. Müller. "Ruhuhuaria reiszi, a new procolophonoid reptile from the Triassic Ruhuhu Basin of Tanzania". English. In: Comptes Rendus Palevol 12 (2013), pp. 487-494.

[23329] Y. Tsujino, Y. Shigeta, H. Maeda, T. Komatsu, and N. Kusuhashi. “Late Triassic ammonoid Sirenites from the Sabudani Formation in Tokushima, Southwest Japan, and its biostratigraphic and paleobiogeographic implications". English. In: Island Arc 22 (2013), pp. 549-561. DOI: 10.1111/iar.12050.

[23330] N. Tsuzuku and N. Kohno. "The oldest record of the Steller sea lion Eumetopias jubatus (Schreber, 1776) from the early Pleistocene of the North Pacific". English. In: PeerJ 8 (2020), e9709. DOI: 10. 7717 / peerj. 9709.

[23331] A. N. Tsvelykh. “The Northern Gannet (Morus bassanus, Pelecaniformes, Sulidae)". English. In: Biology Bulletin 43.9 (2016), pp. 1052-1055.

[23332] A. B. Tucker and R. M. Feldmann. "Fossil Decapod Crustaceans from the Lower Tertiary of the Prince Willam Sound Region, Gulf of Alaska". In: Journal of Paleontology 64.3 (1990), pp. 409-427.

[23333] S. T. Tucker, R. E. Otto, R. M. Joeckel, and M. R. Voorhies. "The geology and paleontology of Ashfall Fossil Beds, a late Miocene (Clarendonian) mass-death assemblage, Antelope County and adjacent Knox County, Nebraska, USA". English. In: Geological Society of America Field Guide 36 (2014), pp. 1-22. DOI: $10.1130 / 2014.0036(01)$.

[23334] T. A. Tumanova. "O novom pantsirnov dinozavre iz iugo-vostochnoy Gobi [A new armored dinosaur from Southeastern Gobi]". Russian. In: Paleontologicheskii Zhurnal 1993.2 (1993), pp. 92-98.

[23335] T. A. Tumanova and V. R. Alifanov. "First record of stegosaur (Ornithischia, Dinosauria) from the Aptian-Albian of Mongolia". English. In: Paleontological Journal 52.14 (2018), pp. 1771-1779. DOI: 10.1134/S0031030118140186.

[23336] T. A. Tumanova, Y. L. Bolotsky, and V. R. Alifanov. "The first finds of armored dinosaurs in the Upper Cretaceous of Russia (Amur region)". In: Paleontological Journal 38.1 (2004), pp. 73-77.

[23337] G. F. Turazzini, M. L. Taglioretti, and R. O. Gomez. "First Fossil Record of the South American Frog Genus Odontophrynus Reinhardt and Lutken, 1862 (Anura, Neobatrachia)". English. In: Journal of Vertebrate Paleontology 36.6 (2016), e1228657. DOI: 10.1080/02724634.2017.1228657.

[23338] I. Turculet. "New data about the Ammonite fauna from the Triassic developed in the Wengen facies at Cataloi (North Dobrujda orogen)". English. In: Geologie Tomul LV 2 (2009), pp. 45-50.

[23339] W. D. Turnbull, E. L. Ludelius Jr., and M. Archer. “Dasyurids, Perameloids, Phalangeroids, and Vombatoids from the Early Pliocene Hamilton Fauna, Victoria, Australia". English. In: Bulletin of the American Museum of Natural History 279 (2003), pp. 513-540.

[23340] A. H. Turner. "Osteology and phylogeny of a new species of Araripesuchus (Crocodyliformes: Mesoeucrocodylia) from the Late Cretaceous of Madagascar". English. In: Historical Biology 18.3 (2006), pp. 255-369. DOI: 10.1080/08912960500516112.

[23341] A. H. Turner and G. A. Buckley. "Mahajangasuchus insignis (Crocodyliformes: Mesoeucrocodylia) cranial anatomy and new data on the origin of the eusuchian-style palate". English. In: Journal of Vertebrate Paleontology 28.2 (2008), pp. 382-408. 
[23342] A. H. Turner and J. O. Calvo. "A new sebecosuchian crocodyliform from the Late Cretaceous of Patagonia". English. In: Journal of Vertebrate Paleontology 25.1 (2005), pp. 87-98.

[23343] A. H. Turner, S. H. Hwang, and M. A. Norell. "A small derived theropod from Öösh, Early Cretaceous, Baykhangor Mongolia". English. In: American Museum Novitates 3557 (2007), pp. 1-27.

[23344] A. H. Turner, S. J. Nesbitt, and M. A. Norell. "A large alvarezsaurid from the Late Cretaceous of Mongolia". English. In: American Museum Novitates 3648 (2009), pp. 1-14.

[23345] A. H. Turner, D. Pol, J. A. Clarke, G. M. Erickson, and M. A. Norell. "A basal dromaeosaurid and size evolution preceding avian flight". English. In: Science 317 (2007), pp. 1378-1381. DOI: 10.1126 /science.1144066.

[23346] C. E. Turner and F. Peterson. Biostratigraphy of dinosaurs in the Upper Jurassic Morrison Formation of the Western Interior, U.S.A. Vol. 99-1. Vertebrate Paleontology in Utah, Utah Geological Survey Miscellaneous Publication. 1999, pp. 77-114.

[23347] S. Turner, J. J. Kuglitsch, and D. L. Clark. "Llandoverian thelodont scales from the Burnt Bluff Group of Wisconsin and Michigan". English. In: Journal of Paleontology 73.4 (1999), pp. 667-676. DOI: $10.1017 / \mathrm{s} 0022336000032480$.

[23348] S. Turner and R. F. Miller. "Protodus jexi Woodward, 1892 (Chondrichthyes), from the Lower Devonian Campbellton Formation, New Brunswick, Canada". English. In: Acta Geologica Polonica 58.2 (2008), pp. 133-145.

[23349] C. S. M. Turney, T. F. Flannery, R. G. Roberts, C. Reid, L. K. Fifield, T. F. G. Higham, Z. Jacobs, N. Kemp, E. A. Colhoun, R. M. Kalin, and N. Ogle. "Late-surviving megafauna in Tasmania, Australia, implicate human involvement in their extinction". English. In: Proceedings of the National Academy of Sciences 105.34 (2008), pp. 12150-12153.

[23350] D. Turnsek. "Upper Cretaceous reef building colonial corals of Gosau facies from Stranice near Slovenske Konjice (Slovenia)". In: Razprave IV. Razreda Sazu 35.1 (1994), pp. 3-41.

[23351] D. Turnsek. Mesozoic corals of Slovenia. English. ZRC SAZU, Ljubljana. 1997, pp. 1-512.

[23352] D. Turnsek. "Tethyan Cretaceous corals in Yugoslavia". English. In: in H. A. Kollmann and H. Zapfe, eds., New aspects on Tethyan Cretaceous fossil assemblages, Schriftenreihe der Erdwissenschaftlichen Kommissionen 9 (1992), pp. 155-170.

[23353] D. Turnsek, T. Dolenec, M. Siblik, B. Ogorelec, O. Ebli, and H. Lobitzer. "Contributions to the fauna (corals, brachiopods) and stable isotopes of the Late Triassic Steinplatte reef/basin-complex, Northern Calcareous Alps, Austria". In: Abhandlungen der geologischen Bundesanstalt 56.2 (1999), pp. 121-140.

[23354] D. Turnsek and A. Kosir. "Bacarella vipavica n. gen., n. sp. (Anthozoa, Scleractinia) from reefal blocks in Lower Eocene carbonate megabeds in the Vipava Valley (SW Slovenia)". English. In: Razprave Slovenska Akademija Znanosti in Umetnosti, Razred za Naravoslovne Vede, 445.3 (2004), pp. $145-169$.

[23355] D. Turnsek and A. Kosir. "Early Jurassic corals from Krim Mountain, Slovenia". English. In: Razprave Slovenska Akademija Znanosti in Umetnosti, Razred za Naravoslovne Vede, IV 41.1 (2000), pp. 81-113.

[23356] D. Turnsek and B. Senowbari-Daryan. "Upper Triassic (Carnian-lowermost Norian) corals from the Pantokrator Limestone of Hydra (Greece)". English. In: Abhandlungen der Geologischen Bundesanstalt Wien 50 (1994), pp. 477-507.

[23357] G. F. Turrisi and S. Ellenberger. "New aulacid wasps from the mid-Cretaceous of Myanmar (Hymenoptera: Evanioidea)". English. In: Cretaceous Research 99 (2019), pp. 334-346. DOI: 10.1016/j. cretres.2019.02.022.

[23358] S. T. Turvey. "Early Ordovician (Arenig) trilobite palaeoecology and palaeobiogeography of the South China Plate". English. In: Palaeontology 48.3 (2005), pp. 519-547. 
[23359] S. T. Turvey, J. Almonte, J. Hansford, R. P. Scofield, J. L. Brocca, and S. D. Chapman. “A new species of extinct Late Quaternary giant tortoise from Hispaniola". English. In: Zootaxa 4277.1 (2017), pp. 1-16.

[23360] S. T. Turvey and D. J. Siveter. "Assignment of the South Chinese Ordovician trilobite Calymene paronai to Neseuretus". English. In: Alcheringa 31.2 (2007), pp. 173-183. DOI: 10.1080/03115510701305157.

[23361] S. T. Turvey and Z. Zhou. "Arenig trilobite associations and faunal changes in Southern Shaanxi, China". English. In: Journal of Asian Earth Sciences 23 (2004), pp. 91-103. DOI: 10.1016 / S13679120(03)00098-1.

[23362] S. T. Turvey and Z. Y. Zhou. "Arenig trilobite associations of Daping, Yichang, Hubei, South China". English. In: Acta Palaeontologica Sinica 41.1 (2002), pp. 10-18.

[23363] T. Tütken and J. Absolon. "Late Oligocene ambient temperatures reconstructed by stable isotope analysis of terrestrial and aquatic vertebrate fossils of Enspel, Germany". English. In: Palaeobiodiversity and Palaeoenvironments 95 (2015), pp. 17-31. DOI: 10.1007/s12549-014-0183-7.

[23364] S. Tuzcu and S. Babayigit. "The occurrence of Donacosmilia corallina de Fromentel (Upper Jurassic) from the Kastamonu region in Turkey". other. In: Türkiye Jeoloji Bülteni (Geological Bulletin of Turkey) 41.1 (1998), pp. 99-107.

[23365] V. P. Tverdokhlebov, G. I. Tverdokhlebova, A. V. Minikh, M. V. Surkov, and M. J. Benton. “Upper Permian vertebrates and their sedimentological context in the South Urals, Russia". English. In: Earth-Science Reviews 69 (2005), pp. 27-77.

[23366] V. P. Tverdokhlebov, G. I. Tverdokhlebova, M. V. Surkov, and M. J. Benton. “Tetrapod localities from the Triassic of the SE of European Russia". English. In: Earth-Science Reviews 60.1-2 (2003), pp. 1-66.

[23367] V. P. Tverdokhlebov, G. I. Tverdokhlebova, M. J. Benton, and G. W. Storrs. “First record of footprints of terrestrial vertebrates from the Upper Permian of the Cis-Urals, Russia". English. In: Palaeontology 40.1 (1997), pp. 157-166.

[23368] J. Tweet, K. Chin, and N. Murphy. An analysis of possible gut contents in a hadrosaurid dinosaur from the Upper Cretaceous (late Campanian) Judith River Formation of Montana. English. 2005.

[23369] R. J. Twitchett, J. M. Feinberg, D. D. O'Connor, W. Alvarez, and L. B. McCollum. “Early Triassic Ophiuroids: their paleoecology, taphonomy and distribution". English. In: Palaios 20 (2005), pp. 213-223.

[23370] D. Tyborowski. "A new ophthalmosaurid ichthyosaur from the Late Jurassic of Owadów-Brzezinki Quarry, Poland". English. In: Acta Palaeontologica Polonica 61.4 (2016), pp. 791-803.

[23371] R. S. Tykoski and A. R. Fiorillo. "An entantiornithine bird from the lower middle Cenomanian of Texas". English. In: Journal of Vertebrate Paleontology 30.1 (2010), pp. 288-292.

[23372] R. S. Tykoski, T. B. Rowe, R. A. Ketcham, and M. W. Colbert. "Calsoyasuchus valliceps, a new crocodyliform from the Early Jurassic Kayenta Formation of Arizona". In: Journal of Vertebrate Paleontology 22.3 (2002), pp. 593-611.

[23373] J. C. Tyler. "Arambourgthurus, a new genus of hypurostegic surgeonfish (Acanthuridae) from the Oligocene of Iran, with a phylogeny of the Nasinae". English. In: Geodiversitas 22.4 (2000), pp. 525537.

[23374] J. C. Tyler. "A new genus and species of surgeon fish (Acanthuridae) with four dorsal-fin spines from the Eocene of Monte Bolca, Italy". English. In: Studi e ricerche sui giacimenti terziari de Bolca. 1999, pp. 257-268.

[23375] J. C. Tyler and A. F. Bannikov. "Relationships of the fossil and recent genera of rabbitfishes (Acanthuroidei: Siganidae)". English. In: Smithsonian Contributions to Paleobiology 84 (1997), pp. 1-35.

[23376] J. C. Tyler and R. Gregorovå. "A new genus and species of Boxfish (Tetraodontiformes: Ostraciidae) from the Oligocene of Moravia, the second fossil representative of the family". English. In: Smithsonian Contributions to Paleobiology 71 (1991), pp. 1-20. 
[23377] J. C. Tyler and N. R. Micklich. "A new genus and species of surgeon fish (Perciformes, Acanthuridae) from the Oligocene of Kanton Glarus, Switzerland". English. In: Swiss Journal of Palaeontology 130 (2011), pp. 203-216. DOI: 10.1007/s13358-011-0016-5.

[23378] J. C. Tyler and F. Santini. "Review and reconstructions of the tetraodontiform fishes from the Eocene of Monte Bolca, Italy, with comments on related Tertiary taxa". English. In: Studi e Ricerche sui Giacimenti Terzari di Bolca. Museo Civico di Storia Naturale di Verona 9 (2002), pp. 47-119.

[23379] J. C. Tyler and L. Sorbini. "New superfamily and three new families of tetraodontiform fishes from the Upper Cretaceous: The earliest and most morphologically primitive plectognaths". English. In: Smithsonian Contributions to Paleobiology 82 (1996), pp. 1-59.

[23380] M. J. Tyler and H. Godthelp. "A new species of Lechriodus Boulenger (Anura: Leptodactylidae) from the Early Eocene of Queensland". English. In: Transactions of the Royal Society of South Australia 117.4 (1993), pp. 187-189.

[23381] T. Tyrberg. "Seabirds and Late Pleistocene marine environments in the Northeast Atlantic and the Mediterranean". English. In: Smithsonian Contributions to Paleobiology 89 (1999), pp. 139-157.

[23382] G. Ubaghs and D. Vizcano. "A new eocrinoid from the Lower Cambrian of Spain". English. In: Palaeontology 33.1 (1990), pp. 249-256.

[23383] C. Ubelacker, U. Jansen, and K. De Baets. "First record of the Early Devonian ammonoid Teicherticeras from the Eifel (Germany): biogeographic and biostratigraphic importance". English. In: Neues Jahrbuch für Geologie und Paläontologie, Abhandlungen 282 (2016), pp. 201-208.

[23384] D. Ubick and J. A. Dunlop. “On the placement of the Baltic amber harvestman Gonyleptes nemastomoides Koch \& Berendt, 1854, with notes on the phylogeny of Cladonychiidae (Opiliones, Laniatores, Travunioidea)". English. In: Mitteilungen aus dem Musuem für Naturkunde Berlin, Geowissenschaftliche Reihe 8 (2005), pp. 75-82.

[23385] M. Ubilla and M. T. Alberdi. "Hippidion sp. (Mammalia, Perissodactyla, Equidae) en Sedimentos del Pleistoceno Superior del Uruguay (Edad Mamifero Luganense)". Spanish. In: Estudios Geologia 46 (1990), pp. 453-464.

[23386] M. Ubilla, D. Perea, and M. Bond. “The Deseadan Land Mammal Age in Uruguay and the report of Scarrittia robusta nov. sp. (Leontiniidae, Notoungulata) in the Fray Bentos Formation (Oligocene - ? Lower Miocene)". English. In: Geobios 27.1 (1994), pp. 95-102.

[23387] M. Ubilla, D. Perea, M. Bond, and A. Rinderknecht. "The first cranial remains of the Pleistocene proterotheriid Neolicaphrium". English. In: Journal of Vertebrate Paleontology 31.1 (2011), pp. 193201.

[23388] M. Ubilla and A. Rinderknecht. “A Late Miocene Dolichotinae (Mammalia, Rodentia, Caviide) from Uruguay, with comments about the relationships of some related fossil species". English. In: Mastozoologa Neotropical 10.2 (2003), pp. 293-302.

[23389] R. Uchimura and R. Majima. "The mixed sea area of warm- and cold-water molluscs of the Japanese early Middle Miocene - The case study in the Furanui Formation, mid-Hokkaido, Japan". Japanese. In: Journal of the Geological Society of Japan 98.12 (1992), pp. 1129-1144.

[23390] N. I. Udovichenko. "Ichthyofauna and age of the Paleogene sands of Osinovo area, Lugansk region". Russian. In: Iskopaemaa fauna i flora Ukrainy: paleoékologieskij i stratigrafieskij aspekty. Sbornik naunyh trudov Instituta geologieskih nauk NAN Ukrainy (2009), pp. 255-261.

[23391] K. Ueda. "A Triassic fossil of scorpion fly from Mine, Japan". English. In: Bulletin of the Kitakyushu Museum of Natural History 10 (1991), pp. 99-103.

[23392] K. Ueda. "A new palaeontinid species from the Lower Cretaceous of Brazil (Homoptera: Palaeontinidae)". English. In: Bulletin of the Kitakyushu Museum of Natural History 16 (1997), pp. 99-104.

[23393] K. Ueda, T. Kim, and T. Aoki. "A new record of an Early Cretaceous fossil dragonfly from Korea". English. In: Bulletin of the Kitakyushu Museum of Natural History and Human History, Series A 3 (2005), pp. 145-152. 
[23394] K. Ueno. "The Permian antitropical fusulinoidean genus Monodiexodina: distribution, taxonomy, paleobiogeography and paleoecology". English. In: Journal of Asian Earth Sciences 26 (2006), pp. 380-404.

[23395] K. Ueno, K. Nagai, N. Nakornsri, and T. Sugiyama. "Upper Carboniferous foraminifers from Phu Tham Maholan, southeast of Wang Saphung, Changwat Loei, northeast Thailand". English. In: Science Reports of the Institute of Geoscience, University of Tsukuba, Section B: Geological Sciences 16 (1995), pp. 29-37.

[23396] K. Ueno and S. Sakagami. "Late Permian fusulinacean fauna of Doi Pha Phlung, north Thailand". English. In: Transactions and Proceedings of the Paleontological Society of Japan, N.S. 164 (1991), pp. 928-943.

[23397] K. Ueno and S. Sakagami. "Middle Permian foraminifers from Ban Nam Suai Tha Sa-at, Changwat Loei, northeast Thailand". English. In: Transactions and Proceedings of the Paleontological Society of Japan, N.S. 172 (1993), pp. 277-291.

[23398] K. Ueno, G. R. Shi, and S. Z. Shen. "Fusulinoideans from the early Midian (late Middle Permian) Metadoliolina dutkevitchi-Monodiexodina sutchanica Zone of the Senkina Shapka section, south Primorye, far east Russia". English. In: Alcheringa 29 (2005), pp. 257-273.

[23399] K. Ueno, T. Shintani, and J. I. Tazawa. "A fusuline fauna from the basal part of the Sakamotozawa Formation in the Kamiyasse area, South Kitakami Belt, Northeast Japan". English. In: Science Reports, Niigata University (Geology) 26 (2011), pp. 23-41.

[23400] K. Ueno, T. Shintani, and J. I. Tazawa. "Fusuline foraminifera from the upper part of the Sakamotozawa Formation, South Kitakami Belt, northeast Japan". English. In: Science Reports, Niigata University (Geology) 24 (2009), pp. 27-61.

[23401] K. Ueno, J. I. Tazawa, and T. Shintani. "Fusuline foraminifera from the basal part of the Sakamotozawa Formation, south Kitakami belt, northeast Japan". English. In: Science Reports, Niigata University (Geology) 22 (2007), pp. 15-33.

[23402] K. Ueno, J. I. Tazawa, and Y. Miyake. "Middle Permian fusulinoideans from Hatahoko in the Nyukawa area, Gifu Prefecture, Mino Belt, central Japan". English. In: Science Reports, Niigata University (Geology) 21 (2006), pp. 47-72.

[23403] M. D. Uhen. "New species of protocetid archaeocete whale, Eocetus wardii (Mammalia: cetacea) from the middle Eocene of North Carolina". English. In: Journal of Paleontology 73.3 (1999), pp. 512528. DOI: $10.1017 /$ S002233600002802X.

[23404] M. D. Uhen. "New protocetid (Mammalia, Cetacea) from the late middle Eocene Cook Mountain Formation of Louisiana". English. In: Journal of Vertebrate Paleontology 18.3 (1998), pp. 664-668. DOI: $10.1080 / 02724634.1998 .10011093$.

[23405] M. D. Uhen. “Form, Function, and Anatomy of Dorudon atrox (Mammalia, Cetacea): An Archaeocete from the Middle to Late Eocene of Egypt". English. In: University of Michigan Papers on Paleontology 34 (2004), pp. 1-222.

[23406] M. D. Uhen. "A new genus and species of archaeocete whale from Mississippi". English. In: Southeastern Geology 43.3 (2005), pp. 157-172.

[23407] M. D. Uhen. A new Xenorophus-like odontocete cetacean from the Oligocene of North Carolina. English. 2005.

[23408] M. D. Uhen. USNM Chesapeake Group Cetacean Collection Data. English. 2007.

[23409] M. D. Uhen. "New protocetid whales from Alabama and Mississippi, and a new cetacean clade, Pelagiceti". English. In: Journal of Vertebrate Paleontology 28.3 (2008), pp. 589-593. DOI: 10.1671 / 0272-4634(2008)28[589:NPWFAA]2.0.CO;2.

[23410] M. D. Uhen. “A new Xenorophus-like odontocete cetacean form the Oligocene of North Carolina and a discussion of the basal odontocete radiation". English. In: Journal of Systematic Palaeontology 6.4 (2008), pp. 433-452. DOI: 10.1017/S1477201908002472.

[23411] M. D. Uhen. A new protocetid whale from the middle Eocene of Mississippi. English. 2011. 
[23412] M. D. Uhen. “A review of North American Basilosauridae". English. In: Alabama Museum of Natural History Bulletin 31.2 (2013), pp. 1-45.

[23413] M. D. Uhen. New specimens of middle Eocene whales (Cetacea, Protocetidae) from New Jersey. English. 2012.

[23414] M. D. Uhen. “New specimens of Protocetidae (Mammalia, Cetacea) from New Jersey and South Carolina". English. In: Journal of Vertebrate Paleontology 34.1 (2014), pp. 211-219. DOI: 10.1080 / 02724634.2013.784707.

[23415] M. D. Uhen. "New material of Natchitochia jonesi and a comparison of the innominata and locomotor capabilities of Protocetidae". English. In: Marine Mammal Science 30.3 (2014), pp. 1029-1066. DOI: $10.1111 / \mathrm{mms} .12100$.

[23416] M. D. Uhen, A. G. Coates, C. A Jaramillo, C. Montes, C. Pimiento, A. Rincon, N. Strong, and J. Velez-Juarbe. "Marine mammals from the Miocene of Panama". English. In: Journal of South American Earth Sciences 30.3-4 (2010), pp. 167-175. DOI: 10.1016/j.jsames.2010.08.002.

[23417] M. D. Uhen and P. D. Gingerich. "Evolution of Coryphodon (Mammalia, Pantodonta) in the late Paleocene and early Eocene of Northwestern Wyoming". English. In: Contributions from the Museum of Paleontology, University of Michigan 29.10 (1995), pp. 259-289.

[23418] M. D. Uhen and P. D. Gingerich. "New genus of dorudontine archaeocete (Cetacea) from the Middle-to-Late Eocene of South Carolina". English. In: Marine Mammal Science 17.1 (2001), pp. 134. DOI: $10.1111 /$ j.1748-7692.2001.tb00979.x.

[23419] M. D. Uhen, N. D. Pyenson, T. J. DeVries, M. Urbina, and P. R. Renne. “New middle Eocene whales from the Pisco Basin of Peru". English. In: Journal of Paleontology 85.5 (2011), pp. 955-969. DOI: 10.1666/10-162.1.

[23420] R. E. Ulansky. “Chungkingosaurus [Chungkingosaurus]”. English. In: Dinologia (2015), pp. 1-8.

[23421] M. R. Ulitzka. "Two new species of Aeolothripidae from Baltic Tertiary amber (Insecta: Thysanoptera)". English. In: Palaeodiversity 8 (2015), pp. 89-94.

[23422] M. R. Ulitzka. "Praemerothrips hoodi Priesner, 1929 and Merothrips balticus sp. nov. - two new fossils of thrips from Baltic Tertiary amber (Thysanoptera: Merothripidae)". English. In: Entomologische Zeitschrift 125 (2015), pp. 213-216.

[23423] M. R. Ulitzka. "A first survey of Cretaceous thrips from Burmese amber including the establishment of a new family of Tubulifera (Insecta: Thysanoptera)". English. In: Zootaxa 4486 (2018), pp. 548-558.

[23424] M. R. Ulitzka. "Revision of the fossil Melanthripidae from Baltic Tertiary (Eocene) amber including a new genus (Insecta: Thysanoptera)". English. In: Entomologische Zeitschrift 127 (2017), pp. 205212.

[23425] M. R. Ulitzka. “Five new species of Rohrthrips (Thysanoptera: Rohrthripidae) from Burmese amber, and the evolution of Tubulifera wings". English. In: Zootaxa 4585 (2019), pp. 27-40.

[23426] M. R. Ulitzka. "A new species of Chiridurothrips Okajima from Miocene amber of the Dominican Republic (Thysanoptera: Phlaeothripidae)". English. In: Zootaxa 4686 (2019), pp. 140-144.

[23427] M. R. Ulitzka. "Two fossil thrips from Ethiopian amber (Thysanoptera) with description of Merothrips aithiopicus sp. n. (Thysanoptera: Merothripidae)". English. In: Zootaxa 4786 (2020), pp. 283-288.

[23428] P. V. Ullmann, Z. M. Boles, and M. J. Knell. "Insights into cranial morphology and intraspecific variation from a new subadult specimen of the pan-cheloniid turtle Euclastes wielandi Hay, 19". English. In: PaleoBios 35 (2018), pp. 1-22.

[23429] P. V. Ullmann, D. Varricchio, and M. J. Knell. “Taphonomy and taxonomy of a vertebrate microsite in the mid-Cretaceous (Albian-Cenomanian) Blackleaf Formation, southwest Montana". English. In: Historical Biology 24.3 (2012), pp. 311-328. DOI: 10.1080/08912963.2011.602405.

[23430] H. Ulrich and R. M. Schmelz. "Enchytraeidae as prey of Dolichopodidae, recent and in Baltic amber (Oligochaeta; Diptera)". English. In: Bonner Zoologische Beiträge 50 (2001), pp. 89-101. 
[23431] E. Unay, H. de Bruijn, and G. Saraç. “The Oligocene rodent record of Anatolia: a review”. English. In: Deinsea 10 (2003), pp. 531-537.

[23432] E. Unay, H. de Bruijn, and G. Sarac. "A preliminary zonation of the continental Neogene of Anatolia based on Rodents". English. In: Distribution and Migration of Tertiary Mammals in Eurasia, Volume 10. A Volume in Honour of Hans de Bruijn. Deinsea 10 (2003), pp. 539-548.

[23433] C. J. Underwood. "Sharks, rays and a chimaeroid from the Kimmeridgian (Late Jurassic) of Ringstead, Southern England". English. In: Palaeontology 45.2 (2002), pp. 297-325.

[23434] C. J. Underwood. "Barremian and Aptian (Cretaceous) sharks and rays from Speeton, Yorkshire, NE England". English. In: Proceedings of the Yorkshire Geological Society 55 (2004), pp. 107-118.

[23435] C. J. Underwood and S. L. Cumbaa. “Chondrichthyans from a Cenomanian (Late Cretaceous) bonebed, Saskatchewan, Canada". English. In: Palaeontology 53 (2010), pp. 903-944. DOI: 10.1111/ j.1475-4983.2010.00969.x.

[23436] C. J. Underwood, A. Goswami, G. V. R. Prasad, O. Verma, and J. J. Flynn. “Marine vertebrates from the 'Middle' Cretaceous (Early Cenomanian) of South India". English. In: Journal of Vertebrate Paleontology 31.3 (2011), pp. 539-552.

[23437] C. J. Underwood, S. F. Michell, and K. J. Veltkamp. “Shark and Ray teeth from the Hauterivian (Lower Cretaceous) of north-east England". English. In: Palaeontology 42.2 (1999), pp. 287-302.

[23438] C. J. Underwood and S. F. Mitchell. "Albian and Cenomanian selachian assemblages from northeast England". English. In: Special Papers in Palaeontology 60 (1999), pp. 9-59.

[23439] C. J. Underwood and J. Rees. "Selachian faunas from the lowermost Purbeck Group of Dorset, southern England". English. In: Special Papers in Palaeontology 68 (2002), pp. 83-101.

[23440] C. J. Underwood and J. Schlogl. "Deep-Water Chondrichthyans from the Early Miocene of the Vienna Basin (Central Paratethys, Slovakia)". English. In: Acta Palaeontologica Polonica 58.3 (2013), pp. 487-509.

[23441] C. J. Underwood and D. J. Ward. "Neoselachian sharks and rays from the British Bathonian (Middle Jurassic)". English. In: Palaeontology 47.3 (2004), pp. 447-501.

[23442] C. J. Underwood and D. J. Ward. “New hemigaleid shark form the late Eocene of Wadi Al-Hitan, Egypt". English. In: Journal of Vertebrate Paleontology 31.3 (2011), pp. 707-711.

[23443] C. J. Underwood, D. J. Ward, C. King, S. M. Antar, I. S. Zalmout, and P. D. Gingerich. "Shark and ray faunas in the Middle and Late Eocene of the Fayum Area, Egypt". English. In: Proceedings of the Geologists' Association 122.1 (2011), pp. 47-66.

[23444] C. J. Underwood and D. J. Ward. "Sharks of the order Carcharhiniformes from the British Coniacian, Santonian and Campanian (Upper Cretaceous)". English. In: Palaeontology 51 (2008), pp. 509536. DOI: $10.1111 /$ j.1475-4983.2008.00757.x.

[23445] D. Ungureanu and E. Barbu. "Endemic features of the Upper Jurassic sponges in the western central Dobrogea (Atarnati-Cechirgea perimeter)". English. In: Acta Palaeontologica Romaniae 4 (2004), pp. 493-502.

[23446] Y. Uni. "Whales, dorphines [dolphins] and porpoises off Shiretoko". English. In: Bulletin of the Shiretoko Museum 27 (2006), pp. 37-46.

[23447] H. Uno and M. Kimura. "Reinterpretation of some cranial structures of Desmostylus hesperus (Mammalia: Desmostylia): a new specimen from the Middle Miocene Tachikaraushinai Formation, Hokkaido, Japan". English. In: Paleontological Research 8.1 (2004), pp. 1-10.

[23448] D. M. Unwin. "First record of pterosaurs from the Early Cretaceous Tetori Group: a wing-phalange from the Amagodani Formation in Shokawa, Gifu Prefecture, Japan". English. In: Bulletin of the National Science Museum, Tokyo, Series C 22 (1996), pp. 37-46.

[23449] D. M. Unwin. The fossil record of Middle Jurassic pterosaurs. English. Vol. 60. The Continental Jurassic, Museum of Northern Arizona Bulletin. 1996, pp. 291-304. 
[23450] D. M. Unwin. "An overview of the pterosaur assemblage from the Cambridge Greensand (Cretaceous) of Eastern England". English. In: Mitteilungen as dem Museum für Naturkunde, Berlin, Geowissenschaftliche Reihe 4 (2001), pp. 189-222.

[23451] D. M. Unwin. "Pterosaur tracks and the terrestrial ability of pterosaurs". English. In: Lethaia 29 (1997), pp. 373-386.

[23452] D. M. Unwin and W. D. Heinrich. "On a pterosaur jaw from the Upper Jurassic of Tendaguru (Tanzania)". English. In: Mitteilungen aus dem Museum für Naturkunde in Berlin, Geowissenschaftliche Reihe 2 (1999), pp. 121-134.

[23453] D. M. Unwin, J. Lü, and N. N. Bakhurina. "On the systematic and stratigraphic significance of pterosaurs from the Lower Cretaceous Yixian Formation (Jehol Group) of Liaoning, China". English. In: Mitteilungen aus dem Museum für Naturkunde in Berlin, Geowissenschaftlichen Reihe 3 (2000), pp. 181-206.

[23454] G. R. Upchurch, P. R. Crane, and A. N. Drinnan. “The Megaflora from the Quantico Locality (Upper Albian), Lower Cretaceous Potomac Group of Virginia". In: Virginia Museum of Natural History 4 (1994), pp. 1-57.

[23455] G. R. Upchurch and D. L. Dilcher. Cenomanian Angiosperm Leaf Megafossils, Dakota Formation, Rose Creek Locality, Jefferson County, Southeastern Nebraska. U.S. Geological Survey Bulletin 1915. 1990.

[23456] P. Upchurch and P. D. Mannion. "The first diplodocid from Asia and its implications for the evolutionary history of sauropod dinosaurs". English. In: Palaeontology 52.6 (2009), pp. 1195-1207.

[23457] P. Upchurch, Y. Tomida, and P. M. Barrett. "A new specimen of Apatosaurus ajax (Sauropoda, Diplodocidae) from the Morrison Formation (Upper Jurassic) of Wyoming, USA". English. In: National Science Museum Monographs 26 (2004), pp. 1-118.

[23458] P. M. Upchurch and J. Martin. “The anatomy and taxonomy of Cetiosaurus (Saurischia, Sauropoda) from the Middle Jurassic of England". English. In: Journal of Vertebrate Paleontology 23.1 (2003), pp. 208-231.

[23459] M. Urban and D. S. Berman. "First occurrence of the late Paleozoic amphibian Zatrachys serratus (Temnospondyli, Zatrachydidae) in the Eastern United States". English. In: Annals of Carnegie Museum 76.3 (2007), pp. 157-164.

[23460] M. A. Urban and M. C. Lamanna. "Evidence of a giant tyrannosaurid (Dinosauria: Theropoda) from the Upper Cretaceous (?Campanian) of Montana". English. In: Annals of Carnegie Museum 75.4 (2006), pp. 231-235.

[23461] M. Urbina and M. Stucchi. "Los cormoranes (Aves: Phalacrocoracidae) del Mio-Plioceno de la Formacion Pisco, Peru". Spanish. In: Boletin de la Sociedad Geologica del Peru 99 (2005), pp. 41-49.

[23462] M. Urlichs. "Revision of some stratigraphically relevant ammonoids from the Cassian Formation (latest Ladinian-Early Carnian, Triassic) of St. Cassian (Dolomites, Italy)". English. In: Neues Jahrbuch für Geologie und Paläontologie, Abhandlungen 283 (2017), pp. 173-204.

[23463] M. Urlichs and U. Vath. "Zur Ceratiten-Stratigraphie im Oberen Muschelkalk (Mitteltrias) bei Göttingen". German. In: Geologisches Jahrbuch Hessen 118 (1990), pp. 127-147.

[23464] D. Urosevic, V. Radulovic, and L. Pesic. "Middle Triassic (Anisian) Brachiopods From the Yugoslavian Carpatho-Balkanides". English. In: Revue de Paleobiologie 11.2 (1992), pp. 469-481.

[23465] J. J. Urrutia, C. I. Montalvo, and G. J. Scillato-Yane. "Dasypodidae (Xenarthra, Cingulata) de la Formación Cerro Azul (Mioceno tardo) de la provincia de La Pampa, Argentina". English. In: Ameghiniana 45.2 (2008), pp. 289-302.

[23466] G. T. Ushatinskaya. "The Teeth Bearing inarticulate brachiopods from the Middle Cambrian of Siberia and Kazakhstan". In: Paleontological Journal 32.5 (1998), pp. 474-478.

[23467] K. Usnarska-Talerzak. "Ramienionogi warstw terebratulowych (rodkowy trias) zachodniej czci Górnego lska [The brachiopods from the Terebratula beds (Middle Triassic) in the western part of Upper Silesia]". other. In: Geological Quarterly 34.4 (1990), pp. 677-696. 
[23468] T. Uyeno and K. Sakamoto. "Spirinchus akagii, a new Miocene smelt from Tottori Prefecture, Japan (Pisces: Osmeriformes, Osmeridae)". English. In: Bulletin of the Natural Science Museum, Tokyo, Series C 25.3,4 (1999), pp. 143-150.

[23469] S. Uzuncimen, U. K. Tekin, Y. Bedi, D. Perncek, E. Varol, and H. Soycan. "Discovery of the Late Triassic (Middle Carnian- Rhaetian) radiolarians in the volcano-sedimentary sequences of the Kocali Complex, SE Turkey: Correlation with the other Tauride units". English. In: Journal of Asian Earth Sciences 40 (2011), pp. 180-200. DOI: 10.1016/j.jseaes.2010.08.004.

[23470] N. E. Vaccari, B. G. Waisfeld, B. D. E. Chatterton, and G. D. Edgecombe. “New raphiophorid trilobites from the Ordovician of Argentina and their biogeographic implications". English. In: Memoirs of the Association of Australasian Palaeontologists 32 (2006), pp. 353-374.

[23471] N. E. Vaccari and B. G. Waisfeld. “Nuevos trilobites de la Formacion Suri (Ordovicico temprano) en la region de Chaschuil, Provincia de Catamarca: Implicancias bioestratigraficas". Spanish. In: Ameghiniana 31.1 (1994), pp. 73-86.

[23472] D. Vachard, P. Clift, and D. Decrouez. “Une association a Pseudodunbarula (Fusulinoide) du Permien Superieur (Djoulfien) remaniee dans le Jurassique d'Argolide (Peloponnese, Grece) [An Upper Permian (Dzhulfian) assemblage with Pseudodunbarula (Fusulinids) reworked in the Jurassic of Argolis Peninsula (Peloponnes, Greece)]". French. In: Revue de Paleobiologie 12.1 (1993), pp. 217242.

[23473] D. Vachard, A. Flores de Dios, and B. Buitron. "Guadalupian and Lopingian (Middle and Late Permian) deposits from Mexico and Guatemala, a review with new data". English. In: Geobios 37 (2004), pp. 99-115.

[23474] A. Vadet, P. Pannier, and C. Marignac. "Les echinides fossiles de l'Oxfordien de Foug". French. In: Societe d'Historie Naturelle du Boulonnais 22.2 (2002), pp. 1-44.

[23475] N. Valdes, J. R. Bourque, and N. S. Vitek. "A new soft-shelled turtle (Trionychidae, Apalone) from the Late Miocene of North-Central Florida". English. In: Bulletin of the Florida Museum of Natural History 55.6 (2017), pp. 117-138.

[23476] C. Valdovinos and S. N. Nielsen. "Molluscs of the Tubul Formation (South-central Chile): Implications for the early Pleistocene climate of the. Southeastern Pacific". English. In: Actas 2 (2006).

[23477] V. Valen, J. Mangerud, E. Larsen, and A. K. Hufthammer. "Sedimentology and stratigraphy in the cave Hamnsundhelleren, western Norway". English. In: Journal of Quaternary Science 11.3 (1996), pp. 185-201.

[23478] A. Valenciano, J. Abella, D. M. Alba, J. M. Robles, M. A. Álvarez-Sierra, and J. Morales. “New Early Miocene Material of Iberictis, the Oldest Member of the Wolverine Lineage (Carnivora, Mustelidae, Guloninae)". English. In: Journal of Mammalian Evolution (2018). DOI: 10.1007 / s10914-0189445-x.

[23479] M. Valent, O. Fatka, V. Micka, and M. Sinág. "Hyoliths with entombed trilobites cryptic behavior of trilobites". English. In: vol. 9. Advances in trilobite research. Madrid: Cuadernos del Museo Geominero. Instituto Geológico y Minero de España, 2008, pp. 411-413.

[23480] M. Valent, O. Fatka, and L. Marek. "Slapylitidae: a new family of hyolithids (Cambrian-?Devonian; Baltica, Laurentia, Gondwana)". English. In: Palaeontologische Zeitschrift 91 (2017), pp. 497-505. DOI: $10.1007 / \mathrm{s} 12542-017-0369-1$.

[23481] J. L. Valentine, D. J. Cole, and A. J. Simpson. "Silurian Linguliformean Brachiopods and Conodonts from the Cobra Formation, Southeastern New South Wales, Australia". English. In: Proceedings of the Linnean Society of New South Wales 127 (2006), pp. 199-234.

[23482] M. Valentini, M. A. Conti, and N. Mariotti. "Lacertoid Footprints of the Upper Permian Arenaria di Val Gardena Formation (Northern Italy)". English. In: Ichnos 14 (2007), pp. 193-218. DOI: 10. $1080 / 10420940601049974$.

[23483] A. Valenzuela-Toro, N. D. Pyenson, C. S. Gutstein, and M. E. Suarez. "A new dwarf seal from the Late Neogene of South America and the evolution of pinnipeds in the southern hemisphere". English. In: Papers in Palaeontology 2.1 (2016), pp. 101-115. DOI: 10.1002/spp2.1033. 
[23484] A. M. Valenzuela-Toro, C. S. Gutstein, R. M. Varas-Malca, M. E. Suarez, and N. D. Pyenson. “Pinniped Turnover in the South Pacific Ocean: New Evidence from the Plio- Pleistocene of the Atacama Desert, Chile". English. In: Journal of Vertebrate Paleontology 33.1 (2013), pp. 216-233. DOI: 10.1080/039.033.0103.

[23485] A. M. Valenzuela-Toro, C. S. Gutstein, M. E. Suarez, R. Otero, and N. D. Pyenson. "Elephant seal (Mirounga sp.) from the Pleistocene of the Antofagasta Region, northern Chile". English. In: Journal of Vertebrate Paleontology (2015), e918883. DOI: 10.1080/02724634.2014.918883.

[23486] A. L. Valerio, C. A. Laurito, and L. D. Gomez. “Un Gliptodonte (Xenarthra, Cingulata) de la Localidad de Chachagua, Provincia de Alajuela, Costa Rica". Spanish. In: Revista Geologica de America Central 32 (2005), pp. 61-63.

[23487] A. L. Valerio and C. A. Laurito. “Cetáceos fósiles (Mammalia, Odontoceti, Eurhinodelphinoidea, Inioidea, Physeteroidea) de la Formación Curré, Mioceno superior (Mephilliano Temprano tardio) de Costa Rica". Spanish. In: Revista Geologica de America Central 46 (2012), pp. 151-160.

[23488] A. L. Valerio and C. A. Laurito. "Dental remains of immature individuals of Rhynchotherium blicki (Frick 1933) of San Gerardo de Limoncito, Coto, Brus, Costa Rica". English. In: Revista Geológica de América Central 39 (2008), pp. 87-91.

[23489] A. L. Valerio and C. A. Laurito. "Nuevos hallazgos de Mammalia, Xenarthra (Cingulata) y confirmación del registro de Pachyarmatherium leiseyi Downing-White,1995 en la localidad de Buenos Aires de Palmares, provincia de Alajuela, Costa Rica". Spanish. In: Revista Geológica de América Central 44 (2011), pp. 131-139.

[23490] A. L. Valerio and C. A. Laurito. "Nueva evidencia de un estadio juvenil de Pliometanastes protistus y su relación con ?Pliometanastes galushai Hirschfeld \& Webb, 1968 (Xernarthra, Megalonychidae) para el Mioceno Superior de Costa Rica". Spanish. In: Revista Geológica de América Central 51 (2014), pp. 159-163.

[23491] A. L. Valerio and C. A. Laurito. "Primer registro de pecares fósiles (Artiodactyla, Tayassuidae) para el Mioceno Superior (Hh3: Hemphilliano tardo) de Costa Rica, América". Spanish. In: Revista Geológica de América Central 62 (2020), pp. 25-47.

[23492] P. Vallati. "Paleotropical pollen grains from the Neuquén Group, Patagonia, Argentina". English. In: Carnets de Géologie 5 (2013), pp. 273-279.

[23493] P. Vallati. "Las primeras angiospermas en el Cretácico de la Cuenca Neuquina (Centro Oeste de Argentina): Aspectos geológicos relacionados". Spanish. In: Revista Brasileira de Paleontologia 9.1 (2006), pp. 83-92.

[23494] P. Vallati. "Asociaciones palinológicas con Angiospermas en el Cretácico Superior de la Cuenca Neuquina, Argentina". English. In: Revista Brasileira de Paleontolgia 13.2 (2010), pp. 143-158. DOI: 10.4072/rbp.2010.2.07.

[23495] P. Vallati. "Middle Cretaceous Microflora from the Huincul Formation (Dinosaurian Beds) in theNeuquén Basin, Patagonia, Argentina". English. In: Palynology 25 (2001), pp. 179-197.

[23496] F. X. Valldeperas. "Les associacions de coralls plans (Scleractinia) de la plataforma carbonatada de Sant Corneli, unitat sud-pirinenca central (Cretaci superior, Santonia) [Platy coral (Scleractinia) associations of the Sant Corneli carbonate platform, southern Central Pyrenees Unit (Upper Cretaceous, Santonian)]". other. In: Butlleti de la Institucio Catalana d'Historia Natural 68 (2000), pp. 7388.

[23497] M. C. Vallejo-Pareja, J. D. Carrillo, J. W. Moreno-Bernal, M. Pardo-Jaramillo, D. F. RodriguezGonzalez, and J. Muñoz-Duran. "Hilarcotherium castanedaii, gen. et sp. nov., a new Miocene astrapothere (Mammalia, Astrapotheriidae) from the Upper Magdalena Valley, Colombia". English. In: Journal of Vertebrate Paleontology (2015). DOI: 10.1080/02724634.2014.903960.

[23498] J. Valls, M. J. Comas-Rengifo, and A. Goy. "Bivalvos del Pliensbachiense en la Seccion de Almonacid de la Cuba (Cordillera Iberica, Espana)". Spanish. In: Coloquios de Paleontologia 54 (2004), pp. 145-178. 
[23499] C. Van Achterberg. "The first known fossil Masoninae (Hymenoptera: Braconidae) from Miocene Dominican amber". English. In: Zoologische Mededelingen 75.21 (2001), pp. 393-396.

[23500] E. N. Van Asperen and R. D. Kahlke. "Dietary traits of the late early Pleistocene bison menneri (Bovidae, mammalian) from its type site Untermassfeld ( central Germany) and the problem of Pleistocene 'wood bison'”. English. In: Quaternary Science Reviews 177 (2017), pp. 299-313.

[23501] B. W. M. van Bakel, P. Artal, R. H B. Fraaije, and J. W. M. Jagt. "Loerenthopluma danielae, A new crab (Decapoda, Brachyura, Retroplumidae) from the Lower Eocene of Northwest Belgium". English. In: Studies on Brachyura (2010), pp. 41-49.

[23502] B. W. M. van Bakel, R. H. B. Fraaije, and J. W. M. Jagt. "A new early Campanian Species of Xanthosia (Decapoda, Brachyura) From Northwestern Germany". English. In: Crustaceana 78.3 (2005), pp. 285-295.

[23503] B. W. M. van Bakel, D. Guinot, P. Artal, R. H. B. Fraaije, and J. W. M. Jagt. "A revision of the Palaeocorystoidea and the phylogeny of raninoidian crabs (Crustacea, Decapoda, Brachyura, Podotremata)". English. In: Zootaxa 3215 (2012), pp. 1-216.

[23504] B. W. M. van Bakel, J. W. M. Jagt, and R. H. B. Fraaije. “A new Pliocene cancrid crab from Oelegem, province of Antwerpen (NW Belgium)". English. In: Cainozoic Research 2.1-2 (2003), pp. 79-85.

[23505] B. W. M. van Bakel, J. W. M. Jagt, and R. H. B. Fraaije. “Clipopagurus obesus, a new species of Oligoene hermit crab from northwest Belgium". English. In: Cainozoic Research 2.1-2 (2003), pp. 109-116.

[23506] B. W. M. van Bakel, J. W. M. Jagt, and PARSE ERROR. “Piacenzian (Pliocene) decapod crustacean faunules from northwest Belgium". English. In: Bulletin of the Mizunami Fossil Museum 30 (2003), pp. 97-108.

[23507] B. W. M. van Bakel, J. W. M. Jagt, P. Artal, and R. H. B. Fraaije. “Harenacorystes johanjansseni, a new Pliocene crab (Crustacea, Decapoda) from the Netherlands, and notes on Miocene-Pliocene corystoid crabs from the North Sea Basin". English. In: Bulletin of the Mizunami Fossil Museum 35 (2009), pp. 79-85.

[23508] W. M. van Bakel, P. Artal, R. H. B. Fraaije, and J. W. M. Jagt. “A New Early Oligocene Crab (Decapoda, Brachyura, Dromiacea) From Northwest Belgium, With Comments On Its Palaeobiology". English. In: Geologica Belgica 12.1-2 (2009), pp. 45-57.

[23509] W. M. van Bakel, R. H. B. Fraaije, J. W. M. Jagt, M. Artal, and P. Artal. “An unexpected diversity of Late Jurassic hermit crabs (Crustacea, Decapoda, Anomura) in Central Europe". English. In: N. Jb. Geol. Palaont. Abh 250.2 (2008), pp. 137-156. DOI: 10.1127/0077-7749/2008/0250-0137.

[23510] M. C. Van Boskirk. "The flora of the Eagle Formation and its significance for Late Cretaceous floristic evolution". PhD thesis. 1998, pp. 1-382.

[23511] P. J. H. van Bree and K. Post. “Over het fossiele baculum van een Walrus gevonden op de bodem van de Noordzee". English. In: Cranium 11.1 (1994), pp. 59-60.

[23512] J. van Dam. The Gliridae from the Upper Eocene of Sosss, Roc de Santa and Claverol (Lleida, Spain). English. Geologa y Paleontologa del Eoceno de la Pobla de Segur (Lleida). 1998, pp. 131-180.

[23513] J. A. Van Dam. “Anourosoricini (Mammalia: Soricidae) from the Mediterranena region: a preQuaternary example of recurrent climate-controlled north-south range shifting". English. In: Journal of Paleontology 78.4 (2004), pp. 741-764.

[23514] D. Van Damme and A. Gautier. Late Cenozoic Freshwater Mollusks of the Wembere-Manonga Formation, Manonga Valley, Tanzania. Neogene Paleontology of the Manonga Valley, Tanzania. Plenum Press, New York and London. 1997, pp. 351-360.

[23515] H. Van Damme. Scale invariance and hydric behaviour of soils and clays. 1995.

[23516] A. Van Danmme. personal communication. English. 1995.

[23517] T. van de Kamp, T. Dos Santos Rolo, T. Baumbach, and L. Krogmann. "Scanning the past - synchrotron X-Ray microtomography of fossil wasps in amber". English. In: Entomologie Heute 26 (2014), pp. 151-160. 
[23518] T. van de Kamp, A. H. Schwermann, T. dos Santos Rolo, P. D. Lösel, T. Engler, W. Etter, T. Faragó, J. Göttlicher, V. Heuveline, A. Kopmann, B. Mähler, T. Mörs, J. Odar, J. Rust, N. Tan Jerome, M. Vogelgesang, T. Baumbach, and L. Krogmann. "Parasitoid biology preserved in mineralized fossils". English. In: Nature Communications 9.3325 (2018), pp. 1-14.

[23519] S. van de Velde, T. A. Yanina, T. A. Neubauer, and F. P. Wesselingh. “The Late Pleistocene mollusk fauna of Selitrennoye (Astrakhan province, Russia): A natural baseline for endemic Caspian Sea faunas". English. In: Journal of Great Lakes Research XXX (2019), pp. XXX-XXX. DOI: 10.1016/j.jglr. 2019.04.001.

[23520] A. van de Weerd, H. de Bruijn, Z. Markovi, and W. Wessels. "Paracricetodontinae (Mammalia, Rodentia) from the late Eocene and early Oligocene of south-east Serbia". English. In: Palaeobiodiversity and Palaeoenvironments 98.3 (2018), pp. 489-508.

[23521] T. van den Berg, D. I. Whiteside, P. A. Viegas, R. Schouten, and M. J. Benton. "The Late Triassic microvertebrate fauna of Tytherington, UK". English. In: Proceedings of the Geologists' Association 123 (2012), pp. 638-648. DOI: 10.1016/j.pgeola.2012.05.003.

[23522] G. D. van den Bergh. "The Late Neogene elephantoid-bearing faunas of Indonesia and their palaeozoogeographic implications. A study of the terrestrial faunal succession of Sulawesi, Flores and Java, including evidence for early hominid dispersal east of Wallace's Line". English. In: Scripta Geologica 117 (1999), pp. 1-419.

[23523] G. D. van den Bergh, J. de Vos, and P. H. Sondzar. "The Late Quaternary palaeogeography of mammal evolution in the Indonesian Archipelago". English. In: Palaeogeography, Palaeoclimatology, Palaeoecology 171 (2001), pp. 385-408.

[23524] L. W. van den Hoek Ostende. "Insectivore faunas from the Lower Miocene of Anatolia. Part 2: Dinosorex (Heterosoricidae)". English. In: Proceedings Koninklijke Nederlandse Akademie van Wetenschappen 98.1 (1995), pp. 1-18.

[23525] L. W. van den Hoek Ostende. "Insectivore faunas from the Lower Miocene of Anatolia. Part 3: Dimylidae". English. In: Proceedings Koninklijke Nederlandse Akademie van Wetenschappen 98.1 (1995), pp. 19-38.

[23526] L. W. van den Hoek Ostende. "Riddleria atecensis nov. gen. nov. sp., a peculiar erinaceid (Erinaceomorpha, Mammalia) from the Lower Miocene of Spain". English. In: Beiträge zur Paläontologie 28 (2003), pp. 1-7.

[23527] L. W. van den Hoek Ostende. "Gliridae (Rodentia, Mammalia) from the Upper Pliocene of Tegelen (province of Limburg, The Netherlands)". English. In: Scripta Geologica 126 (2003), pp. 203-215.

[23528] L. W. van den Hoek Ostende. "Insectivore faunas from the Lower Miocene of Anatolia. Part 1: Erinaceidae". English. In: Proceedings van de Koninklijke Nederlandse Akademie van Wetenschappen 95.4 (1992), pp. 437-467.

[23529] L. W. van den Hoek Ostende. "Insectivore faunas from the Lower Miocene of Anatolia. Part 4: The genus Desmanodon (Talpidae) with the description of a new species from the Lower Miocene of Spain." English. In: Proceedings van de Koninklijke Nederlandse Akademie van Wetenschappen 100.1-2 (1997), pp. 27-65.

[23530] L. W. van den Hoek Ostende. "Insectivores (Erinaceomorpha, Soricomorpha, Mammalia) from the Ramblian of the Daroca-Calamocha area". English. In: Coloquos de Paleontologa Vol extr 1 (2003), pp. 281-310.

[23531] L. W. van den Hoek Ostende and O. Fejfar. "Erinaceidae and Talpidae (Erinaceomorpha, Soricomorpha, Mammalia)". English. In: Beiträge zur Paläontologie 30 (2006), pp. 175-203.

[23532] L. W. van den Hoek Ostende, J. Leloux, F. P. Wesselingh, and C. F. Winkler Prins. "Cenozoic Molluscan types from Java (Indonesia) in the Martin Collection (Division of Cenozoic Mollusca), National Museum of Natural History, Leiden". English. In: NNM Technical Bulletin 5 (2002), pp. 1130. 
[23533] L. W. van den Hoek Ostende, S. Mayda, A. Oliver, A. Madern, V. Hernandez-Ballarin, and P. Pelaez-Campomanes. "Aliveri revisited, a biogeographical appraisal of the early Miocene mammals from the eastern Mediterranean". English. In: Palaeobiodiversity and Palaeoenvironments 95.3 (2015), pp. 271-284.

[23534] L. W. van den Hoek Ostende, A. A. E. van der Geer, and C. L. Wijngaarden. "Why are there no giants at the dwarves feet? Insular micromammals". English. In: Quaternary International 445 (2017), pp. 269-278. DOI: 10.1016/j.quaint.2016.05.007.

[23535] A. van der Geer, J. de Vos, G. Lyras, and M. Dermitzakis. “New data on the Pleistocene Cretan deer Candiacervus sp. II (Cervinae, Mammalia)". English. In: Courier Forschungsinstitut Senckenberg 256 (2006), pp. 131-137.

[23536] A. van der Geer, G. A. Lyras, L. W. van den Hoek Ostende, J. de Vos, and H. Drinia. "A dwarf elephant and a rock mouse on Naxos (Cyclades, Greece) with a revision of the palaeozoogeography of the Cycladic Islands (Greece) during the Pleistocene". English. In: Palaeogeography, Palaeoclimatology, Palaeoecology 404 (2014), pp. 133-144. DOI: 10.1016/j.palaeo.2014.04.003.

[23537] A. A. E. van der Geer. "Uniformity in variety: Antler morphology and evolution in a predator-free environment". English. In: Palaeontologia Electronica 21.1.9A (2018), pp. 1-31.

[23538] R. W. J. van der Ham, J. H. A. van Konijnenburg-van Cittert, and L. Inderherberge. "Seagrass foliage from the Maastrichtian type area (Maastrichtian, Danian, NE Belgium, SE Netherlands)". English. In: Review of Palaeobotany and Palynology 144.3-4 (2007), pp. 301-321.

[23539] R. W. J. M. van der Ham, J. H. A. van Konijnenburg-van Cittert, and J. van der Burgh. "Taxodiaceous conifers from the Maastrichtian type area (Late Cretaceous, NE Belgium, SE Netherlands)". In: Review of Palaeobotany and Palynology 116 (2001), pp. 233-250.

[23540] T. van der Lubbe, U. Richter, and N. Knötschke. "Velociraptorine dromaeosaurid teeth from the Kimmeridgian (Late Jurassic) of Germany". English. In: Acta Palaeontologica Polonica 54.3 (2009), pp. 401-408. DOI: 10.4202/app.2008.0007.

[23541] J. van der Made. “Ungulates from Atapuerca TD6". In: Journal of Human Evolution 37 (1999), pp. 389-413.

[23542] J. van der Made. "Systematics and stratigraphy of the genera Taucanamo and Schizochoerus and the classification of the Palaeochoeridae (Suoidea, Mammalia)". English. In: Proceedings van de Koninklijke Nederlandse Akademie van Wetenschappen 100.1-2 (1997), pp. 127-139.

[23543] J. van der Made and S. T. Hussain. "Horn cores of Sivoreas (bovidae) from the Miocene of Pakistan and utility of their torsion as a taxonomic tool". English. In: Géobios 27.1 (1994), pp. 103-111.

[23544] J. van der Made, J. Morales, S. Sen, and F. Aslan. "The first camel from the Upper Miocene of Turkey and the dispersal of the camels into the Old World". English. In: Comptes Rendus Palevol 1 (2002), pp. 117-122.

[23545] J. van der Made and J. Morales. "Mitilanotherium inexpectatum (Giraffidae, Mammalia) from Huélago (Lower Pleistocene; Guadix-Baza basin, Granada, Spain) - observations on a peculiar biogegraphic pattern". English. In: Estudios Geológicos 67.2 (2011), pp. 613-627. DOI: 10.3989 / egeol.40560.209.

[23546] J. van der Made, K. Stefaniak, and A. Marciszak. "The Polish fossil record of the wolf Canis and the deer Alces, Capreolus, Megaloceros, Dama and Cervus in an evolutionary perspective". English. In: Quaternary International 326-327 (2014), pp. 406-430. DOI: 10.1016/j.quaint.2013.11.015.

[23547] H. van der Plicht, K. Post, and D. Mol. "Over aasvliegen en een mammoetkalf uit de Eurogeul". other. In: Cranium 29.2 (2012), pp. 14-19.

[23548] F. N. Van der Sar, R. Van Glabbeek, W. Wessels, Z. Markovi, and H. de Bruijn. “Insectivores and marsupials from the upper Oligocene of Banovii (Bosnia and Herzegovina)". English. In: Journal of Vertebrate Paleontology 37.6 (2017), e1368529:1-17. DOI: 10.1080/02724634.2017.1368529.

[23549] D. E. van Dijk and H. Geertsema. "A new genus of Permian Plecoptera (Afroperla) from KwaZuluNatal, South Africa". English. In: African Entomology 12.2 (2004), pp. 268-270. 
[23550] D. E. van Dijk and H. Geertsema. "Permian insects from the Beaufort Group of Natal, South Africa". English. In: Annals of the Natal Museum 40 (1999), pp. 137-171.

[23551] D. E. van Dijk and A. V. Gorochov. "The first Permian representative of the family Xenopteridae (Orthoptera: Ensifera)". English. In: African Invertebrates 52 (2011), pp. 571-574.

[23552] N. E. Van Ee, K. E. Cooper, D. S. Kaufman, and G. P. Eberli. “Evaluation of Amino Acid Racemization Variability in Quaternary Corals". English. In: (2012).

[23553] T. van Eldijk, G. Goris, A. Haarhuis, J. Lankamp, H. Winkelhorst, J. Reumer, A. Nel, and T. Wappler. "New fossil insects from the Anisian (Lower to Middle Muschelkalk) from the Central European Basin (Germany and The Netherlands)". English. In: PalZ 91 (2017), pp. 185-194.

[23554] T. J. B. van Eldijk, T. Wappler, P. K. Strother, C. M. H. van der Weijst, H. Rajael, H. Visscher, and B. van de Schootbrugge. "A Triassic-Jurassic window into the evolution of Lepidoptera". English. In: Science Advances 4.e1701568 (2018), pp. 1-7.

[23555] J. van Heerden and B. Rubidge. "The affinities of the early cynodont reptile, Nanictosaurus". English. In: Palaeontologia africana 27 (1990), pp. 41-44.

[23556] J. Van Itterbeeck, Y. L. Bolotsky, P. Bultynck, and P. Godefroit. “Stratigraphy, sedimentology and palaeoecology of the dinosaur-bearing Kundur section (Zeya-Bureya Basin, Amur region, far eastern Russia)". English. In: Geological Magazine 142.6 (2005), pp. 735-750.

[23557] J. Van Itterbeeck, P. Missiaen, A. Folie, V. S. Markevich, D. Van Damme, D. -Y. Guo, and T. Smith. "Woodland in a fluvio-lacustrine environment on the dry Mongolian Plateau during the late Paleocene: Evidence from the mammal bearing Subeng section (Inner Mongolia, P.R. China)". English. In: Palaeogeography, Palaeoclimatology, Palaeoecology 243.1-2 (2007), pp. 55-78.

[23558] T. van Kolfschoten and E. Turner. Early Middle Pleistocene mammalian faunas from Karlich (Kaerlich) and Miesenheim I and their biostratigraphical implications. In C. Turner, ed., The early Middle Pleistocene in Europe, Balkema, Rotterdam. 1996, pp. 227-253.

[23559] T. van Kolfschoten, A. J. van der Meulen, and W. Boenigk. “The Late Pliocene Rodents (Mammalia) from Frechen (Lower Rhine Basin, Germany)". English. In: Mededelingen Nederlands Instituut voor Toegepaste Geowetenschappen, Amsterdam 60 (1998), pp. 161-172.

[23560] J. H. A. van Konijnenburg-van Cittert and K. Bandel. "Jurassic plants from Djebel Tih, Sinai." In: Mitt. Geol.-Paläont. Inst. Univ. Hamburg 85 (2001), pp. 47-64.

[23561] J. H. A. Van Konijnenburg-van Cittert, E. Kustatscher, and M. Wachtler. “Middle Triassic (Anisian) ferns from Kühwiesenkopf (Monte Prá Della Vacca), Dolomites, Northern Italy". English. In: Palaeontology 49.5 (2006), pp. 943-968.

[23562] J. H. A. van Konijnenburg-van Cittert and H. S. Morgans. "The Jurassic Flora of Yorkshire". In: Palaeontological Association Field Guides to Fossils 8 (1999), pp. 1-134.

[23563] J. H. A. Van Konijnenburg-van Cittert and J. Van der Burgh. "Review of the Kimmeridgian flora of Sutherland, Scotland with reference to the ecology and in situ pollen". In: Geologists' Association 107 (1996), pp. 97-105.

[23564] W. Van Neer. Les faunes de vertebres quaternaires en Afrique centrale. French. 1990.

[23565] W. Van Neer. Fish remains from Late Pleistocene and Holocene archaeological sites near Khashm el Girba,Sudan. English. 1994.

[23566] K. van Oorde. “Een oude Moorzaak". other. In: Cranium 25.2 (2008), pp. 17-20.

[23567] P. van Roy. "An aglaspidid arthropod from the Upper Ordovician of Morocco with remarks on the affinities and limitations of Aglaspidida". English. In: Transactions of the Royal Society of Edinburgh 96 (2006), pp. 327-350.

[23568] P. Van Roy, P. J. Orr, J. P. Botting, L. A. Muir, J. Vinther, B. Lefebvre, K. el Hariri, and D. E. G. Briggs. "Ordovician faunas of Burgess Shale type". English. In: Nature (2010), pp. 215-218. DOI: 10.1038/nature09038. 
[23569] G. F. van Tets. "An extinct new species of cormorant (Phalacrocoracidae, Aves) from a Western Australian peat swamp". English. In: Records of the South Australian Museum 27.1 (1994), pp. 135138.

[23570] L. M. Van Valen. "The origin of the plesiadapid primates and the nature of Purgatorius". English. In: Evolutionary Monographs 15 (1994), pp. 1-79.

[23571] B. Van Valkenburgh, F. Grady, and B. Kurten. “The Plio-Pleistocene Cheetah-Like Cat Miracinonyx inexpectatus of North America". English. In: Journal of Vertebrate Paleontology 10.4 (1990), pp. 434-454. DOI: $10.1080 / 02724634.1990 .10011827$.

[23572] A. P. Van Viersen. "New Middle Devonian trilobites form Vireux-Molhain (Ardennes, northern France)". English. In: Senkenbergiana lethaea 86.1 (2006), pp. 63-75.

[23573] A. P. van Viersen and F. Lerouge. "Cornuproetine (proetide) trilobites with nine thorax segments from the Devonian of Morocco, Germany and the Czech Republic". English. In: Palaeontologische Zeitschrift 94 (2020), pp. 227-254.

[23574] A. P. Van Viersen and H. Prescher. "Two new species of scutelluid trilobites formerly known as Scutellum costatum from Frasnian bioherms in Belgium". English. In: Bulletin - Institut royal des sciences naturelles de Belgique. Sciences de la terre 81 (2011), pp. 55-61.

[23575] A. P. Van Viersen, H. Prescher, and J. Savelsbergh. "Description of two new trilobites from the Ahrdorf Formation (Middle Devonian) at the Trilobitenfelder of Gees, Eifel, Rhenish Mountains". English. In: Bulletin de l'Institut royal des Sciences naturelles de Belgique, Sciences de la Terre 79 (2009), pp. 43-53.

[23576] A. P. Van Viersen and H. Presher. "New species of the lichid trilobite Ceratarges from the Middle Devonian in Morocco". English. In: Geologica Belgica 14.3/4 (2011), pp. 193-202.

[23577] H. J. van Vliet and G. A. el Khair. "A new Eocene marine mammal site in the Qattara depression (Egypt)". English. In: Cainozoic Research 7.1-2 (2010), pp. 73-77.

[23578] H. J. Van Vliet, A. S. Schulp, G. A. M. M. Abu El-Kheir, T. M. Paijmans, M. Bosselaers, and C. J. Underwood. "A new site with Oligocene terrestrial mammals and an Oligocene selachian fauna from Minqar Tibaghbagh, the Western Desert of Egypt". English. In: Acta Palaeontologica Polonica 62 (2017). DOI: 10.4202/app.00341.2017.

[23579] N. Vandenberghe, P. Laga, S. Louwye, R. >. Vanhoorne, R. Marquet, F. De Meuter, K. wouters, and H. W. Hagemann. "Stratigraphic interpretation of the Neogene marine-continental record in the Maaseik well (49W0220) in the Roer Valley Graben, NE Belgium". English. In: Memoirs of the Geological Survey of Belgium 52 (2005), pp. 1-39.

[23580] D. Vandermark, J. A. Tarduno, and D. B. Brinkman. "A fossil champsosaur population from the high Arctic: Implications for Late Cretaceous paleotemperatures". English. In: Palaeogeography, Palaeoclimatology, Palaeoecology 248 (2007), pp. 49-59. DOI: 10.1016/j.palaeo.2006.11.008.

[23581] D. Vandermark, J. A. Tarduno, and D. B. Brinkman. “Late Cretaceous Plesiosaur Teeth from Axel Heiberg Island, Nunavut, Canada". English. In: Arctic 59.1 (2006), pp. 79-82.

[23582] D. Vandermark, J. A. Tarduno, D. B. Brinkman, R. D. Cottrell, and S. Mason. "New Late Cretaceous macrobaenid turtle with Asian affinities from the High Canadian Arctic: Dispersal via ice-free polar routes". English. In: Geology 37.2 (2009), pp. 183-186. DOI: 10.1130/G25415A.1.

[23583] E. A. Vangengeim, I. A. Vislobokova, and M. V. Sotnikova. "Large Ruscinian Mammalia in the Territory of the Former Soviet Union". In: Stratigraphy and Geological Correlation 6.4 (1998), pp. 368382.

[23584] F. Vankerkhoven, H. Henderickx, and W. Dekoninck. "A well preserved fossil ant in Baltic amber of the enigmatic genus Gesomyrmex Mayr, 1868 (Hymenoptera: Formicidae)". English. In: Bulletin de la Société Royale Belge d'Entomologie 145 (2009), pp. 87-90. 
[23585] L. Vankova, T. Elbra, P. Pruner, Z. Vasicek, P. Skupien, D. Rehakova, P. Schnabl, M. Kostak, L. Svabenicka, A. Svobodova, M. Bubik, M. Mazuch, K. Cizkova, and S. Kdyr. "Integrated stratigraphy and palaeoenvironment of the Berriasian peri-reefal limestones at tramberk (Outer Western Carpathians, Czech Republic)". English. In: Palaeogeography, Palaeoclimatology, Palaeoecology (2019). DOI: $10.1016 /$ j.palaeo.2019.109256.

[23586] J. M. C. Vannier and J. Y. Chen. "The Early Cambrian colonization of pelagic niches exemplified by Isoxys (Arthropoda)". English. In: Lethaia 33.4 (2000), pp. 295-311.

[23587] J. M. C. Vannier, P. R. Racheboeuf, and J. L. Benedetto. "Silurian-Early Devonian ostracodes from South America (Argentina, Bolivia): preliminary investigations". English. In: Journal of Paleontology 69.4 (1995), pp. 752-772.

[23588] R. M. Varas-Malca, A. J. Altamirano-Sierra, T. DeVries, and M. Urbino. “The earliest known pinniped from the Southern Hemisphere". English. In: Ameghiniana 48.4 (2011), R217.

[23589] R. M. Varas-Malca and A. Valenzuela-Toro. "A basal monachine seal from the middle Miocene of the Pisco Formation, Peru". English. In: Ameghiniana 48.4 (2011), R216-R217.

[23590] C. Varela and R. Rojas-Consuegra. “Especie nueva de Eriosachila Blow y Manning, 1996, (Crustacea: Decapoda), de la Formacion, Colon, Cuba". English. In: Novitates Caribaea 4 (2011), pp. 1720.

[23591] A. I. Varlamov, K. L. Pak, and A. V. Rosova. "The Upper Cambrian of the Chopko River section, Norilsk region, northwestern Siberian Platform: stratigraphy and trilobites". English. In: Paleontological Journal 40.Suppl. 1 (2006), pp. 1-56.

[23592] D. J. Varricchio. Taphonomy of Jack's Birthday site, a diverse dinosaur bone bed. 1993.

[23593] D. J. Varricchio. "A new bird from the Upper Cretaceous Two Medicine Formation of Montana". English. In: Canadian Journal of Earth Sciences 39.1 (2002), pp. 19-26.

[23594] D. J. Varricchio. “Taphonomy of Jack's Birthday Site, a diverse dinosaur bonebed from the Upper Cretaceous Two Medicine Formation of Montana". In: Palaeogeography, Palaeoclimatology, Palaeoecology 114 (1995), pp. 297-323.

[23595] D. J. Varricchio. "Gut contents from a Cretaceous tyrannosaurid: implications for theropod dinosaur digestive tracts". In: Journal of Paleontology 75.2 (2001), pp. 401-406.

[23596] D. J. Varricchio, A. M. Balanoff, and M. A. Norell. "Reidentification of avian embryonic remains from the Cretaceous of Mongolia". English. In: PLoS ONE 10.6 (2015), e0128458:1-12. DOI: 10. 1371/journal.pone.0128458.

[23597] D. J. Varricchio and L. M. Chiappe. "A new enantiornithine bird from the Upper Cretaceous Two Medicine Formation of Montana". English. In: Journal of Vertebrate Paleontology 15.1 (1995), pp. 201204.

[23598] D. J. Varricchio and J. R. Horner. "Hadrosaurid and Lambeosaurid bone beds from the Upper Cretaceous Two Medicine Formation of Montana: taphonomic and biologic implications". English. In: Canadian Journal of Earth Sciences 30 (1993), pp. 997-1006.

[23599] D. J. Varricchio, J. R. Horner, and F. D. Jackson. "Embryos and eggs for the Cretaceous theropod dinosaur Troodon formosus". English. In: Journal of Vertebrate Paleontology 22.3 (2002), pp. 564-576.

[23600] D. J. Varricchio, A. J. Martin, and Y. Katsura. "First trace and body fossil evidence of a burrowing, denning dinosaur". English. In: Proceedings of the Royal Society of London B 274 (2007), pp. 13611368.

[23601] D. J. Varricchio, P. C. Sereno, X. -J. Zhao, L. Tan, J. A. Wilson, and G. H. Lyon. “Mud-trapped herd captures evidence of distinctive dinosaur sociality". English. In: Acta Palaeontologica Polonica 53.4 (2008), pp. 567-578.

[23602] Z. Vasicek. "The oldest (Late Valanginian) Crioceratitinae (heteromorphic ammonoids) from the Central Western Carpathians (Slovakia)". English. In: Geologica Carpathica 56.3 (2005), pp. 245-254.

[23603] Z. Vasicek. "Lower Cretaceous Ammonoidea in the Podbranc quarry (Pieniny Klippen Belt, Slovakia)". English. In: Bulletin of the Czech Geological Survey 77.3 (2002), pp. 187-200. 
[23604] Z. Vasicek. "A remarkable assemblage of Early Barremian ammonites in the Central Western Carpathians (Butkov Quarry, Slovakia)". English. In: Acta Geologica Polonica 56.4 (2006), pp. 421440.

[23605] Z. Vasicek and P. Faupl. "Die Cephalopoden aus den Rossfeldschichten der Reichraminger Decke (Obervalanginium, oberösterreichische Kalkalpen) [Cephalopods from the Rossfeld Formation of the Reichraming Nappe (Late Valanginian, Northern Calcareous Alps, Upper Austria)]". German. In: Jahrbuch der Geologischen Bundesanstalt 139.1 (1996), pp. 101-125.

[23606] Z. Vasicek, D. Rabrenovic, V. J. Radulovic, B. V. Radulovic, and I. Mojsic. “Ammonoids (Desmoceratoidea and Silesitoidea) from the Late Barremian of Boljetin, eastern Serbia". English. In: Cretaceous Research 41 (2013), pp. 39-54.

[23607] Z. Vasicek, D. Rabrenovic, P. Skupien, V. J. Radulovic, B. V. Radulovic, and I. Mojsic. “Ammonites (Phylloceratina, Lytoceratina and Ancyloceratina) and organic-walled dinoflagellate cysts from the Late Barremian in Boljetin, eastern Serbia". English. In: Cretaceous Research 47 (2014), pp. 140159.

[23608] Z. Vasicek and P. Skupien. "Notes on some rare Barremian/Aptian ancyloceratids from the Silesian Unit (Outer Western Carpathians, Czech Republic)". English. In: Journal of the Czech Geological Society 47 (2002), pp. 65-74.

[23609] Z. Vasicek and P. Skupien. "Early Berriasian ammonites from the Stramberk limestone in the Kotouc quarry (Outer Western Carpathians, Czech Republic)". English. In: Annales Societatis Geologorum Poloniae 83 (2013), pp. 329-342.

[23610] Z. Vasicek and P. Skupien. "Tithonian-early Berriasian perisphinctoid ammonites from the Stramberk Limestone at Kotouc Quarry near Stramberk, Outer Western Carpathians (Czech Republic)". English. In: Cretaceous Research 64 (2016), pp. 12-29.

[23611] Z. Vasicek and P. Skupien. "Recent discoveries of Tithonian ammonites in the Stramberk Limestone (Kotouc Quarry, Outer Western Carpathians)". English. In: Annales Societatis Geologorum Poloniae 84 (2014), pp. 131-141.

[23612] S. Vasile, Z. Csiki-Sava, and M. Venczel. "A new madtsoiid snake from the Upper Cretaceous of the Haeg Basin, Western Romania". English. In: Journal of Vertebrate Paleontology 33.5 (2013), pp. 1100-1119.

[23613] N. Vasileiadis, E. Tsoukala, and D. S. Kostopoulos. “The late Miocene bovids from Platania (Drama Basin, Greece), with description of a new species of Paleoryx". English. In: Geobios (2019), pp. 1-36. DOI: 10.1016/j.geobios.2019.06.005.

[23614] K. Vasileiadou, M. Boehme, T. A. Neubauer, G. L. Georgalis, G. E. Syrides, L. Papadopoulou, and N. Zouros. "Early Miocene gastropod and ectothermic vertebrate remains from the Lesvos Petrified Forest (Greece)". English. In: Palaeontologische Zeitschrift (2017).

[23615] K. Vasileiadou, G. Konidaris, and G. D. Koufos. "New data on the micromammalian locality of Kessani (Thrace, Greece) at the Mio-Pliocene boundary". English. In: Palaeobiodiversity and Palaeoenvironments 92.2 (2012), pp. 211-237.

[23616] K. Vasileiadou and G. D. Koufos. "The micromammals from the Early/Middle Miocene locality of Antonios, Chalkidiki, Greece". English. In: Annales de Paléontologie 91.3 (2005), pp. 197-225.

[23617] K. Vasileiadou, G. D. Koufos, and G. E. Syrides. "Silata, a new locality with micromammals from the Miocene/Pliocene boundary of the Chalkidiki peninsula, Macedonia, Greece". English. In: Deinsea 10 (2003), pp. 549-562.

[23618] D. V. Vasilenko. "New Damselflies (Odonata: Synlestidae, Hemiphlebiidae) from the Mesozoic Transbaikalian Locality of Chernovskie Kopi". English. In: Paleontological Journal 39.3 (2005), pp. 280283.

[23619] D. Vasilyan. "Eocene Western European endemic genus Thaumastosaurus: new insights into the question Are the Ranidae known prior to the Oligocene?" English. In: PeerJ 6 (2018), e5511:1-24. 
[23620] D. Vasilyan. "Fish, amphibian and reptilian assemblage from the middle Miocene locality GraanicaBugojno palaeolake, Bosnia and Herzegovina". English. In: Palaeobiodiversity and Palaeoenvironments 100 (2020), pp. 437-455.

[23621] D. Vasilyan, M. Bohme, V. M. Chkhikvadze, Y. A. Semenov, and W. G. Joyce. "A new giant salamander (Urodela, Pancryptobrancha) from the Miocene of Eastern Europe (Grytsiv, Ukraine)". English. In: Journal of Vertebrate Paleontology 33.2 (2013), pp. 301-318. DOI: 10.1080/02724634.2013. 722151.

[23622] D. Vasilyan and M. Bukhsianidze. "The fossil record of the genus Varanus from the Southern Caucasus (Armenia, Georgia)". English. In: PeerJ 8.e8322 (2020), pp. 1-12. DOI: 10.7717/ peerj.8322.

[23623] D. Vasilyan, V. S. Zazhigin, and M. Bohme. "Neogene amphibians and reptiles (Caudata, Anura, Gekkota, Lacertilia, and Testudines) from the south of Western Siberia, Russia, and Northeastern Kazakhstan". English. In: PeerJ (2017). DOI: 10.7717/peerj.3025.

[23624] R. Vasseur, S. Boivin, B. Lathuiliére, I. Lazar, C. Durlet, R. Martindale, S. Bodin, and K. Elhmidi. "Lower Jurassic corals from Morocco with skeletal structures". English. In: Palaeontologia Electronica (2019).

[23625] D. V. Vassilenko. “The first damselfly (Insecta: Odonata, Hemiphlebiidae) recorded from the Turonian of Israel". English. In: Far Eastern Entomologist 278 (2014), pp. 1-7.

[23626] Q. Vautrin, F. Lihoreau, B. Sambou, M. Thiam, J. E. Martin, R. Tabuce, S. Adnet, R. Lebrun, A. -L. Charruault, R. Sarr, and L. Hautier. "From limb to fin: An Eocene protocetid forelimb from Senegal sheds new light on the early locomotor evolution of Cetaceans". English. In: Palaeontology (2019). DOI: $10.1111 /$ pala.12442.

[23627] M. N. Vavilov and V. V. Arkadiev. "Ammonoid remains in the body chambers of the Late Carnian ammonoid Proarcestes from Kotel'nyi Island (New Siberian Islands)". In: Paleontological Journal 32.2 (1998), pp. 34-39.

[23628] M. J. Vavrek and D. B. Brinkman. "The first record of a trionychid turtle (Testudines: Trionychidae) from the Cretaceous of the Pacific Coast of North America". English. In: Vertebrate Anatomy Morphology Palaeontology 5 (2018), pp. 34-37.

[23629] M. J. Vavrek, L. V. Hills, and P. J. Currie. "A hadrosaurid (Dinosauria: Ornithischia) from the Late Cretaceous (Campanian) Kanguk Formation of Axel Heiberg Island, Nunavut, Canada, and its ecological and geographical implications". English. In: Arctic 67.1 (2014), pp. 1-9.

[23630] M. J. Vavrek, H. C. E. Larsson, and N. Rybczynski. “A Late Triassic flora from east-central Axel Heiberg Island, Nunavut, Canada". English. In: Canadian Journal of Earth Sciences 44 (2007), pp. 16531659. DOI: $10.1139 / \mathrm{E} 07-042$.

[23631] M. J. Vavrek, A. M. Murray, and P. R. Bell. "Xiphactinus audax Leidy 1870 from the Puskwaskau Formation (Santonian to Campanian) of northwestern Alberta, Canada and the distribution of Xiphactinus in North America". English. In: Vertebrate Anatomy Morphology Palaeontology 1.1 (2016), pp. 89-100.

[23632] M. J. Vavrek, R. A. Stockey, and G. W. Rothwell. “Osmunda vancouverensis sp. nov. (Osmundaceae), perminerallized fertile frond segments from the lower Cretaceous of British Columbia, Canada". English. In: International Journal of Plant Sciences 167 (2006), pp. 631-637.

[23633] M. J. Vavrek, B. C. Wilhelm, E. E. Maxwell, and H. C. E. Larsson. "Arctic plesiosaurs from the Lower Cretaceous of Melville Island, Nunavut, Canada". English. In: Cretaceous Research 50 (2014), pp. 273-281. DOI: 10.1016/j.cretres.2014.04.011.

[23634] L. Vaz Tassi, A. M. Zavattieri, and O. F. Gallego. "Triassic spinicaudatan fauna from the Cerro de Las Cabras Formation (Cuyo Basin), Mendoza Province (Argentina): Descrption of new species and revisión of previous records". English. In: Ameghiniana 52.2 (2015), pp. 241-264.

[23635] S. H. Vaziri. "A review on Late Scythian to Middle Anisian Ammonoids from the Alam Formation in Nakhlak area, Central Iran". English. In: Journal of Sciences (Islamic Azad University) 21.81 (2011), pp. 201-212. 
[23636] S. H. Vaziri, M. R. Majidifard, and M. Laflamme. “Diverse assemblage of Ediacaran fossils from Central Iran". English. In: Scientific Reports 8.5060 (2018), pp. 1-7. DOI: 10.1038/s41598-018-23442y.

[23637] I. M. Vea and D. A. Grimaldi. "Phylogeny of ensign scale insects (Hemiptera: Coccoidea: Ortheziidae) based on the morphology of Recent and fossil females". English. In: Systematic Entomology 37 (2012), pp. 758-783.

[23638] I. M. Vea and D. A. Grimaldi. "Diverse new scale insects (Hemiptera: Coccoidea) in amber from the Cretaceous and Eocene with a phylogenetic framework for fossil Coccoidea". English. In: American Museum Novitates 3823 (2015), pp. 1-80.

[23639] A. Vecsei and E. Moussavian. "Paleocene reefs on the Maiella Platform margin, Italy: An example of the effects of the Cretaceous/Tertiary boundary events on reefs and carbonate platforms". In: Facies 36 (1997), pp. 123-140.

[23640] F. Vega, V. Davila-Alocer, and H. F. Filkorn. "Characterization of cuticle structure in Late Cretaceous and Early Tretiary decapod Crustacea from Mexico". English. In: Bulletin of the Mizunami Fossil Museum 32 (2005), pp. 37-42.

[23641] F. Vega, T. G. Nyborg, and M. del Carmen Perrilliat. "Mesozoic and Tertiary Decapod Crustacea from Mexico". English. In: Studies on Mexican Paleontology (2006), pp. 79-100.

[23642] F. J. Vega, F. Alvarez, and G. Carbot-Chanona. "Albian penaeoidea (Decapoda, Dendrobranchiata) from Chiapas, southern Mexico". English. In: Memorie della Societa Italiana di Scienze Naturale e del Museo Civico di Storia Naturale di Milano 35.2 (2007), pp. 97-100.

[23643] F. J. Vega, T. Cosma, M. A. Coutino, R. M. Feldmann, T. G. Nyborg, C. E. Schweitzer, and D. A. Waugh. "New middle Eocene decapods (Crustacea) from Chiapas, Mexico". English. In: Journal of Paleontology 75 (2001), pp. 929-946.

[23644] F. J. Vega and G. P. Dietl. "Specialized shell-breaking crab claws in Cretaceous seas". English. In: Biology Letters 4 (2008), pp. 290-293. DOI: 10.1098/rsbl.2008.0031.

[23645] F. J. Vega, R. M. Feldmann, J. L. Villalobos-Hiriart, and R. Gio-Argiez. “A new decapod fauna from the Miocene Tuxpan Formation, eastern Mexico". English. In: Journal of Paleontology 73.3 (1999), pp. 407-413.

[23646] F. J. Vega, R. M. Feldmann, F. Etayo-Serna, H. D. Bermudez-Aguirre, and J. Gomez. “Occurrence of Meyeria magna M'Coy, 1849 in colombia: a widely distributed species during Aptian times". English. In: Boletin De La Socidad Geologica Mexicana 60.1 (2008), pp. 1-10.

[23647] F. J. Vega, P. Garca-Barrera, M. del Carmen Perrilliat, M. A. Coutiño, and R. Mariño-Pérez. "El Espinal, a new plattenkalk facies locality from the Lower Cretaceous Sierra Madre Formation, Chiapas, southeastern Mexico". English. In: Revista Mexicana de Ciencias Geológicas 23.3 (2006), pp. 323-333.

[23648] F. J. Vega, H. Gholamalian, and A. Bahrami. “First record of Miocene crustaceans from Hormozgan Province, southern Iran". English. In: Palaeontologische Zeitschrift 84 (2010), pp. 485-493.

[23649] F. J. Vega and T. F. Lawton. "Upper Jurassic (Lower Kimmeridgian-Olvido) carbonate strata from the La Popa Basin diapirs, NE Mexico". English. In: Boletn de la Sociedad Geológica Mexicana 63.2 (2011), pp. 313-321.

[23650] F. J. Vega, T. Nyborg, G. Kovalchuk, F. Etayo, J. Luque, A. Rojas-Briceño, P. Patarroyo, H. PorrasMúzquiz, A. Armstrong, H. Bermúdez, and L. Garibay. “On some Panamerican Cretaceous crabs (Decapoda: Raninoida)". English. In: Boletn de la Sociedad Geológica Mexicana 62.2 (2010), pp. 262279.

[23651] F. J. Vega, T. Nyborg, R. H. B. Fraaye, and B. Espinosa. "Paleocene Decapod Crustacea From the Rancho Nuevo Formation (Parpras Basin-Difunta Group), Northeastern Mexico". English. In: Journal of Paleontology 81.6 (2007), pp. 1432-1441. 
[23652] F. J. Vega, T. Nyborg, A. Rojas-Briceno, P. Patarroyo, J. Luque, H. Porras-Muzquiz, and W. Stinnesbeck. "Upper Cretaceous Crustacea from Mexico and Colombia: similar faunas and environments during Turonian times". English. In: Revista Mexicana de Ciencias Geologicas 24.3 (2007), pp. 403422.

[23653] F. J. Vega, T. Nyborg, M. A. Coutiño, J. Solé, and O. Hernández-Monzon. “Neogene Crustacea from Southeastern Mexico". English. In: Bulletin of the Mizunami Fossil Museum 35 (2009), pp. 5169.

[23654] F. J. Vega, A. Osso-Morales, and P. Artal. “A new species of crab (Brachyura: Raninoidia: Cenomanocarcinidae) from the Campanian of Morocco: validation of the genus Hasaracancer Jux, 1971". English. In: N. Jb. Geol. Palaont. Abh (2011). DOI: 10.0027/0077-7749/2011/0175.

[23655] F. J. Vega and M. D. C. Perilliat. “Freshwater Gastropods from Early Eocene Difunta Group, Northeastern Mexico". English. In: Journal of Paleontology 66.4 (1992), pp. 603-609.

[23656] F. J. Vega, M. D. C. Perrilliat, and L. M. Mitre-Salazar. "Paleocene ostreids from the Las Encinas Formation (Parras basin, Difunta Group), northeastern Mexico; stratigraphic implications". In: Geological Society of America Special Paper 340 (1999), pp. 105-110.

[23657] F. J. Vega and M. D. C. Perrilliat. “On some Paleocene invertebrates from the Potrerillos Formation (Difunta Group), northeastern Mexico". In: Journal of Paleontology 69.5 (1995), pp. 863-869.

[23658] F. J. Vega, M. Yazdi, and A. Bahrami. "Albian decapod Crustacea from Southeast Isfahan, Central Iran-Kolah-Qazi area". English. In: Bulletin of the Mizunami Fossil Museus 35 (2009), pp. 71-77.

[23659] C. Vega-Dias and C. L. Schultz. "Evidence of archosauriform feeding on dicynodonts in the Late Triassic of southern Brazil". English. In: PaleoBios 27.2 (2007), pp. 62-67.

[23660] A. Vekua, D. Lordkipanidze, G. P. Rightmire, J. Agusti, R. Ferring, G. Maisuradze, A. Mouskhelishvili, M. Nioradze, M. Ponce de Leon, M. Tappen, M. Tvalchrelidze, and C. Zollikofer. "A new skull of early Homo from Dmanisi, Georgia". English. In: Science 297 (2002), pp. 85-89.

[23661] P. M. Velazco, A. J. Buczek, and M. J. Novacek. “Two New Tritylodontids (Synapsida, Cynodontia, Mammaliamorpha) from the Upper Jurassic, Southwestern Mongolia". English. In: American Museum Novitates 3874 (2017), pp. 1-35.

[23662] P. M. Velazco and M. J. Novacek. "Systematics of the genus Palaeictops Matthew, 1899 (Mammalia: Leptictidae), with the description of two new species from the Middle Eocene of Utah and Wyoming". English. In: American Museum Novitates 3867 (2016), pp. 1-42.

[23663] Y. P. Velazco. “Algunos invertebrados fósiles de Huacrapuquio, provincia de Huancayo, departamento de Junn-Perú [Some invertebrate fossils from Huacrapuquio, province of Huancayo, Junin, Peru]". Spanish. In: Revista del Instituto de investigación de la Facultad de minas, metalurgia y ciencias geográficas 11 (2008), pp. 39-48.

[23664] A. J. Veldmeijer. "Pterosaurs from the Lower Cretaceous of Brazil in the Stuttgart collection". English. In: Stuttgarter Beiträge zur Naturkunde Serie B (Geologie und Paläontologie) 327 (2002), pp. 127.

[23665] A. J. Veldmeijer. "Preliminary description of a skull and wing of a Brazilian Cretaceous (Santana Formation; Aptian-Albian) pterosaur (Pterodactyloidea) in the collection of the AMNH". English. In: PalArch, Vertebrate Palaeontology (2003), pp. 1-13.

[23666] A. J. Veldmeijer. “Coloborhynchus spielbergi sp. nov. (Pterodactyloidea) from the Albian (Lower Cretaceous) of Brazil". English. In: Scripta Geologica 125 (2003), pp. 35-139.

[23667] A. J. Veldmeijer, M. Signore, and H. J. M. Meijer. "Description of two pterosaur (Pterodactyloidea) mandibles from the Lower Cretaceous Santana Formation, Brazil". English. In: Deinsea 11 (2005), pp. 67-86.

[23668] J. Velez and F. M. Salinas-Márquez. "A dwarf walrus from the Miocene of Baja California Sur, Mexico". English. In: Royal Society Open Science 5 (2018), p. 180423. DOI: 10.1098/rsos.180423. 
[23669] J. Velez-Juarbe. “Ghost of seagrasses past: Using sirenians as a proxy for historical distribution of seagrasses". English. In: Palaeogeography, Palaeoclimatology, Palaeoecology 400 (2013), pp. 41-49. DOI: $10.1016 /$ j.palaeo.2013.05.012.

[23670] J. Velez-Juarbe. "Ghost of seagrasses past: Using sirenians as a proxy for historical distribution of seagrasses". English. In: Palaeogeography, Palaeoclimatology, Palaeoecology 400.1 (2014), pp. 41-49. DOI: 10.1016/j.palaeo.2013.05.012.

[23671] J. Velez-Juarbe. “Eotaria citrica, sp. nov., a new stem otariid from the Topanga formation of Southern California". English. In: PeerJ 5 (2017), e3022. DOI: 10.7717/ peerj.3022.

[23672] J. Vélez-Juarbe. "A new stem odontocete from the late Oligocene Pysht Formation in Washington State, U.S.A." English. In: Journal of Vertebrate Paleontology 37.5 (2017), e1366916. DOI: 10.1080 / 02724634.2017.1366916.

[23673] J. Vélez-Juarbe, C. A. Brochu, and H. Santos. "A gharial from the Oligocene of Puerto Rico: transoceanic dispersal in the history of a non-marine reptile". English. In: Proceedings of the Royal Society B 274 (2007), pp. 1245-1254.

[23674] J. Velez-Juarbe, D. P. Domning, and N. D. Pyenson. "Iterative Evolution of Sympatric Seacow (Dugongidae, Sirenia) Assemblages during the Past 26 Million Years". English. In: PLoS One 7.2 (2012), e31294. DOI: 10.1371/journal.pone.0031294.

[23675] J. Velez-Juarbe and D. P. Domning. "Fossil Sirenia of the West Atlantic and Caribbean region. IX. Metaxytherium albifontanum, sp. nov." English. In: Journal of Vertebrate Paleontology 34.2 (2014), pp. 444-464. DOI: 10.1080/02724634.2013.799072.

[23676] J. Velez-Juarbe and D. P. Domning. "Fossil Sirenia of the West Atlantic and Caribbean region: X. Priscosiren atlantica, gen. et sp. nov." English. In: Journal of Vertebrate Paleontology 34.4 (2014), pp. 951-964. DOI: 10.1080/02724634.2013.815192.

[23677] J. Velez-Juarbe and D. P. Domning. "Fossil Sirenia of the West Atlantic and Caribbean region. XI. Callistosiren boriquensis, gen. et sp. nov." English. In: Journal of Vertebrate Paleontology (2015), e885034. DOI: $10.1080 / 02724634.2014 .885034$.

[23678] J. Velez-Juarbe, T. Martin, R. D. MacPhee, and D. Ortega-Ariza. “The earliest Caribbean rodents: Oligocene caviomorphs from Puerto Rico". English. In: Journal of Vertebrate Paleontology 34.1 (2014), pp. 157-163. DOI: 10.1080/02724634.2013.789039.

[23679] J. Vélez-Juarbe and T. E. Miller. “First Report of a Quaternary Crocodylian from a Cave Deposit in Northern Puerto Rico". English. In: Caribbean Journal of Science 43.2 (2007), pp. 273-277.

[23680] J. Velez-Juarbe, J. I. Noriega, and B. S. Ferrero. "Fossil dugongidae (Mammalia, Sirenia) from the Paraná Formation (Late Miocene) of Entre Ros Province, Argentina". English. In: Amghiniana 49.4 (2012), pp. 585-593.

[23681] J. Velez-Juarbe and N. D. Pyenson. “Bohaskia monodontoides, a new monodontid (Cetacea, Odontoceti, Delphinoidea) from the Pliocene of the western North Atlantic Ocean". English. In: Journal of Vertebrate Paleontology 32.2 (2012), pp. 476-484.

[23682] J. Velez-Juarbe and A. M. Valenzuela-Toro. "Oldest record of monk seals from the North Pacific and biogeographic implications". English. In: Biology Letters 15 (2019), pp. 1-6. DOI: 10.1098/rsbl. 2019.0108.

[23683] J. Velez-Juarbe and A. Wood. "An early Miocene dugongine (Sirenia: Dugongidae) from Panama". English. In: Journal of Vertebrate Paleontology (2019). DOI: 10.1080/02724634.2018.1511799.

[23684] J. Velez-Juarbe, A. R. Wood, C. de Gracia, and A. J. W. Hendy. "Evolutionary patterns among living and fossil kogiid sperm whales: Evidence from the Neogene of Central America". English. In: PLoS One 10.4 (2015), e0123909. DOI: 10.1371/journal.pone.0123909.

[23685] J. Velez-Juarbe, A. R. Wood, and C. Pimiento. "Pygmy sperm whales (Odontoceti, Kogiidae) from the Pliocene of Florida and North Carolina". English. In: Journal of Vertebrate Paleontology (2016), e1135806. DOI: 10.1080/02724634.2016.1135806. 
[23686] D. W. Veltre, D. R. Yesner, K. J. Crossen, R. W. Graham, and J. B. Coltrain. "Patterns of faunal extinction and paleoclimatic change from mid-Holocene mammoth and polar bear remains, Pribilof Islands, Alaska". English. In: Quaternary Research 70 (2008), pp. 40-50.

[23687] I. Veltz, D. Azar, and A. Nel. "New chironomid flies in Early Cretaceous Lebanese amber (Diptera: Chironomidae)". English. In: African Invertebrates 48 (2007), pp. 169-191.

[23688] M. Venczel. “Late Miocene snakes (Reptilia: Serpentes) form Polgárdi (Hungary): a second contribution". English. In: Acta Zoologica Cracoviensia 41 (1998), pp. 1-22.

[23689] M. Venczel. "Anurans and squamates from the Lower Pliocene (MN 14) Osztramos 1 locality (Northern Hungary)". English. In: Fragmenta Palaeontologica Hungarica 19 (2001), pp. 79-90.

[23690] M. Venczel. "Late Miocene Snakes from Polgárdi". English. In: Acta Zoologica Cracoviensia 37.1 (1994), pp. 1-29.

[23691] M. Venczel. "Lizards from the Late Miocene of Polgárdi (W-Hungary)". English. In: Nymphaea, Folia naturae Bihariae 33 (2006), pp. 25-38.

[23692] M. Venczel and V. A. Codrea. "A new teiid lizard from the Late Cretaceous of the Hateg Basin, Romania and its phylogenetic and palaeobiogeographical relationships". English. In: Journal of Systematic Palaeontology 14.3 (2016), pp. 219-237. DOI: 10.1080/14772019.2015.1025869.

[23693] M. Venczel and V. A. Codrea. "A new Theriosuchus-like crocodyliform from the Maastrichtian of Romania”. English. In: Cretaceous Research 100 (2019), pp. 24-38. DOI: 10.1016/j.cretres.2019.03.018.

[23694] M. Venczel and V. A. Codrea. "A New Proteid Salamander from the Lower Oligocene of Romania, with Notes on the Paleobiogeography of Eurasian Proteids". English. In: Journal of Vertebrate Paleontology 38.e1508027 (2019), pp. 1-10. DOI: 10.1080/02724634.2018.1508027.

[23695] M. Venczel and Z. Csiki. "New frogs from the latest Cretaceous of Haeg Basin, Romania”. English. In: Acta Palaeontologica Polonica 48.4 (2003), pp. 609-616.

[23696] M. Venczel and J. D. Gardner. "The geologically youngest albanerpetontid amphibian, from the Lower Pliocene of Hungary". English. In: Palaeontology 48.6 (2005), pp. 1273-1300.

[23697] M. Venczel, J. D. Gardner, V. A. Codrea, Z. Csiki-Sava, S. Vasile, and A. A. Solomon. “New insights into Europe's most diverse Late Cretaceous anuran assemblage from the Maastrichtian of western Romania". English. In: Palaeobiodiversity and Palaeoenvironments 96.1 (2016), pp. 61-95.

[23698] M. Venczel and J. Hr. "Amphibians and Squamates from the Miocene of Felstárkány Basin, NHungary". English. In: Palaeontographica, Abteilung A: Paleozoology - Stratigraphy 300.1-6 (2013), pp. 117-158.

[23699] M. Venczel, J. Hr, R. R. Huza, and E. Popa. D. Golban. “A new middle Miocene vertebrate fauna from Subpiatr (Bihor County, Romania)". English. In: Nymphaea 12 (2005), pp. 23-38.

[23700] M. Venczel and B. Sanchz. "Lower Miocene Amphibians and Reptiles from Oschiri (Sardinia, Italy)". English. In: Hantkeniana 5 (2006), pp. 72-75.

[23701] M. Venczel and E. Stiuca. "Late middle Miocene amphibians and squamate reptiles from Taut, Romania". English. In: Geodiversitas 30.4 (2008), pp. 731-763.

[23702] M. Venczel and G. Vardai. "The Genus Elaphe in the Carpathian Basin: Fossil Record". English. In: Nymphaea - Folia Naturae Bihariae 28 (2000), pp. 65-82.

[23703] M. J. Vendrasco, R. D. Hoare, and G. L. Bell Jr. “The youngest rostroconch mollusc from North America, Minycardita capitanensis n. sp." English. In: Zootaxa 2603 (2010), pp. 61-64.

[23704] M. J. Vendrasco, A. V. Kouchinsky, S. M. Porter, and C. Z. Fernandez. "Phylogeny and escalation in Mellopegma and other Cambrian molluscs". English. In: Palaeontologia Electronica 14.2 (2011), 11A1-44.

[23705] M. J. Vendrasco, G. Li, S. M. Porter, and C. Z. Fernandez. "New data on the enigmatic OcruranusEohalobia group of Early Cambrian small skeletal fossils". English. In: Palaeontology 56.6 (2009), pp. 1373-1396. DOI: 10.1111/j.1475-4983.2009.00913.x. 
[23706] M. J. Vendrasco, S. M. Porter, A. Kouchinsky, G. Li, and C. Z. Fernandez. “New data on molluscs and their shell microstructures from the Middle Cambrian Gowers Formation, Australia". English. In: Palaeontology 53.1 (2010), pp. 97-135. DOI: 10.1111/j.1475-4983.2009.00922.x.

[23707] M. J. Vendrasco and B. Runnegar. "Late Cambrian and Early Ordovician stem group chitons (Mollusca: Polyplacophora) from Utah and Missouri". English. In: Journal of Paleontology 78.4 (2004), pp. 675-689. DOI: 10.1666/0022-3360(2004)078<0675:lcaeos>2.0.co;2.

[23708] M. J. Vendrasco, T. E. Wood, and B. N. Runnegar. “Articulated Paleozoic fossil with 17 plates greatly expands disparity of early chitons". English. In: Nature 429 (2004), pp. 288-290.

[23709] E. Vennin, J. J. Alvaro, and E. Villas. "High-latitude pelmatozoan-bryozoan mud-mounds from the Late Ordovician northern Gondwana platform". English. In: Geological Journal 33 (1998), pp. 121140.

[23710] E. Vennin, T. Boisseau, J. -N. Proust, and B. Chuvashov. "Influence of eustasy and tectonism on reef architecture in early Permian reef complexes, southern Urals, Russia". English. In: SEPM Special Publication 74 (2002), pp. 205-218.

[23711] E. Vennin, E. Moreno-Eiris, A. Perejon, and J. J. Alvaro. “Fracturacion sinsedimentaria y diagenesis precoz en las bioconstrucciones del Cambrio inferior de Alconera (Ossa-Morena) [Synsedimentary fracturation and early diagenesis in Lower Cambrian bioconstructions of Alconera (Ossa Morena)]". Spanish. In: Revista de la Sociedad Geologica de Espana 14 (2001), pp. 75-88.

[23712] E. Vennin, J. M. Rouchy, C. Chaix, M. M. Blanc-Valleron, A. Caruso, and V. Rommevau. "Paleoecological constraints on reef-coral morphologies in the Tortonian-Early Messinian of the Lorca Basin, SE Spain". English. In: Palaeogeography, Palaeoclimatology, Palaeoecology 213 (2004), pp. 163185.

[23713] B. A. Vento, M. A. Gandolfo, K. C. Nixon, and M. Prámparo. "Paleofloristic assemblage from the Paleogene Ro Guillermo Formation, Argentina: preliminary results of phylogenetic relationships of Nothofagus in South America". English. In: Historical Biology 29.1 (2017), pp. 93-107. DOI: 10. 1080/08912963.2015.1136930.

[23714] B. A. Vento, B. A. Toro, and J. Maletz. "New insights into the paleobiogeography of the Early Ordovician graptolite fauna of northwestern Argentina". English. In: Comptes Rendus Palevol 11 (2012), pp. 345-355. DOI: 10.1016/j.crpv.2012.02.002.

[23715] F. Venturi, C. Nannarone, and M. Bilotta. "Early Pliensbachian ammonites from the Furlo Pass (Marche, Italy): two new faunas for the middle-western Tethys". English. In: Bollettino della Societá Paleontologica Italiana 44 (2005), pp. 81-115.

[23716] F. Venturi, C. Nannarone, and M. Bilotta. "Ammonites from the early Pliensbachian of the Furlo Pass (Marche, Italy): biostratigraphic and paleobiogeographic implications". English. In: Bollettino della Societá Paleontologica Italiana 46 (2007), pp. 1-31.

[23717] S. Venturini. "Segnalazione di un livello marnoso a characee con presunte impronte di dinosauro nell'Aptiano del M. Bernadia (Nimis, Udine) [Notice of a marly characeous level with presumed dinosaur prints in the Aptian of Monte Bernadia (Nimis, Udine)]". Italian. In: Natura Nascosta 11 (1995), pp. 36-37.

[23718] B. Vera. "Revisión del género Transpithecus Ameghino, 1901 (Notoungulata, Interatheriidae) del Eoceno medio de Patagonia, Argentina". Spanish. In: Ameghiniana 49.1 (2012), pp. 60-74.

[23719] B. Vera. "Postcranial morphology of Notopithecus Ameghino, 1897 (Notoungulata, Interatheriidae) from the middle Eocene of Patagonia, Argentina". English. In: Journal of Vertebrate Paleontology 32.5 (2012), pp. 1135-1148.

[23720] B. Vera. "Acoelodus connectus Ameghino, 1901, Sinónimo de Transpithecus obtentus". Spanish. In: Ameghiniana 50.5 (2013), pp. 535-540.

[23721] B. Vera. "Patagonian Eocene Archaeopithecidae Ameghino, 1897 (Notoungulata): systematic revision, phylogeny and biostratigraphy". English. In: Journal of Paleontology (2017). DOI: 10.1017/jpa. 2017.53. 
[23722] B. Vera. "A new species and the record of Hemihegetotherium (Notoungulata, T Hegetotheriidae) in the Middle to Late Miocene of Patagonia, Argentina". English. In: Journal of South American Earth Sciences 93 (2019), pp. 23-35.

[23723] B. Vera, E. Cerdeño, and M. Reguero. “The Interatheriinae from the Late Oligocene of Mendoza (Argentina), with comments on some Deseadan Interatheriidae". English. In: Historical Biology 29.5 (2017), pp. 607-626.

[23724] B. Vera and E. Cerdeño. "Systematic revision of Antepithecus brachystephanus Ameghino, 1901, and dental eruption sequence in Eocene notopithecines (Notoungulata) from Patagonia". English. In: Geobios 47 (2014), pp. 165-181.

[23725] B. Vera and M. D. Ercoli. "Systematic and morphogeometric analyses of Pachyrukhinae (Mammalia, Hegethoteriidae) from the Huayqueras, Mendoza (Argentina): biostratigraphic and evolutionary implications". English. In: Journal of Vertebrate Paleontology 38.3 (2018), e1473410.

[23726] B. Vera, M. Fornasiero, and L. Del Favero. “The Egidio Feruglio's collection in the Museum of Geology and Palaeontology of the University of Padova: its importance to the knowledge of Cenozoic mammals from South America". English. In: Museologia Scientifica 9 (2015), pp. 35-44.

[23727] B. Vera, L. Gonzalez-Ruiz, N. Novo, G. Martin, A. Reato, and M. F. Tejedor. "The Interatheriinae (Mammalia, Notoungulata) of the Friasian sensu stricto and Mayoan (middle to late Miocene), and the fossils from Cerro Zeballos, Patagonia, Argentina". English. In: Journal of Systematic Palaeontology (2018), pp. 1-21. DOI: 10.1080/14772019.2018.1511387.

[23728] B. Vera and J. M. Krause. "New insights into the Kibenikhoria and Ernestokokenia faunas and the implications for the early Eocene of Patagonia, Argentina". English. In: Journal of Vertebrate Paleontology (2020), e1772801:1-21. DOI: 10.1080/02724634.2020.1772801.

[23729] B. Vera, M. Reguero, and L. González-Ruiz. "The Interatheriinae notoungulates from the middle Miocene Collón Curá Formation in Argentina". English. In: Acta Palaeontologica Polonica 62.4 (2017), pp. 845-863. DOI: 10.4202/app.00373.2017.

[23730] B. Vera, M. Tunik, and E. Cerdeño. "The first mammal assemblages from the Malargüe Group: Implications for the Paleogene evolution of the northern Neuquén Basin (Argentina)". English. In: Journal of South American Earth Sciences 99 (2020), 102498:1-14.

[23731] E. I. Vera. “Oligocene ferns from the Rancahué Formation (Aluminé, Neuquén, Argentina): Cuyenopteris patagoniensis nov. gen., nov. sp. (Polypodiales: Blechnaceae/Dryopteridaceae) and Alsophilocaulis calveloi Menéndez emend. Vera (Cyatheales: Cyatheaceae)". English. In: Geobios 43 (2010), pp. 465-478. DOI: 10.1016/j.geobios.2009.12.003.

[23732] E. I. Vera. “Estudios anatómicos en paleofloras del Aptiano de Antártida y Patagonia, y su comparación". Spanish. PhD thesis. 2010, p. 294.

[23733] J. L. Vera-Peláez, M. C. Lozano-Francisco, J. Ramos Fernández, and Y. M. Cortéz Sánchez. “Molluscos del Tirreniense (Pleistoceno Superior) de la Playa la Araña-Cala de Moral (Málaga)". Spanish. In: Revista Española de Paleontologa 19.2 (2004), pp. 251-259.

[23734] F. J. Verdú, R. Royo-Torres, A. Cobos, and L. Alcalá. "Perinates of a new species of Iguanodon (Ornithischia: Ornithopoda) from the lower Barremian of Galve (Teruel, Spain)". English. In: Cretaceous Research 56 (2015), pp. 250-264. DOI: 10.1016/j.cretres.2015.05.010.

[23735] L. Veress and V. A. Codrea. "A freshwater softshelled turtle in the Albesti limestone". English. In: Muzeul OIteniei Craiova 36.1 (2020), pp. 7-20.

[23736] T. Verheyden. "Decapods from the Boom Clay (Rupelian, Oligocene) in Belgium". English. In: Bulletin de l'Institute Royal des Sciences Naturelles de Belgique, Sciences de la Terre 72 (2002), pp. 171191.

[23737] J. R. Verhoff, P. M. Muller, R. M. Feldmann, and C. E. Schweitzer. “A new species of Tumidocarcinidae (Decapoda, Carpilioidea) from the Kambuhel Formation (Paleocene) of Austria". English. In: Annalen des Naturhistorischen Museums in Wien, Serie A 111 (2009), pp. 225-232. 
[23738] O. Verma. "Cretaceous vertebrate fauna of the Cauvery Basin, southern India: Palaeodiversity and palaeobiogeographic implications". English. In: Palaeogeography, Palaeoclimatology, Palaeoecology 431 (2015), pp. 53-67. DOI: 10.1016/j.palaeo.2015.04.021.

[23739] G. J. Vermeij. “Taxonomy, Distribution, and Characters of Pre-Oligocene Members of the Cantharus Group of Pisaniinae (Neogastropoda: Buccinoidea)". English. In: Journal of Paleontology 75.2 (2001), pp. 295-309.

[23740] G. J. Vermeij and G. S. Herbert. "A new species of Stramonita (Gastropoda: Muricidae) from the Late Pliocene of Florida." English. In: The Nautilus 118.4 (2004), pp. 157-159.

[23741] G. J. Vermeij, G. S. Herbert, F. J. Vega, and M. C. Perrilliat. "Mexfusus rotundicostatus, a New Genus and Species of Neogastropod from the Late". English. In: Journal of Paleontology 78.6 (2004), pp. 1123-1127.

[23742] G. J. Vermeij and F. P. Wesselingh. "Neogastropod molluscs from the Miocene of western Amazonia, with comments on marine to freshwater transitions in molluscs". English. In: Journal of Paleontology 76.2 (2002), pp. 265-270.

[23743] J. Vermeulen, P. Lazarin, P. Lépinay, L. Leroyy, and E. Mascarelli. “Ammonites du Barrémien du Sud-Est de la France (Ammonitina, Ancyloceratina, Turrilitina)". English. In: Travaux de Géologie sédimentaire et Paléontologie Série 2: Mémoires 50 (2010), pp. 1-55.

[23744] V. Verna, L. Angiolini, C. Chaouachi, M. Soussi, C. Henderson, V. Davydov, A. Nicora, and M. Bougdar. "Guadalupian brachiopods from Djebel Tebaga de Medenine, south Tunisia". English. In: Rivista Italiana di Paleontologia e Stratigrafia 116.3 (2010), pp. 309-349.

[23745] V. Verna and L. Angiolini. "Systematic palaeontology, in Guadalupian brachiopods from Djebel Tebaga de Medenine, south Tunisia". English. In: Rivista Italiana di Paleontologia e Stratigrafia 116.3 (2010), pp. 309-349.

[23746] V. Verna and L. Angiolini. "Systematic Palaeontology, in Guadalupian brachiopods from western Taurus, Turkey". English. In: Rivista Italiana di Paleontologia e Stratigrafia 117.1 (2011).

[23747] V. Verna, L. Angiolini, S. Crasquin, and A. Nicora. "Guadalupian brachiopods from western Taurus, Turkey". English. In: Rivista Italiana di Paleontologia e Stratigrafia 117.1 (2011).

[23748] E. Vernhet, G. Conesa, and P. O. Bruna. "Reworking processes and deposits in coral reefs during (very) high-energy events: Example from a Pleistocene coral formation (125 ka), La Désirade Island, Lesser Antilles". English. In: Palaeogeography, Palaeoclimatology, Palaeoecology (2017).

[23749] J. Vernoux, R. Garrouste, and A. Nel. "The first psallopinous bug from Lowermost Eocene French amber (Hemiptera: Heteroptera: Miridae)". English. In: Zootaxa 2499 (2010), pp. 63-68.

[23750] J. Vernoux, D. Y. Huang, E. A. Jarzembowski, and A. nel. "The Proterogomphidae: a worldwide Mesozoic family of gomphid dragonflies (Odonata: Anisoptera: Gomphides)". English. In: Cretaceous Research 31 (2010), pp. 94-100.

[23751] J. E. N. Veron. "Environmental control of Holocene changes to the world's most northern hermatypic coral outcrop". English. In: Pacific Science 46.4 (1992), pp. 405-425.

[23752] M. Vervoenen, F. P. Wesselingh, and F. A. D. Van Nieulande. "Mytilys antiquorum J. Sowerby, 1821 and other Pliocene mussels (Mollusca, Bivalvia) from the southern North Sea Basin". English. In: Contributions to Tertiary and Quaternary Geology 37.3-4 (2000), pp. 73-81.

[23753] D. H. Verzi. "The dental evidence on the differentiation of the ctenomyine rodents (Caviomorpha, Octodontidae, Ctenomyinae)". English. In: Acta Theriologica 44.3 (1999), pp. 263-282.

[23754] D. H. Verzi and C. I. Montalvo. "The oldest South American Cricetidae (Rodentia) and Mustelidae (Carnivora): Late Miocene faunal turnover in Central Argentina and the Great American Biotic Interchange". English. In: Palaeogeography, Palaeoclimatology, Palaeoecology 267.3-4 (2008), pp. 284291. DOI: $10.1016 /$ j.palaeo.2008.07.003.

[23755] D. H. Verzi, C. I. Montalvo, and C. M. Deschamps. "Biostratigraphy and biochronology of the Late Miocene of central Argentina: Evidence from rodents and taphonomy". English. In: Geobios 41 (2008), pp. 145-155. 
[23756] D. H. Verzi, A. I. Olivares, and C. C. Morgan. "The oldest South American tuco-tuco (late Pliocene, northwestern Argentina) and the boundaries of the genus Ctenomys (Rodentia, Ctenomyidae)". English. In: Mammalian Biology 75.3 (2010), pp. 243-252.

[23757] D. H. Verzi, A. I. Olivares, and C. C. Morgan. "Systematics and evolutionary significance of the small Abrocomidae from the early Miocene of southern South America". English. In: Historical Biology 29.3 (2017), pp. 411-422. DOI: 10.1080/08912963.2016.1168410.

[23758] D. H. Verzi, A. I. Olivares, P. Hadler, J. C. Castro, and E. P. Tonni. “Occurrence of Dicolpomys (Echimyidae) in the late Holocene of Argentina:" English. In: Quaternary International 490 (2018), pp. 123-131.

[23759] D. H. Verzi and C. A. Quintana. "The caviomorph rodents from the San Andrés Formation, eastcentral Argentina, and global Late Pliocene climatic change". English. In: Palaeogeography, Palaeoclimatology, Palaeoecology 219.3-4 (2005), pp. 303-320. DOI: 10.1016/j.palaeo.2005.01.003.

[23760] D. H. Verzi, E. C. Vieytes, and C. I. Montalvo. "Dental evolution in Neophanomys (Rodentia, Octodontidae) from the late Miocene of central Argentina". English. In: Geobios 44.6 (2011), pp. 621633. DOI: 10.1016/j.geobios.2011.02.008.

[23761] D. H. Verzi, M. G. Vucetich, and C. I. Montalvo. “Octodontid-like Echimyidae (Rodentia): an Upper Miocene episode in the radiation of the family". English. In: Paleovertebrata 23.1-4 (1994), pp. 199-210.

[23762] A. Vescogni, F. Bosellini, C. A. Papazzoni, L. Giusberti, G. Roghi, E. Fornaciari, S. Dominici, and R. Zorzin. "Coralgal buildups associated with the Bolca Fossil-Lagerstätten: new evidence from the Ypresian of Monte Postale (NE Italy)". English. In: Facies 62.21 (2016).

[23763] A. Vescogni, F. R. Bosellini, A. Cipriani, G. Gürler, A. Ilgar, and E. Paganelli. "The Dapazar carbonate platform (Mut Basin, Southern Turkey): Facies and environmental reconstruction of a coral reef system during the Middle Miocene Climatic Optimum". English. In: Palaeogeography, Palaeoclimatology, Palaeoecology 410 (2014), pp. 213-232.

[23764] A. Vescogni, F. R. Bosellini, C. A. Papazzoni, L. Giusberti, G. Roghi, E. Formaciari, S. Dominici, and R. Zorzin. "Coralgal buildups associated with the Bolca Fossil-Lagerstatten: new evidence from the Ypresion of Monte Postale (NE Italy)". English. In: Facies 62.21 (2016), pp. 1-20.

[23765] A. Vescogni, A. Vertino, F. R. Bosellini, M. Harzhauser, and O. Mandic. “New paleoenvironmental insights on the Miocene condensed phosphatic layer of Salento (southern Italy) unlocked by the coralmollusc fossil archive". English. In: Facies 64.7 (2018), pp. 1-21. DOI: 10.1007 / s10347-0180520-9.

[23766] R. I. Vezzosi. "First record of Procariama simplex Rovereto, 1914 (Phorusrhacidae, Psilopterinae) in the Cerro Azul Formation (upper Miocene) of La Pampa Province; remarks on its anatomy, palaeogeography and chronological range". English. In: Alcheringa 36.2 (2012), pp. 157-169. DOI: 10.1080/03115518.2011.597657.

[23767] R. I. Vezzosi, D. Brandoni, E. Brunetto, and M. C. Zalazar. "New remains of Nothrotheriinae (Mammalia, Xenarthra) from Late Pleistocene fluvial deposits of Northern Pampa (Santa Fe Province, Argentina)". English. In: Journal of South American Earth Sciences 89 (2019), pp. 47-54.

[23768] R. I. Vezzosi and L. Kerber. "The southernmost record of a large erethizontid rodent (Hystricomorpha: Erethizontoidea) in the Pleistocene of South America: Biogeographic and paleoenvironmental implications". English. In: Journal of South American Earth Sciences 82 (2018), pp. 76-90.

[23769] N. Vialle, G. Merzeraud, C. Delmer, M. Feist, S. Jiquel, L. Marivaux, A. Ramdarshan, M. VianeyLiaud, El Mabrouk Essid, W. Marzougui, H. K. Ammar, and R. Tabuce. "Discovery of an embrithopod mammal (Arsinoitherium?) in the late Eocene of Tunisia". English. In: Journal of African Earth Sciences 87 (2013), pp. 86-92.

[23770] M. Vianey-Liaud. “Les rongeurs de l’Eocéne terminal et de l'Oligocéne d'Europe comme indicateurs de leur environnement. [Upper Eocene and Oligocene rodents from Europe as indicators of their environment.]" French. In: Palaeogeography, Palaeoclimatology, Palaeoecology 85.1991 (1991), pp. 15-28. 
[23771] M. Vianey-Liaud. “Gliridae (Mammalia, Rodentia) de l'Oligocéne européen: origine de trois genres miocénes". French. In: Coloquios de Paleontologa 1 (2003), pp. 669-698.

[23772] M. Vianey-Liaud, B. Comte, B. Marandat, S. Peigné, J. -C. Rage, and J. Sudre. "A new early late Oligocene (MP 26) continental vertebrate fauna from Saint-Privat-des-Vieux (Alés Basin, Gard, Southern France)". English. In: Geodiversitas 36.4 (2014), pp. 565-622. DOI: 10.5252/g2014n4a4.

[23773] M. Vianey-Liaud and J. Crochet. “Dinosaur eggshells from the Late Cretaceous of Laeguedoc (southern France)". English. In: Revue de Paléobiologie 7 (1993), pp. 237-149.

[23774] M. Vianey-Liaud, H. Gomes Rodrigues, and L. Marivaux. "A new Oligocene Ctenodactylinae (Rodentia: Mammalia) from Ulantatal (nei Mongol): new insight on the phylogenetic origins of the modern Ctenodactylidae". English. In: Zoological Journal of the Linnean Society 160 (2010), pp. 531550.

[23775] M. Vianey-Liaud, A. Khosla, and G. Garcia. "Relationships between European and Indian dinosaur eggs and eggshells of the oofamily Megaloolithidae". English. In: Journal of Vertebrate Paleontology 23.3 (2003), pp. 575-585.

[23776] M. Vianey-Liaud and R. Lebrun. "New data about the oldest European Lagomorpha: Description of the new genus Ephemerolagus nievae gen. nov. et sp. nov". English. In: Spanish Journal of Palaeontology 28.1 (2013), pp. 3-16.

[23777] M. Vianey-Liaud and N. López-Martnez. "Late Cretaceous dinosaur eggshells from the Tremp basin, southern Pyrenees, Lleida, Spain". English. In: Journal of Paleontology 71.6 (1997), pp. 11571171.

[23778] M. Vianey-Liaud, R. Minwer-Barakat, and L. Marivaux. "The rodents from Santpedor-2 (Ebro Basin, NE Spain) confirm the Oligocene age of the latest primates from the Paleogene of Europe". English. In: Geobios 55 (2019), pp. 77-88.

[23779] M. Vianey-Liaud and B. Schmid. “Diversité, datation et paléoenvironnement de la faune de mammiféres oligocéne de Cavalé (Quercy, SO France) : contribution de l'analyse morphométrique des Theridomyinae (Mammalia, Rodentia)". French. In: Geodiversitas 31.4 (2009), pp. 909-941.

[23780] M. Vianey-Liaud, N. Schmidt-Kittler, and L. Marivaux. "The Ctenodactylidae (Rodentia) from the Oligocene of Ulantatal (Inner Mongolia, China)". English. In: Palaeovertebrata 34.3-4 (2006), pp. 111-206.

[23781] E. Vicens. "Intraspecific variability in Hippuritidae in the southern Pyrenees, Spain: Taxonomic implications". English. In: Geologica Romana 28 (1992), pp. 119-161.

[23782] E. Vicens, L. Ardevol, N. Lopez-Martinez, and M. E. Arribas. "Rudist Biostratigraphy in the Campanian-Maastrichtian of the south-central Pyrenees, Spain". English. In: Courier Forschungsinstitut Senckenberg 247 (2004), pp. 113-127.

[23783] E. Vicens, G. Lopez, and A. Obrador. "Facies Succession, Biostratigraphy and Rudist Faunas of Coniacian to Santonian Platform Deposits in the Sant Cornelli Anticline (Southern Central Pyrenees)". English. In: Geobios 31.22 (1998), pp. 403-427.

[23784] Z. Vician, H. Krock, and Z. Kovacs. "New gastropod records from the Cenozoic of Hungary". English. In: Hungarian Geological Society 147.3 (2017), pp. 265-282.

[23785] M. K. Vickaryous, A. P. Russell, P. J. Currie, and X. -J. Zhao. “A new ankylosaurid (Dinosauria: Ankylosauria) from the Lower Cretaceous of China, with comments on ankylosaurian relationships". English. In: Canadian Journal of Earth Sciences 38 (2001), pp. 1767-1780.

[23786] P. Vickers-Rich, T. H. Rich, O. Rieppel, R. A. Thulborn, and H. A. McClure. "A Middle Triassic vertebrate fauna from the Jilh Formation, Saudi Arabia". English. In: Neues Jahrbuch für Geologie und Paläontologie, Abhandlungen 213 (1999), pp. 201-232.

[23787] V. R. Vickery and G. O. Poinar. "Crickets (Grylloptera: Grylloidea) in Dominican amber". English. In: The Canadian Entomologist 126 (1994), pp. 13-22.

[23788] G. Vidal. "Giant acanthomorph acritarchs from the Upper Proterozoic in Southern Norway". In: Palaeontology 33.2 (1990), pp. 287-298. 
[23789] G. Vidal, T. Palacios, M. Moczydlowska, and A. P. Gubanov. "Age constraints from small shelly fossils on the early Cambrian terminal Cadomian Phase in Iberia". English. In: Geologiska Föreningens i Stockholm Förhandlingar 121.655 (1999), pp. 137-143.

[23790] M. Vidal. “Le modéle des biofaciés á Trilobites: un test dans l'Ordovicien inférieur de l'Anti-Atlas, Maroc". French. In: Comptes-Rendus de l'Académie des Sciences, Paris, Sciences de la Terre et des planetes 327 (1998), pp. 327-333.

[23791] C. F. Vidarte and M. M. Calvo. "Restos de Pterosaurios en el Weald de Soria (España) [Skeletal remains of Pterosaurs in Weald in Soria (Spain)]". Portugese. In: Studia Geologica Salmanticensia 32 (1996), pp. 15-22.

[23792] A. Viehofen, C. Hartkopf-Froder, and E. M. Friis. "Inflorescences and flowers of Mauldinia angustifolia sp. nov. (Lauraceae) from middle Cretaceous karst infillings in the Renish Massif, Germany". English. In: International Journal of Plant Sciences 169.7 (2008), pp. 871-889.

[23793] L. I. Viera and J. A. Torres. “Análisis comparativo sobre dos rastros de Dinosaurios Theropodos. Forma de marcha y velocidad [Comparative analysis of two theropod dinosaur tracks. Form of progress and speed]". English. In: Munibe (Ciencias Naturales - Natur Zientsiak) 47 (1995), pp. 5356.

[23794] G. Vierbergen and J. Scheven. "Nine new species and a new genus of Dominican amber ants of the tribe Cephalotini (Hymenoptera: Formicidae)". English. In: Creation Research Society Quarterly 32.3 (1995), pp. 158-170.

[23795] M. Viglino, C. M. Gaetán, J. I. Cuitiño, and M. R. Buono. "First toothless platanistoid from the Early Miocene of Patagonia: The golden age of diversification of the Odontoceti". English. In: Journal of Mammalian Evolution 28 (2021), pp. 337-358. DOI: 10.1007/s10914-020-09505-w.

[23796] M. Viglino, M. R. Buono, C. S. Gutstein, M. A. Cozzuol, and J. I. Cuitiño. “A new dolphin from the early Miocene of Patagonia, Argentina: Insights into the evolution of Platanistoidea in the Southern Hemisphere". English. In: Acta Palaeontologica Polonica 63.2 (2018), pp. 261-277. DOI: 10.4202/app.00441.2017.

[23797] M. Viglino, M. R. Buono, R. E. Fordyce, J. I. Cuitiño, and E. M. G. Fitzgerald. "Anatomy and phylogeny of the large shark-toothed dolphin Phoberodon arctirostris Cabrera, 1926 (Cetacea: Odontoceti) from the early Miocene of Patagonia (Argentina)". English. In: Zoological Journal of the Linnean Society 185 (2019), pp. 511-542. DOI: 10.1093/zoolinnean/zly053.

[23798] P. Vignaud, M. Brunet, B. Guevel, and Y. Jehenne. "Un crane de Diplocynodon (Crocodylomorpha, Alligatoridae) de l'Oligocéne inférieur de Dordogne (France) [A new skull of Diplocynodon (Crocodylomorpha, Alligatoridae): Early Oligocene of the Aquitain Basin (Dordogne, France)]". English. In: Comptes rendus de l'Académie des Sciences Paris, Série $2 a 322$ (1996), pp. 595-601.

[23799] P. Vignaud, P. Duringer, H. T. Mackaye, A. Likius, C. Blondel, J. -R. Boisserie, L. de Bonis, V. Elsenmann, M. -E. Etienne, D. Geraads, F. Guy, T. Lehmann, F. Lihoreau, N. L. -L. Martinez, C. Mourer-Chauvier, O. Otero, J. -C. Rage, M. Schuster, L. Viriot, A. Zazzo, and M. Brunet. "Geology and paleontology of the Upper Miocene Toros-Menalla hominid locality, Chad". English. In: Nature 418 (2002), pp. 152-155.

[23800] J.-D. Vigne, S. Bailon, and J. Cuisin. "Biostratigraphy of amphibians, reptiles, birds and mammals in Corsica and the role of man in the Holocene faunal turnover". English. In: Anthropozoological 25-26 (1997), pp. 587-604.

[23801] V. Viira, R. J. Aldridge, and S. Curtis. "Conodonts of the Kiviõli Member, Viivikonna Formation (Upper Ordovician) in the Kohtla section, Estonia". English. In: Proceedings of the Estonian Academy of Sciences, Geology 55.3 (2006), pp. 213-240.

[23802] V. Viira and R. J. Aldridge. “Upper Wenlock to Lower Prdol (Silurian) conodont biostratigraphy of Saaremaa, Estonia, and a correlation with Britain". English. In: Journal of Micropalaeontology 17 (1998), pp. 33-50. 
[23803] V. Viira and R. Einasto. "Wenlock-Ludlow boundary beds and conodonts of Saaremaa Island, Estonia". English. In: Proceedings of the Estonian Academy of Sciences, Geology 52.4 (2003), pp. 213238.

[23804] V. Viira, A. Löfgren, S. Mägi, and J. Wickström. "An Early to Middle Ordovician succession of conodont faunas at Mäekalda, northern Estonia". English. In: Geological Magazine 138.66 (2001), pp. 99-718. DOI: 10.1017/S0016756801005945.

[23805] B. Vila, R. Gaete, A. Galobart, O. Oms, J. Peralba, and J. Escuer. “Nuevos hallazgos de dinosaurios y otros tetrápodos continentales en los Pirineos sur-centrales y orientales: resultados preliminares [New discoveries of dinosaurs and other continental tetrapods in the south-central and eastern Pyrenees: preliminary results]". English. In: vol. Actas. III Jornadas Internacionales sobre Paleontologa de Dinosaurios y su Entorno. Salas de los Infantes: Colectivo Arqueológico-Paleontológico Salense, 2006, pp. 365-378.

[23806] B. Vila, A. Galobart, J. I. Canudo, J. Le Loeuff, J. Dinarés-Turell, V. Riera, O. Oms, T. Tortosa, and R. Gaete. "The diversity of sauropod dinosaurs and their first taxonomic succession from the latest Cretaceous of southwestern Europe: Clues to demise and extinction". English. In: Palaeogeography, Palaeoclimatology, Palaeoecology 350-352 (2012), pp. 19-38. DOI: 10.1016/j.palaeo.2012.06.008.

[23807] B. Vila, O. Oms, and A. Galobart. "Manus-only titanosaurid trackway from Fumanya (Maastrichtian, Pyrenees): further evidence for an underprint origin". English. In: Lethaia 38 (2005), pp. 211-218.

[23808] B. Vila, O. Oms, J. Marmi, and A. Galobart. “Tracking Fumanya footprints (Maastrichtian, Pyrenees): historical and ichnological overview". English. In: Oryctos 8 (2008), pp. 115-130.

[23809] B. Vila, O. Oms, and Á Galobart. “Probable rastro de terópodo asociado a las huellas de titanosáuridos de Fumanya (Maastrichtiense, Pirineos Surorientales) [Probable theropod trackway associated with the titanosaurid tracks of Fumanya (Maastrichtian, southeastern Pyrenees)]". Spanish. In: Geo-Temas 6.5 (2004), pp. 75-78.

[23810] B. Vila, O. Oms, A. Galobart, K. T. Bates, V. M. Egerton, and P. L. Manning. “Dynamic similarity in titanosaur sauropods: ichnological evidence from the Fumanya dinosaur tracksite (southern Pyrenees)". English. In: PLoS ONE 8.2 (2013), e57408:1-9. DOI: 10.1371/journal.pone.0057408.

[23811] B. Vila, O. Oms, V. Fondevilla, R. Gaete, Á Galobart, V. Riera, and J. I. Canudo. “The latest succession of dinosaur tracksites in Europe: hadrosaur ichnology, track production and palaeoenvironments". English. In: PLoS ONE 8.9 (2013), e72579:1-15. DOI: 10.1371/journal.pone.0072579.

[23812] B. Vila, V. Riera, A. M. Bravo, O. Oms, E. Vicens, R. Estrada, and A. Galobart. “The chronology of dinosaur oospecies in south-western Europe: refinements from the Maastrichtian succession of the eastern Pyrenees". English. In: Cretaceous Research 32.3 (2011), pp. 378-386. DOI: 10.1016/j. cretres.2011.01.009.

[23813] A. P. Vilesov. "Permian neuropterans (Insecta: Myrmeleontida) from the Chekarda locality in the Urals". English. In: Paleontological Journal 29.2 (1995), pp. 115-129.

[23814] A. P. Vilesov and V. G. Novokshonov. "New fossil insects (Myrmeleontida, Jurinida) from the Upper Permian of Eastern Kazakhstan". Russian. In: Paleontological Journal 28 (1994), pp. 81-92.

[23815] A. P. Vilesov and V. G. Novokshonov. "Permian Tillyardembiidae (Insecta, Grylloblattida)". English. In: Paleontological Journal 27.3 (1993), pp. 71-82.

[23816] L. Vilhelmsen and M. S. Engel. "Sambia succinica, a crown group tenthredinid from Eocene Baltic amber (Hymenoptera: Tenthredinidae)". English. In: Insect Systematics \& Evolution 43 (2012), pp. 271281.

[23817] A. Villa, J. Abella, D. M. Alba, S. Almecija, A. Bolet, G. D. Koufos, F. Knoll, A. H. Lujan, J. Morales, J. M. Robles, I. M. Sanchez, and M. Delfino. "Revision of Varanus marathonensis (Squamata, Varanidae) based on historical and new material: morphology, systematics, and paleobiogeography of the European monitor lizards". English. In: PLOS ONE 13.12 (2018), pp. 1-46. DOI: 10. 1371/journal.pone.0207719. 
[23818] A. Villa, H.-A. Blain, L. van den Hoek Ostende, and M. Delfino. “Fossil amphibians and reptiles from Tegelen (Province of Limburg) and the early Pleistocene palaeoclimate of The Netherlands". English. In: Quaternary Science Reviews 187 (2018), pp. 203-219. DOI: 10.1016/j.quascirev.2018.03. 020 .

[23819] A. Villa, H.-A. Blain, and M. Delfino. "The Early Pleistocene herpetofauna of Rivoli Veronese (Northern Italy) as evidence for humid and forested glacial phases in the Gelasian of Southern Alps". English. In: Palaeogeography, Palaeoclimatology, Palaeoecology 490 (2018), pp. 393-403. DOI: 10.1016/j.palaeo.2017.11.016.

[23820] A. Villa, M. Bon, and M. Delfino. "Trapped in a roman well: amphibians and reptiles from Tenuta Zuccarello near Marcon, Venice, Italy". English. In: Historical Biology (2018), pp. 1-16. DOI: 10. 1080/08912963.2018.1470170.

[23821] A. Villa and M. Delfino. "Fossil lizards and worm lizards (Reptilia, Squamata) from the Neogene and Quaternary of Europe: an overview". English. In: Swiss Journal of Palaeontology (2018). DOI: 10.1007/s13358-018-0172-y.

[23822] A. Villa, G. L. Georgalis, and M. Delfino. “The latest Early Pleistocene amphibians and reptiles from Kaiafas (Greece) and the first record of fossil Ophiomorus (Squamata, Scincidae)". English. In: Geobios (2020). DOI: 10.1016/j.geobios.2020.06.010.

[23823] A. Villa, Z. Roek, E. Tschopp, L. W. Van den Hoek Ostende, and M. Delfino. "Palaeobatrachus eurydices, sp. nov. (Amphibia, Anura), the last Western European palaeobatrachid". English. In: Journal of Vertebrate Paleontology 36.6 (2016), e1211664:1-15. DOI: 10.1080/02724634.2016.1211664.

[23824] J. A. Villafaña, G. Marramá, S. Klug, J. Pollerspöck, M. Balsberger, M. Rivadeneira, and J. Kriwet. "Sharks, rays and skates (Chondrichthyes, Elasmobranchii)". English. In: PalZ (2020). DOI: 10. 1007/s12542-020-00518-7.

[23825] A. L. Villafañe, G. I. Schmidt, and E. Cerdeño. “Consideraciones sistemáticas y bioestratigráficas acerca de Thoatheriopsis mendocensis Soria, 2001 (Litopterna, Proterotheriidae)". Spanish. In: Ameghiniana 49.3 (2012), pp. 365-374.

[23826] E. Villalobos-Segura, C. J. Underwood, D. J. Ward, and K. M. Claeson. “The first three-dimensional fossils of Cretaceous sclerorhynchid sawfish: Asflapristis cristadentis gen. et sp. nov., and implications for the phylogenetic relations of the Sclerorhynchoidei (Chondrichthyes)". English. In: Journal of Systematic Palaeontology 17 (2019), pp. 1847-1870. DOI: 10.1080/14772019.2019.1578832.

[23827] T. Villamil. "Paleobiology of two new species of the bivalve Anomia from Colombia and Venezuela and the importance of the genus in recognition of the base of the Turonian". In: Cretaceous Research 17 (1996), pp. 607-632.

[23828] T. Villamil. Chronology, relative sea-level history and a new sequence stratigraphic model for basinal Cretaceous facies of Colombia. English. Vol. 58. in Paleogeographic Evolution and Non-glacial Eustasy, Northern South America, SEPM Special Publication. 1998, pp. 161-216.

[23829] J. B. Villanueva, C. Muizon, and J. P. Souza Filho. “Novos achados de cetaceos longirrostros no Neogeno do Acre, Brasil". Portugese. In: Boletim do Museu Paraense Emilio Goeldi, Ciencias da Terra 2 (1990), pp. 59-64.

[23830] R. Villanueva-Olea, R. Barragán, J. J. Palafox-Reyes, J. C. Jiménez-López, and B. E. Buitrón-Sánchez. "Microfacies and stable isotope analyses from the Carboniferous of the La Joya section in Sierra Agua Verde, Sonora, Mexico". English. In: Boletn de la Sociedad Geológica Mexicana 71.3 (2019), pp. 585-607.

[23831] L. Villar de Seoane. "Cuticular study of Bennettitales from the Springhill Formation, Lower Cretaceous of Patagonia, Argentina". English. In: Cretaceous Research 22 (2001), pp. 461-479. DOI: 10. 1006/cres.2001.0266.

[23832] L. Villar de Seoane. "Equisetites pusillus sp. nov. from the Aptian of Patagonia, Argentina". English. In: Revista del Museo Argentino de Ciencias Naturales, n. s 7.1 (2005), pp. 43-49. 
[23833] L. Villar de Seoane. “New cycadalean leaves from the Anfiteatro de Ticó Formation, Early Aptian, Patagonia, Argentina". English. In: Cretaceous Research 26 (2005), pp. 540-550. DOI: 10.1016 /j. cretres.2005.02.004.

[23834] L. Villar de Seoane. "Equisetites pusillus sp. nov. from the Aptian of Patagonia Argentina". English. In: Revista del Museo Argentino de Ciencias Naturales, nueva serie 7.1 (2005), pp. 43-49.

[23835] L. Villar de Seoane and S. Archangelsky. "Taxonomy and biostratigraphy of Cretaceous megaspores from Patagonia, Argentina". English. In: Cretaceous Research 29 (2008), pp. 354-372. DOI: 10.1016/j.cretres.2007.07.002.

[23836] L. Villar de Seoane, N. R. Cuneo, I. E. Escapa, P. Wilf, and M. A. Gandolfo. “Ginkgoites patagonicus (Berry) comb. nov. from the Eocene of Patagonia, last ginkgoalean record in South America". English. In: International Journal of Plant Sciences 176.4 (2015), pp. 346-363. DOI: 10.1086/680221.

[23837] C. Villarroel, J. Brieva, and A. Cadena. "La Fauna de Mamlferos F6siles del Pleistoceno de Jutua, Municipio de Soata (Boyaca, Colombia)". Spanish. In: Geologa Colombiana 21 (1996), pp. 81-87.

[23838] C. Villarroel and J. Clavijo. "Los Mamiferos Fosiles y las Edades de las Sedimentitas Continentales del Neogeno de la Costa Caribe Colombiana". Spanish. In: Revista de la Academia Colombiana de Ciencias Exactas, Fisicas y Naturales 29.112 (2005), pp. 345-356.

[23839] C. Villarroel, A. E. Concha, and C. Macia. “El Lago Pleistoceno de Soata (Boyaca, Colombia): Consideraciones esratigráficas, paleontológicas y paleoecológicas". Spanish. In: Geologa Colombiana 26 (2001), pp. 79-93.

[23840] C. Villarroel A., T. Sempere, and L. G. Marshall. “Un nuevo Trachytherus (Notoungulata, Mammalia) en el Terciario de la Faja Subandina, norte de Bolivia". English. In: Congreso Geológica de Bolivia, Memorias 9 (1994), pp. 28-32.

[23841] E. Villas. "New Caradoc brachiopods from the Iberian Chains (northeastern Spain) and their stratigraphic significance". In: Journal of Paleontology 66.5 (1992), pp. 772-793.

[23842] E. Villas. "Caradoc through early Ashgill brachiopods from the Central-Iberian Zone (central Spain)". English. In: Géobios 28.1 (1995), pp. 49-84.

[23843] E. Villas and L. R. M. Cocks. "The first early Silurian brachiopod fauna from the Iberian Peninsula". In: Journal of Paleontology 70.4 (1996), pp. 571-588.

[23844] E. Villas, J. Colmenar, and J. C. Gutiérrez-Marco. “Late Ordovician brachiopods from Peru and their palaeobiogeographical relationships". English. In: Palaeontology 52 (2015). DOI: 10.1111/pala. 12152.

[23845] E. Villas, W. Hammann, and D. A. T. Harper. "Foliomena fauna (Brachiopoda) from the Upper Ordovician of Sardinia". English. In: Palaeontology 45.2 (2002), pp. 267-295. DOI: 10.1111/14754983.00237.

[23846] E. Villas, Z. A. Herrera, and G. Ortega. "Early orthid brachiopods from the Tremadocian (Lower Ordovician) of Northwestern Argentina". English. In: Journal of Paleontology 83 (2009), pp. 604613. DOI: 10.1666/08-165R.1.

[23847] E. Villas, D. Vizcano, J. J. Álvaro, J. Destombes, and E. Vennin. “Biostratigraphic control ofătheălatestOrdovician glaciogenic unconformity inăAlnif (Eastern Anti-Atlas, Morocco), based onăbrachiopods". English. In: Geobios 39.5 (2006), pp. 727-737. DOI: 10.1016/j.geobios.2005.05.003.

[23848] N. A. Villavicencio and L. Werdelin. "The Casa del Diablo cave (Puno, Peru) and the late Pleistocene demise". English. In: Quaternary Science Reviews 195 (2018), pp. 21-31.

[23849] B. Villier and G. Carnevale. "A new skeleton of the giant hedgehog Deinogalerix from the Miocene of Gargano, Southern Italy". English. In: Journal of Vertebrate Paleontology 33.4 (2013), pp. 902-923. DOI: 10.1080/039.033.0417.

[23850] L. Villier, D. B. Blake, J. W. M Jagt, and M. Kutscher. "A preliminary phylogeny of the Pterasteridae (Echinodermata, Asteroidea) and the first fossil record: Late Cretaceous of Germany and Belgium". In: Paläontologische Zeitschrift 78.2 (2004), pp. 281-299. 
[23851] L. Villier. Asterozoans. English. 2010.

[23852] L. Villier. "Sea star ossicles from the Callovian black clays of the Luków area, eastern Poland". English. In: Neues Jahrbuch für Geologie und Paläontologie Abhandlungen 247 (2008), pp. 147-160.

[23853] L. Villier. "Asteroids from Barremian calciturbidites of the Serre de Bleyton (Drome, SE France)". English. In: Annalen des Naturhistorischen Museums in Wien, Serie A 112 (2010), pp. 701-732.

[23854] L. Villier, G. Breton, P. Margerie, and D. Néraudeau. "Manfredaster nov. gen. cariniferus nov. sp. un astéride original du Coniacien de Seine-Maritime et révision systématique de la famille des Stauranderasteridae (Echinodermata, Asteroidea)". French. In: Bulletin trimestriel de la Société géologique de Normandie et amis du Muséum du Havre 90.2 (2004), pp. 29-41.

[23855] L. Villier, G. Breton, and F. Atrops. “Une nouvelle étoile de mer (Prothrissacanthias africanus gen. nov. sp. nov.) du Berriasien d'Algérie". French. In: Revue de Paléobiologie 26.2 (2007), pp. 413-424.

[23856] L. Villier, S. Charbonnier, and B. Riou. "Sea stars from Middle Jurassic Lagerstätte of La Voultesur-Rhone (Ardéche, France)". English. In: Journal of Paleontology 83.3 (2009), pp. 389-398.

[23857] L. Villier, M. Kutscher, and C. Mah. "Systematics, palaeoecology, and evolutionary significance of Middle Toarcian Asteroidea (Echinodermata) from the 'Seuil du Poitou', Western France". English. In: Géobios 37.6 (2004), pp. 807-825.

[23858] P. Vincent, N. Bardet, X. P. Suberbiola, B. Bouya, M. Amaghzaz, and S. Meslouh. "Zarafasaura oceanis, a new elasmosaurid (Reptilia: Sauropterygia) from the Maastrichtian Phosphates of Morocco and the palaeobiogeography of latest Cretaceous plesiosaurs". English. In: Gondwana Research 19 (2011), pp. 1062-1073.

[23859] P. Vincent, N. Bardet, and E. Mattioli. "A new pliosaurid from the Pliensbachian (Early Jurassic) of Normandy (Northern France)". English. In: Acta Palaeontologica Polonica (2013). DOI: 10.4202 / app.2011.0113.

[23860] P. Vincent, N. Bardet, A. Houssaye, and M. Amaghzaz. "New plesiosaur specimens from the Maastrichtian Phosphates of Morocco and their implications for the ecology of the latest Cretaceous marine apex predators". English. In: Gondwana Research (2013). DOI: 10.1016/j.gr.2012.11. 011.

[23861] P. Vincent, N. Bardet, and N. Morel. "An elasmosaurid plesiosaur from the Aalenian (Middle Jurassic) of Western France". English. In: Neues Jahrbuch für Geologie und Paläontologie, Abhandlungen 243.3 (2007), pp. 363-370. DOI: 10.1127/0077-7749/2007/0243-0363.

[23862] P. Vincent and R. B. J. Benson. “Anningasaura, a basal plesiosaurian (Reptilia, Plesiosauria) from the Lower Jurassic of Lyme Regis, United Kingdom". English. In: Journal of Vertebrate Paleontology 32.5 (2012), pp. 1049-1063. DOI: 10.1080/02724634.2012.686467.

[23863] P. Vincent, J. E. Martin, V. Fischer, G. Suan, B. Khalloufi, B. Suchéras-Marx, A. Léna, K. Janneau, B. Rouselle, and L. Rulleau. "Marine vertebrate remains from the Toarcian-Aalenian succession of southern Beaujolais, Rhone, France". English. In: Geological Magazine (2013). DOI: 10.1017 / S0016756812000982.

[23864] P. Vincent and G. W. Storrs. "Lindwurmia, a new genus of Plesiosauria (Reptilia: Sauropterygia) from the earliest Jurassic of Halberstadt, northwest Germany". English. In: The Science of Nature 106.5 (2019). DOI: 10.1007/s00114-018-1600-y.

[23865] P. Vincent, R. Weis, G. Kronz, and D. Delsate. “Microcleidus melusinae, a new plesiosaurian (Reptilia, Plesiosauria) from the Toarcian of Luxembourg". English. In: Geological Magazine 156.1 (2019), pp. 99-116. DOI: $10.1017 /$ S0016756817000814.

[23866] R. Vines-Vallverdu, J. Arroyo-Cabrales, I. I. Rivera-Gonzalez, X. P. Rodriguez-Alvarez, A. RubioMora, I. N. Exudate-Eusebio, O. R. Solis-Torres, and C. F. Ardelean. “Recent archaeo-palaeontogical findings from Barranca del Muerto site, Santiago Chazumba, Oaxaca, Mexico". English. In: Quaternary International 431 (2017), pp. 168-180.

[23867] O. Vinn. "Shell structure of helically coiled microconchids from the Middle Triassic (Anisian) of Germany". English. In: Paläontologische Zeitschrift 84 (2010), pp. 495-499. 
[23868] O. Vinn and M. Isakar. “The tentaculitid affinities of Anticalyptraea from the Silurian of Baltoscandia". English. In: Palaeontology 50.6 (2007), pp. 1385-1390. DOI: 10.1111/j.1475-4983.2007.00715.x.

[23869] O. Vinn and M.-A. Motus. "The earliest endosymbiotic mineralized tubeworms from the Silurian of Podolia, Ukraine". English. In: Journal of Paleontology 82.2 (2008), pp. 409-414.

[23870] O. Vinn, U. Toom, and A. Ernst. "Intergrowth of Orbignyella germana Bassler, 1911 (Bryozoa) and". English. In: Palaeontologia Electronica (2018).

[23871] J. A. G. Vintaned, E. Linan, E. Mayoral, M. E. Dies, R. Gozalo, and F. Muñiz. “Trace and soft body fossils from the Pedroche Formation (Ovetian, Lower Cambrian of the Sierra de Córdoba, S Spain) and their relation to the Pedroche event". English. In: Geobios 39 (2006), pp. 443-468.

[23872] J. Vinther, P. Jell, G. Kampouris, R. Carney, R. A. Racicot, and D. E. G. Briggs. "The origin of multiplacophorans - convergent evolution in Aculiferan molluscs". English. In: Palaeontology 55.5 (2012), pp. 1007-1019. DOI: 10.1111/j.1475-4983.2012.01180.x.

[23873] J. Vinther, L. Parry, D. E. G. Briggs, and P. Van Roy. “Ancestral morphology of crown-group molluscs revealed by a new Ordovician stem aculiferan". English. In: Nature (2017). DOI: 10.1038 / nature21055.

[23874] J. Vinther, M. Stein, N. R. Longrich, and D. A. T. Harper. “A suspension-feeding anomalocarid from the Early Cambrian". English. In: Nature 507 (2014), pp. 496-499. DOI: 10.1038/nature13010.

[23875] G. Viohl and M. Zapp. "Schamhaupten, an outstanding Fossil-Lagerstätte in a silicified Plattenkalk around the Kimmeridgian-Tithonian boundary (Southern Franconian Alb, Bavaria)". English. In: Neues Jahrbuch für Geologie und Paläontologie Abhandlungen 245.1 (2007), pp. 127-142. DOI: 10.1127/0077-7749/2007/0245-0127.

[23876] C. C. Visaggi. "Testing for patterns of faunal persistence in the early Oligocene Byram Formation of Mississippi". English. PhD thesis. 2004.

[23877] V. S. Vishnevskaya. The Domanikoid facies of the Russian Platform and basin paleogeography. English. Vol. 177. Crasquin-Soleau, S., and Barrier, É., eds., Peri-Tethys Memoir 3: stratigraphy and evolution of Peri-Tethyan platforms: Mémoires du Muséum national d'Histoire naturelle. 1998, pp. 4569.

[23878] V. S. Vishnevskaya and P. De Wever. "Upper Cretaceous Radiolaria from the Russian Platform (Moscow Basin)". English. In: Revue de Micropaleontologie 41.3 (1998), pp. 235-265.

[23879] V. S. Vishnevskaya and B. L. Murchey. "Climatic affinity and possible correlation of some Jurassic to Lower Cretaceous radiolarian assemblages from Russia and North America". In: Micropaleontology 48.S1 (2002), pp. 89-111.

[23880] V. S. Vishnevskaya and I. E. Pral'nikova. "Jurassic radiolarians from northern Russia". English. In: Stratigraphy and Geological Correlation 7.5 (1999), pp. 473-491.

[23881] V. N. Vishnyakova. "New Paleozoic Spiloblattinidae from Russia”. English. In: Paleontological Journal 27.1A (1993), pp. 135-147.

[23882] V. N. Vishnyakova. “Cockroaches (Insecta, Blattodea) from the Triassic Madygen locality, central Asia". English. In: Paleontological Journal 32 (1998), pp. 505-512.

[23883] L. A. Viskova and A. V. Koromyslova. "Tamanicella gen. nov., a New Genus of Bryozoans Forming the Late Miocene Bioherms of Cape Panagia in the Taman Peninsula (Russia)". English. In: Paleontological Journal 46.1 (2012), pp. 29-43. DOI: 10.1134/S0031030112010145.

[23884] I. A. Vislobokova. “A New Representative of the Hypertraguloidea (Tragulina, Ruminantia) from the Khoer-Dzan Locality in Mongolia, with Remarks on the Relationships of the Hypertragulidae". English. In: American Museum Novitates 3225 (1998), pp. 1-24.

[23885] I. A. Vislobokova. "A new representative of the Family Raoellidae (Suiformes) from the middle Eocene of Khaichin-Ula2, Mongolia". English. In: Paleontological Journal 38.2 (2004), pp. 220-226.

[23886] I. A. Vislobokova. "Artiodactyls from the Middle Eocene of Khaichin-Ula II, Mongolia". English. In: Paleontological Journal 38.1 (2004), pp. 90-96. 
[23887] I. A. Vislobokova. “The Oldest Representative of Entelodontoidea (Artiodactyla, Suiformes) from the Middle Eocene of Khaichin Ula II, Mongolia, and Some Evolutionary Features of This Superfamily". English. In: Paleontological Journal 42.6 (2008), pp. 643-654.

[23888] I. A. Vislobokova and G. Daxner-Höck. “Oligocene - Early Miocene Ruminants from the Valley of Lakes (Central Mongolia)". English. In: Annalen des Naturhistorischen Museums in Wien, Serie A 103 (2002), pp. 213-235.

[23889] I. A. Vislobokova and K. K. Tarasenko. “Finds of Ruminants and New Data on the Stratigraphy of the Late Miocene Locality of Fortep'yanka 2 (Northwest Caucasus, Adygea Republic)". English. In: Paleontological Journal 53.6 (2019), pp. 660-665. DOI: 10.1134/S0031030119060121.

[23890] F. Vitali. "Diplocoelus probiphyllus n. sp., the first known fossil false skin beetle (Coleoptera: Biphyllidae)". English. In: Annales de la Société Entomologique de France 46 (2010), pp. 168-172.

[23891] F. Vitali. "Plectromerus tertiarius new fossil species from Hispaniola (Coleoptera, Cerambycidae, Cerambycinae)". English. In: Lambillionea 104 (2004), pp. 453-458.

[23892] F. Vitali. "Pseudosieversia europaea new species from Baltic amber (Coleoptera, Cerambycidae, Lepturinae)". English. In: Les Cahiers Magellanes 35 (2004), pp. 1-8.

[23893] F. Vitali. "Notes about the European fossil Lepturinae and the description of a new species (Coleoptera, Cerambycidae, Lepturinae)". English. In: Lambillionea 105 (2005), pp. 530-538.

[23894] F. Vitali. "About some interesting fossil and sub-fossil Cerambycidae of the collection Velten (Coleoptera, Cerambycidae)". English. In: Lambillionea 109 (2009), pp. 352-357.

[23895] F. Vitali. “Two new longhorned beetles from Dominican amber (Coleoptera, Cerambycidae)". English. In: Denisia 26 (2009), pp. 223-230.

[23896] F. Vitali. "The cerambycids included in Baltic amber: current knowledge status with the description of new taxa (Coleoptera, Cerambycidae)". English. In: Denisia 26 (2009), pp. 231-242.

[23897] F. Vitali. "New fossil cerambycids (Coleoptera: Cerambycidae) from Baltic amber belonging to the collection Hoffeins". English. In: Baltic Journal of Coleopterology 14 (2014), pp. 103-112.

[23898] F. Vitali. "Saperda caroli n. sp., a new fossil species from Early Eocene of Colorado, with taxonomic remarks on its extinct congeners (Coleoptera, Cerambycidae)". English. In: Les Cahiers Magellanes, NS 17 (2015), pp. 20-28.

[23899] F. Vitali. "Six new fossil Cerambycids included in Baltic and Saxon amber (Coleoptera Cerambycidae)". English. In: Entomapeiron (P.S.) 4 (2011), pp. 1-36.

[23900] F. Vitali. "A new species of Tyrtaeus Champion, 1913 from Dominican amber (Coleoptera Tenebrionidae)". English. In: Entomapeiron (P.S.) 3 (2008), pp. 11-16.

[23901] F. Vitali. "A new fossil species of the genus Stizocera Audinet-Serville, 1834 from Dominican amber (Coleoptera, Cerambycidae)". English. In: Lambillionea 110 (2010), pp. 340-343.

[23902] F. Vitali. "The first fossil of Ibidionini Thomson, 1860 from Dominican amber, with taxonomic notes on the tribe (Coleoptera, Cerambycidae)". English. In: Lambillionea 115 (2015), pp. 7-11.

[23903] F. Vitali. "A new species of Corticeus Piller \& Mitterpacher, 1783 from Dominican amber (Coleoptera Tenebrionidae)". English. In: Entomapeiron (P.S.) 2.1 (2007), pp. 1-6.

[23904] F. Vitali. "A new fossil species of Elaphidion Audinet-Serville, 1834 with systematic notes on the Lamiinae from Dominican amber (Coleoptera Cerambycidae)". English. In: Entomapeiron (P.S.) 2.3 (2007), pp. 29-40.

[23905] F. Vitali. "A new cerambycid from Dominican amber and remarks on the fossil Plectromerusspecies (Coleoptera, Cerambycidae)". English. In: Entomapeiron (P.S.) 1.1 (2006), pp. 1-12.

[23906] F. Vitali. "About two Batrachorhina-species included in Malagasy copal (Coleoptera, Cerambycidae)". English. In: Entomapeiron (P.S.) 1.2 (2006), pp. 13-20.

[23907] F. Vitali. “About some sub-fossil Glaucytini included in Malagasy copal (Coleoptera, Cerambycidae)". English. In: Entomapeiron (P.S.) 2.1 (2007), pp. 7-13. 
[23908] F. Vitali. "Mesalocerus tetropoides n. gen., n. sp. from Baltic amber: the first fossil member of the tribe Anisarthrini Mamaev \& Danilevsky, 1973 (Coleoptera, Cerambycidae)". English. In: Les Cahiers Magellanes, NS 18 (2015), pp. 65-69.

[23909] F. Vitali. "Taxonomic, biological and evolutionistic notes on the Spondylidinae included in Baltic amber (Coleoptera, Cerambycidae)". English. In: Entomapeiron (P.S.) 1.3 (2006), pp. 29-44.

[23910] F. Vitali. “Obrium damgaardi sp. n. (Coleoptera: Cerambycidae), the first fossil species of the genus Obrium Dejean from the Baltic amber". English. In: Baltic Journal of Coleopterology 15 (2015), pp. 165-169.

[23911] F. Vitali. “Eurapatophysis groehni n. gen. and n. sp. (Coleoptera: Cerambycidae) from Baltic amber: the first fossil member of the tribe Apatophyseini Lacordaire, 1869". English. In: Baltic Journal of Coleopterology 12 (2016), pp. 117-122.

[23912] F. Vitali. "Two new fossil species of Tillomorphites Vitali (Coleoptera: Cerambycidae) and remarks on the morphological evolution, mimicry, biogeography and phylogeny of the tribe Tillomorphini". English. In: Baltic Journal of Coleopterology 17 (2017), pp. 147-160.

[23913] F. Vitali. "Procleomenes gouverneuri sp. n. (Coleoptera: Cerambycidae) from Baltic amber: the first fossil member of the tribe Sestyrini Lacordaire, 1869". English. In: Baltic Journal of Coleopterology 18 (2018), pp. 33-38.

[23914] F. Vitali. "Paratimia succinicola sp. n. (Coleoptera: Cerambycidae) from Baltic amber, with palaeogeographical remarks on the tribe Atimiini LeConte, 1873". English. In: Baltic Journal of Coleopterology 20 (2020), pp. 53-60.

[23915] F. Vitali and A. L. Damgaard. “Dicentrus mehli sp. n. (Coleoptera: Cerambycidae) implies close trophic association between Opsimini and Calocedrus, dating back the Baltic amber to the Early Oligocene". English. In: Baltic Journal of Coleopterology 16 (2016), pp. 37-43.

[23916] F. Vitali and S. Ellenberger. "Sparedrus archaicus n. sp., the first false blister beetle (Coleoptera, Oedemeridae) from Burmese amber". English. In: Baltic Journal of Coleopterology 19 (2019), pp. 2327.

[23917] F. Vitali and A. A. Legalov. "A new fossil genus of false blister beetles (Coleoptera: Oedemeridae) from mid-Cretaceous Burmese amber". English. In: Biosis: Biological Systems 1 (2020), pp. 109-115.

[23918] N. S. Vitek. "Giant fossil soft-shelled turtles of North America". English. In: Palaeontologia Electronica 15.1 (2012), 13A.

[23919] N. S. Vitek. "Insights into the Taxonomy and Systematics of North American Eocene Soft-Shelled Turtles from a Well-Preserved Specimen". English. In: Bulletin of the Peabody Museum of Natural History 52.2 (2011), pp. 189-208. DOI: 10.3374/014.052.0201.

[23920] N. S. Vitek and I. G. Danilov. "New material and a reassessment of soft-shelled turtles (Trionychidae) from the Late Cretaceous of Middle Asia and Kazakhstan". English. In: Journal of Vertebrate Paleontology 30.2 (2010), pp. 383-393.

[23921] N. S. Vitek and I. G. Danilov. "New data on the soft-shelled turtles from the Upper Cretaceous Kyrkkuduk locality of souther Kazakhstan". English. In: Proceedings of the Zoological Institute RAS 316.1 (2012), pp. 50-56.

[23922] N. S. Vitek and I. G. Danilov. "Soft-shelled turtles (Trionychidae) from the Bissekty Formation (Upper Cretaceous: Turonian) of Uzbekistan: skull-based taxa and probable skull-shell associations". English. In: Cretaceous Research 43 (2013), pp. 48-58.

[23923] N. S. Vitek and I. G. Danilov. "Soft-shelled turtles (Trionychidae) from the Cenomanian of Uzbekistan". English. In: Cretaceous Research 49 (2014), pp. 1-12.

[23924] N. S. Vitek and I. G. Danilov. "New material of Ulutrionyx ninae from the Oligocene of Kazakhstan, with a review of Oligocene trionychids of Asia". English. In: Journal of Vertebrate Paleontology 35.5 (2015), e973570:1-9. DOI: 10.1080/02724634.2015.973570. 
[23925] N. S. Vitek and W. G. Joyce. "A Review of the Fossil Record of New World Turtles of the Clade PanTrionychidae". English. In: Bulletin of the Peabody Museum of Natural History 56.2 (2015), pp. 185244.

[23926] S. F. Vizcaano and G. J. Scillato-Yané. "An Eocene tardigrade (Mammalia, Xenarthra) from Seymour Island, West Antarctica". English. In: 7.4 (2004), pp. 407-408.

[23927] S. F. Vizcaino, M. Bond, M. A. Reguero, and R. Pascual. “The youngest record of fossil land mammals from Antarctica; its significance on the evolution of the terrestrial environment of the Antarctic Peninsula during the late Eocene". English. In: Journal of Paleontology 72.3 (1997), pp. 348-350.

[23928] S. F. Vizcano, M. S. Bargo, R. F. Kay, R. A. Fariña, M. Di Giacomo, J. M. G. Perry, F. J. Prevosti, N. Toledo, G. H. Cassini, and J. C. Fernicola. "A baseline paleoecological study of the Santa Cruz Formation (late-early Miocene) at the Atlantic coast of Patagonia, Argentina". English. In: Palaeogeography, Palaeoclimatology, Palaeoecology 292.3-4 (2010), pp. 507-519. DOI: 10.1016/j.palaeo.2010. 04.022 .

[23929] S. F. Vizcano and R. A. Fariña. "On the flight capabilities and distribution of the giant Miocene bird Argentavis magnificens (Teratornithidae)". English. In: Lethaia 32.4 (1999), pp. 271-278.

[23930] S. F. Vizcaino, A. Rinderknecht, and A. Czerwonogora. "An Enigmatic Cingulata (Mammalia: Xenarthra) from the Late Miocene of Uruguay". English. In: Journal of Vertebrate Paleontology 23.4 (2003), pp. 981-983.

[23931] E. Vlachos. "A Review of the Fossil Record of North American Turtles of the Clade Pan-Testudinoidea". English. In: Bulletin of the Yale Peabody Museum of Natural History 59.1 (2018), pp. 3-94.

[23932] E. Vlachos. "The Fossil Chelonians of Greece. Systematics - Evolution - Stratigraphy - Palaeoecology". English. PhD thesis. 2015, pp. 1-479.

[23933] E. Vlachos. “The turtles from 'Gilmore's slab': evolution and diversity of the extinct turtle Echmatemys (Testudines: Testudinoidea: Geoemydidae) from the central United States". English. In: Journal of Systematic Palaeontology (2020), pp. 1-24. DOI: 10.1080/14772019.2020.1754938.

[23934] E. Vlachos, I. Cerda, and E. Tsoukala. "The first record of a soft-shelled turtle (Testudines: PanTrionychidae) from southern Balkans (Pliocene, Gefira, N. Greece) and new information from bone histology". English. In: Science of Nature 102.45 (2015), pp. 1-9. DOI: 10.1007 / s00114-0151295-2.

[23935] E. Vlachos and M. Delfino. "Food for thought: Sub-fossil and fossil chelonian remains from Franchthi Cave and Megalopolis confirm a glacial refuge for Emys orbicularis in Peloponnesus (S. Greece)". English. In: Quaternary Science Reviews 150 (2016), pp. 158-171. DOI: 10.1016/j.quascirev.2016.08. 027.

[23936] E. Vlachos, G. L. Georgalis, S. Roussiakis, M. Bohme, and G. Theodorou. "The Pikermian tortoises (Testudines, Testudinidae) from the late Miocene of the South Balkans". English. In: Journal of Vertebrate Paleontology 39.5 (2019), pp. 1-23. DOI: 10.1080/02724634.2019.1711520.

[23937] E. Vlachos, T. Kotsakis, and M. Delfino. "The chelonians from the Latest Miocene-Earliest Pliocene localities of Allatini and Pylea (East Thessaloniki, Macedonia, Greece)". English. In: Comptes Rendus Palevol 14 (2015), pp. 187-205. DOI: 10.1016/j.crpv.2015.01.005.

[23938] E. Vlachos, A. Pérez-Garca, S. Roussiakis, G. L. Georgalis, and B. P. Kear. "Late Miocene tortoises from Samos, Greece: Implications for European Neogene testudinid systematics and distributions". English. In: Journal of Vertebrate Paleontology e1722950 (2020), pp. 1-18. DOI: 10.1080/ 02724634.2020.1722950.

[23939] E. Vlachos, J. Sterli, K. Vasileiadou, and G. Syrides. "A new species of Mauremys (Testudines, Geoemydidae) from the Late Miocene - Pliocene of Central Macedonia (Northern Greece) with excpetionally wide vertebral scutes". English. In: Papers in Palaeontology 5.1 (2019), pp. 177-195. DOI: $10.1002 / \mathrm{spp} 2.1235$.

[23940] E. Vlachos, E. Tsoukala, and J. Corsini. "Cheirogaster bacharidisi, sp. nov., a new species of a giant tortoise from the Pliocene of Thessaloniki (Macedonia, Greece)". English. In: Journal of Vertebrate Paleontology 34.3 (2014), pp. 560-575. DOI: 10.1080/02724634.2013.821409. 
[23941] E. Vlachos and E. Tsoukala. "Testudo cf. graeca from the new Late Miocene locality of Platania (Drama basin, N. Greece) and a reappraisal of previously published specimens". English. In: Bulletin of the Geological Society of Greece 48 (2014), pp. 27-40.

[23942] E. Vlachos and E. Tsoukala. “The diverse chelonians from Milia (Late Pliocene, Grevena, Greece) with a new species of Testudo Linnaeus, 1758 (Testudines, Testudinidae)". English. In: Papers in Palaeontology 2.1 (2016), pp. 71-86. DOI: 10.1002/spp2.1031.

[23943] E. Vlachos, E. Tsoukala, E. Cregut-Bonnoure, C. Guerin, and D. Mol. “The Paradise Lost of Milia (Grevena, Greece; Late Pliocene, Early Villafranchian, MN15/MN16a): faunal composition and diversity". English. In: Quaternary MDPI 1.13 (2018), pp. 1-18. DOI: 10.3390/quat1020013.

[23944] T. Vlachou and G. D. Koufos. "The hipparions (Mammalia, Perissodactyla) from the Turolian locality Nikiti-2 (NIK), Macedonia, N. Greece". English. In: Annales de Paléontologie 88.4 (2002), pp. 215-263.

[23945] R. Vodrazka and L. A. Crame. "First fossil sponge from Antarctica and its paleobiogeographical significance". English. In: Journal of Paleontology 85.1 (2011), pp. 48-57.

[23946] S. Vodrazkova, G. Klapper, and M. A. Murphy. "Early Middle Devonian conodont faunas (Eifelian, costatus-kockelianus zones) from the Roberts Mountains and adjacent areas in central Nevada". English. In: Bulletin of Geosciences 86.4 (2011), pp. 737-764.

[23947] V. Voichyshyn and H. Szaniawski. "Acanthodian jaw bones from Lower Devonian deposits of Podolia, Ukraine". English. In: Acta Palaeontologica Polonica 57.4 (2012), pp. 879-896.

[23948] S. M. Voicu, S. Vasile, and Z. Csiki-Sava. The Cretaceous Swamp just gets bigger: new data on the faunal composition of the Pui Swamp microvertebrate bonebed, Maastrichtian of the Haeg Basin. English. Bucharest, 2018.

[23949] S. Voigt, D. S. Berman, and A. C. Henrici. "First well-established track-trackmaker association of paleozoic tetrapods based on Ichniotherium trackways and diadectid skeletons from the Lower Permian of Germany". English. In: Journal of Vertebrate Paleontology 27.3 (2007), pp. 553-570. DOI: 10.1671/0272-4634(2007)27[553:FWTAOP]2.0.CO;2.

[23950] S. Voigt, A. Hminna, H. Saber, J. W. Schneider, and H. Klein. "Tetrapod footprints from the uppermost level of the Permian Ikakern Formation (Argana Basin, Western High Atlas, Morocco)". English. In: Journal of African Earth Sciences 57.5 (2010), pp. 470-478. DOI: 10.1016/j.jafrearsci.2009. 12.003.

[23951] J. F. Voisin and A. Nel. “Un Lixus fossile du Miocéne français (Coleoptera, Curculionidae)”. French. In: Bulletin de la Société Entomologique de France 98 (1993), pp. 19-21.

[23952] E. H. Vokes. "The genus Truncaria (Gastropoda: Buccinidae) in the Esmeraldas beds of northwestern Ecuador". In: Tulane Studies in Geology and Paleontology 24 (1991), pp. 97-100.

[23953] E. H. Vokes. "On the occurrence of the gastropod genus Cassis in the Esmeraldas fauna, northwestern Ecuador". In: Tulane Studies in Geology and Paleontology 23 (1990), pp. 121-126.

[23954] E. H. Vokes. "A new species of Poirieria (Paziella) (Gastropoda: Muricidae) from the Punta Gavilian Formation, Northern Venezuela". In: Tulane Studies in Geology and Paleontology 29 (1996), pp. 67-68.

[23955] E. H. Vokes. “Neogene Paleontology in the Northern Dominican Republic 18. The Superfamily Volutacea (in part) (Mollusca: Gastropoda)". English. In: Bulletins of American Paleontology 113.354 (1998), pp. 1-54.

[23956] E. H. Vokes. "Cenozoic Muricidae of the western Atlantic region, Part VIII - Murex ss, Haustellum, Chicoreus, and Hexaplex; additions and corrections". English. In: Tulane Studies in Geology and Paleontology 23.1-3 (1990), pp. 1-96.

[23957] H. E. Vokes and E. H. Vokes. "Neogene Paleontology in the northern Dominican Republic: The Genus Spondylus (Bivalvia: Spondylidae)". English. In: Bulletins of American Paleontology 102.339 (1992), pp. 1-40. 
[23958] W. Volkheimer, M. G. Novara, P. L. Narvaéz, and R. A. Marquillas. “Palynological and paleoenvironmental significance of the Tunal Formation (Danian) at its type locality, El Chorro creek (Salta, Argentina)". English. In: Ameghiniana 43.3 (2006), pp. 567-584.

[23959] W. Volkheimer, L. Scafati, and D. L. Melendi. "Palynology of a Danian warm climatic wetland in Central Northern Patagonia, Argentina". English. In: Revista Española de Micropaleontologa 38 (2007), pp. 117-134.

[23960] A. N. Volkov. "New species of Triaplidae from the Babii Kamen' locality (Kuznetsk Basin)". English. In: Paleontological Journal 47 (2013), pp. 94-97.

[23961] M. von Balthazar, K. R. Pedersen, P. R. Crane, M. Stampanoni, and E. M. Friis. "Potomacanthus Lobatus Gen. Et Sp. Nov, A New Flower of Probable Lauraceae from the Early Cretaeous (Early To Middle Albian) of Eastern North America". English. In: American Journal of Botany 94.12 (2007), pp. 2041-2053.

[23962] M. von Balthazar, K. R. Pedersen, P. R. Crane, and E. M. Friis. “Carpestella lacunata gen. et sp. nov., a New Basal Angiosperm Flower from the Early Cretaceous (Early to Middle Albian) of Eastern North America". English. In: International Journal of Plant Sciences 169.7 (2008), pp. 890-898.

[23963] M. von Balthazar, K. R. Pedersen, and E. M. Friis. “Teixeiraea lusitanica, a new fossil flower from the Early Cretaceous of Portugal with affinities to Ranunculales". English. In: Plant Systematics and Evolution 255 (2005), pp. 55-75.

[23964] P. H. von Bitter and G. K. Merrill. "Apparatus composition and structure of the Pennsylvanian conodont genus Gondolella based on assemblages from the Desmoinesian of northwestern Illinois, U.S.A". In: Journal of Paleontology 72.1 (1998), pp. 112-132.

[23965] P. H. von Bitter, S. D. Scott, and P. E. Schenk. “Chemosynthesis: An alternate hypothesis for Carboniferous biotas in bryozoan/microbial mounds, Newfoundland, Canada". English. In: Palaios 7 (1992), pp. 466-484.

[23966] W. von Koenigswald and W.-D. Heinrich. "Mittelpleistozane Saugetierfaunen aus Mitteleuropa der Versuch einer biostratigraphischen Zuordnung". German. In: Kaupia 9 (1999), pp. 53-112.

[23967] R. Vonk and F. R. Schram. “Three new tanaid species (Crustacea, Peracarida, Tanaidacea) from the Lower Cretaceous". English. In: Journal of Paleontology 81 (2007), pp. 1502-1509.

[23968] M. R. Voorhies. "Vertebrate paleontology of the proposed Norden Reservoir Area, Brown, Cherry and Keya Paha counties, Nebraska". In: Technical Report, Division of Archeological Research, Department of Anthropology, University of Nebraska 82-09 (1990).

[23969] M. R. Voorhies. Vertebrate biostratigraphy of the Ogallala Group in Nebraska. English. Geologic Framework and Regional Hydrology: Upper Cenozoic Blackwater Draw and Ogallala Formations, Great Plains. 1990, pp. 115-151.

[23970] M. R. Voorhies and C. L. Timperley. “A New Pronotolagus (Lagomorpha: Leporidae) and Other Leporids from the Valentine Railway Quarries (Barstovian, Nebraska), and the ArchaeolagineLeporine Transition". English. In: Journal of Vertebrate Paleontology 17.4 (1997), pp. 725-737.

[23971] J. T. Voris, F. Therrien, D. K. Zelenitsky, and C. M. Brown. “A new tyrannosaurine (Theropoda:Tyrannosauridae) from the Campanian Foremost Formation of Alberta, Canada, provides insight into the evolution and biogeography of tyrannosaurids". English. In: Cretaceous Research 110 (2020), 104388:1-15.

[23972] A. V. Voronov. "A new Artinskian species of Uraloceras (Ammonoidea) from the southern Urals". English. In: Paleontological Journal 23.2 (1991), pp. 128-130.

[23973] A. Vörös and J. Pálfy. "New stratigraphy of the Pelsonian Substage at Köveskál (Middle Triassic, Balaton Highland, Hungary)". English. In: Fragmenta Palaeonotlogica Hungarica 20 (2002), pp. 5360.

[23974] A. Vörös. "The Pelsonian ammonoid fauna of the Balaton Highland". English. In: Geologica Hungarica, Series Palaeontologica 55 (2003), pp. 71-121. 
[23975] A. Vörös. "Paleoenvironmental distribution of some Middle Triassic ammonoid genera in the Balaton Highland (Hungary)". English. In: Abhandlungen der Geologischen Bundesanstalt 57 (2002), pp. $479-490$.

[23976] A. Vörös. "Bathonian brachiopods from Villany (south Hungary)". English. In: Fragmenta Palaeontologica Hungarica 22 (2004), pp. 1-8.

[23977] A. Vörös. “The Pliensbachian brachiopods of the Bakony Mountains (Hungary)”. English. In: Geologica Hungarica, Series Palaeontologica 58 (2009), pp. 1-300.

[23978] A. Vörös. "Middle Triassic (Anisian) nautilid cephalopods from Aszóf (Balaton Highland, Hungary)". English. In: Fragmenta Palaeontologica Hungarica 19 (2001), pp. 1-14.

[23979] A. Vörös. "Episodic sedimentation on a peri-Tethyan ridge through the Middle-Late Jurassic transition (Villany Mountains, southern Hungary)". English. In: Facies (2011). DOI: 10.1007 / s10347011-0287-8.

[23980] A. Vörös. "Late Anisian Ammonoidea from Szár-hegy (Rudabánya Mts); a Dinaric-type fauna from North Hungary". English. In: Fragmenta Palaeontologica Hungarica 28 (2010), pp. 1-20.

[23981] A. Vörös. "Early Jurassic Koninckinids (Athyridida, Brachiopoda) from Tivoli near Rome, Italy". English. In: Geologica Romana 36 (2002), pp. 169-197.

[23982] A. Vörös. "Bathonian brachiopods from Villany (South Hungary)". English. In: Fragmenta Palaeontologica Hungarica 22 (2004), pp. 1-8.

[23983] A. Vörös. A Balaton-felvidék triász ammonoideái és biosztratigráfiája (Triassic ammonoids and biostratigraphy of the Balaton Highland). other. Vol. 12. Studia Naturalia. 1998, pp. 1-105.

[23984] A. Vörös. “The Upper Anisian ammonoids of the Balaton Highland (Hungary)". English. In: Geologica Hungarica, Series Palaeontologica 60 (2018), pp. 1-241.

[23985] A. Vörös, T. Budai, and I. Szabó. “The base of the Curionii Zone (Ladinian, Triassic) in Felsõörs (Hungary): improved correlation with the Global Stratotype Section". English. In: Central European Geology 51.4 (2008), pp. 325-339. DOI: 10.1556/CEuGeol.51.2008.4.3.

[23986] A. Vörös and R. Kandemir. "A new Early Jurassic brachiopod fauna from the Eastern Pontides(Turkey)". English. In: Neues Jahrbuch für Geologie und Paläontologie Abhandlungen 260.3 (2011), pp. 343-363.

[23987] A. Vörös, J. Szabó, A. Dulai, I. Szente, O. Ebli, and H. Lobitzer. "Early Jurassic fauna and facies of the Schafberg area (Salzkammergut, Austria)". English. In: Fragmenta Palaeontologica Hungarica 21 (2003), pp. 51-82.

[23988] M. Voss. Discoveries of sirenian remains from the early Oligocene of the Rhine-Ruhr area (Germany) and a new look on the genus Halitherium. English. 2007.

[23989] M. Voss, M. S. M. Antar, I. S. Zalmout, and P. D. Gingerich. "Stomach contents of the archaeocete Basilosaurus isis: Apex predator in oceans of the late Eocene". English. In: PLoS One 14.1 (2019), e0209021. DOI: 10.1371/journal.pone.0209021.

[23990] M. Voss and O. Hampe. "Evidence for two sympatric sirenian species (Mammalia, Tethytheria) in the early Oligocene of Central Europe". English. In: Journal of Paleontology 91.2 (2017), pp. 337-367. DOI: $10.1017 /$ jpa.2016.147.

[23991] E. S. Vrba. "New fossils of Alcelaphini and Caprinae (Bovidae: Mammalia) from Awash, Ethiopia, and phylogenetic analysis of Alcelaphini". English. In: Palaeontologia Africana 34 (1997), pp. 127198.

[23992] E. S. Vrba, F. Bibi, and A. G. Costa. "First Asian Record of a late Pleistocene reduncine (Artiodactyla, Bovidae, Reduncini), Sivacobus sankaliai, sp. nov., from Gopnath (Miliolite Formation) Gujarat, India, and a revision of the Asian genus Sivacobus Pilgrim, 1939". English. In: Journal of Vertebrate Paleontology 35.4 (2015).

[23993] E. S. Vrba and J. Gatesy. New antelope fossils from Awash, Ethiopia, and phylogenetic analysis of Hippotragini (Bovidae, Mammalia). 1994. 
[23994] M. Vremir. "An early Eocene freshwater turtle assemblage from the Simleu Basin (NW Romania): Paleobiogeographic significance". English. In: Terra Sebus. Acta Musei Sabesiensis 5 (2013), pp. 597625.

[23995] M. Vremir, R. Blc, Z. Csiki-Sava, S. L. Brusatte, G. Dyke, D. Naish, and M. A. Norell. "Petreti-Arini - An important but ephemeral Upper Cretaceous continental vertebrate site in the southwestern Transylvanian Basin, Romania". English. In: Cretaceous Research 49 (2014), pp. 13-38. DOI: 10.1016/ j.cretres.2014.02.002.

[23996] M. Vremir and V. A. Codrea. "The first Late Cretaceous (Maastrichtian) dinosaur footprints from Transylvania (Romania)". English. In: Studia Universitatis Babes-Boyai, Geologia 47.2 (2002), pp. 93104.

[23997] M. Vremir, G. Dyke, Z. Csiki-Sava, D. Grigorescu, and E. Buffetaut. "Partial mandible of a giant pterosaur from the uppermost Cretaceous (Maastrichtian) of the Haeg Basin, Romania". English. In: Lethaia 51.4 (2018), pp. 493-503. DOI: 10.1111/let.12268.

[23998] M. Vremir, A. W. A. Kellner, D. Naish, and G. J. Dyke. "A new azhdarchid pterosaur from the Late Cretaceous of the Transylvanian Basin, Romania: implications for azhdarchid diversity and distribution". English. In: PLoS ONE 8.1 (2013), e54268. DOI: 10.1371/journal.pone.0054268.

[23999] M. Vremir, M. Witton, D. Naish, G. Dyke, S. L. Brusatte, M. Norell, and R. Totoianu. “A mediumsized robust-necked Azhdarchid pterosaur (Pterodactyloidea: Azhdarchidae) from the Maastrichtian of Pui (Haeg Basin, Transylvania, Romania)". English. In: American Museum Novitates 3827 (2015), pp. 1-16.

[24000] D. Vrsaljko. “The Pannonian Palaeoecology and Biostratigraphy of Molluscs from KostanjekMedvednica Mt. Croatia". English. In: Geologia Croatica 52.1 (1999), pp. 9-27.

[24001] D. Vrsaljko, S. Japundzic, M. Kovacic, Z. Grganic-Vrdoljak, and P. Plese. Vranic: Najznacajnije nalazite fosilnih kitova u Sjevernoj Hrvatskoj. other. 2010.

[24002] P. Vranský. "New blattarians and a review of dictyopteran assemblages from the Lower Cretaceous of Mongolia". English. In: Acta Palaeontologica Polonica 53.1 (2008), pp. 129-136.

[24003] P. Vranský. "A new genus and species of cockroach (Blattida: Phyloblattidae) from the Permian/Triassic boundary beds of Tunguska Basin in eastern Siberia, Russia". English. In: Zootaxa 2353 (2010), pp. 55-61.

[24004] P. Vranský. "Phyloblatta grimaldii sp. nov. a new Triassic cockroach (Insecta: Blattaria) from Virginia". English. In: Entomological Problems 33.1-2 (2003), pp. 51-53.

[24005] P. Vranský. "Late Jurassic Cockroaches (Insecta, Blattaria) from the Houtiyn-Hotgor Locality in Mongolia". English. In: Paleontological Journal 42.1 (2008), pp. 36-42.

[24006] P. Vranský. "Jumping cockroaches (Blattaria, Skokidae fam. n) from the Late Jurassic of Karatau in Kazakhstan". English. In: Biologia Bratislava 62.5 (2007), pp. 588-592.

[24007] P. Vranský. "Transitional Jurassic/Cretaceous Cockroach assemblage (Insecta, Blattaria) from the Shar-Teg in Mongolia". English. In: Geologica Carpathica 55.6 (2004), pp. 457-468.

[24008] P. Vranský. "Lower Cretaceous cockroaches and mantids (Insecta: Blattaria, Mantodea) from the Sharin-Gol in Mongolia". English. In: Entomological Problems 35.2 (2005), pp. 163-167.

[24009] P. Vranský. "A fossil insect in a drilling core sample - cockroach Kridla stastia gen. et sp.nov. (Blattulidae) from the Cretaceous of the Verkhne-Bureinskaya Depression in Eastern Russia". English. In: Entomological Problems 35.2 (2005), pp. 115-116.

[24010] P. Vranský. "Albian cockroaches (Insecta, Blattida) from French amber of Archingeay". English. In: Geodiversitas 31 (2009), pp. 73-98.

[24011] P. Vranský. "A complete larva of a Mesozoic (Early Cenomanian) cockroach (Insecta: Blattaria: Blattulidae) from the Sisteron amber (Alpes de Haute Provence, SE France)". English. In: Geologica Carpathica 59 (2008), pp. 269-272.

[24012] P. Vranský. "Mesozoic relative of the common synanthropic German cockroach (Blattodea)". English. In: Deutsche Entomologische Zeitschrift 55 (2008), pp. 215-221. 
[24013] P. Vranský. “Cretaceous Gondwanian Cockroaches (Insecta: Blattaria)”. English. In: Entomological Problems 34.1-2 (2004), pp. 49-54.

[24014] P. Vranský. "Umenocoleoidea - an amazing lineage of aberrant insects (Insecta, Blattaria)". English. In: AMBA Projekty 7.1 (2003), pp. 1-32.

[24015] P. Vranský. “Central ocellus of extinct cockroaches (Blattida: Caloblattinidae)”. English. In: Zootaxa 1958 (2008), pp. 41-50.

[24016] P. Vranský. “Cockroach as the earliest eusocial animal”. English. In: Acta Geologica Sinica 84 (2010), pp. 793-808.

[24017] P. Vranský. “Unique assemblage of Dictyoptera (Insecta - Blattaria, Mantodea, Isoptera) from the Lower Cretaceous of Bon Tsagaan Nuur in Mongolia". English. In: Entomological Problems 33 (2003), pp. 119-151.

[24018] P. Vranský. "Two new species of Blattaria (Insecta) from the Lower Creataceous of Asia with comments on the origin and phylogenetic position of families Polypagidae and Blattulidae". English. In: Entomological Problems 30.2 (1999), pp. 85-91.

[24019] P. Vranský. “Origin and the early evolution of mantises". English. In: AMBA Projekty 6.1 (2002), pp. 1-16.

[24020] P. Vranský. "Lower Cretaceous Blattaria". English. In: Proceedings of the First International Palaeoentomological Conference (1999), pp. 167-176.

[24021] P. Vranský. English. Cockroaches from Jurassic sediments of the Bakhar Formation in Mongolia. Cham, Switzerland: Springer Nature, 2020, pp. 1-98. DOI: 10.1007/978-3-030-59407-7.

[24022] P. Vranský and J. Ansorge. "Lower Jurassic cockroaches (Insecta: Blattaria ) from Germany and England". English. In: African Invertebrates 48.1 (2007), pp. 103-126.

[24023] P. Vranský and J. Ansorge. “New Lower Cretaceous polyphagid cockroaches from Spain (Blattaria, Polyphagidae, Vitisminae subfam. nov.)" English. In: Cretaceous Research 22 (2001), pp. 157-162.

[24024] P. Vranský and D. Aristov. “Termites (Isoptera) from the Jurassic/Cretaceous boundary: evidence for the longevity of their earliest genera". English. In: European Journal of Entomology 111 (2014), pp. 137-141.

[24025] P. Vranský and D. S. Aristov. “Enigmatic Late Permian cockroaches from Isady, Russia (Blattida: Mutoviidae fam. n)". English. In: Zootaxa 3247 (2012), pp. 19-31.

[24026] P. Vranský and G. Bechly. “New predatory cockroaches (Insecta: Blattaria: Manipulatoridae fam. n.) from the Upper Cretaceous Myanmar amber". English. In: Geologica Carpathica 66 (2015), pp. $133-$ 138.

[24027] P. Vranský, G. Bechly, Q. Q. Zhang, E. A. Jarzembowski, T. Mlynský, L. mdová, P. Barna, M. Kúdela, D. Aristov, S. Bigalk, L. Krogmann, L. Q. Li, Q. Zhang, H. C. Zhang, S. Ellenberger, P. Müller, C. Gröhn, F. Y. Xia, K. Ueda, P. Vaný, D. Valaka, L. Vranská, and B. Wang. “Batesian insect-insect mimicry-related explosive radiation of ancient alienopterid cockroaches". English. In: Biologia 73 (2018), pp. 987-1006.

[24028] P. Vranský, P. Cifuentes-Ruiz, L. Vidlika, F. iampor, and F. J. Vega. "Afro-Asian cockroach from Chiapas amber and the lost Tertiary American entomofauna". English. In: Geologica Carpathica 62 (2011), pp. 463-475.

[24029] P. Vranský, I. Koubová, L. Vranská, J. Hinkelman, M. Kúdela, T. Kúdelová, J. H. Liang, F. Y. Xia, X. J. Lei, X. Y. Ren, L. Vidlika, T. Bao, S. Ellenberger, L. mdová, and M. Barclay. “Early wood-boring mole roach reveals eusociality missing ring". English. In: AMBA Projekty 9 (2019), pp. 1-28.

[24030] P. Vranský, J. H. Liang, and D. Ren. "Advanced morphology and behaviour of extinct earwig-like cockroaches (Blattida: Fuziidae fam. nov.)" English. In: Geologica Carpathica 60.6 (2009), pp. 449 462.

[24031] P. Vranský, J. H. Liang, and D. Ren. "Malformed cockroach (Blattida: Liberiblattinidae) in the Middle Jurassic sediments from China". English. In: Oriental Insects 46 (2012), pp. 12-18. 
[24032] P. Vranský, J. A. Lis, J. Schlögl, M. Guldan, T. Mlynský, P. Barna, and P. Stys. “Partially disarticulated new Miocene burrower bug (Hemiptera: Heteroptera: Cydnidae) from Cerová (Slovakia) documents occasional preservation of terrestrial arthropods in deep-marine sediments". English. In: European Journal of Entomology 112 (2015), pp. 844-854.

[24033] P. Vranský, R. Oruzinsky, P. Barna, L. Vidlika, and C. C. Labandeira. “Native Ectobius (Blattaria: Ectobiidae) from the early Eocene Green River Formation of Colorado and its reintroduction to North America 49 million years later". English. In: Annals of the Entomological Society of America 107 (2014), pp. 28-36.

[24034] P. Vranský, D. Ren, and C. Shih. "Nakridletia ord. n. - enigmatic insect parasites support sociality and endothermy of pterosaurs". English. In: AMBA Projekty 8.1 (2010), pp. 1-16.

[24035] P. Vranský, H. Sendi, D. Aristov, G. Bechly, P. Müller, S. Ellenberger, D. Azar, K. Ueda, P. Barna, and T. Garcia. "Ancient roaches further exemplify 'no land return' in aquatic insects". English. In: Gondwana Research 68 (2019), pp. 22-33. DOI: 10.1016/j.gr.2018.10.020.

[24036] P. Vranský, L. mdová, D. Valaka, P. Barna, L. Vidlika, P. Taká, L. Pavlik, T. Kúdelová, T. S. Karim, D. Zelagin, and D. Smith. "Origin of origami cockroach reveals long-lasting (11 Ma) phenotype instability following viviparity". English. In: The Science of Nature 103.78 (2016), pp. 1-15.

[24037] P. Vranský, L. mdová, H. Sendi, P. Barna, P. Müller, S. Ellenberger, H. Wu, X. Y. Ren, X. J. Lei, D. Azar, J. urka, T. Su, W. Y. Deng, X. H. Shen, J. Lv, T. Bao, and G. Bechly. "Parasitic cockroaches indicate complex states of earliest proved ants". English. In: Biologia 74 (2019), pp. 65-89. DOI: 10.2478/s11756-018-0146-y.

[24038] P. Vranský, T. van de Kamp, D. Azar, A. Prokin, L. Vidlika, and P. Vagovic. “Cockroaches probably cleaned up after dinosaurs". English. In: PLoS One 8.12 (2013), e80560.

[24039] P. Vranský, L. Vidlika, F. iampor, and F. Marsh. "Derived, still living cockroach genus Cariblattoides (Blattida: Blattellidae) from the Eocene sediments of Green River in Colorado, USA". English. In: Insect Science 19 (2012), pp. 143-152.

[24040] P. Vranský, L. Vidlika, P. Barna, E. Bugdaeva, and V. Markevich. "Paleocene origin of the cockroach families Blaberidae and Corydiidae: evidence from Amur River region of Russia". English. In: Zootaxa 3635.2 (2013), pp. 117-126.

[24041] P. Vranský, L. Vranská, M. Beo, T. Bao, X. J. Lei, X. J. Ren, H. Wu, L. mdová, G. Bechly, J. Lv, M. Yeo, and E. Jarzembowski. "Pathogenic DWV infection symptoms in a Cretaceous cockroach". English. In: Palaeontographica Abteilung A 314 (2019), pp. 1-10. DOI: 10.1127/pala/2019/0084.

[24042] P. Vranský and B. Wang. "A new cockroach, with bipectinate antennae, (Blattaria: Olidae fam. nov.) further highlights the differences between the Burmite and other faunas". English. In: Biologia 72 (2017), pp. 1327-1333.

[24043] M. Vucetich, M. Dozo, M. Arnal, and M. Pérez. "New rodents (Mammalia) from the late Oligocene of Cabeza Blanca (Chubut) and the first rodent radiation in Patagonia". English. In: Historical Biology 27.2 (2015), pp. 236-257. DOI: 10.1080/08912963.2014.883506.

[24044] M. G. Vucetich, A. A. Carlini, O. Aguilera, and M. R. Sánchez-Villagra. “The Tropics as Reservoir of Otherwise Extinct Mammals: The Case of Rodents from a New Pliocene Faunal Assemblage from Northern Venezuela". English. In: Journal of Mammalian Evolution 17 (2010), pp. 265-273. DOI: $10.1007 /$ s10914-010-9142-x.

[24045] M. G. Vucetich, C. M. Deschamps, A. I. Olivares, and M. Dozo. “Capybaras, size, shape and time: A model kit". English. In: Acta Palaeontologica Polonica 50.2 (2005), pp. 259-272.

[24046] M. G. Vucetich, C. M. Deschamps, C. C. Morgan, and A. M. Forasiepi. “A New Species of Cardiomyinae (Rodentia, Hydrochoeridae) From Western Argentina. Its Age and Considerations on Ontogeny and Diversity of the Subfamily". English. In: Ameghiniana 48.4 (2011), pp. 556-567.

[24047] M. G. Vucetich, C. M. Deschamps, E. C. Vieytes, and C. I. Montalvo. "Late Miocene Capybaras from Argentina: Skull Anatomy, Taxonomy, Evolution, and Biochronology". English. In: Acta Palaeontologica Polonica 59.3 (2014), pp. 517-535. DOI: 10.4202/app.2012.0063. 
[24048] M. G. Vucetich and A. G. Kramarz. “New Miocene rodents from Patagonia (Argentina) and their bearing on the early radiation of the Octodontoids (Hystricognathi)". English. In: Journal of Vertebrate Paleontology 23.2 (2003), pp. 435-444. DOI: 10.1671/0272-4634(2003)023[0435:NMRFPA]2.0. $\mathrm{CO} ; 2$.

[24049] M. G. Vucetich, M. E. Pérez, M. R. Ciancio, A. A. Carlini, R. H. Madden, and M. J. Kohn. “A new acaremyid rodent (Caviomorpha, Octodontoidea) from Scarritt Pocket, Deseadan (late Oligocene) of Patagonia (Argentina)". English. In: Journal of Vertebrate Paleontology 34.3 (2014), pp. 689-698. DOI: 10.1080/02724634.2013.804414.

[24050] M. G. Vucetich and M. E. Pérez. "The putative cardiomyines (Rodentia, Cavioidea) of the middle Miocene of Patagonia (Argentina) and the differentiation of the Family Hydrochoeridae". English. In: Journal of Vertebrate Paleontology 31.6 (2011), pp. 1382-1386. DOI: 10.1080/02724634.2011.618194.

[24051] M. G. Vucetich and D. H. Verzi. “A peculiar octodontoid (Rodentia, Caviomorpha) with terraced molars from the Lower Miocene of Patagonia (Argentina)". English. In: Journal of Vertebrate Paleontology 16.2 (1996), pp. 297-302. DOI: 10.2307/4523720.

[24052] M. G. Vucetich and D. H. Verzi. “Un nuevo Echimyidae (Rodentia, Hystricognathi) de la edad Colhuehuapiense de Patagonia y consideraciones sobre la sistematica de la familia". Spanish. In: Ameghiniana 28.1-2 (1991), pp. 67-74.

[24053] M. G. Vucetich, E. C. Vieytes, D. H. Verzi, J. I. Noriega, and E. P. Tonni. “Unexpected primitive rodents in the Quaternary of Argentina". English. In: Journal of South American Earth Sciences 20.12 (2005), pp. 57-64. DOI: 10.1016/j.jsames.2005.07.006.

[24054] R. Vullo. "Selachians from the type Campanian area (Late Cretaceous), Charentes ," English. In: Cretaceous Research 26.4 (2005), pp. 1-24.

[24055] R. Vullo, D. Abit, M. Ballévre, J. -P. Billon-Bruyat, R. Bourgeais, É Buffetaut, V. Daviero-Gomez, G. Garcia, B. Gomez, J. -M. Mazin, S. Morel, D. Néraudeau, J. Pouech, J. -C. Rage, J. Schnyder, and H. Tong. "Palaeontology of the Purbeck-type (Tithonian, Late Jurassic) bonebeds of Chassiron (Oléron Island, western France)". English. In: Comptes Rendus Palevol 13.5 (2014), pp. 421-441. DOI: 10.1016/j.crpv.2014.03.003.

[24056] R. Vullo, E. Bernardez, and A. D. Buscalioni. "Vertebrates from the middle?-late Cenomanian La Cabana Formation (Asturias, northern Spain): Palaeoenvironmental and palaeobiogeographic implications". English. In: Palaeogeography, Palaeoclimatology, Palaeoecology 276 (2009), pp. 120-129. DOI: 10.1016/j.palaeo.2009.03.004.

[24057] R. Vullo, Á D. Buscalioni, J. Marugán-Lobón, and J. J. Moratalla. “First pterosaur remains from the Early Cretaceous Lagerstätte of Las Hoyas, Spain: palaeoecological signicance". English. In: Geological Magazine 146 (2009), pp. 931-936.

[24058] R. Vullo, H. Cappetta, and D. Néraudeau. "New sharks and rays from the Cenomanian and Turonian of Charentes, France". English. In: Acta Palaeontologica Polonica 52 (2007), pp. 99-116.

[24059] R. Vullo, F. de Lapparent de Broin, D. Nerudeau, and N. Durrieu. “Turtles from the Early Cenomanian paralic deposits (Late Cretaceous) of Charentes, France". English. In: Oryctos 9 (2010), pp. 3748.

[24060] R. Vullo, G. Garcia, P. Godefroit, A. Cincotta, and X. Valentin. "Mistralazhdarcho maggii, gen. et sp. nov., A New Azhdarchid Pterosaur from the Upper Cretaceous of Southeastern France". English. In: Journal of Vertebrate Paleontology 38.4 (2018), pp. 1-16. DOI: 10.1080 / 02724634.2018. 1502670.

[24061] R. Vullo and E. Gheerbrant. "The oldest modern therian mammal from Europe and its bearing on stem marsupial paleobiogeography". English. In: Proceedings of the National Academy of Sciences 106.47 (2009), pp. 19910-19915. DOI: 10.1073/pnas.0902940106.

[24062] R. Vullo, G. Guinot, and G. Barbe. "The first articulated specimen of the Cretaceous mackerel shark Haimirichia amonensis gen. nov. (Haimirichiidae fam. nov.) reveals a novel ecomorphological adaptation within the Lamniformes (Elasmobranchii)". English. In: Journal of Systematic Palaeontology 14 (2016), pp. 1003-1024. DOI: 10.1080/14772019.2015.1137983. 
[24063] R. Vullo, J. Marugán-Lobón, A. W. A. Kellner, A. D. Buscaloni, B. Gomez, M. de la Fuente, and J. J. Moratalla. "A new crested pterosaur from the Early Cetaceous of Spain: the first European tapejarid (Pterodactyloidea: Azhdarchoidea)". English. In: PLoS ONE 7.7 (2012), e38900. DOI: 10. 1371/journal.pone.0038900.

[24064] R. Vullo, D. Néraudeau, and B. Videt. "Un faciés de type falun dans le Cénomanien basal de Charente-Maritime (France)". French. In: Annales de Paléontologie 89.3 (2003), pp. 171-189.

[24065] R. Vullo, D. Neraudeau, and T. Lenglet. "Dinosaur teeth from the Cenomanian of Charentes, western France: evidence for a mixed Laurasian-Gondwanan assemblage". English. In: Journal of Vertebrate Paleontology 27.4 (2007), pp. 931-943.

[24066] R. Vullo and D. Neraudeau. "Pterosaur remains from the Cenomanian (Late Cretaceous) paralic deposits of Charentes, western France". English. In: Journal of Vertebrate Paleontology 29.1 (2009), pp. 277-282. DOI: 10.1671/039.029.0123.

[24067] R. Vullo and D. Néraudeau. "Cenomanian vertebrate assemblages from southwestern France: a new insight into the European mid-Cretaceous continental fauna". English. In: Cretaceous Research 29.5-6 (2008), pp. 930-935. DOI: 10.1016/j.cretres.2008.05.010.

[24068] R. Vullo, D. Néraudeau, and E. Dépré. "Vertebrate remains from the Cenomanian (Late Cretaceous) plant-bearing lagerstatte of Puy-Puy (Charente-Maritime, France)". English. In: Cretaceous Research (2013).

[24069] R. Vullo and D. Néraudeau. "Additional dinosaur teeth from the Cenomanian (Late Cretaceous) of Charentes, southwestern France". English. In: Comptes Rendus Palevol 9.3 (2010), pp. 121-126. DOI: $10.1016 /$ j.crpv.2010.03.001.

[24070] R. Vullo, J.-C. Rage, and D. Neraudeau. "Anuran and squamate remains from the Cenomanian (Late Cretaceous) of Charentes, western France". English. In: Journal of Vertebrate Paleontology 31.2 (2011), pp. 279-291. DOI: 10.1080/02724634.2011.550355.

[24071] R. Vullo and J.-C. Rage. "The first Gondwanan borioteiioid lizard and the mid-Cretaceous dispersal event between North America and Africa". English. In: The Science of Nature 105 (2018), 61:18.

[24072] M. Wachtler. "The insect-variety of Angaran Early Permian". English. In: Early Permian Origin and Evolution of Angiosperms - The Flowering of Angara-Land. Portland: Oregon Institute of Geological Research, 2017, pp. 89-101.

[24073] S. Wada. "A newly discovered species of living baleen whale". English. In: Nature 426 (2003), pp. 278-281.

[24074] J. B. Waddington, D. M. Rudkin, and J. A. Dunlop. "A new mid-Silurian aquatic scorpion - one step closer to land?" English. In: Biology Letters 11 (2015), p. 20140815. DOI: 10.1098/rsbl.2014.0815.

[24075] J. D. Waele, G. A. Brook, and A. Oertel. “Monk seal (Monachus monachus) bones in Bel Torrente Cave (Central-East Sardinia) and their paleogeographical significance". English. In: Journal of Cave and Karst Studies 71.1 (2009), pp. 16-23.

[24076] A. Wagensommer, M. Latiano, and U. Nicosia. "First report of dinosaur footprints from Madagascar: two tracksites from the Middle Jurassic Bemaraha Formation". English. In: Ichnos 17 (2010), pp. 127-136. DOI: 10.1080/10420941003659527.

[24077] A. Wagensommer, M. Latiano, G. Leroux, G. Cassano, and S. D. Porchetti. “New dinosaur track sites from the Middle Jurassic of Madagascar: ichnotaxonomical, behavioral and palaeoenvironmental implications". English. In: Palaeontology 55.1 (2012), pp. 109-126. DOI: 10.1111/j.14754983.2011.01121.x.

[24078] A. Wagensommer, M. Latiano, H. B. Mocke, and S. D'Orazi Porchetti. "Dinosaur diversity in an Early Jurassic African desert: the significance of the Etjo Sandstone ichnofauna at the Otjihaenamaparero locality (Namibia)". English. In: Neues Jahrbuch für Geologie und Paläontologie Abhandlungen 281.2 (2016), pp. 155-182. DOI: 10.1127/njgpa/2016/0593. 
[24079] B. Waggoner. "Non-trilobite arthropods from the Silver Peak Range, Nevada". English. In: Journal of Paleontology 77 (2003), pp. 706-720. DOI: 10.1017/S0022336000044449P.

[24080] B. M. Waggoner and J. W. Hagadorn. "An unmineralized alga from the Lower Cambrian of California, USA". English. In: Neues Jahrbuch für Geologie und Paläontologie - Abhandlungen 231.1 (2004), pp. 67-83.

[24081] B. M. Waggoner and M. R. Langer. "A new hydroid from the Upper Cretaceous of Mississippi". English. In: Palaeontologische Zeitschrift 67.3/4 (1993), pp. 253-259.

[24082] B. M. Waggoner and G. O. Poinar. "Fossil habrotrochid rotifers in Dominican amber". English. In: Experientia 49 (1993), pp. 354-357.

[24083] H. M. Wagner and D. R. Prothero. Magnetic stratigraphy of the late Pliocene mammal-bearing deposits from Gypsum Ridge, San Bernardino County, California. English. Magnetic Stratigraphy of the Pacific Coast Cenozoic (D. R. Prothero, ed.) 2001, pp. 369-376.

[24084] H. M. Wagner, B. O. Riney, T. A. Deméré, and D. R. Prothero. Magnetic stratigraphy and land mammal biochronology of the nonmarine facies of the Pliocene San Diego Formation, San Diego County, California. English. Magnetic Stratigraphy of the Pacific Coast Cenozoic (D. R. Prothero, ed.) 2001, pp. 359368.

[24085] J. R. Wagner and T. M. Lehman. "An enigmatic new lambeosaurine hadrosaur (Reptilia: Dinosauria) from the Upper Shale Member of the Campanian Aguja Formation of trans-Pecos Texas". English. In: Journal of Vertebrate Paleontology 29.2 (2009), pp. 605-611. DOI: 10.1671/039.029.0208.

[24086] P. J. Wagner. "The utility of fossil data in phylogenetic analyses: a likelihood example using Ordovician-Silurian species of the Lophospiridae (Gastropoda: Murchisoniina)". English. In: American Malacological Bulletin 15.1 (1999), pp. 1-31.

[24087] P. J. Wagner. "Phylogenetics of the earliest anisostrophically coiled gastropods". English. In: Smithsonian Contributions to Paleobiology 88 (1999), pp. 1-132.

[24088] P. J. Wagner. "Phylogenetic analysis of the Lophospiridae (Gastropoda : Pleurotomariina) of the Ordovician and Silurian". English. PhD thesis. 1990, pp. 1-155.

[24089] P. J. Wagner, M. Aberhan, A. Hendy, and W. Kiessling. "The effects of taxonomic standardization on sampling-standardized estimates of historical diversity". English. In: Proceedings of the Royal Society B: Biological Sciences 274 (2007), pp. 439-444.

[24090] R. Wagner. "Amber Bruchomyiinae - descriptions of already known and new species, and the position of the subfamily within Psychodidae (s.l.) (Diptera)". English. In: Studia Dipterologica 13 (2006), pp. 83-95.

[24091] R. Wagner. "A remarkable new species and genus of moth-flies (Diptera, Psychodidae, Psychodinae) from Dominican amber". English. In: Studia Dipterologica 8 (2002), pp. 423-426.

[24092] R. Wagner. "Synopsis of extinct Bruchomyiinae (Diptera, Psychodidae) from Burmese, Baltic and Dominican amber, with descriptions of new genera and species". English. In: Zootaxa 4320 (2017), pp. 100-120.

[24093] R. Wagner, C. Hoffeins, and H. W. Hoffeins. "A fossil nymphomyiid (Diptera) from the Baltic and Bitterfield amber". English. In: Systematic Entomology 25 (2000), pp. 115-120.

[24094] R. Wagner, C. Hoffeins, and H. W. Hoffeins. "Beschreibung einer weiteren Art der Gattung Heleodromia (Diptera, Empididae, Hemerodromiinae) aus dem Bitterfelder Bernstein". German. In: Studia Dipterologica 7 (2000), pp. 19-23.

[24095] R. Wagner and B. R. Stuckenberg. "New fossil and extant species of Nemopalpus Macquart (Diptera: Psychodidae: Bruchomyiinae)". English. In: African Invertebrates 53 (2012), pp. 355-367.

[24096] W. R. Wahl, M. Ross, and J. A. Massare. "Rediscovery of Wilbur Knight's Megalneustes rex site: new material from an old pit". English. In: Paludicola 6.2 (2007), pp. 94-104.

[24097] G. P. Wahlman and M. V. Konovalova. “Upper Carboniferous-Lower Permian Kozhim Carbonate Bank, subpolar Pre-Ural Mountains, northern Russia". English. In: SEPM Special Publication 74 (2002), pp. 219-241. 
[24098] G. P. Wahlman. "Middle and Upper Ordovician symmetrical univalved mollusks (Monoplacophora and Bellerophontina) of the Cincinnati Arch region". English. In: United States Geological Survey Professional Paper 1066.O (1992), pp. 1-123.

[24099] C. B. T. Waid and B. D. Cramer. "Telychian (Llandovery, Silurian) conodonts from the LaPorte City Formation of eastern Iowa, USA (East-Central Iowa Basin) and their implications for global Telychian conodont biostratigraphic correlation". English. In: Palaeontologia Electronica 20.2 (2017), pp. 1-37.

[24100] B. G. Waisfeld, B. D. E. Chatterton, and G. D. Edgecombe. "Systematics of Shumardiidae (Trilobita), with new species from the Ordovician of Argentina". English. In: Journal of Paleontology 75.4 (2001), pp. 827-859. DOI: 10.1666/0022-3360(2001)075<0827:SOSTWN>2.0.CO;2.

[24101] B. G. Waisfeld and T. M. Sanchez. "Trilobites Siluricos de la Formacion Lipeon en el noroeste Argentino (Sierra de Zapla, Provincia de Jujuy)". Spanish. In: Ameghiniana 30.1 (1993), pp. 77-90.

[24102] B. G. Waisfeld and N. E. Vaccari. “Trilobites from the Suri Formation (Lower Ordovician: Floian), Famatina Belt, Argentina". English. In: Memoirs of the Association of Australasian Palaeontologists 37 (2009), pp. 407-426.

[24103] I. Walaszczyk and W. A. Cobban. "Inoceramid fauna and biostratigraphy of the upper Middle Coniacian-lower Middle Santonian of the Pueblo Section (SE Colorado, US Western Interior)". English. In: Cretaceous Research 28 (2007), pp. 132-142.

[24104] I. Walaszczyk and W. A. Cobban. "Palaeontology and stratigraphy of the Middle-Upper Coniacian and Santonian inoceramids of the US Western Interior". English. In: Acta Geologica Polonica 56.3 (2006), pp. 241-348.

[24105] I. Walaszczyk, W. J. Kennedy, and A. R. Paranjape. "Inoceramids and associated ammonite faunas from the uppermost Turonian-lower Coniacian (Upper Cretaceous) of the Anaipadi-Saradamangalam region of the Cauvery Basin, south-east India". English. In: Acta Geologica Polonica 68 (2018), pp. 663-687.

[24106] I. Walaszczyk, R. Marcinowski, T. Praszkier, K. Dembicz, and M. Bienkowska. “Biogeographical and stratigraphical significance of the latest Turonian and Early Coniacian inoceramid/ammonite succession of the Manasoa section on the Onilahy River, south-west Madagascar". In: Cretaceous Research 25 (2004), pp. 543-576.

[24107] M. Waldman and S. E. Evans. "Lepidosauromorph reptiles from the Middle Jurassic of Skye". English. In: Zoological Journal of the Linnean Society 112 (1994), pp. 135-150.

[24108] G. M. Walkden and N. C. Fraser. "Late Triassic fissure sediments and vertebrate faunas: environmental change and faunal succession at Cromhall, south west Britain". English. In: Modern Geology 18 (1993), pp. 511-535.

[24109] C. A. Walker, E. Buffetaut, and G. J. Dyke. "Large euenantiornithine birds from the Cretaceous of southern France, North America and Argentina". English. In: Geological Magazine 144.6 (2007), pp. 977-986. DOI: 10.1017/S0016756807003871.

[24110] C. A. Walker and G. J. Dyke. "Euenantiornithine birds from the Late Cretaceous of El Brete (Argentina)". English. In: Irish Journal of Earth Sciences 27 (2009), pp. 15-62.

[24111] C. A. Walker and G. J. Dyke. "New records of fossil birds of prey from the Miocene of Kenya". English. In: Historical Biology 18.2 (2006), pp. 95-98. DOI: 10.1080/08912960600639434.

[24112] C. A. Walker, G. M. Wragg, and C. J. O. Harrison. "A new shearwater from the Pleistocene of the Canary Islands and its bearing on the evolution of certain Puffinus shearwaters". English. In: Historical Biology 3 (1990), pp. 203-224.

[24113] C. C. Wallace. "New species and records from the Eocene of England and France support early diversification of the coral genus Acropora". English. In: Journal of Paleontology 82.2 (2008), pp. 313328.

[24114] C. C. Wallace and F. R. Bosellini. "Acropora (Scleractinia) from the Oligocene and Miocene of Europe: species longevity, origination and turnover following the Eocene-Oligocene transition". English. In: Journal of Systematic Palaeontology (2014). DOI: 10.1080/14772019.2014.930525. 
[24115] C. C. Wallace, C. A. Chen, H. Fukami, and P. R. Muir. "Recognition of separate genera within Acropora based on new morphological, reproductive and genetic evidence from Acropora togianensis, and elevation of the subgenus Isopora Studer, 1878 to genus (Scleractinia : Astrocoeniidae; Acroporidae)". English. In: Coral Reefs 26.2 (2007), pp. 231-239.

[24116] C. C. Wallace and B. R. Rosen. "Diverse staghorn corals (Acropora) in high-latitude Eocene assemblages: implications for the evolution of modern diversity patterns of reef corals". English. In: Proceedings of The Royal Society B 273 (2006), pp. 975-982. DOI: 10.1098/rspb.2005.3307.

[24117] R. V. S. Wallace, R. Martnez, and T. Rowe. "First record of a basal mammaliamorph from the early Late Triassic Ischigualasto Formation of Argentina". English. In: PLoS ONE 14.8 (2019), e0218791.

[24118] S. C. Wallace and R. C. Hulbert. "A New Machairodont from the Palmetto Fauna (Early Pliocene) of Florida, with Comments on the Origin of the Smilodontini (Mammalia, Carnivora, Felidae)". English. In: PLoS One 8.3 (2013), e561734. DOI: 10.1371/journal.pone.0056173.

[24119] S. C. Wallace and X. Wang. "Two new carnivores from an unusual late Tertiary forest biota in eastern North America". English. In: Nature 431 (2004), pp. 556-559.

[24120] A. Waller, A. Nel, and J. Menier. "Le premier Dilophus fossile de l'ambre dominicain (Diptera: Bibionidae)". French. In: Revue Française d'Entomologie (N.S.) 22 (2000), pp. 149-153.

[24121] T. R. Waller. New phylogenies of the Pectinidae (Mollusca: Bivalvia): Reconciling morphological and molecular approaches. English. Scallops: Biology, Ecology and Aquaculture. 2006, pp. 1-44.

[24122] T. R. Waller and G. D. Stanley. "Middle Triassic pteriomorphian Bivalvia (Mollusca) from the New Pass Range, west-central Nevada: systematics, biostratigraphy, paleoecology, and paleobiogeography". In: Journal of Paleontology 79.Supplement (2005), pp. 1-64.

[24123] D. Walossek, I. Hinz-Schallreuter, J. H. Shergold, and K. J. Muller. Three-dimensional preservation of arthropod integument from the Middle Cambrian of Australia. 1993.

[24124] D. Walossek, C. S. Li, and C. Brauckmann. "A scorpion from the Upper Devonian of Hubei Province, China (Arachnida, Scorpionida)". English. In: Neues Jahrbuch für Geologie und Paläontologie, Montashefte 1990.3 (1990), pp. 169-180.

[24125] D. Walossek and H. Szaniawski. Cambrocaris baltica n. gen. n. sp., a possible stem-lineage crustacean from the Upper Cambrian of Poland. 1991.

[24126] S. Walsh and D. Naish. "Fossil seals from late Neogene deposits in South America: A new pinniped (Carnivora, Mammalia) assemblage from Chile". English. In: Palaeontology 45.4 (2002), pp. 821842.

[24127] S. A. Walsh and J. P. Hume. "A new Neogene marine avian assemblage from north-central Chile". English. In: Journal of Vertebrate Paleontology 21.3 (2001), pp. 484-491.

[24128] S. A. Walsh and M. Suárez. "First postMesozoic record of Crocodyliformes from Chile". English. In: Acta Palaeontologica Polonica 50.3 (2005), pp. 595-600.

[24129] S. A. Walsh and M. E. Suarez. "New penguin remains from the Pliocene of Northern Chile". English. In: Historical Biology 18.2 (2006), pp. 115-126.

[24130] S. L. Walsh. "Late Eocene mammals from the Sweetwater Formation, San Diego County, California". English. In: Pacific Section SEPM 68 (1991), pp. 149-160.

[24131] S. L. Walsh. "Eocene mammal faunas of San Diego County". English. In: Pacific Section SEPM 68 (1991), pp. 161-178.

[24132] S. L. Walsh. "New myomorph rodents from the Eocene of Southern California". English. In: Journal of Vertebrate Paleontology 30.5 (2010), pp. 1610-1621.

[24133] B. Walter. "La faune de bryozoaires de la transgression hauterivienne dans le Bassin de Paris [The bryozoan fauna of the Hauterivian transgression in the Paris Basin]". French. In: Géobios 29.1 (1996), pp. 5-11.

[24134] B. Walter. “Une faune berriasienne de bryozoaires á Musiéges (Jura méridional, Haute-Savoie) [A Berriasian bryozoan fauna from Musiéges (Southern Jura, Haute-Savoie)]". French. In: Géobios 30.3 (1997), pp. 371-377. 
[24135] B. Walter. “Une nouvelle faune de bryozoaires de l’Hauterivien inférieur du Jura [A new bryozoan fauna from the lower Hauterivian of the Jura]". French. In: Géobios 26.5 (1993), pp. 555-574.

[24136] B. Walter. “Les Bryozoaires de l'Urgonien Inferieur de Vaulion (Jura Vaudois, Suisse) - un premier pas vers les faunes barremo-aptiennes [Bryozoa of the Lower Urgonian from Vaulion (Vaudois Jura, Switzerland) - a first step towards the Barremian-Aptian faunas]". French. In: Palaeontographica Abteilung A 226.1-3 (1993), pp. 55-75.

[24137] M. R. Walter, D. U. Rulin, and R. J. Horodyski. “Coiled carbonaceous megafossils from the Middle Proterozoic of Jixian (Tianjin) and Montana". In: American Journal of Science 290-A (1990), pp. 133148.

[24138] A. H. Walton. "Pauromys and other small Sciuravidae (Mammalia: Rodentia) from the middle Eocene of Texas". English. In: Journal of Vertebrate Paleontology 13.2 (1993), pp. 243-261.

[24139] A. H. Walton. "Pauromys and Other Small Sciuravidae (Mammalia: Rodentia) from the Middle Eocene of Texas". English. In: Journal of Vertebrate Paleontology 13.2 (1993), pp. 243-261.

[24140] A. H. Walton. "Rodents of the La Venta Fauna, Miocene, Colombia: Biostratigraphy and Paleoenvironmentl implications". English. PhD thesis. 1990, pp. 1-147.

[24141] B. Wang. "New mollusks and problematic fossils from the Lower Cambrian of China". In: Paleontological Journal 28.4 (1994), pp. 10-17.

[24142] B. Wang. “Discovery of Yindirtemys (Ctenodactylidae, Rodentia, Mammalia) from Late Oligocene of Nei Mongol, China". English. In: Vertebrata PalAsiatica 29.4 (1991), pp. 296-302.

[24143] B. Wang and M. R. Dawson. "A primitive cricetid (Mammalia: Rodentia) from the Middle Eocene of Jiangsu Province, China". English. In: Annals of Carnegie Museum 63.3 (1994), pp. 239-256.

[24144] B. Wang, J. A. Dunlop, P. A. Selden, R. J. Garwood, W. A. Shear, P. Müller, and X. J. Lei. “Cretaceous arachnid Chimerarachne yingi gen. et sp. nov. illuminates spider origins". English. In: Nature Ecology \& Evolution 2.4 (2018), pp. 614-622.

[24145] B. Wang and R. J. Emry. "Eomyidae (Rodentia: Mammalia) from the Oligocene of Nei Mongol, China". English. In: Journal of Vertebrate Paleontology 11.3 (1991), pp. 370-377.

[24146] B. Wang, J. Kathirithamby, and M. S. Engel. “The first twisted-wing parasitoid in Eocene amber from north-eastern China (Strepsiptera: Myrmecolacidae)". English. In: Journal of Natural History 50 (2016), pp. 1305-1313.

[24147] B. Wang and C. Li. "First Paleogene Mammalian Fauna from Northeast China". English. In: Vertebrata PalAsiatica 28.3 (1990), pp. 165-205.

[24148] B. Wang, J. Y. Ma, D. D. McKenna, E. V. Yan, H. C. Zhang, and E. A. Jarzembowski. “The earliest known longhorn beetle (Cerambycidae: Prioninae) and implications for the early evolution of Chrysomeloidea". English. In: Journal of Systematic Palaeontology 12 (2014), pp. 565-574.

[24149] B. Wang, A. G. Ponomarenko, and H. C. Zhang. "Middle Jurassic Coptoclavidae (Insecta: Coleoptera: Dytiscoidea) from China: a good example of mosaic evolution". English. In: Acta Geologica Sinica 84 (2010), pp. 680-687.

[24150] B. Wang, A. G. Ponomarenko, and H. C. Zhang. "A new coptoclavid larva (Coleoptera: Adephaga: Dytiscoidea) from the Middle Jurassic of China, and its phylogenetic implication". English. In: Paleontological Journal 43 (2009), pp. 652-659.

[24151] B. Wang and Z. Qiu. “Notes on Early Oligocene ursids (Carnivora, Mammalia) from Saint Jacques, Nei Mongol, China". English. In: Bulletin of the American Museum of Natural History 279 (2003), pp. 116-124.

[24152] B. Wang, J. Szwedo, and H. C. Zhang. "Jurassic Progonocimicidae (Hemiptera) from China and phylogenetic evolution of Coleorrhyncha". English. In: Science in China Series D: Earth Sciences 52 (2009), pp. 1953-1961.

[24153] B. Wang, J. Szwedo, and H. C. Zhang. "New Jurassic Cercopoidea from China and their evolutionary significance (Insecta: Hemiptera)". English. In: Palaeontology 55 (2012), pp. 1223-1243. 
[24154] B. Wang, F. Y. Xia, T. Wappler, E. Simon, H. C. Zhang, E. A. Jarzembowski, and J. Szwedo. “Brood care in a 100-million-year-old scale insect". English. In: eLife 4 (2015), e05447.

[24155] B. Wang, Z. Yan, Y. Lu, and G. Chen. "Discovery of two mid-Tertiary mammalian faunas from Haiyuan, Ningxia, China". Chinese. In: Vertebrata PalAsiatica 32.4 (1994), pp. 285-296.

[24156] B. Wang, R. Zhai, and M. R. Dawson. “Discovery of Ischyromyinae (Rodentia, Mammalia) from the Middle Eocene of North China". English. In: Vertebrata PalAsiatica 36.1 (1998), pp. 1-12.

[24157] B. Wang, H. Zhang, Y. Fang, D. Wang, and S. Ji. “New data on Cretaceous Palaeontinidae (Insecta: Hemiptera) from China". English. In: Cretaceous Research 29 (2008), pp. 551-560.

[24158] B. Wang, H. Zhang, and D. Azar. “The First Psychodidae (Insecta: Diptera) from the Lower Eocene Fushun Amber of China". English. In: Journal of Paleontology 85.6 (2011), pp. 1154-1159.

[24159] B. Wang, H. C. Zhang, and Y. Fang. "Paleogeographical distribution of Mesozoic Palaeontinidae (Insecta, Hemiptera) in China with description of new taxa". English. In: Acta Geologica Sinica 84 (2009), pp. 31-37.

[24160] B. Wang, H. C. Zhang, and Y. Fang. "Some Jurassic Palaeontinidae (Insecta, Hemiptera) from Daohugou, Inner Mongolia, China". English. In: Palaeoworld 15 (2006), pp. 115-125.

[24161] B. Wang, H. C. Zhang, and Y. Fang. "Middle Jurassic Palaeontinidae (Insecta, Hemiptera) from Daohugou of China". English. In: Alavesia 1 (2007), pp. 89-104.

[24162] B. Wang, H. C. Zhang, Y. Fang, and Y. T. Zhang. "A revision of Palaeontinidae (Insecta: Hemiptera: Cicadomorpha) from the Jurassic of China with descriptions of new taxa and new combinations". English. In: Geological Journal 43 (2008), pp. 1-18.

[24163] B. Wang, H. C. Zhang, and J. Szwedo. "Jurassic Palaeontinidae from China and the higher systematics of Palaeontinoidea (Insecta: Hemiptera: Cicadomorpha)". English. In: Palaeontology 52 (2009), pp. 53-64.

[24164] B. Wang, H. C. Zhang, and Y. Fang. "Gansucossus, a replacement name for Yumenia Hong, 1982 (Insecta, Hemiptera, Palaeontinidae), with description of a new genus". English. In: Zootaxa 1268 (2006), pp. 59-68.

[24165] B. Wang and H. C. Zhang. "A remarkable new genus of Procercopidae (Hemiptera: Cercopoidea) from the Middle Jurassic of China". English. In: Comptes Rendus Palevol 8 (2009), pp. 389-394.

[24166] B. Wang and H. C. Zhang. "Tettigarctidae (Insecta: Hemiptera: Cicadoidea) from the Middle Jurassic of Inner Mongolia, China". English. In: Geobios 42 (2009), pp. 243-253.

[24167] B. Wang and H. C. Zhang. "The Oldest Tenebrionoidea (Coleoptera) from the Middle Jurassic of China". English. In: Journal of Paleontology 85.2 (2011), pp. 266-270.

[24168] B. Wang and H. C. Zhang. "A new ground beetle (Carabidae, Protorabinae) from the Lower Cretaceous of Inner Mongolia, China". English. In: ZooKeys 130 (2011), pp. 229-237.

[24169] B. Wang and H. C. Zhang. "Earliest evidence of fishflies (Megaloptera: Corydalidae): an exquisitely preserved larva from the Middle Jurassic of China". English. In: Journal of Paleontology 84.4 (2010), pp. 774-780.

[24170] B. Wang, H. C. Zhang, and A. G. Ponomarenko. "Mesozoic Trachypachidae (Insecta: Coleoptera) from China". English. In: Palaeontology 55 (2012), pp. 341-353.

[24171] B. Wang, H. C. Zhang, T. Wappler, and J. Rust. "Palaeontinidae (Insecta: Hemiptera: Cicadomorpha) from the Upper Jurassic Solnhofen Limestone of Germany and their phylogenetic significance". English. In: Geological Magazine 147.4 (2010), pp. 570-580.

[24172] B. Wang, H. C. Zhang, Y. Fang, and Y. Duan. "Revision of the genus Sinopalaeocossus Hong (Hemiptera: Palaeontinidae), with description of a new species from the Middle Jurassic of China". English. In: Zootaxa 1349 (2006), pp. 37-45.

[24173] B. Wang, H. C. Zhang, and Y. Fang. "Palaeontinodes reshuitangensis, a new species of Palaeontinidae (Hemiptera, Cicadomorpha) from the Middle Jurassic of Reshuitang and Daohugou of China". English. In: Zootaxa 1500 (2007), pp. 61-68. 
[24174] B. Wang, H. C. Zhang, Y. Fang, and Z. L. Zhang. "A new genus and species of Palaeontinidae (Insecta: Hemiptera) from the Middle Jurassic of Daohugou, China". English. In: Annales Zoologici 56 (2006), pp. 757-762.

[24175] B.-Y. Wang. "Additional rodent material from Houldjin Formation of Erenhot, Nei Mongol, China". English. In: Vertebrata PalAsiatica 46.1 (2008), pp. 21-30.

[24176] B.-Y. Wang. "Late Eocene cricetids (Rodentia, Mammalia) from Nei Mongol, China". English. In: Vertebrata PalAsiatica 45.3 (2007), pp. 195-212.

[24177] B.-Y. Wang. "Late Eocene lagomorphs from Nei Mongol, China”. English. In: Vertebrata PalAsiatica 45.1 (2007), pp. 43-58.

[24178] B.-Y. Wang. "Ageitonomys neimongolensis gen. et sp. nov. (Ctenodactyloidea, Rodentia, Mammalia) from Early Oligocene of Nei Mongol, China". English. In: Vertebrata PalAsiatica 48.1 (2010), pp. 79-83.

[24179] B.-Y. Wang. "First record of Late Eocene insectivores and chiropteres from Nei Mongol, China". English. In: Vertebrata PalAsiatica 46.4 (2008), pp. 249-264.

[24180] B.-Y. Wang. "First record of primate fossils from Late Eocene in Eren Region, Nei Mongol, China". English. In: Vertebrata PalAsiatica 46.2 (2008), pp. 81-89.

[24181] B.-Y. Wang. "Discovery of Late Oligocene Eomyodon (Rodentia, Mammalia) from the Danghe Area, Gansu, China". English. In: Vertebrata PalAsiatica 40.2 (2002), pp. 139-145.

[24182] B.-Y. Wang. "Dipodidae (Rodentia, Mammalia) from the mid-Tertiary deposits in Danghe Area, Gansu, China". English. In: Vertebrata PalAsiatica 41.2 (2003), pp. 89-103.

[24183] B.-Y. Wang. "Late Eocene ctenodactyloids (Rodentia, Mammalia) from Qujing, Yunnan, China". English. In: Vertebrata PalAsiatica 39.1 (2001), pp. 24-42.

[24184] B.-Y. Wang. "A skull of Embolotherium (Perissodactyla, Mammalia) from Erden Obo, Nei Mongol, China". English. In: Vertebrata PalAsiatica 38.3 (2000), pp. 237-240.

[24185] B.-Y. Wang. "Eocene ctenodactyloids (Rodentia, Mammalia) from Nei Mongol, China". English. In: Vertebrata PalAsiatica 39.2 (2001), pp. 98-114.

[24186] B.-Y. Wang. "Oligocene rodents from the Nomogen ( =Nom Khong) Area of Nei Mongol, China, and comments on related stratigraphy". English. In: Vertebrata PalAsiatica 41.3 (2003), pp. 211-219.

[24187] B.-Y. Wang and D. Dashzeveg. "New Oligocene sciurids and aplodontids (Rodentia, Mammalia) from Mongolia". English. In: Vertebrata PalAsiatica 43.2 (2005), pp. 85-99.

[24188] B.-Y. Wang and J. Meng. "Ardynomys (Cylindrodontidae, Rodentia) from Nei Mongol, China". English. In: Vertebrata PalAsiatica 47.3 (2009), pp. 240-244.

[24189] B.-Y. Wang and Z.-X. Qiu. "Discovery of early Oligocene mammalian fossils from Danghe area, Gansu, China". Chinese. In: Vertebrata PalAsiatica 42.2 (2004), pp. 130-143.

[24190] B.-Y. Wang and Z.-X. Qiu. "A new species of Entelodontidae (Artiodactyla ,Mammalia) from Late Eocene of Nei Mongol, China”. English. In: Vertebrata PalAsiatica 40.3 (2002), pp. 194-202.

[24191] B.-Y. Wang and Z.-X. Qiu. “Dipodidae (Rodentia, Mammalia) from the Lower Member of Xianshuihe Formation in Lanzhou Basin, Gansu, China". English. In: Vertebrata PalAsiatica 38.1 (2000), pp. 10-35.

[24192] B.-Y. Wang and Z.-X. Qiu. "Micromammal fossils from red mudstone of Lower Member of Xianshuihe Formation in Lanzhou Basin, China". English. In: Vertebrata PalAsiatica 38.4 (2000), pp. 255273.

[24193] B.-Y. Wang, Z.-X. Qiu, Q. -Z. Zhang, L. -J. Wu, and P. -J. Ning. “Large mammals found from Houldjin Formation near Erenhot, Nei Mongol, China". English. In: Vertebrata PalAsiatica 47.2 (2009), pp. 85-110.

[24194] B.-Y. Wang and P.-Y. Wang. "Discovery of early medial Oligocene mammalian fauna from Kekeamu, Alxa Left Banner, Nei Mongol". Chinese. In: Vertebrata PalAsiatica 29.1 (1991), pp. 64-71. 
[24195] C. Wang, C. K. Shih, and D. Ren. "A new fossil hangingfly (Mecoptera: Cimbrophlebiidae) from the Early Cretaceous of China". English. In: Acta Geologica Sinica 88 (2014), pp. 29-34.

[24196] C. Wang, C. K. Shih, A. P. Rasnitsyn, and M. Wang. "Two new species of Prolyda from the Middle Jurassic of China (Hymenoptera, Pamphilioidea)". English. In: ZooKeys 569 (2016), pp. 71-80.

[24197] C. D. Wang and D. Ren. “Nuurcala obesa sp. n. (Blattida, Caloblattinidae) from the Lower Cretaceous Yixian Formation in Liaoning Province, China". English. In: ZooKeys 318 (2013), pp. 3546.

[24198] C. Y. Wang, K. Weddige, and M. Chuluun. "Age revision of some Palaeozoic strata of Mongolia based on conodonts". English. In: Journal of Asian Earth Sciences 25.5 (2005), pp. 759-771.

[24199] D.-M. Wang and S.-G. Hao. "A new species of vascular plants from the Xujiachong Formation (Lower Devonian) of Yunnan Province, China". In: Review of Palaeobotany and Palynology 114 (2001), pp. 157-174.

[24200] F. Y. Wang, J. Chen, X. Dai, and H. J. Song. "A new Dienerian (Early Triassic) brachiopod fauna from South China and implications for biotic recovery after the Permian-Triassic extinction". English. In: Papers in Palaeontology 3 (2017), pp. 425-439.

[24201] F. Y. Wang, C. K. Shih, D. Ren, and Y. J. Wang. “Quantitative assessments and taxonomic revision of the genus Archirhagio with a new species from Daohugou, China (Diptera: Archisargidae)". English. In: Systematic Entomology 42 (2017), pp. 230-239.

[24202] G. Wang, Y. Li, S. Kershaw, and X. Deng. “Global reef recovery after the end-Ordovician extinction: evidence from late Aeronian coral-stromatoporoid reefs in South China". English. In: Geologiska Föreningen i Stockholm Förhandlingar 136.1 (2014), pp. 286-289. DOI: 10.1080/11035897.2013.853687.

[24203] G. Wang, I. G. Percival, and Y. Y. Zhen. "The youngest Ordovician (latest Katian) coral fauna from eastern Australia, in the uppermost Malachis Hill Formation of central New South Wales". English. In: Alcheringa 44.3 (2020), pp. 356-378. DOI: 10.1080/03115518.2020.1747540.

[24204] G. Wang, R. Zhan, Z. Deng, and C. Yu. "Latest Ordovician and earliest Silurian tabulate corals of South China". English. In: GFF - Journal of the Geological Society of Sweden 136.1 (2014).

[24205] G. F. Wang, H. L. You, S. G. Pan, and T. Wang. "A new crested theropod dinosaur from the Early Jurassic of Yunnan Province, China". English. In: Vertebrata PalAsiatica 55.2 (2017), pp. 177-186.

[24206] G.-X. Wang, R.-B. Zhan, Z. -Q. Deng, and J. -B. Liu. “Paleoecological associations of middle Llandovery (Silurian) corals from Huaying Mountain, eastern Sichuan Province". English. In: Science China Earth Sciences 56.4 (2013), pp. 640-646. DOI: 10.1007/s11430-012-4567-0.

[24207] H. Wang, B. Bai, J. Meng, and Y. Wang. “Earliest known unequivocal rhinocerotoid sheds new light on the origin of Giant Rhinos and phylogeny of early rhinocerotoids". English. In: Scientific Reports 6 (2016), 39607:1-9.

[24208] H. Wang and D. L. Dilcher. "Aquatic Angiosperms from the Dakota Formation (Albian, Lower Cretaceous), Hoisington III locality, Kansas, USA". English. In: International Journal of Plant Sciences 167.2 (2006), pp. 385-401.

[24209] H. Wang, Y. Fang, Q. Q. Zhang, X. K. Lei, B. Wang, E. A. Jarzembowski, and H. C. Zhang. “New material of Sigmaboilus (Insecta, Orthoptera, Prophalangopsidae) from the Jurassic Daohugou Beds, Inner Mongolia, China". English. In: Earth and Environmental Science Transactions of the Royal Society of Edinburgh 107 (2018), pp. 177-183.

[24210] H. Wang, Y. Fang, B. Wang, and H. C. Zhang. "The first discovery of Termitidiinae (Insecta, Orthoptera, Prophalangopsidae) from the Lower Cretaceous of China". English. In: Cretaceous Research 89 (2018), pp. 148-153.

[24211] H. Wang, Y. Fang, B. Wang, and H. C. Zhang. “The Jurassic orthopteran Allaboilus gigantus Ren and Meng, 2006 (Prophalangopsidae) from Beipiao, northeast China and its biostratigraphical significance". English. In: Proceedings of the Geologists' Association 129 (2018), pp. 629-634. 
[24212] H. Wang, Y. N. Fang, Y. Fang, E. A. Jarzembowski, B. Wang, and H. C. Zhang. "The earliest fossil record of true crickets belonging to the Baissogryllidae (Insecta, Orthoptera, Grylloidea)". English. In: Geological Magazine 156 (2019), pp. 1440-1444. DOI: 10.1017/S0016756818000754.

[24213] H. Wang, X. J. Lei, G. Q. Zhang, C. P. Xu, Y. Fang, and H. C. Zhang. “The earliest Gryllotalpinae (Insecta, Orthoptera, Gryllotalpidae) from mid-Cretaceous Burmese amber". English. In: Cretaceous Research 107.104292 (2019). DOI: 10.1016/j.cretres.2019.104292.

[24214] H. Wang, S. Li, Q. Zhang, Y. Fang, B. Wang, and H. C. Zhang. “A new species of Aboilus (Insecta, Orthoptera) from the Jurassic Daohugou beds of China, and discussion of forewing coloration in Aboilus". English. In: Alcheringa 39 (2015), pp. 250-258.

[24215] H. Wang, L. Shao, L. Hao, P. Zhang, I. J. Glasspool, J. R. Wheeley, P. B. Wignall, T. Yi, M. Zhang, and J. Hilton. "Sedimentology and sequence stratigraphy of the Lopingian (Late Permian) coal measures in southwestern China". English. In: International Journal of Coal Geology 85.1 (2011), pp. 168-183. DOI: 10.1016/j.coal.2010.11.003.

[24216] H. Wang, Z. Zhang, L. E. Holmer, S. Hu, X. Wang, and G. Li. "Peduncular attached secondary tiering acrotretoid brachiopods from the Chengjiang fauna: implications for the ecological expansion of brachiopods during the Cambrian explosion". English. In: Palaeogeography, Palaeoclimatology, Palaeoecology 323-325 (2012), pp. 60-67.

[24217] H. Wang, D. R. Zheng, X. D. Hou, X. J. Lei, Q. Q. Zhang, B. Wang, Y. Fang, E. A. Jarzembowski, and H. C. Zhang. "The Early Cretaceous orthopteran Parahagla sibirica Sharov, 1968 (Prophalangopsidae) from the Jiuquan Basin of China and its palaeogeographic significance". English. In: Cretaceous Research 57 (2016), pp. 40-45.

[24218] H. Wang, D. R. Zheng, X. J. Lei, Q. Q. Zhang, X. Y. Ren, B. Wang, Y. Fang, E. A. Jarzembowski, and H. C. Zhang. "A new species of Chifengiinae (Orthoptera: Prophalangopsidae) from the Lower Cretaceous Zhonggou Formation of the Jiuquan Basin, northwest China". English. In: Cretaceous Research 73 (2017), pp. 60-64.

[24219] H. Y. Wang and Y. G. Jin. "On Permianellids (Brachiopoda)". Chinese. In: Acta Palaeontologica Sinica 30.4 (1991), pp. 481-501.

[24220] H.-B. Wang, B. Bai, J. Meng, and Y. -Q. Wang. “A New Species of Forstercooperia (Perissodactyla: Paraceratheriidae) from Northern China with a Systematic Revision of Forstercooperiines". English. In: American Museum Novitates 3897 (2018), pp. 1-41.

[24221] J. Wang. "A new species of Eudinoceras (Pantodonta, Mammalia) from Sishui Shandong Province". English. In: Vertebrata PalAsiatica 32.3 (1994), pp. 200-208.

[24222] J. Wang, O. Béthoux, D. Ren, and Y. Y. Cui. "An insect wing discovered in the Early Permian Taiyuan Formation (Shanxi Province, China)". English. In: Fossil Record 22 (2019), pp. 73-76. DOI: 10.5194/fr-22-73-2019.

[24223] J. Wang, Y. Li, Y. Zhang, and S. Kershaw. "A Middle Ordovician (Darriwilian) Calathium reef complex on the carbonate ramp of the northwestern Tarim Block, northwest China: A sedimentological approach". English. In: Palaeogeography, Palaeoclimatology, Palaeoecology 474 (2016), pp. 1286.

[24224] J. Wang and Y. Tong. "A new phenacodontid condylarth (Mammalia) from the Early Eocene of the Wutu Basin, Shandong". English. In: Vertebrata PalAsiatica 35.4 (1997), pp. 283-289.

[24225] J. Wang and Y. Tong. "A new lophialetid perissodactyl (Mammalia) from the Early Eocene of Wutu Basin, Shandong Province". English. In: Vertebrata PalAsiatica 34.4 (1996), pp. 312-321.

[24226] J. J. Wang, W. T. Zhang, L. S. Wang, and D. Ren. "A new caddisfly (Trichoptera: Polycentropodidae) from Upper Cretaceous amber of Myanmar". English. In: Cretaceous Research 99 (2019), pp. 347-351. DOI: 10.1016/j.cretres.2019.01.021.

[24227] K. B. Wang, Y. X. Zhang, J. Chen, S. Q. Chen, and P. Y. Wang. “A new ankylosaurian from the Late Cretaceous strata of Zhucheng, Shandong Province". Chinese. In: Geological Bulletin of China 39.7 (2020), pp. 958-962. 
[24228] L. Wang, L. Li, Y. Duan, and S. -L. Cheng. "A new iodactylid pterosaur from western Liaoning". English. In: Geological Bulletin of China 25.6 (2006), pp. 737-740.

[24229] M. Wang. "Bivalve fauna from uppermost Permian and lowermost Triassic of Fenghai, Yong'an, Fujian". In: Acta Palaeontologica Sinica 32.4 (1993), pp. 471-475.

[24230] M. Wang, H. Hu, and Z. -H. Li. "A new small enantiornithine bird from the Jehol Biota, with implications for early evolution of avian skull morphology". English. In: Journal of Systematic Palaeontology 14.6 (2014), pp. 481-497. DOI: 10.1080/14772019.2015.1073801.

[24231] M. Wang, D. Li, J. K. O'Connor, Z. Zhou, and H. You. "Second species of enantiornithine bird from the Lower Cretaceous Changma Basin, northwestern China with implications for the taxonomic diversity of the Changma avifauna". English. In: Cretaceous Research 55 (2015), pp. 56-65.

[24232] M. Wang, G. Mayr, J. Zhang, and Z. Zhou. "New bird remains from the Middle Eocene of Guangdong, China". English. In: Acta Palaeontologica Polonica 57.3 (2012), pp. 519-526.

[24233] M. Wang and G. Mayr. "Two new skeletons of the enigmatic, rail-like avian taxon Songzia Hou, 1990 (Songziidae) from the early Eocene of China". English. In: Alcheringa 36.4 (2012), pp. 487-499. DOI: $10.1080 / 03115518.2012 .673302$.

[24234] M. Wang, J. K. O'Connor, and Z. Zhou. "A new robust enantiornithine bird from the Lower Cretaceous of China with scansorial adaptations". English. In: Journal of Vertebrate Paleontology 34.3 (2014), pp. 657-671.

[24235] M. Wang, J. K. O'Connor, Y. -H. Pan, and Z. -H. Zhou. “A bizarre Early Cretaceous enantiornithine bird with unique crural feathers and an ornithuromorph plough-shaped pygostyle". English. In: Nature Communications 8 (2017), p. 14141. DOI: 10.1038/ncomms14141.

[24236] M. Wang, J. K. O'Connor, S. Zhou, and Z. -H. Zhou. “New toothed Early Cretaceous ornithuromorph bird reveals intraclade diversity in pattern of tooth loss". English. In: Journal of Systematic Palaeontology (2020). DOI: 10.1080/14772019.2019.1682696.

[24237] M. Wang, J. K. O'Connor, X. Xu, and Z. Zhou. "A new Jurassic scansoriopterygid and the loss of membranous wings in theropod dinosaurs". English. In: Nature 568 (2019). DOI: 10.1038/s41586019-1137-z.

[24238] M. Wang, A. P. Rasnitsyn, and D. Ren. "A new sawfly fossil from the Lower Cretaceous of China elucidates antennal evolution in the lower Hymenoptera (Pamphilioidea: Praesiricidae: Archoxyelydinae subfam. n.)" English. In: Systematic Entomology 38 (2013), pp. 577-584.

[24239] M. Wang, A. P. Rasnitsyn, C. Shih, and D. Ren. "A new Cretaceous genus of xyelydid sawfly illuminating nygmata evolution in Hymenoptera". English. In: BMC Evolutionary Biology 14 (2014), pp. 131-150. DOI: 10.1186/1471-2148-14-131.

[24240] M. Wang, A. P. Rasnitsyn, C. K. Shih, and D. Ren. "A new fossil genus in Pamphiliidae (Hymenoptera) from China". English. In: Alcheringa 38 (2014), pp. 391-397.

[24241] M. Wang, A. P. Rasnitsyn, and D. Ren. "Two new fossil sawflies (Hymenoptera, Xyelidae, Xyelinae) from the Middle Jurassic of China". English. In: Acta Geologica Sinica 88 (2014), pp. 1027-1033.

[24242] M. Wang, A. P. Rasnitsyn, C. K. Shih, and D. Ren. "Revision of the Genus Rudisiricius (Hymenoptera, Praesiricidae) with six new species from Jehol Biota, China". English. In: Cretaceous Research 52 (2015), pp. 570-578.

[24243] M. Wang, A. P. Rasnitsyn, C. K. Shih, and D. Ren. "New xyelydid sawflies from the Lower Cretaceous of China". English. In: Cretaceous Research 54 (2015), pp. 169-178.

[24244] M. Wang, A. P. Rasnitsyn, C. K. Shih, and D. Ren. “New fossil records of bizarre Ferganolyda (Hymenoptera: Xyelydidae) from the Middle Jurassic of China". English. In: Alcheringa 39 (2015), pp. 99-108.

[24245] M. Wang, A. P. Rasnitsyn, C. K. Shih, M. J. Sharkey, and D. Ren. “New fossils from China elucidating the phylogeny of Praesiricidae (Insecta: Hymenoptera)". English. In: Systematic Entomology 41 (2016), pp. 41-55. 
[24246] M. Wang, A. P. Rasnitsyn, H. Li, C. K. Shih, M. J. Sharkey, and D. Ren. “Phylogenetic analyses elucidate the inter-relationships of Pamphilioidea (Hymenoptera, Symphyta)". English. In: Cladistics 32 (2016), pp. 239-260.

[24247] M. Wang, A. P. Rasnitsyn, Z. Q. Yang, C. K. Shih, H. B. Wang, and D. Ren. “Mirolydidae, a new family of Jurassic pamphilioid sawfly (Hymenoptera) highlighting mosaic evolution of lower Hymenoptera". English. In: Scientific Reports 7.43944 (2017), pp. 1-9.

[24248] M. Wang, A. P. Rasnitsyn, G. Han, and D. Ren. "A new genus and species of basal horntail (Hymenoptera, Siricidae) from the Lower Cretaceous of China". English. In: Cretaceous Research 91 (2018), pp. 195-201.

[24249] M. Wang, A. P. Rasnitsyn, H. C. Zhang, C. K. Shih, and D. Ren. "Revising the systematic position of the extinct family Daohugoidae (basal Hymenoptera)". English. In: Journal of Systematic Palaeontology 17 (2019), pp. 1025-1035. DOI: 10.1080/14772019.2018.1523238.

[24250] M. Wang, C. K. Shih, and D. Ren. “Platyxyela gen. nov. (Hymenoptera, Xyelidae, Macroxyelinae) from the Middle Jurassic of China". English. In: Zootaxa 3456 (2012), pp. 82-88.

[24251] M. Wang, T. A. Stidham, and Z. Zhou. "A new clade of basal Early Cretaceous pygostylian birds and developmental plasticity of the avian shoulder girdle". English. In: Proceedings of the National Academy of Sciences 115.42 (2018), pp. 10708-10713. DOI: 10.1073/pnas.1812176115.

[24252] M. Wang, X.-L. Wang, Y. Wang, and Z. -H. Zhou. "A new basal bird from China with implications for morphological diversity in early birds". English. In: Scientific Reports 6 (2016), p. 19700. DOI: 10.1038/srep19700.

[24253] M. Wang, X. Zheng, J. K. O'Connor, G. T. Lloyd, X. Wang, Y. Wang, X. Shang, and Z. Zhou. “The oldest record of Ornithuromorpha from the Early Cretaceous of China". English. In: Nature Communications 6.6987 (2015). DOI: 10.1038/ncomms7987.

[24254] M. Wang and Z. Zhou. "A morphological study of the first known piscivorous enantiornithine bird from the Early Cretaceous of China". English. In: Journal of Vertebrate Paleontology 37.2 (2017), e1278702:1-13. DOI: 10.1080/02724634.2017.1278702.

[24255] M. Wang, Z.-H. Zhou, and G. -H. Xu. “The first enantiornithine bird from the Upper Cretaceous of China". English. In: Journal of Vertebrate Paleontology 34.1 (2014), pp. 135-145. DOI: 10.1080 / 02724634.2013.794814.

[24256] M. Wang, Z.-H. Zhou, J. K. O'Connor, and N. V. Zelenkov. “A new diverse enantiornithine family (Bohaiornithidae fam. nov.) from the Lower Cretaceous of China with information from two new species". English. In: Vertebrata PalAsiatica 52.1 (2014), pp. 31-76.

[24257] M. Wang, Z.-H. Zhou, and S. Zhou. "A new basal ornithuromorph bird (Aves: Ornithothoraces) from the Early Cretaceous of China with implication for morphology of early Ornithuromorpha". English. In: 176.1 (2016), pp. 207-223. DOI: 10.1111/zoj.12302.

[24258] M. Wang and Z.-H. Zhou. "A new confuciusornithid (Aves: Pygostylia) from the Early Cretaceous increases the morphological disparity of the Confuciusornithidae". English. In: Zoological Journal of the Linnean Society (2018).

[24259] M. Wang and Z.-H. Zhou. “A new enantiornithine (Aves: Ornithothoraces) with completely fused premaxillae from the Early Cretaceous of China". English. In: Journal of Systematic Palaeontology 17.15 (2019), pp. 1299-1312. DOI: 10.1080/14772019.2018.1527403.

[24260] M. L. Wang, L. F. Li, and C. K. Shih. "New fossil wasps (Hymenoptera, Apocrita) from the Middle Jurassic of China". English. In: Insect Systematics \& Evolution 46 (2015), pp. 471-484.

[24261] M. M. Wang, O. Béthoux, S. Bradler, F. M. B. Jacques, Y. Y. Cui, and D. Ren. "Under cover at pre-angiosperm times: a cloaked phasmatodean insect from the Early Cretaceous Jehol Biota". English. In: PLoS One 9.3 (2014), e91290.

[24262] M. Q. Wang. "Late Permian and early Early Triassic ammonoid fauna of Fenghai, Yong'an, Fujian and their stratigraphic significance". Chinese. In: Acta Palaeontologica Sinica 29 (1990), pp. 755-773. 
[24263] M. X. Wang, J. H. Liang, D. Ren, and C. K. Shih. “New fossil Vitimotauliidae (Insecta: Trichoptera) from the Jehol Biota of Liaoning Province, China". English. In: Cretaceous Research 30 (2009), pp. 592598.

[24264] M. X. Wang, Y. Y. Zhao, and D. Ren. “New fossil caddisfly from Middle Jurassic of Daohugou, Inner Mongolia, China (Trichoptera: Philopotamidae)". English. In: Progress in Natural Science 19 (2009), pp. 1427-1431.

[24265] N. Wang, J. Fan, and W. Wang. “Early Carboniferous Fishes (Acanthodian, Actinopterygians, and Chondrichthyes) from the East Sector of North Qilian Mountain, China". English. In: Vertebrata PalAsiatica 42.2 (2004), pp. 89-110.

[24266] N. Wang, F. Jin, W. Wang, and X. Zhu. "Actinopterygian Fishes from the Permian-Triassic Boundary Beds in Zhejiang and Jiangxi Provinces, South China and Mass Extinction, Recovery and Radiation". English. In: Vertebrata PalAsiatica 45.4 (2007), pp. 307-329.

[24267] N. Wang, X. Zhu, F. Jin, and W. Wang. "Chondrichthyan microremains under Permian Triassic Boundary both in Zhejiang and Jiangxi Provinces, China - Fifth report on the fish sequence study near the Permian-Triassic boundary in South China". English. In: Vertebrata PalAsiatica 45.1 (2007), pp. 13-36.

[24268] N. Z. Wang, X. Zhang, M. Zhu, and W. J. Zhao. “A new articulated hybodontoid from Late Permian of northwestern China". English. In: Acta Zoologica 90.1 (2009), pp. 159-170.

[24269] Q. Wang, C. K. Shih, and D. Ren. "The earliest case of extreme sexual display with exaggerated male organs by two Middle Jurassic mecopterans". English. In: PLoS One 8.8 (2013), e71378. DOI: 10.1371/journal.pone.0071378.

[24270] Q. Wang, X. Wang, Z. Zhao, and Y. Jiang. "A new oofamily of dinosaur egg from the Upper Cretaceous of Tiantai Basin, Zhejiang Province, and its mechanism of eggshell formation". English. In: Chinese Science Bulletin 57.28-29 (2012), pp. 3740-3747. DOI: 10.1007/s11434-012-5353-2.

[24271] Q. Wang, X.-L. Wang, Z. -K. Zhao, and Y. -G. Jiang. "[A new oogenus of Elongatoolithidae from the Upper Cretaceous Chichengshan Formation of Tiantai Basin, Zhejiang Province]". Chinese. In: Vertebrata PalAsiatica 48.2 (2010), pp. 111-118.

[24272] Q. Wang, Y. Y. Zhao, and D. Ren. “Two new species of Mesosciophilidae (Insecta: Diptera: Nematocera) from the Yanliao biota of Inner Mongolia, China". English. In: Alcheringa 36 (2012), pp. 509514.

[24273] Q. Wang, Z. Zhao, X. Wang, N. Li, and S. Zou. “A new form of Elongatoolithidae, Undulatoolithus pengi oogen. et oosp. nov. from Pingxiang, Jiangxi, China". English. In: Zootaxa 3746.1 (2013), pp. 194-200.

[24274] Q. Wang, Z.-K. Zhao, X. -L. Wang, and Y. -G. Jiang. "New ootypes of dinosaur eggs from the Late Cretaceous in Tiantai Bain, Zhejiang Province, China". English. In: Vertebrata PalAsiatica 49.4 (2011), pp. 446-449.

[24275] Q. Wang, Z.-K. Zhao, X. -L. Wang, S. -K. Zhang, and Y. -G. Jiang. “New forms of dictyoolithids from the Tiantai Basin, Zhejiang Province of China and a parataxonomic revision of the dictyoolithids". English. In: Vertebrata PalAsiatica 51.1 (2013), pp. 43-54.

[24276] Q. L. Wang, Y. Wang, Y. P. Qi, X. D. Wang, S. J. Choh, D. C. Lee, and D. J. Lee. “Revised conodont and fusuline biostratigraphy of the Bamchi Formation (Pyongan Supergroup) at the Bamchi section, Yeongwol and the Carboniferous-Permian boundary in South Korea". English. In: Alcheringa 42 (2018), pp. 244-257.

[24277] R. Wang, S. Xu, X. Wu, C. Li, and S. Wang. "A new specimen of Shansisuchus shansisuchus Young, 1964 (Diapsida: Archosauriformes) from the Triassic of Shanxi, China". English. In: Acta Geologica Sinica 87.5 (2013), pp. 1185-1197.

[24278] R. Q. Wang, S. Li, D. Ren, and Y. Z. Yao. “New genus and species of the Psyllipsocidae (Psocodea: Trogiomorpha) from mid-Cretaceous Burmese amber". English. In: Cretaceous Research 104.104178 (2019). DOI: 10.1016/j.cretres.2019.07.008. 
[24279] R.-F. Wang, Y. Wang, and D. Y. Hu. “Discovery of a new ornithuromorph genus, Juehuaornis gen. nov." Chinese. In: Global Geology 34.1 (2015), pp. 7-11.

[24280] R.-F. Wang, H.-L. You, S. -C. Xu, S. -Z. Wang, J. Yi, L. -J. Xie, L. Jia, and Y. -X. Li. “A new hadrosauroid dinosaur from the early Late Cretaceous of Shanxi Province, China". English. In: PLoS ONE 8.10 (2013), e77058:1-12. DOI: 10.1371/journal.pone.0077058.

[24281] R.-F. Wang, H.-L. You, S. -Z. Wang, S. -C. Xu, J. Yi, L. -J. Xie, L. Jia, and H. Xing. “A second hadrosauroid dinosaur from the early Late Cretaceous of Zuoyun, Shanxi Province, China". English. In: Historical Biology 29.1 (2017), pp. 17-24. DOI: 10.1080/08912963.2015.1118688.

[24282] S. Wang, C. Sun, C. Sullivan, and X. Xing. "A new oviraptoroid (Dinosauria: Theropoda) from the Upper Cretaceous of southern China". English. In: Zootaxa 3640.2 (2013), pp. 242-257.

[24283] S. Wang, S. Zhang, C. Sullivan, and X. Xing. "Elongatoolithid eggs containing oviraptorid (Theropoda, Oviraptorosauria) embryos from the Upper Cretaceous of Southern China". English. In: BMC Evolutionary Biology 16.1 (2016), pp. 1-21. DOI: 10.1186/s12862-016-0633-0.

[24284] S.-Q. Wang, T. Deng, J. Ye, W. He, and S. -Q. Chen. "Morphological and ecological diversity of Amebelodontidae (Proboscidea, Mammalia) revealed by a Miocene fossil accumulation of an upper-tuskless proboscidean". English. In: Journal of Systematic Palaeontology 15.8 (2017), pp. 601615. DOI: $10.1080 / 14772019.2016 .1208687$.

[24285] T. T. Wang, J. H. Liang, and D. Ren. "Variability of Habroblattula drepanoides gen. et. sp. nov. (Insecta: Blattaria: Blattulidae) from the Yixian Formation in Liaoning, China". English. In: Zootaxa 1443 (2007), pp. 17-27.

[24286] T. T. Wang, D. Ren, J. H. Liang, and C. K. Shih. “New Mesozoic cockroaches (Blattaria: Blattulidae) from Jehol Biota of western Liaoning in China". English. In: Annales Zoologici 57 (2007), pp. 483495.

[24287] W. L. Wang. “On Liaoximordellidae fam. nov. (Coleoptera, Insecta) from the Jurassic of western Liaoning Province, China". Chinese. In: Acta Geologica Sinica 67 (1993), pp. 86-94.

[24288] W. L. Wang. "Some fossil insects (Coleoptera) of western Beijing with discussion of development and succession of the late Mesozoic insect fauna". Chinese. In: Memoirs of Beijing Natural History Museum 56 (1998), pp. 199-206.

[24289] W. L. Wang. "Discovery of Eocene Aphis (Insecta: Homoptera) in amber from Fushun, Liaoning Province, China". Chinese. In: Bulletin of the Chinese Academy of Geological Sciences 27-28 (1993), pp. 175-182.

[24290] W. L. Wang and M. W. Liu. "A new genus and species of Haglidae from late Mesozoic of China, with description of its auditory organs". Chinese. In: Memoirs of Beijing Natural History Museum 55 (1996), pp. 69-77.

[24291] W. L. Wang and M. W. Liu. "A new species of Notocupes from the Cretaceous of Laiyang Basin, Shandong Province". Chinese. In: Memoirs of Beijing Natural History Museum 55 (1996), pp. 79-82.

[24292] W.-H. Wang and L. A. Muir. "Taxonomic and biostratigraphic reappraisal of some early Tremadocian (Ordovician) graptolites from Changde, South China". English. In: Palaeoworld 24.1 (2015), pp. 86-99. DOI: 10.1016/j.palwor.2014.10.008.

[24293] X. Wang. "Phylogenetic systematics of the Hesperocyoninae (Carnivora: Canidae)". English. In: Bulletin of the American Museum of Natural History 221 (1994), pp. 1-207.

[24294] X. Wang. "New material of Osbornodon from the early Hemingfordian of Nebraska and Florida". English. In: Bulletin of the American Museum of Natural History 279 (2003), pp. 163-176.

[24295] X. Wang, G. H. Bachmann, H. Hagdorn, P. M. Sanders, G. Cuny, X. Chen, C. Wang, L. Chen, L. Cheng, F. Meng, and G. Xu. "The Late Triassic black shales of the Guanling area, Guizhou province, south-west China: a unique marine reptile and pelagic crinoid fossil lagerstätte". English. In: Palaeontology 51.1 (2008), pp. 27-61. 
[24296] X. Wang, D. A. Campos, Z. Zhou, and A. W. A. Kellner. "A primitive istiodactylid pterosaur (Pterodactyloidea) from the Jiufotang Formation (Early Cretaceous), northeast China". English. In: Zootaxa 1813 (2008), pp. 1-18.

[24297] X. Wang and O. Carranza-Castaneda. "Earliest hog-nosed skunk, Conepatus (Mephitidae, Carnivora), from the early Pliocene of Guanajuato, Mexico and origin of South American skunks". English. In: Zoological Journal Of The Linnean Society 154.2 (2008), pp. 396-407. DOI: 10.1111/j.10963642.2008.00411.x.

[24298] X. Wang, O. Carranza-Castaneda, and J. J. Aranda-Gomez. “A transitional skunk, Buisnictis metabatos sp nov (Mephitidae, Carnivora), from Baja California Sur and the role of southern refugia in skunk evolution". English. In: Journal Of Systematic Palaeontology 12.3 (2014), pp. 291-302. DOI: 10.1080/14772019.2013.776647.

[24299] X. Wang, A. Cau, M. Kundrát, L. M. Chiappe, Q. Ji, W. Wang, T. Li, and W. Wu. “A new advanced ornithuromorph bird from Inner Mongolia documents the". English. In: Historical Biology (2020). DOI: 10.1080/08912963.2020.1731805.

[24300] X. Wang, L. M. Chiappe, F. Teng, and Q. Ji. "Xinghaiornis lini (Aves: Ornithothoraces) from the Early Cretaceous of Liaoning: An Example of Evolutionary Mosaic in Early Birds". English. In: Acta Geologica Sinica (English Edition) 87.3 (2013), pp. 686-689.

[24301] X. Wang, Z. Csiki, A. Osi, and G. J. Dyke. "The first definitive record of a fossil bird from the Upper Cretaceous (Maastrichtian) of the Haeg Basin, Romania". English. In: Journal of Vertebrate Paleontology 31.1 (2011), pp. 227-230. DOI: 10.1080/02724634.2011.541013.

[24302] X. Wang, W. Downs, J. Xie, and G. Xie. “Didymoconus (Mammalia: Didymoconidae) from Lanzhou Basin, China and its stratigraphic and ecological significance". English. In: Journal of Vertebrate Paleontology 21.3 (2001), pp. 555-564.

[24303] X. Wang, G. J. Dyke, V. Codrea, P. Godefroit, and T. Smith. "A euenantiornithine bird from the Late Cretaceous Haeg Basin of Romania". English. In: Acta Palaeontologica Polonica 56.4 (2011), pp. 853857.

[24304] X. Wang, C. Grohé, D. F. Su, S. C. White, X. Ji, J. Kelley, N. G. Jablonski, T. Deng, Y. You, and X. Yang. "A new otter of giant size, Siamogale melilutra sp. nov. (Lutrinae: Mustelidae: Carnivora), from the latest Miocene Shuitangba site in northeastern Yunnan, south-western China, and a totalevidence phylogeny of lutrines". English. In: Journal of Systematic Palaeontology 16.1 (2018), pp. 3865. DOI: 10.1080/14772019.2016.1267666.

[24305] X. Wang, J.-D. Huang, M. Kundrát, A. Cau, X. -Y. Liu, Y. Wang, and S. -B. Jua. “A new jeholornithiform exhibits the earliest appearance of the fused sternum and pelvis in the evolution of avialan dinosaurs". English. In: Journal of Asian Earth Sciences 199 (2020), p. 104401. DOI: 10.1016/j.jseaes. 2020.104401.

[24306] X. Wang, R. H. Hunt Jr., R. H. Tedford, and E. B. Lander. "First record of immigrant Phoberogale (Mammalia, Ursidae, Carnivora) from Southern California". English. In: Geodiversitas 31.4 (2009), pp. 753-773. DOI: 10.5252/g2009n4a753.

[24307] X. Wang, A. W. A. Kellner, Z. Zhou, and D.d.A. Campos. "A new pterosaur (Ctenochasmatidae, Archaeopterodactyloidea) from the Lower Cretaceous Yixian Formation of China". English. In: Cretaceous Research 28 (2007), pp. 245-260.

[24308] X. Wang, A. W. A. Kellner, Z. Zhou, and D.d.A. Campos. "Discovery of a rare arboreal forest dwelling flying reptile (Pterosauria, Pterodactyloidea) from China". English. In: Proceedings of the National Academy of Sciences 105.6 (2008), pp. 1983-1987.

[24309] X. Wang, A. W. A. Kellner, Z. Zhou, and D.d.A. Campos. "Pterosaur diversity and faunal turnover in Cretaceous terrestrial ecosystems in China". English. In: Nature 437 (2005), pp. 875-879. DOI: 10.1038/nature03982.

[24310] X. Wang, A. W. A. Kellner, S. Jiang, and X. Meng. "An unusual long-tailed pterosaur with elongated neck from western Liaoning of China". English. In: Anais da Academia Brasileira de Ciencias 81.4 (2009), pp. 793-812. 
[24311] X. Wang, A. W. A. Kellner, S. Jiang, X. Cheng, X. Meng, and T. Rodrigues. "New long-tailed pterosaurs (Wukongopteridae) from western Liaoning, China". English. In: Anais da Academia Brasileira de Ciencias 82.4 (2010), pp. 1045-1062. DOI: 10.1590/S0001-37652010000400024.

[24312] X. Wang, A. W. A. Kellner, S. Jiang, and X. Cheng. "New toothed reptile from Asia: close similarities between early Cretaceous pterosaur faunas from China and Brazil". English. In: Naturwissenschaften 99 (2012), pp. 249-257.

[24313] X. Wang, A. W. A. Kellner, S. Jiang, Q. Wang, Y. Ma, Y. Paidoula, X. Cheng, T. Rodrigues, X. Meng, J. Zhang, N. Li, and Z. Zhou. "Sexually dimorphic tridimensionally preserved pterosaurs and their eggs from China". English. In: Current Biology 24 (2014), pp. 1323-1330. DOI: 10.1016/j.cub. 2014.04.054.

[24314] X. Wang, M. Krings, and T. N. Taylor. "A thalloid organism with possible lichen affinity from the Jurassic of northeastern China". English. In: Review of Palaeobotany and Palynology 162 (2010), pp. 591-598. DOI: 10.1016/j.revpalbo.2010.07.005.

[24315] X. Wang, Q. Li, and G. T. Takeuchi. "Out of Tibet: an early sheep from the Pliocene of Tibet, Protovis himalayensis, genus and species nov. (Bovidae, Caprini), and origin of Ice Age mountain sheep". English. In: Journal of Vertebrate Paleontology 35.5 (2016), e1169190. DOI: 10.1080/02724634. 2016.1169190.

[24316] X. Wang and J. Lü. "Discovery of a pterodactylid pterosaur from the Yixian Formation of western Liaoning, China". English. In: Chinese Science Bulletin 46 (2001), pp. 1112-1117.

[24317] X. Wang, M. C. McKenna, and D. Dashzeveg. "Amphicticeps and Amphicynodon (Arctoidea, Carnivora) from Hsanda Gol Formation, Central Mongolia and phylogeny of basal arctoids with comments on zoogeography". English. In: American Museum Novitates 3483 (2005), pp. 1-57.

[24318] X. Wang, J. O'Connor, B. Zhao, L. M. Chiappe, C. Gao, and X. Cheng. "New species of Enantiornithes (Aves: Ornithothoraces) from the Qiaotou Formation in northern Hebei, China". English. In: Acta Geologica Sinica 84.2 (2010), pp. 247-256. DOI: 10.1111/j.1755-6724.2010.00156.x.

[24319] X. Wang, J. K. O'Connor, X. Zheng, M. Wang, H. Hu, and Z. Zhou. "Insights into the evolution of rachis dominated tail feathers from a new basal enantiornithine (Aves: Ornithothoraces)". English. In: Biological Journal of the Linnean Society 113 (2014), pp. 806-819.

[24320] X. Wang, Z. Qiu, and B. Wang. "Hyaenodonts and carnivorans from the early Oligocene to early Miocene of the Xianshuihe Formation, Lanzhou Basin, Gansu Province, China". English. In: Palaeontologia Electronica 8.1 (2005), pp. 1-14.

[24321] X. Wang, T. Rodrigues, S. Jiang, X. Cheng, and A. W. A. Kellner. "An Early Cretaceous pterosaur with an unusual mandibular crest from China and a potential novel feeding strategy". English. In: Scientific Reports 4.6329 (2014). DOI: 10.1038/srep06329.

[24322] X. Wang and B. M. Rothschild. "Multiple Hereditary Osteochondroma in Oligocene Hesperocyon (Carnivora: Canidae)". English. In: Journal of Vertebrate Paleontology 12.3 (1992), pp. 387-394.

[24323] X. Wang, C. Shen, C. Gao, and K. Jin. "New material of Feilongus (Reptilia: Pterosauria) from the Lower Cretaceous Jiufotang Formation of Western Liaoning". English. In: Acta Geological Sinica 88.1 (2014), pp. 13-17.

[24324] X. Wang, S. Stouge, C. Xiaohong, L. Zhihong, W. Chuanshang, S. C. Finney, Z. Qingluan, Z. Zhiqiang, C. Huiming, and B. D. Erdtmann. "The global stratotype section and point for the base of the Middle Ordovician Series and the Third Stage (Dapingian)". English. In: Episodes 32.2 (2009), pp. 96-112.

[24325] X. Wang and R. H. Tedford. "The status of genus Nothocyon Matthew, 1899 (Carnivora): an arctoid not a canid". English. In: Journal of Vertebrate Paleontology 12.2 (1992), pp. 223-229.

[24326] X. Wang and R. H. Tedford. "Basicranial anatomy and phylogeny of primitive canids and closely related miacids (Carnivora, Mammalia)". English. In: American Museum Novitates 3092 (1994).

[24327] X. Wang, R. H. Tedford, and B. E. Taylor. "Phylogenetic systematics of the Borophaginae (Carnivora: Canidae)". English. In: Bulletin of the American Museum of Natural History 243 (1999), pp. 1392. 
[24328] X. Wang and R. H. Tedford. "Fossil dogs (Carnivora, Canidae) from the Sespe and Vaqueros formations in Southern California, with comments on relationships of Phlaocyon taylori". English. In: Natural History Museum of Los Angeles County, Science Series 41 (2008), pp. 255-272.

[24329] X. Wang, Y. Wang, X. Xu, Z. Tang, F. Zhang, and Y. Hu. "Stratigraphic sequence and vertebratebearing beds of the lower part of the Yixian Formation in Sihetun and neighboring area, western Liaoning, China". In: Vertebrata PalAsiatica 36.2 (1998), pp. 81-101.

[24330] X. Wang, D. P. Whistler, and G. T. Takeuchi. "A New Basal Skunk Martinogale (Carnivora, Mephitinae) From Late Miocene Dove Spring Formation, California, and Origin of New World Mephitines". English. In: Journal of Vertebrate Paleontology 25.4 (2005), pp. 936-949. DOI: 10.1671/0272-4634(2005) 025[0936:ANBSMC]2.0.CO;2.

[24331] X. Wang, B. C. Wideman, R. Nichols, and D. L. Hanneman. "A new species of Aelurodon (Carnivora, Canidae) from the Barstovian of Montana". English. In: Journal of Vertebrate Paleontology 24.2 (2004), pp. 445-452.

[24332] X. Wang and X. Xu. "A new iguanodontid (Jinzhousaurus yangi gen. et sp. nov.) from the Yixian Formaton of western Liaoning, China". English. In: Chinese Science Bulletin 46.19 (2001), pp. 16691672.

[24333] X. Wang, H. You, Q. Meng, C. Gao, X. Cheng, and J. Liu. “Dongbeititan dongi, the first sauropod dinosaur from the Lower Cretaceous Jehol Group of western Liaoning Province, China". English. In: Acta Geologica Sinica 81.6 (2007), pp. 911-916.

[24334] X. Wang and R. Zhai. “Carnilestes, a New Primitive Lipotyphlan (Insectivora: Mammalia) from the Early and Middle Paleocene, Nanxiong Basin, China". English. In: Journal of Vertebrate Paleontology 15.1 (1995), pp. 131-145.

[24335] X. Wang, Z. Zhang, C. Gao, L. Hou, Q. Meng, and J. Liu. "A new enantiornithine bird from the Early Cretaceous of western Liaoning, China". English. In: The Condor 112.3 (2010), pp. 432-437. DOI: $10.1525 /$ cond.2010.090248.

[24336] X. Wang, B. Zhao, C. Shen, S. Liu, C. Gao, X. Cheng, and F. Zhang. "New material of Longipteryx (Aves: Enantiornithes) from the Lower Cretaceous Yixian Formation of China with the first recognized avian tooth crenulations". English. In: Zootaxa 3941.4 (2015), pp. 565-578.

[24337] X. Wang and Z. Zhou. "Pterosaur embryo from the Early Cretaceous". English. In: Nature 429 (2004), p. 621.

[24338] X. Wang, Z. Zhou, F. Zhang, and X. Xu. “A nearly completely articulated rhamphorhynchoid pterosaur with exceptionally well-preserved wing membranes and hairs from Inner Mongolia, northeast China". English. In: Chinese Science Bulletin 47 (2002), pp. 226-230.

[24339] X. Wang and Z. Zhou. "A new pterosaur (Pterodactyloidea, Tapejaridae) from the Early Cretaceous Jiufotang Formation of western Liaoning, China and its implications for biostratigraphy". Chinese. In: Chinese Science Bulletin 47.20 (2002), pp. 1521-1527.

[24340] X. D. Wang. “Increase pattern and environmental significance of Kepingophyllum aksuense Wu et Zhou from Early Permian, Xinjiang". Chinese. In: Chinese Science Bulletin 37 (1992), pp. 1108-1111.

[24341] X. D. Wang, C. H. Dietrich, and Y. L. Zhang. "The first fossil Coelidiinae: A new genus and species from mid-Cretaceous Myanmar amber (Hemiptera, Cicadellidae)". English. In: Cretaceous Research 95 (2018), pp. 146-150.

[24342] X. D. Wang, W. Lin, S. Z. Shen, P. Chaodumrong, G. R. Shi, X. J. Wang, and Q. L. Wang. “Early Permian rugose coral Cyathaxonia faunas from the Sibumasu Terrane (Southeast Asia) and the southern Sydney Basin (Southeast Australia): paleontology and paleobiogeography". English. In: Gondwana Research 24 (2013), pp. 185-191.

[24343] X. J. Wang, X. D. Wang, Y. C. Zhang, C. Q. Cao, and D. J. Lee. “Late Permian rugose corals from Gyanyima of Drhada, Tibet (Xizang), southwest China". English. In: Journal of Paleontology 93 (2019), pp. 856-875. DOI: 10.1017/jpa.2019.37. 
[24344] X. R. Wang, Q. Ji, F. F. Teng, and K. M. Jin. "A new species of Yanornis (Aves: Ornithurae) from the Lower Cretaceous strata of Yixian, Liaoning Province". English. In: Geological bulletin of China 32.4 (2013), pp. 601-606.

[24345] X.-D. Wang and T. Sugiyama. "Middle Permian rugose corals from Laibin, Guangzi, South China". English. In: Journal of Paleontology 75.4 (2001), pp. 758-782.

[24346] X.-L. Wang, S.-X. Jiang, J. -Q. Zhang, X. Cheng, X. -F. Yu, Y. -M. Li, G. -J. Wei, and X. -L. Wang. "New evidence from China for the nature of the pterosaur evolutionary transition". English. In: Scientific Reports 7.42763 (2017).

[24347] X.-L. Wang and Z.-H. Zhou. "Two new pterodactyloid pterosaurs from the Early Cretaceous Jiufotang Formation of western Liaoning, China". English. In: Vertebrata PalAsiatica 41.1 (2003), pp. 34-41.

[24348] X.-M. Wang and P. Li. "A new fossil site with a re-worked Paleogene assemblage at Baogeda Ula, central Nei Mongol". English. In: Vertebrata PalAsiatica 49.1 (2011), pp. 114-122.

[24349] X.-M. Wang, H.-J. Wang, and Q. -G. Jiangzuo. "New record of a haplocyonine amphicyonid in early Miocene of Nei Mongol fills a long-suspected geographic hiatus". English. In: Vertebrata PalAsiatica 54.1 (2016), pp. 21-35.

[24350] X.-R. Wang, W.-H. Wu, T. Li, Q. Ji, Y. -X. Li, and J. -F. Guo. "A new titanosauriform dinosaur (Dinosauria: Sauropoda) from Late Jurassic of Junggar Basin, Xinjiang". Chinese. In: Global Geology 38.3 (2019), pp. 581-588.

[24351] X.-Y. Wang, Y.-Q. Wang, R. Zhang, Z. -H. Zhang, X. -L. Liu, and L. -P. Ren. “A new species of Amynodontopsis (Perissodactyla: Amynodontidae) from the Middle Eocene of Jiyuan, Henan, China". English. In: Vertebrata PalAsiatica 58.3 (2020), pp. 188-203.

[24352] Y. Wang. "A new Mesozoic caudate (Liaoxitriton daohugouensis sp. nov.) from Inner Mongolia, China". English. In: Chinese Science Bulletin 49.8 (2004), pp. 858-860.

[24353] Y. Wang. "Taxonomy and stratigraphy of Late Mesozoic anurans and urodeles from China". English. In: Acta Geologica Sinica 78.6 (2004), pp. 1169-1178.

[24354] Y. Wang. "A new zhelestid (Mixotheridia, Mammalia) from the Paleocene of Qianshan, Anhui". Chinese. In: Vertebrata PalAsiatica 33.2 (1995), pp. 114-137.

[24355] Y. Wang. "A new primitive Chalicothere (Perissodactyla, Mammalia) from the early Eocene of Hubei, China". English. In: Vertebrata PalAsiatica 33.2 (1995), pp. 138-159.

[24356] Y. Wang, J. C. Aitchison, and H. Luo. “Devonian radiolarian faunas from South China”. English. In: Micropaleontology 49.2 (2003), pp. 127-145.

[24357] Y. Wang, W. A. Clemens, Y. Hu, and C. Li. "A probably pseudo-tribosphenic upper molar from the Late Jurassic of China and the early radiation of Holotheria". English. In: Journal of Vertebrate Paleontology 18.4 (1998), pp. 777-787.

[24358] Y. Wang and S. E. Evans. "A new short-bodied salamander from the Upper Jurassic/Lower Cretaceous of China". English. In: Acta Palaeontologica Polonica 51.1 (2006), pp. 127-130.

[24359] Y. Wang and K. Q. Gao. “Earliest Asian discoglossid frog from western Liaoning”. English. In: Chinese Science Bulletin 44.7 (1999), pp. 636-642.

[24360] Y. Wang, C. Jin, and J. I. Mead. "New remains of Sinomastodon yangziensis (Proboscidea," English. In: Quaternary International 339-340 (2014), pp. 90-96. DOI: 10.1016/j.quaint.2013.03.006.

[24361] Y. Wang, M. E. H. Jones, and S. E. Evans. "A juvenile anuran from the Lower Cretaceous Jiufotang Formation, Liaoning, China". English. In: Cretaceous Research 28 (2007), pp. 235-244.

[24362] Y. Wang and D. Ren. "Revision of the genus Suljuktocossus Becker-Migdisova, 1949 (Hemiptera, Palaeontinidae), with description of a new species from Daohugou, Inner Mongolia, China". English. In: Zootaxa 1576 (2007), pp. 57-62.

[24363] Y. Wang, D. Ren, and C. K. Shih. "New discovery of Palaeontinid fossils from the Middle Jurassic in Daohugou, Inner Mongolia (Homoptera, Palaeontinidae)". English. In: Science in China Series D: Earth Sciences 50 (2007), pp. 481-486. DOI: 10.1007/s11430-007-0029-5. 
[24364] Y. Wang and D. Ren. "Two new genera of fossil palaeontinids from the Middle Jurassic in Daohugou, Inner Mongolia, China (Hemiptera, Palaeontinidae)". English. In: Zootaxa 1390 (2007), pp. 41-49.

[24365] Y. Wang and D. Ren. "Middle Jurassic Pseudocossus fossils from Daohugou, Inner Mongolia in China (Homoptera, Palaeontinidae)". Chinese. In: Acta Zootaxonomica Sinica 31 (2006), pp. 289293.

[24366] Y. Wang, D. Ren, and C. K. Shih. "Discovery of Middle Jurassic palaeontinids from Inner Mongolia, China (Homoptera: Palaeontinidae)". English. In: Progress in Natural Science 17 (2007), pp. 112116.

[24367] Y. Wang and D. Ren. "New fossil palaeontinids from the Middle Jurassic of Daohugou, Inner Mongolia, China (Insecta, Hemiptera)". English. In: Acta Geologica Sinica 83 (2009), pp. 33-38.

[24368] Y. Wang and C. S. Rose. "Jeholotriton paradoxus (Amphibia: Caudata) from the Lower Cretaceous of southeastern Inner Mongolia, China". English. In: Journal of Vertebrate Paleontology 25.3 (2005), pp. 523-532.

[24369] Y. Wang, S. Shen, C. Cao, W. Wang, C. Henderson, and Y. Jin. “The Wuchiapingian-Changhsingian boundary (Upper Permian) at Meishan of Changxing County, South China". English. In: Journal of Asian Earth Sciences 26 (2006), pp. 575-583.

[24370] Y. Wang, C. K. Shih, J. Szwedo, and D. Ren. "New fossil palaeontinids (Hemiptera, Cicadomorpha, Palaeontinidae) from the Middle Jurassic of Daohugou, China". English. In: Alcheringa 37 (2013), pp. 19-30.

[24371] Y. Wang and J. Wang. "A new brontothere from late Middle Eocene of Qufu, Shandong". English. In: Vertebrata PalAsiatica 35.1 (1997), pp. 68-77.

[24372] Y. Wang, L. Wang, and D. Ren. "Revision of genera Quadraticossus, Martynovocossus and Fletcheriana (Insecta, Hemiptera) from the Middle Jurassic of China with description of a new species". English. In: Zootaxa 1855 (2008), pp. 56-64.

[24373] Y. Wang, M. Wang, J. K. O'Connor, X. Wang, X. Zheng, and X. Zhang. "A new Jehol enantiornithine bird with three-dimensional preservation and ovarian follicles". English. In: Journal of Vertebrate Paleontology 36.2 (2016), e1054496:1-15. DOI: 10.1080/02724634.2015.1054496.

[24374] Y. Wang and W. Du. "The long-ranging macroalga Grypania spiralis from the Ediacaran Doushantuo Formation, Guizhou, South China". English. In: Alcheringa (2016). DOI: 10.1080/03115518.2016. 1127725.

[24375] Y. Wang, Y. C. Zhang, Q. F. Zhang, X. S. Tian, X. Huang, and M. Luo. “The early Wuchiapingian (Late Permian) fusuline fauna from the Penglaitan section, south China". English. In: Papers in Palaeontology 6 (2020), pp. 485-499. DOI: 10.1002/spp2.1310.

[24376] Y. G. Wang and Z. R. Yang. “Discovery of Spathian ammonoid fauna from eastern Kunlun Mountains". Chinese. In: Acta Palaeontologica Sinica 31.3 (1992), pp. 350-356.

[24377] Y. J. Wang, S. L. Du, Y. Z. Yao, and D. Ren. “A new genus and species of burrower bugs (Heteroptera: Cydnidae) from the mid-Cretaceous Burmese amber". English. In: Zootaxa 4585 (2019), pp. 351-359.

[24378] Y. J. Wang, C. C. Labandeira, C. K. Shih, Q. L. Ding, C. Wang, Y. Y. Zhao, and D. Ren. "Jurassic mimicry between a hangingfly and a ginkgo from China". English. In: Proceedings of the National Academy of Sciences 109 (2012), pp. 20514-20519.

[24379] Y. J. Wang, Z. Q. Liu, D. Ren, and C. K. Shih. “New Middle Jurassic kempynin osmylid lacewings from China". English. In: Acta Palaeontologica Polonica 56 (2011), pp. 865-869.

[24380] Y. J. Wang, Z. Q. Liu, X. Wang, C. K. Shih, Y. Y. Zhao, M. S. Engel, and D. Ren. “Ancient pinnate leaf mimesis among lacewings". English. In: Proceedings of the National Academy of Sciences 107.37 (2010), pp. 16212-16215.

[24381] Y. J. Wang, Z. Q. Liu, and D. Ren. "A new fossil lacewing genus from the Middle Jurassic of Inner Mongolia, China (Neuroptera: Osmylidae)”. English. In: Zootaxa 2034 (2009), pp. 65-68. 
[24382] Y. J. Wang, Z. Q. Liu, and D. Ren. "A new fossil lacewing genus and species from the Middle Jurassic of Inner Mongolia, China". English. In: Acta Palaeontologica Polonica 54 (2009), pp. 557560.

[24383] Y. J. Wang, Z. Q. Liu, D. Ren, and C. K. Shih. "A new genus of Protosmylinae from the Middle Jurassic of China (Neuroptera: Osmylidae)". English. In: Zootaxa 2480 (2010), pp. 45-53.

[24384] Y. J. Wang, Q. Yang, Y. N. Cheng, and J. X. Li. “Lopingian (Upper Permian) radiolarian biostratigraphy of south China". English. In: Palaeoworld 15 (2006), pp. 31-53.

[24385] Y. J. Wang, Q. Yang, A. Matsuoka, K. Kobayashi, T. Nagahashi, and Q. G. Zeng. "Triassic radiolarians from the Yarlung Zangbo Suture Zone in the Jinglu area, Zetang County, southern Tibet". English. In: Acta Micropalaeontologica Sinica 19.3 (2002), pp. 215-227.

[24386] Y. M. Wang, M. Wang, C. K. Shih, A. P. Rasnitsyn, J. Yao, D. Ren, and T. P. Gao. “A new sawfly of Megalodontesidae (Insecta, Hymenoptera, Pamphilioidea) with pectinate antennae from the Early Cretaceous of China". English. In: ZooKeys 893 (2019), pp. 115-123.

[24387] Y. M. Wang, M. Wang, A. P. Rasnitsyn, C. K. Shih, D. Ren, D. S. Kopylov, and T. P. Gao. "A new anaxyelid sawfly (Insecta, Hymenoptera, Siricoidea) in mid-Cretaceous Myanmar amber". English. In: Cretaceous Research 109.104372 (2020). DOI: 10.1016/j.cretres.2020.104372.

[24388] Y. M. Wang, H. L. You, and T. Wang. "A new basal sauropodiform dinosaur from the Lower Jurassic of Yunnan Province, China". English. In: Scientific Reports 7.41881 (2017). DOI: 10.1038 / srep41881.

[24389] Y.-M. Wang, J. O'Connor, D. -Q. Li, and H. -L. You. “Previously unrecognised ornithuromorph bird diversity in the Early Cretaceous Changma Basin, Gansu Province, northwestern China". English. In: PLoS ONE 8.10 (2013), e77693. DOI: 10.1371/journal.pone.0077693.

[24390] Y.-Q. Wang and X. Jin. "A new Paleocene tillodont (Tillodontia, Mammalia) from Qianshan, Anhui, with a review of Paleocene tillodonts from China". English. In: Vertebrata PalAsiatica 42.12 (2004), pp. 13-26.

[24391] Y.-Q. Wang, C.-K. Li, Q. Li, and D. -S. Li. "A synopsis of Paleocene stratigraphy and vertebrate paleontology in the Qianshan Basin, Anhui, China". English. In: Vertebrata PalAsiatica 54.2 (2016), pp. 89-120.

[24392] Y.-Q. Wang, J. Meng, X. Jin, K. C. Beard, B. Bai, P. Li, X. -J. Ni, Q. Li, and D. L. Gebo. “Early Eocene perissodactyls (Mammalia) from the Upper Nomogen Formation of the Erlian Basin, Nei Mongol, China". English. In: Vertebrata PalAsiatica 49.1 (2011), pp. 123-140.

[24393] Y.-Q. Wang, J. Meng, X. -J. Ni, and K. C. Beard. “A new early Eocene arctostylopid (Arctostylopida, Mammalia) from the Erlian Basin, Nei Mongol (Inner Mongolia), China". English. In: Journal of Vertebrate Paleontology 28.2 (2008), pp. 553-558.

[24394] Z. Wang and B. Geng. "A new Middle Devonian plant: Metacladophyton tetraxylum gen. et sp. nov". In: Palaeontographica Abteilung B 243 (1997), pp. 85-102.

[24395] Z. G. Wang and J. M. Zhao. "Middle Permian corals from Laibin County, Guangxi". Chinese. In: Acta Palaeontologica Sinica 37 (1998), pp. 40-66.

[24396] N. Wang., S. Yang, F. Jin, and W. Wei. "Early Triassic Hybodontoidea from Tiadong of Guangxi, China". English. In: Vertebrata PalAsiatica 39.4 (2001), pp. 237-250.

[24397] R. Wani, R. S. P. De Ocampo, Y. M. Aguilar, M. A. Zepeda, Y. Kurihara, K. Hagino, H. Hayashi, and T. Kase. "First discovery of fossil Nautilus pompilius Linnaeus, 1758 (Nautilidae, Cephalopoda) from Pangasinan, northwestern Philippines". English. In: Paleontological Research 12.1 (2008), pp. 8995.

[24398] T. Wappler. "New orthopteroid insects from the Upper Triassic Molteno Formation, Karoo Basin, southern Africa". English. In: Acta Geologica Leopoldensia 24.52/53 (2001), pp. 87-104.

[24399] T. Wappler. "Lutetiacader, a Puzzling New Genus of Cantacaderid Lace Bugs (Heteroptera: Tingidae) From the Middle Eocene Messel Maar, Germany". English. In: Palaeontology 49.2 (2006), pp. 435-444. 
[24400] T. Wappler. "New fossil lace bugs (Heteroptera: Tingidae) from the Middle Eocene of the Grube Messel (Germany), with a catalog of fossil lace bugs". English. In: Zootaxa 374 (2003), pp. 1-26.

[24401] T. Wappler. "Systematik, Phylogenie, Taphonomie und Paläoökologie der Insekten aus dem MittelEozän des Eckfelder Maares, Vulkaneifel”. German. In: Clausthaler Geowissenschaften 2 (2003), pp. 1241.

[24402] T. Wappler. “The first lace bug (Insecta: Heteroptera: Tingidae) from the lower Oligocene deposits near Céreste, France". English. In: Neues Jahrbuch für Geologie und Paläontologie, Monatshefte 2004.5 (2004), pp. 278-288.

[24403] T. Wappler. "Haglidae (Insecta: Orthoptera) aus der obertriassichen Molteno-Formation im südlichen Afrika". German. In: Neues Jahrbuch für Geologie und Paläontologie, Abhandlungen 222 (2001), pp. 329352.

[24404] T. Wappler. "Triassische Insekten aus dem Karoo-Becken im südlichen Afrika". German. In: Arbeitskreis Paläontologie Hannover 28 (2000), pp. 68-84.

[24405] T. Wappler. “Dicranoptycha (Insecta: Nematocera: Limoniidae) aus der mitteleozänen Fossillagerstätte Eckfelder Maar bei Manderscheid/Eifel (Deutschland)". German. In: Mainzer Naturwissenschaftliches Archiv 40 (2002), pp. 129-134.

[24406] T. Wappler and N. M. Andersen. "Fossil water striders from the Middle Eocene fossil sites of Eckfeld and Messel, Germany (Hemiptera, Gerromorpha)". English. In: Paläontologische Zeitschrift 78 (2004), pp. 41-52.

[24407] T. Wappler and Y. Ben-Dov. "Preservation of armoured scale insects on angiosperm leaves from the Eocene of Germany". English. In: Acta Palaeontologica Polonica 53 (2008), pp. 627-634.

[24408] T. Wappler, T. De Meulemeester, A. Murat Aytekin, D. Michez, and M. S. Engel. "Geometric morphometric analysis of a new Miocene bumble bee from the Randeck Maar of southwestern Germany (Hymenoptera: Apidae)". English. In: Systematic Entomology 37 (2012), pp. 784-792.

[24409] T. Wappler, G. M. Dlussky, and M. Reuter. "The first fossil record of Polyrhachis (Hymenoptera: Formicidae: Formicinae) from the Upper Miocene of Crete (Greece)". English. In: Paläontologische Zeitschrift 83 (2009), pp. 431-438.

[24410] T. Wappler, G. M. Dlussky, M. S. Engel, J. Prokop, and S. Knor. “A new trap-jaw ant species of the genus Odontomachus (Hymenoptera: Formicidae: Ponerinae) from the Early Miocene (Burdigalian) of the Czech Republic". English. In: Paläontologische Zeitschrift 88 (2014), pp. 495-502. DOI: $10.1007 / \mathrm{s} 12542-013-0212-2$.

[24411] T. Wappler and M. Engel. “The Middle Eocene Bee Faunas of Eckfeld and Messel, Germany (Hymenoptera: Apoidea)". English. In: Journal of Paleontology 77.5 (2003), pp. 908-921.

[24412] T. Wappler and M. S. Engel. "A new record of Mastotermes from the Eocene of Germany (Isoptera: Mastotermitidae)". English. In: Journal of Paleontology 80.2 (2006), pp. 380-385.

[24413] T. Wappler, M. S. Engel, and F. Haas. "The earwigs (Dermaptera: Forficulidae) from the middle Eocene Eckfeld maar, Germany". English. In: Polskie Pismo Entomologiczne 74 (2005), pp. 227-250.

[24414] T. Wappler, F. Grmmson, B. Wang, A. Nel, E. Ólafsson, A. A. Kotov, S. R. Davis, and M. S. Engel. "Before the Big Chill: a preliminary overview of arthropods from the middle Miocene of Iceland (Insecta, Crustacea)". English. In: Palaeogeography, Palaeoclimatology, Palaeoecology 401 (2014), pp. 112.

[24415] T. Wappler, E. Guilbert, C. C. Labandeira, T. Hörnschemeyer, and S. Wedmann. "Morphological and behavioral convergence in extinct and extant bugs: the systematics and biology of a new unusual fossil lace bug from the Eocene". English. In: PLoS One 10.8 (2015), e0133330.

[24416] T. Wappler and E. Heiss. "Flatbugs from Paleogene limnic sediments. I. Messel maar (Heteroptera: Aradidae)". English. In: Polskie Pismo Entomologiczne 75 (2006), pp. 207-217.

[24417] T. Wappler and E. Heiss. "Flatbugs from Paleogene limnic sediments. III. Enspel (Heteroptera: Aradidae)". English. In: Zeitschrift der Arbeitsgemeinschaft Österreichischer Entomologen 58 (2006), pp. 39-44. 
[24418] T. Wappler and E. Heiss. "Flatbugs from Paleogene limnic sediments. II. Eckfeld maar (Heteroptera: Aradidae)". English. In: Mainzer Naturwissenschaftliches Archiv 44 (2006), pp. 53-60.

[24419] T. Wappler, E. Heiss, and S. Wedmann. "New flatbug (Hemiptera: Heteroptera: Aradidae) records from the Middle Eocene Messel Maar, Germany". English. In: Paläontologische Zeitschrift 89 (2015), pp. 653-660.

[24420] T. Wappler, S. Hinsken, J. J. Brocks, A. Wetzel, and C. A. Meyer. "A fossil sawfly of the genus Athalia (Hymenoptera: Tenthredinidae) from the Eocene-Oligocene boundary of Altkirch, France". English. In: Comptes Rendus Palevol 4 (2005), pp. 7-16.

[24421] T. Wappler, C. C. Labandeira, M. S. Engel, R. Zetter, and F. Grmsson. "Specialized and generalized pollen-collection strategies in an ancient bee lineage". English. In: Current Biology 25 (2015), pp. 3092-3098.

[24422] T. Wappler and J. F. Petruleviius. "Priscalestidae, a new damselfly family (Odonata: Lestinoidea) from the Middle Eocene Eckfeld maar of Germany". English. In: Alavesia 1 (2007), pp. 69-73.

[24423] T. Wappler, V. S. Smith, and R. C. Dalgleish. "Scratching an ancient itch: an Eocene bird louse fossil". English. In: Proceedings of the Royal Society B 271.Suppl (2004), S255-S258.

[24424] C. V. Ward, M. G. Leakey, B. Brown, F. Brown, J. Harris, and A. Walker. “South Turkwel: a new Pliocene hominid site in Kenya". English. In: Journal of Human Evolution 36 (1999), pp. 69-95.

[24425] D. J. Ward and C. G. Bonavia. "Additions to, and review of, the Miocene shark and ray fauna of Malta". English. In: The Central Mediterranean Naturalist 3.3 (2001), pp. 131-146.

[24426] L. W. Ward. Mollusks from the Lower Miocene Pollack Farm Site, Kenty County, Delaware: A preliminary analysis. English. Geology and paleontology of the lower Miocene Pollack Farm Fossil Site, Delaware. 1998.

[24427] P. D. Ward, D. T. O. Flannery, E. N. Flannery, and T. F. F. Flannery. “The Paleocene cephalopod fauna from Pebble Point, Victoria (Australia) - fulcrum between two Eras". English. In: Memoirs of Museum Victoria 74 (2016), pp. 391-402.

[24428] P. D. Ward and W. J. Kennedy. "Maastrichtian ammonites from the Biscay region (France, Spain)". English. In: The Paleontological Society Memoir 34 (1993), pp. 1-58.

[24429] P. D. Ward and W. B. Saunders. "Allonautilus: A new genus of living nautiloid cephalopod and its bearing on phylogeny of the Nautilida". English. In: Journal of Paleontology 71.6 (1997), pp. 10541064.

[24430] P. S. Ward. "Ants of the genus Pseudomyrmex (Hymenoptera: Formicidae) from Dominican amber, with a synopsis of the extant Antillean species". English. In: Psyche 99 (1992), pp. 55-85.

[24431] S. Ward, B. Brown, A. Hill, J. Kelley, and W. Downs. "Equatorius: a new hominoid genus from the Middle Miocene of Kenya". English. In: Science 285 (1999), pp. 1382-1386.

[24432] D. Ware, J. F. Jenks, M. Hautmann, and H. Bucher. “Dienerian (Early Triassic) ammonoids from the Candelaria Hills (Nevada, USA) and their significance for palaeobiogeography and palaeoceanography". English. In: Swiss Journal of Geosciences 104 (2011), pp. 161-181.

[24433] W. N. Ware. "A paleoecological study of an in situ peat-forming Carboniferous forest in the Black Warrior Basin, Alabama". PhD thesis. 2001, pp. 1-81.

[24434] K. I. Warheit. "The seabird fossil record and the role of paleontology in understanding seabird community structure". English. In: Biology of Marine Birds. CRC Press, 2002.

[24435] A. Warren. "The South African stereospondyl Microposaurus from the Middle Triassic of the Sydney Basin, Australia". English. In: Journal of Vertebrate Paleontology 32.3 (2012), pp. 538-544.

[24436] A. Warren. "A tetrapod fauna from the Permian of the Sydney Basin". English. In: Records of the Australian Museum 49.1 (1997), pp. 25-33.

[24437] A. Warren. "Laidleria uncovered: a redescription of Laidleria gracilis Kitching (1957), a temnospondyl from the Cynognathus Zone of South Africa". English. In: Zoological Journal of the Linnean Society 122 (1998), pp. 167-185. 
[24438] A. Warren and R. Damiani. "Stereospondyl amphibians from the Elliot Formation of South Africa". English. In: Palaeontologia africana 35 (1999), pp. 45-54.

[24439] A. Warren and C. Marsicano. "A phylogeny of the Brachyopoidea (Temnospondyli, Stereospondyli)". English. In: Journal of Vertebrate Paleontology 20 (2000), pp. 462-483.

[24440] A. Warren, T. M. Rich, and P. Vickers-Rich. “The last last labyrinthodont?" English. In: Palaeontographica Abteilung A 247 (1997), pp. 1-24.

[24441] A. Warren, A. C. Rozefelds, and S. Bull. "Tupilakosaur-like vertebrae in Bothriceps australis, an Australian brachyopid stereospondyl". English. In: Journal of Vertebrate Paleontology 31 (2011), pp. 738-753.

[24442] A. A. Warren. "Karoo tupilakosaurid: a relict from Gondwana". English. In: Transactions of the Royal Society of Edinburgh: Earth Sciences 89 (1998), pp. 145-160.

[24443] A. A. Warren, R. Damiani, and A. M. Yates. "The South African stereospondyl Lydekkerina huxleyi (Tetrapoda, Temnospondyli) in the Lower Triassic of Australia". English. In: Geological Magazine 143.6 (2006), pp. 877-886.

[24444] A. A. Warren and M. N. Hutchinson. "Lapillopsis, a new genus of temnospondyl amphibians from the Early Triassic of Queensland". English. In: Alcheringa 14.2 (1990), pp. 149-158.

[24445] A. A. Warren and S. Turner. "The first stem tetrapod from the Early Carboniferous of Gondwana". English. In: Palaeontology 47.1 (2004), pp. 151-184. DOI: 10.1111/j.0031-0239.2004.00353.x.

[24446] L. V. Warren, T. R. Fairchild, C. Gaucher, P. C. Boggiani, D. G. Poire, L. E. Anelli, and J. C. G. Inchausti. "Corumbella and in situ Cloudina in association with thrombolites in the Ediacaran Itapucumi Group, Paraguay". English. In: Terra Nova 23 (2011), pp. 382-389.

[24447] K. Waskow, D. Grzegorczyk, and P. M. Sander. "The first record of Tyrannoneustes (Thalattosuchia: Metriorhynchidae): a complete skull from the Callovian (late Middle Jurassic) of Germany". English. In: PalZ 92 (2018), pp. 457-480.

[24448] M. Wasmer, M. Hautmann, E. Hermann, D. Ware, G. Roohi, K. Ur-Rehman, A. Yaseen, and H. Bucher. "Olenekian (Early Triassic) bivalves from the Salt Range and Surghar Range, Pakistan". English. In: Palaeontology 55 (2012), pp. 1043-1073.

[24449] K. Watabe and R. L. Kaesler. "Ontogeny of a new species of Paraparchites (Ostracoda) from the Lower Permian Speiser Shale in Kansas". English. In: Journal of Paleontology 78 (2004), pp. 603-611.

[24450] M. Watabe, S. Suzuki, K. Tsogtbaatar, T. Tsubamoto, and M. Saneyoshi. "Report of the HMNSMPC Joint Paleontological Expedition in 2006". English. In: Hayashibara Museum of Natural Sciences Research Bulletin 3 (2010), pp. 11-18.

[24451] M. Watabe, K. Tsogtbaatar, and R. Barsbold. "First discovery of a theropod (Dinosauria) from the Upper Jurassic in Mongolia and its stratigraphy". English. In: Paleontological Research 12.1 (2008), pp. 27-36.

[24452] M. Watabe and K. Tsogtbaatar. "Report on the Japan-Mongolia Joint Paleontological Expedition to the Gobi desert, 2000". English. In: Hayashibara Museum of Natural Sciences Research Bulletin 2 (2004), pp. 45-67.

[24453] M. Watabe, K. Tsogtbaatar, N. Ichinnorov, and R. Barsbold. "Report on the Japan-Mongolia Joint Paleontological Expedition to the Gobi desert, 2001". English. In: Hayashibara Museum of Natural Sciences Research Bulletin 2 (2004), pp. 69-96.

[24454] M. Watabe, K. Tsogtbaatar, and R. M. Sullivan. "A new pachycephalosaurid from the Baynshire Formation (Cenomanian-late Santonian), Gobi Desert, Mongolia". English. In: vol. 53. Fossil Record 3. New Mexico Museum of Natural History and Science Bulletin. Albuquerque: New Mexico Museum of Natural History and Science, 2011, pp. 489-497.

[24455] M. Watabe, K. Tsogtbaatar, L. Uranbileg, and L. Gereltsetseg. "Report on the Japan-Mongolia Joint Paleontological Expedition to the Gobi desert, 2002". English. In: Hayashibara Museum of Natural Sciences Research Bulletin 2 (2004), pp. 97-122. 
[24456] M. Watabe, K. Tsogtbaatar, S. Suzuki, and M. Saneyoshi. “Geology of dinosaur-fossil-bearing localities (Jurassic and Cretaceous: Mesozoic) in the Gobi Desert: Results of the HMNS-MPC Joint Paleontological Expedition". English. In: Hayashibara Museum of Natural Sciences Research Bulletin 3 (2010), pp. 41-118.

[24457] M. Watabe, T. Tsubamoto, and K. Tsogtbaatar. "A new tritylodontid synapsid from Mongolia". English. In: Acta Palaeontologica Polonica 52.2 (2007), pp. 263-274.

[24458] M. Watabe, T. Tsuihiji, S. Suzuki, and K. Tsogtbaatar. "The first discovery of pterosaurs from the Upper Cretaceous of Mongolia". English. In: Acta Palaeontologica Polonica 54.2 (2009), pp. 231-242. DOI: 10.4202/app.2006.0068.

[24459] A. Watanabe, G. E. Erickson, and P. S. Druckenmiller. "An ornithomimosaurian from the Upper Cretaceous Prince Creek Formation of Alaska". English. In: Journal of Vertebrate Paleontology 33.5 (2013), pp. 1169-1175.

[24460] J. Watanabe, A. Koizumi, R. Nakagawa, K. Takahashi, T. Tanaka, and H. Matsuoka. "Seabirds (Aves) from the Pleistocene Kazusa and Shimosa groups, central Japan". English. In: Journal of Vertebrate Paleontology (2020), -e1697277. DOI: 10.1080/02724634.2019.1697277.

[24461] J. Watanabe and H. Matsuoka. "Flightless diving duck (Aves, Anatidae) from the Pleistocene of Shiriya, northeast Japan". English. In: Journal of Vertebrate Paleontology 35.6 (2015), e994745. DOI: 10.1080/02724634.2014.994745.

[24462] J. Watanabe, H. Matsuoka, and Y. Hasegawa. "Pleistocene fossils from Japan show that the recently extinct Spectacled Cormorant (Phalacrocorax perspicillatus) was a relict". English. In: The Auk 135 (2018), pp. 895-907.

[24463] J. Watanabe, H. Matsuoka, and Y. Hasegawa. "Pleistocene non-passeriform landbirds from Shiriya, northeast Japan". English. In: Acta Palaeontologica Polonica 63 (2018), pp. 469-491.

[24464] J. Watanabe, H. Matsuoka, and Y. Hasegawa. "Two species of Uria (Aves: Alcidae) from the Pleistocene of Shiriya, northeast Japan, with description and body mass estimation of a new species". English. In: Bulletin of the Gunma Museum of Natural History 20 (2016), pp. 59-72.

[24465] J. Watanabe, H. Matsuoka, and Y. Hasegawa. "Pleistocene seabirds from Shiriya, northeast Japan: systematics and oceanographic context". English. In: Historical Biology 32 (2020), pp. 671-729. DOI: 10.1080/08912963.2018.1529764.

[24466] B. Waterhouse and Z. Q. Chen. "Brachiopoda from the Late Permian Senja Formation, Manang area, Nepal Himalaya". English. In: Palaeontographica Abteilung A 280.1-3 (2007), pp. 1-69.

[24467] D. M. Waterhouse, B. E. K. Lindow, N. V. Zelenkov, and G. J. Dyke. "Two new parrots (Psittaciformes) from the Lower Eocene Fur Formation of Denmark". English. In: Palaeontology 51.3 (2008), pp. 575-582.

[24468] C. N. Waters, R. B. Haslam, P. Cózar, I. D. Somerville, D. Millward, and M. Woods. “Mississippian reef development in the Cracoe Limestone Formation of the southern Askrigg Block, North Yorkshire, UK". English. In: Proceedings of the Yorkshire Geological Society (2017). DOI: 10.1144/pygs2016374.

[24469] J. A. Waters and C. Klug. "Devonian (Emsian, Givetian) blastoids and crinoids from the Tafilalt, Morocco". English. In: 290.1-3 (2018), pp. 291-299. DOI: 10.1127/njgpa/2018/0771.

[24470] J. A. Waters, C. G. Maples, N. G. Lane, S. Marcus, Liao Zhou-Ting, Liu Lujun, Hou Hong-Fei, and Wang Jin-Xing. "A quadrupling of Famennian pelmatozoan diversity: new Late Devonian blastoids and crinoids from northwest China". English. In: Journal of Paleontology 77.5 (2003), pp. 922948.

[24471] S. B. Waters and A. Arillo. "A new genus of Hybotidae (Diptera, Empidoidea) from Lower Cretaceous amber of Alava (Spain)". English. In: Studia Dipterologica 6 (1999), pp. 59-66.

[24472] R. Watkins. "A silicified deep-water Silurian fauna from SE Wisconsin". English. In: Abstracts with Programs - Geological Society of America 27.3 (1995), pp. 94-94. 
[24473] R. Watkins. "Evolution of Silurian Pentamerid Communities in Wisconsin". In: Palaios 9 (1994), pp. $488-499$.

[24474] R. Watkins. "Guild structure and tiering in a high-diversity Silurian community, Milwaukee County, Wisconsin". English. In: Palaios 6 (1991), pp. 465-478.

[24475] R. Watkins. “The Silurian (Wenlockian) reef fauna of Southeastern Wisconsin”. In: Palaios 8 (1993), pp. 325-338.

[24476] R. Watkins. "Silurian reef-dwelling brachiopods and their ecologic implications". English. In: Palaios 15 (2000), pp. 112-119.

[24477] R. Watkins. "Paleoecology of a low-diversity Silurian community from the Tofta Beds of Gotland". English. In: Palaeontologische Zeitschrift 66 (1992), pp. 405-413.

[24478] R. Watkins and P. J. Coorough. "Silurian sponge spicules from the Racine Formation, Wisconsin". In: Journal of Paleontology 71.2 (1997), pp. 208-214.

[24479] R. Watkins, J. J. Kuglitsch, and P. E. McGee. "Silurian of the Great Lakes region, part 2: Paleontology of the Upper Llandovery Brandon Bridge Formation, Walworth County, Wisconsin". English. In: Milwaukee Public Museum Contributions in Biology and Geology 87 (1994), pp. 1-53.

[24480] R. Watkins and J. J. Kuglitsch. "Lower Silurian (Aeronian) megafaunal and conodont biofacies of the northwestern Michigan Basin". English. In: Canadian Journal of Earth Sciences 34.6 (1997), pp. 753-764. DOI: 10.1139 /e17-062.

[24481] V. Watson. Glimpses from Gondolin: A faunal analysis of a fossil site near Broederstroom, Transvaal, South Africa. 1993.

[24482] L. N. Weaver, D. J. Varrichio, E. J. Sargis, M. Chen, W. J. Freimuth, and G. P. Wilson Mantilla. "Early mammalian social behaviour revealed by multituberculates from a dinosaur nesting site". English. In: Nature Ecology \& Evolution (2020). DOI: 10.1038/s41559-020-01325-8.

[24483] L. N. Weaver, G. P. Wilson, L. J. Krumenacker, K. Mclaughlin, J. R. Moore, and D. J. Varricchio. "New multituberculate mammals from the mid- Cretaceous (lower Cenomanian) Wayan Formation of southeastern Idaho and implications for the early evolution of Cimolodonta". English. In: Journal of Vertebrate Paleontology (2019), e1604532:1-12. DOI: 10.1080/02724634.2019.1604532.

[24484] P. G. Weaver, R. A. Webb, and R. E. Chandler. "Additional echinoderms from the PCS (Lee Creek) phosphate mine, near Aurora, Beaufort County, North Carolina". English. In: Southeastern Geology 44.2 (2005), pp. 73-83.

[24485] G. E. Webb. "Youngest Early Carboniferous (late Visean) shallow-water patch reefs in eastern Australia (Rockhampton Group, Queensland): Combining micro- and macro-scale data". In: Facies 41 (1999), pp. 111-140.

[24486] G. E. Webb. “Earliest known Carboniferous shallow-water reefs, Gudman Formation (Tn1b), Queensland, Australia: Implications for Late Devonian reef collapse and recovery". In: Geology 26.10 (1998), pp. 951-954.

[24487] G. E. Webb. “Lower Carboniferous coral fauna of the Rockhampton Group, east-central Queensland". English. In: Memoir of the Association of Australasian Palaeontologists 10 (1990), pp. 1-167.

[24488] G. E. Webb. "A New Tabulate Coral Species from the Pitkin Formation (Chesterian) of NorthCentral Arkansas”. English. In: Journal of Paleontology 64.4 (1990), pp. 664-666.

[24489] G. E. Webb and P. K. Sutherland. "Coral fauna of the Imo Formation, uppermost Chesterian, northcentral Arkansas". In: Journal of Paleontology 67.2 (1993), pp. 179-193.

[24490] M. W. Webb. A new Paleocene (Tiffanian) mammalian local fauna from near Drayton Valley, central Alberta, Canada. English. 1995.

[24491] M. W. Webb. New Saxonellidae, Plagiomenidae, and Pantolestidae from the late Paleocene of central Alberta, Canada. English. 1998.

[24492] M. W. Webb. A revised summary of Lancian (latest Cretaceous) mammal localities with introduction to a new Lancian locality (Lance Formation) in the southwestern Bighorn Basin. English. Vol. 49. Guidebook - Wyoming Geological Association. 1998, pp. 131-136. 
[24493] S. D. Webb. Hornless ruminants. English. Evolution of Tertiary mammals of North America. 1998, pp. $463-476$.

[24494] S. D. Webb. "Revision of the extinct Pseudoceratinae (Artiodactyla: Ruminantia: Gelocidae)". English. In: Bulletin of the Florida Museum of Natural History 48.2 (2008), pp. 17-58.

[24495] S. D. Webb, B. L. Beatty, G. Poinar, and Jr. "New evidence of Miocene Protoceratidae including a new species from Chiapas, Mexico". English. In: Bulletin of the American Museum of Natural History 279 (2003), pp. 348-367.

[24496] S. D. Webb and J. P. Dudley. "Proboscidea from Leisey Shell Pits, Hillsborough County, Florida". English. In: Bulletin of the Florida Museum of Natural History 37.20 (1995).

[24497] S. D. Webb, R. C. Hulbert, G. S. Morgan, and H. F. Evans. "Terrestrial mammals of the Palmetto Fauna (early Pliocene, latest Hemphillian) from the Central Florida Phosphate District". English. In: Geology and Vertebrate Paleontology of Western and Southern North America: Contributions in Honor of David P. Whistler 41. Los Angeles: Natural History Museum of Los Angeles County, 2008, pp. 293-312.

[24498] S. D. Webb and J. A. Meachen. "On the Origin of Lamine Camelidae Including a New Genus From the Late Miocene of the High Plains". English. In: Bulletin of Carnegie Museum of Natural History 36.1 (2004), pp. 349-362. DOI: 10.2992/0145-9058(2004)36[349:OTOOLC]2.0.CO;2.

[24499] S. D. Webb and F. G. Stehli. "Selenodont artiodactyls (Camelidae and Cervidae) from the Leisey Shell Pits, Hillsborough County, Florida". English. In: Bulletin of the Florida Museum of Natural History 37.19 (1995).

[24500] B. D. Webby. "Ordovician island biotas: New South Wales record and global implications". English. In: Journal and Proceedings of the Royal Society of New South Wales 125 (1992), pp. 51-77.

[24501] B. D. Webby and J. Trotter. “Ordovician sponge spicules from New South Wales, Australia". English. In: Journal of Paleontology 67.1 (1993), pp. 28-41.

[24502] B. Weber, S. Hu, M. Steiner, and F. Zhao. "A diverse ichnofauna from the Cambrian Stage 4 Wulongqing Formation near Kunming (Yunnan Province, South China)". English. In: Bulletin of Geosciences 87.1 (2012), pp. 71-92.

[24503] B. Weber, M. Steiner, S. Evseev, and G. Yergaliev. "First report of a Meishucun-type early Cambrian (Stage 2) ichnofauna from the Malyi Karatau area (SE Kazakhstan): Palaeoichnological, palaeoecological and palaeogeographical implications". English. In: Palaeogeography, Palaeoclimatology, Palaeoecology 392 (2013), pp. 209-231.

[24504] R. Weber and G. Zamudio-Varela. "Laurozamites, a new genus and new species of bennettitalean leaves from the Late Triassic of North America". In: Revista Mexicana de Ciencias Geologias 12.1 (1995), pp. 68-93.

[24505] G. F. Webers, B. Glenister, J. Pojeta Jr., and G. Young. "Devonian fossils from the Ellsworth Mountains, West Antarctica". In: Geological Society of America Memoir 170 (1992), pp. 269-278.

[24506] G. F. Webers, J. Pojeta, and E. L. Yochelson. "Cambrian Mollusca from the Minaret Formation, Ellsworth Mountains, West Antarctica". English. In: Geological Society of America Memoir 170 (1992), pp. 181-248.

[24507] G. D. Webster. “New Permian crinoids from Australia”. English. In: Palaeontology 33 (1990), pp. 4973.

[24508] G. D. Webster. “A canted-cup Permian crinoid Exotikocrinus n. gen. (Crinoidea, Dichocrinidae) from Timor with comments on canted or inclined radial summits". English. In: Palaeoworld 21 (2012), pp. 64-68.

[24509] G. D. Webster. "An Early Permian crinoid fauna from Crete". English. In: Zoosymposia 7 (2012), pp. 101-110.

[24510] G. D. Webster, L. Angiolini, and A. Tintori. "Permian crinoids from the Saiwan and Khuff Formations, southeastern Oman". English. In: Rivista Italiana di Paleontologia e Stratigrafia 115.1 (2009), pp. 27-48. 
[24511] G. D. Webster and S. K. Donovan. "Revision of two species of ? Ulocrinus and a new pelecocrinid crinoid from West Timor". English. In: Palaeoworld 21 (2012), pp. 108-115.

[24512] G. D. Webster and S. K. Donovan. "Before the extinction - Permian platyceratid gastropods attached to platycrinitid crinoids and an abnormal four-rayed Platycrinites s. s. wachsmuthi (Wanner) from West Timor". English. In: Palaeoworld 21 (2012), pp. 153-159.

[24513] G. D. Webster, D. J. Hafley, D. B. Blake, and A. Glass. “Crinoids and Stelleroids (Echinodermata) from the Broken Rib Member, Dyer Formation (Late Devonian, Famennian) of the White River Plateau, Colorado". English. In: Journal of Paleontology 73.3 (1999), pp. 461-486.

[24514] G. D. Webster, J. W. Haggart, C. Saxifrage, B. Saxifrage, C. Gronau, and A. Douglass. “Globally significant Early Permian crinoids from the Mount Mark Formation in Strathcona Provincial Park, Vancouver Island, British Columbia - preliminary analysis of a disappearing fauna". English. In: Canadian Journal of Earth Sciences 46 (2009), pp. 663-674.

[24515] G. D. Webster and P. A. Jell. "New Permian crinoids from Australia". English. In: Memoirs of the Queensland Museum 43.1 (1999), pp. 279-340.

[24516] G. D. Webster and P. A. Jell. "Permian echinoderms from Western Australia”. English. In: Memoirs of the Queensland Museum 32.1 (1992), pp. 311-373.

[24517] G. D. Webster and P. A. Jell. "Early Permian inadunate crinoids from Thailand". English. In: Memoirs of the Queensland Museum 33.1 (1993), pp. 349-359.

[24518] G. D. Webster and N. G. Lane. "New Permian crinoids from the Battleship Wash patch reef in southern Nevada". English. In: Journal of Paleontology 81.5 (2007), pp. 951-965.

[24519] G. D. Webster, C. G. Maples, R. Mawson, and M. Dastanpour. “A cladid-dominated Early Mississippian crinoid and conodont fauna from Kerman Province, Iran and revision of the glossocrinids and rhenocrinids". English. In: Journal of Paleontology 77.sp60 (2003), pp. 1-37. DOI: 10.1666/00223360(2003)77[1:ACEMCA]2.0.CO;2.

[24520] G. D. Webster and U. J. Rakhmonov. "Devonian (Eifelian) disparid crinoids from the Zeravshan Range, southern Tien Shan, Uzbekistan". English. In: Palaeoworld 18 (2009), pp. 235-240.

[24521] G. D. Webster and G. D. Sevastopulo. "Paleogeographic significance of Early Permian crinoids and blastoids from Oman". English. In: Palaeontologische Zeitschrift 81.4 (2007), pp. 399-405.

[24522] G. D. Webster, J. A. Waters, Z. T. Liao, and C. G. Maples. "New Pennsylvanian (Moscovian) echinoderms from Xinjiang Uyghur Autonomous Region, western China". English. In: Palaeoworld 18 (2009), pp. 241-250.

[24523] J. M. Webster, D. A. Clague, J. C. Braga, H. Spalding, W. Renema, C. Kelly, B. Applegate, J. R. Smith, C. K. Paull, J. G. Moore, and D. Potts. "Drowned coralline algal dominated deposits off Lanai, Hawaii; carbonate accretion and vertical tectonics over the last $30 \mathrm{ka}$ ". English. In: Marine Geology 225 (2006), pp. 223-246.

[24524] J. M. Webster and P. J. Davies. "Coral variation in two deep drill cores: significance for the Pleistocene development of the Great Barrier Reef". English. In: Sedimentary Geology 159.1-2 (2003), pp. 61-80.

[24525] J. M. Webster, P. J. Davies, and K. Konishi. "Model of fringing reef development in response to progressive sea level fall over the last 7000 years (Kikai-jima, Ryukyu Islands, Japan)". English. In: Coral Reefs 17 (1998), pp. 289-308.

[24526] M. Webster, R. G. Gaines, and N. C. Hughes. "Microstratigraphy, trilobite biostratinomy, and depositional environment of the Lower Cambrian Ruin Wash Lagerstätte, Pioche Formation, Nevada". English. In: Palaeogeography, Palaeoclimatology, Palaeoecology 268 (2008), pp. 100-122.

[24527] M. J. Wedel, R. L. Cifelli, and R. K. Sanders. "Sauropseidon proteles, a new sauropod from the Early Cretaceous of Oklahoma". English. In: Journal of Vertebrate Paleontology 20.1 (2000), pp. 109114.

[24528] S. Wedmann. "A nemestrinid fly (Insecta: Diptera: Nemestrinidae: cf. Hirmoneura) from the Eocene Messel Pit (Germany)”. English. In: Journal of Paleontology 81.5 (2007), pp. 1114-1117. 
[24529] S. Wedmann, S. Bradler, and J. Rust. "The first fossil leaf insect: 47 million years of specialized cryptic morphology and behavior". English. In: Proceedings of the National Academy of Sciences 104.2 (2007), pp. 565-569.

[24530] S. Wedmann, T. Hörnschemeyer, and H. Schmied. “Fossil water-penny beetles (Coleoptera: Psephenidae: Eubrianacinae) from the Eocene of Europe, with remarks on their phylogenetic position and biogeography". English. In: Palaeontology 54 (2011), pp. 965-980.

[24531] S. Wedmann and V. N. Makarkin. "A new genus of Mantispidae (Insecta: Neuroptera) from the Eocene of Germany, with a review of the fossil record and palaeobiogeography of the family". English. In: Zoological Journal of the Linnean Society 149 (2007), pp. 701-716.

[24532] S. Wedmann, V. N. Makarkin, T. Weiterschan, and T. Hörnschemeyer. "First fossil larvae of Berothidae (Neuroptera) from Baltic amber, with notes on the biology and termitophily of the family". English. In: Zootaxa 3716 (2013), pp. 236-258.

[24533] S. Wedmann, J. M. Pouillon, and A. Nel. “New Palaeogene horntail wasps (Hymenoptera, Siricidae) and a discussion of their fossil record". English. In: Zootaxa 3869 (2014), pp. 33-43.

[24534] S. Wedmann and J. Skartveit. "First record of march flies (Insecta: Diptera: Bibionidae) from the Miocene Graanica mine (Bugojno, Bosnia-Herzegovina)". English. In: Palaeobiodiversity and Palaeoenvironments 100 (2020), pp. 585-591. DOI: 10.1007/s12549-018-00369-w.

[24535] S. Wedmann, T. Wappler, and M. S. Engel. "Direct and indirect fossil records of megachilid bees from the Paleogene of central Europe (Hymenoptera: Megachilidae)". English. In: Naturwissenschaften 96 (2009), pp. 703-712.

[24536] S. Wedmann and D. K. Yeates. “Eocene records of bee flies (Insecta, Diptera, Bombyliidae, Comptosia): their palaeobiogeographic implications and remarks on the evolutionary history of bombyliids". English. In: Palaeontology 51.1 (2008), pp. 231-240.

[24537] R. E. Weems. Part 5. Reptile remains from the Fisher/Sullivan site. 1999.

[24538] R. E. Weems. "The manus print of Kayentapus minor: its bearing on the biomechanics and ichnotaxonomy of early Mesozoic saurischian dinosaurs". English. In: vol. 37. The Triassic-Jurassic Terrestrial Transition. New Mexico Museum of Natural History and Science Bulletin. Albuquerque: New Mexico Museum of Natural History and Science, 2006, pp. 369-378.

[24539] R. E. Weems. "Crocodilians of the Calvert Cliffs". English. In: Smithsonian Contributions to Paleobiology 100 (2018), pp. 213-240.

[24540] R. E. Weems. Part 4. Actinopterygian Fishes from the Fisher/Sullivan Site. English. Virginia Division of Mineral Resources Publication 152. 1999, pp. 53-100.

[24541] R. E. Weems. "Actinopterygian fish remains from the Paleocene of South Carolina". English. In: Transactions of the American Philosophical Society 88.4 (1998), pp. 147-164.

[24542] R. E. Weems. "Paleogene chelonians from Maryland and Virginia". English. In: PaleoBios 31.1 (2014), pp. 1-32.

[24543] R. E. Weems and J. M. Bachman. "Cretaceous anuran and dinosaur footprints from the Patuxent Formation of Virginia". English. In: Proceedings of the Biological Society of Washington 110.1 (1997), pp. 1-17.

[24544] R. E. Weems and J. M. Bachman. "The Lower Cretaceous Patuxent Formation ichnofauna of Virginia". English. In: Ichnos 22.3-4 (2015), pp. 209-219. DOI: 10.1080/10420940.2015.1063493.

[24545] R. E. Weems and K. M. Brown. "More-complete remains of Procolpochelys charlestonensis (Oligocene, South Carolina), an occurrence of Euclastes (upper Eocene, South Carolina), and their bearing on Cenozoic pancheloniid sea turtle distribution and phylogeny". English. In: Journal of Paleontology 91.6 (2017), pp. 1228-1243. DOI: 10.1017/jpa.2017.64.

[24546] R. E. Weems and L. M. Bybell. "Geology of the Black Mingo Group (Paleocene) in the Kingstree and St. Stephen Areas of South Carolina". English. In: Transactions of the American Philosophical Society 88.4 (1998), pp. 9-27. 
[24547] R. E. Weems and L. E. Edwards. "The age and provenance of Eschrichtius cephalus Cope (Mammalia: Cetacea)". English. In: Journal of Vertebrate Paleontology 27.3 (2007), pp. 752-756.

[24548] R. E. Weems, L. E. Edwards, J. E. Osborne, and A. A. Alford. "An Occurrence of the Protocetid Whale Eocetus wardii in the Middle Eocene Piney Point Formation of Virginia". English. In: Journal of Paleontology 85.2 (2011), pp. 271-278. DOI: 10.1666/10-083.1.

[24549] R. E. Weems, L. E. Edwards, and B. Landacre. “Geology and biostratigraphy of the Potomac River Cliffs at Stratford Hall, Westmoreland County, Virginia". English. In: The Geological Society of America Field Guide 47 (2017), pp. 125-152.

[24550] R. E. Weems and R. A. George. "Amphibians and nonmarine turtles from the Miocene Calvert Formation of Delaware, Maryland, and Virginia (USA)". English. In: Journal of Paleontology 87.4 (2013), pp. 53-66.

[24551] R. E. Weems and J. L. Knight. A New Species of Bairdemys (Pelomedusoides: Podocnemididae) from the Oligocene (Early Chattian) Chandler Bridge Formation of South Carolina, USA, and Its Paleobiogeographic Implications for the Genus. English. Morphology and Evolution of Turtles. 2013, pp. 289-303.

[24552] R. E. Weems and A. E. Sanders. “Oligocene Pancheloniid Sea Turtles from the Vicinity of Charleston, South Carolina, U.S.A." English. In: Journal of Vertebrate Paleontology 34.1 (2014), pp. 80-99. DOI: 10.1080/02724634.2013.792826.

[24553] P. Wegierek. "Apterous Phylloxeroidea (Hemiptera, Sternorrhyncha) from Baltic amber". English. In: Acta Zoologica Cracoviensia 46.Suppl (2003), pp. 277-283.

[24554] P. Wegierek. "Cretaceous aphids of the family Canadaphidae (Hemiptera Aphidomorpha)". English. In: Paleontological Journal 25.2 (1991), pp. 143-145.

[24555] P. Wegierek. “Quisqueyaaphis heiei gen. and sp. nov. (Hemiptera: Aphidinea: Greenideidae), new species of aphid from Dominican amber". English. In: Annales Zoologici 51 (2001), pp. 409-415.

[24556] P. Wegierek. "The aphid family Genaphididae (Homoptera, Aphidina) from the Upper Mesozoic of Mongolia". English. In: Polskie Pismo Entomologiczne 61 (1991), pp. 79-84.

[24557] P. Wegierek. "Aphid species (Homoptera: Aphidinea) from the collection of the Baltic amber in the Museum of the Earth, Polish Academy of Sciences, Warsaw (part 2)". English. In: Prace Muzeum Ziemi 44 (1996), pp. 25-39.

[24558] P. Wegierek. "Aphid remains from the Upper Cretaceous (Homoptera: Canadaphididae, Palaeoaphididae)". English. In: Annals of the Upper Silesian Museum, Entomology, Supplement 1 (1993), pp. 5766.

[24559] P. Wegierek. "Aphids (Hemiptera: Sternorrhyncha: Aphidomorpha), in Aphids, true hoppers, jumping plant-lice, scale insects, true bugs and whiteflies (Insecta: Hemiptera) from the Insect Limestone (latest Eocene) of the Isle of Wight, UK". English. In: Earth and Environmental Science Transactions of the Royal Society of Edinburgh 110 (2019), pp. 331-396.

[24560] P. Wegierek, J. Brozek, R. S. Kelly, and B. Wang. "The aphid Hormatalis lancigerens gen. et sp. nov. from Burmese amber sheds new light on the phylogenetic position of the Cretaceous family Isolitaphidae (Hemiptera: Aphidomorpha)". English. In: Cretaceous Research 89 (2018), pp. 292301.

[24561] P. Wegierek, C. Y. Cai, and D. Y. Huang. “New genera and species of aphids (Hemiptera, Aphidomorpha, Burmitaphididae) in mid-Cretaceous Burmese amber". English. In: Cretaceous Research 93 (2018), pp. 318-329.

[24562] P. Wegierek, C. Y. Cai, and D. Y. Huang. “Detailed descriptions of a female and male of the aphids family Parvaverrucosidae (Hemiptera: Aphidomorpha) from mid-Cretaceous amber of Myanmar revealed their new systematic position". English. In: Cretaceous Research 100 (2019), pp. 39-45. DOI: 10.1016/j.cretres.2019.03.019.

[24563] P. Wegierek and D. A. Grimaldi. "A new subfamily of aphids (Hemiptera, Aphidomorpha) from the Early Cretaceous Lebanese amber with a description of the oldest apterous morphs". English. In: Acta Geologica Sinica 84 (2010), pp. 665-672. 
[24564] P. Wegierek, I. Kania, and M. Zmarzly. “Wojciechaphis andrei gen. et sp. nov. (Hemiptera: Aphidomorpha, Drepanosiphidae, Phyllaphidinae), a new aphid genus from Baltic amber". English. In: Polish Journal of Entomology 84 (2015), pp. 351-360.

[24565] P. Wegierek and V. A. Mamontova. "A new fossil species of the genus Stomaphis Walk. (Aphidoidea: Lachnidae)". English. In: Annals of the Upper Silesian Museum, Entomology, Supplement 1 (1993), pp. 37-50.

[24566] P. Wegierek and E. Peñalver. "Fossil representatives of the family Greenideidae (Hemiptera, Aphidoidea) from the Miocene of Europe". English. In: Geobios 35 (2002), pp. 745-757.

[24567] P. Wegierek and D. ya. "New Hormaphididae (Hemiptera, Aphidomorpha) from the Baltic amber and its palaeogeographic significance". English. In: Acta Geologica Sinica 85 (2011), pp. 521-527.

[24568] P. Wegierek, D. ya, A. Homan, C. Y. Cai, and D. Y. Huang. "New genus and species of the extinct aphid family Szelegiewicziidae and their implications for aphid evolution". English. In: The Science of Nature 104.95 (2017), pp. 1-10.

[24569] D. D. Wei, O. Béthoux, Y. X. Guo, J. W. Schneider, and D. Ren. "New data on the singularly rare 'cockroachoids' from Xiaheyan (Pennsylvanian; Ningxia, China)". English. In: Alcheringa 37 (2013), pp. 547-557.

[24570] D. D. Wei, J. H. Liang, and D. Ren. "A new species of Fuziidae (Insecta, Blattida) from the Inner Mongolia, China". English. In: ZooKeys 217 (2012), pp. 53-61.

[24571] D. D. Wei, J. H. Liang, and D. Ren. "A new fossil genus of Fuziidae (Insecta, Blattida) from the Middle Jurassic of Jiulongshan Formation, China". English. In: Geodiversitas 35 (2013), pp. 335343.

[24572] D. D. Wei and D. Ren. "Completely preserved cockroaches of the family Mesoblattinidae from the Upper Jurassic-Lower Cretaceous Yixian Formation (Liaoning Province, NE China)". English. In: Geologica Carpathica 64 (2013), pp. 291-304.

[24573] D. D. Wei, C. K. Shih, and D. Ren. “Arcofuzia cana gen. et sp. n. (Insecta, Blattaria, Fuziidae) from the Middle Jurassic sediments of Inner Mongolia, China". English. In: Zootaxa 3597 (2012), pp. 2532.

[24574] G. J. Wei, C. K. Shih, D. Ren, and Y. J. Wang. "A new burmaeshnid dragonfly from the midCretaceous Burmese amber: elucidating wing base structure of true Odonata". English. In: Cretaceous Research 101 (2019), pp. 23-29. DOI: 10.1016/j.cretres.2019.04.005.

[24575] X. Wei, H. Pu, L. Xu, D. Liu, and J. Lü. “A new oviraptorid dinosaur (Theropoda: Oviraptorosauria) from the Late Cretaceous of Jiangxi Province, southern China". English. In: Acta Geologica Sinica (English Edition) 87.4 (2013), pp. 899-904.

[24576] Z.-Y. Wei and L. Li. "Discovery of a new enantiornithine bird from Lower Cretaceous of western Liaoning, China". English. In: Global Geology 36.3 (2017), pp. 655-662.

[24577] D. M. Weide, C. A. Sidor, K. D. Angielczyk, and R. M. H. Smith. "A new record of Procynosuchus delaharpeae (Therapsida: Cynodontia) from the Upper Permian Usili Formation, Tanzania". English. In: Palaeontologia Africana 44 (2009), pp. 21-26.

[24578] I. Weidig. "New Birds from the Lower Eocene Green River Formation, North America”. English. In: Records of the Australian Museum 62 (2010), pp. 29-44. DOI: 10.3853/j.0067-1975.62.2010.1544.

[24579] O. Weidlich and H. W. Flügel. “Upper Permian (Murghabian) rugose corals from Oman (Ba'id area, Saih Hatat): Community structure and contributions to reefbuilding processes". In: Facies 33 (1995), pp. 229-264.

[24580] O. Weidlich and B. Senowbari-Daryan. "Late Permian 'Sphinctozoans' from reefal blocks of the Ba'id area, Oman Mountains". English. In: Journal of Paleontology 70.1 (1996), pp. 27-46.

[24581] M. Weidmann and L. Ginsburg. "Sur le Gres de la Moliere". English. In: Bulletin de la Societe Vaudoise des Sciences naturelles 86.4 (1999), pp. 213-228. 
[24582] J. C. Weinbaum and A. Hungerbühler. "A revision of Poposaurus gracilis (Archosauria: Suchia) based on two new specimens from the Late Triassic of the southwestern U.S.A." English. In: Palaeontologische Zeitschrift 81.2 (2007), pp. 131-145.

[24583] R. Weis, N. Mariotti, and J. Wendt. "The belemnite genus Rhabdobelus from Middle Jurassic Tethyan sediments of central Italy and Sicily, with a systematic review". English. In: Paläontologische Zeitung 89 (2015), pp. 133-146.

[24584] R. Weis, N. Mariotti, and A. Cencio. "Systematics and evolutionary implications of Early Jurassic belemnites from the Peri-Mediterranean Tethys". English. In: Palaeontologische Zeitschrift 89 (2015), pp. 729-747.

[24585] D. B. Weishampel, D. Grigorescu, and D. B. Norman. "The dinosaurs of Transylvania". English. In: National Geographic Research E Exploration 7.2 (1991), pp. 196-215.

[24586] D. B. Weishampel, C.-M. Jianu, Z. Csiki, and D. B. Norman. “Osteology and phylogeny of Zalmoxes (n. g.), an unusual euornithopod dinosaur from the latest Cretaceous of Romania". English. In: Journal of Systematic Palaeontology 1.2 (2003), pp. 65-123.

[24587] D. B. Weishampel, E. W. A. Mulder, R. W. Dortange, J. W. M. Jagt, C. -M. Jianu, M. M. M. Kuypers, H. H. G. Peeters, and A. S. Schulp. "Dinosaur remains from the type Maastrichtian: an update". English. In: Geologie en Mijnbouw 78.3-4 (1999), pp. 357-365.

[24588] M. I. Weisler. "Life on the edge: prehistoric settlement and economy on Utrk Atoll, northern Marshall Islands". English. In: Archaeology in Oceania 36 (2001), pp. 109-133.

[24589] J.-L. Welcomme, P.-O. Antoine, F. Duranthon, P. Mein, and L. Ginsburg. “Nouvelles decouvertes de vertebres miocenes dans le synclina de Dera Bugti (Balouchistan, Pakistan)". French. In: Comptes Rendus Academie de Science Paris. Sciences de la terr et des planetes 325 (1997), pp. 531-536.

[24590] J.-L. Welcomme and L. Ginsburg. "Mise en évidence de l'Oligocéne sur le territoire des Bugti (Balouchistan, Pakistan)". French. In: Comptes Rendus de l'Académie des Sciences - Series IIA - Earth and Planetary Science 325.12 (1997), pp. 999-1004.

[24591] E. A. Weldon and G. R. Shi. "Global distribution of Permian conulariids and palaeobiogeographical implications". English. In: Gondwana Research 6.4 (2003), pp. 791-802.

[24592] C. H. Wellman. "Morphology and wall ultrastructure in Devonian spores with bifurcate-tipped processes". In: International Journal of Plant Sciences 163.3 (2002), pp. 451-474.

[24593] C. H. Wellman, D. Edwards, and L. Axe. "Permanent dyads in sporangia and spore masses from the Lower Devonian of the Welsh Borderland". In: Botanical Journal of the Linnean Society 127 (1998), pp. 117-147.

[24594] C. H. Wellman, K. Habgood, G. Jenkins, and J. B. Richardson. "A new plant assemblage (microfossil and megafossil) from the Lower Old Red Sandstone of the Anglo-Welsh Basin: its implications for the palaeoecology of early terrestrial ecosystems". In: Review of Palaeobotany and Palynology 109 (2000), pp. 161-196.

[24595] P. Wellnhofer. "Ein Dinosaurier (Hadrosauridae) aus der Oberkreide (Maastricht, HelvetikumZone) des bayerischen Alpenvorlandes [A dinosaur (Hadrosauridae) from the Upper Cretaceous (Maastrichtian, Helvetikum Zone) of the Bavarian Alpine foreland]". German. In: Mitteilungen der Bayerischen Staatssammlung für Paläontologie und Historische Geologie 34 (1994), pp. 221-238.

[24596] P. Wellnhofer. "Weitere Pterosaurierfunde aus der Santana-Formation (Apt) der Chapada do Araripe, Brasilien". German. In: Palaeontographica Abteilung A 215 (1991), pp. 43-101.

[24597] P. Wellnhofer and M. Röper. The ninth specimen of Archaeopteryx from Solnhofen. English. 2005.

[24598] R. E. Wells, A. S. Jayko, A. R. Niem, G. Black, T. Wiley, E. Baldwin, K. Molenaar, K. L. Wheeler, C. B. DuRoss, and R. W. Givler. "Geologic Map and Database of the Roseburg 30 × 60' Quadrangle, Douglas and Coos Counties, Oregon". English. In: United States Geological Survey Open-File Report 00-367 (2000). 
[24599] R. T. Wells, P. F. Murray, and S. J. Bourne. "Pedal morphology of the marsupial lion Thylacoleo carnifex (Diprotodontia: Thylacoleonidae) from the Pleistocene of Australia". English. In: Journal of Vertebrate Paleontology 29.4 (2009), pp. 1335-1340. DOI: 10.1671/039.029.0424.

[24600] C. F. Wellstead. "Taxonomic revision of the Lysorophia, Permo-Carboniferous lepospondyl amphibians". English. In: Bulletin of the American Museum of Natural History 209 (1991), pp. 1-90.

[24601] J. Welman. "The taxonomy of the South African proterosuchids (Reptilia, Archosauromorpha)". English. In: Journal of Vertebrate Paleontology 18 (1998), pp. 340-347.

[24602] B. J. Welton. "A new dalatiid shark (Squaliformes: Daltaiidae) from the early Oligocene of Oregon and California, USA". English. In: Fossil Record 5 (2016), pp. 289-302.

[24603] B. J. Welton. "First report of Orthechinorhinus (Squaliformes: Etmopteriidae) from the Pacific Basin; A new species from Early Oligocene rocks of Oregon, USA". English. In: Fossil Record 5 (2016), pp. 303-308.

[24604] B. J. Welton. "A new archaic basking shark (Lamniformes, Cetorhinidae) from the Late Eocene of Western Oregon, USA, and description of the dentition, gill rakers and vertebrae of the recent basking shark Cetorhinus Maximus (Gunnerus)". English. In: New Mexico Museum of Natural History and Science Bulletin 58 (2013), pp. 1-48.

[24605] B. J. Welton. “Cetorhinus cf. C. maximus (Gunnerus) (Lamniformes: Cetorhinidae), A Basking Shark from the Late Miocene Empire Formation, Coos Bay, Oregon". English. In: Bulletin of the Southern California Academy of Sciences 112.2 (2013), pp. 74-92.

[24606] B. J. Welton and J. L. Goedert. “New fossil species of Somniosus and Rhinoscymnus (Squaliformes: Somniosidae), deep water sharks from Oligocene rocks of Western Washington State, USA". English. In: Fossil Record 5 (2016), pp. 309-326.

[24607] R. Wen, L. E. Babcock, J. Peng, and R. A. Robison. “New edrioasteroid (Echinodermata) from the Spence Shale (Cambrian), Idaho, USA: further evidence of attachment in the early evolutionary history of edrioasteroids". English. In: Bulletin of Geosciences 94.1 (2019), pp. 115-124. DOI: 10.3140/ bull.geosci.1730.

[24608] S.-X. Wen. "Cretaceous bivalves of Kangpa Group, South Xizang, China and their biogeography". English. In: Acta Palaeontologica Sinica 39.1 (2000), pp. 1-27.

[24609] W. Wen, Q. Y. Zhang, C. Y. Zhou, J. Y. Huang, Z. Q. Chen, and M. J. Benton. “A new genus of basal actinopterygian fish from the Anisian (Middle Triassic) of Luoping, Yunnan Province, Southwest China". English. In: Acta Palaeontologica Polonica 57 (2012), pp. 149-160.

[24610] W. Wen, Q. Y. Zhang, S. X. Hu, M. J. Benton, C. Y. Zhou, X. Tao, J. Y. Huang, and Z. Q. Chen. "Coelacanths from the Middle Triassic Luoping Biota, Yunnan, South China, with the earliest evidence of ovoviviparity". English. In: Acta Palaeontologica Polonica 58 (2013), pp. 175-193. DOI: 10.4202/app.2011.0066.

[24611] X. Wenchen and Z. Ning. "Middle Triassic Radiolaria from turbudites in Ziyun, Guizhou South China". English. In: Micropaleontology 46.1 (2000), pp. 73-87.

[24612] A. J. Wendruff, L. E. Babcock, C. S. Wirkner, J. Kluessendorf, and D. G. Mikulic. "A Silurian ancestral scorpion with fossilised internal anatomy illustrating a pathway to arachnid terrestrialisation". English. In: Scientific Reports 10.14 (2020). DOI: 10.1038/s41598-019-56010-z.

[24613] A. J. Wendruff and M. V. H. Wilson. “A fork-tailed coelacanth, Rebellatrix divaricerca, gen. et sp. nov. (Actinistia, Rebellatricidae, fam. nov.), from the Lower Triassic of western Canada". English. In: Journal of Vertebrate Paleontology 32 (2012), pp. 499-511.

[24614] A. J. Wendruff and M. V. H. Wilson. "New Early Triassic coelacanth in the family Laugiidae (Sarcopterygii: Actinistia) from the Sulphur Mountain Formation near Wapiti Lake, British Columbia, Canada". English. In: Canadian Journal of Earth Sciences 50 (2013), pp. 904-910.

[24615] J. Wendt. "Steep-sided carbonate mud mounds in the Middle Devonian of the eastern Anti-Atlas, Morocco". English. In: Geological Magazin 130.1 (1993), pp. 69-83. 
[24616] J. Wendt. "The first tunicate with a calcareous exoskeleton (Upper Triassic, Northern Italy)". English. In: Palaeontology 61.4 (2018), pp. 575-595. DOI: 10.1111/pala.12356.

[24617] J. Wendt, B. Kaufmann, and Z. Belka. "An exhumed Palaeozoic underwater scenery: the Visean mud mounds of eastern Anti-Atlas (Morocco)". English. In: Sedimentary Geology 145 (2001), pp. 215233.

[24618] J. Wendt and B. Kaufmann. “Middle Devonian (Givetian) coral-stromatoporoid reefs in West Sahara (Morocco)". English. In: Journal of African Earth Sciences 44 (2006), pp. 339-350.

[24619] S. Wenz. "Pliodetes nigeriensis, gen. nov. et. sp. nov., a new semionotid fish from the Lower Cretaceous of Gadoufaoua (Niger Republic): phylogenetic comments". English. In: Mesozoic Fishes 2-Systematics and Fossil Record. Munich: Verlag Dr. Friedrich Pfeil, 1999, pp. 107-120.

[24620] S. Wenz. "Les Lepidotes (Actinopterygii, Semionotiformes) de Cretace inferieur (Barremien) de Las Hoyas (Province de Cuenca, Espagne)". French. In: Geodiversitas 25.3 (2003), pp. 481-499.

[24621] S. Wenz and F. J. Poyato-Ariza. "Les Actiopterygiens juveniles du Cretace Inferieur du Montsec et de Las Hoyas (Espagne)". French. In: Geobios 16 (1994), pp. 203-212.

[24622] R. Weppe, C. Blondel, M. Vianey-Liaud, G. Escarguel, T. Pélissié, P. -O. Antoine, and M. J. Orliac. "Cainotheriidae (Mammalia, Artiodactyla) from Dams (Quercy, SW France): phylogenetic relationships and evolution around the Eocene-Oligocene transition (MP19-MP21)". English. In: Journal of Systematic Palaeontology (2019). DOI: 10.1080/14772019.2019.1645754.

[24623] L. Werdelin. "The last amphicyonid (Mammalia, Carnivora) in Africa". English. In: Geodiversitas 31.4 (2009), pp. 775-787.

[24624] L. Werdelin and B. Kurtén. "Allohyaena (Mammalia: Carnivora): giant hyaenid from the Late Miocene of Hungary". English. In: Zoological Journal of the Linnean Society 126.3 (1999), pp. 319334. DOI: 10.1016/S0024-4082(99)80003-X.

[24625] L. Werdelin and M. E. Lewis. "Carnivora from the South Turkwel Hominid Site, Northern Kenya". English. In: Journal of Paleontology 74.6 (2000), pp. 1173-1180.

[24626] R. Werneburg. "Trematosaurus (Amphibia) aus dem Mittleren Buntsandstein (Untertrias) von Thüringen". German. In: Veröffentlichungen des Naturhistorischen Museums Schleusingen 7/8 (1993), pp. 17-29.

[24627] R. Werneburg. “Dissorophoiden (Amphibia) aus dem Grenzbereich Karbon/Perm der Saale-Senke und des Ilfelder Beckens (DDR)". English. In: Zeitschrift fur geologische Wissenschaften Berlin 18 (1990), pp. 665-677.

[24628] R. Werneburg. "Apateon dracyiensis - eine frühe Pionierform der Branchiosaurier aud dem Europäischen Rotliegend. Teil 1: Morphologie". German. In: Veröffentlichungen Naturhist. Museum Schleusingen 16 (2001), pp. 17-36.

[24629] R. Werneburg and D. S. Berman. "Revision of the Aquatic Eryopid Temnospondyl Glaukerpeton avinoffi Romer, 1952, from the Upper Pennsyl Vanian of North America". English. In: Annals of Carnegie Museum 81.1 (2012), pp. 33-60.

[24630] R. Werneburg, S. G. Lucas, J. W. Schneider, and L. F. Rinehart. “First Pennsylvanian Eryops (Temnospondyli) and its Permian Record from New Mexico". English. In: Bulletin of the New Mexico Museum of Natural History and Science 49 (2010), pp. 129-136.

[24631] R. Werneburg, J. W. Schneider, S. Voigt, and A. Belahmira. "First African record of micromelerpetid amphibians (Temnospondyli, Dissorophoidea)". English. In: Journal of African Earth Sciences (2019). DOI: 10.1016/j.jafrearsci.2019.103573.

[24632] R. Werneburg, J. S. Steyer, G. Sommer, G. Gand, J. W. Schneider, and M. Vianey-Liaud. “The earliest tupilakosaurid amphibian with diplospondylous vertebrae from the Late Permian of southern France". English. In: Journal of Vertebrate Paleontology 27.1 (2007), pp. 26-30. DOI: 10.1671 / 02724634(2007)27[26:TETAWD]2.0.CO;2. 
[24633] C. Werner. “Die kontinentale Wirbeltierfauna aus der unteren Oberkreide des Sudan (Wadi Milk Formation) [The continental vertebrate fauna of the lower Upper Cretaceous of Sudan (Wadi Milk Formation)]". German. In: In R. Kohring \& T. Martin (eds.), Miscellanea Palaeontologica 3: Festschrift Bernard Krebs. Berliner Geowissenschaften Abhandlungen, Reihe E 13 (1994), pp. 221-249.

[24634] J. Werner. "Beiträge zur Biostratigraphie der Unteren SüSSwasser-Molasse Süddeutschlands Rodentia und Lagomorpha (Mammalia) aus den Fundstellen der Ulmer Gegend." German. In: Stuttgarter Beiträge zur Naturkunde, Serie B (Geologie und Paläontologie). 200 (1994), pp. 1-263.

[24635] W. Werner, R. R. Leinfelder, F. T. Fürsich, and M. Krautter. "Comparative palaeoecology of marly coralline sponge-bearing reefal associations from the Kimmeridgina (Upper Jurassic) of Portugal and southwestern Germany". In: Courier Forschungsinstitut Senckenberg 172 (1994), pp. 381-397.

[24636] T. Wesener. "The oldest pill millipede fossil: A species of the Asiatic pill millipede genus Hyleoglomeris in Baltic amber (Diplopoda: Glomerida: Glomeridae)". English. In: Zoologischer Anzeiger 283 (2019), pp. 40-45.

[24637] T. Wesener and L. Moritz. "Checklist of the Myriapoda in Cretaceous Burmese amber and a correction of the Myriapoda identified by Zhang (2017)". English. In: Check List 14.6 (2018), pp. 11311140.

[24638] G. D. Wesley and J. J. Flynn. “A revision of Tapocyon (Carnivoramorpha), including analysis of the first cranial specimens and identification of a new species". English. In: Journal of Paleontology 77.4 (2003), pp. 769-783.

[24639] F. P. Wesselingh. "Molluscs from the Miocene Pebas Formation of Peruvian and Colombian Amazonia". English. In: Scripta Geologica 133 (2006), pp. 19-290.

[24640] F. P. Wesselingh, A. Ranzi, and M. E. Räsänen. "Miocene freshwater Mollusca from western Brazilian Amazonia". English. In: Scripta Geologica 133 (2006), pp. 419-437.

[24641] W. Wessels. "Miocene rodent evolution and migration. Muroidea from Pakistan, Turkey and Northern Africa". English. In: Geologica Ultraiectina 307 (2009), pp. 1-290.

[24642] W. Wessels, D. Badamgarav, V. Van Onselen, and G. Daxner-Höck. “Tsaganomyidae (Rodentia, Mammalia) from the Oligocene of Mongolia (Valley of Lakes)". English. In: Annalen des Naturhistorischen Museums in Wien, Serie A 116 (2014), pp. 293-325.

[24643] W. Wessels, O. Fejfar, P. Peláez-Campomanes, A. J. van der Meulen, and H. de Bruijn. “Miocene small mammals from Jebel Zelten, Libya". English. In: Coloquios de Paleontologa, Volumen extraordinario 1 (2003), pp. 619-715.

[24644] W. Wessels, A. A. van de Weerd, H. de Bruijn, and Z. Markovi. "New Melissiodontinae (Mammalia, Rodentia) from the Paleogene". English. In: Palaeobiodiversity and Palaeoenvironments 98.3 (2018), pp. 471-487.

[24645] W. Wessels, A. A. van de Weerd, H. de Bruijn, and Z. Markovi. “Dipodidae (Mammalia, Rodentia) from the Paleogene of south-east Serbia". English. In: Palaeobiodiversity and Palaeoenvironments (2019). DOI: 10.1007/s12549-019-00392-5.

[24646] A. R. West, C. R. Torres, J. A. Case, J. A. Clark, P. M. O'Connor, and M. C. Lamanna. “An avian femur from the Late Cretaceous of Vega Island, Antarctic Peninsula: removing the record of cursorial landbirds from the Mesozoic of Antarctica". English. In: PeerJ 7.e7231 (2019). DOI: 10.7717/ peerj.7231.

[24647] R. M. West, J. H. Hutchison, and J. Munthe. "Miocene vertebrates from the Siwalik Group, Western Nepal". English. In: Journal of Vertebrate Paleontology 11.1 (1991), pp. 108-129.

[24648] G. E. G. Westermann and N. Hudson. "The first find of Eurycephalitinae (Jurassic Ammonitina) in New Zealand and its biogeographic implications". English. In: Journal of Paleontology 65.4 (1991), pp. 689-693.

[24649] J. W. Westgate. "Uintan Land Mammals (Excluding Rodents) From an Estuarine Facies of the Laredo Formation (Middle Eocene, Claiborne Group) of Webb County, Texas". English. In: Journal of Paleontology 64.3 (1990), pp. 454-468. 
[24650] J. W. Westgate. "Dinohyus aff. D. hollandi (Mammalia, Entelodontidae) in Alabama". English. In: Journal of Paleontology 66.4 (1992), pp. 685-687.

[24651] J. W. Westgate. "A New Leptochoerid from Middle Eocene (Uintan) Deposits of the Texas Coastal Plain". English. In: Journal of Vertebrate Paleontology 14.2 (1994), pp. 296-299.

[24652] J. W. Westgate. A giant entelodont from Oligocene deposits of the Texas coastal plain. English. 1993.

[24653] J. W. Westgate. Paleoecology and biostratigraphy of marginal marine gulf coast Eocene vertebrate localities. English. Eocene Biodiversity: Unusual Occurrences and Rarely Sampled Habitats. 2001, pp. 263297.

[24654] J. W. Westgate. "Palaeoecology of a primate-friendly, middle Eocene community from Laredo, Texas and a review of stratigraphic occurrences of Paleogene land mammals across the Gulf Coastal Plain, USA". English. In: Palaeobiodiversity and Palaeoenvironments 92 (2012), pp. 497-505. DOI: $10.1007 / \mathrm{s} 12549-012-0084-6$.

[24655] J. W. Westgate and F. C. Whitmore. "Balaena ricei, a new species of bowhead whale from the Yorktown Formation (Pliocene) of Hampton, Virginia". English. In: Smithsonian Contributions to Paleobiology 93 (2002), pp. 295-312.

[24656] S. R. Westrop. “Upper Cambrian (Marjuman-Steptoean) trilobites from the Port Au Port Group, western Newfoundland". English. In: Journal of Paleontology 66.2 (1992), pp. 228-255.

[24657] S. R. Westrop and J. M. Adrain. “Biogeographic Shifts in a Transgressive Succession: The Cambrian (Furongian, Jiangshanian; Latest Steptoean-Earliest Sunwaptan) Agnostoid Arthropods Kormagnostella Romanenko and Biciragnostus Ergaliev in North America". English. In: Journal of Paleontology 87.5 (2013), pp. 804-817.

[24658] S. R. Westrop, J. M. Adrain, and E. Landing. "The Cambrian (Sunwaptan, Furongian) agnostoid arthropod Lotagnostus Whitehouse, 1936, in Laurentian and Avalonian North America: systematics and biostratigraphic significance". English. In: Bulletin of Geosciences 86.3 (2011), pp. 569-594. DOI: $10.3140 /$ bull.geosci.1256.

[24659] S. R. Westrop and J. D. Eoff. "Late Cambrian (Furongian; Paibian, Steptoean) agnostoid arthropods from the Cow Head Group, western Newfoundland". English. In: Journal of Paleontology 86.2 (2012), pp. 201-237.

[24660] S. R. Westrop, L. A. Knox, and E. Landing. "Lower Ordovician (Ibexian) trilobites from the Tribes Hill Formation, central Mohawk Valley, New York State". English. In: Canadian Journal of Earth Sciences 30 (1993), pp. 1618-1633.

[24661] S. R. Westrop and E. Landing. "Lower Cambrian (Branchian) trilobites and biostratigraphy of the Hanford Brook Formation, southern New Brunswick". English. In: Journal of Paleontology 74.5 (2000), pp. 858-878.

[24662] S. R. Westrop, R. Ludvigsen, and C. H. Kindle. "Marjuman (Cambrian) agnostoid trilobites of the Cow Head Group, western Newfoundland". English. In: Journal of Paleontology 70.5 (1996), pp. 804-829.

[24663] S. R. Westrop, A. R. Palmer, and A. Runkel. "A new Sunwaptan (Late Cambrian) trilobite fauna from the Upper Mississippi valley". English. In: Journal of Paleontology 79.1 (2005), pp. 72-88.

[24664] A. Wetzel and C. A. Meyer. "The Dangers of High-Rise Living on a Muddy Seafloor: An Example of Crinoids from Shallow-Water Mudstones (Aalenian, Northern Switzerland)". English. In: Palaios 21 (2006), pp. 155-167.

[24665] D. Weyer. "Neue Rugosa-Funde aus dem Unter-Famenne von Deutschland Anthozoa, Oberdevon". English. In: Geologische Jahrbruch, Hessen 131 (2004), pp. 203-223.

[24666] P. A. Whalen and E. S. Carter. "Pliensbachian (Lower Jurassic) Radiolaria from Baja California Sur, Mexico". In: Micropaleontology 48.2 (2002), pp. 97-151.

[24667] S. S. Whang and R. S. Hill. "Late Palaeocene Cupressaceae Macrofossils at Lake Bungarby, New South Wales". English. In: Australian Systematic Botany 12.2 (1999), pp. 241-254. DOI: 10.1071 / SB98005. 
[24668] D. S. Wharton. "An enlarged endocranial venous system in Steneosaurus pictaviensis (Crocodylia: Thalattosuchia) from the Upper Jurassic of Les Lourdines, Frances". English. In: Comptes rendus de l'Académie des sciences de la Terre et des Planetes 331 (2000), pp. 221-226.

[24669] P. V. Wheatley and D. R. Ruez Jr. Pliocene Odocoileus from Hagerman Fossil Beds National Monument, Idaho, and comments on the taxonomic status of Odocoileus brachyodontus. English. 2003.

[24670] E. A. Wheeler, T. M. Lehman, and P. E. Gasson. "Javelinoxylon, an Upper Cretaceous dicotyledonous tree from Big Bend National Park, Texas, with presumed Malvalean affinities". In: American Journal of Botany 81.6 (1994), pp. 703-710.

[24671] E. A. Wheeler, J. McClammer, and C. A. LaPasha. "Similarities and differences in dicotyledonous woods of the Cretaceous and Paleocene. San Juan Basin, New Mexico, USA". In: International Association of Wood Anatomists Journal 16.3 (1995), pp. 223-254.

[24672] J. R. Wheeley and R. J. Twitchett. "Palaeoecological significance of a new Griesbachian (Early Triassic)gastropod assemblage from Oman". English. In: Lethaia 38.1 (2005), pp. 37-45.

[24673] J. Whicher and R. Chandler. "Inferior Oolite (Middle Jurassic) hardgrounds and the associated faunas at Coombe Quarry, Mapperton, near Beaminster, Dorset". English. In: Proceedings of the Dorset Natural History and Archaeological Society 130 (2009), pp. 149-153.

[24674] K. Whiso, B. N. Tiwari, S. Bajpai, L. N. Cooper, and J. G. M. Thewissen. "A fossil mammal from marine Eocene strata (Janita Group) of the Mikir Hills, Assam, northeastern India". English. In: Journal of the Palaeontological Society of India 54.1 (2009), pp. 111-114.

[24675] D. P. Whistler and D. W. Burbank. "Miocene biostratigraphy and biochronology of the Dove Spring Formation, Mojave Desert, California, and characterization of the Clarendonian mammal age (late Miocene) in California". English. In: Geological Society America Bulletin 104.6 (1992), pp. 644-658. DOI: 10.1130/0016-7606(1992)104<0644:MBABOT>2.3.CO;2.

[24676] D. P. Whistler and E. B. Lander. “New Late Uintan to Early Hemingfordian Land Mammal Assemblages from the Undifferentiated Sespe and Vaqueros Formations, Orange County, and from the Sespe and Equivalent Marine Formations in Los Angeles, Santa Barbara, and Ventura Counties, Southern California". English. In: Bulletin of the American Museum of Natural History 279 (2003), pp. 231-268. DOI: 10.1206/0003-0090(2003)279<0231:C>2.0.CO;2.

[24677] D. P. Whistler and S. D. Webb. "New goatlike camelid from the Late Pliocene of Tecopa Lake Basin, California". English. In: Contributions in Science, Natural History Museum of Los Angeles County 503 (2005), pp. 1-40.

[24678] J. A. White. “North American Leporinae (Mammalia: Lagomorpha) from late Miocene (Clarendonian) to latest Pliocene (Blancan)". English. In: Journal of Vertebrate Paleontology 11.1 (1991), pp. 6789.

[24679] J. A. White. "A new Sylvilagus (Mammalia: Lagomorpha) from the Blancan (Pliocene) and Irvingtonian (Pleistocene) of Florida". English. In: Journal of Vertebrate Paleontology 11.2 (1991), pp. 243246.

[24680] J. A. White and N. H. Morgan. “The Leporidae (Mammalia, Lagomorpha) from the Blancan (Pliocene) Taunton Local Fauna of Washington". English. In: Journal of Vertebrate Paleontology 15.2 (1995), pp. 366-374.

[24681] J. D. L. White, D. L. White, T. Vallier, G. D. Stanley Jr., and S. R. Ash. “Middle Jurassic strata link Wallowa, Olds Ferry, and Izee terranes in the accreted Blue Mountains island arc, northeastern Oregon". English. In: Geology 20 (1992), pp. 729-732.

[24682] J. M. White, L. Marincovitch, and R. Higgs. "New Miocene fossil discoveries in the Skonun Formation, Queen Charlotte Islands, British Columbia, and implications for basin stratigraphy and climate". English. In: Geological Survey of Canada Bulletin 479 (1994), pp. 85-100.

[24683] T. D. White, G. Suwa, and B. Asfaw. "Australopithecus ramidus, a new species of early hominid from Aramis, Ethiopia”. English. In: Nature 371 (1994), pp. 306-312. 
[24684] M. J. Whitelaw. "Magnetic polarity stratigraphy of Pliocene and Pleistocene fossil vertebrate localities in southeastern Australia". English. In: Geological Society America Bulletin 103 (1991), pp. 14931503.

[24685] M. J. Whitelaw. "Magnetic polarity stratigraphy of Pliocene and Pleistocene fossil vertebrate localities in southeastern Australia". English. In: Geological Society America Bulletin 103.11 (1991), pp. 1493-1503.

[24686] M. J. Whitelaw. "Magnetic polarity stratigraphy of the Pliocene Hamilton and Forsyth's Bank local sections, Hamilton (Victoria), Australia". English. In: Journal of Geology 99.2 (1991), pp. 310-315.

[24687] M. J. Whitelaw. "Magnetic polarity stratigraphy of the Fisherman's Cliff and Bone Gulch vertebrate fossil faunas from the Murray Basin, New South Wales, Australia". English. In: Earth and Planetary Science Letters 104 (1990), pp. 417-423.

[24688] M. J. Whitelaw. "Age constraints on the Duck Ponds and Limeburner's Point mammalian faunas based on magnetic polarity stratigraphy in the Geelong area (Victoria), Australia". English. In: Quaternary Research 39.1 (1993), pp. 120-124.

[24689] D. I. Whiteside, C. J. Duffin, P. G. Gill, J. E. A. Marshall, and M. J. Benton. “The Late Triassic and Early Jurassic fissure faunas from Bristol and South Wales: stratigraphy and setting". English. In: Palaeontologia Polonica 67 (2016), pp. 257-287.

[24690] D. I. Whiteside, C. J. Duffin, and H. Furrer. "The Late Triassic lepidosaur fauna from Hallau, North-Eastern Switzerland, and a new 'basal' rhynchocephalian Deltadectes elvetica gen. et sp. nov." English. In: Neues Jahrbuch für Geologie und Paläontologie 285.1 (2017), pp. 53-74. DOI: 10. $1127 /$ njgpa/2017/0669.

[24691] D. I. Whiteside and C. J. Duffin. "Late Triassic terrestrial microvertebrates from Charles Moore's 'Microlestes' quarry, Holwell, Somerset, UK". English. In: Zoological Journal of the Linnean Society 179 (2017), pp. 677-705. DOI: 10.1111/zoj.12458.

[24692] D. I. Whiteside and J. E. A. Marshall. "The age, fauna and palaeoenvironment of the Late Triassic fissure deposits of Tytherington, South Gloucesterhire, UK". English. In: Geological Magazine 145.1 (2008), pp. 105-147. DOI: 10.1017/S0016756807003925.

[24693] E. T. Whiting and A. K. Hastings. "First Fossil Alligator from the Late Eocene of Nebraska and the Late Paleogene Record of Alligators in the Great Plains". English. In: Journal of Herpetology 49.4 (2015), pp. 560-569.

[24694] E. T. Whiting and J. J. Head. “Neogene crocodylians from the Central Great Plains: spatiotemporal histories and relationships with regional climatic and environmental changes". English. In: Journal of Vertebrate Paleontology 40.1 (2020), e1764007:1-14. DOI: 10.1080/02724634.2020.1764007.

[24695] E. T. Whiting, D. W. Steadman, and K. A. Vliet. "Cranial Polymorphism and Systematics of Miocene and Living Alligator in North America". English. In: Journal of Herpetology 50.2 (2016), pp. 306-315.

[24696] E. T. Whiting, D. W. Steadman, and J. Krigbaum. "Paleoecology of Miocene crocodylians in Florida: Insights from stable isotope analysis". English. In: Palaeogeography, Palaeoclimatology, Palaeoecology 451 (2016), pp. 23-34.

[24697] C. Whitlock and M. R. Dawson. "Pollen and vertebrates of the Early Neogene Haughton Formation, Devon Island, Arctic Canada". English. In: Arctic 43.4 (1990), pp. 324-330.

[24698] J. A. Whitlock and J. A. Wilson Mantilla. “The Late Jurassic sauropod dinosaur 'Morosaurus' agilis Marsh, 1889 reexamined and reinterpreted as a dicraeosaurid". English. In: Journal of Vertebrate Paleontology 40.5 (2020), e1780600:1-28. DOI: 10.1080/02724634.2020.1780600.

[24699] F. C. Whitmore. "Neogene climatic change and the emergence of the modern whale fauna of the North Atlantic Ocean". English. In: Contributions in marine mammal paleontology honoring Frank C. Whitmore, Jr. Proceedings of the San Diego Society of Natural History. 29 (1994), pp. 223-227.

[24700] F. C. Whitmore Jr. "A Paleocene Lungfish, Ceratodus humei Priem 1914, from Jabal Umm Himar, Kingdom of Saudi Arabia”. English. In: vol. 2093. U.S. Geological Survey Bulletin D. 1995, pp. 1-5. 
[24701] M. R. Whitney and C. A. Sidor. "A new therapsid from the Permian Madumabisa Mudstone Formation (Mid-Zambezi Basin) of southern Zambia". English. In: Journal of Vertebrate Paleontology (2016). DOI: 10.1080/02724634.2016.1150767.

[24702] G. R. Whittecar, T. C. Wynn, C. S. Bartlett, and Jr. "Paleoenvironmental analysis of a middle Wisconsinan biota site, southwestern Virginia, U.S.A." English. In: Quaternary Research 68 (2007), pp. 133-140.

[24703] H. B. Whittington. "Hanburia gloriosa: rare trilobite from the Middle Cambrian, Stephen Formation, British Columbia, Canada". In: Journal of Paleontology 72.4 (1998), pp. 673-677.

[24704] R. J. Whittle, S. E. Gabbott, R. J. Aldridge, and J. N. Theron. “Taphonomy and palaeoecology of a Late Ordovician caryocaridid from the Soom Shale Lagerstätte, South Africa". English. In: Palaeogeography, Palaeoclimatology, Palaeoecology 251.3-4 (2007), pp. 383-397.

[24705] M. A. Whyte and M. Romano. Probable sauropod footprints from the Middle Jurassic of Yorkshire, England. English. Vol. 10. Aspects of Sauropod Paleobiology. GAIA. 1995, pp. 15-26.

[24706] M. A. Whyte and M. Romano. "Probable stegosaurian dinosaur tracks from the Saltwick Formation (Middle Jurassic) of Yorkshire, England". English. In: Proceedings of the Geologists' Association 112 (2001), pp. 45-54.

[24707] J. R. Wible, M. J. Novacek, and G. W. Rougier. “New data on the skull and dentition of the Mongolia Late Cretaceous eutherian mammal Zalabdalestes". English. In: Bulletin of the American Museum of Natural History 281 (2004), pp. 1-144. DOI: 10.1206/0003-0090(2004)281<0001:NDOTSA>2.0. $\mathrm{CO} ; 2$.

[24708] J. R. Wible, G. W. Rougier, M. J. Novacek, and R. J. Asher. “Cretaceous eutherians and Laurasian origin for placental mammals near the K/T boundary". English. In: Nature 447 (2007), pp. 10031006.

[24709] J. R. Wible, S. L. Shelley, and S. Bi. "New Genus and Species of Djadochtatheriid Multituberculate (Allotheria, Mammalia) from the Upper Cretaceous Bayan Mandahu Formation of Inner Mongolia". English. In: Annals of Carnegie Museum 85.4 (2019), pp. 285-327.

[24710] J. R. Wible, Y. Wang, C. Li, and M. R. Dawson. "Cranial anatomy and relationships of a new ctenodactyloid (Mammalia, Rodentia) from the early Eocene of Hubei Province, China". English. In: Annals of Carnegie Museum 74.2 (2005), pp. 91-150.

[24711] W. Wichard. “Overview and descriptions of caddisflies (Insecta, Trichoptera) in Dominican amber (Miocene)". English. In: Stuttgarter Beiträge zur Naturkunde Serie B (Geologie und Paläontologie) 366 (2007), pp. 1-51.

[24712] W. Wichard. "Chauliodes, ein GroSSflügler im Baltischen Bernstein, (Megaloptera, Corydalidae)". German. In: Mitteilungen aus dem Geologisch-Paläontologischen Institut der Universität Hamburg 87 (2003), pp. 147-158.

[24713] W. Wichard. "Eine neue Schlammfliege aus dem Baltischen Bernstein (Megaloptera, Sialidae)". German. In: Mitteilungen aus dem Geologisch-Paläontologischen Institut der Universität Hamburg 86 (2002), pp. 253-261.

[24714] W. Wichard. "Köcherfliegen des Dominikanischen Bernsteins XI. Ochrotrichia aliceae n. sp., eine neue fossile Hydroptilidae (Insecta, Trichoptera)". German. In: Mitteilungen aus dem GeologischPaläontologischen Institut der Universität Hamburg 84 (2000), pp. 241-246.

[24715] W. Wichard. "Schlammfliegen aus Baltischem Bernstein (Megaloptera, Sialidae)". German. In: Mitteilungen aus dem Geologisch-Paläontologischen Institut der Universität Hamburg 80 (1997), pp. 197211.

[24716] W. Wichard. "Overview and descriptions of Nevrorthidae in Baltic amber (Insecta, Neuroptera)". English. In: Palaeodiversity 9 (2016), pp. 95-111.

[24717] W. Wichard. "Family Nevrorthidae (Insecta, Neuroptera) in mid-Cretaceous Burmese amber". English. In: Palaeodiversity 10 (2017), pp. 1-5. 
[24718] W. Wichard and D. Azar. "First caddisflies (Trichoptera) in Lower Cretaceous Lebanese amber". English. In: Earth and Environmental Science Transactions of the Royal Society of Edinburgh 107 (2018), pp. 213-217.

[24719] W. Wichard and P. C. Barnard. "Köcherfliegen im Baltischen Bernstein - 5. Nachweis der Gattung Triaenodes (Trichoptera: Leptoceridae)". German. In: Mitteilungen aus dem Geologisch-Paläontologischen Institut der Universität Hamburg 89 (2005), pp. 149-158.

[24720] W. Wichard, T. Buder, and C. Caruso. "Aquatic lacewings of family Nevrorthidae (Neuroptera) in Baltic amber". English. In: Denisia 29 (2010), pp. 445-457.

[24721] W. Wichard and N. Caspers. "Caddisflies of Baltic amber - 2. Fossil species of the genus Rhyacophila". English. In: Proceedings of the Sixth International Symposium on Trichoptera. 1991, pp. 447-451.

[24722] W. Wichard, C. Chatterton, and A. Ross. "Corydasialidae fam. n. (Megaloptera) from Baltic amber". English. In: Insect Systematics \& Evolution 36 (2005), pp. 279-283.

[24723] W. Wichard and M. S. Engel. "A new alderfly in Baltic amber (Megaloptera: Sialidae)". English. In: American Museum Novitates 3513 (2006), pp. 1-9.

[24724] W. Wichard, M. Espeland, and B. Wang. "Caddisflies with unusual hair-fans on the legs in Cretaceous Burmese amber (Insecta, Trichoptera)". English. In: Palaeodiversity 11 (2018), pp. 21-28.

[24725] W. Wichard, M. Espeland, P. Müller, and B. Wang. "New species of caddisflies with bipectinate antennae from Cretaceous Burmese amber (Insecta, Trichoptera: Odontoceratidae, Calamoceratidae)". English. In: European Journal of Taxonomy 653 (2020), pp. 1-17. DOI: 10.5852/ejt.2020.653.

[24726] W. Wichard and C. Lüer. "Phylocentropus swolenskyi n. sp., ein Köcherfliege aus dem New Jersey Bernstein (Trichoptera, Dipseudopsidae)". German. In: Mitteilungen aus dem GeologischPaläontologischen Institut der Universität Hamburg 87 (2003), pp. 131-140.

[24727] W. Wichard, P. Müller, and B. Wang. “The psychomyiid genus Palerasnitsynus (Insecta, Trichoptera) in mid-Cretaceous Burmese amber". English. In: Palaeodiversity 11 (2018), pp. 151-166.

[24728] W. Wichard, P. Müller, and B. Wang. “The philopotamid genus Wormaldia (Insecta, Trichoptera) embedded in mid-Cretaceous Burmese amber". English. In: Palaeodiversity 13 (2020), pp. 39-47.

[24729] W. Wichard and C. Neumann. "Rhyacophila quadrata n. sp., a new caddisfly (Insecta, Trichoptera) from Eocene Baltic amber". English. In: Fossil Record 11 (2008), pp. 19-23.

[24730] W. Wichard, C. Neumann, P. Müller, and B. Wang. "Family Dysoneuridae (Insecta, Trichoptera) in Cretaceous Burmese amber". English. In: Cretaceous Research 82 (2017), pp. 138-146.

[24731] W. Wichard, C. Neumann, and I. Werneburg. "New longhorned caddisfies in Eocene Baltic amber (Insecta, Trichoptera)". English. In: PalZ 92 (2018), pp. 387-394.

[24732] W. Wichard and C. Neumann. "A new bizarre dysoneurid species (Insecta, Trichoptera) in Burmese amber". English. In: Fossil Record 22 (2019), pp. 51-56. DOI: 10.5194/fr-22-51-2019.

[24733] W. Wichard and G. O. Poinar. "Köcherfliegen aus dem Burma Bernstein der oberen Kreide von Myanmar (Insecta, Trichoptera)". German. In: Mitteilungen aus dem Geologisch-Paläontologischen Institut der Universität Hamburg 89 (2005), pp. 129-136.

[24734] W. Wichard, E. Ross, and A. J. Ross. "Palerasnitsynus gen. n. (Trichoptera, Psychomyiidae) from Burmese amber". English. In: ZooKeys 130 (2011), pp. 323-330.

[24735] W. Wichard and M. M. Solorzano. "First caddisfly species from Mexican amber (Insecta: Trichoptera)". English. In: Zootaxa 1378 (2006), pp. 37-48.

[24736] W. Wichard and B. Wang. "New Cretaceous caddisflies from Burmese amber (Insecta, Trichoptera)". English. In: Cretaceous Research 61 (2016), pp. 129-135.

[24737] W. Wichard and B. Wang. "A remarkable caddisfly with bipectinate antennae in Cretaceous Burmese amber (Insecta, Trichoptera)". English. In: Cretaceous Research 69 (2016), pp. 198-203. 
[24738] W. Wichard and B. Wang. "Family Kambaitipsychidae (Insecta, Trichoptera) in mid-Cretaceous Burmese amber". English. In: Cretaceous Research 107.104272 (2019). DOI: 10.1016/j.cretres.2019. 104272.

[24739] W. Wichard, S. Wedmann, and T. Weiterschan. "Spongillaflies (Neuroptera, Sisyridae) in Baltic amber". English. In: Zootaxa 4158 (2016), pp. 117-125.

[24740] W. Wichard and W. Weitschat. "Wasserinsekten im Bernstein, eine paläobiologische Studie". German. In: Entomologische Mitteilungen aus dem Löbbecke-Museum und Aquazoo Beiheft 4 (1996), pp. 1122.

[24741] S. L. Wick. "New evidence for the possible occurrence of Tyrannosaurus in West Texas, and discussion of Maastrichtian tyrannosaurid dinosaurs from Big Bend National Park". English. In: Cretaceous Research 50 (2014), pp. 52-58.

[24742] S. L. Wick and T. M. Lehman. "A new ceratopsian dinosaur from the Javelina Formation (Maastrichtian) of West Texas and implications for chasmosaurine phylogeny". English. In: Naturwissenschaften (2013). DOI: 10.1007/s00114-013-1063-0.

[24743] S. L. Wick and T. M. Lehman. "A complete titanosaur femur from West Texas with comments regarding hindlimb posture". English. In: Cretaceous Research 49 (2014), pp. 39-44.

[24744] S. L. Wick and T. A. Shiller II. "New taxa among a remarkably diverse assemblage of fossil squamates from the Aguja formation (lower Campanian) of west Texas". English. In: Cretaceous Research 114 (2020), p. 104516. DOI: 10.1016/j.cretres.2020.104516.

[24745] N. K. Wideman, S. S. Sumida, and M. O'Neil. A Reassessment of the Taxonomic Status of the Materials Assigned to the Early Permian Tetrapod Genera Limnosceloides and Limnoscelops. English. Vol. 30. The Nonmarine Permian. New Mexico Museum of Natural History and Science Bulletin. 2005, pp. 358-362.

[24746] J. Wieczorek. "Nerineaceans from the Ernstbrunn Limestone (Tithonian, Austria)". English. In: Annalen des Naturhistorischen Museums in Wien 99A (1998), pp. 311-329.

[24747] T. Wiedl, M. Harzhauser, A. Kroh, S. ori, and W. E. Piller. "Ecospace variability along a carbonate platform at the northern boundary of the Miocene reef belt (Upper Langhian, Austria)". English. In: Palaeogeography, Palaeoclimatology, Palaeoecology 370 (2013), pp. 232-246. DOI: 10.1016/j.palaeo. 2012.12.015.

[24748] P. Wiegerek and V. V. Zherikhin. "An Early Jurassic insect fauna in the Holy Cross Mountains". English. In: Acta Palaeontologica Polonica 42 (1997), pp. 539-543.

[24749] G. Wienrich. "Die Fauna des marinen Miozäns von Kevelaer (Niederrhein). Band 2 Bivalvia, Scaphopoda, Cephalopoda, Bryozoa, Annelida, Brachiopoda". German. In: Backhuys Publishers, Leiden 2 (1999), pp. 188-384.

[24750] A. Wier, M. Dolan, D. Grimaldi, R. Guerrero, J. Wagensberg, and L. Margulis. "Spirochete and protist symbionts of a termite (Mastotermes electrodominicus) in Miocene amber". English. In: Proceedings of the National Academy of Sciences 99 (2002), pp. 1410-1413.

[24751] J. P. Wiersma and R. B. Irmis. "A new southern Laramidian ankylosaurid, Akainacephalus johnsoni gen. et sp. nov., from the upper Campanian Kaiparowits Formation of southern Utah, USA". English. In: PeerJ 6.e5016 (2018). DOI: 10.7717/peerj.5016.

[24752] A. Wierzbowski, M. Krobicki, and B. A. Matyja. “The stratigraphy and palaeogeographic position of the Jurassic successions of the Priborzhavske-Perechin Zone in the Pieniny Klippen Belt of the Transcarpathian Ukraine". English. In: Volumina Jurassica 10 (2012), pp. 25-60.

[24753] F. Wiese, M. Kostak, and C. J. Wood. “The Upper Cretaceous belemnite Praeactinocamax plenus (Blainville, 1827) from Lower Saxony (Upper Cenomanian, northwest Germany) and its distribution pattern in Europe". English. In: Palaeontologische Zeitschrift 83 (2009), pp. 309-321.

[24754] J. Wiesner, K. Will, and J. Schmidt. "Two new genera and species of tiger beetles from Baltic amber (Coleoptera: Carabidae: Cicindelinae)". English. In: Insecta Mundi 577 (2017), pp. 1-14. 
[24755] P. B. Wignall, J. P. Zonneveld, R. J. Newton, K. Amor, M. A. Sephton, and S. Hartley. “The end Triassic mass extinction record of Williston Lake, British Columbia". English. In: Palaeogeography, Palaeoclimatology, Palaeoecology 253 (2007), pp. 385-406.

[24756] E. Wijnker, T. J. Bor, F. P. Wesselingh, D. K. Munsterman, H. Brinkhuis, A. W. Burger, H. B. Vonhof, K. Post, K. Hoedemakers, A. C. Janse, and N. Taverne. "Neogene stratigraphy of the Langenboom locality (Noord-Brabant, Netherlands)". English. In: Netherlands Journal of Geosciences 87.2 (2008), pp. 165-180.

[24757] E. Wijnker and S. L. Olson. "A revision of the fossil genus Miocepphus and other Miocene Alcidae (Aves: Charadriiformes) of the western North Atlantic Ocean". English. In: Journal of Systematic Palaeontology 7.4 (2009), pp. 471-487.

[24758] E. W. Wilberg. "A new metriorhynchoid (Crocodylomorpha, Thalattosuchia) from the Middle Jurassic of Oregon and the evolutionary timing of marine adaptations in thalattosuchian crocodylomorphs". English. In: Journal of Vertebrate Paleontology 35.2 (2015), e902846. DOI: 10.1080/02724634. 2014.902846.

[24759] B. C. Wilbur. "Reduction in the number of Early Cambrian helicoplacoid species". English. In: Palaeoworld 15 (2006), pp. 283-293. DOI: 10.1016/j.palwor.2006.10.009.

[24760] R. Wild. “Ein Flugsaurierrest (Reptilia, Pterosauria) aus der Unterkreide (Hauterive) von Hannover (Niedersachen)". German. In: Neues Jahrbuch für Geologie und Paläontologie, Abhandlungen 181 (1990), pp. 241-254.

[24761] R. Wild. “A juvenile specimen of Eudimorphodon ranzii Zambelli (Reptilia, Pterosauria) from the Upper Triassic (Norian) of Bergamo". English. In: Rivista del Museo Civico di Scienze Naturali Bergamo 16 (1994), pp. 91-115.

[24762] T. J. Wild and J. D. Stilwell. "First Cretaceous (Albian) invertebrate fossil assemblage from Batavia Knoll, Perth Abyssal Plain, eastern Indian Ocean: taxonomy and paleoecological significance". English. In: Journal of Paleontology 90 (2016), pp. 959-980.

[24763] G. L. Wilde. "Pennsylvanian-Permian Fusulinaceans of the Big Hatchet Mountains, New Mexico". English. In: New Mexico Museum of Natural History and Science Bulletin 38 (2006), pp. 1-331.

[24764] V. Wilde and H. Frankenhauser. "The Middle Eocene plant taphocoenosis from Eckfeld (Eifel, Germany)". In: Review of Palaeobotany and Palynology 101 (1998), pp. 7-28.

[24765] P. Wilf. "Late Paleocene-early Eocene climate changes in southwestern Wyoming: Paleobotanical analysis". In: Geological Society America Bulletin 112.2 (2000), pp. 292-307.

[24766] P. Wilf. "Rainforest conifers of Eocene Patagonia: attached cones and foliage of the extant southeastAsian and Australasian genus Dacrycarpus (Podocarpaceae)". English. In: American Journal of Botany 99 (2012), pp. 562-584. DOI: 10.3732/ajb.1100367.

[24767] P. Wilf, K. C. Beard, K. S. Davies-Vollum, and J. W. Norejko. “Portrait of a late Paleocene (early Clarkforkian) terrestrial ecosystem; Big Multi Quarry and associated strata, Washakie Basin, southwestern Wyoming". English. In: Palaios 13.6 (1998), pp. 514-532.

[24768] P. Wilf, M. R. Carvahlo, M. A. Gandolfo, and N. R. Cuneo. "Eocene lantern fruits from Gondwanan Patagonia and the early origins of Solanaceae". English. In: Science 377.71 (2017). DOI: 10.1126/ science.aag2737.

[24769] P. Wilf, M. P. Donovan, N. R. Cuneo, and M. A. Gandolfo. “The fossil flip-leaves (Retrophyllum, Podocarpaceae) of". English. In: American Journal of Botany 104.9 (2017), pp. 1-26. DOI: 10.3732/ ajb.1700158.

[24770] P. Wilf, I. H. Escapa, N. R. Cúneo, R. M. Kooyman, K. R. Johnson, and A. Iglesias. "First South American Agathis (Araucariaceae), Eocene of Patagonia". English. In: American Journal of Botany 101.1 (2014), pp. 156-179. DOI: 10.3732/ajb.1300327.

[24771] P. Wilf, K. R. Johnson, N. R. Cúneo, M. E. Smith, B. S. Singer, and M. A. Gandolfo. "Eocene Plant Diversity at Laguna del Hunco and Ro Pichileufú, Patagonia, Argentina". English. In: The American Naturalist 165.6 (2005), pp. 634-650. DOI: 10.1086/430055. 
[24772] P. Wilf, C. C. Labandeira, K. R. Johnson, and B. Ellis. “Decoupled plant and insect diversity after the end-Cretaceous extinction". English. In: Science 313 (2006), pp. 1112-1115.

[24773] P. Wilf, S. A. Little, A. Iglesias, M. C. Zamaloa, M. A. Gandolfo, N. R. Cúneo, and K. R. Johnson. "Papuacedrus (Cupressaceae) in Eocene Patagonia, a new fossil link to Australasian rainforests". English. In: American Journal of Botany 96 (2009), pp. 2031-2047. DOI: 10.3732/ajb.0900085.

[24774] P. Wilf, K. C. Nixon, M. A. Gandolfo, and N. R. Cúneo. “Eocene Fagaceae from Patagonia and Gondwanan legacy in Asian rainforests". English. In: Science 364.6444 (2019), eaaw5139.

[24775] P. Wilf, D. W. Stevenson, and N. R. Cuneo. "The last Patagonian cycad, Austrozamia stockeyi gen. et sp. nov., early Eocene of Laguna del Hunco, Chubut, Argentina". English. In: Botany 94.999 (2016), pp. 817-829. DOI: 10.1139/cjb-2016-0038.

[24776] B. C. Wilhelm and F. R. O'Keefe. "A new partial skeleton of a cryptocleidoid plesiosaur from the Upper Jurassic Sundance Formation of Wyoming". English. In: Journal of Vertebrate Paleontology 30.6 (2010), pp. 1736-1742.

[24777] L. E. Wilkinson, M. T. Young, and M. J. Benton. “A new metriorhynchid crocodilian (Mesoeucrocodylia: Thalattosuchia) from the Kimmeridgian (Upper Jurassic) of Wiltshire, UK". English. In: Palaeontology 51.6 (2008), pp. 1307-1333.

[24778] D. A. Willard. “Early Virgilian palynofloras from the Kinney Quarry, Manzanita Mountains, New Mexico". In: New Mexico Bureau of Mines and Mineral Resources Bulletin 138 (1992), pp. 49-60.

[24779] D. A. Willard, W. A. DiMichele, D. L. Eggert, J. C. Hower, C. B. Rexroad, and A. C Scott. "Paleoecology of the Springfield Coal Member (Desmoinesian, Illinois Basin) near the Leslie Cemetery paleochannel, southwestern Indiana". In: International Journal of Coal Geology 27 (1995), pp. 59-98.

[24780] G. F. Willemsen. "A revision of the Pliocene and Quaternary Lutrinae from Europe". English. In: Scripta Geologica 101 (1992), pp. 1-115.

[24781] B. A. Williams and E. C. Kirk. "New Uintan primates from Texas and their implications for North American patterns of species richness during the Eocene". English. In: Journal of Human Evolution 55.6 (2008), pp. 927-941.

[24782] B. A. Williams and H. H. Covert. "New Early Eocene Anaptomorphine Primate (Omomyidae) From the Washakie Basin, Wyoming, With Comments on the Phylogeny and Paleobiology of Anaptomorphines". English. In: American Journal of Physical Anthropology 93 (1994), pp. 323-340.

[24783] J. A. J. Williams, A. R. C. Milner, and M. G. Lockley. “The Early Jurassic (Hettangian) LDS dinosaur tracksite from the Moenave Formation in St. George, Utah". English. In: vol. 37. The TriassicJurassic Terrestrial Transition. New Mexico Museum of Natural History and Science Bulletin. Albuquerque: New Mexico Museum of Natural History and Science, 2006, pp. 346-351.

[24784] M. Williams. Three new fossil reports from Tesheva Creek, Yazoo County, Mississippi. English. 2002.

[24785] M. Williams, M. J. Benton, and A. Ross. “The Strawberry Bank Lagerstätte reveals insights into Early Jurassic life". English. In: Journal of the Geological Society 172 (2015), pp. 683-692.

[24786] M. Williams, D. J. Siveter, and J. S. Peel. “Isoxys (arthropoda) from the Early Cambrian Sirius Passet Lagerstaette, North Greenland". In: Journal of Paleontology 70.6 (1996), pp. 947-954.

[24787] M. Williams, A. J. D. Tennyson, and D. Sim. “Island differentiation of New Zealand's extinct mergansers (Anatidae: Mergini), with description of a new species from Chatham Island". English. In: Wildfowl 6 (2014), pp. 3-34.

[24788] M. E. Williams. "A new specimen of Tamiobatis vetustus (Chondrichthyes, Ctenacanthoidea) from the Late Devonian Cleveland Shale of Ohio". English. In: Journal of Vertebrate Paleontology 18.2 (1998), pp. 251-260.

[24789] M. E. Williams. “Tooth retention in cladodont sharks: with a comparison between primitive grasping and swallowing, and modern cutting and gouging feeding mechanisms". English. In: Journal of Vertebrate Paleontology 21.2 (2001), pp. 214-226.

[24790] R. J. Williams. "Observations on the London Clay excavation at Aveley, Essex". English. In: Tertiary Research 21.1-4 (2002), pp. 95-112. 
[24791] S. H. Williams and K. K. Stevens. "Late Tremadoc graptolites from western Newfoundland". English. In: Palaeontology 34.1 (1991), pp. 1-47.

[24792] G. Williamson. New orchids from the flora Zambesiaca (Africa) region. 1990.

[24793] T. Williamson and T. Carr. "Bomburia and Ellipsodon (Mammalia: Mioclaenidae) from the Early Paleocene of New Mexico". English. In: Journal of Paleontology 81 (2007), pp. 966-985.

[24794] T. Williamson and A. Weil. "Metatherian Mammals from the Naashoibito Member, Kirtland Formation, San Juan Basin, New Mexico and Their Biochronologic and Paleobiogeographic Significance". English. In: Journal of Vertebrate Paleontology 28 (2008), pp. 803-815.

[24795] T. E. Williamson. "The beginning of the age of mammals in the San Juan Basin, New Mexico; biostratigraphy and evolution of Paleocene mammals of the Nacimiento Formation". English. In: New Mexico Museum of Natural History and Science Bulletin 8 (1996), pp. 1-141.

[24796] T. E. Williamson. "?Brachychampsa sealeyi, sp. nov., (Crocodylia, Alligatoroidea) from the Upper Cretaceous (lower Campanian) Menefee Formation, northwestern New Mexico". English. In: Journal of Vertebrate Paleontology 16.3 (1996), pp. 421-431.

[24797] T. E. Williamson. Review of Hadrosauridae (Dinosauria, Ornithischia) from the San Juan Basin, New Mexico. English. Vol. 17. Dinosaurs of New Mexico. New Mexico Museum of Natural History and Science Bulletin. 2000, pp. 191-213.

[24798] T. E. Williamson, S. L. Brusatte, T. D. Carr, A. Weil, and B. R. Standhardt. "The phylogeny and evolution of Cretaceous-Palaeogene metatherians: cladistic analysis and description of new early Palaeocene specimens from the Nacimiento Formation, New Mexico". English. In: Journal of Systematic Palaeontology 10.4 (2012), pp. 625-651.

[24799] T. E. Williamson and S. L. Brusatte. "Small theropod teeth from the Late Cretaceous of the San Juan Basin, northwestern New Mexico and their implications for understanding latest Cretaceous dinosaur evolution". English. In: PLoS ONE 9.4 (2014), e93190:1-23. DOI: 10.1371/journal.pone. 0093190.

[24800] T. E. Williamson, S. L. Brusatte, R. Secord, and S. Shelley. "A new taeniolabidoid multituberculate (Mammalia) from the middle Puercan of the Nacimiento Formation, New Mexico, and a revision of taeniolabidoid systematics and phylogeny". English. In: Zoological Journal of the Linnean Society 177 (2016), pp. 183-208. DOI: 10.1111/zoj.12336.

[24801] T. E. Williamson and S. L. Brusatte. “New Specimens of the Rare Taeniodont Wortmania (Mammalia: Eutheria) from the San Juan Basin of New Mexico and Comments on the Phylogeny and Functional Morphology of Archaic Mammals". English. In: PLoS ONE 8.9 (2013), e75886:1-35. DOI: 10.1371/journal.pone.0075886.

[24802] T. E. Williamson and T. D. Carr. "A new genus of derived pachycephalosaurian from western North America". English. In: Journal of Vertebrate Paleontology 22.4 (2003), pp. 779-801.

[24803] T. E. Williamson, T. D. Carr, S. A. Williams, and K. Tremaine. "Early ontogeny of pachycephalosaurine squamosals as revealed by juvenile specimens from the Hell Creek Formation, eastern Montana". English. In: Journal of Vertebrate Paleontology 29.1 (2009), pp. 291-294. DOI: 10.1671/039.029.0111.

[24804] T. E. Williamson and D. L. Lofgren. “Late Paleocene (Tiffanian) metatherians from the Goler Formation, California". English. In: Journal of Vertebrate Paleontology 34.2 (2014), pp. 477-482.

[24805] T. E. Williamson and S. G. Lucas. "Meniscotherium (Mammalia, Condylarthra) from the PaleoceneEocene of Western North America)". English. In: New Mex Museum of Natural History Science Bulletin 1 (1992), pp. 1-75.

[24806] T. E. Williamson and S. G. Lucas. "Paleocene vertebrate paleontology of the San Juan Basin, New Mexico". English. In: New Mexico Museum of Natural History Bulletin 2 (1993), pp. 105-136.

[24807] T. E. Williamson, S. G. Lucas, and R. K. Stucky. In: Proceedings of the Denver Museum of Natural History 3.13;1-3 (1996).

[24808] T. E. Williamson and R. M. Sullivan. Reinterpretation of a Parasaurolophus skull from the Upper Cretaceous (Campanian) Kaiparowits Formation, Utah. English. 1997. 
[24809] T. E. Williamson and A. Weil. A Late Puercan (Pu3) microfauna from the San Juan Basin, New Mexico. English. 2002.

[24810] T. E. Williamson and A. Weil. "A new early Paleocene (Puercan) hyopsodontid condylarth from New Mexico". English. In: Acta Palaeontologica Polonica 56.2 (2011), pp. 247-255. DOI: 10.4202/app. 2009.0147.

[24811] T. E. Williamson, A. Weil, and B. Standhardt. "Cimolestids (Mammalia) from the early Paleocene (Puercan) of New Mexico". English. In: Journal of Vertebrate Paleontology 31.1 (2011), pp. 162-180. DOI: $10.1080 / 02724634.2011 .539649$.

[24812] P. Willis, P. Murray, and D. Megirian. "Baru darrowi gen. et sp. nov., a large, broad-snouted crocodyline (Eusuchia: Crocodylidae) from mid-Tertiary freshwater limestones in Northern Australia". English. In: Memoirs of the Queensland Museum 29.2 (1990), pp. 521-540.

[24813] P. M. A. Willis. "Trilophosuchus rackhami gen. et sp. nov., a new crocodilian from the early Miocene limestones of Riversleigh, northwestern Queensland". English. In: Journal of Vertebrate Paleontology 13.1 (1993), pp. 90-98.

[24814] P. M. A. Willis. "New crocodilians from the late Oligocene White Hunter Site, Riversleigh, northwestern Queensland". English. In: Memoirs of the Queensland Museum 41.2 (1997), pp. 423-438.

[24815] P. M. A. Willis. "New crocodilian material from the Miocene of Riversleigh (northwestern Queensland, Australia)". English. In: Crocodilian Biology and Evolution. Sydney: Surrey Beatty and Sons, 2001, pp. 64-74.

[24816] P. M. A. Willis and M. Archer. "A Pleistocene longirostrine crocodilian from Riversleigh: first fossil occurrence of Crocodylus johnstoni Krefft". English. In: Memoirs of The Queensland Museum 28 (1990), pp. 159-163.

[24817] P. M. A. Willis and B. S. Mackness. “Quinkana babarra, a new species of ziphodont mekosuchine crocodile from the Early Pliocene Bluff Downs local fauna, northern Australia with a revision of the genus". English. In: Proceedings of The Linnean Society of New South Wales 116 (1996), pp. 143151.

[24818] P. M. A. Willis and R. E. Molnar. "A longirostrine crocodile from the Early Tertiary of southeastern Queensland". English. In: Alcheringa 15.3 (1991), pp. 229-233.

[24819] P. M. A. Willis, R. E. Molnar, and J. D. Scanlon. “An Early Eocene crocodilian from Murgon, southeastern Queensland". English. In: Kaupia 3 (1993), pp. 27-33.

[24820] P. M. A. Willis and R. E. Molnar. "A new Middle Tertiary crocodile from Lake Palankarinna, South Australia". English. In: Records of The South Australian Museum (Adelaide) 25 (1991), pp. 39-55.

[24821] P. M. A. Willis and R. E. Molnar. "A review of the Plio-Pleistocene crocodilian genus Pallimnarchus". English. In: Proceedings of the Linnean Society of New South Wales 117 (1997), pp. 224-242.

[24822] P. M. A. Willis and J. D. Stilwell. A probable piscivorous crocodile from Eocene deposits of McMurdo Sound, East Antarctica. English. Vol. 76. Paleobiology and Paleoenvironments of Eocene Rocks, McMurdo Sound, East Antarctica . Antarctic Research Series. 2000, pp. 355-358.

[24823] R. Willmann. "Raphidiodea aus dem Lias und die Phylogenie der Kamelhalsfliegen (Insecta: Holometabola)". German. In: Paläontologische Zeitschrift 68 (1994), pp. 167-197.

[24824] R. Willmann and V. Novokshonov. "Neue Mecopteren aus dem oberen Jura von Karatau (Kasachstan) (Insecta, Mecoptera: Orthophlebiidae)". German. In: Paläontologische Zeitschrift 72 (1998), pp. 281-298.

[24825] R. Willmann and V. Novokshonov. "Orthophlebia lithographica - die erste Mecoptere aus dem Solnhofener Plattenkalk (Insecta: Mecoptera, Jura)". German. In: Neues Jahrbuch für Geologie und Paläontologie, Monatshefte 1998 (1998), pp. 529-536.

[24826] S. Wills, P. M. Barrett, and A. Walker. "New dinosaur and crocodylomorph material from the Middle Jurassic (Bathonian) Kilmaluag Formation, Skye, Scotland". English. In: Scottish Journal of Geology 50 (2014), pp. 183-190. DOI: 10.1144/sjg2015-005. 
[24827] M. Wilmsen. "Late Cretaceous nautilids from northern Cantabria, Spain”. English. In: Acta Palaeontologica Polonica 50.1 (2000), pp. 29-43.

[24828] M. Wilmsen and M. F. Aly. "Late Campanian nautiloids from Deir Abu Said, north-western Jordan". English. In: Cretaceous Research 102 (2019), pp. 81-88. DOI: 10.1016/j.cretres.2019.04.009.

[24829] M. Wilmsen and K. J. K. Esser. “Latest Campanian to Early Maastrichtian (Cretaceous) nautiloids from the white chalk of Kronsmoor, northern Germany". English. In: Acta Geologica Polonica 54.4 (2004), pp. 489-498.

[24830] M. Wilmsen and E. Nagm. "Kreide-Fossilien in Sachsen, Teil 1, 7. Ammoniten". German. In: Geologica Saxonica 60 (2014), pp. 201-240.

[24831] M. Wilmsen and E. Nagm. “Upper Cenomanian-Lower Turonian ammonoids from the Saxonian Cretaceous (lower Elbtal Group, Saxony, Germany)". English. In: Bulletin of Geosciences 88 (2013), pp. 647-674.

[24832] M. Wilmsen and E. A. Yazykova. "Campanian (Late Cretaceous) nautiloids from Sakhalin, Far East Russia". English. In: Acta Palaeontologica Polonica 48.3 (2003), pp. 481-490.

[24833] B. Wilson. "A lagoonal interlude with occasional hypersalinity in the deposition of the EarlyMiddle Miocene Brasso Formation of Trinidad". English. In: Journal of South American Earth Sciences 29 (2010), pp. 254-261.

[24834] C. D. Wilson, J. D. Pardo, and J. S. Anderson. "A primitive actinopterygian braincase from the Tournaisian of Nova Scotia". English. In: Royal Society Open Science 5 (2018). DOI: 10.1098 / rsos. 171727.

[24835] E. C. Wilson. "Permian corals from the Spring Mountains, Nevada". English. In: Journal of Paleontology 65.5 (1991), pp. 727-741.

[24836] E. C. Wilson. "Permian corals of Bolivia". English. In: Journal of Paleontology 64.1 (1990), pp. 60-78.

[24837] E. C. Wilson. "Early Permian corals from the Providence Mountains, San Bernardino County, California". English. In: Journal of Paleontology 68 (1994), pp. 938-951.

[24838] E. C. Wilson and R. L. Langenheim Jr. “Early Permian corals from Arrow Canyon, Clark County, Nevada". English. In: Journal of Paleontology 67.6 (1993), pp. 935-945.

[24839] G. P. Wilson, D. C. Das Sarma, and S. Anantharaman. "Late Cretaceous sudamericid gondwanatherians from India with paleobiogeographic considerations of Gondwanan mammals". English. In: Journal of Vertebrate Paleontology 27.2 (2007), pp. 521-531.

[24840] G. P. Wilson, M. Dechesne, and I. R. Anderson. "New latest Cretaceous mammals from northeastern Colorado with biochronologic and biogeographic implications". English. In: Journal of Vertebrate Paleontology 30.2 (2010), pp. 499-520.

[24841] G. P. Wilson, E. G. Ekdale, J. W. Hoganson, J. J. Calede, and A. Vander Linden. “A large carnivorous mammal from the Late Cretaceous and the North American origin of marsupials". English. In: Nature Communications 7 (2016), 13734:1-10.

[24842] G. P. Wilson, R. P. Hilton, and E. S. Gohre. "The first Mesozoic mammal from California”. English. In: PaleoBios 23.1 (2003), pp. 20-23.

[24843] G. P. Wilson and J. A. Riedel. "New specimen reveals deltatheroidan affinities of the North American Late Cretaceous mammal Nanocuris". English. In: Journal of Vertebrate Paleontology 30.3 (2010), pp. 872-884.

[24844] H. M. Wilson. "First Mesozoic scutigeromorph centipede, from the Lower Cretaceous of Brazil". English. In: Palaeontology 44 (2001), pp. 489-495.

[24845] H. M. Wilson. “A new scolopendromorph centipede (Myriapoda: Chilopoda) from the Lower Cretaceous (Aptian) of Brazil". English. In: Journal of Paleontology 77 (2003), pp. 73-77.

[24846] H. M. Wilson. "Zosterogrammida, a new order of millipedes from the middle Silurian of Scotland and the upper Carboniferous of Euramerica". English. In: Palaeontology 48 (2005), pp. 1101-1110. 
[24847] H. M. Wilson. "Juliformian millipedes from the Lower Devonian of Euramerica: implications for the timing of millipede cladogenesis in the Paleozoic". English. In: Journal of Paleontology 80 (2006), pp. 638-649.

[24848] H. M. Wilson and L. I. Anderson. "Morphology and taxonomy of Paleozoic millipedes (Diplopoda: Chilognatha: Archipolypoda) from Scotland". English. In: Journal of Paleontology 78.1 (2004), pp. 169184. DOI: 10.1666/0022-3360(2004)078<0169:MATOPM>2.0.CO;2.

[24849] H. M. Wilson, E. B. Daeschler, and S. Desbiens. “New flat-backed archipolypodan millipedes from the Upper Devonian of North America". English. In: Journal of Paleontology 79 (2005), pp. 738-744.

[24850] H. M. Wilson and J. T. Hannibal. “Taxonomy and trunk-ring architecture of pleurojulid millipedes (Diplopoda: Chilognatha: Pleurojulida) from the Pennsylvanian of Europe and North America". English. In: Journal of Paleontology 79 (2005), pp. 1105-1119.

[24851] H. M. Wilson and D. M. Martill. "A new japygid dipluran from the Lower Cretaceous of Brazil". English. In: Palaeontology 44 (2001), pp. 1025-1031.

[24852] J. A. Wilson, M. S. Malkani, and P. D. Gingerich. "A sauropod braincase from the Pab Formation (Upper Cretaceous, Maastrichtian) of Balochistan, Pakistan". English. In: Gondwana Geological Magazine, Special Volume 5 (2005), pp. 101-109.

[24853] J. A. Wilson, M. S. Malkani, and P. D. Gingerich. “New crocodyliform (Reptilia, Mesoeucrocodylia) from the Upper Cretaceous Pab Formation of Vitakri, Balochistan (Pakistan)". English. In: Contributions from the Museum of Paleontology, University of Michigan 30.12 (2001), pp. 321-336.

[24854] J. A. Wilson and D. M. Mohabey. "A titanosauriform (Dinosauria: Sauropoda) axis from the Lameta Formation (Upper Cretaceous: Maastrichtian) of Nand, central India". English. In: Journal of Vertebrate Paleontology 26.2 (2006), pp. 471-479.

[24855] J. A. Wilson, D. M. Mohabey, S. E. Peters, and J. J. Head. "Predation upon hatchling dinosaurs by a new snake from the Late Cretaceous of India". English. In: PLoS Biology 8.3 (2010), e1000322. DOI: 10.1371/journal.pbio.1000322.

[24856] J. A. Wilson and A. C. Runkel. "Prolapsus, a large sciuravid rodent, and new eomyids from the late Eocene of Trans-Pecos Texas". English. In: Pearce-Sellards Series 48 (1991), pp. 1-30.

[24857] J. A. Wilson, P. C. Sereno, S. Srivastava, D. K. Bhatt, A. Khosla, and A. Sahni. "A new abelisaurid (Dinosauria, Theropoda) from the Lameta Formation (Cretaceous, Maastrichtian) of India". In: Contributions from the Museum of Paleontology, University of Michigan 31.1 (2003), pp. 1-42.

[24858] J. A. Wilson and J. W. Westgate. "A Lophodont Rodent from the Middle Eocene of the Gulf Coastal Plain, Texas". English. In: Journal of Vertebrate Paleontology 11.2 (1991), pp. 257-260.

[24859] J. P. Wilson and D. W. Fowler. "The easternmost occurrence of Saurornitholestes from the Judith River Formation, Montana, indicates broad biogeographic distribution of Saurornitholestes in the Western Interior of North America". English. In: Historical Biology (2020). DOI: 10.1080/08912963. 2020.1862828 .

[24860] J. P. Wilson, J. P. Grotzinger, W. W. Fischer, K. P. Hand, S. Jensen, A. H. Knoll, J. Abelson, J. M. Metz, N. Mcloughlin, P. A. Cohen, and M. M. Tice. "Deep-water incised valley deposits at the EdiacaranCambrian boundary in Southern Namibia contain abundant Treptichnus pedum". English. In: Palaios 27 (2012), pp. 252-273.

[24861] J. P. Wilson, M. J. Ryan, and D. C. Evans. "A new, transitional centrosaurine ceratopsid from the Upper Cretaceous Two Medicine Formation of Montana and the evolution of the 'Styracosaurusline' dinosaurs". English. In: Royal Society Open Science 7 (2020), p. 200284. DOI: 10.1098 / rsos. 200284.

[24862] L. E. Wilson. "Comparative taphonomy and paleoecological reconstruction of two microvertebrate accumulations from the Late Cretaceous Hell Creek Formation (Maastrichtian), eastern Montana". English. In: Palaios 23 (2008), pp. 289-297. DOI: 10.2110/palo.2007.p07-006r.

[24863] L. E. Wilson, K. Chin, S. Cumbaa, and G. Dyke. "A high latitude hesperornithiform (Aves) from Devon Island: palaeobiogeography and size distribution of North American hesperornithiforms". English. In: Journal of Systematic Palaeontology 9.1 (2011), pp. 9-23. 
[24864] M. Wilson, S. Kenady, and R. Schalk. “Late Pleistocene Bison antiquus from Orcas Island, Washington, and the biogeographic importance of an early postglacial land mammal dispersal corridor from the mainland to Vancouver Island". English. In: Quaternary Research 71.1 (2009), pp. 49-61. DOI: 10.1016/j.yqres.2008.09.001.

[24865] M. A. Wilson, H. R. Feldman, J. C. Bowen, and Y. Avni. "A new equatorial, very shallow marine sclerozoan fauna from the Middle Jurassic (late Callovian) of southern Israel". English. In: Palaeogeography, Palaeoclimatology, Palaeoecology 263.1-2 (2008), pp. 24-29.

[24866] M. A. Wilson and T. J. Palmer. “The earliest Gastrochaenolites (Early Pennsylvanian, Arkansas, USA): An Upper Paleozoic bivalve boring?" English. In: Journal of Paleontology 72.4 (1998), pp. 769 772.

[24867] M. A. Wilson, O. Vinn, and T. E. Yancey. "A new microconchid tubeworm from the Lower Permian (Artinskian) of central Texas, USA". English. In: Acta Palaeontologica Polonica (2011).

[24868] M. A. Wilson, O. Vinn, and T. J. Palmer. "Bivalve borings, bioclaustrations and symbiosis in corals from the Upper Cretaceous (Cenomanian) of southern Israel". English. In: Palaeogeography, Palaeoclimatology, Palaeoecology 414 (2014), pp. 243-245.

[24869] M. E. J. Wilson and M. J. Evans. "Sedimentology and diagenesis of Tertiary carbonates on the Mangkalihat Peninsula, Borneo: implications for subsurface reservoir quality". English. In: Marine and Petroleum Geology 19 (2002), pp. 873-900.

[24870] M. E. J. Wilson and S. W. Lokier. "Siliciclastic and volcaniclastic influences on equatorial carbonates: insights from the Neogene of Indonesia". In: Sedimentology 49.3 (2002), pp. 583-601.

[24871] M. E. J. Wilson and B. R. Rosen. Implications of paucity of corals in the Paleogene of SE Asia: plate tectonics or centre of origin? English. Biogeography and Geological Evolution of SE Asia. Backhuys Publishers, Leiden. 1998, pp. 165-195.

[24872] M. V. H. Wilson. Taphonomy of a mass-death layer of fishes in the Paleocene Paskapoo Formation at Joffre Bridge, Alberta Canada. 1996.

[24873] M. V. H. Wilson. "Paleocene Amiid Fish from Jabal Umm Himar, Kingdom of Saudi Arabia". English. In: vol. 2093. U.S. Geological Survey Bulletin C. 1995, pp. 1-5.

[24874] M. V. H. Wilson and G.-Q. Li. "Osteology and systematic position of the Eocene salmonid Eosalmo driftwoodensis Wilson from western North America". English. In: Zoological Journal of the Linnean Society 125 (1999), pp. 279-311.

[24875] T. Winchester-Seeto. “Chitinozoa from the Early Devonian (Lochkovian-Pragian) Garra Limestone, central New South Wales, Australia". English. In: Journal of Paleontology 67.5 (1993), pp. $738-$ 758.

[24876] G. J. Windholz, M. A. Baiano, F. Bellardini, and A. Garrido. “New Dicraeosauridae (Sauropoda, Diplodocoidea) remains from the La Amarga Formation (Barremian-Aptian, Lower Cretaceous), Neuquén Basin, Patagonia, Argentina". English. In: Cretaceous Research (2021). DOI: 10.1016/j. cretres.2020.104629.

[24877] R. Windolf. "Dinosaurierfunde in Niedersachsen [Dinosaur finds in Lower Saxony]". English. In: Arbeitskreis Paläontologie Hannover 26 (1998), pp. 1-7.

[24878] S. L. Wing, J. Alroy, and L. J. Hickey. "Plant and mammal diversity in the Paleocene to Early Eocene of the Bighorn Basin". English. In: Palaeogeography, Palaeoclimatology, Palaeoecology 115 (1995), pp. 117-155.

[24879] S. L. Wing, F. Herrera, C. A. Jaramillo, C. Gómez-Navarro, P. Wilf, and C. C. Labandeira. “Late Paleocene fossils from the Cerrejón Formation, Colombia, are the earliest record of Neotropical rainforest". English. In: Proceedings of the National Academy of Sciences 106.44 (2009), pp. 1862718632. DOI: $10.1073 /$ pnas.0905130106.

[24880] O. Wings, A. Broschinski, and N. Knotschke. New theropod and ornithopod dinosaur trackways from the Berriasian of Münchehagen (Lower Saxony, Germany). English. 2005. 
[24881] O. Wings, M. Rabi, J. W. Schneider, L. Schwermann, G. Sun, C. -F. Zhou, and W. G. Joyce. “An enormous Jurassic turtle bone bed from the Turpan Basin of Xinjiang, China". English. In: Naturwissenschaften 99.11 (2012), pp. 925-935. DOI: 10.1007/s00114-012-0974-5.

[24882] O. Wings, P. M. Sander, T. Tütken, D. Fowler, and G. Sun. Growth and life history of Asia's largest dinosaur. English. 2007.

[24883] O. Wings, D. Schwarz-Wings, and D. W. Fowler. “New sauropod material from the Late Jurassic part of the Shishugou Formation (Junggar Basin, Xinjiang, NW China)". English. In: Neues Jahrbuch für Geologie und Paläontologie Abhandlungen 262.2 (2011), pp. 129-150.

[24884] O. Wings, D. Schwaz-Wings, H. -U. Pfretzschner, and T. Martin. “Overview of Mesozoic crocodylomorphs from the Junggar Basin, Xinjiang, Northwest China, and description of isolated crocodyliform teeth from the Late Jurassic Liuhuanggoi locality". English. In: Palaeobiodiversity and Palaeoenvironments 90 (2010), pp. 283-294. DOI: 10.1007/s12549-010-0033-1.

[24885] A. Winkler, F. L. J. Flynn, and Y. Tomida. "Fossil lagomorphs from the Potwar Plateau, northern Pakistan". English. In: Palaeontologia Electronica 14.3 (2011), pp. 1-16.

[24886] A. J. Winkler. Systematics, Paleobiogeography, and Paleoenvironmental Significance of Rodents from the Ibole Member, Manonga Valley, Tanzania. Neogene Paleontology of the Manonga Valley, Tanzania. Plenum Press, New York and London. 1997, pp. 311-332.

[24887] A. J. Winkler. "Systematics and biogeography of middle Miocene rodents from the Muruyur Beds, Baringo District, Kenya". English. In: Journal of Vertebrate Paleontology 12.2 (1992), pp. 236-249.

[24888] A. J. Winkler and F. Grady. "The Middle Pleistocene Rodent Atopomys (Cricetidae: Arvicolinae) from the Eastern and South-Central United States". English. In: Journal of Vertebrate Paleontology 10.4 (1990), pp. 484-490.

[24889] A. J. Winkler, L. MacLatchy, and M. Mafabi. "Small Rodents and a Lagomorph from the Early Miocene Bukwa Locality, Eastern Uganda". English. In: Palaeontologia Electronica 8.1; 24A (2005), pp. 1-12.

[24890] D. A. Winkler. Sedimentary Facies and Biochronology of the Upper Tertiary Ogallala Group, Blanco and Yellow House Canyons, Texas Panhandle. English. Geologic Framework and Regional Hydrology: Upper Cenozoic Blackwater Draw and Ogallala Formations, Great Plains. 1990, pp. 39-55.

[24891] D. A. Winkler, E. M. Gomani, and L. L. Jacobs. "Comparative taphonomy of an Early Cretaceous sauropod quarry, Malawi, Africa". English. In: Y.-N. Lee (ed.), 2000 International Dinosaur Symposium for Kosong County in Korea. Paleontological Society of Korea Special Publication 4 (2000), pp. 99 114.

[24892] D. A. Winkler, L. L. Jacobs, J. D. Congleton, and W. R. Downs. "Life in a sand sea: biota from Jurassic interdunes". English. In: Geology 19 (1991), pp. 889-892.

[24893] D. A. Winkler, P. A. Murry, and L. L. Jacobs. "Early Cretaceous (Comanchean) vertebrates of central Texas". English. In: Journal of Vertebrate Paleontology 10.1 (1990), pp. 95-116.

[24894] D. A. Winkler, P. A. Murry, and L. L. Jacobs. “A new species of Tenontosaurus (Dinosauria: Ornithopoda) from the Early Cretaceous of Texas". English. In: Journal of Vertebrate Paleontology 17.2 (1997), pp. 330-348.

[24895] D. A. Winkler and P. J. Rose. "Paleoenvironment at Jones Ranch, an Early Cretaceous sauropod quarry in Texas, U.S.A." English. In: Journal of the Paleontological Society of Korea 22.1 (2006), pp. 7789.

[24896] J. D. Winkler and M. Sánchez-Villagra. "A nesting site and egg morphology of a Miocene turtle from Urumaco, Venezuela: Evidence of marine adaptations in pelomedusoides". English. In: Palaeontology 49.3 (2006), pp. 641-646.

[24897] J. R. Winkler. "Two new genera of fossil Korynetinae from Baltic amber (Coleoptera, Cleridae)". English. In: Acta Universitatis Carolinae, Biologica 34 (1990), pp. 371-381.

[24898] C. F. Winkler Prins. "Some Spiriferid brachiopods from the Permian of Timor (Indonesia)". English. In: Proceedings of the Royal Society of Victoria 120 (2008), pp. 389-400. 
[24899] K. Winsor, H. A. Curran, L. Greer, and B. Glumac. “Unusual Holocene serpulid-tufa bioherms, Enriquillo Valley, Dominican. Republic: Morphologies and paleoenvironmental implications". English. In: Palaios 27 (2012), pp. 693-706.

[24900] T. Wintrich, H. Hagdorn, and P. M. Sander. "An enigmatic marine reptile-the actual first record of Omphalosaurus in the Muschelkalk of the Germanic basin". English. In: Journal of Vertebrate Paleontology 37.6 (2017), e1384739. DOI: 10.1080/02724634.2017.1384739.

[24901] T. Wintrich, S. Hayashi, A. Houssaye, Y. Nakajima, and P. M. Sander. “A Triassic plesiosaurian skeleton and bone histology inform on evolution of a unique body plan". English. In: Science Advances 3 (2017), e1701144.

[24902] M. G. E. Wippich. "Valanginian (Early Cretaceous ) ammonite faunas from the western High Atlas, Morocco, and the recognition of western Mediterranean 'standard' zones". In: 24 (2003), pp. 357374.

[24903] W. Witaliski. “Aclerogamasus stenocornis sp. n., a fossil mite from the Baltic amber (Acari: Gamasida: Parasitidae)". English. In: Genus 11.4 (2000), pp. 619-626.

[24904] L. M. Witmer and K. D. Rose. "Biomechanics of the jaw apparatus of the gigantic Eocene bird Diatryma: implications for diet and mode of life". English. In: Paleobiology 17.2 (1991), pp. 95-120.

[24905] L. M. Witmer and D. B. Weishampel. Remains of theropod dinosaurs from the Upper Cretaceous St. Mary River Formation of northwestern Montana, with special reference to a new maniraptoran braincase. English. 1993.

[24906] F. A. Wittler. “Ein Ichthyosaurier aus dem Cenoman des Munsterlandes". German. In: Arbeitskreis Paläontologie Hannover 29 (2001), pp. 76-81.

[24907] F. A. Wittler and R. Roth. "Fauna und Biostratigraphie im Lias gamma/delta Grenzbereich südwestlich Lotte bei Osnabrück (Jura, NW-Deutschland)". German. In: Arbeitskreis Paläontologie Hannover 31 (2003), pp. 14-30.

[24908] F. A. Wittler, R. Roth, and J. Legant. "Die Nautiliden der oberen Kreide (Cenoman-Campan) von Süd- und Westrand des Münsterländer Beckens". German. In: Arbeitskreis Paläontologie Hannover 27 (1999), pp. 1-52.

[24909] M. P. Witton. "A new azhdarchoid pterosaur from the Crato Formation (Lower Cretaceous, Aptian?) of Brazil". English. In: Palaeontology 51 (2008), pp. 1289-1300.

[24910] M. P. Witton. "A new species of Tupuxuara (Thalassodromidae, Azhdarchoidea) from the Lower Cretaceous Santana Formation of Brazil, with a note on the nomenclature of Thalassodromidae". English. In: Cretaceous Research 30 (2009), pp. 1293-1300.

[24911] M. P. Witton, D. M. Martill, and M. Green. “On pterodactyloid diversity in the British Wealden (Lower Cretaceous) and a reappraisal of Palaeornis cliftii Mantell, 1844". English. In: Cretaceous Research 30 (2009), pp. 676-686.

[24912] J. D. Witts, V. C. Bowman, P. B. Wignall, J. A. Crame, J. E. Francis, and R. J. Newton. “Evolution and extinction of Maastrichtian (Late Cretaceous) cephalopods from the López de Bertodano Formation, Seymour Island, Antarctica". English. In: Palaeogeography, Palaeoclimatology, Palaeoecology 418 (2015), pp. 193-212.

[24913] B. J. Witzke and M. E. Johnson. Silurian brachiopod and related benthic communities from carbonate platform and mound environments of Iowa and surrounding areas. Paleocommunities-a case study from the Silurian and Lower Devonian. 1999, pp. 806-840.

[24914] B. J. Witzke, R. M. McKay, B. J. Bunker, and F. J. Woodson. Stratigraphy and paleoenvironments of Mississippian strata in Keokuk and Washington Counties, southeast Iowa. 1990.

[24915] F. Witzmann and T. Gassner. "Metoposaurid and mastodonsaurid stereospondyls from the TriassicJurassic boundary of Portugal". English. In: Alcheringa 32 (2008), pp. 37-51.

[24916] F. Witzmann, O. Hampe, B. M. Rothschild, U. Joger, R. Kosma, D. Schwarz, and P. Asbach. "Subchondral cysts at synovial vertebral joints as analogies of Schmorl's Nodes in a sauropod dinosaur from Niger". English. In: Journal of Vertebrate Paleontology 36.2 (2016), e1080719:1-11. DOI: 10.1080/ 02724634.2016.1080719. 
[24917] F. Witzmann, S. Sachs, and C. J. Nyhuis. "A new species of Cyclotosaurus (Stereospondyli, Capitosauria) from the Late Triassic of Bielefeld, NW Germany, and the intrarelationships of the genus". English. In: Fossil Record 19 (2016), pp. 83-100. DOI: 10.5194/fr-19-83-2016.

[24918] F. Witzmann, R. R. Schoch, and M. W. Maisch. "A relict basal tetrapod from Germany: first evidence of a Triassic chroniosuchian outside Russia". English. In: Naturwissenschaften 95 (2008), pp. 67-72.

[24919] F. Witzmann and S. Voigt. "An Eryops-like interclavicle from the Early Permian of the Saar-Nahe Basin, and a discussion of temnospondyl interclavicle characters". English. In: Palaeontologische Zeitschrift (2014). DOI: 10.1007/s12542-014-0235-3.

[24920] W. J. Woelkerling, B. Granier, and D. Dias-Brito. "Heydrichia (?) poignantii, sp. nov. (Sporolithaceae, Sporolithales, Rhodophyta), a 100 million year old fossil coralline red alga from north-eastern Brazil, and a new Hauterivian record of Sporolithon from Switzerland". English. In: Notebooks on Geology 14.7 (2014).

[24921] M. Wojto, I. Kania, and K. Kope. "Sylvicola Harris, 1780 (Diptera: Anisopodidae) in the Eocene resins". English. In: Annales Zoologici 68 (2018), pp. 849-866.

[24922] M. Wojto, I. Kania, and W. Krzemiski. "Review of Mycetobia Meigen, 1818 (Diptera, Anisopodidae) in the Eocene ambers". English. In: Zootaxa 4544 (2019), pp. 1-40.

[24923] G. WoldeGabriel, T. D. White, G. Suwa, P. Renne, J. de Heinzelin, W. K. Hart, and G. Heiken. "Ecological and temporal placement of early Pliocene hominids at Aramis, Ethiopia". English. In: Nature 371 (1994), pp. 330-333.

[24924] K. Wolf-Schwenninger. "The oldest fossil record of Lymexylidae (Insecta: Coleoptera) from the Lower Cretaceous Crato Formation of Brazil". English. In: Insect Systematics \& Evolution 42 (2011), pp. 205-212.

[24925] R. Wolfart. "Middle Cambrian Faunas (Brachiopoda, Mollusca, Trilobita) from Exotic Limestone Blocks, Reilly Ridge, North Victoria Land, Antarctica; their Biostratigraphic and Paleogeographic Significance". English. In: Geologisches Jahrbuch B/84 (1994), pp. 1-161.

[24926] D. G. Wolfe. Theropod dinosaur tracks from the Upper Cretaceous (Turonian) Moreno Hill Formation of New Mexico. English. Vol. 35. Late Cretaceous Vertebrates from the Western Interior. New Mexico Museum of Natural History and Science Bulletin. 2006, pp. 115-117.

[24927] D. G. Wolfe and J. I. Kirkland. Zuniceratops christopheri n. gen. E n. sp., a ceratopsian dinosaur from the Moreno Hill Formation (Cretaceous, Turonian) of west-central New Mexico. English. Vol. 14. S. G. Lucas, J. I. Kirkland, and J. W. Estep (eds.), Lower and Middle Cretaceous Terrestrial Ecosystems, New Mexico Museum of Natural History and Science Bulletin. 1998, pp. 307-317.

[24928] R. J. Wolff. "A new species of Thiodina (Araneae: Salticidae) from Dominican amber". English. In: Acta Zoologica Fennica 190 (1990), pp. 405-408.

[24929] P. J. Wolniewicz. "Late Famennian stromatoporoids from Debnik Anticline, southern Poland". English. In: Acta Palaeontologica Polonica 54.2 (2009), pp. 337-350. DOI: 10.4202/app.2007.0096.

[24930] M. Wolsan and B. Lange-Badré. "An arctomorph carnivoran skull from the Phosphorites du Quercy and the origin of procyonids". English. In: Acta Palaeontologica Polonica 41.3 (1996), pp. 277-298.

[24931] C. G. Won, S. H. Jon, K. S. So, and L. J. Hyon. "First record of a beetle (Coleoptera: Cupedidae) from the Lower Cretaceous of the Democratic People's Republic of Korea". English. In: Cretaceous Research 114.104276 (2020). DOI: 10.1016/j.cretres.2020.104276.

[24932] M.-Z. Won and R. Below. "Cambrian Radiolaria from the Georgina Basin, Queensland, Australia". English. In: Micropaleontology 45.4 (1999), pp. 325-363.

[24933] M.-Z. Won and W. J. Iams. "Late Cambrian radiolarian faunas and biostratigraphy of the Cow Head Group, western Newfoundland". English. In: Journal of Paleontology 76.1 (2002), pp. 1-33.

[24934] T. E. Wong. "The Paleocene-Eocene succession in the Guiana Basin". English. In: Bulletin de la Société Belge de Géologie 103 (1994), pp. 281-291. 
[24935] N. Wonganan and M. Caridroit. "Middle to Upper Permian radiolarian faunas from chert blocks in Pai area, northwestern Thailand". English. In: Eclogae Geologicae Helvetiae 99.1 (2006), S133-S139.

[24936] T. Wongwanich, A. J. Boucot, C. H. C. Brunton, M. R. House, and P. R. Racheboeuf. "Namurian fossils (brachiopods, goniatites) from Satun Province, southern Thailand". In: Journal of Paleontology 78.6 (2004), pp. 1072-1085.

[24937] A. R. Wood and N. M. Ridgwell. "The first Central American Chalicothere (Mammalia, Perissodactyla) and the paleobiogeographic implications for small-bodied schizotheriines". English. In: Journal of Vertebrate Paleontology 35.3 (2015), e923893. DOI: 10.1080/02724634.2014.923893.

[24938] B. Wood. Koobi Fora Research Project: Hominid Cranial Remains. 1991.

[24939] G. D. Wood. "The acritarch Proteolobus walli gen et sp. nov. from the Devonian Iquiri Formation of Bolivia: a possible coenobial alga". English. In: Micropaleontology 43.3 (1997), pp. 325-331.

[24940] J. R. Wood and S. Briden. "South Georgian diving petrel (Pelecanoides georgicus) bones from a Maori midden on Otago Peninsula, New Zealand". English. In: Notornis 55 (2008), pp. 46-47.

[24941] J. R. Wood, K. J. Mitchell, R. P. Scofield, A. J. D. Tennyson, A. E. Fidler, J. M. Wilmshurst, B. Llamas, and A. Cooper. "An extinct nestorid parrot (Aves, Psittaciformes, Nestoridae) from the Chatham Islands, New Zealand". English. In: Zoological Journal of the Linnean Society 172 (2014), pp. 185-199.

[24942] J. R. Wood and J. M. Wilmshurst. "Late Quaternary terrestrial vertebrate coprolites from New Zealand". English. In: Quaternary Science Reviews 98 (2014), pp. 33-44.

[24943] R. Wood. "Palaeoecology of a post-extinction reef: Famennian (Late Devonian) of the Canning Basin, North-Western Australia". English. In: Palaeontology 47.2 (2004), pp. 415-445.

[24944] R. Wood. "Palaeoecology of a Late Devonian back reef: Canning Basin, Western Australia". English. In: Palaeontology 43.4 (2000), pp. 671-703.

[24945] R. Wood, A. Y. Zhuravlev, and C. T. Anaaz. "The ecology of Lower Cambrian buildups from Zuune Arts, Mongolia: implications for early metazoan reef evolution". English. In: Sedimentology 40.5 (1993), pp. 829-858.

[24946] R. C. Wood. "Paleocene Pelomedusid Turtles from Jabal Umm Himar, Kingdom of Saudi Arabia". English. In: vol. 2093. U.S. Geological Survey Bulletin E. 1995, pp. 1-5.

[24947] M. O. Woodburne. "Reappraisal of the Cormohipparion from the Valentine Formation, Nebraska". English. In: American Museum Novitates 3163 (1996), pp. 1-56.

[24948] M. O. Woodburne. "Phyletic diversification of the Cormohipparion occidentale complex (Mammalia; Perissodactyla, Equidae), Late Miocene, North America, and the origin of the Old World Hippotherium datum". English. In: Bulletin of the American Museum of Natural History 306.1 (2007), pp. 1-138. DOI: 10.1206/0003-0090(2007)306[1:PDOTCO]2.0.CO;2.

[24949] M. O. Woodburne. "A new occurrence of Cormohipparion, with implications for the Old World Hippotherium Datum". English. In: Journal of Vertebrate Paleontology 25.1 (2005), pp. 256-257. DOI: 10.1671/0272-4634(2005)025[0256:ANOOCW]2.0.CO;2.

[24950] M. O. Woodburne, F. J. Goin, M. S. Raigemborn, M. Heizler, J. N. Gelfo, and E. V. Oliveira. "Revised timing of the South American early Paleogene land mammal ages". English. In: Journal of South American Earth Sciences 54 (2014), pp. 109-119. DOI: 10.1016/j.jsames.2014.05.003.

[24951] M. O. Woodburne, B. J. MacFadden, J. A. Case, M. S. Springer, N. S. Pledge, J. D. Power, J. M. Woodburne, and K. B. Springer. "Land Mammal Biostratigraphy and Magnetostratigraphy of the Etadunna Formation (Late Oligocene) of South Australia". English. In: Journal of Vertebrate Paleontology 13.4 (1994), pp. 483-515.

[24952] M. O. Woodburne, R. H. Tedford, C. C. Swisher, and III. "Lithostratigraphy, biostratigraphy, and geochronology of the Barstow Formation, Mojave Desert, southern California". English. In: Geological Society America Bulletin 102.4 (1990), pp. 459-477.

[24953] N. Woodman and J. W. Branstrator. "The Overmyer Mastodon (Mammut Americanum) from Fulton County, Indiana". English. In: American Midland Naturalist 158.1 (2008), pp. 125-146. DOI: 10.1674/0003-0031(2008)159[125:TOMMAF]2.0.CO;2. 
[24954] C. D. Woodroffe, D. M. Kennedy, D. Hopley, C. E. Rasmussen, and S. G. Smithers. “Holocene reef growth in Torres Strait". English. In: Marine Geology 170 (2000), pp. 331-346.

[24955] C. D. Woodroffe and R. F. McLean. "Pleistocene morphology and Holocene emergence of Christmas (Kiritimati) Island, Pacific Ocean". English. In: Coral Reefs 17 (1998), pp. 235-248.

[24956] C. D. Woodroffe and R. F. McLean. "Reef islands of the Cocos (Keeling) Islands". English. In: Atoll Research Bulletin 403 (1994), pp. 1-36.

[24957] C. D. Woodroffe, S. A. Short, D. R. Stoddart, T. Spencer, and R. S. Harmon. "Stratigraphy and chronology of Late Pleistocene reefs in the Southern Cook Islands, south Pacific". English. In: Quaternary Research 35 (1991), pp. 246-263.

[24958] C. D. Woodroffe, D. R. Stoddart, T. Spencer, T. P. Scoffin, and A. W. Tudhope. "Holocene emergence in the Cook Islands, south Pacific". English. In: Coral Reefs 9 (1990), pp. 31-39.

[24959] D. C. Woodruff. "A new titanosauriform from the Early Cretaceous Cloverly Formation of Montana". English. In: Cretaceous Research 36 (2012), pp. 58-66. DOI: 10.1016/j.cretres.2012.02.003.

[24960] R. E. Woodruff. "A new fossil species of stag beetle from Dominican Republic amber,with Australasian connections (Coleoptera: Lucanidae)". English. In: Insecta Mundi 0098 (2009), pp. 1-10.

[24961] M. A. Woods. "The macrofossil biostratigraphy of the Turonian and Coniacian (Upper Cretaceous, Chalk Group) of southeast Devon". In: Proceedings of the Geologistst'Association 113.4 (2002), pp. 333-344.

[24962] M. A. Woods and N. S. Jones. "The sedimentology and biostratigraphy of a temporary exposure of Blackdown Greensand (Lower Cretaceous, upper Albian) at Blackborough, Devon". English. In: Proceedings of the Ussher Society 9.1 (1996), pp. 37-40.

[24963] J. M. Woollett. "Living in the narrows: subsistence economy and culture change in Labrador Inuit society during the Contact Period". English. In: World Archaeology 30 (1999), pp. 370-387.

[24964] C. Woolley. "The first scarabaeid beetle (Coleoptera, Scarabaeidae, Melolonthinae) described from the Mesozoic (Late-Cretaceous) of Africa". English. In: African Invertebrates 57 (2016), pp. 53-66.

[24965] C. H. Woolley, N. D. Smith, and J. J. W. Sertich. "New fossil lizard specimens from a poorly-known squamate assemblage in the Upper Cretaceous (Campanian) San Juan Basin, New Mexico, USA". English. In: PeerJ 8 (2020), e8846:1-30.

[24966] G. Wörheide. “The reef cave dwelling ultraconservative coralline demosponge Astrosclera willeyana Lister 1900 from the Indo-Pacific". English. In: Facies 38 (1998), pp. 1-88.

[24967] D. M. Work. “The lower Mississippian (Kinderhookian) ammonoid Goniocyclus from the Hannibal Shale, Missouri". In: Journal of Paleontology 76.1 (2002), pp. 187-189.

[24968] D. M. Work and D. R. Boardman. "Mapesites; a new Upper Pennsylvanian (lower Virgilian) ammonoid from Kansas". In: Journal of Paleontology 77.6 (2003), pp. 1195-1197.

[24969] D. M. Work and W. L. Manger. "Masonoceras, a new karagandoceratid ammonoid from the lower Mississippian (Lower Osagean) of Kentucky". In: Journal of Paleontology 76.3 (2002), pp. 574-577.

[24970] D. M. Work and R. H. Mapes. "New occurrences of the Pennsylvanian index ammonoid Dunbarites from the North American Midcontinent". English. In: Journal of Paleontology 83 (2009), pp. 405-413.

[24971] D. M. Work and C. E. Mason. "Mississippian (middle Osagean) ammonoids from the Nada Member of the Borden Formation, Kentucky". English. In: Journal of Paleontology 77.3 (2003), pp. 593596.

[24972] D. M. Work and C. E. Mason. "Mississippian (Late Osagean) ammonoids from the New Providence SHale Member of the Borden Formation, North-Central Kentucky". English. In: Journal of Paleontology 78.6 (2004), pp. 1128-1137.

[24973] D. M. Work and C. E. Mason. "Mississippian (Early Osagean) Cave Run Lake ammonoid fauna, Borden Formation, northeastern Kentucky". English. In: Journal of Paleontology 79.4 (2005), pp. 719 725. 
[24974] D. M. Work, C. E. Mason, and D. R. Boardman. "Pennsylvanian (Atokan) ammonoids from the Magoffin Member of the Four Corners Formation, eastern Kentucky". English. In: Journal of Paleontology 86 (2012), pp. 403-416.

[24975] K. Workman Ford. Stratigraphic positions of marine reptile and dinosaur specimens in the Moreno Formation, in the Tumey Hills and Panoche Hills, Fresno County, California. English. Vol. 35. Late Cretaceous Vertebrates from the Western Interior. New Mexico Museum of Natural History and Science Bulletin. 2006, pp. 407-410.

[24976] M. P. Worley-Georg and J. J. Eberle. "Additions to the Chadronian Mammalian Fauna, Florissant Formation, Florissant Fossil Beds National Monument, Colorado". English. In: Journal of Vertebrate Paleontology 26.3 (2006), pp. 685-696. DOI: 10.1671/0272-4634(2006)26[685:ATTCMF]2.0.CO;2.

[24977] T. Woroncowa-Marcinowska. “Upper Devonian goniatites and co-occurring conodonts from the Holy Cross Mountains: studies of the Polish Geological Institute collections". English. In: Annales Societatis Geologorum Poloniae 76 (2006), pp. 113-160.

[24978] T. H. Worthy. "Fossil bones of Hooker's sea lions in New Zealand Caves". English. In: New Zealand Natural Sciences 19 (1992), pp. 31-39.

[24979] T. H. Worthy. “A mid-Pleistocene rail from New Zealand". English. In: Alcheringa 21 (1997), pp. 7178.

[24980] T. H. Worthy. "Holocene breeding of sea lions (Phocarctos hookeri) at Delaware Bay, Nelson, South Island, New Zealand". English. In: New Zealand Natural Sciences 21 (1994), pp. 61-70.

[24981] T. H. Worthy. "Descriptions and phylogenetic relationships of two new genera and four new species of Oligo-Miocene waterfowl (Aves: Anatidae) from Australia". English. In: Zoological Journal of the Linnean Society 156 (2009), pp. 411-454. DOI: 10.1111/j.1096-3642.2008.00483.x.

[24982] T. H. Worthy. "A remarkable fossil and archaeological avifauna from Marfells Beach, Lake Grassmere, South Island, New Zealand". English. In: Records of the Canterbury Museum 12 (1998), pp. 79 176.

[24983] T. H. Worthy. "The fossil megapodes (Aves: Megapodiidae) of Fiji with descriptions of a new genus and two new species". English. In: Journal of the Royal Society of New Zealand 30 (2000), pp. 337-364.

[24984] T. H. Worthy. "A giant flightless pigeon gen. et sp. nov. and a new species of Ducula (Aves: Columbidae), from Quaternary deposits in Fiji". English. In: Journal of the Royal Society of New Zealand 31 (2001), pp. 763-794.

[24985] T. H. Worthy. "A new extinct species of snipe Coenocorypha from Vitilevu, Fiji". English. In: Bulletin of the British Ornithologists' Club 123 (2003), pp. 90-103.

[24986] T. H. Worthy. "The fossil rails (Aves: Rallidae) of Fiji with descriptions of a new genus and species". English. In: Journal of the Royal Society of New Zealand 34 (2004), pp. 295-314.

[24987] T. H. Worthy. "Fossils indicate Pelecanoides georgicus had large colonies at Mason Bay, Stewart Island, New Zealand". English. In: Notornis 45 (1998), pp. 229-246.

[24988] T. H. Worthy. "Quaternary fossil fauna of South Canterbury, South Island, New Zealand". English. In: Journal of the Royal Society of New Zealand 27.1 (1997), pp. 67-162. DOI: 10.1080/03014223.1997. 9517528.

[24989] T. H. Worthy. "The Holocene fossil waterfowl fauna of Lake Poukawa, North Island, New Zealand". English. In: Tuhinga 15 (2004), pp. 77-120.

[24990] T. H. Worthy. "Descriptions and phylogenetic relationships of a new genus and two new species of Oligo-Miocene cormorants (Aves: Phalacrocoracidae) from Australia". English. In: Zoological Journal of the Linnean Society 163 (2011), pp. 277-314.

[24991] T. H. Worthy. "A new species of Oligo-Miocene darter (Aves: Anhingidae) from Australia". English. In: The Auk 129.1 (2012), pp. 96-204. DOI: 10.1525/auk.2012.11204.

[24992] T. H. Worthy, A. Anderson, and C. Sand. "An extinct Austral snipe (Aves : Coenocorypha) from New Caledonia”. English. In: Emu 113 (2013), pp. 383-393. 
[24993] T. H. Worthy, A. J. Anderson, and R. E. Molnar. "Megafaunal expression in a land without mammals - the first fossil faunas from terrestrial deposits in Fiji (Vertebrata: Amphibia, Reptilia, Aves". English. In: Senckenbergiana biologica 79.2 (1999), pp. 237-242.

[24994] T. H. Worthy and W. E. Boles. "Australlus, a new genus for Gallinula disneyi (Aves: Rallidae) and a description of a new species from Oligo-Miocene deposits at Riversleigh, Northwestern Queensland, Australia". English. In: Records of the Australian Museum 63 (2011), pp. 61-67. DOI: 10.3853/j.0067-1975.63.2011.1563.

[24995] T. H. Worthy and D. V. Burley. "Prehistoric avifaunas from the Kingdom of Tonga". English. In: Zoological Journal of the Linnean Society 189 (2019), pp. 998-1045. DOI: 10.1093/zoolinnean/zlz110.

[24996] T. H. Worthy and J. A. Grant-Mackie. "Late-Pleistocene avifaunas from Cape Wanbrow, Otago, South Island, New Zealand". English. In: Journal of the Royal Society of New Zealand 33.1 (2003), pp. 427-485.

[24997] T. H. Worthy, S. J. Hand, J. M. T. Nguyen, A. J. D. Tennyson, J. P. Worthy, R. P. Scofield, W. E. Boles, and M. Archer. "Biogeographical and phylogenetic implications of an Early Miocene wren (Aves: Passeriformes: Acanthisittidae) from New Zealand". English. In: Journal of Vertebrate Paleontology 30.2 (2010), pp. 479-498.

[24998] T. H. Worthy, S. J. Hand, M. Archer, R. P. Scofield, and V. L. De Pietri. “Evidence for a giant parrot from the Early Miocene of New Zealand". English. In: Biology Letters 15 (2019), p. 20190467. DOI: 10.1098/rsbl.2019.0467.

[24999] T. H. Worthy, S. J. Hand, J. P. Worthy, A. J. D. Tennyson, and R. P. Scofield. “A Large Fruit Pigeon (Columbidae) from the Early Miocene of New Zealand". English. In: The Auk 126.3 (2009), pp. 649656.

[25000] T. H. Worthy, W. D. Handley, M. Archer, and S. J. Hand. “The Extinct Flightless Mihirungs (Aves, Dromornithidae): Cranial Anatomy, a New Species, and Assessment of Oligo-Miocene Lineage Diversity". English. In: Journal of Vertebrate Paleontology 36.3 (2016), e1031345. DOI: 10.1080 / 02724634.2015.1031345.

[25001] T. H. Worthy, S. Hawkins, S. Bedford, and M. Spriggs. "Avifauna from the Teouma Lapita site, Efate Island, Vanuatu, including a new genus and species of megapode". English. In: Pacific Science 69 (2015), pp. 205-254.

[25002] T. H. Worthy and R. N. Holdaway. "Taphonomy of two holocene microvertebrate deposits, Takaka Hill, Nelson, New Zealand, and identification of the avian predator responsible". English. In: Historical Biology 12.1 (1996), pp. 1-24.

[25003] T. H. Worthy and R. N. Holdaway. "Quaternary fossil faunas from caves in Takaka Valley and on Takaka Hill, northwest Nelson, South Island, New Zealand". English. In: Journal of the Royal Society of New Zealand 24.3 (1994), pp. 297-391.

[25004] T. H. Worthy and P. Jouventin. "The fossil avifauna of Amsterdam Island, Indian Ocean". English. In: Avian Paleontology at the Close of the 20th Century: Proceedings of the 4th International Meeting of the Society of Avian Paleontology and Evolution, Washington, D.C, 4-7 June 1996. Smithsonian Contributions to Paleobiology 89 (1999), pp. 39-66.

[25005] T. H. Worthy and N. S. Pledge. "A shelduck (Anatidae: Tadorna) from the Pliocene of South Australia". English. In: Transactions of the Royal Society of South Australia 131.1 (2007), pp. 107-115. DOI: 10.1080/03721426.2007.10887072.

[25006] T. H. Worthy and J. D. Scanlon. "An Oligo-Miocene magpie goose (Aves: Anseranatidae) from Riversleigh, northwestern Queensland, Australia". English. In: Journal of Vertebrate Paleontology 29.1 (2009), pp. 205-211. DOI: 10.1671/039.029.0103.

[25007] T. H. Worthy, A. J. D. Tennyson, M. Archer, A. M. Musser, S. J. Hand, C. Jones, B. J. Douglass, J. A. McNamara, and R. M. D. Beck. "Miocene mammal reveals a Mesozoic ghost lineage on insular New Zealand, southwest Pacific". English. In: Proceedings of the National Academy of Sciences 103.51 (2006), pp. 19419-19423. 
[25008] T. H. Worthy, A. J. D. Tennyson, C. Jones, J. A. McNamara, and B. J. Douglas. "Miocene waterfow1 and other birds from central Otago, New Zealand". English. In: Journal of Systematic Palaeontology 5.1 (2007), pp. 1-39.

[25009] T. H. Worthy, A. J. D. Tennyson, R. B. Scofield, and S. J. Hand. “Early Miocene fossil frogs (Anura: Leiopelmatidae) from New Zealand". English. In: Journal of the Royal Society of New Zealand 43.4 (2013), pp. 211-230.

[25010] T. H. Worthy, A. J. D. Tennyson, and R. P. Scofield. “Fossils reveal an early Miocene presence of the aberrant gruiform Aves: Aptornithidae in New Zealand". English. In: Journal of Ornithology 152 (2011), pp. 669-680.

[25011] T. H. Worthy, A. J. D. Tennyson, M. Archer, and R. P. Scofield. “First Record of Palaelodus (Aves: Phoenicopteriformes) from New Zealand". English. In: Records of the Australian Museum 62 (2010), pp. 77-88.

[25012] T. H. Worthy, A. J. D. Tennyson, S. J. Hand, and R. P. Scofield. "A new species of the diving duck Manuherikia and evidence for geese (Aves: Anatidae: Anserinae) in the St Bathans Fauna (Early Miocene), New Zealand". English. In: Journal of the Royal Society of New Zealand 38.2 (2008), pp. 97114.

[25013] T. H. Worthy, A. J. D. Tennyson, and R. P. Scofield. "An early Miocene diversity of parrots (Aves, Strigopidae, Nestorinae) from New Zealand". English. In: Journal of Vertebrate Paleontology 31.5 (2011), pp. 1102-1116.

[25014] T. H. Worthy, R. Walter, and A. J. Anderson. "Fossil and archaeological avifauna of Niue Island, Pacific Ocean". English. In: Notornis 45 (1998), pp. 177-190.

[25015] T. H. Worthy, J. P. Worthy, A. J. D. Tennyson, and R. P. Scofield. “A Bittern (Aves: Ardeidae) from the Early Miocene of New Zealand". English. In: Paleontological Journal 47.11 (2013), pp. 1331-1343.

[25016] T. H. Worthy, J. P. Worthy, A. J. D. Tennyson, S. W. Salisbury, S. J. Hand, and R. P. Scofield. Miocene fossils show that kiwi (Apteryx, Apterygidae) are probably not phyletic dwarves. English. Proceedings of the 8th International Meeting of the Society of Avian Paleontology and Evolution. Vienna: Naturhistorischesmuseum Wien, 2013, pp. 63-80.

[25017] T. H. Worthy and G. M. Wragg. "A new genus and species of pigeon (Aves: Columbidae) from Henderson Island, Pitcairn Group". English. In: Islands of Inquiry: Colonisation, Seafaring and the Archaeology of Maritime Landscapes. ANU Press, 2008, pp. 499-510.

[25018] T. H. Worthy and G. M. Wragg. "A new species of Gallicolumba: Columbidae from Henderson Island, Pitcairn Group". English. In: Journal of the Royal Society of New Zealand 33 (2003), pp. 769 793.

[25019] T. H. Worthy and A. M. Yates. "A review of the smaller birds from the late Miocene Alcoota local faunas of Australia with a description of a new anatid species". English. In: Proceedings of the 9th International Meeting of the Society of Avian Paleontology and Evolution, 9 (2018), pp. 221-252.

[25020] M. Wosik, M. B. Goodwin, and D. C. Evans. "A nestling-sized skeleton of Edmontosaurus (Ornithischia, Hadrosauridae) from the Hell Creek". English. In: Journal of Vertebrate Paleontology e1398168 (2018), pp. 1-19. DOI: 10.1080/02724634.2017.1398168.

[25021] T. Wotte. "Evidence and facial position of reef mounds in the Lower Cambrian of the DoberlugTorgau area". German. In: Neues Jahrbuch für Geologie und Paläontologie, Abhandlungen 233.3 (2004), pp. 397-422.

[25022] T. Wotte. "The youngest cambroclaves: Cambroclavus absonus from the Middle Cambrian of the Cantabrian Zone (Northwest Spain)". English. In: Journal of Paleontology 83.1 (2009), pp. 128-134.

[25023] T. Wotte and M. Mergl. "Brachiopods from the Lower-Middle Cambrian Láncara Formation of the Cantabrian Mountains, Northwest Spain". English. In: Memoirs of the Association of Australasian Palaeontologists 33 (2007), pp. 101-122.

[25024] T. Wotte and F. A. Sundberg. "Small shelly fossils from the Montezuman-Delamaran of the Great Basin in Nevada and California". English. In: Journal of Paleontology 91.5 (2017), pp. 883-901. DOI: 10.1017/jpa.2017.8. 
[25025] A. J. Wonica. “Balticoleria michaeli, gen. et spec. nov. from Eocene Baltic amber (Diptera: Heleomyzidae)". English. In: Genus 14 (2007), pp. 83-88.

[25026] A. J. Wonica. "Protoorbellia hoffeinsorum gen. and sp. nov., a new heleomyzid genus and species of the tribe Orbelliini Gorodkov from Baltic amber (Diptera: Heleomyzidae)". English. In: Annales Zoologici 56 (2006), pp. 147-151.

[25027] A. J. Wonica. "Gedanoleria eocenica - a new genus and species from Eocene Baltic amber (Diptera: Heleomyzidae), with notes on heleomyzid-like flies from African copal". English. In: Polish Journal of Entomology 88 (2019), pp. 395-406. DOI: 10.2478/pjen-2019-0026.

[25028] A. J. Wonica and A. Palaczyk. "A new genus and species of Heleomyzidae (Diptera) from Baltic amber". English. In: Polskie Pismo Entomologiczne 74 (2005), pp. 373-378.

[25029] G. M. Wragg. “The fossil birds of Henderson Island, Pitcairn Group: natural turnover and human impact, a synopsis". English. In: Biological Journal of the Linnean Society 56 (1995), pp. 405-414.

[25030] G. M. Wragg and T. H. Worthy. "A new species of extinct imperial pigeon (Ducula: Columbidae) from Henderson Island, Pitcairn Group". English. In: Historical Biology 18 (2006), pp. 131-144.

[25031] A. D. Wright. "A homoeomorph of the articulate brachiopod Dicoelosia from the Upper Ordovician Hulterstad fauna of Öland, Sweden". English. In: Geologiska Föreningens i Stockholm Förhandlingar 115 (1993), pp. 65-75.

[25032] A. D. Wright and V. Jaanusson. "New genera of Upper Ordovician triplesiid brachiopods from Sweden". English. In: Geologiska Föreningens i Stockholm Förhandlingar 115.2 (1993), pp. 93-108.

[25033] A. D. Wright and J. Y. Rong. "Co-existence of interarea and palintrope: contribution of a new pentameride brachiopod from the Upper Ordovician of Sweden". English. In: Transactions of the Royal Society of Edinburgh 98 (2008), pp. 263-269.

[25034] A. D. Wright and M. Rubel. "A review of the morphological features affecting the classification of clitambonitidine brachiopods". English. In: Palaeontology 39.1 (1996), pp. 53-76.

[25035] A. J. Wright. "Acastid trilobites from the Baton Formation (Early Devonian), New Zealand". In: New Zealand Journal of Geology and Geophysics 33.1 (1990), pp. 49-53.

[25036] D. B. Wright. "Evolution of sexually dimorphic characters in peccaries (Mammalia, Tayassuidae)". English. In: Paleobiology 19.1 (1993), pp. 52-70.

[25037] D. F. Wright, S. R. Cole, and W. I. Ausich. "Biodiversity, systematics, and new taxa of cladid crinoids from the Ordovician Brechin Lagerstätte". English. In: Journal of Paleontology (2019). DOI: $10.1017 /$ jpa.2019.81.

[25038] D. F. Wright and P. A. Selden. "A trigonotarbid arachnid from the Pennsylvanian of Kansas". English. In: Journal of Paleontology 85 (2011), pp. 871-876.

[25039] D. F. Wright and A. L. Stigall. "Species-level phylogenetic revision of the Ordovician orthide brachiopod Glyptorthis from North America". English. In: Journal of Systematic Palaeontology 12.8 (2014), pp. 893-906. DOI: 10.1080/14772019.2013.839584.

[25040] D. F. Wright and A. L. Stigall. "Phylogenetic revision of the Late Ordovician orthid brachiopod genera Plaesiomys and Hebertella from Laurentia". English. In: Journal of Paleontology 87.6 (2013), pp. 1107-1128. DOI: 10.1666/12-083.

[25041] D. F. Wright and U. Toom. "New crinoids from the Baltic region (Estonia): fossil tip-dating phylogenetics constrains the origin and Ordovician-Silurian diversification of the Flexibilia (Echinodermata)". English. In: Palaeontology 60.6 (2017). DOI: 10.1111/pala.12324.

[25042] J. K. Wright. "The Aulacostephanidae (Ammonoidea) of the Oxfordian/Kimmeridgian boundary beds (Upper Jurassic) of southern England". English. In: Palaeontology 53 (2010), pp. 11-52.

[25043] J. K. Wright. "Speciation in the cardioceratinid ammonites of the Costacardia Subzone (Cordatum Zone) of the Oxfordian of Skye". English. In: Scottish Journal of Geology 48.1 (2012), pp. 61-72. DOI: 10.1144/0036-9276/01-441. 
[25044] J. L. Wright. "Ichnological evidence for the use of the forelimb in iguanodontid locomotion". English. In: Special Papers in Palaeontology 60 (1999), pp. 209-219.

[25045] J. L. Wright, D. M. Unwin, M. G. Lockley, and E. C. Rainforth. "Pterosaur tracks from the Purbeck Limestone Formation of Dorset, England". English. In: Proceedings of the Geologists' Association 108 (1997), pp. 39-48.

[25046] S. Wroe. "Muribacinus gadiyuli, (Thylacinidae: Marsupialia), a very plesiomorphic thylacinid from the Miocene of Riversleigh, northwestern Queensland, and the problem of paraphyly for the Dasyuridae (Marsupialia)". English. In: Journal of Paleontology 70.6 (1996), pp. 1032-1044.

[25047] S. Wroe. "A new 'bone-cracking' dasyurid (marsupialia), from the Miocene of Riversleigh, northwestern Queensland". English. In: Alcheringa 22.3 (1998), pp. 277-284. DOI: 10.1080/03115519808619205.

[25048] S. Wroe. "The geologically oldest dasyurid, from the Miocene of Riversleigh, North-West Queensland". English. In: Palaeontology 42.3 (1999), pp. 501-527.

[25049] S. Wroe. "A new genus and species of dasyuromorphian from the Miocene of Riversleigh, Southern Australia". English. In: Menoirs of the Australian Association of Palaeontologists 25 (2001), pp. 5359.

[25050] S. Wroe. "Maximucinus muirheadae, gen. et sp. nov. (Thylacinidae: Marsupialia), from the Miocene of Riversleigh, north-western Queensland, with estimates of body weights for fossil thylacinids". English. In: Australian Journal of Zoology 49 (2001), pp. 603-614. DOI: 10.1071/ZO01044.

[25051] S. Wroe and B. S. Mackness. "A new genus and species of dasyurid from the Pliocene Chinchilla Local Fauna of south-eastern Queensland". English. In: Alcheringa 24.4 (2000), pp. 319-326.

[25052] S. Wroe and B. S. Mackness. "Additional material of Dasyurus dunmalli from the Pliocene Chinchilla local fauna of Queensland and its phylogenetic implications". English. In: Memoirs of the Queensland Museum 45.2 (2000), pp. 641-645.

[25053] R. Wrona. "Early Cambrian molluscs from glacial erratics of King George Island, West Antarctica". In: Polish Polar Research 24.3-4 (2003), pp. 181-216.

[25054] R. Wrona and A. Y. Zhuravlev. "Early Cambrian archaeocyaths from glacial erratics of King George Island (South Shetland Islands), Antarctica". English. In: Palaeontologia Polonica 55 (1996), pp. 9-36.

[25055] T. Wrzolek. "Rugose corals from the Devonian Kowala Formation of the Holy Cross Mountains". English. In: Acta Palaeontologica Polonica 37.2-4 (1992), pp. 217-254.

[25056] F. Wu, Y. Sun, W. Hao, D. Jiang, G. Xu, Z. Sun, and A. Tintori. "New species of Saurichthys (Actinopterygii: Saurichthyidae) from Middle Triassic (Anisian) of Yunnan Province, China". English. In: Acta Geologica Sinica 83.3 (2009), pp. 440-450.

[25057] F. Wu, Y. Sun, G. Xu, W. Hao, D. Jiang, and Z. Sun. "New Saurichthyid Actinopterygian Fishes from the Anisian (Middle Triassic) of Southwestern China". English. In: Acta Palaeontologica Polonica 56.3 (2011), pp. 581-614.

[25058] F. X. Wu, M. M. Chang, Y. L. Sun, and G. H. Xu. "A new saurichthyiform (Actinopterygii) with a crushing feeding mechanism from the Middle Triassic of Guizhou (China)". English. In: PLoS One 8.12 (2013), e81010.

[25059] F. X. Wu, Y. L. Sun, and G. Y. Fang. "A new species of Saurichthys from the Middle Triassic (Anisian) of southwestern China". English. In: Vertebrata PalAsiatica 56 (2018), pp. 273-294.

[25060] H. Wu, D. Coty, and M. Ding. "First artematopodid beetle in Mexican amber and its biogeographic implications (Coleoptera, Artematopodidae)". English. In: Alcheringa 39 (2015), pp. 508-513.

[25061] H. Wu and D. Y. Huang. "A new species of Liadotaulius (Insecta: Trichoptera) from the Middle Jurassic of Daohugou, Inner Mongolia". English. In: Acta Geologica Sinica 86 (2012), pp. 320-324.

[25062] H. Wu, L. Q. Li, and M. Ding. “The first cyclaxyrid beetle from Upper Cretaceous Burmese amber (Coleoptera: Cucujoidea: Cyclaxyridae)". English. In: Cretaceous Research 91 (2018), pp. 66-70.

[25063] H. T. Wu, W. H. He, G. R. Shi, K. X. Zhang, T. L. Yang, Y. Zhang, Y. F. Xiao, B. Chen, and S. B. Wu. "A new Permian-Triassic boundary brachiopod fauna from the Xinmin section, southwestern Guizhou, south China and its extinction patterns". English. In: Alcheringa 42 (2018), pp. 339-372. 
[25064] H. T. Wu, Y. Zhang, and Y. L. Sun. "A mixed Permian-Triassic boundary brachiopod fauna from Guizhou province, South China". English. In: Rivista Italiana di Paleontologia e Stratigrafia 125 (2019), pp. 609-630.

[25065] Q. Wu, T. Zhang, C. K. Shih, D. Ren, Y. Y. Zhao, and T. P. Gao. “New vespids from mid-Cretaceous amber of northern Myanmar provide evidence for the phylogenetic relationships of Priorvespinae (Hymenoptera: Vespidae)". English. In: Cretaceous Research 113.104495 (2020). DOI: 10.1016 / j . cretres.2020.104495.

[25066] R. Wu, I. G. Percival, and R. B. Zhan. "Biodiversification of Early to Middle Ordovician conodonts: a case study from the Zitai Formation of Anhui Province, eastern China". English. In: Alcheringa 34.1 (2010), pp. 75-86. DOI: 10.1080/03115510903343501.

[25067] S. Y. Wu, W. Krzemiski, A. Soszyska-Maj, and D. Ren. "New fossil representative of the genus Helius (Diptera, Limoniidae) from the little known and newly discovered locality Caergen Village of northeastern Tibetan Plateau (China)". English. In: Palaeontologia Electronica 22.1.2A (2019), pp. 18.

[25068] W. Wu, J. Meng, J. Ye, and X. Ni. "Propalaeocastor (Rodentia, Mammalia) from the Early Oligocene of Burqin Basin, Xinjiang". English. In: American Museum Novitates 3461 (2004), pp. 1-16.

[25069] W. Wu, A. Yang, D. Janussen, M. Steiner, and M. Zhu. “Hexactinellid sponges from the early Cambrian black shale of South Anhui, China". English. In: Journal of Paleontology 79.6 (2005), pp. 10431051.

[25070] W. Wu, C. Zhou, W. Sun, and C. Sun. "The First Vertebrate Assemblage Dominated by Fishes and Turtles of the Jehol Biota in Jilin Province, NE China". English. In: Acta Geologica Sinica 92.5 (2018), pp. 2028-2029.

[25071] W. Wu, M. Zhu, and M. Steiner. "Composition and tiering of the Cambrian sponge communities". English. In: Palaeogeography, Palaeoclimatology, Palaeoecology 398 (2014), pp. 86-96.

[25072] W.-h. Wu, Z.-m. Dong, Y. -w. Sun, C. -t. Li, and T. Li. "[A new sauropod dinosaur from the Cretaceous of Jiutai, Jilin, China]". English. In: Global Geology 25.1 (2006), pp. 6-9.

[25073] W.-h. Wu, P. Godefroit, and D. -y. Hu. "[Bolong yixianensis gen. et sp. nov.: a new iguanodontoid dinosaur from the Yixian Formation of western Liaoning, China]". Chinese. In: Geology and Resources 19.2 (2010), pp. 127-133.

[25074] W.-H. Wu, C.-F. Zhou, O. Wings, T. Sekiya, and Z. -M. Dong. "A new gigantic sauropod dinosaur from the Middle Jurassic of Shanshan, Xinjiang". Chinese. In: Global Geology 32.3 (2013), pp. 437446.

[25075] W.-Y. Wu, J. Meng, J. Ye, X. -J. Ni, and S. -D. Bi. "Restudy of the Late Oligocene dormice from northern Junggar Basin". English. In: Vertebrata PalAsiatica 54.1 (2016), pp. 36-50.

[25076] W.-Y. Wu, J. Meng, J. Ye, and X. J. Ni. "The first finds of Eomyids (Rodentia) from the Late Oligocene-Early Miocene of the Northern Junggar Basin, China". English. In: Beiträge zur Paläontologie 30 (2006), pp. 469-479.

[25077] W.-Y. Wu, J. Ye, S. -D. Bi, and J. Meng. "The discovery of Late Oligocene dormice from China". English. In: Vertebrata PalAsiatica 38.1 (2000), pp. 36-42.

[25078] X.-C. Wu, Y.-N. Cheng, T. Sato, and H. -Y. Shan. “Miodentosaurus brevis Cheng et al. 2007 (Diapsida: Thalattosauria): its postcranial skeleton and phylogenetic relationships". English. In: Vertebrata PalAsiatica 47 (2009), pp. 1-20.

[25079] X.-C. Wu, J. Liu, and J. -L. Li. "The anatomy of the first archosauriform (Diapsida) from the terrestrial Upper Triassic of China". English. In: Vertebrata PalAsiatica 39 (2001), pp. 251-265.

[25080] X.-C. Wu. Late Triassic-Early Jurassic sphenodontians from China and the phylogeny of the Sphenodontida. English. In N. C. Fraser \& H.-D. Sues (eds.), In the Shadow of the Dinosaurs: Early Mesozoic Tetrapods. Cambridge University Press, Cambridge. 1994, pp. 38-69. 
[25081] X.-C. Wu, D. B. Brinkman, and R. C. Fox. "A new crocodylian (Archosauria) from the basal Paleocene of the Red Deer River Valley, southern Alberta". English. In: Canadian Journal of Earth Sciences 38.12 (2001), pp. 1689-1704.

[25082] X.-C. Wu and D. B. Brinkman. "A new crocodylomorph of mesosuchian grade from the Upper Cretaceous upper Milk River Formation, southern Alberta". English. In: Journal of Vertebrate Paleontology 13.2 (1993), pp. 153-160.

[25083] X.-C. Wu, D. B. Brinkman, and A. P. Russell. "Sunosuchus junggarensis sp. nov. (Archosauria: Crocodyliformes) from the Upper Jurassic of Xinjiang, People's Republic of China". English. In: Canadian Journal of Earth Sciences 33.4 (1996), pp. 606-630.

[25084] X.-C. Wu, D. B. Brinkman, D. A. Ebert, and D. R. Braman. "A new ceratopsid dinosaur (Ornithischia) from the uppermost Horseshoe Canyon Formation (upper Maastrichtian), Alberta, Canada". English. In: Canadian Journal of Earth Sciences 44 (2007), pp. 1243-1265. DOI: 10.1139/E07-011.

[25085] X.-C. Wu, D. B. Brinkman, and A. P. Russell. "A new alligator from the Upper Cretaceous of Canada and the relationships of early eusuchians". English. In: Palaeontology 39.2 (1996), pp. 351375.

[25086] X.-C. Wu, D. B. Brinkman, and J. -C. Lu. "A new species of Shantungosuchus from the Lower Cretaceous of Inner Mongolia (China), with comments on S. chuhsienensis Young, 1961 and the phylogenetic position of the genus". English. In: Journal of Vertebrate Paleontology 14.2 (1994), pp. 210 229.

[25087] X.-C. Wu and D. B. Brinkman. "A new crocodylian (Eusuchia) from the uppermost Cretaceous of Alberta, Canada". English. In: Canadian Journal of Earth Sciences 52 (2015), pp. 590-607.

[25088] X.-C. Wu, Y.-N. Cheng, C. Li, L. -J. Zhao, and T. Sato. "New information on Wumengosaurus delicatomandibularis Jiang et al, 2008 (Diapsida: Sauropterygia), with a revision of the osteology and phylogeny of the taxon". English. In: Journal of Vertebrate Paleontology 31.1 (2011), pp. 70-83.

[25089] X.-C. Wu, Z.-W. Cheng, and A. P. Russell. "Cranial anatomy of a new crocodyliform (Archosauria: Crocodylomorpha) from the Lower Cretaceous of Song-Liao Plain, northeastern China". English. In: Canadian Journal of Earth Sciences 38 (2001), pp. 1653-1663.

[25090] X.-C. Wu, P. J. Currie, Z. Dong, S. Pan, and T. Wang. "A new theropod dinosaur from the Middle Jurassic of Lufeng, Yunnan, China". English. In: Acta Geologica Sinica 83.1 (2009), pp. 9-24.

[25091] X.-C. Wu, A. P. Russell, and D. B. Brinkman. "A review of Leidyosuchus canadensis Lambe, 1907 (Archosauria: Crocodylia) and an assessment of cranial variation based upon new material". English. In: Canadian Journal of Earth Sciences 38 (2001), pp. 1665-1687.

[25092] X.-C. Wu, J.-R. Shi, L. -Y. Dong, T. D. Carr, and J. Yi. "A new tyrannosauroid from the Upper Cretaceous of Shanxi, China". English. In: Cretaceous Research 108 (2020), 104357:1-13.

[25093] X.-C. Wu, H.-D. Sues, and A. Sun. "A plant-eating crocodyliform reptile from the Cretaceous of China". English. In: Nature 376 (1995), pp. 678-680. DOI: 10.1038/376678a0.

[25094] X.-C. Wu, H.-D. Sues, and Z. -M. Dong. "Sichuanosuchus shuhanensis, a new ? Early Cretaceous protosuchian (Archosauria: Crocodyliformes) from Sichuan (China), and the monophyly of Protosuchia". English. In: Journal of Vertebrate Paleontology 17.1 (1997), pp. 89-103.

[25095] X.-C. Wu and H.-D. Sues. “Reassessment of Platyognathus hsui Young 1944 (Archosauria: Crocodyliformes) from the Lower Lufeng Formation (Lower Jurassic) of Yunnan, China". English. In: Journal of Vertebrate Paleontology 16.1 (1996), pp. 42-48.

[25096] X.-C. Wu, L.-J. Zhao, T. Sato, S. -X. Gu, and X. -S. Jin. "A new specimen of Hupehsuchus nanchangensis Young, 1972 (Diapsida, Hupehsuchia) from the Triassic of Hubei, China". English. In: Historical Biology 28.1-2 (2016), pp. 43-52. DOI: 10.1080/08912963.2015.1013953.

[25097] X.-J. Wu, L. A. Schepartz, W. Liu, and E. Trinkaus. "Antemortem trauma and survival in the late Middle Pleistocene human cranium from Maba, South China". English. In: Proceedings of the National Academy of Sciences (2011). DOI: 10.1073/pnas.1117113108. 
[25098] Y. Wu, H.-L. You, and X. -Q. Li. "Dinosaur-associated Poaceae epidermis and phytoliths from the Early Cretaceous of China". English. In: National Science Review 5 (2018), pp. 721-727. DOI: $10.1093 / \mathrm{nsr} / \mathrm{nwx} 145$.

[25099] Y.-S. Wu. "A latest Permian non-reef calcisponge fauna from Laibin, Guangxi, southern China and its significance". English. In: Journal of Palaeogeography 6.1 (2017), pp. 60-68.

[25100] J. Wunderlich. "Descriptions of fossil spider (Araneae) taxa mainly in Baltic amber, as well as on certain related extant taxa". English. In: Beiträge zur Araneologie 5 (2008), pp. 44-139.

[25101] J. Wunderlich. "The dominance of ancient spider families of the Araneae: Haplogynae in the Cretaceous, and the late diversification of advanced ecribellate spiders of the Entelegynae after the Cretaceous-Tertiary boundary extinction events, with descriptions of new families". English. In: vol. 5. Beiträge zur Araneologie. 2008, pp. 524-674.

[25102] J. Wunderlich. "Die ersten fossilen Becherspinnen (Fam. Cyatholipidae) in Baltischem und Bitterfelder Bernstein (Arachnida: Araneae)". German. In: Mitteilungen aus dem Geologisch-Paläontologischen Institut der Universität Hamburg 75 (1993), pp. 231-241.

[25103] J. Wunderlich. “Die ersten fossilen Speispinnen (Fam. Scytodidae) im Baltischen Bernstein (Arachnida: Araneae)". German. In: Mitteilungen aus dem Geologisch-Paläontologischen Institut der Universität Hamburg 75 (1993), pp. 243-247.

[25104] J. Wunderlich. "Zwei neue Arten der Familie Falltürspinnen (Araneae: Ctenizidae) aus dem Baltischen Bernstein". German. In: Entomologische Zeitschrift 110 (2000), pp. 345-348.

[25105] J. Wunderlich. “Beschreibung der ersten fossilen Spinnen der Unterfamilien Mysmeninae (Anapidae) und Erigoninae (Linyphiidae) im Dominikanischen Bernstein (Arachnida: Araneae)". German. In: Entomologische Zeitschrift 108 (1998), pp. 363-367.

[25106] J. Wunderlich. "Beschreibung der ersten fossilen Spinne der Familie Leptonetidae: Eoleptona kutscheri n. gen., n. sp. in Sächsischem Bernstein (Arachnida: Araneae)". German. In: Entomologische Zeitschrift 101 (1991), pp. 21-26.

[25107] J. Wunderlich. “On extant European spiders of the tribe Mangorini (Araneae: Araneidae) and two doubtful taxa in Baltic amber". English. In: vol. 6. Beiträge zur Araneologie. 2011, pp. 9-18.

[25108] J. Wunderlich. "Taxonomy of extant and fossil (Eocene) European ground spiders of the family Gnaphosidae (Araneae), with a key to the genera, and descriptions of new taxa". English. In: vol. 6. Beiträge zur Araneologie. 2011, pp. 19-97.

[25109] J. Wunderlich. "Spiders of the family Prodidomidae (Araneae) from Europe and Madagascar". English. In: vol. 6. Beiträge zur Araneologie. 2011, pp. 98-107.

[25110] J. Wunderlich. “On extant and fossil (Eocene) holarctic sac spiders (Araneae: Clubionidae), with descriptions of new taxa". English. In: vol. 6. Beiträge zur Araneologie. 2011, pp. 121-157.

[25111] J. Wunderlich. "New extant taxa of the spider family Theridiosomatidae (Araneae) from Laos and on some fossil taxa". English. In: vol. 6. Beiträge zur Araneologie. 2011, pp. 427-444.

[25112] J. Wunderlich. "Some subrecent spiders (Araneae) in copal from Madagascar". English. In: vol. 6. Beiträge zur Araneologie. 2011, pp. 445-460.

[25113] J. Wunderlich. "Some fossil spiders in Dominican amber (Araneae: Hersilidae, Theridiidae, Gnaphosidae)". English. In: vol. 6. Beiträge zur Araneologie. 2011, pp. 461-471.

[25114] J. Wunderlich. "Some fossil spiders (Araneae) in Eocene European ambers". English. In: vol. 6. Beiträge zur Araneologie. 2011, pp. 472-538.

[25115] J. Wunderlich. "Some fossil spiders (Araneae) in Cretaceous ambers". English. In: vol. 6. Beiträge zur Araneologie. 2011, pp. 539-557.

[25116] J. Wunderlich. "New subrecent species of spiders in copal from Madagasar, and on the relationships of the Copaldictyninae Wunderlich 2004 (Araneae: Linyphiidae, Theridiidae, Ditynidae and Titanoecidae)". English. In: vol. 7. Beiträge zur Araneologie. 2012, pp. 75-88. 
[25117] J. Wunderlich. "New fossil spiders (Araneae) in Eocene amber from the Ukraine". English. In: vol. 7. Beiträge zur Araneologie. 2012, pp. 89-93.

[25118] J. Wunderlich. "New fossil spiders (Araneae) of eight families in Eocene Baltic amber, and revisions of selected taxa". English. In: vol. 7. Beiträge zur Araneologie. 2012, pp. 94-149.

[25119] J. Wunderlich. "On the fossil spider (Araneae) fauna in Cretaeous ambers, with descriptions of new taxa from Myanmar (Burma) and Jordan, and on the relationships of the superfamily Leptonetoidea". English. In: vol. 7. Beiträge zur Araneologie. 2012, pp. 157-232.

[25120] J. Wunderlich. "Description of the first fossil Ricinulei in amber from Burma (Myanmar), the first report of this arachnid order from the Mesozoic and from Asia, with notes on the related extinct order Trigonotarbida". English. In: vol. 7. Beiträge zur Araneologie. 2012, pp. 233-244.

[25121] J. Wunderlich. "The fossil mygalomorph spiders (Araneae) in Baltic and Dominican amber and about extant members of the family Micromygalidae". English. In: vol. 3. Beiträge zur Araneologie. 2004, pp. 595-631.

[25122] J. Wunderlich. "Fossil spiders (Araneae) of the superfamily Dysderoidea in Baltic and Dominican amber, with revised family diagnoses". English. In: vol. 3. Beiträge zur Araneologie. 2004, pp. 633746.

[25123] J. Wunderlich. "Fossil and extant spiders (Araneae) of the superfamily Eresoidea s.l., with special reference to the Archaeidae and remarks on some higher taxa of the superfamily Araneoidea". English. In: vol. 3. Beiträge zur Araneologie. 2004, pp. 747-808.

[25124] J. Wunderlich. "On selected higher and lower taxa of fossil and extant spiders of the superfamily Oecobioidea, with a provisional Cladogram (Araneae: Hersiliidae and Oecobiidae)". English. In: vol. 3. Beiträge zur Araneologie. 2004, pp. 809-848.

[25125] J. Wunderlich. "Fossil spiders of the family Uloboridae (Araneae) in Baltic and Dominican amber". English. In: vol. 3. Beiträge zur Araneologie. 2004, pp. 851-886.

[25126] J. Wunderlich. "The fossil spiders of the family Deinopidae in Baltic and Dominican amber". English. In: vol. 3. Beiträge zur Araneologie. 2004, pp. 887-897.

[25127] J. Wunderlich. "The fossil spiders (Araneae) of the families Tetragnathidae and Zygiellidae n. stat. in Baltic and Dominican amber, with notes on higher extant and fossil taxa". English. In: vol. 3. Beiträge zur Araneologie. 2004, pp. 899-955.

[25128] J. Wunderlich. "Fossil taxa of the family Araneidae (Araneae) inclusively Nephilinae in Baltic and Dominican amber, with the description of a new extinct subfamily and notes on selected extant taxa". English. In: vol. 3. Beiträge zur Araneologie. 2004, pp. 956-997.

[25129] J. Wunderlich. "The fossil Theridiosomatidae (Araneae) in Baltic and Dominican amber". English. In: vol. 3. Beiträge zur Araneologie. 2004, pp. 998-1019.

[25130] J. Wunderlich. "The fossil spiders of the family Anapidae s. 1. (Araneae) in Baltic, Dominican and Mexican amber and their extant relatives, with the description of a new subfamily Comarominae". English. In: vol. 3. Beiträge zur Araneologie. 2004, pp. 1020-1111.

[25131] J. Wunderlich. "On the relationships of the families of the superfamily Araneoidea (Araneae) and their kin, with cladograms, remarks on the origin of the orb web and description of the new and extinct families Baltsuccinidae and Protheridiidae in Tertiary Baltic amber". English. In: vol. 3. Beiträge zur Araneologie. 2004, pp. 1112-1154.

[25132] J. Wunderlich. "The fossil spiders (Araneae) of the family Cyatholipidae in Baltic amber". English. In: vol. 3. Beiträge zur Araneologie. 2004, pp. 1155-1188.

[25133] J. Wunderlich. "The fossil spiders (Araneae) of the family Synotaxidae in Baltic amber". English. In: vol. 3. Beiträge zur Araneologie. 2004, pp. 1189-1239.

[25134] J. Wunderlich. "Remarks on the fossil spiders (Araneae) of the family Nesticidae in amber, with the description of a new species in Baltic amber". English. In: vol. 3. Beiträge zur Araneologie. 2004, pp. 1240-1244. 
[25135] J. Wunderlich. “Fossil pirate spiders (Araneae: Araneoidea: Mimetidae s. 1.) in Baltic and Dominican amber, with notes on intrafamiliar higher taxa". English. In: vol. 3. Beiträge zur Araneologie. 2004, pp. 1249-1278.

[25136] J. Wunderlich. "Descriptions of the first fossil spiders (Araneae) of the family Pimoidae in Baltic amber". English. In: vol. 3. Beiträge zur Araneologie. 2004, pp. 1279-1297.

[25137] J. Wunderlich. "The fossil spiders of the family Linyphiidae in Baltic and Dominican amber (Araneae: Linyphiidae)". English. In: vol. 3. Beiträge zur Araneologie. 2004, pp. 1298-1373.

[25138] J. Wunderlich. "Fossil spiders of the family Amaurobiidae (Arachnida: Araneae) in Baltic and Dominican amber". English. In: vol. 3. Beiträge zur Araneologie. 2004, pp. 1377-1379.

[25139] J. Wunderlich. "Fossil spiders of the family Dictynidae s. 1., including Cryphoecinae and Hahniinae in Baltic and Dominican amber and copal from Madagascar, and on selected extant Holarctic taxa, with new descriptions and diagnoses". English. In: vol. 3. Beiträge zur Araneologie. 2004, pp. 1380-1482.

[25140] J. Wunderlich. "Fossil spiders (Araneae) of the family Agelenidae s. str. in Baltic amber". English. In: vol. 3. Beiträge zur Araneologie. 2004, pp. 1483-1488.

[25141] J. Wunderlich. "The fossil Zoropsidae in Baltic amber with revised diagnoses of the family Zoropsidae and its fossil and extant higher taxa". English. In: vol. 3. Beiträge zur Araneologie. 2004, pp. $1489-1522$.

[25142] J. Wunderlich. "Spiders (Araneae) of the extinct family Insecutoridae Petrunkevitch 1942 in Baltic amber". English. In: vol. 3. Beiträge zur Araneologie. 2004, pp. 1523-1531.

[25143] J. Wunderlich. "Fossil spiders of the family Pisauridae (Araneae) in Baltic and Dominican amber". English. In: vol. 3. Beiträge zur Araneologie. 2004, pp. 1532-1541.

[25144] J. Wunderlich. "Members of the family Trechaleidae (Araneae) in Baltic and Dominican amber?" English. In: vol. 3. Beiträge zur Araneologie. 2004, pp. 1542-1553.

[25145] J. Wunderlich. "Fossil spiders (Araneae) of the family Oxyopidae in Baltic and Dominican amber". English. In: vol. 3. Beiträge zur Araneologie. 2004, pp. 1554-1556.

[25146] J. Wunderlich. "Proof of presence of the family Lycosidae (Araneae) in Baltic and Dominican amber?" English. In: vol. 3. Beiträge zur Araneologie. 2004, pp. 1557-1558.

[25147] J. Wunderlich. "Fossil spiders (Araneae) of the extinct family Ephalmatoridae Petrunkevitch 1950 in Baltic amber". English. In: vol. 3. Beiträge zur Araneologie. 2004, pp. 1559-1577.

[25148] J. Wunderlich. "Fossil spiders (Araneae) of the family Zodariidae in Baltic amber, with remarks on their subfamilies including the Cryptothelinae and the Homalonychinae". English. In: vol. 3. Beiträge zur Araneologie. 2004, pp. 1578-1611.

[25149] J. Wunderlich. "Fossil spiders (Araneae) of the families Clubionidae and Miturgidae (questionable) in Baltic and Dominican amber". English. In: vol. 3. Beiträge zur Araneologie. 2004, pp. 16121622.

[25150] J. Wunderlich. "The fossil spiders of the family Liocranidae in Baltic and Dominican amber". English. In: vol. 3. Beiträge zur Araneologie. 2004, pp. 1623-1635.

[25151] J. Wunderlich. "Fossil spiders of the family Corinnidae in Baltic and Dominican amber". English. In: vol. 3. Beiträge zur Araneologie. 2004, pp. 1636-1680.

[25152] J. Wunderlich. "Fossil spiders (Araneae) of the family Gnaphosidae in Baltic and Dominican amber". English. In: vol. 3. Beiträge zur Araneologie. 2004, pp. 1681-1685.

[25153] J. Wunderlich. "Members of the family Philodromidae (Araneae) in Baltic amber?" English. In: vol. 3. Beiträge zur Araneologie. 2004, pp. 1689-1693.

[25154] J. Wunderlich. "Fossil spiders of the family Trochanteriidae (Araneae) in Baltic, Dominican and Mexican amber, with a revision of the genus Sosybius Koch and Berendt 1854". English. In: vol. 3. Beiträge zur Araneologie. 2004, pp. 1699-1732. 
[25155] J. Wunderlich. "Fossil spiders of the family Selenopidae in Dominican amber". English. In: vol. 3. Beiträge zur Araneologie. 2004, pp. 1733-1736.

[25156] J. Wunderlich. "The new spider (Araneae) family Borboropactidae from the tropics and fossil in Baltic amber". English. In: vol. 3. Beiträge zur Araneologie. 2004, pp. 1737-1746.

[25157] J. Wunderlich. "Fossil crab spiders (Araneae: Thomisidae) in Baltic and Dominican amber". English. In: vol. 3. Beiträge zur Araneologie. 2004, pp. 1747-1760.

[25158] J. Wunderlich. "Fossil jumping spiders (Araneae: Salticidae) in Baltic and Domican amber, with remarks on Salticidae subfamilies". English. In: vol. 3. Beiträge zur Araneologie. 2004, pp. 17611819.

[25159] J. Wunderlich. "Fossil spiders (Araneae) in Early Tertiary amber from the Ukraine". English. In: vol. 3. Beiträge zur Araneologie. 2004, pp. 1821-1829.

[25160] J. Wunderlich. "Subrecent spiders (Araneae) in copal from Madagascar, with description of new species". English. In: vol. 3. Beiträge zur Araneologie. 2004, pp. 1830-1853.

[25161] J. Wunderlich. "Two new fossil spider species in Copal from Colombia (Araneae: Oonopidae and Dictynidae)". English. In: vol. 3. Beiträge zur Araneologie. 2004, pp. 1854-1859.

[25162] J. Wunderlich. "Description of two fossil taxa of spiders (Araneae: Oonopidae, Pholcidae) in Chinese amber". English. In: vol. 3. Beiträge zur Araneologie. 2004, pp. 1860-1863.

[25163] J. Wunderlich. "Report on spider (Araneae) of the families Araneidae and Zygiellidae in Lebanese amber". English. In: vol. 3. Beiträge zur Araneologie. 2004, pp. 1864-1865.

[25164] J. Wunderlich. "Spatiator martensi n. sp., a second species of the extinct spider family Spatiatoridae in Eocene Baltic amber (Araneae)". English. In: Zootaxa 1325 (2006), pp. 313-318.

[25165] J. Wunderlich. "Description of an unusual fossil crab spider (Araneae: Thomisidae s. 1.: Stephanopinae) in Eocene Baltic amber". English. In: vol. 9. Mesozoic Spiders (Araneae): Ancient Spider Faunas and Spider Evolution, Beiträge zur Araneologie. 2015, pp. 7-14.

[25166] J. Wunderlich. "Frozen behaviour: the oldest fossil proofs of spider eating spiders (Araneae) in 45 million years old Eocene Baltic amber and in 100 million years old Cretaceous amber of Myanmar (Burmite)". English. In: vol. 9. Mesozoic Spiders (Araneae): Ancient Spider Faunas and Spider Evolution, Beiträge zur Araneologie. 2015, pp. 15-20.

[25167] J. Wunderlich. "On the evolution and the classification of spiders, the Mesozoic spider faunas, and descriptions of new Cretaceous taxa mainly in amber from Myanmar (Burma) (Arachnida: Araneae)". English. In: vol. 9. Mesozoic Spiders (Araneae): Ancient Spider Faunas and Spider Evolution, Beiträge zur Araneologie. 2015, pp. 21-408.

[25168] J. Wunderlich. "New and rare fossil Arachnida in Cretaceous Burmese amber (Amblypygi, Ricinulei and Uropygi: Thelyphonida)". English. In: vol. 9. Mesozoic Spiders (Araneae): Ancient Spider Faunas and Spider Evolution, Beiträge zur Araneologie. 2015, pp. 409-436.

[25169] J. Wunderlich. "New extinct taxa of the arachnid order Ricinulei, based on new fossils preserved in mid Cretaceous Burmese amber". English. In: Ten Papers on Fossil and Extant Spiders (Araneae). Beiträge zur Araneologie 10 (2017), pp. 48-71.

[25170] J. Wunderlich. "New and rare fossil spiders (Araneae) in mid Cretaceous amber from Myanmar (Burma), including the description of new extinct families of the suborders Mesothelae and Opisthothelae, as well as notes on the taxonomy, the evolution and the biogeography of the Mesothelae". English. In: vol. 10. Ten Papers on Fossil and Extant Spiders (Araneae). Beiträge zur Araneologie. 2017, pp. 72-279.

[25171] J. Wunderlich. “What is a spider?" English. In: Beiträge zur Araneologie 12 (2019), pp. 1-32.

[25172] J. Wunderlich and R. Milki. "Description of the extinct new subfamily Microsegestriinae (Araneae: Segestriidae) in Cretaceous Lebanese Amber". English. In: vol. 3. Beiträge zur Araneologie. 2004, pp. 1867-1873.

[25173] J. Wunderlich and P. Müller. "Fossil spiders (Araneae) in Cretaceous Burmese amber". English. In: Beiträge zur Araneologie 11 (2018), pp. 1-177. 
[25174] J. Wunderlich and P. Müller. "New and already described fossil spiders (Araneae) of 20 families in mid and Late Cretaceous Burmese ambers, with notes on spider phylogeny, evolution and classification". English. In: Beiträge zur Araneologie 13 (2020), pp. 22-164.

[25175] B. M. Wynd, B. R. Peecook, M. R. Whitney, and C. A. Sidor. "The first occurrence of Cynognathus crateronotus (Cynodontia: Cynognathia) in Tanzania and Zambia, with implications for the age and biostratigraphic correlation of Triassic strata in southern Pangea". English. In: Journal of Vertebrate Paleontology 37.Sup. 1 (2018), pp. 228-239.

[25176] J. G. Wynn, Z. Alemseged, R. Bobe, D. Geraads, D. Reed, and D. C. Roman. “Geological and palaeontological context of a Pliocene juvenile hominin at Dikika, Ethiopia". English. In: Nature 443 (2006), pp. 332-336.

[25177] P. N. Wyse Jackson. “Bryozoa from the Lower Carboniferous (Visean) of County Fermanagh, Ireland". English. In: Bulletin of the Natural History Museum, Geology Series 52.2 (1996), pp. 119-171.

[25178] A. R. Wyss, J. J. Flynn, M. A. Norell, C. C. Swisher III, R. Charrier, M. J. Novacek, and M. C. McKenna. "South America's earliest rodent and recognition of a new interval of mammalian evolution". In: Nature 365 (1993), pp. 434-437.

[25179] A. R. Wyss, J. J. Flynn, and D. A. Croft. "New Paleogene Notohippids and Leontiniids (Toxodontia; Notoungulata; Mammalia) from the Early Oligocene Tinguiririca Fauna of the Andean Main Range, Central Chile". English. In: American Museum Novitates 3903 (2018), pp. 1-42.

[25180] A. R. Wyss, M. A. Norell, J. J. Flynn, M. J. Novacek, R. Charrier, M. C. McKenna, C. C. Swisher III, D. Frassinetti, P. Salinas, and M. Jin. "A new early Tertiary mammal fauna from central Chile: implications for Andean stratigraphy and tectonics". In: Journal of Vertebrate Paleontology 10.4 (1990), pp. 518-522.

[25181] A. Xafis, E. Tsoukala, N. Solounias, O. Mandic, M. Harzhauser, F. Grmsson, and D. Nagel. "Fossil Giraffidae (Mammalia, Artiodactyla) from the late Miocene of Thermopigi (Macedonia, Greece)". English. In: Palaeontologia Electronica 22.3.67 (2019), pp. 1-38.

[25182] Y.-h. Xi. “Gastropods from Fentou Formation of Jiangsu and Anhui provinces". English. In: Acta Palaeontologica Sinica 36.2 (1997), pp. 238-244.

[25183] Y.-h. Xi and W. Yu. "New materials of Silurian gastropods from SW. China". Chinese. In: Acta Palaeontologica Sinica 29.5 (1990), pp. 620-629.

[25184] F. S. Xia. "The cystoporate bryozoan Cassianopora from the early Norian (Late Triassic) and its phylogenetic relations". English. In: Acta Micropalaeontologica Sinica 16 (1999), pp. 5-21.

[25185] F. S. Xia, S. G. Zhang, and Z. Z. Wang. "The oldest bryozoans: new evidence from the Late Tremadocian (Early Ordovician) of East Yangtze Gorges in China". English. In: Journal of Paleontology 81.6 (2007), pp. 1308-1326.

[25186] H. Xianguang and J. Bergstrom. "Palaeoscolecid worms may be nematomorphs rather than annelids". In: Lethaia 27.1 (1994), pp. 11-17.

[25187] S. Xiao, J. Hu, X. Yuan, R. L. Parsley, and R. Cao. "Articulated sponges from the Lower Cambrian Hetang Formation in southern Anhui, South China: their age and implications for the early evolution of sponges". English. In: Palaeogeography, Palaeoclimatology, Palaeoecology 220 (2005), pp. 89117. DOI: $10.1016 /$ j.palaeo.2002.02.001.

[25188] S. Xiao and A. H. Knoll. "Fossil preservation in the Neoproterozoic Doushantuo phosphorite Lagerstatte, South China". English. In: Lethaia 32.3 (1999), pp. 219-240.

[25189] S. Xiao, X. Yuan, M. Steiner, and A. H. Knoll. "Macroscopic carbonaceous compressions in a terminal Proterozoic shale: a systematic reassessment of the Miaohe biota, south China". English. In: Journal of Paleontology 76.2 (2002), pp. 347-376.

[25190] L. Xiao-Bo, Z. Mei-Sheng, and W. Yi-Ni. "Two Early Cretaceous fishes discovered from the most northern area of China: implications for the palaeobiogeography of the Jehol Biota". English. In: Geological Journal 46 (2011), pp. 323-332. 
[25191] J.-F. Xie, S.-K. Zhang, X. -S. Jin, D. -Q. Li, and L. -Q. Zhou. “A new type of dinosaur eggs from Early Cretaceous of Gansu Province, China". English. In: Vertebrata PalAsiatica 54.1 (2016), pp. 79 88.

[25192] C. Y. Xing, C. K. Shih, Y. Y. Zhao, and D. Ren. “New protodiplatyids (Insecta: Dermaptera) from the Lower Cretaceous Yixian Formation of northeastern China". English. In: Cretaceous Research 64 (2016), pp. 59-66.

[25193] C. Y. Xing, C. K. Shih, Y. Y. Zhao, and D. Ren. “New earwigs in Protodiplatyidae (Insecta: Dermaptera) from the Middle Jurassic Jiulongshan Formation of northeastern China". English. In: Zootaxa 4205 (2016), pp. 180-188.

[25194] H. Xing, D.-Y. Wang, F. -L. Han, C. Sullivan, Q. -Y. Ma, Y. -M. He, D. W. E. Hone, R. -H. Yan, F. -M. Du, and X. Xu. "A new basal hadrosauroid dinosaur (Dinosauria: Ornithopoda) with transitional features from the Late Cretaceous of Henan Province, China". English. In: PLoS One 9.6 (2014), e98821. DOI: 10.1371/journal.pone.0098821.

[25195] L. Xing, P. R. Bell, P. J. Currie, M. Shibata, K. Tseng, and Z. Dong. "A sauropod rib with an embedded theropod tooth: direct evidence for feeding behaviour in the Jehol Group, China". English. In: Lethaia 45 (2012), pp. 500-506.

[25196] L. Xing, M. W. Caldwell, and R. Chen. “A mid-Cretaceous embryonic-to-neonate snake in amber from Myanmar". English. In: Science Advances 4 (2018), eaat5042:1-8.

[25197] L. Xing, H. Klein, M. G. Lockley, J. Li, J. Zhang, M. Matsukawa, and J. Xiao. “Chirotherium Trackways from the Middle Triassic of Guizhou, China". English. In: Ichnos 20.2 (2013), pp. 99-107. DOI: 10.1080/10420940.2013.788505.

[25198] L. Xing, M. G. Lockley, J. Zhang, H. Klein, J. Y. Kim, W. S. Persons IV, M. Matsukawa, X. Yu, J. Li, G. Chen, and Y. Hu. "Upper Cretaceous dinosaur track assemblages and a new theropod ichnotaxon from Anhui Province, eastern China". English. In: Cretaceous Research 49 (2014), pp. 190-204. DOI: 10.1016/j.cretres.2014.03.003.

[25199] L. Xing, M. G. Lockley, R. T. McCrea, G. D. Gierlinski, L. G. Buckley, J. Zhang, L. Qi, and C. Jia. "First record of Deltapodus tracks from the Early Cretaceous of China". English. In: Cretaceous Research 42.1 (2013), pp. 55-65. DOI: 10.1016/j.cretres.2013.01.006.

[25200] L. Xing, M. G. Lockley, H. You, G. Peng, X. Tang, H. Ran, T. Wang, J. Hu, and W. S. Persons. “Early Jurassic sauropod tracks from the Yimen Formation of Panxi region, southwest China: ichnotaxonomy and potential trackmaker". English. In: Geological Bulletin of China 35.6 (2016), pp. 851855.

[25201] L. Xing, M. G. Lockley, H. Klein, P. L. Falkingham, J. Y. Kim, R. T. McCrea, J. Zhang, W. S. Persons, T. Wang, and Z. Wang. "First Early Jurassic small ornithischian tracks from Yunnan Province, southwestern China". English. In: Palaios 31 (2016), pp. 516-524. DOI: 10.2110/palo.2015.074.

[25202] L. Xing, M. G. Lockley, Y. Tang, H. Klein, J. Zhang, W. S. Persons, H. Dai, and Y. Ye. “Theropod and ornithischian footprints from the Middle Jurassic Yanan Formation of Zizhou County, Shaanxi, China". English. In: Ichnos 22.1 (2015), pp. 1-11. DOI: 10.1080/10420940.2014.985670.

[25203] L. Xing, M. G. Lockley, J. Zhang, A. R. C. Milner, H. Klein, D. Li, W. S. Persons, and J. Ebi. “A new Early Cretaceous dinosaur track assemblage and the first definite non-avian theropod swim trackway from China". English. In: Chinese Science Bulletin 58.19 (2013), pp. 2370-2378. DOI: 10. 1007/s11434-013-5802-6.

[25204] L. Xing, M. G. Lockley, G. Yang, A. Mayor, H. Klein, W. S. Persons, Y. Chen, G. Peng, Y. Ye, and J. Ebi. "Tracking a legend: an Early Cretaceous sauropod trackway from Zhaojue County, Sichuan Province, southwestern China". English. In: Ichnos 22.1 (2015), pp. 22-28. DOI: 10.1080/10420940. 2014.988788.

[25205] L. Xing, M. G. Lockley, H. Klein, W. S. Persons IV, M. Wei, L. Chen, and M. Wang. “The first record of Cretaceous non-avian dinosaur tracks from the Qinghai-Tibet Plateau, China". English. In: Cretaceous Research 115 (2020), p. 104549. DOI: 10.1016/j.cretres.2020.104549. 
[25206] L. Xing, A. Mayor, Y. Chen, J. D. Harris, and M. E. Burns. “The folklore of dinosaur trackways in China: impact on paleontology". English. In: Ichnos 18.4 (2011), pp. 213-220. DOI: 10.1080 / 10420940.2011.634038.

[25207] L. Xing, T. Miyashita, P. J. Currie, H. You, and Z. Dong. "A new basal eusauropod from the Middle Jurassic of Yunnan, China, and faunal compositions and transitions of Asian sauropodomorph dinosaurs". English. In: Acta Palaeontologica Polonica 60.1 (2015), pp. 145-154.

[25208] L. Xing, T. Miyashita, J. Zhang, D. Li, Y. Te, T. Sekiya, F. Wang, and P. J. Currie. "A new sauropod dinosaur from the Late Jurassic of China and the diversity, distribution, and relationships of mamenchisaurids". English. In: Journal of Vertebrate Paleontology 35.1 (2015), e889701:1-17. DOI: 10.1080/02724634.2014.889701.

[25209] L. Xing, K. Niu, and S. E. Evans. "Inter-amphibian predation in the Early Cretaceous of China". English. In: Scientific Reports 9 (2019), 7751:1-5.

[25210] L. Xing, J. K. O'Connor, L. M. Chiappe, R. C. McKellar, N. Carroll, H. Hu, M. Bai, and F. Lei. “A new enantiornithine bird with unusual pedal proportions found in amber". English. In: 29 (2019), pp. 1-6. DOI: 10.1016/j.cub.2019.05.077.

[25211] L. Xing, G. Peng, M. G. Lockley, Y. Ye, H. Klein, J. Zhang, and W. S. Persons. "Early Cretaceous sauropod and ornithopod trackways from a stream course in Sichuan Basin, southwest China". English. In: vol. 68. Fossil Record 4. New Mexico Museum of Natural History and Science Bulletin. Albuquerque: New Mexico Museum of Natural History and Science, 2015, pp. 319-326.

[25212] L. Xing, E. M. Roberts, J. D. Harris, M. K. Gingras, H. Ran, J. Zhang, X. Xu, M. E. Burns, and Z. Dong. "Novel insect traces on a dinosaur skeleton from the Lower Jurassic Lufeng Formation of China". English. In: Palaeogeography, Palaeoclimatology, Palaeoecology 388.2 (2013), pp. 58-68. DOI: 10.1016/j.palaeo.2013.07.028.

[25213] L. Xing, B. M. Rothschild, H. Ran, T. Miyashita, W. S. Persons IV, T. Sekiya, J. Zhang, T. Wang, and Z. Dong. "Vertebral fusion in two Early Jurassic sauropodomorph dinosaurs from the Lufeng Formation of Yunnan, China". English. In: Acta Palaeontologica Polonica 60.3 (2015), pp. 643-649. DOI: 10.4202/app.00001.2013.

[25214] L. Xing, E. L. Stanley, M. Bai, and D. C. Blackburn. “The earliest direct evidence of frogs in wet tropical forests from Cretaceous Burmese amber". English. In: Scientific Reports 8 (2018), 8770:1-8. DOI: $10.1038 / \mathrm{s} 41598-018-26848-\mathrm{w}$.

[25215] L. Xing, F. Wang, S. Pan, and W. Chen. "[The discovery of dinosaur footprints from the middle Cretaceous Jiaguan Formation of Qijiang County, Chongqing City]". Chinese. In: Acta Geologica Sinica 81.11 (2007), pp. 1591-1602.

[25216] L. Xing, J. Zhang, H. Klein, A. Mayor, Y. Chen, H. Dai, M. E. Burns, J. Gao, Y. Tang, and S. Dong. "Dinosaur tracks, myths and buildings: the Jin Ji (Golden Chicken) stones from Zizhou area, northern Shaanxi, China". English. In: Ichnos 22.3-4 (2015), pp. 227-234. DOI: 10.1080/10420940. 2015.1059334.

[25217] L.-d. Xing, G. D. Gierlinski, J. D. Harris, and J. D. Divay. "A probable crouching theropod dinosaur trace from the Tuchengzi Formation in Chicheng area, Hebei Province, China". English. In: Geological Bulletin of China 31.1 (2012), pp. 20-25.

[25218] L.-d. Xing, J. D. Harris, D. -h. Sun, and H. -q. Zhao. “The earliest known deinonychosaur tracks from the Jurassic-Cretaceous boundary in Hebei Province, China". English. In: Acta Palaeontologica Sinica 48.4 (2009), pp. 662-671.

[25219] L.-d. Xing, J. D. Harris, Z. -m. Dong, Y. -1. Lin, W. Chen, S. -b. Guo, and Q. Ji. “Ornithopod (Dinosauria: Ornithischia) tracks from the Upper Cretaceous Zhutian Formation in the Nanxiong Basin, Guangdong, China and general observations on large Chinese ornithopod footprints". English. In: Geological Bulletin of China 28.7 (2009), pp. 829-843.

[25220] L.-d. Xing, J. D. Harris, and C. -k. Cheng. "Dinosaur tracks from the Lower Cretaceous Mengtuan Formation in Jiangsu, China and morphological diversity of local sauropod tracks". English. In: Acta Palaeontologica Sinica 49.4 (2010), pp. 448-460. 
[25221] L.-D. Xing, J. D. Harris, G. D. Gierlinski, M. K. Gingras, J. D. Divay, Y. -G. Tang, and P. J. Currie. "Early Cretaceous pterosaur tracks from a buried dinosaur tracksite in Shandong Province, China". English. In: Palaeoworld 21.1 (2012), pp. 50-58. DOI: 10.1016/j.palwor.2012.02.004.

[25222] L.-d. Xing, J. D. Harris, S. Toru, F. Masato, and Z. -m. Dong. “Discovery of dinosaur footprints from the Lower Jurassic Lufeng Formation of Yunnan Province, China and new observations on Changpeipus". English. In: Geological Bulletin of China 28.1 (2009), pp. 16-29.

[25223] L.-d. Xing, J. D. Harris, X. -y. Feng, and Z. -j. Zhang. “Theropoda (Dinosauria: Saurischia) tracks from the Lower Cretaceous Yixian Formation at Sihetun Village, Liaoning Province, China and possible track makers". English. In: Geological Bulletin of China 28.6 (2009), pp. 705-712.

[25224] L.-D. Xing, J. D. Harris, C. -K. Jia, Z. -J. Luo, S. -N. Wang, and J. -F. An. “Early Cretaceous birddominated and dinosaur footprint assemblages from the northwestern margin of the Junggar Basin, Xinjiang, China". English. In: Palaeoworld 20 (2011), pp. 308-321. DOI: 10.1016/j.palwor. 2011.01.001.

[25225] L.-D. Xing, M. G. Lockley, W. Chen, G. D. Gierlinksi, J. -J. Li, W. S. Persons, M. Matsukawa, Y. Ye, M. K. Gingras, and C. -W. Wang. "Two theropod track assemblages from the Jurassic of Chongqing, China, and the Jurassic Stratigraphy of Sichuan Basin". English. In: Vertebrata PalAsiatica 51.2 (2013), pp. 107-130.

[25226] L.-D. Xing, M. G. Lockley, Q. -F. Wang, Z. -D. Li, H. Klein, W. S. Persons, Y. Ye, and M. Matsukawa. "Earliest records of dinosaur footprints in Xinjiang, China". English. In: Vertebrata PalAsiatica 52.3 (2014), pp. 340-348.

[25227] L.-D. Xing, M. G. Lockley, H. Klein, J. -P. Zhang, T. Wang, W. S. Persons, and Z. -M. Dong. “A tetrapod footprint assemblage with possible swim traces from the Jurassic-Cretaceous boundary, Anning Formation, Konglongshan, Yunnan, China". English. In: Palaeoworld 25 (2016), pp. 444452. DOI: 10.1016/j.palwor.2015.06.002.

[25228] L.-D. Xing, M. G. Lockley, J. -P. Zhang, H. Klein, S. B. Kümmell, W. S. Persons, and H. -W. Kuang. "Theropod tracks from the Lower Jurassic of Gulin area, Sichuan Province, China". English. In: Palaeoworld 26 (2017), pp. 115-123. DOI: 10.1016/j.palwor.2015.11.003.

[25229] L.-D. Xing, M. G. Lockley, J. -P. Zhang, H. Klein, T. Wang, S. B. Kümmell, and M. E. Burns. "A theropod-sauropod track assemblage from the Middle-Upper Jurassic Shedian Formation at Shuangbai, Yunnan Province, China, reflecting different sizes of trackmakers: review and new observations". English. In: Palaeoworld 25.1 (2016), pp. 84-94. DOI: 10.1016/j.palwor.2015.05.003.

[25230] Y. Xinglian, Z. Yuanlong, W. Weiyi, Z. Haolin, and Z. Yajie. "Phragmodictya jinshaensis sp. nov., a hexactinellid dictyosponge from the Cambrian of Jinsha, south China". English. In: GFF - Geological Society of Sweden 136.1 (2014), pp. 309-313.

[25231] C. P. Xu, Y. Fang, S. Heads, Q. Zhang, E. A. Jarzembowski, and B. Wang. “The first Orthoptera (Insecta) from the Triassic of China". English. In: Alcheringa 44 (2020), pp. 93-98. DOI: 10.1080 / 03115518.2019.1662485.

[25232] C. P. Xu, Y. Fang, and E. A. Jarzembowski. "A new pygmy mole cricket (Orthoptera: Tridactyloidea: Tridactylidae) from mid-Cretaceous Burmese amber". English. In: Cretaceous Research 111.104371 (2020). DOI: 10.1016/j.cretres.2020.104371.

[25233] C. P. Xu, Y. Fang, and H. Wang. "A new mole cricket (Orthoptera: Gryllotalpidae) from midCretaceous Burmese amber". English. In: Cretaceous Research 112.104428 (2020). DOI: 10.1016/j. cretres.2020.104428.

[25234] C. P. Xu, E. A. Jarzembowski, and Y. Fang. "A new stick insect (Phasmatodea: Susumanioidea) from the Lower Cretaceous Wealden Group of southern England". English. In: Cretaceous Research 112.104387 (2020). DOI: 10.1016/j.cretres.2020.104387.

[25235] C. P. Xu, H. C. Zhang, E. A. Jarzembowski, and Y. Fang. “The first Ripipterygidae (Orthoptera: Caelifera: Tridactyloidea) from mid-Cretaceous Burmese amber". English. In: Cretaceous Research 112.104356 (2020). DOI: 10.1016/j.cretres.2020.104356. 
[25236] C. P. Xu, H. C. Zhang, E. A. Jarzembowski, and Y. Fang. "A new stick insect (Phasmatodea: Susumaniidae) from the Lower Cretaceous Yixian Formation of China". English. In: Cretaceous Research 114.104258 (2020). DOI: 10.1016/j.cretres.2020.104258.

[25237] C. P. Xu, H. C. Zhang, E. A. Jarzembowski, and Y. Fang. “The first ground cricket (Orthoptera: Trigonidiidae: Nemobiinae) from mid-Cretaceous Burmese amber". English. In: Cretaceous Research 115.104481 (2020). DOI: 10.1016/j.cretres.2020.104481.

[25238] G. Xu and R. E. Grant. "Brachiopods near the Permian-Triassic boundary in South China". In: Smithsonian Contributions to Paleobiology 76 (1994), pp. 1-68.

[25239] G.-H. Xu and F.-X. Wu. "A deep-bodied ginglymodian fish from the Middle Triassic of eastern Yunnan Province, China, and the phylogeny of lower neopterygians". English. In: Chinese Science Bulletin 57.1 (2012), pp. 111-118.

[25240] G. H. Xu. "Feroxichthys yunnanensis gen. et sp. nov. (Colobodontidae, Neopterygii), a large durophagous predator from the Middle Triassic (Anisian) Luoping Biota, eastern Yunnan, China". English. In: PeerJ 8.e10229 (2020). DOI: 10.7717 / peerj.10229.

[25241] G. H. Xu and K. Q. Gao. "A new scanilepiform from the Lower Triassic of northern Gansu Province, China, and phylogenetic relationships of non-teleostean Actinopterygii". English. In: Zoological Journal of the Linnean Society 161 (2011), pp. 595-612.

[25242] G. H. Xu, X. Y. Ma, and L. J. Zhao. "A large peltopleurid fish (Actinopterygii: Peltopleuriformes) from the Middle Triassic of Yunnan and Guizhou, China". English. In: Vertebrata PalAsiatica 56 (2018), pp. 106-120.

[25243] G. H. Xu and X. Y. Ma. "A Middle Triassic stem-neopterygian fish from China sheds new light on the peltopleuriform phylogeny and internal fertilization". English. In: Science Bulletin 61 (2016), pp. 1766-1774.

[25244] G. H. Xu and X. Y. Ma. “Taxonomic revision of Asialepidotus shingyiensis Su, 1959 (Halecomorphi, Holostei) from the Middle Triassic (Ladinian) of Guizhou and Yunnan, China". English. In: Research \& Knowledge 3 (2017), pp. 36-38.

[25245] G. H. Xu, X. Y. Ma, and Y. Ren. "Fuyuanichthys wangi gen. et sp. nov. from the Middle Triassic (Ladinian) of China highlights the early diversification of ginglymodian fishes". English. In: PeerJ 6 (2018), e6054.

[25246] G. H. Xu, X. Y. Ma, F. X. Wu, and Y. Ren. "A Middle Triassic kyphosichthyiform from Yunnan, China, and phylogenetic reassessment of early ginglymodians". English. In: Vertebrata PalAsiatica 57 (2019), pp. 181-204.

[25247] G. H. Xu, C. C. Shen, and L. J. Zhao. "Pteronisculus nielseni sp. nov., a new stem-actinopteran fish from the Middle Triassic of Luoping, Yunnan Province, China". English. In: Vertebrata PalAsiatica 52 (2014), pp. 364-380.

[25248] G. H. Xu and C. C. Shen. "Panxianichthys imparilis gen. et sp. nov., a new ionoscopiform (Halecomorphi) from the Middle Triassic of Guizhou, China". English. In: Vertebrata PalAsiatica 53 (2015), pp. 1-15.

[25249] G. H. Xu, L. J. Zhao, K. Q. Gao, and F. X. Wu. "A new stem-neopterygian fish from the Middle Triassic of China shows the earliest over-water gliding strategy of the vertebrates". English. In: Proceedings of the Royal Society B (2012).

[25250] G. H. Xu, L. J. Zhao, and M. I. Coates. "The oldest ionoscopiform from China sheds new light on the early evolution of halecomorph fishes". English. In: Biology Letters 10 (2014), p. 20140204.

[25251] G. H. Xu, L. J. Zhao, and C. C. Shen. "A Middle Triassic thoracopterid from China highlights the evolutionary origin of overwater gliding in early ray-finned fishes". English. In: Biology Letters 11 (2015), p. 2014960.

[25252] G. H. Xu and L. J. Zhao. "A Middle Triassic stem-neopterygian fish from China shows remarkable secondary sexual characteristics”. English. In: Science Bulletin 61 (2016), pp. 338-344. 
[25253] H. K. Xu, S. Z. Shen, and L. R. Cheng. “Linoldhamininae, a new subfamily of Lyttoniidae Waagen, 1883 (Brachiopoda) from the Guadalupian (Middle Permian) Xiala Formation in the Xainza area, northern Tibet". English. In: Journal of Paleontology 79.5 (2005), pp. 1012-1018.

[25254] H. P. Xu, C. Q. Cao, D. X. Yuan, Y. C. Zhang, and S. Z. Shen. "Lopingian (Late Permian) brachiopod faunas from the Qubuerga Formation at Tulong and Kujianla in the Mt. Everest area of southern Tibet, China". English. In: Rivista Italiana di Paleontologia e Stratigrafia 124 (2018), pp. 139-162.

[25255] H. P. Xu, Y. C. Zhang, F. Qiao, and S. Z. Shen. "A new Changhsingian brachiopod fauna from the Xiala Formation at Tsochen in the central Lhasa Block and its paleogeographical implications". English. In: Journal of Paleontology 93 (2019), pp. 876-898. DOI: 10.1017/jpa.2019.28.

[25256] H.-H. Xu, Y. Wang, C. M. Berry, and C. -Y. Cai. “Two species of Haskinsia Grierson \& Banks (Lycopsida) from the Middle Devonian of Xinjiang, China, and consideration of their palaeogeographical significance". English. In: Botanical Journal of the Linnean Society 157 (2008), pp. 633-644.

[25257] K. Xu, Y. Li, R. Li, and R. Wang. "Discovery of the Dinosaur fossil in Heishan, Liaoning and its stratigraphical significance". Chinese. In: Journal of stratigraphy (=Dicengxue-zazhi) 22.3 (1998), pp. 227-231.

[25258] L. Xu, Y. Kobayashi, Y. -N. Lee, Y. Liu, K. Tanaka, X. Zhang, S. Jia, and J. Zhang. "A new ornithomimid dinosaur with North American affinities from the Late Cretaceous Qiupa Formation in Henan Province of China". English. In: Cretaceous Research 32.1 (2011), pp. 213-222.

[25259] L. Xu, J. Lü, X. Zhang, S. Jia, W. Hu, J. Zhang, Y. Wu, and Q. Ji. "[A new nodosaurid ankylosaur from the Cretaceous of Ruyang, Henan Province]". Chinese. In: Acta Geologica Sinica 81.4 (2007), pp. 433-438.

[25260] L. Xu, X. Wu, J. Lu, S. Jia, J. Zhang, H. Pu, and X. Zhang. “A new lizard (Lepidosauria: Squamata) from the Upper Cretaceous of Henan, China". English. In: Acta Geologica Sinica 88 (2014), pp. 10411050.

[25261] L. Xu, X. Zhang, H. Pu, S. Jia, J. Zhang, J. Lü, and J. Meng. "Largest known Mesozoic multituberculate from Eurasia and implications for multituberculate evolution and biology". English. In: Scientific Reports 5 (2015), 14950:1-11. DOI: 10.1038/srep14950.

[25262] Q. Xu. "Some remarks on Chenjiawo Fauna". English. In: Vertebrata PalAsiatica 34.1 (1996), pp. 4157.

[25263] S.-C. Xu, H.-L. You, J. -W. Wang, S. -Z. Wang, J. Yi, and L. Jia. “A new hadrosauroid dinosaur from the Late Cretaceous of Tianzhen, Shanxi Province, China". English. In: Vertebrata PalAsiatica 54.1 (2016), pp. 67-78.

[25264] X. Xu, Y.-N. Cheng, X. -L. Wang, and C. -H. Chang. "An unusual oviraptorosaurian dinosaur from China". In: Nature 419 (2002), pp. 291-293.

[25265] X. Xu, J. Choiniere, Q. -W. Tan, R. B. J. Benson, J. Clark, C. Sullivan, Q. Zhao, F. -L. Han, Q. -Y. Ma, Y. -M. He, S. Wang, H. Xing, and L. Tan. "Two early Cretaceous fossils document transitional stages in alvarezsaurian dinosaur evolution". English. In: Current Biology 28 (2018), pp. 2853-2860. DOI: 10.1016/j.cub.2018.07.057.

[25266] X. Xu, J. N. Choiniere, M. Pittman, Q. Tan, D. Xiao, Z. Li, J. M. Clark, M. A. Norell, D. W. E. Hone, and C. Sullivan. "A new dromaeosaurid (Dinosauria: Theropoda) from the Upper Cretaceous Wulansuhai Formation of Inner Mongolia, China". English. In: Zootaxa 2403 (2010), pp. 1-9.

[25267] X. Xu, J. M. Clark, C. A. Forster, M. A. Norell, G. M. Erickson, D. A. Eberth, C. Jai, and Q. Zhao. "A basal tyrannosauroid dinosaur from the Late Jurassic of China". English. In: Nature 439 (2006), pp. 715-718.

[25268] X. Xu and J. M. Clark. "The presence of a gigantic theropod in the Jurassic Shishugou Formation, Junggar Basin, western China". English. In: Vertebrata PalAsiatica 46.2 (2008), pp. 157-160.

[25269] X. Xu, J. M. Clark, J. Mo, J. Choiniere, C. A. Forster, G. M. Erickson, D. W. E. Hone, C. Sullivan, D. A. Eberth, S. J. Nesbitt, Q. Zhao, R. Hernández, C. -k. Jia, F. -1. Han, and Y. Gou. "A Jurassic ceratosaur from China helps clarify avian digital homologies". English. In: Nature 459.7249 (2009), pp. 940-944. DOI: $10.1038 /$ nature08124. 
[25270] X. Xu, P. Currie, M. Pittman, L. Xing, Q. Meng, J. Lü, D. Hu, and C. Yu. “Mosaic evolution in an asymmetrically feathered troodontid dinosaur with transitional features". English. In: Nature Communications 8 (2017), 14972:1-12. DOI: 10.1038/ncomms14972.

[25271] X. Xu, C. A. Forster, J. M. Clark, and J. Mo. "A basal ceratopsian with transitional features from the Late Jurassic of northwestern China". English. In: Proceedings of the Royal Society of London B 273 (2006), pp. 2135-2140.

[25272] X. Xu and F.-L. Han. "A new oviraptorid dinosaur (Theropoda: Oviraptorosauria) from the Upper Cretaceous of China". English. In: Vertebrata PalAsiatica 48.1 (2010), pp. 11-18.

[25273] X. Xu, P. J. Makovicky, X. -1. Wang, M. A. Norell, and H. -1. You. "A ceratopsian dinosaur from China and the early evolution of the Ceratopsia". English. In: Nature 416 (2002), pp. 314-317.

[25274] X. Xu, M. A. Norell, X. Kuang, X. Wang, Q. Zhao, and C. Jin. "Basal tyrannosauroids from China and evidence for protofeathers in tyrannosauroids". In: Nature 431 (2004), pp. 680-684.

[25275] X. Xu, M. A. Norell, X. -1. Wang, P. J. Makovicky, and X. -c. Wu. "A basal troodontid from the Early Cretaceous of China". English. In: Nature 415 (2002), pp. 780-784.

[25276] X. Xu and M. A. Norell. "A new troodontid dinosaur from China with avian-like sleeping posture". English. In: Nature 431 (2004), pp. 838-841.

[25277] X. Xu and Z.-C. Qin. "A new tiny dromaeosaurid dinosaur from the Lower Cretaceous Jehol Group of western Liaoning and niche differentiation among the Jehol dromaeosaurids". English. In: Vertebrata PalAsiatica 55.2 (2017), pp. 129-144.

[25278] X. Xu, C. Sullivan, M. Pittman, J. N. Choiniere, D. Hone, P. Upchurch, Q. Tan, D. Xiao, L. Tan, and F. Han. "A monodactyl nonavian dinosaur and the complex evolution of the alvarezsauroid hand". English. In: Proceedings of the National Academy of Sciences 108.6 (2011), pp. 2338-2342. DOI: 10.1073/pnas.1011052108.

[25279] X. Xu, Q. Tan, J. Wang, X. Zhao, and L. Tan. “A gigantic bird-like dinosaur from the Late Cretaceous of China". English. In: Nature 447 (2007), pp. 844-847.

[25280] X. Xu, Q.-W. Tan, C. Sullivan, F. -L. Han, and D. Xiao. “A short-armed troodontid dinosaur from the Upper Cretaceous of Inner Mongolia and Its implications for troodontid evolution". English. In: PLoS One 6.9 (2011), e22916:1-12. DOI: 10.1371/journal.pone.0022916.

[25281] X. Xu, Q.-W. Tan, S. Wang, C. Sullivan, D. W. E. Hone, F. -L. Han, Q. -Y. Ma, L. Tan, and D. Xiao. "A new oviraptorid from the Upper Cretaceous of Nei Mongol, China, and its stratigraphic implications". English. In: Vertebrata PalAsiatica 51.2 (2013), pp. 85-101.

[25282] X. Xu, Q.-W. Tan, Y. -L. Gao, Z. -Q. Bao, Z. -G. Yin, B. Guo, J. -Y. Wang, L. Tan, Y. -G. Zhang, and H. Xing. "A large-sized basal ankylopollexian from East Asia, shedding light on early biogeographic history of Iguanodontia". English. In: Science Bulletin 63 (2018), pp. 556-563.

[25283] X. Xu, Z.-L. Tang, and X. -L. Wang. "A therizinosauroid dinosaur with integumentary structures from China". English. In: Nature 399 (1999), pp. 350-354.

[25284] X. Xu, P. Upchurch, P. D. Mannion, P. M. Barrett, O. R. Regalado-Fernandez, J. Mo, J. Ma, and H. Liu. "A new Middle Jurassic diplodocoid suggests an earlier dispersal and diversification of sauropod dinosaurs". English. In: Nature Communications 9 (2018), 2700:1-9. DOI: 10.1038/s41467018-05128-1.

[25285] X. Xu, D.-Y. Wang, C. Sullivan, D. W. E. Hone, F. -L. Han, R. -H. Yan, and F. -M. Du. “A basal parvicursorine (Theropoda: Alvarezsauridae) from the Upper Cretaceous of China". English. In: Zootaxa 2413 (2010), pp. 1-19.

[25286] X. Xu, K. Wang, X. Zhao, C. Sullivan, and S. Chen. “A new leptoceratopsid (Ornithischia: Ceratopsia) from the Upper Cretaceous of Shandong, China and its implications for neoceratopsian evolution". English. In: PLoS One 5.11/e13835 (2010), pp. 1-14. DOI: 10.1371/journal.pone.0013835.

[25287] X. Xu, K. Wang, K. Zhang, Q. Ma, L. Xing, C. Sullivan, D. Hu, S. Cheng, and S. Wang. “A gigantic feathered dinosaur from the Lower Cretaceous of China". English. In: Nature 484 (2012), pp. 92-95. DOI: $10.1038 /$ nature10906. 
[25288] X. Xu, K.-B. Wang, X. -J. Zhao, and D. -J. Li. “First ceratopsid dinosaur from China and its biogeographical implications". English. In: Chinese Science Bulletin 55.16 (2010), pp. 1631-1635. DOI: 10.1007/s11434-009-3614-5.

[25289] X. Xu and X. Wang. "New psittacosaur (Ornithischia, Ceratopsia) occurrence from the Yixian Formation of Liaoning, China and its stratigraphical significance". English. In: Vertebrata PalAsiatica 36.2 (1998), pp. 147-158.

[25290] X. Xu and X. Wang. "A new troodontid (Theropoda: Troodontidae) from the Lower Cretaceous Yixian Formation of western Liaoning, China". English. In: Acta Geologica Sinica 78.1 (2004), pp. 22 26.

[25291] X. Xu and X.-L. Wang. "Troodontid-like pes in the dromaeosaurid Sinornithosaurus". English. In: Y.-N. Lee (ed.), 2000 International Dinosaur Symposium for Kosong County in Korea. Paleontological Society of Korea Special Publication 4 (2000), pp. 179-188.

[25292] X. Xu, X.-L. Wang, and X. -C. Wu. “A dromaeosaurid dinosaur with a filamentous integument from the Yixian Formation of China". English. In: Nature 401 (1999), pp. 262-266.

[25293] X. Xu and X.-L. Wang. "A new maniraptoran dinosaur from the Early Cretaceous Yixian Formation of western Liaoning". English. In: Vertebrata PalAsiatica 41.3 (2003), pp. 195-202.

[25294] X. Xu, X.-L. Wang, and H. -L. You. "A primitive ornithopod from the Early Cretaceous Yixian Formation of Liaoning". English. In: Vertebrata PalAsiatica 38.4 (2000), pp. 318-325.

[25295] X. Xu, X.-L. Wang, and H. -L. You. “A juvenile ankylosaur from China”. English. In: Naturwissenschaften 88 (2001), pp. 297-300.

[25296] X. Xu and X.-L. Wang. "A new dromaeosaur (Dinosauria: Theropoda) from the Early Cretaceous Yixian Formation of western Liaoning". English. In: Vertebrata PalAsiatica 42.2 (2004), pp. 111-119.

[25297] X. Xu, H. You, K. Du, and F. Han. "An Archaeopteryx-like theropod from China and the origin of Avialae". English. In: Nature 475 (2011), pp. 465-470. DOI: 10.1038/nature10288.

[25298] X. Xu and F. Zhang. "A new maniraptoran dinosaur from China with long feathers on the metatarsus". English. In: Naturwissenschaften 92 (2005), pp. 173-177.

[25299] X. Xu, X. Zhang, Q. Tan, X. Zhao, and L. Tan. “A new titanosaurian sauropod from Late Cretaceous of Nei Mongol, China". English. In: Acta Geologica Sinica 80.1 (2006), pp. 20-26.

[25300] X. Xu, Z.-H. Zhang, P. C. Sereno, X. -J. Zhao, X. -W. Kuang, J. Han, and L. Tan. "A new therizinosauroid (Dinosauria, Theropoda) from the Upper Cretaceous Iren Dabasu Formation of Nei Mongol". English. In: Vertebrata PalAsiatica 40.3 (2002), pp. 228-240.

[25301] X. Xu, Q. Zhao, M. Norell, C. Sullivan, D. Hone, G. Erickson, X. Wang, F. Han, and Y. Guo. “A new feathered maniraptoran dinosaur fossil that fills a morphological gap in avian origin". English. In: Chinese Science Bulletin 54.3 (2009), pp. 430-435. DOI: 10.1007/s11434-009-0009-6.

[25302] X. Xu, Q. Zhao, C. Sullivan, Q. -W. Tan, M. Sander, and Q. -Y. Ma. “The taxonomy of the troodontid IVPP V 10597 reconsidered". English. In: Vertebrata PalAsiatica 50.2 (2012), pp. 140-150.

[25303] X. Xu, X. Zhao, and J. M. Clark. "A new therizinosaur from the Lower Jurassic Lower Lufeng Formation of Yunnan, China". English. In: Journal of Vertebrate Paleontology 21.3 (2001), pp. 477483.

[25304] X. Xu, X.-J. Zhao, J. -C. Lü, W. -B. Huang, Z. -Y. Li, and Z. -M. Dong. “A new iguanodontian from Sangping Formation of Neixiang, Henan and its stratigraphical implication". English. In: Vertebrata PalAsiatica 38.3 (2000), pp. 176-191.

[25305] X. Xu, X. Zheng, and H. You. "A new feather type in a nonavian theropod and the early evolution of feathers". English. In: Proceedings of the National Academy of Sciences 106.3 (2009), pp. 832-834. DOI: $10.1073 /$ pnas.0810055106.

[25306] X. Xu, X. Zheng, C. Sullivan, X. Wang, L. Xing, Y. Wang, X. Zhang, J. K. O'Connor, F. Zhang, and Y. Pan. "A bizarre Jurassic maniraptoran theropod with preserved evidence of membranous wings". English. In: Nature (2015). DOI: 10.1038/nature14423. 
[25307] X. Xu, Z. Zhou, and X. Wang. "The smallest known non-avian theropod dinosaur". English. In: Nature 408 (2000), pp. 705-708.

[25308] X. Xu, Z. Zhou, X. Wang, X. Kuang, F. Zhang, and X. Du. "Four-winged dinosaurs from China". English. In: Nature 421 (2003), pp. 335-340.

[25309] Z. F. Xu, M. Olmi, and J. H. He. "Dryinidae of the Oriental region (Hymenoptera: Chrysidoidea)". English. In: Zootaxa 3614 (2013), pp. 1-460.

[25310] A. Yabe, K. Ogasawara, and A. Obuse. "Plant and molluscan fossil assemblages rom the Lower Miocene Kunugidaira Formation in the southern part of the Joban coal-field". English. In: Journal of the Geological Society of Japan 101.7 (1995), pp. 532-548.

[25311] H. Yabe and R. Hirayama. "Selachian fauna from the Upper Miocene Senhata Formation, Boso Peninsula, Central Japan". English. In: Natural History Research 5 (1998), pp. 33-61.

[25312] Y. Yabumoto. "A New Mesozoic coelacanth from Brazil (Sarcopterygii, Actinistia)". English. In: Paleontological Research 12.4 (2007), pp. 329-343.

[25313] Y. Yabumoto. “Early Cretaceous freshwater fish fauna in Kyushu, Japan". English. In: Bulletin of the Kitakyushu Museum of Natural History 13 (1994), pp. 107-254.

[25314] Y. Yabumoto and P. M. Brito. "A new Triassic coelacanth, Whiteia oishii (Sarcopterygii, Actinistia) from West Timor, Indonesia". English. In: Paleontological Research 20 (2016), pp. 233-246.

[25315] Y. Yabumoto and A. Neuman. "A coelacanth scale from the Upper Triassic Pardonet Formation, British Columbia, Canada". English. In: Paleontological Research 8 (2004), pp. 337-340.

[25316] Y. Yabumoto and T. Uyeno. "Late Mesozoic and Cenozoic fish faunas of Japan". English. In: The Island Arc 3 (1994), pp. 255-269.

[25317] Y. Yabumoto and T. Uyeno. "Inabaperca taniurai, a new genus and species of Miocene percoid fish from Tottori Prefecture, Japan". English. In: Bulletin of the Natural Science Museum, Tokyo, Series C 26.3.4 (2000), pp. 93-106.

[25318] Y. Yabumoto and T. Uyeno. “Coreoperca maruoi, a new species of freshwater percoid fi sh from the". English. In: Bulletin of the Kitakyushu Museum of Natural History and Human History, Series A 7 (2009), pp. 103-112.

[25319] Y. Yabumoto and T. Uyeno. "A new Miocene ponyfish of the genus Leiognathus (Pisces, Leiognathidae) from Tottori Prefecture, Japan". English. In: Bulletin of the National Science Museum, Tokyo, Series C 20.2 (1994), pp. 67-77.

[25320] Y. Yabumoto and S. Y. Yang. "The first record of the Early Cretaceous freshwater fish, Wakinoichthys aokii, from Korea". English. In: Bulletin of the Kitakyushu Museum of Natural History 19 (2000), pp. 105-110.

[25321] P. Yadagiri. "The osteology of Kotasaurus yamanpalliensis, a sauropod dinosaur from the Early Jurassic Kota Formation of India". English. In: Journal of Vertebrate Paleontology 21.2 (2001), pp. 242252.

[25322] U. G. Yakouya-Moubamba and B. Musavu Moussavou. "Les échinides du Turonien de la Formation de l'Azilé du bassin cotier gabonais dans la région de Libreville Sud". French. In: Annales de Paléontologie 103 (2017), pp. 101-112.

[25323] K. Yamada, S. Yamamoto, and Y. Takahashi. “Aphrastomedes anthocoroides, a remarkable new cimicomorphan genus and species (Hemiptera: Heteroptera) from Upper Cretaceous Burmese amber". English. In: Cretaceous Research 84 (2017), pp. 442-450.

[25324] T. Yamada. "Structurally preserved Zamites bayeri Kvacek from the Coniacian Kashima Formation (Yezo Group) of Hokkaido, Japan". English. In: Cretaceous Research 2009 (2007), pp. 1-6.

[25325] T. Yamada and M. Kato. "Regnellites nagashimae gen. et sp. nov., the oldest macrofossil of Marsileaceae from the upper Jurassic to lower Cretaceous of western Japan". In: International Journal of Plant Sciences 163.5 (2002), pp. 715-723. 
[25326] H. Yamagishi. "Elasmobranch remains from the Taho Limestone (Lower-Middle Triassic) of Ehime Prefecture, Southwest Japan". English. In: vol. 3. Mesozoic Fishes 3 - Systematics, Paleoenvironments and Biodiversity. München, Germany: Verlag Dr. Friedrich Pfeil, 2004, pp. 565-574.

[25327] H. Yamagishi and T. Fujimoto. "Chondrichthyan remains from the Akasaka limestone formation (Middle Permian) of Gifu Prefecture, central Japan". English. In: Bulletin of the Kanagawa Prefectural Museum (Natural Sciences) 40 (2011), pp. 1-6.

[25328] N. Yamagiwa, T. Asami, and A. Hosono. "A redescription of Permian Rugosa Waagenophyllum (Waagenophyllum) compactum Minato \& Kato, 1965". English. In: Bulletin of the National Science Museum, Tokyo, Series C 25 (1999), pp. 105-110.

[25329] N. Yamagiwa, K. Hisada, and M. Tamura. "Early Cretaceous Hexacorals from the western part of the Sanchu area, Kanto Mountains". English. In: Bulletin of the Natural Science Museum, Tokyo, Series C 24.1-2 (1998), pp. 55-66.

[25330] S. Yamamoto. "The first fossil of dasycerine rove beetle (Coleoptera: Staphylinidae) from Upper Cretaceous Burmese amber: Phylogenetic implications for the omaliine group subfamilies". English. In: Cretaceous Research 58 (2016), pp. 63-68.

[25331] S. Yamamoto. “The oldest tachyporine rove beetle in amber (Coleoptera, Staphylinidae): A new genus and species from Upper Cretaceous Burmese amber". English. In: Cretaceous Research 65 (2016), pp. 163-171.

[25332] S. Yamamoto. "Discovery of the oxyporine rove beetle in the Mesozoic amber and its evolutionary implications for mycophagy (Coleoptera: Staphylinidae)". English. In: Cretaceous Research 74 (2017), pp. 198-204.

[25333] S. Yamamoto. "A new genus of Brochocoleini beetle in Upper Cretaceous Burmese amber (Coleoptera: Archostemata: Ommatidae)". English. In: Cretaceous Research 76 (2017), pp. 34-39.

[25334] S. Yamamoto. "Fossil evidence of elytra reduction in ship-timber beetles". English. In: Scientific Reports 9.4938 (2019), pp. 1-10.

[25335] S. Yamamoto, E. Caron, and S. Bortoluzzi. "Propiestus archaicus, the first Mesozoic amber inclusion of piestine rove beetles and its evolutionary and biogeographical significance (Coleoptera: Staphylinidae: Piestinae)". English. In: Journal of Systematic Palaeontology 17 (2018), pp. 1037-1050.

[25336] S. Yamamoto, V. V. Grebennikov, and Y. Takahashi. “Kekveus jason gen. et sp. nov. from Cretaceous Burmese amber, the first extinct genus and the oldest named featherwing beetle (Coleoptera: Ptiliidae: Discheramocephalini)". English. In: Cretaceous Research 90 (2018), pp. 412-418.

[25337] S. Yamamoto, M. A. Jäch, and Y. Takahashi. “Discovery of the first hydraenid beetle in amber, with description of a new genus and species (Coleoptera: Staphylinoidea: Hydraenidae)". English. In: Cretaceous Research 78 (2017), pp. 27-33.

[25338] S. Yamamoto, M. Maruyama, and J. Parker. “Evidence for social parasitism of early insect societies by Cretaceous rove beetles". English. In: Nature Communications 7.13658 (2016), pp. 1-9.

[25339] S. Yamamoto and M. Maruyama. "A new genus and species of the rove beetle tribe Mesoporini from Baltic amber (Coleoptera: Staphylinidae: Aleocharinae)". English. In: Historical Biology 29 (2017), pp. 203-207.

[25340] S. Yamamoto and M. Maruyama. "Phylogeny of the rove beetle tribe Gymnusini sensu n. (Coleoptera: Staphylinidae: Aleocharinae): implications for the early branching events of the subfamily". English. In: Systematic Entomology 43 (2017), pp. 183-199.

[25341] S. Yamamoto and A. Solodovnikov. “The first fossil Megalopsidiinae (Coleoptera: Staphylinidae) from Upper Cretaceous Burmese amber and its potential for understanding basal relationships of rove beetles". English. In: Cretaceous Research 59 (2016), pp. 140-146.

[25342] S. Yamamoto and Y. Takahashi. "Coproporus electron sp. nov., the first tachyporine rove beetle in Dominican amber (Coleoptera, Staphylinidae)". English. In: PalZ 90 (2016), pp. 629-635.

[25343] S. Yamamoto, Y. Takahashi, and J. Parker. "Evolutionary stasis in enigmatic jacobsoniid beetles". English. In: Gondwana Research 45 (2017), pp. 275-281. 
[25344] S. Yamamoto and Y. Takahashi. "First discovery ofăfossil Coloninae inăCretaceous Burmese amber (Coleoptera, Staphylinoidea, Leiodidae)". English. In: PalZ 92 (2018), pp. 195-201.

[25345] S. Yamamoto and Y. Takahashi. "First and oldest Leptochirini rove beetles illuminate diverse cephalic structures in the Cretaceous (Coleoptera: Staphylinidae: Osoriinae)". English. In: Systematic Entomology 44 (2019), pp. 588-611.

[25346] H. Yamano, K. Sugihara, T. Watanabe, M. Shimamura, and K. Hyeong. "Coral reefs at 34řN, Japan: Exploring the end of environmental gradients". English. In: Geology 40.9 (2012), pp. 835-838.

[25347] S. Yamashita and M. Kimura. "Occurrence of Early Pliocene otariid fossil in Numata-cho, Hokkaido". Japanese. In: Chikyu Kagaku 44 (1990), pp. 53-60.

[25348] E. V. Yan. "New beetle species of the genus Lasiosyne (Coleoptera, Lasiosynidae) from the Late Jurassic and Early Cretaceous of Russia and Mongolia". English. In: Paleontological Journal 46 (2012), pp. 589-600.

[25349] E. V. Yan. "A new genus of elateriform beetles (Coleoptera, Polyphaga) from the Middle-Late Jurassic of Karatau". English. In: Paleontological Journal 43 (2009), pp. 78-82.

[25350] E. V. Yan, R. G. Beutel, and A. G. Ponomarenko. "+Peltosynidae, a new beetle family from the Middle-Late Triassic of Kyrgyzstan: its affinities with Polyphaga (Insecta, Coleoptera) and the groundplan of this megadiverse suborder". English. In: Journal of Systematic Palaeontology 16 (2017), pp. 515-530.

[25351] E. V. Yan, R. G. Beutel, and J. F. Lawrence. "Whirling in the late Permian: ancestral Gyrinidae show early radiation of beetles before Permian-Triassic mass extinction". English. In: BMC Evolutionary Biology 18.33 (2018), pp. 1-10.

[25352] E. V. Yan, R. G. Beutel, J. F. Lawrence, M. I. Yavorskaya, T. Hörnschemeyer, H. Pohl, D. V. Vassilenko, A. S. Bashkuev, and A. G. Ponomarenko. "Archaeomalthus-(Coleoptera, Archostemata) a 'ghost adult' of Micromalthidae from Upper Permian deposits of Siberia?" English. In: Historical Biology 32 (2020), pp. 1019-1027. DOI: 10.1080/08912963.2018.1561672.

[25353] E. V. Yan, J. F. Lawrence, R. Beattie, and R. G. Beutel. “At the dawn of the great rise: +Ponomarenkia belmonthensis (Insecta: Coleoptera), a remarkable new Late Permian beetle from the Southern Hemisphere". English. In: Journal of Systematic Palaeontology 16 (2017), pp. 611-619.

[25354] E. V. Yan and B. Wang. "A New Genus of Elateriform Beetles (Coleoptera, Polyphaga) from the Jurassic of Daohugou, China". English. In: Paleontological Journal 44 (2010), pp. 297-302.

[25355] E. V. Yan, B. Wang, and H. C. Zhang. "First record of the beetle family Lasiosynidae (Insecta: Coleoptera) from the Lower Cretaceous of China". English. In: Cretaceous Research 40 (2013), pp. $43-$ 50.

[25356] E. V. Yan, B. Wang, A. G. Ponomarenko, and H. Zhang. "The most mysterious beetles: Jurassic Jurodidae (Insecta: Coleoptera) from China". English. In: Gondwana Research 25 (2014), pp. 214225.

[25357] E. V. Yan, B. Wang, and H. C. Zhang. "A new lasiosynid beetle from the Middle Jurassic of China with remarks on the systematic position of Lasiosynidae". English. In: Comptes Rendus Palevol 13 (2014), pp. 1-8.

[25358] E. V. Yan, B. Wang, and H. Zhang. “Two new genera of Lasiosynidae (Insecta, Coleoptera) from the Lower Cretaceous of Russia and Mongolia, and principal trends of the morphological evolution of the family". English. In: Paleontological Journal 48 (2014), pp. 500-511.

[25359] E. V. Yan, B. Wang, E. A. Jarzembowski, and H. C. Zhang. "The earliest byrrhoids (Coleoptera, Elateriformia) from the Jurassic of China and their evolutionary implications". English. In: Proceedings of the Geologists' Association 126 (2015), pp. 211-219.

[25360] E. V. Yan and H. C. Zhang. "New Beetle Species of the Formal Genus Artematopodites (Coleoptera: Polyphaga), with Remarks on the Taxonomic Position of the Genera Ovivagina and Sinonitidulina". English. In: Paleontological Journal 44 (2010), pp. 451-456. 
[25361] T. Z. Yan, S. Q. Wang, and Y. P. Qi. “Ostracodes from the Chuanshan Formation at the Shencun section of Tonglu, Zhejiang". Chinese. In: Acta Palaeontologica Sinica 44 (2005), pp. 247-259.

[25362] Z. Yan, M. Bai, and D. Ren. "A new fossil Hybosoridae (Coleoptera: Scarabaeoidea) from the Yixian Formation of China". English. In: Zootaxa 3478 (2012), pp. 201-204.

[25363] Z. Yan, M. Bai, and D. Ren. "A new genus and species of fossil Hybosoridae (Coleoptera: Scarabaeoidea) from the Early Cretaceous Yixian Formation of Liaoning, China". English. In: Alcheringa 37 (2013), pp. 139-145.

[25364] Z. Yan, G. V. Nikolajev, and D. Ren. "A new, well-preserved genus and species of fossil Glaphyridae (Coleoptera, Scarabaeoidea) from the Mesozoic Yixian Formation of Inner Mongolia, China". English. In: ZooKeys 241 (2012), pp. 67-75.

[25365] J. Yanagida. Permian brachiopods from the Tsunemori Formation, SW Japan, and their paleobiogeographic implication. English. Brachiopods. Proceedings of the Third International Brachiopod Congress. 1996, pp. 313-315.

[25366] J. Yanagida, J. Imamura, and M. Kawai. "Reexamination of the brachiopod fauna from the Permian Karita Formation, southwest Japan". English. In: Memoirs of the Faculty of Science, Kyushu University, Series D, Earth and Planetary Science 28.1 (1993), pp. 1-21.

[25367] J. Yanagida and N. Nakornsri. "Permian brachiopods from the Khao Hin Kling area near Phetchabun, north-central Thailand". English. In: Bulletin of the Kitakyushu Museum of Natural History 18 (1999), pp. 105-136.

[25368] J. Yanagida and A. Pillevuit. "Permian brachiopods from Oman". English. In: Memoirs of the Faculty of Science, Kyushu University, Series D, Earth and Planetary Science 28 (1994), pp. 61-99.

[25369] T. E. Yancey and G. D. Stanley. "Giant alatoform bivalves in the Upper Triassic of western North America". In: Palaeontology 42.1 (1999), pp. 1-23.

[25370] T. E. Yancey, G. D. Stanley, W. E. Piller, and M. A. Woods. "Biogeography of the Late Triassic wallowaconchid megalodontoid bivalves". English. In: Lethaia 38 (2005), pp. 351-365.

[25371] T. E. Yancey, E. E. Strong, and R. A. Hanger. "The genus Vesperispira (Gastropoda: Pleurotomarioidea) from the Permian of two displaced terranes, western United States". English. In: Journal of Paleontology 74.4 (2000), pp. 741-744.

[25372] A. Yang, M. Zhu, J. Zhang, and G. Li. "Early Cambrian eodiscoid trilobites of the Yangtze Platform and their stratigraphic implications". English. In: Progress in Natural Science 13.11 (2003), pp. 861866.

[25373] B. Yang, X. Lai, P. B. Wignall, H. Jiang, C. Yan, and Y. Sun. "A newly discovered earliest Triassic chert at Gaimao section, Guizhou southwestern China". English. In: Palaeogeography, Palaeoclimatology, Palaeoecology 344-345 (2010), pp. 69-77. DOI: 10.1016/j.palaeo.2012.05.019.

[25374] B. Yang, M. Steiner, G. X. Li, and H. Heupp. “Terreneuvian small shelly faunas of East Yunnan (South China) and their biostratigraphic implication". English. In: 398 (2014), pp. 28-58. DOI: 10. 1016/j.palaeo.2013.07.003.

[25375] D. Yang, C. K. Shih, and D. Ren. “The earliest pygidicranid (Insecta: Dermaptera) from the Lower Cretaceous of China". English. In: Cretaceous Research 52 (2015), pp. 329-335.

[25376] D. Z. Yang and F. Q. Yang. "New materials of Late Permian ammonoids from southeastern Hubei". Chinese. In: Acta Palaeontologica Sinica 31.5 (1992), pp. 595-604.

[25377] F. Q. Yang and X. Q. Xiong. "Early Late Permian cephalopods from southeastern Laibin, Guangxi". Chinese. In: Acta Palaeontologica Sinica 29.2 (1990), pp. 193-203.

[25378] G. Yang, Y. Yao, and D. Ren. "A new species of Protopsyllidiidae (Hemiptera, Sternorrhyncha) from the Middle Jurassic of China". English. In: Zootaxa 3274 (2012), pp. 36-42.

[25379] G. Yang, Y. Z. Yao, and D. Ren. "Poljanka strigosa, a new species of Protopsyllidiidae (Hemiptera, Sternorrhyncha) from the Middle Jurassic of China". English. In: Alcheringa 37 (2013), pp. 125-130. 
[25380] H. R. Yang, C. F. Shi, M. S. Engel, Z. P. Zhao, D. Ren, and T. P. Gao. “Early specializations for mimicry and defense in a Jurassic stick insect". English. In: National Science Review 8.nwaa056 (2020). DOI: $10.1093 / \mathrm{nsr} /$ nwaa056.

[25381] H. R. Yang, X. C. Yin, X. D. Lin, C. Wang, C. K. Shih, W. W. Zhang, D. Ren, and T. P. Gao. “Cretaceous winged stick insects clarify the early evolution of Phasmatodea". English. In: Proceedings of the Royal Society B 286.20191085 (2019). DOI: 10.1098/rspb.2019.1085.

[25382] J. Yang, M. R. Smith, T. Lan, J. -B. Hou, and X. -G. Zhang. “Articulated Wiwaxia from the Cambrian Stage 3 Xiaoshiba Lagerstätte". English. In: Scientific Reports 4 (2014), p. 4643. DOI: 10.1038/ srep04643.

[25383] J. K. Yang and Y. C. Hong. "Drakochrysa, an Early Cretaceous new genus of Chrysopidae (Insecta: Neuroptera) from Laiyang basin, Shandong Province". Chinese. In: Geoscience - Journal of Graduate School, China University of Geosciences 4 (1990), pp. 15-26.

[25384] J.-T. Yang, H.-L. You, D. -Q. Li, and D. -L. Kong. “[First discovery of polacanthine ankylosaur dinosaur in Asia]". Chinese. In: Vertebrata PalAsiatica 51.4 (2013), pp. 265-277.

[25385] N. Yang, D. Ren, and O. Béthoux. “The 'Megasecoptera-Diaphanopterodea' twilight zone epitomized by a new insect from Xiaheyan (Early Pennsylvanian; China)". English. In: Alcheringa 44 (2020), pp. 273-278. DOI: 10.1080/03115518.2020.1737228.

[25386] P. Yang, C. Ji, D. Jiang, R. Motani, A. Tintori, Y. Sun, and Z. Sun. “A new species of Qianichthyosaurus (reptilia: Ichthyosauria) from Xingyi Fauna (Ladinian, Middle Triassic) of Guizhou". English. In: Acta Scientiarum Naturalium Universitatis Pekinensis 49.6 (2013), pp. 1002-1008.

[25387] Q. Yang. "Taxonomic studies of Upper Jurassic (Tithonian) Radiolaria from the Taman Formation, east-central Mexico". English. In: Palaeoworld (special issue) 3 (1993), pp. 1-164.

[25388] Q. Yang, Z. Y. Chen, and F. L. Jia. "Ambarticus myanmaricus gen. et sp. nov., the first diving beetle from mid-Cretaceous amber of northern Myanmar (Coleoptera, Dytiscidae, Dytiscinae)". English. In: Cretaceous Research 102 (2019), pp. 1-6. DOI: 10.1016/j.cretres.2019.05.005.

[25389] Q. Yang, V. N. Makarkin, and D. Ren. "Remarkable New Genus of Gumillinae (Neuroptera: Osmylidae) from the Jurassic of China". English. In: Annals of the Entomological Society of America 103.6 (2010), pp. 855-859.

[25390] Q. Yang, V. N. Makarkin, and D. Ren. “Two interesting new genera of Kalligrammatidae (Neuroptera) from the Middle Jurassic of Daohugou, China". English. In: Zootaxa 2873 (2011), pp. 6068.

[25391] Q. Yang, V. N. Makarkin, S. L. Winterton, A. V. Khramov, and D. Ren. "A remarkable new family of Jurassic insects (Neuroptera) with primitive wing venation and its phylogenetic position in Neuropterida". English. In: PLoS One 7.9 (2012), e44762.

[25392] Q. Yang, V. N. Makarkin, and D. Ren. “New fossil Mesochrysopidae (Neuroptera) from the Mesozoic of China". English. In: Zootaxa 3597 (2012), pp. 1-14.

[25393] Q. Yang, V. N. Makarkin, and D. Ren. “A new genus of the family Panfiloviidae (Insecta, Neuroptera) from the Middle Jurassic of China". English. In: Palaeontology 56 (2013), pp. 49-59.

[25394] Q. Yang, V. N. Makarkin, and D. Ren. "Two new species of Kalligramma Walther (Neuroptera: Kalligrammatidae) from the Middle Jurassic of China". English. In: Annals of the Entomological Society of America 107 (2014), pp. 917-925.

[25395] Q. Yang, V. N. Makarkin, C. K. Shih, and D. Ren. “New Aetheogrammatidae (Insecta: Neuroptera) from the Lower Cretaceous Yixian Formation, China". English. In: Cretaceous Research 55 (2015), pp. 25-31.

[25396] Q. Yang, C. F. Shi, X. C. Li, H. Pang, and D. Ren. “The first fossil brown lacewing from the Miocene of the Tibetan Plateau (Neuroptera, Hemerobiidae)". English. In: ZooKeys 726 (2018), pp. 145-154.

[25397] Q. Yang, C. F. Shi, D. Ren, Y. J. Wang, and H. Pang. "New genus and species of sisyrids (Insecta, Neuroptera) from the Late Cretaceous Myanmar amber". English. In: ZooKeys 739 (2018), pp. 151158. 
[25398] Q. Yang, C. F. Shi, and D. Ren. "A new genus and species of berothids (Insecta, Neuroptera) from the Late Cretaceous Myanmar amber". English. In: ZooKeys 864 (2019), pp. 99-109.

[25399] Q. Yang, C. F. Shi, H. Pang, and D. Ren. "A new genus of giant lacewing (Insecta, Neuroptera, Ithonidae) from the Middle Jurassic of China". English. In: Zootaxa 4613 (2019), pp. 375-378.

[25400] Q. Yang, C. F. Shi, Z. H. Lai, H. Pang, and D. Ren. “New araripeneurids (Insecta: Neuroptera) from Upper Cretaceous amber of northern Myanmar". English. In: Cretaceous Research 108.104350 (2019). DOI: 10.1016/j.cretres.2019.104350.

[25401] Q. Yang, Y. J. Wang, C. C. Labandeira, C. K. Shih, and D. Ren. "Mesozoic lacewings from China provide phylogenetic insight into evolution of the Kalligrammatidae (Neuroptera)". English. In: BMC Evolutionary Biology 14.126 (2014), pp. 1-30.

[25402] Q. Yang, Y. Y. Zhao, and D. Ren. “An exceptionally well-preserved fossil Kalligrammatid from the Jehol Biota". English. In: Chinese Science Bulletin 54 (2009), pp. 1732-1737.

[25403] S.-Y. Yang, M. G. Lockley, R. Greben, B. R. Erickson, and S. -K. Lim. “Flamingo and duck-like bird tracks from the Late Cretaceous and Early Tertiary: evidence and implications". English. In: Ichnos 4 (1995), pp. 21-34.

[25404] X. G. Yang, D. Ren, and C. K. Shih. “New fossil hangingflies (Mecoptera, Raptipeda, Bittacidae) from the Middle Jurassic to Early Cretaceous of northeastern China". English. In: Geodiversitas 34 (2012), pp. 785-799.

[25405] X. G. Yang, C. K. Shih, D. Ren, and J. Petruleviius. “New Middle Jurassic hangingflies (Insecta: Mecoptera) from Inner Mongolia, China". English. In: Alcheringa 36 (2012), pp. 195-201.

[25406] X. G. Yang, C. K. Shih, and D. Ren. “New fossil hangingflies (Insecta: Mecoptera: Raptipedia: Cimbrophlebiidae) from the Middle Jurassic of Inner Mongolia, China". English. In: Palaeontology 56 (2013), pp. 711-726.

[25407] X.-L. Yang, Y.-L. Zhao, L. E. Babcock, and J. Peng. "A new vauxiid sponge from the Kaili Biota (Cambrian Stage 5), Guizhou, South China". English. In: Geological Magazine (2017). DOI: 10.1017/ S0016756816001229.

[25408] Y. Yang, H. Y. Li, B. Wang, W. W. Zhang, and X. Y. Liu. "New beaded lacewings (Neuroptera: Berothidae) from the mid-Cretaceous of Myanmar with specialized cephalic structures". English. In: Cretaceous Research 108.104348 (2019). DOI: 10.1016/j.cretres.2019.104348.

[25409] Y. Yang, W. Wu, P. -E. Dieudonné, and P. Godefroit. "A new basal ornithopod dinosaur from the Lower Cretaceous of China". English. In: PeerJ 8 (2020), e9832:1-44. DOI: 10.7717/ peerj.9832.

[25410] J. Yans, J. Dejax, D. Pons, L. Taverne, and P. Bultynck. “The iguanodons of Bernissart (Belgium) are middle Barremian to earliest Aptian in age". English. In: Bulletin de l'Institut Royal des Sciences Naturelles de Belgique, Science de la Terre 76 (2006), pp. 91-95.

[25411] A. Yao, K. Kuwahara, Y. Ezaki, J. Liu, W. Hao, Y. Luo, and G. Kuang. "Permian and Triassic radiolarians from the western Guangxi area, China". English. In: Journal of Geosciences, Osaka City University 48 (2005), pp. 81-93.

[25412] A. Yao, K. Kuwahara, J. Yao, Z. Ji, and J. Li. "Permian radiolarians from the so-called Gufeng Formation of the Laibin-Liuzhou area, Guangxi, China". English. In: Journal of Geosciences 50.6 (2007), pp. 67-81.

[25413] H. Yao, R. Zhang, J. Pojeta, J. Sha, and J. Wang. "Late Triassic megalodontids (Bivalvia) from the headwaters of the Yangtze River, Qinghai Province, West China". English. In: Journal of Paleontology 81.6 (2007), pp. 1327-1347.

[25414] H. Z. Yao, R. J. Zhang, Q. F. Duan, X. C. Sheng, Z. J. Niu, J. X. Wang, B. F. Zeng, and J. H. Wu. "Jurassic rocks, bivalves, and depositional environments of the source area of the Yangtze River, Qinghai Province, western China". English. In: Sci China Earth Sci 54.8 (2011), pp. 1136-1148. DOI: 10.1007/s11430-011-4223-0. 
[25415] L. Yao and M. Aretz. “Upper Visean (Mississippian) metazoan-microbial reefs from Guangxi, South China: Insights regarding reef recovery after the end-Devonian extinction". English. In: Palaeogeography, Palaeoclimatology, Palaeoecology (2020). DOI: 10.1016/j.palaeo.2020.109994.

[25416] L. Yao, X. Wang, W. Lin, Y. Li, S. Kershaw, and W. Qie. "Middle Viséan (Mississippian) coral biostrome in central Guizhou, southwestern China and its palaeoclimatological implications". English. In: Palaeogeography, Palaeoclimatology, Palaeoecology 439 (2016).

[25417] X. Yao, C.-C. Liao, C. Sullivan, and X. Xu. "A new transitional therizinosaurian theropod from the Early Cretaceous Jehol Biota of China". English. In: Scientific Reports 9.5026 (2019), 5026:1-12. DOI: 10.1038/s41598-019-41560-z.

[25418] X. Yao, X.-L. Wang, C. Sullivan, S. Wang, T. A. Stidham, and X. Xu. “Caenagnathasia sp. (Theropoda: Oviraptorosauria) from the Iren Dabasu Formation (Upper Cretaceous: Campanian) of Erenhot, Nei Mongol, China". English. In: Vertebrata PalAsiatica 53.4 (2015), pp. 291-298.

[25419] Y. Yao, W. Cai, and D. Ren. "Pristinochterus gen. n. (Hemiptera: Ochteridae) from the Upper Mesozoic of northeastern China". English. In: European Journal of Entomology 104 (2007), pp. 827-835.

[25420] Y. T. Yao, W. T. Zhang, D. Ren, and C. K. Shih. "New fossil Ochteridae (Hemiptera: Heteroptera: Ochteroidea) from the Upper Mesozoic of north-eastern China, with phylogeny of the family". English. In: Systematic Entomology 36 (2011), pp. 589-600.

[25421] Y. Z. Yao, W. Z. Cai, D. Ren, and C. K. Shih. "New fossil rhopalids (Heteroptera: Coreoidea) from the Middle Jurassic of Inner Mongolia, China". English. In: Zootaxa 1384 (2006), pp. 41-58.

[25422] Y. Z. Yao, W. Z. Cai, and D. Ren. "The first discovery of fossil rhopalids (Heteroptera: Coreoidea) from Middle Jurassic of Inner Mongolia, China". English. In: Zootaxa 1269 (2006), pp. 57-68.

[25423] Y. Z. Yao, W. Z. Cai, and D. Ren. “The oldest known fossil plant bug (Hemiptera: Miridae), from Middle Jurassic of Inner Mongolia, China". English. In: Zootaxa 1442 (2007), pp. 37-41.

[25424] Y. Z. Yao, W. Z. Cai, and D. Ren. "Fossil flower bugs (Heteroptera: Cimicomorpha: Cimicoidea) from the Late Jurassic of northeast China, including a new family Vetanthocoridae". English. In: Zootaxa 1360 (2006), pp. 1-40.

[25425] Y. Z. Yao, W. Z. Cai, D. A. Rider, and D. Ren. "Primipentatomidae fam. nov. (Hemiptera: Heteroptera: Pentatomomorpha), an extinct insect family from the Cretaceous of north-eastern China". English. In: Journal of Systematic Palaeontology 11 (2013), pp. 63-82.

[25426] Y. Z. Yao, W. Z. Cai, and D. Ren. "The first fossil Cydnidae (Hemiptera: Pentatomoidea) from the Late Mesozoic of China". English. In: Zootaxa 1388 (2007), pp. 59-68.

[25427] Y. Z. Yao, W. Z. Cai, and D. Ren. "New Jurassic fossil true bugs of the Pachymeridiidae (Hemiptera: Pentatomomorpha) from northeast China". English. In: Acta Geologica Sinica 82 (2008), pp. 35-47.

[25428] Y. Z. Yao, W. Z. Cai, and D. Ren. "Sinopachymeridium popovi gen. and sp. nov. - a new fossil true bug (Heteroptera: Pachymeridiidae) from the Middle Jurassic of Inner Mongolia, China". English. In: Annales Zoologici 56 (2006), pp. 753-756.

[25429] Y. Z. Yao, W. Z. Cai, X. Xu, C. K. Shih, M. S. Engel, X. T. Zheng, Y. Y. Zhao, and D. Ren. “Bloodfeeding true bugs in the Early Cretaceous". English. In: Current Biology (2014).

[25430] Y. Z. Yao, D. Ren, D. A. Rider, and W. Z. Cai. "Phylogeny of the infraorder Pentatomomorpha based on fossil and extant morphology, with description of a new fossil family from China". English. In: PLoS One 7.5 (2012), e37289.

[25431] Y. Z. Yao, W. T. Zhang, and D. Ren. “The first report of Mesoveliidae (Heteroptera: Gerromorpha) from the Yixian Formation of China and its significance". English. In: Alcheringa 36 (2012), pp. 107116.

[25432] J. M. Yarnell. University of Montana. English. 2000.

[25433] J. M. Yarnell, G. D. Stanley, and C. J. R. Hart. “New paleontological investigations of Upper Triassic shallow-water reef carbonates (Lewes River Group) in the Whitehorse area, Yukon". English. In: Yukon Exploration and Geology 1998. Exploration, Geological Services Division, Yukon, Indian, and Northern Affairs Canada, 1999, pp. 179-184. 
[25434] A. M. Yates. "A new species of the primitive dinosaur Thecodontosaurus (Saurischia: Sauropodomorpha) and its implications for the systematics of early dinosaurs". In: Journal of Systematic Palaeontology 1.1 (2003), pp. 1-42.

[25435] A. M. Yates. "The species taxonomy of the sauropodomorph dinosaurs from the Löwenstein Formation (Norian, Late Triassic) of Germany". English. In: Palaeontology 46.2 (2003), pp. 317-337.

[25436] A. M. Yates. "A new theropod dinosaur from the Early Jurassic of South Africa and its implications for the early evolution of theropods". English. In: Palaeontologia Africana 41 (2005), pp. 105-122.

[25437] A. M. Yates. "A second specimen of Blikanasaurus (Dinosauria: Sauropoda) and the biostratigraphy of the lower Elliot Formation". English. In: Palaeontologia africana 43 (2008), pp. 39-43.

[25438] A. M. Yates. "The first complete skull of the Triassic dinosaur Melanorosaurus Haughton (Sauropodomorpha: Anchisauria)". English. In: Special Papers in Palaeontology 77 (2007), pp. 9-55.

[25439] A. M. Yates. "Solving a dinosaurian puzzle: the identity of Aliwalia rex Galton". English. In: Historical Biology 19.1 (2007), pp. 93-123.

[25440] A. M. Yates. "A new tiny rhytidosteid (Temnospondyli: Stereospondyli) from the Early Triassic of Australia and the possibility of hidden temnospondyl diversity". English. In: Journal of Vertebrate Paleontology 20.3 (2000), pp. 484-489. DOI: 10.1671/0272-4634(2000)020[0484:ANTRTS]2.0.CO;2.

[25441] A. M. Yates. "The Lapillopsidae: a new family of small temnospondyls from the Early Triassic of Australia". English. In: Journal of Vertebrate Paleontology 19.2 (1999), pp. 302-320.

[25442] A. M. Yates. "The oldest South Australian cowries (Gastropoda: Cypraeidae) from the Paleogene of the St Vincent Basin". English. In: Alcheringa 33.1 (2009), pp. 23-31. DOI: 10.1080/03115510802618219.

[25443] A. M. Yates. "Two new cowries (Gastropoda: Cypraeidae) from the middle Miocene of South Australia". English. In: Alcheringa 32.4 (2008), pp. 353-364. DOI: 10.1080/03115510802417927.

[25444] A. M. Yates. "The biochronology and palaeobiogeography of Baru (Crocodylia: Mekosuchinae) based on new specimens from the Northern Territory and Queensland, Australia". English. In: PeerJ 5 (2017), e3458:1-45. DOI: 10.7717/peerj.3458.

[25445] A. M. Yates. "A new species of long-necked turtle (Pleurodira: Chelidae: Chelodina) from the late Miocene Alcoota Local Fauna, Northern Territory, Australia". English. In: PeerJ 1:e170 (2013), pp. 1-24.

[25446] A. M. Yates, M. F. Bonnan, J. Neveling, A. Chinsamy, and M. G. Blackbeard. "A new transitional sauropodomorph dinosaur from the Early Jurassic of South Africa and the evolution of sauropod feeding and quadrupedalism". English. In: Proceedings of The Royal Society B 277.1682 (2010), pp. 787-794. DOI: 10.1098/rspb.2009.1440.

[25447] A. M. Yates, M. F. Bonnan, and J. Neveling. "A new basal sauropodomorph dinosaur from the Early Jurassic of South Africa". English. In: Journal of Vertebrate Paleontology 31.3 (2011), pp. 610625.

[25448] A. M. Yates and J. W. Kitching. "The earliest known sauropod dinosaur and the first steps towards sauropod locomotion". In: Proceedings of the Royal Society of London B 270.1525 (2003), pp. 17531758.

[25449] A. M. Yates and N. S. Pledge. "A Pliocene mekosuchine (Eusuchia: Crocodilia) from the Lake Eyre Basin of South Australia". English. In: Journal of Vertebrate Paleontology 37.1 (2017), e1244540:1-15. DOI: $10.1080 / 02724634.2017 .1244540$.

[25450] A. M. Yates and D. P. Sengupta. "A lapillopsid temnospondyl from the Early Triassic of India". English. In: Alcheringa 26 (2002), pp. 201-208.

[25451] M. Yazdi, A. Bahrami, and J. Leloux. "Funginella? isfahanensis n. sp. from the upper Albian of Iran". English. In: Revista Mexicana de Ciencias Geológicas 28.2 (2011), pp. 226-234.

[25452] M. Yazdi-Moghadam. "Early Oligocene Larger Foraminiferal Biostratigraphy of the Qom Formation, South of Uromieh (NW Iran)". English. In: Turkish Journal of Earth Sciences 20.6 (2011), pp. 847856. DOI: 10.3906/yer-0910-6. 
[25453] E. A. Yazykova, D. Peryt, and T. D. Zonovia. “The Cenomanian/Turonian boundary in Sakhalin, Far East Russia: ammonites, inoceramids, foraminifera, and radiolarians". English. In: New Zealand Journal of Geology and Geophysics 47 (2004), pp. 291-320.

[25454] J. Ye, J. Meng, and W. -Y. Wu. "Discovery of Paraceratherium in the northern Junggar Basin of Xinjiang". English. In: Vertebrata PalAsiatica 41.3 (2003), pp. 220-229.

[25455] J. Ye, J. Meng, W. -Y. Wu, and S. -Y. Wu. "The discovery of Late Eocene mammal fossils from Burqin of Xinjiang". English. In: Vertebrata PalAsiatica 40.3 (2002), pp. 203-210.

[25456] J. Ye, J. Meng, W. -Y. Wu, and X. -J. Ni. "Late Eocene-early Oligocene lithological and biological Stratigraphy in the Burqin region of Xinjiang". English. In: Vertebrata PalAsiatica 43.1 (2005), pp. 49-60.

[25457] X. N. Ye, G. Yao, C. K. Shih, D. Ren, and Y. J. Wang. "New bee flies from the mid-Cretaceous Myanmar amber (Brachycera: Asiloidea: Bombyliidae)". English. In: Cretaceous Research 100 (2019), pp. 513. DOI: 10.1016/j.cretres.2019.03.026.

[25458] Y. Ye. "A new genus of Sinemydidae from the Late Jurassic of Neijiang, Sichuan". Chinese. In: Vertebrata PalAsiatica 37.2 (1999), pp. 81-87.

[25459] Y. Ye, Y.-H. Gao, and S. Jiang. "A new genus of sauropod from Zigong, Sichuan". Chinese. In: Vertebrata PalAsiatica 43.3 (2005), pp. 175-181.

[25460] Y. Ye and X. Pi. "[A new genus of Chengyuchelyidae from Dashanpu, Zigong, Sichuan]". Chinese. In: Vertebrata PalAsiatica 35.3 (1997), pp. 182-188.

[25461] D. K. Yeates and D. Grimaldi. "A new Metatrichia window fly (Diptera: Scenopinidae) in Dominican amber, with a review of the systematics and biogeography of the genus". English. In: American Museum Novitates 3078 (1993), pp. 1-8.

[25462] A. N. Yegorov and L. E. Popov. "A new Lower Permian lingulid from the Siberian Platform". English. In: Paleontological Journal 24.4 (1990), pp. 107-112.

[25463] H.-K. Yeh. "Fossil turtles from Dashanpu, Zigong, Sichuan". Chinese. In: Vertebrata PalAsiatica 28.4 (1990), pp. 305-311.

[25464] K.-Y. Yeh. “Taxonomic studies of Triassic radiolaria from Busuanga Island, Philippines”. English. In: Bulletin of National Museum of Natural Science, Taichung, Taiwan 2 (1990), pp. 155-63.

[25465] K.-Y. Yeh and Y.-N. Cheng. "Radiolarians from the Lower Jurassic of the Busuanga Island, Philippines". English. In: Bulletin of the National Museum of Natural Science (Taiwan) 11 (1998), pp. 1-65.

[25466] J. E. Yellen, A. S. Brooks, E. Cornelissen, M. Mehlman, and K. Stewart. A middle stone age worked bone industry from Katanda, Upper Semliki Valley,Zaire. 1995.

[25467] L. Yeomans and T. Richter. "Exploitation of a seasonal resource: bird hunting during the late Natufian at Shubayqa 1". English. In: International Journal of Osteoarchaeology 28 (2018), pp. 95-108.

[25468] H. Yi, J. P. Tennant, M. T. Young, T. J. Challands, D. Foffa, J. D. Hudson, D. A. Ross, and S. L. Brusatte. "An unusual small-bodied crocodyliform from the Middle Jurassic of Scotland, UK, and potential evidence for an early diversification of advanced neosuchians". English. In: Earth and Environmental Science Transactions of the Royal Society of Edinburgh (2017). DOI: 10.1017/S1755691017000032.

[25469] W. J. Yi. "Ostracodes from the Upper Permian and Lower Triassic at the Kongtongshan section of Datian, Fujian". Chinese. In: Acta Palaeontologica Sinica 43 (2004), pp. 556-570.

[25470] W. J. Yi. "Ostracode fauna from Lower Permian Chihsia Formation of Guangping in Datian, Fujian". Chinese. In: Acta Palaeontologica Sinica 32.5 (1993), pp. 561-586.

[25471] I. O. Yilmaz. "Taxonomic and Paelogeographic Approaches to the Dasyclad Algae in the Upper Jurassic (Kimmeridgian)-Upper Cretaceous (Cenomanian) Peritidal Carbonates of the Fele (YassÝbel) Area (Western Taurides, Turkey)". English. In: Turkish Journal of Earth Sciences 8 (1999), pp. 81101.

[25472] G. Yin, R. P. Tripp, Z. Zhou, and W. Yuan. "Trilobites and biofacies of the Ordovician Pagoda Formation, Donggongsi of Zunyi, Guizhou Province, China". English. In: Transactions of the Royal Society of Edinburgh 90 (1999), pp. 203-220. 
[25473] J. Yin and J. A. Grant-Mackie. "Late Triassic-Jurassic bivalves from volcanic sediments of the Lhasa block, Tibet". English. In: New Zealand Journal of Geology and Geophysics 48 (2005), pp. 555576.

[25474] J. Yin and C. A. McRoberts. "Latest Triassic-earliest Jurassic bivalves of the Germig formation from Lanongla (Tibet, China)". English. In: Journal of Paleontology 80.1 (2006), pp. 104-120.

[25475] J. Yin, P. L. Smith, J. Pálfy, and R. Enay. "Ammonoids and the Triassic/Jurassic boundary in the Himalayas of southern Tibet". English. In: Palaeontology 50.3 (2007), pp. 711-737.

[25476] J. Yin, H. Yao, and J. Sha. "First record of the Early Jurassic Lupherella fauna (Bivalvia) in eastern Guangdong, southeast China". English. In: New Zealand Journal of Geology E Geophysics 47 (2004), pp. 321-326.

[25477] Z. Yin, M. Zhu, E. H. Davidson, D. J. Bottjer, F. Zhao, P, and Tafforeau. "Sponge grade body fossil with cellular resolution dating $60 \mathrm{Myr}$ before the Cambrian". English. In: Proceedings of the National Academy of Science (2015). DOI: 10.1073/pnas.1414577112.

[25478] Z. W. Yin, C. Y. Cai, D. Y. Huang, and L. Z. Li. "Specialized adaptations for springtail predation in Mesozoic beetles". English. In: Scientific Reports 7.98 (2017), pp. 1-7.

[25479] Z. W. Yin, C. Y. Cai, D. Y. Huang, and L. Z. Li. "A second species of the genus Cretoleptochromus Cai \& Huang (Coleoptera: Staphylinidae: Scydmaeninae) from mid-Cretaceous Burmese amber". English. In: Cretaceous Research 75 (2017), pp. 115-119.

[25480] Z. W. Yin, C. Y. Cai, and D. Y. Huang. "Last major gap in scydmaenine evolution filled (Coleoptera: Staphylinidae)". English. In: Cretaceous Research 84 (2017), pp. 62-68.

[25481] Z. W. Yin, C. Y. Cai, and D. Y. Huang. "New zorapterans (Zoraptera) from Burmese amber suggest higher paleodiversity of the order in tropical forests". English. In: Cretaceous Research 84 (2017), pp. $168-172$.

[25482] Z. W. Yin, C. Y. Cai, and A. F. Newton. "Beetle with long 'nose' - A bizarre stem scydmaenine in amber from". English. In: Cretaceous Research 89 (2018), pp. 98-106.

[25483] Z. W. Yin, C. Y. Cai, and D. Y. Huang. "A potentially diverse fauna of springtail-hunting scydmaenines during the late Mesozoic (Coleoptera, Staphylinidae, Scydmaeninae)". English. In: Cretaceous Research 90 (2018), pp. 163-167.

[25484] Z. W. Yin, C. Y. Cai, D. Y. Huang, and M. S. Engel. "Zorotypus dilaticeps sp. nov., a remarkable zorapteran (Zoraptera) in mid-Cretaceous Burmese amber". English. In: Cretaceous Research 91 (2018), pp. 126-130.

[25485] Z. W. Yin and C. Y. Cai. “A new fossil species of Euroleptochromus Jaoszyski (Coleoptera: Staphylinidae: Scydmaeninae) from Eocene Baltic amber". English. In: Zootaxa 4500 (2018), pp. 146-150.

[25486] Z. W. Yin and C. Y. Cai. "A new species of minute Scydmaenini (Coleoptera: Staphylinidae: Scydmaeninae) in mid-Cretaceous amber from Myanmar". English. In: Cretaceous Research 101 (2019), pp. 70-75. DOI: 10.1016/j.cretres.2019.05.001.

[25487] Z. W. Yin, S. A. Kurbatov, G. Cuccodoro, and C. Y. Cai. “Cretobrachygluta gen. nov., the first and oldest Brachyglutini in mid-Cretaceous amber from Myanmar (Coleoptera: Staphylinidae: Pselaphinae)". English. In: Acta Entomologica Musei Nationalis Pragae 59 (2019), pp. 101-106. DOI: 10.2478/aemnp-2019-0008.

[25488] Z. W. Yin, J. Parker, C. Y. Cai, D. Y. Huang, and L. Z. Li. "A new stem bythinine in Cretaceous Burmese amber and early evolution of specialized predatory behaviour in pselaphine rove beetles (Coleoptera: Staphylinidae)". English. In: Journal of Systematic Palaeontology 16 (2017), pp. 531-541.

[25489] Z. W. Yin, D. Y. Zhou, C. Y. Cai, D. Y. Huang, and M. S. Engel. "Pangusyndicus gen. nov.: a new mid-Cretaceous scydmaenine with reduced antennae and prothoracic gland (Coleoptera, Staphylindiae: Scydmaeninae)". English. In: Journal of Systematic Palaeontology 17 (2018), pp. 909 921. 
[25490] Z. W. Yin, D. Y. Zhou, and C. Y. Cai. “The genus Scydmobisetia Jaoszyski \& Yamamoto, 2016 in Upper Cretaceous Burmese amber (Coleoptera, Staphylinidae, Scydmaeninae)". English. In: Entomologische Blätter und Coleoptera 114 (2018), pp. 483-490.

[25491] Z. W. Yin, D. Y. Zhou, C. Y. Cai, and A. F. Newton. "Transitional fossils illuminate early evolution of the ant-like stone beetle tribe Leptomastacini (Coleoptera: Staphylinidae: Scydmaeninae)". English. In: Journal of Systematic Palaeontology 17 (2019), pp. 2031-2042. DOI: 10.1080/14772019.2019. 1584924.

[25492] E. L. Yochelson. "Macroscenella (Mollusca) from the Middle Ordovician of Wisconsin - a reinterpretation and reassignment". English. In: Journal of Paleontology 68.6 (1994), pp. 1252-1256.

[25493] E. L. Yochelson and G. F. Webers. "A restudy of the Late Cambrian molluscan fauna of Berkey (1898) from Taylors Falls, Minnesota". English. In: Minnesota Geological Survey Report of Investigations 64 (2006), pp. 1-60.

[25494] E. A. Yolkin, A. I. Kim, K. Weddige, J. A. Talent, and M. R. House. "The basal Emsian GSSP in Zinzil'ban Gorge, Uzbekistan". In: Courier Forschungs-Institut Senckenberg 225 (2000), pp. 17-25.

[25495] E. K. Yoo. “Carboniferous Mollusca from the Tamworth Belt, New South Wales, Australia". English. In: Records of the Australia Museum 46.2 (1994), pp. 63-120. DOI: 10.3853/j.0067-1975.46.1994. 18.

[25496] K. Yoshida, T. Kimura, and Y. Hasegawa. "New cetothere (Cetacea: Mysticeti) from the Miocene Chichibumachi Group, Japan". English. In: Bulletin of the Saitama Museum of Natural History 20-21 (2003), pp. 1-10.

[25497] H. Yoshikazu, K. Toshiyiku, and K. Yoshiki. "Fossil physeterid from the Miocene Urizura Formation, Taga Group, Ibaraki, Japan". English. In: Bulletin of the Gunma Museum of Natural History 10 (2006), pp. 25-36.

[25498] K. Yoshino and A. Matsuoka. "Mode of occurrence and taphonomy of the heteromorph ammonite Pravitoceras sigmoidale Yabe from the Upper Cretaceous Izumi Group, Japan". English. In: Cretaceous Research 62 (2016), pp. 74-85.

[25499] K. Yoshizawa and C. Leinhard. "Bridging the gap between chewing and sucking in the hemipteroid insects: new insights from Cretaceous amber". English. In: Zootaxa 4079 (2016), pp. 229-245.

[25500] K. Yoshizawa and C. Lienhard. "+Cormopsocidae: A new family of the suborder Trogiomorpha (Insecta: Psocodea) from Burmese amber". English. In: Entomological Science 23 (2020), pp. 208-215. DOI: $10.1111 /$ ens.12414.

[25501] H. You and Z. Dong. "A new protoceratopsid (Dinosauria: Neoceratopsia) from the Late Cretaceous of Inner Mongolia, China". English. In: Acta Geologica Sinica 77.3 (2003), pp. 299-303.

[25502] H. You, Q. Ji, M. C. Lamanna, J. Li, and Y. Li. "A titanosaurian sauropod dinosaur with opsithocoelous caudal vertebrae from the early Late Cretaceous of Liaoning province, China". English. In: Acta Geologica Sinica 78.4 (2004), pp. 907-911.

[25503] H. You, Q. Ji, J. Li, and Y. Li. "A new hadrosauroid dinosaur from the mid-Cretaceous of Liaoning, China". English. In: Acta Geologica Sinica 77.2 (2003), pp. 148-154.

[25504] H. You, Q. Ji, and D. Li. "Lanzhousaurus magnidens gen. et sp. nov. from Gansu Province, China: the largest-toothed herbivorous dinosaur in the world". English. In: Geological Bulletin of China 24.9 (2005), pp. 785-794.

[25505] H. You, D. Li, Q. Ji, M. C. Lamanna, and P. Dodson. “On a new genus of basal neoceratopsian dinosaur from the Early Cretaceous of Gansu Province, China". English. In: Acta Geologica Sinica 79.5 (2005), pp. 593-597.

[25506] H. You, D. Li, L. Zhou, and Q. Ji. "Huanghetitan liujiaxiaensis, a new sauropod dinosaur from the Lower Cretaceous Hekou Group of Lanzhou Basin, Gansu Province, China". English. In: Geological Review 52.5 (2006), pp. 668-674.

[25507] H. You, D. Li, and W. Liu. "A new hadrosauriform dinosaur from the Early Cretaceous of Gansu Province, China". English. In: Acta Geologica Sinica 85.1 (2011), pp. 51-57. 
[25508] H. You, E. M. Morschhauser, D. Li, and P. Dodson. "Introducing the Mazongshan Dinosaur Fauna". English. In: Auroraceratops rugosus (Ornithischia, Ceratopsia) from the Early Cretaceous of northwestern Gansu Province, China. Society of Vertebrate Paleontology Memoir 18. Journal of Vertebrate Paleontology 38.supplement (2019), pp. 1-11. DOI: 10.1080/02724634.2017.1396995.

[25509] H. You, J. O'Connor, L. M. Chiappe, and Q. Ji. "A new fossil bird from the Early Cretaceous of Gansu Province, northwestern China". English. In: Historical Biology 17 (2005), pp. 7-14. DOI: 10.1080/08912960500284851.

[25510] H. You, F. Tang, and Z. Luo. "A new basal titanosaur (Dinosauria: Sauropoda) from the Early Cretaceous of China". English. In: Acta Geologica Sinica 77.4 (2003), pp. 424-429.

[25511] H. You, X. Xu, and X. Wang. "A new genus of Psittacosauridae (Dinosauria: Ornithopoda) and the origin and early evolution of marginocephalian dinosaurs". English. In: Acta Geologica Sinica 77.1 (2003), pp. 15-20.

[25512] H.-L. You, Y. Azuma, T. Wang, Y. -M. Wang, and Z. -M. Dong. "The first well-preserved coelophysoid theropod dinosaur from Asia". English. In: Zootaxa 3873.3 (2014), pp. 233-249.

[25513] H.-L. You and D.-Q. Li. “The first well-preserved Early Cretaceous brachiosaurid dinosaur in Asia". English. In: Proceedings of the Royal Society B 276.1675 (2009), pp. 4077-4082. DOI: 10.1098/ rspb.2009.1278.

[25514] H.-l. You, D.-q. Li, L. -q. Zhou, and Q. Ji. “Daxiatitan binglingi: a giant sauropod dinosaur from the Early Cretaceous of China". English. In: Gansu Geology 17.4 (2008), pp. 1-10.

[25515] H.-L. You and D.-Q. Li. "A new basal hadrosauriform dinosaur (Ornithischia: Iguanodontia) from the Early Cretaceous of northwestern China". English. In: Canadian Journal of Earth Sciences 46 (2009), pp. 949-957. DOI: 10.1139/E09-067.

[25516] H.-L. You, Z.-X. Luo, N. H. Shubin, L. M. Witmer, Z. -L. Tang, and F. Tang. “The earliest-known duck-billed dinosaur from deposits of late Early Cretaceous age in northwest China and hadrosaur evolution". In: Cretaceous Research 24 (2003), pp. 348-355.

[25517] H.-L. You, K. Tanoue, and P. Dodson. "New data on cranial anatomy of the ceratopsian dinosaur Psittacosaurus major". English. In: Acta Palaeontologica Polonica 53.2 (2008), pp. 183-196.

[25518] G. A. Young, D.-J. Lee, and J. P. Noble. "Halysitid and Auloporid tabulate corals from the Gascons and West Point Formations (Silurian), Gaspe, Quebec, Canada". In: Journal of Paleontology 65.5 (1991), pp. 715-726.

[25519] G. A. Young and J. P. A. Noble. “Silurian Proporidae and Plasmoporidae (Anthozoa, Tabulata) from the Chaleurs Bay region, Canada". In: Journal of Paleontology 64.2 (1990), pp. 184-199.

[25520] G. A. Young and J. P. A. Noble. "Silurian Heliolitidae (Anthozoa, Tabulata) from the Chaleurs Bay region, Canada". In: Journal of Paleontology 64.1 (1990), pp. 44-60.

[25521] G. A. Young and J. P. A. Noble. "Silurian tabulate coral biostratigraphy and biofacies of northern New Brunswick and the southern Gaspe Peninsula". English. In: Canadian Journal of Earth Sciences 27.9 (1990), pp. 1143-1158.

[25522] G. C. Young. "An Ordovician vertebrate from western New South Wales, with comments on Cambro-Ordovician vertebrate distribution patterns". English. In: Alcheringa 33 (2009), pp. 79 89.

[25523] G. C. Young. "Ordovician Microvertebrate Remains from the Amadeus Basin, Central Australia". English. In: Journal of Vertebrate Paleontology 17.1 (1997), pp. 1-25.

[25524] G. C. Young. "An Asterolepidoid Antiarch (Placeoderm Fish) from the Early Devonian of the Georgina Basin, Central Australia". English. In: Alcheringa 8.1 (2008), pp. 65-79.

[25525] G. C. Young, V. N. Karatajute-Talimaa, and M. M. Smith. "A possible Late Cambrian vertebrate from Australia". English. In: Nature 383 (1996), pp. 810-812.

[25526] G. C. Young and J. A. Long. "New arthrodires (placoderm fishes) from the Aztec Siltstone (late Middle Devonian) of southern Victoria Land, Antarctica". English. In: Australian Journal of Zoology 62 (2014), pp. 44-62. 
[25527] G. C. Young, J. A. Long, and A. Ritchie. “Crossopterygian fishes from the Devonian of Antarctica: systematics, relationships and biogeographic significance". English. In: Records of the Australian Museum, Supplement 14 (1992), pp. 1-77.

[25528] G. C. Young and H.-P. Schultze. “New osteichthyans (bony fishes) from the Devonian of Central Australia". English. In: Mitteilungen aus dem Museum für Naturkunde in Berlin, Geowissenschaften Reihe 8 (2005), pp. 13-35.

[25529] M. T. Young. “Filling the 'Corallian Gap': re-description of a metriorhynchid crocodylomorph from the Oxfordian (Late Jurassic) of Headington, England". English. In: Historical Biology (2013). DOI: 10.1080/08912963.2012.760559.

[25530] M. T. Young and M. B. Andrade. "What is Geosaurus? Redescription of Geosaurus giganteus (Thalattosuchia: Metriorhynchidae) from the Upper Jurassic of Bayern, Germany". English. In: Zoological Journal of the Linnean Society 157.3 (2009), pp. 551-585. DOI: 10.1111/j.1096-3642.2009. 00536.x.

[25531] M. T. Young, M.B.d. Andrade, S. L. Brusatte, M. Sakamoto, and J. Liston. “The oldest known metriorhynchid super-predator: a new genus and species from the Middle Jurassic of England, with implications for serration and mandibular evolution in predacious clades". English. In: Journal of Systematic Palaeontology (2013). DOI: 10.1080/14772019.2012.704948.

[25532] M. T. Young, M.B.d. Andrade, J. -J. Cornée, L. Steel, and D. Foffa. “Re-description of a putative Early Cretaceous teleosaurid from France, with implications for the survival of metriorhynchids and teleosaurids across the Jurassic-Cretaceous Boundary". English. In: Annales de Paléontologie 100.2 (2014), pp. 165-174.

[25533] M. T. Young, S. L. Brusatte, M. Ruta, and M. B. de Andrade. "The evolution of Metriorhynchoidea (Mesoeucrocodylia, Thalattosuchia): an integrated approach using geometric morphometrics, analysis of disparity, and biomechanics". English. In: Zoological Journal of the Linnean Society 158.4 (2010), pp. 801-859. DOI: 10.1111/j.1096-3642.2009.00571.x.

[25534] M. T. Young, S. L. Brusatte, M. B. Andrade, J. B. Desojo, B. L. Beatty, L. Steel, M. S. Fernández, M. Sakamoto, J. I. Ruiz-Omeñaca, and R. R. Schoch. "The cranial osteology and feeding ecology of the metriorhynchid crocodylomorph genera Dakosaurus and Plesiosuchus from the Late Jurassic of Europe". English. In: PLoS ONE 7.9 (2012), e44985. DOI: 10.1371/journal.pone.0044985.

[25535] M. T. Young, M. B. de Andrade, S. Etches, and B. L. Beatty. "A new metriorhynchid crocodylomorph from the Lower Kimmeridge Clay Formation (Late Jurassic of England), with implications for the evolution of dermatocranium ornamentation in Geosaurini". English. In: Zoological Journal of the Linnean Society 169 (2013), pp. 820-848.

[25536] M. T. Young, A. K. Hastings, R. Allain, and T. J. Smith. "Revision of the enigmatic crocodyliform Elosuchus felixi de Lapparent de Broin, 2002 from the Lower-Upper Cretaceous boundary of Niger: potential evidence for an early origin of the clade Dyrosauridae". English. In: Zoological Journal of the Linnean Society 179.2 (2016), pp. 377-403. DOI: 10.1111/zoj.12452.

[25537] M. T. Young, S. Hua, L. Steel, D. Foffa, S. L. Brusatte, S. Thuring, O. Mateus, J. I. Ruiz-Omenaca, P. Havlik, Y. Lepage, and M. B. de Andrade. "Revision of the Late Jurassic teleosaurid genus Machimosaurus (Crocodylomorpha, Thalattosuchia)". English. In: Royal Society Open Science 1 (2014), p. 140222.

[25538] M. T. Young and L. Steel. “Evidence for the teleosaurid crocodylomorph genus Machimosaurus in the Kimmeridge Clay Formation (Late Jurassic) of England". English. In: Historical Biology (2013). DOI: 10.1080/08912963.2013.793320.

[25539] M. T. Young, L. Steel, and H. Middleton. "Evidence of the metriorhynchid crocodylomorph genus Geosaurus in the Lower Kimmeridge Clay Formation (Late Jurassic) of England". English. In: Historical Biology (2013). DOI: 10.1080/08912963.2013.801468. 
[25540] M. T. Young, L. Steel, M. P. Rigby, E. A. Howlett, and S. Humphrey. “Largest known specimen of the genus Dakosaurus (Metriorhynchidae: Geosaurini) from the Kimmeridge Clay Formation (Late Jurassic) of England, and an overview of Dakosaurus specimens discovered from this formation (including reworked specimens from the Woburn Sands Formation)". English. In: Historical Biology (2014).

[25541] M. T. Young, J. P. Tennant, S. L. Brusatte, T. J. Challands, N. C. Fraser, N. D. L. Clark, and D. A. Ross. "The first definitive Middle Jurassic atoposaurid (Crocodylomorpha, Neosuchia), and a discussion on the genus Theriosuchus". English. In: Zoological Journal of the Linnean Society 176.2 (2016), pp. 443-462.

[25542] R. G. Young. "A dinosaur nest in the Jurassic Morrison Formation, western Colorado". English. In: Guidebook for Dinosaur Quarries and Tracksites Tour, Western Colorado and Eastern Utah. Grand Junction, CO: Grand Junction Geological Society, 1991, pp. 1-15.

[25543] M. Yousefirad, T. Khamooshi, and R. Shaabanian. "Late Permian brachiopod fauna in northwestern Iran". English. In: Earth Sciences Research Journal 17 (2013), pp. 67-71.

[25544] M. Youssef and A. S. El-Sorogy. "Paleoecology of Benthic Foraminifera in Coral Reefs Recorded in the Jurassic Tuwaiq Mountain Formation of the Khashm Al-Qaddiyah Area, Central Saudi Arabia". English. In: Journal of Earth Science 26.2 (2015), pp. 224-235.

[25545] C. Yu, A. Prieto-Marquez, T. Chinzorig, Z. Badamkhatan, and M. Norell. "A neoceratopsian dinosaur from the Early Cretaceous of Mongolia and the early evolution of Ceratopsia". English. In: Communications Biology 3 (2020), 499:1-8.

[25546] K. Yu, D. Liu, C. Shen, J. Zhao, T. Chen, J. Zhong, H. Zhao, and C. Song. "High-frequency climatic oscillations recorded in a Holocene coral reef at Leizhou Peninsula, South China Sea". English. In: Science in China D 45.12 (2002), pp. 1057-1067.

[25547] W. Yu. "Early Ordovician gastropods from the Canning Basin, Western Australia". English. In: Records of the Western Australia Museum 16.3 (1993), pp. 437-458.

[25548] W. Yu. "Early Cambrian stenothecoid molluscs from China". English. In: Records of the Western Australian Museum 18 (1996), pp. 209-217.

[25549] W. Yü and E. L. Yochelson. "Some Late Cambrian molluscs from Liaoning Province, China". English. In: Records of the Western Australia Museum 19 (1999), pp. 379-389.

[25550] X. Yu. "[Characteristics of dinosaur fossils from southern Anhui and their significance for stratigraphic position]". Chinese. In: Regional Geology of China 17.3 (1998), pp. 278-284.

[25551] X. Yu. "[The occurrence features of dinosaur's fossils in the Xiuning area, south Anhui]". Chinese. In: Geology of Anhui 9.2 (1999), pp. 94-99.

[25552] Y. L. Yu, A. lipiski, R. A. B. Leschen, D. Ren, and H. Pang. “New genera and species of barkgnawing beetles (Coleoptera: Trogossitidae) from the Yixian Formation (Lower Cretaceous) of western Liaoning, China". English. In: Cretaceous Research 53 (2015), pp. 89-97.

[25553] Y. L. Yu, S. R. Davis, C. K. Shih, D. Ren, and H. Pang. "The earliest fossil record of Belidae and its implications for the early evolution of Curculionoidea (Coleoptera)". English. In: Journal of Systematic Palaeontology 17 (2019), pp. 2105-2117. DOI: 10.1080/14772019.2019.1588401.

[25554] Y. L. Yu, C. S. Deng, J. Kolibá, A. lipiski, D. Ren, J. H. Jin, and H. Pang. "The first record of Cretaceous thaneroclerids (Insecta: Coleoptera) from the Burmese amber". English. In: Annales Zoologici 67 (2017), pp. 549-554.

[25555] Y. L. Yu, Y. Hsiao, A. lipiski, J. H. Jin, D. Ren, and H. Pang. “A new Late Cretaceous genus and species of polypore fungus beetles (Coleoptera, Tetratomidae) from northern Myanmar". English. In: Cretaceous Research 68 (2016), pp. 34-39.

[25556] Y. L. Yu, R. A. B. Leschen, A. lipiski, D. Ren, and H. Pang. "The first fossil bark-gnawing beetle from the Middle Jurassic of Inner Mongolia, China (Coleoptera: Trogossitidae)". English. In: Annales Zoologici 62 (2012), pp. 245-252. 
[25557] Y. L. Yu, A. Slipiski, C. Reid, C. K. Shih, H. Pang, and D. Ren. “A new longhorn beetle (Coleoptera: Cerambycidae) from the Early Cretaceous Jehol Biota of western Liaoning in China". English. In: Cretaceous Research 52 (2015), pp. 453-460.

[25558] Y. L. Yu, A. Slipiski, H. Pang, and D. Ren. "A new genus and two new species of Buprestidae (Insecta: Coleoptera) from the Yixian Formation (Lower Cretaceous), Liaoning, China". English. In: Cretaceous Research 52 (2015), pp. 480-489.

[25559] Y. L. Yu, A. lipiski, C. K. Shih, H. Pang, and D. Ren. “A new fossil jewel beetle (Coleoptera: Buprestidae) from the Early Cretaceous of Inner Mongolia, China". English. In: Zootaxa 3637 (2013), pp. 355-360.

[25560] Y. L. Yu, A. lipiski, R. A. B. Leschen, D. Ren, and H. Pang. "Enigmatic Mesozoic bark-gnawing beetles (Coleoptera: Trogossitidae) from the Jiulongshan Formation in China". English. In: Annales Zoologici 64 (2014), pp. 667-676.

[25561] Y. L. Yu, A. lipiski, D. Ren, and H. Pang. “The first fossil Limnichidae from the Upper Cretaceous Burmese amber (Coleoptera: Byrrhoidea)". English. In: Annales Zoologici 68 (2018), pp. 843-848.

[25562] Y. L. Yu, A. lipiski, J. F. Lawrence, E. Yan, D. Ren, and H. Pang. “Reconciling past and present: Mesozoic fossil record and a new phylogeny of the family Cerophytidae (Coleoptera: Elateroidea)". English. In: Cretaceous Research 99 (2019), pp. 51-70. DOI: 10.1016/j.cretres.2019.02.024.

[25563] Y.-L. Yu, K.-B. Wang, S. -Q. Chen, C. Sullivan, S. Wang, P. -Y. Wang, and X. Xu. "A new caenagnathid dinosaur from the Upper Cretaceous Wangshi Group of Shandong, China, with comments on size variation among oviraptorosaurs". English. In: Scientific Reports 8 (2018), p. 5030. DOI: 10.1038/s41598-018-23252-2.

[25564] A. H. Yuan, S. Crasquin-Soleau, Q. L. Feng, and S. Z. Gu. "Latest Permian deep-water ostracods from southwestern Guangxi, south China". English. In: Journal of Micropalaeontology 26 (2007), pp. 169-191.

[25565] C. Yuan. "A new genus and species of Sapeornithidae from Lower Cretaceous in western Liaoning, China". English. In: Acta Geologica Sinica 82.1 (2008), pp. 48-55.

[25566] C. Yuan, L. Xu, X. Zhang, Y. Xi, Y. Wu, and Q. Ji. "A new species of Gobiconodon (Mammalia) from western Liaoning, China and its implication for the dental formula of Gobiconodon". English. In: Acta Geologica Sinica 83.2 (2009), pp. 207-211.

[25567] C.-X. Yuan, Q. Ji, Q. -J. Meng, A. R. Tabrum, and Z. -X. Luo. “Earliest Evolution of Multituberculate Mammals Revealed by a New Jurassic Fossil". English. In: Science 341 (2013), pp. 779-783.

[25568] D. D. Yuan, D. Ren, and Y. J. Wang. “New beaded lacewings (Neuroptera: Berothidae) from Upper Cretaceous Myanmar amber". English. In: Cretaceous Research 68 (2016), pp. 40-48.

[25569] J. L. Yuan and Y. Li. "Lower-Middle Cambrian boundary and trilobite fauna at Laoyingshan, Huainan, Anhui". Chinese. In: Acta Palaeontologica Sinica 38.4 (1999), pp. 407-422.

[25570] J. L. Yuan and G. Z. Yin. "New polymerid trilobites from the Chefu Formation in early Late Cambrian of eastern Guizhou". English. In: Acta Palaeontologica Sinica 37.2 (1998), pp. 137-172.

[25571] J. L. Yuan and G. Z. Yin. “On taxonomic position of Late Cambrian Protaitzehoia Yang (Trilobita)". English. In: Acta Palaeontologica Sinica 40.3 (2001), pp. 343-350.

[25572] J. L. Yuan, Y. L. Zhao, and J. Q. Mao. "On a new genus Acanthophillipsia of Ditomopyginae Hupe, 1953 from Lower Permian of Guiyang, South China". Chinese. In: Acta Palaeontologica Sinica 31 (1992), pp. 39-52.

[25573] J. L. Yuan, Y. L. Zhao, Z. Z. Wang, Z. Zhen, and X. Y. Chen. "A preliminary study on Lower-Middle Cambrian boundary and trilobite fauna at Balang, Taijiang, Guizhou, south China". Chinese. In: Acta Palaeontologica Sinica 36.4 (1997), pp. 494-524.

[25574] W. W. Yuan, Z. Q. Zhou, Z. J. Zhou, and Q. J. Lia. “Proetid trilobites from the middle Telychian (Llandovery, Silurian) Ningqiang Formation, Shaanxi, China". English. In: Palaeoworld 29.4 (2020), pp. 672-681. DOI: 10.1016/j.palwor.2019.12.004. 
[25575] X. Yuan, Z. Chen, S. Xiao, C. Zhou, and H. Hua. "An early Ediacaran assemblage of macroscopic and morphologically differentiated eukaryotes". English. In: Nature 470 (2011), pp. 390-393.

[25576] X. Yuan, J. Li, and R. Cao. "A diverse metaphyte assemblage from the Neoproterozoic black shales of south China". English. In: Lethaia 32 (1999), pp. 143-155.

[25577] Y. A. Yudina. "New brachiopod species from the Upper Frasnian deposits of the South Timan". English. In: Paleontological Journal 31.3 (1997), pp. 312-320.

[25578] Y. Yue, D. Ren, and A. Solodovnikov. "The oldest fossil species of the rove beetle subfamily Oxyporinae (Coleoptera: Staphylinidae) from the Early Cretaceous (Yixian Formation, China) and its phylogenetic significance". English. In: Journal of Systematic Palaeontology 9 (2011), pp. 467-471.

[25579] Y. L. Yue, J. J. Gu, Q. Yang, J. M. Wang, and D. Ren. “The first fossil species of subfamily Piestinae (Coleoptera: Staphylinidae) from the Lower Cretaceous of China". English. In: Cretaceous Research 63 (2016), pp. 63-67.

[25580] Y. L. Yue, G. Makranczy, and D. Ren. "A Mesozoic species of Anotylus (Coleoptera, Staphylinidae, Oxytelinae) from Liaoning, China, with the earliest evidence of sexual dimorphism in rove beetles". English. In: Journal of Paleontology 86 (2012), pp. 508-512.

[25581] Y. L. Yue, D. Ren, and A. Solodovnikov. "Megolisthaerus chinensis gen. et sp.n. (Coleoptera: Staphylinidae incertae sedis ): an enigmatic rove beetle lineage from the Early Cretaceous". English. In: Insect Systematics \& Evolution 41 (2010), pp. 317-327.

[25582] Y. L. Yue, Y. Y. Zhao, and D. Ren. “Three new Mesozoic staphylinids (Coleoptera) from Liaoning, China”. English. In: Cretaceous Research 31 (2010), pp. 61-70.

[25583] Y. L. Yue, Y. Y. Zhao, and D. Ren. "Glabrimycetoporus amoenus, a new tachyporine genus and species of Mesozoic Staphylinidae (Coleoptera) from Liaoning, China". English. In: Zootaxa 2225 (2009), pp. 63-68.

[25584] Z. Yue. "Early Cambrian small shelly fossil Sinosachites from southwest China". English. In: Acta Palaeontologica Sinica 43.2 (2004), pp. 164-178.

[25585] J. Yugan, C. H. C. Brunton, and S. S. Lazarev. “Gondolininae, a new Carboniferous productide brachiopod subfamily". In: Journal of Paleontology 72.1 (1998), pp. 7-10.

[25586] C.-g. Yun. "Teihivenator gen. nov., a new generic name for the tyrannosauroid dinosaur Laelaps macropus (Cope, 1868; preoccupied by Koch, 1836)". English. In: Journal of Zoological and Bioscience Research 4.2 (2017), pp. 7-13.

[25587] C.-g. Yun. "A subadult frontal of Daspletosaurus torosus (Theropoda: Tyrannosauridae) from the Late Cretaceous of Alberta, Canada with implications for tyrannosaurid ontogeny and taxonomy". English. In: Palarch's Journal of Vertebrate Palaeontology 17.2 (2020), pp. 1-13.

[25588] C.-S. Yun. “Ordovician cephalopods from the Maggol Formation of Korea”. English. In: Paleontological Research 3.3 (1999), pp. 202-221.

[25589] C.-S. Yun. "Three Ordovician cephalopods from the Jigunsan Formation of Korea". English. In: Paleontological Research 3.2 (1999), pp. 65-80.

[25590] C.-S. Yun, J.-D. Lim, and S. -Y. Yang. “The first crocodyliform (Archosauria: Crocodylomorpha) from the Early Cretaceous of Korea". English. In: Current Science 86.9 (2004), pp. 1200-1201.

[25591] H. Yun, X. Zhang, L. Li, M. Zhang, and W. Liu. "Skeletal fossils and microfacies analysis of the lowermost Cambrian in the southwestern margin of the North China Platform". English. In: Journal of Asian Earth Sciences 129 (2016), pp. 54-66. DOI: 10.1016/j.jseaes.2016.07.029.

[25592] N. N. Yunakov and A. G. Kirejtshuk. "New genus and species of broad-nosed weevils from Baltic amber and notes on fossils of the subfamily Entiminae (Coleoptera, Curculionidae)". English. In: ZooKeys 160 (2011), pp. 73-96.

[25593] T. S. Yurtsever, U. K. Tekin, and I. H. Demirel. "First evidence of the Cenomanian/Turonian boundary event (CTBE) in the Alakircay Nappe of the Antalya Nappes, southwest Turkey". English. In: Cretaceous Research 24 (2003), pp. 41-53. 
[25594] P. M. P. Zaborski. “Some Upper Cretaceous ammonites from southern Nigeria”. English. In: Journal of African Earth Sciences 10.3 (1990), pp. 565-581.

[25595] P. M. P. Zaborski and N. J. Morris. "The Late Cretaceous ammonite genus Libycoceras in the Iullemmeden Basin (West Africa) and its palaeogeographical significance". English. In: Cretaceous Research 20 (1999), pp. 63-79.

[25596] G. G. Zacarias, M. S. de la Fuente, M. S. Fernandez, and A. E. Zurita. “Nueva especie de tortuga terrestre gigante del género Chelonoidis Fitzinger, 1835 (Cryptodira: Testudinidae), del miembro inferior de la FormacióN Toropí/ Yupoí (Pleistoceno Tardío/ Lujanense), Bella Vista, Corrientes, Argentina". Spanish. In: Ameghiniana 50.3 (2013), pp. 298-318.

[25597] G. G. Zacarias, M. S. de la Fuente, and A. E. Zurita. “Testudinoidea Fitzinger (Testudines: Cryptodira) de la Formación Torop/Yupo (ca. 58-28 ka) en la provincia de Corrientes, Argentina: taxonoma y aspectos paleoambientales". Spanish. In: Revista Brasileira de Paleontologia 17.3 (2014), pp. 389-404. DOI: 10.4072/rbp.2014.3.09.

[25598] G. G. Zacarias, A. R. Miño-Boilini, A. E. Zurita, and A. Francia. "Campamento Vespucio, una nueva localidad con mamferos pleistocenos en la provincia de Salta, Argentina". English. In: Estudios Geologicos 68.2 (2012), pp. 277-285. DOI: 10.3989/egeol.40472.147.

[25599] L. G. Zachos. “Type locality designation for the Middle Eocene echinoid Fibularia texana (Twitchell)”. English. In: Journal of Paleontology 64.4 (1990), p. 659.

[25600] L. G. Zachos and A. Molineux. "Echinoid fauna from a Late Oligocene (Chattian) reef at Damon Mound, Brazoria County, Texas". English. In: Palaeogeography, Palaeoclimatology, Palaeoecology 243 (2007), pp. 79-91.

[25601] L. G. Zachos, A. Smadi, and F. Ahmad. "Oligocene Echinoids from Wadi Al Ghadaf, Jordan". English. In: Rivista Italiana di Paleontologia e Stratigrafia 114.1 (2008), pp. 41-49.

[25602] S. P. Zack. "The first North American Propterodon (Hyaenodonta: Hyaenodontidae), a new species from the late Uintan of Utah". English. In: PeerJ 7.e8136 (2019), pp. 1-32. DOI: 10.7717/ peerj.8136.

[25603] S. P. Zack, T. A. Penkrot, D. W. Krause, and M. C. Maas. "A new apheliscine condylarth mammal from the late Paleocene of Montana and Alberta and the phylogeny of hyopsodontids". English. In: Acta Palaeontologica Polonica 50.4 (2005), pp. 809-830.

[25604] S. P. Zack, K. D. Rose, L. T. Holbrook, K. Kumar, R. S. Rana, and T. Smith. “An enigmatic new ungulatelike mammal from the early Eocene of India". English. In: Papers in Palaeontology (2019). DOI: $10.1002 /$ spp2.1288.

[25605] I. Zagora and K. Zagora. "Ein Werrakarbonat (Ca1) - Riff im deutschen Anteil der Ostsee". German. In: Freiberger Forschungshefte C466 (1997), pp. 19-31.

[25606] K. Zagorsek. "New Anisian (Middle Triassic) Bryozoa (Trepostomata) from the Vysoka Formation (Male Karpaty Mts., western Carpathians) Slovakia". In: Geologica Carpathica 44.1 (1993), pp. 4958.

[25607] K. Zagorsek, S. Filipescu, and K. Holcová. "New Middle Miocene Bryozoa from Garbova de Sus (Romania) and their relationship to the sedimentary environment". English. In: Geologica Carpathica 61.6 (2010), pp. 495-512. DOI: 10.2478/v10096-010-0031-2.

[25608] K. Zagorsek and K. Holcova. "A bryozoan and foraminifera association from the Miocene of Podbrezice, south Moravia (Czech Republic): an environmental history". English. In: Bryozoan Studies 2004. Leiden: A.A. Balkema Publishers, 2005, pp. 383-396.

[25609] K. Zágorek and A. Kroh. "Cretaceous Bryozoa from Scharrergraben (Santonian, Gosau Group, Eastern Alps)". English. In: Geologica Carpathica 54.6 (2003), pp. 395-407.

[25610] H. Zaher, D. Pol, A. B. Carvalho, P. M. Nascimento, C. Riccomini, P. Larson, R. Juarez-Valieri, R. Pires-Domingues, N. J. da Silva, and D.d.A. Campos. "A complete skull of an Early Cretaceous sauropod and the evolution of advanced titanosaurians". English. In: PLoS One 6.2 (2011), e16663:1-10. DOI: 10.1371/journal.pone.0016663. 
[25611] H. Zaher, D. Pol, A. B. Carvalho, C. Riccomini, D. Campos, and W. Nava. "Redescription of the Cranial Morphology of Mariliasuchus amarali, and Its Phylogenetic Affinities (Crocodyliformes, Notosuchia)". English. In: American Museum Novitates 3512 (2006), pp. 1-40.

[25612] M. Zahner and W. Brinkmann. "A Triassic averostran-line theropod from Switzerland and the early evolution of dinosaurs". English. In: Nature Ecology \& Evolution 3 (2019), pp. 1146-1152. DOI: 10.1038/s41559-019-0941-z.

[25613] P. Zahradnk and J. Háva. "New Ptinidae (Coleoptera: Bostrichoidea) from Baltic amber with a list of known fossil species". English. In: Studies and Reports, Taxonomical Series 10 (2014), pp. 629-646.

[25614] P. Zahradnk and J. Háva. "Two new Stephanopachys species from Baltic amber (Coleoptera: Bostrichoidea: Bostrichidae)". English. In: Studies and Reports, Taxonomical Series 11 (2015), pp. 433435.

[25615] P. Zahradnk and J. Háva. "Three new species of Trichodesma LeConte, 1861 from Baltic amber (Coleoptera: Ptinidae: Anobiinae)". English. In: Folia Heyrovskyana, Series A 25 (2017), pp. 89-92.

[25616] P. Zahradnk and J. Háva. "Gastrallus michalskii sp. nov., a new species of tribe Gastrallini (Coleoptera: Ptinidae) from Eocene Baltic amber". English. In: Acta Biologica Universitatis Daugavpiliensis 19 (2019), pp. 231-233.

[25617] J. A. Zajic, A. R. Milner, and J. Klembara. "The first partially articulated amphibian (Temnospondlyi: Dissorophoidea) from the Line Formation (Stephanian C, central Bohemia)". English. In: Vestnik Ustredniho Ustavu Geologickeho 65 (1990), pp. 329-337.

[25618] V. A. Zakharov, F. Baudin, O. S. Dzyuba, V. Daux, K. V. Zverev, and M. Renard. "Isotopic and faunal record of high paleotemperatures in the Kimmeridgian of Subpolar Urals". English. In: Russian Geology and Geophysics 46.1 (2005), pp. 3-20.

[25619] V. A. Zakharov and A. A. Kasumzade. “On the boreal genus Buchia (Bivalvia) from the Tithonian of the lesser Caucasus". English. In: Stratigraphy and Geological Correlation 13.6 (2005), pp. 606-612.

[25620] V. A. Zakharov, V. A. Kazanenkov, and Y. I. Bogomolov. "Biostratigraphy of the Neocomian of the northern Ob' region". English. In: Russian Geology and Geophysics 40.8 (1999), pp. 1117-1129.

[25621] Y. D. Zakharov. "Carnian and Norian Sirenitid ammonoids of the north-western circum-Pacific and their role in the Late Triassic faunal successions". English. In: Memoires de Geologie (Lausanne) 30 (1997), pp. 137-144.

[25622] Y. D. Zakharov. "Examples of Late Olenekian invertebrate successions: Paper 2. Arctic Siberia (Mengilyakh Creek)". English. In: Albertiana 35 (2007), pp. 52-58.

[25623] Y. D. Zakharov. "Ammonoid succession of Setorym River (Verkhoyansk area) and problem of Permian-Triassic boundary in Boreal Realm". English. In: Journal of China University of Geosciences 13 (2002), pp. 107-123.

[25624] Y. D. Zakharov. "Systematic palaeontology, in Latest Permian and Triassic carbonates of Russia: new palaeontological findings, stable isotopes, Ca-Mg ratio, and correlation". English. In: Developments in Palaeontology and Stratigraphy 18 (2000), pp. 141-171. DOI: 10.1016/S0920-5446(00)80010-2.

[25625] Y. D. Zakharov, L. G. Bondarenko, O. P. Smyshlyaeva, and A. M. Popov. "Late Smithian (Early Triassic) ammonoids from the Anasibirites nevolini zone of South Primorye, Russian far east". English. In: New Mexico Museum of Natural History and Science Bulletin 61 (2013), pp. 597-612.

[25626] Y. D. Zakharov, M. E. Melnikov, A. M. Popov, S. P. Pletnev, V. D. Khudik, and T. A. Punina. "Cephalopod and brachiopod fossils from the Pacific: Evidence from the Upper Cretaceous of the Magellan Seamounts". English. In: Geobios 45 (2012), pp. 145-156.

[25627] Y. D. Zakharov, M. Mousavi Abnavi, M. Yazdi, and M. Ghaedi. “New species of Dzhulfian (Late Permian) ammonoids from the Hambast Formation of central Iran". English. In: Paleontological Journal 44.6 (2010), pp. 614-621.

[25628] Y. D. Zakharov and N. Moussavi Abnavi. "The ammonoid recovery after the endPermian mass extinction: Evidence from the IranTranscaucasia area, Siberia, Primorye, and Kazakhstan". English. In: Acta Palaeontologica Polonica 58 (2013), pp. 127-147. 
[25629] Y. D. Zakharov and L. Mu. "Systematic palaeontology, in Roadoceras (Permian Ammonoidea) from the Qubuerga Formation in the Mt Everest area in southern Tibet". English. In: Gondwana Research 7 (2004), pp. 863-869.

[25630] Y. D. Zakharov, A. Oleinikov, and G. V. Kotlyar. Late Changxingian ammonoids, bivalves, and brachiopods in South Primorye. English. Late Palaeozoic and Early Mesozoic Circum-Pacific Events and Their Global Correlation. 1997, pp. 142-146.

[25631] Y. D. Zakharov, A. M. Popov, and G. I. Buryi. “Triassic Ammonoid succession in South Primorye: 2. Middle Olenekian Tirolites - Amphistephanites Zone". In: Albertiana 29 (2004), pp. 29-37.

[25632] Y. D. Zakharov, A. M. Popov, and G. I. Buryi. “Triassic Ammonoid succession in South Primorye: 3. Late Olenekian - Early Anisian Zones (Neocolumbites insignis, Subcolumbites multiformis, Ussuriphyllites amurensis and Leiophyllites pradyumna)". English. In: Albertiana 31 (2004), pp. 5464.

[25633] Y. D. Zakharov and A. M. Popov. "Examples of Late Olenekian invertebrate successions: Paper 1. Western Tethys (Dolnapa, Mangyshlak)". English. In: Albertiana 35 (2007), pp. 46-51.

[25634] Y. D. Zakharov, A. M. Popov, and A. S. Biakov. "Late Permian to Middle Triassic palaeogeographic differentiation of key ammonoid groups: evidence from the former USSR". English. In: Polar Research 27 (2008), pp. 441-468.

[25635] Y. D. Zakharov, Y. Shigeta, A. M. Popov, G. I. Buryi, A. V. Oleinikov, E. A. Dorukhovskaya, and T. M. Mikhalik. "Triassic Ammonoid succession in South Primorye: 1. Lower Olenekian Hedenstroemia bosphorensis and Anasibirites nevolini Zones". English. In: Albertiana 27 (2002), pp. 4264.

[25636] Y. D. Zakharov and O. P. Smyshlyaeva. "New middle Olenekian (Early Triassic) ammonoids of South Primorye". English. In: Paleontological Journal 50 (2016), pp. 229-238.

[25637] Y. D. Zakharov and Y. Shigeta. "Gyronautilus, a new genus of Triassic Nautilida from South Primorye, Russia". English. In: Paleontological Research 4.4 (2000), pp. 231-234.

[25638] Yu.D. Zakharov, M. S. Arkhangelsky, N. G. Zverkov, I. V. Borisov, and A. M. Popov. “Age of Beds with Ichthyosaur Tholodus in South Primorye". English. In: Russian Journal of Pacific Geology 9.5 (2015), pp. 390-397. DOI: 10.1134/S1819714015050073.

[25639] M. Zakrevskaya. "Paleoecological reconstruction of the Ediacaran benthic macroscopic communities of the White Sea (Russia)". English. In: Palaeogeography, Palaeoclimatology, Palaeoecology 410 (2014), pp. 27-38. DOI: 10.1016/j.palaeo.2014.05.021.

[25640] M. Zakrzewska and W. Gika. "In the Eocene, the extant genus Caladomyia occurred in the Palaearctic (Diptera: Chironomidae: Tanytarsini)". English. In: Polish Journal of Entomology 82 (2013), pp. 397403.

[25641] M. Zakrzewska and W. Gika. "The oldest known chironomids of the tribe Tanytarsini (Diptera: Chironomidae) indicate plesiomorphic character states". English. In: Geobios 47 (2014), pp. 335343.

[25642] M. Zakrzewska and W. Gika. "The Tanytarsini (Diptera: Chironomidae) in the collection of the Museum of Amber Inclusions, University of Gdansk". English. In: Zootaxa 3946 (2015), pp. 347360.

[25643] M. Zakrzewska and W. Gika. “Eonandeva gen. nov., a new distinctive genus from Eocene Baltic amber (Diptera: Chironomidae)". English. In: Zootaxa 4044 (2015), pp. 577-584.

[25644] M. Zakrzewska, W. Krzemiski, and W. Gika. "Towards the diversity of non-biting midges of the tribe Tanytarsini from Eocene Baltic amber (Diptera: Chironomidae)". English. In: Palaeontologia Electronica 19.2.18A (2016), pp. 1-21.

[25645] M. Zakrzewska, H. Singh, E. Wagner-Wysiecka, and W. Gika. "Minute and diverse in fossil sticky stuff: Tanytarsini (Diptera: Chironomidae) from early Eocene Indian Cambay amber". English. In: Zoological Journal of the Linnean Society 189 (2020), pp. 1398-1425. DOI: 10.1093/zoolinnean/zlz159. 
[25646] M. Zakrzewska, F. Stebner, M. Puchalski, H. Singh, and W. Gika. "A peculiar leg structure in the first non-biting midge described from Cambay amber, India (Diptera: Chironomidae)". English. In: Earth and Environmental Science Transactions of the Royal Society of Edinburgh 107 (2018), pp. 255261.

[25647] R. J. Zakrzewski. "New Species of Blancan Woodrat (Cricetidae) from North-Central Kansas". English. In: Journal of Mammalogy 72.1 (1991).

[25648] J. A. Zalasiewicz and S. Tunnicliff. “Uppermost Ordovician to lower Silurian Graptolite Biostratigraphy of the Wye Valley, Central Wales". English. In: Palaeontology 37.Part 3 (1994), pp. 695-720.

[25649] I. S. Zalmout, M. S. M. Antar, E. A. Shafy, M. H. Metwally, E. -B. E. Hatab, and P. D. Gingerich. "Priabonian sharks and rays (Late Eocene: Neoselachii) from Minqar Tabaghbagh in the Western Qattara Depression, Egypt". English. In: Contributions from the Museum of Paleontology, University of MIchigan 32.6 (2012), pp. 71-90.

[25650] I. S. Zalmout and P. D. Gingerich. "Late Eocene sea cows (Mammalia, Sirenia) from Wadi al Hitan in the western desert of Fayum, Egypt". English. In: University of Michigan Papers on Paleontology 37 (2012), pp. 1-158.

[25651] I. S. Zalmout, H. A. Mustafa, and P. D. Gingerich. "Priabonian Basilosaurus isis (Cetacea) from the Wadi Esh-Shallala Formation: First marine mammal from the Eocene of Jordan". In: Journal of Vertebrate Paleontology 20.1 (2000), pp. 201-204.

[25652] I. S. Zalmout, H. A. Mustafa, and J. A. Wilson. "Karkaemys arabicus, a new side-necked turtle (Pleurodira, Bothremydidae) from the Upper Cretaceous Wadi Umm Ghudran Formation of Karak, Jordan". English. In: Contributions from the Museum of Paleontology, University of Michigan 31.6 (2005), pp. 155-177.

[25653] I. S. Zalmout, W. J. Sanders, L. M. MacLatchy, G. F. Gunnell, Y. A. Al-Mufarreh, M. A. Ali, A.A. H. Nasser, A. M. Al-Masari, S. A. Al-Sobhi, A. O. Nadhra, A. H. Matari, J. A. Wilson, and P. D. Gingerich. "New Oligocene primate from Saudi Arabia and the divergence of apes and Old World monkeys". English. In: Nature 466 (2010), pp. 360-364.

[25654] I. S. Zalmout, M. Ul-Haq, and P. D. Gingerich. “New species of Protosiren (Mammalia, Sirenia) from the early middle Eocene of Balochistan (Pakistan)". English. In: Contributions from the Museum of Paleontology, University of Michigan 31.3 (2003), pp. 79-87.

[25655] J. Zalohar, T. Hitij, and M. Kriznar. “Two new species of seahorses (Syngnathidae, Hippocampus) from the Middle Miocene (Sarmatian) Coprolitic Horizon in Tunjice Hills, Slovenia: the oldest fossil record of seahorses". English. In: Annales de Paleontologie 95 (2009), pp. 71-96.

[25656] J. Zamagni, A. Kosir, and M. Mutti. "The first microbialite-coral mounds in the Cenozoic (Uppermost Paleocene) from the Northern Tethys (Slovenia): Environmentally-triggered phase shifts preceding the PETM?" English. In: Palaeogeography, Palaeoclimatology, Palaeoecology 274.1-2 (2009), pp. 1-17.

[25657] J. Zamagni, M. Mutti, and A. Kosir. "Evolution of shallow benthic communities during the Late Paleocene-earliest Eocene transition in the Northern Tethys (SW Slovenia)". English. In: Facies 54 (2008), pp. 25-43. DOI: 10.1007/s10347-007-0123-3.

[25658] M. C. Zamaloa. "A new species of Nothofagidites, N. americanus, from Patagonia and Antarctica". English. In: Review of Palaeobotany and Palynology 72 (1992), pp. 49-53.

[25659] M. C. Zamaloa. "Miocene algae and spores from Tierra del Fuego, Argentina". English. In: Alcheringa 28.1 (2004), pp. 205-227. DOI: 10.1080/03115510408619282.

[25660] M. C. Zamaloa. "Palinoflora y ambiente en el Terciario del nordeste de Tierra del Fuego, Argentina". Spanish. In: Revista del Museo Argentino de Ciencias Naturales 2 (2000), pp. 43-51.

[25661] M. C. Zamaloa, M. A. Gandolfo, C. C. González, E. J. Romero, N. R. Cúneo, and P. Wilf. “Casuarinaceae from the Eocene of Patagonia, Argentina". English. In: International Journal of Plant Sciences 167 (2006), pp. 1279-1289. DOI: 10.1086/507873. 
[25662] M. C. Zamaloa and E. J. Romero. "Some Spores and Pollen from the Cullen Formation (Upper Eocene to Middle Oligocene), Tierra Del Fuego, Argentina". English. In: 14 (1990), pp. 123-133.

[25663] M. C. Zamaloa and E. J. Romero. "Neogene palynology of Tierra del Fuego, Argentina: conifers". English. In: Alcheringa 29 (2005), pp. 113-121. DOI: 10.1080/03115510508619563.

[25664] F. Zamani, M. Yazdi, A. Bahrami, C. Girard, C. Spalletta, and H. Ameri. "Middle Givetian to late Famennian (Middle to Late Devonian) conodonts from the northern margin of Gondwana (Kerman region, Central Iran)". English. In: Historical Biology (2020). DOI: 10.1080 / 08912963.2020. 1819997.

[25665] J. J. Zambito. Work with Thayer collections, Yale Peabody Accession 7112, published, in part, New perspectives on transitions between ecological-evolutionary subunits in the type interval for coordinated stasis, James J Zambito IV, Carlton E Brett, Gordon C Baird, Sarah E Kolbe, Arnold I Miller; Paleobiology. English. 2008.

[25666] J. J. Zambito. Field notes and samples, published, in part, New perspectives on transitions between ecologicalevolutionary subunits in the type interval for coordinated stasis, James J Zambito IV, Carlton E Brett, Gordon C Baird, Sarah E Kolbe, Arnold I Miller; Paleobiology. English. 2008.

[25667] J. C. Zamboni. "Contribution to the knowledge of the aquatic paleoentomofauna from Santana Formation (Araripe basin, Lower Cretaceous, northeast Brazil) with description of new taxa". English. In: Acta Geologica Leopoldensia 24.52/53 (2001), pp. 129-135.

[25668] M. Zammit. "Australasia's first Jurassic ichthyosaur fossil: an isolated vertebra from the Lower Jurassic Arataura Formation of North Island, New Zealand". English. In: Alcheringa (2011), pp. 17521754. DOI: 10.1080/03115518.2010.497056.

[25669] M. Zammit. “A review of Australasian ichthyosaurs". English. In: Alcheringa (2010), pp. 1-12.

[25670] M. Zammit, R. M. Norris, and B. P. Kear. "The Australian Cretaceous ichthyosaur Platypterygius australis: A description and review of postcranial remains". English. In: Journal of Vertebrate Paleontology 30.6 (2010), pp. 1726-1735.

[25671] A. L. V. Zamora and C. A. L. Mora. "Revisión del primer hallazgo de Eremotherium laurillardii (Xenarthra: Megatheriidae) en Costa Rica". Spanish. In: Brenesia 62 (2004), pp. 83-88.

[25672] S. Zamora. "Morphology and phylogenetic interpretation of a new Cambrian edrioasteroid (Echinodermata) from Spain". English. In: Palaeontology 56.Part 2 (2013), pp. 421-431.

[25673] S. Zamora. "Equinodermos del Cámbrico medio de las Cadenas Ibéricas y de la zona Cantábrica (Norte de España)". Spanish. PhD thesis. 2009, pp. 1-307.

[25674] S. Zamora, J. J. Alvaro, and D. Vizcano. "Pelmatozoan echinoderms from the Cambrian-Ordovician transition of the Iberian Chains (NE Spain): early diversification of anchoring strategies". English. In: Swiss Journal of Geosciences 102.1 (2009), pp. 43-55. DOI: 10.1007/s00015-009-1314-4.

[25675] S. Zamora and J. J. Alvaro. "Testing for a decline in diversity prior to extinction: Languedocian (latest midCambrian) distribution of cinctans (Echinodermata) in the Iberian Chains, NE Spain". English. In: Palaeontology 53.6 (2010), pp. 1349-1368.

[25676] S. Zamora, J. J. Álvaro-Blasco, A. Miguel, J. Colmenar, J. Esteve, E. Fernández-Martnez, L. P. Fernández, J. C. Gutiérrez-Marco, J. L. Suárez Andrés, E. Villas, and J. Waters. “Field trip: Palaeozoic echinoderms from Northern Spain". English. In: Progress in Echinoderm Palaeobiology. Madrid: Instituto Geológico y Minero de España, 2015, pp. 209-288.

[25677] S. Zamora, R. Gozalo, and E. Liñán. "Middle Cambrian gogiid echinoderms from Northeast Spain: Taxonomy, palaeoecology, and palaeogeographic implications". English. In: Acta Palaeontologica Polonica 54 (2009), pp. 253-265. DOI: 10.4202/app.2008.0010.

[25678] S. Zamora, B. Lefebvre, I. Hosgör, C. Franzen, E. Nardin, O. Fatka, and J. J. Álvaro. “The Cambrian edrioasteroid Stromatocystites (Echinodermata): Systematics, palaeogeography, and palaeoecology". English. In: Geobios 48.5 (2015), pp. 417-426. DOI: 10.1016/j.geobios.2015.07.004. 
[25679] S. Zamora, E. Liñán, P. Domnguez Alonso, R. Gozalo, and J. A. Gámez Vintaned. “A Middle Cambrian edrioasteroid from the Murero biota (NE Spain) with Australian affinities". English. In: $A n$ nales de Paléontologie 93 (2007), pp. 249-260. DOI: 10.1016/j.annpal.2007.09.003.

[25680] S. Zamora, I. A. Rahman, and A. B. Smith. "Plated Cambrian Bilaterians Reveal the Earliest Stages of Echinoderm Evolution". English. In: PLoS ONE 7.6 (2012), e38296:1-e38296:11. DOI: 10.1371/ journal.pone.0038296.

[25681] S. Zamora, I. A. Rahman, and A. B. Smith. "The ontogeny of Cinctans (stem-group Echinodermata) as revealed by a new genus, Graciacystis, from the middle Cambrian of Spain". English. In: Palaeontology 56.Part 2 (2013), pp. 399-410.

[25682] S. Zamora and A. B. Smith. "A new Middle Cambrian stem-group echinoderm from Spain: Palaeobiological implications of a highly asymmetric cinctan". English. In: Acta Palaeontologica Polonica 53 (2008), pp. 207-220.

[25683] S. Zamora and A. B. Smith. "The oldest isorophid edrioasteroid (Echinodermata) and the evolution of attachment strategies in Cambrian edrioasteroids". English. In: Acta Palaeontologica Polonica 55.3 (2010), pp. 487-494.

[25684] S. Zamora and A. B. Smith. "Cambrian stalked echinoderms show unexpected plasticity of arm construction". English. In: Proceedings of the Royal Society B 279 (2011), pp. 293-298.

[25685] S. Zamora, J. Sprinkle, and C. D. Sumrall. "A revaluation of rhipidocystid echinoderms based on a new flattened blastozoan from the Upper Ordovician of Maryland, USA". English. In: Acta Palaeontologica Polonica 65 (2020).

[25686] S. Zamora, C. D. Sumrall, and J. Sprinkle. "New long-stemmed eocrinoid from the Furongian Point Peak Shale Member". English. In: Journal of Paleontology 89.1 (2015), pp. 187-193. DOI: 10. 1017/jpa.2014.16.

[25687] S. Zamora, C. D. Sumrall, X. -J. Zhu, and B. Lefebvre. "A new stemmed echinoderm from the Furongian of China and the origin of Glyptocystitida (Blastozoa, Echinodermata)". English. In: Geological Magazine 154.3 (2017), pp. 465-475. DOI: 10.1017/S001675681600011X.

[25688] M. Zamorano, M. De Los Reyes, D. G. Poiré, and G. J. Scillato-Yané. “Primer registro fehaciente de Nopachtus coagmentatus (Xenarthra, Cingulata, Glyptodontidae) en la región Pampeana, Argentina. Contexto estratigráfico". Spanish. In: Estudios Geológicos 71.1 (2015), e027. DOI: 10.3989/ egeol.41808.339.

[25689] M. Zamorano, G. G. Moreno, N. E. Vaccari, C. M. Falcón, A. M. Combina, and R. A. Bonini. "Primer registro de Nopachtus coagmentatus (Xenarthra, Glyptodontidae) para la Provincia de Catamarca, Argentina. Revisión del género Nopachtus". Spanish. In: Estudios Geológicos 73.2 (2017), e067. DOI: 10.3989/egeol.42809.449.

[25690] M. Zamorano and C. Oliva. "Restos de +Panochthus Burmeister (Xenarthra; Cingulata; Glyptodontidae) registrados en áreas de altura: descripción y comentarios". English. In: Revista del Museo de La Plata 5.2 (2020), pp. 411-422.

[25691] M. Zamorano and G. J. Scillato-Yané. “Nueva y Más Reciente Especie de Plohophorus Ameghino (Xenarthra, Glyptodontidae) del Marplatense Inferior (Barrancalobense, Plioceno Tardo), de Barranca de los Lobos (Provincia de Buenos Aires)". English. In: Ameghiniana 48.3 (2011), pp. 399404.

[25692] M. Zamorano, G. J. Scillato-Yane, L. R. Gonzalez Ruiz, and A. E. Zurita. “Revisión de los géneros Nopachtus Ameghino y Phlyctaenopyga Cabrera (Xenarthra, Glyptodontidae, Hoplophorinae) del Mioceno tardo y Plioceno de Argentina". Spanish. In: Revista del Museo Argentino de Ciencas Naturales 13.1 (2011), pp. 59-68.

[25693] M. Zamorano, M. Taglioretti, A. E. Zurita, G. J. Scillato-Yane, and Y. F. Scaglia. “El registro más antiguo de Panochthus (Xenarthra, Glyptodontidae)". Spanish. In: Estudios Geologicos 70.1 (2014), e004. DOI: 10.3989/egeol.41443.289. 
[25694] L. R. Zamoras and A. Matsuoka. "Early Late Jurassic radiolarians from the clastic unit in Busuanga Island, North Palawan, Philippines". English. In: Science Reports of the Niigata University, Ser. E (Geology) 15 (2000), pp. 91-109.

[25695] A. B. Zamuner. "Araucarioxylon petriellae n.sp., una posible glossopteridal de la Formacion Melo (Permico Inferior), Uruguay". Spanish. In: Ameghiniana 33.1 (1996), pp. 77-82.

[25696] S. Zan, C. B. Wood, G. W. Rougier, L. Jin, J. Chen, and C. R. Schaff. "A new middle Cretaceous zalambdalestid mammal from a new locality in Jilin Province, northeastern China". English. In: Journal of the Paleontological Society of Korea 22.1 (2006), pp. 153-172.

[25697] S.-Q. Zan, J. Chen, L. -Y. Jin, and T. Li. "A primitive ornithopod from the Early Cretaceous Quantou Formation of central Jilin, China". English. In: Vertebrata PalAsiatica 43.3 (2005), pp. 182-193.

[25698] A. Zanetti, M. Perreau, and A. Solodovnikov. "Two new fossil species of Omaliinae from Baltic amber (Coleoptera: Staphylinidae) and their significance for understanding the Eocene-Oligocene climate". English. In: Arthropod Systematics \& Phylogeny 74 (2016), pp. 53-64.

[25699] R. Zangerl. "The problem of vast numbers of cladodont shark denticles in the Pennsylvanian Excello Shale of Pike County, Indiana". English. In: Journal of Paleontology 69.3 (1995), pp. 556-563.

[25700] L. E. Zanno, S. Drymala, S. J. Nesbitt, and V. P. Schneider. “Early crocodylomorph increases top tier predator diversity during rise of dinosaurs". English. In: Scientific Reports 5.9276 (2015), pp. 16. DOI: $10.1038 /$ srep09276.

[25701] L. E. Zanno, D. D. Gillette, L. B. Albright, and A. L. Titus. "A new North American therizinosaurid and the role of herbivory in 'predatory' dinosaur evolution". English. In: Proceedings of the Royal Society B: Biological Sciences (2009). DOI: 10.1098/rspb.2009.1029.

[25702] L. E. Zanno, A. B. Heckert, S. E. Krzyzanowski, and S. G. Lucas. Diminutive metoposaurid skulls from the Upper Triassic Blue Hills (Adamanian: latest Carnian) of Arizona. English. Vol. 21. Upper Triassic Stratigraphy and Paleontology, New Mexico Museum of Natural History and Science Bulletin. 2002, pp. 121-125.

[25703] L. E. Zanno and P. J. Makovicky. “Neovenatorid theropods are apex predators in the Late Cretaceous of North America". English. In: Nature Communications 4 (2013), pp. 1-9.

[25704] L. E. Zanno and S. D. Sampson. "A new oviraptorosaur (Theropoda, Maniraptora) from the Late Cretaceous (Campanian) of Utah". English. In: Journal of Vertebrate Paleontology 25.4 (2005), pp. 897904.

[25705] L. E. Zanno, R. T. Tucker, A. Canoville, H. M. Avrahami, T. A. Gates, and P. J. Makovicky. “Diminutive fleet-footed tyrannosauroid narrows the 70-million-year gap in the North American fossil record". English. In: Communications Biology 2.1 (2019), 61:1-12. DOI: 10.1038/s42003-019-0308-7.

[25706] L. E. Zanno, D. J. Varricchio, P. M. O'Connor, A. L. Titus, and M. J. Knell. “A new troodontid theropod, Talos sampsoni gen. et sp. nov., from the Upper Cretaceous Western Interior Basin of North America". English. In: PLoS ONE 6.9 (2011), e24487:1-20. DOI: 10.1371/journal.pone.0024487.

[25707] M. K. Zapalski. "New tabulate corals from the Tournaisian of the Cracow area, Poland". English. In: Acta Geologica Polonica 52.4 (2002), pp. 497-500.

[25708] M. K. Zapalski and B. Berkowski. "The oldest species of ? Yavorskia (Tabulata) from the Upper Famennian of the Holy Cross Mountaians (Poland)". English. In: Acta Geologica Polonica 62.2 (2012), pp. 197-204.

[25709] M. K. Zapalski and C. Klug. "Trilobite sclerites as attachment surface for Emsian tabulate corals of Hamar Laghdad (Anti-Atlas, Morocco)". English. In: 290.1-3 (2018), pp. 111-115. DOI: 10.1127/ njgpa/2018/0769.

[25710] S. Zaragoza-Caballero and P. Velasco-de León. “Una especie nueva de Epicauta (Coleoptera: Meloidae) del Plioceno del Estado de Hidalgo, México". Spanish. In: Revista Mexicana de Ciencias Geológicas 20 (2003), pp. 154-159. 
[25711] M. Zarski, G. Jakubowski, and E. Gawor-Biedowa. "The first Polish find of lower Paleocene crocodile Thoracosaurus Leidy, 1852: geological and palaeontological description". English. In: Geological Quarterly 42.2 (1998), pp. 141-160.

[25712] M. Zato. "Bajocian-Bathonian (Middle Jurassic) ammonites from the Polish Jura. Part 1: Families Phylloceratidae, Nannolytoceratidae, Sonniniidae, Strigoceratidae, Oppeliidae and Lissoceratidae". English. In: Palaeontographica Abteilung A 292 (2010), pp. 65-113.

[25713] M. Zato. "Bajocian-Bathonian (Middle Jurassic) ammonites from the Polish Jura. Part 2: Families Stephanoceratidae, Perisphinctidae, Parkinsoniidae, Morphoceratidae and Tulitidae". English. In: Palaeontographica Abteilung A 292 (2010), pp. 115-213.

[25714] M. Zato, H. Hagdorn, and T. Borszcz. “Microconchids of the species Microconchus valvatus (Münster in Goldfuss, 1831) from the Upper Muschelkalk (Middle Triassic) of Germany". English. In: Palaeobiodiversity and Palaeoenvironments 94 (2014), pp. 453-461.

[25715] M. Zato, G. Niedwiedzki, M. Rakociski, H. Blom, and B. P. Kear. “Earliest Triassic metazoan bioconstructions in East Greenland reveal a pioneering benthic community from immediately after the end-Permian mass extinction". English. In: Global and Planetary Change (2018). DOI: 10.1016/j. gloplacha.2018.05.009.

[25716] M. Zato, P. D. Taylor, and O. Vinn. "Early Triassic (Spathian) post-extinction microconchids from western Pangea". English. In: Journal of Paleontology 87 (2013), pp. 159-165.

[25717] M. S. Zavada. "The ultrastructure of angiosperm pollen from the Lower Cenomanian of the Morondova Basin, Madagascar". English. In: Grana 42.1 (2003), pp. 20-32.

[25718] T. J. Zavortink and G. O. Poinar. "Anopheles (Nyssorhynchus) dominicanus sp. n. (Diptera: Culicidae) from Dominican amber". English. In: Annals of the Entomological Society of America 93 (2000), pp. 1230-1235.

[25719] T. J. Zavortink and G. O. Poinar. "Toxorhynchites (Toxorhynchites) mexicanus, n. sp.. (Diptera: Culicidae) from Mexican amber: a new world species with old world affinities". English. In: Proceedings of the Entomological Society of Washington 110 (2008), pp. 116-125.

[25720] C. Zazo, J. L. Goy, C. J. Dabrio, V. Soler, C. Hillaire-Marcel, B. Ghaleb, J. A. Gonzalez-Delgado, T. Bardaji, and A. Cabero. "Quaternary marine terraces on Sal Island (Cape Verde archipelago)". English. In: Quaternary Science Reviews 26 (2007), pp. 876-893.

[25721] C. Zazo, J. L. Goy, C. J. Dabrio, T. Bardaj, C. Hillaire-Marcel, B. Ghaleb, J. -A. Gonzalez-Delgado, and V. Soler. "Pleistocene raised marine terraces of the Spanish Mediterranean and Atlantic coasts: Records of coastal uplift, sea-level highstands and climate changes". English. In: Marine Geology 194.1-2 (2001), pp. 103-133.

[25722] G. D. Zazula, P. G. Hare, and J. E. Storer. "New Radiocarbon-Dated Vertebrate Fossils from Herschel Island: Implications for the Palaeoenvironments and Glacial Chronology of the Beaufort Sea Coastlands". English. In: Arctic 62.3 (2009), pp. 273-280.

[25723] S. Zazzali, S. Crasquin, J. -F. Deconinck, and Q. Feng. “Biodiversity across the GuadalupianLopingian Boundary: first results on the ostracod (Crustacea) fauna, Chaotian section (Sichuan Province, South China)". English. In: Geodiversitas 37.3 (2015), pp. 283-313. DOI: 10.5252/g2015n3a1.

[25724] F. J. Zeballo and M. F. Tortello. "Trilobites del Cambrico tardio-Ordovicico temprano del area de Alfarcito, Tilcara, Cordillera Oriental de Jujuy, Argentina [Late Cambrian-Early Ordovician trilobites from the Alfarcito area, Tilcara, Oriental Cordillera, Jujuy, Argentina]". Spanish. In: Ameghiniana 42.1 (2005), pp. 127-142.

[25725] K. E. Zeigler, A. B. Heckert, and S. G. Lucas. A new species of Desmatosuchus (Archosauria: Aetosauria) from the Upper Triassic of the Chama Basin, north-central New Mexico. English. Vol. 21. Upper Triassic Stratigraphy and Paleontology, New Mexico Museum of Natural History and Science Bulletin. 2002, pp. 215-219.

[25726] K. E. Zeigler, S. G. Lucas, and A. B. Heckert. "Variation in the Late Triassic Canjilon quarry (Upper Chinle Group, New Mexico) phytosaur skulls: a case for sexual dimorphism". In: Paläontologische Zeitschrift 77.2 (2003), pp. 341-351. 
[25727] A. Zeiri, A. Nel, and R. Garrouste. "A new libelluloid family from the Eocene Green River Formation (Colorado, USA) (Odonata, Anisoptera)". English. In: Zootaxa 4032 (2015), pp. 290-296.

[25728] A. Zeiss, A. Benetti, and N. Pezzoni. "A new ammonite fauna from the Tithonian (Semiformiceras/Verruciferum Zone) of the Lessinian Alps, Verona Province, Northern Italy". English. In: Palaeopelagos Special Publication 1 (1994), pp. 367-381.

[25729] D. K. Zelenitsky, K. Carpenter, and P. J. Currie. "First record of elongatoolithid theropod eggshell from North America: the Asian oogenus Macroelongatoolithus from the lower Cretaceous of Utah". English. In: Journal of Vertebrate Paleontology 20.1 (2000), pp. 130-138.

[25730] D. K. Zelenitsky and L. V. Hills. "Normal and pathological eggshells of Spheroolithus albertensis, oosp. nov., from the Oldman Formation (Judith River Group, Late Campanian), southern Alberta". English. In: Journal of Vertebrate Paleontology 17.1 (1997), pp. 167-171.

[25731] D. K. Zelenitsky, L. V. Hills, and P. J. Currie. “Parataxonomic classification of ornithoid eggshell fragments from the Oldman Formation (Judith River Group; Upper Cretaceous), southern Alberta". English. In: Canadian Journal of Earth Sciences 33 (1996), pp. 1655-1667.

[25732] D. K. Zelenitsky and L. V. Hills. “An egg clutch of Prismatooiitlbus lewis oosp. nov. from the Oldman Formation (Upper Cretaceous) Devil's Coulee, southern Alberta". English. In: Canadian Journal of Earth Sciences 33 (1996), pp. 1127-1131.

[25733] D. K. Zelenitsky and W. J. Sloboda. Eggshells. English. Dinosaur Provincial Park: A Spectacular Ancient Ecosystem Revealed. Indiana University Press, Bloomington. 2005, pp. 398-404.

[25734] D. K. Zelenitsky and F. Therrien. "Unique maniraptoran egg clutch from the Upper Cretaceous Two Medicine Formation of Montana reveals theropod nesting behaviour". English. In: Palaeontology 51.6 (2008), pp. 1253-1259. DOI: 10.1111/j.1475-4983.2008.00815.x.

[25735] N. V. Zelenkov. "New finds and revised taxa of Early Pliocene birds from Western Mongolia". English. In: Society of Avian Paleontology and Evolution Proceedings 2013 (2013), pp. 153-170.

[25736] N. V. Zelenkov. "A New Duck from the Middle Miocene of Mongolia, with Comments on Miocene Evolution of Ducks". English. In: Paleontological Journal 46.5 (2012), pp. 520-530.

[25737] N. V. Zelenkov. "Diving Ducks from the Middle Miocene of Western Mongolia". English. In: Paleontological Journal 45.2 (2011), pp. 191-199.

[25738] N. V. Zelenkov. "A swan-sized anseriform bird from the late Paleocene of Mongolia". English. In: Journal of Vertebrate Paleontology 39 (2019), e1531879:1-8. DOI: 10.1080/02724634.2018.1531879.

[25739] N. V. Zelenkov and A. O. Averianov. "Synsacrum of a primitive bird from the Upper Cretaceous of Uzbekistan". English. In: Paleontological Journal 45.3 (2011), pp. 314-319.

[25740] N. V. Zelenkov and A. O. Averianov. "A historical specimen of enantiornithine bird from the Early Cretaceous of Mongolia representing a new taxon with a specialized neck morphology". English. In: Journal of Systematic Palaeontology (2015). DOI: 10.1080/14772019.2015.1051146.

[25741] N. V. Zelenkov and E. N. Kurochkin. "Dabbling Ducks (Aves: Anatidae) from the Middle Miocene of Mongolia". English. In: Paleontological Journal 46.4 (2012), pp. 421-429.

[25742] N. V. Zelenkov, E. N. Kurochkin, A. A. Karhu, and P. Ballmann. "Birds of the Late Pleistocene and Holocene from the Palaeolithic Djuktai cave site of Yakutia, eastern Siberia". English. In: Oryctos 7 (2008), pp. 217-226.

[25743] N. V. Zelenkov and E. N. Kurochkin. “Two new waterfowl species (Aves: Anseriformes) from the Upper Pleistocene of Yakutia: the first extinct species of Quaternary birds from Russia". English. In: Paleontological Journal 48 (2014), pp. 645-654.

[25744] N. V. Zelenkov and A. V. Panteleyev. "Three bird taxa (Aves: Anatidae, Phasianidae, Scolopacidae) from the Late Miocene of the Sea of Azov (Southwestern Russia)". English. In: Paläontologische Zeitschrift 89 (2015), pp. 515-527.

[25745] N. V. Zelenkov, A. V. Panteleyev, and A. A. Yarkov. "New finds of hesperornithids in the European Russia, with comments on the systematics of Eurasian Hesperornithidae". English. In: Paleontological Journal 51 (2017), pp. 547-555. 
[25746] N. V. Zelenkov, T. A. Stidham, N. Martynovich, N. V. Volkova, Q. Li, and Z. Qui. “The middle Miocene duck, Chenoanas (Aves, Anatidae): New species, phylogeny and geographical range". English. In: Papers in Paleontology 4.3 (2018), pp. 309-326. DOI: 10.1002/spp2.1107.

[25747] N. I. Zelentsov, V. A. Baranov, E. E. Perkovsky, and N. A. Shobanov. "First records on non-biting midges (Diptera: Chironomidae) from the Rovno amber". English. In: Russian Entomological Journal 21 (2012), pp. 79-87.

[25748] P. Zell, J. A. Crame, W. Stinnesbeck, and S. Beckmann. "The bivalve Anopaea (Inoceramidae) from the Upper Jurassic -lowermost Cretaceous of Mexico". English. In: Journal of South American Earth Sciences 60 (2015), pp. 92-103.

[25749] P. Zell, W. Stinnesbeck, S. Beckmann, T. Adatte, and F. Hering. "The Berriasian-Valanginian (Early Cretaceous) boundary transition at Santa Catarina Ticuá, Oaxaca state, southern Mexico: ammonites, bivalves, calpionellids and their paleobiogeographic significance". English. In: Journal of South American Earth Sciences 62 (2015), pp. 33-57.

[25750] P. Zell and W. Stinnesbeck. "Kimmeridgian (Late Jurassic) cold-water idoceratids (Ammonoidea) from southern Coahuila, northeastern Mexico, associated with Boreal bivalves and belemnites". English. In: Revista Mexicana de Ciencias Geológicas 32 (2015), pp. 11-20.

[25751] P. Zell and W. Stinnesbeck. "Paleobiology of the latest Tithonian (Late Jurassic) ammonite Salinites grossicostatum inferred from internal and external shell parameters". English. In: PLoS One 11.1 (2016), e0145865.

[25752] D. Zeng, B. Liu, and Y. Huang. Reefs through geological ages in China. English. Reefs through geological ages in China. 1994, pp. 1-104.

[25753] H. Zeng, F. C. Zhao, Z. J. Yin, and M. Y. Zhu. "Appendages of an early Cambrian metadoxidid trilobite from Yunnan, SW China support mandibulate affinities of trilobites and artiopods". English. In: (2017), pp. 1-23. DOI: 10.1017/S0016756817000279.

[25754] H. Zeng, F. C. Zhao, Z. J. Yin, G. X. Li, and M. Y. Zhu. "A Chengjiang-type fossil assemblage from the Hongjingshao Formation (Cambrian Stage 3) at Chenggong, Kunming, Yunnan". English. In: Chinese Science Bulletin 59.25 (2014), pp. 3169-3175. DOI: 10.1007/s11434-014-0419-y.

[25755] Q. Zeng. "Pseudokoninckina, a new genus of koninckinoid brachiopods from Zhuganpo formation of late Triassic (Carnian), Xinpu area, Guanling, Guizhou, southwest China". Chinese. In: Acta Palaeontologica Sinica 45.1 (2006), pp. 69-76.

[25756] Y. Zeng, L. J. Jiang, Y. Ke, Q. Lu, L. Zhao, J. D. Liang, H. Hu, and L. H. Bo. “The relationship between species diversity and ecosystem function (productivity) of the late Middle Permian brachiopods community at the region of Hechuan, Chongqing, China". English. In: Science in China, Earth Sciences 55 (2012), pp. 1248-1254.

[25757] Y. Zeng, M. Liu, Z. L. Wang, and W. Chen. "Changhsingian sea level changes and brachiopod diversity in the upper Yangtze region". English. In: Science in China Series D: Earth Sciences 50 (2007), pp. 343-349.

[25758] L. Zerche. “Eine neue Art der Gattung Adinopsis Cameron aus dem Baltischen Bernstein (Coleoptera: Staphylinidae, Aleocharinae, Deinopsini)". German. In: Beiträge zur Entomologie 49 (1999), pp. 97105.

[25759] G. A. Zerova. “Vipera (Daboia) ukrainica - a new viper (Serpentes; Viperidae) from the Middle Sarmatian (Upper Miocene) of the Ukraine". English. In: Neues Jahrbuch für Geologie und Paläontologie, Abhandlungen 184.2 (1992), pp. 235-249.

[25760] W. Zessin. "Ploetzgerarus krempieni n. gen. et sp. - eine neue Geraride (Insecta: Panorthoptera: Geraridae) aus dem Oberkarbon (Stepanium C) von Plötz bei Halle (Deutschland)". German. In: Virgo, Mitteilungsblatt des Entomologischen Vereins Mecklenburg 12 (2009), pp. 22-29.

[25761] W. Zessin. "Zwei neue Insektenreste (Megasecoptera, Odonatoptera) aus dem Westfalium D (Oberkarbon) des Piesberges bei Osnabrück, Deutschland". German. In: Virgo, Mitteilungsblatt des Entomologischen Vereins Mecklenburg 9 (2006), pp. 37-45. 
[25762] W. Zessin. "Die Phylogenie der Protomyrmeleontidae unter einbeziehung neuer Oberliassischer funde (Odonata: Archizygoptera sens. nov.)" German. In: Odonatologica 20.1 (1991), pp. 97-126.

[25763] W. Zessin. "Thueringoedischia trostheidei nov. gen. et nov. sp. (Insecta, Orthoptera) aus dem unteren Rotliegenden von Thüringen". German. In: Veröffentlichungen Naturkundemuseum Erfurt 1997 (1997), pp. 172-183.

[25764] W. Zessin. “Überblick über die paläozoischen Libellen (Insecta, Odonatoptera)". German. In: Virgo, Mitteilungsblatt des Entomologischen Vereins Mecklenburg 11 (2008), pp. 5-32.

[25765] W. Zessin. “Neue Insekten aus dem Moler (Paläozän/Eozän) von Dänemark Teil 1 (Odonata: Epallagidae, Megapodagrioniidae)". German. In: Virgo, Mitteilungsblatt des Entomologischen Vereins Mecklenburg 14 (2011), pp. 64-73.

[25766] W. Zessin. “Eine weitere neue Geraride, Hirsutgerarus saxonicus n. gen. n. sp. (Insecta: Panorthoptera: Geraridae), aus dem Oberkarbon (Stephanium C) von Plötz bei Halle (Deutschland)". German. In: Virgo, Mitteilungsblatt des Entomologischen Vereins Mecklenburg 15 (2012), pp. 10-17.

[25767] W. Zessin. “Neue Insekten aus dem Moler (Paläozän/Eozän) von Dänemark Teil 3 (Orthoptera: Caelifera: Eumastacidae, Tetrigidae)". English. In: Virgo, Mitteilungsblatt des Entomologischen Vereins Mecklenburg 19 (2017), pp. 77-83.

[25768] W. Zessin. "Eine neue fossile Libelle (Libellulidae: Randecktrum ebi gen. nov. sp. nov.) aus dem Miozän des Randecker Maars". German. In: Libellula Supplement 15 (2019), pp. 203-216.

[25769] W. Zessin and C. Brauckmann. "Aulertupus tembrocki n. gen. et sp. (Odonatoptera: Meganisoptera: Aulertupidae n. fam.) aus dem Ober-Karbon von Mazon Creek, Illinois (USA)". German. In: Virgo, Mitteilungsblatt des Entomologischen Vereins Mecklenburg 13.2 (2010), pp. 36-43.

[25770] W. Zessin, C. Brauckmann, and E. Gröning. "Rasnitsynala sigambrorum gen. et sp. n., a small odonatopterid (Eomeganispotera,Erasipteridae) from the early Late Carboniferous of Hagen-Vorhalle (Germany)". English. In: ZooKeys 130 (2011), pp. 57-66.

[25771] W. Zessin, J. Zalohar, and T. Hitij. "A new fossil dragonfly (Insecta, Odonata, Libellulidae) of the Miocene (Lower-Sarmatian) of the Tunjice Hills, Slovenia". English. In: Virgo, Mitteilungsblatt des Entomologischen Vereins Mecklenburg 11 (2008), pp. 86-96.

[25772] H. Zettel and E. Heiss. "Baptista vetai sp n (Heteroptera: Veliidae), a microveliine bug from Eocene Baltic amber". English. In: Zeitschrift der Arbeitsgemeinschaft Österreichischer Entomologen 63 (2011), pp. $43-48$.

[25773] H. Zettel and E. Heiss. "New species of water striders (Hemiptera: Heteroptera: Gerromorpha: Hydrometridae, Gerridae) from Eocene Baltic amber". English. In: Annalen des Naturhistorischen Museums in Wien, Serie A 113 (2011), pp. 543-553.

[25774] I. Zghal, R. Damotte, and H. Bismuth. “Les ostracodes de l'Albien du Koudiat el Beida (J. Mrhila, Tunisie centrale)". French. In: Revue de Micropaléontologie 39.1 (1996), pp. 67-90.

[25775] R. Zhai, R. L. Ciochon, Y. Tong, D. E. Savage, M. Morlo, P. A. Holroyd, and G. F. Gunnell. “An aberrant amphicyonid mammal from the latest Eocene of the Bose Basin, Guangxi, China". English. In: Acta Palaeontologica Polonica 48.2 (2003), pp. 293-300.

[25776] R. Zhan, D. A. T. Harper, J. Jin, Y. Liang, J. Liu, L. Stemmerik, and S. Stouge. “Middle Ordovician Aporthophyla brachiopod fauna from the roof of the world, southern Tibet". English. In: Palaeontology 57.1 (2014), pp. 141-170. DOI: 10.1111/pala.12058.

[25777] R. Zhan and J. Jin. "Brachiopods from the Middle Orodvician Shihtzupu Formation of Yunnan Province, China". English. In: Acta Palaeontologica Polonica 50.2 (2005), pp. 365-393.

[25778] R. Zhan, J. Jin, J. Rong, P. Chen, and G. Yu. "Strophomenide brachiopods from the Changwu Formation (Late Katian, Late Ordovician) of Chun'an, western Zhejiang, south-east China". English. In: Palaeontology 51.3 (2008), pp. 737-766.

[25779] R. Zhan, J. Jin, and P. Chen. “Early-mid Ordovician Yangtzeella (Syntrophiidina, Brachiopoda) and its evolutionary significance". English. In: Palaeontology 53.1 (2010), pp. 77-96. 
[25780] R. Zhan, J. Jin, J. Rong, and Y. Liang. “The earliest known strophomenoids (Brachiopoda) from early Middle Ordovician rocks of South China". English. In: Palaeontology 56.5 (2013), pp. 11211148. DOI: $10.1111 /$ pala.12039.

[25781] R. Zhan, J. Jin, and P. Chen. "Brachiopod diversification during the Early-Mid Ordovician: an example from the Dawan Formation, Yichang area, central China". English. In: Canadian Journal of Earth Sciences 44 (2007), pp. 9-24. DOI: 10.1139/E06-069.

[25782] R. Zhan and O. Vinn. "Cornulitid epibionts on brachiopod shells from the Late Ordovician (middle Ashgill) of East China". English. In: Estonian Journal of Earth Sciences 56.2 (2007), pp. 101-108.

[25783] R. B. Zhan, J. B. Liu, I. G. Percival, J. S. Jin, and G. P. Li. "Biodiversification of Late Ordovician Hirnantia Fauna on the Upper Yangtze Platform, South China". English. In: Science China - Earth Sciences 53.12 (2010), pp. 1800-1810. DOI: 10.1007/s11430-010-4071-3.

[25784] R. B. Zhan, J. Y. Rong, J. S. Jin, Y. Liang, and W. W. Yuan. “Discovery of a Late Ordovician Foliomena fauna in the Tarim desert, Northwest China". English. In: Palaeoworld 23 (2014), pp. 125-142. DOI: 10.1016/j.palwor.2013.11.002.

[25785] R.-B. Zhan and J. Jin. “Brachiopods from the Dashaba Formation (Middle Ordovician) of Sichuan Province, south-west China". English. In: Special Papers in Palaeontology 74 (2005), pp. 1-63.

[25786] R.-B. Zhan and J. Jin. "New data on the Foliomena fauna (Brachiopoda) from the Upper Ordovician of South China". English. In: Journal of Paleontology 79.4 (2005), pp. 670-686.

[25787] R.-B. Zhan, J. Jin, J. -Y. Rong, X. -J. Zhu, and N. -R. Han. “Late Cambrian brachiopods from Jingxi, Guangxi Province, South China". English. In: Alcheringa 34 (2010), pp. 99-133.

[25788] R.-b. Zhan, J.-y. Rong, J. Jin, and L. R. M. Cocks. "Late Ordovician brachiopod communities of southeast China". English. In: Canadian Journal of Earth Sciences 39 (2002), pp. 445-468. DOI: 10. 1139/E01-094.

[25789] R.-b. Zhan, G. Wang, and R. Wu. "Late Ordovician Foliomena Fauna (Brachiopoda) of South China". English. In: Journal of Earth Science 21 (2010), pp. 64-69.

[25790] B. L. Zhang, G. Fleck, D. Y. Huang, A. Nel, D. Ren, X. D. Cheng, and Q. B. Lin. "New isophlebioid dragonflies (Odonata: Isophlebioptera: Campterophlebiidae) from the Middle Jurassic of China". English. In: Zootaxa 1339 (2006), pp. 51-68.

[25791] B. L. Zhang, D. Ren, C. Q. Zhou, and H. Pang. "New genus and species of fossil dragonflies (Insecta: Odonata) from the Yixian Formation of northeastern China". English. In: Acta Geologica Sinica 80 (2006), pp. 327-335.

[25792] B. L. Zhang, D. Ren, and H. Pang. "New dragonflies (Insecta: Odonata: Gomphaeschnidae) from the Yixian Formation in Inner Mongolia, China". English. In: Progress in Natural Science 18 (2008), pp. 59-64.

[25793] B. L. Zhang, D. Ren, and H. Pang. "New Isophlebioid Dragonflies from the Middle Jurassic of Inner Mongolia, China (Insecta: Odonata: Isophlebioptera: Campterophlebiidae)". English. In: Acta Geologica Sinica 82 (2010), pp. 1104-1114.

[25794] B. L. Zhang, D. Ren, and H. Pang. "Telmaeshna paradoxica gen. et sp. nov., a new fossil dragonfly (Insecta: Odonata: Anisoptera) from the Yixian Formation, Liaoning, China". English. In: Zootaxa 1681 (2008), pp. 62-68.

[25795] B.-M. Zhang, X.-H. Chen, and L. Cheng. "Discovery of Macrocnemus cf. fuyuanensis of the Middle Triassic in Xinyi, Guizhou Province, SW China". English. In: Geology and Mineral Resources of South China 2 (2010), p. 7.

[25796] C. Zhang, H. Bucher, and S. Z. Shen. "Griesbachian and Dienerian (Early Triassic) ammonoids from Qubu in the Mt. Everest area, southern Tibet". English. In: Palaeoworld 26 (2017), pp. 650662.

[25797] F. Zhang, P. G. P. Ericson, and Z. Zhou. "Description of a new enantiornithine bird from the Early Cretaceous of Hebei, northern China". English. In: Canadian Journal of Earth Sciences 41.9 (2004), pp. 1097-1107. DOI: 10.1139/E04-055. 
[25798] F. Zhang and X. D. Wang. "Special lateral increase in a Permian rugose coral Kepingophyllum aksuence Wu et Chow". English. In: Acta Geologica Sinica 85 (2011), pp. 465-470.

[25799] F. Zhang, Z. Zhou, X. Xu, and X. Wang. "A juvenile coelurosaurian theropod from China indicates arboreal habits". English. In: Naturwissenschaften 89.9 (2002), pp. 394-398.

[25800] F. Zhang and Z. Zhou. "A primitive enantiornithine bird and the origin of feathers". English. In: Science 290 (2000), pp. 1955-1959.

[25801] F. Zhang and Z. Zhou. "Leg feathers in an Early Cretaceous bird". English. In: Nature 431 (2004), p. 925.

[25802] F. Zhang, Z. Zhou, X. Xu, X. Wang, and C. Sullivan. "A bizarre Jurassic maniraptoran from China with elongate ribbon-like feathers". English. In: Nature 455 (2008), pp. 1105-1108.

[25803] G. Zhang, Y. Wang, M. E. H. Jones, and S. E. Evans. "A new Early Cretaceous salamander (Regalerpeton weichangensis gen. et sp. nov.) from the Huajiying Formation of northeastern China". English. In: Cretaceous Research 30.3 (2009), pp. 551-558.

[25804] G. X. Zhang and Y. C. Hong. "A new family Drepanochaitophoridae (Homoptera: Aphidoidea) from Eocene Fushun amber of Liaoning province, China". English. In: Entomologia Sinica 6 (1999), pp. 127-134.

[25805] H. Zhang, A. P. Rasnitsyn, and J. F. Zhang. “Two ephialtitid wasps (Insecta, Hymenoptera, Ephialtitoidea) from the Yixian Formation of western Liaoning, China". English. In: Cretaceous Research 23 (2002), pp. 401-407.

[25806] H. Zhang and A. P. Rasnitsyn. "Pelecinid wasps (Insecta, Hymenoptera, Proctotrupoidea) from the Cretaceous of Russia and Mongolia". English. In: Cretaceous Research 25 (2004), pp. 807-825.

[25807] H. Zhang, S. Xiao, Y. Liu, X. Yuan, B. Wan, A. D. Muscente, T. Shao, H. Gong, and G. Cao. “Armored kinorhynch-like scalidophoran animals from the early Cambrian". English. In: Nature Scientific Reports 5.16521 (2015), pp. 1-10. DOI: 10.1038/srep16521.

[25808] H. C. Zhang. "A new genus of Elateridae (Insecta, Coleoptera) from Lower-Middle Jurassic of Junggar Basin, Xinjiang, China". Chinese. In: Acta Micropalaeontologica Sinica 14 (1997), pp. 71-77.

[25809] H. C. Zhang. "Jurassic palaeontinids from Karamai, Xinjiang, with a discussion of Palaeontinidae (Homoptera: Palaeontinidae) in China". English. In: Entomologica Sinica 4 (1997), pp. 312-323.

[25810] H. C. Zhang. "Mesozoic Insects of Orthophlebiidae (Insecta, Mecoptera) from Junggar Basin, Xinjiang, China". English. In: Acta Palaeontologica Sinica 35.4 (1996), pp. 442-456.

[25811] H. C. Zhang. "Early Cretaceous insects from the Dalazi Formation of the Zhixin basin, Jilin Province, China". English. In: Palaeoworld 7 (1997), pp. 75-103.

[25812] H. C. Zhang. "First discovery of fossil Haglidae (Orthoptera) in northwest China". Chinese. In: Entomotaxonomia 18 (1996), pp. 249-252.

[25813] H. C. Zhang and A. P. Rasnitsyn. "Some ichneumonids (Insecta, Hymenoptera, Ichneumonoidea) from the upper Mesozoic of China and Mongolia". English. In: Cretaceous Research 24 (2003), pp. 193-202.

[25814] H. C. Zhang, A. P. Rasnitsyn, D. J. Wang, and Y. T. Zhang. "Some hatchet wasps (Hymenoptera, Evaniidae) from the Yixian Formation of western Liaoning, China". English. In: Cretaceous Research 28 (2007), pp. 310-316.

[25815] H. C. Zhang and A. P. Rasnitsyn. “Nevaniinae subfam. n, a new fossil taxon (Insecta: Hymenoptera: Evanioidea: Praeaulicidae) from the Middle Jurassic of Daohugou in Inner Mongolia, China". English. In: Insect Systematics \& Evolution 38 (2007), pp. 149-166.

[25816] H. C. Zhang and A. P. Rasnitsyn. "Two new anaxyelid sawflies (Insecta, Hymenoptera, Siricoidea) from the Yixian Formation of western Liaoning, China". English. In: Cretaceous Research 27 (2006), pp. 279-284.

[25817] H. C. Zhang, A. P. Rasnitsyn, and J. F. Zhang. "Pelecinid wasps (Insecta: Hymenoptera: Proctotrupoidea) from the Yixian Formation of western Liaoning, China". English. In: Cretaceous Research 23 (2002), pp. 87-98. 
[25818] H. C. Zhang, A. P. Rasnitsyn, and J. F. Zhang. "The oldest known scoliid wasps (Insecta, Hymenoptera, Scoliidae) from the Jehol biota of western Liaoning, China". English. In: Cretaceous Research 23 (2002), pp. 77-86.

[25819] H. C. Zhang and A. P. Rasnitsyn. "Middle Jurassic Praeaulacidae (Insecta: Hymenoptera: Evanioidea) of Inner Mongolia and Kazakhstan". English. In: Journal of Systematic Palaeontology 6 (2008), pp. $463-487$.

[25820] H. C. Zhang, Q. F. Wang, and J. F. Zhang. "Some Jurassic homopteran insects from the Junggar basin, Xinjiang, China". English. In: Acta Palaeontologica Sinica 42.4 (2003), pp. 548-551.

[25821] H. C. Zhang, J. F. Zhang, and D. T. Wei. "Discovery of Trematothoracinae (Insecta) in the Upper Jurassic of W. Liaoning, China with a discussion of its phylogeny". English. In: Acta Palaeontologica Sinica 40 (2001), pp. 224-228.

[25822] H. C. Zhang and J. F. Zhang. "A new genus and two new species of Hymenoptera (Insecta) from the Upper Jurassic Yixian Formation of Beipiao, western Liaoning". English. In: Acta Micropalaeontologica Sinica 17 (2000), pp. 286-290.

[25823] H. C. Zhang and J. F. Zhang. "Proctotrupoid wasps (Insecta, Hymenoptera) from the Yixian Formation of western Liaoning Province". English. In: Acta Micropalaeontologica Sinica 18 (2001), pp. 1128.

[25824] H. C. Zhang and J. F. Zhang. "Xyelid sawflies (Insecta, Hymenoptera) from the Upper Jurassic Yixian Formation of western Liaoning, China". English. In: Acta Palaeontologica Sinica 39 (2000), pp. 476-492.

[25825] H. C. Zhang and J. F. Zhang. “A new genus of Mesoserphidae (Hymenoptera Proctotrupoidea) from the Upper Jurassic of northeast China". English. In: Entomotaxonomia 22 (2000), pp. 279-282.

[25826] H. C. Zhang, D. R. Zheng, B. Wang, Y. Fan, and E. A. Jarzembowski. “The largest known odonate in China: Hsiufua chaoi Zhang et Wang, gen. et sp. nov. from the Middle Jurassic of Inner Mongolia". English. In: Chinese Science Bulletin (2013), pp. 1-6. DOI: 10.1007/s11434-012-5567-3.

[25827] H. C. Zhang and J. F. Zheng. "Discovery of Praeaulacidae (Insecta Hymenoptera) in China and its significance". Chinese. In: Acta Micropalaeontologica Sinica 17 (2000), pp. 416-421.

[25828] H. Q. Zhang, C. K. Shih, D. Ren, and Y. J. Wang. "New Alavesia species from mid-Cretaceous Burmese amber highlight genitalic structural homology (Diptera: Empidoidea: Atelestidae)". English. In: Cretaceous Research 116.104573 (2020). DOI: 10.1016/j.cretres.2020.104573.

[25829] J. Zhang. "Aeschnidiid nymphs from the Jehol biota (latest Jurassic-Early Cretaceous), China, with a discussion of the family Aeschnidiidae (Insecta, Odonata)". English. In: Cretaceous Research 20 (1999), pp. 813-827.

[25830] J. Zhang. "Some anisopodoids (Insecta: Diptera: Anisopodoidea) from late Mesozoic deposits of northeast China". English. In: Cretaceous Research 28 (2007), pp. 281-288. DOI: 10.1016/j.cretres. 2006.05.008.

[25831] J. Zhang. "New Fossil Osteoglossomorph from NingXia, China". English. In: Journal of Vertebrate Paleontology 24.3 (2004), pp. 515-524. DOI: 10.1671/0272-4634(2004)024[0515:NFOFNC]2.0.CO;2.

[25832] J. Zhang. "Two Shark Finspines (Hybodontoidea) from the Measozoic of North China". English. In: Journal of Vertebrate Paleontology 28.2 (2007), pp. 277-280.

[25833] J. Zhang, D. Li, M. Li, M. G. Lockley, and Z. Bai. “Diverse dinosaur-, pterosaur-, and bird-track assemblages from the Hakou Formation, Lower Cretaceous of Gansu Province, northwest China". English. In: Cretaceous Research 27 (2006), pp. 44-55.

[25834] J. Zhang, B. Sun, and X. Zhang. English. Miocene insects and spiders from Shanwang, Shandong. 1994, pp. 1-298.

[25835] J. Zhang and K. Yuan. "Archaeocyath reefs from the Lower Cambrian Tianheban Formation at Wangjiaping, Yichang, Hubei and their diagenesis". Chinese. In: Scientia Geologica Sinica 29.3 (1994), pp. 236-245. 
[25836] J. Zhang and H. Zhang. "Two new species of archisargids (Insecta: Diptera: Archisargidae) from the Upper Jurassic Daohugou Formation (Inner Mongolia, northeastern China)". English. In: $\mathrm{Pa}$ leontological Journal 37 (2003), pp. 409-412.

[25837] J. F. Zhang. "Three distinct but rare kovalevisargid flies from the Jurassic Daohugou biota, China (Insecta, Diptera, Brachycera, Kovalevisargidae)". English. In: Palaeontology 54.1 (2011), pp. 163170.

[25838] J. F. Zhang. “New species of Palaeobolbomyia Kovalev and Ussatchovia Kovalev (Diptera, Brachycera, Rhagionidae) from the Callovian-Oxfordian (Jurassic) Daohugou biota of China: Biostratigraphic and paleoecologic implications". English. In: Geobios 43 (2010), pp. 663-669.

[25839] J. F. Zhang. "New winter crane flies (Insecta: Diptera: Trichoceridae) from the Jurassic Daohugou Formation (Inner Mongolia, China) and their associated biota". English. In: Canadian Journal of Earth Sciences 43 (2006), pp. 9-22.

[25840] J. F. Zhang. “New mesosciophilid gnats (Insecta: Diptera: Mesosciophilidae) in the Daohugou biota of Inner Mongolia, China". English. In: Cretaceous Research 28 (2007), pp. 297-301.

[25841] J. F. Zhang. "New mayfly nymphs from the Jurassic of northern and northeastern China (Insecta: Ephemeroptera)". English. In: Paleontological Journal 40.5 (2006), pp. 553-559.

[25842] J. F. Zhang. "Revision and description of water boatmen from the Middle-Upper Jurassic of northern and northeastern China (Insecta: Hemiptera: Heteroptera: Corixidae)". English. In: Paleontological Journal 44.5 (2010), pp. 515-525.

[25843] J. F. Zhang. "Records of bizarre Jurassic Brachycerans in the Daohugou biota, China (Diptera, Brachycera, Archisargidae and Rhagionemestriidae)". English. In: Palaeontology 53.2 (2010), pp. 307317.

[25844] J. F. Zhang. "First description of axymyiid fossils (Insecta: Diptera: Axymyiidae)". English. In: Geobios 37 (2004), pp. 687-694.

[25845] J. F. Zhang. “Two new species of Palaeoarthroteles Kovalev and Mostovski (Diptera, Rhagionidae) from the Callovian-Oxfordian (Jurassic) Daohugou biota of China". English. In: Geobios 44 (2011), pp. 635-639.

[25846] J. F. Zhang. “The first find of chrysomelids (Insecta: Coleopetra: Chrysomeloidea) from CallovianOxfordian Daohugou biota of China". English. In: Geobios 38 (2005), pp. 865-871.

[25847] J. F. Zhang. “New Mesozoic Protopleciidae (Insecta: Diptera: Nematocera) from China". English. In: Cretaceous Research 28 (2007), pp. 289-296.

[25848] J. F. Zhang. "A proscoliine wasp (Insecta: Hymenoptera: Scoliidae) from Shandong peninsula, east Asia". English. In: Cretaceous Research 27 (2006), pp. 788-791.

[25849] J. F. Zhang. "New representatives of Cretoscolia (Insecta: Hymenoptera: Scoliidae) from eastern China". English. In: Cretaceous Research 25 (2004), pp. 229-234.

[25850] J. F. Zhang. "The most primitive earwigs (Archidermaptera, Dermaptera, Insecta) from the Upper Jurassic of the Nei Monggol Autonomous Region, northeastern China". English. In: Acta Micropalaeontologica Sinica 19 (2002), pp. 348-362.

[25851] J. F. Zhang. "Fossil Coleoptera from Laiyang, Shandong Province". English. In: Acta Entomologica Sinica 35 (1992), pp. 331-338.

[25852] J. F. Zhang. "New horseflies and water snipe-flies (Diptera: Tabanidae and Athericidae) from the Lower Cretaceous of China". English. In: Cretaceous Research 36 (2012), pp. 1-5.

[25853] J. F. Zhang. “Distinct but rare archisargid flies from Jurassic of China (Diptera, Brachycera, Archisargidae) with discussion of the systematic position of Origoasilus pingquanensis Zhang et al, 2011". English. In: Journal of Paleontology 86 (2012), pp. 878-885.

[25854] J. F. Zhang. "Snipe flies (Diptera: Rhagionidae) from the Daohugou Formation (Jurassic), Inner Mongolia, and the systematic position of related records in China". English. In: Palaeontology 56 (2013), pp. 217-228. 
[25855] J. F. Zhang. “Orientisargidae fam. n, a new Jurassic family of Archisargoidea (Diptera, Brachycera), with review of Archisargidae from China". English. In: ZooKeys 238 (2012), pp. 57-76.

[25856] J. F. Zhang. "A contribution to the knowledge of Insects from the Late Mesozoic in Southern Shaanxi and Henan Provinces, China". Chinese. In: Palaeoworld 2 (1993), pp. 49-56.

[25857] J. F. Zhang. "Congqingia rhora gen. nov., spec. nov. - A new dragonfly from the Upper Jurassic of Eastern China (Anisozygoptera: Congqingiidae fam. nov.)" English. In: Odonatologica 21.3 (1992), pp. 375-383.

[25858] J. F. Zhang. "Three new species of Mesosciophilid gnats from the Middle-Late Jurassic of China (Insecta: Diptera: Nematocera: Mesosciophilidae)". English. In: Pakistan Journal of Biological Sciences 11.22 (2008), pp. 2567-2572.

[25859] J. F. Zhang. “Two new genera and one new species of Jurassic Axymyiidae (Diptera: Nematocera), with revision and redescription of the extinct taxa". English. In: Annals of the Entomological Society of America 103 (2010), pp. 455-464.

[25860] J. F. Zhang. “A new gigantic species of Eoptychopterina (Diptera: Eoptychopteridae) from Jurassic of northeastern China". English. In: Oriental Insects 38 (2004), pp. 173-178.

[25861] J. F. Zhang. "Eight new species of the genus Eopelecinus (Hymenoptera: Proctotrupoidea: Pelecinidae) from the Laiyang Formation, Shandong Province, China". English. In: Paleontological Journal 39 (2005), pp. 417-427.

[25862] J. F. Zhang. "Descriptions of two new genera and two new species of Baissodidae from China (Sphecoidea, Hymenoptera)". English. In: Acta Entomologica Sinica 35 (1992), pp. 483-489.

[25863] J. F. Zhang. "Kalligrammatid lacewings from the Upper Jurassic Daohugou Formation in Inner Mongolia, China". English. In: Acta Geologica Sinica 77 (2003), pp. 141-147.

[25864] J. F. Zhang. "Nematoceran dipterans from the Jurassic of China (Insecta, Diptera: Limoniidae, Tanyderidae)". English. In: Paleontological Journal 38 (2004), pp. 522-527.

[25865] J. F. Zhang. "New Miocene species of Bibionidae (Insecta: Diptera) with discussion on taxonomic position of Clothonopsis miocenica". Chinese. In: Acta Palaeontologica Sinica 32 (1993), pp. 141-150.

[25866] J. F. Zhang. "Discovery of primitive fossil earwigs (Insecta) from Late Jurassic of Laiyang, Shandong and its significance". Chinese. In: Acta Palaeontologica Sinica 33 (1994), pp. 229-245.

[25867] J. F. Zhang. "A new species of Tanychora Townes (Hymenoptera, Ichneumonidae)". Chinese. In: Acta Palaeontologica Sinica 30 (1991), pp. 502-504.

[25868] J. F. Zhang. "New genera and new species of Chironomidae (Diptera, Insecta) from Late Jurassic of China". Chinese. In: Acta Palaeontologica Sinica 30 (1991), pp. 556-569.

[25869] J. F. Zhang. "New fossil species of Apoidea (Insecta: Hymenoptera)". Chinese. In: Acta Zootaxonomica Sinica 15 (1990), pp. 83-91.

[25870] J. F. Zhang. "Two new genera and species of Heloridae (Hymenoptera) from late Mesozoic of China". Chinese. In: Entomotaxonomia 14 (1992), pp. 222-228.

[25871] J. F. Zhang. "A new family of Neuroptera (Insecta) from the late Mesozoic of Shandong, China". English. In: Science in China (Series B) 34 (1991), pp. 1105-1111.

[25872] J. F. Zhang. "Going further into late Mesozoic Mesolygaeids (Heteroptera, Insecta)". Chinese. In: Acta Palaeontologica Sinica 30 (1991), pp. 679-704.

[25873] J. F. Zhang. “Jurassic limoniid dipterans from China (Diptera: Limoniidae)". English. In: Oriental Insects 40 (2006), pp. 115-126.

[25874] J. F. Zhang. “Archisargoid flies (Diptera, Brachycera, Archisargidae and Kovalevisargidae) from the Jurassic Daohugou biota of China, and the related biostratigraphical correlation and geological age". English. In: Journal of Systematic Palaeontology 13 (2015), pp. 857-881.

[25875] J. F. Zhang. "Pseudapiocera shandongensis gen. et sp. nov., a protapiocerid fly (Diptera: Brachycera: Protapioceridae) from the Early Cretaceous Jehol biota, China". English. In: Alcheringa 39 (2015), pp. 459-464. 
[25876] J. F. Zhang. "New male eremochaetid flies (Diptera, Brachycera, Eremochaetidae) from the Lower Cretaceous of China". English. In: Cretaceous Research 49 (2014), pp. 205-213.

[25877] J. F. Zhang. "On the enigmatic Sinonemestrius Hong \& Wang, 1990, with description of a new species based on a complete fossil fly (Diptera, Brachycera, Tabanomorpha, Heterostomidae)". English. In: Deutsche Entomologische Zeitschrift 64 (2017), pp. 61-67.

[25878] J. F. Zhang, V. B. Golub, Y. A. Popov, and D. E. Shcherbakov. “Ignotingidae fam. nov. (Insecta: Heteroptera: Tingoidea), the earliest lace bugs from the upper Mesozoic of eastern China". English. In: Cretaceous Research 26 (2005), pp. 783-792.

[25879] J. F. Zhang and N. J. Kluge. “Jurassic larvae of mayflies (Ephemeroptera) from the Daohugou Formation in Inner Mongolia, China". English. In: Oriental Insects 41 (2007), pp. 351-366.

[25880] J. F. Zhang and H. J. Li. “New taxa of snipe flies (Diptera: Brachycera: Rhagionidae) in the Daohugou biota, China". English. In: Paleontological Journal 46 (2012), pp. 157-163.

[25881] J. F. Zhang and E. D. Lukashevich. “The oldest known net-winged midges (Insecta: Diptera: Blephariceridae) from the late Mesozoic of northeast China". English. In: Cretaceous Research 28 (2007), pp. 302-309.

[25882] J. F. Zhang and A. P. Rasnitsyn. "New extinct taxa of Pelecinidae sensu lato (Hymenoptera: Proctotrupoidea) in the Laiyang Formation, Shandong, China". English. In: Cretaceous Research 27 (2006), pp. 684-688.

[25883] J. F. Zhang and A. P. Rasnitsyn. “Minute members of Baissinae (Insecta: Hymenoptera: Gasteruptiidae) from the upper Mesozoic of China and limits of the genus Manlaya Rasnitsyn, 1980". English. In: Cretaceous Research 25 (2004), pp. 797-805.

[25884] J. F. Zhang, X. H. Wang, and G. Z. Xu. "A new genus and two new species of fossil staphylinids (Coleoptera) from Laiyang, Shandong Province, China". Chinese. In: Entomotaxonomia 14 (1992), pp. 277-281.

[25885] J. F. Zhang and H. Zhang. "New findings of larval and adult aeschnidiids (Insecta: Odonata) in the Yixian Formation, Liaoning Province, China". English. In: Cretaceous Research 22 (2001), pp. 334450. DOI: $10.1006 /$ cres.2001.0273.

[25886] J. F. Zhang and H. C. Zhang. "Kalligramma jurarchegonium, sp. nov. (Neuroptera: Kalligrammatidae) from the Middle Jurassic of northeastern China". English. In: Oriental Insects 37 (2003), pp. 301-308.

[25887] J. F. Zhang, S. Zhang, and L. Y. Li. "Mesozoic gadflies (Insecta: Diptera)". Chinese. In: Acta Palaeontologica Sinica 32 (1993), pp. 662-672.

[25888] J. F. Zhang and X. Y. Zhang. "Fossil insects of cicada (Homoptera) and true bugs (Heteroptera) from Shanwang, Shandong". Chinese. In: Acta Palaeontologica Sinica 29 (1990), pp. 337-348.

[25889] J. F. Zhang and X. Y. Zhang. "New genus and new species of sawflies (Hymenoptera: Tenthredinidae) in Miocene from Shanwang, China". Chinese. In: Entomotaxonomia 12 (1990), pp. 29-35.

[25890] J. L. Zhang and P. W. Zhou. "Some Late Cambrian trilobites from Kushan Formation of Qingshuihe, Inner Mongolia". Chinese. In: Acta Palaeontologica Sinica 32.6 (1993), pp. 740-746.

[25891] J. P. Zhang, L. D. Xing, G. D. Gierlinski, F. D. Wu, M. Z. Tian, and P. J. Currie. "[First record of dinosaur trackways in Beijing, China]". Chinese. In: Chinese Science Bulletin 57.2-3 (2012), pp. 144152. DOI: $10.1360 / 972011-1963$.

[25892] J. Q. Zhang and J. Chen. "A stalk-eyed true bug in mid-Cretaceous Burmese amber (Hemiptera, Pentatomomorpha, Yuripopovinidae)". English. In: Cretaceous Research 110.104391 (2020). DOI: 10. 1016/j.cretres.2020.104391.

[25893] J. X. Zhang, C. K. Shih, J. F. Petruleviius, and D. Ren. "A new fossil eomeropid (Insecta, Mecoptera) from the Jiulongshan Formation, Inner Mongolia, China". English. In: Zoosystema 33 (2011), pp. 443450.

[25894] J. X. Zhang, C. K. Shih, and D. Ren. "A new fossil eomeropid (Insecta, Mecoptera) from the Yixian Formation, Liaoning, China". Chinese. In: Acta Zootaxonomica Sinica 37 (2012), pp. 68-71. 
[25895] J.-L. Zhang, Q. Wang, S. -X. Jiang, X. Cheng, N. Li, R. Qiu, X. -J. Zhang, and Z. -L. Wang. “Review of historical and current research on the Late Cretaceous dinosaurs and dinosaur eggs from Laiyang, Shandong". English. In: Vertebrata PalAsiatica 55.2 (2017), pp. 187-200.

[25896] J.-L. Zhang, X.-L. Wang, Q. Wang, S. -X. Jiang, X. Cheng, N. Li, and R. Qiu. “A new saurolophine hadrosaurid (Dinosauria: Ornithopoda) from the Upper Cretaceous of Shandong, China". English. In: Anais da Academia Brasileira de Ciencias 91.2 (2019), e20160920.

[25897] K. Y. Zhang, J. H. Li, D. Yang, and D. Ren. "A new species of Archirhagio Rohdendorf, 1938 from the Middle Jurassic of Inner Mongolia of China (Diptera: Archisargidae)". English. In: Zootaxa 1984 (2009), pp. 61-65.

[25898] K. Y. Zhang, D. Yang, D. Ren, and F. C. Ge. "New Middle Jurassic tangleveined flies from Inner Mongolia, China". English. In: Acta Palaeontologica Polonica 53.1 (2008), pp. 161-164.

[25899] K. Y. Zhang, D. Yang, and D. Ren. "A new genus and species of Middle Jurassic rhagionids from China (Diptera, Rhagionidae)". English. In: Biologia 63 (2008), pp. 113-116.

[25900] K. Y. Zhang, D. Yang, and D. Ren. "A new brachyceran family Origoasilidae Fam. Nov. from the late Mesozoic of China (Insecta: Diptera)". English. In: Acta Geologica Sinica 85.5 (2011), pp. 994997.

[25901] K. Y. Zhang, D. Yang, and D. Ren. "Middle Jurassic fossils of the genus Sharasargus from Inner Mongolia, China (Diptera: Archisargidae)". English. In: Entomological Science 11 (2008), pp. 269272.

[25902] K. Y. Zhang, D. Yang, and D. Ren. "Notes on the extinct family Protapioceridae, with description of a new species from China (Insecta: Diptera: Asiloidea)". English. In: Zootaxa 1530 (2007), pp. 2732.

[25903] K. Y. Zhang, D. Yang, and D. Ren. "The first snipe fly (Diptera: Rhagionidae) from the Middle Jurassic of Inner Mongolia, China". English. In: Zootaxa 1134 (2006), pp. 51-57.

[25904] K. Y. Zhang, D. Yang, D. Ren, and C. K. Shih. "New archisargids from China (Insecta: Diptera)". English. In: Entomological News 13 (2010), pp. 75-80.

[25905] K. Y. Zhang, D. Yang, D. Ren, and C. K. Shih. "An evolutional special case in the lower Orthorrhapha: some attractive fossil flies from the Middle Jurassic of China (Insecta: Diptera: Brachycera)". English. In: Zoological Journal of the Linnean Society 158 (2010), pp. 563-572.

[25906] K. Y. Zhang, D. Yang, D. Ren, and C. K. Shih. "The oldest Calosargus Mostovski, 1997 from the Middle Jurassic of China (Diptera: Brachycera: Archisargidae)". English. In: Zootaxa 1645 (2007), pp. 1-17.

[25907] K. Y. Zhang, D. Yang, and D. Ren. “The first Middle Jurassic Protobrachyceron Handlirsch fly (Diptera: Brachycera: Protobrachyceridae) from Inner Mongolia (China)". English. In: Zootaxa 1879 (2008), pp. 61-64.

[25908] K. Y. Zhang, D. Yang, D. Ren, and C. K. Shih. "The earliest species of the extinct genus Archisargus from China (Diptera: Brachycera: Archisargidae)". English. In: Annales Zoologici 57 (2007), pp. 827832.

[25909] K. Y. Zhang, D. Yang, and D. Ren. "New short-horned flies (Diptera: Eremochaetidae) from the Early Cretaceous of China". English. In: Zootaxa 3760 (2014), pp. 479-486.

[25910] M. S. Zhang. "New trilobites from the Upper Cambrian Changshanian stage of Eastern Liaoning, NE China". Chinese. In: Acta Palaeontologica Sinica 38.1 (1999), pp. 106-113.

[25911] Q. Zhang, D. S. Kopylov, A. P. Rasnitsyn, Y. Zheng, and H. C. Zhang. “Burmorussidae, a new family of parasitic wasps (Insecta, Hymenoptera) from mid-Cretaceous Burmese amber". English. In: Papers in Palaeontology 6 (2020), pp. 593-603. DOI: 10.1002/spp2.1312.

[25912] Q. Zhang, A. P. Rasnitsyn, B. Wang, and H. C. Zhang. "Myanmarinidae, a new family of basal Apocrita (Hymenoptera: Stephanoidea) from mid-Cretaceous Burmese amber". English. In: Cretaceous Research 81 (2017), pp. 86-92. 
[25913] Q. Zhang, A. P. Rasnitsyn, B. Wang, and H. C. Zhang. “New data about the enigmatic wasp from mid-Cretaceous Burmese amber (Hymenoptera, Stephanoidea, Aptenoperissidae)". English. In: Cretaceous Research 84 (2017), pp. 173-180.

[25914] Q. Zhang, A. P. Rasnitsyn, B. Wang, and H. C. Zhang. "Peleserphidae, a new family of basal proctotrupomorphs (Hymenoptera: Proctotrupoidea) from mid-Cretaceous Burmese amber". English. In: Cretaceous Research 86 (2017), pp. 66-72.

[25915] Q. Zhang, A. P. Rasnitsyn, and H. C. Zhang. "Burmusculidae, a new and basal family of pompiloid wasps from the Cretaceous of Eurasia (Hymenoptera: Pompiloidea)". English. In: Cretaceous Research 91 (2018), pp. 341-349.

[25916] Q. Zhang, A. P. Rasnitsyn, and H. C. Zhang. "New female of Aptenoperissus from mid-Cretaceous Burmese amber (Hymenoptera, Stephanoidea, Aptenoperissidae)". English. In: Cretaceous Research 92 (2018), pp. 8-11.

[25917] Q. Zhang, A. P. Rasnitsyn, and H. C. Zhang. “New Angarosphecidae (Insecta: Hymenoptera: Apoidea) from the Lower Cretaceous of northeastern China". English. In: Paleontological Journal 52 (2018), pp. 414-420.

[25918] Q. Zhang, A. P. Rasnitsyn, B. Wang, and H. C. Zhang. "Hymenoptera (wasps, bees and ants) in mid-Cretaceous Burmese amber: A review of the fauna". English. In: Proceedings of the Geologists' Association 129 (2018), pp. 736-747.

[25919] Q. Zhang, H. C. Zhang, A. P. Rasnitsyn, and E. A. Jarzembowski. "A new genus of Scoliidae (Insecta: Hymenoptera) from the Lower Cretaceous of northeast China". English. In: Cretaceous Research 52 (2015), pp. 579-584.

[25920] Q. Zhang, H. C. Zhang, A. P. Rasnitsyn, H. Wang, and M. Ding. "New Ephialtitidae (Insecta: Hymenoptera) from the Jurassic Daohugou beds of Inner Mongolia, China". English. In: Palaeoworld 23 (2014), pp. 276-284.

[25921] Q. P. Zhang, J. F. Zhang, Y. T. Fang, H. C. Zhang, and B. Wang. “An endoparasitoid Cretaceous fly and the evolution of parasitoidism". English. In: The Science of Nature 103.2 (2016), pp. 1-7.

[25922] Q. Q. Zhang, K. Y. Chen, Y. T. Wang, R. X. Xue, E. A. Jarzembowski, and B. Wang. "Long-proboscid zhangsolvid flies in mid-Cretaceous Burmese amber (Diptera: Stratiomyomorpha)". English. In: Cretaceous Research 98 (2019), pp. 18-25. DOI: 10.1016/j.cretres.2019.01.019.

[25923] Q. Q. Zhang, X. K. Li, B. Q. Xu, Y. M. Zhu, R. Q. Lu, B. Wang, and D. K. Yeates. "Two new genera of Apsilocephalidae from mid-Cretaceous Burmese amber". English. In: Cretaceous Research 84 (2017), pp. 525-532.

[25924] Q. Q. Zhang, W. Mey, J. Ansorge, T. A. Starkey, L. T. McDonald, M. E. McNamara, E. A. Jarzembowski, W. Wichard, R. Kelly, X. Y. Ren, J. Chen, H. C. Zhang, and B. Wang. "Fossil scales illuminate the early evolution of lepidopterans and structural colors". English. In: Science Advances 4 (2018), e1700988.

[25925] Q. Q. Zhang, A. Nel, D. Azar, and B. Wang. "New Chinese psocids from Eocene Fushun amber (Insecta: Psocodea)". English. In: Alcheringa 40 (2016), pp. 366-372.

[25926] Q. Q. Zhang, J. F. Zhang, and B. Wang. "A remarkable brachyceran fly (Diptera: Tabanomorpha) from Late Cretaceous Burmese amber". English. In: Cretaceous Research 67 (2016), pp. 1-7.

[25927] Q. Q. Zhang, J. F. Zhang, and B. Wang. "First record of the subfamily Archinemestriinae in the family Nemestrinidae (Diptera: Brachycera) from Upper Cretaceous Burmese amber". English. In: Cretaceous Research 75 (2017), pp. 141-145.

[25928] Q. Q. Zhang, J. F. Zhang, and B. Wang. “New bizarre flies from mid-Cretaceous Burmese amber (Diptera, Rhagionemestriidae)". English. In: Cretaceous Research 110.104347 (2020). DOI: 10.1016/j. cretres.2019.104347.

[25929] Q. Y. Zhang, S. X. Hu, C. Y. Zhou, T. Lu, and J. K. Bai. "New occurrence of Xiphosura in China". Chinese. In: Progress in Nature Science 19 (2009), pp. 1090-1093. 
[25930] Q.-N. Zhang, H.-L. You, T. Wang, and S. Chatterjee. "A new sauropodiform dinosaur with a 'sauropodan' skull from the Lower Jurassic Lufeng Formation of Yunnan Province, China". English. In: Scientific Reports 8 (2018), 13464:1-12. DOI: 10.1038/s41598-018-31874-9.

[25931] S. Zhang and C. R. Barnes. "Late Ordovician to Early Silurian Conodont faunas from the Kolyma Terrane, Omulev Mountains, Northeast Russia, and their paleobiogeographic affinity". English. In: Journal of Paleontology 81.3 (2007), pp. 490-512.

[25932] S. Zhang and C. R. Barnes. "A New Llandovery (Early Silurian) Conodont Biozonation and Conodonts from the Becscie,Merrimack, and Gun River Formations, Anticosti Island, Québec". English. In: Memoir (The Paleontological Society) (2002).

[25933] S. Zhang and C. R. Barnes. "Late Ordovician- Early Silurian conodont biostratigraphy and thermal maturity, Hudson Bay Basin". English. In: Bulletin of Canadian Petroleum Geology 55.3 (2007), pp. 179-216.

[25934] S. Zhang, D. Jowett, and C. Barnes. "Hirnantian (Ordovician) through Wenlock (Silurian) conodont biostratigraphy, bioevents, and integration with graptolite biozones, Cape Phillips Formation slope facies, Cornwallis Island, Canadian Arctic Islands". English. In: Canadian Journal of Earth Sciences 54.9 (2017), pp. 936-960. DOI: 10.1139/cjes-2017-0023.

[25935] S. Zhang, K. Mirza, and C. R. Barnes. “Upper Ordovician - Upper Silurian conodont biostratigraphy, Devon Island and southern Ellesmere Island, Canadian Arctic Islands, with implications for regional stratigraphy, eustasy, and thermal maturation". English. In: Canadian Journal of Earth Sciences 53.9 (2016), pp. 931-949.

[25936] S. G. Zhang and C. Y. Sun. "Early Cambrian small shelly fossils from Chaohu area, Anhui". Chinese. In: Acta Micropalaeontologica Sinica 8.1 (1991), pp. 19-40.

[25937] S. H. Zhang, S. P. Xie, Y. Zhang, B. Wang, P. Zhang, X. Zeng, and Y. Yu. "A new species of dance fly (Diptera, Empidoidea, Atelestidae) from mid-Cretaceous Burmese amber". English. In: Cretaceous Research 118.104660 (2020). DOI: 10.1016/j.cretres.2020.104660.

[25938] S.-G. Zhang. "Exothecal structures of the calathiids and their significance". Chinese. In: Acta Palaeontologica Sinica 34.5 (1995), pp. 619-634.

[25939] S.-K. Zhang. "[A parataxonomic revision of the Cretaceous faveoloolithid eggs of China]". Chinese. In: Vertebrata PalAsiatica 48.3 (2010), pp. 203-219.

[25940] S.-K. Zhang and Q. Wang. "[A new species of ovaloolithids from Turpan Basin in Xinjiang, China]". Chinese. In: Vertebrata PalAsiatica 48.1 (2010), pp. 71-75.

[25941] T. W. Zhang, C. S. Luo, C. F. Shi, Q. Yang, and D. Ren. "New species of green lacewings (Insecta, Neuroptera) from the Lower Cretaceous of China". English. In: Cretaceous Research 115.104564 (2020). DOI: 10.1016/j.cretres.2020.104564.

[25942] W. Zhang, L. E. Babcock, L. Xiang, W. Sun, H. Luo, and Z. Jiang. “Lower Cambrian stratigraphy of Chengjiang, eastern Yunnan, China with special notes on Chinese Parabadiella, Moroccan Abadiella and Australian Abadiella huoi". English. In: Acta Palaeontologica Sinica 40.294 (2001), pp. -309 .

[25943] W. Zhang, M. S. Engel, Y. Yao, D. Ren, and C. Shih. “The Mesozoic family Archegocimicidae and phylogeny of the infraorder Leptopodomorpha (Hemiptera)". English. In: Journal of Systematic Palaeontology 12 (2013), pp. 93-111.

[25944] W. Zhang, L. Xiang, Y. Liu, and X. Meng. "Cambrian stratigraphy and trilobites from Henan". English. In: Palaeontologia Cathayana 6 (1995), pp. 1-166.

[25945] W. T. Zhang, P. T. Deng, J. J. Wang, P. Zhang, Z. Guo, and D. Ren. “A new jaw-moth (Lepidoptera: Micropterigidae) from mid-Cretaceous Burmese amber". English. In: Cretaceous Research 116.104609 (2020). DOI: 10.1016/j.cretres.2020.104609.

[25946] W. T. Zhang, H. Li, C. K. Shih, A. B. Zhang, and D. Ren. "Phylogenetic analyses with four new Cretaceous bristletails reveal inter-relationships of Archaeognatha and Gondwana origin of Meinertellidae". English. In: Cladistics 34 (2018), pp. 384-406. 
[25947] W. T. Zhang, C. K. Shih, C. C. Labandeira, J. C. Sohn, D. R. Davis, J. A. Santiago-Blay, O. Flint, and D. Ren. "New fossil Lepidoptera (Insecta: Amphiesmenoptera) from the Middle Jurassic Jiulongshan Formation of northeastern China". English. In: PLoS One 8.11 (2013), e79500.

[25948] W. T. Zhang, C. K. Shih, C. C. Labandeira, and D. Ren. "A new taxon of a primitive moth (Insecta: Lepidoptera: Eolepidopterigidae) from the latest Middle Jurassic of northeastern China". English. In: Journal of Paleontology 89 (2016), pp. 617-621.

[25949] W. T. Zhang, C. K. Shih, and D. Ren. "Two new fossil caddisflies (Amphiesmenoptera: Trichoptera) from the Middle Jurassic of northeastern China". English. In: Alcheringa 41 (2017), pp. 22-29.

[25950] W. T. Zhang, C. K. Shih, Y. H. Shih, and D. Ren. "A new macrolepidopteran moth (Insecta, Lepidoptera, Geometridae) in Miocene Dominican amber". English. In: ZooKeys 965 (2020), pp. 73-84. DOI: 10.3897 / zookeys.965.54461.

[25951] W. T. Zhang, J. J. Song, Y. Z. Yao, and D. Ren. “A new fossil Saldidae (Hemiptera: Heteroptera: Leptopodomorpha) from the Early Cretaceous in China". English. In: Zootaxa 3273 (2012), pp. 6368.

[25952] W. T. Zhang, J. J. Wang, C. K. Shih, and D. Ren. “Cretaceous moths (Lepidoptera: Micropterigidae) with preserved scales from Myanmar amber". English. In: Cretaceous Research 78 (2017), pp. 166173.

[25953] W. T. Zhang, Y. Z. Yao, D. Ren, and Y. Y. Zhao. "First description of fossil Naucoridae (Heteroptera: Nepomorpha) from late Mesozoic of China". English. In: Acta Geologica Sinica 85 (2011), pp. 490500 .

[25954] W. T. Zhang, Y. Z. Yao, and D. Ren. “New shore bug (Hemiptera, Heteroptera, Saldidae) from the Early Cretaceous of China with phylogenetic analyses". English. In: ZooKeys 130 (2011), pp. 185198.

[25955] W. T. Zhang, Y. Z. Yao, and D. Ren. "A revision of the species Notonecta xyphiale (Popov, 1964) (Heteroptera: Notonectidae)". English. In: Cretaceous Research 22 (2012), pp. 159-164.

[25956] W. T. Zhang, Y. Z. Yao, and D. Ren. "Phylogenetic analysis of a new fossil Notonectidae (Heteroptera: Nepomorpha) from the Late Jurassic of China". English. In: Alcheringa 36 (2012), pp. 239250.

[25957] W. T. Zhang, Y. Z. Yao, and D. Ren. "A new Early Cretaceous shore bug (Hemiptera: Heteroptera: Saldidae) from China". English. In: Zootaxa 3647 (2013), pp. 585-592.

[25958] W. W. Zhang, W. Z. Cai, W. Z. Li, X. K. Yang, and S. Q. Ge. “A new species of Chresmodidae from Mid-Cretaceous amber discovered in Myanmar". English. In: Zoological Systematics 42 (2017), pp. 243-247.

[25959] W. W. Zhang, M. X. Guo, X. K. Yang, and M. Bai. “A new species of ice crawlers from Burmese amber (Insecta: Grylloblattodea)". English. In: Zoological Systematics 41 (2016), pp. 327-331.

[25960] W.-T. Zhang and L. E. Babcock. "Helcionelloid mollusk from the Lower Cambrian Heilinpu Formation, Chengjiang, Yunnan". In: Acta Palaeontologica Sinica 41.3 (2002), pp. 303-307.

[25961] X. Zhang. "Early Cambrian palaeoscolecid cuticles from Shaanxi,China". In: Journal of Paleontology 70.2 (1996), pp. 275-279.

[25962] X. Zhang, J. Lü, J. Li, L. Yang, W. Hu, S. Jia, Q. Ji, and C. Zhang. “A new sauropod dinosaur from the Late Cretaceous Gaogou Formation of Nanyang, Henan Province". English. In: Acta Geologica Sinica 83.2 (2009), pp. 212-221.

[25963] X. Zhang, D. Ren, and Y. Z. Yao. "A new species of Foveopsis Shcherbakov (Hemiptera: Fulgoromorpha: Fulgoroidea: Perforissidae) from mid-Cretaceous Burmese amber". English. In: Cretaceous Research 79 (2017), pp. 35-42.

[25964] X. Zhang, D. Ren, and Y. Z. Yao. "A new genus and species of Mimarachnidae (Hemiptera: Fulgoromorpha: Fulgoroidea) from mid-Cretaceous Burmese amber". English. In: Cretaceous Research 90 (2018), pp. 168-173. 
[25965] X. Zhang, D. Ren, and Y. Z. Yao. “A new family Jubisentidae fam. nov. (Hemiptera: Fulgoromorpha: Fulgoroidea) from the mid-Cretaceous Burmese amber". English. In: Cretaceous Research 94 (2019), pp. 1-7. DOI: 10.1016/j.cretres.2018.10.012.

[25966] X. Zhang, C. K. Shih, Y. Y. Zhao, and D. Ren. “New species of Cimbrophlebiidae (Insecta: Mecoptera) from the Middle Jurassic of northeastern China". English. In: Acta Geologica Sinica 89 (2015), pp. 14821496.

[25967] X. Zhang, D. Wang, R. Liu, Z. Wei, Y. Hua, Y. Wang, Z. Chen, and L. Wang. “The Yangtze River dolphin or baiji (Lipotes vexillifer): population status and conservation issues in the Yangtze River, China". English. In: Aquatic conservation: Marine and freshwater ecosystems 13 (2003), pp. 51-64.

[25968] X. Zhang and S. Wang. "First report of Eozygodon (Mammutidae, Proboscidea) in Eurasia". English. In: Historical Biology (2020). DOI: 10.1080/08912963.2020.1723579.

[25969] X. H. Zhang. "The Late Carboniferous and Early Permian rugose corals from Ziyun County and Qinglong County, south Guizhou". Chinese. In: Acta Palaeontologica Sinica 41 (2002), pp. 283-294.

[25970] X. L. Zhang and H. Hua. "Soft-bodied fossils from the Shipai Formation, Lower Cambrian of the Three Gorge area, South China". English. In: Geological Magazine 142.5 (2005), pp. 1-11.

[25971] X. W. Zhang, D. Ren, H. Pang, and C. K. Shih. "Late Mesozoic chresmodids with forewing from Inner Mongolia, China (Polyneoptera: Archaeorthoptera)". English. In: Acta Geologica Sinica 84 (2009), pp. 38-46.

[25972] X. W. Zhang, D. Ren, H. Pang, and C. K. Shih. "A water-skiing chresmodid from the Middle Jurassic in Daohugou, Inner Mongolia, China (Polyneoptera: Orthopterida)". English. In: Zootaxa 1762 (2008), pp. 53-62.

[25973] X. W. Zhang, D. Ren, H. Pang, and C. K. Shih. "A new genus and species of Chresmodidae (Insecta: Gryllones) from Upper Jurassic-Lower Cretaceous of Yixian Formation, Inner Mongolia, China". English. In: Zootaxa 1702 (2008), pp. 26-40.

[25974] X.-G. Zhang, X.-G. Hou, and C. C. Emig. "Evidence of lophophore diversity in Early Cambrian Brachiopoda". English. In: Proceedings of the Royal Society, London B (Suppl.) 270 (2003), S65-S68.

[25975] X.-H. Zhang, X. Xu, X. -J. Zhao, P. C. Sereno, X. -W. Kuang, and L. Tan. “A long-necked therizinosauroid dinosaur from the Upper Cretaceous Iren Dabasu Formation of Nei Mongol, People's Republic of China". English. In: Vertebrata PalAsiatica 39.4 (2001), pp. 282-290.

[25976] X.-L. Zhang, W. Liu, and Y. -L. Zhao. “Cambrian Burgess Shale-type Lagerstäten in South China: Distribution and significance". English. In: Gondwana Research 14 (2008), pp. 255-262. DOI: 10. 1016/j.gr.2007.06.008.

[25977] X.-L. Zhang and D.-G. Shu. "A new arthropod from the Chengjiang Lagerstatte, Early Cambrian, southern China". English. In: Alcheringa 29 (2005), pp. 185-194.

[25978] Y. Zhang, E. Gong, W. Huang, M. A. Wilson, C. Guan, X. Li, L. Wang, J. Wang, and Z. Miao. “Factors controlling the development of Fomichevella coral bioconstructions in the Gzhelian-Asselian (Late Pennsylvanian-early". English. In: Palaeobiodiversity and Palaeoenvironments (2020). DOI: 10. 1007/s12549-020-00431-6.

[25979] Y. Zhang, W. H. He, G. R. Shi, and K. X. Zhang. "A new Changhsingian (Late Permian) Rugosochonetidae (Brachiopoda) fauna from the Zhongzhai section, southwestern Guizhou Province, South China". English. In: Alcheringa 37 (2013), pp. 223-247.

[25980] Y. Zhang, W. H. He, G. R. Shi, K. X. Zhang, and H. T. Wu. "A new Changhsingian (Late Permian) brachiopod fauna from the Zhongzhai section (South China) Part 3: Productida". English. In: Alcheringa 39 (2015), pp. 295-314.

[25981] Y. Zhang, K. Li, and Q. Zeng. "A new species of sauropod from the Late Jurassic of the Sichuan Basin (Mamenchisaurus jingyanensis sp. nov.)" Chinese. In: Journal of the Chengdu University of Technology 25.1 (1998), pp. 61-68.

[25982] Y. Zhang, Y. Li, and A. Munnecke. "Late Ordovician microbial reefs in the Lianglitag Formation (Bachu, Tarim, NW China)”. English. In: Facies (2014). 
[25983] Y. Zhang, Y. Li, G. Wang, and A. Munnecke. “Windward and leeward margins of an Upper Ordovician carbonate platform in the Central Tarim Uplift, Xinjiang, northwestern China". English. In: Palaeogeography, Palaeoclimatology, Palaeoecology 474 (2017), pp. 79-88. DOI: 10.1016/j.palaeo. 2016.12.040.

[25984] Y. Zhang, J. O'Connor, L. Di, M. Qingin, T. Sigurdsen, and L. M. Chiappe. "New information on the anatomy of the Chinese Early Cretaceous Bohaiornithidae (Aves: Enantiornithes) from a subadult specimen of Zhourornis hani". English. In: PeerJ 2 (2014), e407.

[25985] Y. Zhang, G. R. Shi, W. H. He, K. X. Zhang, and H. T. Wu. "A new Changhsingian (Late Permian) brachiopod fauna from the Zhongzhai section (South China), Part 2: Lingulida, Orthida, Orthotetida and Spiriferida". English. In: Alcheringa 38 (2014), pp. 480-503.

[25986] Y. Zhang and Z. Yang. A new complete osteology of Prosauropoda in Lufeng Basin, Yunnan, China. Chinese. Yunnan Publishing House of Science and Technology, Kunming, China. 1995, pp. 1-100.

[25987] Y. C. Zhang, L. R. Cheng, and S. Z. Shen. "Late Guadalupian (Middle Permian) fusuline fauna from the Xiala Formation in Xainza County, central Tibet: implication for the rifting time of the Lhasa block". English. In: Journal of Paleontology 84 (2010), pp. 955-973.

[25988] Y. C. Zhang, S. Z. Shen, G. R. Shi, Y. Wang, D. X. Yuan, and Y. J. Zhang. "Tectonic evolution of the Qiangtang Block, northern Tibet during the Late Cisuralian (Late Early Permian): Evidence from fusuline fossil records". English. In: Palaeogeography, Palaeoclimatology, Palaeoecology 350-352 (2012), pp. 139-148.

[25989] Y. C. Zhang, Y. Wang, Y. J. Zhang, and D. X. Yuan. “Kungurian (Late Cisuralian) fusuline fauna from the Cuozheqiangma area, northern Tibet and its palaeobiogeographical implications". English. In: Palaeoworld 21 (2012), pp. 139-152.

[25990] Y. J. Zhang, C. K. Shih, A. P. Rasnitsyn, D. Ren, and T. P. Gao. “A new Early Cretaceous flea from China". English. In: Acta Palaeontologica Polonica 65 (2020), pp. 99-107. DOI: 10.4202 / app.00680. 2019.

[25991] Y. L. Zhang, E. P. Gong, M. A. Wilson, C. Q. Guan, and B. L. Sun. "A large coral reef in the Pennsylvanian of Ziyun County, Guizhou (south China): The substrate and initial colonization environment of reef-building corals". English. In: Journal of Asian Earth Sciences 37 (2010), pp. 335-349.

[25992] Y.-d. Zhang and R. A. Fortey. "The Proximal Development and Thecal Structure of the Ordovician Graptolites Tylograptus and Sinograptus". English. In: 44.3 (2001), pp. 553-573. DOI: 10.1111 / 1475-4983.00191.

[25993] Y.-D. Zhang and A. C. Lenz. "Early Devonian graptolites of Southwest Yunnan, China". English. In: Journal of Paleontology 72.2 (1998), pp. 353-360.

[25994] Z. Zhang, D. Chen, H. Zhang, and L. Hou. "A large enantiornithine bird from the Lower Cretaceous of China and its implication for lung ventilation". English. In: Biological Journal of the Linnean Society 113 (2014), pp. 820-827.

[25995] Z. Zhang, L. M. Chiappe, G. Han, and A. Chinsamy. "A large bird from the Early Cretaceous of China: new information on the skull of enantiornithines". English. In: Journal of Vertebrate Paleontology 33.5 (2013), pp. 1176-1189. DOI: 10.1080/02724634.2013.762708.

[25996] Z. Zhang and A. Feduccia. "A late Miocene accipitrid (Aves, Accipitriformes) from Nebraska and its implications for the divergence of Old World vultures". English. In: PloS One 7.11 (2012), e48842. DOI: 10.1371/journal.pone.0048842.

[25997] Z. Zhang, C. Gao, Q. Meng, J. Liu, L. Hou, and G. Zheng. “Diversification in an Early Cretaceous avian genus: evidence from a new species of Confuciusornis from China". English. In: Journal of Ornithology 150.4 (2009), pp. 783-790. DOI: 10.1007/s10336-009-0399-x.

[25998] Z. Zhang, L. Hou, Y. Hasegawa, J. O'Connor, L. D. Martin, and L. M. Chiappe. “The first Mesozoic heterodactyl bird from China". English. In: Acta Geologica Sinica 80.5 (2006), pp. 631-635.

[25999] Z. Zhang, L. E. Holmer, and G. Li. "First report of linguloid brachiopods with soft parts from the lower Cambrian (Series 2, Stage 4) of the Three Gorges area, South China". English. In: Annales de Paléontologie 101.3 (2015), pp. 167-177. DOI: 10.1016/j.annpal.2015.04.002. 
[26000] Z. Zhang, X. Zheng, G. Zheng, and L. Hou. "A new Old World vulture (Falconiformes: Accipitridae) from the Miocene of Gansu Province, northwest China". English. In: Journal of Ornithology 151.2 (2010), pp. 401-408. DOI: 10.1007/s10336-009-0468-1.

[26001] Z. Zhang, Z. Zhou, and M. J. Benton. "A primitive confuciusornithid bird from China and its implications for early avian flight". English. In: Science in China Series D: Earth Sciences 51.5 (2008), pp. 625-639.

[26002] Z. F. Zhang, L. E. Holmer, C. B. Skovsted, G. A. Brock, G. E. Budd, D. J. Fu, X. L. Zhang, D. G. Shu, J. Han, J. N. Liu, H. Z. Wang, A. Butler, and G. X. Li. "A sclerite-bearing stem group entoproct from the early Cambrian and its implications". English. In: Scientific Reports 3.1066 (2013), pp. 1-7. DOI: $10.1038 /$ srep01066.

[26003] Z. J. Zhang. "New Early Cretaceous lalacid from Jingxi basin of Beijing, China (Homoptera, Fulgoroidea)". English. In: Acta Zootaxonomica Sinica 27 (2002), pp. 20-23.

[26004] Z. J. Zhang, Y. C. Hong, L. W. Lu, X. S. Fang, and Y. G. Jin. "Shenzhousia qilianshanensis gen. et sp. nov. (Protodonata, Meganeuridae), a giant dragonfly from the Upper Carboniferous of China". English. In: Progress in Natural Science 16.3 (2006), pp. 328-330.

[26005] Z. J. Zhang, Y. C. Hong, and Z. Y. Li. "Description of a new fossil genus and species Huaxiasciophilites jingxiensis (Diptera: Mesosciophilidae) from Early Cretaceous Jingxi basin of Beijing, China". English. In: Entomologica Sinica 8 (2001), pp. 193-198.

[26006] Z. J. Zhang, L. W. Lu, Y. G. Jin, X. S. Fang, and Y. C. Hong. "Discovery of fossil insects in the Tuodian Formation, central Yunnan". Chinese. In: Geological Bulletin of China 22 (2003), pp. 452455.

[26007] Z. J. Zhang, J. W. Schneider, and Y. C. Hong. "The most ancient roach (Blattodea): a new genus and species from the earliest Late Carboniferous (Namurian) of China, with a discussion of the phylomorphogeny of early blattids". English. In: Journal of Systematic Palaeontology 11 (2013), pp. 2740.

[26008] Z.-F. Zhang, D.-G. Shu, J. Han, and J. -N. Liu. "New data on the rare Chengjiang (Lower Cambrian, South China) linguloid brachiopod Xianshanella haikouensis". English. In: Journal of Paleontology 80.2 (2006), pp. 203-211.

[26009] Z.-Q. Zhang. "A new species of Shaanxispira (Bovidae, Artiodactyla, Mammalia) from the Bahe Formation, Lantian, China". English. In: Vertebrata PalAsiatica 41.3 (2003), pp. 230-239.

[26010] Z.-Q. Zhang, A. W. Gentry, A. Kaakinen, L. -P. Liu, J. P. Lunkka, Z. -D. Qiu, S. Sen, R. S. Scott, L. Werdelin, S. -H. Zheng, and M. Fortelius. "Land mammal faunal sequence of the late Miocene of China: new evidence from Lantian, Shaanxi Province". English. In: Vertebrata PalAsiatica 40.3 (2002), pp. 165-176.

[26011] R. D. Zhantiev. "New species of late Eocene dermestid beetles (Coleoptera, Dermestidae) from the Rovno and Baltic ambers". English. In: Paleontological Journal 40.5 (2006), pp. 560-563. DOI: 10.1134/S0031030106050108.

[26012] F. Zhao, J. Caron, D. J. Bottjer, S. Hu, Z. Yin, and M. Zhu. “Diversity and species abundance patterns of the early Cambrian (Series 2, Stage 3) Chengjiang Biota from China". English. In: (2013).

[26013] F. C. Zhao, S. X. Hu, J. B. Caron, M. Y. Zhu, Z. J. Yin, and M. Lu. "Spatial variation in the diversity and composition of the Lower Cambrian (Series 2, Stage 3) Chengjiang Biota, Southwest China". English. In: Palaeogeography, Palaeoclimatology, Palaeoecology 346/347 (2012), pp. 54-65.

[26014] H. Y. Zhao, M. Bai, C. K. Shih, and D. Ren. "Two new glaphyrids (Coleoptera, Scarabaeoidea) from the Jehol Biota, China". English. In: Cretaceous Research 59 (2016), pp. 1-9.

[26015] J. M. Zhao and X. S. Zhu. "Early Permian Maokou Formation rugose corals from Xintang, Yichun, Jiangxi". Chinese. In: Acta Palaeontologica Sinica 30 (1991), pp. 90-99.

[26016] J. X. Zhao, D. Ren, and C. K. Shih. "Enigmatic earwig-like fossils from Inner Mongolia, China”. English. In: Insect Science 17 (2010), pp. 459-464. 
[26017] J. X. Zhao, C. K. Shih, D. Ren, and Y. Y. Zhao. “New primitive fossil earwig from Daohugou, Inner Mongolia, China (Insecta: Dermaptera: Archidermaptera)". English. In: Acta Geologica Sinica 85 (2011), pp. 75-80.

[26018] J. X. Zhao, Y. Y. Zhao, C. K. Shih, D. Ren, and Y. J. Wang. “Transitional fossil earwings - a missing link in Dermaptera evolution". English. In: BMC Evolutionary Biology 10.344 (2010), pp. 1-10.

[26019] L.-J. Zhao, J. Liu, C. Li, and T. He. "A new thalattosaur, Concavispina biseridens gen. et sp. nov. from Guanling, Guizhou, China”. Chinese. In: Vertebrata PalAsiatica 51.1 (2013), pp. 24-28.

[26020] L. J. Zhao and L. W. Lu. "A new genus of Early Triassic perleidid fish from Changxing, Zhejiang, China". Chinese. In: Acta Palaeontologica Sinica 46 (2007), pp. 238-243.

[26021] L.-J. Zhao, C. Li, J. Liu, and T. He. "A new armored placodont from the Middle Triassic of Yunnan Province, southwestern China". English. In: Vertebrata PalAsiatica 46 (2008), pp. 171-177.

[26022] L.-J. Zhao, T. Sato, J. Liu, C. Li, and X. -C. Wu. "A new skeleton of Miodentosaurus brevis (Diapsida: Thalattosauria) with a further study of the taxon". English. In: Vertebrata PalAsiatica 48.1 (2010), pp. 1-10.

[26023] M. Zhao, C. L. Sun, D. L. Dilcher, Y. L. Na, and D. H. Xing. "A new species of Baiera from the Early Cretaceous Jehol Biota of southeastern Jilin, China". English. In: Palaeoworld 25 (2016), pp. 251-262.

[26024] Q. Zhao, P. M. Barrett, and D. A. Eberth. "Social behaviour and mass mortality in the basal ceratopsian dinosaur Psittacosaurus (Early Cretaceous, People's Republic of China)". English. In: Palaeontology 50.5 (2007), pp. 1023-1029. DOI: 10.1111/j.1475-4983.2007.00709.x.

[26025] W.-J. Zhao and M. Zhu. "Siluro-Devonian vertebrate biostratigraphy and biogeography of China". English. In: Palaeoworld 19.1-2 (2010), pp. 4-26. DOI: 10.1016/j.palwor.2009.11.007.

[26026] X. Zhao. "A new mid-Jurassic sauropod (Klamelisaurus gobiensis gen. et sp. nov.) from Xinjiang, China". Chinese. In: Vertebrata PalAsiatica 31.2 (1993), pp. 132-138.

[26027] X. Zhao, Z. Cheng, and X. Xu. "The earliest ceratopsian from the Tuchengzi Formation of Liaoning, China". English. In: Journal of Vertebrate Paleontology 19.4 (1999), pp. 681-697.

[26028] X. Zhao, Z. Cheng, X. Xu, and P. J. Makovicky. “A new ceratopsian from the Upper Jurassic Houcheng Formation of Hebei, China". English. In: Acta Geologica Sinica 80.4 (2006), pp. 467-473.

[26029] X. Zhao, D. Li, G. Han, H. Zhao, F. Liu, L. Li, and X. Fang. "Zuchengosaurus maximus from Shandong Province". Chinese. In: Acta Geoscientia Sinica 28.2 (2007), pp. 111-122.

[26030] X. D. Zhao, A. Bashkuev, L. Chen, and B. Wang. "The first hangingfly from mid-Cretaceous Burmese amber (Mecoptera: Bittacidae)". English. In: Cretaceous Research 70 (2016), pp. 147-151.

[26031] X. D. Zhao, B. Wang, A. S. Bashkuev, C. Aria, Q. Q. Zhang, H. C. Zhang, W. T. Tang, and M. S. Engel. "Mouthpart homologies and life habits of Mesozoic long-proboscid scorpionflies". English. In: Science Advances 6.eaay1259 (2020). DOI: 10.1126/sciadv.aay1259.

[26032] X. D. Zhao, Q. Q. Zhang, E. A. Jarzembowski, L. Chen, and B. Wang. “A new earwigfly from midCretaceous Burmese amber (Mecoptera: Meropeidae)". English. In: Cretaceous Research 66 (2016), pp. 136-140.

[26033] X. D. Zhao, X. Y. Zhao, L. Chen, and B. Wang. "The earliest tiger beetle from the Lower Cretaceous of China (Coleoptera: Cicindelinae)". English. In: Cretaceous Research 94 (2019), pp. 147-151. DOI: 10.1016/j.cretres.2018.10.019.

[26034] X. D. Zhao, X. Y. Zhao, E. A. Jarzembowski, and B. Wang. "The first whirligig beetle larva from mid-Cretaceous Burmese amber (Coleoptera: Adephaga: Gyrinidae)". English. In: Cretaceous Research 99 (2019), pp. 41-45. DOI: 10.1016/j.cretres.2019.02.015.

[26035] X. D. Zhao, X. Y. Zhao, B. Wang, E. Jarzembowski, Y. Fang, and L. Chen. “The first corydalid larva (Megaloptera: Corydalidae) with gut-contents from the Early Cretaceous Jehol biota of northeastern China". English. In: Cretaceous Research 100 (2019), pp. 46-50. DOI: 10.1016/j.cretres.2019.03. 015. 
[26036] X. D. Zhao, X. Y. Zhao, L. Chen, Q. Zhang, and B. Wang. "A new species of Eomeropidae (Insecta: Mecoptera) from the Middle Jurassic of China". English. In: Proceedings of the Geologists' Association 130 (2019), pp. 691-695. DOI: 10.1016/j.pgeola.2019.10.005.

[26037] X. Y. Zhao, X. D. Zhao, E. A. Jarzembowski, L. Chen, and B. Wang. "First record of adult Coptoclava longipoda Ping (Coleoptera: Coptoclavidae) from the Lower Cretaceous of Laiyang, China". English. In: Cretaceous Research 92 (2018), pp. 205-209.

[26038] X. Y. Zhao, X. D. Zhao, E. Jarzembowski, Y. Tian, and L. Chen. “The first record of brachypsectrid larva from mid-Cretaceous Burmese amber (Coleoptera: Polyphaga)". English. In: Cretaceous Research 113.104493 (2020). DOI: 10.1016/j.cretres.2020.104493.

[26039] X.-J. Zhao and P. J. Currie. "A large crested theropod from the Jurassic of Xinjiang, People's Republic of China". English. In: Canadian Journal of Earth Sciences 30.10-11 (1994), pp. 2027-2036.

[26040] X.-j. Zhao, K.-b. Wang, and D. -j. Li. "[Huaxiaosaurus aigahtens]". Chinese. In: Geological Bulletin of China 30.11 (2011), pp. 1671-1688.

[26041] Y. Zhao, R. L. Parsley, and J. Peng. "Basal Middle Cambrian short-stalked eorinoids from the Kali Biota: Guizhou Province, China". English. In: Journal of Paleontology 82.2 (2008), pp. 415-422.

[26042] Y.-L. Zhao, R. L. Parsley, and J. Peng. “Early Cambrian eocrinoids from Guizhou Province, South China". English. In: Palaeogeography, Palaeoclimatology, Palaeoecology 254 (2007), pp. 317-327. DOI: 10.1016/j.palaeo.2007.03.020.

[26043] Y.-L. Zhao, C. D. Sumrall, R. L. Parsley, and J. Peng. "Kailidiscus, a new plesiomorphic edrioasteroid from the basal Middle Cambrian Kaili biota of Guizhou Province, China". English. In: Journal of Paleontology 84.4 (2010), pp. 668-680.

[26044] Z. Zhao. "New anthracothere materials from the Paleogene of Guangxi". English. In: Vertebrata PalAsiatica 31.3 (1993), pp. 183-190.

[26045] Z. Zhao, L. Qui, and X. Zhang. “Fossilized yolk preserved in a dinosaur egg”. English. In: Journal of Fossil Research 32.1 (1999), pp. 1-4.

[26046] Z. Zhao, J. Ye, H. Li, and Z. Yan. "Extinction of the dinosaurs across the Cretaceous-Tertiary boundary in Nanxiong Basin, Guangdong Province". English. In: Vertebrata PalAsiatica 29.1 (1991), pp. 1-20.

[26047] Z. K. Zhao, X. Y. Mao, Z. F. Chai, G. C. Yang, F. C. Zhang, and Z. Yan. "Geochemical environmental changes and dinosaur extinction during the Cretaceous-Paleogene $(\mathrm{K} / \mathrm{T})$ transition in the Nanxiong Basin, South China: Evidence from dinosaur eggshells". English. In: Chinese Science Bulletin 54.5 (2009), pp. 806-815.

[26048] Z. P. Zhao, P. Eggleton, X. C. Yin, T. P. Gao, C. K. Shih, and D. Ren. “The oldest known mastotermitids (Blattodea: Termitoidae) and phylogeny of basal termites". English. In: Systematic Entomology 44 (2019), pp. 612-623.

[26049] Z. P. Zhao, X. C. Yin, C. K. Shih, T. P. Gao, and D. Ren. "Termite colonies from mid-Cretaceous Myanmar demonstrate their early eusocial lifestyle in damp wood". English. In: National Science Review 7 (2020), pp. 381-390. DOI: 10.1093/nsr/nwz141.

[26050] Z.-K. Zhao. In K. Carpenter, K. F. Hirsch, and J. R. Horner (eds.), Dinosaur Eggs and Babies, Cambridge University Press, Cambridge. English. Dinosaur Eggs and Babies, Cambridge University Press, Cambridge. 1994, pp. 184-203.

[26051] Z.-K. Zhao and R. Li. "First record of Late Cretaceous hypsilophodontid eggs from Bayan Manduhu, Inner Mongolia". English. In: Vertebrata PalAsiatica 31.2 (1993), pp. 77-84.

[26052] Z. Zhe-kun, W. L. Crepet, and K. C. Nixon. "The earliest fossil evidence of the Hamamelidaceae: Late Cretaceous (Turonian) inflorescences and fruits of Altingioideae". In: American Journal of Botany 88.5 (2001), pp. 753-766.

[26053] Y. Zhen. "Succession of coral associations during a Givetian transgressive-regressive cycle in Queensland". English. In: Acta Palaeontologica Polonica 41.1 (1996), pp. 59-88. 
[26054] Y. Zhen. "Givetian rugose corals from the northern margin of the Burdekin Basin, north Queensland". English. In: Alcheringa 18 (1994), pp. 301-343.

[26055] Y. Zhen. "Late Emsian rugose corals of the Mount Podge area, Burdekin Basin, north Queensland". English. In: Alcheringa 19 (1995), pp. 193-234.

[26056] Y. Y. Zhen, R. S. Nicoll, L. S. Normore, I. G. Percival, J. R. Laurie, and L. M. Dent. “Ordovician conodont biostratigraphy of the Willara Formation in the Canning Basin, Western Australia". English. In: Palaeoworld (2020). DOI: 10.1016/j.palwor.2020.06.006.

[26057] Y. Y. Zhen, I. G. Percival, R. A. Cooper, J. E. SImes, and A. J. Wright. “Darriwilian (Middle Ordovician) conodonts from Thompson Creek, Nelson Province, New Zealand". English. In: Memoirs of the Association of Australasian Palaeontologists 37 (2009), pp. 25-53.

[26058] Z. Zhen, Y. Zhang, and I. G. Percival. “Early Sandbian (Late Ordovician) conodonts from the Yenwashan Formation, western Zhejiang, South China". English. In: Alcheringa 33.2 (2009), pp. 133161. DOI: $10.1080 / 03115510902844160$.

[26059] B. Y. Zheng, D. Ren, and Y. J. Wang. "A new species of Lasiosmylus from the Early Cretaceous, China clarifies its genus-group placement in Ithonidae (Neuroptera)". English. In: ZooKeys 636 (2016), pp. 41-50.

[26060] B. Y. Zheng, D. Ren, and Y. J. Wang. “Earliest true moth lacewing from the Middle Jurassic of Inner Mongolia, China". English. In: Acta Palaeontologica Polonica 61 (2016), pp. 847-851.

[26061] D. R. Zheng. “Odonatans in lowermost Cenomanian Kachin amber: updated review and a new hemiphlebiid damselfly". English. In: Cretaceous Research 118.104640 (2020). DOI: 10.1016/j.cretres. 2020.104640.

[26062] D. R. Zheng, S. C. Chang, E. A. Jarzembowski, and B. Wang. “The first aeshnoid dragonfly (Odonata: Anisoptera: Telephlebiidae) from mid-Cretaceous Burmese amber". English. In: Cretaceous Research 72 (2016), pp. 105-109.

[26063] D. R. Zheng, S. C. Chang, B. Wang, and H. C. Zhang. “New Early Cretaceous dragonfly Sinojagoria magna Li et al., 2012 (Odonata, Gomphaeschnidae) emending the Chinese tribe Sinojagorini". English. In: Cretaceous Research 74 (2017), pp. 192-197.

[26064] D. R. Zheng, S. C. Chang, A. Nel, E. A. Jarzembowski, D. Zhuo, and B. Wang. "Electrodysagrion lini gen. et sp. nov., the oldest Dysagrionini (Odonata: Zygoptera: Dysagrionidae) from midCretaceous Burmese amber". English. In: Cretaceous Research 77 (2017), pp. $44-48$.

[26065] D. R. Zheng, S. C. Chang, and B. Wang. "A new dysagrionid damselfly (Odonata: Zygoptera: Palaeodysagrion) from mid-Cretaceous Burmese amber". English. In: Alcheringa 42 (2017), pp. 300304.

[26066] D. R. Zheng, S. C. Chang, V. Perrichot, S. Dutta, A. Rudra, L. Mu, R. S. Kelly, S. Li, Q. Zhang, J. Wong, J. Wang, H. Wang, Y. Fang, H. C. Zhang, and B. Wang. "A Late Cretaceous amber biota from central Myanmar". English. In: Nature Communications 9.3170 (2018), pp. 1-6.

[26067] D. R. Zheng, S. C. Chang, A. Nel, E. A. Jarzembowski, D. Zhuo, H. C. Zhang, and B. Wang. “A new Gondwanan dragonfly (Odonata: Anisoptera: Araripegomphidae) from mid-Cretaceous Burmese amber". English. In: Cretaceous Research 92 (2018), pp. 168-173.

[26068] D. R. Zheng, S. C. Chang, H. Wang, Y. Fang, J. Wang, C. Q. Feng, G. W. Xie, E. A. Jarzembowski, H. C. Zhang, and B. Wang. "Middle-Late Triassic insect radiation revealed by diverse fossils and isotopic ages from China". English. In: Science Advances 4 (2018), eaat1380.

[26069] D. R. Zheng, C. Dong, H. Wang, Y. F. Ye, B. Wang, S. C. Chang, and H. C. Zhang. “The first damseldragonfly (Odonata: Isophlebioidea: Campterophlebiidae) from the Middle Jurassic of Shaanxi Province, northwestern China". English. In: Alcheringa 41 (2017), pp. 509-513.

[26070] D. R. Zheng, E. A. Jarzembowski, S. C. Chang, and B. Wang. "A new true dragonfly (Odonata, Anisoptera, Gomphaeschnaoidini) from mid-Cretaceous Burmese amber". English. In: Proceedings of the Geologists' Association 127 (2016), pp. 629-632. 
[26071] D. R. Zheng, E. A. Jarzembowski, S. C. Chang, B. Wang, and H. C. Zhang. “New cymatophlebiid dragonflies from the Lower Cretaceous of China and England (Odonata: Anisoptera: Cymatophlebiinae, Valdaeshninae)". English. In: Cretaceous Research 90 (2018), pp. 311-317.

[26072] D. R. Zheng, T. Jiang, A. Nel, E. A. Jarzembowski, S. C. Chang, H. C. Zhang, and B. Wang. "Paraburmagomphidae fam. nov., a new gomphid dragonfly family (Odonata: Anisoptera) from mid-Cretaceous Burmese amber". English. In: Cretaceous Research 92 (2018), pp. 214-219.

[26073] D. R. Zheng, A. Nel, B. Wang, E. A. Jarzembowski, S. C. Chang, and H. C. Zhang. "The discovery of the hindwing of the Early Cretaceous dragonfly Sinaktassia tangi Lin, Nel \& Huang, 2010 (Odonata, Aktassiidae) in northeastern China". English. In: Cretaceous Research 61 (2016), pp. 8690.

[26074] D. R. Zheng, A. Nel, B. Wang, E. A. Jarzembowski, S. C. Chang, and H. C. Zhang. "The first Early Cretaceous damsel-dragonfly (Odonata: Stenophlebiidae: Stenophlebia) from western Liaoning, China". English. In: Cretaceous Research 61 (2016), pp. 124-128.

[26075] D. R. Zheng, A. Nel, B. Wang, E. A. Jarzembowski, S. C. Chang, and H. C. Zhang. "A new damseldragonfly from the Lower Jurassic of northwestern China and its paleobiogeographic significance". English. In: Journal of Paleontology 90 (2016), pp. 485-490.

[26076] D. R. Zheng, A. Nel, B. Wang, E. A. Jarzembowski, S. C. Chang, and H. C. Zhang. “The first Triassic 'Protodonatan' (Zygophlebiidae) from China: stratigraphical implications". English. In: Geological Magazine 154 (2017), pp. 169-174.

[26077] D. R. Zheng, A. Nel, E. A. Jarzembowski, S. C. Chang, H. C. Zhang, F. Y. Xia, H. Y. Liu, and B. Wang. "Extreme adaptations for probable visual courtship behaviour in a Cretaceous dancing damselfly". English. In: Scientific Reports 7.44932 (2017), pp. 1-8.

[26078] D. R. Zheng, A. Nel, H. Wang, B. Wang, E. A. Jarzembowski, S. C. Chang, and H. C. Zhang. “The first Late Triassic Chinese triadophlebiomorphan (Insecta: Odonatoptera): biogeographic implications". English. In: Scientific Reports 7.1476 (2017), pp. 1-7.

[26079] D. R. Zheng, A. Nel, S. C. Chang, E. A. Jarzembowski, D. Zhuo, and B. Wang. "Paracoryphagrionidae fam. nov., a pseudostigmatoid damselfly from mid Cretaceous Burmese amber showing regular series of triangular cells (Odonata: Zygoptera: Coenagrionida)". English. In: Cretaceous Research 81 (2017), pp. 93-97.

[26080] D. R. Zheng, A. Nel, S. C. Chang, B. Wang, and H. C. Zhang. "A new progobiaeshnid dragonfly (Odonata, Aeshnoptera) from the Lower Cretaceous of Liaoning Province, NE China". English. In: Cretaceous Research 90 (2018), pp. 1-6.

[26081] D. R. Zheng, A. Nel, E. A. Jarzembowski, S. C. Chang, Z. C. Zhou, and B. Wang. "The second mesomegaloprepid damselfly (Odonata: Zygoptera) from mid-Cretaceous Burmese amber". English. In: Cretaceous Research 90 (2018), pp. 131-135.

[26082] D. R. Zheng, A. Nel, S. C. Chang, E. A. Jarzembowski, H. C. Zhang, and B. Wang. "A wellpreserved true dragonfly (Anisoptera: Gomphides: Burmagomphidae fam. nov.) from Cretaceous Burmese amber". English. In: Journal of Systematic Palaeontology 16 (2018), pp. 881-889.

[26083] D. R. Zheng, A. Nel, and E. A. Jarzembowski. "The first Cretaceous damselfly of the Jurassic family Steleopteridae (Odonata: Zygoptera), from Surrey, England". English. In: Cretaceous Research 93 (2018), pp. 1-3.

[26084] D. R. Zheng, A. Nel, H. C. Zhang, S. C. Chang, E. A. Jarzembowski, D. Zhuo, and B. Wang. "A highly diverse coenagrionoid damselfly group (Odonata: Zygoptera: Burmacoenagrionidae fam. nov.) from mid-Cretaceous Burmese amber". English. In: Journal of Systematic Palaeontology 17 (2017), pp. 239-253.

[26085] D. R. Zheng, A. Nel, E. A. Jarzembowski, S. C. Chang, H. C. Zhang, and B. Wang. "Exceptionally well-preserved dragonflies (Insecta: Odonata) in Mexican amber". English. In: Alcheringa 43 (2018), pp. 157-164. 
[26086] D. R. Zheng, A. Nel, E. A. Jarzembowski, J. Wang, H. C. Zhang, and B. Wang. "New gomphaeschnid dragonflies (Odonata: Anisoptera: Aeshnoptera) from mid-Cretaceous Burmese amber". English. In: Cretaceous Research 100 (2019), pp. 138-144. DOI: 10.1016/j.cretres.2019.03.027.

[26087] D. R. Zheng, T. M. Shi, H. Wang, S. C. Chang, L. H. Dou, B. Wang, and H. C. Zhang. “Honghea xui gen. et sp. nov., the second Earliest Jurassic damsel-dragonfly (Odonata: Campterophlebiidae) from the Junggar Basin, NW China". English. In: Comptes Rendus Palevol 17 (2018), pp. 346-350.

[26088] D. R. Zheng, B. Wang, E. A. Jarzembowski, S. C. Chang, and A. Nel. “The first fossil Perilestidae (Odonata: Zygoptera) from mid-Cretaceous Burmese amber". English. In: Cretaceous Research 65 (2016), pp. 199-205.

[26089] D. R. Zheng, B. Wang, E. A. Jarzembowski, S. C. Chang, and A. Nel. "Burmadysagrioninae, a new subfamily (Odonata: Zygoptera: Dysagrionidae) from mid-Cretaceous Burmese amber". English. In: Cretaceous Research 67 (2016), pp. 126-132.

[26090] D. R. Zheng, B. Wang, and S. C. Chang. "Palaeodisparoneura cretacica sp. nov., a new damselfly (Odonata: Zygoptera: Platycnemididae) from mid-Cretaceous Burmese amber". English. In: Comptes Rendus Palevol 16 (2017), pp. 235-240.

[26091] D. R. Zheng, B. Wang, A. Nel, E. A. Jarzembowski, H. C. Zhang, and S. C. Chang. "Mesostictinae subfam. nov., an archaic group of platystictid damselflies (Odonata: Zygoptera) from midCretaceous Burmese amber". English. In: Journal of Systematic Palaeontology 17 (2017), pp. 1-8.

[26092] D. R. Zheng and B. Wang. "The second hemiphlebiid damselfly (Odonata: Zygoptera) from midCretaceous Burmese amber". English. In: Alcheringa 43 (2018), pp. 257-260.

[26093] D. R. Zheng, H. Wang, E. A. Jarzembowski, B. Wang, S. C. Chang, and H. C. Zhang. “New data on Early Cretaceous odonatans (Stenophlebiidae, Aeschnidiidae) from northern China". English. In: Cretaceous Research 67 (2016), pp. 59-65.

[26094] D. R. Zheng, H. Wang, A. Nel, L. H. Dou, Z. L. Dai, B. Wang, and H. C. Zhang. "A new damseldragonfly (Odonata: Anisozygoptera: Campterophlebiidae) from the earliest Jurassic of the Junggar Basin, northwestern China". English. In: Alcheringa 43 (2019), pp. 563-567. DOI: 10.1080 / 03115518.2019.1623321.

[26095] D. R. Zheng, H. C. Zhang, Q. Zhang, S. Li, H. Wang, Y. Fang, Q. Liu, E. A. Jarzembowski, E. Yan, and B. Wang. "The discovery of an Early Cretaceous dragonfly Hemeroscopus baissicus Pritykina, 1977 (Hemeroscopidae) in Jiuquan, Northwest China, and its stratigraphic implications". English. In: Cretaceous Research 52 (2015), pp. 316-322.

[26096] D. R. Zheng, H. C. Zhang, B. Wang, and S. C. Chang. "A new species of damsel-dragonfly (Odonata: Stenophlebiidae: Cretastenophlebia) from the Lower Cretaceous of the Jiuquan Basin, northwestern China". English. In: Earth and Environmental Science Transactions of the Royal Society of Edinburgh 107 (2018), pp. 185-189.

[26097] D. R. Zheng, Q. Q. Zhang, S. C. Chang, and B. Wang. "A new damselfly (Odonata: Zygoptera: Platystictidae) from mid-Cretaceous Burmese amber". English. In: Cretaceous Research 63 (2016), pp. 142-147.

[26098] D. R. Zheng, Q. Q. Zhang, A. Nel, E. A. Jarzembowski, Z. C. Zhou, S. C. Chang, and B. Wang. "New damselflies (Odonata: Zygoptera: Hemiphlebiidae, Dysagrionidae) from mid-Cretaceous Burmese amber". English. In: Alcheringa 41 (2017), pp. 12-21.

[26099] J.-J. Zheng, L.-T. Zheng, and X. -S. Huang. “New materials of Pseudictopidae (Anagalida, Mammalia) from the Early Middle Paleocene of Qianshan Basin, Anhui". English. In: Vertebrata PalAsiatica 37.1 (1999), pp. 9-17.

[26100] L. Zheng, H. Bao, Y. Wu, L. Sun, H. Jiang, J. Ren, Z. Huang, and L. Liu. “Distinguishing coral reef facies from coral-bearing open platform facies: Examples from Ordovician Ordos Basin, Northwest China". English. In: Palaeogeography, Palaeoclimatology, Palaeoecology 495 (2018), pp. 72-86. DOI: 10.1016/j.palaeo.2017.12.031. 
[26101] T. Zheng, Y. Bai, Q. Wang, X. Zhu, K. Fang, Y. Yao, Y. Zhao, and X. Wang. "A new ootype of dinosaur egg (Faveoloolithidae: Duovallumoolithus shangdanensis oogen. et oosp. nov.) from the Late Cretaceous in the Shangdan Basin, Shaanxi Province, China". English. In: Acta Geologica Sinica (English Edition) 92.3 (2018), pp. 897-903.

[26102] W. Zheng, X. Jin, M. Shibata, Y. Azuma, and F. -M. Yu. "A new ornithischian dinosaur from the Cretaceous Liangtoutang Formation of Tiantai, Zhejiang Province, China". English. In: Cretaceous Research 34 (2012), pp. 208-219. DOI: 10.1016/j.cretres.2011.11.001.

[26103] W. Zheng, X. Jin, M. Shibata, and Y. Azuma. “An early juvenile specimen of Bolong yixianensis (Ornithopoda: Iguanodontia from the Lower Cretaceous of Ningcheng County, Nei Mongol, China". English. In: Historical Biology (2013).

[26104] W. Zheng, X. Jin, and X. Xu. "A psittacosaurid-like basal neoceratopsian from the Upper Cretaceous of central China and its implications for basal ceratopsian evolution". English. In: Scientific Reports 5 (2015), 14190:1-9. DOI: 10.1038/srep14190.

[26105] W.-J. Zheng, X.-S. Jin, Y. Azuma, Q. -Y. Wang, K. Miyata, and X. Xu. "The most basal ankylosaurine dinosaur from the Albian-Cenomanian of China, with implications for the evolution of the tail club". English. In: Scientific Reports 8.3711 (2018). DOI: 10.1038/s41598-018-21924-7.

[26106] X. Zheng, S. Bi, X. Wang, and J. Meng. "A new arboreal haramiyid shows the diversity of crown mammals in the Jurassic period". English. In: Nature 500 (2013), pp. 199-202. DOI: 10.1038 / nature12353.

[26107] X. Zheng, J. K. O'Connor, X. Wang, Y. Wang, and Z. Zhou. “Reinterpretation of a previously described Jehol bird clarifies early trophic evolution in the Ornithuromorpha". English. In: Proceedings of the Royal Society of London B 285 (2018), 20172494:1-10.

[26108] X. Zheng, X. Xu, H. You, Q. Zhao, and Z. Song. "A short-armed dromaeosaurid from the Jehol Group of China with implications for early dromaeosaurid evolution". English. In: Proceedings of the Royal Society B: Biological Sciences (2009). DOI: 10.1098/rspb.2009.1178.

[26109] X. Zheng, Z. Zhang, and L. Hou. "A new enantiornithine bird with four long rectrices from the Early Cretaceous of northern Hebei, China". English. In: Acta Geologica Sinica 81.5 (2007), pp. $703-$ 708.

[26110] X.-T. Zheng, J. K. O'Connor, X. -L. Want, X. -M. Zhang, and Y. Wang. “New information on Hongshanornithidae (Aves: Ornithuromorpha) from a new subadult specimen". English. In: Vertebrata PalAsiatica 52.2 (2014), pp. 217-232.

[26111] X.-T. Zheng, H.-L. You, X. Xu, and Z. -M. Dong. “An Early Cretaceous heterodontosaurid dinosaur with filamentous integumentary structures". English. In: Nature 458 (2009), pp. 333-336. DOI: 10. 1038/nature07856.

[26112] Y. Zheng, J. Chen, and X. L. Wang. "A new genus and species of Tettigarctidae from the Mesozoic of northeastern China (Insecta, Hemiptera, Cicadoidea)". English. In: ZooKeys 632 (2016), pp. 4755.

[26113] Y. Zheng and J. Chen. "A new mesoserphid wasp from the Middle Jurassic of northeastern China (Hymenoptera, Proctotrupoidea)". English. In: European Journal of Taxonomy 379 (2017), pp. 1-8.

[26114] Y. Zheng and J. Chen. "New material of Xyelydidae (Hymenoptera) from the Lower Cretaceous Yixian Formation of China". English. In: Palaeoworld 27 (2018), pp. 374-381.

[26115] Y. Zheng, J. Chen, J. Q. Zhang, and H. C. Zhang. "New fossil sawflies (Hymenoptera, Xyelidae) from the Middle Jurassic of northeastern China". English. In: Alcheringa 44 (2020), pp. 115-120. DOI: $10.1080 / 03115518.2019 .1641618$.

[26116] Y. Zheng, Q. Zhang, J. Chen, and H. C. Zhang. “A remarkably new basal wasp with uniquely transformed forewing in mid-Cretaceous Burmese amber (Hymenoptera, Syspastoxyelidae)". English. In: Cretaceous Research 104.104172 (2019). DOI: 10.1016/j.cretres.2019.07.002.

[26117] V. V. Zherikhin. Pattern of Insect Burial and Conservation. English. History of Insects. 2002, pp. 1763. 
[26118] V. V. Zherikhin. “Tertiary brachycerid weevils (Coleoptera: Brachycerida) from the collections of Muséum Nationale d'Histoire Naturelle, Paris, with a review of other fossil Brachyceridae". English. In: Paleontological Journal 34.Suppl 3 (2000), S333-S343.

[26119] V. V. Zherikhin. "A new genus and species of Lophioneuridae from Burmese amber (Thripida (=Thysanoptera): Lophioneurina)". English. In: Bulletin of the Natural History Museum, Geology Series 56 (2000), pp. 39-41.

[26120] V. V. Zherikhin. “A weevil of the tribe Curculionini (Insecta: Coleoptera, Curculionidae) from the Paleogene of Havighorst, Germany". English. In: Mitteilungen aus dem Geologisch-Paläontologischen Institut der Universität Hamburg 78 (1995), pp. 145-148.

[26121] V. V. Zherikhin and V. G. Gratshev. "Fossil Curculionoid Beetles (Coleoptera, Curculionoidea) from the Lower Cretaceous of Northeastern Brazil". English. In: Paleontological Journal 38.5 (2004), pp. 528-537.

[26122] V. V. Zherikhin and V. G. Gratshev. “Obrieniidae, fam. nov., the oldest Mesozoic weevils (Coleoptera, Curculionoidea)". English. In: Paleontological Journal 27.1A (1993), pp. 50-68.

[26123] V. V. Zherikhin and V. G. Gratshev. “The Early Cretaceous weevils from Sierra del Montsec, Spain (Insecta : Coleoptera : Curculionoidea)". English. In: Cretaceous Research 18 (1997), pp. 625-632.

[26124] V. V. Zherikhin and V. G. Gratshev. "A new weevil-beetle (Insecta, Coleoptera, Nemonychidae) from the Lower Cretaceous of Spain". English. In: Paleontological Journal 37 (2003), pp. 407-408.

[26125] Z. Zhicheng, H. Willems, and Z. Binggao. “Marine Cretaceous-Paleogene biofacies and ichnofacies in southern Tibet, China, and their sedimentary significance". English. In: Marine Micropaleontology 32 (1997), pp. 3-29.

[26126] C.-F. Zhou. "A new eucryptodiran turtle from the Early Cretaceous Jiufotang Formation of western Liaoning, China". English. In: Zootaxa 2676 (2010), pp. 45-56.

[26127] C.-F. Zhou. "A second specimen of Manchurochelys manchoukuoensis Endo \& Shikama, 1942 (Testudines: Eucryptodira) from the Early Cretaceous Yixian Formation of western Liaoning, China". English. In: Zootaxa 2534 (2010), pp. 57-66.

[26128] C.-F. Zhou. "New material of Elanodactylus prolatus Andres \& Ji, 2008 (Pterosauria: Pterodactyloidea) from the Early Cretaceous Yixian Formation of western Liaoning, China". English. In: Neues Jahrbuch für Geologie und Paläontologie, Abhandlungen (2010). DOI: 10.1127/0077-7749/2009/ 0022.

[26129] C.-F. Zhou. "New material of Chaoyangopterus (Pterosauria: Pterodactyloidea) from the Early Cretaceous Jiufotang Formation of western Liaoning, China". English. In: Neues Jahrbuch für Geologie und Paläontologie Abhandlungen 257.3 (2010), pp. 341-350. DOI: 10.1127/0077-7749/2010/0081.

[26130] C.-F. Zhou. "A possible azhdarchid pterosaur from the Lower Cretaceous Qingshan Group of Laiyang, Shandong, China". English. In: Journal of Vertebrate Paleontology 30.6 (2010), pp. 17431746.

[26131] C.-F. Zhou. "Cranial morphology of a Scaphognathus-like pterosaur, Jianchangnathus robustus, based on a new fossil from the Tiaojishan Formation of western Liaoning, China". English. In: Journal of Vertebrate Paleontology 34.3 (2014), pp. 597-605.

[26132] C.-F. Zhou, K.-Q. Gao, R. C. Fox, and S. -H. Chen. “A new species of Psittacosaurus (Dinosauria: Ceratopsia) from the Early Cretaceous Yixian Formation, Liaoning, China". English. In: Palaeoworld 15.1 (2006), pp. 100-114. DOI: 10.1016/j.palwor.2005.11.001.

[26133] C.-F. Zhou, K.-Q. Gao, H. -Y. Yi, J. -Z. Xue, Q. -G. Li, and R. C. Fox. “Earliest filter-feeding pterosaur from the Jurassic of China and ecological evolution of Pterodactyloidea". English. In: Royal Society Open Science 4.160672 (2017).

[26134] C.-F. Zhou and M. Rabi. "A sinemydid turtle from the Jehol Biota provides insights into the basal divergence of crown turtles". English. In: Scientific Reports 5 (2015), 16299:1-12. DOI: 10.1038 / srep16299. 
[26135] C.-F. Zhou, M. Rabi, and W. G. Joyce. "A new specimen of Manchurochelys manchoukuoensis from the Early Cretaceous Jehol Biota of Chifeng, Inner Mongolia, China and the phylogeny of Cretaceous basal eucryptodiran turtles". English. In: BMC Evolutionary Biology 14.77 (2014), pp. 116. DOI: $10.1186 / 1471-2148-14-77$.

[26136] C.-F. Zhou and R. R. Schoch. "New material of the non-pterodactyloid pterosaur Changchengopterus pani Lü, 2009 from the Late Jurassic Tiaojishan Formation of western Liaoning". English. In: Neues Jahrbuch für Geologie und Paläontologie Abhandlungen 260 (2011), pp. 265-275.

[26137] C.-F. Zhou, S. Wu, T. Martin, and Z. -X. Luo. "A Jurassic mammaliaform and the earliest mammalian evolutionary adaptations". English. In: Nature 500 (2013), pp. 163-167.

[26138] C.-f. Zhou, W.-h. Wu, T. Sekiya, and Z. -m. Dong. "[A new titanosauriformes dinosaur from Jehol Biota of western Liaoning, China]". Chinese. In: Global Geology 37.2 (2018), pp. 327-333.

[26139] C.-F. Zhou, W.-H. Wu, and M. Rabi. "Presence of the Jehol Biota turtle Ordosemys liaoxiensis in the Early Cretaceous Hengtongshan Formation of southern Jilin Province, China". English. In: Fossil Record 22 (2019), pp. 57-64.

[26140] G. Zhou, R.-C. Zheng, R. -C. Zheng P. Luo, W. Liu, and J. -M. Jin. “Sedimentary Characteristics of Yingshan Reefs of Middle Ordovician in Xike'er Area, Tarim Basin". Chinese. In: Xingjiang Petroleum Geology 31.4 (2010), pp. 365-368.

[26141] M. Zhou, Z. Cheng, and Y. Wang. "A mammalian lower jaw from the Jurassic of Lingyuan, Liaoning". Chinese. In: Vertebrata PalAsiatica 29.3 (1991), pp. 165-175.

[26142] M. Zhou, M. Chow, and Y. Wang. "An anthracothere lower premolar from Liaoning". English. In: Vertebrata PalAsiatica 29.4 (1991), pp. 323-326.

[26143] M. Zhou, D.-Y. Jiang, R. Motani, A. Tintori, C. Ji, and Z. -Y. Sun. “The cranial osteology revealed by three-dimensionally preserved skulls of the Early Triassic ichthyosauriform Chaohusaurus chaoxianensis (Reptilia: Ichthyosauromorpha) from Anhui, China". English. In: Journal of Vertebrate Paleontology (2017), e1343831. DOI: 10.1080/02724634.2017.1343831.

[26144] S. Zhou, J. K. O'Connor, and M. Wang. "A new species from an ornithuromorph (Aves: Ornithothoraces) dominated locality of the Jehol Biota". English. In: Chinese Science Bulletin (2014). DOI: $10.1007 / \mathrm{s} 11434-014-0669-8$.

[26145] S. Zhou, Z. Zhou, and J. O'Connor. "A new piscivorous ornithuromorph from the Jehol Biota". English. In: Historical Biology (2013).

[26146] S. Zhou, Z.-H. Zhou, and J. K. O'Connor. "A new basal beaked ornithurine bid from the Lower Cretaceous of western Liaoning, China". Chinese. In: Vertebrata PalAsiatica 50.1 (2012), pp. 9-24.

[26147] S.-A. Zhou, Z.-H. Zhou, and J. K. O'Connor. "Anatomy of the basal ornithuromorph bird Archaeorhynchus spathula from the Early Cretaceous of Liaoning, China". English. In: Journal of Vertebrate Paleontology 33.1 (2013), pp. 141-152. DOI: 10.1080/02724634.2012.714431.

[26148] S.-q. Zhou and Z.-j. Feng. "[Studies on the occurrence beds of Oölithus and their relations to the upper-lower boundarues in Henan province]". Chinese. In: Resources Survey E Environment 23.1 (2002), pp. 68-76.

[26149] X. Zhou and P. D. Gingerich. "New Species of Hapalodectes (Mammalia, Mesonychia) from the Early Wasatchian, Early Eocene of Northwestern Wyoming". English. In: Contributions from the Museum of Paleontology, University of Michigan 28.9 (1991), pp. 215-220.

[26150] X. Zhou, Z. Wang, H. Yang, L. Zhang, and J. Han. “Large-scale Tazhong Ordovician reef-flat oilgas field in the Tarim Basin of China". English. In: Acta Geologica Sinica - English Edition 83.1 (2009), pp. 179-188.

[26151] X. Zhou, R. Zhai, P. D. Gingerich, and L. Chen. "Skull of a new mesonychid (Mammalia, Mesonychia) from the late Paleocene of China". English. In: Journal of Vertebrate Paleontology 15.2 (1995), pp. 387-400.

[26152] X. Zhou and F. Zhang. "Two new ornithurine birds from the Early Cretaceous of western Liaoning, China". English. In: Chinese Science Bulletin 46.15 (2001), pp. 1258-1264. 
[26153] X.-Y. Zhou, R. V. Pegas, M. E. C. Leal, and N. Bonde. "Nurhachius luei, a new istiodactylid pterosaur (Pterosauria, Pterodactyloidea) from the Early Cretaceous Jiufotang Formation of Chaoyang City, Liaoning Province (China) and comments on the Istiodactylidae". English. In: PeerJ 7 (2019), e7688. DOI: $10.7717 /$ peerj.7688.

[26154] Y. L. Zhou, M. S. Caterino, A. lipiski, and C. Y. Cai. "Cretohisteridae, a new beetle family from the Early Cretaceous of China, and its implications for the early evolution of the basal group of Histeroidea (Coleoptera)". English. In: Systematic Entomology 43 (2018), pp. 716-728.

[26155] Y. L. Zhou, M. S. Caterino, D. Ren, and A. lipiski. "Phylogeny and evolution of Mesozoic and extant lineages of Histeridae (Coleoptera), with discovery of a new subfamily Antigracilinae from the Lower Cretaceous". English. In: Cladistics 36 (2020), pp. 521-539. DOI: 10.1111/cla.12418.

[26156] Y. L. Zhou, A. lipiski, D. Ren, and J. Parker. “A Mesozoic clown beetle myrmecophile (Coleoptera: Histeridae)". English. In: eLife 8.e44985 (2019). DOI: 10.7554/eLife.44985.

[26157] Z. Zhou. "Discovery of a new enantiornithine bird from the Early Cretaceous of Liaoning, China". Chinese. In: Vertebrata PalAsiatica 33.2 (1995), pp. 99-113.

[26158] Z. Zhou. "A new and primitive enantiornithine bird from the Early Cretaceous of China". English. In: Journal of Vertebrate Paleontology 22.1 (2002), pp. 49-57.

[26159] Z. Zhou, J. Clarke, F. Zhang, and O. Wings. "Gastroliths in Yanornis: an indication of the earliest radical diet-switching and gizzard plasticity in the lineage leading to living birds?" English. In: Naturwissenschaften 91.12 (2004), pp. 571-574.

[26160] Z. Zhou, J. Clarke, and F. Zhang. "Insight into diversity, body size and morphological evolution from the largest Early Cretaceous enantiornithine bird". English. In: Journal of Anatomy 212.5 (2008), pp. 565-577.

[26161] Z. Zhou, W. L. Crepet, and K. C. Nixon. "The earliest fossil evidence of the Hamamelidaceae: Late Cretaceous (Turonian) inflorescences and fruits of Altingioideae". In: American Journal of Botany 88 (2001), pp. 753-766.

[26162] Z. Zhou, B. F. Glenister, and W. M. Furnish. “Endemic Permian ammonoid genus Yinoceras, central Hunan, south China". English. In: Journal of Paleontology 76.3 (2002), pp. 424-430.

[26163] Z. Zhou and M. Liengjarern. "Lower Permian perrinitid ammonoid faunas from Thailand". English. In: Journal of Paleontology 78.2 (2004), pp. 317-339.

[26164] Z. Zhou, B. D. Webby, and W. Yuan. "Ordovician trilobites from the Yingan Formation of northwestern Tarim, Xinjiang, northwestern China". English. In: Alcheringa 19.1 (1995), pp. 47-72.

[26165] Z. Zhou and G. Yin. "Ordovician (Darriwilian-early Katian) trilobite faunas of northwestern Tarim, Xinjiang, China". English. In: Memoirs of the Association of Australasian Palaeontologists 46 (2014), pp. 1-142.

[26166] Z. Zhou and F. Zhang. "A long-tailed, seed-eating bird from the Early Cretaceous of China". English. In: Nature 418 (2002), pp. 405-409.

[26167] Z. Zhou and F. Zhang. "Largest bird from the Early Cretaceous and its implications for the earliest avian ecological diversification". English. In: Naturwissenschaften 89.1 (2002), pp. 34-38. DOI: 10. 1007/s00114-001-0276-9.

[26168] Z. Zhou and F. Zhang. "Anatomy of the primitive bird Sapeornis chaoyangensis from the Early Cretaceous of Liaoning, China". English. In: Canadian Journal of Earth Sciences 40 (2003), pp. $731-$ 747. DOI: $10.1139 / \mathrm{E} 03-011$.

[26169] Z. Zhou and F. Zhang. "Discovery of an ornithurine bird and its implication for Early Cretaceous avian radiation". English. In: Proceedings of the National Academy of Sciences 102.32 (2005), pp. 18998-19002. DOI: 10.1073/pnas.0507106102.

[26170] Z. Zhou and F. Zhang. "A beaked basal ornithurine bird (Aves, Ornithurae) from the Lower Cretaceous of China". English. In: Zoologica Scripta 35.4 (2006), pp. 363-373. 
[26171] Z. Zhou, F. Zhang, and Z. Li. "A new Lower Cretaceous bird from China and tooth reduction in early avian evolution". English. In: Proceedings of the Royal Society B 277 (2010), pp. 219-227. DOI: 10.1098/rspb.2009.0885.

[26172] Z.-H. Zhou, F.-C. Zhang, and Z. -H. Li. "A new basal ornithurine bird (Jianchangornis microdonta gen. et sp. nov.) from the Lower Cretaceous of China". English. In: Vertebrata PalAsiatica 10 (2009), pp. 299-310.

[26173] Z. Q. Zhou and Z. Y. Zhou. "Late Ordovician trilobites from the Zhusilenghaierhan area, Ejin Banner, western Inner Mongolia, China". English. In: Memoirs of the Association of Australasian Palaeontologists 32 (2006), pp. 383-411.

[26174] Z. R. Zhou. "Unusually large specimens of the Permian ammonoid Guiyangoceras from Hunan, south China". English. In: Paleontological Journal 41 (2007), pp. 123-127.

[26175] Z. R. Zhou. "Permian basinal ammonoid sequence in Nanpanjiang area of South China - possible overlap between basinal Guadalupian and platform-based Lopingian". English. In: Journal of Paleontology 91.Memoir 74 (2017), pp. 1-95.

[26176] Z. R. Zhou, B. F. Glenister, and W. M. Furnish. “An exceptionally large representative of Permian ammonoid Shengoceras from Guangxi, South China". English. In: Acta Palaeontologica Sinica 39 (2000), pp. 76-80.

[26177] Z. R. Zhou and Z. R. Yang. "Permian ammonoids from Xinjiang, northwest China". English. In: Journal of Paleontology 79 (2005), pp. 378-388.

[26178] Z. R. Zhou, D. S. Zhu, F. Y. Li, and Y. H. Hu. "Permian Maokouan nearshore sea of south China and its ammonoid fauna". Chinese. In: Acta Palaeontologica Sinica 34 (1995), pp. 525-548.

[26179] Z.-H. Zhou and X.-L. Wang. "A new species of Caudipteryx from the Yixian Formation of Liaoning, northeast China". English. In: Vertebrata PalAsiatica 38.2 (2000), pp. 111-127.

[26180] Z. R. Zhou. "Bizarre Permian ammonoid subfamily Aulacogastrioceratinae from southeast China". English. In: Journal of Paleontology 81.4 (2007), pp. 797-799.

[26181] M. Zhu, P. E. Ahlberg, W. Zhao, and L. Jia. "First Devonian tetrapod from Asia”. English. In: Nature 420 (2002), p. 760. DOI: 10.1038/420760a.

[26182] M. Zhu, P. E. Ahlberg, Z. Pan, Y. Zhu, T. Qiao, W. Zhao, L. Jia, and J. Lu. “A Silurian maxillate placoderm illuminates jaw evolution”. English. In: Science 354.6310 (2016), pp. 334-336. DOI: 10. 1126/science.aah3764.

[26183] M. Zhu, P. E. Ahlberg, W. -J. Zhao, and L. -T. Jia. “A Devonian tetrapod-like fish reveals substantial parallelism in stem tetrapod evolution". English. In: Nature Ecology \& Evolution 1 (2017), pp. 14701476. DOI: $10.1038 / \mathrm{s} 41559-017-0293-5$.

[26184] M. Zhu, J. G. Gehling, S. Xiao, Y. Zhao, and M. L. Droser. "Eight-armed Ediacara fossil preserved in contrasting taphonomic windows from China and Australia". English. In: Geology 36.11 (2008), pp. 867-870. DOI: 10.1130/G25203A.1.

[26185] M. Zhu and J. Wang. "Silurian vertebrate assemblages of China". English. In: Courier Forschungsinstitut Senckenberg 223 (2000), pp. 161-168.

[26186] M. Zhu, X. Yu, and P. E. Ahlberg. "A primitive sarcopterygian fish with an eyestalk". English. In: Nature 410.6824 (2001), pp. 81-84. DOI: 10.1038/35065078.

[26187] M. Zhu, W. Zhao, L. Jia, J. Lu, T. Qiao, and Q. Qu. “The oldest articulated osteichthyan reveals mosaic gnathostome characters". English. In: Nature 458 (2009), pp. 469-474.

[26188] R. X. Zhu, R. Potts, F. Xie, K. A. Hoffman, C. L. Deng, C. D. Shi, Y. X. Pan, H. Q. Wang, R. P. Shi, Y. C. Wang, G. H. Shi, and N. Q. Wu. "New evidence on the earliest human presence at high northern latitudes in northeast Asia." In: Nature 431 (2004), pp. 559-562.

[26189] S. Zhu. "[A stegosaur fossil from YingShan County, Sichuan Province]". Chinese. In: Sichuan Wen Wu 1 (1994), pp. 8-14. 
[26190] X. J. Zhu, N. C. Hughes, and S. C. Peng. "On a new species of Shergoldia Zhang and Jell, 1987 (Trilobita), the family Tsinaniidae and the order Asaphida". English. In: Memoirs of the Association of Australasian Palaeontologists 34 (2007), pp. 243-253.

[26191] X.-F. Zhu, K.-Y. Fang, Q. Wang, X. -H. Lu, W. -Q. Wu, Y. -L. Du, Z. -Q. Huang, and X. -L. Wang. "The first Stalicoolithus shifengensis discovered in a clutch from the Sanshui Basin, Guangdong Province". English. In: Vertebrata PalAsiatica 57.1 (2019), pp. 77-83.

[26192] X.-J. Zhu, S. Zamora, and B. Lefebvre. “Morphology and Palaeoecology of a New Edrioblastoid from the Furongian of". English. In: Acta Palaeontologica Polonica 59.4 (2014), pp. 921-926. DOI: 10.4202/app.2012.0116.

[26193] Z. Zhu and S. Peng. "Eoshumardia (Trilobita, Cambrian), a junior synonym of Koldinioidia". English. In: Alcheringa 30.2 (2006), pp. 183-189. DOI: 10.1080/03115510608619312.

[26194] Z. G. Zhu and J. M. Zhao. "Late late Carboniferous and earliest Permian rugose corals from Jiangxi". Chinese. In: Acta Palaeontologica Sinica 31.6 (1992), pp. 657-677.

[26195] A. V. Zhuravlev. "Conodont response to the middle Visean (Early Carboniferous) ecological event - preliminary data". In: Courier Forschtimmeinstitut Senckenberg 245 (2003), pp. 255-259.

[26196] A. V. Zhuravlev. "A new Siphonodella species (Conodonta) from the Lower Carboniferous of the Northern Urals". Russian. In: Paleontologicheskii Zhurnal 3 (1994), pp. 138-139.

[26197] A. V. Zhuravlev. "Signatures of Mid-Tournaisian biotic event in North Urals". Russian. In: Biulleten Moskovskogo Obsgchestva Ispytateleii Prirody. Otdelenie Geologicheskoe 78.1 (2003), pp. 26-32.

[26198] A. V. Zhuravlev. "Conodonts of the Polygnathus pollocki Druce group (Upper Devonian, Lower Frasnian) from the East European Platform". In: Proceedings of the Estonian Academy of Sciences. Geology. 48.1 (1999), pp. 35-47.

[26199] A. V. Zhuravlev. "Conodont associations of the Nemda Formation (Kazanian Stage, Volga-Vyatka area)". Russian. In: Regionalnaya geologia i metallogeniya 23 (2005), pp. 69-73.

[26200] A. V. Zhuravlev. Conodonts of the Polotnyany Zavod section (Lower Carboniferous, west Russia). Russian. 2005.

[26201] A. V. Zhuravlev. Conodonts of the Bolkhov section (Upper Devonian, East European Platform). Russian. 2006.

[26202] A. V. Zhuravlev. Konodonty verkhnego devona - nizhnego karbona severo-vostoka Evropeyskoy Rossii [Conodonts of the Upper Devonian - Lower Carboniferous of north-east of European Russia]. Russian. Zhuravlev, A.V. Konodonty verkhnego devona - nizhnego karbona severo-vostoka Evropeyskoy Rossii. VSEGEI Publ., St. Petersburg, Russia. 2003, pp. 1-85.

[26203] A. V. Zhuravlev. "Early Permian conodonts from the Olenya-10 borehole, north of Timan-Pechora Province". English. In: Permophiles 52 (2008), pp. 11-14.

[26204] A. V. Zhuravlev, I. O. Evdokimova, and E. V. Sokiran. SEDIMENTARY ENVIRONMENTS AND FOSSILS OF THE SYAS FORMATION (UPPER DEVONIAN, EAST OF THE MAIN DEVONIAN FIELD. English. 2005.

[26205] A. V. Zhuravlev, O. L. Kossovaya, D. B. Sobolev, and Y. A. Vevel. "Biostratigraphy of the Lower Tournaisian (Lower Carboniferous) shallow-water deposits of the Eastern Part of the Timan-Pechora Province". In: Newsletter on Carboniferous Stratigraphy 17 (1999), pp. 22-26.

[26206] A. V. Zhuravlev, G. V. Kotlyar, and S. B. Shishlov. "Paleobiogeoraphical and biostratigraphical analysis of the Kazanian (Middle Permian) conodonts of the east Russian Platform - preliminary results". English. In: Permophiles 48 (2006), pp. 15-20.

[26207] A. Y. Zhuravlev and D. I. Gravestock. "Archaeocyaths from Yorke Peninsula, South Australia and archaeocyathan Early Cambrian zonation". English. In: Alcheringa 18.1 (1994), pp. 1-54.

[26208] V. S. Zhuravlev and A. V. Pakhnevich. "Brachiopods of the superfamily Richthofenioidea (Productida) from the Permian of Darvaz Range, Tajikistan". English. In: Paleontological Journal 53 (2019), pp. 381-388. DOI: 10.1134/S0031030119040154. 
[26209] I. T. Zhuravleva, I. A. Konyaeva, D. V. Osadchaya, and A. S. Boyarinov. "Biostratigraphy of the Kiya River section. - Early Cambrian Archaeocyaths and spicular sponges from the Kiya River section (Kuznetsk Alatau)". English. In: Annales de Paléontologie 83.1 (1997), pp. 3-92.

[26210] L. V. Zhuzhgova. "A new miomopteran (Insecta: Miomoptera) from the Lower Permian of the Urals". English. In: Neues Jahrbuch für Geologie und Paläontologie, Monatshefte 2002.5 (2002), pp. 273276.

[26211] H. Zibrowius. "The southern Astroides calycularis in the Pleistocene of the northern Mediterranean - an indicator of climatic changes (Cnidaria, Scleractinia)". English. In: Geobios 28.1 (1995), pp. 9-16.

[26212] A. M. Ziegler, P. M. Rees, and S. V. Naugolnykh. "The Early Permian floras of Prince Edward Island, Canada: differentiating global from local effects of climate change". In: Canadian Journal of Earth Sciences 39 (2002), pp. 223-238.

[26213] K. E. Ziegler, A. B. Heckert, and S. G. Lucas. The vertebrate fauna of the Upper Triassic (Revueltian) Snyder Quarry. English. Vol. 24. Paleontology and Geology of the Snyder Quarry, New Mexico Museum of Natural History and Science Bulletin. 2003, pp. 71-79.

[26214] R. Ziegler. "Insectivores (Lipotyphla) and bats (Chiroptera) from the Late Miocene of Austria". English. In: Annalen Naturhistorisches Museum Wien 107A (2006), pp. 93-196.

[26215] R. Ziegler. "Erinaceidae and Dimylidae (Lipotyphla) from the Upper Middle Miocene of South Germany". English. In: Senckenbergiana lethaea 85.1 (2005), pp. 131-152.

[26216] R. Ziegler. "Shrews (Soricidae, Mammalia) from Middle Miocene karstic fissure fill sites of Petersbuch near Eichstätt, southern Franconian Alb (Bavaria)". English. In: Paläontologische Zeitschrift 77.2 (2003), pp. 303-322.

[26217] R. Ziegler. "Moles (Talpidae) from the late Middle Miocene of South Germany." English. In: Acta Palaeontologica Polonica 48.4 (2003), pp. 617-648.

[26218] R. Ziegler. "Marsupialia und Insectivora (Mammalia) aus den oberoligozänen Spaltenfüllungen Herrlingen 8 und Herrlingen 9 bei Ulm (Baden-Württemberg)". German. In: 77.1/2 (1998), pp. 101143.

[26219] R. Ziegler. "The insectivores (Erinaceomorpha and Soricomorpha, Mammalia) from the Late Miocene hominoid locality Rudabánya". English. In: Palaeontographia Italica 90 (2005), pp. 53-81.

[26220] R. Ziegler. "Plesiosoricids from early Oligocene fissure fillings in South Germany, with remarks on plesiosoricid phylogeny". English. In: Acta Palaeontologica Polonica 54.3 (2009), pp. 365-371.

[26221] R. Ziegler. "Moles (Talpidae, Mammalia) from Early Oligocene karstic fissure fillings in South Germany". English. In: Geobios 45 (2012), pp. 501-513.

[26222] R. Ziegler. "The nyctitheriids (Lipotyphla, Mammalia) from Early Oligocene fissure fillings in South Germany". English. In: Neues Jahrbuch für Geologie und Paläontologie Abhandlungen 246.2 (2007), pp. 183-203.

[26223] R. Ziegler, T. Dahlmann, and G. Storch. 4. Marsupialia, Erinaceomorpha and Soricomorpha (Mammalia). English. Vol. 108A. Oligocene-Miocene Vertebrates from the Valley of Lakes (Central Mongolia): Morphology, phylogenetic and stratigraphic implications. Annalen des Naturhistorischen Museums in Wien. 2007, pp. 53-164.

[26224] R. Ziegler and G. Storch. "Mammals from the Cyrena Beds of Offenbach (Hesse) - Biostratigraphic correlation". English. In: Neues Jahrbuch für Geologie und Paläontologie Abhandlungen 248.3 (2008), pp. 267-278.

[26225] J. S. Zijlstra. "A new oryzomyine (Rodentia: Sigmodontinae) from the Quaternary of Curaçao (West Indies)". English. In: Zootaxa 3534 (2012), pp. 61-68.

[26226] J. S. Zijlstra, L. J. Flynn, and W. Wessels. "The westernmost tarsier: A new genus and species from the Miocene of Pakistan". English. In: Journal of Human Evolution 65 (2013), pp. 544-550. DOI: 10.1016/j.jhevol.2013.06.015. 
[26227] J. S. Zijlstra and L. J. Flynn. “Hedgehogs (Erinaceidae, Lipotyphla) from the Miocene of Pakistan, with description of a new species of Galerix". English. In: Palaeobiodiversity and Palaeoenvironments 95 (2015), pp. 477-495. DOI: 10.1007/s12549-015-0190-3.

[26228] J. S. Zijlstra, P. A. Madern, and L. W. van den Hoek Ostende. “New genus and two new species of Pleistocene oryzomyines (Cricetidae: Sigmodontinae) from Bonaire, Netherlands Antilles". English. In: Journal of Mammalogy 91.4 (2010), pp. 860-873. DOI: 10.1644/09-MAMM-A-208.1.

[26229] J. S. Zijlstra, D. A. McFarlane, L. W. van den Hoek Ostende, and J. Lundberg. "New rodents (Cricetidae) from the Neogene of Curaçao and Bonaire, Dutch Antilles". English. In: Palaeontology 57.5 (2014), pp. 895-908. DOI: 10.1111/pala.12091.

[26230] L. Zili, D. Zaghbib-Turki, L. Alegret, I. Arenillas, and E. Molina. "Foraminiferal turnover across the Paleocene/Eocene boundary at the Zumaya section, Spain: record of a bathyal gradual mass extinction". English. In: Revista Mexicana de Ciencias Geológicas 26.3 (2009), pp. 729-744.

[26231] N. Zimicz, P. Payrola, and C. del Papa. “New, Late Miocene mammalian assemblage from the Palo Pintado Formation (Northwestern Argentina)". English. In: Journal of South American Earth Sciences 81 (2018), pp. 31-44. DOI: 10.1016/j.jsames.2017.11.003.

[26232] J. Zinke. "Small theropod teeth from the Upper Jurassic coal mine of Guimarota (Portugal)". English. In: Paläontologische Zeitschrift 72.1/2 (1998), pp. 179-189.

[26233] J. Zinke and O. W. M. Rauhut. "Small theropods (Dinosauria, Saurischia) from the Upper Jurassic and Lower Cretaceous of the Iberian Peninsula". English. In: In R. Kohring E T. Martin (eds.), Miscellanea Palaeontologica 3: Festschrift Bernard Krebs. Berliner Geowissenschaften Abhandlungen, Reihe E 13 (1994), pp. 163-177.

[26234] J. Zinke, J. J. G. Reijmer, M. Taviani, W. C. Dullo, and B. Thomassin. "Facies and faunal assemblage changes in response to the Holocene transgression in the Lagoon of Mayotte (Comoro Archipelago, SW Indian Ocean)". English. In: Facies 50 (2005), pp. 391-408.

[26235] W. J. Zinsmeister and J. D. Stilwell. "First record of the family Ringiculidae (Gastropoda) from the middle Tertiary of Antarctica". English. In: Journal of Paleontology 64.3 (1990), pp. 373-376.

[26236] J. Zitt. “Geinitzaster gen. n. (Asteroidea, Echinodermata) from Upper Cenomanian strata of the Bohemian Cretaceous basin". English. In: Geologica Carpathica 56.4 (2005), pp. 317-326.

[26237] J. Zitt. "The asteroid genus Haccourtaster (Echinodermata, Goniasteridae) in the Bohemian Cretaceous Basin, Czech Republic". English. In: Cretaceous Research 26 (2005), pp. 225-237.

[26238] J. tt, C. Löser, O. Nekvasilová, L. Hradecká, and L. vábenická. “Pedboj and Hoher Stein: Two sites of mass roveacrinid occurrence (Crinoidea, Cenomanian, Bohemian-Saxonian Cretaceous Basin)". English. In: Cretaceous Research 94 (2019), pp. 80-107. DOI: 10.1016/j.cretres.2018.08.015.

[26239] J. Zitt, R. Vodrázka, L. Hradecká, M. Svobodová, and K. Zágorsek. “Late Cretaceous environments and communities as recorded at Chrtnky (Bohemian Cretaceous Basin, Czech Republic)". English. In: Bulletin of Geosciences 81.1 (2006), pp. 43-79.

[26240] M. Zobaa, C. Sanchez-Botero, C. Browne, F. E. Oboh-Ikuenobe, and M. I. Ibrahim. “Kerogen and palynomorph analyses of the mid-Cretaceous Bahariya Formation and Abu Roash G Member, North Western Desert, Egypt". English. In: Gulf Coast Association of Geological Societies Transactions 58 (2008), pp. 933-943.

[26241] D. Zoboli and G. L. Pillola. “Upper Pleistocene Mammal Assemblage from Su Concali Quarry (Samatzai, Southern Sardinia, Italy)". English. In: Revista Italiana di Paleontologia e Stratigrafia 123.2 (2017), pp. 243-254.

[26242] O. Zompro. "The Phasmatodea and Raptophasma n. gen., Orthoptera incertae sedis, in Baltic amber (Insecta: Orthoptera)". English. In: Mitteilungen aus dem Geologisch-Paläontologischen Institut der Universität Hamburg 85 (2001), pp. 229-261.

[26243] O. Zompro. "Inter- and intra-ordinal relationships of the Mantophasmatodea, with comments on the phylogeny of polyneopteran orders (Insecta: Polyneoptera)". English. In: Mitteilungen aus dem Geologisch-Paläontologischen Institut der Universität Hamburg 89 (2005), pp. 85-116. 
[26244] P. Zong, R. T. Becker, and X. P. Ma. “Upper Devonian (Famennian) and Lower Carboniferous (Tournaisian) ammonoids from western Junggar, Xinjiang, northwestern China - stratigraphy, taxonomy and palaeobiogeography". English. In: Palaeobiodiversity and Palaeoenvironments 95 (2015), pp. 159-202.

[26245] J.-P. Zonneveld. “Middle Triassic biostromes from the Liard Formation, British Columbia, Canada: oldest examples from the Mesozoic of NW Pangea". In: Sedimentary Geology 145.3-4 (2001), pp. 317341.

[26246] J.-P. Zonneveld, G. F. Gunnell, and W. S. Bartels. “Early Eocene fossil vertebrates from the southwestern Green River Basin, Lincoln and Uinta counties, Wyoming". English. In: Journal of Vertebrate Paleontology 20.2 (2000), pp. 369-386.

[26247] J.-P. Zonneveld and G. F. Gunnell. “A new species of cf. Dilophodon (Mammalia; Perissodactyla) from the early Bridgerian of southwestern Wyoming". English. In: Journal of Vertebrate Paleontology 23.3 (2003), pp. 652-658.

[26248] J.-P. Zonneveld, C. M. Henderson, G. D. Stanley Jr., M. J. Orchard, and M. K. Gingras. “Oldest scleractinian coral reefs on the North American craton: Upper Triassic (Carnian), northeastern British Columbia, Canada". English. In: Palaeogeography, Palaeoclimatology, Palaeoecology 243.3-4 (2007), pp. 421-450.

[26249] J. P. Zonneveld, S. G. Pemberton, T. D. A. Saunders, and R. K. Pickerill. “Large, robust $<\mathrm{i}>$ Cruziana $</ \mathrm{i}>$ from the Middle Triassic of Northeastern British Columbia: Ethologic, Biostratigraphic, and Paleobiologic significance". English. In: Palaios 17.5 (2002), pp. 435-448.

[26250] K. Zorlu, S. Inan, M. Gül, N. nan, M. A. Kurt, and M. Alpaslan. "Geological Evolution of the Ulukla Basin (Late Cretaceous - Eocene) Central Anatolia, Turkey". English. In: Yerbilimleri 32.2 (2011), pp. 151-170.

[26251] I. Zorn. "Holoplanktonic gastropods from the early Messinian of the Heraklion Basin (Crete, Greece)". English. In: Contributions to Tertiary and Quaternary Geology 34.1-2 (1997), pp. 31-45.

[26252] R. O. Zorzin, S. T. Castellani, V. I. Frisone, and E. R. Quaggiotto. “Le campagne di scavo del Museo Paleontologico di Roncá in localitá Monte Duello (Comune di Montecchia di Crosara) e Valle della Chiesa (Comune di Roncá), nei Monti Lessini veronesi (Italia settentrionale): primi risultati". Italian. In: Bollettino del Museo Civico di Storia Naturale di Verona 36 (2012), pp. 53-62.

[26253] S.-L. Zou, Q. Wang, and Z. -L. Wang. "A new oospecies of parafaveoloolithids from the Pingxiang Basin, Jiangxi Province of China". English. In: Vertebrata PalAsiatica 51.2 (2013), pp. 102-106.

[26254] X. D. Zou, M. Balini, D. Y. Jiang, A. Tintori, Z. Y. Sun, and Y. L. Sun. "Ammonoids from the Zhuganpo Member of the Falang Formation at Nimaigu and their relevance for dating the Xingyi fossil-Lagerstätte (late Ladinian, Guizhou, China)". English. In: Rivista Italiana di Paleontologia e Stratigrafia 121 (2015), pp. 135-161.

[26255] S. Zouhri. “Un nouvel équidé, Hipparion molayense nov. sp., dans le gisement turolien de Molayan en Afghanistan". French. In: Geobios 29.4 (1996), pp. 437-454.

[26256] S. Zouhri, D. Geraads, S. El Boughabi, and A. El Harfi. “Discovery of an Upper Miocene Vertebrate fauna near Tizi N’Tadderht, Skoura, Ouarzazate Basin (Central High Atlas, Morocco)". English. In: Comptes Rendus Palevol 11 (2012), pp. 455-461.

[26257] S. Zouhri, P. D. Gingerich, N. Elboudali, S. Sebti, A. Noubhani, M. Rahali, and S. Meslouh. “New marine mammal faunas (Cetacea and Sirenia) and sea level change in the Samlat Formation, Upper Eocene, near Ad-Dakhla in southwestern Morocco". English. In: Comptes Rendus Palevol 13.7 (2014), pp. 599-610. DOI: 10.1016/j.crpv.2014.04.002.

[26258] S. Zouhri, P. D. Gingerich, S. Adnet, E. Bourdon, S. Jouve, B. Khalloufi, A. Amane, N. Elboudali, J. C. Rage, F. de Lapparent De Broin, A. Kaoukaya, and S. Sebti. "Middle Eocene vertebrates from the sabkha of Gueran, Atlantic coastal basin, Saharan Morocco, and their peri-African correlations". English. In: Comptes Rendus Geoscience 350.6 (2018), pp. 310-318. DOI: 10.1016/j.crte.2018.06.006. 
[26259] S. Zouhri, P. D. Gingerich, N. Elboudali, W. Bouzarzar, A. Amana, and O. Saddiqi. Discovery of a new middle-upper Eoecne vertebrate locality (sabkha of Lebreij) in the Sahara Desert, southeastern Morocco. English. 2019.

[26260] S. Zouhri, P. D. Gingerich, B. Khalloufi, N. Elboudali, A. Amane, W. Bouzarzar, and O. Saddiqi. The middle-upper Eocene Vertebrate record from Taraya-Laayoune-Dakhla Antlantic Basin (Morocco). English. 2019.

[26261] S. Zouhri, B. Khalloufi, E. Bourbon, F. de Lapparent de Broin, J. C. Rage, L. M'Haidrat, P. D. Gingenrich, and N. Elboudali. "Marine vertebrate fauna from the late Eocene Samlat Formation of Ad-Dakhla, southwestern Morocco". English. In: Geological Magazine (2017). DOI: 10.1017/ S0016756817000759.

[26262] V. Zuchuat, A. R. N. Sleveland, R. J. Twitchett, H. H. Svensen, H. Turner, and L. E. Augland. “A new high-resolution stratigraphic and palaeoenvironmental record". English. In: Palaeogeography, Palaeoclimatology, Palaeoecology 554 (2020), p. 109732.

[26263] G. R. Zug. “Turtles of the Lee Creek Mine (Pliocene: North Carolina)". English. In: Smithsonian Contributions to Paleobiology 90 (2001), pp. 203-218.

[26264] P. Zügel. "Discovery of a radiolarian fauna from the Tithonian of the Solnhofen area (Southern Franconian Alb, southern Germany)". In: Paläontologische Zeitschrift 71.3-4 (1997), pp. 197-209.

[26265] P. Zügel, W. Riegraf, G. Schweigert, and G. Dietl. “Radiolaria from the Nusplingen Lithographic Limestone (Late Kimmeridgian, SW Germany)". English. In: Stuttgarter Beiträge zur Naturkunde, Serie B (Geologie und Paläontologie) 268 (1998), p. 43.

[26266] G. Zulauf, J. Blau, W. Dörr, T. Klein, J. Krahl, E. Kustatscher, R. Petschik, and B. van de Schootbrugge. "New U-Pb zircon and biostratigraphic data of the Tyros Unit, eastern Crete: constraints on Triassic palaeogeography and depositional environment of the eastern Mediterranean". English. In: Zeitschrift der Deutschen Gesellschaft für Geowissenschaften 164.2 (2013), pp. 337-352.

[26267] V. A. Zullo, L. Marincovich, and Jr. "Balanoid barnacles from the Miocene of the Alaska Peninsula, and their relevance to the extant boreal barnacle fauna". In: Journal of Paleontology 64 (1990), pp. $128-135$.

[26268] V. A. Zullo. "Revision of the balanid barnacle genus Concavus Newman, 1982, with the description of a new subfamily, two new genera, and eight new species". English. In: The Paleontological Society Memoir 27 (1992), pp. 1-46.

[26269] V. A. Zullo, M. P. Katuna, and K. C. Herridge. "Scapellomorph and balanomorph barnacles (Cirripedia) from the upper Oligocene Ashley Formation, Charleston County, South Carolina". English. In: South Carolina Geology 34.1 \& 2 (1992), pp. 57-67.

[26270] V. A. Zullo and R. T. Perreault. "Arcoscalpellum toulmini Weisbord and Zeugmatolepas sp. (Cirripedia, Thoracica) from the lower Paleocene of Alabama". English. In: Journal of Paleontology 65.2 (1991), pp. 267-270.

[26271] M. Zunino. “The first dung beetle retrieved from Coprinisphaeridae ichnofossils: Phanaeus violetae n. sp. (Coleoptera: Scarabaeinae) from Ecuadorian cangahua balls". English. In: Acta Zoológica Mexicana (n.s.) 29 (2013), pp. 219-226.

[26272] M. Zunino and G. Pavia. "Lower to Middle Miocene Mollusc assemblages from the Torino Hills (NW Italy): Synthesis of new data and chronostratigraphical arrangement". English. In: Rivista Italiana di Paleontologia e Stratigrafia 115.3 (2009), pp. 349-370.

[26273] R. L. Zuparko and G. O. Poinar. "Aivalykus dominicanus (Hymenoptera: Braconidae), a new species from Dominican amber". English. In: Proceedings of the Entomological Society of Washington 99 (1997), pp. 744-747.

[26274] R. L. Zuparko and V. A. Trjapitzin. “Copidosoma archeodominica (Hymenoptera: Encyrtidae), a new species from Dominican amber". English. In: The Pan-Pacific Entomologist 89 (2013), pp. 230233. 
[26275] A. E. Zurita. "Los Hoplophorini (Xenarthra, Glyptodontidae) del Araucanense (Mioceno tardoPlioceno) del noroeste de la Argentina: sistemática, paleobiogeografa y paleoambientes". Spanish. In: Ameghiniana 44.2 (2007), pp. 257-269.

[26276] A. E. Zurita and S. A. Aramayo. "New remains of Eosclerocalyptus tapinocephalus (Cabrera) (Mammalia, Xenarthra, Glyptodontidae): description and implications for its taxonomic status". English. In: Rivista Italiana di Paleontologia e Stratigrafia 113.1 (2007), pp. 57-66.

[26277] A. E. Zurita, M. Camacho, A. R. Miño-Boilini, A. M. Candela, F. Cuadrelli, C. M. Krmpotic, and N. Sols. "Xenarthra (Mammalia) from a new late Neogene fossiliferous locality in Northwestern Argentina". English. In: Journal of South American Earth Sciences 80 (2017), pp. 229-236. DOI: 10. 1016/j.jsames.2017.09.023.

[26278] A. E. Zurita, A. A. Carlini, G. J. Scillato-Yané, and E. P. Tonni. "Mamferos extintos del Cuaternario de la Provincia del Chaco (Argentina) y su relación con aquéllos del este de la región pampeana y de Chile". Spanish. In: Revista geológica de Chile 31.1 (2004), pp. 65-87.

[26279] A. E. Zurita, A. A. Carlini, and G. J. Scillato-Yane. "A new species of Neosclerocalyptus Paula Couto, 1957 (Xenarthra, Glyptodontidae, Hoplophorinae) from the middle Pleistocene of the Pampean region, Argentina". English. In: Geodiversitas 30.4 (2008), pp. 779-791.

[26280] A. E. Zurita and B. S. Ferrero. “Una nueva especie de Neuryurus Ameghino (Mammalia, Glyptodontidae) en el Pleistoceno tardo de la Mesopotamia de Argentina". Spanish. In: Geobios 42 (2009), pp. 663-673.

[26281] A. E. Zurita, G. M. Gasparini, E. Soibelzon, M. A. Alcaraz, and A. R. Mino-Boilini. “Mamiferos Pleistocenos del Oeste de la Region Pampeana, Argentina". English. In: Revista Espanola de Paleontologia 22.1 (2007), pp. 77-87.

[26282] A. E. Zurita, D. D. Gillette, F. Cuadrelli, and A. A. Carlini. "A tale of two clades: Comparative study of Glyptodon Owen and Glyptotherium Osborn (Xenarthra, Cingulata, Glyptodontidae". English. In: Geobios 51.3 (2018), pp. 247-258. DOI: 10.1016/J.GEOBIOS.2018.04.004.

[26283] A. E. Zurita, L. R. González Ruiz, A. J. Gómez-Cruz, and J. E. Arenas-Mosquera. “The most complete known Neogene Glyptodontidae (Mammalia, Xenarthra, Cingulata) from northern South America: taxonomic, paleobiogeographic, and phylogenetic implications". English. In: Journal of Vertebrate Paleontology 33.3 (2013), pp. 696-708.

[26284] A. E. Zurita, A. R. Mino-Boilini, A. A. Carlini, M. Iriondo, and M. A. Alcaraz. "Paleontologa del Chaco Oriental. Una nueva localidad con mamferos fósiles pleistocenos en el ro Bermejo (Formosa, Argentina)". Spanish. In: Revista Mexicana de Ciencias Geológicas 26.2 (2009), pp. 277-288.

[26285] A. E. Zurita, A. R. Miño-Boilini, E. Soibelzon, G. J. Scillato-Yané, G. M. Gasparini, and F. ParedesRos. "First record and description of an exceptional unborn specimen of Cingulata Glyptodontidae: Glyptodon Owen (Xenarthra)". English. In: Comptes Rendus Palevol 8 (2009), pp. 573-578.

[26286] A. E. Zurita, A. R. Miño-Boilini, E. Soibelzon, A. A. Carlini, and F. Paredes Ros. "The diversity of Glyptodontidae (Xenarthra, Cingulata) in the Tarija valley (Bolivia): systematic, biostratigraphic and paleobiogeographic aspects of a particular assemblage". English. In: Neues Jahrbuch für Geologie und Paläontologie - Abhandlungen 251.2 (2009), pp. 225-237. DOI: 10.1127/0077-7749/2009/02510225.

[26287] A. E. Zurita, A. R. Miño-Boilini, A. Francia, and J. E. Arenas-Mosquera. “The Pleistocene Glyptodontidae Gray, 1869 (Xenarthra: Cingulata) of Colombia and some considerations about the South American Glyptodontinae". English. In: Revista Brasileira de Paleontolgia 15.3 (2012), pp. 273-280. DOI: $10.4072 / \mathrm{rbp} .2012 .3 .04$.

[26288] A. E. Zurita, C. Oliva, A. Dondas, E. Soibelzon, and F. I. Isla. “El registro más completo de un Hoplophorini (Xenarthra: Glyptodontidae) para los Pisos/Edades Chapadmalalense-Marplatense (Plioceno tardo-Pleistoceno temprano)". Spanish. In: Revista del Museo Argentino de Ciencias Naturales 13.1 (2011). 
[26289] A. E. Zurita, E. V. Oliveira, P. Toriño, S. M. Rodriguez-Bualó, G. J. Scillato-Yané, C. Luna, and J. Krapovickas. "On the taxonomic status of some Glyptodontidae (Mammalia, Xenarthra, Cingulata) from the Pleistocene of South America". English. In: Annales de Paléontologie 97 (2011), pp. 6383. DOI: 10.1016/J.ANNPAL.2011.07.003.

[26290] A. E. Zurita, E. Soibelzon, G. J. Scillato-Yane, and M. Cenizo. "The earliest record of Neuryurus Ameghino (Mammalia, Glytodontidae, Hoplophorinae)". English. In: Alcheringa: An Australasian Journal of Palaeontology 33.1 (2009), pp. 49-57. DOI: 10.1080/03115510802618250.

[26291] A. E. Zurita, L. H. Soibelzon, E. Soibelzon, G. M. Gasparini, M. M. Cenizo, and H. Arzani. “Accesory protection structures in Glyptodon Owen (Xenarthra, Cingulata, Glyptodontidae)". English. In: Annales de Paleontologie 96.1 (2010), pp. 1-11. DOI: 10.1016/j.annpal.2010.01.001.

[26292] A. E. Zurita, M. Taglioretti, M. de los Reyes, C. Oliva, and F. Scaglia. "First Neogene skulls of Doedicurinae (Xenarthra, Glyptodontidae): morphology and phylogenetic implications". English. In: Historical Biology 28.3 (2016), pp. 423-432. DOI: 10.1080/08912963.2014.969254First.

[26293] A. E. Zurita, M. Taglioretti, M. Zamorano, G. J. Scillato-Yané, Carlos Luna C., D. Boh, and M. M. Saffer. "A new species of Neosclerocalyptus Paula Couto (Mammalia: Xenarthra: Cingulata): the oldest record of the genus and morphological and phylogenetic aspects". English. In: Zootaxa 3721.4 (2013), pp. 387-398.

[26294] A. E. Zurita and R. Tomassini. “Revisión de un Hoplophorini poco conocido, Sclerocalyptus lineatus Ameghino (Mammalia, Xenarthra, Glyptodontidae) de edad Montehermosense (Mioceno Tardo - Plioceno temprano) de la Argentina". Spanish. In: Studia Geologica Salmanticensia 42 (2006), pp. 11-20.

[26295] A. E. Zurita, M. Zamorano, G. J. Scillato-Yane, L. R. Gonzalez-Ruiz, S. Rodriguez-Bualo, B. R. Duran, and R. C. Paz. "An exceptional Pleistocene specimen of Panochthus burmeister (Xenarthra, Glyptodontoidea) from Bolivia: Its contribution to the understanding of the Early-Middle Pleistocene Panochthini". English. In: Comptes Rendus Palevol 10 (2011), pp. 655-664.

[26296] A. E. Zurita, M. Zamorano, G. J. Scillato-Yané, S. Fidel, M. Iriondo, and D. D. Gillette. “A new species of Panochthus Burmeister (Xenarthra, Cingulata, Glyptodontidae) from the Pleistocene of the Eastern Cordillera, Bolivia". English. In: Historical Biology 29.8 (2017), pp. 1076-1088.

[26297] M. Zuschin, M. Harzhauser, and O. Mandic. "The Stratigraphic and Sedimentologic Framework of Fine-Scale Faunal Replacements in the Middle Miocene of the Vienna Basin (Austria)". English. In: Palaios 22.3 (2007), pp. 285-295. DOI: 10.2110/palo.2005.p05-023r.

[26298] M. A. Zuykov. "Platystrophia (Orthida, Brachiopoda) from the Arenig and Lowermost Llanvirn of Northwestern Russia". English. In: Proceedings of the Estonian Academy of Sciences (Eesti Teaduste Akadeemia Toimetised) 48.4 (1999), pp. 195-212.

[26299] M. A. Zuykov and S. H. Butts. “Glyptorthis (Forste, 1914) and Bassettella New Genus (Brachiopoda: Orthida) from the Late Ordovician of the East Baltic". English. In: Journal of Paleontology 82.1 (2008), pp. 197-200.

[26300] M. A. Zuykov and E. Egerquist. "A new Platystrophia-like brachiopod genus from Ordovician Boda Limestone of Dalarna, Sweden". English. In: Geologiska Föreningen i Stockholm Förhandlingar 127.1 (2005), pp. 1-5.

[26301] M. A. Zuykov and D. A. T. Harper. "Platystrophia (Orthida) and new related Ordovician and Early Silurian brachiopod genera". English. In: Estonian Journal of Earth Sciences 56 (2007), pp. 1134.

[26302] M. A. Zuykov and L. Hints. "New species of Estlandia (Clitambonitidina, Brachiopoda) in the Upper Ordovician of the East Baltic". English. In: Proceedings of the Estonian Academy of Sciences, Geology 51.3 (2002), pp. 135-142.

[26303] M. A. Zuykov, S. S. Terentiev, and D. A. T. Harper. "New endemic brachiopod and echinoderm genera from the Upper Ordovician of the St. Petersburg region, northwestern Russia". English. In: Geological Society of Sweden, Geologiska Föreningen 130.2 (2008), pp. 87-93. 
[26304] N. G. Zverkov, M. S. Arkhangelsky, J. M. Pardo Pérez, and P. A. Beznosov. “On the Upper Jurassic ichthyosaur remains from the Russian north". English. In: Proceedings of the Zoological Institute RAS 319.1 (2015), pp. 81-97.

[26305] N. G. Zverkov and D. V. Grigoriev. "An unrevealed lineage of platypterygiines (Ichthyosauria) with peculiar forefin structure and semiglobal distribution in the mid- Cretaceous (AlbianeCenomanian)". English. In: Cretaceous Research 115 (2020). DOI: 10.1016/j.cretres.2020.104550.

[26306] N. G. Zverkov and E. M. Pervushov. "A gigantic pliosaurid from the Cenomanian (Upper Cretaceous) of the Volga Region, Russia". English. In: Cretaceous Research 110 (2020). DOI: 10.1016/j. cretres.2020.104419.

[26307] N. G. Zverkov and N. E. Prilepskaya. "A prevalence of Arthropterygius (Ichthyosauria: Ophthalmosauridae) in the Late Jurassic —earliest Cretaceous of the Boreal Realm". English. In: PeerJ 7 (2019), e6799. DOI: 10.7717 / peerj.6799.

[26308] E. A. Zvonok. "On the problematic Eocene cetacean from Nagornoye site (Kirovograd prov., Ukraine) and the significance of archaeocetes for stratigraphic research". Russian. In: Geolog Ukrainy 1-2 (2012), pp. 87-93.

[26309] E. A. Zvonok, I. G. Danilov, E. V. Syromyatnikova, and N. I. Udovichenko. “Remains of Sea Turtles from the Ikovo Locality (Lugansk Region, Ukraine; Middle Eocene)". English. In: Paleontological Journal 47.6 (2013), pp. 607-617. DOI: 10.1134/S0031030113050134.

[26310] E. A. Zvonok and I. G. Danilov. "A revision of fossil turtles from the Kiev Clays (Ukraine, Middle Eocene) with comments on the history of the collection of fossil vertebrates of A. S. Rogovich". English. In: Proceedings of the Zoological Institute RAS 321.4 (2017), pp. 485-516.

[26311] E. A. Zvonok and I. G. Danilov. "Paleogene Turtles of Crimea”. English. In: Paleontological Journal 53.1 (2019), pp. 62-73.

[26312] E. A. Zvonok and P. P. Skutschas. “On a Tomistomine Crocodile (Crocodylidae, Tomistominae) from the Middle Eocene of Ukraine". English. In: Paleontological Journal 45.6 (2011), pp. 661-664.

[26313] E. A. Zvonok and P. B. Snetkov. "New findings of snakes of the genus Palaeophis Owen, 1841 (Acrochordoidea: Palaeophiidae) from the Middle Eocene of Crimea". English. In: Proceedings of the Zoological Institute RAS 316.4 (2012), pp. 392-400.

[26314] E. A. Zvonok, E. V. Syromyatnikova, I. G. Danilov, and A. F. Bannikov. “A Sea Turtle (Cheloniidae) from the Middle Eocene of the North Caucasus". English. In: Paleontological Journal 53.5 (2019), pp. 530-539.

[26315] E. A. Zvonok, N. I. Udovichenko, and A. V. Bratishko. "New Data on the Morphology and Systematic Position of the Sea Turtle Allopleuron qazaqstanense Karl et al. from the Middle Eocene of Kazakhstan". English. In: Paleontological Journal 49.2 (2015), pp. 176-189.

[26316] E. A. Zvonok, N. V. Zelenkov, and I. G. Danilov. “A new unusual waterbird (Aves, ?Suliformes) from the Eocene of Kazakhstan". English. In: Journal of Vertebrate Paleontology 36.1 (2016), e1035783. DOI: 10.1080/02724634.2015.1035783.

[26317] Y. Zvonok, G. Mayr, and L. Gorobets. "New material of the Eocene marine bird Kievornis". English. In: Vertebrata PalAsiatica 53.7 (2015), pp. 238-244.

[26318] S. Zyabrev and A. Matsuoka. “Late Jurassic (Tithonian) radiolarians from a clastic unit of the Khabarovsk complex (Russian Far East): Significance for subduction accretion timing and terrane correlation". In: The Island Arc 8 (1999), pp. 30-37.

[26319] D. ya, V. Blagoderov, and P. Wegierek. "Juraphididae, a new family of aphids and its significance in aphid evolution". English. In: Systematic Entomology 39 (2014), pp. 506-517.

[26320] D. ya, A. Homan, B. Franielczyk, and P. Wegierek. "Revised concept of the fossil genus Oviparosiphum Shaposhnikov, 1979 with the description of a new genus (Hemiptera, Sternorrhyncha, Aphidomorpha)". English. In: ZooKeys 483 (2015), pp. 9-22. 
[26321] D. ya, A. Homan, and P. Wegierek. "Polyphyly of the extinct family Oviparosiphidae and its implications for inferring aphid evolution (Hemiptera, Sternorrhyncha)". English. In: PLoS One 12.4 (2017), e0174791.

[26322] D. ya and A. Solodovnikov. "First extinct representative of the rove beetle subtribe Acylophorina from Baltic amber, and its phylogenetic placement". English. In: Journal of Systematic Palaeontology 17 (2017), pp. 157-167.

[26323] D. ya, P. Wegierek, K. Owocki, and G. Niedwiedzki. “Insects and crustaceans from the latest Earlyearly Middle Triassic of Poland". English. In: Palaeogeography, Palaeoclimatology, Palaeoecology 371 (2013), pp. 136-144.

[26324] D. ya and P. Wegierek. "The oldest Palaeoaphididae (Insecta: Hemiptera: Aphidomorpha) from the Late Jurassic/Early Cretaceous locality of Khotont (Mongolia)". English. In: Insect Systematics E Evolution 44 (2013), pp. 149-155.

[26325] D. ya and P. Wegierek. "The oldest representatives of the aphid family Ellinaphididae and phylogenetic relationships within the family". English. In: Cretaceous Research 52 (2015), pp. 348-356.

[26326] D. ya, S. Yamamoto, K. Wolf-Schwenninger, and A. Solodovnikov. "Cretaceous origin of the unique prey-capture apparatus in megadiverse genus: stem lineage of Steninae rove beetles discovered in Burmese amber". English. In: Scientific Reports 7.45904 (2017), pp. 1-15.

[26327] D. ya, S. Yamamoto, and J. Jenkins Shaw. "Total-evidence approach reveals an extinct lineage of Paederinae rove beetles from Cretaceous Burmese amber". English. In: Palaeontology 62 (2019), pp. 935-949. DOI: 10.1111/pala.12435.

[26328] M. akovi. "New Early Triassic (Smithian) ammonoids from Gornji Breli (southern Montenegro)". English. In: Austrian Journal of Earth Sciences 110.2 (2017).

[26329] D. uri. "The Early Miocene herpetofauna (Amphibia and Squamata) from Sibnica, Serbia". English. In: Special Issue of the Natural History Museum in Belgrade: Life on the Shore - geological and palaeontological research in the Neogene of Sibnica and vicinity (Leva Basin, Central Serbia) Part 1 (2016), pp. 57-61.

[26330] E. O. Zvonok. "Seredno- verhnoeocenov reptil Ukrani: nov vdomost pro msceznahodenna j taksonomne rozmatta". other. In: Tezi dopovdej vseukransko naukovo konferenc ńZnaenna kompleksnih ltobostratigrafnih doslden pd as poukv nafti gazuż 2011 (2011), pp. 32-33.

[26331] E. O. Zvonok. Lutetskie reptilii mestonahodenia Ak-Kaa (Krym, Ukraina): predvaritelnye dannye. Russian. 2011.

[26332] M. J. Arrouy, C. Gaucher, D. G. PoirÃ̃', S. Xiao, L. E. GÃşmez Peral, L. V. Warren, N. Bykova, and F. Quaglio. "A new record of late Ediacaran acritarchs from La providencia group (Tandilia System, Argentina) and its biostratigraphical significance". English. In: Journal of South American Earth Sciences (2019), pp. - .

[26333] A. Bell and M. J. Everhart. "A New Specimen of Parahesperornis (Aves: Hesperornithiformes) from the Smoky Hill Chalk (Early Campanian) of Western Kansas". English. In: Transactions of the Kansas Academy of Science 112 (2009), pp. 7-14.

[26334] I. Y. Bolotskii, Y. L. Bolotskii, and A. P. Sorokin. "The First Find of an Ungual Phalanx of a Dromaeosaurid Dinosaur (Dinosauria: Dromaeosauridae) from the Blagoveshchensk Area of Late Cretaceous Dinosaurs (Amur Region, Russia)". English. In: Doklady Earth Sciences 484.1 (2019), pp. 18-20.

[26335] C. Brauckmann, D. R. Chestnut, and J. R. Jennings. "New spilapterid insect from the Breathitt Formation (Middle Pennsylvanian, Westphalian B) of eastern Kentucky, USA". English. In: Neues Jahrbuch fãijr Geologie und PalÃd'ontologie, Monatshefte 1993.11 (1993), pp. 641-647.

[26336] F. Briss Ãşn Egli, F. L. Agnolãn, and F. E. Novas. "A new specimen of Velocisaurus unicus (Theropoda, Abelisauroidea) from the Paso CÃşrdoba locality (Santonian), RÃo Negro, Argentina". English. In: Journal of Vertebrate Paleontology 36.4 (2016), e1119156:1-12. 
[26337] E. Buffetaut, D. Grigorescu, and Z. Csiki. Giant azhdarchid pterosaurs from the terminal Cretaceous of Transylvania (western Romania). English. Vol. 217. Palaeobiology and Evolution of Pterosaurs; Geological Society, London, Special Publications. 2003, pp. 91-104.

[26338] M. L. Casanovas-Cladellas, J. V. SantafÃ̂l'-Llopis, and A. Isidro-Llorens. "Pararhabdodon isonensis n. gen. n. sp. (Dinosauria). Estudio mofolÃşgico, radio-tomogrÃąicico y consideraciones biomecanicas [Pararhabdodon isonensis n. gen. n. sp. (Dinosauria). Morphological, radio-tomographic analysis and biomechanical considerations]". Spanish. In: Paleontologia i EvoluciÃş 26-27 (1993), pp. 121-131.

[26339] M. L. Casanovas-Cladellas, J. V. SantafÃ̂l'-Llopis, and C. Santisteban-BovÃ̃l. “Dacentrurus armatus (Stegosauria, Dinosauria) del CretÃącico Inferior de Los Serranos (Valencia, EspaÃ $\pm a$ ) [Dacentrurus armatus (Stegosauria, Dinosauria) from the Lower Cretaceous of Los Serranos (Valencia, Spain)]". Spanish. In: Revista EspaÃ \pm ola de Paleontolog Ãa 10.2 (1995), pp. 273-283.

[26340] T. Chitoku. "Pterosaur bone from the Upper Cretaceous of Enbetsu, Hokkaido". Japanese. In: The Bulletin of the Hobetsu Museum 12 (1996), pp. 17-24.

[26341] T. D. Cook, M. G. Newbrey, A. M. Murray, M. V. H. Wilson, K. Shimada, G. T. Takeuchi, and J. D. Stewart. "A Partial Skeleton of the Late Cretaceous Lamniform Shark, Archaeolamna kopingensis, from the Pierre Shale of Western Kansas, U.S.A." English. In: Journal of Vertebrate Paleontology 31.1 (2011), pp. 8-21.

[26342] T. D. Cook, M. V. H. Wilson, and M. G. Newbrey. "The First Record of the Large Cretaceous Lamniform Shark, Cardabiodon ricki, from North America and a New Empirical Test for Its Presumed Antitropical Distribution". English. In: Journal of Vertebrate Paleontology 30.3 (2010), pp. 643-649.

[26343] Z. Csiki. "New evidence of armoured titanosaurids in the Late Cretaceous - Magyarosaurus dacus from the Hateg Basin (Romania)". English. In: Oryctos 2 (1999), pp. 93-99.

[26344] T. M. Cullen, M. J. Ryan, C. Schroder-Adams, P. J. Currie, and Y. Kobayashi. "An ornithomimid (Dinosauria) bonebed from the Late Cretaceous of Alberta, with implications for the behaviour, classification, and stratigraphy of North American ornithomimids". English. In: PLoS ONE 8.3 (2013), e58853:1-9.

[26345] L. de Bonis, G. D. Koufos, and S. Sen. "A giraffid from the middle Miocene of the island of Chios, Greece". English. In: Palaeontology 40.1 (1997), pp. 121-133.

[26346] S. de Valais, V. Filippi, S. Molinas, and R. Souberlich. “DescripciÃşn de una huella de terÃşpodo de la FormaciÃşn Misiones: primer fÃşsil mesozoico fidedigno de Paraguay [Description of a theropod footprint from the Misiones Formation: first reliable Mesozoic fossil from Paraguay]". English. In: Andean Geology 39.3 (2012), pp. 541-547.

[26347] D. A. Eberth, D. C. Evans, D. B. Brinkman, F. Therrien, and L. S. Russell. “Dinosaur biostratigraphy of the Edmonton Group (Upper Cretaceous), Alberta, Canada: evidence for climate influence". English. In: Canadian Journal of Earth Sciences 50 (2013), pp. 701-726.

[26348] M. D. Ezcurra, M. J. Trotteyn, L. E. Fiorelli, M. Belen von Baczko, and J. R. A. Tarborda. “The oldest rhynchosaur from Argentina: a Middle Triassic rhynchosaurid from the Cha Ã \pm ares Formation (Ischigualasto-Villa UniÃşn Basin, La Rioja Province)". English. In: Palaeontologische Zeitschrift 88.4 (2014), pp. 453-460.

[26349] R. A. GarcÃa. "A giant tooth from the Late Cretaceous (middle Campanian-lower Maastrichtian) of Patagonia, Argentina: An enormous titanosaur or a large toothed titanosaur?" English. In: Cretaceous Research 41 (2013), pp. 82-85.

[26350] R. Gay. Sexual dimorphism in the Early Jurassic theropod dinosaur Dilophosaurus and a comparison with other related forms. English. The Carnivorous Dinosaurs. Indiana University Press, Bloomington. 2005, pp. 277-283.

[26351] B. J. GonzÃąlez Riga. "Speeds and stance of titanosaur sauropods: analysis of Titanopodus tracks from the Late Cretaceous of Mendoza, Argentina". English. In: Anais da Academia Brasileira de Ciencias 83.1 (2011), pp. 279-290. 
[26352] D. Grigorescu. "The "Tustea Puzzle": hadrosaurid (Dinosauria, Ornithopoda) hatchlings associated with Megaloolithidae eggs in the Maastrichtian of the Hateg Basin (Romania)". English. In: Ameghiniana 47.1 (2010), pp. 89-97.

[26353] M. L. Guignard, A. G. Martinelli, and M. B. Soares. "Postcranial anatomy of Riograndia guaibensis (Cynodontia: Ictidosauria)". English. In: Geobios 53 (2019), pp. 9-21.

[26354] T.-M. Han and B. Runnegar. "Megascopic Eukaryotic Algae from the 2.1-Billion-Year-Old Negaunee Iron-Formation, Michigan". English. In: Science 257.5067 (1992), pp. 232-235.

[26355] P. J. Hancox and B. S. Rubidge. "The first specimen of the Mid-Triassic dicynodont Angonisaurus from the Karoo of South Africa: implications for the dating and biostratigraphy of the Cynognathus Assemblage Zone, Upper Beaufort Group". English. In: South African Journal of Science 92 (1996), pp. 391-392.

[26356] A. W. Harvey. “New names for Miocene hermit crabs (Decapoda, Anomura, Paguridae)”. English. In: Crustaceana 71 (1998), pp. 119-121.

[26357] R. V. Hill, J. A. McCartney, E. Roberts, M. BouarÃl', F. Sissoko, and M. A. O’Leary. “Dyrosaurid (Crocodyliformes: Mesoeucrocodylia) Fossils from the Upper Cretaceous and Paleogene of Mali: Implications for Phylogeny and Survivorship across the K/T Boundary". English. In: American Museum Novitates 3631 (2008), pp. 1-19.

[26358] R. Hofmann and P. M. Sander. "The first juvenile specimens of Plateosaurus engelhardti from Frick, Switzerland: isolated neural arches and their implications for developmental plasticity in a basal sauropodomorph". English. In: PeerJ 2 (2014), e458-.

[26359] R. J. Horn $\tilde{A}_{j}$. "Barrandicellopsis, a new Ordovician archinacelloid genus (Mollusca, Gastropoda)". English. In: Bulletin of the Czech Geological Survey 75.2 (2000), pp. 145-152.

[26360] R. J. Horn $\tilde{A}_{j}$. "Mode of life of some Silurian and Devonain platyceratids". English. In: Bulletin of the Czech Geological Survey 75.2 (2000), pp. 135-143.

[26361] A. Kaim. "Gradual evolution of the Early Cretaceous marine gastropod Rissoina lineage in central Poland". English. In: Acta Palaeontologica Polonica 47.4 (2002), pp. 667-672.

[26362] J. Kriwet. "A New Pycnodont Fish Genus (Neopterygii: Pycnodontiformes) from the Cenomanian (Upper Cretaceous) of Mount Lebanon". English. In: Journal of Vertebrate Paleontology 24.3 (2004), pp. 525-532.

[26363] M. C. Lamanna, J. B. Smith, Y. S. Attia, and P. Dodson. "From dinosaurs to dyrosaurids (Crocodyliformes): removal of the post-Cenomanian (Late Cretaceous) record of Ornithischia from Africa". English. In: Journal of Vertebrate Paleontology 24.3 (2004), pp. 764-768.

[26364] Y. Laurent, E. Buffetaut, and J. Le Loeuff. “Un crane de Thoracosaurine (Crocodylia, Crocodylidae) dans le Maastrichtian Superieur du Sud de la France". French. In: Oryctos 3 (2000), pp. 19-27.

[26365] C. A. Laurito and A. L. Valerio. "Primer registro fÃşsil de Pliometanastes sp. (Mammalia, Xenarthra, Megalonychidae) para el Mioceno superior de Costa Rica, AmÃl'rica Central. Una nueva pista en la compresi Âşn del pre-GABI". Spanish. In: Revista GeolÃşgica de AmÃl'rica Central 47 (2012), pp. 95-108.

[26366] J. Le Loeuff, S. Khansubha, E. Buffetaut, V. Suteethorn, H. Tong, and C. Souillat. “Dinosaur footprints from the Phra Wihan Formation (Early Cretaceous of Thailand". In: Comptes Rendus Palevol 1 (2002), pp. 287-292.

[26367] H. LÃúser. "Revision of Actinastrea, the most common Cretaceous coral genus". English. In: PalÃd'ontologische Zeitschrift 86 (2012), pp. 15-22.

[26368] D. M. Lovelace. An articulated partial postcranial skeleton of a small ornithopod (C.F. Othnielia) dinosaur (Morrison Formation, Alcova, Wyoming). English. 2006.

[26369] S. G. Lucas, A. B. Heckert, J. W. Estep, and O. J. Anderson. "Stratigraphy of the Upper Triassic Chinle Group, Four Corners Region". English. In: New Mexico Geological Society Guidebook 48 (1997), pp. 81-107. 
[26370] S. G. Lucas, R. M. Sullivan, and J. A. Spielmann. The giant crocodylian Deinosuchus from the Upper Cretaceous of the San Juan Basin, New Mexico. English. Vol. 35. Late Cretaceous Vertebrates from the Western Interior. New Mexico Museum of Natural History and Science Bulletin. 2006, pp. 245248.

[26371] P. K. Maithy and R. Babu. "Organic-walled microfossils from the Ganurgarh Shale Formation (Bhander Group, Vindhyan Supergroup), Hoshangabad, Madhya Pradesh, India". English. In: Journal of The Palaeontological Society of India 38 (1993), pp. 43-49.

[26372] E. Malafaia, F. Ortega, F. Escaso, B. Silva, G. Ramaheiro, P. Dantas, C. Moniz, and F. Barriga. “AnÃąlisis preliminar de un nuevo ejemplar de Allosaurus del Grupo LourinhÃč (JurÃassico Superior de Torres Vedras, Portugal) [A preliminary account of a new Allosaurus individual from the Lourinh Ã č Group (Upper Jurassic of Torres Vedras, Portugal)]". Spanish. In: IV Jornadas Internacionales sobre Paleontolog Ãa de Dinosaurios y su Entorno Actas (2009), pp. 243-251.

[26373] M. S. Malkani. “Cervicodorsal, dorsal and sacral vertebrae of Titanosauria (sauropod dinosaurs) discovered from the latest Cretaceous Dinosaur Beds/Vitakri Member of Pab Formation, Sulaiman foldbelt, central Pakistan". English. In: Journal of Applied and Emerging Sciences 1.3 (2006), pp. 188-196.

[26374] D. M. Martill, M. P. Witton, and A. Gale. "Possible azhdarchoid pterosaur remains from the Coniacian (Late Cretaceous) of England". English. In: Zitteliana B 28 (2008), pp. 209-218.

[26375] J. E. Martin, J. Raslan-LoubatiÃl', and J.-M. Mazin. “Cranial anatomy of Pholidosaurus purbeckensis from the Lower Cretaceous of France and its bearing on pholidosaurid affinities". English. In: Cretaceous Research 66 (2016), pp. 43-59.

[26376] M. Matsukawa, M. Futakami, M. G. Lockley, C. Peiji, C. Jinhua, C. Zhenyao, and U. L. Bolotsky. "Dinosaur footprints from the Lower Cretaceous of eastern Manchuria, northeastern China: implications for the recognition of an ornithopod ichnofacies in East Asia". English. In: Palaios 10 (1995), pp. 3-15.

[26377] M. A. Medeiros and C. L. Schultz. "Rayososaurus (Sauropoda, Diplodocoidea) no meso-CretÃaceo do norte-nordeste Brasiliero [Rayososaurus (Sauropoda, Diplodocoidea) from the mid-Cretaceous of north-northeastern Brazil]". Portugese. In: Revista Brasileira de Paleontologia 7.2 (2004), pp. 275279.

[26378] M. Mercuzot, P. Pellenard, C. Durlet, C. Bougeault, C. Meister, J. Dommergues, N. Thibault, F. Baudin, O. Mathieu, L. Bruneau, E. Huret, and K. E. Hmidi. "Carbon-isotope events during the Pliensbachian (Lower Jurassic) on the African and European margins of the NW Tethyan Realm". English. In: Newsletters on Stratigraphy (2019), pp. - .

[26379] U. Nicosia, F. M. Petti, G. Perugini, S. D’Orazi Porchetti, E. Sacchi, M. A. Conti, N. Mariotti, and A. Zarattini. "Dinosaur tracks as paleogeographic constraints: new scenarios for the Cretaceous geography of the Periadriatic region". English. In: Ichnos 14 (2007), pp. 69-90.

[26380] A. P. Nutman, V. C. Bennett, C. R. L. Friend, M. J. Van Kranendonk, and A. R. Chivas. "Rapid emergence of life shown by discovery of 3,700-million-year-old microbial structures". English. In: Nature 537 (2016), pp. 535-539.

[26381] G. S. Odin, P. Courville, M. Machalski, and W. A. Cobban. The Campanian-Maastrichtian ammonite fauna from Tercis (Landes, France); a synthetic view. Vol. 19. Developments in Palaeontology and Stratigraphy. 2001, pp. 550-567.

[26382] F. Ortega, J. L. Sanz, F. Barroso-Barcemilla, O. Cambra-Moo, F. Escaso, M. GarcÃa-Oliva, F. Marcos Fern Ãąndez, A. PÃl'rez GarcÃa, M. Segura, and A. Torices. Macrovertebrados del Cret Ãacico Superior de "Lo Hueco" (Fuentes, Cuenca) [Macrovertebrates from the Upper Cretaceous of "Lo Hueco" (Fuentes, Cuenca)]. Spanish. 2008.

[26383] D. C. Parris, B. S. Grandstaff, and W. B. Gallagher. "Fossil fish from the Pierre Shale Group (Late Cretaceous): Clarifying the biostratigraphic record". English. In: Geological Society of America Special Papers 427 (2007), pp. 99-109. 
[26384] A. Paulina Carabajal, R. A. Coria, P. J. Currie, and E. B. Koppelhus. "A natural cranial endocast with possible dicraeosaurid (Sauropoda, Diplodocoidea) affinities from the Lower Cretaceous of Patagonia". English. In: Cretaceous Research 84 (2018), pp. 437-441.

[26385] X. Pereda-Suberbiola, J. I. Canudo, J. Company, P. Cruzado-Caballero, and J. I. Ruiz-Omenaca. "Hadrosauroid dinosaurs from the Latest Cretaceous of the Iberian Peninsula". English. In: Journal of Vertebrate Paleontology 29.3 (2009), pp. 946-951.

[26386] A. PÃl'rez-GarcÃa. “A new genus for 'Testudo' gigas, the largest European Paleogene testudinid". English. In: Journal of Vertebrate Paleontology 36.1 (2016), e1030024:1-9.

[26387] E. Peri, A. Collareta, G. Insacco, and G. Bianucci. “An Inticetus-like (Cetacea: Odontoceti) postcanine tooth from the Pietra leccese (Miocene, southeastern Italy) and its palaeobiogeographical implications". English. In: Neues Jahrbuch fÃ̈ijr Geologie und PalÃd'ontologie - Abhandlungen 291.2 (2019), pp. 221-228.

[26388] G. V. R. Prasad and J. C. Rage. "A discoglossid frog in the latest Cretaceous (Maastrichtian) of India. Further evidence for a terrestrial route between India and Laurasia in the latest Cretaceous". English. In: Comptes Rendus de l'Academie des Sciences, SÃl'rie II, Mecanique, Physique, Chimie, Sciences de l'Univers, Sciences de la Terre 313.2 (1991), pp. 273-278.

[26389] J. Prokop and A. Nel. "A new genus and species of Homoiopteridae from the Upper Carboniferous of the Intra-Sudetic basin, Czech Republic (Insecta: Palaeodictyoptera)". English. In: European Journal of Entomology 101 (2004), pp. 583-589.

[26390] T. Rossmann, D. E. Berg, and S. Salisbury. "Studies on Cenozoic crocodiles: 3. Gavialosuchus cf. gaudensis (Eusuchia: Tomistomidae) from the Lower Miocene of south Germany". English. In: Neues Jahrbuch fãijr Geologie und PalÃd'ontologie, Monatshefte 1999.6 (1999), pp. 321-330.

[26391] M. A. Safer, M. C. Chabou, and M. Y. Laghouag. Amoura (Djebel Bou Kahil, AlgÃl'rie): un site d'int Ál'r Äłt patrimonial majeur [Amoura (Djebel Bou Kahil, Algeria): a site of major patrimonial interest]. English. 2011.

[26392] K. A. O. Salih, D. C. Evans, R. Bussert, N. Klein, M. Nafi, and J. MÃijller. "First record of Hyposaurus (Dyrosauridae, Crocodyliformes) from the Upper Cretaceous Shendi Formation of Sudan". English. In: Journal of Vertebrate Paleontology 36.1 (2016), e1115408:1-9.

[26393] D. R. Schwimmer, G. E. Hooks, and B. Johnson. "Revised taxonomy, age, and geographic range of the large lamniform shark Cretodus semiplicatus". English. In: Journal of Vertebrate Paleontology 22.3 (2002), pp. 704-707.

[26394] M. Sharma and Y. Shukla. "Mesoproterozoic coiled megascopic fossil Grypania spiralis from the Rohtas Formation, Semri Group, Bihar, India". English. In: Current Science 96.12 (2009), pp. 16361640.

[26395] P. P. Skutschas, I. G. Danilov, T. M. Kodrul, and J. Jin. "The first discovery of an alligatorid (Crocodylia, Alligatoroidea, Alligatoridae) in the Eocene of China". English. In: Journal of Vertebrate Paleontology 34.2 (2014), pp. 471-476.

[26396] T. Smith and V. Codrea. "Red iron-pigmented tooth enamel in a multituberculate mammal from the Late Cretaceous Transylvanian "Hateg Island"”. English. In: PLoS ONE 10.7 (2015), pp. 1-16.

[26397] T. Sulej. “Osteology, variability, and evolution of Metoposaurus, a temnospondyl from the Late Triassic of Poland". English. In: Palaeontologia Polonica 64 (2007), pp. 29-139.

[26398] C. Sullivan, D. W. E. Hone, T. D. Cope, Y. Liu, and J. Liu. "A new occurrence of small theropod tracks in the Houcheng (Tuchengzi) Formation of Hebei Province, China". English. In: Vertebrata PalAsiatica 47.1 (2009), pp. 35-52.

[26399] D. Suzuki, H. Saegusa, and H. Furutani. Newly found hadrosaurid fossil co-producing broadleaf fossils from Sumoto, west central Japan. English. 2005.

[26400] T. Tsuihiji, R. Barsbold, M. Watanabe, K. Tsogbataar, T. Chinzorig, Y. Fujiyama, and S. Suzuki. “An exquisitely preserved troodontid theropod with new information on the palatal structure from the Upper Cretaceous of Mongolia". English. In: Naturwissenschaften (2014), pp. -. 
[26401] F. Vega, N. Bruce, L. Serrano, G. A. Bishop, and M. del Carmen Perrillat. "A rewiew of the Lower Cretaceous (Tlayua Formation: Albian) Crustacea from Tepexi de Rodrigues, Puebla, Central Mexico". English. In: Bulletin of the Mizunami Fossil Museum 32 (2005), pp. 25-30.

[26402] M. Wang and D. Liu. “Taxonomical reappraisal of Cathayornithidae (Aves: Enantiornithes)". English. In: Journal of Systematic Palaeontology (2015), pp. - .

[26403] D. B. Weishampel and C.-M. Jianu. "New theropod dinosaur material from the Hateg Basin (Late Cretaceous, western Romania)". English. In: Neues Jahrbuch fãijr Geologie und PalÃd'ontologie, Abhandlungen 200.3 (1996), pp. 387-404.

[26404] H. M. Wilson. "A new genus of archipolypodan millipede from the Coseley Lagerst Ãd'tte, Upper Carboniferous, UK". English. In: Palaeontology 48 (2005), pp. 1097-1100.

[26405] D. A. Winkler, M. J. Polcyn, and L. L. Jacobs. “New sauropod dinosaur material from Jones Ranch: a large Comanchean nonmammalian tetrapod from texas". English. In: Earth and Environmental Science Transactions of the Royal Society of Edinburgh 103 (2013), pp. 1-11.

[26406] X.-C. Wu, A. P. Russell, and S. L. Cumbaa. "Terminonaris (Archosauria: Crocodyliformes): new material from Saskatchewan, Canada, and comments on its phylogenetic relationships". English. In: Journal of Vertebrate Paleontology 21.3 (2001), pp. 492-514.

[26407] L.-D. Xing. "Report of dinosaur trackways from Lower Jurassic Ziliujing Formation of Gulin area, Sichuan, China". Chinese. In: Geological Bulletin of China 29.11 (2010), pp. 1730-1732.

[26408] S. Zhu, M. Zhu, A. H. Knoll, Z. Yin, F. Zhao, S. Sun, Y. Qu, M. Shi, and H. Liu. “Decimetre-scale multicellular eukaryotes from the 1.56-billion-year-old Gaoyuzhuang Formation in North China". English. In: Nature Communications (2016), pp.--.

[26409] A. E. Zurita, A. A. Carlini, D. Gillette, and R. Sanchez. "Late Pliocene Glyptodontinae (Xenarthra, Cingulata, Glyptodontidae) of South and North America: Morphology and paleobiogeographical implications in the GABI". English. In: Journal of South American Earth Siences 31.43892 (2011), pp. 178-185.

[26410] K. Shimada. "Skeletal and dental anatomy of lamniform shark, Cretalamna appendiculata, from Upper Cretaceous Niobrara Chalk of Kansas". English. In: Journal of Vertebrate Paleontology 27 (2007), pp. 584-602.

[26411] C. D. Sumrall, C. E. Brett, T. A. Dexter, and A. Bartholomew. "An enigmatic blastozoan echinoderm fauna from central Kentucky". English. In: Journal of Paleontology 83.5 (2009), pp. 739-749. 


\section{Data contributors}

A. Aguilar, A. Behrensmeyer, A. Benabbas, A. Buczek, A. Cárdenas, A. Chiarenza, A. Clement, A. Delelli, A. Doyle, A. Dunhill, A. EL Manharawy, A. Garcia Selles, A. Girndt, A. Glass, A. Graur, A. Hendy, A. Henshaw, A. Jukar, A. Kidd, A. Kinchloe, A. Kocsis, A. Kourmadas, A. Krug, A. Lauchstedt, A. Levy, A. Lin, A. Liparini, A. Louderback, A. McGowan, A. Miller, A. Munro, A. Murch, A. Noshirvan, A. Nuetzel, A. Raymond, A. Rees, A. Restrepo, A. Rincon, A. Rojas, A. Saeed, A. Smith, A. Spencer-Lee, A. Stafford, A. Stigall, A. Tomasovych, A. Tuell, A. Turner, A. Webber, A. Wisniewski, A. Zaffos, A. Zhuravlev, A.-C. da Silva, B. Allen, B. Beatty, B. Bookhagen, B. Brenneis, B. Deline, B. Gee, B. Kaphingst, B. Kröger, B. Mamo, B. Peecook, B. Santos, B. Seuss, B. Shipps, B. Tiffney, B. Wilborn, C. Bell, C. Bernard, C. Boyd, C. Cervato, C. Chan, C. Feng, C. Ferguson, C. Feuerabendt, C. Glavich, C. Hall, C. Hotton, C. Jaramillo, C. Labandeira, C. Lombardi, C. Looy, C. Luo, C. Marshall, C. Martinez, C. Peredo, C. Pimiento, C. Powers, C. Reddin, C. Schweitzer, C. Shaffer, C. Sidor, C. Simpson, C. Stanbury, C. Story, C. Suarez-Gomez, C. VanBuren, C. Violaris, C. Visaggi, D. Balseiro, D. Bottjer, D. Brandt, D. Buick, D. Carlson, D. Cashmore, D. Contreras, D. Croft, D. Dimitrijevic, D. Ehrenburg, D. Erwin, D. Gendry, D. Hempfling, D. Horvath, D. Juhász, D. Korn, D. Lamb, D. Lazarus, D. Liebsch, D. Lovelace, D. Mathieson, D. Mertz, D. Muscente, D. Nicholson, D. Perez, D. Rasch, D. Reed, D. Robinson, D. Royer, D. Schramm, D. Smith, D. Sunderlin, D. Weinstein, D. Wellmanns, D. Wright, E. Andres, E. Childs, E. Dunne, E. Fara, E. Hansen, E. Jarochowska, E. Johnson, E. Kido, E. Kovács, E. Kowalski, E. Kustatscher, E. Leckey, E. Orzechowski, E. Petsios, E. Stiles, E. Velasquez , E. Vlachos, F. Cecca, F. Fearnhead, F. Franeck, F. Fursich, F. Herrera, F. Marx, F. Reichel, F. Verbruggen, F. Villegas-Garin, G. Ballen, G. Benevento, G. Doria, G. Halstead-Johnson, G. Harrison, G. Liggett, G. Lloyd, G. McBrinn, G. Motz, G. Slater, G. Smith, G. Stanley, G. Varnham, H. Agic, H. Drum, H. Lindon, H. Mewis, H. O’Regan, H. Pfefferkorn, H. Shepherd, H. Sims, H. Street, H. Wang, J. Allen, J. Alroy, J. Anderson, J. Bardin, J. Beasecker, J. Benefield, J. Benito Moreno, J. Bloch, J. Bonelli, J. Bryant, J. Burns, J. Carrillo, J. Cassara, J. Ceballos, J. Conaty, J. Damuth, J. David, J. Dummasch, J. Finarelli, J. Fosdick, J. Fröbisch, J. Head, J. Hunter, J. Jenkins, J. Joo, J. Kao, J. Karr, J. Kriwet, J. Marcot, J. Martinelli, J. Millet, J. Mordaunt, J. Moreno, J. Mueller, J. Pálfy, J. Parham, J. Payne, J. Person, J. Richter, J. Sandlin, J. Sepkoski, J. Sessa, J. So, J. Sullivan, J. Tennant, J. Villafana, J. Villari, J. Wertheim, J. Wittmer, J. Zamagni, J. Zambito, J. Zijlstra, K. Badyrka, K. Bauer, K. Beard, K. Bulinski, K. De Baets, K. Feser, K. Hassell, K. Hendy, K. Johnson, K. Koverman, K. Layou, K. Magoulick, K. Maguire, K. Manish, K. Okamoto, K. Sághi, K. Sears, K. Strang, K. Straub, K. Tracy, K. Williams, K. Ziegler, L. Baltzly, L. Cavin, L. Cole, L. Craig, L. Eccles, L. Edwards, L. Fall, L. Gannon, L. Harfoush, L. Ivany, L. Liow, L. Macaluso, L. Mora-Rojas, L. Mulvey, L. Murdoch, L. Na, L. Nicholson, L. Park Boush, L. Petruny, L. Rasia, L. Sallan, L. Shadan, L. Spahr, L. van den Hoek Ostende, L. Villier, L. White, M. Aberhan, M. Apel, M. Arakaki, M. Bean, M. Bell, M. Bosnakoff, M. Broehl, M. Carrano, M. Christie, M. Chua, M. Clapham, M. Coates, M. Domansky, M. Donovan, M. Foote, M. Gomez Correa, M. Gonzalez, M. Hopkins, M. Hudgins, M. Jones, M. Kosnik, M. Kotyk, M. Kouvari, M. Krause, M. Laflamme, M. Manojlovic, M. Nelson, M. Nimke, M. O'Leary, M. Oreska, M. Patzkowsky, M. Pavia, M. Reynolds, M. Riess, M. Ross, M. Sameh, M. Shalap, M. Smith, M. Sommers, M. Troy, M. Uhen, M. Vallejo, M. Vavrek, M. Walther, N. Bonuso, N. Brand, N. Famoso, N. Heim, N. Herrera Sánchez, N. Jud, N. Kelley, N. Labell, N. Nagalingum, N. Ochsenknecht, N. Pyenson, N. Smith, N. Stilkerich, N. Visalden, O. Gjata, O. Rauhut, O. Will, P. Barrett, P. Borkow, P. Coster, P. Elliott, P. Gensel, P. Harnik, P. Harries, P. Hearn, P. Holroyd, P. Kampouridis, P. Mannion, P. Monarrez, P. Nätscher, P. Niccum, P. Novack-Gottshall, P. Santamarina, P. Vazquez, P. Wagner, P. Wall, P. Wilf, P. Wolniewicz, Q. Jamison, Q. Li, R. Bateman, R. Benson, R. Butler, R. Close, R. Gastaldo, R. Hulbert, R. Krause, R. Lupia, R. McClees-Funinan, R. Owen, R. Plotnick, R. Potts, R. Reisz, R. Rogers, R. Sehtia, R. Whatley, R. Yoder, S. Alam, S. Cole, S. Cote, S. Crasquin, S. Devincenzi, S. Evers, S. Finnegan, S. Gouiric-Cavalli, S. Gouwy, S. Haegele, S. Henderson, S. Hicks, S. Holland, S. Jacquet, S. Jankowski, S. Kolbe, S. Kuemmell, S. Low, S. Mahmood, S. McMullen, S. Miller, S. Mondal, S. Nurnberg, S. Olroyd, S. Ostrowski, S. Paxson, S. Pendleton, S. Peters, S. Schachat, S. Tremblay, S. Triple, S. Trubovitz, S. Tucker, S. Tweedt, S. Wagner, S. Weinberg, S. Wing, S. Yost, T. Challands, T. Cleary, T. Danelian, T. Hanson, T. Hegna, T. Liebrecht, T. Naeher, T. Olszewski, T. Schossleitner, T. Smith, T. Tsubamoto, T. Wolfe, T. Wong Hearing, U. Balthasar, U. Merkel, U. Smith, V. Choe, V. Egerton, V. Fischer, V. Karadi, V. Maciel, V. Piazza, V. Ramirez, V. Syverson, W. Ausich, W. Clyde, W. Foster, W. Glaeser, W. Kiessling, W. Puijk, W. Rhodes, W. Stein, X. Wang, Z. Newman, Z. Tredwell 